\title{
$\mathbf{X X X}$ \\ ENCONTRO ANUAL \\ DE INICIAÇĀO CIENTIÍFICA
}

CIÊNCIA, TECNOLOGIA E CONDIÇÃO HUMANA:

DESAFIOS, AÇÕES E COMPROMISSOS

29 e 30 de Outubro de 2020 


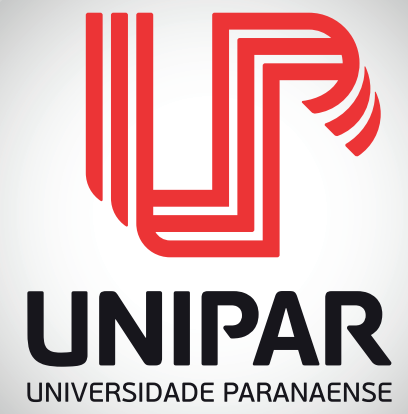




\section{UNIVERSIDADE PARANAENSE COORDENADORIA DE PESQUISA E EXTENSÃO}

\section{RESUMOS EXPANDIDOS DO XIX ENCONTRO ANUAL DE INICIAÇÃO CIENTÍFICA DA UNIPAR}

Departamento de Editoração e Divulgação Científica - DEDIC Umuarama - PR 
Ficha Catalográfica

E56 Encontro Anual de Iniciação Científica da UNIPAR (19.: 2020: Umuarama, PR).

XIX Encontro Anual de Iniciação Científica da UNIPAR, de 29 a 30 de outubro de 2020. -- Umuarama : UNIPAR, 2020.

Realização: Universidade Paranaense - UNIPAR.

ISBN 978-65-87557-08-3

1. Pesquisa científica. I. Universidade Paranaense. II. Título.

(21. ed.) CDD: 001.4

Bibliotecária Responsável Inês Gemelli CRB 9/966

DOI: http://dx.doi.org/10.25110/xixeaic. 2020 


\section{UNIVERSIDADE PARANAENSE}

Mantenedora

ASSOCIAÇÃO PARANAENSE DE ENSINO E CULTURA - APEC

Reitor

Carlos Eduardo Garcia

Vice-Reitora Executiva

Neiva Pavan Machado Garcia

Chefe de Gabinete da Reitoria

Rogério Dutra

Diretor Executivo de Gestão de Assuntos Comunitários Cássio Eugênio Garcia

Diretora Executiva de Gestão da Cultura e Divulgação Institucional Claudia Elaine Garcia Custódio

Diretor Executivo de Gestão de Planejamento Acadêmico

Sônia Regina da Costa Oliveira

Diretor Executivo de Gestão de Recursos Financeiros

Rui de Souza Martins

Diretor Executivo de Gestão das Relações Trabalhistas Janio Tramontin Paganini

Diretor Executivo de Gestão dos Assuntos Jurídicos

Lino Massayuki Ito

Diretora Executiva de Gestão e Auditoria de Bens Materiais Permanentes e de Consumo

Rosilamar de Paula Garcia

Diretora Executiva de Gestão da Educação a Distância Ana Cristina de Oliveira Cirino Codato

Diretor Executivo de Gestão da Dinâmica Universitária José de Oliveira Filho

Diretora Executiva de Gestão do Ensino Superior Maria Regina Celi de Oliveira

Coordenadora de Pesquisa e Extensão

Evellyn Claudia Wietzikoski Lovato

Coordenador de Pós-Graduação

Emerson Luiz Botelho Lourenço

Coordenadoria de Ciências Biológicas, Médicas e da Saúde Irinéia Paulina Baretta

Coordenadoria de Ciências Humanas, Lingüística, Letras e Artes, de Ciências Sociais Aplicadas e de Educação

Fernanda Garcia Velasquez

Coordenadoria de Ciências Exatas, Agrárias, Tecnológicas e Geociências Giani Andrea Linde Colauto

Diretor Geral do Campus Umuarama

Fernanda Garcia Velasquez

Diretor Geral do Campus Toledo

Angelo Alfredo Sucolott

Diretora Geral do Campus Paranavaí

Edwirge Vieira Franco

Diretora Geral do Campus Guaíra

Hugo Miranda Mendes da Silva

Diretor Geral do Campus Cianorte

Dieine Aparecida Cescon

Diretor Geral do Campus Cascave

Gelson Luiz Uecker

Diretor Geral do Campus Francisco Beltrão

Claudemir José de Souza

Diretora do Instituto de Ciências Exatas, Agrárias, Tecnológicas e

Geociências

Giani Andrea Linde Colauto
COMISSÃO ORGANIZADORA

Membros da Comissão Organizadora

Prof. Dr. Celso Hiroshi Iocohama

Prof. ${ }^{\text {a }}$ Dr. ${ }^{\text {a }}$ Daniela Dib Gonçalves Repetti

Prof. Dr. Emerson Luiz Botelho Lourenço

Prof. ${ }^{a}$ Dr. ${ }^{a}$ Evellyn Claudia Wietzikoski Lovato

Prof Dr. Nelson Barros Colauto

Secretária

Thaís Camilla Rodrigues

COMITÊ CIENTÍFICO

Prof. ${ }^{a}$ Dr. ${ }^{a}$ Evellyn Claudia Wietzikoski Lovato Prof. ${ }^{a}$ Dr. ${ }^{a}$ Ana Carolina Soares Fraga Zaze

Prof. Dr. Jorge Antonio Vieira

Prof. Dr. Luciano Seraphim Gasques

Prof. a Dr. ${ }^{a}$ Maria Elena Martins Diegues

Prof ${ }^{a} \mathrm{Dr}^{\mathrm{a}}$ Lucimar Pereira Bonett

Prof. Dr. Ricardo Marcelo Abrão

Prof. Dr. Rodrigo Oliva

\section{COMISSÃO CIENTÍFICA DE APOIO}

Eliane Cristina Ussifati

Gabriela Fernanda Tozati

COPEX

COPEX

COPEX

egina Esperança

Karina Oliveira Campos

Marcos Antonio Ribeiro Pereira

COPEX

DEDIC

COPEX

Rafaela Kaulfuss da Rosa

DEDIC

COPEX

Thainá Fogaça Santos

Thaís Camilla Rodrigues 
ADEMIR FARIA PIRES

ADRIANA KUNEN

ALAN PABLO GRALA

ALANA CAROLINE MOSSOI

ALBINO GABRIEL TURBAY JUNIOR

ALESSANDRA FREI SILVA

ALESSANDRO RODRIGUES PERONDI

ALEXANDRE MAGNO AUGUSTO MOREIRA

ALUANA MORAES

ALYSSON RAMALHAIS

ANA CAROLINA SOARES FRAGA ZAZE

ANA CLEIA DE OLIVEIRA CIRINO

ANA DANIELA LOPES

ANA PAULA TORQUETI GAVIOLI

ANA SILVIA DEGASPERI IEKER

ANDERSON FELIPE FERREIRA

ANDRE LUIZ URBANO

ANDREIA ASSUNCAO SOARES

ANGELICA GIOSA CANDIDO

ANNA FERNANDA SCALLA MENOTTI

ANTONIO LUIZ DE OLIVEIRA ALVES

ARNALDO GOMES DO AMARAL

ATILA SILVESTRE

AUDREW JACKSON DEMOZZI

BARBARA COSSETTIN COSTA BEBER

BRUNINI

BRUNO DOTA PAULIV

BRUNO MARTINS DUARTE ORTIZ

BRUNO SMOLAREK DIAS

CAMILA CRISTIANE FORMAGGI SALES

RIBEIRO

CAMILA PEREIRA GIROTTO

CAMILA RIGOBELLO

CARLA MARIA MARIANO FERNANDEZ DE

ANDRADE

CARLA ROSEANE ZANFRILLI PAGANINI

CARLOS DANIEL DE SIQUEIRA

CORADETTE

CAROLINA AMARAL TAVARES

CAROLINE ZANELLA CAGNINI

CASSIO DE PAULA XAVIER

CELSO HIROSHI IOCOHAMA

CESAR AUGUSTO HOFFMANN

CINTHIA THIESEN OTANI

CINTIA DE SOUZA ALFERES ARAUJO

CLAUDIA REGINA DE SOUZA PEREIRA DE

CASTRO

CLEBER DE SOUZA RELLI

CRISTIANE BEATRIZ DAHMER COUTO

CRISTIANE CLAUDIA MEINERZ

CRISTINE BONACINA

DAIANE CORTEZ RAIMONDI

DAISY CRISTINA RODRIGUES

DANIELA DE CASSIA FAGLIONI B

CERANTO

DANIELA DIB GONCALVES

DANIELE DE CARVALHO HAURANI

DANIELLE ANDRESSA OLIVEIRA SESTARI

DENISE ALVES LOPES

DIEGO JOSE BALDISSERA

DIELY MELONARI DALLA COSTA

DIOGO DE ARAUJO LIMA

DORA DE CASTRO AGULHON SEGURA

DURCELINA SCHIAVONI BORTOLOTI

EDISON FRANCA LANGE JUNIOR

EDIVAN JOSE CUNICO

EDSON GERONIMO

EDUARDA MAGANHA DE ALMEIDA

EDUARDO MAFFEI

EDUARDO VEDOVETTO SANTOS

ELISE POLLI

ELIZABETI DE MATOS MASSAMBANI

EVELLYN CLAUDIA WIETZIKOSKI LOVATO

EVERLEI CAMARA

FABIO RICARDO ACENCIO
FERNANDA MARIA POLTRONIERI

FERNANDA MARIA POLTRONIERI

FERNANDO RIGO BOTELHO

FILIPE CORREA PACHECO

FRANCISCO ROMERO JUNIOR

FRANCISLAINE APARECIDA DOS REIS

LIVERO

GABRIELA DE CONTO BETT

GABRIELA FERNANDA TOZATI

GERALDO SCRAMIN NETO

GIANI ANDREA LINDE COLAUTO

GILBERTO ALVES

GILMARA GONCALVES BOLONHEIZ

GIOVANA MIOTO DE MOURA

GISELLE FELIZ SANTIAGO

GIULIANA ZARDETO SABEC

GLACY JAQUELINE DA SILVA

GRACIANE BARBOZA DA SILVA

GUILHERME SERAFIM

GUSTAVO RATTI DA SILVA

HELIDA MARA MAGALHAES

HELOISA CRISTINA LUIZ CAPPELLARI

HERBERT CORREA BARROS

HORACIO MONTESCHIO

IGO HENRIQUE SILVA NUNES

INDIOMARA BARATTO

ISABEL CRISTINA DA SILVA CAETANO

ISABEL CRISTINA GOZER

ISABELA CARVALHO DOS SANTOS

ISABELLE LUIZ RAHAL

IZABELA CAMILOTTI DORNELES

JANAINA STRAPAZZON RAFAGNIN

JAQUELINE HOSCHEID

JAYME RODRIGUES DIAS JUNIOR

JEFFERSON J AMARAL DOS SANTOS

JORGE ANTONIO VIEIRA

JORGELINO PEDRO DE SANTANA JUNIOR

JOSE LAURINDO DE SOUZA NETTO

JOSE LUIZ BORSATTO JUNIOR

JOSE MIGUEL GARCIA MEDINA

JULIA IZABELLE TONETO ROMANO

MAZIERO

JULIANA LUIZA MAZARO

JULIANA SILVEIRA DO VALLE

JUSCELINO PIRES DA FONSECA

KAMILA REZENDE

KARINE DELGADO SOUZA

KAROLAINE BEZERRA

KELLY CARDOSO

KLISSIA ROMERO FELIZARDO

LAIS FERNANDA JUCHEM DO

NASCIMENTO

LAIS SILVA ZIMIANI

LEONARDO FRATINI XAVIER DE SOUZA

LETICIA BIANCA PINHEIRO

LETICIA NADAL

LIDIANE NUNES BARBOSA

LILIAN CRISTINA PINHEIRO GOTO

LISSANDRA GUIMARAES GIL JUCHEM

LORENA NERIS BARBOZA

LUANA TEDESCO

LUCAS GOMES DE OLIVEIRA

LUCAS TOZZI

LUCIANA KAZUE OTUTUMI FARIAS

LUCYELENA AMARAL PICELL

LUIS IRAJA NOGUEIRA DE SA JUNIOR

LUIZ AUGUSTO MUGNAI VIEIRA JUNIOR

LUIZ FERNANDO GUARNIERI PASSOS

LUIZ FERNANDO TOMAZINHO

LUIZ GUSTAVO DO AMARAL

LUIZ MANOEL GOMES JUNIOR

LUIZ ROMULO ALBERTON

MARCELLA RIBEIRO DA COSTA

MARCELO ALBERTO ELIAS

MARCELO FIGUEIRO BALDI
MARCIA VALERIA AGUILAR CARRARO SEIXAS

MARCO AURELIO CUNHA DEL VECHIO

MARCOS JOSE ALVES DE LIMA

MARIA DO CARMO DE O NOGUEIRA

MARIA FERNANDA MIRANDA PEZENTE

MARIA GRACIELA IECHER FARIA NUNES

MARIA LUSSANDRA DOMINGUES LOVERA

MARIANA NATALE FIORELLI FABICHE

MARIANA SARTORI NOVAK

MARILEISA BARBOSA

MARISANGELA ISABEL WIETZIKOSKI

HALABURA

MASSAKI FUJIMURA JUNIOR

MAURO SERGIO DA ROCHA

MAYKON CESAR SPOLTI FERREIRA

MICHEL ELIAS DE AZEVEDO OLIVEIRA

MIRIAM FECCHIO CHUEIRI

MIRIAN COZER

MONICA CRISTINA MANIEZO TAVARES

NATALIA CILIAO DE ALMEIDA

NATALIE BERTELIS MERLINI

NATAN GALVES SANTANA

NATHIELLE MIRANDA

ODAIR ALBERTON

OLAVO BILAC QUARESMA DE OLIVEIRA

FILHO

ORLANDO VAN UFFELEN

ORLETE MARIA POMPEU DE LIMA

PATRIK AMERICO POLLIZELLO LOPES

PAULA MONTANHINI FAVETTA

PAULO CESAR DE SOUSA

PEDRO FRANCISCO RIBEIRO

PEDRO HENRIQUE MARANGONI

PRISCILA MEGDA JOAO JOB ZAGO

RAFAEL MILANI DA COSTA

RAFAELLY ANDRESSA MAILHO FARIAS

RANULFO PIAU JUNIOR

RAQUEL LAURIANO RODRIGUES FINK

RENATA TORRI SALDANHA

RENATO CHERUBINI FACIO

RICARDO DE MELO GERMANO

RICARDO MARCELO ABRAO

RODRIGO LEITE ARRIEIRA

ROSIARA ROSARIA DIAS MAZIERO

ROSILEY BERTON PACHECO

SALVIANO TRAMONTIN BELETTINI

SAMANTHA WIETZIKOSKI SATO

SILVIA GRACIELE HULSE DE SOUZA

SILVIA MARA OLIVEIRA GUIMARAES

SIVONEI SIMAS

SONIA MARIA MORO DO NASCIMENTO

SUELEN PEREIRA RUIZ HERRIG

SUELLEN LAIS VICENTINO VIEIRA

TALITA BIANCHIN BORGES

TANIA ARNECKE PEREIRA

TANIA HARUMI UCHIDA

THAIS CRISTINA GUTSTEIN NAZAR

THIAGO HENRIQUE DE BONA

THIAGO MATTOS DE OLIVEIRA

THIAGO MORETO FIORI

VANESSA RODRIGUES DO NASCIMENTO

VANILDA DE SOUSA LACERRA NUNES

VICTOR ANTONIO CANCIAN

VIRGINIA TELLES SCHIAVO WRUBEL

VITOR HUGO RAMOS MACHADO

VIVIANNE AUGUSTA PIRES

VOLMIR PITT BENEDETTI

WANESSA DE CAMPOS BORTOLUCCI

WESLEY ALVES TRINDADE

WESLEY FERNANDO FERRARI

WILSON PEREIRA DE ASSIS

ZILDA CRISTIANI GAZIM 


\section{APRESENTAÇÃO}

O Encontro Anual de Iniciação Científica da UNIPAR têm como principais objetivos viabilizar a divulgação dos resultados de projetos de pesquisa produzidos anualmente por professores pesquisadores, acadêmicos do ensino fundamental, graduação e pós-graduação, além de profissionais e demais interessados da própria instituição e de instituições externas.

Trata-se do maior evento que acontece no Município de Umuarama (interior do Paraná) e região. A heterogeneidade dos participantes permite uma ampla discussão dos mais diversos assuntos relacionados aos avanços da pesquisa desenvolvida pela instituição.

Neste ano, diante de um cenário atípico, de uma pandemia que revolucionou a vida de todos nós, remodelamos o evento e adotamos um formato inovador e tecnológico, contando com todo o suporte que a UNIPAR disponibiliza.

Destacamos que aprimoramos as ferramentas para que a discussão científica ocorra mesmo virtualmente, através dos Chats.

Participam da Comissão Organizadora a Coordenadoria de Pesquisa e Extensão e os Coordenadores dos Programas de Pós-Graduação Stricto Sensu ofertados pela instituição.

No intuito de estimular o interesse pela pesquisa em alunos de graduação, com objetivo de formar recursos humanos qualificados para a pesquisa científica, a UNIPAR criou Programas de Iniciação Científica: 1) Programa Institucional de Bolsas de Iniciação Científica - PIBIC; 2) Programa Externo de Bolsas de Iniciação Científica - PEBIC e PEBIC-Jr; e 3) Programa de Iniciação Científica - PIC. No PIBIC os acadêmicos recebem bolsas (120) oriundas de recursos da arrecadação da Universidade Paranaense. No PEBIC, as bolsas são custeadas por órgãos/agências de fomento externo, destacando-se o Conselho Nacional de Desenvolvimento Científico e Tecnológico (CNPq) 10 bolsas vigência, 03 bolsa de PIBITI e 08 bolsas destinada ao PEBIC EM-CNPq (2020/2021), e Fundação Araucária (2020/2021) 10 bolsas vigentes. Enquanto no PIC, no ano e 2020, são 436 acadêmicos da graduação presencial, 13 acadêmicos da educação à distância, que participam dos projetos de pesquisa de forma voluntária. Além destes podemos citar a participação de 35 acadêmicos dos cursos de pós-graduação Lato e Stricto Sensu nos projetos de pesquisa institucional.

O número de inscritos e de trabalhos apresentados nos Encontros de Iniciação Científica da UNIPAR, durante sua trajetória, encontram-se demonstrado no quadro a seguir:

\begin{tabular}{|l|l|c|c|}
\hline ANO & \multicolumn{1}{|c|}{ EVENTO } & $\begin{array}{c}\mathbf{N}^{\mathbf{o}} \text {. DE } \\
\text { INSCRITOS }\end{array}$ & $\begin{array}{c}\mathbf{N}^{\mathbf{0}} \text {. DE } \\
\text { TRABALHOS }\end{array}$ \\
\hline 2002 & I Encontro Anual de Iniciação Científica & 426 & 414 \\
\hline 2003 & II Encontro Anual de Iniciação Científica & 479 & 366 \\
\hline 2004 & III Encontro Anual de Iniciação Científica & 586 & 526 \\
\hline 2005 & IV Encontro Anual de Iniciação Científica & 1.089 & 680 \\
\hline 2006 & V Encontro Anual de Iniciação Científica & 922 & 724 \\
\hline 2007 & VI Encontro Anual de Iniciação Científica & 927 & 838 \\
\hline 2008 & VII Encontro Anual de Iniciação Científica & 945 & 759 \\
\hline 2009 & $8^{\circ}$ Encontro Anual de Iniciação Científica & 892 & 712 \\
\hline 2010 & $9^{\circ}$ Encontro Anual de Iniciação Científica & 808 & 773 \\
\hline 2011 & $10^{\circ}$ Encontro Anual de Iniciação Científica & 1.081 & 861 \\
\hline 2012 & $11^{\circ}$ Encontro Anual de Iniciação Científica & 1.182 & 932 \\
\hline 2013 & $12^{\circ}$ Encontro Anual de Iniciação Científica & 1.171 & 835 \\
\hline 2014 & $13^{\circ}$ Encontro Anual de Iniciação Científica & 1.383 & 919 \\
\hline 2015 & $14^{\circ}$ Encontro Anual de Iniciação Científica & 1.638 & 1.025 \\
\hline 2016 & $\begin{array}{l}\text { I Congresso Internacional de Ciência, Tecnologia e Inovação e XV } \\
\text { Encontro Anual de Iniciação Científica da UNIPAR. }\end{array}$ & 2.163 & 1.492 \\
\hline 2017 & $\begin{array}{l}\text { II Congresso Internacional de Ciência, Tecnologia e Inovação e XVI } \\
\text { Encontro Anual de Iniciação Científica da UNIPAR. }\end{array}$ & 2.345 & 1.684 \\
\hline 2018 & $\begin{array}{l}\text { III Congresso Internacional de Ciência, Tecnologia e Inovação e XVII } \\
\text { Encontro Anual de Iniciação Científica da UNIPAR. }\end{array}$ & 2.208 & 1.763 \\
\hline 2019 & $\begin{array}{l}\text { IV Congresso Internacional de Ciência, Tecnologia e Inovação e XVIII } \\
\text { Encontro Anual de Iniciação Científica da UNIPAR }\end{array}$ & 1.902 & 1.421 \\
\hline 2020 & XIX Encontro Anual de Iniciação Científica da UNIPAR & Inscrições & 1.245 \\
\hline Fonte: COPEX - UNIPAR & & \\
\hline
\end{tabular}

Fonte: COPEX - UNIPAR. 
A UNIPAR investe anualmente em professores, materiais de projetos de pesquisa e bolsas de iniciação científica de uma forma equitativa, no ano de 2020 são 155 pesquisadores, sendo estes mestres e doutores vinculados entre seus cursos de graduação e pós-graduação. Em função disso, a maior parte da produção científica da UNIPAR concentra-se nas áreas de conhecimento de Ciências da Saúde, Biológicas e Ciências Sociais Aplicadas, como podemos visualizar no quadro abaixo, mediante o número de trabalhos apresentados nos Encontros de Iniciação Científica da UNIPAR:

\begin{tabular}{|c|c|c|c|c|c|c|c|c|c|c|c|c|c|c|c|c|c|c|}
\hline $\begin{array}{c}\text { ÁREA DE } \\
\text { CONHECIMENTO }\end{array}$ & $\begin{array}{c}\text { I } \\
\text { EAIC }\end{array}$ & $\begin{array}{c}\text { II } \\
\text { EAIC }\end{array}$ & $\begin{array}{c}\text { III } \\
\text { EAIC }\end{array}$ & \begin{tabular}{|c|} 
IV \\
EAIC
\end{tabular} & $\begin{array}{c}\mathrm{V} \\
\text { EAIC }\end{array}$ & $\begin{array}{c}\text { VI } \\
\text { EAIC }\end{array}$ & $\begin{array}{c}\text { VII } \\
\text { EAIC }\end{array}$ & $\begin{array}{l}8^{\circ} \\
\text { EAIC }\end{array}$ & $\begin{array}{c}9^{\circ} \\
\text { EAIC }\end{array}$ & $\begin{array}{l}10^{\circ} \\
\text { EAIC }\end{array}$ & $\begin{array}{l}11^{\circ} \\
\text { EAIC }\end{array}$ & $\begin{array}{l}12^{\circ} \\
\text { EAIC }\end{array}$ & $\begin{array}{l}13^{\circ} \\
\text { EAIC }\end{array}$ & $\begin{array}{l}{14^{\circ}}^{\circ} \\
\text { EAIC }\end{array}$ & $\begin{array}{c}\text { I } \\
\text { CICTI } \\
\text { e } \\
\text { XV } \\
\text { EAIC }\end{array}$ & $\begin{array}{c}\text { II } \\
\text { CICTI } \\
\text { e } \\
\text { XVI } \\
\text { EAIC }\end{array}$ & $\begin{array}{c}\text { III } \\
\text { CICTI } \\
\text { e } \\
\text { XVII } \\
\text { EAIC }\end{array}$ & $\begin{array}{c}\text { IV } \\
\text { CICTI } \\
\text { e } \\
\text { XVIII } \\
\text { EAIC }\end{array}$ \\
\hline $\begin{array}{l}\text { Ciências Exatas e da } \\
\text { Terra }\end{array}$ & 48 & 45 & 59 & 64 & 49 & 51 & 84 & 27 & 29 & 36 & 31 & 33 & 60 & 36 & 79 & 43 & 42 & 31 \\
\hline Ciências Biológicas & 59 & 58 & 101 & 139 & 150 & 159 & 135 & 131 & 142 & 144 & 135 & 94 & 88 & 88 & 88 & 125 & 103 & 75 \\
\hline Engenharias & 0 & 06 & 02 & 02 & 01 & 0 & 02 & 04 & 8 & 10 & 17 & 23 & 40 & 89 & 184 & 239 & 258 & 161 \\
\hline Ciências da Saúde & 132 & 105 & 91 & 147 & 183 & 258 & 264 & 242 & 229 & 227 & 300 & 220 & 242 & 264 & 465 & 511 & 477 & 406 \\
\hline Ciências Agrárias & 33 & 22 & 46 & 39 & 48 & 90 & 71 & 82 & 87 & 107 & 104 & 108 & 148 & 163 & 203 & 270 & 298 & 262 \\
\hline $\begin{array}{l}\text { Ciências Sociais } \\
\text { Aplicadas }\end{array}$ & 72 & 73 & 109 & 188 & 197 & 159 & 114 & 136 & 193 & 239 & 249 & 265 & 237 & 283 & 354 & 361 & 425 & 352 \\
\hline Ciências Humanas & 30 & 28 & 69 & 71 & 65 & 65 & 79 & 83 & 79 & 84 & 82 & 85 & 86 & 79 & 119 & 132 & 157 & 131 \\
\hline $\begin{array}{l}\text { Linguística, Letras e } \\
\text { Artes }\end{array}$ & 40 & 29 & 49 & 30 & 31 & 14 & 10 & 5 & 2 & 04 & 03 & 02 & 01 & 01 & 00 & 03 & 03 & 03 \\
\hline Outros & - & - & - & - & - & - & - & 2 & 4 & 10 & 11 & 05 & 17 & 22 & - & - & - & - \\
\hline TOTAL & 414 & 366 & 526 & 680 & 724 & 838 & 759 & 712 & 773 & 861 & 932 & 835 & 919 & 1.025 & 1.492 & 1.684 & 1.763 & 1.421 \\
\hline
\end{tabular}

Fonte: COPEX - UNIPAR.

Certamente, a dedicação dos acadêmicos e professores tem impulsionado a pesquisa científica da Universidade Paranaense. Parabenizamos os pesquisadores pelo compromisso e pelos resultados obtidos e agradecemos imensamente o apoio da Universidade Paranaense, do Conselho Nacional de Desenvolvimento Científico e Tecnológico (CNPq), e da Fundação Araucária.

Desejamos um momento de aprimoramento científico a todos os participantes do Evento.

Prof. ${ }^{a}$ Dr. ${ }^{a}$ Evellyn Claudia Wietzikoski Lovato

Coordenadora de Pesquisa e Extensão 
GRUPO 1: BIOLÓGICAS E AFINS 


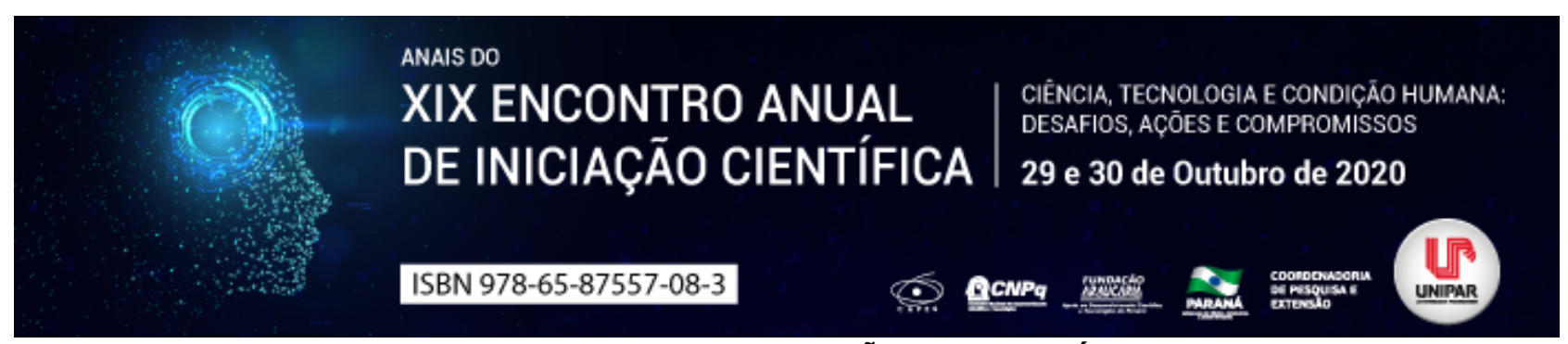

AYAHUASCA E SUA RELAÇÃO COM A SAÚDE

\title{
${ }^{1}$ LUIZ FERNANDO ABATI MIRANDA, ${ }^{2}$ DANIELA DIB GONÇALVES
}

\author{
${ }^{1}$ Discente do Curso de Sistemas de Informação EAD/UNIPAR \\ ${ }^{1}$ Docente da UNIPAR
}

Introdução: Ayahuasca é uma planta usada por diferentes tribos indígenas nativo da região Amazônica os Kaxinawá, Yaminawá, Sharanawa, Asshaninka, Airo-pai e Barana (MORAIS, 2014). A Ayahuasca, é a mistura de duas plantas, o Cipó Banisteriopsis caapi conhecido popularmente por mariri, pertencente da família Malpighiaceae, nativo da Amazônica e dos Andes, está espalhado por toda América do Sul. O mariri compõe alcalóides $\beta$-carbolinas harmina (HRM), harmalina (HRL) e tetra-hidroharmalina (THH). A outra planta é Psycotria viridis conhecida como chacrona, pertence à família dos Rubiaceae, sua composição tem alcalóide indólico (MORAIS, 2014). A preparação do chá de Ayahuasca é realizada em um recipiente grande onde é colocado o cipó e chacrona em camadas alternadas e o restante com água. Esse material é fervido, por um período de 5 horas até atingir uma coloração marrom, depois é coado em uma peneira e armazenado em um recipiente plástico de 1litro esterilizado (MORAIS, 2014).

Objetivo: $\mathrm{O}$ objetivo do estudo foi descrever os principais compostos bioativos relacionado às ações antioxidante, antiparasitária e antimicrobiana da Ayahuasca por meio de uma revisão de literatura.

Desenvolvimento: O ritual da Ayahuasca é relacionado a um encontro consigo mesmo, quer dizer que a pessoa pode sentir, ter contato com aquilo que considera dela, próprio seu, espiritual e de cura. O chá é um elemento de cosmologia, um ritual de mitos e religioso (GOMES et al., 2005), além disso, tem diferentes propriedades terapêuticas que podem ser utilizado para fins de saúde. Os extratos das folhas de $P$. viridis e de caules de $B$. caapi, possuem ações farmacológicas relacionado aos seus alcalóides isolados que possuem ação, na resistência bacteriana e outras doenças infecciosas que representam maior causa de morte no mundo (AZEVEDO, 2018). O extrato de B. caapi possui a inibição de enzimas MAO-A pela harmina, que demonstra a capacidade de alcalóide que estimula a liberação da dopamina na doença de Parkinson (AZEVEDO, 2018). Os antioxidantes são representados pelos agonistas da dopamina ou inibidores da MAO que podem atuar na proteção contra a neurodegeneração, tendo papel importante também no tratamento do Parkinson (MOTTA, 2013). Os efeitos antiparasitários foram constatados pelo aumento das células linfócitos $T$ citotóxicos que produzem alcalóides isoquinolínicos e triptamínicos, importantes agentes profiláticos de doenças parasitárias tropicais (MENEGUETTI \& MENEGUETTI, 2014).

Conclusão: $O$ chá de Ayahuasca vem sendo utilizado por diferentes tribos indígenas em rituais ou até mesmo em etimologia (ciência que estuda origem e significado das palavras). Essa planta é composta por diferentes produtos bioativos para uso na medicina natural para diferentes tratamentos, tem efeito comprovado na ação antioxidante, antiparasitária e antimicrobiana.

\section{Referências}

AZEVEDO, M.C. Estudo de atividades biológicas dos extratos de folhas de Psychotria viridis (Ruiz \& Pav.) e de caules de Banisteriopsis caapi [(Spruce ex Griseb) C.V. Morton] e incorporação em formulações micelares. Universidade Federal de Ouro Preto UFOP. Ouro Preto-MG, 2018.

BRUNO, V. Ayahuasca no tratamento da farmacodependência à cocaína: possíveis intervenções terapêuticas. São Paulo, 2019.

GOMES, B.R.; SOARES, K.A. de.; SILVA, R.C. da.; COSTA, T.G.C. da. O sentido do uso ritual da Ayahuasca no templo do mestre Yajé. Universidade Presbiteriana Mackenzie. São Paulo-SP, 2005.

MENEGUETTI, D.U.O. de.; MENEGUETTI, N.F.S.P. Benefícios a saúde ocasionados pela ingestão da Ayahuasca: contexto social e ação neuropsicológica, fisioimunológica, microbiológica e parasitária. Cadernos Brasileiros de Saúde Mental, ISSN 19842147, Florianópolis, v.6, n.13, p.104-121, 2014.

MORAIS, J.A. de. Toxicidade aguda e crônica do chá ayahuasca (banisteriopsis caapi e psychotria viridis), por análise histológica em ratas wistar. Universidade de Brasília - UB. Brasília-DF, 2014.

MOTTA, L.S.G. Toxicidade aguda, neurotoxicidade, toxicidade reprodutiva e embriotoxicidade do chá ayahuasca (Banisteriopsis caapi e Psychotria viridis) em ratas wistar. Universidade de Brasília. Brasília-DF, 2013. 


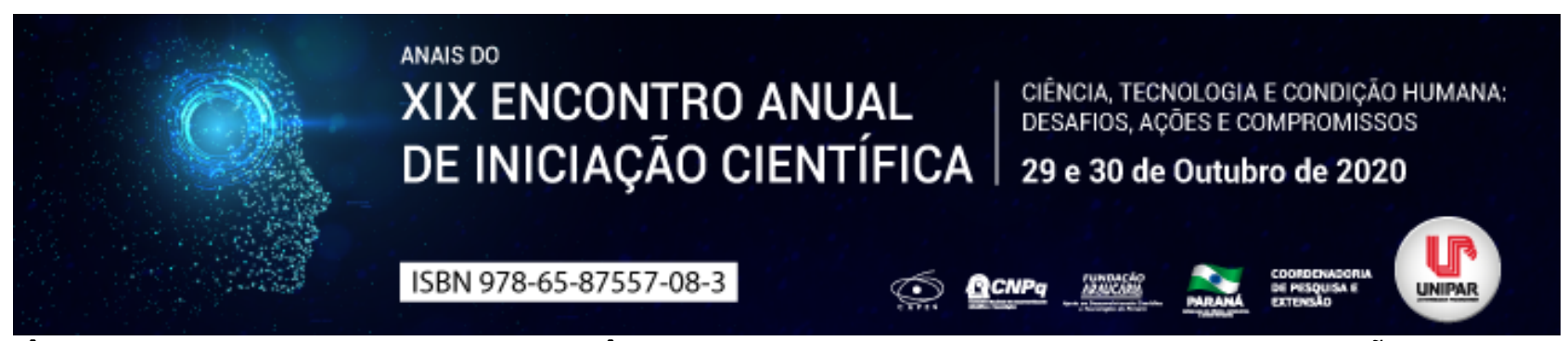

PREVALÊNCIA DE MICRORGANISMOS PATOGÊNICOS PRESENTES NA MICROBIOTA ORAL DE CÃES COM DOENÇAS PERIODONTAIS

\author{
${ }^{1}$ ISABEL CRISTINA DA SILVA CAETANO , ${ }^{2}$ KAROLINE FRANCIANI CARDOSO LOPES, ${ }^{3}$ ISABELA CARVALHO DOS \\ SANTOS, ${ }^{4}$ TÚLIO TOZZI FENDRIGO, ${ }^{5}$ LIDIANE NUNES BARBOSA, ${ }^{6}$ DANIELA DIB GONÇALVES
}

\author{
${ }^{1}$ KAROLINE FRANCIANI CARDOSO LOPES \\ ${ }^{1}$ Pós-graduanda do PPG em Ciência Animal, UNIPAR \\ ${ }^{2}$ Pós-graduanda do PPG em Ciência Animal, UNIPAR \\ ${ }^{3}$ Discente Medicina Veterinária, bolsista PEBIC CNPq \\ ${ }^{4}$ Docente do PPG em Ciência Animal, UNIPAR \\ ${ }^{5}$ Docente do PPG em Ciência Animal, UNIPAR
}

Introdução: A doença periodontal é uma das afecções mais comuns no cão, é um termo generalista aplicado às lesões inflamatórias, induzidas pela presença de placa dentária (GORREL, 2004). Iniciam-se como uma infecção na gengiva, seguida frequentemente pela destruição dos tecidos periodontais, causadas por bactérias acumuladas na superfície dos dentes (TAVARES, 2014). Microrganismos presentes na cavidade oral podem estar associados a doença periodontal, incluindo bactérias Gram-positivas (SANTOS, 2018). Os cuidados diários com a cavidade oral dos cães precisam se tornar um hábito, visto que pesquisas apontam que a doença periodontal pode ser a origem de doenças sistêmicas mais graves, podendo colocar em risco a vida do animal (PAVLICA et al., 2008; TAVARES, 2014). Uma higiene bucal efetiva é a forma mais simples para prevenir as doenças periodontais (ALBANDAR; RAMS, 2002).

Objetivo: O objetivo desta pesquisa foi verificar a prevalência de microrganismos patogênicos presentes na microbiota oral de cães com doenças periodontais.

Material e métodos: O projeto foi aprovado pelo Comitê de Ética em Pesquisa Envolvendo Experimentação Animal (CEPEEA) da Universidade Paranaense UNIPAR parecer número 34185/2018. Durante o atendimento de rotinas dos animais os responsáveis assinaram um termo de consentimento para a participação na pesquisa. Foram coletadas amostras de swab oral de 20 cães e encaminhadas sob refrigeração ao Laboratório de Medicina Veterinária Preventiva e Saúde Pública do Programa de Pós-graduação em Ciência Animal com Ênfase em Produtos Bioativos da Universidade Paranaense (UNIPAR). Foram realizados os isolamentos e identificação bioquímica dos isolados bacterianos e de acordo com protocolos estabelecidos pelo laboratório.

Resultados: Das 20 amostras orais processadas, quinze (15) amostras apresentaram crescimento em meio Manitol e após identificação foram detectados Staphylococcus spp. em treze (13) amostras (65\%) e Streptococcus spp. em duas (2) amostras (10\%). Em cinco (5) amostras (25\%) não houve crescimento.

Discussão: A doença periodontal afeta $75 \%$ dos cães entre quatro e oito anos de idade (GIOSO, 2003). Diferentes estudos corroboram com os resultados deste que também detectaram maior prevalência de isolados de Staphylococcus spp. como demonstrado em Fernandópolis (SP) em amostras de swabs da cavidade oral de cães (FRIAS; KOZUSNY-ANDREANI; PRINA, 2018) e em Brasília (DF) em pesquisa com 20 cães da raça Labrador Retriever onde detectaram prevalência de bactérias em amostras coletadas no espaço subgengival, os gêneros bacterianos mais isolados foram Staphylococcus spp. e Pasteurella e de acordo com os autores, foram isolados microrganismos em 95\% dos cães avaliados, demonstrando que há presença de bactérias no espaço subgengival da maioria dos cães com doenças periodontais (FONSECA et al., 2011). Os microrganismos encontrados neste estudo enaltecem a sua importância em saúde única, já que a espécie canina está inserida no seio familiar de forma constante e com o compartilhamento dos mesmos espaços pode possibilitar a transferência de microrganismos patogênicos do animal para seu tutor.

Conclusão: As bactérias em elevadas quantidades associada a falta de higiene bucal e outros fatores predisponentes, como o estado imunológico, raça, idade, alimentação, limpeza profilática e quantidade de saliva produzida podem ser os possíveis fatores de susceptibilidade para o aparecimento de doenças periodontais em cães, por este motivo a importância de sua detecção para posterior cuidados de higiene da cavidade oral evitando assim problemas maiores na saúde do animal.

Agradecimentos: A UNIPAR e CAPES pelo financiamento desta pesquisa.

\title{
Referências
}

ALBANDAR, Jasim M.; RAMS, Thomas E. Global epidemiology of periodontal diseases: an overview. Periodontology 2000, Copenhagen, v. 29, n. 1, p. 7-10, june. 2002.

FONSECA, Stella Alves da; GALERA, Paula Diniz; BRITO, Daiana Lima; PERECMANIS, Simone; SILVA, Anahí Souza; 
CARDOSO, Larissa Borges; MARÇOLA, Tatiana Guerrero; DRUMMOND, Vinícius Oliveira; PIMENTEL, Concepta McManus. Análise microbiológica da placa bacteriana da doença periodontal em cães e o efeito da antibioticoterapia sobre ela. Ciência Rural, Santa Maria, v.41, n.8, p.1424-1429, ago., 2011.

FRIAS, Danila Fernanda Rodrigues; KOZUSNY-ANDREANI, Dora Inés; PRINA, Ricardo Miranda. Identificação da Microbiota Gengival de Cães Aparentemente Hígidos. Nucleus, v.15, n.1, abr. 2018.

GIOSO, Marco Antônio. Odontologia: Para o Clínico de Pequenos Animais. 5. Ed. São Paulo: ieditora; 2003.

GORREL, Cecília. Veterinary Dentistry for the General Practitioner. Philadelphia: W.B. Saunders, p. $224,2004$.

PAVLICA, Zlatko, et al. Periodontal disease burden and pathological changes in organs of dogs. Journal of veterinary dentistry, Chorlton, Manchester, v. 25, n. 2, p. 97-105, june. 2008.

SANTOS, José Diogo Macieira de Menezes. Relação entre a doença periodontal e doenças sistêmicas bacterianas no cão: Um estudo retrospectivo. Orientador: Vanessa Rodrigues de Freitass de Almeida Carvalho e Maria Manuela Castilho Monteiro de Oliveira. 2018. 58f. Dissertação (Mestrado Integrado em Medicina Veterinária), Universidade de Lisboa, Lisboa, 2018.

TAVARES, Marta Monteiro Pais. Caracterização de Enterococcus spp. Isolados da boca e do coração de cães com doença periodontal. Orientador: Claudia Margarida Pamela Beato Godinho Correia de Oliveira Miguel e Berta Maria Fernandes Ferreira São Braz. 2014. 107f. Dissertação (Mestrado Integrado em Medicina Veterinária), Universidade de Lisboa, Lisboa, 2014. 


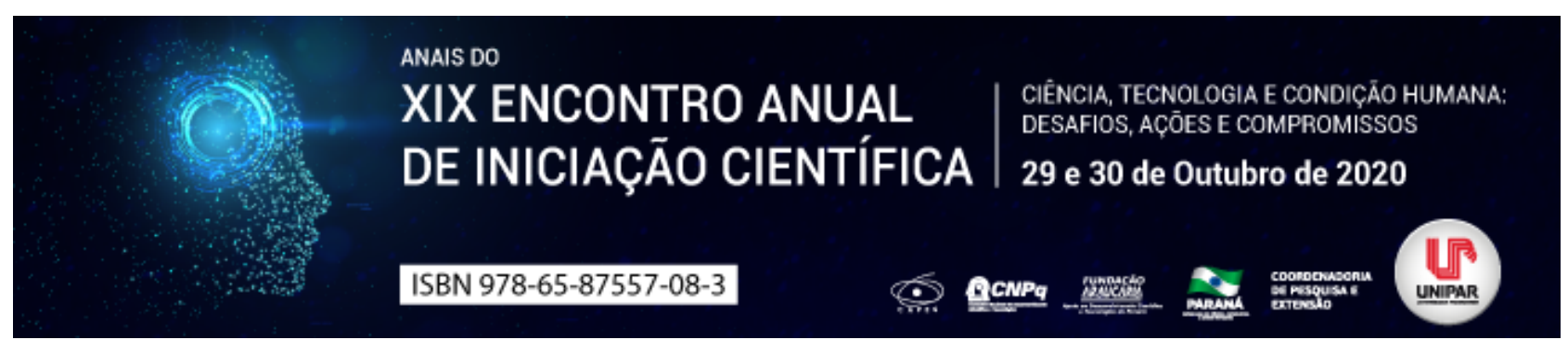

DENTIFRÍCIO NÃO FLUORETADO A BASE DE TANSAGEM (Plantago australis Lam) PARA CÃES

\title{
${ }^{1}$ TULIO TOZZI FEDRIGO, ${ }^{2}$ ISABEL CRISTINA DA SILVA CAETANO , ${ }^{3}$ ISABELA CARVALHO DOS SANTOS , ${ }^{4}$ MARIANA DO NASCIMENTO COELHO, ${ }^{5}$ LIDIANE NUNES BARBOSA, ${ }^{6}$ DANIELA DIB GONCALVES
}

\author{
${ }^{1}$ Discente Medicina Veterinária, bolsista PIBIT CNPq \\ ${ }^{1}$ Pós-Graduanda do PPG em Ciência Animal, UNIPAR \\ ${ }^{2}$ Pós-Graduandos do PPG em Ciência Animal, UNIPAR \\ ${ }^{3}$ Discente Ensino Médio, bolsista PEBIC CNPq \\ ${ }^{4}$ Docente PPG em Ciência Animal, UNIPAR \\ ${ }^{5}$ Docente PPG em Ciência Animal, UNIPAR
}

Introdução: Das doenças que afetam a cavidade oral, as periodontais são as mais comuns e frequentes, exercendo uma ação extremamente maléfica, e afetando diretamente a saúde e bem estar de animais como os cães (PAVLICA et al., 2008). Para os cães, recomenda-se que os cuidados com a cavidade oral seja um hábito, uma vez que pesquisas já demonstraram que afeccões periodontais podem ser a origem de outras, sistêmicas de caráter grave, gerando risco a vida do animal (TAVARES, 2014). Os dentifrícios, são produtos possuintes de vários compostos terapêuticos, utilizados para escovação, sendo o principal meio de profilaxia para estas enfermidades, sendo assim, se classifica como um habito benéfico-preventivo e os dentifrícios disponibilizados comercialmente, normalmente contém flúor (MARTINS et al., 2012), e seu uso em cães não é aconselhável, pois possuem toxicidade para os mesmos (GIOSO, 2007). Sendo assim, os compostos de origem natural e seus derivados são cada vez mais estudados para estes fins (CORDEIRO et al.,2006). Um exemplo de fitoterápico é a Plantago australis Lam, tansagem, que pode ser inserida em formulações desta índole, para a prevenção e tratamento de disturbios periodontais em animais de companhia, sem toxidade.

Objetivo: Esta revisão de literatura objetiva demonstrar como o hábito do uso de dentifrícios a base de Plantago australis Lam, Tansagem, pode ser benéfica à saúde de animais de companhia como os cães, considerando que, é crescente a preocupação e busca por saúde e bem estar dos pets por parte de seus tutores.

Desenvolvimento: As doenças periodontais, basicamente se apresentam como lesões inflamatórias, resultantes pela presença de placa dentária, e estas se iniciam como uma infecção gengival, podendo chegar a destruição de tecidos periodontais, tudo isso ocorre como consequência do acúmulo de bactérias na superfície dos dentes (TAVARES, 2014; NOVAK, 2002). A higiene bucal efetiva, de forma habitual, se classifica como a melhor forma profilática destas doenças (ALBANDAR; RAMS, 2002). Esta higiene pode ser realizada com o uso de dentifrícios, além de auxiliarem na higienização dentaria, os mesmos auxiliam na redução da cárie, de doenças gengivais e periodontais, de cálculo dentário, de hipersensibilidade dentária, além da halitose. Estes, possuem importante valor terapêutico, pois apresentam grande diversidade de componentes em suas formulações. Normalmente nas composições, estão presentes agentes de polimento, detergentes, flavorizantes, solventes, umectantes, aglutinantes, edulcorantes, conservantes e o seu princípio ativo (CURY, 2002; MARTINS ET AL. 2012). Os dentifrícios disponibilizados comercialmente, normalmente contém flúor (MARTINS et al. 2012), o que é comum e não problemático para humanos, porém, é inviável para cães, já que podem trazer problemas de toxidade para animais. (GIOSO, 2007). Sendo assim, frequentemente os compostos de origem natural e seus derivados vem sendo estudados, a amplitude da utilização de fitoterápicos e de plantas medicinais é considerável, sendo utilizados também na saúde bucal (CORDEIRO et al., 2006). A Tansagem (Plantago australis Lam.), por sua vez, se classifica como um fitoterápico, possuinte de propriedades antibacterianas, adstringentes, desintoxicantes, expectorantes, analgésicas e anti-inflamatórias, e por isso também pode ser utilizada em formulações saudáveis como de um dentifrício não tóxico para cães (sem flúor), assim sendo utilizado no tratamento de doenças periodontais nos mesmos, e se apresentando extremamente benéfica, considerando todos os danos que as doenças periodontais podem causar ao animal, além de não possuir toxidade ao mesmo (HOLETZ et al., 2002). Havendo a possibilidade, é interessante que a escovação seja praticada desde a fase de filhote, para que na fase adulta, o cão já esteja habituado, obtendo assim maior sucesso na prática. Para a escovação dentária, a recomendação é que se use escovas ou dedeiras específicas para cães, disponibilizadas comercialmente, a escova ideal deve ser escolhida da forma e tamanho que melhor se adapte ao formato e tamanho da boca do animal, que varia de acordo com sua raça e/ou porte, ela deve principalmente conter cerdas macias (DUPONT, 1998).

Conclusão: A utilização da tansagem como princípio ativo de um dentifrício para cães, pode ser considerada saudável e economicamente viável, uma vez que possua propriedades antibacterianas, e sem toxidade para os mesmos. O uso de dentifrícios não fluoretados é de caráter profilático, o que torna a prática de escovação extremamente importante para que 
animais de companhia como os cães, não desenvolvam doenças periodontais, ou que sejam tratadas caso já desenvolvidas, já que podem afetar diretamente a saúde do cão, gerando doenças subsequentes mais serias.

\section{Referências}

ALBANDAR, J. M.; RAMS, T. E. Periodontol 2000 Global epidemiology of periodontal diseases 29. Copenhagen, Denmark: Munksgaard Blackwell, 2002.

CURY J. A. Dentifrícios: como escolher e como indicar. In: Associação Paulista dos Cirurgiões-Dentistas. Odontologia. São Paulo: Artes Médicas - Divisão Odontológica, p.281-95, 2002.

DUPONT, G. A. Prevention of periodontal disease. Vet Clin North Amer: small anim pract, v. 28, n. 5, p. 1129-1145, 1998.

GIOSO, M. A. Odontologia veterinária para o clínico de pequenos animais. 2. ed. São Paulo: Manole. 2007. p.1-23.

HARVEY, C. E.; EMILY, P. P. Small animal dentistry. St. Louis: Mosby, 1993. p. 413.

HOLETZ, F. B.; PESSINI, G. L.; SANCHES, N. R.; CORTEZ, D. A. G.; NAKAMURA, C. V.; DIAS FILHO, B. P. Screening of some plants used in the Brazilian folk medicine for the treatment of infectious diseases. Memórias do Instituto Oswaldo Cruz, Rio de Janeiro, v. 97, n. 7, p. 1027-1031, 2002.

MARTINS, R. S.; MACÊDO, J. B.; MUNIZ, F. W. M. G.; CARVALHO, R. D. S.; MOREIRA, M. M. S. M. Composição, princípios ativos e indicações clínicas dos dentifrícios: uma revisão da literatura entre 1989 e 2011. J. Health Sci. Inst, v. 30, n. 3, 2012.

MARTINS, R. S.; MACÊDO, J. B.; MUNIZ, F. W. M. G.; CARVALHO, R. D. S.; MOREIRA, M. M. S. M. Composição, princípios ativos e indicações clínicas dos dentifrícios: uma revisão da literatura entre 1989 e 2011. J. Health Sci. Inst, v. 30, n. 3, 2012.

NOVAK, M. J. Classification of diseases and conditions affecting periodontium. Clinical periodontology, p. 64-73, 2002.

PAVLICA, Z.; PETELIN, M.; POLONA, J.; ERZEN, D.; CROSSLEY, D.; SKALERIC, U. Periodontal disease burden and pathological changes in organs of dogs. Journal of veterinary dentistry, v. 25, n. 2, p. 97-105, 2008.

TAVARES, M. M. P. Caracterização de Enterococcus spp. Isolados da boca e do coração de cães com doença periodontal. 2014. Dissertação - Mestrado Integrado Em Medicina Veterinária - Faculdade de Medicina Veterinária Universidade de Lisboa. Lisboa, 117p., 2014. 


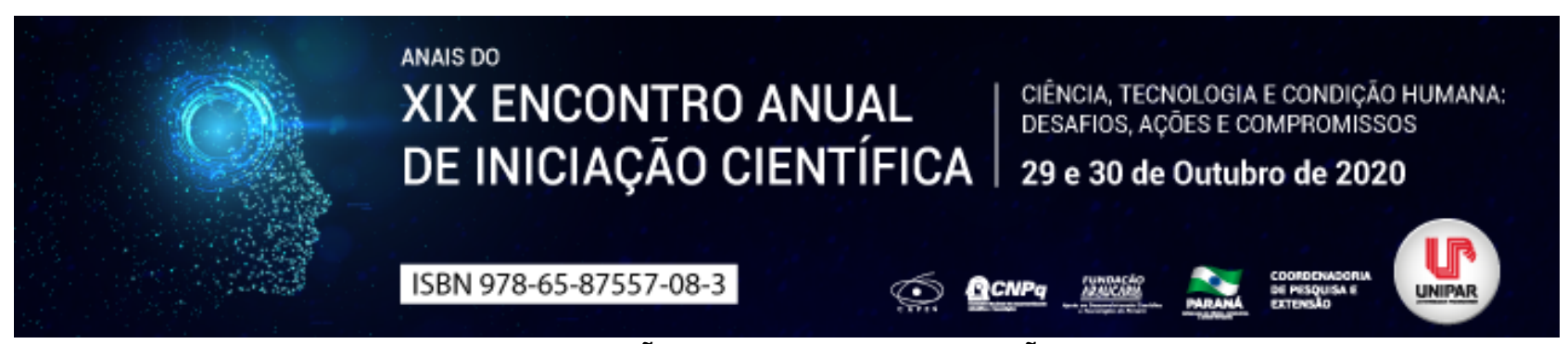

TOXOPLASMOSE EM CÃES ERRANTES DE REGIÃO FRONTEIRIÇA

\title{
${ }^{1}$ LUCAS LIMA DA SILVA, ${ }^{2}$ KAWANY GABRIELI ZANETTI FAZOLI, ${ }^{3}$ MARIANA DO NASCIMENTO COELHO, ${ }^{4}$ ELOIZA TELES CALDART, ${ }^{5}$ DANIELA DIB GONÇALVES
}

\author{
${ }^{1}$ Discente Medicina Veterinária, bolsista PIBIC UNIPAR \\ ${ }^{1}$ Discente Medicina Veterinária, bolsista PEBIC Fundação araucária \\ ${ }^{2}$ Discente Ensino Médio, bolsista PEBIC CNPq \\ ${ }^{3}$ Docente Medicina Veterinária, UEL \\ ${ }^{4}$ Docente PPG em Ciência Animal, UNIPAR
}

Introdução: O Toxoplasma gondii é o protozoário causador da toxoplasmose, doença a qual pode-se encontrar em vários continentes, esse parasito infecta principalmente animais de sangue quente, como gato, cão e humanos inclusive, sendo seu hospedeiro definitivo, o gato pois é o principal transmissor, já que eliminam os oocitos pelas fezes e os mesmos esporulam no meio ambiente, se tornando infectantes (GENNARI et al., 2015; RODRIGUES et al., 2016).

A sua principal via de contaminação é oral, ou seja, por ingestão, seja ela de forma direta ou indireta, ingerindo as fezes contaminadas do felino, água contaminada ou qualquer alimento contaminado, facilitando a infecção de cães errantes, os quais estão expostos a esses alimentos no ambiente, após esses canídeos se infectarem eles podem apresentar sinais clínicos como: convulsão, ataxia, paresia, plegia, mialgia, tremores, abortamento, nascimento prematuro, secreção nasal e tosse (FERREIRA et al., 2016; OLIVEIRA, 2018).

Objetivos: Pesquisar anticorpos anti-Toxoplasma gondii em cães de região fronteiriça

Material e Metodos: Foi realizado a contenção de 20 cães errantes, SRD (sem raça definida), de ambos os sexos, com idade variando de dois a oito anos da cidade de Assis Chateubriant, localizada a $131 \mathrm{Km}$ do Paraguai e por isso é considerada uma região fronteiriça. A coleta de sangue foi realizada por meio da punção da veia jugular onde aproximadamente $10 \mathrm{~mL}$ de sangue foram coletados e encaminhados para o Laboratório de Zoonoses e Saúde Pública da Universidade Estadual de Londrina. Para detectar anticorpos anti-T. gondii os soros foram submetidos à prova de imunofluorescência indireta (IFI) (CAMARGO, 1974) utilizando conjugado comercial anti dog IgG (FITC Sigma ${ }^{\circledR}$, EUA). Os soros foram testados em diluições sequenciais na base quatro até 1:4096, sendo considerados reagentes aqueles que apresentaram taquizoítos fluorescentes a um título $\geq 16$.

Resultados: Das amostras testadas, 11 (55\%) foram consideradas. Relacionado ao título de anticorpos, cinco amostras (25\%) reagiu para título de 16, quarto (20\%) para títulos de 64, e duas (10\%) para título de 256.

Discussão: Neste trabalho foram encontrados anticorpos contra T. gondii em $55 \%$ (11) das amostras testadas, sendo o resultado superior ao de um estudo realizado por Ferreira et al. (2016), quem em 598 cães com sinais clínicos de toxoplasmose atendidos no, Hospital Veterinário Escola, em Londrina, Paraná, 43,21\% (259) foram positivos na IFI e inferior ao de Pasquali et al. (2019), quem em 211 amostras de cães coletadas nas mesorregiões oeste e serrana de Santa Catarina, 69,19\% (146) foram positivos pela técnica de hemaglutinação indireta (IHT).

Segundo Hafemann et al. (2018), com a aproximação do ser humano com o animal domestico, deve-se atribuir maior importância para infecções de caráter zoonótico, pois esses animais podem ser hospedeiros intermediários, reservatórios e sentinelas de algumas dessas enfermidades como a toxoplasmose por exemplo. Porém esses animais considerados sentinelas, isto é, animais que não são os hospedeiros definitivos e não transmitem a doença, podendo apresentar sinais clinico da enfermidade caso infectado, que é o caso da espécie canina que servirá de alerta para a população e de grande interesse para a comunidade local (NEVES, 2019; RODRIGUES et al., 2016). Devido a isto os animais sentinelas se fazem necessários, para que se possa identificar um possível surto da doença ou risco de infecção humana em um determinado local, sendo assim de extrema importância para a saúde pública (RODRIGUES et al., 2016). As regiões de fronteira têm grande importância se tratando de doenças de caráter zoonotico, pois se tratam de regiões estratégicas para controle da mesma, em vista ao seu fluxo migratório e comercial, sendo necessário bloquear a propagação desse tipo de doença (ARAÚJO; RAMOS; JULIANO, 2019)

Conclusão: A toxoplasmose é uma zoonose que requer atenção, principalmente nas regiões de fronteira sendo elas regiões de fluxo migratório e comercial intensos, facilitando a propagação da doença, por esses motivos se tronam importantes os animais sentinelas como o cão, pois os mesmos ajudam a identificar a doença e alertar a saúde publica para que se possa realizar o controle da mesma, antes que ela se propague.

\section{Referências}

ARAÚJO, L. T. R.; RAMOS, L. T.; JULIANO, R. S. Região fronteiriça e epidemiologlia: estudo da esporotricose e sua relação na 
dinâmica da fronteira Brasil-Bolívia. In: Embrapa Pantanal-Artigo em anais de congresso (ALICE). In: SEMINÁRIO DE ESTUDOS FRONTEIRIÇOS, 6., 2017, Corumbá. Onde as fronteiras se encontram: anais. Corumbá: UFMS, 2017.

FERREIRA, F. P. et al. Frequency of anti-Toxoplasma gondii antibodies in dogs with clinical signs consistent with toxoplasmosis. Ciencia Animal Brasileira, Universidade Federal De Goias, v. 17, n. 4, p. 640 - 646, 2016.

GENNARI, S. M. et al. Anticorpos contra Toxoplasma gondii em roedores e marsupiais da Mata Atlântica, estado de São Paulo, Brasil. Revista Brasileira de Parasitologia Veterinária, v. 24, n. 3, p. 379-382, 2015.

HAFEMANN, D. C. M. et al. Detection of anti-Leptospira spp., anti-Brucella spp., and anti-Toxoplasma gondii antibodies in stray dogs Deteç̧ão de anticorpos anti-Leptospira spp., anti-Brucella spp., and anti-Toxoplasma gondii em cães errantes. Semina: Ciências Agrárias, v. 39, n. 1, p. 167-176, 2018.

NEVES, L. C. Cães sentinelas no monitoramento de contaminantes inorgânicos ambientais. 2019. Dissertação (Mestrado em Ecologia de Biomas Tropicais) - Universidade Federal de Ouro Preto, Ouro Preto, 2019.

OLIVEIRA, W. M. Toxoplasmose congênita e a importância do diagnóstico e suas formas clínicas na gestação no estado de Rondônia no período de 2013 a 2017. 2018. Monografia (Bacharel em biomedicina). Centro Universitário São Lucas, Porto Velho, 2018.

PASQUALI, A. K. S. et al. SOROPREVALÊNCIA DE TOXOPLASMA GONDII EM CÃES E GATOS DOMICILIADOS NAS MESORREGIÕES OESTE E SERRANA DE SANTA CATARINA, BRASIL. Seminário de Iniciação Científica, Seminário Integrado de Ensino, Pesquisa e Extensão e Mostra Universitária, p. e22068-e22068, 2019.

RODRIGUES, J. Y. et al. Soroprevalência de Toxoplasma gondii em cães de comunidades ribeirinhas do Pantanal de Mato Grosso, Brasil. Revista Brasileira de Parasitologia Veterinária, v. 25, n. 4, p. 531-535, 2016. 


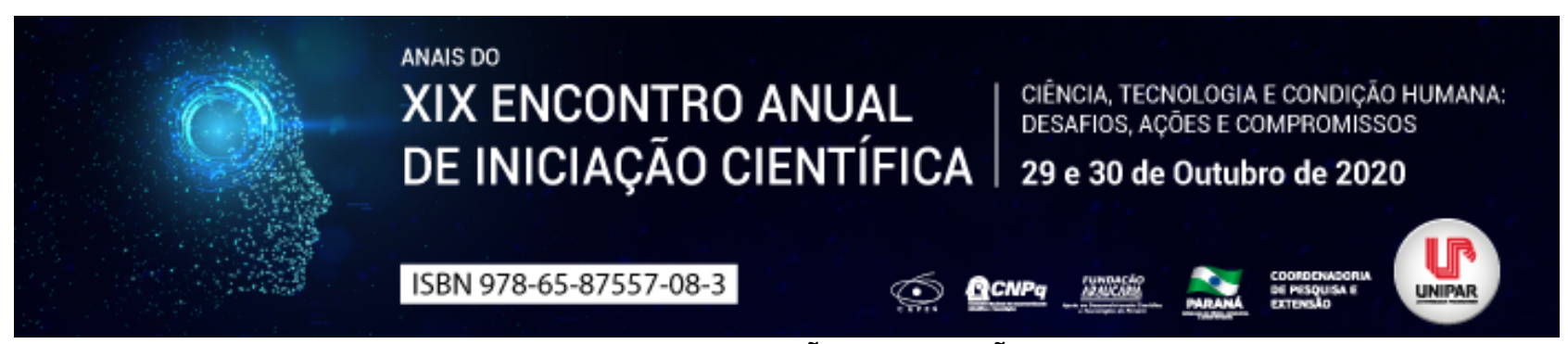

Escherichia coli EM FERIDAS DE CÃES - REVISÃO DE LITERATURA

\begin{abstract}
${ }^{1}$ MAteus Augusto garcia SOUZA, ${ }^{2}$ EDSON GERONIMO , ${ }^{3}$ WELINGTON GIDEAO MACHAdO DE LIMA, ${ }^{4}$ DANIELA DIB GONCALVES
\end{abstract}

${ }^{1}$ Discente de Medicina Veterinária, PIBIC/UNIPAR

${ }^{1}$ Pós-Graduanda do PPG em Ciência Animal, UNIPAR

${ }^{2}$ Pós-Graduanda do PPG em Ciência Animal, UNIPAR

${ }^{3}$ Docente PPG em Ciência Animal, UNIPAR

Introdução: A bactéria Escherichia coli, pertencente à família Enterobacteriaceae, apresenta formato de bacilo e faz parte do grupo de bactérias Gram-negativas, sendo, anaeróbia facultativa (BRAZIL, 2001). As principais formas de transmissão acontecem por meio do contato físico com a bactéria, através do consumo de água ou alimentos contaminados, podendo afetar o organismo de humanos e animais (PELCZAR, CHAN e KRIEG, 1997). Porém, determinado conjunto de cepas do gênero E.coli mantém uma relação mutualística com o hospedeiro, pois realizam importantes atividades ao organismo habitado, sem prejudicalo, como metabolizar e absorver diferentes vitaminas e substâncias, bem como o carboidrato, lipídeos e aminoácidos, assim a bactéria é considerada de devida importância a saúde dos seres vivos, tendo até mesmo a capacidade de produzir catálise (BRAZIL 2001).

Objetivo: Descrever por meio de revisão de literatura a importância da Escherichia coli para a espécie canina.

Desenvolvimento: A Escherichia coli é encontrada em abundância na microbiota animal, e devido a sua capacidade de realizar ações benéficas ao hospedeiro, como atuar no processo de absorção e ocupar locais na mucosa intestinal, assim, ela impede a fixação de bactérias patogênicas, controlando possíveis proliferações bacterianas, no organismo, sendo considerada uma relação positiva para ambos (FERREIRA; KNOBL et al., 2009). Entretanto, determinados grupos da E.coli possuem estirpes com características distintas de virulência, apresentando riscos á saúde animal por apresentarem características patogênicas (CROXEN; FINLAY, 2010). Quando patogênica, a presença da bactéria em ferimentos como mordidas por outro animal e atropelamento podem gerar complicações no quadro, porém, para que ocorra o tratamento do canino, cabe ao médico veterinário avaliar o quadro do paciente e identificar o método necessário, podendo apenas ser feito a limpeza continua do local, o uso de bandagens e ter uma boa evolução, ou por motivos de idade do paciente ora outro motivo que ocasione uma piora no quadro, é indicado o uso de antibióticos para controlar a colonização bacteriana (ARIAS E PEREIRA et al. 2002). Outro delito gerado pelas cepas patogênicas, são as infecções extra-intestinais, que causam ao hospedeiro uma diarreia, muitas vezes frugal, mas, que pode evoluir a um caso de síndrome hemolítica urêmica (KAPER et al., 2004). Por consequência, é preciso que aconteça um tratamento inicial, onde o animal é continuamente hidratado, para que não haja avanços, e se houver, deve-se fazer o uso de antimicrobianos, para não ocasionar a morte do animal (JOHNSON et al., 2009). Portanto, para evitar mais enfermidades envolvendo a $E$. coli, é preciso que aconteça alguns cuidados, como o isolamento dos infectados, para não acontecer o contado com demais espécies, impedindo assim, mais contaminações, e por fim manter a higiene básica no cotidiano dos animais de companhia e de seus tutores (RON 2010).

Conclusão: Depreende-se, portanto, que a Escherichia coli mantém uma relação harmônica com o hospedeiro, dessa forma, todos os processos realizados pela bactéria são de aura importância. No entanto, nem todas as cepas de E.coli são inofensivas, visto que algumas podem causar doenças ao organismo, ademais, as cepas patogênicas apresentam alta resistência a antibióticos, logo, é preciso que as medidas de prevenção sejam cumpridas para impedir mais casos, e através do isolamento bacteriano, novas pesquisas possam ser realizadas e com os resultados, novos métodos de tratamento eficazes possam ser feitos.

\title{
Referências
}

CARNEIRO, L. C. Avaliação de Escherichia coli em manipuladores de alimento da cidade de Morrinhos- GO. Vita et Sanitas: Revista de saúde, Trindade, v. 2, n. 2, fev. 2008.

ARIAS, M. V. B. et al. Identificação da suscetibilidade antimicrobiana de bactérias isoladas de cães e gatos com feridas traumáticas contaminadas e infectadas. Semina: Revista de Ciências Agrarias, Londrina, v. 29, n. 4, p. 861-874, out./dez. 2008.

BÉLANGER, L.; et al. Escherichia coli de reservatórios de animais como fonte de potencial de E.coli patogênica extra-intestinal humana, FEMS Imunology and medical microbiology: Revista de saúde, European, v. 62, n. 1, p .1-10, jun. 2011.

LOPES, E. S. et al. Isolamento de Salmonella spp e Escherichia coli de psitaciformes: relevância em saúde pública, Arquivo Instituto Biologia: Revista do Instituto Biológico, São Paulo v. 83, n 10, p. 1- 10, set. 2016. 
Coordenadoria de Pesquisa e Extensão - COPEX

Departamento de Editoraçāo e Divulgaçāo Científica - DEDIC 


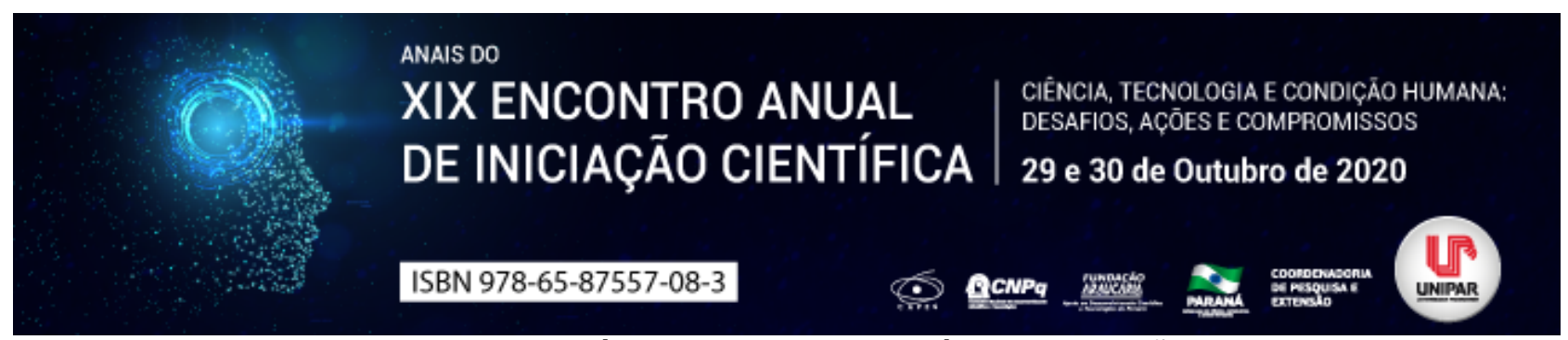

AYAHUASCA E SEU USO TERAPÊUTICO ANTIPARASITÁRIO REVISÃO DE LITERATURA

\begin{abstract}
1'LAISA MARINA ROSA REY, ${ }^{2}$ ALEC GABRIEL PEREIRA ROCHA, ${ }^{3}$ MATEUS AUGUSTO GARCIA SOUZA, ${ }^{4}$ ADRIANE CORDEIRO TREVISANI, ${ }^{5}$ REGIANE PEREIRA BAPTISTA DA SILVA,${ }^{6}$ DANIELA DIB GONCALVES
\end{abstract}

${ }^{1}$ Discente de Medicina Veterinária, PIBIC/UNIPAR
${ }^{1}$ Discente de Medicina Veterinária, PIBIC/UNIPAR
${ }^{2}$ Discente de Medicina Veterinária, PIBIC/UNIPAR
${ }^{3}$ Doutoranda do PPG em Ciência Animal, UNIPAR
${ }^{4}$ Doutoranda do PPG em Ciência Animal, UNIPAR
${ }^{5}$ Docente PPG em Ciência Animal, UNIPAR

Introdução: Ayahuasca (do quíchua, aya, espírito, alma; waska, trepadeira, cipó), normalmente traduzida como cipó dos espíritos , é um composto psicoativo da Amazônia, geralmente preparado pela combinação de duas plantas (APUD, 2019). A ayahuasca é utilizada como medicina tradicional em rituais espirituais e culturais e acredita-se que tenha propriedades curativas (TUPPER, 2009; RUFFELL et al., 2020). A cultura indígena é rica em conhecimentos sobre os poderes medicinais da natureza, entretanto, poucos são os dados relacionados à plantas utilizadas no tratamento de parasitoses (DOS SANTOS et al., 2018).

Objetivo: O objetivo deste trabalho é revisar o uso terapêutico antiparasitário do chá Ayahuasca, pesquisando na literatura dados que comprovem tal efeito.

Desenvolvimento: A ayahuasca é o resultado do cozimento do cipó Banisteriopsis caapi com as folhas do arbusto Psichotria viridis (DE ASSIS, 2014). O chá apresenta um aspecto viscoso de forte coloração marrom-escuro, resultado da fervura da composição das duas plantas, a casca e o tronco do cipó em conjunto com as folhas do arbusto (DE SOUZA, 2006; DE SOUZA, 2011). Ayahuasca tem sido utilizada pelos povos nativos da Amazônia há milhares de anos, envolvendo usos múltiplos, entre eles: prevenção, diagnóstico e tratamento de doenças. (MAIA, 2020). O vômito intenso e a diarreia ocasional que o chá induz podem limpar o corpo de vermes e outros parasitos (ANDRITZKY, 1989), e os próprios alcalóides da harmala demonstraram ser anti-helmínticas, assim, essa ação é dupla, uma ação direta sobre os parasitas atua matando os parasitas, e os parasitas são expulsos através do aumento da motilidade intestinal (HASSAN, 1967). O chá de ayahuasca age também contra infestações gastrointestinais como protozoários causadores de malária, leishmaniose, tripanossomíase e toxoplasmose (MCKENNA, 2004; CALLAWAY, 2011). Em florestas de áreas de risco contra esses parasitos, o uso da ayahuasca poderia explicar o importante papel profilático diante dessas graves doenças parasitárias (DE SOUZA, 2011).

Conclusão: Com isso, concluí-se que o uso terapêutico antiparasitário utilizando o chá de Ayahuasca é eficaz contra parasitos de importância na saúde humana e animal. A relação entre o chá de ayahuasca e seu uso como antihelmíntico é quase escasso na literatura atual, novos trabalhos devem ser conduzidos com intúito de demonstrar maiores benefícios do chá.

\title{
Referências
}

ANDRITZKY, Walter. Sociopsychotherapeutic Functions of Ayahuasca Healing in Amazonia. Journal of Psychoactive Drugs. San Francisco, v. 21, n. 1, p. 77-89, mar. 1989.

APUD, Ismael. Ayahuasca en el tratamiento de adicciones. Estudio de cuatro casos tratados en IDEAA, desde una perspectiva interdisciplinaria. Interdisciplinaria, Buenos Aires, v. 36, n. 1, p. 133-154, jun. 2019.

CALLAWAY, J. C. Various alkaloid profiles in decoctions of Banisteriopsis caapi. Journal of Psychoactive Drugs, v.37, n. 2, p.151-155, set. 2011.

DE ASSIS, Cleber Lizardo; FARIA, Deyse Ferraciolli; LINS, Laís Fernanda Tenório. Bem-estar subjetivo e qualidade de vida em adeptos de ayahuasca. Psicologia \& Sociedade, Belo Horizonte, v. 26, n. 1, p. 224-234, abr. 2014.

DE SOUZA, André Pierre. Alkaloids and ayahuasca tea: a correlation of hallucinogen-induced I"altered states of consciousnessl".

Revista Brasileira de Plantas Medicinais, Botucatu, v.13, n. 3, p. 349-358, abr. 2011.

DE SOUZA, André Pierre. Um químico e o curandeiro: plantas de poder, xamãs e as moléculas do miticismo. Rio de Janeiro: Portal Literário, Editora Aberta, 2006.

DOS SANTOS, Deyvison Rhuan Vasco; DOS SANTOS, Jéssica Vieira; DE ANDRADE, Wbaneide Martins; DOS SANTOS-LIMA, Thayse Macedo. et al. Plantas antiparasitárias utilizadas pelos indígenas Kantaruré-Batida (Ne-Brasil): Etnobotânica e riscos de erosão dos saberes locais. Ambiente \& Sociedade, São Paulo, v. 21, p. 1-20, jul. 2018.

HASSAN, I. Some folk uses of Peganum harmala in India and Pakistan. Economic Botany, v. 21, n.3, p. 384, 1967.

MAIA, Lucas de Oliveira. Uso ritual da Ayahuasca durante o tratamento de doenças físicas graves: um estudo qualitativo. 
Orientador: Luis Fernando Farah de Tófoli. 2020. 198 f. Tese (Doutor em Ciências) Universidade Estadual de Campinas, Campinas, 2020.

MCKENNA, Dennis J. Clinical investigations of the therapeutic potential of Ayahuasca: rationale and regulatory challenges. Pharmacology \& Therapeutics, v.102, n. 2, p. 111-129, 2004.

TUPPER, Kenneth W. Ayahuasca healing beyond the Amazon: the globalization of a traditional indigenous entheogenic practice. Glob Netw, Canadá, v. 9, n. 1, p. 117-36. 2009.

RUFFELL, Simon; NETZBAND Nige; BIRD, Catherine; YOUNG, Allan H.; JURUENA, Mario F. The pharmacological interaction of compounds in ayahuasca: a systematic review. Brazilian Journal of Psichiatry, Brazil, n. 1516, 03 jul. 2020. Disponível em: http://dx.doi.org/10.1590/1516-4446-2020-0884. Acesso em: 11 ago. 2020.

Coordenadoria de Pesquisa e Extensão - COPEX

Departamento de Editoraçāo e Divulgaçāo Científica - DEDIC 


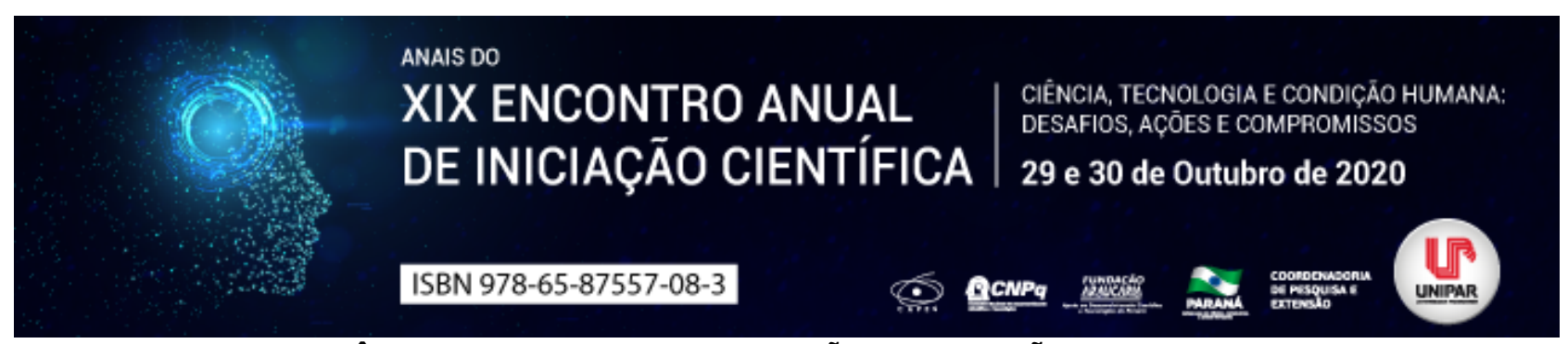

RESISTÊNCIA ANTIMICROBIANA EM CÃES DE REGIÕES FRONTEIRIÇAS

\begin{abstract}
${ }^{1}$ LAISA MARINA ROSA REY, ${ }^{2}$ KAWANY GABRIELI ZANETTI FAZOLI, ${ }^{3}$ TULIO TOZZI FEDRIGO, ${ }^{4}$ CARLOS RENATO DE FREITAS GUAITOLINI, ${ }^{5}$ MELISSA MARCHI ZANIOLO, ${ }^{6}$ DANIELA DIB GONÇALVES
\end{abstract}

\author{
${ }^{1}$ Discente de Medicina Veterinária, PIBIC/UNIPAR \\ ${ }^{1}$ Discentes de Medicina Veterinária, PEBIC/UNIPAR \\ ${ }^{2}$ Discentes de Medicina Veterinária, PEBIC/UNIPAR \\ ${ }^{3}$ Pós-doutorando CNPq PPG em Ciência Animal, UNIPAR \\ ${ }^{4}$ Pós-Graduanda do PPG em Ciência Animal, UNIPAR \\ ${ }^{5}$ Docente PPG em Ciência Animal, UNIPAR
}

Introdução: O território brasileiro apresenta um total de $23.102 \mathrm{~km}$ de fronteira, sendo $15.735 \mathrm{~km}$ de fronteira seca e $7.367 \mathrm{~km}$ de fronteira marítima (SOUTO et al., 2016). São muitas as nominações atribuídas às fronteiras e segundo Foucher (2009), elas podem ser reconhecidas como problema, limite ou até mesmo oportunidade de vida. A resistência bacteriana aos diferentes fármacos fez-se uma das principais preocupações para a saúde humana, e está se tornando um problema na medicina veterinária (ARIAS, 2012).

Objetivo: O objetivo deste trabalho foi avaliar o perfil de resistência antibacteriana in vitro de bactérias Gram negativas de cães de duas regiões fronteiriças.

Material e Métodos: No início de 2020, após o projeto ser aprovado no Comitê de ética em Pesquisa Envolvendo Experimentação animal da UNIPAR sob protocolo 37765/2020, foram coletadas 35 amostras de swabs vaginais e prepuciais de cães de uma Sociedade de Amparo de Animais de uma cidade do noroeste do Paraná que faz divisa (110 km) com o Paraguai e também foram coletadas amostras de cães errantes de uma cidade do estado de Santa Catarina que faz divisa $(5,8 \mathrm{~km}) \mathrm{com}$ a Argentina. Os swabs foram transferidos em caixas de isopor com gelo reciclável e encaminhados ao Laboratório de Microbiologia da Universidade Paranaense UNIPAR para realização do isolamento bacteriano. Para isso, foram introduzidos individualmente em tubos contendo $3 \mathrm{~mL}$ de meio Brain Heart Infusion (BHI) e incubados em estufa à $37^{\circ} \mathrm{C}$ por 24 horas. Após esse período, as culturas obtidas foram semeadas por estriamento em placas contendoÁgar MacConkey e Ágar Sangue e incubadas à $37^{\circ} \mathrm{C}$ por 24 horas. As amostras foram coradas e submetidas à técnica de Gram e a cultura que compõem o kit para Enterobactérias. 36 das amostras foram classificadas como Gram negativas. Para a realização do teste de susceptibilidade aos antimicrobianos foram realizados pela metodologia de disco difusão em ágar de acordo com os critérios estabelecidos pelo Clinical Laboratory and Standards Institute utilizando os antimicrobianos Amoxicilina + Ácido Clavulânico, Ampicilina, Aztreonan, Ceftazidima, Cefalotina, Cefoxetina, Clindamicina, Cloranfenicol, Ceftriaxona, Cefotaxima, Enrofloxacina, Gentamicina, Metronidazol, Norfloxacina, Oxacilina, Penicilina, Sulfazotrim, Tetraciclina e Tobramicina, em seguida, os halos de inibição foram medidos ( $\mathrm{mm}$ ) e os resultados obtidos foram registrados (BrCAST, 2019). Os diferentes microrganismos foram avaliados como sensíveis, intermediários e resistentes.

Resultados: Foram coletados 35 swabs vaginais e prepuciais, dentre essas amostras 30 eram fêmeas (85,71\%) e 5 machos $(14,29 \%)$ de diversas raças e idades. Este trabalho visa o estudo das bactérias identificadas como Gram negativas, 15 (21,42\%) amostras. Todas as amostras foram positivas para microrganismos (100\%). Os antimicrobianos que apresentaram maior resistência foram clindamicina, metronidazol, oxacilina e penicilina 100\% (15/15), Ampicilina 80\% (12/15), cefoxitina 46,6\% (7/15), cefalotina 40\% (6/15) de resistência e 26,6\% (4/15) com resultado intermediário e amoxicilina e ác.clavulânico com 40\% (6/15).

Discussão: A falha no tratamento com o metronidazol está associada a prescrições inadequadas, quando o microrganismo não é identificado adequadamente (LOESHE et al., 1992). Não isolamos bactérias anaeróbias e segundo VEGANI et al. (2004), são sobre essas bactérias que o metronidazol apresenta bons resultados. Pereira (2011) constatou que bactérias Gram negativasem isolados de piometras caninas, apresentaram resistência a amoxicilina e ácido clavulânico, ampicilina, cefalotina, cefoxitina e a penicilina, semelhante aos nossos resultados.Santana et al., (2012), relatou que a ampicilina e a cefalotina mostraram baixos índices de susceptibilidade em enterobactérias, instruindo que a utilização desses antibióticos deve ser feito somente após os resultados do antibiograma. Sugere-se a identificação de bactérias e a detecção de sua sensibilidade antimicrobiana para evitar o uso inadequado de antibióticos, impedindo a resistência antimicrobianaem animais domésticos (ARIAS et al., 2008).

Conclusão: O perfil de isolados bacterianos em swabs vaginais e prepuciais manifestaram presença de resistência antimicrobiana em enterobactérias, o que pode ser considerado um problema de saúde pública de grande magnitudejá que são animais errantes e de regiões fronteiriças. Trabalhos que relatem resistência antimicrobiana em amostras vaginais e prepuciais de cães são escassos na literatura, porém, a detecção de tais resistências é importante para um tratamento de sucesso em 


\section{Referências}

ARIAS, M. V. B.; CARRILHO, C. M. D. M. Resistência antimicrobiana nos animais e no ser humano. Há motivo para preocupação?. Semina: Ciências Agrárias, Londrina, v. 33, n. 2, p. 775-790, abr. 2012.

ARIAS, M. V. B. et al. Identificação da suscetibilidade antimicrobiana de bactérias isoladas de cães e gatos com feridas traumáticas contaminadas e infectadas. Semina: Ciências Agrárias, Londrina, v. 29, n. 4, p. 861-874, 2008.

FOUCHER, M. Obsessão por fronteiras. Tradução de Cecília Lopes. São Paulo: Radical Livros, 2009.

LOESCHE, W.J. et al. Metronidazole in periodontitis: reduced need for surgery. Journal of Clinical Periodontology, v.19, n.2, p.103-112, 1992.

PEREIRA, A. R. V. C. Atibioresistência em Piometra Canina. Orientador: Dr Luís Lima Lobo. 2011. 65 f. Dissertação (Mestrado integrado em Medicina Veterinária) Universidade e Lusófona de Humanidades e Tecnologias, Lisboa, 2011.

SOUTO, A. M. B. et al. Novas tecnologias na segurança nacional, Revista Faipe, Cuiabá, v.6, n. 1, 2016.

VERGANI, S.A. et al. Systemic use of metrhonidazole in the treatment of chronic periodontitis: a pilot study using clinical, microbiological and enzymatic evaluation. Brazilian Oral Research, v.18, n.2, p.121-127, 2004.

SANTANA, T. C. F. S. et al.Prevalência e resistência bacteriana aos agentes antimicrobianos de primeira escolhas nas infecções do trato urinário no município de São Luís-MA. Revista de Patologia Tropical, Maranhão, V. 41, 2012. 


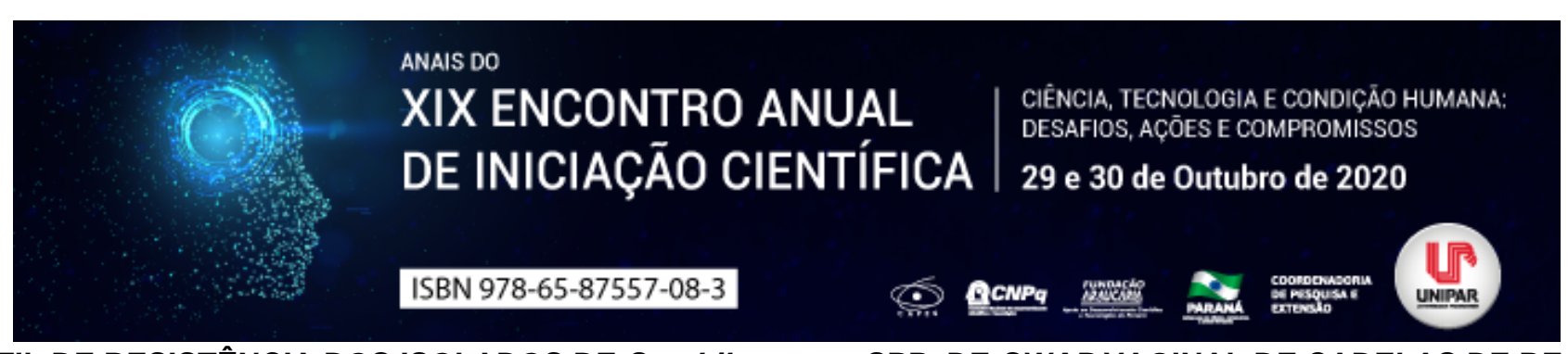

PERFIL DE RESISTÊNCIA DOS ISOLADOS DE Staphilococcus SPP. DE SWAB VAGINAL DE CADELAS DE REGIÃO FRONTEIRIÇA

\title{
${ }^{1}$ CARLOS RENATO DE FREITAS GUAITOLINI, ${ }^{2}$ LAISA MARINA ROSA REY, ${ }^{3}$ MELISSA MARCHI ZANIOLO , ${ }^{4}$ ISABELA CARVALHO DOS SANTOS , ${ }^{5}$ ROSIARA ROSARIA DIAS MAZIERO, ${ }^{6}$ DANIELA DIB GONCALVES
}

\author{
${ }^{1}$ Bolsista PNPD/CAPES, PPG em Ciência Animal, UNIPAR \\ ${ }^{1}$ Acadêmica do Curso de Medicina Veterinária da UNIPAR \\ ${ }^{2}$ Acadêmica do Curso de Doutorado Em Ciencia Animal Com Enfase Em Produtos Bioativos da UNIPAR \\ ${ }^{3}$ Acadêmica do Curso de Doutorado Em Ciencia Animal Com Enfase Em Produtos Bioativos \\ ${ }^{4}$ Docente da UNIPAR \\ ${ }^{5}$ Docente da UNIPAR
}

Introdução: O convívio entre animais e seres humanos é um tema controverso e dentro da Saúde Pública ainda gera polêmicas. Pode-se levar em consideração os benefícios trazidos por esta população animal e se estimular esta convivência (DELTA SOCIETY, 2004), ou considerar os animais como uma importante fonte de infecção. Temos mais de cem doenças que os animais domésticos podem transmitir (MORRISON 2001, WONG, 1999). Os antimicrobianos usados em animais pertencem essencialmente às mesmas classes de antimicrobianos usados em seres humanos. Em animais de companhia, os antimicrobianos são utilizados na prevenção e tratamento de doenças infecciosas, feridas traumáticas e na profilaxia cirúrgica. Quase 50\% dos antimicrobianos produzidos mundialmente são utilizados em seres humanos, a outra metade empregada na profilaxia e tratamento de doenças em animais de companhia, extermínio de pragas na agricultura e também como promotor de crescimento animal (MOTA et al., 2005; GUARDABASSI; JENSEN; KRUSE, 2010), incluindo a aquicultura (TEUBER, 2001; CARNEIRO et al., 2007).

Objetivos: Pesquisar o perfil de resistência dos isolados de Staphylococcus spp. de swab vaginal de cadelas de região fronteiriça.

Material e Métodos: Foram coletados swabs vaginais de um total de 20 cadelas, 10 em Umuarama/PR, região de fronteira com o Paraguai e 10 em Dionísio Cerqueiro, região de fronteira com a Argentina. Após a coleta os materiais biológicos foram encaminhados ao Laboratório de Medicina Veterinária Preventiva e Saúde Pública do PPG em Ciência Animal com Ênfase em Produtos Bioativos para posterior processamento das amostras, realização das técnicas laboratoriais e análise dos dados. As amostras foram colhidas com swab estéril. Houve uma limpeza externa prévia da vagina antes da coleta. Após a coleta o swab foi introduzido em tubo contendo $3 \mathrm{~mL}$ de meio Brain Heart Infusion (BHI) e incubados em estufa à $37^{\circ} \mathrm{C}$ por 24 horas para posterior isolamento bacteriano. Após este período, as culturas obtidas foram semeadas por estriamento em placas contendo Ágar Sangue e incubadas a $37^{\circ} \mathrm{C}$ por 24 horas para isolamento de bactérias. O isolado foi submetido à análise das características macroscópicas e coloração de Gram (KONEMAN E ALLEN, 2008). Os testes de susceptibilidade aos antimicrobianos foram realizados pela metodologia da disco difusão em ágar de acordo com os critérios estabelecidos pelo Clinical Laboratory and Standards Institute (CLSI, 2018). O inóculo bacteriano foi padronizado de acordo com a escala 0,5 de McFarland e a suspensão bacteriana foi inoculada em placas contendo ágar Mueller Hinton com o auxílio de swab. Posteriormente discos impregnados com antimicrobianos foram colocados e as placas incubadas $\left(37^{\circ} \mathrm{C} / 18-24 \mathrm{~h}\right)$. Os halos de inibição foram medidos $(\mathrm{mm})$ e os resultados obtidos registrados. Foram testados os seguintes antibióticos (ATB): AMO Amoxicilina $(10 \mu \mathrm{g})$, AMC- Amicacina $(10 \mu \mathrm{g})$, AMP Ampicilina $(10 \mu \mathrm{g})$, CTX Cefotaxina (30 $\mu \mathrm{g})$, CFO Cefoxitina (30 $\mu \mathrm{g})$, CTF- Ceftiofur $(30 \mu \mathrm{g})$, CRO Ceftriaxiona $(30 \mu \mathrm{g})$, CIP Ciprofloxacina $(5 \mu \mathrm{g})$, CLO Cloranfenicol (30 $\mu \mathrm{g})$, ENO Enrofloxacina $(5 \mu \mathrm{g})$, GEN Gentamicina $(10 \mu \mathrm{g})$, IMP Imipenem $(10 \mu \mathrm{g})$, MPM Meropenem (10 $\mu \mathrm{g})$, SUT Sulfazotrim (Sulfametoxazol/Trimetoprim) $(25 \mu \mathrm{g})$, TET Tetraciclina $(30 \mu \mathrm{g})$, TOB Tobramicina $(10 \mu \mathrm{g})$, OXA Oxacilina $(1 \mu \mathrm{g})$.

Resultados: $31,47 \%$ das amostras apresentaram resistência a pelo menos 5 dos 17 ATBs testados. Os antibióticos que apresentaram maior porcentagem de resistência foram SUT (65\%, 13 amostras), TET (60\%, 12 amostras) TOB (70\%, 12 amostras) e OXA (55\%, 11 amostras). A multirresistência geral, quando comparamos todas as amostras e todos os antimicrobianos, foi de $29,97 \%$.

Discussão: A convivência estreita entre humanos e animais de estimação pode ser responsável pela transmissão de bactérias multirresistentes como já foi relatado em estude de UMBER; BENDER, 2009. A displicência dos responsáveis na relação com seus animais pode levar a transmissão, tanto do animal para seu responsável quanto do responsável para seu animal, de doenças ou bactérias multirresistentes a eles mesmos ou ainda aos demais contactantes que vivem na mesma residência (TATIBANA; DA COSTA-VAL, 2009). 
Conclusão: Estudos sobre a resistência bacteriana de swabs vaginais de cadelas são escassos na literatura, por isso são importantes os estudos nesta área. A convivência cada vez mais íntima entre homens e cães pode se tornar uma fonte de transmissão de resistência bacteriana e novos estudos a procura de genes de resistência devem ser conduzidos.

\section{Referências}

CARNEIRO, D. O.; FIGUEIREDO H. C. P.; PEREIRA JUNIOR, D. J.; LEAL, C. A. G.; LOGATO, P. V. R. Perfil de susceptibilidade de bactérias isoladas em diferentes sistemas de cultivo de tilápia-do-nilo (Oreochromis niloticus). Arquivos Brasileiros de Medicina Veterinária e Zootecnia, Belo Horizonte, v. 59, n. 4, p. 869-876, 2007.

CLSI (Clinical and Laboratory Standards Institute). Performance standards for antimicrobial susceptibility testing: 23rd informational supplement (M100-S23). Wayne, PA: CLSI; 2018.

DELTA SOCIETY. Health benefits of companion animal and therapy animals. , 2004.

GUARDABASSI, L.; JENSEN, L. B.; KRUSE, H. Guia de antimicrobianos em veterinária. Porto Alegre: Artmed, 268 p., 2010.

KONEMAN, E.W.; ALLEN, S.D.; JANDA, W.M. et al. Diagnóstico microbiológico-texto e atlas colorido. 6.ed. Rio de Janeiro: Guanabara Koogan, 2008. 1760p.

MORRISON G . Zoonotic infections from pets. Postgrad Med, v. 110, n.1, p.24-48, 2001.

MOTA, R. A.; FREITAS, M. F. L.; PORTO, W. J. N.; SILVA, L. B. G. Utilização indiscriminada de antimicrobianos e sua contribuição a multirresistência bacteriana. Brazilian Journal of Veterinary Research and Animal Science, São Paulo, v. 42, n. 6, p. 465-470, 2005.

SEIMENIS, A.M. The spread of zoonoses and other infectious diseases through the international trade of animals and animal products. Veterinaria Italiana, v.44, p.591-599, 2008.

TATIBANA, L. S.; COSTA-VAL, A. P. Relação homem-animal de companhia e o papel do médico veterinário. Revista Veterinária e Zootecnia em Minas, n. 103, 2009.

TEUBER, M. Veterinary use and antibiotic resistance. Current Opinion in Microbiology, New York, v. 4, n. 5, p. 493-499, 2001.

UMBER, J. K.; BENDER, J. B. Pets and antimicrobial resistance. Veterinary Clinics North America: Small Animal Practice, Philadelphia, v. 39, n. 2, p. 279-292, 2009.

WONG, S. K.; FEINSTEIN, L. H.; HEIDMANN, P. Healthy pets, healty people. JAVMA. v. 215, n. 3, p. 335-8, 1999. 


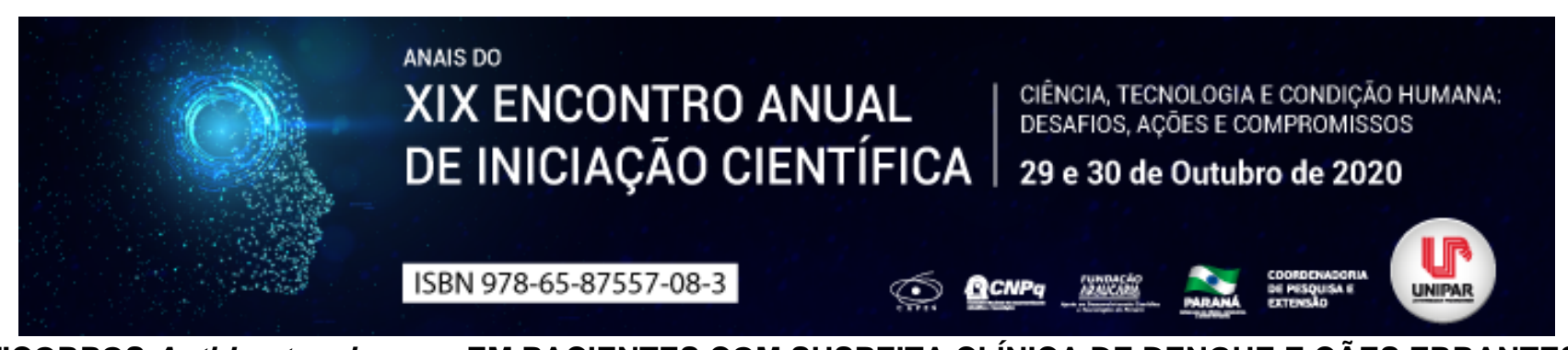

ANTICORPOS Anti-Leptospira spp. EM PACIENTES COM SUSPEITA CLÍNICA DE DENGUE E CÃES ERRANTES DO MUNICÍPIO DE ASSIS CHATEAUBRIAND, PARANÁ

\author{
${ }^{1}$ KAWANY GABRIELI ZANETTI FAZOLI, ${ }^{2}$ LUCAS LIMA DA SILVA, ${ }^{3}$ MARIANA DO NASCIMENTO COELHO, ${ }^{4}$ TULIO TOZZI \\ FEDRIGO, ${ }^{5}$ ARIANNE PERUZO PIRES GONCALVES, ${ }^{6}$ DANIELA DIB GONCALVES
}

\author{
${ }^{1}$ Acadêmico bolsista do PEBIC/ Fundação Araucária \\ ${ }^{1}$ Acadêmico do Curso de Medicina Veterinária da UNIPAR \\ 23Discente Ensino Médio, bolsista PEBIC CNPq \\ ${ }^{3}$ Acadêmico do Curso de Medicina Veterinária da UNIPAR \\ ${ }^{4}$ Acadêmica do Curso de Doutorado Em Ciencia Animal Com Enfase Em Produtos Bioativos da UNIPAR \\ ${ }^{5}$ Docente da UNIPAR
}

Introdução: A leptospirose é uma enfermidade infectocontagiosa causa pela bactéria do gênero Leptospira spp. de grande interesse em saúde única por ser uma zoonose de caráter endêmica e epidêmica, com alto índice de infeção em períodos com elevada pluviosidade (BRASIL, 2014; JESUS et al., 2012; PELISSARI et al., 2011). O homem, hospedeiro terminal e acidental da doença, se infecta ao entrar em contato com a urina de animais infectados principalmente roedores, bovinos, suínos, equinos e os cães por meio do contato com água, lama ou solo contaminado. A penetração do microrganismo ocorre através da pele com lesões, pele íntegra quando imersa em água por longo tempo ou mucosas (ALLAN et al., 2015; COSTA et al., 2015; BRASIL, 2014). Os cães errantes são infectados ao entrar em contato com uma fonte contaminada com Leptospira spp. Se tornando importantes reservatórios e responsáveis pela permanência do foco de infecção, sendo muitas vezes hospedeiros assintomáticos (FAINE et al., 1999). Os sinais clínicos da leptospirose humana, não são patognomônicos e as pessoas infectadas podem apresentar febre, dores pelo corpo, dor de cabeça, icterícia, insuficiência renal e hemorragia (BRASIL, 2014; BRASIL, 2009). A dengue, enfermidade causada pelo vírus Arbovírus que apresenta os sorotipo 1, 2, 3 e 4. Este vírus é transmitido aos humanos através da picada de insetos, especialmente pelo mosquito Aedes aegypti, que necessita de água parada para se proliferar, sendo os períodos chuvosos de maior transmissão do vírus. Os sinais clínicos da dengue se caracterizam por febre alta, dores musculares e ao redor dos olhos, dor de cabeça, podendo aparecer manchas avermelhadas pelo corpo, em casos graves pode ocorrer hemorragia (BRASIL, 2014; SILVA et al., 2019). Considerando-se que a leptospirose tem amplo espectro clínico, assim como a dengue, o principal diagnóstico diferencial em fase precoce da leptospirose, é para a dengue, podendo ser assintomáticas ou evoluindo para quadros clínicos característicos de ambas as doenças como febre alta, dores de cabeça e no corpo, podendo evoluir para óbito, tendo os maiores surtos diagnosticados em épocas com grande capacidade pluviométricas (SILVA et al., 2019).

Objetivo: O objetivo deste trabalho foi pesquisar anticorpos anti-Leptospira spp. em cães errantes e em pacientes com suspeita clínica de dengue atendidos pelo Sistema Único de Saúde (SUS) do município de Assis Chateaubriand, Paraná.

Materiais e métodos: Foram coletadas amostras de sangue por punção venosa de 30 pacientes com suspeita clínica de dengue do município Assis Chateaubriand (PR) no período de outubro de 2018 a novembro de 2019 por profissionais da enfermagem da Unidade de Saúde Local. Também foi realizada a coleta de $10 \mathrm{~mL}$ de sangue de aproximadamente 30 cães errantes não domiciliados, do município de Assis Chateaubriand (PR). O sangue foi mantido em temperatura ambiente até a retração do coágulo e acondicionada e armazenada a $-20^{\circ} \mathrm{C}$. As amostras foram submetidas ao teste de Soroaglutinação Microscópica (SAM) para pesquisa de anticorpos anti-Leptospira spp. Amostras que apresentaram títulos $\geq 100$ foram consideradas reagentes.

Resultados: Relacionado aos pacientes, 100\% foram consideradas negativa na SAM e das amostras de cães, cinco (10,20\%) apresentaram-se reagentes.

Discussão: Este trabalho mostra que (10,20\%) das amostras de soro de cães errantes, são reagentes para Leptospira spp. Assim como, BENITEZ et al., (2010) observou em seu trabalho a soropositividade de 21,21\% das amostras para leptospirose em cães errantes do campus da UEL-PR. Na região noroeste do estado do Paraná, um cão errante assintomático de um canil privado se mostrou positivo para leptospirose, segundo GONÇALVES et al., (2011). Concluindo assim, que este resultado reforça a importância do controle de cães errantes nas regiões urbanas, tal medida, auxilia na prevenção e controle para a leptospirose humana. A maioria das infecções humanas ocorre em área urbana e em ambientes domiciliares (BRASIL, 2016), desta forma é importante lembrar que a positividade no pequeno número de cães não descarta possibilidade de infecção humana, pois, os animais utilizados são animais errantes e não houve a coleta a domicilio, sendo necessária a realização de novos estudos. A incidência da leptospirose é subestimada devido a quadros clínicos que podem ser confundidos com resfriados, gripe e até mesmo a dengue, passando por muitas vezes despercebidas pelos médicos e pacientes. As notificações e o diagnóstico da 
doença são mais frequentes entre os casos graves (BRASIL, 2016).

Conclusão: Neste estudo pode-se, perceber que a baixa prevalência nos animais sugere no reflexo da negatividade nos humanos, tendo em vista que os principais responsáveis pela transmissão humana são os animais infectados muitas vezes assintomáticos que disseminam pela urina o patógeno no meio ambiente.

\section{Referências}

ALLAN, K.J. et al. Zoonosis and a Paradigm for One Health" in Africa. PLoS Neglectrd Tropical Diseases., v.14, n. 9, p. 1-2, 2015.

BENITEZ, A. et al. Leptospirose em cães errantes encontrados em campus universitário: avaliação sorológica e exame direto da urina. Ciências Agrárias. v. 31, n. 1, p. 191-196, 2010.

BRASIL. MINISTÉRIO DA SAÚDE. Secretaria de Vigilância em Saúde. Leptospirose. In: Guia de vigilância epidemiológica Brasília: Ministério da Saúde, ed. 7, v. 8, p. 15, 2009.

BRASIL. MINISTÉRIO DA SAÚDE. Secretaria de Vigilância em Saúde. Guia leptospirose: diagnóstico e manejo clínico. Brasília, Secretaria de Vigilância em Saúde, 2014.

BRASIL. MINISTÉRIO DA SAÚDE. Secretaria de Vigilância em Saúde. Indicadores e Dados Básicos para a Saúde; Brasilía, 2016.

COSTA, F. et al. Global Morbidity and Mortality of Leptospirosis: A Systematic Review. PLoS Neglected Tropical Diseases, v.9, n.9, p.1-19, 2015.

GONÇALVES, D. D. et al. Leptospirose em cão errante da região Noroeste do estado do Paraná relato de caso. Arquivo de ciências veterinárias e zoologia da Unipar. v. 14, n. 1, 2011.

JESUS, M. S. et al. Cases distribution of leptospirosis in City of Manaus, State of Amazonas, Brazil, 2000-2010. Revista da Sociedade Brasileira de Medicina Tropical, v. 45, n. 6, p. 713- 716, 2012.

MOLINA, C. V. et al. Sero-epidemiological survey for brucellosis, leptospirosis and toxoplasmosis in free-ranging Alouatta caraya and Callithrix penicillata from Sao Paulo State, Brazil. Journal of Medical Primatology, v. 43, n. 3, p. 197-201, 2014.

PELISSARI, D. M. et al. Revisão sistemática dos fatores associados à leptospirose no Brasil, 2000-2009. Epidemiologia e Serviços de Saúde, v. 20, n.4, p. 565-574, 2011.

SILVA, A. C. R. et al. Informação sobre dengue entre usuários da estratégia saúde da família. Biológicas e saúdes. v. 9, n. 29, 2019.

Coordenadoria de Pesquisa e Extensão - COPEX

Departamento de Editoraçāo e Divulgaçāo Científica - DEDIC 


\title{
ANAIS DO XIX ENCONTRO ANUAL | CIÊNCIA, TECNOLOGIA E CONDIÇĀO HUMANA: DESAFIOS, AÇŌES E COMPROMISSOS DE INICIAÇĀO CIENTÍFICA 29 e 30 de Outubro de 2020 \\ ISBN 978-65-87557-08-3

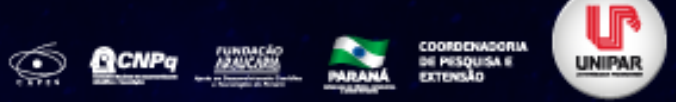 \\ PROTOCOLO DE CRIOPRESERVAÇÃO DE SÊMEN CANINO UTILIZANDO CICLODEXTRINA LIGADA AO COLESTEROL (CLC) - REVISÃO DE LITERATURA
}

\section{${ }^{1}$ RENATA PATRICIA RIGOTO, ${ }^{2}$ CARLOS RENATO DE FREITAS GUAITOLINI, ${ }^{3}$ ROSIARA ROSARIA DIAS MAZIERO}

\author{
${ }^{1}$ Acadêmico bolsista do PEBIC/Fundação Araucária \\ ${ }^{1}$ Acadêmico do Curso de Programa Nacional de Pos-doutorado -PNPD/CAPES da UNIPAR \\ ${ }^{2}$ Docente da UNIPAR
}

Introdução: Os protocolos utilizados para a criopreservação de sêmen canino normalmente seguem àqueles utilizados para outras espécies domésticas, deste modo os resultados de cinética e viabilidade espermáticas pós-descongelação são muito baixos, exigindo que novos estudos sejam realizados. Neste sentido, o cão é um excelente modelo experimental para a criopreservação de sêmen humano, visto que no homem a qualidade espermática é muito baixa (SANTOS et al., 2016). Para tanto, a ciclodextrina ligada ao colesterol (CLC) tem melhorado a qualidade do sêmen congelado/descongelado em diversas espécies, porém, poucos estudos relatam seu uso na criopreservação de espermatozoides caninos (KHAN et al., 2017).

Objetivo: Avaliar a eficácia da utilização de ciclodextrina ligada ao colesterol (CLC) sobre a criopreservação do sêmen canino.

Desenvolvimento: $O$ processo de criopreservação é a interrupção artificial do progresso de maturação espermática pósejaculação. Deste modo, a congelação é utilizada para preservar constituintes celulares, evitando o rompimento das organelas. Entretanto, como este processo envolve a redução da temperatura, desidratação celular, congelação e descongelação, pode ocorrer a diminuição da viabilidade celular e sua função normal (SOUZA et al., 2018). Neste sentido, estudos tem demonstrado que as ciclodextrinas ligadas ao colesterol (CLC) adicionadas ao meio diluidor, antes do processo de criopreservação, tem melhorado a integridade da membrana plasmática dos espermatozoides, além de reduzir as demais crioinjúrias (UÇAN et al., 2016). Assim, autores mostram que em equinos, bovinos, suínos, ovinos, caprinos, bisão americano e em cães foram observadas melhoras na qualidade do sêmen congelado / descongelado, pela adição de diferentes concentrações de colesterol durante a criopreservação, permitindo a manutenção de elevado teor de colesterol na membrana plasmática espermática, impedindo que as células sofram a maturação e capacitação precoce, aumentando sua viabilidade (SOUZA et al., 2018). Durante o processo de criopreservação espermática, inicialmente o ejaculado deve ser refrigerado da temperatura corpórea à temperatura ambiente $\left(37^{\circ}\right.$ $\mathrm{C}$ até $20^{\circ} \mathrm{C}$ ), porém, este processo não causa maiores danos aos espermatozoides, desde que estejam manipulados e diluídos adequadamente (MAZIERO et al., 2019). Entretanto, o estresse inicial ocorre quando os espermatozoides passam da temperatura ambiente para a temperatura final de armazenagem do sêmen refrigerado, sendo uma faixa crítica no processo de refrigeração, devido à ocorrência da fase de transição dos fosfolipídios da membrana plasmática do estado líquido-cristalino para o estado de gel. Neste período crítico, mais precisamente de $19^{\circ} \mathrm{C}$ a $8^{\circ} \mathrm{C}$, os espermatozoides devem ser refrigerados numa taxa de refrigeração de $0,05^{\circ} \mathrm{C}$ por minuto, para que não ocorram danos irreversíveis, que irão causar queda nos índices de fertilidade (LIMA et al., 2019). Os danos decorrentes desta faixa de refrigeração são denominados conjuntamente de choque frio . Assim, a presença de colesterol no diluente para criopreservação espermática reduz os danos celulares, pela prevenção do choque térmico, uma vez que a diminuição da temperatura com o uso da CLC faz com que a membrana plasmática permaneça num estado fluído intermediário ao invés do estado gelatinoso, na fase de transição. Adicionalmente, o colesterol também possui ação estabilizadora e moduladora da fluidez de membrana a temperatura corpórea (HARTWIG et al., 2014). Em cães, Khan et al. (2017) mostraram que a adição de ciclodextrina ligada ao colesterol ao sêmen canino resultou em aumento dos parâmetros de cinética e viabilidade espermáticas, quando utilizada na concentração de $2 \mathrm{mg} / \mathrm{mL}$. Adicionalmente, concentrações superiores a 2 $\mathrm{mg} / \mathrm{mL}$ acarretaram efeitos deletérios na qualidade do ejaculado. Portanto, novos trabalhos são necessários para confirmar e identificar os mecanismos de interação entre colesterol e a membrana espermática (HARTWIG et al., 2014).

Conclusão: Conclui-se que muitos fatores estão envolvidos no processo de criopreservação espermática e que em cães, poucos estudos relatam a utilização de CLC na viabilidade da membrana plasmática. Entretanto, sabe-se que a perda de colesterol da membrana plasmática pode causar capacitação prematura, reduzindo a viabilidade dos espermatozoides criopreservados no trato reprodutivo da fêmea, reduzindo a taxa da fertilidade. Desta forma, a correta utilização das ciclodextrinas pode favorecer a incorporação ou extração de colesterol das membranas plasmáticas, protegendo a célula durante o processo de criopreservação.

\section{Referências}

HARTWIG, F. P.; LISBOA, F. P.; HARTWIG, F. P.; MONTEIRO, G. A.; MAZIERO, R. R. D.; FREITAS-DELL'AQUA, C. P.; ALVARENGA, M. A.; PAPA, F. O.; DELL'AQUA JR, J. A. Use of cholesterol-loaded cyclodextrin: An alternative for bad cooler stallions. Theriogenology, v. 81, p. 340-346, 2014.

KHAN, J.; TAHIR, M. Z.; KLALID, A.; SATTAR, A.; AHMAD, N. Effect of cholesterol-loaded cyclodextrins on cryosurvival of dog 
spermatozoa. Reproduction in Domestic Animals, v. 52, n. 2, p. 265-268, 2017.

LIMA, J.S.; GUAITOLINI, C.R.F.; CRESPILHO, A.C.; FREITAS-DELL'AQUA, C.P.; MARTINS, M.I.M.; RIGOTO, R.P.; MARQUES, A.B.; HIDALGO, M.M.T.; MAZIERO, R.R.D. Efeito de meios diluidores na congelabilidade do semen canino. Brazilian Journal of Development, v. 5, n. 9, p. 15841-15855, 2019.

MAZIERO, R.R.D.; GUAITOLINI, C.R.F.; GUASTI, P.N.; MONTEIRO, G.A.; MARTIN, I.; SILVA, J.P.M.; CRESPILHO, A.M.; PAPA, F.O. Effect of Using Two Cryopreservation Methods on Viability and Fertility of Frozen Stallion Sperm. Journal of Equine Veterinary Science, v. 72, p. 37-40, 2019.

SANTOS, J. F. P.; GOSMES, E. T.; SIQUEIRA, A. K. M.; CARDOSO, R. C. S. Andrologia e criopreservação de sêmen de cães. Revista Brasileira de Reprodução Animal, v. 40, n. 4, p. 167-179, 2016.

SOUZA, W. L.; MORAES, E. A.; COSTA, J. M. S.; GRAHAM, J. K. Cholesterol-loaded cyclodextrin in fresh goat sperm improves cryosurvival rates. Revista Brasileira de Ciências Veterinárias, v. 23, n. 1, p. 93-98, $2016 a$.

SOUZA, W. L.; MORAES, E. A.; OLIVEIRA, R. P. Colesterol carregado pela ciclodextrina sobre a criopreservação dos espermatozoides de garanhões da raça Nordestina. Pesquisa Veterinária Brasileira, v. 38, n. 5, p. 991-996, 2018.

UÇAN, U.; KÜÇÜK, N.; AHMAD, E.; NASEER, Z.; AKSOY, M.; SERIN, İ.; CEYLAN, A. Effect of different sugars supplemented to the extender in combination with cholesterol-loaded cyclodextrin (CLC) on post-thaw quality of ram spermatozoa. Small Ruminnants Research, v. 136, p. 243-246, 2016. 


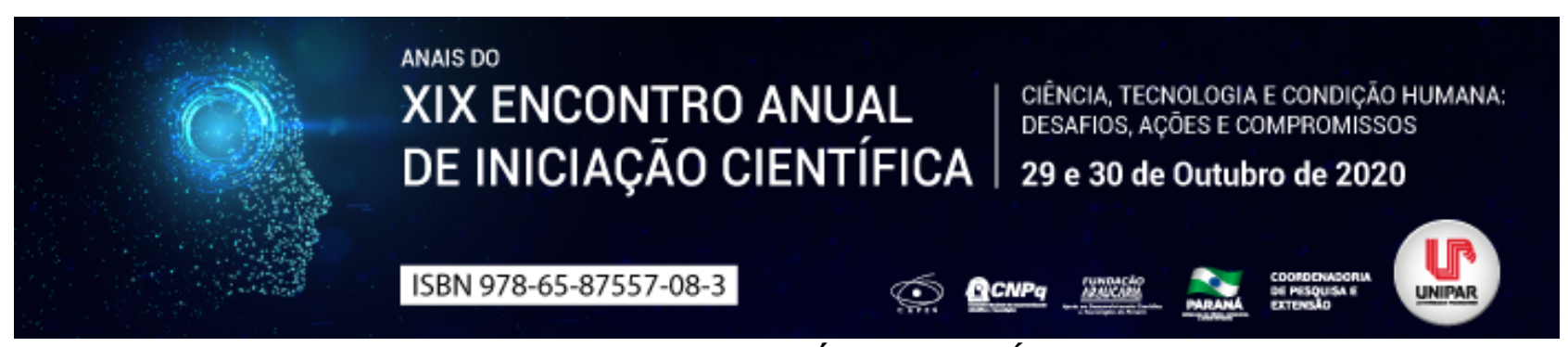

MOSAICISMOS E POLIMORFISMOS GENÉTICOS NA SÍNDROME DE TURNER

${ }^{1}$ THALYA VITORIA BECHER, ${ }^{2}$ LUCIANO SERAPHYN GASQUES, ${ }^{3}$ DENISE ALVES LOPES, ${ }^{4}$ DANIELE GARCIA DE ALMEIDA SILVA, ${ }^{5}$ IRINEIA PAULINA BARETTA, ${ }^{6}$ ROSILEY BERTON PACHECO

${ }^{1}$ Acadêmica bolsista do PIBIC/UNIPAR

${ }^{1}$ Docente da UNIPAR

${ }^{2}$ Docente da UNIPAR

${ }^{3}$ Docente da UNIPAR

${ }^{4}$ Docente da UNIPAR

${ }^{5}$ Docente da UNIPAR

Introdução: A Síndrome de Turner (ST) foi publicada pela primeira vez em 1938 por Henry Turner, entretanto, em 1930 o pediatra alemão Otto Ullrich já havia descrito o caso de uma menina de oito anos com sinais sugestivos de ST. Assim, a síndrome também é denominada de Ullrich-Turner (MARQUI, 2015). Trata-se uma cromossomopatia que ocorre pela presença de um cromossomo $X$ e perda total ou parcial do segundo cromossomo sexual, ou seja, é caracterizada pela monossomia do X, tendo uma incidência de 1/2.500 recém-nascidos do sexo feminino (OLIVEIRA; JORGE; QUEIROS, 2014). Porém, de acordo com Barros et al (2009), os mosaicismos dos cromossomos sexuais apresentados pelos pacientes portadores da Síndrome de Turner vem desmontando a imagem estereotipada do cariótipo clássico $(45, \mathrm{X})$ e os polimorfismos genéticos existentes influenciam na gravidade de manifestações clínicas e na resposta ao tratamento da ST, segundo Marqui (2015).

Objetivo: Analisar a existência de mosaicismos e alterações estruturais no cariótipo de indivíduos com a Síndrome de Turner e as implicações dos polimorfismos nas manifestações clínicas e na resposta ao tratamento da doença.

Desenvolvimento: A ST possui grande variabilidade fenotípica, podendo se manifestar desde a forma clássica, apresentando sinais clínicos importantes, como: baixa estatura, disgenesia gonadal (que leva à amenorreia primária, atraso no desenvolvimento puberal e esterilidade), além de alterações cardiovasculares e renais, obesidade, deficiência auditiva, osteoporose, doenças tireoidianas, entre outros (SUZIGAN, 2004), até aquela com poucos sinais dismórficos, passando praticamente despercebida. 0 cariótipo mais frequente $(45, X)$, foi encontrado em $40-60 \%$ das pacientes, sendo o restante composto por mosaicismos e alterações estruturais (MARQUI, 2015). Para a identificação da constituição cromossômica do indivíduo, é realizado o exame do cariótipo, que confirma o diagnóstico. De acordo com Barros et al (2009), num estudo com 260 pacientes, houve predomínio do cariótipo 45,X (em 41,5\% dos indivíduos), seguido de aberrações estruturais com ou sem mosaicismo (33,8\% - sendo o isocromossomo de braço longo do cromossomo $X$ e os cromossomos marcadores as aberrações estruturais mais encontradas), mosaicos sem aberração estrutural e sem cromossomo $Y(22,3 \%)$ e, por fim, mosaicos com cromossomo $Y$ íntegro (2,3\%). Além disso, segundo Marqui (2015), os polimorfismos de único nucleotídeo (SNPs: single nucleotide polymorphisms) podem estar envolvidos na etiologia da ST, visto que, dependendo de sua localização, modificam o funcionamento do gene e da proteína formada. Em estudos, ainda conforme exposto por Marqui (2015), quanto ao gene de referência GHR, o polimorfismo GHRd3 demonstrou associação positiva na resposta à terapia com hormônio de crescimento recombinante humano (rhGH); já os polimorfismos -202 A/C IGFBP3 e SOCS-2 constituíram genótipos desfavoráveis para a estatura adulta. Em relação à densidade mineral óssea (DMO) e o gene de referência VDR, os polimorfismos Bsml, Fokl e Cdx2 foram associados positivamente à DMO e sua detecção precoce poderia ser útil para predizer osteopenia grave em pacientes com ST; o polimorfismo no gene ER-a (estrogen receptor-alpha) também obteve associação positiva ao tratamento com estroprogestágeno. Considerando que os pacientes com ST apresentam alto risco para doenças autoimunes, principalmente relacionadas à tireoide, investigou-se os polimorfismos no gene PTPN22 (protein tyrosine phosphatase, non-receptor type 22) e observou-se que a variação alélica C1858T predispõe a um risco maior para doenças autoimunes. Por fim, quanto à não disjunção cromossômica, tendo como referência o gene MTHFR, o genótipo $1298 C$ Coi o mais frequente e associado a risco elevado de aneuploidia (MARQUI, 2015). Outros polimorfismos são investigados, mas ainda existem poucos estudos acerca do tema.

Conclusão: A partir desses achados confirma-se que a imagem estereotipada do $45, X$, clássico na ST, vem sendo desmontada, visto que não há mais um cariótipo nem fenótipo específicos, fazendo-se necessária a investigação e solicitação de cariotipagem para indivíduos do sexo feminino com baixa estatura, independente da presença de quadro dismórfico e atraso puberal, sendo o diagnóstico precoce imprescindível para a identificação de anomalias congênitas e/ou adquiridas associadas a certos cariótipos da Síndrome de Turner e, assim, para a obtenção de sucesso na abordagem terapêutica.

\section{Referências}


BARROS, Beatriz Amstalden et al. A inclusão de novas técnicas de análise citogenética aperfeiçoou o diagnóstico cromossômico da síndrome de Turner. Arq Bras Endocrinol Metab, São Paulo, v. 53, n. 9, p. 1137-1142, dez. 2009.

MARQUI, Alessandra Bernadete Trovó de. Síndrome de Turner e polimorfismo genético: uma revisão sistemática. Rev. paul. pediatr. São Paulo, v. 33, n. 3, p. 363-370, set. 2015.

OLIVEIRA, Pedro; JORGE, Joana; QUEIROS, Otília. Entre os genes e a mente síndroma de Turner e manifestações psicopatológicas. Nascer e Crescer, Porto, v. 23, supl. 1, p. 14-15, mar. 2014.

SUZIGAN, Lígia Z. C. et al. A percepção da doença em portadoras da síndrome de Turner. J. Pediatr. (Rio J.), Porto Alegre, v. 80, n. 4, p. 309-314, ago. 2004.

Coordenadoria de Pesquisa e Extensão - COPEX

Departamento de Editoraçāo e Divulgaçāo Científica - DEDIC 


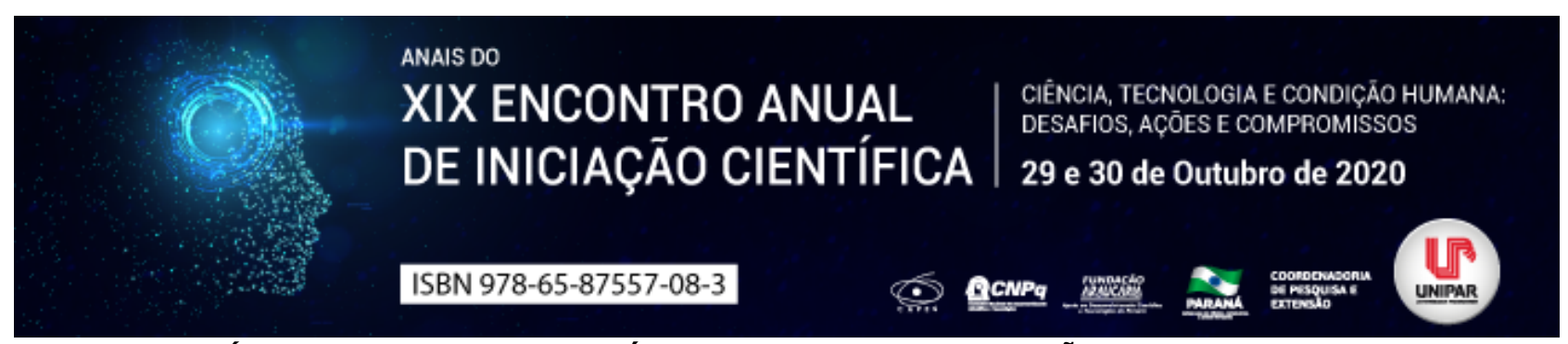

SÍNDROME DE DOWN, GENÉTICA E PROLE: UMA REVISÃO DE LITERATURA

\begin{abstract}
${ }^{1}$ KAMUNI AKKACHE COUTINHO, ${ }^{2}$ THALYA VITORIA BECHER, ${ }^{3}$ DENISE ALVES LOPES, ${ }^{4}$ DANIELE GARCIA DE ALMEIDA SILVA, ${ }^{5}$ IRINEIA PAULINA BARETTA, ${ }^{6}$ ROSILEY BERTON PACHECO
\end{abstract}

\author{
${ }^{1}$ Acadêmica do Curso de Medicina da UNIPAR \\ ${ }^{1}$ Acadêmica do Curso de Medicina da UNIPAR \\ ${ }^{2}$ Docente da UNIPAR \\ ${ }^{3}$ Docente da UNIPAR \\ ${ }^{4}$ Docente da UNIPAR \\ ${ }^{5}$ Docente da UNIPAR
}

Introdução: A Síndrome de Down (SD), descrita pelo médico John Langdon Down como mongolismo em 1866 devido às semelhanças físicas observadas nas crianças com atraso mental na época e comprovada a etiologia da trissomia do 21 pelo geneticista Jérôme Lejeune em 1958, é uma alteração genética e é a mais frequente em humanos, que tem como possíveis causas três bases citogenéticas: a trissomia livre do cromossomo 21, que ocorre em 95\% dos casos; translocação; e mosaicismo (MATA; PIGNATA, 2014). Esses indivíduos têm como características biológicas gerais a baixa estatura, retardo mental, dismorfia facial, hipotonia muscular general, complicação como o defeito congênito do coração (COELHO, 2016). A SD pode ter relação com fatores genéticos e ambientais assim como com o envelhecimento paterno/materno, em que propiciam maiores chances de erros na divisão celular, conforme expresso por Mata e Pignata (2014), evidenciando-se, a partir das consequências para a prole, à importância de explorar tal tema.

Objetivo: Compreender as causas que levam a SD e as possibilidades de indivíduos férteis gerarem filhos com essa síndrome.

Desenvolvimento: A Síndrome de Down ocorrer a partir de três anormalidades cromossômicas: a trissomia simples na qual acontece uma não disjunção cromossômica-distribuição incorreta do cromossomo-, levando a junção de um cromossomo a mais com o par 21 (indivíduo com 47 cromossomos), sendo que 95\% dos casos têm origem do óvulo e 5\% origina-se do espermatozóide; a translocação, que pode envolver o cromossomo 14 ou o 15, em que parte do cromossomo 21 extra se une a esses outros cromossomos, mesmo que haja apenas 46 cromossomos esse indivíduo manifesta SD, este é o único dos casos que a genética pode ser herdada de um dos pais, presente em $3 \%$ dos casos; e o mosaicismo, que ocorre em $2 \%$ dos casos e apresenta-se de forma mais agressiva, tem origem da não disjunção mitótica nas primeiras divisões de um zigoto normal, afetando somente partes das células, logo, algumas células têm 47 cromossomos e outras 46 (MATA; PIGNATA, 2014). A idade materna acima dos 35 anos tem influência sobre a ocorrência da SD, uma vez que as meninas nascem com todos os seus ovócitos já formados e durante a vida os ovócitos amadurecem e envelhecem, aumentando a ocorrência de não disjunção cromossômica assim como nos homens, que apesar de produzirem espermatozoides constantemente, com o envelhecer podem comprometer a formação dos gametas (MATA; PIGNATA, 2014). Conforme Coelho (2016), há uma incidência de 1 caso de SD a cada 100 crianças em mães dos 40-44 anos e 1 caso de SD a cada 50 crianças em mães acima dos 45 anos. Entretanto, segundo Mata e Pignata (2014), de forma aleatória podem ocorrer anormalidades genéticas, independente da idade dos progenitores, sendo que cerca de $80 \%$ das crianças com SD nascem de mulheres com idade inferior a 35 anos. Nesse sentido, é possível avaliar que as chances de progenitores cromossomicamente normais e férteis em gerar filhos com SD é variável e depende de diversos fatores como presença de alterações genéticas em parentes próximos ou em filho anterior, exposição de pelo menos um dos cônjuges à radiação e ou produtos químicos diversos, filhos gerados por pai com mais de 55 anos e/ou mãe com mais de 35 anos, histórico de abortamento, entre outros fatores, sendo difícil de avaliar a incidência nesses casais (MUSTACCHI, 2000). Sobre as probabilidades de indivíduos férteis com SD gerar descendentes sem a mesmo mutação genética varia de acordo com a presença ou ausência da variação nos progenitores, sendo assim, quando o casal é formado por uma pessoa com a trissomia 21 livre e outra sem o distúrbio, há $50 \%$ de chances de filhos sem trissomia 21; quando ambos apresentam a SD a possibilidade de prole normal é de $25 \%$, havendo um aumento do risco de abortos, por gerar a tetrassomia 21, incompatível com a vida; e em casos de SD por translocação cromossômicas 21/21, a probabilidade de filhos normais é de $50 \%$ quando o (a) parceiro (a) não manifesta a síndrome (MOREIRA; GUSMÃO, 2002). Sob esse olhar, conforme Moreira e Gusmão (2002) a fertilidade, no geral, é maior nas mulheres do que nos homens com SD, mesmo que haja desenvolvimento normal das características sexuais secundárias. Das características biológicas as manifestações observadas são deficiência mental, braquicefalia, ponte nasal achatada, prega epicântica, língua projetada, prega simiesca, clinodactilia do quinto dedo da mão, defeitos congênitos do coração, visão e audição, baixa estatura, hiperflexibilidade das articulações, face redonda (COELHO, 2016). 
Conclusão: É possível observar que a SD é a alterações genéticas mais comum em humanos e que entre suas principais causas a trissomia do 21 é a mais frequente acometendo $95 \%$ dos casos. Entre os fatores que favorecem a disjunção cromossômica a mais conhecida e estudada é a idade materna/paterna avançada, além disso, outros fatores podem influenciar para que indivíduos geneticamente normais tenham filhos com SD. Ademais, observa-se que pessoas com essa síndrome podem ter uma prole sem a mesma alteração, sendo que a incidência vai depender da presença ou não da SD em um ou ambos os cônjuges.

\section{Referências}

COELHO, Charlotte. A Síndrome de Down. O Portal Psicologia, [s. I.], 13 mar. 2016. Disponível em: https://www.psicologia.pt/artigos/textos/A0963.pdf. Acesso em 08 julho 2020.

MATA, Cecilia Silva; PIGNATA, Maria Izabel Barnez. Síndrome de Down: aspectos históricos, biológicos e sociais. TCEM, [s. I.], p. 1-15, 2014. Disponível em: https://files.cercomp.ufg.br/weby/up/80/o/TCEM2014-Biologia-CeciliaSilvaMAta.pdf. Acesso em: 08 julho 2020.

MOREIRA, Lilia; GUSMÃO, Fabio. Aspectos genéticos e sociais da sexualidade em pessoas com síndrome de Down. Revista Brasileira Psiquiatria, n. 24, v. 2, 2002.

MUSTACCHI, Zan; PERES, Sergio. Genética baseada em evidências: Síndrome e Heranças, ed. 1, Editora: CID editora, 2000.

Coordenadoria de Pesquisa e Extensão - COPEX

Departamento de Editoraçāo e Divulgaçāo Científica - DEDIC 


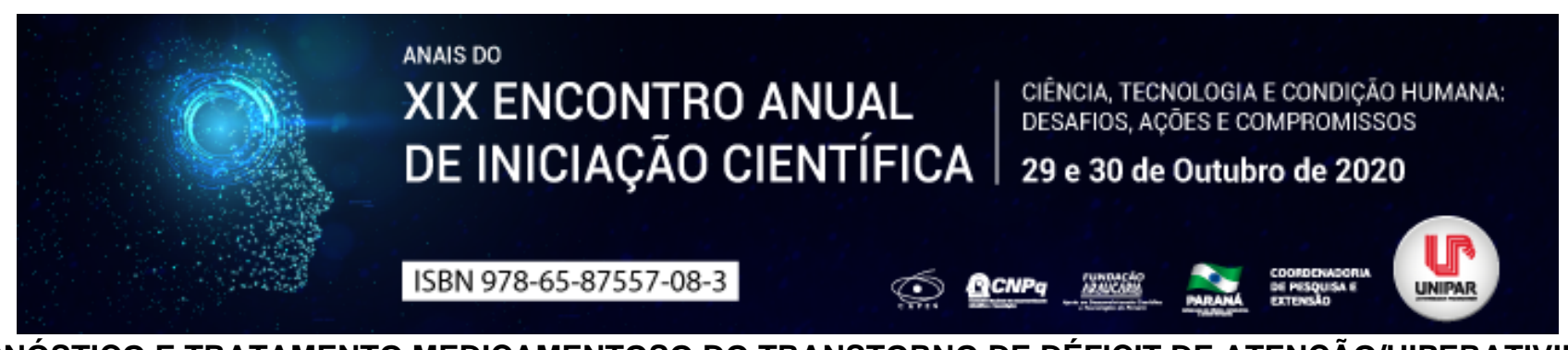

DIAGNÓSTICO E TRATAMENTO MEDICAMENTOSO DO TRANSTORNO DE DÉFICIT DE ATENÇÃO/HIPERATIVIDADE (TDAH): UM DESAFIO AOS PROFISSIONAIS DE SAÚDE

\author{
${ }^{1}$ FRANCINNY JUSTEN AMARAL , ${ }^{2}$ KAROLLINY PEREIRA CESAR, ${ }^{3}$ BRUNA LARISSA COSTA, ${ }^{4}$ DORA DE CASTRO \\ AGULHON SEGURA
}

\author{
${ }^{1}$ Acadêmica do Curso de Farmácia da UNIPAR \\ ${ }^{1}$ Acadêmica do Curso de Farmácia da UNIPAR \\ ${ }^{2}$ Acadêmica do Curso de Farmácia da UNIPAR \\ ${ }^{3}$ Docente da UNIPAR
}

Introdução: O transtorno do déficit de atenção e hiperatividade (TDAH) é um distúrbio neuropsiquiátrico frequentemente diagnosticado e tratado em crianças e adolescentes (SCAHILL; SCHWAB-STONE, 2000). O transtorno apresenta etiologia complexa e multifatorial com forte componente genético. É mais comum ser diagnosticado em meninos, porém afeta ambos os gêneros. É considerado um problema de saúde pública na medida em que relaciona-se com diversas áreas da sociedade, tais como, educação e inclusão social (BIEDERMAN et al., 2004). O diagnóstico possuí critérios específicos e deve ser feito por profissional capacitado, assim como o tratamento medicamentoso que requer indicação profissional especializada. Um medicamento frequentemente utilizado para o tratamento deste distúrbio é o metilfenidato (GREENHILL et al., 2006). Esses dois aspectos do transtorno do déficit de atenção e hiperatividade, diagnóstico e tratamento, apresentam-se como desafios para os profissionais de saúde, sobretudo, na sociedade atual na qual o sofrimento humano juntamente com as insatisfações cotidianas são transformados em doenças e tratados com medicamentos (CAPONI, 2009).

Objetivo: Abordar, com embasamento teórico de literatura especializada, aspectos relacionados ao diagnóstico e tratamento medicamentoso do transtorno de déficit de atenção e hiperatividade.

Desenvolvimento: As crianças com transtorno de déficit de atenção e hiperatividade (TDAH) possuem como principal característica a dificuldade de concentração. São hiperativas e muitas vezes apresentam impulsividade. Este transtorno pode comprometer o desempenho escolar na medida em que os envolvidos não são propensos a se concentrarem e seguirem instruções. Não raramente a singularidade dos portadores resulta em dificuldades no convívio familiar e no relacionamento com outras crianças. O diagnóstico é complexo, requer uma avaliação clínica detalhada englobando os sintomas presentes e passados bem como o grau de prejuízo funcional (POSNER; POLANCZYK; SONUGA-BARKE, 2020). O transtorno é definido como um padrão persistente de desatenção e/ou hiperatividade-impulsividade que interfere no funcionamento da vida diária e no desenvolvimento. Em crianças e adolescentes o diagnóstico é feito na presença de seis ou mais sintomas de desatenção e/ou hiperatividade e impulsividade. Tais sintomas são heterogenios e envolvem, por exemplo, inquietude, desatenção, dispersão, impulsividade, irritação e desorganização. Alguns questionários validados são utilizados na identificação desses sintomas. Já para o diagnóstico em jovens e adultos cinco sintomas já são suficientes para realizar o diagnóstico. Geralmente o tratamento é voltado para o uso de fármacos específicos. Os psicoestimulantes constituem a primeira escolha medicamentosa para tratamento dos sintomas. O metilfenidato bloqueia transportadores pré-sinápticos de dopamina e norepinefrina, e deste modo aumenta a transmissão das catecolaminas. Estudos demostram que o metilfenidato proporciona ganho de qualidade de vida ao portador. Uma meta-análise que incluiu mais de 10.000 crianças e adolescentes evidenciou que o metilfenidato apresentou efeito moderado à alto para redução dos sintomas observados por médicos e professores (CORTESE et al., 2018). Os principais efeitos colaterais do metilfenidato são classificados como leves, os mais comumente descritos são diminuição do apetite, insônia, boca seca e náuseas (GREENHILL et al., 2006). No entanto, verifica-se um aumento expressivo da produção e consumo mundial de metilfenidato. Em 1990 a produção mundial deste fármaco foi de 2,8 toneladas, saltando para 63 toneladas no ano de 2012 , sendo os Estados Unidos responsável por 97\% da produção total (ORTEGA et al., 2010). No Brasil um estudo realizado entre 2013 e 2014 identificou o metilfenidato como medicamento mais utilizado em doenças crônicas na faixa etária de 06 a 12 anos (PIZZOL et al., 2016). Esse aumento na produção do metilfenidato não está relacionado somente ao aumento de casos de transtorno do déficit de atenção e hiperatividade, e consequente aumento de seu uso para o tratamento. O diagnóstico complexo, com baixa especificidade, contribui para que ocorra indicação de uso de metilfenidato para pessoas que não possuem de fato tal transtorno. Além disso indivíduos saudáveis, sobretudo, estudantes e profissionais do meio acadêmico, estão fazendo uso de metilfenidato para obterem melhora no desempenho cognitivo (FARDIN; ANTUNES; ROCHA, 2015). O crescente uso de medicamentos por pessoas não doentes pode ser evidência da chamada farmaceuticalização: processo social no qual condições comportamentais e corporais, inerentes a vida humana, são consideradas passíveis de tratamento medicamentoso (BUSFIELD, 2015). 
Conclusão: $O$ transtorno do déficit de atenção e hiperatividade é uma doença que, devido sua característica de comprometer atividades intelectuais e cognitivas, traz grande prejuízo a qualidade de vida e potencialidades do portador. Trata-se de um transtorno com diagnóstico complexo que deve ser realizado por profissionais altamente qualificados e em contexto multidisciplinar. O metilfenidato parece ser a intervenção medicamentosa mais indicada para o tratamento, contudo o uso abusivo desta medicação por pessoas sadias, seja devido a diagnósticos errôneos ou a contextos sociais, tem contribuído para o expressivo aumento na produção desse psicofármaco.

\section{Referências}

BIEDERMAN, J. et al. Gender effects on attention-deficit/hyperactivity disorder in adults, revisited. Biological Psychiatry, v. 55, n. 7, p. 692 700, 2004.

BUSFIELD, J. Assessing the overuse of medicines. Social Science and Medicine, v. 131, p. 199 206, 2015.

CAPONI, S. Biopolítica e medicalização dos anormais. Physis Revista de Saúde Coletiva, v. 19, n. 2, p. 529 549, 2009.

CORTESE, S. et al. Comparative efficacy and tolerability of medications for attention-deficit hyperactivity disorder in children, adolescents, and adults: a systematic review and network metaanalysis. The Lancet Psychiatry, v. 5, n. 9, p. 727 738, 2018.

FARDIN, C. E.; ANTUNES, J.; ROCHA, D. A. Uso Indiscriminado do Metilfenidato para o aperfeiçoamento cognitivo em indivíduos saudáveis. Uningá Review, v. 23, p. 98 103, 2015.

GREENHILL, L. et al. Efficacy and safety of immediate-release methylphenidate treatment for preschoolers with ADHD. Journal of the American Academy of Child and Adolescent Psychiatry, v. 45, n. 11, p. 1284 1293, 2006.

ORTEGA, F. et al. A ritalina no Brasil: Produções, discursose práticas. Interface: Communication, Health, Education, v. 14, n. 34, p. 499 510, 2010.

PIZZOL, T. S. D. et al. Use of medicines and other products for therapeutic purposes among children in Brazil. Revista de Saúde Pública, v. 50, n. 02, p. 1 13, 2016.

POSNER, J.; POLANCZYK, G. V.; SONUGA-BARKE, E. Attention-deficit hyperactivity disorder. The Lancet, v. 395, n. 10222, p. $450 \quad 462,2020$.

SCAHILL, L.; SCHWAB-STONE, M. Epidemiology of ADHD in school-age children. Child and Adolescent Psychiatric Clinics of North America, v. 9, n. 3, p. 541 555, 2000. 


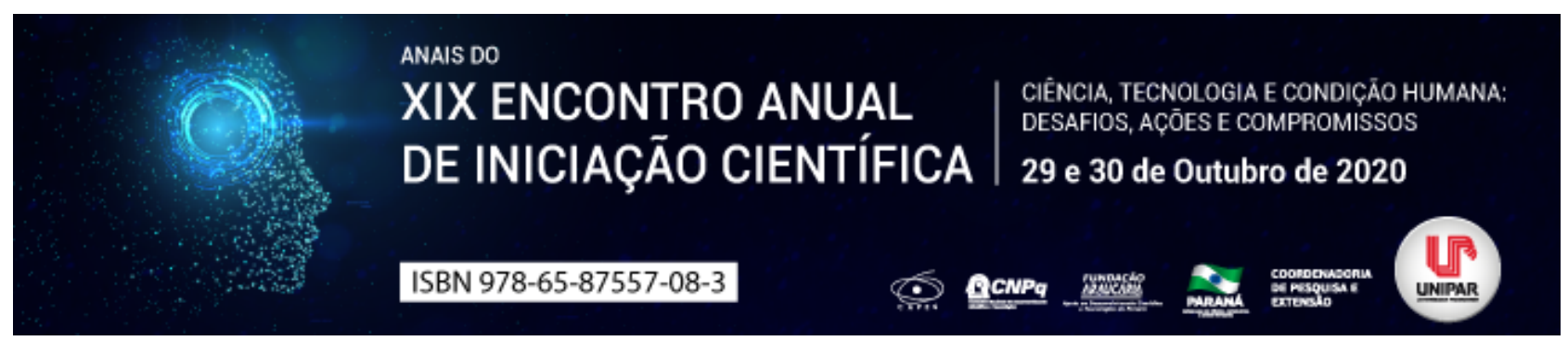

COVID-19 EM PEQUENOS ANIMAIS

\begin{abstract}
${ }^{1}$ ANA LUISA CANO, ${ }^{2}$ ADRIANE CORDEIRO TREVISANI, ${ }^{3}$ ISABELA CARVALHO DOS SANTOS, ${ }^{4}$ REGIANE PEREIRA BAPTISTA DA SILVA, ${ }^{5}$ DANIELA DIB GONCALVES
\end{abstract}

\author{
${ }^{1}$ Acadêmica do Curso de Medicina Veterinária - UNIPAR \\ ${ }^{1}$ Acadêmica do Curso de Doutorado Em Ciencia Animal Com Enfase Em Produtos Bioativos da UNIPAR- Taxista CAPES \\ ${ }^{2}$ Acadêmica do Curso de Doutorado Em Ciencia Animal Com Enfase Em Produtos Bioativos - Bolsista CAPES \\ ${ }^{3}$ Acadêmica do Curso de Doutorado Em Ciencia Animal Com Enfase Em Produtos Bioativos - Taxista CAPES \\ ${ }^{4}$ Docente da UNIPAR
}

Introdução: Os coronavírus (CoV) são um grupo de vírus de RNA de fita simples envelopados, que podem infectar pessoas e animais. Estes pertecem à subfamília Orthocoronavirinae, família Coronaviridae, e ordem Nidovirales (LIMONGI; OLIVEIRA, 2020). Os coronavírus dos grupos alfa e beta, geralmente, infectam mamíferos, enquanto os coronavírus gama e delta, geralmente, infectam aves e peixes (LOPES et al., 2020). Em dezembro de 2019, foi identificado, em pessoas que frequentaram um mercado atacadista de frutos do mar e de animais exóticos em Wuhan, China, a presença de um novo CoV, denominado SARS-CoV-2, responsável pela COVID-19 (LIMONGI; OLIVEIRA, 2020), que foi resultado de mutações ou recombinações virais que ofereceram ao vírus capacidade de sobressair-se do ciclo animal-animal e, através de hospedeiros intermediários, passaram a infectar humanos, rapidamente se espalhando pelo mundo de forma pandêmica (LOPES et al., 2020). O novo coronavírus utiliza a enzima conversora de angiotensina ACE2 como receptor, a mesma porta de entrada do SARS-CoV-1, causador da SARS que surgiu em 2013. Os animais de companhia ou pets, particularmente cães e gatos, ganharam muita visibilidade nesse contexto devido ao contato próximo com as pessoas e por apresentarem o receptor ACE2 com elevada identidade para as sequências de aminoácidos dos humanos (RISTOW; CARVALHO; GEBARA, 2020).

Objetivo: O objetivo deste trabalho foi buscar, por meio de pesquisas científicas registradas em diferentes bases de dados, informações a respeito da COVID-19 e sua relação com os animais de companhia, especialmente cães e gatos.

Desenvolvimento: Os membros da grande família Coronaviridae tendem a ser espécie-específicos e podem causar doenças respiratórias, gastrintestinais, hepáticas, renais e neurológicas em diferentes espécies animais, como cães, gatos, bovinos, suínos, equinos, aves, inclusive em seres humanos (DELAl et al, 2020). Em cães, o coronavírus entérico canino pode causar diarreia leve, enquanto que o coronavírus respiratório é parte do complexo respiratório canino, já nos gatos, o coronavírus felino é responsável pela peritonite infecciosa felina (PIF) (DELAl et al, 2020). No final de fevereiro de 2020, um cão macho, idoso de 17 anos, da raça Lulu da Pomerânia, que apresentava múltiplas comorbidades, residente em Hong Kong, no sudeste da China, foi testado como fraco positivo para SARS-CoV-2 nos resultados moleculares por reação em cadeia pela polimerase em tempo real (RT-PCR), revelando nos dados do Departamento de Agricultura, Pesca e Conservação (AFCD), sugerindo possivelmente uma transmissão humano-animal, já que, anteriormente, o tutor havia testado positivo (LOPES et al., 2020). O sequenciamento genético do SARS-CoV-2 encontrado no cão e nas pessoas próximas a ele que foram confirmadas infectadas, e as sequências virais foram muito semelhantes, indicando que o vírus se espalhou entre as pessoas do ambiente domiciliar e, consequentemente, pode ter infectado o cão (LOPES et al., 2020). Outra informação relevante é que esse cão não apresentou sinais clínicos característicos da doença e, possivelmente, não passou a ser considerado uma fonte de contaminação para outros animais e/ou seres humanos (LOPES et al., 2020). Em março de 2020, um gato doméstico da Bélgica, foi testado como forte positivo em amostras submetidas ao RT-PCR para diagnóstico de COVID-19. Nesse caso o animal desenvolveu alguns sinais clínicos sugestivos da doença, como diarreia, vômito e problemas respiratórios, o seu tutor também havia testado positivo para a doença após retornar de uma viagem ao norte da Itália. A aparente semelhança dos sintomas do felino com o dos humanos se deve, possivelmente, à similaridade nos receptores das células respiratórias, o que pode facilitar a entrada do vírus, tornando os gatos mais susceptíveis para desenvolver a doença (LOPES et al., 2020). Contudo, acredita-se que se trata de uma transmissão humano-animal (LOPES et al., 2020). Até o momento, sabe-se que a principal via de transmissão do vírus continua sendo por meio do contato entre pessoas (RISTOW; CARVALHO; GEBARA, 2020). Ainda assim, pessoas suspeitas ou confirmadas para COVID-19 devem minimizar o contato direto com seus pets para evitar alguma transmissão em potencial, e a principal razão é que o vírus pode ser indiretamente carreado pelo animal para uma pessoa não infectada funcionando como um lenço, copo, ou um objeto contaminado com o vírus (RISTOW; CARVALHO; GEBARA, 2020).

Conclusão: Atualmente, existem poucas evidências científicas de que os animais domésticos possam infectar-se com o SARSCoV-2. No momento, há alguns questionamentos sobre a possibilidade de transmissão humano-animal e de animais servirem como carreadores do vírus para outros animais ou humanos, não havendo, ainda, nenhuma informação científica comprovada de 
que cães e gatos sejam importantes transmissores na cadeia epidemiológica da COVID-19. Entretanto, alguns estudos apontam que gatos, possivelmente, são mais sensíveis ao vírus que cães, sendo necessário mais estudos e monitoramento contínuo de animais de estimação.

\section{Referências}

DELAI, R. R. et al. O novo coronavírus e os animais de companhia. Clínica Veterinária, v. 25, n. 146, p. 20-32, 2020.

LIMONGI, J. E.; DE OLIVEIRA, S. V. COVID-19 e a abordagem One Health (Saúde Única): uma revisão sistemática. Vigilância Sanitária em Debate: Sociedade, Ciência \& Tecnologia, v. 8, 22 maio, 2020.

LOPES, O. F. M. et al. COVID-19 e os animais domésticos: há alguma evidência de relação entre eles?. Journal of Health \& Biological Sciences, v. 8, n. 1, p. 1-6, 2020.

RISTOW, L. E.; CARVALHO, O. V.; GEBARA, R. R. COVID-19 in felines, their role in human health and possible implications for their guardians and health surveillance. Epidemiologia e Serviços de Saúde, v. 29, n. 3, p. e2020228, 2020.

Coordenadoria de Pesquisa e Extensão - COPEX

Departamento de Editoraçāo e Divulgaçāo Científica - DEDIC 


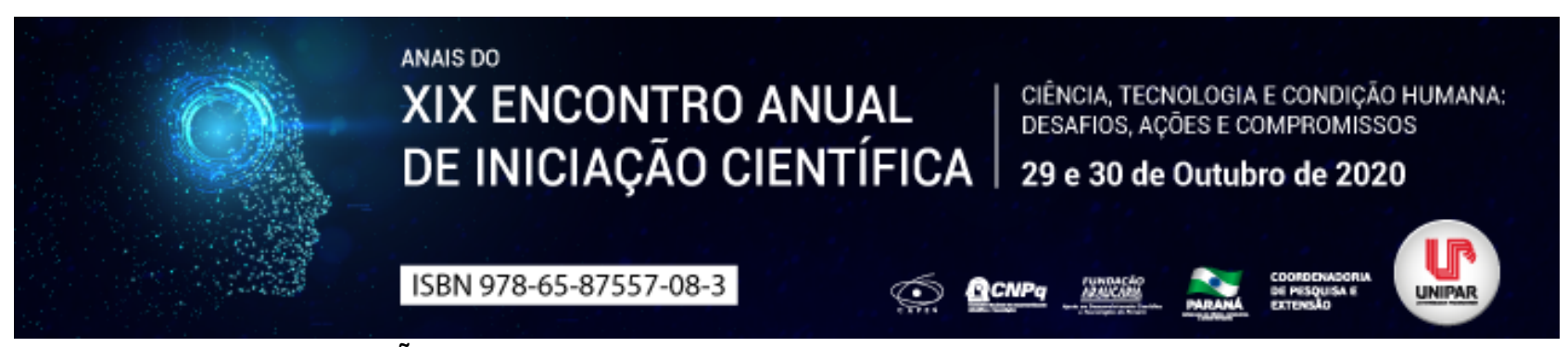

INDUÇÃO DE PUBERDADE EM NOVILHAS NELORE E CRUZADAS

\begin{abstract}
${ }^{1}$ ALECSANDRO SILVA DE LIMA ELIAS, ${ }^{2}$ CARLOS RENATO DE FREITAS GUAITOLINI, ${ }^{3}$ ALYSON LIBERALI ARAUJO, ${ }^{4}$ DANIELLE ANDRESSA OLIVEIRA SESTARI, ${ }^{5}$ ROSIARA ROSARIA DIAS MAZIERO
\end{abstract}

\author{
${ }^{1}$ Discente de Mestrado do programa de Pós-graduação em Ciência Animal - UNIPAR (Bolsa PIT-UNIPAR) \\ ${ }^{1}$ Acadêmico do Curso de Programa Nacional de Pos-doutorado -pnpd/capes da UNIPAR \\ ${ }^{2}$ Discente de Mestrado do programa de Pós-graduação em Ciência Animal - UNIPAR \\ ${ }^{3}$ Mestranda do PPG em Ciência Animal - TAXISTA PROSUP/CAPES - UNIPAR \\ ${ }^{4}$ Docente da UNIPAR
}

Introdução: A reprodução de bovinos no Brasil busca novas biotecnologias para que ocorra maior número de inseminações artificiais e gestações, com a diminuiçãodo período de serviço e, deste modo, aumentando a eficiência reprodutiva do rebanho. Uma das alternativas para melhorar a produtividade de um rebanho, é o adiantamento da idade reprodutiva dos animais, assim, estudos mostram que a substituição do dispositivo intravaginal, por progesterona injetável pode promover resultados interessantes, podendo ser uma estratégia para fazendas que não possuem o dispositivo, previamente utilizado, para induzir a ovulação (LEMES, 2018).

Objetivo: Revisar sobre os protocolos de indução da puberdade em novilhas.

Desenvolvimento: Na tentativa de se incrementar a quantidade de novilhas com corpo lúteo ao início da estação de monta, diversos tratamentos hormonais, com o uso de progesterona e estrógeno, foram desenvolvidos para induzir a primeira ovulação dessas fêmeas jovens (SÁ FILHO et al., 2015). Tal exposição pode modular o funcionamento do eixo hipotalâmico-hipofisáriogonadal, aumentando a secreção de gonadotrofinas e induzindo a puberdade.Os protocolos de indução de ciclicidade comumente utilizado em novilhas, geralmente consistem em expor o animal ao um implante de progesterona. Pelo fato de não ter um aumento significativo da taxa de prenhez, busca-se uma forma melhor de submeter às novilhas aos protocolos de inseminação artificial em tempo fixo (IATF). A exposição prolongada a um progestágeno, não é eficiente para aumentar a taxa de prenhez de novilhas pré-púberes e púberes submetidas à inseminação artificial em tempo fixo (PFEIFER et al. 2009). A produção da progesterona ocorre durante o ciclo estral normal seguido ou não de gestação por uma glândula transitória, o corpo lúteo, e sua função é preparar o endométrio para manter uma possível gestação. O ambiente uterino devidamente preparado pela progesterona fornece as condições mais favoráveis para o desenvolvimento do concepto (BINELLI, 2004). Várias formas de introduzir este hormônio vêm sendo utilizado nos protocolos de IATF e os efeitos benéficos da progesterona estão associados a certas categorias animais. Além disso, o uso desta biotecnologia reprodutiva deve ser direcionado estrategicamente (TORTORELLI 2018).

Conclusão: A chance de concepção em novilhas é maior a partir do momento que ela esteja ciclando normalmente, isto é, púberes, logo se as novilhas tiverem uma condição corporal boa, aumenta a qualidade do parto e consequentemente bezerros de melhor qualidade, gerando aprimoramento na produção e maior renda aos produtores.

\title{
Referências
}

BARUSELLI, P.S.; et al. Estratégias para aumentar a produção de embriões em bovinos. Anais do XXIII Congresso Brasileiro de Reprodução Animal (CBRA-2019); Gramado, RS, 15 a 17 de maio de 2019.

BINELLI, M.; et al. Atualizações sobre estratégias antiluteolíticas para o aumento da fertilidade em bovinos. Simpósio Internacional de Reprodução Animal Aplicada, v. 1, n. 2004, p. 191-198, 2004.

FREITAS, B. G.; Influência do desenvolvimento corporal na resposta aos programas de sincronização para inseminação artificial em tempo fixo em novilhas Nelore de 14 meses de idade. DISSERTAÇÃO, Universidade de São Paulo, 2015.

Instituto Brasileiro de Geografia e Estatística IBGE. 2017. Disponível em: https://www.ibge.gov.br/ Acesso em: 20 jul. 2020.

LEMES, K.M.; Comparação da eficiência de diferentes formulações à base de progesterona para indução da puberdade e desempenho reprodutivo em novilhas da raça Nelore. 2018. Tese de Doutorado. Universidade de São Paulo.

PFEIFER; et al. Efeito da duração do tratamento com progestágeno e da maturidade sexual na taxa de prenhez em novilhas de corte: avaliação econômica e biológica. Bras. Zootec., v.38, n.7, p.1205-1210, 2009.

SÁ FILHO, M. F.; et al. Impact of progesterone and estradiol treatment before the onset of the breeding period on reproductive performance of Bosindicus beef heifers. Animal reproductionscience, 30 jun. 2015.

TORTORELLI, G.; A utilização de progesterona injetável, pós inseminação artificial em tempo fixo, em vacas de leite de alta produção como estratégia para melhoria da eficiência reprodutiva em propriedade leiteira. 2018. Dissertação 
(Mestrado em Gestão e Inovação na Indústria Animal) - Faculdade de Zootecnia e Engenharia de Alimentos, Universidade de São Paulo, Pirassununga, 2018. doi:10.11606/D.74.2019.tde-24042019-110259. Acesso em: 2019-08-16.

Coordenadoria de Pesquisa e Extensão - COPEX

Departamento de Editoraçāo e Divulgaçāo Científica - DEDIC 


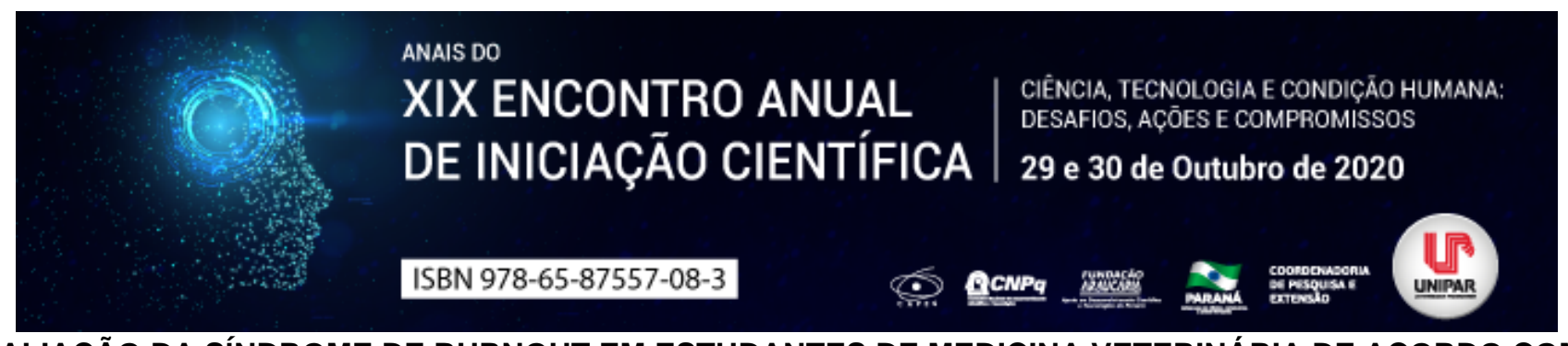

\title{
AVALIAÇÃO DA SÍNDROME DE BURNOUT EM ESTUDANTES DE MEDICINA VETERINÁRIA DE ACORDO COM O GÊNERO
}

\author{
${ }^{1}$ Victor Luiz Gomes Batista, ${ }^{2}$ ANA CLARA AGUILAR SANTOS, ${ }^{3}$ DÉBORA RIBEIRO ORLANDO, ${ }^{4}$ ERIC FRANCELINO \\ ANDRADE
}

${ }^{1}$ Acadêmico UFVJM/PIBIC/CNPq

${ }^{1}$ Acadêmico UFVJM

${ }^{2}$ Docente UFVJM

${ }^{3}$ Docente UFVJM

Introdução: A Síndrome de Burnout (SB) é uma resposta prolongada aos fatores estressantes emocionais e de relações pessoais que se desenvolvem de forma crônica no ambiente laboral e é definido pelas três dimensões da exaustão, descrença e ineficácia (MASLACH; SCHAUFELI; LEITER, 2001). Desta forma, considerando que a SB pode contribuir para a desistência e retenção no curso superior, torna-se importante investigar a prevalência desta síndrome em estudantes.

Objetivos: Avaliar a prevalência de síndrome de SB em estudantes de Medicina Veterinária considerando o gênero.

Materiais e Métodos: O presente estudo foi aprovado pela Comissão de Ética em Pesquisa (CEP) sob protocolo 29356620.4.0000.5108. Participaram do estudo 79 estudantes (65 mulheres e 14 homens) do curso de Medicina Veterinária da Universidade Federal dos Vales do Jequitinhonha e Mucuri, com idade entre 18 e 45 anos. Para avaliação da SB, foi utilizado o Maslach Burnout Inventory Student Survey, que contém 15 questões distribuídas em três dimensões (1. Exaustão Emocional; 2. Descrença; 3. Eficiência Acadêmica). Cada questão apresenta a possibilidade de resposta em escala Likert de sete itens (0 nunca a 6 sempre). Desta forma, quanto maior o valor do somatório obtido em cada dimensão, ou no total, maior o escore de SB apresentado pelo indivíduo. Além disso, para cada dimensão, adotou-se uma classificação quanto ao nível de Burnout. Assim, a exaustão emocional, avaliada usando o somatório das cinco questões, foi classificada como baixa em valores de 0 a 9 , moderada em valores de 10-14 ou alta quando o somatório foi superior a 14. Para a dimensão descrença, calculada usando o somatório de quatro questões a classificação baixa foi atribuída para o resultado do somatório entre 0 e 1, moderado entre 2 e 6 e alta para valores acima de 7. Na dimensão eficiência acadêmica, que contém seis questões, as classificações foram as seguintes: baixa $\leq$ 22; moderada $=23-27$ e alta $\geq 28$ ). Os dados foram submetidos a Análise de Variância (ANOVA) e as médias comparadas por teste $t$ de student. A frequência de indivíduos situados em cada nível da SB de acordo com o gênero, foi analisada pelo teste do qui-quadrado. Foram consideradas diferenças significativas um nível de probabilidade menor que $5 \%(p<0,05)$.

Resultados: Foi observado que na dimensão Exaustão Emocional, houve maior frequência de mulheres classificadas com nível alto de SB em relação a homens, enquanto esta proporção foi inversa no nível baixo e moderado $(p<0,05)$. Na dimensão

Descrença observou-se maior frequência de mulheres situadas no nível alto e maior frequência de homens no nível baixo $(p<$ $0,05)$. Já na dimensão Eficiência Acadêmica houve maior frequência de indivíduos do sexo masculino situados no nível alto ( $p$ $<0,05)$ enquanto não se observou diferença significativa para as demais classificações. Os valores médios na dimensão Exaustão Emocional foram maiores em mulheres que em homens $(p<0,05)$. Não houve diferença significativa entre os sexos para as médias obtidas nas dimensões Descrença e eficiência acadêmica

Discussão: Os resultados encontrados corroboram com os obtidos por Medeiros et al. (2018) que observaram que mulheres apresentavammaiores escores de SB nas dimensões exaustão emocional e descrença . Conforme escrito por Seeman (1997) os estrógenos, principalmente o estradiol possui um efeito neuroprotetor e neutralizador de efeitos dos glicocorticóides que causam o estresse. Porém, as variações cíclicas deste hormônio durante os ciclos menstruais podem alterar sua função, causando respostas de estresse maiores nas mulheres.

Conclusão: Estudantes de Medicina Veterinária do sexo feminino apresentam maiores níveis de SB com elevados escores de exaustão emocional e descrença e baixos escores de eficiência acadêmica

\section{Referências}

DEARY, Ian John; WATSON, Roger; HOGSTON, Richard. A longitudinal cohort study of burnout and attrition in nursing students.Journal of Advanced Nursing, v. 43, n. 1, p. 71 81, jul. 2003. Disponível em: https://pubmed.ncbi.nlm.nih.gov/12801398/. Acesso em: 8 mai. 2019.

GARCIA, Lenice Pereira; BENEVIDES-PEREIRA, Ana Maria Teresa. Investigando o Burnout em Professores Universitários. Revista Eletrônica InterAçãoPsy, v.1, n.1, p.76-89, ago. 2003. Disponível em:https://docplayer.com.br/11762483-Garcia-I-p-etal-investigando-o-burnout-em-professores-universitarios76.html. Acesso em: 16 jul.2020. 
MASLACH, Christina; SCHAUFELI, Wilmar; LEITER, Michael. Job burnout. Annual review of psychology, v. 52, n. 1, p. 397422, fev. 2001. Disponível em: https://www.annualreviews.org/doi/full/10.1146/annurev.psych.52.1.397. Acesso em: 20 jul. 2020. MEDEIROS, Mirna Rossi Barbosa; CAMARGO, José Fernando; BARBOSA, Luiza Augusta Rossi; CALDEIRA, Antônio Prates. Saúde Mental de Ingressantes no Curso Médico: uma Abordagem segundo o Sexo. Revista Brasileira de Educação Médica, v. 42, n.3, p. 214-221, jul./set. 2018. Disponível em: https://doi.org/10.1590/1981-52712015v42n3rb20170008. Acesso em: 16 jun. 2020.

REIS, Clara Figueira ; MIRANDA, Gilberto José; FREITAS, Sheizi Calheira. Ansiedade e Desempenho Acadêmico: Um Estudo com Alunos de Ciências Contábeis. Advances in Scientific and Applied Accounting, v.10, n. 3, p. 319-333, Set./Dez. 2017. Disponível em:https://asaa.anpcont.org.br/index.php/asaa/article/download/356/194. Acesso em: 17 jul. 2020.

SEEMAN, Mary Violette. Psychopathology in women and men: Focus on female hormones. The American Journal of Psychiatry, v. 154, n. 12, p. 1641-1647, dez. 1997. Disponível em: https://doi.org/10.1176/ajp.154.12.1641. Acesso em: 17 jul. 2020.

Coordenadoria de Pesquisa e Extensão - COPEX

Departamento de Editoraçāo e Divulgaçāo Científica - DEDIC 


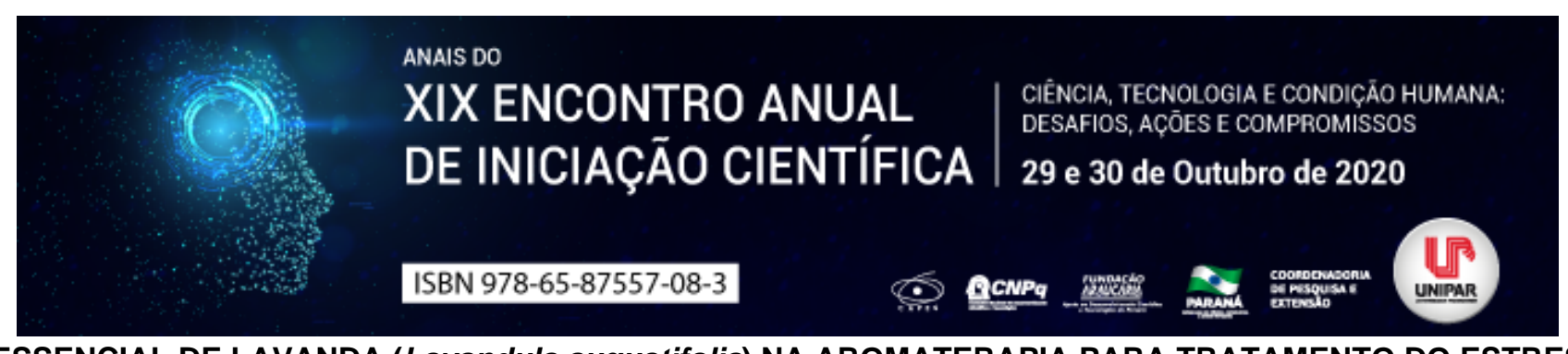

ÓLEO ESSENCIAL DE LAVANDA (Lavandula augustifolia) NA AROMATERAPIA PARA TRATAMENTO DO ESTRESSE EM ANIMAIS

\begin{abstract}
${ }^{1}$ MARCO AURELIO CUNHA DEL VECHIO, ${ }^{2}$ KAROLAINE BEZERRA, ${ }^{3}$ MARIANA HACHICHO ALMEIDA, ${ }^{4}$ FERNANDA SANDRI, ${ }^{5}$ DANIELA DIB GONÇALVES, ${ }^{6}$ LIDIANE NUNES BARBOSA
\end{abstract}

\author{
${ }^{1}$ Médico Veterinário, Mestrando em Ciência animal, bolsista PROSUP/CAPES, UNIPAR \\ ${ }^{1}$ Médico Veterinário, Mestrando em Ciência animal, bolsista PROSUP/CAPES, UNIPAR \\ ${ }^{2}$ Discente de Nutrição, PIBIC, UNIPAR \\ ${ }^{3}$ Discente de Nutrição, PIBIC, UNIPAR \\ ${ }^{4}$ Docente do programa de Pós-graduação em Ciência Animal, UNIPAR \\ ${ }^{5}$ Docente do programa de Pós-graduação em Ciência Animal, UNIPAR
}

Introdução: A aromaterapia é a ciência que estuda a terapêutica em que se utilizam óleos essenciais, no tratamento e/ou prevenção de problemas físicos, psicológicos e energéticos, visando proporcionar o bem-estar tanto físico como mental (Laszo, 2008). Alguns óleos essenciais podem minimizar os sintomas do estresse, contribuindo, para um equilíbrio e melhora na qualidade de vida (Hoare, 2010). As plantas com propriedades terapêuticas constituem uma importante fonte de compostos biologicamente ativos a qual necessitam de estudos (OLIVEIRA et al., 2006).

Objetivo: Contribuir para estudos relacionados a aromaterapia em animais utilizando a lavanda (Lavandula augustifolia) no controle do estresse melhorando a qualidade de vida.

Desenvolvimento: Estudos relacionados ao óleo essencial de lavanda (Lavandula augustifolia) demonstram que a exposição de cães ao aroma proporciona o relaxamento e alivio da excitação causada por viagens longas ou a locais novos (Graham et al., 2005). Os estudos de (Clarence et al., 2012) demostram que 15 minutos de aromaterapia utilizando o óleo essencial de lavanda (L. augustifolia) proporcionou a redução da frequência cardíaca em equinos em uma pesquisa relacionada o controle do estresse. O uso do óleo essencial da lavanda proporcionou efeito sedativo em ratos de laboratório e ovelhas (Buchbauer et al., 1991; Hawken et al., 2011). Herz 2009, relata que a lavanda é capaz de restaurar o controle e regular as funções corporais no sistema nervoso parassimpático, após uma resposta de fuga ou luta proporcionando relaxamento. Clarence et. al, (2012) referem que a aromaterapia utilizando lavanda (L. augustifolia) poderia auxiliar na redução do estresse em cavalos durante exames e/ou quando estão em treinamento para competições, melhorando a recuperação dos animais. Existem diversas hipóteses farmacológicas sobre a ação e efeitos dos aromas no humor, fisiológia e comportamento, devido a capacidade direta e indireta do aroma interagir e afetar o sistema nervoso autônomo, central, imune e/ou endócrino (Lis-Balchin \& Hart, 1999). Em estudos com animais notou-se que o óleo essencial da lavanda tem efeito sedativo (Buchbauer et al., 1993) anestésico local (Ghelardini et al., 1999). O linalol presente na lavanda afeta os neurotransmissores autônomos reduzindo a pressão arterial (Tanida et al., 2006).

Conclusão: Pesquisas utilizando o óleo essencial de lavanda (Lavandula augustifolia) para melhorar a qualidade de vida dos animais abrem portas na medicina veterinária na busca por tratamentos alternativos, há necessidade de pesquisas para ampliar essa área, devido a escassez de dados científicos relacionados a aromaterapia em animais.

\title{
Referências
}

BUChBAUER, G., JIROVETZ, L., JÄGER, W., DIETRICH, H., PLANK, C. Aromatherapy: evidence for sedative effects of the essential oil of lavender after inhalation. Zeitschrift für Naturforschung C. v.46, p. 1067-72, Nov./Dec. 1991.

BUCHBAUER, G., JIROVETZ, L., JAGER, W., PLANK, C., DIETRICH, H. Fragrance compounds and essential oils with sedative effects upon inhalation. Journal of Pharmaceutical Sciences. v. 82, p. 660 664, Jun. 1993.

CLARANCE, E. F., HARRY, F. K., JUSTIN, B. Effect of Lavander Aromatherapy on Acute-Stressed Horses. Journal Of Equipe Veterinary Science. Los Angeles, v. 33, p. 67-69, Jun. 2012.

GRAHAM, L., WELLS, D.L., HEPPER, P.G. The influence of olfactory stimulation on the behaviour of dogs housed in a rescue shelter. Applied Animal Behaviour Science. 91(1-2):143-53, May. 2005.

GHELARDINI, C., GALEOTTI, N., SALVATORE, G., MAZZANTI, G. Local anaesthetic activity of the essential oil of Lavandula angustifolia. Planta Medica. v. 65, p. 700 703, Dec. 1999.

HAWKEN, P., FIOL, C., BLACHE, D.B. Behavioral reactivity to psychosocial stress determines the effects of lavender oil on anxiety in sheep. Journal Of Animal Science. v. 89, p. 10, Jan. 2011.

HERZ, R.S. Aromatherapy facts and fiction: a scientific analysis of olfactory effects on mood, physiology and behavior. International Journal Of Neuroscience. v. 119, p. 263-90, Aug. 2009. 
HOARE, J. Guia completo de Aromaterapia. São Paulo: Editora Pensamento, 2010.

LASZLO, F. Curso Aromaterapia. Modulo I. Minas gerais, 2008

LIS-BALCHIN, M., HART, S. Studies on the mode of action of the essential oil of lavender (Lavandula angusifolia P. Miller). Phytotherapy Research. v. 13, p. 540 542, Sep. 1999.

OLIVEIRA, R. A. et al. Estudo da interferência de óleos essenciais sobre a atividade de alguns antibióticos usados na clínica. Revista Brasileira de Farmacognosia, v. 16, n. 1, p. 77-82, Mar. 2006.

TANIDA, M., NIIKIMA, A., SHEN, J., NAKAMURA, T., NAGAI, K. Olfactory stimulation with scent of lavender oil affects autonomic neurotransmission and blood pressure in rats. Neuroscience Letters. v. 398 (1 2 2), p. 155 160, May. 2006.

Coordenadoria de Pesquisa e Extensão - COPEX

Departamento de Editoraçāo e Divulgaçāo Científica - DEDIC 


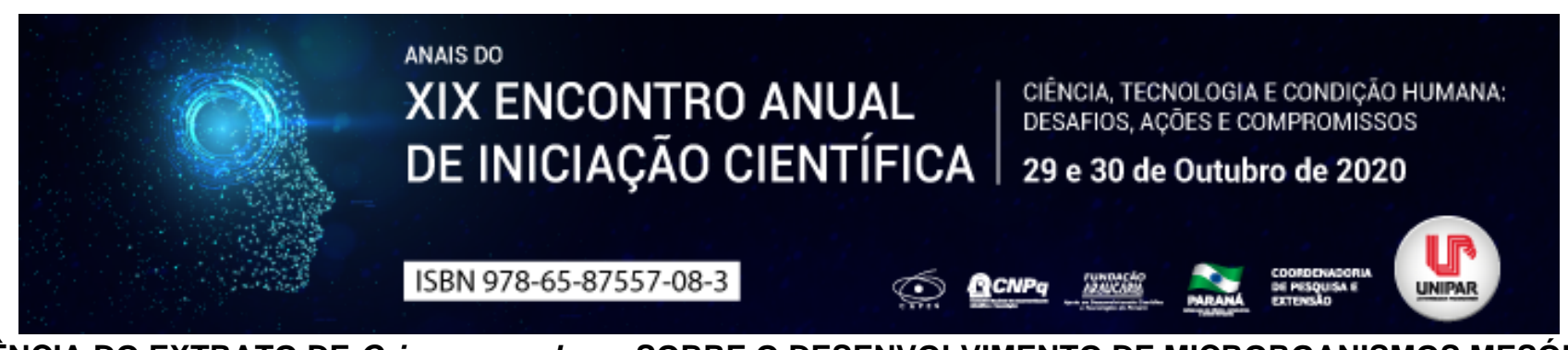

INFLUÊNCIA DO EXTRATO DE Origanum vulgare SOBRE O DESENVOLVIMENTO DE MICRORGANISMOS MESÓFILOS E PSICROTRÓFICOS EM QUEIJO FRESCAL

\author{
${ }^{1}$ ISABELA CARVALHO DOS SANTOS, ${ }^{2}$ MARCO AURELIO CUNHA DEL VECHIO, ${ }^{3}$ GEISIELE GOMES DA SILVA, ${ }^{4}$ NATHALIA \\ GOMES EKO LEGNANI, ${ }^{5}$ GABRIELLE IZIDORO GAZOLLA, ${ }^{6}$ LIDIANE NUNES BARBOSA
}

\author{
${ }^{1}$ Doutoranda PPG em Ciência Animal com Ênfase em Produtos Bioativos/ Bolsista - Prosup/CAPES \\ ${ }^{1}$ Mestrando PPG em Ciência Animal com Ênfase em Produtos Bioativos/ Taxista - Prosup/CAPES \\ ${ }^{2}$ Discente de Nutrição, PIBIC, UNIPAR \\ ${ }^{3}$ Discente de Nutrição, PIC, UNIPAR \\ ${ }^{4}$ Nutricionista autônoma \\ ${ }^{5}$ Docente da UNIPAR
}

Introdução: O queijo frescal é popularmente conhecido, além de ser um dos mais produzidos e comercializados do Brasil, possui um sabor bem suave e um alto teor de umidade, porém, como grande parte dos alimentos de origem animal, se deterioram com facilidade por vários fatores, dentre eles, a contaminação microbiana presente no alimento (PINTO et al., 2011). Os mesófilos são microrganismos presentes em alimentos de origem animal, e têm o poder de se multiplicar em temperaturas entre $10^{\circ} \mathrm{C}$ e $45^{\circ} \mathrm{C}$ e estão associados à qualidade e à forma de conservação do produto, já as bactérias psicrotróficas podem se multiplicar em temperaturas abaixo de $7^{\circ} \mathrm{C}$ (FERREIRA; LIMA; COELHO, 2014). Os extratos de plantas podem ser extraídos de suas raízes, folhas e ramos, estes extratos apresentam compostos como o carvacrol, timol, e carvona, originados de seu metabolismo secundário, que possuem atividade antimicrobiana, mostrando uma alternativa natural para aumentar a vida de prateleira dos alimentos (POMBO et al., 2018). As plantas utilizadas como condimentos também possuem substâncias antibacterianas, dentre elas, o orégano (Origanum vulgare), que possui compostos fenólicos como o timol e o carvacrol (POMBO et al., 2018).

Objetivo: Avaliar a atividade do extrato do orégano sobre microrganismos mesófilos e psicrotróficos, durante a vida de prateleira do queijo frescal.

Material e Métodos: O extrato hidroalcoólico a $70^{\circ}$ de orégano, foi obtido pela adição do respectivo solvente ao orégano, com posterior homogeneização e remoção deste sob pressão reduzida, então, o extrato foi liofilizado e conservado em freezer (PITARO; FIORANI; JORGE; 2012). O queijo frescal foi preparado em laticínio de pequeno porte com utilização de leite pasteurizado, além da formulação inicial (controle sem extrato), foram fabricados também queijos adicionados do extrato de orégano em pó: T1 $(0,5 \mathrm{~g}$ de extrato de orégano $/ \mathrm{Kg})$, T2 $(1 \mathrm{~g} / \mathrm{Kg})$ e T3 $(3 \mathrm{~g} / \mathrm{Kg})$, definidas com base em testes com o extrato do orégano in vitro onde a concentração inibitória mínima do extrato foi igual a $500 \mathrm{mg} / \mathrm{ml}$. Considerando o prazo de consumo do produto, as análises foram realizadas no $1^{\circ}$ dia após a fabricação, $5^{\circ}$ e $8^{\circ}$, sendo as amostras acondicionadas em embalagens fechadas à temperatura de $4^{\circ} \mathrm{C}$. Foram analisadas três amostras referentes a cada concentração, em duplicata. A partir do alimento foram preparadas diluições decimais seriadas. Para os mesófilos, foi aplicada a técnica Pour Plate em Plate Count Agar (PCA), onde $1 \mathrm{ml}$ de cada diluição foi depositada em placa estéril, seguida de adição de volume de aproximadamente 20 ml de PCA fundido. Com a homogeneização e solidificação do ágar, as placas foram incubadas (35ㄷ $/ 48 \mathrm{~h})$, e para a contagem de psicrotróficos, foi realizada a semeadura de $0,1 \mathrm{ml}$ de cada diluição na superfície de placas de PCA e distribuição com alça de Drigalski; após incubação ( $7^{\circ} \mathrm{C} / 10$ dias), a contagem das unidades formadoras de colônia (UFC) foi realizada nas placas contendo entre 25 e 250 UFC e a obtenção dos valores realizada segundo Morton (2001). Posteriormente os valores foram transformados e expressos em Log UFC/g. A análise estatística dos dados foi efetuada por meio da análise descritiva das variáveis em estudo, mediante a distribuição de frequência absoluta e relativa para as variáveis categóricas e medidas de tendência central (média \pm erro padrão da média) para as variáveis contínuas.

Resultados: Para as bactérias mesófilas das amostras de queijo controle e dos queijos tratados no primeiro dia apresentou uma variação de 5,60 a 5,86 log UFC/g; já no quinto, variou de 6,62 a 6,72 log UFC/g e no oitavo, de 7,32 a 7,50 log UFC/g. Nas bactérias psicrotróficas a contagem variou de 5,72 a 5,83 log UFC/g, no primeiro dia, já no quinto, de 6,49 a 6,60 log UFC/g, e no oitavo, a variação foi de 7,52 a 7,67 log UFC/g, atestando o crescimento destas bactérias, nas amostras controle, T1, T2 e T3, com aumento gradativo em função dos dias de armazenamento, não havendo diferença estatística entre os tratamentos.

Discussão: Rosa (2004) analisou carga bacteriana psicrotrófica do queijo minas frescal através da técnica de semeadura por profundidade em PCA encontrando uma carga bacteriana de 5,67 log UFC/g, e em relação aos mesófilos, utilizando a mesma técnica, encontrou carga bacteriana de 6,48 log UFC/g, resultados similares aos do presente trabalho. Já Sangaletti et al. (2009), encontraram uma contaminação de psicrotróficos e mesófilos, no primeiro dia de armazenamento, inferior às encontradas neste 
trabalho, com valores médios de 3,13 e 3,75 logs UFC/g, respectivamente, e apenas no décimo dia os valores médios alcançaram as médias encontradas neste trabalho. De acordo com a RDC no 12 (BRASIL, 2001), não há um valor préestabelecido para estes microrganismos em queijos com alto teor de umidade, mas eles servem de indicadores da qualidade higiênico-sanitária, estado de conservação e manipulação do leite utilizado na fabricação do queijo, sendo o ponto mais importante na determinação da qualidade do leite e dos seus derivados (FERREIRA; LIMA; COELHO, 2014).

Conclusão: As concentrações de extrato de orégano utilizadas não apresentaram atividade inibitória sobre o desenvolvimento de microrganismos mesófilos e psicrotróficos, portanto a adição deste extrato não favorece condições para o aumento da vida de prateleira deste produto alimentício.

\section{Referências}

BRASIL. Decreto n 3029, de 16 de abril de 1999. Resolução-RDC n 12, de 02 de janeiro de 2001 . Estabelece critérios e padrões microbiológicos para alimentos.

Diário Oficial da União, Brasília, 2001

FERREIRA H.; LIMA H.; COELHO T. Microrganismos indicadores em alimentos de origem animal. Universidade Federal Rural do Semiárido UFERSA - Programa de Pós-graduação em Ciência Animal PPGCA. 2014

MORTON, R. D. Aerobic Plate Count. In: DOWNES F. P; ITO, K. (Eds). Compendium of Methods for the Microbiological Examination of Foods. Washington:Apha, 2001. p. 63-67

PINTO, F. G. S. et al. Qualidade microbiológica de queijo minas frescal comercializado no município de Santa Helena, PR, Brasil. Arquivos do Instituto Biológico, São Paulo, v. 78, n. 2, p. 191-198, abr./jun., 2011

PITARO, S. P.; FIORANI, L. V.; JORGE, N. Potencial antioxidante dos extratos de manjericão (Ocimum basilicum Lamiaceae) e orégano (Origanum vulgare Lamiaceae) em óleo de soja. Revista Brasileira de Plantas Medicinais, Paulínia, p. 686- 691, 2012 POMBO, J. C. P. et al. Efeito antimicrobiano e sinergístico de óleos essenciais sobre bactérias contaminantes de alimentos. Segurança Alimentar e Nutricional, Campinas, v. 25, n. 2, p. 108-117, 2018

ROSA, V. P. Efeitos da atmosfera modificada e da irradiação sobre as

características microbiológicas, físico-químicas e sensoriais do queijo Minas

frescal. Dissertação (Mestrado em Ciência e Tecnologia de Alimentos) - Escola Superior de Agricultura Luiz de Queiroz, Universidade de São Paulo, 2004

SANGALETTI, N. et al. Estudo da vida útil do queijo minas. Ciência e Tecnologia

de Alimentos, v, 29 n. 2 p. 262-269, Campinas, 2009 


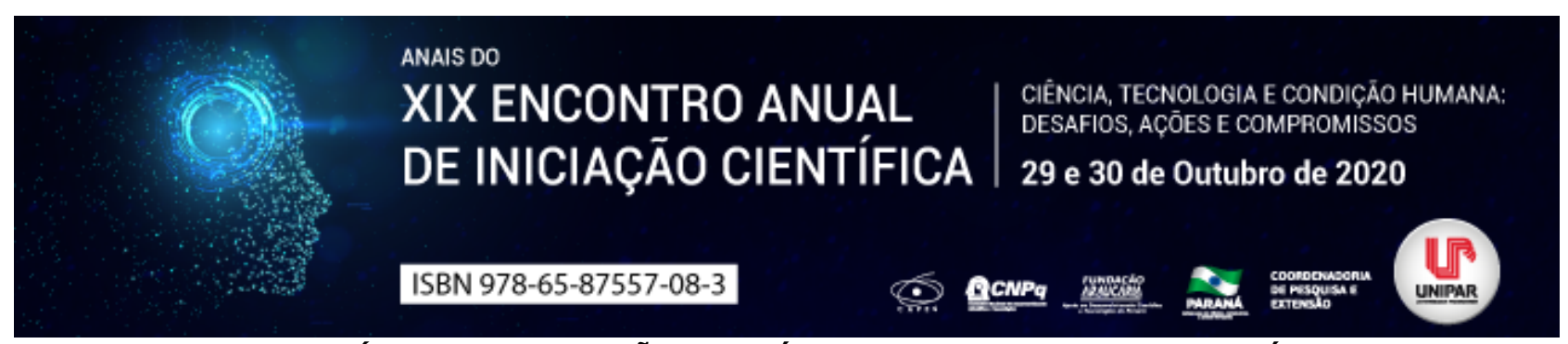

FIBROSE CÍSTICA: ALTERAÇÕES GENÉTICAS, MOLECULARES E BIOLÓGICAS

${ }^{1}$ LEONARDO LUIZ CASTELLI JUNIOR, ${ }^{2}$ BEATRIZ CORRÊA CERNKOVIC, ${ }^{3}$ DENISE ALVES LOPES, ${ }^{4}$ IRINEIA PAULINA BARETTA, ${ }^{5}$ JOSÉ RICARDO SKOLMOVSKI DA SILVA, ${ }^{6}$ ROSILEY BERTON PACHECO

\author{
${ }^{1}$ Acadêmico bolsista do PIBIC/UNIPAR \\ ${ }^{1}$ Acadêmico do Curso de Medicina da UNIPAR \\ ${ }^{2}$ Docente da UNIPAR \\ ${ }^{3}$ Docente da UNIPAR \\ ${ }^{4}$ Docente da UNIPAR \\ ${ }^{5}$ Docente da UNIPAR
}

Introdução: A Fibrose Cística (FC), também designada como mucoviscidose, ou popularmente Doença do beijo salgado, tem característica autossômica recessiva, e é apresentada por manifestações principalmente no trato respiratório, digestório e no pâncreas (CABELLO, 2011). Euro-descendentes são a população mais suscetível, sendo a FC a doença genética de caráter autossômico recessivo mais frequente nessa população, com incidência de 1 a cada 2.500 nascidos vivos (PEREIRA; KIEHL; SANSEVERINO, 2011). No entanto o que mais preocupa é o tratamento sintomático da doença, característica de uma doença sem cura, sendo necessário diagnóstico precoce para aumentar a expectativa de vida (SANTOS et al, 2017). Concomitantemente a possibilidade de morte precoce do paciente com $\mathrm{FC}$, e a taxa de apenas $50 \%$ de sobrevida em pacientes da terceira idade segundo o Ministério da Saúde (2017), é extremamente importante estudos para aprofundamento desta comorbidade.

Objetivo: Compreender os principais processos biológicos, genéticos e moleculares freneticamente alterados nos indivíduos acometidos com Fibrose Cística.

Desenvolvimento: De forma sólida, a Fibrose Cística está relacionada com o gene CFTR (Cystic Fibrosis Transmembrane Condutance Regulator), o qual se encontra no braço longo do cromossomo 7, e sua expressão nas células epiteliais, onde ocorre a codificação da proteína CFTR a partir desse gene. Essa proteína está relacionada com o transporte de íons cloro através da membrana plasmática, modulação de outros canais iônicos, entre outras funções, as quais são alteradas na FC e culminam nos processos biológicos típicos da doença (PEREIRA; KIEHL; SANSEVERINO, 2011). Para que ocorra a FC, o gene CFTR deve necessariamente ter sofrido uma mutação, a qual é classificada em seis tipos de acordo com os processos envolvidos nela, podendo então: I ocorrer um defeito na transição da proteína; II retenção da proteína no reticulo endoplasmático e assim é degradada; III ocorrer defeito na regulação da proteína; IV ocorrer um defeito de condutância; $V$ reduzir o número dos canais de cloreto; ou VI alterar a estabilidade da CFTR (PESSOA et al, 2015). A partir de uma dessas alterações do gene pode-se então gerar as proteínas CFTR defeituosas e assim culminar no processo fisiológico da doença, onde há diminuição da secreção de cloreto e aumento da absorção de sódio, compondo então de forma anômala os mucos. Este muco alterado acumula-se e obstrui os ductos dos órgãos afetados (principalmente pulmão, pâncreas e intestino) e a partir disso as devidas manifestações. No pulmão a FC se inicia com retenção, nos bronquíolos, de secreção viscosa e espessa, tendo alterações no muco de forma secundaria, e assim ocorrendo as manifestações de hipersecreção, tosse crônica, entre outras, tornado este órgão susceptível também a infecções bacterianas, e de forma mais grave podendo ter broquiectasia e insuficiência pulmonar. No pâncreas a FC gera acidez, alterações na passagem de aníons e redução do conteúdo hídrico, ocorrendo a obstrução dos ductos e por isso é observado frequentemente fibrose pancreática. Já as alterações intestinais da FC como diarreia crônica e fezes volumosas, gordurosas, brilhantes e fétidas, são secundarias as alterações pancreáticas, na qual a obstrução dos canalículos não permite que o conteúdo enzimático chegue ao duodeno e realize os processos digestórios adequadamente (SANTOS et al, 2017). Dentre essas alterações biológicas decorrentes das anormalidades genéticas e moleculares na FC, a mais significativa é a ocorrida no tecido pulmonar, responsável pela maior parcela na morbidade e mortalidade, principalmente por conta da broquiectasia e insuficiência pulmonar. Esse índice de óbito e a gravidade da doença, principalmente a pulmonar, se consolida concomitante as alterações sistêmicas e ao tratamento unicamente sintomático. Não havendo tratamento curativo as manifestações são mais difíceis de controlar e assim a doença se torna alvo de tema inconclusivo na medicina (CABELLO, 2011).

Conclusão: Portanto, a partir da análise da doença seguindo os eventos desde as alterações genéticas, moleculares e por fim biológicas, pode-se entender a Fibrose Cística como uma doença grave de acometimento multissistêmico a qual se demostra de forma abrupta e significativa no trato respiratório por conta dos eventos pulmonares mais graves. Tendo assim, junto a conclusão de ser uma doença sem cura até o momento, a necessidade de cuidado especial com os pacientes acometidos por esta doença, e a busca por mais estudos de cura para a mesma. 


\section{Referências}

CABELLO, Giselda Maria Kalil de. Avanços da Genética na Fibrose Cística. Revista do Hospital Universitário Pedro Ernesto, UERJ, v. 10, n. 4, Outubro/ Dezembro. 2011.

MINISTÉRIO DA SAÚDE. Programa Nacional de Triagem Neonatal (PNTN). Fibrose Cística (FC). Brasília, DF, 2017.

PEREIRA, Maria Luiza Saraiva; KIEHL, Mariana Fitarelli; SANSEVERINO, Maria Teresa Vieira. A Genética Na Fibrose Cística. Rev HCPA; v.31, n.2, pp.160-167. 2011.

PESSOA, Ingrid Lacerda et al. Fibrose cística: aspectos genéticos, clínicos e diagnósticos. Brazilian Journal of Surgery and Clinical Research BJSCR. v.11,n.4,pp.30-36. 2015.

SANTOS, Yasmim Queiroz et al. Aspectos genéticos e clínicos da fibrose cística. Enciclopédia Biosfera, Centro Científico Conhecer - Goiânia, v.14 n.25; p.1460. 2017. 


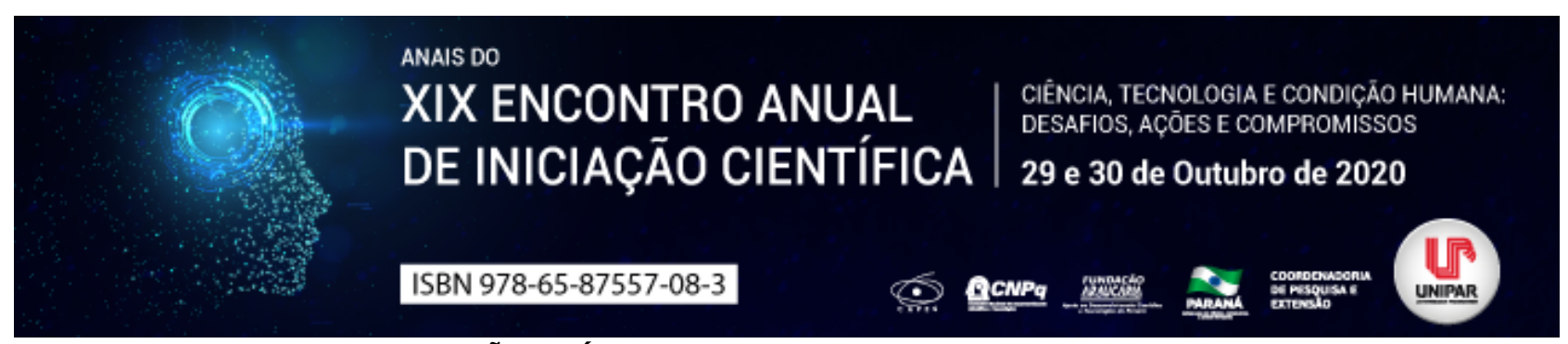

MANIFESTAÇÃO CLÍNICA DOS QUATRO SOROTIPOS DE DENGUE

${ }^{1}$ PRISCILA LUZIA PEREIRA NUNES, ${ }^{2}$ ELIEZER FERREIRA DA SILVA, ${ }^{3}$ CRISTIANE CLAUDIA MEINERZS, ${ }^{4}$ MARIA ELENA MARTINS DIEGUES, ${ }^{5}$ IRINEIA PAULINA BARRETA, ${ }^{6}$ ROSILEY BERTON PACHECO

\author{
${ }^{1}$ Discente do Curso de Medicina da UNIPAR \\ ${ }^{1}$ Discente do Curso de Medicina/UNIPAR \\ ${ }^{2}$ Docente da UNIPAR \\ ${ }^{3}$ Docente da UNIPAR \\ ${ }^{4}$ Docente da UNIPAR \\ ${ }^{5}$ Docente da UNIPAR
}

Introdução: A dengue apresenta quadro clínico de início repentino e amplo, variando desde formas assintomáticas e sintomáticas até quadros graves com hemorragias e choque (SINGHI; KISSOON; BANSAL, 2007). O vírus do dengue pertence à família dos flavivírus e são vírus que só contêm RNA. É classificado no meio científico como um arbovírus, os quais são transmitidos pelos mosquitos Aedes aegypti (BRASIL, 2002). São conhecidos quatro tipos de vírus presentes no Brasil: Den-1, Den-2, Den-3 e a Den-4 (GONÇALVES et al, 2015). É importante reconhecer se existe diferenças entre eles, para a colaboração e otimização dos manejos clínicos bem como do reestabelecimento da saúde (SANTOS et al, 2015).

Objetivo: Analisar a manifestação clínica dos quatro sorotipos de dengue existentes no Brasil.

Desenvolvimento: A dengue é uma arbovirose de grande incidência no Brasil e se configura como um dos principais problemas de saúde pública no mundo, principalmente nas regiões tropicais e subtropicais (GONÇALVES et al, 2015). O quadro clínico da dengue clássica é muito variável. A primeira manifestação é a febre alta, de início abrupto, seguida de cefaléia, mialgia, prostração, artralgia, anorexia, astenia, dor retroorbital, náuseas, vômitos, exantema e prurido cutâneo. Hepatomegalia dolorosa pode ocorrer, ocasionalmente, desde o aparecimento da febre. Os adultos podem apresentar pequenas manifestações hemorrágicas, como petéquias e epistaxe (BRASIL, 2002). Já na dengue hemorrágica, os sintomas iniciais são semelhantes aos da dengue clássica, porém evoluem rapidamente para manifestações hemorrágicas e/ou derrames cavitários e/ou choque (SINGHI; KISSOON; BANSAL, 2007). Todos os quatro sorotipos de dengue 1, 2, 3 e 4 podem gerar formas assintomáticas, brandas e graves, incluindo fatais. O sorotipo DEN-3 é o tipo mais virulento, seguido pelo DEN-2, DEN-4 e DEN-1. Os quatro vírus podem ocasionar a dengue grave na primeira infecção, porém com maior frequência após a segunda ou terceira (BRASIL, 2002). É importante ressaltar que não existe diferença entre sinais e sintomas para cada sorotipo e a única diferença que existe é que uma vez contraído um dos quatro vírus existentes por um dos subtipos, o organismo por meio do seu sistema imunológico, gera imunidade a tal subtipo, não contraindo o mesmo novamente, podemos contrair a dengue apenas quatro vezes, isto é, uma vez para cada subtipo. A partir da primeira vez contraída a doença, os sintomas passam a ser mais severos (SANTOS et al, 2015). Cerca de $20 \%$ a $50 \%$ das pessoas infectadas podem apresentar uma manifestação subclínica, isto é, são expostos à picada do mosquito da dengue, entretanto, não apresentam sinais ou sintomas, embora fiquem imunes ao sorotipo com a qual se infectaram. A partir de tal cenário, é válido salientar que é de suma importância que ao surgirem os primeiros sintomas, o paciente recorra a um atendimento médico, tendo em vista que manifestações iniciais podem ser confundidas com outras viroses febris agudas e não servem para indicar o grau de gravidade da doença (BRASIL, 2002).

Conclusão: Apesar de existirem no Brasil quatro sorotipos de dengue, sendo a DEN-2 o mais virulento, todos os tipos de vírus podem ocasionar formas assintomáticas como sintomáticas. Por isso, é necessário que o indivíduo se atente para as manifestações clínicas, independente do grau da virulência, para ser assistido pelo atendimento médico.

\title{
Referências
}

BRASIL. Ministério da Saúde. Fundação Nacional de Saúde. Dengue: aspectos epidemiológicos, diagnóstico e tratamento. Brasília: Fundação Nacional de Saúde, 2002.

GONCALVES, Ronaldo Pinheiro et al. Contribuições recentes sobre conhecimentos, atitudes e práticas da população brasileira acerca da dengue. Saúde soc., São Paulo, v. 24, n. 2, p. 578-593, Jun. 2015.

SANTOS, Amanda Aparecida Costa et al. Dengue: Sorotipos e suas adversidades. Revista Unilus. São Paulo, v. 13, n. 30, Out. 2015.

SINGHI, Sunit; KISSOON, Niranjan; BANSAL, Arun. Dengue e dengue hemorrágico: aspectos do manejo na unidade de terapia intensiva. J. Pediatr. (Rio J.), Porto Alegre, v. 83, n. 2, supl. p. S22-S35, May 2007. 
Coordenadoria de Pesquisa e Extensão - COPEX

Departamento de Editoraçāo e Divulgaçāo Científica - DEDIC 


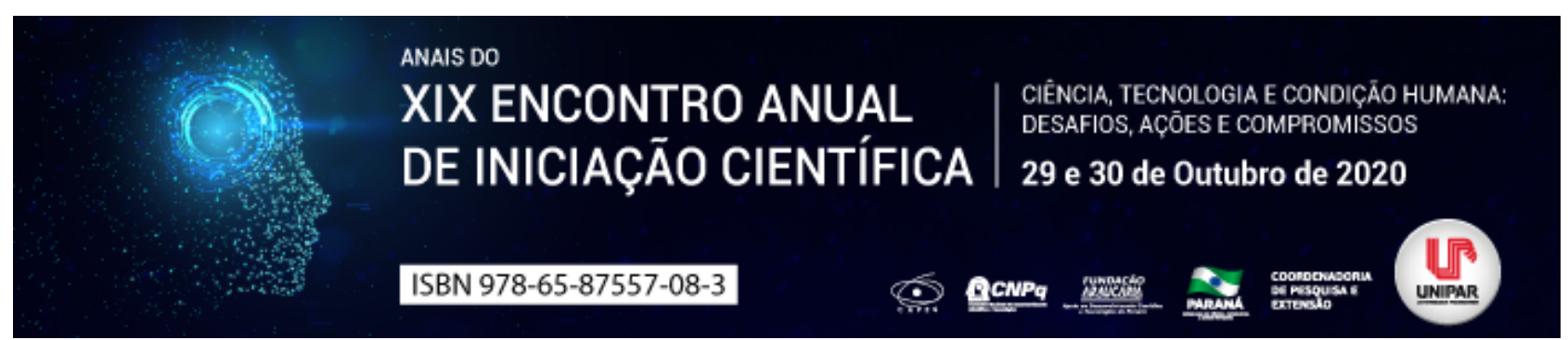

ALOPECIA PSICOGÊNICA FELINA - RELATO DE CASO

\begin{abstract}
${ }^{1}$ REGIANE PEREIRA BAPTISTA DA SILVA , ${ }^{2}$ SALVIANO TRAMONTIN BELETTINI, ${ }^{3}$ ANA MARIA QUESSADA, ${ }^{4}$ DANIELA DIB GONÇALVES
\end{abstract}

${ }^{1}$ Doutoranda do PPG em Ciência Animal, UNIPAR

${ }^{1}$ Docente da UNIPAR

23Docente do PPG em Ciência Animal, UNIPAR

33 Docente do PPG em Ciência Animal, UNIPAR

Introdução: A alopecia psicogênica felina é um transtorno dérmico de causa comportamental obsessivo-compulsivo desenvolvido por estresses ambientais e ansiedade (HNILICA, 2012). Deflagra alopecia ou hipotricose crônica simétrica e bilateral produzido por lambeduras constantes, observada como anormalidade primária (SCOTT; MILLER.; GRIFFIN, 1996). O animal lambe vigorosamente e/ou masca os pêlos em uma área particular até deixar tonsurado, comumente observados em regiões facilmente alcançadas, tais como face medial de membro pélvico, regiões lombossacra dorsal lateral e abdominal ventral (HNILICA, 2012). Acredita-se que a causa principal da ansiedade sejam fatores psicológicos ligados ao ambiente, como introdução de outro animal ou ainda um recém-nascido na residência, mas outras causas também são relatadas como novos móveis, mudanças do local do comedouro e das bandejas sanitárias, viagens, hospitalização, perda de território e pobre enriquecimento ambiental (HNILICA, 2012; WILLEMSE, 1989). O diagnóstico é realizado por exclusão de outras dermatopatias associado ao histórico por estresse e ansiedade (SOUZA, et al., 2004). Como tratamento é indicado remover a causa base do estresse e introduzir enriquecimento ambiental associado ou não ao uso de ansiolíticos como por exemplo a fluoxetina (SOUZA, et al., 2004).

Relato de caso: Foi atendido, no Hospital Veterinário Universitário, um paciente felino, sem raça definida, fêmea de seis anos de idade. $\mathrm{Na}$ anamnese, o tutor relata que o paciente reside em apartamento e observou perda de pelos progressiva e lambedura excessiva durante ao longo de 15 dias em região lombossacra dorsal lateral. Ao exame físico, verificou-se completa normalidade dos parâmetros clínicos vitais. A inspeção dermatológica revelou hipotricose simétrica e bilateral, pelos dilacerados, com aspecto tonsurado nas áreas afetadas. Realizou a exclusão de outras dermatopatias e como tratamento é necessário cuidar do estresse e da ansiendade com a introdução de enriquecimento ambiental com brinquedos indicados para os felinos e adequação de prateleiras nas paredes do apartamento. No retorno após 30 dias foi evidente a melhora clínica do paciente com ausência de lambeduras excessivas e total ausência de hipotricose.

Discussão: O paciente desenvolveu a alopecia psicogênica com lambedura excessiva simétrica e bilateral evidente e hipotricose em região lombossacra dorsal bilateral após situações de confinamento em apartamento com pobre enriquecimento ambiental que desencadearam alterações no comportamento resultando em estresse e evidente transtorno dérmico de causa comportamental obsessivo-compulsivo concordando com os autores Hnilica, (2012); Souza, (2004) e Scott; Miller.; Griffin, (1996). Nos animais submetidos a estresse, supõe - se que ocorra um aumento dos níveis dos hormônios indutor dos melanócitos e adrenocorticotrópico, levando a uma maior produção de endorfinas, as quais podem gerar o comportamento anormal de lambedura, devido ao seu efeito narcótico (WILLEMSE et al., 1989; SCOTT et al., 1996). Sabe-se que, se os problemas que levaram ao desenvolvimento do distúrbio puderem ser removidos, pode-se evidenciar melhora em cerca de 30 dias associado ou não ao uso de ansiolíticos (SCOTT; MILLER.; GRIFFIN, 1996). Hnilica, (2012), descreve tratamento com a remoção do estresse psicológico, causa base associado ao enriquecimento ambiental. Dê acordo com Valdés, (2014) a conduta terapêutica se baseia na interação entre o tutor com brincadeiras rotineiras e entretenimento.

Conclusão: De acordo com o resultado obtido no tratamento da alopecia psicogênica pode-se inferir que o enriquecimento ambiental com prateleiras e com a rotina na interação entre o tutor por meio de brinquedos é eficaz para o tratamento desta dermatose psicogênica.

\title{
Referências
}

HNILICA, K.A. Dermatologia de pequenos animais. 3 ed. Rio de Janeiro: Elsevier, 2012, p. 331-332.

SCOTT, D. W.; MILLER, W. H.; GRIFFIN C. E. Dermatoses psicogênicas. In: Dermatologia de Pequenos Animais. 5.ed. Rio de Janeiro: Interlivros, 1996. Cap.14. p.790-802.

SOUZA, M. G. et. al. Uso da fluoxetina no tratamento de tricotilomania felina. Ciência Rural, v.34, n. 3, p. 917 920, 2004.

WILLEMSE, T. et al. Feline psycogenic alopecia and the role of the opioid system. In: VON TSCHARNER, C.; HALLIWELL, R.E.W. Advances in veterinary dermatology. London : Baillière Tindall, 1989. p.195-198. 
VALDÉS, M. C. C. Alopecia psicogênica felina. Bioagrociencias, v. 7, n. 2, p. 29 - 38.

Coordenadoria de Pesquisa e Extensão - COPEX

Departamento de Editoraçāo e Divulgaçāo Científica - DEDIC 


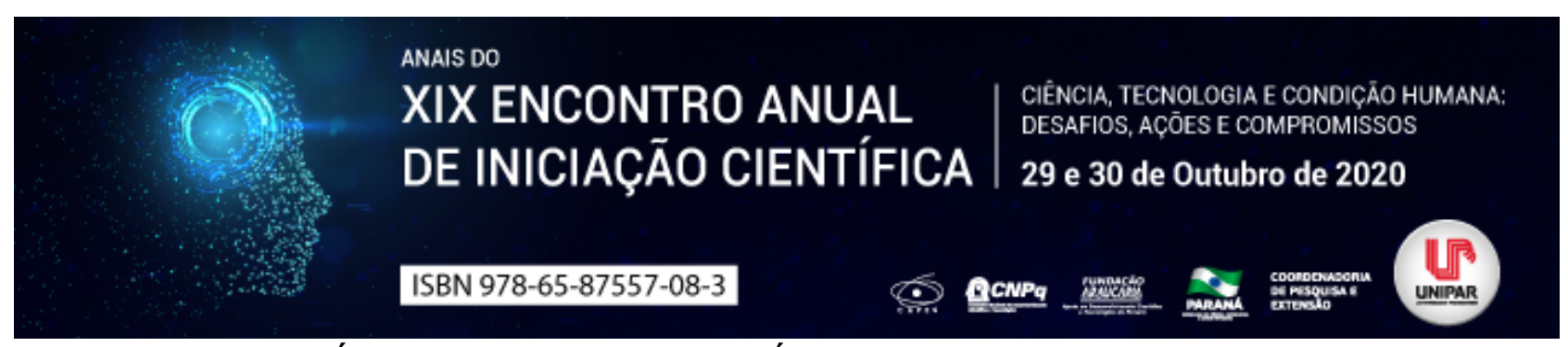

EUTANÁSIA NA MEDICINA VETERINÁRIA E OS TERMOS RELACIONADOS

\begin{abstract}
${ }^{1}$ LUIZ GUSTAVO FIGUEIREDO RODRIGUES, ${ }^{2}$ MARCIELY BRAGA CLAUDIANO , ${ }^{3}$ ALYSSON RAMALHAIS, ${ }^{4}$ MARIANA COLTRO, ${ }^{5}$ TALITA BIANCHIN BORGES, ${ }^{6}$ ANA MARIA QUESSADA
\end{abstract}

\author{
${ }^{1}$ Acadêmico do PIC/UNIPAR \\ ${ }^{1}$ Acadêmica do PIC/UNIPAR \\ ${ }^{2}$ Acadêmico do Curso de Mestrado Em Ciencia Animal Com Enfase Em Produtos Bioativos/UNIPAR \\ ${ }^{3}$ Acadêmica do PIC/UNIPAR \\ ${ }^{4}$ Médica Veterinária responsável técnica da Sociedade de Amparo Animais de Umuarama, SAAU \\ ${ }^{5}$ Professora do Programa de pós-graduação em Ciência Animal da UNIPAR
}

Introdução: A eutanásia, termo derivado do grego (eu: bom; thanos: morte), significa boa morte ou morte sem sofrimento. É definida também como a indução da cessação da vida animal, por meio de método tecnicamente aceitável e cientificamente comprovado, observando sempre os princípios éticos (CFMV, 2012). Já os termos relacionados, distanásia e ortotanásia, possuem significados distintos. A distanásia é o prolongamento exagerado da vida de um paciente. Trata-se da atitude médica que, visando salvar a vida do paciente, submete-o a grande sofrimento (BOTONI et al., 2012). Enquanto a ortotanásia (orto: certo; thanatos: morte), é quando não se aplica métodos extraordinários e artificiais para a manutenção da vida do doente. Em oposição, aplica-se cuidados paliativos que permitem que a morte siga seu curso natural (PAZINATTO e PUJOL, 2019). Os termos eutanásia, distanásia e ortotanásia são de extrema importância, pois, são conceitos que, além de fazerem parte da rotina do médico veterinário, são importantes para entender a real necessidade de suas aplicações e os outros aspectos associados.

Objetivo: Realizar uma revisão bibliográfica que possibilite entender a eutanásia na medicina veterinária e os aspectos que a abrangem, como métodos, critérios, bem-estar animal, aplicações e legislações. Ademais, entender os termos ortotanásia e distanásia e as relações que eles possuem com a medicina veterinária.

Desenvolvimento: Amplamente discutida, a eutanásia, procedimento terapêutico (tratando uma determinada doença) flui em diversos aspectos. No sentido de suas aplicações, ela é utilizada quando o animal estiver em desarmonia com o bem-estar, constituir ameaça à saúde pública, ameaça à fauna nativa e ao meio ambiente (CFMV, 2012). Também, quando o animal for objeto de atividades científicas, devidamente aprovadas por uma Comissão de Ética para o Uso de Animais (CFMV, 2012). Na maior parte dos casos, é utilizada em animais resultantes de pesquisas, portadores de doenças incuráveis ou que estejam em um sofrimento pertinente (vítimas de acidentes sem nenhuma chance de sobrevivência e recursos viáveis, por exemplo). Os critérios devem ser fundamentados em métodos indolores e que conduzam à perda da consciência rápida, sendo um método apropriado à espécie (considerando idade e estado do animal) e que requeiram o mínimo de contenção possível, evitando a excitação dos animais (OLIVEIRA et al., 2002). Em relação aos métodos, a eutanásia é dividida em métodos químicos (injetáveis, inalatórios e por imersão) e físicos (decapitação, eletrocussão, exsanguinação e outros). Os métodos físicos, mediante trauma físico cerebral, devem causar perda imediata da consciência. Os químicos, realizados mediante o uso de substâncias químicas devem prontamente produzir a inconsciência do animal (OLIVEIRA et al., 2002). Um ponto fundamental da eutanásia, é o bem-estar animal, que compreende o estado do corpo e da mente do animal (na expressão da naturalidade do animal e na ausência de estados de medo, estresse ou dor), na medida em que a sua natureza (características genéticas se manifestam em raça e temperamento) é satisfeita (SIQUEIRA e BASTOS, 2020). É importante que o bem-estar animal esteja altamente presente na eutanásia, pois, além dela visar promover esse estado ao animal, ele deve ser considerado durante todo o processo da aplicação, evitando e amenizando mais estresse e desconforto ao animal. É importante destacar também, que a eutanásia, é vigorada por legislações, instruindo e determinando os métodos e as punições para práticas inadequadas. Uma delas, é a Resolução № 1.000 (CFMV, 2012), que legisla sobre métodos aceitos e inaceitáveis para cada espécie animal. No caso do não cumprimento, o médico veterinário estará sujeito a responder processo ético profissional. Já outra Resolução, a № 1.236 (CFMV, 2018), dispõe sobre processo da eutanásia realizado de forma inadequada, sem observância do disposto nesta Resolução. Neste caso, o profissional está sujeito às penalidades previstas nos Códigos de Ética das respectivas profissões, com prejuízo das sanções cíveis, penais ou administrativas, no que couber. Os outros termos relacionados à eutanásia, que são a ortotanásia (não prolongamento do tratamento) e distanásia (tratamento sem necessidade) são importantes, pois, caminham lado a lado da eutanásia. Tais procedimentos estão presentes no cotidiano, as vezes são até mesmo utilizados e nem são reconhecidos, por isso a necessidade de identificação, por terem aplicabilidade nos animais. É de suma importância que estes conceitos sejam vistos com a visão de qualidade de vida ao animal, mesmo que posa significar o seu fim, para que sejam evitados protocolos de tratamentos sem necessidade, extenuantes e onerosos ao animal e ao proprietário (BOTONI et al., 2012). 
Conclusão: A eutanásia é um procedimento terapêutico importante. Por isso, é fundamental entender legislação sobre o tema, suas aplicações e os métodos de execução, considerando o bem-estar animal para evitar o menor desconforto possível. Os termos derivados, ortotanásia e distanásia, também devem ser compreendidos, pois, são importantes e podem ser aplicados aos animais.

\section{Referências}

BOTONI, Larissa S. et al. Distanásia ou eutanásia: quando você colocaria o ponto final? Medvep, v. 10, n. 32, p. 108-111. 2012. CONSELHO FEDERAL DE MEDICINA VETERINÁRIA. Resolução № 1.000 de 11 de maio de 2012. Dispõe sobre procedimentos e métodos de eutanásia em animais e dá outras providências. Manual de Legislação do Sistema CFMVICRMVs: módulo II. Brasília, 2015, $8^{a}$ edição.

CONSELHO FEDERAL DE MEDICINA VETERINÁRIA. Resolução No 1.236 de 26 de outubro de 2018. Define e caracteriza crueldade, abuso e maus-tratos contra animais vertebrados, dispõe sobre a conduta de médicos veterinários e zootecnistas e dá outras providências. Diário oficial da união: seção 1. Brasília, out. 2018, edição 208, p. 133.

DINIZ, Maria Helena. O estado atual do Biodireito. $3^{a}$ Edição, São Paulo: Saraiva, 2006.

OLIVEIRA, Humberto P.; ALVES, Geraldo E.S.; REZENDE, Cleuza M.F. Eutanásia em Medicina Veterinária. Belo Horizonte, 2002. Disponível em: encurtador.com.br/gxES6. Acesso em: 24 ago. 2020.

PAZZINATO, Márcia M.; PUJOL, Sebastião A.C. Direito penal médico e os hard cases: eutanásia, suicídio assistido, distanásia e ortotanásia. Revista de Direito Penal e Processo Penal, v. 1, n. 2, p. 54-83, 2019

SIQUEIRA, Vinícius C.; BASTOS, Paula A.S. Bem-estar animal para clínicos veterinários. Brazilian Journal of health Review, v. 3, n. 2, p. 1713-1746, 2020. 


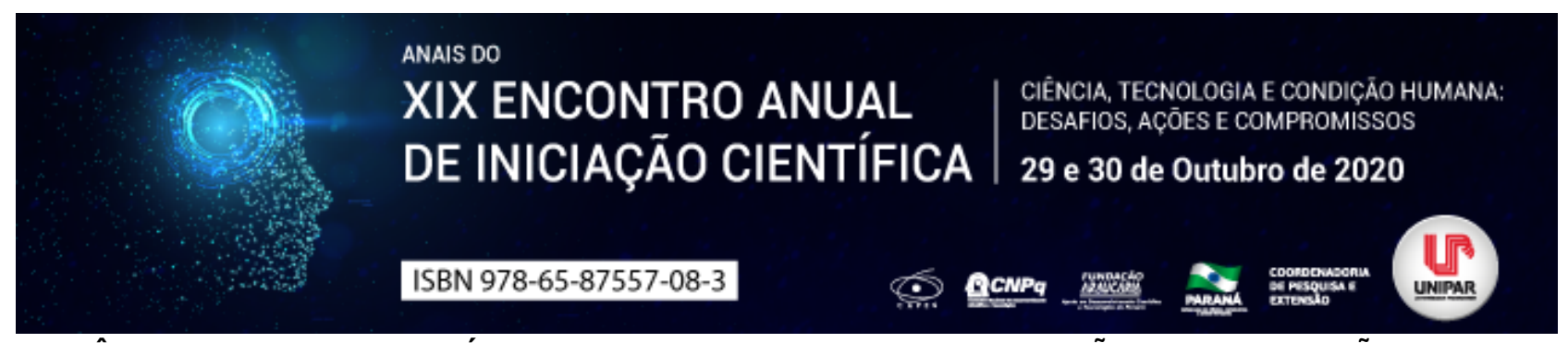

IMPORTÂNCIA DO CONFORTO TÉRMICO PARA A MELHORIA DA PRODUÇÃO E REPRODUÇÃO DE BOVINOS

\begin{abstract}
1'LUCCA HIROITI SAKASHITA, ${ }^{2}$ VITOR HUGO INOUE CORREA, ${ }^{3}$ GUSTAVO POMARO, ${ }^{4}$ MARIA EDUARDA BORBA ALEM, ${ }^{5}$ ROSIARA ROSARIA DIAS MAZIERO
\end{abstract}

\footnotetext{
${ }^{1}$ Acadêmico do curso de Medicina Veterinária da Unipar, Bolsista PIC/UNIPAR

${ }^{1}$ Acadêmico do curso de Medicina Veterinária da Unipar, Bolsista PIC/UNIPAR

${ }^{2}$ Acadêmico do curso de Medicina Veterinária da Unipar, Bolsista PIC/UNIPAR

${ }^{3}$ Acadêmica do curso de Medicina Veterinária da Unipar, Bolsista PIC/UNIPAR

${ }^{4}$ Docente do curso de Medicina Veterinária da UNIPAR
}

Introdução: A pecuária brasileira consiste em sua maioria pela criação extensiva, a pasto. Desta forma, os animais sofrem grandes impactos pelas condições climáticas adversas e surgem as preocupações com as condições dos animais, com o intuito de proporcionar conforto ao animal, para evitar gastos de energia e consequentemente perda de peso. Assim, no Brasil, cada vez mais se fala de bem-estar e conforto ambiental e os criadores devem se atentar as exigências, visando aperfeiçoar a produção e se adequar as demandas do mercado. Neste sentido, os animais da raça Nelore são conhecidos por serem resistentes e rústicos ideais ao nosso clima tropical, porém, ainda sim, são afetados pelas condições térmicas. Animais como Alberdeen Angus, Wagyu, entre outros, por pertencerem a regiões com clima completamente diferente ao nosso, são mais sensível ao calor, e como alternativa, os criadores de gado de corte das regiões de regiões tropicais estão se adaptando e escolhendo animais de cruzamento industrial como o Aberdeen Angus (Bos taurus taurus) x Nelore (Bos taurus indicus), os quais se adaptam melhor a temperaturas mais elevadas e consequentemente, perdem menos peso (ALBUQUERQUE et al., 2000).

Objetivo: Avaliar os efeitos do estresse térmico na atividade reprodutiva e produtiva de bovinos.

Desenvolvimento: Os efeitos do estresse térmico afetam diretamente a reprodução, estudos de Hans Selye (1936), pioneiro neste assunto mostra que o estresse térmico é acompanhado por um acréscimo do eixo hipotalâmico-hipofisário-adrenal (HHA) e por um decréscimo na função reprodutiva. Os hormônios relacionados ao estresse podem influenciar a função sexual do eixo hipotalâmico-hipofisário-gonadal (HHG). Além disso, o estresse térmico pode causar alterações na homeostase desregulamentação da temperatura corporal, podendo afetar a redistribuição de fluxo sanguíneo do centro do corpo para a periferia, causando a perda de calor sensível e assim reduzindo o consumo de ração e alteração no balanço energético e distribuição de nutrientes (JORDAN, 2003). Neste contexto, animais não adaptados ao clima tropical, apresentam queda do desempenho produtivo e reprodutivo, levando a inabilidade do animal (COSTA et al., 2016). Assim, observa-se que o estro das fêmeas bovinas em locais quentes chegam a durar de 8-10 horas, dificultando a deteç̧ão do cio, que normalmente apresentam 14-18 horas em locais com temperaturas amenas (COSTA et al., 2016). Adicionalmente, as vacas em lactação apresentam-se muito sensíveis ao calor, devido às exigências metabólicas nesta fase. LEW et al. (2003) mostram que altas temperaturas 10 dias antes do estro estão associadas a baixa fertilidade, levando a baixa produção de esteroides sexuais. Estes mesmos autores mostraram também que o cultivo de células da teca e da granulosa incubadas por mais de 3 horas à $42^{\circ} \mathrm{C}$ levou a morte celular. Com relação à produção de leite, vacas sob estresse térmico reduzem o consumo de alimentos, acarretando a hipofunção da tireóide, com a energia despendida para eliminar o excesso de calor corporal (MELO et al., 2016). Já em machos bovinos, clima quente afeta a produção espermática devido à redução na taxa de crescimento corporal e testicular correlacionada com a disponibilidade nutricional (COSTA E SILVA, 2004). Esta reduzida taxa de crescimento do testículo é acompanhada da diminuição de espermatócitos e maturação de espermátides principalmente devido à redução da capacidade esteroidogênica das células de Leydig, levando a uma significativa redução da produção espermática (JORDAN, 2003).

Conclusão: Diante do abordado, podemos concluir que o estresse térmico, afeta diretamente o desempenho dos animais, comprometendo a eficiência reprodutiva e produtiva do rebanho, com queda do ganho de peso e desenvolvimento corporal. Deste modo, é cabível a adoção de medidas que sejam favoráveis à adaptação dos animais, como também a seleção de raças que suportem condições mais desfavoráveis.

\title{
Referências
}

ALBUQUERQUE, L.H.; WECHESLE, F.S.; BACCARI JUNIOR, F.; GONÇALVES, H.C. Efeitos do estresse térmico sobre a 
produção, composição química do leite e respostas termorreguladoras de cabras da raça alpina. Revista Brasileira de Zootecnia, v. 29, n. 6, p.1632-1641, 2000.

COSTA, A.N.L.; ARAÚJO, A.A.; ARAÚJO, E.P. Efeitos do estresse térmico na reprodução de fêmeas bovinas. Revista Brasileira de Reprodução Animal, v. 40, n. 4, p. 123-125, 2016

JORDAN, E.R. Effects of Heat Stress on Reproduction. Journal of Dairy Science, v. 86, p. E104-E114, 2003.

LEW, B.J.; MEIDAN, R.; WOLFENSON, D. Concentrações hormonais e desenvolvimento folicular de vacas leiteiras em hipertermia sazonal e aguda. Arquivo Brasileiro de Medicina Veterinária e Zootecnia, v. 58, n. 5, p. 816-822, 2006.

MELO, A.F.; MOREIRA, J.M.; SARDINHA, H.C. Efeitos do estresse térmico na produção de vacas leiteiras: Revisão. Pubvet, v. 10, n. 10, p. 721-730, 2016.

SELYE, H. A syndrome produced by diverse nocuous agents. Nature, v. 138, n. 4, p. 32, 1936.

Coordenadoria de Pesquisa e Extensão - COPEX

Departamento de Editoraçāo e Divulgaçāo Científica - DEDIC 


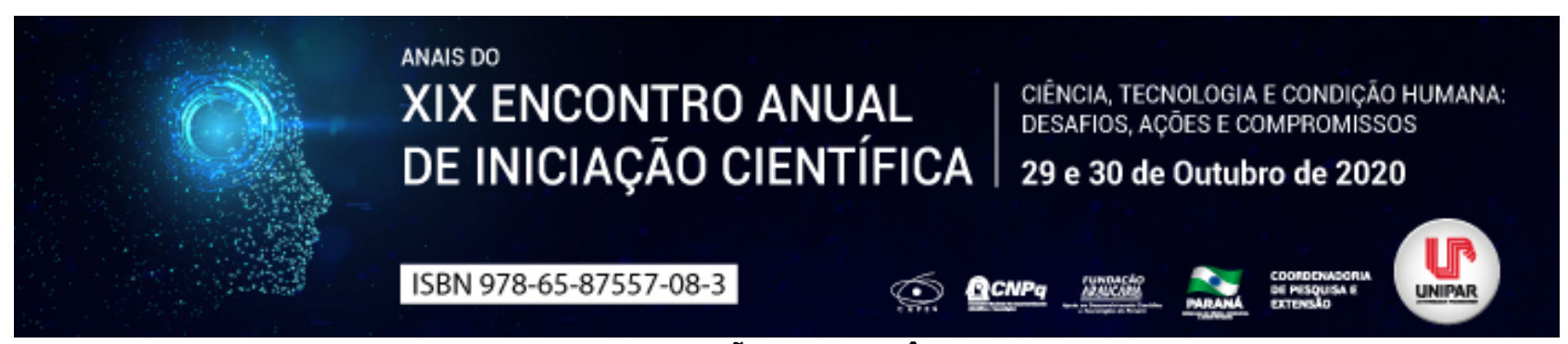

CRIOPRESERVAÇÃO DE SEMÊNS EQUINOS

\title{
${ }^{1}$ MARIA LETICIA LINHARES MACHADO, ${ }^{2}$ ALANA TIETE VIAJANTE, ${ }^{3}$ CELINA DOS SANTOS MONTEIRO, ${ }^{4}$ CARLOS RENATO DE FREITAS GUAITOLINI, ${ }^{5}$ ROSIARA ROSARIA DIAS MAZIERO
}

\author{
${ }^{1}$ Acadêmica do curso de Medicina Veterinária da Unipar, PIC/UNIPAR \\ ${ }^{1}$ Acadêmica do Curso de Medicina Veterinária da Unipar, PIC/UNIPAR \\ ${ }^{2}$ Acadêmica do Curso de Medicina Veterinária da Unipar, PIBIC/UNIPAR \\ ${ }^{3}$ Acadêmico do Curso de Programa Nacional de Pos-doutorado -pnpd/capes da UNIPAR \\ ${ }^{4}$ Docente da UNIPAR
}

Introdução: Há 60 anos deu início a criopreservação de sêmen com a descoberta do glicerol, o qual é utilizado como crioprotetor, assim permite que os espermatozoides sejam congelados e armazenados, obtendo sucesso na inseminação artificial. A criopreservação minimiza perdas com a morte do reprodutor de valor comercial ou também para preservar o genoma determinada raça ou de animais em extinção (WATSON, 2000).

Objetivo: Revisar sobre as limitações encontradas para se obter uma boa criopreservação de sêmen equino e sua utilização em larga escala.

Desenvolvimento: A fertilidade do sêmen congelado é inferior à do sêmen fresco, o que impede sua utilização em larga escala nos equinos, e apesar dos benefícios do uso dos crioprotetores, não encontramos um meio diluidor que permita a sobrevivência de $100 \%$ das células espermáticas após a congelação/descongelação do ejaculado. Assim, para existir sucesso na fertilização do oócito, o metabolismo espermático, a motilidade progressiva, as enzimas e proteínas acrossomais devem ser preservadas para que ocorra a sobrevivência do espermatozoide dentro do trato reprodutivo feminino e consequentemente, a ligação com a zona pelúcida. A destruição de alguns destes componentes ligados ao processo de fertilização, acarretará a redução da fertilidade (AMANN \& PICKETT, 1987). Deste modo, o processo de criopreservação espermática deve ser realizado de forma adequada, principalmente, com uma velocidade de congelação controlada, visto que se realizada de forma muito lenta ocasionará alta concentração de sais intracelulares, levando a desidratação intensa, danificando o espermatozoide, e se a taxa de congelação for rápida demais, os cristais de gelo intracelulares se formaram (BALL et al., 2000) rompendo a membrana. Neste sentido, estudos mostram que a motilidade de espermatozoides equinos, associando os crioprotetores glicerol (GLI) e dimetilformamida (DMF) foi mais efetiva do que utilizando apenas um crioprotetor. O glicerol é o crioprotetor mais utilizado na espécie equina, apesar do grau de toxidade que oferece a célula, e pelo comprometimento da fertilidade, ainda é considerado o crioprotetor mais eficaz (AMANN \& PICKETT, 1987). A dimetilformamida possui amidas menos viscosas e menos solúveis em água se comparadas ao glicerol, que acarreta menor permeabilidade da membrana, porém esta característica é favorável para a criopreservação, pois diminui a possibilidade de danos celulares por estresse osmótico provocado consequentemente pelo glicerol (BALL \& VO, 2001). O estresse osmótico/choque osmótico é uma das principais causas da baixa viabilidade do sêmen e a utilização de crioprotetores com maior permeabilidade possibilita minimizar este estresse osmótico (GOMES et al., 2002). A adição do crioprotetor em múltiplas etapas, associada ao resfriamento da amostra lentamente antes do processo de congelação, é o tratamento mais eficaz para preservar a viabilidade (GOMES et al., 2002). A associação do glicerol com a dimetilformamida mostrou ser uma boa opção para a criopreservação de sêmen equino (NEVES NETO et al., 2004). A taxa de prenhez foi similar para éguas inseminadas com $2 \%$ e $3 \%$ de GLI (46\% e 58\%, respectivamente) comparada com $2 \%$ DMF $(50 \%)$, depois de serem avaliados por VIDAMENT (2005).

Conclusão: Com a procura crescente pelos produtores, a necessidade de protocolos de congelamento e inseminação que proporcionem alta taxa de fertilização são cada vez maiores, mas devido a diferença entre raças e garanhões ainda não existe um protocolo certeiro e eficiente para a congelação. Neste sentido, mais estudos devem ser realizados em busca do protocolo ideal para criopreservação espermática.

\section{Referências}

AMANN, R.P.; PICKETT, B.W. Principles of cryopreservation and a review of cryopreservation of stallion spermatozoa. Journal of Equine Veterinary Science, v.7, p.145-173, 1987.

BALL, B.A.; GRAVANCE, C.G.; MEDINA, V.; BAUMBER, J.; LIU, I.L.M. Catalase activity in equine semen. American Journal of Veterinary Research, v.61, p.1026-1030, 2000.

BALL, B.A.; VO, A. Osmotic tolerance of equine spermatozoa and the effects of soluble cryoprotectants on equine sperm motility, viability and membrane potential. Journal of Andrology, v.22, p.1061, 2001. 
GOMES, G.M.; JACOB, J.C.F.; MEDEIROS, A.S.L.; PAPA, F.O.; ALVARENGA, M.A. Improvement of stallion spermatozoa preservation with alternative cryoprotectants for the Mangalarga Marchador breed. Theriogenology, v.58, p.277-279, 2002.

NEVES NETO, J.R.; MERCANTE, C.F.J.; ARRUDA, R.P. Fertilidade do sêmen congelado equino em etilenoglicol e glicerol. In: Congresso Brasileiro de Reprodução Animal, 11, 1995, Belo Horizonte. Anais... Belo Horizonte: CBRA, 1995. p.292. Resumo. VIDAMENT, M. French field results (1985-2005) on factors affecting fertility of frozen stallion semen. Animal Reproduction Science, v.89, p.115-136, 2005.

WATSON, P.F. The cause of reduced fertility with cryopreserved semen. Animal Reproduction Science, v.60, p.481-492, 2000.

Coordenadoria de Pesquisa e Extensão - COPEX

Departamento de Editoraçāo e Divulgaçāo Científica - DEDIC 


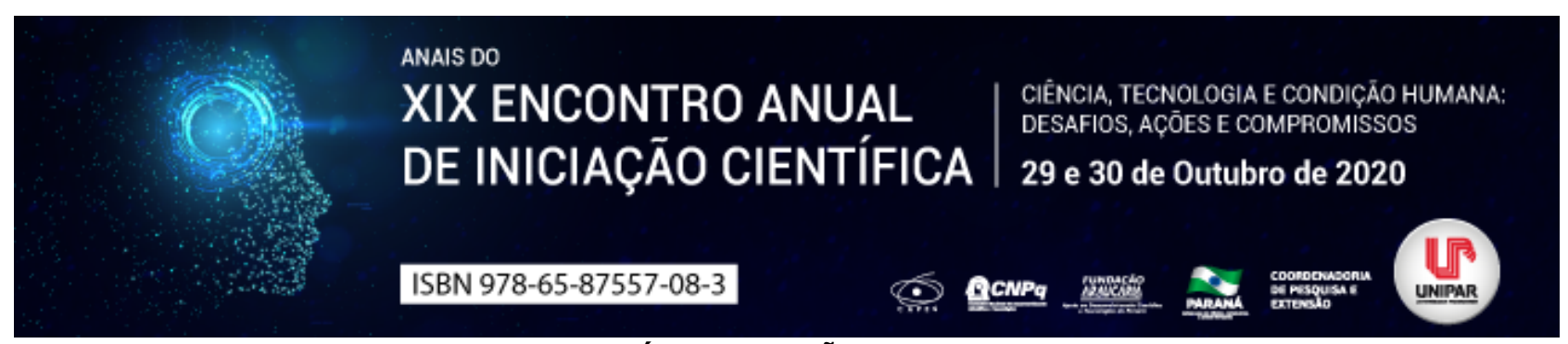

EPIDEMIOLOGIA E RISCO ANESTÉSICO DE CÃES PORTADORES DE OTOHEMATOMA

\begin{abstract}
${ }^{1}$ GIULIANA CAVALCANTI DOS SANTOS, ${ }^{2}$ MARIANA COLTRO, ${ }^{3}$ ALYSSON RAMALHAIS, ${ }^{4}$ ANNA JULIA BARBOSA SANT ANNA, ${ }^{5}$ ANA CAROLINE SOARES CERANTO, ${ }^{6}$ ANA MARIA QUESSADA
\end{abstract}

\author{
${ }^{1}$ Discente de Medicina Veterinária, PIBIC/UNIPAR \\ ${ }^{1}$ Discente de Medicina Veterinária, PIC/UNIPAR \\ ${ }^{2}$ Discente do Mestrado Em Ciência Animal Com Enfase Em Produtos Bioativos,UNIPAR \\ ${ }^{3}$ Discente do Ensino Médio, PEBIC-JR/UNIPAR \\ ${ }^{4}$ Discente de Medicina Veterinária, PEBIC/CNPQ/UNIPAR \\ ${ }^{5}$ Orientadora de PIC/PIBIC/UNIPAR
}

Introdução: O otohematoma $(\mathrm{OH})$ ou hematoma aural, é caracterizado pelo acúmulo de sangue dentro da placa cartilaginosa auricular ou ao longo dela (FOSSUM, 2001; GOTTHELF, 2007). Essa afecção ocorre em decorrência de fatores como otite, ectoparasitas, doença de Cushing, doenças imunomediadas, existência de corpos estranhos, tumores e pólipos no conduto auditivo (JOYCE, 2000). Sua formação se dá por uma lesão vascular da artéria auricular ou fratura da cartilagem auricular. Isto causa hemorragia, gerada pelo auto-traumatismo, prurido, agitação constante da cabeça e desconforto do animal (HENDERSON; HORNE, 2007), acarretando aumento de peso da orelha e dor (GOTTHELF, 2007). A terapia pode ser feita por meio de medicamentos, porém, a drenagem cirúrgica é o tratamento de escolha (EURIDES et al., 2008; SMEAK, 2008). O paciente deve ser avaliado antes da cirurgia, considerando-se o histórico clínico e exames complementares, obtendo-se a classificação do estado físico e risco anestésico do mesmo, preconizada pela Sociedade Americana de Anestesiologistas (ASA, 2014). Essa classificação possibilita estimar os riscos de possíveis complicações anestésicas e cirúrgicas, bem como, fornece o prognóstico do paciente.

Objetivo: O objetivo deste trabalho foi registrar os aspectos epidemiológicos relacionados ao $\mathrm{OH}$ em cães atendidos em um Hospital Veterinário, classificando-os de acordo com o estado físico e risco anestésico.

Material e Métodos: Essa pesquisa foi aprovada pelo Comitê de Ética em experimentação com animais da instituição onde foi realizado - parecer $n^{\circ}$ 063/11. Esse trabalho foi realizado em um Hospital Veterinário Universitário (HVU), durante um período de sete meses. Foram avaliados 25 cães que foram encaminhados para fazer uma drenagem cirúrgica de $\mathrm{OH}$. Foram obtidas informações epidemiológicas como: principais raças acometidas, sexo, idade e comprometimento de uma ou ambas as pinas. Antes da cirurgia foi feita avaliação clínica por um único avaliador e exames complementares como hemograma e bioquímico sérico. Os pacientes foram classificados de acordo com o seu estado físico e risco anestésico segundo a Sociedade Americana de Anestesiologistas (ASA), Na Medicina Veterinária, a classificação ASA varia de I a $\mathrm{V}$, caracterizando o paciente de hígido a moribundo (ASA, 2014). Utilizou-se a técnica cirúrgica descrita por Fossum (2001). No pós-cirúrgico, foi realizada a bandagem da pina operada por 48 horas. Foram prescritos meloxicam, tramadol e solução antimicrobiana para limpeza da ferida. Recomendouse o uso do colar elisabetano. A retirada dos pontos cirúrgicos foi realizada 10 dias após a cirurgia.

Resultados e Discussão: Durante o período de levantamento de dados, foram realizadas 90 drenagens de $\mathrm{OH}$ no $\mathrm{HVU}$, representando 19\% das cirurgias realizadas em cães (474) no período analisado. Foram registrados dados epidemiológicos desta enfermidade em 25 cães. Dentre estes, os percentuais de raças acometidas foram: sem raça definida (64\%), pastor alemão (24\%), labrador (4\%), weimaraner (4\%) e daschund (4\%;). O otohematoma no HVU foi frequente em animais com pinas pendulares e de menor ocorrência em cães com pinas eretas. Provavelmente esse achado está relacionado com o fato de que animais com orelhas pendulares apresentam mais otopatias do que os animais de orelhas eretas (CARDOSO et al., 2011). Em relação ao sexo mais acometido, obteve-se maior percentagem nas fêmeas (56\%), quando comparadas aos machos (44\%). Este dado pode estar relacionado a variações no atendimento de machos e fêmeas, comuns em hospitais veterinários. Quanto às idades mais acometidas, observou-se que os valores variaram entre três e 12 anos. Sugere-se que animais nesta faixa de idade sejam mais acometidos por dermatopatias, entre elas a otite externa, que pode predispor ao otohematoma (SANTOS, 2008). Nos animais acompanhados houve apenas cães classificados como ASA II e ASA III com índices semelhantes, obedecendo aos critérios descritos para esta classificação (ASA, 2014). Os animais classificados como ASA II apresentavam anemia, sem apresentarem enfermidades sistêmicas. Os cães classificados como ASA III apresentaram sinais de doença sistêmica moderada (FUTEMA, 2002), suspeitando-se principalmente de erliquiose devido aos achados hematológicos; podendo estar associada ao otohematoma (GRAÇA, 2010). A drenagem do OH não pode ser considerada como uma cirurgia eletiva, visto que alguns pacientes apresentavam desconforto. Nos pacientes que foram analisados, a ausência de efeitos adversos e óbitos provavelmente está relacionada ao fato de que a drenagem de otohematoma é uma cirurgia considerada limpa-contaminada 
(ARIAS et al., 2013), pouco invasiva e sem envolvimento de estruturas anatômicas importantes que pudessem comprometer sistemicamente os pacientes.

Conclusão: No trabalho analisado o otohematoma foi mais comum em animais com orelhas pendulares, de meia idade e fêmeas, sendo a apresentação unilateral a mais frequente. Em relação à classificação ASA, os animais foram classificados em ASA II e III, principalmente devido a anormalidades hematológicas como anemia. Não ocorreram óbitos.

\section{Referências}

ASA - AMERICAN SOCIETY OF ANESTHESIOLOGISTS. ASA Physical Status Classification System. 2014. Disponível em: file:///C:/Users/Usuario/Desktop/asa-physical-status-classification-system.pdf. Aceso em: 20 jun. 2020.

ARIAS, Mônica. V. Bahr et al. Estudo da ocorrência de infecção hospitalar em cães e gatos em um centro cirúrgico veterinário universitário. Pesquisa Veterinária Brasileira, Rio de Janeiro, v. 33, n. 6, p. 771-779, 2013.

CARDOSO, Mauro José Lahm et al. Dermatopatias em cães: revisão de 257 casos. Archives of Veterinary Science, Curitiba, v.16, n.2, p.66-74, 2011.

EURIDES, Duvaldo et al. Drenagem de otohematoma em cães. Revista Portuguesa de Ciências Veterinárias, Lisboa, v. 103, p. 565-566, 2008.

FOSSUM, Theresa Welch. Cirurgia do ouvido. In: Cirurgia de pequenos animais. São Paulo, Roca, 2001. Cap. 14. p. $171-197$. FUTEMA, Fábio. Avaliação pré-anestésica. In: FANTONI, D. T.; CORTOPASSI, S. R. G. Anestesia em cães e gatos. São Paulo: Roca, 2002. Cap. 5, p.59-63.

GRAÇA, José Carlos Lentilhas da. Otohematoma estudo retrospectivo de 6 anos: possíveis etiologias. 2010. 120f. Dissertação (Mestrado Integrado em Medicina Veterinária) Faculdade de Medicina Veterinária, Universidade Técnica de Lisboa, Lisboa, 2010.

GOTTHELF, Louis N. Doenças do Ouvido em pequenos animais. 2.ed. São Paulo, Roca, 2007. 368 p.

HENDERSON; HORNE. Pina. In: SLATTER, D. Manual de cirurgia de pequenos animais. 3. ed. São Paulo: Manole, 2007. v. 1. Cap. 121. p. 1737-1746.

JOYCE, J. Canine aural haematoma. Waltham focus, v. 10, n. 4, p.4-8, 2000.

SANTOS, Sara Isabel Rosário. Otohematoma canino: epidemiologia e terapêutica. 2008. 78f. Dissertação. (Mestrado integrado em Medicina Veterinária) Faculdade de Medicina Veterinária, Universidade Técnica de Lisboa, Lisboa, 2008.

SMEAK, D. D. Cirurgia de meato acústico externo e pavilhão auricular. In: BIRCHARD, S. J.; SHERDING, R. G. Manual Saunders de clínica de pequenos animais. São Paulo: Roca, 2008. Cap. 60, p.595-606. 


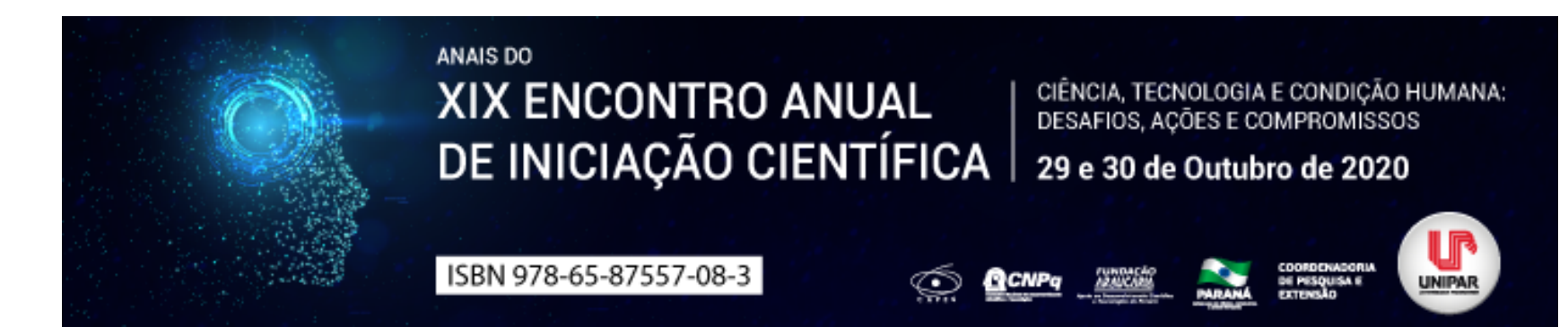

QUANTIFICAÇÃO DE NEURÔNIOS GIEMSA ${ }^{+}$DO JEJUNO DE RATOS EXPOSTOS AO DIABETES, TABAGISMO E HIPERCOLESTEROLEMIA TRATADOS COM Baccharis trimera

\begin{abstract}
${ }^{1}$ Flavio de Souza Júnyor, ${ }^{2}$ PAULA MONTANHINI FAVETTA, ${ }^{3}$ WESLEY ALVES TRINDADE, ${ }^{4}$ GRAZIELLI DE FATIMA SERENINI , ${ }^{5}$ NATALIA NAMIE MIZUGUCHI, ${ }^{6}$ RICARDO DE MELO GERMANO
\end{abstract}

\author{
${ }^{1}$ Discente do Instituto Federal do Paraná - Bolsista PEBIC-JR CNPq/UNIPAR \\ ${ }^{1}$ Doutoranda em Ciência Animal com Ênfase em Produtos Bioativos da UNIPAR - Bolsista PROSUP/CAPES \\ ${ }^{2}$ Mestrando em Ciência Animal com Ênfase em Produtos Bioativos da UNIPAR - Taxista PROSUP/CAPES \\ ${ }^{3}$ Mestre em Ciência Animal com Ênfase em Produtos Bioativos pela UNIPAR \\ ${ }^{4}$ Discente do Curso de Enfermagem da UNIPAR - Bolsista PIBIC \\ ${ }^{5}$ Docente do Programa de Pós-Graduação em Ciência Animal com Ênfase em Produtos Bioativos da UNIPAR
}

Introdução: O plexo mioentérico, uma subdivisão do Sistema Nervoso Entérico (SNE), constitui uma cadeia linear de neurônios organizados em gânglios que se estende pelo trato gastrointestinal (TGI), controlando o peristaltismo (GUYTON; HALL, 2011; GARTNER, 2017). O SNE apresenta-se bastante sensível e vulnerável a lesões e pode ser afetado por diversas doenças, provocando alterações no funcionamento do TGI (FERREIRA; OLIVEIRA; ODA, 2015). Dentre elas, estão os fatores de risco associados às doenças cardiovasculares, como o diabetes mellitus (DM), tabagismo e dislipidemia (ADA, 2019; McCarthy et al., 2015; Pereira, 2014). Uma das terapias utilizadas para distúrbios relacionados ao TGI é o tratamento com a espécie Baccharis trimera, conhecida popularmente como carqueja, devido seus efeitos antioxidantes, hepatoprotetores e anti-inflamatórios (BELTRAME; et al., 2009; SOUZA et al., 2019).

Objetivo: Avaliar os efeitos do extrato de $B$. trimera sobre a população total de neurônios mioentéricos, corados pela técnica de Giemsa, do jejuno de ratos induzidos ao DM e expostos ao tabagismo e à dieta hipercolesterolêmica.

Material e Métodos: Todos os procedimentos realizados no presente estudo foram aprovados pelo comitê de ética da UNIPAR (protocolo n. 1000/2018). Foram utilizados 25 ratos machos da linhagem Wistar. Os animais foram divididos em cinco grupos ( $n=5 / g r u p o): ~ C-$ (animais normoglicêmicos, não dislipidêmicos e não tabagistas); C+ (diabéticos, dislipidêmicos e tabagistas, tratados com veículo); BT30 (animais diabéticos, dislipidêmicos e tabagistas, tratados com 30mg/kg de B. trimera); BT100 (animais diabéticos, dislipidêmicos e tabagistas, tratados com 100mg/kg de B. trimera) e BT300 (animais diabéticos, dislipidêmicos e tabagistas, tratados com 300mg/kg de B. trimera). A indução ao DM ocorreu após jejum de 12 horas, via intraperitoneal $60 \mathrm{mg} / \mathrm{kg}$ de estreptozotocina. Após a indução do DM, os animais receberam dieta padrão comercial da marca Purina ${ }^{\circledR}$ com $0,5 \%$ de colesterol da Sigma-Aldrich ${ }^{\circledR}$ em $6,75 \mathrm{ml}$ de óleo de milho para cada $75 \mathrm{~g}$ de ração comercial para a indução da dislipidemia. Em seguida, os animais foram expostos à inalação de ar filtrado ou fumaça de 9 cigarros comerciais, 5 dias por semana, durante 1 hora por dia, por quatro semanas. O tratamento com as diferentes doses de carqueja ocorreu nas últimas duas semanas de experimento, via gavagem, uma vez por dia, ressuspendido em água filtrada. Após quatro semanas de experimento, os animais foram submetidos a eutanásia, realizada por aprofundamento anestésico, utilizando isoflurano em câmara de saturação de 1-3\%. Determinado o óbito foi realizada incisão ventral e coletado o jejuno para a marcação da população total de neurônios pela técnica de coloração básica de Giemsa. Após a fixação, o jejuno foi seccionado ao longo do eixo longitudinal em nível da inserção do mesentério, e microdissecado ao estereomicroscópio. Em seguida, foram desidratados em série crescente de álcoois, diafanizados em xilol, e colocadas entre lâmina e lamínula de vidro com resina sintética. Sob microscopia de luz utilizando-se de um aumento de 200x e de um sistema de análise de imagem de alta resolução, foram realizadas capturas de imagens de 120 campos microscópicos aleatórios por preparado de membrana, sendo contempladas igualmente as áreas mesentérica, intermediária e antimesentérica. Após a quantificação os dados obtidos foram analisados estatisticamente pela ANOVA e pós-teste Tukey.

Resultados: Foi encontrada redução significativa na quantidade média de neurônios totais presentes em $\mathrm{mm}^{2}$ de preparos de membrana de jejuno nos grupos C+ $(109,21)$ e tratados com a fração do extrato de carqueja (BT30 91,46; BT100 81,29; BT300 $94,03)$, quando comparados ao grupo C- $(163,82)$.

Discussão: De acordo com Tronchini et al. (2012), foi relatado a redução da população total de neurônios mioentéricos do jejuno de ratos induzidos ao DM após quatro meses de experimento, quando comparados aos normoglicêmicos. Além disso, Freitas et al. (2008), após o mesmo período de tempo, mencionaram uma redução de 37,9\% na população total de neurônios de animais diabéticos em relação ao grupo não-diabético. No presente estudo, a redução dos neurônios foi significativa após quatro semanas de exposição ao diabetes, isto pode ser decorrente da associação do estado diabético a mais dois fatores de risco, a 
hipercolesterolemia e o tabagismo, acelerando o processo de redução neuronal. Pereira et al. (2008), em um modelo experimental semelhante ao de Freitas et al. (2008), observaram que densidade neuronal nitrérgica, neurônios inibitórios, não diferiram nos grupos, indicando a alta resistência dessa subpopulação neuronal à ação de radicais livres encontrados em concentrações elevadas no quadro de DM. Nesse sentido, a redução da população total de neurônios mioentéricos está atrelada, exclusivamente, a subpopulação de neurônios colinérgicos, neurônios excitatórios encontrados na parede do tubo digestório.

Conclusão: As diferentes doses de carqueja não apresentaram efeitos protetores sobre os neurônios mioentéricos, visto que houve uma redução significativa na população total de neurônios corados pela técnica de Giemsa.

\section{Referências}

AMERICAN DIABETES ASSOCIATION. Pharmacologic approaches to glycemic treatment: Standards of Medical Care in Diabetes 2019. Diabetes care, v. 42, n.1, jan. 2019.

BELTRAME, F. L. et al. Avaliação da qualidade das amostras comercias de Baccharis trimera L. (Carqueja) vendidas no Estado do Paraná. Acta Scientiarum Health Sciences, Maringá v. 31, n. 1, mai, 2009.

FERREIRA, P. E. B.; BELÉM, M. O.; ODA, J. Y. O efeito do uso de antioxidantes na prevenção e tratamento da neuropatia diabética no sistema nervoso entérico. Arquivo de Ciências de Saúde da UNIPAR, Umuarama, v. 19, n. 2, mai. 2015.

FREITAS, P. et al. Myenteric neurons and intestinal mucosa of diabetic rats after ascorbic acid supplementation. World Journal of Gastroenterology, v.14, n.42, nov. 2008.

GARTNER, L. P. Tratado de histologia. 4 ed. Rio de Janeiro: Elsevier, 2017.

GUYTON, A. C.; HALL, J. E. Tratado de Fisiologia Médica. 12 ed. Rio de Janeiro: Elsevier, 2011.

MCCARTHY, E. et al. Radiology and mesenteric ischaemia. Clinical radiology, v. 70, n. 7, jul. 2015.

PEREIRA, P. M. C. O tabaco e a doença inflamatória intestinal. 2014. Dissertação (mestrado) - Universidade do Porto, Portugal, 2014.

PEREIRA, R. V. F. et al. Vitamin E supplementation in rats with experimental diabetes mellitus: Analysis of myosin-V and nNOS immunoreactive myenteric neurons from terminal ileum. Journal of Molecular Histology, v. 39, out. 2008.

SOUZA, M. M. Q. et al. Baccharis trimera (Less.) DC: An Innovative Cardioprotective Herbal Medicine Against Multiple Risk Factors for Cardiovascular Disease. Journal of Medicinal Food, v. 23, n.6, jun, 2019.

TRONCHINI, E. A. et al. Supplementation with $0.1 \%$ and $2 \%$ vitamin e in diabetic rats: analysis of myenteric neurons immunostained for myosin-V and nNOS in the jejunum. Arquivo de Gastroenterologia, São Paulo, v. 49, n. 4, dez. 2012. 


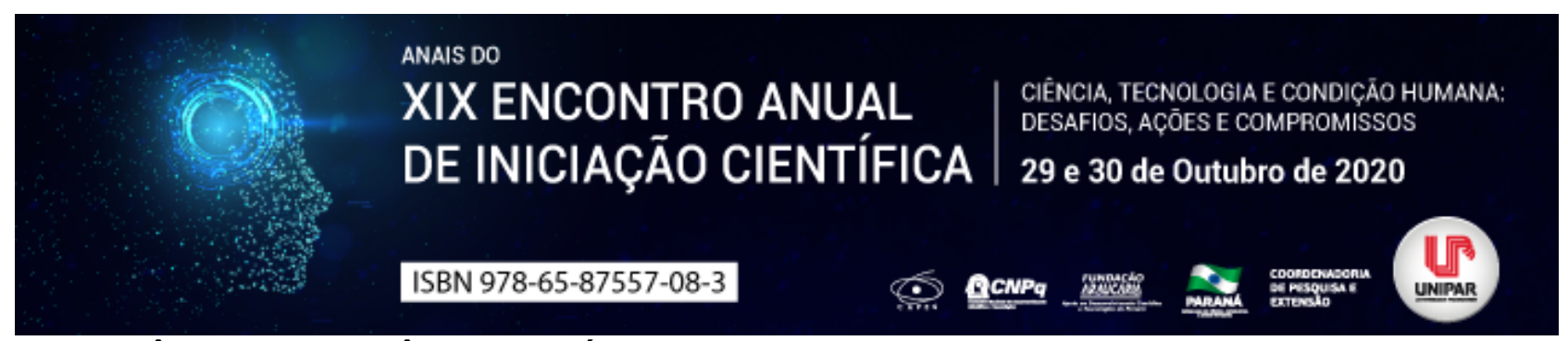

\title{
RESISTÊNCIA DE NEURÔNIOS NITRÉRGICOS EM RATOS EXPOSTOS AO DIABETES, TABAGISMO E DISLIPIDEMIA TRATADOS COM CARQUEJA
}

\author{
${ }^{1}$ NATALIA NAMIE MIZUGUCHI, ${ }^{2}$ PAULA MONTANHINI FAVETTA, ${ }^{3}$ MARCELO ALBERTO ELIAS, ${ }^{4}$ GRAZIELLI DE FATIMA \\ SERENINI, ${ }^{5}$ WESLEY ALVES TRINDADE, ${ }^{6}$ RICARDO DE MELO GERMANO
}

\begin{abstract}
${ }^{1}$ Discente do curso de Enfermagem, PIBIC/UNIPAR
${ }^{1}$ Discente Doutoranda no PPG em Ciência Animal com Ênfase em Produtos Bioativos/UNIPAR

${ }^{2}$ Discente Doutorando no PPG em Ciência Animal com Ênfase em Produtos Bioativos da UNIPAR

${ }^{3}$ Mestre em Ciência Animal com Ênfase em Produtos Bioativos pela UNIPAR

${ }^{4}$ Discente no Mestrado no PPG m Ciência Animal com Ênfase em Produtos Bioativos da UNIPAR

${ }^{5}$ Docente do Programa de Pós-graduação em Ciência Animal - Docente de Fisiologia da UNIPAR
\end{abstract}

Introdução: O Sistema Nervoso Entérico (SNE) é formado por uma rede de neurônios na parede do trato gastrintestinal (TGI) com dois principais plexos o mioentérico e o submucoso (FERREIRA; BELÉM; ODA,2015). Os neurônios nitrérgicos e colinérgicos representam a maioria dos neurônios da população mioentérica (PHILLIPS, 2003). A subpopulação nitrérgica tem função inibitória no controle de motilidade do TGI (JARVINEN, et al., 1999). A Baccharis trimera, da família Asteraceae, conhecida popularmente como carqueja é utilizada na medicina popular e na produção de fitoterápicos (BORELLA; FONTOURA, 2002), tendo como propriedade terapêutica a ação hepatoprotetora, antioxidante e hipoglicemiante (KARAM et al., 2013).

Objetivo: Quantificar os neurônios nitrérgicos corados pela técnica de NADPH-diaforase em ratos induzidos ao diabetes e expostos ao tabagismo e dislipidemia, tratados com fração do extrato de carqueja.

Material e métodos: Todos os procedimentos realizados no presente estudo foram aprovados pelo comitê de ética da UNIPAR (protocolo n. 1000/2018). Foram utilizados 25 ratos machos da linhagem Wistar, com peso médio de 324,5g. Esses animais foram separados em cinco grupos experimentais: grupo controle negativo (C-), animais normoglicêmicos, não tabagistas, que receberam dieta comercial padrão, o grupo controle positivo $(C+)$ : animais diabéticos, tabagistas e hipercolesterolêmica, e três grupos com animais diabéticos, dislipidêmicos e tabagistas tratados com diferentes doses de carqueja sendo BT $30 \mathrm{mg} / \mathrm{kg}$, BT $100 \mathrm{mg} / \mathrm{kg}$ e BT $300 \mathrm{mg} / \mathrm{kg}$. A indução ao diabetes foi realizada via intraperitoneal, com $60 \mathrm{mg} / \mathrm{kg}$ de estreptozotocina, para desenvolver a dislipidemia, receberam uma dieta com adição de $0,5 \%$ de colesterol em ração comercial, e para a indução do tabagismo, foram expostos à inalação de fumaça de nove cigarros comerciais $(0,8 \mathrm{mg}$ de nicotina, $10 \mathrm{mg}$ de alcatrão e $10 \mathrm{mg}$ de monóxido de carbono), através de um aparato, durante cinco dias por semana e uma hora por dia. $\mathrm{O}$ experimento durou quatro semanas e durante as últimas duas semanas, os animais foram tratados com diferentes doses de B. trimera (30, 100 e 300 $\mathrm{mg} / \mathrm{kg}$ ) (SOUZA et al., 2019) via gavagem, uma vez por dia, ressuspendido por água filtrada, no volume de 0,28ml. O controle negativo possuía ratos normoglicêmicos, não dislipidêmicos e não expostos ao tabaco, tratados com veículo (água filtrada), o controle positivo, ratos diabéticos, dislipidêmicos e tabagistas, tratados com veículo (água filtrada), o grupo BT 30 possuía ratos diabéticos, dislipidêmicos e tabagistas, tratados com $30 \mathrm{mg} / \mathrm{kg}$ de B. trimera, BT 100 possuía ratos diabéticos, dislipidêmicos e tabagistas, tratados com $100 \mathrm{mg} / \mathrm{kg}$ de B. trimera e BT 300 possuía ratos diabéticos, dislipidêmicos e tabagistas, tratados com $300 \mathrm{mg} / \mathrm{kg}$ de B. trimera. Após o experimento, os animais foram submetidos a eutanásia, realizada por aprofundamento anestésico, utilizando isoflurano em câmara de saturação de 1 a 3\%. Os segmentos do intestino delgado foram coletados para a quantificação de neurônios nitrérgicos, e foi utilizada a técnica de histoquímica da nicotinamida adenina dinucleotídeo fosfato diaforase (NADPH-diaforase), proposta por Scherer-Singler e colaboradores (1983). Os dados foram avaliados estatisticamente pelo teste ANOVA.

Resultados: De acordo com a análise estatística realizada, Não houve alterações significativas no número de neurônios nitrérgicos, no entanto, nos grupos diabéticos, C+ (36,07\%), BT30 (46,71\%), BT100 (58,24\%) e BT300 (45,02\%), apresentaram maior percentual de neurônios desta subpopulação mioentérica, em relação ao grupo C- $(29,03 \%)$.

Discussão: Em um experimento realizado por Silverio et al. (2009), com ratos diabéticos induzidos por estreptozocina com $35 \mathrm{mg} / \mathrm{kg}$, via intravenosa, e suplementados com ácido ascórbico e processados pela técnica da NADPH-diaforase durante 90 dias, também não foram observaram diferenças significativas na quantificação de neurônios mioentéricos do íleo. Em outro experimento Furlan, Molinari, Miranda-Neto (2004), foi avaliado os neurônios mioentéricos do jejuno de ratos diabéticos durante sete dias, induzido por estreptozocina (35 $\mathrm{mg} / \mathrm{kg}$, via intravenosa), corados com NADPH-diaforase positivos, não houve alterações significativas na quantidade. A semelhança com nossos resultados, os experimentos mencionados evidenciam a resistência desta subpopulação neuronal ao diabetes, embora, cabe destacar que no presente trabalho além do diabetes os ratos foram expostos ao tabagismo e a dieta hipercolesterolêmica, intensificando possíveis danos fisiológicos, contudo, não foi suficiente para 
reduzir a expressão dos neurônios nitrérgicos.

Conclusão: Com base nos resultados e das circunstâncias em que o experimento foi realizado, não foram observadas alterações significativas na subpopulação nitrérgica, de ratos induzidos ao diabetes e expostos ao tabagismo e dieta hipercolesterolêmica, tratados com a carqueja, permitindo sugerir que os neurônios nitrérgicos são mais resistentes aos efeitos deletérios aos quais foram expostos.

\section{Referências}

BORELLA, J. C.; FONTOURA, A. Avaliação do perfil cromatográfico e do teor de flavonóides em amostras de Baccharis trimera (Less.) DC. Asteraceae (carqueja) comercializadas em Ribeirão Preto, SP, Brasil. Revista Brasileira de Farmacognosia, Maringá, v. 12, n. 2, p. 63-67, Dec. 2002. Disponível em: https://cutt.ly/vfMwCcj. Acesso em: 29/07/2020.

FERREIRA, P. E. B.; BELEM, M. O.; ODA, J. Y. O Efeito do uso de Antioxidantes na Prevenção e Tratamento da Neuropatia Diabética no Sistema Nervoso Entérico. Arquivos de Ciência de Saúde da UNIPAR, Umuarama, v. 19, n. 2, p. 115-123, 2015. Disponível em: https://cutt.ly/WfMw1Ya. Acesso em: 27/07/2020.

FURLAN, M.M.D.P.; MOLINARI, S.L.; MIRANDA-NETO; M.H. Resposta dos neurônios mioentéricos do duodeno de ratos ao diabetes de curto prazo. Arquivos de Ciência de Saúde da UNIPAR, Umuarama, 8(2), mai./ago. p.95-99, 2004. Disponível em: https://cutt.ly/EfMw9VO. Acesso em: 30/07/2020.

JARVINEN, M. K. et al. Nitric oxide syntase-containing neurons in the myenteric plexus of the rat gastrointestinaltract: distribution and regional density. Anatomy and Embryology, Berlin, v.199, p.99-112, 1999. Disponível em: https://cutt.ly/sfMwliQ. Acesso em: 29/07/2020.

KARAM, T. K. et al. Carqueja (Baccharis trimera): utilização terapêutica e biossíntese. Revista brasileira de plantas medicinais, Botucatu, v. 15, n. 2, p. 280-286, 2013. Disponível em: https://cutt.ly/CfMwSH1. Acesso em: 29/07/2020.

PHILLIPS, R. J.; KIEFFER, E. J.; POWLEY, T L. Aging of the myenteric plexus: neuronal loss is specific to cholinergic neurons. Autonomic Neuroscience, Amsterdam, v. 106, p. 69 83, 2003. Disponível em: https://cutt.ly/JfMeeBW. Acesso em: 30/07/2020.

SILVERIO, S. M. et al. Effects of ascorbic acid supplementation in ileum myenteric neurons of streptozotocin-induced diabetic rats. Pesquisa Veterinária Brasileira, Rio de Janeiro, v. 29, n. 4, p. 295- 302, 2009. Disponível em: https://cutt.ly/xfMeumn. Acesso em: 28/07/2020. 


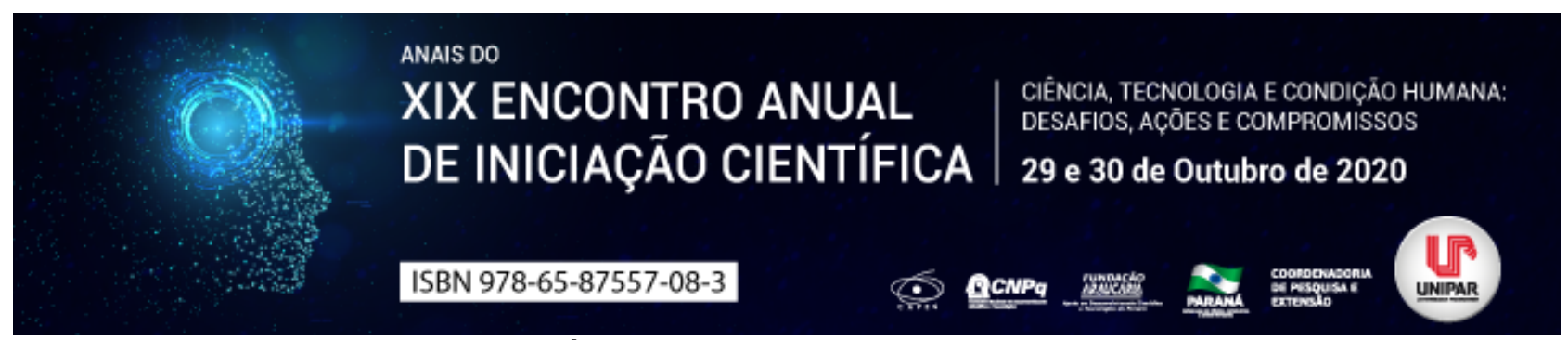

POTENCIAL EFEITO TOXICOLÓGICO DO BISFENOL A NO SISTEMA NERVOSO CENTRAL

\begin{abstract}
${ }^{1}$ NATALIA NAMIE MIZUGUCHI, ${ }^{2}$ PAULA MONTANHINI FAVETTA, ${ }^{3}$ EDSON GERONIMO , ${ }^{4}$ WESLEY ALVES TRINDADE , ${ }^{5}$ FLAVIO DE SOUZA JUNYOR, ${ }^{6}$ RICARDO DE MELO GERMANO
\end{abstract}

${ }^{1}$ Discente do curso de Enfermagem, PIBIC/UNIPAR
${ }^{1}$ Discente Doutoranda no PPG em Ciência Animal com Ênfase em Produtos Bioativos/UNIPAR
${ }^{2}$ Discente Doutorado Em Ciência Animal Com Enfase Em Produtos Bioativos/UNIPAR
${ }^{3}$ Discente no Mestrado no PPG em Ciência Animal com Ênfase em Produtos Bioativos/UNIPAR
${ }^{4}$ Discente do Instituto Federal do Paraná - Bolsista PEBIC-JR CNPq/Unipar
${ }^{5}$ Docente do Programa de Pós-graduação em Ciência Animal - Docente de Fisiologia da UNIPAR

Introdução: O Bisfenol A (BPA) é um composto utilizado na fabricação de plásticos de policarbonato e resinas epóxi, seu uso ocorre tanto para o armazenamento de alimentos e bebidas quanto para outros produtos plásticos como brinquedos e mamadeiras, porém, quando submetido a altas temperaturas, decréscimo de $\mathrm{pH}$ ou uso prolongado, o BPA pode ser liberado no alimento, representando um contaminante (EDAES; RIBEIRO; SOUZA, 2019). O BPA representa um importante disruptor endócrino, tanto para animais quanto para humanos, podendo afetar diretamente o metabolismo de hormônios, como a produção, liberação, transporte, ligação ou eliminação de hormônios naturais, além de possíveis alterações no Sistema Nervoso Central (SNC), principalmente quando há a exposição ainda nas primeiras etapas da vida (MORGAN et al., 2017).

Objetivo: Realizar uma revisão bibliográfica a respeito dos efeitos do Bisfenol A no Sistema Nervoso Central em humanos na infância e outros animais não humanos juvenis.

Desenvolvimento: O presente trabalho consiste numa revisão de literatura, utilizando o banco de dados eletrônico Google Acadêmico , com as seguintes palavras-chave: bisfenol A, BPA, disruptores endócrinos, Sistema Nervoso Central . Foram selecionados cinco artigos de 2017 a 2020, foram excluídos artigos que não estavam relacionados com Bisfenol A e o Sistema Nervoso Central. Devida sua característica mais resistente, o BPA é amplamente utilizado e destinado principalmente a produtos de contato alimentar (EDAES; RIBEIRO; SOUZA, 2019). Com composição semelhante ao estrógeno, hormônio feminino, o BPA pode atuar como desregulador endócrino, e em baixas doses, pode apresentar danos sobre a fertilidade, SNC, câncer, diabetes, obesidade, puberdade precoce, doenças cardíacas e também alterações no comportamento (JARDIM et al., 2017). Com relação ao SNC, de acordo com Szymanska e Gonkowski (2018), os efeitos tóxicos do BPA causam inibição da sinaptogênese, desvios no desenvolvimento dendriticos e alterações nas concentrações de cálcio nos neurônios, essas alterações podem gerar problemas na função cognitiva e no SNC. A exposição ao BPA no período pré-natal e pós-natal, desempenha alterações comportamentais na vida adulta e também prejuízos na aprendizagem e memória, essas alterações são devido a redução da densidade e número de neurônios nas áreas subcorticais (DAVIS; CURTIS, 2020).

Conclusão: Algumas consequências negativas da exposição ao BPA são conhecidas, porém, questões importantes ainda permanecem, como a relação da exposição prolongada na idade adulta. São necessários novos estudos a fim de identificar os efeitos desta exposição no desenvolvimento da saúde de forma mais ampla.

\title{
Referências
}

DAVIS, R. L.; CURTIS, K. S. Estrogen disruptors and neuroimmune signaling in obesity: focus on bisphenol A. Current Opinion in Toxicology, v. 19, p. 15-20, 2020.

EDAES, F. S.; RIBEIRO, S. M; SOUZA, C.B. MALEFÍCIOS DO BISFENOL A NA SAÚDE HUMANA E MEIO AMBIENTE. UNILUS Ensino e Pesquisa, v. 15, n. 41, p. 146-161, 2019.

JARDIM, N. S. et al. Alterações sexo-específicas na memória e homeostase glutamatérgica induzidas por bisfenol A em camundongos: efeito do disseleneto de difenila. 2017.

MORGAN, M. et al. Environmental estrogen-like endocrine disrupting chemicals and breast cancer. Molecular and cellular endocrinology, v. 457, p. 89-102, 2017.

SZYMANSKA, K.; GONKOWSKI, S. Bisphenol A - Induced changes in the enteric nervous system of the porcine duodenum. Neurotoxicology, v. 66, p. 78-86, 2018. 


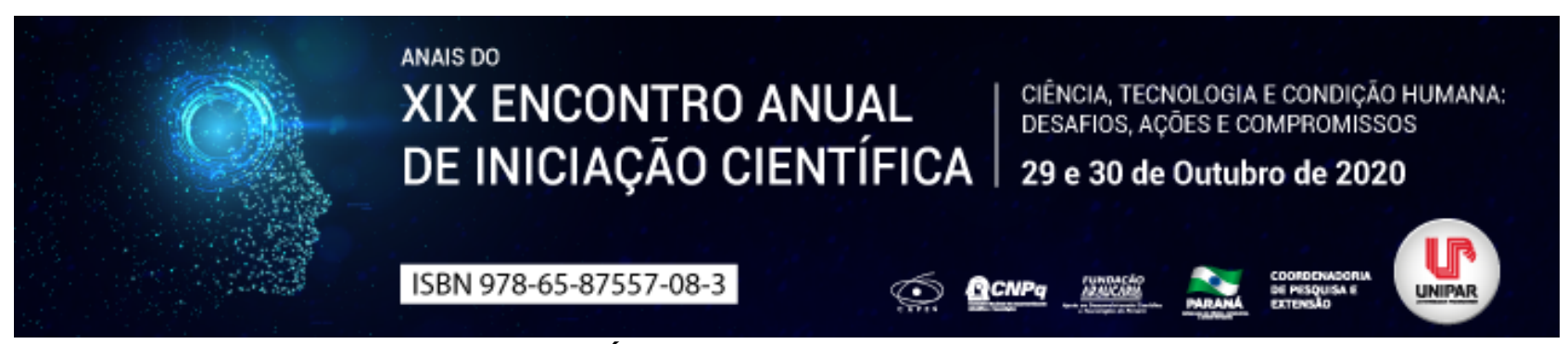

SINAIS CLÍNICOS DE ERLIQUIOSE CANINA

\begin{abstract}
${ }^{1}$ TAYMILI ALVES DA SILVA, ${ }^{2}$ LUAN VINICIUS TEZZEI MAIA, ${ }^{3}$ LUIZ GUSTAVO FIGUEIREDO RODRIGUES, ${ }^{4}$ BRUNA MENEGATE NASCIMENTO, ${ }^{5}$ ALYSSON RAMALHAIS, ${ }^{6}$ ANA MARIA QUESSADA
\end{abstract}

\author{
${ }^{1}$ Discente do curso de Medicina Veterinária, Bolsista PIBIC, Universidade Paranaense, (UNIPAR) \\ ${ }^{1}$ Acadêmico do Curso de Medicina Veterinária da UNIPAR, Bolsista Pibic \\ ${ }^{2}$ Acadêmico do Curso de Medicina Veterinária da UNIPAR, Bolsista Pic \\ ${ }^{3}$ Aprimoranda em Medicina Veterinária, UNIPAR \\ ${ }^{4}$ Acadêmico do Curso de Mestrado Em Ciencia Animal Com Enfase Em Produtos Bioativos - UNIPAR \\ ${ }^{5}$ Docente da UNIPAR
}

Introdução: Ehrlichia canis é uma rickettsia pertencente à família Anaplasmataceae, de vida intracelular obrigatória de células hematopoiéticas maduras ou imaturas e de monócitos caninos. É o agente etiológico da Erliquiose Monocítica Canina (EMC) e, além da espécie canina, há relatos de infecção em seres humanos e indícios de infecção em felídeos domésticos (BRAGA et al., 2013; PEREZ et al., 2006). A distribuição da erliquiose atualmente se encontra ampla. Sua prevalência tem aumentado em algumas regiões do Brasil. A severidade da doença depende da idade do animal, alimentação, suscetibilidade racial, doenças concomitantes e virulência da cepa infectante (SILVA et al., 2010).

Objetivo: O objetivo desta revisão é discutir sobre os principais sinais clínicos encontrados em cães diagnosticados com erliquiose canina.

Desenvolvimento: A Ehrlichia canis é transmitida pelo vetor Rhipicephalus sanguineus, conhecido popularmente como carrapato marrom que acomete animais de todas as espécies. Este vetor é encontrado principalmente nas regiões tropicais e temperadas (ISOLA et al; 2012). Os sinais clínicos da EMC podem apresentar-se em fases aguda, subclínica ou crônica, sendo a trombocitopenia bem como sinais envolvendo a depleção sanguínea em geral, comum a todas as fases (MCCLURE et al., 2010). Na fase aguda, no hemograma, é possível se verificar características como anemia normocítica normocrômica, acompanhada de trombocitopenia (MENDONÇA et al., 2005). Ainda na fase aguda, os sinais clínicos podem ser mais graves dependendo da virulência da cepa de $E$. canis; Tais sinais parecem ser exacerbados na presença de coinfecções com outros agentes, também transmitidos pelo mesmo carrapato vetor, como outras riquétsias e protozoários (GAL et al., 2007; UNVER et al., 2008). A fase subclínica é caracterizada pela persistência da $E$. canis no animal e dura em torno de 40 a 120 dias. Muitas vezes os animais não apresentam manifestações clínicas, mas, em alguns casos, apresentam letargia e anorexia. Cães imunocompetentes podem eliminar o agente durante a fase subclínica, mas é raro, devido à persistência e a obrigatoriedade desse parasita ser intracelular, resultando na fase crônica da infecção. Podem ser observados sinais de hemorragia, edema periférico, emagrecimento, distúrbios neurológicos, aumento de volume das articulações, hepatomegalia e esplenomegalia (BORIN et al., 2009; BREITSCHWERDT, 2004; STICH et al., 2008). Na fase crônica, os sinais clínicos são ausentes ou discretos em alguns cães. Entretanto, em outros animais os sinais podem ser graves e potencialmente fatais. Os achados clínicos podem variar de acordo com os órgãos predominantemente afetados. Pode ocorrer esplenomegalia, glomerulonefrite, insuficiência renal, pneumonite intersticial, uveíte anterior, meningite associada à ataxia cerebelar, depressão, paresia, hiperestesia, anorexia e perda de peso. Também pode aparecer nessa fase pancitopenia (BREITSCHWERDT, 2004; STICH et al., 2008). Quanto ao diagnóstico depende das diferentes fases e das múltiplas manifestações clínicas da doença. O diagnóstico pode ser feito por meio da deteç̧ão do DNA do agente por PCR, a partir de amostra de sangue circulante. (NAKAGHI et al., 2008; FARIA et al., 2010). A associação do resultado do hemograma em que o animal apresenta trombocitopenia e anemia aliado aos sinais clínicos é o meio diagnóstico mais utilizado. (ISOLA et al., 2012). No tratamento da erliquiose, principalmente na fase aguda da doença, a Doxiciclina na dose de10 $\mathrm{mg} / \mathrm{kg}$, via oral, uma vez ao dia, durante 28 dias, é o fármaco de eleição, com recuperação clínica em 24-72h (NEER \& HARRUS, 2006).

Conclusão: A erliquiose canina é uma doença muito grave, podendo ser fatal. Ela tem um diagnóstico complexo e seu vetor é de difícil controle. As manifestações clínicas são inesperadas pois, há três fases e, geralmente, quando o tutor percebe, o animal já está em um quadro clínico avançado. Se for tratada precocemente tem um bom prognóstico.

\title{
Referências
}

BREITSCHWERDT, E.B.R. In: ETTINGER, S.J.; FELDMAN, E.C. Tratado de medicina interna veterinária: doenças do cão e do gato. 5. ed. Rio de Janeiro: Guanabara Koogan, 2004. p. 422-429.

BORIN, S.; CRIVELENTI, L.Z; FERREIRA, F.A. Aspectos epidemiológicos, clínicos e hematológicos de 251 cães portadores de 
mórula de Ehrlichia spp. naturalmente infectados. Arquivo Brasileiro de Medicina Veterinária e Zootecnia, v.61, n.3, p.566571, 2009.

GAL, A. et al. Coinfection with multiple tick-borne and intestinal parasites in a 6-week-old dog. Canadian Veterinary Journal, v. 48, n.6, p. 619-22, 2007.

ISOLA, J.G.M.P.; CADIOLI, F.A.; NAKAGE, A.P.M. Erliquiose canina-revisão de literatura. Revista Científica Eletrônica de Medicina Veterinária, v. 11, n.18, 2012.

MENDONÇA, C.S. et al. Erliquiose canina: Alterações hematológicas em cães

domésticos naturalmente infectados. Bioscience Journal. v.21, n.1, p.167-174, 2005.

MCCIURE, J.C. et al. Efficacy of a doxycycline treatment regimen initiated during three different phases of experimental ehrlichiosis. Antimicrobial Agents and Chemotherapy, v. 54, n.12, p.5012 5020, 2010.

NAKAGHI, A.C.H. et al. Canine ehrlichiosis: clinical, hematological, serological and molecular aspects. Ciência Rural. v.38, n.3, p.700-766, 2008.

NEER, T.M. \& HARRUS, S. Canine monocytotropic ehrlichiosis and neorickettsiosis (E. canis, E. chaffeensis, E. ruminantium, N. sennetsu, and N. risticii infections). In: GREENE, C. E. Infectious Diseases of the Dog and Cat, Saint Louis: Saunders Elsevier, 2006. p. 203-2016.

PEREZ, M. et al. Infection with Ehrlichia canis accompanied by clinical signs in Venezuela. Annals of New York Academy Science, v. 1078, p. 110-117, 2006.

SILVA, J.N. et al. Soroprevalência de anticorpos antiehrlichia canis em cães de Cuiabá, Mato Grosso. Revista Brasileira de Parasitologia Veterinária, v.19, n.2, p.108-111, 2010.

UNVER, A. et al. An acute severe ehrlichiosis in a dog experimentally infected with a new virulent strain of Ehrlichia canis. Clinical Microbiology and Infection, v. 15, p. 1-3, 2008.

Coordenadoria de Pesquisa e Extensão - COPEX

Departamento de Editoraçāo e Divulgaçāo Científica - DEDIC 


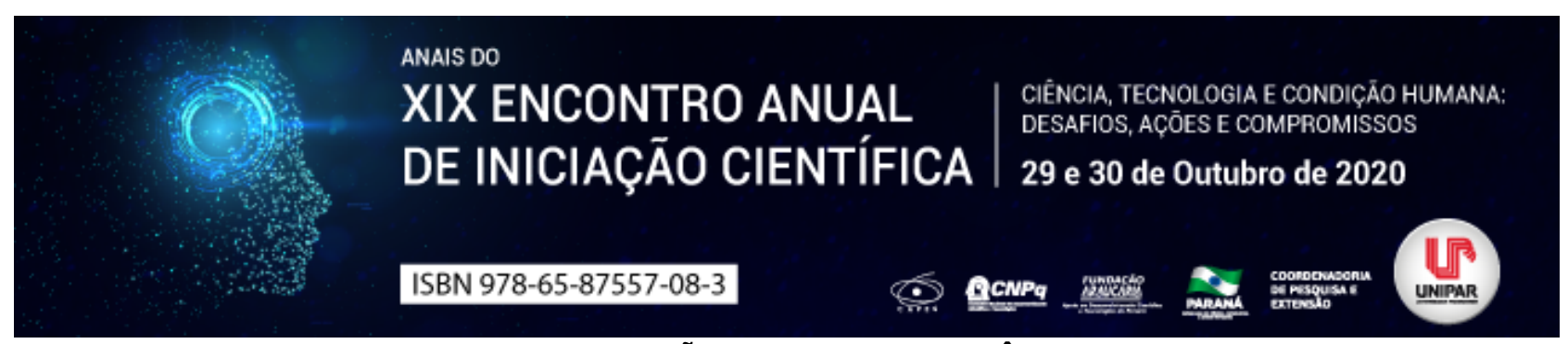

Staphilococcus aureus: UMA REVISÃO SOBRE A RESISTÊNCIA A ANTIMICROBIANOS

\author{
${ }^{1}$ ANA BEATRIZ DOS SANTOS SERRAGLIO, ${ }^{2}$ ANTONIO HENRIQUE RUZZON MARTINS, ${ }^{3}$ JOAO PAULO QUESSADA \\ ALIBERTI, ${ }^{4}$ THATIANY CEVALLOS MENEGUCCI, ${ }^{5}$ LUCIANO SERAPHIM GASQUES
}

\begin{abstract}
${ }^{1}$ Discente do curso de Medicina/UNIPAR
${ }^{1}$ Discente do curso de Medicina/UNIPAR

${ }^{2}$ Discente do curso de Medicina/UNIPAR

${ }^{3}$ Docente do curso de Medicina/UNIPAR

${ }^{4}$ Docente do curso de Medicina/UNIPAR
\end{abstract}

Introdução: Os estafilococos são cocos Gram positivos imóveis, anaeróbios facultativos e estáveis perante alterações ambientais. A propagação dessa bactéria ocorre de maneira acelerada e, quando cultivadas em meio sólido, agrupam-se em cachos, podendo ser visualizados por microscopia óptica através da coloração de Gram (TRABULSI e ALTERTHUM, 2015). Staphylococcus aureus, espécie mais comum do gênero causadora de infecções, pode ser encontrado colonizando diversos sítios anatômicos, tais como faringe, vagina, axilas, pele (períneo, tronco e membros superiores) e, em especial, a cavidade nasal anterior. Logo, em condições como a diminuição da imunidade ou a quebra da barreira cutânea, torna-se patogênico, sendo considerado o agente etiológico mais comum em infecções cutâneas, como infecções pós-cirúrgicas, infecções de pele e subcutâneo, abscessos, e também infecções sistêmicas, como pneumonias, osteomielites, endocardites e bacteremias (GELATTI, 2009). A virulência do S. aureus é mediada por enzimas e toxinas, caráter invasivo e agilidade no desenvolvimento de resistência aos antimicrobianos (TRABULSI e ALTERTHUM, 2015), sendo esse último a temática do presente trabalho.

Objetivo: Compreender cepas de S. aureus resistentes aos antimicrobianos e a importância de estudá-las.

Desenvolvimento: $O$ uso da penicilina para o tratamento de infecções estafilocócicas foi desqualificado quando, de acordo com Rito (2008, apud HIRAMATSU et al., 2002), em 1942, foi relatado a existência de cepas produtoras de $\beta$-lactamase, enzima responsável por hidrolisar o anel $\beta$-lactâmico dessa classe de antimicrobiano. A meticilina foi lançada em 1960 como alternativa terapêutica para cepas de $S$. aureus resistentes. No entanto, um ano depois já haviam relatos de resistência à droga, denominando as novas variantes como $S$. aureus resistentes à meticilina (MRSA). Nos MRSA, ocorre a formação de uma nova proteína ligadora de penicilina (PBP - penicillin-binding protein), a PBP2a que, por apresentar menor afinidade aos agentes $\beta$ lactâmicos, catalisa a transpeptidação e carboxipeptidação do peptideoglicano, exercendo seu papel na síntese da parede celular bacteriana mesmo na presença destas drogas. A codificação da PBP2a, segundo Rito (2008, apud ITO et al., 2001), ocorre a partir do gene mecA, um segmento de DNA inserido ao elemento mec (estrutura móvel exógena associada ao cromossomo em um sítio específico, localizada próximo à replicação dos S. aureus). Desse modo, a presença da PBP2a causa uma baixa afinidade do local de ligação não só com a meticilina, mas também com o restante do conjunto PPR (compostos penicilinapenicilinase resistente), composto por: oxacilina, meticilina, nafcilina, cloxacilina e dicloxacilina (ROSSI e ANDREAZZI, 2005). O glicopeptídeo vancomicina, existente desde 1956, começou a ser usado como opção terapêutica ao MRSA. Diferentemente dos antimicrobianos $\beta$-lactâmicos, essa droga atua ligando-se especificamente a um dos substratos das PBPs (resíduo D-alanil-Dalanina), comprometendo a síntese de peptideoglicano e enfraquecendo a parede celular bacteriana. Há registros de dois fenótipos resistentes a glicopeptídeos - Vancomycin Intermediate S. aureus - VISA e Vancomycin Resistent S. aureus - VRSA os quais diferem de acordo com sua concentração inibitória mínima (CIM) e mecanismos de resistência. O uso incorreto da vancomicina pode promover o aparecimento de cepas VISA, o qual conta com o engrossamento da parede celular e, consequentemente, com o aumento do número de sítios de ligação de D-alanil-D-alanina. Além disso, algumas cepas expelem pedaços de parede celular que atuam como falsos alvos para a vancomicina. O VRSA surgiu a partir do gene VanA, resultado da transferência de material genético do Enterococcus sp. resistente a vancomicina (VRE) para o $S$. aureus, o que possibilitou a expressão de D-alanil-D-lactato, no lugar de D-alanil-D-alanina, em um terminal do pentapeptídeo no precursor do peptideoglicano (TRABULSI e ALTERTHUM, 2015). Devido a pequena quantidade de VRSA, a vancomicina continua sendo a escolha terapêutica em casos de MRSA, devendo ser utilizada com cautela para evitar a disseminação das cepas resistentes (CONG, YANG e RAO, 2020).

Conclusão: Por meio de pesquisa na literatura médica especializada, entende-se que os mecanismos de resistência desse patógeno envolvem a penicilina, a meticilina (MRSA) e os glicopeptídeos (GRSA). Dessa forma, nota-se que a partir do sequenciamento de $S$. aureus, grupos de linhagens que possuem diferentes graus de virulência, fazendo com que o desenvolvimento de mecanismos de resistência aos antimicrobianos seja diretamente relacionado com a antibioticoterapia escolhida. A capacidade de adaptação e resistência dessa espécie se deve a sua habilidade de englobar genes de outras 
espécies, o que torna necessário um entendimento do funcionamento da patogenicidade desse perigoso agente infeccioso, para poder orientar os profissionais clínicos na racionalização da antibioticoterapia, minimizando assim, as chances de seleção de cepas resistentes (e multirresistentes) aos antimicrobianos.

\section{Referências}

CERQUEIRA, Ellayne Souza; ALMEIDA, Rogeria Comastri de Castro. Staphylococcus aureus resistente à meticilina (MRSA) em alimentos de origem animal: uma revisão sistemática. Rev Inst Adolfo Lutz, v. 72, n. 4, p. 268-81. 2013.

CONG, Y.; YANG, S.; RAO, X. Vancomycin resistant Staphylococcus aureus infections: A review of case updating and clinical features. Journal os Advanced Research, v. 21, p. 169-176, 2020.

GELATTI, Luciane Cristina et al. Staphylococcus aureus resistentes à meticilina: disseminação emergente na comunidade. Anais Brasileiros de Dermatologia, v. 84, n. 5, p. 501-506, 2009.

RITO, Priscila da Nobrega. Caracterização de cepas de Staphylococcus resistentes à meticilina quanto a produção de biofilme, resistência a antimicrobianos e realização do perfil e da tipificação clonal. 2008. 68 p. Dissertação (Mestrado)

Fundação Oswaldo Cruz, Instituto Nacional de Controle de Qualidade em Saúde, Programa de Pós-Graduação em Vigilância Sanitária, Rio de Janeiro, 2008.

ROSSI, Flávia; ANDREAZZI, Denise B. Resistência bacteriana: interpretando o antibiograma. [S.I: s.n.], 2005.

TRABULSI, Luiz Rachid; ALTERTHUM, Flavio. Microbiologia. 6 ed. Atheneu. 2015.

Coordenadoria de Pesquisa e Extensão - COPEX

Departamento de Editoraçāo e Divulgaçāo Científica - DEDIC 


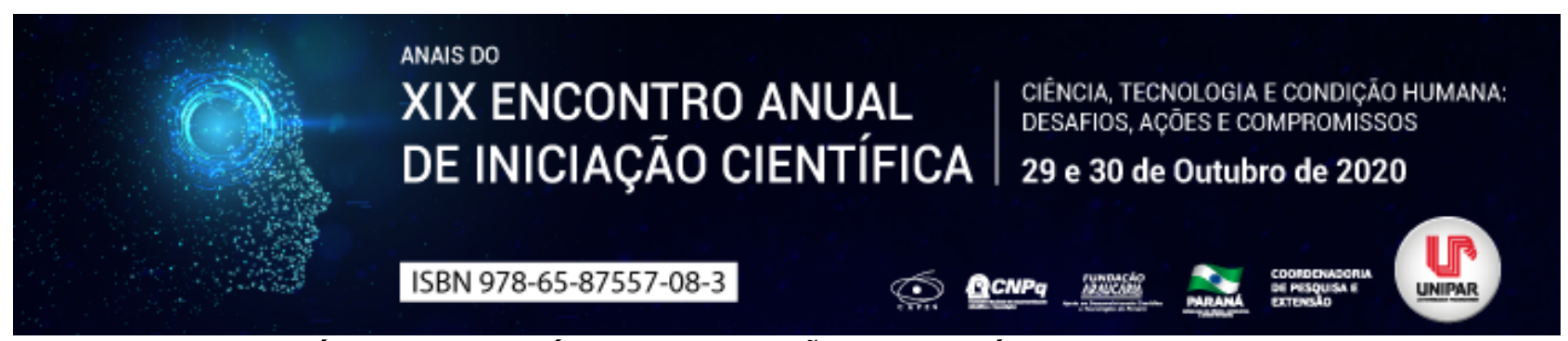

PRODUTOS DE ÓLEO DE COPAÍBA: PROSPECÇÃO TECNOLÓGICA BASEADA EM PATENTES

${ }^{1}$ Dyêggo Carvalho Amorim, ${ }^{2}$ MAGNA ALVES XAVIER, ${ }^{3}$ LUÍZA MARIA OLIVEIRA CAVALCANTE, ${ }^{4}$ LUCAS BARBOSA CAVALCANTE, ${ }^{5}$ BRUNO SAMPAIO GONÇALVES, ${ }^{6}$ LIDIA AUDREY ROCHA VALADAS MARQUES

${ }^{1}$ Unichristus
${ }^{1}$ Unichristus
${ }^{2}$ Unichristus
${ }^{3}$ Unichristus
${ }^{4}$ Unichristus
${ }^{5}$ Docente da UNIPAR

Introdução: O uso de produtos naturais com moléculas biologicamente ativas em diferentes tipos de formulações e formas de aplicações tem sido pesquisado como meio preventivo de doenças bucais. Estudos comprovam o potencial terapêutico da Copaifera spp ou copaíba em diversas funções, nas quais destacam-se as propriedades anti-inflamatória e antimicrobiana (PIERI, 2009). O óleo-resina de copaíba é um exemplo de derivado de extrato vegetal que tem sido amplamente utilizado e encontrado principalmente em regiões neotropicais, para as quais diversas atividades farmacológicas foram documentadas ao longo dos anos, se destacando a antimicrobiana e anti-inflamatória (BIESKI et al., 2015). Estudos prospectivos em bancos de propriedade intelectual são importantes para aumentar a competitividade e, assim, gerar novos produtos em várias áreas de pesquisa (FERREIRA; GUIMARÃES; CONTADOR, 2009).

Objetivo: Objetivou-se realizar um estudo prospectivo de patentes de produtos que contenham resina de óleo de copaíba para uso medico no banco de propriedade intelectual do Brasil, o Instituto Nacional de Propriedade Industrial (INPI).

Material e Métodos: A pesquisa foi realizada por meio de relatórios de patentes no INPI. Informações relevantes que descrevem a invenção no documento de patente foram coletadas, processadas e descritas.

Resultados: A pesquisa encontrou 76 patentes usando a resina de óleo de copaíba. Após analise, excluiu-se os produtos veterinários, odontológicos e inseticidas, totalizando 53 depósitos. As patentes foram depositadas entre 1986 e 2019 , totalizando $18,9 \%$ de patentes de invenção, 3,7\% de modelos de utilidade e $77,3 \%$ em análise. Todas as patentes eram de origem brasileira e relacionadas a formulações.

Discussão: Os investimentos em patentes estão cada vez mais difundidos, pois todo o funcionamento do sistema capitalista está relacionado à inovação e ao avanço científico e tecnológico. As patentes, como propriedades intelectuais são exemplos de indicadores do desenvolvimento do país. Observa-se quanto aos produtos indicados que a produção no setor esta mais relacionada a produtos cosméticos (AMADEI; TORKOMIAN, 2009; FERREIRA; GUIMARÃES; CONTADOR, 2009; BIESKI et al.,2015).

Conclusão: A maioria das patentes encontradas está relacionada à finalidade dermatológica, especificamente com propriedades antimicrobiana e anti-inflamatória.

\section{Referências}

AMADEI, José Roberto Plácido; TORKOMIAN, Ana Lúcia Vitale. As patentes nas universidades: análise dos depósitos das universidades públicas paulistas. Ciência da Informação, v. 38, n. 2, p. 9-18, 2009.

BIESKI, Isanete Geraldini Costa et al. Ethnobotanical study of medicinal plants by population of valley of Juruena region, legal amazon, Mato Grosso, Brazil. Journal of Ethnopharmacology, v. 173, p. 383-423, 2015.

FERREIRA, Ademir Antônio; GUIMARÃES, Edílson Rodrigues; CONTADOR, José Celso. Patente como instrumento competitivo e como fonte de informação tecnológica Patent as a competitive tool and as a source of technological information. Gestão \& Produção, v. 16, n. 2, p. 209-221, 2009.

PIERI, Fabio Alessandro; MUSSI, Maria Carolina; MOREIRA, Maria Aparecida S. Óleo de copaíba (Copaifera sp.): histórico, extração, aplicações industriais e propriedades medicinais. Revista Brasileira de Plantas Medicinais, v. 11, n. 4, p. 465-472, 2009. 


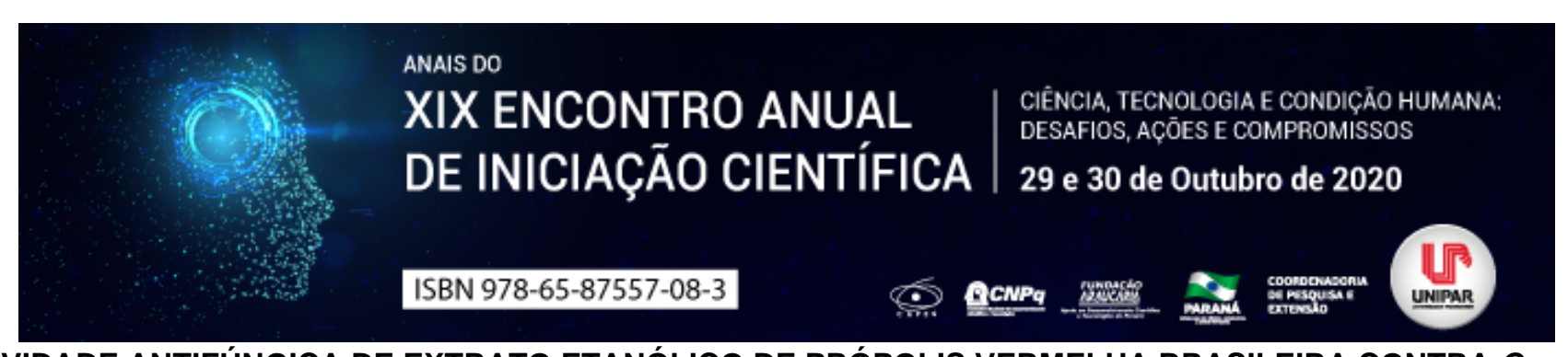

ATIVIDADE ANTIFÚNGICA DE EXTRATO ETANÓLICO DE PRÓPOLIS VERMELHA BRASILEIRA CONTRA Candida albicans

\author{
${ }^{1}$ Karine Jorge Alves Bezerra, ${ }^{2}$ DEUSIMAR ROMEU CAVALCANTE FILHO, ${ }^{3}$ LEONARDO JORGE ALVES BEZERRA, ${ }^{4}$ SANDRA \\ MARA DA SILVA LIMA, ${ }^{5}$ FRANCISCO JOSIMAR GIRAO JUNIOR
}

\author{
${ }^{1}$ Unichristus \\ ${ }^{1}$ Unichristus \\ 2Unichristus \\ ${ }^{3}$ Estudante de Nutrição, Instituto Federal de Educação, Ciência e Tecnologia do Ceará. \\ ${ }^{4}$ Docente da UNIQ
}

Introdução: A própolis é a resina responsável pelo selamento das colmeias de abelhas e provém da coleta de material orgânico em diversos tipos de vegetais. Diversas propriedades da própolis vêm sendo estudadas, dentre elas atividade antimicrobiana contra bactérias, fungos e vírus; atividade anti-inflamatória, imunomoduladora e cicatrizante (ANAUATE-NETTO et al., 2013; LUSTOSA et al.,2008).

Objetivos: O presente trabalho analisou in vitro a atividade antifúngica de solução composta de extrato de própolis vermelha brasileira sobre espécie Candida albicans (ATCC 10231) a fim de determinar a Concentração Inibitória Mínima (CIM).

Material e Métodos: Para esse estudo, utilizou-se placas de microdiluição de 96 poços onde as cepas de Candida foram incubadas em $37^{\circ} \mathrm{C}$ por $24 \mathrm{~h}$ e, após, semeadas em meio Ágar Sabouraud Dextrose. Testou-se soluções diluídas em água destilada nas concentrações $0,20 \mathrm{~g} / \mathrm{mL}, 0,30 \mathrm{~g} / \mathrm{mL}$ e $0,40 \mathrm{~g} / \mathrm{mL}(20,30$ e 40). Como Controle de Crescimento utilizou -se fungos e meio de crescimento, para testar viabilidade das cepas, Controle Positivo Nistatina suspensão comercial 100.000 UI/mL e Controle de Esterilidade Meio de Crescimento, testando não contaminação do meio de crescimento. Os testes foram realizados em triplicata e os dados obtidos analisados por teste Kruskal-Wallis, com nível de significância de 95 ( $p<0,05)$.

Resultados: Os resultados indicaram que todas amostras foram sensíveis ao extrato analisado e a CIM foi obtida com a solução de $0,30 \mathrm{~g} / \mathrm{mL}(30)$.

Discussão: Os flavonoides são considerados um dos componentes da própolis, o qual é indicado como responsável pelos efeitos antitumoral, anestésica, antiviral, antiinflamatório, antimicrobiano, e em especial, antifúngico. Longhini et al. (2007) mostrou em seus experimentos resultados promissores em relação à utilização da própolis como agente antifúngico sobre 67 leveduras de interesse médico (BUENO-SILVA et al., 2013).

Conclusão: Conclui-se que o extrato de própolis pode ser uma alternativa contra o gênero Candida, entretanto são necessários maiores estudos que comprovem sua ação antifúngica com outras espécies.

\title{
Referências
}

ANAUATE-NETTO, Camillo; MARCUCCI, Maria Cristina; PAULINO, Niraldo et al. Effects of Typified Propolis on Mutans Streptococci and Lactobacilli: a Randomized Clinical Trial. Brazilian Dental Science, v. 16, n. 2, 2013.

BUENO-SILVA, Bruno; ALENCAR, Severino M.; KOO, Hyun et al. Anti-Inflammatory and Antimicrobial Evaluation of Neovestitol and Vestitol Isolated from Brazilian Red Propolis. Journal of Agricultural and Food Chemistry, v. 61, n. 19, p. 45464550 , 2013.

LONGHINI, Renata; RAKSA, Sheila M.; OLIVEIRA, Ana Carla P. et al. Obtenção de extratos de própolis sob diferentes condições e avaliação de sua atividade antifúngica. Revista Brasileira de Farmacognosia, v. 17, n. 3, p. $388395,2007$.

LUSTOSA, Sarah R.; GALINDO, Alexandre B.; NUNES, Lívio C. C. et al. Própolis: atualizações sobre a química e a farmacologia. Revista Brasileira de Farmacognosia, v. 18, n. 3, p. 447 454, 2008. 


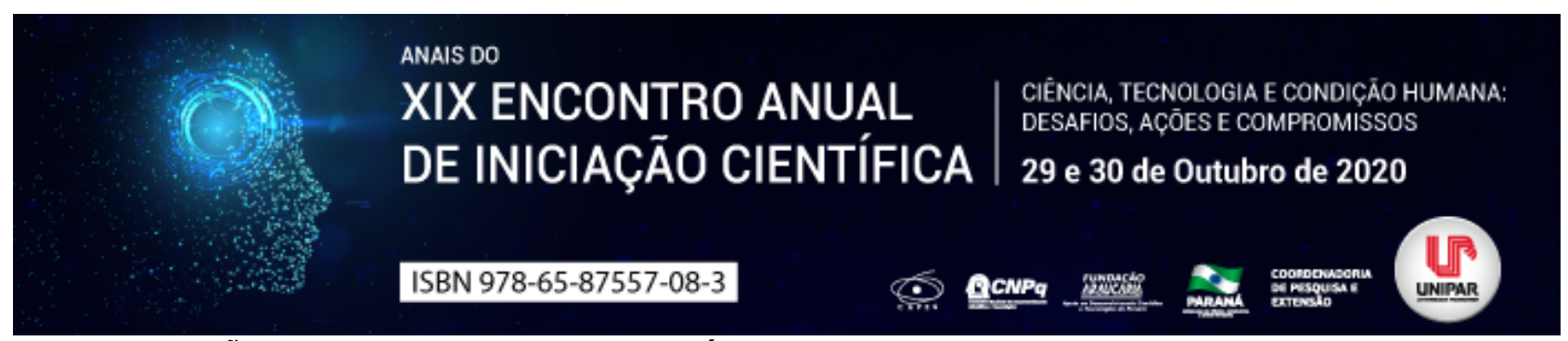

AVALIAÇÃO In vitro DE EXTRATO DE PRÓPOLIS VERMELHA CONTRA Streptococcus mutans

${ }^{1}$ Karine Jorge Alves Bezerra, ${ }^{2}$ DEUSIMAR ROMEU CAVALCANTE FILHO, ${ }^{3}$ LEONARDO JORGE ALVES BEZERRA, ${ }^{4}$ SANDRA MARA DA SILVA LIMA, ${ }^{5}$ FRANCISCO JOSIMAR GIRAO JUNIOR

\author{
${ }^{1}$ Unichristus \\ ${ }^{1}$ Unichristus \\ ${ }^{2}$ Unichristus \\ ${ }^{3}$ Estudante de Nutrição, Instituto Federal de Educação, Ciência e Tecnologia do Ceará. \\ ${ }^{4}$ Docente da UNIQ
}

Introdução: A própolis é oriunda da mistura da secreção mandibular das abelhas e resina de diversos vegetais. Dentre os constituintes químicos presentes na própolis vermelha pode-se citar o vestitol e neovestitol, isoflavonoides que demonstraram atividade antimicrobiana frente ao Streptococcus mutans.

Objetivos: O objetivo deste estudo foi avaliar o efeito antimicrobiano do extrato de própolis vermelha brasileira (PVB) contra cepas de Streptococcus mutans (S. mutans) in vitro.

Material e Métodos: Cepas de S. mutans ATCC UA159 foram utilizadas no presente estudo. Para a avaliação da atividade antimicrobiana, utilizou-se o método de microdiluição em caldo de cultura. A cepa foi ativada por incubação a $37^{\circ} \mathrm{C}$ durante a noite em meio de cultura Brain Heart Infusion (BHI), em frasco anaeróbio. Aos poços das microplacas foram adicionados $100 \mu \mathrm{L}$ de caldo BHI, $20 \mu \mathrm{L}$ das substâncias testadas (grupos experimentais), em concentrações variando de $100 \mu \mathrm{L} / \mathrm{mL}$ a $0,0488 \mu \mathrm{L} / \mathrm{mL}$, e $80 \mu \mathrm{L} / \mathrm{mL}$ da suspensão microbiana padronizada (106 UFC/mL). As microplacas foram incubadas durante 24 horas em estufa bacteriológica a $37^{\circ} \mathrm{C}$. Valores médios e desvios padrão foram calculados. Foram aplicados ANOVA seguida pelo teste de Dunnett, o valor de $\mathrm{p}$ inferior a 0,05 foi considerado significativo.

Resultados: O extrato de PVB apresentou atividade antimicrobiana contra S. mutans até a concentração de $0,3906 \mu \mathrm{g} / \mathrm{mL}$.

Discussão: Resultados encontrados por George e Kasliwal (2017) demonstram atividades antimicrobianas, antiparasitárias e antioxidantes da própolis vermelha. No entanto, novos estudos com diferentes concentrações são necessários para avaliar a eficácia do extrato contra o microorganismo em questão.

Conclusão: O extrato de PVB mostrou certa atividade antimicrobiana contra S.mutans.

\title{
Referências
}

BUENO-SILVA, Bruno; ALENCAR, Severino M.; KOO, Hyun et al. Anti-Inflammatory and Antimicrobial Evaluation of Neovestitol and Vestitol Isolated from Brazilian Red Propolis. Journal of Agricultural and Food Chemistry, v. 61, n. 19, p. 4546-4550, 2013. GEORGE, Rajani Mary; KASLIWAL, Akash V. Effectiveness of Propolis, Probiotics And Chlorhexidine on Streptococcus Mutans And Candida Albicans: An In-Vitro Study. IOSR Journal of Dental and Medical Sciences, v. 16, n. 3, p. 15-18, 2017.

LOBO, Patrícia Leal Dantas. et al. Dose-response evaluation of a novel essential oil against Mutans streptococci in vivo. Phytomedicine, v. 18, n. 7, p. 551-556, 2011.

SANTOS, Vagner Rodrigues. Synergic effect of associated green, red and brown Brazilian propolis extract onto Streptococcus mutans and Streptococcus sanguinis. African Journal of Pharmacy and Pharmacology, v. 7, n. 9, p. 2006-2010, 2013. 


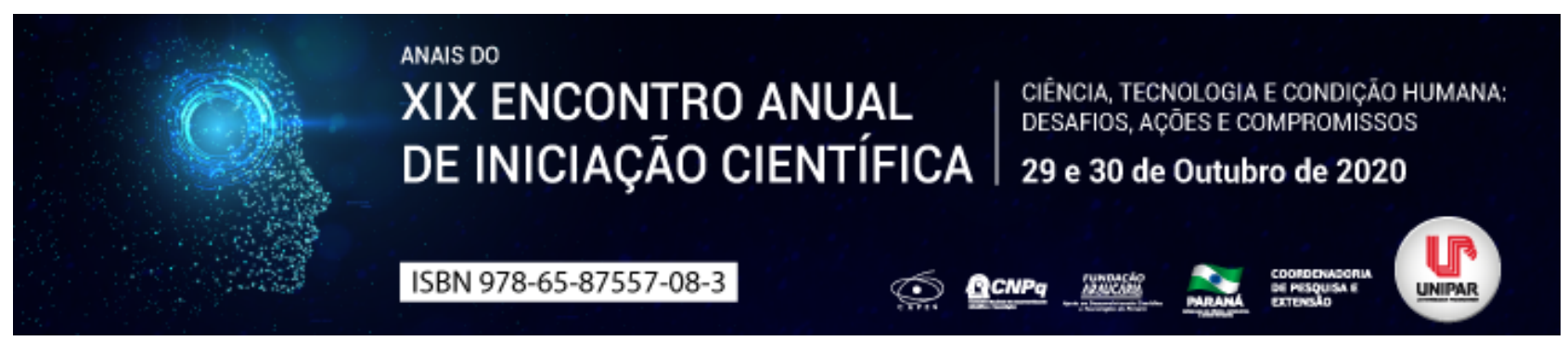

ATIVIDADE IN VITRO DE Copaifera langsdorffii SOBRE Candida albicans

\begin{abstract}
${ }^{1}$ Jaciara Simões Benevides Sousa, ${ }^{2}$ DEUSIMAR ROMEU CAVALCANTE FILHO, ${ }^{3}$ LEONARDO JORGE ALVES BEZERRA, ${ }^{4}$ SANDRA MARA DA SILVA LIMA, ${ }^{5}$ FRANCISCO JOSIMAR GIRAO JUNIOR
\end{abstract}

\author{
${ }^{1}$ Unichristus \\ 1Unichristus \\ 2Unichristus \\ ${ }^{3}$ Estudante de Nutrição, Instituto Federal de Educação, Ciência e Tecnologia do Ceará. \\ ${ }^{4}$ Docente da UNIQ
}

Introdução: Produtos naturais biologicamente ativos têm sido pesquisados como meio de prevenir e tratar diversas doenças. A copaíba é uma planta comum na América Latina e África Ocidental, pertencente à família Fabaceae, subfamília Caesalpinioideae, é nativa da floresta amazônica e comum na região do Mato Grosso, sendo a espécie com maior importância na região de seu georeferenciamento. Estudos evidenciam o potencial terapêutico da Copaifera spp, ou copaíba, destacando-se as propriedades anti-inflamatória e antimicrobiana. Estudos também comprovam propriedades analgésica, cicatrizante, anti-séptica, antitumoral, germicida e diurética (ARIF et al., 2009; BIESKI et al., 2015; PIERI et al., 2009; SIMÕES et al., 2016;VEIGA JUNIOR; PINTO, 2002). Já a Candida albicans faz parte da microbiota humana normal e coloniza a cavidade oral, o trato gastrointestinal e o trato geniturinário de 70\%, ou mais, da população, como um agente comensal (MAVOR; THEWES; HUBE, 2005).

Objetivos: Avaliar in vitro a atividade fungicida do óleo de copaíba (Copaifera langsdorffii) sobre espécies de Candida albicans (ATCC 10231), determinando a Concentração Inibitória Mínima (CIM) e Concentração Fungicida Mínima (CFM).

Material e Métodos: O óleo-resina foi obtido através da perfuração do tronco da copaibeira com um trado e posterior inserção de um tubo de PVC, por onde o óleo escoa. Foram utilizadas placas de microdiluição de 96 poços nas quais as cepas de Candida albicans foram incubadas a $37^{\circ} \mathrm{C}$ durante 24 horas e semeadas em meio Ágar Sabouraud Dextrose. Testou-se soluções diluídas em água destilada nas concentrações $0,20 \mathrm{~g} / \mathrm{mL}, 0,30 \mathrm{~g} / \mathrm{mL}$ e $0,40 \mathrm{~g} / \mathrm{mL}$. Para estabelecer o Controle de Crescimento utilizou-se fungos e meio de crescimento, para testar viabilidade das cepas. A Nistatina em forma de suspensão comercial 100.000 UI/mL foi o controle positivo. Os testes foram realizados em triplicata e os dados obtidos analisados por teste Kruskal-Wallis, com $\alpha=0,05$. Resultados: Na leitura das amostras, todas demonstraram sensibilidade ao extrato analisado, havendo inibição com a solução $0,20 \mathrm{~g} / \mathrm{mL}$. Entretanto, não foi observado efeito fungicida (CFM) nas concentrações testadas.

Discussão: Um estudo realizado no estado do Pará obteve inibição do crescimento fúngico com concentração de 0,16 g/mL, também não observando atividade fungicida (DEUS; ALVES; ARRUDA, 2011). Dessa maneira, os resultados indicam a necessidade de estudos posteriores para analisar se há inibição com concentrações inferiores à menor testada nesse estudo, bem como a utilização de maiores concentrações para reavaliar o potencial fungicida evidenciado em outros estudos (BIESKI et al., 2015; DA TRINDADE; DA SILVA; SETZER, 2018).

Conclusão: Este estudo indicia que o óleo-resina de copaíba pode ser uma alternativa contra o gênero Candida, entretanto são necessários maiores estudos para avaliação e possível comprovação de ação antifúngica.

\title{
Referências
}

ARIF, Tasleem; BHOSALE, Jitendra D.; KUMAR, Naresh et al. Natural products antifungal agents derived from plants. Journal of Asian Natural Products Research, v. 11, n. 7, p. 621 638, 2009.

BIESKI, Isanete Geraldini Costa et al. Ethnobotanical study of medicinal plants by population of valley of Juruena region, legal amazon, Mato Grosso, Brazil. Journal of ethnopharmacology, v. 173, p. 383-423, 2015.

DEUS, R.J.A; ALVES, C.N; ARRUDA, M.S.P. Avaliação do efeito antifúngico do óleo resina e do óleo essencial de copaíba (Copaifera multijuga Hayne). Rev. bras. plantas med., Botucatu , v. 13, n. 1, p. 01-07, 2011.

MAVOR, A.; THEWES, S.; HUBE, B. Systemic Fungal Infections Caused by Candida Species: Epidemiology, Infection Process and Virulence Attributes. Current Drug Targets, v. 6, n. 8, p. 863 874, 2005.

PIERI, F.A., MUSSI, M.C., MOREIRA, M.A.S. Óleo de copaíba (Copaifera sp.): histórico, extração, aplicações industriais e propriedades medicinais. Revista Brasileira de Plantas Medicinais, v.11, n.4, p.465-472, 2009.

SIMÕES, Cláudia A.C.G.; CONDE, Nikeila C. de Oliveira; VENÂNCIO, Gisely N. et al. Antibacterial Activity of Copaiba Oil Gel on Dental Biofilm. The Open Dentistry Journal, v. 10, n. Suppl-1, M6, p. 188 195, 2016.

DA TRINDADE, Rafaela; DA SILVA, Joyce; SETZER, William. Copaifera of the Neotropics: A Review of the Phytochemistry and Pharmacology. International Journal of Molecular Sciences, v. 19, n. 5, p. 1511, 2018. 
VEIGA JUNIOR, V.F.; Pinto, A.C. O Gênero Copaifera L.Química nova, v.25, n.2, p.273-286, 2002.

Coordenadoria de Pesquisa e Extensão - COPEX

Departamento de Editoraçāo e Divulgaçāo Científica - DEDIC 


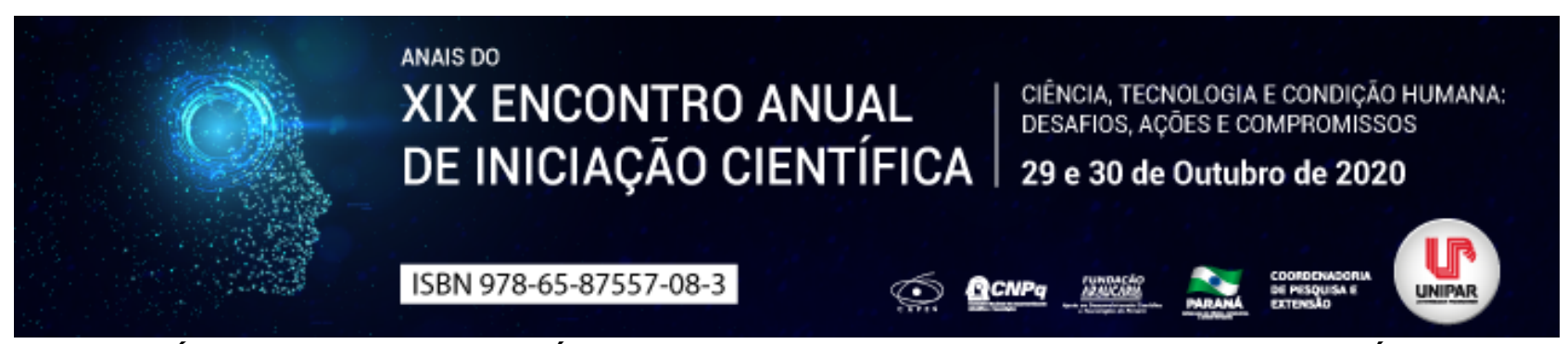

POSSÍVEIS EFEITOS TOXICOLÓGICOS DO BISFENOL A NO SISTEMA NERVOSO ENTÉRICO

\begin{abstract}
${ }^{1}$ EDSON GERONIMO , ${ }^{2}$ PAULA MONTANHINI FAVETTA, ${ }^{3}$ MARIA BEATRIZ NAUFEL CARVALHO, ${ }^{4}$ ANA LETICIA MIKA YASSUE, ${ }^{5}$ WESLEY ALVES TRINDADE , ${ }^{6}$ RICARDO DE MELO GERMANO
\end{abstract}

\begin{abstract}
${ }^{1}$ Discente do Curso de Farmácia PIBIC/ Unipar Unidade Sede Umuarama PR.
${ }^{1}$ Doutoranda em Ciência Animal com Ênfase em Produtos Bioativos, Bolsista PROSUP- CAPES/UNIPAR

${ }^{2}$ Discente do Curso de Nutrição PIBIC/ Unipar Unidade Sede Umuarama Pr.

${ }^{3}$ Discente do Curso de Nutrição PIBIC/ Unipar Unidade Sede Umuarama Pr.

${ }^{4}$ Mestrando em Ciência Animal com Ênfase em Produtos Bioativos, Taxista PROSUP- CAPES/UNIPAR

${ }^{5}$ Docente da Pós-graduação em Ciência Animal com Ênfase em Produtos Bioativos/UNIPAR
\end{abstract}

Introdução: O Bisfenol A conhecido popularmente como BPA, abrange a produção de plásticos, como embalagens de alimentos, bebidas e diversos utensílios de uso diário, apesar da sua aplicação na indústria, ele pode atuar como desregulador endócrino com alto poder toxicológico, principalmente em fases iniciais da vida, sabe-se que o BPA causa um impacto negativo no organismo, acometendo órgãos reprodutivos, nervosos, sistemas endócrinos e imunológicos (SZYMANSKA; CALKA; GONKOWSKI, 2018). O sistema digestório também é apontado como alvo para o BPA, uma vez que este composto está constantemente em contato com alimentos, e os órgãos do trato gastrointestinal, são os primeiros a entrarem em contato com os alimentos (BHATNAGAR; ANSTOPOULOS, 2017) possivelmente contaminados com o BPA.

Objetivo: Realizar uma revisão bibliográfica a respeito dos efeitos do Bisfenol A no Sistema Nervoso Entérico.

Desenvolvimento: $O$ presente trabalho consiste numa revisão de literatura, utilizando o banco de dados eletrônico Google Acadêmico , com as seguintes palavras-chave: absorção, bisfenol A, BPA, Sistema digestório, Sistema Nervoso Entérico . Foram encontrados cinco artigos de 2017 a 2020 que contemplaram as palavras-chave utilizadas. O sistema digestório é responsável pela digestão e absorção de nutrientes e também atua como uma barreira, composta de células epiteliais que selecionam a entrada de nutrientes e impedem a entrada de substancias nocivas, o aumento da permeabilidade intestinal pode trazer como consequência inflamações, translocação bacteriana e infecções intestinais, este aumento na permeabilidade pode ser causado pelo BPA, que interrompe a função da barreira intestinal por meio de apoptose e também por inibir a proliferação de células epiteliais no cólon (FENG et al., 2019). De acordo com a Anvisa (2013), o BPA possui capacidade de lixiviação, podendo contaminar alimentos e bebidas por dois processos: a difusão de resíduos durante o processo de fabricação e hidrólise pela alteração da temperatura, $\mathrm{pH}$ e até mesmo substâncias presentes nos alimentos e bebidas armazenados no mesmo. Os efeitos multidirecionais do BPA no organismo, principalmente ao que tange o Sistema Nervoso Entérico (SNE) ainda é pouco esclarecido, sabe-se que há uma alteração na barreira intestinal, alterações nos receptores de estrogênio presentes nas células epiteliais e também as células imunes do trato gastrointestinal, estas alterações podem estar envolvidas em diversos processos inflamatórios (SZYMANSKA; GONKOWSKI, 2018). Szymanska, Calka e Gonkowski (2018), desenvolveram um estudo com 15 porcas da raça Piétrain, durante oito semanas, que tinha como objetivo investigar a influência de doses baixas $(0,05 \mathrm{mg} / \mathrm{kg})$ e altas $(0,5 \mathrm{mg} / \mathrm{kg})$ de BPA nas estruturas neurais imunorreativas do tipo óxido nítrico sintase neuronal, no trato gastrointestinal utilizando a técnica de imunofluorescência, tendo como resultado prejuízos nos neurônios entéricos nitrérgicos e também nas fibras nervosas, as autoras ainda destacam que as alterações dependem do segmento intestinal e que mesmo nas menores doses, o BPA apresentou não ser neutro ao organismo. Em outro estudo realizado por Szymanska e Gonkowski (2018), também com doses altas $(0,5 \mathrm{~g} / \mathrm{kg})$ e baixas $(0,05 \mathrm{mg} / \mathrm{kg})$ de BPA, administrado durante 28 dias, no duodeno de porcas, demonstrou mudanças visíveis nos neurônios entéricos por imunofluorescência, em ambos estudos. A menor dose foi baseada na dose de ingestão diária tolerável permitida, de 0,05mg/kg de peso corporal/dia (EFSA, 2013).

Conclusão: De acordo com as informações disponibilizadas na literatura, o BPA apresenta alterações fisiológicas sobre o sistema digestório e também nos neurônios entéricos, mesmo em curto prazo e com doses toleráveis. Conclui-se que ainda se faz necessário novos estudos, de forma a explicar os mecanismos deste efeito do BPA no organismo no sistema digestório.

\title{
Referências
}

AGÊNCIA NACIONAL DE VIGILÂNCIA SANITÁRIA. Bisfenol A. 2013. Disponível em Acesso em: 22/06/2020.

BHATNAGAR, Amit; ANASTOPOULOS, loannis. Adsorptive removal of bisphenol A (BPA) from aqueous solution: a review. Chemosphere, v. 168, p. 885-902, 2017.

EFSA. Draft Scientific Opinion on the risks to public health related to the presence of bisphenol A (BPA) in foodstuffs Part: exposure assessment. EFSA J., p. 1-314, 2013. 
FENG, Ling et al. Bisphenol A increases intestinal permeability through disrupting intestinal barrier function in mice. Environmental Pollution, v. 254, p. 112960, 2019.

SZYMANSKA, K.; CALKA, J.; GONKOWSKI, S. Nitric oxide as an active substance in the enteric neurons of the porcine digestive tract in physiological conditions and under intoxication with bisphenol A (BPA). Nitric Oxide, v. 80, p. 1-11, 2018.

SZYMANSKA, Kamila; GONKOWSKI, Slawomir. Bisphenol A-Induced changes in the enteric nervous system of the porcine duodenum. Neurotoxicology, v. 66, p. 78-86, 2018.

Coordenadoria de Pesquisa e Extensão - COPEX

Departamento de Editoraçāo e Divulgaçāo Científica - DEDIC 


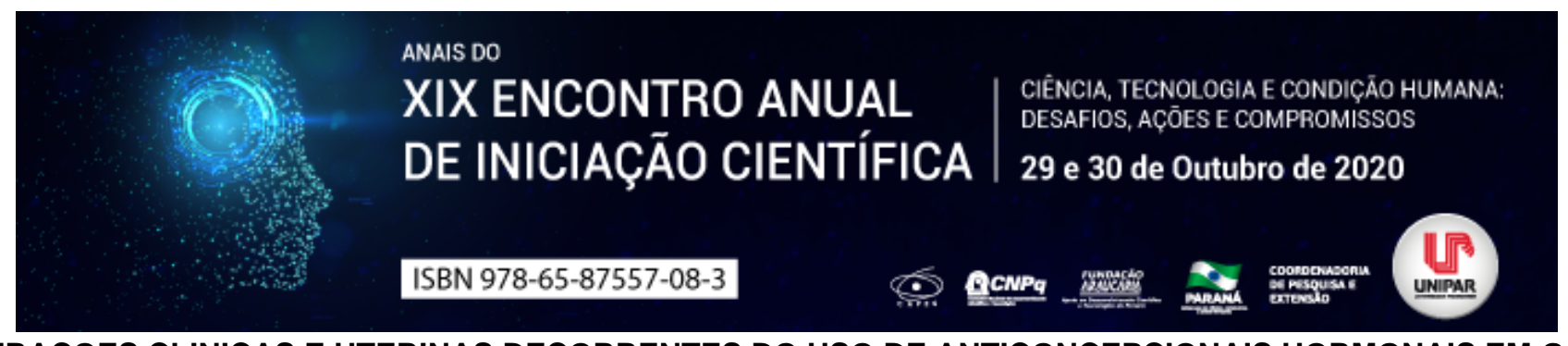

ALTERACOES CLINICAS E UTERINAS DECORRENTES DO USO DE ANTICONCEPCIONAIS HORMONAIS EM GATAS

\begin{abstract}
${ }^{1}$ ANA CAROLINE SOARES CERANTO, ${ }^{2}$ ALYSSON RAMALHAIS, ${ }^{3}$ GIULIANA CAVALCANTI DOS SANTOS, ${ }^{4}$ LUAN VINICIUS TEZZEI MAIA, ${ }^{5}$ RAFAEL MARTINS BASTOS, ${ }^{6}$ ANA MARIA QUESSADA
\end{abstract}

\author{
${ }^{1}$ Academico Bolsista do PEBIC/ CNPq \\ ${ }^{1}$ Acadêmico do Curso de Mestrado Em Ciencia Animal Com Enfase Em Produtos Bioativos - Turma Xv da UNIPAR \\ ${ }^{2}$ Acadêmica do Curso de Medicina Veteriñ̃ $j$ ria da UNIPAR

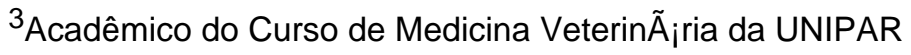 \\ ${ }^{4}$ Acadêmico do Curso de Medicina Veteriñ̃ $;$ ria da UNIPAR \\ ${ }^{5}$ Docente da UNIPAR
}

Introdução: As fêmeas felinas geralmente geram proles numerosas principalmente porque têm gestação curta, são multíparas e podem alcançar a maturidade sexual a partir de seis meses de idade (HONÓRIO et al., 2017). Desta maneira, o controle populacional de tais animais é bastante debatido nos tempos atuais. Além disso, tal controle populacional possibilita a diminuição de zoonoses, enfermidades bastante importantes no Brasil. Para evitar a concepção em gatas muitos tutores optam por utilizar anticoncepcionais hormonais. No entanto, a utilização de anticoncepcionais em gatas produz efeitos colaterais graves. Há relatos de associação com tumores mamários (TOGNI et al., 2013; ARAÚJO et al., 2017), morte fetal (ARAÚJO et al., 2014) piometra (EVANGELISTA et al., 2011; ARAÚJO et al., 2017,) abortos, hiperplasia mamária (ARAÚJO et al., 2017).

Objetivo: O objetivo deste trabalho foi acompanhar gatas submetidas à administração de anticoncepcionais para registrar a ocorrência de alterações clínicas

Material e Métodos: O projeto foi aprovado pelo comitê de ética da Unipar com o número de protocolo 34626/2018. Dez gatas clinicamente saudáveis e que nunca tinham tomado anticoncepcional foram selecionadas para participar do estudo. Após o exame clínico (exame físico e exames laboratoriais) e ultrassonográfico foi administrado aos animais os anticoncepcionais. Trinta e noventa dias após a administração dos anticoncepcionais, todos os animais foram examinados novamente, repetindo-se os exames realizados na consulta inicial. Noventa dias após a aplicação do anticoncepcional, todas as gatas foram castradas cirurgicamente. Todos os dados obtidos foram anotados em fichas individuais e comparados com os dados obtidos no primeiro exame.

Resultados e Discussão: Trinta dias após a administração do anticoncepcional, todas a gatas apresentaram aumento generalizado das glândulas mamárias. Provavelmente este aumento das glândulas mamárias está relacionado à progesterona, pois os anticoncepcionais hormonais utilizados em gatas, são, em sua maioria progestágenos (moléculas semelhantes à progesterona). Com o decorrer do tempo é provável que as gatas do estudo apresentariam a enfermidade denominada hiperplasia mamária felina. Tal enfermidade é comum em gatas que foram submetidas à aplicação do anticoncepcional (FILGUEIRA et al., 2015; ARAÚJO et al., 2017). Das dez gatas incluídas no trabalho, nove gatas apresentaram piometra (90\% ou 9/10). Apesar de não ser comum nas gatas, a presença de piometra é frequente nesta espécie quando ocorre a administração de fármacos anticonceptivos (HEDLUND, 2007; SILVEIRA et al., 2013; MOURA et al., 2016). Chamou a atenção o fato de que a piometra se instalou em curto período de tempo (90 dias) e com uma única aplicação. A maioria dos efeitos colaterais dos contraceptivos para cadelas e gatas podem ser evitados se os fármacos forem administrados no período adequado que é 7-15 dias antes do cio (VASETSKA \& MASS, 2017). No entanto, as fases do ciclo estral de cadelas e gatas só podem ser reconhecidas por meio de testes exclusivos do médico veterinário (SILVA, 2016).

Conclusão: Anticoncepcionais produzem alterações patológicas graves em gatas após uma única aplicação. Tais fármacos devem ser vendidos sob estrita indicação veterinária.

\title{
Referências
}

ARAÚJO, L.S.; ARAÚJO, N.L.S.; ALFARO, C.E.P.; CARNEIRO, R.S. Morte fetal em cadelas e gatas submetidas a tratamento com anticoncepcionais atendidas no Hospital Veterinário da Universidade Federal de Campina Grande. Acta Veterinaria Brasilica, v.8, Supl. 2, p. 193-194, 2014.

ARAÚJO, E.K.D.; MOURA, V.M.; HONÓRIO, T.G.A.F.; ALVES, R.A.; FONSECA, A.P.B.; RODRIGUES, M.C.; KLEIN, R.P. Principais patologias relacionadas aos efeitos adversos do uso de fármacos contraceptivos em gatas em Teresina

PI. PUBVET. v.11, n.3, p. 256-261, 2017.

FILGUEIRA, K.D.; REIS, P.F.C.C.; MACÊDO, L.B.; OLIVEIRA, I.V.P.M.; PIMENTEL, M.M.L.; RECHE JÚNIOR, A. Caracterização clínica e terapêutica de lesões mamárias não neoplásicas em fêmeas da espécie felina. Acta Veterinaria Brasilica, v.9, n.1, 
p.98-107, 2015.

HEDLUND, C. S. Cirurgia dos sistemas reprodutivo e genital. In: FOSSUM, T. W. Cirurgia de pequenos animais. 2. ed. São Paulo: Roca, 2007. p. 619-672.

MOURA, R.B.R.; JACOB, T.M.; VOSS, G.P.; SANTOS, A.P.D.; ROSA, P.R.B. Estudo dos efeitos de contraceptivos. I Mostra de iniciação científica e tecnológica. Fundação Educacional de Andradina. Faculdade de Ciências Agrárias de Andradina, 2016. Anais. p. 68-72. Disponível em: >.

SILVA, L.D.M. Controle do ciclo estral em cadelas. Revista Brasileira de Reprodução Animal, v.40, n.4, p.180-187, 2016.

SILVEIRA, C.P.B.; MACHADO, E.A.A.; SILVA, W.M.; MARINHO, T.C.M.S.; FERREIRA, A.R.A; BURGER, C.P.; COSTA NETO, J.M. Estudo retrospectivo de ovariossalpingo-histerectomia em cadelas e gatas atendidas em Hospital Veterinário Escola no período de um ano. Arquivo Brasileiro de Medicina Veterinária e Zootecnia. v. 65, n.2, p.335-340, 2013.

VASETSKA, A.I. e Mass, A.A. 2017. The use of hormone containing contraceptive drugs and their effects on the reproductive system of dogs and cats. Journal for Veterinary Medicine, Biotechnology and Biosafety 3(1): 21-25.

Coordenadoria de Pesquisa e Extensão - COPEX

Departamento de Editoraçāo e Divulgaçāo Científica - DEDIC 


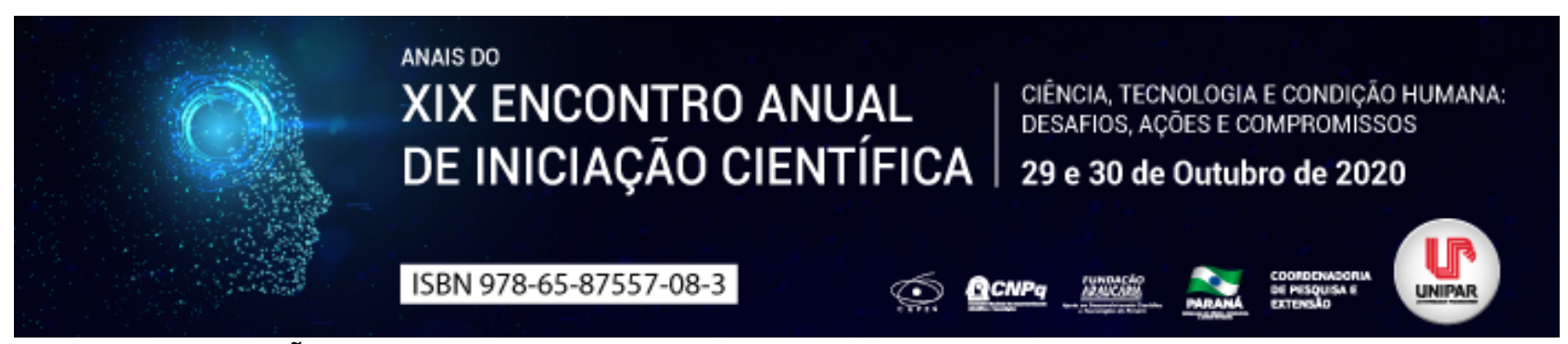

INDUÇÃO DA PUBERDADE EM NOVILHAS COM O USO DA HORMONIOTERAPIA

\begin{abstract}
${ }^{1}$ MARIA EDUARDA BORBA ALEM, ${ }^{2}$ GUSTAVO POMARO, ${ }^{3}$ LUCCA HIROITI SAKASHITA, ${ }^{4}$ VITOR HUGO INOUE CORREA, ${ }^{5}$ ROSIARA ROSARIA DIAS MAZIERO
\end{abstract}

\author{
${ }^{1}$ Acadêmica do PIC/UNIPAR \\ ${ }^{1}$ Acadêmico do Curso de Medicina Veterinária da UNIPAR \\ ${ }^{2}$ Acadêmico do Curso de Medicina Veterinária da UNIPAR \\ ${ }^{3}$ Acadêmico do Curso de Medicina Veterinária da UNIPAR \\ ${ }^{4}$ Docente da UNIPAR
}

Introdução: A reprodução das novilhas é indispensável para a lucratividade de uma propriedade, visto que deste modo ocorre a transmissão de material genético, aumentando a eficiência do rebanho. Atualmente vários protocolos hormonais têm sido usados para induzir a puberdade em novilhas. Estes protocolos consistem em associações de diversos hormônios como $\mathrm{GnRH}$ (hormônio liberador de gonadotrofinas), estrógeno (E2), progesterona (P4) ou progestágenos, prostaglandina (PGF2a), entre outros. Para tanto, a precocidade sexual da fêmea bovina, avaliada por meio da idade à puberdade ou idade ao primeiro parto,constitui-se um dos parâmetros mais confiáveis quando se deseja mensurar e elevar a eficiência reprodutiva do rebanho, pois expressa, em linhas gerais, o melhor índice para avaliação da fertilidade inerente a uma fêmea (MARSON et al., 2004).

Objetivo: Avaliar os benefícios hormonais da indução da puberdade em novilhas e consequente o aumento eficiência reprodutiva de um rebanho.

Desenvolvimento: A puberdade de uma fêmea consiste na primeira manifestação do primeiro estro, associado a uma ovulação potencialmente fértil, seguido pelo desenvolvimento do corpo lúteo e por uma fase luteal de duração normal, característico de cada espécie em particular (MORAN et al., 1989). Contudo, em novilhas, a maturidade sexual, fase em que o animal atinge a plena capacidade reprodutiva, é atingida pela ocorrência de três ciclos estrais consecutivos completos, em intervalos regulares acrescidos dos sinais externos de comportamento de estro (ROMANO, 1997). Neste sentido, vários são os protocolos hormonais utilizados para o adiantamento da ciclicidade em novilhas, os quais baseiam-se em agentes luteolíticos como a prostaglandina F2 a e análogos sintéticos, que podem ou não ser associados a substâncias como a P4 e os progestágenos que prolongam artificialmente o estado funcional do corpo lúteo. Os agentes luteolíticos também podem ser associados ao GnRH, gonadotrofinas coriônicas (hCG e eCG) e estrógenos os quais induzem a ovulação (FONSECA \& MAFFILI, 2002). Estudos mostram que quanto antes as novilhas atingirem a puberdade, melhores serão os resultados da IATF. Portanto, o protocolo de indução de ciclicidade pode ser realizado de 30 a 40 dias previamente à estação de monta das novilhas. Entretanto, se não houver tempo para tal, estudos indicam que os efeitos positivos da indução de puberdade já podem ser observados com 12 dias de intervalo entre a indução e o início do protocolo para IATF (SÁ FILHO et al., 2015).

Conclusão: Os protocolos hormonais de sincronização de estro podem apresentar um impacto econômico na produção de bezerros e de leite, tendo em vista que estes tratamentos podem induzir a puberdade adiantando a idade ao primeiro parto e conseqüentemente melhorando a eficiência reprodutiva e produtiva de fêmeas bovinas.

\title{
Referências
}

FONSECA, J.F.; MAFFILI, V.V. Biotecnologias da reprodução de ruminantes. In: VII Jornada de Medicina Veterinária da Unipar. Umuarama-PR, 2002.

MARSON, E. P.; GUIMARÃES, J.D.; MIRANDA NETO, T. Puberdade e maturidade sexual em novilhas de corte. Revista Brasileira de Reprodução Animal, v. 28, p, 1-64, 2004.

MORAN, C.; QUIRKE, S.J.; ROCHE, J.F. Puberty in heifers: a review. Animal Reproduction Science, v.18, p.167-182, 1989.

ROMANO, M. C. Efeito do nível nutricional sabre a antecipação da idade à puberdade e caracterização de dinâmica folicular nos períodos pré e pós-púbere em novilhas Nelore. São Paulo, 1997. 103p.(Tese em medicina veterinária) Faculdade de Medicina Veterinária e Zootecnia, Universidade de São Paulo.

SÁ FILHO, M. F.; NASSER, L. F. T.; PENTEADO, L.; PRESTES, R.; MARQUES, M. O.; FREITAS, B. G.; MONTEIRO, B. M.; FERREIRA, R. M.; GIMENES, L. U.; BARUSELLI, P. S. Impact of progesterone and estradiol treatment before the onset of the breeding period on reproductive performance of Bos indicus beef heifers. Animal Reproduction Science, v. 30, p. 234-245, 2015 . 
Coordenadoria de Pesquisa e Extensão - COPEX

Departamento de Editoraçāo e Divulgaçāo Científica - DEDIC 


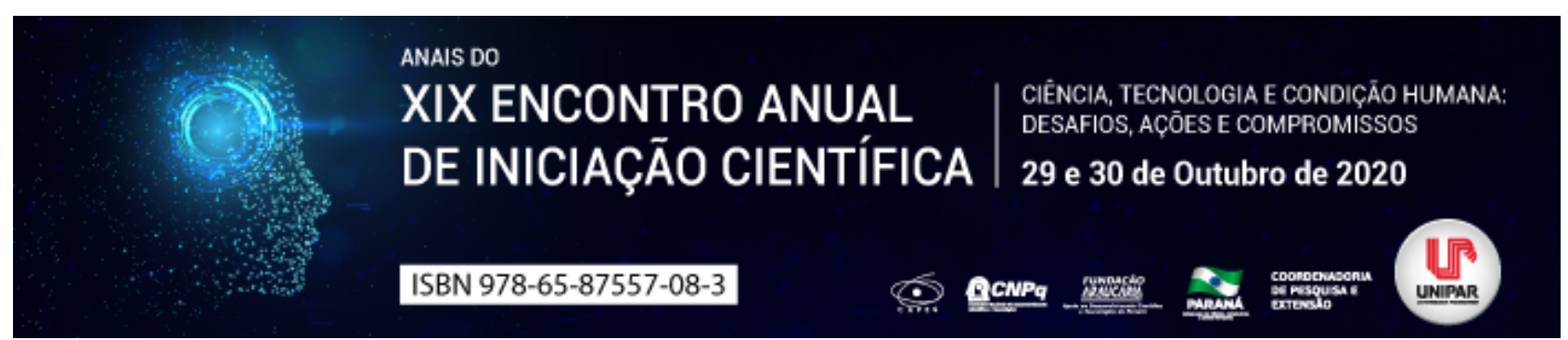

UMA REVISÃO DA RELAÇÃO DO GENE FTO COM A OBESIDADE E A SÍNDROME METABÓLICA

\title{
${ }^{1}$ GABRIELA CORREA ALBERTI, ${ }^{2}$ MARIA ELENA MARTINS DIEGUES, ${ }^{3}$ LUCIANO SERAPHIM GASQUES
}

\author{
${ }^{1}$ Discente da UNIPAR \\ ${ }^{1}$ Docente da UNIPAR \\ ${ }^{2}$ Docente da UNIPAR
}

Introdução: Segundo a Organização Mundial da Saúde, obesidade é uma doença desinente do acúmulo de gordura no organismo, sendo considerada um fator de risco significativo ao desenvolvimento de outras doenças crônicas não transmissíveis. Além disso, é importante ressaltar que a patologia está ligada a questões históricas, ecológicas, econômicas, sociais, culturais, políticas e fatores predisponentes genéticos. Os fatores genéticos geram divergências na taxa de metabolismo basal, na resposta à quantidade e metabolização de alimentos, sendo os responsáveis por $24 \%$ a $40 \%$ de alteração do IMC (COUTINHO, 2007). Ademais, há uma enzima ligada no ajuste do ácido desoxirribonucleico (DNA), no metabolismo dos ácidos graxos e na modificações pós-traducionais que em seres humanos, é codificada como FTO (Fat Mass and Obesity Gene) gene encontrado no cromossomo 16. Logo, a variação do gene FTO está ligada ao IMC e ao diabetes mellitus tipo 2 (TORKAMANI, 2020).

Objetivo: Relacionar a variação comum do gene FTO com o aumento do índice de massa corpórea (IMC) e a sua ligação com o desenvolvimento da síndrome metabólica. Além de correlacionar com divergência étnica e seu desenvolvimento.

Desenvolvimento: Há um avanço nos estudos do gene FTO, sendo observado a presença deste no núcleo arqueado paraventricular, dorsomedial e ventromedial no hipotálamo, que são áreas do cérebro responsáveis pelo controle de apetite. Por meio desta observação, pesquisas demonstraram que camundongos que expressavam abundantemente o gene FTO, possuíam aumento de gordura e aumento de ingestão de alimentos. Sendo assim, foi despertado o estudo em humanos, em que pessoas com no mínimo um dos alelos de risco de obesidade da FTO desenvolveram aumento do consumo energético, diminuição de saciedade e excepcionalmente foi notado que a mudança no gasto de energia eram relacionadas ao aumento do IMC (TORKAMANI, 2020). Outrossim, por meio da relevância de que o aumento do índice de massa corpórea está ligado diretamente a obesidade, é observado que a resistência à insulina, doenças hepática gordurosa não alcoólica, hiperglicemia, hipertensão e dislipidemia quando associadas em conjunto definem a síndrome metabólicas que são preditores fundamentais da diabetes tipo 2 (FREATHY, 2008.) Entrementes, estudos demonstram que o IMC diverge de acordo com a etnia, sendo que em grupos de brancos europeus a associação com diabetes tipo 2 foi integralmente explícita pela associação com o IMC. Já em asiáticos a relação não é tão significativa assim, pois foi comprovado que os indianos desenvolvem diabetes com um menor IMC comparado com os europeus brancos, sendo que para qualquer IMC, os indianos possuem uma maior preponderância de desenvolvimento de diabetes. Logo, é notório que estudos mostram que a variante do FTO com a diabetes mellitus tipo 2 pode não ser totalmente medidas pelo IMC, quando se trata de diferenças étnicas (YAINIK, 2009).

Conclusão: A luz de todo exposto, se tem que o gene FTO controla a homeostase energética, sendo responsável pela regulação do acúmulo de gordura corporal, então assim relacionado ao aumento do índice de massa corpórea e a obesidade. O aumento do IMC é um fator preditor ao desenvolvimento da diabetes mellitus tipo 2, porém pode ocorrer resultados variados quando o assunto é relacionado a diferenças étnicas.

\section{Referências}

ALI, Torkamani. Obesity, FTO, and Type 2 Diabetes. Literature review corrente through: Feb 27, 2020. Disponível em: https://emedicine.medscape.com/article/1969692-overview. Acesso em 21 de jul de 2020.

BRASIL. Ministério da Saúde. Portão de saúde do SUS. Obesidade. Disponível em: https://www.saude.gov.br/atencaoespecializada-e-hospitalar/especialidades/obesidade. Acesso em: 21 de jul de 2020.

COUTINHO, Walmir; DUALIB, Patrícia. Etiologia da obesidade. Revista da ABESO, v. 7, n. 30, p. 1-14, 2007.

YAJNIK, Chittaranjan S. et al. FTO gene variants are strongly associated with type 2

diabetes in South Asian Indians. Diabetologia, v. 52, n. 2, p. 247-252, 2009.

FREATHY, Rachel M. et al. Common variation in the FTO gene alters diabetes-related metabolic traits to the extent expected given its effect on BMI. Diabetes, v. 57, n. 5, p.

1419-1426, 2008. 
Coordenadoria de Pesquisa e Extensão - COPEX

Departamento de Editoraçāo e Divulgaçāo Científica - DEDIC 


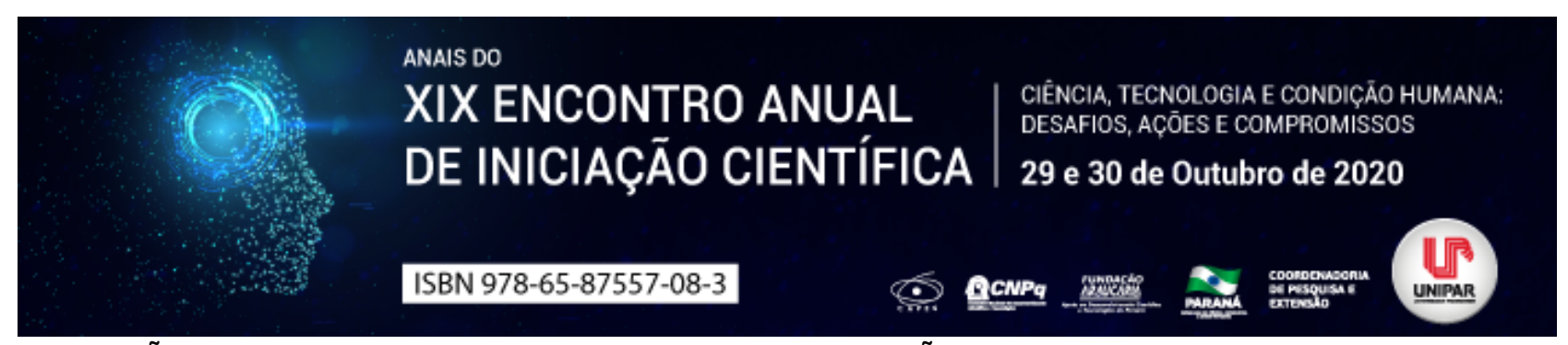

CONGELAÇÃO DE ESPERMATOZOIDES EQUINOS COM A ADIÇÃO DE Eugenia uniflora L (PITANGA) AO MEIO DILUIDOR COMERCIAL - REVISAO DE LITERATURA

\author{
${ }^{1}$ DANIEL CAMPOS GIOSA , ${ }^{2}$ DANIELLE ANDRESSA OLIVEIRA SESTARI, ${ }^{3}$ FERNANDA CORREA BIGATTAO, ${ }^{4}$ IZABELA DE \\ OLIVEIRA BORGHI, ${ }^{5}$ ALECSANDRO SILVA DE LIMA ELIAS, ${ }^{6}$ ROSIARA ROSARIA DIAS MAZIERO
}

\author{
${ }^{1}$ Discente do Mestrado do programa de Pós-graduação em Ciência Animal - UNIPAR \\ ${ }^{1}$ Discente do Mestrado do programa de Pós-graduação em Ciência Animal - TAXISTA CAPES/PROSUP - UNIPAR \\ ${ }^{2}$ Acadêmica do Curso de Medicina Veterinaria da UNIPAR \\ ${ }^{3}$ Acadêmica do Curso de Medicina Veterinária da UNIPAR \\ ${ }^{4}$ Discente do Mestrado do programa de Pós-graduação em Ciência Animal - UNIPAR \\ ${ }^{5}$ Docente da UNIPAR
}

Introdução: A criopreservação espermática traz enormes benefícios a reprodução de animais de importância agropecuária, também por contribuir na conservação de material genético de espécies ameaçadas de extinção. Assim, o sucesso da congelação depende da efetividade do processamento do ejaculado, para que ocorra o bloqueio completo da atividade metabólica da célula, que se iniciam prematuramente nos testículos e que continuam ao percorrer os epidídimos e após a ejaculação (VISHWANATH \& SHANNON, 2000). Neste sentido, os antioxidantes atuam no combate dos efeitos nocivos provocados pelos radicais livres, proporcionando melhor qualidade do sêmen fresco e criopreservado (SILVA, 2018).

Objetivo: Revisar sobre os efeitos de antioxidantes no meio diluidor para congelação de espermatozoides equino.

Desenvolvimento: Com algumas dificuldades de transporte do sêmen em grandes distâncias e para a preservação de algumas linhagens de garanhões, o sêmen equino congelado tem sido muito utilizado (JULIANI, 2008). Contudo, a criopreservação do sêmen equino ainda é limitada, pois a sensibilidade das células espermáticas é muito alta, visto que os procedimentos de congelação lesionam suas membranas causando efeitos nocivos ao espermatozoide (OLIVEIRA, 2011). Os meios diluidores utilizados para a criopreservação têm como objetivo de promover proteção adequada dos espermatozoides contra os efeitos nocivos de variação de temperaturas (ALVARENGA et al., 2005). Durante este processo, ocorre um aumento evidente na produção de espécies reativas de oxigênio e a peroxidação lipídica do ejaculado (RESTREPO, 2018). Neste sentido, algumas substâncias antioxidantes diminuem ou previnem a oxidação do substrato, se tornando assim um redutor oxidativo mais potente (BETANCUR, 2012). Assim, autores relatam que o extrato hidroalcoólico de folhas de Eugenia uniflora L (pitanga) apresentou atividade antioxidante in vitro (AURICCHIO, 2007). Neste contexto, não existem relato de utilização da pitanga como um agente antioxidante adicionado ao meio diluidor para sêmen equino. Os antioxidantes nas células espermáticas agem de duas formas, impedir a produção dos EROs ou interromper a reação em cadeia que ocorre durante peroxidação lipídica (SILVA e GUERRA, 2012). A utilização de antioxidantes naturais, como a quercetina foi relatada na literatura com resultados positivos durante o processo de congelação do sêmen equino, capaz de reduzir os danos oxidativos causados aos espermatozoides, em especial dos garanhões considerados subcongeladores. Entretanto, durante a refrigeração do sêmen equino não implicou em beneficio à cinética espermática ou redução no estresse oxidativo. Para as células refrigeradas submetidas à estresse por ácido aracdônico a adição da quercetina mostrou relevante capacidade de controlar os danos oxidativos. Portanto a incorporação de quercetina, um antioxidante natural não enzimático, ao meio foi efetiva em reduzir os danos oxidativos das células submetidas à congelação ou quimicamente estressadas (LIMA, 2016).

Conclusão: $O$ processo de congelação de sêmen equino ocasiona crioinjúrias à célula espermática, além de induzir a produção de radicais livres. Assim, a adição de extrato de pitanga pode auxiliar como agente antioxidante no ejaculado, mostrando-se uma alternativa para se alcançar sucesso na criopreservação espermática nesta espécie.

\title{
Referências
}

ALVARENGA, M.A. et al. Amides as cryoprotectant for freezing stallion semen: a review. Animal Reproduction Science, v.89, p.105-113, 2005.

AURICCHIO, Mariángela T. et al. Atividades antimicrobiana e antioxidante e toxicidade de Eugenia uniflora. Latin American Journal of Pharmacy, v. 26, n. 1, p. 76, 2007.

BETANCUR, Giovanni Restrepo; PIZARRO, Edison J.; ROJANO, Benjamín Alberto. Estrés oxidativo en el semen equino criopreservado. Revista Lasallista de investigación, v. 9, n. 1, p. 128-136, 2012.

SILVA, Amanda Formigoni et al. Efeito da adição de antioxidantes sobre a viabilidade do sêmen bovino. Arquivos de Ciências Veterinárias e Zoologia da UNIPAR, v. 21, n. 4, 2018. 
JULIANI, G. C.; HENRY, M. Efeito do glicerol, etilenoglicol, acetamida e leite desnatado na criopreservação de espermatozoides equinos. Arquivo Brasileiro de Medicina Veterinária e Zootecnia, v. 60, n. 5, p. 1103-1109, 2008.

OLIVEIRA, Rodrigo Arruda de et al. Antioxidante na viabilidade do sêmen equino congelado e refrigerado. 2011.

RESTREPO, Giovanni; ROJANO, Benjamín A. Actividad antioxidante del isoespintanol y el timol en el semen equino criopreservado. Revista de Investigaciones Veterinarias del Perú, v. 29, n. 1, p. 205-216, 2018

SILVA, L.F.M.C. Estudo sobre a redução do estresse oxidativo em sêmen equino a partir da adição de quercetina nos diluentes de refrigeração e congelação. Dissertação (Mestrado). Faculdade de Medicina Veterinária e Zootecnia, FMVZ, Unesp, Botucatu, 2016.

VISHWANATH, R.; SHANNON, P. Storage of bovine semen in liquid and frozen state. Animal Reproduction Science, v.62, p.23-53, 2000.

Coordenadoria de Pesquisa e Extensão - COPEX

Departamento de Editoraçāo e Divulgaçāo Científica - DEDIC 


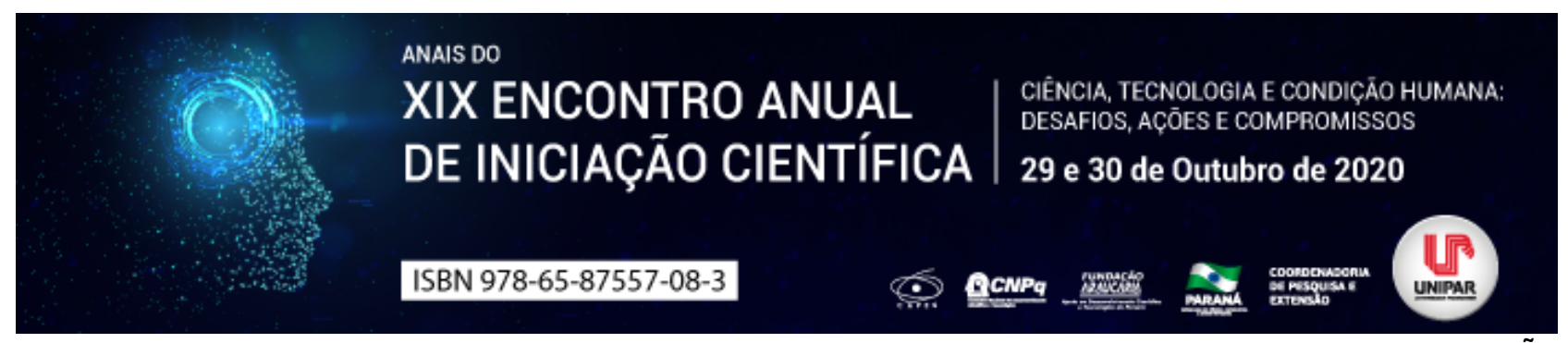

PESQUISA DE ANTICORPOS ANTI-Leptospira spp. EM MORADORES DE ASSIS CHATEAUBRIAND, REGIÃO DE FRONTEIRA COM O PARAGUAI

\author{
${ }^{1}$ EMILY LIMA DA SILVA, ${ }^{2}$ ISABELA CARVALHO DOS SANTOS , ${ }^{3}$ MATEUS AUGUSTO GARCIA SOUZA, ${ }^{4}$ ARIANNE PERUZO \\ PIRES GONÇALVES, ${ }^{5}$ DANIELA DIB GONCALVES
}

\author{
${ }^{1}$ Discente Ensino Médio, bolsista PEBIC CNPq \\ ${ }^{1}$ Doutorado Em Ciencia Animal Com Enfase Em Produtos Bioativos - Bolsista CAPES \\ ${ }^{2}$ Acadêmico do Curso de Medicina Veterinária da UNIPAR \\ ${ }^{3}$ Pós-Graduanda do PPG em Ciência Animal, UNIPAR \\ ${ }^{4}$ Docente da UNIPAR
}

Introdução: A Leptospirose é uma doença infecciosa transmitida a animais vertebrados através de vias de transmissão como água, solo e fômites contaminados. É uma doença mais comum em regiões de clima tropical e subtropical, como nas Américas, no Brasil é comum ocorrerem surtos epidêmicos durante as épocas chuvosas, a doença também é vista como um risco ocupacional, atingindo trabalhadores do campo, principalmente de arrozais e canaviais, tratadores de animais, mineradores, etc. Um melhor controle da doença é feito a partir da integração de medidas profiláticas. Após um animal ser infectado e imunizado, é obtida a vacina contendo os sorovares de Leptospira spp. (SIMÕES et al., 2016).

Objetivo: Pesquisa de anticorpos anti-Leptospira spp. em uma cidade de região fronteiriça.

Material e Métodos: Este projeto foi aprovado pela Plataforma Brasil / UNIPAR sob protocolo CAAE: 94669818.2.0000.0109. Foi realizado a coleta de sangue de 15 moradores de ambos os sexos e com idade superior a 18 anos que procuraram a Unidade Básica de Saúde de Assis Chateaubriand (Paraná) apresentando febre e dor muscular. Assis Chateaubriand (Paraná) está localizada a $131 \mathrm{Km}$ do Paraguai e por isso é considerada uma região fronteiriça. A coleta de sangue foi realizada por meio de punção venosa de $5 \mathrm{~mL}$ conduzida por profissionais da área de enfermagem. Posterior os soros foram encaminhados para o Laboratório de Leptopsirose da Universidade Estadual de Londrina. Para detectar anticorpos anti-Leptospira spp. os soros foram submetidos à prova de soroaglutinação microscópica (SAM) e foi utilizada a diluição de 1:100 como ponto de corte (FAINE et al., 1999).

Resultados: Das 15 amostras testadas, nenhuma apresentou-se reagente ao teste diagnóstico.

Discussão: O aumento de casos de leptospirose está diretemante ligado a impactos ambientais e sociais, e o local de mais provavel infecção é o domicilio, devendo ser realizados aperfeiçoamentos nas medidas de controle da doença, tendo em vista a estreita relação entre homem, animal e meio ambiente. (PAULA, 2005; SUGUIURA, 2019). Pode-se observar que para Paula (2005) a doença acompanhou o regime pluviométrico, onde o aumento de casos aconteceu entre os meses de Janeiro e março, assim como no trabalho de Suguiura (2019), já o menor número de casos veio em períododos próximos, sendo o do primeiro entre março e maio, já no segundo entre julho e setembro. Tal resultado é diferente do presente trabalho, pois, apesar de as épocas de maior pluviosidade serem as mesmas (OLIVEIRA; AMARAL, 2011), não houve casos positivos. No trabalho de Paula (2005), demonstraram que as medidas de prevenção devem ser estabelecidas a nível municipal, se baseando em estudos de abrangência estadual e até mesmo nacional do perfil epidemilógico da doença, mesmo que de forma geral. Este estudo também provou ser útil como indicadores sociais pelo fato da doença atingir pricipalmente as classes menos favorecidas. Este trabalho mostra que os municípios devem tomar medidas municipais, direcionadas aos históricos do município. Já no trabalho de Suguiura (2019) houve um acompanhamento das notificações de agravos no Paraná, trazendo informações sobre o número de pessoas infectadas, dividindo por idade, sexo, raça, local de residência, e se eram habitantes de áreas urbanas.

Conclusão: A ausência de casos de leptospirose neste trabalho provavelmente reflete as condições sociais e infra-estrutura apresentada no município de Assis Chateaubriand que tem o reflexo positivo das ações realizadas também pela vigilância sanitária, além, de conter uma rede de saneamento básico adequada, que contribuindo assim, com os índices mostrados neste trabalho.

\title{
Referências
}

FAINE, S.; et al. Leptospira and leptospirosis. 2th ed. Melbourne: Medical Science. p. 272, 1999.

OLIVEIRA, E.; AMARAL, L. Estudo da relação dos fatores climáticos e casos de dengue no município de Assis Chateaubriand, Paraná. Engenharia Ambiental: Pesquisa e Tecnologia, v. 8, n. 2, 2011.

PAULA, E. V. Leptospirose Humana: uma análise climato-geográfica de sua manifestação no Brasil, Paraná e Curitiba. In: Simpósio Brasileiro de Sensoriamento Remoto, 7., 2005, Goiânia. Anais [...]. Goiânia: INPE, 2005. p. $2301-2308$. 
SIMÕES, L. S. et al. Leptospirose Revisão. PUBVET, v. 10, p. 111-189, 2015.

SUGUIURA, I. M. S. Leptospirose no estado do Paraná, Brasil: uma abordagem de saúde única. Revista de Saúde Pública do Paraná, v. 2, n. 2, p. 77-84, 2019.

Coordenadoria de Pesquisa e Extensão - COPEX

Departamento de Editoraçāo e Divulgaçāo Científica - DEDIC 


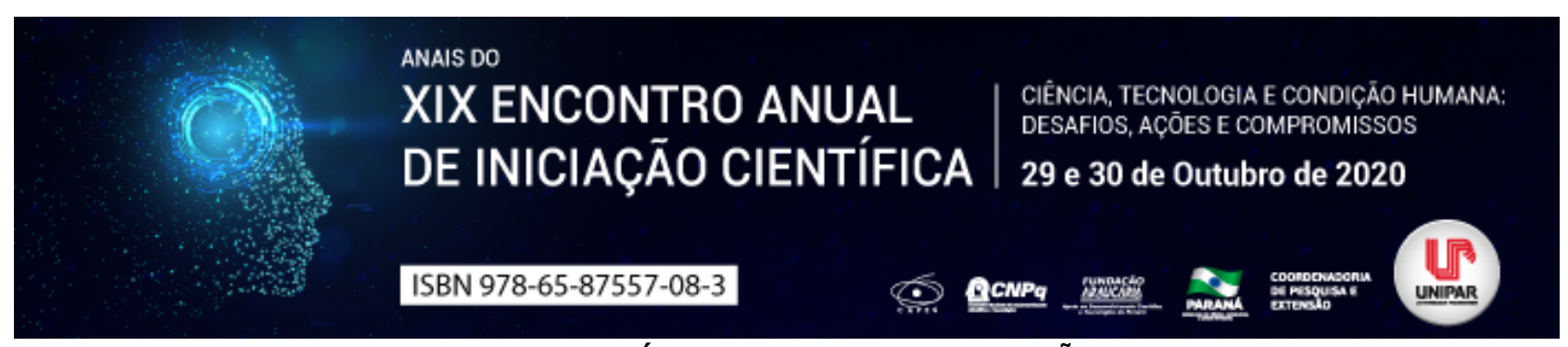

CARDIOMIOPATIA HIPERTRÓFICA EM FELINOS - REVISÃO DE LITERATURA

\begin{abstract}
${ }^{1}$ RAPHAELA FLOES DAVILA, ${ }^{2}$ GEOVANA CRISTINA SARTORI ANDRE, ${ }^{3}$ GIULIANA CAVALCANTI DOS SANTOS, ${ }^{4}$ ELISIANI VITORIA GASPARETTO VENTURA, ${ }^{5}$ ALYSSON RAMALHAIS, ${ }^{6}$ ANA MARIA QUESSADA
\end{abstract}

\begin{abstract}
${ }^{1}$ Acadêmica do Curso de Medicina Veterinária, PIC/Unipar
${ }^{1}$ Acadêmica do Curso de Medicina Veterinária bolsista PIBIC/Unipar

${ }^{2}$ Acadêmica do Curso de Medicina Veterinária bolsista PIBIC/Unipar

${ }^{3}$ Acadêmica do Curso de Medicina Veterinária bolsista PIBIC/Unipar

${ }^{4}$ Acadêmico de Mestrado em Ciência Animal com ênfase em produtos bioativos, PIC/Pós-graduação UNIPAR

${ }^{5}$ Programa de Pós-graduação em Ciência Animal com ênfase em produtos bioativos, UNIPAR
\end{abstract}

Introdução: A cardiomiopatia hipertrófica $(\mathrm{CMH})$ é a afecção cardíaca mais comum nos felinos domésticos. A CMH ocorre quando há comprometimento funcional ou uma anormalidade no músculo cardíaco (MURAKAMI; ROMÃO; REIS, 2015). Caracteriza-se por espessamento do miocárdio ventricular esquerdo e do septo interventricular, causando disfunção diastólica com elevação da pressão de enchimento (WARE, 2014). Com a dificuldade da entrada de sangue nos ventrículos, ocorre a possibilidade de desenvolvimento da insuficiência cardíaca congestiva (ICC) (ZAMBONI ; ROMÃO, 2015). A etiologia da CMH pode ser primária, com envolvimento da transmissão de um gene alterado, ou,secundária, sendo resultado de doenças primárias. Dentre elas estão o hipertireoidismo, a hipertensão sistêmica e a estenose subaórtica (WARE, 2014; FABRETTI et al., 2016).

Objetivo: Este trabalho tem como objetivo demonstrar, através da literatura, as raças mais acometidas pela doença, seus sinais clínicos e melhores formas de diagnósticos.

Desenvolvimento: A CMH tende a apresentar uma predisposição hereditária em algumas raças felinas, com maior prevalência nas raças Maine coon, Persa, American short hair, Ragdoll, English short hair e Sphynx (ALBERIGI, 2019). Apesar de afetar majoritariamente raças puras, tem sido cada vez mais observada em gatos de raças indeterminadas (PELLEGRINO, 2014). Gatos machos representam cerca de $75 \%$ dos animais afetados. Embora haja uma ampla faixa de distribuição etária, a maior incidência ocorre entre cinco a sete anos. (FABRETTI et al., 2016; VALÉRIO, 2017). Quando se relaciona à fisiopatologia, os mecanismos pelos quais mutações de proteínas do sarcômero determinam a $\mathrm{CMH}$ tem caráter ainda especulativo. A hipótese é de que a proteína anormal, produzida pelo gene mutante, resulta em movimento disfuncional nos sarcômeros, sobrecarregando os funcionais (PELLEGRINO, 2014). O miocárdio então, compensa essas unidades disfuncionais, repondo-as por novos sarcômeros. O resultado é um coração com o dobro de sarcômeros que deveriam possuir (SILVEIRA et al 2015). Sua forma secundária está frequentemente associada a enfermidades, como obstrução ao fluxo ventricular, hipertensão arterial sistêmica, e doenças metabólicas, como hipertireoidismo ou insuficiência renal (MURAKAMI; ROMÃO; REIS, 2015). Os animais podem apresentar-se assintomáticos ou com sutis sinais clínicos, o que torna difícil o diagnóstico (VILELA et al, 2019). Geralmente, os pacientes com $\mathrm{CMH}$, apresentam-se à consulta já em fase avançada da doença, com sinais clínicos como a taquipneia, dispneia, anorexia, letargia e mucosas pálidas (ARIOZA; SILVA, 2017). Em casos mais graves, apresentam tromboembolismo arterial e ICC na forma descompensada (PELLEGRINO, 2014). Alguns fatores importantes como estresse, doenças sistêmicas, procedimentos cirúrgicos e anestésicos errôneos podem aumentar os sinais clínicos (ZAMBONI; ROMÃO, 2015). Muitos felinos podem apresentarse assintomáticos durante toda vida, acarretando a morte súbita (VILELA et al, 2019). Em exames de rotina, durante a auscultação cardíaca, pode ser identificado arritmia ou sopro, principalmente na valva mitral (NÓBREGA, 2011). A radiografia torácica simples pode ser útil no diagnóstico da $\mathrm{CMH}$, pois torna possível a avaliação do tamanho, formato cardíaco e vasculatura pulmonar. No entanto, em alguns casos, a hipertrofia pode não estar aparente (MURAKAMI; ROMÃO; REIS, 2015). Quanto ao eletrocardiograma (ECG) as alterações mais comuns são taquiarritmias ventriculares e desvio de eixo para a esquerda (ARIOZA; SILVA, 2017). Para diagnóstico confirmatório, deve se realizar o ecocardiograma, que permite a avaliação anatômica, medidas de espessura das paredes do septo interventricular e dos ventrículos, tamanho das câmaras cardíacas, presença de trombo cardíaco em átrio ou em aurícula e avaliação da função sistólica e diastólica (VILELA et al, 2019). A melhor maneira para melhorar a qualidade de vida desses pacientes é a redução da carga de trabalho cardíaco, o controle de arritmias, minimização da isquemia e o controle da ICC presente (NÓBREGA, 2011).

Conclusão: A cardiomiopatia hipertrófica é a principal cardiopatia em felinos, por isso é de grande importância que felinos das raças predispostas apresentem-se em consultas de rotina. O diagnóstico complexo desta afecção se dá por conta de existir como doença primária do miocárdio ou secundária a uma série de doenças sistêmicas. A verificação dos exames de eletrocardiograma e radiografia para a suspeita inicial da doença, mas principalmente do ecocardiograma, se mostram fundamentais para o diagnóstico precoce, garantindo um melhor prognóstico para o paciente. 


\section{Referências}

ALBERGI, B.R.S. et al. Comparative study of the clinical and echodopplercardiographic aspects of left ventricular hypertrophy and hypertrophic cardiomyopathy in cats (Felis catus). Brazilian Journal of Veterinary Medicine, 2019. DOI: https://doi.org/10.29374/2527-2179.bjvm103419.

ARIOZA, N.A.F.; SILVA, P.R. Cardiomiopatia Hipertrófica Felina. $1^{\circ}$ ed. São Paulo: ICESP PROMOVE, 2017. p.1291-1294.

FABRETTI, A.K., et al. Cardiomiopatia Hipertrófica em Gatos da Raça Persa: relato de caso. Portal de Periódicos-UEM, 2016, p. 17-20. Disponível em: https://cutt.ly/nd4xG8a.

MURAKAMI, V.Y.; ROMÃO, F.G.; REIS, G.F.M. Tromboembolismo Arterial Decorrente da Cardiomiopatia Hipertrófica em Felino. Almanaque de Medicina Veterinária e Zootecnia, 2015, p. 9-18. Disponível em: https://cutt.ly/ed4kz1s.

NÓBREGA, S.C.C. Cardiomiopatia Hipertrófica Felina: a propósito de $\mathbf{5}$ casos clínicos. Dissertação (Mestrado Integrado em Medicina Veterinária) Faculdade de Medicina Veterinária, Universidade Técnica de Lisboa, 2011. Disponível em: https://cutt.ly/7d4xcx1.

PELLEGRINO, A. Avaliação genética de gatos da raça Persa: mapeamento da mutação relacionada à cardiomiopatia hipertrófica de origem familial. Tese (Doutorado em Clínica Veterinária) Faculdade de Medicina Veterinária e Zootecnia, Universidade de São Paulo, 2014. DOI: https://doi.org/10.11606/T.10.2016.tde-08042015-140837.

SILVEIRA, J.A.M., et al. Cardiomiopatia hipertrófica felina: aspectos relevantes. Revista Brasileira de Higiene e Sanidade Animal, 2015, p. 465-476. Disponível em: http://www.repositorio.ufc.br/handle/riufc/21444.

VALÉRIO, R.T. Clínica de Animais de Companhia, 2017. Disponível em: http://hdl.handle.net/10174/20764.

VILELA, R.F., et al. Cardiomiopatia hipertrófica em felinos domésticos: revisão de literatura. Fórum acadêmico da Faculdade Vértice, Univértix, 2019. Disponível em: https://cutt.ly/zd8FXEU.

WARE, W. Doenças miocárdicas do gato. In: NELSON, R.; COUTO, G. Medicina Interna de Pequenos Animais, 2014, p. 145158.

ZAMBONI, V.A.G.; ROMÃO, F.G. Cardiomiopatia Hipertrófica Felina: relato de caso. Almanaque de Medicina Veterinária e Zootecnia, 2015, p. 36-48. Disponível em: https://cutt.ly/sd8GFLx 


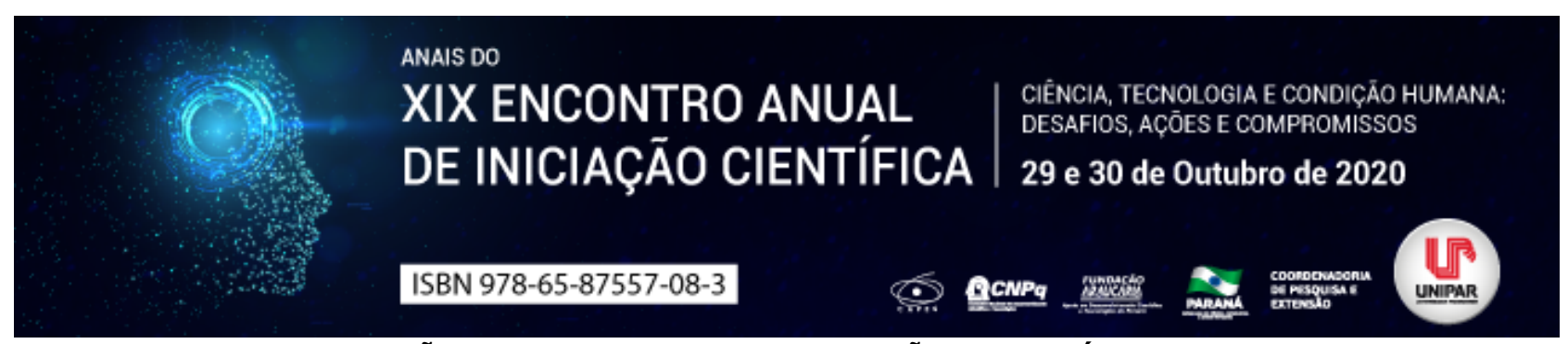

AVALIAÇÃO DE RECEPTORAS DE EMBRIÃO NA ESPÉCIE BOVINA

\begin{abstract}
${ }^{1}$ GUSTAVO POMARO, ${ }^{2}$ LUCCA HIROITI SAKASHITA, ${ }^{3}$ VITOR HUGO INOUE CORREA, ${ }^{4}$ MARIA EDUARDA BORBA ALEM, ${ }^{5}$ ROSIARA ROSARIA DIAS MAZIERO
\end{abstract}

\author{
${ }^{1}$ Acadêmico do PIC/UNIPAR \\ ${ }^{1}$ Acadêmico do Curso de Medicina VeterinÃ $\tilde{A}_{j}$ ia da UNIPAR \\ ${ }^{2}$ Acadêmico do Curso de Medicina Veterin $\tilde{A}_{j}$ ria da UNIPAR \\ ${ }^{3}$ Acadêmica do Curso de Medicina VeterinÃ iria da UNIPAR \\ ${ }^{4}$ Docente da UNIPAR
}

Introdução: Para que uma fêmea possa ser considerada receptora de embrião é necessária uma avaliação criteriosa do seu sistema genital, associada à avaliação do estado de condição corporal deste animal. Neste contexto, a seleção de receptoras é considerada uma das principais etapas de um programa de transferência de embriões (TE), influenciando diretamente no retorno financeiro ao utilizar esta biotecnologia. Entretanto, encontramos um grande desafio para encontrar um número suficiente de receptoras para atender à demanda de um programa de TE em bovinos (DANTAS et al., 2018).

Desenvolvimento: A pecuária brasileira passou e passa por diversos processos de transformações, os quais têm como objetivo maximizar a produtividade, pelo uso de tecnologias que possam permitir lucro na produção. Com o propósito de melhorar a capacidade reprodutiva, utilizando animais geneticamente superiores, muitos protocolos hormonais foram aperfeiçoados, e o processo de super ovulação tornou possível a ovulação múltipla e posterior transferência de embriões (DANTAS et al., 2018).O desenvolvimento destas biotecnologias permitiu o aumento dos índices reprodutivos em fêmeas bovinas, maior intensidade de seleção, diminuição do intervalo entre gerações, maior disponibilidade de animais para reposição (PENNA, 1993).Além disso, permitiu que uma fêmea de elevado padrão genético fosse utilizada de uma forma mais racional, fornecendo um grande número de descendentes, num curto espaço de tempo. No entanto, o processo de super ovulação e transferência de embriões in vivo apresentam custo elevado e variação nos resultados, devido aos fatores que influenciam a resposta ovulatória de doadoras, que afetam a fertilização e a viabilidade embrionária e aqueles relacionados ao programa e ao manejo animal. Neste sentido, as receptoras de embriões necessitam estar devidamente preparadas, para isso, é imprescindível a avaliação clínica geral, exames para a detecção de brucelose e tuberculose, administração de vermífugos e ecto parasiticidas, exame ginecológico completo (vaginoscopia e palpação transretal) para verificação da saúde genital e a fase do ciclo estral. Além disso, deve selecionar receptoras de porte compatível com a raça do embrião a ser inovulado e que sejam capazes de produzir leite suficiente para amamentar e permitir que a cria se desenvolva de forma desejada. Necessita-se ainda, avaliar tamanho e qualidade do corpo lúteo, pois ele é responsável pela produção de progesterona, que vai controlar o ambiente uterino, essencial ao desenvolvimento embrionário e à manutenção da prenhez (HONORATTO et al., 2013). O método mais usual e prático para a escolha de receptoras ainda é a projeção do corpo lúteo $(\mathrm{CL})$ por palpação retal. Estes mesmos autores discorreram sobre esta metodologia não ser a mais adequada, visto que um CL com pequena projeção poder apresentar uma grande porção inclusa no estroma ovariano. Diante destes fatos, a avaliação ultrassonográfica é de suma importância, pois irá permitir a avaliação e completa visualização do CL.

Conclusão: Podemos concluir que o successo de um programa de transferência de embrião depende do correto manejo dos animais, seleção de doadoras e receptoras de adequadas, alimentação dos animais balanceada, qualidade do sêmen, habilidade dos técnicos, controle do estro, manejo geral da propriedade e estacionalidade climática, que irão interferir diretamente nos resultados finais de prenhez. Vale ressaltar que a alta variabilidade de resposta à superestimulação ovariana pode ser decorrente do tratamento hormonal, atividade biológica e dose de hormônios utilizados, fatores individuais, idade e raça da doadora. As causas da taxa de concepção baixa são inerentes ao embrião, à receptora, ao ambiente e ao método de inovulação. Assim, fica claro que para o sucesso da utilização das biotecnologias reprodutivas, vários parâmetros devem ser avaliados, e a escolha correta de uma receptora de embrião é indispensável.

\title{
Referências
}

DANTAS, K. S. A.; CAMPELLO, C. C.; DANTAS, R. A. A.; NUNES, J. F. Seleção de receptoras em um programa de transferência de embriões (pive) em bovinos no nordeste do Brasil. Ciência Animal, v. 28, n. 1, p. 3-16, 2018.

hONORATO, M. T.; FERRO, R. A. C.; FERRO, D. A. C.; SANTOS, K. J. C.; COSTA, M. A.; RODRIGUES FILHO, J. L. Importância da escolha de receptoras em um programa de transferência de embriões em bovinos. PUBVET, v. 7, n. 19, ed. 242, Art. 1601, 2013. 
PENNA, FERNANDES, ARMSTRONG, THATCHER. Avaliação do corpo lúteo, contratilidadeuterina e concentrações plasmáticas de progesterona e estradiolem receptorasde embriões bovinos. Ciência Animal Brasileira, v. 10, n. 1, p. 174-183, jan./mar. 2009 .

Coordenadoria de Pesquisa e Extensão - COPEX

Departamento de Editoraçāo e Divulgaçāo Científica - DEDIC 


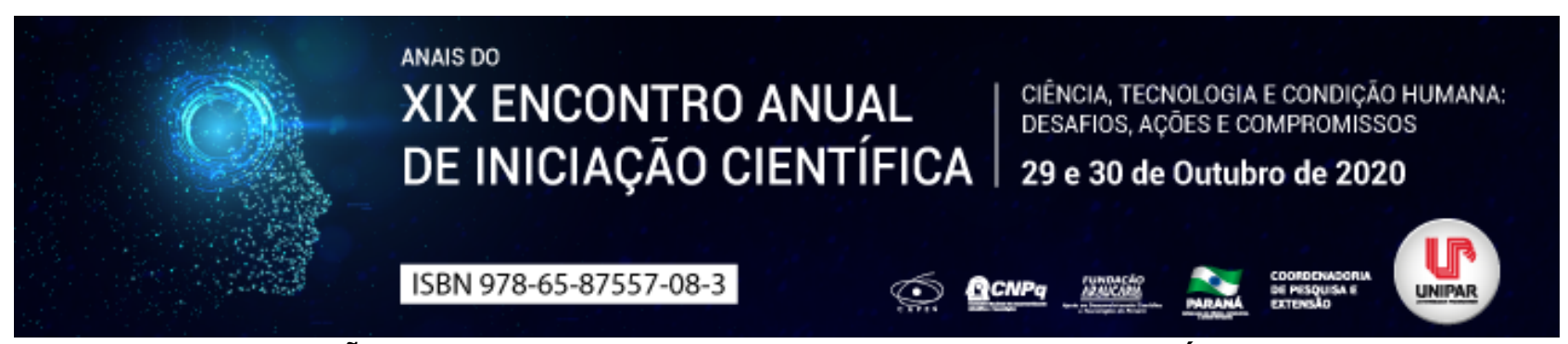

ATUALIZAÇÕES NO TRATAMENTO DA CARDIOMIOPATIA HIPERTRÓFICA FELINA

\begin{abstract}
${ }^{1}$ Karolyne Oliveira Bastos, ${ }^{2}$ ISABELA LOPES MASSITEL, ${ }^{3}$ SIBELY AIVA FLORES, ${ }^{4}$ MELISSA SANCHES MONGELLI, ${ }^{5}$ MARCOS FERRANTE, ${ }^{6}$ JOÃO VITOR FERNANDES COTRIM DE ALMEIDA
\end{abstract}

\begin{abstract}
${ }^{1}$ Graduanda em Medicina Veterinária, Universidade Federal de Lavras (UFLA)
${ }^{1}$ Graduanda em Medicina Veterinária, Universidade Estadual de Maringá (UEM)

${ }^{2}$ Graduanda em Medicina Veterinária, Universidade Federal de Lavras (UFLA)

${ }^{3}$ Graduanda em Medicina Veterinária, Universidade Federal de Lavras (UFLA)

${ }^{4}$ Professor do Departamento de Medicina Veterinária, UFLA

${ }^{5}$ Médico veterinário, mestre em Ciências Veterinárias do DMV - UFLA
\end{abstract}

Introdução: A cardiomiopatia hipertrófica $(\mathrm{CMH})$ caracteriza-se por uma hipertrofia do miocárdio sem dilatação do ventrículo esquerdo (VE) (CÔTÉ et al., 2004), podendo ser obstrutiva ou não obstrutiva. É a cardiopatia mais comum em gatos (SILVEIRA et al., 2015). Um sistema para classificar cardiomiopatias publicado recentemente foi desenvolvido a fim de fornecer uma estrutura para prognóstico e tomada de decisão terapêutica. Este sistema apresenta quatro estágios ( $A$, B, C e D) baseados no fenótipo da cardiomiopatia, e propõe alternativas de tratamento para cada um deles (VIRGINIA et al., 2020).

Objetivo: Apresentar atualizações no tratamento para a cardiomiopatia hipertrófica felina.

Desenvolvimento: A CMH é o distúrbio cardíaco mais comum em gatos, principalmente em idosos e machos (SILVEIRA et al., 2015). Caracteriza-se por hipertrofia miocárdica e VE não dilatado (CÔTÉ et al., 2004), nas formas obstrutiva ou não obstrutiva. Um consenso publicado pelo Journal of Veterinary Internal Medicine desenvolveu uma classificação das cardiomiopatias visando fornecer uma estrutura para prognóstico e tomada de decisão terapêutica, a partir da divisão da enfermidade em quatro estágios (A, B, C e D), baseados no fenótipo da cardiomiopatia (VIRGINIA et al., 2020). O estágio A inclui gatos que estão predispostos à cardiomiopatia, mas não têm evidência de doença. O estágio B descreve gatos com cardiomiopatia, mas sem sinais clínicos. $\mathrm{O}$ estágio $B$ ainda é subdividido em B1: gatos com aumento de átrio esquerdo (AE) leve a moderado e baixo risco de insuficiência cardíaca congestiva (ICC) ou tromboembolismo arterial (TEA), e B2: gatos com aumento de AE moderado a grave e com maior risco de ICC ou TEA. Gatos com sinais de ICC ou TEA são classificados como estágio C, e aqueles com sinais de ICC refratários ao tratamento são classificados como estágio D. Não se recomenda o tratamento para gatos em estágio A. Para aqueles em estágio B1, recomenda-se monitoramento anual para detectar uma possível progressão para o estágio B2. Para gatos B1 em que há obstrução da via de saída do VE (OVSVE) e aumento na frequência cardíaca, o atenolol pode ser considerado (JACKSON et al., 2015). O atenolol e o sotalol são também capazes de diminuir a ectopia ventricular e controlar a fibrilação atrial em gatos sintomáticos. (CÔTÉ et al., 2004; JACKSON et al., 2015) Gatos em estágio B2 têm alto risco de desenvolver ICC ou TEA. A tromboprofilaxia com clopidogrel é recomendada quando fatores de risco para TEA estão presentes. Para pacientes sob alto risco de TEA, pode-se associar outros antitrombóticos, como a aspirina ou um inibidor do fator Xa (ex: apixaban) (VIRGINIA et al., 2020). Gatos em estágio $C$ agudo podem apresentar edema pulmonar ou derrame pleural. Recomenda-se oxigenoterapia, furosemida intravenosa e, quando há derrame pleural, toracocentese (SILVEIRA et al., 2015). A sedação (p. ex., medetomidina) também deve ser considerada. A fluidoterapia intravenosa é contraindicada em gatos com congestão evidente, edema ou derrame (VIRGINIA et al., 2020). O pimobendan pode ser usado em gatos em estágio C agudo com sinais de baixo rendimento cardíaco, desde que não haja OVSVE (HAMBROOK et al., 2018). Se não houver melhora, pode-se considerar infusão contínua de dobutamina. Uma vez estabilizados, recomenda-se que os pacientes recebam alta o mais rápido possível, indicando-se reavaliar a ICC e a função renal após 3 a 7 dias. Para gatos em estágio C crônico, furosemida é o principal fármaco usado para o controle de edema pulmonar e derrames (PAYNE et al., 2018). Embora os inibidores da enzima conversora de angiotensina (ex.: enalapril) ainda sejam usados por alguns cardiologistas, não há indícios de que eles interfiram na evolução da CMH até o estágio C. O tratamento profilático com clopidogrel é recomendado em qualquer paciente com histórico de ICC e dilatação de AE (MURAKAMI et al., 2015). Recomenda-se que gatos em estágio C sejam reexaminados em intervalos de 2-4 meses. A mensuração pelo tutor da frequência respiratória em repouso pode fornecer informações úteis para ajustar a medicação. Para pacientes em estágio $\mathrm{D}$, torasemida pode substituir a furosemida. Espironolactona também pode ser considerada para o manejo de ICC crônica. Em gatos com disfunção sistólica, recomenda-se pimobendan e suplementação com taurina, quando deficiente (VIRGINIA et al., 2020). Relativamente ao manejo para TEA, justifica-se a eutanásia quando há um comprometimento do bemestar e um prognóstico ruim, contudo se a analgesia é adequada e existem fatores prognósticos favoráveis (p. ex. apenas um membro afetado), uma tentativa de tratamento pode ser considerada (VIRGINIA et al., 2020). A analgesia é uma prioridade no 
manejo de TEA nas primeiras 24 horas (MURAKAMI et al., 2015), recomendando-se fentanil, hidromorfina ou metadona. $O$ tratamento trombolítico não é recomendado para gatos com TEA (VIRGINIA et al., 2020).

Conclusão: A abordagem terapêutica da cardiomiopatia hipertrófica felina deve se basear no estadiamento proposto pelo consenso do Journal of Veterinary Internal Medicine, sendo necessário realizar um diagnóstico preciso e considerar a individualidade de cada caso.

\section{Referências}

CÔTÉ, Etienne. et al. Atrial fibrillation in cats: 50 cases (1979 2002), Journal of the American Veterinary Medical Association, v. 225, n. 2, p. 256-260, julho, 2004. Disponível em: https://cutt.ly/mfhLjZY. Acesso em: 26 jul. 2020.

HAMBROOK, Lydia E.; BENNETT, Peter F. Effect of pimobendan on the clinical outcome and survival of cats with non-taurine responsive dilated cardiomyopathy, Journal of feline medicine and surgery, v. 14, n.4, p. 233-239, janeiro, 2012. Disponível em: https://cutt.ly/afhLlic. Acesso em: 26 jul. 2020.

JACKSON, Bethany L. et al. Effect of atenolol on heart rate, arrhythmias, blood pressure, and dynamic left ventricular outflow tract obstruction in cats with subclinical hypertrophic cardiomyopathy, Journal of Veterinary Cardiology, v. 17, p. S296-S305, dezembro, 2015. Disponível em: https://cutt.ly/ZfhLI7D. Acesso em: 26 jul. 2020.

MURAKAMI, Vanessa Yurika. et al. Tromboembolismo Arterial Decorrente de Cardiomiopatia Hipertrófica em Felino - Arterial Thromboembolism Resulting in Feline Hypertrophic Cardiomyopathy, Almanaque de Medicina Veterinária e Zootecnia, v. 1, $\mathrm{n}$. 2, p. 9-18, julho, 2015. Disponível em: https://cutt.ly/MfhLzBG. Acesso em: 2 ago. 2020.

PAYNE, Jessie Rose. et al. Population characteristics and survival in 127 referred cats with hypertrophic cardiomyopathy (1997 to 2005), Journal of Small Animal Practice, v. 51, n. 10, p. 540-547, 2010. Disponível em: https://cutt.ly/MfhLcGj. Acesso em: 27 jul. 2020.

SILVEIRA, João Alison de Moraes. et al. Cardiomiopatia hipertrófica felina: aspectos relevantes, Revista Brasileira de Higiene e Sanidade Animal, v. 9, n. 3, p. 465-476, 2015. Disponível em: https://bityli.com/nkQ4g. Acesso em: 29 jul. 2020.

VIRGINIA, Luis Fuentes. et al. ACVIM consensus statement guidelines for the classification, diagnosis, and management of cardiomyopathies in cats, Journal of Veterinary Internal Medicine, v. 34, n. 3, p. 1062 1077, abril, 2020. Disponível em: https://bityli.com/BoHFZ. Acesso em: 26 jul. 2020. 


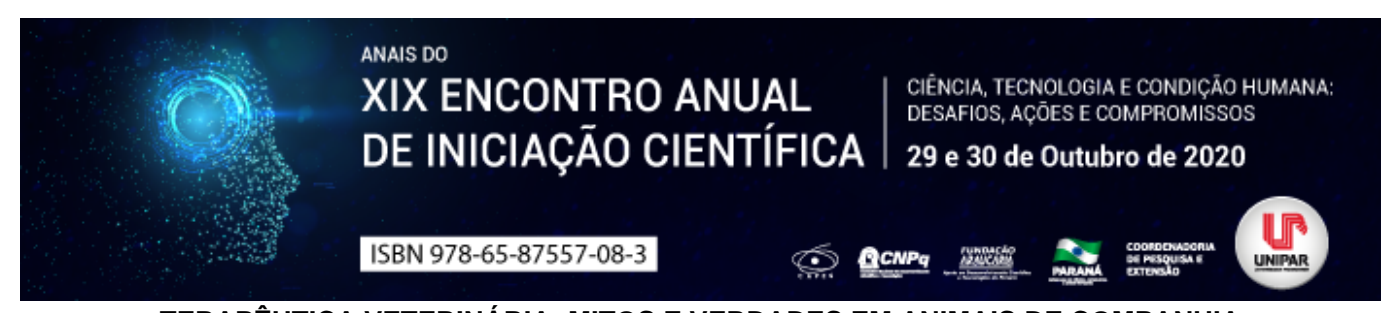

TERAPÊUTICA VETERINÁRIA: MITOS E VERDADES EM ANIMAIS DE COMPANHIA

${ }^{1}$ BRUNA EDUARDA DIAS SARRANO, ${ }^{2}$ NATALIE BERTELIS MERLINI, ${ }^{3}$ FRANCISLAINE APARECIDA DOS REIS LIVERO

${ }^{1}$ Acadêmica do curso de Medicina Veterinária da UNIPAR, bolsista PIBIC/UNIPAR

${ }^{1}$ Docente e Pesquisadora do PPG em Ciência Animal com Ênfase em Bioativos - UNIPAR

${ }^{2}$ Docente do Mestrado Profissional - UNIPAR

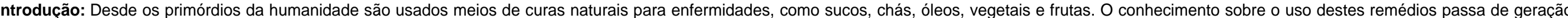

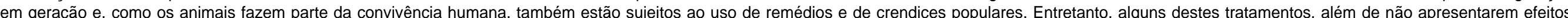
terapêuticos, podem ser tóxicos (HANDL; IBEN, 2010)

Objetivo: Elucidar misticismos de tratamentos para algumas afecções normalmente vistas no cotidiano da clínica médica de animais de companhia.

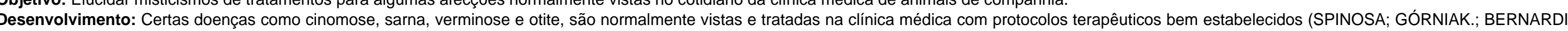

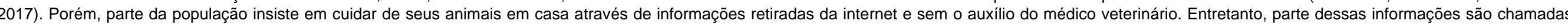

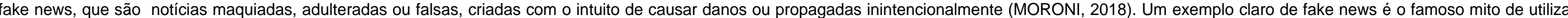

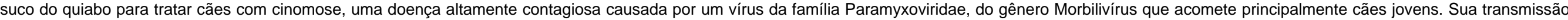

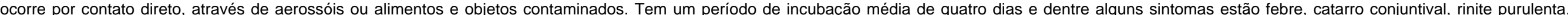

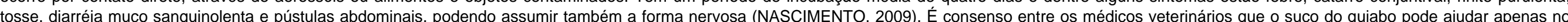

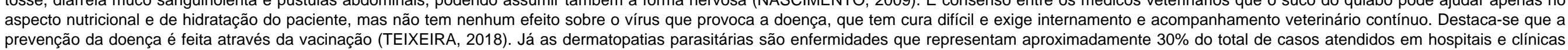

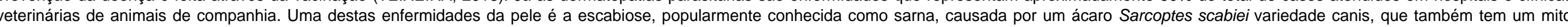

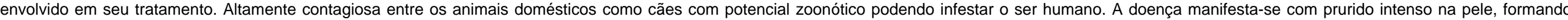

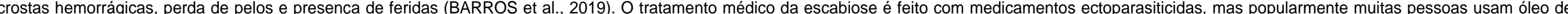

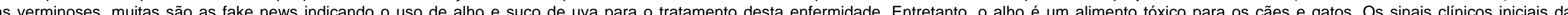

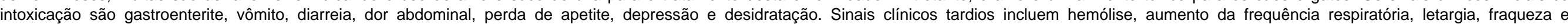

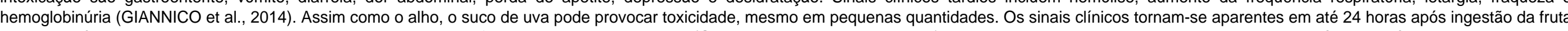

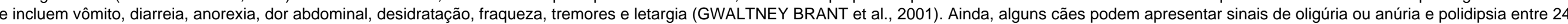

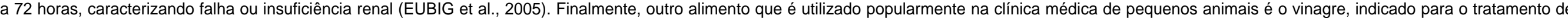

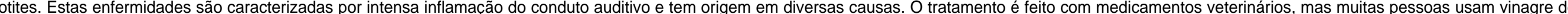

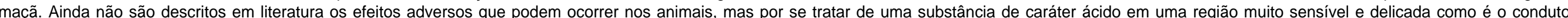
auditivo dos animais, podem ocorrer irritações que acentuam ainda mais o quadro inflamatório (LINZMEIER; ENDO; LOT, 2009).

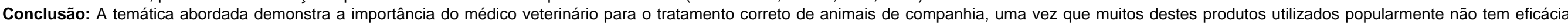
científica comprovada e podem provocar intoxicações e lesões em cães e gatos.

Referências

ALVES, Célia; PIO, Casimiro; GOMES, Paulo. Determinação de hidrocarboneto voláteis e semi-voláteis na atmosfera. Química Nova, v.29 n.3, 2006.

BARROS, Fernanda de Cássia Pereira; et al. A importância da sarna sarcóptica na Medicina Veterinária: revisão. Pubvet, v.13, n.7, a376, p.1-5, 2019.

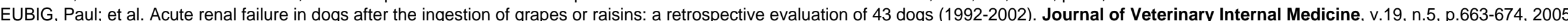

GIANNICO, Amália Turner; PONCZEK, Clara Alita Corona; JESUS, Aline Spina; et al. Alimentos tóxicos para cães e gatos. Colloquium Agrariae, v.10, n.1, p.69-86, 2014.

GWALTNEY-BRANT, Sharon; et al. Renal failure associated with ingestion of grapes or raisins in dogs. Journal of the American Veterinary Medical Association, v.218, n.10, p.1555-1556, 2001.

HANDL, Stefanie; IBEN, C. Foodstuffs toxic to small animal A review. The European Journal of Companion Animal Practice, v.20, n.1, p.36-44, 2010.

LINZMEIER, Geise Lissiane.; ENDO, Rosilaine Mieko.; LOT, Rômulo Francis Estangari. Otite externa. Revista Científica Eletrônica de Medicina Veterinária. Periódicos Semestral, n.12, p.1-6, 2009.

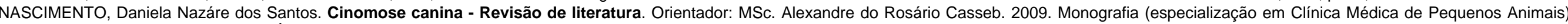

- Universidade Federal Rural do Semi Árido, Belém, Pará, 2009.

MORONI, Juliana. Possíveis impactos de fake news na percepção-ação coletiva. Revista Filosófica Temática, v. 3, n.1, p. 130-160, 2018. 


\section{SPINOSA, Helenice de Souza; GÓRNIAK, Silvana Lima; BERNARDI, Maria Martha. Farmacologia Aplicada à Medicina Veterinária. Ed. 6॰. Editora Guanabara Koogan LTA, 2017.}

TEIXEIRA, Lucas Borges. Suco de quiabo não cura cachorros com doenças graves. UOL Confere, 07 dez., 2018. Disponivel em: https://noticias.bol.uol.com.br/ultimas-noticias/brasil/2018/12/07/suco-de-quiabonao-cura-cachorros-com-doencas-

graves.htm\#: : text=FALSO\%3A\%20Suco\%20de\%20quiabo\%20n\%C3\%A30\%20cura\%20doen\%C3\%A7as\&text=Suco\%20de\%20quiabo\%20n\%C3\%A30\%20s\%C3\%B3,comum\%20entre\%20donos\%20de\%20cachorros. Acesso em: 02 julho 2020.

Coordenadoria de Pesquisa e Extensão - COPEX

Departamento de Editoraçāo e Divulgaçāo Científica - DEDIC 


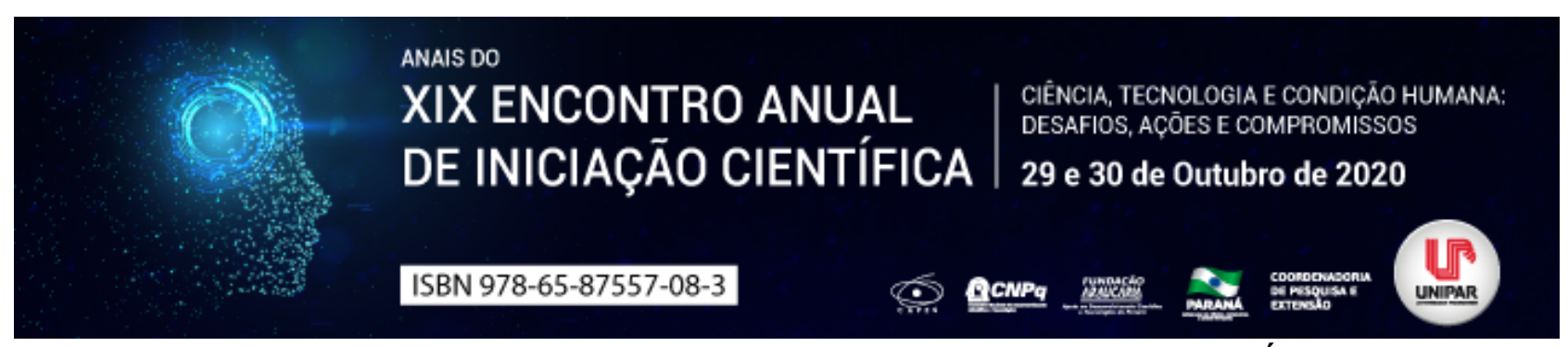

USO CRITERIOSO DOS ANTIMICROBIANOS NA MEDICINA VETERINÁRIA

\begin{abstract}
${ }^{1}$ Karolyne Oliveira Bastos, ${ }^{2}$ LUCIANA DE CASTRO BARCELOS, ${ }^{3}$ ISABELA LOPES MASSITEL, ${ }^{4}$ LILLIAN PEREIRA GOUVEIA, ${ }^{5}$ HUMBERTO DE MELLO BRANDÃO, ${ }^{6}$ MARCOS FERRANTE
\end{abstract}

\begin{abstract}
${ }^{1}$ Graduanda em Medicina Veterinária, Universidade Federal de Lavras (UFLA)
${ }^{1}$ Graduanda em Medicina Veterinária, Universidade Federal de Lavras (UFLA)

${ }^{2}$ Graduanda em Medicina Veterinária, Universidade Estadual de Maringá (UEM)

${ }^{3}$ Graduanda em Medicina Veterinária, Universidade Federal de Lavras (UFLA)

${ }^{4}$ Pesquisador da EMBRAPA - Gado de Leite, Juiz de Fora/MG

${ }^{5}$ Professor do Departamento de Medicina Veterinária, UFLA
\end{abstract}

Introdução: O principal objetivo da terapia antimicrobiana é o sucesso no tratamento da infeç̧ão. Entretanto, esse conceito tem sido modificado para incluir a prevenção da resistência microbiana. Tanto medicamentos humanos quanto veterinários influenciam a resistência desenvolvida por microrganismos (BOOTHE, 2006). Assim sendo, é necessário promover a conscientização e o treinamento dos profissionais atuantes na saúde animal e na saúde humana para a devida utilização de antimicrobianos, já que a resistência microbiana é um problema de saúde pública.

Objetivo: Abordar estratégias que podem prevenir ou adiar a resistência microbiana através de uma conduta terapêutica mais criteriosa dos profissionais de saúde animal.

Desenvolvimento: A resistência aos antibióticos é antiga, protegendo os organismos produtores de antibióticos de seus próprios produtos e protegendo os micróbios suscetíveis da ação dos antimicrobianos (DA COSTA, 1999), e hoje é um dos principais objetos de estudo nas áreas da saúde. Os antimicrobianos estão entre os fármacos mais prescritos em hospitais, e seu uso indiscriminado tem como uma das consequências a resistência bacteriana (RIBEIRO et al., 2018). Tanto medicamentos humanos quanto veterinários influenciam a resistência desenvolvida por microrganismos (BOOTHE, 2006), por isso o uso irracional de antibióticos é um problema de saúde pública. Antimicrobianos são administrados em animais produtores de alimentos para controlar e prevenir doenças (MOTA et al., 2005), mas também como promotores de crescimento, desde 1940 (VIEIRA et al., 2017). Esta prática exerce uma pressão seletiva para genes resistentes a antimicrobianos, levando à emergência de resistência nas bactérias presentes em animais produtores de alimentos (MOTA et al., 2005). A atenção aos antimicrobianos na veterinária começou com o uso em animais de produção, mas tem migrado para animais de companhia, uma vez que estudos mostram que esses podem atuar como um reservatório de organismos zoonóticos potencialmente resistentes a antibióticos (SOUZA, 2018). Algumas causas contribuintes para o desenvolvimento de resistência são o uso desnecessário de antimicrobianos, dose inadequada, duração insuficiente da terapia e a utilização de combinações de antimicrobianos (MOTA, 2005). Para evitar o fenômeno da resistência, a primeira decisão a ser tomada é determinar a necessidade de tratamento com esta classe de fármacos. A decisão inclui confirmar, quando possível, a existência de infecção; a identificação da etiologia; a necessidade de tratamento da infecção; e, caso algum tratamento seja necessário, se os antimicrobianos devem fazer parte da terapia (BOOTHE, 2006). A escolha do fármaco deve ser baseada em uma expectativa de eficácia clínica, baixa toxicidade e baixa influência sobre a seleção de bactérias multirresistentes (MOTA et al., 2005). A citologia diagnóstica deve ser realizada sempre que possível a fim de identificar os microrganismos envolvidos e orientar na escolha do antibiótico. Além disso, é necessário controlar regularmente a sensibilidade a antimicrobianos e o resíduo de antimicrobianos utilizados na produção animal (QUESSADA et al., 2010; RIBEIRO et al., 2018). Métodos baseados em diagnóstico molecular (p. ex.: PCR) são ferramentas importantes no diagnóstico de doenças infecciosas e de bactérias multirresistentes (BOOTHE, 2006). A via de aplicação deve assegurar concentrações ativas de antibiótico no local da infecção e limitar a exposição de outros sistemas ao antibiótico, a fim de minimizar o desenvolvimento de resistência da flora bacteriana normal (TAVARES, 2013). A perfusão do tecido também deve ser avaliada para uma maior eficácia no uso de antimicrobianos. Uma perfusão adequada é necessária antes que a difusão do antibiótico pelo tecido infectado possa ocorrer (ADAMS, 2003). A duração do tratamento também influencia no uso criterioso de antimicrobianos. A maioria das infecções em animais respondem bem com 5 a 10 dias de terapia. Em geral, o tratamento deve continuar por 1 ou 2 dias após a resolução dos sinais clínicos. É importante que o tratamento não seja mais longo do que o necessário, ou será preciso realizar reavaliações regulares do processo da doença quanto à terapia escolhida (TAVARES, 2013). O alto percentual de resistência em alguns antibióticos demonstra como a grande utilização de agentes antimicrobianos, principalmente, de amplo espectro de ação contribui para o aparecimento de resistência (RIBEIRO et al., 2018). Escolher um antibiótico de espectro mais restrito também ajudará a limitar, embora provavelmente não impeça, o desenvolvimento de resistência (BOOTHE, 2006).

Conclusão: $O$ advento da resistência bacteriana ao longo de décadas devido ao uso excessivo de antimicrobianos revela que 
estes não são medicamentos inócuos. É necessário promover a conscientização dos profissionais de saúde para uma utilização criteriosa dos antimicrobianos e colocar em prática as medidas de profilaxia para a resistência microbiana que já foram bem apresentadas na literatura científica.

\section{Referências}

ADAMS, R. H. Farmacologia e terapêutica em veterinária. 8. ed. Rio de Janeiro: Guanabara Koogan, 2003.

BOOTHE, D. M. Principles of antimicrobial therapy. Veterinary Clinics: Small Animal Practice, v. 36 n.5, p. 1003-1047, 2006.

Da COSTA, D. M. L. Ototoxicidade dos antibióticos aminoglicosídeos e sistema eferente: comparação entre a administração aguda e crônica com a gentamicina e os efeitos agudos de outros antibióticos. Revista HCPA, v. 19, n. 2, p. 186-196, 1999.

GUARDABASSI, L.; SCHWARZ, S.; LLOYD, D. H. Pet animals as reservoirs of antimicrobial-resistant bacteria. Journal of antimicrobial chemotherapy, v. 54 n. 2, p. 321-332, agosto, 2004.

MAIORKA, A. et al. Utilização de Prebióticos, Probióticos ou Simbióticos em Dietas para Frangos. Rev. Bras. Cienc. Avic., Campinas, v. 3, n. 1, p. 75-82, janeiro, 2001.

MOTA, R. A. I. Utilização indiscriminada de antimicrobianos e sua contribuição a multirresitência bacteriana. Brazilian Journal of Veterinary Research and Animal Science, 2005, v. 42, n.6, p. 465-470, Dezembro, 2005.

QUESSADA, A. M. et al. Uso de medicamentos sem prescrição médico-veterinária. Veterinária Notícias, v. 16, n. 1, setembro, 2010.

RIBEIRO, R. C. N.; CORTEZI, A. M.; GOMES, D. E. Utilização racional de antimicrobianos na clínica veterinária. Revista Científica, v. 1, n. 1, novembro, 2018.

SOUZA, M. M. Avaliação da resistência antimicrobiana de bactérias isoladas de infecções em Pequenos Animais na Região de Umuarama. 2018. Dissertação (Mestrado em Produção Sustentável e Saúde Animal) Universidade Estadual de Maringá, Paraná, 2018.

TAVARES, W. Antibióticos e quimioterápicos para o clínico. 5. ed. São Paulo: Editora Atheneu, 2013.

VIEIRA, P. N; VIEIRA, S. L. V. Uso irracional e resistência a antimicrobianos em hospitais. Arquivos de Ciências da Saúde da UNIPAR, v. 21, n. 3, dezembro, 2017. 


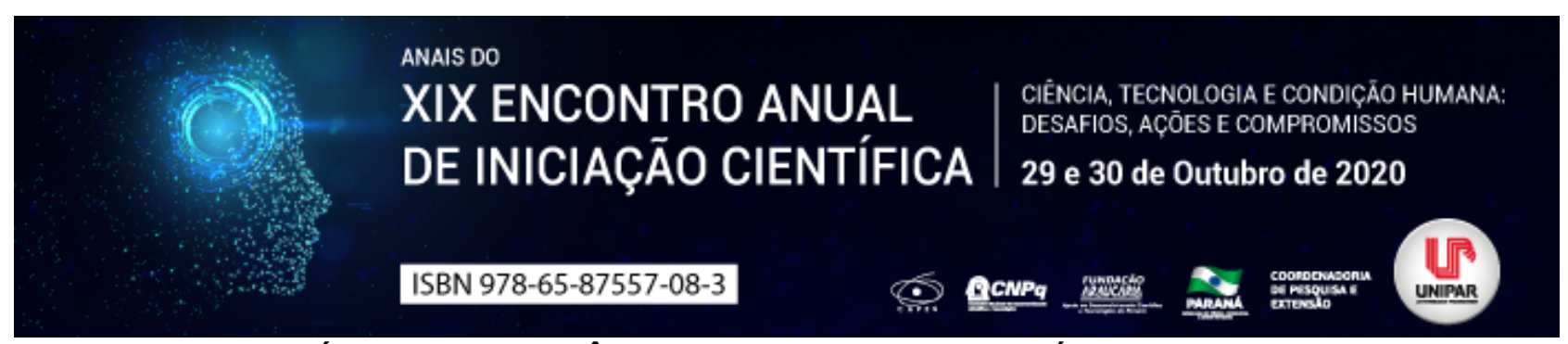

USO DE ANTIBIÓTICOS E RESISTÊNCIA BACTERIANA NA PECUÁRIA LEITEIRA E DE CORTE

\begin{abstract}
${ }^{1}$ Melissa Sanches Mongelli, ${ }^{2}$ EMANUELY RAMOS TAMEIRÃO , ${ }^{3}$ IZABEL CRISTINA TAVARES , ${ }^{4}$ ISABELA LOPES MASSITEL , ${ }^{5}$ HUMBERTO DE MELLO BRANDAO,${ }^{6}$ MARCOS FERRANTE
\end{abstract}

\author{
${ }^{1}$ Acadêmica do curso de Medicina Veterinária da Universidade Federal de Lavras (UFLA) \\ ${ }^{1}$ Acadêmica do curso de Medicina Veterinária da UFLA \\ ${ }^{2}$ Acadêmica do curso de Medicina Veterinária da UFLA \\ ${ }^{3}$ Acadêmica do curso de Medicina Veterinária da Universidade Estadual de Maringá (UEM) \\ ${ }^{4}$ Pesquisador da EMBRAPA-Gado de Leite, Juiz de Fora, MG, Brasil \\ ${ }^{5}$ Docente do departamento de Medicina Veterinária da UFLA
}

Introdução: Os agentes antimicrobianos são essenciais à manutenção da saúde e do bem-estar de seres humanos e animais. Dessa forma, desde 2005 a Organização Mundial de Saúde (OMS, 2019) lista periodicamente os antimicrobianos mais utilizados na medicina, classificando-os de acordo com sua importância. Com enfoque na produção animal, sabe-se que o uso não se limita somente na terapêutica das infecções, mas também como profiláticos, metafiláticos e promotores de crescimento. Nota-se que a Organização Mundial de Sanidade Animal (OIE, 2019) listou os agentes antimicrobianos mais relevantes na medicina veterinária, classificando-os como de importância crítica, elevada ou importantes. Sendo assim, salienta-se que o uso de antibióticos em animais de produção deve ser cada vez mais controlado, a fim de prevenir o desenvolvimento da resistência bacteriana, a qual já é considerada uma crise mundial de saúde pública (MCEWEN et al., 2017). Além disso, a Instrução Normativa (IN) no 41 , de 23 de outubro de 2017 instituiu o Programa Nacional de Prevenção e Controle da Resistência aos Antimicrobianos na Agropecuária

AgroPrevine, o qual contém planos estratégicos para monitorar e analisar o uso excessivo de antimicrobianos na produção animal. Em síntese, a IN e ambas as listas estabelecidas para seres humanos e animais fornecem informações necessárias ao equilíbrio entre saúde humana e animal, fundamental dentro dos conceitos de saúde única.

Objetivos: Relatar os principais antimicrobianos utilizados na pecuária de corte e leite, contemplando os conceitos de saúde única.

Desenvolvimento: Em uma pesquisa realizada pelo Departamento de Agricultura dos Estados Unidos (2007) em rebanhos leiteiros, verificou-se que o uso mais comum da terapia antimicrobiana é para o tratamento de mastite, laminites, doenças reprodutivas, doenças respiratórias e, por último, diarreias/doenças entéricas. Já em confinamentos de gado de corte, uma pesquisa do mesmo órgão, em 2017, aborda o uso de antibióticos na ração, água e de forma terapêutica individual ou coletiva. Observa-se que as elevadas taxas de antimicrobianos na ração são principalmente para promoção de crescimento dos animais, sendo os ionóforos a principal classe utilizada, e para tratamento preventivo de doenças respiratórias, com uso primário da clortetraciclina. Em suma, 80 \% dos confinamentos utilizam a administração individual dos antimicrobianos para fins terapêuticos. De acordo com a OIE (2019), os grupos farmacológicos de relevância crítica para os bovinos são: (1) aminociclitol utilizado para infecções respiratórias (IR) ; (2) aminoglicosídeos IR, infecções digestivas (ID) e sepse; (3) afenicóis IR e pasteurelose; (4) cefalosporinas de $3^{a}$ geração mastite e IR; (5) macrolídeos IR e abcessos de fígado; (6) penicilinas IR, sepse e infecções urinárias; (7) quinolonas IR, sepse e ID; (8) sulfonamidas afecções de origem bacteriana, coccídeos e protozoário; (9) tetraciclinas Escherichia coli e anaplasmose. Em contrapartida, analisando a lista da OMS acerca de antimicrobianos de importância crítica para a medicina, nota-se que cefalosporinas, macrolídeos e quinolonas possuem máxima prioridade, ou seja, são fármacos usados para infecções hospitalares graves em seres humanos, e que, portanto, têm risco elevado de produzir cepas bacterianas resistentes. Além disso, os aminoglicosídeos e as penicilinas são de grande prioridade, sendo um nível abaixo das citados anteriormente.

Conclusão: Verifica-se que a maioria dos produtores de leite e gado de corte utilizam antibioticoterapia de forma irregular. Além disso, os grupos farmacológicos mais usados são os de importância crítica para a medicina, permitindo o crescimento dos casos de resistência bacteriana. Dessa forma, salienta-se a importância da consulta dos planos governamentais e mundiais para reconhecer e equilibrar as necessidades tanto da saúde animal quanto da saúde pública, a fim de que os princípios de saúde única sejam implementados a nível mundial.

\title{
Referências
}

BRASIL. Instrução Normativa no 41, de 23 de outubro de 2017. Programa Nacional de Prevenção e Controle da Resistência aos Antimicrobianos na Agropecuária AgroPrevine. Diário Oficial da União, Brasília, ed.215, s.1, p. 5, 09 nov/2017.

DEPARTAMENTO DE AGRICULTURA DOS ESTADOS UNIDOS - ANIMAL E FITOSSANIDADE INSPEÇÃO SERVIÇO. 
Antimicrobial Use and Stewardship on U.S. Feedlot, 2017. Washington, Maio 2019. Disponível em: https://www.aphis.usda.gov/animal_health/nahms/amr/downloads/amu-feedlots_1.pdf. Acesso em: 13 agost. 2020

DEPARTAMENTO DE AGRICULTUTRA DOS ESTADOS UNIDOS - ANIMAL E FITOSSANIDADE INSPEÇÃO SERVIÇO. ANTIBIOTIC. Use on U.S. Dairy Operations, 2002 and 2007. Washington, Out 2008. Disponível em: file:///C:/Users/monge/Desktop/melissa\%20di/CONGRESSO\%20UNIMNPAR/Diarr\%C3\%A9ia/Dairy07_is_AntibioticUse_1.pdf.

Acesso em: 13 agost. 2020

MCEWEN, Scott A; COLLIGNON, Petter J. Antimicrobial resistance: a one health perspective. Microbiol Spectrum, v.6, n.2, Março, 2018. Disponível em: doi:10.1128/microbiolspec.ARBA-0009-2017 Acesso em: 13 agost 2020.

ORGANIZACIÓN MUNDIAL DE LA SALUD (OMS). Lista OMS de antimicrobianos de importancia crítica para la medicina humana (lista OMS de AIC), p.2, 2019. Disponível em: https://apps.who.int/iris/handle/10665/325037. Acesso em: 13 agost 2020. ORGANIZACIÓN MUNDIAL DE SANIDAD ANIMAL (OIE). Lista de agentes antimicrobianos importantes para la medicina veterinária, p.9, 2019.

https://www.oie.int/fileadmin/Home/esp/Our_scientific_expertise/docs/pdf/AMR/E_OIE_Lista_antimicrobianos_Julio2019.pdf. Acesso em: 13 agost 2020. 


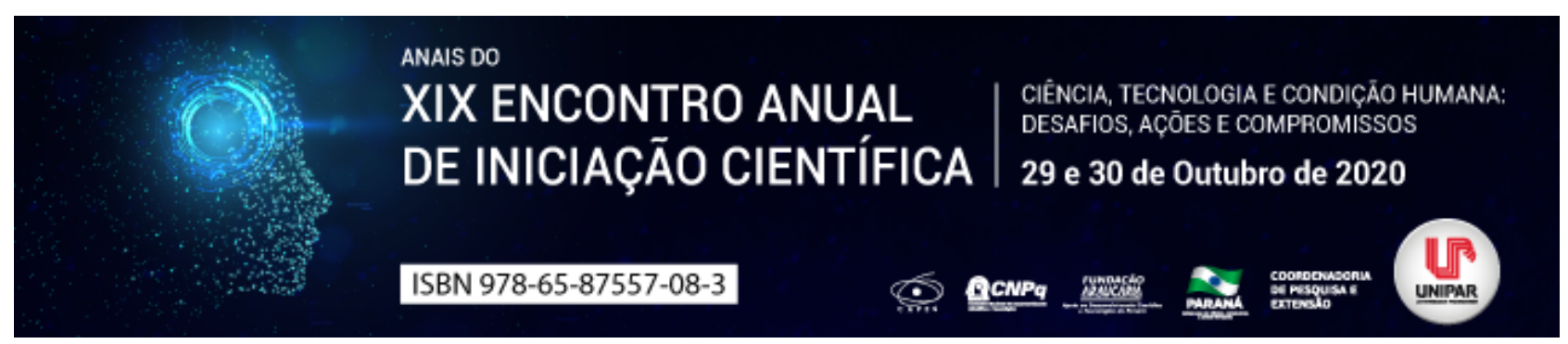

ANTIBIOTICOTERAPIA EM BEZERROS COM DIARREIA

\begin{abstract}
${ }^{1}$ Melissa Sanches Mongelli, ${ }^{2}$ SIBELY AIVA FLORES, ${ }^{3}$ IZABEL CRISTINA TAVARES, ${ }^{4}$ ISABELA LOPES MASSITEL, ${ }^{5}$ MARCOS FERRANTE, ${ }^{6}$ JOÃO VITOR FERNANDES COTRIM DE ALMEIDA
\end{abstract}

\author{
${ }^{1}$ Acadêmica do curso de Medicina Veterinária da Universidade Federal de Lavras (UFLA) \\ ${ }^{1}$ Acadêmica do curso de Medicina Veterinária da UFLA \\ ${ }^{2}$ Acadêmica do curso de Medicina Veterinária da UFLA \\ ${ }^{3}$ Acadêmica do curso de Medicina Veterinária da Universidade Estadual de Maringá (UEM) \\ ${ }^{4}$ Docente do departamento de Medicina Veterinária da UFLA \\ ${ }^{5}$ Médico Veterinário, Mestre em Ciências Veterinárias do departamento de Medicina Veterinária da UFLA
}

Introdução: A diarreia é a principal causa de mortalidade de bezerros pré-desmamados, tanto na pecuária leiteira quanto de corte (SMITH, 2015). Independentemente do agente etiológico, a fisiopatogenia da doença cursa com elevado número de coliformes bacterianos no intestino delgado e aumento da suscetibilidade à bacteremia (CONSTABLE, 2009). De acordo com Smith (2015), a administração oral de antibióticos para prevenção da diarreia não é recomendada. No entanto, o uso destes em animais com sintomatologia sistêmica, os quais apresentam maior risco de desenvolver sepse, pode ser uma forma de tratamento bastante eficaz (BERGE et al., 2009). Nesse contexto, verifica-se a importância de reduzir o uso de antibióticos em animais de produção para evitar o desenvolvimento de resistência bacteriana, já considerada uma crise de saúde pública global (SMITH, 2015; MCEWEN et al., 2017). Desde 2005 a OMS lista periodicamente os antimicrobianos utilizados na medicina, classificando-os de acordo com sua importância e probabilidade de gerar cepas resistentes. Ante o exposto, cabe ao médico veterinário escolher o antibiótico que melhor combata a infecção, dê suporte ao tratamento da diarreia e não tenha risco elevado de produzir resistência.

Objetivo: Avaliar as alternativas de antibioticoterapia para tratamento de diarreia em bezerros, considerando uma perspectiva de saúde única.

Desenvolvimento: A manutenção da saúde do bezerro é uma das prioridades na bovinocultura, porém, ainda são encontrados elevados índices de mortalidade antes do desmame, sendo a diarreia uma das principais causas no Brasil (SOARES, 2013). Desta forma, iniciou-se a utilização de antibióticos por via oral para prevenir a ocorrência de tal afecção. Contudo, na maioria dos estudos não foi demonstrado efeito positivo na diminuição da mortalidade (SMITH, 2015). Sendo assim, Smith (2015) relata três princípios para se prevenir a diarreia em bezerros: (1) uso de vacina contra Escherichia coli em animais gestantes; (2) garantir excelente colostragem; (3) promoção da sanidade ambiental. Já no tratamento com antibióticos, o foco é diminuir o número de bactérias coliformes no intestino delgado, prevenindo a bacteremia (BERGE et al., 2009). Pelo menos 1/3 dos animais que apresentam diarreia vão desenvolver bacteremia, sendo que as taxas sobem ainda mais quando há falha na colostragem. O uso de antibióticos para o tratamento de diarreias é justificado, desde que o animal apresente sinais sistêmicos, para prevenir essa condição e minimizar os danos ao intestino delgado. Entretanto, os antimicrobianos autorizados na terapêutica da diarreia não são considerados muito eficazes. Por via parenteral, indica-se o ceftiofur, o qual mantém elevada concentração plasmática $(0.25$ $\mathrm{ug} / \mathrm{ml}$ ) e inibi o crescimento de $90 \%$ de E. coli. Além disso, pode ser utilizado também a ampicilina parenteral (SMITH, 2015). Desta forma, Smith (2015) aborda que os principais antibióticos com efeitos significativos para o tratamento das diarreias são o ceftiofur, amoxicilina e ampicilina. Analisando a lista da OMS dos antimicrobianos de importância crítica para a medicina, observa-se que o ceftiofur é de máxima prioridade - última escolha em medicina veterinária (MV) - para o ser humano, ou seja, tal grupo farmacológico só é utilizado em infecções hospitalares graves. Já ampilicina e amoxicilina são de grande prioridade (penúltima escolha em MV). Dessa forma, nota-se que os principais antibióticos usados para o tratamento das diarreias em bezerros possuem significativa importância na medicina, e por isso devem ser utilizados com bastante prudência na MV, de acordo com as orientações da bula e do médico veterinário.

Conclusão: Nota-se que a terapia antimicrobiana para diarreia em bezerros somente é recomendada quando o animal apresenta sinais sistêmicos, sendo os principais antibióticos ampicilina, amoxicilina e ceftiofur. Concluiu-se que há poucos antibióticos indicados, fazendo-se necessário mais pesquisas para otimizar a antibioticoterapia.

\title{
Referências
}

BERGE A. C; MORRE, D. A; BESSER, T. E; SISCHO, W. M. Targeting therapy to minimize antimicrobial use in preweaned calves: Effects on health, growth, and treatment costs. J. Dairy Sci, v. 92, n.9, p.4707 4714, Set, 2009. Disponível em: doi 10.3168 / jds.2009-2199. Acesso em: 13 agost 2020. 
CONSTABLE, Peter D. Treatment of Calf Diarrhea: Antimicrobial and Ancillary Treatments. Vet Clin Food Anim, v.25, p.101 120, Março,2009. Disponível em: doi- 10.1016 / j.cvfa.2008.10.012. Acesso em: 13 agost 2020.

MCEWEN, Scott A; COLLIGNON, Petter J. Antimicrobial resistance: a one health perspective. Microbiol Spectrum, v.6, n.2, Março, 2018. Disponível em: doi -10.1128/microbiolspec.ARBA-0009-2017 Acesso em: 13 agost 2020.

ORGANIZACIÓN MUNDIAL DE LA SALUD (OMS). Lista OMS de antimicrobianos de importancia crítica para la medicina humana (lista OMS de AIC), p.2, 2019. Disponível em: https://apps.who.int/iris/handle/10665/325037. Acesso em: 13 agost 2020. SMITH, Geof. Antimicrobial Decision Making for Enteric Diseases of Cattle. Vet Clin Food Animal, v.31, n.1, p.47-69, Março, 2015. Disponível em: doi:10.1016/j.cvfa.2014.11.004. Acesso em: 13 agost 2020.

SOARES, Marcelo Cezar. Diarreia e acidose metabólica em bezerros leiteiros: efeito da composição do concentrado inicial e avaliação do probiótico. 2013. Dissertação para obtenção do título de mestre em Ciência Animal e Pastagens Universidade de São Paulo Escola Superior de Agricultura "Luiz de Queiroz" Piracicaba 2013.

Coordenadoria de Pesquisa e Extensão - COPEX

Departamento de Editoraçāo e Divulgaçāo Científica - DEDIC 


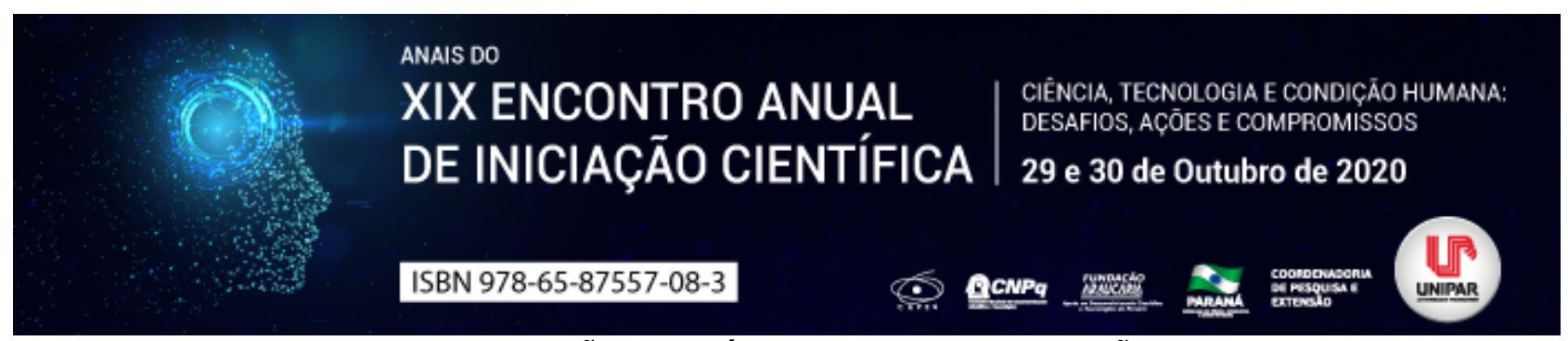

REABSORÇÃO DENTÁRIA FELINA: UMA REVISÃO

\begin{abstract}
${ }^{1}$ NATALIA SARAIVA RODRIGUES, ${ }^{2}$ NATALIE BERTELIS MERLINI
\end{abstract}

\author{
${ }^{1}$ Mestranda em Ciência Animal, Universidade Paranaense UNIPAR, bolsista PIT/UNIPAR \\ ${ }^{1}$ Professora Doutora, Programa de Pós-Graduação em Ciência Animal, Universidade Paranaense UNIPAR
}

Introdução: A reabsorção dentaria felina é uma doença subdiagnosticada e de alta incidência nos gatos, que se caracteriza pela perda dentária devido a reabsorção do tecido dental duro (AVDC, 2019). Os sinais clínicos incluem principalmente dor intensa e hiperplasia gengival inflamatória (THOMAS et al., 2017; WATANABE et al., 2016; BOOIJ-VRIELING et al., 2010; SENN et al., 2010; BOOIJ-VRIELING et al., 2009; DELAURIER et al., 2005). O diagnóstico se baseia na anamnese, sinais clínicos, inspeção visual e radiografias sob anestesia geral (AVDC, 2019). O tratamento de escolha é a extração dentaria (AVDC, 2019).

Objetivo: Revisar os pontos principais da reabsorção dentária felina.

Desenvolvimento: A reabsorção dentaria felina (RDF), conhecida antigamente como lesão de reabsorção odontoclástica felina (LEROF), é uma doença oral comum e subdiagnosticada em gatos que se caracteriza pela perda dentaria causada pela reabsorção do tecido duro dental, que começa no cemento e progride para a dentina da raiz, da coroa ou ambos (AVDC, 2019; THOMAS et al., 2017; WATANABE et al., 2016; MESTRINHO et al., 2013; BOOIJ-VRIELING et al., 2010; SENN et al., 2010; BOOIJ-VRIELING et al., 2009; DELAURIER et al., 2005; REITER et al., 2005). A reabsorção se diferencia em dois tipos, uma com características inflamatórias e outra que inicialmente é não inflamatória, mas que pode se tornar inflamatória devido a presença de cálculo dental. Na primeira, o defeito resultante da reabsorção é preenchido por tecido de granulação, já na segunda ele é preenchido por tecido ósseo (EICKHOFF, 2011; BOOIJ-VRIELING et al., 2010; BOOIJ-VRIELING et al., 2009; REITER et al., 2005). Qualquer dente pode ser afetado por RDF, mas os dentes mais acometidos são os terceiros pré-molares (WATANABE et al., 2016; MESTRINHO et al., 2013; BOOIJ-VRIELING et al., 2010; DELAURIER et al., 2005). A etiologia desta doença permanece desconhecida e há varias teorias referente a ela, segundo uma delas há uma associação entre a prevalência de lesão de reabsorção dentaria felina e a alta concentração sérica de vitamina D3, que nos felinos só é obtida por meio da alimentação (WATANABE et al., 2016; MESTRINHO et al., 2013; BOOIJ-VRIELING et al., 2010; BOOIJ-VRIELING et al., 2009; DELAURIER et al., 2005). A American Veterinary Dental College (AVDC) classifica as RDF de acordo com sua severidade em cinco estágios e quanto a localização da reabsorção em três tipos. No estágio 1 há uma pequena perda de cemento e/ou esmalte. No 2 há uma moderada perda desses elementos, além de perda de dentina. No terceiro estágio há uma grande perca de tecido dentário com comprometimento da cavidade pulpar. Já o estágio 4 é dividido em a , b e c . No estágio $4 a$ a coroa e a raiz são igualmente afetadas, no $4 \mathrm{~b}$ a coroa é a mais afetada e no $4 \mathrm{c}$ a raiz é a mais afetada. Por fim, o estágio 5 se caracteriza pela presença de restos remanescentes do dente afetado recoberto completamente por gengiva. Os tipos de reabsorção são baseados na aparência radiográfica do dente afetado, sendo o tipo 1 caracterizado pela presença de focos de radioluscência em um dente de radiopacidade e espaço de ligamento periodontal normais. No tipo 2 há uma diminuição da radiopacidade do dente e estreitamento ou desaparecimento do espaço de ligamento periodontal. Já o tipo 3 possui a aparência do tipo 1 e 2 juntos. Os sinais clínicos dessa patologia incluem halitose, dor intensa, anquilose, disfagia, ptialismo, perda de peso, anorexia, desidratação, letargia, dificuldade para se alimentar, alterações comportamentais e hiperplasia gengival inflamatória, sendo este um sinal patognomônico desta doença (THOMAS et al., 2017; WATANABE et al., 2016; BOOIJ-VRIELING et al., 2010; SENN et al., 2010; BOOIJ-VRIELING et al., 2009; DELAURIER et al., 2005). O tratamento de escolha é extrair o dente afetado, uma vez que a contínua reabsorção leva a exposição dos feixes nervosos, o que causa uma dor intensa no animal. Caso não seja possível extrair o dente, pode-se realizar a amputação da coroa. Não se recomenda realizar a restauração dentaria (AVDC, 2019; THOMAS et al., 2017; WATANABE et al., 2016; SENN et al., 2010). O diagnóstico é através de anamnese, sinais clínicos, inspeção visual e radiografias sob anestesia geral. As radiografias são essenciais para o diagnóstico precoce desta doença, além de serem necessárias para o acompanhamento da evolução e tratamento da RDF. É indicado realizar radiografias de boca inteira, pois outros dentes podem estar afetados (AVDC, 2019; WATANABE et al., 2016). A AVDC recomenda que todos os gatos com RDF repitam exames radiográficos anualmente.

Conclusão: Pelo fato de a reabsorção dentária felina ser uma doença de grande incidência, subdiagnosticada e de etiologia desconhecida é importante realizar mais estudos sobre o assunto e divulgar mais informações sobre esta doença.

\title{
Referências
}

AMERICAN VETERINARY DENTAL COLLEGE. AVDC Nomenclature. Meridian, [s.d.]. Disponível em: https://avdc.org/avdcnomenclature/. Acesso em: 20 de jul. de 2020.

AMERICAN VETERINARY DENTAL COLLEge. AVDC Position Statements. Meridian, [s.d.]. Disponível em: 
https://avdc.org/about/. Acesso em: 20 de jul. de 2020.

WATANABE, B. C. et al. Lesão de Reabsorção Dentária Felina Relato de Caso. Revista Eletrônica Biociências, Biotecnologia e Saúde, Curitiba, n. 15, p. 152-154, maio/ago. 2016.

THOMAS, S. et al. Prevalence of feline calicivirus in cats with odontoclastic resorptive lesions and chronic gingivostomatitis. Research in Veterinary Science, Londres, v. 111, p. 124-126, 2017.

MESTRINHO, L. A. Risk Assessment of Feline Tooth Resorption: A Portuguese Clinical Case Control Study. Journal of veterinary dentistry, Thousand Oaks, v. 30, n. 2, p. 78-83, 2013.

EICKHOFF, Markus. Odontologia em gatos prevenção, diagnóstico e tratamento, Tijuca: Revinter, 2011.

BOOIJ-VRIELING, H. E. et al. Increased vitamin D-driven signalling and expression of the vitamin D receptor, MSX2, and RANKL in tooth resorption in cats. European Journal of Oral Sciences, Singapura, v. 118, p. 39-46, 2010.

SENN, D. et al. Immunohistochemical Localization of Osteoclastogenic Cell Mediators in Feline Tooth Resorption and Healthy Teeth. Journal of veterinary dentistry, Thousand Oaks, v. 27, n. 2, p. 75-83, 2010.

BOOIJ-VRIELING, H. E. et al. Inflammatory cytokines and the nuclear vitamin D receptor are implicated in the pathophysiology of dental resorptive lesions in cats. Veterinary Immunology and Immunopathology, Amsterdam, v. 132, p. $160166,2009$.

DELAURIER, A. et al. A Scanning Electron Microscopy Study of Idiopathic External Tooth Resorption in the Cat. Journal of periodontology, Chicago, v. 76, n. 7, p. 1106-1112, 2005.

REITER, A. M. et al. Evaluation of calciotropic hormones in cats with odontoclastic resorptive lesions. American journal of veterinary research, Chicago, v. 66, n. 8, p. 1446-1452, 2005.

Coordenadoria de Pesquisa e Extensão - COPEX

Departamento de Editoraçāo e Divulgaçāo Científica - DEDIC 


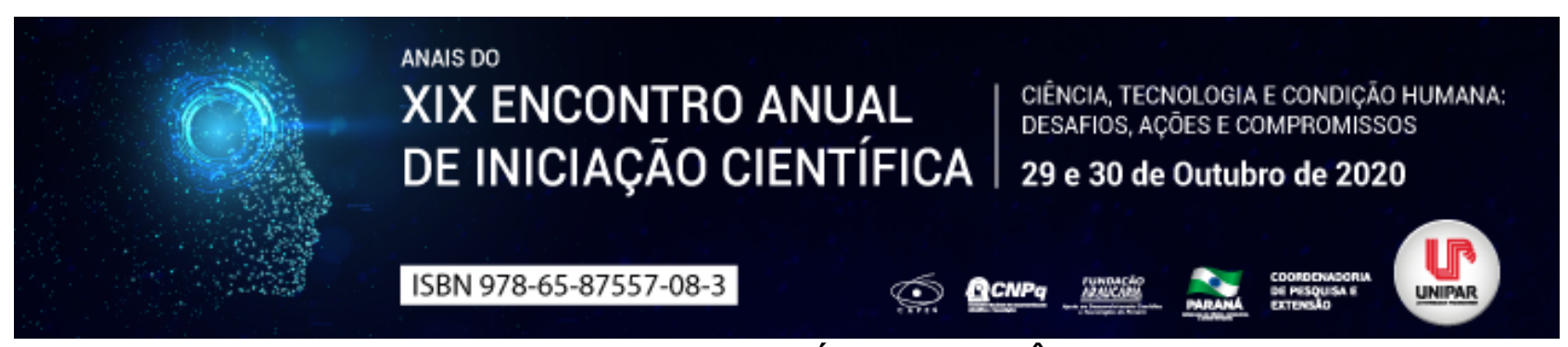

ATIVIDADE DO CARVACROL SOBRE BACTÉRIAS PATOGÊNICAS EM ALIMENTOS

\begin{abstract}
${ }^{1}$ Jefferson Alessandro Schmitz Junior, ${ }^{2}$ ISABELA CARVALHO DOS SANTOS, ${ }^{3}$ ISABELLA ARANTES TOBBIN, ${ }^{4}$ JÚLIA MUNARETTO ZONIN, ${ }^{5}$ DANIELA DIB GONÇALVES, ${ }^{6}$ LIDIANE NUNES BARBOSA
\end{abstract}

\author{
${ }^{1}$ Discente Ensino Médio, PEBIC EM CNPq \\ ${ }^{1}$ Doutoranda PPG em Ciência Animal com Ênfase em Produtos Bioativos/ Bolsista - Prosup/CAPES \\ ${ }^{2}$ Discente de Medicina, PIBIC, UNIPAR \\ ${ }^{3}$ Discente de Medicina, PIC, UNIPAR \\ ${ }^{4}$ Docente- UNIPAR \\ ${ }^{5}$ Docente da UNIPAR
}

Introdução: O uso de óleos essenciais no controle de microrganismos resistentes a antimicrobianos convencionais vem apresentando resultados promissores. O surgimento da resistência bacteriana é devido a mutações genéticas espontâneas ou oriundas de estímulos e recombinação de genes (LIMA et al., 2017). Acredita-se que as propriedades antibacterianas de alguns óleos essenciais se devem aos seus compostos fenólicos. O carvacrol e seu isômero timol, por exemplo, são encontrados no óleo essencial Origanum vulgare. Esses compostos fenólicos exercem atividade antibacteriana, lesando as membranas plasmáticas lipídicas das células, comprometendo a homeostase do pH e o equilíbrio de íons orgânicos, impedindo a divisão celular e causando desidratação das células (ARAUJO; LONGO, 2016).

Objetivos: Avaliar o potencial do carvacrol frente microrganismos de importância em alimentos, bem como os mecanismos de ação desse composto utilizando a literatura.

Desenvolvimento: A literatura aponta o carvacrol como principal composto na atividade antibacteriana de vários óleos essenciais. De acordo com Araujo e Longo (2016) esse composto é responsável por aumentar a permeabilidade da membrana, causando perda de ATP citoplasmático da célula da bactéria. Essa ação deve-se a sua capacidade de interagir com a membrana citoplasmática, podendo se dissolver na bicamada lipídica, alinhando-se entre as cadeias de ácido graxos (ARAUJO; LONGO, 2016). A presença do grupo hidroxila $(\mathrm{OH})$ na molécula desses compostos fenólicos se apresenta como um importante agente contra as bactérias. Ultee, Bennik e Moezelaar (2002) avaliaram a atividade antibacteriana do carvacrol frente a Bacillus cereus e observaram que a atividade se deve a presença do grupo hidroxila desse composto e a sua capacidade de deslocar elétrons, fazendo com que além de desestabilizar a membrana plasmática das bactérias, o carvacrol promova também uma troca de prótons, causando uma redução do gradiente de pH nessa estrutura celular. Os estudos de Veldhuizen et al. (2006) atribuem a presença do grupo hidroxila na molécula do carvacrol como agente importante, mas não essencial em sua ação frente a bactéria Gram-negativa Escherichia coli e a bactéria Gram-positiva Staphylococcus aureus, revelando que a utilização de constituintes análogos ao carvacrol sem a presença da hidroxila apresentaram também características bactericidas, entretanto 3 vezes menores em relação ao carvacrol. A utilização de alguns compostos fenólicos em conjunto, como o carvacrol e o timol, pode potencializar a atividade contra microrganismos. A mistura desses dois compostos promoveu um maior aumento de permeabilidade na membrana plasmática da bactéria Gram-positiva Listeria innocua com relação a utilização desses compostos separados, promovendo a perda de lipossacarídeos essenciais para o funcionamento das células da bactéria (GARCíA-GARCíA; LÓPEZ-MALO; PALOU, 2010). Escherichia coli, um importante indicador higiênico-sanitário, foi isolada de refeições servidas em restaurantes self-service, apontando a necessidade de maior cuidado com a higiene durante a preparação de alimentos deste tipo (CHOUMAN; PONSANO; MICHELIN, 2010). Todas as bactérias citadas anteriormente são encontradas em alimentos e são responsáveis por diversos tipos de toxintoxicações alimentares, felizmente, compostos naturais que possuem carvacrol como constituintes fenólicos em sua composição surgem então como um potencial agente contra essas bactérias, já que na literatura há diversos estudos que demonstram o potencial desse composto contra diversos tipos de bactérias encontradas em alimentos, sejam elas Gram-positivas ou Gram-negativas.

Conclusão: A revisão mostrou que o carvacrol surge como um aliado contra diversos tipos de bactérias patogênicas encontradas em alimentos. Esse composto interage com a membrana celular causando a morte bacteriana. Alguns autores apontam a hidroxila presente na molécula do carvacrol como potencializador da ação antibacteriana, uma vez que esse promove a troca de elétrons entre o composto e a membrana plasmática da bactéria, promovendo uma diminuição no gradiente de $\mathrm{pH}$.

\title{
Referências
}

ARAUJO, Márcio; LONGO, Priscila. Teste da ação antibacteriana in vitro de óleo essencial comercial Origanum vulgare (orégano) diante das cepas de Escherichia coli e Staphylococcus aureus. Arquivos do Instituto Biologico, v. 8, e0702014, p. 1-7, abr. 
2016.

CHOUMAN, Karina; PONSANO, Elisa; MICHELIN, Aparecida. Qualidade microbiológica de alimentos servidos em restaurantes self-service. Revista Instituto Adolfo Lutz, v. 69, n. 2, p. 261-266, mai. 2010.

GARCÍA-GARCÍA, Rebeca; LÓPEZ-MALO, Aurelio; PALOU, Enrique. Bactericidal Action of Binary and Ternary Mixtures of Carvacrol, Thymol, and Eugenol against Listeria inoccua. Journal of Food Science, v. 76, n. 2, p. 95-100, nov. 2010.

LIMA, Dijaci; et al. Estudo da atividade antibacteriana dos monoterpenos timol e carvacrol contra cepas de Escherichia coli produtoras de $\beta$-lactamases de amplo espectro. Pan-Amazônica de Saúde, v. 8, n.1, p. 17-21, out. 2017.

ULTEE, Annemieke; BENNIK, Marjon; MOEZELAAR, Roy. The phenolic hidorxyl Group of carvacrol is essential for action against the foodborne pathogen Bacillus cereus. Applied and Environmental Microbiology, v. 68. n. 4, p. 1561-1568, abr. 2002.

VELDHUIZEN, Edwin; et al. Structural Requirements for the Antimicrobial Activity of Carvacrol. Journal of Agricultural Food Chemistry, v. 54, n. 5, p. 1874-1879, jan. 2006. 


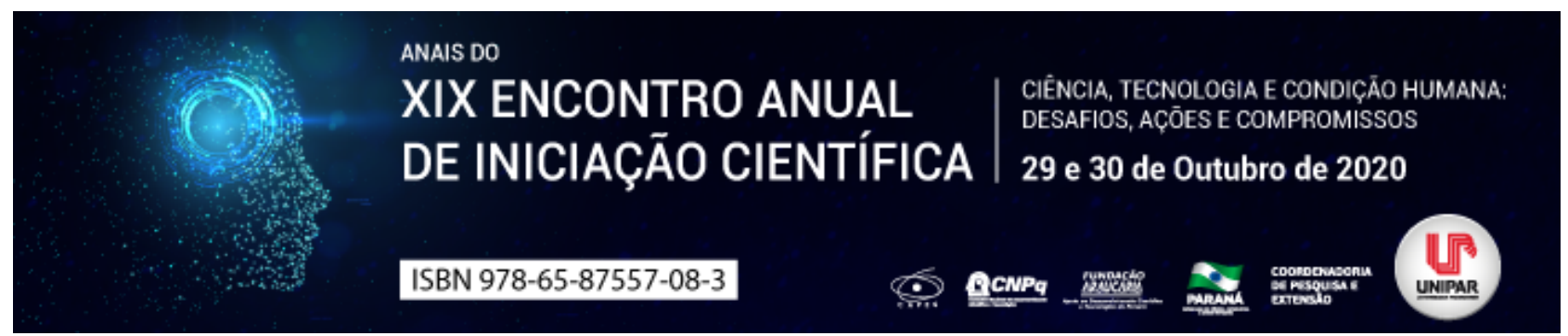

INSEMINAÇÃO ARTIFICIL EM TEMPO FIXO-(IATF) EM BOVINOS - REVISÃO DE LITERATUIRA

\begin{abstract}
${ }^{1}$ VITOR HUGO INOUE CORREA, ${ }^{2}$ LUCCA HIROITI SAKASHITA, ${ }^{3}$ MARIA EDUARDA BORBA ALEM, ${ }^{4}$ GUSTAVO POMARO, ${ }^{5}$ ROSIARA ROSARIA DIAS MAZIERO
\end{abstract}

\footnotetext{
${ }^{1}$ Acadêmico do curso de Medicina Veterinária da Unipar, Bolsista PIC/UNIPAR

${ }^{1}$ Acadêmico do curso de Medicina Veterinária da Unipar, Bolsista PIC/UNIPAR

${ }^{2}$ Acadêmico do curso de Medicina Veterinária da Unipar, Bolsista PIC/UNIPAR

${ }^{3}$ Acadêmico do curso de Medicina Veterinária da Unipar, Bolsista PIC/UNIPAR

${ }^{4}$ Docente da UNIPAR
}

Introdução: A inseminação em tempo fixo (IATF) é uma importante ferramenta em qualquer modalidade de exploração relacionada à bovinocultura. Quando bem aplicada pode, além de viabilizar o melhoramento genético de forma mais rápida, incrementar a performance reprodutiva (FERREIRA et al., 2000). A técnica da IATF permite que o produtor escolha o momento de inseminar as vacas sem a necessidade de esperar que a natureza determine. Assim, esta ferramenta tem movimentado o dia a dia das fazendas e dos grupos de pesquisa em reprodução animal. Pela técnica, as vacas tem ovulação induzida, e a inseminação artifical pode ser feita com data marcada. A IATF é uma realidade na pecuária brasileira e sua utilização proporciona maior produção e qualidade agregada ao rebanho (BARUSELLI e CARVALHO, 2003).

Objetivo: Apresentar os benefícios que a IATF pode trazer em uma propriedade, seja leiteira ou gado de corte visando o melhoramento genético do rebanho.

Desenvolvimento: A biotecnologia de IATF permite que exista todo o controle reprodutivo de um rebanho, além de ser possível otimizar o trabalho, visto que é possível realizar a inseminação artificial de um elevado número de animais, num único dia. Além disso, é possível fazer a programação do momento do nascimento dos bezerros, com o incremento do número de nascimento de animais por estação de monta (BARUSELLI e CARVALHO, 2004). Para iniciar um protocolo de IATF são necessárias algumas recomendações para bons resultados, como: as fêmeas devem estar em boa condição corporal e com mais de 45 dias de pósparto. Já as novilhas, devem ter apresentado um ou dois ciclos estrais e peso corporal adequado para o início da fase reprodutiva. Neste contexto, é necessário também que exista infraestrutura adequada, para reduzir o estresse animal e facilitar e possibilitar segurança para os profissionais e o rebanho (DELPRETE, 2020). Nos dias atuais para o gado de corte é utilizado o chamado Cruzamento Industrial, que é o cruzamento das raças Européias (Britânica e Continental), com zebuínos, aumenta o ganho de peso e o peso de carcaça em relação aos animais zebuínos. Os resultados mostram claramente que o cruzamento com raças européias (taurinas) melhora de maneira expressiva os índices produtivos em relação ao zebu (BARUSELLI e CARVALHO, 2004). Os protocolos de sincronização baseiam-se em duas estratégias básicas, como a indução da regressão do corpo lúteo, para que todos os animais do grupo entrem na fase folicular ao mesmo tempo e mantenham mais ou menos esta sincronização durante o estro e alongar a fase luteínica artificialmente, administrando uma fonte exógena de progesterona aos animais, de forma que todos entrem na fase folicular simultaneamente, após a retirada do bloqueio farmacológico (SÁ FILHO et al, 2008).

Conclusão: Conclui-se que se seguida todas as exigências citadas acima a IATF é uma excelente maneira de melhoramento genético e padronização de rebanhos.

\title{
Referências
}

BARUSELLI, P. S.; CARVALHO, N. A. T. Artificial insemination in developing countries.In: Congresso Nazionale sull allevamentodel buflo ,2, 2003, Roma. Anais... proceedings Roma: [s.n.], 2003. p. 177-192.

DELPRETE, Sâmila. Esteves. IATF: Saiba tudo sobre essa técnica. 2011. Atílio Vivácqua, ES. 2011.

FERRAZ, H. T., VIU, M. A. O., LOPES, D. T. Sincronização da ovulação para realização da inseminação artificial em tempo fixo em bovinos de corte. PUBVET, V.2, N.12, Mar4, 2008.

FERREIRA, A. M.; VIANA, J. H. M.; SÁ, W. F. Restrição alimentar e atividade ovariana luteal cíclica pós-parto em vacas girolando. Pesquisa Agropecuária Brasileira, Brasília, v. 35, n. 12, p. 2521-2528, out. 2000.

SÁ FILHO, M. F.; GUIMENES, L. U.; SALES, J. N. S., CREPALDI, G. A.; MEDALHA, A. G.; BARUSELLI, P. S. IATF em novilha. SIMPÓSIO INTERNACIONAL DE REPRODUÇÃO ANIMAL APLICADA. 3, 2008, Londrina.Anais Londrina, p.54-67, 2008. 


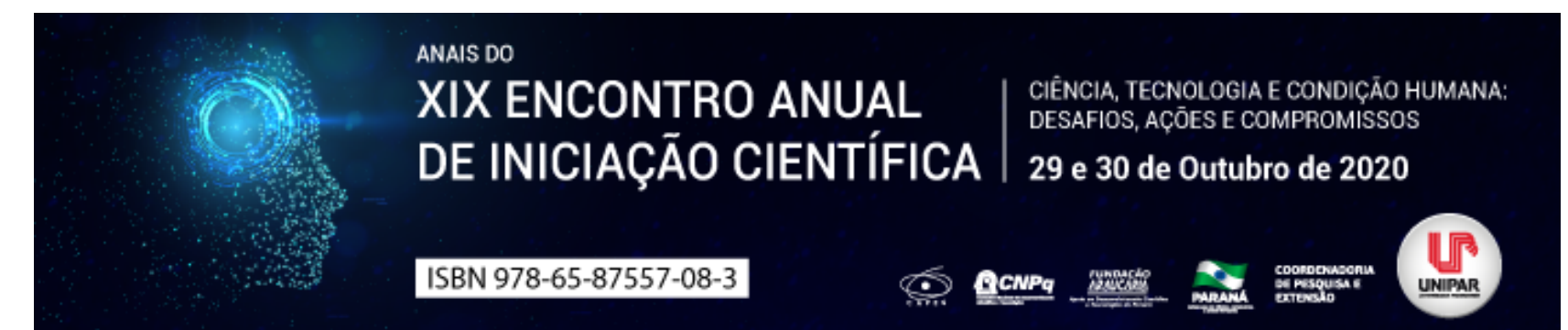

\title{
INTERAÇÃO ENTRE O MECANISMO DE AÇÃO DO GENE LEPR, SEUS POLIMORFISMOS E AS ASSOCIAÇÕES CLÍNICAS OBESOGÊNICAS
}

\section{${ }^{1}$ AMANDA SIHNEL CORTEZ DA SILVA, ${ }^{2}$ MARIA LUIZA MARCHI SILVA, ${ }^{3}$ LUCIANO SERAPHIM GASQUES}

\author{
${ }^{1}$ Acadêmica bolsista do PEBIC/CNPQ \\ ${ }^{1}$ Acadêmica do Curso de Medicina da Universidade Paranaense (UNIPAR) \\ ${ }^{2}$ Docente da Universidade Paranaense (UNIPAR)
}

Introdução: A obesidade vem tomando níveis cada vez mais ascendentes e epidêmicos. Marques-Lopes, et al. (2004) aclaram que a etiologia deste quadro é multifatorial, sendo, no entanto, elencado dois fatores principais: as condições genéticas e ambientais. Por seu turno, os genes intervêm e regulam o equilíbrio da gordura corporal em aproximadamente $40 \%$, sendo sua ação mediada por mecanismos do sistema nervoso. Dentre os genes de destaque, Machado, Monteiro e Pinto (2015) sobrelevam o da leptina (LEP) e o do receptor da leptina (LEPR), os mais importantes sinais periféricos da homeostase energética, que objetivam instituir o grau de saciedade. Nesse contexto, quando detectado polimorfismos nesses genes, a repercussão prevista tange à obesidade e, para além, outras comorbidades e associações decorrentes dessa interação obesogênica (LIMA; GLANER; TAYLOR, 2010).

Objetivo: O estudo tem por intuito aclarar o mecanismo de ação do gene do LEPR, estabelecendo um vínculo entre seus polimorfismos e a fisiopatologia obesa, além de expor os liames que podem repercutir dessa relação e, para mais, potenciais tratamentos.

Desenvolvimento: Segundo Dagogo-Jack (2015), desde a descoberta do genes ob , uma longa jornada científica obesogênica foi trilhada e seu clímax se perfez com a descoberta da leptina. O autor aborda que a organização genômica de seu receptor é estruturada quando do início da atividade dos promotores P1 e P2. O primeiro destes origina duas transcrições diferentes através de um splicing alternativo. Isso gera duas proteínas distintas sem homologia na sequência de aminoácidos: o OB-RGRP/endospanin-1 e o LEPR em suas cinco isoformas, sendo apenas a isoforma OB-R capaz de transmitir o sinal para introduzir leptina na célula. Negrão e Licínio (2000) observam que a produção da LEP ocorre principalmente pelo tecido adiposo, perpassa a corrente sanguínea, atravessa a barreira hematoencefálica, e no hipotálamo se liga a receptores específicos dos peptídios neuronais. Dagogo-Jack (2015) prossegue explicando que a ativação e ligação da LEP ao LEPR é mediada por dois domínios: o receptor de citoquina $\mathrm{CRH} 2$ e a imunoglobulina Ig. Assim, quatro LEPRs (em seus domínios) se ligam à duas moléculas de LEP (no respectivo sítio de ligação). Por sua vez, a sinalização da LEPR ocorre quando a tirosina quinase JAK2 age e recruta as proteínas STATs, essencialmente a STAT3, que possui efeitos diretos sob a saciedade. A fisiopatologia obesogênica, conforme Dagogo-Jack (2015), foi apurada em 1988, quando detectada mutação de um splicing anormal da a transcrição do LEPR. Nesta direção, o principal mecanismo associado é a resistência à LEP, sendo os outros a produção insuficiente da LEP ou uma sensibilidade parcial ou total da LEP no sítio de ligação. Qualquer seja a situação, a motivação deriva de um polimorfismo e/ou de algum embaraço na via neural. Alusivo às associações clínicas obesogênicas por LEP/LEPR, a primeira menção valorosa concerne a sua relação com o sono. A LEP é secretada em pulsos ao longo do dia, sendo seu pico de durante a noite (NEGRÃO; LíCINIO, 2000). Assim, a privação do sono provoca, dentre outras coisas, a diminuição da secreção de LEP (ABESO, 2016). Outra comorbidade associada à LEP é o câncer de mama. Cleveland, et al. (2010) elucidam que há um aumento modesto no risco de desenvolver essa patologia quando da mutação, principalmente em mulheres obesas na pósmenopausa. Adita-se às associações vinculadas aos polimorfismos da LEP/LEPR as psicopatologias. Pereira e Brandão (2014, p. 152) arguem que alterações nas cascatas inflamatórias, nas hormonas reguladoras do apetite (leptina, adiponectina e resistina) e no eixo hipotálamo-hipófise-supra-renal podem constituir mecanismos de correlação entre as patologias psiquiátricas e a obesidade . Intrínseca relação é vislumbrada também entre a LEP e a Síndrome do Ovário Policístico (SOP). Nesse passo, conduz raciocínio Lecke (2010) ao declarar que a expressão gênica de LEP no tecido adiposo subcutâneo em mulheres obesas com SOP se apresenta em níveis superiores àquelas de peso normal. Sobre o tratamento com LEP recombinante, a ABESO (2016) afirma a rara efetividade, não sendo satisfatória na obesidade poligênica, que é majoritária. Dias, et al. (2012) complementam que há importância em identificar os casos de mutações obesogênica em crianças, tido que isso propicia a possibilidade de alterar o curso do tratamento, escolher a terapia mais adequada e permitir aconselhamento genético para famílias afetadas. Outras intervenções são apontadas, entretanto, mais estudos são necessários para conclusão do tratamento adequado.

Conclusão: Os polimorfismos obesogênicos podem acarretar desde a perda da percepção de saciedade, redução da capacidade do controle de equilíbrio do gasto energético, assim como uma maior tendência às comorbidades. Também vale ressaltar que a alteração nos genes da LEP e/ou LEPR podem dificultar a perda de peso e gordura, sendo necessária uma intervenção mais 


\section{Referências}

ASSOCIAÇÃO BRASILEIRA PARA O ESTUDO DA OBESIDADE E DA SÍNDROME METABÓLICA. Diretrizes brasileiras de obesidade 2016. 4. ed. São Paulo: ABESO, 2016.

CLEVELAND, Rebecca. J.; et al. Common Genetic Variations in the LEP And LEPR Genes, Obesity and Breast Cancer Incidence and Survival. Breast Cancer Research and Treatment, Netherlands, p. 745 752, 2010.

DAGOGO-JACK, Sam. Leptin: Regulation and Clinical Applications. 1. ed. Cham: Springer International Publishing, 2015.

DIAS, Natasha Favoretto; et. al. Ausência de Mutação no Gene Receptor de Leptina em Crianças Gravemente Obesas. Arquivo brasileiro de endocrinologia metabólica, São Paulo, v. 56, n. 3, p. 178 183, 2012.

LIMA, William Alves; GLANER, Maria Fátima; TAYLOR, Aline Pic. Fenótipo da Gordura, Fatores Associados e o Polimorfismo rs9939609 do Gene FTO. Revista Brasileira de Cineantropometria \& Desempenho Humano, Brasília, v. 12, n. 2, p.164 - 172, 2010.

LECKE, Sheila Bünecker. Níveis Séricos e Expressão Gênica de Leptina, Adiponectina e Aromatase em Tecido Adiposo de Mulheres Com a Síndrome dos Ovários Policísticos. 2010. 99 f. Tese (Doutorado) Universidade Federal do Rio Grande do Sul, Porto Alegre, 2010.

MACHADO, Wallace; MONTEIRO, Estêvão Rios; PINTO, Verônica Salerno. Leptina e Exercício Físico: Mecanismos Para Controle do Peso Corporal. Revista Brasileira de Prescrição e Fisiologia do Exercício, São Paulo, v .9, n. 54, p.471 - 480, 2015.

MARQUES-LOPES, Iva; et al. Aspectos genéticos da obesidade. Revista de Nutrição, Campinas, v. 17, n. 3, p. 327-338, 2004. NEGRÃO, André B.; LICÍNIO, Júlio. Leptina: o diálogo entre adipócitos e neurônios. Arquivo Brasileiro de Endocrinologia Metabólica, São Paulo, v. 44, n. 3, p. 205 - 214, 2000.

PEREIRA, Cláudia; BRANDAO, Isabel. Uma Perspectiva da Psicopatologia da Obesidade. Arquivos de Medicina, Porto, v. 28, n. 5, p. 152-159, 2014. 


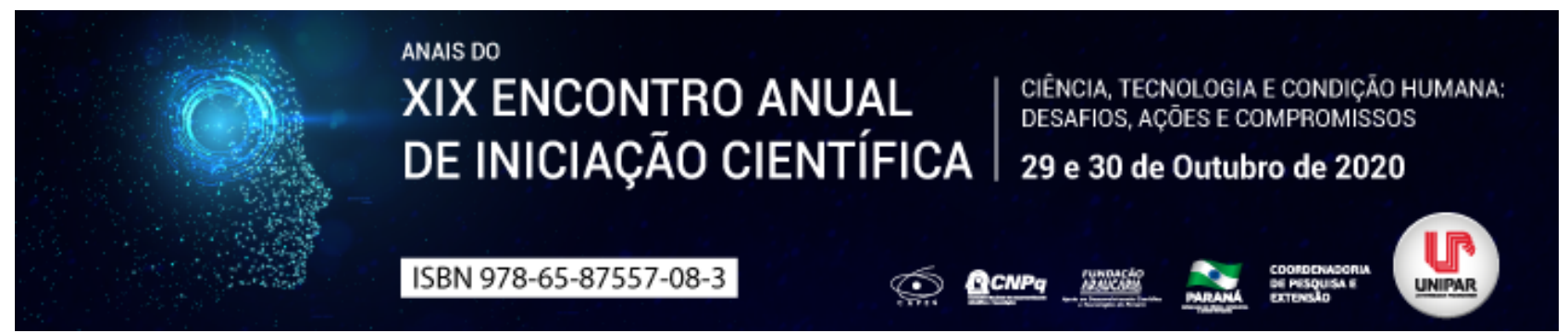 \\ REDUÇÃO DA MASSA CORPORAL DE RATOS INDUZIDOS AO DIABETES E EXPOSTOS AO TABAGISMO E DIETA HIPERCOLESTEROLÊMICA TRATADOS COM CARQUEJA
}

\begin{abstract}
${ }^{1}$ Flavio de Souza Júnyor, ${ }^{2}$ PAULA MONTANHINI FAVETTA, ${ }^{3}$ MARCELO ALBERTO ELIAS, ${ }^{4}$ WESLEY ALVES TRINDADE, ${ }^{5}$ NATALIA NAMIE MIZUGUCHI, ${ }^{6}$ RICARDO DE MELO GERMANO
\end{abstract}

\begin{abstract}
${ }^{1}$ Discente do Instituto Federal do Paraná - Bolsista PEBIC-JR CNPq/UNIPAR
${ }^{1}$ Doutoranda em Ciência Animal com Ênfase em Produtos Bioativos da UNIPAR - Bolsista PROSUP/CAPES

${ }^{2}$ Doutorando em Ciência Animal com Ênfase em Produtos Bioativos da UNIPAR

${ }^{3}$ Mestrando em Ciência Animal com Ênfase em Produtos Bioativos da UNIPAR - Taxista PROSUP/CAPES

${ }^{4}$ Discente do Curso de Enfermagem da UNIPAR - Bolsista PIBIC

${ }^{5}$ Docente do Programa de Pós-Graduação em Ciência Animal com Ênfase em Produtos Bioativos da UNIPAR
\end{abstract}

Introdução: Segundo a Organização Mundial da Saúde e a Organização Pan-Americana de Saúde (2019), doenças cardiovasculares (DCV) são as principais causas de morte no mundo, sendo responsáveis por 32\% da mortalidade em 2017. Dentre suas múltiplas causalidades estão os fatores de risco modificáveis adquiridos ao longo do tempo e relacionados a hábitos de vida inadequados, como o tabagismo, diabetes mellitus, obesidade e dislipidemia (SOUZA et al., 2019). A obesidade é acompanhada de uma maior morbidade e uma menor longevidade, estando fortemente associada a outros fatores de DCV (MENDES et al., 2006). Devido a essa alta morbimortalidade, há uma grande necessidade de se desenvolver novos agentes terapêuticos com maior eficácia e menos efeitos colaterais. Dentre as terapias consideradas promissoras para DCV está o tratamento com a espécie Baccharis trimera, conhecida popularmente como carqueja, utilizada devido seus efeitos hepatoprotetores e hipocolesterolêmicos (SOUZA et al., 2019).

Objetivo: Analisar os efeitos do extrato de B. trimera sobre a massa corporal de ratos induzidos ao diabetes mellitus e expostos tabagismo e dieta hipercolesterolêmica.

Material e Métodos: Todos os procedimentos realizados no presente estudo foram aprovados pelo comitê de ética da UNIPAR (protocolo n. 1000/2018). Foram utilizados 25 ratos machos da linhagem Wistar, com massa inicial média de 324,5g. Os animais foram divididos em cinco grupos ( $\mathrm{n}=5 / \mathrm{grupo}$ ): C- (animais normoglicêmicos, não dislipidêmicos e não tabagistas); $\mathrm{C}+$ (diabéticos, dislipidêmicos e tabagistas, tratados com veículo); BT30 (animais diabéticos, dislipidêmicos e tabagistas tratados com $30 \mathrm{mg} / \mathrm{kg}$ de B. trimera); BT100 (animais diabéticos, dislipidêmicos e tabagistas tratados com 100 mg/kg de B. trimera) e BT300 (animais diabéticos, dislipidêmicos e tabagistas tratados com 300mg/kg de B. trimera). A indução ao diabetes ocorreu após jejum de 12 horas, via intraperitoneal $60 \mathrm{mg} / \mathrm{kg}$ de estreptozotocina. Após a indução do diabetes, os animais receberam dieta padrão comercial da marca Purina ${ }^{\circledR}$ com $0,5 \%$ de colesterol da Sigma-Aldrich ${ }^{\circledR}$ em $6,75 \mathrm{ml}$ de óleo de milho para cada $75 \mathrm{~g}$ de ração comercial para a indução da dislipidemia. Em seguida, os animais foram expostos à inalação de ar filtrado ou fumaça de nove cigarros comerciais $(0,8 \mathrm{mg}$ de nicotina, $10 \mathrm{mg}$ de alcatrão e $10 \mathrm{mg}$ de monóxido de carbono), cinco dias por semana, durante uma hora por dia, por quatro semanas. O tratamento com as diferentes doses de carqueja ocorreu nas últimas duas semanas de experimento, via gavagem, uma vez por dia, diluído em água filtrada. Após as quatro semanas de experimento, os animais foram submetidos a um jejum de 12 horas, posteriormente, foram coletadas amostras de sangue para avaliar os níveis plasmáticos de colesterol e triglicerídeos e tiveram novamente suas massas medidas. Os dados obtidos foram submetidos a análise estatística pela ANOVA e quando houve diferença, foi realizado o pós-teste $T$, para confirmação dos dados, utilizando-se o software Bioestat@.

Resultados: Após o experimento, verificou-se alterações nas massas corporais dos animais estudados. A massa média corpórea do grupo C- alterou de 329,6g para 379,0g, evidenciando um ganho equivalente a 13,03\% em relação à massa média inicial. Em relação aos demais grupos, observou-se uma redução da massa corpórea, sendo, no grupo C+ massa inicial $248,8 \mathrm{~g}$ e massa final 244,2g, BT30 massa inicial 284,8g e massa final 257,2g, BT100 massa inicial 268,0g e massa final 233,4g, BT300 massa inicial $256,6 \mathrm{~g}$ e massa final $250,0 \mathrm{~g}$. Nesse sentido, após a análise estatística dos dados pelo Teste $\mathrm{T}$, foi constatado uma redução significativa no grupo BT100 quando comparado aos demais grupos analisados, que foram induzidos ao diabetes, tabagismo e dieta hipercolesterolêmica. Além disso, verificou-se que o extrato de $B$. trimera reduziu os valores de perfil lipídico nos grupos que receberam doses de 30 e $100 \mathrm{mg} / \mathrm{kg}$ quando comparado ao grupo $\mathrm{C}+$, tratados com veículo.

Discussão: De acordo com outros experimentos, como em Lívero et al. (2016), camundongos induzidos a esteatose hepática e tratados com 30mg/kg de B. trimera apresentaram níveis de triglicerídeos e colesterol total reduzidos. Ainda, Souza et al. (2019), neste mesmo modelo experimental, também na dose de $30 \mathrm{mg} / \mathrm{kg}$, encontraram redução no perfil lipídico, de colesterol e triglicerídeos. Em vista disso, infere-se que a $B$. trimera reverteu estas alterações, o que pode ser atribuído a sua ação 
hipolipemiante. Souza et al. (2019), ainda apontam que a redução do perfil lipídico pode estar atrelada a atividade hipolipemiante da espécie $B$. trimera, capaz de reduzir a produção de gordura pelo fígado a partir do excesso de glicose, o que poderia justificar a perda de massa nos animais tratados com o extrato da carqueja.

Conclusão: $O$ tratamento com $100 \mathrm{mg} / \mathrm{kg}$ de $B$. trimera apresentou-se significativo sobre a redução da massa corporal de ratos da linhagem Wistar induzidos ao diabetes mellitus e expostos ao tabagismo e dieta hipercolesterolêmica, esta redução pode estar associada a diminuição da síntese hepática de lipídios o que reduziria a deposição destes nos tecidos adiposos.

\section{Referências}

LíVERO, F. A. R. et al. Hydroethanolic extract of Baccharis trimera ameliorates alcoholic fatty liver disease in mice. ChemicoBiological Interactions, $\quad$ v. 260 dez, 2016. Disponível em: https://www.sciencedirect.com/science/article/abs/pii/S0009279716304252. Acesso em: 24 jul. 2020.

MENDES, M. J. F. L. et al. Associação de fatores de risco para doenças cardiovasculares em adolescentes e seus pais. Revista Brasileira de Saúde Materno Infantil, v. 6, n.1, mai, 2006. Disponível em: http://www.scielo.br/scielo.php? script=sci_arttext\&pid=S1519-38292006000500007\&lng=pt\&nrm=iso. Acesso em: 24 jul. 2020.

PAN AMERICAN HEALTH ORGANIZATION, WORLD HEALTH ORGANIZATION. 57th Directing Council: 71th Session of The Regional Committee Of Who For The Americas. Resolution CD57/8. Plan of action for the elimination of industrially produced trans-fatty acids 2020-2025. 2019.

SOUZA, M. M. Q. et al. Baccharis trimera (Less.) DC: An Innovative Cardioprotective Herbal Medicine Against Multiple Risk Factors for Cardiovascular Disease. Journal of Medicinal Food, v. 23, n.6, jun, 2019. Disponível em: https://www.liebertpub.com/doi/full/10.1089/jmf.2019.0165. Acesso em: 24 jul. 2020. 


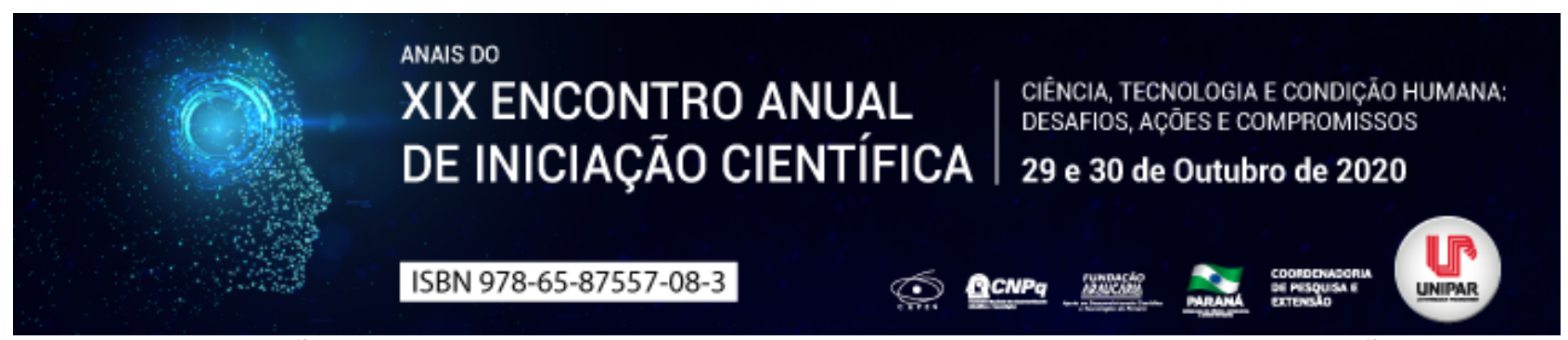

A RELAÇÃO ENTRE A DIABETES MELLITUS TIPO 2 E O GENE FTO: UMA REVISÃO

\author{
${ }^{1}$ FATIMA HASSAN SAFIEDDINE, ${ }^{2}$ HIGOR DIAS DO PRADO, ${ }^{3}$ LUIZ GUSTAVO MARTINS, ${ }^{4}$ RICARDO MARCELO ABRAO, \\ ${ }^{5}$ MARIA ELENA MARTINS DIEGUES, ${ }^{6}$ LUCIANO SERAPHIM GASQUES
}

\author{
${ }^{1}$ Acadêmico PIC/Unipar \\ ${ }^{1}$ Acadêmico do Curso de Medicina da UNIPAR \\ ${ }^{2}$ Acadêmico do Curso de Medicina da UNIPAR \\ ${ }^{3}$ Docente da UNIPAR \\ ${ }^{4}$ Docente da UNIPAR \\ ${ }^{5}$ Docente da UNIPAR
}

Introdução: Em 2017, aproximadamente 32\% dos brasileiros apresentavam algum grau de sobrepeso sendo que, entre estes, 6,8 milhões de indivíduos apresentavam obesidade. Indivíduos com obesidade ou sobrepeso tem cerca de 3 vezes mais chances de desenvolverem diabetes mellitus tipo 2 (DM2). Quanto a sua etiologia, a obesidade é muito variada, porém, como mecanismo geral, derivam de um desequilíbrio entre o consumo e o gasto de energia. Um dos possíveis mecanismos que podem gerar esse desequilíbrio é decorrente da expressão de variantes do gene FTO, o qual aumenta a probabilidade do risco para o desenvolvimento da obesidade (YOUNUS et al, 2017).

Objetivo: Averiguar, através de revisão bibliográfica, o efeito dos polimorfismos rs9939609 e rs17817449 do gene FTO e sua relação de diabetes mellitus tipo 2 .

Desenvolvimento: Estudos comparativos referentes a variantes genéticas rs9939609 e rs17817449 do gene FTO em pacientes com obesidade e DM2 possuindo o SNP com o alelo T (timidina), tanto em homozigose quanto em heterozigose, apresentam um risco consideravelmente maior para o DM2 em comparação ao indivíduos portadores do tipo selvagem, caracterizado pelo nucleotídeo de Adenina (A) (YOUNUS et al, 2017). Testes envolvendo o silenciamento do gene FTO demonstrou que o miR-495 é alvo direto do gene e induz a transformação de macrófagos em macrófagos pró-inflamatórios do tipo M1 e do aumento a resistência à insulina em camundongos com DM2, o que indica a predisposição direta do gene no desenvolvimento de diabetes mellitus tipo 2 (HU et al, 2019). Ademais, a associação do polimorfismo para os genes omentin Val109Asp e o FTO rs9939609 também apresentam uma relação significativa positiva em indivíduos com sobrepeso/obesidade, caracterizando que sua variação genética pode alterar o metabolismo da insulina e ser correlacionada ao DM2 devido a sua resistência. Desse modo, uma avaliação do genoma nestas sequências polimórficas pode ser útil na previsão do DM2 (KHOSHI et al, 2019). Por fim, estudos recentes demonstram que a expressão do FTO hepático afeta o metabolismo da glicose e lipídios a partir de uma atividade anormal das vias de sinalização hepáticas envolvendo FTO, podendo estar vinculada diretamente a deficiências metabólicas como obesidade, DM2 e doença hepática gordurosa não alcoólica (DHGNA). Assim, o entendimento dessas vias pode levar a abordagens terapêuticas específicas visando o FTO hepático (MIZUNO et al, 2018).

Conclusão: A resistência à insulina e o acúmulo de gordura no tecido adiposo visceral são pontos para o desenvolvimento do diabetes tipo 2. Dessa forma, foi possível observar que a atuação dos SNPs rs9939609 e rs17817449 do gene FTO estão envolvidos com o aumento da incidência o diabetes tipo 2.

\footnotetext{
Referências

$\mathrm{HU}$, F. et al. C. MiR-495 regulates macrophage M1/M2 polarization and insulin resistance in high-fat diet-fed mice via targeting FTO. Pflugers Arch. 2019; 471(11-12): 1529-1537. doi:10.1007/s00424-019-02316-w.

$\mathrm{KHOSHI}$, A. et al. Association of Omentin rs2274907 and FTO rs9939609 gene polymorphisms with insulin resistance in Iranian individuals with newly diagnosed type 2 diabetes. Lipids Health Dis. 2019; 18(1): 142. Published 2019 Jun 14. doi:10.1186/s12944-019-1085-5.

MIZUNO, T. M. Gene associado à massa gorda e à obesidade (FTO), glicose hepática e metabolismo lipídico. 2018. Disponível em: https://pubmed.ncbi.nlm.nih.gov/30388740/.

NEERA, J. et al. Silencing of the FTO gene inhibits insulin secretion: An in vitro study using GRINCH cells. Mol Cell Endocrinol. 17-472: 10; 2018. Doi: 10.1016/j.mce.2018.06.003.

YOUNUS, L. A. et al. FTO gene polymorphism (rs9939609 and rs17817449) as predictors of Type 2 Diabetes Melittus in obese Iraqi population. Gene. 84-627: 79, 2017. Doi: 1016/j.gene.2017.06.005.
} 
Coordenadoria de Pesquisa e Extensão - COPEX

Departamento de Editoraçāo e Divulgaçāo Científica - DEDIC 


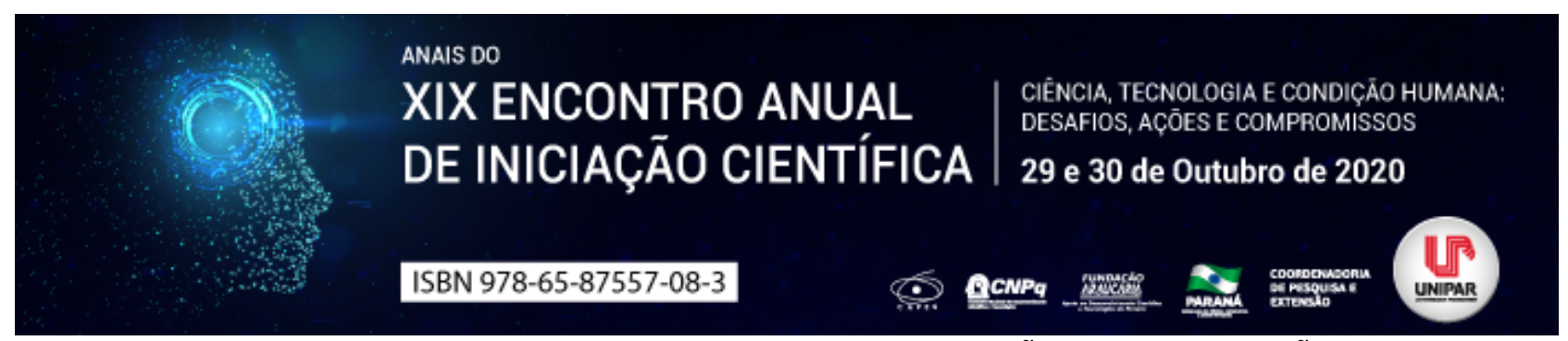

ANALGESIA MULTIMODAL PARA CONTROLE DA DOR E SEDAÇÃO EFETIVA EM CÃES E GATOS

\begin{abstract}
${ }^{1}$ Luciana de Castro Barcelos, ${ }^{2}$ SIBELY AIVA FLORES, ${ }^{3}$ BRUNA CHRISTINA FERNANDES SOARES, ${ }^{4}$ EMANUELY RAMOS TAMEIRÃO, ${ }^{5}$ MARCOS FERRANTE, ${ }^{6}$ JOÃO VITOR FERNANDES COTRIM DE ALMEIDA
\end{abstract}

\begin{abstract}
${ }^{1}$ Acadêmica do curso de Medicina Veterinária da Universidade Federal de Lavras
${ }^{1}$ Acadêmica do curso de Medicina Veterinária da Universidade Federal de Lavras

${ }^{2}$ Acadêmica do curso de Medicina Veterinária da Universidade Federal de Lavras

${ }^{3}$ Acadêmica do curso de Medicina Veterinária da Universidade Federal de Lavras

${ }^{4}$ Professor do departamento de Medicina Veterinária da Universidade Federal de Lavras

${ }^{5}$ Mestre em ciências veterinárias do departamento de Medicina Veterinária da UFLA
\end{abstract}

Introdução: A eficácia da analgesia ao longo de todo o processo da anestesia é um importante fator para garantia e manutenção da saúde e do bem-estar do paciente. Melhora a segurança anestésica, pois diminui a dose de anestésicos, e reduz a probabilidade de efeitos adversos mediados pela anestesia inalatória, como hipotensão e hipoventilação (GRUBB et al., 2020). Além disso, otimiza o resultado do trans e pós-operatório, pois minimiza as consequências da dor, como cicatrização tardia, redução de motilidade intestinal e até mesmo mudanças de comportamento (GRUBB et al., 2020). A utilização de vários medicamentos de diferentes classes, cada um com atividade em locais distintos da via da dor, promove alívio ou elimina esta em várias regiões ou fontes (GRUBB et al., 2020). De acordo com Fossum (2014), a analgesia multimodal é a tentativa de controle da dor em diferentes mecanismos de ação, mediante o uso de fármacos e técnicas que potencializam a eficácia da terapia analgésica, sendo um método amplamente utilizado na medicina veterinária.

Objetivo: Avaliar as diversas alternativas para elaboração de um protocolo de analgesia multimodal para controle da dor e sedação efetiva em cães e gatos.

Desenvolvimento: Para se elaborar um protocolo analgésico multimodal para cães e gatos, deve-se lembrar que este pode ser usado nas quatro fases da anestesia, ou seja, durante a pré-anestesia, indução, manutenção transoperatória e recuperação pósoperatória. Os grupos de fármacos usados podem ser de anti-inflamatórios não esteroides (AINEs), que exercem função de inibir a enzima cicloxigenase, inibindo a ação inflamatória pela diminuição dos mediadores inflamatórios (FOSSUM, 2014), como carprofeno ou cetoprofeno. Outra classe que é utilizada é dos opióides, indicados para dor discreta a moderada, como buprenorfina e butorfanol, enquanto a morfina, metadona e hidromorfona são indicadas para dor moderada e intensa - além do fentanil, um opióide sintético mais potente que a morfina (FOSSUM, 2014). Agonistas alfa-2, como dexmedetomidina e medetomidina, proporcionam sedação e analgesia, e seus efeitos analgésicos são sinérgicos aos dos opióides, aumentando os efeitos daqueles menos potentes (GRUBB et al., 2020). A acepromazina é um fenotiazínico muito utilizado, que promove relaxamento muscular sem acompanhamento de analgesia; quando associado a um opióide é capaz de gerar neuroleptoanalgesia (GRIMM, 2017), que é um estado de tranquilização com intensa analgesia e sem perda de consciência. A cetamina é um fármaco dissociativo que também induz estado de analgesia e anestesia sem perda de consciência, e quando utilizada na analgesia multimodal atua na dor somática e analgesia na dor visceral, podendo se sobrepor aos opióides (FOSSUM, 2014). Os benzodiazepínicos possuem ação ansiolítica, sedativa, anticonvulsivante e promovem até relaxamento muscular (FOSSUM, 2014). Na fase pré-anestésica, pode ser administrada acepromazina na dose de 0,02-0,05 mg/kg via intravenosa (IV), intramuscular (IM) ou subcutânea (SC). Agonistas alfa-2, como dexmedetomidina na dose de $2,5 \mu \mathrm{g} / \mathrm{kg}$ IV ou $5 \mu \mathrm{g} / \mathrm{kg}$ IM, ou medetomidina na dose de $5 \mu \mathrm{g} / \mathrm{kg} \mathrm{IV}$ ou $10 \mu \mathrm{g} / \mathrm{kg} \mathrm{IM}$, também podem ser utilizadas. O uso de benzodiazepínicos também é comum, como diazepam na dose de 0,2 mg/kg IV ou midazolam na dose de 0,2 mg/kg IV ou IM; pode-se associar o midazolam com a morfina na dose de 0,1-0,2mg $/ \mathrm{kg}$ IV ou 0,2-0,4 mg/kg IM; ou butorfanol 0,2-0,4 mg/kg IV ou IM (FOSSUM, 2014). Na fase de indução, pode-se administrar opióides, como fentanil na dose de 0,001-0,005 mg/kg IV; morfina na dose de 0,25-1 mg/kg IM ou IV (de forma lenta); metadona na dose de $0,2-0,4 \mathrm{mg} / \mathrm{kg}$ IV ou 0,2-0,4 mg/kg IM. Podem ser também utilizados buprenorfina na dose de 0,01-0,03 mg / $\mathrm{kg}$ IM ou IV, ou butorfanol na dose de 0,2-0,4 mg/kg IV ou IM ( GRUBB et al., 2020; FOSSUM, 2014). A analgesia durante a manutenção anestésica pode ser feita por meio de opióides, lidocaína, cetamina e agonistas alfa-2, combinados ou não. Pode-se realizar infusão contínua de hidromorfona na dose de 0,025-0,1 mg/kg/h IV; fentanil entre 10-30 $\mu \mathrm{g} / \mathrm{kg} / \mathrm{h}$ IV durante o transoperatório; cetamina na dose de $10 \mu \mathrm{g} / \mathrm{kg} / \mathrm{min} \mathrm{IV}$; ou as combinações de fentanil, lidocaína, cetamina (FLK) e morfina, lidocaína e cetamina (MLK) ( FOSSUM, 2014), bastante utilizadas e difundidas na medicina veterinária. Finalmente, na última fase que compreende a recuperação no pós-operatório do paciente, podem ser administrados AINEs, opióides ou agonistas alfa-2 (bolus) (GRUBB et al.,2020), além do uso de anestésicos locais e terapias não farmacológicas de controle da dor, como massagem, exercício, hidroterapia e acupuntura (FOSSUM, 2014). O uso de antibióticos profiláticos na 
pré-anestesia, no transoperatório e no pós-operatório evita o crescimento de patógenos.

Conclusão: A escolha dos fármacos para os protocolos de analgesia multimodal é de extrema importância, visto que cada um age de uma forma, podendo gerar mais ou menos efeitos adversos. Com isso, devemos analisar o fármaco ideal para o paciente em questão, para se ter uma analgesia efetiva e para que não haja malefícios à saúde do animal.

\section{Referências}

FOSSUM, Theresa Welch. Cirurgia de pequenos animais. 4. ed. Rio de Janeiro: Elsevier, 2014.

GRIMM, Kurt. A; LAMONT, Leigh A.; TRANQUILLI, William J.; GREENE, Stephen A.; ROBERTSON, Sheilah A. Lumb \& Jones, Anestesiologia e analgesia em veterinária. 5. ed. Rio de Janeiro: Roca, 2017.

GRUBB,Tamara; SAGER, Jennifer; GAYNOR, James S.; MONTGOMERY, Elizabeth; PARKER, Judith A.; SHAFFORD, Heidi; TEARNEY, Caitlin. 2020 AAHA. Anesthesia and Monitoring Guidelines for Dogs and Cats*. American Animal Hospital Association, mar/abr. 2020. Disponível em:https://www.aaha.org/globalassets/02-guidelines/2020anesthesia/anesthesia_and_monitoring-guidelines_final.pdf. Acesso em: 07 ago. 2020. 


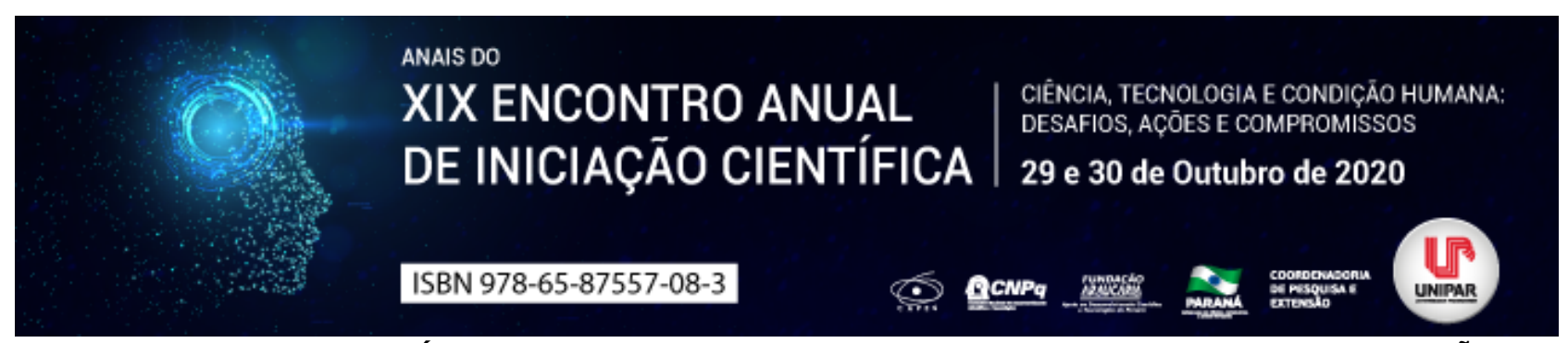

PRINCIPAIS CARACTERÍSTICAS DA PERITONITE INFECCIOSA FELINA RESUMO DE REVISÃO

\begin{abstract}
${ }^{1}$ Isabela Lopes Massitel, ${ }^{2}$ DANILO BARBOSA VIANA, ${ }^{3}$ BRUNA CHRISTINA FERNANDES SOARES, ${ }^{4}$ JOÃO VITOR FERNANDES COTRIM DE ALMEIDA, ${ }^{5}$ MARCOS FERRANTE
\end{abstract}

\begin{abstract}
${ }^{1}$ Discente do curso de Medicina Veterinária UEM campus Umuarama
${ }^{1}$ Residente em Clínica Médica de Animais de Companhia UEL

${ }^{2}$ Discente do curso de Medicina Veterinária UFLA

${ }^{3}$ Mestre em Ciências Veterinárias UFLA

${ }^{4}$ Docente do curso de Medicina Veterinária UFLA
\end{abstract}

Introdução: A Peritonite Infecciosa Felina (PIF) é uma doença viral e letal que acomete felinos (PEDERSEN, 2014). Animais mais jovens, devido a eventuais falhas imunológicas, e aqueles que vivem em locais de grandes aglomerações possuem maior predisposição à infecção pela PIF. (CASAGRANDE; MACHADO, 2016). Os sinais clínicos diferem entre a PIF efusiva e não efusiva. A efusão, presente na forma efusiva, caracteriza-se por derrames abdominais e serosite fibrinosa, podendo o paciente apresentar anorexia, perda de peso, dispneia, taquipneia e aumento de volume abdominal (BIRCHARD; SHERDING, 2013). Já a PIF não efusiva é caracterizada por reações inflamatórias granulomatosas com sinais clínicos inespecíficos (LITTLE, 2015). O método padrão ouro de diagnóstico consiste na histopatologia por biópsia de tecidos envolvidos (BIRCHARD; SHERDING, 2013). Objetivo: Neste trabalho serão abordadas as principais características da Peritonite Infecciosa Felina, como etiologia, sinais clínicos, diagnóstico e tratamento.

Desenvolvimento: A PIF é causada pelo coronavírus entérico, RNA vírus envelopado que se multiplica em enterócitos e macrófagos, podendo persistir no ambiente por até sete semanas (JERICÓ et al., 2015). O vírus da PIF é resultante de uma mutação do coronavírus entérico felino, que quando este não está mutado, causa apenas enterite na espécie (JERICÓ at al., 2015). O vírus é excretado pela via fecal-oral, ocorrendo a contaminação pelo contato através da autohigienização ou alimentação do felino (HORA, 2016). A predisposição ocorre em uma faixa etária de três meses a três anos de idade e em gatos idosos (WORTHING et al., 2012). A incidência em animais jovens ocorre devido a uma imaturidade do sistema imune (BISSET et al., 2009) e nos animais mais velhos devido ao declíneo da função imunitária, principalmente pela presença de comorbidades (WORTHING et al., 2012) A forma efusiva corresponde a mais de $80 \%$ dos casos de PIF e caracteriza-se por polisserosites fibrinosas como pericardite, pleurite e peritonite. Outros sinais clínicos incluem febre, anorexia, perda de pesa, icterícia e linfadenomegalia mesentérica. A PIF não efusiva é a forma mais desafiadora quanto ao diagnóstico, já que pode apresentar somente sinais inespecíficos, como anorexia e apatia. Podem ser observadas lesões piogranulomatosas em órgãos como intestino, fígado, pulmões, rins, coração, olhos e sistema nervoso central (SNC) (JERICÓ at al., 2015; LITTLE, 2015). O diagnóstico ante mortem é muito difícil, já que os sinais clínicos são inespecíficos e não há nada patognomônico. Nos exames laboratoriais é comum encontrar alterações como hiperglobulinemia, hipoalbuminemia, anemia normocítica normocrômica leve ou moderada, leucocitose por neutrofilia e linfopenia (NELSON e COUTO, 2015). Exames radiográficos e ultrassonográficos também podem ser úteis no auxílio ao diagnóstico, podendo evidenciar efusões pleurais, abdominais e melhor avaliação de todos as vísceras do paciente (NELSON e COUTO, 2015). A análise da efusão abdominal mostra-se de grande importância em pacientes que a possui (AUGUST, 2011). A efusão na PIF é classificada como um transudato modificado a exsudato e normalmente tem um elevado conteúdo proteico, semelhante ao de um exsudato. O conteúdo celular aproxima-se de um transudato puro ou modificado. Em alguns animais, a titulação de anticorpos do coronavírus é maior na efusão que o soro (NELSON e COUTO, 2015). É importante ressaltar que os anticorpos detectados por ELISA (Ensaio de Imunoabsorção Enzimática) e IFI (Imunofluorescência Indireta) para coronavírus do tipo entérico não fornece um diagnóstico definitivo, pois não há como diferenciar se este vírus está mutado ou não (CASAGRANDE; MACHADO, 2016). No teste de Reação em Cadeira da Polimerase (PCR), ocorre o mesmo problema. Apesar de ser altamente sensível e específico, este não diferencia as cepas (PEDERSEN, 2014). Pode-se ainda realizar a pesquisa por antígenos em macrófagos por imuno-histoquímica e imunofluorescência (AUGUST, 2011). O teste de Rivalta é outro teste que vêm sido usado há muito tempo a partir da análise da efusão (HARTAMANN et al., 2003). Uchida (2017) afirma que o teste de Rivalta é barato e de fácil realização, porém a leitura é subjetiva e pode apresentar resultados falso-positivos em linfomas ou peritonites bacterianas. A histopatologia de tecidos acometidos é considerada o padrão ouro, sendo coletada por biópsia locais acometidos ante mortem ou material post mortem (BIRCHARD; SHERDING, 2013). Não existe tratamento específico ou eficaz, é realizado somente suporte sintomático e controle da resposta imunológica, pois a maioria dos pacientes sofrem eutanásia ou morrem em dias ou semanas após o diagnóstico (ULIANA, 2012).

Conclusão: Conclui-se que a PIF é uma enfermidade grave que acomete os felinos. Os sinais clínicos podem ser poucos 
específicos e não há métodos efetivos de diagnóstico ante mortem. O prognóstico é ruim em qualquer apresentação da doença e o diagnóstico definitivo é realizado somente post mortem.

\section{Referências}

AUGUST, J. R.; Medicina interna de felinos, $6^{\mathrm{a}}$ ed., 2011.

BIRCHARD, S.J.; SHERDING, R.G. Manual Saunders de Clínica de Pequenos Animais. 3 ed. São Paulo: Roca, 2013.

BISSETT, S.A.; STONE, M.L..; MALIK, R; NORRIS, J.M.; O'BRIEN, C;; MANSFIELD, C. S.; NICHOLLS, J. M. Observed occurrence of Tritrichomonas foetus and other enteric parasites in Australian cattery and shelter cats. Journal of Feline Medicine and Surgery, v. 11, n.10, p. 803 807, 2009.

CASAGRANDE, T.; MACHADO, D. D. Peritonite Infecciosa Felina: Relato de Dois Casos. Ciência e Cidadania, v.2, n.1, p. 103119, 2016.

HARTMANN, K. et al. Comparison of Different Tests to Diagnose Feline Infectious Peritonitis. Journal of veterinary internal medicine, v. 17, p. 781-790, 2003.

HORA, A. S. Coronavírus Felino. In: MAZZOTI, G. A., ROZA, M. R. Medicina Felina Essencial: Guia Prático. Doenças infectocontagiosas, p. 669-674, 2016.

JERICÓ, M.M.; KOGIKA, M.M.; NETO, J.P.A. Tratado de Medicina Interna de Cães e Gatos. Rio de Janeiro, 1 ed, 2015. LITTLE, Susan E. O gato: Medicina Interna. Rio de Janeiro: Roca, 2015.

NELSON R. W.; COUTO C. G. Medicina Interna de Pequenos Animais. $5^{a}$ ed., Rio de Janeiro: Ed. Elsevier, cap 94. pag. 13441347. 2015.

PEDERSEN, N.C. An update on feline infectious peritonitis: Diagnostics and therapeutics. The veterinary journal, v. 201, p. 133$141,2014$.

ULIANA L. M. A., BRITO H. F. V., MONTAÑO P. Y., LASKOSKY L. M., KNOPF T. A., LOCATELLI-DITTRICH R. Medvep Revista Científica de Medicina Veterinária - Pequenos Animais e Animais de Estimação. v.10, n.35, p.46-53, 2012.

UCHIDA, C. Y. Avaliação dos principais métodos de diagnóstico ante mortem da peritonite infecciosa felina. Trabalho de conclusão de curso. Universidade Estadual Paulista, Araçatuba, 2017.

WORTHING, K. A., WIGNEY, D. I., DHAND, N. K., FAWCETT, A., MCDONAGH, P., MALIK, R. \& NORRIS, J. M. Risk factors for feline infectious peritonitis in Australian cats. Journal of Feline Medicine and Surgery, v.14, n.6, p. 405 12, 2012. 


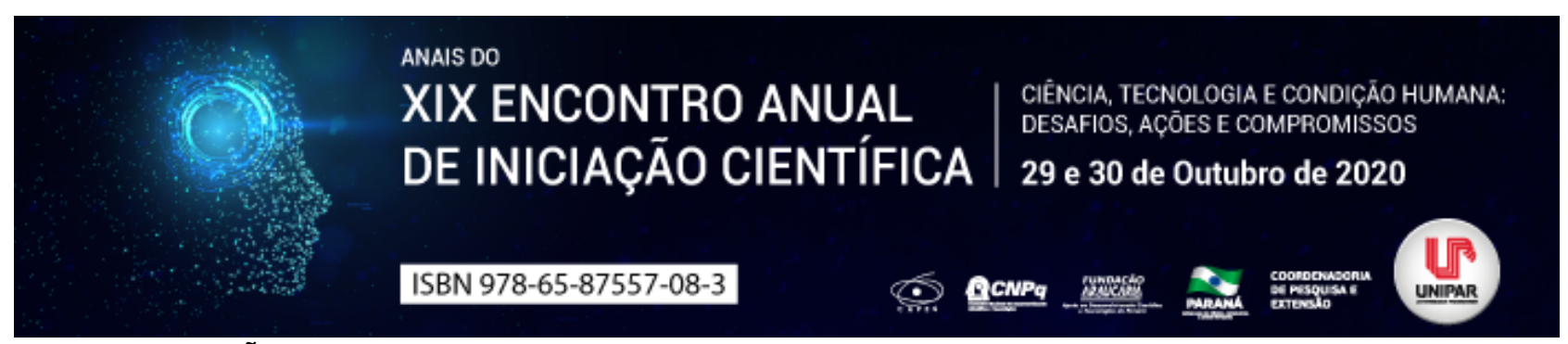

REVISÃO DE LITERATURA SOBRE OS PRINCIPAIS POLIMORFISMOS DO GENE FTO

\begin{abstract}
${ }^{1}$ DANILLO PRECHLAK DE SOUZA, ${ }^{2}$ NARA RUBIA GONCALVES, ${ }^{3}$ MARIA ELENA MARTINS DIEGUES, ${ }^{4}$ RICARDO MARCELO ABRAO, ${ }^{5}$ LUCIANO SERAPHIM GASQUES
\end{abstract}

\author{
${ }^{1}$ Acadêmico do PIC/UNIPAR \\ ${ }^{1}$ Acadêmico do PIC/UNIPAR \\ ${ }^{2}$ Docente da UNIPAR \\ ${ }^{3}$ Docente da UNIPAR \\ ${ }^{4}$ Docente da UNIPAR
}

Introdução: $O$ aumento da acessibilidade a alimentos com grande valor energético e do sedentarismo na sociedade ocidental atual associados aos fatores genéticos têm sido disparadores do excesso de peso e obesidade na população, o que têm gerado preocupação. O gene FTO (do inglês: fat mass and obesity associated) vem sendo objeto de estudos, isso devido a alguns de seus SNPs (polimorfismos de nucleotídeo simples) estarem comumente associados ao metabolismo do tecido adiposo e ao acúmulo de gordura corporal (KOLAČKOV et al., 2020), além de outros desfechos como a influência das concentrações séricas de vitamina B12 (SURENDRAN et al., 2019).

Objetivo: O objetivo do presente resumo é revisar na literatura os principais SNPs do gene FTO associados a fenótipos de adiposidade, além de sua relação com a concentração sérica de vitamina B12.

Desenvolvimento: O FTO é um gene, localizado no cromossomo 16 em humanos. Apresenta 92 SNPs de conhecida importância científica, dos quais 26 estão relacionados ao IMC (índice de massa corporal) (LIMA; GLANER; TAYLOR, 2010), sendo o aumento deste, associado a uma perda de 6,5 a 13,7 anos na expectativa de vida (FONSECA et al., 2020). Sabe-se que polimorfismos do FTO estão fortemente ligados aos prognósticos genéticos de obesidade, ainda, sugere-se que variantes do FTO levam a superexpressão do mRNA da grelina, o hormônio da fome, elevando assim os níveis plasmáticos deste hormônio, potencialmente estimulando os indivíduos a consumir alimentos calóricos (SURENDRAN et al., 2019). Já no hipotálamo, região caracterizada pelo domínio da ingesta de alimentos e gasto energético, onde a concentração de mRNA do FTO é alta (KOLAČKOV et al., 2020), este tem a capacidade de desmetilação do gene, resultando em uma maior expressão de mRNA, o que resulta em uma maior concentração da proteína, indicando que o FTO atuaria de forma mais significativa na promoção do acúmulo excessivo de gordura (LIMA; GLANER; TAYLOR, 2010). O SNP rs9939609, encontrado no primeiro íntron do FTO, é o mais estudado devido ao sucesso em sua genotipagem, o que permite associações com menores possibilidades de erro. É constituído por dois alelos, A e T, sendo o alelo A intimamente relacionado a um maior acúmulo de gordura corporal, em especial ao apresentar-se em homozigose (AA). Estudos apontam que os homozigotos europeus do supracitado SNP apresentaram, aproximadamente, 1,2 vezes mais chance de manifestar sobrepeso, ainda, 1,3 de desenvolver obesidade e, por fim, 22\% mais chance de demonstrar obesidade severa. Já em relação à homozigotos $\mathrm{T}$, estes são, em média, $3 \mathrm{~kg}$ mais leves que os homozigotos A, e 1,5kg em relação aos heterozigotos (AT) (LIMA; GLANER; TAYLOR, 2010). Somado a este fator, embora tenha sido eliminada a ocorrência de diabetes tipo II como manifestação do FTO, Lima; Glaner; Taylor, (2010), indicou-se que o SNP rs9939609 está diretamente ligado ao IMC e aumento de peso em indivíduos com diabetes tipo II (KOLAČKOV et al., 2020). Ainda, estudos deste SNP na população brasileira indicou forte associação com obesidade extrema e modelos de adiposidade (FONSECA et al., 2020). Isso evidencia que embora o rs9939609 não seja fator determinante para a ocorrência do diabetes, ele é influenciador de fenótipos correlacionados a essa doença crônica. Sobre os polimorfismos rs8050136 e rs2388405, um estudo, realizado na população asiática, indicou uma associação entre essas formas do FTO e concentrações muito inferiores de vitamina B12. Ainda, são fortemente associados à diabetes tipo II e obesidade, sendo tais ligações de grande interdependência. Tal fato ocorre devido a esses polimorfismos impactarem no aumento do IMC, sendo essa elevação potencial interferência negativa na deficiência da B12, o que se observa como resultante da característica forma que a população obesa se nutre, através de alimentos pobres em nutrientes, indo contra a elevação das necessidades nutricionais e do aumento corporal e efeitos fisiológicos da condição (SURENDRAN et al., 2019). Os SNPs rs9939609, rs9930506, rs1421085 e rs1121980, em pessoas não obesas, apresentaram resultados que os relacionaram à traços de obesidade, principalmente em termos de aumento do IMC. Estes MAFs (frequências alélicas menores) do FTO, que variam conforme grupos étnicos, após investigação, mostraram diferenças entre a periodicidade dos alelos relacionados ao fenótipo, interferindo no índice de massa corporal, na distribuição de gordura e outros traços da obesidade (KOLAČKOV et al., 2020). Isso é observado também no polimorfismo rs1861868, embora associado ao sobrepeso em outras análises, Lunardi et al. (2015) mostraram que em idosas brasileiras não caucasianas não foi possível observar associações entre o polimorfismo e fenótipos de adiposidade, sugerindo ainda que a 
influência genética na obesidade é atenuada com o aumento da idade em função do estilo de vida.

Conclusão: Foi possível evidenciar a relação de fenótipos de adiposidade e alguns SNPs do gene FTO, ainda que a expressão se mostre de maneira diferente conforme a população estudada. Por fim, conclui-se também a relação de alguns destes SNPS com baixas concentrações séricas de vitamina B12 no organismo.

\section{Referências}

FONSECA, Ana Carolina Proença da et al. Genetic variants in the fat mass and obesity-associated (FTO) gene confer risk for extreme obesity and modulate adiposity in a Brazilian population. Genet. Mol. Biol., Ribeirão Preto, v. 43, n. 1, e20180264, 2020. DOI: https://doi.org/10.1590/1678-4685-gmb-2018-0264. Disponível em: http://www.scielo.br/scielo.php? script=sci_arttext\&pid=S1415-47572020000100111\&Ing=en\&nrm=iso. Acesso em: 20 julho 2020. Epub Mar 06, 2020.

LIMA, William Alves; GLANER, Maria Fátima; TAYLOR, Aline Pic. I"Fat phenotype, associated factors and rs9939609 polymorphism of the FTO gene.l" Brazilian Journal of Kinanthropometry and Human Performance 12.2 (2010): 164-172. Disponível em: https://www.scielo.br/pdf/rbcdh/v12n2/a12v12n2.pdf. Acesso em: 20 julho 2020.

LUNARDI, Cláudia Cruz et al. Estudo de associação entre polimorfismos no gene FTO e composição corporal em idosas brasileiras. Motri., Ribeira de Pena, v. 11, n. 4, p. 26-35, dez. 2015. DOI: http://dx.doi.org/10.6063/motricidade.3514. Disponível em: http://www.scielo.mec.pt/scielo.php?script=sci_arttext\&pid=S1646-107X2015000400004\&lng=pt\&nrm=iso. Acesso em: 20 julho 2020.

KOLAČKOV, Katarzyna et al. The frequencies of haplotypes of FTO gene variants and their association with the distribution of body fat in non-obese poles. Advances in Clinical and Experimental Medicine, v. 25, n. 1, p. 33-42, 2016. Disponível em https://pubmed.ncbi.nlm.nih.gov/26935496/. Acesso em: 20 julho 2020.

SURENDRAN, Shelini et al. Evidence for the association between FTO gene variants and vitamin B12 concentrations in an Asian Indian population. Genes Nutr 14, 26 (2019). DOI: https://doi.org/10.1186/s12263-019-0649-3. Disponível em: https://genesandnutrition.biomedcentral.com/articles/10.1186/s12263-019-0649-3. Acesso em: 20 julho 2020.

Coordenadoria de Pesquisa e Extensão - COPEX

Departamento de Editoraçāo e Divulgaçāo Científica - DEDIC 


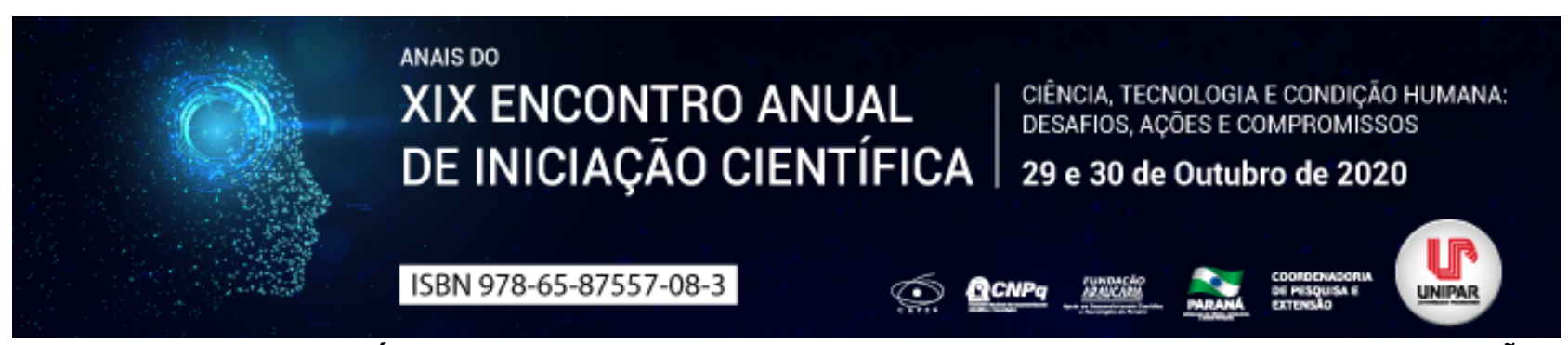

PRINCIPAIS CARACTERÍSTICAS DO HIPERALDOSTERONISMO EM FELINOS RESUMO DE REVISÃO

\begin{abstract}
$1_{\text {Isabela Lopes Massitel, }}^{2}$ DANILO BARBOSA VIANA, ${ }^{3}$ SIBELY AIVA FLORES, ${ }^{4}$ MELISSA SANCHES MONGELLI, ${ }^{5}$ JOÃO VITOR FERNANDES COTRIM DE ALMEIDA, ${ }^{6}$ MARCOS FERRANTE
\end{abstract}

\author{
${ }^{1}$ Discente do curso de Medicina Veterinária UEM campus Umuarama \\ ${ }^{1}$ Residente em Clínica Médica de Animais de Companhia UEL \\ ${ }^{2}$ Discente do curso de Medicina Veterinária UFLA \\ ${ }^{3}$ Discente do curso de Medicina Veterinária UFLA \\ ${ }^{4}$ Mestre em Ciências Veterinárias UFLA \\ ${ }^{5}$ Docente da curso de Medicina Veterinária - UFLA
}

Introdução: O hiperaldosteronismo ou Síndrome de Conn é uma enfermidade pouco diagnosticada, que se caracteriza pela secreção em excesso de mineralocorticóides, principalmente de aldosterona, pelas glândulas adrenais podendo resultar em hipertensão arterial, desordens eletrolíticas e metabólicas nos felinos (GALAC et al., 2010). A ocorrência pode ser de causa primária, devido a neoplasias ou hiperplasia adrenal, ou secundária a algumas afecções sistêmicas, não ocorrendo predisposição de raça ou gênero (DJAJADININGRAT-LAANEN et al., 2011). Os sinais clínicos são correlacionados à hipertensão arterial e hipocalemia, podendo ser observado letargia, dor muscular e descolamento de retina (HARVEY E REFSAL, 2012). Para o diagnóstico são realizadas mensurações da aldosterona e renina plasmática, pressão arterial, além de ultrassonografia abdominal (HARVEY E REFSAL, 2012). O tratamento pode ser clínico ou cirúrgico (GALAC et al., 2010).

Objetivo: Abordar as principais características, como causas, sinais clínicos, diagnóstico e tratamento do hiperaldosteronismo em felinos.

Desenvolvimento: $O$ hiperaldosteronismo é a enfermidade adrenocortical mais comum nos felinos, caracterizando-se pelo excesso de secreção de aldosterona. Felinos idosos, com idade média de 13 anos, são os mais acometidos, não ocorrendo predisposição de gênero ou raça (DJAJADININGRAT-LAANEN et al., 2011). A aldosterona é um mineralocorticóide produzido pela zona glomerulosa da glândula adrenal, tendo papel importante na regulação do tônus vascular e nas concentrações de sódio e potássio (CONNELL et al., 2008; DYCE et al., 2010; BENTO et al., 2016). Quando secretada em excesso, a aldosterona induz o remodelamento vascular e vasoconstrição, além de retenção de sódio e aumento da excreção de potássio, levando a hipertensão, desequilíbrios ácidos-básicos e eletrolíticos, característicos do hiperaldosteronismo (HARVEY E REFSAL, 2012; BENTO et al., 2016). A ocorrência desta doença pode ser de causa primária ou secundária. A causa primária está relacionada a secreção autônoma de aldosterona pela adrenal decorrente de neoplasias, principalmente adenomas ou adenocarcinomas unilaterais, ou hiperplasia nodular idiopática da zona glomerulosa do córtex adrenal (DJAJADININGRATLAANEN et al., 2011). Quando a causa é secundária, ocorre envolvimento do sistema renina-angiotensina-aldosterona devido a injúria renal, insuficiência cardíaca e/ou hepática (SCHULMAN, 2010; DJAJADININGRAT-LAANEN et al., 2011). Os pacientes acometidos podem apresentar letargia, depressão mental, andar plantígrado, paresia flácida associada a hiporreflexia, disfagia, ventroflexão cervical que são sinais característicos da polimiopatia hipocalêmica (DJAJADININGRAT-LAANEN et al., 2011; BENTO et al., 2016). Além disso, manifestações oculares, como hifema e descolamento de retina, além de hipertrofia miocárdica e injúrias renais podem ocorrer devido a hipertensão (BENTO et al., 2016). O diagnóstico é realizado com base na presença dos sinais clínicos característicos e dosagens hormonais específicas. Os testes hormonais mais utilizados são dosagem de aldosterona e renina plasmática, sendo a última útil para diferenciar os casos primários dos secundários. A relação aldosterona creatinina urinária também pode ser utilizada, sendo que quando aumentada pode indicar hiperaldosteronismo (KOOISTRA, 2020). A ultrassonografia e tomografia computadorizada são exames muito úteis e podem ser utilizados para a localização dos tumores adrenais e seu estadiamento (DJAJADININGRAT-LAANEN et al., 2011; HARVEY E REFSAL, 2012). A adrenalectomia unilateral é o tratamento de escolha para pacientes com neoplasia adrenal unilateral sem sinais de metástase, ocorrendo após a cirurgia, remissão de todos os sinais clínicos (GALVAO \& CHEW, 2011; KOOISTRA, 2020). Quando o procedimento cirúrgico não é indicado, como nos casos de comorbidades associadas, presença de metástases distantes, neoplasia adrenocortical irressecável ou hiperplasia adrenal idiopática, o tratamento clínico é indicado. Baseia-se na administração de gluconato de potássio na dose de 2-6 mEq/gato a cada 12 horas associado a bloqueadores de receptores de mineralocorticóides, como a espironolactona na dose de 2mg/kg, a cada 12 horas (GALAC et al., 2011; HARVEY E REFSAL, 2012). Para a hipertensão, o fármaco de escolha é o anlodipino na dose de $0,1 \mathrm{mg} / \mathrm{kg}$ ou 1,25mg/gato, uma vez ao dia, inicialmente (DJAJADININGRATLAANEN et al., 2011). Os bloqueadores de angiotensina II, como a telmisartana, são agentes anti-hipertensivos menos eficazes por não bloquearem os efeitos da aldosterona (KOOISTRA, 2020). O prognóstico para os pacientes submetidos à adrenalectomia e sem complicações 
no pós-cirúrgico é bom. Os pacientes tratados clinicamente sobrevivem em média de 2,5 a 32 meses (HARVEY E REFSAL, 2012).

Conclusão: Conclui-se que o hiperaldosteronismo é uma doença importante em felinos e deve ser investigada em pacientes com hipertensão e hipocalemia ainda sem causa definida. O diagnóstico baseia-se principalmente nos sinais clínicos, dosagens hormonais específicas e exames de imagem, a fim de se obter um diagnóstico preciso e proceder as medidas terapêuticas adequadas.

\section{Referências}

BENTO, D.D.; ZAHN, F.S.; DUARTE, L.C.; MACHADO, L.H.A. Feline primary hyperaldosteronism: an emerging endocrine disease. Ciência Rural, v.46, n.4, p.686-693,2016.

CONNELL, J.M.C.; MACKENZIE, S.M.; FREEL, E.M.; FRASER, R.; DAVIES, E. A life time of aldosterone excess: long-term consequences of altered regulation of aldosterone production for cardiovascular function. Endocrine Reviews, v. 29, n. 2, p.133$154,2008$.

DJAJADININGRAT-LAANEN, S.; GALAC, S.; KOOISTRA, H. Primary hyperaldosteronism: expanding the diagnostic net. Journal of Feline Medicine and Surgery, v. 13, n. 9, p. 641-650, 2011.

DYCE, K.M.; SACK, W.O.; WENSING, C.J.G. The endocrine glands. In K.M. Dyce, W.O. Sack \& C.J. Wensing, Textbook of veterinary anatomy. p. 221-222, 2010.

GALAC, S.; REUSCH, C.E.; KOOISTRA, H.S.; RIJNBERK, A. Adrenals. In A. Rijnberk, H.S. Kooistra (eds.), Clinical endocrinology of dogs and cats: an illustrated text. 2ed., p. 93-154, 2010.

GALVAO, J.F.B.; CHEW, D.J. Metabolic Complications of Endocrine Surgery in Companion Animals. Veterinary Clinics of North America: Small Animal Practice, v. 41, p. 847-868, 2011.

HARVEY, A.M.; REFSAL, K.R. Feline hyperaldsoteronism. In C.T. Mooney \& M.E. Peterson, BSAVA Manual of canine and feline endocrinology. 4ed., p. 204-214, 2012.

KOOISTRA, H.S. Primary Hyperaldosteronism in Cats: An Underdiagnosed Disorder. Veterinary Clinics of North America: Small Animal Practice, v. 50, n.5, p. 1053-1063, 2020.

SCHULMAN, R. L. Feline primary hyperaldosteronism. Veterinary Clinics of North America: Small Animal Practice, v. 40, n. 2, p.353-359, 2010. 


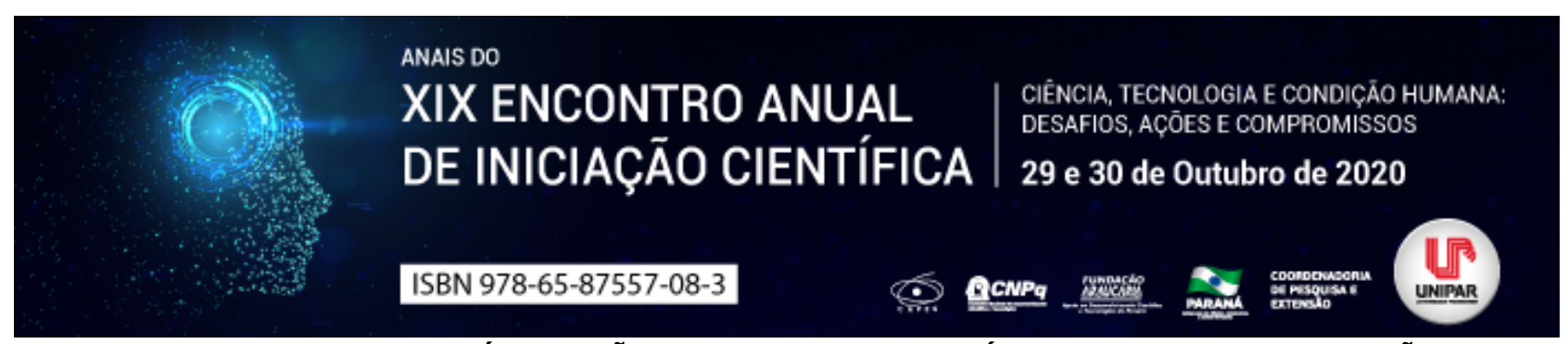

USO DE ANTIINFLAMATÓRIOS NÃO ESTEROIDAIS EM SUÍNOS RESUMO DE REVISÃO

\begin{abstract}
$1_{\text {Izabel Cristina Tavares, }}{ }^{2}$ KAROLYNE OLIVEIRA BASTOS, ${ }^{3}$ MELISSA SANCHES MONGELLI, ${ }^{4}$ BRUNA CHRISTINA FERNANDES SOARES, ${ }^{5}$ MARCOS FERRANTE, ${ }^{6}$ JOÃO VITOR FERNANDES COTRIM DE ALMEIDA
\end{abstract}

${ }^{1}$ Discente do curso de Medicina Veterinária na Universidade Federal de Lavras
${ }^{1}$ Discente do curso de Medicina Veterinária na Universidade Federal de Lavras
${ }^{2}$ Discente do curso de Medicina Veterinária na Universidade Federal de Lavras
${ }^{3}$ Discente do curso de Medicina Veterinária na Universidade Federal de Lavras
${ }^{4}$ Professor do Departamento de Medicina Veterinária da Universidade Federal de Lavras
${ }^{5}$ Médico Veterinário, Mestre em Ciências Veterinárias DMV Universidade Federal de Lavras

Introdução: A inflamação é uma reação do corpo a lesões nos tecidos, e consiste no recrutamento de células e extravasamento de proteínas plasmáticas através dos vasos sanguíneos. A liberação de histamina, substância $P$ e outros mediadores por mastócitos e macrófagos causa aumento no fluxo sanguíneo local, exsudação de proteínas e ativação das terminações nervosas, resultando nos sinais cardinais da inflamação: calor, rubor, edema, dor e perda de função (SCHOOS et al, 2019). Muitas são as condições em que suínos de granjas comerciais estão sujeitos a desenvolver inflamações, que prejudicam a saúde, o bem-estar e a produtividade do animal. Nestas situações há indicações do uso de antiinflamatórios não esteroidais (AINEs), porém são escassos os estudos que investigaram a eficácia, os efeitos colaterais e possíveis consequências destes fármacos em diferentes condições, a partir de regimes terapêuticos distintos.

Objetivo: Abordar os principais determinantes de inflamações em suínos, de acordo com a categoria do animal, e descrever os protocolos atualmente empregados nestas situações.

Desenvolvimento: Há relatos de uso dos AINEs durante e após a castração de leitões, porém, esses são insuficientes para controle da dor, sendo necessária a utilização de anestésicos. Os AINEs mais indicados para o procedimento são: meloxicam, inibidor preferencial da cicloxigenase 2 (COX-2) que pode atenuar a dor pós-operatória, e cetoprofeno, que atua como AINE periférico e central (um dos mais potentes), e é inibidor não seletivo da COX e do mediador da resposta inflamatória aguda, o metabólito da 5-lipoxigenase leucotrieno B (SCHOOS et al, 2019). Os problemas de locomoção em suínos são recorrentes, e estão associados não somente ao alojamento (piso e gaiolas), mas também ao manejo, à nutrição, genética e a eventuais patógenos infecciosos. PAIRIS-GARCIA et al (2015) mostraram que a flunixina (2,2 mg/kg) mitigou a sensibilidade à dor rapidamente (1 hora após a administração); MUSTONEN et al (2011) examinaram a claudicação em porcas, e as trataram diariamente com cetoprofeno durante 5 dias. A claudicação melhorou significativamente, após 5 dias, em mais de 50 \% do grupo tratado, e não houve efeitos adversos (p.ex: irritação gastrointestinal). Apesar destes estudos, o tratamento com anti-inflamatórios é de difícil execução, devido às diferentes causas, e pelo tratamento ser muitas vezes empregado apenas na fase crônica da doença. Alguns estudos avaliaram o uso de AINEs para a terapia antiinflamatória e antipirética em porcas com Síndome da Disgalaxia Pós-Parto (SDP), e concluíram que meloxicam, cetoprofeno e flunixina são drogas promissoras para tal finalidade. TUMMARUK et al (2013) mostraram que a partir do tratamento com flunixina (0,5 mg/kg IM uma vez após o parto e, se necessário, 24 h depois), o número de porcas com febre diminuiu significativamente de $61,3 \%$, no dia 1, para $22,6 \%$ no dia 3 pósparto, indicando que a flunixina representa um bom candidato para alívio da SDP em porcas com alto risco de distúrbios pósparto. HIRSCH et al (2003) trataram porcas acometidas de mastite com antibióticos sistêmicos, oxitocina e meloxicam ou flunixina. Ambos os AINEs foram eficazes em melhorar os sinais clínicos das porcas, no entanto, a mortalidade dos leitões foi significativamente menor nas ninhadas doentes das porcas tratadas com meloxicam em comparação com as ninhadas das fêmeas tratadas com flunixina. SWINKELS et al (1994) compararam tratamentos com cetoprofeno (3 mg/kg IM) e flunixina (2 $\mathrm{mg} / \mathrm{kg}$ IM) em um experimento com Actinobacillus pleuropneumoniae. Os autores demonstraram que o cetoprofeno teve efeito antipirético altamente significativo a partir de 2 horas da administração, e que este durou cerca de 8 horas; já no grupo tratado com flunixina tal efeito não foi tão proeminente. As lesões de pleuropneumonia hemorrágica fibrinosa, por outro lado, apareceram nos dois grupos. VIEHMANN et al (2013) avaliaram os efeitos do cetoprofeno e de um tratamento antibiótico adequado em um estudo de infecção experimental por Haemophilus parasuis. Os animais que receberam ambos os fármacos apresentaram diminuição mais rápida da temperatura corporal e maior ganho de peso diário em comparação com o grupo tratado apenas com antibiótico. WALLGREN et al (1995) investigaram varrões desafiados por Salmonella typhimurium e tratados com flunixina (2,2 $\mathrm{mg} / \mathrm{kg} 10 \mathrm{~min}$ antes do desafio). Os sinais de endotoxemia aguda apareceram mais tardiamente e foram mais leves, e 1 hora a mais se passou até que a temperatura retal se elevasse e as concentrações de cortisol aumentassem em comparação com o grupo controle, o que confirmou uma forte ação antiendotoxina da flunixina. 
Conclusão: Conclui-se que dentre as causas de inflamação em suínos, as principais são a castração cirúrgica de leitões, SDP em matrizes, além dos problemas locomotores e respiratórios. Atualmente os AINEs mais utilizados e com melhores resultados nessas situações são o meloxicam, cetoprofeno e flunixin.

\section{Referências}

HIRSCH, A. C.; PHILIPP, H.; KLEEMANN, R. Investigation on the efficacy of meloxicam in sows with mastitis metritis agalactia syndrome. Journal of veterinary pharmacology and therapeutics, v. 26, n. 5, p. 355-360, 2003

MUSTONEN, K.; ALA-KURIKKA, E.; ORRO, T; PELTONIEMI, O.; RAEKALLIO, M.; VAINIO, O.; HEINONEN, M. Oral ketoprofen is effective in the treatment of non-infectious lameness in sows. Veterinary journal, London, v. 190, n.1, p. 55-59, 2010

PAIRIS-GARCIA, M.; JOHNSON, A. K. .; BRUNS, C. E.; COETZEE, J. F.; KARRIKER, L. A.; MILLMAN, S. T.; STALDER, K. J. Measuring the efficacy of flunixin meglumine and meloxicam for lame sows using a GAITFour pressure mat and an embedded microcomputer-based force plate system. Journal of Animal Science. v. 93, n.5, p. 2100, 2015

SCHOOS, A.; DEVREESE, M.; MAES, D. G. D. Use of non-steroidal antiinflammatory drugs in porcine health management. Veterinary Record, Merelbeke, Belgium, V.185, n.6, p.172, 2019

SWINKELS, J. M.; PIJPERS, A.; VERNOOY, J. C. M.; VAN NES, A.; VERHEIJDEN, J. H. M. Effects of ketoprofen and flunixin in pigs experimentally infected with Actinobacillus pleuropneumoniae. Journal of veterinary pharmacology and therapeutics, $v$. 17, n.4, p. 299-303, 1994

TUMMARUK, P.; SANG-GASSANEE, K. Effect of farrowing duration, parity number and the type of anti-inflammatory drug on postparturient disorders in sows: a clinical study. Tropical Animal Health and Production, v. 45, n.4, 2012

VIEHMANN, M.; POSTIASI, S.; BALKA, G.; SPERGSER, J PALZER, A.; HENNIG-PAUKA, I.; LADINIG, A. Evaluation of the efficacy of a combination therapy of an antibiotic and a NSAID following an experimental Haemophilus parasuis infection in nursery piglets. Tierärztliche Praxis G: Großtiere/Nutztiere, v. 41, n.4, p. 225-232, 2013

WALLGREN, M.; KINDAHL, H.; RODRIGUEZ-MARTINEZ, H. Modulation of endotoxin-induced andrological alterations by flunixin meglumine in the boar. Journal of Veterinary Medicine Series A, v. 42, n.1-10, p. 357-369, 1995 


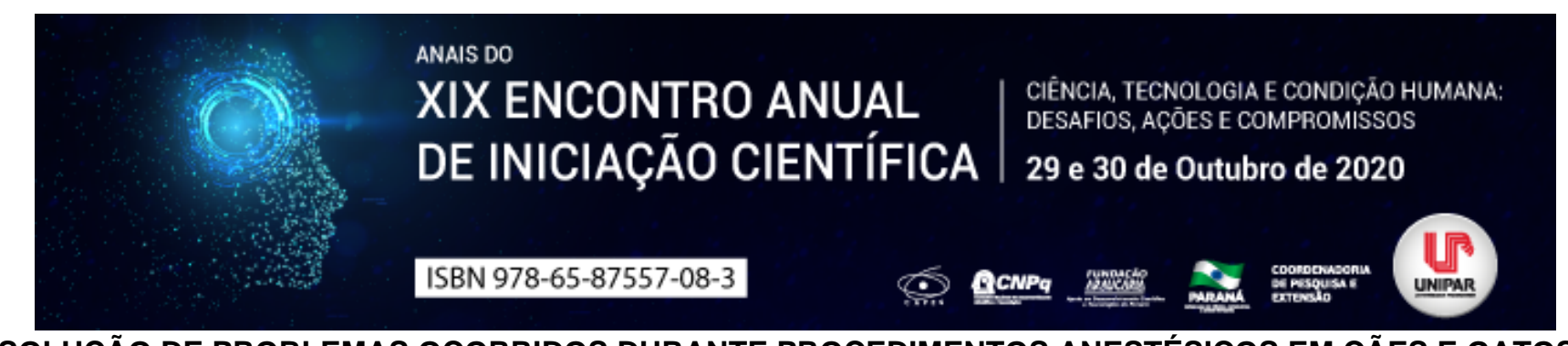

SOLUÇÃO DE PROBLEMAS OCORRIDOS DURANTE PROCEDIMENTOS ANESTÉSICOS EM CÃES E GATOS

\begin{abstract}
${ }^{1}$ Luciana de Castro Barcelos, ${ }^{2}$ LUCAS WANSER FONSECA GONZAGA, ${ }^{3}$ LILIAN PEREIRA GOUVEIA, ${ }^{4}$ ISABELA LOPES MASSITEL, ${ }^{5}$ MARCOS FERRANTE, ${ }^{6}$ JOÃO VITOR FERNANDES COTRIM DE ALMEIDA
\end{abstract}

\begin{abstract}
${ }^{1}$ Acadêmica do curso de Medicina Veterinária da Universidade Federal de Lavras
${ }^{1}$ Acadêmico do curso de Medicina Veterinária da Universidade Federal de Lavras

${ }^{2}$ Acadêmica do curso de Medicina Veterinária da Universidade Federal de Lavras

${ }^{3}$ Acadêmica do curso de Medicina Veterinária da Universidade Estadual de Maringá

${ }^{4}$ Professor do departamento de Medicina Veterinária da Universidade Federal de Lavras

${ }^{5}$ Mestre em ciências veterinárias do departamento de Medicina Veterinária da UFLA
\end{abstract}

Introdução: É imprescindível que a resolução de complicações anestésicas, de curta ou longa duração, seja eficaz, e busque garantir o bem-estar e a saúde do paciente. Os principais sistemas acometidos durante um procedimento que envolva uso de anestésico são o cardiovascular e respiratório, sendo comum quadros de hipotensão ou hipertensão, arritmias, taquicardia, hipoventilação, hipoxemia e bradipneia (GRUBB et al., 2020). É fundamental que o médico veterinário saiba reconhecer estes, de modo a tentar solucioná-los ou reverter tais situações, garantindo, por conseguinte, a sobrevivência do animal submetido à anestesia (GRUBB et al., 2020; ROBERTSON et al., 2018)

Objetivo: Levantamento bibliográfico das complicações nos sistemas cardiovascular e respiratório durante procedimentos anestésicos em cães e gatos.

Desenvolvimento: Durante procedimentos anestésicos, o sistema cardiovascular pode ser afetado por quadros de hipotensão, resultando em valores da pressão sistólica abaixo de $80 / 90 \mathrm{mmHg}$ ou de pressão arterial média abaixo de $60 \mathrm{mmHg}$. Em situações nas quais o animal esteja sob anestesia inalatória, pode ser utilizado um cristalóide IV (5 $20 \mathrm{mg} / \mathrm{kg}$, dependendo das necessidades do paciente), como ringer com lactato de sódio ou solução $\mathrm{NaCl}$ a $0,9 \%$, e/ou uma solução colóide (1 $5 \mathrm{~mL} / \mathrm{kg})$ administrada por via intravenosa (IV) em bolus, como dextranos 40 ou 70 (GRUBB et al., 2020; DAVIS et al., 2013). Pode-se utilizar também um fluxo de cristalóide IV de 10 a $15 \mathrm{~mL} / \mathrm{kg} / \mathrm{h}$ para controle da hipotensão e manutenção da perfusão sanguínea (DAVIS et al., 2013). Em situações de bradicardia, pode ser administrado um anticolinérgico, como atropina, ou simpatomimético (efedrina 0,1-0,2 $\mathrm{mg} / \mathrm{kg}$ bolus), e pode ser administrado também um inotrópico positivo ou vasoconstritor, como dopamina ou norepinefrina (GRUBB et al., 2020). A bradicardia pode ser causada por planos profundos com anestésicos intravenosos, e aconselha-se superficializar a anestesia e ventilar o paciente logo em seguida. Por outro lado, em algumas situações menos comuns, pode ocorrer hipertensão quando a pressão arterial sistêmica está acima de 120-140 mmHg, ou em casos de pressão sistólica acima de 160-180 mmHg (GRUBB et al., 2020). Deve-se avaliar, portanto, se isso ocorre devido à superficialização do plano anestésico, ou se o paciente não foi anestesiado de forma adequada, o que gera menos analgesia e pode ocasionar reflexos de dor, elevando, consequentemente, a pressão (ROBERTSON et al., 2018). Em vista disso, os opióides podem ser usados caso o paciente se torne hipertenso de forma persistente, e não se recomenda aumentar a concentração do vaporizador na tentativa de diminuir a pressão (GRUBB et al., 2020). Podem ocorrer também quadros de taquicardia (frequência cardíaca acima de 180 batidas por minuto em cães e de 150-190 batidas por minuto em gatos), devendo ser avaliado se não estes não foram causados por profundidade anestésica inadequada, pelo uso de medicamentos como alfaxalona, atropina e dopamina, ou por estímulo nocivo (HASKINS, 2017). O sistema respiratório pode ser acometido pelo quadro de hipoventilação, exigindo que se avalie a possibilidade do animal se encontrar em profundidade anestésica excessiva (GRUBB et al., 2020; PASCOE et al., 2017) ou pela administração de medicações que ocasionem alterações no ritmo respiratório, como a morfina (HASKINS, 2017). Podese contornar essa situação a partir de ventilação por pressão positiva, caso a medida do dióxido de carbono ao final da expiração (ETCO2) esteja acima de $60 \mathrm{mmHg}$ (hipercapnia) e o status hemodinâmico se apresente estável; sempre deve ser avaliado se a ETCO2 no paciente anestesiado gira em torno de 40 a $50 \mathrm{mmHg}$ (GRUBB et al., 2020). Além disso, podem acontecer situações em que o animal apresente hipoxemia, mas é raro quando este se encontra entubado e recebendo o adequado suporte de oxigênio. Pacientes que apresentam coloração acinzentada a azulada das mucosas (cianose) sinalizam que há hipoxemia grave, pois é um sinal tardio (GRUBB et al., 2020; HASKINS, 2017). Esse quadro se desenvolve quando o animal está com níveis de hemoglobina saturada com oxigênio (SpO2) abaixo de 95 \% (GRUBB et al., 2020). Deve-se atentar se o paciente está entubado de forma correta e se o suprimento de oxigênio está na faixa adequada, pois se o problema persistir pode até mesmo ocorrer falta de oxigênio nos tecidos por déficit de perfusão (GRUBB et al., 2020). Os casos de bradipneia ocorrem quando há plano anestésico profundo, mas que podem ser facilmente resolvidos pela superficialização deste e por hiperventilação com oxigênio (GRUBB et al., 2020; PASCOE et al., 2017). 
Conclusão: Solucionar eventuais complicações anestésicas, tal qual as supracitadas, pode evitar que o paciente tenha sequelas ou até mesmo que venha a óbito. Por isso, é fundamental que o médico veterinário adeque o procedimento anestésico aos sinais clínicos que aparecem durante toda e qualquer intervenção no paciente.

\section{Referências}

DAVIS, Harold. et al. AAHAIAAFP Fluid Therapy Guidelines for Dogs and Cats. American Animal Hospital Association, 2013. Disponível em: https://www.aaha.org/globalassets/02-guidelines/fluid-therapy/fluid_therapy_guidelines.pdf. Acesso em 07 ago. 2020

GRUBB, Tamara. et al. Anesthesia and Monitoring Guidelines for Dogs and Cats*. American Animal Hospital Association, mar/abr. 2020. Disponível em: https://www.aaha.org/globalassets/02-guidelines/2020-anesthesia/anesthesia_and_monitoringguidelines_final.pdf. Acesso em: 07 ago. 2020

HASKINS, Steve C. Monitoramento de Pacientes Anestesiados. In: GRIMM, Kurt. A. et al. Lumb \& Jones, Anestesiologia e analgesia em veterinária. 5. ed. Rio de Janeiro: Roca, 2017.

PASCOE, Peter J.; PYPENDOP, Bruno H. Anestesia e analgesia comparada em cães e gatos. In: GRIMM, Kurt. A. et al. Lumb \& Jones, Anestesiologia e analgesia em veterinária. 5. ed. Rio de Janeiro: Roca, 2017.

ROBERTSON, Sheilah A. et al. AAFP Feline Anesthesia Guidelines. American Association of Feline Practitioners, 2018. Disponível em: https://www.catvets.com/guidelines/practice-guide-lines/anesthesia-guidelines. Acesso em: 07 ago. 2020 


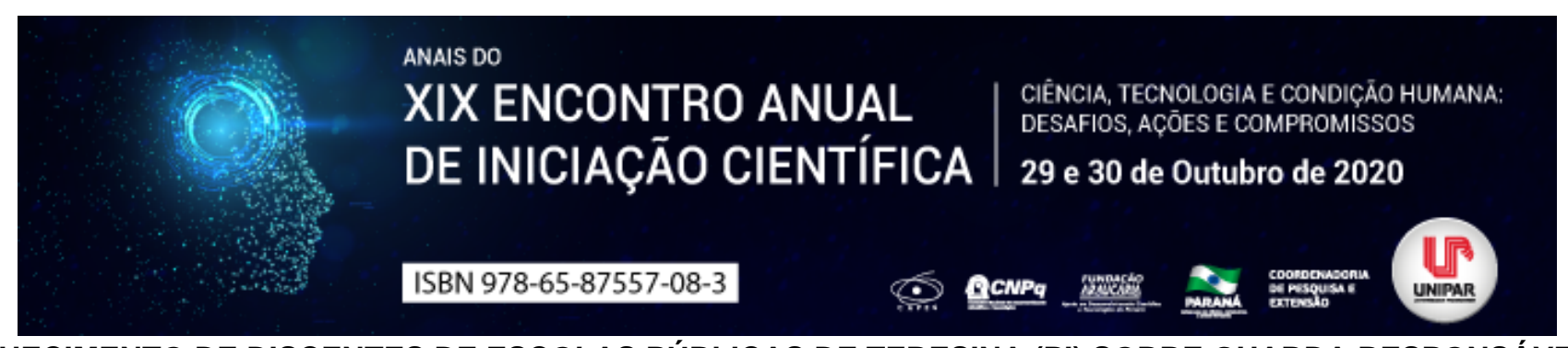

CONHECIMENTO DE DISCENTES DE ESCOLAS PÚBLICAS DE TERESINA (PI) SOBRE GUARDA RESPONSÁVEL DE ANIMAIS DE ESTIMAÇÃO E ZOONOSES

\author{
${ }^{1}$ Carolina Aguera, ${ }^{2}$ ALYSSON RAMALHAIS, ${ }^{3}$ HELOISA FABIANE MARTINS BONOMO, ${ }^{4}$ TAYMILI ALVES DA SILVA, ${ }^{5}$ VINICIUS \\ SILVEIRA DE QUEIROZ, ${ }^{6}$ ANA MARIA QUESSADA
}

\author{
${ }^{1}$ Acadêmico bolsista do PEBIC - JR / CNPQ \\ ${ }^{1}$ Acadêmico do Curso de Mestrado Em Ciencia Animal Com Enfase Em Produtos Bioativos da UNIPAR \\ ${ }^{2}$ Acadêmica do Curso de Medicina Veteriñ̃ $j$ ria da UNIPAR \\ ${ }^{3}$ Acadêmica do Curso de Medicina Veterin $\tilde{A}_{j}$ ria da UNIPAR \\ ${ }^{4}$ Acadêmico do Curso de Medicina Veteriñ̃ $j$ ria da UNIPAR \\ ${ }^{5}$ Docente da UNIPAR
}

Introdução: Animais abandonados são um grande problema para saúde pública. Tais animais podem ser reservatórios e transmissores de doenças zoonóticas, as quais afetam os humanos (KAY et al., 2017). De acordo com estimativas da OMS (Organização Mundial da Saúde), cerca 10 milhões de gatos e 20 milhões de cães vivem em situações errantes (OMS, 2012). Em Teresina (PI) há ainda muitos casos de prevalência e reincidência de zoonoses, principalmente Leishmaniose Visceral (DRUMOND; COSTA, 2012). Por isso medidas de educação em saúde precisam ser tomadas para os proprietários dos animais em especial crianças e adolescentes para haver uma diminuição das zoonoses.

Material e Métodos: Foram feitas entrevistas com 1.680 estudantes em duas escolas de ensino fundamental e médio em Teresina $(\mathrm{Pl})$, com o objetivo de avaliar o nível de conhecimento dos estudantes sobre determinadas doenças zoonóticas e cuidados com animais de estimação.

Resultados e Discussão: Mais da metade dos estudantes não sabe o que são zoonoses (51,25\%; 861/1.680). Entre os que sabem (48,75\%; 819 / 1.680), a televisão foi a principal fonte de conhecimento (34,54\%; 283/819). Esse meio de comunicação tem grande alcance na população brasileira (RIBEIRO, 2018). A vacinação é a prática mais conhecida de Guarda Responsável (98,80\%; 1.666 / 1.680), sendo que é essencial para a saúde animal (DAY et al., 2016) Provavelmente, este resultado se deve ao fato de que em Teresina (PI) ocorre a vacinação antirrábica gratuita. A castração foi reconhecida como um dos mandamentos de Guarda Responsáveis por 510 estudantes (30,36\%). Isso explica por que a castração ainda é incomum em Teresina (PI) (SILVA et al., 2017). Provavelmente, isso se deve principalmente à falta de informação, resistência cultural dos proprietários e dificuldades financeiras (SILVA et al., 2009). A existência de animais abandonados não castrados pode levar à formação de superpopulação, acidentes, crueldade aos animais e disseminação de zoonoses, fato que merece destaque por ser um grave risco à Saúde Pública (KAY et al., 2017). A vermifugação nos animais de estimação é praticada por 51,82\% (797/1.538) dos estudantes, demonstrando que essa prática ainda exige maior divulgação, pois as Zoonoses causadas por parasitas intestinais de cães constituem um problema permanente de Saúde Pública, tornando a desparasitação de cães e gatos um dos atos indispensáveis nas cidades Brasileiras (TORRES; OTRANTO, 2014).Quatrocentos e noventa e três estudantes (32,05\%) afirmaram que seu animal tem livre acesso à rua. Este acesso livre às ruas pode levar a acidente de trânsito, lesões por brigas com outros cães, mordedura de pessoas e outros agravos (PAIXÃO; MACHADO, 2015; KAY et al., 2017). A porcentagem de estudantes que relata que sua família havia abandonado um animal foi de 43,21\% (726 / 1.680), e a principal razão para isso foi o surgimento de uma doença que a família não tinha condições de tratar. Tal fato é detectado no Brasil (PAIXÃO; MACHADO, 2015). Aproximadamente metade dos alunos considera o cão como o principal transmissor da Raiva. No entanto, o gato tem um papel importante na Raiva urbana no Brasil, incluindo tendência de crescimento de sua importância epidemiológica (RODRIGUES et al., 2017)

Conclusão: Concluiu-se que os estudantes de escolas públicas de Teresina possuem pouco conhecimento sobre a Guarda Responsável de animais e sobre Zoonoses. Esta descoberta deve servir como um alerta para os gestores da cidade para desenvolver campanhas para reduzir o abandono de animais e a progressão de Zoonoses.

\title{
Referências
}

DAY, M. J. et al. Diretrizes para a vacinação de cães e gatos: compiladas pelo grupo de diretrizes de vacinação (VGG) da associação veterinária mundial.Journal of Small Animal Practice. v.57, 2016.

DRUMOND, K.O.; COSTA, F.A.L. Forty years of visceral leishmaniasis in the state of Piaui: a review. Revista do Instituto de Medicina Tropical, v. 53, n.1, p. 3-11,2011.

KAY A. et al. A. Scoping review of published research on the population dynamics and control practices of companion animals. 
Preventive Veterinary Medicine. v. 144, p. 40-52, 2017.

PAIXÃO, R. L.; MACHADO, J. C. Conexões entre o comportamento do gato doméstico e casos de maus-tratos, abandono e não adoção. Revista brasileira de direito animal. v. 10, n. 20, p.137-168, 2015.

RIBEIRO, E. F. Transmídia e convergência na TV aberta brasileira. Revista Temática. v. 14, n. 8, 2018.

SILVA, F. A. N. et al. Posse responsável de cães no bairro Buenos Aires na cidade de Teresina (PI). Ars Veterinária,v.25, n.1, p. 14-17, 2009.

TORRES, F. D.; OTRANTO, D. Dogs, cats, parasites, and humans in Brazil: opening the black box. Parasites \& Vectors, v. 7 , n.1, p.7-22, 2014.

Coordenadoria de Pesquisa e Extensão - COPEX

Departamento de Editoraçāo e Divulgaçāo Científica - DEDIC 


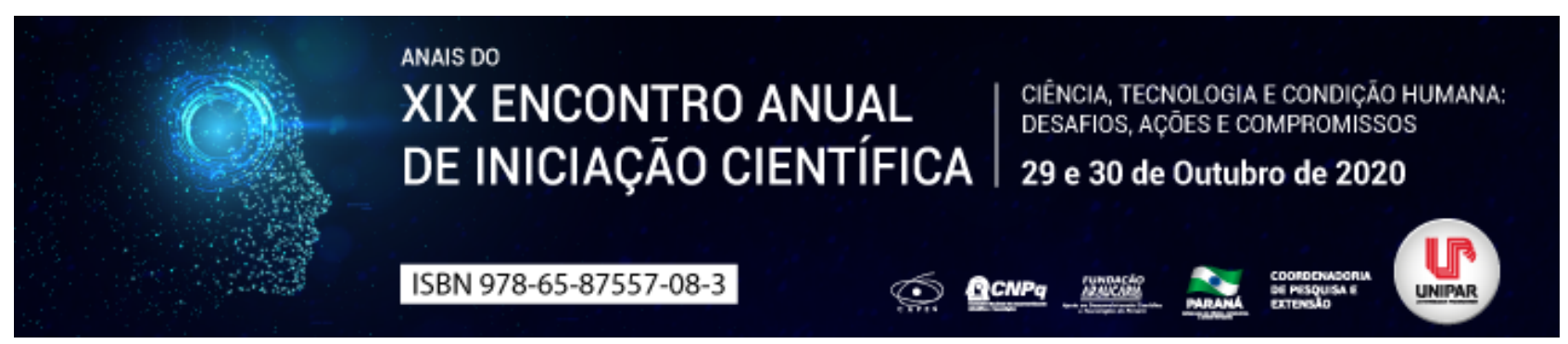

TOXICOLOGIA DO EXTRATO VEGETAL DE Eugenia uniflora L. (PITANGA)

\begin{abstract}
${ }^{1}$ GUILHERME DONADEL, ${ }^{2}$ MARIANA DALMAGRO, ${ }^{3}$ JOAO ANTONIO BERTA DE OLIVEIRA, ${ }^{4}$ YURI PELICANO DOMINGUES, ${ }^{5}$ SALVIANO TRAMONTIN BELETTINI, ${ }^{6}$ EMERSON LUIZ BOTELHO LOURENCO
\end{abstract}

\author{
${ }^{1}$ Discente do Mestrado em Ciência Animal e Produtos Bioativos (PROSUP/CAPES),UNIPAR, Umuarama- PR \\ ${ }^{1}$ Acadêmica do Curso de Farmácia da UNIPAR \\ ${ }^{2}$ Acadêmico do Curso de Medicina Veterinária da UNIPAR \\ ${ }^{3}$ Acadêmico do Curso de Medicina Veterinária da UNIPAR \\ ${ }^{4}$ Docente da UNIPAR \\ ${ }^{5}$ Docente da UNIPAR
}

Introdução: Dentre as plantas com propriedades medicinais destaca-se a Eugenia uniflora L. da família (Myrtaceae), cuja origem é a mata atlântica Brasileira, no qual é eficaz para o tratamento de várias enfermidades, possuindo atividades farmacológicas de anti-inflamatórios, antioxidantes, analgésicos, anti-hipertensivo, antibacteriano, antifúngico sendo que sua ação se dá através do consumo de suas folhas e frutos, pois são nestes que há fonte de nutrientes presentes (SOBEH et al., 2019). Doenças causadas por fungos e bactérias acometem mulheres, devido as alterações causadas na flora vaginal, tendo em vista que alguns tratamentos com o passar do tempo se tornam ineficazes devido a resistências dos patógenos aos produtos utilizados (HOLANDA,2007). Sendo assim, novas buscas por terapias alternativas desde que comprovadamente viáveis; como é o caso da Eugenia uniflora L. demonstrem possuir um importante efeito benéfico frente a este tipo de patógeno (SILVA-ROCHA et al., 2015).

Objetivo: Avaliar o uso da Eugenia uniflora L. veiculado na forma de gel e extrato, frente a teste de tolerância de administração na região vaginal e comportamento do ciclo estral em diferentes doses.

Metodologia: Foram utilizados 56 fêmeas de Rattus norvegicus, da linhagem Wistar com 90 a 100 dias de vida, divididas em oito grupos de sete animais por grupo composto por, controle negativo, controle positivo, gel 5, 10 e 15\%, extrato 5,10 e $15 \%$ sendo o volume de aplicação baseado na dose terapêutica humana da formulação galênica ou no volume máximo aplicável à espécie animal, utilizado creme vaginal e extrato de E. uniflora nas concentrações de 5,10 e 15\%, realizando a aplicação uma vez ao dia, com o auxílio de swab sobre a cavidade vaginal durante o período de 14 dias. Os parâmetros avaliados foram a região vaginal, sinais clínicos (por exemplo, sinais de dor) e secreção vaginal (por exemplo, sangue, muco). Foram realizados esfregaços vaginais antes do início dos tratamentos e durante os tratamentos por amostragem de cada grupo, realizados com auxílio de micropipeta, através de lavagens vaginais com $50 \mu \mathrm{L}$ de água destilada e posterior avaliação, a fresco, em microscopia ótica (200x). Todos os procedimentos realizados foram aprovados pelo comitê de ética em pesquisa envolvendo experimentação animal da unipar (CEPEEA/Unipar) em reunião realizada em 25/05/2020, sob número de protocolo 38108/2020.

Resultado: Os resultados obtidos no experimento, mostraram que o uso do gel a base do extrato de $E$. uniflora, utilizado na região vaginal das ratas, não apresentou sinais clínicos de irritação, dor e secreção no local de aplicação. Com relação ao ciclo estral, avaliado em todas as ratas, não foi evidenciado diferença em todos os animais avaliados. Portanto, não foi possível constatar nenhum tipo de toxicidade nos parâmetros avaliados com a planta referida.

Discussão: $O$ experimento demonstrou que o uso do gel vaginal a base do extrato de $E$. uniflora não apresentou diferença entre os grupos testados na questão de sinais clínicos como irritação, dor, presença de secreção ou alteração do ciclo estral onde todos os animais permaneceram em condições normais durante o período do experimento. Em trabalho realizado por Amorim, Santos (2003) com gel vaginal de aroeira em mulheres o estudo apresentou efeito benéfico em $87 \%$ (por cento) dos casos tratados sem relatos de ardor, secreção colaborando com esse trabalho. Em estudo realizado por Silva et al. (2015) o efeito de feromônios de machos em relação as fêmeas, fez com que ocorresse o prolongamento dos períodos estrais de proestro e estro, e diminuição do períodos de metaestro e diestro, o que não corroboram com os resultados obtidos em nosso trabalho pois as fêmeas não foram expostas com machos e não ocorreu interferência na utilização do extrato mantendo o seu ciclo estral natural. Tendo em vista que não ocorreu diferença entre as concentrações testadas de 5,10 e 15\%, pode ser recomendado a utilização do gel de $E$. uniflora na concentração de $5 \%$ visando seu menor custo e mantendo seus efeitos benéficos.

Conclusão: Concluímos que o extrato de E. uniflora na forma de gel vaginal não apresentou alteração na região de administração não apresentando efeito adverso e sem alteração do ciclo estral.

\title{
Referências
}

AMORIM, M. M. R.; SANTOS, L. C. Tratamento da vaginose bacteriana com gel vaginal de Aroeira (Schinus terebinthifolius 
Raddi): ensaio clínico randomizado. Revista Brasileira de Ginecologia e Obstetrícia, v. 25, n. 2, p. 95-102, 2003.

HOLANDA, A. A. R et al. Candidíase vulvovaginal: sintomatologia, fatores de risco e colonização anal concomitante. Revista Brasileira de Ginecologia e Obstetrícia, v. 29, n. 1, p. 3-9, 2007.

SILVA, G. R. da et al. Pherormones from male domestic mice influences the sexual function and gonadal steroids levels of female laboratory rats. Arquivo Ciência Veterinaria Zoologia da UNIPAR, Umuarama, v. 18, n. 2, p. 95-101-, abr./jun. 2015.

SILVA-ROCHA, W. P et al. Effect of the crude extract of Eugenia uniflora in morphogenesis and secretion of hydrolytic enzymes in Candida albicans from the oral cavity of kidney transplant recipients. BMC complementary and alternative medicine, v. 15, n. 1 , p. 6, 2015.

SOBEH, M. et al. Chemical profiling of secondary metabolites of Eugenia uniflora and their antioxidant, anti-inflammatory, pain killing and anti-diabetic activities: A comprehensive approach. Journal of ethnopharmacology, v. 240, p. 111939, 2019.

Coordenadoria de Pesquisa e Extensão - COPEX

Departamento de Editoraçāo e Divulgaçāo Científica - DEDIC 


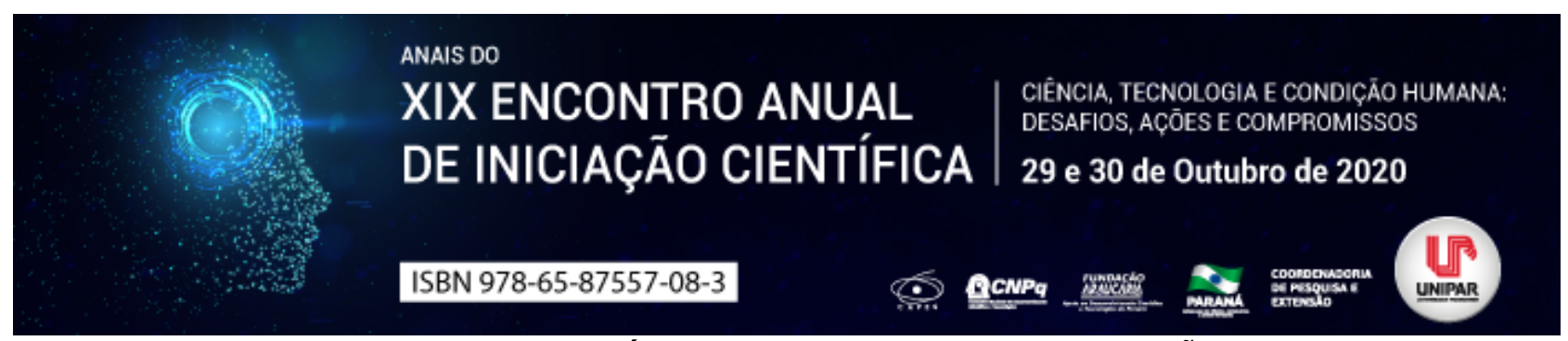

MORTALIDADE ANESTÉSICA EM EQUINOS E CLASSIFICAÇÃO ASA

\begin{abstract}
${ }^{1}$ GEOVANA CRISTINA SARTORI ANDRE, ${ }^{2}$ TAYMILI ALVES DA SILVA, ${ }^{3}$ ALEC GABRIEL PEREIRA ROCHA, ${ }^{4}$ ANA CAROLINE SOARES CERANTO, ${ }^{5}$ ALYSSON RAMALHAIS, ${ }^{6}$ ANA MARIA QUESSADA
\end{abstract}

\author{
${ }^{1}$ Discente - Curso de Medicina Veterinária - PIBIC UNIPAR \\ ${ }^{1}$ Discente - Curso de Medicina Veterinária - PIBIC UNIPAR \\ ${ }^{2}$ Discente - Curso de Medicina Veterinária - PIBIC UNIPAR \\ ${ }^{3}$ Discente - Curso de Medicina Veterinária - PEBIC UNIPAR \\ ${ }^{4}$ Mestrando em Ciência Animal com ênfase em produtos bioativos, UNIPAR \\ ${ }^{5}$ Orientadora, UNIPAR
}

Introdução: A anestesia e a analgesia passaram a ser aliados nas clínicas com o objetivo de minimizar a dor em procedimentos cirúrgicos, permitindo que os procedimentos cirúrgicos sejam feitos de forma segura, desde os procedimentos simples até os mais complexos. O procedimento anestésico inclui uma medicação pré-anestésica (MPA) para sedar e reduzir o estresse do animal. A MPA reduz as complicações durante os procedimentos cirúrgicos (RODRIGUES et al., 2017). A garantia de uma anestesia com bons resultados é determinada pela avaliação do período pré anestésico. A classificação ASA que é uma classificação do risco anestésico de acordo com a Sociedade americana de Anestesiologia mostra- se uma ferramenta segura, diminuindo os riscos de complicações no animal (SENIOR et al., 2013). Entretanto, mesmo com a utilização desta ferramenta, sabe-se que os cavalos são mais propensos a sofrerem mortalidade anestésica em comparação com pessoas, cães e gatos (SENIOR et al., 2013). As razões para isto não são inteiramente claras, mas provavelmente estão relacionadas aos efeitos da depressão cardio respiratória que ocorre durante a anestesia nesta espécie (TAYLOR e CLARKE, 2009).

Objetivo: Realizar um levantamento na literatura sobre classificação ASA em equinos e mortalidade anestésica nesta espécie.

Desenvolvimento: Anestesia geral em equinos oferece muitos riscos, pois requer o equino em decúbito (BARROSO et al., 2016). Por isso, o cavalo deve ser observado com todos os cuidados possíveis ao se deitar e ao se levantar. O cavalo é um animal muito pesado o que causa compressão dos seus músculos, quando está em decúbito durante a cirurgia. Os riscos ocorrem pela queda da função cardiovascular, hipotensão, redução do débito cardíaco, depressão respiratória e hipoventilação associados ao uso de agentes anestésicos voláteis. (DÓRIA et al., 2009). O intestino grosso comprime o pulmão causando uma maior dificuldade para respirar. Devido a isso há uma redução de oxigênio para o organismo. A frequência cardíaca é reduzida progressivamente, podendo assim ocorrer uma parada cardíaca. Desta forma, esta é uma das causas mais frequentes de óbito durante a anestesia geral em equinos. Constata- se por mortalidade o número de indivíduos que vêm a óbito em um determinado intervalo de tempo (RODRIGUES et al., 2017). As taxas elevadas de morbidade e mortalidade associadas à anestesia estão ligadas aos conhecimentos, habilidade e experiência do anestesista, a duração e o tipo de procedimentos cirúrgicos, as técnicas de monitoramento utilizadas e a disponibilidade de terapias emergenciais (BARROSO et al., 2016). Para uma anestesia de sucesso, os animais podem ser classificados nas seguintes categorias da sociedade Americana de Anestesiologia (ASA) I, II, III, IV e $\mathrm{V}$ que varia do animal saudável ao moribundo e pode ser acrescentada a letra E em emergências (ASA, 2014). Tal classificação possui relação com a morbidade e mortalidade anestésica. Além disso, indica os riscos de possíveis complicações anestésicas. Neste tipo de classificação são analisados os dados do exame físico e complementares do paciente para que se possa instituir os procedimentos anestésicos adequados (RODRIGUES et al., 2017). Na maioria dos casos, o óbito não é causado somente pelos fármacos utilizados, mas tanto no procecedimento anestésico quanto nas doenças primárias que o paciênte pode manifestar (CORRÊA et al., 2009). A classificação ASA permite a identificação do risco de mortalidade em até 2472 horas após a anestesia. Possibilita, ainda, identificar maior risco de desenvolvimento de hipotermia trans operatória grave (PORTIER e IDA, 2018). Nos equinos que serão submetidos a procedimentos anestésicos deve ser realizado jejum de sólidos por pelo menos 12 horas (NATALINI, 1994; THURMON \& SHORT, 2013). Os equinos apresentam risco de ter o estômago rompido durante a queda na indução, caso este esteja repleto (BARROSO et al., 2016). É importante destacar que agentes anestésicos inalatórios podem causar depressão da função cardiovascular, hipotensão, redução do débito cardíaco, depressão respiratória, hipoventilação e hipercapnia (RODRIGUES et al., 2017). Por isso, neste tipo de anestesia em equinos, o risco é significativo, e, em até sete dias após o procedimento anestésico e cirúrgico, 1\% dos animais vem a óbito (BARROSO et al., 2016). Portanto, devem ser realizados muitos estudos para melhorar a segurança da anestesia geral em equinos. Em cavalos submetidos a uma anestesia geral por causa de síndrome cólica, o nível de mortalidade é alto quando comparado a outros procedimentos. Algumas medicações, como os agonistas alfa-2 adrenérgicos, possuem efeitos depressores intensos sobre a motilidade gastrointestinal. (BARROSO et al., 2016). Por isso, devem ser evitados em pacientes submetidos à anestesia geral 
devido a alterações gastrintestinais como síndrome cólica. A mortalidade anestésica em equinos é pouco registrada na literatura, especialmente no Brasil. No entanto, há relatos de que na espécie equina a mortalidade anestésica é alta (BIDWELL et al., 2007; JOHNSTON, 1991; JOHNSTON et al., 2002; JOHNSTON, 2005). Todavia estes altos índices se referem à anestesia geral em retrospectivas realizadas no exterior. Assim sendo, ainda há muito para se estudar e muitas questões a serem respondidas sobre como realizar a melhor anestesia para equinos (BETTSCHART-WOLFENSBERGER, 2017).

Conclusão: Devido a essa alta mortalidade a anestesia geral em equinos deve ser evitada quando possível. Médicos veterinários que trabalham com equinos devem se aprofundar no estudo da anestesia para maior segurança e qualidade em seus atendimentos. Tal estudo possibilita aos anestesistas selecionar fármacos mais indicados nos procedimentos e tomar decisões rápidas em casos de emergências. Esta conduta evita acidentes e salva vidas. Deve-se ter em mente que o bem estar do animal sempre é mais importante garantindo um procedimento sem dor e seguro.

\section{Referências}

BARROSO, Camila Goersch. Noções de anestesia em equinos. Ciência Animal, v. 1, n. 26, p. 1-7, 2016.

BETTSCHART-WOLFENSBERGER, R. Cavalos. In: GRIMM, K.A. et al. Lumb \& Jones Anestesiologia e analgesia veterinária. 5 ed. Rio de Janeiro: Guanabara Koogan, 2017. cap. 46. p. 857-866.

BIDWELL, L.A.; BRAMLAGE, L.R.; ROOD, W.A. Equine perioperative fatalities associated with general anaesthesia at a private practice a retrospective case series. Veterinary Anaesthesia and Analgesia, v. 34, n. 1, p. 23 30, 2007.

CORRÊA, André Luíz. Índice de mortalidade durante procedimentos anestésicos: estudo retrospectivo (1996-2006). Ciência Rural, v. 39, n. 9, p. 2-8, 2009.

DÓRIA, Renata Gebara Sampaio. Anestesia or isofluorano em equinos submetidos a infusão contínua de medetomidina ou xilazina. Ciência rural, v. 39, n. 2, p 447- 452, 2009.

JOHNSTON, G. M. Confidential enquiry into perioperative equine fatalities. Equine Veterinary Educcation, v. 3, p. 5 6, 1991.

JOHNSTON, G. M. EASTMENT J, WOOD J, TAYLOR P. The confidential enquiry into perioperative equine fatalities (CEPEF): mortality results of Phases 1 and 2. Veterinary Anaesthesia and Analgesia. v. 29, p. 159 70, 2002.

JOHNSTON, G. M. Findings from the CEPEF epidemiological studies into equine perioperative complications. Equine Veterinary Educcation, v. 15, p. 64 68, 2005.

NATALINI, Cláudio corrêa. Anestesia em equinos com detomidina e tiletaminazolazepam. Ciência rural, v. 24, n. 2, p. 317-322. 1994.

POTIER, Karine. IDA, Keila, Kazue. The ASA Physical Status Classification: What Is the Evidence for Recommending Its Use in Veterinary Anesthesia?-A Systematic Review. Frontiers in Veterinary Science, v. 5, n. $204,2018$. https://doi.org/10.3389/fvets.2018.00204.

RODRIGUES, Nhirneyla, Marques et al. Estado físico e riscos anestésicos em cães e gatos. PUBVET, v. 11, n. 8, p. 781-788, 2017.

SENIOR, Jonathan Mark. Morbidity, Mortality, and Risk of General Anesthesia in Horses. Veterinary Clinics: Equine Practice, v. 29, n. 1, p. 1-18, 2013. 


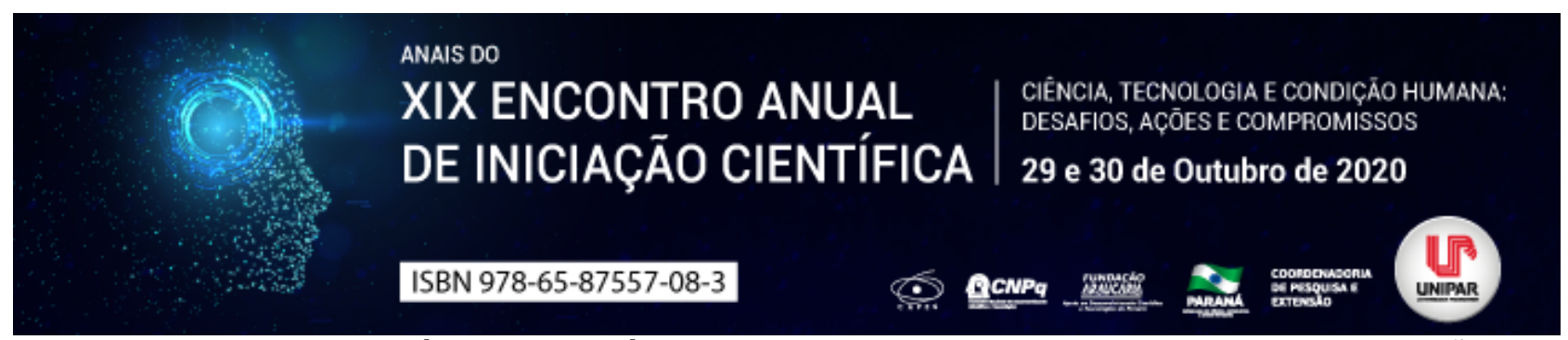

O PAPEL DO SISTEMA ÚNICO DE SAÚDE NO COMBATE A DENGUE: UM ESTUDO DE REVISÃO

${ }^{1}$ EDINEU LOPES DOS SANTOS JUNIOR, ${ }^{2}$ PRISCILA LUZIA PEREIRA NUNES, ${ }^{3}$ CRISTIANE CLAUDIA MEINERZ, ${ }^{4}$ DANIELE FERREIRA ONORIO, ${ }^{5}$ IRINÉIA PAULINA BARETTA,${ }^{6}$ ROSILEY BERTON PACHECO

\author{
${ }^{1}$ Acadêmico do PIC/UNIPAR \\ ${ }^{1}$ Acadêmico Bolsista do PBIC/UNIPAR \\ ${ }^{2}$ Docente da UNIPAR \\ ${ }^{3}$ Docente da UNIPAR \\ ${ }^{4}$ Docente da UNIPAR \\ ${ }^{5}$ Docente da UNIPAR
}

Introdução: A dengue é uma doença tropical de transmissão vetorial, com vetor o mosquito Aedes aegypti, a doença possui caráter agudo, não é contagiosa, e ocorre em 128 países ao redor do mundo, colocando bilhões de pessoas em risco diariamente (ARAÚJO et al., 2015). Como essa é uma doença de alto índice sintomático, demonstra-se também a necessidade de evita-la, o que a torna um problema de saúde pública, deixando de ser um problema apenas ao indivíduo acometido (SANTOS et al., 2017). Ainda em tempos atuais se faz complexo o combate a dengue. Atividade essa realizada com medidas profiláticas pelo SUS através de seus Agentes Comunitários de Saúde e pelos Agentes de Controle de Endemias (BRASIL, 2009).

Objetivo: Demostrar as atividades realizadas pelo Sistema Único de Saúde (SUS) e suas equipes de endemias no combate a dengue.

Desenvolvimento: O SUS provém informações sobre como evitar a dengue a partir de cartazes, palestras, visitas domiciliares e pelos próprios funcionários de Unidades Básicas de Saúde e muito se ouvem sobre isso, no entanto, poucos relacionam essas medidas ao SUS (BRASIL, 2009). Outras medidas profiláticas feitas por Agentes Comunitários de Saúde (ACS) e pelos Agentes de Controle de Endemias (ACE) que são pouco faladas e muito realizadas são o Bloqueio de Transmissão e a Delimitação de Foco (SMS, 2020). O Bloqueio de Transmissão é feito em no mínimo nove quarteirões a cada direção com ponto inicial um caso confirmado de dengue. Isso é, em um círculo ao redor da casa de um infectado, é feita uma busca por larvas e tratamento desses focos, concomitantemente, são providas informações profiláticas a dengue a nível individual (repelentes, tela em janelas, etc.), enquanto a Delimitação de Foco consiste em um círculo de até 300 metros a partir de um foco inicial, onde os ACS ou ACE passam orientando as pessoas daquela região ao mesmo tempo em que buscam outros focos de dengue (SMS, 2020). Outras atividades, onde não se tem contato com a população, como a busca em terrenos baldios por focos de reprodução do Aedes aegypti, são também feitos por agentes do SUS, realizações essas onde a população desconhece os autores.

Conclusão: De acordo com o supracitado, nota-se o papel do SUS na conscientização da população sobre a dengue, com intermédio de diversas atividades, sendo elas de forma direta, ou seja, com contato com a população ou através de ações sem envolvimento social. Portanto, conclui-se que o SUS visa o bem estar biopsicossocial da população mesmo que ela não saiba seus feitos.

\title{
Referências
}

ARAUJO, Valdelaine Etelvina Miranda de. et al. Aumento da carga de dengue no Brasil e unidades federadas, 2000 e 2015 : análise do Global Burden of Disease Study 2015. Revista Brasileira de Epidemiologia, São Paulo, v. 20, supl. 1, p. 205216, mai 2017. Disponível em: . Acesso em: 15/07/2020.

BRASIL. Ministério da Saúde. Secretaria de Vigilância em Saúde. Departamento de Vigilância Epidemiológica. Diretrizes nacionais para prevenção e controle de epidemias de dengue. Ministério da Saúde, Secretaria de Vigilância em Saúde, Departamento de Vigilância Epidemiológica. Brasília : Ministério da Saúde, 2009. 160 p. Disponível em: https://bvsms.saude.gov.br/bvs/publicacoes/diretrizes_nacionais_prevencao_controle_dengue.pdf. Acesso em: 15/07/2020.

SANTOS, Rafaelle Pereira de Lara. et al. Casos de dengue no estado de São Paulo. Revista Saúde em Foco, n. 9, p. 135-142, 2017.

SECRETARIA MUNICIPAL DE SAÚDE DE CURITIBA (SMS). Dengue: Bloqueios de transmissão e delimitação de focos. 2020. Disponível em: http://www.saude.curitiba.pr.gov.br/orientacao-e-prevencao/dengue/bloqueio-e-delimitacao.html. Acesso em: 15/07/2020. 
Coordenadoria de Pesquisa e Extensão - COPEX

Departamento de Editoraçāo e Divulgaçāo Científica - DEDIC 


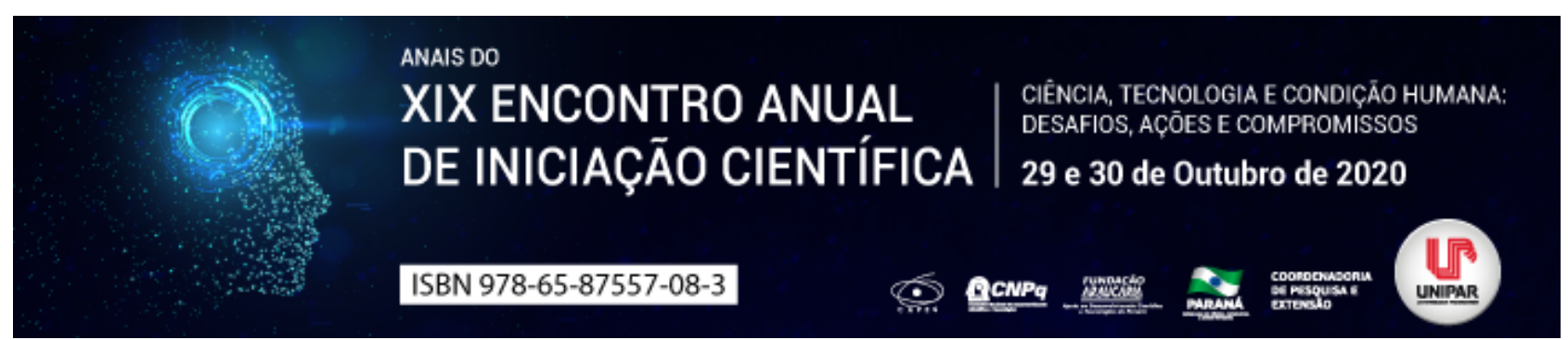

CLASSIFICAÇÃO DA HIPERTENSÃO PULMONAR EM CÃES

\begin{abstract}
${ }^{1}$ Bruna Chrisina Fernandes Soares, ${ }^{2}$ MELISSA SANCHES MONGELLI, ${ }^{3}$ SIBELY AIVA FLORES, ${ }^{4}$ LUCAS WAMSER FONSECA GONZAGA, ${ }^{5}$ MARCOS FERRANTE, ${ }^{6}$ JOÃO VITOR FERNANDES COTRIM DE ALMEIDA
\end{abstract}

\author{
${ }^{1}$ Acadêmica do curso de Medicina Veterinária da Universidade Federal de Lavras \\ ${ }^{1}$ Acadêmica da UFLA \\ ${ }^{2}$ Acadêmica da UFLA \\ ${ }^{3}$ Acadêmico da UFLA \\ ${ }^{4}$ Docente do Departamento de Medicina Veterinária da Universidade Federal de Lavras \\ ${ }^{5}$ Med. Veterinário, mestre em Ciências Veterinárias do DMV - UFLA
}

Introdução: A hipertensão pulmonar (HP) canina pode ser definida como uma elevação na pressão arterial pulmonar sistólica acima de $25 \mathrm{mmHgL}$ (REINERO, 2020), o que caracteriza um estado hemodinâmico e fisiopatológico presente em uma ampla variedade de doenças cardiovasculares, respiratórias e sistêmicas. Tradicionalmente, a HP é uma complicação decorrente de outra doença primária e, ocasionalmente, pode ocorrer de forma idiopática. A pressão arterial pulmonar é influenciada pelo fluxo sanguíneo, pela resistência vascular e pela pressão venosa pulmonar. A pressão arterial pulmonar permanece baixa em condições homeostáticas, pois a densa rede de capilares pulmonares acomoda o grande volume sanguíneo proveniente das artérias pulmonares. Mas, devido às complexas interações entre fatores genéticos e ambientais - a maioria ainda pouco compreendida em cães - a homeostase da circulação pulmonar pode ser perturbada. Esses distúrbios podem levar a um aumento excessivo no fluxo sanguíneo pulmonar e da resistência vascular pulmonar, ou até mesmo à elevação da pressão venosa pulmonar (REINERO, 2020). Por se tratarem de fatores altamente dinâmicos e interdependentes, quando um deles falha, pode desencadear alterações nos outros dois, gerando o distúrbio fisiopatológico da vasculatura pulmonar (REINERO, 2020).

Objetivo: Classificar os cães com hipertensão pulmonar de modo a simplificar as estratégias de tratamento e monitoração dos pacientes.

Desenvolvimento: A hipertensão pulmonar (HP) canina é, muitas vezes, secundária ou concomitante a outros distúrbios, por isso o ideal é que se faça uma abordagem multidisciplinar do paciente com suspeita de HP. O correto diagnóstico depende de diferentes exames, entre eles os de caráter hemodinâmicos (cateterização) e de imagem (ecocardiograma, ecocardiografia e Doppler). Desta forma, os achados ecocardiográficos, por mais que possam indicar os problemas vasculares de forma precoce, sempre devem ser interpretados no contexto de outros achados clínicos e nunca isoladamente (KELLIHAN, 2012). Em alguns casos, a origem dos distúrbios que causam HP pode não ser reconhecida, principalmente quando a ecocardiografia não é realizada ou quando sinais clínicos atribuíveis à doença primária dominam o quadro clínico. Após confirmada a presença da HP, os cães podem ser classificados em 6 grupos distintos, levando em consideração a causa da enfermidade, a apresentação clínica, as características hemodinâmicas, a fisiopatologia e os possíveis tratamentos. Essa classificação é uma adaptação do sistema utilizado na medicina para seres humanos (SIMONNEAU, 2013), e visa melhorar a avaliação diagnóstica, além de otimizar o manejo terapêutico de cães com HP. Os canídeos, portanto, podem se encaixar em um dos 6 grupos, quais sejam: Grupo 1, hipertensão arterial pulmonar; Grupo 2, doença cardíaca esquerda; Grupo 3, doença respiratória ou hipóxia; Grupo 4, êmbolos, trombos ou tromboembolia pulmonar; Grupo 5, doença parasitária (Dirofilaria spp. e Angiostrongylus spp.); e Grupo 6, distúrbios multifatoriais ou com mecanismos pouco claros (REINERO, 2020). A caracterização de cada grupo é muito importante, pois irá fornecer informações críticas para melhor orientar as recomendações terapêuticas e monitoramento dos pacientes, além de facilitar futuros estudos clínicos (SIMONNEAU, 2004). A abordagem do tratamento da HP concentra-se em estratégias para diminuir o risco de progressão e complicações da(s) doença(s) nos pacientes. Para tanto, os cães com HP devem ser monitorados quanto à melhora, condição estática ou progressão, e qualquer distúrbio subjacente identificado deve ser tratado e monitorado concomitantemente (REINERO, 2020).

Conclusão: Neste contexto, esse sistema de classificação se torna muito importante, pois guiará os procedimentos que serão realizados em cada animal visando melhorar sua qualidade de vida e aumentar a longevidade. Desta forma, o refinamento desse esquema de classificação provavelmente será necessário no futuro, para que atenda, com cada vez mais precisão, a necessidade individualizada de cada paciente.

\title{
Referências
}

HEIDI, Kellihan B.; STEPIEN, Rebecca. Pulmonary Hypertension in Dogs: Diagnosis and therapy. Veterinary Clinical Small Animal, Madison, v. 40, p. 623-641, 2010. Disponivel em: . Acesso em: 22 ago 2020. 
KELLIHAN, Heidi B.; STEPIEN, Rebecca. Pulmonary hypertension in canine degenerative mitral valve disease. Journal of Veterinary Cardiology, v. 14, p. 149-164, 2012. Disponivel em: . Acesso em: 22 ago 2020.

REINERO, Carol et al. ACVIM consensus statement guidelines for the diagnosis. Journal of Veterinary Internal Medicine. v. 34, p. 549 573, 2020. Disponivel em: . Acesso em: 22 ago 2020.

SERRES, François J. et al. Doppler echocardiography-derived evidence of pulmonary arterial hypertension in dogs with degenerative mitral valve disease: 86 cases (2001-2005). Journal of the American Veterinary Medical Association, v. 11, p. 1772-1778, 2006. Disponivel em: . Acesso em: 22 ago 2020.

SIMONNEAU, Gerald et al. Clinical classification of pulmonary hypertension. Journal of the American College of Cardiology, v. 43, n. 12, p. 5-12, 2004. Disponivel em: . Acesso em: 22 ago 2020.

SIMONNEAU, Gerald et al. Updated clinical classification of pulmonary hypertension. Journal of the American College of Cardiology, v. 12, p. 5-12, 2014. Disponivel em: . Acesso em: 22 ago 2020.

Coordenadoria de Pesquisa e Extensão - COPEX

Departamento de Editoraçāo e Divulgaçāo Científica - DEDIC 


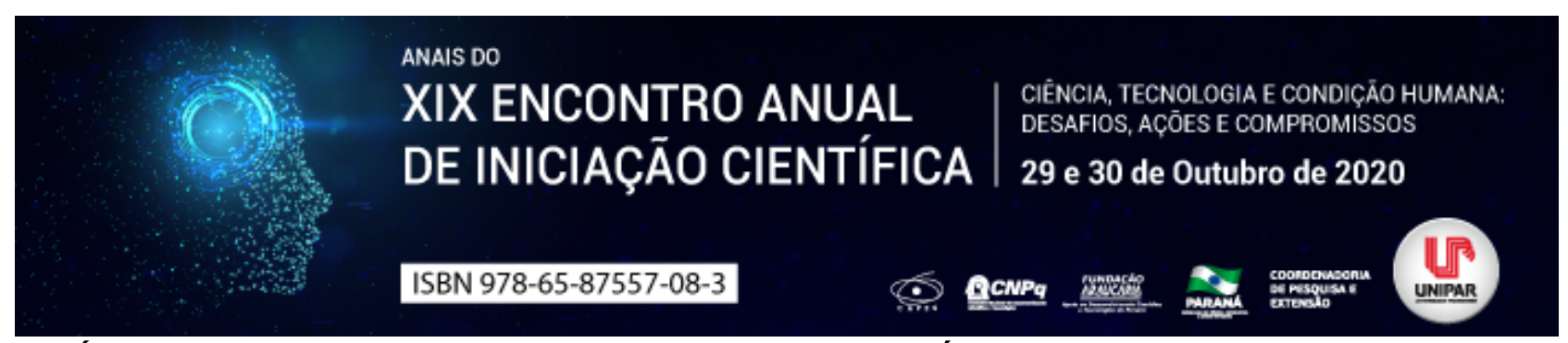

FAMÍLIA ZINGIBERACEAE: POTENCIAL MEDICINAL DAS ESPÉCIES Zingiber officinale roscoe E Alpinia purpurata (VIELL.) K. SCHUM

\title{
${ }^{1}$ FERNANDA SPESIA ANTONIO, ${ }^{2}$ LILIANA DE SOUSA BAIA, ${ }^{3}$ FELIPE ANDRÉ PEREIRA RAMOS, ${ }^{4}$ LAURIETI DE ALMEIDA, ${ }^{5}$ ANDREIA ASSUNCAO SOARES
}

\author{
${ }^{1}$ Acadêmica do Curso de Medicina Veterinária Bolsista PIBIC - UNIPAR \\ ${ }^{1}$ Acadêmica do Curso de Medicina Veterinária Bolsista PIBIC - UNIPAR \\ ${ }^{2}$ Mestrando Profissional de Plantas Medicinais e Fitoterápicos na Atenção Básica/UNIPAR. \\ ${ }^{3}$ Acadêmica Ensino Médio PEBIC EM-JR/CNPq/UNIPAR \\ ${ }^{4}$ Docente da UNIPAR
}

Introdução: Atualmente, a família Zingiberaceae tem recebido grande atenção pela sua capacidade de produzir muitos compostos bioativos que são úteis como alimentos, ervas e especiarias, aromatizantes e temperos. Várias propriedades medicinais já foram reportadas sobre os gengibres, tais como a atividade antioxidante, antimicrobiana, anti-inflamatória e analgésica são algumas delas. (HASAN, 2012). Uma das espécies mais conhecidas é o Zingiber officinale Roscoe, popularmente conhecido como gengibre comestível, sendo muito cultivado para uso como especiaria e medicinal (SUHAD et al., 2012). A espécie Alpinia purpurata (Viell.) K. Schumpor sua vez, tem sido investigada como potencial medicinal, pois várias partes da planta possuem compostos bioativos (compostos fenólicos) apresentando eficiência terapêutica (SUMABRANIAN; SUJA, 2011; CHAN; WONG, 2015).

Objetivo: Relatar as propriedades medicinais das espécies Zingiber officinale Roscoe e Alpinia purpurata(Viell.) K. Schum.

Desenvolvimento: Várias espécies de plantas e especiarias são bem conhecidas pelos seus efeitos antioxidantes e antimicrobianos, a partir de seu óleo essencial e extratos, que possuem uma grande quantidade de compostos bioativos, tais como os compostos fenólicos (MAJHENIC et al, 2007; SAHOO et al, 2014). Esses correspondem a uma gama enorme de substâncias (fenóis simples, ácidos fenólicos, cumarinas, flavonóides, taninos e ligninas) que frequentemente são de grande polaridade, muito reativas à ação de enzimas (SOARES, 2002). A família Zingiberaceae tem recebido muita atenção, justamente porque diversas espécies da família produzem muitos compostos bioativos que são úteis em alimentos como ervas e especiarias; aromatizantes e temperos; nas indústrias farmacêuticas e de cosméticos como agentes antioxidantes e antimicrobianos (CHEN et al., 2008; CHAN; WONG, 2015). Na família Zingiberaceae destacam-se os gengibres, reconhecidos como seguros pela American Foodand Drug Administration (FDA) e não possuem efeitos colaterais quando consumidos em quantidades moderadas (SPINELLA, 2001; AZIZI et al., 2015). O Zingiber officinale Roscoe é popularmente conhecido como gengibre, e é de origem Asiática. Atualmente, a China esta sendo a maior produtora do Zingiber officinale Roscoe. (CHAN; WONG, 2015). Porém, ele também é amplamente cultivado em países tropicais e subtropicais, principalmente para ser utilizado em forma de especiarias, condimentos e medicinal. A parte mais utilizada da planta é o rizoma. (KAUSHIK; GOYAL, 2011; SUHAD et al., 2012). Alpinia purpurata, outra espécie da família Zingiberaceae, é conhecida mundialmente e amplamente no Brasil, entretanto seu uso medicinal é pouco difundido (KOBAYASHI, et al, 2007). Estudos fotoquímicos das folhas do gengibre, principalmente do gênero Alpinia demonstraram compostos importantes com atividade antioxidante tais como, flavonoides, ácidos fenólicos entre outros. A espécie ainda é pouco estudada, atualmente, somente dois compostos foram identificados a partir do rizoma e cinco compostos a partir das folhas, e nenhum a partir das flores. A piperina foi o primeiro alcaloide reportado da espécie Alpinia purpurata.

Conclusão: É de suma importância que cada vez mais, pesquisas sejam realizadas para demonstrar cientificamente o potencial medicinal de espécies como as Zingiber officinale Roscoe e Alpinia purpurata(Viell.) K. Schum, e também de outras espécies e famílias. As propriedades medicinais das espécies Zingiber officinale Roscoe e Alpinia purpurata são muito relevantes. Embora, o uso medicinal da Alpinia purpurata ser pouco difundido (KOBAYASHI, et al, 2007), a espécie demonstra grande propriedade antioxidantedevido à presença de flavonoides, ácidos fenólicos de acordo com estudos fotoquímicos.

\section{Referências}

AZIZI, A. et al. In vitro Effectof Zingiber officinale Extracton Growthof Streptococcus mutans and Streptococcus sanguinis. International Journal of Dentistry, p. 1-5, 2015.

CHAN, E. W. C., WONG, S. K. Phytochemistry and pharmacology of ornamental gingers, Hedychium coronarium and Alpinia purpurata: a review. Journal of Integrative Medicine, v. 13, n.6, p. 368-379, 2015.

CHEN, I-N. et al. Antioxidant and Antimicrobial activity of Zingiberaceae plants in Taiwan.Plant Foods Human Nutrition, n. 63, p. 15-20, 2008. 
HASAN, H. A. et al. Chemical Composition and Antimicrobial Activity of the Crude Extracts isolated from Zingiber officinale by Different Solvents. Pharmaceut Anal Acta, v. 3, n. 9, p. 1-5, 2012.

KAUSHIK,P.;GOYAL,P.Evaluation of Various Crude Extracts Zingiber officinale Rhizome for Potential Antibacterial Activity: A Study in vitro. Advances in Microbiology, n. 1, p. 7-12, 2011.

KOBAYASHI, K. D. et al. Ornamental Ginger, Redand Pink. Ornamentals and Flowers, v. 37, p.1-8, 2007.

MAJHENIC L. et al. Antioxidant and antimicrobial activity of guarana seed extracts. Food Chemistry, v. 104, n. 3, p. 1258-68, 2007

SAHOO, S. et al. Chemical composition, antioxidant and antimicrobial activity of essential oil and extract of Alpinia malaccensis Roscoe (Zingiberaceae). International Journal of Pharmacy and Pharmaceutical Sciences, v. 6, n. 7, p. 183-188, 2014.

SOARES, S. E. Phenolicacids as antioxidants. Revista de Nutrição (Campinas), v. 15, n. 1, p. 71-81, 2002.

SPINELLA, M. The Psychopharmacology of herbal Medications:Plants Drugs that Atler Mind, Brain and Behavior.United States: MIT Press LTd, 2001. 590 p.

SUHAD, A. et al. Study the Antibacterial Activity of Zingiber officinale roots against some of pathogenic bacteria. Al Mustansiriya Journal Science, v. 23, n. 3, p.63- 70, 2012.

SUMABRANIAN, V.; SUJA, S. Phytochemical Screening of Alpinia purpurata(Vieill). Research Journal of Pharmaceutical, Biological and Chemical Sciences, v. 2, n. 3, p. 866-871, 2011. 


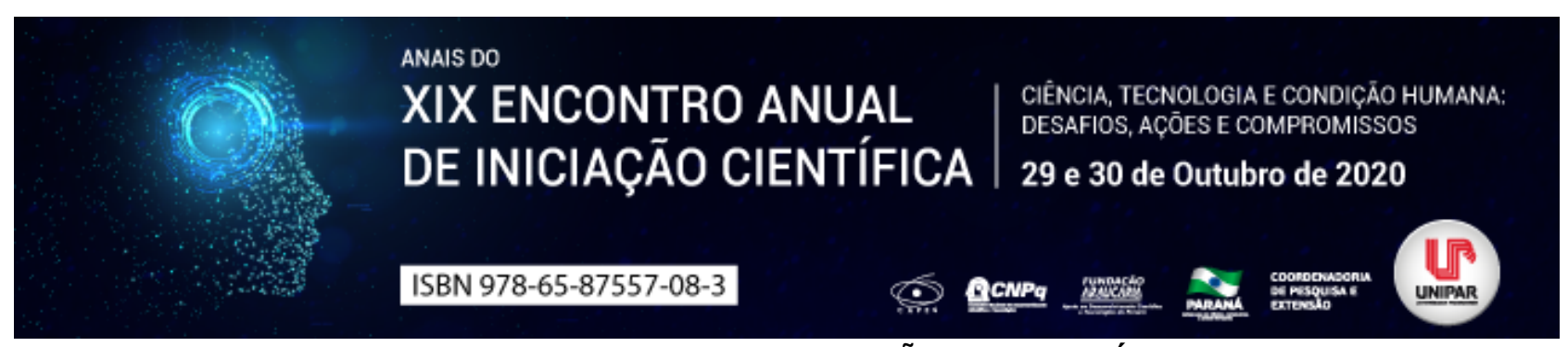

DIRETRIZES PARA O TRATAMENTO DE INFECÇÕES REPIRATÓRIAS EM GATOS

\begin{abstract}
${ }^{1}$ Sibely Aiva Flores, ${ }^{2}$ LILLIAN PEREIRA GOUVEIA, ${ }^{3}$ EMANUELY RAMOS TAMEIRÃO, ${ }^{4}$ KAROLYNE OLIVEIRA BASTOS, ${ }^{5}$ LUCIANA DE CASTRO BARCELOS, ${ }^{6}$ MARCOS FERRANTE
\end{abstract}

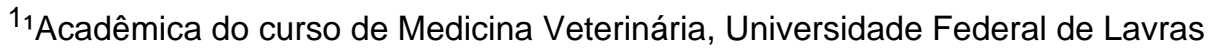

${ }^{1_{1}}$ Acadêmica do curso de Medicina Veterinária, Universidade Federal de Lavras

${ }^{2}{ }_{1}$ Acadêmica do curso de Medicina Veterinária, Universidade Federal de Lavras

${ }^{3_{1}}$ Acadêmica do curso de Medicina Veterinária, Universidade Federal de Lavras

${ }^{4_{1}}$ Acadêmica do curso de Medicina Veterinária, Universidade Federal de Lavras

${ }^{5}$ Docente do Departamento de Medicina Veterinária, Universidade Federal de Lavras
\end{abstract}

Introdução: As infecções bacterianas do trato respiratório de felinos podem ser primárias ou secundárias, e compreendem um conjunto de patologias de grande relevância na rotina veterinária. Entre as condições mais observadas, estão: doença do trato respiratório felino, bronquite, pneumonia e piotórax. No entanto, a falta de diretrizes para o tratamento de tais enfermidades contribui para o emprego inadequado de antibióticos. O sucesso da antibioticoterapia - e consequente prevenção de resistência bacteriana - está associado à escolha correta do fármaco, baseando-se em avaliação criteriosa do paciente e estudos acerca da eficácia dos antibióticos contra os patógenos mais comuns de cada infecção. Além disso, traçar um paralelo com a terapêutica na medicina pode auxiliar na eleição dos medicamentos, evitando-se aqueles de uso prioritário para seres humanos, e que, portanto, possuem maior risco de desenvolver cepas bacterianas resistentes.

Objetivo: Abordar os protocolos terapêuticos mais utilizados no tratamento de infecções respiratórias de origem bacteriana em gatos.

Desenvolvimento: A doença do trato respiratório felino é uma síndrome na qual o desenvolvimento de infecção bacteriana secundária é possível. Entre os sinais estão descargas nasais e oculares, espirros e conjuntivite (VERONEZI, 2017). Na infecção aguda, caso as secreções não se apresentem mucopurulentas, o uso de antibióticos não é recomendado; quando há secreção mucopurulenta, mas não se conhece o agente infeccioso, a administração de antibiótico também não é indicada. Na medicina, a antibioticoterapia é indicada somente quando não ocorre evolução do quadro dentro de 10 dias, ou caso os sinais piorem entre o quinto e sétimo dia. Em gatos, por sua vez, deve ser considerada a utilização de doxiciclina - $5 \mathrm{mg} / \mathrm{kg}$ por via oral (VO), duas vezes por dia (BID), ou $10 \mathrm{mg} / \mathrm{kg}$ VO, uma vez ao dia (SID), durante 7 a 10 dias - quando o animal apresentar, além de secreção mucopurulenta, febre, letargia ou anorexia no período de observação (10 dias) (LAPPIN et al., 2017). Nos casos de bronquite, a inflamação dos brônquios pode ter inúmeras causas, e o tratamento com antibióticos não é recomendado, haja vista que o quadro geralmente é autolimitante ou seja, não necessita de antibioticoterapia para haver melhora. Entretanto, caso o panorama clínico seja grave (febre, comprometimento alveolar, distrição respiratória, etc.), pode-se fazer uso empírico da doxiciclina (5 mg/kg VO; BID ou $10 \mathrm{mg} / \mathrm{kg}$ VO; SID, por 7 a 10 dias. Se o tratamento se mostrar efetivo, recomenda-se continuar até uma semana após desparecimento dos sintomas (LAPPIN et al., 2017). Pneumonias bacterianas são um desafio quanto ao tratamento, devendo ser considerado, portanto, o tipo da pneumonia, prescrições anteriores de antibióticos e principalmente identificação do agente. Em pneumonias aspirativas sem quadro de sepse, a utilização de cefalosporinas de primeira geração, como cefazolina - $25 \mathrm{mg} / \mathrm{kg}$ pela via subcutânea (SC), intramuscular (IM) ou intravenosa (IV), três vezes ao dia (TID), por 4 a 6 semanas, demostra ser eficiente. Se há sepse, a administração simultânea de enrofloxacina (5 mg/kg VO;SID) e marbofloxacina (2,7 - 5,5 mg/kg VO;SID) com antimicrobianos contra organismos Gram-positivos e anaeróbios, a exemplo de ampicilina (22 - $30 \mathrm{mg} / \mathrm{kg}$ IV;SC;TID) e clindamicina (10 - $15 \mathrm{mg} / \mathrm{kg}$ VO;SC;BID) é indicada (LAPPIN et al., 2017). Se a suspeita for de pneumonia por Streptococcus equi, o uso de amoxicilina com clavulanato de potássio é desnecessária, pois não há indícios que esta bactéria possua beta-lactamases. É comum a utilização concomitante de antimicrobianos e glicocorticoides na medicina, tendo em vista que infecções bacterianas causam imunossupressão na espécie humana. Contudo, na medicina veterinária, ainda são escassos dados que justifiquem o emprego do protocolo, que visa reduzir os efeitos da condição supracitada. O piotórax se manifesta por acúmulo de líquido séptico no espaço pleural, e nos felinos, a maioria das bactérias é oriunda da orofaringe. Pela escassez de dados, é contraindicada a aplicação de antibióticos no espaço pleural. A recomendação é administrar enrofloxacina (5 mg/kg IM;IV;SID) ou marbofloxacina (2,7 - 5,5 mg/kg VO;SID), com piperacilina-tazobactam (50 $\mathrm{mg} / \mathrm{kg} \mathrm{IV}$, quatro vezes ao dia), para animais imunocompetentes. Outro fármaco eficaz é a pradofloxacina (7,5 mg/kg VO;SID) (LAPPIN et al., 2017), duração ideal de 4 a 6 semanas. Ao se avaliar a lista da OMS, outra estratégia terapêutica pode ser implementada, por exemplo, utilizando-se ampicilina (20 mg/kg IV; TID) com enrofloxacina ( $5 \mathrm{mg} / \mathrm{kg}$ SC;VO;SID) (JESSEN et al., 2019). 
Conclusão: A escolha de antibióticos para o tratamento de infecções do trato respiratório felino deve ser criteriosa, e, além de considerar o histórico do animal, os exames físicos e o agente infeccioso a ser combatido, o médico veterinário deve priorizar aqueles medicamentos que não sejam de importância máxima para seres humanos, a fim de evitar casos de resistência bacteriana.

\section{Referências}

JESSEN, L. R.; DAMBORG, P.; SPOHR, A.; SØRENSEN, T. M.; LANGHORN, R.; GOERICKE-PESCH, S.; HOUSER, G.; WILLESEN, J.; SCHJÆERFF, M.; ERIKSEN, T.; JENSEN, V. F.; GUARDABASSI, L. Antibiotic Use Guidelines for Companion Animal Practice (2nd ed.). The Danish Small Animal Veterinary Association. V. 2, 2019. (https://www.ddd.dk/sektioner/familiedyr/antibiotikavejledning/Documents/AB_uk_2019.pdf). Acesso em: 15 ago. 2020.

LAPPIN, M. R.; BLONDEAU, J.; BOOTHE, D.; BREITSCHWERDT, E. B.; GUARDABASSI, L.; LLOYD, D. H.; PAPICH, M. G.; RANKIN, S. C.; SYKES, J. E.; TURNIDGE, J.; WEESE, J.S. Antimicrobial use Guidelines for Treatment of Respiratory Tract Disease in Dogs and Cats: Antimicrobial Guidelines Working Group of the International Society for Companion Animal Infectious Diseases. Journal of Veterinary Internal Medicine. 2017; v. 31, n. 2, p. 279-294, mar./abr. 2017.

ORGANIZACIÓN MUNDIAL DE LA SALUD. (2017). Critically important antimicrobials for human medicine. V.5, 2017. http://who.int/foodsafety/publications/antimicrobials-fifth/en/ Acesso em: 15 ago. 2020.

VERONEZI, Tayná Mayer. Estudo retrospectivo da prevalência de infecção bacteriana do trato respiratório superior através da análise da cultura bacteriológica e antimicrobiana em felinos domésticos. 2017. 53f. Monografia (Bacharelado em Medicina Veterinária)-Faculdade de Veterinária da Universidade Federal do Rio Grande do Sul, Porto Alegre, 2017. 


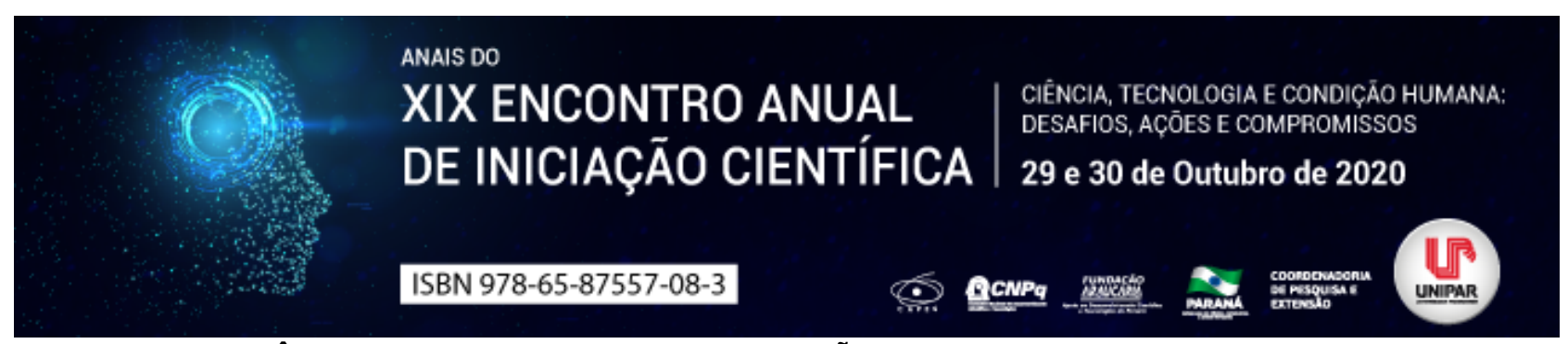

PARÂMETROS UTILIZADOS PARA INDUÇÃO DE CICLICIDADE EM NOVILHAS

\title{
${ }^{1}$ CELINA DOS SANTOS MONTEIRO, ${ }^{2}$ CARLOS RENATO DE FREITAS GUAITOLINI, ${ }^{3}$ MARIA LETICIA LINHARES MACHADO, ${ }^{4}$ AULY BEATRIZ TRINDADE, ${ }^{5}$ ROSIARA ROSARIA DIAS MAZIERO
}

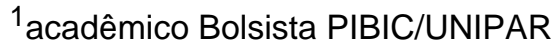 \\ ${ }^{1}$ Acadêmico do Curso de Programa Nacional de Pos-doutorado - PNPD/capes da UNIPAR \\ ${ }^{2}$ Acadêmica do Curso de Medicina Veterinária da UNIPAR \\ ${ }^{3}$ Acadêmica do Curso de Medicina Veterinária da UNIPAR \\ ${ }^{4}$ Docente da UNIPAR
}

Introdução: O Brasil possui aproximadamente 214,69 milhões de bovinos distribuído em uma área de 164,70 milhões de hectares, a taxa de ocupação é de 1,33cab/ha (IBEG, 2019). Porém a taxa de desfrute é baixa em relação a outros países produtores, a taxa de desfrute anual do rebanho nos Estados Unidos é de 38\%, na Austrália 30,9\% e no Brasil é de apenas 19,2\% (FERREIRA, 2012). Diante destes dados é notável a necessidade produzir mais arrobas por hectare sem a expansão de territórios, pela necessidade de ferramentas que melhorem a eficiência de nossos rebanhos. O desenvolvimento da eficiência da pecuária está diretamente ligado a redução do intervalo de partos (CLARO JÚNIOR et al., 2010).

Objetivo: Verificar se a realização de protocolo de indução de ciclicidade é eficaz, para o adiantamento da entrada dos animais nos programas de reprodução assistida.

Desenvolvimento: Tendo em vista que as biotecnologias da reprodução contribuem para o melhoramento genético do rebanho brasileiro e consequentemente valorizam os nossos animais, pelo aumento da produção cab/ha e aumento dos lucros dos produtores, a inseminação artificial em tempo fixo (IATF) é recomendada nos rebanhos bovinos independentemente da categoria das fêmeas, contanto que as mesmas apresentem um escore corporal adequado, boas condições nutricionais e sanitárias (FARIA 2019). Quando se trata de protocolos de adiantamento da ciclicidade em novilhas, a PGF2a (prostaglandina) é um dos hormônios indispensáveis e tem como ação principal a lise do corpo lúteo desencadeando uma nova onda de crescimento folicular. A administração de PGF2a como indutor de ciclicidade diminui o nível sérico de progesterona (P4), não apresentando melhoras na taxa de concepção quando utilizada no mesmo dia da inseminação (MARQUES, 2018).Sendo assim associa-se a aplicação de P4 com PGF2a para que seja possível a obtenção de uma melhor taxa de concepção (CARVALHO 2004). O GnRH (hormônio liberador de gonadotrofinas) é utilizado nos protocolos de ciclicidade, este por sua vez está relacionado a diminuição da perda embrionária, provoca aumento no nível de P4 circulante, e também causar luteinização dos folículos (MOHAMMADI 2019). O protocolo para indução de ciclicidade é baseado na inserção de dispositivo intravaginal de progesterona, deve permanecer por 12 dias, após esse período, o dispositivo é retirado e aplica-se fonte exógena de estrógeno. Recentemente estudos mostram que é possível a substituição do dispositivo intravaginal por progesterona injetável, sendo assim uma estratégia para propriedades que não possuam o dispositivo previamente utilizado (LEMES, 2017). Segundo RODRIGUES (2014) protocolos de IATF em novilhas, com início após 12 dias da indução tiveram maior diâmetro folicular e no momento da retirada do dispositivo e posteriormente maiores taxas de prenhez (45,5\% de prenhez positiva), aos 14 dias a taxa de prenhez menor $(40,6 \%)$.

Conclusão: Espera-se que as novilhas entrem em ciclicidade precocemente e consequentemente obtenha-se taxa de concepção elevada das fêmeas bovinas ao utilizar progesterona injetável.

\author{
Referências \\ CARVALHO, J.B.P. Sincronização da ovulação com dispositivo intravaginal de progesterona (CIDR) em novilhas Bos indicus, \\ Bos indicus x Bos taurus e Bos taurus. Tese (Doutorado em Medicina Veterinária) - São Paulo - SP, Universidade de São Paulo - \\ USP, 2004. 122p. \\ CLARO JÚNIOR, I; SÁ FILHO, O. G; PERES, R. F. G; AONO, F. H. S; DAY, M. L; VASCONCELOS, J. L. M. Reproductive \\ performance of prepubertal Bos indicus heifers after progesterone-based treatments. Theriogenology, v.74, p. $903911,2010$. \\ Instituto Brasileiro de Geografia e Estatística IBGE. 2017. Disponível em: . Acesso em: 18 Julho 2020. \\ FARIA, M. B; TAVARES, A. F. Desempenho reprodutivo de vacas nelore submetidas protocolos de inseminação artificial em \\ tempo fixo. Orientadora: Alessandra Epifânio Rodrigues. 48 f. 2019. Trabalho de conclusão de curso (Graduação em Zootecnia) \\ Universidade Federal Rural da Amazônia, Campus Paragominas, 2019. \\ FERREIRA, E. M.; FERRAZ JUNIOR, M. V. C.; NEPOMUCENO, D. D.; BIEHL, M. V.; Mendes, C.Q.; PIRES, A. V. Efeito da \\ produção de novilhas à pasto sobre a puberdade. In: Rosane Cláudia Rodrigues; Michelle de Oliveira Parante. (Org.).
}


SIMPRUPASTO: O uso da ciência e de tecnologias para a mudança de paradigmas. 1ed. Chapadinha: Edufma, 2012, v. 1, p. 128-158.

MARQUES, J. C. S. Aplicação de PGF2a no momento da inseminação artificial em tempo fixo em vacas mestiças de corte. 2018. 22 f. Trabalho de Conclusão de Curso (Graduação em Medicina Veterinária) Universidade Federal de Uberlândia, Uberlândia, 2018.

MOHAMMADI, A.; SEIFI, H.; FARZANEH, N; Effect of prostaglandin F2 $\alpha$ and GnRH administration at the time of artificial insemination on reproductive performance of dairy cows. Veterinary Research Forum, 2019; 10(2): 153-158. doi: 10.30466/vrf.2018.87502.2136

Coordenadoria de Pesquisa e Extensão - COPEX

Departamento de Editoraçāo e Divulgaçāo Científica - DEDIC 


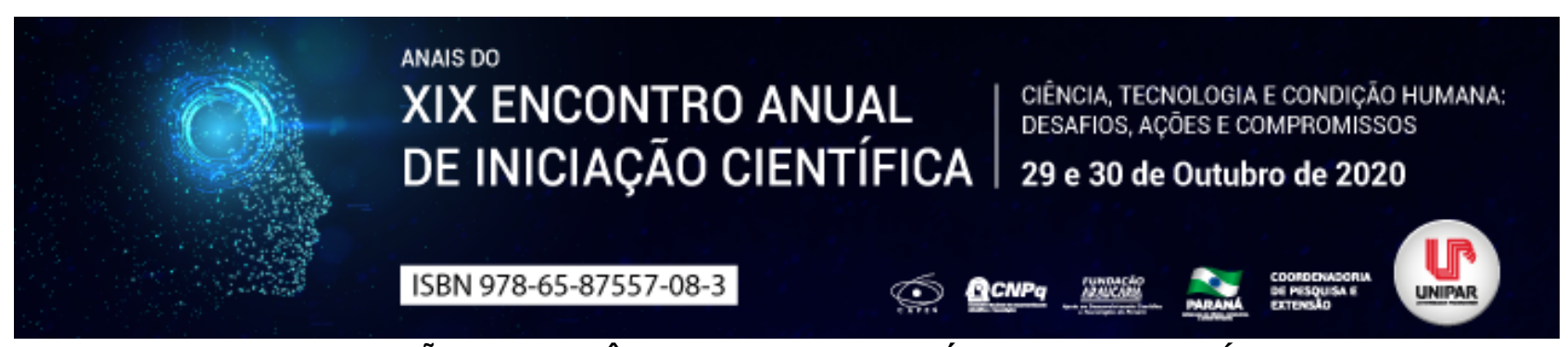

REGRESSÃO ESPONTÂNEA DE TUMOR VENÉREO TRANSMISSÍVEL

\begin{abstract}
${ }^{1}$ MARIANA COLTRO, ${ }^{2}$ GEOVANA CRISTINA SARTORI ANDRE, ${ }^{3}$ ALYSSON RAMALHAIS, ${ }^{4}$ ALEC GABRIEL PEREIRA ROCHA, ${ }^{5}$ BRUNA MENEGATE NASCIMENTO, ${ }^{6}$ ANA MARIA QUESSADA
\end{abstract}

\author{
${ }^{1}$ Acadêmico do PIC/UNIPAR \\ ${ }^{1}$ Bolsista PIBIC/UNIPAR \\ ${ }^{2}$ Acadêmico do Curso de Mestrado Em Ciencia Animal Com Enfase Em Produtos Bioativos \\ ${ }^{3}$ Bolsista PIBIC/UNIPAR \\ ${ }^{4}$ Aprimoranda Medicina Veterinaria, UNIPAR \\ ${ }^{5}$ Docente da UNIPAR
}

Introdução: O tumor venéreo transmissível (TVT) é uma neoplasia contagiosa de células redondas, que acomete cães de ambos os sexos. Também é conhecido por tumor de Sticker , granuloma venéreo ou sarcoma transmissível (JOHNSON, 1994). O tumor afeta principalmente a mucosa da genitália externa dos cães. A transmissão se dá pelo coito, quando então há o contato das células tumorais vivas com as membranas mucosas do animal (JOHNSTON, 1998). A transmissão venérea é a mais comum (JOHNSON,1994), embora o TVT possa ser facilmente transplantado para outros locais anatômicos por meio dos atos de lamber e farejar (JOHNSON, 1994; O'KEEFE, 1997). Por isso pode se desenvolver em outras regiões do corpo, sobretudo nas mucosas oral, ocular, nasal e anal (JOHNSON, 1994). O TVT é sensível a diversos agentes quimioterápicos. Entretanto a vincristina, administrada uma vez por semana como um agente único, é extremamente eficaz. A remissão completa é obtida em mais de 90\% dos cães tratados e os animais permanecem livres da doença (SILVA et al., 2007).

Objetivo: Relatar um caso raro de regressão espontânea de tumor venéreo transmissível canino.

Relato de Caso: Foi atendida no Hospital Veterinário Universitário (HVU) da Universidade Federal do Piauí uma cadela, três anos, sem raça definida, com presença de grande massa localizada na genitália externa. O proprietário relatou que a cadela apresentava a massa há aproximadamente quatro meses, mas que a presença do tumor não afetou o apetite do animal nem o ato de urinar. Relatou também que o animal tinha o hábito de lamber a vulva. Ao exame físico foi observado que o animal apresentava parâmetros normais, porém com presença de massa tipo couve-flor de aproximadamente 5 cm de diâmetro localizado em toda a extensão da vulva. A massa apresentava-se bastante vascularizada, hiperêmica, com secreção purulenta, odor fétido e áreas de necrose. Foi solicitado exame citológico e histopatológico, que revelaram a presença de células características de tumor venéreo transmissível. Depois de diagnosticada a doença o proprietário foi avisado para dar início ao tratamento semanal com sulfato de vincristina. Entretanto, o mesmo relatou que o nódulo localizado na vulva da cadela havia sumido após 10 dias da primeira ida ao HVU. A cadela foi novamente levada ao hospital para que o médico veterinário pudesse examiná-la e comprovar o caso de regressão. Ao exame físico foi observado que o tumor havia regredido completamente, porém a mucosa da genitália apresentava-se moderadamente hiperêmica. Foi novamente solicitado exame citológico, que revelou a ausência das células tumorais. Como não foi realizado nenhum tratamento no animal e o exame citológico não acusou a presença de TVT, o caso foi diagnosticado como regressão.

Discussão: Em cães adultos e imunocompetentes o TVT pode ter regressão espontânea e fornecer certo grau de imunidade ao animal (PÉREZ; DAY, MOZOS, 1998). Isso ocorre quando o animal apresenta o tumor de três a seis meses (HIGGINS, 1966). No caso relatado o animal tinha três anos (adulto), possuía parâmetros normais ao exame físico e apresentava o tumor há quase quatro meses. A regressão, de TVT, está associada com aumento do infiltrado de linfócitos no tumor e caracteriza-se por aumento de apoptose das células tumorais e fibrose (GONZALEZ et al., 2000). O infiltrado de linfócitos foi observado no exame histopatológico e o exame hematológico revelou que o organismo do animal estava reagindo contra a doença (resposta celular), pelo aumento dos leucócitos totais circulantes. Nesse caso, o animal não apresentava dificuldade ao urinar, porém o tumor apresentava secreção purulenta constatando que havia infecção bacteriana (VARASCHIN et al., 2001; SILVA et al., 2007). Provavelmente a hiperemia observada na vulva da cadela após a regressão se deva à infecção pré-existente. Embora a cadela tivesse o hábito de lamber a vulva não havia sinais de lesões tumorais em outras regiões, que podem ser afetadas pela lambedura e farejo (JOHNSON, 1994; O’KEEFE, 1997). Esse caso chamou atenção, pois não é comum casos de regressão espontânea de tumor venéreo transmissível canino.

Conclusão: Em raros casos pode ocorrer regressão espontânea de TVT em cães, o que foi observado no caso em questão.

\title{
Referências
}

HIGGINS, D.A. Observations on the canine transmissible venereal tumour as seen in the Bahamas. Veterinary Record, v.79, n.3, 
p.67-71, 1966.

GONZALEZ, C. M. et al. Canine transmissible venereal tumour: a morphological and immunohistochemical study of 11 tumours in growth phase and during regression after chemotherapy. Journal of Comparative Pathology, v.122, p.241-248, 2000.

JOHNSTON, S.D. Sistemas reprodutivos. In: SLATTER, D. (Ed.). Manual de cirurgia de pequenos animais. 2. ed. v.2. São Paulo: Manole, 1998. Cap. 159. p.2566-2583

JOHNSON, C.A. Infecções genitais e tumor venéreo transmissível. In: NELSON, R.W.; COUTO, C.G. Fundamentos de medicina interna de pequenos animais. Rio de Janeiro: Guanabara Koogan S.A, 1994.Cap.62, p.522-525

O'KEEFE, D.A. Tumores do sistema genital e glândulas mamárias. In: ETTINGER, S.J; FELDMAN, E.C.

(Ed.). Tratado de medicina interna veterinária: moléstias do cão e do gato. 4. ed. v.2. São Paulo: Manole, 1997. Cap.131. p.2344-2351.

SILVA, M.C.V. et al. Avaliação epidemiológica, diagnóstica e terapêutica do tumor venéreo transmissível (TVT) na população canina atendida no hospital veterinário da UFERSA. Acta Veterinaria Brasílica, v.1,n.1, p.28-32, 2007.

VARASCHIN, M.S. et al. Tumor venéreo transmissível canino na região de Alfenas, Minas Gerais: formas de apresentação clínico-patológicas. Revista Clínica Veterinária, v.32, p.40- 48, 2001. 


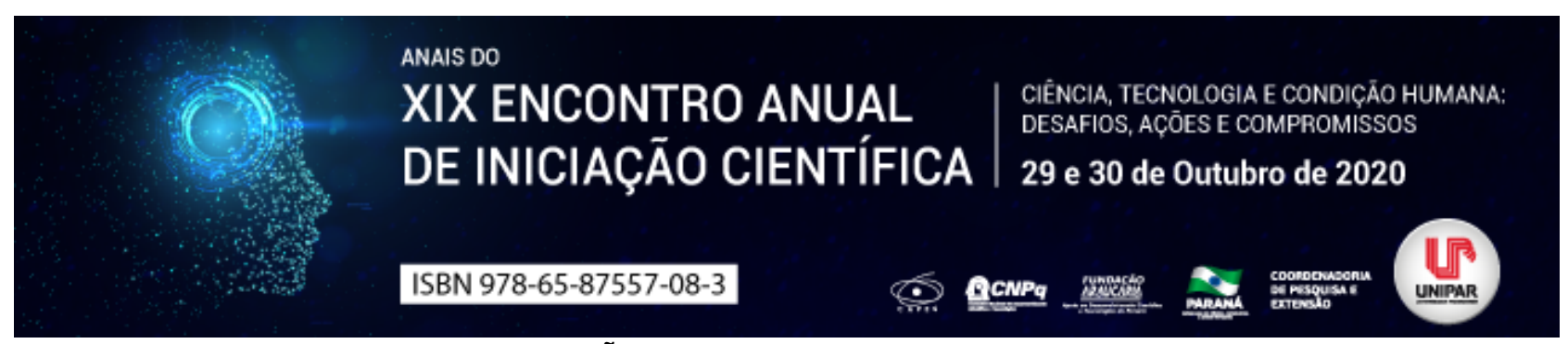

ATUALIZAÇÃO SOBRE PIOMETRA EM CADELAS

\title{
${ }^{1}$ THAYS KAROLLYNI AMARAL GOMES, ${ }^{2}$ CARLOS RENATO DE FREITAS GUAITOLINI, ${ }^{3}$ ROSIARA ROSARIA DIAS MAZIERO
}

\author{
${ }^{1}$ Acadêmico do PIC/UNIPAR \\ ${ }^{1}$ Acadêmico do Curso de Programa Nacional de Pos-doutorado -pnpd/capes da UNIPAR \\ ${ }^{2}$ Docente da UNIPAR
}

Introdução: A piometra é caracterizada por um processo inflamatório do trato genital das fêmeas caninas, levando ao acúmulo de secreção purulenta no lúmem uterino que provém de uma hiperplasia endometrial cística associada a uma infecção bacteriana (Weiss et al., 2004; Toniollo et al., 2000; Jones et al., 2007). O seu estabelecimento é resultado da influência hormonal à virulência das infecções bacterianas e à capacidade individual de combater essas infecções (Weiss et al., 2004; Toniollo et al., 2000; Jones et al., 2007). Acomete o sistema reprodutor de cadelas mais idosas, entre os 6 e 11 anos de idade, embora seja comum, ainda é preocupante, pois o número de letalidade é alto, e se não for tratada corretamente pode levar a óbito (Ferreira, 2006). Este resumo apontará os sintomas, diagnóstico e também o tratamento para esta doença (Wanke; Gobello, 2006).

Objetivo: Revisar sobre os aspectos clínicos e possíveis tratamentos da piometra canina.

Desenvolvimento: A piometra é causada a partir de certas bactérias que são capazes de se reproduzir no útero, como a Escheria coli (mais comum). Essa doença ocorre a partir de mudanças hormonais no útero, pela atividade indevida de respostas à progesterona, por algum motivo desconhecido, resultando em uma hiperplasia endometrial cística. Assim, ocorre acúmulo de líquidos nas glândulas endometriais e no lúmen uterino (Henriques et al., 2016). De acordo com Smith (2006), existem 2 tipos de piometra: de cérvix aberta e fechada, na piometra de cérvix aberta haverá corrimento vaginal e os cornos uterinos não estarão muito dilatados, as paredes do útero ficam espessas, com hipertrofia e fibrose de miométrio. Já na piometra de cérvix fechada, as paredes do útero se encontrarão finas e o útero distendido, com o endométrio atrofiado e infiltrado com linfócitos e plasmócitos. Os sinais clínicos presentes são: letargia, anorexia, depressão, poliúria, polidipsia, vômito, diarréia, perda de peso, presença de corrimento vulvar e desidratação (Troxel et al., 2002). O diagnóstico depende do histórico clínico, exames físicos e complementares (Troxel et al., 2002). Pelo histórico saberemos se foi utilizado estrógenos para prevenir a gestação, se foi usado progestina para suprimir o estro, a fase do ciclo estral em que a cadela está e ocorrência de partos. No tratamento, a ovariosalpingohisterectomia $(\mathrm{OSH})$ é indicada, porém se o animal tiver um grande risco para a cirurgia, ele é exposto ao tratamento clínico, onde não tem perigo de riscos anestésicos e cirúrgicos. O tratamento medicamentoso pode ser realizado com antiprogestágenos (aglepristone). Eles se fixam aos receptores uterinos com uma afinidade três vezes maior que a progesterona, diminuindo a concentração desta no útero, aumentando a contração do miométrio e promovendo dilatação da cérvix. São usados principalmente associados a prostaglandina sintética. A dose utilizada é $10 \mathrm{mg} / \mathrm{kg}$ nos dias um, dois, oito, quinze e trinta do tratamento (Wanke; Gobello, 2006). Embora o tratamento clínico não seja indicado pela maioria dos autores, nos casos de piometra de cérvix fechada, Fieni (2006) em um estudo utilizando dezessete cadelas com essa patologia, observou abertura da cérvix após a segunda aplicação do aglepristone na dose de $10 \mathrm{mg} / \mathrm{kg}$ em todas as cadelas sendo que o período para a abertura foi em média de vinte e cinco horas, sugerindo que atualmente a cirurgia pode não ser o único tratamento nesses casos. Melandri et al., (2019) verificaram que 100\% (174/174) das fêmeas tratadas com aglepristone responderam ao tratamento. Além disso, verificaram também que a eficácia não depende do tipo de piometra, visto que dois dias após a administração de aglepristone, o colo uterino se abre nos casos de piometra fechada. A abertura cervical e as contrações uterinas induzidas indiretamente pela aglepristone são seguidas pela evacuação de um grande volume de secreção purulenta, com uma melhora significativa nas condições gerais. (Jurka P; Max A; Hawryńska K; Snochowski M, 2010). As condições sistêmicas também se beneficiam da antibioticoterapia, que tem uma ação dupla: primeiro, elimina bactérias do útero e, segundo, evita a difusão de microrganismos pela corrente sanguínea. (Wiebe VJ; Howard JP, 2009) Idealmente, os testes de cultivo e antibiograma devem ser realizados antes do início de uma antibioticoterapia empírica, mas no caso desta doença, a antibioticoterapia pode ser iniciada no momento do diagnóstico para garantir uma recuperação rápida e segura da cadela. (Wiebe VJ; Howard JP, 2009)

Conclusão: Com isso, médicos veterinários devem atentar-se a esta doença, pois ela é frequente, e carrega consigo o desencadeamento para outras doenças com grande mortalidade, assim, nossa obrigação é examinar e diagnosticar o paciente rapidamente, porque tratando-a mais cedo, rápido, e corretamente, as chances que o paciente tem de vencer a doença são maiores.

\section{Referências}

FIENI, F. Clinical evaluation of the use of aglepristone, with or without cloprostenol, to treat cystic endometrial hyperplasiapyometra complex in bitches. Theriogenology, v. 66, p. 1550-1556, 2006. 
HENRIQUES, S. et al. Immunomodulation in the canine endometrium by uteropathogenic Escherichia coli. Veterinary Research, v. 47, p. $114,2016$.

MELANDRI, M. et al. Fertility outcome after medically treated pyometra in dogs. Journal of Veterinary Science, v. 20, n. 4, e39, 2019.

RIBEIRO, L.G.R. Patologias do sistema reprodutor em cães e gatos. Mestranda do Programa de Pós-graduação em Ciência Animal nos Trópicos, 2016.

FILHO, S.P.G. el al Piometra em cadelas: revisão de literatura. Revista Científica Eletrônica de Medicina Veterinária, v. 9, n. 18, Junho, 2012.

ROMAGNOLI, S. Canine Pyometra: Pathogenesis, Therapy and Clinical Cases, WSAVA, Junho, 2002.

SILVA, E.E.P. Piometra Canina. Tese (Graduação em Medicina Veterinária). Universidade Júlio de Mesquita Filho, São Paulo, 2009.

WANKE, M.M.; GOBELLO, C. Reproduction en Caninos y Felinos Domesticos. 1ª ed. Buenos Aires: Inter.-Medica editorial, 2006, 309p. 


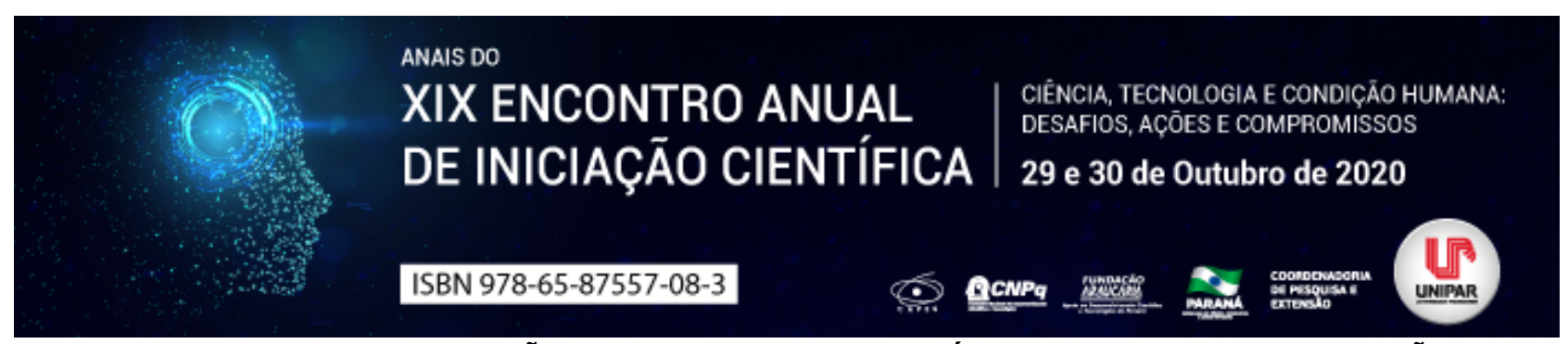

A DENGUE E A SUA RELAÇÃO COM O SANEAMENTO BÁSICO: UM ESTUDO DE REVISÃO

\author{
${ }^{1}$ CAROLINA LUZIANA DE LIMA VALERIO, ${ }^{2}$ MÁRIO MARQUES PEREIRA FILHO, ${ }^{3}$ CRISTIANE CLAUDIA MEINERZ, ${ }^{4}$ DANIELE \\ FERREIRA ONORIO, ${ }^{5}$ IRINEIA PAULINA BARRETA, ${ }^{6}$ ROSILEY BERTON PACHECO
}

\author{
${ }^{1}$ Acadêmica Bolsista do PIBIC/UNIPAR \\ ${ }^{1}$ Acadêmico Bolsista do PIBIC/UNIPAR \\ ${ }^{2}$ Docente da UNIPAR \\ ${ }^{3}$ Docente da UNIPAR \\ ${ }^{4}$ Docente da UNIPAR \\ ${ }^{5}$ Docente da UNIPAR
}

Introdução: A dengue é uma doença febril aguda, transmitida pelo Aedes aegypti. É considerada uma endemia em território brasileiro por apresentar um potencial de disseminação do mosquito vetor que são favoráveis por condicionantes climáticas tropicais e incidente em meio urbano (GOULART et al, 2016). De acordo com Maciel, Felipe e Lima (2015), as ações de saneamento têm como objetivo proporcionar a uma população um meio salubre que abranja todos os serviços básicos capaz de garantir saúde e qualidade de vida, mas quando são falhos geram ambientes patogênicos que propiciam a população água contaminada, acumulo de resíduos e situações precárias de higiene. Além de pontuar que a carência desses recursos pode estar relacionada propriamente aos casos da dengue no país.

Objetivo: Avaliar as condições dos serviços básicos de saneamento e sua relação com os casos de dengue por meio de revisão bibliográfica.

Desenvolvimento: A dengue é a arbovirose de maior incidência que se tornou um problema de saúde pública mundial. Apresentando quatro sorotipos diferentes que provocam alterações nas manifestações clínicas (BARBOSA e SILVA, 2015). O Aedes aegypti é um mosquito urbano, doméstico, que busca no interior das casas o seu acesso ao homem (GOULART et al, 2016). Para Brito (2018) a precariedade dos serviços de saneamento básico pode ser um dos fatores que impulsionam a proliferação do mosquito. $\mathrm{O}$ autor define o saneamento como um conjunto de serviços essenciais que permite o acesso à água potável, a coleta e ao tratamento dos esgotos, drenagem e limpeza urbana e a gestão dos resíduos sólidos. Esses serviços têm como finalidade promover saúde pública e propiciar um meio saudável. No Brasil a escassez das ações de saneamento atinge 35 milhões de pessoas em falta de abastecimento de água e apenas $46 \%$ de todo o esgoto produzido no país é tratado (TRATA BRASIL, 2020). Barbosa e Silva (2015) explicam que o armazenando de água por falta do serviço de abastecimento gera um ambiente de reprodução propício para o vetor. A falta da coleta de lixo resulta em objetos destinados em locais inadequados que servem de acúmulo para águas da chuva e se tornam criadouros do mosquito (BRITO, 2018). Queiroz, Silva e Heller (2020) pontuam que 1.544 .987 casos notificados no ano de 2019 no Brasil podem ter sido causados pela privação de usufruir do fornecimento de água e de ambientes saneados. Os expressivos números de portadores da doença retratam problemas sociais que afetam toda a população, mas que a grande parcela se refere aqueles que não são contemplados pelos serviços básicos. $\mathrm{E}$ esses dados são indícios das relevantes pesquisas que tem buscado identificar a relação entre as arboviroses e os serviços de saneamento. De acordo com Maciel, Felipe e Lima (2015) como prevenção para essas doenças é preciso que seja feitos investimentos nos serviços de saneamento básico porque quando a água é distribuída de maneira potável, o esgoto é coletado e tratado, o lixo tem uma correta destinação e a drenagem urbana exerce sua função, esses serviços deixam de afetar a qualidade de vida e passam a contribuir com a diminuição da proliferação de doenças, mas não com e erradicação, por se tratar de um conjunto de fatores que dependem da conscientização da população e de investimentos na infraestrutura por parte das políticas públicas.

Conclusão: A dengue é uma doença de grande ocorrência no Brasil e proporciona impactos para a saúde pública. Os serviços de saneamento básico não atendem a toda a população e essa carência reflete na saúde das pessoas. Relacionar a precariedade dos serviços de saneamento básico com os possíveis casos de dengue é um aspecto importante e deve ser considerado no planejamento e controle desses recursos ao evidenciar que a ineficiência seja capaz de contribuir para uma maior incidência desta doença, já que o Brasil apresenta baixos índices de saneamento.

\title{
Referências
}

BARBOSA, Isabelle Ribeiro; SILVA, Lúcio Pereira da. Influência dos determinantes sociais e ambientais na distribuição espacial da dengue no município de Natal-RN. Revista Ciência Plural. Natal, v.1, n.3, p. 62-75, 2015.

BRITO, Rildonn Raniel Silva. Análise espacial de casos notificados de dengue e sua relação com as condições de 
saneamento básico: um estudo na cidade de Parnaíba-PI. 2018. 48f. Trabalho de conclusão de curso (monografia) Tecnologia em Geoprocessamento, Instituto Federal de Educação, Ciência e Tecnologia, Teresina, 2018.

GOULART, Sheila de Oliveira, et al. Dengue no Brasil: Gestão de políticas públicas de controle e erradicação. Revista Estudo e Debate. Lajeado, v.23, n.2, p. 280-295, 2016.

Instituto Trata Brasil. Ranking do Saneamento. $2020 . \quad$ Disponível http://tratabrasil.com.br/images/estudos/itb/ranking_2020/Relatorio_Ranking_Trata_Brasil_2020_Julho_.pdf. Acesso em 16 Jun de 2020

MACIEL, Ana Beatriz Câmara; FELIPE, Jairo Alves; LIMA, Zuleide Maria Carvalho. Os problemas de saneamento e seus impactos sobre a saúde pública do município de Dona Inês-PB. Revista OKARA: Geografia em debate. João Pessoa. v. 9, n.3, p. 524-541, 2015.

QUEIROZ, Josiane Teresinha Matos de; SILVA, Priscila Neves; HELLER, Léo. Novos pressupostos para o saneamento no controle de arboviroses no Brasil. Cadernos de Saúde Pública. Rio de Janeiro, v. 36, n. 5, maio. 2020.

Coordenadoria de Pesquisa e Extensão - COPEX

Departamento de Editoraçāo e Divulgaçāo Científica - DEDIC 


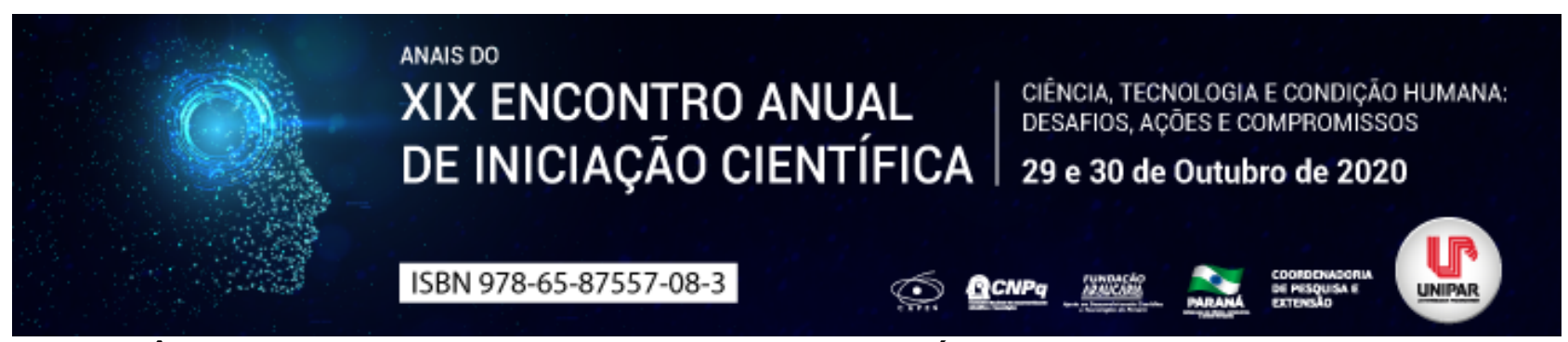

IMPORTÂNCIA DA PRESENÇA DE TANINOS NAS PARTES AÉREAS DA Piper amalago L. - Piperaceae

\begin{abstract}
${ }^{1}$ MARCELLA RIBEIRO DA COSTA, ${ }^{2}$ GIANI ANDREA LINDE, ${ }^{3}$ CARLA MARIA MARIANO FERNANDEZ, ${ }^{4}$ ZILDA CRISTIANI GAZIM
\end{abstract}

${ }^{1}$ Doutoranda em Biotecnologia Aplicada à Agricultura, Unipar, Umuarama PR

${ }^{1}$ Docente do Programa de Pós-graduação em Biotecnologia Aplicada à Agricultura, Unipar, Umuarama PR

${ }^{2}$ Docente do Programa de Pós-graduação em Biotecnologia Aplicada à Agricultura, Unipar, Umuarama PR

${ }^{3}$ Docente da UNIPAR

Introdução: A importância da medicina alternativa, em especial no Brasil, baseada em plantas medicinais, deve-se ao elevado custo do desenvolvimento de compostos sintéticos, já que a maioria da matéria-prima é importada da China e Índia, inviabilizando desta forma, sua aquisição pela população. Vale salientar que a utilização de plantas medicinais traz vantagens ambientais já que são produtos biodegradáveis e seu suprimento é autossustentável devido à diversidade da flora medicinal (HAMMOND et al., 1997). A família Piperaceae é predominante da América do Sul e, o gênero Piper tem cerca de 2000 espécies (QUIJANO-ABRIL, CALLEJAS-POSADA e MIRANDA-ESQUIVEL, 2006). Piper amalago L. é um arbusto pertencente à família Piperaceae, nativa do México, conhecida popularmente no Brasil como jaborandi-manso, jaborandi-falso e jaborandinhandi. Vários estudos relataram que as espécies do gênero Piper apresentam em sua composição compostos fenólicos, amidas, flavonoides, terpenos, alcaloides e taninos (MGBEAHURUIKE et al., 2017). Plantas ricas em taninos são empregadas na medicina tradicional como remédios para o tratamento de diversas moléstias (HASLAM, 1996). Taninos são compostos fenólicos derivados do metabolismo secundário de plantas que podem ser divididos em dois grupos: taninos condensados e hidrolisados (COSTA et al., 2008). Taninos condensados são oligômeros e polímeros formados pela ligação de dois ou mais monômeros de flavan-3-ol (catequina) ou flavan-3-4-diol. Estão presentes em gimnospermas e angiospermas, principalmente em plantas lenhosas e em outras classes de vegetais muito utilizados para a alimentação humana e animal (SALUNKHE e CHAVAN., 1989). Os taninos hidrolisáveis são compostos que após hidrólise produzem carboidratos e ácidos fenólicos. São unidos por ligações éster-carboxila, sendo prontamente hidrolisáveis em condições ácidas ou básicas (HAGERMAN e BUTLER, 1978). São encontrados em abundância em folhas, frutas, vagens de dicotiledôneas, mas não têm sido detectados em monocotiledôneas (LEWIS e YAMAMOTO, 1989).

Objetivo: Investigar a presença de taninos nas partes aéreas (folhas e galhos) da Piper amalago L.

Metodologia: Inicialmente o material vegetal foi coletado no Horto Medicinal da Unipar - Universidade Paranaense (07/03/2020), no período matutino, localizado em Umuarama - PR. Posteriormente, as partes aéreas do material vegetal (folhas e galhos) foram secas em temperatura ambiente e, a secagem foi confirmada através do cálculo de teor de umidade, obtendo uma perda de água de $79,40 \%$. Em seguida, os taninos foram avaliados utilizando $5,0 \mathrm{~g}$ das folhas pulverizadas e preparado um decocto com 100 $\mathrm{mL}$ de água destilada por 15 minutos. A seguir, foi adicionado uma solução de cloreto férrico a $1,0 \%$ onde o surgimento de um precipitado de tonalidade azul escuro indica a presença de taninos condensados, e verde, a presença de taninos hidrolisáveis. A confirmação dos taninos foi realizada pela reação de acetato básico de chumbo e ácido acético, indicando a formação de um precipitado esbranquiçado na presença de taninos hidrolisáveis.

Resultados: Foi constatado através do teste de cloreto férrico $\left(\mathrm{FeCl}_{3}\right)$, a formação de uma coloração verde intenso sugerindo a presença de taninos hidrolisáveis, que foi confirmado pelo teste de identificação, onde verificou-se a formação de um precipitado esbranquiçado com o acetato de chumbo $\left(\mathrm{Pb}(\mathrm{Aco})_{2}\right)$.

Discussão: A presença de taninos hidrolisados nas folhas de Piper amalago também foi confirmada por Ravani et al. (2013) que identificaram a presença de taninos no extrato etanólico das partes vegetativas aéreas obtido por Soxhlet de Piper amalago coletada em Curitiba, Paraná, Brasil. O papel biológico dos taninos nas plantas tem sido investigado e acredita-se que esteja envolvido na defesa química das plantas contra o ataque de herbívoros vertebrados ou invertebrados (TEMMINK et al., 1989) e contra microrganismos patogênicos (TAKECHI et al., 1985). Os taninos auxiliam no processo de cicatrização de feridas, queimaduras e inflamações através da formação de uma camada protetora (complexo taninos/proteínas e/ou polissacarídeos) sobre a pele ou mucosa danificada (HASLAM, 1989). Os taninos também apresentam baixa digestibilidade, podem também ter efeitos benéficos, como melhorar a absorção de aminoácidos e efeito anti-helmíntico (COSTA et al., 2008). Além disso os taninos também têm aplicação na indústria alimentícia como clareadores e antioxidantes de cerveja, vinhos e sucos de frutas (DA CRUZ MONTEIRO e BRANDELLI, 2017).

Conclusão: Através da prospecção fitoquímica foi possível constatar que o decocto das partes aéreas de Piper amalago L. apresenta taninos hidrolisados em sua composição química, mostrando o potencial desta planta para futuras aplicações em 


\section{Referências}

COSTA, C. T. C. et al. Taninos e sua utilização em pequenos ruminantes. Embrapa Caprinos e Ovinos-Artigo em periódico indexado (ALICE), 2008.

DA CRUZ MONTEIRO, Siomara; BRANDELLI, Clara Lia Costa. Farmacobotânica: Aspectos Teóricos e Aplicação. Artmed Editora, 2017.

HAGERMAN, Ann E.; BUTLER, Larry G. Protein precipitation method for the quantitative determination of tannins. Journal of Agricultural and Food chemistry, v. 26, n. 4, p. 809-812, 1978.

HAMMOND, J. A.; FIELDING, D.; BISHOP, S. C. Prospects for plant anthelmintics in tropical veterinary medicine. Veterinary research communications, v. 21, n. 3, p. 213-228, 1997.

HASLAM, Edwin. Plant polyphenols: vegetable tannins revisited. CUP Archive, 1989.

HASLAM, Edwin. Natural polyphenols (vegetable tannins) as drugs: possible modes of action. Journal of natural products, v. 59, n. 2, p. 205-215, 1996.

LEWIS, Norman G.; YAMAMOTO, Etsuo. Tannins their place in plant metabolism. In: Chemistry and significance of condensed tannins. Springer, Boston, MA, 1989. p. 23-46.

MGBEAHURUIKE, Eunice Ego et al. Bioactive compounds from medicinal plants: Focus on Piper species. South African Journal of Botany, v. 112, p. 54-69, 2017.

QUIJANO-ABRIL, Mario Alberto; CALLEJAS-POSADA, Ricardo; MIRANDA-ESQUIVEL, Daniel Rafael. Areas of endemism and distribution patterns for Neotropical Piper species (Piperaceae). Journal of Biogeography, v. 33, n. 7, p. 1266-1278, 2006.

RAVANI, Greici T. et al. Investigação Fitoquímica e antioxidante de partes vegetativas aéreas de Piper amalago L. Cadernos da Escola de Saúde, v. 2, n. 10, 2013.

SALUNKHE, Dattajirao K.; CHAVAN, J. K. Dietary tannins: consequences and remedies. CRC Press, 1989.

TAKECHI, Masayuki et al. Structure and antiherpetic activity among the tannins. Phytochemistry, v. 24, n. 10, p. 2245-2250, 1985.

TEMMINK, J. H. M. et al. Acute and sub-acute toxicity of bark tannins in carp (Cyprinus carpio L.). Water Research, v. 23, n. 3, p. 341-344, 1989. 


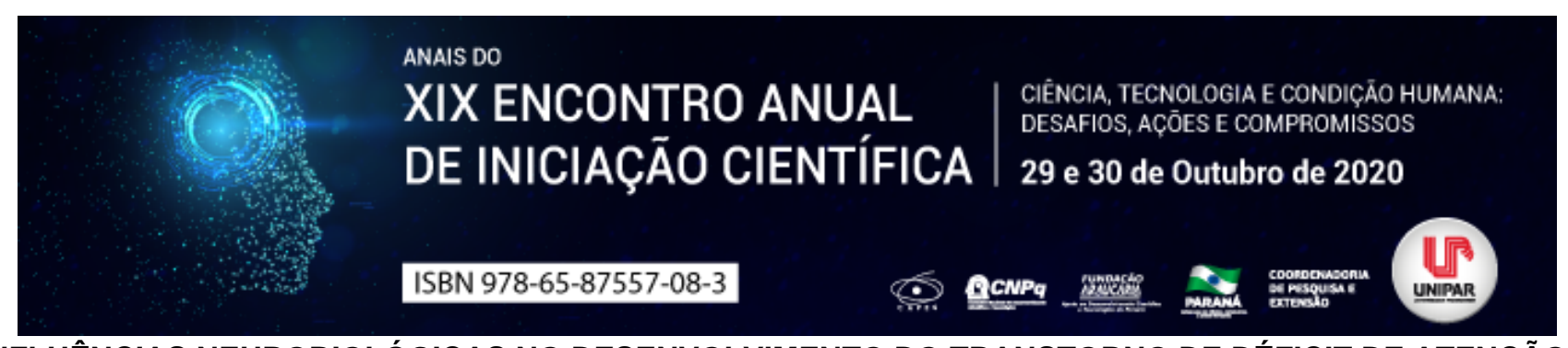

INFLUÊNCIAS NEUROBIOLÓGICAS NO DESENVOLVIMENTO DO TRANSTORNO DE DÉFICIT DE ATENÇÃO E HIPERATIVIDADE

\author{
${ }^{1}$ MARIA LUIZA MARCHI SILVA, ${ }^{2}$ VITOR ROQUE SAUER, ${ }^{3}$ CAMILA DE MORAES GOLÇALVES, ${ }^{4}$ ROSILEY BERTON \\ PACHECO
}

\footnotetext{
${ }^{1}$ Acadêmica de Medicina da UNIPAR

${ }^{1}$ Acadêmico de Medicina da UNIPAR

${ }^{2}$ Acadêmica de Pedagogia da UNIP

${ }^{3}$ Docente da UNIPAR
}

Introdução: O Transtorno de Déficit de Atenção e Hiperatividade (TDAH) é considerado um dos transtornos psiquiátricos infantis mais comuns (LAVAGNINO; BARBERO; FOLGUERA, 2018). É caracterizado pela desatenção, hiperatividade e impulsividade, sendo desencadeado geralmente durante a infância e pode persistir até a idade adulta (DUTRA et al., 2017). Suas causas podem estar ligadas a processos psicológicos básicos, evolutivamente ligados a uma disfunção do sistema nervoso central (CARBONI ROMÁN et al., 2006).

Objetivo: Reconhecer os aspectos neurobiológicos envolvidos no Transtorno de Déficit de Atenção e Hiperatividade (TDAH).

Desenvolvimento: O TDAH é um transtorno neurobiológico caracterizado com sintomas de impulsividade, inquietude e desatenção. Segundo Sibley et al. (2016), os primeiros sinais do transtorno são identificados na infância pelos pais e professores que associam a dificuldade de aprendizado e baixo rendimento escolar com a doença. É estimado que cerca de 3 a $5 \%$ das crianças de todas as regiões são acometidas pela doença sendo mais prevalente em meninos do que meninas (KARANDE, 2005). Nos cinco primeiros anos de vida das crianças é possível observar descompromisso com as atividades escolares, passando de uma atividade a outra sem o respectivo término, já em adultos a doença é responsável por problemas de desatenção, comprometendo assim a vida cotidiana e profissional (CRUZ; OKAMOTO; FERRAZZA, 2016). Dutra et al. (2017), mostra que há uma menor atividade cerebral do córtex pré-frontal dos portadores, sendo esta região responsável por inibição comportamental, atenção seletiva, autocontrole, criação de estratégias para resolver problemas e planejamentos. Há estudos sobre alterações genéticas nos sistemas dopaminérgico, noradrenérgico e serotoninérgico, sendo principal o neurotransmissor relacionado a dopamina (DE SOUSA VIÉGAS; DE OLIVEIRA, 2014).

Conclusão: Tendo em vista os aspectos observados, compreende-se que o TDAH é um transtorno neurobiológico, de acordo com estudos sua causa é de fator hereditário, afetando crianças e adultos, o transtorno apresenta problemas de atenção e/ou hiperatividade, problemas de organização, dificuldades em cumprir regras e horários, dificultando o desempenho escolar, profissional e social do indivíduo.

\title{
Referências
}

CARBONI ROMÁN, A. et al. Bases neurobiológicas de las dificultades de aprendizaje. Revista de neurología, 2006.

CRUZ, M. G. A.; OKAMOTO, M. Y.; FERRAZZA, D. de A. O caso Transtorno do Déficit de Atenção e Hiperatividade (TDAH) e a medicalização da educação: uma análise a partir do relato de pais e professores. Interface - Comunicação, Saúde, Educação, [S.L.], v. 20, n. 58, p. 703-714, 15 abr. 2016.

DE SOUSA VIÉGAS, L.; DE OLIVEIRA, A. R. F. TDAH: conceitos vagos, existência duvidosa. Nuances: estudos sobre Educação, v. 25, n. 1, p. 39-58, 2014.

DUTRA, T. et al. Estimulação cerebral não invasiva excitatória sobre a atenção de adultos com sintomas do transtorno de déficit de atenção e hiperatividade. Summa Psicológica UST, v. 14, n. 2, p. 72-83, 2017.

KARANDE, S. Attention deficit hyperactivity disorder: a review for family physicians. Indian Journal Of Medical Sciences, [S.L.], v. 59, n. 12, p. 547, 2005. Scientific Scholar.

LAVAGNINO, N. J.; BARBERO, S.; FOLGUERA, G. Caracterización, alcances y dificultades de lasl" bases biológicasl" del Trastorno por Déficit de Atención e Hiperactividad (TDAH). Un enfoque desde la Filosofía de la Biología. Physis: Revista de Saúde Coletiva, v. 28, p. e280110, 2018.

SIBLEY, M. H. et al. Defining ADHD symptom persistence in adulthood: optimizing sensitivity and specificity. Journal Of Child Psychology And Psychiatry, [S.L.], v. 58, n. 6, p. 655-662, 19 set. 2016. 


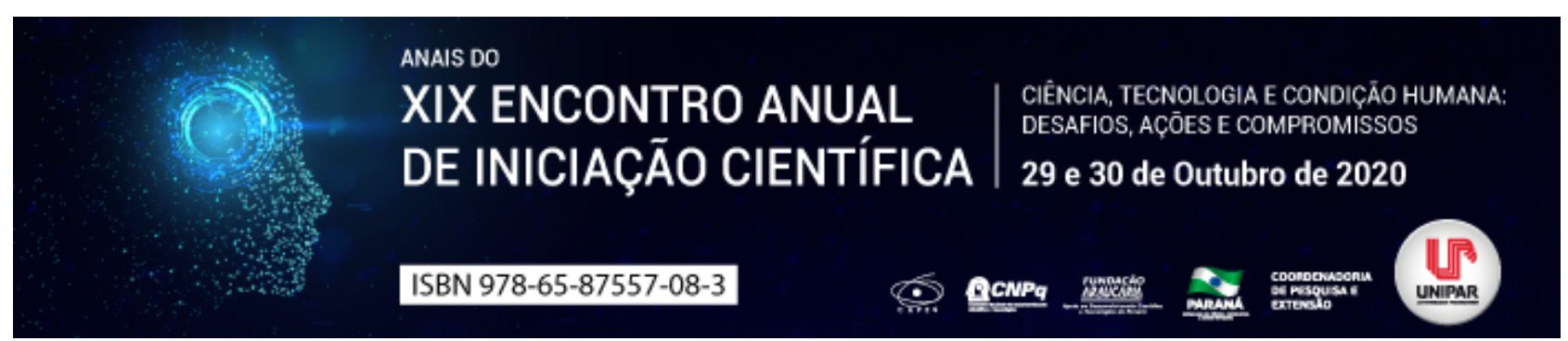

ATIVIDADES ANTIMICROBIANAS DE ÓLEOS ESSENCIAIS DE MIRTÁCEAS

\begin{abstract}
${ }^{1}$ KELLY REGINA DE JESUS DUARTE PEREIRA, ${ }^{2}$ MURILLO DAVID SILVA, ${ }^{3}$ GISELE BRITO FAVARIM, ${ }^{4}$ JESSE LAHOS BORGES, ${ }^{5}$ RANULFO PIAU JUNIOR
\end{abstract}

\author{
${ }^{1}$ Acadêmica do curso de Medicina Veterinária da Unipar - PIBIC/UNIPAR \\ ${ }^{1}$ Discente de Medicina Veterinária PIC/UNIPAR \\ ${ }^{2}$ Discente de Medicina Veterinária PIC/UNIPAR \\ ${ }^{3}$ Doutorando da Pós-graduação em Ciência Animal com Ênfase em Produtos Bioativos- UNIPAR \\ ${ }^{4}$ Docente do curso de Medicina Veterinária e do Mestrado e Doutorado em Ciência Animal com Ênfase em Produtos Bioativos- \\ UNIPAR
}

Introdução: O Brasil é agraciado com uma das maiores biodiversidades do planeta. Em relação à flora, existem o uso medicinal de espécies vegetais. Entre os diferentes produtos naturais originados de plantas, podem ser destacados os óleos essenciais (OE), os quais são misturas complexas de compostos orgânicos, originados do metabolismo secundário das plantas e utilizados para a preparação de misturas aromatizantes, licores, perfumes, artigos de higiene, para mascarar o cheiro de tinta e borracha, na síntese orgânica fina, como matéria-prima para a elaboração de produtos, entre outras aplicações (CRAVEIRO et al., 1981).

Objetivo: Fazer uma revisão sobre as atividades antimicrobianas de óleos essenciais de mirtáceas.

Desenvolvimento:A Familia Myrtaceae é muito utilizada para uso de tratamentos farmacêutico e terapêuticos. É bem representada também na maioria dos estudos florísticos e fitossociológicos (NARVAES et al., 2008). Muitas de suas espécies também são cultivadas, seja por conta dos frutos, seja com finalidade ornamental ou, ainda, para a extração de essências de valor comercial (SILVA et al., 2005). A atividade terapêutica dessas plantas pode ser atribuída aos óleos essenciais ou a alguma de suas substâncias isoladas, o que vem sendo comprovado cientificamente. O foco está sobre os gêneros Eugenia, Myrcia, Psidium e Campomanesia, cujas substâncias são utilizadas na medicina popular. Os óleos essenciais são compostos aromáticos voláteis são ocorrência natural de plantas, folhas, raízes, flores, caules, cascas, sementes. Também tem os métodos de extração tais como: hidrodestilação, prensagem (frutos cítricos), extração por solventes orgânicos, enfleurage, CO2 supercrítico, microondas por hidrodestilação e destilação a vapor. Os óleos essenciais, caracterizados por um amplo grupo de constituintes químicos, têm estimulado novas pesquisas e a procura por substâncias biologicamente ativas e eficazes, especialmente contra microrganismos através de ensaios antimicrobianos (FIGUEIREDO et al., 2008). No entanto, pela sua ampla utilização, o estudo dos óleos essenciais, apresentam-se de maneira multidisciplinar, devido a grande abrangência de ações biológicas, bem como por sua aplicabilidade em diferentes linhas de produção, em práticas terapêuticas e popular (MACHADO JÚNIOR, 2011). Uma alternativa eficaz e econômica tem sido o desenvolvimento e o uso de produtos naturais com propriedades antimicrobianas. Dessa forma, é bastante incentivada a investigação por antibióticos de ocorrência natural (DUARTE, 2006). O potencial antimicrobiano dos óleos essenciais frente a uma diversidade de microrganismos tem sido atribuído aos fenilpropanoides: éter etílico de carvacrol, cinamaldeído, eugenol, p-cimeno e timol. Assim como para os terpenoides: acetato de bornila, acetato de geranila, $\alpha$ - bisabolol, $\alpha$ e $\beta$-pineno, aromadendreno, carvona, citronelal, 1,8-cineol, geraniol, mentona, mirceno, nerol e terpin-4-ol (BURT, 2004). Deve-se levar em consideração técnica usada, o meio de cultura, os microrganismos, e o tipo de óleo essencial. De acordo com as características dos óleos essenciais como volatilidade, insolubilidade em água e complexidade, os resultados podem ser interferidos e talvez não identificar o potencial antimicrobiano da amostra (NASCIMENTO et al., 2007). Existem vários mecanismos em que os microrganismos podem resistir aos efeitos dos antimicrobianos, tais como: alteração na estrutura molecular dos antimicrobianos, produção de enzimas que inativam a droga, alteração das proteínas dos pontos-alvo nas paredes das células, alvos modificados da DNA-girase, mutações de permeabilidade e modificações ribossômicas (CATÃO et al., 2005). Geralmente, as bactérias apresentam disponibilidade genética de adquirir e transmitir resistência às drogas utilizadas. E esta problemática, acarreta um uso indefinido dos antibióticos e sugere-se um controle na sua utilização, bem como a ampliação de pesquisas que auxiliem na compreensão deste mecanismo genético de resistência (AMOROSO, 2002).

Conclusão: As espécies estudadas apresentaram diversos compostos em sua composição química, apresentando potencial para a indústria, em especial a farmacêutica. Cujo principal efeito estudado são as atividades antimicrobianas desses compostos.

\title{
Referências
}

AMOROSO, M. C. M. Uso e diversidade de plantas medicinais em Santo Antônio do Leverger, MT, Brasil. Acta Botanica Brasilica,v.16, n. 2, p.189-203, 2002.

BURT, S. Essential oils: their antibacterial properties and potential applications in foods-a review. International Journal of Food. 
v. 94, p. 223 253, 2004.

CATÃO, R. M. R.; BARBOSA-FILHO, J. M.; GUTIERREZ, S. J. C.; LIMA, E. O. L.; PEREIRA, M. S. V.; ARRUDA, T. A.; ANTUNES, R. M. P. Avaliação da atividade antimicrobiana de Riparinas sobre cepas de Staphylococcus aureus e Escherichia coli multirresistentes. Revista Brasileira de Análises Clínicas, v.37, n.4, p.247-279, 2005.

CRAVEIRO, A. A., FERnANDES, A. G., ANDRADE, C. H. S., MATOS, F. J. A.; ALENCAR, J. W.; MACHADO, M. I. L. Óleos essenciais de plantas do Nordeste. Fortaleza: UFC, 1981.210 p.

DUARTE, M. C. T. Atividade antimicrobiana de plantas medicinais e aromáticas utilizadas no Brasil. MultiCiências, v.7, 2006.

FIGUEIREDO, A. C.; BARROSO, J. G.; PEDRO, L. G.; SCHEFFER, J. J. C. Factors affecting secondary metabolite production in plants: volatile components and essential oils affecting volatile and essential oil production in plants. Flavour and Fragrance Journal, v. 23, n. 4, p. 213 226, 2008.

MACHADO, B. F. M. T.; JUNIOR, A. F. Óleos essenciais: aspectos gerais e usos em terapias naturais. Caderno acadêmico, v. 3, n. 2, p. 105-127, 2011.

NARVAES, L. S.; LONGHI, S. J.; BRENA, D. A. Florística e classificação da regeneração natural em floresta Ombrófila Mista na Floresta Nacional de São Francisco de Paula, RS. Ciência Florestal, Santa Maria, v. 18, n. 2, p. 233-245, 2008.

NASCIMENTO, P. F. C.; NASCIMENTO, A. C.; RODRIGUES, C. S. Atividade antimicrobiana dos óleos essenciais: uma abordagem multifatorial dos métodos. Revista Brasileira de Farmacognosia, v. 17, n. 1, p. 108-113, 2007.

SILVA, C. V.; BILIA D. A. C.; BARBEDO, C. J. Fracionamento e germinação de sementes de Eugenia. Revista Brasileira de Sementes, v. 27, n. 1, p. 86-92, 2005.

Coordenadoria de Pesquisa e Extensão - COPEX

Departamento de Editoraçāo e Divulgaçāo Científica - DEDIC 


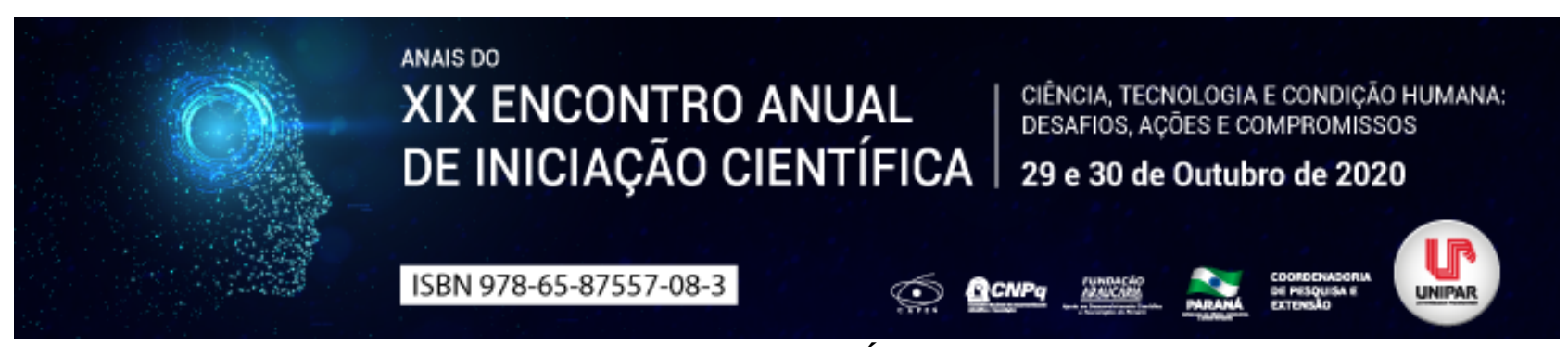

Staphylococcus aureus: O DESAFIO CONTÍNUO DA ANTIBIOTICOTERAPIA

\begin{abstract}
${ }^{1}$ ISABELLA ARANTES TOBBIN, ${ }^{2}$ JEFFERSON ALESSANDRO SCHMITZ JUNIOR, ${ }^{3}$ JULIA MUNARETTO ZONIN, ${ }^{4}$ GABRIELA FAVERO ESPOLADOR, ${ }^{5}$ DANIELA DIB GONÇALVES, ${ }^{6}$ LIDIANE NUNES BARBOSA
\end{abstract}

\author{
${ }^{1}$ Acadêmico bolsista do PIBIC/UNIPAR \\ ${ }^{1}$ Discente Ensino Médio, PEBIC EM CNPq \\ ${ }^{2}$ Discente de Medicina, PIC, UNIPAR \\ ${ }^{3}$ Mestranda PPG em Ciência Animal com Ênfase em Produtos Bioativos \\ ${ }^{4}$ Docente- UNIPAR \\ ${ }^{5}$ Docente da UNIPAR
}

Introdução: Staphylococcus aureus é uma bactéria da família Micrococcaceae do grupo dos cocos Gram-positivos. São organismos comensais que compõem a microbiota humana e provocam infecções por contato quando o sistema imunológico do indivíduo está comprometido (SANTOS et al., 2007). Com a descoberta dos antibióticos, foi uma das primeiras bactérias a serem controladas, entretanto, devido ao uso indiscriminado dos antimicrobianos, sua grande capacidade de colonização e alta virulência, tornou-se um dos patógenos que mais corroboram às infecções hospitalares, visto que novas cepas resistentes surgem a cada novo antibiótico produzido (MIMICA, 2018). Nesse sentido, cresceu o investimento e o interesse na investigação dos antimicrobianos naturais, como os óleos essenciais, bem como na maior racionalização e vigilância microbiológica (FERENZ et al., 2014).

Objetivo: Analisar por meio de revisão da literatura a disseminação de cepas resistentes de Staphylococus aureus aos antimicrobianos e a necessidade de investimento e inovação na síntese e criação de novos antibióticos

Desenvolvimento: O Staphylococcus aureus possui no ser humano seu principal reservatório, presente em diferentes sítios anatômicos como a garganta, o intestino, a pele e as fossas nasais causando desde quadros simples como furúnculos e foliculites até infecções sistêmicas como a pneumonia. O contágio ocorre por meio da invasão direta do S. aureus nos tecidos ou através de toxinas produzidas que rompem o epitélio, comprometendo adesões celulares e empregando diferentes estratégias para sua sobrevivência e proliferação, tais como a captação de nutrientes, a neutralização da fagocitose e a inibição de respostas humorais (OLIVEIRA et al., 2014). Em 1940, com a chegada da penicilina e o seu uso para o tratamento de infecções, o S. aureus foi controlado, mas, dentro de pouco tempo passou a apresentar resistência ao antimicrobiano e, em 1959, a resistência já alcançava uma taxa de $80 \%$, incluindo outros beta-lactâmicos como a aminopenicilina, amoxicilina e ampicilina (OLIVEIRA et al., 2014). A meticilina e oxacilina, antimicrobianos resistentes a atividade da beta-lactamase enzima que hidrolisa o anel betalactâmico inibindo a ação dos antibióticos beta-lactâmicos solucionaram por pouco tempo a problemática, entretanto, em 1990, foram relatadas infecções adquiridas na comunidade, pelos CA-MRSA (community-acquired methicillin- resistant Staphylococcus aureus) que apresentam genes de resistência à meticilina, e também cepas com o fator PVL (Panton-Valentine de leucocidina) que corroboram a infecções de alta letalidade como a pneumonia necrotizante. A principal resposta terapêutica ao tratamento das infecções por CA-MRSA veio com a clindamicina e em seguida pela vancomicina, porém o uso indiscriminado desse glicopeptídeo resultou também na emergência de resistência, levando ao uso atual da linezolida e a daptomicina (MIMICA, 2018). O mecanismo de resistência se dá por meio de mutação em seus genes ou aquisição de genes de resistência pela transferência horizontal, estando diretamente relacionado ao uso indiscriminado em sua antibioticoterapia, ao descaso com a dosagem e ao tempo de duração do tratamento. Nesse contexto, o conhecimento e a vigilância microbiológica de cepas de valor epidemiológico

a exemplo das cepas MRSA bem como o conhecimento sobre seu mecanismo de resistência e patogenicidade é de grande relevância para a sua racionalização e produção de novos antibióticos (SANTOS et al., 2007). Em razão do aumento da quantidade de bactérias resistentes aos antibióticos atuais, vem crescendo a investigação dos efeitos de antimicrobianos naturais. O uso do antibiótico em menores doses, menor frequência de aplicação, redução da toxicidade e diminuição do desenvolvimento da resistência são alguns pontos positivos potenciais desses produtos (ZIEMSKA; RAJNISZ; SOLECKA, 2013). Nesse sentido, se destacam os óleos essenciais (OEs), os quais são obtidos pelo metabolismo secundário de plantas e através de estudos com a metodologia de disco-difusão mostraram eficiência antimicrobiana. Segundo Ferenz (2014) plantas do gênero Cymbopogon flexuosus possuem atividade antibacteriana contra o Staphylococcus aureus e de acordo com Santos (2011) o óleo essencial de Origanum vulgare composto principalmente de carvacrol também apontou halos de inibição contra o patógeno. A síntese de antibióticos derivados de substâncias bioativas embora se apresente como uma alternativa eficaz, dependem muito estudo e investimento visto sua estrutura complexa.

Conclusão: A emergência de bactérias resistentes do S. aureus, até mesmo aos antibióticos mais recentes e eficazes, evidência 
a urgência de um programa de vigilância microbiológica que auxilia no reconhecimento de cepas de valor epidemiológico, visando sua contenção antes da disseminação de infecções graves, além do uso de antimicrobianos corretos. Ademais, foi possível constatar a importância da pesquisa e do investimento científico na síntese e na criação de novos antibióticos, como os óleos essenciais de plantas, eficazes no controle de cepas resistentes e multirresistentes.

\section{Referências}

FERENZ, Mariane et al. Ação Antimicrobiana de óleos essenciais contra Staphylococcus Aureus e Pseudomonas Aeruginosa. Blucher Food Science Proceedings, v. 1, n. 1, p. 35-36, 2014.

OLIVEIRA, Caio Ferreira de et al. Emergência de Staphylococcus aureus resistentes aos antimicrobianos: um desafio contínuo. Revista de Ciências Médicas e Biológicas, v. 13, n. 2, p. 242-247, 2014.

SANTOS, André Luis dos et al. Staphylococcus aureus: visitando uma cepa de importância hospitalar. Jornal Brasileiro de Patologia e Medicina Laboratorial, v. 43, n. 6, p. 413-423, 2007.

ZIEMSKA, Joanna; RAJNISZ, Aleksandra; SOLECKA, Jolanta. New perspectives on antibacterial drug research. Central European Journal of Biology, v. 8, n. 10, p. 943-957, 2013.

MIMICA, Marcelo Jenné. Atualização sobre detecção laboratorial de resistência a antimicrobianos em Staphylococcus aureus/Update on the laboratory detection of antimicrobial resistance in Staphylococcus aureus. Arquivos Médicos dos Hospitais e da Faculdade de Ciências Médicas da Santa Casa de São Paulo, v. 57, n. 3, p. 129-134, 2018.

SANTOS, Juliana Cantalino et al. Atividade antimicrobiana in vitro dos óleos essenciais de orégano, alho, cravo e limão sobre bactérias patogênicas isoladas de vôngole. Semina: Ciências Agrárias, v. 32, n. 4, p. 1557-1564, 2011. 


\title{
ANAIS DO \\ XIX ENCONTRO ANUAL | CIÊNCIÁ, TECNOLOGIA E CONDIÇÃO HUMANA: XESAFIOS, AÇŌES E COMPROMISSOS \\ DE INICIAÇĀO CIENTÍFICA 29 e 30 de Outubro de 2020 \\ ISBN 978-65-87557-08-3 \\ $\leftarrow$ PCNPq \\ ATIVIDADE ANTIBACTERIANA DOS EXRTATOS DE Zingiber Officinale Roscoe: ASPECTOS RELEVANTES SOBRE OS COMPOSTOS BIOATIVOS E MECANISMO DE AÇÃO
}

\section{${ }^{1}$ LILIANA DE SOUSA BAIA, ${ }^{2}$ LAURIETI DE ALMEIDA, ${ }^{3}$ GRACIELE MOREIRA DO NASCIMENTO, ${ }^{4}$ FELIPE ANDRÉ PEREIRA RAMOS, ${ }^{5}$ ANDREIA ASSUNCAO SOARES}

\author{
${ }^{1}$ Acadêmica bolsista do PIBIC / CNPQ \\ ${ }^{1}$ Acadêmica Ensino Médio PEBIC EM-JR / CNPq / UNIPAR \\ ${ }^{2}$ Acadêmica do Curso de Nutrição Bolsista do PIBIC / CNPQ / UNIPAR \\ ${ }^{3}$ Mestrando Profissional de Plantas Medicinais e Fitoterápicos na Atenção Básica / UNIPAR \\ ${ }^{4}$ Docente da UNIPAR
}

Introdução: A família Zingiberaceae recebe atenção por conter muitos compostos bioativos que são primordiais em alimentos como ervas, especiarias e na indústria farmacêutica e cosmética como agentes antimicrobianos e antioxidantes (SHARIFI-RAD et al., 2017; CHAN; WONG, 2015; CHEN et al., 2008). O gengibre tem sido pesquisado por conter características medicinais como, atividade antibacteriana contra bactérias Gram-positivas e Gram-negativas. Essas informações são de extrema importância, pois podem colaborar na produção de produtos farmacêuticos e terapêuticos proporcionando uma melhora na qualidade de vida (GUPTA; SHARMA; 2014; SUHAD et al., 2012).

Objetivo: O objetivo desse trabalho foi relatar a atividade antibacteriana dos extratos de Zingiber officinale Roscoe: aspectos relevantes sobre os compostos bioativos e mecanismos de ação.

Desenvolvimento: As plantas têm um papel importante nos fármacos tradicionais contra varias doenças. O potencial medicinal dessas plantas encontram-se nos compostos bioativos que produzem uma ação fisiológica benéfica aos organismos que as consomem (GUPTA; SHARMA, 2014). Os extratos do Zingiber officinale e seus principais compostos são os gingeróis, com atividade biológica com alto potencial farmacológico, atuando como antioxidante, antiinflamatório, analgésico, antitrombótico, hiploglicêmico e antimicrobiano, o rizoma do gengibre (Zingiber officinale) contém aproximadamente 1 a $4 \%$ dos óleos voláteis responsáveis pelo aroma, sabor e potencial medicinal do gengibre(SHAREEF et al., 2016; SHARIFI-RAD et. al., 2017).O gingerol é um composto fenólico que em contato com a parede celular das bactérias leva a perda de permeabilidade e ruptura da membrana promovendo a morte e danos celulares, assim, tais compostos bioativos inibem o crescimento microbiano (SUHAD et al. 2012; HASAN et al., 2012; RAHMANI; SHABRMI; ALY, 2014). Estudos mostram que os compostos bioativos do gengibre (Zingiber officinale) podem ser um excelente antimicrobiano contra diversos agentes, tais como as bactérias gram-negativas e gram- positivas (VORAVUTHIKUNCHAI, 2007; GUPTA; SHARMA; 2014; SUHAD et al., 2012). Os antimicrobianos encontrados nas plantas medicinais, que são de origem natural podem atuar contra infecções causadas por microrganismos. Na atualidade a atenção para as plantas medicinais e especiarias têm sido de imensurável interesse no que se refere ao potencial medicinal (VORAVUTHIKUNCHAI, 2007). São necessárias pesquisas in vivo e in vitro para avaliar a eficácia dos extratos dos gengibres e proporcionar novas estratégias para o uso medicinal e terapêutico (RAHMANI; SHABRMI; ALY, 2014).

Conclusão: Por meio desta revisão, pode-se concluir que a maioria das pesquisas e estudos já realizados evidenciam que o gengibre (Zingiber officinale) possui diversas propriedades, farmacológicas e terapêuticas que podem ser utilizadas na saúde única. Dessa forma, os estudos indicam que os extratos de Zingiber officinale possuem características antibacterianas tanto contra bactérias gram-positivas quanto para as bactérias gram-negativas.

\section{Referências}

CHAN, E. W. C.; WONG, S. K. Phytochemistry and pharmacology of ornamental gingers, HedychiumcoronariumandA/piniapurpurata:areview. Journal of Integrative Medicine, Beijing, v. 13, n. 6, p. 368-379, 2015.

CHEN, I.-N.; CHANG, C.-C.; NG, C.-C.; WANG, C.-Y.; SHYU, Y.-T.; CHANG, T.-L. Antioxidant and antimicrobial activity of Zingiberaceae plants in Taiwan. Plant Foods Human Nutrition, Dordrecht, v. 63, n. 1, p. 15-20, 2008.

GUPTA, S. K.; SHARMA, A. Medicinal properties of Zingiber officinale Roscoe - A review. Journal of Pharmacy and Biological Sciences, v. 9, n. 5, p. 124-129, 2014.

HASAN, H. A. et al. Chemical Composition and Antimicrobial Activity of the Crude Extracts isolated from Zingiber officinale by Different Solvents. Pharmaceut Anal Acta, v. 3, n. 9, p. 1-5, 2012.

RAHMANI, A. H.; SHABRMI, F. M. AL.; ALY, S. M. Active ingredients of ginger as potencial candidates in the prevention and treatment of diseases via modulation of biological activities. International Journal Pathophysiolol Pharmacol, v. 6, n. 2, p. 125- 
136, 2014.

SHAREEF, H. K.; MUHAMMED, H. J.; HUSSEIN,H. M.; HAMEED, I. H. Antibacterial effecdt of gingerZingiber officinale roscoe and bioactive chemicalanalysis using gas chromatography mass spectrum. Oriental Journal of Chemistry, Bhopal, v. 32, n. 2, p. 817-837, 2016.

SHARIFI-RAD, M.; VARONI, E. M.; SALEHI, B.; SHARIFI-RAD, J.; MATTHEWS, K. R.; AYATOLLAHI, S. A.; KOBARFARD, F.; IBRAHIM, S. A.; MNAYER, D.; ZAKARIA, Z. A.; SHARIFI-RAD, M.; YOUSAF, Z.; IRITI, M.; BASILE, A.; RIGANO, D. Plants of the genus Zingiber as a source of bioactive phytochemicals: from tradition to fharmacy. Molecules, Naples, v. 22, n. 2145, p. 1- 20, 2017. SUHAD, A. et al. Study the Antibacterial Activity of Zingiber officinale roots against some of pathogenic bacteria. AlMustansiriya Journal Science, v. 23, n. 3, p.63- 70, 2012.

VORAVUTHIKUNCHAI,S.P.FamilyZingiberaceaecompoundsasfunctionalantimicrobials, antioxidants, and antiradicals.Food,v,1, $\mathrm{n}$. 2, p. 227-240, 2007.

Coordenadoria de Pesquisa e Extensão - COPEX

Departamento de Editoraçāo e Divulgaçāo Científica - DEDIC 


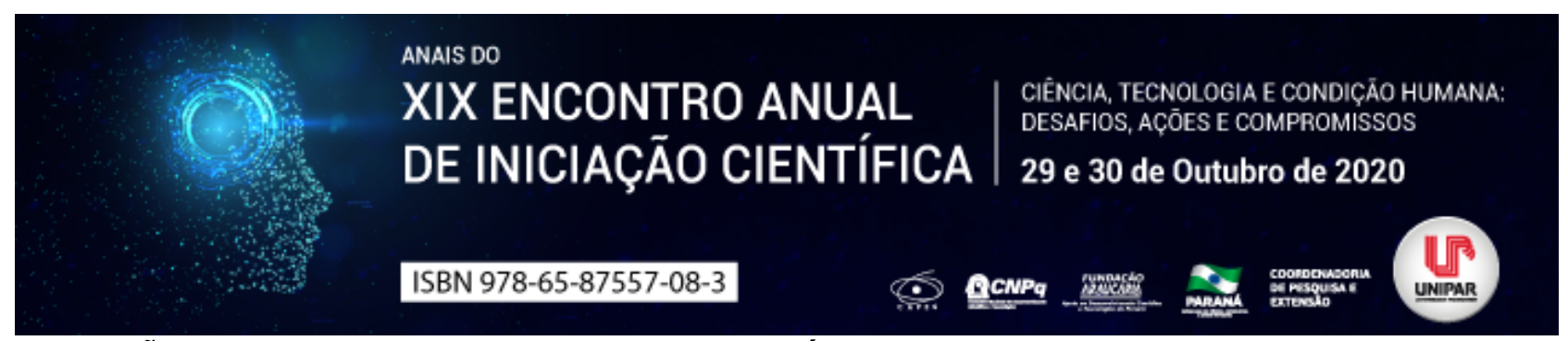

ANÁLISE DE CÃES SUBMETIDOS A PROCEDIMENTOS CIRÚRGICOS E CLASSIFICADOS COMO ASA III DE ACORDO COM A SOCIEDADE AMERICANA DE ANESTESIOLOGISTAS

\author{
${ }^{1}$ ANDRESSA GAVASSI DE FRANCA, ${ }^{2}$ TALITA BIANCHIN BORGES, ${ }^{3}$ BRUNA MENEGATE NASCIMENTO, ${ }^{4}$ ALYSSON \\ RAMALHAIS, ${ }^{5}$ THAÍS CAMASO DE SÁ, ${ }^{6}$ ANA MARIA QUESSADA
}

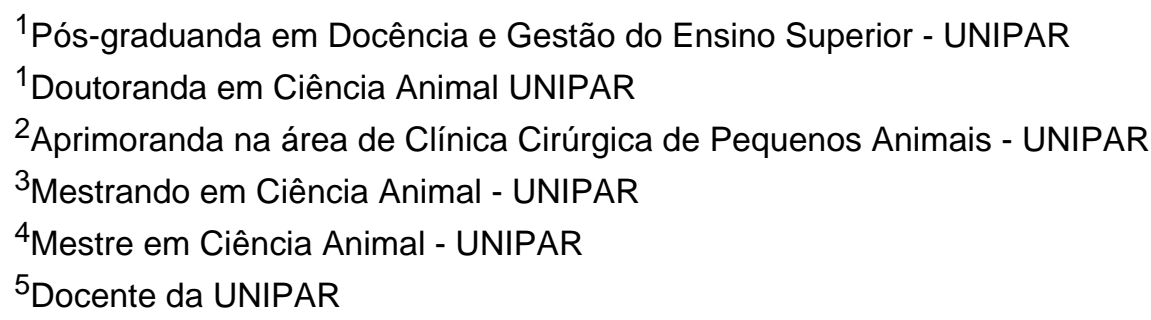

Introdução: A classificação de estado físico ASA (Sociedade Americana de Anestesiologistas) é uma ferramenta importante para a avaliação pré-anestésica do paciente. Assim, é utilizada em diversos estudos por possuir estreita relação com a morbidade e mortalidade anestésica. Essa classificação varia de I a V, de acordo com o estado clínico do paciente. A categoria ASA III é utilizada para pacientes portadores de doença sistêmica moderada (ASA, 2014).

Objetivo: Analisar cães classificados como ASA III, principalmente em relação à mortalidade.

Material e Métodos: Com a autorização do Comitê de Ética em Experimentação Animal foi realizado no Hospital Veterinário da Universidade Federal do Piauí a avaliação pré-anestésica de 243 caninos. Os cães foram avaliados clinicamente e foi realizada a classificação ASA. Em pacientes atendidos emergencialmente foi acrescentado o qualificador E (emergência). Após calssificação, 101 pacientes foram classificados como ASA III. Destes animias, foram registradas as principais intervenções cirúrgicas realizadas, altas clínicas e óbitos trans e pós-operatórios. Todos os pacientes tiveram acompanhamento até alta clínica ou óbito. Os dados foram tabulados e submetidos à estatística descritiva, cujos resultados foram apresentados em percentagens. Resultados e discussão: A anemia foi a alteração mais marcante nos cães ASA III. Tal alteração aumenta os riscos, em virtude da menor capacidade de transporte de oxigênio e das poucas reservas em casos de perdas sanguíneas cirúrgicas (SHMON, 2007). Na categoria ASA III ( $n=101$ animais), categoria de maior número de pacientes neste estudo, foram realizadas cirurgias terapêuticas eletivas $(78 / 101 ; 77,23 \%)$ e terapêuticas emergenciais $(23 / 101 ; 22,77 \%)$. O primeiro grupo foi composto por pacientes submetidos a mastectomia $(24 / 78 ; 30,77 \%)$, redução de fratura $(17 / 78 ; 21,79 \%)$, drenagem de otohematoma (11/78; $14,10 \%)$, sutura de ferida complexa (3/78; 3,85\%), enucleação do globo ocular (3/78; 3,85\%), retirada de tumor cutâneo (2/78; 2,56\%), orquiectomia (aumento prostático) (2/78; 2,56\%), ablação escrotal (dermatite) (2/78; 2,56\%), correção de entrópio (2/78; $2,56 \%)$, herniorrafia perineal $(2 / 78 ; 2,56 \%)$, herniorrafia umbilical $(1 / 78 ; 1,28 \%)$, cistotomia (1/78; $1,28 \%)$, biópsia incisional $(1 / 78$; $1,28 \%)$, amputação de membro $(1 / 78 ; 1,28 \%)$, retirada de neoplasia perianal $(1 / 78 ; 1,28 \%)$, sialoadenectomia $(1 / 78 ; 1,28 \%)$, sepultamento da glândula de terceira pálpebra $(1 / 78 ; 1,28 \%)$ e laparotomia exploratória $(1 / 78 ; 1,28 \%)$. Portanto, a mais frequente foi mastectomia. Isto ocorreu porque tumores mamários são a mais frequente neoplasia em cães, com incidência de $16,70 \%$ (FIGUERA, et al., 2008) a 36,3\% (PIRES et al., 2003) chegando a 52\% nas fêmeas. Nas emergências, o procedimento mais comum foi a ovariosalpingohisterectomia (OSH) devido a fetos mortos $(7 / 23 ; 30,40 \%)$. Esta cirurgia é uma das mais comuns na rotina cirúrgica de cães (SILVEIRA et al., 2013). Os outros procedimentos emergenciais foram cesariana seguida de OSH (7/23; $30,40 \%)$, redução de prolapso retal $(2 / 23 ; 8,70 \%)$, correção de eventração $(2 / 23 ; 8,70 \%)$, redução de fratura $(2 / 23 ; 8,70 \%)$, retirada de corpo estranho esofágico (1/23; 4,35\%), ablação escrotal (1/23; 4,35\%) e sutura de ferida (1/23; 4,35\%). Ocorreu um óbito em pacientes desta categoria $(n=101)$. Este óbito ocorreu no pós-operatório (30h após cirurgia) em paciente submetido à retirada de corpo estranho esofágico (osso). Tal afecção é tida com uma emergência gastrointestinal importante em cães e gatos (HERNANDÉZ, 2010; MUDADO et al., 2012). Em casos de corpos estranhos esofágicos o diagnóstico precoce é fundamental, pois o retardo no atendimento pode resultar em complicações graves ao paciente principalmente perfuração, que tem alta mortalidade (MUDADO et al., 2012).

Conclusão: Pacientes classificados como ASA III podem apresentar mortalidade, principalmente no pós-operatório. As mastectomias são frequentes na rotina cirúrgica veterinária.

\footnotetext{
Referências

AMERICAN SOCIETY OF ANESTHESIOLOGISTS (ASA). A physical status classification system. 2014. Disponível em: . Acesso em: 25 ago. 2020.
} 
FIGUERA, R.A.; SOUZA, M.C.S.; SILVA, M.C.; BRUM, J.S.; GRAÇA, D.L.; KOMMERS, G.D.; IRIGOYEN, L.F.; BARROS, C.S.L. Causas de morte e razões para eutanásia de cães da Mesorregião do Centro Ocidental Rio-Grandense (1965-2004). Pesquisa Veterinária Brasileira, v. 28, n.4, p.223-230, 2008. Disponível em: . Acesso em: 18 ago. 2020.

HERNANDÉZ, C. A. Emergencias gastrointestinales en perros y gatos. Revista CES Medicina Veterinária y Zootecnia, v. 5, n. 2, p. 69-85, 2010. Disponível em: < http://www.imbiomed.com.mx/1/1/articulos.php? method=showDetail\&id_articulo=67469\&id_seccion=3041\&id_ejemplar=6783\&id_revista=185> Acesso em: 20 ago. 2020 .

MUDADO, M. A.; DEL CARLO, R. J.; BORGES, A. P. B., COSTA, P. R. S. Obstrução do trato digestório em animais de companhia, atendidos em um Hospital Veterinário no ano de 2010. Revista Ceres, v. 59, n.4, p. 434-445, 2012. Disponível em: Acesso em: 21 ago. 2020.

PIRES, M.A.; TRAVASSOS, S.F.; PIRES, I. Neoplasias em canídeos - Um estudo descritivo de 6 anos. Revista Portuguesa de

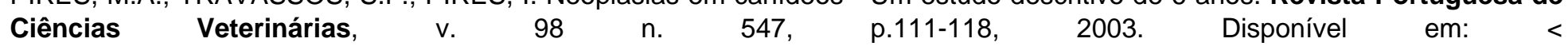
http://www.fmv.utl.pt/spcv/PDF/pdf9_2003/547_111_118.pdf >. Acesso em: 21 ago. 2020.

SHMON, C. Avaliação e preparação do paciente e da equipe cirúrgica. In: SLATTER, D. Manual de cirurgia de pequenos animais. 3ed. São Paulo: Manole, 2007. v.1. Cap.12. p. 162-170.

SILVEIRA, C.P.B. et al. Estudo retrospectivo de ovariossalpingo-histerectomia em cadelas e gatas atendidas em Hospital Veterinário Escola no período de um ano. Arquivo Brasileiro de Medicina Veterinária e Zootecnia. v. 65, n.2, p.335-340, 2013. 


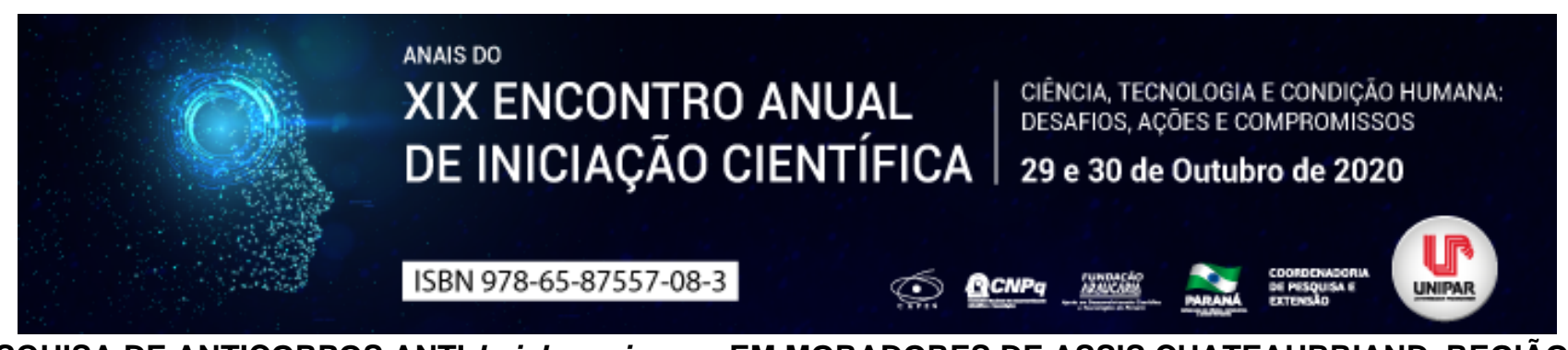

PESQUISA DE ANTICORPOS ANTI-Leishmania spp. EM MORADORES DE ASSIS CHATEAUBRIAND, REGIÃO DE FRONTEIRA COM O PARAGUAI

\author{
${ }^{1}$ Mariana do Nascimento Coelho, ${ }^{2}$ ISABELA CARVALHO DOS SANTOS, ${ }^{3}$ MATEUS AUGUSTO GARCIA SOUZA, ${ }^{4}$ ARIANNE \\ PERUZO PIRES GONÇALVES, ${ }^{5}$ DANIELA DIB GONCALVES
}

\author{
${ }^{1}$ Discente Ensino Médio, bolsista PEBIC CNPq \\ ${ }^{1}$ Acadêmica do Curso de Doutorado Em Ciência Animal com ênfase em produtos Bioativos - Bolsista CAPES - UNIPAR \\ ${ }^{2}$ Acadêmico do Curso de Medicina Veterinária da UNIPAR \\ ${ }^{3}$ Acadêmica do Curso de Doutorado Em Ciencia Animal Com ênfase em produtos Bioativos \\ ${ }^{4}$ Docente da UNIPAR
}

Introdução: A leishmaniose é uma doença infectoparasitária, que tem como agente etiológico o protozoário do gênero Leishmania spp., pertencente à família Trypanosomatidae, ordem Kinetoplastida (MANSUETO et al., 2014). A Leishmania, primitivamente é transmitida de mamíferos silvestres, os reservatórios, para o homem, hospedeiro, pela picada de flebotomíneos, que são os vetores. Porém, esta doença, antes encontradas em ambientes silvestres e rurais, têm avançado para regiões urbanas, principalmente periferias de grandes centros, que não possuem condições básicas de higiene e saneamento (MANSUETO et al., 2014). Por ter caráter sistêmico, a leishmaniose apresenta uma diversidade de sinais e alterações dependentes da resposta imune do indivíduo, no hemograma, as alterações encontradas são trombocitopenia, anemia normocítica normocrômica, linfopenia, leucocitose com desvio à esquerda e teste de Coombs positivo. Os sinais clínicos dependem do sistema acometido, e esses não ajudam no diagnóstico por serem inespecíficos e que podem ser confundidos com os de outras enfermidades, incialmente o local onde os primeiros sinais são detectados são na pele, por ser este o local da picada e deposição dos parasitos (LIMA et al., 2002; MANSUETO et al., 2014).

Objetivo: Pesquisa de anticorpos anti-Leishmania spp. em uma cidade de região fronteiriça.

Material e Métodos: Este projeto foi aprovado pela Plataforma Brasil / UNIPAR sob protocolo CAAE: 94669818.2.0000.0109. Foi realizado a coleta de sangue de 15 moradores de ambos os sexos e com idade superior a 18 anos que procuraram a Unidade Básica de Saúde de Assis Chateaubriand (Paraná) apresentando febre e dor muscular. Assis Chateaubriand (Paraná) está localizada a $131 \mathrm{Km}$ do Paraguai e por isso é considerada uma região fronteiriça. A coleta de sangue foi realizada por meio de punção venosa de $5 \mathrm{~mL}$ conduzida por profissionais da área de enfermagem. Posterior os soros foram encaminhados para o Laboratório de Zoonoses e Saúde Pública da Universidade Estadual de Londrina. As amostras de soro humano foram analisadas por imunofluorescência indireta (IFI) para determinar a prevalência de anti-Leishmania spp. Anticorpos IgG de acordo com Oliveira et al. (2008). As lâminas de IFI foram preparadas usando promastigotas de L. infantum; amostras com títulos iguais ou superiores a 40 foram consideradas positivas para anticorpos contra Leishmania. Conjugados anti-IgG humanos (FITC Sigma $\left.{ }^{\circledR}, E U A\right)$ foram padronizados e em 1: 1200. Controles positivos e negativos foram incluídos em cada lâmina testada. As amostras consideradas positivas foram diluídas em série duas vezes até não serem mais positivas.

Resultados: Das 15 amostras testadas, nenhuma apresentou-se reagente ao teste diagnóstico.

Discussão: Silveira et al. (1999) agrupou o número de pacientes positivos atendidos pelo Laboratório de Ensino e Pesquisa em Análises Clínicas, da Universidade Estadual de Maringá (LEPAC/UEM) na década de 90, foram utilizadas diferentes técnicas para o diagnóstico laboratorial para Leishmania spp., a intradermorreação de Montenegro (IDRM) apresentou positividade de $95,1 \%$, seguindo-se a IFI de $64,4 \%$ e o parasitológico de $59,4 \%$. Também foi observado que a associação entre IFI e IDRM, alcançou uma positividade de $98,8 \%$ e a do parasitológico e IDRM uma positividade de $97,2 \%$. O presente trabalho não tem amostras positivas para anticorpos anti-Leishmania spp., mostrando a necessidade de mais testes diagnósticos para a confirmação de resultados. Já o trabalho de Lima et al. (2002) apontou que houve notificação de leishmaniose em 276 municípios do Paraná, contudo, sabe-se que há concentração de notificações desta doença nos municípios que servem como sede das regionais de saúde da Secretaria de Saúde do Estado do Paraná, uma vez que alguns dos tratamentos vêm sendo feito, em serviços desses municípios. Aproximadamente $94 \%$ dos casos de leishmaniose tegumentar no Estado do Paraná ocorreram nas regiões com clima subtropical úmido. Houve predomínio de leishmaniose nas áreas em que a média anual das temperaturas mínimas é acima de $14^{\circ} \mathrm{C}$, e a média anual das temperaturas máximas acima de $25^{\circ} \mathrm{C}$, que abrangem as regiões norte e oeste do Estado do Paraná, coincidindo com áreas de alto grau de destruição da vegetação nativa, em decorrência da exploração agrícola por monoculturas, especialmente de milho, soja e cana-de-açúcar, e pastagens. Apesar de a cidade de Assis Chateaubriand apresentar estas características climáticas (OLIVEIRA; AMARAL, 2011), não houve amostras positivas no presente trabalho, reforçando a necessidade de maiores estudos para compreender melhor a epidemiologia desta enfermidade. 
Conclusão: Novos estudos devem ser conduzidos com para melhor compreensão da epidemiologia desta enfermidade parasitária já que no local do estudo há condições favoráveis para a proliferação do mosquito vetor.

\section{Referências}

LIMA, A. P. et al. Distribuição da leishmaniose tegumentar por imagens de sensoreamento remoto orbital, no Estado do Paraná, Brasil. Anais Brasileiros de Dermatologia, v. 77, n. 6, p. 681-692, 2002.

MANSUETO, P. et al. Leishmaniasis in travelers: a literature review. Travel medicine and infectious disease, v. 12, n. 6, p. 563581, 2014.

OLIVEIRA, T. M. F. et al. Study of cross-reactivity in serum samples from dogs positive for Leishmania sp., Babesia canis and Ehrlichia canis in enzyme-linked immunosorbent assay and indirect fluorescent antibody test. Revista Brasileira de Parasitologia Veterinária, v. 17, n. 1, p. 7-11, 2008.

OLIVEIRA, E.; AMARAL, L. Estudo da relação dos fatores climáticos e casos de dengue no município de Assis Chateaubriand, Paraná. Engenharia Ambiental: Pesquisa e Tecnologia, v. 8, n. 2, 2011.

SILVEIRA, T. G. V. et al. Observações sobre o diagnóstico laboratorial e a epidemiologia da leishmaniose tegumentar no Estado do Paraná, sul do Brasil. Revista da Sociedade Brasileira de Medicina Tropical, v. 32, n. 4, p. 413-423, 1999. 


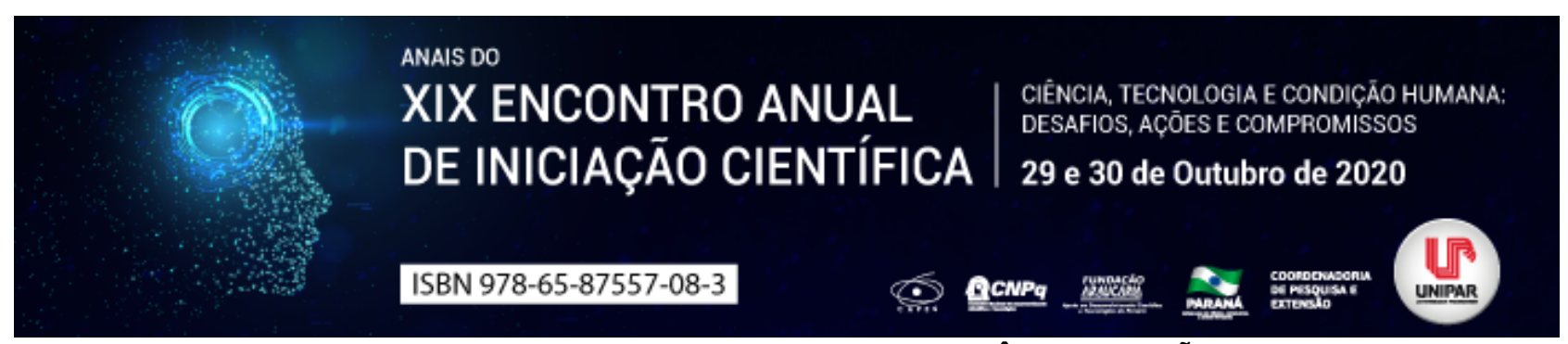

NECROSE AVASCULAR DA CABEÇA DO FÊMUR EM CÃO

\begin{abstract}
${ }^{1}$ BRUNA MENEGATE NASCIMENTO, ${ }^{2}$ VINICIUS SILVEIRA DE QUEIROZ, ${ }^{3}$ ALYSSON RAMALHAIS, ${ }^{4}$ GEOVANA CRISTINA SARTORI ANDRE, ${ }^{5}$ THAINA PIZANE DA SILVA, ${ }^{6}$ ANA MARIA QUESSADA
\end{abstract}

\author{
${ }^{1}$ Aprimoranda em Clínica cirúrgica veterinária, Universidade Paranaense (UNIPAR) \\ ${ }^{1}$ Acadêmico de Medicina Veterinária, Bolsista PIC - UNIPAR \\ ${ }^{2}$ Mestrando em ciência animal com ênfase em produtos bioativos, UNIPAR \\ ${ }^{3}$ Acadêmico de Medicina Veterinária, Bolsista PIC - UNIPAR \\ ${ }^{4}$ Acadêmico de Medicina Veterinária, Bolsista PIBIC - UNIPAR \\ ${ }^{5}$ Docente Orientadora da UNIPAR
}

Introdução: A necrose avascular da cabeça do fêmur também pode ser nomeada como necrose asséptica da cabeça do fêmur, doença de Legg-Calvé-Perthes ou osteonecrose (PARRA-CASTRO et al., 2017). Em cães, a enfermidade foi relatada em 1935 por Tutt (CROVACE et al., 2020). Esta enfermidade consiste na deficiência de suprimento sanguíneo na epífise femoral, levando à necrose avascular (SANTANA FILHO et al., 2011). Esta doença ocorre principalmente em cães jovens de pequeno porte, podendo ser uni ou bilateral (SCHULZ, 2014), sem distinção de prevalência entre fêmeas ou machos (CROVACE et al., 2020). Os sinais clínicos são claudicação, dificuldade em sustentar o próprio peso, dor, limitação de movimentos e pode progredir para atrofia muscular do membro afetado (SIMPSON; LEWIS, 2009). O diagnóstico padrão ouro para confirmação é o exame radiográfico (PINNA et al., 2014). O tratamento mais comum é o cirurgico (colocefalectomia), porém pode resultar em pseudoartrose e diferença no comprimento dos membros pélvicos (PARRA-CASTRO et al., 2017).

Objetivo: O objetivo é fazer uma revisão sobre necrose avascular da cabeça do fêmur em cães.

Desenvolvimento: A necrose avascular da cabeça do fêmur é uma enfermidade que ocorre geralmente antes do fechamento fisário completo da cabeça do fêmur, com caráter não inflamatório, prevalente em cães jovens e sua etiologia não é bem estabelecida. Algumas hipóteses incluem fatores hereditários, pressão intracapsular, disturbios hormonais, enfartamento da cabeça do fêmur e má conformaçãos anatômica (SCHULZ, 2014). O diagnóstico é realizado por meio de exame clínico e físico minucioso, acompanhado de exame radiográfico uma vez que os sinais clínicos são inespecíficos. Ocorre claudicação, impotência funcional, dor, atrofia muscular e restrição a movimentos (BANDIERA et al., 2019). No exame físico, o paciente apresenta desconforto na extensão da articulação coxofemural, principalmente com rotação interna. Quando realizada abdução da articulação coxofemoral há presença de dor (SANTANA FILHO et al., 2011). No exame radiográfico, para o diagnóstico da enfermidade, a melhor projeção é a ventrodorsal da região pélvica. Podem ser visualizadas aumento do espaço articular, incongruência articular e deformação das superficies articulares nos casos mais avançados da doença (BANDIERA et al., 2019). As alterações radiográficas são classificadas em cinco graus. No inicio da enfermidade há diminuição da densidade proximo à linha da epífise. No segundo grau, há aumento no espaço da articulação. No terceiro grau, o aspecto anterolateral do acetábulo está mais espesso com início de osteófitos. No quarto grau há irregularidade ou achatamento da superficie articular da cabeça do fêmur. No quinto grau (mais severo) ocorre desprendimento de fragmentos da cabeça do fêmur (PARRA-CASTRO et al., 2017; SANTANA FILHO et al., 2011) e descontinuidade da superfície articular (BANDIERA et al., 2019). O tratamento conservador é o menos indicado, pois em menos de $25 \%$ dos casos há a diminuição da dor do paciente, ou seja, mesmo nos casos iniciais os resultados não são satisfatórios. Ele consiste no repouso absoluto do paciente por até 8 semanas para que haja alteração na área afetada por tecido de granulação e a tensão que recebe a cabeça do femur seja suportada (SANTANA FILHO et al., 2011). A cirurgia é frequentemente indicada como tratamento ouro, sendo preferencialmente realizada a colocefalectomia. Tal técnica consiste na excisão do colo e cabeça femural, para que haja a formação de uma pseudoartrose. Neste tipo de tratamento, a dor e claudicação desaparecem (SIMPSON; LEWIS, 2009) entre 84 a 100\% dos casos (SANTANA FILHO et al., 2011). Outra técnica cirúrgica indicada é a denervação da articulação, com rompimento de duas fibras nervosas (glúteo cranial e isquiático), levando a um tratamento permanente da dor (SILVA et al., 2017). Recentemente, outro tratamento está sendo proposto, utilizando-se células mononucleares da medula óssea. Estas células auxiliam na regeneração do local afetado sendo considerada uma terapia minimamente invasiva (CROVACE et al., 2020). No pós-operatório da técnica cirurgica de colocefalectomia, o paciente pode apresentar claudicação, pois com a retirada dos fragmentos osseos ocorre um encurtamento do membro. Pode ocorrer, ainda, dor localizada e diminuição nos movimentos (COSTA NETO et al., 2012).

Conclusão: Diante do exposto, conclui-se que o diagnóstico ouro da enfermidade é realizado pelo exame radiográfico. Para tratamento, a colocefalectomia é a melhor forma de cessar a dor do paciente com necrose avascular da cabeça do fêmur. Novos estudos devem ser realizados para verificação da efetividade de tratamentos atuais como implantação de células troncos na 
articulação.

\section{Referências}

BANDIERA, F. C. et al. Diagnóstico da necrose asséptica da cabeça do fêmur em cães por meio do exame radiográfico. Brazilian Journal of Animal and Environmental Research, v. 2, n. 5, p. 1754-1760, 2019.

COSTA NETO, J. M. Da et al. Excisão artroplástica da cabeça e colo femorais associada à denervação acetabular e ao retalho do músculo bíceps femoral em cães. PUBVET, v. 6, n. 20, art.1381, 2012.

CROVACE, A. $\mathrm{M}$ et al. Treatment of monolateral legg-calvé-perthes disease with autologous bone marrow mononuclear cells in 32 dogs. Veterinary and Comparative Orthopaedics and Traumatology, v. 3, n. 1, p.1-10, 2020. DOI: 10.1055/s-00401701470.

DA SILVA, C. C et al. Utilização da denervação acetabular no controle analgésico permanente após ressecção artroplástica de cabeça e colo femoral em cão relato de caso. Revista Eletrônica Biociências, Biotecnologia e Saúde, v.10, n.19, p. 209-210, 2017.

PARRA-CASTRO, E.; VERGARA, A.; SILVA-MOLANO, R. F. Autologous platelet concentrates as treatment for avascular necrosis of femoral head in a dog. Topics in Companion Animal Medicine. v. 31, n. 1, p.31-35, 2017.

PINNA, S.; LANDUCCI, F.; CELLA, V. Pulsed eletromagnetic field for the treatment of canine Legg-Calvé-Perthes disease. Pakistan Veterinary Journal. v. 35, n. 2, p. 245-247, 2014.

SANTANA FILHO, M. V. S. et al. Doença de Legg-Calvé-Perthes: Revisão bibliográfica, PUBVET, v. 5. n. 9, 2011. Dísponivel em: http://www.pubvet.com.br/artigo/1518/doenccedila-de-legg-calveacute-perthes-revisatildeo-bibliograacutefica. Acesso em: 06 jul. 2020.

SCHULZ, Kurt S. Afecções articulares. In: FOSSUM, T. W. Cirurgia de pequenos animais. 4 ed. Elsevier, 2014. p. 3437-3937. SIMPSON, D. J.; LEWIS, D. D. Fractures of the Femur. In: SLATTER, D. Manual de cirurgia de pequenos animais. 3. ed. São Paulo: Manole, 2009. p. 2059-2089. v.2. 


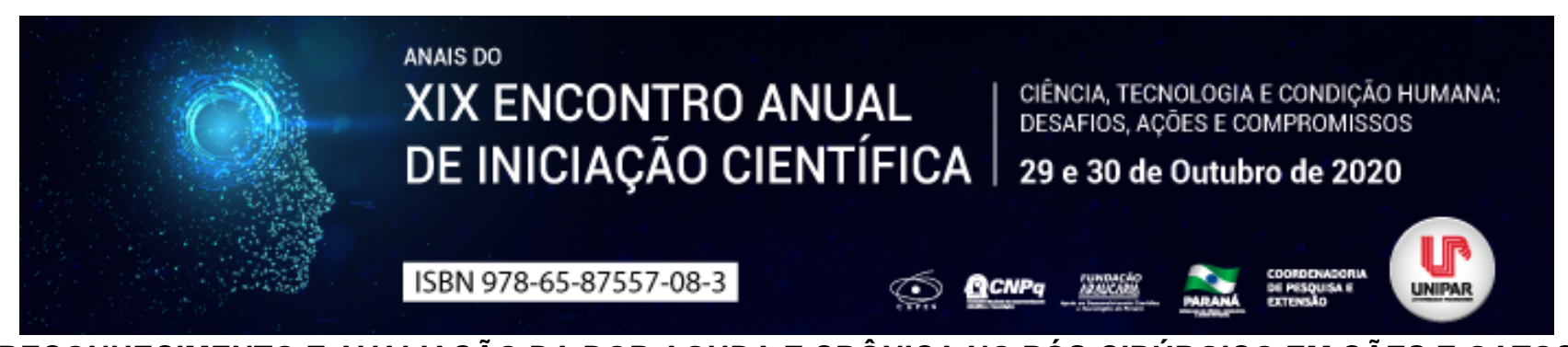

RECONHECIMENTO E AVALIAÇÃO DA DOR AGUDA E CRÔNICA NO PÓS-CIRÚRGICO EM CÃES E GATOS

\begin{abstract}
${ }^{1}$ Emanuely Ramos TameirÃEo, ${ }^{2}$ BRUNA CHRISTINA FERNANDES SOARES, ${ }^{3}$ LUCAS WAMSER FONSECA GONZAGA, ${ }^{4}$ LUCIANA DE CASTRO BARCELOS, ${ }^{5}$ ISABELA LOPES MASSITEL, ${ }^{6}$ MARCOS FERRANTE
\end{abstract}

\begin{abstract}
${ }^{1}$ Discente do curso de Medicina Veterinária na Universidade Federal de Lavras (UFLA)
${ }^{1}$ Discente do curso de Medicina Veterinária na Universidade Federal de Lavras (UFLA)

${ }^{2}$ Discente do curso de Medicina Veterinária na Universidade Federal de Lavras (UFLA)

${ }^{3}$ Discente do curso de Medicina Veterinária na Universidade Federal de Lavras (UFLA)

${ }^{4}$ Discente do curso de Medicina Veterinária da Universidade Estadual de Maringá (UEM)

${ }^{5}$ Docente do curso de Medicina Veterinária da Universidade Federal de Lavras (UFLA)
\end{abstract}

Introdução: A fim de garantir o bem-estar dos pacientes, o médico veterinário tem a responsabilidade de reconhecer, avaliar, prevenir e tratar a dor procurando minimizar esse sofrimento da melhor forma possível. (MATHEWS et al., 2014). Entretanto, ainda há um intervalo de tempo muito grande entre o reconhecimento e tratamento da dor. Apesar dos avanços da medicina veterinária, a capacidade de se diagnosticar a dor de forma eficiente apresenta consideráveis limitações, a principal delas é a falta de diretrizes e protocolos bem definidos para tratamento da dor. (MATHEWS et al., 2014). Também, deve-se considerar o fato do diagnóstico ser baseado na observação do comportamento individual e impacto fisiológico ao animal, sendo que a identificação e quantificação dessa experiência dolorosa em animais pode ser mal interpretada, refletindo, portanto, em um diagnóstico impreciso e tratamento inadequado (BRONDANI et al., 2012).

Objetivo: Abordar fundamentos para o reconhecimento e avaliação da dor na rotina prática pós-cirúrgico de pequenos animais.

Desenvolvimento: A dor é uma experiência exclusivamente individual, tanto nos seres humanos como nos animais, o que torna um desafio avaliar a forma como é assimilada por cada indivíduo. Nos animais, utilizam-se sinais comportamentais e o reconhecimento das prováveis causas de dor para conduzir o manejo. (MATHEWS et al., 2014). De uma forma simples, pode-se classificar a dor em aguda e crônica. Segundo a World Small Animal Veterinary Association (WSAVA), por meio da Global Pain Guidelines for Recognition, Assessment and Treatment of Pain, a dor aguda, geralmente, está associada a lesão tecidual ou doença, com função de alterar o comportamento do animal para evitar ou minimizar a lesão e otimizar as condições para a cicatrização, tendo seu fim quando a cicatrização está completa. Já a dor crônica, é uma dor persistente associada a processos nos quais não ocorreu cicatrização ou que sofreram remissão. Para a avaliação da dor aguda no gato deve-se levar em consideração a localização anatômica e duração da cirurgia, a variabilidade individual, idade e estado sanitário do paciente. Recomenda-se que durante a avaliação, o paciente deva ser observado à distância. Durante a análise observar expressões faciais e postura, já que podem sofrer alteração em gatos submetidos a dor, podem ocorrer as seguintes alterações: sobrancelhas franzidas, olhos semicerrados e cabeça abaixada, também podem constituir indicadores de dor a diminuição da atividade, perda de apetite, imobilidade, esconder-se, vocalização, lambedura excessiva de uma região corporal específica, comportamento de proteção, suspensão da higiene, agressividade, andar anormal, alternância do peso ou a adoção de posições de sentado e deitado anormais. Alguns gatos não exibem comportamento evidente que indique estado doloroso e apesar do sono constituir um sinal de conforto, é importante garantir que o gato repousa numa posição fisiológica (relaxado, enrolado) pois há casos que os gatos permanecem estáticos por dor excessiva ao fazer qualquer movimento, outros ainda fingem dormir quando estão sob estresse. (MATHEWS et al., 2014). Para avaliação da dor aguda no cão, também é importante considerar a idade, raça, temperamento individual e a presença de agentes estressantes, bem como a localização anatômica da lesão ou duração da cirurgia. Alguns sinais comportamentais de dor no cão incluem alterações na postura, vocalização, reação ao toque e na interação com seres humanos, diminuição do apetite e alterações de mobilidade como claudicação ou relutância em se movimentar. (MATHEWS et al., 2014). Diferentemente do gato, no cão há escalas definidas para a classificação da dor aguda, sendo a mais recomendada a Escala de Classificação Numérica (Numerical Rating Scale NRS), que avaliam dor em uma escala de 0 a 10 de acordo com comportamento do paciente com sensibilidade e especificidade maior em relação às demais. (MATHEWS et al., 2014). Com relação à dor crônica, em ambas as espécies, pode estar associada a uma doença crônica sendo que as alterações comportamentais associadas com esse tipo de dor podem ter um desenvolvimento gradual só observada muitas vezes pelo próprio tutor. Portanto, os tutores constituem uma fonte-chave de informação relativa aos animais que sofrem de dor crônica podendo ser submetidos a questões fechadas, direcionadas para relatar alterações no comportamento dos seus gatos e cães. Algumas categorias como o temperamento e mobilidade do animal, execução de atividades, estado de repouso, vigília e atividade social, com envolvimento pessoas e outros animais podem ser usadas para avaliação da dor crônica determinando o impacto, e também, alívio da mesma nas duas espécies. (MATHEWS et al., 2014). 
Conclusão: Em suma, o reconhecimento e a avaliação da dor em cães e gatos com base em diretrizes específicas, constituem na observação e conhecimento do comportamento do animal, bem como é a chave para determinar o grau e duração do tratamento para possibilitar ao paciente uma melhor qualidade de vida.

\section{Referências}

BRONDANI, J.T et al. Validade e responsividade de uma escala multidimensional para avaliação de dor pós-operatória em gatos. Arquivo Brasileiro de Medicina Veterinária e Zootecnia. Universidade Federal de Minas Gerais, Escola de Veterinária, v. 64, n. 6, p. 1529-1538, 2012.

MATHEWS, $\mathrm{K}$ et al. Guidelines for recognition, assessment and treatment of pain. Journal of Small Animal Practice. v. 55, n. 6, p. E10-E68, 2014. 


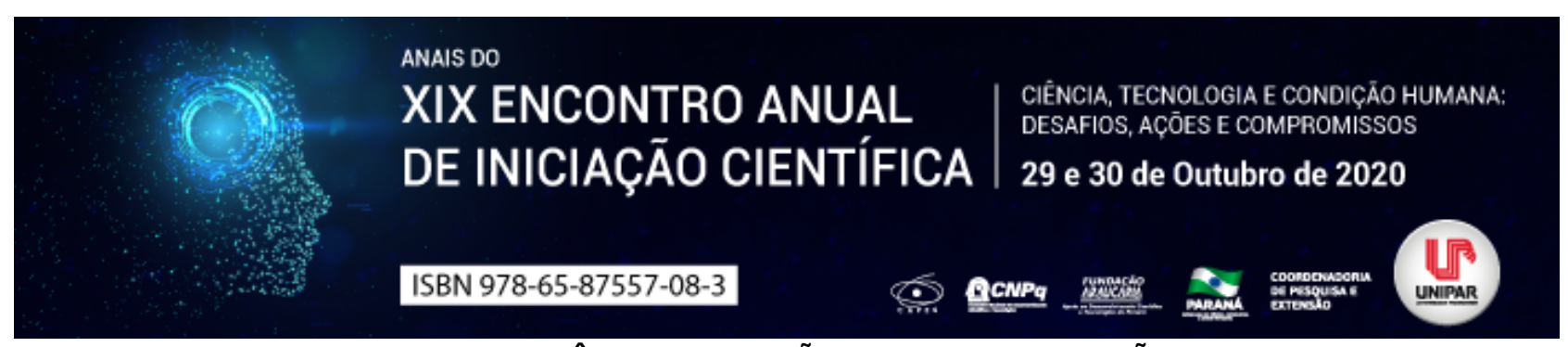

POSSIBILIDADES TERAPÊUTICAS EM CÃES COM HIPERTENSÃO PULMONAR

\begin{abstract}
${ }^{1}$ Bruna Chrisina Fernandes Soares, ${ }^{2}$ LILIAN PEREIRA GOUVEIA, ${ }^{3}$ EMANUELY RAMOS TAMEIRÃO, ${ }^{4}$ LUCAS WAMSER FONSECA GONZAGA, ${ }^{5}$ SIBELY AIVA FLORES, ${ }^{6}$ MARCOS FERRANTE
\end{abstract}

\begin{abstract}
${ }^{1}$ Acadêmica do curso de Medicina Veterinária da UFLA
${ }^{1}$ Acadêmica do curso de Medicina Veterinária da UFLA

${ }^{2}$ Acadêmica do curso de Medicina Veterinária da UFLA

${ }^{3}$ Acadêmico do curso de Medicina Veterinária da UFLA

${ }^{4}$ Acadêmica do curso de Medicina Veterinária da UFLA

${ }^{5}$ Docente do Departamento de Medicina Veterinária da UFLA
\end{abstract}

Introdução: A hipertensão pulmonar (HP) é definida pelo aumento da pressão arterial pulmonar, e quase sempre é um problema secundário ou concomitante a outros distúrbios (REINERO, 2020). Posteriormente ao diagnóstico, os canídeos com HP podem ser classificados em seis grupos, segundo o Colégio Americano de Medicina Veterinária Interna (ACVIM), sendo estes: Grupo 1 , hipertensão arterial pulmonar; Grupo 2, doença cardíaca esquerda; Grupo 3, doença respiratória ou hipóxia; Grupo 4, êmbolos, trombos ou tromboembolia pulmonar; Grupo 5, doença parasitária (Dirofilaria spp. e Angiostrongylus spp.); e Grupo 6, distúrbios multifatoriais ou com mecanismos pouco claros (REINERO, 2020).

Objetivo: Avaliar as possibilidades terapêuticas para cães com hipertensão pulmonar.

Desenvolvimento: Por se tratar de um distúrbio sistêmico, o tratamento da HP se orienta não apenas por estratégias para reduzir a progressão e as complicações dessa, como também pelo tratamento de doenças subjacentes e fatores contribuintes tanto quanto pela terapia destinada especificamente à HP. No que concerne à redução dos riscos e complicações, indica-se igualmente aos seis grupos: evitar exercícios físicos intensos; evitar prenhez; evitar viagens aéreas e altitudes elevadas; vacinar contra patógenos respiratórios (MABONI, 2019) e verminoses cardiorrespiratórias; evitar submeter o animal à anestesia geral, como em cirurgias eletivas. Para a maioria dos cães do Grupo 1, o uso de oxigênio $(O)$ hospitalar ou residencial tem efeitos benéficos, sendo, portanto, recomendado (FARBER, 2018); além disso, a oclusão dos shunts com repercussão hemodinâmica, a flebotomia com reposição de fluido e o uso de hidroxiureia são intervenções recomendadas em animais com policitemia. Para o Grupo 2 é necessário reduzir a pressão venosa pulmonar, como nos casos em que há regurgitação da válvula mitral ou insuficiência cardíaca congestiva (ICC) esquerda, mas não é recomendado o uso de inibidores da fosfodiesterase 5 (sildenafila) como primeira opção. Para o Grupo 3 é essencial tratar a doença respiratória de base e, desta forma, atenuar os sinais clínicos, melhorando a qualidade de vida do paciente. Também é ideal que os pacientes obesos percam peso, e para os animais com doenças obstrutivas crônicas das vias aéreas pode ser feito o uso de antitussígenos, sedação e antibióticos quando necessário. Já nos casos de doenças pulmonares primárias, como bronquites e pneumonias, deve ser feito o tratamento específico para tal enfermidade. No caso de obstrução venosa pulmonar é necessário fazer a desobstrução cirúrgica ou o tratamento conservativo. Para o Grupo 4, deve ser feito o uso de antitrombóticos, heparina, aspirina, rivaroxaban, apixaban, clopidogrel e ativador de plasminogênio, ou realizar a trombectomia, considerando a individualidade do caso. Para o grupo 5, de maneira geral, o animal deve ser internado e fazer uso de antiparasitários, mas é necessário seguir os consensos específicos das enfermidades (ELSHEIKHA, 2014), segundo a American Heartworm Society. Para o Grupo 6, que envolve causas multifatoriais ou idiopáticas, o tratamento deve ser personalizado, focando-se na sintomatologia apresentada pelo paciente. Há ainda alternativas adjuvantes de tratamento, as quais a despeito de não terem comprovação, podem auxiliar em casos específicos. Um dos exemplos é o pimobendan, que apresenta efeito vasodilatador inotrópico e sistêmico, e promove melhora da função sistólica do ventrículo direito (VD) (VISSER, 2015) - mas ainda não há evidências de que ele melhore a HP. A milrinona, por sua vez, apresentou resultado positivo na melhora da função do VD em cães com HP experimental (CHEN, 1998). Alguns inibidores da tirosinase são eficazes na melhora da HP em seres humanos (SATO, 2019), mas costumam apresentar efeitos adversos graves e, em cães, não há estudos que comprovem seu efeito. O mesmo ocorre com a L-arginina (L-A), um aminoácido essencial que é convertido em óxido nítrico (NO) quando se une ao $\mathrm{O}$. A administração oral desta aumentou o número de marcadores de NO em cães saudáveis (FLYNN, 2017), mas não houve diferença quando se fez a comparação entre cães com HP tratados com L-A e sildenafila juntos ou somente com sildenafila (SOUZA, 2005). Em síntese, os fatores como custo do atendimento, recursos financeiros do cliente e comprometimento com o tratamento, além do correto diagnóstico da HP, podem interferir no tempo de sobrevivência do paciente, o que dificulta o prognóstico de cães com HP. Independentemente da causa, uma vez iniciado o tratamento específico, os animais devem ser monitorados quanto à melhora, condição estática ou progressão, usando-se recomendações de consensos veterinários (REINERO, 2020). 
Conclusão: As estratégias adotadas para o tratamento dependem da classificação do paciente e do quadro clínico apresentado. Todas estas buscam a melhora da qualidade de vida e o aumento da longevidade do animal, além de diminuir os riscos e complicações dos procedimentos. Desta forma, é essencial que haja um tratamento específico e personalizado ao cão com HP, além do devido monitoramento do animal.

\section{Referências}

CHEN, Edward. et al. Hemodynamic and inotropic effects of milrinone after heart transplantation in the setting of recipient pulmonary hypertension. Journal of Heart and Lung Transplantation, Durham, n. 17, p. 669-678, jul. 1998.

ELSHEIKHA, Hany et al. Recent advances in the epidemiology, clinical and diagnostic features, and control of canine cardiopulmonary angiostrongylosis. Veterinary Research. v. 45, n. 92, sep. 2014.

FARBER, Harrison. et al. Use of supplemental oxygen in patients with pulmonary arterial hypertension in REVEAL. Journal of Heart and Lung Transplantation. n. 37, p. 948-955, mar. 2018.

FLYNN, K. et al. Plasma I-citrulline concentrations in I-arginine-supplemented healthy dogs. Journal of Veterinary Cardiology, Madison. n. 19, p. 376-383, ago. 2017.

MABONI, Grazieli. et al. Canine infectious respiratory disease: new insights into the etiology and epidemiology of associated pathogens. PLoS One, Athens, v. 14, n. 4, abr. 2019.

REINERO, Carol. et al. ACVIM consensus statement guidelines for the diagnosis, classification, treatment, and monitoring of pulmonary hypertension in dogs. Journal of Veterinary Internal Medicine, Columbia, v. 34, p. 549 573, jan. 2020.

SATO, Haruka et al. Beneficial effects of Imatinib in a patient with suspected pulmonary Veno-occlusive disease. Tohoku Journal of Experimental Medice, Tohoku, v. 247, n. 2, p. 69-73, fev. 2019.

SOUZA-SILVA, Allethea. et al. Hemodynamic effects of combined sildenafil and L-arginine during acute pulmonary embolisminduced pulmonar hypertension. European Journal Pharmacology, Ribeirão Preto, n. 524, p. 126-131, nov. 2005.

VISSER, Lance et al. Echocardiographic assessment of right ventricular systolic function in conscious healthy dogs following a single dose of pimobendan versus atenolol. Journal of Veterinary Cardiology, Columbus, v.17, n.f 3, p.161-172, sep. 2015. 


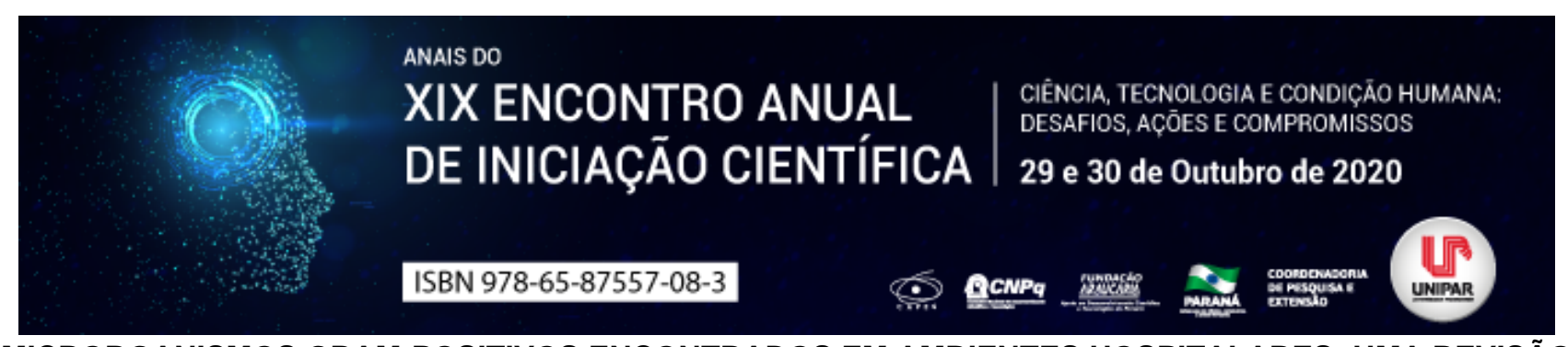

MICRORGANISMOS GRAM-POSITIVOS ENCONTRADOS EM AMBIENTES HOSPITALARES: UMA REVISÃO

\begin{abstract}
${ }^{1}$ ANA LUISA CANO, ${ }^{2}$ ISABELA CARVALHO DOS SANTOS, ${ }^{3}$ SANDRA GEANE PEREIRA DE SOUZA, ${ }^{4}$ ANA CLÁUDIA SOUZA ANDRADE, ${ }^{5}$ REGIANE PEREIRA BAPTISTA DA SILVA, ${ }^{6}$ DANIELA DIB GONCALVES
\end{abstract}

\author{
${ }^{1}$ Acadêmica do Curso de Medicina Veterinária - UNIPAR \\ ${ }^{1}$ Acadêmica do Curso de Doutorado Em Ciencia Animal Com Enfase Em Produtos Bioativos - Bolsista CAPES \\ ${ }^{2}$ Acadêmica do Curso de Doutorado Em Ciencia Animal Com Enfase Em Produtos Bioativos - Bolsista CAPES - Taxista CAPES \\ ${ }^{3}$ Acadêmica do Curso de Doutorado Em Ciencia Animal Com Enfase Em Produtos Bioativos - Taxista CAPES \\ ${ }^{4}$ Acadêmica do Curso de Doutorado Em Ciencia Animal Com Enfase Em Produtos Bioativos - Taxista CAPES \\ ${ }^{5}$ Docente da UNIPAR
}

Introdução: O Ministério da Saúde define, na portaria n 2616 de 12 de maio de 1998, infecção hospitalar (IH) ou nosocomial como aquela adquirida após admissão do paciente e que se manifeste durante a internação ou após a alta, estando relacionada com a internação em si ou a procedimentos hospitalares (GUILARDUCCI et al., 2012). Para a maioria das infecções hospitalares são reconhecidas duas fontes de contaminação: a endógena e a exógena (FERNANDO et al., 2015). Na infecção endógena os contaminantes fazem parte da flora normal do sistema, enquanto que na exógena, a contaminação é proveniente do ambiente, equipe médica e/ou material cirúrgico (FERNANDO et al., 2015). A infecção hospitalar representa um dos principais problemas da qualidade da assistência médica, pois se configura como problema econômico, devido a alta frequência de incidência e sua letalidade. Além de custos diretos, tais como internação, intervenções médico-cirúrgicas e medicamentos, há custos indiretos, como aqueles representados pela impossibilidade de retorno ao mercado de trabalho e custos inatingíveis ou difíceis de avaliar economicamente, como os distúrbios provocados pela dor, mal-estar, isolamento, sendo causas do sofrimento experimentado pelo paciente (GUILARDUCCI et al., 2012). O ambiente hospitalar, além de selecionar agentes infecciosos resistentes, reúne pessoas com diferentes vulnerabilidades à infecção, apresenta intensa realização de procedimentos invasivos, aspectos que o caracterizam como um ambiente favorável à propagação de $\mathrm{IH}$. Sendo assim, a higiene e a limpeza do ambiente constituem formas de controlar a contaminação ambiental, auxiliando na prevenção da infecção por micro-organismos resistentes aos antimicrobianos (GUILARDUCCl et al., 2012).

Objetivo: O objetivo deste trabalho foi buscar, por meio de pesquisas científicas registradas em diferentes bases de dados, informações a respeito dos principais micro-organismos presentes em superfícies e/ou equipamentos das unidades hospitalares.

Desenvolvimento: $O$ ambiente de serviços de saúde, principalmente as áreas críticas nas quais se encontram pacientes debilitados, pode contribuir para a multiplicação e a disseminação de micro-organismos potencialmente patógenos até mesmo bactérias multirresistentes e consequentemente favorecer a incidência de infecções relacionadas à assistência à saúde (DRESCH et al., 2018). Fatores como a capacidade de os micro-organismos sobreviverem em superfícies inanimadas, a dificuldade de remoção dos patógenos e a falta de limpeza específica desses ambientes contribuem para reforçar indícios de que superfícies hospitalares representam fontes de colonização e de disseminação de patógenos (DRESCH et al., 2018). Sendo assim equipamentos, utensílios para alimentação, comadres, termômetros, bacias, roupas de cama e roupas de uso pessoal também podem ser considerados reservatórios de micro-organismos patogênicos, e como são objetos frequentemente manuseados, colaboram para a transmissão dos patógenos (DRESCH et al., 2018). A ocorrência das infecções nosocomiais tem sido reconhecida crescentemente em medicina humana, os patógenos mais comumente identificados são os cocos Grampositivos como espécies de Staphyloccoccus spp e Enterococcus, membros da família Enterobacteriaceae (ARIAS; CARRILHO et al., 2012). O S. aureus resistente à meticilina (MRSA) é um problema de muita relevância, se constituindo em uma das principais causas de infecção em pacientes hospitalizados, este micro-organismo também está despontando como causa de infecção comunitária em pessoas sem fatores de risco para a ocorrência de infecção hospitalar (ARIAS; CARRILHO et al., 2012). Em seres Humanos é causa comum de infecções cutâneas superficiais e invasivas, como septicemias bacteremias, pneumonia, osteomielite, infecção do sítio cirúrgico e endocardite, restando poucas opções terapêuticas contra este micro-organismo (ARIAS; CARRILHO et al., 2012). Já as enterococos são bactérias comensais da microbiota intestinal de seres humanos e animais. Os enterococos multirresistentes se constituem patógenos de grande importância nas infecções nosocomiais em pacientes críticos (ARIAS; CARRILHO et al., 2012). Os enterococos resistentes à vancomicina (VRE) emergiram como um problema mundial, com grande aumento da sua prevalência nos hospitais (ARIAS; CARRILHO et al., 2012). O conhecimento destes microorganismos circulantes é de extrema importância, a fim de mapear os micro-organismos na ISC e a sua resistência aos antimicrobianos utilizados, uma vez que a emergência de micro-organismos multirresistentes responsáveis por graves infecções hospitalares ocorre rotineiramente (FERNANDO et al., 2015). 
Conclusão: Em termos de saúde pública, a resistência bacteriana representa um risco à qualidade de vida humana conquistada ao longo dos anos com o avanço da microbiologia, das engenharias, farmácia e da medicina, comprometendo o orçamento dos sistemas de saúde, sejam eles públicos ou privados, além de intensificar outro problema de saúde pública de grande relevância: as infecções hospitalares. A prevenção das doenças infecto parasitárias para ser efetiva requer a realização de boas práticas de higiene por parte da população e medidas profiláticas que considerem a natureza do estímulo-doença, fatores ambientais e a interação do hospedeiro humano e o estímulo-doença que deve ser eliminado ou ser reduzido a um nível insignificante antes que a interação com o hospedeiro humano ocorra.

\section{Referências}

ARIAS, M.V. B; CARRILHO, C.M.D.M. Antimicrobial resistance in animals and in human being. There is reason for concern?. Semina: Ciências Agrárias, v. 33, n. 2, p. 775-790, 2012.

DRESCH, F. et al. Contamination of surfaces located in intensive care units and operating rooms: a systematic review of the literature. Journal of Epidemiology and Infection Control, v. 8, n. 1, p. 85-91, 2018.

FERNANDO, F.S. et al. Avaliação microbiana de sítio cirúrgico relacionado ao tempo de procedimento e resistência a antimicrobianos em cães e gatos. Revista de Ciência Veterinária e Saúde Pública, v. 2, n. 1, p. 26-33, 2015.

GUILARDUCCI, D.S. et al. Avaliação da carga microbiana e determinação de micro-organismos resistentes em áreas hospitalares. Principia: Caminhos da Iniciação Científica, v. 16, p. 64-72, 2012.

Coordenadoria de Pesquisa e Extensão - COPEX

Departamento de Editoraçāo e Divulgaçāo Científica - DEDIC 


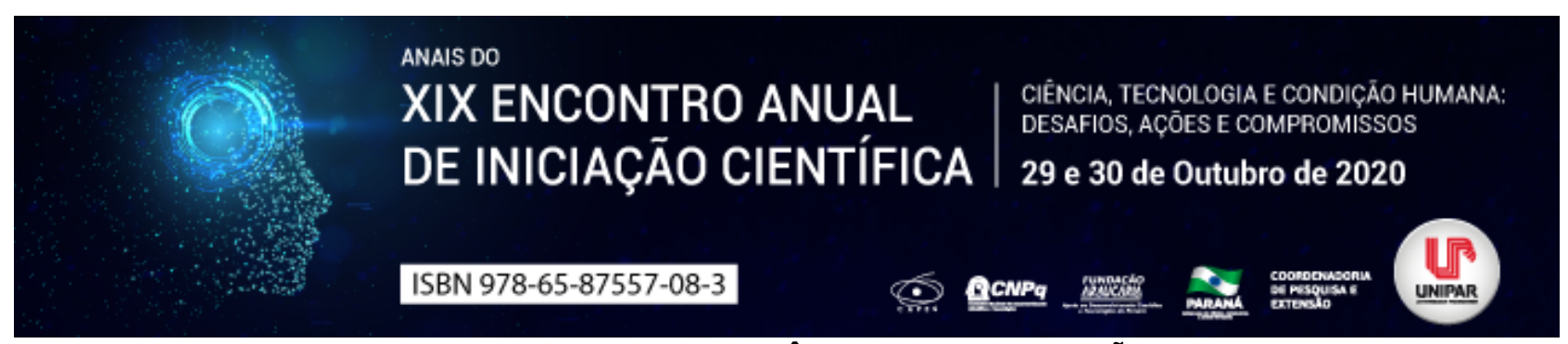

ANTIOXIDANTES EM MEIO DILUIDOR DE SÊMEN OVINO - REVISÃO DE LITERATURA

\author{
${ }^{1}$ JULIA POSTAL TRENTO, ${ }^{2}$ ANA FLAVIA MARCON, ${ }^{3}$ DERICK DE ALMEIDA MARCHI, ${ }^{4}$ SARAH LISSONI COBO, ${ }^{5}$ RANULFO \\ PIAU JUNIOR
}

${ }^{1}$ Acadêmica do curso de Medicina Veterinária da Unipar, bolsista PEBIC/CNPq

${ }^{1}$ Discente de Medicina Veterinária PIC/UNIPAR

${ }^{2}$ Discente de medicina Veterinária PIC/UNIPAR

${ }^{3}$ Discente de medicina Veterinária PIC/UNIPAR

${ }^{4}$ Docente do curso de Medicina Veterinária e do Mestrado e Doutorado em Ciência Animal com Ênfase em Produtos BioativosUNIPAR.

Introdução: No Brasil, a ovinocultura vem se destacando como alternativa de produção e rentabilidade para pequenos, médios e grandes produtores. Nesta perspectiva, há necessidade de se conhecer o material genético e o potencial produtivo e reprodutivo dos animais produzidos (PACHECO, et al., 2010).Dessa forma, a otimização do sistema produtivo terá como principal limitante a eficiência reprodutiva do rebanho. Essa eficiência pode ser incrementada com a adequação e emprego de biotécnicas de reprodução assistida(FONSECA, etal., 2014). A criopreservação seminal é uma biotécnica que permite a sobrevivência prolongada do sêmen, uma vez que os espermatozóides não sobrevivem por muito tempo no sêmen in natura. Apresenta vantagens como a otimização do uso de reprodutores; transporte de material genético para outras regiões; possibilidade de criar bancos de sêmen, dependendo apenas de um botijão criogênico e possibilidade de melhora de rebanhos para diversos produtores. Esse procedimento, no entanto, depende de meios de preservação que proporcionem um ambiente favorável para que os espermatozóides, no momento da descongelação, permaneçam com a capacidade fecundante, tornando possível o processo final de inseminação artificial e fecundação (CABRAL, 2018).

Objetivo: Revisar a importância da criopreservação do sêmen utilizando antioxidantes como meio diluidor do sêmen ovino.

Desenvolvimento: Inseminação artificial (IA) e a criopreservação de sêmen são biotecnologias queauxiliam o melhoramento genético, porém estas técnicas se tornam limitadas devido ao fato do sêmen criopreservado ovino ser ineficiente na inseminação artificial cervical e limitado na inseminação por laparoscopia, apresentando baixos índices de prenhez, além do alto custo e da falta de mão de obra especializada (MAGGI, et al., 2018). O processo de criopreservação de sêmen reduz a motilidade e a viabilidade espermática, após o descongelamento, devido à ocorrência de alterações estruturais e funcionais nos espermatozóides, especialmente na membrana plasmática, acrossoma, peça intermediária e axonema .Tais danos podem ser minimizados com a adição de substâncias crioprotetoras aos diluentes de sêmen, que protegem as células espermáticas durante o congelamento, reduzindo os danos provocados pela formação de cristais de gelo e alterações osmóticas (CORCINI, et al., 2010).As espécies reativas de oxigênio (ROS), ou radicais livres, são íons de oxigênio diatômicos gerados através de sistemas biológicos aeróbicos ou parcialmente aeróbicos. Estes são relevantes mediadores de injúrias à célula espermática e estão correlacionados com a diminuição da capacidade de penetração do espermatozóide no ovócito, o que decorre da redução da motilidade e aumento de anormalidades na morfologia dos gametas masculinos (MONTEIRO, 2015). A composição do meio diluidor utilizado para congelação de sêmen é de fundamental importância, uma vez que a diluição diminui a concentração de antioxidantes, o que promove uma instabilidade entre antioxidantes e oxidantes gerando um estresse celular (NASCIMENTO, 2016). As células espermáticas podem ter estresse oxidativo adicional, tornando necessária a proteção exógena , por possuírem poucos mecanismos capazes de evitar parcialmente ou totalmente a produção de EROs, e prevenir a peroxidação excessiva dos substratos. Desta forma, a proteção antioxidante adicional nas células espermáticas, durante a maturação e o armazenamento, quando as células necessitam combater o estresse oxidativo e, ao mesmo tempo, manter a habilidade de produção de EROs para execução de seus processos fisiológicos (SOUZA, et al., 2017).

Conclusão: Durante o processo de criopreservação os espermatozóides são submetidos a injúrias decorrente do estresse térmico, o que promove alterações funcionais e estruturais às células, podendo resultar em queda na motilidade e comprometimento da capacidade de fertilizar; Portanto a incorporação de agentes antioxidantes aos meios diluidores durante a refrigeração e congelação espermática é indicado como uma importante ferramenta para reduzir os danos decorrentes da elevação nos níveis de EROs resultantes do processo de criopreservação.

\title{
Referências
}

CABRAL, Leonardo Alves Rodrigues. Criopreservação de sêmen caprino em meio à base de água de coco em pó adicionado de diferentes concentrações de acetato de alfa tocoferol. 2018. Tese (Mestrado) Universidade Estadual do 
Ceará, Fortaleza, 2018.

CORCINI, Carine Dahl. et al. Efeito do álcool polivinílico na criopreservação de espermatozóides de ovinos. PUBVET, Londrina, v. 4, n. 21, ed. 126, 2010 Disponível em: https://www.pubvet.com.br/artigo/2276/efeito-do-aacutelcool-poliviniacutelico-nacriopreservaccedilatildeo-de-espermatozoacuteides-de-ovinos Acesso: 20 agosto 2020.

FONSECA, Jeferson Ferreira; CRUZ, Renata do Carmo; OLIVEIRA, Maria Emilia Franco; FRANCO, Maria Emilia; SOUZAFABJAN, Joanna Maria Gonçalves; VIANA, João Henrique Moreira. Biotecnologias Aplicadas à Reprodução de Ovinos e Caprinos, Brasilia, DF, Embrapa, 2014. Disponivel em: https://ainfo.cnptia.embrapa.br/digital/bitstream/item/133578/1/LivroBiotecnologias-aplicadas-completo.pdf Acesso em: 19 agosto 2020.

MAGGI, Gabriel; DACAMPO, Lucas DalleLaste; CARVALHO, Natan da Cruz; ROUBER, Lucio Pereira; CIBIN, Francielli Webber Santos; BRUM, Daniela dos Santos. Avaliação do estresse oxidativo de amostras de sêmen ovino criopreservadas com retirada do plasma seminal. Anais do $10^{\circ}$ SALÃO INTERNACIONAL DE ENSINO, PESQUISA E EXTENSÃO - SIEPE Universidade federal do Pampa, Santana do livramento, 6 a 8 de novembro de 2018.

MONTEIRO, Juliana Arandas Borda. Efeitos da suplementação oral do óleo de arroz na congelabilidade do sêmen ovino. 2015. Tese (mestrado) Universidade Federal Rural de Pernambuco, Recife, PE, 2015.

NASCIMENTO, Anna Lauren Costa. Potencial antioxidante do extrato aquoso do fruto do noni em diluente para congelação de sêmen ovino. Tese (mestrado) Universidade Federal de Sergipe, São Cristóvão, SE, 2016.

PACHECO, A. , QUIRINO, C.R. Comportamento sexual em ovinosRev. Bras. Reprod. Anim., Belo Horizonte, v.34, n.2, p.8797, abr./jun. 2010. Disponível em www.cbra.org.br. Acesso em: 19 agosto 2020.

SOUZA W.L., MORAIS E.A. \& TONIOLLI R. Adição de antioxidantes ao sêmen de carneiros e seus efeitos após a descongelação. Pesquisa Veterinária Brasileira. v. $37, \quad$ n. $5, \quad$ p. 471-478, 2017. Disponível em: https://www.scielo.br/pdf/pvb/v37n5/1678-5150-pvb-37-05-00471 Acesso em: 20 agosto 2020 


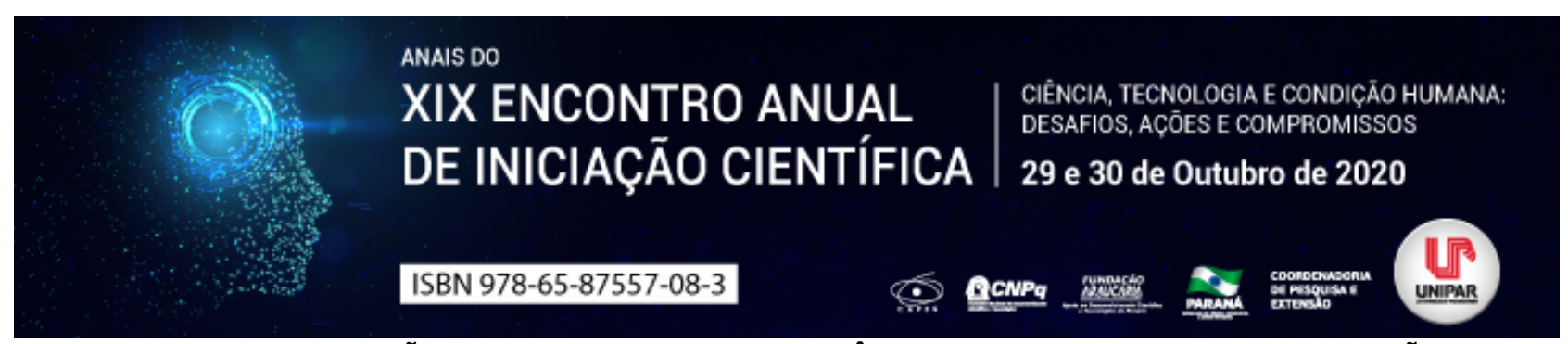

EFEITOS DA ADIÇÃO DE ANTIOXIDANTES NO SÊMEN EQUINO ESTUDO DE REVISÃO

\begin{abstract}
${ }^{1}$ IZABELA DE OLIVEIRA BORGHI, ${ }^{2}$ FERNANDA CORREA BIGATTAO, ${ }^{3}$ AULY BEATRIZ TRINDADE, ${ }^{4}$ CARLOS RENATO DE FREITAS GUAITOLINI, ${ }^{5}$ ROSIARA ROSARIA DIAS MAZIERO
\end{abstract}

\author{
${ }^{1}$ Discente, Curso de Medicina Veterinária, bolsista PIBIC- UNIPAR \\ ${ }^{1}$ Discente, Curso de Medicina Veterinária, bolsista PIBIC- UNIPAR \\ ${ }^{2}$ Discente, Curso de Medicina Veterinária, bolsista PEBIC- UNIPAR \\ ${ }^{3}$ Pós-Doutorando do Programa de Pós-graduação em Ciência Animal UNIPAR \\ ${ }^{4}$ Docente da UNIPAR
}

Introdução: A utilização das biotecnologias da reprodução em equinos vem crescendo cada dia, contribuindo para a preservação e armazenamento de germoplasma. A criopreservação traz vantagens no melhoramento genético dos animais, permitindo o uso de reprodutores de alto padrão zootécnico, além de preservar espermatozoides de animais de alto valor comercial, por um longo período (BARRETO et al., 2008). Neste sentido, a adição de agentes antioxidantes aos meios diluidores para criopreservação seminal, podem otimizar o processo e consequentemente, elevar as taxas de prenhez das fêmeas equinas.

Objetivo: Avaliar a utilização de agentes antioxidantes em meios diluidores de sêmen equino, a fim de minimizar as crioinjúrias nos espermatozoides, e consequentemente proporcionar a melhora das taxas de fertilidade de éguas.

Desenvolvimento: As técnicas do processamento utilizadas na criopreservação espermática vêm sendo bastante estudadas para evitar as injúrias provocas neste processo. Em equinos, a utilização de sêmen criopreservado é um dos motivos da baixa taxa de fertilidade das fêmeas. Alguns fatores que limitam o sucesso desta biotécnica são a adequada avaliação espermática previamente ao processo de criopreservação, uso de diluidores corretos descritos para a espécie equina, utilização de antioxidantes, velocidade e tempo de centrifugação, filtragem, curva de refrigeração e congelação, tempo de equilíbrio da ação dos crioprotetores e concentração espermática por dose inseminante (FURST, 2006). Durante o processo de criopreservação um dos fatores importante é a refrigeração prévia a congelação do sêmen equino, conferindo maior longevidade aos espermatozoides no período pós-descongelação (SILVA, 2018). Outro fator importante é a adição de crioprotetores e o uso de aditivos antioxidantes eficazes, que contribuam para a integridade das células espermáticas. Para avaliar a ação de antioxidantes adicionados em sêmen criopreservados é preciso utilizar peroxidação lipídica. Alguns antioxidantes como, Hidroxi butiltolueno (BHT) e extrato etanólico da casca do caule do mufumbo (Cumbretum leprosum) ao diluidor Botucrio $®$ não resultou em melhoras na qualidade seminal pós-criopreservação, mas houve diminuição dos radicais livres formados (SANTOS, 2019). Khalifa et al. (2008) mostraram que o diluidor a base de gema de ovo com a adição de cisteína melhorou a qualidade do sêmen póscriopreservação. Outros autores mostraram também que a adição dos antioxidantes (glutationa peroxidase e cisteina) ao diluidor Botucrio ${ }^{\circledR}$ nas concentrações de $1 \mathrm{U}$ e $5 \mathrm{U}$ de glutationa peroxidase e nas concentrações de $0.5 \mathrm{mM}$ e $1 \mathrm{Mm}$ de cisteina não favoreceu a melhora na integridade dos espermatozoides criopreservados, mas os parâmetros de cinética espermática foram preservados, como a velocidade média do percurso e a velocidade curvilinear, após 60 minutos de incubação (BARROS, 2013). Além disso, a adição destes antioxidantes foi eficaz no processo de refrigeração a $12^{\circ} \mathrm{C}$ e a incubação a $37^{\circ} \mathrm{C}$ por 12 horas, com dados similares de gestação ao se realizar a inseminação artificial com sêmen fresco (OLIVEIRA, 2013).

Conclusão: Concluiu-se que a criopreservação espermática equina, traz benefícios a reprodução de animais de alto valor genético, mas os índices de fertilidade ainda são inferiores quando comparado ao sêmen fresco. A adição de antioxidantes aos meios diluidores são capazes de melhorar a cinética espermática, favorecendo assim, o aumento das taxas de prenhez nestes animais

\title{
Referências
}

BARRETO, M. A. P.; SILVA, J. F. S.; FAGUNDES, B.; CAIADO, J. R. C.; SOUZA, G. V.; SHIMOYA, A.. Efeito De Proteínas Do Plasma Seminal Equino Com Massa Superior A 10 Kda Concentradas 10 Vezes Sobre A Congelabilidade Do Sêmen. Revista Brasileira de Zootecnia, v.37, n. 12, p. 2115-2119, 2008.

BARROS, M.K.. Efeito da adição de glutationa peroxidase e cisteína ao diluidor de congelação do sêmen equino. Arquivo Brasileiro de Medicina Veterinária e Zootecnia, v.65, n.2, p.430-438, 2013.

FURST, R. Efeitos de diferentes tempos de equilíbrio, taxas de congelação e concentrações espermáticas na fertilidade do sêmen equino. 2006. p.66. Tese (Doutorado) - Universidade Federal de Viçosa, Minas Gerais,2006.

KHALIFA, T. A. A., LYMBEROPOULOS, A. G.; EL-SAIDY, B. E. Testing usability of butylated hydroxytoluene in conservation of goat semen. Reproduction in Domestic Animals, v. 43, n. 5, p. 525-530, 2008. 
OLIVEIRA, A.F.D. Efeito da Adição de Antioxidantes sobre Espermatozoides Equinos mantidos sob Temperatura de Transporte e Inseminação Artificial. BBR Biochemistry and Biotechnology Reports - ISSN 2316-5200 Número Especial, Goiana, v. 2, n. 3, p. 25-28, 2013.

OLIVEIRA, S.N. Efeito Do Glicerol E Amidas Em Diferentes Curvas De Refrigeração Sobre A Qualidade Do Sêmen Congelado Equino. 2020.p.90. Tese (doutorado) - Faculdade de Medicina Veterinária e Zootecnia da Universidade Estadual Paulista Júlio de Mesquita Filho - UNESP, Campus de Botucatu, 2020.

OSÓRIO, J.P. Princípios do Congelamento de Sêmen do Garanhão, UNOPAR Cient., Ciênc. Biol. Saúde, Londrina, v. 10, n. 2, p. 15-22, 2008

SANTOS, F.A. Uso de peroxidação lipídica na avaliação da ação de antioxidante em sêmen criopreservado. PUBVET, v.13, n.8, a399, p.1-7, 2019.

SILVA, R.O.F. Avaliações Dos Parametros Do Semen Equino Pré E Pós-Congelamento Após Separação Dos Espermatozoides Com A Utilização De Lã De Vidro. 2018. P.53. Disertação (Mestrado) -Universidade Federal de Santa Maria, Rio Grande do Sul, 2018.

SOUZA, G.V. Criopreservação De Sêmen Equino: Desenvolvimento De Equipamentos Ara Congelamento Em Aceleração E Para Descongelamento Ultra-rápido $\left(9^{\circ} \mathrm{Cl} 4 \mathrm{Seg}\right.$.). 2006. Tese (Doutorado) - Universidade Estadual do Norte Fluminense, Campos dos Goytacazes- Rio de Janeiro, 2006.

Coordenadoria de Pesquisa e Extensão - COPEX

Departamento de Editoraçāo e Divulgaçāo Científica - DEDIC 


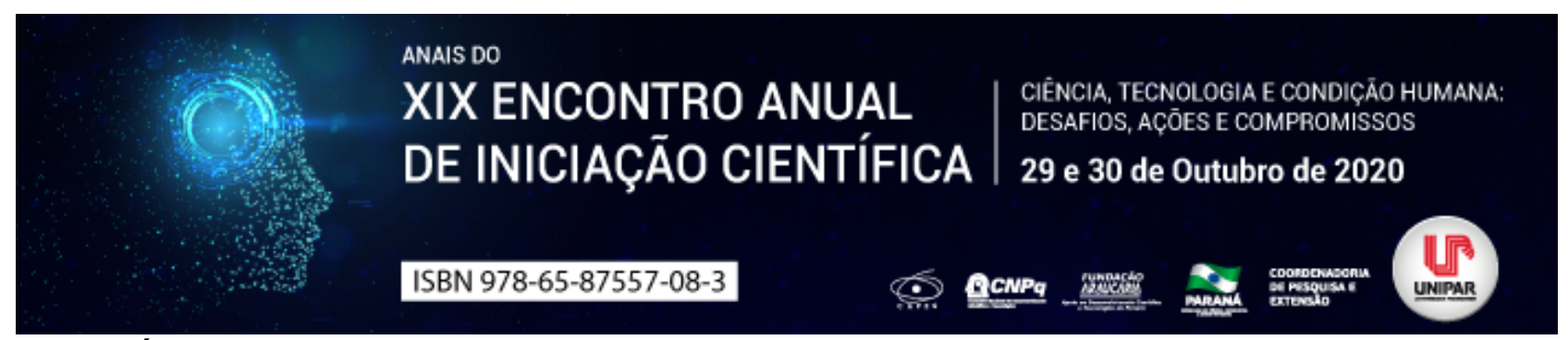

DIAGNÓSTICO E TERAPIA ANTIMICROBIANA DA FOLICULITE BACTERIANA SUPERFICIAL CANINA

\begin{abstract}
${ }^{1}$ Emanuely Ramos TameirÃ£o, ${ }^{2}$ IZABEL CRISTINA TAVARES, ${ }^{3}$ LUCAS WAMSER FONSECA GONZAGA, ${ }^{4}$ LUCIANA DE CASTRO BARCELOS, ${ }^{5}$ MARCOS FERRANTE, ${ }^{6}$ JOÃO VITOR FERNANDES COTRIM DE ALMEIDA
\end{abstract}

\begin{abstract}
${ }^{1}$ Discente do curso de Medicina Veterinária na Universidade Federal de Lavras (UFLA)
${ }^{1}$ Discente do curso de Medicina Veterinária na Universidade Federal de Lavras (UFLA)

${ }^{2}$ Discente do curso de Medicina Veterinária na Universidade Federal de Lavras (UFLA)

${ }^{3}$ Discente do curso de Medicina Veterinária na Universidade Federal de Lavras (UFLA)

${ }^{4}$ Docente do curso de Medicina Veterinária da Universidade Federal de Lavras (UFLA)

${ }^{5}$ Mestrando em Ciências Veterinárias do Departamento de Medicina Veterinária da Universidade Federal de Lavras (UFLA)
\end{abstract}

Introdução: A foliculite bacteriana superficial (FBS) é uma dermatite causada principalmente por Staphylococcus pseudintermedius. Trata-se de uma patologia comum em cães, que, apesar de ocorrer na forma primária, é mais comumente encontrada como uma complicação de doenças alérgicas ou endócrinas (ALQUEIDÃO, 2018). Isso faz com que haja dificuldade no diagnóstico e insucesso no tratamento antimicrobiano, sendo observada, muitas vezes, recorrência da doença e repetição do tratamento. Fatores como esses levam ao surgimento de bactérias multirresistentes, particularmente de $S$. pseudintermedius resistente à meticilina (MRSP). Ante o exposto, deve-se atentar para a necessidade de gerenciamento no tratamento antimicrobiano de FBS em cães (HILLIER et al, 2014).

Objetivo: Revisar as indicações atuais para o diagnóstico e tratamento da FBS em cães, focado no racional de antimicrobianos.

Desenvolvimento: A emergência de colônias de MRSP e consequente preocupação com o número crescente de casos de resistência antimicrobiana levaram à criação de linhas de orientação, pelo grupo de trabalho da International Society for Companion Animal Infectious Diseases (ISCAID), descrevendo métodos para o diagnóstico e tratamento da FBS. (ALQUEIDÃO, 2018; HILLIER et al, 2014). A maioria dos diagnósticos para casos de FBS está baseada em sinais clínicos e na presença de lesões características da doença, porém, não há evidências de que essas difiram entre infecções causadas pelos diferentes estafilococos. (BAJWA, 2016; HILLIER et al, 2014). Considerando-se esse fato, a citologia da pele lesionada é um poderoso teste para diagnóstico da enfermidade, e considerada obrigatória quando lesões típicas não estão presentes ou há fraca resposta à terapia antimicrobiana (HILLIER et al, 2014). A cultura bacteriana, por sua vez, é essencial para indicar a probabilidade de resistência ao antimicrobiano escolhido para tratamento da FBS, além de ser empregada em casos com pouca redução da extensão das lesões com terapia antimicrobiana, ou quando há surgimento de novas lesões após o início desta. Já o teste de sensibilidade a antibióticos é indicado quando, a despeito de haver agente bacteriano envolvido, não é possível predizer a suscetibilidade deste de forma acurada. Para analisar a resistência de S. pseudintermedius, a difusão em disco é a técnica mais indicada (ALQUEIDÃO, 2018; BAJWA, 2016). Com relação às recomendações para o tratamento de FBS, deve-se considerar em primeiro lugar a natureza da doença em cada paciente, para que se determine a melhor terapia a partir de fatores como gravidade e extensão das lesões, resistência antimicrobiana, doença concomitante e capacidade do proprietário realizar terapia tópica ou sistêmica. (ALQUEIDÃO, 2018; HILLIER et al, 2014). A terapia tópica é uma alternativa de tratamento vantajosa para lesões localizadas de FBS, em estágio inicial de FBS generalizada, quando as lesões são leves, ou para ajudar a prevenir a recorrência da enfermidade enquanto são realizados diagnósticos de doenças subjacentes primárias à foliculite. (BLOOM, 2014; HILLIER et al, 2014). Quanto à terapia antimicrobiana sistêmica, deve-se considerar que a seleção do fármaco se baseia principalmente na prevalência local de estafilococos resistentes, então, como alternativa, a ISCAID desenvolveu uma ferramenta que classifica, em três categorias, os antimicrobianos usados no tratamento de FBS canina. Os fármacos de primeira escolha, clindamicina ou lincomicina, as cefalosporinas de $1^{\mathrm{a}}$ geração (p. ex.: cefalexina) e a associação de amoxicilina com clavulanato de potássio são indicados quando o diagnóstico é claro e não há fatores de risco para o desenvolvimento de resistência antimicrobiana. Podem ser adicionadas sulfonamidas, potencializadas por trimetoprima e ormetoprima, em casos nos quais a suscetibilidade regional e/ou local de S. pseudintermedius seja conhecida, por meio de estudos de sensibilidade, como os antibiogramas realizados na rotina clínica (HILLIER et al, 2014). Já os de segunda escolha podem ser usados quando a seleção empírica de antimicrobiano sistêmico de primeira escolha e terapia tópica não são adequadas, e as culturas indicam suscetibilidade a estes fármacos, os quais podem ser: a doxiciclina ou minociclina, o cloranfenicol, as fluoroquinolonas e as cefalosporinas de $3^{a}$ geração, entretanto, os dois últimos são antibióticos classificados como máxima prioridade de risco de resistência para saúde humana, logo, não recomendados para uso na medicina veterinária. (BLOOM, 2014; HILLIER et al, 2014; SCALDAFERRI et al, 2020). Por fim, os fármacos de última escolha incluem medicamentos reservados para infecções altamente resistentes; não se recomenda o uso desses, que a título de exemplo são a linezolida, teicoplanina e vancomicina (HILLIER et al, 
2014).

Conclusão: Em suma, para diagnóstico e tratamento da foliculite bacteriana superficial canina é essencial uma ferramenta que visa racionalizar o uso de antimicrobianos, classificando-os em três grupos de escolha para que, assim, o $S$. pseudintermedius resistente à meticilina e outras bactérias multirresistentes, que afetam a saúde animal e humana, possa ser mitigada.

\section{Referências}

ALQUEIDÃO, Soraia Dias. Resistência a antibióticos em isolados de cães com foliculite superficial bacteriana: estudo retrospectivo. 2018. Dissertação (Mestrado em Medicina Veterinária) - Universidade Lusófona de Humanidade e Tecnologias, Lisboa, Portugal, 2018.

BAJWA, Jangi. Canine superficial pyoderma and therapeutic considerations. The Canadian Veterinary Journal, v. 57, n. 2, p. 204 206, 2016. Disponível em: https://www.ncbi.nlm.nih.gov/pmc/articles/PMC4713004/pdf/cvj_02_204.pdf. Acesso em: 2 set. 2020.

BLOOM, Paul. Canine superficial bacterial folliculitis: current understanding of its etiology, diagnosis and treatment. The Veterinary Journal, v. 199, n. 2, p. 217-222, 2014. Disponível em: https://doi.org/10.1016/j.tvjl.2013.11.014. Acesso em: 2 set. 2020.

HILLIER, Andrew. et al. Guidelines for the diagnosis and antimicrobial therapy of canine superficial bacterial folliculitis (Antimicrobial Guidelines Working Group of the International Society for Companion Animal Infectious Diseases). Vet dermatology, v. 25, n. 3, p. 163-175, 2014.

SCALDAFERRI, Laura Gaspar. et al. Formas de resistência microbiana e estratégias para minimizar: uma revisão. PUBVET v. 14, n. 8, a621, p. 1-10, ago., 2020. Disponível em: https://doi.org/10.31533/pubvet.v14n8a621.1-10. Acesso em: 22 ago. 2020. 


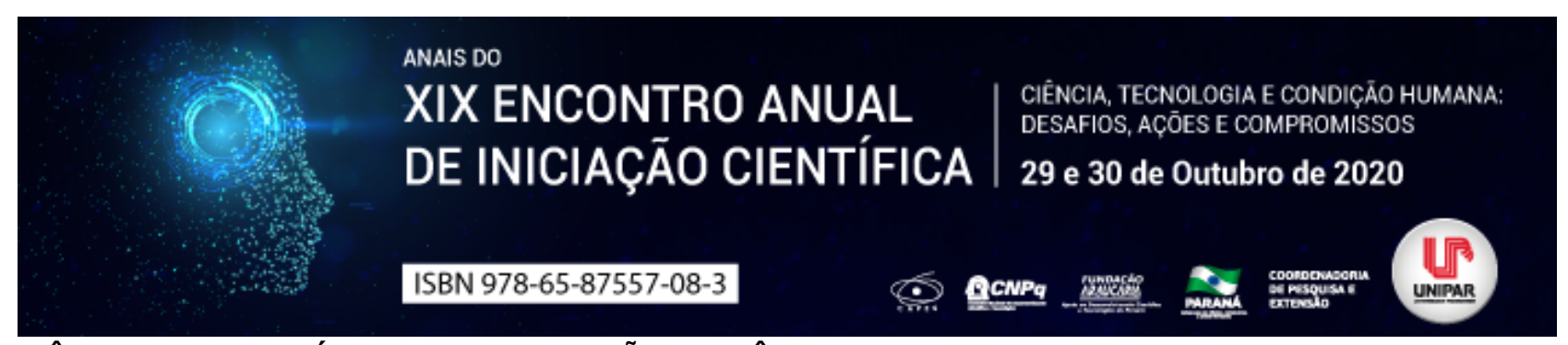

\title{
IMPORTÂNCIA DO DIAGNÓSTICO DE GESTAÇÃO EM FÊMEAS BOVINAS DESTINADAS AO ABATE E SEU IMPACTO ECONÔMICO- REVISÃO DE LITERATURA
}

\author{
${ }^{1}$ DANIELLE ANDRESSA OLIVEIRA SESTARI, ${ }^{2}$ BRUNO ARGENTON DE BARROS, ${ }^{3}$ ALYSON LIBERALI ARAUJO, \\ ${ }^{4}$ ALECSANDRO SILVA DE LIMA ELIAS, ${ }^{5}$ CARLOS RENATO DE FREITAS GUAITOLINI, ${ }^{6}$ ROSIARA ROSARIA DIAS MAZIERO
}

\author{
${ }^{1}$ Discente De Mestrado Do Programa De Pós-Graduação Em Ciência Animal -Taxista CAPES/PROSUP- UNIPAR \\ ${ }^{1}$ Acadêmico do Curso de Medicina Veterinária da UNIPAR \\ ${ }^{2}$ Acadêmico do Curso de Mestrado Em Ciência Animal Com Ênfase Em Produtos Bioativos - Turma XIV da UNIPAR \\ ${ }^{3}$ Acadêmico do Curso de Mestrado Em Ciência Animal Com Ênfase Em Produtos Bioativos - Turma XIV da UNIPAR \\ ${ }^{4}$ Acadêmico do Curso de Programa Nacional de Pos-doutorado -pnpd/capes da UNIPAR \\ ${ }^{5}$ Docente da UNIPAR
}

Introdução: A bovinocultura de corte possui grande destaque econômico no setor agropecuário e tem impulsionado o agronegócio mundial (RODRIGUES et al., 2020). No Brasil temos o maior rebanho bovino comercial do mundo, onde a pecuária tem mostrado sua força, responsável por movimentar aproximadamente $\mathrm{R} \$ 597,22$ bilhões do PIB nacional (ABIEC, 2019). Com as mudanças e exigências do mercado consumidor de carne bovina, a indústria brasileira registrou recordes de abates de fêmeas nos últimos anos. Esta categoria animal quando não vai para a reprodução, são destinadas ao abate e produzem uma carne de qualidade muito apreciada por sua maciez e acabamento de gordura, características obtidas com mais facilidade em fêmeas (NETO, 2019). No entanto é de extrema importância a realização do diagnóstico de gestação antes de serem destinadas ao frigorífico, para que não seja realizado o abate quando a fêmea se encontre prenhe.

Objetivo: Ressaltar a importância do diagnóstico de gestação em fêmeas bovinas que serão destinadas ao abate e seu reflexo econômico quando não realizado.

Desenvolvimento: Com o aumento da demanda pelo consumo da carne de fêmea bovina torna-se imprescindível o diagnóstico de gestação antes do abate, para assim atender as recomendações do RIISPOA (Regulamento de Inspeção Industrial e Sanitária de Produtos de Origem Animal), onde regulamenta no Art. 113, cita que deve ser evitado o abate de fêmeas em estado adiantado de gestação (terço final), sendo essas carcaças destinadas à esterilização (SORNAS et al., 2014). Este regulamento é embasado no fato de que o consumo desta carne seja impróprio, pois pode oferecer riscos à saúde humana pela possível transmissão de Brucelose ao consumidor, uma vez que as fêmeas prenhe são mais susceptíveis à infecção por Brucella abortus (GIUFFRIDA et al., 2010). Porém, a realidade brasileira é que as carcaças que não apresentam evidência de infecção, de maneira geral, são comercializadas livremente (DANTAS, 2019). Outro fator impactante economicamente é rendimento de carcaça (relação entre o peso da carcaça e o peso vivo do bovino abatido), em que as fêmeas gestantes apresentam um menor rendimento quando comparado às não prenhes, com menor ganho de peso (redução de $12,2 \%)$, menor rendimento $(5,5 \%$ menos), e pior conversão alimentar (13,3\% maior) (WREN, 2008). SORNAS et al. (2014) também relataram que as maiores perdas médias relacionadas ao rendimento, tanto em percentagem como em reais são verificadas a partir do segundo trimestre gestacional, mais expressivas no terço final, representando até cerca de $8 \%$ do total do peso da carcaça ou equivalente a $R \$ 350,00$ por animal no $9^{\circ}$ mês de gestação, dependendo do valor pago pela @ do animal, levando em conta que peso do útero e do feto, podem chegar a $80 \mathrm{~kg}$ e volume de 55 litros no final da gestação (FERREIRA, 2010). Apesar desses fatores ainda serem muito comuns, o envio de fêmeas ao abate sem a realização do diagnóstico de gestação, demonstra claramente um manejo inadequado, notado em grande parte da pecuária nacional (SORNAS et al., 2014). Com isso é de extrema importância o diagnóstico gestacional precedente ao abate, para avaliar de forma rápida com auxílio de aparelho ultrassonográfico (BELTRAME et al., 2010), via palpação transretal (BALL e PETERS, 2006).

Conclusão: Observou-se no presente levantamento a importância do diagnóstico gestacional em fêmeas bovinas destinadas ao abate, uma vez que o abate de fêmeas prenhe implica em menor rendimento de carcaça refletindo negativamente no lucro desses animais.

\section{Referências}

Associação Brasileira das Indústrias Exportadoras de Carne ABIEC. Perfil da Pecuária no Brasil. 2019

BALL, P. J. H.; PETERS, A. A. R. Reprodução em bovinos. 3. ed. cap 11, p. 134-147. ROCA 2006.

BELTRAME, Renato Travassos. et al. Aplicações da ultra-sonografia na obstetrícia animal. Publicações em Medicina Veterinária e Zootecnia., Londrina, v. 4, n. 27. 2010.

DANTAS, Fagner. et al. Prenhez, biometria uterina e fetal em bovinos abatidos no município de Morrinhos-GO. 2019. 
FERREIRA, A. de M. Gestação em bovinos. In: Reprodução da Fêmea Bovina: Fisiologia aplicada. Juiz de Fora, MG: Edição do autor, 2010, Cap. IX, p.345-394.

RODRIGUES, Alexandra Soares. et al. Eficácia Do Uso Distintos Estimulantes Do Crescimento Folicular Em Um Protocolo Para latf Em Fêmeas Nelore. Archives of Veterinary Science, v. 25, n. 1, 2020.

SORNAS, Aline Souza; JÚNIOR, Paulo Rossi; MOIZES, Fernanda Aparecida Fragoso. Impacto do abate de vacas prenhes sob parâmetros de carcaça e sua influência no resultado econômico. Archives of Veterinary Science, v. 19, n. 4, 2014.

GIUFFRIDA, R.; PAES, A. C.; da SILVA, R. C. Doenças infecciosas da reprodução. In: PIRES, A.V. Bovinocultura de corte. Volume II. Piracicaba: FEALQ, 2010, Cap. 51, p.959-992

WREN, G. Managing pregnant feedlot heifers. In: Drovers Cattle Network, 2008. Disponível em: . Acesso em: 06 ago. 2020.

NETO, HYBERVILLE. O abate de novilhas é o maior registrado nos últimos 10 anos. Pasto extraordinário. 20 jun. 2019. Disponível em: https://pastoextraordinario.com.br/abate-de-novilhas-recorde-2019/ Acesso em: 06 ago. 2020.

Coordenadoria de Pesquisa e Extensão - COPEX

Departamento de Editoraçāo e Divulgaçāo Científica - DEDIC 


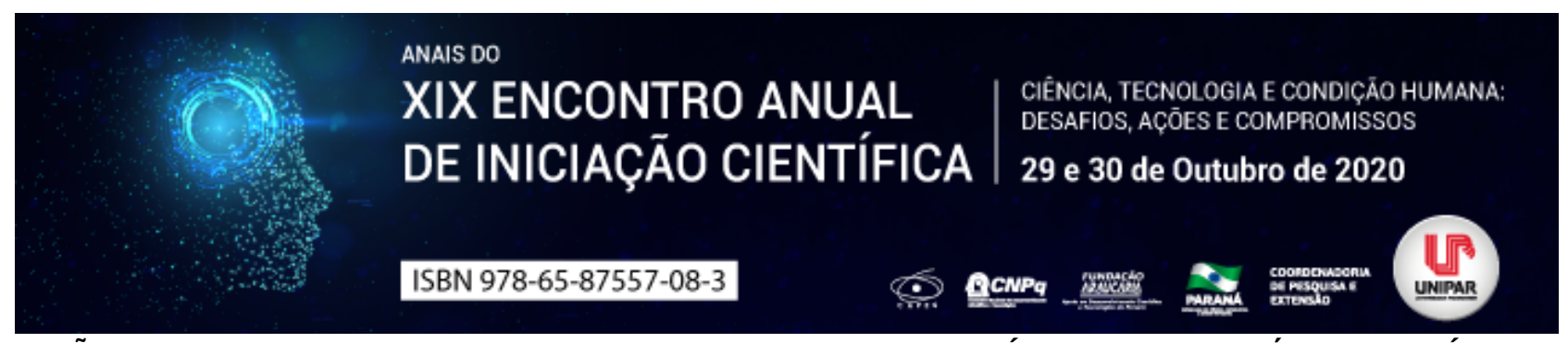

\title{
A RELAÇÃO ENTRE O POLIMORFISMO RS9939609 DO GENE FTO E A SÍNDROME DO OVÁRIO POLICÍSTICO: UMA REVISÃO
}

\author{
${ }^{1}$ GABRIELA ALVES DE OLIVEIRA, ${ }^{2}$ MARCELA OLIVEIRA CHIAVARI FREDERICO, ${ }^{3}$ RICARDO MARCELO ABRAO, ${ }^{4}$ LUCIANO \\ SERAPHIM GASQUES
}

${ }^{1}$ Acadêmica de Medicina - UNIPAR
${ }^{1}$ Docente da UNIPAR
${ }^{2}$ Docente da UNIPAR
${ }^{3}$ Docente da UNIPAR

Introdução: O gene denominado Fat Mass and Obesity Associed (FTO) possui associação com a obesidade e o aumento do IMC. Esse possui alguns variantes comuns, entre estes o Single Nucleotide Polymorphism (SNP) rs9939609, o qual apresenta o nucleotídeo A como alelo e que apresenta risco para as patologias associadas a obesidade quando da sua presença no indivíduo (BRANAVAM et al., 2020). A Síndrome do Ovário Policístico (SOP), por sua vez, é uma disfunção endócrina, caracterizada por anovulação/oligovulação, hiperandrogenismo e ovários policísticos (BARBER et al., 2008) geralmente está associada a obesidade. Nesse âmbito, é pertinente que se levante o questionamento de que o polimorfismo rs9939609 do gene FTO pode estar envolvido na patogenia da SOP.

Objetivo: O presente estudo objetiva revisar a relação sugerida através dados de prevalência entre o polimorfismo estudado (rs9939609) do gene FTO e a fisiopatologia da Síndrome do Ovário Policístico.

Desenvolvimento: O FTO é um gene localizado no cromossomo 16, encontrado em diversos tecidos que atua na regulação da gordura corporal e no balanço energético. O polimorfismo rs9939609 está localizado no $1^{\circ}$ intron desse gene, e sua representação se dá através de dois alelos, A e T, sendo o A mais associado ao aumento de gordura corporal e no IMC (BARBER et al., 2008). Sabe-se que o balanço energético é regulado $40 \%$ por heranças genéticas, portanto, esse SNP tem um grande impacto na gordura corporal (TAN et al., 2010). Bem como o polimorfismo, a Síndrome estudada tem em comum a origem genética, ou seja, sua manifestação é predisposta pelo genótipo, e determinada em conjunto com o fenótipo, o que levanta a hipótese de que há uma correlação entre esses fatores (BRANAVAN et al., 2020). A prevalência desse SNP em mulheres acometidas por ela, bem como uma prevalência de 40 a 80\% de sobrepeso ou obesidade nessas pacientes (TAN et al., 2010). Branavan et al., (2020) apontam para resultados que mostram que os genótipos co-dominante AA, dominante AT ou AA, e recessivo AA, apresentaram maiores riscos de desenvolver a SOP indicando a associação entre o FTO e a SOP. Tan et al. (2010) realizou seu estudo na Universidade de Duisburg-Essen, na Alemanha, e conclui que o efeito gerado pelo rs9939609 sobre o IMC foi maior em mulheres acometidas por SOP quando comparado com as mulheres sem a síndrome, além de estar associada a maior resistência a insulina apontando para maiores índices no IMC que refletem uma ação patogênica do polimorfismo no mecanismo da síndrome.

Ainda no mesmo sentido, Barber et al. (2008) evidenciou um aumento de frequência de SOP com a presença do alelo A. Sobre o IMC, os resultados mostram um aumento em pacientes policísticas com a presença deste SNP, mesmo após o ajuste entre os dois grupos. Dessa forma, conclui-se que o polimorfismo influencia o índice de massa gorda, IMC, e obesidade, afetando assim o perfil metabólico das pacientes, entretanto, os autores defendem que a presença desse gene não é um fator determinante na suscetibilidade da SOP. Em 2015, Ramos e Spritzer, realizaram um estudo avaliando a prevalência desses SNP em mulheres com SOP no sul do Brasil, e o mesmo apresenta que em níveis hormonais, de IMC, e ao risco de síndrome metabólica, os resultados analisados entre os indivíduos com e sem o SNP foram similares, apresentando alterações somente a nível de insulina em jejum, onde os níveis de glicose os indivíduos AT e AA alterados. Cai, Liu e Mou (2014) realizam um análise com base em outros estudos de diferentes etnias, e mostraram uma associação entre o rs9939609 e o risco de SOP somente para a população do leste asiático, indicando que ocorre pelos efeitos do gene sobre a adiposidade, e intolerância à glicose, sugerindo que a presença desse SNP leva a um aumento na ingestão de energia, redução da sensação de saciedade e oxidação lipídica. Além disso, sugerem que os efeitos relacionados a obesidade gerados pelo polimorfismo estudado são duas vezes maiores em mulheres com SOP, entretanto, essa relação não se faz presente nos demais estudos de outras etnias além das mulheres do leste asiático.

Conclusão: Conclui-se que existe uma associação entre o SNP rs9939609 (alelo A) e a SOP, e os estudos apontam que essa relação ocorre de forma indireta através do aumento do IMC, embora exista alguma discrepância entre os autores.

\section{Referências}


BARBER, T. M. et al. Association of variants in the fat mass and obesity associated (FTO) gene with polycystic ovary syndrome. Diabetologia, v. 51, n. 1, p. 1153 1158, 14 maio 2008. DOI 10.1007/s00125-008-1028-6. Disponível em: https://pubmed.ncbi.nlm.nih.gov/18478198/. Acesso em: 26 jun. 2020.

TAN, Susanne et al. Large effects on body mass index and insulin resistance of fat mass and obesity associated gene (FTO) variants in patients with polycystic ovary syndrome (PCOS). BMC Medical Genetics, Essen, Alemanha, v. 11, p. 1-6, 21 jan. 2010. DOI 10.1186/1471-2350-11-12. Disponível em: https://bmcmedgenet.biomedcentral.com/articles/10.1186/1471-2350-11-12. Acesso em: 26 jun. 2020.

RAMOS, Ramon B.; SPRITZER, Poli Mara. FTO gene variants are not associated with polycystic ovary syndrome in women from Southern Brazil. Gene - Elsevier, Amsterdã, ano 2015, v. 510, p. 25 29, 12 jan. $2015 . \quad$ DOI https://doi.org/10.1016/j.gene.2015.01.012. Disponível

em: https://www.sciencedirect.com/science/article/pii/S0378111915000281. Acesso em: 26 jun. 2020.

BRANAVAN, Umayal et al. In depth analysis of the association of FTO SNP (rs9939609) with the expression of classical phenotype of PCOS: a Sri Lankan study. BMC Medical Genetics, Sri Lanka, ano 2020, v. 21, p. 1-9, 12 fev. 2020. DOI https://doi.org/10.1186/s12881-020-0961-1. Disponível em: https://bmcmedgenet.biomedcentral.com/articles/10.1186/s12881020-0961-1. Acesso em: 27 jun. 2020.

CAI, Xianli; LIU, Chibo; MOU, Sihua. Association between Fat Mass- and Obesity- Associated (FTO) Gene Polymorphism and Polycystic Ovary Syndrome: A Meta-Analysis. PLoS ONE, Londres, Inglaterra, v. 9, n. 1, p. 1-5, 22 jan. 2014. DOI 10.1371/journal.pone.0086972. id=10.1371/journal.pone.0086972\&type=printable. Acesso em: 30 jun. 2020. 


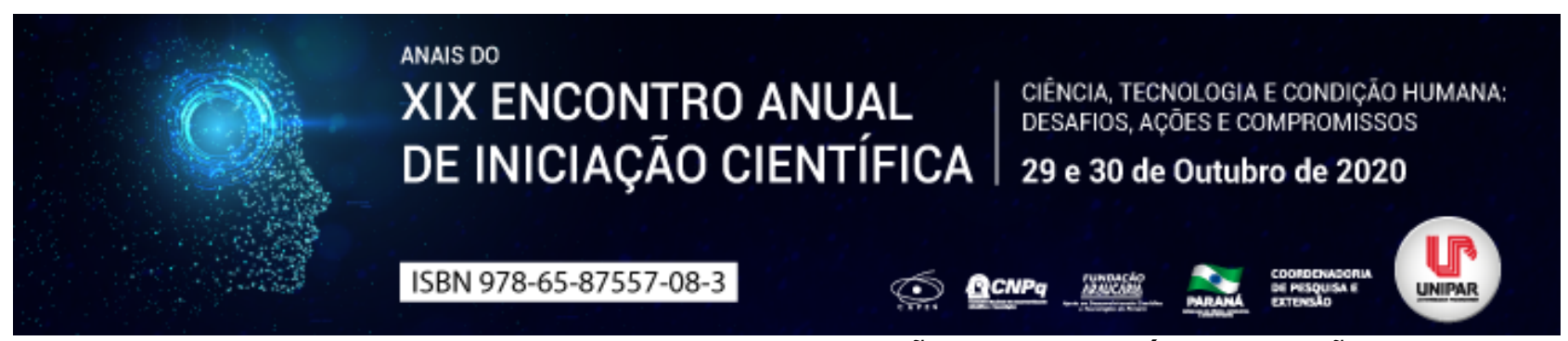

DIRETRIZES PARA O TRATAMENTO DE INFECÇÕES RESPIRATÓRIAS EM CÃES

\begin{abstract}
${ }^{1}$ Sibely Aiva Flores, ${ }^{2}$ EMANUELY RAMOS TAMEIRÃO, ${ }^{3}$ LILLIAN PEREIRA GOUVEIA, ${ }^{4}$ MELISSA SANCHES MONGELLI, ${ }^{5}$ HUMBERTO DE MELLO BRANDAO, ${ }^{6}$ MARCOS FERRANTE
\end{abstract}

\author{
${ }^{1_{1}}$ Acadêmica do curso de Medicina Veterinária, Universidade Federal de Lavras \\ ${ }^{1_{1}}$ Acadêmica do curso de Medicina Veterinária, Universidade Federal de Lavras \\ ${ }^{2}{ }_{1}$ Acadêmica do curso de Medicina Veterinária, Universidade Federal de Lavras \\ ${ }^{3_{1}}$ Acadêmica do curso de Medicina Veterinária, Universidade Federal de Lavras \\ ${ }^{4}$ Pesquisador da EMBRAPA Gado de Leite, Juiz de Fora, MG, Brasil \\ ${ }^{5}$ Docente do Departamento de Medicina Veterinária, Universidade Federal de Lavras
}

Introdução: As doenças infecciosas do trato respiratório dos cães são extremamente relevantes na rotina clínica veterinária, pois correspondem a grande parte da casuística. Entre as patologias mais frequentes estão: a traqueobronquite infecciosa canina, bronquite, pneumonia e piotórax. No entanto, profissionais enfrentam dificuldades ao prescreverem a antibioticoterapia, pois faltam diretrizes para o tratamento dessas enfermidades (LAPPIN et al., 2017). A prescrição deve considerar que muitas classes de antibióticos utilizados na medicina veterinária, são indicadas para humanos no tratamento de doenças infecciosas e, portanto, sua administração deve ser criteriosa visando evitar a resistência antimicrobiana (OMS, 2017).

Objetivo: Abordar os protocolos terapêuticos mais utilizados no tratamento de infecções respiratórias de origem bacteriana em cães.

Desenvolvimento: A traqueobronquite infecciosa canina possui alta morbidade e a letalidade depende da evolução da doença. Os sinais clínicos agudos iniciais envolvem tosse com ou sem espirros (MORAL, 2014). Geralmente, é causada por vírus e tem resolução espontânea dentro de 10 dias, sem uso de antibióticos. A antibióticoterapia somente é indicada caso o animal apresente, junto com a descarga nasal mucopurulenta, febre, letargia e inapetência (LAPPIN et al., 2017). Entretanto bactérias podem estar envolvidas na infecção primária, a exemplo de Bordetella bronchiseptica, Pasteurella sp., Streptoccocus equi subsp. zooepidemicus, Pseudomonas sp e Mycoplasma spp. (MOCHIZUKI et al., 2008). A B. bronchiseptica é zoonótica e pode afetar pessoas imunocomprometidas, portanto o tratamento correto de cães infectados é uma questão de saúde pública (FERNANDES \& COUTINHO, 2004). Suspeita-se de infecção por S.equi subsp. zooepidemicus quando há pneumonia hemorrágica e morte súbita (LAPPIN et al., 2017). A indicação para cães que apresentem sintomas da traqueobronquite sem suspeita de pneumonia, é o uso empírico da doxiciclina $5 \mathrm{mg} / \mathrm{kg}$, via oral (VO) duas vezes por dia (BID) ou $10 \mathrm{mg} / \mathrm{kg}$, VO uma vez ao dia (SID), por 7 a 10 dias. Casos de bronquite em cães são frequentes e a causa é multifatorial, os animais podem desenvolver bronquite crônica e broncopneumonia. Trata-se de uma inflamação bronquiolar e apesar de não ser exclusivamente bacteriana, infecções secundárias podem ocorrer nos brônquios. Presença de inflamação neutrofílica e cultura bacteriana positiva sugerem bronquite bacteriana primária ou secundária. Quando há manifestação de sinais graves (febre, comprometimento alveolar, distrição respiratória, etc), é recomendado o uso de doxiciclina $5 \mathrm{mg} / \mathrm{kg}$, VO; BID ou $10 \mathrm{mg} / \mathrm{kg}$, VO; SID por 7 a 14 dias (LAPPIN et al., 2017). A pneumonia bacteriana canina é comum em filhotes, ainda assim, a doença em cães adultos requer medidas de controle da infecção. Os principais patógenos envolvidos nas infecções são: Streptococcus equi subsp. zooepidemicus, S. canis, Mycoplasma cynos, e Bordetella bronchiseptica. O tratamento empírico recomendado é doxiciclina 5mg/kg,VO; BID ou $10 \mathrm{mg} / \mathrm{kg}$ VO; SID, por 7 a 10 dias. Em casos de pneumonia aspirativa, é recomendado amoxicilina com clavulanato de potássio $12.5 \mathrm{mg} / \mathrm{kg}$ VO BID por 4 a 6 semanas (JESSEN et al., 2019). Em pacientes não estáveis, com risco de sepse e que façam uso de suporte de oxigênio, é indicado ampicilina $20 \mathrm{mg} / \mathrm{kg}$ intravenoso (IV) três vezes ao dia (TID) com enrofloxacina $5 \mathrm{mg} / \mathrm{kg}$ subcutâneo (SC) ou VO; SID por 4 a 6 semanas (JESSEN et al., 2019), sendo a clindamicina 5-10 mg/kg IV BID uma opção para substituir a ampicilina pois o uso desta é de prioridade para humanos (OMS, 2017). O tratamento deve ser continuado até haver comprovação de melhora por radiografia e hemograma, caso a melhora não seja observada em até três dias, deve-se considerar mudança de fármaco. O piotórax é o acúmulo de líquido séptico no espaço pleural e em cães, sua patogenia não é bem elucidada. Porém, a cavidade oral e o trato respiratório superior parecem ser a fonte da maioria dos patógenos que causam essa condição (STILLION \& LETENDRE, 2015). O protocolo indicado é a administração parenteral de enrofloxacina $5 \mathrm{mg} / \mathrm{kg}$ subcutâneo SC, marbofloxacina $2.75 .5 \mathrm{mg} / \mathrm{kg}$ IV SID ou clindamicina $5-10 \mathrm{mg} / \mathrm{kg}$ IV BID, por 4 a 6 semanas, combinada com a drenagem pleural. A utilização da ampicilina $20 \mathrm{mg} / \mathrm{kg}$ IV TID com enrofloxacina $5 \mathrm{mg} / \mathrm{kg}$ SC ou VO SID, também é recomendada com duração de 4-6 semanas de tratamento, podendo ser prolongado dependendo dos sinais clínicos (LAPPIN et al., 2017).

Conclusão: A escolha do fármaco para o tratamento das enfermidades do trato respiratório em cães deve ser criteriosa e a 
criação de protocolos específicos para a utilização dos medicamentos de acordo com a infecção é crucial para auxiliar médicos veterinários, beneficiando o paciente pela eficácia e segurança, evitando o emprego incorreto de antibióticos no atendimento.

\section{Referências}

FERNANDES, S. C.; COUTINHO, S. D. Traqueobronquite infecciosa canina revisão. Revista do Instituto de Ciências da Saúde. V. 22, n. 4, out/dez 2004.

JESSEN, L. R.; DAMBORG, P.; SPOHR, A.; SØRENSEN, T. M.; LANGHORN, R.; GOERICKE-PESCH, S.; HOUSER, G.; WILLESEN, J.; SCHJ/ERFF, M.; ERIKSEN, T.; JENSEN, V. F.; GUARDABASSI, L. Antibiotic Use Guidelines for Companion Animal Practice. The Danish Small Animal Veterinary Association. V. 2, 2019. Disponível em: www.ddd.dk/sektioner/familiedyr/antibiotikavejledning/Documents/AB_uk_2019.pdf. Acesso em: 15 ago. 2020.

LAPPIN, M. R.; BLONDEAU, J.; BOOTHE, D.; BREITSCHWERDT, E. B.; GUARDABASSI, L.; LLOYD, D. H.; PAPICH, M. G.; RANKIN, S. C.; SYKES, J. E.; TURNIDGE, J.; WEESE, J. S. Antimicrobial use Guidelines for Treatment of Respiratory Tract Disease in Dogs and Cats: Antimicrobial Guidelines Working Group of the International Society for Companion Animal Infectious Diseases. Journal of Veterinary Internal Medicine. 2017; v.31, n.2, p.279-294, mar./abr. 2017.

MOCHIZUKI, M.; YACHI, A.; OHSHIMA, T.; OHUCHI, A.; ISHIDA, T. Etiologic study of upper respiratory infections of household dogs. The Journal of Veterinary Medical Science. V. 70, n.6, p.63-569, jun. 2008.

MORAL, C. M. Avaliação dos factores de risco da traqueobronquite infeciosa canina. 2014. 76f. Dissertação (Mestre em Medicina Veterinária) - Faculdade de Medicina Veterinária da Universidade Lusófona de Humanidades e Tecnologias, Lisboa, 2014.

ORGANIZCIÓN MUNDIAL DE LA SALUD. Critically important antimicrobials for human medicine. V.5, 2017. Disponível em: who.int/foodsafety/publications/antimicrobials-fifth/en/ Acesso em: 15 ago. 2020.

STILLION J. R.; LETENDRE J. A. A clinical review of the pathophysiology, diagnosis, and treatment of pyothorax in dogs and cats. Journal of Veterinary Emergency and Critical Care. V.25, n.1, p.113-129, jan 2015. 


\title{
ANAIS DO XIX ENCONTRO ANUAL | GIÊNCIA, TECNOLOGIAE CONDIÇĀO HUMANA: DESAFIOS, AÇŌES E COMPROMISSOS DE INICIAÇÃO CIENTÍFICA 29 e 30 de Outubro de 2020 \\ ISBN 978-65-87557-08-3

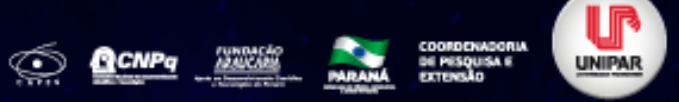 \\ PREVALÊNCIA DA IMUNODEFICIÊNCIA VIRAL FELINA E LEUCEMIA VIRAL FELINA EM UMA CLÍNICA VETERINÁRIA ESPECIALIZADA
}

\section{${ }^{1}$ ANA CLAUDIA DE SOUZA ANDRADE, ${ }^{2}$ YASMIM CECHIM, ${ }^{3}$ ALANA HERCULANO DOS SANTOS, ${ }^{4}$ ISADORA SCHENEKEMBERG VANDRESEN, ${ }^{5}$ PATRÍCIA DIANA SCHWARZ, ${ }^{6}$ DANIELA DIB GONCALVES}

\author{
${ }^{1}$ Profa. Ma. Doenças infecciosas UNIVEL, Doutoranda do PPG em Ciência Animal- UNIPAR \\ ${ }^{1}$ Médica Veterinária \\ ${ }^{2}$ Graduanda, $10^{\circ}$ período Medicina Veterinária do Centro Universitário Campo Real \\ ${ }^{3}$ Graduanda, $10^{\circ}$ período Medicina Veterinária do Centro Universitário Campo Real \\ ${ }^{4}$ Profa do Curso de Medicina Veterinária do Centro Universitário Campo Real \\ ${ }^{5}$ Docente da UNIPAR
}

Introdução: A Imunodeficiência Viral Felina (FIV) e a Leucemia Viral Felina (FeLV) são doenças, causadas por vírus pertencentes à família Retroviridae, que infectam felídeos. Estes, podem ser acometidos por uma ou ambas doenças. Machos, não castrados, que vivem em comunidade, são mais sujeitos a essas infecções (ALVES et al., 2015; COELHO et al., 2011). De acordo com LITTLE et al. (2009), essas infecções são 3,43\% maior em animais com acesso à rua. O FIV é transmitido por inoculação direta do vírus presente na saliva e na corrente sanguínea, através de mordidas durante brigas, o que torna o macho adulto, não castrado, o principal disseminador da doença. O FeLV é transmitido principalmente pela saliva. Depois de contaminado, o felino pode apresentar infecção progressiva ou não, determinando desta forma os sinais que irá apresentar (FIGUEIREDO e ARAÚJO, 2011). O vírus da FIV replica-se principalmente em linfócitos T e B, macrófagos e astrócitos. Os sinais clínicos podem aparecer pelo efeito direto do vírus ou por infecções secundárias, desenvolvidos pela imunodeficiência (NELSON, 2015). Segundo RANSEY et al. (2010), os felinos positivos para FIV costumam apresentar sinais como: gengivite e estomatite, secreção ocular, febre e ainda secreção nasal crônica. Para o diagnóstico da FIV, os animais podem ser submetidos à pesquisa de antígenos do vírus em neutrófilos e plaquetas pelo método ELISA, que é feito com amostras de sangue total, plasma, soro, saliva ou lagrimas (LITTLE, 2015). A infecção por FeLV se estabelece de duas a seis semanas após a exposição ao vírus, o animal pode entrar em viremia, ocorrendo alta replicação viral, principalmente na medula óssea (SILVA et al., 2018; LOAR, 1993). Ela pode ser classificada em subtipos, de acordo com a sua virulência e patogenicidade: A, B, C e T. Todos os subtipos são advindos do A e causam sinais clínicos diversos, dentre eles uma anemia grave, que pode ser fatal em poucas semanas (LOAR, 1993; FIGUEIREDO e ARÁUJO, 2011; CHANDLER et al., 2006). Pode apresentar sinais clínicos como: anemia, dispneia, anorexia, febre, gengivite, estomatite, massas intra-abdominais, mucosas hipocoradas, aumento dos rins, esplenomegalia, hepatomegalia, azotemia e aumento das enzimas hepáticas (NORSWORTHY et al., 2009). O diagnóstico de ambas as doenças é realizado pela associação do exame clínico com os exames complementares, como testes laboratoriais de ensaio Imunoenzimático (ELISA) ou reação em cadeia pela polimerase (PCR) (MIYAZAWA, 2002; LOAR, 1993).

Objetivo: Verificar a prevalência de FIV e FeLV em felinos atendidos no período de agosto de 2016 à agosto de 2017 em uma clínica veterinária especializada em felinos no município de Cascavel, PR.

Material e Métodos: Trata-se de estudo descritivo de dados coletados em uma clínica veterinária especializada de felinos no município de Cascavel-PR, onde realizou-se o levantamento de dados dos casos de felinos diagnosticados com FIV e FeLV, no período de agosto de 2016 à agosto de 2017, totalizando 517 prontuários de pacientes sadios ou doentes, que foram testados com amostra de soro, plasma ou sangue total, como triagem pré-vacinal. Os testes utilizados foram das marcas SNAP® Combo IDEXX, que é um kit de imunocromatografia de fluxo bidirecional e o ALERE®/BIONOTE, kit de imunocromatografia de fluxo lateral unidirecional, consideradas atualmente as marcas de maior confiabilidade no mercado.

Resultados: Foram analisados 517 prontuários de felinos, de ambos os sexos, sendo 257 fêmeas e 259 machos. Obtendo um resultado de $13(2,51 \%)$ animais positivos para FIV, 60 (11,61\%) animais positivos para FeLV e quatro $(0,77 \%)$ animais positivos para ambas as doenças. Analisando separadamente machos e fêmeas, encontramos quatro $(1,56 \%)$ fêmeas positivas para FIV, trinta $(11,67 \%)$ fêmeas positivas para FeLV, nove $(2,47 \%)$ machos positivos para FIV e trinta $(11,58 \%)$ machos positivos para FeLV. Observou-se ainda uma maior frequência da positividade para FIV em machos em relação às fêmeas, sendo 17 dos 302 machos do estudo.

Discussão: FIV e FeLV são doenças infecciosas de extrema importância para a Medicina Felina, pois não têm tratamento eficaz ou cura, havendo, no entanto, prevenção no caso do FeLV, através da vacinação. De acordo com JERICó et al. (2015), animais infectados por retroviroses devem ser isolados e tratados contra possíveis infecções secundárias. Segundo TURRAS (2014), felinos adultos apresentam maior prevalência de FIV, contudo, observou-se neste estudo, uma relação maior de animais adultos 
positivos para o FeLV, que segundo o mesmo autor, acometeria animais mais jovens.

O resultado obtido nesse período foi semelhante ao de MARCOLA (2011) no Distrito Federal, onde detectou que $2 \%$ de 400 animais eram positivos para FIV. Já SILVA (2007), em Porto Alegre-RS, encontrou prevalência inferior à deste estudo para FeLV, a qual foi 10,8\%, sendo sete animais de 65 testados. Em Maringá-PR, ROSA et al. (2011) tem como resultado uma prevalência maior em FeLV comparado a FIV, corroborando com a prevalência encontrada nesse estudo. LITTLE (2015) afirma que felinos infectados por retrovírus podem permanecer clinicamente saudáveis por longos períodos, o que os tornam disseminadores silenciosos dessas doenças.

Conclusão: Conclui-se que a prevalência das doenças pesquisadas estão conformes às encontradas na literatura científica e que testes diagnósticos de triagem pré-vacinal são importantes para detecção e prevenção de retroviroses em felinos, devendo ser realizados de forma rotineira, reduzindo assim o número de infectados, através de imunização prévia e medidas preventivas. É dever do médico veterinário orientar tutores quanto a prevenção tanto da FIV quanto da FeLV, ou ainda, quando já instaladas, das medidas paliativas para que seu prognóstico se torne menos reservado.

\section{Referências}

ALVES'1, Maria Cecília Rodrigues et al. Leucemia viral felina: revisão. PUBVET, v. 9, p. 052-100, 2015.

CHANDLER, E. A.; GASKELL, C. J.; GASKELL, R. M. Clínica e terapêutica em felinos. Editora Roca, 2006.

COELHO, F. M. et al. Ocorrência do vírus da leucemia felina em Felis cattus em Belo Horizonte. Arquivo Brasileiro de Medicina Veterinária e Zootecnia, v. 63, n. 3, p. 778-783, 2011. Disponível em: http://www.scielo.br/scielo.php?pid=s010209352011000300037\&script=sci_arttext

FIGUEIREDO, Andreza Soriano; ARAÚJO JÚNIOR, João Pessoa. Vírus da leucemia felina: análise da classificação da infecção, das técnicas de diagnóstico e da eficácia da vacinação com o emprego de técnicas sensíveis de detecção viral. Ciência Rural, v. 41, n. 11, p. 1952-1959, 2011.

JERICÓ, Márcia Marques; KOGIKA, Márcia Mery; DE ANDRADE NETO, João Pedro. Tratado de medicina interna de cães e gatos. Grupo Gen-Guanabara Koogan, 2015.

LEITE, R. C.; REIS, J. K. P.; OlIVEIRA, A. P.; NASCIMENTO, P. M. P.; OLIVEIRA, F. G.; NAVESs, J. H. F. F.; RODRIGUES, A. P. S. Gasparini, M. R.; Alves, F.; OLIVEIRA,. H. S.; RAJÃO, D. S.; GALINARI, G. C. F. 2013.retroviroses dos animais domésticos. veterinária e zootecnia. Disponível em : http://www.fmvz.unesp.br/rvz/index.php/rvz/article/view/654/447

LITTLE. S. E. O gato: medicina interna. 1. ed. Rio de janeiro: Roca, 2015.

MARÇOLA, Tatiana Guerrero. Estudo da avaliação laboratorial e ocorrência da infecção pelo vírus da imunodeficiência felina e co-infecções em felinos domésticos de diferentes localidades do Distrito Federal. 2011.

MEINERZ, Ana Raquel Mano et al. Frequência do virus da leucemia felina (VLFe) em felinos domésticos (Felis catus) semidomiciliados nos municípios de Pelotas e Rio Grande. Ciência Animal Brasileira, v. 11, n. 1, p. 90-93, 2010. Disponível em: https://www.revistas.ufg.br/vet/article/view/438/8063

NORSWORTHY, Gary. D.; CRYSTALI, Michell ; GRACE Shares. Fhooshee.; TILLEY, Larry. .O paciente felino. 3. ed. são paulo: roca.cap 45, 2009.

ROSA, Veruska Martins da et al. ESTUdo EPIDEMIOLÓgICO DE INFECçÕES PELO VíRUS DA LEUCEMIA E IMUNODEFICIÊNCIA FELINA, EM GATOS DOMÉSTICOS DO MUNICÍPIO DE MARINGÁ. 2011.Disponível em: http://www.cesumar.br/prppge/pesquisa/epcc2011/anais/veruska_martins_da_rosa3.pdf

SHERDING, R. G. Manual Saunders: clínica de pequenos animais. São Paulo: Roca, 1998.

TAKANO, Tomomi et al. Comparative study of the plasma globulin level, CD21- B-cell counts and FOXP3 mRNA expression level in CD4+ T-cells for different clinical stages of feline immunodeficiency virus infected cats. Research in veterinary science, v. 92 , n. 1, p. 157-161, 2012.

TURRAS, Mariana Cabral Campello. D. Estudo da prevalência de fiv/felv numa população de 88 gatos errantes da região metropolitana de lisboa. universidade lusófona de humanidades etecnologias faculdade de medicina veterinária lisboa, 2014. Disponível em: http://recil.grupolusofona.pt/bitstream/handle/10437/5417/tese\%20mariana\%20turras.pdf?sequence=1 


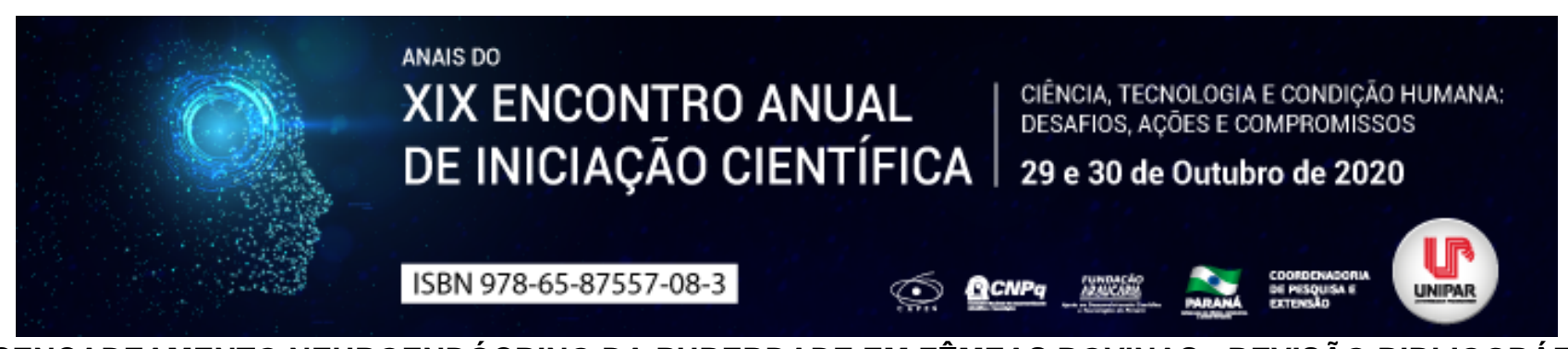

DESENCADEAMENTO NEUROENDÓCRINO DA PUBERDADE EM FÊMEAS BOVINAS - REVISÃO BIBLIOGRÁFICA

\begin{abstract}
${ }^{1}$ ALYSON LIBERALI ARAUJO, ${ }^{2}$ ALECSANDRO SILVA DE LIMA ELIAS, ${ }^{3}$ DANIELLE ANDRESSA OLIVEIRA SESTARI, ${ }^{4}$ BRUNO ARGENTON DE BARROS, ${ }^{5}$ CARLOS RENATO DE FREITAS GUAITOLINI, ${ }^{6}$ ROSIARA ROSARIA DIAS MAZIERO
\end{abstract}

\author{
${ }^{1}$ Discente do PPG em Ciência Animal com ênfase Em Produtos Bioativos UNIPAR \\ ${ }^{1}$ Discente do PPG em Ciência Animal com ênfase Em Produtos Bioativos UNIPAR \\ ${ }^{2}$ Discente do PPG em Ciência Animal com ênfase Em Produtos Bioativos UNIPAR \\ ${ }^{3}$ Discente do Curso de Medicina Veterinária da UNIPAR \\ ${ }^{4}$ Discente do Programa Nacional de Pós-doutorado -PNPD/CAPES UNIPAR \\ ${ }^{5}$ Docente da UNIPAR
}

Introdução: O crescente aumento pelo consumo de carne gera uma maior exigência na velocidade de produção de bovinos, neste sentido o conhecimento e adiantamento da puberdade é uma das alternativas para que o ciclo de produção seja mais rápido. Para isto, existem protocolos hormonais para a indução da ciclicidade em novilhas, entretanto, deve-se conhecer detalhadamente as características apresentadas pelos animais durante este período.

Objetivo: Este trabalho tem como objetivo relatar pontos essenciais do conhecimento da puberdade de fêmeas bovinas.

Desenvolvimento: A puberdade é definida como a manifestação do primeiro estro, entretanto, o primeiro cio geralmente é descrito como silencioso, pois as fêmeas não apresentam sinais característicos desta fase, como aceitação de monta, atração pelo macho, vulva edemaciada, entre outros, além disso, existe uma baixa fertilidade do animal, pela baixa produção de hormônios gonadotróficos insuficientes para desencadear a ovulação (MONTEIRO 2010). Neste contexto, pouco se sabe sobre o desencadeamento do processo fisiológico da puberdade das fêmeas bovinas e uma das hipóteses mais aceitas é o

gonadostat , também conhecida como sensibilidade diferencial aos esteroides ovarianos . Esta teoria sugere que existe um feedback negativo de esteroides sexuais o eixo hipotalâmico-hipofisário-gonadal (HHG), tornando-o sensível ao estímulo gonadotrófico. Durante a fase pré-púbere, se inicia a produção de esteróides ovarianos, em concentração muito baixa, o qual permite o bloqueio do HHG (l'Anson et al., 2000). O mecanismo neuroendócrino é uma interação de sinapses químicas hipotalâmicas é estimulado pelo sistema nervoso central e por aminoácidos excitatórios, que se comunicam com a adenohipófise e regulam a secreção pulsátil do LH (hormônio luteinizante). No período pré- púbere existem fortes evidências de que o neurotransmissor GABA seja predominante e atue como o principal bloqueador da produção de LH. Já os neurotransmissores capazes de estimular a produção que são norepinefrina, noradrenalina, neuropeptídio $Y$ são liberados na comunicação neural estimulam a produção de LH (CARDOSO e NOGUEIRA, 2007). Com a idade púbere se aproximando, o hipotálamo torna-se menos sensível aos esteroides ovarianos, os quais não conseguem mais realizar o feedback negativo iniciando assim a síntese de GnRH (hormônio liberador de gonadotrofinas) o que irá desencadear a puberdade (TERASAWA e FERNANDEZ, 2001). Além dos mecanismos neuroendócrinos para o desencadeamento da puberdade, as fêmeas devem apresentar uma idade mínima, relacionada como índices nutricionais, sanidade e genética (ALMEIDA et al., 2013).

Conclusão: Assim pode-se concluir que o conhecimento do processo de desencadeamento da puberdade é de extrema importância para que as biotecnologias da reprodução possam ser utilizadas, principalmente o adiantamento da ciclicidade de novilhas.

\title{
Referências
}

ALMEIDA, O. et al., Endocrinologia da puberdade em fêmeas bovinas. Revista Científica Eletrônica de Medicina Veterinária, v. 11, n. 20, p. 1-13, 2013.

CARDOSO, Daniel; DE PAULA NOGUEIRA, Guilherme. Mecanismos neuroendócrinos envolvidos na puberdade de novilhas. Arquivos de Ciências Veterinárias e Zoologia da Unipar, 10.1, 2007.

l'ANSON $\mathrm{H}$, et al., Inibição central da secreção hormonal que liberta gonadotrofina no crescimento. Ovelhas hipogonadotrópicas restritas, Endocrinologia, Volume 141, Edição 2, 1 de fevereiro de 2000, Páginas 520-527, Disponivel em: https://doi.org/10.1210/endo.141.2.7308. Acesso em 20/08/2020.

MONTEIRO, Claudia Dias; BICUDO, Sony Dimas; TOMA, Hugo Shisei. Puberdade em fêmeas ovinas. Pubvet, 4: Art. P. 850857, 2010. Disponivel em: http://www.pubvet.com.br/artigo/2313/puberdade-emfecircmeas-ovinas. Acesso em 20/08/2020.

TERASAWA, E. I.; FERNANDEZ, David L. Neurobiological mechanisms of the onset of puberty in primates. Endocrine reviews, v. 22, n. 1, 2001. Disponivel em: https://academic.oup.com/edrv/article/22/1/111/2424159. Acesso em 20/08/2020. 
Coordenadoria de Pesquisa e Extensão - COPEX

Departamento de Editoraçāo e Divulgaçāo Científica - DEDIC 


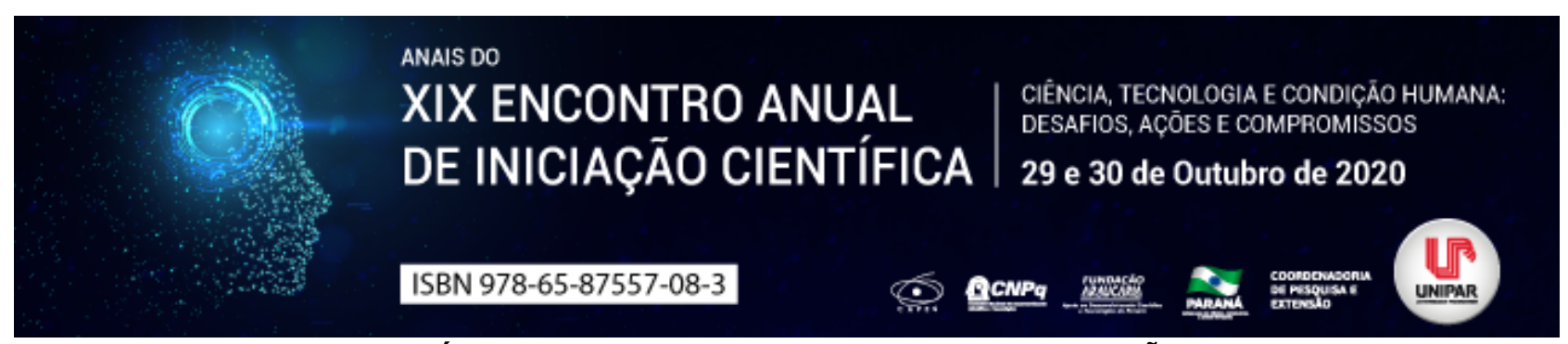

DESAFIOS DO DIAGNÓSTICO DA LEUCEMIA VIRAL FELINA REVISÃO DE LITERATURA

\begin{abstract}
${ }^{1}$ Luisa Faria Kyprianou, ${ }^{2}$ MARIANA DE RESENDE COELHO, ${ }^{3}$ CLAUDINE BOTELHO DE ABREU, ${ }^{4}$ ANA FLAVIA SILVA PEREIRA, ${ }^{5}$ RUTHNEA APARECIDA LAZARO MUZZI
\end{abstract}

\begin{abstract}
${ }^{1}$ Discente do curso de Medicina Veterinária da Universidade Federal de Lavras
${ }^{1}$ Doutoranda em Ciências Veterinárias da Universidade Federal de Lavras

${ }^{2}$ Doutoranda em Ciências Veterinárias da Universidade Federal de Lavras

${ }^{3}$ Discente do curso de Medicina Veterinária da Universidade Federal de Lavras

${ }^{4}$ Professora Titular do Departamento de Medicina Veterinária da Universidade Federal de Lavras
\end{abstract}

Introdução: A leucemia viral felina (FeLV) apresenta distribuição mundial e é causada por um retrovírus do gênero Gammaretrovirus. Possui como material genético RNA de fita simples, o qual é transcrito em provírus (DNA viral) pela enzima transcriptase reversa na célula do hospedeiro e é integrado no genoma da célula infectada. Como consequência ele induz depressão do sistema imune levando ao desenvolvimento de anemia, leucemia e linfoma (HARTMANN, 2012). A FeLV é transmitida de forma vertical (via transplacentária) e horizontal (por meio de saliva, fezes, leite e urina, contato direto entre gatos ou por transfusão sanguínea) (ALVES RODRIGUES, 2015). Os cuidados de prevenção como isolamento do animal infectado e restrições de acesso à rua dos animais saudáveis são medidas efetivas. Associado a esses cuidados, a vacinação é uma importante ferramenta no controle da doença (ALVES RODRIGUES, 2015). O diagnóstico correto é essencial para o controle da infecção na população felina. Uma falha nesse diagnóstico pode levar a um tratamento incorreto e/ou maior exposição dos gatos ao vírus, podendo causar danos à saúde do animal (LEVY, et al., 2008).

Objetivo: A revisão tem como objetivo apresentar atualizações sobre os principais testes diagnósticos utilizados em cada fase da doença viral.

Desenvolvimento: A FeLV pode ter três tipos de apresentação clínica. A primeira delas é a infecção abortiva, com ocorrência de 4-11\% dos gatos (LITTLE, et al., 2020), onde há resposta imune eficaz, ocorrendo a neutralização do vírus na fase inicial da infecção. Nesses casos, o felino não apresenta viremia e não são detectados antígenos no sangue, apenas anticorpos (HARTMANN, 2012). Um segundo tipo de apresentação é a infeção regressiva, com ocorrência de 1-2\% dos animais (LITTLE, et al., 2020), onde o vírus consegue estabelecer uma viremia primária, se integrando nas células de defesa como provírus e se multiplicando nos linfócitos. Porém, se o sistema imune do hospedeiro for atuante, pode ser que haja um controle da viremia antes que a infecção chegue a medula óssea (LEVY, et al., 2008). Nessa fase inicial pode apresentar alguns sinais clínicos como apatia, linfoadenomegalia e pirexia. Por fim, ainda existe a infecção progressiva, com ocorrência de 0,5-2\% dos gatos (LITTLE, et al., 2020), que ocorre quando o animal não produziu imunidade contra o vírus e a infecção evolui para uma viremia secundária. Nesse caso, além de se estabelecer na medula óssea e nos órgãos linfoides, há neutrófilos e plaquetas infectadas, contribuindo para a evolução da doença (LITTLE, et al., 2020). Dentre os diferentes testes disponíveis para detecção da FeLV, o método mais utilizado como triagem é o ELISA. Esse teste é o principal método utilizado para detectar o antígeno viral da proteína p27 do capsídeo em sangue total, saliva, lágrimas, soro ou plasma (ALVES RODRIGUES, 2015). O soro é o meio que gera menos resultados falso-positivos e falso-negativos constituindo-se bom marcador para detecção da infecção. Esse teste detecta animais positivos a partir da quarta semana de infecção (FLYNN, et al., 2002). Já o teste de imunofluorescência indireta (IFI) assim como o ELISA, tem como base a detecção do antígeno p27, porém, sua detecção é em neutrófilos e plaquetas infectados obtidos de esfregaços sanguíneos ou de medula óssea (JARRETT, et al., 1973). Todavia, a IFI não é considerada um teste adequado de triagem, pois se torna positivo a partir do momento em que a infecção atinge a medula óssea, indicando que o animal está infectado e virêmico, não sendo capaz de detectar animais no início da infecção (LUTZ, et al., 2009; FERNANDES, 2015). A PCR de quantificação de ácidos nucleicos (DNA e RNA) são geralmente usados quando os resultados forem discordantes da clínica e para melhor entendimento do estado de evolução da doença e deteç̧ão viral em qualquer região do organismo (LITTLE, et al., 2020). Sendo assim, na fase abortiva os animais geralmente testam negativo para ELISA, IFI e PCR e RT-PCR. Na fase regressiva da doença, inicialmente antígenos são detectados nos testes diagnósticos como ELISA, IFI, PCR, mas, após semanas ou meses, se o animal for imunocompetente, os testes ELISA e IFI passam a ter resultados negativos, porém a PCR ainda pode ter resultado positivo devido à presença de RNA/DNA proviral ainda circulante (HARTMANN, 2012). Entretanto, se o animal não produziu uma imunidade contra o vírus, a infecção evolui para uma viremia secundária, passando para a fase progressiva, onde os testes ELISA, PCR, IFI, RT-PCR têm resultado positivo, pois são bastante sensíveis à alta difusão do vírus pelo organismo.

Conclusão: Os gatos podem ser testados em várias circunstâncias e por diferentes razões, sendo que um único protocolo de teste não deve ser recomendado para os animais. Dessa forma, a implementação de protocolos de testes individuais, bem como 
medidas de prevenção são fundamentais para um melhor controle da doença.

\section{Referências}

ALVES RODRIGUES, MC. Leucemia Viral Felina: Revisão. Publicações em Medicina Veterinária e Zootecnia: Pubvet, Maringá, v. 9, n. 2, p. 86-100, Fevereiro, 2015

FERNANDES, KM. Diagnóstico de infecção pelo virus da Leucemia Felina (FeLV): Implicações na prática clinica. 2015. Monografia (Pós graduação em Medicina Veterinária). Centro de Estudos Superiores de Maceio. São Paulo/SP, 2015.

FLYNN, JN.; DUNHAM, SP.; WATSON, V.; JARRETT, O. Longitudinal analysis of feline leukemia virus-specific cytotoxic T lymphocytes: correlation with recovery from infection. Journal of Virology, v.76, n. 5, Março, 2002. Disponível em: . Acesso em: 18 de Agosto de 2020

HARTMANN, K. Infecção pelo vírus da Leucemia Felina. In: GREENE, CE.; FORD, RB. Doenças Infecciosas do Cão e do Gato. 4.ed. São Paulo: Gen Roca, 2012, p. 254-255

JARRETT, W.; JARRETT, O.; MACKEY, L.; et al.; Horizontal transmission of leukemia virus and leukemia in the cat. Journal of the National Cancer Institute, v. 51, n. 3, 01 de Setembro, 1973. Disponivel em: Acesso em: 18 de Agosto de 2020.

LEVY, J.; CRAWFORD, C.; HARTMANN, K.; et al. American Association of Feline Practitioners: feline retrovirus management guidelines. Journal of Feline Medicine and Surgery, v.10, n. 3, 01 de Julho, 2008. Disponível em:. Acesso em: 18 de Agosto de 2020.

LITTLE, S.; LEVY, J.; HARTMANN, K.; et al. 2020 AAFP Feline Retrovirus Testing and Management Guidelines. Journal of Feline Medicine and Surgery. v. 22, n. 1, 09 de Janeiro, 2020. Disponivel em:. Acesso em: 18 de Agosto de 2020.

LUTZ, H.; ADDIE, D.; BELAK, S.; et al. Feline Leukaemia ABCD guidelines on prevention and management. Journal of Feline Medicine and Surgery, v. 11, n. 7, Julho, 2009. Disponível em:. Acesso em: 18 de Agosto de 2020 


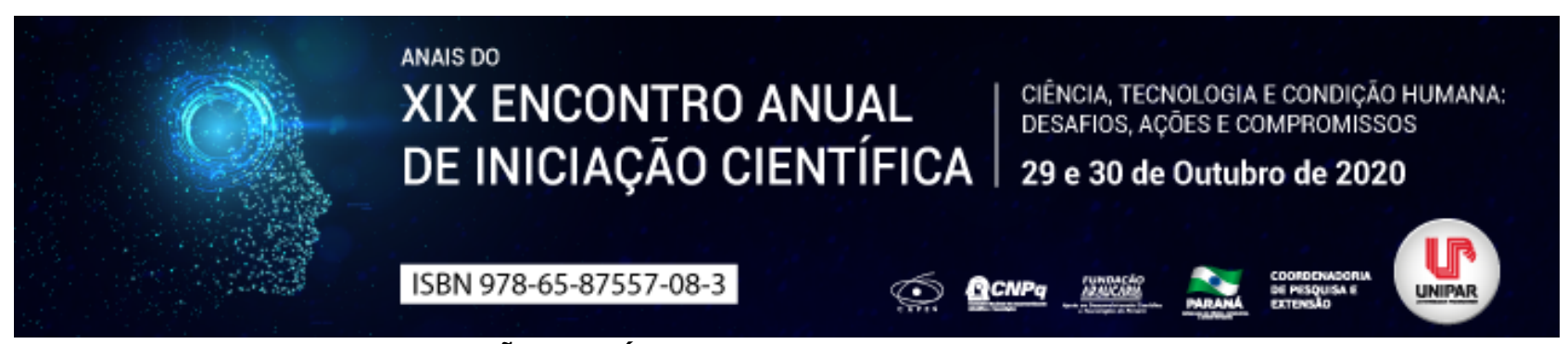

BIOACUMULAÇÃO DE LÍTIO EM LINHAGENS DE Ganoderma lucidum

\begin{abstract}
${ }^{1}$ GUSTAVO RATTI DA SILVA , ${ }^{2}$ BRUNNA DE OLIVEIRA PEREIRA, ${ }^{3}$ EDUARDA CAROLINA AMARAL, ${ }^{4}$ GIANI ANDREA LINDE COLAUTO, ${ }^{5}$ MARIA GRACIELA IECHER FARIA NUNES, ${ }^{6}$ FRANCISLAINE APARECIDA DOS REIS LIVERO
\end{abstract}

\author{
${ }^{1}$ Discente do PPG em Ciência Animal com Ênfase em Produtos Bioativos/Taxista - Prosup/CAPES \\ ${ }^{1}$ Programa de Iniciação Científica Ensino Médio UNIPAR \\ ${ }^{2}$ Discente do Mestrado Profissional em Plantas Medicinais e Fitoterápicos na Atenção Básica, Bolsista PIT \\ ${ }^{3}$ Docente da Pós-Graduação em Biotecnologia Aplicada à Agricultura - UNIPAR \\ ${ }^{4}$ Docente da Pós-Graduação em Biotecnologia Aplicada à Agricultura - UNIPAR \\ ${ }^{5}$ Docente do Mestrado Profissional em Plantas Medicinais e do PPG em Ciência Animal - UNIPAR
}

Introdução: O Ganoderma lucidum, conhecido popularmente como Reishi, um basidiomiceto pertencente ao filo Basidiomycota, é um dos cogumelos medicinais mais populares do mundo (HIKINO et al., 1985; MATUTE et al., 2011). Este produto natural têm a capacidade de bioacumular metais de interesse farmacológico e nutricional em sua estrutura micelial, sendo assim uma estratégia particularmente interessante para controlar a solubilidade e disponibilidade dos metais (YOKOTA et al., 2016; FARIA et al., 2019). Um destes metais é o lítio, uma das principais drogas utilizadas no tratamento do transtorno de humor bipolar, com ação preventiva contra suicídio (CHI-TSO; CHUANG, 2011).

Objetivo: Avaliar a produção de biomassa e a capacidade de bioacumulação de lítio em duas linhagens de Ganoderma lucidum. Materiais e Métodos: Utilizou-se duas linhagens de G. Iucidum (U17-1 e U17-2) pertencentes à micoteca do Laboratório de Biologia Molecular da Universidade Paranaense, mantidos em placas de Petri com meio de extrato de malte à $28^{\circ} \mathrm{C}$ por 10 dias para a produção do inóculo. Na sequência, três plugs de $0,5 \mathrm{~mm}$ de diâmetro do meio de cultivo contendo o micélio foram transferidos para um Erlenmeyer contendo extrato de malte e solução de carbonato de lítio, nas concentrações de 0 (controle) 10 , $20,30,40$ e $50 \mathrm{ppm}$ ( 6 frascos para cada concentração), autoclavados previamente (30 minutos, $121^{\circ} \mathrm{C}$ ), que permaneceram no escuro $\left(15 \mathrm{dias}, 28^{\circ} \mathrm{C}\right)$. Após o crescimento realizou-se a abertura das linhagem pela metodologia de Yokota et al. (2016) com modificações, a determinação de biomassa micelial seca $(\mathrm{mg} / \mathrm{mL})$, a concentração de lítio $(\mathrm{ug} / \mathrm{g})$ nas amostras foi determinada por espectrofotômetro de absorção atômica de chama.

Resultados: A adição de 10, 20, 30, 40 e 50 ppm de lítio na linhagem U17-1 gerou uma produção de biomassa micelial de 5,63, $3,28,3,06,0,79$ e $0,13 \mathrm{mg} / \mathrm{mL}$, respectivamente. Já para a linhagem U17-2 a adição de 10, 20, 30, 40 e 50 ppm de lítio promoveu produção de $7,19,7,72,7,54,4,68$ e $0,31 \mathrm{mg} / \mathrm{mL}$, respectivamente. Na ausência de lítio houve produção de $6,11 \mathrm{mg} / \mathrm{mL}$ de biomassa micelial na linhagem U17-1 e de $7,95 \mathrm{mg} / \mathrm{mL}$ na linhagem U17-2. Em relação a bioacumulação de lítio, com a incorporação de 10, 20, 30, 40 e 50 ppm de lítio a linhagem U17-1 bioacumulou 398,8, 794,4, 848,8, 1124 e 5639 ug/g de lítio, respectivamente. Na linhagem U17-2 a incorporação de 10, 20, 30,40 e 50 ppm de lítio teve uma bioacumulação de 351,2, 296,7, 338,8, 400,3 e 2554 ug/g de lítio, respectivamente. Ainda, na ausência de lítio houve uma bioacumulção de 7,72 ug/g de lítio para a linhagem U17-1 e de 8,78 ug/g de lítio na linhagem U17-2.

Discussão: Faria et al. (2019) estudaram o Lentinus crinitus, um outro fungo pertencente ao filo Basidiomycota e encontraram que este fungo tem uma maior produção de biomassa, porém observaram redução da bioacumulação de lítio a partir da concentração de $30 \mathrm{ppm}$. Já com outro basidiomiceto, o Pleurotus ostreatus, Faria et al. (2018) relataram que a partir da concentração de 40 ppm a bioacumulação de lítio decai, e em relação à produção de biomassa, também há uma queda em todas as concentrações testadas (5 - $100 \mathrm{ppm})$. No presente estudo encontrou-se resultados parecidos com os trabalhos de Faria et al. $(2018 ; 2019)$ uma vez que quanto maior a concentração de lítio menor foi a biomassa micelial produzida. Entretanto a bioacumulação de lítio aumentou em todas concentrações testadas. Ainda, ao comparar-se as duas linhagens de fungos, observou-se uma diferença entre bioacumulação de lítio e a produção de biomassa micelial. A linhagem U17-1 possui um potencial maior para a bioacumulação de lítio, mas com uma produção de biomassa micelial menor, enquanto que a linhagem U17-2 apresentou uma maior produção de biomassa micelial, com uma bioacumulaçao de lítio menor. Estes resultados indicam que a linhagem U17-1 é mais promissora para a acumulação de lítio, podendo ser uma alternativa para o desenvolvimento de novos medicamentos para o tratamento do transtorno bipolar. Entretanto, estudos de toxicidade e eficácia devem ser conduzidos. Conclusão: A linhagem U17-1 foi superior em relação a bioacumulação de lítio e a linhagem U17-2 foi superior em produção de biomassa micelial.

\title{
Referências
}

CHI-TSO, Chiu; CHUANG, De-Maw. Neuroprotective action of lithium in disorders of the central nervous system. Journal of 
Central South University Medical Sciences, China, v. 36, n. 6, p. 461, june. 2011.

FARIA, Maria Graciela lecher. et al. Lithium bioaccumulation in Lentinus crinitus mycelial biomass as a potential functional food. Chemosphere, Oxford, v. 235, p. 538-542, nov. 2019.

FARIA, Maria Graciela lecher. et al. Bioaccumulation of lithium $\left(\mathrm{Li}_{2} \mathrm{CO}_{3}\right)$ in mycelia of the culinary-medicinal oyster mushroom, Pleurotus ostreatus (Agaricomycetes). International Journal of Medicinal Mushrooms, United States, v. 20, n. 9, jan. 2018.

HIKINO, Hiroshi. et al. Isolation and hypoglycemic activity of ganoderans A and B, glycans of Ganoderma lucidum fruit bodies. Planta Medica, Stuttgart, v. 51, n. 04, p. 339-340, mar. 1985.

MATUTE, Ramiro González. et al. Copper and zinc bioaccumulation and bioavailability of Ganoderma lucidum. Journal of Medicinal Food, United States, v. 14, n. 10, p. 1273-1279, oct. 2011.

YOKOTA, Meire Emiko. et al. Iron translocation in Pleurotus ostreatus basidiocarps: production, bioavailability, and antioxidant activity. Genetics and Molecular Research, Brazil, v. 15, n. 1, p. 1-10, feb. 2016.

Coordenadoria de Pesquisa e Extensāo - COPEX

Departamento de Editoraçāo e Divulgaçāo Científica - DEDIC 


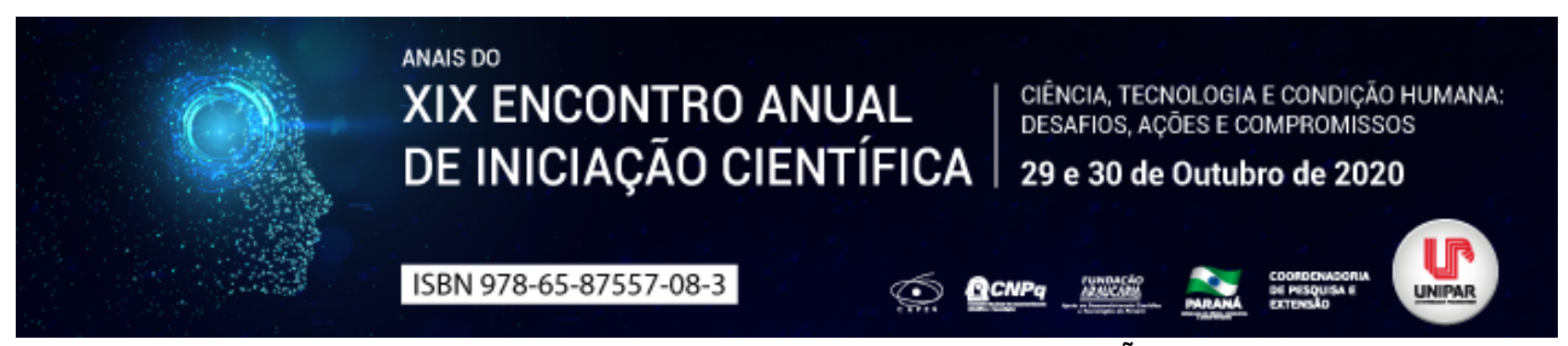

\title{
Musca domestica E Periplaneta americana NA EPIDEMIOLOGIA DE TRANSMISSÃO DE Cystoisospora suis EM UMA MATERNIDADE SUÍNA
}

\author{
${ }^{1}$ Vinicius Dahm, ${ }^{2}$ ARIELLE APARECIDA LARA , ${ }^{3}$ RICARDO BABINSKI BREGONDE, ${ }^{4}$ ANA PAULA MOLINARI CANDEIAS, \\ ${ }^{5}$ GERALDO CAMILO ALBERTON, ${ }^{6}$ SILVIA CRISTINA OSAKI
}

\author{
${ }^{1}$ Acadêmico do curso de Medicina Veterinária da UFPR-Setor Palotina \\ ${ }^{1}$ Mestre em Ciência animal pela Universidade Federal do Paraná Setor Palotina \\ ${ }^{2}$ Acadêmico do curso de Medicina Veterinária da UFPR-Setor Palotina \\ ${ }^{3}$ Mestranda em Ciência animal pela UFPR Setor Palotina \\ ${ }^{4}$ Docente da Universidade Federal do Paraná-Setor Palotina \\ ${ }^{5}$ Docente da Universidade Federal do Paraná-Setor Palotina
}

Introdução: Segundo Campos et al. (2012), o fator sanitário é um dos maiores empecilhos da produção de suínos no Brasil. O elevado número de animais por unidade de área, somado ao íntimo contato entre eles e a perda de sanidade são fatores determinantes que facilitam a disseminação destes agentes (CRUZ, 2015). A cistoisosporose é um exemplo de uma importante doença parasitária, causada em suínos pelo Cystoisospora suis (MUNDT et al., 2005), afetando principalmente os leitões na maternidade (SHRESTHA et al., 2015). De maneira geral, parasitas podem ser transmitidos pelo contato direto entre os indivíduos, veiculados por água, solo ou alimentos contaminados, além dos vetores, veiculadores animados e contato com objetos contaminados (fômites). Em uma Unidade Produtora de Leitões (UPL), a contaminação ambiental é o principal fator para a transmissão de coccidiose. Esta ocorre principalmente pela presença de resíduos de fezes dos leitões de lotes anteriores (LABER et al., 2002) e pelo carreamento de outras salas por insetos, roedores e funcionários (STINGELIN, 2017).

Objetivo: O trabalho teve como objetivo a avaliação do potencial de disseminação de oocistos de $C$. suis a partir de moscas e baratas, em uma granja de maternidade suína tecnificada, localizada no município de Palotina, Paraná.

Material e Métodos: O Projeto foi aprovado pela Comissão de Ética no Uso de Animais da Universidade Federal do Paraná, com protocolo número 25/2017. As coletas foram realizadas em uma granja de maternidade localizada na cidade de Palotina Paraná, no inverno de 2017 e verão de 2018 em duas salas de maternidade. Para a captura das moscas, foram instaladas em cada sala armadilhas do tipo Bola da Zumbafly ${ }^{\circledR}$ que foram colocadas no alojamento das matrizes na sala de maternidade, dois dias antes do parto. As mesmas permaneceram instaladas durante todo o período de aleitamento dos leitões, sendo retiradas ao desmame dos mesmos, que ocorreu aos 21 dias. A avaliação da captura desses insetos era realizada semanalmente, durante o período. Já as baratas, foram coletadas manualmente. Os insetos capturados foram alocados em recipientes fechados, e armazenados à $4^{\circ} \mathrm{C}$. Os mesmos foram congelados com nitrogênio líquido, macerados e preparados para a extração do material genético, que foi realizada com o kit de extração (DNeasy Blood \& Tissue Kit) da Qiagen ${ }^{\circ}$. Para a realização da reação em cadeia pela polimerase (PCR) utilizou-se, mix pronto GoTaq Green Master Mix - Promega®; $1 \mu \mathrm{M}$ de cada primer; $5 \mu \mathrm{L}$ de DNA extraído e água Milli-Q autoclavada qsp $25 \mu \mathrm{L}$. O primer utilizado foi ITSF (5'-CCG TTG CTC CTA CCG ATT GAG TG-3') e EMR7 (5'-GCA TTT CGC TGC GTC CTT CAT CG-3') (SAMARASINGHE et al, 2008). As amostras foram submetidas à eletroforese em gel de agarose a $1,5 \%$ e coradas em Brometo de etídio.

Resultados: A presença de insetos no interior da granja foi praticamente insignificante, diante disso, a captura desses vetores ocorreu somente no período do verão, mesmo com a ausência de controle de insetos durante o período do inverno. Em relação à técnica da PCR, nenhuma das amostras testadas detectou o material genético de Cystoisospora suis.

Discussão: Apesar de neste estudo não serem encontradas provas da veiculação mecânica de oocistos do protozoário em questão, Linhares et al (2012) preconizam o controle de moscas e roedores, pois estes podem atuar na disseminação mecânica dos oocistos entres os leitões. Segundo Fayer (1980), devido ao tamanho diminuto dos oocistos de coccídios, estes podem ser transportados de uma localidade a outra por invertebrados, roupas, mãos e botas de tratadores e veterinários, favorecendo a infecção de animais susceptíveis, não corroborando o presente estudo, provavelmente devido à pouca quantidade de insetos coletados. Na cidade de Ekpoma, Nigéria, Nmorsi et al (2006) ao estudarem quatro espécies sinantrópicas de moscas como carreadoras de parasitos gastrointestinais, encontraram a presença Isospora belli em todas as espécies pesquisadas, comprovando o papel destes insetos na epidemiologia da transmissão de isosporose em humanos, enfermidade muito semelhante à cistoisosporose suína. Além disso, a presença de moscas e baratas já foram correlacionadas com o aumento de doenças parasitárias zoonóticas uma vez que podem contaminar alimentos (BESANA; PALLER, 2020), evidenciando ainda mais o importante papel destes insetos, não só na saúde animal, mas também em um contexto de Saúde Única.

Conclusão: No presente estudo, as baratas e as moscas não apresentaram a presença do agente não sendo possível veicular a 


\section{Referências}

BESANA, C. M.; PALLER, V. G. V. Evaluation of Selected Slaughterhouses and Parasites of Slaughtered Livestock in Cotabato Province, Mindanao, Philippines. J. of Livestock Science, v. 11, p. 67 76, 2020.

CAMPOS, T. M. et. al; Coccidiose suína; Revista eletrônica Nutritime; artigo 157 ; Mar/abr 2012. Disponível: https://www.nutritime.com.br/arquivos_internos/artigos/157v9n2p_.1726_1739_MARCO\%202012. Acesso: 31 ago. 2020.

CRUZ, R. M. Atividade de fungos sobre ovos, larvas e oocistos de parasitas de ungulados silvestres e do cão. 2015. Dissertação (Mestrado) - Universidade de Lisboa, Lisboa, 2015.

FAYER, R. Epidemiology of protozoan infections: The coccidia. Vet. Parasitol., v. 6, n. 1 3, p. 75103,1 jan. 1980.

LABER, K. E. et al. Laboratory Animal Medicine. Chapter 15: Biology and Diseases of Swine. Laboratory Animal Medicine. 2. Ed. American College of Laboratory Animal Medicine, 2002. p. 615.

LINHARES G.F.C. et al. Endoparasitoses. In: SOBESTIANSKY, J.; BARCELLOS, D. Doenças dos Suínos. Goiânia: Cânone Editorial, 2012. pp. 433-466.

MUNDT, H.-C. et al. Occurrence of Isospora suis in Germany, Switzerland and Austria. J. of Vet. Med. Series B, v. 52, n. 2, p. 93 97, 1 mar. 2005.

NMORSI, O. P. G.; UKWANDU, N. C. D.; AGBOZELE, G. E. Detection of some gastrointestinal parasites from four synanthropic flies in Ekpoma, Nigeria. J Vect Borne Dis., v. 43, p. 136-139, Setemebro. 2006.

SAMARASINGHE, B.; JOHNSON, J.; RYAN, U. Phylogenetic analysis of Cystoisospora species at the rRNA ITS1 locus and development of a PCR-RFLP assay. Experimental Parasitol., v. 118, n. 4, p. 592 595, 1 abr. 2008.

SHRESTHA, A. et al. Cystoisospora suis - A model of mammalian cystoisosporosis. Frontiers in Vet. Science, v. 2, n. 68. 30 nov. 2015.

STINGELIN, G. M. Protocolos de utilização de toltrazuril para o controle da coccidiose em leitões naturalmente infectados. Dissertação (Mestrado). Faculdade de Medicina Veterinária e Zootecnia, campus de Botucatu, 2017. 


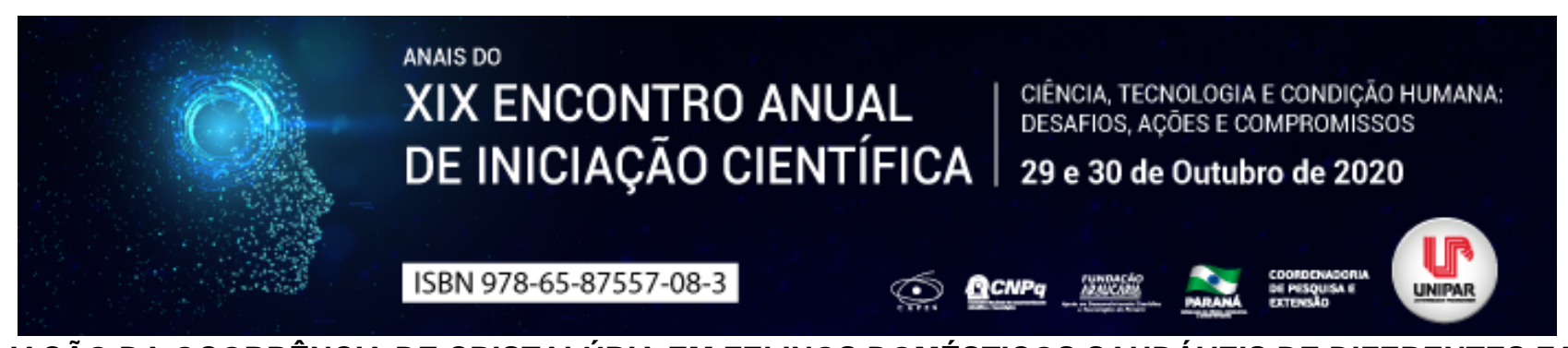

\title{
AVALIAÇÃO DA OCORRÊNCIA DE CRISTALÚRIA EM FELINOS DOMÉSTICOS SAUDÁVEIS DE DIFERENTES FAIXAS ETÁRIAS
}

\author{
${ }^{1}$ Luisa Faria Kyprianou, ${ }^{2}$ MARIANA DE RESENDE COELHO, ${ }^{3}$ LUIZ EDUARDO DUARTE DE OLIVEIRA, ${ }^{4}$ THAIS GOMES \\ BARBOSA, ${ }^{5}$ NAYARA FERREIRA ARAUJO DA CRUZ, ${ }^{6}$ RUTHNEA APARECIDA LAZARO MUZZI
}

${ }^{1}$ Discente do curso de Medicina Veterinária da Universidade Federal de Lavras
${ }^{1}$ Doutoranda em Ciências Veterinárias da Universidade Federal de Lavras
${ }^{2}$ Doutorando em Ciências Veterinárias da Universidade Federal de Lavras
${ }^{3}$ Discente do curso de Medicina Veterinária da Universidade Federal de Lavras
${ }^{4}$ Discente do curso de Medicina Veterinária da Universidade Federal de Lavras
${ }^{5}$ Professora Titular do Departamento de Medicina Veterinária da Universidade Federal de Lavras

Introdução: Os cristais urinários são formados a partir da saturação e precipitação de minerais em suspensão na urina, sendo a recipitação dependente do pH urinário (OLIVEIRA, 2017). Os gatos, devido ao hábito de ingerir menor volume de água, possuem uma urina naturalmente concentrada, o que favorece a formação de cristais (ARIZA, et al., 2016). A cristalúria em si não é uma doença e não precisa ser tratada, a menos que esteja associada a complicações. Uma de suas possíveis consequências é a formação de urólitos (THRALL, et al. 2015; KHAN, 2016), mas nos gatos ela também está associada a doença do trato urinário inferior dos felinos (DTUIF). Pode ocorrer em gatos assintomáticos, mas isso não dita que os cristais integram um achado incidental, demandando assim, um acompanhamento do paciente para impedir que haja complicações (BUFFINGTON, 2001). Dito isso, é de suma importância observar e analisar a incidência desses cristais, para que assim possamos estimar a prevalência da cristaluria.

Objetivo: Este trabalho tem como objetivo avaliar a incidência de cristais urinários em felinos domésticos saudáveis de diferentes faixas etárias.

Material e Métodos: O estudo foi conduzido no Hospital Veterinário da instituição, sendo previamente aprovado pela Comissão de Ética no Uso de Animais sob o protocolo $n^{\circ}$ 088/18. Foram utilizados 87 gatos, de diferentes raças e ambos os sexos, divididos por idade em 4 grupos: G1 com 25 filhotes (de idade inferior a 6 meses); G2 com 19 jovens (7 meses a 2 anos e 11 meses); G3 com 11 adultos (3 anos a 6 anos e 11 meses); G4 com 14 animais de meia-idade (7 anos de idade a 10 anos e 11 meses). Somente foram incluídos no estudo animais sem alterações no exame físico geral, hemograma, bioquímica renal e hepática. Para obtenção da urina os animais foram contidos manualmente e submetidos a cistocentese, realizando-se previamente a antissepsia rotineira. Após a coleta as amostras foram identificadas, protegidas da luz e imediatamente conduzidas ao laboratório de Patologia Clínica Veterinária da instituição para realização de urinálise completa.

Resultados e discussão: Foi observada uma maior incidência de cristais nos animais do G4 (50\%), seguido do G1 (36\%), G2 (26\%) e G3 (18\%). Os cristais de estruvita foram encontrados com maior frequência em todos os grupos estudados (G1=70\%; G2=80\%; G3=66,6\%; G4=71,4\%). Os de fosfato amorfo, urato amorfo e carbonato de cálcio foram observados em menor frequência. Assim como observado nesse estudo, os dados da literatura indicam que os cristais de estruvita são o complexo de minerais mais frequentemente encontrado em gatos. No presente estudo não foi possível comparar a incidência entre raças uma vez que a grande maioria dos animais utilizados não apresentava padrão racial definido. Quanto a idade, Stevenson e Markwell (2001) descreveram uma maior prevalência de cristais em gatos entre 5 a 7 anos (STEVENSON, et al., 2001). Os resultados do presente trabalho não corroboram esses dados uma vez que foi observada maior incidência de cristais nas urinas dos animais dos grupos G1e G4. Os gatos utilizados nesse estudo eram alimentados principalmente com ração comercial seca e, o manejo nutricional era realizado de maneiras diferentes entre os tutores. Sendo assim, não foi possível fazer uma correlação entre a nutrição e a cristalúria nos animais estudados. A constituição da dieta tem influência direta sobre o pH urinário que é ponto chave para formação de determinados tipos de cristais (GRAUER, 2015). No presente trabalho foi observada íntima correlação entre o $\mathrm{pH}$ da urina e os tipos de cristais formados, sendo os de urato amorfo encontrados em urinas ácidas (pH $<6,5)$, enquanto os de estruvita, fosfato amorfo e carbonato de cálcio foram encontrados em urinas neutras ou alcalinas $(\mathrm{pH}>6,5)(\mathrm{SINK}, 2006)$. A partir desse experimento foi possível reforçar a teoria de que a cristalúria é um achado frequente em gatos assintomáticos (THRALL, et al., 2015; KHAN, 2016; OSBORNE, 2010). Apesar disso ela pode predispor, quando grave e persistente, ao desenvolvimento de urolitíase e DTUIF (GUNN, et al., 2004). Segundo Osborne (2010) ausência de sinais clínicos pode ser explicada pelo pequeno tamanho dos cristais com menor chance de induzir complicações, como foi observado tabém neste trabalho. Apesar de não haver necessidade de terapia em felinos assintomáticos é importante se atentar para o surgimento de sinais clínicos. O estímulo a ingestão de água pode contribuir para a diminuição da densidade urinária, desfavorecendo a saturação e precipitação dos 
minerais para formação dos cristais (OLIVEIRA, 2017).

Conclusão: A cristalúria pode ocorrer em felinos de todas as idades, mesmo que assintomáticos. Como essa condição está associada a doenças relativamente frequentes, como urolitíase e DTUIF, o clínico deve estar atento para sua ocorrência, orientando os tutores no manejo dos animais e identificando-a precocemente, reduzindo assim possíveis complicações.

\section{Referências}

ARIZA, PC. et al. Tratamento da urolitíase em cães e gatos: abordagens não cirúrgicas. Enciclopédia Biosfera, Centro Científico Conhecer, v. 13, n. 23, 05 de Maio, 2016. Disponível em: http://www.conhecer.org.br/enciclop/2016a/agrarias/tratamento.pdf. Acesso em: 18 de Agosto de 2020

BUFFINGTON, Charles Anthony. Feline lower urinary uroliths (flutd). Urology Nutrition v. 21, n. 5, p. 401-450, 2001.

GRAUER, GC. Manifestações clínicas dos distúrbios urinários; Urolítiase canina. In: RICHARD, N.; GRAUER, G.C; (eds.) Medicina Interna de Pequenos Animais. Rio de Janeiro, Elsevier Editora, v. 11, n. 7, p. 705-714, Julho, 2015.

GUNN-MOORE, D.; SHENOY, C. Oral glucosamine and the management of feline idiopathic cystitis. Journal of Feline Medicine and Surgery v. 6, n. 4, 01 de Agosto, 2004.

KHAN, SR. Renal tubular damage/dysfunction: key to the formation of kidney stones. Urological research, v. 34, n. 2,11 de Janeiro, 2006.

OLIVEIRA, LVC. Ocorrência de cristalúria em cães e gatos atendidos no hospital veterinário da UnB. Orientadora: Giane Regina Paludo, 2017. Monografia (Graduação em Medicina Veterinária) Universidade de Brasilia, Brasilia - DF, 2017.

OSBORNE, C. Is your crystalluria interpretation crystal clear? DVM Newsmagazine, Maio, 2010. Disponivel: https://www.dvm360.com/view/your-crystalluria-interpretation-crystal-clear. Acesso em: 19 de Agosto, 2020.

SINK C.; FELDMAN B. Urinálise e hematologia para o clínico de pequenos animais: Laboratorial para o Clínico de Pequenos Animais. São Paulo. $1^{\text {a }}$ edição. Editora Roca. 2006.

STEVENSON, A.; MARKWELL, P. A comparison of urine parameters produced by healthy Labradors and Miniature Schnauzers. American Journal of Veterinary Research v. 62, n. 11, Novembro, 2001.

THRALL, MA. Urinalise. In: THRALL, MA.; WEISER, G.; ALLISON, RW.; CAMPBELL, TW. Hematologia e Bioquímica Clínica Veterinária. Rio de Janeiro: Guanabara Koogan, $2^{\circ}$ ed. Grupo Editora Nacional: Roca, 2015. p. 718-744.

Coordenadoria de Pesquisa e Extensão - COPEX

Departamento de Editoraçāo e Divulgaçāo Científica - DEDIC 


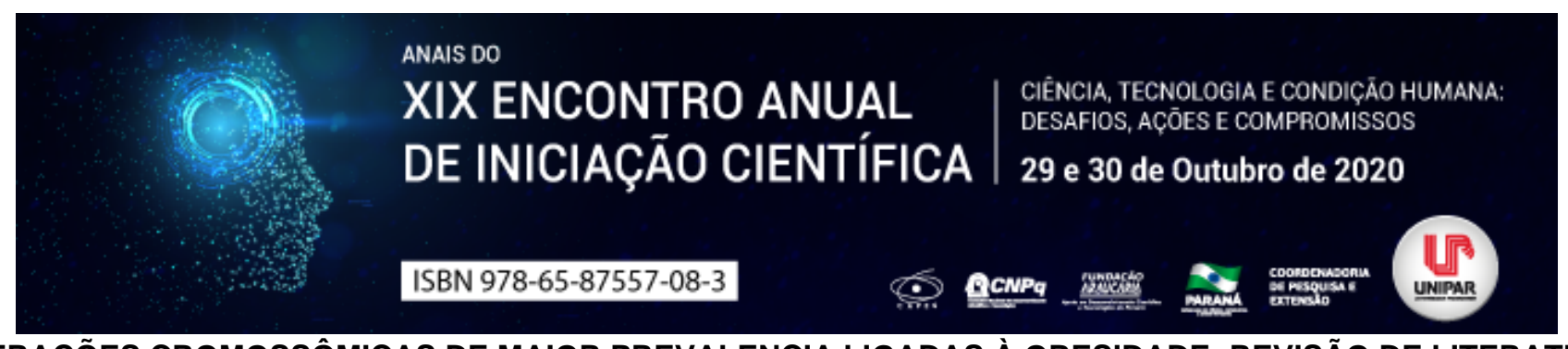

ALTERAÇÕES CROMOSSÔMICAS DE MAIOR PREVALENCIA LIGADAS À OBESIDADE: REVISÃO DE LITERATURA

\author{
1LUCIANO SERAPHIM GASQUES, ${ }^{2}$ LEONARDO LUIZ CASTELLI JUNIOR, ${ }^{3}$ JOSE RICARDO SKOLMOVSKI DA SILVA, \\ ${ }^{4}$ DANIELE GARCIA DE ALMEIDA SILVA, ${ }^{5}$ IRINEIA PAULINA BARETTA, ${ }^{6}$ ROSILEY BERTON PACHECO
}

\author{
${ }^{1}$ Acadêmico do curso de Nutrição/PIC/UNIPAR \\ ${ }^{1}$ Acadêmico do Curso de Medicina/PIBIC/UNIPAR \\ ${ }^{2}$ Docente da UNIPAR \\ ${ }^{3}$ Docente da UNIPAR \\ ${ }^{4}$ Docente da UNIPAR \\ ${ }^{5}$ Docente da UNIPAR
}

Introdução: A obesidade pode ser definida como um acúmulo excessivo de gordura no tecido adiposo e geralmente é resultante de um consumo calórico excessivo. É caracterizada em indivíduos que apresentam o índice de Massa Corpórea maior ou igual a $30 \mathrm{Kg} / \mathrm{m}^{2}$. Esta patologia constitui um dos principais fatores de risco para várias outras doenças não transmissíveis (DNTs) como diabetes mellitus tipo 2 (DM2), doenças cardiovasculares, hipertensão arterial, acidente vascular cerebral e alguns tipos de câncer (BRASIL, 2020). Entre as muitas possíveis causas, a obesidade geralmente está associada à baixos níveis de atividade física, alterações neuroendócrinas, uso de medicamentos específicos, lesão hipotalâmica, hipotiroidismo e a fatores genéticos (OLIVEIRA et al. 2009). Com relação aos fatores genéticos, obesogênese se divide em três grupos: a) aqueles derivados de SNPs (Single Nucleotide Polymorphism) em genes específicos que atuam como herança monogênica; b) aqueles que atuam através da interação vários genes para expressão do fenótipo, também conhecida como poligênica; c) além daquelas associadas a alterações na estrutura ou ao número dos cromossomos, estas últimas especificamente caracterizando as principais síndromes genéticas conhecidas e assim a obesidade sindrômica (REIS, 2015). A obesidade em indivíduos acometidos de síndromes genéticas desencadeia, além dos fatores de risco já citados, outras complicações como pulmonares, renais, ortopédicas, doenças cardiovasculares, elevando assim o grau de comorbidades associadas a síndrome (NAVARRO et al. 2013).

Objetivos: Verificar na literatura as alterações cromossômicas mais frequentes associadas à obesidade sindrômica assim como a possível fisiopatogenia da obesidade nestes casos.

Desenvolvimento: Foi possível identificar três principais síndromes associadas a alteração da estrutura ou do número de cromossomos que se apresentam associadas à obesidade: a síndrome de Prader-Willi, a síndrome de Down (SD) e a síndrome de Turner (ST) entre outras menos frequentes. A SPW é caracterizada pela deleção do segmento 15q11-13. Esta é a síndrome mais comumente relacionada a obesidade. Entre suas características marcantes principais estão aquelas envolvidas com a gênese da obesidade como a hipotonia e a hiperfagia. A manifestação da obesidade se inicia em torno de 8 anos de idade e costuma avançar até a obesidade mórbida (REIS, 2015). Navarro et al. (2013) descreve alta prevalência de obesidade associada à SD. A prevalência do peso superior ao desejado na SD acomete $96 \%$ das mulheres e $71 \%$ dos homens. Geralmente é caracterizada pela trissomia do cromossomo 21 ou por uma translocação Robertsoniana. Em adultos o acometimento da tireoide ocorre em 39\% em indivíduos SD, sendo a alteração mais comum, o hipotiroidismo. A obesidade destes indivíduos geralmente está associada ao alto consumo de alimentos calóricos, ao hipotiroidismo, aos baixos níveis de atividade e à hipotonia (característica das SD), sendo que estas duas últimas características, levam ao um gasto energético mais baixo nestes indivíduos quando comparado aos demais. A ST é caracterizada pela monossomia do cromossomo sexual $X$ e possui um elevado número de portadores acometido pela obesidade. A causa das alterações anatômicas e fisiológicas inerentes à obesidade nestes indivíduos é geralmente está associado ao hipotiroidismo que afeta de 15\% a 30\% das pacientes. Geralmente o início do processo ocorre no período após a amenorreia (MARANHÃO, 2008). Santos (2014), descreve ainda outras síndromes menos frequentes associadas a obesidade como as deleções 1p36, 2q37, 6q16.2, 9q34.3, a síndromes WAGR, Smith-Magenis e de Bardet-Bield entre outras. Tendo em vista que a obesidade pode agravar o quadro clínico destes pacientes, é importante que haja um controle visando sempre a minimizar os riscos de comorbidades aos portadores destas síndromes.

Conclusão: Foi possível verificar que as três síndromes genéticas mais frequentes associadas à obesidade são a Síndrome de Prader-Willi, a síndrome de Down e a síndrome de Turner, sendo que os principais mecanismos envolvidos com a gênese da obesidade nestes casos estão a hipotonia, a redução do gasto energético e o hipotiroidismo.

\title{
Referências
}

BRASIL, MINISTÉRIO DA SAÚDE. 04/3

Dia Mundial da Obesidade. 03 de Abril, 2020. Disponível em: 
http://bvsms.saude.gov.br/ultimas-noticias/3134-04-3-dia-mundial-da-obesidade. Acesso em: 18 de ago. 2020.

MARANHÃO, Marcius Vinícius M. Turner syndrome and anesthesia. Revista Brasileira de Anestesiologia, v. 58, n. 1, p. 84-89, 2008.

NAVARRO, Antonio Coppi et al. Relação da síndrome de Down com a obesidade. Revista Brasileira de Obesidade, Nutrição e Emagrecimento, v. 2, n. 11, p 412-422, 2013.

OLIVEIRA, Raquel Cordeiro et al. A farmacoterapia no tratamento da obesidade. RBONE-Revista Brasileira de Obesidade, Nutrição e Emagrecimento, v. 3, n. 17, p 375-388, 2009.

REIS, Bianca Fujita dos. Análise cromossômica por microarray em pacientes com deficiência intelectual associada à obesidade. Dissertação de mestrado. Universidade de São Paulo. 2015.

SANTOS, Mauren Fernanda Moller dos. Estudo genético de síndromes associadas à obesidade. Tese de Doutorado. Universidade de São Paulo. 2014.

Coordenadoria de Pesquisa e Extensão - COPEX

Departamento de Editoração e Divulgaçāo Científica - DEDIC 


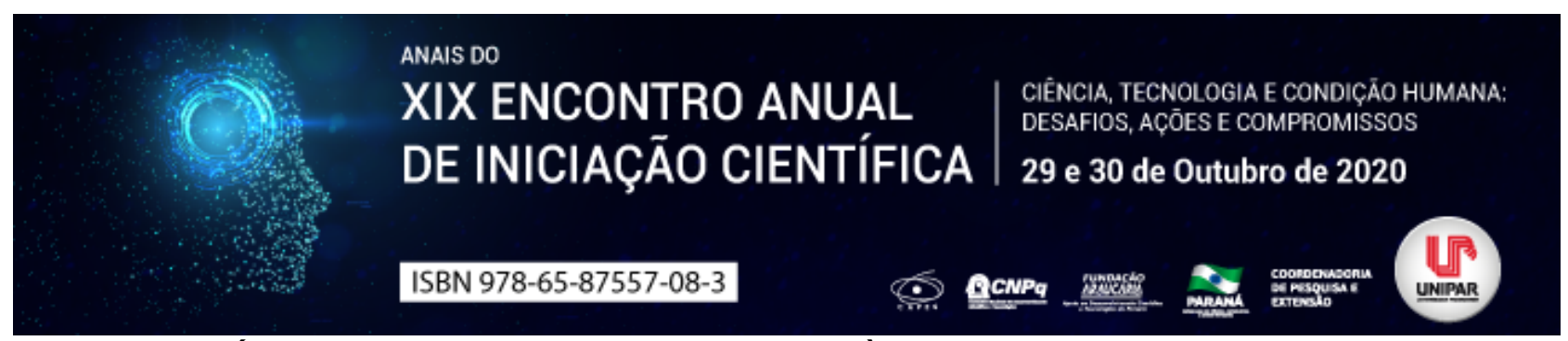

SÍNDROME DE LOEFFLER RELACIONADA ÀS PARASITOSES INTESTINAIS

\author{
${ }^{1}$ GABRIELA ALVES DE OLIVEIRA, ${ }^{2}$ HELOISA GURALESKI SIQUEIRA, ${ }^{3}$ ISABELLE LAGUILIO FIALHO, ${ }^{4}$ LUCAS PARIZI \\ ALVES, ${ }^{5}$ RENATO RICCI KAUFFMANN, ${ }^{6}$ MARCELA MADRONA MORETTO DE PAULA
}

\author{
${ }^{1}$ Acadêmica de Medicina - UNIPAR \\ ${ }^{1}$ Acadêmica do Curso de Medicina da UNIPAR \\ ${ }^{2}$ Acadêmica do Curso de Medicina da UNIPAR \\ ${ }^{3}$ Acadêmico do Curso de Medicina da UNIPAR \\ ${ }^{4}$ Docente da UNIPAR \\ ${ }^{5}$ Docente da UNIPAR
}

Introdução: Originalmente, a síndrome de Loeffler foi descrita como uma pneumonia eosinofílica aguda benigna de etiologia desconhecida, que se caracterizava por infiltrados pulmonares migratórios e manifestações clínicas mínimas. Em alguns pacientes, essas características clínicas podem ser causadas por parasitos ou fármacos (LOSCALZO, 2014). Alguns parasitos intestinais, podem apresentar ciclos pulmonares gerando infiltrados fugazes no pulmão na denominada síndrome de Loeffler (MACIEL, 2017). De acordo com Silva (2011), no Brasil, as doenças causadas por esses parasitas ocorrem em diversas regiões do país, seja em zona rural ou urbana e em diferentes faixas etárias, predominantes na infância.

Objetivo: Relacionar a síndrome de Loeffler com as parasitoses intestinais mais prevalentes no Brasil, bem como seus sinais e sintomas, achados clínicos e possíveis diagnósticos diferenciais.

Desenvolvimento: Em países em desenvolvimento, tal qual o Brasil, as helmintíases são consideradas um problema de saúde pública devido à dificuldade encontrada ao controle dos parasitas, além da morbidade causada por eles (LOPES et al., 2017). Algumas das infecções de helmintos podem causar comprometimento respiratório, devido ao ciclo biológico do verme, que acaba adentrando na pequena circulação do organismo humano, por penetração ou ingestão oral. O Ciclo de Loss, também conhecido como ciclo pulmonar, dá-se quando os nematelmintos penetram no corpo do hospedeiro e caem na corrente sanguínea, seguindo para o pulmão, onde podem sofrer mudanças. Eles causam o rompimento dos capilares e se instalam na árvore alveolar, ascendendo pelos brônquios até alcançar a faringe, onde são expelidos ou engolidos (NEVES, 2005). Entre os vermes que podem causar tal quadro respiratório estão Ascaris lumbricoides, Necator americanus, Ancylostoma duodenale e Strongyloides stercoralis (ALVES, SOUSA e SANCHES, 2012). A síndrome de Loeffler caracteriza-se por ser uma pneumonite eosinofílica transitória, por reação de hipersensibilidade imediata, resultante da migração pulmonar das larvas de parasitas, sobretudo de helmintos. Uma característica significativa da síndrome é seu curso clínico benigno. Ressalta-se, que a patologia pode acontecer em indivíduos de qualquer faixa etária. Clinicamente falando, esta síndrome é caracterizada por uma autolimitação dentro de 1 a 2 semanas. Em termos de laboratório, há um aumento da eosinófilos no sangue, mas nem sempre é evidente e pode estar entre 500-1000 células $/ \mathrm{mm} 3$ e, em alguns casos, pode até não ser existente (ALVES, SOUSA e SANCHES, 2012). O quadro clínico é característico a uma doença pulmonar, semelhante a uma pneumonia (NEVES, 2005). A tosse seca é o sintoma mais comum, podendo estar presente também febre baixa, dispnéia do tipo asmatiforme, e mais raramente, pode ocorrer hemoptise, mialgia, anorexia e urticária. Os sintomas surgem 10 a 16 dias após o início da infecção, seja a ingestão do ovo ou a penetração das larvas, dependendo do verme. Deve-se, então, investigar a história social e de viagem para áreas de risco neste período. O exame físico pode ser normal ou apresentar sibilos e crepitações finas à ausculta pulmonar. Podendo, ainda, associar-se a manifestações extra-pulmonares como hepatomegalia, reações meníngeas ou erupção cutânea prurítica (ALVES, SOUSA e SANCHES, 2012). As alterações radiológicas habituais são múltiplas lesões, pouco delimitadas, do tipo alveolar condensante, migratórias ou evanescentes. Mais raramente, nos casos mais graves, podem-se observar pneumonia fraca e bronquiectasias. Há outras doenças pulmonares que geram eosinofilia, como pneumonia eosinofílica aguda, aspergilose broncopulmonar alérgica e a síndrome de Churg-Strauss, portanto, a Síndrome de Loeffler exige um diagnóstico diferencial bem realizado, com anamnese criteriosa para saber se houve exposição a algum fator desencadeante para demais patologias. Baseado em achados clínicos e laboratoriais, como as múltiplas lesões reveladas na radiografia torácica, sinal sugestivo dessa doença, o exame de fezes positivo para ovos ou larvas dos parasitas e a presença de larvas nos escarros é capaz de confirmar o diagnóstico (LOPES et al., 2005). No que tange o tratamento, corticóides sistêmicos são utilizados para suprimir os sintomas clínicos e sinais radiológicos, bem como diminuir a eosinofilia, nesse caso, um fármaco muito utilizado é a Prednisona (LOPES et al., 2005). Todavia, após a confirmação laboratorial de parasita, é indicado drogas anti-helmínticas para evitar demais manifestações da parasitose e o agravamento do caso, os fármacos mais utilizados nesse viés são o Albendazol e Metronidazol (ALVES, SOUSA e SANCHES, 2012). 
Conclusão: Afere-se, portanto, que algumas parasitoses intestinais podem vir a possuir relação com doenças pulmonares. Considerando a grande prevalência das parasitoses, em nosso meio, é necessário conhecer a Síndrome de Loeffler, sua relação com essas helmintíases e possíveis diagnósticos diferenciais, sabendo-se que aparece em situações específicas, muitas vezes sendo difícil de diagnosticar.

\section{Referências}

ALVES, A. C. A.; SOUSA, A. M. de; SANCHES, C. S. Síndrome de Loeffler. Revista Paraense de Medicina, v. 26; n.2, 2012. LOPES, AJ et. al. Síndrome de Löffler. Pulmão. Rio de Janeiro, 2005, vol. 14, nº 4, p. 325-327.

LOSCALZO, Joseph (Org.). PNEUMOLOGIA E MEDICINA INTENSIVA DE HARRISON. 2. ed. Porto Alegre: Artmed, 2014. MACIEL, Renato; AIDÉ, Miguel Abidon (ORG). PRÁtICA PNEUMOLóGICA. 2 Ed. Rio de Janeiro: GUANABARA KOOGAN, 2017.

NEVES, David Pereira et al. Parasitologia Humana. 11a. ed. Rio de Janeiro: Atheneu, 2005.

SILVA, Jefferson Conceição et al.Parasitismo por Ascaris lumbricoides e seus aspectos epidemiológicos em crianças do Estado do Maranhão. Rev. Soc. Bras. Med. Trop., Uberaba , v. 44, n. 1, p. 100-102, Feb. 2011.

Coordenadoria de Pesquisa e Extensão - COPEX

Departamento de Editoraçāo e Divulgaçāo Científica - DEDIC 


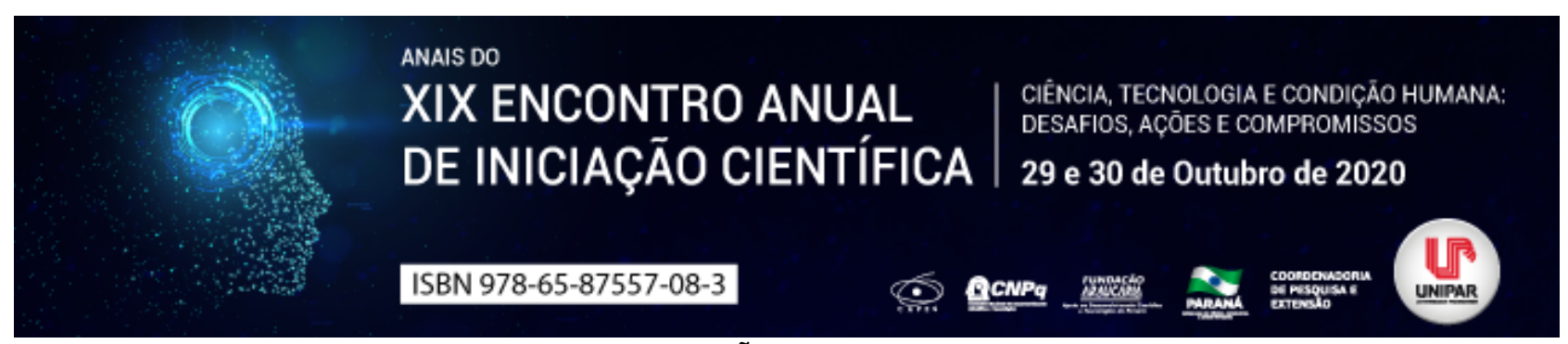

PROTOCOLOS PARA INDUÇÃO DE CICLICIDADE EM NOVILHAS

\section{${ }^{1}$ HENRIQUE MISTURA, ${ }^{2}$ VITOR HUGO INOUE CORREA, ${ }^{3}$ ROSIARA ROSARIA DIAS MAZIERO}

${ }^{1}$ Discente do Curso de Medicina Veterinária da UNIPAR Bolsista PIC

${ }^{1}$ Discente do Curso de Medicina Veterinária da UNIPAR Bolsista PIC

${ }^{2}$ Docente do curso de Medicina Veterinária da UNIPAR

Introdução: A indução da puberdade de novilhas tem como objetivo deixá-las aptas para reproduzir mais cedo e aumentar o seu condicionamento fisiológico para que sua reprodução tenham bons resultados (SOUSA, 2018). Assim, na atual situação econômica do Brasil é necessário que haja agilidade dos produtores quanto a reprodução de seus rebanhos, por isto nos últimos anos vem acontecendo um melhoramento no potencial genético, tendo como amparo técnicas como a Inseminação Artificial (IA) e a Inseminação Artificial em Tempo Fixo (IATF) (PALHANO, 2012).

Objetivo: Avaliar protocolos que induzem a ciclicidade em novilhas da raça Nelore.

Desenvolvimento: Nos sistemas de criação de bovinos, o sistema de cria feito de forma adequada prioriza a fertilidade das fêmeas. Deste modo, quanto mais precocemente as fêmeas de reposição estiverem maduras sexualmente, maior serão os índices gestacionais da estação de monta e mais rápido será o retorno financeiro sobre o investimento. Assim, um dos fatores determinantes para o sucesso da pecuária de corte é o início da puberdade de novilhas dentro do sistema de produção animal (SÁ FILHO et al., 2010). Para tanto, a maioria das novilhas deve estar apresentando ciclo estral regular já ao início desta estação, desta forma, a puberdade é o marco inicial do processo reprodutivo e produtivo, com reflexos nos aspectos econômicos e no melhoramento genético, uma vez que sua antecipação proporciona retorno mais rápido do investimento, aumenta a vida útil das matrizes, ao mesmo tempo em que permite maior intensidade de seleção e reduz o intervalo entre gerações, resultando assim em maior ganho genético (EMERICK et al., 2009). Sabe-se que na fase que antecede a puberdade ocorre um aumento na secreção do Hormônio Liberador de Gonadotrofinas $(\mathrm{GnRH})$ que desencadeia um aumento na liberação de LH (hormônio luteizante), restabelecendo a atividade gonadal e dando início ao período de maturidade sexual (EVANS et al., 1992). Muitos autores relatam sucesso na indução da ciclicidade em novilhas utilizando progestágeno oral ou intravaginal (MARTIN et al., 2008; RODRIGUES et al., 2013). SILVEIRA et al. (2020) mostram que ao utilizar progesterona injetável para indução da puberdade em novilhas taurinas trouxe resultados animadores. Tanto o uso de progesterona injetável ou progesterona injetável mais cipionato de estradiol foram eficazes em induzir a ciclicidade em novilhas taurinas, mas o protocolo somente com progesterona é o mais indicado pelos autores, pois, evita um manejo a mais, reduzindo estresse e dispensa a utilização de uma dose de cipionato de Estradiol, reduzindo assim também custos. Outro estudo realizado por ARAÚJO (2019), mas com novilhas zebuínas, aos serem submetidas ao protocolo com implante intravaginal de progesterona ( $4^{\circ}$ uso) associado a $2 \mathrm{ml}$ de benzoato de estradiol mostraram que $82 \%$ das novilhas se tornaram cíclicas, apresentando a eficácia deste protocolo.

Conclusão: A indução da ciclicidade em novilhas apresenta bons resultados, desde que seja feito um protocolo hormonal adequado para cada espécie.

\section{Referências}

ARAUJO, A. C. C.; BEZERRA, A. R. A.; MURTA, D. V. F.; FIGUEIREDO, V. C. S.. Efeito indução da ovulação em novilhas com protocolo de ciclicidade. Brazilian Journal of Development, v. 5, n. 11, p. 24286-24290.

EMERICK, L.; DIAS, J.; GONÇALVES, P.; VALE FILHO, V. Aspectos relevantes sobre a puberdade em fêmeas. Revista Brasileira de Reprodução Animal, v. 33, n. 1, p. 10, 2009.

MARTIN, J. L.; CREIGHTON, K. W.; MUSGRAVE, J. A.; KLOPFENSTEIN, T. J.; CLARCK, D.; ADAMS, D.C.; FUNSTON, R.N . Effect of prebreeding body weight or progestin exposure before breeding on beef heifer performance through the second breeding season. Journal of Animal Science, v. 86, n. 2, p. 451-459, 2008.

PALHANO, H.B.; JESUS, V. L. T.; FIGUEIREDO, M. A.; BALDRIGHI, J.M.; MELLO M.R.B. Efeito da ciclicidade de vacas nelore sobre as taxas de concepção e de prenhez após protocolos de sincronização para inseminação artificial em tempo fixo. Revista Brasileira de Medicina Veterinária e Zootecnia, v. 34, n. 1, p. 63-68., 2012.

RODRIgUeS, A. D.; PERES, R. F.; LEMES, A. P.; MARTINS, T.; PEREIRA, M.H.C.; DAY, M.L.; VASCONCELOS, J.L.M. Progesterone-based strategies to induce ovulation in pre-pubertal Nellore heifers. Theriogenology, V. 79, n. 1, p. 135-141, 2013. SA FILHO, M. F.; TORRES-JUNIOR, J. R.; PENTEADO, L.; GIMENES, L. U.; FERREIRA, R.M.; AYRES, H.; CASTRO E PAULA, L.A.; SALES, J.N.S .; BARUSSELI, P.S. Equine chorionic gonadotropin improves the efficacy of a progestin-based fixed-time artificial insemination protocol in Nelore (Bos indicus) heifers. Animal Reproduction Science, v. 118, n. 2-4, p. 182-187, 2010.

SILVEIRA, G.J.M.; FERNANDES, M.S.; PESSOA, G.A.; MARTINI, A.P.; GUERREIRO, B.M.; FREITAS, B.G. Uso da 
progesterona injetável na indução da ciclicidade em novilhas pré-púberes: taxa de prenhez à IATF. Inovação e Pluralidade na Medicina Veterinária, v. 3, n. 9, p. 56-64, 2020.

SOUSA, S.R.S. Indução da ciclicidade com progesterona injetável em novilhas da raça Nelore. Dissertação (Mestrado), Universidade Federal do Piauí (UFPI), 2018.

Coordenadoria de Pesquisa e Extensão - COPEX

Departamento de Editoraçāo e Divulgaçāo Científica - DEDIC 


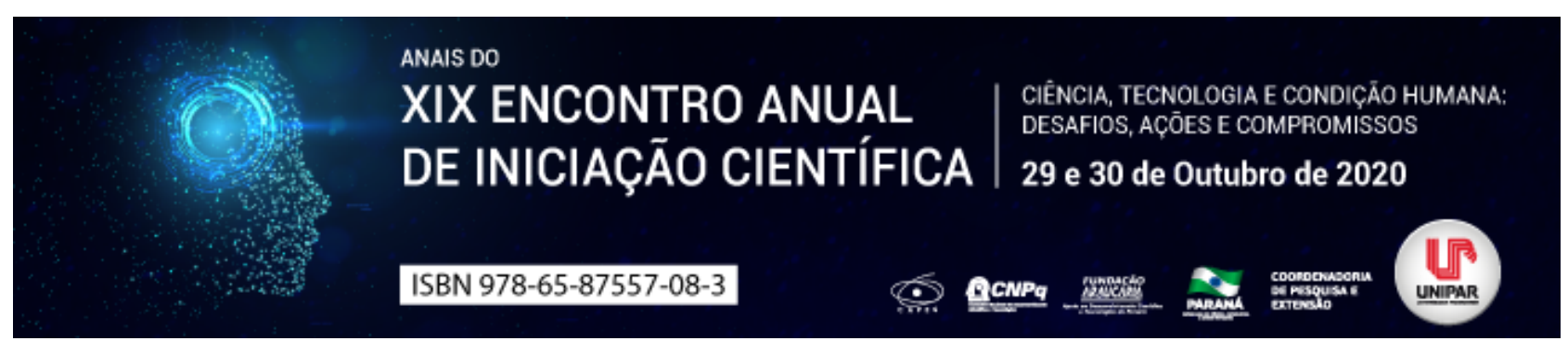

USO DE BIOMATERIAIS NA CICATRIZAÇÃO DE FERIDAS REVISÃO

\begin{abstract}
${ }^{1}$ GUILHERME DE ALMEIDA FAHEL CHUEIRI, ${ }^{2}$ WESLEY ALVES TRINDADE, ${ }^{3}$ LIDIA KAZUE IUKAVA, ${ }^{4}$ PAULA MONTANHINI FAVETTA, ${ }^{5}$ MARCELO ALBERTO ELIAS, ${ }^{6}$ RICARDO DE MELO GERMANO
\end{abstract}

\author{
${ }^{1}$ Acadêmico bolsista do PIBIC/UNIPAR \\ ${ }^{1}$ Acadêmico do Curso de Administração da UNIPAR \\ ${ }^{2}$ Acadêmica do Curso de Biomedicina da UNIPAR \\ ${ }^{3}$ Acadêmica do Curso de Doutorado Em Ciencia Animal Com Enfase Em Produtos Bioativos - Turma V da UNIPAR \\ ${ }^{4}$ Acadêmico do Curso de Doutorado Em Ciencia Animal Com Enfase Em Produtos Bioativos - Turma Iv da UNIPAR \\ ${ }^{5}$ Docente da UNIPAR
}

Introdução: A cicatrização de feridas é um processo complexo que envolve uma cascata de reações biológicas iniciadas em resposta a uma lesão (SAHANA; REKHA, 2018). Nesse processo, as principais interações são de células imunes (neutrófilos, monócitos, macrófagos, linfócitos), células não imunes (endoteliais, queratinócitos, fibroblastos), mediadores solúveis (citocinas e fatores de crescimento) e componentes extracelulares (SAHANA; REKHA, 2018). A cicatrização ocorre com quatro fases: hemostasia, inflamação, proliferação e remodelação (ZAREI; SOLEIMANINEJAD, 2018). Estudos revelaram diversas maneiras em relação ao processo de cicatrização como: Aplicação de células-tronco, que secretam diversos fatores de crescimento, ataduras líquidas formadas com polímeros (hirdrofóbicos, anfif́licos), pele de tilápia, entre vários outros. (ZAREl; SOLEIMANINEJAD, 2018; SALAMONE et al., 2016; LIMA-JUNIOR et al., 2017).

Objetivo: Realizar uma revisão de literatura sobre a utilização de diferentes biomateriais na cicatrização de feridas.

Desenvolvimento: Para revisão foi realizado uma busca na plataforma de pesquisa internacional do PubMed (www.pubmed.com), utilizando os descritores: biomaterials and wound healing . Foram utilizados artigos publicados a partir de 2017 que possuíam o objetivo principal a utilização de biomateriais e/ou biopolímeros no processo de cicatrização de feridas. Biopolímeros são moléculas orgânicas sintetizadas pelos organismos vivos, tendo como estrutura uma sequência de monômeros repetidos de aminoácidos, monossacarídeos, nucleotídeos ou ésteres mantidos por ligações covalentes para formar moléculas maiores. Se caracterizam por possuir origens diversas como plantas (amido,celulose e borracha natural), animal (colágeno, ácido hialurônico e quitosana), bactérias (celulose bacteriana, exopolissacarídeos), fungos (quitina) e algas (alginato) (SAHANA; REKHA, 2018), sendo materiais não medicamentosos, podem ser usados para suplementar ou substituir a função de tecidos e órgãos do corpo (SHAH et al., 2019).Por conta de suas origens, os polímeros oferecem vantagens sobre os materiais sintéticos devido á biocompatibilidade, biodegradabilidade, menos antigenicidade e renovabilidade (SAHANA; REKHA, 2018). A utilização dos biopolímeros resulta em diversas vantagens como: Colágeno - Induz a proliferação de fibroblastos, induz a secreção de componentes da matriz extracelular, por fibroblastos, e são quimiotáticos para macrófagos; Celulose - Retenção de umidade, absorção de exsudado; Ácido hialurônico - Produz um estimulo de fibroblastos e queratinócitos (proliferação e migração) e atua como anti-inflamatório (SAHANA; REKHA, 2018). O uso de alguns biopolímeros pode ser limitado ou não recomendado para pacientes alérgicos a determinados materiais ou com relação ao ferimento do paciente (SHAH et al., 2019).

Conclusão: A utilização de biomateriais como biopolímeros pode ser de grande eficiência, visto que sua utilização pode auxiliar o organismo no processo de cicatrização, aumentando a proliferação de células, estímulos celulares, atividade anti-inflamatórias.

\title{
Referências
}

SAHANA, T. G.; REKHA, P. D. Biopolymers: Applications in wound healing and skin tissue engineering. Molecular biology reports, Netherlands, v. 45, n. 6, p. 2857-2867, 2018.

ZAREI, F.; SOLEIMANINEJAD, M. Role of growth factors and biomaterials in wound healing. Artificial cells, nanomedicine, and biotechnology, Abingdon, v. 46, n. sup1, p. 906-911, 2018.

SALAMONE, J. C. et al. Grand challenge in biomaterials-wound healing. Regenerative biomaterials, Oxford, v. 3, n. 2, p. 127128, 2016.

SHAH, S. A. et al. Biopolymer-based biomaterials for accelerated diabetic wound healing: A critical review. International journal of biological macromolecules, Amsterdam, v. 139, p. 975-993, 2019.

LIMA-JUNIOR, E. M. et al. Uso da pele de tilápia (Oreochromis niloticus), como curativo biológico oclusivo, no tratamento de queimaduras. Revista Brasileira de Queimaduras, Goiânia, v.16, n.1, p. 10-17, 2017. 
Coordenadoria de Pesquisa e Extensão - COPEX

Departamento de Editoraçāo e Divulgaçāo Científica - DEDIC 


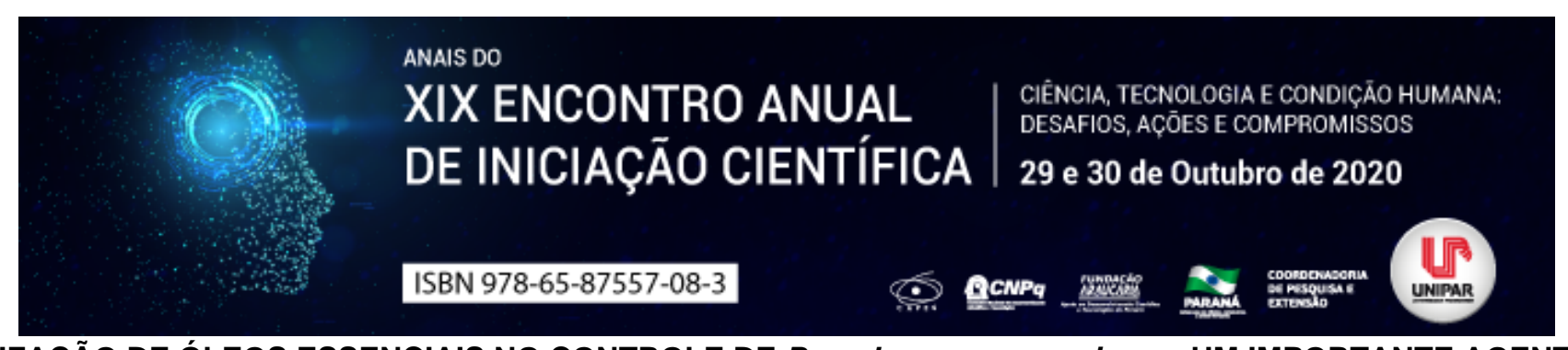

UTILIZAÇÃO DE ÓLEOS ESSENCIAIS NO CONTROLE DE Pseudomonas aeruginosa, UM IMPORTANTE AGENTE DE INFECÇÕES

\begin{abstract}
${ }^{1}$ JULIA MUNARETTO ZONIN, ${ }^{2}$ ISABELLA ARANTES TOBBIN, ${ }^{3}$ JEFFERSON ALESSANDRO SHMITZ JUNIOR, ${ }^{4}$ GABRIELA FAVERO ESPOLADOR, ${ }^{5}$ LIDIANE NUNES BARBOSA
\end{abstract}

\author{
${ }^{1}$ Discente do curso de Medicina, PIC, UNIPAR \\ ${ }^{1}$ Discente do curso de Medicina, PIBIC, UNIPAR \\ ${ }^{2}$ Discente Ensino Médio, PEBIC EM CNPq \\ ${ }^{3}$ Mestranda PPG em Ciência Animal com Ênfase em Produtos Bioativos \\ ${ }^{4}$ Docente da UNIPAR
}

Introdução: A Pseudomonas aeruginosa é uma bactéria Gram-negativa oportunista, ubiquitária, que compõe a microbiota humana, e é um patógeno humano muito conhecido, principalmente, devido à sua resistência à antibióticos. Essa bactéria costuma infectar a pele, tecidos e os tratos urinário e respiratório. Tendo em vista o crescente número de cepas resistentes e do limitado arsenal terapêutico existente, diversos óleos essenciais (OEs) têm sido estudados e analisados no combate à $P$. aeruginosa e outras bactérias multirresistentes (DANTAS, 2018).

Objetivo: Analisar por meio de revisão da literatura quais óleos essenciais apresentam ação antibacteriana contra a Pseudomonas aeruginosa, considerando que essa bactéria é resistente à maioria dos antibióticos existentes atualmente.

Desenvolvimento: A $P$. aeruginosa é um dos principais agentes de infecção nosocomial e possui grande importância clínica devido a expressão de múltipla resistência a antibacterianos associada a uma difícil erradicação da doença, o que consequentemente ocasiona elevados índices de morbidade e mortalidade (NEVES et al., 2011). Quase todos os materiais e equipamentos hospitalares (principalmente com componentes líquidos), podem servir de reservatório para a $P$. aeruginosa, incluindo equipamentos de ventilação assistida, fluídos de administração intravenosa e desinfetantes (PAVIANI; STADNIK; HEINEK, 2003). A P. aeruginosa costuma ter uma maior incidência entre os pacientes da UTI do que outras bactérias comumente hospitalares, e geralmente causa pneumonia, e infecções no trato urinário, em feridas cirúrgicas, na corrente sanguínea e em queimados (PAVIANI; STADNIK; HEINEK, 2003; SILVA.; KIMURA; COIMBRA, M, 2012). O melhor tratamento baseia-se na combinação de antibióticos de diversas classes, incluindo penicilinas que apresentaram atividade anti pseudomonas e cefalosporinas de amplo espectro associado com beta-lactâmicos. Entretanto, apesar de determinados fármacos terem boa atividade contra a $P$. aeruginosa, não podem ser consideradas uma terapia 100\% eficaz contra a mesma (DANTAS, 2018). Além da característica intrínseca de apresentar baixo nível de sensibilidade aos antimicrobianos, mecanismos de resistência têm sido identificados na espécie bacteriana, como: hiperexpressão de bombas de efluxo; produção de $\beta$-lactamases; e perda ou expressão reduzida de proteínas de membrana externa. Frequentemente, isolados de $P$. aeruginosa apresentam resistência a diferentes classes de antibióticos, inclusive contra cefalosporinas de terceira e quarta gerações e carbapenêmicos. Por estas razões, as infecções causadas por cepas de $P$. aeruginosa multirresistentes estabelecem dificuldade para a terapia antimicrobiana (FUENTEFRIA et al., 2008).Tendo em vista a resistência dessa bactéria aos medicamentos conhecidos atualmente, várias pesquisas vêm sendo desenvolvidas e direcionadas para a investigação de novos agentes antimicrobianos provenientes de plantas, como os óleos essenciais e outros produtos naturais. Os óleos essenciais (OEs) são produtos voláteis, provenientes de metabolismo secundário de plantas aromáticas, que apresentam propriedades biológicas diferenciadas, dentre elas, a atividade contra microrganismos. A atividade antimicrobiana varia de acordo com o óleo utilizado, dos compostos majoritários e do tipo de bactéria (COSTA, 2009). Dantas (2018) realizou uma revisão integrativa de artigos publicados no período de 2008 a 2018, e os resultados encontrados foram que os óleos essenciais que mostraram ação inibitória contra a $P$. aeruginosa, baseando se em estudos in vitro, são extraídos das seguintes plantas: Cinnamomum zeylanicum, Origanum vulgare L., Zingiber officinale, Aloysia gratíssima, Cymbopogon nardus, Cymbopogon winterianus, Caryophyllus aromaticus L., Cinnamomum cassia, Eucalyptus paniculada e Myracrodruon urundeuva. Os óleos menos tóxicos e mais seguros no combate à P. aeruginosa são do $O$. vulgare e C. zeylanicum, sendo a última a espécie mais eficaz contra a bactéria. A concentração inibitória mínima (CIM) fornece a menor concentração utilizada do óleo que exibe ação contra o agente a ser exposto, e o trabalho de Dantas analisou os resultados da CIM dos óleos apresentados, constatando que os óleos com forte atividade contra a $P$. aeruginosa, foram C. zeylanicum, O. vulgare L., C. aromaticus L. e Z. officinale. O artigo de Costa (2009) também traz que os óleos essenciais de $C$. zeylanicum e $O$. vulgare $L$. exibiram uma rápida atividade bactericida (alguns minutos) em relação aos antibióticos convencionais (horas). Esses resultados foram obtidos com a $P$. aeruginosa mas também com outras cepas de bactérias multirresistentes. 
Conclusão: Devido a falta de antibióticos eficazes contra essa bactéria, as pesquisas com produtos naturais, especialmente com os óleos essenciais, têm-se tornado cada vez mais frequentes. Partindo da leitura das pesquisas pode-se concluir que as plantas cujos óleos essenciais foram mais eficazes contra essa bactéria foram o $O$. vulgare e $C$. zeylanicum, que apresentaram atividade bactericida em menor tempo em relação aos antibióticos demonstrando ser uma alternativa terapêutica potencial.

\section{Referências}

COSTA, A. C. Atividade antibacteriana dos óleos essenciais de Origanum vulgare L. e Cinnamomum zeylanicum B. contra bactérias multirresistentes. Tese (Doutorado em Produtos Naturais e Sintéticos Bioativos) - Universidade Federal da Paraíba, João Pessoa, 2009.

DANTAS, T. F. O. A. Óleos essenciais com atividade contra Pseudomonas aeruginosa: uma revisão integrativa. Trabalho de Conclusão de Curso (Bacharelado em Farmácia) - Universidade Federal de Campina Grande, 2018.

FIGUEIREDO, E. A. P. et al. Pseudomonas Aeruginosa: Freqüência de Resistência a Múltiplos Fármacos e Resistência Cruzada entre Antimicrobianos no Recife/PE*. Revista Brasileira de Terapia Intensiva, v. 19. n. 4, p. 421-427, out-dez, 2007.

FUENTEFRIA, D. B. et al. Pseudomonas aeruginosa: disseminação de resistência antimicrobiana em efluente hospitalar e água superficial. Revista da Sociedade Brasileira de Medicina Tropical, v. 41, n.5, p. 470-473, set-out, 2008.

NEVES, P. R. et al. Pseudomonas aeruginosa multirresistente: um problema endêmico no Brasil. Jornal Brasileiro de Patologia e Medicina Laboratorial. v. 47. n. 4. p. 409-420, ago, 2011.

PAVIANI, E. R.; STADNIK, C. B.; HEINEK, I. Estudo da epidemiologia e perfil de sensibilidade da Pseudomonas aeruginosa. Infarma Ciências Farmacêuticas, v. 15, n. 11-12, p. 66-70, nov-dez, 2003.

SILVA, N. F. V.; KIMURA, C. A.; COIMBRA, M. V. S. Perfil de sensibilidade antimicrobiana das pseudomonas aeruginosa isoladas de pacientes da unidade de tratamento intensiva de um hospital público de brasília. Revisa, v. 1, n 1. p. 19-24, jan-jun, 2012. 


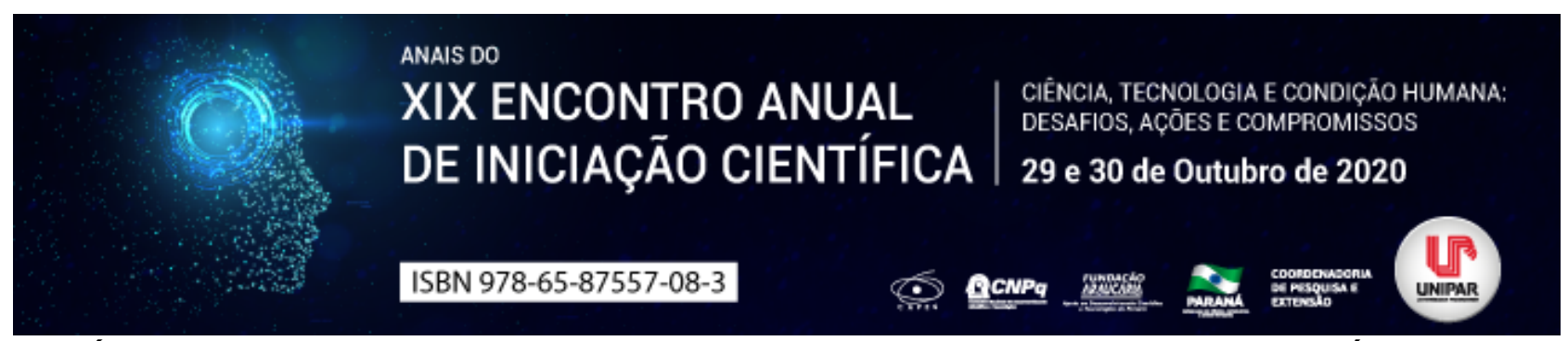

SÍNDROME DE KLINEFELTER: MOTIVOS QUE LEVAM A POUCOS E TARDIOS DIAGNÓSTICOS

\author{
${ }^{1}$ BEATRIZ CORREA CERNKOVIC, ${ }^{2}$ KAMUNI AKKACHE COUTINHO, ${ }^{3}$ DENISE ALVES LOPES, ${ }^{4}$ JOSÉ RICARDO \\ SKOLMOVSKI DA SILVA, ${ }^{5}$ IRINEIA PAULINA BARETTA, ${ }^{6}$ ROSILEY BERTON PACHECO
}

\begin{abstract}
${ }^{1}$ Acadêmica do PIC/UNIPAR
${ }^{1}$ Acadêmica do PIBIC/UNIPAR

${ }^{2}$ Docente do curso de medicina/UNIPAR

${ }^{3}$ Docente da UNIPAR

${ }^{4}$ Docente do curso de medicina/UNIPAR

${ }^{5}$ Docente do curso de medicina/UNIPAR
\end{abstract}

Introdução: A Síndrome de Klinefelter (SK) é resultado da deficiência genética com cariótipo 47, XXY, determinada geneticamente pela duplicação do cromossomo $X$. São alterações tardias, mais evidentes na puberdade, que a caracterizam. Os pacientes portadores de SK podem apresentar hipodesenvolvimento dos caracteres sexuais secundários, hipogonadismo hipergonadotrófico e ainda azoospermia (ausência de espermatozoide no sêmen). Ainda não se conhece muito sobre o exato mecanismo para a determinação da deficiência androgênica apresentando variância no grau de disfunção das células de Leydig. Além disso, o curso dessa síndrome é crônico com sérios impactos sobre o sistema reprodutor masculino, tendo alta importância na causa de infertilidade em nível mundial (MAIA et al, 2002).

Objetivo: Identificar os motivos que fazem a Síndrome de Klinefelter ser diagnosticada tão pouco e tardiamente em seus portadores.

Desenvolvimento: No estudo realizado por Pacenza et al. (2010), afirmou-se que entre o sexo masculino a Síndrome de Klinefelter é a aberração cromossômica mais comum, estimada em 1:600 recém-nascidos. Nele também consta que a SK foi diagnosticada mais frequentemente na faixa etária de 11 a 20 anos, compreendendo $46,8 \%$ dos casos e que $83,7 \%$ dos portadores apresentaram o cariótipo clássico $47, \mathrm{XXY}$, enquanto $7,1 \%$ apresentaram mosaicismo $47, \mathrm{XXY} / 46, \mathrm{XY}$.

Ademais, a SK tem como consequência deficiências nos caracteres sexuais como o hipogonadismo que é o impedimento da produção adequada do hormônio sexual e, também, o aumento do tecido das mamas (ginecomastia) causado por um desequilíbrio na produção deste hormônio (BREMNER, SMYTH 1998 apud SIQUEIRA, 2019). Porém, ainda que os pacientes possam apresentar todas as anormalidades dessa síndrome, eles não necessariamente desenvolverão conjuntamente essas características ocasionadas em decorrência das alterações cromossômicas (GRAÇA 2006 apud SIQUEIRA, 2019).

Por outro lado, para essa síndrome, observou-se que os pacientes procuram pouco os médicos e que estes nem sempre se atentam ao diagnóstico, sendo dois dos motivos para a Síndrome de Klinefelter ser uma doença tão pouco diagnosticada, ainda que tenha sido descrita pela primeira vez há mais de sete décadas. Desse modo, apenas cerca de $25 \%$ dos maiores de idade são diagnosticados, grande parte quando buscam sobre a infertilidade e/ou hipogonadismo. Já nas fases que antecedem a puberdade são diagnosticados menos de $10 \%$ de todos os casos (TINCANI, 2012).

Ainda mais, sem o tratamento correto é possível que ocorram complicações no desenvolvimento desses portadores. Já quando adequado é possível que eles se desenvolvam normalmente, para isso, precisa ser iniciado precocemente com a oferta de um ambiente favorável, apoio psicológico e cognitivo e, também, reposição hormonal (testosterona) que geralmente se inicia por volta dos 12 anos com a chegada da puberdade (LÓPEZ, 2008).

Por fim, os exames pré-natais podem ser utilizados para diagnosticar alterações do cariótipo relativo aos cromossomos sexuais, essa sondagem permite que portadores da SK possam antecipar as informações e os tratamentos, podendo mudar positivamente o desenvolvimento psicológico e corporal. Já quanto à fertilidade, notou-se a possibilidade de recuperação de espermatozoides através de biopse testicular em pacientes com menos de 35 anos, utilizando esses em uma futura fertilização in vitro (ASZPIS et al. 2006 apud SIQUEIRA, 2019).

Conclusão: $O$ diagnóstico acontece mais tardiamente nessa síndrome pelo fato de que o desenvolvimento dos caracteres presentes na SK acontece na puberdade do sexo masculino. Sendo essa pouco diagnosticada quando crianças e, menos ainda, quando recém-nascidos, pois nessas fases não apresentam desenvolvimento significativo desses caracteres. Além disso, não há por parte dos homens muita procura aos médicos, geralmente só ocorre a procura quando querem tratar infertilidade. Portanto, quanto antes diagnosticada melhor o prognóstico para a Síndrome de Klinefelter.

\title{
Referências
}

LÓPEZ, Mercé Artigas. Síndrome de Klinefelter. Junta Directiva de la Asociación Española de Pediatría, p. 49, 2008. 
MAIA, Frederico F.R. et al . Diagnóstico tardio da síndrome de Klinefelter: relato de caso. Arq Bras Endocrinol Metab, São Paulo, v. 46, n. 3, p. 306-309, June 2002. Available from . access on 27 July 2020.

PACENZA, Carina Natalia et al. Síndrome de Klinefelter en las distintas edades: experiencia multicéntrica. Revista Argentina de Endocrinología y Metabolismo, v. 47, n. 4, p. 29-39, 2010.

SIQUEIRA, Thomaz Décio Abdalla. COMPREENDENDO OS SINTOMAS DA SÍNDROME DE KLINEFELTER. BIUS-Boletim Informativo Unimotrisaúde em Sociogerontologia, v. 11, n. 4, p. 1-16, 2019.

TINCANI, Bruna J. et al . Síndrome de Klinefelter: diagnóstico raro na faixa etária pediátrica. J. Pediatr. (Rio J.), Porto Alegre , v. 88, n. 4, p. 323-327, ago. 2012 . Disponível em . acessos em 27 jul. 2020.

Coordenadoria de Pesquisa e Extensão - COPEX

Departamento de Editoraçāo e Divulgaçāo Científica - DEDIC 


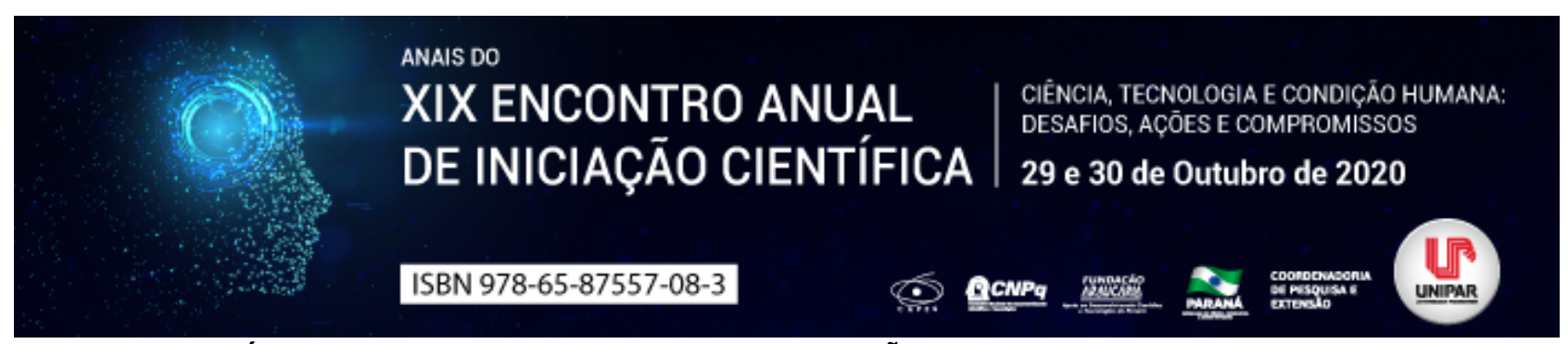

EFICÁCIA DE PROTOCOLO DE SUPEROVULAÇÃO EM VACAS DA RAÇA JERSEY

\begin{abstract}
${ }^{1}$ AULY BEATRIZ TRINDADE, ${ }^{2}$ FERNANDA CORREA BIGATTAO, ${ }^{3}$ IZABELA DE OLIVEIRA BORGHI, ${ }^{4}$ CELINA DOS SANTOS MONTEIRO, ${ }^{5}$ CARLOS RENATO DE FREITAS GUAITOLINI, ${ }^{6}$ ROSIARA ROSARIA DIAS MAZIERO
\end{abstract}

\begin{abstract}
${ }^{1}$ Discente do Curso de Medicina Veterinária Bolsista PEBIC/CNPq UNIPAR
${ }^{1}$ Discente do Curso de Medicina Veterinária Bolsista PIBIC/UNIPAR

${ }^{2}$ Discente do Curso de Medicina Veterinária - BolsistaPIBIC/ UNIPAR

${ }^{3}$ Discente do Curso de Medicina Veterinária - BolsistaPIBIC/ UNIPAR

${ }^{4}$ Pós-Doutorando do Programa de Pós-graduação em Ciência Animal UNIPAR

${ }^{5}$ Docente da UNIPAR
\end{abstract}

Introdução: A superovulação (SOV) em bovinos tornou-se uma técnica de grande valia para o aumento e desempenho dos rebanhos brasileiros, uma vez que, permite que uma fêmea consiga produzir vários embriões em um curto intervalo de tempo (OLIVEIRA et al., 2009).As fêmeas da raça Jersey apresentam peculiaridades no que se refere a biotecnologia de superovulação e transferência de embriões e atualmente, é a segunda raça leiteira criada no mundo, devido às suas características de precocidade, alta capacidade de adaptar-se a vários tipos de climas, manejo e condições geográficas, prolificidade com boa capacidade de reprodução, facilidade de parição e longevidade (CREPALDI, 2009).

Objetivo:Este estudo teve como objetivo avaliar a eficácia do tratamento superovulatório com $400 \mathrm{UI}$ de FSH em doadoras das vacas da raça Jersey e taxa de prenhez em fêmeas receptoras.

Material e Métodos: Foram utilizadas 10 vacas doadoras de embriões da raça Jersey, pluríparas, com idade entre 7 e 8 anos, pertencentes a uma propriedade particular localizada em Moreira Sales, no estado do Paraná e 60 vacas receptoras de embriões. Para o protocolo de superovulação das vacas doadoras foi utilizado no dia 0 (D0) dispositivo intravaginal impregnado com $1 \mathrm{~g}$ de progesterona (Cronipress $\AA$ Mono Dose; BiogenesisBagó, Brasil) e aplicado 2,5 mg de $17 \beta$ estradiol (17beta $®$; Botupharma Biotecnologia Animal, Brasil), via intramuscular. No dia 4 (D4) iniciaram-se as aplicações de FSH (D4 400 UI, D5

300UI, D6 $200 \mathrm{UI}$ e D7 $100 \mathrm{UI}$ ) em doses decrescentes, duas vezes ao dia (12 em 12 horas- Folltropin®, Tecnopec, Brasil). No dia 7 (D7), o implante de progesterona foi retirado, administrado via intramuscular de $2 \mathrm{mg}$ de cipionato de estradiol $(E C P \circledast$, Zoetis; Brasil) e $150 \mu \mathrm{g}$ de prostaglandina (Croniben $®$, Biogenesis Bago). No dia 8 (D8) foi administrado 10,5 mcgdeGnRH (Gonaxal®, Biogenesis Bago), e no dia 9 (D9) foi realizada a inseminação artificial. Nas vacas receptoras, utilizou dispositivo intravaginal impregnado com $1 \mathrm{~g}$ de progesterona (Cronipress ${ }^{\circledR}$ Mono Dose; BiogenesisBagó, Brasil)e $2 \mathrm{mg}$ de benzoato de estradiol administrado via intramuscular, dois dias antes sincronização das doadoras. No dia nove (D9) foi retirado o

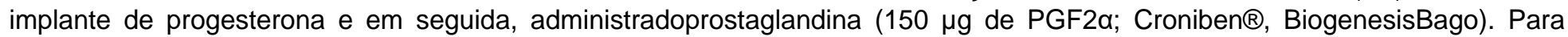
todas as análises foi adotado o nível de significância de $5 \%$.

Resultados:Foram efetuadas 15 colheitas e utilizadas 60 vacas receptoras. Foram colhidas 99estruturas, com 54embriões transplantados, numa média de 5,4 embriões por doadora, proporcionando 2,6 animais prenhes por colheita. A taxa de prenhes foi de foi de $44 \%$.

Discussão:estudo mostra que ao superovular 57 animais da raça GirLeiteiro(Bosindicus), os autores verificaram que o tratamento hormonal com $400 \mathrm{UI}$ de FSH proporcionou 65 embriões viáveis (PRADO et al., 2007). Estes resultados mostram que no nosso estudo o protocolo superovulatórios com 400 UI, também foi mais eficaz para a recuperação de embriões viáveis, visto que foram recuperados 5,4 por doadora.Vieira (2013) avaliou dados de 1.562 tratamentos superovulatórios (609 em vacas em lactação e 953 novilhas da raça holandesa) e 4.076 transferências de embrião em receptoras holandesas em lactação. No geral, a taxa de concepção aos 31 dias foi de 31,0\% e aos 45 dias foi de 25,3\%, com perda gestacional entre 31 e 45 dias de 18,3\% em receptoras Holandesas lactantes. No presente estudo, verificamos uma perda gestacional de $8 \%$, mostrando que talvez os embriões oriundos da raça Jersey tenham maior resistência ou que as receptoras de embriões utilizadas no nosso estudo, por não estarem lactantes evitaram uma exacerbada perda embrionária.

Conclusão: Podemos concluir que o protocolo de superovulação utilizado em vacas da raça Jersey foi eficaz, visto que os dados de recuperação embrionária e prenhez foram semelhantes aos resultados obtidos com outros estudos de raças taurinas relatados na literatura.

\title{
Referências
}

CREPALDI, G. A. Eficácia de diferentes protocolos de indução de ovulação e de intervalos de inseminação em vacas de corte submetidas à IATF. 2009. 87. Dissertação (Mestrado em Reprodução Animal)

Faculdade de Medicina Veterinária e 
Zootecnia, Universidade de São Paulo, 2009.

OLIVEIRA, C. M. G.; OLIVEIRA FILHO, B. D.; GAMBARINI, M. L.; VIU, M. A. O.; LOPES, D. T.; SOUSA, A. P. F. Effects of biostimulation and nutritional supplementation on pubertal age and pregnancy rates of Nelore heifers (Bosindicus) in a tropical environment. Animal Reproduction Science, v.113, p. 38-43, 2009.

PRADO, F. R. A.; TONIOLLO, G. H.; OLIVEIRA, J. A. Superestimulação ovariana em vacas da raça Gir leiteiro com uso de diferentes concentrações de FSH. Arquivos deVeterinaria, v. 23, n. 3, p. 172-177, 2008.

VIEIRA, L.M. Fatores associados à produção e à sobrevivência embrionária em programas de superovulação e transferência de embriões em fêmeas da raça Holandesa em clima tropical. 2013. Tese de Doutorado. Universidade de São Paulo.

Coordenadoria de Pesquisa e Extensāo - COPEX

Departamento de Editoraçāo e Divulgaçāo Científica - DEDIC 


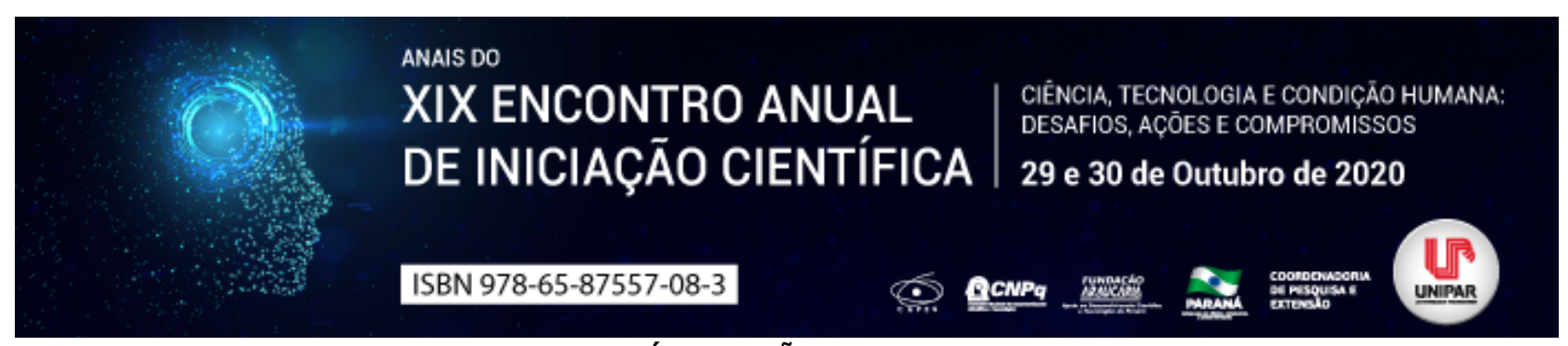

\title{
EFEITOS ADVERSOS DO USO DE ANTI-INFLAMATÓRIOS NÃO ESTEROIDAIS EM FELINOS E ASPECTOS PREVENTIVOS - RESUMO DE REVISÃO
}

\section{$1_{\text {LILLIAN PEREIRA GOUVEIA, }}^{2}$ LUCAS WAMSER FONSECA GONZAGA, ${ }^{3}$ KAROLYNE OLIVEIRA BASTOS, ${ }^{4}$ MARCOS FERRANTE5, ${ }^{5}$ MARIA DE FÁTIMA SANTOS, ${ }^{6}$ JOÃO VITOR FERNANDES COTRIM DE ALMEIDA}

\author{
${ }^{1}$ Acadêmica do curso de Medicina Veterinária - Universidade Federal de Lavras \\ ${ }^{1}$ Acadêmico do curso de Medicina Veterinária na Universidade Federal de Lavras (UFLA) \\ ${ }^{2}$ Acadêmica do curso de Medicina Veterinária - Universidade Federal de Lavras \\ ${ }^{3}$ Docente no departamento de Medicina Veterinária Universidade Federal de Lavras \\ ${ }^{4}$ Doutorado em Plantas Medicinais, Aromáticas e Condimentares - Universidade Federal de Lavras \\ ${ }^{5}$ Mestre em Ciências Veterinárias Universidade Federal de Lavras
}

Introdução: Os anti-inflamatórios não esteroidais (AINEs) são muito utilizados na clínica médica de pequenos animais, tanto para controle da dor quanto como terapia complementar. O tratamento da dor crônica em gatos vem sendo um grande desafio na medicina veterinária, devido à dificuldade de reconhecimento daquela quando estes são comparados aos cães, e à ocorrência de efeitos adversos em pacientes submetidos a terapia a longo prazo com AINEs (MONTEIRO et al., 2019). Em virtude dos mecanismos de ação da maioria destes fármacos, os principais efeitos colaterais acometem rins e trato gastrointestinal pela inibição das cicloxigenases (COX-1 e/ou COX-2), que são enzimas expressas na maioria dos tecidos e fundamentais em determinados processos fisiológicos (SPARKES et al., 2010). A utilização dessa classe farmacológica em pacientes felinos com algumas doenças concomitantes demanda ainda mais precauções, com isso foram descritos alguns protocolos que possibilitam aumentar a margem de segurança da utilização desses fármacos a longo prazo.

Objetivo: Abordar os principais efeitos adversos ocasionados pela utilização de AINEs a longo prazo em felinos, além de protocolos que visam minimizar tais efeitos.

Desenvolvimento: Os benefícios da utilização de AINEs se devem à inibição da produção de prostaglandinas (PGs) e tromboxanos, por meio da quebra do ácido araquidônico pelas cicloxigenases e lipoxigenases, que são mediadores químicos fundamentais para o desenvolvimento do processo inflamatório. As PGs desempenham importantes funções, como homeostasia vascular, proteção gástrica e coagulação sanguínea, além de estarem relacionadas a processos fisiopatológicos, como dor e inflamação. A inibição da COX-1 é uma das principais causas de efeitos colaterais dos AINEs, sendo úlceras gástricas e lesões renais os mais comuns (GOWAN et al., 2011). Diante desse contexto, foram desenvolvidas drogas com seletividade para COX-2; atualmente, no entanto, sabe-se que a inibição desta enzima também pode provocar impactos negativos no organismo do paciente. Para felinos, apesar de relatos indicarem que não há diferença na eficácia de AINEs específicos para uma das cicloxigenases, a utilização de fármacos seletivos para COX-2 pode reduzir ou evitar efeitos colaterais nesta espécie (SPARKES et al., 2010). A ocorrência de algumas enfermidades no paciente felino gera a necessidade de uma análise mais individualizada sobre o uso desses fármacos. Visto que as PGs desempenham um papel importante na fisiologia renal, durante a filtração glomerular, produção de renina e equilíbrio eletrolítico, em gatos com histórico de doença renal crônica deve-se preconizar a utilização de AINEs seletivos COX-2, como meloxicam, e ser realizado monitoramento da hidratação, e dos níveis de sódio e potássio (SURDYK et al., 2013; JUNIOR et al., 2016). Os efeitos colaterais relacionados com o trato grastrointestinal, como úlceras gástricas, são amplamente descritos, e o papel fisiológico das cicloxigenases na proteção da mucosa gástrica está diretamente associada a este problema. Estudos demonstram que a utilização a longo prazo de AINEs seletivos para COX-2 apresenta uma margem de segurança maior que a observada em tratamentos com AINEs seletivos para COX-1; além disso, estes trabalhos preconizam a administração desses fármacos durante ou após as refeições. Em felinos hepatopatas recomendase redução na dose de AINEs e monitoramento do paciente por exames bioquímicos. Apesar da ocorrência de hepatotoxicidade pelo uso prolongado de AINEs ser rara, alguns fatores, como a via de metabolização de certos fármacos, podem causar uma piora no quadro de gatos com acometimento hepático pré-existente (MONTEIRO et al., 2019). São indicados determinados protocolos para monitoramento do paciente felino submetido à terapia com AINEs, buscando minimizar eventuais danos provocados pelo uso a longo prazo destes medicamentos. Dentre eles estão: a avaliação do histórico do paciente, o exame hematológico completo, avaliação bioquímica, priorizando os níveis de ureia e creatinina, das enzimas alanina aminotransferase $(A L T)$ e fosfatase alcalina (ALP), e de sódio e potássio, análise dos parâmetros urinários antes e após o início da terapia, monitoramento da perfusão renal, suplementação com potássio durante o tratamento, a fim de se evitar o desenvolvimento de hipercalcemia, utilização de uma dosagem mínima efetiva do AINE - podendo ser ajustada de acordo com a resposta do paciente 
à terapia -, manutenção da hidratação e de bom estado pressórico e volêmico, administração de medicação por via oral juntamente com alimento, e análise dos demais fármacos aos quais o animal faz uso, com o propósito de mapear as possíveis interações com os AINEs (SPARKES et al., 2010).

Conclusão: Os efeitos colaterais decorrentes da utilização a longo prazo de AINEs podem ser reduzidos ou evitados com o monitoramento prévio do paciente felino, empregando-se a posologia adequada e respeitando as individualidades de cada animal.

\section{Referências}

GOWAN, R. A.; LINGARD, A. E.; JOHNSTON, L. Retrospective case-control study of the effects of long-term dosing with meloxicam on renal function in elderly cats with degenerative joint disease. Journal of Feline Medicine and Surgery, v. 13, $p$. 752-761, 2011.

MONTEIRO, B.; STEAGALL, P. V. M.; LASCELLES, B. D. X.; ROBERTSON, S.; MURRELL, J. C.; KRONEN, P. W.; YAMASHITA, K. Long-term use of non-steroidal anti-inflammatory drugs in cats with chronic kidney disease: from controversy to optimism. Journal of Small Animal Practice, v. 60, n. 8, p. 459-462, 2019.

JUNIOR, J. A. V.; CATAPAN, D. C.; FRAIZ, F. V.; JUNIOR, P. V. M.; DO PRADO, A. M. B.; ANATER, A.; PIMPÃO, C. T. Utilização do meloxicam como anti-inflamatório e analgésico em gatos. Revista Acadêmica Ciência Animal, v. 14, p. 109-117, 2016.

SPARKES, A. H.; HEIENE, R.; LASCELLES, B. D. X.; MALIK, R.; SAMPIETRO, L. R.; ROBERTSON, S.; TAYLOR, P. ISFM and AAFP consensus guidelines: long-term use of NSAIDs in cats. Journal of Feline Medicine \& Surgery, v. 12, n. 7, p. 521-538, 2010.

SURDYK, K. K.; BROWN, C. A.; BROWN, S. A. Evaluation of glomerular filtration rate in cats with reduced renal mass and administered meloxicam and acetylsalicylic acid. American Journal of Veterinary Research, v. 74, p. 648-665, 2013. 


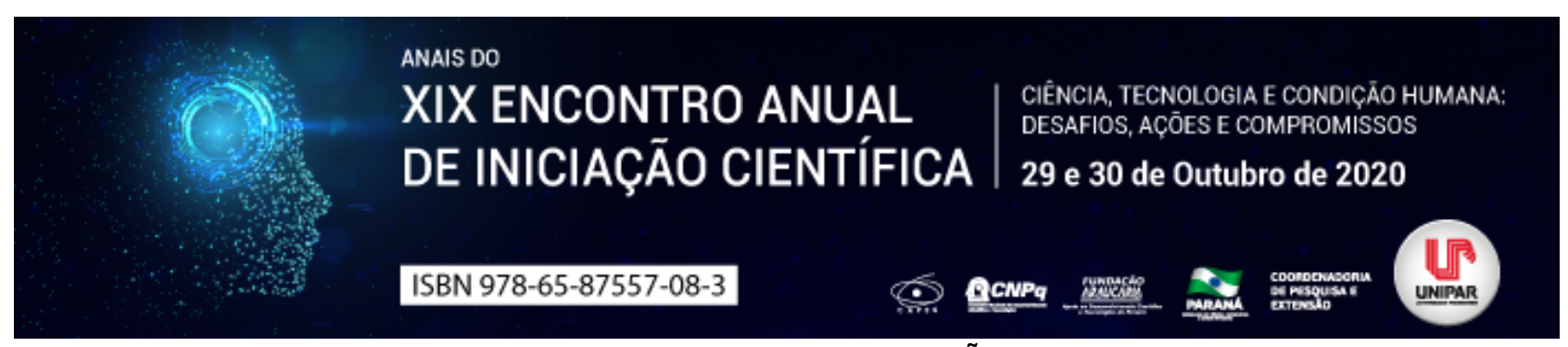

FIBRINA RICA EM PLAQUETAS - PRF: REVISÃO DE LITERATURA

\begin{abstract}
${ }^{1}$ GIOVANA DANTAS GROSSI, ${ }^{2}$ NATÁLIA SARAIVA RODRIGUES, ${ }^{3}$ MARIA CLARA UCKER COSTODIO, ${ }^{4}$ GABRIELA JULIANA LOPES, ${ }^{5}$ WILLIAN FONTINI MARANGON, ${ }^{6}$ NATALIE BERTELIS MERLINI
\end{abstract}

\begin{abstract}
${ }^{1}$ Acadêmica do Curso de Medicina Veterinária, bolsista PIBIC/UNIPAR
${ }^{1}$ Mestranda/o em Ciência Animal, Universidade Paranaense UNIPAR, bolsista PIT/UNIPAR

${ }^{2}$ Acadêmica do Curso de Medicina Veterinária, bolsista PIBIC/UNIPAR

${ }^{3}$ Médica Veterinária Autônoma.

${ }^{4}$ Mestranda/o em Ciência Animal, Universidade Paranaense UNIPAR, bolsista PIT/UNIPAR

${ }^{5}$ Docente do programa de pós graduação em ciência animal com ênfase em produtos bioativos, Universidade paranaense Unipar.
\end{abstract}

Introdução: A cicatrização é um processo complexo estimulado e regulado por fatores de crescimento (VAHABI et al, 2015). Pelo fato das plaquetas atuarem na liberação destes fatores, foi criado em 1990 a primeira geração de agregados plaquetários, o Plasma Rico em Plaquetas (PRP), que é derivado de sangue autólogo rico em plaquetas e fatores de crescimento (GHANAATI et al, 2014; VAHABI et al, 2015; HORIMIZU et al, 2017; WANG et al, 2017). O PRP foi criado com o objetivo de promover uma aceleração no processo de cicatrização de tecidos moles e duros ao se aumentar os fatores de crescimento derivados do sangue (HORIMIZU et al, 2017; WANG et al, 2017; UTOMO et al, 2018). Porém este agregado plaquetário possui algumas desvantagens quanto a sua fabricação (GHANAATI et al, 2014; HORIMIZU et al, 2017; MIRON et al, 2017; UTOMO et al, 2018; LACERDA et al, 2020). Com o objetivo de solucionar estes problemas, melhorar e agilizar o método de preparo, foi criada a segunda geração de agregados plaquetários, a Fibrina Rica em Plaquetas (PRF) (GHANAATI et al, 2014; HORIMIZU et al, 2017; MIRON et al, 2017; WANG et al, 2017; UTOMO et al, 2018; LACERDA et al, 2020).

Objetivo: A finalidade dessa revisão é explanar sobre os conceitos do PRF, seu método de preparo e suas aplicações.

Desenvolvimento: A PRF, foi desenvolvida na frança por Choukroun e colaboradores (2001), e é uma segunda geração de concentrado de plaquetas amplamente utilizado para acelerar a cicatrização dos tecidos moles e duros. O PRF é um concentrado de plaquetas obtido através do sangue do próprio paciente e o seu preparo é através da centrifugação rápida do sangue sem a adição de anticoagulantes ou trombina exógena para a ativação plaquetária (GHANAATI et al, 2014; HORIMIZU et al, 2017; MIRON et al, 2017; UTOMO et al, 2018; LACERDA et al, 2020). O PRF possui plaquetas, fatores de crescimento e glóbulos brancos dispostos em uma rede tridimensional de fibrina capaz de imitar a matriz extracelular e, por ser totalmente autólogo, há poucas chances de reações adversas (GHANAATI et al, 2014; HORIMIZU et al, 2017; UTOMO et al, 2018; LACERDA et al, 2020). Na obtenção da Fibrina Rica em Plaquetas, durante o processo de centrifugação, as plaquetas serão ativadas devido à ausência do anticoagulante, o que vai dar início então a cascata de coagulação. No final da centrifugação é possível observar três partes no tubo, células vermelhas de sangue na parte inferior, a Fibrina Rica em Plaquetas na parte central e o Plasma pobre em Plaquetas na parte superior (GUPTA et al., 2011; VAHABI et al, 2015; LACERDA et al, 2020). Para o preparo é necessário tubo de ensaio esterilizados secos, seringas descartáveis e uma centrífuga. Na obtenção é realizada a coleta de $10 \mathrm{ml}$ de sangue do paciente sem a adição de qualquer anticoagulante e imediatamente é centrifugado a $3000 \mathrm{rpm}$ durante 10 minutos (GUPTA et al., 2011). Segundo estudos, a velocidade e duração da centrifugação influencia na contagem e distribuição das plaquetas e demais componentes sanguíneos, o que levou ao desenvolvimento de vários protocolos de obtenção do PRF, entre eles está o PRF avançado (a-PRF) e o PRF injetável (i-PRF) (GHANAATI et al, 2014; HORIMIZU et al, 2017; MIRON et al, 2017; LACERDA et al, 2020). O a-PRF apresenta maiores concentrações de plaquetas na parte distal do coágulo (GHANAATI et al, 2014). Já o iPRF, que é o PRF em sua forma líquida, pode ser utilizado sozinho ou combinado à vários biomateriais e possui maior celularidade que o PRF tradicional, após a centrifugação se obtém duas partes, uma de cor alaranjada (i-PRF) e a outra composta pelo restante do material sanguíneo (MIRON et al, 2017; WANG et al, 2017; LACERDA et al, 2020). O PRF tem sido utilizado com sucesso na área da odontologia promovendo a cicatrização e regeneração tecidual e em procedimento de revitalização e revascularização da polpa dentária (HARTSHORNE E GLUCKMAN, 2016c), bem como utilizados em processos regenerativos em que se faz uso do i-PRF polimerizado com enxerto ósseo (MOURÃO et al, 2015). O uso do PRF também é descrito em pesquisas com cicatrização cutânea (CAMARGO, 2013), quanto a diferenciação de osteoblastos in vitro (He et al. 2009) e quanto a reparação de lesão no nervo ciático (LICHTENFELS, 2012), sendo todas estás pesquisas realizadas em ratos.

Conclusão: O Plasma Rico em Fibrina é um agregado plaquetário de fácil obtenção utilizado na medicina para a cicatrização de tecidos duros e moles, apresentando como principal vantagem ser totalmente autólogo, o que diminui a ocorrência de reações adversas. 


\section{Referências}

CAMARGO, F. F. Efeito do plasma rico em plaquetas e da fibrina rica em plaqueta na cicatrização de feridas cutâneas em ratos. 2013. Tese (Mestrado em Medicina e ciências da saúde), área de concentração em Clínica Cirúrgica Universidade Católica do Rio Grande do Sul.

DE LACERDA, Caio Botelho Vieira. Plasma rico em fibrina como carreador de biomaterial para reconstrução alveolar após exodontia: relato de caso. Revista Fluminense de Odontologia, n. 53, 2020.

GHANAATI, Shahram et al. Advanced platelet-rich fibrin: a new concept for cell-based tissue engineering by means of inflammatory cells. Journal of Oral Implantology, v. 40, n. 6, p. 679-689, 2014.

GUPTA, V. et al. Regenerative potential of platelet-rich fibrin in destistry: Literature Review. Asian Journal of Oral Health \& Allied Sciences, v.1, n.1, p.22-28, Jan./Mar. 2011.

HARTSHORNE, J.; GLUCKMAN, H. A comprehensive clinical review of Platelet Rich Fibrin (PRF) and its role in promoting tissue healing and regeneration in dentistry. Part III: Clinical indications of PRF in implant dentistry, periodontology, oral surgery and regenerative endodontics. Int. Dentistry Afr. Ed. v.6, n.5, p.64-79, 2016c.

$\mathrm{HE}$, Ling et al. A comparative study of platelet-rich fibrin (PRF) and platelet-rich plasma (PRP) on the effect of proliferation and differentiation of rat osteoblasts in vitro. Oral Surgery, Oral Medicine, Oral Pathology, Oral Radiology, and Endodontology, v. 108, n. 5, p. 707-713, 2009.

HORIMIZU, Makoto et al. Synergistic effects of the combined use of human-cultured periosteal sheets and platelet-rich fibrin on bone regeneration: An animal study. Clinical and experimental dental research, v. 3, n. 4, p. 134-141, 2017.

LICHTENFELS, M. Efeito do Plasma rico em Plaquetas e de Plaqueta rica em Fibrina na regeneração de lesões com perda de substância do nervo ciático em ratos. Tese (Mestrado) Pontifícia Universidade Católica do Rio Grande do Sul. Porto Alegre, p.54-60. 2012.

MIRON, Richard J. et al. Injectable platelet rich fibrin (i-PRF): opportunities in regenerative dentistry?. Clinical oral investigations, v. 21, n. 8, p. 2619-2627, 2017.

MOURÃ̃, C. F. A. B.; VALIENSE, H.; MELO, E. R.; MOURÃO, N. B. M. F.; MAIA, M. D-C. Obtenção da fibrina rica em plaquetas injetável (i-PRF) e sua polimerização com enxerto ósseo. Ver. Col. Bras. Cir. v.42, n.6, p.421-423. 2015.

UTOMO, Dwikora N. et al. Implantation of platelet rich fibrin and allogenic mesenchymal stem cells facilitate the healing of muscle injury: An experimental study on animal. International Journal of Surgery Open, v. 11, p. 4-9, 2018.

VAHABI, Surena. et al. Effects of plasma rich in growth factors and platelet-rich fibrin on proliferation and viability of human gingival fibroblasts. Journal of dentistry (Tehran, Iran), v. 12, n. 7, p. 504, 2015.

WANG, Xuzhu. et al. Effects of an injectable platelet-rich fibrin on osteoblast behavior and bone tissue formation in comparison to platelet-rich plasma. Platelets, v. 29, n. 1, p. 48-55, 2018. 


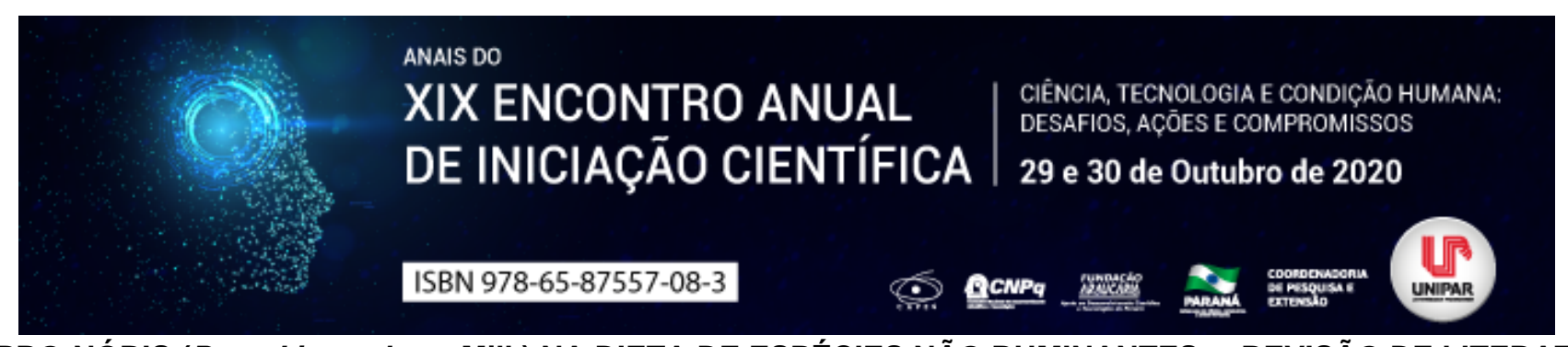

ORA-PRO-NÓBIS (Pereskia aculeata Mill.) NA DIETA DE ESPÉCIES NÃO RUMINANTES REVISÃO DE LITERATURA

\begin{abstract}
${ }^{1}$ NATIELLI BELOTTI PAIE, ${ }^{2}$ AGUINALDO YOSHIO NAKAMURA, ${ }^{3}$ MARIA EDUARDA GRAEFF, ${ }^{4}$ ANDRÉIA ASSUNÇÃO SOARES, ${ }^{5}$ TANIARA SUELEN MEZALIRA, ${ }^{6}$ LUCIANA KAZUE OTUTUMI FARIAS
\end{abstract}

\author{
${ }^{1}$ Acadêmica do curso de Medicina Veterinária - Bolsista PIBIC/UNIPAR \\ ${ }^{1}$ Doutorando em Ciência Animal com Ênfase em Produtos Bioativos, UNIPAR, taxista PROSUP/CAPES \\ ${ }^{2}$ Acadêmica do Curso de Medicina Veterinária da UNIPAR \\ ${ }^{3}$ Professora do Mestrado em Plantas Medicinais e Fitoterápicos na Atenção Básica e do Programa de Pós-graduação em Ciência \\ Animal, UNIPAR \\ ${ }^{4}$ Doutoranda em Ciência Animal com Ênfase em Produtos Bioativos, UNIPAR, taxista PROSUP/CAPES \\ ${ }^{5}$ Professora do curso de Medicina Veterinária e do Programa de Pós-graduação em Ciência Animal, UNIPAR
}

Introdução: A Pereskia aculeata Mill. é uma planta da família das Cactáceas, conhecida popularmente como ora-pro-nóbis. Apresenta um elevado valor nutricional, tanto no caule como nas folhas, podendo ser utilizada como complemento na alimentação animal (LOPES JUNIOR et al., 2012). Além disso, a utilização de alimentos alternativos na dieta dos animais é crescente, e o uso de ora-pro-nóbis pode trazer diversos benefícios, devido ao seu baixo custo, fácil acesso, alta disponibilidade da planta, além de possuir alto teor de proteína, cálcio e ferro (GIRÃO, 1997). Pelo fato da proteína ser um dos nutrientes mais caros e de fundamental importância na alimentação dos animais, o uso de fontes vegetais ricas em proteína que possam auxiliar na redução dos custos tem sido incentivado.

Objetivo: Fazer uma revisão sobre o uso da ora-pro-nóbis na dieta de espécies animais não-ruminantes.

Desenvolvimento: Os estudos utilizando a ora-pro-nóbis concentram-se principalmente na nutrição humana, sendo que os trabalhos com alimentação animal ainda são escassos. Os trabalhos relatados na presente revisão utilizando-se da ora-pro-nóbis foram desenvolvidos em leitões (LOPES JUNIOR et al., 2012), codornas japonesas (SCHMIDT; DIAS, SILVA, 2018) e frangos de corte (SILVA et al., 2018). Para verificar os efeitos da inclusão da parte aérea da $P$. aculeata Mill. na dieta de matrizes suínas no terço final da gestação até o primeiro dia de vida dos leitões, sobre o peso de leitões ao nascer, Lopes Junior et al. (2012) avaliaram dois tratamentos com a inclusão das folhas da farinha de ora-pro-nóbis (3 e 4,5g/kg) na ração e não detectaram diferenças significativas no peso dos leitões ao nascer, porém, verificaram menor $(P<0,05)$ concentração de ferro no sangue dos leitões que receberam 4,5 gramas de ora-pro-nóbis por quilo de ração. A criação de suínos em confinamento reduz o contato com o ferro que está presente no solo, sendo necessário disponibilizar ao organismo dos leitões, para prevenir um quadro de anemia e possível morte (MOURA, 2008). No entanto, no trabalho de Lopes et al. (2012) pelo fato dos autores não terem observado efeito na redução de anemia de leitões com o uso da farinha das folhas de $P$. aculeata, novos estudos são necessários para definir o melhor nível de inclusão. Em codornas japonesas em postura Schmidt, Dias e Silva (2018) avaliando a inclusão de três níveis (0,6 e 12\%) das folhas desidratadas de ora-pro-nóbis verificaram que o melhor nível foi o de $6 \%$ pela melhoria da produtividade, coloração da gema e não alteração da qualidade da casca. Em frangos de corte, Silva et al. (2018) avaliaram a inclusão da farinha de ora-pro-nobis (0,1, 2 e 3\%) em relação ao rendimento de carcaça e cortes nobres e os autores não verificaram diferenças entre os tratamentos em relação aos parâmetros avaliados, demonstrando que o mesmo pode ser utilizado como uma opção para a redução de custos da dieta de frangos de corte.

Conclusão: Conclui-se que a ora-pro-nóbis pode ser utilizada na dieta de animais não ruminantes, como leitões, codornas de postura e frangos de corte, sem comprometer o desempenho e pelo fato de apresentar baixo custo e alta disponibilidade, tornase uma importante opção na complementação da alimentação de diferentes espécies animais não-ruminantes. Novos estudos são necessários visando avaliar o uso da ora-pro-nóbis na dieta dos animais na forma de extrato, visando associar os benefícios da planta associado aos seus compostos bioativos.

\footnotetext{
Referências

GIRÃO, Lúcio Vilela Carneiro. et.al. Avaliação da composição bromatológica de ora-pro-nóbis. Universidade Federal de Lavras (UFLA), Campus Universitário, 1997.

LOPES JUNIOR, Neilton José et al. Utilização da parte aérea da ora-pro-nóbis (Pereskia aculeata Mill) na dieta de matrizes suínas no terço final da gestação até o primeiro dia de vida do leitão. In: SEMANA DE CIÊNCIA E TECNOLOGIA DO INSTITUTO FEDERAL DE MINAS GERAIS, 1., 5., 2012, MINAS GERAIS. Anais [...]. MINAS GERAIS: IFMG, 2012.

MOURA, Mariana de Souza. Suplementação de ferro para leitões (revisão). Programa de pós - graduação em ciência animal. Universidade Federal de Mato Grosso Do Sul, Campo Grande, 2008.
} 
SCHMIDT, Davi; DIAS, Luciana Thie Seki; SILVA, Janaina Della Torre. Desempenho produtivo e qualidade de ovos de codornas alimentadas com ora-pro-nóbis. In: CONGRESSO DE INICIAÇÃO CIENTíFICA DA UNIVERSIDADE FEDERAL DE SÃO CARLOS, 2018, ARARAS. Anais [...] ARARAS. UFSCar, 2018.

SILVA, Valéria Bonifácia Marra da. et.al. Rendimento de carcaça e cortes nobres de frangos alimentadas com farinha da folha de ora-pro-nóbis (Pereskia aculeata). Instituto Federal Goiano, Campos Rio Verde, 2018.

Coordenadoria de Pesquisa e Extensão - COPEX

Departamento de Editoraçāo e Divulgaçāo Científica - DEDIC 


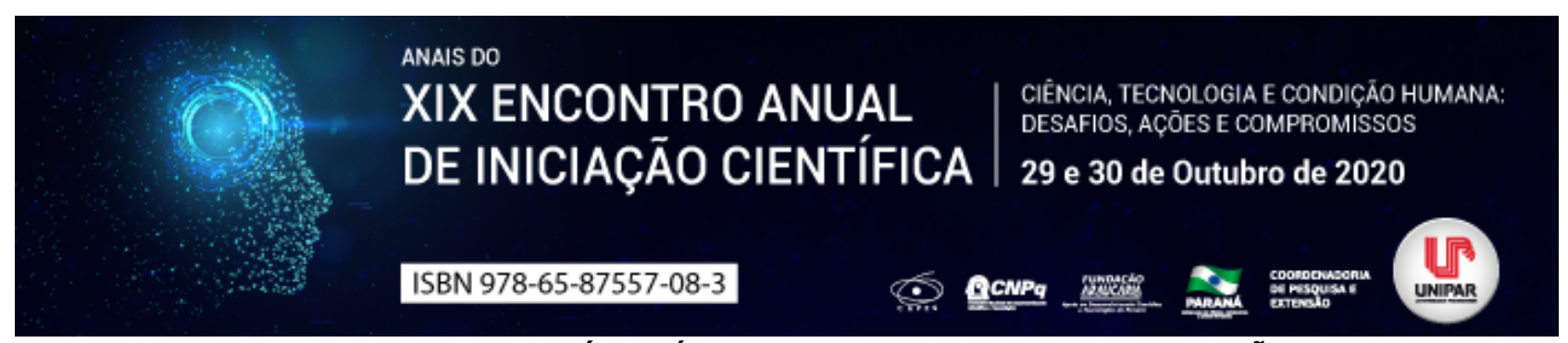

LACASE DE Panus strigellus É ESTÁVEL EM DIFERENTES CONCENTRAÇÕES DE SAL

\begin{abstract}
${ }^{1}$ GABRIEL TRAMONTINI PEREIRA, ${ }^{2}$ GABRIELLA FERNANDES DA SILVA, ${ }^{3}$ THIAGO TEODORO SANTANA, ${ }^{4}$ JULIANA SILVEIRA DO VALLE
\end{abstract}

\begin{abstract}
${ }^{1}$ Acadêmico de Farmácia, Bolsista PEBIC/CNPq, Universidade Paranaense - UNIPAR
${ }^{1}$ Acadêmica de Estética e Cosmética, Bolsista PEBIC/CNPq, Universidade Paranaense - UNIPAR

${ }^{2}$ Doutorando em Biotecnologia Aplicada à Agricultura, Universidade Paranaense - UNIPAR

${ }^{3}$ Docente de Farmácia e de Biotecnologia Aplicada à Agricultura, UNIPAR, Umuarama PR
\end{abstract}

Introdução: Panus strigellus é um basidiomiceto endêmico da América e que está presente em todo o Brasil (VARGAS-ISLA et al., 2015). É utilizado na cultura de povos indígenas da Amazônia como alimento e para fins medicinais (VARGAS-ISLA et al., 2015). P. strigellus é capaz de produzir várias enzimas, como a amilase, celulase, esterase e lipase. Produz também lacase, que pode ser utilizada na biorremediação, estabilização de vinhos e tratamento de água, como na biodegradação de corantes industriais (CARDOSO et al., 2018). O pH influencia o crescimento e a produção enzimática por fungos, pois afeta a membrana celular e o grau de dissociação de íons, o que interfere na absorção de nutrientes e minerais (MARIM et al., 2018). Efluentes têxteis coloridos têm altas concentrações de sal o que pode interferir no reconhecimento molecular entre o substrato e a enzima (OTTONI et al., 2016). Assim, ao buscar por novas enzimas com potencial para descoloração é importante avaliar como o sal pode afetar a atividade enzimática em diferentes condições.

Objetivo: Avaliar a estabilidade de lacase de Panus strigellus produzida em meios com diferentes pHs iniciais diante de diferentes concentrações de $\mathrm{NaCl}$.

Material e Métodos: $\mathrm{O}$ fungo Panus strigellus U16-7 foi cultivado em meio extrato de malte $2 \%$ a $28{ }^{\circ} \mathrm{C}$ por quinze dias em câmara BOD. O pH inicial do meio de cultivo foi ajustado para 4, 5, 6, 7, 8 e 9. No décimo quinto dia o meio foi separado do micélio e uma alíquota do extrato enzimático foi misturada com soluções de $\mathrm{NaCl}$ nas concentrações de $0,0,6 \mathrm{M}, 1,2 \mathrm{M}, 1,8 \mathrm{M}$, $2,4 \mathrm{M}$ e $3 \mathrm{M}$. Após 1 hora a $28^{\circ} \mathrm{C}$ determinou-se a atividade de lacase pela oxidação do ABTS (referência). A atividade residual de lacase foi estimada em relação a atividade enzimática antes da incubação com sal. Todos os ensaios seguiram o delineamento inteiramente casualizado e os resultados foram analisados por análise de variância (ANOVA). As diferenças entre as médias aritméticas foram determinadas pelo teste de Scott-Knott a 5\% de probabilidade. O coeficiente de correlação de Pearson ( $r$ ) entre as variáveis concentração de sal e atividade de lacase foi determinado.

Resultados: A lacase produzida por $P$. strigellus em meios com diferentes pHs iniciais apresentou estabilidade variável em diferentes concentrações de $\mathrm{NaCl}$. A lacase produzida em meio com pH 4 mostrou ser pouco estável em distintas concentrações de sal e manteve menos de $10 \%$ da atividade em todas as concentrações avaliadas. O cultivo em pH 5 produziu lacase relativamente estável com perda gradual de atividade em concentrações maiores de sal, contudo a enzima manteve $50 \%$ da sua atividade em 1,2 M de NaCl. Os resultados indicam correlação negativa muito forte $(r=-0,98)$ entre a concentração de $\mathrm{NaCl}$ e a atividade de lacase em pH 5. A lacase produzida em pH 6 manteve até $41 \%$ de atividade residual em 1,2 M de sal, mas $31 \%$ em $1,8 \mathrm{M}$, o que indica correlação negativa muito forte $(\mathrm{r}=-0,93)$ entre a concentração de $\mathrm{NaCl}$ e a atividade de lacase. Com o pH inicial do meio em 7 a lacase manteve mais de $80 \%$ de atividade em $0,6 \mathrm{M}$ de $\mathrm{NaCl}$ e $70 \%$ em $1,2 \mathrm{M}$ demonstrando uma correlação negativa forte $(\mathrm{r}=-0,85)$ entre a concentração de $\mathrm{NaCl}$ e a atividade residual de lacase. A lacase produzida em $\mathrm{pH} 8$ demonstrou a maior estabilidade em sal, mantendo $64 \%$ e $56 \%$ da atividade em concentrações extremas de sal de $2,4 \mathrm{M}$ e $3 \mathrm{M}$, respectivamente. A lacase proveniente do meio com pH 9 mostrou estabilidade menor, com manutenção de $\sim 36 \%$ em 0,6 M de sal, o que indicou forte correlação negativa $(r=-0,74)$ entre as duas variáveis. Os resultados sugerem, portanto, que as lacases produzidas em meios com pH entre 6 e 8 mostraram maior estabilidade em concentrações de sal de 0,6 M a 2,4 M.

Discussão: Este é o primeiro relato da produção de lacase de $P$. strigellus em diferentes condições de $\mathrm{pH}$ e da estabilidade enzimática em diferentes concentrações de sal. Ainda não se conhece a estrutura das lacases de $P$. strigellus, mas sabe-se que o sal afeta a estrutura de outras lacases. Proteínas tolerantes ao sal contém mais aminoácidos carregados negativamente do que carregados positivamente, o que pode favorecer um arranjo estrutural mais adequado em condições de maior salinidade, resultando em tolerância ao sal (LI et al., 2020). Moreira Neto et al. (2011) avaliaram a capacidade de 25 espécies de basidiomicetos em descolorir o corante azul-19 na presença de sal $(0,2 \mathrm{M})$ e relataram que o sal inibiu a atividade enzimática de 11 espécies. Embora nem todos os tipos de sais possuam efeitos inibitórios na atividade de lacase, a presença de $\mathrm{NaCl}$ reduz a descoloração dos corantes, pois possui efeitos inibitórios em atividades enzimáticas. Soluções de $\mathrm{NaCl}$ apresentam elevada força iônica, o que afeta tanto a performance enzimática quanto a solubilidade dos produtos da reação, desta forma, forças iônicas altas podem inibir totalmente a atividade de lacase (MOHAJERSHOJAEI; KHOSRAVI; MAHMOODI, 2014). 
Conclusão: A lacase produzida em pH inicial 8 mostrou a maior estabilidade mesmo em concentrações extremas de $\mathrm{NaCl}$. O estudo demonstra potencial na utilização da lacase de Panus strigellus em efluentes têxteis que apresentem altas concentrações de sais.

\section{Referências}

CARDOSO, Bruna K. et al. Panus strigellus laccase decolorizes anthraquinone, azo, and triphenylmethane dyes. Biocatalysis and Agricultural Biotechnology, v. 16, p. 558-563, 2018.

$\mathrm{LI}$, Zhi et al. Mechanism of the salt activation of laccase Lac15. Biochemical and Biophysical Research Communications, $v$. 521, n. 4, p. 997-1002, 2020.

MARIM, R. A. et al. Lentinus crinitus strains respond differently to cultivation $\mathrm{pH}$ and temperature. Genetics and Molecular Research, v. 17, n. 1, 2018.

MOHAJERSHOJAEI, Khashayar; KHOSRAVI, Alireza; MAHMOODI, Niyaz M. Decolorization of dyes using laccase enzyme from single and binary systems. Desalination and Water Treatment, v. 52, n. 10-12, p. 1895-1902, 2014.

MOREIRA NETO, Sérgio L. et al. Novel salt and alkali tolerant neotropical basidiomycetes for dye decolorisation in simulated textile effluent. World Journal of Microbiology and Biotechnology, v. 27, n. 11, p. 2665, 2011.

OTTONI, Cristiane et al. High laccase expression by Trametes versicolor in a simulated textile effluent with different carbon sources and pHs. International Journal of Environmental Research and Public Health, v. 13, n. 8, p. 778, 2016.

VARGAS-ISLA, Ruby et al. Relationship between Panus lecomtei and P. strigellus inferred from their morphological, molecular and biological characteristics. Mycoscience, v. 56, n. 6, p. 561-571, 2015. 


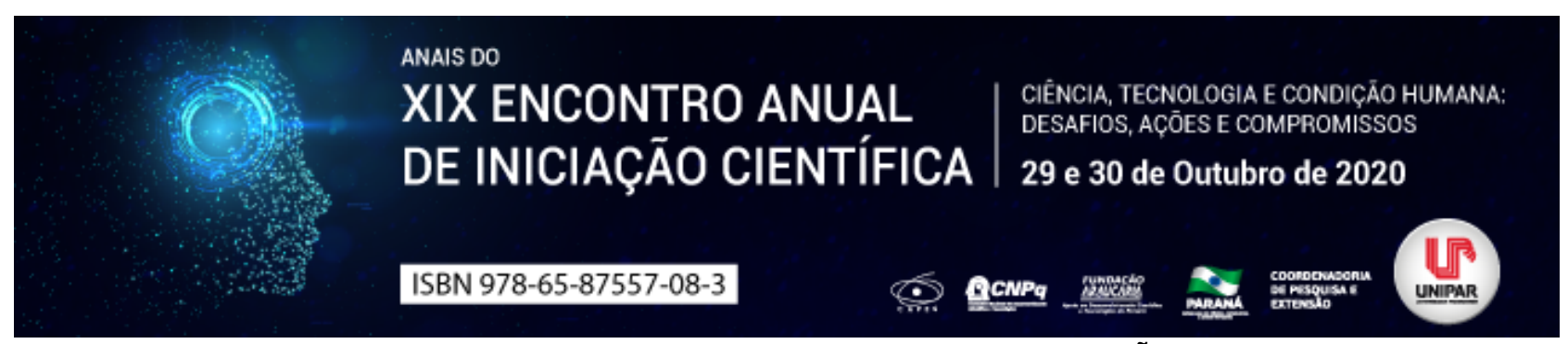

CULTIVO DE Trametes polyzona SOB LUZ LED PARA PRODUÇÃO DE LACASE

\begin{abstract}
${ }^{1}$ VINICIUS MINORU INAMURA, ${ }^{2}$ KATIELLE VIEIRA AVELINO, ${ }^{3}$ MARISANGELA ISABEL WIETZIKOSKI HALABURA,
${ }^{4}$ JULIANA SILVEIRA DO VALLE
\end{abstract}

\begin{abstract}
1 11Acadêmico PEBIC Ensino Médio CNPq/UNIPAR e Colégio Monteiro Lobato, Umuarama PR
${ }^{1}$ Doutoranda em Biotecnologia Aplicada à Agricultura, Bolsista CAPES, UNIPAR

${ }^{2}$ Doutoranda em Biotecnologia Aplicada à Agricultura, Bolsista CAPES, UNIPAR

${ }^{3}$ Docente da pós-Graduação em Biotecnologia Aplicada à Agricultura, UNIPAR
\end{abstract}

Introdução: Trametes polyzona é um fungo da podridão branca da madeira e, por isso, secreta enzimas para a degradação da parede celular vegetal como lacases, manganês e lignina peroxidases. A lacase (polifenol oxidase, E.C. 1.10.3.2) é responsável por oxidar compostos fenólicos e aromáticos da lignina enquanto reduz oxigênio molecular à água (CARDOSO et al., 2018). Sua ampla variedade de substratos permite que fungos produtores de lacase como $T$. polyzona sejam capazes de oxidar outros compostos com aneis aromáticos em suas estruturas como corantes, desreguladores endócrinos como o bisfenol $\mathrm{A}$, fármacos e outros poluentes (LING et al., 2015). Em fungos a luz pode afetar respostas fisiológicas como crescimento, reprodução, pigmentação, produção de ezimas, metabolismo secundário, entre outras (IDNURM; HEITMANT, 2005). Acredita-se que todos os fungos possuam sistemas de resposta à luz onde atuam sistemas de fotosensores específicos que respondem a diferentes comprimentos de onda (CORROCHANO, 2019). Fotorreceptores são proteínas que contêm grupos químicos sensíveis à luz e que modulam suas atividades ao serem estimulados, desencadeando uma cascata de sinalização para que o fungo possa se adaptar ao meio em que se encontra (FISCHER et al., 2017).

Objetivos: Realizar o cultivo de Trametes polyzona sob diferentes comprimentos de onda de luz para produção de lacase.

Material e métodos: T. polyzona U16-5 foi cultivado em meio ágar-extrato de malte (2\%) a 28 oC na ausência de luz por sete dias para produção de inóculo. Três discos de meio sólido colonizado pelo micélio de cada linhagem foram usados para inocular o meio para produção de lacase. O cultivo em meio líquido foi feito em extrato de malte $(20 \mathrm{~g} / \mathrm{L})$ previamente autoclavado a 121 ${ }^{\circ} \mathrm{C}$ por 20 minutos. Após inoculação os frascos foram mantidos a $28 \mathrm{oC}$ por 15 dias na ausência de luz (controle) ou sob iluminação contínua com diodos emissores de luz (LED) azul (450 $495 \mathrm{~nm}$ ), verde $\left(\begin{array}{lll}495 & 570 \mathrm{~nm}\end{array}\right)$ ou vermelha $(620750$ $\mathrm{nm}$ ). Os LED foram mantidos com fluxo de iluminação de saída de $20 \mu \mathrm{mol} \mathrm{m}-2 \mathrm{~s}-1$. No final do período de cultivo o meio líquido contendo enzimas extracelulares foi separado do micélio por filtração e utilizado para determinação da atividade de lacase pela oxidação do ABTS (SANTANA et al., 2018). Todos os ensaios seguiram o delineamento inteiramente casualizado e os resultados foram analisados por análise de variância (ANOVA). As diferenças entre as médias aritméticas foram determinadas pelo teste de Scott-Knott a 5\% de probabilidade.

Resultados: Os resultados demonstraram que o cultivo em luz verde e vermelha aumentou a atividade de lacase de T. polyzona, enquanto a luz azul reduziu a atividade de lacase comparado ao controle (escuro). Sob luz verde o aumento da atividade de lacase foi de $12 \%$ e sob luz vermelha o aumento foi de $29 \%$. A redução da atividade de lacase após cultivo em luz azul foi de $31 \%$ comparada ao controle. Verificou-se forte correlação positiva entre comprimento de onda de luz visível e atividade de lacase de T. polyzona, ou seja, quanto maior o comprimento de onda (faixa do vermelho) maior a atividade de lacase deste fungo.

Discussão: Até o momento não há na literatura informações sobre os tipos de fotorreceptores de $T$. polyzona e nossos resultados são os primeiros sobre o efeito da luz na atividade de lacase desta espécie. A luz de diferentes comprimentos de onda afeta de forma distinta a produção de lacases por fungos. Grassi et al. (2018), relataram que o cultivo de Polyporus tricholoma e $P$. arcularioides sob luz reduziu a atividade de lacase, porém, gerando um grupo de enzimas distinto do observado no cultivo no escuro. Segundo Hernández et al. (2016), as luzes azul e verde reduziram mais a atividade de lacase de Pycnoporus sanguineus do que a luz vermelha. Para Janusz et al. (2018) a luz azul aumentou a atividade de lacase de Cerrena unicolor enquanto as luzes verde e vermelha aumentaram a atividade de lacase de Phlebia lindtneri. Nossos resultados ao serem comparados com os dados da literatura indicam que a produção de lacase em respsota à luz varia entre espécies. O uso de luz LED para estimular a produção enzimática pode ser uma opção de custo relativamente baixo para produzir enzimas com grande potencial biotecnológico.

Conclusão: Os resultados indicam que a exposição do micélio de $T$. polyzona a diferentes comprimentos de onda de luz afeta a atividade de lacase. 
decolorizes anthraquinone, azo, and triphenylmethane dyes. Biocatalysis and Agricultural Biotechnology, v. 16, p. 558-563, 2018.

CORROCHANO, Luis M. Light in the fungal world: from photoreception to gene transcription and beyond. Annual Review of Genetics, v. 53, p. 149-170, 2019.

FISCHER, Reinhard et al. The complexity of fungal vision. The Fungal Kingdom, p. 441-461, 2017.

GRASSI, Emanuel; ROBLEDO, Gerardo; LEVIN, Laura. Influence of light on lignin-degrading activities of fungal genus Polyporus s. str. Journal of Basic Microbiology, v. 58, n. 11, p. 947-956, 2018.

HERNÁNDEZ, Christian A. et al. Light-induced inhibition of laccase in Pycnoporus sanguineus. Folia Microbiologica, v. 61, n. 2, p. 137-142, 2016.

IDNURM, Alexander; HEITMAN, Joseph. Photosensing fungi: phytochrome in the spotlight. Current Biology, v. 15, n. 20, p. R829-R832, 2005.

JANUSZ, Grzegorz et al. Comparative transcriptomic analysis of Cerrena unicolor revealed differential expression of genes engaged in degradation of various kinds of wood. Microbiological Research, v. 207, p. 256-268, 2018.

LING, Zhuo-Ren et al. An extracellular laccase with potent dye decolorizing ability from white rot fungus Trametes sp. LAC-01. International Journal of Biological Macromolecules, v. 81, p. 785-793, 2015.

SANTANA, Thiago Teodoro et al. Metallic-aromatic compounds synergistically induce Lentinus crinitus laccase production. Biocatalysis and Agricultural Biotechnology, v. 16, p. 625-630, 2018.

Coordenadoria de Pesquisa e Extensão - COPEX

Departamento de Editoraçāo e Divulgaçāo Científica - DEDIC 


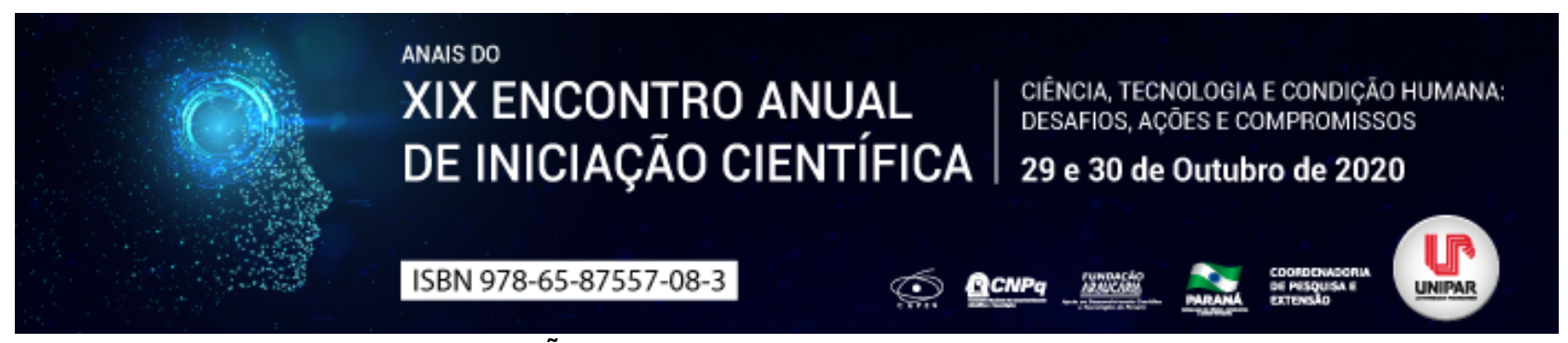

FUNGOS BASIDIOMICETOS NA REMOÇÃO DE MICROPOLUENTES PROVENIENTES DE PRODUTOS DE HIGIENE PESSOAL E LIMPEZA

\author{
${ }^{1}$ GABRIELLE ZAMARA DE MELO, ${ }^{2}$ JULIANA SILVEIRA DO VALLE
}

\author{
${ }^{1}$ Acadêmica de Farmácia, PIC, Universidade Paranaense UNIPAR, UMUARAMA PR \\ ${ }^{1}$ Docente de Farmácia e de Biotecnologia Aplicada à Agricultura, UNIPAR, Umuarama PR
}

Introdução: A água como sendo o composto mais importante para a vida vem sofrendo alterações causadas em decorrência da presença de micropoluentes. São considerados micropoluentes as substâncias tóxicas, orgânicas ou minerais, com propriedades biocumulativas que ocorrem no ambiente, porém em concentrações muito baixas usualmente em microgramas por litro (KIDD et al., 2007). Os produtos de higiene pessoal e limpeza (PHPL) são grandes geradores de micropoluentes que são introduzidos ao meio ambiente através de diversas atividades humanas como pelo esgoto doméstico, efluentes de indústrias e hospitais (YANG et al., 2017). Estas substâncias, mesmo em mínimas concentrações, podem ser a causa de possíveis disfunções no sistema endócrino e reprodutivo, e de alterações metabólicas da biota e do ser humano (PETRIE et al., 2015). As estações de tratamento de esgoto não possuem equipamentos que consigam remover todos os micropoluentes e purificar $100 \%$ da água. Devido à situação apresentada, são necessários estudos que encontrem alternativas ao tratamento tradicional de águas a fim de melhorar a qualidade da mesma. Uma das possibilidades é o uso de processos de biorremediação, onde organismos vivos são utilizados para degradar e remover estes micropoluentes (KASSEM, 2019).

Objetivo: Realizar uma revisão de literatura sobre o potencial do uso de enzimas produzidas por fungos na biodegradação de micropoluentes provenientes de produtos de higiene pessoal e limpeza.

Desenvolvimento: Os micropoluentes são considerados contaminantes emergentes uma vez que sua detecção no ambiente é difícil e, por isso, até recentemente não eram considerados um risco ambiental. Entretanto, o avanço de técnicas analíticas demostrou que os micropoluentes são vários e sua presença no ambiente está relacionada à atividade humana (KASPRZYKHORDERN et al., 2009). Dentre os micropoluentes derivados de PHPL que chegam comumente ao ambiente podemos citar: preservativos como parabenos; bactericidas ou desinfetantes como metiltriclosano, triclocarban (TCC) e triclosan (TCS); repelentes de insetos como o N,N-dietil-m-toluamida (DEET); fragrâncias como galaxolida (HHCB) e tonalida (AHTN); filtro solar como 2-etil-hexil-4-trimetoxicinamato (EHMC), 4-metil-benzilideno-cânfora (4-MBC), metoxicinamato de octila (OMC), benzofenona e octil-triazona (OC), entre outros (YANG et al., 2017). A remoção dessas substâncias é um processo complicado pois depende das propriedades químicas e biológicas de cada uma delas como hidrofilicidade, solubilidade, volatilidade, biodegradabilidade e capacidade de absorção, o que faz como que na maioria das vezes eles sejam removidos parcialmente (YANG et al., 2017). Um caminho que tem se mostrado eficaz na remoção destas substâncias se dá por meio de processos de biorremediação utilizando fungos basidiomicetos. Estes organismos, são eficientes em degradarem contaminantes do ambiente e convertem as moléculas em dióxido de carbono, água e biomassa (LITCHFIELD, 2005). Isto ocorre graças a produção de várias enzimas para degradação da lignina incluindo a manganês peroxidase, lignina peroxidase e lacases (CARDOSO et al., 2018). Gago-Ferrero et al. (2012) mostram que Trametes versicolor degradou totalmente os compostos de filtros solares benzofenona-1 e benzofenona-3 em menos de 24 horas. Songulashvili et al. (2014) apresentaram a avaliação da transformação do bacteriostático e micropoluente tóxico triclosan usando lacase imobilizada de Coriolopsis sp. e verificaram a eliminação de $90 \%$ da toxicidade do composto. Vallecillos et al. (2017) relataram que a lacase de T. versicolor foi eficiente em degradar as fragrâncias galaxolida em $70 \%$ e a tonalida em $42 \%$.

Conclusão: A utilização de enzimas produzidas a partir de fungos basidiomicetos têm se mostrado altamente eficaz na remoção dos micropoluentes provenientes de produtos de higiene pessoal e limpeza da água.

\title{
Referências
}

KIDD, Karen A. et al. Collapse of a fish population after exposure to a synthetic estrogen. Proceedings of the National Academy of Sciences, v. 104, n. 21, p. 8897-8901, 2007.

YANG, Yi et al. Occurrences and removal of pharmaceuticals and personal care products (PPCPs) in drinking water and water/sewage treatment plants: A review. Science of the Total Environment, v. 596, p. 303-320, 2017.

PETRIE, Bruce; BARDEN, Ruth; KASPRZYK-HORDERN, Barbara. A review on emerging contaminants in wastewaters and the environment: current knowledge, understudied areas and recommendations for future monitoring. Water research, v. 72, p. 3-27, 2015.

KASPRZYK-HORDERN, Barbara; DINSDALE, Richard M.; GUWY, Alan J. The removal of pharmaceuticals, personal care products, endocrine disruptors and illicit drugs during wastewater treatment and its impact on the quality of receiving 
waters. Water research, v. 43, n. 2, p. 363-380, 2009.

GAGO-FERRERO, Pablo et al. Evaluation of fungal-and photo-degradation as potential treatments for the removal of sunscreens BP3 and BP1. Science of the total environment, v. 427, p. 355-363, 2012.

DEBASTE, Frédéric; SONGULASHVILI, George; PENNINCKX, Michel J. The potential of Cerrena unicolor laccase immobilized on mesoporous silica beads for removal of organic micropollutants in wastewaters. Desalination and Water Treatment, v. 52, n. 10-12, p. 2344-2347, 2014.

VALLECILLOS, Laura. et al. Degradation of synthetic fragrances by laccase-mediated system. Journal of hazardous materials, v. 334, p. 233-243, 2017.

Coordenadoria de Pesquisa e Extensāo - COPEX

Departamento de Editoraçāo e Divulgaçāo Científica - DEDIC 


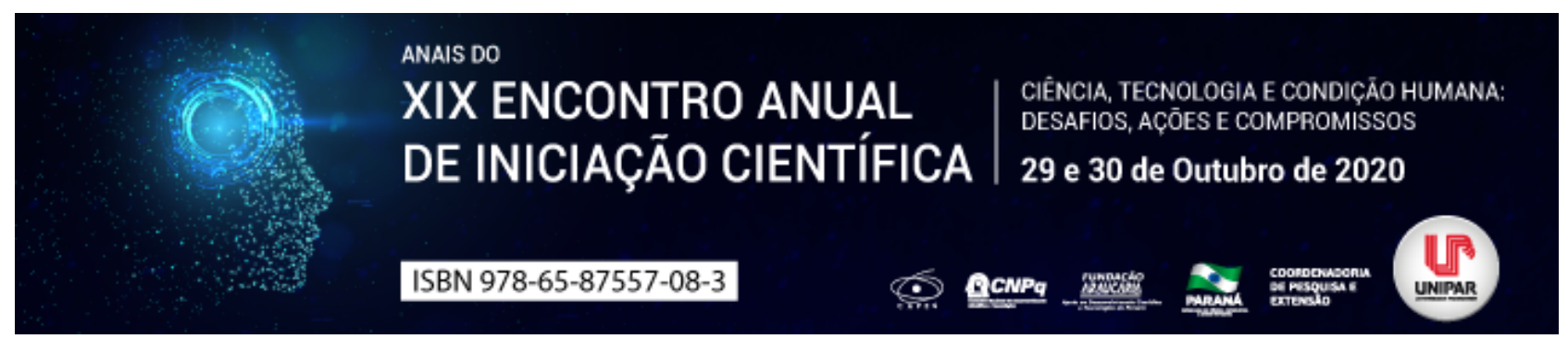

EFEITO DO pH INICIAL DO MEIO DE CULTIVO NA ATIVIDADE DE LACASE DE Panus strigellus

\begin{abstract}
${ }^{1}$ GABRIELLA FERNANDES DA SILVA, ${ }^{2}$ GABRIEL TRAMONTINI PEREIRA , ${ }^{3}$ THIAGO TEODORO SANTANA , ${ }^{4} J U L I A N A$ SILVEIRA DO VALLE
\end{abstract}

\author{
${ }^{1}$ aAcadêmica de Estética e Cosmética, Bolsista PEBIC/CNPq, Universidade Paranaense - UNIPAR \\ ${ }^{1}$ Acadêmico de Farmácia, Bolsista PEBIC/CNPq, Universidade Paranaense - UNIPAR \\ ${ }^{2}$ Doutorando em Biotecnologia Aplicada à Agricultura, Bolsista CAPES, Universidade Paranaense - UNIPAR \\ ${ }^{3} \mathrm{dD}$ ocente de Estética e Cosmética, Farmácia e Biotecnologia Aplicada à Agricultura, Universidade Paranaense - UNIPAR
}

Introdução: Panus strigellus é um fungo distribuído nas regiões subtropicais e tropicais da América onde é encontrado na região amazônica e é consumido como alimento por grupos indígenas como os da etnia Yanomami (VARGAS-ISLA et al., 2015). Sua capacidade para crescer em madeira em decomposição o caracteriza como um fungo lignocelulolítico, característica relacionada à produção de enzimas hidrolíticas como celulases e hemicelulases, além de oxidases e peroxidases como a lacase, manganês peroxidase (MnP) e a lignina peroxidase (LiP). Por isso, tais fungos degradam todos os componentes das paredes celulares das plantas além de vários compostos recalcitrantes e poluentes ambientais (CARDOSO et al., 2018). A lacase tem muitas aplicações nas indústrias têxtil, de papel e celulose, biorremediação e desintoxicação de poluentes ambientais (COUTO; TOCAHERRERA, 2007). Contudo, a produção de lacases por fungos pode ser influenciada por fatores como o pH do meio de cultivo, temperatura, fontes de carbono e nitrogênio, luz entre outros (MARIM et al., 2018). Até o momento não há dados na literatura sobre como o $\mathrm{pH}$ do meio de cultivo afeta a produção de enzimas.

Objetivos: Avaliar a influência do pH inicial do meio de cultivo sobre a atividade de lacase de $P$. strigellus.

Material e Métodos: A linhagem de Panus strigellus U16-7 da coleção de culturas da UNIPAR foi avaliada. A linhagem foi cultivada por sete dias em meio ágar-extrato-de-malte (AEM) $2 \%(\mathrm{~m} / \mathrm{v})$ a $28^{\circ} \mathrm{C}$ na ausência de luz para a produção de inóculo. Três discos de $6 \mathrm{~mm}$ de diâmetro contendo micélio sem setoriamento foram utilizados para inocular os meios de produção enzimática. A produção de lacase ocorreu em frascos Erlenmeyer (250 mL) contendo $100 \mathrm{~mL}$ de meio de cultivo extrato de malte $2 \%(\mathrm{~m} / \mathrm{v})$. Antes da inoculação do fungo o pH do meio de cultivo foi ajustado para 4, 5, 6, 7, 8 e 9 pela adição de soluções de $\mathrm{HCl}$ $(0,1 \mathrm{M})$ ou $\mathrm{NaOH}(0,1 \mathrm{M})$. Os frascos foram mantidos no escuro, a $28^{\circ} \mathrm{C}$ por 15 dias e no $15^{\circ}$ dia de cultivo as culturas foram filtradas para separação do micélio e do extrato enzimático (EE) que foi utilizado na determinação da atividade da lacase pela oxidação do ABTS (VALLE et al., 2014).Todos os ensaios seguiram o delineamento inteiramente casualizado e os resultados foram analisados por análise de variância (ANOVA). As diferenças entre as médias aritméticas foram determinadas pelo teste de Scott-Knott a $5 \%$ de probabilidade.

Resultados: A atividade de lacase em todos os meios de cultivo foi detectada após o quinto dia de cultivo. O pico de atividade máxima de lacase ocorreu no $15^{\circ}$ dia de cultivo $\left(-30000 \mathrm{U} \mathrm{L}^{-1}\right)$, menos para o meio com pH 4 cujo pico ocorreu no $10^{\circ}$ dia $(23000$ $\pm 467 \mathrm{U} \mathrm{L}^{-1}$ ). Por volta do $10^{\circ}$ dia de cultivo os meios com o pH inicial de 4 e 6 apresentavam as maiores atividade de lacase, porém, ao final de 15 dias a atividade de lacase observada em todos os meios não mostrou diferença estatística ( $p \leq 0,05$ ), exceto no meio com pH 4 cuja atividade de lacase sofreu grande redução.

Discussão: Nosso estudo é o primeiro a relatar os efeitos do pH inicial do meio de cultivo na produção de lacase de $P$. strigellus. O micélio deste fungo mostrou ser tolerante às diferenças de $\mathrm{pH}$ do meio produzindo elevada atividade de lacase em todas as condições de $\mathrm{pH}$. Usualmente o crescimento celular ocorre em uma faixa limitada e específica de $\mathrm{pH}$ em torno da neutralidade, mas há microrganismos que podem tolerar pHs mais ácidos ou alcalinos (Cervantes-Chávez et al. 2010). Sivakumar et al. (2010) cultivaram Ganoderma sp. em meio contendo amido e pH inicial entre 4,5 e 6,5 e relataram maior produção de lacase em pH 6. Isto indica que em outras espécies de cogumelos assim como em $P$. strigellus o pH influencia a produção de lacase. Muitas das respostas dos fungos às mudanças de $\mathrm{pH}$ do ambiente são reguladas por uma via metabólica de sinalização conhecida como Pal/Rim e as mais estudadas incluem a secreção enzimática e a síntese secundária de metabólitos (WU et al., 2016). Esse sistema regulatório garante que as moléculas expostas ao meio ambiente (como enzimas extracelulares) sejam produzidas apenas sob condições de pH que permitam sua ação efetiva (PEÑALVA et al., 2008).

Conclusão: A atividade da lacase de $P$. strigellus ao longo do cultivo é maior quando o pH inicial do meio é 6 , contudo após 15 dias não há diferença entre as atividades de lacase obtidas sob diferentes $\mathrm{pH}$.

\title{
Referências
}

CARDOSO, Bruna Karen. et al. Panus strigellus laccase decolorizes anthraquinone, azo, and triphenylmethane dyes. Biocatalysis and Agricultural Biotechnology, v. 16, p. 558-563, 2018. 
CERVANTES-CHÁVEZ José Antonio. et al. Functional analysis of the pH responsive pathway Pal/Rim in the phytopathogenic basidiomycete Ustilago maydis. Fungal Genetics and Biology, v. 47, n. 5, p. 446-457, 2010.

COUTO, Susana Rodríguez; TOCA-HERRERA, José L. Laccase production at reactor scale by filamentous fungi. Biotechnology Advances, v. 25, n. 6, p. 558-569, 2007.

MARIM, Renan A. et al. Lentinus crinitus strains respond differently to cultivation pH and temperature. Genetics and Molecular Research, v. 17, n. 1, 2018.

PEÑALVA, Miguel A. et al. Ambient pH gene regulation in fungi: making connections. Trends in Microbiology, v. 16, n. 6, p. 291300, 2008.

SIVAKUMAR, R. et al. Isolation, screening and optimization of production medium for thermostable laccase production from Ganoderma sp. International Journal of Engineering, Science and Technology, v. 2, n. 12, p. 7133-7141, 2010.

VALLE, J. S. et al. Optimum conditions for inducing laccase production in Lentinus crinitus. Genetics and Molecular Research, v. 13, n. 4, p. 8544-8551, 2014.

VARGAS-ISLA, Ruby. et al. Relationship between Panus lecomtei and P. strigellus inferred from their morphological, molecular and biological characteristics. Mycoscience, v. 56, n. 6, p. 561-571, 2015.

WU, Feng-Li. et al. The pH-responsive transcription factor PacC regulates mycelial growth, fruiting body development, and ganoderic acid biosynthesis in Ganoderma lucidum. Mycologia, v. 108, n. 6, p. 1104-1113, 2016.

Coordenadoria de Pesquisa e Extensão - COPEX

Departamento de Editoraçāo e Divulgaçāo Científica - DEDIC 


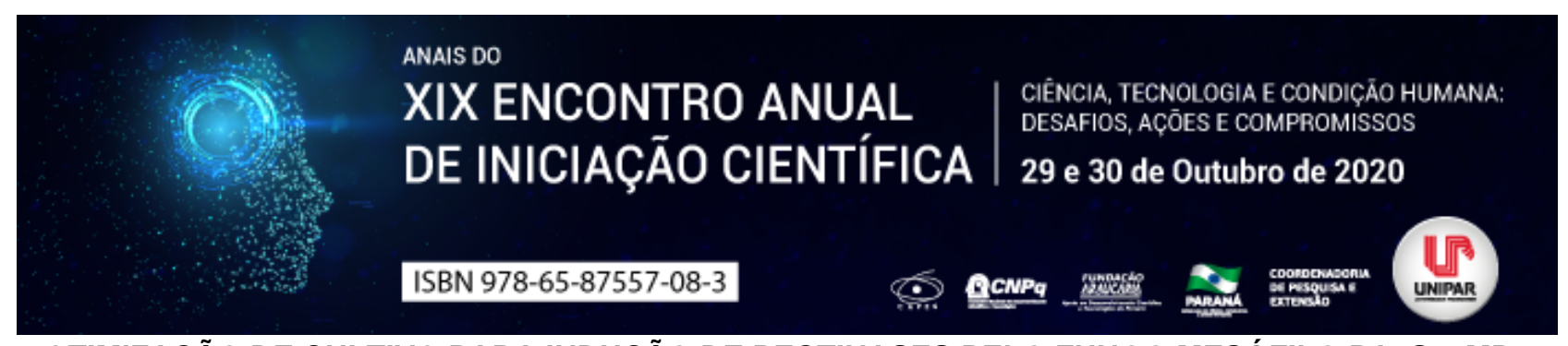

OTIMIZAÇÃO DE CULTIVO PARA INDUÇÃO DE PECTINASES PELO FUNGO MESÓFILO PA3S20MB

\begin{abstract}
${ }^{1}$ Vitoria Maciel Delai, ${ }^{2}$ LETICIA MARA RASBOLD, ${ }^{3}$ JOSÉ LUIZ DA CONCEIÇÃO SILVA, ${ }^{4}$ MARINA KIMIKO KADOWKI, ${ }^{5}$ RITA DE CÁSSIA GARCIA SIMÃO, ${ }^{6}$ ALEXANDRE MALLER
\end{abstract}

\begin{abstract}
${ }^{1}$ Discente, Curso de Farmácia, Centro de Ciências Médicas e Farmacêuticas, Universidade Estadual do Oeste do Paraná
${ }^{1}$ Discente, Programa de Pós-Graduação em Ciências Farmacêuticas, CCMF, Universidade Estadual do Oeste do Paraná

${ }^{2}$ Docente, Programa de Pós-Graduação em Ciências Farmacêuticas, CCMF, Universidade Estadual do Oeste do Paraná

${ }^{3}$ Docente, Programa de Pós-Graduação em Ciências Farmacêuticas, CCMF, Universidade Estadual do Oeste do Paraná

${ }^{4}$ Docente, Programa de Pós-Graduação em Ciências Farmacêuticas, CCMF, Universidade Estadual do Oeste do Paraná

${ }^{5}$ Docente, Curso de Farmácia, Programa de Pós-Graduação em Ciências Farmacêuticas, CCMF, Universidade Estadual do Oeste do Paraná
\end{abstract}

Introdução: A parede celular vegetal consiste em uma estrutura rígida composta principalmente de celulose, hemicelulose, pectina e lignina (HOUSTON et al., 2016). As pectinases são enzimas hidrolíticas que catalisam a degradação das substâncias pécticas, atuando de forma sinérgica na lamela média e na parede celular primária das plantas (TRINDADE et al., 2016). Elas são produzidas por plantas, fungos filamentosos, leveduras e bactérias (UENOJO; PASTORE, 2007). A produção enzimática por fungos filamentosos varia de acordo com as condições de cultivo, que podem ser testadas em conjunto para verificar a influência de cada variável em experimentos pré-estabelecidos ( $\mathrm{LI}$ et al., 2007). Ademais, as pectinases possuem elevado potencial biotecnológico devido a suas aplicações na indústria alimentícia e de bebidas, na manufatura de papel e como aditivo em ração. Sendo, de grande importância otimizar as condições de cultivo para maior produção dessa enzima.

Objetivo: Determinar o melhor meio de cultura e definir a melhor fonte de carbono para maior produção enzimática.

Material e Métodos: O fungo mesófilo PA3S20MB foi obtido da coleção de microrganismos do Laboratório de Bioquímica do Centro de Ciências Médicas e Farmacêuticas da Unioeste. A atividade pectinolítica foi determinada através da metodologia descrito por Miller (1959), utilizando pectina cítrica $1 \%$ dissolvida em tampão acetato de sódio $50 \mathrm{mM} \mathrm{pH} \mathrm{5,0} \mathrm{como} \mathrm{substrato.}$ Uma unidade enzimática foi a quantidade de enzima que liberou $1 \mu \mathrm{mol}$ de ácido galacturônico por minuto por mL. As proteínas foram determinadas através do método de Bradford (1976) empregando albumina de soro bovina (BSA) como padrão. Para determinar o melhor meio de cultivo para a produção de pectinases, o fungo foi inoculado em sete meios: Adams, Czapeck, Khanna, Klausen, Maller, SR, Vogel (MALLER et al., 2013) com composições distintas, suplementados com $1 \%$ de casca de laranja e incubados em estufa do tipo BOD à $28{ }^{\circ} \mathrm{C}$. Para verificar a melhor fonte de carbono, os cultivos líquidos foram suplementados com $1 \%$ de 18 diferentes fontes de carbono, previamente secas e moídas (glicose, pectina, bagaço de cana, bagaço de cevada, casca de banana, casca de batata, casca de laranja, casca de limão, casca de maçã, coroa de abacaxi, fibra de maracujá, fibra de trigo, palha de trigo, palha de arroz, palha de feijão, palha de milho, sabugo de milho, sorgo de biomassa) e incubados a $28^{\circ} \mathrm{C}$ por $144 \mathrm{~h}$, em condição estacionária, seguido de dosagem de atividade e proteína.

Resultados: O meio Khanna foi o melhor meio de cultivo para indução de pectinases pelo fungo PA3S20MB, apresentando atividade enzimática e específica de $8,972 \mathrm{U} / \mathrm{mL}$ e $7,987 \mathrm{U} / \mathrm{mg}$, respectivamente. Verificou-se que houve semelhança na concentração de proteínas secretados pelo fungo nos diferentes meios de cultivo, entre 0,90 e 1,37, exceto no meio Klausen, que apresentou a menor quantidade $(0,55 \mathrm{mg} / \mathrm{mL})$. Em relação a melhor fonte de carbono, a produção de pectinases teve maior indução no cultivo suplementado com casca de maçã, com atividade relativa e concentração de proteínas de $130 \%$ (em comparação com a indução pelo controle positivo - pectina) e $0,557 \mathrm{U} / \mathrm{mL}$, respectivamente. Sendo que, essa fonte apresentou o menor valor de proteínas, quando comparado aos demais, exceto o extrato enzimático do cultivo suplementado com glicose (controle negativo do experimento).

Discussão: O meio Khanna é composto, exclusivamente, por uma solução de sais de Khanna [20X]. Esse fato pode sugerir que o misto de sais presente nessa solução favoreceu a produção de pectinases, já que ela não faz parte da constituição de nenhum dos outros meios de cultivo em estudo. Já a semelhança na concentração de proteínas secretadas pelo fungo nos diferentes meios de cultivo, pode indicar que os diferentes meios induziram, apenas, uma modificação na composição de enzimas secretadas, alterando, assim, o resultado da atividade pectinolítica, mas nem tanto a quantidade de proteínas. PAGNONCELI (2018) estudando a purificação, caracterização e aplicação de uma exo-poligalacturonase de Penicillium janthinellum VI2R3M verificou que o meio Khanna também foi melhor para a produção de pectinases. Ademais, a utilização de cascas e outros subprodutos agroindustriais é considerável viável para o crescimento microbiano, uma vez que a estrutura desses resíduos tem como principais componentes: pectina, lignina, amido, celulose, hemicelulose e proteínas, servindo como fonte de carbono e energia (PANDEY, 2003). Dessa maneira, a casca de maçã, por possuir pectina em sua composição, é um substrato ideal para a 
indução de pectinases. No caso do fungo em estudo, a casca de maçã além de induzir a maior atividade enzimática apresentou a menor concentração de proteínas, indicando que o microrganismo secretou menores quantidades de outras proteínas deferentes da de interesse (pectinases).

Conclusão: A partir dos resultados obtidos, infere-se que a produção enzimática, realmente, varia de acordo com as condições de cultivo e que a máxima produção pelo fungo PA3S20MB foi obtida em meio Khanna, suplementado com $1 \%$ de casca de maçã.

\section{Referências}

BRADFORD, M. M. A rapid and sensitive method for the quantitation of microgram quantities of protein utilizing the principle of protein-dye binding. Analytical Biochemistry, v. 72, 248 254, 1976.

HOUSTON, Kelly, TUCKER, Matthew R., CHOWDHURY, Jamil, SHIRLEY, Neil, LITTLE, Alan. The Plant Cell Wall: A Complex and Dynamic Structure as Revealed by the Responses of Genes under Stress Conditions. Frontiers in Plant Science, v. 7 , 1 18, 2016.

$\mathrm{LI}$, Yin, CUI, Fengjie, LIU, Zhiqiang, XU, Yingying, ZHAO, Hui. Improvement of xylanase production by Penicillium oxalicum ZH-30 using response surface methodology. Enzyme and Microbial Technology, v. 40, 1381-1388, 2007.

MALLER, A., VICI, A.C., FACCHINI, F.D.A., DA SILVA, T.M., KAMIMURA, E.S., RODRIGUES, M.I., JORGE, J.A., TERENZI, H.F. \& POLIZELI, M.L.T.M. Increase of the phytase production by Aspergillus japonicus and its biocatalyst potential on chicken feed treatment. J Basic Microbiol, v. 53, 1-9, 2013.

MILLER, G. L. Use of dinitrosalicylic acid reagent for determination of reducing sugar. Analytical Chemistry, v. 31,426428 , 1959.

PANDEY, Ashok. Solid-state fermentation. Biochemical Engineering Journal, v. 13, n. 2-3, p. 81-84, 2003.

PAGNONCELI, Juliana. Purificação, caracterização e aplicação de uma exo-poligalacturonase de penicillium janthinellum VI2R3M. Dissertação (Mestrado em Ciências Farmacêuticas) - Universidade Estadual do Oeste do Paraná, Cascavel, 2018.

TRINDADE, Lucas Vinícius, DESAGIACOMO, Carla, POLIZELI, Maria de Lurdes Teixeira Moraes, DAMASIO, André Ricardo de Lima, LIMA, Aline Margarete Furuyama, GOMES, Eleni, BONILLA-RODRIGUEZ. Gustavo Orlando. Biochemical characterization, thermal stability, and partial sequence of a novel exo-polygalacturonase from the thermophilic fungus Rhizomucor pusillus A13.36 obtained by submerged cultivation. BioMed Research International, v. 2016, 1-2, 2016.

UENOJO, Mariana, PASTORE, Glaucia Maria. Pectinases: aplicações industriais e perspectivas. Quimica Nova, São Paulo, Campinas, v. 30, 388-394, 2007. 


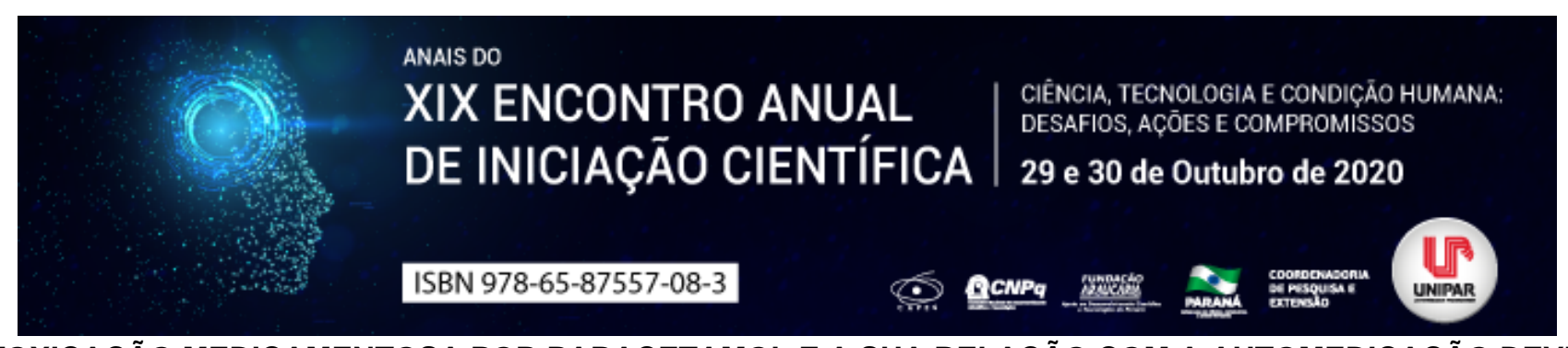

INTOXICAÇÃO MEDICAMENTOSA POR PARACETAMOL E A SUA RELAÇÃO COM A AUTOMEDICAÇÃO DEVIDO A COMPRA FACILITADA

\author{
${ }^{1}$ BRUNA DA SILVA OLIVEIRA, ${ }^{2}$ CAROLINE MERIGO SOTT, ${ }^{3}$ CASSIA MERIGO SOTT, ${ }^{4}$ JEAN CARLOS BILIBIO, ${ }^{5}$ ANDERSON \\ FELIPE FERREIRA
}

\author{
${ }^{1}$ Acadêmica do Curso de Biomedicina da UNIPAR \\ ${ }^{1}$ Acadêmica do Curso de Biomedicina da UNIPAR \\ ${ }^{2}$ Acadêmica do Curso de Biomedicina da UNIPAR \\ ${ }^{3}$ Acadêmico do Curso de Biomedicina da UNIPAR \\ ${ }^{4}$ Docente da UNIPAR
}

Introdução: Os medicamentos estão entre os principais agentes capazes de desencadear intoxicações em seres humanos. No Brasil, existe a cultura de acesso facilitado aos medicamentos, especialmente os analgésicos que podem ser adquiridos sem prescrição, estimulando a automedicação. A quantidade de produtos novos e o excesso de propaganda sobre medicamentos e laboratórios influenciam a compra e o consumo indiscriminado. Na listagem de medicamentos usados de forma inadequada o Paracetamol ganha destaque devido ao seu uso recorrente, provocando reações adversas e toxicidade hepática (PINTO, 2015). É necessário ampliar o conhecimento das principais implicações do uso inadequado do Paracetamol e as consequências desse consumo para a saúde humana. Compreender a prática da automedicação, bem como o fácil acesso aos fármacos é de grande importância, pois o desconhecimento da população quanto aos efeitos adversos favorece o crescimento dos casos de intoxicação medicamentosa (PINTO, 2015).

Objetivo: Pesquisar através de levantamento bibliográfico com as palavras-chave: Paracetamol, Intoxicação Medicamentosa, Automedicação com busca realizada em sites da Scielo, Pubmed e Instituições de Ensino e Pesquisa, afim de identificar a frequência e as consequências do uso indiscriminado do Paracetamol e a sua relação quadros de toxicidade.

Desenvolvimento: Valverde (2019) define o Paracetamol como um Medicamento Isento de Prescrição (MIPs) que possui ação analgésica, antipirético, anti-inflamatório, usado para alívio de dores e febre. Faz parte do grupo de medicamentos muito usado por crianças e gestantes por apresentar baixas reações adversas e pouca interação medicamentosa. Seu uso indiscriminado provoca errupção cutânea, cólica abdominal, diminuição da produção de urina e reação anafilática. Doses elevadas de Paracetamol no organismo aumentam as substâncias tóxicas no fígado, que sofre para degradá-las, provocando danos hepáticos, bem como distúrbios de coagulaçao e redução da atividade hepática. A ausência de conhecimento da população sobre os benefícios e malefícios dos medicamentos, a falta de hábito de fazer a leitura das bulas dos remédios, bem como a falta de entendimento sobre o uso racional de medicamentos são as principais causas de intoxicação medicamentosa, gerando graves problemas de saúde pública (CORUJA, 2012). Quando a administração do Paracetamol é feita de acordo com a posologia indicada, o seu uso é seguro e eficaz. Quando não é respeitada, há sobrecarga do metabolismo e produção excessiva de Nacetil-p-benzoquinoma imina, metabólico reativo que diminui a glutationa hepática que é um antioxidante responsável pela proteção dos hepatócitos de possíveis danos como a necrose hepática. A intoxicação por paracetamol, pode ser confirmada por meio de exames bioquímicos, como a dosagem das enzimas Alanina aminotransferase (ALT) e Aspartato aminotransferase (AST), ambos usados para avaliar os danos hepatócitos (GLINKA, 2018). A Albumina é usada para avaliar a função hepática devido a avaliação da capacidade de síntese proteica, revelando a integridade das funções hepáticas. Já para avaliar a quantidade de ingestão do Paracetamol e o provável risco de toxicidade, deve-se realizar a dosagem de Acetaminofeno sérico e avaliar juntamente com o tempo pós exposição ao fármaco o normograma de Rumack-Matthew, usado para estimar a probabilidade de hepatotoxicidade (GLINKA, 2018). O tratamento depende do tempo da ingestão da droga, com lavagem gástrica ou carvão ativado, reduzindo o efeito tóxico do fármaco, com desintoxicação através do uso de N-acetilcisteína (NAC). A NAC age no aumento da glutationa, que serve como um precursor dessa enzima, agindo como um substituto da glutationa, combinando-se ao NAPQI, sendo convertido a cisteina e conjugado do mercaptato (NESI, 2012). Em termos de toxicologia, ela acompanha o homem desde os primórdios, especialmente pela variedade de plantas tóxicas existentes e pelos venenos dos animais. Quanto aos medicamentos, como fatores que contribuem para o aumento da automedicação temos o poder das indústrias que influenciam os médicos, as propagandas enganosas, o número de farmácias existentes, a compra de medicamentos sem receita médica, as prescrições indevidas e a indicação de balconistas e vendedores (CAIRES, 2018). Dentre os principais riscos da automedicação pode-se destacar os erros de dosagem dos medicamentos, as interações medicamentosas, o aumento da resistência bacteriana, o intervalo de administração incorreto e a duração do tratamento. Além disso, a automedicação pode mascarar algumas doenças e até levar a óbito. 
Conclusão: O Paracetamol causa lesões hepáticas que vão desde uma leve intoxicação (errupções cutâneas, cólica abdominal, diminuição da produção de urina e náuseas) até reação anafilática e necrose hepática. Se faz necessário, ampliar o conhecimento da população sobre as reações causadas pelo Paracetamol e diminuindo os índices de interação medicamentosa e automedicação.

\section{Referências}

CAIRES, C. R.S; BARONI, C.C; PEREIRA, L. L.V. Intoxicação Medicamentosa com foco nos efeitos do Paracetamol. Revista Científica Unilago, v. 1, n. 1, 2018.

CORUJA, C. I. K. Intoxicação por Paracetamol no Rio Grande do Sul. Universidade Federal do Rio Grande do Sul. Porto Alegre, 2012. Disponível em: Acesso em: 15. Ago. 2020.

GLINKA, C. RIBEIRO, C. N. M. O papel do Paracetamol na Hepatite medicamentosa. Revista Biociências, Biotecnologia e Saúde, v. 11, n. 21, maio-agosto, 2018.

NESI, R. S. Estudo clínico-epidemiológico das intoxicações por Paracetamol registradas no Centro de Informações de Santa Catarina no período de janeiro de 2003 a dezembro de 2010. Universidade Federal de Santa Catarina. Florianópolis, 2012. Disponível em: Acesso em: 12. Ago. 2020.

PINTO, N. Q. O; SILVA, G. A; SANTOS, E. C.G; BRITO, N. J. N. Atuação do Profissional Farmacêutico frente ao uso de Paracetamol como medicamento de venda livre. Revista Científica FACIDER, n. 07, 2015.

VALVERDE, D. L. B; SALDANHA, J. O; SOUSA, O. F. R. Os Riscos da Automedicação com ênfase no uso indiscriminado dos analgésicos de venda livre. Faculdade Unida de Campinas. Goiânia, 2019. Disponível em: Acesso em: 15. Ago. 2020. 


\title{
-

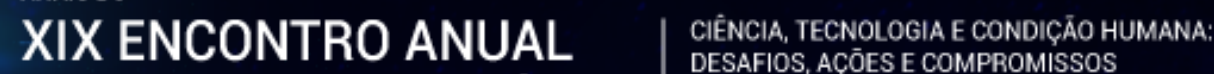 DE INICIACÃO CIENTÍFICA DESAFIOS, AGOESS EOMPROMISSOS DE INICIAÇĀO CIENTÍFICA 29 e 30 de Outubro de 2020 \\ ISBN 978-65-87557-08-3

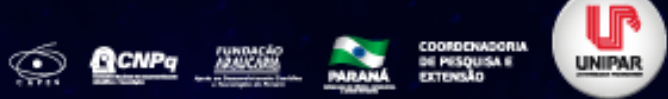 \\ OCORRÊNCIA DA IMUNODEFICIÊNCIA FELINA EM GATOS DOMÉSTICOS NO MUNICÍPIO DE UMUARAMA, PR ESTUDO RESPECTIVO
}

\author{
${ }^{1}$ MARIA CLARA UCKER COSTODIO, ${ }^{2}$ JAQUELINE BRUNA DE MELO, ${ }^{3}$ GIOVANA DANTAS GROSSI, ${ }^{4}$ DEBORAH CAROLINE \\ SEPÚLVEDAS DIAS, ${ }^{5}$ NATALIA SARAIVA RODRIGUES, ${ }^{6}$ NATALIE BERTELIS MERLINI
}

\begin{abstract}
${ }^{1}$ Discente do Curso de Medicina Veterinária da Universidade Paranaense UNIPAR, Bolsista PIBIC.
${ }^{1}$ Médica Veterinária Residente do Programa de Aprimoramento em Clínica Médica de Cães e Gatos da Universidade Paranaense UNIPAR

${ }^{2}$ Discente do Curso de Medicina Veterinária da Universidade Paranaense UNIPAR, Bolsista PIBIC

${ }^{3}$ Médica Veterinária Autônoma

${ }^{4}$ Mestranda em Ciência Animal, Universidade Paranaense UNIPAR, bolsista PIT/UNIPAR

${ }^{5}$ Docente do Programa de Pós-Graduação em Ciência Animal com Ênfase em Produtos Bioativos da Universidade Paranaense UNIPAR
\end{abstract}

Introdução: Atualmente os gatos estão presentes em grande parte dos domicílios, e de acordo com Instituto Pet Brasil, que atualiza dados recolhidos pelo IBGE, em 2018, contabilizou-se 23,9 milhões de gatos, de 2013 até 2018 , o percentual de casas que escolheram o gato como pet, cresceu 8,1\%. E para estes animais viverem bem, é de suma importância o conhecimento sobre as principais doenças infecciosas que acometem os gatos doméstico, como exemplo, o vírus da imunodeficiência felina (FIV), que é um retrovírus exógeno pertencente a família Retroviridae, sendo do gênero Lentivirus (HARTMANN, 2012). A transmissão é a partir de mordeduras e arranhaduras, onde o vírus é eliminado através do sangue ou saliva (GREENE, 2005; KENNEDY, LITTLE, 2015). Estes animais além de apresentarem diversas manifestações clinicas, como febre, anemia, infecções, problemas respiratórios, emagrecimento, correm o risco de contraírem infecções secundárias devido a baixa imunidade que o vírus proporciona (CRAWFORD, 2011).

Objetivo: O objetivo deste trabalho foi verificar a ocorrência de infecção da imunodeficiência felina em gatos domésticos do município de Umuarama, PR.

Materiais e métodos: Analisou-se os prontuários de 73 felinos que realizaram teste rápido (Teste SNAP FIV/FELV Combo IDEXX) no município de Umuarama, PR, no período de Janeiro de 2018 até Junho de 2020.

Resultados: O grupo de animais os quais os testes foram realizados, constituíam de 29 fêmeas e 44 machos, sendo 65 animais sem raça definida (SRD), Siamês (3), Persa (3), Ragdoll (1) e Sphinix (1). Foram encontrados 10 (13\%) animais positivos para FIV, sendo 9 machos e 1 fêmea, todos SRD.

Discussão: Estima-se que a prevalência de gatos infectados com FIV seja de 12\% da população felina doméstica mundial (RAVAZZOLO \& COSTA, 2007). Devido ao modo de transmissão do vírus, através de mordeduras e arranhaduras, pesquisas de diversos países demonstraram que os gatos machos e adultos constituem maior predisposição para infecção, geralmente com idade superior a seis anos, com acesso a ambiente externo (SOUZA e TEIXEIRA, 2003; GREENE, 2005; CHANDLER, et al., 2006), uma vez que os machos tem maior exposição ambiental pois partem em busca de fêmeas para o acasalamento e por serem mais propensos a comportamentos agressivos como lutas para proteção do território (YILMAZ e ILGAZ, 2000). Ainda em relação a predisposição de gênero, Santos et al. (2013) encontraram 61,75 \% dos casos positivos corresponderam a machos, o que também é apresentado por Gleich et al. (2009), que no mesmo estudo, em relação a predisposição racial observou maior prevalência em animais SRD do que em animais de raça pura. Em estudo realizado em Belo Horizonte 4,14 \% dos felinos foram positivos para FIV (TEIXEIRA, et al. 2009). Lemos, et al. (2019) identificaram 12,5\% de animais positivos, similar ao que foi encontrado neste estudo. Essas variações podem se dar de acordo com o estilo de vida dos indivíduos estudados, domiciliados, semi-domiciliados ou de abrigos (LEMOS, et al. 2019; TEIXEIRA, et al. 2009). O prognóstico para FIV varia de acordo com o estágio em que o paciente se encontra, no entanto, o animal pode ficar assintomático por anos após diagnóstico. Contudo, após esse período, 20\% dos animais infectados vem a óbito (GRACE, 2011). Os testes para detecção de retroviroses devem ser realizados sempre, mesmo que o indivíduo já tenha histórico de testes negativos. O diagnóstico pode ser realizado através de testes imunocromatografia, PCR e ELISA, sendo este último o utilizado para o levantamento dos dados da presente pesquisa (KENNEDY, LITTLE, 2015). É recomendado o isolamento dos animais positivos para evitar a contaminação de novos indivíduos e também para diminuir a chances do paciente soropositivo adquirir outras doenças ou infecções secundárias. (GRACE, 2011), demonstrando a importância de testar a população felina. Ainda não há uma vacina comprovada para a FIV, por isto, a importância de manter os animais dentro de casa e as visitas regulares ao médico veterinário para que se realize o teste sorológico para detecção do agente infeccioso. Medidas como essas, podem eliminar as chances dos felídeos contraírem e 
contaminarem outros gatos. (FILONI et al., 2005).

Conclusão: Como conclusão, pode-se confirmar que a maior incidência de FIV foi em machos, e considerando o impacto na qualidade e período de vida do animal, é de suma importância realizar o teste de todos os felinos, restringir o acesso à rua e através de acompanhamento clínico periódico, dar suporte as enfermidades secundárias a infecção do vírus.

\section{Referências}

CHANDLER, E. A.; GASKELL, C. J.; GASKELL, R. M. Clínica Terapêutica em Felinos. $3^{a}$ ed. São Paulo: Ed. Roca. 2006. p. 632.

CRAWFORD, C. Progressos no diagnóstico de infecções retrovirais. In Medicina Interna de Felinos, 2011. p. 53-62.

FIGUEREIDO, Andreza Soriano.; ARAUJO, Junior João Pessoa. Vírus da leucemia felina: análise da classificação da infecção, da técnicas de diagnóstico e da eficácia da vacinação com emprego de técnicas sensíveis de detecção viral. Ciência Rural. Santa Maria. V.41, n.11, p.1952-1959, Nov. 2011.

GLEICH, Sabine E.; KRIEGER, Stefan.; HARTMANN, Katrin. Prevalência do vírus da imunodeficiência felina e do vírus da leucemia felina entre gatos de clientes e fatores de risco para infecção na Alemanha. Journal of Feline Medicine and Surgery. v. 11, n. 12, pág. 985-992, 2009.

GREENE, Craig. E. Infectious Deseases of the Dog and Cat. $3^{a}$ ed. Philadelphia, 2005, p, 1376.

HARTMANN, Katrin. Feline leukemia virus infection. In: Greene, C.E. Infectious disease of the dog and cat. 3.ed. Georgia: Elsevier. 2012. p, 108-136.

INSTITUTO PET BRASIL. Censo Pet: 139,3 milhões de animais de estimação no Brasil. Disponível em: http://institutopetbrasil.com/imprensa/censo-pet-1393-milhoes-de-animais-de-estimacao-no-brasil/. Acesso em: 07 jun. 2020.

LEMOS, Marinara.; OLIVEIRA, Juciene Silva.; ALMEIDA, Sabrina Jesus.; OLIVEIRA, Priscila Gomes.; FERRAZ, Henrique Trevizoli.; LOPES, Dyomar Toledo.; SATURINO, Klaus Casaro.; BORGES, Karla Irigaray Nogueira.; RAMOS, Dirceu Guilherme de Souza.; BRAGA, Isis Assis. Ocorrência da leucemia felina e imunodeficiência felina em gatos domésticos do município de Mineiros, Goiás. Pubvet, v. 13, p. 148, 2019.

KENNEDY, Melissa; LITTLE, Susan E. Doenças Virais. In: LITTLE, Susan E. O Gato: Medicina Interna. Rio de Janeiro: Roca, 2015. p. 9781046.

GRACE, Sharon Fooshee. Feline Immunodefi ciency Virus Infection. In: NORSWORTHY, G.D. The Feline Patient. $4^{\mathrm{a}}$ ed. Ames: Wiley-Blackwell, 2011. p. 179-180.

SANTOS, Denise Langanke.; LUCAS, Ronaldo.; LALLO, Maria Anete. Epidemiologia Da Imunodeficiência Viral, Leucemia Viral E Peritonite Infecciosa Em Felinos Procedentes De Um Hospital Veterinário. Revista Acadêmica Ciência Animal, v. 11, n. 2, p. 161-168, 2013.

SOUZA, Heloísa Justen Moreira.; TEIXEIRA, C.H.R. Medicina e Cirurgia Felina. $1^{\mathrm{a}}$ ed. Rio de Janeiro: Ed. Lf Livros, 2003. p 475.

TEIXEIRA, Bruno Marques.; RAJÃO, Daniela Souza.; HADDAD, João Paulo Amaral.; LEITE, R.C.; REIS, Jenner Karlisson Pimenta. Ocorrência do vírus da imunodeficiência felina e do vírus da leucemia felina em gatos domésticos mantidos em abrigos no município de Belo Horizonte. Arquivo Brasileiro de Medicina Veterinária e Zootecnia, v. 59, n. 4, p. 939-942, 2007. YILMAZ, H.; ILGAZ, A.; HARBOUR, D. A. Prevalence of FIV and FeLV infections in cats in Istanbul. Journal of Feline Medicine and Surgery, v.2, 2000. p. 69-70. 


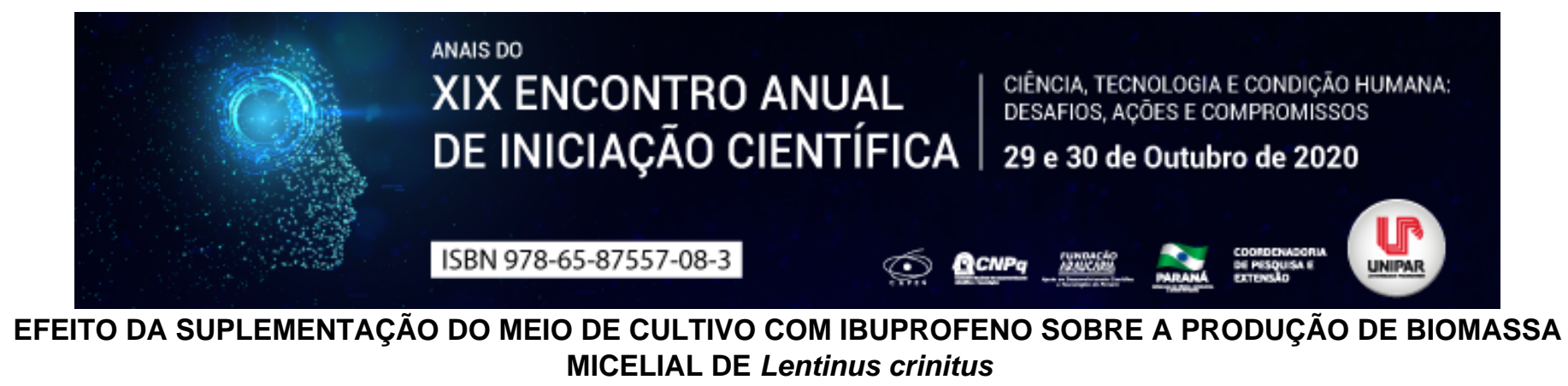

${ }^{1}$ Maria Clara Rios Ferreira, ${ }^{2}$ ADMA SORAIA SEREA KASSEM, ${ }^{3}$ JULIANA SILVEIRA DO VALLE

${ }^{1}$ Acadêmica de Química, Instituto Federal do Paraná (IFPR) e bolsista de Iniciação Científica, UNIPAR e CNPq
${ }^{1}$ Mestranda da Pós-Graduação em Biotecnologia Aplicada à Agricultura da UNIPAR, bolsista CAPES
${ }^{2}$ Docente da Pós-Graduação em Biotecnologia Aplicada à Agricultura da UNIPAR

Introdução: Micropoluentes ocorrem em concentrações muito baixas, usualmente em microgramas por litro e os principais são fármacos, produtos de limpeza e higiene pessoal, pesticidas e produtos químicos em geral, além de produtos da degradação destes compostos (OLICÓN-HERNÁNDEZ; GONZÁLEZ-LÓPEZ; ARANDA, 2017). Fármacos chegam ao ambiente através de atividades humanas como pelo esgoto doméstico, descarte direto, efluentes da indústria farmacêutica e hospitais (BECKER et al., 2016). Anti-inflamatórios não esteroidais (AINES) se destacam como micropoluentes devido ao seu alto consumo, toxicidade e persistência no ambiente. Entre os AINES mais consumidos está o ibuprofeno que no ambiente, pode causar toxicidade aos animais aquáticos e ao meio ambiente (CHRISTEN et al., 2010). Maneiras mais econômicas e sustentáveis para a degradação de micropoluentes têm sido estudadas, entre elas o uso de organismos vivos. Lentinus crinitus é capaz de degradar todos os componentes da parede celular vegetal e para isso produz enzimas extracelulares que por suas características bioquímicas também são capazes de degradar fármacos poluentes (STENHOLM et al., 2019). Contudo, a degradação eficiente depende da habilidade do fungo em crescer na presença dos poluentes.

Objetivo: Avaliar a produção de biomassa micelial de Lentinus crinitus cultivado em meio suplementado com diferentes concentrações de ibuprofeno.

Material e métodos: Foram usadas duas linhagens de Lentinus crinitus (U3397 e U19-6) da coleção de culturas da UNIPAR. As linhagens foram cultivadas em meio ágar-extrato-de-malte (AEM) $2 \%(\mathrm{~m} / \mathrm{v})$ a $28{ }^{\circ} \mathrm{C}$ por sete dias para produção de inóculo. Em seguida o fungo foi inoculado em $100 \mathrm{~mL}$ de meio extrato de malte $(2 \%, \mathrm{~m} / \mathrm{v})$, onde foram adicionadas $0,2,2,20$, ou $200 \mu \mathrm{g} \mathrm{L}^{-1}$ de ibuprofeno (GUILOSKI et al., 2017). Três dias após a inoculação o fármaco foi adicionado ao meio de cultivo e os frascos foram mantidos por 15 dias a $28^{\circ} \mathrm{C}$ em cultivo estático ou sob agitação (190 rpm). No $15^{\circ}$ dia o micélio foi recuperado por filtração e foi seco a $60^{\circ} \mathrm{C}$ até massa constante. Os ensaios seguiram o delineamento inteiramente casualizado e os resultados analisados por análise de variância (ANOVA). As diferenças entre as médias foram determinadas pelo teste de Scott-Knott a 5\% de probabilidade.

Resultados: As duas linhagens de L. crinitus cresceram na presença de todas as concentrações de ibuprofeno, exceto quando $200 \mu \mathrm{g} \mathrm{L}^{-1}$ foram adicionados ao meio onde não houve crescimento. A adição de 0,2 ou $2 \mu \mathrm{g} \mathrm{L}^{-1}$ de ibuprofeno não afetou o crescimento de L. crinitus U3397, tanto no cultivo estático quanto agitado. Porém, na presença de $20 \mu \mathrm{g} \mathrm{L}^{-1}$ de ibuprofeno o crescimento em cultivo estático foi $49 \%$ menor que o controle sem ibuprofeno enquanto sob agitação a biomassa não diferiu do controle. Lentinus crinitus U19-4 produziu mais biomassa no cultivo agitado. A adição de 0,2 a $20 \mu \mathrm{g} \mathrm{L}^{-1}$ de ibuprofeno não afetou o crescimento de $L$. crinitus U19-4 em cultivo estático comparado ao controle sem ibuprofeno. Contudo, em cultivo agitado, a biomassa foi 1,3 vezes menor na presença de $0,2 \mu \mathrm{g} \mathrm{L}^{-1}, 1,4$ vezes menor na presença de $2 \mu \mathrm{g} \mathrm{L}^{-1}$, e $2 x$ menor na presença de $20 \mu \mathrm{g} \mathrm{L}-1$.

Discussão: Apesar da possibilidade de uso de fungos na remoção de micropoluentes, problemas como redução severa do crescimento e produtividade dos organismos diante dos poluentes e seus subprodutos podem ser um entrave às aplicações. Micropoluentes podem atuar como estressores que provocam respostas celulares que podem inibir o crescimento e a divisão celular, reduzir a viabilidade celular, causar alterações da morfologia das células, afetar a estrutura e função da membrana plasmática e o metabolismo (JIA et al., 2014). Desta forma, avaliar a tolerância ao estresse provocado pela exposição aos micropoluentes é importante no desenvolvimento de bioprocessos para biorremediação. Lentinus crinitus mostrou ser tolerante à presença de ibuprofeno nas concentrações avaliadas crescendo em todas as condições, exceto quando $200 \mu \mathrm{g} \mathrm{L}^{-1}$ foram adicionados ao meio. O crescimento pode ser reflexo da capacidade do fungo em reduzir os níveis de AINE no meio por ação de enzimas extracelulares e/ou intracelulares (ASIF et al., 2017). Rodarte-Morales et al. (2011) relataram que a adição de $2000 \mu \mathrm{g}$ $\mathrm{L}^{-1}$ de ibuprofeno misturado a outros fármacos não limitou o crescimento de Phanerochaete chrysosporium em meio líquido. Cruz-Morató et al. (2013) demonstraram que Trametes versicolor ao ser inoculado em efluente hospitalar contendo vários fármacos foi capaz de manter crescimento constante e atividade da biomassa além de degradar totalmente o ibuprofeno. 
Microrganismos têm mecanismos que Ihes permitem sobreviver e permanecer ativos diante do estresse ambiental e $L$. crinitus mostrou capacidade de sobreviver na maioria das concentrações de ibuprofeno demonstrando potencial para aplicação em biorremediação.

Conclusão: Lentinus crinitus mostrou potencial para uso na degradação do ibuprofeno, crescendo normalmente na maioria das concentrações do fármaco impostas a ele. Mesmo existindo outras linhagens de fungos que são comprovadamente eficazes, não se descarta a possibilidade do uso do $L$. crinitus para este fim.

\section{Referências}

ASIF, Muhammad B. et al. Degradation of pharmaceuticals and personal care products by white-rot fungi $A$ critical review. Current Pollution Reports, v. 3, n. 2, p. 88-103, 2017.

BECKER, Dennis et al. Removal of antibiotics in wastewater by enzymatic treatment with fungal laccase degradation of compounds does not always eliminate toxicity. Bioresource Technology, v. 219, p. 500-509, 2016.

CHRISTEN, Verena et al. Highly active human pharmaceuticals in aquatic systems: a concept for their identification based on their mode of action. Aquatic Toxicology, v. 96, n. 3, p. 167-181, 2010.

CRUZ-MORATÓ, Carles et al. Degradation of pharmaceuticals in non-sterile urban wastewater by Trametes versicolor in a fluidized bed bioreactor. Water Research, v. 47, n. 14, p. 5200-5210, 2013.

GUILOSKI, Izonete C. et al. Effects of environmentally relevant concentrations of the anti-inflammatory drug diclofenac in freshwater fish Rhamdia quelen. Ecotoxicology and Environmental Safety, v. 139, p. 291-300, 2017.

JIA, Haiyang et al. Enhancing stress-resistance for efficient microbial biotransformations by synthetic biology. Frontiers in Bioengineering and Biotechnology, v. 2, p. 44, 2014.

OLICÓN-HERNÁNDEZ, Darío R.; GONZÁLEZ-LÓPEZ, Jesús; ARANDA, Elisabet. Overview on the biochemical potential of filamentous fungi to degrade pharmaceutical compounds. Frontiers in Microbiology, v. 8, p. 1792, 2017.

RODARTE-MORALES, Angelica et al. Degradation of selected pharmaceutical and personal care products (PPCPs) by white-rot fungi. World Journal of Microbiology and Biotechnology, v. 27, n. 8, p. 1839-1846, 2011.

STENHOLM, Åke et al. Removal of diclofenac from a non-sterile aqueous system using Trametes versicolor with an emphasis on adsorption and biodegradation mechanisms. Environmental Technology, v. 40, n. 19, p. 2460-2472, 2019. 


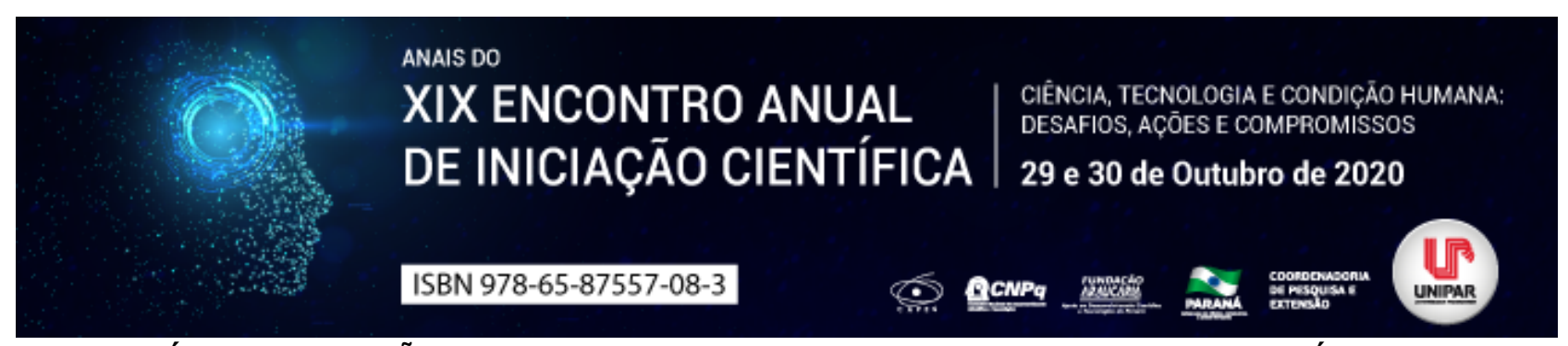

PERFIL HEMATOLÓGICO PARA CÃES ADULTOS SADIOS ATENDIDOS NO HOSPITAL VETERINÁRIO DA UNIVERSIDADE ESTADUAL DE MARINGÁ (UEM)

\author{
${ }^{1}$ Leticia Coelho Araujo, ${ }^{2}$ JÚLIA SAYUMI SAITO, ${ }^{3}$ CYNTHIA PENONI VOLPI ABREU, ${ }^{4}$ ESTÉFANI RINALDI, ${ }^{5}$ MARILDA \\ ONGHERO TAFFAREL, ${ }^{6}$ ANDRÉ MARCOS SANTANA
}

\begin{abstract}
${ }^{1}$ Acadêmica do Curso de Medicina Veterinária, Universidade Estadual de Maringá (UEM), Campus Regional de Umuarama
${ }^{1}$ Acadêmica do Curso de Medicina Veterinária, Universidade Estadual de Maringá (UEM), Campus Regional de Umuarama

${ }^{2}$ Docente do Departamento de Medicina Veterinária, Universidade Estadual de Maringá (UEM), Campus Regional de Umuarama

${ }^{3}$ Acadêmica do Curso de Medicina Veterinária, Universidade Estadual de Maringá (UEM), Campus Regional de Umuarama

${ }^{4}$ Docente do Departamento de Medicina Veterinária, Universidade Estadual de Maringá (UEM), Campus Regional de Umuarama

${ }^{5}$ Docente do Departamento de Medicina Veterinária, Universidade Estadual de Maringá (UEM), Campus Regional de Umuarama
\end{abstract}

Introdução: O perfil hematológico é de suma importância na clínica médica de cães, uma vez que este auxilia no estabelecimento do diagnóstico e prognóstico do animal. Por este exame, é possível obter informações sobre o estado clínico geral do animal, anemias, policitemias, infecções bacterianas, parasitológicas ou virais, alterações plaquetárias, neoplasias, entre outros, e especialmente detectar alterações em pacientes assintomáticos. O perfil hematológico dos animais pode variar de acordo com a raça, alimentação, idade, manejo, estado fisiológico do animal e condições geográficas e habitacionais, e para uma melhor interpretação do hemograma e um diagnóstico preciso, é fundamental se basear em valores próprios para cada população de animais, dado que a maior parte dos valores de intervalos de referência (IR) hematológicos que estão disponíveis são de literatura antiga e estrangeira, dificultando na exatidão da interpretação do exame (TESSER et al., 2016; RIBEIRO et al., 2018).

Objetivo: Avaliar o hemograma (eritrograma, leucograma e contagem de plaquetas) de cães clinicamente sadios atendidos no Hospital Veterinário da Universidade Estadual de Maringá (UEM), Campus Regional de em Umuarama-PR, visando a criação de IR próprios para o Laboratório de Patologia Clínica Veterinária desta unidade.

Material e métodos: Foram coletadas amostras de sangue de 100 cães adultos, entre 1 e 10 anos, clinicamente sadios atendidos na rotina do Hospital Veterinário (UEM Umuarama), mediante punção da veia cefálica, utilizando um sistema de coleta a vácuo após antissepsia local com álcool iodado, em tubos plásticos siliconizados contendo EDTA, para realização de hemograma (eritrograma, leucograma e contagem de plaquetas). Apenas os animais submetidos a procedimentos eletivos, como ovariohisterectomia, orquiectomia, vacinação e doação de sangue foram designados ao projeto. Dos animais previamente selecionados, foram analisadas as descrições da anamnese (histórico clínico) e exame físico geral, e apenas os animais que apresentaram o exame físico geral sem alterações, com consistência de fezes firmes e sem presença de sangue/muco, turgor cutâneo normal/olhos brilhantes e temperatura retal dentro da normalidade para a espécie foram incluídos. De cada amostra de sangue venoso colhida, foram aferidos os dados relativos às contagens de hemácias (He), hematócrito (Ht), concentração de hemoglobina $(\mathrm{Hb})$, contagem de leucócitos e contagem de plaquetas, , utilizando aparelho automático. A contagem diferencial de leucócitos foi realizada a partir da contagem em esfregaço sanguíneo corado (Panótico Rápido) de 100 células, em microscopia óptica (GARCIA-NAVARRO, 1994). Os índices hematimétricos VCM (volume corpuscular médio) e CHCM (concentração de hemoglobina corpuscular média) também foram calculados. Após a obtenção de todos os dados, estes foram dispostos na forma de média e desvio padrão.

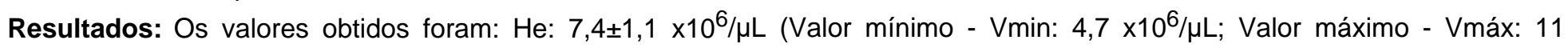

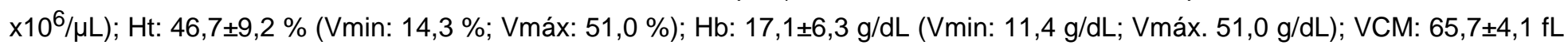

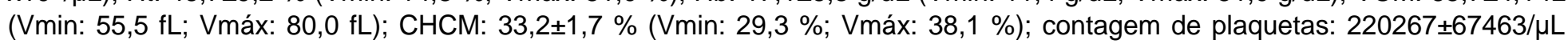

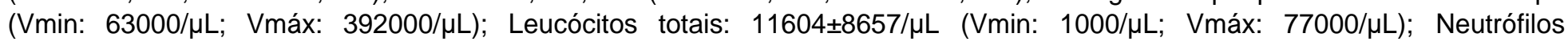

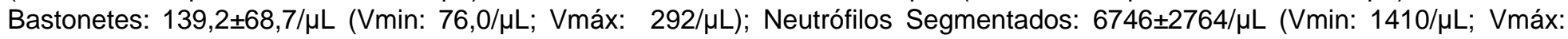

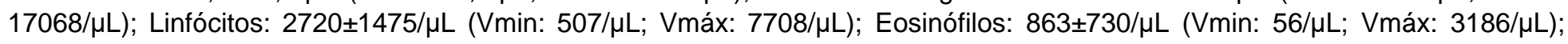
Basófilos: 0,00 $\pm 0,00 / \mu \mathrm{L}$.

Discussão: Os IR são um componente integral dos testes de diagnóstico laboratorial e da tomada de decisão clínica e representam distribuições estimadas de valores de referência de populações saudáveis de indivíduos comparáveis. No trabalho de Backschat (2017), que avaliou 69 cães da raça Dachshund, observou-se valores médios de hematócrito (54,7 \%) e contagem de plaquetas $(307000 / \mu \mathrm{L})$ maiores que os encontrados em nosso trabalho, provavelmente porque o autor buscava por particularidades e pelo padrão de normalidade da raça estudada. Ferreira et al. (2011) considerou em seu estudo o clima 
equatorial da região, abrangendo o período experimental à parte da estação considerada mais quente, e ao avaliar 113 cães de diferentes raças e idade, observou valores para contagem de hemácias de 6,38 $\pm 0,84 \times 10^{6} / \mu \mathrm{L}$ e para VMC de $69,6 \pm 4,28 \mathrm{fL}$ diferentes dos nossos, possivelmente em decorrência do clima e temperatura local estudados. Assim sendo, ressalta-se a importância, no momento da utilização de IR na prática clínica, que se leve em consideração aspectos como a raça e região, entre outros fatores.

Conclusão: O presente trabalho ressalta a importância da obtenção de IR próprios, uma vez que esse é suscetível à variações e é essencial para diagnosticar enfermidades com maior legitimidade e segurança. Observa-se, também, a necessidade de mais estudos sobre o tema em relação a diferentes grupos, como raças, espécies, faixas etárias e regiões, a fim de se obter uma análise mais precisa dos parâmetros

\section{Referências}

BACKSCHAT, P. S. Avaliação dos Parâmetros Hematológicos e Bioquímicos de Cães Adultos da Raça Dachshund. Orientador: Maria Helena Matiko Akao Larsson. 2017. 71 f. Dissertação (Pós-Graduação em Clínica Veterinária) Universidade de São Paulo, São Paulo, 2004.

FERREIRA, G. S.; MASSON, G. C. I. H.; GALVÃO, A. L. B.; LÉGA, E.; MENESES, A. M. C.; SOUZA, A. M. A. Determinação de Novos Parâmetros do Hemograma em Cães Saudáveis da Região Norte do Brasil. Archives of Veterinary Science, v. 16, n. 2, aug., 2011.

GARCIA-NAVARRO, C.E.K. Manual de Hematologia Veterinária. 1.ed. São Paulo: Livraria Varela, 1994. p. 169.

RIBEIRO, M. M.; ALVES, J. S.; SAMPAIO, W. S.; BARROS, E. S.; CHAVES, D. P. Perfil Hematológico de Caninos Recém nascidos do Município de São Luís Maranhão. PUBVET, v.12, n.1, a13, p.1-5, jan., 2018.

TESSER, S.; CAVAGNOLLI, N. I.; TORRIANI, T.; RODRIGUES, A. D. Perfil hematológico de cães e gatos na cidade de Bento Gonçalves, Rio Grande do Sul, Brasil. Arq. Ciênc. Vet. Zool. UNIPAR, Umuarama, v.19, n.1, p.47-51, jan./mar., 2016. 


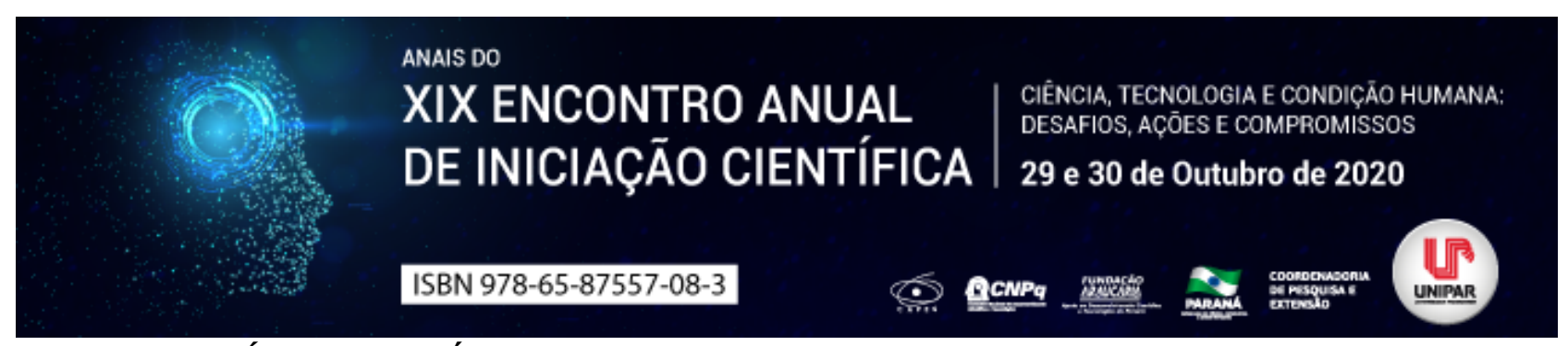

ALTERNATIVAS CLÍNICAS E CIRÚRGICAS PARA O TRATAMENTO DA CERATITE ULCERATIVA: UMA REVISÃO

\begin{abstract}
${ }^{1}$ ANA MARIA CANDIDO FERREIRA , ${ }^{2}$ LARISSA DE MATOS VIEIRA , ${ }^{3}$ NATALIA SARAIVA RODRIGUES, ${ }^{4}$ ANNA BEATRIZ DONAIDI SPAGNOLLI, ${ }^{5}$ GABRIELA JULIANA LOPES, ${ }^{6}$ NATALIE BERTELIS MERLINI
\end{abstract}

\author{
${ }^{1}$ Acadêmica do Curso de Medicina Veterinária, bolsista do PIBIC/UNIPAR \\ ${ }^{1}$ Acadêmica do Curso de Medicina Veterinária, bolsista do PIBIC/UNIPAR \\ ${ }^{2}$ Mestranda em Ciência Animal, Universidade Paranaense - UNIPAR, Bolsista PIT/UNIPAR \\ ${ }^{3}$ Acadêmica do Curso de Medicina Veterinária, bolsista do PIBIC/UNIPAR \\ ${ }^{4}$ Médica Veterinária autônoma
}

${ }^{5}$ Docente do Programa de Pós-graduação em Ciência Animal com ênfase em produtos bioativos, Univerdade Paranaense UNIPAR

Introdução: A ulceração corneana é uma das afecções oculares mais comum em cães. Isso decorre devido a maior exposição da córnea ao ambiente, visto que é a região mais externa do olho, tornando-se predisposta a traumas. Ademais, por ser uma doença ocular progressiva é considerada uma emergência oftálmica, pois pode ocorrer perfurações oculares e consequentemente acarretar na perda de visão (CREMONINI, et al. 2007; LAUS, 2009). Sob o prisma dos tratamentos, diversas técnicas cirúrgicas e condutas clinicas podem são propostas para a reparação de tal afecção (CREMONINI, et al. 2007; LAUS, 2009).

Objetivo: Esse trabalho tem como objetivo realizar uma revisão bibliográfica sobre as diferentes condutas terapêuticas utilizadas para a reparação de ulceras de córneas e seus respectivos efeitos.

Desenvolvimento: Devida a alta incidência da afecção, inúmeras técnicas cirúrgicas e vários fármacos são propostos para reparação corneana. Na literatura o tratamento adotado para conduta clínica da úlcera de córnea, consiste no uso de agentes como os colírios antimicrobianos, os lubrificantes e as drogas antiproteases (GELLAT, 2013; LAUS, 2009). Merlini et al. (2014) e Donatti et al. (2013) estudaram o uso do plasma rico em plaquetas (PRP) na reparação corneana, enquanto o primeiro utilizou em cães o segundo aplicou em coelhos, ambas pesquisas utilizaram um grupo com a forma de colírio e outro com tampão, e concluíram que o plasma rico em plaquetas foi efetivo no tratamento da lesão corneana, ainda nesta linha de pesquisa Ferreira (2019), estudou o uso do plasma rico em plaquetas alogênico aquecido em cães, e concluiu que este se apresenta de forma equiparável ao PRP autólogo. Ferreira et al. (2013) realizou um estudo comparando o uso do enxerto conjuntival 360 e implante de membrana amniótica criopreservada em cães com úlcera de córnea e concluiu que o implante de membrana amniótica criopreservada é mais eficaz no tratamento de ulceras de córneas profundas em relação ao uso do enxerto conjuntival $360^{\circ}$. Segundo Cremonini et al. (2007), realizaram um estudo sobre a eficácia da membrana amniótica canina criopreservada sobre a deficiência de células límbicas em coelhos, demonstrou que o tratamento não foi eficiente para corrigir essa deficiência de células germinativas, mas obteve um ótimo resultado no processo de cicatrização da córnea. Perches et al. (2012) em seu estudo para avaliar os efeitos do colírio de óleo essencial de Citrus lemon em diferentes concentrações, obteve resultados positivos para o tratamento de ulceras superficiais, sem ocorrer irritações nas conjuntivas, favorecendo a cicatrização corneana. Silva et al. (2015) relatou o uso do flap de terceira pálpebra para o tratamento de úlcera em melting, demonstrando ser um método eficaz. Mazzi et al. (2018) relatou o caso no qual utilizou como tratamento a oxigenoterapia hiperbárica para ceratite ulcerativa em cão, evidenciando cicatrização corneana; porém o artigo reforça a necessidade de mais estudos sobre a técnica. Andrade et al. (1999) foram os primeiros a estudar o uso da capsula renal equina comparado com o enxerto de conjuntiva pediculado, e demonstrou uma cicatrização de cornea semelhante entre as duas técnicas. Dularent et al. (2014), estudaram o uso do enxerto de pericárdio bovino (Tutopatch) para correção cirúrgica de úlceras de cornea, e concluiram que o mesmo apresenta-se como uma opção promissora para a reconstrução cirúrgica da córnea. Goulle (2012) e Vanone et al., (2007), descrevem o uso do enxerto de submucosa intestinal suína (SIS) no reparo cirúrgico de lesões corneais, os autores concluíram que o enxerto com SIS pode ser uma alternativa de tratamento cirúrgico eficaz comparado os métodos tradicionais de enxerto de conjuntiva, visto que o uso da SIS apresentou boa transparência e preservou a integridade corneana, garantindo assim a manutenção da visão. Guiffrida (2017), avaliou o uso da a membrana de poli(butileno adipato-cotereftalato) (PBAT) e amido termoplástico (TPS) em úlcera de córnea complicadas de cães e conclui que o uso da PBAT/TPS apresenta-se como uma alternativa viável para o tratamento da afeção em questão.

Conclusão: A presente revisão demonstra a variedade de fármacos utilizados no tratamento clínico e de diversas técnicas cirúrgicas para o manejo de ulcera de córnea, demonstrando como o campo da pesquisa com cicatrização corneana é promissor. 


\section{Referências}

ANDRADE, Alexandre L. The use of preserved equine renal capsule to repair lamellar corneal lesions in normal dogs. Veterinary Ophthalmology, v.2, p. 79-82. 1999.

CREMONINI, Daniela Nogueira. Transplante de membrana amniótica canina criopreservada para cicatrização de córnea com deficiência de células límbicas em coelhos. Arquivo Brasileiro de Medicina Veterinária e Zootecnia, v. 59, n. 6, p. 1462-1467, 2007.

DONATTI, C. Uso do plasma rico em plaquetas no reparo de úlceras de córnea profundas induzidas em coelhos. Avaliação clínica e histomorfométrica. Arquivo Brasileiro de Medicina Veterinária e Zootecnia, v. 65, n. 3, p. 809-818, junho. 2013.

DULAURENT, Thomas. Use of bovine pericardium (Tutopatch) graft for surgical repair of deep melting corneal ulcers in dogs and corneal sequestra in cats. Veterinary Ophthalmology, v. 17, n. 2, p. 91 99. 2014.

FERREIRA, Annalú Pinton. Uso do Plasma Rico em Plaquetas Autólogo e Alogênico Aquecido no Tratamento de Ceratite Ulcerativa em Cães. Orientadora: Cláudia Valéria Seullner Brandão. 2019. Dissertação (Mestre em Biotecnologia Animal)

Faculdade de Medicina Veterinária e Zootecnia da Universidade Estadual Paulista, São Paulo, 2019.

FERREIRA, Gabriel Thadeu Nogueira Martins. Aspectos clínicos do enxerto conjuntival $360^{\circ}$ e do implante da membrana amniótica criopreservada no tratamento de úlceras de córnea em cães. Semina: Ciências Agrárias, Londrina, v. 34, n. 3, p. 1239-1251, maio/jun. 2013.

GOULLE, F. Use of porcine small intestinal submucosa for corneal reconstruction in dogs and cats: 106 cases. BSAVA. Journal of Small Animal Practice, v. 53, p. 34 43, january. 2012.

LAUS, José Luiz. Oftalmologia Clínica e Cirurgia em Cães e Gatos, Editora Roca, 230p. 2009. MAZZI, Marcelo Fialho. Ceratite ulcerativa corneana traumática em cão: tratamento com oxigenoterapia hiperbárica. PUBVET, v.12, n.12, p.1-8, Dez. 2018.

MAZZI, Marcelo Fialho. Ceratite ulcerativa corneana traumática em cão: tratamento com oxigenoterapia hiperbárica. PUBVET, v.12, n.12, p.1-8, Dez. 2018.

MERLINI, Natalie Bertelis. Uso de plasma rico em plaquetas em úlceras de córnea em cães. Arquivo Brasileiro de Medicina Veterinária e Zootecnia, v. 66, n. 6, p. 1742-1750, 2014.

PERCHES, C. S. Uso do colírio de Citrus lemon em úlceras de córnea induzidas em coelhos. Arquivo Brasileiro de Medicina Veterinária e Zootecnia, v. 64, n. 5, p. 1161-1168, 2012.

RODRIGUES, Giovanna Giuffrida. Avaliação de úlceras de córnea complicadas em cães, tratadas com a membrana de poli(butileno adipato-cotereftalato) (PBAT) e amido termoplástico (TPS). Orientador: Alexandre Lima de Andrade. 2017. Dissertação (Mestre em Ciência Animal) - Faculdade de Medicina Veterinária Unesp, São Paulo, 2017.

SILVA, Ana Paula de Souza Martins. Flap de terceira pálpebra para tratamento de úlcera de córnea colagenolítica difusa em cão: relato de caso. ENCICLOPÉDIA BIOSFERA, Centro Científico Conhecer, Goiânia, v.11 n.22, p. 1296. 2015.

VANORE, Maria. Surgical repair of deep melting ulcers with porcine small intestinal submucosa (SIS) graft in dogs and cats. Veterinary Ophthalmology, v. 10, n. 2, p. 93-99, mar/apr. 2007. 


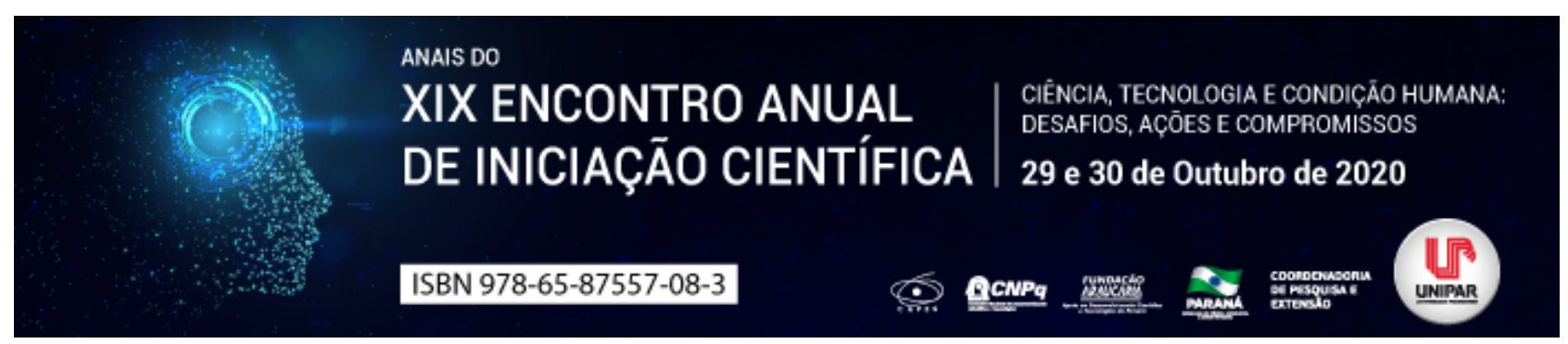

CIRURGIA RECONSTRUTIVA PARA TRATAMENTO DA DERMATITE PERIVULVAR GRAVE

\begin{abstract}
${ }^{1}$ KETLEN DE OLIVEIRA CORANDIN, ${ }^{2}$ DEBORAH CAROLINE SEPÚLVEDA DIAS, ${ }^{3}$ GIOVANA DANTAS GROSSI, ${ }^{4}$ ANA MARIA CANDIDO FERREIRA, ${ }^{5}$ LARISSA ANDRIELLY PETROLINE STEL, ${ }^{6}$ NATALIE BERTELIS MERLINI
\end{abstract}

\begin{abstract}
${ }^{1}$ Discente do Curso de Medicina Veterinária da Universidade Paranaense UNIPAR - PIC/UNIPAR
${ }^{1}$ Médica Veterinária autônoma

${ }^{2}$ Acadêmica do Curso de Medicina Veterinária, bolsista - PIBIC/UNIPAR

${ }^{3}$ Discente do Curso de Medicina Veterinária da Universidade Paranaense - Unipar, bolsista PIBIC/UNIPAR

${ }^{4}$ Acadêmica do Curso de Medicina Veterinária da UNIPAR - PIC/UNIPAR

${ }^{5}$ Docente do programa de pós graduação em ciência animal com ênfase em produtos bioativos Universidade Paranaense Unipar
\end{abstract}

Introdução: A dermatite perivulvar é comum em cadelas obesas e fêmeas com vulva infantil, devido ao aparecimento de dobras cutâneas vulvares, o que predispõe em algumas situações a retenção de urina e secreções vaginais na região perivulvar, levando a doenças secundárias como a dermatite perivulvar superficial, levando a manifestações clínicas que incluem: dor e odor perineal, vaginites, infecção do trato urinário ascendente e polaquiuria (MACPHAIL, 2014; FOSSUM, 2014). A remoção das dobras vulvares excessivas por episioplastia (vulvoplastia) é a cirurgia restauradora de escolha (RANEN e ZUR; 2005). O presente estudo teve como objetivo relatar o tratamento em uma cadela obesa com dermatite perivulvar grave mediante correção cirúrgica pela técnica de episioplastia.

Relato de caso: Foi atendida um canino, fêmea, Beagle, de 3 anos, 18,6 kg, com escore de condição corporal (ECC) 8/9, em que a tutora relatava odor fétido e desconforto perivulvar a cerca de 2 anos. Paciente já havia sido submetido a diversos tratamentos clínicos sem resposta efetiva, sendo então indicado procedimento cirúrgico reconstrutivo. Animal foi posicionado em decúbito dorsal com os membros pélvicos estendidos cranialmente, após antissepsia foi demarcada a área de pele em excesso a ser removida. Iniciou-se com incisão na comissura vulvar ventral em forma crescente circundando a vulva nas bordas laterais e dorsal, em seguida foi realizado uma segunda incisão em forma crescente medial e paralela a primeira para dermarcar a elipse de pele a ser retirada, o excesso de pele foi então removida e iniciou-se a sutura do tecido subcutâneo com nylon 3-0 em padrão Walking suture e síntese de pele com o fio Nylon 3-0 padrão simples interrompido. Durante o pós-operatório animal foi submetido a curativos a cada 12 horas com auxílio de clorexidine aquoso, solução fisiológica e rifamicina spray além de medicamentos orais como cefalexina $30 \mathrm{mg} / \mathrm{kg}$ a cada 12 horas por 10 dias, meloxicam $0,1 \mathrm{mg} / \mathrm{kg}$ a cada 24 horas por 3 dias, dipirona $25 \mathrm{mg} / \mathrm{kg}$, cada 8 horas por dia por 5 dias e cloridrato de tramadol $5 \mathrm{mg} / \mathrm{kg}$ a cada 8 horas e uso do colar elisabetano. Após 15 dias, os pontos foram retirados e mediante avaliação o resultado cosmético foi favorável.

Discussão: A obesidade pode levar ao aparecimento de dobras cutâneas vulvares, que predispõe ao acumulo de secreções acarretando secundariamente a dermatite perivulvar, no caso em questão o animal apresenta um ECC 8/9, ou seja, quadro de obesidade, fato este que levou ao excesso de pele na região, a literatura ainda traz que fêmeas castradas precocemente, apresentam vulva infantil que também pode levar a dobras vulvares (MACPHAIL, 2014; FOSSUM, 2014). De acordo com o histórico do animal nota-se um tempo prolongado de tratamento clínico sem sucesso, tratamento este que sempre é orientado antes da correção cirúrgica, diante dá resposta ineficaz ao tratamento prévio o procedimento cirúrgico de correção é indicado (FOSSUM, 2014). A técnica cirúrgica descrita neste relato condiz com de outros trabalhos (Ribeiro, 2019; LAIGHTER et. al; 2001; HAMMEL e BJORLING, 2012), com exceção da escolha do decúbito, o qual preconiza-se o decúbito ventral, porém optou-se pelo decúbito dorsal com os membros pélvicos estendidos, que proporcionou maior facilidade na visualização das estruturas e manipulação trans-cirúrgica. Estudos mostram que $94 \%$ dos cães apresentam resolução completa da dermatite perivulvar e sinais clínicos após episioplastia, já a minoria dos animais que apresentam recidiva dos sinais é em decorrência de ganho de peso (LAIGHTER et. al; 2001). Devido à resolução dos sinais clínicos, o tratamento cirúrgico foi eficaz por meio da técnica utilizada, no entanto o tutor foi orientado quanto o controle de peso do animal.

Conclusão: A episioplastia é um tratamento eficaz de baixa morbidade para os quadros de dobras vulvares excessivas que levam a dermatite perivulvar recidivante.

\title{
Referências
}

FOSSUM, T. W. Cirurgia de pequenos animais. 4.ed. Rio de Janeiro: Elsevier, 2014

HAMMEL, S. P.; BJORLING, D. E. Results of Vulvoplasty for Treatment of Recessed Vulva in Dogs. Journal of the American Animal Hospital Association, v. 38, Jan, 2002. 
Lightner BA, McLoughlin MA, Chew DJ, Beardsley SM, Matthews HK. Episioplasty for the treatment of perivulvar dermatitis or recurrent urinary tract infections in dogs with excessive perivulvar skin folds: 31 cases (1983-2000). J Am Vet Med Assoc. 2001;219(11):1577-1581. doi:10.2460/javma.2001.219.1577

MACPHAIL,C.M.Cirurgia do Sistema tegumentar. In: FOSSUM, T.W. Cirurgia de pequenos animais. 4.ed. Rio de Janeiro: Elsever, 2014. Cap.16, p. 635-716.

Ranen E, Zur G. Perivulvar dermatitis in a cat treated by episioplasty. J Small Anim Pract. 2005;46(12):582-584. doi:10.1111/j.1748-5827.2005.tb00290.x

RIBEIRO I. M. B.; CORREIA A. L.; MARINHO P. T. V. EPISIOPLASTIA EM CADELA COM DIAGNÓSTICO DE VULVA INFANTIL E PELE VULVAR SOBRESALENTE: Relato de caso. 11 JORNADA CIENTíFICA E TECNOLOGIA DO IFSULDEMINAS. 2019.

Coordenadoria de Pesquisa e Extensão - COPEX

Departamento de Editoraçāo e Divulgaçāo Científica - DEDIC 


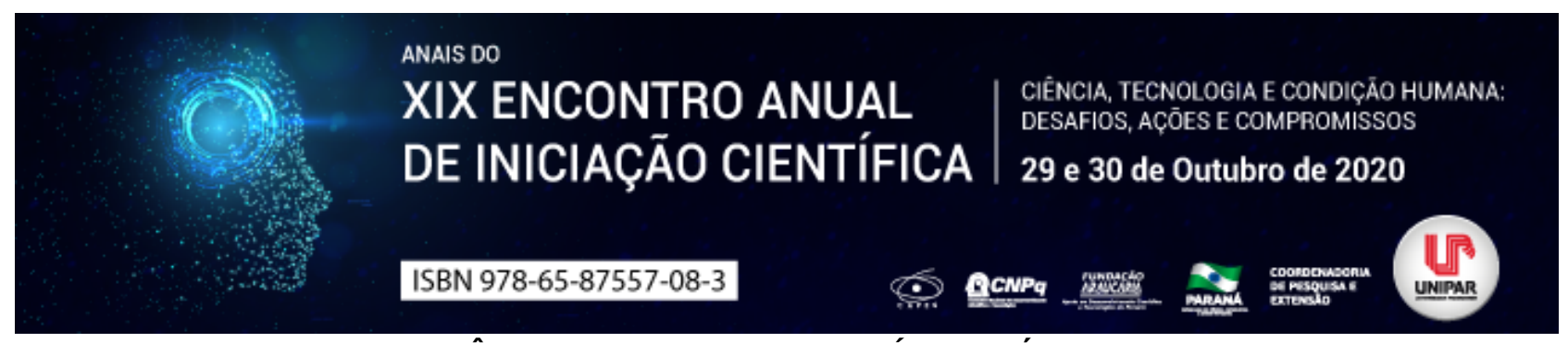

\title{
VALORES DE INTERVALOS DE REFERÊNCIA PARA PERFIL BIOQUÍMICO-SÉRICO RENAL EM OVINOS DA RAÇA SANTA INÊS: COMPARAÇÃO ENTRE MACHOS E FÊMEAS
}

\author{
${ }^{1}$ Bianca Bisconsim Ganasin, ${ }^{2}$ AMANDA GASPARUCHO BOSSI, ${ }^{3}$ DANIELA GOMES DA SILVA, ${ }^{4}$ ANTONIO CAMPANHA \\ MARTINEZ, ${ }^{5}$ JOSÉ JURANDIR FAGLIARI, ${ }^{6}$ ANDRÉ MARCOS SANTANA
}

\begin{abstract}
${ }^{1}$ Discente do Curso de Medicina Veterinária, Universidade Estadual de Maringá (UEM)
${ }^{1}$ Discente do Curso de Medicina Veterinária, Universidade Estadual de Maringá (UEM)

${ }^{2}$ Pós-Graduanda do Departamento de Clínica e Cirurgia Veterinária, FCAV/UNESP, Campus de Jaboticabal

${ }^{3}$ Docente do Departamento de Medicina Veterinária, Universidade Estadual de Maringá (UEM)

${ }^{4}$ Docente do Departamento de Clínica e Cirurgia Veterinária, FCAV/UNESP, Campus de Jaboticabal

${ }^{5}$ Docente do Departamento de Medicina Veterinária, Universidade Estadual de Maringá (UEM)
\end{abstract}

Introdução:A ovinocultura de corte é uma atividade promissora no Brasil, que atingiu uma posição de destaque no agronegócio brasileiro e vem sendo reconhecida como uma boa alternativa para a diversificação no campo (RAINERI, 2014). Dados da Pesquisa da Pecuária Municipal apontaram um aumento de 4,5\% no rebanho nacional, comparado ao ano anterior, estimando no total 18,41 milhões de cabeças (COSTA, 2019). Aliado às práticas de manejo, a prevenção e controle das doenças em ovinos é um fator fundamental para o sucesso do empreendimento (RETORE, 2015). Com base nestes argumentos, a avaliação laboratorial baseada em intervalos de referência (IR) específicos para a idade de abate, se torna uma ferramenta adequada para o monitoramento da saúde de um rebanho, garantindo um produto final de qualidade. Além disso, é de grande interesse avaliar possíveis diferenças de valores de IR entre machos e fêmeas, visto que fisiologicamente elas podem ocorrer (LIMA, 2015).

Objetivo: Este estudo tem como finalidade descrever valores de IR para as variáveis uréia e creatinina, relacionadas ao perfil bioquímico renal para ovinos em idade de abate, evidenciando diferenças destes parâmetros entre machos e fêmeas.

Materiais e Métodos: O presente estudo foi aprovado pelo CEUA (Protocolo 023640/14). Foram inclusos nos grupos experimentais 102 ovinos sadios da raça Santa Inês em idade de abate (4 a 6 meses), 43 machos (G1) e 59 fêmeas (G2). Foi verificado o estado de saúde dos animais através de exame físico geral (FEITOSA, 2008) e hemograma, e inclusos apenas animais que apresentaram todos os parâmetros dentro da normalidade. Para a realização do perfil bioquímico-sérico foram coletadas amostras de sangue através de punção da veia jugular e armazenadas em tubos plásticos siliconizados sem anticoagulante (BD Vacutainer, $10 \mathrm{~mL}$ ). As amostras foram centrifugadas a $1000 \times \mathrm{g}$, por 10 minutos para a retração do coágulo e posteriormente foram armazenadas em tubos Eppendort e congeladas (-20 graus) até o momento de análise. Foram avaliadas duas variáveis que compõe o perfil bioquímico renal: uréia e creatinina. Os testes foram realizados utilizando conjuntos de reagentes de uso comercial (Labtest Diagnóstica). As leituras dos parâmetros bioquímicos foram feitas em espectrofotômetro semi-automático (Labquest, Labtest Diagnóstica) com comprimentos de onda específicos para cada constituinte. Os IR foram determinados de acordo com as diretrizes da Sociedade Americana de Patologia Clínica Veterinária (FRIEDRICHS et al., 2012). Foi aplicado o teste de Anderson-Darling, Dixon e Tukey para análise de normalidade dos dados, identificação de outliers e diferenças estatísticas entre grupos, utilizando o ReferenceValueAdvisor.

Resultados: Foi possível realizar o cálculo dos limites inferiores e superiores dos IR, e os resultados para concentrações séricas de creatinina (mg/dL) foram: 1,05 a 1,99 (G1) e 1,16 a 1,97 (G2). As concentrações séricas de uréia (mg/dL) foram: 25,2 a 56,5 (G1) e 19,6 a 66,1 (G2). Não foram observadas diferenças significativas entre machos e fêmeas para as concentrações séricas de creatinina e uréia.

Discussão: A uréia é sintetizada no fígado a partir da amônia e do bicarbonato e é o principal meio de excreção do nitrogenio em animais (THRALL, 2015). É excretada principalmente na urina, sendo filtrada no glomérulo e parcialmente reabsorvida de forma passiva nos túbulos (VERLANDER, 2008). A creatinina é excretada unicamente por via renal, uma vez que não é reabsorvida ou reaproveitada pelo organismo. Tanto a uréia quanto a creatinina são excretados por filtração glomerular, e conforme ocorre a diminuição da taxa de filtração glomerular, as concentrações plasmáticas dessas substancias aumentam (THRALL, 2015). A avaliação das concentrações séricas de creatinina e uréia tem grande valor na avaliação da função renal, visto que, o aumento das concentrações destas variáveis no soro ou plasma, ocorrem devido à perda da capacidade de excreção destas, pelos rins (THRALL et al, 2015). Em ruminantes, o aumento destas variáveis pode indicar glomerulopatias, sendo a amiloidose glomerular a mais comum. Além disso, podem ser indicativos de insuficiência renal aguda por decorrência de processos inflamatórios, nefrose tubular tóxica e distúrbios imunológicos (SCHOTT et al., 2006). A literatura é escassa no que se refere à valores de referência de ovinos em idade de abate, contudo, os resultados obtidos neste trabalho corroboram com os estudos realizados por Lima et al (2015). Houve semelhança nos valores de uréia para animais de 3-5 meses, e em ambos os trabalhos não houve diferença entre 
machos e fêmeas. Quanto ao IR de creatinina, foi observada uma diferença no valor, e também, no estudo de Lima et al (2015) ocorreu uma diferença entre os sexos, que não foi observada em nosso estudo.

Conclusão: Não foram observadas diferenças signficativas nos valores de IR entre machos e fêmeas. No entanto, os IR para perfil bioquímico renal específicos para ovinos em idade de abate é uma ferramenta essencial no diagnóstico de lesões em trato urinário, desta forma, contribuindo para uma conduta clínica mais correta e assertiva

\section{Referências}

COSTA, José Alexandre Agiova et al. Produção de ovinos de corte em sistema integrado. In: BUNGENSTAB, Davi José et al. ILPF Inovação com integração de lavoura, pecuária e floresta. 1ª edição. Brasília: Embrapa, 2019. p 245-261.

FEITOSA, Francisco Leydson. Semiologia Veterinária: a arte do diagnóstico. 2. ed. São Paulo: Roca, 2008. 754p.

FRIEDRICHS, Kristen et al. ASVCP referenceintervalguidelines: determinationof de novo referenceintervals in veterinaryspeciesandotherrelatedtopics. VeterinaryClinicalPathology, v. 41, p. 441-453, 2012.

LIMA, Misael Brito et al. Intervalos de referência sanguíneos e a influência da idade e sexo sobre parâmetros hematológicos e bioquímicos de ovinos da raça Santa Inês criados na Amazônia Oriental. Acta Amazonica, [S.L.], v. 45, n. 3, p. 317-322, set. 2015.

RAINERI, Camila; SANTOS, Fernanda Ferreira; GAMEIRO, Augusto Hauber. Ovinocultura de corte no Brasil: balanço de 2013 e perspectivas para 2014. Revista de Educação Continuada em Medicina Veterinária e Zootecnia do CRMV-SP, São Paulo, v. 12, n. 3, p. 12-17, 2014.

RETORE, Marciana; CORREA, Elton Bock. Principais Doenças Diagnosticadas nos Rebanhos Ovinos de Mato Grosso do Sul. $1^{\mathrm{a}}$ edição, Dourados, Embrapa, 2015

SCHOTT H. C.; METRE, D. C.; DIVERS, T. J. Doenças do Sistema Renal. In: SMITH, B. P. Medicina Interna de Grandes Animais. $3^{\mathrm{a}}$ Edição. Barueri: Editora Manole, 2006. P. 824872.

VERLANDER, J. W. Fisiologia Renal. IN: CUNNINGHAM, J.G; KLEIN, B.G. Tratado de Fisiologia Veterinária. 4. ed. Rio de Janeiro: Elsevier, 2008. p. 531-568. 


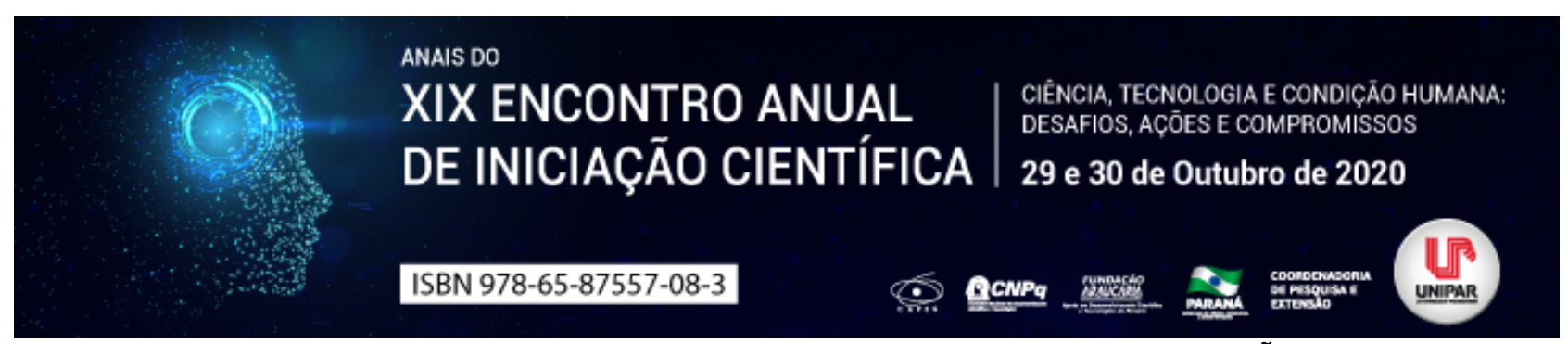

UNCARIA TOMENTOSA NO TRATAMENTO DE DEMODICOSE EM CÃES

\author{
${ }^{1}$ ELISIANI VITORIA GASPARETTO VENTURA, ${ }^{2}$ ALYSSON RAMALHAIS, ${ }^{3}$ ANNA JULIA BARBOSA SANT ANNA, ${ }^{4}$ RAPHAELA \\ FLÓES D ÁVILA, ${ }^{5}$ RAFAEL MARTINS BASTOS, ${ }^{6}$ ANA MARIA QUESSADA
}

\author{
${ }^{1}$ Acadêmica de Medicina Veterinária Pibic Unipar; \\ ${ }^{1}$ Mestrando em Ciência Animal da Unipar \\ ${ }^{2}$ Pibic ensino médio da Unipar \\ ${ }^{3}$ Acadêmica de Medicina Veterinária, Pic Unipar \\ ${ }^{4}$ Acadêmico de Medicina Veterinária, Unipar, Pebic Fundação Araucária \\ ${ }^{5}$ Docente da UNIPAR
}

Introdução: Desde os tempos mais remotos o homem sempre recorreu à natureza, buscando encontrar soluções para os seus problemas de saúde (CUNHA et al., 2003). A Uncaria Tomentosa, popularmente conhecida como unha-de-gato é uma planta medicinal nativa das Américas, mundialmente empregada devido às suas atividades anti-inflamatórias e imunomodulatórias. (MENDES, 2014). A demodicose canina (DC), é uma dermatite resultante da multiplicação excessiva de ácaros do gênero Demodex na pele dos cães. É uma doença multifatorial em que a presença do ácaro se conjuga com fatores genéticos e imunológicos do animal (GRIFFIN et al.,1993). A transmissão de Demodex canis ocorre por contato direto da progenitora para a sua ninhada, ou entre os cachorros da ninhada, durante as primeiras 48 a 72 horas pós-parto (SCOTT et al., 2001). A transmissão intrauterina parece não acontecer, pois em cachorros abortados ou nascidos por cesariana e separados das mães infectadas não foi possível demonstrar ácaros (LEITÃO e LEITÃO, 2003). Na prática clínica veterinária, a demodicose canina pode ser uma doença frustrante em seu tratamento. Devido a isso, sugere-se uma abordagem integrativa utilizando-se fitoterápicos, nutrição e acupuntura. Tal abordagem proporciona resolução mais rápida do problema porque auxilia nos desequilíbrios subjacentes produzidos pela enfermidade (TSAKIRIS-VASILOPOULOS, 2019).

Objetivo: Realizar uma revisão de literatura sobre a utilização de uncaria tomentosa no tratamento da demodicose canina.

Desenvolvimento: O ácaro Demodex canis faz parte da microbiota da pele e condutos auditivos dos cães, estimando-se que 30 a 80\% da população canina é portadora assintomática destes ácaros (NESBITT \& ACKERMAN, 1999). Recentemente, foi demonstrado pela técnica PCR em tempo real que, embora em pequenas quantidades, estes ácaros habitam a pele de cães saudáveis, confirmando-se formalmente este fato (RAVERA et.al., 2013). Assim, o agente etiológico não é o único responsável pelo desenvolvimento da doença. A DC é uma doença multifatorial que envolve fatores genéticos, imunológicos, parasitários, bacterianos, ecológicos cutâneos e ambientais (VERDE, 2005). A hipótese que diferenças na virulência de D. canis poderiam estar implicadas no desenvolvimento da DC foi considerada improvável, pois em cães da mesma ninhada sujeitos às mesmas populações de ácaros, uns desenvolvem a doença e outros mantem-se normais (MILLER et al., 2012). Atualmente, considera-se que a predisposição hereditária e a imunossupressão das células T estão envolvidas na proliferação excessiva de D. canis (MILLER et al., 2012). No tratamento da DC deve sempre ser considerado o estado geral do paciente, ou seja, é importante manter uma nutrição adequada, realizar o controle dos parasitas, do estresse, de doenças sistêmicas e piodermites bacterianas. Todos estes fatores podem contribuir para a imunossupressão, tornando assim a DC mais difícil de tratar (MILLER et al., 2012). A Uncaria tomentosa tem sido indicada para inúmeras enfermidades por possuir em sua composição mais de 50 princípios ativos, sendo alguns mais comuns e de maior importância terapêutica (BIESKI, 2006). Alguns autores relatam que a U. tomentosa tem propriedades imunoestimulantes (ALONSO, 2015; ARAÚJO, 2013; PORTAL VETERINARIA, 2003). Tal efeito imunoestimulantes pode estar relacionado ao fato de que a U. tomentosa age como estimulante de células progenitoras mielóides (FARIAS et al., 2011). Devido a estas propriedades imunoestimulantes a planta pode ser utilizada no tratamento da Demodicose em cães com bons resultados (PORTAL VETERINARIA, 2003, OLIVEIRA et al., 2016). Em um estudo em que se empregou a U. tomentosa no tratamento da Demodicose em um cão houve aumento expressivo de linfócitos. Como a doença produz linfopenia, este aumento de linfócitos foi benéfico para o paciente. Este cão teve completa recuperação da enfermidade (OLIVEIRA et al., 2016). Apesar dos efeitos benéficos no tratamento da doença são necessários mais estudos com maior número de animais e experimentos controlados para que os efeitos sejam devidamente comprovados.

Conclusão: A planta U. tomentosa tem potencial para ser utilizada como imunoestimulantes. Entretanto são necessários estudos com outras doenças e com maior número de animais para que os efeitos benéficos da planta possam ser comprovados.

\title{
Referências
}

ALONSO, J. Tratado de Fitofármacos e Nutracéuticos. São Paulo: A.C. Farmacêutica, 2015. 1124p. 
ARAUJO,et.al.Uncaria tomentosa: adjuvante no Tratamento do Câncer de Mama. 2013.Tese (Doutorado em Bioquímica Toxicologia), Universidade Federal de Santa Maria, Santa Maria, 2013.

CCAHUANA,et.al.Antimicrobial activity of Uncaria tomentosa against oral human pathogens.Brazilian oral research, v. $21, n$. 1 , p. 46-50, 2007.

CUNHA, et.al O. Plantas e produtos vegetais em fitoterapia, Serviço de educação e bolsas. Lisboa: Fundação Calouste Gulbenkian, 2003. 738 p.

FARIAS, I. et al. Uncaria tomentosa stimulates the proliferation of myeloid progenitor cells. Journal of Ethnopharmacology, v.137, p.856-863, 2011.

GRIFFIN C.E.et.al Demodicosis. In: GRIFFIN, C. E. Current Veterinary Dermatology. Michiga: Mosby, 1993. p. 72-94.

LEITÃO, J.P.A. et.al.Demodicose canina. Revista Portuguesa de Ciências Veterinárias, v. 103, n. 567-568, p.135-149, 2003.

MENDES,et.al. Avaliação dos possíveis efeitos tóxicos e imunotóxicos da Uncaria tomentosa em ratos. 2014. Dissertação. (Mestrado em patologia experimental e comparada) - Faculdade de Medicina Veterinária e Zootecnia, Universidade de São Paulo, São Paulo, 2014.

MILLER, W.; GRIFFIN, C.; CAMPBELL, K. Muller and Kirk's Small Animal Dermatology. 7.e. Philadelhia: Saunders, 2012. 948p.

NESBITT, et.al.Canine and Feline Dermatology. New Jersey: Veterinary Learning Systems, 1999. 500p.

RAVERA, et. al. Small Demodex populations colonize most parts of the Skin of healthy dogs.

SCOTT, D.; MILLER, W.; GRIFFIN, C. Muller and Kirk's Small Animal Dermatology. 6.e. Philadelphia: W.B. Saunders, 2001. 1552p.

TSAKIRIS-VASILOPOULOS, A. An integrative approach to demodectic mange. 2019. Disponível em: https://ivcjournal.com/integrative-approach-demodicosis/ ERDE, M. Canine demodicosis: treatment protocol. In: NAVC NORTH AMERICAN VETERINARY CONFERENCE. 8., 2005, Orlando. Proceedings [...]. Orlando: NAVC, 2005. p. 299-300. 


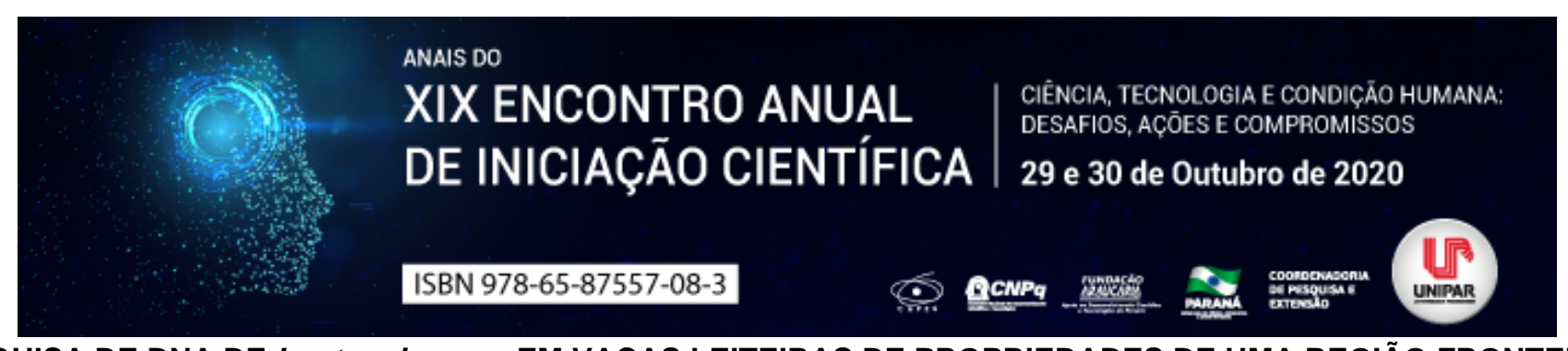

PESQUISA DE DNA DE Leptospira spp. EM VACAS LEITEIRAS DE PROPRIEDADES DE UMA REGIÃO FRONTEIRIÇA

\begin{abstract}
$1_{\text {ISABELA CARVALHO DOS SANTOS, }}^{2}$ REGIANE PEREIRA BAPTISTA DA SILVA, ${ }^{3}$ ANA CLAUDIA SOUZA ANDRADE, ${ }^{4}$ LUCAS LIMA DA SILVA, ${ }^{5}$ LIDIANE NUNES BARBOSA, ${ }^{6}$ DANIELA DIB GONCALVES
\end{abstract}

\begin{abstract}
${ }^{1}$ Acadêmica do Curso de Doutorado Em Ciencia Animal Com Enfase Em Produtos Bioativos - Bolsista CAPES
${ }^{1}$ Acadêmica do Curso de Doutorado Em Ciencia Animal Com Enfase Em Produtos Bioativos - Taxista CAPES

${ }^{2}$ Acadêmica do Curso de Doutorado Em Ciencia Animal Com Enfase Em Produtos Bioativos - Taxista CAPES

${ }^{3}$ Acadêmico do Curso de Medicina VeterinÃ

${ }^{4}$ Docente UNIPAR

${ }^{5}$ Docente da UNIPAR
\end{abstract}

Introdução: A leptospirose é uma doença de destaque na Saúde Única, pois trata-se de uma zoonose de distribuição mundial, principalmente em áreas tropicais, subtropicais e rurais, causada por espiroquetas do gênero Leptospira, tal enfermidade pode afetar qualquer animal de sangue quente, inclusive humanos, que podem ser os hospedeiros erráticos ou hospedeiros finais deste micro-organismo (HAMOND et al., 2014). Os que sobrevivem a esta doença tornam-se portadores crônicos e disseminadores deste micro-organismo que tem como ponto de predileção e de reservatório os rins e trato urinário (LIEGEON; DELORY; PICARDEAU, 2018; SIMÕES et al., 2016). Algumas formas da leptospirose podem ser mais brandas, causando uma doença subclínica no portador, porém existem infecções que causam desde uma febre que pode durar entre 10 e 20 dias à insuficiência renal severa, crônica ou aguda, e a morte (FAINE, 1998). A urina é a principal via para a eliminação de Leptospira e, portanto, tem um importante papel na semeadura desta no ambiente, sendo transmitido, direta ou indiretamente, a um novo hospedeiro via lama, solo ou água contaminados penetrando ativamente por micro abrasões na pele, mucosas, inalações de aerossóis, ingestão de água contaminada, além da contaminação materno-fetal (BARRAGAN et al., 2017; SIMÕES et al., 2016).

Objetivo: Este trabalho teve como objetivo pesquisar DNA de Leptospira spp. na urina de vacas leiteiras de propriedades localizadas em uma cidade de região de fronteira.

Material e Métodos: Foi coletada a urina de 51 vacas leiteiras, com problemas reprodutivos e não vacinadas contra Leptospira spp., pertencentes à 13 propriedades da cidade de Guaíra, localizada a 21,8 quilômetros da fronteira com o Paraguai, e, então, enviadas ao laboratório de Medicina Veterinária Preventiva e Saúde Pública do Programa de Pós Graduação em Ciência Animal com Ênfase em Produtos Bioativos da UNIPAR, unidade de Umuarama- PR. Para a pesquisa de DNA de Leptospira spp. Foi realizada a reação em cadeia pela polimerase (PCR) como teste diagnostico, e as amostras de DNA de urina foram extraídas com o PureLink Genomic DNA Mini Kit (Invitrogen, EUA), posteriormente, o DNA extraído foi submetido à nested-PCR (n-PCR) usando os iniciadores A (5'-GGCGGCGCGTCTITAAACATG-3'), B (5'-TTCCCCCCAT TGAGCAAGATT-3'), C (5'CAAGTCAAGCGGAGTAGCAA-3') e D (5'-CTTAACCTGCTGCCTCCCGTA-3'), como descrito por Mérien et al. (1992). O produto final da amplificação do n-PCR foi submetido à eletroforese em gel de agarose $2 \%$ e visualizado por luz ultravioleta em transiluminador. O peso molecular do produto foi estimado por comparação com um marcador molecular de $100 \mathrm{bp}$. As amostras consideradas positivas após n-PCR foram submetidas a nova amplificação de DNA usando primers específicos para o gene SecY: F (5'-ATGCCGATCATTTTTGCTTC-3') e R (5'-CCGTCCCTTAATTTTAGACTTCTTC-3') para identificar e confirmar a espécie genética (AHMED et al., 2006).

Resultados: Não houve identificação do DNA de Leptospira spp. dentre as amostras analisadas.

Discussão: O gado pode se tornar portador temporário ou permanente e liberar leptospiras em sua urina, contaminando, assim, solo e água, sendo mais confiável para o diagnóstico de infecção leptospiriral direta. (BARRAGAN et al., 2017; PINNA et al., 2018). Oliveira et al. (2018), obtiveram resultado superior a este estudo onde detectaram uma amostra positiva na amplificação de DNA de amostras de urina de fêmeas de corte, também utilizando o primer secY, enquanto o presente trabalho não obteve qualquer resultado positivo, tal resultado pode se dar tanto pela possibilidade de a infecção estar na forma crônica, quanto pela distância de 113,8 km entre o local de coleta e o laboratório onde as análises foram realizadas, esta distância pode ter dificultado a detecção deste microrganismo devido a possíveis contaminações ou ainda devido a degradação da amostra pelo ph ácido da urina (FAINE et al., 1998). Hamond et al. (2014), focam no uso da PCR para detecção da Leptospira spp. na urina do gado, pensando em um programa de controle de sucesso, já que animais soronegativos e sororreativos podem eliminar leptospiras pela urina, evidenciando que o presente trabalho necessita de outros exames para poder afirmar a negatividade do rebanho.

Conclusão: Apesar de a urina ser considerada a melhor amostra a ser colhida para detecção de Leptospira spp. o presente trabalho não detectou DNA desta espiroqueta dentre as amostras testadas, mostrando a necessidade de mais exames, além da coleta de outros materiais para o entendimento desta patologia no rebanho local. 
Agradecimentos: UNIPAR pelo financiamento desta pesquisa e ao CNPq pela bolsa produtividade.

\section{Referências}

AHMED, N. et al. Multilocus sequence typing method for identification and genotypic classification of pathogenic Leptospira species. Annals of clinical microbiology and antimicrobials, v. 5, n. 1, p. 28, 2006.

BARRAGAN, V. et al. Meta-analysis to estimate the load of Leptospira excreted in urine: beyond rats as important sources of transmission in low-income rural communities. BMC research notes, v. 10, n. 1, p. 71, 2017.

FAINE, S. 1998. Leptospirosis. Capítulo 42. p. 849-869. In COLLIER, L.; BALOWS, A.; SUSSMAN, M. Topley and Wilson's microbiology and microbial infections. 9a ed. Vol 3. Bacterial infections, HAUSLER, W. J.; SUSSMAN, M (ed). Arnold, London. UK. HAMOND, C. et al. Urinary PCR as an increasingly useful tool for an accurate diagnosis of leptospirosis in livestock. Veterinary research communications, v. 38, n. 1, p. 81-85, 2014.

LIEGEON, G.; DELORY, T.; PICARDEAU, M. Antibiotic susceptibilities of livestock isolates of leptospira. International journal of antimicrobial agents, v. 51, n. 5, p. 693-699, 2018.

MERIEN, F. et al. Polymerase chain reaction for detection of Leptospira spp. in clinical samples. Journal of clinical microbiology, v. 30, n. 9, p. 2219-2224, 1992.

OLIVEIRA, A. F. et al. Serological diagnosis and molecular characterization of Leptospira spp. in the blood and urine of bovine females from refrigerated slaughterhouses. Semina: Ciências Agrárias, Londrina, v. 39, n. 3, p. 1125-1134, 2018.

PINNA, M. H. et al. Detection of bovine carriers of Leptospira by serological, bacteriological, and molecular tools. Tropical animal health and production, v. 50, n. 4, p. 883-888, 2018.

SIMÕES, L. S. et al. Leptospirose Revisão. PUBVET, v. 10, p. 111-189, 2015. 


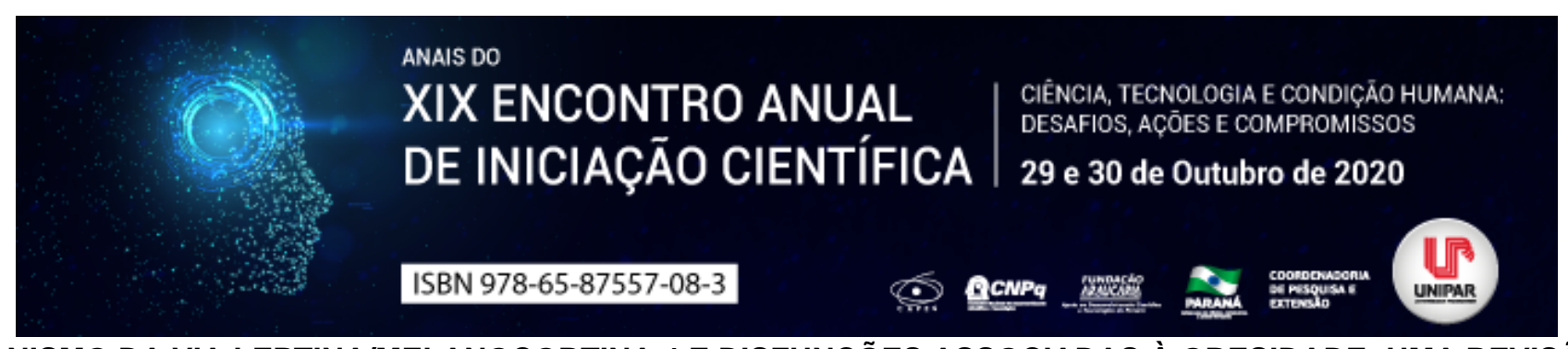

MECANISMO DA VIA LEPTINA/MELANOCORTINA 4 E DISFUNÇÕES ASSOCIADAS À OBESIDADE: UMA REVISÃO DE LITERATURA

\title{
${ }^{1}$ DAVI CORREA PEREIRA, ${ }^{2}$ LUCIANO SERAPHIM GASQUES
}

\author{
${ }^{1}$ Acadêmico do curso de Medicina da UNIPAR, bolsista PEBIC/CNPQ \\ ${ }^{1}$ Docente da UNIPAR
}

Introdução: A via do receptor hipotalâmico da melanocortina 4 (MC4R) integra o controle da ingestão de alimentos com a produção de hormônios do balanço energético, leptina e insulina, assim, desempenha um importante papel no controle do peso corporal (BALDINI; PHELAN, 2019). Alterações nesta via podem resultar em descontroles, e desta forma mutações associadas a estas proteínas podem gerar variações na regulação do apetite e da saciedade, o que pode acarretar no desenvolvimento de obesidade grave e de início precoce (DUBERN, 2015).

Objetivo: Esta revisão de literatura visa levantar os conhecimentos sobre a via fisiológica na qual integra o receptor hipotalâmico da melanocortina 4 (MC4R) e seu envolvimento no controle do aporte alimentar, bem como do mecanismo que condiciona a obesidade em portadores de mutações no gene MC4R.

Desenvolvimento: Durante o estado alimentado, hormônios liberados na corrente sanguínea são responsáveis pela sinalização de neurônios hipotalâmicos, os quais indiretamente promovem a redução da ingesta e o aumento do gasto calórico na via conhecida como sistema da melanocortina. Dentre tais hormônios, destacam-se a leptina, originária das células adiposas, e a insulina, formada a partir das células $\beta$ pancreáticas. Após a ingestão de alimentos, tornam-se circulantes do plasma sanguíneo, com capacidade de penetração na barreira hematoencefálica, alcançando assim receptores do núcleo arqueado hipotalâmico (BALDINI; PHELAN, 2019). Células hipotalâmicas expressam receptores da leptina (LepR) e da insulina (ISR), também conhecidos como neurônios pró-opiomelanocortina (POMC), responsáveis pela formação de hormônio estimulante amelanócito ( $\alpha-M S H)$ a partir de POMC quando ativados (DUBERN, 2015). O gene MC4R, também conhecido por BMIQ20, tratase de um intronless codificador de peptídeo ligado a membrana pertencente à família dos receptores acoplados à proteína $G$ da melanocortina (GPCRs) (NCBI, 2020). Neurônios MC4R encontrados no núcleo paraventricular (PVN) do hipotálamo são ativados por a-MSH originário de populações neuronais POMC do núcleo arqueado hipotalâmico, resultando em um sinal de saciedade e de controle do aporte alimentar. É também relatado um grupo distinto de neurônios antagonistas de MC4R, a partir da síntese de neuropeptídeo orexigênico $\mathrm{Y}$ (NPY) e de proteína relacionada ao agouti (AgRP) no estado de jejum , responsáveis pela ingestão de alimentos (BALDINI; PHELAN, 2019). Mutações da perda de função (LoF) na via MC4R são responsáveis por diversas formas monogênicas de obesidade precoce, incluindo o hormônio leptina, LepR, $P O M C$ e genes MC4R, além de pró-hormônio convertase 1 (PCSK1), com importante função enzimática (AYERS et al., 2018). Portadores de mutações MC4R apresentam aumento de massa gorda e massa magra, elevada densidade mineral óssea, e marcante hiperfagia precoce. Esta alteração genética caracteriza a causa mais prevalente de obesidade oligogênica conhecida, com tendência à transmissão autossômica dominante, expressão clínica variável, e sem a presença de fenótipos óbvios adicionais (DUBERN, 2015). Alguns fármacos, a exemplo do setmelanotide, têm estimulado a expressão e função do receptor MC4R, resultando em perda de peso em indivíduos obesos que expressam variantes do gene (BALDINI; PHELAN, 2019). A influência da alimentação e da atividade física também é relatada na modulação da via e do fenótipo obeso. Além disso, a sequenciação direta do gene MC4R permite a identificação de alterações mutacionais, podendo fazer-se necessária na seleção de doentes elegíveis para o tratamento (DUBERN, 2015).

Conclusão: Foi possível uma análise bibliográfica dos conhecimentos que sustentam a via leptina/melanocortina 4 no controle do aporte alimentar. Além disso, foi possível a caracterização do gene MC4R e o reconhecimento de sua importância na etiologia e terapêutica da obesidade precoce.

\section{Referências}

AYERS, K. L. et al.. Melanocortin 4 Receptor Pathway Dysfunction in Obesity: Patient Stratification Aimed at MC4R Agonist Treatment. The Journal of Clinical Endocrinology \& Metabolism, $2018 . \quad$ Disponível em: https://www.ncbi.nlm.nih.gov/pmc/articles/PMC7263790/. Acesso em jul. 2020.

BALDINI, Giulia; PHELAN, Kevin D.. The Melanocortin Pathway and Control of Appetite-progress and Therapeutic Implications. Journal of Endocrinology, 2019. Disponível em: https://www.ncbi.nlm.nih.gov/pmc/articles/PMC6500576/. Acesso em jul. 2020. DUBERN, Beatrice. Mutações MC4R e MC3R. In: FRELUT, Marie-Laure. The ECOG's eBook on Child and Adolescent Obesity. 2015. Disponível em: https://ebook.ecog-obesity.eu/. Acesso em: 24. jun. 2020.

NATIONAL CENTER OF BIOTECHNOLOGY INFORMATION. MC4R melanocortin 4 receptor [ Homo sapiens (human) ]. 
Bethesda MD, 07 jun. 2020. Disponível em: https://www.ncbi.nlm.nih.gov/gene?Db=gene\&Cmd=DetailsSearch\&Term=4160. Acesso em: 25 jul. 2020.

Coordenadoria de Pesquisa e Extensão - COPEX

Departamento de Editoraçāo e Divulgaçāo Científica - DEDIC 


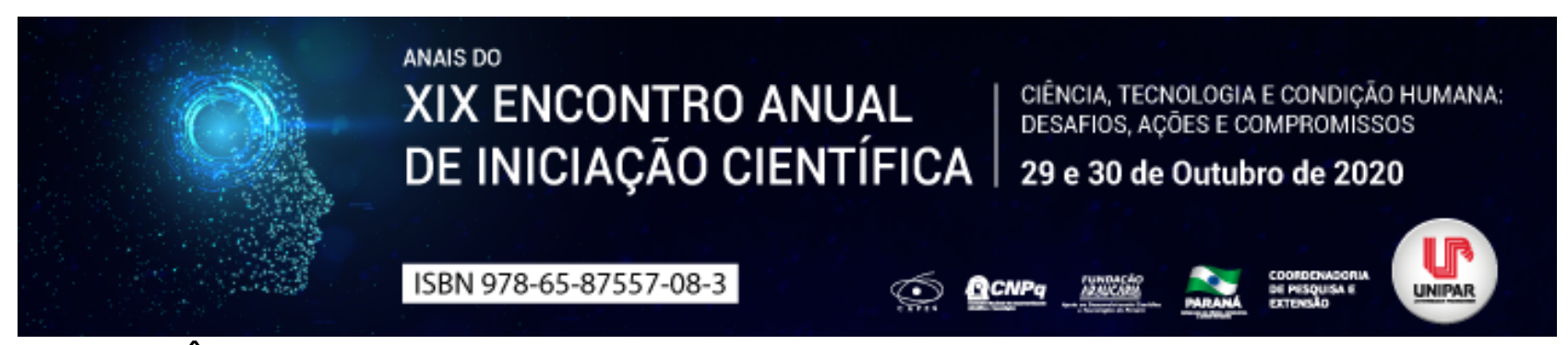

\title{
PERFIL DE RESISTÊNCIA ANTIMICROBIANA DE Escherichia coli ORIUNDAS DE AMOSTRAS DE SWAB DE CARCAÇAS DE FRANGOS DE CORTE
}

\author{
${ }^{1}$ NATALIA SA OLIVEIRA, ${ }^{2}$ IZABELA CAMILOTTI DORNELES, ${ }^{3}$ CAMILA DE CUFFA MATUSAIKI, ${ }^{4}$ ELOISE MARCIELLI \\ MARTINS FERREIRA, ${ }^{5}$ TANIARA SUELEN MEZALIRA, ${ }^{6}$ LUCIANA KAZUE OTUTUMI FARIAS
}

${ }^{1}$ Acadêmica do curso de Medicina Veterinária, UNIPAR, bolsista PIBIC/UNIPAR
${ }^{1}$ Doutoranda em Ciência Animal com Ênfase em Produtos Bioativos, UNIPAR, taxista PROSUP/CAPES
${ }^{2}$ Acadêmica do curso de Medicina Veterinária, UNIPAR, bolsista PEBIC/CNPq
${ }^{3}$ Acadêmica do curso de Medicina Veterinária, UNIPAR, bolsista PIBIC/UNIPAR
${ }^{4}$ Doutoranda em Ciência Animal com Ênfase em Produtos Bioativos, UNIPAR, taxista PROSUP/CAPES
${ }^{5}$ Professora do curso de Medicina Veterinária e do Programa de Pós-graduação em Ciência Animal, UNIPAR

Introdução: Na produção avícola, o principal objetivo é a criação de animais de alta produtividade aliada à qualidade dos produtos finais, e para isso, o melhoramento genético, associado aos avanços da nutrição e manejo, tem sido fundamental (LINZMEIER, 2009). Os antimicrobianos têm sido usados constantemente na produção de frangos de corte para prevenir ou tratar infecções, visando, além disso, a diminuição da mortalidade relacionada com doenças bacterianas, como a colibacilose (QUEIROZ; ALVES; PERES, 2014). A colibacilose é uma doença causada pela bactéria Escherichia coli, a qual pertence à família Enterobacteriaceae, sendo responsável por provocar grandes perdas econômicas na produção de frangos em todo mundo (CORRÊA, 2013). O uso indiscriminado dos antimicrobianos resultou no desenvolvimento de populações bacterianas resistentes, e, além disso, nos últimos anos, o mercado consumidor tem apresentado restrição ao consumo de carne de aves alimentadas com rações tratadas com antimicrobianos (LINZMEIER, 2009). Isso pode ser justificado pelo fato de que são cada vez maiores os índices de resistência bacteriana frente a diversos antimicrobianos de importância para a saúde humana e veterinária (ZANATTA, 2004).

Objetivo: Avaliar o percentual de resistência antimicrobiana de isolados de Escherichia coli oriundos de amostras de swab de carcaça de frango de corte.

Materiais e métodos: Foram isolados seis cepas de Escherichia coli oriundas de amostras de swab de carcaças de frangos de corte de um abatedouro localizado na região oeste do estado do Paraná, após aprovação no Comitê de Ética em Pesquisa Envolvendo Experimentação Animal sob protocolo 35408/2019. Cada amostra foi formada por um pool de 10 swabs de carcaça em diferentes etapas do abate. Para a realização do swab foi utilizado um molde estéril de $25 \mathrm{~cm}^{2}$ o qual foi passado com o uso de um swab estéril em duas áreas de $25 \mathrm{~cm}^{2}$ (peito e dorso), totalizando uma área de pele de $50 \mathrm{~cm}^{2}$, conforme metodologia descrita por Rodrigues et al. (2008). Esses swabs foram acondicionados em sacos plásticos estéreis contendo $30 \mathrm{~mL}$ de água peptonada tamponada a $0,1 \%$, o qual foi posteriormente homogeneizado por um minuto para análise. Com a utilização da técnica de estriamento por esgotamento as amostras foram semeadas em ágar MacConkey para isolamento de bactérias gramnegativas. Após semeadura, as placas foram mantidas em estufa a $37^{\circ} \mathrm{C}$ por 24 horas para isolamento de colônias puras. As colônias de coloração rósea a avermelhada, foram submetidas às provas bioquímicas para identificação da bactéria Escherichia coli. Após identificação, foi feito o ensaio de disco-difusão em ágar (CLSI, 2018). Os antimicrobianos utilizados foram: amoxicilina, ampicilina, gentamicina, tobramicina, amicacina, ciprofloxacina, cefoxitina, ceftriaxona, cloranfenicol, cefotaxima, tetraciclina e sulfazotrim.

Resultados: Verificou-se que o percentual de resistência para os isolados de Escherichia coli variou de zero a $50 \%$ para os diferentes antimicrobianos avaliados. Os antibióticos com maior percentual de resistência foram: gentamicina e sulfazotrim com $50 \%$ de resistência (3/6). Para os antimicrobianos ampicilina e cefotaxima verificou-se 33,33\% de resistência (2/6). Por outro lado, não foi detectada resistência para os antimicrobianos amoxicilina, tobramicina, amicacina e cefoxitina.

Discussão: Segundo Gonçalves (2012) observaram alto perfil de resistência para norfloxacina (83,3\%), tetraciclina (95\%) e eritromicina ( $98 \%$ a $100 \%$ ) em cepas de Escherichia coli oriundas de frangos. O autor ainda enfatiza que tal nível de resistência aos antimicrobianos nas cepas de E. coli demonstra a real necessidade do seu uso correto, em criações de frangos de corte, com o objetivo de tratar possíveis infecções pela bactéria nas aves. A terapia antimicrobiana é uma das medidas de controle para reduzir infecções causadas pela $E$. coli, porém, o seu uso indiscriminado pode resultar no desenvolvimento de populações bacterianas resistentes e que foi encontrado no presente trabalho. Salienta-se ainda que os antimicrobianos com maior perfil de resistência foram oriundos de diferentes classes: aminoglicosídeos (gentamicina), sulfonamidas (sulfazotrim) e betalactâmicos (ampicilina e cefotaxima). Isso demonstra que os isolados de Escherichia coli oriundos de amostras de swab de carcaça de 
frangos de corte, podem estar apresentando perfil de multiresistência, ou seja, resistência a três ou mais classes de antimicrobianos (MOTA; OLIVEIRA; SOUTO, 2018). Em vista disso, recomenda-se que os antimicrobianos sejam utilizados de forma prudente, a fim de preservar o uso terapêutico em animais e seres humanos (CARDOSO et al., 2015).

Conclusão: Verificou-se alto perfil de resistência aos antimicrobianos de isolados de Escherichia coli de carcaças de frangos de corte. Os maiores perfis de resistência foram encontrados para os antimicrobianos: gentamicina, sulfazotrim, ampicilina e cefotaxima. No entanto, mesmo baixos perfis de resistência, podem causar perdas econômicas mundiais, uma vez que o antimicrobiano não agirá da forma desejada no controle das contaminações por bactérias nas carcaças de frango de corte.

\section{Referências}

CARDOSO, A. L. S. P. et al. Resistência antimicrobiana de Escherichia coli isolada de aves comerciais. Biológico, São Paulo, V.81, p. 1-8, 2019.

CORRÊA, F. A. F. Pesquisa de bactérias com determinação do perfil de sensibilidade em vísceras comestíveis de frango de corte, penas e camas de aviários. 2013. 48 f. Dissertação (Mestrado em ciência animal) Universidade federal de Goiás, Goiânia, 2013.

Clinical and Laboratory Standards Institute (CLSI) 2018. Performance standars for antimicrobial susceptibility testing. CLSI document M100. Wayne (PA).

GONÇALVES, P. M. R.. et al. Perfil de resistência antimicrobiana de isolados de Escherichia coli positiva para gene iss em frango de corte na idade de abate. Enciclopédia Biosfera, Goiânia, v.8, n.15, p. 1288-1294, 2012.

LINZMEIER, L. G. et al. Uso de antibióticos em aves de produção. Revista cientifica eletrônica de medicina veterinária, São Paulo, v. 7, n. 12, 2009. Disponível em: http://faef.revista.inf.br/imagens_arquivos/arquivos_destaque/976s3vLOvIY3TKW_20136-24-16-28-21.pdf. Acesso em: 15 ago. 2020.

MOTA, F. S. et al. Perfil e prevalência de resistência aos antimicrobianos de bactérias Gram-negativas isoladas de pacientes de uma unidade de terapia intensiva. Educere: Revista Brasileira de Análises Clinicas, Goiânia , 2018.

QUEIROZ, L. L.; ALVES, T. S.; PERES, J. C. O. Perfil de Sensibilidade das Cepas Escherichia coli Isoladas de Carcaças de Frangos Congelados Comercializados no Distrito Federal. In: CONGRESSO LATINO AMERICANO DE MICROBIOLOGIA E HIGIENE DE ALIMENTOS, 12...2014, São Paulo. Anais [...]. São Paulo: Blucher, 2014.

RODRIGUES, D. R. et al. Jejum pré-abate e suas implicações no metabolismo animal, integridade intestinal e qualidade da carne de frangos de corte. Enciclopédia Biosfera, Goiânia, v. 13, n .24, p.616-629, 2016.

ZANATTA, G. F. et al. Suscetibilidade de amostras de Escherichia Coli de origem aviária a antimicrobianos. Arquivos do Instituto Biológico, São Paulo, v.71, n.3, p.283-286, 2004. 


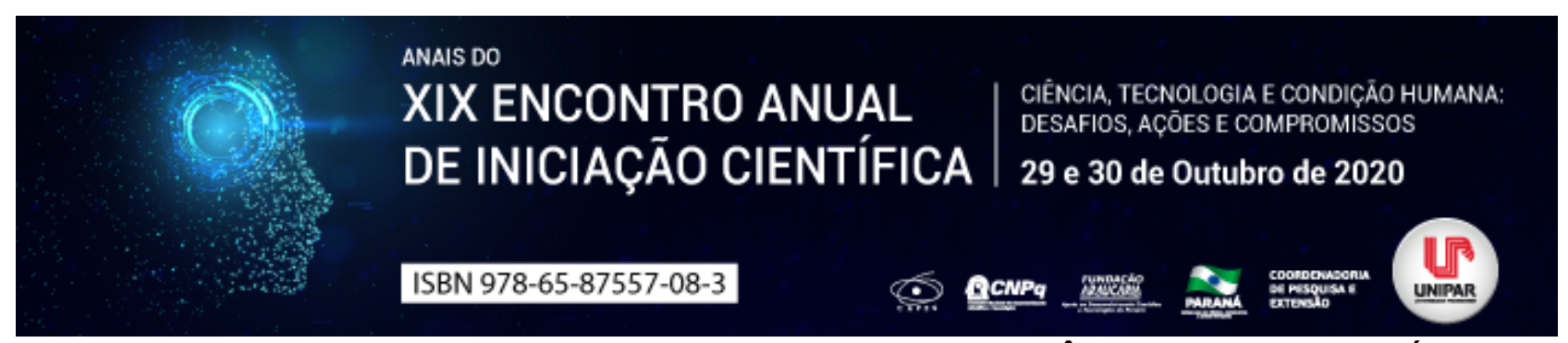

\title{
ATIVIDADE ANTIOXIDANTE DO EXTRATO DE Origanum vulgare E SUA INFLUÊNCIA EM PRODUTO LÁCTEO DURANTE ARMAZENAMENTO REFRIGERADO
}

\author{
${ }^{1}$ MARCO AURELIO CUNHA DEL VECHIO, ${ }^{2}$ ISABELA CARVALHO DOS SANTOS, ${ }^{3}$ ISABEL CRISTINA DA SILVA CAETANO, \\ ${ }^{4}$ JUNIOR CEZAR BARBOSA, ${ }^{5}$ ANDREIA ASSUNÇÃO SOARES, ${ }^{6}$ LIDIANE NUNES BARBOSA
}

\author{
${ }^{1}$ Médico(a) Veterinário(a), Mestrando em Ciência Animal com Ênfase em Produtos Bioativos, Bolsista Prosup/CAPES, UNIPAR \\ ${ }^{1}$ Doutorando em Ciência Animal com Ênfase em Produtos Bioativos, Bolsista Prosup/CAPES, UNIPAR. \\ ${ }^{2}$ Doutorando em Ciência Animal com Ênfase em Produtos Bioativos, Bolsista Prosup/CAPES, UNIPAR. \\ ${ }^{3}$ Nutricionista. \\ ${ }^{4}$ Docente do Programa de Pós Graduação em Ciência Animal, UNIPAR. \\ ${ }^{5}$ Docente do Programa de Pós Graduação em Ciência Animal, UNIPAR.
}

Introdução: As plantas são conhecidas por fornecerem sabor e aroma. Estudos comprovam o potencial antioxidante como estas muitas vezes estão inseridas nos grupos alimentares e a busca pela população por uma alimentação saudável, pesquisas relacionadas ao uso das plantas como conservantes em alimentos é crescente, principalmente pela aceitação (TRAJANO et al., 2009). O orégano (Origanum vulgare L.) é uma erva arbustiva e perene, nativa da Europa e Ásia, sendo catalogadas 38 espécies deste gênero no mundo (ALIGIANNIS et al., 2001). As propriedades conservantes estão relacionadas aos óleos essenciais, ácidos orgânicos, ésteres, fenóis e os álcoois, por possuírem potencial antibacteriano e características antioxidantes (STEURER, 2008). A oxidação lipídica, impõe obstáculos relacionados ao tempo de vida útil e de prateleira de gorduras e óleos (RAMALHO; JORGE, 2005).

Objetivo: Demonstrar a relevância do uso do extrato de Origanum vulgare como potencial antioxidante no produto lácteo durante armazenamento refrigerado.

Material e Métodos: As plantas foram cultivadas em canteiros experimentais no horto medicinal localizado no Campus 2 da Universidade Paranaense, Umuarama, Paraná. Folhas e caules foram depositados em bandejas e secas em estufa com circulação de ar a $40^{\circ} \mathrm{C}$ por 24 horas. Após a secagem, o material foi peneirado e armazenado a $-20^{\circ} \mathrm{C}$ protegidos da luz. A obtenção do extrato hidroalcoólico a $70^{\circ}$ foi realizada pela adição do respectivo solvente ao orégano. $\mathrm{O}$ extrato foi liofilizado e conservado em freezer. O preparo do queijo frescal foi realizado em laticínio local de pequeno porte sendo utilizado leite, sal (15 $\mathrm{g} / \mathrm{L})$, cloreto de cálcio $(0,25 \mathrm{~mL} / \mathrm{L})$ e enzimas coagulantes de mucor miehei $(0,08 \mathrm{~mL} / \mathrm{L})$. Foram produzidas oito unidades de cada tipo de amostra e essas após a dessoragem foram acondicionadas, embaladas e mantidas a temperatura de $4^{\circ} \mathrm{C}$. Sendo intitulado 3 tratamentos controles $1(0,5 \mathrm{~g}), 2(1 \mathrm{~g})$ e $3(3 \mathrm{~g})$ de Extrato de Orégano. A oxidação lipídica do queijo foi avaliada medindo-se o conteúdo de malondialdeído (MDA) usando o teste 2-tiobarbitúrico (WVYNCKE, 1970). Os resultados foram expressos em miligramas de MDA por quilo de amostra. O teste de substâncias reativas ao ácido tiobarbitúrico baseou-se na reação do ácido tiobarbitúrico com os produtos de decomposição de hidroperóxidos (BORGES et al, 1999).

Resultados: Os testes realizados revelaram que o queijo independente de tratamento, teve pouca oxidação e, portanto, não foi estatisticamente significativo a ação do orégano no $7^{\circ}, 15^{\circ}$ e $30^{\circ}$ dia de armazenamento, porém no queijo controle tratado 3 ( $3 \mathrm{~g}$ de Extrato de Orégano) notou-se redução da oxidação lipídica.

Discussão: As indústrias alimentícias tem buscado evitar a potencial nocividade dos aditivos alimentares sintéticos e desenvolver novos alimentos funcionais contendo ingredientes promotores da saúde (CALEJA et al., 2015). Sendo assim muitas pesquisas vem sendo desenvolvidas enfatizando a busca de compostos alternativos úteis e viáveis para um emprego racional como conservantes naturais na produção de alimentos (SOUZA et al., 2005). Em uma pesquisa realizado, Diego (2010), relata de forma significativa a conservação de pizzas prontas utilizando o óleo essencial de Origanum vulgare. Joelmir (2015), apontou que o óleo essencial de orégano apresentou uma boa atividade antioxidante, com valores de $\mathrm{EC}_{50}$ aproximados aos de compostos considerados como de excelente capacidade de conservação de queijos frescos. Brewer (2011), relata que o óleo essencial de O. vulgare, pode apresentar sinergia entre outros antioxidantes de formula, potencializando sua ação, demostrado em um estudo realizado associando eritorbato de sódio a linguiça suína frescal.

Conclusão: A busca por formas de conservação de alimentos frescos é um desafio para a indústria, a modo de prolongar a vida de prateleira dos produtos, a redução significativa da oxidação lipídica é promissora. Pesquisas são necessárias visando formas de aproveitamento do potencial conservante do Origanum vulgare a fim ampliar a oferta de alimentos saudáveis.

\section{Referências}

ALIGIANNIS, N. Composição e atividade antimicrobiana dos óleos essenciais de duas espécies de Origanum. Journal Of 
Agricultural and Food Chemistry. Sep, 2001.

BORGES, M. F. M.; SILVA, F. A. M.; FERREIRA, M. A. Métodos para avaliação do grau de oxidação lipídica e da capacidade antioxidante. Química Nova, Portugal, v. 22, n. 1, p. 94-103, 1999.

Brewer, M. S. Natural Antioxidants: Sources, Compounds, Mechanisms of Action, and Potential Applications. Comprehensive Reviews in Food Science and Food Safety, v.10, p.221-247, 2011.

CALEJA, C. et al. Foeniculum vulgare Mill. as natural conservation enhancer and health promoter by incorporation in cottage cheese. Journal of Functional Foods, Portugal, v. 12, p. 428-438, Jan. 2015.

DIEGO, A. B. et al. Avaliação de filme incorporado com óleo essencial de orégano para conservação de pizza pronta. Revista Ceres. São Paulo, v. 57, n. 3, p. 283-291, Jun. 2010.

JOELMIR, P. G. Produção e conservação de queijos frescos adicionados de óleos essenciais. Universidade Federal do Rio Grande, Santo Antônio da Patrulha, 2015.

RAMALHO, V. C, JORGE, N. Antioxidantes utilizados em óleos, gorduras e alimentos gordurosos. Quimica Nova. São Paulo, V.4, 2006.

SOUZA, E. L. et al. Orégano (Origanum vulgare L., Lamiaceae): uma especiaria como potencial fonte de compostos antimicrobianos. Higiene Alimentar, São Paulo, v. 19, n.132, p. 40-45, Abr. 2005.

STEURER, F. Especiarias: aplicações e propriedades. 2008. 30 f. Trabalho Acadêmico (Bacharelado em Química de Alimentos) - Universidade Federal de Pelotas, 2008.

TRAJANO, V. N.; Lima, E. O.; SOUZA, E. L.; TRAVASSOS, A. E. R. Propriedade antibacteriana de óleos essenciais de especiarias sobre bactérias contaminantes de alimentos. Ciência e Tecnologia de Alimentos, Campinas, v. 29, n. 3, p. 542-545, Set. 2009.

WVYNCKE, W. Direct determination of the thiobarbituric acid value in trichloroacetic acid extracts of fish as a measure of oxidative rancidity. Fette-Scifen Anstrichmittel, Belgica, v. 72, p. 1084-1087, 1970. 


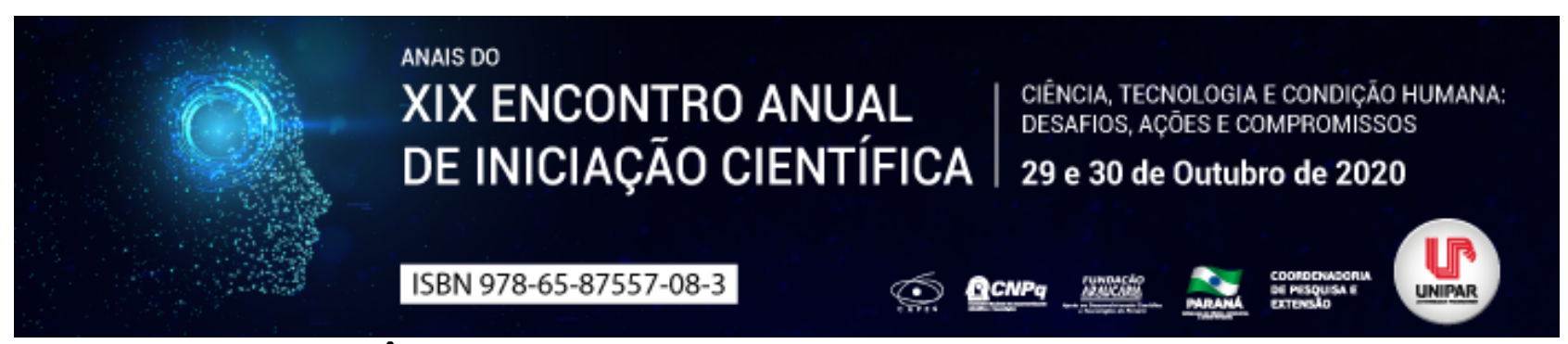

CONTROLE DA ÊMESE NA QUIMIOTERAPIA: EFEITOS PROMISSORES DO GENGIBRE

\begin{abstract}
${ }^{1}$ MARIA EDUARDA GUIMARAES DOS SANTOS, ${ }^{2}$ EDUARDA CAROLINA AMARAL, ${ }^{3}$ FRANCISLAINE APARECIDA DOS REIS LIVERO
\end{abstract}

\author{
${ }^{1}$ Discente do Curso de Farmácia/PIC-UNIPAR \\ ${ }^{1}$ Discente do Mestrado Profissional em Plantas Medicinais e Fitoterápicos na Atenção Básica, Bolsista PIT \\ 2Docente do Mestrado Profissional em Plantas Medicinais e Fitoterápicos na Atenção Básica e do PPG em Ciência Animal - \\ UNIPAR
}

Introdução: O gengibre (Zingiber officinale Roscoe) originário das florestas tropicais do Sudoeste da Ásia, atualmente é cultivado nas Antilhas, Havaí, África, Austrália e no Brasil (PALHARIN et al., 2008). É uma planta conhecida pelos seus nutrientes, sendo muito utilizado tanto na culinária quanto na medicina. Seu princípio ativo, o chamado de gingerol, além de promover o sabor picante do gengibre, apresenta importantes ações anti-inflamatória, antiemética e antioxidante (PRATO, 2010), ultimamente vem sendo conhecido por aliviar náusea e vômito durante a quimioterapia realizada para o tratamento de pacientes com câncer, doença que vem crescendo substancialmente a cada dia. Em 2020 o número de novos casos registrados em homens foi de 65.840, já em mulheres foi de 66.280 (INCA 2020).

Objetivo: Revisar a literatura descrevendo os efeitos do gengibre sobre a náusea e o vômito de pacientes oncológicos, apresentando o Zingiber officinale como tratamento alternativo para o controle de efeitos adversos gástricos da quimioterapia.

Desenvolvimento: Se o vômito não for controlado rapidamente, os pacientes podem sofrer por desnutrição, danos na mucosa, ruptura do trato intestinal e pneumonia por aspiração (PALATTY et al., 2013). Um estudo realizado com 22 pacientes com câncer em que já tinham realizado duas sessões de quimioterapia, receberam antieméticos e mais 4 cápsulas comestíveis de gengibre. Observou-se diminuição significativa de náuseas e vômitos, comparados aos outros 22 pacientes que receberam placebo (MONTAZERI et al., 2013). Em pacientes de 8 à 21 anos com sarcomas ósseos recém diagnosticados em tratamento com antieméticos, utilizou-se o pó da raiz do gengibre em cápsula (1 e $2 \mathrm{~g}$ para pacientes entre 20 e $40 \mathrm{~kg}$ ou entre 40 e $60 \mathrm{~kg}$, respectivamente) como terapia complementar e mostrou resultados positivos para a diminuição da NVIQ aguda tardia (PILLAI et al., 2010). Os resultados destas pesquisas são promissores, embora as pesquisas tenham sido conduzidas em diferentes tipos de câncer, o que dificulta a comprovação da eficácia geral do uso do gengibre como terapia adjuvante na quimioterapia. Cada tipo de câncer possui um protocolo quimioterápico a ser seguido, então não se pode comprovar ou recusar a eficácia do gengibre no uso contra náusea e vômito causados pela quimioterapia e nem basear em resultados por tipo de câncer ( ZICK et al. 2008).

Conclusão: Os estudos apresentados mostraram resultados significativos para comprovação da eficácia do uso do gengibre, porém, não são conclusivos. Testes devem ser realizados para comprovar a eficácia do uso terapêutico do gengibre para o controle de náuseas e vômitos induzidos pela quimioterapia.

\title{
Referências
}

BRAY, Freddie; FERLAY, Jacques; SOERJOMATARAM, Isabelle; SIEGEL, Rebecca; TORRE, Lindsey; JEMAL, Ahmedin. Estatísticas globais de câncer 2018: estimativas GLOBOCAN de incidência e mortalidade em todo o mundo para 36 cânceres em 185 países. CA: um jornal de câncer para clínicos v. 68, n. 6, pág. 394-424, 2018.

INCA Estimativa de Câncer no Brasil, 2020. Disponível em: inca.gov.br/numeros-de-cancer. Acesso em: 17 ago. 2020.

MONTAZERI, Sadat, Akram; RAEI, Mehdi; GHANBARI, Atefeh.; DADGARI, Ali.; HAMIDZADEH, Azam. Effect of herbal therapy to intensity chemotherapy-induced nausea and vomiting in cancer patients. Iranian Red Crescent Medical Journal, v. 15, n. 2, pág. 101, 2013.

PALATTY, Princy Louis; HANIADKA, Raghavendra; VALDER, Bacyshia; ARORA, Rajesh.; BALIGA, Manjeshwar Shrinath. Ginger in the prevention of nausea and vomiting: a review. Critical reviews in food science and nutrition, v. 53, n. 7, p. 659-669, 2013.

PALHARIN, Luiz Henrique di Creddo; FIGUEIREDO NETO, Eliseu; CAMARGO LOPES, Matheus Pereira; BOSQUÊ, Gislaine Galvão. Estudo sobre gengibre na medicina popular. Revista Científica. 2008.

PILLAI, Anu Kochanujan; SHARMA, Kamlesh; GUPTA, Yogendra; BAKHSHI, Sameer. Anti-emetic effect of ginger powder versus placebo as an add-on therapy in children and young adults receiving high emetogenic chemotherapy. Pediatric blood \& cancer, v. 56, n. 2 , p. $234-238,2011$.

PRATO, Tiago Sartorelli. Influência da secagem sobre compostos medicinais e de pungência do gengibre. Dissertação (Mestrado) - Universidade Estadual Paulista, Instituto de Biociências, Letras e Ciências Exatas, 2010.

ZICK, Suzanna; DJURIC, Zora; RUFFIN, Mack; LITZINGER, Amie; NORMOLLE, Daniel; ALRAWI, Sara; BRENNER, Dean. 
Pharmacokinetics of 6-gingerol, 8-gingerol, 10-gingerol, and 6-shogaol and conjugate metabolites in healthy human subjects. Cancer Epidemiology and Prevention Biomarkers. v. 17, n. 8. p. 1930-1936, 2008.

Coordenadoria de Pesquisa e Extensão - COPEX

Departamento de Editoraçāo e Divulgaçāo Científica - DEDIC 


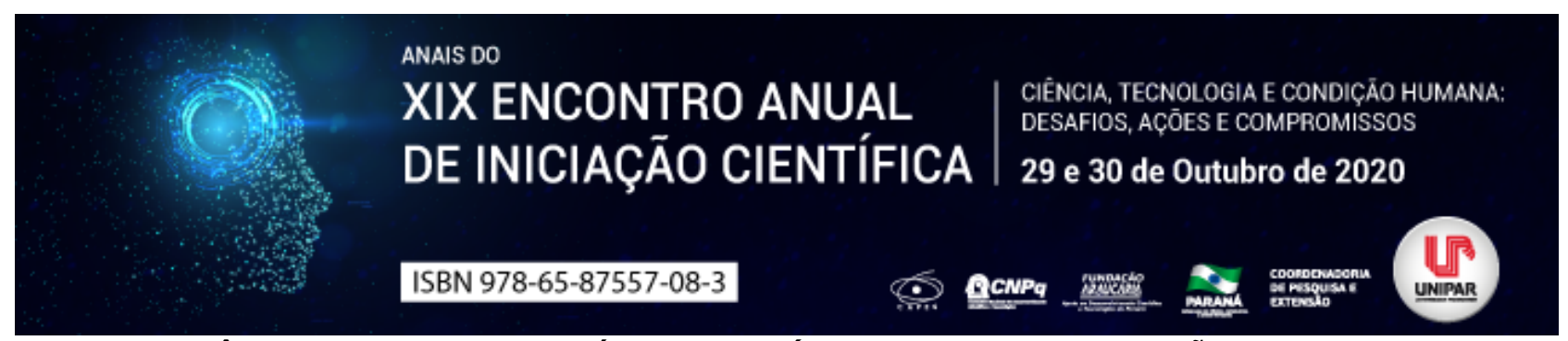

A IMPORTÂNCIA DA CISTITE IDIOPÁTICA NA CLÍNICA DE FELINOS: REVISÃO DE LITERATURA

\begin{abstract}
${ }^{1}$ Karen Verdério Mariano, ${ }^{2}$ ANA PAULA NUNES RODRIGUES,${ }^{3}$ CAROLINE HELENA ROCHA , ${ }^{4}$ GABRIELY AMARO DE OLIVEIRA BORGES, ${ }^{5}$ LARISSA BATISTA DA SILVA, ${ }^{6}$ MAURO HENRIQUE BUENO DE CAMARGO
\end{abstract}

\begin{abstract}
${ }^{1}$ Acadêmica da Universidade Estadual de Maringál Campus Umuarama
${ }^{1}$ Acadêmica da Universidade Estadual de Maringál Campus Umuarama

${ }^{2}$ Acadêmica da Universidade Estadual de Maringál Campus Umuarama

${ }^{3}$ Acadêmica da Universidade Estadual de Maringál Campus Umuarama

${ }^{4}$ Acadêmica da Universidade Estadual de Maringál Campus Umuarama

${ }^{5}$ Docente da Universidade Estadual de Maringá - DMV - Umuarama
\end{abstract}

Introdução: O termo cistite refere-se a uma inflamação vesical e o termo idiopática caracteriza a etiologia desconhecida da doença (OLIVEIRA et al., 2017). Felinos em que os sinais clínicos não se restringem ao trato urinário inferior, manifestando-se em outros sistemas como gastrointestinal, cardiovascular e outros, se enquadram na denominada Síndrome de Pandora, ainda de caráter idiopático (OLIVEIRA et al., 2017).

Objetivo: Revisar os aspectos fisiopatológicos, principais sinais clínicos, métodos de diagnóstico bem como os possíveis tratamentos da cistite idiopática felina,

Desenvolvimento: Na rotina médico-veterinária, a doença do trato urinário inferior dos felinos é comum. Entre as causas, observa-se a urolitíase, estenoses uretrais, cistite bacteriana, traumas e outros, mas, quando não identificada a causa, diagnostica-se como cistite idiopática felina (CIF). A doença pode também se classificar em obstrutiva e não obstrutiva (ASSIS e TAFFAREL, 2018). A obstrutiva é a mais comum (SANTOS e ALESSI, 2016). A CIF causa uma inflamação intersticial da bexiga, de etiologia desconhecida, isto é, idiopática (NUNES, 2015). Considera-se que fatores estressantes, sistema nervoso simpático (SNS) e resposta do eixo hipotálamo hipófise adrenal estão relacionados a esse processo (MORAIS; VIANA, 2019). Devido suas diversas formas de manifestação, presume-se que a CIF se refere a uma patologia de diferentes razões, como obesidade, confinamento e conflitos com outros gatos. (FORRESTER; TOWELL, 2015; SPARKES, 2018). O estresse contínuo nos gatos desencadeia uma série de fatores neurológicos até ser identificado como CIF, assim, ao receber o estímulo estressante de forma crônica, o hipotálamo é estimulado a liberar corticotrofinas, e a hipófise anterior ou adeno-hipófise irá liberar o hormônio corticotrófico, estimulando os núcleos do tronco cerebral a ativar o sistema nervoso simpático (SNS), levando a produção de epinefrina e norepinefrina. Assim, em gatos com CIF, o SNS excitatório passa a ser inibido erroneamente pelos esteróides adrenocorticais, como por exemplo o cortisol, logo imagina-se que o aumento da atividade simpática eleve a permeabilidade do epitélio da vesícula urinária, aumentado a atividade sensorial aferente, levando aos sinais clínicos observados. O mesmo processo de estresse e liberação de corticotrofinas em gatos normais teria outro resultado, nesse caso ocorreria um feedback negativo no hipotálamo, tronco cerebral e hipófise anterior pela ação dos corticoesteróides (FORRESTER; TOWELL, 2015). O sistema de resposta ao estresse eleva sua atividade no SNS aumentando a vazão da medula espinhal para a vesícula urinária, julga-se que esse aumento leve a uma inflamação neurogênica, elevando a permeabilidade da mucosa da bexiga e, além disso ocorre a liberação de citocinas inflamatórias das células do epitélio da bexiga e exacerbação da sensibilidade dos nervos aferentes. Deste modo, o cérebro recebe a informação que chega até ele pelas vias aferentes da bexiga como um estímulo doloroso, potencializando o estresse e resultando em um ciclo vicioso envolvendo o cérebro e a bexiga urinária, sendo necessário uma abordagem direcionada a essas duas áreas durante o tratamento do gato com CIF (BURNS, 2015). A CIF é diagnosticada por exclusão, isto é, devido à ausência de sinais patognomônicos deve-se avaliar e excluir todas as outras possíveis causas de DTUIF (ASSIS e TAFFAREL, 2018; JÚNIOR, 2019). Deve-se proceder uma boa anamnese, detalhando o histórico do paciente, inclusive alimentar e ambiental, conhecendo a evolução dos sinais clínicos e as alterações de comportamento (ASSIS e TAFFAREL, 2018; JÚNIOR, 2019). Em seguida um exame físico adequado deve revelar se a doença é obstrutiva ou não. No primeiro caso nota-se vesícula distendida e repleta, no segundo ocorre pequena repleção e parede espessada (JÚNIOR, 2019). Alguns exames complementares úteis são urinálise, cultura de urina, hemograma, bioquímico sérico e exames de imagem (radiografia, ultrassonografia, cistografia, cistoscopia e uroendoscopia) (ASSIS e TAFFAREL, 2018; JÚNIOR et al., 2019; OLIVEIRA et al., 2017). Os sinais clínicos mais relatados são periúria, polaquiúria, hematúria, estrangúria, disúria, tentativas múltiplas e prolongadas de urinar com vocalização e agitação, lambedura compulsiva das zonas perineal/inguinal e alopecia (GUNN-MORE, 2008 apud ALHO et al.,2016). O tratamento consiste em diminuir os sintomas, reduzir a frequência de manifestações clínicas e aumentar a sobrevida do animal já que não há cura (JÚNIOR et al., 2019). Ao realizar o diagnóstico, e constatar obstrução o animal deve ser estabilizado com fluidos intravenosos e em seguida proceder uma 
cistocentese descompressiva (NELSON; COUTO, 2015). Os fármacos utilizados são anti-inflamatórios, ansiolíticos, analgésicos, anti-depressivos, além de feromônios que reduzem a ansiedade e sinais clínicos (NELSON; COUTO, 2015). O tratamento da CIF não obstrutiva é a abordagem de Modificação Multimodal Ambiental (OLIVEIRA et al., 2017).

Conclusão: Conhecer a fisiopatologia e a clínica da CIF é fundamental para o tratamento adequado do paciente felino por ela acometido.

\section{Referências}

ALHO, A. M.; PONTES, J. P.; POMBA, C. Epidemiologia, Diagnóstico e Terapêutica da Cistite Idiopática Felina. Revista Electronica de Veterinaria, v. 17, n. 11, 2016. Disponível em: http://www.veterinaria.org/revistas/redvet

ASSIS, M.F.; TAFFAREL, M.O. Doença do trato urinário inferior dos felinos: abordagem sobre cistite idiopática e urolitíase em gatos. Enciclopédia Biosfera Centro Científico Conhecer, v.15, n. 27, p. 390-404, 2018.

BURNS, K. FIC why all the stress? National Association of Veterinary Technicians in America, p. 8 11, 2015.

FORRESTER, S. D.; TOWELL, T. L. Feline Idiopathic Cystitis. Veterinary Clinics of North America - Small Animal Practice, v. 45, n. 4, p. $783806,2015$.

FRANCISCO ANTÔNIO FÉLIX XAVIER JÚNIOR et al. A CISTITE IDIOPÁTICA FELINA: O QUE DEVEMOS SABER. Ciência Animal, v.29, n.1, p. 63, 2019.

JÚNIOR, F. A. F. X. et al. A Cistite Idiopática Felina: O que devemos saber. Ciência Animal, v. 29, n. 1, p. 63-82, 2019.

MORAIS, G. B. DE; VIANA, D. D. A. A CISTITE IDIOPÁTICA FELINA: O QUE DEVEMOS SABER. Ciência Animal, v. 29, n. 1, p. 63 82, 2019.

NELSON, R. W.; COUTO, C. G. Medicina Interna de Pequenos Animais. 5. ed. Rio de Janeiro: Elsevier Editora Ltda., 2015.

NUNES, M. Clínica e Cirurgia de Animais de Companhia - Cistite Idiopática Felina. n. 81, p. 122, 2015.

NUNES, M. B. DOS S. F. Clínica e Cirurgia de Animais de Companhia - Cistite Idiopática Felina. [s.I.] UNIVERSIDADE DE ÉVORA, 2015.

OLIVEIRA, M. R. B. et al. Diagnosticando a cistite idiopática felina: Revisão. PUBVET, v. 11, n. 9, p. 864-876, 2017.

PORTUGAL, A. F.; CASTRO, G. RELAÇÃO ENTRE DOENÇA DO TRATO URINÁRIO E FATORES DE STRESSE AMBIENTAL EM GATOS. Repositório Científico Lusófona, p. 66, 2015.

SANTOS, R.L.; ALESSI, A.C. Patologia Veterinária. 2.ed. Rio de Janeiro: Roca, 2016. 856p.

SPARKES, A. Understanding feline idiopathic cystitis. Veterinary Record, n. April, p. 486 487, 2018.

Coordenadoria de Pesquisa e Extensão - COPEX

Departamento de Editoraçāo e Divulgaçāo Científica - DEDIC 


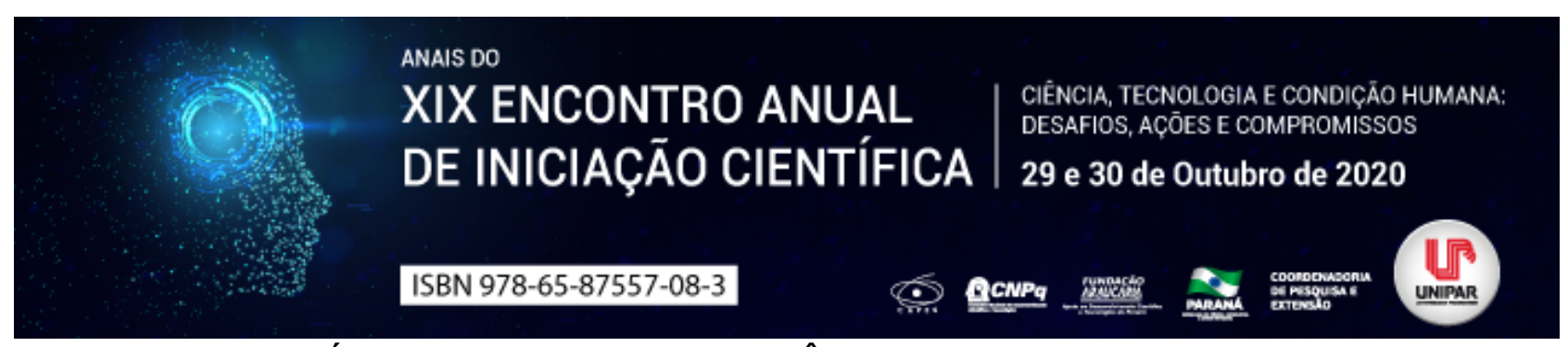

USO DE ÓLEOS ESSENCIAIS NA TERAPÊUTICA DA OTITE EXTERNA CANINA

\author{
${ }^{1}$ Fernanda Zandoná de Oliveira, ${ }^{2}$ DANIELA THAIS FERREIRA, ${ }^{3}$ FERNANDA DE PAULA ROLDI VIEIRA
}

\author{
${ }^{1}$ Discente do curso de Medicina Veterinária Universidade Estadual de Maringá, campus Umuarama. \\ ${ }^{1}$ Médica Veterinária Universidade Estadual de Maringá, campus Umuarama. \\ ${ }^{2}$ Mestre em Ciências Veterinárias Universidade Federal do Espírito Santo
}

Introdução: Otite externa é a inflamação do meato acústico externo, podendo envolver também o pavilhão auricular. Alguns fatores favorecem a ocorrência dessa infecção em cães, tais como predisposição racial, estenose de canal auditivo e umidade no local (FONSECA, 2018). Os agentes mais presentes no canal auditivo externo de cães portadores de otite externa são as bactérias dos gêneros Staphylococcus, Streptococcus, Pseudomonas, Proteus, Corynebacterium, Enterococcus, coliformes e leveduras do gênero Malassezia (FONSECA, 2018). Os micro-organismos S. pseudointermedius, Streptococcus sp. e Malassezia sp. compõem a microbiota natural dos cães, entretanto a ocorrência de disbioses nesta região podem favorecer a multiplicação destes, ocasionando infecção (OLIVEIRA, 2004). Atualmente a resistência bacteriana aos antimicrobianos é considerada um grave problema de saúde pública (MATSUNAGA; HAYAKAWA, 2018) e diversos estudos tem demonstrado a presença de microorganismos multirresistentes em infecções otológicas (CARVALHO et al., 2018; BOURÉLY et al., 2019), levando a um aumento na busca por alternativas aos tratamentos alopáticos convencionais. Nesse contexto, os óleos essenciais (OEs) são aplicáveis como alternativa natural e biologicamente ativa, tendo sua atividade antimicótica e antibacteriana demonstrada em diversos estudos (DANTAS, 2018).

Objetivo: Esta revisão tem por objetivo reunir e difundir informações sobre o uso dos OEs como alternativa aos antimicrobianos sintéticos com ênfase no tratamento da otite externa canina.

Desenvolvimento: Em um estudo realizado por Carvalho et al. (2018) foi traçado o perfil de resistência dos isolados de Staphylococcus spp. resistentes à meticilina (SMR) em cães com otite externa, no qual se demonstrou que a ocorrência de 11,47\% de SMR, evidenciando a ocorrência crescente destes microrganismos nas infecções otológicas. Oliveira et al. (2009) avaliaram o efeito inibitório do óleo essencial de aroeira sobre os microrganismos presentes em otites de cães atendidos no Hospital Veterinário da Universidade Federal de Pernambuco. Alguns dos pacientes submetidos ao teste não apresentaram cura microbiológica, porém, obtiveram redução da sintomatologia clínica apresentada inicialmente, como dor, prurido e secreção. Os resultados obtidos sugerem que o OE de aroeira apresenta potencial inibitório frente a alguns agentes etiológicos presentes na infecção otológica, mas sua ação varia conforme a concentração utilizada, uma vez que a 0,1\% teve efeito contra Proteus sp., a 0,5\% contra Staphylococcus spp. e na concentração de 1\% contra Malassezia sp., Staphylococcus spp. e Proteus sp. Um experimento desenvolvido por Jesus (2011) avaliou a suscetibilidade de isolados de Malassezia sp. sensíveis e resistentes ao fluconazol frente aos OEs de orégano, orégano mexicano e canela. Os resultados demonstraram atividade fungicida in vitro destes OEs frente a Malassezia sp., independente da sensibilidade ou resistência ao fluconazol. Nos estudos realizados por Sim et al. (2019) avaliou-se a atividade in vitro dos OEs de orégano, de tomilho, bem como seus componentes majoritários carvacrol e timol frente a 100 isolados de cães com otite externa. Os dados obtidos revelaram atividade bactericida e fungicida, incluindo de alguns isolados altamente resistentes a antimicrobianos. Esses OEs e seus principais constituintes fenólicos possuem potencial para serem mais investigados in vivo para a terapêutica da otite externa canina. Bismarck et al. (2020) testaram a atividade in vitro de 22 óleos essenciais frente a isolados de Malassezia sp. provenientes de ouvidos caninos, obtendo como resultado que a maioria dos OEs testados foi eficaz in vitro contra M. pachydermatis, com destaque para os OEs de capim-limão, canela, cravo e orégano, os quais demonstraram forte atividade antifúngica. Os autores afirmam que tais resultados fornecem a base científica para a aplicabilidade dos OEs em medicina veterinária, corroborando com os demais autores citados.

Conclusão: Os resultados in vitro demonstram grande potencial de alguns OEs como alternativa às infecções otológicas, incluindo aquelas com presença de microrganismos resistentes, contudo são necessários mais estudos, sobretudo in vivo, onde a aplicabilidade de tais componentes seja demonstrada afim de assegurar seu uso na rotina clínica de animais de companhia.

\title{
Referências
}

BISMARCK, D. et al. Antifungal in vitro activity of essential oils against clinical isolates of Malassezia pachydermatis from canine ears: a report from a practice laboratory. Complementary Medicine Research, v. 27, n. 3, p. 143-154, 2020.

BOURÉLY, C. et al. Antimicrobial resistance patterns of bacteria isolated from dogs with otitis. Epidemiology \& Infection, v. 147, 2019.

CARVALHO, L. C. A. et al. Ocorrência de Staphylococcus spp. resistente à meticilina em otite externa canina. RBAC, v. 51, n. 4, p. 342-7, 2019. 
DANTAS, T. de F. O. de A. Óleos essenciais com atividade contra Pseudomonas aeruginosa: uma revisão integrativa. 2018. (Monografia em Farmácia) Universidade Federal de Campina Grande, Cuité, 2018.

FONSECA, M. P. Otite externa canina : um estudo de caso retrospectivo sobre a etiologia e o perfil de suscetibilidade aos antimicrobianos. 2018. Dissertação (Mestrado Integrado em Medicina Veterinária) Universidade de Lisboa, Lisboa, 2018. JESUS, F. P. K. Susceptibilidade de isolados de Malassezia pachidermatys sensíveis e resistentes ao fluconazol frente à antifúngicos e óleos essenciais. 2011. Dissertação ( Mestrado em farmacologia aplicada à produção animal) Universidade de Santa Maria, Santa Maria, 2011.

MATSUNAGA, N.; HAYAKAWA, K. Estimating the impact of antimicrobial resistance. The Lancet Global Health, v. 6, n. 9 , september, 2018. Disponível em: https://www.thelancet.com/journals/langlo/article/PIIS2214-109X(18)30325-5/fulltext. Acesso em: 04 set. 2020.

OLIVEIRA, D. M. N. M. et al. Avaliação da atividade antimicrobiana do óleo essencial de aroeira (Schinus terebinthifolius, Raddi), em cães com otite externa. Revista Braileira de Medicina Veterinária, Recife, v. 26, p. 79-82, 2004.

SIM, J. X. F. et al. Antimicrobial activity of thyme oil, oregano oil, thymol and carvacrol against sensitive and resistant microbial isolates from dogs with otitis externa. Veterinary Dermatology, v. 30, n. 6, p. 159 e 524, 2019. 


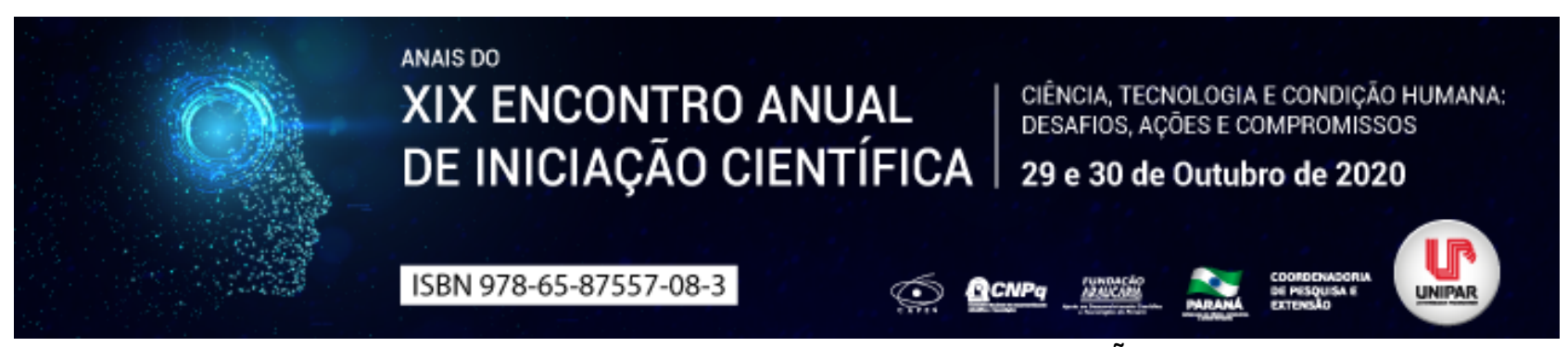

BRUCELOSE NO REBANHO BOVINO REVISÃO

\title{
${ }^{1}$ SARAH LISSONI COBO, ${ }^{2}$ DERICK DE ALMEIDA MARCHI, ${ }^{3}$ FILIPE CORREA PACHECO, ${ }^{4}$ RANULFO PIAU JUNIOR
}

\author{
${ }^{1}$ Acadêmica do PIC UNIPAR. \\ ${ }^{1}$ Acadêmico do PIC UNIPAR. \\ ${ }^{2}$ Mestrando do curso de Pós-graduação de Ciência Animal com ênfase em Produtos Bioativos \\ ${ }^{3}$ Docente da UNIPAR
}

Introdução: A Brucelose é uma zoonose causadora de impactos negativos afetando tanto a saúde animal quanto humana, a mesma possui como agente etiológico as bactérias do gênero Brucella spp (PEREIRA, 2015). Segundo Dias (2018) existem atualmente seis espécies diferentes, podendo ter como hospedeiro várias espécies de animais domésticos e silvestres, inclusive o homem. Entre elas estão: B. abortus (bovinos); B. melitensis (caprinos); B. suis (suínos); B. canis(caninos); B. ovis (ovinos) e B. neotomae (rato do deserto, Neotomae lepida). É considerada uma doença de evolução crônica, que na espécie bovina está relacionada à esfera reprodutiva (VASQUES; NARDI JÚNIOR; MARTINS, 2018). Nas fêmeas é caracterizada pelo o aborto no terço final da gestação (CORBEL, 2006, apud OLIVEIRA, 2016, metrite (inflamação uterina), retenção de placenta, infertilidade e consequentemente queda na produção (NARDI JÚNIOR et al., 2012). Já nos machos, a doença está associada a uma infecção nas glândulas testiculares, a qual caracteriza a vesiculite (RADOSTITS et al.,2007, apud NARDI JÚNIOR et al.), que pode se estender a casos de orquite e epididimite, levando a infertilidade do animal infectado (NICOLETTI,1986).

Objetivo: Discorrer acerca da brucelose bovina e seus meios de prevenção.

Desenvolvimento: As perdas relacionadas a brucelose, no que diz respeito ao rebanho bovino, são atribuídas as bactérias do gênero Brucella abortus a qual, de modo geral, afeta a esfera reprodutiva de todo o rebanho. Levando em consideração os prejuízos causados por essa doença surgiram programas de controle e erradicação da brucelose mundialmente. Neste âmbito, no Brasil, em 2001 foi criado um programa denominado Programa Nacional de Controle e Erradicação da Brucelose e Tuberculose Animal (PNCEBT), cujo objetivo é erradicar a brucelose bovina, bem como a tuberculose. Assim, desde a criação do programa o rebanho bovino brasileiro, especificamente as fêmeas de 3 a 8 meses, vem recebendo vacinação obrigatória, cuja dose é única (MAPA, 2017), contendo bactérias ativas que estimulam a produção de linfócitos T sensibilizados de longa vida, agindo na corrente sanguínea circulando a procura de brucelas livres. Quando estes à encontram, geram uma resposta imune ativando os macrófagos e outros tipos de linfócitos que agem eliminando a infecção (JONES;ROOPER, 1996 apud GUIMARÃES, 2011). Atualmente no mercado existem dois tipos de vacinas para a prevenção da brucelose, sendo respectivamente, B19 e RB51. A primeira (B19) foi descrita pelo médico veterinário bacteriologista do Departamento de Indústria Animal dos Estados Unidos da América, Jonh Buck em 1930, contendo amostras vivas de Brucella abortus, estirpe de B19, sendo estável e causando reações mínimas. Segundo Guimarães (2011) é indicada para fêmeas jovens, pois pode causar orquite nos machos e abortos se aplicada durante a gestação. Contudo, a vacina B19 induz a formação de anticorpos contra o lipopolissacarídeo liso, dando a possibilidade de interferência no diagnóstico sorológico da doença. Já a segunda (RB51), é fabricada a partir de amostras de Brucella abortus rugosa atenuada, possuindo efeitos semelhantes a B19 com a diferença de não ocasionar formação de anticorpos anti-lipopolissacarídeo, não interferindo no diagnóstico sorológico. Alguns estudos apontam ainda que a vacinação com estirpe RB51 garante proteção contra infecções por B. abortus, B. melitensis, B. suis e B. ovis (SCHURIG, 1997 apud GUIMARÃES, 2011).

Conclusão: Dessa maneira, através do presente estudo conclui-se que a prevalência brucelose bovina no pais, em partes, é causada pelo negligenciamento na vacinação, tendo em vista sua obrigatoriedade. Sendo assim, deve-se fazer a prevenção da mesma por meio de monitoramento dos rebanhos e identificação dos animais contaminados através de exames.

\section{Referências}

DIAS, Isabel Cristina Lopes. Prevenção de zoonoses ocupacionais em abatedouros de bovinos. Vivências, Rio Grande do Sul, v. 8, n. 15, p. 89-98, 2012.

GUIMARÃES, Guilherme de Oliveira. Programa Nacional de Controle e Erradicação de Brucelose e Tuberculose Animal (PNCEBT): evolução no controle da Brucelose bovina de 2001 a 2010. Monografia (Bacharelado em Medicina Veterinária). Universidade de Brasília/ Faculdade de Agronomia e Medicina Veterinária, Brasília, 2011.

MINISTÉRIO DA AGRICULTURA, PECUÁRIA E ABASTECIMENTO (MAPA). Instrução Normativa n¹0, de 3 de março de 2017. Diário oficial da União: Brasília, edição 116, seção 1, p. 4, jun. 2017. Disponível em : http://www.in.gov.br/materia/- 
/asset_publisher/Kujrw0TZC2Mb/content/id/19124587/do1-2017\%E2\%80\%9306-20-instrucao-normativa-n-10-de-3-de-marco-de2017\%E2\%80\%9319124353. Acesso em 18 de jul. de 2020.

NARDI JÚNIOR, Geraldo et al. Brucelose em touros: uma visão da doença no Brasil com ênfase ao diagnóstico e sua importância ao agronegócio. Revista Tekhene e Logos, Botucatu-SP, v. 3, n. 3, nov. 2012.

NICOLETTI, P. Brucellosis on bovine reproductive efficiency. In: MORROW, D.A. Current therapy in theriogenoly. Philadelphia: W.B. Saunders, 1986. p.271-274.

OLIVEIRA, C .F. M. Sanidade animal: brucelose. 2012. Relatório final de estágio (Mestrado integrado em Medicina Veterinária). Instituto de Ciências Biomédicas Abel Salazar/ Universidade do Porto, Portugal, 2012.

PEREIRA, L. P. B. Brucelose em pequenos ruminantes Região de Trás-os-Montes e Alto Douro. 2015. Relatório final de estágio (Mestrado integrado em Medicina Veterinária). Instituto de Ciências Biomédicas Abel Salazar/ Universidade do Porto, Portugal, 2015.

VASQUES, Cainan.; NARDI JÚNIOR, G.; MARTINS, E.A. Diagnóstico da brucelose bovina e sua importância ao agronegócio. $7^{a}$ Jornada Científica e tecnológica da FATEC de Botucatu-SP, out./nov. 2018. Disponível em: http://www.jornacitec.fatecbt.edu.br/index.php/VIIJTC/VIIJTC/paper/view/1637. Acesso em 18 de jul. de 2020.

Coordenadoria de Pesquisa e Extensão - COPEX

Departamento de Editoraçāo e Divulgaçāo Científica - DEDIC 


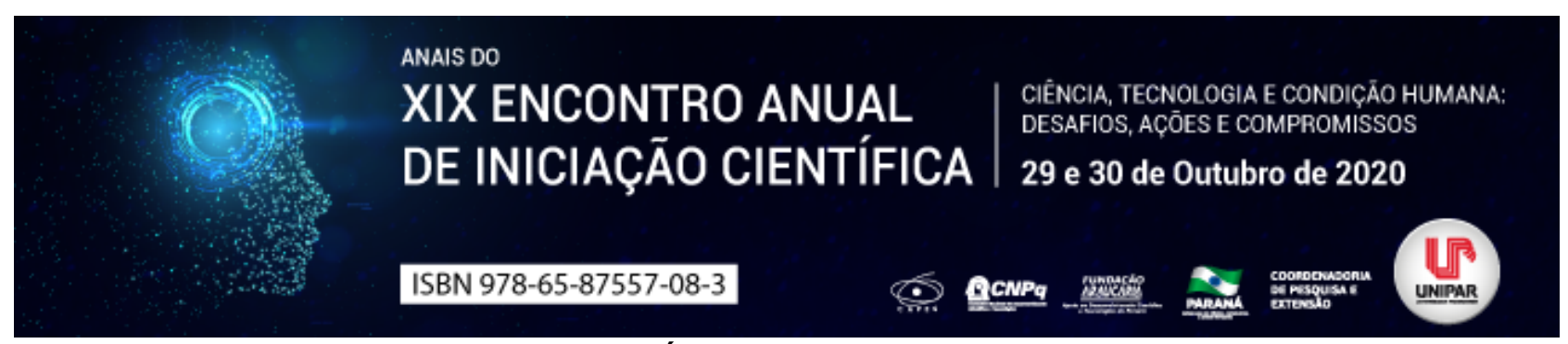

O USO DE PROBIÓTICOS EM BOVINOS LEITEIROS

\title{
${ }^{1}$ JOAO LUIS DOMINGUES FERREIRA, ${ }^{2}$ VICTORIA DOS REIS VOLPATTO, ${ }^{3}$ VANDERSON DOS SANTOS SILVA, ${ }^{4}$ FILIPE CORREA PACHECO, ${ }^{5}$ RANULFO PIAU JUNIOR
}

\author{
$1_{1}$ Discente de Medicina Veterinária PIBIC/UNIPAR \\ ${ }^{1}$ Acadêmica do Curso de Medicina VeterinÃ $\tilde{A}_{j}$ ria da UNIPAR \\ ${ }^{2}$ Acadêmico do Curso de Medicina Veterin $\tilde{A}_{j}$ ria da UNIPAR \\ ${ }^{3}$ Acadêmico do Curso de Medicina VeterinÃ iria da UNIPAR \\ ${ }^{4}$ Docente da UNIPAR
}

Introdução: Nas últimas décadas tem se percebido uma grande preocupação com a segurança alimentar, principalmente no que se refere aos resíduos de antibióticos nos alimentos de origem animal (FILGUEIRAS, 2011). Uma das alternativas tem sido o uso de aditivos probióticos (microrganismos vivos) na dieta de vacas em lactação ou animais em fase de aleitamento (KREHBIEL et al., 2003). Os probióticos tem a capacidade de prevenir a colonização de patógenos indesejáveis no intestino, melhorando a saúde e o desempenho animal, diminuindo ainda o risco de acidose ruminal em vacas leiteiras, melhorando também a resposta imune em vacas e bezerros (FILGUEIRAS, 2011).

Objetivo: Elucidar o mecanismo de ação dos probióticos bacterianos, demonstrando os principais benefícios de seu fornecimento na suplementação de bovinos leiteiros.

Desenvolvimento: Os mecanismos de ação dos probióticos no organismo animal ainda não estão bem definidos, mas acreditasse que os mesmos apresentem pelo menos quatro tipos de mecanismos de ação que causam benefícios ao hospedeiro. Sendo eles: a exclusão competitiva, seja por nutrientes ou por sítios de ativação; síntese de bacteriocinas que agem como antibióticos naturais; prevenção da acidose ruminal; e ativação do sistema imune (GARCIA, 2008). Relatou-se que os microrganismos presentes no trato gastrointestinal (TGI) precisam aderir à mucosa intestinal para produzir suas toxinas, uma vez que a adesão evita que os mesmos sejam eliminados pelos movimentos peristálticos (SALMINEN; ISOLAURI; SALIMEN, 1996). Dessa forma fica evidenciada a importância de se fornecer de forma contínua doses diárias de probióticos, para que se maximize seu efeito benéfico ao hospedeiro (COPPOLA; TURNES, 2004). A maioria dos relatos sobre ação dos probióticos na prevenção de acidose ruminal é atribuído as leveduras, que podem atuar controlando os níveis de oxigênio no ambiente ruminal e estimulando o crescimento de bactérias desejáveis no rúmen através de pequenos grupos de peptídeos não identificados ainda, que estimulam o crescimento desses microrganismos (BARBOSA; DE FARIA; VILELA, 2004). Além de seu papel na digestão e absorção dos nutrientes, o TGI fornece ao animal proteção contra a presença de antígenos presentes nos alimentos e microrganismos patogênicos que colonizam o lúmen intestinal. Estas respostas podem ser inespecíficas (inatas) ou específicas (adaptativas) (KREHBIEL et al., 2003). Os probióticos podem atuar no intestino ativando o sistema imune, reforçando a barreira da mucosa e suprimindo as inflamações intestinais (SAXELIN et al., 2005). De acordo com Timmerman et al. (2005) utilizando um composto com cepas de Lactobacillus, Lactococcus e Enterococcus na alimentação de bezerros recém-nascidos, verificou-se redução nos casos de diarreia, e também no número de dias que os animais permaneciam com diarreia, nos animais que ingeriram probiótico durante o experimento, apresentando diferença estatística $(P<0,05)$ para os animais do grupo controle (TIMMERMAN et al.,2005).

Conclusão: Com o presente trabalho pode-se de forma sucinta elucidar os principais benefícios do uso de probióticos em patologias comuns na produção com bovinos leiteiros e seu mecanismo de ação. Também se faz presente a importância no uso de métodos alternativos para redução do uso de antibióticos e seus resíduos nos produtos de origem animal.

\section{Referências}

BARBOSA, Fabiano Alvim; DE FARIA, Gustavo Alves; VILELA, Herbert. Leveduras vivas na nutricao de bovinos (UMA REVISÃO). Bioscience Journal, v. 20, n. 1, 2004.

COPPOLA, Mario de Menezes; TURNES, Carlos. Probióticos e resposta imune. Ciência rural, v. 34, n. 4, p. 1297-1303, 2004.

FILGUEIRAS, Evando Alves. Aditivos probióticos bacterianos na alimentação de bovinos leiteiro: Fatores genéticos e ambientais que influenciam o desempenho dos animais. Orientador: Dr. Cláudio Ulhôa Magnabosco EMBRAPA CERRADOS. 2011. 6 f. Dissertação (Mestrado Produção Animal) - Universidade Federal de Goiás Escola de Veterinária e Zootecnia Programa de Pós-Graduação em Ciência Animal, Goiânia, 2011.

GARCIA, Gisela. Rojas. Caracterização microbiológica e avaliação de uma cepa de Bacillus subtilis no desempenho de bezerros da raça holandesa. 2008. 68f. Tese (Doutorado em Microbiologia Agropecuária) - Faculdade de Ciências Agrárias e 
Veterinária Universidade Estadual Paulista Julio de Mesquita, Jaboticabal.

KREHBIEL, Clint. R. et al. Bacterial direct-fed microbials in ruminant diets: Performance response and mode of action. Journal of Animal Science, Champaign, v. 81, (Suplemento especial 2), p.120 - 132, 2003.

SALMINEN, S.; ISOLAURI, E.; SALIMEN, E. Clinical uses of probiotics for stabilizing the gut mucosal barrier: successful strains and future challenges. Antonie van Leeuwenhoek, Amsterdam, v. 70, p. 347 358. 1996.

SAXELIN, Maija. et al. Probiotic and other functional microbes: from markets to mechanisms. Current opinion in biotechnology, v. 16, n. 2, p. 204-211, 2005.

TIMMERMAN, Harro. M. et al. Health and growth of veal calves fed milk replacers with or without probiotics. Journal of DairyScience, v. 88, n. 6, p. 2154-2165, 2005. 


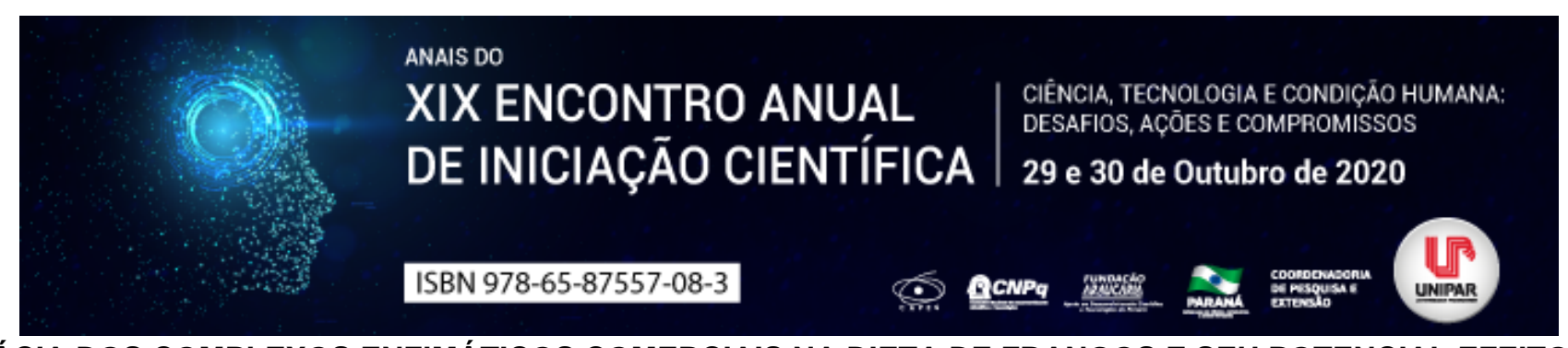

\title{
A EFICÁCIA DOS COMPLEXOS ENZIMÁTICOS COMERCIAIS NA DIETA DE FRANGOS E SEU POTENCIAL EFEITO SOBRE A PRODUÇÃO ANIMAL ESTUDO DE REVISÃO
}

\author{
${ }^{1}$ BRUNA BEATRIZ MARINHO DA SILVA, ${ }^{2}$ EDUARDO HERRERA DIAS, ${ }^{3}$ TANIARA SUELEN MEZALIRA, ${ }^{4}$ PAULA \\ MONTANHINI FAVETTA, ${ }^{5}$ LUCIANA KAZUE OTUTUMI FARIAS, ${ }^{6}$ RICARDO DE MELO GERMANO
}

\author{
${ }^{1}$ Acadêmica do curso de Medicina Veterinária, bolsista PEBIC/CNPq/UNIPAR \\ ${ }^{1}$ Mestrando em Ciência Animal com Ênfase em Produtos Bioativos, UNIPAR, taxista PROSUP/CAPES \\ ${ }^{2}$ Acadêmica do Curso de Doutorado Em Ciencia Animal Com Enfase Em Produtos Bioativos - Turma Iv da UNIPAR \\ ${ }^{3}$ Acadêmica do Curso de Doutorado Em Ciencia Animal Com Enfase Em Produtos Bioativos - Turma V da UNIPAR \\ ${ }^{4}$ Docente da UNIPAR \\ ${ }^{5}$ Docente da UNIPAR
}

Introdução: Os mecanismos envolvidos na absorção de nutrientes são dependentes de células epiteliais que revestem a mucosa intestinal das aves, sendo assim, qualquer alteração em sua integridade interfere no transporte de nutrientes, resultando em falhas no desenvolvimento e engorda da ave (PATRÍcIO et al., 2016). Estudos apontam que a comprovada eficiência de enzimas em dietas tem estimulado seu uso em associação a outros ingredientes, representando um dos principais avanços na nutrição, pois elas podem melhorar a digestão e absorção dos ingredientes, reduzir os efeitos antinutrientes e ainda, fornecer à ave melhor capacidade de digerir componentes da dieta devido a esses fatores, houve crescente interesse no emprego de enzimas exógenas nas dietas das aves.

Objetivo: Avaliar o uso de enzimas na dieta de frangos, ressaltando os inúmeros benefícios que a mesma pode gerar na produção animal, a partir de uma revisão da literatura.

Desenvolvimento: A sobrevivência e o bom desempenho das aves dependem da obtenção adequada de energia e compostos químicos pelo organismo e isso se dá devido a dieta balanceada oferecida a esses animais, além disso para que isso ocorra é necessário que o trato digestivo apresente características estruturais funcionais adequadas (ROMER; PARSONS, 1981). A membrana mucosa do intestino delgado apresenta inúmeras estruturas que aumentam sua superfície e consequentemente aumentam a área de absorção dos nutrientes; uma dessas estruturas são as vilosidades intestinas, que são projeções alongadas da mucosa (epitélio e lâmina própria) em direção ao lúmen do intestino delgado (JUNQUEIRA, 2003). Os processos de absorção são dependentes de mecanismos de transporte que ocorrem na membrana das células epiteliais da mucosa, sendo assim, a integridade destas estruturas é de vital importância, já que é a via de entrada dos nutrientes para o desenvolvimento das aves (MAIORKA et al., 2004). É importante ressaltar que trato gastrintestinal para realizar suas funções possui a inervação extrínseca, formada pelos nervos simpáticos e parassimpáticos, além da inervação intrínseca, constituída pelo SNE (LANGLEY et al., 1921), sendo ele muito sensível as variações na dieta dos animais. Enzimas exógenas têm sido incorporadas às dietas dos animais com o intuito de melhorar o desempenho das aves, pois atuam como catalisadores biológicos no metabolismo dos animais e essas se destacam dentre os aditivos alimentares pois possuem grande eficácia (FORTES et al., 2012). Segundo Fortes et al. (2012) o principal efeito da adição de enzimas nas dietas à base de milho e farelo de soja é a melhoria da digestibilidade dos nutrientes, sendo assim, o aumento no ganho de peso dos animais pode ter ocorrido pela maior disponibilidade de nutrientes, resultando em melhor aproveitamento desses no trato digestivo das aves. Outro fator relevante é que as enzimas têm sido consideradas como componentes naturais alternativos no uso de antibióticos na alimentação animal, porque o uso desses componentes atende à crescente preocupação da opinião pública mundial quanto à redução do uso de produtos químicos na alimentação animal (TEIXEIRA, 2007). A suplementação a partir de um complexo enzimático promove melhor digestibilidade dos nutrientes presentes nas dietas, degradando os complexos de fibras solúveis, reduzindo a viscosidade da digesta através da degradação das arabinoxilanas solúveis das paredes celulares dos grãos, ocasionando melhor digestibilidade dos demais nutrientes. (FORTES et al., 2012). Segundo Conte et al. (2002) e Costa et al. (2004) as aves que fizeram uso de complementação enzimática em suas dietas obtiveram maior ganho de peso do que aves alimentadas com rações sem suplementação enzimática, sendo que segundo Tejedor et al. (2001) o aumento no ganho de peso se deu pela adição da enzima fitase ao incremento na digestibilidade ileal da proteína bruta, do cálcio e do fósforo

Considerações finais: Baseando-se nas pesquisas que vem sendo realizadas, é possível inferir que o uso de enzima na dieta de frangos proporciona inúmeros benefícios, desde redução de custos, melhor aproveitamento dos nutrientes presentes nas rações, diminuem a viscosidade da digesta, melhoram a digestibilidade dos alimentos de baixa qualidade, diminuem a umidade da cama, desse modo, as enzimas são excelentes aditivos nas rações. 


\section{Referências}

CONTE, A. J. et al. Efeito da fitase e xilanase sobre a energia metabolizável do farelo de arroz integral em frangos de corte. Ciência e Agrotecnologia, Lavras, v.26, n.6, p.1289-1296, 2002.

COSTA, F. et al. Utilização de um complexo multienzimático em dietas de frangos de corte. Ciência Animal Brasileira, [s. l.], v. 5, ed. 2, p. 63-71, 2004.

COSTA, M.; BROOKES, S. J. H. The enteric nervous system. The American Journal of Gastroenterology, v. 89, n. 8, p. S12937, 1994.

FORTES, BRUNO et al. Avaliação de programas nutricionais com a utilização de carboidrases e fitase em rações de frangos de corte. Ciência Animal Brasileira, Goiânia, ano 2012, v. 13, p. 24 - 32, 2012.

JUNQUEIRA, Luiz. et al. Picrosirius staining plus polarization microscopy, a specific method for collagen detection in the tissue sections. Histochem Journal, [s. I.], ed. 11, p. 247- 255, 1979.

LANGLEY, J. The autonomic nervous system, Part I. Cambridge: W. Heffer, 1921.

MAIORKA, Alex. et al. Impacto da saúde intestinal na produtividade avícola. V simpósio Brasil sul de avicultura, Chapecó, SC Brasil, ano 2004, p. 1 - 11, 5 abr. 2004.

PATRÍCIO, L. et al. A importância da qualidade intestinal no desempenho de frangos de corte. Ouro fino saúde animal, Cravinhos, SP, 4 jul. 2016.

ROMER, A. et al. Anatomia Comparada. México: Interamericana, 1981.

TEIXEIRA, M. Anátomo-clínica e biologia em frangos de corte experimentalmente infectados com eimeria acervulina e suplementados com betaína. 2007. 60 f. Tese (Doutorado em Ciências Veterinárias) - Universidade Federal Rural do Rio de Janeiro, Seropédica, 2007.

TEJEDOR, A. T. et al. Efeito da adição de enzimas em dietas de frangos de corte à base de milho e farelo de soja sobre a digestibilidade ileal de nutrientes. Revista Brasileira de Zootecnia, Viçosa, v. 30, n. 3, p. 809-816, 2001. 


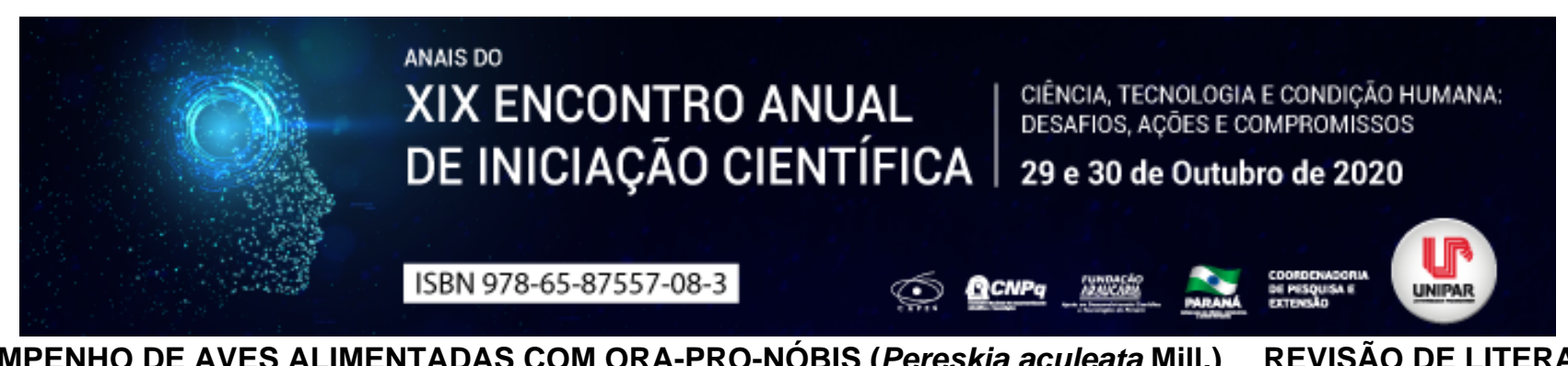

DESEMPENHO DE AVES ALIMENTADAS COM ORA-PRO-NÓBIS (Pereskia aculeata Mill.) REVISÃo DE LITERATURA

\begin{abstract}
${ }^{1}$ MARIA EDUARDA GRAEFF, ${ }^{2}$ CAMILA DE CUFFA MATUSAIKI, ${ }^{3}$ IZABELA CAMILOTTI DORNELES3, ${ }^{4}$ NATIELLI BELOTTI PAIE, ${ }^{5}$ TANIARA SUELEN MEZALIRA, ${ }^{6}$ LUCIANA KAZUE OTUTUMI FARIAS
\end{abstract}

\author{
${ }^{1}$ Acadêmica do curso de Medicina Veterinária - Bolsista PIBIC/UNIPAR \\ ${ }^{1}$ Acadêmica do Curso de Medicina Veterinária -Bolsista pebic/CNPq \\ ${ }^{2}$ Doutoranda em Ciência Animal com Ênfase em Produtos Bioativos, UNIPAR, taxista PROSUP/CAPES \\ ${ }^{3}$ Acadêmica do curso de Medicina Veterinária - Bolsista PIBIC/UNIPAR \\ ${ }^{4}$ Doutoranda em Ciência Animal com Ênfase em Produtos Bioativos, UNIPAR, taxista PROSUP/CAPES \\ ${ }^{5}$ Professora do curso de Medicina Veterinária e do Programa de Pós-Graduação em Ciência Animal, UNIPAR
}

Introdução: Segundo dados da Associação Brasileira de Proteína Animal (ABPA, 2020), referente à produção mundial de carne de frango e ovos no ano de 2019, o Brasil se posicionou no terceiro lugar em termos de produção de carne de frango no mundo e continua como o maior exportador. Em relação à produção de ovos, dados do relatório ABPA (2020) em relação ao ano de 2018 demonstra que o principal destino da produção é para o mercado interno (99,6\%). Segundo Coutinho et al. (2012), devido ao alto custo com a formulação de ração para a produção de aves, pesquisadores têm buscado alimentos alternativos para a composição das rações, capazes de gerar desempenhos semelhantes ao uso do milho e do farelo de soja e com custo reduzido. Nesse aspecto, Augusta e Nascimento (2013) citam que a ora-pro-nóbis ( $P$. aculeata) apresenta alto teor de proteína bruta, é rica em nutrientes como ferro e cálcio, além de ser de fácil cultivo, sendo por isso, muito utilizada na alimentação humana. Essas características, também justificam sua utilização como alimento na nutrição de aves em relação ao desempenho produtivo.

Objetivo: Fazer uma revisão de literatura sobre o desempenho produtivo de aves com o uso de ora-pro- nóbis (Pereskia aculeata Mill.).

Desenvolvimento: Na presente revisão foram abordados trabalhos com o uso da ora-pro-nóbis na alimentação de codornas japonesas , um mercado promissor pela pratica de produção em ovos quanto para produção de carne, sua carne apresentando alto teor proteico ,baixo teor de gordura e aminoácidos essenciais (COUTINHO et al., 2012; GAZZOLA et al., 2018) e trabalhos de frangos de corte (SILVA et al., 2018). Segundo Coutinho et al. (2012), a utilização de ora-pro-nobis (P. aculeata) em rações traz melhorias nos aspectos de reprodução e qualidade de ovos de codornas japonesas, reduzindo os custos das rações demonstrando a importância de sua utilização, já que o mercado busca qualidade dos ovos aliado à redução do custo. A ora-pronóbis ( $P$. aculeata ) apresenta em sua composição compostos fenólicos, e que apresenta relação com sua capacidade antioxidante (TURRANI; BRITES, 2018), demonstrando sua importância e interesse em relação à prevenção ao aparecimento de doenças, já que possibilita o sequestro de radicais livres (AUGUSTA; NASCIMENTO, 2013). Segundo Gazzola et al. (2018) em um levantamento de dados visando caracterizar a ora-pro-nóbis ( $P$. aculeata) como um possível alimento alternativo a ser utilizado na dieta de codornas japonesas, verificaram que a mesma possui em média 23,9\% de proteína, 4,9\% de lipídeos, 19,7\% fibras e $30,2 \%$ carboidratos, dentre outros e concluíram que por suas características pode ser utilizado como alimento alternativo na dieta de codornas japonesas. Silva et al. (2018), avaliando o uso da farinha de ora-pro-nóbis ( $P$. aculeata) em rações para frangos de corte nas concentrações de $0,1,2$ e $3 \%$ de farinha, não verificaram diferença no rendimento de carcaça e cortes (asa, coxa, sobrecoxa e peito) de aves abatidas aos 42 dias, comprovando que a farinha pode ser utilizada para reduzir os custos das rações sem afetar o desempenho dos animais.

Conclusão: Conclui-se que a ora-pro-nóbis pode ser utilizada na alimentação de aves sem comprometer o desempenho, no entanto, são necessários novos estudos são necessários, com o objetivo de definir o melhor nível de inclusão tanto na forma de farinha como na forma de extrato, associado ao seu potencial antioxidante, nível proteico e custo, visando principalmente baratear os custos das rações e tornar a ora-pro-nóbis um alimento alternativo.

\title{
Referências
}

ABPA. Associação Brasileira de Proteína Animal. Relatório anual 2020. Disponível em: https://abpa-br.org/wpcontent/uploads/2020/05/abpa_relatorio_anual_2020_portugues_web.pdf. Acesso em: 23 ago. 2020.

AUGUSTA, Ivanilda; NASCIMENTO, Maria Kamila de Oliveira. Avaliação do teor de compostos fenólicos e atividade antioxidantes de ora-pro-nobis (Pereskia aculeata Mill.). 2013. Disponível em: https://www.ppmac.org/sites/default/files/compostos_fenolicos_ora_pro_nobis.pdf. Acesso em: 23 ago. 2020.

COUTINHO, Juliano José de Oliveira; OLIVEIRA, Jeferson Éder Ferreira; MACHADO, Luiz Carlos. Uso da ora-pro-nóbis para 
codornas japonesas em fase de postura. In: SEMANA DE CIÊNCIA E TECNOLOGIA DO IFMG CAMPUS DE BABUÍ, 5., 2012., Bambuí. Anais [...] Bambuí: Instituto Federal de Minas Gerais, 2012.

GAZZOLA, Suellen Susin et al. Caracterização da ora-pro-nóbis como um possível alimento alternativo na nutrição de codornas japonesas. In: SALÃO INTERNACIONAL DE ENSINO, PESQUISA E EXTENSÃO DA UNIPAMPA, 10., 2018, Santana do Livramento. Anais [...] Santa do Livramento: Universidade Federal do Pampa, 2018.

SILVA, Valéria Bonifácia Marra da et al. Rendimento de carcaças e cortes nobre de frangos alimentadas com farinha de folhas de ora-pro-nóbis (Pereskia aculeata Miller). In: CONGRESSO ESTADUAL DE INICIAÇÃO CIENTÍFICA E TECNOLÓGICA DO INSTITUTO FEDERAL GOIANO, CONGRESSO DE PESQUISA E PÓS-GRADUAÇÃO NO CAMPUS RIO VERDE, SEMINÁRIO DE AVALIAÇÃO DOS PROGRAMAS DE PÓS-GRADUAÇÃO DO INSTITUTO FEDERAL GOIANO, 7., 7., 8., 2018, Rio Verde. Anais [...] Rio Verde: IFG, 2018.

TURANI, Daiane; BRITES, Juliana Salete Rotini. Caracterização química e otimização da extração de compostos fenólicos e antioxidantes de ora-pro-nóbis (Pereskia aculeata Miller) desidratado. Orientadora: Tahis Regina Baú. 2018. 38f. Monografia (Tecnologia em Alimentos) - Instituto Federal Santa Catarina, São Miguel do Oeste, 2018. 


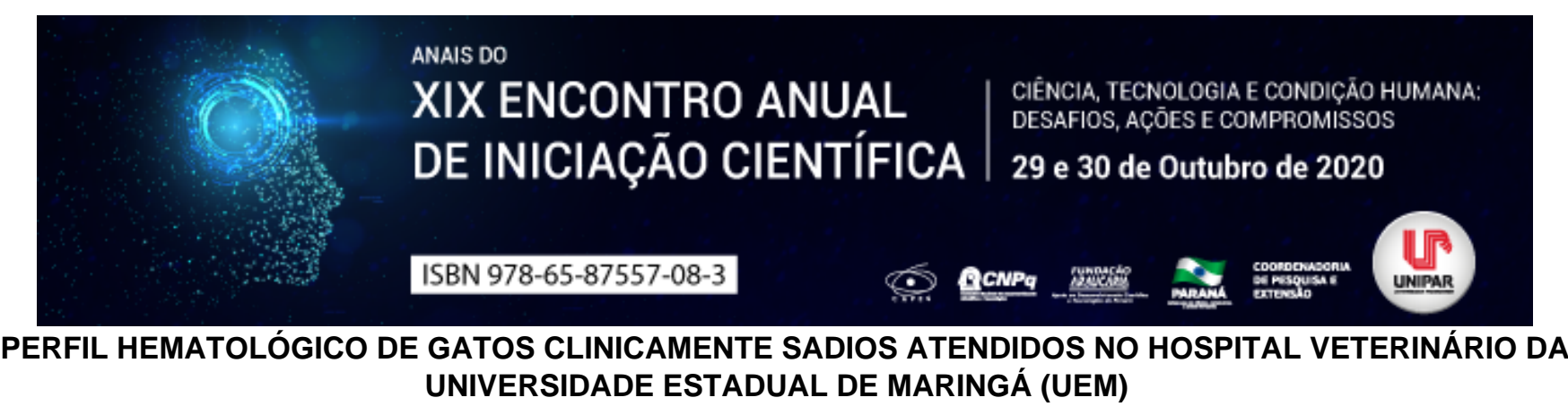

\author{
${ }^{1}$ Júlia Sayumi Saito, ${ }^{2}$ LETÍCIA COELHO ARAÚJO, ${ }^{3}$ STHEFANY PRISCILA DA CUNHA, ${ }^{4}$ CYNTHIA PENONI VOLPI ABREU, \\ ${ }^{5}$ MARILDA ONGHERO TAFFAREL, ${ }^{6}$ ANDRÉ MARCOS SANTANA
}

\begin{abstract}
${ }^{1}$ Acadêmica do Curso de Medicina Veterinária, Universidade Estadual de Maringá (UEM), Campus Regional de Umuarama.
${ }^{1}$ Acadêmica do Curso de Medicina Veterinária, Universidade Estadual de Maringá (UEM), Campus Regional de Umuarama.

${ }^{2}$ Acadêmica do Curso de Medicina Veterinária, Universidade Estadual de Maringá (UEM), Campus Regional de Umuarama.

${ }^{3}$ Docente do Departamento de Medicina Veterinária, Universidade Estadual de Maringá (UEM), Campus Regional de Umuarama.

${ }^{4}$ Docente do Departamento de Medicina Veterinária, Universidade Estadual de Maringá (UEM), Campus Regional de Umuarama.

${ }^{5}$ Docente do Departamento de Medicina Veterinária, Universidade Estadual de Maringá (UEM), Campus Regional de Umuarama.
\end{abstract}

Introdução: O hemograma é uma ferramenta essencial na clínica de pequenos animais, visto que por meio desse pode-se obter informações primordiais sobre hemácias, leucócitos e plaquetas para fins diagnóstico, prognóstico e para monitoramento do animal (BIONDO 2005), além de avaliar o funcionamento do sistema imune do paciente (RIBEIRO et al., 2018). No entanto, para uma avaliação adequada deste exame, faz-se necessário o conhecimento dos valores de intervalo de referência (IR) do hemograma de animais saudáveis, bem como das causas de suas possíveis variações, uma vez que sofrem influências significativas do ambiente externo devido às variáveis relacionadas ao clima, à pressão atmosférica e à altitude de cada região (RIBEIRO et al., 2018). Ademais, a interpretação do hemograma também é influenciada por diferenças relacionadas a idade, raça, manejo, alimentação e estado fisiológico do animal, além da alteração existente entre as espécies, como em cães e gatos (TESSER et al., 2016). Somado a isso, sabe-se que a maioria dos valores de referência se encontram na literatura estrangeira (KANEKO et al., 1997), dificultando a exatidão nas interpretações quando aplicados em animais de outra nacionalidade. À luz do exposto, para a correta interpretação dos perfis séricos é indispensável contar com valores de referência apropriados para cada região e a população em particular, sendo essencial que cada laboratório possua o seu próprio valor, a fim de evitar o uso de IR inadequados, os quais levam ao sobre ou sub-diagnóstico de doenças, comprometendo o bem-estar do animal.

Objetivo: O presente estudo tem como objetivo avaliar o hemograma de felinos, visando a criação de valores próprios de maior exatidão para o Laboratório de Patologia Clínica do Hospital Veterinário da Universidade Estadual de Maringá na cidade de Umuarama PR.

Materiais e métodos: Foram coletadas 50 amostras de sangue, mediante punção da veia cefálica, de gatos entre 4 meses e 20 anos de idade, clinicamente sadios atendidos na rotina do Hospital Veterinário (UEM Umuarama). Neste estudo, foram incluídos apenas gatos doadores de sangue ou que vieram ao hospital para castração e check-up, uma vez que não apresentaram nenhuma enfermidade. Dos animais previamente selecionados, foram analisadas as descrições da anamnese (histórico clínico) e exame físico geral, e apenas os amimais que não apresentaram alterações foram incluídos. As amostras de sangue foram coletadas utilizando um sistema de coleta a vácuo (tubos plásticos siliconados contendo EDTA), após antissepsia local com álcool iodado. De cada amostra de sangue venoso colhida, foram aferidos os dados relativos às contagens de hemácias $(\mathrm{He})$, hematócrito $(\mathrm{Ht})$, concentração de hemoglobina $(\mathrm{Hb})$, contagem de leucócitos e contagem de plaquetas, utilizando aparelho automático. A contagem diferencial de leucócitos foi realizada a partir da contagem em esfregaço sanguíneo corado (Panótico Rápido) de 100 células, em microscopia óptica. Os índices hematimétricos VCM (volume corpuscular médio) e CHCM (concentração de hemoglobina corpuscular média) também foram calculados. Após a obtenção de todos os dados, estes foram dispostos na forma de média e desvio padrão.

Resultados: Obteve-se os seguintes resultados referentes à média e ao desvio padrão das amostras coletadas: He: $8,34 \pm 1,10$

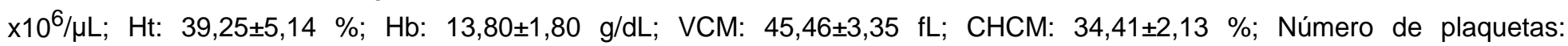

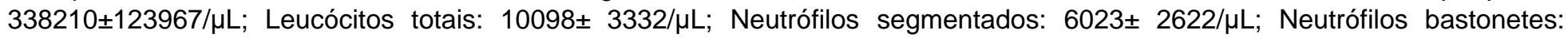

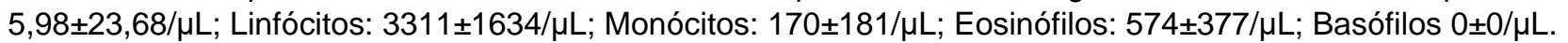

Discussão: Os valores médios dos parâmetros sanguíneos ficaram dentro dos limites citados por BUSH (1991) e REBAR (1998). No estudo realizado por COSTA (2008), com gatos persa e sem raça definida da cidade de Uberlândia-MG, os valores referentes a hematócrito, concentrações de hemoglobina, VCM e número de linfócitos foram inferiores aos obtidos pelo presente estudo. SOUZA et al. (2006), em trabalho realizado com gatos sem raça definida na cidade de Niterói-RJ, observaram valores de número de hemácias, hematócrito, concentrações de hemoglobina, CHCM e número de linfócitos inferiores aos desta pesquisa. Ademais, as médias apresentadas por ARAUJO (2019), estudando gatos sem raça definida na cidade de Belém-PA, dentre as pesquisas 
analisadas, foram as que mais se aproximaram das obtidas neste estudo. Tais diferenças, provavelmente, devem-se às influências do ambiente externo, ao manejo e às individualidades de cada animal, como citados acima, além dos diferentes métodos de análise de amostras utilizados.

Conclusão: É essencial que cada laboratório determine suas próprias referências para hemograma, com o intuito de obter resultados mais fidedignos ao analisar amostras de animais da rotina. Ademais, a região de Umuarama ainda carece de pesquisas sobre as particularidades do perfil hematológico de gatos da região e de determinações de valores de referências próprios, tornado este estudo um passo inicial importante.

\section{Referências}

ARAUJO, V. S. Perfil hematológico de gatos oriundo do projeto vida digna da Universidade Federal Rural da Amazônia, Belém, Pará, Brasil. Orientador: André Meneses. 2019. 38 f. Dissertação (Trabalho de Conclusão de Residência) Universidade Federal Rural da Amazônia, Pará, 2019.

BIONDO, A. W. Interpretação do leucograma. In: GONZÁlEZ, Félix H. Diaz; SANTOS, Andrea Pires. Anais do II Simpósio de Patologia Clínica Veterinária da Região do Sul do Brasil. Porto Alegre: Universidade Federal do Rio Grande do Sul, 2005 . p. 29-35.

BUSH, B. M. Interpretation of laboratory results for small animal clinicians. Oxford: Blackwell Scientific Publications, 1991. COSTA, A. S. Perfil hematológico e bioquímico sérico de gatos domésticos (Felis catus - Linnaeus, 1758) da raça persa e mestiços. Orientador: José Jacomini. 2008. 49 f. Dissertação (Mestrado em Ciências Veterinárias) Faculdade de Medicina Veterinária, Minas Gerais, 2008.

KANEKO, J. J.; HARVEY, J. W.; BRUSS, M. L. Clinical Biochemistry of Domestic Animals. 6. Ed. San Diego: Academic Press, 2008.

REBAR, A. H. Hemogram Interpretation for Dogs and Cats. Missouri: The Gloyd Group Inc, 1998.

RIBEIRO, M. M.; ALVES, J. da S.; SAMPAIO, W. S.; BARROS, E. de S.; CHAVES, D. P. Perfil Hematológico de Caninos Recémnascidos do Município de São Luís Maranhão. PubVet, v.12, n.1, a13, p.1-5, Jan. 2018.

SOUZA, A. M. de; SÁ, A. G. de; SILVA, C. F. G. K. da; VEZONE, V. S.; ALMOSNY, N. R. P. Perfil Hematológico e Freqüência de Hemoparasitos em Gatos Domésticos (Felis catus Linnaeus, 1758) da Região de Niterói, Rio de Janeiro, Brasil. Niterói RJ, 2006. Disponível em: https://docplayer.com.br/3465151-Perfil-hematologico-e-frequencia-de-hemoparasitose.html. Acesso em: 21 jul. 2020.

TESSER, S.; CAVAGNOLLI, N. I.; TORRIANI, T.; RODRIGUES, Adriana Dalpicolli. Perfil Hematológico de Cães e Gatos na Cidade de Bento Gonçalves, Rio Grande do Sul, Brasil. Arq. Ciênc. Vet. Zool. UNIPAR, Umuarama, v. 19, n. 1, p. 47-51, jan./mar. 2016. 


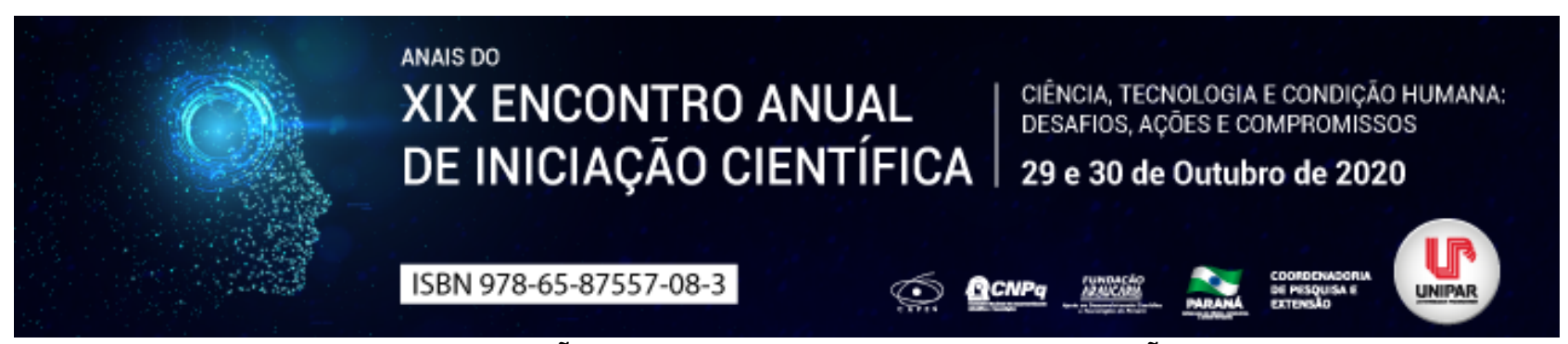

MANEJO NUTRICIONAL EM CÃES E GATOS CARDIOPATAS REVISÃO DE LITERATURA

\begin{abstract}
${ }^{1}$ Bruna Bagatim de SouZa, ${ }^{2}$ LAURA MARIANA TONETE, ${ }^{3}$ CAROLINE HELENA ROCHA, ${ }^{4}$ LARISSA EDINA PERIN PEREIRA, ${ }^{5}$ BRUNA CAROLINA MARQUARDT , ${ }^{6}$ MAURO HENRIQUE BUENO DE CAMARGO
\end{abstract}

\begin{abstract}
${ }^{1}$ Acadêmica do curso de Medicina Veterinária UEM
${ }^{1}$ Acadêmica do curso de Medicina Veterinária UEM

${ }^{2}$ Acadêmica do curso de Medicina Veterinária UEM

${ }^{3}$ Acadêmica do curso de Medicina Veterinária UEM

${ }^{4}$ Mestranda no Programa de Pós-Graduação em Produção Sustentável e Saúde Animal UEM

$5_{3}$ Docente do curso de Medicina Veterinária UEM/Umuarama-PR
\end{abstract}

Introdução: Com a abertura de novas empresas de rações no último século, surgiu o crescimento em estudos na nutrição animal, e sua importância na gestão de patologias, incluindo a doença cardíaca, onde a nutrição desempenha importante papel na sua prevenção e tratamento( PANTOJA et al., 2018).

Objetivo: O presente trabalho tem como objetivo abordar a influência da nutrição na prevenção de cardipopatias, melhorando a saúde do coração, trazendo alguns nutrientes de dietas industrializadas e naturais (caseiras) importantes para o funcionamento cardíaco.

Desenvolvimento: A insuficiência cardíaca congestiva (ICC) leva a queda na capacidade cardiovascular de manter a circulação sanguínea normal, sendo insuficiente o volume de sangue bombeado e o débito cardíaco alterado. A nutrição tem papel adjuvante no tratamento, mas fundamental para diminuir a progressão da doença e minimizar os medicamentos necessários, levando a melhor qualidade de vida do paciente. Seu objetivo principal é evitar que os animais apresentem caquexia (FREEMAN, 2009), já que em animais com ICC ocorre a perda de massa magra, uma vez que os aminoácidos liberados dos músculos são sua fonte primária de energia. A caquexia cardíaca aumenta suas necessidades energéticas, e altera seu metabolismo, influenciando na interleucina-1 e no fator de necrose tumoral, ambos ligados a menor sobrevida ( CASE, 2011). A gordura, fonte de ácidos graxos (AGs), fornece mais energia que os outros minerais, além de dar maior palatabilidade, favorecer o apetite e proporcionar o fornecimento de menores quantidades de alimento, o que facilita a ingestão de nutrientes mais frescos, melhorando a ingestão. É uma ótima aliada para evitar a caquexia, o ácido eicosapentaenoico (EPA) e o ácido docosahexaenoico (DHA) são AGs $\omega$-3, essenciais derivados de fontes marinhas, e seus efeitos combinados visam à redução da ação dos mediadores pró-inflamatórios, estão presentes em quantidades satisfatórias no óleo de peixe (KROLL, 2016). As ações antiarrítmicas destes AGs são atribuídas à sua capacidade em alterar a eletrofisiologia das células cardíacas, pois se ligam à proteínas dos canais de sódio na membrana celular e estabilizam a atividade elétrica dos cardiomiócitos, mantendo os canais inativos por um longo período de tempo (SILVA, 2017). Já em relação a proteína, este macronutriente não deve ser restrito, a menos que o animal apresente doença renal. É uma importante fonte para manter a massa muscular. Um aminoácido importante é a taurina, devido seu poder antioxidante e por ser um nutriente chave para o tratamento de algumas cardiopatias. Além deste, a suplementação com arginina em pacientes com ICC apresentou melhora na qualidade de vida, na performance ventricular esquerda, pois é responsável pela manutenção do tônus vascular normal e restringe anormalidades diastólicas (FONTANIVE et al., 2009) e condensa o óxido nítrico, um agente endógeno presente em altos níveis em animais cardiopatas (FREEMAN; RUSH, 2006). Também vale lembrar da carnitina, uma amina quaternária composta por dois aminoácidos essenciais, a qual compõe em altas concentrações os músculos esquelético e cardíaco. Quando presente na forma de L-carnitina exerce a função de transportar ácidos graxos do exterior para dentro da mitocôndria. Em geral, sua suplementação na dieta pode melhorar o desempenho da função miocárdica e a produção de energia (KROLL, 2016). Vitaminas também devem ser consideradas na suplementação alimentar, pois animais com insuficiência cardíaca possuem aumento no estresse oxidativo e redução de antioxidantes, como as vitaminas E e C, sugerindo um desequilíbrio entre dano oxidativo e proteção por antioxidantes, que se acumula com a produção de radicais livres, os quais possuem efeitos citotóxicos e inotrópicos negativos (FREEMAN; RUSH, 2006). A coenzima Q10, uma quinolona lipossolúvel, também com poder antioxidante, demonstrou preservar as alterações funcionais e estruturais do coração, associadas à isquemia e reperfusão (BONAKDAR; GUARNERI, 2005). Por fim, pacientes cardiopatas também devem receber dietas com quantidade adequada de magnésio, pois a falta deste pode potencializar arritimias cardíacas e diminuir a contratilidade do coração, contribuindo para a fraqueza muscular. Já o potássio precisa estar em quantidades moderadas para evitar tanto a hipocalemia quanto a hipercalemia (KROLL, 2016). No Brasil estão disponíveis algumas rações eficazes para o suporte nutricional de animais cardiopatas. Algumas marcas como Royal Canin, Hill's, entre outras, possuem produtos com ingredientes balanceados e estruturados para cardiopatas (NELSON \& COUTO, 2015). Outra 
alternativa é a dieta caseira, porém sua preparação necessita do acompanhamento de profissionais habilitados em nutrição animal (KROLL et al., 2010).

Conclusão: A nutrição pode modular a cardiopatia por meio da diminuição de sua progressão e da minimização do número de medicamentos necessários, promovendo qualidade de vida ou, em casos raros, atuando na cura da doença. Portanto, atenção à dieta em todos os estágios da doença cardíaca é essencial para a otimização dos cuidados aos pacientes cardiopatas.

\section{Referências}

BONAKDAR, R. A.; GUARNERI, E. Coenzyme Q10. American Family Physician, v. 72, n. 6, p. 1065-1070, 2005.

CASE L.P.; DARISTOTLE L.; HAYEK M.G.; RAASCH M.F. Nutrition and the heart. In: CASE, L.P.; DARISTOTLE, L; HAYEK, M.G.; RAASCH, M.F. Canine and feline nutrition, a resource for companion animal professionals. 3. ed. Missouri: Mosby Elsevier; 2011. p.511-520.

FONTANIVE, P. et al. Effects of L-arginine on the Minnesota Living with Heart Failure Questionnaire quality-of-life score in patients with chronic systolic heart failure. Med Sci Monit, v.15, n.12, p.606-611, 2009.

FREEMAN, L.M.; RUSH, J.E. Cardiovascular diseases: nutritional modulation. In: PIBOT, P.; BIOUGE, V., ELLIOT, D. Encyclopedia of canine clinical nutrition. Aniwa SAS 2006; p.316-341.

FREEMAN, L. M.. Nutritional management of heart disease. In J. D. Bonagura \& D. C. Twedt (Eds.), Kirk's current veterinary therapy . St. Louis: Saunders. 2009. P. 704-708.

.KROLL, F. S. et al. A importância do sódio no manejo nutricional de cães e gatos cardiopatas. MEDVEP. p. 608-614, 2010.

KROLL, F. Como a nutrição pode auxiliar os cães cardiopatas. Portal Vet, São Paulo, v. 1, n. 1, p. 1-1, 26 fev. 2016.

NELSON, R. W.; COUTO, C. G. Medicina interna de pequenos animais. Amsterdan: Elsevier Editora. 2015.

PANTOJA, J.; CABRAL, I.S.; FARIAS, T.S.; AMARAL, T.E.S.; BARBOSA, C.R.. Alimentação de cães e gatos cardiopatas. PUBVET, v. 12, p. 133, 2018.

SILVA, P. S. . Influência da suplementação de ácidos graxos poli-insaturados ômega-3 nos perfis de citocinas e lipídico de pacientes portadores de cardiopatia chagásica crônica. 2017. 98f. 2017. Tese (Doutorado). Instituto Nacional de Infectologia Evandro Chagas, Rio de Janeiro, 2017. 


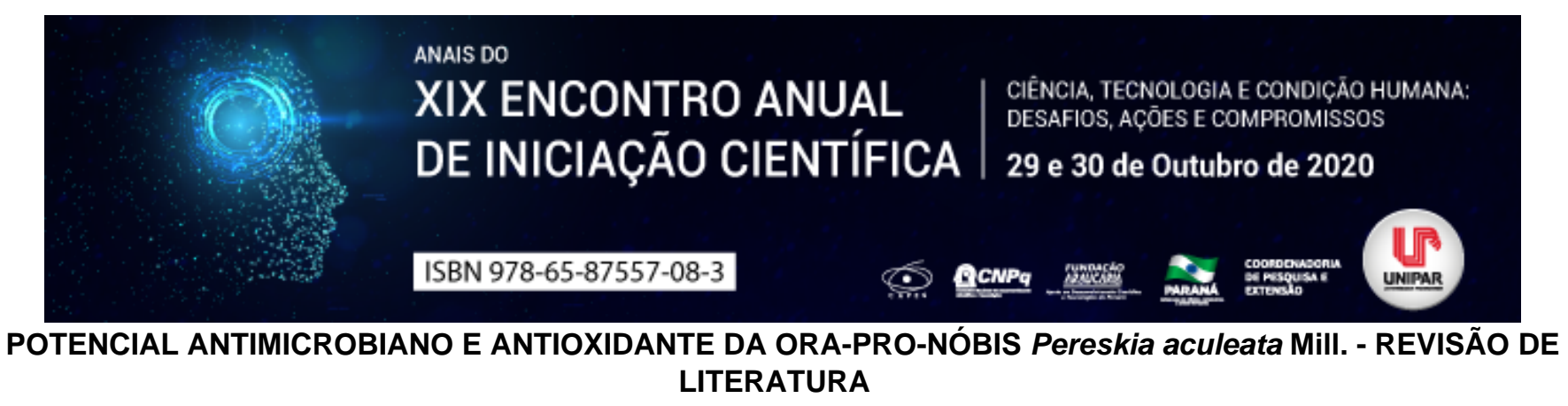

\begin{abstract}
${ }^{1}$ TANIARA SUELEN MEZALIRA, ${ }^{2}$ MARIA EDUARDA GRAEFF, ${ }^{3}$ NATIELLI BELOTTI PAIE, ${ }^{4}$ EZILDA JACOMASSI, ${ }^{5}$ ANDREIA ASSUNCAO SOARES, ${ }^{6}$ LUCIANA KAZUE OTUTUMI FARIAS
\end{abstract}

\author{
${ }^{1}$ Doutoranda em Ciência Animal com Ênfase em Produtos Bioativos,UNIPAR, taxista PROSUP/CAPES \\ ${ }^{1}$ Acadêmica do Curso de Medicina VeterinÃiria da UNIPAR \\ ${ }^{2}$ Acadêmica do Curso de Medicina VeterinÃ iria da UNIPAR \\ ${ }^{3}$ Professora do Mestrado em Plantas Medicinais e Fitoterápicos na Atenção Básica, UNIPAR \\ ${ }^{4}$ Professora da Pós-graduação em Ciência Animal com Ênfase em Produtos Bioativos e do Mestrado em Plantas Medicinais e \\ Fitoterápicos, UNIPAR \\ ${ }^{5}$ Professora do Programa de Pós-graduação em Ciência Animal com Ênfase em Produtos Bioativos, UNIPAR.
}

Introdução: A busca por antioxidantes e antimicrobianos naturais tem aumentado nos últimos anos. A razão disso se deve aos benefícios da utilização de plantas capazes de prevenir doenças e até mesmo melhorar a qualidade de alimentos, seja para fins nutritivos ou de conservação (AUGUSTA; DO NASCIMENTO, 2013; SOUSA et al., 2014; VARGAS, 2017). Dentre elas, destacase a Pereskia aculeata Mill., pertencente a família Cactaceae e conhecida popularmente como ora-pro-nóbis, com alto valor nutritivo. Assim, muito utilizada como complemento alimentar devido seu alto teor de proteínas, fibras e minerais, tem apresentado interesse científico devido à suas propriedades antioxidantes e antimicrobianas, além de suas propriedades farmacológicas e nutricionais (AGOSTINI-COSTA et al, 2012; RODRIGUES, 2016).

Objetivo: Realizar uma revisão bibliográfica relacionado ao potencial antioxidante e antimicrobiano da ora-pro-nóbis.

Desenvolvimento: Substâncias antioxidantes são aquelas capazes de impedir ou reduzir os danos oxidativos provocados principalmente por radicais livres ao DNA, proteínas e lipídeos, ou capazes de sequestrar espécies reativas de oxigênio causadoras de iniciação e propagação de doenças (SOUSA, et al., 2014; VARGAS, 2017) e por isso tem sido utilizado na conservação de alimentos e ração animal, visando o retardo da oxidação lipídica, que é considerado um dos principais fatores de deterioração de alimentos (RODRIGUES, 2016). Augusta e Nascimento (2013) avaliando o teor de compostos fenólicos e atividade antioxidante do extrato de folhas ora-pro-nóbis, por meio do método de determinação de compostos fenólicos totais e outro com base no sequestro do radical livre 2,2-difenil-1-picril-hidrazil (DPPH) obtiveram teores de compostos fenólicos (495mg/100g ácido gálico) maiores que os encontrados por Agostini-Costa et al. (2012) na extração dos frutos de ora-pro-nóbis utilizando etanol a $90^{\circ} \mathrm{C}$, que resultou em $64,9 \pm 1,1 \mathrm{mg}$ de equivalente de ácido gálico. Por sua vez, os resultados deste estudo indicaram que os frutos podem ser fontes de substâncias bioativas, como os carotenoides antioxidantes, responsáveis por reduzir o risco de desenvolver algumas doenças degenerativas. Pinto et al. (2012), reportaram atividade citotóxica e antioxidante das folhas de ora-pro-nóbis, dando ênfase aos fenóis, flavonoides e alcaloides. Vargas (2017) avaliou diferentes extratos das folhas secas de ora-pro-nóbis obtidos no verão e no inverno, e na determinação de compostos fenólicos obteve os maiores teores nos extratos de verão, e consequentemente na avaliação da atividade antioxidante pelo método DPPH também obteve os maiores resultados nos extratos do verão, visto que os compostos fenólicos são os principais responsáveis pelo potencial antioxidante das substâncias. Compostos fenólicos e flavonoides totais também foram encontrados no trabalho de Rodrigues (2016), o qual avaliou a capacidade antioxidante do extrato das folhas de ora-pro-nóbis com aplicação em mortadela e concluiu que a ora-pronóbis apresenta grande potencial como antioxidante natural principalmente em alimentos passiveis de oxidação lipídica, por outro lado, o extrato $(10 \mu \mathrm{L})$ não apresentou atividade antimicrobiana frente aos microrganismos: Staphylococcus aureus ATCC 25923, Bacillus cereus ATCC 14579, Salmonella enterica subsp. enterica sorovar Enteretidis ATCC 13076, sorovar Choleraesuis ATCC 10708 e sorovar Typhimurium ATCC 14028, Pseudomonas aeruginosa ATCC 10145, Escherichia coli ATCC 25922, Enterococcus faecalis ATCC 19433 e Enterobacter aerogenes ATCC 13048, testados pelo método disco difusão. No entanto, a atividade antimicrobiana foi evidenciada no trabalho realizado por Vargas (2017), no qual um dos extratos de ora-pro-nóbis obtidos no inverno inibiu o crescimento da bactéria Staphylococcus aureus, apresentando potencial antimicrobiano, sendo que a única diferença entre os extratos testados foi a estação de coleta das folhas. Segundo o autor, no inverno a planta pode produzir alguma substância diferente ou variação na produção de algum composto capaz de apresentar a atividade antimicrobiana. A capacidade antimicrobiana do óleo essencial da planta Pereskia aculeata foi testada frente aos microrganismos Staphylococcus epidermidis e Klebsiella pneumoniae (BELO et al., 2020) e os autores constataram que o óleo essencial possui atividade antimicrobiana, porém essa atividade não foi observada em porcentagens inferiores a $90 \%$, o que pode ser justificado pela presença de substâncias ativas com alta capacidade antimicrobiana no óleo essencial da planta Pereskia aculeata pelos quais as 
cepas destes patógenos são sensíveis (BELO et al., 2020).

Conclusão: A presença de compostos bioativos com propriedades antioxidantes e antimicrobianas evidencia a utilização da planta Pereskia aculeata como forma alternativa natural, sendo de grande interesse para novos estudos.

\section{Referências}

AGOSTINI-COSTA, Tânia da Silveira et al. Carotenoids profile and total polyphenols in fruits of Pereskia aculeata Mill. Revista Brasileira de Fruticultura, Jaboticabal, v. 34, n.1, p. 234-238, Mar. 2012.

AUGUSTA, Ivanilda Maria; DO NASCIMENTO, Kamila de Oliveira. Avaliação do teor de compostos fenólicos e atividade antioxidante de Ora-pro-nobis (Pereskia aculeata mill.) Higiene Alimentar, São Paulo,v. 27, n. 218/219, 2013.

BELO, Thiago Caetano Andrade et al. Analysis of the antimicrobial capacity of Pereskia aculeata in front of bacterial microrganisms: Staphylococcus epidermidis and Klebsiella pneumoniae. Brazilian Journal of Development, Curitiba, v. 6, n. 6, p. 40025-40033, Jun. 2020.

PINTO, Nícolas de Castro Campos et al. Cytotoxic and antioxidant activity of Pereskia aculeata Miller. Pharmacology online, Paestum, v. 3, p. 63-69, Dez. 2012.

RODRIGUES, Angela Souza. Atividade antioxidante e antimicrobiana de extratos de Ora-pro-nobis (Pereskia aculeata Mill.) e sua aplicação em mortadela. 2016. 91 f. Dissertação (Mestrado em Ciência Tecnologia dos alimentos)Universidade Federal de Santa Maria, Centro de Ciências Rurais, Rio Grande do Sul, 2016.

SOUSA, Raquel Maria Ferreira et al. Atividade antioxidante de extratos de folhas de Ora-pro-nóbis (Pereskia aculeata Mill.) usando métodos espectrofotométricos e voltamétricos in vitro. Bioscience Journal, Uberlândia, v. 30, n. 3, Jun. 2014.

SOUZA, Lucéia Fátima. Aspectos fitotécnicos, bromatológicos e componentes bioativos de Pereskia aculeata, Pereskia grandifolia e Anredera cordifolia. 2014. 125 f. Tese (Doutorado em fitotecnia)-Faculdade de Agronomia, Universidade Federal do Rio Grande do Sul, Porto Alegre, 2014.

VARGAS, Aline Garcias de. Influência da sazonalidade na composição química e nas atividades antioxidante e antimicrobiana das folhas de ora-pro-nobis (Pereskia aculeata Miller). 2017. 80 f. Dissertação (Mestrado em tecnologia de processos químicos e bioquímicos)-Universidade Tecnológica Federal do Paraná, Pato Branco, 2017. 


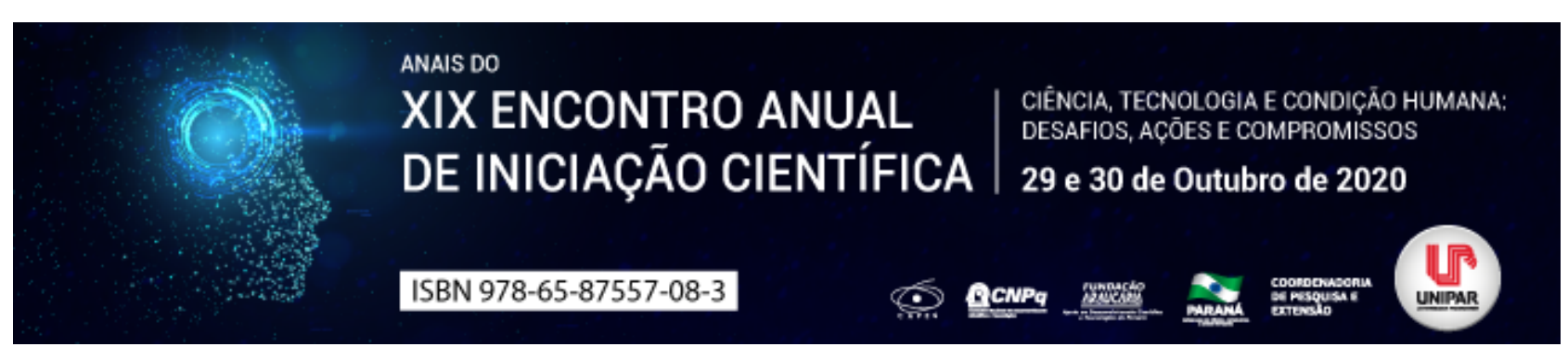

EFEITOS BIOLOGICOS DAS PLANTAS MEDICINAIS [Anacardium occidentale, Costus spiralis (Jacq.), Bidens pilosa]: REVISÃO DE LITERATURA

\author{
${ }^{1}$ AMANDA NASCIMENTO VASQUES DE SOUZA, ${ }^{2}$ PRISCILA MEGDA JOÃO JOB ZAGO, ${ }^{3}$ EVELLYN CLAUDIA WIETZIKOSKI \\ LOVATO
}

${ }^{1}$ Mestranda do Mestrado Profissional em Plantas Medicinais e Fitoterápicos na Atenção Básica, Universidade Paranaense

${ }^{1}$ Mestranda do Mestrado Profissional em Plantas Medicinais e Fitoterápicos na Atenção Básica, Universidade Paranaense

${ }^{2}$ Docente da UNIPAR

Introdução: Recentemente estudos evidenciam um grande interesse crescente no uso de terapias complementares, especialmente vegetais, esse crescimento está ligado a fatores nos quais se destacam o sofrimento com os resultados obtidos em tratamentos com a medicina convencional, os efeitos indesejáveis e prejuízos causados pelo uso abusivo ou incorreto de medicamentos, as dificuldades de acesso aos medicamentos por parte da população aos medicamentos e a crença popular de que o natural é inofensivo (SHIAVO et al.,2017).

Objetivo: $O$ objetivo do presente estudo é descrever as propriedades medicinais das plantas Anacardium occidentale, Costus spiralis (Jacq.), Bidens pilosa.

Desenvolvimento: Sabe-se que as plantas medicinais são uma fonte potencial de novas substâncias fitoquímicas com efeitos terapêuticos benéficos, a Anacardium occidentale (Anacardiaceae) é uma árvore nativa da Brasil e também encontrado em países tropicais como Malásia e Índia (Região de Konkan). A planta é incorporada por possuir atividades antibacterianas, antifúngicas, antioxidante e rica fonte de diversos grupos de plantas de produtos químicos (DESAI et al.,2017). Costus spiralis é uma planta da Amazônia brasileira reconhecida por seus valores médicos e ornamentais, é comumente usada na medicina popular para tratar infecções urinárias, algumas patologias como pedras nos rins e para o tratamento de diabetes, apresenta também ação como antioxidante, agente antibacteriano e diurético, plantas de regiões tropicais apresentam maior diversidade de microrganismos endofíticos em comparação com as encontradas em regiões temperadas (ASCÊNCIO et al.,2014). Bidens pilosa $L$. é uma erva comestível e tem sido tradicionalmente usado para uma ampla gama de doenças em muitos países, a planta possui atividades biológicas e farmacológicas, como anti-malária, anti-alérgico, anti-hipertensivo e relaxante muscular, anticancerígeno, anti-diabético, anti-inflamatório, antimicrobiano, antioxidante, esta erva tem uma grande propriedade terapêutica benéfica e é possivelmente usado como complemento ou alternativa a medicamentos em alguns casos específicos (XUAN.,2016).

Conclusão: Portanto a revisão permitiu constatar a importância das plantas medicinais citadas e seu grande potencial de utilização, tendo em vista seu uso popular e estudos científicos que mostram ação antimicrobiana e anti-inflamatória é de interesse tecnológico que seja realizado mais estudos para a produção de medicamentos afim de aumentar o uso popular.

\title{
Referências
}

ASCÊNCIO P G M, et al. Chemical Assessment and Antimicrobial and Antioxidant Activities of Endophytic Fungi Extracts Isolated from Costus spiralis (Jacq.) Roscoe (Costaceae). Volume 2014. Evidence-Based Complementary and Alternative Medicine DESAI, Dhananjay, et al. ANACARDIUM OCCIDENTALE: FOUNTAIN OF PHYTOCHEMICALS; THE QUALITATIVE PROFILING. World Journal of Pharmaceutical Research. Volume 6, Issue 5, 585-592, 2017.

SCHIAVO, Morgana et al. Conhecimento sobre plantas medicinais por mulheres em processo de envelhecimento. Semina: Ciências Biológicas e da Saúde, v. 38, n. 1, p. 45-60, 2017.

XUAN T D; KHANH T D. Chemistry and pharmacology of Bidens pilosa: an overview. Journal of Pharmaceutical Investigation (2016) 46:91 132 


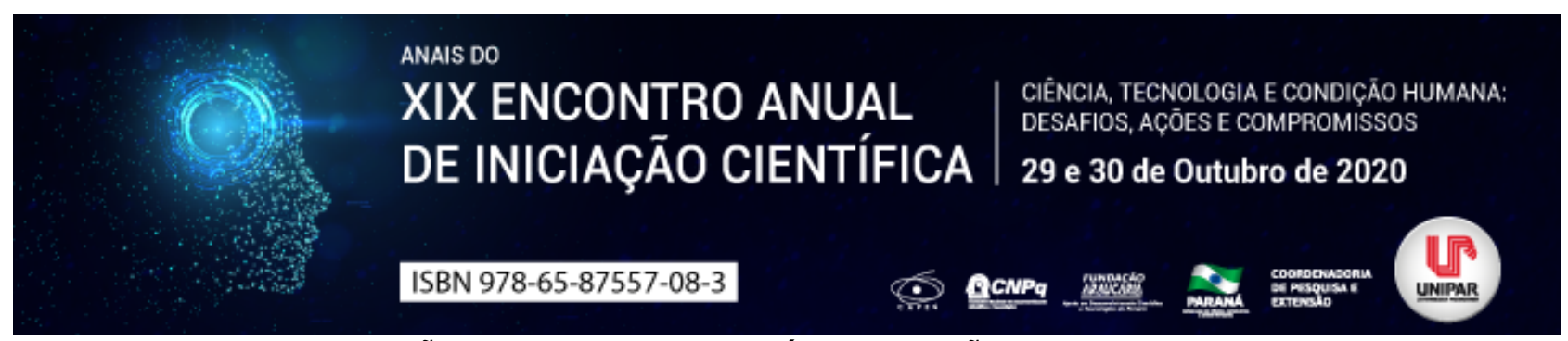

PERFURAÇÃO INTESTINAL TRAUMÁTICA EM CÃO RELATO DE CASO

${ }^{1}$ LARISSA DE MATOS VIEIRA, ${ }^{2}$ GABRIELA JULIANA LOPES, ${ }^{3}$ CAROLINE BARBOSA LIMA, ${ }^{4}$ ADILSON PAULO MARCHIONI CABRAL, ${ }^{5}$ ANNA BEATRIZ DONAIDI SPAGNOLLI, ${ }^{6}$ NATALIE BERTELIS MERLINI

\author{
${ }^{1}$ Acadêmico Bolsista PIBIC/UNIPAR \\ ${ }^{1}$ Medica Veterinária Autônoma \\ ${ }^{2}$ Mestranda Universidade Estadual de Maringá /UEM \\ ${ }^{3}$ Mestrando Universidade Estadual Paulista/ UNESP/Jaboticabal/Sp \\ ${ }^{4}$ Acadêmico bolsista PIBIC/UNIPAR \\ ${ }^{5}$ Docente da UNIPAR
}

Introdução: O traumatismo aparece estatisticamente como uma das principais causas de morte em cães e gatos (COSTA, 2014). Em medicina veterinária, as principais etiologias relacionadas a traumatismo são: atropelamento, brigas entre animais, quedas e por agressões de seres humanos (ROCHLITZ, 2004; HOLOWAYCHUK, 2011). Entre as etiologias citadas o atropelamento por veículos automotivos é o de maior ocorrência nas emergências médicas veterinárias (RADLINSKY, 2014; SCREMIN, 2017). A lesão do trauma é classificada de acordo com duas origens, contundente e penetrante. O tipo contundente se caracteriza por casos de acidentes com veículo automotor e quedas de alturas, já o penetrante são considerados os casos de brigas de interação, perfurações por objetos pontiagudos e por arma de fogo de caráter intencional ou acidental (SCREMIN, 2017). Dentre as principais lesões que o trauma abdominal pode levar podemos citar: ruptura de órgãos parenquimatosos e órgãos ocos, sendo a lesão em órgãos gastrointestinais as menos frequentes.

Objetivo: Sendo assim esse trabalho tem como objetivo relatar o caso de um cão que após acidente automobilístico apresentou perfuração intestinal.

Relato de Caso: Canino, pinscher de 6 anos, macho de 3kg, foi atendido com histórico que havia sido atropelado há 7 dias, e que no quinto dia pós trauma animal começou a ter vômitos e hiporexia. No exame físico notou-se dor abdominal na região epigástrica e temperatura de 39,8, demais parâmetros dentro dos valores fisiológicos para a espécie. Apesar do trauma, não foi constatado na avaliação ortopédico nenhuma alteração. Animal foi internado para analgesia e tratamento sintomático, porém não apresentou melhora em 24 horas, sendo então realizado ultrassonografia abdominal a qual evidenciou imagem sugestiva de peritonite e presença de liquido livre, o mesmo foi puncionado para coleta o qual apresentou coloração marrom escuro e cheiro pútrido. Diante do quadro o animal foi então encaminhado para celiotomia exploratória onde foi localizado que uma porção do jejuno de $5 \mathrm{~cm}$ apresentava necrose e perfuração, realizado assim enterectomia com anastomose intestinal do segmento. No pósoperatório (PO) foi administrado ceftriaxona $(30 \mathrm{mg} / \mathrm{kg}$ ), metronidazol $(25 \mathrm{mg} / \mathrm{kg})$, dipirona $(25 \mathrm{mg} / \mathrm{kg})$, tramadol $(5 \mathrm{mg} / \mathrm{kg})$ e meloxicam $(0,1 \mathrm{mg} / \mathrm{kg})$, e a alimentação iniciada com dieta liquida 24 horas após a cirurgia. Aos 10 dias de PO animal apresentava completa recuperação e recebeu alta médica.

Discussão: Segundo os dados extraídos da literatura sobre principais causas de morte em cães em área metropolitana de São Paulo, observou que de um total de 2011 animais 268 (13,8\%) dos óbitos em cães, foram por traumatismo, relatado como a terceira causa mais importante (BENTUBO, 2007). Assim como o estudo de Scremin (2017) refere 17 de um total de 36 casos de traumatismo, o atropelamento como a principal causa de morte ou razão para eutanásia dos animais. Fighera et al., (2008), avaliou 155 casos fatais de traumatismo por atropelamento, sendo que 16 destes foi devido a ruptura de órgão oco, incluindo vesícula urinária (9), estômago (2), intestino grosso (1) e intestino delgado, este último remetendo três casos, infere-se diante disso que a ruptura de órgãos gastrointestinais acontece em uma menor prevalência, decorrente da grande mobilidade destes na cavidade abdominal. Os sinais como hipertermia, distensão abdominal, dor à palpação, vômito e diarreia podem ser verificados nos casos de peritonite. (STRAUSS e CALY, 2003). A peritonite séptica pode ser decorrente de traumatismos na cavidade abdominal, devido à perfuração de víscera oca, que leva ao extravasamento do conteúdo do trato gastrointestinal para o abdômen. O paciente com peritonite requer intervenção cirúrgica na cavidade abdominal (JUTKOWITZ, 2005; RIESER, 2005), pois ocorre alta taxa de mortalidade se não for tratada adequadamente, podendo evoluir para sepse e disfunção múltipla de órgãos (WONG, 2005). O diagnóstico deve ser feito através da ultrassonografia e a coleta do liquido livre para análise. No caso citado, o animal apresentava $5 \mathrm{~cm}$ de tecido necrosante na porção do jejuno, necessitando então de encaminhamento para cirurgia. Situações em que há comprometimento por necrose ou perfuração intestinal exigem enterectomias e enteroanastomoses (HERNÁNDEZ, 2010; RADLINSKY, 2014; PRATSCHKE, 2017). Geralmente nestes casos de peritonite, os protocolos antibióticos incluem $\beta$-lactâmicos combinados com fluoroquinolonas e metronidazol. (ELLISON, 2008). Assim como as opções de tratamento sugeridas pela Surgical Infection Society aplicáveis em pacientes de Medicina Veterinária, incluem o uso 
de agentes $\beta$-lactâmicos como as cefalosporinas de terceira geração (exemplo: ceftiofur, cefotaxima) isoladas ou em combinação com metronidazol (RAGETLY et al., 2011).

Conclusão: $O$ presente trabalho reitera a importância da realização de uma anamnese e exame físico detalhado nos animais vítimas de traumatismo, visando a rápida identificação e intervenção, minimizando as evoluções dos casos de sepse e diminuindo a mortalidade.

\section{Referências}

BENTUBO, H. D. L. Life expectation and causes of death in dogs in the metropolitan area of São Paulo (Brazil). Ciência Rural, v. 37, n. 4, p. 1021- 1026, 2007.

COSTA, S. A. B. Manejo do paciente politraumatizado na clínica de animais de companhia. 2014. Tese de Doutorado. Universidade de Lisboa. Faculdade de Medicina Veterinária. 2014.

ELLISON, G. W. New approaches in the surgical management of septic peritonitis. The Australian and New Zeland College of veterinary scientists. Florida, Science week, 2008. Disponivel em: . Acesso em: 24 de agosto de 2020.

HOLOWAYCHUK, M. K; HANEL, R. M; DARREN W. R; ROGERS, L; O'KEEFE, K; e MONTEITH, G. Prospective multicenter evaluation of coagulation abnormalities in dogs following severe acute trauma. Journal of veterinary emergency and critical care, v. 24, n. 1, p. 93-104, 2014.

JUTKOWITZ, L.A. Reproductive emergencies. Veterinary Clinics of North America: Small Animal Practice, Philadelphia, v.35, n.2, p.397-420, 2005.

RAGETLY, G. R., BENNETT, R.A., e RAGETELY, C. A. Septic peritonitis: treatment and prognosis. Internal Medicine Compendium. v. 33, n.10. 2011.

RIESER, T.M. Urinary tract emergencies. Veterinary Clinics of North America: Small Animal Practice, Philadelphia, v.35, n.2, p.359-373, 2005.

ROCHLITZ, Irene. Clinical study of cats injured and killed in road traffic accidents in Cambridgeshire. Journal of Small Animal Practice, v. 45, n. 8, p. 390-394, 2004.

SCREMIN, Rafaela Dal Paz. Estudo retrospectivo de cães atendidos no HVU com trauma abdominal no período de abril de 2014 a junho de 2017. Orientador: Sérgio Santalucia Ramos da Silva. 2017. 36 f. Monografia (Graduação em Medicina Veterinária). Medicina Veterinária Tubarão, 2017.

STRAUSS, E; CALY, R.W. Peritonite bacteriana espontânea. Revista da Sociedade Brasileira de Medicina Tropical, São Paulo, v.36, n.6, p.711-717, 2003.

TOBIAS, K. M., e JOHNSTON, S. A. Veterinary surgery: small animal. 1 edição, v.2, Set. Elsevier Health Sciences. 2013.

WONG, P.F. Antibiotic regimens for secondary peritonitis of gastrointestinal origin in adults. In: Cochrane review abstracts, 2005.

HERNÁNDEZ, C. A. Emergencias gastrointestinales en perros y gatos. Revista CES Medicina Veterinaria y Zootecnia, Medellín, Colombia, v. 5, n. 2, jul-dez. 2010, 69-85 p.

RADLINSKY, M.G. Cirurgia do sistema digestório. In: FOSSUM, T. W. Cirurgia de Pequenos Animais. 4.ed. Rio de Janeiro: Elsevier, 2014, 497-516 p.

PRATSCHKE, K. Intestinal surgery in small animals how to prevent it leaking? Veterinary Ireland Journal, Ireland, v.7, n.3, 2017.

FIGHERA, RAFAEL ALMEIDA, et al., Aspectos patológicos de 155 casos fatais de cães atropelados por veículos automotivos. Ciência Rural, v38, n.5, p.1375-1380, Agosto, 2008. 


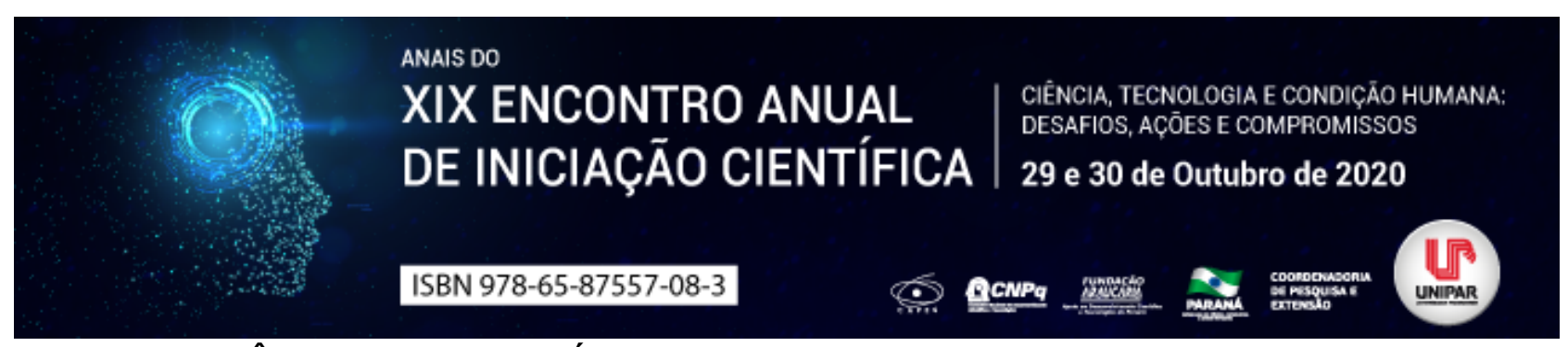

INFLUÊNCIA DO JEJUM PRÉ-ABATE NA PERDA DE PESO DE FRANGOS DE CORTE

\begin{abstract}
${ }^{1}$ IZABELA CAMILOTTI DORNELES, ${ }^{2}$ NATIELLI BELOTTI PAIE, ${ }^{3}$ ELOISE MARCIELLI MARTINS FERREIRA, ${ }^{4}$ TANIARA SUELEN MEZALIRA, ${ }^{5}$ ANDREIA ASSUNCAO SOARES, ${ }^{6}$ LUCIANA KAZUE OTUTUMI FARIAS
\end{abstract}

\begin{abstract}
${ }^{1}$ Doutoranda em Ciência Animal com Ênfase em Produtos Bioativos, UNIPAR, taxista PROSUP/CAPES
${ }^{1}$ Acadêmica do curso de Medicina Veterinária, UNIPAR, bolsista PIBIC/UNIPAR

${ }^{2}$ Acadêmica do curso de Medicina Veterinária, UNIPAR, bolsista PIBIC/UNIPAR

${ }^{3}$ Doutoranda em Ciência Animal com Ênfase em Produtos Bioativos, UNIPAR, taxista PROSUP/CAPES

${ }^{4}$ Professora do Mestrado em Plantas Medicinais e Fitoterápicos na Atenção Básica e da Pós-Graduação em Ciência Animal, UNIPAR

${ }^{5}$ Professora do curso de Medicina Veterinária e do Programa de Pós-Graduação em Ciência Animal com Ênfase em Produtos Bioativos, UNIPAR
\end{abstract}

Introdução: O jejum pré-abate de frangos de corte é a primeira etapa do manejo pré-abate e consiste na retirada da ração do animal horas antes de abate (LUDTKE et al., 2015). Tal prática tem como principal finalidade a redução dos níveis de contaminação das carcaças por meio do esvaziamento do trato gastrointestinal (MONLEON, 2013). O tempo que essas aves permanecem em jejum é muito importante, sendo esse uma somatória entre o tempo de jejum no aviário, apanha, transporte e área de espera (VIEIRA, 2012). Dessa forma, o jejum pré-abate deve ser realizado em torno de seis a oito horas antes da apanha, finalizando em oito a 12 horas (MENDES, 2001). A perda de peso durante o período de jejum pré-abate ocorre principalmente em função do esvaziamento do trato gastrointestinal (VIEIRA, 2012), porém, o aumento no tempo de permanência das aves em jejum tem correlação direta com o aumento da perda de peso, relacionado à mobilização de gorduras e proteína do organismo do animal para manter o mesmo em homeostase (MONLEON, 2013). O tempo de jejum exacerbado gera também alterações no pH da carne, comprometendo sua qualidade (MACARI et al., 2014), aumenta a desidratação do animal (VIEIRA, 2012) e também tem impacto significativo no bem-estar do animal.

Objetivos: Avaliar o percentual de perda de peso de frangos de corte em decorrência do tempo de jejum pré-abate de dois lotes pertencentes a uma integradora localizada na região oeste do Estado do Paraná.

Material e Métodos: O presente trabalho foi submetido ao Comitê de Ética da Universidade Paranaense, sendo aprovado sob protocolo 35408/2019. Foram acompanhados os procedimentos de jejum pré-abate de dois lotes de frangos de corte pertencentes a uma integradora localizada na região oeste do Estado do Paraná. Para a análise da influência do tempo de jejum pré-abate na perda de peso dos animais foram primeiramente identificados, por meio de dois lacres enumerados (um na pata e outro na asa) 40 frangos de corte de cada aviário selecionado para o estudo. Os animais foram em seguida pesados individualmente, por meio de balança, no começo do jejum pré-abate, ainda no aviário, e novamente no descarregamento das caixas de transporte, já no frigorífico, para a avaliação da perda de peso decorrente ao tempo de jejum pré-abate. O tempo de jejum pré-abate compreendeu então o tempo de permanência desses animais no aviário, somado da apanha, transporte e área de espera. Os resultados foram expressos na forma de porcentagem (\%).

Resultados: No primeiro aviário onde foram acompanhados os procedimentos de jejum pré-abate os animais permaneceram em jejum por 10 horas e 30 minutos, onde os valores de perda de peso variaram entre 0,77\% e 11,71\%, valor mínimo e máximo, respectivamente, com mediana de 4,41\%. Já no segundo aviário os animais permaneceram em jejum pré-abate por 11 horas e 30 minutos (uma hora a mais em relação ao primeiro aviário) e os valores variaram entre $0,52 \%$ e $13,29 \%$, valor mínimo e máximo, respectivamente, com mediana de 3,45\%. A partir de tais resultados, pode-se perceber que o segundo aviário apresentou maior variação nos valores de perda de peso quando comparado ao primeiro aviário.

Discussão: Existem alguns fatores que influenciam na perda de peso, como a idade do animal, sexo, temperatura do aviário e área de espera e o tempo de permanência nas caixas transportadoras (MONLEON, 2013). O tempo de jejum pré-abate está diretamente relacionado a perda de peso, uma vez que quanto maior o tempo de permanência desses animais em jejum, maior será a perda de peso (LUDTKE et al., 2015). Uma das causas dessa perda é a desidratação da carcaça, a qual tem início logo após o começo do procedimento de jejum (MENDES, 2001). Em pesquisa realizada por Assay Junior et al (2005), onde foram avaliadas a perda de peso em relação a diferentes tempos de jejum pré-abate, os autores verificaram média de perda de peso de $4,99 \%$ em 10 horas de jejum e 5,51\% de perda de peso em 11 horas de jejum pré-abate, demonstrando que quanto maior o tempo de jejum, maior é a perda de peso dos animais. No entanto, o que se pode perceber na presente pesquisa que a perda de peso é variável de animal para animal, uma vez que o aviário com maior tempo de jejum pré-abate apresentou o menor valor de mediana de perda de peso quando comparado ao primeiro aviário, o qual permaneceu menor tempo em jejum. O jejum pré-abate 
é uma ferramenta essencial, porém, apesar de necessário ele promove a perda de peso, e quando essa perda é exacerbada, ela tem impacto negativo tanto para a indústria como para o produtor, o qual terá sua remuneração reduzida (ROSA, s/d).

Conclusão: $O$ tempo de jejum pré-abate influência diretamente na perda de peso da carcaça, porém, o percentual de perda, apesar do tempo de jejum, pode variar de animal para animal. Dessa forma, o controle do tempo de jejum pré-abate é uma ferramenta extremamente importante tanto para a indústria alimentícia como para o produtor, além de garantir o bem-estar dos animais.

\section{Referências}

ASSAYAG JUNIOR, Mário Sérgio. et al. Efeito da duração do jejum pré-abate sobre peso corporal de frangos de corte aos 45 dias de idade. Brazilian Journal of Veterinary Research and Animal Science, São Paulo, v. 42, n.3, p. 188-192, 2005.

LUDTKE, Charli Beatriz. et al. Abate Humanitário de aves. 2 ed. São Paulo: World Animal Protection, 2015.

MACARI, Marcos. et al. Produção de Frangos de Corte. 2 ed. Campinas: Facta, 2014.

MENDES, Ariel Antônio. Jejum Pré-abate em Frangos de Corte. Brazilian Journal of Poultry Sciente, Campinas, v. 3, n.3, 2001.

MONLEON, Rafael. Manejo de pré-abate em frangos de corte. 2013 . Disponível em: http://en.aviagen.com/assets/Tech_Center/BB_Foreign_Language_Docs/Portuguese/Manejo-de-pr-abate-em-frangos-decorte.pdf. Acesso em: 30 jul. 2020.

ROSA, Paulo Sérgio. Pré-abate. $\quad$ s/d. Disponível em: https://www.agencia.cnptia.embrapa.br/gestor/frango_de_corte/arvore/CONT000fc6egldw02wx5eo0a2ndxy4j5mnhe.html. Acesso em: 30 jul. 2020.

VIEIRA, Sérgio L. Qualidade de carcaça de frangos de corte: uma avaliação a partir dos locais de produção. 2 ed. São Paulo: Rede Editora e Serviços de Clipping Ltda, 2012.

Coordenadoria de Pesquisa e Extensão - COPEX

Departamento de Editoraçāo e Divulgaçāo Científica - DEDIC 


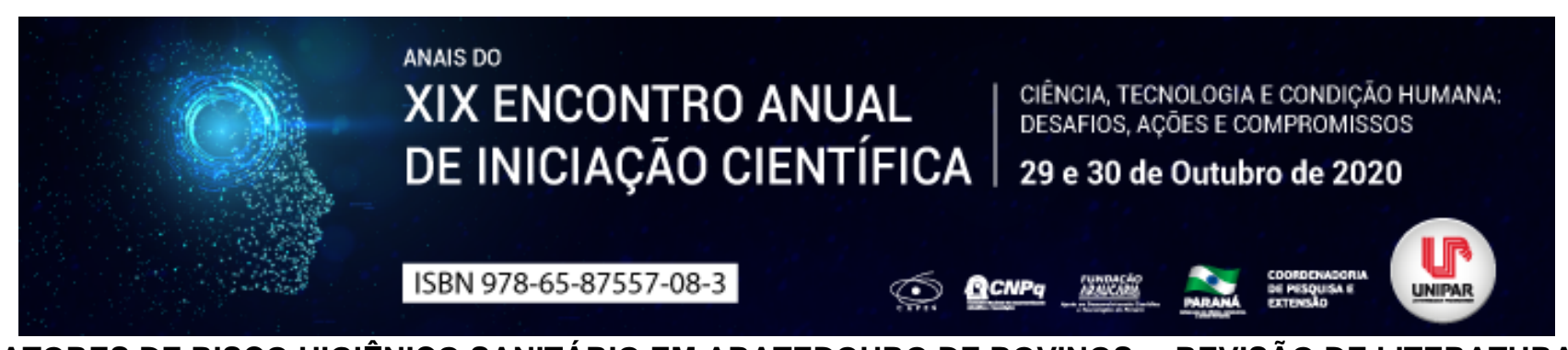

FATORES DE RISCO HIGIÊNICO SANITÁRIO EM ABATEDOURO DE BOVINOS REVISÃO DE LITERATURA

\begin{abstract}
${ }^{1}$ KAROLAINE BEZERRA, ${ }^{2}$ MARCO AURELIO CUNHA DEL VECHIO, ${ }^{3}$ ISABELA CARVALHO DOS SANTOS, ${ }^{4}$ DANIELA DIB GONÇALVES, ${ }^{5}$ LIDIANE NUNES BARBOSA
\end{abstract}

$\begin{array}{ll}{ }^{1} \text { Mestranda(o) PPG em Ciência Animal com Ênfase em Produtos Bioativos/Taxista } & \text { Prosup/CAPES } \\ { }^{1} \text { Mestranda(o) PPG em Ciência Animal com Ênfase em Produtos Bioativos/Taxista } & \text { Prosup/CAPES } \\ { }^{2} \text { Doutoranda PPG em Ciência Animal com Ênfase em Produtos Bioativos/Bolsista } & \text { Prosup/CAPES }\end{array}$

${ }^{3}$ Docente PPG em Ciência Animal UNIPAR

${ }^{4}$ Docente da UNIPAR

Introdução: A carne é um alimento rico em nutrientes, gerando grandes quantidades de proteínas, vitaminas como retinol, vitamina B12 e minerais como ferro, selênio e zinco, com maior biodisponibilidade do que outras fontes alimentares (NIYONZIMA et al., 2016). Os miúdos de bovinos obtidos durante o processo de abate também são fonte de nutrientes para a população mundial e somam expressiva importância econômica à produção dos abatedouros frigoríficos (SOUZA et al., 2017). A carne bovina pela sua capacidade de alterações fisiológicas, bioquímicas e microbiológicas, necessita de cuidado a mais no processo de produção e distribuição, principalmente a respeito das condições higiênico-sanitárias (RITTER et al., 2001). De acordo com dados da Organização Mundial de Saúde (OMS, 2002), as carnes ocupam o segundo lugar entre os produtos de origem animal envolvidos em doenças transmitidas por alimentos (DTA's). Esta situação ocorre devido aos microrganismos patogênicos pertencentes à microbiota natural dos animais de corte, presentes principalmente no trato digestório do animal, e que contaminam as carcaças e equipamentos ao longo da linha de processamento (ALBAN et al., 2005).

Objetivo: Avaliar fatores de risco higiênico sanitário em abatedouros de bovinos através de revisão da literatura.

Desenvolvimento: O crescimento da população humana e a melhoria das condições econômicas, tem levado a um consumo maior por produtos cárneos. Simultaneamente o avanço da qualidade e normas de biossegurança para atender os consumidores (ALBAN et al., 2005). Sendo assim, é necessário atenção à gestão da qualidade nos frigoríficos, com os padrões microbiológicos, à sanidade e a ausência de substâncias nocivas, garantindo assim a segurança do alimento (TOLEDO, 2001). Dados da Secretaria de Vigilância em Saúde SVS (2019) indicam que 5,3\% de 2.350 surtos registrados no Brasil no período de 2009 a 2018 são oriundos de carne bovina in natura, processados e miúdos. Escherichia coli (23,4\%), Salmonella spp. (11,3\%) e Staphylococcus aureus (9,4\%) foram os principais agentes etiológicos identificados em 2.431 surtos de DTA's. Segundo Dutra (2006), dentro de um processamento industrial os alimentos podem ser contaminados por microrganismos patogênicos e deteriorantes, resultado de condições higiênico sanitária insatisfatória durante o processamento. Essa contaminação pode ser de pessoas doentes ou conteúdos gastrointestinais dos animais abatidos, e devido às más práticas de fabricação. Com esse tipo de situação as indústrias de processamento de carne buscam sempre desenvolver, implementar e gerenciar efetivamente os programas de controle de perigos, por meio de Boas Práticas de Fabricação (BPF), Procedimentos Sanitários Operacionais (PSO), Procedimento Padrão de Higiene Operacional (PPHO) e Análise de Perigos e Pontos Críticos de Controle (APPCC), o que tem melhorado a qualidade do produto (BRASIL, 2005).

Conclusão: Conclui-se no presente trabalho a importancia do controle dos programas de qualidade em abatedouros bovinos, afim de minimizar os efeitos dos fatores de risco higienico sanitário, e assim tornar a carne bovina um alimento mais seguro, sem risco a saúde única.

\title{
Referências
}

ALBAN, L.; STÄRK, K. D. C. Where should the effort be put to reduce the Salmonella presence in the slaughtered swine carcass effectively?. Preventive Veterinary Medicine. Holanda, v.68, p.63-79, 2005.

BRASIL. Ministério da Agricultura Pecuária e Abastecimento. Procedimentos de Verificação dos Programas de Autocontrole. Brasília: Ministério da Agricultura. Disponível em: http://dzetta.com.br/info/wp-content/uploads/2011/06/dzetta-Circular-175-de16-de-maio-de-2005.pdf. Acesso: 05 ago. 2020.

BRASIL. Ministério da Saúde. Surtos de doenças transmitidas por alimentos no Brasil. Disponível em http://www.saude.gov.br/saude-de-a-z/doencas-transmitidas-por-alimentos. Acesso: 03 ago. 2020.

DUTRA, M. G. B. As múltiplas faces e desafios de uma profissão chamada medicina veterinária. Revista do Conselho Federal de Medicina Veterinária. Brasília. v. 12, n. 37, p. 49-56. 2006.

NIYONZIMA, E.; ONGOL, M.P.; BROSTAUX, Y.; KORSAK, K. N.; KAMONYO, A.; SINDIC, M. Daily intake and bacteriological quality of meat consumed in the households of Kigali, Rwanda. Food Control, Inglaterra, nov. 2016, n. 57116. Science Direct. 
Disponível em: https://www.sciencedirect.com/journal/food-control. Acesso em: 25 jul. 2020.

ORGANIZAÇÃO MUNDIAL DA SAÚDE OMS. Resolução EB 105. Segurança alimentar: Uma revolução da diretoria executiva da organização mundial da saúde. 2002.

RITTER, R.; SANTOS, D.; BERGMANN, G. P. Contaminação bacteriana de carne bovina moída comercializada em bancas do mercado público de Porto Alegre. Higiene Alimentar, São Paulo, v. 15, n. 85, p. 50-56, 2001.

SOUZA, S. P.; KLEM, M. C. A.; COSTA, K.P.; SILVA, L. F. Principais causas de condenação de fígado bovino em estabelecimento sob Serviço de Inspeção Federal na Zona da Mata mineira. Arquivo Brasileiro de Medicina Veterinária e Zootecnia, Belo Horizonte, v. 69, n. 4, p. 1054-1061. 2017.

TOLEDO, J. C. Gestão da qualidade na agroindústria. Gestão agroindustrial. 2. ed. São Paulo: Atlas, 2001.

Coordenadoria de Pesquisa e Extensão - COPEX

Departamento de Editoraçāo e Divulgaçāo Científica - DEDIC 


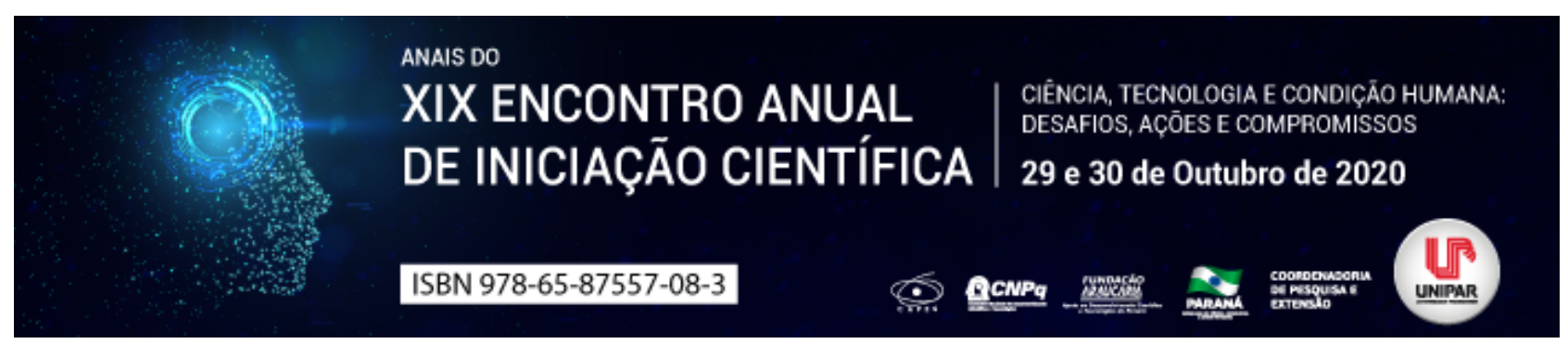

PAPILOMA INVERTIDO CANINO: RELATO DE CASO

\begin{abstract}
${ }^{1}$ Joana Cristina Smaha de Jesus Lima, ${ }^{2}$ KARIM CRISTHINE PASE MONTAGNINI, ${ }^{3}$ JULIANA DAS CHAGAS GOULART , ${ }^{4}$ ARTHUR COLOMBARI CHENG, ${ }^{5}$ ELVIN LENON ERNESTO CHERUBINI, ${ }^{6}$ ALINE DE MARCO VIOTT
\end{abstract}

\begin{abstract}
${ }^{1}$ Discente no Programa de Pós Graduação em Ciência Animal, Universidade Federal do Paraná, Setor Palotina, Palotina, Paraná
${ }^{1}$ Discente no Programa de Pós Graduação em Ciência Animal, Universidade Federal do Paraná, Setor Palotina, Palotina, Paraná

${ }^{2}$ Residente em Anatomia Patológica, Universidade Federal do Paraná, Setor Palotina, Palotina, Paraná

${ }^{3}$ Residente em Anatomia Patológica, Universidade Federal do Paraná, Setor Palotina, Palotina, Paraná

${ }^{4}$ Médico Veterinário, Clínica Veterinária Planeta Bicho, Francisco Beltrão, Paraná

${ }^{5}$ Professor adjunto de Patologia Veterinária, Universidade Federal do Paraná, Setor Palotina, Palotina, Paraná
\end{abstract}

Introdução: A dermatologia é uma área que gradativamente ganha importância na medicina veterinária, e estima-se que entre $20 \%$ e $75 \%$ dos atendimentos veterinários realizados em clínicas e hospitais estão diretamente relacionados às doenças de pele (GASPARETTO et al., 2013). Dentre as afecções que podem acometer a pele tanto em cães quanto de gatos, são relatados os tumores benignos, como os papilomas. O papilomavirus canino (CPV), por sua vez, é caracterizado por induzir tumores benignos em virtude da infecção de células epiteliais por DNA de papilomavirus espécie-específico, onde oncogenes virais induzem o crescimento e a divisão das células epiteliais do hospedeiro, causando instabilidade e mutações cromossômicas. Em cães, já foram identificados cinco tipos de CPV e em gatos, já foram identificados oito tipos de papilomavirus (HNILICA, 2012). Os papilomas invertidos, por sua vez, são considerados neoplasias endofíticas incomuns da pele, causadas pela infecção do CPV-1, CPV-2 e CPV-6 (GOLDSCHMIDT; GOLDSCHMIDT, 2017), sendo os cães de até três anos normalmente diagnosticados (GROSS et al., 2005). Desta forma, relata-se um caso de papiloma invertido em um canino diagnosticado através de exame histopatológico e histórico clinico.

Relato de Caso: Um canino, fêmea, sem raça definida, com três de anos de idade, foi atendida no Hospital Veterinário da UFPR, com histórico de lesão nodular supurativa em região ventral há nove meses, onde era realizado tratamento à base de antibióticos, porém sem sucesso. Foi realizada exérese do nódulo e o mesmo, remetido ao LPV. Macroscopicamente, o nódulo era alopecico

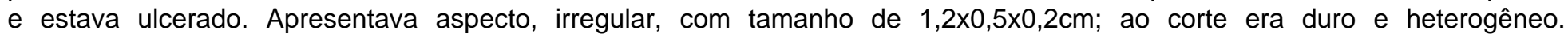
Microscopicamente, observou-se proliferação neoplásica de células epiteliais, de crescimento expansivo, moderadamente celular, bem delimitado e não encapsulado. As células neoplásicas eram arredondadas a ovaladas, com limites celulares indistintos, agrupadas em formato de xícara e possuiam núcleo central de queratina ou células paraqueratóticas, sustentadas por moderado estroma fibrovascular. O citoplasma era discreto, redondo, ora distinto, ora indistinto e o núcleo era central, com cromatina finalmente pontilhada e quando visível, havia um nucléolo evidente. Anisocitose, anisocariose e pleomorfismo eram leves e não foram visualizadas figuras de mitose. As alterações histológicas confirmam o quadro de papilomatose invertida.

Discussão: As alterações microscópicas foram compatíveis com papiloma invertido, conforme descrito por Gross et al. (2005). Quanto a região acometida, segundo Hnilica (2012) e Goldschmidt e Goldschmidt (2017), as lesões são comumente encontradas em membros posteriores e no abdômen, apresentando-se como lesões solitárias de 1-2cm de diâmetro, corroborando com o presente caso. Conforme Gross et al. (2005), normalmente a idade dos cães acometidos pelo papiloma invertido é inferior de três anos de idade. Em contrapartida, Goldschmidt e Goldschmidt (2017), afirmam que não há predisposição sexual, racial e de idade para a ocorrência da condição. Por ser uma lesão que não sofre regressão espontânea (GROSS et al., 2005), a excisão cirúrgica é recomendada.

Conclusão: Apesar de incomuns, os papilomas invertidos devem ser considerados diagnósticos diferenciais em afecções cutâneas, uma vez que dentre as enfermidades que acometem os pequenos animais, as dermatológicas possuem ampla casuística. Destaca-se também, a histopatologia como forma de diagnóstico precisa.

\title{
Referências
}

GASPARETTO, Naiani. D; TREVISAN, Yolanda. P. A; ALMEIDA, Nayara. B. et al. Prevalência das doenças de pele não neoplásicas em cães no município de Cuiabá, Mato Grosso. Pesquisa Veterinária Brasileira. v.33, n.3, p. 359-362. Março, 2013.

GOLDSCHMIDT, Michael. H; GOLDSCHMIDT, Kyle. H. Epithelial and Melanocytic Tumors of Skin. In: MEUTEN, Donald. J. Tumors in Domestic Animals. 5. ed. Ames, lowa: John Wiley \& Sons Inc, 2017. p. 88-141.

GROSS, Thelma. L; IHRKE, Peter. J; WALDER, Emily. J. et al. Skin Diseases of the Dog and Cat: Clinical and Histopathologic Diagnosis. 2. ed. Blackwell Science, 2005. 
HNILICA, Keith. A. Dermatologia em Pequenos Animais: Atlas colorido e guia terapêutico. 3. ed. Rio de Janeiro: Elsevier, 2012.

Coordenadoria de Pesquisa e Extensão - COPEX

Departamento de Editoraçāo e Divulgaçāo Científica - DEDIC 


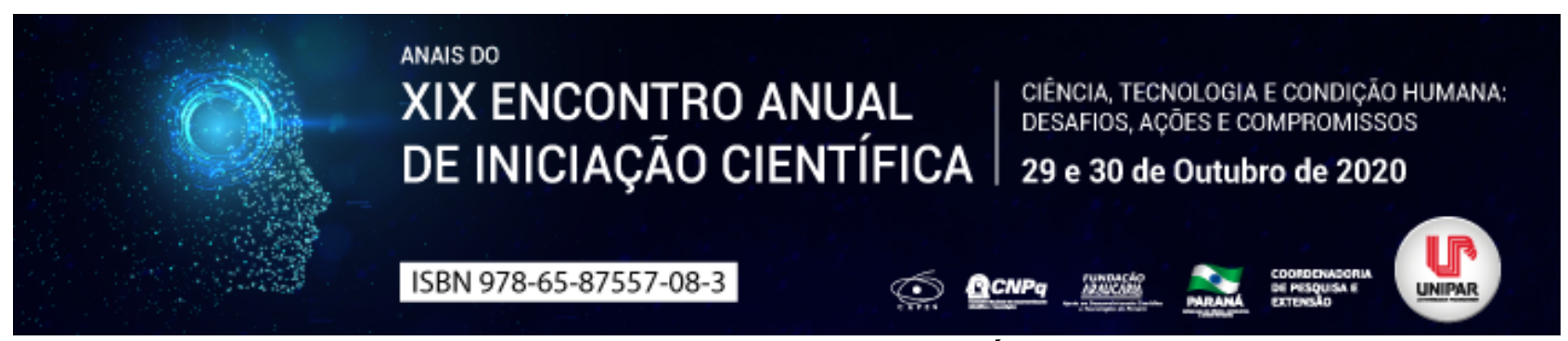

NOVOS MEDICAMENTOS ANTIEPILÉTICOS

\title{
${ }^{1}$ MARIANE DE ALMEIDA MACHADO, ${ }^{2}$ LETICIA RODRIGUES GENARIO, ${ }^{3}$ SUELLEN LAIS VICENTINO VIEIRA
}

\author{
${ }^{1}$ Acadêmica do curso de Farmácia Unipar

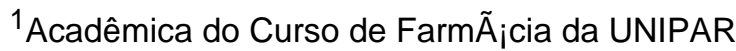 \\ ${ }^{2}$ Docente da UNIPAR
}

Introdução: A epilepsia é uma enfermidade do Sistema Nervoso Central (SNC) que causa um transtorno na neurotransmissão, do qual consequentemente os neurônios acabam sendo disparados de forma descontrolada e os impulsos nervosos gerando sintomatologias como crises convulsivas ou comportamento e sensações incomuns, além de poder ocorrer perda de consciência (CABOCLO, 2019). Atualmente a epilepsia afeta quase 50 milhões de pessoas pelo mundo, sendo considerada uma das mais comuns doenças neurológicas, acometendo pessoas de todas as idades, porém tem uma incidência maior em crianças e idosos com mais de 60 anos, sem discriminação por sexo ela acaba atingindo uma quantidade bem relevante da população mundial. A terapêutica medicamentosa está disponível há muito tempo da qual apresentam falhas em relação a um resultado eficaz, sendo que o desenvolvimento de novos fármacos para o tratamento dessa doença se faz importante (VIDAURRE, 2019).

Objetivo: Conhecer a forma farmacológica de cada novo medicamento antiepilético e sua interação no organismo.

Desenvolvimento: A epilepsia é uma doença muito antiga, porém que se demorou para compreender a enfermidade. Os sintomas mais comuns é a crise tônico-clônica, chamada habitualmente de convulsão , outras crises, entretanto, podem não ser reconhecidas por pacientes, seus familiares e até mesmo por médicos, pois apresentam manifestações sutis, como alteração discreta de comportamento, olhar parado e movimentos automáticos, em crianças, por exemplo, é comum a ocorrência de crises de ausência (GOMES, 2006). É necessário um diagnóstico baseado na avaliação do histórico do paciente, com informações sobre os tipos de crises apresentadas, a idade de início dos sintomas, história familiar, além de exames complementares como o eletroencefalograma, tomografia de crânio e a ressonância magnética do cérebro (CABOCLO, 2019). Os medicamentos normalmente usados segundo a Associação Brasileira de Epilepsia são o Fenobarbital, Fenitoína, Valproato, Carbamazepina, Lamotrigina, Vigabatrina, Topiramato, Benzodiazepínicos e Oxcarbazepina (ABE, 2017). Porém estes medicamentos acabam não sendo mais totalmente eficazes, além da possibilidade de acontecer vários efeitos adversos que podem atrapalhar a qualidade de vida de quem carrega consigo essa patologia. Com a tecnologia é possível se obter avanços também na terapia medicamentosa como o desenvolvimento de novos fármacos que podem atuar de uma maneira mais eficaz em seus mecanismos de ação diminuindo assim a ocorrência de efeitos colaterais. Os fármacos chamados medicamentos antiepiléticos de terceira geração como a Eslicarbazepina é um inibidor dos canais de sódio dependentes de voltagem, comparando a medicamentos de outras gerações tem menos efeito anticonvulsivante, $67 \%$ da droga é eliminada pelos rins sem qualquer alteração e os indutores enzimáticos podem aumentar sua eliminação A incidência de hiponatremia (1,5\%) e erupção cutânea (3\%) é menor do que a da carbamazepina. Fosfenitoína é um pró-fármaco da fenitoína e, portanto, atua nos canais de sódio dependentes de voltagem, tem menos efeitos adversos do que a fenitoína (dor, flebite e problemas cardiovasculares). A infusão de fenitoína leva 30 minutos versus 10 minutos com fosfenitoína. A brivaracetam possui estrutura semelhante ao levetiracetam, mas possui seletividade e afinidade 15-30 vezes maior para a proteína SV2A necessária ao funcionamento das vesículas sinápticas. Os efeitos adversos são mínimos: irritabilidade, sonolência e fadiga, porém sua eliminação é aumentada por indutores enzimáticos. A alopregnenolona (SAGE 547) é um metabólito da progesterona no SNC e periférico e modula os receptores GABA-A sinápticos e extra-sinápticos. Isso é importante, pois nas crises prolongadas ocorre internalização dos receptores sinápticos, o que não ocorre nos receptores pré-sinápticos (VIDAURRE, 2019).

Conclusão: O tratamento da epilepsia data de anos, com medicamentos que provocam uma série de efeitos colaterais e refratariedade. A pesquisa e o desenvolvimentos de fármacos destinados ao tratamento da doença é necessária, para substituir a terapia existente ou atuar em associações se necessário.

\section{Referências}

ABE - Associação Brasileira de Epilepsia. EFEITOS ADVERSOS DAS DROGAS ANTIEPILÉTICAS. Associação Brasileira de Epilepsia. 2017. Disponível em:https://www.epilepsiabrasil.org.br/tratamento. Acesso em: 11/08/2020.

CABOCLO, Luis Otavio S. F.. Epilepsia, São Paulo, 27 de Fevereiro de 2019. Disponível em:https://www.einstein.br/doencassintomas/epilepsia. Acesso em: 11/08/2020.

GOMES, Marleide da Mota. História da epilepsia: um ponto de vista epistemológico. Journal of Epilepsy Clinical and Neurophysiology. v. 12, n. 3, p. 161-167, 2006. Disponível em:https://www.scielo.br/scielo.php?script=sci_arttext\&pid=S167626492006000500009. Acesso em: 11/08/2020. 
VIDAURRE, Jorge. HERBST, James. Nuevos fármacos antiepilépticos. Medicina. v.79, n. 2, p. 48-53, 2019. Disponível em:http://www.scielo.org.ar/scielo.php?script=sci_arttext\&pid=S0025-76802019000700012\&lang=pt. Acesso em:11/08/2020.

Coordenadoria de Pesquisa e Extensão - COPEX

Departamento de Editoraçāo e Divulgaçāo Científica - DEDIC 


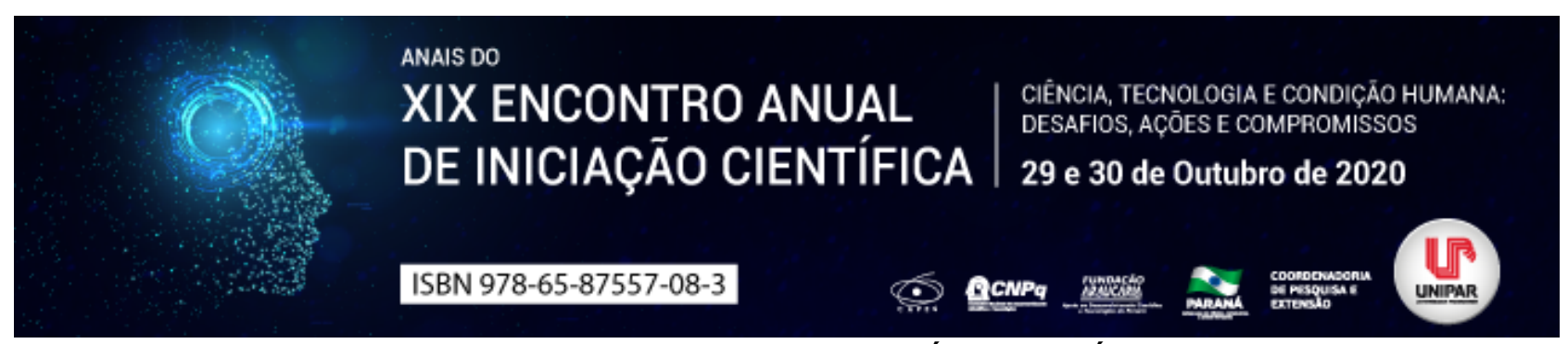

OS ESTUDOS DA ISOFLAVONA SOBRE A SUA PROVÁVEL EFICÁCIA NA MENOPAUSA

\author{
${ }^{1}$ MARIANE DE ALMEIDA MACHADO, ${ }^{2}$ LETICIA RODRIGUES GENARIO, ${ }^{3}$ MONICA MICHELI ALEXANDRE , ${ }^{4}$ FABIOLA \\ COSTA TAKAKUA, ${ }^{5}$ MARINA GIMENES
}

\begin{abstract}
${ }^{1}$ Acadêmica do curso de Farmácia da UNIPAR
${ }^{1}$ Acadêmica do Curso de Farmácia da UNIPAR

${ }^{2}$ Acadêmica do Curso de Medicina da UNIPAR

${ }^{3}$ Acadêmica do Curso de Medicina da UNIPAR

${ }^{4}$ Docente da UNIPAR
\end{abstract}

Introdução: De origem orgânica e natural, o fármaco Isoflavona é um composto denominado como fitoterápico, ou seja, aquele o qual se obtém através de uma planta medicinal. Apresenta uma estrutura química semelhante à dos estrógenos, hormônio feminino relacionado à ovulação da mulher, cujo declínio pode causar sintomas desagradáveis, em uma fase da vida das mulheres que se inicia por volta dos 45 a 50 anos, conhecido como menopausa. São fitoestrógenos derivados da soja, que apresentam atividades estrogênicas devido a semelhança química. Segundo Frederico Lui Filho et al. (2015) a menopausa pode pode ocorrer de forma natural ou artificial e é caracterizado pela parada da produção hormonal ovariana, com alguns possíveis desconfortos, como os vasomotores, como fogachos e sudorese, a atrofia genital e os transtornos psicológicos que podem provocar prejuízo pessoal e implicação social de grande importância (FREEMAN, 2010).

O tratamento dos sintomas climatéricos e a prevenção de doenças relacionadas envolve mudanças relacionadas à alimentação, exercícios físicos, eliminar o tabagismo e utilização de medicamentos sendo a mais comum a a reposição hormonal, com vários aspectos negativos e dessa forma a escolha pela isoflavona tem sido uma boa opção.

Objetivo: Analisar os estudos publicados sobre a Isoflavona que avaliam a sua possível eficácia no controle da menopausa.

Desenvolvimento: A menopausa pode ser determinada como a última menstruação da mulher e isso ocorre pois segundo Varella (2020) Quando morrem os últimos folículos, os ovários entram em falência e as concentrações dos hormônios femininos, estrogênio e progesterona, caem irreversivelmente. Essa queda hormonal causa uma série de sintomas, de primeiro a mulher passa pelo climatério o período antecedente da menopausa onde sintomas se intensificam de acordo com a diminuição dos folículos entre eles: ondas de calor, alterações ou variações emocionais, depressão, ansiedade, insônia, diminuição da libido, alterações de humor, dores de cabeça e enxaqueca, fadiga fora do comum (SOARES, 2014), outros como a irregularidade nos ciclos menstruais, sintomas psíquicos, podendo levar até uma possível depressão, alterações na pele, cabelos, unhas, alteração de distribuição de gordura pelo corpo entre outros sintomas (VARELLA, 2020). A alimentação e a qualidade de vida das mulheres influenciam muito para que não sejam tanto acometidas pelos sintomas da menopausa, é necessário manter uma alimentação equilibrada, estar sempre com seu índice de massa corporal dentro das normalidades para que esses fatores não interfiram ainda mais, pois o número de incidências em doenças cardiovasculares na pós menopausa nas mulheres vem sendo a principal causa de mortalidade e morbidade em mulheres, confirmado por Carmignani et al. (2014)

Alterações nos lipídios e lipoproteínas no momento da menopausa podem contribuir significativamente para um aumento do risco de desenvolvimento de DCV ao longo da vida da mulher. A Isoflavona vem sendo estudada sobre seus possíveis efeitos benéficos em mulheres que estão na menopausa com indicações que podem melhorar os sintomas. Estudo realizado por (NAHAS et al., 2003) mostrou que o grupo tratado com isoflavona ocorreu alívio completo das ondas de calor em $44 \%$ das pacientes contra $12 \%$ sob placebo, ou seja notaram melhora dos sintomas vasomotores com suplementação dietética de soja. Os mesmos autores em 2007 afirmam que o extrato de isoflavona de soja exerceu efeitos favoráveis sobre os sintomas vasomotores e boa adesão, fornecendo uma alternativa terapêutica segura e eficaz para mulheres na pós-menopausa (NAHAS et al., 2007). Albertazzi e Purdie (2002) concluíram que o uso das isoflavonas no climatério reduziu em 40 a $50 \%$ dos fogachos, com doses de 50 a 80 mg/dia. Em uma revisão realizada por Varaschini, Mendel e Suyenaga (2011) mostrou que as isoflavonas apresentam redução de queixas de fogachos, assim como diminuição da osteoporose, porém não se evidenciou qualquer efeito sobre alterações urogenitais e sintomas psicológicos. Além de poder contribuir para a melhora da menopausa a ingestão de uma alimentação ricamente enriquecida com soja (isoflavonas) podem neutralizar ou diminuir a taxa de oxidação do colesterol LDL, como resultado desse efeito antioxidante, de acordo com Carmignani et al.(2014).

Conclusão: Conclui-se então com a posição de que a Isoflavona pode contribuir não somente para a melhoria de sintomas de uma menopausa, mas como também pode influenciar em melhorias nos níveis de colesterol que a mulher pode desenvolver durante esse período de mudanças hormonais. Estudos ainda estão sendo realizados para dimensionar medidas de resultados padronizadas que reflitam as prioridades dos pacientes, médicos e pesquisadores. 


\section{Referências}

ALBERTAZZI, Paola; PURDIE, David W. The nature and utility of the phytoestrogens: a review of the evidence. Maturitas, v. 42, n. 3, p.173-185, 2002.

CARMIGNANI, Lúcio Omar et al . The effect of soy dietary supplement and low dose of hormone therapy on main cardiovascular health biomarkers: a randomized controlled trial. Rev. Bras. Ginecol. Obstet., Rio de Janeiro , v. 36, n. 6, p. 251-258, June 2014. Disponivel em: https://bit.ly/2DfVgEd. Acesso em 21 de Agosto de 2020.

FREDERICO LUI FILHO, Jeffrey et al. Epidemiologia da menopausa e dos sintomas climatéricos em mulheres de uma região metropolitana no sudeste do Brasil: inquérito populacional domiciliar. Rev. Bras. Ginecol. Obstet.; v.37, n.4, p.152-8, 2015.

FREEMAN, Ellen W. Associations of depression with the transition to menopause. Menopause. v.17, n.4, p. 823-7, 2010.

NAHAS, Eliana Aguiar Petri et al. Efeitos da isoflavona sobre os sintomas climatéricos e o perfil lipídico na mulher em menopausa. Rev. Bras. Ginecol. Obstet., Rio de Janeiro , v. 25, n. 5, p. 337-343, June 2003. Disponível em: https://bit.ly/32LE1Di. Acesso em 21 de Agosto de 2020.

NAHAS, Eliana AP. et al. Efficacy and safety of a soy isoflavone extract in postmenopausal women: a randomized, double-blind, and placebo-controlled study. Maturitas, v. 58, n. 3, p. 249-258, 2007.

SOARES, Lia da Silva. Enfrentamento do Período Climatério pelas Profissionais da Saúde. 2014. Monografia apresentada como requisito para Conclusão de Curso de psicologia da UFRR-Universidade Federal de Roraima. Boa Vista, RR 2014.

VARASCHINI, Adriana; MENDEL, Monique Theissen; SUYENAGA, Edna Sayuri. ISOFLAVONAS DE SOJA NO TRATAMENTO DOS SINTOMAS DO CLIMATÉRIO: O QUE É CIENTIFICAMENTE VALIDADO? Revista Conhecimento Online, v. 2, p. 136$154,2011$.

VARELLA, Drauzio. MENOPAUSA E CLIMATÉRIO. 2020. Disponível em: https://bit.ly/3ID6T9m. Acesso em 24 de Ago. de 2020. 


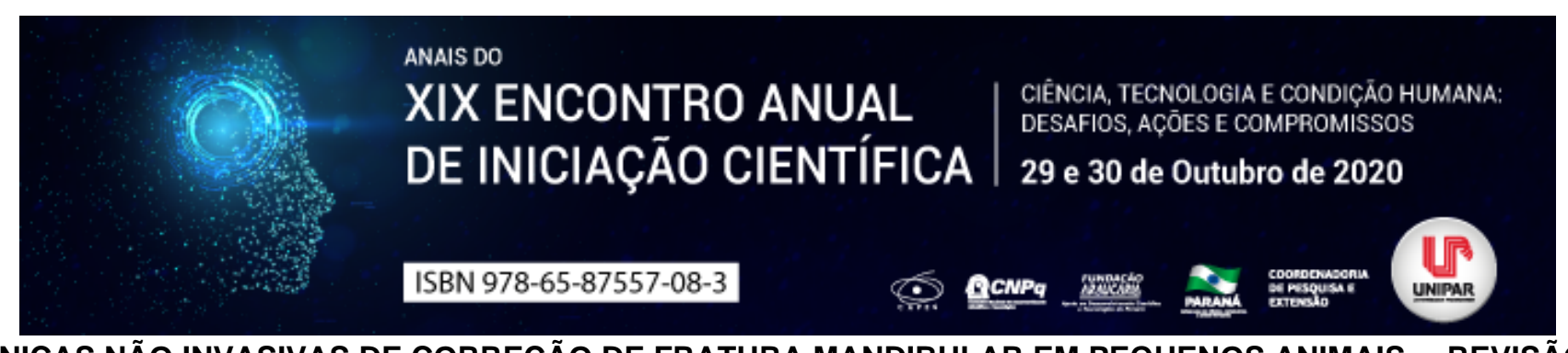

\title{
TÉCNICAS NÃO INVASIVAS DE CORREÇÃO DE FRATURA MANDIBULAR EM PEQUENOS ANIMAIS REVISÃO DE LITERATURA
}

\begin{abstract}
${ }^{1}$ Bruna Carolina Marquardt, ${ }^{2}$ BRUNA BAGATIM DE SOUZA, ${ }^{3}$ LAURA MARIANA TONETE, ${ }^{4}$ LARISSA ÉDINA PERIN PEREIRA, ${ }^{5}$ CAROLINE HELENA ROCHA, ${ }^{6}$ MAURO HENRIQUE BUENO DE CAMARGO
\end{abstract}

\begin{abstract}
${ }^{1}$ Mestranda no Programa de Pós-Graduação em Produção Sustentável e Saúde Animal UEM/Umuarama-PR
${ }^{1}$ Discente do curso de Medicina Veterinária UEM/Umuarama-PR

${ }^{2}$ Discente do curso de Medicina Veterinária UEM/Umuarama-PR

${ }^{3}$ Discente do curso de Medicina Veterinária UEM/Umuarama-PR

${ }^{4}$ Discente do curso de Medicina Veterinária UEM/Umuarama-PR

${ }^{5}$ Docente do curso de Medicina Veterinária UEM/Umuarama-PR
\end{abstract}

Introdução: As fraturas mandibulares são geralmente causadas por trauma, mas podem também ser resultado de periodontites graves ou neoplasias, e apesar dessas fraturas poderem ocorrer em cães de qualquer idade, os animais mais jovens estão sob maior risco, no entanto, com o aumento da população de cães de raças pequenas, a idade média dos cães que apresentam fratura de mandíbula tem se elevado, principalmente relacionada a falta de profilaxia dentária regular (FOSSUM, 2014). Um estudo, com mais de 500 animais, demonstrou que as fraturas de mandíbula correspondem a 11,4\% das fraturas registradas em gatos e 2,5\% das registradas em cães (PHILLIPS, 1979), além disso constatou-se que as brigas entre os cães, e os traumas automobilísticos são as duas maiores causas de fraturas (LOPES et al., 2005). O diagnóstico pode ser realizado por meio da apresentação clínica, exame físico e diagnóstico por imagem, com radiografias da mandíbula. Vistas especiais como as intraorais também podem ser necessárias, assim como a tomografia computadorizada, que pode auxiliar o diagnóstico no caso de fraturas de difícil visualização no exame radiográfico (FOSSUM, 2014).

Objetivo: realizar revisão acerca das técnicas não invasivas de correção de fratura mandibular, ampliando o conhecimento sobre o assunto, tendo em vista a prevalência desse tipo de fratura na rotina veterinária e as inovações que têm sido descritas.

Desenvolvimento: Tala interdental reforçada com fio: No estudo realizado por Guzu e Hennet (2017), as fraturas foram reduzidas de maneira fechada para restaurar a oclusão dos dentes caninos e o alinhamento dos segmentos ósseos conforme determinado por radiografias, exame oral e palpação da borda ventral do corpo da mandíbula. As fraturas foram imobilizadas com fio de aço inoxidável de dimensão variável de acordo com o tamanho do cão e os fios foram colocados entre o canino inferior e o primeiro ou segundo molar. Se o dente canino estivesse ausente ou apresentasse mobilidade moderada ou grave, o canino oposto era utilizado. Um canal intraósseo era realizado no osso alveolar atrás do dente, ou colocava-se um parafuso de titânio verticalmente no osso alveolar, se o primeiro molar não fornecesse ancoragem suficiente. Posteriormente o fio era passado pelo canal ou ao redor do parafuso utilizando diversas técnicas de fiação interdental simples continua. O objetivo da fiação era corrigir a linha de fratura e fornecer estabilidade primária até colocação do composto acrílico. A resina foi colocada diretamente sobre o fio e dentes, e o excesso de material foi removido com broca de diamante. As reavaliações clinicas incluíram inspeção, palpação do local da fratura, avaliação da oclusão dentária e processo inflamatório oral, bem como a estabilidade do dispositivo. As radiografias foram repetidas conforme o necessário, com objetivo de monitorar a cicatrização e os sinais de infecção. O resultado do estudo demonstrou que a técnica pode ser utilizada para tratar fraturas do corpo mandibular em cães de raças pequenas, se a fratura não for severamente triturada, e se pelo menos o dente canino e o primeiro molar puderem ser utilizados para ancoragem. Já as lesões mais graves, como as que apresentam dentes na linha de fratura estão associadas a uma cicatrização óssea mais lenta (GUZU e HENNET, 2017). Adesivo mineral-orgânico a base de fosfato de cálcio-fosfoserina: O novo mineral a base de fosfato de cálcio-fosfoserina é uma mistura de formas de pó de fosfato de tetracálcio e fosfoserina, que deve ser misturado em meio aquoso. Quando misturado, se torna ajustável e cria fortes ligações à superfície dos implantes ósseos e metálicos (KIRILLOVA et al., 2018). A combinação das propriedades do material servem como um mecanismo que permite a estabilização de fraturas, sendo concomitantemente reabsorvido e incorporado ao osso cicatrizado. Sabe-se que o material é seguro, e reabsorvido, por meio de estudos realizados em cães (COCHRAN et al., 2020). No estudo de Geddes et al. (2020), o adesivo foi testado e comparado com outras formas de fixação mandibular não invasiva. O adesivo mineral orgânico foi preparado com a adição de água para injeção ao pó seco. Após concluída a mistura o material foi transferido para uma seringa e injetado em ambas as superfícies da fratura. Os grupos que foram testados com outros métodos de fixação foram preparados, e em seguida foram realizados testes mecânicos com aplicação de carga para imitar as forças que agem na mandíbula. Como resultado, o grupo com adesivo e composto mineral-orgânico apresentou melhor resultado que o grupo testado com fio e composto, sendo assim, o uso de adesivo ósseo reabsorvível e composto pode proporcionar uma fixação mais resistente do que aquela com fio 
interdental e composto, no reparo de fraturas mandibulares em cães.

Conclusão: Pode-se concluir através desta revisão que as técnicas cirúrgicas não invasivas têm ganhado popularidade devido às boas experiências clínicas com compostos odontológicos na Medicina Veterinária, além de minimizar a exposição cirúrgica do local da fratura.

\section{Referências}

COCHRAN, David L.; JONES, Archie; SUGITA, Ryushiro; BROWN, Michael C.; PRASAD, Hari; ONG, Joo L.; POLLACK, Alan; KAY, George W. Immediate Dental Implant Stabilization in a Canine Model Using a Novel Mineral-Organic Adhesive: 4-Month Results. The International Journal of Oral \& Maxillofacial Implants, v. 35, n. 1, p. 39 51, 2020.

FOSSUM, T. W. Cirurgia de Pequenos Animais. $4^{\mathrm{a}}$ ed. Rio de Janeiro: Elsevier Ltd, 2014.

GEDDES, Alexander T.; THATCHER, Graham P.; HETZEL, Scott; McCABE, Ronald P.; VANDEREBY, Ray Jr.; SNYDER, Christopher J. Biomechanical Testing of a Calcium Phosphate-Phosphoserine Based Mineral-Organic Adhesive for Non-invasive Fracture Repair of Mandibular Fractures in Dogs. Frontiers in Veterinary Science, v. 7, 27 fev. 2020.

GUZU, Michel; HENNET, Philippe R. Mandibular body fracture repair with wire-reinforced interdental composite splint in small dogs. Veterinary Surgery, v. 46, n. 8, p. 1068 1077, 1 nov. 2017.

KIRILLOVA, Alina; KELLY, Cambre; WINDHEIN, Natalia V.; GALL, Ken. Bioinspired Mineral-Organic Bioresorbable Bone Adhesive. Advanced healthcare materials, v. 7, n. 17, p. e1800467, 2018.

LOPES, Fernanda M.; GIOSO, Marco A.; FERRO, Daniel G.; LEON-ROMAN, Marco A.; VENTURINI, Michèle A. F. A.; CORREA, Herbert L. Oral Fractures in Dogs of Brazil-A Retrcspective Study. . [S.I: s.n.], 2005.

PHILLIPS, I R. A survey of bone fractures in the dog and cat. J. small A $\mathbf{n}$ h. Pract. New Wanstead, London: [s.n.], 1979.

Coordenadoria de Pesquisa e Extensão - COPEX

Departamento de Editoraçāo e Divulgaçāo Científica - DEDIC 


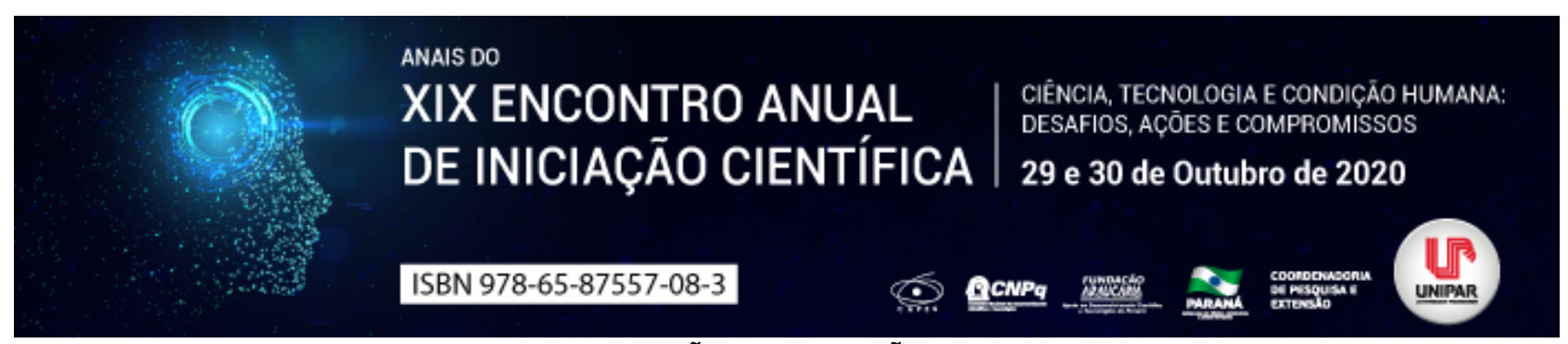

ATRESIA ANAL EM CÃES REVISÃO DE LITERATURA

\begin{abstract}
${ }^{1}$ Laura Mariana Tonete, ${ }^{2}$ LARISSA ÉDINA PERIN PEREIRA, ${ }^{3}$ BRUNA CAROLINA MARQUARDT, ${ }^{4}$ BRUNA BAGATIM DE SOUZA, ${ }^{5}$ CAROLINE HELENA ROCHA, ${ }^{6}$ MAURO HENRIQUE BUENO DE CAMARGO
\end{abstract}

\author{
${ }^{1}$ Discente do curso de Medicina Veterinária UEM/Umuarama-PR \\ ${ }^{1}$ Discente do curso de Medicina Veterinária UEM/Umuarama-PR \\ ${ }^{2}$ Mestranda no Programa de Pós-Graduação em Produção Sustentável e Saúde Animal UEM/Umuarama-PR \\ ${ }^{3}$ Discente do curso de Medicina Veterinária UEM/Umuarama-PR \\ ${ }^{4}$ Discente do curso de Medicina Veterinária UEM/Umuarama-PR \\ ${ }^{5}$ Docente do curso de Medicina Veterinária UEM/Umuarama-PR
}

Introdução: As malformações anorretais congênitas são raras em cães e gatos filhotes, no entanto, a atresia anal é a mais frequentemente encontrada (MAHLER E WILLIAMS, 2005). A atresia anal é definida como uma alteração anatômica congênita, que resulta na falta de comunicação entre o reto e o períneo através do ânus (MCGEADY et al., 2006), e normalmente está associada a fístula retovaginal, que consiste na comunicação entre o reto e a vagina (MANJABOSCO et al., 2013). A verdadeira prevalência da atresia em cães ainda é pouco conhecida, pois muitos pacientes sãos submetidos à eutanásia ou vão ao óbito anteriormente ao diagnóstico (MAHLER E WILLIAMS, 2005).

Objetivo: revisar a literatura acerca da atresia anal em cães, ampliando os conhecimentos dentro do tema, visto que se trata de uma condição rara para o paciente canino.

Desenvolvimento: A atresia anal é uma alteração que acomete a abertura anal e reto terminal, resultando no fechamento da saída anal e/ou em via anormal expulsando as fezes por meio da vagina ou da uretra (CARMO et al, 2016). Pode ser classificada conforme as alterações anatômicas e é dividida em quatro tipos. No tipo I os animais apresentam estenose congênita do ânus. No II, ocorre persistência da membrana anal, e o reto termina em fundo cego, em um local imediatamente cranial ao ânus imperfurado. O tipo III também apresenta o ânus fechado, porém, a bolsa cega do reto está situada mais cranial do que observado no tipo II. E IV, o reto proximal termina em um fundo cego dentro do canal pélvico, com ânus e reto distais normais (WILLIAMS E NILES, 2015). Os sinais clínicos do paciente com atresia anal poderão ser observados entre os 30 e 90 dias de idade (ARONSON, 2007) e varia de acordo com o tipo da atresia. No tipo I, observa-se sinais de constipação e tenesmo após o desmame e no exame físico da região perineal há abertura anal estenosada. Nos tipos II, III e IV, os neonatos tornam-se subdesenvolvidos, anoréxicos ou agitados após 4 semanas de vida, apresentam dilatação abdominal e defecação ausente, podendo apresentar megacólon. É possível, também, observar saliência perineal que dependerá do nível de atresia anal (ARONSON, 2007). Os sinais clínicos são suficientes para estabelecer o diagnóstico, no entanto a radiografia contrastada é necessária para determinar a presença de fístulas, o tipo de atresia apresentado pelo paciente, e se há presença de megacólon secundário (PRASSINOS et al., 2003). O tratamento indicado para essa anomalia congênita é a correção cirúrgica, sendo eficaz no reestabelecimento das funções normais dos tratos geniturinário e gastrointestinal, proporcionando qualidade de vida ao canino, no entanto, o animal deve ser encaminhado para cirurgia o mais rápido possível para evitar o agravamento das condições físicas, megacólon irreversível e possível infecção do trato urinário descendente (VALENTE et al., 2014). A alta contaminação pode levar à deiscência de sutura, tornando-se uma das principais complicações pós-operatórias; estenose retal, megacólon e incontinência fecal em caso de ausência do esfíncter anal ou lesão durante o procedimento cirúrgico também podem atrapalhar o sucesso pós-operatório (BRIGHT, 2008). Em casos onde a cirurgia não possa ser realizada de imediato, a terapia de suporte deve ser empregada, visando a minimização dos sinais clínicos (BONFADA, 2018). Em animais com fístulas associadas, requerem-se cultura bacteriana da urina, para a administração apropriada de antibióticos após a realização da cirurgia corretiva (PRASSINOS et al., 2003). O prognóstico dessa patologia é reservado, pois há a possibilidade do desenvolvimento de um megacólon que pode ocorrer devido à impactação fecal advinda de uma constipação, e o risco de infecção pós-operatória é bastante elevado (ARONSON, 2007; BRIGHT, 2008). O tempo entre o diagnóstico e o início do procedimento cirúrgico podem determinar o sucesso da cirurgia, visto que tal anomalia pode acarretar constipação severa e tenesmo, e, em casos de fístulas, pode causar infecção bacteriana de todo o trato reprodutivo (VALENTE et al., 2014).

Conclusão: Visto que se trata de uma anomalia de condição rara, porém com alto índice de óbito entre os pacientes caninos, salienta-se, com o presente resumo, a importância do diagnóstico precoce da afecção, evidenciando a relevância da execução correta da técnica cirúrgica empregada e trazendo qualidade de vida ao paciente.

\title{
Referências
}


ARONSON, L. Reto e Ânus. In: SLATTER, D. Manual de Cirurgia de Pequenos Animais, 3. ed., São Paulo, Manole, 2007, p. 682-708.

BONFADA, P. A. H. Relatório de Estágio Curricular Supervisionado em Medicina Veterinária. 2018. 43f. Monografia (Graduação em Medicina Veterinária) , Unijuí, 2018.

BRIGHT, R. M. Cirurgia Anorretal. In: BIRCHARD, S. J.; SHERDING, R. G. Manual Saunders Clínica de Pequenos Animais, São Paulo, Roca, 2008, p. 887.

MAHLER, S.; WILLIAMS, G. Preservation of the Fistula for Reconstruction of the Anal Canal and the Anus in Atresia Ani and Rectovestibular Fistula in 2 Dogs, Vet Surg., v. 34, n. 2, mar.-abr., 2005. Disponível em: https://pubmed.ncbi.nlm.nih.gov/15860106/. Acesso em: 21 ago. 2020.

MANJABOSCO, C. B.; SPIER, J. D.; MULLER, D. C. M. Atresia Anal Associada com Fístula Retrovaginal em um Cão, XXI Seminário de Iniciação Científica, Salão do Conhecimento Unijuí, ago., $2013 . \quad$ Disponível em: https://www.publicacoeseventos.unijui.edu.br/index.php/salaoconhecimento/article/view/1974. Acesso em: 22 ago. 2020.

MCGEADY, T. A.; QUINN, P. J.; FITZPATRICK, E. S.; RYAN, M. T. Veterinary Embryology, Oxford, Blackwell Publishing, 2006. PRASSINOS, N. N.; PAPAZOGLOU, L.G.; ADAMAMA-MORAITOU, K. K.; GALATOS, A. D.; GOULETSOU, P.; RALLIS, T. S. Congenital Anorectal Abnormalities in Six Dogs, Vet Record, v. 153, n. 3, jul., 2003. Disponível em: https://veterinaryrecord.bmj.com/content/153/3/81. Acesso em: 22 ago. 2020.

VALENTE, F. S.; FRATINI, L. M.; BIANCHI, S. P.; MOMBACH, V. S.; GUTIERREZ, L. G.; GOUVÊA, A. S.; BECK, C. A. C.; CONTESINI, E. A. Atresia Anal Associada à Fístula Retovaginal em Cadela, Acta Scientiae, v. 42, n. 1, jul., 2014. Disponível em: https://www.redalyc.org/articulo.oa?id=289039188007. Acesso em: 22 ago. 2020.

WILLIAMS, J. M.; NILES, J. D. BSAVA Manual de Cirurgia Abdominal em Cães e Gatos, São Paulo, MedVet, 2015. 


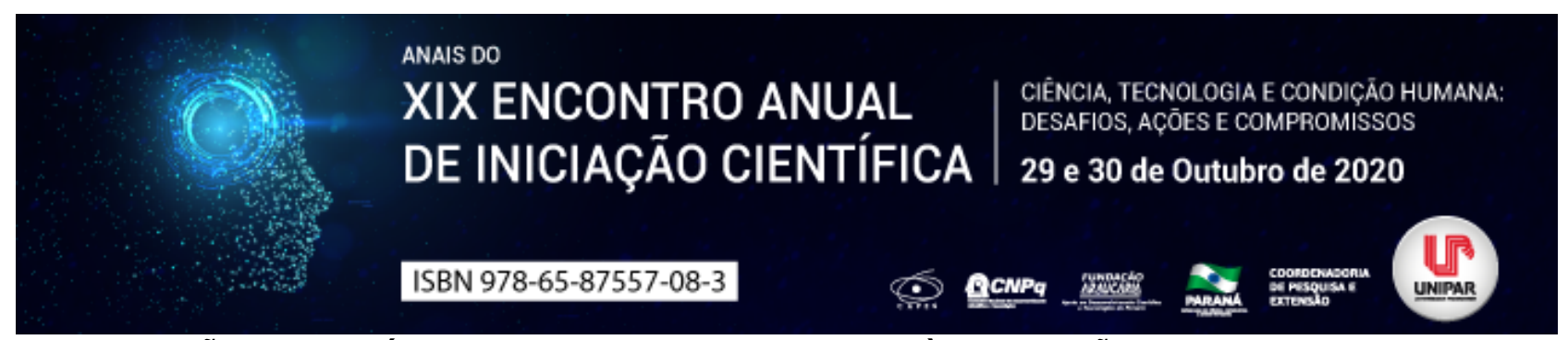

ALTERAÇÕES PATOLÓGICAS EM CADELA SUBMETIDAS À APLICAÇÃO DE ANTICONCEPCIONAL

\begin{abstract}
1LUAN VINICIUS TEZZEI MAIA, ${ }^{2}$ ALEC GABRIEL PEREIRA ROCHA, ${ }^{3}$ ALYSSON RAMALHAIS, ${ }^{4}$ CAROLINA AGUERO, ${ }^{5}$ HELOISA FABIANE MARTINS BONOMO, ${ }^{6}$ ANA MARIA QUESSADA
\end{abstract}

\author{
${ }^{1}$ PIBIC/UNIPAR \\ ${ }^{1}$ Acadêmica do Curso de Medicina Veterinária da UNIPAR \\ ${ }^{2}$ Acadêmico do Curso de Mestrado Em Ciencia Animal Com Enfase Em Produtos Bioativos - Turma Xv da UNIPAR \\ ${ }^{3}$ Bolsista de Ensino Médio \\ ${ }^{4}$ Acadêmica do Curso de Medicina Veterinária da UNIPAR \\ ${ }^{5}$ Docente da UNIPAR
}

Introdução: Devido à superpopulação de animais nas ruas a castração de cães e gatos é uma importante prática nos dias atuais. Tal conduta previne maus tratos, abandono e zoonoses. Dentre os métodos de contracepção existem o método cirúrgico ovariossalpingo-histerectomia e a utilização de anticoncepcionais. A onde são utilizados por possuírem preços acessíveis e serem de fácil acesso. A utilização de anticoncepcional sem a indicação de um médico veterinário pode ocasionar vários problemas como piometra, maceração fetal, hiperplasia endometrial, hiperplasia mamária e tumores mamários (LIMA et al., 2009; ARAÚJO et al., 2017). A esterilização cirúrgica, além de ser uma opção definitiva apresenta raros efeitos indesejáveis. Adicionalmente, promove vários benefícios como diminuição de problemas comportamentais, prevenção de tumores de mama e outras enfermidades como piometra, hiperplasia vaginal e pseudociese (SILVA et al., 2015).

Objetivo: O trabalho teve o objetivo de acompanhar cadelas submetidas à aplicação de anticoncepcionais pela primeira vez para registro de alterações patológicas.

Material e Métodos: O projeto foi aprovado pelo comitê de ética em experimentação animal da Universidade Paranaense com o protocolo 34.626/5018. Foram selecionados 20 tutores que iriam administrar anticoncepcionais em cadelas pela primeira vez. Todos os tutores efetuaram a compra do anticoncepcional e foram abordados por estudantes de Medicina veterinária logo após a conclusão da compra para inclusão no projeto. Após concordarem com a participação, os tutores foram instruídos a não administrar o anticoncepcional e levar suas cadelas para exame e inclusão no projeto. Antes da aplicação do anticoncepcional, todas as cadelas foram examinadas clinicamente. Foram realizados anamnese, exame físico, hemograma, exames bioquímicos, ultrassonografia abdominal e citologia vaginal. Foram selecionadas apenas cadelas saldáveis para evitar que a aplicação do anticoncepcional causasse agravamento de qualquer enfermidade presente. Uma vez selecionadas, as cadelas foram submetidas à administração do anticoncepcional adquirido pelo tutor. Trinta dias e noventa dias após a administração dos anticoncepcionais, todas as cadelas foram examinadas novamente, repetindo-se os exames realizados na consulta inicial. Noventa dias após a administração dos anticoncepcionais todas as cadelas foram submetidas à ovariossalpingo-histerectomia por método convencional (STONE, 2007).

Resultados e Discussão: A aplicação de anticoncepcional em cadelas só pode ser considerada segura se o animal estiver saudável no momento da administração (ROMAGNOLI, 2006; MAENHOUDT et al., 2018). Desta froma, só foram incluídas no projeto cadelas saudáveis do ponto de vista clínico e laboratorial. Quando as cadelas foram examinadas novamente aos trinta dias, não foram observadas alterações nos hemogramas e exames ultrassonográficos. No entanto, no exame físico, 12 cadelas (60\%) apresentaram hiperplasia mamária. Esta alteração se deve à ação do progestágeno sobre a glândula mamária. Uma das funções da progesterona é promover o desenvolvimento do tecido alveolar mamário (ENGLAND, 1998). Existe relato de associação entre tumores de mama em cadelas e administração de anticoncepcionais (HONÓRIO et al., 2017). Durante o exame físico também foi observado que duas cadelas apresentavam dermatoses no local da aplicação. Em uma revisão de literatura há citação de que os anticoncepcionais podem causar alterações cutâneas em cadelas (MAENHOUDT et al., 2018). Após a retirada do útero das cadelas constatou-se que em 18 cadelas (90\%), o órgão apresentou alterações macroscópicas compatíveis com hiperplasia endometrial cística. Destas cadelas, cinco apresentaram secreção do tipo purulenta no útero em associação à hiperplasia endometrial cística. A presença de pus associada à hiperplasia endometrial cística caracteriza piometra (KEMPISTY et al., 2013). Portanto, cinco cadelas hígidas apresentaram piometra com uma única aplicação de anticoncepcional. Ao exame microscópico apenas uma cadela apresentou o tecido uterino completamente normal, conforme classificação proposta na literatura (MONTEIRO et al., 2009). Tal cadela se encontrava em anestro, de acordo com exame citológico realizado no dia em que o anticoncepcional foi administrado. As bulas dos anticoncepcionais utilizados no presente estudo informam que o fármaco deve ser administrado no anestro para minimização dos efeitos colaterais (Anticion, S/D; Inibidex, S/D). Entretanto, o reconhecimento da fase do ciclo estral de cadelas só pode ser realizado por meio de citologia vaginal, exame restrito ao médico 
veterinário (SILVA, 2016).

Conclusão: Uma única aplicação de anticoncepcional foi suficiente para causar alterações patológicas em cadelas saudáveis. Sugere-se que o fármaco seja vendido apenas sob supervisão médica, com retenção de receita.

\section{Referências}

ANTICION S/D. Anticion. Disponível em: https://www.vetsmart.com.br/cg/produto/660/anticion. Acesso em 15 Agosto 2020. ARAÚJO, Estéfane Kelly Dias, et al. Principais patologias relacionadas aos efeitos adversos do uso de fármacos contraceptivos em gatas. PUBVET, v. 11, p. 207-312, 2017.

ENGLAND G.C.W. Pharmacological control of reproduction in the dog and bitch, p. 209-226. In: SIMPSON, G, ENGLAND, G.; HARVEY, M (Eds), Manual of small animal reproduction and neonatology. Iowa: Elsevier, 1998. p. $247-279$.

HONÓRIO T.G.A.F., Fonseca A.P.B., Araújo E.K.D., Moura V.M., Chaves R.A.A., Rodrigues M.C., Klein R P. 2017. Implicações patológicas após o uso de anticoncepcional, em cadelas situadas em Teresina PI. Pubvet. v, 11, n.2, p.176-180. 2017. INIBIDEX S/D. Inibidex. Disponível em: https://www.vetsmart.com.br/cg/produto/1803/inibidex. Acesso em 15 Agosto. 2020 KEMPISTY B. Endometritis and pyometra in bitches: a review. Veterinary Medicine, v. 58, n. 6, p.:289-297, 2013.

LIMA J.G.P. et al. Uso de Anticoncepcional em cadelas: problema ou solução? Anais da IX Jornada de Ensino, Pesquisa e Extensão JEPEX. 2009.

MAENHOUDT C., Santos N.R. \& Fontbonne A. Manipulation of the oestrous cycle of the bitch-what works for now. Reprod. D, v.omest. Anim. v.53, n.3, p.44-52, 2018.

MONTEIRO C.M.R., Perri S.H.V., Carvalho R.G. \& Koivisto M.B. 2009. Histologia e morfometria em cornos uterinos de cadelas nulíparas, multíparas e tratadas com contraceptivos. Pesq. Vet. Bras. v.29, n.10, p.:847-851, 2009.

ROMAGNOLI S. 2006. Control of Reproduction in Dogs and Cats: Use and Misuse of Hormones. Disponível em SILVA L.D.M. 2016. Controle do ciclo estral em cadelas. Rev. Bras. Reprod. Anim. 40(4):180-187.

SILVA, T.C.; BASSOLI, A.G.; QUEIROZ JÚNIOR, J.P.; FERREIRA-SILVA, J.C.; ANDRADE, M.B. Castração pediátrica em cães e gatos: revisão da literatura. Medicina Veterinária (UFRPE), v.9, n.1-4, p.20-25, 2015.

STONE E.A. 2007. Ovário e útero, p. 1487-1502. In: Slatter DH (Ed), Manual de cirurgia de pequenos animais. $3^{a}$ ed. Manole, Barueri, SP. 


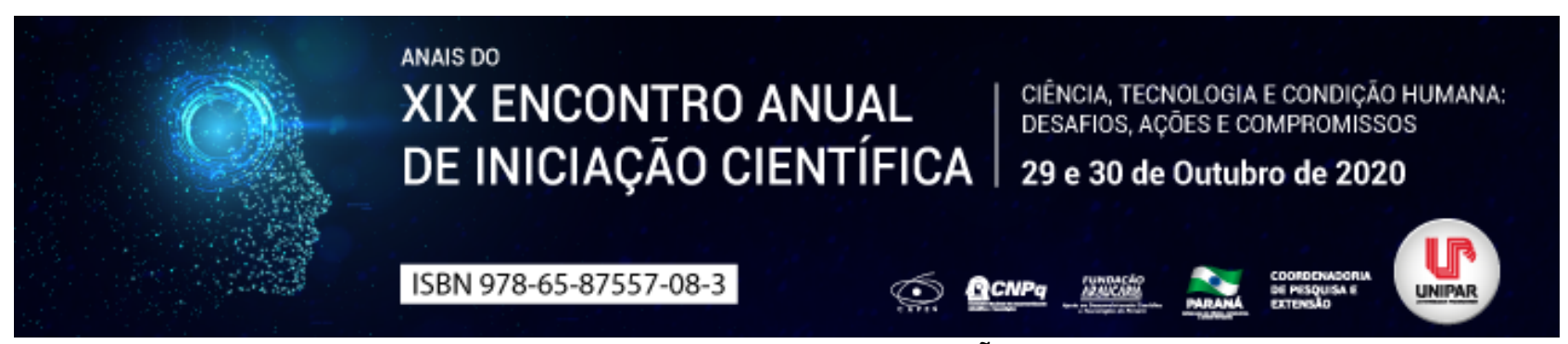

POSTECTOMIA EM EQUINO COM LESÃO PENIANA

\begin{abstract}
${ }^{1}$ Arisla Villas Boas Lizzi, ${ }^{2}$ JEFERSON CARLOS GANDINI, ${ }^{3}$ DANTHYSE MIYOKO OHNO MÜLLER DE SOUZA, ${ }^{4}$ MAYARA NAYANE SACOMAN ROCHA NEVES, ${ }^{5}$ DEREK WILLY GALDIOLI SILVEIRA, ${ }^{6}$ MAX GIMENEZ RIBEIRO
\end{abstract}

\author{
${ }^{1}$ Discente do curso de Medicina Veterinária-UEM \\ ${ }^{1}$ Médico Veterinário Residente em Clínica Médica e Cirúrgica de Grandes Animais-UEM \\ ${ }^{2}$ Médico Veterinário Residente em Clínica Médica e Cirúrgica de Grandes Animais-UEM \\ ${ }^{3}$ Discente do curso de Medicina Veterinária-UEM \\ ${ }^{4}$ Discente do curso de Medicina Veterinária-UEM \\ ${ }^{5}$ Docente do curso de Medicina Veterinária-UEM
}

Introdução: As neoplasias cutâneas na região de prepúcio e pênis não são raras, principalmente em animais que possuem a região despigmentada e desprovida de pelos.( SCOTT \& MILLER, 2004) Entre os tumores neoplásicos que acometem os equinos, o sarcóide e o carcinoma de células escamosas são os de maior prevalência, já nos tumores não neoplásicos, o tecido de granulação exuberante (TGE) e habronemose são de maior predominância. (VIANA et al., 2014). Um diagnóstico preciso e tratamento adequado são importantes para a fertilidade do rebanho, pois o aumento do volume do pênis e prepúcio, apesar de não alterar diretamente a produção e qualidade espermática, afeta a habilidade dos machos cobrirem as fêmeas, devido a dor no momento do ato da monta e na ereção. (DIAS et al.,2013; SCHUMACKER, 2006) O objetivo do presente trabalho é relatar um caso de lesão em região de base peniana, bem como descrever os possíveis diagnósticos para tal lesão, clinicamente.

Relato de caso: Foi atendido no setor de grandes animais do Hospital Veterinário da UEM- campus Umuarama, um cavalo castrado, sem raça definida, de 23 anos, pesando $440 \mathrm{~kg}$, cuja queixa principal era a presença de uma massa ulcerada na base do pênis. O proprietário já havia realizado tratamento de ferida de verão, mais conhecida como habronemose, sob recomendação de outro veterinário, não obtendo resultado significativo. Foi relatado também que o animal apresentou hematúria, porém não detectado durante atendimento. Ao exame físico, os parâmetros como temperatura, coloração de mucosas, hidratação, linfonodos e batimentos cardíacos e respiratórios encontravam-se dentro da normalidade. A lesão na base peniana estava ulcerada e com ausência de miíase, havia acúmulo de esmegma. Segundo o proprietário, foi notado o início da lesão há um ano com progressão contínua. Como exame complementar, foi realizado hemograma, no qual o hematócrito estava abaixo do valor de referência. Também, foi coletado um fragmento do nódulo e indicado um exame histopatológico, para o proprietário, porém o mesmo se recusou a realizá-lo. Entretanto, optou-se pela postectomia como procedimento cirúrgico, sob suspeitas de CCE, habromenose cutânea e TGE. Até o dia do procedimento cirúrgico, com o intuito de diminuir edema local, foi realizada a limpeza da ferida com água e PVPI degermante $10 \%$, e aplicação de ducha com água fria durante 20 minutos, duas vezes ao dia. O procedimento foi realizado no Centro Cirúrgico de Grandes Animais da UEM-Umuarama. Após medicação pré-anestésica com xilazina $(0,5 \mathrm{mg} / \mathrm{kg})$, a indução anestésica foi realizada com cetamina $(2,2 \mathrm{mg} / \mathrm{kg})$ e éter gliceril guaiacol (EGG) $(0,5 \mathrm{mg} / \mathrm{kg})$. A anestesia foi mantida com isoflurano e houve infusão contínua de lidocaína sem vasoconstritor (50 $\mu \mathrm{g} / \mathrm{kg} / \mathrm{min})$ e cetamina $(0,1 \mathrm{mg} / \mathrm{kg} / \mathrm{min})$. O procedimento teve duração de 1 hora. O tratamento pós-operatório foi realizado com $15 \mathrm{ml} / \mathrm{IM}$ de Penicilina, $9 \mathrm{ml} / \mathrm{IV}$ de Flunixin e 10ml/IV de Acetato de Dexametasona todos uma vez ao dia, e curativo local, conforme descrito anteriormente, foi mantido por 7 dias.

Discussão: Devido ao fato de não ter sido realizado um exame histopatológico para diagnóstico preciso, o presente caso relatado obtém 3 possíveis diagnósticos, todos com a presença de ulcerações como característica. A habronemose cutânea é causada por larvas do nematóide Habronema spp., sendo caracterizada pelo seu desenvolvimento rápido, podendo atingir $30 \mathrm{~cm}$ de diâmetro em poucos meses, prurido intenso, que pode levar a automutilação e coloração castanho avermelhado. Tais características diferem do presente caso. Além disso, a lesão começa com pequenas pápulas com centro erodido, como no animal em questão. (DIAS et al., 2013). Segundo Knottenbelt e Pascoe (1998), o CCE é a neoplasia que mais acomete animais castrados, de qualquer idade, corroborando com o presente caso. Entretanto, também é caracterizada por necrose, odor forte, lesões com aspecto de couve-flor, geralmente iniciadas na glande do pênis, disúria e perda de peso, características não encontradas na lesão do animal descrito. (MACFADDEN \& PACE, 1991). O tecido de granulação exuberante pode ser ocasionado por tratamento prolongado, lesões em locais de maior movimentação, como membros, e infecções. (RESENDE et al., 2019) Geralmente, assim que a abertura na lesão é preenchida, o tecido de granulação para de crescer, permitindo a epitelização. Porém, pelos motivos mencionados acima, o tecido de granulação pode continuar a crescer, formando um tecido exuberante irregular e com muitos sulcos, que se projetam sobre a margem da lesão. (Pollock \& Schumacher, 2012) Condição presente devido ao histórico de habronemose do animal. O TGE pode causar hemorragia no pênis e material purulento na glande 
e processo uretral. (DIAS et al., 2013) Características ausentes no animal em questão.

Conclusão: Inúmeros fatores podem dar origem ao aumento do volume em pênis e prepúcio nos equinos, sendo facilmente confundidos entre si por apresentarem características e sinais clínicos semelhantes. Sendo assim, exames complementares, como o histopatológico, são fundamentais para um diagnóstico preciso e subsequente tratamento adequado com resultados satisfatórios.

\section{Referências}

DIAS, M.C., et al. Penectomia em Equino com Carcinoma de Células Escamosas. Enciclopédia Biosfera, Centro Científico Conhecer- Goiânia, v.9, n.17; p.2018, 2013.

KNOTTENBELT, D. C. \& PASCOE, R. R. Distúrbios reprodutivos. Pênis e Prepúcio. In: KNOTTENBELT, D. C.; Afecções e Distúrbios do Cavalo. Editora Manole. 1ed., cap.11, p.405-412, 1998.

MACFADDEN, K. E.; PACE, L. W. Clinical manifestations of squamous cell carcinoma in horses. Compendium on Continuing Education for the Practising Veterinarian, v. 13, n. 4, p.669 675, 1991.

RESENDE, C., et al. Uso de Triancinolona no Tratamento de Tecido de Granulação Exuberante em Equinos: Relato de Três Casos Clínicos. PUBVET v.13, n.6, a358, p.1-8, jun., 2019.

SCOTT, D.W., MILLER, W. H. J.; Dermatologia Eqüina. Intermedica Editorial XXI2004. Buenos Aires República Argentina, p. 625, 2004.

SCHUMACKER, J.; Penis and prepuce. In: Auer \& Stick.; Equine Surgery. Elsevier Saunders. 3ed., cap.66, 2006, p. 816-817. VIANA, L.F.S., et al. Tratamentos Complementares para Feridas com Tecido de Granulação Exuberante em um EquinoRelato de Caso. Revista Brasileira de Medicina Veterinária, 36(4):417-420, 2014. 


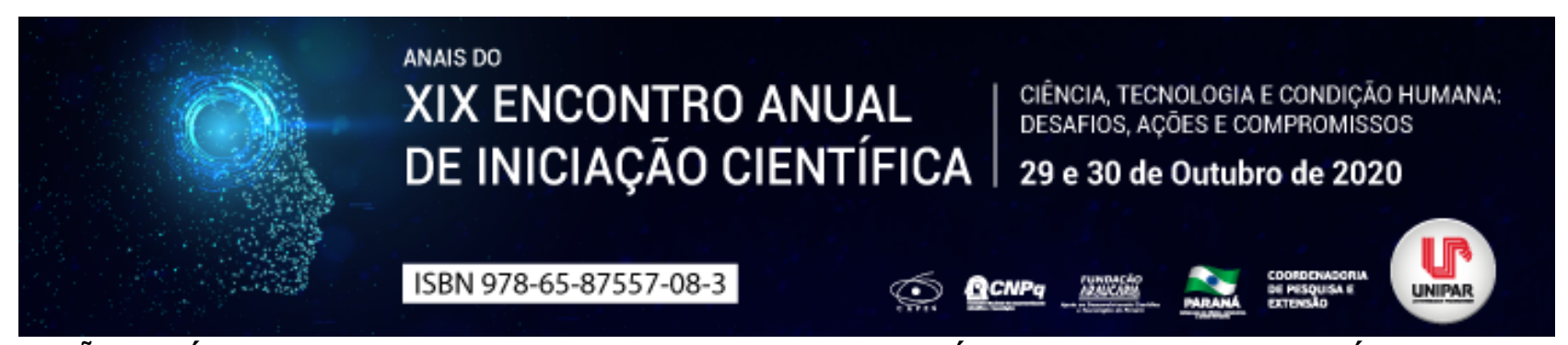

UTILIZAÇÃO DE ÓLEOS ESSENCIAIS COM PROPRIEDADES ANALGÉSICAS E ANTI-INFLAMATÓRIAS EM ANIMAIS

\begin{abstract}
${ }^{1}$ LILLIAN PEREIRA GOUVEIA, ${ }^{2}$ MELISSA SANCHES MONGELLI, ${ }^{3}$ KAROLYNE OLIVEIRA BASTOS, ${ }^{4}$ MARCOS FERRANTE, ${ }^{5}$ ELISÂNGELA ELENA NUNES CARVALHO, ${ }^{6}$ MARIA DE FÁTIMA SANTOS
\end{abstract}

\begin{abstract}
${ }^{1}$ Acadêmica do curso de Medicina Veterinária - Universidade Federal de Lavras
${ }^{1}$ Acadêmica do curso de Medicina Veterinária - Universidade Federal de Lavras

${ }^{2}$ Acadêmica do curso de Medicina Veterinária - Universidade Federal de Lavras

${ }^{3}$ Docente no departamento de Medicina Veterinária Universidade Federal de Lavras

${ }^{4}$ Docente no departamento de Ciências dos Alimentos - Universidade Federal de Lavras

${ }^{5}$ Discente doutoranda em Plantas Medicinais, Aromáticas e Condimentares - Universidade Federal de Lavras
\end{abstract}

Introdução: O controle da dor por meio da utilização de drogas sintéticas é amplamente difundido na Medicina Veterinária. Contudo, muitas destas possuem efeitos colaterais indesejáveis que podem limitar seu uso. A partir do avanço de pesquisas em farmacologia veterinária, a presença de substâncias, em plantas, com mecanismo de ação similar ao de anti-inflamatórios não esteroidais (AINEs) tem sido cada vez mais investigada. Trabalhos sobre a fisiologia da dor têm embasado estudos que demonstram a eficácia, em animais, de substâncias com propriedades analgésicas e anti-inflamatórias presentes em determinadas plantas.

Objetivo: Demonstrar a eficácia de óleos essenciais com propriedades anti-inflamatórias e analgésicas em testes com animais. Desenvolvimento: Foi realizada inicialmente uma busca nas bases de dados dos Periódicos da CAPES no ano de 2019, utilizando-se os descritores I"anti-inflamatoryl"; I"essential oin"; I"animal modelsl"; I"carrageenanl" e "volatile oil", sendo identificados 39 artigos. Destes, foram verificados quais demonstravam relatos, em testes in vivo, de ação anti-inflamatória e antinociceptiva de óleos essenciais (OEs) extraídos de plantas medicinais. A partir deste levantamento foram selecionados quatro artigos, dos quais os seguintes pontos foram analisados: testes para verificar atividade anti-inflamatória; teste nociceptivo e a planta medicinal utilizada. A partir dos artigos selecionados para esta revisão foi verificado: $1^{0}$ - que a maioria dos trabalhos utilizaram o estimulo à inflamação pela indução de dor (edema de pata de rato) empregando-se o teste de carragenina. $2^{\circ}$ - testes com placa quente foram empregados para medir a atividade nociceptiva. Trata-se de um modelo comportamental no qual são observados atos como lamber ou retirar a pata da fonte do estímulo doloroso. Outro teste utilizado consistia na indução da dor periférica por meio da injeção de ácido acético na pata de camundongos, a fim de se avaliar o nível de contorções dos animais e a atividade analgésica de determinada substância após administração do meio irritante e $3^{\circ}$ as plantas utilizadas nestes trabalhos foram Artemisia sieberi Besser (Asteraceae), Phyllanthus muellerianus (Kuntze) Exell (Phyllanthaceae), Cymbopogon schoenanthus (L.) Spreng. (Poaceae) e Bougainvillea glabra Choisy (Nyctaginaceae). O experimento com óleo essencial (OE) de A. sieberi constatou uma quantidade significativa de cânfora no óleo, sendo esta uma das responsáveis pelos efeitos antiinflamatórios e analgésicos da planta. A atividade analgésica da cânfora se deve à capacidade de ativar o canal TRPV1 e dessensibilizar o receptor de capsaicina - trata-se do principal mecanismo molecular de atuação dos analgésicos convencionais. Foi realizada administração intraperitoneal do OE na dosagem de $1 \mathrm{mg} / \mathrm{kg}$ nos animais do experimento, além da aplicação de morfina nos indivíduos do grupo controle, para comparar o grau de analgesia (PISHGAHZADEH et al., 2019). A pesquisa com o OE de $P$. muellerianus sobre seu potencial anti-inflamatório foi executada empregando os mesmos testes para indução da dor: teste de placa quente para avaliação da atividade nociceptiva e teste do edema para avaliação da atividade anti-inflamatória, utilizando-se a carragenina por via subcutânea, na dose de 0,1 ml a 1\%. As dosagens utilizadas do óleo foram de 100, 200,300 e $400 \mathrm{mg} / \mathrm{kg}$, demonstrando uma variação na atividade anti-inflamatória que se apresentou mais elevada nas primeiras horas, reduzindo gradativamente. O diclofenaco foi utilizado no grupo controle como referência, e quando se comparou o efeito desse com o óleo foram obtidos resultados significativos, ou seja, efeitos mais eficazes que fármacos tradicionais, como aspirina administrada Via oral. Além disso, as doses administradas foram capazes deprimir os nociceptores e provavelmente atuaram como analgésicos opioides (OGUNWANDE et al., 2019). A atividade anti-inflamatória e analgésica do OE de C. schoenanthus cujo principal componente é a peritritona (62\%), foi comprovada por meio do teste de contorção, teste de placa quente e formalina. Utilizou-se neste experimento a morfina na dose de $5 \mathrm{mg} / \mathrm{kg}$ e ácido mefenâmico na dose de $30 \mathrm{mg} / \mathrm{kg}$, além do óleo obtido a partir da parte área de C. schoenanthus nas doses de 60, 100 e $200 \mathrm{mg} / \mathrm{kg}$. Foi realizado o teste da carragenina, em intervalos de 30 minutos, 1, 2, 3 e 4 horas. Foram obtidos, ao final do experimento, ótimos resultados no que diz respeito à atividade analgésica e anti-inflamatória da substância (TALAEI et al.,2019). A último trabalho analisado realizou seus testes com a planta $B$. glabra, onde foi verificado que o OE apresentou atividade dependente da concentração e do tempo sobre o ação antiinflamatório e antinociceptivo (OGUNWANDE et al., 2019). 
Conclusão: É possível comprovar a atividade anti-inflamatória e analgésica dos óleos essenciais, devido à semelhança do seu mecanismo de ação com o de fármacos tradicionais e assim possibilitar novas alternativas para a terapêutica veterinária, que contemplam uma possível redução de efeitos indesejáveis nos pacientes.

\section{Referências}

OGUNWANDE, Isiaka A. et al. Chemical composition, anti-nociceptive and anti-inflammatory activities of essential oil of Bougainvillea glabra. Journal of Ethnopharmacology, v. 232, p.188-192, mar. 2019. doi: 10.1016/j.jep.2018.12.017

OGUNWANDE, Isiaka. A. et al. Chemical constituents, anti-nociceptive and anti-inflammatory activities of essential oil of Phyllanthus muellerianus. Natural Product Communications, p.1-7, May 2019. doi: 10.1177/1934578X19846356

PISHGAHZADEH, Elahe; SHAFAROODI, Hamed; ASGARPANAH, Jinous. Analgesic and antiinflammatory activities of the essential oil from Artemisia sieberi Besser. Brazilian Journal of Pharmaceutical Sciences v. 55, p. 1-7, dec. 2019. doi: 10.1590/s2175-97902019000217011.

TALAEI, Mahshid Golestaneh; MOUSAVI, Zahra; JAHANDIDEH, Maryam. Anti-Inflammatory activity of Cymbopogon schoenanthus essential oil in animal models. Research Journal of Pharmacognosy, v.6, n.3, p.61-68, 2019. doi: 10.22127/rjp.2019.89466

The Plant List, a working listo f all plant species. Disponível: http://theplantlist.org/. Acesso em: 28 jul. 2020. 


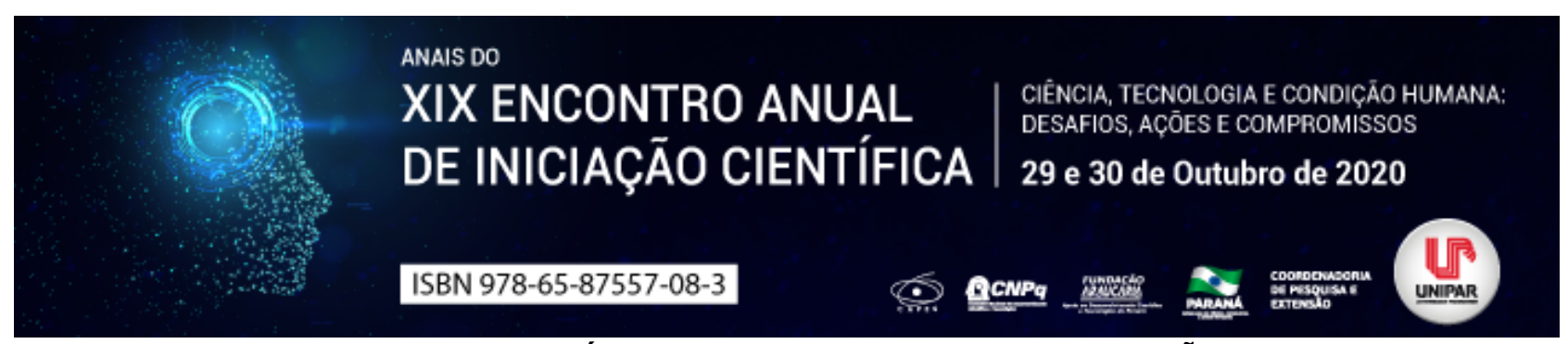

USO DE PROBIÓTICOS EM OVINOS DE CORTE - REVISÃO

\begin{abstract}
${ }^{1}$ SELMA ALVES RODRIGUES, ${ }^{2}$ EMANUEL BUENO MORERIA, ${ }^{3}$ VANDERSON DOS SANTOS SILVA, ${ }^{4}$ GABRIEL COELHO GIMENES, ${ }^{5}$ RANULFO PIAU JUNIOR
\end{abstract}

\author{
${ }^{1}$ Acadêmico Bolsista do PEBIC / Fundação Araucária \\ ${ }^{1}$ Bolsista PIBICjr/CNPq \\ ${ }^{2}$ Mestrando da curso de Pós-graduação de Ciência Animal com ênfase em Produtos Bioativos UNIPAR \\ ${ }^{3}$ Médico Veterinário \\ ${ }^{4}$ Docente da UNIPAR
}

Introdução: Os ovinos estão entre as primeiras espécies domesticadas pelo homem. Ovis aries são os ovinos domésticos caracterizados por serem animais rústicos, produtivos, prolíferos, ocupam pouco espaço e possuem uma alta capacidade de adaptação a diversos sistemas de produção, portanto a espécie está presente em praticamente todo o mundo. O Brasil possui 18,0 milhões de ovinos, onde a maior população se concentra na região nordeste do país, possuindo $64,2 \%$ do rebanho brasileiro (IBGE, 2019). O uso empírico de antibióticos e quimioterápicos como aditivos e promotores de crescimento nas dietas dos animais tem se tornado uma pratica rotineira, porém, a utilização frequente e prolongado resulta no desenvolvimento de cepas de micro-organismos resistentes, que podem dificultar o uso terapêutico desses antimicrobianos na medicina veterinária e também humana (ALVES et al., 2007). Diversas pesquisas têm se concentrado em estudar aditivos alimentares que não sejam antibióticos para os animais, dentre eles estão as: enzimas, leveduras, probióticos, entre outros ( MONFERDINI; DUARTE, 2010). Objetivo: fazer um levantamento teórica sobre o uso de probióticos como aditivos na produção de ovinos de corte.

Desenvolvimento: Os probióticos são micro-organismos vivos que podem trazer benefícios para a saúde do hospedeiro, quando administrados de forma correta, podem ser uma alternativa aos tratamentos convencionais com antibióticos e outros produtos químicos que deixam resíduos na carne e no leite. Além de não deixar resíduos no produto final, também podem ser administrados como forma de prevenção de doenças acrescentando imunidade e bem-estar (TIRAPEGUI, 2013). Além dos efeitos benéficos que os probióticos trazem a saúde do hospedeiro, são observados efeitos no desempenho, conversão alimentar e ganho de peso nos animais (PINHEIRO; SOBRINHO; YAMAMOTO, 2007). O uso de probióticos na alimentação vem sendo utilizado como uma forma de alternativa para atender as exigências internacionais dos importadores de carnes, já que os antibióticos que são usados como promotores de crescimento, não estão sendo bem aceitos pelo fato de se ter o risco de apresentar resíduos na carne quanto do leite (RIGOBELO, 2014). Uma vez que os antibióticos usados como promotores de crescimento podem não ser bem aceitos devido ao risco de apresentar em resíduos tanto na carne como no leite. Além disso, atualmente os consumidores vem aumentando a preocupação com sua saúde, preferindo consumir alimentos mais saudáveis, livres de possíveis resíduos nos alimentos de origem animal (JORGE et al., 2006). Os probióticos são aditivos que possuem micro-organismos vivos que fortalecem a microbiota intestinal e ajudam o bom funcionamento do trato gastrointestinal, melhorando o desempenho dos animais. várias ações benéficas são atribuídas ao uso dos probióticos, entretanto, seu mecanismo de ação ainda não está inteiramente elucidado. Entre os principais modos de ação dos probióticos, pode-se citar: Competição por sítios de ligação; este conceito ficou conhecido, também, com o nome de "exclusão competitival". As bactérias dos probióticos ocupam os sítios de ligação na mucosa intestinal e ruminal, formando uma barreira física às bactérias patogênicas. Assim, as bactérias patogênicas ficariam em menor número pela competição, produção de substâncias antibacterianas as bactérias dos probióticos produzem compostos como as bacteriocinas, ácidos graxos voláteis de cadeia curta e peróxido de hidrogênio que possuem ação antibacteriana, especificamente em relação às bactérias patogênicas. (MONFERDINI; DUARTE, 2010) .Os probióticos podem trazer benefícios à saúde do animal, seja de ordem nutricional ou de forma terapêutica (PRASAD et al., 1999). O uso de probióticos pode ser uma boa alternativa na produção de ovinos de corte.

Conclusão: Conclui-se que o uso de probióticos em ovinos podem trazer grandes benefícios para a sua produção de ovinos de corte, aumentando o desempenho, ajudando no ganho de peso e aumentando a imunidade.

\title{
Referências
}

ALVES, M. P. A. P. et al. Uso de probiótico composto por Lactobacillus acidophilus, Streptococcus faecium e Sacharomyces cerevisae na dieta de vitelos bovinos: efeitos sobre 0 desempenho e a qualidade da carne. Braz. J. vet. Res. anim. Sci.. São Paulo, v. 37, n. 5, p. 416-422, 2007.

ARENAS, S. E. et al. Efeito do probiótico Proenzime® no ganho de peso de bovinos. Arch. Zootec., v.56, n. 213, p. 75-78, 2007. IBGE. Pesquisa Produção Pecuária Municipal, 2019.(www.ibege.gov.br) 
JORGE, C. F. J. F. et al. Efeito de um aditivo alimentar contendo probiótico e enzimas digestivas no ganho de peso de bovinos nelore em regime de pasto. In: IV ENCONTRO DE PESQUISA E INICIACÃ̃ CIENTÍFICA DO ESTADO E DA REGIÃO DO PANTANAL. Campo Grande, Anais... p. 69-79, 2006.

MONFERDINI, R.; DUARTE, K. M. R. Uso de probióticos na produção animal. PUBVET, v.4, n. 35, ed. 140, art. 944, 2010.

PINHEIRO, R. S. B.; SOBRINHO, A. G. S.; YAMAMOTO, S. M. Desempenho de cordeiros lactantes recebendo probiótico em comedouros privativos. Archives of Veterinary Science, v. 11, n.3. p.38-42, 2007.

PRASAD, J. et al. Selection and characterisation of Lactobacillus and Bifidobacterium strains for use as probiotics. International Dairy Journal, v.8, p.993 1002, 1999.

RIGOBELO, E. C. et al. Utilização de probiótico e monensina sódica sobre o desempenho produtivo e características de carcaça de bovinos Nelore terminados em confinamento. Rev. Bras. Saúde e Produção Animal, v.15 n.2 p.415-424, 2014.

TIRAPEGUI, J. Nutrição fundamentos e aspectos atuais. Rio de Janeiro: Atheneu, 2013, 504p.

Coordenadoria de Pesquisa e Extensão - COPEX

Departamento de Editoraçāo e Divulgaçāo Científica - DEDIC 


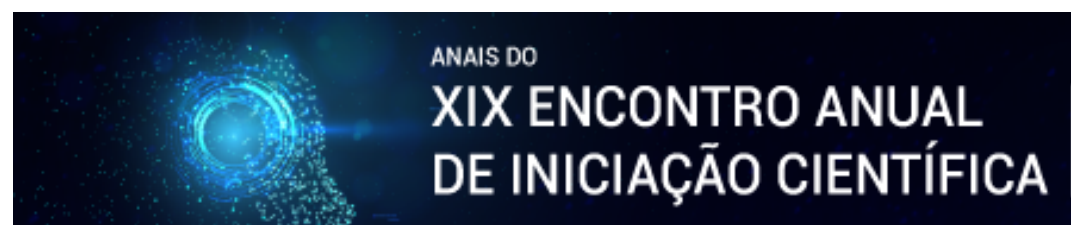

CIÊNCIA, TECNOLOGIA E CONDIÇĀO HUMANA: DESAFIOS, AC̄ŌES E COMPROMISSOS

DE INICIAÇÃO CIENTÍFICA 29 e 30 de Outubro de 2020

ISBN 978-65-87557-08-3

6 둘

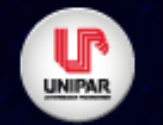

\title{
EFEITO ANTIMICROBIANO DOS ÁCIDOS ORGÂNICOS FRENTE A CEPAS DE Salmonella spp. ISOLADAS DE FRANGOS DE CORTE REVISÃO DE LITERATURA
}

\author{
${ }^{1}$ ELOISE MARCIELLI MARTINS FERREIRA, ${ }^{2}$ IZABELA CAMILOTTI DORNELES, ${ }^{3}$ NATALIA SA OLIVEIRA, ${ }^{4}$ AGUINALDO \\ YOSHIO NAKAMURA, ${ }^{5}$ TANIARA SUELEN MEZALIRA , ${ }^{6}$ LUCIANA KAZUE OTUTUMI FARIAS
}

\begin{abstract}
${ }^{1}$ Acadêmica do curso de Medicina Veterinária, UNIPAR, bolsista PIBIC/UNIPAR
${ }^{1}$ Doutoranda em Ciência Animal com Ênfase em Produtos Bioativos, UNIPAR, taxista PROSUP/CAPES

${ }^{2}$ Acadêmica do curso de Medicina Veterinária, UNIPAR, bolsista PIBIC/UNIPAR

${ }^{3}$ Doutorando em Ciência Animal com Ênfase em Produtos Bioativos, UNIPAR, taxista PROSUP/CAPES

${ }^{4}$ Doutoranda em Ciência Animal com Ênfase em Produtos Bioativos, UNIPAR, taxista PROSUP/CAPES

${ }^{5}$ Professora do curso de Medicina Veterinária e do Programa de Pós-Graduação em Ciência Animal com Ênfase em Produtos Bioativos, UNIPAR
\end{abstract}

Introdução: O crescimento e expansão da avicultura tanto no Brasil quanto no mundo aliado à busca por aditivos alternativos aos antimicrobianos melhoradores de desempenho, têm contribuído com o aumento do uso de ácidos orgânicos. Por definição, ácidos orgânicos são compostos que possuem uma ou mais carboxila em sua molécula e na avicultura têm se utilizado os ácidos fracos de cadeia curta (C1-C7) (DIBNER; BUTTIN, 2002) tais como o ácido acético, propiônico, butírico, cítrico, benzóico, fórmico, lático, fumárico, dentre outros. Além disso, esses ácidos por seu caráter de inibição do crescimento microbiano têm sido amplamente utilizados na indústria alimentícia e na nutrição animal por sua relação não somente com a redução do $\mathrm{pH}$, mas também com seu efeito flavorizante e quelante (por sua ligação com metais-íons) que possibilitam por sua vez sua utilização como sanitizante de carcaças (BELLAVER; SCHEUERMANN, 2004). O uso dos ácidos orgânicos como sanitizante de carcaça é uma prática ocorrente em alguns países, como os Estados Unidos e União Europeia (COMISSÃO, 2013), desde que sejam aprovados pelas autoridades sanitárias competentes, porém no Brasil ainda não é uma prática permitida pela legislação brasileira (PALUDO, 2015). No entanto, por seu efeito antimicrobiano, justifica sua utilização na água ou ração de frangos de corte principalmente no período que antecede o abate, visando reduzir a contaminação microbiana por Salmonella spp. (FRESCHI, 2014).

Objetivo: Fazer uma revisão sobre a eficácia de ácidos orgânicos frente a cepas de Salmonella spp. isolados de frangos de corte.

Desenvolvimento: Em estudo realizado por Pickler et al. (2014) os autores realizaram teste in vitro para determinar a CIM (concentração inibitória mínima) dos ácidos orgânicos frente à Salmonella Minessota e verificaram que, os valores de CIM variaram entre $0,39 \%$ a 3,12\% entre os diferentes blends testados, sendo o menor resultado para o blend composto por ácido acético, fórmico, cítrico e ascórbico e a maior CIM para o blend composto por ácido lático, fumárico, cítrico e fórmico. Zabot et al. (2018) compararam a eficácia de dois ácidos orgânicos frente a cepas de S. Heidelberg, S. Typhymurium e S. Enteritidis e 54 isolados de Salmonella spp. oriundos do abate de frangos de corte e comprovaram que a CIM variou de acordo com o ácido testado, o tempo de exposição e a cepa de Salmonella avaliada, apresentando variação entre 0,5 a 2,0\% para o ácido lático e $1,0 \%$ para o peracético. Além disso, os autores constataram que quando testado o ácido lático na água de chiller artificialmente contaminada com Salmonella spp., o ácido lático na concentração de 2,0\% foi capaz de reduzir completamente o crescimento da Salmonella spp., demonstrando o efeito antimicrobiano do ácido orgânico. Silva (1998) enfatiza que a atividade antimicrobiana dos ácidos orgânicos está relacionada com a redução do $\mathrm{pH}$, da mínima dissociação do ácido, da toxicidade da molécula, da concentração do ácido, tempo e método de aplicação e temperatura. Em um experimento realizado por Nicolau (2016) o autor comparou a eficácia de três concentrações $(0,2$ e $5 \%)$ do ácido lático na eliminação da bactéria Salmonella spp. em carcaças contaminadas com S. Enteritidis. Os autores selecionaram carcaças de frangos de corte oriundos de um abate e após evisceradas e lavadas foram contaminadas individualmente com $10^{4}$ Unidades Formadoras de Colônia (UFC) de S. Enteritidis. Em seguida, as carcaças foram submetidas às etapas de pré-resfriamento (tanque com água à $16^{\circ} \mathrm{C}$ ) e resfriamento (tanque com água à $4^{\circ} \mathrm{C}$ ). Quando as carcaças atingiram $7^{\circ} \mathrm{C}$, as mesmas foram retiradas para escorrer o excesso e água, sendo posteriormente pulverizado $100 \mathrm{~mL}$ de solução de ácido lático. O autor verificou que o ácido lático pulverizado nas carcaças foi capaz de reduzir o percentual de carcaças positivas para Salmonella spp. na concentração de 5\%, ficando apenas 33,3\% de carcaças positivas, o que demonstra sua eficácia.

Conclusão: Conclui-se que os ácidos orgânicos apresentam efeito antimicrobiano frente a cepas de Salmonella spp., entretanto, sua eficácia depende de alguns fatores como, concentração, tempo de aplicação, temperatura, tipo de ácido e método de 
aplicação.

\section{Referências}

BELLAVER, C.; SCHEUERMANN, G. Aplicações dos ácidos orgânicos na produção de aves de corte. Anais da Conferência AVESUI; 2004; Florianópolis, Santa Catarina. Brasil. Itu: Gessulli; 2004. p.1-16.

COMISSÃO DAS COMUNIDADES EUROPEIAS. Regulamento (UE) N 101/2013 da Comissão de 4 de fevereiro de 2013. Utilização do ácido lático para reduzir a contaminação superficial microbiológica das carcaças de bovinos. Bruxelas: Comissão das Comunidades Europeias, 05 fev. 2013. Disponível em: https://eur-lex.europa.eu/LexUriServ/LexUriServ.do? uri=OJ:L:2013:034:0001:0003:PT:PDF. Acesso em: 30 jul. 2020.

DIBNER, J. J.; BUTTIN, P. Use of organic acids as a model to study the impact of gut microflora on nutrition and metabolism. Journal of Applied Poultry Research, v. 11, n. 4, p. 453- 463, 2002.

FRESCHI, Janaine Basaglia. Ácidos orgânicos isolados ou associados em dietas de frangos de corte. Dissertação (mestrado) - Universidade Estadual Paulista Júlio de Mesquita Filho, Faculdade de Engenharia, 2014. Disponível em: .

NICOLAU, J. P. Controle de Salmonella spp. em carcaças de frango pelo uso de descontaminantes químicos durante o processo de abate e as consequências na qualidade da carne. 2016. 75f. Tese (Doutorado em Ciência Animal) Faculdade de Medicina Veterinária, Universidade Estadual Paulista (UNESP).

PALUDO, Joana. Eficiência do uso de sanitizantes na higienização de carcaças de frango com contaminação fecal. 2015. Trabalho de Conclusão de Curso (Medicina Veterinária) Universidade Federal do Rio Grande do Sul, Porto Alegre, 2015.

PICKLER, Larissa. et al. Resposta imunológica e uso de ácidos orgânicos em frangos desafiados com Salmonella Minnesota. Acta Scientiae Veterinariae, v. 42, n. 1, p. 1-9, 2014.

ZABOT, Sandra. et al. Ácidos orgânicos e compostos clorados para controle de Salmonella spp. em frangos. Segurança Alimentar e Nutricional, Campinas, v. 25, n. 1, p. 76-84, 2018. 


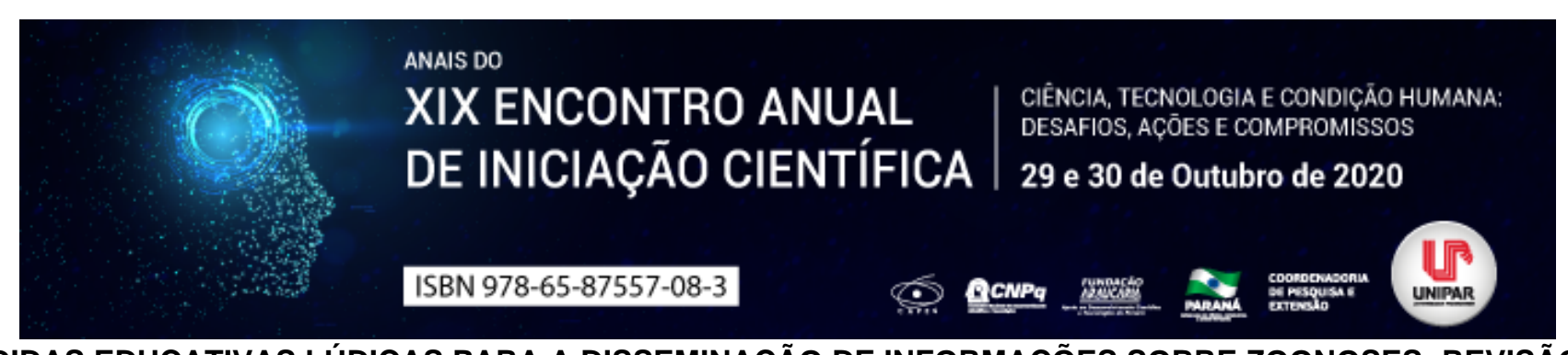

MEDIDAS EDUCATIVAS LÚDICAS PARA A DISSEMINAÇÃO DE INFORMAÇÕES SOBRE ZOONOSES- REVISÃO DE LITERATURA

\author{
${ }^{1}$ Dirce Consuelo Coronato Correia, ${ }^{2}$ SHEILA REZLER WOSIACKI
}

\author{
${ }^{1}$ Acadêmica do curso de Medicina Veterinária-UEM \\ ${ }^{1}$ Docente da UEM
}

Introdução: Visto que nos dias atuais a forma lúdica e dinâmica tem ganhado ênfase nos meios de ensino, principalmente no meio infantil, torna-se importante essa utilização no meio veterinário, principalmente acerca das zoonoses que afetam tanto os animais quanto os seres humanos, de todas as idades.

Objetivo: Criação de medidas educativas lúdicas para crianças como forma de disseminação da informação sobre zoonoses para toda a comunidade.

Desenvolvimento: Diante das condições dos oferecidas aos animais, as situações aos quais se vive hoje e o conhecimento populacional acerca do assunto, é de suma importância a criação de programas educativos na comunidade e em escolas, para repasse de informações sobre zoonoses (FERREIRA et al, 2013), já que no Brasil, 44\% das casas apresentam ao menos um cão e 17\% ao menos um gato (INSTITUTO BRASILEIRO DE GEOGRAFIA E ESTATÍSTICA, 2013). Entende-se por zoonoses doenças com transmissão de agentes patogênicos de animais para seres humanos, e várias são as enfermidades que podem ser contraídas pelos seres humanos por meio do contato direto ou indireto com os animais, representando cerca de $75 \%$ das doenças emergentes. A falta dos programas públicos de educação sanitária dificulta a percepção e entendimento, sobre os riscos sanitários aos quais as pessoas e os animais estão expostos (THRUSFIELD, 2004). Dentre as principais zoonoses destaca-se a raiva, que existe há mais de quatro mil anos e é considerada a primeira enfermidade que os animais, no caso, o cão, poderiam transmitir aos seres humanos, sendo praticamente 100\% letal. (SCHNEIDER,1994.) Destaca-se também a Leishmaniose visceral, principalmente nas Américas, onde constitui-se um problema de saúde pública eminente, pois é uma doença de transmissão vetorial e com ciclo zoonótico estabelecido nessa localidade (PAHO/WHO, 2017), pois no meio ambiente urbano, o cão é o reservatório principal na transmissão de L. infantum (sin.) e L. chagasi (PAHO/WHO, 2017; LECA et al., 2015). Outra zoonose muito importante que deve ser estudada é a toxoplasmose pois a mesma ocorre com frequência em humanos sob a forma de infecção crônica e assintomática, sendo alvo de várias críticas na criação de felídeos (REY, 2002). Um estudo realizado por Silvano e colaboradores (2010) demonstrou que há necessidade de educar as pessoas acerca do manejo e cuidado com os animais, onde a extensão veterinária é de grande valia para disseminação de conhecimentos e conscientização quanto as principais zoonoses e os cuidados que devem ser tomados com os animais. Portanto é de grande valia a implementação de medidas educativas lúdicas eficazes para a disseminação de informações sobre os cuidados e medidas necessárias para 0 controle de zoonoses, pois a ludicidade é um assunto que tem ganhado grande foco no espaço nacional, principalmente na educação infantil, porque sabe-se que o brinquedo é a essência da infância, logo o seu uso possibilita uma maior propagação do conhecimento, visto que o lúdico tem como principal finalidade favorecer o desenvolvimento da pessoa humana numa dinâmica de inter atuação lúdica, estimulando o processo de estruturação afetivo cognitivo da criança, socializam criativamente o jovem e mantêm o espírito de realização no adulto. Geralmente as atividades lúdicas oferecem como objetivo, oportunizar uma maneira diferente para a criança brincar, ao mesmo tempo, que ela brinca ela se desenvolve, interage com outras crianças e adultos e tem acesso ao conhecimento indiretamente (NILES; ROCHA, 2014). Por conseguinte, compreende-se que as atividades lúdicas são de suma importância para o aprendizado pois possibilitam a incorporação de valores, o desenvolvimento cultural, assimilando novos conhecimentos, e desenvolvendo a sociabilidade e também a criatividade.

Conclusão: Por fim, entende-se que a medidas educativas lúdicas para crianças leva ao conhecimento não só para as crianças que participam, mas sim a toda comunidade envolvida com estas crianças, como os pais por exemplo, além de ser uma forma atrativa e divertida de se obter conhecimento, visto que as zoonoses deveriam ser conhecidas e evitadas por todos nos dias atuais.

\title{
Referências
}

FERREIRA, V.F.; BERNARDO, A.C.; FERREIRA, G.S.; PAULA, E.M.N.; SOUSA, D.B.; MEIRELLES-BARTOLI, R.B. Formação de multiplicadores em saúde pública veterinária por meio de palestras para professores dos anos iniciais do ensino público na cidade de jataí Go, Brasil. Revista Ars Veterinaria, v. 29, p. 109, 2013

INSTITUTO BRASILEIRO DE GEOGRAFIA E ESTATISTICA. IBGE. Acesso e utilização dos serviços de saúde, acidentes e violências Brasil, Grandes Regiões e Unidades da Federação. Rio de Janeiro. Umuarama, 2020 Disponível em:< https://www.ibge.gov.br/> . Acesso em: 26 ago 2020. 
LECA, N. F. et al. Epidemiology of canine leishmaniasis in southern Bahia, Brazil. Acta Tropica. v. 148, p. 115-119, 2015. NILES, Rubia Paula Jacob; SOCHA, Kátia. A importância das atvidades lúdicas na educação infantil. Ágora- Revista de Divulgação Científica, Santa Catarina, v. 19, n. 1, p. 80-94, jan/jun 2014.

PAHO. Pan American Health Organization. Plan of action to strengthen the surveilance and control of leishmaniasis in the américas 2017-2022, 2017.

REY, L. Bases da Parasitologia Médica, 2.ed., Rio de Janeiro: Guanabara Koogan, 2002, 379p.

Schneider MC, Burgoa CS. Tratamiento contra la rabia humana: un poco de su historia. Revista Saúde Pública 1994.

SILVANO, D.; BENDAS, A.J.R.; MIRANDA, M.G.N.; PINHÃO, R.; ALMEIDA, M. F.; LABARTHE, N.V.; PAIVA, J.P. Divulgação dos princípios da guarda responsável: uma vertente possível no trabalho de pesquisa a campo. Revista Eletrônica Novo Enfoque,v. 09, n. 09, p.64 86, 2010.

THRUSFIELD, M. Epidemiologia Veterinária. 2.ed. São Paulo: Roca. 2004. 


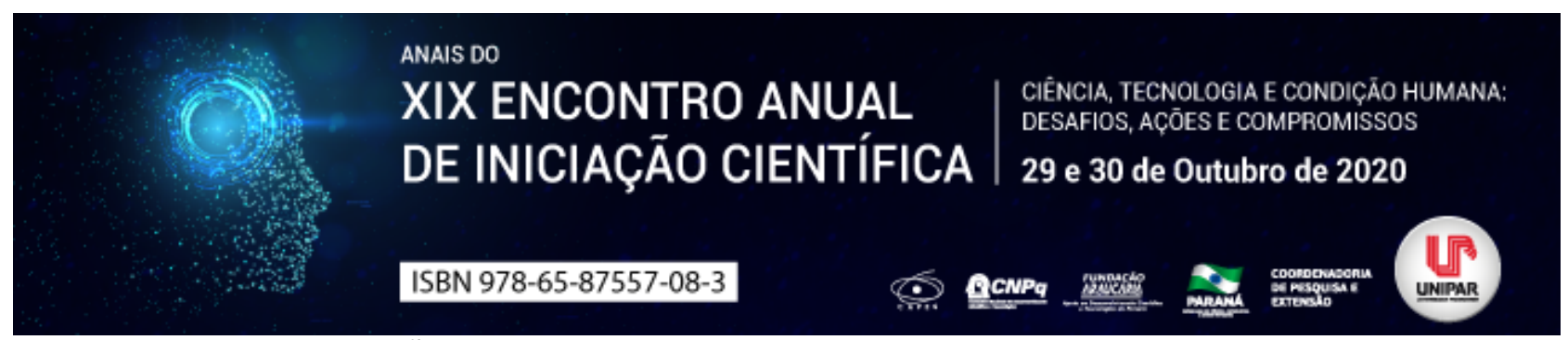

PRINCIPAIS CAUSAS NÃO INFECCIOSAS RELACIONADAS A MORTALIDADE NEONATAL CANINA

\begin{abstract}
${ }^{1}$ Caroline Helena Rocha , ${ }^{2}$ BRUNA BAGATIM DE SOUZA, ${ }^{3}$ LARISSA ÉDINA PERIN PEREIRA, ${ }^{4}$ LAURA MARIANA TONETE, ${ }^{5}$ BRUNA CAROLINA MARQUARDT, ${ }^{6}$ MAURO HENRIQUE BUENO DE CAMARGO
\end{abstract}

\begin{abstract}
${ }^{1}$ Acadêmica do curso de Medicina Veterinária UEM/Umuarama-PR
${ }^{1}$ Acadêmica do curso de Medicina Veterinária UEM/Umuarama-PR

${ }^{2}$ Acadêmica do curso de Medicina Veterinária UEM/Umuarama-PR

${ }^{3}$ Acadêmica do curso de Medicina Veterinária UEM/Umuarama-PR

${ }^{4}$ Mestranda no Programa de Pós-Graduação em Produção Sustentável e Saúde Animal UEM/Umuarama-PR

${ }^{5}$ Docente do curso de Medicina Veterinária UEM/Umuarama-PR
\end{abstract}

Introdução: A neonatologia é uma área da medicina veterinária responsável por estudar, tratar e diagnosticar filhotes recémnascidos (AMARAL, 2019). Este período não apresenta uma definição clara, mas geralmente estende-se do nascimento até a sexta semana de vida, sendo esta a fase que exige cuidados especiais para filhotes da espécie canina, pois, em geral são mais dependentes e apresentam também uma imaturidade de várias vias fisiológicas relacionadas com a recém perda da proteção uterina (FEITOSA et al., 2018). Decorrente desta nova adaptação, os filhotes tornam-se mais susceptíveis a enfermidades, podendo, em casos mais severos, irem a óbito (SOUZA, 2017). A mortalidade neonatal é relativamente alta na espécie canina, este percentual pode variar entre 20 e 30\%, chegando até 100\% em algumas ninhadas, sendo a raça e o tamanho corporal fatores que devem ser levados em consideração (OSORIO, 2016). Deste modo, o acompanhamento veterinário nesse período inicial pode aumentar a sobrevivência neonatal, eliminando ou controlando fatores que podem acarretar em possíveis perdas, as quais ocasionam grandes danos financeiros, e principalmente emocionais para tutores e proprietários de canis (MAMÃO, 2018).

Objetivo: O presente trabalho tem como objetivo realizar uma revisão literária sobre os principais fatores não infecciosos que corroboram para a mortalidade neonatal de cães.

Desenvolvimento: A transição da vida uterina para o meio externo traz ao recém-nascido uma série de alterações fisiológicas, sendo o estabelecimento da função pulmonar um dos eventos mais críticos deste período, somado a ele, a transferência da imunidade passiva, adaptação das funções circulatórias, metabólicas e alimentares são de suma importância para sobrevivência neonatal (FEITOSA et al., 2018). Neste cenário de alta vulnerabilidade, são inúmeros os fatores não infecciosos que podem acarretar na mortalidade precoce dos neonatos, dentre eles, hipóxia, transtornos no aleitamento, ambiente inadequado e traumas são os mais comumente relatados (SOUZA, 2017). A frequência respiratória normal em filhotes é de 15 a 35 movimentos por minuto (MPM), a qual é aferida por meio da observação dos movimentos torácicos, porém, quando apresentam um quadro de hipóxia, os sinais observados são frequência respiratória superior a 40 MPM, frequência cardíaca diminuída e uma vocalização estridente (CHAVES, 2011). Quadros de hipóxia têm maior incidência entre os neonatos prematuros nascidos em parto cirúrgico (SOUZA, 2017). Outra enfermidade relacionada com fatores respiratórios é a síndrome da angústia respiratória neonatal (SARN), caracterizada clinicamente por cianose, polipneia, bradicardia e vocalização expiratória; em muitos casos filhotes portadores desta síndrome são afastados da ninhada o que acarretaria em possível óbito (SOUZA, 2017). Em relação à amamentação, é importante salientar que neonatos caninos nascem hipogamaglobulinêmicos, e é através da ingestão do leite materno que se dá a transferência da imunidade passiva, além de ser sua fonte de nutrientes (ALBUQUERQUE, 2019). Portanto, em casos que ocorram algum distúrbio ou jejum, mesmo que por um curto período de tempo, podem resultar em um quadro de hipoglicemia, visto que, neonatos não apresentam reservas de gordura corporal mínima nem capacidade metabólica para produzir glicose a partir de precursores (CHAVES, 2011). No caso de filhotes órfãos, deve-se criar medidas especiais, como a substituição do leite materno e cuidados redobrados com o ambiente (OSÓRIO, 2016). O local destinado tanto para o filhote órfão, quanto para o filhote com a cadela, deve contar com um ambiente confinado que mantenha os neonatos dentro, e ao mesmo tempo permita o livre acesso da mãe, este local deve ser forrado com material que forneça conforto, fácil higienização, não proporcione risco ao recém-nascido e acompanhe o ritmo de crescimento dos mesmos, além de possuir uma temperatura adequada, pois, ambientes frios podem levar a quadros de hipotermia, e ambientes quentes podem ocasionar em desidratação. Tais fatores são de extrema importância, pois, a inadequação em algum destes determina a sobrevivência da ninhada neste momento (CHAVES,2011). Junto ao ambiente, outro fator externo que está relacionado com a mortalidade neonatal são possíveis traumas, muitas das vezes ocasionados de maneira acidental, pela falta de experiência da mãe ou até mesmo por alterações comportamentais. Um trauma comumente relatado é o esmagamento de filhotes pela própria mãe, o qual pode ser evitado com um ambiente adequado e constante supervisão (SOUZA,2017).

Conclusão: Exames na cadela quanto à saúde geral e reprodutiva, antes e após o parto, alimentação ou suplementação 
alimentar de filhotes que não conseguem mamar, fornecimento de um ambiente adequado com o período de vida do recémnascido e especialização de veterinários na área de neonatologia, são fatores importantes para redução da taxa de mortalidade neonatal canina. Por fim, conclui-se que os neonatos estão apenas no início da vida, devemos nos comprometer ao máximo para Ihes dar um início de vida saudável.

\section{Referências}

ALBUQUERQUE, Suzane de Cássia Moraes et al. Determinação da qualidade imunológica do colostro de cadelas por refratometria. Pubvet, [s. I.], v. 13, ed. 11, p. 1-6, nov 2019.

AMARAL, Mônica Correia; CASALI, Caroline Campagnoli; PEREIRA, João Filipi Scheffer. Relação do peso corpóreo materno e do neonato canino nascido de cesariana eletiva. Congresso Brasileiro de Reprodução Animal, Gramado, v. 43, ed. 2, p. 629683, abr/jun 2019.

CHAVES, Marcela Silva. NEONATOLOGIA EM CÃES E GATOS: ASPECTOS RELEVANTES DA FISIOLOGIA E PATOLOGIA: Revisão de literatura e relato de caso de Diprosopo Tetraoftalmo. Orientador: Christina Malm. 2011. 40 p. Monografia (Especialização) Residência Médico Veterinária: Clínica Cirúrgica e Obstetrícia de Pequenos animais - Universidade Federal de Minas Gerais, Belo Horizonte, 2011.

FEITOSA, Caroline Sant' Anna; CERQUEIRA, Hévila Dutra Barbosa de; APTEKMANN, Karina Preising; TRIVILIN, Leonardo Oliveira. Obstetrícia veterinária para clínicos de pequenos animais.In: TRIVILIN, LEONARDO OLIVEIRA et al. Tópicos especiais em Ciência Animal VII. ALEGRE: CAUFES, 2018. cap. 6, p. 83-96. ISBN 978-85-54343-12-5.

MAMÃO, Leonardo Dias. Avaliação clínica, laboratorial e hemogasométrica de cadelas e neonatos em parto distócico e cesariana eletiva. Orientador: Christina Malm. 2018. p. 119. Tese (Doutorado) Ciência Animal, Medicina e Cirurgia Veterinárias) - Universidade Federal de Minas Gerais, Minas Gerais, 2018.

SOUZA, Tayse Domingues. Mortalidade fetal e neonatal canina. Orientador: Renato de Lima Santos. 2017.140 p. Tese (Doutorado em Ciência Animal, área de concentração: Patologia Animal) - Universidade Federal de Minas Gerais, Belo Horizonte, 2017.

OSÓRIO, Tchainyse Mussi Goerhing. Cuidados Neonatais em Pequenos Animais Revisão de Literatura. Orientador: Jair Duarte da Costa Júnior. 2016. 70 p. TRABALHO DE CONCLUSÃO DE CURSO (Graduação em Medicina Veterinária) Faculdade de Agronomia e Medicina Veterinária da Universidade de Brasília, Brasília, 2016. 


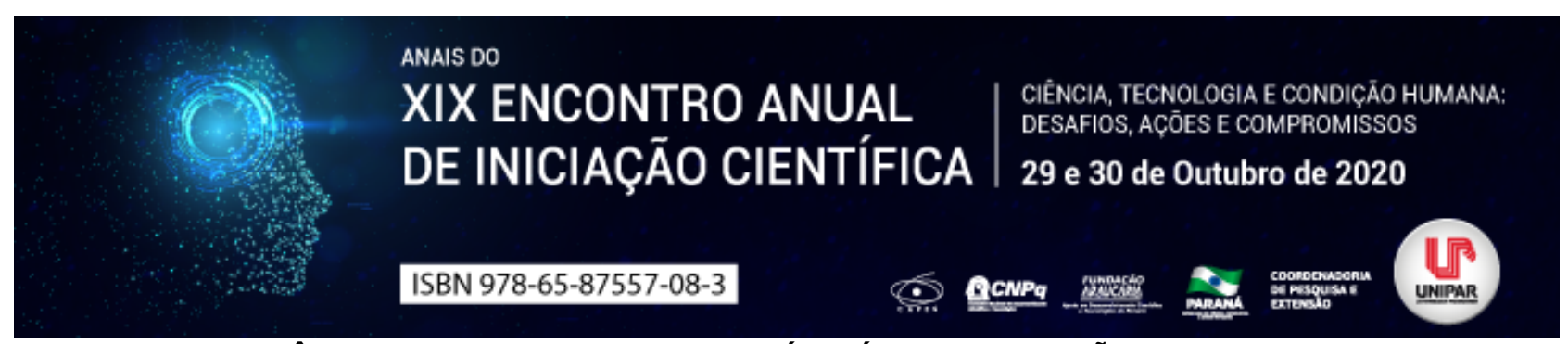

RESISTÊNCIA ANTIMICROBIANA NA SAÚDE ÚNICA REVISÃO DE LITERATURA

\begin{abstract}
${ }^{1}$ KAROLAINE BEZERRA, ${ }^{2}$ MARCO AURELIO CUNHA DEL VECHIO, ${ }^{3}$ GABRIELA FAVERO ESPOLADOR, ${ }^{4}$ MARIANA HACHICHO ALMEIDA, ${ }^{5}$ FERNANDA SANDRI, ${ }^{6}$ LIDIANE NUNES BARBOSA
\end{abstract}

\author{
${ }^{1}$ Mestranda(o) PPG em Ciência Animal com Ênfase em Produtos Bioativos/Taxista Prosup/CAPES

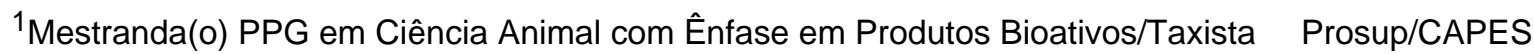 \\ ${ }^{2}$ Mestranda PPG em Ciência Animal com Ênfase em Produtos Bioativos \\ ${ }^{3}$ Discente de Nutrição, PIBIC, UNIPAR \\ ${ }^{4}$ Discente de Nutrição, PIBIC, UNIPAR \\ ${ }^{5}$ Docente da UNIPAR
}

Introdução: A resistência bacteriana aos antimicrobianos em decorrência ao uso exagerado destes fármacos, vem sendo relevante no mundo todo. Pois os antimicrobianos são usados para tratamentos e prevenção de enfermidades infecciosas em humanos e animais (ARIAS, 2012). Os animais como cães e gatos, podem se tornar fontes de resistência antimicrobiana pelo uso indevido destes fármacos, como também infectados por diversas bactérias multirresistentes provindas dos seres humanos por conta da proximidade com os pets (GUARDABASSI, 2004).

Objetivo: No presente trabalho tem por objetivo ressaltar a importância da resistência antimicrobiana na saúde única.

Desenvolvimento: Na medicina veterinária o uso de antimicrobianos é para efeitos de bem-estar animal, prevenção e contagio de doenças infecciosas, eficácia na produção animal, prevenção da transmissão de zoonoses e segurança dos produtos de origem animal. Sendo assim, essenciais para a medicina veterinária (UNGEMACH, 2006). Os antimicrobianos utilizados em animais de companhia são de uso para infecções de pele, otite externa, infecções respiratórias, infecções no trato urinário, gastrointestinal, profilaxia cirúrgica entre outras, sendo alguns desses fármacos as penicilinas, cefalosporinas, lincosamidas, tetraciclinas, sulfas potencializadas, fluorquinolona e diversas outras classes. Algumas bactérias de interesse clinico, são zoonóticas sendo gram-negativas, entre elas a Salmonella spp., Campylobacter spp., Escherichia coli, Staphylococcus spp., Enterococcus sp. (ARIAS, 2012). O aumento na resistência aos antimicrobianos na medicina veterinária pode ser alarmante, pois as bactérias isoladas com reservatórios de genes resistentes são encontradas nos seres humanos também (SRINIVISAN, 2007). Tornando-se um problema no ecossistema em que os genes de resistência e bactérias resistentes migram constantemente entre os diversos meios, em alguns estudos, comprova-se, que a resistência nos animais se originou das estações de tratamento de esgoto (SINGER, 2003). As atividades comerciais e o transporte entre países também justificam a presença de bactérias resistentes em populações remotas humanas e animais (MARTINEZ, 2009). Com isso desafios são exigidos para prevenção e controle a resistência aos antimicrobianos pelos estados e municípios brasileiros. Cabe a todas instituições governamentais promover a conscientização populacional, sendo eles indivíduos, profissionais da saúde, agricultores, empresários e gestores públicos, para que os problemas sejam enfrentados de acordo (BRASIL, 2017).

Conclusão: A prescrição criteriosa de antimicrobianos deve ser alcançada pela educação continuada de veterinários e médicos, com esclarecimentos à população sobre a real indicação destes produtos, para que não ocorra resistência antimicrobiana.

\title{
Referências
}

ARIAS, M. V. B.; CARRILHO, C. M. D. M. Resistência antimicrobiana nos animais e no ser humano. Há motivo para preocupação? Semina: Ciências Agrárias, v.33, n.2. p. 775-790. 2012.

BRASIL. Ministério da Saúde, Resistência antimicrobiana: enfoque multilateral e resposta brasileira. Disponível em: https://portalarquivos2.saude.gov.br/images/pdf/2018/outubro/22/18_Tatiana_Estrela.pdf. Acesso: 29 ago. 2020

GUARDABASSI, L.; SCHWARZ, S.; LLOYD, D. H. Pets animals as reservoirs of antimicrobial-resistant bacteria. Journal of Antimicrobial Chemotherapy, London, v. 54, n. 2, 2004.

MARTINEZ, J. L. Environmental pollution by antibiotics and by antibiotic resistance determinants. Environmental Pollution, Amsterdam, v. 157, n. 11, p. 2893-2902, 2009.

SINGER, R. S.; FINCH, R.; WEGENER, H. C.; BYWATER, R.; WALTERS, J.; LIPSITCH, M. Antibiotic resistance the interplay between antibiotic use in animals and human beings. Lancet Infectious Diseases, New York, v. 3, n. 1, p. 47-51, 2003.

SRINIVASAN, V.; GILLESPIE, B. E.; LEWIS, M. J.; NGUYEN, L. T.; HEADRICK, S. I.; SCHUKKEN, Y. H.; OLIVER, S. P. Phenotypic and genotypic antimicrobial resistance patterns of Escherichia coli isolated from dairy cows with mastitis. Veterinary Microbiology, Amsterdam, v. 124, n. 3, p. 319-328, 2007.

UNGEMACH, F. R.; MÜLLER-BAHRDT, D.; ABRAHAM. G. Guidelines for prudent use of antimicrobials and their implications on 
antibiotic usage in veterinary medicine International Journal of Medical Microbiology, Stuttgart, v. 296, p. 33-38, 2006.

Coordenadoria de Pesquisa e Extensāo - COPEX

Departamento de Editoraçāo e Divulgaçāo Científica - DEDIC 


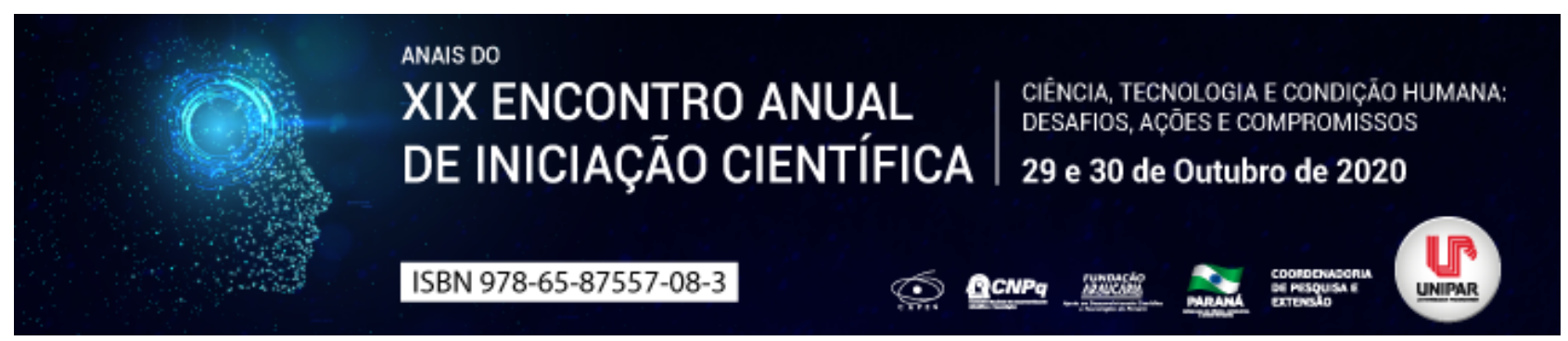

FATORES ANTE E POST MORTEM QUE INFLUENCIAM A MACIEZ DA CARNE BOVINA

\title{
${ }^{1}$ Dirce Consuelo Coronato Correia, ${ }^{2}$ JESSICA PRISCILA DA PAZ, ${ }^{3}$ SARAH DE ANDRADE DIAS RODRIGUES
}

\author{
${ }^{1}$ Acadêmica do curso de Medicina Veterinária-UEM \\ ${ }^{1}$ Acadêmica do curso de Medicina Veterinária-UEM \\ 2Docente da UEM
}

Introdução: A maciez da carne se apresenta como a característica sensorial de maior relevância para que o consumidor realize a compra do produto, ou seja, estipulada pela capacidade com que a carne se deixa mastigar, podendo ser analisada subjetivamente ou de forma objetiva através da força de cisalhamento (ZAPATA, et al., 2000).

Objetivo: Este estudo tem como objetivo demonstrar a necessidade do conhecimento de ferramentas e estratégias, para aprimorar os fatores ante e post mortem que influenciam na maciez da carne.

Desenvolvimento: Nos últimos anos a pecuária de corte brasileira desenvolveu-se, através da expansão da fronteira agrícola, tornou-se o maior rebanho comercial do mundo, o segundo maior produtor de carne bovina e adquiriu a posição de maior exportador. Atualmente tem embarcado ao exterior cerca de $20 \%$ do total produzido de carne bovina, ficando o restante (80\%) para abastecimento do mercado interno (Associação Brasileira das Indústrias Exportadoras de Carne - ABIEC). Mediante esse referencial, que envolve o Brasil, vale destacar o termo qualidade, que se baseia num conjunto de atributos que satisfaçam o consumidor ou até mesmo, que superem suas expectativas, que vem desde as percepções necessidades e resultados obtidos por cada indivíduo (MAGALHÃES, et al., 2016). Mesmo apresentando resultados produtivos satisfatórios, a carne brasileira é considerada como de média a baixa qualidade devido à falta de maciez. Dikeman et al. (2005) relataram em uma pesquisa de mercado que $72 \%$ dos consumidores preferiam carnes mais macias e que $51 \%$ pagariam a mais por isso. Alguns atributos estão intimamente relacionados com a qualidade final do produto, como fatores ante mortem (FELíCIO, 1993) Entre eles a genética do animal, idade, sexo, o manejo nutricional, o uso de promotores de crescimento e o manejo pré-abate, estão principalmente relacionado ao estresse, que pode causar depleção parcial ou total da reserva de glicogênio, que consequentemente causaria o rigor mortis na primeira hora. Visto que a reserva energética deve ser suficiente para sustentar o metabolismo anaeróbico e produzir ácido lático. Já nos fatores post mortem, destacam-se o método de suspensão das carcaças, velocidade de resfriamento, estimulação elétrica, maturação, e o método de cocção, sendo características que estão diretamente relacionadas com a maciez e precisam ser avaliadas. Outras análises que corroboraram para verificação da maciez é a análise da atividade enzimática (calpastatina), índice de fragmentação miofiblilar, comprimento de sarcômero, conteúdo de colágeno, expressão de genes e a abundância proteica (FELÍCIO, 1997). Sendo estes os principais fatores que influenciam na maciez da carne bovina, por conseguinte compreende-se que a maciez da carne é influenciada principalmente pela atuação do sistema proteolítico das calpaínas, durante o processo de maturação pós-mortem (PEDREIRA, et al.,2003)

Conclusão: Compreende-se que é de suma importância que sejam realizadas avaliações da maciez da carne, visto que o Brasil se encontra como um dos principais produtores de carne bovina, logo deve atentar-se aos fatores ante e post mortem para que indubitavelmente sejam postos em prática, visto que desde os produtores até a indústria frigorífica, possuem conhecimento, ferramentas e estratégias para buscar um alimento de melhor qualidade.

\section{Referências}

Associação Brasileira da Indústria Exportadora de Carne Bovina. Disponível em: Acesso em 27 ago 2020.

DIKEMAN, M.E. et al. Phenotypic ranges and relationships among carcass and meat palatability traits for fourteen cattle breeds, and heritabilities and expected progeny differences for Warner-Bratzler shear force in three beef cattle breeds. Journal of Animal Science, v.83, p.2461-2467, 2005. Disponível em: . Acesso em: 27 ago. 2020.

FELICIO, P. E. de. Fatores que influenciam na qualidade da carne bovina. In: A. M. Peixoto; J. C. Moura; V. P. de Faria. (Org.). Produção de Novilho de Corte. 1.ed. Piracicaba: FEALQ, 1997.

Felício, P.E. de. 1993. Fatores ante e post-mortem que influenciam na qualidade da carne vermelha. Anais dos Simpósios da 30a.Reunião Anual da Sociedade Brasileira de Zootecnia. Rio de Janeiro-RJ, p.43-52.

MAGALHÃES, Danielle Rodrigues et al. Socio-economic factors affecting the consumer provision in meat with certification of origin Belo Horizonte, Minas Gerais, Brazil. Arquivos do Instituto Biológico, São Paulo, v. 83, n. 1, p. 1-8, abr. 2016

PEDREIRA, Aparecida Carla de Moura Silveira et al. Propionato de cálcio no amaciamento do músculo Longissimus dorsi de bovinos de corte. Revista Brasileira de Zootecnia, São Paulo, v. 32, n. 5, p. 1213-1219, out. 2003.

Review. Acta Scientiarum. Animal Sciences, n. 35, p. 335-347, 2013.

ZAPATA, J. F. F.et al.Estudo da qualidade da carne ovina do nordeste brasileiro: propriedades físicas e sensorial. Food 
Science And Technology, Campinas, v. 20, n. 2, p. 1213-1219, ago. 2000.

Coordenadoria de Pesquisa e Extensão - COPEX

Departamento de Editoraçāo e Divulgaçāo Científica - DEDIC 


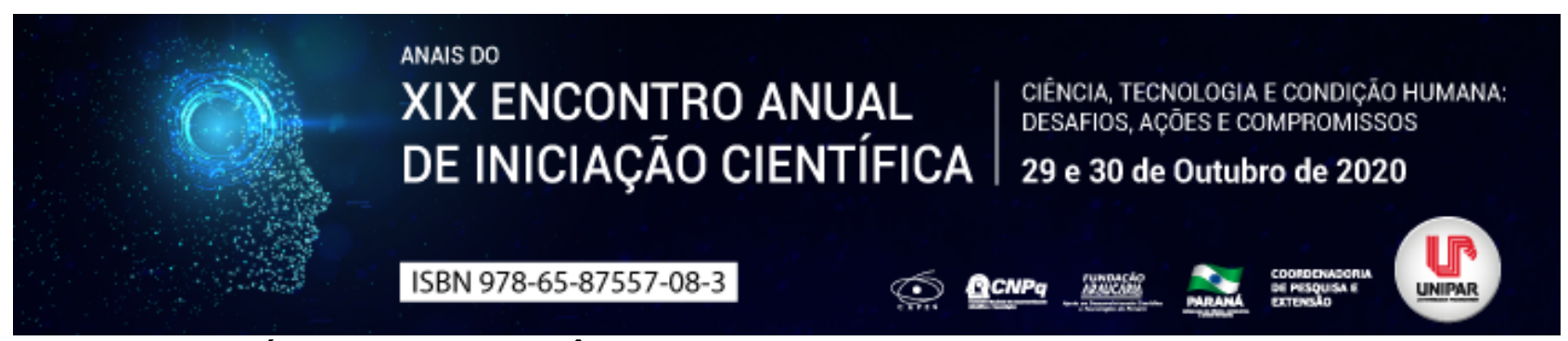

BÓCIO DISORMONOGÊNICO EM FETO DE CAPRINO: RELATO DE CASO

\begin{abstract}
${ }^{1}$ Joana Cristina Smaha de Jesus Lima, ${ }^{2}$ KARIM CRISTHINE PASE MONTAGNINI, ${ }^{3}$ EDUARDO MICHELON DE NASCIMENTO, ${ }^{4}$ FRANSAEL FRANKLYN DE ARAÚJO, ${ }^{5}$ GEANE MACIEL PAGLIOSA, ${ }^{6}$ ALINE DE MARCO VIOTT
\end{abstract}

\begin{abstract}
${ }^{1}$ Discente no Programa de Pós Graduação em Ciência Animal, Universidade Federal do Paraná, Setor Palotina, Palotina, Paraná
${ }^{1}$ Discente no Programa de Pós Graduação em Ciência Animal, Universidade Federal do Paraná, Setor Palotina, Palotina, Paraná

${ }^{2}$ Residente em Clínica Médica de Grandes Animais, Universidade Federal do Paraná, Setor Palotina, Palotina, Paraná

${ }^{3}$ Residente em Clínica Médica de Grandes Animais, Universidade Federal do Paraná, Setor Palotina, Palotina, Paraná

${ }^{4}$ Professor adjunto de Clínica Médica de Grandes Animais, Universidade Federal do Paraná, Setor Palotina, Palotina, Paraná

${ }^{5}$ Professor adjunto de Patologia Veterinária, Universidade Federal do Paraná, Setor Palotina, Palotina, Paraná
\end{abstract}

Introdução: O aumento de volume de glândula tireoide não neoplásico e não inflamatório ocorre em todos os animais domésticos, inclusive em aves, mamíferos marinhos, primatas não humanos e no homem. Esse aumento pode ser difuso ou nodular e geralmente reflete no comprometimento da síntese de hormônios tireoidianos, sendo que a redução destes, resulta em elevação compensatória dos níveis séricos de TSH, que por sua vez, causa hipertrofia e hiperplasia das células foliculares da tireoide e consequente aumento da glândula (bócio). Os mecanismos etiopatogênicos que resultam na síntese inadequada de tiroxina e na diminuição, na concentração sanguínea de T3 e T4, incluem dietas deficientes em iodo, compostos bociogênicos e defeito genético nas enzimas responsáveis pela biossíntese dos hormônios tireoidianos. A baixa concentração destes hormônios é detectada pelo hipotálamo e hipófise, provocando aumento na produção de TSH, que resulta em hipertrofia e hiperplasia das células foliculares (secretora) (ECCO; LANGORHR, 2016). Há alguns subtipos de bócio reconhecidos: difuso hiperplásico, coloide por excesso de iodeto, multifocal hiperplásico e congênito dyshormonogenetic (SINGH; BEIGH, 2013), sendo este último importante para fetos e neonatos. Desta forma, relata-se um caso de bócio disormonogênico em feto de caprino diagnosticado pelo Laboratório de Patologia Veterinária (LPV), da Universidade Federal do Paraná (UFPR), Setor Palotina.

Relato de Caso: Foi encaminhado ao LPV, um caprino, macho, Boer, abortado com aproximadamente 131 a 151 dias de gestação, para exame necroscópico. Segundo proprietário o rebanho possuía histórico de abortos e natimortalidade. Macroscopicamente, observou-se ausência total de folículos pilosos e os membros torácicos apresentavam-se levemente avermelhados. Ao corte havia edema leve de subcutâneo. Na região cervical ventral, observou-se acentuado aumento de volume bilateral na região de glândula tireoide, e ao corte, a mesma encontrava-se acentuadamente aumentada e avermelhada (sugestivo de bócio). Os rins e o fígado estavam levemente avermelhados. Microscopicamente, os alvéolos pulmonares apresentavam leve quantidade de material puntiforme amarronzado (compatível com mecônio) no seu lúmen. Na tireoide, os folículos se apresentavam irregulares, distendidos, revestidos por uma a duas camadas de células epiteliais cilíndricas, com citoplasma acentuadamente eosinofílico, sendo que no lúmen destes, notava-se intenso material amorfo intensamente eosinofílico difuso (coloide). As alterações macroscópicas e microscópicas, foram compatíveis com bócio disormonogênico.

Discussão: $O$ iodo tem um papel muito importante no organismo e caso haja deficiência pode ocasionar o bócio, entre eles o bócio congênito (GOLBERT, 2006). A possível causa da ocorrência do bócio nos animais desta propriedade, é o fato deles não receberem uma dieta com suplementação de sal adequada. Macroscopicamente animais com bócio apresentam aumento bilateral acentuado da tireoide, com coloração vermelho-escura, devido ao aumento da vascularização, decorrente do estímulo constante do TSH (ROSOL; GRONE, 2016). O aumento dos níveis séricos de TSH se dá pela diminuição dos níveis de t3 e T4 circulantes, já que a glândula acometida não consegue sintetizar esses hormônios. No bócio congênito pode haver ainda mixedema cutâneo e alopecia multifocal ou difusa, (PAULíKOVÁ et al., 2002, KOIKKALAINEN et al., 2014, PANZIERA et al., 2014), lesões observadas no presente caso. Quanto as lesões microscópicas, o bócio apresenta dois estágios: hiperplásico e o de involução coloidal. O estágio hiperplásico é caracterizado por marcada hiperplasia e hipertrofia do epitélio folicular com aumento de tecido intersticial, e pela diminuição do lúmen coloidal, podendo ser observado ainda projeções papilares do epitélio folicular. O estágio coloidal é caracterizado pelo aumento considerável do lúmen coloidal, associado à diminuição do tecido intersticial e um afinamento do epitélio folicular (KUMAR et al., 2010, PANZIERA et al., 2014, ROSOL; GRÖNE, 2016). De acordo com as lesões histológicas observadas, a lesão foi classificada como coloidal indicando cronificação do processo lesivo.

Conclusão: O diagnóstico de bócio congênito disormonogênico foi realizado através do histórico da propriedade associado as lesões anatomopatológicas. O fornecimento de iodo e a análise da concentração nas dietas dos animais é de suma importância, assim evitando alterações causadas por essa patologia.

\title{
Referências
}


ECCO, R.; LANGOHR, I. M. Sistema Endócrino. In: SANTOS, R. de L.; ALESSI, A. C. Patologia Veterinária. Roca. Cap 13. p. 703-749, 2016.

GOLBERT, L. Implicações do Aumento da da Expressão do Proto-Oncogene Ras no Bócio Multinodular. Orientador: Ana Luiza Maria. Dissertação de Mestrado. Universidade Federal do Rio Grande do Sul. 2006.

KOLKKALAINEN, K. et al. Congenital hypothyroidism and dysmaturity syndrome in foals: first reported case in Europe. Equine Veterinary Education, v. 26, n. 4, p. 181-189, 2014.

KUMAR, A.; GUPTA, K.; BHAT, GR. Caesarean section for treatment of fetal dystocia due to goitre in a doe. Intas Polivet. v.15, n. 2, p.349-350, 2014.

PANZIERA, W.; et al. Bócio congênito em caprinos no noroeste do Rio Grande do Sul, Brasil. Ciência Rural. v. 44, n. 12, p. 2217- 2220, 2014.

PAULÍKOVÁ, I. et al. lodine toxicity in ruminants. Veterinární Medicína. v. 47, n. 12, p. 343-350, 2002.

ROSOL, T. J.; GRÖNE, A. Endocrine glands. In: MAXIE, Grant; JUBB; Kennedy; Palmer's. Pathology of domestic animals. 6 ed. San Diego: Elsevier. 2016, p. 269-357.

SINGH, R.; BEIGH, S. A. Diseases of Thyroid in Animals and Their Management. In: CARREIRA, R. P. Insights from Veterinary Medicine. Intech Rijeka, Croatia, Cap. 9, 2013, p. 233-240.

Coordenadoria de Pesquisa e Extensão - COPEX

Departamento de Editoraçāo e Divulgaçāo Científica - DEDIC 


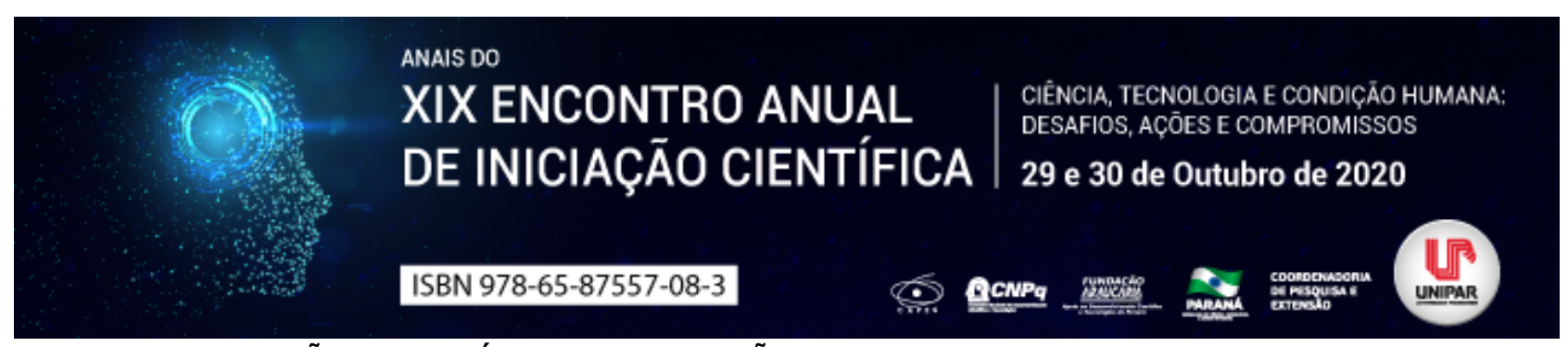

REAÇÃO ANAFILÁTICA A APLICAÇÃO DE DIPROPIONATO DE IMIDOCARB

\begin{abstract}
${ }^{1}$ ANNA BEATRIZ DONAIDI SPAGNOLLI, ${ }^{2}$ DEBORAH CAROLINE SEPÚLVEDA DIAS, ${ }^{3}$ GABRIELA JULIANA LOPES, ${ }^{4}$ LARISSA DE MATOS VIEIRA , ${ }^{5}$ ANA MARIA CANDIDO FERREIRA,${ }^{6}$ NATALIE BERTELIS MERLINI
\end{abstract}

\begin{abstract}
${ }^{1}$ Discente do curso de Medicina Veterinária da Universidade Paranaense UNIPAR, bolsista PIBIC/UNIPAR
${ }^{1}$ Médica Veterinária autônoma

${ }^{2}$ Médica Veterinária autônoma

${ }^{3}$ Discente do curso de Medicina Veterinária da Universidade Paranaense

UNIPAR, bolsista PIBIC/UNIPAR

${ }^{4}$ Discente do curso de Medicina Veterinária da Universidade Paranaense UNIPAR, bolsista PIBIC/UNIPAR

${ }^{5}$ Docente do programa de pós-graduação em ciência animal com ênfase em produtos bioativos, Universidade paranaenseUnipar.
\end{abstract}

Introdução: O dipropionato de imidocarb é um composto derivado da combinação das carbanilidas com as diamidinas, que neste último encontra-se o diminazeno, principio este que é relatado como o causador de efeitos colaterais a aplicação da medicação (SPINOSA et al., 2015). O aceturato de diminazeno é um medicamento quimioterápico sintético com ação antiprotozoária comumente utilizado na clínica médica de pequenos animais para o tratamento de algumas doenças parasitárias, como babesiose (SILVA et al. 2008). A intoxicação por essa medicação é descrita em cães desde a década de 1970, no entanto existem poucos relatos sobre essa toxicose (VIAL \& GORENFLOT.,2006). Dentre os sinais clínicos resultante da intoxicação, grande parte são neurológicos, como alteração do nível de consciência, tetraparesia, rigidez extensora e crise convulsiva. Em alguns casos, os cães acometidos apresentaram sinais de síndrome cerebelar, como tremores musculares generalizados, e/ou de síndrome vestibular, como ataxia, inclinação de cabeça e quedas com possibilidade de evolução para coma e morte. No entanto, outros sinais como sialorreia, náuseas, vômitos, diarreia, queda na pressão sanguínea, taquipnéia, dispnéia, micção frequente, espasmos musculares, também são relatados (MILLER et al., 2005; SPINOSA et al., 2015). O presente trabalho teve por objetivo relatar o caso de um canino que apresentou reação anafilática a aplicação de dipropionato de imidocab.

Relato de caso: Foi atendido um canino, Boxer de 4 anos, $28 \mathrm{~kg}$, estava sendo tratado para erliquiose com doxiciclina e suspeitou-se de infecção concomitante por babesiose. Diante disto realizou-se aplicação de imidocarb na dose de $5 \mathrm{mg} / \mathrm{kg}$ por via subcutânea, após administração prévia de atropina $0,044 \mathrm{mg} / \mathrm{kg}$ pela mesma via. Decorrido 15 minutos da aplicação animal começou a apresentar edema palpebral, urticária, seguido de vômito e diarreia. O quadro evoluiu para obnubilação e amaurose. O paciente foi então colocado na fluidoterapia e aferido pressão arterial sistêmica (PAS), revelando hipotensão (60mmHg). Diante do quadro, foi iniciado prova de carga com $15 \mathrm{ml} / \mathrm{kg}$ por 10 minutos e administrado dexametasona 0,5mg/kg por via intravenosa. Para estabelecer a PAS foram necessárias mais duas provas de carga. Duas horas depois o nível de consciência foi recuperado houve melhora no edema e na urticária. $O$ animal foi mantido em monitoração intensiva e após 24 horas recuperou a visão. Após dois dias de internação o paciente recebeu alta médica.

Discussão: A Reação Anafilática é uma reação de hipersensibilidade potencialmente fatal, que pode ocorrer minutos após a exposição a um alérgeno e afetar vários sistemas orgânicos, são relatados sinais como edema de face, prurido e pápulas pelo corpo, e em cães sintomas como vômito e diarreia também são descritos e poder progredir para sinais respiratórios e choque, (RABELO, 2013). A partir do momento em que houve sinais clínicos de anafilaxia, iniciou-se as condutas para reversão do quadro, que consistiram na reversão da hipotensão com fluidoterapia e aplicação de dexametasona, (RABELO, 2013). De qualquer maneira, diversos autores demonstram que há uma marcada variação individual na suscetibilidade de cães em desenvolver reação ao uso desse princípio ativo (VAN HEERDEN., 1981). Além disso, casos de reações com sinais clínicos intensos dificilmente são revertidos (AFIP; 2000), no entanto, em decorrência da imediata identificação e tratamento da resposta anafilática foi possível reverter o quadro clínico. A taxa de absorção do imidocarb administrado por via subcutânea é de 15 a 60 minutos, podendo ter a ocorrência de reações tóxicas nesse intervalo, mas sempre dependendo da taxa metabólica de cada indivíduo (GRECU et al, 2016). A aplicação prévia de atropina deve-se aos efeitos colinérgicos indesejáveis que, eventualmente podem ocorrer com o uso do imidocarb (ANDRADE \& SANTARÉM, 2002). No caso em questão o animal apresentou sinais clínicos condizentes com reação anafilática e manifestações descritas no caso de toxicidade pelo composto, os sinais neurológicos apresentados são relatados devido a lesão que podem ocorrer ao nível do cerebelo, mesencéfalo e tálamo/cortical, justificando a obnubilação e amaurose (SPINOSA et al., 2015).

Conclusão: Os possíveis efeitos colaterais do dipropionato de imidocarb, devem ser sempre mencionados e explicado aos tutores, e, a sua utilização realizada somente quando necessário e se possível com diagnóstico definitivo em mãos. Sempre respeitando a dose recomendada e com monitoramento, lembrando que cada animal pode responder de forma diferente a 
aplicação.

\section{Referências}

AFIP 2000. Armed Forces Institute of Pathology Wednesday Slide Conference, 18:4.

ANDRADE, S.F.; SANTARÉM, V.A. Endoparasiticidas e ectoparasiticidas. In: ANDRADE, S.F. Manual de terapêctica veterinária. 2.ed. Roca: São Paulo, 2002. p.437-476.

MILLER, D. M. et al. The pharmacokinetics of diminazene aceturate after intramuscular administration in healthy dogs. Journal of the South African Veterinary Association, Africa do sul, v. 76, n. 3, p. 146-150, set. 2005.

SILVA, Aleksandro Schafer da et al. Aceturato de diminazeno e dipropionato de imidocarb no controle de infecção por Trypanosoma evansi em Rattus norvegicus infectados experimentalmente. Ciência Rural, Santa Maria, v. 38, n. 5, p. 1357-1362, ago. 2008.

RABELO, R. C. Emergências de pequenos animais: condutas clínicas e cirúrgicas no paciente grave. Rio de Janeiro: Elsevier, 2013. P. 1160.

SPINOSA GS, GÓRNIAK SL, BERNARDI MM. Farmacologia Aplicada à Medicina Veterinária, $5^{a}$ ed., Rio de Janeiro: Guanabara Koogan, 2015.

VAN HEERDEN, J. Diamidine poisoning in a dog. Journal of the South African Veterinary Association, Africa do sul, v. 52 , $n$. 4, p. 338, dez.1981.

VIAL, Henri J.; GORENFLOT, A. Chemotherapy against babesiosis. Veterinary parasitology, v. 138, n. 1-2, p. 147-160, mai. 2006. 


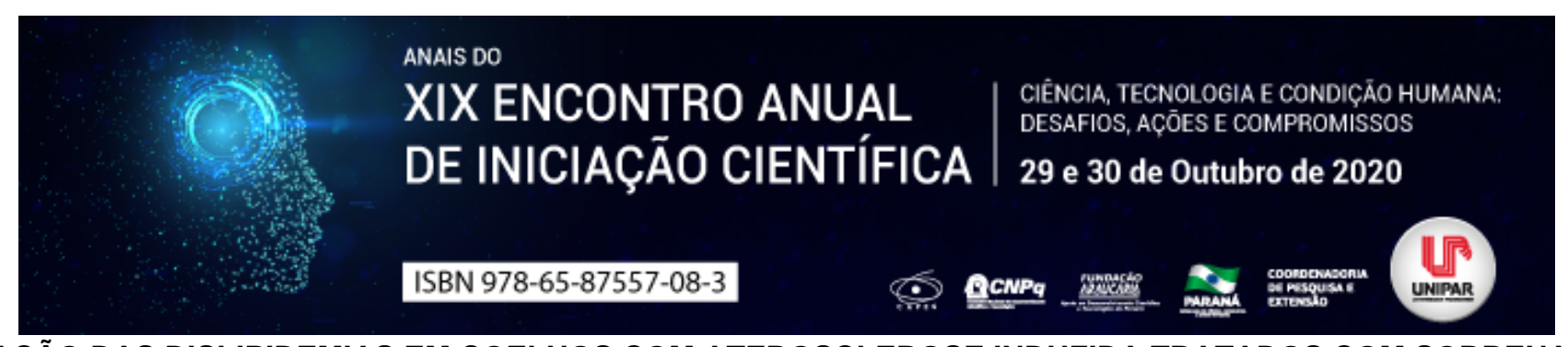

\title{
AVALIAÇÃO DAS DISLIPIDEMIAS EM COELHOS COM ATEROSCLEROSE INDUZIDA TRATADOS COM SOBRENADANTE ETANOICO DO INFUSO DE Plinia cauliflora
}

\author{
${ }^{1}$ ALAN DA SILVA LISBOA, ${ }^{2}$ GUILHERME DONADEL, ${ }^{3}$ JOAO ANTONIO BERTA DE OLIVEIRA, ${ }^{4}$ GUILHERME DONADEL, \\ ${ }^{5}$ MARIA DAMARIS RIBEIRO CAVALCANTE, ${ }^{6}$ EMERSON LUIZ BOTELHO LOURENCO
}

\author{
${ }^{1}$ ACADEMICO BOLSISTA DO PIBIC/UNIPAR \\ ${ }^{1}$ Acadêmico do Curso de Medicina Veterin $\tilde{A}_{j}$ ria da UNIPAR \\ ${ }^{2}$ Acadêmico do Curso de Medicina Veterin $\tilde{A}_{j}$ ria da UNIPAR \\ ${ }^{3}$ Acadêmico do Curso de Medicina Veterin $\tilde{A}_{j}$ ria da UNIPAR \\ ${ }^{4}$ Acadêmica do Curso de Medicina VeterinÃ iria da UNIPAR \\ ${ }^{5}$ Docente da UNIPAR
}

Introdução: A aterogênese é caracterizada pelo desenvolvimento de placas gordurosas, denominadas placas de ateroma, na superfície interna da parede das arteriais, sendo que cristais de colesterol, juntamente com a proliferação celular, podem ocasionar a projeção da placa para o lúmen arterial, causando redução acentuada do fluxo sanguíneo podendo gerar oclusão completa do vaso (BECKSTROM et al., 2007), a formação destas placas é ocasionada por diversos fatores desde genéticos, tabagismo, obesidade, sedentarismo, hipertensão, sexo e idade. A fitoterapia é a modalidade de tratamento em crescente expansão nos últimos anos, principalmente em função do alto custo dos medicamentos industrializados e índice elevado de efeitos colaterais, dentre eles os distúrbios hepáticos causados pelas sinvastatinas utilizadas em longo prazo (FLORENCIO, $\mathrm{V}$;; JUNIOR, $\mathrm{V}$,; 2008). O fitoterápico pode representar um medicamento de fácil aceitação pelas comunidades, pois pertence ao arsenal terapêutico tradicional construído culturalmente (FARSNWORTH, 1985).

Objetivo: Avaliar o índice de aterogênese no arco aórtico, aorta torácica, abdominal, ilíaca, artérias carótidas e femorais após 60 dias de dieta enriquecida com $1 \%$ de colesterol com e sem tratamento por 30 dias com o extrato bruto de $P$. cauliflora, que foram armazenadas em blocos para avalição macroscópica e microscópica.

Metodologia: Aorta torácico foi removida e logo após o arco aórtico (Tronco Braquiocefalico) até na bifurcação ilíaca (artéria ilíaca externa) e posteriormente foi aberta em sua disposição ventral. Anatomicamente a aorta é dividida em torácica e abdominal. A Aorta foi fixada em solução de formalina a 10\% tamponada. Após 48 horas de fixação, enxaguada com álcool a $70 \%$ e imersa em a solução de Herxheime contendo Sudão-IV, $70 \%$ de álcool etílico (500 ml) e acetona (500ml) à temperatura ambiente durante 15 minutos. Os tecidos foram transferidos para $80 \%$ de etanol em 15 minutos e lavado em água corrente por 1 hora para remover o excesso coloração (UZMA SHAHID et al 2011). A superfície luminal foi então avaliada para lesões sudanofílicas. A deposição lipídica na aorta foi determinada por morfologia. Avaliação da porcentagem da aorta coberta por lesões visualizado pela coloração de gordura da região entre o tronco Braquiocefalico da aorta a bifurcação da artéria aorta lliaca foram realizadas. As lesões sudonofilicas foram examinadas em microscópio anatômico. O experimento foi realizado após aprovação do comitê de ética experimental sob o protocolo número no 9767/2016.

Resultado: As análises macroscópicas das aortas torácica, abdominal e ilíaca de coelhos em modelo de dislipidemia quando foram tratadas com extratos de $P$. cauliflora em diferentes doses $(10,30,100 \mathrm{mg} / \mathrm{kg}$ ), demonstraram efeito arterioprotetor (30 e $100 \mathrm{mg} / \mathrm{Kg}$ ), quando foram comparados os números de lesões com os grupos controle positivo ou tratados com o medicamento de referência (Sinvastatina 2,5 mg). Quando comparados os grupos dos animais das doses de (30 e $100 \mathrm{mg} / \mathrm{kg}$ ) foi observada uma redução de $33,3 \%$ em relação ao grupo sinvastatina que reduziu em $16,6 \%$ as lesões e isto resultou em uma diferença de $16,7 \%$ aproximadamente entre os grupos. Estes achados mostram que o extrato de Plinia cauliflora em análises macroscópicas é mais eficiente que a sinvastatina no modelo aqui realizado.

Discussão: O local onde as lesões se concentram é na aorta torácica, como o descrito por UZMA SHAHID et al 2011.Todos os tratamentos são protetores, confirmados na observação do número de lesões e na graduação em relação estas lesões. Além disso, os tratamentos com Sinvastatina não demonstraram seu efeito protetor contra a formação das placas de ateroma ou redução do número de lesões sudanofílicas. Por outro lado, para confirmação mais estreita da importância dos efeitos protetores dos extratos de Plinia cauliflora, devem ser realizadas análises histopatológicas e morfométricas para confirmação quali e quantitativa de sua ação no modelo experimental aqui realizado (SHAHID, U.; BUTT, S. A \& ZAREEN, N. 2011).

Conclusão: Os estudos aqui conduzidos demonstram o importante papel hipolipemiante dos extratos de Plinia cauliflora em modelo experimental de dislipidemia. No entanto, estudos de eficácia e segurança desta planta devem ser conduzidos no intuito de que a mesma seja considerada uma promissora alternativa no tratamento desta importante doença 


\section{Referências}

BECKSTROM, B.W. et al. Correlation between carotid area calcifications and periodontitis: a retrospective study of digital panoramic radiographic findings in pretreatment cancer patients. Oral

Surg. Oral Med. Oral Pathol. Oral Radiol. Endod., v.103, p.359- 366, 2007.

FARSNWORTH, N. R. Medicinal plants in therapy. Bull W. H. O. [S.I.], v. 63, p. 956-981, 1985.

FLORENCIO, V.; JUNIOR, V. Estudo do consumo de plantas medicinais na Região Centro-Norte do Estado do Rio de Janeiro: aceitação pelos profissionais de saúde e modo de uso pela população. Revista Brasileira de Farmacognosia [S.I.], v. 18, n. 2, p. 308-313, 2008.

SHAHID, U.; BUTT, S. A. \& ZAREEN, N. Patterns of sudanophilic lesions at ostia of descending thoracic and abdominal aorta in cholesterol-fed adult rabbits. Int. J. Morphol., 29(3):742-746,201

Coordenadoria de Pesquisa e Extensão - COPEX

Departamento de Editoraçāo e Divulgaçāo Científica - DEDIC 


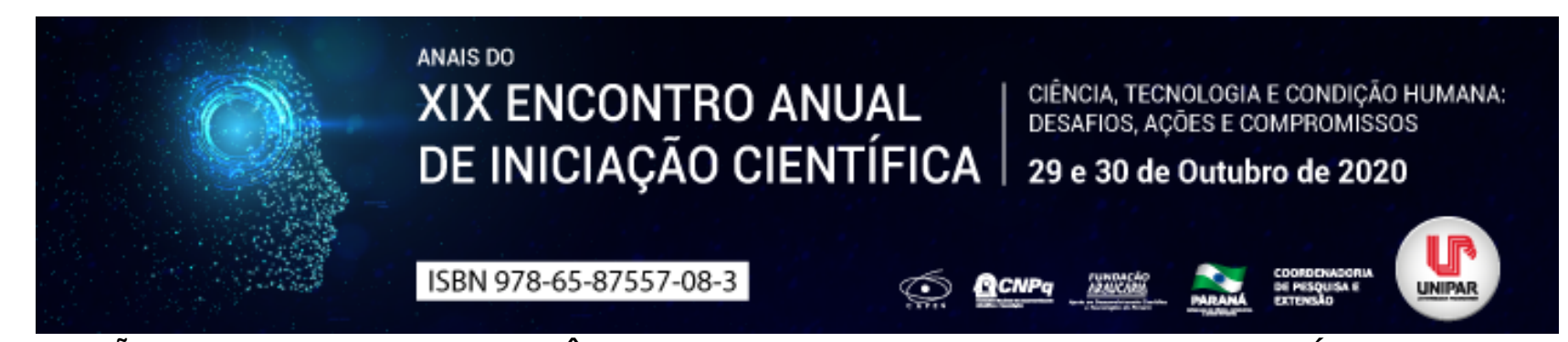

\title{
AVALIAÇÃO DO EFEITO DA TRANSFERÊNCIA DE IMUNIDADE PASSIVA NO SORO SANGUÍNEO DE BEZERROS BUBALINOS JAFARABADI NO PRIMEIRO MÊS DE VIDA
}

\author{
${ }^{1}$ Maria Eduarda Canassa, ${ }^{2}$ GABRIELE MORTEAN DA SILVA, ${ }^{3}$ DANIELA GOMES DA SILVA, ${ }^{4}$ BÁRBARA CRISTINA \\ MAZZUCATTO, ${ }^{5}$ JOSÉ JURANDIR FAGLIARI, ${ }^{6}$ ANDRÉ MARCOS SANTANA
}

\begin{abstract}
${ }^{1}$ Acadêmica do curso de Medicina Veterinária da UEM
${ }^{1}$ Acadêmica do curso de Medicina Veterinária da UEM

${ }^{2}$ Pós-Graduanda do Departamento de Clínica e Cirurgia Veterinária, FCAV/UNESP, Campus de Jaboticabal

${ }^{3}$ Docente do Departamento de Medicina Veterinária, Universidade Estadual de Maringá (UEM)

${ }^{4}$ Docente do Departamento de Clínica e Cirurgia Veterinária, FCAV/UNESP, Campus de Jaboticabal

${ }^{5}$ Docente do Departamento de Medicina Veterinária, Universidade Estadual de Maringá (UEM)
\end{abstract}

Introdução: Na bubalinocultura, o primeiro mês de vida é um período crítico onde ocorrem maiores taxas de mortalidade, decorrentes principalmente de problemas respiratórios e digestivos (SHIRAHRE et al., 2014). Feitosa et al. (2001) relata que o aumento de mortalidade pode decorrer de falhas na transferência de imunidade passiva (TIP), visualizada por inadequada atividade sérica de GGT e de concentrações séricas de proteínas totais (PT) e IgG. Uma vez que a placenta dessa espécie não permite a passagem de imunoglobulinas, a avaliação da TIP é fundamental para a saúde do bezerro, podendo auxiliar na intervenção precoce de animais imunossuprimidos (TIZARD, 2014). Considerando a escassez de estudos relativos a TIP em búfalos (SOUZA et al., 2020), bem como o acompanhamento do efeito da TIP no soro sanguíneo ao longo do primeiro mês de vida, foi realizado este trabalho.

Objetivo: Avaliar o efeito da TIP nos parâmetros bioquímico-séricos de bezerros bubalinos, ao longo do primeiro mês de vida.

Material e Métodos: Este trabalho foi aprovado pelo CEUA (Protocolo: 010885-08). Todos os bezerros mamaram o colostro antes do início das coletas de sangue. Coletou-se amostras de sangue em 10 momentos: animais entre 0-3 (M1), 4-6 (M2), 7-9 (M3), 10-12 (M4), 13-15 (M5), 16-18 (M6), 19-21 (M7), 22-24 (M8), 25-27 (M9) e 28-30 (M10) dias de vida. As amostras foram coletadas mediante punção da veia jugular. As concentrações séricas de PT e albumina e as atividades séricas de GGT foram mensurados utilizando conjuntos de reagentes de uso comercial e as leituras feitas em espectrofotômetro semi-automático. As concentrações de IgG e a IgA foram analisadas através da SDS-PAGE. Os dados foram apresentados na forma de média e desvio padrão.

Resultados: As concentrações de PT (g/dL) foram de 8,44 (M1), 7,79 (M2) e 8,15 (M3), com posterior diminuição em M4 (6,33), que seguiu em concentrações mais baixas até o M10 $(6,72)$. Da mesma forma, as globulinas $(\mathrm{g} / \mathrm{dL})$ apresentaram uma diminuição de M4 (3,52) a M10 (3,67), quando comparados aos momentos iniciais: 5,88 (M1), 4,98 (M2), 5,40 (M3). As concentrações de albumina (g/dL) iniciais foram de 2,56 (M1), 2,81 (M2) e 2,75 (M3), e não apresentaram oscilações até o final do experimento (M10: 3,06). As concentrações de $\mathrm{IgG}(\mathrm{g} / \mathrm{dL}$ ) foram de 3,05 (M1), 2,37 (M2) e 2,52 (M3), sofrendo uma diminuição a partir do M4 $(1,22)$, que persistiu até os 30 dias (M10: 1,17). As concentrações de $\mathrm{IgA}(\mathrm{g} / \mathrm{dL}$ ) alteraram-se pouco no decorrer dos momentos: 0,46 (M1) e concentrações mínimas e máximas de 0,38 (M4) e 0,64 (M6), respectivamente. As atividades séricas de GGT (U/L) iniciais foram de 288 (M1) e diminuíram drasticamente até M4 (51,3). Após o M4, as atividades séricas reduziram gradativamente até o final do experimento (M10: 19,1).

Discussão: Uma vez que são escassos estudos que avaliem a TIP na espécie bubalina, neste trabalho foram mensurados os parâmetros PT, ALB, GLOB, IgG, IgA e GGT, ao longo dos primeiros 30 dias de vida. Constatou-se que as concentrações de IgG em M1 e M2 foram de 3,05 e 2,37 g/dL, respectivamente, resultados estes inferiores aos de Souza et al. (2020), que foram de $3,45 \mathrm{~g} / \mathrm{dL}$ às 24 horas de vida, e superiores aos de um estudo com bezerros leiteiros entre $X$ e 4 meses de vida, onde foi estabelecido a média de 2-2,5 g/dL como eficiente para se obter uma adequada TIP (CHIGERWE et al., 2015). Os valores obtidos para IgA em nosso estudo se mantiveram constantes no decorrer dos 30 dias. Quando comparado com a literatura, os animais no M1 tiveram média de 0,46 g/dL, o que foi inferior ao relatado por Souza et al. (2020): 0,54 g/dL. Para PT, também foram obtidas maiores concentrações nos animais mais jovens (M1: 8,44 g/dL) com conseguinte redução e variação após os 3 dias de vida. Souza et al. (2020) relatou concentrações de 4,82 g/dL no momento Oh com pico $24 \mathrm{~h}$ após a ingestão do colostro $(8,47 \mathrm{~g} / \mathrm{dL})$ e afirmou que esse aumento é um parâmetro indireto confiável para verificar uma adequada TIP. Em nossos resultados, as concentrações de albumina não sofrem grandes variações, no entanto, para globulinas foi obtido altas concentrações nos primeiros 3 dias (M1: $5,88 \mathrm{~g} / \mathrm{dL}$ ). Dessa forma, a elevação de PT está ligada a transferência passiva de imunoglobulinas. No caso da GGT, a maior concentração ocorreu no M1 (288 U/L) com redução no decorrer do experimento. No entanto, quando comparado a dados da literatura (SOUZA et al., 2019; SOUZA et al., 2020), nossas médias foram inferiores. 
Ambos os estudos (SOUZA et al., 2019; SOUZA et al., 2020) relataram baixas concentrações de GGT antes da ingestão de colostro Oh e pico às 24 horas, com sucessivo decréscimo. A redução dos níveis séricos de GGT foi descrita como resultado da maturação intestinal e degradação enzimática no intestino, associada, a baixa produção endógena (THOMPSON E PAULI, 1981).

Conclusão: Foi possível avaliar o efeito da TIP, ao longo de 30 dias, no soro sanguíneo de bezerros bubalinos, cinética esta que pode ser utilizada como meio de detecção de falhas na TIP, bem como servir de base de dados para clínicos durante a interpretação de exames laboratoriais nesta fase de vida dos animais.

\section{Referências}

CHIGERWE, Munashe; HAGEY, Jill V; ALY, SharifS. Determination of neonatal serum immunoglobulin G concentrations associated with mortality during the first 4 months of life in dairy heifer calves. Journal of Dairy Research. 18 set. 2015. Disponível em: https://doi.org/10.1017/S0022029915000503. Acesso em: 29/08/20.

FEITOSA, Francisco Leydson F. Semiologia Veterinária. A arte do diagnóstico: cães, gatos, equinos, ruminantes e silvestres. Roca. (2):754. 2008.

FEITOSA, Francisco Leydson Fonni; BIRGEL, Eduardo Harry; CIARLINI, Paulo César; MENDES, Luís Cláudio Nogueira; PERRI, Silvana Helena Venturoli. Transferência de imunidade passiva colostral e a morbidade e mortalidade de bezerros neonatos. Rev. Educ. Contin., São Paulo, v. 4, p. 9-15, 2001.

REECE, William Omar. Editores associados ERICKSON, Howard H., GOFF, Jesse P., UEMURA, Etsuro E. Dukes: Fisiologia dos animais domésticos, 13. Ed., Rio de Janeiro: Guanabara Koogan, 2017.

SHIVAHRE, Pushp Raj; GUPTA, A. K.; PANMEI, A.; BHAKAT M.; KUMAR V.; DASH, SK.; Dash S and A. Upadhyay. Mortality pattern of Murrah buffalo males in an organised herd. Veterinary World, v.7, p.356-359, maio. 2014.

SOUZA, Damazio C. de; SILVA, Daniela Gomes da; FONSECA, Lana Cristine Coelho; FIORI, Letícia de Castro; MONTEIRO, Bruno Moura; BERNARDES, Otávio; VIANA, Rinaldo Batista; FAGLIARI, José Jurandir. Passive Immunity Transfer in Water Buffaloes (Bubalus bubalis). Front. Vet. Sci. v.7, p.1 a 8, 17, jun. 2020.

SOUZA, DC., SILVA, DG., ROCHA, TG., MONTEIRO, BM., PEREIRA, GT., FIORI, L.B, VIANA, R.B., FAGLIARI, J.J. Serum biochemical profile of neonatal buffalo calves. Arq. Bras. Med. Vet. Zootec., v.71, n.1, p.187-196, 2019.

THOMPSON, J. C; PAULI, J. V. Colostral transfer of gamma glutamyl transpeptidase in calves. N.Z.Vet. J: 29, p. 223-6. 1981.

TIZARD, Ian R. Imunologia veterinária: Ian R. Tizard, 9. ed., Rio de Janeiro, Elsevier, 2014.

Coordenadoria de Pesquisa e Extensão - COPEX

Departamento de Editoraçāo e Divulgaçāo Científica - DEDIC 


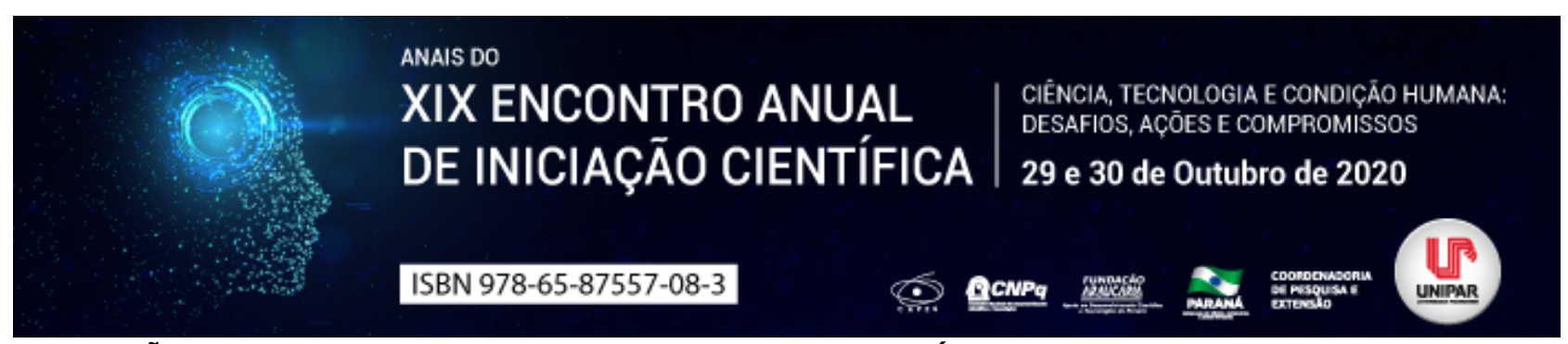

\title{
BIODEGRADAÇÃO DE ANTIMICROBIANOS POR ENZIMAS LIGNINOLÍTICAS DE FUNGOS COMO ALTERNATIVA PARA REMOÇÃO DE MICROPOLUENTES
}

\author{
${ }^{1}$ PEDRO HENRIQUE LIMA MARCHETTI, ${ }^{2}$ JULIANA SILVEIRA DO VALLE
}

\author{
${ }^{1}$ Acadêmico de Farmácia, Bolsista PIBIC/UNIPAR \\ ${ }^{1}$ Docente de Farmácia e da Pós-Graduação em Biotecnologia Aplicada à Agricultura, Universidade Paranaense, UNIPAR
}

Introdução: Fármacos estão entre os poluentes emergentes ou compostos químicos não comumente monitorados que apresentam potencial de toxidade ao meio ambiente (HERMANN et al., 2015). Exemplos são os antibióticos e anticoncepcionais, que são muito utilizados pela população. Isso acontece, pois, após serem metabolizados no organismo, os antibióticos e seus metabólitos são excretados e chegam ao esgoto, seguindo a corrente de água até chegar as ETEs (estações de tratamento de esgoto) e nem sempre são tratados de maneira adequada. Ao entrar nas ETEs, alguns desses compostos permanecem na água podendo gerar desenvolvimento de resistência em bactérias patogênicas, genotoxicidade, distúrbios endócrinos entre outros (HOLANDA, 2019). Embora o nivel de concentração seja baixo, o prejuizo causado por eles evidencia a importância de estudos sobre métodos de degradação eficientes para estes compostos (HOLANDA, 2019).

Objetivo: Realizar revisão da literatura sobre o potencial de biodegradação de antimicrobianos por enzimas ligninolíticas de basidiomicetos.

Desenvolvimento: Fungos conhecidos como fungos da podridão branca da madeira são capazes de degradar as complexas estruturas da lignina, além da celulose e hemicelulose da parede celular vegetal, utilizando enzimas extracelulares (HERMANN et al., 2015). Por serem especialistas na degradação da madeira estes fungos produzem grande variedade de ligninases como as peroxidases e lacase (MARIM et al., 2018). As ligninases são conhecidas por sua ampla variedade de substratos, particularmente compostos com estrutura fenólica ou aromática, incluindo muitos poluentes emergentes como fármacos (VISHWAKARMA et al., 2019). A aplicação destas enzimas na degradação de micropoluentes ambientais é uma alternativa aos tratamentos físicoquímicos e microbiológicos tradicionais, pois a técnica é ecologicamente correta e de menor custo (TAVARES et al., 2012), viabilizando o método. Estudos avaliaram o potencial de fungos da podridão branca da madeira na biorremediação. RodarteMorales et al. (2010) avaliaram a capacidade dos fungos da podridão branca Bjerkandera sp., Bjerkandera adusta e P. chrysosporium em degradar o antibiótico sulfametoxazol (1 mg/L) durante o cultivo em meio líquido por 14 dias. Os autores relataram que $P$. chrysosporium havia removido 32\% do fármaco após 4 dias de cultivo e $100 \%$ em 14 dias. Já Bjerkandera sp. e B. adusta promoveram apenas $20 \%$ de degradação em 4 dias, porém removeram totalmente o antibiótico ao final do cultivo. O fungo Phanerochaete chrysosporium imobilizado em grânulos de plástico, removeu com grande eficiência a ciprofloxacina, eritromicina e sulfametoxazol, reduzindo estes antibióticos em 70\%, 90\% e 60\%, respectivamente, após cinco dias (ACCINELLI et al., 2010). Becker et al. (2016) empregaram a lacase de Trametes versicolor em um biorreator para a degradação de uma mistura de 38 antibióticos (10 $\mathrm{g} / \mathrm{L}$ cada) dentre eles 12 sulfonamidas, seis penicilinas, 10 fluoroquinolonas, quatro quinolonas, quatro tetraciclinas, metronidazol e trimetoprim. A lacase foi empregada associada a um mediador (siringaldeído) e, da mistura de 38 antibióticos, 32 sofreram remoção maior que 50\% em 24 horas. Zhang et al. (2019) relataram que as peroxidases de $P$. chrysosporium degradaram totalmente a sulfadiazina $(10 \mathrm{mg} / \mathrm{L})$ em seis dias.

Conclusão: O uso de fungos da podridão branca em biorremediação de antibióticos é uma abordagem promissora oferecendo uma perspectiva para uso de bioprocessos no tratamento de efluentes contaminados.

\section{Referências}

ACCINELLI, Cesare. et al. Removal of oseltamivir (Tamiflu) and other selected pharmaceuticals from wastewater using a granular bioplastic formulation entrapping propagules of Phanerochaete chrysosporium. Chemosphere, v. 81, n. 3, p. 436-443, 2010.

BECKER, Dennis. et al. Removal of antibiotics in wastewater by enzymatic treatment with fungal laccase-degradation of compounds does not always eliminate toxicity. Bioresource Technology, v. 219, p. 500-509, 2016.

HERMANN, Aline Cristine. Biodegradação dos antimicrobianos sulfametoxazol e trimetoprima por enzimas ligninolíticas de basidiomicetos. 2015. Trabalho de Conclusão de Curso - Universidade Tecnológica Federal do Paraná, Curitiba, 2015.

HOLANDA, Fabrício Holanda Biodegradação do cloranfenicol por fungos endofíticos isolados de Bertholletia excelsa (Castanha-do-Brasil). 2019. Dissertação (Mestrado em Ciências Farmacêuticas) - Universidade Federal do Amapá, Macapá. 2019.

MARIM, Renan Alberto. et al. Lentinus crinitus strains respond differently to cultivation pH and temperature. Genetics and Molecular Research, v. 17, n. 1, 2018.

RODARTE-MORALES, Angelica et al. Degradation of selected pharmaceutical and personal care products (PPCPs) by white-rot 
fungi. World Journal of Microbiology and Biotechnology, v. 27, n. 8, p. 1839-1846, 2011.

TAVARES, Ana Paula M. Produção de lacase para potencial aplicação como oxidante na indústria papeleira. Dissertação (Doutorado em Engenharia Química) - Pós-graduação em Engenharia Química, Universidade de Aveiro, Aveiro, 2006.

VISHWAKARMA, Pratima. Role of Macrofungi in Bioremediation of Pollutants. In: Microbial Metabolism of Xenobiotic Compounds. Springer, Singapore, 2019. p. 285-304.

ZHANG, Ting. et al. Sulfadiazine biodegradation by Phanerochaete chrysosporium: Mechanism and degradation product identification. Chemosphere, v. 237, p. 124418, 2019.

Coordenadoria de Pesquisa e Extensão - COPEX

Departamento de Editoraçāo e Divulgaçāo Científica - DEDIC 


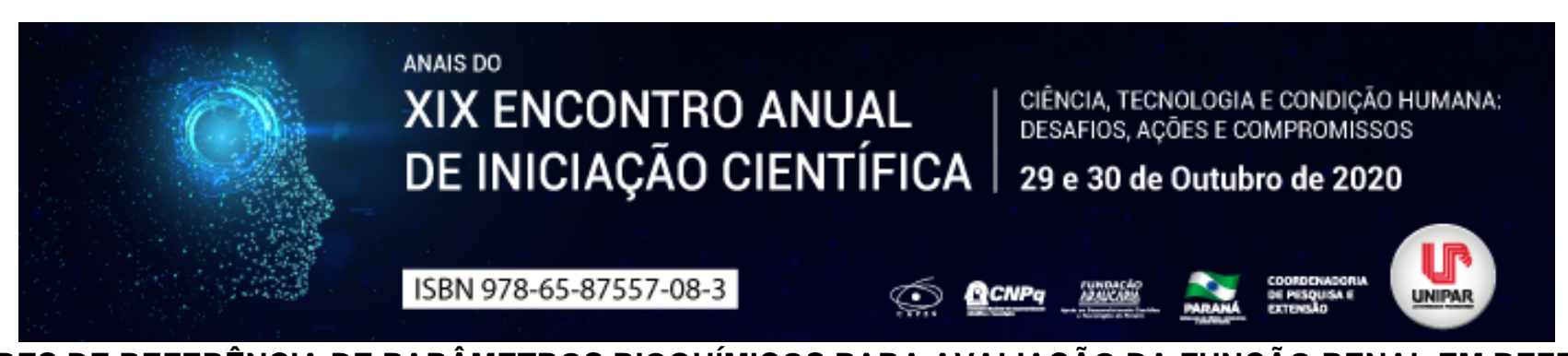

VALORES DE REFERÊNCIA DE PARÂMETROS BIOQUÍMICOS PARA AVALIAÇÃO DA FUNÇÃO RENAL EM BEZERROS BUBALINOS JAFARABADI NO PRIMEIRO MÊS DE VIDA

\begin{abstract}
${ }^{1}$ Gabriele Mortean da Silva, ${ }^{2}$ MARIA EDUARDA CANASSA, ${ }^{3}$ DANIELA GOMES DA SILVA, ${ }^{4}$ BÁRBARA CRISTINA MAZZUCATTO, ${ }^{5}$ JOSÉ JURANDIR FAGLIARI, ${ }^{6}$ ANDRÉ MARCOS SANTANA
\end{abstract}

\begin{abstract}
${ }^{1}$ Discente do Curso de Medicina Veterinária, Universidade Estadual de Maringá (UEM
${ }^{1}$ Discente do Curso de Medicina Veterinária, Universidade Estadual de Maringá (UEM)

${ }^{2}$ Pós-Graduanda do Departamento de Clínica e Cirurgia Veterinária, FCAV/UNESP, Campus de Jaboticabal

${ }^{3}$ Docente do Departamento de Medicina Veterinária, Universidade Estadual de Maringá (UEM)

${ }^{4}$ Docente do Departamento de Clínica e Cirurgia Veterinária, FCAV/UNESP, Campus de Jaboticabal

${ }^{5}$ Docente do Departamento de Medicina Veterinária, Universidade Estadual de Maringá (UEM)
\end{abstract}

Introdução: Devido à alta taxa de mortalidade neonatal em búfalos (FAGLIARI et al., 1998), é essencial a realização de uma avaliação precisa do estado do animal doente, em geral obtida através de exame físico e análises auxiliares laboratoriais. Neste sentido, o perfil bioquímico sérico pode auxiliar na avaliação, por exemplo, da funcionalidade renal. No entanto, para uma correta interpretação das alterações é necessário a determinação de intervalos de referência (IR) adequados para a espécie e para a faixa etária avaliada. Neste contexto, sabe-se que no primeiro mês de vida, o organismo passa por uma série de adaptações necessárias a vida extrauterina, em especial os rins, responsáveis pela homeostase (KURZ e WILLETT, 1991). Neste sentido, de acordo com Benesi et al. (2004), os componentes bioquímicos utilizados para determinar a função renal, ureia e creatinina, sofrem influência do fator etário, sendo reflexo do desenvolvimento renal. Considerando que publicações relativas a IR de perfil bioquímico-sérico de parâmetros utilizados para avaliação da função renal em búfalos da raça Jafarabadi, no primeiro mês de vida, são escassos na literatura, foi realizado este trabalho.

Objetivo: Determinar IR de parâmetros bioquímico-séricos relacionados a função renal de bezerros bubalinos Jafarabadi sadios entre 0-7 (G1), 8-15 (G2) e 16-30 (G3) dias de vida.

Material e métodos: $O$ estado de saúde dos animais que participaram do experimento foi verificado por exame físico geral (FEITOSA, 2008). Assim, bezerros bubalinos entre 0-7 (G1, $n=42), 8-15(G 2, n=45)$ e 16-30 (G3, $n=60)$ dias de vida foram selecionados. Amostras de sangue foram coletadas mediante punção da veia jugular para avaliação das concentrações séricas de creatinina e uréia, mensuradas em espectrofotômetro semi-automático, utilizando conjuntos de reagentes de uso comercial. Os parâmetros avaliados foram submetidos à análise de variância (ANOVA) para comparação entre pares de medias $(p<0,05)$. Os IR foram determinados de acordo com as diretrizes da ASVCP (FRIEDRICHS et al., 2012). O teste de Anderson-Darling, teste de Dixon e de Tukey foram utilizados para avaliar a normalidade e para identificar outliers (Reference Value Advisor - RVA) (GEFFRÉ et al., 2011). Este trabalho foi aprovado pelo CEUA (Protocolo: 010885-08).

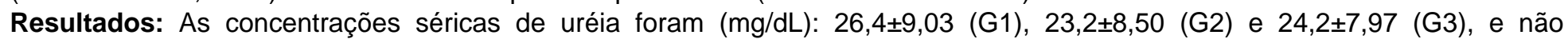
observou-se diferenças estatísticas entre os grupos para esta variável. As concentrações séricas de creatinina foram (mg/dL):

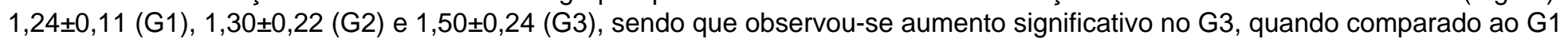
e G2. Assim sendo, com os dados gerados, foi possível realizar o cálculo dos limites inferiores e superiores dos IR das variáveis: 1) IR para ureia (mg/dL): 13,02 a 50,13 (G1), 9,55 a 43,10 (G2) e 10,58 a 42,29 (G3). 2) IR para creatinina (mg/dL): 1,06 a 1,45 (G1), 0,97 a 1,76 (G2) e 0,97 a 2,18 (G3).

Discussão: Neste trabalho, foram calculados IR de variáveis indicadoras de função renal. Constatou-se que as médias do G3, para creatinina, quando comparadas com dados da literatura, foram semelhantes aos encontrados por Fagliari et al. (1998) em bezerros bubalinos da mesma faixa etária. No entanto, as médias dos G1 e G2 foram inferiores as constatadas por Fagliari et al. (1998) em bezerros bubalinos da mesma faixa etária, estando mais próximas as concentrações encontradas por estes mesmos autores em bezerros bovinos da raça Nelore e Holandesa. Em relação aos IR, os três grupos apresentaram limite inferior próximos, sendo também semelhantes aos encontrados por Ellah et al., (2014), que definiu IR para búfalos entre 1 e 2 anos e idade. No entanto, o limite superior mostrou-se diferente para os três grupos, em especial no G3 que atingiu as maiores concentração e portanto apresentou limite superior acima do G1 e G2. Comparando com a literatura, observou-se que os limites superiores, quando comparados com o trabalho de Ellah et al., (2014), mostram-se menores no G1, semelhantes no G2 e maiores no G3. Em relação as concentrações séricas de uréia, Fagliari et al. (1998) relatou, para bezerros bubalinos de 15 e 30 dias de vida, médias de 22,1 e 22,4 mg/dL, respectivamente, sendo semelhantes ao encontrado em nosso trabalho. Fagliari et al. (1998) também descreveram, para bezerros bovinos das raças Nelore e Holandesa, concentrações séricas médias de uréia de $15,1 \mathrm{mg} / \mathrm{dL}$ (15 dias de vida) e 16,0 mg/dL (30 dias de vida) para bezerros Nelore, e de 16,6 mg/dL (15 dias de vida) e 14,9 
$\mathrm{mg} / \mathrm{dL}$ (30 dias de vida) para bezerros da raça Holandesa, valores estes inferiores aos encontrados em nosso trabalho com bezerros bubalinos. Assim sendo, é possível que níveis mais elevados de uréia sejam particularidades de bezerros bubalinos (FAGLIARI et al., 1998).

Conclusão: Foi possível calcular IR para uréia e creatinina em bezerros bubalinos sadios entre 0-7 (G1), 8-15 (G2) e 16-30 (G3) dias de vida. Dessa forma, nossos resultados podem ajudar a estabelecer um banco de dados fisiológico, que contribua para o monitoramento de alterações laboratoriais decorrentes de doenças nesta espécie animal.

\section{Referências}

BENESI, Fernando José; COELHO, Clarisse Simões; LEAL, Marta Lizandra do Rêgo; MIRANDOLA, Regina Mieko Sakata; LISBÔA, Júlio Augusto Naylor. Parâmetros bioquímicos para avaliação da função renal e do equilíbrio hidroeletrolítico em bezerras sadias, da raça Holandesa, no primeiro mês de vida. Braz. J. vet. Res. anim. Sci., São Paulo, v. 42, n. 4, p. 291-298, 2005.

ELLAH, Mahmoud R. AbD; HAMED, Mahmoud R.; IBRAHIM, Maha I.; RATEB, Derar R.; HASSAN, Z. Serum biochemical and haematological reference intervals for water buffalo (Bubalus bubalis) heifers. Journal of the South African Veterinary Association. v. 85, p. 1-7, 2014. Disponível em: https://jsava.co.za/index.php/jsava/article/view/962/1333. Acesso em: 10/08/2020.

FAGLIARI, José Jurandir; SANTANA, A. E.; LUCAS, F.A.; FILHO, E. Campos; CURI, P.R. Constituintes sanguíneos de bovinos recém nascidos das raças Nelore (Bos Indicus) e holandesa (Bos taurus) e de bubalinos (Bubalus bubalis) da raça Murrah. Arq. Bras. Med.Vet. Zootec., v. 50, n. 3, p. 253-262, 1998.

FEITOSA, F. L. F. Semiologia Veterinária: a arte do diagnóstico. 2. ed. São Paulo: Roca, 2008. 754p.

GEFFRÉ, A.; CONCORDET, D.; BRAUN, J.P.; TRUMEL, C. Reference Value Advisor: a new freeware set of macroinstructions to calculate reference intervals with Microsoft Excel. Veterinary Clinical Pathology, v. 40, p. 107-112, 2011.

KANEKO, J. Jerry; HARVEY John W.; BRUSS Michael L. Clinical Biochemistry of domestic animals. In: PIERRE, Braun jean; LELEBVRE, herve P. Kidney function and damage. Elsevier, 6. ed. 2008. p. 483-509.

KURZ, M. M.; WILLETT L. B. W. PHYSIOLOGY AND MANAGEMENT Carbohydrate, Enzyme, and Hematology Dynamics in Newborn Calves. Journal of Dairy Science, vol. 74, No.7, 1991. Disponível em: https://www.sciencedirect.com/science/article/pii/S0022030291783835. Acesso em: 06/08/2020. 


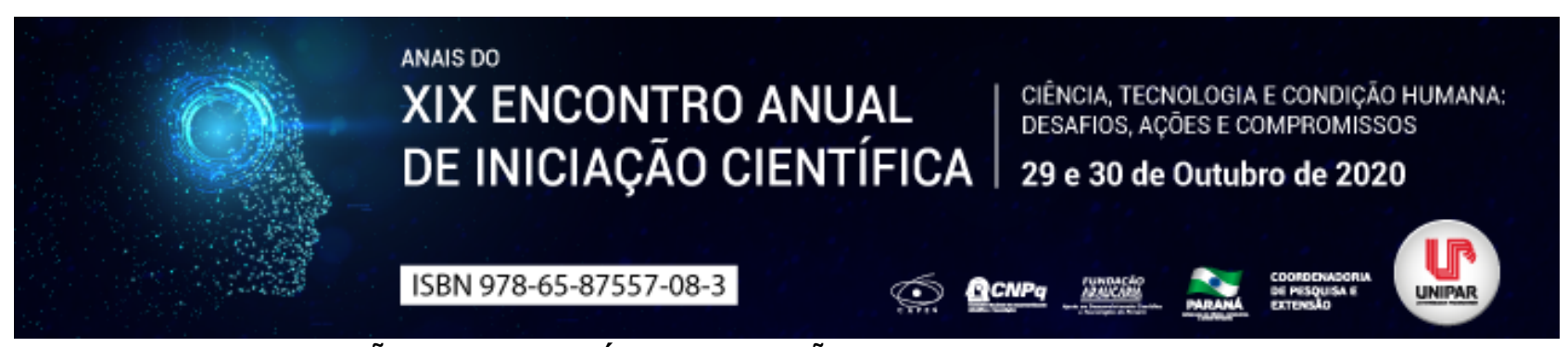

ALTERAÇÕES HEMATOLÓGICAS EM CÃES POSITIVOS PARA BABESIOSE

\title{
${ }^{1}$ Mathias Fuzette Amaral, ${ }^{2}$ NATHÁLIA PERUGINI, ${ }^{3}$ JESSICA SUEMI ALMEIDA KIKUTI, ${ }^{4}$ ANDRÉ MARCOS SANTANA
}

\begin{abstract}
${ }^{1}$ Discente do Curso de Medicina Veterinária - Universidade Estadual de Maringá - UEM
${ }^{1}$ Discente do Curso de Medicina Veterinária - Universidade Estadual de Maringá - UEM

${ }^{2}$ Acadêmica do Curso de Aprimoramento Em Medicina Veterinaria - Laboratorio Clinico de Medicina Veterinaria Preventiva da UNIPAR

${ }^{3}$ Docente do Departamento de Medicina Veterinária, Universidade Estadual de Maringá (UEM), Campus Regional de Umuarama
\end{abstract}

Introdução: A babesiose canina está relacionada a três gêneros: Babesia canis, Babesia rossee e Babesia vogelli (CARVALHO et al., 2018). Trata-se de um hematozoário do gênero Babesia spp, classificados no Filo Apicomplexa, Subfilo Sporozoa, Classe Aconoidasida, Ordem Piroplasmida e Família Babesiidae (BRANDÃO; HAGIWARA, 2002; DUARTE et al., 2008; SÁ, 2007). Sua transmissão ocorre quando um cão saudável é picado por um carrapato (hospedeiro intermediário) do gênero Rhipicephalus sanguineus contaminado pela babesia, o que leva a inoculação no cão (hospedeiro definitivo). O parasita na corrente sanguínea do hospedeiro definitivo, adentra nos eritrócitos, onde começa a se reproduzir assexuadamente por divisão binária até esses eritrócitos se romperem, liberando mais parasitas que irão infectar novas hemácias, causando uma anemia hemolítica regenerativa. Outra forma de infecção é por transfusão sanguínea de animais soropositivos para animais saudáveis (DIAS; FERREIRA, 2016).

Objetivo: Objetivo deste trabalho foi realizar uma revisão de literatura evidenciando as principais alterações hematológicas em cães positivos para babesiose.

Desenvolvimento: A patogenicidade da babesiose depende do mecanismo de ação do agente causador e diversos fatores relacionados ao hospedeiro definitivo como: idade; estado imunológico; doenças concomitantes, visto que tornam o animal mais predisposto a manifestações mais graves da doença. Assim, essa enfermidade tem diversas apresentações clínicas, desde uma anemia leve até uma síndrome de disfunção múltipla e falência de órgãos que podem levar o animal a óbito (IRWIN, 2009). Quando o animal é infectado, ocorre hemólise das hemácias devido a uma lesão oxidativa na membrana destas células, que se rompe por uma fragilidade decorrente da presença do parasita no interior dos eritrócitos. Além da hemólise causada pelo parasita, acontece também uma tendência, das hemácias que não sofreram lise, de sofrerem apoptose e eritrofagocitose por causa das alterações que ocorrem na membrana dessas células. Estas alterações induzem o sistema mononuclear fagocítico, principalmente o baço e o fígado, a removerem eritrócitos que apresentam tais alterações morfológicas e funcionais. Assim, a babesiose pode desencadear esses dois mecanismos conjuntos de hemólise intravascular e hemólise extravascular, o que potencializa a manifestação clínica da doença (ETTINGER; FELDMAN, 2004; IRWIN, 2009). Todas as espécies de Babesia estão relacionadas a sinais clínicos e alterações patológicas tais como esplenomegalia, anorexia, anemia, trombocitopenia e pirexia (ETTINGER; FELDMAN, 2004; IRWIN, 2009). Todos estes sinais clínicos estão relacionados com o potencial da Babesia em causar hemólise, e assim se apresentam em duas formas, uma mais intensa a aguda e a hiperaguda. Nestas formas de apresentação, ocorre a liberação de fatores pró-inflamatórios, que são pirogênios, acarretando em uma reação inflamatória sistêmica, febre, e consequentemente apatia, anorexia, letargia e sinais clássicos de hemoglobinemia e hemoglobinúria. Pode também causar bilirrubinemia, sendo que se tiver aumento de bilirrubina conjugada, significa que existe uma sobrecarga hepática ocasionando icterícia e hepatoesplenomegalia (COUTO, 2015; NELSON; SÁ, 2007). A anemia inicial após a infecção geralmente é normocítica normocrômica e de baixa expressividade. No entanto, há medida que a doença progride a anemia também pode progredir, tornando-se macrocítica, hipocrômica e regenerativa. A reticulose pode acompanhar o quadro conforme a gravidade da anemia presente. Não se tem um padrão bem definido para as alterações leucocitárias na babesiose. Assim sendo, pode-se observar leucocitose, neutrofilia, neutropenia, linfocitose e eosinofilia. Ademais, animais assintomáticos positivos para babesia podem conviver com o parasita sem a manifestação de sinais clínicos e sem sinais de anormalidades hematológicas. Porém, se ocorrer um enfraquecimento do sistema imunológico, o animal pode voltar a manifestar os sinais clínicos da doença (CARVALHO et al., 2018).

Conclusão: Podemos concluir que a babesiose canina é uma doença que leva a variadas alterações hematológicas, principalmente a quadros de anemia que podem ser de leve a grave e alterando de normocítica, normocrômica para macrocítica, hipocrômica, regenerativa. Ademais, a reticulose é um parâmetro importante para analisar a gravidade da doença e as alterações leucocitárias são muito variadas. Desta forma, é de extrema importância associar os sinais clínicos da doença com as alterações hematológicas. 


\section{Referências}

BRANDÃO, L.; HAGIWARA, M. K. Babesiose canina: revisão. Clínica Veterinária, v. 7, n.41, p.50-59, 2002.

CARVALHO, S. M. R. et al. Pesquisa de Babesia spp. e Ehrlichia spp. em cães assintomáticos, atendidos no Hospital Veterinário da Universidade Federal do Piauí. Pubvet, v. 12, p. 139, 2018.

DIAS, V. A. C. M.; FERREIRA, F. L. A. Babesiose canina: Revisão. Pubvet, v. 10, p. 873-945, 2016.

DUARTE, S. C. et al. Diagnóstico parasitológico e molecular da babesiose canina na cidade de Goiânia

GO. Revista de

Patologia Tropical, v.37, n.3, p.229-236, 2008.

ETTINGER, S. J.; FELDMAN, E. C. Tratado de medicina interna veterinária: doenças do cão e do gato. 5. ed. Rio de Janeiro: Guanabara Koogan, 2004.

IRWIN, P. J. Canine babesiosis: from molecular taxonomy to control. Parasites \& vectors, v. 2, n. S1, p. S4, 2009.

NELSON, R.; COUTO, C. G. Medicina interna de pequenos animais. 5. ed. Elsevier Brasil, 2015.

SÁ, A. G. Babesiose canina. Monografia de Especialização em Patologia Clínica Veterinária, Universidade Castelo Branco. Rio de Janeiro, p. 48. 2007. 


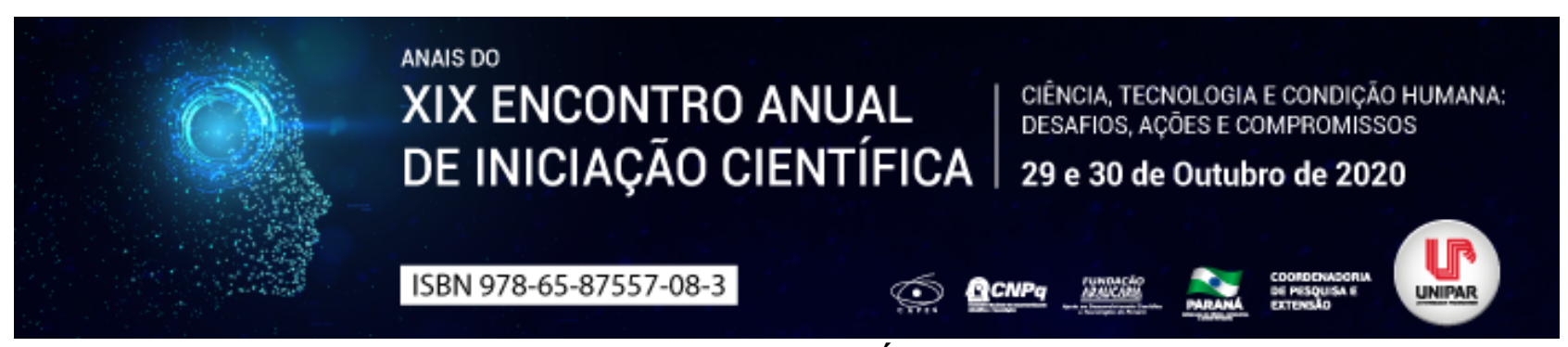

PIPELINE DE CONTROLE DE QUALIDADE E PRÉ-PROCESSAMENTO DE RNA-seq

\author{
${ }^{1}$ Jean Silva de Souza, ${ }^{2}$ MAURO ANTÔNIO ALVES CASTRO
}

${ }^{1}$ Discente do Programa de Pós-graduação em Bioinformática - Universidade Federal do Paraná - UFPR - Curitiba-PR

${ }^{1}$ Docente do Programa de Pós-graduação em Bioinformática - Universidade Federal do Paraná - UFPR - Curitiba-PR

Introdução: O sequenciamento de RNA através de sequenciadores de próxima geração (NGS), possibilitam o estudo da abundância de genes, assim como a identificação de genes diferencialmente expressos. O output deste tipo de sequenciamento é denominado de RNA-seq e atualmente é a principal técnica utilizada para análise de expressão de RNAs (WANG; GERSTEIN; SNYDER, 2009). O RNA-seq pode sofrer contaminação de primers durante o preparo e sequenciamento da biblioteca de cDNA, assim como obter determinações imprecisas das sequências de nucleotídeos. O controle de qualidade e o pré-processamento de dados de sequenciamento especialmente NGS tem ganhado destaque devido a sua utilização (CHEN et al., 2018). Neste trabalho apresentamos um pipeline para estimar os níveis de transcrição de RNAs em amostras de tecidos tumorais obtidas da Coorte de Câncer de Próstata CRUK-Cl.

Objetivo: Desenvolver um pipeline para pré-processar dados brutos de RNA-seq de uma coorte de pacientes com câncer de próstata visando obter matrizes de expressão.

Material e Métodos: As amostras foram coletadas pelo Cancer Research UK Cambridge Institute e o RNA das amostras foi processado e sequenciado por colaboradores do Dana-Farber Cancer Institute. As leituras de RNA foram obtidas pela tecnologia RNA-seq da Paired-End Illumina e convertidos em arquivos FASTQ. Fizemos o controle de qualidade (QC) usando os programas FastQC (ANDREWS, 2010) e MultiQC (Ewels et al., 2016). Identificamos adaptadores Illumina nos arquivos FASTQ, que requereram etapas adicionais de filtragem e limpeza das leituras. Usamos os programas fastp (CHEN et al., 2018) e Cutadapt (MARTIN, 2011) para remover os adaptadores e limpar as leituras com baixos índices de qualidade. A quantificação da expressão de transcritos foi feita com o Salmon (PATRO et al., 2017). Utilizamos como transcriptoma de referência a versão 34 do transcriptoma do genoma humano do projeto GENCODE (GENCODE, 2020). Após a quantificação, construímos as matrizes de expressão gênica utilizando o pacote R/Bioconductor tximeta. Também disponibilizamos um tutorial de como construir as matrizes com o pacote R/Bioconductor tximport. Realizamos a anotação dos transcritos utilizando o pacote R/Bioconductor AnnotationHub.

Resultados: Antes da limpeza e filtragem dos arquivos, algumas leituras possuíam baixos índices de qualidade, variando a média de seus scores entre 0 à 5 . A maioria das leituras, possuíam altos índices de qualidade e as médias de seus scores ficaram entre 15 à 35. Após a limpeza e filtragem dos arquivos, nenhuma média de score de qualidade ficou entre 0 à 20 , todas ficaram entre 20 à > 35. Após a limpeza e filtragem dos dados, notou-se um decaimento do conteúdo de $\mathrm{N}$ nas leituras, demonstrando a eficiência das ferramentas utilizadas. Conseguimos remover os adaptadores com o fastp e o Cutadapt. Quantificamos os transcritos, construímos e anotamos as matrizes de expressão.

Discussão: A combinação dos programas FastQC e MultiQC para o QC foi suficiente para detectarmos os índices de qualidade do sequenciamento, conteúdo de $\mathrm{N}$ e a contaminação de adaptadores em análises High-thoughput. O FastQC gerou um conjunto de estatísticas com os resultados do QC dos arquivos FASTQ, e o MultiQC agrupou esses resultados em um único arquivo. As ferramentas fastp e Cutadapt limparam o conjunto de dados removendo todos os adaptadores identificados pelo FastQC e fastp. A vantagem do fastp é que ele identifica e remove adaptadores presentes nas leituras, e conforme os parâmetros especificados à ele, também podemos verificar o QC antes e depois da limpeza, filtrar sequências com tamanhos específicos, assim como bases com baixos índices de qualidade (CHEN et al., 2018). Os adaptadores identificados pelo FastQC que o fastp não identificou, foram removidos pelo Cutadapt. O Cutadapt localiza e remove sequências de adaptadores e outros tipos de sequências indesejadas, tolera uma taxa de erros e aceita caracteres curinga IUPAC, o que foi útil para a remoção de adaptadores Illumina com diferentes index (MARTIN, 2011). O mapeamento e a quantificação dos transcritos foram feitas com o Salmon. Ele utiliza novos algoritmos fornecendo estimativas de expressão mais precisa e considera atributos experimentais e vieses observados em dados de RNA-seq (PATRO et al., 2017).

Conclusão: O pipeline desenvolvido demonstrou estabilidade e rapidez no tratamento dos dados brutos de RNA-seq, gerando as matrizes expressão que futuramente serão depositadas em repositórios públicos. Com estas matrizes nossa equipe poderá dar continuidade às análises de seguimento que incluem, por exemplo, análise de expressão diferencial e anotação funcional. O pipeline está disponível no GitHub (github.com/souzajs/pipeline_pre-processing_RNAseq_data) com exemplos de amostras do GEO-NCBI. 
ANDREWS, Simon. FastQC: A Quality Control Tool for High Throughput Sequence Data. 2010. Disponível em: http://www.bioinformatics.babraham.ac.uk/projects/fastqc/. Acesso em: 22 ago. 2020.

CHEN, Shifu; ZHOU, Yanqing; CHEN, Yaru; GU, Jia. fastp: an ultra-fast all-in-one FASTQ preprocessor. Bioinformatics, v. 34 , n. 17, p. 884-890, september. 2018.

EWELS, Philip; MAGNUSSON, Mans; LUNDIN, Sverker; KÄLLER, Max. MultiQC: summarize analysis results for multiple tools and samples in a single report. Bioinformatics, v. 32, n. 19, p. 3047-3048, October. 2016.

GENCODE. The gencode project: Encyclopedia of genes and gene variants. Human, version 34 GRCh38. Disponível em: https://www.gencodegenes.org/. Acesso em: 22 ago. 2020.

MARTIN, Marcel. Cutadapt removes adapter sequences from high-throughput sequencing reads. EMBnet.journal, v. 17, n. 1, p. 10-12. 2011.

PATRO, Rob; DUGGAL, Geet; LOVE, Michael, I.; IRIZARRY, Rafael, A.; KINGSFORD, Carl. Salmon provides fast and biasaware quantification of transcript expression. Nature Methods, v. 14, p. 417-419. 2017.

WANG, Zhong; GERSTEIN, Mark; SNYDER, Michael. RNA-Seq: a revolutionary tool for transcriptomics. Nature Reviews Genetics, v. 10, p. 57-63, January. 2009. 


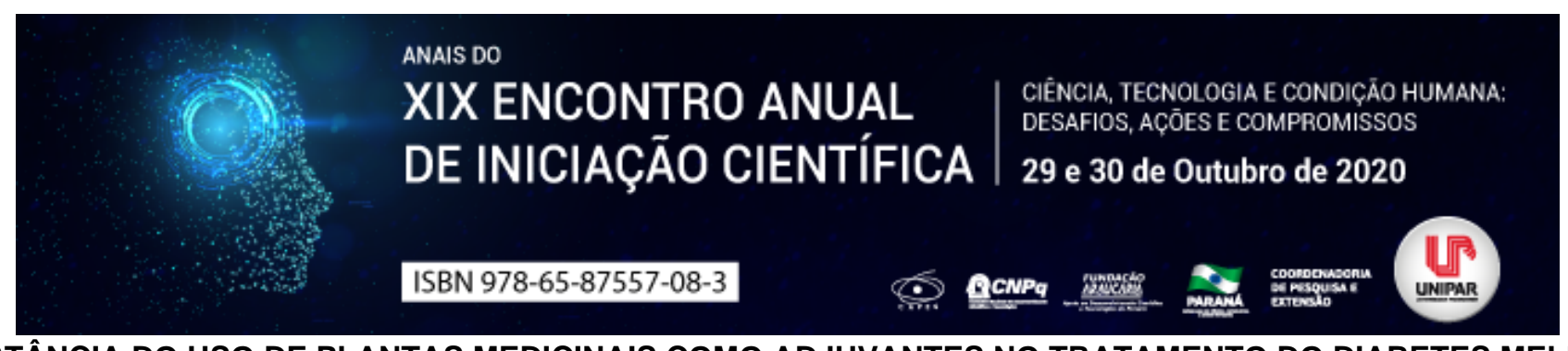

IMPORTÂNCIA DO USO DE PLANTAS MEDICINAIS COMO ADJUVANTES NO TRATAMENTO DO DIABETES MELLITUS

\author{
1JOAO VITOR BARBOSA DO CARMO, ${ }^{2}$ MATEUS ROVIERO DA SILVA, ${ }^{3}$ LORENA NERIS BARBOZA
}

$\begin{array}{llll}{ }^{1} \text { Discente do Curso de Farmácia } & \text { UNIPAR } & \text { Umuarama } & \text { PR } \\ { }^{1} \text { Discente do Curso de Farmácia } & \text { UNIPAR } & \text { Umuarama } & \text { PR } \\ { }^{2} \text { Docente do Curso de Farmácia } & \text { UNIPAR } & \text { Umuarama } & \text { PR }\end{array}$

Introdução: O diabetes mellitus caracteriza-se por uma doença crônica, resultando em distúrbios de lipídios, proteínas e carboidratos, tal alteração é promovida pela elevação de glicose sanguínea (hiperglicemia), isso acontece devido à insuficiência da produção de insulina ou pela sua resistência. Quando não tratado corretamente, ambos os tipos de diabetes poderão desencadear complicações, tais como retinopatia, hipertensão arterial, doenças coronarianas, patologias renais, doenças micro e macro vasculares, entre outras (CETTO; HEINRICH, 2005). Geralmente, a amputação ocorre em decorrência das alterações vasculares e/ou neurológicas peculiares da doença, que são responsáveis pelo pé diabético , esse de fato é umas das complicações mais comuns do diabetes não tratado. Projeções da OMS mostraram que há em média 220 milhões de pessoas no mundo com diabetes, sendo que este número provavelmente dobrará entre 2005 a 2030 (CECILIO et al., 2008). Dessa forma, visto as complicações oriundas do diabetes não tratado e o exponencial desenvolvimento dessa doença na população, a demanda por terapias com menor custo e melhor adesão do paciente pode representar um benefício para melhores investimentos na área da saúde e consequentemente melhor tratamento ao paciente diabético (CETTO; HEINRICH, 2005). Assim, as plantas medicinais representam $25 \%$ de origem dos medicamentos mundialmente, sendo que a maior flora encontra-se no Brasil, e estudos vem comprovando que as plantas medicinais apresentam efeitos terapêuticos para inúmeras doenças, inclusive para o diabetes mellitus (SANTOS, 2012).

Objetivo: Investigar com base em revisão de literatura a influência de algumas espécies vegetais como adjuvante ao tratamento do diabete mellitus e suas possíveis complicações decorrentes.

Desenvolvimento: Estudos demostraram que a prevalência do diabete mellitus está associada principalmente aos idosos, sendo que esses na grande maioria dos casos desconhecem o diagnóstico da doença e a outra parcela não faz o tratamento adequado (PAIVA et al., 2006). Uma das principais complicação do diabetes inclui a xerose nos pés que de acordo com Barco e Giménez Arnau (2008) caracteriza-se por uma desordem da pele por ressecamento anormal e desconfortável, com alterações de desequilíbrio de umidade e oleosidade na camada da derme. A xerose geralmente conduz ao desenvolvimento de fissuras, representando um fator de risco para o desenvolvimento de úlceras nos pés de pacientes diabéticos (FEDERICI et al., 2012). Em pacientes diabéticos o processo de cicatrização é lento, e a maior parte das complicações é em relação aos problemas nos vasos sanguíneos, que devido a hiperglicemia, esses vasos são danificados gerando problemas com a irrigação sanguínea e consequentemente dificultando o processo de cicatrização. Segundo Thakur et al. (2011) muitos estudos focado no desenvolvimento de cosméticos com as plantas medicinais são usados no tratamento de xerose e feridas do pé diabético e apresentam uso terapêutico por auxiliar no processo de coagulação sanguínea, cicatrização da pele e combate de infecções. Além disso, apresentam segurança em seu uso tópico, são acessíveis e econômicos. Entre os principais compostos medicinais já descritos e utilizados na clínica inclui-se a aloe vera, óleo de girassol e o óleo de copaíba. Ademais, diferentes estudos retratam o uso de plantas medicinais como forma de tratamento medicamento, apresentando efeitos hipoglicemiantes, entre as diversas espécies já estudadas e promissoras inclui-se a carqueja, pata de vaca, sálvia, melão de são caetano e quebra pedra (BORGES et al., 2008; CECILIO et al., 2008). Sabe-se que para o controle do diabetes é necessário que o paciente apresente uma alimentação equilibrada e o hábito regular de exercícios físicos, uma vez que os níveis glicêmicos estão descontrolados é necessário incluir o tratamento farmacológico entre os medicamentos disponíveis para o controle do diabetes estão os hipoglicemiantes orais e a insulina. Assim, as plantas medicinais que apresenta comprovação dos seus efeitos hipoglicemiantes podem atuar de forma a complementar o tratamento do diabetes, sendo vantajoso por apresentar um menor custo, e cujos benefícios adicionam-se aos da terapia convencional (BORGES et al., 2008). Para tanto, são necessários maiores investimentos para estudos científicos nessa área de maneira a levar à comprovação da eficácia dessas espécies como hipoglicemiantes garantindo a segurança no uso clínico para os pacientes, bem como a confiança na prescrição por parte dos profissionais de saúde (CECILIO et al., 2008).

Conclusão: As plantas medicinais apresentam um extenso uso que inclui desde aplicações tópicas para o tratamento de complicações decorrentes do diabetes como no caso da xerose, bem como apresentando efeitos promissores para uso sistêmico como hipoglicemiante oral. No entanto, ainda são necessários mais estudos que comprove os mecanismo de ação envolvidos, bem como a segurança para o uso terapêutico. De fato, o Brasil é rico em diversidades de espécies que podem contribuir como coadjuvante para o tratamento de inúmeras doenças, inclusive o diabetes mellitus. 


\section{Referências}

BARCO, D.; GIMÉNEZ-ARNAU, A. Xerosis: a dysfunction of the epidermal barrier. Actas Dermo-Sifiliográficas, v. 99, n.9, p.671-682, 2008.

BORGES, K. B.; BAUTISTA, B. H.; GUILERA, S. Diabetes - utilização de plantas medicinais como forma opcional de tratamento. Revista Eletrônica de Farmácia, v.5, p.12-20, 2008.

CECÍlIO, A. B.; RESENDE, L. B.; COSTA, A. C.; COTTA, M. M.; GIACOMINI, L. F.; GOMES, L. C.; \& OLIVEIRA, F. Q. Espécies vegetais indicadas no tratamento do diabetes. Revista Eletrônica de Farmácia, v.5, n.3, p.23-8, 2008.

CETTO, A.A.; HEINRICH, M. Mexican plants with hypoglycemic effect used in the treatment of diabetes. Journal of Ethnopharmacology, v.99, p.325-48, 2005.

FEDERICI, A.; FEDERICI, G.; \& MILANI, M. An urea and carnosine based cream (Ureadin Rx Db ISDIN) shows greater efficacy in the treatment of severe xerosis of the feet in type 2 diabetic patients in comparison with glycerol-based emollient cream. BioMed Central Dermatology, v.12, n.16, p.1-6, 2012.

PAIVA, D. C. P. D.; BERSUSA, A. A. S.; \& ESCUDER, M. M. L. Avaliação da assistência ao paciente com diabetes e/ou hipertensão pelo Programa Saúde da Família do Município de Francisco Morato, São Paulo, Brasil. Caderno de Saúde Pública, v.22, p.377-85, 2006. Disponível $\quad$ em https://www.scielo.br/scielo.php?pid=S0102 311X2006000200015\&script=sci_abstract\&tlng=pt acesso: 27 de julho 2020.

SANTOS, M. M.; NUNES, M. G. S.; \& MARTINS, R. D. Uso empírico de plantas medicinais para tratamento de diabetes. Revista Brasil plantas medicinais vol.14 n.2, 2012.

THAKUR, R.; JAIN, N.; PATHAK, R.; \& SANDHU, S.S. Practices in Wound Healing Studies of Plants. Evidence-Based Complementary and Alternative Medicine, p.1-17, 2011. 


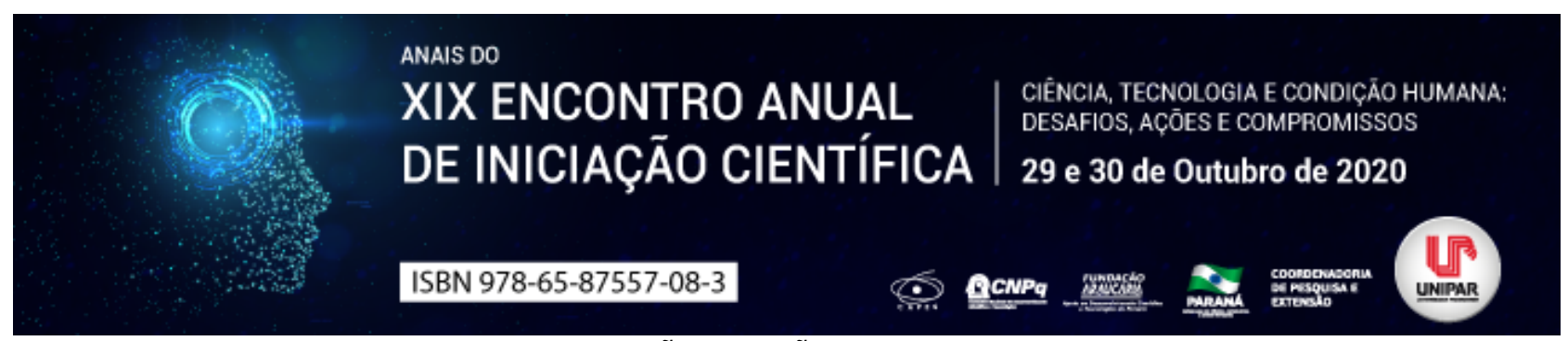

INTUSSUSCEPÇÃO EM CÃES-RELATO DE CASO

\section{${ }^{1}$ Isadora Gobo Medeiros, ${ }^{2}$ ISIS CLEÓPATRA COELHO CHAVES,${ }^{3}$ ODUVALDO CÂMARA MARQUES PEREIRA JÚNIOR}

${ }^{1_{1}}$ Graduanda do curso de Medicina Veterinária. Ciências Biológicas e afins, Medicina Veterinária, Universidade Estadual de Maringá UEM, cam

${ }^{1}$ Graduanda do curso de Medicina Veterinária. Ciências Biológicas e afins, Medicina Veterinária, Universidade Estadual de Maringá UEM, cam

${ }^{2}$ Professor adjunto do Departamento de Medicina Veterinária DMV, Ciências Biológicas e afins, Medicina Veterinária,

UUniversidade Estadual d

Introdução: Intussuscepção é a invaginação de um segmento do trato gastrintestinal (intussuscepto), para o lúmen do segmento anexo (intussuscipiente) (HEDLUNG et al .2002). Essa anormalidade é mais comumente observada em cães (CHERYL et al., 2005). Habitualmente é encontrada em animais jovens, pois os mesmos são propensos a desenvolverem uma hipermotilidade secundária, possíveis infecções bacterianas e/ou parasitárias, desenvolvimento de enterites virais e o aparecimento de corpo estranho linear (ANDERLINE et al., 2006). Várias são as apresentações clínicas que se associam a tal doença, tais como a perda de peso, inapetência, disorexia, êmese, apatia, prostação, diarreia hemorrágica, assim como distensão intestinal, isquemia, obstrução intestinal, sem contar a peritonite focal ou difusa (ARONSON et al., 2000).

Relato de Caso: Uma fêmea canina, sem raça definida (SRD), pesando 9,380 kg foi atendida pelo serviço do Hospital Veterinário de Umuarama, da Universidade Estadual de Maringá - UEM, localizado no campus de Umuarama/PR. A tutora referiu como queixa principal o desinteresse pela comida e a presença de muitos carrapatos. Na anamnese o proprietário informou que havia resgatado o animal da rua há 4 meses. Segundo ele o animal estava mal há cerca de 4 semanas, apresentando alguns episódios de êmese aliada a diarreia. Nesse período de 4 semanas a tutora chegou a procurar atendimento profissional em clínica particular na cidade de Umuarama, quando foi prescrito tratamento para hemoparasitose e gastrite (um comprimido de Doxiciclina (100mg) SID/22 dias, Ranitidina (15mg) 2ml BID/22 dias e um comprimido de Hemolitan BID/20 dias), o qual a tutora afirmou não ter realizado corretamente. A tutora relatou que o animal apresentava comportamento bem ativo, latindo e correndo no quintal com frequência, porém em termos de alimentação ultimamente só estava aceitando carne bovina, frango e fígado (todos cozidos). Referiu ainda ser o animal vacinado, porém não se lembrava quando tinha sido feita a vermifugação. A cadela apresentava um contactante cão adulto assintomático. Ao exame físico a paciente apresentou hipertermia (39, $7^{\circ} \mathrm{C}$ ), frequência cardíaca (FC) de 152bpm, frequência respiratória (FR) de 56mpm, hidratação normal e TPC de dois segundos, apresentou também as mucosas pálidas. A suspeita clínica inicial foi de hemoparasitose, confirmada ao hemograma. Foi prescrito então Doxiciclina 10mg/kg SID por 28 dias. Nove dias depois o animal retornou apresentando grave hiporexia, diarreia de coloração enegrecida e forte odor e episódios de vômito. Neste dia foi realizado exame físico onde se constatou TR de $38^{\circ} \mathrm{C}$, FC de 110bpm, FR de 56mpm e TPC: 2 segundos. Além disso, foi verificado que o cão apresentava uma desidratação de 6-7\%, mucosas pálidas, estava deprimida, magra e apresentava dor à palpação abdominal, com presença de estrutura tubular em região mesogástrica. Por este motivo foi solicitado exame ultrassonográfico, no qual foi visibilizada região de alças intestinais apresentando múltiplas linhas concêntricas correspondentes às camadas da parede intestinal em corte transversal (Figura 1), bem como várias camadas paralelas em cortes longitudinais, hiperecoicos e hipoecoicos alternados (Figura 2), indicando a presença de intussuscepção íleo-cólica. Diante do quadro apresentado foi indicada a realização imediata de procedimento cirúrgico para correção da intussuscepção. Na avaliação pré-anestésica foi verificado que se tratava de paciente ASA 3, apresentando desidratação moderada, frequência cardíaca de 136bpm, hematócrito 34\%, proteínas plasmáticas totais 4,1mg/dl. Foi aplicada como medicação pré-anestésica o Midazolam 0,3mg/kg associado a Metadona 0,3mg/kg, ambos por via intramuscular. A indução foi realizada com Propofol com dose ao efeito por via intravenosa. Os analgésicos administrados no trans-operatório foram Fentanil Bolus 2,5ug/kg, seguido de Fentanil em infusão 5ug/kg/hr. A manutenção anestésica foi realizada com Isoflurano em oxigênio a 100\%. Uma Enterectomia com Enteroanastomose foi realizada. O animal foi posicionado em decúbito dorsal, foi realizada incisão cutânea ampla em linha média. A incisão da parede abdominal foi realizada pela linha alba. O segmento afetado foi localizado (íleo-ceco-cólon) (Figura 4) e parte da intussuscepção foi reduzida por manipulação. Durante este procedimento observou-se ruptura de porção do intussuscepto em consequência de necrose. Um segmento intestinal de aproximadamente $10 \mathrm{~cm}$ foi removido, envolvendo a junção íleo-ceco-cólica (Figura 5). A enteroanastomose foi realizada com vycril 3-0 em padrão simples interrompido. A anastomose na sequência foi omentalizada, seguida da síntese da parede abdominal e pele de forma rotineira. O pós operatório da paciente teve em primeiro momento um jejum total. O animal foi mantido sob com solução de Ringer com lactato no volume/hora de $27 \mathrm{ml}$. A cada $500 \mathrm{ml}$ de Ringer Lactato foi adicionado $30 \mathrm{ml}$ de glicose $50 \%$. A medicação para o pós-cirúrgico foi dipirona $25 \mathrm{mg} / \mathrm{kg}$ IV TID, Ceftriaxona 30mg/kg IV BID, Metronidazol 15mg/kg IV BID, 
Meloxicam 0,1 mg/kg IV SID, Tramadol 6mg/kg SC TID, Ranitidina 4mg/kg SC BID e Ondasetrona 0,1 mg/kg IV BID.

Com seis dias de pós-operatório a prescrição passou a ser dieta pastosa e água, permanecendo a prescrição de ceftriaxona. Após mais dois dias o animal recebeu alta médica e retornou para casa liberado para a alimentação seca e sem prescrição medicamentosa. Após dois meses do procedimento cirúrgico a tutora, em contato telefônico, referiu que o animal havia ganhado peso corporal, apresentava-se ativo, se alimentando normalmente e sem qualquer alteração.

Discussão e Conclusão: $O$ exame ultrassonográfico é fundamental para o diagnóstico da intussuscepção em cães. A correta escolha da técnica cirúrgica para o tratamento desta afecção, bem como a correta terapêutica pós-operatória levam à completa recuperação do paciente.

\section{Referências}

ANDERLINE , G. P. O. S et al. Intussuscepção ileocecal:relato de caso. Revista Nosso Clínico , [s. I.], v. 9, n. 52, p. 30-35, 2006.

APPLEWHITE, A. A. et al. Complications of enteroplication for the prevention of intussusception recurrence in dogs: 35 cases, Journal of the American Veterinary Medical Association, ed. 10, p. 1415-1418, 2001.

ARONSON, L. R. et al. Gastrointestinal emergencies. Veterinary Clinics of North America: Small Animal Practice, [s. I.], v. 30, ed. 3, p. 555-579, 2000.

CHERYL , S. H. et al. Intussuscepção. Cirurgia em pequenos animais , [s. I.], ed. 2, p. 391-393, 2005.

HEDLUNG, C. S. et al. Cirurgia de pequenos animais. FOSSUM, T. W: [s. n.], 2002. 322-349 p.

MAGALHÃES, F. J. R. et al. INTUSSUSCEPÇÃO INTESTINAL EM CADELA DIAGNÓSTICADO ATRAVÉS DA ULTRASONOGRAFIA ABDOMINAL: RELATO DE CASO. Relato de caso , [s. I.], 2009. 


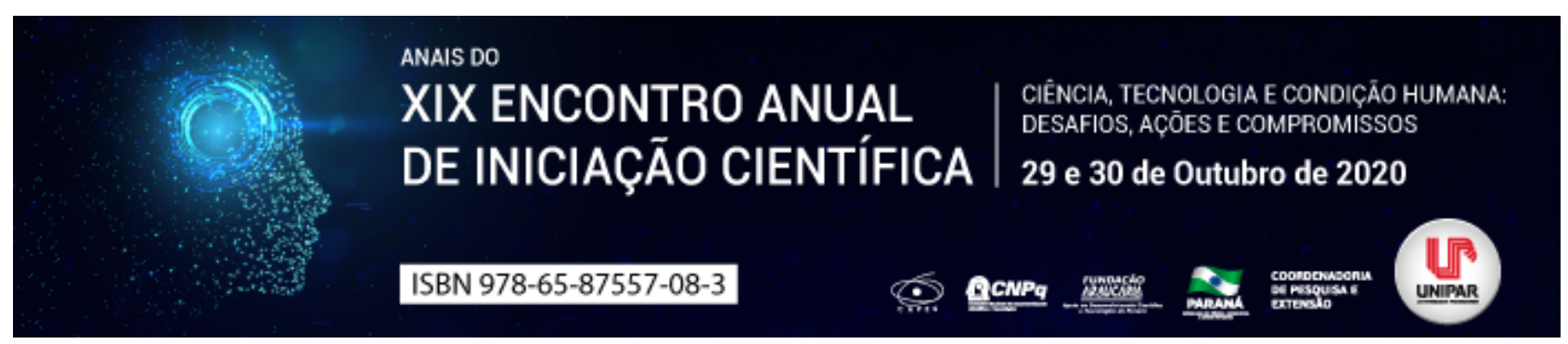

CORPO ESTRANHO LINEAR EM FELINO - RELATO DE CASO

\title{
${ }^{1}$ Isis Cleópatra Coelho Chaves, ${ }^{2}$ ISADORA GOBO MEDEIROS, ${ }^{3}$ ODUVALDO CÂMARA MARQUES PEREIRA JÚNIOR
}

\begin{abstract}
${ }^{1}$ Graduanda do curso de Medicina Veterinária. Ciências Biológicas e afins, Medicina Veterinária, Universidade Estadual de Maringá UEM, campu

${ }^{1}$ Graduanda do curso de Medicina Veterinária. Ciências Biológicas e afins, Medicina Veterinária, Universidade Estadual de Maringá UEM, campu
\end{abstract}

${ }^{2}$ Professor adjunto do Departamento de Medicina Veterinária DMV, Ciências Biológicas e afins, Medicina Veterinária,

1Universidade Estadual d

Introdução: As espécies mais acometidas pela ocorrência de corpos estranhos são os cães, embora os felinos sejam os mais acometidos por corpo estranho linear (CEL) devido ao hábito de brincar com cordões e fios (ROSA, 2015). Além disso, o CEL é considerado uma emergência cirúrgica e caso não atendida poderá levar a óbito o animal (BRETANO, 2010). Durante o exame físico é importante a verificação da cavidade oral do felino, pois fio pode estar ancorado ao frênulo da língua. O sintoma primário é o vômito, mas pode não ocorrer. Há outros sinais como apatia, anorexia, dispneia, dor abdominal, inquietação, febre e disfagia. Para auxiliar o diagnóstico são usadas ultrassonografia, radiografia simples ou contrastada e endoscopia. O tratamento é cirúrgico e consiste na remoção do CEL por meio da gastrotomia e enterotomias (TRICHEZ, 2018).

Relato de caso: Um paciente da espécie felina, sem raça definida, fêmea, castrada, com 18 meses de idade foi encaminhada para o Hospital Veterinário de Umuarama, da Universidade Estadual de Maringá, diretamente ao setor de diagnóstico por imagem para realização de radiografia e ultrassonografia abdominais. A tutora, médica veterinária, referiu que o animal havia permanecido em casa sozinho durante a noite. Ao amanhecer, quando a tutora retornou de seu plantão, esta ofereceu comida para o animal, porém ele recusou, fato que não costumava ocorrer. Logo em seguida a tutora refere ter encontrado um dos brinquedos do animal, que era composto por um cordão, totalmente destruído e faltando grande porção do cordão. Observou ainda um vômito de diâmetro pequeno com um pedaço do cordão próximo ao brinquedo, logo suspeitou de ingestão do cordão, pois não encontrou o restante do brinquedo pela casa. Imediatamente após o ocorrido a tutora levou o animal ao Hospital Veterinário para avaliação clínica e realização de exames. Ao exame físico não foram observadas alterações dignas de nota. A avaliação da cavidade oral foi negativa para a presença de CEL. Ao exame radiográfico simples abdominal foi observada presença de alças intestinais plissadas em região mesogástrica, com discreto conteúdo de radiopacidade gás e líquido, sugerindo a presença de corpo estranho linear intestinal. Optou-se então pela realização do exame ultrassonográfico abdominal, o qual revelou porção de duodeno com parede plissada e conteúdo luminal linear hiperecogênico, indicando a presença do CEL. Desta forma, o animal foi imediatamente submetido a procedimento cirúrgico de enterotomia para a remoção do CEL. A conduta anestésica para a realização do procedimento cirúrgico foi como medicação pré-anestésica o Midazolam 0,3mg/kg associado a Metadona $0,3 \mathrm{mg} / \mathrm{kg}$, ambos por via intramuscular. A indução foi realizada com Propofol com dose ao efeito por via intravenosa associado a Fentanil Bolus 2,5ug/kg, seguido de Fentanil em infusão $5 \mathrm{ug} / \mathrm{kg} / \mathrm{hr}$. A manutenção anestésica foi realizada com Isoflurano em oxigênio a 100\%. Para o procedimento cirúrgico o animal foi posicionado em decúbito dorsal. Foi realizada incisão cutânea ampla em linha média. A incisão da parede abdominal foi realizada pela linha alba. O segmento duodenal afetado foi localizado e exposto, e observado o plissamento da parede duodenal causado pela presença do CEL. Dois pontos de enterotomia medindo $1 \mathrm{~cm}$ de extensão cada foram realizados na face antimesentérica da alça intestinal de forma a permitir a completa remoção do CEL. A síntese intestinal foi realizada com vycril 3-0 em padrão simples interrompido, seguida da síntese da parede abdominal e pele de forma rotineira.

Discussão: Embora, gatos sejam animais hábitos alimentares seletivos, é comum a ingestão de CEL devido a brincadeiras com cordões (TRICHEZ, 2018). De modo geral os CELs, após a ingestão, podem causar vômito devido à obstrução da saída do estômago, distensão e/ou irritação do epitélio deste. Embora seja o sinal clínico mais frequente, é possível que não ocorra (FOSSUM, 2015). No presente caso o paciente apresentou um episódio de vômito contendo fragmento do fio ingerido. Pouco tempo decorreu entre a ingestão do CEL e seu diagnóstico e tratamento. Sessegolo (2016) referiu serem a ultrassonografia e radiografia abdominal são os exames mais solicitados, embora haja outros meios de diagnóstico para o CEL em felino. Pelo exame diagnóstico do CEL no felino relatado, pois pode-se visualizar o plissamento da alça intestinal. Os CEL são conceituados como emergências cirúrgicas devido a riscos de ruptura intestinal e infecção generalizada (BRETANO, 2010). Desta forma, optou-se no presente caso pela imediata resolução cirúrgica por meio de enterotomia, a qual foi realizada segundo a técnica descrita por Fossum (2015). A completa recuperação clínica do paciente reflete a correta escolha do tratamento empregado.

Conclusão: Os exames ultrassonográfico e radiográfico são fundamentais para o diagnóstico da presença de CELs em felinos. A correta escolha da técnica cirúrgica para o tratamento desta afecção leva à completa recuperação do paciente. 


\section{Referências}

BRENTANO, Lucas Mathias. Cirurgia gástrica em cães. 2010. Orientador: Emerson Antonio Contesini. Monografia (Graduação em Medicina Veterinária) Universidade Federal do Rio Grande do Sul, Porto Alegre, 2010.

FOSSUM, Theresa Welch. Doenças específicas. In: FOSSUM, Theresa Welch. Cirurgia de Pequenos Animais. 4 ed. Rio de Janeiro: Elsevier editora Itda, 2015. p. 13361365.

ROSA, Camila Lima et al. Corpo estranho linear em felino Relato de caso. IX EPCC Encontro Internacional de Produção Cientifica UniCesumar. Anais eletrônicos, n. 9, p 4 8, nov. 2015.

SESSEGOLO, Tayana Marchese. Corpo estranho gástrico em felino Relato de caso. 2016. Orientador: Márcio Poletto Ferreira. Monografia (Especialização em Clínica Médica de felinos domésticos) Universidade Federal do Rio Grande do Sul, Porto Alegre, 2016.

SILVA, Luciana Carandina et al. Avaliação ultrassonográfica gástrica em pequenos animais. Veterinária e Zootecnia, Botucatu, 20 (4) 567-575, p. 567 575, dez. 2013.

TRICHEZ, Giovanna. Corpo estranho linear em gato: Relato de caso. 2018. Orientador: Vanessa Sasso Padilha. Monografia (Graduação em Medicina Veterinária) Universidade Federal de Santa Catarina, Curitibanos, 2018.

Coordenadoria de Pesquisa e Extensão - COPEX

Departamento de Editoraçāo e Divulgaçāo Científica - DEDIC 


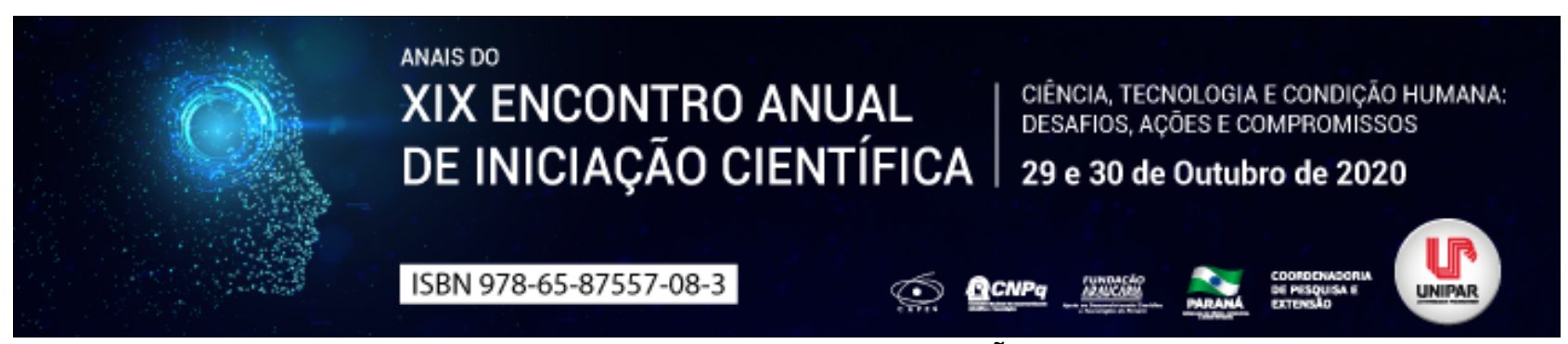

CORPO ESTRANHO LINEAR EM FELINO - REVISÃO DE LITERATURA

\section{${ }^{1}$ Isis Cleópatra Coelho Chaves, ${ }^{2}$ ISADORA GOBO MEDEIROS , ${ }^{3}$ ODUVALDO CÂMARA MARQUES PEREIRA JÚNIOR}

${ }^{1}$ Graduanda do curso de Medicina Veterinária. Ciências Biológicas e afins, Medicina Veterinária, Universidade Estadual de Maringá UEM, campu

${ }^{1}$ Graduanda do curso de Medicina Veterinária. Ciências Biológicas e afins, Medicina Veterinária, Universidade Estadual de Maringá UEM, campu

${ }^{2}$ Professor adjunto do Departamento de Medicina Veterinária DMV, Ciências Biológicas e afins, Medicina Veterinária,

1Universidade Estadual d

Introdução: Corpos estranhos são classificados como objetos ingeridos pelo animal e que não possam ser digeridos (FOSSUM, 2015), como utensílios plásticos, fios e cordões, os últimos dois itens são classificados como corpos estranhos lineares. O corpo estranho linear (CEL) é uma enfermidade comum na rotina da clínica médica de felinos, principalmente filhotes e jovens que possuem o costume de brincar com tecido, linha de costura, barbantes, meias de nylon, fio dental e cordas cortantes (SANTOS; TROUILLET, 2003). Tal enfermidade é conceituada como emergência cirúrgica devido aos riscos de ruptura intestinal e infecção generalizada (BRETANO, 2010).

Objetivo: A revisão de literatura objetiva descrever o corpo estranho linear, discutindo sobre a importância da enfermidade e seus fatores, como: anamnese, diagnostico, tratamentos, eventuais complicações e resultado do prognóstico.

Desenvolvimento: Anamnese e principais sinais clínicos. De modo geral os CELs, após a ingestão, podem causar vômito devido à obstrução da saída do estômago, distensão do estomago e/ou irritação do epitélio deste. Embora seja o sinal clínico mais frequente, é possível que nem todas as ocorrências de corpos estranhos apresentem vômito. A verificação da presença de CEL na cavidade oral de felinos é importante, pois o fio pode estar enraizado no frênulo da língua do animal. Além disso, a palpação da região abdominal para checagem de dor abdominal. Caso o CEL esteja parado na região intestinal, pode-se sentir as alças intestinais plissadas (TRICHEZ, 2018; FOSSUM, 2015). Sinais clínicos como apatia, perda de peso, respiração difícil, eliminação forçada do conteúdo alimentar ingerido, animal inquieto, febre e disfagia também podem ser relatados à anamnese ou verificados durante o exame físico (NELSON; COUTO, 2015). Diagnóstico: Diagnóstico por imagem: A ultrassonografia e radiografia abdominal são os exames mais solicitados (SESSEGOLO, 2016). Corpos estranhos podem ser classificados de duas maneiras pelo exame radiográfico: radiopacos ou radiolucentes. $O$ primeiro pode ser visto pela radiografia simples e o segundo pela radiografia contrastada que delineia os CELs. A ultrassonografia pode avaliar motilidade, espessura e estrutura do epitélio gástrico (SILVA et al, 2013). E a endoscopia que é mais sensível para identificar CELs, sendo possível a realização de biopsia e retirada geralmente com menos de quatro dias, sem a necessidade de intervenção cirúrgica (FOSSUM, 2015). Exames laboratoriais: Os achados laboratoriais podem ser apesentados sem alteração ou com aumento da albumina sérica, desidratação, hemoconcentração e azotemia. Em quadro de vômito a consequência da perda de secreção do estomago será alcalose metabólica devido a pouco cloro e potássio. Pode ocorrer acidose metabólica e lática devido à desidratação (TRICHEZ, 2018). Tratamento e pré-operatório: O tratamento para os casos de CELs é primariamente cirúrgico, sendo contraindicada tração oral ou anal da extremidade livre do CEL, pois pode resultar em laceração total da mucosa gastrointestinal, ruptura intestinal completa, ruptura esofágica, com consequente formação de cicatrizes que podem levar a estenose da parede do órgão afetado (SANTOS; TROUILLET, 2003). Casos de desiquilíbrios acidobásicos devem ser tratados e corrigidos antes do início do procedimento cirúrgico, com isso também deve-se manter o animal em jejum por doze horas, afim que o conteúdo alimentar não acarrete problemas de vômito e aspiração (TRICHEZ 2018; FOSSUM, 2015). Gastrotomia: A gastrotomia é um método cirúrgico utilizado para realizar o acesso do estomago via incisão da parede do estômago, o qual é essencial para casos de remoção de corpos estranhos. É importante a manipulação correta e uso de sucção para diminuir o derrame gástrico e checagem do trato gastrointestinal (TRICHEZ, 2018; FOSSUM, 2015). Enterotomia: A enterotomia é a técnica que realiza uma incisão no intestino e vai até o lúmen do mesmo. A incisão será por meio da linha alba que permitirá a visualização total do abdômen. Deve-se lavar o intestino com solução salina de temperatura morna a fim de ajudar na circulação e movimentos peristálticos e mensurar a tensão, pois pode ocorrer a laceração da espessura da borda mesentérica intestinal (FOSSUM, 2015; TRICHEZ, 2018). Prognóstico: O prognóstico em geral é considerado bom, mas dependerá da profilaxia e prováveis resseções (FOSSUM, 2015; TRICHEZ, 2018). Complicações: O CEL se não tratado pode acarretar a complicações, como: peritonite devido a perfuração da parede intestinal levando a uma inflamação e infecção; a gastrite devida irritação da mucosa gástrica gerada pelo CEL ou vômitos intermitentes, além de alças intestinais plissadas, obstrução, achatamento das paredes da parte do intestino distal e lacerações das paredes gástricas e intestinais (KRUININGEN, 1998).

Conclusão: O CEL é uma emergência cirúrgica que caso não seja tratada junto com as alterações laboratoriais poderá levar a 
complicações, pioras no prognóstico e até mesmo o óbito do animal. Os exames de imagem são essenciais e indispensáveis ao diagnóstico. A remoção cirúrgica do CEL requer conhecimento das técnicas cirúrgicas e geralmente culmina em sucesso e evita eventuais complicações.

\section{Referências}

BRENTANO, Lucas Mathias. Cirurgia gástrica em cães. 2010. Orientador: Emerson Antonio Contesini. Monografia (Graduação em Medicina Veterinária) Universidade Federal do Rio Grande do Sul, Porto Alegre, 2010.

FOSSUM, Theresa Welch. Doenças específicas. In: FOSSUM, Theresa Welch. Cirurgia de Pequenos Animais. 4 ed. Rio de Janeiro: Elsevier editora Itda, 2015. p. 13361365.

KRUININGEN, Herbert J. Van. Sistema gastrointestinal. In: CARLTON, William W.; MCGAVIN, M. Donald. Patologia veterinária especial de Thomson. Porto Alegre: ARTMED, 1998. p. 1394.

SANTOS, A.E.; TROUILLET, A.V.P. Emergência Gastrintestinal: Corpo Estranho Linear. In: SOUZA, H. J. Coletâneas em Medicina e Cirurgia Felina. Rio de Janeiro: LF Livros de Veterinária, 2003.

SESSEGOLO, Tayana Marchese. Corpo estranho gástrico em felino Relato de caso. 2016. Orientador: Márcio Poletto Ferreira. Monografia (Especialização em Clínica Médica de felinos domésticos) Universidade Federal do Rio Grande do Sul, Porto Alegre, 2016.

SILVA, Luciana Carandina et al. Avaliação ultrassonográfica gástrica em pequenos animais. Veterinária e Zootecnia, Botucatu, 20 (4) 567-575, p. $567 \quad$ 575, dez. 2013.

NELSON, Richard William; COUTO, C. Guillermo. Manifestações clínicas de distúrbios gastrintestinais. In: NELSON, Richard William; COUTO, C. Guillermo. Medicina Interna de Pequenos Animais. 5 ed. Rio de Janeiro: Elsevier editora Itda, 2015. p. 11061170.

TRICHEZ, Giovanna. Corpo estranho linear em gato: Relato de caso. 2018. Orientador: Vanessa Sasso Padilha. Monografia (Graduação em Medicina Veterinária) Universidade Federal de Santa Catarina, Curitibanos, 2018.

WILLARD, M.D. Distúrbios do Sistema Digestório. In: NELSON, R.W.; COUTO, C.G. Medicina Interna de Pequenos Animais. 4 ed. Rio de Janeiro: Elvesier, 2010, 351-484 p. 


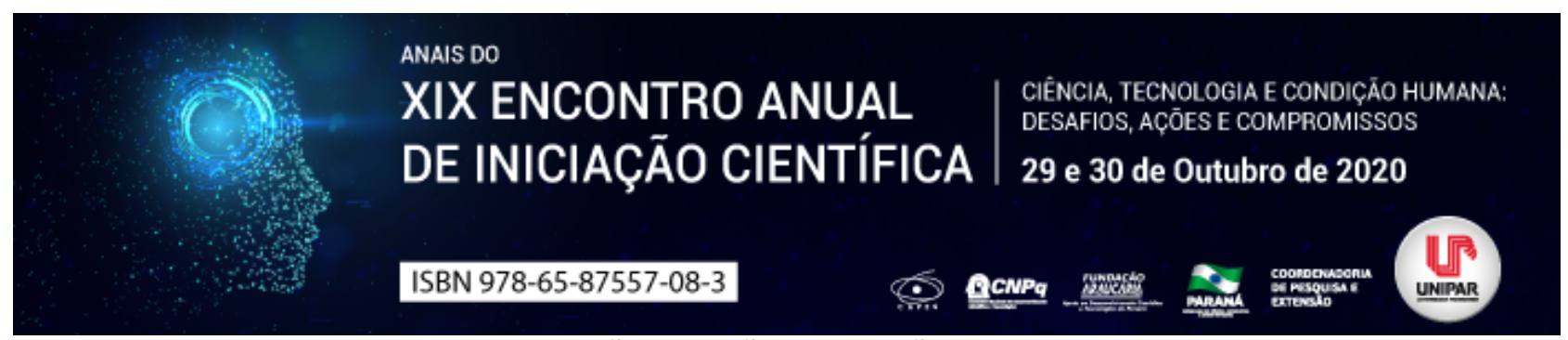

INTUSSUSCEPÇÃO EM CÃES-REVISÃO DE LITERATURA

\section{${ }^{1}$ Isadora Gobo Medeiros, ${ }^{2}$ ISIS CLEÓPATRA COELHO CHAVES, ${ }^{3}$ ODUVALDO CÂMARA MARQUES PEREIRA JÚNIOR}

${ }^{1}$ Graduanda do curso de Medicina Veterinária. Ciências Biológicas e afins, Medicina Veterinária, Universidade Estadual de Maringá UEM, cam

${ }^{1}$ Graduanda do curso de Medicina Veterinária. Ciências Biológicas e afins, Medicina Veterinária, Universidade Estadual de Maringá UEM, cam

${ }^{2}$ Professor adjunto do Departamento de Medicina Veterinária DMV, Ciências Biológicas e afins, Medicina Veterinária,

1 Universidade Estadual d

Introdução: A intussuscepção é uma emergência cirúrgica que acomete com certa frequência pequenos animais e é caracterizada pela invaginação de um segmento do trato gastrintestinal (intussuscepto), para o lúmen do segmento anexo (intussuscipiente). A afecção tem incidência, na maioria dos casos, em animais juvenis, apresentando como característica a hipermotilidade secundária a enterites virais. O diagnóstico de suspeita é definido durante o exame físico por meio de palpação abdominal e é confirmado ultrassonograficamente pela visibilização de múltiplas camadas intestinais concêntricas (imagem em alvo ou olho de boi ) num corte transversal e pela identificação de múltiplas camadas intestinais sobrepostas paralelas num corte longitudinal.

Objetivo: O objetivo dessa revisão de literatura é descrever a intussuscepção intestinal, abordando seus fatores epidemiológicos, identificação de sinais clínicos comumente encontrados em rotina, melhores técnicas/métodos de diagnóstico e aqueles principalmente indicados, aliado ao tratamento de escolha e possíveis complicações deste.

Desenvolvimento: Intussuscepção é a invaginação de um segmento do trato gastrintestinal (intussuscepto), para o lúmen do segmento anexo (intussuscipiente) (HEDLUNG et al .2002). Constantemente é visualizada na porção normógrada, isto é, no seguimento peristáltico, contudo, existem casos de ocorrência no sentido retrógrado (APPLEWHITE et al. 2001). Outra classificação passível de ser utilizada é referente ao número de intussuscepções, tendo potencial de serem únicas, várias ou compostas (LEVITT et al., 1992). SINAIS CLÍNICOS: Dentre os sinais clínicos podemos destacar desde alterações inespecíficas, tais como: anorexia, depressão, letargia, êmese, diarreia hemorrágica que por sua vez leva a um quadro de perda de peso, sendo consequência do bloqueio intestinal, crescimento bacteriano elevado, obstrução da porção atingida e isquemia. Somado a isso, casos de peritonite focal ou difusa são comumente registrados (ARONSON et al., 2000). DIAGNÓSTICO: O exame físico é, na maioria das vezes, suficiente para o estabelecimento do diagnóstico. Inúmeros casos podem ser diagnosticados por meio da palpação abdominal, situando e demarcando uma arquitetura tubular sólida, que por sua vez, precisa ser distinguida de conteúdo fecal ou corpo estranho (GUILFORD et al., 1996). O reconhecimento tem como base a anamnese, exame físico e exames complementares, como o ultrassom abdominal e a radiografia simples, contudo, a ultrassonografia é tida como o recurso de escolha para as avaliações (MAGALHÃES F.J.R. et al, 2009). . Ao exame ultrassonográfico são evidenciadas várias linhas concêntricas correspondentes às camadas da parede intestinal do intussuscipiente e intussuscepto em corte transversal, bem como várias camadas paralelas em cortes longitudinais, hiperecoicos e hipoecoicos alternados (LAMB et al., 1998). TRATAMENTO: O tratamento de escolha para os casos de intussuscepção é a intervenção cirúrgica, em que procedimentos visando a redução manual são realizadas até ser completamente desfeita a intussuscepção. Em caso de insucesso, opta-se pela ressecção da porção acometida enterectomeia, seguida por enteroanastomose (BROWN, 2003). Assim, o método a ser utilizado pode variar de acordo com a viabilidade e estágio da lesão intestinal (MACPHAIL, 2002).A anestesia indicada é a geral. O manejo visceral é capaz de provocar bradicardia, todavia, a atropina $(0,02-0,04 \mathrm{mg} / \mathrm{kg}$, SC, IM ou IV) controla essa modificação. A manutenção da temperatura corporal do paciente é fundamental durante o procedimento cirúrgico, de forma que, devido à exposição das vísceras, não ocorra hipotermia. A glicemia precisa ser mantida em constante monitoramento anteriormente e posteriormente a cirurgia, se dando ênfase a animais jovens. (FOSSUM, 2008). Constatada a necessidade da realização de enterectomia, deve-se manipular os dedos ou pinças com a finalidade de obstruir o lúmen nos extremos da porção intestinal afetada tem como objetivo principal reduzir o derrame de quimo. Deve-se transeccionar o intestino com o bisturi ou até mesmo uma tesoura Metzenbaum na borda exterior da pinça. Aspirar os limites intestinais, deslocar quaisquer detritos adjunto as margens do gume com o auxílio de uma esponja de gaze úmida. Seccionar a mucosa herniada com a tesoura citada anteriormente, antes de começar a anastomose término-terminal (FOSSUM, 2014). POSSÍVEIS COMPLICAÇÕES: As complicações mais recorrentes no pós-operatório são recidivas do quadro, íleo paralítico, obstrução entérica, deiscência da anastomose, síndrome do intestino curto e peritonite (APPLEWHITE et al. 2001). Alguns estudos correlacionam a reincidência em pacientes tratados com o uso de fármacos que atuam no sistema nervoso para aliviar a dor no trans ou pós-operatório. O mecanismo não está evidenciado, contudo, se discute um aumento do tônus muscular (APPLEWHITE 
et al. 2001). O uso em escala de opioides pode auxiliar para o atraso do trânsito gastrointestinal e para a piora do íleo paralítico. Alternativas como concepção de válvulas intestinais e esfíncteres artificiais, prolongamento e aferição intestinal ou a transplante de porções intestinais já foram realizadas (GUILFORD et al., 1996).

Conclusão: A intussuscepção é uma enfermidade complexa, tendo em vista que necessita de um conhecimento e diagnóstico rápidos com a finalidade de se prevenir possíveis contratempos mais graves. A união da ultrassonografia com o procedimento cirúrgico possibilita um ótimo prognóstico para o paciente, garantindo assim o bem estar e a qualidade de vida do paciente.

\section{Referências}

ARONSON, L. R. et al. Gastrointestinal emergencies. Veterinary Clinics of North America: Small Animal Practice, [s. I.], v. 30, ed. 3, p. 555-579, 2000.

APPLEWHITE, A. A. et al. Complications of enteroplication for the prevention of intussusception recurrence in dogs: 35 cases, Journal of the American Veterinary Medical Association, ed. 10, p. 1415-1418, 2001.

BARKER, I. K. et al. The alimentary system. Pathology of domestic animal, [s. I.], p. 101, 1993.

BILELLO, J. F. et al. Retrograde jejunojejunal intussusception secondary to metastatic melanoma. Mayo Clinic Proceedings, [s. I.], v. 80, ed. 8, p. 1098, 2005.

BROWN, D. C. Small intestines. Textbook of small animal surgery, Philadelphia: Saunders, p. 644-664, 2003.

CASTRO, P. F. et al. Prolapso ou intussuscepção de reto: reduzir ou amputar, eis a questão!. Brazilian Journal of Veterinary Research and Animal Science, [s. I.], v. 40, p. 137-138, 2003.

FOSSUM, Theresa Welch et al. Cirurgia de pequenos animais. Roca, 2008.

FOSSUM, Theresa Welch et al. Cirurgia de pequenos animais. Roca, 2014.

GUILFORD, W. G. et al. Intestinal obstruction, pseudo-obstruction and foreign bodies. Strombeck's small animal gastroenterology, [s. I.], p. 487-502, 1996.

HEDLUNG, C. S. et al. Cirurgia de pequenos animais. FOSSUM, T. W: [s. n.], 2002. 322-349 p.

LEVITT, L. et al. Intussusception in dogs and cats: a review of thirty-six cases, The Canadian Veterinary Journal, n. 10, ed. 33, p. 660-664, 1992.

LAMB, C. R. et al. Ultrasonographic features of intestinal intussusception in 10 dogs. Journal of Small Animal Practice, [s. I.], v. 39, ed. 9, p. 437-441, 1998.

MACPHAIL, C. et al. Gastrointestinal obstruction. Clinical Techniques in Small Animal Practice, [s. I.], v. 17, ed. 4, p. 178-183, 2002

MAGAlHÃES, F. J. R., Camargo, N. I., Neto, J. C. M., de Oliveira, E., Neto, C., Santiago, T. A., \& Wischral, H. C. M. F. A. (2009). Intussuscepção intestinal em cadela diagnósticado através da ultrassonografia abdominal: relato de caso. 


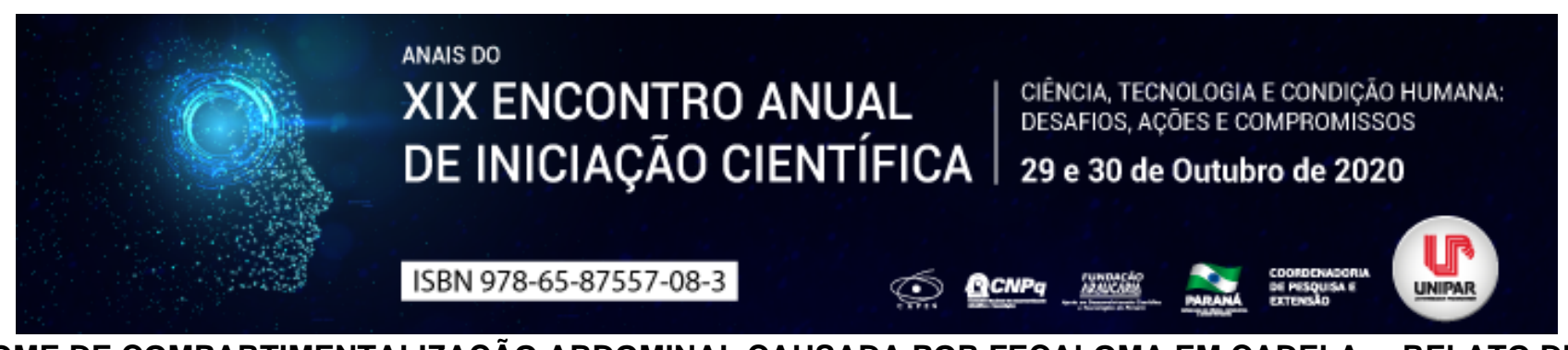

SÍNDROME DE COMPARTIMENTALIZAÇÃO ABDOMINAL CAUSADA POR FECALOMA EM CADELA RELATO DE CASO

\author{
${ }^{1}$ Laura Mariana Tonete, ${ }^{2}$ LARISSA ÉDINA PERIN PEREIRA, ${ }^{3}$ BRUNA CAROLINA MARQUARDT, ${ }^{4}$ GABRIEL COELHO \\ GIMENES, ${ }^{5}$ FERNANDA DE PAULA ROLDI VIEIRA
}

\author{
${ }^{1}$ Discente do curso de Medicina Veterinária UEM/Umuarama-PR \\ ${ }^{1}$ Discente do curso de Medicina Veterinária UEM/Umuarama-PR \\ ${ }^{2}$ Mestranda no Programa de Pós-Graduação em Produção Sustentável e Saúde Animal UEM/Umuarama-PR \\ ${ }^{3}$ Mestre em Ciência Animal UNIPAR \\ ${ }^{4}$ Mestre em Ciências Veterinárias Universidade Federal do Espírito Santo
}

Introdução: Fecalomas são uma forma severa de impactação fecal, caracterizada pelo ressecamento das fezes que ficam retidas no interior do intestino grosso (ALVES et al., 2019). Os sinais clínicos apresentados são constipação, tenesmo e disquesia, podendo causar megacólon, distúrbio em que o intestino grosso apresenta dilatação e hipomotilidade (FOSSUM, 2008). Através de anamnese e exame físico é possível presumir a ocorrência do quadro, no entanto são necessários exames de imagem, como a radiografia simples, para determinar o diagnóstico (THRALL, 2010). O fecaloma pode ser tratado de maneira conservativa pela administração de laxantes e remoção das fezes através de enemas, entretanto, em casos mais graves é necessária a remoção cirúrgica (YUCEL et al., 2012). A síndrome de compartimentalização abdominal decorre do aumento excessivo da pressão intra-abdominal, afetando severamente a função e viabilidade de órgãos e tecidos, culminando em anormalidades hemodinâmicas, respiratórias, renais e neurológicas que muitas vezes resultam no óbito do paciente (WALKER E CRIDDLE, 2003; DEENICHIN, 2008).

Relato de caso: Em uma clínica veterinária de Umuarama-PR foi atendida uma cadela sem raça definida, de 15 anos de idade e 20,6 kg apresentando dificuldade para defecar. O tutor relatou que o animal apresentava episódios de tenesmo manifestando melhoras rápidas, no entanto o último episódio já durava aproximadamente 3 dias e a cadela havia apresentado aumento significativo de abdômen. Na tentativa de facilitar a saída das fezes, realizou-se enema a partir de sondagem retal com injeção de soro fisiológico aquecido e glicerina, contudo a manobra não foi bem sucedida. Foi efetuada ultrassonografia abdominal e constatou-se a presença de conteúdo obstrutivo formador de sombra acústica na região de cólon descendente e transverso. Realizou-se então radiografia simples para o diagnóstico definitivo, sendo observado conteúdo de radiopacidade compatível com possível corpo estranho, visto que a cadela possuía histórico de ingestão de couro, por residir em selaria. Sendo assim, optou-se pela intervenção cirúrgica. Foi realizado hemograma, o qual revelou anemia normocítica hipocrômica (hematócrito $33,7 \%$ ) e leucocitose com desvio à esquerda ( $9 \%$ de bastões), entretanto o exame bioquímico não revelou alterações hepáticas ou renais. Em menos de 24 horas após o atendimento foi realizada a enterotomia da paciente, onde constatou-se a presença de um fecaloma de grandes dimensões, resultando em 1,2 kg de fezes. No pós-operatório a paciente permaneceu em fluidoterapia e foram administrados Meloxicam $(0,2 \mathrm{mg} / \mathrm{kg} / \mathrm{IV})$, Ceftriaxona (30mg/kg/IV), Metronidazol (15mg/kg/lV), Metadona (0,3mg/kg/IM), Tramadol ( $4 \mathrm{mg} / \mathrm{kg} / \mathrm{SC})$, Dipirona ( $25 \mathrm{mg} / \mathrm{kg} / \mathrm{IM})$ e Lactulose (4mI/VO), além de jejum com retorno gradativo da consistência alimentar. A paciente foi mantida aquecida e apresentava-se responsiva a estímulos, entretanto sua temperatura se mantinha abaixo de $36^{\circ} \mathrm{C}$. Após 24 horas da realização da cirurgia a paciente apresentou profunda apatia e manteve-se hipotérmica, ainda que sob aquecimento constante. Assim, optou-se pela administração de fluidoterapia intravenosa aquecida, entretanto sem sucesso na estabilização da paciente, a mesma veio a óbito aproximadamente 36 horas após a cirurgia.

Discussão: Alguns fatores como idade avançada, constipação crônica e dieta desbalanceada são predisponentes ao desenvolvimento de fecalomas (GARISTO et al., 2009). A paciente em questão era idosa, obesa, com dificuldade crônica para defecar e recebia alimentação de baixa qualidade nutricional. Acredita-se que a cadela tenha apresentado síndrome de compartimentalização devido à grande compressão abdominal resultante do acúmulo excessivo de fezes, e que a alteração abrupta da pressão intra-abdominal possa ter contribuído para uma evolução desfavorável do quadro. O fecaloma possui caráter obstrutivo, o que de acordo com Walker e Criddle (2003) pode ter sido um fator de risco para o desenvolvimento da síndrome de compartimentalização abdominal. Em concordância, Dörfelt et al. (2012) afirmam que o volume excessivo das vísceras abdominais associado a condições que limitem a expansão da parede abdominal são fatores contribuintes para o aumento da pressão intra-abdominal, levando à síndrome da compartimentalização, a qual é representada por efeitos deletérios cardiovasculares, pulmonares, renais, gastrointestinais e hepáticos em virtude da diminuição do fluxo sanguíneo e do débito cardíaco. Segundo Deenichin (2008), a síndrome é observada quando há aumento da pressão intra-abdominal com duração de 
seis ou mais horas, como foi observado na cadela no presente relato, a qual apresentava o quadro há alguns dias.

Conclusão: A retenção fecal prolongada pode se tornar grave a ponto de induzir a formação de fecalomas, levando à compressão e congestão das vísceras abdominais, além de aumento da pressão intra-abdominal, culminando em síndrome de compartimentalização. Sendo assim, é imprescindível salientar a importância do diagnóstico e intervenção precoces como fatores determinantes para um prognóstico favorável.

\section{Referências}

ALVES, J. L. C.; SILVA, N. C. S. L.; BEZERRA, H. A.; MENDONÇA, M. S. B.; SANTOS, V. P. A.; GOMES, L. C. V. M.; DINIZ, A. N. Diagnóstico Ultrassonográfico de Fecaloma Secundário a Hiperplasia Prostática Benigna em Cão Relato de Caso, Anais da VI Semana de Medicina Veterinária SEMVET UFAL, v. 2, out., 2019. Disponível em: https://www.seer.ufal.br/index.php/medvet/article/view/8370/7052. Acesso em: 21 ago. 2020.

DEENICHIN, G. Abdominal Compartment Syndrome, Surgery Today, v. 38, jan., 2008. Disponível em: https://link.springer.com/article/10.1007/s00595-007-3573-x. Acesso em: 25 ago. 2020.

DÖRFELT, R.; AMBRISKO, T. D.; MOENS, Y. Influence of Fentanyl on Intra-abdominal Pressure During Laparoscopy in Dogs, Veterinary Anaesthesia and Analgesia, v. 39, n. 4, mar., 2012. Disponível em: https://europepmc.org/article/med/22414245.Acesso em: 25 ago. 2020.

FOSSUM, T. W. Cirurgia de Pequenos Animais, 3. ed., Rio de Janeiro, Elsevier, 2008.

GARISTO, J. D.; CAMPILLO, L.; EDWARDS, E.; HARBOUR, M.; ERMOCILLA, R. Giant Fecaloma in a 12-year-old-boy: a Case Report, Cases Journal 2, v. 127, fev., 2009. Disponível em: https://casesjournal.biomedcentral.com/articles/10.1186/1757-1626-2127. Acesso em: 25 ago. 2020.

THRALL, D. E. Diagnóstico de Radiologia Veterinária, 5. ed., Rio de Janeiro, Saunders, 2010.

WALKER, J.; CRIDDLE, L. M. Pathophysiology and Management of Abdominal Compartment Syndrome, AJCC, v. 12, n. 4, jul., 2003. Disponível em: https://aacnjournals.org/ajcconline/article-abstract/12/4/367/213/Pathophysiology-and-Management-ofAbdominal?redirectedFrom=fulltext. Acesso em: 25 ago. 2020.

YUCEL, A. F.; AKDOGAN, R. A.; GUCER, H. A Giant Abdominal Mass: Fecaloma, Clinical Gastroenterology and Hepatology, v. 10, n. 2, fev., 2012. Disponível em: https://www.cghjournal.org/article/S1542-3565(11)00690-2/fulltext. Acesso em: 21 ago. 2020. 


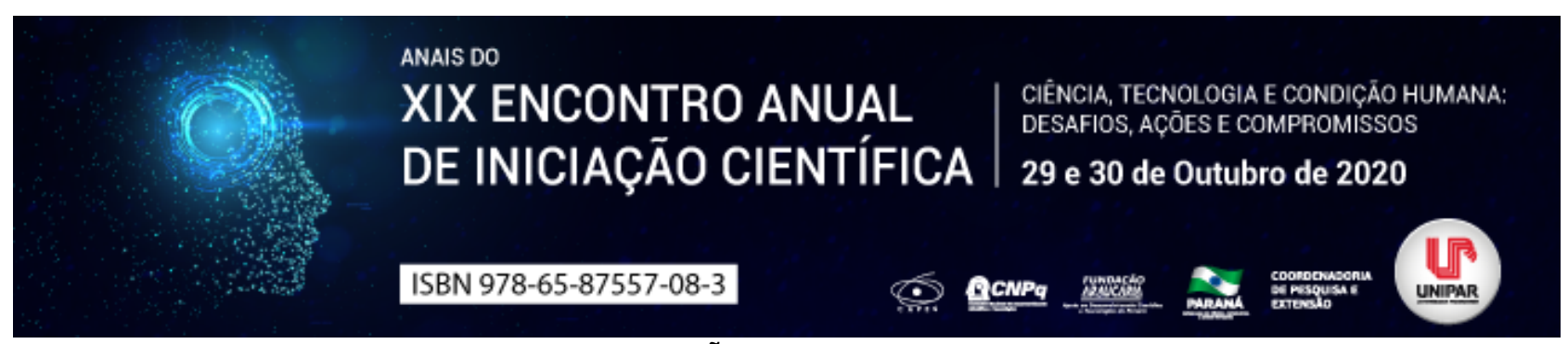

MICRORGANISMOS INDICADORES DE CONTAMINAÇÃO NAS PLANTAS CULTIVADAS NAS HORTAS COMUNITÁRIAS: CONTROLE DE QUALIDADE

\title{
${ }^{1}$ LETICIA MARTINS HILDEBRAND, ${ }^{2}$ GRACIELE MOREIRA DO NASCIMENTO, ${ }^{3}$ FELIPE ANDRÉ PEREIRA RAMOS, ${ }^{4}$ CLEUSA FERNANDES RAMOS, ${ }^{5}$ ANDRÉIA ASSUNÇÃO SOARES
}

\author{
${ }^{1}$ Acadêmica do curso de Medicina Veterinária PIBIC/ UNIPAR \\ 1 Acadêmica do curso de Nutrição PIBIC/UNIPAR \\ ${ }^{2}$ Mestrando Profissional de Plantas Medicinais e Fitoterápicos na Atenção Básica/UNIPAR \\ 3 Acadêmica Ensino Médio PEBIC EM-JR/CNPq/UNIPAR \\ ${ }^{4}$ Docente Mestrado Profissional de Plantas Medicinais e Fitoterápicos na Atenção Básica e Mestrado e Doutorado em Ciência \\ Animal com Ênfase em
}

Introdução: Cada vez mais os espaços públicos são ocupados por ações coletivas e que estimulam a convivência e a harmonia com o ambiente. Uma destas ações nas grandes cidades são as hortas comunitárias. Além de promoverem a integração, revitalizam o uso de espaços ociosos e são uma alternativa de produção e acesso a alimentos frescos e saudáveis. O Projeto Interdisciplinar Plantando Sabores (implementação da horta) do Colégio Estadual do Campo Benjamim Antônio Motter, tem por finalidade a busca pela valorização dos povos campesinos e a perspectiva da sustentabilidade, que vem sendo uma meta para as escolas do campo. A implantação da horta na escola como um espaço educador sustentável é necessário porque estimula a incorporação, a percepção e a valorização da dimensão educativa a partir do meio ambiente. As plantas produzidas na horta são destinadas a merenda escolar e também para fins terapêuticos/medicinais. O trabalho realizado na horta busca a interdisciplinaridade, onde explora a relação dos alunos com a natureza, e os impactos que suas ações podem ocasionar ao meio, bem como a educação para a saúde através de aspectos nutricional e alimentar, mostrando também a necessidade do reaproveitamento de materiais. Dessa forma, a verificação de microrganismos indicadores de contaminação e o potencial antioxidante das plantas medicinais cultivadas na horta, será de fundamental importância para contribuir e melhorar as condições e manejo da horta, proporcionando alimentos seguros e saudáveis para a população consumidora.

Objetivo: O objetivo desse trabalho foi relatar os aspectos sobre o controle de qualidade das plantas medicinais (microrganismos indicadores de contaminação) cultivadas nas hortas comunitárias.

Desenvolvimento: Hortas comunitárias são hortas instaladas em local de uso coletivo, cedido por um grupo de pessoas que geralmente mora nas redondezas ou está agrupado em associação. A horta pode funcionar coletivamente, onde todas as atividades são realizadas por todos e a produção é repartida, ou o espaço da horta é dividido em canteiros, que fica sob a responsabilidade de uma pessoa ou família. A produção que exceder pode ser comercializada ou trocada por outros alimentos (HENZ; ALCÂNTARA, 2009). A produção é normalmente orgânica, sem a utilização de agrotóxicos, e consequentemente propicia aos consumidores um alimento mais seguro e mais saudável; desenvolvimento local: a produção local é valorizada e proporciona oportunidades de desenvolvimento para as pessoas, trocas de conhecimento e de experiências e ainda favorece a cultura popular (EMBRAPA, 2002). Os medicamentos fitoterápicos disponibilizados pelo MS são: espinheira-santa, guaco, alcachofra, aroeira, cáscara-sagrada, garra-do-diabo, isoflavona-de-soja, unha-de-gato, hortelã, babosa, salgueiro e plantago (BRASIL, 2012). Segundo o Ministério da Saúde, os fitoterápicos são medicamentos que desempenham um papel importante em cuidados contra dores, inflamações, disfunções e outros incômodos, ampliando as alternativas de tratamento seguras e eficazes. A horta é importante sob o ponto de vista nutricional, e também como forma de terapia ocupacional, na melhoria do hábito de consumo das pessoas, na economia das famílias e até na manutenção e/ou melhoria da saúde e prevenção de doenças (TERSO, 2013). Plantas medicinais, nativas ou cultivadas, são suscetíveis ao ataque por ácaros, nematoides e fungos e o controle dessas pragas é um desafio ao produtor, pois não existem pesticidas registrados para o uso em plantas medicinais. Técnicas como a rotação de culturas, fertilização e irrigação apropriadas e a inserção de plantas aromáticas, de forma alternada com hortaliças e espécies frutíferas, que atuem como atraentes de inimigos naturais dessas pragas ou como repelentes, também podem auxiliar na prevenção de doenças compondo um sistema agroflorestal que dificulta a proliferação dessas pragas (CARVALHO et al., 2010). Toda a cadeia produtiva, desde o plantio, colheita, processamento, armazenamento e transporte das plantas medicinais, deixa-as suscetíveis à contaminação por uma variedade de resíduos e microrganismos, em parte por esses processos serem realizados, na maioria das vezes, sem os devidos cuidados de higiene e controle sanitário (SOUZA; LIONZO; PETROVICK, 2006). O controle e a avaliação da carga microbiológica e parasitológica das plantas medicinais são determinantes para a garantia da qualidade, e caso não sejam adequadamente cumpridos podem comprometer a utilização destas como adjuvantes na melhoria do estado de saúde do indivíduo. (RATAJCZAK et al., 2015; SOUZA; LIONZO; PETROVICK, 2006). 
Conclusão: Com este trabalho espera-se a verificação de micro-organismos indicadores de contaminação e o potencial antioxidante das plantas medicinais contribuindo e melhorando as condições e manejo da horta, proporcionando alimentos seguros e saudáveis para a população consumidora. Oferecendo benefícios para a saúde e bem-estar da comunidade envolvida, as estratégias de sustentabilidade e integração entre o homem com o meio ambiente proporcionando um ambiente equilibrado e possibilitando uma melhoria na qualidade de vida da comunidade.

\section{Referências}

BRASIL. MINISTÉRIO DA SAÚDE. Portal da Saúde: Relação Nacional de Medicamentos Essenciais

(RENAME). 2013. Disponível em:

prt0533_28_03_2012.html> Acesso em: jul. 2020.

CARVALHO, P.G.B.; MACHADO, C.M.M.; MORETTI, C.L.; FONSECA, M.E.N. Hortaliças como alimentos funcionais. Horticultura Brasileira, v. 24, n. 4, p. 397-404, 2006.

EMBRAPA. Critérios para o levantamento de sistemas de produção na Embrapa. Brasília, DF: Embrapa SGE, 2002. 17 p. HENZ, G. P.; ALCÂNTARA, F. A. de. Hortas: o produtor pergunta, a Embrapa responde / editores técnicos, Brasília, DF: Embrapa Informação Tecnológica, 2009. 237 p.

RATAJCZAK, M. et al. Microbiological quality of nonsterile pharmaceutical products. Saudi Pharmaceutical Journal, v. 23, n. 3, p. 303 307, 2015.

TERSO, M. M. Horta Orgânica: Alimentação Saudável/Qualidade de Vida, vol. 1, Paraná: Governo do Estado. Secretaria da Educação - Cadernos PDE, 2 


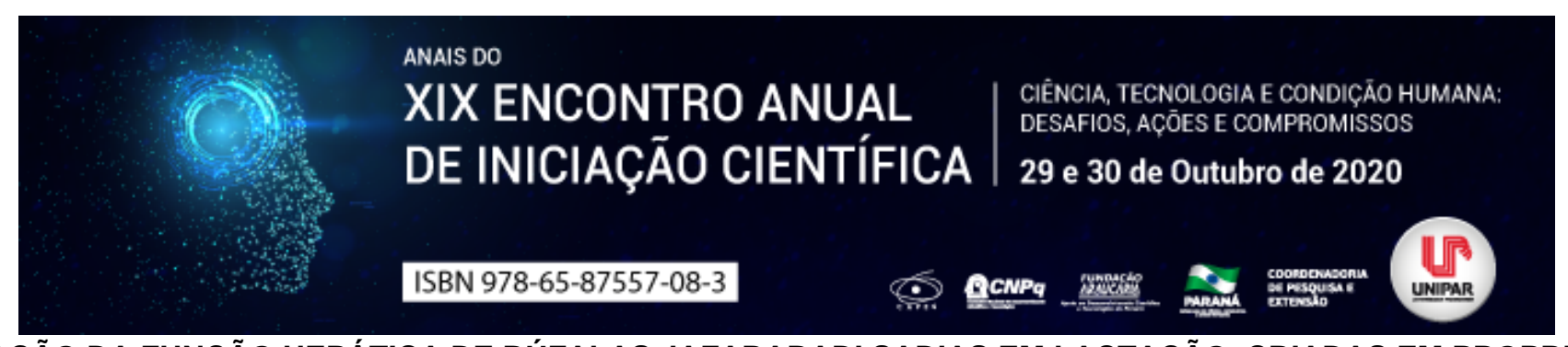

\title{
AVALIAÇÃO DA FUNÇÃO HEPÁTICA DE BÚFALAS JAFARABADI SADIAS EM LACTAÇÃO, CRIADAS EM PROPRIEDADE NO ESTADO DE SÃO PAULO
}

\author{
${ }^{1}$ Paulo Roberto de Abreu Tavares, ${ }^{2}$ DANIELA GOMES DA SILVA, ${ }^{3}$ ANA CAROLINE CANDIA PALHANO, ${ }^{4}$ JOSÉ JURANDIR \\ FAGLIARI, ${ }^{5}$ ANDRÉ MARCOS SANTANA
}

\begin{abstract}
${ }^{1}$ Discente do curso de Medicina Veterinária da Universidade Estadual de Maringá/Campus de Umuarama
${ }^{1}$ Pós-Graduanda do Departamento de Clínica e Cirurgia Veterinária, FCAV/UNESP, Campus de Jaboticabal

${ }^{2}$ Discente do curso de Medicina Veterinária da Universidade Estadual de Maringá/Campus de Umuarama

${ }^{3}$ Docente do Departamento de Clínica e Cirurgia Veterinária, FCAV/UNESP, Campus de Jaboticabal

${ }^{4}$ Docente do Departamento de Medicina Veterinária, Universidade Estadual de Maringá (UEM), Campus Regional de Umuarama
\end{abstract}

Introdução: Os exames bioquímicos são rotineiramente utilizados na avaliação da saúde dos animais domésticos, sendo necessário comparar os resultados obtidos, em animais doentes, com os intervalos de referência calculados para animais sadios, para que se possa corretamente identificar anormalidades e diagnosticar enfermidades (GEORGE et al., 2010a). Dados publicados propõem valores que muitas vezes são obtidos em diferentes condições nutricionais e climáticas, o que muitas vezes torna difícil a interpretação dos resultados em búfalos (ELLAH et al., 2013). Neste sentido, embora existam alguns estudos que visam estabelecer intervalos de referência para parâmetros bioquímicos em bubalinos adultos (GOMES et al., 2010a, GOMES et al., 2010b), estes são realizados com outras raças, em outras regiões e com animais em diferentes faixas etárias daqueles propostos em nosso trabalho. Assim sendo, é importante que trabalhos com este tema sejam realizados no Brasil e em diferentes regiões do país, levando também em consideração as diferentes faixas etárias, sexo dos animais e respectivas raças.

Objetivo: Este trabalho teve como objetivo avaliar a atividade sérica de enzimas ligadas a função hepática de búfalas Jafarabadi adultas sadias em lactação, entre 3 e 10 anos de idade, criadas em uma propriedade situada no estado de São Paulo.

Material e Métodos: Coletou-se amostras de búfalas Jafarabadi adultas em lactação $(n=23)$, de uma propriedade situada no estado de São Paulo. O estado de saúde dos animais que participaram do experimento foi verificado por exame físico geral (FEITOSA, 2008). As amostra de sangue venoso, coletadas mediante punção da veia jugular, em tubos plásticos siliconizados sem anticoagulante, foram submetidas a centrifugação ( $1000 \mathrm{x} \mathrm{g,} 10$ minutos), e alíquotas do soro foram armazenados em tubos eppendorf e congelados $\left(-20^{\circ} \mathrm{C}\right)$ até o momento de análise dos parâmetros do perfil bioquímico-sérico. A atividade sérica das variáveis aspartato aminotransferase (AST), fosfatase alcalina (ALP) e gama glutamiltransferase (GGT) foram mensuradas utilizando-se conjuntos de reagentes de uso comercial (Labtest Diagnóstica), e as leituras dos parâmetros foram realizadas em espectrofotômetro semi-automático com comprimentos de onda específicos para cada constituinte.

Resultados: Apenas os animais que se apresentaram sadios após a realização do exame físico geral participaram do

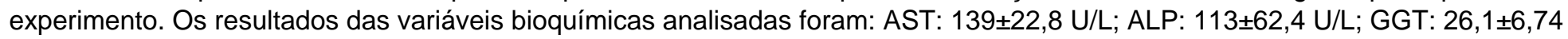
U/L.

Discussão: Fontes et al. (2014), em seus estudos com búfalos criados na Amazônia Oriental da raça Murrah, em faixa etária entre oito meses a dois anos de idade, obteveram atividades séricas de GGT (22,90 $\pm 9,0 \mathrm{U} / \mathrm{L})$ semelhantes aqueles encontrados no nosso trabalho. No entanto, as atividades séricas de AST $(174,80 \pm 70,6 \mathrm{U} / \mathrm{L})$ e ALP $(264,80 \pm 132,7 \mathrm{U} / \mathrm{L})$ foram maiores que as encontradas em nosso trabalho, o que pode estar associado a influência de variações fisiológicas relacionadas ao sexo e idade. Gomes et al. (2010) constataram que a atividade sérica de AST foi menor (92,3 U/L) em bezerros bubalinos Murrah com idade entre 0 - 3 meses, aumentando em animais com faixa etária entre 4 e 6 meses (128 U/L), entre 7 e 12 meses (177 U/L) e acima de um ano (143 U/L), reforçando a importância do desenvolvimento de valores de referência que levam em consideração a faixa etária. Esses mesmos autores (Gomes et al., 2010) observaram atividade enzimática sérica da GGT de 35,9 U/L (animais de 0-3 meses), 19,6 U/L (animais de 4-6 meses), 25,1 U/L (animais de 7-12 meses) e 33,3 U/L (animais acima de um ano), e concluíram que os constituintes bioquímicos avaliados sofrem influência do fator etário. Ellah et al., (2013), estudando búfalas prenhes criadas em fazendas no centro do Egito, observaram atividades séricas de AST, ALT e ALP significativamente mais elevadas em búfalas até o sexto meses de prenhes (AST: $61,2 \pm 19,8 \mathrm{U} / \mathrm{L}$; ALT: $27,6 \pm 10,1 \mathrm{U} / \mathrm{L}$; ALP: $170 \pm 58,3 \mathrm{U} / \mathrm{L}$ ) quando comparadas a

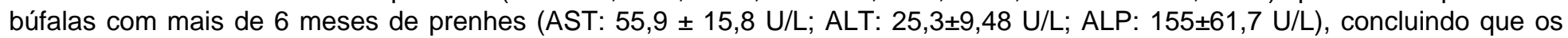
períodos de gestação influenciam nas atividades séricas de enzimas relacionadas a função hepática. Ademais, neste trabalho de Ellah et al. (2013), as atividades séricas de AST e ALP se apresentaram menores e maiores, respectivamente, aos encontrados em nosso trabalho.

Conclusão: Os valores registrados neste trabalho, assim como em outras pesquisas relacionadas a este tema, são guias úteis para interpretar dados bioquímicos de búfalas em diferentes faixas etárias, diferentes regiões geográficas, de diferentes raças e 
submetidos a diferentes sistemas de manejo, servindo de melhor orientação para médicos veterinários atuantes no campo para interpretação de exames laboratoriais e diagnósticos das principais patologias que acometem a função hepática nessa espécie animal. Além disso, esses dados enriquecerão a literatura vigente e servirão de base de dados para pesquisas futuras.

\section{Referências}

ELLAH, Mahmoud Rushdi Abd, HAMED, Maha I, DERAR RI.; RATEB, HZ. Comparative study on reference values for blood constituents during pregnancy in buffaloes (Bubalus bubalis). Journal of Advanced Veterinary Research, v. 3, p. 36 46. Jan. 2013.

FEITOSA, Francisco Leydon F. Semiologia Veterinária.. A arte do diagnóstico: cães, gatos, equinos, ruminantes e silvestres. 2. ed. Roca. São. Paulo 754p. 2008.

FONTES, Deiseane G.; MONTEIRO, Maria Vivina B.; JORGE, Ediene M.; OLIVEIRA, Carlos Magno C.; RITTER, Rhuan A.; BARBOSA NETO, José Diomedes; SILVA FILHO, Ednaldo; MONTEIRO, Frederico O.B. Perfil hematológico e bioquímico de búfalos (Bubalus bubalis) na Amazônia Oriental. Pesquisa Veterinária Brasileira, v.34, n 1, p.57-63, dezemb. 2014.

GEORGE, Jeanne W.; SNIPES, Joy; LANE, V. Michael. Comparison of bovine hematolo-gy reference intervals from 1957 to 2006. Veterinary Clinical Pathology, v 39, n 2, p. 138-148. 2010.

GOMES, Viviani; MADUREIRA, Karina Medici; BLAGITZ, Maiara G.; GALDINO, J.; VANTIM G.; BENESI, Fernando J. Valores de referência e influência do etário sobre os parâmetros bioquímicos utilizados para avaliação da função hepática de bubalinos hígidos da raça Murrah. Ars Veterinária, v.26, n.3, p.128-131, dezemb. 2010a.

GOMES, Viviani; MOURA, Jéssica A.; MADUREIRA, Karina Medici; BAPTISTELLA, Fernanda; KITAMURA, Sandra Satiko; BLAGITZ, Maiara G.; BENESI, Fernando J. Valores de referencia e influencia da idade no eritrograma de bubalinos da raça Murrah. Pesquisa Veterinária Brasileira, v. 30, p.301-304, abril. 2010b. 


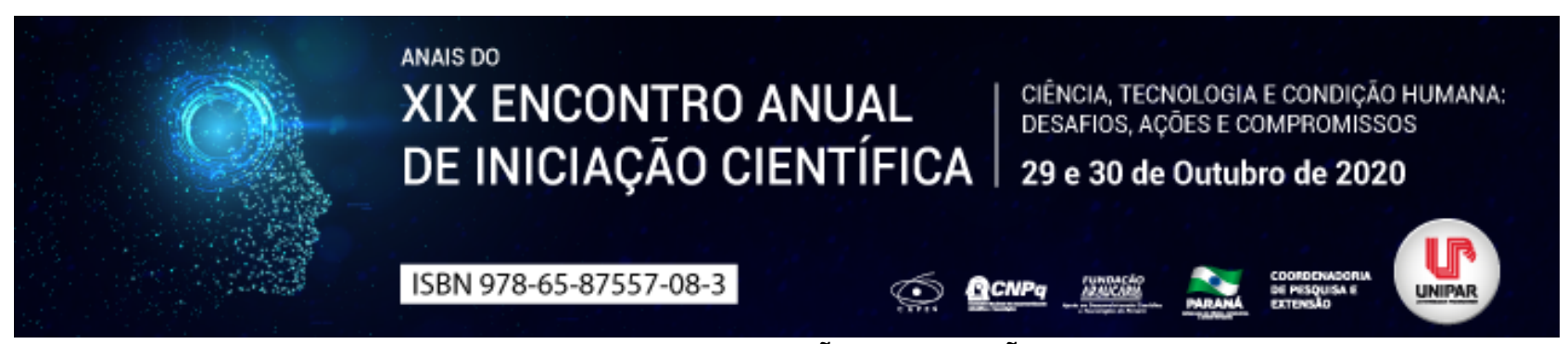

USO DA AUTO-HEMOTERAPIA EM CÃES - REVISÃO DE LITERATURA

\begin{abstract}
${ }^{1}$ Larissa Édina Perin Pereira, ${ }^{2}$ LAURA MARIANA TONETE, ${ }^{3}$ BRUNA BAGATIM DE SOUZA, ${ }^{4}$ BRUNA CAROLINA MARQUARDT, ${ }^{5}$ CAROLINE HELENA ROCHA, ${ }^{6}$ MAURO HENRIQUE BUENO DE CAMARGO
\end{abstract}

\author{
${ }^{1}$ Discente do curso de Medicina Veterinária UEM/Umuarama-PR \\ ${ }^{1}$ Discente do curso de Medicina Veterinária UEM/Umuarama-PR \\ ${ }^{2}$ Discente do curso de Medicina Veterinária UEM/Umuarama-PR \\ ${ }^{3}$ Mestranda no Programa de Pós-Graduação em Produção Sustentável e Saúde Animal UEM/Umuarama-PR \\ ${ }^{4}$ Discente do curso de Medicina Veterinária UEM/Umuarama-PR \\ ${ }^{5}$ Docente do curso de Medicina Veterinária UEM/Umuarama-PR
}

Introdução: a auto-hemoterapia (AHT) é uma prática de uso clínico crescente na medicina veterinária, mas ainda se trata de um procedimento terapêutico sem comprovação científica, por não haver estudos clínicos que comprovem os seus benefícios. No entanto, nos últimos anos, a busca por esse novo procedimento vem aumentando. O processo de retirada do sangue venoso do animal e sua aplicação na musculatura provocam uma resposta imunológica inespecífica, e essa condição pode desencadear a melhora de alguns sinais (CESARINO et al, 2008). A AHT proporciona uma estimulação do sistema imunológico, proporcionando elevação nos anticorpos (SANTOS et al., 2011). O uso da terapia visa prolongar a vida do animal com mais qualidade de vida (QUESSADA et al., 2010).

Objetivo: revisar a literatura acerca da AHT e suas principais aplicações terapêuticas.

Desenvolvimento: é crescente o número de usuários, bem como a lista de doenças que podem ser tratadas com a autohemoterapia, tanto em humanos como em animais. Os antibióticos têm seu campo de ação quase que limitado às doenças bacterianas, enquanto que a imunoterapia específica e inespecífica abrange horizontes bem amplos, quase não restando nenhum campo da patologia humana em que a imunologia não tenha maior ou menor participação em seus mecanismos patogênicos (BACAL et al., 2006). É um procedimento que consiste em aplicações de sangue autólogo, geralmente coletados da veia jugular e aplicados nos músculos semitendinoso ou semimembranoso (QUESSADA et al., 2010; BORGES et al., 2014). O volume de sangue é variável, mas conforme relatado por Borges et al (2014) o volume de sangue varia de acordo com o peso do animal, para animais até $5 \mathrm{~kg}$ estipula-se 2,5ml, animais entre $5 \mathrm{~kg}$ a10kg, $5 \mathrm{ml}$, com 10kg a15kg aplica-se 7,5ml, e 10ml para animais acima de $15 \mathrm{~kg}$. Animais tratados com auto-hemoterapia apresentam melhora significativa para diferentes tipos de enfermidades de forma direta ou em conjunto com outros tratamentos, como dermatites (ROMANO, et al., 2019), papilomas (BAMBO et. al., 2012), tumores venéreos ( CASTRO et. al., 2017) e parvovirose (BORGES et al,2014). Romano (2019) relatou que no tratamento de dermatite atópica a auto-hemoterapia foi eficaz, estabilizou o perfil leucocitário e levou a imunomodelação, além da remissão dos sinais clínicos apresentados (hiperpigmentação, alopecia, prurido e áreas multifocais pruriginosa disseminadas por toda a superfície cutânea). Também se mostrou como um tratamento sem efeitos adversos conhecidos, favorecendo a recuperação do paciente. No caso da parvovirose, Borges et al. (2014) relataram que dez animais tratados com $\mathrm{AHT}$, em conjunto com fármacos, tiveram uma melhora mais rápida em comparação com o grupo que foi tratado somente com fármacos padrão. O custo financeiro dessa técnica é baixo, o que pode permitir auxílio, também, a cães de tutores com restrições financeiras (ROMANO et al, 2019).

Conclusão: A AHT é uma técnica de baixo custo, com baixa necessidade de materiais específicos e de fácil aplicação, porém, apesar de publicações com bons resultados, ainda é uma técnica que exige maior comprovação científica, e estudos padronizados, avaliando se fatores como idade, sexo, ou raça, entre outros, interferem na eficácia do tratamento.

\title{
Referências
}

BACAL, N. S.; BOTELHO, L. G.; SANTOS, M. F. M., IOSHIDA, M.R.; LAZARO, R. J Agregação plaquetária - importância préanalítica evidenciada em 1.058. Centro de hematologia de São Paulo. 2006.

BAMBO, O, Cardoso JMM, Dimande A, Mapatse M, Sntos IFC. Auto-hemoterapia no tratamento da papilomatose oral canina relato de caso. Medvep Dermato-Revista de Educação Continuada em Dermatologia e AlergologiaVeterinária 2012, p.38-44

BORGES, O. M. M.; SOUZA, A. P.; MENDES, R. S.; ARAúJO, K. N.; TORRES, L. M.; DANTAS, A. K. F. P. Clinical effectiveness of autohemotherapy as na adjunct treatment of canine parvovirus. Acta Scientiae Veterinariae, v.42, n.1, p.1-7, 2014.

CASTRO, B.; ALEJANDRO, A.; MARROQUIN, M.; HUMBERTO, E.; ORTIZ, Q.; ALEJANDRA, M.; PARRA, S.; MAURICIO, D. REDVET Revista Electrônica de Veterinária - Autohemoterapia como adyuvante em el tratamiento del Tumor Venéreo 
Transmisible (TVT) en canino: descripción de un caso clínico; v.8 n5, 2017.

CESARINO M., ÁVILA D.F., FERNANDES C.C., SILVA C.B., SCHERER D.L., DIAS T.A.; MENDONÇA C.S., CASTRO J.R. Efeito da autohemoterapia associada com clorabutanol no tratamento da papilomatose oral em cão (Canis familiaris) Relato de caso. In: SEMANA CIENTíFICA DE MEDICINA VETERINÁRIA DE UBERLÂNDIA, 20., 2008, Uberlândia. Universidade Federal de Uberlândia, p. 62.

ROMANO, A.L., Auto-hemoterapia como tratamento para dermatite atópica em cães, 2019, 29f. Trabalho de Conclusão de curso (graduação em Medicina Veterinária) Instituto Federal Goiano, Urutaí, 2019.

QUESSADA, A.M.; CARVALHO, C.J.S.; OLIVEIRA, R.N.; COSTA, P.M. Autohemoterapia como adjuvante no tratamento de mastocitoma em cão: relato de caso. Revista Brasileira de Ciência Veterinária, v.17, n.3/4, p.108-110, 2010.

SANTOS, I.F.C., BAMBO, O., CARDOSO, J.M.M., Dimande, A., Mapatse, M. Uso da autohemoterapia no tratamento da papilomatose oral canina. In: MOSTRA CIENTIFICA DE CIÊNCIAS AGRÁRIAS, 7.,2011, Botucatu.

Coordenadoria de Pesquisa e Extensão - COPEX

Departamento de Editoraçāo e Divulgaçāo Científica - DEDIC 


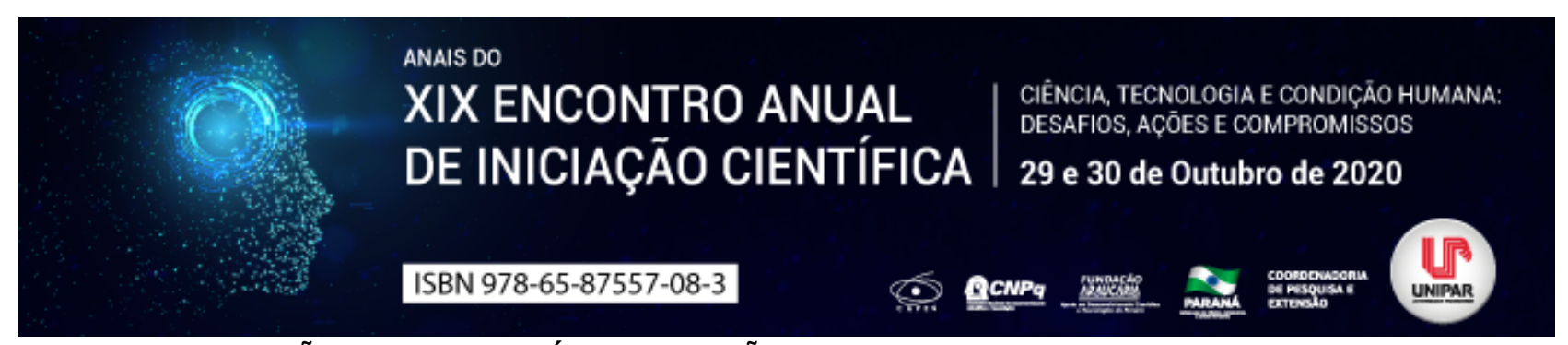

COLETA E AVALIAÇÃO DE MEDULA ÓSSEA EM CÃo POSITIVO PARA Leishmania spp- RELATO DE CASO

\author{
${ }^{1}$ Maria Leticia da Silveira Ames, ${ }^{2}$ GUSTAVO BALDASSO, ${ }^{3}$ MARCONI RODRIGUES DE FARIAS, ${ }^{4}$ RITA MARIA VENANCIO \\ MANGRICH ROCHA
}

\author{
${ }^{1}$ Medica Veterinária aprimoranda em diagnóstico laboratorial \\ ${ }^{1}$ Medico Veterinário aprimorando da clinica medica de pequenos animais \\ ${ }^{2}$ Docente da PUCPR \\ ${ }^{3}$ Docente da PUCPR
}

Introdução: A avaliação da medula óssea (MO) é um exame que necessita de cuidados na fase de obtenção de amostra e, no manuseio das técnicas necessárias. Diversas são as abordagens diagnósticas, as quais variam de acordo com a doença em análise, bem como com as diferentes possíveis causas e a presença ou não de agentes etiológicos com predileção por células proliferativas.

Relato de Caso: Um cão, macho, SRD, com 11 meses, vindo de Limeiras- SP, foi atendido na Clínica Veterinária escola- CVEPUCPR, com quadro de apatia, lesões cutâneas e linfonodomegalia. Já havia sido submetido à tratamento com itraconazol, contudo, sem apresentar melhoras. As alterações observadas nos exames laboratoriais foram: Linfopenia $\left(285 / \mathrm{mm}^{3}\right)$, trombocitopenia $\left(140.000 / \mathrm{mm}^{3}\right)$, proteína plasmática $(11,8 \mathrm{~g} / \mathrm{dL})$ e globulina $(9,3 \mathrm{~g} / \mathrm{dL})$. A partir desses resultados fora sugerido a realização de teste rápido para Leishmania IgG/lgM, o qual resultou positivo. Diante disso, fora realizada a coleta e avaliação da MO. O procedimento foi realizado em ambiente estéril, com o paciente em decúbito ventral sob efeito de anestesia geral. Nesse relato, a punção foi feita na asa do ílio com a agulha illinois ${ }^{\circledR}$. Após a coleta do líquido, foram feitas 15 lâminas pelo método de squash e coradas através do método de may grunwald (MGG). A avaliação quantitativa de diferencial celular se deu a partir da contagem de 500 células proliferativas presentes na $\mathrm{MO}$, as quais foram distribuídas de acordo com as suas características morfológicas e grau de maturação celular das linhagens de eritrócitos, leucócitos e plaquetas. Após a contagem, realizou-se a proporção da relação células mielóides/eritróide, as quais expressam a proporção do número total de células granulocíticas (mielóide) e o total de eritrócitos nucleados da série eritrocitária, o que permitiu o controle da proliferação celular, fundamental para o diagnóstico definitivo de hipoplasias e hiperplasias de quaisquer linhagens celulares presentes (HARVEY, J.W.; 2001). Enquanto que, a avaliação qualitativa fora desenvolvida seguindo as características morfológicas presentes na MO durante a observação da lâmina, incluída a proporção de quantidade celular e gotículas de gordura.

Discussão: As punções da MO podem ser feitas nos ossos longos (fêmur e úmero), ou em ossos achatados (asa do ílio, costelas e esterno), com agulhas apropriadas para a penetração da matriz óssea (MULLER, R. D. C. M.; 2009). De acordo com a literatura, a leishmaniose é transmitida pelo mosquito hematófago, fêmea, da Lutzomyia spp, e causa lesões cutâneas, alterações viscerais e hematopoéticas como, por exemplo, anemias, leucopenias/leucocitose, linfopenia/linfocitose, e distúrbios plaquetários (ALMEIDA, V. A, 2017). Uma pesquisa feita por Carla de Oliveira Honse (2014), demonstrou que as alterações encontradas em MO de animais naturalmente infectados por Leishmania spp eram: hipoplasias ou hiperplasias celular, aumento do estoque de ferro e principalmente a presença de amastigotas fagocitadas por células mono e multinucleadas. Entretanto, no relato supracitado, não foram observadas alterações significativas nas células proliferativas da MO, tampouco observadas presenças de amastigotas, conforme também descrito no estudo realizado por Almeida (2017). A explicação para a linfopenia é a migração destas células para órgãos linfóides acometidos pela Leishmania (HONSE, 2014). A hiperglobulinemia está atrelada à defesa do organismo contra o antígeno (FREITAS, 2012). E a trombocitopenia pode estar relacionada a uma reação imuno-mediada pela exposição ao antígeno (ALMEIDA, 2017).

Conclusão: A leishmaniose é uma zoonose de distribuição mundial, com grande impacto na saúde pública e, deve ser notificada às autoridades competentes, sempre que diagnosticada (BISETTO JÚNIOR, 2015). Em casos de leishmaniose, conclui-se que, é importante dar ênfase à fisiopatogenia da doença, bem como aos exames laboratoriais, e à coleta de MO no prognóstico do paciente positivado para leishmaniose spp. Esses cuidados, verificam-se como essenciais à manutenção da qualidade de vida do animal e para detectar o correto tratamento.

\title{
Referências
}

ALMEIDA, V. A.; Alterações na medula óssea e distúrbios hematológicos na leishmaniose visceral canina: 101. f Tese do doutorado (pós- graduação em Patologia Humana)- Universidade Federal da Bahia, Salvador- BA, 2017.

BISETTO JUNIOR, A. et al. Manual técnico de leishmanioses caninas. Curitiba, 2015. Disponível em: https://www.crmvpr.org.br/uploads/publicacao/arquivos/Manual-tecnico-de-leishmanioses-caninas.pdf. Acesso em: 28, jul. 2020. 
FREITAS, J. C. C.; et. al. Clinical and laboratory alterations in dogs naturally infected by Leishmania chagasi. Revista da Sociedade Brasileira de Medicina Tropical, Rio de Janeiro, v. 45, n. 1, p. 24-29, 2012.

HARVEY, J.W. Atlas of veterinary hematology: blood and bone marrow of domestic animals. Philadelphia: W.B. Saunders Company, 2001. 228p.

HONSE, C. O. Avaliação citopatológica da medula óssea e perfil hematológico de cães naturalmente infectados por Leishmania (Leishmania) chagasi. Rio de Janeiro; 2014. 81f. Tese [Doutorado em Pesquisa Clínica em Doenças Infecciosas] Instituto de Pesquisa Clínica Evandro Chagas.

MULLER, R. D. C. M.; et al.; Técnicas e sítios de coleta de medula óssea em cães e gatos: Revisão bibliográfica. ciência Rural, Santa Maria- SC, v.39, n.1, p. 141- 147, jan.2009.

Coordenadoria de Pesquisa e Extensão - COPEX

Departamento de Editoraçāo e Divulgaçāo Científica - DEDIC 


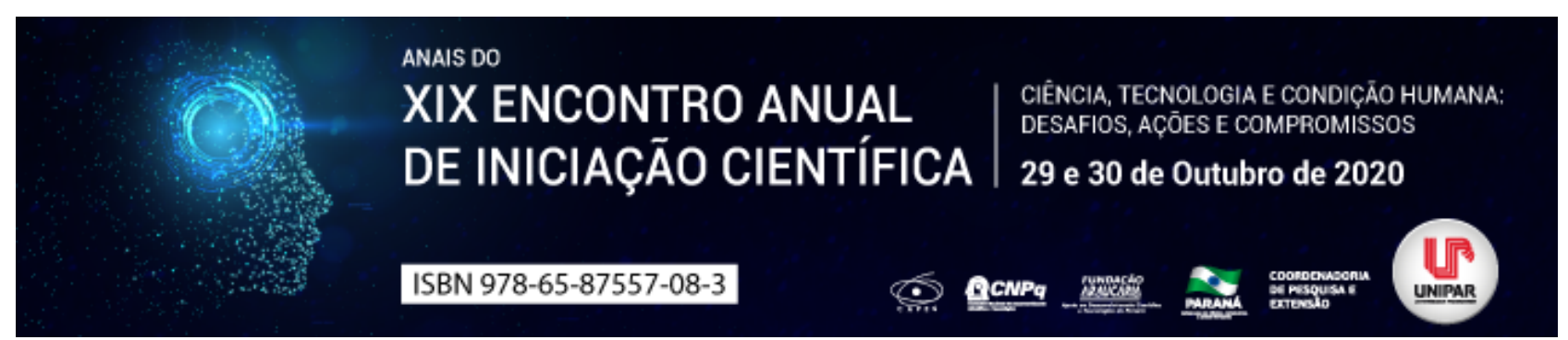

FLAP CONJUNTIVAL OCULAR EM EQUINO COM ÚLCERA DE CÓRNEA APÓS LESÃO TRAUMÁTICA

\begin{abstract}
${ }^{1}$ Danthyse Miyoko Ohno Müller de Souza, ${ }^{2}$ JEFERSON CARLOS GANDINI, ${ }^{3}$ LUCAS VALEIRAS GADDINI, ${ }^{4}$ DEREK WILLY GALDIOLI SILVEIRA, ${ }^{5}$ MAYARA NAYANE SACOMAN ROCHA NEVES, ${ }^{6}$ MAX GIMENEZ RIBEIRO
\end{abstract}

\begin{abstract}
${ }^{1}$ Médico Veterinário Residente em Clínica Médica e Cirúrgica de Grandes Animais UEM/Campus Umuarama-PR
${ }^{1}$ Médico Veterinário Residente em Clínica Médica e Cirúrgica de Grandes Animais UEM/Campus Umuarama-PR

${ }^{2}$ Médico Veterinário Residente em Clínica e Cirurgia de Grandes Animais com Ênfase em Anestesiologia UEM/Campus Umuarama-PR

${ }^{3}$ Discente do curso de Medicina Veterinária UEM/Campus Regional de Umuarama-PR

${ }^{4}$ Discente do curso de Medicina Veterinária UEM/Campus Regional de Umuarama-PR

${ }^{5}$ Docente do curso de Medicina Veterinária UEM/Campus Regional de Umuarama-PR
\end{abstract}

Introdução: As enfermidades oftalmológicas em equinos possuem diferentes etiologias e patogenias que podem comprometer a qualidade da visão em graus variados. A ocorrência dessas afecções na clínica veterinária de equinos varia de $3 \%$ a $27 \%$, comumente diagnosticadas são as doenças da úvea, com prevalência de aproximadamente $50 \%$ e as de córnea, com prevalência de até $28 \%$ das afecções oftalmológicas (SOMMER, 1984; SZEMES \& GERHARDS, 2000). Embora seja uma das enfermidades mais comuns da clínica médica equina, a úlcera de córnea é um dos problemas mais desafiadores na oftalmologia, uma vez que o sucesso no tratamento é menos frequente quando comparado a outras espécies. A córnea dos equinos tem o maior tempo de cicatrização e maior probabilidade de infecção, dessa maneira os resultados são piores. Os equinos possuem olhos proeminentes favorecendo acidentes traumáticos, sendo esta a causa principal para o desenvolvimento de ulceras de córnea, deste modo as infecções secundárias precisam ser consideradas.

Relato de caso: Foi atendido há campo no estado do Mato Grosso do Sul um equino fêmea SRD de oito anos de idade que pesava 380 quilos $(\mathrm{Kg})$. O animal não era domado e seria utilizado apenas para reprodução, a mesma apresentava alterações no olho esquerdo. Durante anamnese o proprietário relatou que o animal foi encontrado enroscado em uma cerca com o lado da afecção em contato com o chão o que possivelmente levou ao trauma. No exame clínico geral realizado o animal apresentava-se de acordo com os parâmetros vitais dentro dos limites fisiológicos. No exame clínico especifico foram observados a presença de míase, opacidade da córnea, blefaroespasmo, lacrimenjamento intenso, hiperemia conjuntival, edema, hipópio e dor ocular, caracterizado pela relutância ao toque, como o propósito do atendimento era outro, nossos recursos eram escassos sendo possível somente a inspeção ocular e o teste de fluoresceína que tem como objetivo detectar úlceras, avaliar a integridade da córnea, determinar a qualidade da película lacrimal e avaliar a potência do ducto nasolacrimal. Após o exame foi possível constatar a presença de úlcera de córnea profunda com possível perfuração ocular mas sem extravasamento do humor aquoso. O tratamento de escolha foi flap conjuntival que consiste na transposição do tecido da conjuntiva bulbar ou palpebral para a superfície corneana lesionada, já que permite a cicatrização precoce da córnea devido ao grande aporte vascular conjuntival. Além de tudo é uma técnica de simples realização facilitando a visualização de estruturas ao redor da lesão. A medicação pré anestésica foi feita com xilazina à $0,8 \mathrm{mg} / \mathrm{kg}$ pela via intravenosa (IV), e indução anestésica intravenosa com cetamina (2.2 $\mathrm{mg} / \mathrm{kg}$ ) associada a diazepam $(0.11 \mathrm{mg} / \mathrm{kg})$. Após indução, foi realizado técnicas de anestesia regional com bloqueio peribulbar com $10 \mathrm{ml}$ de lidocaína e bloqueio do nervo auriculopalpebral com $3 \mathrm{ml}$ de lidocaína. Iniciou-se lavagem do globo ocular utilizando solução fisiológica, retirada de miíases e assim realizado antissepsia. Em seguida fizemos um debridamento da córnea e realizou-se uma incisão em região dorsal de conjuntiva bulbar e divulsão da mesma até o local de lesão corneana. Para finalizar, prosseguiu-se com a ráfia do flap sobre a córnea, utilizando fio poliglactina $n^{\circ} 6,0$ e padrão de sutura simples separado e fechamento parcial da pálpebra com nylon $n^{\circ} 0$ Foi prescrito para o pós operatório anti-inflamatório flunexin meglumine $8 \mathrm{ml}$ uma vez ao dia durante 5 dias, via intravenosa, antibiótico penicilina $12 \mathrm{ml}$ uma vez ao dia durante 7 dias, via intramuscular, pomada epitesan e colírio Still por 7 dias. Após 30 dias foi retirado a sutura da pálpebra e observou-se melhora significativa na córnea e nos sinais clínicos que não eram mais evidentes.

Resultado e Discussões: Como já foi citado o prognostico no tratamento de úlceras é muito reservado, ainda mais em casos como estes, com úlcera de córnea profunda e possível perfuração do globo ocular, a princípio o tratamento de escolha era a enucleação devido as condições no qual o animal se encontrava e por ser uma afecção de difícil cicatrização. Embora exista riscos no procedimento escolhido o mesmo é um dos mais indicado para esse tipo de problema. Como descrito por (SMITH, 1994) onde os procedimentos cirúrgicos mais comumente empregados para ulceração de córnea são: algum tipo de pedículo conjuntival, transposição córneo esclerótica, ceratoplastia e tarsorrafia. Neste caso optou-se pelo flap conjuntival. Que dentre os riscos deste procedimento os mais comuns são complicações na cicatrização em tempo apropriado, apresentam infecção 
secundária, tem fonte progressiva de irritação ou nova ulceração, têm um componente colagenase, associando-se a vascularização da córnea ou se agravam apesar do tratamento apropriado (REED; BAYLY, 2000). Nessa situação não tivemos nenhuma alteração ou complicação e o mesmo apresentou uma melhora em 30 dias.

Conclusão: Apesar dos riscos e complicações que comumente acometem este tipo de caso, o procedimento de escolha apresentou boa recuperação e uma boa aparência estética.

\section{Referências}

REED, S. M.; BAYLY, W. M. Medicina Interna Equina. 1 ed. Rio de Janeiro, RJ: Guanabara, 2000. p. 635-645.

SOMMER, U. Vorkommen und Behandlung von Augenkrankheiten beim Pferd. 100f. Tese (Doutorado em Medicina Veterinária) - Pós-graduação em Medicina Veterinária, Tierärztliche Hochschule Hannover,1984.

SMITH, B. P. Tratado de Medicina Interna de Grandes Animais. 1. ed. v. 2. São Paulo, SP: Manole, 1994. p. 1199-1200.

SZEMES, P.; AGERHARDS, H. Untersuchungen zur Prävalenz der equinen rezidivierenden Uveitis im Grobraum Köln Bonn.

Praktischer Tierarzt, v. 81, n. 5, p. 408-420, 2000. 


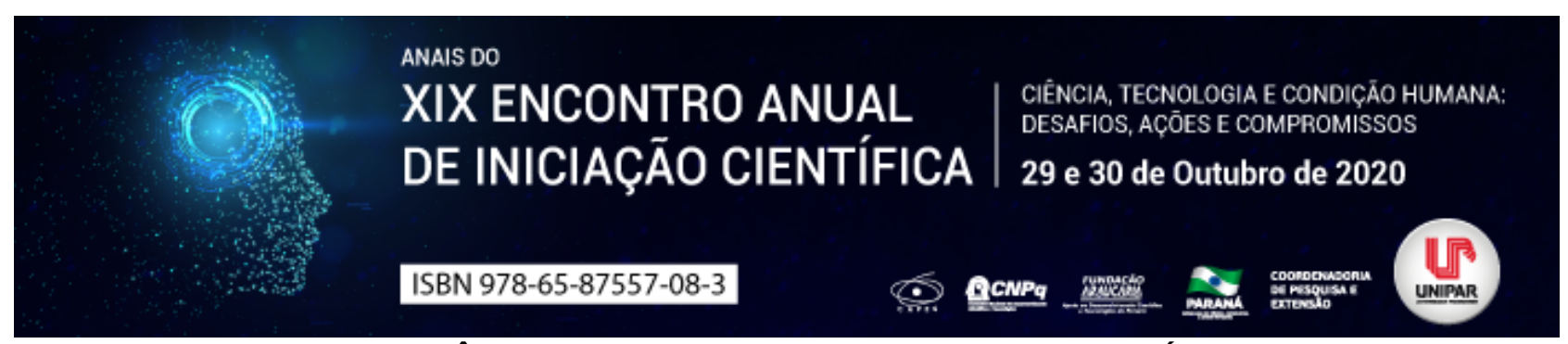

RESISTÊNCIA ANTIMICROBIANA: UMA AMEAÇA INVISÍVEL

\title{
${ }^{1}$ CRISTIANA PINTO DE SOUZA, ${ }^{2}$ DIELY MELONARI DALLA COSTA
}

\author{
${ }^{1}$ Acadêmica do curso de Biomedicina da UNIPAR \\ ${ }^{1}$ Docente da UNIPAR
}

Introdução: A resistência antimicrobiana é tida como ameaça à saúde pública mundial pois compromete a eficácia de antibióticos utilizados no combate à infecções comuns (FRACAROLLI et al, 2007). Cerca de 700 mil pessoas morrem ao ano no mundo por resistência antimicrobiana e a estimativa é que em 2050 esse número aumentará para 10 milhões (WHO, 2019). A resistência acontece naturalmente entre os microrganismos em seu processo evolutivo, mas o uso excessivo e inapropriado, más condições de saneamento básico, aumento de pacientes imunodeprimidos, e muitas vezes tratamentos empíricos, permitem com que esse processo aconteça com maior rapidez e de forma disseminada (TEIXEIRA et al., 2019).

Objetivo: Abordar o desafio da resistência antimicrobiana como ameaça para a saúde da população e a importância de ações conscientes no manejo de antimicrobianos.

Desenvolvimento: Antimicrobianos são substâncias capazes de impedir o desenvolvimento ou destruir fungos e bactérias. São chamados de bactericidas quando destroem e bacteriostáticos quando impedem o desenvolvimento, podendo ser produzidos de forma natural no metabolismo de um microrganismo ou de forma artificial industrial (GUIMARÃES et al, 2010). A resistência dos microrganismos pode ser intrínseca (resistente naturalmente) ou adquirida, que ocorre por meio de alterações genéticas, como modificação cromossomal e por troca de material genético com outros microrganismos (TRAVOSSOS e MIRANDA, 2010). Há diversos mecanismos de resistência aos antimicrobianos, como a produção microbiana de enzimas que destroem ou alteram os antimicrobianos, alterações na permeabilidade da membrana plasmática microbiana, modificação no local de atuação do antimicrobiano, bombeamento ativo do antimicrobiano para fora do microrganismo e criação de biofilmes (COSTA e JUNIOR, 2017). O tratamento para infecções com microrganismos resistentes é geralmente mais demorado pela dificuldade de tratamentos eficazes e de maior custo devido hospitalização prolongada e necessidade de alteração de antibióticos diferentes dos utilizados inicialmente (LOUREIRO et al., 2016). Segundo a Organização Mundial de Saúde (2020), ações de controle e prevenção devem ser tomadas em todos os âmbitos sociais, desde o indivíduo na tomada dos antimicrobianos somente com orientações médicas, visto que o uso irracional contribui com a resistência adquirida, o setor político na promoção de programas que esclareçam à população a gravidade da resistência e oriente cuidados pertinentes, os profissionais de saúde na prescrição correta e cuidados de higiene durante suas atividades, para evitar a veiculação de infecções, e até mesmo o setor agrário, visto que os antimicrobianos também fazem parte do manejo do solo e da terapêutica dos animais. Além destas ações, o combate à emergência de infecções por microrganismos resistentes também pode ser abordado por meio de programas e diretrizes próprios, elaborados pelos órgãos competentes de cada país, incentivados pela Organização Mundial da Saúde (ANVISA, 2017). Conclusão: $O$ conhecimento e aplicabilidade de ações que evitem o surgimento de novos microrganismos resistentes é de extrema importância e determinante no combate dessa problemática que, cada vez mais, apresenta índices elevados de letalidade e preocupa órgãos mundiais de saúde. A ausência de antimicrobianos eficazes contra os resistentes também serve de estímulo para grupos de pesquisa, que buscam novos compostos com características promissoras para o desenvolvimento de novos fármacos.

\section{Referências}

AGÊNCIA NACIONAL DE VIGILÂNCIA SANITÁRIA (ANVISA). Diretriz Nacional para Elaboração de Programa de Gerenciamento do Uso de Antimicrobianos em Serviços de Saúde. Gerência de Vigilância e Monitoramento em Serviços de Saúde - GVIMS Gerência Geral de Tecnologia em Serviços de Saúde - GGTES Brasília, 28 de dezembro de 2017.

COSTA, Anderson Luiz Pena; SILVA JUNIOR, Antonio Carlos Souza. Resistência bacteriana aos antibióticos e Saúde Pública: uma breve revisão de literatura. Estação Científica (UNIFAP), v. 7, n. 2, p. 45, 2017.

FRACAROLLI, Isabela Fernanda Larios; OLIVEIRA, Samuel Andrade; MARZIALE, Maria Helena Palucci. Colonização bacteriana e resistência antimicrobiana em trabalhadores de saúde: revisão integrativa. Acta Paulista de Enfermagem, v. 30, n. 6, p. $651657,2017$.

GUIMARÃES, Denise Oliveira; MOMESSO, Luciano Silva; PUPO, Mônica Tallarico. Antibióticos: Importância terapêutica e perspectivas para a descoberta e desenvolvimento de novos agentes. Química Nova, v. 33, n. 3, p. 667 679, 2010.

LOUREIRO, Rui João; ROQUE, Fátima; RODRIGUES, Antonio Teixeira; HERDEIRO, Maria Tereza; RAMALHEIRA, Elmano. O uso dos antibióticos e as resistências bacterianas: breves notas sobre a sua evolução. Revista portuguesa de saúde pública, v.35, n. 1, p.74-84, 2016. 
TEIXEIRA, Alysson Ribeiro.; FIGUEIREDO, Ana Flávia Costa.; FRANÇA, Rafaela Ferreira. Resistência Bacteriana Relacionada Ao Uso Indiscriminado De Antibióticos. Revista Saúde em Foco, v. 11, p. 853 875, 2019.

TRAVOSSOS, Ingrid. O.; MIRANDA, Kelly. C. V. Resistência bacteriana como consequência do uso inadequado antibióticos. Infarma, v. 22, n. 5/6, p. 54-59, 2010.

WORLD HEALTH ORGANIZATION (WHO). Antibiotc resistance, 2020. Disponível em: https://www.who.int/news-room/factsheets/detail/antibiotic-resistance. Acesso em: 27 ago. 2020.

WORLD HEALTH ORGANIZATION (WHO). No Time to Wait: Securing the future from drug-resistant infections. Report to the Secretary-General of the United Nations. April, 2019.

Coordenadoria de Pesquisa e Extensão - COPEX

Departamento de Editoraçāo e Divulgaçāo Científica - DEDIC 


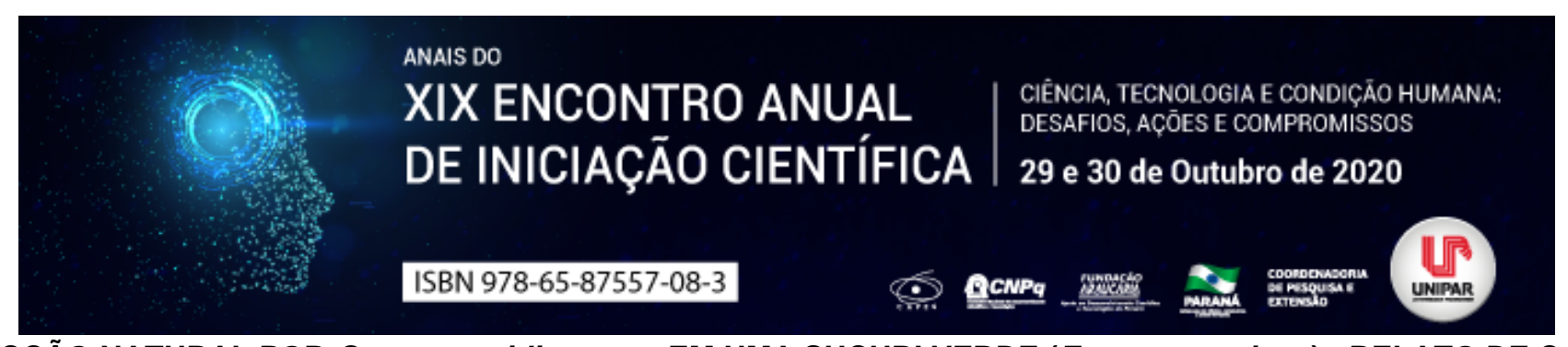

INFECÇÃO NATURAL POR Cryptosporidium spp. EM UMA SUCURI VERDE (Eunects murinus) - RELATO DE CASO

\begin{abstract}
${ }^{1}$ Vinicius Dahm, ${ }^{2}$ ARTHUR COLOMBARI CHENG, ${ }^{3}$ KARIM CRISTHINE PASE MOTAGNINI, ${ }^{4}$ JULIANA DAS CHAGAS GOULART, ${ }^{5}$ ALCIDES BRANCO DA SILVA JÚNIOR, ${ }^{6}$ ALINE DE MARCO VIOTT
\end{abstract}

\author{
${ }^{1}$ Discente da Universidade Federal do Paraná-Setor Palotina \\ ${ }^{1}$ Programa de Residência em Medicina Veterinária da UFPR-Palotina \\ ${ }^{2}$ Mestranda em Ciência animal pela Universidade Federal do Paraná Setor Palotina \\ ${ }^{3}$ Programa de Residência em Medicina Veterinária da UFPR-Palotina \\ ${ }^{4}$ Médico Veterinário Autônomo São Paulo \\ ${ }^{5}$ Docente da Universidade Federal do Paraná-Setor Palotina
}

Introdução: A criptosporidiose é uma enfermidade oportunista causada pelo protozoário do gênero Cryptosporidium spp., conhecida por ocorrer tanto em animais como em humanos. O coccídeo apresenta ciclo monóxeno, diferindo-se de outros coccídeos, pois apresentam quatro esporozoítos sem a presença de esporocistos. Durante o ciclo há a formação de dois tipos de oocistos, a maioria apresentam a parede espessa, forma resistente as condições ambientais e eliminada nas fezes, e o segundo apresenta a parede delgada, os quais rompem-se ainda dentro do hospedeiro e liberam os esporozoítos, sendo esse o mecanismo da autoinfecção (PAIVA, 2012).

Duas espécies do gênero Cryptosporidium são responsáveis pela infeção em répteis, sendo Cryptosporidium serpentis o mais comum em serpentes e o $C$. saurophilum em lagartos. Apesar de nas outras espécies animais a infecção por este coccídeo ser autolimitante, em serpentes a doença tem caráter crônico podendo levar, em grande parte dos casos, a morte do animal mesmo em pacientes imunocompetentes (XIAO et al., 2004).

Em serpentes, diferentemente da grande maioria dos animais, o parasitismo ocorre na mucosa gástrica, levando a uma gastrite hipertrófica com perda da morfologia normal da mucosa pela formação de tecido conjuntivo e dilatação dos túbulos gástricos (GREINER, 2003). As manifestações clínicas observadas são anorexia, emagrecimento, regurgitação, aumento de volume em região gástrica (terço médio) e morte (PAIVA, 2012).

O objetivo do presente estudo foi relatar um caso de infecção natural por Cryptosporidium spp. em uma Eunects murinus (Sucuri verde) de vida livre, bem como a caracterização histopatológica das lesões em mucosa gástrica.

Relato de Caso: Foi remetido ao Laboratório de Patologia Veterinária (LPV) da Universidade Federal do Paraná Setor Palotina um fragmento de mucosa estomacal de uma Eunects murinus de vida livre, de $15 \mathrm{~kg}$, com histórico de aumento de volume em porção final de segundo terço medindo aproximadamente 15 centímetros de diâmetro. Na microscopia, observou-se hiperplasia difusa acentuada das células da mucosa estomacal, os quais arranjavam-se em pólipos estruturados sobre densa matriz colagenosa. Por vezes, havia proliferação do epitélio gástrico em meio ao estroma colagenoso formando ácinos bem diferenciados e áreas multifocais leves de hemorragia. Somadas a essas alterações, notou-se em meio as células hipertrofiadas da mucosa, estruturas parasitárias refringentes com aproximadamente $2 \mu \mathrm{m}$ de diâmetro compatíveis com Cryptosporidium spp.

Discussão: Apesar das infecções por Cryptosporidium serpentis serem mais comuns em serpentes de cativeiro (GREINER, 2003), existem relatos em animais de vida livre, como observado no presente caso.

Esse animal apresentava histórico de aumento de volume em terço médio semelhando ao observado em outros trabalhos que descrevem lesões por Cryptosporidium em repteis. (Paiva 2012). O diagnóstico de gastrite por protozoário causada por Cryptosporidium foi possível devido a evidenciação de formas parasitárias na mucosa gástrica, porem nem sempre esse agente é observado (Carvalho 2018). O Cryptosporidium induz à proliferação de células da mucosa gástrica, com atrofia de glândulas gástricas, excesso de secreção de muco. Essas lesões acarretam em gastrite hiperplásica levando a aumento da espessura da parede estomacal e das pregas longitudinais, aumento do diâmetro do estômago e redução do lúmen gástrico. A gastrite hiperplásica observada na microscopia do presente caso foi condizente com a lesão causada pelo protozoário e compatível com o achado clínico de aumento de volume abdominal. Em contrapartida Brower e Cranfield (2001) não observaram nenhuma lesão histopatológica no estômago das serpentes estudadas demonstrando que o agente pode estar presente sem causar qualquer tipo de lesão associada. A relevância do Cryptosporidum serpentis à saúde pública ainda não é bem elucidada, visto que não há relatos da infecção em humanos (ZAHEDI et al., 2016). Entretanto, existem trabalhos recentes em bovinos infectados (CHEN \& QUIU, 2012), demonstrando que a epidemiologia da transmissão desse agente pode sofrer alterações. Outros estudos devem ser realizados para demonstrar sua real importância em um contexto de Saúde Única.

Conclusão:Com base nos achados microscópicos pôde-se confirmar o diagnóstico clínico de Criptosporidiose, ressaltando a importância do exame histopatológico como ferramenta de diagnóstico. 


\section{Referências}

BROWER, A. I.; CRANFIELD, M. R. Cryptosporidium sp.-associated enteritis without gastritis in rough green snakes (Opheodrys aestivus) and a common garter snake (Thamnophis sirtalis). Journal of Zoo and Wildlife Medicine, v. 32, n. 1, p. 101 105, 2001.

CARVALHO, T. J. F. Parasitas gastrointestinais em répteis de uma coleção comercial. Dissertação (Mestrado em Medicina Veterinária) Universidade de Lisboa, Lisboa, 2018.

CHEN, F.; QIU, H. Identification and characterization of a Chinese isolate of Cryptosporidium serpentis from dairy cattle. Parasitology Research, v. 111, n. 4, p. 1785 1791, 11 out. 2012.

GREINER, E. C. Coccidiosis in reptiles. Seminars in Avian and Exotic Pet Medicine, v. 12, n. 1, p. 4956 , jan. 2003.

PAIVA, P. R. S. de O. Avaliação clínica, sorológica e parasitológica de serpentes naturalmente infectadas com Cryptosporidium serpentis. Dissertação (Mestrado em Epidemiologia experimental aplicada às zoonoses) Faculdade de Veterinária e Zootecnia da Universidade de São Paulo, São Paulo, 2012.

XIAO, L. et al. Genetic Diversity of Cryptosporidium spp. in Captive Reptiles. Applied and environmental Microbiology, v. 70, n. 2, p. $891899,2004$.

ZAHEDI, A. et al. Public health significance of zoonotic Cryptosporidium species in wildlife: Critical insights into better drinking water management. International Journal for Parasitology: Parasites and Wildlife, v. 5, n. 1, p. 88-109, 1 abr. 2016.

Coordenadoria de Pesquisa e Extensão - COPEX

Departamento de Editoraçāo e Divulgaçāo Científica - DEDIC 


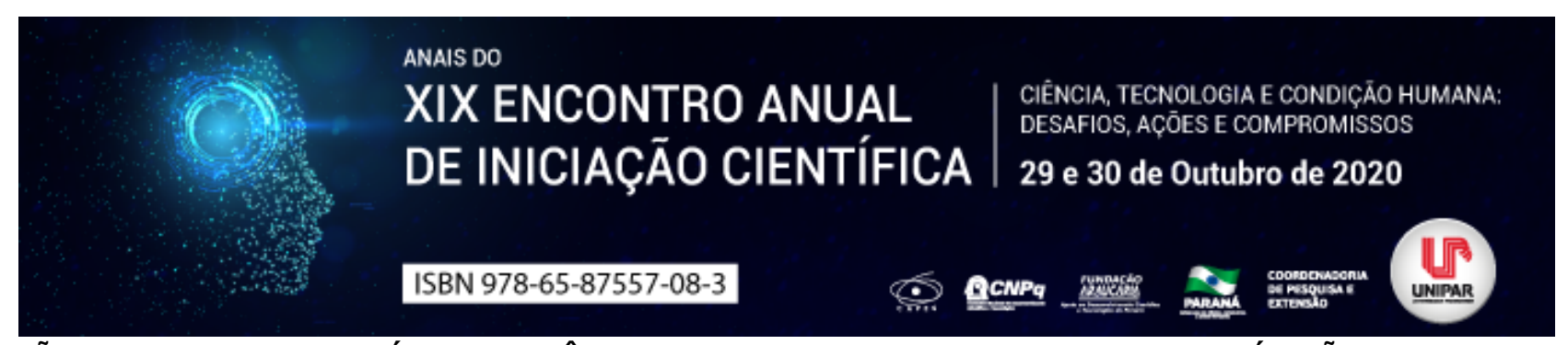

\title{
AVALIAÇÃO DE TOXICIDADE APÓS USO CRÔNICO DE Vitex Megapotâmica (SPRENG) EM ÓRGÃOS DE METABOLISMO E EXCREÇÃO
}

\author{
${ }^{1}$ MARIA DAMARIS RIBEIRO CAVALCANTE, ${ }^{2}$ ALAN DA SILVA LISBOA, ${ }^{3}$ JOAO ANTONIO BERTA DE OLIVEIRA, ${ }^{4}$ YURI \\ PELICANO DOMINGUES, ${ }^{5}$ GUILHERME DONADEL, ${ }^{6}$ EMERSON LUIZ BOTELHO LOURENCO
}

\author{
${ }^{1}$ Acadêmico bolsista do PIBIC/UNIPAR \\ ${ }^{1}$ Acadêmico do Curso de Medicina VeterinÃiria da UNIPAR \\ ${ }^{2}$ Acadêmico do Curso de Medicina VeterinÃ iria da UNIPAR \\ ${ }^{3}$ Acadêmico do Curso de Medicina VeterinÃ iria da UNIPAR \\ ${ }^{4}$ Discente do Mestrado em Ciência Animal e Produtos Bioativos \\ ${ }^{5}$ Docente da UNIPAR
}

Introdução: A Vitex megapotamica (Spreng) Moldeke, é uma planta utilizada na medicina tradicional como adjuvante na terapêutica de várias enfermidades. Sua indicação de uso popular abrange de afecções reumáticas, distúrbios pulmonares, antiinflamatória entre outras (CZERNIEWICZ et al., 2017; ZANATTA et al., 2007). No entanto, os dados sobre o efeito da Vitex Megapotamica descritos na literatura são escassos no que se diz respeito à utilização segura da planta. A fitoterapia realiza uma efetiva contribuição no que se diz respeito à saúde. Por isto, faz-se cada vez mais necessário garantir que a ação terapêutica seja constante e identificar os efeitos adversos, garantindo assim a qualidade. A comprovação de processos analíticos deve garantir, através de pesquisas, a eficácia do medicamento (KLEIN et al., 2009). Os efeitos toxicológicos das plantas podem ou não estar presentes, o que agrava a utilização para fins terapêuticos apenas com o conhecimento empírico. E por este motivo, as realizações de testes toxicológicos são de extrema necessidade, pois somente desta forma, pode-se averiguar a segurança para o uso da fitoterapia (FERNANDES et al., 2016).

Objetivo: Avaliar os efeitos do tratamento com doses repetidas (90 dias) por via oral com o Extrato Metanólico Vitex Megapotamica em ratos, machos e fêmeas.

Materiais e Métodos: Para determinação da toxicidade oral pré-clínica subcrônica do Extrato Metanólico Vitex Megapotâmica (EMVM) os animais foram divididos em 4 grupos com 8 animais por sexo em cada grupo (OECD, 1998). Para cada grupo foi administrado por via oral (com auxílio de uma sonda orogástrica rígida), uma vez o dia (pela manhã), diferentes doses do EMVM ou veículo por 90 dias, em um volume constante $5 \mathrm{~mL} / \mathrm{kg}$. Grupo Controle: água filtrada $5 \mathrm{~mL} / \mathrm{Kg}$, Grupos tratamento: (100, $300 \mathrm{e}$ $900) \mathrm{mg} / \mathrm{kg}$ do EMVM. A dose de $100 \mathrm{mg} / \mathrm{kg}$ corresponde a dose terapêutica para ratos. A partir dela foram determinadas as demais doses. A maior dose, $900 \mathrm{mg} / \mathrm{Kg}$, foi calculada através da aplicação do fator de segurança, 10 vezes a dose terapêutica. Uma dose intermediária de $300 \mathrm{mg} / \mathrm{Kg}$ foi estipulada visando identificar se os efeitos tóxicos que podem ser encontrados são ou não dose-dependente. Os animais tiveram seu peso corporal registrado diariamente e sinais de toxicidade como diarréia, piloereção, tremores, salivação e convulsões, foram monitorados durante todo o período experimental (90 dias). Todos os procedimentos experimentais realizados foram aprovados pelo Comitê de Ética e Pesquisa Envolvendo Experimentação Animal (CEPEEA) da UNIPAR, sob o protocolo no 31622/2017.

Resultados: Não foi possível verificar diferenças significativas em relação aos parâmetros avaliados de peso relativo e absoluto de fígado, rim, e baço de ratos machos e fêmeas tratados com EMVM nas doses de 100, 300 e $900 \mathrm{mg} / \mathrm{kg}$. Os dados estão representados através de seus grupos pela média e erro padrão. Peso relativo do fígado, grupo controle $2,51 \pm 0,07$, dose $100 \mathrm{mg}$ $2,47 \pm 0,07$, dose $300 \mathrm{mg} 2,37 \pm 0,08$, dose $900 \mathrm{mg} 2,44 \pm 0,05$, peso relativo do rins, grupo controle $0,23 \pm 0,02$, dose $100 \mathrm{mg}$ $0,29 \pm 0,00$, dose $300 \mathrm{mg} 0,28 \pm 0,01$ dose $900 \mathrm{mg} 0,30 \pm 0,00$, peso relativo do baço, grupo controle $0,15 \pm 0,01$, dose $100 \mathrm{mg}$ $0,15 \pm 0,00$, dose $300 \mathrm{mg} 0,14 \pm 0,00$ dose $900 \mathrm{mg} 0,14 \pm 0,00$ sendo esses valores encontrados no grupo dos ratos machos, já na categoria das fêmea o peso relativo do fígado no grupo controle foi de $2,52 \pm 0,13$, dose $100 \mathrm{mg} 2,50 \pm 0,07$, dose $300 \mathrm{mg} 2,53 \pm 0,09$

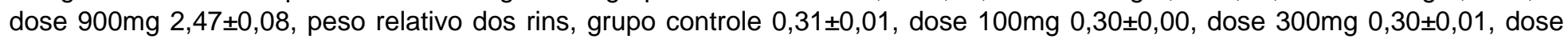
$900 \mathrm{mg} 0,29 \pm 0,00$, peso relativo do baço, grupo controle $0,19 \pm 0,00$, dose $100 \mathrm{mg} 0,18 \pm 0,01$, dose $300 \mathrm{mg} 0,20 \pm 0,01$, dose $300 \mathrm{mg}$ $0,20 \pm 0,00$, valores de $p<0,05$ pelo teste ANOVA de duas vias seguido pelo teste de Bonferroni.

Discussão: No presente estudo, não foram observadas alterações significativas no peso relativo e absoluto de fígado, rins e baço de ratos machos e fêmeas tratados com o EMVM. Porém, até o presente momento não existia nenhum estudo toxicológico para avaliar a segurança do uso da Vitex megapotamica por um período de 90 dias, relacionado ao peso relativo dos órgãos.

Conclusão: Concluímos que o extrato de $V$. megapotamica não se apresentou tóxico para os animais no período de tratamento nas doses propostas, não sendo observado diferenças significativas em relação ao peso absoluto e relativo dos órgãos avaliados, propondo assim, que o extrato utilizado não apresentou toxicidade no período avaliativo. 


\section{Referências}

CZERNIEWICZ, A. et al. Plants from the Brazilian Traditional Medicine: species from the books of the Polish physician. Revista Brasileira de Farmacognosia, Curitiba, v. 27, n. 1812, p. 388 400, 2017.

FERNANDES, M. P. C.; FÉLIX, R. S.; NOBRE, O. M. Toxicity of herbal medicines with interest to SUS: a review. Semina: Ciências Biológicas e da Saúde, Londrina, v. 37, n. 1, p. 83-96, jan./jun., 2016.

KLEIN, T. et al. Fitoterápicos: um mercado promissor. Revista Ciência Farmacêutica Básica Aplicada-Unesp, Araraquara, v. 30, n. 3, p. 241-248, 2009.

ZANATTA, L. et al. Effect of crude extract and fractions from Vitex megapotamica leaves onhyperglycemia in alloxan-diabetic rats. Journal of Ethnopharmacology, Lausanne, n. 109, p. 151-154, feb., 2007.

Coordenadoria de Pesquisa e Extensāo - COPEX

Departamento de Editoraçāo e Divulgaçāo Científica - DEDIC 


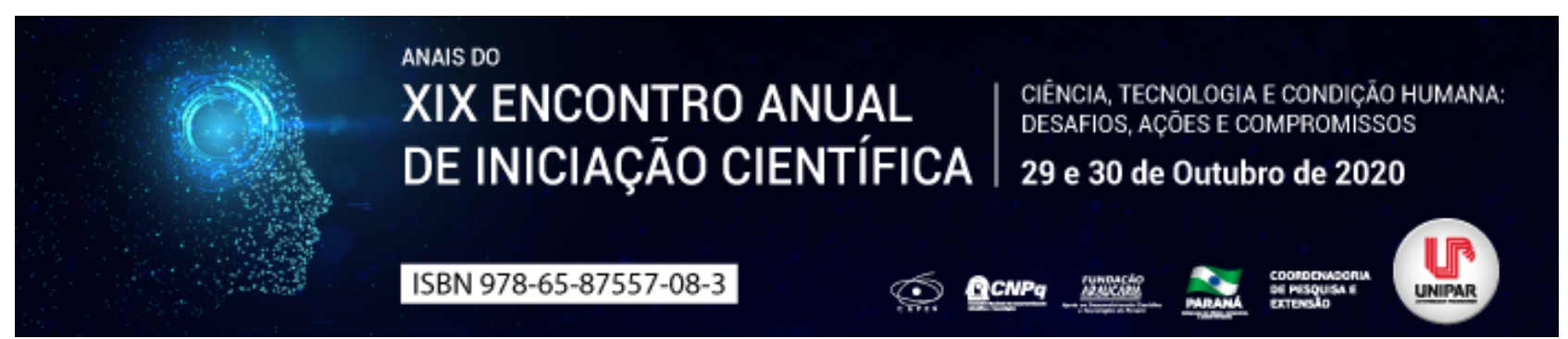

DIFERENCIAÇÃO GENÉTICA DE DOIS MORFOTIPOS DE Piper regnellii (Miq.) C. DC. var regnellii

\begin{abstract}
${ }^{1}$ Jean Silva de Souza, ${ }^{2}$ JÉSSICA DE SOUZA ALVES, ${ }^{3}$ THOMAZ MANSINI CARRENHO FABRIN, ${ }^{4}$ EZILDA JACOMASSI, ${ }^{5}$ LUCIANO SERAPHIM GASQUES
\end{abstract}

\begin{abstract}
${ }^{1}$ Programa de Pós-Graduação em Bioinformática - Universidade Federal do Paraná - UFPR - Curitiba-PR
${ }^{1}$ Programa de Pós-Graduação em Química - Universidade Estadual de Maringá - UEM - Maringá-PR

${ }^{2}$ Programa de Pós-graduação em Ecologia de Ambientes Aquáticos Continentais - Universidade Estadual de Maringá - UEM Maringá-PR

${ }^{3}$ Docente de Mestrado Profissional em Plantas Medicinais e Fitoterápicos na Atenção Básica - Universidade Paranaense UNIPAR - Umuarama-PR

${ }^{4}$ Docente do Curso de Medicina - Universidade Paranaense - UNIPAR Umuarama-PR
\end{abstract}

Introdução: Piper regnellii conhecida popularmente como pariparoba ou caapeba, é uma planta herbácea pertencente à família Piperaceae, distribuída em regiões tropicais e subtropicais (SALATINO; SILVA, 1975). As folhas de Piper são utilizadas como extrato bruto em atividade anti-inflamatória, antitumoral e atividade inibitória (GUO et al., 2019; FUERTES et al., 2018). No entanto, as semelhanças morfológicas entre as diferentes espécies de Piper acarretam problemas na identificação de suas espécies, resultando em identificações errôneas (SALATINO; SILVA, 1975). Neste sentido, a análise da diversidade genética das espécies de plantas, assim como, a análise da delimitação de espécies e de filogenias tem sido efetivamente auxiliada por análises de sequências específicas de DNA, e extensivamente utilizadas para estabelecer relações filogenéticas entre as espécies (KOBAYASHI; FUSE; TAMURA, 2019). Neste trabalho identificamos dois morfotipos de P. regnellii var. regnellii utilizando a sequência parcial da região intergênica $t r n L-t r n F$ como marcador genético.

Objetivo: Identificar dois morfotipos de Piper regnellii (Miq.) C. DC var. regnellii, utilizando como marcador genético a sequência parcial da região intergênica $t r n L-t r n F$.

Material e Métodos: As amostras foram coletadas a partir das folhas de dois morfotipos de $P$. regnelli provenientes do Horto Medicinal do Campus 2 da Universidade Paranaense no município de Umuarama-PR. A extração do DNA foi realizada utilizando o kit PureLink TM Genomic Plant DNA Purification Kit conforme o protocolo especificado. A amplificação do locus trnL-trnF foi realizada através da reação em cadeia da polimerase (PCR) com os primers descritos por Reid, Plunkett e Peters (2006): trn-c-F (5'-GGAAATCGGTAGACGCTACG-3') e trn-f-R (5'-ATTTGAACTGGTGACACGAG-3'). A PCR foi conduzida em termociclador com um ciclo inicial de $94^{\circ} \mathrm{C}$ por $3 \mathrm{~min}$; seguida de 40 ciclos de $94^{\circ} \mathrm{C}$ por $30 \mathrm{~s} ; 53^{\circ} \mathrm{C}$ por $30 \mathrm{~s} \mathrm{e} 72^{\circ} \mathrm{C}$ por 3 min. Os amplicons obtidos foram visualizados por eletroforese horizontal em gel de agarose $1 \%$ e sua purificação ocorreu conforme o protocolo descrito por Rosenthal, Coutelle e Craxton (1993). As amostras foram sequenciadas utilizando o primer Forward Trn-c-F em sequenciador $A B I$. $O$ resultado do sequenciamento foi editado conforme a qualidade de cada nucleotídeo, fazendo uso do software UGENE v. 34. Em seguida, procedeu-se a busca de sequências homólogas por alinhamento local com o algoritmo BLASTn. Por fim, utilizou-se o software MEGAX para alinhar as sequências de $P$. regnellii com sequências de Piper com a região trnL-trnF do GenBank.

Resultados: A região trnL-trnF das amostras de $P$. regnellii sequenciadas foram confirmadas utilizando o BLASTn. O alinhamento final apresentou $495 \mathrm{pb}$. As sequências editadas foram submetidas ao GenBank porém os seus IDs não estão disponíveis. A comparação entre as sequências dos dois morfotipos e as sequências de Piper, evidenciou 23 sítios variáveis no total $(4,65 \%)$. Os valores da distância evolutiva entre todas as sequências avaliadas variaram entre $0.0 \%$ à $3.6 \%$. A média da distância intraespecífica para as espécies com duas ou mais sequências foi $0.0 \%$. No entanto, o locus estudado foi capaz de diferenciar os dois morfotipos de $P$. regnellii na posição 280 do alinhamento, alegando a diferença de um indel entre os dois morfotipos, gerando $0.2 \%$ de diferença entre eles.

Discussão: As sequências também foram submetidas à análise BLASTn e resultaram em altas similaridades com sequências de Piper, assim como Roslim e Heman (2017) com as sequências de Gluta, porém, o GenBank não tinha sequências de P. regnellii para confirmá-las, mas tinha sequências de outras espécies do gênero Piper. Outros estudos têm trabalhado com a região trnLtrnF apresentando-a como um bom marcador molecular na análise de relações filogenéticas (BUERKI et al., 2012), distinção de espécies e identificação de novas espécies (YURTSEVA; KUZNETSEVA; MAVRODIEV, 2016). Os resultados mostraram que os dois morfotipos pertencem, possivelmente, a uma mesma espécie, mas quando é feita a identificação usando um DNA barcoding, é necessário que tenha a sequência da mesma região do organismo de interesse em um banco de dados públicos como o GenBank, porém, o GenBank não tinha as sequências da região trnL-trnF para $P$. regnellii.

Conclusão: A utilização do marcador molecular trnL-trnF revelou ser eficaz na identificação da espécie estudada, porém, não 


\section{Referências}

BUERKI, Sven et al. Straightening out the screw-pines: A first step in understanding phylogenetic relationships within Pandanaceae. Mol. Phyl. Pand., v. 61, n. 5, p. 1010-1020. 2012.

FUERTES, Cesar, M. et al. Actividad inhibitoria in vitro de extractos etanólicos de plantas del génera Anno y Piper sobre promastigotes de Leishmania braziliensis. Rev Peru Med Integrativa, v. 3, n. 3, p. 112-117. 2018.

GUO, Ziyan et al. Anti-inflammatory and antitumour activity of various extracts and compounds from the fruits of Piper longum L. Journ. Pharmacy. Pharmaco., v. 71, p. 1162-1171. 2019.

KOBAYASHI, Yukihiro, H.; FUSE, Shizuka; TAMURA, Minoru, N. Biosystematic Studies on the Family Piperaceae(Piperales) I. Plastid DNA Phylogeny and Chromosome Number of Peperomia subgenus Micropiper. Acta Phyto. Geobot., v. 70, n.1, p. 1-17. 2019.

REID, Jill, D.; PLUNKETT, Gregory, M.; PETERS, Gerald, A. Phylogenetic relationships in the heterosporous fern genus Azolla (Azollaceae) based on DNA sequence data from three noncoding regions. Int. Journ. Plant Scien., v. 167, n. 3, p. 529-538. 2006.

ROSENTHAL, André; COUTELLE, Oliver. Large-scale production of DNA sequencing templates by microtitre format PCR. Nuc. Aci. Res., v. 21, n. 1, p. 173-174. 1993.

ROSLIM, Dewi, Indriyani; HERMAN, Herman. Application of rpf16 Intron and trnL-trnF Intergenic Spacer Sequences to Identify Rengas Clone Riau. Biosaintifika, v. 9, n. 2, p. 209-216. 2017.

SALATINO, Antonio; SILVA, José, Bozani da. Anatomia e óleo essencial das folhas de Piper regnellii (miq.) C. Dc. Var. Regnellii. Bol. Bot. USP, v. 3, p. 95-106. 1975.

YURTSEVA, Olga; KUZNETSOVA, Oxana, I.; MAVRODIEV, Evgeny, V. A broadly sampled 3-loci plastid phylogeny of Atraphaxis (Polygoneae, Polygonoideae, Polygonaceae) reveals new taxa: I. Atraphaxis kamelinii spec. nov. from Mongolia. Phytotaxa, v. 268, n. 1, p. 1-24. 2016. 


\title{
ANAIS DO \\ XIX ENCONTRO ANUAL | CIĖNCIA, TECNOLOGIA E CONDIÇĀO HUMANA: DE INICIAC̄̃̃ CIENTÍ́FICA AC̄öES E COMPROMISSOS \\ DE INICIAÇÃO CIENTÍFICA 29 e 30 de Outubro de 2020 \\ ISBN 978-65-87557-08-3 \\ ons \\ ERITROGRAMA, LEUCOGRAMA E CONTAGEM DE PLAQUETAS DE BÚFALAS JAFARABADI ADULTAS EM LACTAÇÃO, CRIADAS EM PROPRIEDADE NO ESTADO DE SÃO PAULO
}

\author{
${ }^{1}$ Paulo Roberto de Abreu Tavares, ${ }^{2}$ DANIELA GOMES DA SILVA, ${ }^{3}$ ANA CAROLINE CANDIA PALHANO, ${ }^{4}$ JOSÉ JURANDIR \\ FAGLIARI, ${ }^{5}$ ANDRÉ MARCOS SANTANA
}

\begin{abstract}
${ }^{1}$ Discente do curso de Medicina Veterinária da Universidade Estadual de Maringá/Campus de Umuarama
${ }^{1}$ Pós-Graduanda do Departamento de Clínica e Cirurgia Veterinária, FCAV/UNESP, Campus de Jaboticabal

${ }^{2}$ Discente do curso de Medicina Veterinária da Universidade Estadual de Maringá/Campus de Umuarama

${ }^{3}$ Docente do Departamento de Clínica e Cirurgia Veterinária, FCAV/UNESP, Campus de Jaboticabal

${ }^{4}$ Docente do curso de Medicina Veterinária da Universidade Estadual de Maringá
\end{abstract}

Introdução: No Brasil, o búfalo (Bubalis bubalis) é reconhecido como um animal rústico , que tem a capacidade de se adaptar e manter sua produção (CARVALHAL \& COSTA, 2018). Apesar de encontrarmos alguns estudos avaliando o perfil hematológico de búfalos adultos sadios (ELLAH et al., 2013a, ELLAH et al., 2013b), muitos destes avaliam os valores de referência em animais em diferentes condições climáticas (regiões), diferentes sistemas de manejo e alimentação e com diferentes raças. Dessa forma, é sempre importante que se estude valores de referência para animais sadios levando-se em consideração estes fatores, pois diferenças no eritrograma e leucograma podem ser atribuídas à temperatura ambiente, ao tipo e quantidade de alimento fornecido, ao sistema de manejo e a raça, entre outros (PRITCHARD et al., 2009).

Objetivo: Levando em consideração essas informações, este trabalho teve como objetivo avaliar o eritrograma, o leucograma e a contagem de plaquetas de búfalas adultas sadias em lactação, entre 3 e 10 anos de idade, criadas em uma propriedade situada no estado de São Paulo.

Material e Métodos: Coletou-se amostras de búfalas Jafarabadi adultas em lactação $(n=23)$, de uma propriedade situada no estado de São Paulo. O estado de saúde dos animais que participaram do experimento foi verificado por exame físico geral (FEITOSA, 2008) e temperatura retal. De cada amostra de sangue venoso, coletadas mediante punção da veia jugular em tubos siliconados contendo anticoagulante EDTA, foram aferidos dados referentes ao eritrograma (contagem de hemácias - He, concentração de hemoglobina - Hb, hematócrito - Ht), leucograma (leucócitos totais, linfócitos, neutrófilos segmentados - NS, neutrófilos bastonetes - NB, monócitos, eosinófilos e basófilos) e contagem de plaquetas, em aparelho automático. A contagem diferencial de leucócitos foi realizada a partir da contagem em esfregaço sanguĩneo corado de 100 células, em microscopia óptica (GARCIA-NAVARRO; PACHCALY, 1994). Os índices hematimétricos VCM, HCM e CHCM também foram calculados. Os resultados foram dispostos na forma de média e desvio padrão.

Resultados: Apenas os animais que se apresentaram sadios após a realização do exame físico geral participaram do experimento. A temperatura retal dos animais variou entre 35,6 a $38,3^{\circ} \mathrm{C}$. Os resultados das variáveis hematológicas analisadas

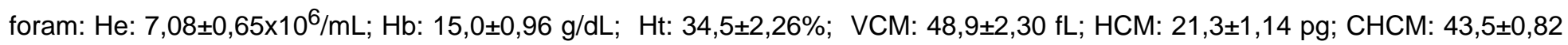
g/dL; número de plaquetas: $205 \pm 54,7 \times 10^{3} / \mu \mathrm{L}$; Leucócitos totais: $9430 \pm 1390 / \mu \mathrm{L}$; Linfócitos: $3410 \pm 1040 / \mu \mathrm{L} ; \mathrm{NS}$ : $4870 \pm 1150 / \mu \mathrm{L}$; NB: 33 $\pm 46 / \mu \mathrm{L}$; Monócitos: $146 \pm 102 / \mu \mathrm{L}$; Eosinófilos: $875 \pm 259 / \mu \mathrm{L}$; Basófilos $87 \pm 113 / \mu \mathrm{L}$.

Discussão: Parâmetros hematológicos obtidos em búfalos da raça Murrah, de oito meses a dois anos de idade, criados na Amazônia Oriental (FONTES et al., 2014), mostraram contagem de He $\left(7,60 \pm 1,80 \times 10^{6} / \mathrm{mL}\right.$ ) maiores que os encontrados em nosso trabalho. Além disso, comparado ao nosso trabalho, estes autores (FONTES et al., 2014) também evidenciaram menores concentrações de $\mathrm{Hb}(11,1 \pm 1,80 \mathrm{~g} / \mathrm{dL}), \mathrm{HCM}(14,8 \pm 1,90 \mathrm{pg})$ e CHCM $(31,8 \pm 2,60 \mathrm{~g} / \mathrm{dL})$, além de maiores contagens de plaquetas $\left(327 \pm 139 \times 10^{3} / \mu \mathrm{L}\right)$, linfócitos $(8100 \pm 3700 / \mu \mathrm{l})$ e monócitos $(300 \pm 900 / \mu \mathrm{l})$. Segundo esses autores (FONTES et al., 2014), alguns desses parâmetros podem sofrer influência devido a variações fisiológicas relacionadas ao sexo e idade dos animais, corroborando com as observações de Gomes et al., (2010), que argumentaram que as oscilações relacionadas com as faixas etárias são importantes fatores a serem levados em consideração na interpretação do eritrograma de animais da espécie bubalina e no diagnóstico das enfermidades que acometem estes animais.

Conclusão: Conclui-se que os valores médios obtidos neste trabalho para variáveis que constituem o hemograma de búfalas em lactação, visando a criação de valores de referência para animais criados no Estado de São Paulo, podem futuramente ser utilizados por médicos veterinários atuantes no campo para interpretação de alterações laboratoriais que ocorrem nas principais patologias que acometem essa categoria de animais, nessa faixa etária.

\section{Referências}


CARVALHAL, Monique Valéria de Lima; COSTA, Franciely de Oliveira. Produção e bem-estar de búfalas (Bubalus bubalis) leiteiras: uma revisão. Revista acadêmica: ciência animal. DOI: 10.7213/1981-4178.2018.161102, maio 2018.

ELLAH, Mahmoud Rushdi Abd, HAMED, Maha I, DERAR RI... Serum biochemical and hematological reference values for lactating buffaloes. Comparative Clinical Pathology. DOI 10.1007/s00580-013-1760-2, June 2013a.

ELLAH, Mahmoud Rushdi Abd, HAMED, Maha I, DERAR RI.; RATEB, HZ. Comparative study on reference values for blood constituents during pregnancy in buffaloes (Bubalus bubalis). Journal of Advanced Veterinary Research, v. 3, p. 36 46. Jan. 2013b.

FEITOSA, Francisco Leydson F. Semiologia Veterinária.. A arte do diagnóstico: cães, gatos, equinos, ruminantes e silvestres. 2. ed. Roca. São. Paulo 754p. 2008.

FONTES, Deiseane G.; MONTEIRO, Maria Vivina B.; JORGE, Ediene M.; OLIVEIRA, Carlos Magno C.; RITTER, Rhuan A.; BARBOSA NETO, José Diomedes; SILVA FILHO, Ednaldo; MONTEIRO, Frederico O.B. Perfil hematológico e bioquímico de búfalos (Bubalus bubalis) na Amazônia Oriental. Pesquisa Veterinária Brasileira, v.34, n 1, p.57-63, dezemb. 2014.

GARCIA-NAVARRO, Carlos Eugenio Kantek; PACHCALY, José Ricardo. Manual de hematologia veterinária. Varela, São Paulo 169p. 1994.

GOMES, Viviani; MOURA, Jéssica A.; MADUREIRA, Karina Medici; BAPTISTELLA, Fernanda; KITAMURA, Sandra Satiko; BLAGITZ, Maiara G.; BENESI, Fernando J. Valores de referencia e influencia da idade no eritrograma de bubalinos da raça Murrah. Pesquisa Veterinária Brasileira, v. 30, p.301-304, abril. 2010.

PRITCHARD, Joy C.; BURN, Charlotte C.; BARR, Alistair RS.;WHAY, Helen R. Haematological and serum biochemical reference values for apparently healthy working horses in Pakistan. Research in Veterinary Science, v. 87, p. 389-395, May 2009. 


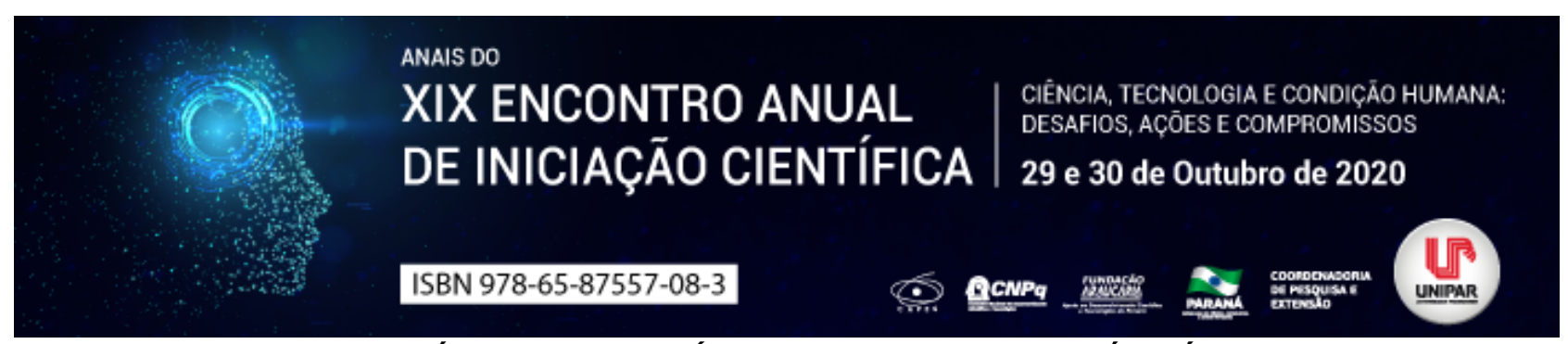

PROBIÓTICOS E BENEFÍ́CIOS PROPORCIONADOS Á SAÚDE

\title{
${ }^{1}$ LUANA DE OLIVEIRA BARBOZA, ${ }^{2}$ DIELY MELONARI DALLA COSTA
}

\author{
${ }^{1}$ Acadêmica do curso de Biomedicina da UNIPAR \\ ${ }^{1}$ Docente da UNIPAR
}

Introdução: O termo probiótico, originado da Grécia, significa para vida e, inicialmente, determinava compostos ou extratos de tecidos capazes de estimular o desenvolvimento microbiano (LILLY e STILLWELL, 1965 apud CHEN e WALKER, 2005). Atualmente, a definição de probiótico mais aceita internacionalmente é a de microrganismos vivos que, quando administrados em quantidades adequadas, conferem um benefício a saúde do hospedeiro (UNFAO/WHO, 2002).

Objetivo: Demonstrar, a partir da literatura existente, os benefícios promovidos pelos probióticos, bem como sua origem e modo de ação no organismo humano.

Desenvolvimento: A procedência dos resultados convenientes pelo uso de probióticos foi demonstrada no início do século $X X$ pelo microbiologista russo Eli Metchnikoff. A partir da observação de povos da região dos Bálcans, levantou a teoria de que a vida poderia ser prolongada pela ingestão diária de leites fermentados (PEREIRA, 2012). Os probióticos auxiliam controlando a microbiota intestinal, mantendo a mesma estável após uso de antimicrobianos, proporcionam resistência gastrointestinal à colonização de organismos patogênicos, concedem melhor digestão de lactose em indivíduos intolerantes pela quebra do composto, amenizam a constipação, permitem elevada absorção de minerais e produzem vitaminas (PEREIRA, 2012). A utilização de probióticos também é eficaz na prevenção de diarreias em crianças desnutridas ou em pacientes hospitalizados, diarreia dos viajantes, diarreia associada a antibióticos, bem como outras diarreias bacterianas e contra atividade de Helicobacter pylori (LINARES, ROSS e STANTON, 2015; GUARNER e MALAGELADA, 2003). Também já demonstraram potencial capacidade de regular níveis de colesterol e estimular a angiogênese intestinal (KERRY et al., 2018). Entre os gêneros probióticos destacam-se Bifidobacterium e Lactobacillus, principalmente L. acidophilus (BALDEÓN, NARANJO e GRANJA, 2008). Podem ser isolados do trato gastrointestinal de mamíferos e também são encontrados em alimentos fermentados, ou ainda como medicamentos e suplementos alimentares (PEREIRA, 2012). O real mecanismo de ação do probióticos não está inteiramente determinado, sendo sugerido o mesmo atribuído à microbiota intestinal: redução da permeabilidade intestinal com produção de mucina, que reduz o trânsito de bactérias e suas toxinas, competição por nutrientes essenciais e por sítios de adesão no epitélio intestinal, excluindo cepas patógenas, produção de substâncias antimicrobianas e estimulação do sistema imune na produção de compostos anti-inflamatórios (MORAIS e JACOB, 2006; CAST, 2007; JUNGERSEN et al., 2014).

Conclusão: De acordo com esta revisão, foi possível observar a importância dos probióticos e sua utilização, sendo que, mesmo seu mecanismo de ação não estando perfeitamente elucidado, evidências científicas já confirmam diversos efeitos benéficos capazes de promover melhor qualidade de vida ao usuário.

\section{Referências}

BALDEÓN MANUEL, NARANJO GABRIELA, GRANJA DIEGO. Effect of infant formula with probiotics on intestinal microbiota. Archivos Latinoamericanos de Nutricion, v. 58 n.1 p. 5-11, 2008.

CAST (Council for Agricultural Science and Technology. 2007. Probiotics: Their Potential to Impact Human Health. Issue Paper 36, Ames, lowa.

CHEN CHANG CHIN, WALKER ALLAN. Probiotics and prebiotics: role in clinical disease states. Adv Pediatr, v. 52 n.1, p. 77-113, 2005.

FAO/WHO (Food and Agriculture Organization/Organization/World Health). Working Group Report on Drafting Guidelines for the Evalution of Probiotics in Food. Londres, Ontário, Canadá: FAO/WHO, 2002.

GUARNER, Francisco; MALAGELADA, Juan-R. Gut flora in health and disease. The Lancet, v. 360, p. 512-519, 2003.

JUNGERSEN, Mikkel; WIND, Anette; JOHANSEN, Eric; CHRISRTENSEN, Jeffrey E; STUER-LAURIDSEN, Birgitte; ESKESEN, Dorte. The Science behind the Probiotic Strain Bifidobacterium animalis subsp. lactis BB-12. Microorganisms, v. 2, p. 92-110, 2014.

KERRY, Rout George; PATRA, Jayanta Kumar; GOUDA, Sushanto; PARK, Yooheon; SHIN, Han-Seung; DAS, Gitishree. Benefacion of probiotics for human health: A review. Journal of Food and Drug Analysis, v. 26, p. 927-939, 2018.

LINARES, Daniel M; ROSS, Paul; STANTON, Catherine. Beneficial Microbes: The pharmacy in the gut. Bioengineered, v. 7, n. 1, p. 11-20, 2016.

MORAIS, Mauro Batista; JACOB, Cristina Miuke Abe. O papel dos probióticos e prebióticos na prática pediátrica. Jornal de Pediatria, v. 82, n. 5, 2006. 
PEREIRA, Beatriz Silva. Seleção de Meio de Cultura para Determinação da Viabilidade de Bifidobactérias Durante a Vida de Prateleira de Bebida Láctea Fermentada com Soro de Leite Nanofiltrado. 2012. 108 f. Dissertação (Mestrado em Ciências de Alimentos) Universidade Federal de Minas Gerais, Belo Horizonte, 2012.

Coordenadoria de Pesquisa e Extensão - COPEX

Departamento de Editoraçāo e Divulgaçāo Científica - DEDIC 


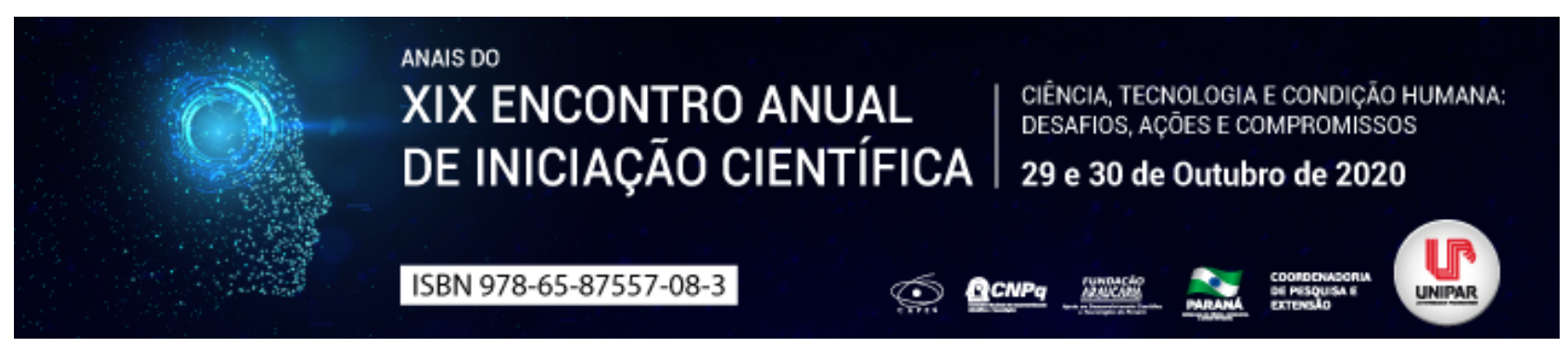

ADIANTAMENTO DA PUBERDADE EM NOVILHAS

\begin{abstract}
${ }^{1}$ BRUNO ARGENTON DE BARROS, ${ }^{2}$ ALYSON LIBERALI ARAUJO, ${ }^{3}$ HUGO HENRIQUE MARTIN CAMPOS, ${ }^{4}$ NATHALIA SOUZA JAMARCHI, ${ }^{5}$ DANIELLE ANDRESSA OLIVEIRA SESTARI, ${ }^{6}$ ROSIARA ROSARIA DIAS MAZIERO
\end{abstract}

\author{
${ }^{1}$ Acadêmico bolsista PIBIC/CNPQ \\ ${ }^{1}$ Acadêmico do Curso de Mestrado Em Ciencia Animal Com Enfase Em Produtos Bioativos - Turma Xiv da UNIPAR \\ ${ }^{2}$ Acadêmico do Curso de Medicina Veterin $\tilde{A}_{j}$ ria da UNIPAR \\ ${ }^{3}$ Acadêmico bolsista do PIBIC/CNPQ \\ ${ }^{4}$ Dicente de mestrado do programa de pós-graduação em ciência animal-taxista CAPES/PROSUP-UNIPAR \\ ${ }^{5}$ Docente da UNIPAR
}

Introdução: A indução da ciclicidade é uma das vantagens determinantes para uma boa produtividade e lucratividade na pecuária. A antecipação de idade ao primeiro parto (IPP) é uma das manobras mais utilizadas na pecuária para se obter uma maior eficiência, gerando mais lucratividade na cadeia e carne e leite (DIAS et al., 2004). O atraso para o primeiro estro e consequentemente a concepção tardia pode acarretar a perdas de econômicas. Vários hormônios são utilizados para induzir ciclicidade e também fazer uma boa antecipação da primeira ovulação pós-parto em primíparas melhorando o desempenho dessa categoria (MENEGHETTI e VASCONCELOS, 2008).

Objetivo: Revisar sobre os protocolos de indução da ciclicidade utilizando progesterona injetável, para um aumento na taxa de concepção e gestação em novilhas.

Desenvolvimento: De acordo com o Instituto Nacional de Geografia e Estatística (IBGE, 2018), existem cerca de 213,5 milhões cabeças de gado no Brasil, estando atrás apenas da Índia, a qual ocupa o primeiro lugar número de bovinos no mundo. Neste seguimento, pode-se notar que a pecuária moderna busca novas biotecnologias para a diminuição no período de serviço e no aumento da eficiência reprodutiva do rebanho (FREITAS, 2015). O uso das biotécnicas aplicadas à reprodução proporciona uma melhor genética e assim, agrega maior valor aos animais, favorecendo um bom retorno econômico. Entretanto, ainda verificamos que o uso dessas biotécnicas são limitadas no Brasil, visto que apenas $13 \%$ das matrizes são inseminadas artificialmente (BARUSELLI, 2019). Um dos hormônios indispensáveis é a prostaglandina (PGF2a) que apresenta como ação principal a lise do corpo lúteo, possibilitando uma nova dominância de crescimento folicular. Quando se utiliza da PGF2a, o nível de progesterona (P4) sérica diminui, isto pode levar uma pequena perda na taxa de concepção. Desta forma, pode-se associar a aplicação de progesterona (P4) juntamente com a PGF2a, possibilitando que a taxa de concepção seja maior (CARVALHO, 2004). Outro hormônio utilizado nos protocolos de inseminação artificial em tempo fixo é o GnRH (hormônio liberador de gonadotrofinas) uma vez que apresenta relação direta com a diminuição da perda embrionária, pela elevação do nível de progesterona circulante, além de auxiliar no aumento do folículo pré-ovulatório, gerando um corpo lúteo maior (MOHAMMADI, 2019).Existem diversos protocolos para o adiantamento da ciclicidade em novilhas, a uma diferença significativa entre novilhas nelores (Bos taurus indicus) e as cruzadas (Bos taurus taurus), as novilhas cruzadas tem uma puberdade antecipada que pode atingir aos 15 meses, já as nelores podem levar até 36 meses de idade para atingir a puberdade, um dos motivos que podem levar o animal a ter a puberdade tardia são os fatores ambientais, como época de nascimento, doenças e principalmente a nutrição (NOGUEIRA, 2004). Assim, o protocolo mais utilizado para a indução de puberdade encontrado no mercado é a inserção de dispositivo intravaginal de progesterona que permanece durante 12 dias no animal, após esse período é feita a aplicação de uma fonte exógena de estrógeno. Alguns estudos buscam formas mais práticas e menos evasivas para fazer a substituição do dispositivo intravaginal por progesterona injetável, assim pode-se utilizar de outras estratégias para a indução da puberdade, principalmente para as fazendas que não possuem o dispositivo previamente utilizado (SÁ FILHO et al., 2012).

Conclusão: Conclui-se que os protocolos hormonais para adiantamento da ciclicidade em novilhas deve estar associado a outros fatores como época de nascimento, doenças e principalmente a nutrição. Além disso, existem diferenças no tipo de administração utilizada, como intramuscular ou intravaginal. Assim, entendendo estes fatores, espera-se que as novilhas possam adiantar a puberdade e consequentemente, elevar a taxa de concepção desta categoria animal.

\title{
Referências
}

BARUSELLI, Pietro Sampaio et al. Estratégias para aumentar a produção de embriões em bovinos. Rev. Bras. Reprod. Anim, v. 43, n. 2, p. 315-326, 2019.

CARVALHO, João Batista Pereira de. Sincronização da ovulação com dispositivo intravaginal de progesterona (CIDRÂ®) em novilhas Bos indicus, Bos indicus x Bos taurus e Bos taurus. 2004. Tese de Doutorado. Universidade de São Paulo. 
DIAS, Laila Talarico; EL FARO, Lenira; ALBUQUERQUE, Lúcia Galvão de. Estimativas de herdabilidade para idade ao primeiro parto de novilhas da raça Nelore. Revista Brasileira de Zootecnia, v. 33, n. 1, p. 97-102, 2004.

FREITAS, Bruno Gonzalez de. Influência do desenvolvimento corporal na resposta aos programas de sincronização para inseminação artificial em tempo fixo em novilhas Nelore de 14 meses de idade. 2015. Tese de Doutorado. Universidade de São Paulo.CIDADES, I. B. G. E. Instituto Brasileiro de Geografia e Estatística. 2018.

MENEGHETTI, M.; VASCONCELOS, José Luiz Moraes. Mês de parição, condição corporal e resposta ao protocolo de inseminação artificial em tempo fixo em vacas de corte primíparas. Arquivo Brasileiro de Medicina Veterinária e Zootecnia, v. 60, n. 4, p. 786-793, 2008.

MOHAMMADI, Abolfazl; SEIFI, Hesam A .; FARZANEH, Nima. Efeito da administração de prostaglandina F2a e GnRH no momento da inseminação artificial sobre o desempenho reprodutivo de vacas leiteiras. In: Fórum de Pesquisa Veterinária . Faculdade de Medicina Veterinária, Universidade Urmia, Urmia, Irã, 2019. p. 153

NOGUEIRA, GP Puberdade em bovinos bos indicus (Zebu) da América do Sul. Ciência da reprodução animal , v. 82, p. 361372, 2004.

SÁ FILHO, M. F. et al. Manejo reprodutivo estratégico e IATF em novilhas e vacas primíparas zebuínas de corte. SIMPósıo INTERNACIONAL DE REPRODUÇÃO ANIMAL APLICADA, v. 5, 2012.

Coordenadoria de Pesquisa e Extensão - COPEX

Departamento de Editoraçāo e Divulgaçāo Científica - DEDIC 


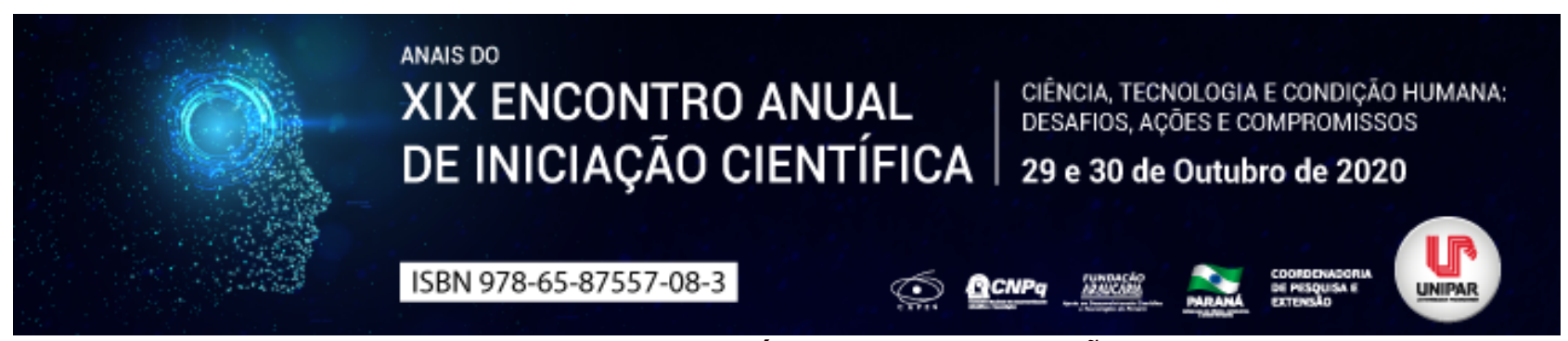

LEUCEMIA LINFOBLÁSTICA AGUDA EM CÃO

\begin{abstract}
${ }^{1}$ Taise Garcia Besler, ${ }^{2}$ ÉRIKA BENEVENUTE, ${ }^{3}$ JORGE BENEVENUTE, ${ }^{4}$ MONIQUE TOGNI, ${ }^{5}$ MONIQUE TOGNI
\end{abstract}

\begin{abstract}
${ }^{1}$ Discente de Medicina Veterinária Centro Universitário Integrado de Campo Mourão, Campo Mourão PR
${ }^{1}$ Médica Veterinária do Hospital Veterinário Benevet, Santiago RS

${ }^{2}$ Médico Veterinário do Hospital Veterinário Benevet, Santiago RS

${ }^{3}$ Docente da Universidade Integrada do Alto Uruguai e das Missões, Santiago RS

${ }^{4}$ Docente da Universidade Integrada do Alto Uruguai e das Missões, Santiago RS
\end{abstract}

Intrdução: Leucemias são neoplasias malignas de células percursoras hematopoiéticas que se originam na medula óssea e atingem a circulação sanguínea. As leucemias linfóides são divididas em Leucemias Linfoblásticas Aguda (LLA) e Leucemias Linfocíticas Crônica (LLC), sendo a aguda mais grave (MEUTEN, 2017). Suas células podem ou não atingir a circulação, quando o ocorrem são denominadas leucemias leucêmicas (FIGHERA; GRAÇA, 2016).

Objetivo: O objetivo do presente trabalho é relatar uma leucemia linfoblástica aguda em cão com marcada presença de células neoplásicas na circulação (leucemia leucêmica).

Relato de caso: Em dezembro de 2019 um cão da raça Poodle, macho, com 10 anos de idade, pesando aproximadamente 7,5kg deu entrada no HOSPITAL VETERINÁRIO - BENEVET em Santiago, RS. Na anamnese o proprietário relatou que o animal apresentava-se apático e no exame clinico não apresentou alterações em linfonodos. O exame radiográfico não demonstrou nenhuma alteração, já o exame ultrassonografico evidenciou um aumento no fígado e leve no baço. No hemograma os valores de eritrócito, hematócrito e de hemoglobina estavam abaixo dos valores de referência, os valores de HCM e CHCM estavam normais e as plaquetas diminuídas, os reticulócitos estavam aumentados indicando uma anemia normocítica normocrômica regenerativa e trombocitopenia. O exame apresentou também leucocitose com $>200.850 \mathrm{~K} / \mu \mathrm{L}$, neutrofilia, monocitose e eosinofilia. No exame bioquímico o tempo de protrombina, globulinas, fosfatase alcalina e alanina aminotransferase encontravamse aumentadas.

$\mathrm{Na}$ citologia do esfregaço sanguíneo foi observada marcada presença de células neoplásicas linfocíticas em diferentes fases de maturação, com áreas de predomínio de células linfoblásticas (blastos), que apresentavam um núcleo grande, de formato redondo a oval, com cromatina frouxa e presença de nucléolo com citoplasma moderado e levemente basofílico, também foram encontradas acentuada atipía celular e poucas mitoses. Concluindo-se tratar de uma Leucemia Linfoblástica Aguda. O tratamento de escolha foram a internação, antibioticoterapia e quimioterapia, porém o tutor solicitou para que fossem somente prescritos medicamentos para que o tratamento tivesse continuidade em casa. Foram prescritos os seguintes medicamentos, para alteração hematológica, Prednisona 20 Mg, Hemolitan Gold, Combiron, Cobavital, Ciprofloxacina 500 Mg, Gaviz 10 Mg e HepVet Comp e dieta hipercalórica com Nutralife + Recovery. O proprietário não retornou com o animal para uma reavaliação e realização da quimioterapia, não sendo possível acompanhar o andamento clínico do paciente.

Discussão: Segundo Meuten (2017), as LLA são neoplasias malignas e uma das mais agressivas na Medicina Veterinária. Os cães com LLA tem curtos tempos de sobrevivência medidos em dias a semanas, sendo o tempo médio de sobrevida de 8 dias, num intervalo de 5 a 46 dias. De acordo com os autores Fighera; Graça (2016) a suspeita clínica das LLA frequentemente é estabelecida a partir de algum achado do hemograma. Isso ocorre porque quase todos os sinais apresentados pelo paciente com LLA são inespecíficos como neste animal. As características clínicas da doença avançada incluem linfocitose e envolvimento sistêmico do fígado, baço e outros órgãos e sinais de insuficiência hepática ou renal. (MEUTEN, 2017). O mesmo autor cita que os achados laboratoriais incluem anemia, neutropenia e trombocitopenia são esperadas na maioria dos cães com LLA, sinais encontrados no cão deste relato. A amenia e a trombocitopenia foram decorrentes obliteração do canal medular atribuida a grande quantidade de celulas neoplasicas na medula óssea. O aumento da atividade serica de fosfatase alcalina e alanina aminotransferase, bem como aumento do fígado e baço demonstram acometimento destes órgãos, frequente em leucemias como citado anteriormente e encontrado em relatos semelhantes (TOMAZ et al., 2013). O paciente foi diagnosticado com Leucemia Linfóblastica Aguda, através do histórico, resultados de hemograma, visualização e identificação de linfoblastos imaturos no esfregaço sanguíneo. Citologicamente são encontradas nas LLA linfoblástos de tamanho variados com núcleos grandes e nucleolos pequenos, a cromatina não possui agregações grosseiras. (MEUTEN, 2017). O diagnóstico de LLA pode ser realizado através da morfologia dos linfócitos, como realizado neste caso, diferentemente de outros distúrbios linfoproliferativos (AVERY \& AVERY, 2007). Segundo Thrall (2006), a quimioterapia mesmo com associações a prednisona, ou outros medicamentos, o tratamento pode resultar na remissão da doença, mas por um curto período, sendo o prognóstico do paciente descavoravel. 
Conclusão: A Leucemina Linfoblástica Aguda é uma neoplasia pouco diagnosticada em cães, principalmente por apresentar sinais inespecíficos e de dificil diagnóstico, sendo importante a realização do esfregaço sanguineo com diferencial leucocitário e para a identificação de células neoplásicas. A etiologia das LLA é incerta e seu prognóstico desfavoravel, tendo o paciente um curto periodo de vida.

\section{Referências}

AVERY A.C., AVERY P.R. Determining the signifi cance of persistent lymphocytosis. Veterinary Clinics of North America, Small Animal Practice. 2007.

FIGHERA R.A.; Graça D.L. 2016. Sistema hematopoiético, p.311-405. Santos R.L. \& Alessi A.C. (Eds), Patologia Veterinária. $2^{\mathrm{a}}$ ed. Roca, Rio de Janeiro.

MEUTEN, J.D Tumors in domestic animals. Description: Fifth edition. | Ames, lowa: John Wiley \& Sons Inc., 2017.

THRALL, M. A. et al. Hematologia e Bioquímica Clínica Veterinária. São Paulo: Roca, p.141-169, 2006.

TOMAZ, K. L. R; DO VALE, A.M; SOTO-BLANCO, B. Leucemia linfoblástica aguda em um cão. Acta Scientiae Veterinariae, 2013. 


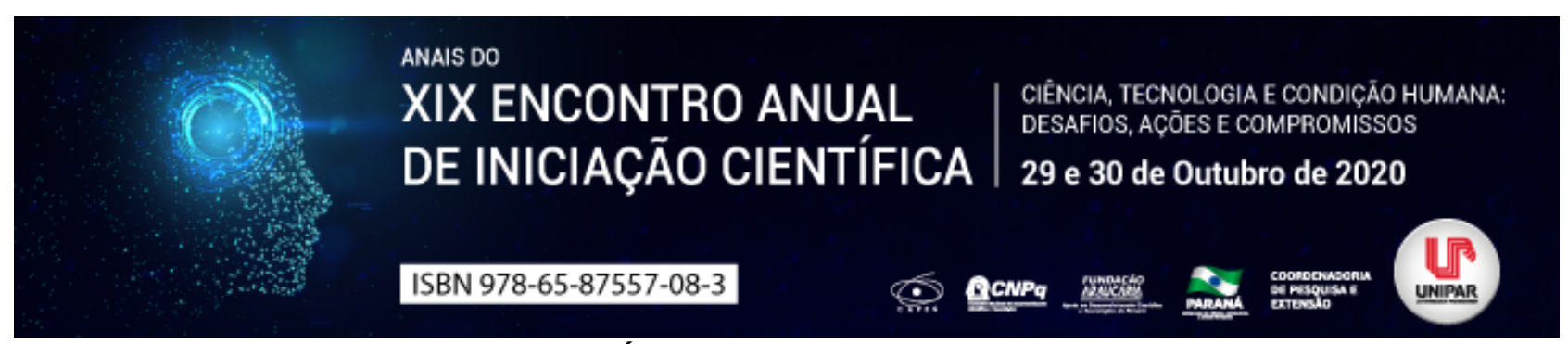

BENEFÍCIOS DA OZONIOTERAPIA

\begin{abstract}
${ }^{1}$ Arisla Villas Boas Lizzi, ${ }^{2}$ MAYARA NAYANE SACOMAN ROCHA NEVES, ${ }^{3}$ DIRCE CONSUELO CORONATO CORREIA, ${ }^{4}$ MAX GIMENEZ RIBEIRO
\end{abstract}

${ }^{1}$ Acadêmica da UEM
${ }^{1}$ Acadêmica da UEM
${ }^{2}$ Acadêmica da UEM
${ }^{3}$ Docente da UEM

Introdução: A ozonioterapia consiste no uso de ozônio, como medicamento ativo, no tratamento das mais variadas doenças, mostrando-se eficiente em diversas enfermidades circulatórias, inflamatórias e infecciosas, como: trombose, colite e erliquiose, respectivamente. Além disso, segundo a literatura, a ozonioterapia em associação com a acupuntura, pode prevenir algumas doenças, aumentando a imunidade do animal. A associação também é usada em pacientes com paralisia. Essa terapia, apesar de pouco comentada, vem sendo cada vez mais estudada, tanto para melhor esclarecer sua forma de ação e comprovar seus benefícios, quanto para desenvolvimento de protocolo de concentração.

Objetivo: O objetivo deste estudo é avaliar a eficiência da ozonioterapia como terapia integrativa promissora.

Desenvolvimento: O ozônio é um gás formado por três átomos de oxigênio (O3), sendo uma forma menos estável do oxigênio encontrado na atmosfera (O2). Sua primeira utilização foi em 1856 para desinfecção de salas cirúrgicas e, a partir de 1860, para o tratamento de água. (MERHI, et al, 2019) A ozonioterapia veterinária surgiu quando Pelozzi utilizou uma mistura O2 - O3 para desinfectar uma ferida na pata de um cavalo durante a Primeira Guerra Mundial (FREITAS, 2011). Portanto, o ozônio de aplicação médica é uma mistura de no máximo $5 \%$ de ozônio e $95 \%$ de oxigênio. A concentração utilizada no campo da medicina varia entre 1 e $100 \mathrm{mg}$ de ozônio para cada litro de oxigênio de acordo com a via de administração e a doença a ser tratada; sua meia-vida é de aproximadamente 40 min a $20^{\circ} \mathrm{C}$ (HERNÁNDEZ et al., 2001; DI MAURO et al., 2019). O Ministério da Saúde reconhece a ozonioterapia como uma das 29 práticas integrativas e complementares oferecidas pelo SUS, em virtude de seu baixo custo, segurança comprovada e reconhecimento. Segundo esse, o ozônio medicinal, nos seus diversos mecanismos de ação, representa um estímulo que contribui para a melhora de diversas doenças, uma vez que pode ajudar a recuperar de forma natural a capacidade funcional do organismo humano e animal. No processo de ozonização, quando realizado através de práticas, dosagens e tempo de exposição adequados, não são encontrados resíduos e a ação é mais eficaz, além de estarem comprovadas as propriedades germicidas do O3 (FREITAS, 2011). Assim, o ozônio possui capacidade anti-inflamatória, analgésica e imunoestimulante, caracterizando-se por aumentar o aporte de oxigênio a todas as células do organismo, melhorando a respiração celular. Ao entrar em contato com os fluídos corpóreos, a mistura de oxigênio e ozônio reage em milésimos de segundo, formando espécies reativas de oxigênio (EROs) e produtos da lipoperoxidação lipídica (LOPs), gerando um estresse oxidativo transitório e controlado, que irá promover uma ação biológica e melhorar a produção de enzimas antioxidantes, promovendo uma ação antioxidante no organismo $(\mathrm{BOCCl}, 2002)$. Acredita-se que a aplicação do uso médico do ozônio, devido seu baixo custo de investimento e manutenção, sua facilidade de aplicação e resultados clínicos, é, entre as terapias bioxidantes, a mais promissora (FREITAS, 2011). O ozônio é eficiente em diversas enfermidades circulatórias e inflamatórias. Além disso, exposição sanguínea a baixas concentrações contribuiu para a proteção das células ao estresse oxidativo (FREITAS, 2011). Outras atribuições do 03 são: estímulo à produção de citocinas, síntese de anticorpos, ativação de linfócitos $\mathrm{T}$, melhora da oxigenação e do metabolismo celular por meio de vasodilatação e aumento da resposta enzimática antioxidativa, potente oxidante de compostos orgânicos e inorgânicos e precipitante de metais pesados. Também, já foi mencionado na literatura a capacidade da ozonioterapia de reduzir a agregação placentária, além de atuar como antialérgico e anti-inflamatório. Logo, sua aplicação pode ser realizada por via subcutânea, intramuscular, intradiscal, intracavitária (espaços peritoneal e pleural), intravaginal, intrauretral e vesical, bem como auto-hemoterapia ozonizada (PENIDO, 2010).

Conclusão: Segundo a literatura pesquisada, a ozonioterapia tem se mostrado eficiente no tratamento de diversas doenças tanto de caráter inflamatório quanto microbiano, não deixa resíduos no corpo do animal, promove a inativação de microrganismos, além de apresentar baixo custo. Devemos frisar que a terapia com o O3 não deve ser a terapia principal no tratamento das enfermidades, entretanto, conclui-se que, como terapia coadjuvante, pode trazer muitos benefícios.

\title{
Referências
}

BOCCl, V. Oxygen-Ozon Therapy a Critical Evalution. 2002 Springer.

DI MAURO, R. et al. The biochemical and pharmacological properties of ozone: the smell of protection in acute and chronic 
diseases. Int. J. Sci. 2019, 20, 634. Doi:10.3390/ijms20030634.

FREITAS, A. I. A. Eficiência da Ozonioterapia como protocolo de tratamento alternativo das diversas enfermidades na Medicina Veterinária (Revisão de literatura): PUBVET, Londrina, v. 5, n. 30, ed. 177, Art. 1194, 2011.

HERNÁNDEZ O.; GONZÁLEZ, R. Ozonoterapia en úlceras flebostáticas. Rev Cubana Cir, 2001, v. 40(2), p. 123-129.

MERHI, Z. et al. Ozone therapy: a potential therapeutic adjunct for improving female reproductive health. Med Gas Res. 2019; 9 (2): 101-105.

PENIDO, B. R.; LIMA, C. A.; FERREIRA, L. F. L. Aplicações da ozonioterapia na clínica veterinária. PUBVET, Londrina, v. 4, n. 40, ed. 145, Art. 978, 2010

Práticas Integrativas e Complementares (PICS): quais são e para que servem. Disponível em http://saude.gov.br/saude-de-az/praticas-integrativas-e-complementares: Acesso em: 20 ago. 2020.

Coordenadoria de Pesquisa e Extensão - COPEX

Departamento de Editoraçāo e Divulgaçāo Científica - DEDIC 


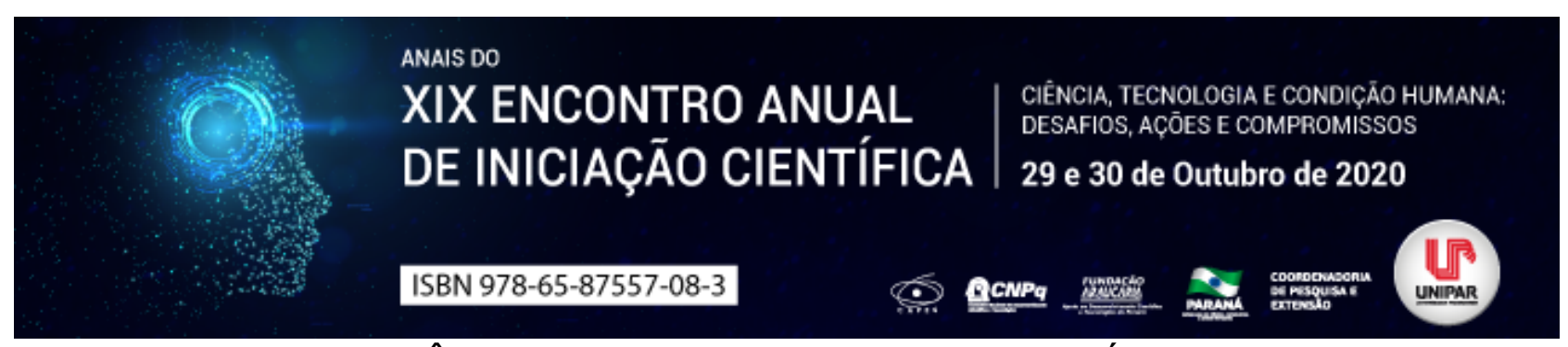

PREVALÊNCIA DE COVID-19 NO ESTADO DO PARANÁ, BRASIL

\begin{abstract}
${ }^{1}$ ADRIANE CORDEIRO TREVISANI, ${ }^{2}$ ISABELA CARVALHO DOS SANTOS, 3JOÃO PEDRO CORDEIRO TREVISANI, ${ }^{4}$ DANIELA DIB GONCALVES
\end{abstract}

\begin{abstract}
${ }^{1}$ Acadêmica de Doutorado do Programa de Pós-graduação em Ciência Animal com Ênfase em Produtos Bioativos da UNIPAR
${ }^{1}$ Acadêmica de Doutorado do Programa de Pós-graduação em Ciência Animal com Ênfase em Produtos Bioativos da UNIPAR

${ }^{2}$ Acadêmico de Graduação em Medicina da UFPR

${ }^{3}$ Docente do Programa de Pós-Graduação Ciência Animal com Ênfase em Produtos Bioativos da UNIPAR
\end{abstract}

Introdução: O vírus SARS-CoV-2 provoca a enfermidade denominada COVID-19, que foi identificada pela primeira vez na cidade de Wuhan, China, em dezembro de 2019, local onde se iniciou o surto da doença, tornando-se a primeira pandemia causada por coronavírus em data de 11 de março de 2020 (ORGANIZAÇÃO MUNDIAL DA SAÚDE, 2020a). De acordo com relatório de situação da OMS, até o dia 24 de agosto de 2020, o número de casos globais era de 23.050.000, havendo cerca de 800.000 mortes. O país com o maior número de casos e mortes são os Estados Unidos, possuindo cerca de $24 \%$ dos casos e 22\% das mortes globais (ORGANIZAÇÃO MUNDIAL DA SAÚDE, 2020b). O Brasil, segundo o Ministério da Saúde, até o dia 26 de agosto de 2020 contava com 3.717.156 casos e 117.665 mortes, sendo o $2^{\circ}$ em número de casos globais. No país, São Paulo aparece em $1^{\circ}$ lugar, representando cerca de $21 \%$ dos casos e $25 \%$ das mortes (BRASIL, 2020a). De acordo com informe epidemiológico da Secretaria de Saúde do Estado, o Paraná, até o dia 26 de agosto de 2020, possuía 120.920 casos, e 3.064 mortes (PARANÁ, 2020a). O fato de ainda não haver cura, tratamento ou vacina contra a doença demonstra a grande importância de dados epidemiológicos. Com eles, torna-se possível elaborar estratégias e políticas de saúde, contribuindo, assim, para o conhecimento acerca do curso da COVID-19 no estado.

Objetivo: Este estudo tem por objetivo determinar a prevalência de COVID-19 no Paraná conforme as variáveis contidas em dados oficiais da Secretaria de Saúde do Estado e compará-las a outras regiões e estudos, no intuito de avaliar a situação pandêmica no estado.

Material e Métodos: Os dados epidemiológicos de COVID-19 foram obtidos no dia 26 de agosto a partir da seção CORONAVÍRUS EM NÚMEROS do portal da transparência da Secretaria de Saúde do Estado do Paraná (PARANÁ, 2020b). Estes possuem variáveis de sexo, faixa etária e município, divididos em confirmados, recuperados e óbitos. Os dados foram transcritos em tabelas para o Microsoft ${ }^{\circledR}$ Excel $($ 2016. A variável faixa etária foi estratificada em três estratos: 0 a 19 anos (criança e adolescentes), 20 a 59 anos (adultos) e maior ou igual a 60 anos (idosos). Por fim, foram calculadas taxas de prevalência destas variáveis.

Resultados: No Paraná, considerando a população de 11.433.957 habitantes (BRASIL, 2020b), estimada pelo Instituto Brasileiro de Geografia e Estatística (IBGE) em 2019, a prevalência de COVID-19 na população foi de 1,1\% e a letalidade da doença foi de $2,5 \%$. As prevalências de casos confirmados foram de $47,6 \%$ no sexo masculino e $52,4 \%$ no sexo feminino. A maior taxa de prevalência de confirmações foi encontrada na faixa etária de 20 a 59 anos, totalizando $76,9 \%$ dos casos, e a menor na faixa de 0 a 19 anos, com 9,2\%. A maior taxa de letalidade foi encontrada na faixa etária idosa, sendo de $13,6 \%$, e a menor em crianças e adolescentes, sendo de $0,08 \%$. A taxa de letalidade do sexo masculino $(3,2 \%)$ foi maior que do sexo feminino $(1,9 \%)$. A prevalência de recuperados foi de $66,3 \%$ do total de casos confirmados, sendo que a faixa etária de maiores de 60 anos teve a menor prevalência $(56,1 \%)$. Já nas faixas etárias de crianças, adolescentes e adultos, a prevalência de recuperados foi semelhante, sendo de $67,8 \%$ e $68 \%$, respectivamente. Entre sexos, a prevalência de recuperados também foi semelhante: $66,2 \%$ no sexo masculino e $66,5 \%$ no sexo feminino.

Discussão: A prevalência de casos confirmados e óbitos no Paraná foi menor quando comparada com a prevalência de casos confirmados e de óbitos no país (prevalência de 1,8\% de casos confirmados e 3,2\% de óbitos no Brasil). Na região Sul do Brasil, o estado também teve menor prevalência de casos confirmados que o estado de Santa Catarina (1,9\%), porém maior que o Rio Grande do Sul (1,0\%). Já a letalidade no Paraná foi menor que o estado do Rio Grande do Sul $(2,8 \%)$ e maior que Santa Catarina (1,6\%) (BRASIL, 2020a). Existem diversos fatores que interferem nos dados epidemiológicos nas regiões, mas, no caso da CoVID-19, o número de testes realizados é um fator de grande relevância, tendo em vista a grande subnotificação do país (PRADO, 2020). No Paraná, a exemplo, houve aumento considerável de notificações por Síndrome Respiratória Aguda Grave não especificada, comparado ao ano de 2019 (PARANÁ, 2019, 2020a). Observou-se elevada letalidade na faixa etária maior ou igual a 60 anos de idade, e em pacientes com comorbidades, frequentemente idosos, considerados grupos de risco (GRASSELLI, 2020). Igualmente, a prevalência de recuperados foi menor na faixa etária maior ou igual a 60 anos, devido, provavelmente, à alta letalidade da doença no grupo. Já na variável sexo, a letalidade se mostrou maior no sexo masculino 
comparado ao sexo feminino. Um provável motivo dessa diferença pode ser evidenciado no estudo de Zeng et al. (2020), no qual observou-se que, em mulheres, há maior produção de IgG no estágio inicial da doença e, consequentemente, concentração relativamente maior de anticorpos contra SARS-CoV-2 comparado a homens.

Conclusão: Com este estudo foi possível determinar as prevalências de COVID-19 no Paraná e determinar seus fatores de risco relacionados a faixa etária e sexo.

\section{Referências}

BRASIL. Painel de casos de doença pelo coronavírus 2019 (COVID-19) no Brasil pelo Ministério da Saúde. Ministério da Saúde, 2020a. Disponível em: . Acesso em: 26 de agosto de 2020.

BRASIL. Cidades e Estados. Instituto Brasileiro de Geografia e Estatística, 2020b. Disponível em: . Acesso em: 26 de agosto de 2020.

GRASSELLI, Giacomo et al. Baseline characteristics and outcomes of 1591 patients infected with SARS-CoV-2 admitted to ICUs of the Lombardy Region, Italy. Jama, 2020.

ORGANIZAÇÃO MUNDIAL DA SAÚDE. Q\&A on coronaviruses (COVID-19). World Health Organization, 2020a. Disponível em: . Acesso em: 26 de agosto de 2020.

ORGANIZAÇÃO MUNDIAL DA SAÚDE. Coronavirus disease (COVID-19) Situation Report 107, Geneva: World Health Organization, 2020b (WHO Coronavirus disease Situation Report). Disponível em: . Acesso em: 26 de agosto de 2020.

PARANÁ. Secretaria da Saúde. CORONAVíRUS (COVID-19) INFORME EPIDEMIOLÓGICO, Curitiba, 2020a. Disponível em: . Acesso em: 26 de agosto de 2020.

PARANÁ. Secretaria da Saúde. CORONAVíRUS EM NÚMEROS, Curitiba, 2020b. Disponível em: . Acesso em: 26 de agosto de 2020.

PARANÁ. Secretaria da Saúde. Informe Influenza SE 01 a 34, Curitiba, 2019. Disponível em: . Acesso em: 26 de agosto de 2020.

PRADO, Marcelo Freitas do et al. Análise da subnotificação de COVID-19 no Brasil. Revista Brasileira de Terapia Intensiva, $v$. 32, n. 2, p. 224-228, 2020.

ZENG, Fanfan et al. A comparison study of SARS-CoV-2 IgG antibody between male and female COVID-19 patients: a possible reason underlying different outcome between sex. Journal of Medical Virology, 2020. 


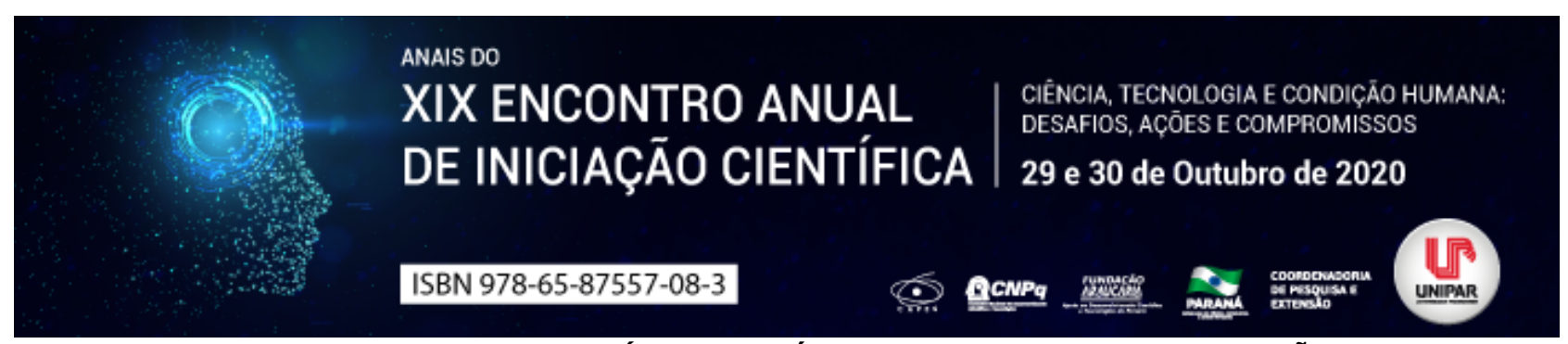

TRATAMENTO DA CANDIDÍASE COM ÓLEOS ESSENCIAIS: UMA REVISÃO

\begin{abstract}
${ }^{1}$ BRUNA MONTEIRO SANCHES, ${ }^{2}$ GABRIELA ALVES DE OLIVEIRA, ${ }^{3}$ MARCELO FARIA SANCHES, ${ }^{4}$ MARCELA MADRONA MORETTO DE PAULA
\end{abstract}

\author{
${ }^{1}$ Acadêmica do Curso de Medicina da UNIPAR \\ ${ }^{1}$ Acadêmica do Curso de Medicina da UNIPAR \\ ${ }^{2}$ Ginecologista e Obstetra pela Febrasgo. \\ ${ }^{3}$ Docente da UNIPAR
}

Introdução: Atualmente, o uso de fármacos contra a infecção por Candida sp têm manifestado efeitos adversos e resistência por parte dos microorganismos. Assim, busca-se uma nova opção no tratamento da candidíase baseada no uso de substâncias antifúngicas naturais, a exemplo, os óleos essenciais. Baseado nisso, seu uso vem crescendo devido a sua atividade no combate aos organismos patogênicos, apresentando potencial eficácia por meio de sua atuação sobre a estrutura celular.

Objetivo: Revisar o tratamento através de fármacos na infecção por Candida $s p$, apresentando a alternativa terapêutica dos óleos essenciais.

Desenvolvimento: Barbosa et al. (2018) define óleos essenciais (OE) como uma substância concentrada de compostos voláteis extraídos de plantas. Apesar de divergirem muito em relação à suas composições, em geral os óleos possuem compostos oxigenados, como os fenóis, álcoois, ésteres, éteres, cetonas, aldeídos, óxidos, hidrocarbonetos, além dos terpenos, enxofre orgânico, compostos nitrogenados e derivados do benzeno. Atualmente, possui registro de cerca de 3.000 OE e ao longo dos anos esses líquidos tem ganhado popularidade, visto suas propriedades antivirais, antifúngicas, antiparasitárias, antioxidantes e antibacterianas, por conta da alta concentração de seus compostos. Segundo Barbedo; Sgarbi (2010), a candidíase vulvovaginal (CVV), por sua vez, é a vaginite aguda mais comum nos países tropicais, sendo muito prevalente em mulheres adolescentes ou adultas. Essa patologia não é considerada uma IST e é caracterizada como um processo micótico causado por fungos pertencentes à Candida $s p$ que estão presentes na colonização normal da pele, trato gastrointestinal e genitourinário, mas que devido à fatores externos ou mecanismos de defesa do organismo, desenvolvem um quadro infeccioso. À luz de Tozzo; Grazziotin (2020), a mesma ocorre por múltiplas causas, entre elas o uso de anticoncepcionais orais, uso de corticóides, uso prolongado de antibióticos, má higiene íntima, distúrbios do sistema endócrino, uso de roupas íntimas sintéticas, relações sexuais desprotegidas, uso de imunossupressores, entre outras formas. Lima et al. (2006) pontua que as infecções por candida têm sido tratadas através de uma grande quantidade de fármacos antisépticos e antifúngicos, como ácido salicílico e a família dos azóis (cetoconazol, econozal, sulconazol, miconazol, clotrimazol, fluconazol). No entanto, Barbosa et al. (2018) propõe que nos últimos anos os usos de tratamentos farmacológicos têm gerado toxicidade e colaborado na resistência deste microrganismo contra antifúngicos, por isso, passou a se buscar alternativa para o tratamento, isto é, uma substância com propriedades capazes de agir contra microrganismos sem alterar as condições do hospedeiro. A partir disso, surgiram as pesquisas que sugerem o uso de óleos essenciais com características antifúngicas no tratamento da candidíase por apresentarem uma composição que garante as propriedades já descritas (LIMA et al., 2006). De acordo com Barbosa et al. (2018), o uso de terapias alternativas têm aumentado de forma significativa em todo o mundo nos últimos anos, o que se deve principalmente à ampla insatisfação com a eficácia de medicamentos farmacêuticos e com a ocorrência de efeitos adversos que esses podem ocasionar. Alguns óleos essenciais possuem propriedades antioxidantes e antimicrobianas devido à suas altas características lipofílicas, permitindo assim, a segmentação da camada lipídica da membrana celular bacteriana e da mitocôndria de fungos. Esse desarranjo na estrutura causado nos organismos invasores causa o aumento da permeabilidade dessas estruturas, ocasionando assim, o extravasamento de íons e de outros conteúdos celulares, o que implica na lise da célula (BARBOSA et al., 2018). Frente a isso, tem sido estudado o uso dos óleos essenciais que apresentam propriedades antifúngicas. Até então, $60 \%$ dos óleos já descritos possuem essa característica, enquanto $35 \%$ possui propriedade antibacteriana, o que levanta a hipótese de que o tratamento para esses agentes pode se dar por propriedades naturais apresentadas nos óleos essenciais. Logo, Lima et al. (2006) realizou um estudo onde foi notado que os óleos essenciais avaliados (Cinnamomum zeylanicum, Citrus limonum, Corymbia citriodora, Eugenia uniflora, Peumus boldus, Rosmarinus officinalis) apresentaram efetividade de inibição em pelo menos uma cepa fúngica, o que ocorreu pela formação de halos de inibição do crescimento microbiano de pelo menos $10 \mathrm{~mm}$. A atividade biológica dos óleos essenciais se dá por compostos como citral, pineno, cineol, cariofileno, elemeno, furanodieno, imoneno, eugenol, eucaliptol, carvacrol, que garantem as propriedades descritas (LIMA et al., 2006).

Conclusão: Conclui-se que embora ainda que haja pouca pesquisa acerca dessa proposta terapêutica, o uso dos óleos essenciais apresenta fortes indícios de eficácia no combate a candidíase. 


\section{Referências}

TOZZO, Aline Bergamo; GRAZZIOTIN , Neiva Aparecida. CANDIDÍASE VULVOVAGINAL. PERSPECTIVA, Erechim, RS, ano 133, v. 36, n. 1, p. 53-62, 1 mar. 2012. Disponível em: http://www.uricer.edu.br/site/pdfs/perspectiva/133_250.pdf. Acesso em: 22 ago. 2020.

BARBOSA, Janaina Priscila et al. Atividade anti-Candida de óleos essenciais de espécies de Eucalyptus. 2018.73 f. Dissertação (Mestrado) - Curso de Odontologia, Universidade Estadual de Campinas, Piracicaba, Sp, 2018. Disponível em: http://repositorio.unicamp.br/bitstream/REPOSIP/331640/1/Barbosa_JanainaPriscila_M.pdf. Acesso em: 03 ago. 2020.

BARBEDO, Leonardo S; SGARBI, Diana BG. Candidíase. Jornal Brasileiro de Doenças Sexualmente Transmissíveis, São Domingos, Niterói RJ, v. 22, n. 1, p. 22-38, 25 abr. 2010. Disponível em: http://ole.uff.br/wpcontent/uploads/sites/303/2018/02/r22-1-2010-4-Candidiase.pdf. Acesso em: 22 ago. 2020.

LIMA, Igara de Oliveira et al. Atividade antifúngica de óleos essenciais sobre espécies de Candida. Revista Brasileira de Farmacognosia, João Pessoa, PB, Brasil, v. 16, n. 2, p. 197-2001, 18 fev. 2006. DOI ISSN 0102-695X. Disponível em: https://www.scielo.br/pdf/rbfar/v16n2/v16n2a11.pdf. Acesso em: 17 ago. 2020.

Coordenadoria de Pesquisa e Extensão - COPEX

Departamento de Editoraçāo e Divulgaçāo Científica - DEDIC 


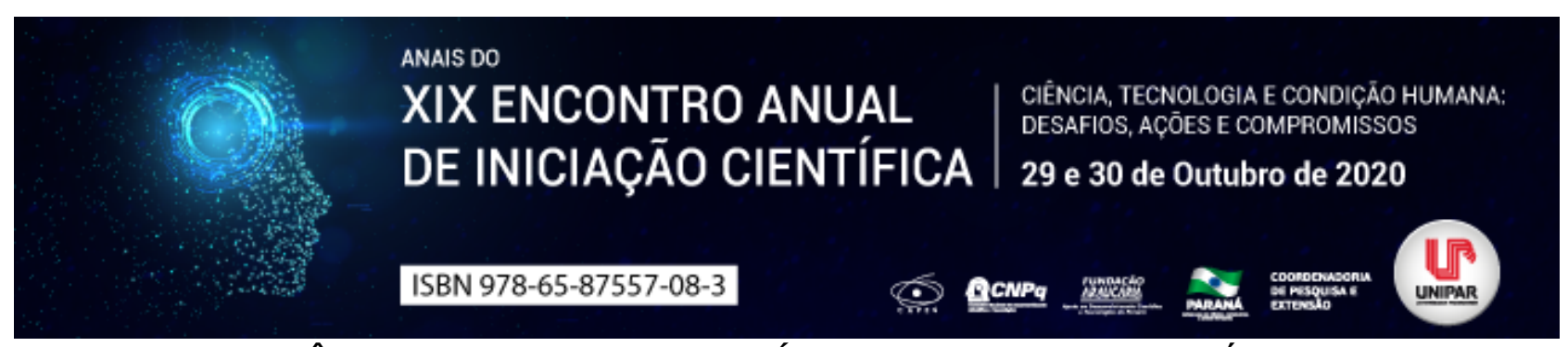

PREVALÊNCIA DE COVID-19 NO MUNICÍPIO DE UMUARAMA, PARANÁ, BRASIL

\begin{abstract}
${ }^{1}$ ADRIANE CORDEIRO TREVISANI, ${ }^{2}$ ISABELA CARVALHO DOS SANTOS , 3 JOÃO PEDRO CORDEIRO TREVISANI, ${ }^{4}$ DANIELA DIB GONCALVES
\end{abstract}

\begin{abstract}
${ }^{1}$ Acadêmica de Doutorado do Programa de Pós-graduação em Ciência Animal com Ênfase em Produtos Bioativos da UNIPAR
${ }^{1}$ Acadêmica de Doutorado do Programa de Pós-graduação em Ciência Animal com Ênfase em Produtos Bioativos da UNIPAR

${ }^{2}$ Acadêmico de Gradução em Medicina da UFPR

${ }^{3}$ Docente do Programa de Pós-Graduação Ciência Animal com Ênfase em Produtos Bioativos da UNIPAR
\end{abstract}

Introdução: O vírus SARS-CoV-2 provoca a enfermidade denominada COVID-19, que foi identificada pela primeira vez na cidade de Wuhan, China, em dezembro de 2019, local onde se iniciou o surto da doença, tornando-se a primeira pandemia causada por coronavírus em data de 11 de março de 2020 (ORGANIZAÇÃO MUNDIAL DA SAÚDE, 2020a).

De acordo com relatório de situação da OMS, até o dia 24 de agosto de 2020, o número de casos globais era de 23.050.000, havendo cerca de 800.000 mortes. O país com o maior número de casos e mortes são os Estados Unidos, possuindo cerca de $24 \%$ dos casos e $22 \%$ das mortes globais (ORGANIZAÇÃO MUNDIAL DA SAÚDE, 2020b).

O Brasil, segundo o Ministério da Saúde, até o dia 26 de agosto de 2020 contava com 3.717.156 casos e 117.665 mortes, sendo o $2^{\circ}$ em número de casos globais. No país, São Paulo aparece em $1^{\circ}$ lugar, representando cerca de $21 \%$ dos casos e $25 \%$ das mortes (BRASIL, 2020a). De acordo com informe epidemiológico da Secretaria de Saúde do Estado, o Paraná, até o dia 26 de agosto de 2020, possuía 120.920 casos, e 3.064 mortes (PARANÁ, 2020a). O fato de ainda não haver cura, tratamento ou vacina contra a doença demonstra a grande importância de dados epidemiológicos. Com eles, torna-se possível elaborar estratégias e políticas de saúde, contribuindo, assim, para o conhecimento acerca do curso da COVID-19 no estado.

Objetivo: Este estudo tem por objetivo determinar a prevalência de COVID-19 em Umuarama, no Paraná conforme as variáveis contidas em dados oficiais da Secretaria de Saúde do Estado e compará-las a outras regiões e estudos, no intuito de avaliar a situação pandêmica no município.

Material e Métodos: Os dados epidemiológicos de COVID-19 foram obtidos no dia 26 de agosto a partir da seção CORONAVÍRUS EM NÚMEROS do portal da transparência da Secretaria de Saúde do Estado do Paraná (PARANÁ, 2020b). Estes possuem variáveis de sexo, faixa etária e município, divididos em confirmados, recuperados e óbitos. Os dados foram transcritos em tabelas para o Microsoft ${ }^{\circledR}$ Excel ${ }^{\circledR}$ 2016. A variável faixa etária foi estratificada em três estratos: 0 a 19 anos (criança e adolescentes), 20 a 59 anos (adultos) e maior ou igual a 60 anos (idosos). Por fim, foram calculadas taxas de prevalência destas variáveis.

Resultados: Em Umuarama, considerando a população de 111.557 habitantes (BRASIL, 2020b), estimada pelo Instituto Brasileiro de Geografia e Estatística (IBGE) em 2019, a prevalência de COVID-19 na população foi de 0,7\% e a letalidade da doença foi de $1,5 \%$. As prevalências de casos confirmados foram de $45,8 \%$ no sexo masculino e $54,2 \%$ no sexo feminino. A maior taxa de prevalência de casos foi encontrada na faixa etária de 20 a 59 anos, totalizando $76,6 \%$, e a menor na faixa de 0 a 19 anos com 9,7\%. A maior taxa de letalidade encontrada foi na faixa etária idosa, sendo de $9,2 \%$ e a menor crianças e adolescentes, sendo de $0 \%$. A taxa de letalidade do sexo masculino $(1,7 \%)$ foi maior que do sexo feminino $(1,4 \%)$. A prevalência de recuperados foi de $75,2 \%$ do total de casos confirmados, sendo que a faixa etária de maiores de 60 anos teve a menor prevalência (65,1\%). A faixa etária de crianças, adolescentes teve a maior prevalência de recuperados, sendo de $85,7 \%$, enquanto o grupo de 20 a 59 anos a prevalência de recuperados foi de $75,7 \%$. Entre sexos, a prevalência de recuperados foi semelhante: $76,1 \%$ no sexo masculino e $74,4 \%$ no sexo feminino.

Discussão: A prevalência de casos confirmados e óbitos em Umuarama foi menor quando comparada com a prevalência de casos confirmados e de óbitos no estado (prevalência de 1,1\% de casos confirmados e 2,5\% de óbitos no Paraná) (PARANÁ, 2020a). O munícipio é o $26^{\circ}$ em número de casos confirmados, $18^{\circ}$ em recuperados e $32^{\circ}$ em de óbitos no estado. Já na incidência de casos $/ 100.000$ habitantes, Umuarama se encontra em $209^{\circ}$ e na incidência de óbitos $/ 100.000$ habitantes, em $233^{\circ}$ (PARANÁ, 2020a).

Existem diversos fatores que interferem nos dados epidemiológicos nas regiões, mas, no caso da COVID-19, o número de testes realizados é um fator de grande relevância, tendo em vista a grande subnotificação do país (PRADO, 2020). No Paraná, a exemplo, houve aumento considerável de notificações por Síndrome Respiratória Aguda Grave não especificada, comparado ao ano de 2019 (PARANÁ, 2019, 2020a). Observou-se elevada letalidade na faixa etária maior ou igual a 60 anos de idade, e em pacientes com comorbidades, frequentemente idosos, considerados grupos de risco (GRASSELLI, 2020). Igualmente, a prevalência de recuperados foi menor na faixa etária maior ou igual a 60 anos, devido, provavelmente, à alta letalidade da 
doença no grupo. Já na variável sexo, a letalidade se mostrou maior no sexo masculino comparado ao sexo feminino. Um provável motivo dessa diferença pode ser evidenciado no estudo de Zeng et al. (2020), no qual observou-se que, em mulheres, há maior produção de IgG no estágio inicial da doença e, consequentemente, concentração relativamente maior de anticorpos contra SARS-CoV-2 comparado a homens.

Conclusão: Com este estudo foi possível determinar as prevalências de COVID-19 no munícipio de Umuarama e determinar seus fatores de risco relacionados a faixa etária e sexo.

\section{Referências}

BRASIL. Painel de casos de doença pelo coronavírus 2019 (COVID-19) no Brasil pelo Ministério da Saúde. Ministério da Saúde, 2020a. Disponível em: . Acesso em: 26 de agosto de 2020.

BRASIL. Cidades e Estados. Instituto Brasileiro de Geografia e Estatística, 2020b. Disponível em: . Acesso em: 26 de agosto de 2020.

GRASSELLI, Giacomo et al. Baseline characteristics and outcomes of 1591 patients infected with SARS-CoV-2 admitted to ICUs of the Lombardy Region, Italy. Jama, 2020.

ORGANIZAÇÃO MUNDIAL DA SAÚDE. Q\&A on coronaviruses (COVID-19). World Health Organization, 2020a. Disponível em: . Acesso em: 26 de agosto de 2020.

ORGANIZAÇÃO MUNDIAL DA SAÚDE. Coronavirus disease (COVID-19) Situation Report 107, Geneva: World Health Organization, 2020b (WHO Coronavirus disease Situation Report). Disponível em: . Acesso em: 26 de agosto de 2020.

PARANÁ. Secretaria da Saúde. CORONAVíRUS (COVID-19) INFORME EPIDEMIOLÓGICO, Curitiba, 2020a. Disponível em: . Acesso em: 26 de agosto de 2020.

PARANÁ. Secretaria da Saúde. CORONAVÍRUS EM NúMEROS, Curitiba, 2020b. Disponível em: . Acesso em: 26 de agosto de 2020.

PARANÁ. Secretaria da Saúde. Informe Influenza SE 01 a 34, Curitiba, 2019. Disponível em: . Acesso em: 26 de agosto de 2020.

PRADO, Marcelo Freitas do et al. Análise da subnotificação de COVID-19 no Brasil. Revista Brasileira de Terapia Intensiva, v. 32, n. 2, p. 224-228, 2020.

ZENG, Fanfan et al. A comparison study of SARS-CoV-2 IgG antibody between male and female COVID-19 patients: a possible reason underlying different outcome between sex. Journal of Medical Virology, 2020. 


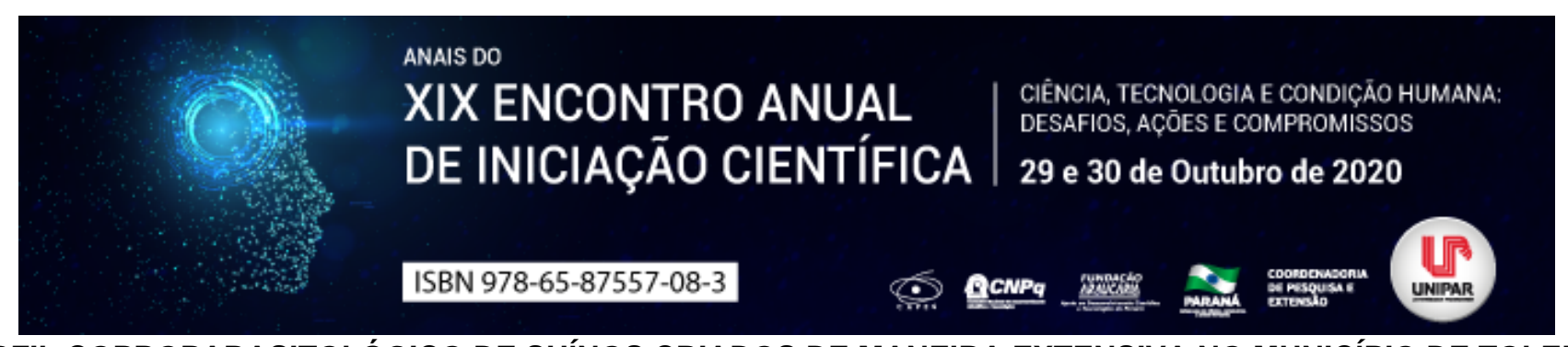

PERFIL COPROPARASITOLÓGICO DE SUÍNOS CRIADOS DE MANEIRA EXTENSIVA NO MUNICÍPIO DE TOLEDO PARANÁ

\author{
${ }^{1}$ Ricardo Babinski Bregonde, ${ }^{2}$ ANA PAULA MOLINARI CANDEIAS, ${ }^{3}$ VINICIUS DAHM, ${ }^{4}$ DANIELA BORGES DA CRUZ, \\ ${ }^{5}$ NELSON LUIZ MELLO FERNANDES, ${ }^{6}$ SIVIA CRISTINA OSAKI
}

\begin{abstract}
${ }^{1}$ Discente do curso de Medicina Veterinária da UFPR-Palotina
${ }^{1}$ Mestranda no Programa de Pós-Graduação em Ciência Animal da UFPR Palotina

${ }^{2}$ Discente do curso de Medicina Veterinária da UFPR Palotina

${ }^{3}$ Discente do curso de Medicina Veterinária da UFPR Palotina

${ }^{4}$ Docente do curso de Medicina Veterinária da UFPR Palotina

${ }^{5}$ Docente do curso de Medicina Veterinária da UFPR Palotina
\end{abstract}

Introdução: Os suínos são os animais domésticos mais afetados por parasitas, apresentando grande suscetibilidade a infecções parasitárias. Esses organismos podem atuar de diferentes formas no hospedeiro, diminuindo a resistência orgânica, retardando o desenvolvimento dos animais e tornando-os mais sensíveis a outras doenças oportunistas (ESMINGER, 1970; GONÇALVEZ, 2008). Nesse contexto, a criação extensiva ou de subsistência, se apresenta como agravante do problema, pois o deficitário manejo de vermifugação dos animais eleva as chances de infecções parasitárias. Além disso, um grande número de enteroparasitos que infectam os suínos, podem também afetar o homem. Nesse contexto, a vigilância epidemiológica se mostra de suma importância na prevenção desses agentes em suínos e humanos, pois devido à proximidade na convivência, tendem a compartilhar o mesmo ambiente o que pode resultar na contaminação de afluentes e solo, principalmente em sistemas de criação extensiva, que normalmente carecem de métodos de destinação correta dos excrementos.

Objetivo: O trabalho teve por objetivo realizar uma investigação do perfil coproparasitológico de suínos criados de maneira extensiva no município de Toledo Paraná.

Material e Métodos: O presente estudo foi aprovado pelo Comitê de Ética no Uso de Animais da Universidade Federal do Paraná-Palotina com o protocolo de número 25/2017. As coletas ocorreram em duas propriedades rurais distintas localizadas no município de Toledo. As amostras de fezes foram colhidas diretamente da ampola retal dos suínos, num total de dez amostras, sendo seis da primeira e quatro da segunda propriedade. Todas as amostras foram submetidas às técnicas de Willis-Mollay (1921) e Sheather (1923).

Resultados: Das 10 amostras testadas, todas foram positivas em pelo menos uma das técnicas utilizadas (10/10) e 80\% foram positivas para as duas técnicas (8/10). Os parasitas encontrados foram Ascaris spp. e oocistos de coccídios, ambos com 70\% de ocorrência (7/10), seguidos por Estrongilídeo com 40\% (4/10), Estrongyloide, Estrongylida e Giardia spp. com 30\% (3/10), Ancilostomídeo, Sarcocysta e Cystoisospora spp. todos com 10\% de ocorrência (1/10 animais). Dentre os animais estudados, apenas 30\% (3/10) não possuíam infecções parasitárias mistas. Um dos animais chegou a apresentar sete tipos distintos, demonstrando grande variabilidade de infecção parasitária. Em relação às técnicas usadas, a de Willis-Mollay apresentou positividade em todos os animais testados (10/10) e a de Sheather permitiu identificar a infecção em 80\% dos animais (8/10). Não houve diferença na ocorrência dos parasitos em relação às propriedades.

Discussão: Os resultados encontrados permitem verificar a alta ocorrência de infecções parasitárias em animais assintomáticos e aparentemente saudáveis. Ressaltando a importância do manejo antiparasitário, pois em sua ausência, verificou-se que 100\% dos animais apresentavam algum tipo de infecção parasitária, sendo esse, de suma importância para o controle dessas parasitoses. Os resultados do estudo corroboram parcialmente os encontrados por Aguiar (2009), que ao estudar parasitos grastintestinais de suínos naturalizados de criações familiares no Distrito Federal, encontrou uma ocorrência de oocistos de coccídios de $71,77 \%$, resultado praticamente igual ao encontrado no presente trabalho. Entretanto, verificou uma ocorrência de Ascaris suum de $27,69 \%$, diferindo dos $70 \%$ encontrados nesse caso. A diferença pode estar no número de amostras, além da origem das mesmas, enquanto os suínos utilizados nesse trabalho eram provenientes da região Oeste do estado do Paraná, os utilizados por Aguiar eram oriundos do DF, onde o clima difere de maneira bastante acentuada. Dos enteroparasitos encontrados, o gênero Giardia spp. apresenta caráter zoonótico e grande importância para a saúde pública, sendo comumente disseminados por meio de água contaminada. O íntimo contato dos animais ao solo e a incorreta destinação dos excrementos, pode favorecer a contaminação direta e indireta dos afluentes situados próximos aos locais de criação, e caso essa água seja ingerida por humanos, pode levar a infecção destes e consequentemente ao desenvolvimento dos quadros sintomáticos característicos, tais como a diarreia.

Conclusão: Conclui-se, portanto, que as infecções parasitárias estão presentes nos suínos estudados criados de maneira 
extensiva.

\section{Referências}

AGUIAR, Patrícia Coutinho. Aspectos epidemiológicos das parasitoses gastrintestinais de suínos naturalizados de criações familiares do Distrito Federal. 2009. 100 f. Dissertação (Mestrado em Saúde Animal). Universidade de Brasília, Brasília, 2009.

ESMINGER, M.E. Swine Sciente. 4. Ed. Danville: The Interstate Printers \& Publishers, Inc. 1970.

GONÇALVES, Landreani Ramirez. Freqüência de endoparasitos e considerações sobre as espécies do gênero Eimeria Schneider, 1875 (Apicomplexa: Eimeriidae) em suínos do município de Rio Claro, microrregião do vale do Paraíba sul fluminense, Estado do Rio de Janeiro. 2008. 72 f. Dissertação (Mestrado em Microbiologia Veterinária) - Instituto de Veterinária, Universidade Federal Rural do Rio de Janeiro, Seropédica - RJ, 2008.

SHEATHER, A. L. The detection of intestinal protozoa and mange parasites by a floatation technique. Journal of Comparative Pathology and Therapeutics, London, v. 36, n. 4, p. 266-275, 1923.

WILLIS, I. I. A simple levitation method for the detection of hookworm ova. Medical Journal of Austrália, v. 8, p. 375-376, 1921. 


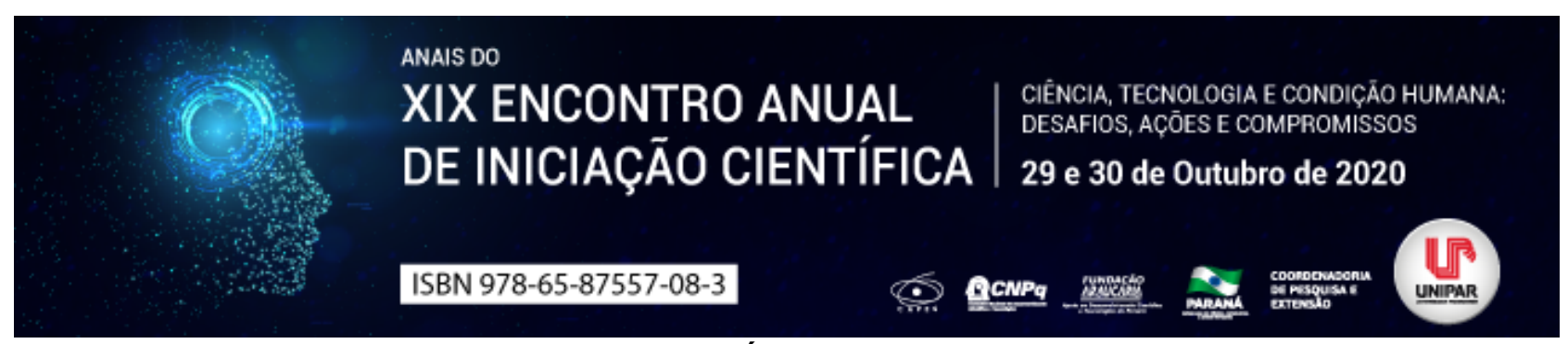

MANEJO DA DOR ONCOLÓGICA EM PEQUENOS ANIMAIS

\begin{abstract}
${ }^{1}$ Lucas Wamser Fonseca Gonzaga, ${ }^{2}$ ISABELA LOPES MASSITEL, ${ }^{3}$ LUCIANA DE CASTRO BARCELOS, ${ }^{4}$ LILLIAN PEREIRA GOUVEIA, ${ }^{5}$ KAROLYNE OLIVEIRA BASTOS, ${ }^{6}$ MARCOS FERRANTE
\end{abstract}

${ }^{1}$ Graduando em Medicina Veterinária pela Universidade Federal de Lavras

${ }^{1}$ Graduanda em Medicina Veterinária pela Universidade Estadual de Maringá

${ }^{2}$ Graduanda em medicina veterinária pela universidade federal de Lavras

${ }^{3}$ Graduanda em Medicina Veterinária pela Universidade Federal de Lavras

${ }^{4}$ Graduanda em Medicina Veterinária pela Universidade Federal de Lavras

${ }^{5}$ Doscente do departamento de Medicina Veterinária da Universidade Federal de Lavras

Introdução: A incidência de lesões oncológicas em animais de companhia tem aumentado nos últimos anos. Durante a evolução da neoplasia o paciente pode desenvolver um quadro de dor, sendo o manejo desta importante antes, durante e depois do tratamento, principalmente nos casos em que a doença está mais avançada (BERNO e MENDES, 2015). Nestes, entretanto, o tratamento deve ser predominantemente paliativo, isto é, focado em amenizar os efeitos do tumor sem necessariamente curá-lo (ANTUNES, et al., 2008).

Objetivo: Descrever abordagens terapêuticas utilizadas para o tratamento da dor oncológica em cães e gatos.

Desenvolvimento: Atualmente já se tem conhecimento de que a dor é um problema que vai além do bem-estar animal, levando a uma série de alterações fisiológicas que podem interferir na resposta do animal a outros tratamentos. A dor eleva o risco potencial de ocorrerem infecções oportunistas, uma vez que está frequentemente associada ao aumento no tempo de hospitalização dos pacientes (DYSON, 2008). A Associação Internacional para o Estudo da Dor (IASP) define dor como uma experiência sensorial e emocional desagradável associada à lesão tecidual, ou potencial, ou descrita em termos desta lesão . A dor oncológica, por sua vez, pode ser causada pela compressão de raízes nervosas, ou originada diretamente pelas lesões ou espasmos musculares na região lesionada (MATHEWS, et al., 2014). Concomitantemente ao aumento da expectativa de vida dos cães vem ocorrendo um aumento significativo dos casos de câncer nestes animais (PORTILHO, et al., 2015). A maior parte dos pacientes oncológicos precisarão de abordagens terapêuticas para controlar a dor e os demais sinais clínicos das neoplasias (BERNO e MENDES, 2015). A prevalência de dor varia de $50 \%$ nos pacientes em estágio intermediário da neoplasia, a $80 \%$ em indivíduos no estágio avançado ou com síndrome paraneoplásica (BERNO e MENDES, 2015). Segundo Looney (2010), o tratamento oncológico pode ser dividido em três etapas: a primeira diz respeito ao tratamento da patologia subjacente por meio de quimioterapia, radioterapia ou cirurgia, a fim de controlar a evolução da doença; a segunda se refere às abordagens utilizadas para impedir a transdução, transmissão e percepção da dor, isto é, as abordagens utilizadas para tratar a dor em si, incluindo as farmacológicas; a terceira etapa consiste em intervenções para reduzir a dor, com a finalidade de melhorar a saúde de forma global a partir dos cuidados paliativos. Existem várias modalidades de fármacos que podem ser utilizados para o tratamento da dor, porém, deve-se priorizar as alternativas menos invasivas (ANTUNES, et al., 2008). Para se iniciar o tratamento da dor oncológica o ideal é que as três etapas apresentadas na escala da Organização Mundial da Saúde sejam obedecidas (BERNO e MENDES, 2015). A primeira etapa consiste em utilizar anti-inflamatórios não esteroidais (AINEs) com ou sem uso de adjuvantes, tendo em vista que essa dor é considerada de grau leve. Na segunda etapa a dor passa a ser moderada, e a administração de AINEs não é o suficiente para o controle dessa. Assim, o emprego de analgésicos opioides fracos, como a codeína e o tramadol, passa a ser necessário. Na terceira etapa a dor passar ser considerada severa, e a utilização de opioides passa a ser necessária, como morfina via oral. Também pode ser utilizado fentanila pela via transdérmica, sendo que essa via oferece uma maneira de se administrar o fármaco de forma lenta e contínua (ALEIXO e TUDURY, 2005). No pós operatório podem ser administrados alfa-2 agonistas, que atum sinergicamente com os opioides (BERNO e MENDES, 2015), e os AINEs não devem ser utilizados em pacientes nefropatas e hepatopatas. Em primeiro lugar, o tratamento pode ser direcionado à patologia subjacente por meio de quimioterapia, cirurgia e radiação, que são métodos que tentam controlar o processo de evolução da doença (FLÔR, 2006). Além disso, podem ser empregados outros tratamentos farmacológicos, como o uso de anticonvulsivantes e bloqueios neurológicos. Também podem ser realizadas abordagens não farmacológicas, como acupuntura e fisioterapia (BERNO e MENDES, 2015). Em alguns casos pode ser instituído tratamento com uso de adjuvantes, como antagonistas do receptor N-metil D-aspartato (NMDA), antidepressivos tricíclicos (amitriptilina), gabapentina, tramadol e corticóides (sem utilização de AINEs) (MATHEWS, et al., 2014). Conclusão: Foram discutidas algumas abordagens farmacológicas da dor, levando em consideração o fato de que o paciente possui uma neoplasia avançada ou em evolução. A abordagem terapêutica deve ser baseada no grau da dor, e incluir o manejo farmacológico e não farmacológico. São necessários mais estudos para o manejo domiciliar dos casos de dor severa em 
evolução.

\section{Referências}

ALEIXO, G. A. D. S.; TUDURY, E. A. Utilização de Opióides na Analgesia de Cães e Gatos. Veterinária Notícias, Uberlândia, MG, v. 11, n. 2, p. 31-42, 2005.

ANTUNES, M. I. P. P.; MORENO, K.; GRUMADAS, C. E. S. Avaliação e Manejo da Dor em Cães e Gatos com Câncer - Revisão. Arq. Ciênc. Vet. Zool. Unipar, Umuarama, PR, v. 11, n. 2, p. 113-119, 2008.

BERNO, M. D. B.; MENDES, A. R. Dor Oncológica em Pequenos Animais Revisão de Literatura. REVISTA CIENTíFICA DE MEDICINA VETERINÁRIA, Garça, SP, n. 24, 2015.

DYSON, D. H. Analgesia and Chemical Restraint for the Emergent Veterinary Patient. Veterinary Clinics of North America: Small Animal Practice, v. 38, n. 6, p. 1329-1352, 2008. Disponível em: https://doi.org/10.1016/j.cvsm.2008.06.007. Acesso em 28 ago. 2020

FLÔR, P. B. Avaliação da eficácia e segurança do emprego do tramadol para analgesia em cães portadores de dor oncológica. Dissertação (Mestre em Medicina Veterinária). Faculdade de Medicina Veterinária e Zootecnia, universidade de São Paulo. São Paulo SP. 2006.

LOONEY, A. Oncology pain in veterinary patients. Topics in Companion Animal Medicine, v. 25, n. 1, p. 32-44, 2010. Disponível em: https://doi.org/10.1053/j.tcam.2009.10.008. Acesso em 28 ago. 2020

MATHEWS, K. et al. Gidelines for recognition, assessment and tratment of of pain. Journal of Small Animal Practice, v. 55, n. 6, p. E10-E68, Jun 2014. Disponível em: https://wsava.org/wp-content/uploads/2020/01/Recognition-Assessment-and-Treatment-ofPain-Guidelines.pdf. Acesso em 28 ago. 2020

PORTILHO, C. A. et al. Casuística de Cães e Gatos Atendidos Com Suspeita de Neoplasia no Hospital Veterinário Univiçosa no Período de 2010 a 20141. Revista científica Univiçosa, Viçosa, MG, v. 7, n. 1, p. 294-300, 2015.

Coordenadoria de Pesquisa e Extensão - COPEX

Departamento de Editoração e Divulgaçāo Científica - DEDIC 


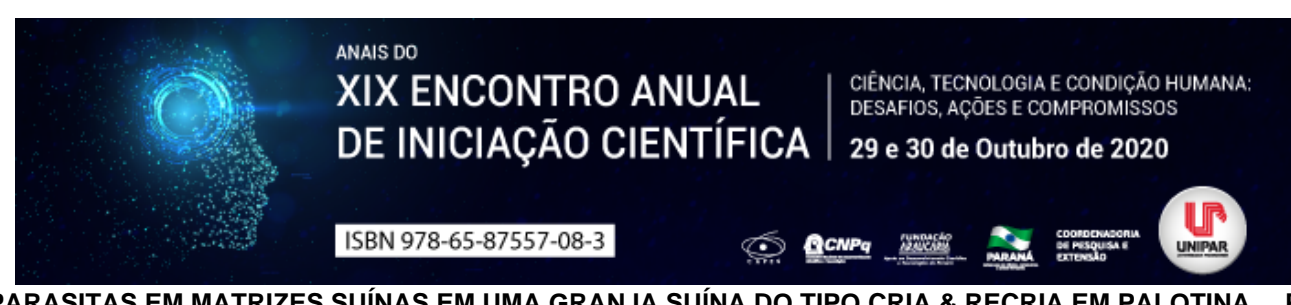

ENDOPARASITAS EM MATRIZES SUÍNAS EM UMA GRANJA SUÍNA DO TIPO CRIA \& RECRIA EM PALOTINA PARANÁ

${ }^{1}$ Ricardo Babinski Bregonde, ${ }^{2}$ ARIELLE APARECIDA LARA, ${ }^{3}$ VINICIUS DAHM, ${ }^{4}$ ANA PAULA MOLINARI CANDEIAS, ${ }^{5}$ GERALDO CAMILO ALBERTON, ${ }^{6}$ SIVIA CRISTINA OSAKI

${ }^{1}$ Discente do curso de Medicina Veterinária da UFPR-Palotina

${ }^{1}$ Mestre em Ciência Animal pela UFPR-Palotina

${ }^{2}$ Discente do curso de Medicina Veterinária da UFPR Palotina

${ }^{3}$ Mestranda no Programa de Pós-Graduação em Ciência Animal da UFPR Palotina

${ }^{4}$ Docente do curso de Medicina Veterinária da UFPR Palotina

${ }^{5}$ Docente do curso de Medicina Veterinária da UFPR Palotina

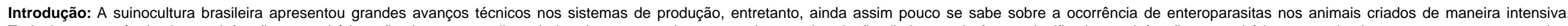

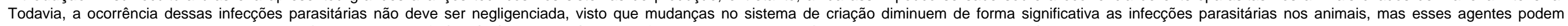

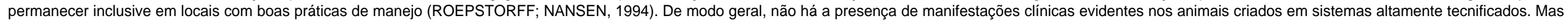

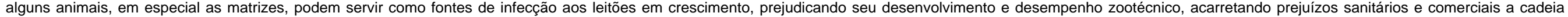
produtiva (NISHI et al., 2000).

Objetivo: $\mathrm{O}$ trabalho teve por objetivo relatar a ocorrência de enteroparasitas em matrizes suínas lactantes em uma granja do tipo cria e recria no município de Palotina, região Oeste do estado do Paraná, Brasil.

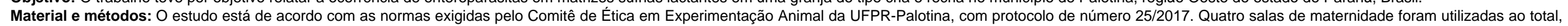

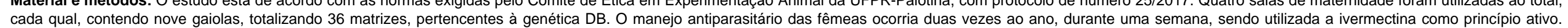

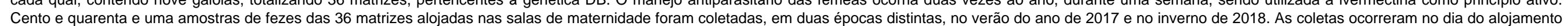

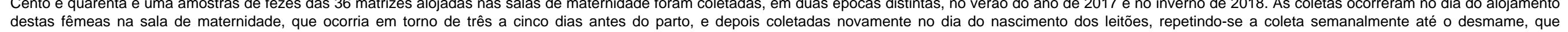
destas fêmeas na sala de maternidade, que ocorria em torno de três a cinco dias antes do parto, e depois coletadas novamente no dia do nascimento dos leitões, repetindo-se a coleta semante
normalmente ocorria aos 21 dias de vida dos leitões. As amostras de fezes foram coletadas diretamente da ampola retal e submetidas às técnicas de Willis-Mollay (1921) e método de Sheather (1923).

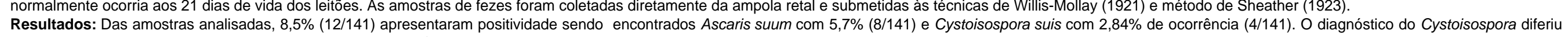

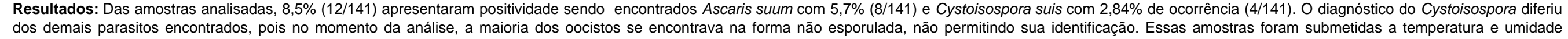
adequadas, e após uma semana foram novamente avaliadas, onde foram observados oocistos esporulados, contendo dois esporocistos e quatro esporozoítos cada, característicos do gênero Cystoisospora spp.

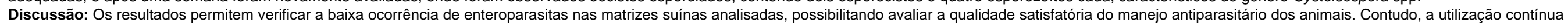

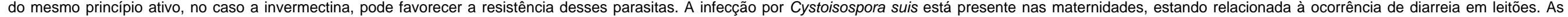

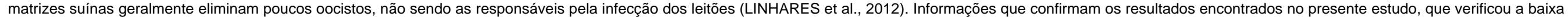

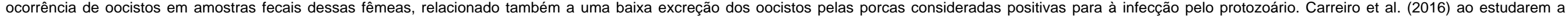

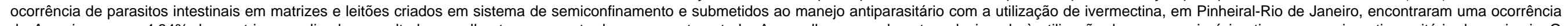

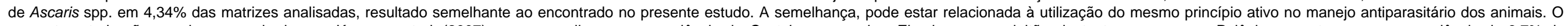

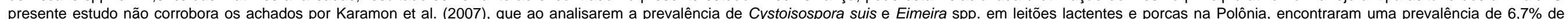

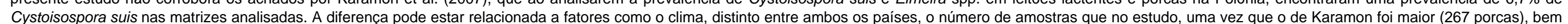
como o número de propriedades (104), o que pode ter contribuído para uma maior detecção do protozoário.

Conclusão: Conclui-se que os animais estudados não apresentaram uma alta carga parasitária.

\section{Referências}

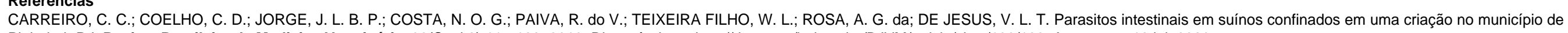
Pinheiral- RJ. Revista Brasileira de Medicina Veterinária, 38(Supl.2):117-122, 2016. Disponível em: http://rbmv.org/index.php/BJVM/article/view/199/129. Acesso em 12 jul. 2020.

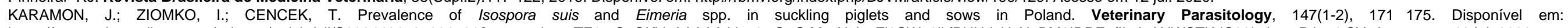

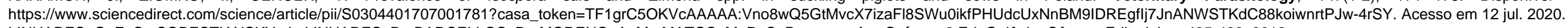

LINHARES, G. F. C.; SOBESTIANSKY, J.; LINHARES, D.; BARCELLOS, D.; MORENO, A. M.; MATOS, M. P. C. Doenças dos Suínos. 2 Ed. Goiânia: Cânone Editorial, p. 435-466, 2012.

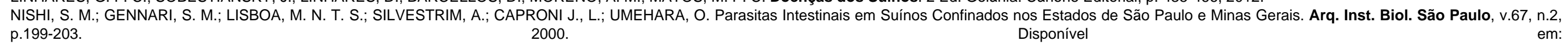

https://www.researchga

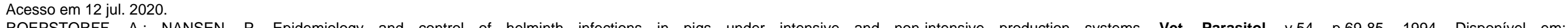
ROEPSTORFF, A.; NANSEN, P. Epidemiology and control of helminth infections in
https://www.sciencedirect.com/science/article/abs/pii/0304401794900841. Acesso em 12 jul. 2020.

SHEATHER, A. L. The detection of intestinal protozoa and mange parasites by a floatation technique. Journal of Comparative Pathology and Therapeutics, London, v. $36, \mathrm{n}$. 4, p. $266-275,1923$. 


\section{WILLIS, I. I. A simple levitation method for the detection of hookworm ova. Medical Journal of Austrália, v. 8, p. 375-376, 1921.}

Coordenadoria de Pesquisa e Extensão - COPEX

Departamento de Editoraçăo e Divulgaçăo Cientifica - DEDIC 


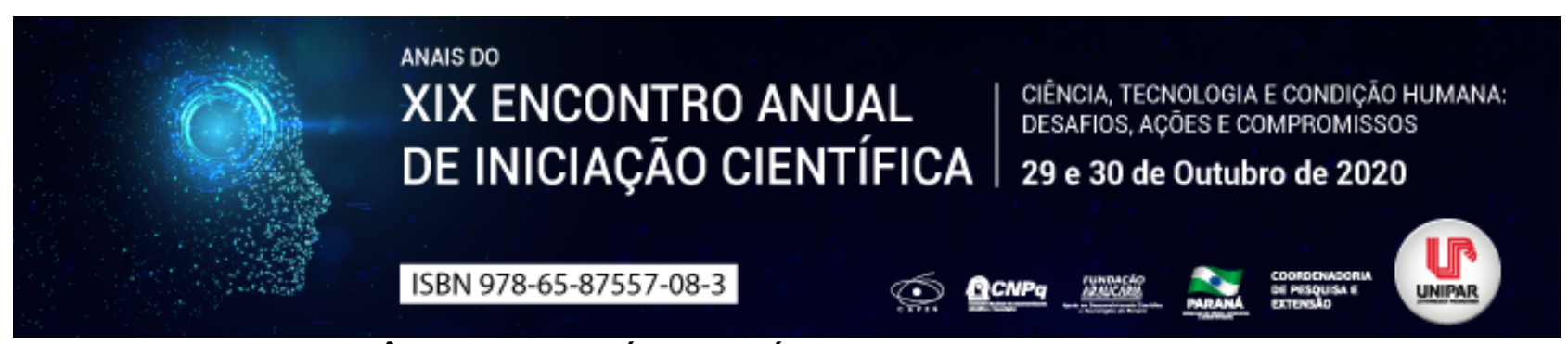

INSUFICIÊNCIA PANCREÁTICA EXÓCRINA CANINA - RELATO DE CASO

\author{
${ }^{1}$ Gisele Saiki Silva, ${ }^{2}$ DIEGO DARE DA SILVA
}

\author{
${ }^{1}$ Médica Veterinária Residente em Clínica Médica de Pequenos Animais - UEM Campus Umuarama-PR \\ ${ }^{1}$ Docente da UEM
}

Introdução: O pâncreas é considerado uma glândula mista que atua no sistema digestório por meio da produção de suco pancreático e no sistema endócrino produzindo hormônios como a insulina e o glucagon (MOREIRA et al., 2017). A insuficiência pancreática exócrina (IPE) caracteriza-se por uma deficiente produção de suco pancreático pelos ácinos pancreáticos que leva a uma má digestão e consequente má absorção de nutrientes, vitaminas e minerais (PATARROYO et al., 2013). A atrofia acinar pancreática secundária à destruição imunomediada é a causa mais comum de insuficiência pancreática exócrina (WESTERMARCK; WIBERG, 2006). Entretanto, sabe-se também que pancreatite crônica, neoplasia pancreática e hipoplasia pancreática podem levar à IPE (PATARROYO et al., 2013). Cães da raça Pastor Alemão são os mais comumente acometidos, sendo geralmente cães adultos-jovens, de 2 a 5 anos (PAPINI et al., 2008). É um diagnóstico diferencial importante em doenças que cursam com diarreia crônica. O teste de Imunorreatividade Semelhante à Tripsina (TLI) é o mais utilizado para a confirmação do diagnóstico (MOREIRA et al., 2017). O tratamento se baseia principalmente na suplementação enzimática por via oral junto às refeições. (PATARROYO, 2013; TANS, 2005). O objetivo do presente trabalho é relatar um caso de insuficiência pancreática exócrina em um cão atendido no Hospital Veterinário da Universidade Estadual de Maringá.

Relato de Caso: O presente estudo, descreve o caso de um cão macho, sem raça definida, de 13 anos de idade, 10,1 kg, que foi encaminhado para atendimento clínico com histórico de emagrecimento progressivo, polifagia, coprofagia e aumento do volume fecal há seis meses. Neste período também foi relatado diarreia amarelada esporadicamente. Ao exame físico o animal apresentou-se hidratado, com frequência cardíaca de 136 batimentos por minuto (bpm); Frequência respiratória de 24 movimentos por minuto (mpm); Temperatura retal de $38,1^{\circ} \mathrm{C}$ e mucosas normocoradas. Foi observado hiperqueratose de ponte nasal, esclerose de lente bilateral e caquexia com atrofia muscular generalizada. Aos exames de bioquímica sérica, apresentou aumento de marcadores hepáticos: Alanina transaminase (ALT) e fosfatase balcalina (FA), cujo valores foram 718,2 UI/L e 356 UI/L respectivamente. Não apresentou alterações ao hemograma, demais bioquímicos e ultrassonografia abdominal. Foi realizado o SNAP $\mathrm{CPL} \otimes($ IDEXX Laboratories) que é um teste rápido semiquantitativo para a dosagem da lipase específica canina cujo resultado estava dentro dos valores de normalidade $(<200 \mu \mathrm{g} / \mathrm{L})$. Inicialmente foi prescrito o protetor hepático silimarina pelo período de 20 dias, e ao fim do tratamento houve normalização dos marcadores hepáticos. Entretanto, o animal permaneceu com os sinais clínicos referidos anteriormente (polifagia, fezes volumosas, diarreia intermitente e emagrecimento). Foi então realizada a dosagem de TLI e o resultado foi $1 \mu \mathrm{g} / \mathrm{L}$ (Valores de referência 5 a $35 \mu \mathrm{g} / \mathrm{L}$ ) confirmando o diagnóstico de IPE. Foi prescrito pancreatina em pó na dose de $5 \mathrm{~g}$ a cada 12 horas, junto à alimentação e Omeprazol $1 \mathrm{mg} / \mathrm{kg}$ por via oral a cada 12 horas, 1 hora antes de cada alimentação. Após 30 dias do início do tratamento o animal apresentava-se assintomático e com melhora do score corporal. Houve um ganho de $1,3 \mathrm{~kg}$ que equivale a $12 \%$ no peso corporal anterior.

Disussão: A IPE é uma doença que acomete prevalentemente animais adultos jovens da raça Pastor Alemão, porém cães de diversas idades e faixa etária já foram descritos (PATARROYO \& CUERO, 2013; LUCCA, 2017; MOREIRA et. Al., 2017). A causa mais comum do desenvolvimento da doença é a atrofia acinar pancreática, seguido de pancreatite crônica e neoplasias pancreáticas (LUCCA, 2017; PATARROYO \& CUERVO, 2013). Segundo Sherding et al. (2008), quando a IPE está associada à pancreatite crônica, o animal pode apresentar sinais clínicos em qualquer idade incluindo animais idosos, já em quadros de atrofia acinar pancreática os sinais clínicos se apresentarão comumente antes dos quatro anos de idade. Apesar de ser raro a atrofia acinar de forma tardia, no presente relato o animal apresentou sinais clínicos da doença aos 13 anos de idade e não apresentou quaisquer sinais clínicos ou laboratoriais de pancreatite crônica. O diagnóstico padrão ouro se faz pela avaliação da concentração sérica de tripsinogênio através da TLI (MOREIRA et al., 2017; LUCCA, 2017). O tratamento pode variar conforme o estado clínico do animal, a gravidade do caso e o grau de atrofia pancreática (PATARROYO \& CUERVO, 2013). Porém a utilização da pancreatina junto a alimentação se mostrou um importante recurso terapêutico para o controle da doença.

Conclusão: A IPE é um diagnóstico diferencial importante quando se tem diarreia crônica e emagrecimento progressivo associado à polifagia inclusive em animais de idade mais avançada. A dosagem de TLI é o teste mais indicado para diferenciar IPE de outras causas de má-digestão ou má-absorção. O prognóstico é favorável, com a suplementação enzimática e o manejo dietético adequado a maioria dos animais tornam-se assintomáticos.

\title{
Referências
}

LUCCA, R. P. da V. de. Insuficiência pancreática exócrina em cão - relato de caso. Arq. Ciênc. Vet. Zool. UNIPAR, 
Umuarama, v. 20, n. 2, p. 83-86, abr./jun. 2017.

MOREIRA, T. de A. et al., A. A. Patologias pancreáticas em cães: revisão de literatura. Arq. Ciênc. Vet. Zool. UNIPAR, Umuarama, v. 20, n. 2, p. 109-115, abr./jun. 2017.

PAPINI, S. D. J. P. et al. Atrofia do pâncreas exócrino em pastor alemão. Clinica Veterinária, São Paulo, n. 73, p. 50-54, 2008.

PATARROYO, Camilo Guarín; CUERVO, Fabian Rodrigo Sánchez. Insuficiencia Pancreatica Exócrina (IPE) em Canina. Revista Logos, Ciencias e Tecnologia, vol. 5, núm. 1, jul./dez. 2013, p. 84-96, Bogotá, Colômbia.

SHERDING, R. G.; BICHARD, S. J.; JOHNSON, S. E. Doenças e cirurgia do pâncreas exócrino In: Manual Saunders - Clínica de pequenos animais, 3. ed. São Paulo: Roca, 2003, p. 965-974.

WESTERMARCK, E.; WIBERG, M. E. Effects of diet on clinical signs of exocrine pancreatic insufficiency in dogs. Journal of American Veterinary Medical Association, v. 228, p. 225-229, 2006.

Coordenadoria de Pesquisa e Extensão - COPEX

Departamento de Editoraçāo e Divulgaçāo Científica - DEDIC 


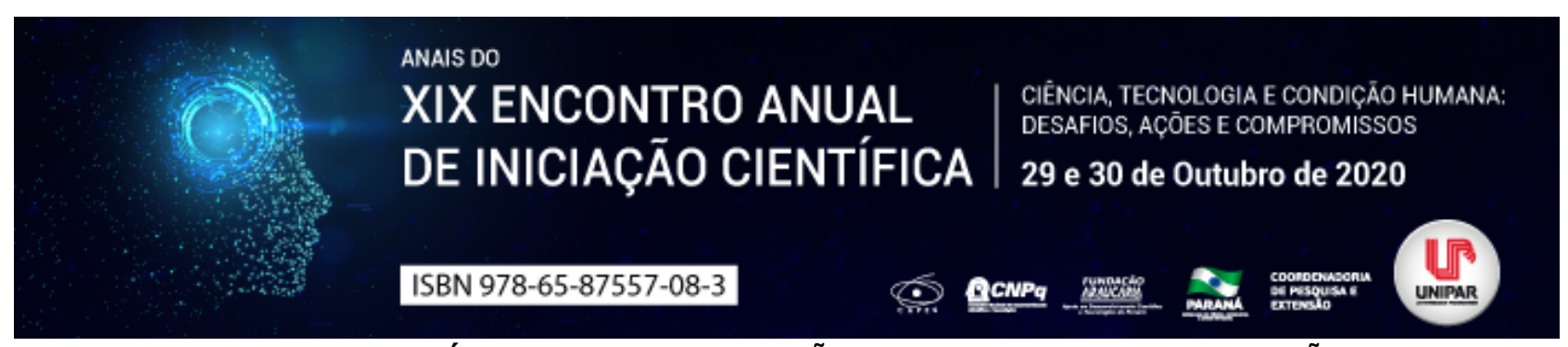

ABORDAGENS TÉCNICAS PARA INGESTÃO DE CORPO ESTRANHO EM CÃES

\begin{abstract}
${ }^{1}$ ALYSON LIBERALI ARAUJO, ${ }^{2}$ ALECSANDRO SILVA DE LIMA ELIAS, ${ }^{3}$ DANIELLE ANDRESSA OLIVEIRA SESTARI, ${ }^{4}$ BRUNO ARGENTON DE BARROS, ${ }^{5}$ CARLOS RENATO DE FREITAS GUAITOLINI, ${ }^{6}$ ROSIARA ROSARIA DIAS MAZIERO
\end{abstract}

\begin{abstract}
${ }^{1}$ Acadêmico do Curso de Mestrado do Programa de Pós-graduação em Ciência Animal com ênfase em produtos bioativos UNIPAR

${ }^{1}$ Acadêmico do Curso de Mestrado do Programa de Pós-graduação em Ciência Animal com ênfase em produtos bioativos UNIPAR

${ }^{2}$ Acadêmica do Curso de Mestrado do Programa de Pós-graduação em Ciência Animal com ênfase em produtos bioativos UNIPAR

${ }^{3}$ Acadêmico do Curso de Medicina Veterinária da UNIPAR

${ }^{4}$ Acadêmico do Curso de Programa Nacional de Pos-doutorado -PNPD/CAPES da UNIPAR

${ }^{5}$ Docente da UNIPAR
\end{abstract}

Introdução: A ingestão de corpo estranho por animais domésticos tem sido muito frequente na rotina hospitalar, assim, com base neste aumento, é necessário o aprimoramento sobre as técnicas, exames e condutas para o rápido atendimento à estes animais (FOSSUM, 2005).

Objetivo: Revisar sobre abordagens clínicas e cirúrgicas de ingestão de corpo estranho por pequenos animais.

Desenvolvimento: Os cães são uma espécie que frequentemente e indiscriminadamente ingerem pedras, brinquedos plásticos, sacos de cozinha, entre outros objetos. Neste contexto é indispensável que a anamnese e alguns sinais clínicos já possam ser característicos desta patologia emergencial (FOSSUM, 2005). Segundo PARRA et al na anamnese de corpo estranho (CE) são comuns alguns achados incluindo engasgos, anorexia, ptialismo, inquietação, tentativas de vômito, regurgitação, disfagia. Ao exame fisico deve-se apurar a auscuta de movimentação peristáltica intestinal, porém para se confirmar um diagnóstico é nescessária a realização de exames complementares. As radiografias simples ou contrastadas juntamente com a endoscopia para diagnóstico de corpo estranho são as mais confiáveis, entretanto se as estruturas ingeridas forem radiolúcidas podem dificultar o diagnóstico (PARRA, 2012). LIMA (2007) afirma que a junção dos achados clínicos, baseando-se principalmente no histórico do animal, seguido de exame físico geral e exames complementares são essenciais para o diagnóstico definitivo. Se confirmado o diagnóstico, realiza-se uma avaliação do fluxo gastrointestinal imediata e monitorada no intuito de observar obstrução. Se não forem diagnosticados no imediato sinais de obstrução, não se indica primariamente a intervenção cirúrgica (BRESCIANI et, al., 1999). Para uma boa conduta antes de toda intervenção cirúrgica, inicialmente devem ser realizados exames pré-cirúrgicos que indicam algumas patologias que podem ser corrigidas antes do procedimento, como nos casos de hipovolemia que possam ser corrigidas, juntamente com a reposiçãos de fluidos. MENESES (2007) cita que para o paciente cirúrgico, as avaliações pré-cirúrgicas são particularmente úteis para se minimizar complicações cirúrgicas e anestésicas que possam vir a ocorrer, como choque hipovolêmico, além de permitir a busca por doenças concomitantes. VEIGA et al afirmam que a fluidoterapia ajuda a restabelecer as funções renais, melhorando também os efeitos anestésicos. A antbioticoterapia profilática também deve ser adotada por ser uma cirurgia considerada de alto risco de contaminação, para LIMA (2007) a administração de antibióticos no pré-cirúrgico deve ser de amplo espectro de ação, principalmente para o combate as bactérias gram-negativas, além das gram-positivas, possibilitando um pós-cirúrgico com menos complicações e risco de contaminação secundária. $O$ procedimento cirurgico em caso de corpo estranho deve ser guiada pela a avaliação radiográfica, e por fim a laparotomia exploratória. Grande parte das vezes os CE são encontrados no estômago e nas alças intestinais, tanto no intestino grosso quanto no delgado (BOJRAB, 2005). Deve-se realizar uma laparotomia exploratória no intestino verificando e expondo todos os seguimentos na procura de novas obstruções. Na gastrotomia expôem-se o estômago e o isola o com compressas, a incisão é na área entre as curvatura maior e menor. Segundo FOSSUM (2005) deve-se realizar a incisão entre as curvaturas, devido a região ser hipovascularisada. Seguindo para a retirada do CE, deve-se tomar cuidado com o líquido gástrico, e por fim um padrão de rafia. O padrão de fechamento do estômago é de sutura seromuscular invertido duas camadas com cushing e contínua simples (FOSSUM, 2005). Na enterotomia o principal cuidado a ser tomado é o de interupção do fluxo fecal, com intenção de evitar peritonite por se tratar de uma cirurgia altamente contaminante, pela grande proporção bacteriana localizada no intestino. Solicitar ao auxiliar ocluir o lúmen utilizando dois dedos ou usar uma pinça intestinal atraumática (Doyen) ou um dreno de Penrose como torniquete para ocluir o lúmen intestinal para evitar extravasamento de conteúdo (FOSSUM, 2005). Finalmente, a incisão deve ser adequada ao tamanho do corpo estranho.

Conclusão: A ingestão de corpo estranho é uma importante patologia na clínica de pequenos animais, neste sentido, 


\section{Referências}

BOJRAB, M. J. Técnicas atuais em cirurgia de pequenos animais. 5ed. São Paulo: Roca, 2005.

BRESCIANI, K.D.S. et, al. Cestranhos Gastrintestinais em ção, Arsveterinaria e zootecnica revista cientifica online, ars veterinaria, v. 15 n. 3, 1999. Disponível em: Acesso em 05/08/2020.

FOSSUM T. W. Cirurgia do sistema digestório $4^{a}$ edição FOSSUM T. W. cirurgia de pequenos animais. Rio de Janeiro RJ, elsevter Itda, 2005. p. 479-544.

LIMA, R.O.C.; clínica e cirurgia de pequenos animais. 2007. Monografia. Universidade Federal de Goias - Campus Jataí, Goiás, Brasil, Revista da UFG 2007.

MENESES., I.D.S.; Avaliação clínica e laboratorial pré-operatória para cirurgias eletivas. 2007 monografia - UFBA, Revista da UFBA Bahia Brasil 2007.

PARRA,T.C,; BRENO, M.D.B.; GUIMARÃES, A.C.M.; ANDRADE, L.C.A.; MOSQUINI, A.F.; MONTANHA, F.P. INGESTÃO DE CORPO ESTRANHO EM CÃES RELATO DE CASO, Revista cientifica eletrônica de medicina veterinária, periódico semestral, n. 18, Janeiro, 2012. Disponível em: . Acesso em 05/08/2020.

VIEGA, A.L.G.; MIZIARA, H.R., ARGRIMANI, D.S.R., REGAZZI, F.M., SILVA, L.C.G., LUCIO, C.F., VANNUCCHI, C.I., Abordagem diagnóstica e terapêutica das principais afecções uterinas em cadelas Publicado na revista portuguesa de ciências veterinárias, Faculdade de Medicina Veterinária e Zootecnia, Universidade de São Paulo (USP), São Paulo Brasil 2013.

VEIGA, G.A.L., et, al. Abordagem diagnóstica e terapêutica das principais afecções uterinas em cadelas. Revista Portuguesa de Ciências Veterinárias, v. 108. n. 585 - 586 , p . 9 - 6, 2013. 


\title{
XIX ENCONTRO ANUAL \\ CIÉNCIA, TECNOLOGIA E CONDIÇĀO HUMANA: DESAFIOS, AÇŌES E COMPROMISSOS \\ DE INICIAÇĀO CIENTÍFICA 29 e 30 de Outubro de 2020
}

ISBN 978-65-87557-08-3

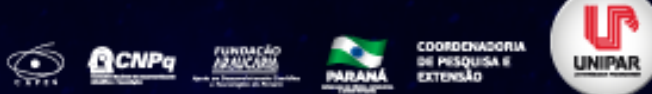

OCORRÊNCIA DE ÁCAROS CAUSADORES DE SARNA EM CÃES ATENDIDOS NO HOSPITAL VETERINÁRIO DA UNIVERSIDADE FEDERAL DO PARANÁ SETOR PALOTINA

${ }^{1}$ Laura Zanella Souza, ${ }^{2}$ BRUNA ÁVILA TORRES, ${ }^{3}$ ANA PAULA MOLINARI CANDEIAS, ${ }^{4}$ ANDRÉ LUIS VRIESMAN BENINCA, ${ }^{5}$ NELSON LUÍS MELLO FERNANDES

\author{
${ }^{1}$ Médica Veterinária Residente / Programa de Residência em Medicina Veterinária da Universidade Federal do Paraná Setor \\ Palotina \\ ${ }^{1}$ Médica Veterinária Residente / Programa de Residência em Medicina Veterinária da Universidade Federal do Paraná Setor \\ Palotina \\ ${ }^{2}$ Mestrado em Ciência Animal / Universidade Federal do Paraná Setor Palotina \\ ${ }^{3}$ Mestrado em Ciência Animal / Universidade Federal do Paraná Setor Palotina \\ ${ }^{4}$ Departamento de Ciências Veterinárias UFPR - Setor Palotina
}

Introdução: As dermatopatias de causas parasitárias possuem importância não só por sua incidência nos atendimentos em clínica veterinária, mas também por algumas possuírem potencial zoonótico. Dentre os ácaros causadores de sarna em cães, destacam-se as causadas por ácaros da família Demodecidae, gênero Demodex e as causadas por ácaros da família Sarcoptidae (gêneros Sarcoptes e Notoedres) (DUNN, 2001).

Objetivo: O objetivo deste estudo foi identificar o principal ácaro causador de sarna em cães atendidos no Hospital Veterinário da UFPR Setor Palotina, nos períodos de junho de 2019 a agosto de 2020.

Relato de caso: Foram coletadas amostras de raspado de pele de (54) cães atendidos na rotina do hospital veterinário. Os cães tinham de 2 meses a 9 anos, de diferentes sexos e raças. Todos os cães apresentaram lesões características em regiões de cabeça e patas. O diagnóstico foi realizado no Laboratório de Doenças Parasitárias UFPR Palotina, com utilização de microscópio óptico (10x). Dos cães estudados 9 foram positivos, sendo 8 para presença de Demodex canis e 1 positivo para presença de Sarcoptes scabiei.

Discussão: Entre os casos positivos, chama a atenção a maior incidência de sarnas demodécicas e sarcópticas, o que condiz com o que é descrito por DUNN (2001). A sarna sarcóptica também pode acometer humanos, sendo considerada de importância zoonótica, como descrito por AIELLO (2001), fazendo-se necessário que o médico veterinário informe os riscos ao tutor. Dentre os animais estudados, haviam machos e fêmeas, mostrando que as sarnas não possuem predileção de sexo ou raça, como já relatado por SCOTT (1995) e CURTS (2004). A maior incidência de sarna nos cães estudados, foi a demodécica (88,8\%), sendo que destas, a maioria (87,5\%) eram pacientes jovens, o que corrobora com dados descritos por PINHO et al. (2015).

Conclusão: Devido significativa incidência e potencial zoonótico de dermatopatias por ácaros de sarna, se faz necessário realização de estudos com base em achados clínicos, proporcionando a elaboração de estratégias de controle para evitar a disseminação desses parasitas. A demodicose causada pelo Demodex canis se mostra a principal entre as dermatopatias causadas por ácaros de sarna nos cães atendidos no H.V UFPR em Palotina- PR.

\section{Referências}

AIELLO, Susan. Manual Merck de veterinária. 8. ed. São Paulo: Roca, 2001.p.547 548.

CURTS, Cathy. Current trends in the treatment of Sarcoptes, Cheyletiella and otodectes mite infestations in dogs and cats. Veterinary Dermatology. V. 15, p. 108-114, mar. 2004.

DUNN, John. Tratado de medicina de pequenos animais. São Paulo: Roca, 2001.

PINHO, Renato; MONZÓN, Marcos Fernández; SIMÕES, João. Dermatologia veterinária em animais de companhia. São Paulo: Artes Médicas, 2015.

SCOTT, Danny; MILLER, William; GRIFFIN, Craig. Parasitic skin diseases: Small Animal Dermatology. 5. ed. Philadelphia: W. B. Saunders, 1995.p.417-432. 


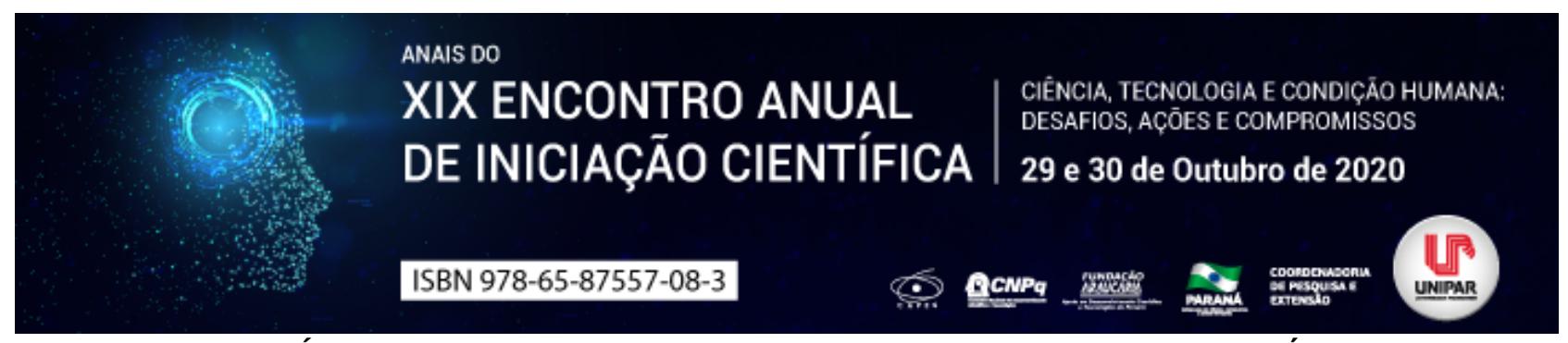

PRINCIPAIS PROTEÍNAS DE FASE AGUDA IDENTIFICADAS NA MASTITE ESTAFILOCÓCICA EM OVINOS

\author{
${ }^{1}$ Amanda Gasparucho Bossi, ${ }^{2}$ ANDRÉ MARCOS SANTANA
}

${ }^{1}$ Discente do curso de Medicina Veterinária, Universidade Estadual de Maringá UEM/ Campus de Umuarama

${ }^{1}$ Docente de Medicina Veterinária, Universidade Estadual de Maringá UEM/ Campus de Umuarama

Introdução: A mastite é uma inflamação da glândula mamária que causa grandes prejuízos na cadeia produtiva, tanto para a produção de leite quanto para a ovinocultura de corte. Esta enfermidade pode ser desencadeada por diferentes mecanismos, um deles é decorrente de infecções bacterianas, sendo um dos principais agentes etiológicos da mastite clinica o Staphylococcus aureus, que pode levar a alterações locais na glândula mamária e também sistêmicas (COSTA et al., 2010). Este patógeno é causador de tipos graves de mastite além de ser responsável pela produção de enterotoxinas termoestáveis importantes para a cadeia alimentar e patogênese da infecção (CONTRERAS et al., 2007). Para que esta infecção não cause prejuízos ainda maiores, é importante a realização de um diagnóstico rápido e precoce da mastite causada pelo Staphylococcus aureus e das mastites estafilocócicas em geral. Desta forma, a identificação e utilização de proteínas de fase aguda (PFA) que se alteram durante processos inflamatórios, para fins diagnóstico, instituição de tratamento precoce e caracterização de um correto prognóstico de processos infecciosos, como as mastites, pode ser de grande utilidade para a espécie ovina.

Objetivo: Esta revisão tem como objetivo estudar algumas das principais PFA relacionadas a mastite estafilocócica em ovinos.

Desenvolvimento: Estudos referentes a identificação de PFA na mastite causada por Staphylococcus aureus e mastites estafilocócicas em geral são escassos em ovinos. Contudo, é de grande importância o entendimento das alterações decorrentes da mastite, visto que quanto maior o domínio sobre o tema, melhores as chances de intervenções precoces e consequentemente melhora no rendimento na ovinocultura. Dentre as PFA estudadas no soro sanguíneo, algumas podem sofrer diminuição e outras aumento de suas concentrações devido a um processo inflamatório, e desta forma podem ter grande potencial para utilização como biomarcadores (ECKERSALL; BELL 2010). A haptoglobina pode ser considerada uma das principais PFA, visto que em ovelhas hígidas seus níveis são considerados imperceptíveis, enquanto que em processos inflamatórios pode haver aumento em seus níveis séricos de até 80 vezes (CECILIANI et al., 2012). Costa et al. (2010) e Simplício et al. (2017) conduziram experimentos relacionados a mastite por Staphylococcus aureus em ovelhas, observando elevação sérica da haptoglobina em 14,0 e 5,8 vezes, respectivamente. Além disso, Lemos et al. (2015), observou aumento de sete vezes nas concentrações de haptoglobina no soro lácteo de glândulas mamárias infectadas, porém não houve discriminação do agente etiológico causador. Outra proteína importante é a a1-glicoproteína ácida que apresenta propriedades imunomoduladoras e atua como transportadora no plasma (CECILIANI et al., 2012). Após o estimulo inflamatório, esta proteína se eleva no soro sanguíneo e apresenta resposta prolongada, que pode indicar uma função como marcador de alterações crônicas em ovinos (CECILIANI et al., 2012). Em ovelhas com mastite por estafilococos foi observada elevação de 3,5 vezes das concentrações séricas dessa glicoproteína (SIMPLícIO et al., 2017), o que poderia caracterizá-la como uma PFA. A ceruloplasmina é considerada a principal proteína sérica transportadora de cobre, fundamental para cicatrizar feridas, além de proteger tecidos e células de compostos oxidantes provenientes de fagócitos que desempenham ação contra microrganismos (CONTIN et al., 2015), desta forma é considerada uma importante proteína de fase aguda. Em um estudo comparativo entre diferentes enfermidades agudas em ovinos, foi possível observar que as concentrações séricas de ceruloplasmina em animais que apresentaram mastite foram elevadas nos primeiros dias do estudo (SIMPLíCIO et al., 2015). Em outro estudo, sobre mastite por Staphylococcus aures, constatou-se aumento da concentração sérica de ceruloplasmina em seis vezes quando comparado ao grupo controle (COSTA et al., 2010), sendo que essa alteração pode ser devido a função biocatalisadora e anti-inflamatória desta proteína (COSTA et al., 2010).

Conclusão: Através dos resultados expostos nesta revisão de literatura, pode-se concluir, que a ceruloplasmina, haptoglobina e a1-glicoproteína ácida representam importantes indicadores de inflamação relacionados a mastite estafilocócica em ovinos. Assim sendo, trabalhos devem ser conduzidos no sentido de elucidar a potencial utilização destas proteínas como biomarcadores para a mastite nesta espécie animal.

\title{
Referências
}

CECILIANI, Fabrizio et al. Acute phase proteins in ruminants. J. Proteomics, v. 75, p. 4207-4231, jul. 2012.

CONTIN, Catarina Micali et al. Proteínas de fase aguda: revisão de literatura. R. Investigação, v. 14, n. 2, p 73-76, 2015. ISSN 21774780.

CONTRERAS, Antonio et al. Mastitis in small ruminants. Small Ruminant Res., v. 68, n. 1-2, p. 145-153, mar. 2007.

COSTA, Nivaldo de Azevêdo et al. Proteinograma e teores de cobre, ferro e zinco no soro sanguíneo de ovelhas da raça Santa Inês com mastite experimental por Staphylococcus aureus. Pesq. Vet. Bras., Rio de Janeiro, v. 30, n. 5, p. 435-442, mai. 2010. 
Disponível em: http://www.scielo.br/scielo.php?script=sci_arttext\&pid=S0100-736X2010000500011\&lng=en\&nrm=iso. Acesso em: 24 jul. 2020.

ECKERSALL, Peter D.; BELL, Rory. Biomarkers of infection and inflammation in veterinary medicine. Vet. J., v.185, n. 1, p. 2327, jul. 2010.

LEMOS, Vânia F. et al. Effects of intramammary infection on whey proteinograms of sheep during lactation. Pesq. Vet. Bras., Rio de Janeiro, v. 35, n. 3, p. 230-236, mar. 2015. Disponível em: http://www.scielo.br/scielo.php?script=sci_arttext\&pid=S0100736X2015000300230\&lng=en\&nrm=iso. Acesso em: 24 jul. 2020.

SIMPLícIO, K.M.M.G. et al. Proteínas de fase aguda em ovinos portadores de enfermidades agudas de ocorrência natural. $\mathbf{R}$. Investigação, v. 14, n. 6, p 67-73, 2015. ISSN 21774080.

SIMPLíCIO, K.M.M.G. et al. Serum concentrations of acute phase proteins in goats and ewes with naturally acquired Staphylococcus aureus mastitis. Arq. Bras. Med. Vet. Zootec., Belo Horizonte, v. 69, n. 2, p. 285-292, abr. 2017. Disponível em: http://www.scielo.br/scielo.php?script=sci_arttext\&pid=S0102-09352017000200285\&lng=en\&nrm=iso. Acesso em 24 jul. 2020.

Coordenadoria de Pesquisa e Extensão - COPEX

Departamento de Editoraçāo e Divulgaçāo Científica - DEDIC 


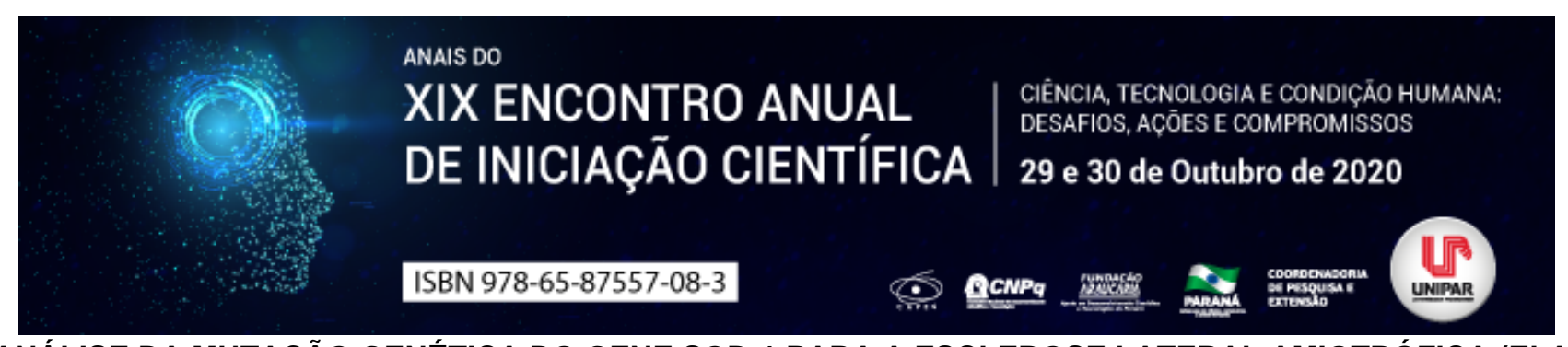

ANÁLISE DA MUTAÇÃO GENÉTICA DO GENE SOD-1 PARA A ESCLEROSE LATERAL AMIOTRÓFICA (ELA)

\author{
${ }^{1}$ LUIS FERNANDO ESPINOZA LUIZAR, ${ }^{2}$ AMANDA HECK SCHEUER, ${ }^{3}$ AMANDA SIHNEL CORTEZ DA SILVA, ${ }^{4}$ JULIA \\ TAMIOZZO BENINI, ${ }^{5}$ LUCIANO SERAPHIM GASQUES, ${ }^{6}$ DENISE ALVES LOPES
}

\author{
${ }^{1}$ Acadêmico do Curso de medicina da UNIPAR \\ ${ }^{1}$ Acadêmica do Curso de Medicina da UNIPAR \\ ${ }^{2}$ Acadêmica do Curso de Medicina da UNIPAR \\ ${ }^{3}$ Acadêmica do Curso de Medicina da UNIPAR \\ ${ }^{4}$ Docente da UNIPAR \\ ${ }^{5}$ Docente da UNIPAR
}

Introdução: A Esclerose Lateral Amiotrófica (ELA) foi relatada em 1869 por Jean-Martin Charcot, e se caracteriza pela morte dos neurônios motores. Os primeiros sintomas mais comuns da ELA são a atrofia e fraqueza muscular, fasciculações, cãibras, hipertonia e hiperreflexia. A princípio, ocorre a paralisia de membros superiores sem perda de sensação, acompanhada de rigidez muscular resultante de espasmo e deformação muscular por contratura. Aproximadamente $20 \%$ dos casos habituais de esclerose lateral amiotrófica (ELA) são causados por mutações na enzima Cu, Zn-superóxido dismutase (SOD-1). Geralmente, os portadores dessa doença vão a óbito em decorrência da deficiência respiratória, uma vez que a doença possui como característica uma diminuição muscular, podendo nesse caso se agravar e levar à morte. Além disso, não se conhece maneiras de se prevenir o surgimento da ELA, nem retardar a velocidade com que avança sobre o organismo (VOLTARELLI, 2004; CASSEMIRO, 2003). Ademais, na ELA mantêm-se preservadas faculdades tais como a inteligência, juízo, memória, os movimentos oculares e os órgãos dos sentidos, e em alguns casos, as funções vesical, intestinal e sexual (ABRELA, 2007). A principal função da enzima SOD1 é destruir os radicais de superóxidos, produzidos como subprodutos naturais das reações produtoras de energia da célula. Entretanto, não é a redução na atividade do SOD1 que leva a ELA familiar, e sim um ganho de alguma função tóxica ou reação oxidativa que dá início às alterações neuropatológicas.

Objetivo: Este trabalho tem como objetivo avaliar a distância genética e a filogenia de sequências do mRNA (RNA mensageiro) dos genes SOD1 na espécie humana e disponíveis no banco de dados da NCBI (National Center for Biotechnology Information).

Material e métodos: Através do programa Blast, disponível no site do NCBI, foram analisados as sequências de RNA mensageiro do gene SOD-1 (super oxidase desmutase) seguindo os critérios de e $=0$ e com todas as

sequências alinhadas de RNA mensageiro do SOD-1 com 595 pb (pares de bases). As análises foram desenvolvidas no programa MEGA X, o alinhamento foi realizado através do algoritmo Clustal W, e a escolha do melhor parâmetro/modelo de filogenia foi decidida através do algoritmo Find best DNA/Protein models (ML), ou seja, foi executada através do método de máxima verossimilhança.

Resultados: Ao utilizar os critérios de seleção foram encontrados um clado com 9 sequências de mRNA sem mutação e mais dois clados com uma sequência de mRNA cada e que apresentam discrepâncias entre si e com o clado anterior. A distância $p$ média encontrada foi de 0,0014, o que significa que a sequência desse RNA mensageiro é de suma importância para o organismo, visto que apresenta baixa variabilidade genética e com poucos pontos de mutação. Para análise filogenética, o cálculo de melhor modelo indicou o parâmetro de JC (Jukes and Cantor) para a reconstrução filogenética. Além disso, foi possível encontrar quatro pontos de mutação em uma sequência analisada de $595 \mathrm{pb}$ (pares de bases).

Discussão: Como o gene superóxido dismutase (SOD1) atua na destruição dos radicais de superóxido, entretanto, sua diminuição leva ao desenvolvimento da ELA (FONSECA, 2012). Este possui evidência no processo de atrofia muscular, e desse modo apresentou uma baixa variabilidade genética. De acordo com a distância analisada tornou-se executável a reconstrução da filogenia do SOD1. A despeito das variações no gene é presumível a mutação que provoca mudanças no funcionamento dele, pois existem dois clados com sequências individuais que possuem discrepâncias entre si (CERQUEIRA, 2007).

Conclusão: O gene SOD1 apresenta baixa variabilidade genética ao evidenciar sua vulnerabilidade para a espécie humana. A análise de filogenia transmite um clado com nove sequências bem definidas sem mutação.

\title{
Referências
}

CALADO, E.F.; LANG, C.E. Psicopatologia Fundamental e a morte na doença Esclerose Lateral Amiotrófica. Psicologia \& Saberes, v. 3, n. 3, 2014.

CERQUEIRA, F.M. Consequências da expressão da enzima Cu, Zn-superóxido dismutase (SOD1) e sua mutante G93A em neuroblastomas. Implicações para a esclerose lateral amiotrófica. Orientadora: Ohara Augusto. 2007. 82 p. Dissertação 
(Mestrado) Universidade de São Paulo. Programa de Pós-graduação em Ciências (Bioquímica). Instituto de Química, São Paulo, 2007.

FONSECA, L.A. et al. Orientações emergenciais para profissionais que assistem pacientes com Esclerose Lateral Amiotrófica. Revista Neurociências, v. 20, n. 2, p. 260-265, 2012.

STANICH, P. Suplementação nutricional em pacientes com doença do neurônio motorlesclerose lateral amiotrófica. Orientador: Acary Souza Bulle Oliveira. 2003. 119 p. Tese (Mestrado em Ciências) Universidade Federal de São Paulo. Escola Paulista de Medicina. Programa de Pós-Graduação em Neurociências, São Paulo, 2003.

Coordenadoria de Pesquisa e Extensão - COPEX

Departamento de Editoraçāo e Divulgaçāo Científica - DEDIC 


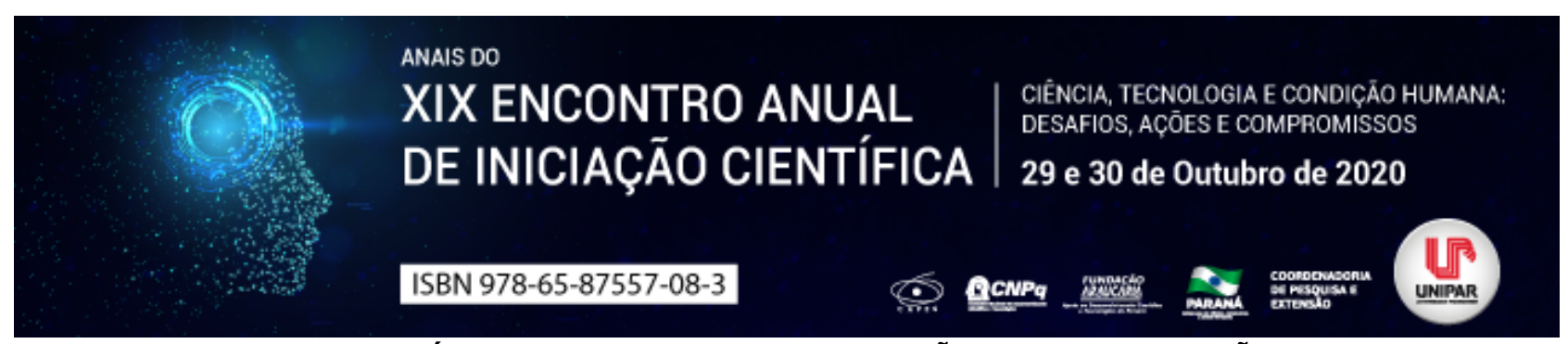

USO DE ÓLEOS ESSENCIAIS NA PRODUÇÃO ANIMAL - REVISÃO

\begin{abstract}
${ }^{1}$ PATRICIA STANOGA DE ALMEIDA NASCIMENTO, ${ }^{2}$ DERICK DE ALMEIDA MARCHI, ${ }^{3}$ JESSE LAHOS BORGES, ${ }^{4}$ FILIPE CORREA PACHECO, ${ }^{5}$ RANULFO PIAU JUNIOR
\end{abstract}

\author{
${ }^{1}$ Discente UNIPAR Bolsista PIBIC/UNIPAR \\ ${ }^{1}$ Acadêmico do Curso de Medicina Veterinária-PIC-UNIPAR \\ ${ }^{2}$ Doutorando da Pós-graduação em Ciência Animal Com Enfase Em Produtos Bioativos - UNIPAR \\ ${ }^{3}$ Mestrando da Pós-graduação em Ciência Animal Com Enfase Em Produtos Bioativos - UNIPAR \\ ${ }^{4}$ Docente da UNIPAR
}

Introdução: A proibição do uso de promotores de crescimento como mecanismo preventivo de situações de disbiose com depressão da microbiota indesejável determinou que pesquisadores e nutricionistas buscassem novas alternativas, surgindo como a alternativa a utilização de diferentes óleos essenciais que preservem o equilíbrio no trato gastrintestinal, atuando como uma barreira defensiva para evitar a multiplicação de bactérias patogênicas na mucosa intestinal e,consequentemente, eliminar os distúrbios que venham a afetar a digestão e a absorção de nutrientes (SANTIN et al., 2001). Como alternativa ao uso de antibióticos promotores de crescimento tem sido estudado: o uso de probióticos, prebióticos, enzimas, ácidos orgânicos e extratos vegetais (JEAUROUND, 2002). Conforme pesquisa realizada por Brugalli (2003), a utilização de óleos ou extratos herbais nas rações tem como requisito básico a não toxicidade aos animais,

Objetivo: Fazer uma revisão sobre o uso de óleos essências na produção animal.

Desenvolvimento: $O$ termo óleo essencial, também conhecido como óleos voláteis, refere-se a líquido obtidos a partir de derivados de plantas ou produzidos sinteticamente (JESUS, 2007; ZHANG et al., 2005). Muitos pesquisadores acreditam que a associação de diferentes óleos na dieta animal, proporcionam melhores resultados no desempenho animal, e essa melhora é atribuída ao sinergismo dos componentes dos óleos (LANGHOUT, 2000). Estudos de Oetting (2005) citam que a ação dos óleos essenciais está no controle de patógenos pela atividade antimicrobiana, atividade antioxidante, melhora na digestão por meio do estímulo da atividade enzimática e absorção de nitrogênio, além de outros efeitos relacionados às alterações na histologia do epitélio intestinal (CHILANTE et al., 2012). Os óleos essenciais agem ainda no processo de digestibilidade dos alimentos, através da estimulação do aumento da produção de saliva, do suco gástrico e pancreático, consequentemente aumentando a secreção de enzimas e auxiliando na melhora da digestibilidade dos nutrientes (MELLOR, 2000). Alguns estudos comprovam essa eficácia do sinergismo dos óleos essenciais, Losa (2001), trabalhando com frango de corte, e a associação de diferentes óleos essenciais foi possível à redução de $70 \%$ de animais acometidos por Clostridium perfringes, e promovendo melhora no desempenho animal quando comparadas às aves que receberam o tratamento de eleição com sulfato de zinco. Em estudos de, Zhou et al. (2007) avaliaram o potencial antimicrobiano de óleos essenciais frente à Salmonella typhimurium e observaram que a associação dos princípios ativos principais do óleo essencial de canela e orégano (cinamaldeido + timol; cinamaldeído + carvacrol; timol + carvacrol) apresentou maior inibição contra S. typhimurium, mostrando efeito sinérgico entre os princípios ativos (LEITE et al., 2012).

Conclusão: Estudos demonstram a eficácia do uso de óleos essências na produção animal. Adicionados à dieta dos animais são capazes de aumentar a produtividade, melhorar a qualidade da ração e as condições de higiene, além de melhorar a qualidade dos alimentos derivados desses animais.

\title{
Referências
}

BRUGALLI, I. Alimentação alternativa: a utilização de fitoterápicos ou nutracêuticos como moduladores da imunidade e desempenho animal. In: SIMPÓSIO SOBRE MANEJO E NUTRIÇÃO DE AVES E SUÍNOS, 1., 2003, Campinas. Anais... Campinas: CBNA, 2003. p. 167-182.

CHILANTE, R. B.; KUSSAKAWA, K. C. K.; FLEMMING, J. S. Efeitos da utilização de óleos essenciais na alimentação de aves matrizes pesadas. Revista Acadêmica de Ciências Agrárias e Ambientais, v. 10, p. 387-394. 2012.

JEAUROUND, E. et al. Supplementation of diets with herbal extracts enhances growth performance in newly-weaned piglets. Journal of Animal Science, v. 20, suppl. 1, p. 394, 2002.

JESUS, D. C. Avaliação dos efeitos da adicao do oleo essencial de oregano (Oreganum vulgare) na dieta, sobre a fisiologia e a produtividade de codornas japonesas (Coturnix coturnix japonica). 2007. 117f. Dissertacao de Mestrado. Universidade de Brasilia, 2007.

LEITE, P. et al. Aditivos fitogênicos em rações de frangos. Enciclopédia Biosfera, v. 8, n. 1, p. 9-26. 2012. 
LOSA, R. The use of essential oils in animal nutrition. Cahiers Options Mediterraneennes, v. 54, p. 39-44, 2001.

MELLOR, S. Herbs and spices promote health and growth. Pig Progress, v. 16, n. 4, p. 18-21 2000.

OETTING, L. L. Extratos vegetais como promotores do crescimento de leitões recém-desmamados. 2005. (Doutorado em Agronomia) - Universidade de São Paulo, Piracicaba, 2005.

SANTIN, E. et al. Performance and intestinal mucosa development of broiler chickens fed diets containing Sacharomyces cerevisae cell wall. The Journal of Applied Poultry Research, v. 10, n. 2, p. 236-244, 2001.

ZHANG, K.Y. et al. Evaluation of Microencapsulated Essential Oils and Organic Acids in Diets for Broiler Chickens. International Journal of Poultry Science, v.9, n.4, p.612- 619, 2005.

ZHOU, F. et al. The antibacterial effect of cinnamaldehyde, thymol, carvacrol and their combinations against the foodborne pathogen Salmonella typhimurium. Journal of food safety, v. 27, n. 2, p. 124-133, 2007.

Coordenadoria de Pesquisa e Extensão - COPEX

Departamento de Editoraçāo e Divulgaçāo Científica - DEDIC 


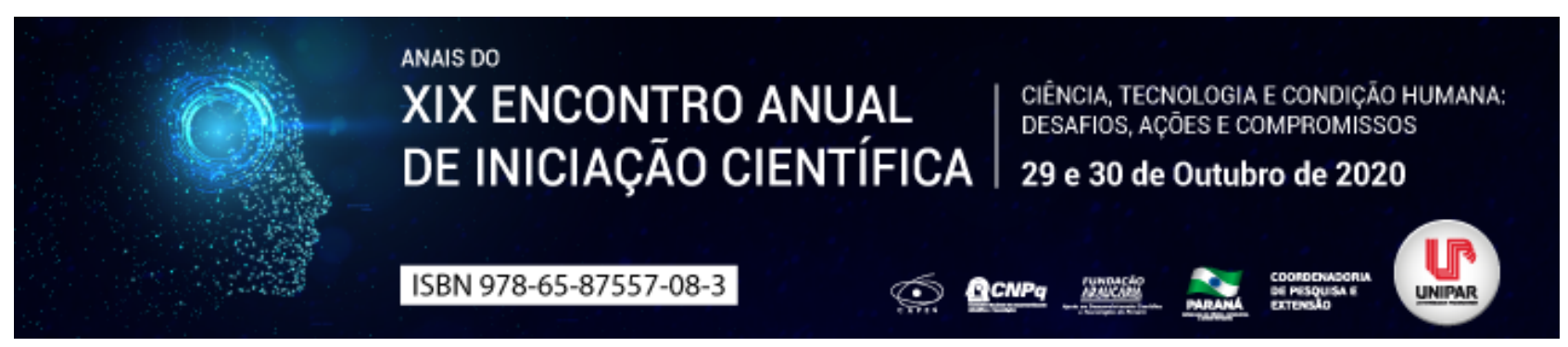

MANEJO DA DOR EM CADELAS E GATAS GESTANTES

\begin{abstract}
${ }^{1}$ Lucas Wamser Fonseca Gonzaga, ${ }^{2}$ KAROLYNE OLIVEIRA BASTOS, ${ }^{3}$ LUCIANA DE CASTRO BARCELOS, ${ }^{4}$ BRUNA CHRISTINA FERNANDES SOARES, ${ }^{5}$ MARCOS FERRANTE, ${ }^{6}$ JOÃO VITOR FERNANDES COTRIM DE ALMEIDA
\end{abstract}

\begin{abstract}
${ }^{1}$ Graduando em medicina veterinária pela universidade federal de Lavras
${ }^{1}$ Graduanda em medicina veterinária pela universidade federal de Lavras

${ }^{2}$ Graduanda em medicina veterinária pela universidade federal de Lavras

${ }^{3}$ Graduanda em medicina veterinária pela universidade federal de Lavras

${ }^{4}$ Doscente do departamento de medicina veterinária da Universidade Federal de Lavras

${ }^{5}$ Médico veterinário e mestre em Ciências Veterinárias do Departamento de Medicina Veterinária da Universidade Federal de Lavras
\end{abstract}

Introdução: Existem poucos estudos disponíveis acerca da farmacologia dos analgésicos em cadelas e gatas gestantes; os trabalhos são majoritariamente realizados em seres humanos e animais de laboratório. Sabe-se que durante a gestação o animal passa por alterações fisiológicas na unidade materno-fetal, as quais alteram a farmacodinâmica, farmacocinética e distribuição do fármaco para o feto (MATHEWS, et al., 2014). A dor é um mecanismo que alerta para uma lesão real ou potencial, que desencadeia uma série de reações para retirar o estímulo nocivo para limitar ou reduzir os danos (ALVES, et al., 2017).

Objetivo: Revisar na bibliografia as abordagens terapêuticas utilizadas para o tratamento da dor em cadelas e gatas gestantes.

Desenvolvimento: A Associação Internacional para o Estudo da Dor (IASP) define dor como uma experiência sensorial e emocional desagradável associada à lesão tecidual, real ou potencial, ou descrita em termos desta lesão . A dor pode ser compreendida como um sinal de alerta, que tem como função proteger o organismo de danos reais ou potenciais, culminando em uma série de reações que induzem comportamentos específicos para redução ou afastamento de determinado estímulo doloroso. A partir dos avanços na área de bem-estar animal, reforçou-se a importância da prevenção e do tratamento da dor nos pacientes veterinários (ALVES, et al., 2017). As fêmeas gestantes podem ser submetidas a um eventual tratamento cirúrgico, ou sofrerem lesões acidentais, sendo necessária uma abordagem terapêutica específica para o tratamento da dor nestes animais. Contudo, segundo estudos realizados em seres humanos, determinadas alterações fisiológicas associadas à unidade materno-placentáriafetal podem alterar a resposta do paciente gestante a um fármaco analgésico: diminuição na motilidade gastrointestinal, refluxo esofágico, vómito, aumento no fluxo sanguíneo cutâneo, o que eleva à absorção de medicamentos administrados pela via transdérmica, ampliação do conteúdo total de água corporal e da gordura corporal total, diminuição da concentração de albumina sérica, alteração da atividade de enzimas hepáticas e expansão da função renal (MATHEWS, 2008). A barreira placentária, por ser lipoproteica, apresenta permeabilidade a fármacos lipossolúveis, porém, alguns fármacos lipossolúveis são transportados pela glicoproteína-P, de forma que não atingem altas concentrações no feto. Por outro lado, drogas hidrossolúveis têm menor probabilidade de atravessar aquela e chegar no feto (MATHEWS, KRONEN, et al., 2014). Outro fator que pode influenciar o efeito de analgésicos é a fase na qual aquele se encontra, ou seja, uma droga administrada na fase inicial e na fase final da gestação pode apresentar efeitos diferentes. O fígado do feto canino não é capaz de metabolizar substâncias farmacológicas, e, por conseguinte, a eliminação destes se dá por mecanismos renais imaturos ou por difusão, levando-os de volta à placenta (MATHEWS, 2008). Opioides são os fármacos mais utilizados para tratar a dor em cadelas e gatas gestantes (MATHEWS, et al., 2014). Fentanil, petidina (meperidina), butorfanol e nalbufina atingem concentrações mais elevadas nos fetos por serem lipossolúveis (MATHEWS, et al., 2014). Recomenda-se, no entanto, que o uso desta classe farmacológica não seja prolongado (MATHEWS, 2008). No terço final da gestação o fluxo sanguíneo na pele da mãe está elevado, e, por conseguinte, um opioide administrado pela via transdérmica possui boa absorção (MATHEWS, et al., 2014). O fentanil pode ser usado desta forma, porém, deve-se atentar às concentrações do medicamento no feto (ALEIXO e TUDURY, 2005). Devido à possibilidade de haver efeitos que interfiram no desenvolvimento fetal, além do risco de teratogênese, os anti-inflamatórios não esteroidais devem ser evitados em pacientes gestantes. A quetamina, por sua vez, atravessa a placenta de forma rápida, mas não foram identificadas consequências no feto durante a organogênese e antes do parto em estudos realizados com ratazanas, camundongos, coelhos e cães. Por aumentar o tônus uterino, a quetamina deve ser evitada durante a gestação, assim como alfa2 agonistas, os quais reduzem o fluxo sanguíneo para o útero. Já os anestésicos locais (lidocaína, bupivacaína e ropivacaína) são amplamente recomendados, tanto por serem seguros quanto não teratogênicos (MATHEWS, et al., 2014). No caso de cesariana, pode ser realizada medicação pré-anestésica com opioide por via intramuscular ou intravenosa, com ou sem acepromazina. A indução e a manutenção anestésica podem ser executadas com alfaxalona ou propofol, até que ambas as drogas atinjam o respectivo efeito. Após intubação, a manutenção anestésica também pode ser implementada com isoflurano 
(MATHEWS, et al., 2014).

Conclusão: Foram apresentados fármacos e protocolos utilizados para tratamento da dor em pacientes gestantes. São necessários mais estudos em cães e gatos, de modo que as estratégias terapêuticas sejam otimizadas.

\section{Referências}

ALEIXO, G. A. D. S.; TUDURY, E. A. UTILIZAÇÃO DE OPIÓIDES NA ANALGESIA DE CÃES E GATOS. Veterinária Notícias, Uberlândia, MG, v. 11, n. 2, p. 31-42, 2005.

ALVES, J. E. D. O. et al. MECANISMOS FISIOPATOLÓGICOS DA NOCICEPÇÃO E BASES DA ANALGESIA PERIOPERATÓRIA EM PEQUENOS ANIMAIS. Acta Biomedica Brasiliensia, v. 8, n. 1, p. 56-68, 2017.

MATHEWS, K. A. Pain management for the pregnant, lactating, and neonatal to pediatric cat and dog. Vet Clin Small Anim, v. 38, n. 6, p. 1291-1308, 2008.

MATHEWS, K. et al. Gidelines for recognition, assessment and tratment of of pain. Journal of Small Animal Practice, v. 55, n. 6, p. E10-E68, 2014. 


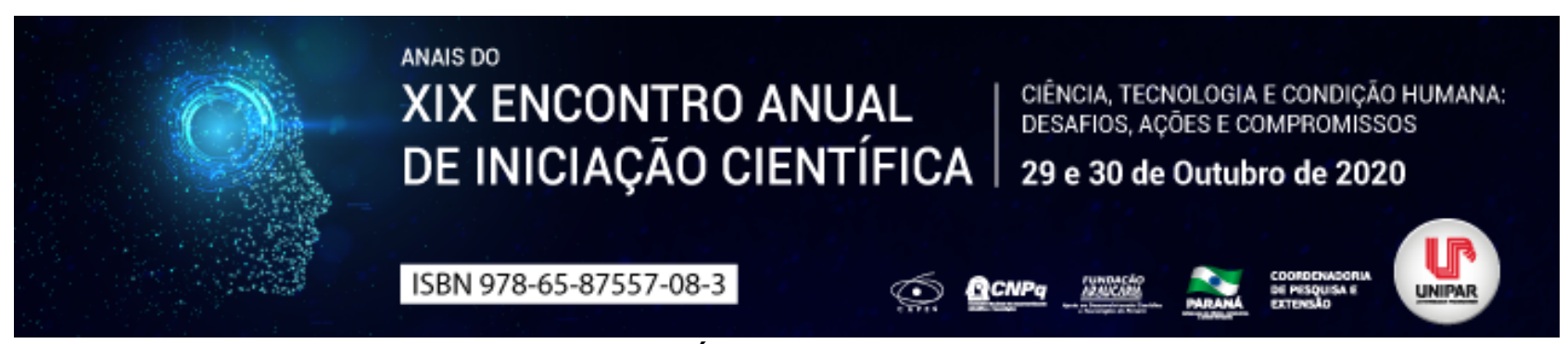

MORFOLOGIA ESPERMÁTICA DO CERVO Rusa timorenses

\begin{abstract}
${ }^{1}$ Gabriela Geraldo de Lima, ${ }^{2}$ TAINA LORRAINE PEREIRA AZEVEDO, ${ }^{3}$ ANNA RAQUEL GRIMAS ALMEIDA, ${ }^{4}$ JULIANE PATRÍCIA SIPP, ${ }^{5}$ FELIPPE AZZOLINI, ${ }^{6}$ ANTONIO CAMPANHA MARTINEZ
\end{abstract}

\author{
${ }^{1}$ Acadêmico do curso de Medicina Veterinária da Universidade Estadual de Maringá \\ ${ }^{1}$ Acadêmico do curso de Medicina Veterinária da Universidade Estadual de Maringá \\ Campus Umuarama, PR \\ ${ }^{2}$ Mestre em Medicina Veterinária \\ ${ }^{3}$ Médico Veterinário do Zoológico de Dois Vizinhos, PR \\ ${ }^{4}$ Médico Veterinário do Zoológico de Dois Vizinhos, PR \\ ${ }^{5}$ Docente da Universidade Estadual de Maringá- UEM
}

Introdução: Os cervos são conhecidos e caçados por seres humanos há milênios, e o ciclo anual de crescimento de seus chifres tem sido uma fonte de fascinação e folclore. O Cervo Rusa timorensis é nativo da Indonésia e foi introduzido no Sudeste de Kalimantan, Nova Guiné, o Bismarck Arquipélago, Nova Caledônia, Austrália e Nova Zelândia. De acordo com a União Internacional para Conservação da Natureza, é uma espécie vulnerável. O cervo tem sido mantido em cativeiro por muito tempo, devido a caça e também para criopreservação. Em 1977 foi criada a primeira fazenda para a única espécie de veados nativos da Malásia, veados Sambar (Rusa unicolor), iniciada pelo Departamento de Vida Selvagem e Parque Nacional, entretanto a alta demanda por carne de veado fez com que fosse importado várias outras espécies, entre elas o Rusa timorensis, pois a Malásia corria risco de caçar cervos selvagens devido ao decréscimo de carne disponível no mercado consumidor. Em 2001, a população de Rusa timorensis cultivada na Austrália foi de 25.000 cervos. A espécie também foi cultivada experimentalmente na Indonésia, Papua e Nova Guiné (VOS, 1982 apud MAHRE, 2014; ZAKARIA et al, 2016). Os machos e as fêmeas atingem a maturidade sexual aos 18 meses de idade, geralmente de julho até o final de agosto, devido ao fotoperíodo e a evolução no estro das fêmeas. Neste momento os machos se tornam muito agressivos e territoriais (SIMONE, 1986).

Em relação à qualidade espermática do Cervo Rusa timorensis o número de trabalho é escasso e com longos anos de publicação. Em 2014 foi realizado um estudo que relatou informações sobre os atributos padrão do esperma e descreve a estrutura da superfície dos espermatozoides normais e anormais do Cervo Rusa timorensis, no qual concluiu-se que não há diferenças no tamanho, forma e estrutura superficial entre espermatozoides dos diferentes veados e diferentes meses das estações férteis (MAHRE, 2014). Atualmente, os veterinários podem trabalhar com a maioria dos cervos em zoológicos, fazendas e na natureza, com envolvimento crescente em programas de conservação para espécies de cervos ameaçadas, tanto in situ quanto ex situ. Dessa forma, é de extrema importância o desenvolvimento de trabalhos que analisem a morfologia espermática para criopreservação de material genético e auxilie no melhoramento genético dos países criadores e consumidores de carne de cervo.

Objetivo: Este trabalho teve como objetivo avaliar a morfologia espermática de Cervos Rusa timorensis.

Material e Métodos: Este experimento teve aprovação pelo Comitê de Ética no Uso de Animais da UNISEP (Protocolo 010/2018). Os animais utilizados nesta pesquisa estavam alojados no Zoológico UNISEP, na cidade de Dois Vizinhos PR. Foram realizadas duas coletas de sêmen em datas diferentes, uma no mês de julho e outra no mês de agosto, de um total de 4 animais, cada animal foi coletado apenas uma vez com o auxílio de um eletroejaculador, os animais estavam devidamente sedados. Após a coleta de amostras seminais, foi realizado um esfregaço seminal, que foi seco ao ar e posteriormente corado com Solução de Cerovsky. Posteriormente foi feito a captura da imagem de 200 espermatozoides, com auxílio do software ImageJ e mensurado o comprimento e largura da cabeça espermática e comprimento da peça intermediária e principal da cauda. Resultados: Os resultados obtidos foram colocados em valores expressos em micrômetros e contém, respectivamente, valores médios, mínimos e máximos de cada parte mensurada, que foram: comprimento da cabeça com 8,16; 7,24; 9,17; largura da cabeça com 4,48; 3,82; 5,14; peça intermediária com 12,04; 9,64; 14,46; peça principal da cauda com 34,20; 24,51; 40,68; comprimento total da cauda com 46,24; 33,77; 55,14.

Discussão: Em comparativo com o estudo realizado por Mahre, 2014, em que foi avaliado a morfologia espermática de Cervos Rusa timorensis, o comprimento da cabeça foi de $7,8 \mu \mathrm{m}$, a largura da cabeça foi de $4,2 \mu \mathrm{m}$, a peça intermediaria de $13,2 \mu \mathrm{m}$ e 0 comprimento da cauda de $42,6 \mu \mathrm{m}$, não houve diferenças consideráveis em relação aos valores encontrados nas mensurações espermáticas no estudo atual.

Conclusão: Concluímos que este estudo serve como parâmetro referencial básico da morfologia espermática da espécie, considerando o comprimento médio total do espermatozoide, $54,4 \mu \mathrm{m}$, do Cervo Rusa timorensis o comprimento da cabeça compreende $15 \%$ e o comprimento total da cauda a $85 \%$. 


\section{Referências}

MAHRE, M. B. et al. Sperm attributes and morphology on Rusa timorensis: Light and scanning electron microscopy. Animal reproduction science, v. 148, n. 3-4, p. 245-250, 2014.

SIMONE, V. M. Reproductive performance and maternal behaviour in farmed Rusa deer (Cervus (rusa) timorensis). Applied Animal Behaviour Science, v. 15, n. 2, p. 147-159, 1986.

ZAKARIA, M. A. Growth and reproductive performances of farmed timorensis deer, Cervus timorensis. Pertanika Journal of Tropical Agricultural Science, p. 79-86. 2016.

Coordenadoria de Pesquisa e Extensão - COPEX

Departamento de Editoraçāo e Divulgaçāo Científica - DEDIC 


\title{
- temem DE INICIAÇĀO CIENTÍFICA 29 e 30 de Outubro de 2020 \\ ISBN 978-65-87557-08-3
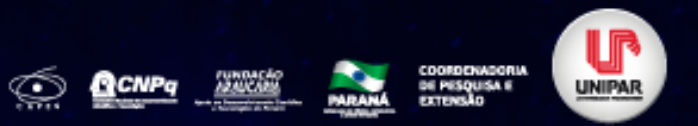 \\ DETERMINAÇÃO DE VALORES DE INTERVALO DE REFERÊNCIA PARA PROTEÍNAS DE FASE AGUDA EM OVINOS SANTA INÊS MACHOS E FÊMEAS EM IDADE DE ABATE
}

\author{
${ }^{1}$ Amanda Gasparucho Bossi, ${ }^{2}$ BIANCA BISCONSIM GANASIN, ${ }^{3}$ DANIELA GOMES DA SILVA, ${ }^{4}$ JOSÉ JURANDIR FAGLIARI, \\ ${ }^{5}$ ANTONIO CAMPANHA MARTINEZ, ${ }^{6}$ ANDRÉ MARCOS SANTANA
}

\begin{abstract}
${ }^{1}$ Discente do Curso de Medicina Veterinária, Universidade Estadual de Maringá UEM/ Campus de Umuarama.
${ }^{1}$ Discente do Curso de Medicina Veterinária, Universidade Estadual de Maringá UEM/ Campus de Umuarama.

${ }^{2}$ Pós-Graduanda do Departamento de Clínica e Cirurgia Veterinária, FCAV/UNESP, Campus de Jaboticabal.

${ }^{3}$ Docente do Departamento de Clínica e Cirurgia Veterinária, FCAV/UNESP, Campus de Jaboticabal.
\end{abstract}

${ }^{4}$ Docente do Departamento de Medicina Veterinária, Universidade Estadual de Maringá

${ }^{5}$ Docente do Departamento de Medicina Veterinária, Universidade Estadual de Maringá

UEM/ Campus de Umuarama.

UEM/ Campus de Umuarama.

Introdução: A ovinocultura no Brasil é uma atividade crescente. Logo, o monitoramento da sanidade dos rebanhos é cada vez mais necessário. Assim para um adequado monitoramento de doenças em rebanhos, a utilização de indicadores de processos inflamatórios específicos para a espécie pode auxiliar no rastreamento de animais doentes. Neste sentido, algumas proteínas, denominadas proteínas de fase aguda (PFA) podem se alterar em mais de $25 \%$ em respostas a citocinas pró-inflamatórias, podendo ser consideradas potenciais biomarcadores quantitativos de doenças (ECKERSALL; BELL, 2010), logo, devem ser estudadas em ovinos para esta finalidade. Para isso, a técnica de eletroforese em gel de poliacrilamida contendo dodecil sulfato de sódio (SDS-PAGE) é considerada simples e de baixo custo, permitindo detecção de concentrações proteicas muito baixas e a identificação de PFA (GORDON, 1995). Por estes motivos constitui-se em uma importante ferramenta no estudo de potenciais biomarcadores de doenças. No entanto, para estudarmos estas alterações em processos patológicos, é fundamental a determinação de valores de intervalos de referência (IR) de PFA para a espécie ovina em machos e fêmeas, e em faixas etárias específicas, como a idade de abate (4-6 meses) sendo importante para o monitoramento de doenças, considerando-se que o destino final dos animais é o consumo humano.

Objetivo: Determinar os valores de IR para PFA no soro sanguíneo de ovinos em idade de abate, evidenciando diferenças destes parâmetros entre machos e fêmeas, visto que para utilizar estas proteínas no auxílio ao monitoramento de doenças em rebanhos, deve-se ter valores confiáveis de animais saudáveis, tanto machos quanto fêmeas.

Material e Métodos: Este estudo foi aprovado pela CEUA (Protocolo 023640/14). Fizeram parte deste experimento 43 machos (G1) e 59 fêmeas (G2), totalizando 102 ovinos da raça Santa Inês em idade de abate. Destes animais, amostras de sangue foram coletadas através de punção da veia jugular, em tubos plásticos siliconizados sem anticoagulante, para análise da proteína total (PT), realizadas em espectrofotômetro semi-automático, e para análise das frações proteicas por meio de técnica de SDS-PAGE (GORDON, 1995). Foram utilizados o teste de Anderson-Darling, Dixon e Tukey para analisar normalidade dos dados, identificar outliers e avaliar diferenças estatísticas entre grupos. Os limites inferior e superior do IR e IC $90 \%$ foram determinados de acordo com as diretrizes da Sociedade Americana de Patologia Clínica Veterinária (ASVCP), utilizando o Reference Value Advisor.

Resultados: Através da técnica SDS-PAGE, foi possível a identificação das frações proteicas albumina, ceruloplasmina, betahaptoglobina e alfa-haptoglobina. Ademais, utilizando os valores de PT, foi possível realizar o cálculo das concentrações séricas de globulinas. Assim sendo, foi possível determinar os limites superiores e inferiores dos IR das seguintes proteínas: Proteína total (mg/dL): 5190 a 8366 (G1) e 5015 a 8902 (G2); Albumina (mg/dL): 3102 a 4992 (G1) e 2984 a 5422 (G2); Globulinas (mg/dL): 1775 a 3687 (G1) e 1749 a 3762 (G2); Haptoglobina total (mg/dL): 6.53 a 179 (G1) e 2.78 a 137 (G2); Beta-haptoglobina (mg/dL): 6.94 a 116 (G1) e 2.78 a $114(\mathrm{G} 2) ;$ Alfa-haptoglobina (mg/dL): 0.00 a 24.9 (G1) e 0.00 a 31.9 (G2); Ceruloplasmina (mg/dL): 1.78 a 51.8 (G1) e 2.57 a 43.9 (G2).

Discussão: As PFA séricas possuem a característica de alterarem-se durante processos inflamatórios, infecciosos ou durante o estresse (MURATA, 2004). Assim, são classificadas em PFA positiva ou negativa, quando suas concentrações se elevam ou diminuem no soro sanguíneo, respectivamente (CECILIANI et al., 2012). A albumina e a transferrina são classificadas como PFA negativa, sendo que a haptoglobina e a ceruloplasmina constituem as PFA positivas (MURATA, 2004). Considerando estes aspectos ligados a dinâmica das PFA, ressalta-se a importância em avaliar as concentrações séricas destas em condições fisiológicas, analisando particularidades ligadas ao sexo dos animais. Neste sentido, avaliamos os IR e também IR para machos e fêmeas. Entretanto, não foi observado no presente estudo diferenças relacionadas ao sexo para os parâmetros estudados e literatura referente ao tema é escassa. Porém, foi observado diferença entre os sexos nas concentrações séricas de ceruloplasmina no estudo realizado por Dinler et al. (2020), no entanto neste experimento foram utilizados cordeiros neonatos. Os 
resultados de Nowroozi-Asl, Nazifi e Bahari (2008) para haptoglobina, não apresentaram diferença significativa entre machos e fêmeas, corroborando com os valores encontrados do presente estudo. Lepherd et al. (2009), realizando experimento com fêmeas desmamadas com idade média de 12 semanas, observaram concentrações séricas de PT, globulinas, albumina e haptoglobina semelhantes aos encontrados em nosso trabalho.

Conclusão: Considerando a escassez de estudos com PFA em ovinos, sendo importante para auxílio ao diagnóstico de quadros inflamatórios, a realização de estudos referentes a determinação dos valores de IR para as PFA para ovinos em idade de abate, inclusive diferenciando resultados para fêmeas e machos.

\section{Referências}

CECILIANI, Fabrizio et al. Acute phase proteins in ruminants. J. Proteomics, v. 75, p. 4207-4231, jul. 2012.

DINLER, Ceren et al. Reference intervals for serum amyloid A, haptoglobin, ceruloplasmin, and fibrinogen in apparently healthy neonatal lambs. Vet. Clin. Pathol., p. 1-7, 2020.

ECKERSALL, Peter D.; BELL, Rory. Biomarkers of infection and inflammation in veterinary medicine. Vet. J., v.185, n. 1, p. 2327, jul. 2010.

GORDON, Arthur Hugh. Electrophoresis of proteins in polyacrylamide and starch gels. Nova York, Elsevier, p. $213,1995$.

LEPHERD, Michelle L. et al. Haematological, biochemical and selected acute phase protein reference intervals for weaned female Merino lambs. Aust. Vet. J., v. 87, n. 1, p. 5-11, 2009.

MURATA, Hideo; SHIMADA, Nobuaki; YOSHIOKA, Miyako. Current research on acute phase proteins in veterinary diagnosis: an overview. Vet. J., Londres, v. 168, p. 24-40, 2004.

NOWROOZI-ASL, Ardavan; NAZIFI, Saeed; BAHARI, A. Determination of serum haptoglobin reference value in clinically healthy Iranian fat-tailed sheep. Iran J. Vet. Res., v. 9, n. 2, p. 171-173, 2008. 


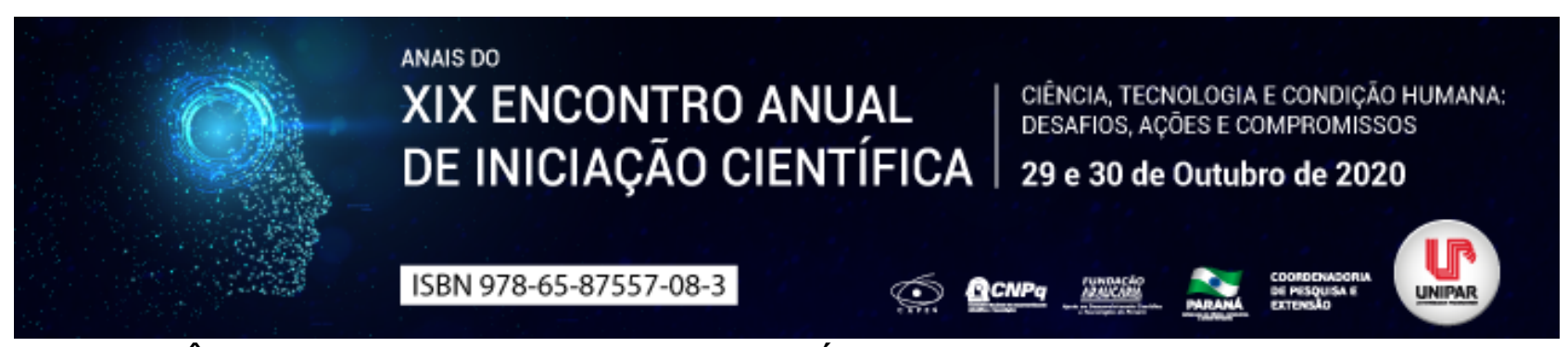

PERFIL DE RESISTÊNCIA AOS ANTIMICROBIANOS DE BACTÉRIAS GRAM-NEGATIVAS ISOLADOS DE AMOSTRAS DE SWABS DE CARCAÇA DE FRANGOS DE CORTE

\author{
${ }^{1}$ CAMILA DE CUFFA MATUSAIKI, ${ }^{2}$ RAFAELA GALVES FERREIRA, ${ }^{3}$ IZABELA CAMILOTTI DORNELES, ${ }^{4}$ ELOISE MARCIELLI \\ MARTINS FERREIRA, ${ }^{5}$ NATALIA SA OLIVEIRA, ${ }^{6}$ LUCIANA KAZUE OTUTUMI FARIAS
}

\begin{abstract}
${ }^{1}$ Acadêmica do Curso de Medicina Veterinária, UNIPAR, bolsista PEBIC/CNPq
${ }^{1}$ Acadêmica do Curso de Medicina Veterinária, UNIPAR, bolsista PEBIC/CNPq

${ }^{2}$ Doutoranda em Ciência Animal com Ênfase em Produtos Bioativos, UNIPAR, taxista PROSUP/CAPES

${ }^{3}$ Acadêmica do Curso de Medicina Veterinária, UNIPAR, bolsista PIBIC/UNIPAR

${ }^{4}$ Acadêmica do Curso de Medicina Veterinária, UNIPAR, bolsista PIBIC/UNIPAR

${ }^{5}$ Professora do curso de Medicina Veterinária e da Pós-graduação em Ciência Animal, UNIPAR
\end{abstract}

Introdução: O Brasil é o maior exportador mundial de carne de frango e para se manter nessa posição, constantes avaliações relacionadas às Boas Práticas de Fabricação (BPF) e manutenção da qualidade da produção de carne de frango por meio da Implantação e verificação do Sistema de Análise de Perigos e Pontos Críticos de Controle devem ser incentivados. Por outro lado, o uso indiscriminado dos antibióticos na alimentação animal, pode ter contribuído para o desenvolvimento de populações bacterianas resistentes (FULLER, 1989), determinando desequilíbrio na simbiose entre a microbiota desejável e o animal (MULDER, 1991). Sendo assim, o monitoramento da contaminação das carcaças de frangos de corte e a avaliação do perfil de resistência dos micro-organismos contaminantes aos principais antimicrobianos utilizados na medicina humana e veterinária são de extrema importância.

Objetivo: Avaliar o perfil de resistência aos antimicrobianos de bactérias Gram-negativas isoladas de amostras de swab de carcaças de frangos de corte oriundos de um abatedouro localizado na região oeste do estado do Paraná.

Materiais e Métodos: Foram colhidas 12 amostras de swab de carcaças de frangos de corte de um abatedouro localizado na região oeste do estado do Paraná, Brasil. Após a rotina de processamento e identificação das cepas bacterianas por meio da realização de provas bioquímicas, foi feito o procedimento para determinação do perfil de resistência pelo método de discodifusão em ágar (CLSI, 2018). As colônias isoladas foram inoculadas em meio BHI (Brain Heart Infusion). Em seguida, a suspensão foi ajustada para se obter concentração bacteriana correspondente a turbidez 0,5 da escala de Mc Farland que corresponde a aproximadamente $1,5 \times 10^{8}$ UFC por $\mathrm{mL}$ aproximadamente. Posteriormente, o swab foi inoculado na superfície da placa de ágar Müeller-Hinton, esfregando o swab em toda a superfície do ágar. Foram testados sete antibióticos: cefoxitina, ceftriaxona, cefotaxima, ampicilina, amoxicilina + clavulanato, ciprofloxacina e sulfazotrim. Após colocação dos discos, as placas foram incubadas, a $37^{\circ} \mathrm{C}$. Após 18-24 horas de incubação, os halos foram medidos em milímetros com o auxílio de uma régua, sendo classificados em sensível, intermediário ou resistente.

Resultados: Foram isoladas três espécies de bactérias gram-negativas das carcaças de frangos de corte de um abatedouro localizado na região oeste do estado do Paraná, sendo Escherichia coli (8/12; 66,67\%), Enterobacter cloacae (3/12; 25\%) e Enterobacter aerogenes (1/12; 8,33\%). Os antimicrobianos que apresentaram maior resistência independente do microorganismo isolado foram: ampicilina (6/12, 50\%), sulfazotrim (4/12, 33,3\%), amoxicilina + clavulanato, ceftriaxona e cefotaxima com 25\% (3/12). Foi possível verificar que, dentre as espécies identificadas a bactéria que demonstrou maior perfil de resistência foi a Enterobacter aerogenes com 71,4\% (5/7).

Discussão: São observadas no Brasil, instabilidade na qualidade dos alimentos disponíveis aos consumidores devido às dimensões continentais do país, dificultando o amplo conhecimento relacionado à circulação e o verdadeiro impacto da disseminação de microrganismos patogênicos. Nos últimos anos, houve alterações nas preferências dos consumidores, os quais acarretaram mudanças na formulação e distribuição dos alimentos, sendo utilizadas novas técnicas de processamento, conservação e de embalagens (CALIL et al., 2008). Dessa forma, verificou-se aumento na preocupação dos consumidores em relação à inocuidade dos produtos consumidos, em virtude da ocorrência de enfermidades associadas ao consumo de alimentos contaminados por microrganismos patogênicos (REMBIAŁKOWSKA; ŚREDNICKA, 2009). Essa resistência de patógenos isolados de carnes pode estar relacionada diretamente ao uso indiscriminado de antimicrobianos em animais de produção, como no caso das aves, reforçando aos criadores o uso prudente dos antimicrobianos (KILONZO-NTHENGE et al., 2008). Um estudo desenvolvido por Asgharpour et al. (2014), com cepas de Salmonella Infantis isoladas de frango de corte no Irã, os autores verificaram níveis de resistência mais elevados aos encontrados neste estudo, com 70\% para amoxacilina e 66\% para trimetoprima-sulfametoxazol. No presente trabalho, o maior percentual de resistência encontrado foi para o antimicrobiano 
ampicilina (50\%). Salienta-se que no presente trabalho as amostras de swab de carcaça foram obtidas em etapas anteriores à etapa de embalagem, demonstrando que novos estudos são necessários visando avaliar o perfil de resistência de bactérias gram-negativas antes da embalagem final com o objetivo de avaliar se mesmo após resfriamento as carcaças albergam bactérias resistentes.

Conclusão: Conclui-se que a carcaça de frangos de corte de um abatedouro localizado na região oeste do estado do Paraná apresenta bactérias gram-negativas resistentes aos antimicrobianos. A Escherichia coli foi o principal micro-organismo isolado $(66,67 \%)$, no entanto, em termos de resistência a bactéria que apresentou maior perfil foi a Enterobacter aerogenes (71,4\%).

\section{Referências}

ASGHARPOUR, F.; RAJABNIA, R.; SHAHANDASHTI, E. F.; MARASHI, M. A.; KHALILIAN, M.; MOULANA, Z. Investigation of class I integron in Salmonella infantis and its association with drug resistance. Jundishapur Journal of Microbiology, Irã, v. 7.5, n. 5, 2014.

BRASIL. Ministério da Agricultura. Instrução Normativa n.13, de 30 de novembro de 2004. Regulamento técnico sobre aditivos para produtos destinados à alimentação animal, segundo as boas práticas de fabricação, contendo os procedimentos sobre avaliação de segurança de uso, registro e comercialização, constante dos anexos desta instrução normativa. Brasília, 2004.

CALIL, R.M.; SCARELLI, E.; MODELLI, K.D.; CALIL, E.M.B. Campilobacterioses: o agente, a doença e a transmissão por alimentos. São Paulo: Livraria Varela. $1^{\mathrm{a}}$ ed. p. 129. 2008.

Clinical and Laboratory Standards Institute (CLSal) 2018. Performance standars for antimicrobial susceptibility testing. CLSI document M100. Wayne (PA).

FULLER, R. Probiotics in man and animals: a review. Journal of Applied Bacteriology, Reino Unido, p. 365-378, 1989.

KILONZO-NTHENGE, A.; NAHASHON, S. N.; CHEN, F.; ADEFOPE, N. Prevalence and antimicrobial resistance of pathogenic bacteria in chicken and guinea fowl. Poultry Science, Champaign, v. 87, n. 9, p. 1841-1848, 2008.

MULDER, R. W. A. W. Probiotics as a tool against Salmonella contamination. Misset World Poultry, n. 7, p. 36-37, 1991.

REMBIAŁKOWSKA, E.; ŚREDNICKA, D. Organic food quality and impact on human health. Agronomy Research, Saku, v. 7, n. 2, p. 719-727, 2009. 


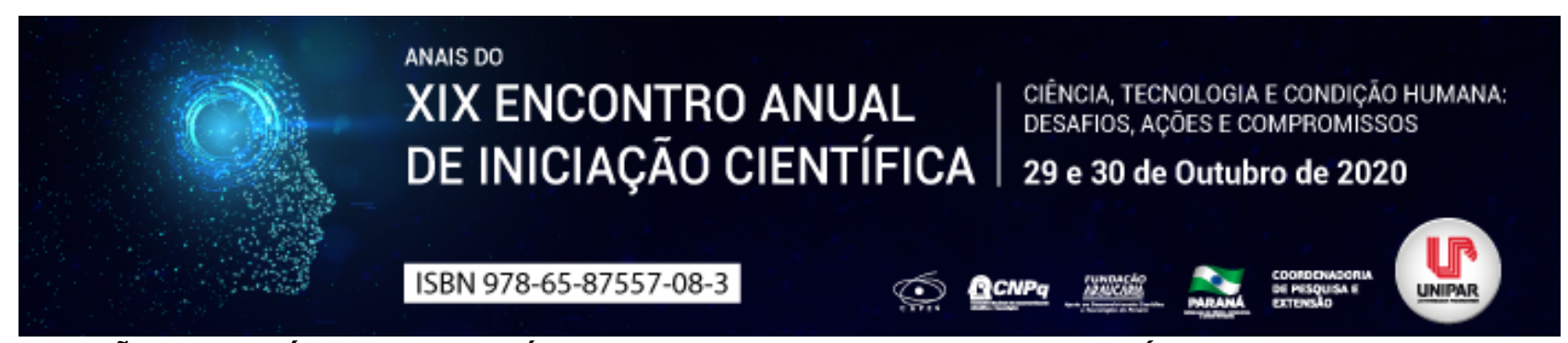

\title{
CONCENTRAÇÕES DE URÉIA NO SORO LÁCTEO DE VACAS COM MASTITE SUBCLÍNICA, AVALIADAS EM DIFERENTES INTERVALOS DE CONTAGEM DE CÉLULAS SOMÁTICAS
}

\author{
${ }^{1}$ ANA CAROLINE CANDIA PALHANO, ${ }^{2}$ PAULO ROBERTO DE ABREU TAVARES, ${ }^{3}$ ANDRÉ MARCOS SANTANA
}

\author{
${ }^{1}$ Acadêmica do Curso de Medicina Veterinária UEM \\ ${ }^{1}$ Acadêmico do Curso de Medicina Veterinária UEM \\ ${ }^{2}$ Docente da UEM
}

Introdução: A concentração de nitrogênio uréico no leite (NUL) vem sendo proposta como um indicador para o monitoramento da nutrição protéica de vacas em lactação (JONKER et al., 2002), uma vez que apresenta boa correlação com a concentração de nitrogênio uréico no plasma (NUP) ou no sangue (NUS) (MEYER, 2003). Porém, para interpretar os dados de concentração de NUL corretamente, é importante levar em consideração que outros fatores não-nutricionais (MEYER, 2003), tais como a mastite, talvez interfiram na proporção entre NUS e NUL. Essa interferência pode ocorrer porque durante o processo inflamatório que acompanha a mastite, observa-se um aumento de permeabilidade capilar na glândula mamária, ocorrendo extravasamento de componentes do sangue para o leite e vice-versa, podendo elevar ou diminuir susbstancialmente a concentração destes no leite (KITCHEN, 1981). Neste contexto, na glândula infectada, as células de defesa que chegam ao leite devido ao aumento de permeabilidade capilar, podem representar até 99\% das células presentes no leite (PHILPOT \& NICKERSON, 1991). Desse modo, o aumento de CCS do leite pode indicar o grau de infecção da glândula mamária (MACHADO et al., 2000), expressando a gravidade da inflamação. Assim sendo, a CCS é utilizada para avaliar a sanidade da glândula mamária de vacas, e sinaliza perdas significativas de produção e alterações da qualidade do leite (RANGEL et al, 2013).

Objetivo: Considerando que a CCS é um ótimo indicador da severidade do processo inflamatório instalado na glândula mamária durante a mastite, e considerando que este processo inflamatório pode interferir nas concentrações de componentes do leite, este trabalho propõe descrever a relação entre níveis de CCS e NUL em vacas leiteiras, tema este ainda pouco explorado na literatura.

Material e Métodos: Foram coletadas amostras de leite de quartos mamários de 20 vacas em lactação, em uma propriedade no município de Diamante do Norte (PR), durante a primeira ordenha do dia. Inicialmente, foram coletados $50 \mathrm{~mL}$ de leite de cada quarto mamário, em frascos contendo dicromato de potássio (1\%), para análise de CCS, realizada pelo método automático com contador eletrônico infravermelho (Somacount 300). Posteriormente, foram coletados $15 \mathrm{~mL}$ de amostras de leite para análise das concentrações da uréia no soro lácteo. No laboratório, separou-se o soro lácteo através da adição de uma solução de renina $5 \%$ à amostra e posterior centrifugação. A partir dos resultados de CCS, as amostras foram divididas em cinco grupos: Amostras de leite de quartos mamários de vacas com CCS entre 0-100000 (G1, n=26), 100000-200000 (G2, n=15), 200000-400000 (G3, $\mathrm{n}=17), 400000-1000000(\mathrm{G} 4, \mathrm{n}=13)$ e $>1000000(\mathrm{G} 5, \mathrm{n}=7)$ células $/ \mathrm{mL}$. A análise de uréia foi realizada utilizando reagente de uso comercial (Labtest Diagnóstica), e as leituras realizadas em espectofotômetro semi-automático. Os dados foram submetidos à análise de variância (ANOVA) e ao teste de Tukey $(p<0,05)$.

Resultados: As concentrações de uréia (mg/dL) no soro lácteo foram: G1: 11,49; G2: 10,81; G3: 9,89; G4: 10,09; G5: 9,71. Através dos resultados encontrados, observou-se diminuição significativa das concentrações de uréia no G3, G4 e G5, quando comparado ao G1. No entanto, observou-se que o G2 não diferiu estatisticamente de outros grupos experimentais (G1, G3, G4 e G5) e que o G3, G4 e G5 não apresentaram diferenças estatísticas entre si para as concentrações de uréia.

Discussão: Winckler (2019), após avaliar 4817 testes para CCS de 620 rebanhos e categorizar estes rebanhos em baixa $(<15 \%$ de animais com CCS $\geq 200000$ células $/ \mathrm{mL}$ ), média $(>15 \%$ e $<45 \%$ de animais com CCS $>200000$ células $/ \mathrm{mL}$ )e alta $(>45 \%$ de animais com CCS $>200000$ células $/ \mathrm{mL}$ ) prevalência de mastite subclínica, concluiu que o NUL não apresentou variação entre as categorias de prevalência, mesmo os animais apresentando variáveis valores de CCS, uma vez que o estudo foi feito com animais com CCS de 50000 a 2500000 células $/ \mathrm{mL}$. Em outros estudos, Wolfschoon-Pombo (1981) relatou que a mastite pode influenciar nas concentrações de uréia de quartos mamários infectados e Harmeyer e Martens (1980) observaram menores concentrações de uréia no leite de quartos mamários de caprinos com elevada CCS. Entretanto, Eicher et al (1999) não observaram influência da CCS, medida indiretamente com o uso do California Mastitis Test , sobre as concentrações de uréia no leite, nem mesmo quando as amostras foram coletadas de quartos diferentes.

Conclusão: Os resultados nos permitem concluir que houve uma diminuição das concentrações de uréia no soro lácteo em amostras com CCS acima de 200000 células $/ \mathrm{mL}$. No entanto, enquanto alguns trabalhos concluem que existe uma possível interferência nas concentrações de uréia devido a mastite subclínica, alguns trabalhos relatam não haver tal interferência. Assim, é importante que trabalhos futuros sejam realizados para elucidar os mecanismos envolvidos, na tentativa de determinar a existência ou não de interferência da mastite subclínica nas concentrações de uréia no soro lácteo. 


\section{Referências}

EICHER, R.; BOUCHARD, E.; TREMBLAY, A. Cow level sampling factors affecting analysis and interpretation of milk urea concentrations in 2 dairy herds. Canadian Veterinary Journal, v.40, n.7, p. 487-492, jul, 1999.

HARMEYER, J.; MARTENS, H. Aspects of urea metabolism in ruminants with reference to the goat. Journal of Dairy Science, v. 63, n. 10, p. 1707-1728, oct, 1980.

JONKER, J. S.; KOHN, R. A; HIGH, J. Use of milk urea nitrogen to improve dairy cow diets. Journal of Dairy Science, v. 85, n. 4, p. 939-946, apr, 2002.

KITCHEN, B. J. Reviews of the progress of dairy science: Milk compositional changes and related diagnostic tests. Journal of Dairy Research, Kobenhavn, v. 48, n. 2, p. 167-188, feb, 1981.

MACHADO, P. F.; PEREIRA, A. R.; SARRIES, G. A, Composição do leite de tanques de rebanhos brasileiros distribuídos segundo sua contagem de células somáticas. Revista Brasileira de Zooteecnia, v. 29, p. 1883-1886, 2000.

MEYER, P. M. FATORES NÃO-NUTRICIONAIS QUE AFETAM AS CONCENTRAÇÕES DE NITROGÊNIO URÉICO NO LEITE. Orientador: Paulo Fernando Machado. 2003. Tese (Doutorado em Ciencia Animal e Pastagens) Universidade de São Paulo, Piracicaba, 2003.

PHILPOT, W. N.; NICKERSON, S.C. Mastitis: count attack. Naperville: Babson Bros, 1991. p.150.

RANGEL, A. H. do N.; ARAÚJO, V. M.; BEZERRA, K. C.; BARRETO, M. L. de J.; MEDEIROS, H. R.; LIMA JÚNIOR, D. M. de. Avaliação da qualidade do leite cru com base na contagem de células somáticas em rebanhos bovinos comerciais no estado do Rio Grande do Norte, Brasil. Archives of Veterinary Science. v. 18, n. 1, p. 40-45, 2013.

WINCKLER, J. P. P. Prevalência da mastite subclínica em rebanhos brasileiros e o efeito sobre a composição do leite. Orientador: Paulo Fernando Machado. 2019. Tese (Doutorado em Ciências) Universidade de São Paulo - Escola Superior de Agricultura Luiz de Queiroz). Piracicaba, 2019.

WOLFSCHOON-POMBO, A. F. Investigations on the amount and composition of NPN in milk. 1981. Thesis (PhD) University of Munich. Munich, 1981. 


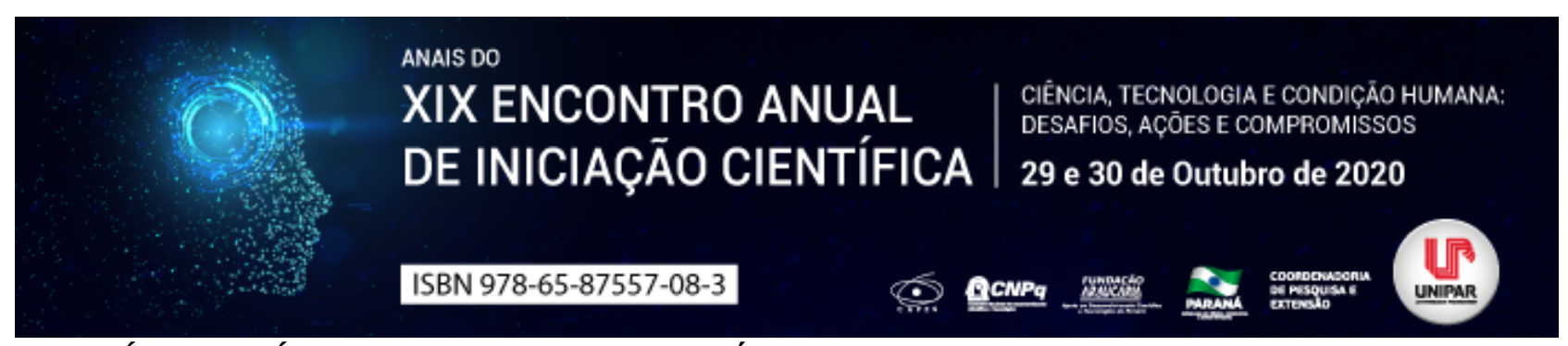

PERFIL BIOQUÍMICO DE ÍONS E MINERAIS NO SORO LÁCTEO DE OVINOS COM MASTITE INFECCIOSA SUBCLÍNICA

\begin{abstract}
${ }^{1}$ Natália Parpinelli, ${ }^{2}$ GABRIELA MENDONÇA SERVILHERI, ${ }^{3}$ YURI DA SILVA BONACIN, ${ }^{4}$ DANIELA GOMES DA SILVA, ${ }^{5}$ ANTONIO CAMPANHA MARTINEZ, ${ }^{6}$ ANDRÉ MARCOS SANTANA
\end{abstract}

\begin{abstract}
${ }^{1}$ Discente do Curso de Medicina Veterinária da Universidade Estadual de Maringá (UEM), campus Umuarama-PR
${ }^{1}$ Discente do Curso de Medicina Veterinária da Universidade Estadual de Maringá (UEM), campus Umuarama-PR

${ }^{2}$ Pós-Graduando(a) do Departamento de Clínica e Cirurgia Veterinária, FCAV/UNESP, Campus de Jaboticabal

${ }^{3}$ Pós-Graduando(a) do Departamento de Clínica e Cirurgia Veterinária, FCAV/UNESP, Campus de Jaboticabal

${ }^{4}$ Docente do Departamento de Medicina Veterinária, Universidade Estadual de Maringá UEM/ Campus de Umuarama

53 Docente do Departamento de Medicina Veterinária, Universidade Estadual de Maringá UEM/ Campus de Umuarama
\end{abstract}

Introdução: O Brasil possui um rebanho de 13.789 .345 ovinos, destinados à produção de carne, lã e leite (IBGE, 2017). A inflamação da glândula mamária (GM) pode se manifestar de forma subclínica, em que não há mudanças visíveis no úbere e leite, mas há redução na produção de leite e alterações em sua composição, aumento em contagem de células somáticas (CCS) e presença de patógeno na secreção. Pode também se manifestar de maneira clínica, em que há sinais de inflamação no tecido mamário (hiperemia, edema, aumento de temperatura) e mudanças visuais e de composição do leite (BATAVANI et al., 2007). Neste contexto, a mastite acarreta em perdas econômicas no rebanho, pois pode causar morte precoce, redução na produção de leite e redução no ganho de peso de cordeiros (SILVA et al., 2013). Devido ao alto custo da aplicação rotineira de exames bacteriológicos, a utilização de parâmetros alternativos para o diagnóstico precoce da mastite é essencial para garantir o bem estar animal, qualidade do leite e produtividade do rebanho (BATAVANI et al., 2007).

Objetivo: Avaliar o perfil bioquímico de íons e minerais do soro lácteo de ovinos com mastite subclínica, para obter informações que possam auxiliar no diagnóstico e acompanhamento terapêutico.

Material e Métodos: Amostras de leite foram coletadas de fêmeas ovinas, cruzamento entre as raças Santa Inês e Dorper, com idade de 4-8 meses. Destes animais, fez-se o exame ultrassonográfico (US) das GM e a CCS das amostras de leite, constituindose os grupos experimentais: Amostras de soro lácteo de glândulas mamárias (GM) sem alteração no US e CCS $<300.000$ células/mL (G1, $n=19 \mathrm{GM}$ ), com alteração no US e CCS < 300.000 células/mL (G2, $n=18 \mathrm{GM}$ ) e com alteração no US e CCS > 1.000.000 células $/ \mathrm{mL}(\mathrm{G} 3, \mathrm{n}=11 \mathrm{GM}$ ). Destes animais, ainda foram coletadas amostras de leite em tubos falcon de $50 \mathrm{~mL}$ para realização do perfil bioquímico do soro lácteo, para as variáveis $\mathrm{Cl}$, Na e K. A análise destas variáveis foram realizadas utilizando reagentes de uso comercial (Labtest Diagnóstica) e espectrofotômetro semi-automático com comprimentos de onda específicos para cada constituinte. Os resultados encontrados foram submetidos à análise de variância (ANOVA) e ao teste de Tukey $(p<0,05)$. O projeto foi aprovado pela Comissão de Ética no Uso de Animais (CEUA) da Universidade Estadual Paulista Júlio Mesquita Filho, protocolo no 017013/18.

Resultados: Observou-se, através dos resultados obtidos, diferenças significativas do G1 em relação ao G3 e do G2 em relação ao $\mathrm{G} 3$, para $\mathrm{Cl}(\mathrm{p}=0,0288), \mathrm{Na}(\mathrm{p}=0,0006)$ e $\mathrm{K}(\mathrm{p}=0,0046)$, enquanto o $\mathrm{G} 1$ e $\mathrm{G} 2$ tiveram médias semelhantes entre si para estes

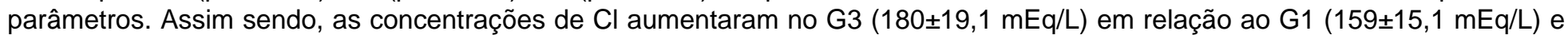
G2 $(160 \pm 15,6 \mathrm{mEq} / \mathrm{L})$. Da mesma forma, as concentrações de Na aumentaram no $\mathrm{G} 3(165 \pm 20,4 \mathrm{mEq} / \mathrm{L})$ em relação ao $\mathrm{G} 1$ $(136 \pm 13,4 \mathrm{mEq} / \mathrm{L})$ e $\mathrm{G} 2(140 \pm 12,5 \mathrm{mEq} / \mathrm{L})$. De forma diferente, as concentrações de $\mathrm{K}$ diminuíram no $\mathrm{G} 3(26,6 \pm 5,33 \mathrm{mEq} / \mathrm{L}) \mathrm{em}$ relação ao G1 $(33,3 \pm 4,13 \mathrm{mEq} / \mathrm{L})$ e $\mathrm{G} 2(34,1 \pm 4,72 \mathrm{mEq} / \mathrm{L})$.

Discussão: A mastite resulta em aumento da permeabilidade vascular e, também, danos ao epitélio secretor da glândula mamária. Consequentemente, $\mathrm{Na}$ e $\mathrm{Cl}$, que se apresentam em grandes concentrações no fluido extracelular, extravasam para o lúmen do alvéolo. Assim, para manutenção da osmolaridade entre os meios, espera-se a diminuição dos níveis de potássio no leite, proporcionalmente (BATAVANI et al., 2007). Neste contexto, Sanchez et al. (2015), em estudo com cabras com mastite clínica e subclínica, observaram, no soro lácteo, aumento das concentrações de $\mathrm{Na}$ e $\mathrm{Cl}$ e diminuição de $\mathrm{K}$, resultados estes que corroboram com os achados do nosso trabalho. Da mesma forma, Silva et al. (2013) também relataram redução significativa nas concentrações de $\mathrm{K}$ do soro lácteo de ovelhas com mastite, assim como aumento nas concentrações de $\mathrm{Na}$. Em bovinos, Batavani et al. (2007) também observaram o mesmo comportamento, com aumento nas concentrações de $\mathrm{Na}$ e $\mathrm{Cl}$ e decréscimo nas concentrações de $\mathrm{K}$ no soro lácteo de vacas com mastite subclínica.

Conclusão: $\mathrm{O}$ presente trabalho evidenciou alterações significativas nas concentrações de $\mathrm{Cl}, \mathrm{Na}$ e $\mathrm{K}$ no soro lácteo de ovinos com mastite, os quais podem, potencialmente, serem utilizados como biomarcadores da mastite nesta espécie animal. 
BATAVANI, R.A.; ASRI, S.; NAEBZADEH, H. The effect of subclinical mastitis on milk composition in dairy cows. Iranian Journal of Veterinary Research, v. 8, n. 3(20), p. 205-11, 2007.

IBGE (2017). Censo agropecuário 2017. Disponível em: https://sidra.ibge.gov.br/tabela/6930. Acesso em 18 de agosto de 2020.

SANCHEZ, D.C.C. Perfil bioquímico dos soros lácteo e sanguíneo de cabras com mastite de ocorrência natural. 2015. xii, 49 p. Tese (doutorado) - Universidade Estadual Paulista Júlio de Mesquita Filho, Faculdade de Ciências Agrárias e Veterinárias de Jaboticabal, 2015.

SILVA, J.S.C.; GUARANÁ, E.L.S.; LEMOS, V.F.; SOARES, P.C.; AFONSO, J.A.B.; MENDONÇA, C. L. Metabolismo energético, proteico e mineral de ovelhas Santa Inês hígidas e com mastite subclínica. Pesquisa Veterinária Brasileira, v. 33, n. 9, p. 1087 96, 2013.

Coordenadoria de Pesquisa e Extensão - COPEX

Departamento de Editoraçāo e Divulgaçāo Científica - DEDIC 


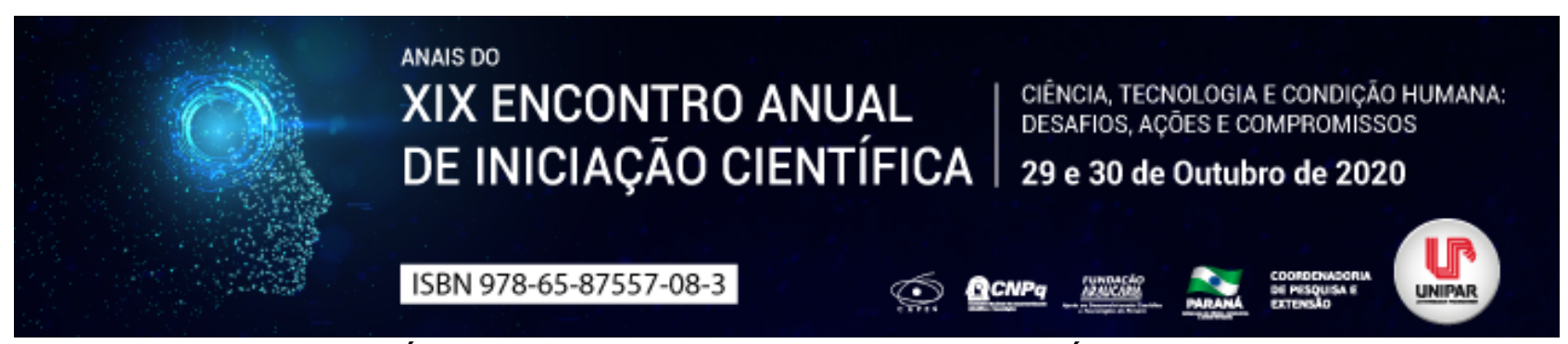

SONDA NASOGÁSTRICA DE DUPLA VIA PARA LAVAGEM GÁSTRICA EM EQUINOS

\author{
${ }^{1}$ Stephani Talia Nardoni Venâncio, ${ }^{2}$ JEFERSON CARLOS GANDINI, ${ }^{3}$ FERNANDA GRAZIELI BARRAGAN, ${ }^{4}$ MAX GIMENEZ \\ RIBEIRO
}

${ }^{1}$ Dicente do curso de Medicina Veterinária, Universidade Estadual de Maringá (UEM), Campus Regional de Umuarama.

${ }^{1}$ Dicente da residência em Clínica e Cirurgia em Grandes Animais do departamento de Medicina Veterinária, Universidade Estadual de Maringá.

${ }^{2}$ Dicente da residência em Clínica e Cirurgia em Grandes Animais do departamento de Medicina Veterinária, Universidade Estadual de Maringá.

${ }^{3}$ Docente do departamento de Medicina Veterinária, Universidade Estadual de Maringá (UEM).

Introdução: O uso da sondagem por via nasogástrica permite a eliminação de gás e conteúdo gástrico, não possibilitando assim a ruptura do estômago, proporcionando um conforto imediato ao paciente, além de acelerar o processo fisiológico do esvaziamento gástrico e estimular o reflexo gastrocólico (FERNANDES, 2009). Na síndrome cólica onde ocorre dor visceral abdominal, é sabido que na maioria das vezes se dá por distúrbios digestivos (ALVES, 1994). As dores causadas no animal são consequências de aumento de pressão na luz intestinal, mudança na posição das alças, contrações espásticas ou de alterações inflamatórias de tubo digestivo. No ponto de vista patogênico essas situações podem ser causadas por uma obstrução intestinal ou fermentações indesejadas (FAGLIARI; SILVA; 2002). Nesse sentido a utilização da sonda pode ser tida como forma de tratamento, ao realizar a lavagem gástrica proporcionando a descompressão do estômago (FERNANDES, 2009). De acordo com o exposto, o presente trabalho irá relatar sobre a produção e utilização de um protótipo de uma sonda nasogástrica de dupla via.

Objetivo: O objetivo deste projeto é confeccionar um protótipo de sonda nasogástrica de dupla via.

Materiais e métodos: Foi utilizado uma sonda nasogástrica de silicone medindo aproximadamente $3 \mathrm{~m}$ de comprimento com diâmetro de 1,5 cm, para servir como retorno para o conteúdo gástrico. Além da sonda, se utilizou três extensores de equipo de 1,20 m para realizar a função de condutor de água para o estômago. Devido os extensores não possuírem comprimento suficiente para acompanhar a sonda, eles foram acoplados uns aos outros e fixados em suas extremidades utilizando super cola (Alma super). Com o intuito de fabricar um protótipo de dupla via os extensores de equipo foram passados por dentro da sonda, e para realizar a fixação das extremidades na parte lateral da sonda também foi utilizado a super cola (Alma super). Foi necessário o uso de um motor de bomba d'água de para-brisa para a impulsionar a água através do extensor de equipo, gerando pressão suficiente para proporcionar um turbilhão no estômago permitindo o refluxo do conteúdo gástrico. A bomba possui $12 \mathrm{v}$ de potência, com isso, foi utilizado uma fonte para computador com o objetivo de mantê-la funcionando. Durante o teste in vitro, percebeu-se a eficácia do sistema utilizando a bomba d'água. Então, se realizou o teste in vivo em um potro de aproximadamente 2,5 anos de idade do Campus Fazenda da Universidade Estadual de Maringá (UEM) no Hospital Veterinário de Grandes Animais.

Resultados: Ao realizar o teste in vitro se obteve sucesso na utilização da sonda. Já no teste in vivo, o fluxo simultâneo aconteceu de forma eficaz, onde a água foi impulsionada e o refluxo voltou concomitantemente, porém para que isso ocorresse foi necessário o uso da pressão contraria exercida com a boca. Foi observado um retorno pequeno de conteúdo gástrico, tornando a lavagem mais lenta.

Discussão: Lopes (2015) relata que sondas nasogástricas comerciais de maior diâmetro, desenvolvidas para equinos, são mais vantajosas, pois, torna possível fornecer grandes volumes de maneira rápida e também drenar os mesmos nos casos em que ocorra algum desconforto, ou seja, são muito eficazes para o tratamento de descompressão gástrica nos casos de cólica. E de acordo com Mora (2009) a introdução da sonda nasogástrica deve ser realizada em todos os animais com tal afecção. O modelo de sonda proposto e testado nesse trabalho atende as características descritas por Lopes, demonstrando um bom desempenho na descompressão do estômago. Ademais, durante o experimento foi observado que o diâmetro do extensor de equipo não foi suficiente, conduzindo um baixo fluxo de água não permitindo retorno de grandes volumes de refluxo, tornando o procedimento mais lento. Sugere-se aumentar o diâmetro do extensor de equipo em alguns $\mathrm{mm}$ para melhores resultados.

Conclusão: Diante do que foi apresentado, o protótipo alcançou resultados significativos, demostrando a funcionalidade do circuito, mas que podem ser melhorados com o aumento do calibre do extensor de equipo.

\title{
Referências
}

ALVES, Geraldo Eleno Silveira. Anamnese. In: Fórum de Gastroenterologia equina, I, 1994. Diagnóstico em cólica equina. Curitiba: Colégio Brasileiro de Cirurgia e Anestesiologia Veterinária, 1994. p.3-16. 
FAGLIARI, José Jurandir; SILVA, Suadney de Lima. Hemograma e proteinograma plasmático de equinos hígidos e de equinos acometidos por abdômen agudo, antes e após laparotomia. Arq. Bras. Med. Vet. Zoote., v.54, p.559-567, 2002. Disponível em: https://www.scielo.br/scielo.php?pid=S0102-09352002000600001\&script=sci_arttext. Acesso em: 23/09/2020.

FERNANDES, Carina Simões. Factores de prognóstico da cólica em equinos. Orientador: Dr. José Manuel Cardoso de Souza Prazeres. 2009. Dissertação (Mestrado Integrado Em Medicina Veterinária) - Universidade técnica de Lisboa, Lisboa, 2009.

LOPES, Marco Aurélio Ferreira. Enteral Fluid Therapy. In: FIELDING, Lagdon., MAGDESIAN, Kiragos Gary: Equine Fluid Therapy. lowa: John Wiley \& Sons, Inc, 2015. p. 261-278.

MORA, Sara Cristina Farrajota. Resoluções cirúrgicas de cólicas em equinos: critérios, desenvolvimento e pós-operatório. Orientador: Doutor Eduardo Malschitzky. 2009. Dissertação (Mestrado em Clínica e cirurgia de equinos) Universidade Técnica de Lisboa, Lisboa, 2009.

Coordenadoria de Pesquisa e Extensão - COPEX

Departamento de Editoraçāo e Divulgaçāo Científica - DEDIC 


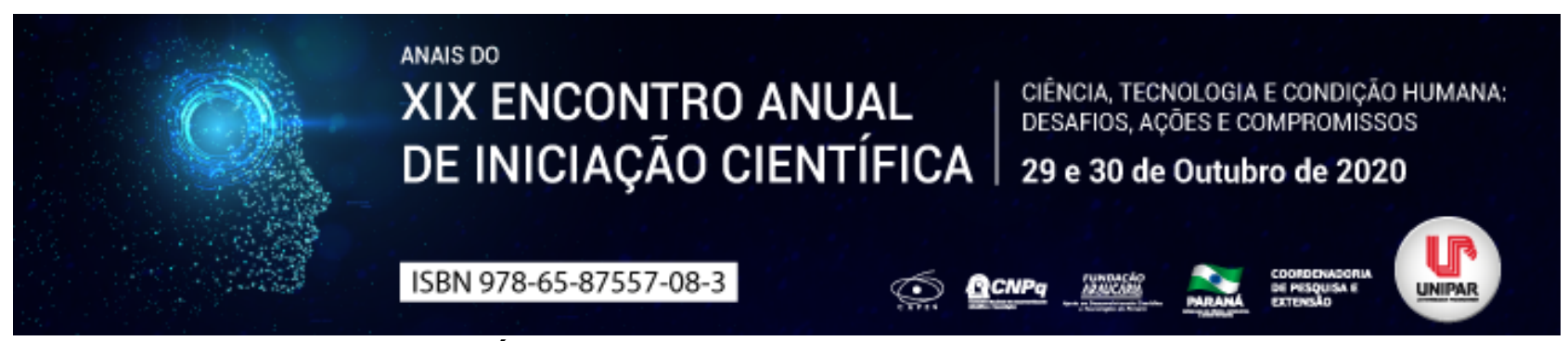

CESARIANA EM ÉGUA DEVIDO A DISTOCIA FETAL RELATO DE CASO

\begin{abstract}
${ }^{1}$ Gabriela Geraldo de Lima, ${ }^{2}$ DEREK WILLY GALDIOLI SILVEIRA, ${ }^{3}$ MAYARA NAYANE SACOMAN ROCHA NEVES, ${ }^{4}$ DANTHYSE MIYOKO OHNO MÜLLER DE SOUZA, ${ }^{5}$ JEFERSON CARLOS GANDINI, ${ }^{6}$ MAX GIMENEZ RIBEIRO
\end{abstract}

\begin{abstract}
${ }^{1}$ Acadêmico do curso de Medicina Veterinária da Universidade Estadual de Maringá
${ }^{1}$ Acadêmico do curso de Medicina Veterinária da Universidade Estadual de Maringá

${ }^{2}$ Acadêmico do curso de Medicina Veterinária da Universidade Estadual de Maringá

${ }^{3}$ Médico (a) Veterinário (a) Residente do Hospital Veterinário UEM

${ }^{4}$ Médico (a) Veterinário (a) Residente do Hospital Veterinário UEM

${ }^{5}$ Docente da Universidade Estadual de Maringá- UEM

Campus Umuarama, PR
Campus Umuarama, PR
Campus Umuarama, PR
\end{abstract}

Introdução: A gestação da égua varia em torno de 330 a 340 dias, e é influenciada por fatores fetais, maternos, genéticos e ambientais (PRESTES, 2017). O parto normal na espécie equina dura em torno de 30 minutos, e é influenciado por contrações vigorosas da musculatura uterina, abdominal e diafragmática e a expulsão da placenta ocorre em até duas horas após o parto (PRESTES, 2000; PRESTES, 2017). A posição anatômica normal do potro deve ser a apresentação longitudinal anterior, posição superior e atitude estendida, qual quer alteração nesta posição retrata um parto distócico (PRESTES, 2000). A distocia é qualquer problema que interfira no nascimento de um potro, apesar de apresentar uma taxa extremamente baixa, a distocia na maioria dos casos leva a morte do potro, pois a égua continua com contrações para a expulsão do feto mesmo ele estando em uma posição que impeça sua saída, causando traumas no trato reprodutivo, podendo evoluir para um prolapso uterino ou outras complicações (ENGLAND, 2005). Algumas posições do potro que causam a distocia podem ter apresentação dos membros anteriores dobrados, membro anterior esticado para trás, desvio lateral da cabeça e pescoço, desvio ventral da cabeça, membros posteriores esticados até a cabeça, posição de cão-sentado, apresentação ventral transversa, membros posteriores dobrados, flexão da bacia (posição de cão-sentado reversa) (LANÇA, 2010). Este relato tem por objetivo descrever uma distocia, que teve por consequência, a cesariana em uma égua e suas possíveis complicações.

Relato de Caso: Uma égua, Quarto de milha, 10 anos, 540 kg, foi atendida no Hospital veterinário da Universidade Estadual de Maringá, campus Umuarama- PR, no dia 21/08/2020 apresentando sinais de distocia. Após avaliação, constatou-se que o potro, que já estava sem vida, apresentava-se com o membro posterior apontado para fora e desvio lateral de cabeça e pescoço com o membro anterior ventralmente. No exame clínico, o animal estava com 56 de frequência cardíaca (FC), 36 de frequência respiratória (FR), $37,1^{\circ} \mathrm{C}$ de temperatura retal (TR), mucosas normocoradas, tempo de preenchimento capilar de 3 segundos e motilidade dentro da normalidade. Após a realização de manobras obstétricas para tentar reverter o quadro de distocia, optou-se pela cesariana devido ao insucesso e pelo animal estar em trabalho de parto a aproximadamente 8 horas. Imediatamente após a cirurgia, todos os sinais clínicos chegaram na normalidade, sem sinais de toxemia devido a cirurgia ter sido asséptica. Os medicamentos de escolha para o pós-operatório foram Gentamicina 60ml SID/IV diluído em 500ml de ringer lactato, Dimetilsulfóxido 300ml SID/IV diluído em 3L de soro, Flunixina Meglumina 3ml IM/QUID, Penicilina 18ml IM/BID, Fenilbutazona 12ml IV/BID e Cetamina 3ml ORAL/BID, este tratamento se manteve por 3 dias. No quarto dia de pós-operatório, foi realizada a lavagem uterina com uma solução estéril de Permanganato de potássio em uma proporção de 6 comprimidos para 3L e o tratamento sistêmico foi substituído por Ceftiofur $14 \mathrm{ml}$ IM/SID, e se manteve Cetamina e Fenilbutazona. Após sete dias de pósoperatório, a paciente apresentou involução uterina desejável. Com dez dias de pós-operatório, a paciente continua internada para a retirada dos pontos e com um bom prognostico.

Discussão: Freeman et al. (1999) avaliou 116 éguas que apresentavam parto distócico, destas 68 foram submetidas a cesariana, e apenas 7 vieram a óbito, justificando assim tal procedimento, que se mostrou seguro e com uma alta taxa de sobrevida.

Conclusão: Conclui-se assim, que a cesariana, apesar de ser um procedimento com baixa casuística, se mostrou segura no relato apresentado, não tendo complicações pós-operatórias devido ao rápido encaminhamento do animal ao hospital e ao pouco tempo de evolução da distocia, fator determinante para o bom prognostico do animal e sua recuperação.

\title{
Referências
}

FREEMAN, D. E. et al. Caesarean section and other methods for assisted delivery: comparison of effects on mare mortality and complications. Equine Veterinary Journal, v. 31, n. 3, p. 203-207, 1999.

ENGLAND, G. C. W. Fertility and Obstetrics in the Horse. 3. ed. Oxford, Uk: Blackwell Publishing, 2005.

LANÇA, F. O parto da égua e suas possíveis complicações. Disponível em: Acesso em: 27 ago. 2020. 
PRESTES, N. C. O parto distócico e as principais emergências obstétricas em equinos. Revista de Educação Continuada em Medicina Veterinária e Zootecnia do CRMV-SP, v. 3, n. 2, p. 40-46, 2000.

PRESTES, N. C.; FERNANDA, C. L. Obstetrícia veterinária. Grupo Gen-Guanabara Koogan, 2017.

Coordenadoria de Pesquisa e Extensão - COPEX

Departamento de Editoraçāo e Divulgaçāo Científica - DEDIC 


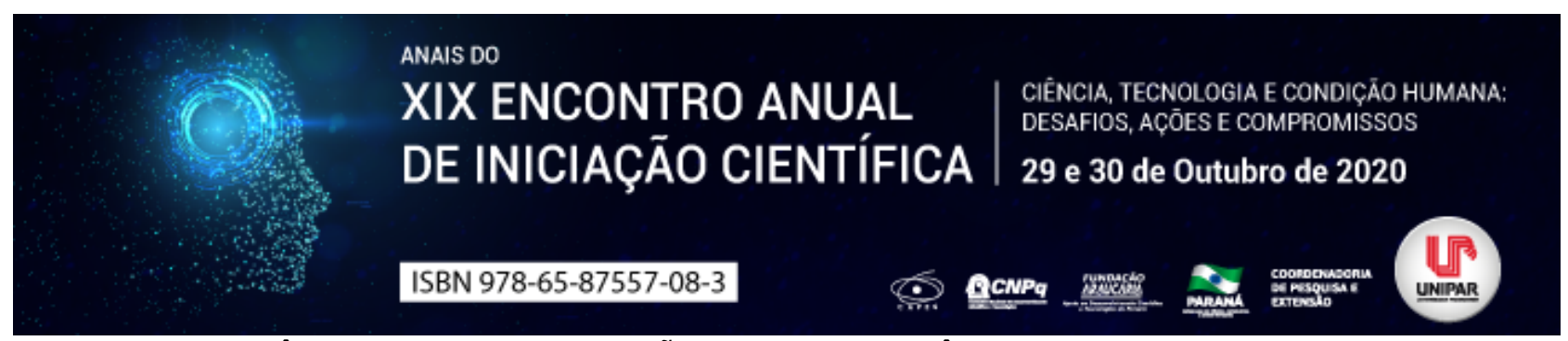

ENXERTO CUTÂNEO PARA EPITELIZAÇÃO DE FERIDA CRÔNICA EM EQUINO: RELATO DE CASO

\begin{abstract}
${ }^{1}$ LARISSA KOZIKOSKI, ${ }^{2}$ GIOVANNA FERNANDA JARDIM, ${ }^{3}$ FILIPE CORREA PACHECO, ${ }^{4}$ ANDRE GIAROLA BOSCARATO, ${ }^{5}$ LUIZ ROMULO ALBERTON
\end{abstract}

\author{
${ }^{1}$ Acadêmica do Curso de Medicina Veterinária, PIBIC/UNIPAR \\ ${ }^{1}$ Acadêmica do Curso de Medicina VeterinÃ $\tilde{A}_{j}$ ria da UNIPAR \\ ${ }^{2}$ Acadêmico do Curso de Medicina VeterinÃ $\tilde{A}_{j}$ ria da UNIPAR \\ ${ }^{3}$ Docente da UNIPAR \\ ${ }^{4}$ Docente da UNIPAR
}

Introdução: Os equinos são animais herbívoros que possuem um temperamento muito ativo e ágil. Devido a estas suas características eles são muito susceptíveis a acidentes. Estes acidentes podem ser ocasionados por instalações inadequadas para os hábitos destes animais como, por exemplo, cercas de arame farpado, baias mal dimensionadas ou até mesmo por um manejo inadequado (PAGANELA et al., 1991). Essas ocorrências se dão 60\% na região do carpo, tarso e segmentos distais. Devido a isso, o enxerto de pele é indicado para defeitos de pele de espessura total que não podem ser fechados usando técnicas de sutura convencionais ou técnicas cirúrgicas reconstrutivas e que requerem muito tempo para cicatrizar. Isso se aplica, em feridas no carpo ou no jarrete ou abaixo dele, levando em conta que essas feridas são incapazes de contração significativa e a epitelização dessas feridas é lenta e resulta em uma cicatriz frágil e demorada (SCHUMACHER et al., 2017). O objetivo deste trabalho é relatar o tratamento com o uso de enxerto autólogo com auxílio de punch dermatológico de ferida lacerada na região da articulação metacarpofalangeana de um equino.

Relato de Caso: Foi atendido no Hospital Veterinário da Universidade Paranaense UNIPAR, um equino, macho, alazã e aproximadamente 20 anos de idade. Apresentava emaciação pronunciada e uma ferida no membro pélvico esquerdo, que já havia recebido tratamento, com debridamento cirúrgico e curativos, onde não obteve sucesso. Ao exame clínico, observou-se ferida com características de cronicidade na face cranial da região da articulação metacarpofalangeana, com tecido de granulação exuberante e áreas de calcificação. Para o tratamento, optou-se pelo debridamento cirúrgico da ferida. Após o procedimento, a ferida foi tratada por segunda intenção, utilizando-se pomada de clorexidine a $0,7 \%$ como cobertura primária, seguido por cobertura secundária com ataduras de gaze, algodão ortopédico e ataduras de crepe. Após 14 dias, a ferida apresentava totalmente preenchida por tecido de granulação de aspecto homogêneo e ausência de sinais de infecção. Optou-se pela realização de enxerto cutâneo, para acelerar o processo cicatricial. Após sedação com cloridrato de detomidina e bloqueio infiltrativo local na superfície cervical esquerda, realizou-se tricotomia e preparo cirúrgico padrão. Foram colhidos os fragmentos, com auxílio de punch dermatológico com $6 \mathrm{~mm}$ de diâmetro. Utilizando o mesmo punch, foram produzidos leitos no tecido de granulação onde os fragmentos foram implantados, totalizando XVIII enxertos. Devido a baixa invasividade do procedimento e os cuidados de assepsia, não julgou-se necessário utilizar fármacos antiinflamatórios e antimicrobianos. Após o procedimento foi aplicado bandagem, com objetivo de proteção e ajuda na coagulação, na qual foi mantida por 4 dias, sendo posteriormente substituída a cada 48 horas, onde foi utilizado solução fisiológica estéril e gazes para limpeza, sendo feita delicadamente para não retirar nenhum implante. Sendo repetido este mesmo procedimento de troca de curativo até 10 dias. Após esse processo a ferida iniciou um processo de contração, onde alguns desses implantes coalesceram com a pele, onde estes conseguiram se fundir, apresentando sucesso de 10 implantes fundido. E nesse período ocorreu um processo de contração da ferida, sendo este, um acontecido normal de uma cicatrização.

Discussão: Segundo estudos, o emprego de enxerto cutâneo autólogo, mostra-se excelente alternativa para a diminuição do tempo de cicatrização, bem como custos com tratamentos, além de execução relativamente simplificada com o animal em estação (MARTINS et al., 2018). A contração ocorrida no processo da cicatrização geralmente inicia-se em feridas profundas na segunda semana após a lesão, uma vez que neste período, encontra-se densamente povoada por fibroblastos e pode continuar por várias semanas (FRANZ et al., 2007). Sendo considerado altamente benéfico, pois reduz a área de superfície da ferida original em 40 a 80\% (DI PIETRO; BURNS, 2003). Além de ter sido realizado o debridamento, onde nos períodos iniciais, afeta a cicatrização de forma positiva. Tendo o objetivo de reduzir o número de bactérias, sujidades e as taxas de tecidos desvitalizados, reduzindo o período inflamatório (STEINER et al., 2019). Em casos de feridas crônicas ou indolentes, onde os fibroblastos apresentam-se senescentes, benefícios foram observados por repetidos desbridamentos. A estimulação cirúrgica promove um acúmulo de plaquetas e assim, reinicia-se o processo de cicatrização (DART et al., 2005). Outra forma de obter-se desbridamento é permitir a ação de proteases contidas no próprio exsudato (CAVALCANTE; LIMA, 2012) ou através da utilização de cremes enzimáticos à base de colagenases (PROVOST, 2012), bromelina e uréia (CAVALCANTE; LIMA, 2012), com 
resultados variáveis entre si.

Conclusão: Conclui-se, através dos resultados positivos deste relato, que a utilização do enxerto autólogo com auxílio de punch, se mostra uma boa alternativa para o tratamento de feridas em equinos. Desde que realizado corretamente possui boa resposta, auxiliando na redução do tempo de cicatrização.

\section{Referências}

CAVALCANTE, B.L.L.; LIMA, U.T.S. Relato de experiência de uma estudante de Enfermagem em um consultório especializado no tratamento de feridas. Journal of nursing health, v.2, n.1, p.94-103, Pelotas, Jan/Jun, 2012.

DART, A. J.; DOWLING, B. A.; SMITH, L. C. Topical treatments in equine wound management. The Veterinary Clinics of North America. Equine Practice, Philadelphia, v. 21, n. 1, p. 77-89, 2005.

DI PIETRO, L. A; BURNS, A.L. Wound healing methods and protocols. Nova Jérsei: Humana Press. 2003.

FRANZ, M. G.; STEED, D.L.; ROBSON, M.C. Optimizing healing of the acute wound by minimizing complications. Current Problems Surgery, v. 44, p.691, 2007.

MARTINS, W.D.C.; et al. Graft of Small Patch of Partial Thickness in Equine Wound. Acta Scientiae Veterinariae, v. 46, supl. 1, p. 252, 2018.

PAGANELA, C. J. et al. Efeito do Açúcar na Cicatrização por Segunda intenção: Estudo Experimental em Ratos. Acta de Cirurgia Brasileira, v.65, p.65, 1991.

PROVOST P.J. Wound healing. In: AUER J.A, STICK J.A. Equine Surgery, 4 ed., p.50-52, Elsevier Saunders: St Louis, 2012.

SCHUMACHER, J. et al. Enxerto de Pele. Administrador Geral, Cap.18, 2017.

STEINER, D. et al. Considerações sobre o Processo de Cicatrização em Feridas Dermais em Equinos. Enciclopédia Biosfera: Centro Científico Conhecer, Goiânia, v.16, n.29, p. 524, 2019. 


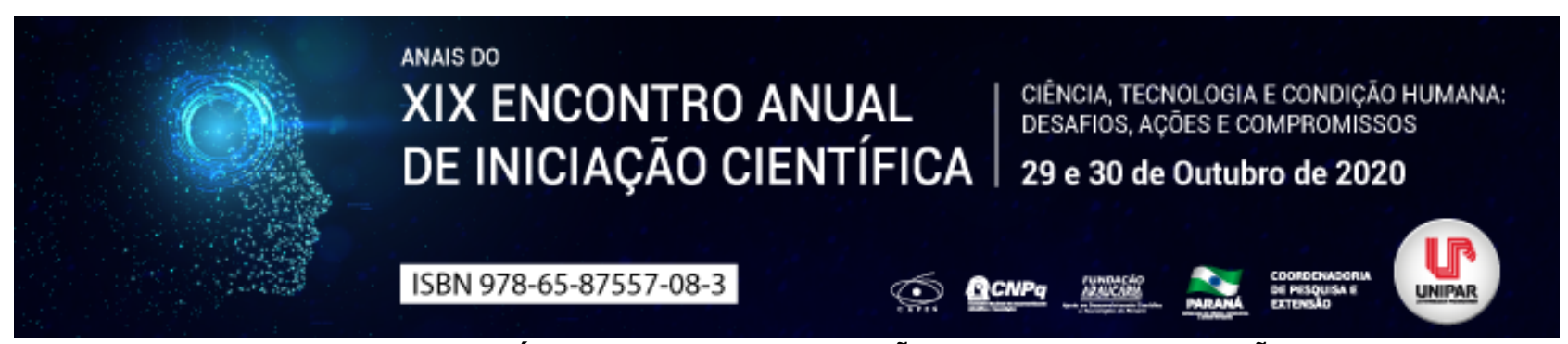

EVENTOS BIOLÓGICOS NA CICATRIZAÇÃO DE FERIDAS: REVISÃO

\begin{abstract}
${ }^{1}$ WESLEY ALVES TRINDADE,${ }^{2}$ GUILHERME DE ALMEIDA FAHEL CHUEIRI, ${ }^{3}$ LIDIA KAZUE IUKAVA, ${ }^{4}$ PAULA MONTANHINI FAVETTA, ${ }^{5}$ MARCELO ALBERTO ELIAS, ${ }^{6}$ RICARDO DE MELO GERMANO
\end{abstract}

\author{
${ }^{1}$ Mestrando do Programa de Ciência Animal da UNIPAR, Bolsista PIC/PG, Taxista PROSUP/CAPES \\ ${ }^{1}$ Discente do Curso de Medicina Veterinária da UNIPAR, Bolsista PIBIC/UNIPAR \\ ${ }^{2}$ Mestranda do Programa de Plantas Medicinais e Fitoterápicos, Bolsista PIC/PG, Bolsista PIT/UNIPAR \\ ${ }^{3}$ Doutoranda do Programa de Ciência Animal da UNIPAR, Bolsista PIC/PG, Bolsista PROSUP/CAPES \\ ${ }^{4}$ Doutorando do Programa de Ciência Animal da UNIPAR, Bolsista PIC/PG, Taxista PROSUP/CAPES \\ ${ }^{5}$ Docente do Programa de Pós-Graduação em Ciência Animal da UNIPAR
}

Introdução: A reparação tecidual através da cicatrização de feridas, consiste num processo biológico cuja principal função é reestabelecer a integridade do local lesionado, além de manter funções importantes deste órgão (SORG et al., 2016). Após uma lesão na pele, há a perda da continuidade física do local, resultando em uma série de eventos como deposição de colágeno, proliferação e diferenciação celular, deposição de plaquetas, liberação de mediadores químicos, entre outros, na tentativa de fechamento do leito tecidual (GONZALES, 2016; SILVA et al., 2018).

Objetivo: Realizar uma revisão de literatura sobre a cicatrização de feridas, discorrendo sobre as diferentes fases do processo cicatricial.

Desenvolvimento: Para a revisão foi realizada uma busca na plataforma de pesquisa internacional do PubMed (www.pubmed.com), utilizando os descritores: cicatrização de feridas; reparação tecidual, wound healing. Foram selecionados e utilizados artigos publicados a partir do período de 2014 que possuíam objetivo principal o estudo do processo cicatricial fisiológico. A pele é reconhecida como o maior órgão do corpo, por possuir processos fisiológicos importantes como termorregulação, barreira mecânica de proteção a agentes do ambiente, equilíbrio de fluidos, tornando-a componente importante ao organismo (SORG et al., 2016). Existem etiologias multivariadas que desencadeiam lesões na pele, sendo elas os traumas, estímulos térmicos, químicos, elétricos, resultando numa disfunção tecidual e celular (GONZALES et al., 2016) e, quando isso ocorre, o organismo desenvolve eventos para que se realize esta reparação tecidual, sendo descritas na literatura por três fases sucessivas, conhecidas como inflamatória, proliferativa e remodelamento (KASUYA; TOKURA, 2014; SILVA et al., 2018; VIBERT et al., 2018; WANG et al., 2018). A primeira etapa da cicatrização inicia-se através da fase inflamatória imediatamente após a lesão com duração aproximada de três dias, geralmente iniciada pela ativação da agregação plaquetária, promovendo manutenção dos vasos sanguíneos, através de uma rede de fibrinas, que por sua vez, se torna além de uma barreira contra invasão de microrganismo, como também possibilitar o influxo de células no local lesado (GONZALES et al., 2016). Os neutrófilos são as primeiras células de defesas a chegarem no local da lesão para realizar fagocitose de restos celulares, bem como produtos de matriz extracelular, microrganismos e debris teciduais, além de liberarem citocinas pró-inflamatórias (CHHABRA et al., 2017; WANG et al., 2018). Na sequência diversos monócitos se deslocam dos vasos até a lesão, diferenciando-se em macrófagos para realizarem fagocitose, mas, também realizarem a liberação de uma série de fatores de crescimento que auxiliarão no desencadeamento da produção de novos tecidos (SORG et al., 2016). A fase proliferativa é caracterizada pelos eventos conhecidos como angiogênese, fibroplasia e reepitelização, desempenhados simultaneamente, com a finalidade de promover a produção de uma nova matriz extracelular e tecido de granulação (KASUYA; TOKURA, 2014). Nesta fase há a presença de muitas células, marcadas principalmente pelos fibroblastos, queratinócitos e células endoteliais, responsáveis pela produção da matriz extracelular, composta por ácido hialurônico, elastina, proteoglicanos e predominantemente por colágeno tipo III, além de liberarem citocinas e fatores de crescimento que auxiliarão no desenvolvimento desta etapa, que possui duração de dias a semanas (GONZALES et al., 2016; WANG et al., 2018). A última fase da cicatrização é a de remodelamento, ocorrendo entre o décimo quarto dia após a lesão, podendo durar anos (SILVA et al., 2018). Nesta fase final há a tentativa de recuperar a estrutura normal do tecido, por meio do remodelamento do tecido de granulação e posterior formação de um tecido cicatricial acelular por apoptose destas células (GONZALES et al., 2016). Este remodelamento ocorre através da degradação da matriz extracelular formada, através da ação das metaloproteinases que sinalizam para a diminuição da formação de colágeno tipo III e o aumento da produção de colágeno tipo I, que são caracterizadas por serem fibras organizadas e espessas, tornando a cicatriz resistente a força de tensão (WANG et al., 2018). A literatura ressalta a possibilidade de alterações no processo de cicatrização de feridas, através de fatores internos, externos ou sistêmicos que possam prejudicar a reparação tecidual, atrasando o processo cicatricial (CHHABRA et al., 2017; GONZALES et al., 2016) ou tornando uma cicatriz exuberante (WANG et al., 2018).

Conclusão: Manter a integridade da pele é extremamente importante para o organismo, já que ela auxilia na manutenção da 
homeostase. Os eventos biológicos envolvidos na cicatrização de feridas, demonstram ser refinados e que envolvem uma série de células necessárias para que a reparação tecidual seja completamente realizada. No entanto, é de grande importância a realização de novos estudos, para elucidar e entender cada vez mais este processo.

\section{Referências}

CHHABRA, S. et al. Wound healing concepts in clinical practice of OMFS. Journal of Maxillofacial and Oral Surgery, New Delhi, v. 16, n. 4, p. 403-423, 2017.

GONZALEZ, A. C. O. et al. Wound healing-A literature review. Anais brasileiros de dermatologia, Rio de Janeiro, v. 91, n. 5, p. 614-620, 2016.

KASUYA, A; TOKURA, Y. Attempts to accelerate wound healing. Journal of dermatological science, Amsterdam, v. 76, n. 3, p. 169-172, 2014.

SILVA, J. R. et al. Wound healing and omega-6 fatty acids: From inflammation to repair. Mediators of inflammation, Sylvania, v. 2018, p. 17, 2018.

SORG, H. et al. Skin wound healing: an update on the current knowledge and concepts. European Surgical Research, Basel, v. 58, n. 1-2, p. 81-94, 2016.

VIBERT, L.; DAULNY, A.; JARRIAULT, S. Wound healing, cellular regeneration and plasticity: the elegans way. The International journal of developmental biology, Vizcaya, v. 62, n. 6-7-8, p. 491, 2018.

WANG, P. H. et al. Wound healing. Journal of the Chinese Medical Association, Taipei, v. 81, p. 94-101, 2018. 


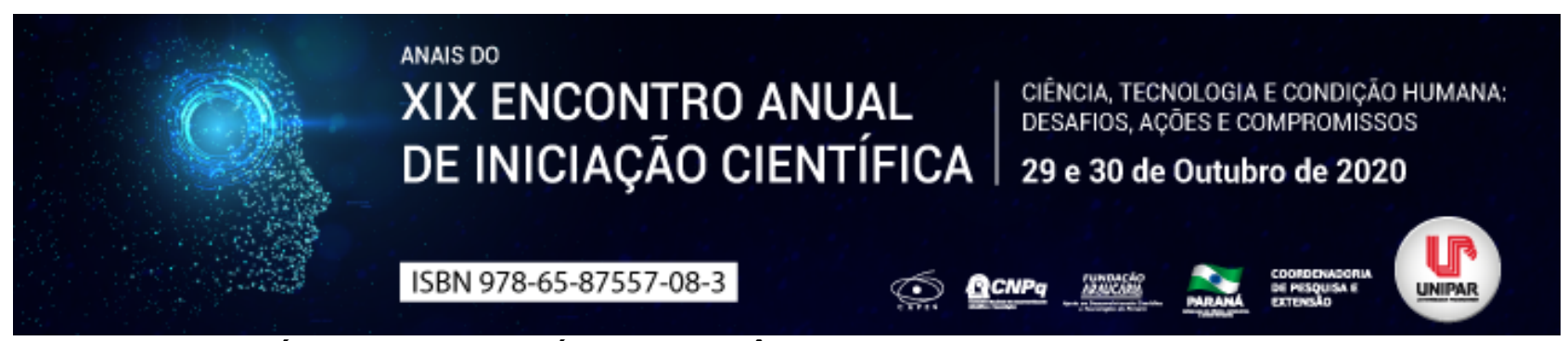

HÉRNIA DIAFRAGMÁTICA CONGÊNITA EM EQUINO:RELATO DE CASO

\begin{abstract}
${ }^{1}$ Natália Pazzini Nunes, ${ }^{2}$ ANA CAROLINA BONORINO ANTUNES, ${ }^{3}$ DIOI BATAGLIN SEVERO, ${ }^{4}$ ALISSON LEONARDO NUNES MARTINS, ${ }^{5}$ FERNANDO BORGES LORENZINI, ${ }^{6}$ MONIQUE TOGNI MARTINS
\end{abstract}

${ }^{1}$ Discente do curso de medicina veterinária, Universidade Regional do Alto Uruguai e das Missões Veterinária Santiago -RS Brasil
${ }^{1}$ Discente do curso de medicina veterinária, Universidade Regional do Alto Uruguai e das Missões Veterinária Santiago -RS Brasil
${ }^{2}$ Discente do curso de medicina veterinária, Universidade Regional do Alto Uruguai e das Missões Veterinária Santiago -RS Brasil
${ }^{3}$ Discente do curso de medicina veterinária, Universidade Regional do Alto Uruguai e das Missões Veterinária Santiago -RS Brasil
${ }^{4}$ Discente do curso de medicina veterinária, Universidade Regional do Alto Uruguai e das Missões Veterinária Santiago -RS Brasil
${ }^{5}$ Docente do curso de medicina veterinária, Universidade Regional do Alto Uruguai e das Missões Veterinária Santiago -RS Brasil

Introdução: A terminologia hérnia diafragmática descreve afeç̧ão em que alguns órgãos apresentam deslocamento da sua posição anatômica através de um anel herniário natural ou traumático. A hérnia diafragmática ocorre devido a uma ruptura da continuidade do músculo diafragma, permitindo que os órgãos abdominais sejam projetados para dentro da cavidade torácica. A sua classificação é realizada de acordo com a sua origem etiológica, pode ser dividia em adquirida ou congênita, sendo a primeira frequentemente associadas a lesões traumáticas e a segunda, um evento mais comum em pacientes pediátricos no qual, o distúrbio já está presente ao nascimento. (READ;BELLENGER,2007). As hérnias diafragmáticas de origem congênitas ocorrem devido a falha na fusão ou no desenvolvimento incompleto da membrana pleuroperitoneal durante a formação diafragmática, a qual, é responsável pela separação entre o diafragma e o abdome ou também, devido ao desenvolvimento defeituoso do seio transverso. (HUNT; JOHNSON, 2007).

O objetivo desse relato é descrever as alterações anatomopatológicas da hérnia diafragmática congênita em um potro e apresentar aos profissionais da área essa afecção incomum em equinos.

Relato de caso: O cadáver de um potro neonato da raça crioula foi doado para a Universidade Integrada do Alto Uruguai e das Missões na cidade de Santiago-RS, para a necropsia. Na necropsia o animal apresentava mucosas ocular e oral acentuadamente pálidas. $\mathrm{Na}$ abertura da cavidade abdominal havia uma comunicação com o tórax através de uma laceração no diafragma. $\mathrm{Na}$ abertura da cavidade torácica evidenciou-se o estômago, porção do fígado, ceco e intestino delgado comprimindo o coração e os pulmões. Os pulmões estavam colabados (atelectasia), possuindo coloração vermelho escuro e áreas mediais mais claras e aderências da pleura visceral à parietal e ao corte estava compacto. $\mathrm{O}$ diafragma não apresentava fechamento completo, possuindo uma abertura de aproximadamente $10 \mathrm{~cm}$ na porção lateral direita. Não foram observados sinais de trauma. Discussão: Os dados encontrados na literatura consideram que dentre os casos de hérnia diafragmática, 77 a $85 \%$ dos casos apresentam origem traumática, enquanto apenas 5 a 10\% são de origem congênita, com os demais casos clínicos sem etiologia definida. (DO PRADO et al., 2013). A frequência de malformação adquirida ou congênita variam em diferentes populações, idade ou sexo entre as espécies de animais, geralmente estão associadas a episódios recentes de traumas ou aumento da pressão intra-abdominal acarretando a uma ruptura, caracterizada por um orifício com bordas lisas na região do diafragma respectivamente. (HART, S. K.; BROWN, J. A, 2009). As alterações de necropsia encontradas no tórax, pulmão, fígado, intestinos e diafragma sugerem tratar-se de alterações congênitas, hérnia diafragmática, devido a uma malformação significativa do diafragma. Atelectasia pulmonar significa distensão incompleta dos alvéolos, este termo é usado para descrever pulmões que não se expandiram com o ar por ocasiões adquiridas ou congênitas como observados neste relato. Macroscopicamente, nos casos de atelectasia congênita, os pulmões podem apresentar-se completamente atelectásicos, tanto em animais natimortos que não tiveram nenhum movimento respiratório, como também, em neonatos com respiração fraca. Nesses casos, os pulmões têm coloração vermelho escura devido à separação das paredes alveolares por ar. (SANTOS, R. L; GUEDES, R.M.C 2017). Independentemente da sua origem, seja ela traumática ou congênita, a hérna diafragmática é uma patologia incomum na espécie equina, podendo causar repercussões sistêmicas variadas e complicações diversas. Em muitos casos o diagnóstico é realizado com base nos achados de anamnese, exames físicos ou necropsia devido à dificuldade de identificar a localização do defeito ao longo do diafragma. (ROMERO, A. E., RODGERSON D. H. 2010). Conforme um levantamento dos casos relatados nas bibliografias referente às hérnias diafragmáticas, cerca de $40 \%$ dos casos foram diagonsticados somente na necropsia. (KELMER, G. et. al 2008).

Conclusão: De acordo com os achados macroscópicos apresentados na necropsia e a ausência de sinais traumáticos o caso em questão foi diagnosticado como hérnia diafragmática congênita. Malformações congênitas em equinos são alterações patológicas pouco discutidas no Brasil, tornando os dados regionais ainda mais escassos. Isto demonstra a importância da disseminação de informações sobre novas ocorrências de malformações nessa espécie. 


\section{Referências}

DO PRADO, T. D. et al. Hérnia diafragmática em cães. Enciclopédia Biosfera, Goiânia, v. 9, n. 16, p. 1229-1241, 2013.c HART, S. K.; Bronw, J. A. Diaphragmatic hernia in horses: 44 cases (1986-2006). Journal of VeterinaryEmergency and Critical Care, San Antonio, v.19, n.4, p.357-362, 2009.

HUNT, G.B.; Johnson, K. A. Hérnia diafragmática, pericárdica e hiatal. In: Slatter, D. Manual de cirurgia de grandes animais. 3. ed. São Paulo: Manole, 2007. p. 470-487.

KELMER, G.; KRAMER, J.; WILSON, D. A. Diaphragmatic hernia: etiology, clinical presentation,and diagnosis. Comp Cont Ed Equine Edition, Yardley,v. 3, p. 28-35, 2008

READ, R. A.; Bellenger, C. R. Hérnias. In: Slatter, D. Manual de cirurgia de pequenos animais. 3. ed. Barueri: Manole, 2007. p. 446-448

ROMERO, A. E.; Rodgerson, D. H. Diaphragmatic herniation in the horse: 31 cases from 2001-2006.Canadian Veterinary Journal, n.51, p.1247-1250, 2010.

SANTOS, R. L; Guedes, R.M.C. Sistema respiratório, In: Santos, Lima, R. D., ALESSI, Carlos, A. Patologia Veterinária $2^{a}$ edição. Rio de Janeiro Editora Roca, 2017 p. 14- 42; p 67-97; 


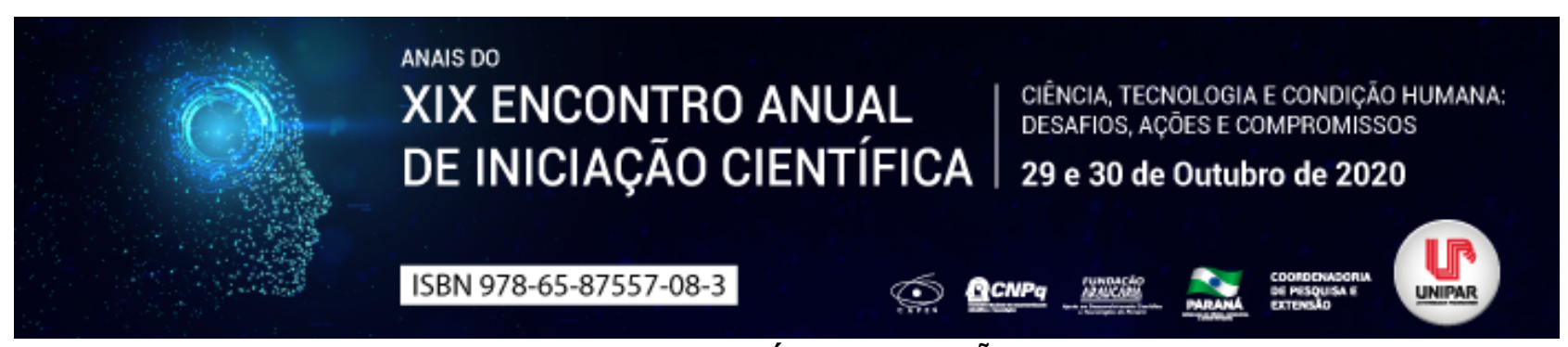

USO DE PROBIÓTICOS EM CÃES

${ }^{1}$ EMANUELLE MARIA DE SOUZA SILVA, ${ }^{2}$ SARAH LISSONI COBO, ${ }^{3}$ GABRIEL COELHO GIMENEZ, ${ }^{4}$ FILIPE CORREA PACHECO, ${ }^{5}$ RANULFO PIAU JUNIOR

\author{
${ }^{1}$ Acadêmica do Curso de Medicina Veterinária da Unipar, bolsista PIBIC/Unipar \\ ${ }^{1}$ Acadêmica do Curso de Medicina Veterinária - PIC/UNIPAR \\ ${ }^{2}$ Mestre em Ciência Animal \\ ${ }^{3}$ Mestrando no Curso de Pós-graduação em Ciência Animal com Ênfase em Produtos Bioativos \\ ${ }^{4}$ Docente da UNIPAR
}

Introdução: Muitos estudos voltados à nutrição animal vêm se desenvolvendo na busca de alimentos com probióticos, para que além de nutrir de maneira balanceada, ajudam na prevenção de problemas digestivos que podem resultar em má absorção dos nutrientes (GRZESKOWIAK et al., 2015). Probióticos podem ser definidos como microrganismos que podem ser usados na situação em que o equilíbrio da microbiota intestinal do animal possa estar sendo afetado (SILVA et al., 2013). Uma melhor compreensão da ação desses microrganismos é pré-requisito tanto para o desenvolvimento racional de probióticos seguros e eficazes, como para o respaldo do uso terapêutico desses produtos (GRZESKOWIAK et al., 2015).

Objetivo: O objetivo deste trabalho foi fazer uma revisão sobre o uso de probióticos em cães.

Desenvolvimento: Os microrganismos mais comumente utilizados como probióticos são geralmente componentes não patogênicos da microbiota normal, pertencentes aos gêneros Lactobacillus, Bifidobacterium e em menor escala aos gêneros Enterococcus e Streptococcus. Bactérias pertencentes ao gênero Bacillus e leveduras como Sacharomyces boulardii e Sacharomyces cerevisiae, também são utilizadas como probióticos. (BERBEL et al., 2016). Os probióticos são eficientemente utilizados em alguns casos estressantes como mudança de alimentação, viagens e exposições para locais novos, parto e desmame, estresse ambiental, durante e após tratamento com antibióticos ou na promoção da estabilidade da microbiota intestinal não patogênica nos recém-nascidos. As características essenciais para um microrganismo ser considerado probiótico são: sobreviver, crescer e se fixar ao epitélio intestinal, enfrentar condições adversas, como a produção de sais biliares, sucos gástrico, pancreático e entérico, colonizarem o intestino e ter capacidade antagônica às bactérias prejudiciais (FERNANDES et al., 2000). A maioria dos probióticos para cães e gatos disponíveis no mercado não são obtidos da microbiota intestinal canina ou felina, mas da microbiota intestinal suina, aviária ou humana. Porém, estudos apontam que os microrganismos podem exercer efeitos específicos para as espécies e, portanto, probióticos caninos ou felinos de sucesso seriam idealmente derivados do trato gastrintestinal de cães e gatos. (MCCOY; GILLILAND, 2007; SILVA et al., 2013). Há uma variedade de probióticos comerciais disponíveis destinados a cães e gatos, no entanto, o probiótico manipulado oferece vantagens por se tratar de um produto personalizado, além da manipulação veterinária ser um campo de atuação em expansão para o profissional farmacêutico, porém deve ter cautela pois os probióticos podem apresentar efeitos diferentes a depender da dosagem, formas de administração, bactérias e espécie-alvo, utilizadas na terapia (GRZEŚKOWIAK et al., 2015).

Conclusão: Mais pesquisas devem ser feitas para observar as ações dos probióticos em cães. $\mathbf{O}$ uso de probióticos em cães podem ser utilizados para ajudar a melhorar a saúde e a integridade intestinal destes animais.

\title{
Referências
}

BERBEL, C. Z. et al. Probióticos no Tratamento de Dermatite Atópica e Acne. Visão Acadêmica, Curitiba, v. 45, p. 94 115, 2016.

FERNANDES, P. C. C. et al. Viabilidade do uso de probióticos na alimentação de monogástricos. Cadernos Técnicos da Escola de Veterinária (UFMG), Belo Horizonte, n.31, p. 53-71, 2000.

GRZEŚKOWIAK, Ł. et al. Microbiota and probiotics in canine and feline welfare. Anaerobe, London, v. 34, p. $1423,2015$. MCCOY, S.; GILLILAND, S. E. Isolation and characterization of Lactobacillus species having potential for use as probiotic cultures for dogs. Journal of Food Science, Campinas, v. 72, n. 3, 2007.

SILVA, B. C. et al. In vitro assessment of functional properties of lactic acid bacteria isolated from faecal microbiota of healthy dogs for potential use as probiotics. Beneficial Microbes, Netherlands, v. 4, n. 3, p. 267 276, 2013. 


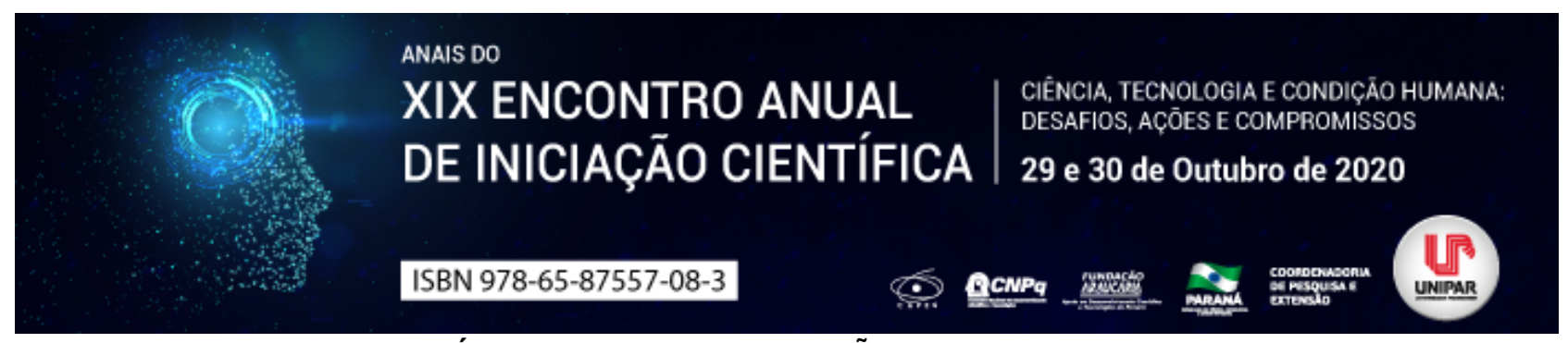

EFEITO DO USO DE ADITIVO PROBIÓTICO NA SUPLEMENTAÇÃO DE BOVINOS EM REGIME EXTENSIVO - REVISÃO

\author{
${ }^{1}$ NATHALIA SOUZA JAMARCHI, ${ }^{2}$ HUGO HENRIQUE MARTIN CAMPOS, ${ }^{3}$ EMANUEL BUENO MOREIRA, ${ }^{4}$ FILIPE CORREA \\ PACHECO, ${ }^{5}$ RANULFO PIAU JUNIOR
}

${ }^{1}$ Acadêmico bolsista PIBIC/UNIPAR

${ }^{1}$ Acadêmico do Curso de Medicina Veterinária da UNIPAR

${ }^{2}$ Bolsista PEBICjr/CNPq

${ }^{3}$ Mestrando da Pós-graduação em Ciência Animal com Ênfase em Produtos Bioativos - UNIPAR

${ }^{4}$ Docente do curso de Medicina Veterinária e do mestrado e doutorado em Ciência Animal com Ênfase em Produtos Bioativos UNIPAR

Introdução: Na ultima década, os probióticos vêm ganhando espaço no mercado devido ao seu bom desempenho em relação aos animais, melhorando o manejo nutricional, sanitário e o melhoramento genético. Essas leveduras e/ou bactérias tem como objetivo auxiliar no ganho de peso desses animais, resultando em uma boa qualidade no produto final (ALMEIDA et al., 2013; ALMADA et al., 2017; SANTOS, 2018).

Objetivo: O objetivo deste trabalho fazer uma revisão sobre o uso de probióticos no desempenho de animais no regime extensivo.

Desenvolvimento: $O$ uso de probióticos na alimentação de ruminantes faz com que os microrganismos reduzam o oxigênio ruminal, resultando em um aumento de outros microrganismos que colonizam o rúmen, fazendo com que haja uma maior degradação das fibras. Sendo assim, há um aumento no aproveitamento das fibras, aumentando a eficiência alimentar, obtendose um ganho de peso desses animais (SANTOS, 2018). O uso de probióticos está crescendo para que o uso de antibióticos não seja mais utilizado, pois são capazes de deixar resíduos no produto final, tanto na carne como no leite. São capazes de aumentar a resposta imune dos animais. No trabalho de Santos (2018) 100 animais foram utilizados para o experimento, sendo divididos em dois lotes de 50 animais, mantidos em piquetes coletivos, onde tinham acesso ao cocho com suplementação, durante 90 dias, no grupo $1 \mathrm{com}$ a presença de probióticos e no grupo $2 \mathrm{sem}$ probióticos, como resultado concluíram que a suplementação de bovinos mestiços Nelore a pasto com aditivo probiótico, levou a um aumento significativo no ganho de peso e retorno econômico em relação ao grupo controle. O aumento obtido no ganho de peso vivo dos bovinos $(10,10 \mathrm{~kg}$ com rendimento de carcaça de 52\%) suplementados com probiótico (T1) em relação ao controle (T2) levou a um ganho bruto de R $\$ 54,25$ por animal. $\mathrm{O}$ custo do probiótico adicionado à mistura mineral proteinada durante o período experimental foi de $\mathrm{R} \$ 3,27$ por animal, resultando em ganho líquido de aproximadamente $\mathrm{R} \$ 50,00$ por animal em noventa dias. No trabalho de Almada et al. (2017) apesar de não haver diferença estatística para o ganho de peso dos animais tratados com probióticos e prebioticos, ocorreu um melhor rendimento quanto este parâmetro nos grupos que receberam probióticos e com a simbiose de probióticos e prebióticos, segundo os autores a simbiose, aparentemente, também proporcionou um aumento no consumo médio diário. Outro estudo avaliou o efeito do probiótico, Proenzime ${ }^{\circledR}$, adicionado à mistura mineral no ganho de peso de bovinos, com idade de aproximadamente 12 meses, em sistema de pastejo extensivo. Pesaram-se os bezerros nos dias 0 e 30 de 30 a 90 dias e 0 a 90 dias. Os resultados mostraram um aumento significativo no ganho de peso nos animais do grupo que recebeu probióticos nos primeiros 30 dias (ALMEIDA et al., 2013).

Conclusão: $O$ uso de aditivos probióticos na alimentação de bovinos pode apresentar bons resultados, devendo ai ser mais estudado, porem já com resultados positivos apresentados na literatura pode ser um importante aliado dos profissionais da rea que buscam uma maior produção, aliada ao desenvolvimento sustentável e ao uso de produtos naturais.

\title{
Referências
}

ALMADA, A. F. B. et al. Desempenho de novilhas da raça Nelore Mediante o uso de betaglucanas e probióticos. Arq. Cienc. Saúde UNIPAR, Umuarama, v.21, n. 3, p. 175-179, Set./Dez. 2017.

ALMEIDA, L. E. et al. Utilização de probióticos sobre o ganho de peso em bovinos da raça nelore. Colloquium Agrarie, v. 9, n. 1, p. 25-30, Jan-Jun, 2013.

SANTOS, S. A. Efeito do uso de aditivo probiótico na suplementação de bovinos em regime extensivo a pasto. Revista Alomorfina, Presidente Prudente, v.2, n.1, p;53-62, nov. 2018. 



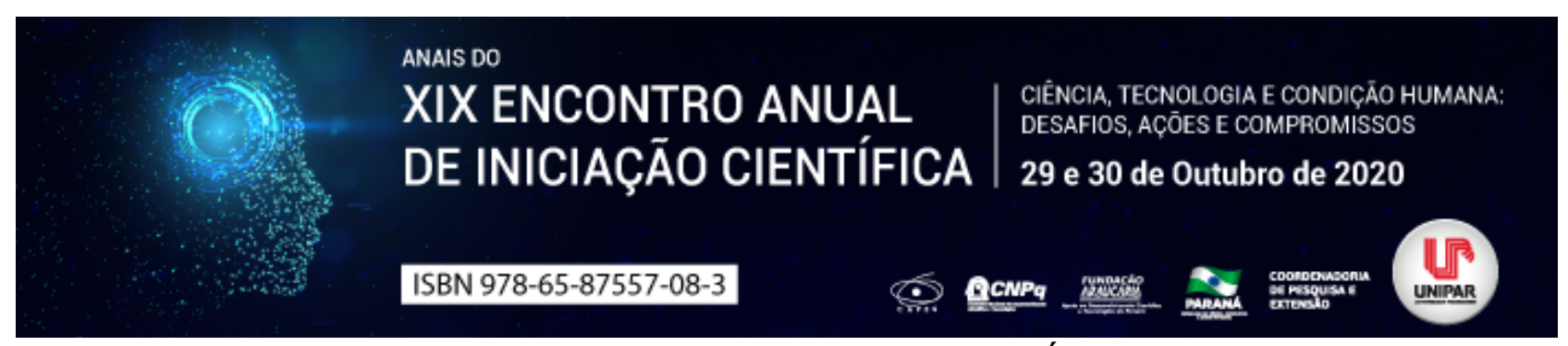

Platynosomum fastosum EM ANIMAL ATENDIDO NO HOSPITAL VETERINÁRIO DA UNIVERSIDADE FEDERAL DO PARANÁ SETOR PALOTINA (HVPIUFPR)

\author{
${ }^{1}$ Bruna Ávila Torres, ${ }^{2}$ LAURA ZANELLA SOUZA, ${ }^{3}$ ANA PAULA MOLINARI CANDEIAS, ${ }^{4}$ ARTHUR COLOMBARI CHENG, \\ ${ }^{5}$ ANDRÉ LUIZ VRIESMAN BENINCA, ${ }^{6}$ NELSON LUIZ MELLO FERNANDES
}

\author{
${ }^{1}$ Médica Veterinária Residente na Área de Doenças Parasitárias dos Animais do Programa de Residência em Medicina \\ Veterinária Campus Palotina \\ ${ }^{1}$ Médica Veterinária Residente na Área de Doenças Parasitárias dos Animais do Programa de Residência em Medicina \\ Veterinária Campus Palotina \\ ${ }^{2}$ Mestranda no Programa de Pós-graduação em Ciência Animal - Universidade Federal do Paraná Setor Palotina \\ ${ }^{3}$ Médico Veterinário Residente na Área de Anatomia Patológica do Programa de Residência em Medicina Veterinária Campus \\ Palotina - Universidade \\ ${ }^{4}$ Mestre em Ciência Animal - Universidade Federal do Paraná Setor Palotina \\ ${ }^{5}$ Docente da Universidade Federal do Paraná
}

Introdução: O gênero Platynosomum pertence à classe Trematoda, as espécies mais comuns são o $P$. fastosum, $P$. illiciens e $P$. concinnum. Tem como hospedeiros definitivos felinos domésticos ou selvagens, seu ciclo biológico envolve três hospedeiros intermediários o caracol da terra, isópodes terrestres, como besouros e percevejos, e as lagartixas ou sapos. Alguns pássaros insetívoros podem atuar como hospedeiro paratênico no ciclo (PAULA, 2010). Podem ser encontrado em regiões tropicais e subtropicais, no Brasil, tem sido relatado em cidades de todas as regiões, sudeste, nordeste, norte, centro-oeste e sul (JORGE et al., 2020). Os sinais clínicos são inespecíficos e se modificam de acordo com a quantidade de trematódeos presente no trato biliar, sendo comumente confundida com outras enfermidades. Favorece aparecimento de contaminação bacteriana secundária e contribui para o desenvolvimento de colangite e abscessos hepáticos, e aumenta o risco de colangiocarcinoma e colangite piogênica (JORGE et al., 2020). O diagnóstico pode ser realizado através do método de observação de ovos nas fezes de felinos, pela sedimentação em formalina-éter (LIMA et al., 2008). Os métodos de avaliação direta e Willis-Mollay, são capazes de identificar o parasito e seus ovos no exame coproparasilógico, porém pode ocorrer falso negativo, se houver obstrução do ducto biliar e os ovos não conseguem atingir o lúmen intestinal (JORGE et al., 2020). O diagnóstico definitivo se dá através de biópsia hepática por meio de citologia do conteúdo biliar com visualização dos ovos operculados ou da forma adulta do parasito na bile (JORGE et al., 2020). O tratamento depende da carga parasitária, da gravidade das lesões, se o diagnóstico foi realizado a tempo de reverter a situação clínica do animal (PAULA, 2010). Dentre os fármacos anti-helmínticos de escolha para o tratamento está o praziquantel, que vem demonstrando bons resultados em animais acometidos pela platinossomíase (CAMPOS et al., 2018). A prevenção consiste em evitar a ingestão do hospedeiro intermediário, a lagartixa, controlando a presença deste no ambiente residencial ou restringindo o acesso à rua. A castração também pode ser utilizada, visto que gatos castrados tendem a ficar mais em casa devido a mudança de comportamento com a diminuição da produção dos hormônios sexuais (JORGE et al., 2020). O presente trabalho teve como objetivo, descrever um caso de infecção natural por $P$. fastosum em um gato (Felis catus) recebido no Laboratório de Patologia Animal (LPA) da Universidade Federal do Paraná (UFPR), Setor Palotina.

Relato de caso: Foi encaminhado para necropsia ao LPA da UFPR - Setor Palotina, um felino doméstico, fêmea, com 3kg, 8 anos, castrada. No histórico, ausência de informações sobre vermifugações e vacinações, o animal possuía livre acesso à rua e foi encaminhado para atendimento médico veterinário devido à um trauma por atropelamento, fora realizado exames de imagem constatando fraturas múltiplas de ílio, ísquio e púbis, com comprometimento neurológico. Devido ao quadro o animal foi eutanasiado. Na análise macroscópica do fígado não foi notoado nenhuma alteração, entretanto, na avaliação interna do fígado e vesícula biliar, foi possível observar presença de estruturas com formato de folha, em grande quantidade, sugestivas de Platynosomum spp. Líquido da vesícula biliar foi colhido e encaminhado para o Laboratório de Doenças Parasitárias dos animais (DOPA) HVP/UFPR para identificação do parasito através de microscopia direta.

Discussão: O animal do presente estudo, mesmo castrado, possuía acesso a ambiente extradomicialiar, segundo o proprietário não possuía nenhum sinal clinico suspeito para platinossomíase, mesmo com alta carga parasitária encontrada. Segundo Lima et al.. (2008) o instinto natural predatório do gato assegura o completo ciclo de vida dessa parasitose que é comum em gatos de vida livre e não castrados, assim como observado em nosso estudo, onde o animal possuía livre acesso ao ambiente extradomiciliar (ou a rua). Na maioria das vezes a infecção por $P$. fastosum é assintomática devido ao tempo de parasitismo e a reação imunológica individual do hospedeiro ao parasito, que pode ser bem tolerados pelos felinos (FRONDANA et al., 2015;)

Conclusão: Por conta de diversos fatores, muitos animais podem ser assintomáticos nas infecções por $P$. fastosum, desta forma, 
torna-se importante realizar o diagnóstico precoce, através do exame de fezes, pois em casos mais graves pode haver complicações severas, entre elas, obstrução de ductos biliares e cirrose hepática, comprometendo a vida do animal.

\section{Referências}

CAMPOS, Nayara Camatta; SIQUEIRA, Daniele Fassina de; PERIN, Lívia Reisen; OLIVEIRA, Luanna Castro; CAMPOS, Diefrey Ribeiro; MARTINS, Isabella Vilhena Freire. Infecção natural por Platynosomum fastosum em felino doméstico no município de Alegre, Espírito Santo e sucesso no tratamento com praziquantel. Medicina Veterinária (UFRPE), v. 12, n. 1, p. 17-21, 2018 FRONDANA, Luca; MORAES, Andressa Vieira de; FISCHER, Elisa; STURION, André Luiz Torrecillas; KITAMURA, Eunice Akemi; CLAUS, Marlise Pompeo; MILCZEWSKI, Viviane. Relato do primeiro diagnóstico parasitológico de Platynosomum, looss (1907) em felino no estado de Santa Catarina. Evetos Institudo Federal Catarinense Câmpus Araquari. 7 e 8 de Outubro de 2015.

JORGE, Ana Luiza Teixeira Amado; FREITAS, Dilma Mendes de; BORGES, Franciele Júlia Coelho; LACERDA, Moacir Santos de, MARIA, Bruna Piva.; SÁ, Simone Scarpin de.; ROSADO, Isabel Rodrigues; ALVES, Endrigo Gabellini Leonel. Colecistoduodenostomia para tratamento de obstrução biliar secundária a platinossomose felina. Acta Scientiae Veterinariae, vol.48, março, 2020. Disponível em: https://www.seer.ufrgs.br/ActaScientiaeVeterinariae/article/view/100612/0. Acesso em: 21, ago. 2020.

LIMA, Gabriela S.; DABUS, Daniela M. M.; TRENTIN, Thays C. Platynosomum factosum. Revista Científica Eletrônica de Medicina Veterinária, Ano VI, n. $11, \quad$ jun, $2008 . \quad$ Disponível http://faef.revista.inf.br/imagens_arquivos/arquivos_destaque/qfVQ8YIAaRhrETw_2013-6-13-15-31-11.pdf. Acesso em: 19 ago. 2020.

PAULA, Carolina Lechinski. Platinosomíase em felinos domésticos: um diferencial para obstrução biliar. Trabalho de conclusão de curso (Bacharelado em Medicina Veterinária) - Faculdade de Medicina Veterinária e Zootecnia. Universidade Estadual Paulista, Botucatu, 2010. 


\title{
(

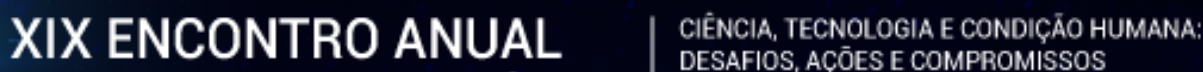 DE INICIACÃO CIENTÍFICA DESAFIOS, ACOESS ECOMPROMISSOS DE INICIAÇĀO CIENTIFFICA 29 e 30 de Outubro de 2020 \\ ISBN 978-65-87557-08-3

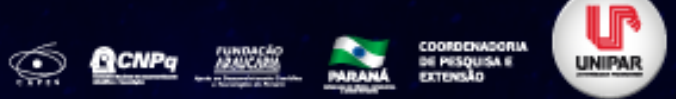 \\ USO DE CÚRCUMA E PIMENTA DO REINO EM QUEIJO QUARK PRODUZIDOS COM KEFIR E CULTURA INDUSTRIAL TIPO O: AVALIAÇÃO MICROBIOLÓGICA
}

\author{
${ }^{1}$ MATHEUS SOUZA ROCHA, ${ }^{2}$ DHARA RIBEIRO MELO, ${ }^{3}$ HELOYSA MARIA SOTTORIVA, ${ }^{4}$ LUCIANA KAZUE OTUTUMI \\ FARIAS, ${ }^{5}$ GILBERTO ALVES
}

\author{
${ }^{1}$ Acadêmico bolsista do PIBIC/UNIPAR \\ ${ }^{1}$ Acadêmica do Curso de Medicina VeterinÃ $j$ ria da UNIPAR \\ ${ }^{2}$ Acadêmica do Curso de Medicina VeterinÃ $j$ ria da UNIPAR \\ ${ }^{3}$ Docente da UNIPAR \\ ${ }^{4}$ Docente da UNIPAR
}

Introdução: Originado da região do Cáucaso o kefir contém principalmente bactérias ácido-láticas e leveduras, componentes esses fazem com que mesmo possua ação probiótica, a partir da inoculação de seus grãosé produzida uma bebida fermentada de consistência cremosa possuindo uma efervescência natural devido a formação de gás carbono(MONTANUCCI et al., 2012, POGACIC et al., 2013).O Queijo Quark é um queijo fresco de fermentação lática que pode ser consumido salgado ou doce, sendo nesse caso chamado de petitSuisse, a incorporação ou crescimento de culturas probióticas do queijo tem sido citada como uma boa alternativa devido a lenta passagem do mesmo pelo intestino, assim contribuindo para o processo de colonização (YUHARA et al., 2014). De coloração amarela a curcumina é o principal composto ativo da Curcuma longa, estudos demonstram que ela possui atividades farmacológicas contra diversas doenças crônicas, melhora a cicatrização de feridas e protege contra lesões hepáticas entre outros benefícios e sua ação anticancerígena vem sendo investigada sugerindo um papel tanto preventivo como para tratamento de diversos tipos de câncer (SCOLZE, 2014), porém a curcumina é pouco absorvida pela mucosa intestinal e quando consumida juntamente com a piperina esta é capaz de aumentar a sua biodisponibilidade em até $2.000 \%$ (SCOLZE, 2014). A piperina está presente em diversos gêneros Piper, porém é mais abundante nos frutos de Piper nigrummas conhecida no Brasil como pimenta do reino. (FERREIRA, 2012).

Objetivo: Avaliar a estabilidade dos microrganismos provenientes de uma cultura comercial para queijos e de kefir empregados como cultura starter em queijos Quark produzidos com adição de Cúrcuma e Pimenta do reino e mantidos sob refrigeração.

Material e metodos: Os queijos foram produzidos com fermentação do leite integral durante $24 \mathrm{~h}$ com posterior dessoragem em sacos plásticos esterilizados por $4 \mathrm{~h}$. Após esse período os mesmos foram pesados e adicionados 1,5\% de sal e dividido em 4 lotes, onde T1 Queijo cultura O com adição de 0,20 de cúrcuma em pó, T2 queijo cultura O com adição de 0,20\% de cúrcuma em pó e $0,1 \%$ de pimenta do reino, T3 queijo cultura kefir com adição de 0,20\% de cúrcuma em pó, T4 queijo cultura kefir com adição de o,20\% de cúrcuma em pó e 0,1\% de pimenta do reino. Os queijos foram embalados e armazenados em refrigeração por 21 dias quando se realizou a contagem dos mesófilos anaeróbios.

Resultados: Os resultados foram para as contagens de mesófilos anaeróbios após um dia de fabricação foram 5,12 log UFC/g para queijos produzidos com a cultura O e 5,57 log UFC/g para queijos produzidos com kefir; após 21 dias foram encontrados 6,47 log UFC/g o T1, 6,94 log UFC/g para o T2, 6,73 log UFC/g para o T3 e 6,06 log UFC/g para T4.

Discussão: De maneira geral as contagens encontradas para ambas as análises são próximas às encontradas na literatura para queijo quark. Melo et al (2018) encontraram valores para bolores e leveduras próximos aos encontrados no presente trabalho.Yuhara et al. (2014) também encontraram valores próximos aos encontrados nesse trabalho, porém não foram encontrados na literatura queijos quark adicionados de cúrcuma e/ou pimenta do reino.

Conclusão: Pode-se afirmar que as culturas láticas empregadas na fabricação de queijos foram estáveis durante o armazenamento a temperatura de refrigeração com e sem a adição de pimenta do reino.

\section{Referências}

FERREIRA, W. S., LOPES, T. N.; LIMA, M.E.F. Piperina, seus Análogos e Derivados: Potencial como Antiparasitários Ferreira. Revista Virtual de Química. V. n.4, p. 208-224, 2012.

MELO, D. R. Quark cheese produced with kefir ans agave inulin. Arquivo Ciências Veterinárias e Zoologia da UNIPAR, Umuarama, v. 21, n. 3, p. 87-92, jul./set. 2018.

MONTANUCCI, F. D. et al. Effect of starter culture and inulin addition on microbial viability, texture, and chemical characteristics of whole or skim milk Kefir. Ciência e Tecnol de Alimentos. v. 32, n. 4, p. 850-861, 2012.

SCOLZE, A, F, A. Biodisponibilidade da curcumina. Revista Brasileira de Nutrição Clínica Funcional. V.14, n.60, p.20-24, 2014. 
YUHARA, T. T.; MATSUBARA, S. T, SANTOS, J. S; GARCIA, S. Produção de queijo tipo quark funcional contendo exopolissacarídeosproductionoffunctional quark cheesecontainingexopolysaccharides. Revista do Instituto de Laticínios Cândido Tostes. v. 69, n. 6, p. 387-394, 2014.

Coordenadoria de Pesquisa e Extensão - COPEX

Departamento de Editoraçāo e Divulgaçāo Científica - DEDIC 


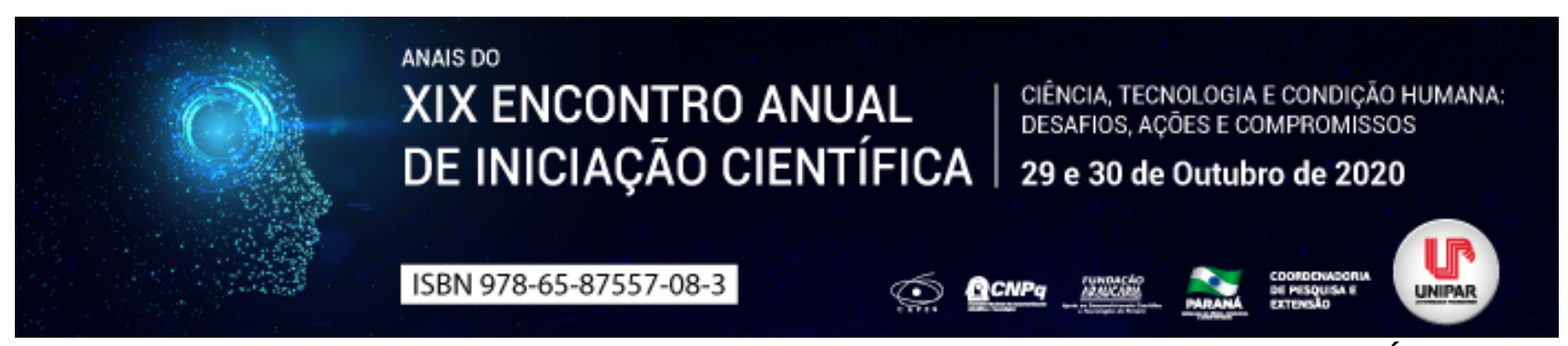

CONSTITUINTES DA DIETA DE Salvator merianae (SQUAMATA, TEIIDAE) EM VIDA LIVRE NA PLANÍCIE PANTANEIRA

\begin{abstract}
${ }^{1}$ Adriana Cristina de Faria, ${ }^{2}$ PATRÍCIA SILVA MATIS, ${ }^{3}$ DANIELE APARECIDA ALVARENGA ARRIEL, ${ }^{4}$ FLÁVIO DE REZENDE GUIMARÃES, ${ }^{5}$ JOSÉ RICARDO DE SOUZA, ${ }^{6}$ CARLOS EDUARDO PEREIRA DOS SANTOS
\end{abstract}

${ }^{1}$ Acadêmica de Zootecnia/Universidade Federal de Mato Grosso
${ }^{1}$ Acadêmica de Medicina Veterinária/Universidade Federal de Mato Grosso
${ }^{2}$ Docente de Engenharia Florestal/Universidade Federal de Uberlândia
${ }^{3}$ Docente de Medicina Veterinária/Universidade Federal de Mato Grosso
${ }^{4}$ Docente de Medicina Veterinária/Universidade Federal de Mato Grosso
${ }^{5}$ Docente de Medicina Veterinária/Universidade Federal de Mato Grosso

Introdução: Teiú é um lagarto da família Teiidae, comumente caçado por alguns povos indígenas para subsistência, também utilizado como animal de estimação e considerado fonte de couro e carne na Argentina (KIEFER; SAZIMA 2002). Pode atingir $1,40 \mathrm{~m}$ de comprimento e $5 \mathrm{~kg}$ de massa corporal, procura alimento com auxílio da língua bífida, que capta partículas no ar (WINCK; CECHIN 2008). Ocupa florestas e áreas abertas e possui dieta generalista (KIEFER \& SAZIMA, 2002). Embora diversos estudos foram realizados sobre seu comportamento alimentar (DA SILVA, 2013; DE OLIVEIRA CABRAL, 2016), poucos são referentes aos animais do Cerrado e Pantanal.

Objetivo: O objetivo foi investigar a dieta de Salvator merianae de vida livre entre ecótonos Cerrado e Pantanal.

Material e Métodos: Dois exemplares de S. merianae (Teiú) encontrados atropelados na faixa de rodagem da MT-040 (CuiabáMimoso) e MT-060 (Várzea Grande-Poconé), Mato Grosso, Brasil, foram examinados e um necropsiado. A fitofisionomia foi fotografada e as coordenadas obtidas por GPS (Garmin portátil) registradas. A atividade foi amparada pelas licenças SISBIO 55104 e SEMA 336972/2018, e pertence ao projeto sobre epidemiologia de colisões entre animais silvestres e veículos nas rotas pavimentadas de acesso da baixada cuiabana à planície pantaneira, registro 275/Propeq/2017 e CRMV-MT. Coletaram-se frutos da cavidade celomática de ambos os lagartos, as sementes foram removidas daqueles, sendo algumas destinadas ao plantio direto e outras beneficiadas. As sementes foram enviadas ao Laboratório de Sementes da Faculdade de Engenharia Florestal da Universidade Federal de Mato Grosso para germinação. Para identificação dos frutos coletados, quatro foram encaminhados ao Herbário Central. Para avaliar a viabilidade das sementes e auxiliar na identificação, de um dos animais foram retirados e abertos com estilete seis frutos já secos. Em seguida, foram dispostas em caixas de poliestireno (gerbox de $11 \times 11 \times 3,5 \mathrm{~cm}$ ) contendo papel mata-borrão umedecido com água destilada, com volume de 2,5 vezes o seu peso. O material foi mantido em câmara de germinação a $25^{\circ} \mathrm{C}$ por 30 dias e avaliada diariamente (BRASIL, 2009). Ademais, de ambos, realizou-se o plantio direto de 12 frutos não beneficiados (seis de cada), em recipiente de concreto retangular, com substrato de terra preta, observados por 180 dias desde a germinação.

Resultados: Os locais de registro apresentavam fitofisionomia similares, com antropização, pasto, reserva de cerrado e várzea. Um dos animais estava em decomposição avançado e cavidade celomática aberta com mais de 50 frutos no interior, com aproximadamente $2 \mathrm{~cm}$ de diâmetro e período de óbito estimado de $72 \mathrm{~h}$ em 11/17 na MT-060 (15059'03.1 /56²8'11.9 ). Outro foi encontrado pós-colisão, em 11/19 na MT-040 (15²3'19.3 /56¹9'18.2 ). A necropsia feita no Laboratório de Anatomia Veterinária da UFMT, constatou a presença de nove frutos, larvas de Lepidoptera (mais de 50 completas e incompletas) e um Tropidurus spp. As sementes coletadas foram plantadas e não foi observada germinação nem das sementes beneficiadas e submetidas à câmara de germinação do primeiro animal, nem daquelas submetidas ao plantio direto.

Discussão: Os resultados indicam que, também no Pantanal, a dieta de Teiús inclui frutos. É possível que as sementes tenham perdido a capacidade germinativa devido à deterioração em que os frutos foram encontrados, ou que fosse necessária outra metodologia para quebra de dormência, não testada, devido à pequena quantidade amostral. Nos frutos do plantio direto, o pericarpo pode ter impedido a absorção de água e gases pela semente. Embora o aspecto do fruto seja semelhante à goiabinha , nome comum na região, muitas espécies de plantas no Cerrado produzem frutos análogos, contudo, da mesma família. Segundo Torenzan-Silingardi e Oliveira (2004), é da família Myrtaceae, gênero Myrcia, com 374 espécies catalogadas. A família é a sétima mais expressiva em número de espécies no Cerrado (MENDONÇA,1998), floresce de julho a outubro nas estações mais quentes e chuvosas, e amadurece em dezembro. Neste caso, na região estudada é comum a estação quente e seca de maio a outubro, embora a florada de muitas espécies seja no período de stress hídrico. O encontro dos lagartos com frutos dessa família é consonante com a época de frutificação (11/17 e 11/19). Castro e Galetti (2004) validaram que um dos frutos de maior consumo por S. merianae, encontrados nas fezes de animais cativos em São Paulo, foram da família Myrtaceae, apoiando nossos achados. Ainda, o forrageamento em longas distâncias pode justificar o não encontro de exemplares botânicos 
similares no entorno do local onde os espécimes foram encontrados. A dieta generalista é consonante com a literatura (KIEFER; SAZIMA 2002; DA SILVA, 2013), considerando o registro de frutos, invertebrados e predação de um pequeno lagarto.

Conclusão: Este achado aponta que S. merianae inclui frutos na sua dieta, com potencial de dispersar sementes, como as da Myrtaceae, nas regiões do Cerrado e Pantanal. Os achados sobre a dieta generalista, incluindo predação, justificam a continuidade e o aprofundamento de estudos, incipientes na região.

\section{Referências}

BRASIL. Ministério da Agricultura, Pecuária e Abastecimento. Regras para análise de sementes. 1.ed. Brasília: MAPA, 2009. CASTRO, Everaldo Rodrigo de \& GALETTI, Mauro. Frugivoria e dispersão de sementes pelo lagarto teiú Tupinambis merianae (Reptilia: Teiidae). Papéis Avulsos de Zoologia, São Paulo, v.44, n.6, p.91-97, 2004.

DA SILVA, Eric Aian Pereira; SANTOS, Tarcísio Dourado; LEITE, Graziela Nunes; RIBEIRO, Leonardo Barros. Tropidurus hispidus (Squamata: Tropiduridae) and Leptodactylus cf. fuscus (Anura: Leptodactylidae) as prey of the teiid lizards Salvator merianae and Ameiva ameiva. Herpetology Notes, Estados Unidos, v.6, mar. 2013.

DE OLIVEIRA CABRAL, Sofia; KATZENBERGER, Marco; DE OLIVEIRA, Hugneide Souza; DA SILVA, Renata Keli e CALABUIG, Cecilia. Salvator merianae (Black-and-white Tegu) Diet. Herpetological Review, Estados Unidos, v.50, n.1, p.144, mar. 2016.

KIEFER, Mara Cíntia \& SAZIMA, Ivan. Diet of juvenile tegu lizard Tupinambis merianae (Teiidae) in southeastern Brazil. Amphibia-Reptilia, Leiden, v.23, n.1, p.105-108, jan. 2002.

MENDONÇA, Roberta Cunha de; FELFILI, Jeanine Maria; WALTER, Bruno Machado Teles; SILVA JUNIOR, Manoel Cláudio da; Rezende, Alba Valéria; Filgueiras, Tarciso Sousa; NOGUEIRA, Paulo Ernane. Flora vascular do Cerrado. In: SANO, S.M.; ALMEIDA, S.P. Cerrado: ambiente e flora. Planaltina: EMBRAPA, 1998, p. 289-556.

TORENZAN-SILINGARDI, Helena Maura \& OLIVEIRA, Paulo Eugênio Alves Macedo de. Phenology and reproductive ecology of Myrcia rostrata and M. tomentosa (Myrtaceae) in Central Brazil. Phyton, Horn, v.44, n.1, p.23-43, jun. 2004.

WINCK, Gisele Regina \& CECHIN, Sonia Zanini. Hibernation and emergence pattern of Tupinambis merianae (Squamata: Teiidae) in the Taim Ecological Station, southern Brazil. Journal of Natural History, London, v.42, n.3-4, p.239 247, jan. 2008. 


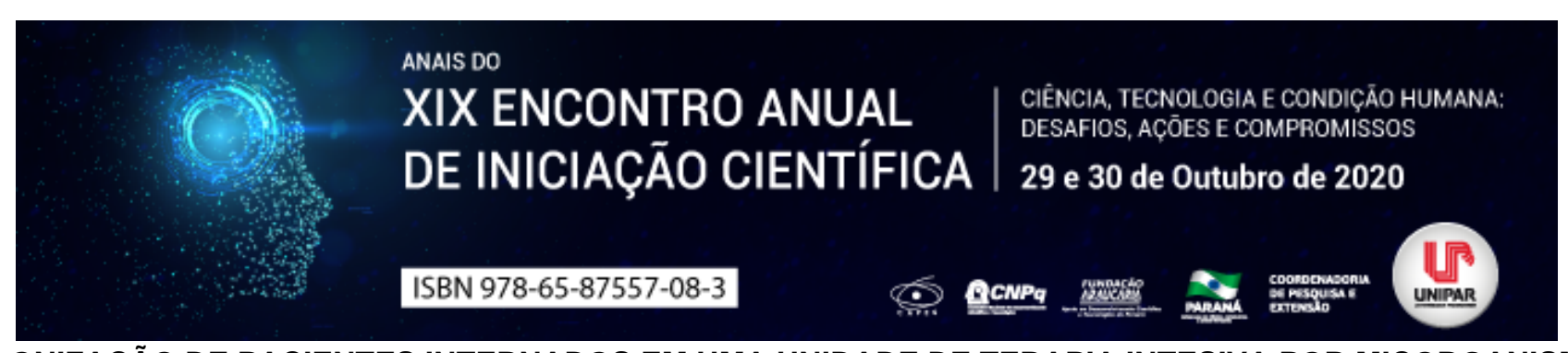

\title{
COLONIZAÇÃO DE PACIENTES INTERNADOS EM UMA UNIDADE DE TERAPIA INTESIVA POR MICORGANISMOS MULTIRRESISTENTES E DE IMPORTÂNCIA HOSPITALAR
}

\author{
${ }^{1}$ MARIANGELA CAUZ, ${ }^{2}$ NATIELI RAUBER NICOLAU, ${ }^{3}$ RAQUEL BIRCK, ${ }^{4}$ MARIA HELENA BRANDELEIRO WERLANG , \\ ${ }^{5}$ DEBORA VANDRESEN, ${ }^{6}$ VOLMIR PITT BENEDETTI
}

\begin{abstract}
${ }_{1}^{1}$ Discente PIBIC/UNIPAR, Universidade Paranaense, Francisco Beltrão - PR
${ }^{1}$ Discente PIC/UNIPAR, Universidade Paranaense, Francisco Beltrão - PR

${ }^{2}$ Discente PIC/UNIPAR, Universidade Paranaense, Francisco Beltrão - PR

${ }^{3}$ Enfermeira do Hospital Regional do Sudoeste do Paraná, Francisco Beltrão - PR

${ }^{4}$ Docente de Farmácia da Unisep União do Sudoeste de Ensino, Francisco Beltrão - PR

${ }^{5}$ Docente UNIPAR, Universidade Paranaense, Francisco Beltrão PR
\end{abstract}

Introdução: As infecções relacionadas à assistência à saúde constituem-se como um grave problema de saúde pública mundial, apresentando elevada incidência em unidades de terapia intensiva. Nesse contexto, os pacientes internados em Unidades de Terapia Intensiva (UTIs) correm um grave risco de desenvolverem infecções por agentes microbianos, interferindo negativamente na qualidade de vida e elevando as taxas de morbimortalidade nesses pacientes (FERREIRA, et al., 2019). Para minimizar esses riscos, busca-se conhecer os principais fatores epidemiológicos e os agentes envolvidos nas infecções que acometem esses pacientes. Diante disso, a equipe clínica mantém a monitorização contínua desses pacientes por meio de técnicas de vigilância epidemiológica realizadas com culturas de com swab nasal e retal.

Objetivo: Este trabalho busca analisar a microbiota intestinal e nasal de pacientes adultos internados em uma unidade de terapia intensiva de um hospital público do sudoeste do Paraná, investigando a presença de microrganismos multirresistentes e de importância hospitalar.

Material e Métodos: Foram analisados os prontuários e realizado a cultura de swab retal e nasal de 24 pacientes internados na UTI. A partir do material biológico coletado, caracterizou-se a microbiota bacteriana e fúngica, bem como a determinação do padrão de sensibilidade frente aos antimicrobianos, utilizando a metodologia preconizada por Koneman et al. (2008). Esse trabalho seguiu os trâmites éticos legais para pesquisa (1639297).

Resultados: Dos 24 pacientes analisados até o período que se encontravam internados na UTI adulto do Hospital Regional do Sudoeste do Paraná, $37,55 \%$ eram do sexo masculino e $62,5 \%$ do feminino. Referente à colonização, observou-se que $70,8 \%$ (17) dos pacientes foram colonizados por leveduras, e destes o trato intestinal (swab retal) foi o que apresentou o maior índice de colonização com 70,8\% (17), superior ao trato respiratório (swab nasal) $25 \%$ (6). No quesito que analisa a frequência de isolamento das espécies de leveduras, observou-se que $50 \%$ pertenciam à espécie Candida albicans, seguido de C. glabrata $(16,6 \%)$ e C. tropicalis (16,6\%). Estes são dados parciais da pesquisa, pois as demais informações sobre os pacientes, somente serão obtidas quando for possível retomar as atividades acadêmicas no Hospital Regional do Sudoeste do Paraná, pois o estudo foi interrompido em decorrência da pandemia do Corona Vírus.

Discussão: Neste estudo observou-se um alto índice de colonização por leveduras $(70,8 \%)$ nos investigados, este fato pode ser justificado, pois paciente hospitalizado em UTIs é mais susceptíveis a desenvolverem infecções quando comparados aos pacientes dos demais setores hospitalares, devido a sua gravidade clínica, a idade elevada, a terapia com imunossupressores, o uso rotineiro de antimicrobianos de amplo espectro, o tempo prolongado de internação e o desequilíbrio do sistema imunológico. Ainda, a alta complexidade no atendimento, a manipulação direta e a utilização de procedimentos invasivos são fatores que expõem o indivíduo à colonização por microrganismos resistentes, oferecendo alto risco a infecções e favorecendo a seletividade de microrganismos, inclusive os multirresistentes (SILVA, et al., 2019). Segundo Nunes et al. (2019) várias espécies de fungos são responsáveis pelos altos índices de óbitos em pacientes internados na UTI, pois podem causar quadros clínicos variados nesses indivíduos, desde infecções superficiais até sistêmicas, sobretudo em imunossuprimidos. Os dados obtidos neste estudo, referente a maior frequência de isolamento da espécie Candida albicans, coincidem com o que comenta Nunes et al. (2019) e Marçon (2019) os quais responsabilizam esta espécies pela maioria dos números de caso de infecções fúngicas em pacientes internados na UTI. Entretanto os autores comentam que outras espécies de leveduras também podem ser isoladas deste tipo de pacientes, incluindo C. tropicalis, C. parapsilosis, C. krusei, e C. glabrata.

Conclusão: Neste estudo foi observado que os adultos do sexo feminino, apresentaram maior percentual de colonização por leveduras. Observou-se também que o trato intestinal foi mais colonizado que o trato respiratório e que a espécie de levedura com maior frequência de isolamento foi Candida albicans. 


\section{Referências}

FERREIRA, Glenda Roberta Oliveira Naiff, et al. Perfil epidemiológico das infecções relacionadas a assistência à saúde em unidade de terapia intensiva adulto. Journal of Epidemiology and Infection Control. v. 9, n.4, 2019.

KONEMAN, Elmer, et al. Diagnóstico microbiológico - texto e atlas colorido. 6.ed. Guanabara Koogan. Rio de Janeiro, 2008. MARÇON, Camila. Caracterização de Candida spp. isoladas da corrente sanguínea de pacientes internados em hospital terciário de Bauru São Paulo. 2019. Dissertação (Mestrado em Doenças Tropicais), Faculdade de Medicina, Universidade Estadual Paulista Júlio de Mesquita Filho, Botucatu, 2019.

NUNES, Michellangelo, et al. Leveduras clínicas isoladas de pacientes em unidade de terapia intensiva: avaliação quanto à capacidade de aderência. Revista Eletrônica da Estácio Recife. v. 5, n. 2, p.1-8, 2019.

SILVA, Laís Santos, et al. Perfil das infecções relacionadas à assistência à saúde em um centro de terapia intensiva de Minas Gerais. Journal of Epidemiology and Infection Control. v. 9, n. 4, 2019.

Coordenadoria de Pesquisa e Extensão - COPEX

Departamento de Editoraçāo e Divulgaçāo Científica - DEDIC 


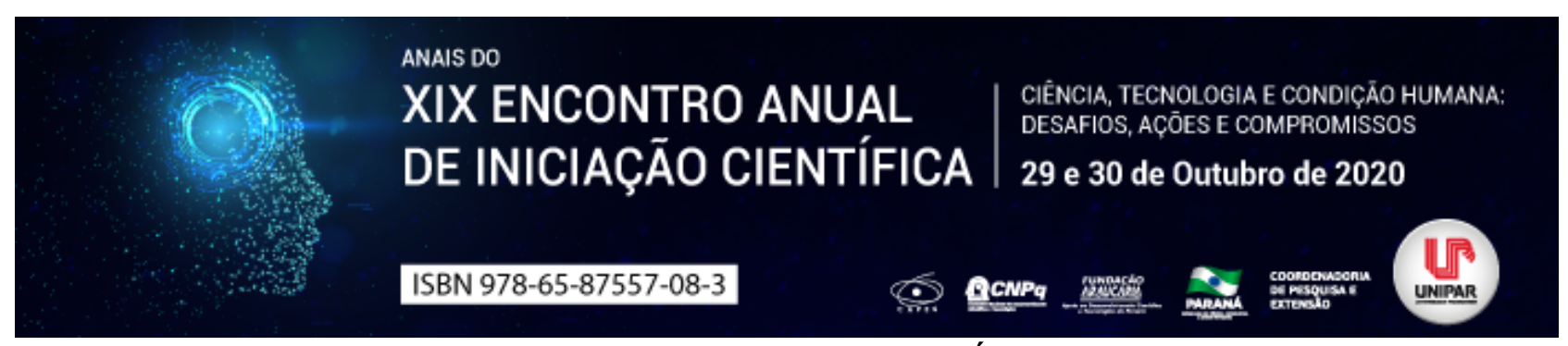

EPIDEMIOLOGIA DE FAUNA SILVESTRE ATROPELADA ENTRE CUIABÁ

MT E PARQUE NACIONAL DO PANTANAL

\begin{abstract}
${ }^{1}$ Adriana Cristina de Faria, ${ }^{2}$ PATRÍCIA SILVA MATIS, ${ }^{3}$ FLÁVIO DE REZENDE GUIMARÃES, ${ }^{4}$ JOSÉ RICARDO DE SOUZA, ${ }^{5}$ CARLOS EDUARDO PEREIRA DOS SANTOS
\end{abstract}

\begin{abstract}
${ }^{1}$ Acadêmica de Zootecnia/Universidade Federal de Mato Grosso
${ }^{1}$ Acadêmica de Medicina Veterinária/Universidade Federal de Mato Grosso

${ }^{2}$ Docente de Medicina Veterinária/Universidade Federal de Mato Grosso

${ }^{3}$ Docente de Medicina Veterinária/Universidade Federal de Mato Grosso

${ }^{4}$ Docente de Medicina Veterinária/Universidade Federal de Mato Grosso
\end{abstract}

Introdução: Cuiabá é considerada a principal rota de acesso ao Parque Nacional do Pantanal Mato-Grossense, em Poconé. Este é constituído pelos biomas Cerrado e Pantanal e reúne uma das maiores biodiversidades faunísticas do planeta. A rodovia é a principal ligação entre Cuiabá e Poconé, atravessando os biomas, e por isso atropelamentos da fauna silvestre é muito frequente. As rodovias afetam a vida selvagem, fragmentando habitats e alterando artificialmente o comportamento e a movimentação dos animais (CASTRO et al., 2020; PINTO et. al, 2020). No Pantanal Mato-Grossense e no Cerrado, estudos são incipientes sobre o efeito das estradas na biodiversidade a par com a quase ausência de medidas mitigatórias. Assim, um elevado número de vítimas fatais, devido a colisões entre veículos e a fauna em migração, mostram a necessidade de estudos que avaliem os impactos quantitativos e qualitativos.

Objetivo: O objetivo da investigação é mensurar a quantidade de vertebrados silvestres mortos por atropelamento entre 2017 a 2020, no trajeto Cuiabá-Poconé, Mato Grosso, Brasil.

Material e Métodos: A coleta de dados foi obtida com inserções semanais da equipe no trecho para Poconé da BR-070 e MT060, entre 2017 a 2020. O trajeto corresponde a $100 \mathrm{~km}$ e foi percorrido com automóvel em velocidade máxima de $50 \mathrm{~km} / \mathrm{h}$. As observações eram realizadas em dupla ou trio, para maior precisão e redução de falhas, possíveis pela presença de animais pequenos em permeio à vegetação que margeia as rotas. Em cada sinistro eram compilados o nome vulgar e cientifico, classe, período estimado de óbito, coordenadas geográficas e altitude com GPS (Garmin portátil), fitofisionomia adaptada de Calderano Filho et al. (2005), número ordinário, data, temperatura ambiente e umidade relativa do ar, aferidas com multímetro portátil, e registro fotográfico do animal e ambiente. O período de óbito, quando em estado de decomposição avançado, foi obtido de acordo com a condição da carcaça e entomofauna. Observações como desmates, queimadas, pastagens e atividades agropecuárias também foram catalogadas. Os procedimentos em campo e em laboratório foram autorizados pelas licenças: Sistema de Autorização e Informação em Biodiversidade (n55104); processo n³36972/2018 da Secretaria de Estado do Meio Ambiente; registro 275/Propeq/2017 da Pró-Reitoria de Pesquisa/UFMT; Anotação de Responsabilidade Técnica junto ao Conselho Regional de Medicina Veterinária (n¹0232) e Comitê de Ética no Uso em Animais (n²3108.210049/2017-22).

Resultados: Entre 2017 e 2020 houve um total de 2.259 animais mortos por atropelamento, sendo 38,42\% da classe Mammalia, 24,08\% Reptilia, 21,43\% Amphibia, 15,98\% Aves e 0,09\% não identificados. As ordens mais representativas foram a Anura (21,43\% dos espécimes), Squamata (21,34\%) e Carnivora (18,95\%). Já dentre as famílias, a Canidae (9,52\%), Colubridae $(7,30 \%)$ e Procyonidae (6,33\%) foram as mais observadas. Quanto às espécies figuram o Cerdocyon thous (9,25\%), Tamandua tetradactyla (4,07\%) e Hydrochoerus hydrochaeris (3,85\%). Ainda foram encontrados animais ameaçados de extinção e classificados como vulneráveis (ICMBIO, 2018), como o Myrmecophaga tridactyla (0,89\%), Puma yagouaroundi (0,49\%), Chrysocyon brachyurus (0,04\%) e Leopardus wiedii (0,09\%).

Discussão: A maioria dos estudos sobre ecologia de estradas são realizados na América do Sul, sendo a maioria no Brasil. Em trabalhos de revisão, mamíferos, aves, répteis e anfíbios são os mais estudados, sendo a ordem decrescente de ocorrência por atropelamentos anfíbios, répteis, mamíferos e pássaros (PINTO et. al, 2020). Neste estudo, as aves foram a classe menos figurada, corroborando o trabalho de Brum et al. (2018) também realizado no Mato Grosso, e contradiz o de Fischer et al. (2018), que encontraram uma maior quantidade nas estradas do Mato Grosso do Sul. Salienta-se que apenas anfíbios grandes foram computados pela metodologia empregada e dados relativos a esta espécie são geralmente subestimados em comparação com as outras, no entanto, os atropelamentos são mais numerosos. A predominância de mamíferos, dentre os animais registrados neste estudo, vai ao encontro dos resultados de Brum et al. (2018) e Valadão et al. (2018). Alguns espécimes ameaçados, frequentes no Pantanal e Cerrado, foram comumente relatados em diferentes estudos, tais como o atropelamento de Myrmecophaga tridactyla e Chrysocyon brachyurus (Brum et. al, 2018; Valadão et al., 2018). No seu estudo, Valadão et al. (2018) informa a presença de quase todos os animais ameaçados encontrados neste trabalho. Nos últimos estudos publicados do Cerrado e Pantanal, há variação de espécies e classes mais representativas, tal como o período de coleta de dados, o que pode 
influenciar a quantidade e variedade de espécimes, conforme Castro et al. (2020) que obteve anfíbios mais numerosos, e Rodríguez-Castro et al. (2017) répteis.

Conclusão: Elevado número de diferentes vertebrados silvestres morreu por atropelamento no período estudado. O quantitativo real pode estar subestimado, considerando coleta semanal. Os resultados mostram a necessidade de aprofundar investigações e adoção de medidas mitigatórias ao risco de colisões.

\section{Referências}

BRUM, T. R. et al. Effects of Roads on the Vertebrates Diversity of the Indigenous Territory Paresi and its Surrounding. Brazilian Journal of Biology, v.78, n.1, jun. 2018. Disponível em: https://www.scielo.br/pdf/bjb/v78n1/1519-6984-bjb-1519698408116.pdf. Acesso em: 10 ago. 2020.

CALDERANO FILHO, Braz et al. Uso e Cobertura das Terras da Área do Entorno do Reservatório da Usina Hidrelétrica de Tombos, no Estado de Minas Gerais. 1 ed. Rio de Janeiro: Embrapa Solos, 2005.

CASTRO, Rejane Elizabeth Esteves et al. Atropelamentos de Vertebrados em uma Área de Mata Atlântica na Rodovia MG260 em Cláudio, Minas Gerais, Brasil. Revista NBC, v.10, n.19, jul. 2020. Disponível em: https://www.metodista.br/revistas/revistas-izabela/index.php/bio/issue/view/151. Acesso em: 10 ago. 2020.

FISCHER, Wagner; GODOI, Raquel Faria; FILHO, Antonio Conceição Paranhos. Roadkill Records of Reptiles and Birds in Cerrado and Pantanal Landscapes. Check List, v.14, n.5, aug. 2018. Disponível em: https://checklist.pensoft.net/article/26813. Acesso em: 10 ago. 2020.

ICMBIO. Livro Vermelho da Fauna Brasileira Ameaçada de Extinção: Volume I. 1 ed. Brasília: ICMBio, 2018.

PINTO, Fernando; CLEVENGER, Anthony; GRILO, Clara. Effects of Roads on Terrestrial Vertebrate Species in Latin America. Environmental Impact Assessment Review. Amsterdã. v.81, n.1, p.1-8, mar. 2020.

RODRÍGUEZ-CASTRO, Karen Giselle et al. Using DNA Barcode to Relate Landscape Atributes to Small Vertebrate Roadkill. Biodiversity and Conservation. Berlim. v.26, n.5, p.1161 1178, jan. 2017.

VALADÃO, Martins; BASTOS, Lilian Freitas; CASTRO, Carolina Pötter. Atropelamentos de Vertebrados Silvestres em Quatro Rodovias no Cerrado, Mato Grosso, Brasil. Multi-Science Journal, v.1, n.12, mai. 2018. Disponível em: https://www.ifgoiano.edu.br/periodicos/index.php/multiscience/article/view/447. Acesso em: 10 ago. 2020. 


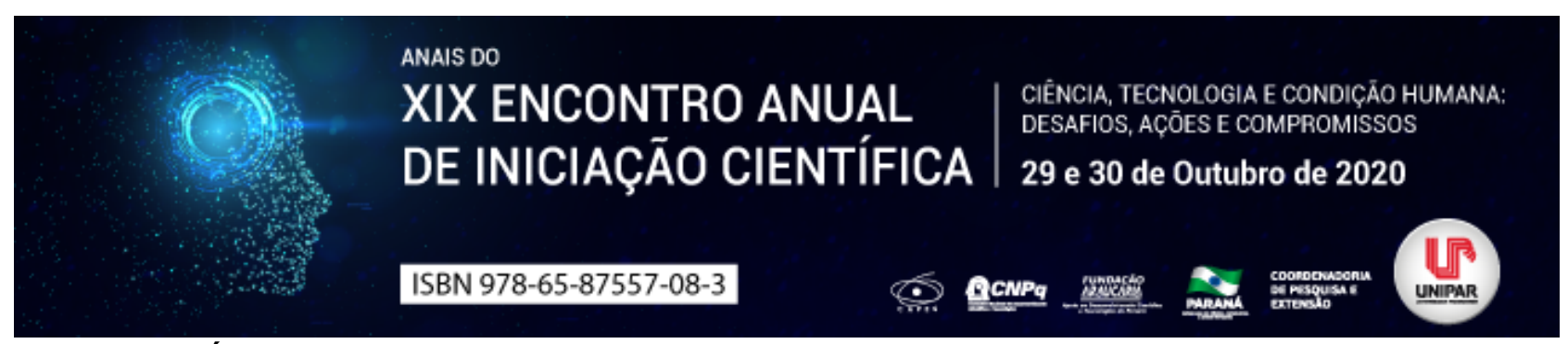

DERMÓIDE OCULAR EM CALOPSITA (NYMPHICUS HOLLANDICUS) RELATO DE CASO

\begin{abstract}
${ }^{1}$ MARIANA DA SILVA NEVES, ${ }^{2}$ JAQUELINE BRUNA DE MELO, ${ }^{3}$ DEBORAH CAROLINE SEPÚLVEDA DIAS, ${ }^{4}$ MARIA CLARA UCKER COSTODIO, ${ }^{5}$ KETLEN DE OLIVEIRA CORANDIN, ${ }^{6}$ NATALIE BERTELIS MERLINI
\end{abstract}

\begin{abstract}
${ }^{1}$ Mestranda em Ciência Animal, Universidade Paranaense UNIPAR bolsista CNPQ/PROSUP
${ }^{1}$ Médica Veterinária Residente do Programa de Aprimoramento em Clínica Médica de Cães e Gatos da Universidade Paranaense UNIPAR.

${ }^{2}$ Médica Veterinária Autônoma

${ }^{3}$ Discente do Curso de Medicina Veterinária da Universidade Paranaense UNIPAR, PIBIC/UNIPAR.

${ }^{4}$ Discente do Curso de Medicina Veterinária da Universidade Paranaense UNIPAR, PIC/UNIPAR.

${ }^{5}$ Docente do programa de pós-graduação em ciência animal com ênfase em produtos bioativos, Universidade paranaenseUnipar.
\end{abstract}

Introdução: Nos últimos anos, observou-se aumento dos atendimentos oftalmológicos em aves, esse aumento não se deve somente pelo mercado pet, mas também com preocupação relacionada questões ambientais. A saúde oftálmica das aves interfere diretamente na qualidade de vida do animal, principalmente na alimentação e interação com o ambiente (BAYÓN et al., 2007). O Dermóide é uma afecção ocular congênita de origem embrionária e seu desenvolvimento pode se dar em córnea, pálpebra, conjuntiva e terceira pálpebra. É caracterizada pela presença de tecido cutâneo ectópico, principalmente das camadas ectoderme e mesoderme, podendo ou não apresentar pelos ou penas, que é o caso em aves, e esta característica é um fator determinante para o surgimento dos sinais clínicos (SLATTER, 2005). Os sinais clínicos mais observados são blefaroespasmo, congestão conjuntival, epífora e inflamação da córnea, podendo inclusive, ocasionar ulcerações nessa última (MOORE, 2005; SLATTER, 2005). O diagnóstico do dermóide é realizado através dos sinais clínicos e exame oftalmológico, que é similar ao exame em mamíferos, exceto por algumas particularidades anatômicas e fisiológicas. (GELATT et al., 2013; BAYON et al., 2007). O tratamento de escolha é a exérese cirúrgica do dermóide ocular, sendo indicada a remoção completa para que não ocorra recidiva. (SLATTER, 2005). O objetivo do presente trabalho é relatar um caso de dermóide ocular em calopsita (Nymphicus hollandicus).

Relato de Caso: Uma calopsita (Nymphicus hollandicus) de seis meses de idade foi atendida no Hospital Veterinário da Universidade Paranaense, com queixa de blefaroespasmo e secreção ocular em olho direito, tutor ainda referiu que desde o primeiro mês de vida o animal apresentava uma mancha no mesmo. No exame oftalmológico foi observado opacidade corneana central e um tecido elevado no canto lateral do olho direito que se estendia da córnea até a conjuntiva bulbar (corneoconjuntival), para o exame mais detalhado foi realizado a biomicroscopia em lâmpada de fenda onde ficou evidente a presença de folículos e pequenas penas no tecido. O olho esquerdo não apresentou alterações. Diante das características macroscópicas o diagnóstico foi de dermóide ocular. $\mathrm{O}$ tutor foi orientado a realizar a ceratectomia superficial, o mesmo optou por não realizar o procedimento. Discussão: $O$ dermóide é uma alteração congênita descrita com frequência em animais jovens, sendo caracterizado pela presença de tecido cutâneo (epiderme, derme, folículos pilosos e pelos) de localização que não aquele de origem (SLATTER, 2005). No presente relato, a biomicroscopia com lâmpada de fenda, foi essencial para evidenciar as características macroscópicas do tecido (GELATT et al., 2013). Existem poucos relatos na literatura desta afecção em aves, neste caso o diagnóstico foi mediante as características macroscópicas e do histórico do animal (BAYON et al., 2007).

A presença ou ausência de pelos/penas é considerado um fator determinante para o aparecimento e severidade dos sinais oculares, neste caso o animal apresentava secreção ocular, blefaroespasmo e opacidade corneana. Corroborando com os sinais clínicos citados por autores (MOORE, 2005; SLATTER, 2005; GELLATT et al., 2013).

O tratamento de eleição consiste na exérese cirúrgica do dermóide, sendo indicada a ceratectomia superficial (SLATTER, 2005; GELATT et al., 2013), neste relato está foi a indicação, porém o tutor optou por não realizar a cirurgia.

Conclusão: O dermóide, apesar de raro em aves, pode levar a danos oculares graves, devendo ser devidamente diagnosticado e tratado precocemente para garantir a saúde ocular.

\title{
Referências
}

BAYÓN, A.; ALMELA, R. M.; TALAVERA, J. Avian ophthalmology. European Journal of Companion Animal Practice, v.17, n.3, p.253-266, 32 dez. $2007 . \quad$ Disponível $\quad$ em: https://pdfs.semanticscholar.org/34db/d490ff86bb045a6d4b18df3b5d4642f2f240.pdf. Acesso em: 26 ago. 2020.

GELATT, K.N.; GILGER, B.C.; KERN, T.J. Veterinary Ophthalmology. AMES: WileyBlackwell, 2013. 
MOORE, P.A. Feline Corneal Disease. Clinical Techniques in Small Animal Practice, v. 20, pp. 83-93, Maio, 2005. Disponível em: https://www.sciencedirect.com/science/article/abs/pii/S1096286704001082. Acesso em: 10 ago. 2020.

SLATTER, D. Córnea e Esclera. In: SLATTER, D. Fundamentos de Oftalmologia Veterinária. 3a ed. São Paulo: Roca; 2005. p.283- 338.

Coordenadoria de Pesquisa e Extensāo - COPEX

Departamento de Editoraçāo e Divulgaçāo Científica - DEDIC 


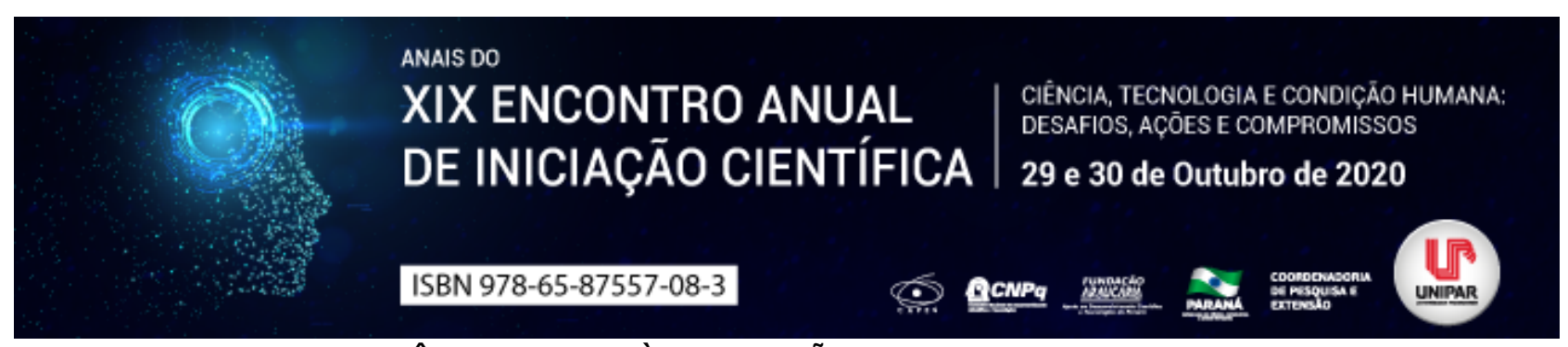

DERMATOSE CUTÂNEA DEVIDO À APLICAÇÃO DE ANTICONCEPCIONAL EM CADELA

\begin{abstract}
${ }^{1}$ THAINA PIZANE DA SILVA, ${ }^{2}$ MARCIELY BRAGA CLAUDIANO, ${ }^{3}$ MARIANA COLTRO, ${ }^{4}$ RAFAEL MARTINS BASTOS, ${ }^{5}$ ALYSSON RAMALHAIS, ${ }^{6}$ ANA MARIA QUESSADA
\end{abstract}

${ }^{1}$ Discente do curso de Medicina Veterinária, PIBIC/UNIPAR

${ }^{1}$ Discente do curso de Medicina Veterinária, PIC/UNIPAR

${ }^{2}$ Discente do curso de Medicina Veterinária, PIC/UNIPAR

${ }^{3}$ Discente do curso de Medicina Veterinária, PEBIC Araucária,/UNIPAR

${ }^{4}$ Discente no programa de pós-graduação em Ciência Animal com ênfase em produtos bioativos- Unipar

${ }^{5}$ Docente da UNIPAR, Orientadora

Introdução: O controle reprodutivo em animais domésticos é um problema mundial de saúde única, sendo que propostas e técnicas vêm sendo estudadas de forma a atingir este objetivo. Além dos aspectos de bem-estar animal, as superpopulações de cães e gatos nas ruas propiciam a veiculação de zoonoses, com particular preocupação ao vírus da raiva (ALMEIDA et al., 2011). A forma amplamente utilizada para o controle reprodutivo em animais domésticos é a farmacológica, principalmente pela administração de progestágenos (ROMAGNOLI, 2002), inclusive no Brasil (MACIEL et al., 2019; SCHMITT et al., 2020), sendo essa a forma mais acessível financeiramente principalmente para tutores carentes. Esta forma de anticoncepção é caracterizada por anticoncepcionais veterinários encontrados sob a forma de soluções injetáveis ou comprimidos de hormônios esteroides que atuam retardando ou suprimindo a fase de aceitação sexual, eliminando assim as características comportamentais inerentes a essa fase como, por exemplo, o sangramento nas cadelas (VIGO et al., 2011). Estudos demonstram frequência alta de complicações observadas após o uso de progestágenos em cadelas e gatas, especialmente quando aplicados em outras fases que não o anestro. A administração destes medicamentos leva a problemas como piometra, maceração fetal, hiperplasia endometrial, hiperplasia mamária, tumores mamários (LIMA et al., 2009; ARAÚJO et al., 2017), reações cutâneas no local de aplicação, resistência insulínica entre outros (ROMAGNOLI, 2002).

Objetivo: $O$ presente relato tem o objetivo de descrever a ocorrência de dermatose cutânea em uma cadela no local de administração de anticoncepcional.

Relato de caso: Foram selecionadas 20 cadelas que participaram de um projeto de pesquisa sobre aplicação de anticoncepcionais nestas fêmeas. Dentre estas cadelas foi incluída uma cadela da raça Dachshund de 2,5 anos pesando 6,300 $\mathrm{kg}$. Antes da aplicação do anticoncepcional, o animal foi examinado clinicamente. Foram realizados anamnese, exame físico, hemograma, exames bioquímicos (proteínas totais, cálcio, ureia, creatinina e alanina aminotransferase), ultrassonografia abdominal e citologia vaginal. A cadela foi selecionada para o projeto porque não apresentou alterações patológicas em todos estes exames. A cadela foi submetida à administração do anticoncepcional adquirido pelo tutor, de acordo com a metodologia do projeto. O fármaco foi aplicado por via subcutânea na região abdominal lateral direita. Trinta dias e noventa dias após a administração dos anticoncepcional a cadela foi examinada novamente, repetindo-se os exames realizados na consulta inicial. Nestes exames observou-se que a cadela apresentava uma alteração na pele na qual se notava adelgaçamento cutâneo e alteração de coloração no local da aplicação do fármaco (anticoncepcional).

Discussão: Durante o exame físico, após 30 dias e 90 dias após a aplicação do anticoncepcional, a cadela apresentou dermatose no local da aplicação. Tal dermatose se caracterizou por adelgaçamento da pele no local da aplicação e alteração da coloração do pelo . Na análise da ficha do animal detectou-se que o fármaco aplicado nesta cadela tinha como princípio ativo o acetato de medroxiprogesterona. Esta dermatose está citada na bula do fármaco utilizado (Anticion, S/D). É importante destacar que a cadela estava completamente hígida antes da aplicação do anticoncepcional. A higidez foi comprovada por exame físico e laboratorial. Além disso, houve apenas uma aplicação do anticoncepcional. Para inclusão no projeto foram selecionadas cadelas que nunca tinham tomado anticoncepcional. Na literatura brasileira não foram encontrados relatos de alterações cutâneas associadas ao uso de anticoncepcionais em cadelas. Em uma revisão de literatura há citação de que os anticoncepcionais podem causar alterações cutâneas em cadelas, mas não são listadas referências (MAENHOUDT et al., 2018).

Conclusão: Uma única aplicação de anticoncepcional injetável (dose de bula) na cadela do presente relato foi capaz de causar alteração patológica cutânea. Sugere-se que este fármaco seja aplicado sob estrita supervisão médico-veterinária, sendo um item obrigatório na bula deste tipo de medicamento.

\title{
Referências
}

ALMEIDA M.F. Controle de populações caninas: considerações técnicas e éticas. Revista Brasileira de Direito Animal. v. 6, $n$ 
8, 2011.

ANTICION. Bula. S/D. Disponível em: http://www.ucbvet.com/produto/14/6/anticion>. Acesso em 15 nov. 2019.

ARAÚJO, B. Clinical and epidemiological study in dogs with thoracolumbar vertebrae fractures and luxations. Pesquisa veterinária brasileira. v. 37, n 8, p. 866-870, 2017.

LIMA, Jane glayce Pereira. Uso dAnticoncepcional em cadelas: problema ou solução?: Anais da IX Jornada de Ensino, Pesquisa e Extensão JEPEX. 2009.

MAENHOUDT, C.Manipulation of the oestrous cycle of the bitch-what works for now. Reprodução doméstica animal, v. 53, $n$ 3, p. 44-52, 2018.

MACIEL, L.M. Esclarecimento da população de Dourados MS sobre o uso indiscriminado de anticoncepcionais como agente causador de hiperplasia mamária. Veterinária e zootecnia. v. 26, p.1-8, 2019.

ROMAGNOLI, S. Clinical use of hormones in the control of reproduction in bitches and queens. Veterinary Sciences Congress, Oeiras, v. 10, n 12, p. 162-166, 2002.

SCHMITT, C.;PEREIRA, K. Saúde reprodutiva de cães e gatos. Brazilian Journal of Development. v. 6, $n$ 1, p. 23882401, 2020

VIGO, F. et al. Progestógenos: farmacologia e uso clínico. Femina, v. 39, n 3, p. 128-137, 2011. 


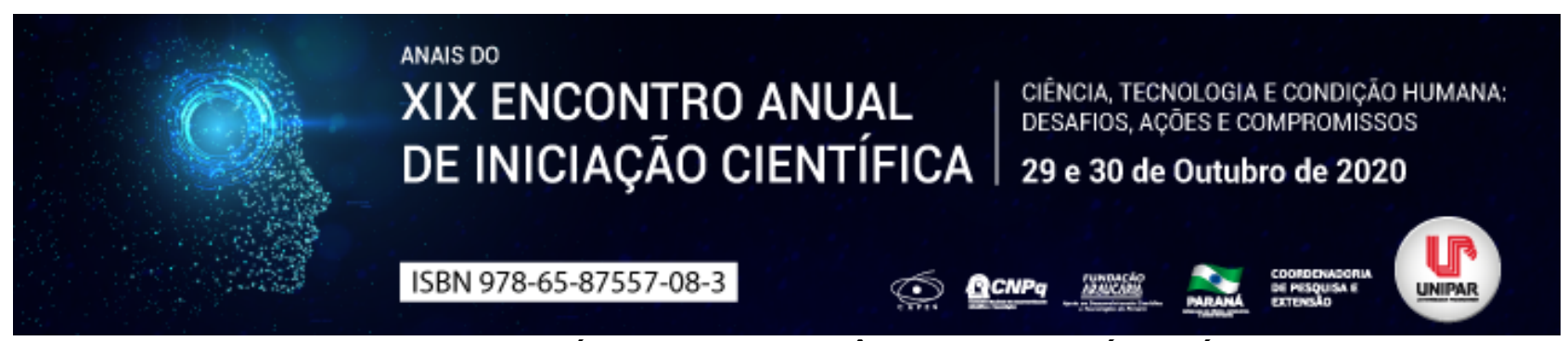

ZOONOSES PARASITÁRIAS DE IMPORTÂNCIA PARA SAÚDE PÚBLICA

\begin{abstract}
${ }^{1}$ Bruna Ávila Torres, ${ }^{2}$ LAURA ZANELLA SOUZA, ${ }^{3}$ ANA PAULA MOLINARI CANDEIAS, ${ }^{4}$ ANDRÉ LUIZ VRIESMAN BENINCA, ${ }^{5}$ NELSON LUIZ MELLO FERNANDES
\end{abstract}

\begin{abstract}
${ }^{1}$ Médica Veterinária Residente na Área de Doenças Parasitárias dos Animais do Programa de Residência em Medicina Veterinária Campus Palotina -

${ }^{1}$ Médica Veterinária Residente na Área de Doenças Parasitárias dos Animais do Programa de Residência em Medicina Veterinária Campus Palotina -

${ }^{2}$ Mestranda no Programa de Pós-graduação em Ciência Animal - Universidade Federal do Paraná Setor Palotina

${ }^{3}$ Mestre em Ciência Animal - Universidade Federal do Paraná Setor Palotina

${ }^{4}$ Docente da Universidade Federal do Paraná
\end{abstract}

Introdução: O termo zoonose é definido segundo a organização mundial de saúde como infecções que são adquiridas através do contato entre animais e humanos, que podem ser transmitidas de forma indireta ou direta, sendo um grande problema de saúde pública (CORRÊA et al., 2020).

Nos dias atuais os animais de estimação têm grande liberdade dentro dos domicílios e a relação entre o homem e animal, vem se tornando cada vez mais próxima, o que favorece a transmissão de doenças parasitárias, representando um risco potencial a saúde (MAATEN et al., 2016). Mundialmente, existem mais de 1,5 bilhões de pessoas infectadas por helmintos, através do contato com o solo, água ou alimentos contaminados, e muitas dessas são transmitidas por animais. As crianças são mais suscetíveis devido a imaturidade imunológica e exposição aos parasitas através de brincadeiras com animais e/ou em locais contaminados como praças, além da ingestão de alimentos sem higienização (CORRÊA et al., 2020).

Objetivo: $O$ presente trabalho tem como objetivo caracterizar brevemente as zoonoses parasitárias de importância para saúde pública, ressaltando a importância da prevenção e controle.

Desenvolvimento: Dentre os helmintos infectantes mais prevalentes, estão: os ascarídeos Toxocara sp., que é responsável pela síndrome larva migrans visceral, que ocorre pela ingestão acidental de ovos, que eclodem em larvas que podem migrar para diversos órgãos, como pulmão, fígado, coração e cérebro (ROCHA et al., 2019); e os helmintos, pertencentes à família Ancylostomidae, principalmente a espécie Ancylostoma braziliense, que é responsável pela síndrome larva migrans cutânea, que ocorre pela migração do parasito pela pele, que gera forte prurido, e leva o paciente muitas vezes a se coçar, provocando escoriações na pele com infecções microbianas secundárias (MONTEIRO, 2018). Segundo a Organização Mundial de Saúde, as doenças diarreicas matam aproximadamente 525.000 crianças menores de cinco anos no mundo. Uma proporção significativa dessas doenças é transmitida pela água ou alimentos contaminados, através da ingestão dos oocistos, que se desenvolvem e se multiplicam no duodeno, e pode ser prevenida através de água potável, saneamento e higiene adequados. Cerca de $7 \%$ da população humana mundial abriga a Giardia sp.. O Cryptosporidium sp. assim como Giardia sp., tem ampla distribuição mundial, mas sua ocorrência está associada a crianças e pacientes imunologicamente debilitados (CAMA; MATHISON, 2015). Estes são protozoários que infectam as vilosidades do trato gastrointestinal de uma grande variedade de hospedeiros vertebrados, incluindo humanos. Ambos são os causadores de diarreia mais isolados em humanos, sendo por isso alvo de grande preocupação devido ao seu potencial zoonótico (BONSERE et al., 2020). Outra doença transmitida através da água ou alimentos contaminados é a hidatidose ou equinococose, que ocorre pela ingestão de ovos do Echinococcus granulosus, mas também pode ocorrer pelo contato direto com cão infectado contendo ovos em torno do ânus ou em outras partes do corpo. Em nível global, estima-se que mais de um milhão de pessoas são afetadas pela hidatidose anualmente, resultando em cerca de 19.300 mortes no mundo, sendo uma ameaça à saúde pública. Os cistos hidáticos desenvolvem-se principalmente no fígado e pulmões, no entanto estes podem surgir em qualquer tecido ou órgão interno (ex. coração, osso, músculo, tecido nervoso, etc) pela disseminação hematogênica, podendo desenvolver eosinofilia alérgica, com a ruptura acidental de um cisto que leva a reações de hipersensibilidade aguda, constituindo complicações clínicas (SILVA, 2017). Uma verminose transmitida de forma semelhante por alimentos contaminados, frutas e verduras mal lavadas, água contaminada, mãos sujas, objetos contaminados é a Teníase, uma doença intestinal causada pela ingestão de ovos de Taenia sp., geralmente assintomática, mas pode causar dores abdominais, náuseas, debilidade, perda de peso, flatulência, diarreia intercalada com constipação, tontura, apetite excessivo e vômito. Em casos de infestações maciças pode ocorrer eliminação das proglótides através do ânus e das fezes, e raramente pode haver perfuração intestinal e peritonite. O problema maior está na ocorrência da cisticercose, também causada pela Taenia sp., mas quando ingerido carne bovina ou suína contendo cisticercos viáveis, o cisticerco aloja-se em diversas partes do organismo, como tecidos musculares ou subcutâneos, globo ocular e com mais frequência no sistema nervoso central (neurocisticercose), inclusive 
intramedular, o que traz maiores repercussões clínicas (SOOSARAEl et al., 2017).

Conclusão: Pode-se concluir que as doenças zoonóticas são de grande importância a saúde pública, divido aos seus altos potenciais de contaminação e patogenicidade principalmente em crianças.

\section{Referências}

BONSERE, Wevellen C. P.; MIORANZA, Sônia L.; FARIÑA, Luciana O.; SANTOS, Keitia C.; AYALA, Thaís S. Surtos de criptosporidiose pelo mundo: uma revisão sistemática, Revista Brasileira de Meio Ambiente, v.8, n.2. p. 062-073, abr. 2020

CORRÊA, M.; LOPES, G.; SANTOS, M.; DORNELES, G.; MARTINS, A.; HIRSCHMANN, L. Doenças Parasitárias: Orientação Educativa Em Escolas De Dom Pedrito E Região. Anais do Salão Internacional de Ensino, Pesquisa e Extensão, v. 11, n. 3, 18 fev. 2020.405, 2018.

MAATEN, Talina Sterneberg-Van Der; TURNER, Dennis; VAARTEN; Jan. Benefits and risks for people and livestock of keeping companion animals: searching for a healthy balance. Journal of Comparative Pathology, v. 155, n. 1, p. S8-S17, 2016.

MONTEIRO, Nathália Miguel Costa; GONÇALVES, Carolina Araújo; RODIRGUES, Alexandre Abdelaziz; OLIVEIRA, Rafael Campos; LIMA, Jaqueline Ataíde Silva; AVELAR, Juliana Boaventura; DE CASTRO, Ana Maria; REZENDE, Hânstter Hállison Alves. Ocorrência de potenciais agentes causadores larva migrans em parques e praças públicas em Aparecida de Goiânia, Goiás, Brasil. Rev. Biol. Neotrop. / J. Neotrop. Biol., Goiânia, v. 15, n. 2, p. 73-77, jul.-dez. 2018

ROCHA, Marcia Juciele da; WEBER, Douglas Mroginski; COSTA, Jales Pereira da. Prevalência de larvas migrans em solos de parques públicos da cidade de Redenção, estado do Pará, Brasil. Revista Pan Amazônica de Saúde, 2019.

SILVA, Marta B. R. Situação Em Portugal De Equinococose/Hidatidose: Epidemiologia, Patogénese, Clínica, Imunologia, Tratamento E Prevenção. Dissertação (Relatório de Estágio-Mestrado em Análises Clínicas). Orientadora: Ana Catarina Ferreira Rombo, Universidade de Lisboa, Faculdade de Farmácia, Lisboa, 2017.

SOOSARAEI, Masoud; ALIZADEH, Shahriar; FAKHAR, Mahdi; BANIMOSTAFAVI, Elham Sadat; HEZARJARIBI, Hajar Ziaei; Intestinal perforation and peritonitis due to Taenia saginata: A case report from Iran. Annals of Medicine and Surgery 24(C), Oct. 2017. 


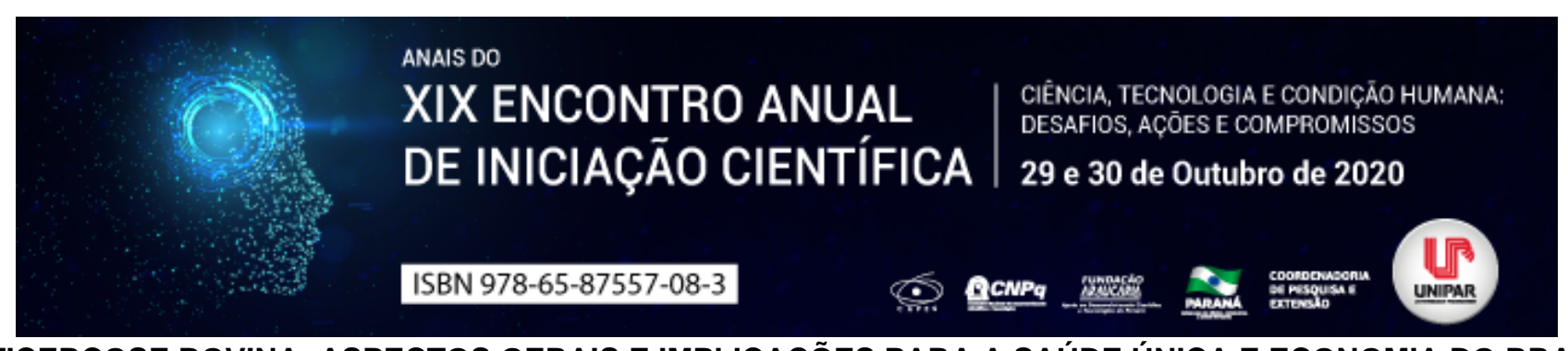

CISTICERCOSE BOVINA: ASPECTOS GERAIS E IMPLICAÇÕES PARA A SAÚDE ÚNICA E ECONOMIA DO BRASIL

\begin{abstract}
${ }^{1}$ Gabriely Amaro de Oliveira Borges, ${ }^{2}$ ANDRÉ PEREIRA LOPES, ${ }^{3}$ LUCAS MATHEUS SILVA ALVES, ${ }^{4}$ FERNANDA DE PAULA ROLDI VIEIRA
\end{abstract}

${ }^{1}$ Discente do curso de Medicina Veterinária UEM/Umuarama-PR

${ }^{1}$ Discente do curso de Medicina Veterinária UEM/Umuarama-PR

${ }^{2}$ Discente do curso de Medicina Veterinária UEM/Umuarama-PR

${ }^{3}$ Mestre em Ciências Veterinárias - Universidade Federal do Espírito Santo

Introdução: A cisticercose bovina é uma zoonose causada por cestoides da espécie Taenia saginata, sendo o homem o hospedeiro definitivo e o bovino o hospedeiro intermediário. A cisticercose bovina é endêmica no Brasil, com maior ocorrência nas regiões Centro-oeste, Sudeste e Sul. Além da importância para a saúde pública, a enfermidade possui importância econômica acarretando perdas estimadas em R\$ 1.185 .000 somente nos últimos cinco anos (DUTRA et al., 2012; SCOT CONSULTORIA, 2020; FARM NEWS, 2020).

Objetivo: Esta revisão bibliográfica tem como objetivo discorrer sobre a importância da cisticercose bovina para a saúde pública e economia no Brasil.

Desenvolvimento: A cisticercose bovina é uma zoonose de grande importância em saúde pública, sobretudo nos países em desenvolvimento onde as precárias condições sanitárias e socioeconômicas favorecem a transmissão (NEVES, 2010). A doença é causada por cestoides da espécie Taenia saginata, com os quais os bovinos se contaminam através da ingestão de ovos que geralmente são encontrados em pastagens e água contaminada por fezes humanas. No interior do hospedeiro intermediário os ovos passam pelo trato digestivo e disseminam as oncosferas pela circulação sanguínea e linfática, depois se implantam em diversos órgãos, principalmente nos músculos, desenvolvendo a forma larval do parasito: Cysticercus bovis, que se tornará infectante para o homem após 12 semanas (SILVA; COSTACRUZ, 2010). O homem se comporta como hospedeiro definitivo do parasito, contaminando-se através do consumo de carne bovina crua ou mal passada contendo Cysticercus bovis viáveis (MONTEIRO et al. 2006). Um humano com teníase pode eliminar milhares de ovos por dia, podendo estes sobreviverem no ambiente por meses (SANTOS; BARROS, 2009). O diagnóstico da teníase em humanos comumente se dá por observação pessoal, através da eliminação espontânea de proglotes, porém pode ser realizado através de exames coproparasitológicos, submetendo as fezes aos métodos de Hoffmann, fita gomada ou tamisação. Devido ao seu caráter subclínico e considerando não ser uma doença de notificação obrigatória, há escassos registros sobre a ocorrência da teníase humana em território nacional (BRASIL, 1998). Normalmente os bovinos não apresentam evidencias clínicas da presença do cisticerco. Quando presentes, os sintomas relacionam-se aos locais de distribuição dos cisticercos, normalmente sendo os músculos da mastigação e tecidos cerebrais, resultando em dificuldade para apreender o alimento e para mastigar e podendo também ser observado nas alterações cerebrais, respectivamente, em casos de alto grau de infecção (RIBEIRO; TELLES; BALIAN, 2012). O Brasil é um país endêmico para cisticercose bovina devido à falta de saneamento básico em muitas regiões e ao modo de produção extensiva que propicia a infecção dos animais. A maior prevalência desta enfermidade, segundo um estudo realizado no período de janeiro de 2007 a abril de 2010, ocorre nas regiões Centro-oeste Sudeste e Sul do Brasil, sendo mais observado nos estados de São Paulo (3,34\%), Mato Grosso do Sul (1.34\%) e Paraná (2,91\%). Os estados de Alagoas, Amazonas e Pará tiveram prevalência de 0,001\% e nove estados (Pernambuco, Distrito Federal, Amapá, Piauí, Ceará, Rio Grande do Norte e Maranhão) não tiveram diagnósticos para a doença. Segundo este mesmo estudo, as maiores taxas de infecção ocorreram nas cidades abaixo da latitude $10^{\circ} 00$ '00' 'S, compatível com as regiões Centro-oeste, Sudeste e Sul (DUTRA et al., 2012). Além da importância sanitária da enfermidade, a cisticercose leva a incontáveis prejuízos econômicos devido ao descarte de carcaças infectadas na inspeção (NEVES, 2010). Um levantamento dos registros de dados do Sistema de Inspeção Federal (SIF) demonstrou que, dos anos 2016 a junho de 2020 , 474 carcaças foram condenadas por cisticercose no Brasil (MAPA, 2020), o que representa aproximadamente R\$1.185.000 em perdas considerando a média de preço do boi no período (SCOT CONSULTORIA, 2020; FARM NEWS, 2020).

Conclusão: A cisticercose bovina representa risco à saúde pública, além de resultar em perdas econômicas consideráveis. Os dados de prevalência evidenciam o problema da falta de saneamento básico no país e a necessidade em munir a população de informação para que esta seja capaz de interromper a propagação da doença em humanos e animais.

\title{
Referências
}

BRASIL. Guia De vigilância epidemiológica 1998. Ministério Da Saúde Fundação Nacional De Saúde Centro Nacional De Epidemiologia, v. 40 Edição, p. 523, 1998. 
CARCAÇA bovina atinge o maior preço nominal dos últimos dois anos. SCOT CONSULTORIA. Disponível em: https://www.scotconsultoria.com.br/noticias/todas-noticias/49259/carcaca-bovina-atinge-o-maior-preco-nominal-dos-ultimosdois-anos.htm. Acesso em: 22 jul. 2020.

DUTRA, L. H. et al. The prevalence and spatial epidemiology of cysticercosis in slaughtered cattle from Brazil. Semina: Ciências Agrárias, v. 33, n. 5, p. 1887-1896, 30 out. 2012. Universidade Estadual de Londrina. http://dx.doi.org/10.5433/16790359.2012 v33n5p1887.

MINISTÉRIO DA AGRICULTURA PECUÁRIA E ABASTECIMENTO MAPA. Destino de Matérias Primas e Produtos por UF (Mapa H). Disponível em: . Acesso em: 21 jul. 2020.

MINISTÉRIO DA SAÚDE. Doenças infecciosas e parasitárias. Ministério da Saúde. $8^{0}$ edição, p. 192, 2010.

MONTEIRO, L. L. et al. Diagnóstico imunológico e anatomopatológico da cisticercose bovina. Revista Higiene Alimentar, v. 20 , p. 44-48, 2006.

NEVES, D. P. et al. Parasitologia humana, 11ed. São Paulo: Atheneu, p. 227, 2010.

PESO de carcaça de bovinos por região do Brasil. FARM NEWS. Disponível em: http://www.farmnews.com.br/mercado/carcacade-bovinos/\#: :text=O\%20peso\%20de\%20carca\%C3\%A7a\%20de,Sudeste\%2C\%20com\%20259\%2C56kg. Acesso em: 22 jul. 2020.

RIBEIRO, N. A. S.; TELLES, E. O.; BALIAN, S. C. O Complexo Teníase Humana-Cisticercose: ainda um sério problema de saúde pública. Revista de Educação Continuada em Medicina Veterinária e Zootecnia do CRMV-SP, v. 10, n. 1, p. $2025,2012$.

SANTOS, J. M. G.; BARROS, M. C. R. B. Cysticercus bovis e cysticercus cellulosae: endoparasitas de importância no comércio da carne. Revista em Agronegocio e Meio Ambiente, v. 2, n. 1, p. 21 39, 2009.

SILVA, C. V.; COSTACRUZ, J. M. A glance at Taenia saginata infection, diagnosis, vaccine, biological control and treatment. Infectious Disorders Drug Targets, v. 10, n. 5, p. 313, 2010.

Coordenadoria de Pesquisa e Extensão - COPEX

Departamento de Editoraçāo e Divulgaçāo Científica - DEDIC 


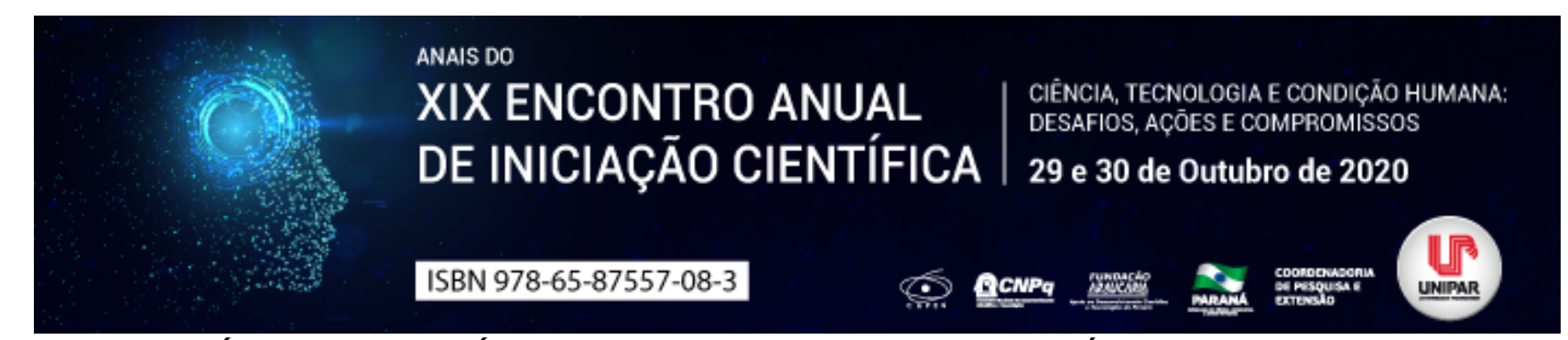

PERFIL BIOQUÍMICO DE PROTEÍNAS, INCLUINDO ENZIMAS, NO SORO LÁCTEO DE OVINOS COM MASTITE INFECCIOSA SUBCLÍNICA

\begin{abstract}
${ }^{1}$ Gabriela Mendonça Servilheri, ${ }^{2}$ NATÁLIA PARPINELLI, ${ }^{3}$ YURI DA SILVA BONACIN, ${ }^{4}$ ANTONIO CAMPANHA MARTINEZ, ${ }^{5}$ ANDRÉ MARCOS SANTANA
\end{abstract}

\begin{abstract}
${ }^{1}$ Discente do Curso de Medicina Veterinária da Universidade Estadual de Maringá (UEM), campus Umuarama-PR
${ }^{1}$ Discente do Curso de Medicina Veterinária da Universidade Estadual de Maringá (UEM), campus Umuarama-PR

${ }^{2}$ Pós-Graduando do Departamento de Clínica e Cirurgia Veterinária, FCAV/UNESP, Campus de Jaboticabal

${ }^{3}$ Docente do Departamento de Medicina Veterinária, Universidade Estadual de Maringá UEM/ Campus de Umuarama

${ }^{4}$ Docente do Departamento de Medicina Veterinária, Universidade Estadual de Maringá UEM/ Campus de Umuarama
\end{abstract}

Introdução: A mastite é a resposta inflamatória da glândula mamária (GM) frente a infecções, traumas e alterações fisiológicas e metabólicas (ALKANIP et al., 2014), sendo causa de perdas econômicas devido aos custos com tratamento, serviços veterinários e reposição de animais mortos ou abatidos (SILVA et al., 2013). A mastite se apresenta na forma clínica, quando há sinais de inflamação, como hiperemia e hipertermia (SANCHEZ, 2015), e subclínica, em que os animais podem se apresentar clinicamente saudáveis (SILVA et al., 2013). Devido à mastite, ocorre aumento da permeabilidade da barreira sangue-leite e vasodilatação dos vasos sanguíneos da glândula mamária, fato que permite que constituintes celulares do sangue e moléculas extravasem para o leite (KATSAFADOU et al., 2019). Por esse fato, o estudo de proteínas como indicador de inflamação do úbere pode ser útil no diagnóstico da afecção (PYÖRÄLÄ, 2003) e para prognóstico e monitoração do animal, assim como a contagem de células somáticas (CCS).

Objetivo: Estudar o perfil bioquímico de proteínas, incluindo enzimas, no soro lácteo de ovinos com mastite subclínica, com o intuito de obter informações auxiliares úteis no diagnóstico e acompanhamento pós-terapêutico.

Material e Métodos: Foram utilizadas fêmeas ovinas resultado do cruzamento entre as raças Dorper e Santa Inês com idade entre 4 e 8 meses. Destes animais, fez-se o exame ultrassonográfico (US) das GM e a CCS das amostras de leite, constituindose os grupos experimentais: Amostras de soro lácteo de glândulas mamárias (GM) sem alteração no US e CCS < 300.000 células/mL (G1, n=19 GM), com alteração no US e CCS < 300.000 células/mL (G2, n=18 GM) e com alteração no US e CCS > 1.000.000 células/mL (G3, n=11 GM). Destes animais, ainda foram coletadas amostras de leite em tubos falcon de $50 \mathrm{~mL}$ para realização do perfil bioquímico do soro lácteo, para as variáveis proteínas totais, albumina, GGT, ALP e LDH. Estas variáveis foram realizadas utilizando-se conjuntos de reagentes de uso comercial (Labtest Diagnóstica). As leituras dos parâmetros bioquímicos foram realizadas em espectrofotômetro semi-automático com comprimentos de onda específicos para cada constituinte. Os resultados foram submetidos à análise de variância (ANOVA) e ao teste de Tukey $(p<0,05)$. O uso dos animais foi autorizado pela Comissão de Ética no Uso de Animais (CEUA) da Universidade Estadual Paulista (UNESP), protocolo $\mathrm{n}^{\circ}$ 017013/18.

Resultados: Os resultados obtidos evidenciaram diferenças significativas entre o G1 e o G3 e entre o G2 e o G3, para o GGT $(p=0,0210)$, ALP ( $p=0,0791)$ e LDH ( $p=0,0002)$, enquanto o G1 e G2 tiveram médias semelhantes entre si para esses parâmetros.

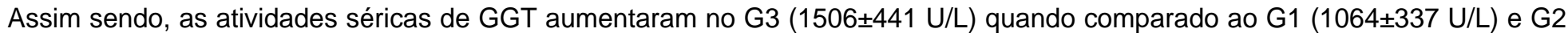
(995 $\pm 385 \mathrm{U} / \mathrm{L})$. Da mesma forma, as atividades séricas de ALP aumentaram no G3 (1019 \pm 602 U/L) quando comparado ao G1 $(769 \pm 259 \mathrm{U} / \mathrm{L})$ e $\mathrm{G} 2(632 \pm 202 \mathrm{U} / \mathrm{L})$. Ainda, também observou-se que as atividades séricas de LDH aumentaram no G3 (96,8 \pm 135

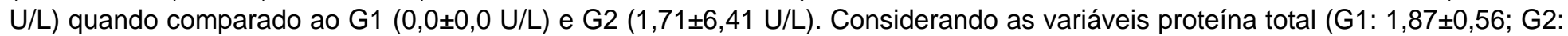

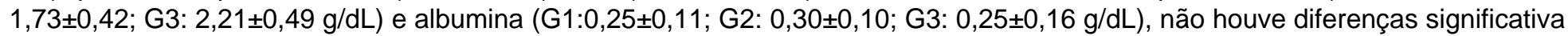
entres os grupos.

Discussão: Maristela et al. (2015), ao estudarem o soro lácteo de ovelhas com mastite, observaram que não houve diferenças significativas entre ovinos saudáveis e com mastite para a variável proteína total, corroborando com o nosso trabalho. No entanto, Sanchez (2015), ao estudar o soro lácteo de cabras sadias e com mastite, relatou maiores concentrações de proteína total e albumina em casos de mastite. Em relação a albumina, Batavani et al. (2007) relataram aumento significativo no soro lácteo de vacas com mastite, diferente do relatado em nosso trabalho. As enzimas GGT, ALP e LDH apresentaram-se aumentadas nos animais com mastite clínica na nossa pesquisa, achados estes similares aos descritos por Sanchez (2015), para GGT e ALP, em cabras com mastite clínica e subclínica. Paithane et al. (2017) também relatou aumento de ALP em ovelhas com mastite e relacionou tal aumento à agregação marcada de neutrófilos e aos danos teciduais causados pela mastite na glândula mamária. Batavani et al. (2007) também observou atividade aumentada de LDH no soro lácteo de vacas com mastite, relacionando este aumento à possível liberação da enzima por leucócitos desintegrados e células parenquimatosas do úbere. 
Conclusão: Os resultados encontrados no estudo indicam que a variação na atividade enzimática de GGT, LDH e ALP no soro lácteo de ovinos com mastite evidenciam um importante potencial destas variáveis para uso como biomarcadores de mastite ovina.

\section{Referências}

ALKANIP, M.E.; QUINTELA-BALUJA, M.; BOHME, K.; FERNÁNDEZ-NO, I.; CAAMAÑO-ANTELO, S.; CALO-MATA, P.; BARROS-VELÁZQUEZ, J. The Immunology of Mammary Gland of Dairy Ruminants between Healthy and Inflammatory Conditions. Journal of Veterinary Medicine, v. 2014, p. 1-32, 2014.

BATAVANI, R.A.; ASRI, S.; NAEBZADEH, H. The effect of subclinical mastitis on milk composition in dairy cows. Iranian Journal of Veterinary Research, v. 8, n. 3(20), p. 205-11, 2007.

IBGE (2017). Censo agropecuário 2017. Disponível em: https://sidra.ibge.gov.br/tabela/6930. Acesso em 18 de agosto de 2020. KATFASADOU, A.; POLITIS, A.P.; MAVROGIANNI, V.S.; BARBAGIANNI, M.S.; VASILEIOU, N.G.C.; FTHENAKIS, G.C.; FRAGKOU, I.A. Mammary Defences and Immunity against Mastitis in Sheep. Animals, v. 9, n. 726, p. 1-17, 2019. MARISTELA, R.; RUSEK, N. CAJA, G.; SALDO, J.; LEITNER, G. Small Ruminant Research, v. 125, p. 127 36, 2015. PYÖRÄLÄ, S. Indicators of inflammation in the diagnosis of mastitis. Veterinary Research, v. 34, p. 565-578, 2003.

SANCHEZ, D.C.C. Perfil bioquímico dos soros lácteo e sanguíneo de cabras com mastite de ocorrência natural. 2015. xii, 49 p. Tese (doutorado) - Universidade Estadual Paulista Júlio de Mesquita Filho, Faculdade de Ciências Agrárias e Veterinárias de Jaboticabal, 2015.

SILVA, J.S.C.; GUARANÁ, E.L.S.; LEMOS, V.F.; SOARES, P.C.; AFONSO, J.A.B.; MENDONÇA, C. L. Metabolismo energético, proteico e mineral de ovelhas Santa Inês hígidas e com mastite subclínica. Pesquisa Veterinária Brasileira, v. 33, n. 9, p. 1087 96, 2013. 


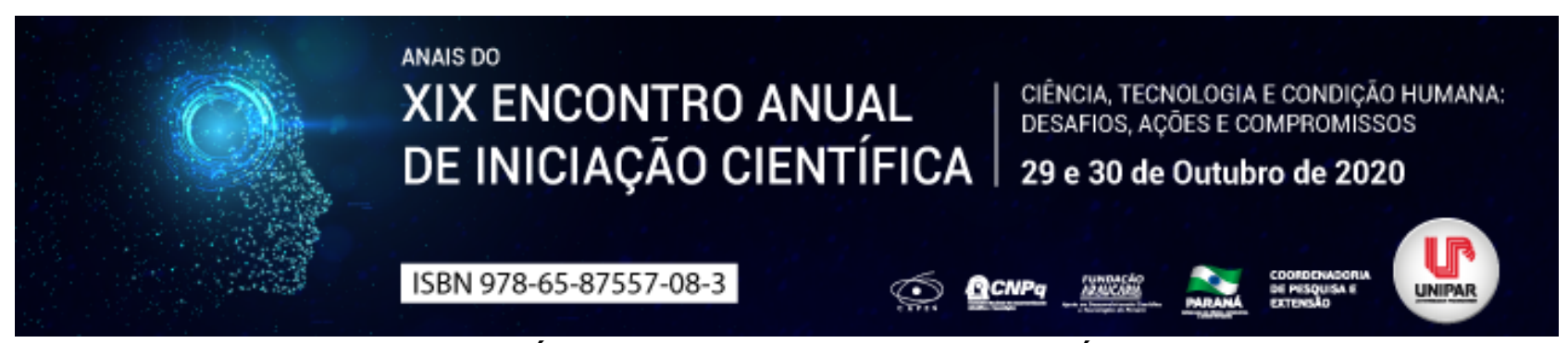

CARDIOMIOPATIA HIPERTRÓFICA FELINA EM GATA ASSINTOMÁTICA: RELATO DE CASO

\begin{abstract}
${ }^{1}$ Ana Carolina Bonorino Antunes, ${ }^{2}$ NATÁLIA PAZZINI NUNES, ${ }^{3}$ RAMMY VARGAS CAMPOS, ${ }^{4}$ ANDRIELI MACHADO CORTES, ${ }^{5}$ JORGE BENEVENUTE, ${ }^{6}$ MONIQUE TOGNI MARTINS
\end{abstract}

\begin{abstract}
${ }^{1}$ Discente do curso de Medicina Veterinária, Universidade Regional Integrada do Alto Uruguai e das Missões, Santiago-RS, Brasil
${ }^{1}$ Discente do curso de Medicina Veterinária, Universidade Regional Integrada do Alto Uruguai e das Missões, Santiago-RS, Brasil

${ }^{2}$ Médica Veterinária, Hospital Veterinário BeneVet, Santiago-RS, Brasil

${ }^{3}$ Médica Veterinária, Hospital Veterinário BeneVet, Santiago-RS, Brasil

${ }^{4}$ Médico Veterinário, Hospital Veterinário BeneVet, Santiago-RS, Brasil

${ }^{5}$ Docente do curso de Medicina Veterinária, Universidade Regional Integrada do Alto Uruguai e das Missões, Santiago-RS, Brasil
\end{abstract}

Introdução: A cardiomiopatia é uma doença cardíaca progressiva classificada em cardiomiopatia dilatada, hipertrófica e restritiva. A cardiomiopatia hipertrófica é uma hipertrofia proeminente do miocárdio ventricular que ocorre quando o septo interventricular causa uma redução da câmara ventricular, consequentemente, diminui o débito cardíaco (OCARINO, N.M., et al. 2016). Além disso, esta doença é uma das mais relevantes causas de mortes em felinos (SILVA, A.C., et al. 2013). Porém, alguns animais podem apresentar-se como assintomáticos por anos (SILVEIRA, J.A.M., et al. 2015).

Desse modo, o presente trabalho tem como objetivo relatar a causa da morte de uma gata com cardiomiopatia hipertrófica felina assintomática com complicações cardiorrespiratórias após ovariosalpingohisterectomia (OSH) eletiva.

Relato de caso: Foi atendido no BeneVet Hospital Veterinário na cidade de Santiago-RS um felino, com três anos de idade, fêmea, com a finalidade de ser realizada uma OSH eletiva. No exame clínico o animal não apresentou alterações. Como medida pré-operatória, foi realizado exames básicos como hemograma e bioquímico, o qual foi observado alteração apenas um leve aumento no hematócrito. Como protocolo anestésico, foi ministrado cloridrato de Midazolam associado com Metadona e Acepran, sendo realizado Cetamina $1 \mathrm{mg}$ com a manutenção de Propofol $3 \mathrm{mg}$. O procedimento cirúrgico de OSH foi realizado sem qualquer intercorrência. No pós-cirúrgico o felino foi direcionado para uma sala de recuperação e após sendo encaminhado, posteriormente para casa. A gata retornou ao HV com dispneia.

Foi realizado exame de ultrassonografia que detectou líquido no tórax. Por fim, o animal não resistiu e veio a óbito. Nos achados da necropsia constatou-se presença de líquido no tórax, edema e hemorragia pulmonar. Ao corte fluía líquido avermelhado. $\mathrm{O}$ coração estava pálido, com vasos superficiais ingurgitados e ao corte transversal apresentou um marcado espessamento concêntrico do miocárdio, especialmente no ventrículo esquerdo. Determinando-se assim a causa da morte o edema e hemorragia pulmonar associado à cardiomiopatia hipertrófica.

Discussão: A cardiomiopatia hipertrófica pode ser caracterizada como primária (idiopática) ou secundária e definida como aumento (hipertrofia) do ventrículo esquerdo que causa uma rigidez em sua câmara gerando uma alteração diastólica. $\mathrm{O}$ avanço da doença causa aumento de pressão das veias pulmonares com posterior edema pulmonar e insuficiência cardíaca (MATTEUCCI, G., 2011). Neste relato, a gata foi submetida a OSH eletiva e subsequente alterações respiratórias e morte por edema pulmonar. Os sinais clínicos recorrentes da cardiomiopatia hipertrófica felina são: taquipneia, dispneia e tosse (WARE, A.W, 2015). Sinais apresentados por esta gata após receber alta do hospital. Na sua forma assintomática ainda pode ser detectada através de sopros (ZAMBONI V.A.G, ROMÃO F.G. 2015). Entretanto, a gata não apresentou sopro ao exame clínico. O uso de anestésicos em pacientes cardíacos pode agravar os sintomas da doença, visto que esses fármacos podem causar distúrbios como alteração do ritmo, da frequência cardíaca e do débito cardíaco corroborando para a disfunção cardíaca. (TEODÓZIO, D.R., 2019). Além disso, segundo Zamboni; Romão (2015) e Silveira (2015) o fator estresse tem suma importância no desencadear os sintomas. Portanto, sugere-se que o uso destes fármacos associado ao fator estresse desencadeou as alterações cardiorrespiratórias observadas. O edema pulmonar em paciente cardiopata é decorrente de alteração da pressão hidrostática causado por insuficiência cardíaca esquerda (KLEIN, B.G., 2014). Dados estes compatíveis com os achados de necropsia. Dentre outros possíveis diagnósticos estão o exame físico, eletrocardiograma, radiografia, testes rápidos que visam positivar o histórico familiar genético do animal e o ecocardiograma, sendo este o mais recomendado (SILVA, AC et al., 2013). Porém, associar estes exames a uma cirurgia eletiva, tornando-os de rotina, eleva consideravelmente os valores financeiros de procedimentos simples, sendo este o real motivo de recusa na realização destes exames pelos tutores, principalmente em animais assintomáticos. Dessa forma, o diagnóstico precoce de cardiomiopatia hipertrófica felina em animais assintomáticos ainda é um desafio na rotina do Médico Veterinário.

Conclusão: De acordo com os sinais clínicos e as alterações macroscópicas nos achados de necropsia a morte do animal foi causada pelo edema pulmonar difuso associado à cardiomiopatia hipertrófica felina. O diagnóstico desta enfermidade possui 
grande importância clínica, visto que é uma doença cardíaca muito comum, porém, muitas vezes assintomática e de alta mortalidade em felinos, o que a torna um desafio para profissionais da área na rotina da clínica cirúrgica veterinária.

\section{Referências}

KLEIN, Bradley G. Cunningham tratado de fisiologia veterinária. 5. ed. Rio de Janeiro: Elsevier, 2014.

MATTEUCCI, Guilherme. Cardiomiopatia hipertrófica felina: revisão bibliográfica. Orientador: Prof. Dr. Sony Dimas Bicudo. 2011. 20 f. Monografia (Graduação em Medicina Veterinária) - Faculdade de Medicina Veterinária e Zootecnia da Universidade Júlio de Mesquita Filho campus Botucatu, Botucatu, 2011.

OCARINO, Natália de Melo et al. Sistema Cardiovascular. In: SANTOS, Renato de Lima; ALESSI, Antonio Carlos. Patologia Veterinária, 2. ed. Rio de Janeiro: Roca, 2016. p. 98-159.

SILVA, Adriana Cristina da et al. Feline Hypertrophic cardiomyopathy: an echocardiographic approach. Arch. med. vet., Valdivia, v. 45, n. 1, p. 1-6, 2013 . Disponível em: https://scielo.conicyt.cl/scielo.php?script=sci_arttext\&pid=S0301732X2013000100002\&lang=pt. Acesso em: 17 jul. 2020.

SILVEIRA, João Alisson de Moraes et al. Cardiomiopatia Hipertrófica Felina: aspectos relevantes. Revista Brasileira de Higiene e Sanidade Animal, v.9, n.3, Janeiro, 2015. Disponível em: http://www.higieneanimal.ufc.br/seer/index.php/higieneanimal/article/view/274. Acesso em: 17 de jul. de 2020.

TEODÓZIO, Débora Rosa. Anestesia em cães cardiopatas. Orientador: Eduardo Raposo Monteiro. 2019. 49f. Monografia (Graduação em Medicina Veterinária) Universidade Federal do Rio Grande do Sul, Porto Alegre, 2019.

WARE, Wendy A. Doenças Miocárdicas do Gato. In: NELSON, Richard W; COUTO, C. Guilhermo. Medicina interna de pequenos animais. 5.ed. - Rio de Janeiro: Guanabara Koogan, 2015.

ZAMBONI, Vinícius Aquiles Gomes; ROMÃO, Felipe Gazza. Cardiomiopatia hipertrófica felina: relato de caso. Alm. Med. Vet. Zoo, $\quad$ v. $\quad 1, \quad$ n. $\quad 1, \quad$ fevereiro, $2015 . \quad$ Disponível $\quad$ em: http://www.fio.edu.br/revistamv/arquivos/v1/CARDIOMIOPATIA\%20HIPERTR\%C3\%93FICA\%20FELINA.pdf. Acesso em: 24 jul. 2020. 


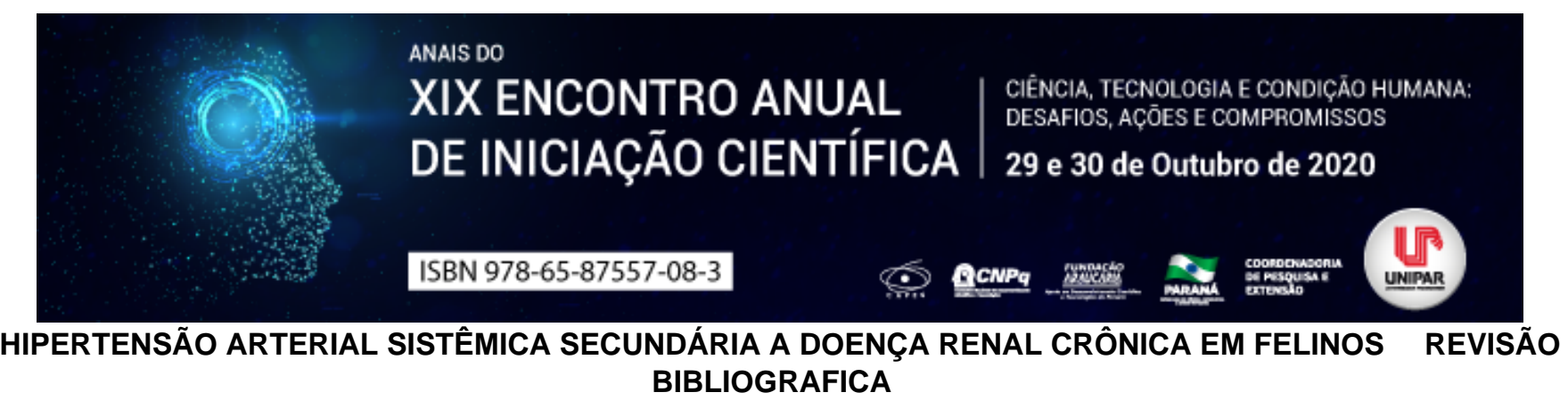

\author{
${ }^{1}$ JAQUELINE BRUNA DE MELO, ${ }^{2}$ JÉSSICA SUEMI ALMEIDA KIKUTI, ${ }^{3}$ POLLYANA LINHARES SALA, ${ }^{4}$ GABRIELA JULIANA \\ LOPES, ${ }^{5}$ NATÁLIA SARAIVA RODRIGUES, ${ }^{6}$ NATALIE BERTELIS MERLINI
}
${ }^{1}$ Médica Veterinária Residente do Programa de Aprimoramento em Clínica Médica de Cães e Gatos da Universidade Paranaense UNIPAR.

${ }^{1}$ Médica Veterinária Residente do Programa de Aprimoramento em Patologia Clínica da Universidade Paranaense UNIPAR.

${ }^{2}$ Médica Veterinária Autônoma

${ }^{3}$ Médica Veterinária Autônoma

${ }^{4}$ Mestranda em Ciência Animal, Universidade Paranaense UNIPAR, bolsista PIT/UNIPAR

${ }^{5}$ Docente do Programa de Pós-Graduação em Ciência Animal com Ênfase em Produtos Bioativos da Universidade Paranaense UNIPAR.

Introdução: A doença renal crônica é o produto de uma série de alterações primárias que levam a perda progressiva dos néfrons de maneira irreversível (CANNON, 2016), resultando na deficiência de excreção de metabólitos pelos rins. O aumento desses metabólitos no sangue é denominado de azotemia, e é observada quando $75 \%$ dos néfrons tem sua função perdida. Sistemicamente a perca de função leva a alterações acido-básicas, de homeostase e endócrinas. É uma doença progressiva e estima-se que afeta de 1-3\% dos felinos geriátricos (CHEW et al. 2011). Como consequência da alteração na homeostase, a hipertensão é um achado comum em gatos com doença renal crônica e quando não tratada, pode levar a lesões em outros órgãos como olhos, coração e Sistema Nervoso Central (SNC) (CANNON, 2016; CHEW, 2011).

Objetivos: Realizar uma revisão bibliográfica sobre as atualizações referente a hipertensão arterial felina secundária a doença renal crônica.

Desenvolvimento: A doença renal crônica ocorre devido a uma junção de fatores que levaram a lesões nos néfrons, resultando na diminuição da taxa de filtração glomerular (TFG). Na maioria dos casos as lesões não são causadas por doenças especificas, mas sim pela exposição a episódios de obstrução, urolitíase, hipóxia ou exposição a toxinas, que vieram a ocorrer ao longo da vida do paciente (CANNON, 2016). Pode afetar de 1-3\% de felinos geriátricos (CHEW, 2011). Porém em estudo realizado por Moreira (2014), a doença renal crônica representou 13,28\% dos diagnósticos em gatos senis em um hospital veterinário. Os gatos tendem a elevar o nível de pressão com a idade, porém pacientes com a doença renal tem mais chances de desenvolver hipertensão (BIJSMANS et al. 2015), podendo ser encontrada em 19-65\% desses pacientes. A hipertensão implica em lesões em órgãos chamados de alvo como olhos, SNC, coração e inclusive lesões renais que levam a progressão da doença renal (CANNON, 2016; CHEW, 2011). Sua etiologia ainda não está claramente elucidada, porém alguns gatos apresentaram ativação do sistema renina-angiotensina-aldosterona e hiperaldosteronismo (SYME et al. 2002; SPARKES et al. 2016). A Internacional Renal Interest Society (IRIS, 2019) considera a hipertensão como parte do subestadiamento do paciente renal, e são considerados hipertensos gatos com pressão arterial sistêmica acima de $160 \mathrm{mmHg}$. A partir desses valores o paciente já pode apresentar lesões em órgãos alvo, demonstrando sinais clínicos decorrentes da hipertensão. Em estudo, notou-se que 65\% dos gatos hipertensos apresentavam alguma alteração cardíaca, quando comparado com os não-hipertensos (SYME et al. 2002). Já Stiles et al. (1994) observou que $80 \%$ dos gatos com hipertensão secundária a doença renal, apresentavam retinopatia hipertensiva, podendo levar como consequência a cegueira súbita. Para o diagnóstico são métodos confiáveis de mensuração não-invasiva o oscilométrico e doppler vascular, garantindo que o paciente esteja tranquilo durante o procedimento para confiabilidade dos valores (SPARKES et al., 2016). Pressões entre 140-159mmHg, caracterizam o paciente pré-hipertenso, com baixo risco de lesão em órgãos alvo, devendo ser acompanhado (TAYLOR et al., 2017). Entre 160-179mmHg são considerados hipertensos com moderado risco de lesão a órgãos alvo, já acima $180 \mathrm{mmHg}$ tem alto risco de lesão a órgãos alvo, sendo que esses valores devem se manter de 1-2 semanas para confirmar a hipertensão, exceto em casos onde já existem sinais de lesão em órgão alvo. A terapia tem como objetivo manter a pressão abaixo de $160 \mathrm{mmHg}$, manejando o paciente sem lhe causar hipotensão, diminuindo assim as chances de lesão nos órgãos alvos (IRIS, 2019). O tratamento recomendado pela IRIS, (2019), em felinos é realizado com amlodipina, que é um bloqueador de canais de Ca, e se mostra eficaz e com baixas evidências de efeitos adversos (CHEW, 2011) ou com bloqueador do receptor de angiotensina, o telmisartana. Alguns pacientes não respondem bem a monoterapia (TAYLOR et al., 2017), sendo necessário a combinação da amlopidina com telmisartana. É importante verificar o estado de hidratação do felino antes da associação da terapia, para evitar mais danos aos rins pela diminuição da TGF (IRIS, 2019). O paciente deve ser monitorado periodicamente, após estabilização, a cada 3 meses (TAYLOR 
et al., 2017).

Conclusão: Conclui-se que a avaliação da pressão arterial sistêmica é de suma importância no felino com suspeita de doença renal crônica, pois com diagnóstico e tratamento precoce, as chances de lesões em outros órgãos diminuem e consequentemente melhora a qualidade e expectativa de vida do paciente.

\section{Referências}

BIJSMANS, E. S; JEPSON, R.E.; Y.M. CHANG; H.M. SYME; ELLIOTT, J. Changes in systolic blood pressure over time in healthy cats and cats with chronic kidney disease. Journal of Veterinary Internal Medicine, v. 29, n. 3, p. 855-861, 2015.

CANNON, Martha. Diagnosis and investigation of chronic kidney disease in cats. In Practice, v. 38, n. Suppl 3, p. 2-9, 2016. Disponível em: https://inpractice.bmj.com/content/38/Suppl_3/2.fullAcesso em: 27 ago. 2020.

CHEW, Dennis J.; DIBARTOLA, Stephen P.; SCHENCK, Patricia. Canine And Feline Nephrology And Urology, Second Edition, Missouri, 2011, Saunders, an imprint of Elsevier Inc. p. 145

International Renal Interest Society. IRIS Staging of CKD (modified 2019). Disponível em: http://www.iriskidney.com/pdf/IRIS_Staging_of_CKD_modified_2019.pdf Acesso em: 28 ago. 2020.

International Renal Interest Society. Treatment recomendations of CKD in cats (2019). Disponível em: http://www.iriskidney.com/pdf/IRIS_CAT_Treatment_Recommendations_2019.pdf Acesso em: 28 ago. 2020.

MOREIRA, Leticia Fontoura. Principais afecções diagnosticadas em felinos geriatras no Hospital de Clínicas Veterinárias da UFRGS entre 2013 e 2014. 2014. Trabalho de Conclusão de Curso em Medicina Veterinária. Universidade Federal do Rio Grande do Sul. Porto Alegre RS, 2014. Disponível em: https://www.lume.ufrgs.br/handle/10183/196913 Acesso em: 28 ago. 2020.

SPARKES, Andrew H.; CANEY, Sarah; CHALHOUB, Serge; ELLIOTT, Jonathan; FINCH, Natalie; GAJANAYAKE, Isuru; LANGSTON, Catherine; LEFEBVRE, Hervé; WHITE, Joanna; QUIMBY, Jessica. ISFM consensus guidelines on the diagnosis and management of feline chronic kidney disease. Journal of Feline Medicine and Surgery , v. 18, n. 3, pág. 219-239, 2016. Disponível em: https://journals.sagepub.com/doi/full/10.1177/1098612X16631234 Acesso em: 27 ago. 2020.

STILES, J.; POLZIN, D. J.; BISTNER, S. I. The prevalence of retinopathy in cats with systemic hypertension and chronic renal failure or hyperthyroidism. Ophthalmic Literature, v. 1, n. 48, p. 62, 1995. Disponivel em: https://www.infona.pl/resource/bwmeta1.element.elsevier-12ea5bdb-2a8f-3eda-8174-a2196725810b. Acesso em: 28 ago. 2020.

SYME, Harriet M.; BARBER, Penney J.; MARKWELL, Peter J.; ELLIOTT, Jonathan. Prevalence of systolic hypertension SMALL ANIMALS in cats with chronic renal failure at initial evaluation. Journal of the American Veterinary Medical Association, v. 220, n. 12, pág. 1799-1804, 2002. Disponível em: https://avmajournals.avma.org/doi/abs/10.2460/javma.2002.220.1799Acesso em: 27 ago. 2020.

TAYLOR, Samantha S.; SPARKES, Andrew H.; BRISCOE, Katherine; CARTER, Jenny; SALA, Salva Cervantes; JEPSON, Rosanne E.; REYNOLDS, Brice S.; SCANSEN, Brian A. ISFM consensus guidelines on the diagnosis and management of hypertension in cats. Journal of feline medicine and surgery, 2017. Disponível em: https://journals.sagepub.com/doi/full/10.1177/1098612X17693500 Acesso em: 27 ago. 2020. 


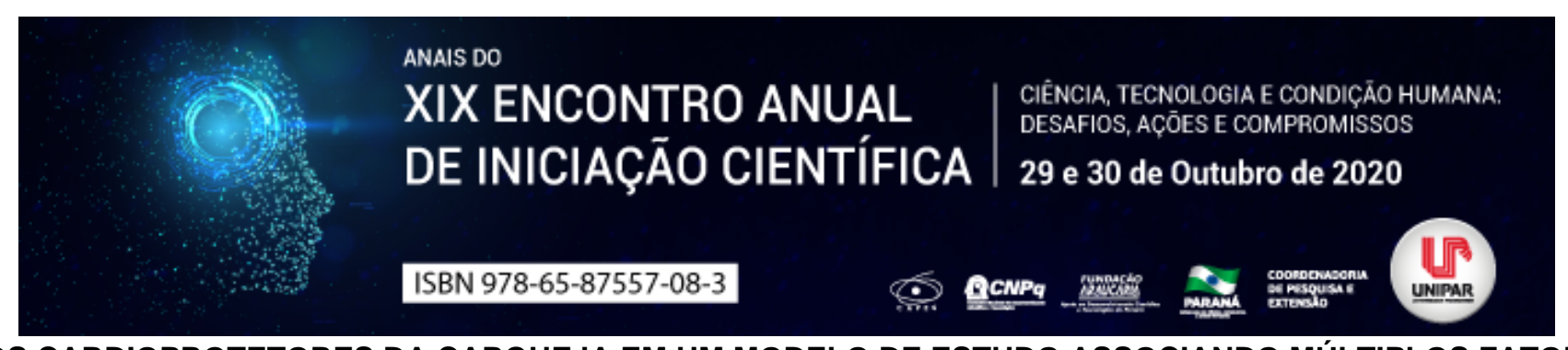

EFEITOS CARDIOPROTETORES DA CARQUEJA EM UM MODELO DE ESTUDO ASSOCIANDO MÚLTIPLOS FATORES DE RISCO

\author{
${ }^{1}$ EDUARDA CAROLINA AMARAL, ${ }^{2}$ FERNANDA DE ABREU BRAGA, ${ }^{3}$ GUSTAVO RATTI DA SILVA, ${ }^{4}$ FRANCISLAINE \\ APARECIDA DOS REIS LIVERO
}

${ }^{1}$ Discente do Mestrado Profissional em Plantas Medicinais e Fitoterápicos na Atenção Básica/ PIC-PG - UNIPAR

${ }^{1}$ Discente do Curso de Medicina, bolsista PEBIC/CNPq

${ }^{2}$ Discente do PPG em Ciência Animal com Ênfase em Produtos Bioativos/Taxista - Prosup/CAPES

${ }^{3}$ Docente do Mestrado Profissional em Plantas Medicinais e Fitoterápicos e PPG em Ciência Animal - UNIPAR

Introdução: As doenças cardiovasculares (DCV) são as maiores contribuidoras para o desenvolvimento das doenças crônicas em todo o mundo, e essa alta ocorrência se explica pelo conjunto de fatores de risco tradicionais aos quais a população está exposta, como alcoolismo e tabagismo (HOYERT; XU, 2012; APPELMAN et al., 2015). O uso excessivo do álcool pode levar a um aumento de triglicérides e sua associação com bebidas energéticas além de ser um hábito frequente, potencializa suas consequências sobre o sistema cardiovascular (LAITINEN et al., 2012; MENCl et al., 2013; PATRICK; MACUADA; MAGGS, 2016). Outra prática crescente entre adolescentes e jovens adultos é o fumo do narguilé, o qual contém substâncias tóxicas capazes de provocar efeitos adversos sobre muitos órgãos (EL-ZAATAR; CHAMI, ZAATARI, 2015). A fim de elucidar os efeitos cardioprotetores da Baccharis trimera (Less.) DC., também conhecida como carqueja, esse modelo de estudo associou o fumo de narguilé ao consumo de bebidas alcoólica e energética em ratos.

Objetivo: Investigar o efeito cardioprotetor da Baccharis trimera no sistema cardiovascular em um modelo de estudo associando a fumo de narguilé e consumo de bebidas alcoólica e energética em ratos.

Material e Métodos: $O$ modelo foi desenvolvido em ratos Wistar machos $(n=8)$, com 2 meses de idade, que durante 10 semanas receberam ração comercial padrão, dieta líquida com álcool 10\% ou água ad libitum, energético (2 mL/kg, uma vez ao dia, por gavagem) e foram expostos à fumaça do narguilé (uma hora/dia, cinco dias/semana) ou ar filtrado. Nas últimas 4 semanas, os animais foram tratados com fração solúvel em etanol de B. trimera (30, 100 e 300 mg/kg), ou com veículo (água filtrada; grupo controle) uma vez ao dia, por gavagem. Um grupo de animais não expostos aos fatores de risco e tratados com veículo compôs o grupo basal. Ao final do experimento a pressão arterial sistólica, diastólica, média e frequência cardíaca foram mensuradas. Todo o protocolo experimental foi aprovado pelo Comitê de Ética em Pesquisa Envolvendo Experimentação Animal (CEPEEA) da UNIPAR (número 36948/2020). Os dados foram previamente analisados quanto à homogeneidade da variância e à normalidade da distribuição. Utilizou-se o teste ANOVA de uma via, seguido de teste de Newman-Keuls como pós-teste, utilizando-se o programa Graphpad Prism versão 6.0. O nível de significância adotado foi de $95 \%(p<0,05)$.

Resultados: Observou-se um aumento significativo na frequência cardíaca $(279,8 \pm 8,02$ BPM), pressão arterial sistólica (110,1 \pm $4,219 \mathrm{~mm} \mathrm{Hg})$, diastólica $(76,72 \pm 2,94 \mathrm{~mm} \mathrm{Hg})$ e média $(92,92 \pm 5,08 \mathrm{~mm} \mathrm{Hg})$ nos animais do grupo controle em comparação ao grupo basal (183,3 \pm 5,37 BPM; 89,9 $\pm 2,92 \mathrm{~mm} \mathrm{Hg} ; 59,75 \pm 1,93 \mathrm{~mm} \mathrm{Hg}$; e 68,95 $\pm 3,21 \mathrm{~mm}$ Hg, respectivamente). O tratamento com $30 \mathrm{mg} / \mathrm{kg}$ de B. trimera normalizou a frequência cardíaca (177,5 $\pm 6,74$ BPM), pressão arterial sistólica (85,45 $\pm 3,1 \mathrm{~mm}$ Hg), diastólica $(59,82 \pm 2,72 \mathrm{~mm} \mathrm{Hg})$ e média $(73,61 \pm 2,37 \mathrm{~mm} \mathrm{Hg})$. Na dose de $100 \mathrm{mg} / \mathrm{kg}$ observou-se também uma efeito protetor

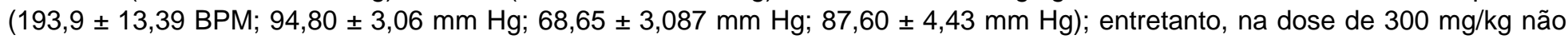
observou-se diferença estatística entre os grupos.

Discussão: Segundo El-Zaatari e colaboradores (2015), as alterações cardiovasculares provocadas pelo uso do narguilé a curto prazo são o aumento da frequência cardíaca e da pressão arterial. De acordo com Gardner e Mouton (2015), o álcool afeta o coração de maneira indireta, aumentando a pressão arterial através da modulação do sistema renina-angiotensina e da estimulação das vias de sinalização adrenérgicas, resultando em excesso de norepinefrina e efeitos cardiotóxicos; e direta, as altas concentrações de acetaldeído, atuam como toxina nos cardiomiócitos, resultando em disfunção mitocondrial e perda de proteínas contráteis. Em relação às bebidas energéticas, Miles-Chan e colaboradores (2015), afirmam que causam aumento da contratilidade miocárdica, da frequência cardíaca e do volume sistólico. Em ambos os estudos citados, os autores observaram de maneira isolada os fatores de risco em humanos, e ao comparar os fatores de risco em associação neste estudo pré-clínico, observa-se um aumento relevante dos parâmetros cardiovasculares, assegurando que os efeitos descritos de maneira isolada ocorrem também em associação, validando a hipótese sobre os efeitos prejudiciais da combinação dos múltiplos fatores de risco no sistema cardiovascular. Além disso, foi observado um importante efeito cardioprotetor com a menor dose da $B$. trimera, comprovando uma maior eficácia em sua utilização no sistema cardiovascular, reduzindo as chances de efeitos adversos, os níveis de toxicidade, e atestando a viabilidade da formulação de fitoterápicos seguros e eficazes. 
Conclusão: A associação dos múltiplos fatores de risco teve por consequência um aumento na frequência cardíaca e na pressão arterial dos animais. Entretanto, a B. trimera como agente terapêutico cardioprotetor neste modelo de estudo se mostrou muito promissor, resultando em reversão do quadro em sua menor dose.

\section{Referências}

APPELMAN, Yolande. et al. Sex differences in cardiovascular risk factors and disease prevention. Atherosclerosis, v. 241, n. 1, p. 211 218. 2015.

EL-ZAATARI, Ziad M.; CHAMI, Hassan. A.; ZAATARI, Ghazi. S. Health effects associated with waterpipe smoking. Tobacco Control, v. 24, n. Suppl 1, p. i31-i43. 2015.

GARDNER, Jason D.; MOUTON, Alan J. Alcohol effects on cardiac function. Comprehensive Physiology, v. 5, n. 2, p. $791-802$. 2015

HOYERT, Donna L.; XU, Jiaquan. Deaths: Preliminary data for 2011. National Vital Statistics Reports, v. 61, n. 6, p. 1/51. 2012.

LAITINEN, Tomi T. et al. Ideal cardiovascular health in childhood and cardiometabolic outcomes in adulthood: the Cardiovascular Risk in Young Finns Study. Circulation, v. 125, n. 16, p. 1971-1978. 2012.

$\mathrm{MENCl}$, Daniele. et al. Acute effects of an energy drink on myocardial function assessed by conventional echo-Doppler analysis and by speckle tracking echocardiography on young healthy subjects. Journal of Amino Acids, v. 2013, p. 7. 2013.

MILES-CHAN, Jennifer L. et al. The blood pressure-elevating effect of Red Bull energy drink is mimicked by caffeine but through different hemodynamic pathways. Physiological Reports, v. 3, n. 2. 2015.

PATRICK, Megan E.; MACUADA, Carlos; MAGGS, Jennifer L. Who uses alcohol mixed with energy drinks? Characteristics of college student users. Journal of American College Health, v. 64, n. 1, p. 74-79. 2016. 


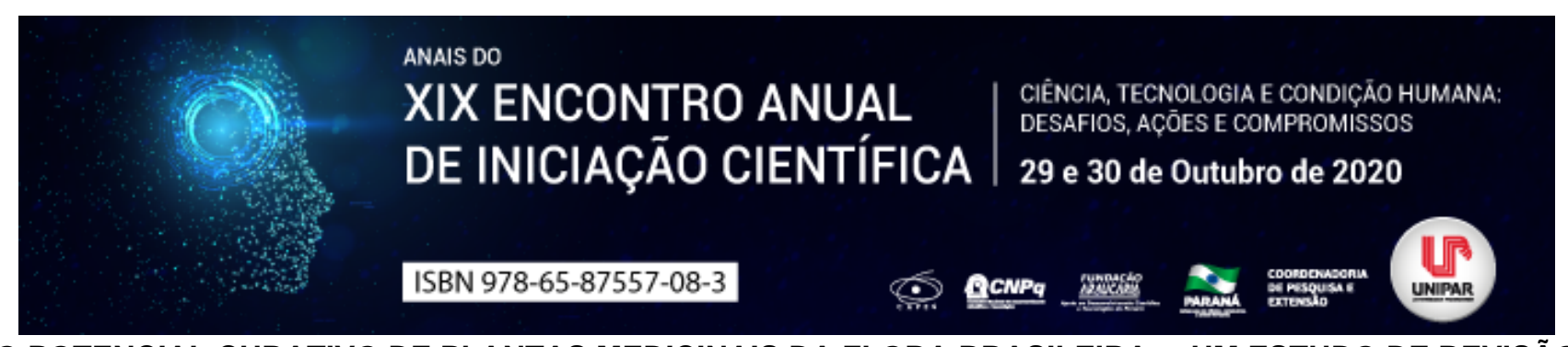

O POTENCIAL CURATIVO DE PLANTAS MEDICINAIS DA FLORA BRASILEIRA UM ESTUDO DE REVISÃO

\begin{abstract}
${ }^{1}$ HELOYSA PIRES, ${ }^{2}$ GUILHERME DE ALMEIDA FAHEL CHUEIRI, ${ }^{3}$ WESLEY ALVES TRINDADE, ${ }^{4}$ LIDIA KAZUE IUKAVA, ${ }^{5}$ PAULA MONTANHINI FAVETTA, ${ }^{6}$ RICARDO DE MELO GERMANO
\end{abstract}

\begin{abstract}
${ }^{1}$ Discente do curso de Medicina Veterinária da UNIPAR, Bolsista PIBIC/UNIPAR
${ }^{1}$ Discente do curso de Medicina Veterinária da UNIPAR, Bolsista PIBIC/UNIPAR

${ }^{2}$ Mestrando do Programa de Ciência Animal da UNIPAR, PIC/PG, Taxista PROSUP/CAPES

${ }^{3}$ Mestranda do Programa de Plantas Medicinais e Fitoterápicos, PIC/PG, Bolsista PIT/UNIPAR

${ }^{4}$ Doutoranda do Programa de Ciência Animal da UNIPAR, PIC/PG, Bolsista PROSUP/CAPES

${ }^{5}$ Docente do Programa de Pós-Graduação em Ciência Animal da UNIPAR
\end{abstract}

Introdução: A natureza é fonte de tratamentos medicinais há milhares de anos, com o uso de plantas como fonte para o desenvolvimento de medicamentos e para a extração de compostos ativos (ATAIDE et al., 2018). No Brasil, o uso de plantas medicinais e produtos naturais tem papel central na atenção primária à saúde, pois algumas comunidades têm pouco ou nenhum acesso aos medicamentos (MARMITT et al., 2018). A população brasileira tem longa tradição no uso de plantas medicinais para o tratamento de diferentes doenças agudas e crônicas. Isso chamou a atenção de Pesquisadores brasileiros e algumas empresas farmacêuticas brasileiras que estudam plantas medicinais nativas e seus princípios ativos. Mais recentemente, o uso de novas tecnologias, como abordagens proteômicas e genômicas, levou a um interesse recorrente em produtos naturais tanto da academia quanto de empresas farmacêuticas (DUTRA et al., 2016).

Objetivo: O objetivo deste estudo foi realizar uma revisão bibliográfica sobre o potencial curativo das plantas medicinais com enfoque nas plantas de origem brasileira

Desenvolvimento: Por milhares de anos, a natureza tem sido uma fonte de tratamentos medicinais, e os sistemas baseados em plantas continuam a desempenhar um papel essencial na atenção primária à saúde em todo o mundo, com compostos naturais sendo usados no cuidado de feridas de pele, especialmente devido a seus efeitos antiinflamatórios, antimicrobianos, e propriedades estimuladoras de células (PAZYAR et al, 2014). As informações sobre os benefícios quantitativos para a saúde humana de medicamentos à base de plantas ainda são raras ou dispersas, limitando sua avaliação adequada, necessitando mais estudos de alta qualidade necessários para estabelecer com firmeza a eficácia clínica das plantas. Nesse cenário, mais recentemente, pesquisas têm sido realizadas para comprovar a eficácia dos medicamentos fitoterápicos e para melhor compreender sua ação (DAS; BEHERA; PRAMANIK, 2017; PAZYAR et al., 2014). Uma planta é considerada medicinal quando é usada na reversão de diferentes condições de saúde, e quando esse efeito é atribuído à ação de seus constituintes, cuja atividade pode ser comprovada cientificamente (CHEN; CLAPP; MAGEN, 2004). Só com os avanços no campo da farmácia e da química é que o estudo das plantas medicinais torna-se uma ciência baseada em métodos experimentais (CECHINEL, 2012 ). Anteriormente e também atualmente em regiões menos desenvolvidas, o uso medicinal de plantas era geralmente empírico, e as informações eram passadas entre gerações em uma população nativa. Assim, este método ainda persiste em áreas rurais como o Cerrado brasileiro. Diante da enorme biodiversidade do Cerrado brasileiro, são poucos estudos etnobotânicos, e poucos são comprovados cientificamente (NETO et al., 2020). De todo potencial fitoterápico brasileiro apenas $8 \%$ das 55.000 espécies de plantas catalogadas já haviam sido estudadas para compostos bioativos e apenas 1.100 dessas espécies foram avaliadas quanto às suas propriedades medicinais (WALKER, 2013; SIMÕES et al., 2003). A população brasileira tem longa tradição no uso de plantas medicinais para tratamento de diferentes doenças agudas e crônicas. Isso chamou a atenção de Pesquisadores brasileiros e algumas empresas farmacêuticas brasileiras para estudar plantas medicinais nativas e seus princípios ativos (DUTRA et al., 2016). As políticas brasileiras têm incentivado a pesquisa para o desenvolvimento de medicamentos fitoterápicos, priorizando a proteção da biodiversidade e promovendo maior acesso a tratamentos seguros e eficazes desde 2006 (MARMITT et al., 2018). O Brasil passou a avaliar os medicamentos fitoterápicos de acordo com os mesmos padrões de segurança e qualidade dos medicamentos convencionais em 2004. Assim, o Ministério da Saúde brasileiro implantou a Política Nacional de Plantas Medicinais e Fitoterápicas (BRASIL, 2006), que, a partir de 2009, listava 71 plantas medicinais com diferentes propriedades terapêuticas, que foram então classificadas como de interesse para o Sistema Único de Saúde (BRASIL, 2009). Do total de estudos revisados referentes ao potencial curativo de plantas e ervas quase $40 \%$ foram realizados por pesquisadores brasileiros. Isso demonstra o aumento da ênfase no desenvolvimento e na pesquisa de medicamentos fitoterápicos de base vegetal no Brasil (MARMITT et al., 2018).

Conclusão: Apesar da abundante biodiversidade brasileira e das milhares de publicações acadêmicas sobre plantas em periódicos científicos internacionais revisado por pares, poucas patentes e medicamentos foram derivados desses estudos. Sem 
dúvida, grandes esforços devem ser feitos para melhorar o desenvolvimento do mercado de medicamentos derivados de plantas no Brasil.

\section{Referências}

ATAIDE, J. A. et al. Natural actives for wound healing: A review. Phytotherapy Research, Chichester, v. 32, n. 9, p. 1664-1674, 2018.

BRASIL. Ministério da Saúde. Secretaria de Ciência, Tecnologia e Insumos Estratégicos, Departamento de Assistência Farmacêutica. Política Nacional de Plantas Medicinais e Fitoterápicos. Brasília: Ministério da Saúde, p. 60, 2006.

BRASIL. Ministério da Saúde. RENISUS - Relação Nacional de Plantas Medicinais de Interesse ao SUS. Espécies vegetais. Portal, Saúde, 2009.

CECHINEL-FILHO, V. Plant Bioactives and drug discovery: Principles, practices and perspectives. John Wiley \& Sons, 2012.

CHEN, Y.; CLAPP, C. E.; MAGEN, H. Mechanisms of plant growth stimulation by humic substances: The role of organo-iron complexes. Soil Science and Plant Nutrition, Japan, v. 50, n. 7, p. 1089-1095, 2004.

DAS, U.; BEHERA, S. S.; PRAMANIK, K. Ethno-herbal-medico in wound repair: An incisive review. Phytotherapy Research, Chicheste, v. 31, n. 4, p. 579-590, 2017.

DUTRA, R. C. et al. Medicinal plants in Brazil: Pharmacological studies, drug discovery, challenges and perspectives. Pharmacological research, Amsterdam, v. 112, p. 4-29, 2016.

MARMITT, D. J. et al. The healing properties of medicinal plants used in the Brazilian public health system: a systematic review. Journal of wound care, London, v. 27, n. Sup6, p. S4-S13, 2018.

NETO, J. A. R. et al. Using the plants of Brazilian Cerrado for wound healing: From traditional use to scientific approach. Journal of Ethnopharmacology, Limerick, p. 112547, 2020.

PAZYAR, N. et al. Skin wound healing and phytomedicine: a review. Skin pharmacology and physiology, Switzerland, v. 27, n. 6, p. 303-310, 2014.

SIMÕES, C. M. O. et al. Farmacognosia: da planta ao medicamento. 05 ed. Editora da UFRGS /Editora UFSC, Florianópolis, 2003.

WALKER, T. O. D. The medicines trade in the Portuguese Atlantic world: acquisition and dissemination of healing knowledge from Brazil (c. 1580 1800). Social history of medicine, Oxford, v. 26, n. 3, p. 403-431, 2013.

Coordenadoria de Pesquisa e Extensāo - COPEX

Departamento de Editoraçāo e Divulgaçāo Científica - DEDIC 


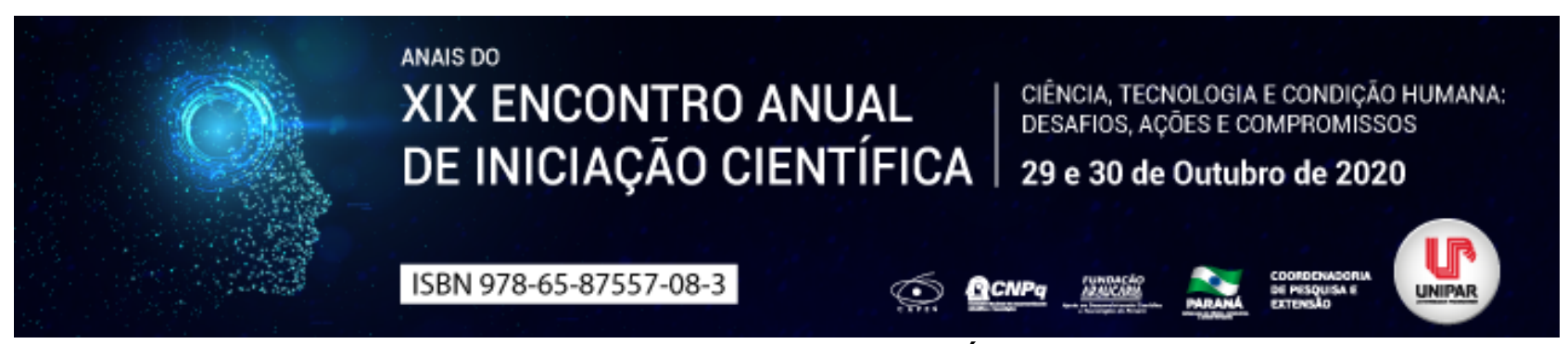

TRATAMENTO REPRODUTIVO COM PESSÁRIOS EM OVINOS

\author{
${ }^{1}$ TAINA LORRAINE PEREIRA AZEVEDO, ${ }^{2}$ GABRIELA GERALDO DE LIMA, ${ }^{3}$ LUAN SITÓ DA SILVA, ${ }^{4}$ ANTONIO CAMPANHA \\ MARTINEZ
}

${ }^{1}$ Discente do curso de Medicina Veterinária pela Universidade Estadual de Maringá (UEM).

${ }^{1}$ Discente do curso de Medicina Veterinária pela Universidade Estadual de Maringá (UEM).

${ }^{2}$ Mestrando pela Universidade Estadual de Maringá ( UEM).

${ }^{3}$ Docente do curso de Medicina Veterinária pela Universidade Estadual de Maringá (UEM).

Introdução: Os ovinos domésticos (ovis aries) apresentaram mais de 1,1 bilhão de animais pelo mundo em 2016, no Brasil, somaram cercam de 18,4 milhões, responsáveis pela produção de carne, leite, lã e couro (FAO, 2019). O crescente consumo e comercialização são responsáveis pelo desenvolvimento de manejos reprodutivos, condições sanitárias, nutricionais e de bemestar animal adequado a fim de alcançar melhor eficiência reprodutiva. Estacionalidade reprodutiva, prolificidade e período curto de gestação são características da espécie ovina. Os ovinos são poliéstricos estacionais de dia curtos, ou seja, apresentam a fase de estro, geralmente no outono. Em áreas subequatoriais, animais que possuem um bom aborte nutricional ciclam o ano todo, devido a menor interferência luminosa. Apresentam cinco meses de gestação, capazes de parir em média 2,1 cordeiros em um ano. E comummente, apresentam parto gemelar fator dependente de uma boa dieta nutricional, as fêmeas multíparas apresentam maior prolificidade do que as fêmeas prímiparas. A sincronização de cio é uma tecnologia frequentemente adotada em animais de produção, possuindo inúmeras vantagens como: uso máximo dos reprodutores, sincronização de partos facilitando o manejo sanitário e nutricional, lotes homogêneos de cria e recria, uso eficiente da inseminação artificial, parição no outono/inverno e aumento do número de partos durante a vida reprodutiva do animal. A sincronização de cio baseia se na concentração de animais em estro em intervalo de tempo restrito durante estação de acasalamento, onde o estro é manifestado por meio de técnicas que utilizam hormônios, programas de luz artificial e efeito macho. O tratamento comumente utilizado são pessários intravaginais impregnados com acetato de medroxiprogesterona, acetato de fluorogestone ou implante que possuem norgestomet, em torno de sete a 16 dias alcançando sucesso reprodutivo durante a estação reprodutiva e não reprodutiva (PACHECO et al, 2010; Riet-Correa et al, 2007).

Objetivo: Verificar a eficiência de dois tempos de permanência de pessário reprodutivo em ovelhas.

Material e Métodos: Foram utilizadas 20 fêmeas ovinas e dois protocolos diferentes de sincronização de cio, um grupo de ciclo curto (sete dias) e outro de ciclo longo (12 dias), ambos com 10 animais. No dia zero foi inserido o pessário contendo 50mg de acetato de medroxiprogesterona $\left(\right.$ Anticion $^{\circledR}$ ) com aplicador intravaginal em cada animal, o grupo de ciclo curto foi feita a retirada sete dias após a inserção e aplicação de 20mg de prostaglandina (Prolise) no momento da remoção, já o grupo do ciclo longo foi retirado no dia 12 e também feita aplicação de 20mg de prostaglandina. Após a retirada foi colocado o macho, com colar marcador, juntamente às ovelhas para monta controlada durante 16 dias, passado mais 15 dias foi realizado o diagnóstico ultrassonográfico de prenhez.

Resultados: Todas as ovelhas do ciclo longo manifestaram vulvovaginite e aderência de pessários. Não houve diferença entre as taxas de prenhez. No ciclo considerado curto, sete ovelhas emprenharam, já no ciclo longo, cinco animais emprenharam.

Discussão: É sabido que utilização do ciclo longo nos ovinos leva ovulação de folículos mais jovens e não somente dos mais maduros, entretanto animais que ciclam frequentemente não há este desafio. Foi observado que o efeito de indução de estro por meio de protocolos longo e curto nas ovelhas e em cabras, sobre os parâmetros reprodutivos, o protocolo de dia curto apresentou resultados mais robustos em cabras para taxa de fertilidade ao diagnóstico de gestação, taxa de fertilidade ao parto e número de cabritos pelo total de cabras inseminadas (STELLFLUG et al, 1994). Ao contrário, em ovelhas, o protocolo longo mostrou média superior em 19,4 \% para a taxa de fertilidade ao parto quando comparado às cabras. RUBIANES et al., (2000) compararam maior eficiência quando associaram ciclo curto mais aplicação de gonadotrofina coriônica equina (eCG) . No estudo realizado por CATARINO (2019) comparando ciclo longo e curto, neste caso o longo com 12 dias e o curto com oito dias, observou menor taxa de fertilidade ao diagnóstico de gestação e menor taxa de fertilidade ao parto nos ciclos curtos.

Conclusão: Não há diferença na taxa de prenhez ao utilizar sincronização do estro com pessário vaginal inserido por 7 ou 12 dias.

\title{
Referências
}

CATARINO, J. M. G. Comparação de protocolos sincronizativos curtos e longos em raças autóctones de ovinos e caprinos. 2019. Dissertação de Mestrado. 
FAO. Dairy production and products. Small ruminants. 2017. Disponível em: http://www.fao.org/dairy-productionproducts/production/dairy-animals/small-ruminants/en/ Acesso em: 19 ago. 2020.

PACHECO, A.; QUIRINO, C. R. Comportamento sexual em ovinos. Revista Brasileira de Reprodução Animal, v. 34, n. 2, p. 87-97, 2010.

RIET-CORREA, F.; MENDEZ, M. C. Mortalidade perinatal em ovinos. p. 417-424. In: RIET-CORREA, F.; SCHILD, A. L.; MENDEZ, M. C.; LEMOS, R. A. A. Doenças de ruminantes e equinos. $2^{\text {a }}$ edição, São Paulo, Varela, v. 2, p.574, 2001.

STELLFLUG, J. N.; RODRIGUEZ, F.; LAVOIE, V. A.; GLIMP, H. A., Influence of simulated photoperiod alteration and induced estrus on reproductive performance of spring-born Columbia and Targhee ewe lambs, Journal of Animal Science, Volume 72 , Issue 1, p. 29 33, January 1994.CATARINO, J. M. G. Comparação de protocolos sincronizativos curtos e longos em raças autóctones de ovinos e caprinos. 2019. Dissertação de Mestrado.

FAO. Dairy production and products. Small ruminants. 2017. Disponível em: http://www.fao.org/dairy-productionproducts/production/dairy-animals/small-ruminants/en/ Acesso em: 19 ago. 2020.

PACHECO, A.; QUIRINO, C. R. Comportamento sexual em ovinos. Revista Brasileira de Reprodução Animal, v. 34, n. 2, p. 87-97, 2010.

RIET-CORREA, F.; MENDEZ, M. C. Mortalidade perinatal em ovinos. p. 417-424. In: RIET-CORREA, F.; SCHILD, A. L.; MENDEZ, M. C.; LEMOS, R. A. A. Doenças de ruminantes e equinos. $2^{\mathrm{a}}$ edição, São Paulo, Varela, v. 2, p.574, 2001.

STELLFLUG, J. N.; RODRIGUEZ, F.; LAVOIE, V. A.; GLIMP, H. A., Influence of simulated photoperiod alteration and induced estrus on reproductive performance of spring-born Columbia and Targhee ewe lambs, Journal of Animal Science, Volume 72 , Issue 1, p. 29 33, January 1994. 


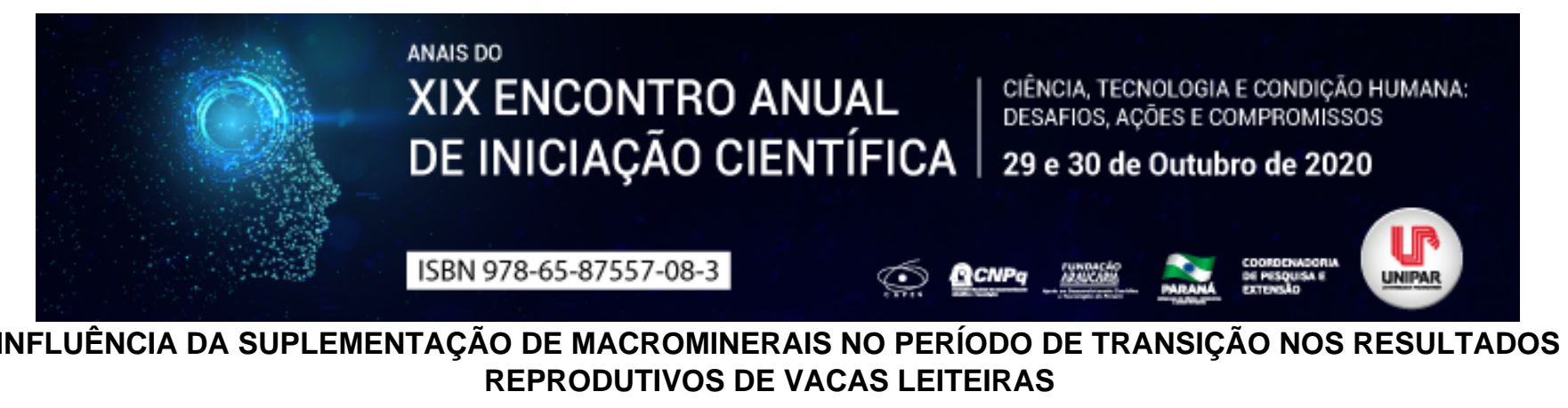

${ }^{1}$ Sarah Araujo Amorim dos Santos, ${ }^{2}$ JESSICA PRISCILA DA PAZ , ${ }^{3}$ SARAH DE ANDRADE DIAS RODRIGUES

\author{
${ }^{1}$ ACADÊMICA DE MEDICINA VETERINÁRIA UEM \\ ${ }^{1}$ ACADÊMICA DE MEDICINA VETERINÁRIA UEM \\ ${ }^{2}$ Docente da UEM
}

Introdução: Vacas leiteiras experienciam um déficit nutricional acompanhado por deficiência imune e por um balanço energético negativo, sendo observada também a redução na ingestão de ração no período de transição. Em razão do status metabólico supracitado, as vacas ficam mais suscetíveis a enfermidades no começo do período pré e pós-parto, o que pode impactar negativamente na fertilidade das mesmas (MACMILLAN et al., 2020).

Objetivo: A revisão bibliográfica ora apresentada visa realizar um levantamento da influência dos macrominerais, magnésio ( $\mathrm{Mg}$ ) e cálcio (Ca), durante o período de transição e nos resultados reprodutivos de vacas leiteiras.

Desenvolvimento: Durante o período de transição, compreendendo três semanas antes e depois do parto, vacas leiteiras demandam maior quantidade de nutrientes para suprir as exigências nutricionais do feto, assim como para o desenvolvimento da glândula mamária (JOLAZADEH et al, 2018). Tendo isso em vista, a concentração sérica de magnésio pode ser um biomarcador útil de saúde no pré e pós-parto, assim como de desempenho reprodutivo (JEONG et al., 2018). Vacas lactantes podem esgotar a reserva de $\mathrm{Mg}$ rapidamente uma vez que sua concentração no colostro é cerca de três vezes maior que no leite normal (TSIOULPAS; GRANDISON; GRANDISON, 2007). Tal fato pode levar a uma hipomagnesemia, se não for reposto, a qual está correlacionada com uma hiperexcitabilidade, visto que o Mg mantém o potencial elétrico das membranas nervosas e musculares (NATIONAL RESEARCH COUNCIL, 2005). Juntamente a isso, a literatura confirma que baixas concentrações circulantes de Mg interferem nas concentrações de Ca podendo levar a hipocalcemia (GOBIKRUSHANTHA et al., 2020), já que o Mg influência na produção do hormônio da paratireóide (GOFF, 2008). De fato foi relatado que vacas suplementadas com Mg, durante o período de transição, apresentaram baixa ocorrência de doenças como distocia, retenção de placenta, endometrite e claudicação (JEONG et al., 2018). Ademais, vacas leiteiras que se encontravam com alta concentração de Mg no plasma exibiram taxas superiores de retomada da ciclicidade na oitava semana, maior probabilidade de sucesso à inseminação artificial no $150 \mathrm{~d}$ in milk- DIM (150 dia pós-parto) e prenhes no 210 DIM, resultando em um encurtamento médio de 25 dias entre parto e concepção (JEONG et al., 2018). Esses resultados corroboram com os dados de outro estudo o qual demonstrou que vacas que não se encontravam prenhas no 150 DIM continham baixa concentração de Mg. Esse acontecimento pode indicar uma redução do consumo de matéria seca e consequentemente um balanço energético negativo (MACMILLAN et al., 2020), posto que o Mg é adquirido por meio da dieta (GOFF, 2008). Somando a isso, pesquisas também revelam que elevadas concentrações de Ca na dieta evidenciam resultados reprodutivos com uma perspectiva positiva, contando com baixos distúrbios metabólicos (RYAN et al., 2019). Isso foi demonstrado por Ryan e colaboradores (2019), visto que vacas submetidas à dieta com alto teor de Ca, no pré-parto, dispuseram de uma diminuição no número de dias até a ovulação, uma tendência a diminuição do serviço por taxa de concepção e uma propensão a aumentar a proteína ocludina da proteína de junção oclusiva (RYAN et al., 2019), a qual ajuda na manutenção da impermeabilidade do útero, mantendo uma barreira contra agentes externos (RYAN et al., 2019). Já outras pesquisas demostraram que vacas que possuem baixa concentração sérica de Ca tem um índice maior de distúrbios de saúde no pré e pós-parto visto que exibiram altas concentrações de ácidos graxos não esterificados e aspartato aminotransferase, os quais são indicadores de balanço energético negativo e um aumento na circulação de ureia, a qual sinaliza um provável aumento na mobilização de proteínas do músculo para contrapor o déficit de energia(GOBIKRUSHANTHA et al., 2020). Resultados também expressaram que a proporção de vacas ciclando no 35 DIM (GOBIKRUSHANTHA et al., 2020) e detecção de prenhes após a primeira IA tendeu a ser reduzida em vacas com baixa concentração de Ca e um período de serviço maior (MACMILLAN et al., 2020).

Conclusão: Associando as informações recrutadas dos artigos revisados, é notório a influência da suplementação de macrominerais, magnésio e cálcio, de modo positivo na performance reprodutiva de vacas leiteiras durante o período de transição, como o encurtamento do período de serviço, maiores taxas reprodutivas e a prevenção contra possíveis patologias.

\title{
Referências
}

GOBIKRUSHANTH,Mohanathas;MACMILLAN,Kira;BEHROUZI,Amir;LÓPEZ-HELGUERA,Irene;HOFF, Brent; COLAZO,Marcos G. Circulating $\mathrm{Ca}$ and its relationship with serum minerals, metabolic and T nutritional profiles, health disorders, and productive and reproductive outcomes in dairy cows. Livestock Science, v. 233, Mar, 2020. Disponível em: 
https://www.sciencedirect.com/science/article/abs/pii/S1871141319317226?via\%3Dihub. Acesso em: 19 ago. 2020.

GOFF, Jesse. The monitoring, prevention, and treatment of milk fever and subclinical hypocalcemia in dairy cows. The Veterinary Journal, v. 176, n. 1, Abr, 2008. Disponível em:https://www.sciencedirect.com/science/article/abs/pii/S1090023307004248? via\%3Dihub. Acesso em: 22 ago .2020.

JEONG,Jae; CHOI,In; MOON,Sung;KANG,Hyung;KIM,IIl. Relationship between serum magnesium concentration during the transition period, peri- and postpartum disorders, and reproductive performance in dairy cows. Livestock Science, v. 213, Jul, 2018. Disponível em: https://www.sciencedirect.com/science/article/abs/pii/S1871141318301094?via\%3Dihub. Acesso em : 23 ago. 2020.

JOLAZADEH,Alireza;MOHAMMADABADI,Tahereh;DEHGHAN-BANADAKY,Mehdi;CHAJI,Morteza; GARCIA,Miriam. Effect of supplementing calcium salts of $n-3$ and n-6 fatty acid to pregnant nonlactating cows on colostrum composition, milk yield, and reproductive performance of dairy cows. Animal Feed Science and Technology, v. 247, Jan, 2019. Disponível em: https://www.sciencedirect.com/science/article/pii/S0377840118309957?via\%3Dihub. Acesso em: 19 ago. 2020.

MACMILLAN, Kira; GOBIKRUSHANTH, Mohanathas; LOPEZ HELGUERA, Irene; BEHROUZI, Amir; COLAZO, Marcos. Relationships between early postpartum nutritional and metabolic profiles and subsequent reproductive performance of lactating dairy cows. Theriogenology, v. $151, \quad$ Jul, $2020 . \quad$ Disposição https://www.sciencedirect.com/science/article/abs/pii/S0093691X20302065?via\%3Dihub. Acesso em: 18 ago. 2020.

National Research Council. Mineral tolerance of animals. 7.ed. Washington, DC.: National Academy Press, 2005.

RYAN, Kelly; GUADAGNIN, Anna; GLOSSON, K.; BASCOM, Scott; ROWSON, Angela; STEELMAN, Andrew; CARDOSO, Felipe. Increased dietary calcium inclusion in fully acidified prepartum diets improved postpartum uterine health and fertility when fed to Holstein cows. Theriogenology, v. 142, Jan, $2020 . \quad$ Disponível https://www.sciencedirect.com/science/article/abs/pii/S0093691X19304674. Acesso em: 18 ago. 2020.

TSIOULPAS, Alexandros; GRANDISON, Alistair; LEWIS, Michael. Change in physical properties of bovine milk from the colostrum period to early lactation. Journal of Dairy Science, v. 90, n. 11, Nov, $2007 . \quad$ Disponível em: https://www.sciencedirect.com/science/article/pii/S0022030207719690. Acesso em: 22 ago. 2020. 


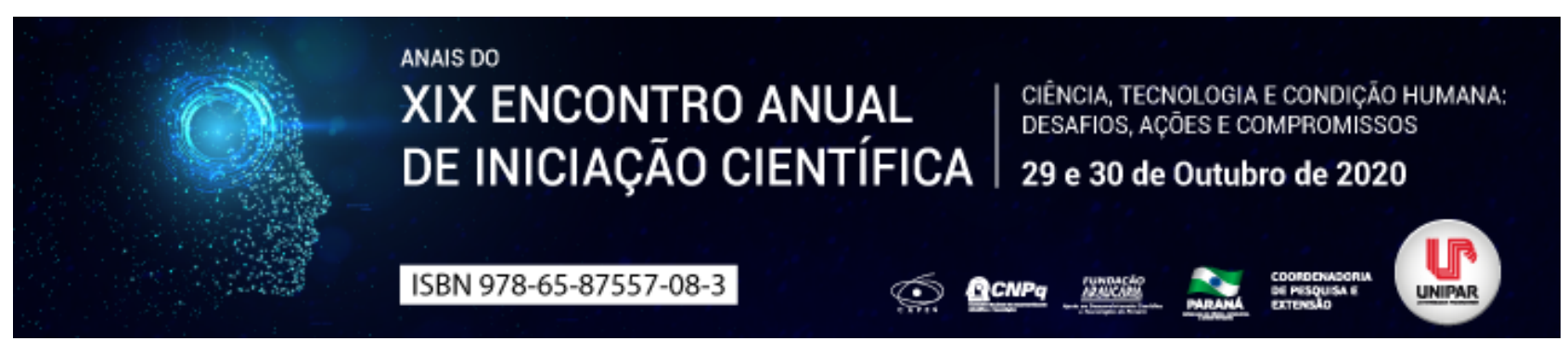

OBSTRUÇÃO ESOFÁGICA EM POTRO RELATO DE CASO

\begin{abstract}
${ }^{1}$ Derek Willy Galdioli Silveira, ${ }^{2}$ JEFERSON CARLOS GANDINI, ${ }^{3}$ DANTHYSE MIYOKO OHNO MÜLLER DE SOUZA, ${ }^{4}$ ARISLA VILLAS BOAS LIZZI, ${ }^{5}$ GABRIELA GERALDO DE LIMA, ${ }^{6}$ MAX GIMENEZ RIBEIRO
\end{abstract}

\author{
${ }^{1}$ Discente de Medicina Veterinária UEM/Campus Regional de Umuarama-PR \\ ${ }^{1}$ Médico Veterinário Residente em Clínica Médica e Cirúrgica de Grandes Animais \\ ${ }^{2}$ Médico Veterinário Residente em Clínica Médica e Cirúrgica de Grandes Animais \\ UEM/Campus Umuarama-PR \\ ${ }^{3}$ Discente de Medicina Veterinária \\ UEM/Campus Regional de Umuarama-PR \\ ${ }^{4}$ Discente de Medicina Veterinária \\ UEM/Campus Regional de Umuarama-PR \\ ${ }^{5}$ Docente do curso de Medicina Veterinária UEM/Campus Regional de Umuarama-PR
}

Introdução: A obstrução esofágica é a afeção de esôfago com maior ocorrência nos equinos, decorrente de obstrução física por alimento ou corpos estranhos (CAMACHO \& ANDREWS, 2015). A obstrução primária pode ocorrer pela rápida ingestão de alimentos, de má qualidade ou mal mastigados. Em animais jovens, as obstruções podem ocorrer por conta da mastigação inadequada, erupção dentária, ingestão de corpos estranhos e distúrbios congênitos. Já nos idosos ocorre devido a neoplasias, mastigação imprópria ou a presença de úlceras orais. A obstrução também pode ser de origem secundária, onde fatores externos diminuem o lúmen do esôfago por compressão, como neoplasias e abcessos (MUELLER \& MOORE, 2008). O sinal clinico mais observado em casos de obstrução esofágica é a incapacidade de deglutição de alimentos ou água, chamada de disfagia. $\mathrm{O}$ animal deve engolir saliva ou saliva misturada com alimentos e podem fazer múltiplas tentativas de engolir. Isso pode levar a tosse e, muitas vezes, a água e / ou alimento sai das narinas, resultando em uma descarga nasal espessa, com presença de particulas de alimentos (DUGGAN, 2004). As obstruções ainda podem ser classificadas quanto a localização, podendo ser em região cervical ou torácica. Na obstrução cervical, na maioria das vezes, é possível identificar uma massa sobre a traqueia por meio de palpação. Quando a obstrução é em região torácica, não há a possibilidade de se realizar a palpação, sendo reservado o prognóstico. A realização de exames de ultrassonografia, radiografia, endoscopia e a incapacidade de introduzir sonda nasogástrica podem confirmar o diagnóstico (MUELLER \& MOORE, 2008).

Relato de Caso: No dia 26 de junho de 2020, foi encaminhado para o Hospital Veterinário da UEM, campus Umuarama, um potro macho, da raça Quarto de Milha, com 1 ano e 4 meses de idade, pesando 300 quilos. Durante a anamnese, o proprietário relatou que havia feito alterações na dieta do animal, onde o mesmo se alimentava de ração, e passou a ser fornecido quirera de milho. Depois de 10 dias após a troca do alimento, o potro começou a demonstrar dificuldades na deglutição, notou-se o surgimento de uma massa no pescoço do animal, além disso, também apresentava descarga nasal. Na propriedade, o animal foi medicado com anti inflamatório flunixim meglumine e com antibiótico penicilina, porém, não havendo responsividade ao tratamento. Ao realizar o exame físico, o paciente apresentou temperatura retal de $37,5^{\circ} \mathrm{C}$, na auscultação pulmonar não havia alterações, com frequência respiratória de 16 movimentos por minuto, frequência cardíaca de 40 batimentos por minuto, e tempo de reperfusão capilar de 2 segundos, e a massa cervical estava situada na região proximal do esofago, com consistência firme e aderida, com aproximadamente 10 centímetros de diâmetro. A fim de um diagnóstico preciso, foi realizado o exame de endoscopia, onde foi possivel observar focos inflamatórios, com coloração e aspecto diferentes do esofago sadio. No ponto em que havia o edema cervical, o esofago estava com seu lúmen reduzido, observando-se área de estenose, que dificultava o animal na deglutição, confirmando assim a obstrução esofágica. Dado o diagnóstico, institui-se o tratamento com ranitidina $2 \mathrm{mg} / \mathrm{kg}$ intavenoso duas vezes ao dia e omeprazol $10 \mathrm{~g}$ via oral, uma vez ao dia, a fim de reduzir a inflamação esofágica. $O$ paciente teve alta no dia 27 de junho, sob orientação para retornar com a antiga dieta gradativamente, restringir o fornecimento de quirera de milho, e manter o tratamento estabelecido.

Discussão: $O$ animal citado no relato, teve um quadro de obstrução esofágica pela formação de edema, devido á alimentação de baixa qualidade, fazendo com que houvesse dificuldade na deglutição. No trabalho realizado por Arruda (2019), na UFPB, no campus de Areia/PB, foi relatado um atendimento a um animal que estava em um quadro de obstrução por corpo estranho, o qual foi diagnosticado através do histórico, exame radiológico e endoscópico, que no caso era um caroço de manga, onde o mesmo foi submetido ao procedimento de esofagotomia, a fim de realizar a desobstrução. Houve tentativas de remover o corpo estranho através de sondagem, porém, sem sucesso. Em um relato descrito por Mariz (2017), também na UFPB, o paciente atendido também apresentava sinais como a dificuldade de deglutição e descarga nasal. Durante a auscultação pulmonar, foi notado a presença de sibilos no pulmão. Além disso, o animal foi submetido a um exame ultrassonográfico da região torácica, onde foram observados áreas e pontos hiperecóicos na porção ventral do parênquima pulmonar, evidenciando sinais de pneumonia. Esse paciente veio a óbito, e na necrópsia notou-se uma massa no esôfago, que impedia a passagem da ingesta, 
voltando e fazendo falsa via, desencadeando o quadro de pneumonia aspirativa.

Conclusão: O animal citado acima, foi atendido com o intuito de realizar o diagnóstico da afecção esofágica, tendo como motivo principal o exame endoscópico, onde foi possível detectar a causa da obstrução com exito.

\section{Referências}

ARRUDA, David Bezerra Assuncao Kessuane de. Obstrução esofágica e esofagotomia em estação em equino - Relato de caso / Orientação: Natália Matos Souza Azevedo. Monografia (Graduação) - UFPB/CCA- Areia, 2019.

CAMACHO-LUNA P \& ANDREWS FM. Esophageal Disease. In Robinson's Current Therapy in Equine Medicine ed. Sprayberry, K.A. \& Robinson, N.E., Saunders Elsevier, EUA, ISBN: 978-1-4557-4555-5, pp. 274-275, 2015.

DUGGAN V.E. ET BENTZ B.G. - Oesophageal Obstruction in Horses. Compend. Association of equine practices. 26 (11), $877-$ 884, 2004.

MARIZ, Eduardo Lourenço. Obstrução esofágica em equino Relato de caso. Orientação: Isabella de Oliveira Barros. Monografia (Graduação) - UFPB Areia, 2017.

MUELLER, P. \& MOORE, J. Gastrointestinal emergencies and other causes of colic. In J. ORSINI \& T. DIVERS, Equine Emergencies: Treatment and Procedures (3 $\mathbf{e d}$.). St. Louis: Saunders, Elsevier Inc. 2008.

Coordenadoria de Pesquisa e Extensão - COPEX

Departamento de Editoraçāo e Divulgaçāo Científica - DEDIC 


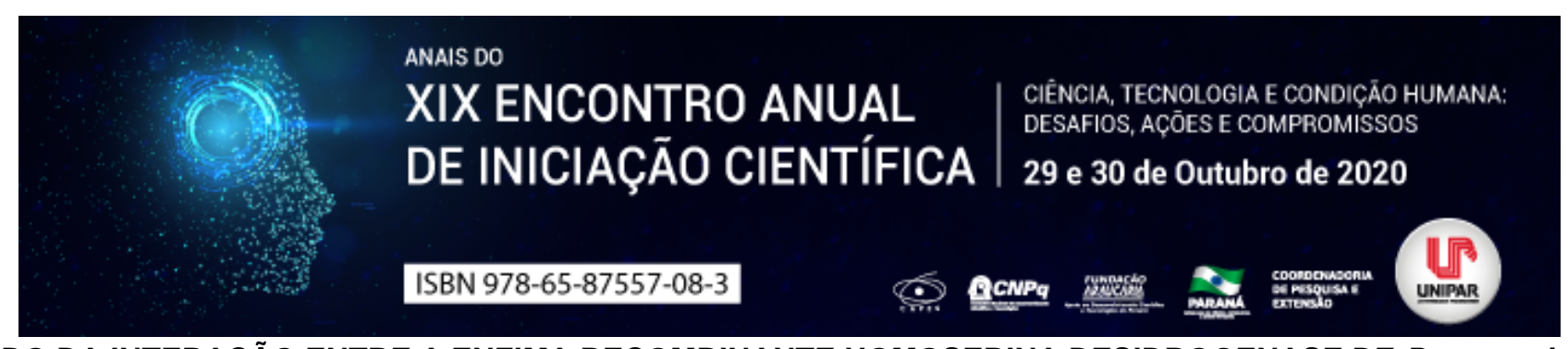

ESTUDO DA INTERAÇÃO ENTRE A ENZIMA RECOMBINANTE HOMOSERINA DESIDROGENASE DE Paracoccidioides brasiliensis COM O INIBIDOR HS2

\author{
${ }^{1}$ Samara Bossa Aleixo, ${ }^{2}$ KAUANA CAROLINE DOS SANTOS GARCIA, ${ }^{3}$ ELISANGELA ANDRADE ÂNGELO, ${ }^{4}$ GISELE DE \\ FREITAS GAUZE, ${ }^{5}$ FERNANDA CANDURI, ${ }^{6}$ FLÁVIO AUGUSTO VICENTE SEIXAS
}

\begin{abstract}
${ }^{1}$ Acadêmica do PIC/UEM
${ }^{1}$ Acadêmica do PIC/UEM

${ }^{2}$ Doutorado em Biologia Celular e Molecular PBC/UEM

${ }^{3}$ Professora do Programa de pós-graduação em Química PQU/UEM

${ }^{4}$ Professora do Programa de pós-graduação em Química IQSC/USP

${ }^{5}$ Professor do Mestrado em Produção Sustentável e Saúde Animal PPS/UEM
\end{abstract}

Introdução: A paracoccidioidomicose (PCM), uma das mais pertinentes infecções fúngicas na América Latina, é responsável por alto número de óbitos no Brasil (BAGATIN et al., 2017). Seu agente etiológico é o Paracoccidioides brasiliensis, cuja infecção se dá pela inalação ou por feridas cutâneas, podendo se alastrar para outros órgãos e causar infecções secundárias em linfonodos, pele, mucosas e glândulas suprarrenais. O tratamento farmacológico para a PCM consiste em antifúngicos de amplo espectro por vários meses (até dois anos), o que pode levar ao abandono da medicação pelo paciente, surgimento de cepas resistentes e ainda sequelas como a fibrose pulmonar (YASUDA et al., 2006). Nesse sentido, pesquisas com o objetivo de desenvolver novos antifúngicos têm importância científica e médica. Desse modo, a homoserina desidrogenase, uma enzima constituinte de fungos e bactérias e ausente em mamíferos, vem sendo analisada como alvo de fármacos (THOMAS et al., 1993). Moléculas que inibam a HSD são potenciais candidatos a agentes farmacológicos contra esta infecção (DELABARRE et al., 2000).

Objetivo: Avaliar a interação da enzima recombinante homoserina desidrogenase de Paracoccidioides brasiliensis (PbHSD) com molécula candidata a fármaco HS2 por meio de estudos de binding.

Materiais e métodos: Foi feito um tampão de trabalho tris- $\mathrm{HCl} 50 \mathrm{mM}+\mathrm{NaCl} 20 \mathrm{mM}$ em pH 8.0. A enzima recombinante PbHSD a $2,8 \mathrm{mg} / \mathrm{mL}$ foi gentilmente cedida pela Dra. Fernanda Canduri do IQSC-USP. Um volume de $200 \mathrm{uL}$ foram lavados com $2 \mathrm{~mL}$ de tampão de trabalho e concentrada até $\sim 5,5 \mathrm{mg} / \mathrm{mL}=140 \mu \mathrm{M}$ em $100 \mu \mathrm{L}$. O ligante HS2 (2,8 mg) foi dissolvido em $300 \mu \mathrm{L}$ de DMSO + $60 \mu \mathrm{L} \mathrm{NaOH} \mathrm{0,1M}$, estando na concentração final de 7,8 mg/mL. Para o experimento de estabilidade da droga frente a exposição a luz UV, foram adicionados $796 \mu \mathrm{L}$ de tampão de trabalho em 2 cubetas (amostra e referência), e a linha de base coletada entre 500 a $225 \mathrm{~nm}$. Em seguida foi adicionado $4 \mu \mathrm{L}$ de DMSO na referência e $4 \mu \mathrm{L}$ de solução HS2 na amostra, sendo coletado um espectro de varredura no tempo 0 minutos e, a cada 10 minutos até 40 minutos. Para a titulação da solução de HS2 com $\mathrm{PbHSD}$ recombinante, foi adicionado em uma cubeta $797 \mu \mathrm{L}$ de tampão tris- $\mathrm{HCl} 50 \mathrm{mM}+\mathrm{NaCl} 20 \mathrm{mM}$ pH $8,0, \mathrm{mais} 2 \mu \mathrm{L}$ de solução de NADP+ 6 mM (cofator) e foi feita uma linha de base. Em seguida, adicionou-se 1,5 $\mu \mathrm{L}$ da solução de HS2 na amostra e 1,5 $\mu \mathrm{L}$ de DMSO na referência e, um espectro foi coletado. Alíquotas de $5 \mu \mathrm{L}$ da solução estoque de PbHSD na concentração de $140 \mu \mathrm{M}$ dissolvida no mesmo tampão, foram adicionadas e, um espectro foi coletado após 2 minutos de cada adição. O mesmo experimento foi realizado com a albumina do soro bovino (BSA) como controle positivo da reação. Os ensaios, tanto com $\mathrm{PbHSD}$ quando com BSA, foram realizados em duplicata. O experimento foi feito em um espectrofotômetro de varredura modelo UV1650-PC (Shimadzu, Japan) com temperatura controlada de $25^{\circ} \mathrm{C}$.

Resultados: No experimento de estabilidade com o HS2 não sofreu variação espectral, o que indica que a droga é estável frente a exposição a luz UV. A constante de dissociação do HS2 na PbHSD foi de $\sim 6,4$ uM enquanto que a constante de dissociação do HS2 na BSA foi de $\sim, 7$ uM. Este resultado sugere que a BSA tem maior afinidade com o HS2 em relação à PbHSD. Este experimento demonstrou que o HS2 se liga a um alvo específico atuando como drug like , uma característica desejada para candidatos a fármacos.

Discussão: Fármacos (e moléculas ativas) estão sujeitos a degradação por exposição ao calor ou a luz UV, o que causa variação no espectro de absorção (Abs), o que pode interferir nos estudos da atividade. Assim, se a Absorbância variar em função da exposição a luz do espectrofotômetro, não seria possível determinar se a origem da variação foi ocasionada pela inibição da enzima ou pela degradação da droga. A constante de ligação, da ordem de micromolar é bastante promissora, pois, embora o desejável seja obter valores da ordem de nanomolar, é possível fazer pequenas modificações químicas na estrutura do HS2 para aumentar sua afinidade. De qualquer forma, os resultados apresentados neste trabalho são interessantes pois não há no mercado fármacos cujo alvo seja a enzima HSD. Embora não seja objetivo deste trabalho, nossos colaboradores já observaram a atividade antibacteriana in vitro do HS2, demonstrando a efetividade do candidato a fármaco, porém, ensaios de citotoxicidade deverão ser realizados. 
Conclusão: Os resultados sugerem que a molécula HS2 se liga na enzima PbHSD com uma constante de ligação (KB) de 6,4 \pm $1,4 \mu \mathrm{M}$ confirmando os resultados encontrados nas simulações de docking publicadas em trabalhos anteriores por nosso grupo (SEIXAS et al., 2017), o qual identificou o HS2 como possível candidato a inibidor da PbHSD. Como era de se esperar, a Soro Albumina Bovina possui uma afinidade maior pelo HS2 em relação a PbHSD, com uma constante de ligação (KB) de 4,7 $\pm 1,0$ $\mu \mathrm{M}$.

\section{Referências}

BAGATIN, Mariane C. et al. Targeting homoserine dehydrogenase from Paracoccidioides Genus against systemic fungal 3 infections. Antimicrobial Agents and Chemotherapy, V. 61, n. 9, Aug, 2017. Disponível em: https://aac.asm.org/content/aac/early/2017/06/20/AAC.00165-17.full.pdf Acesso em: 28 ago. 2020.

BAGATIN, Mariane $C$. et al. Targeting the homoserine dehydrogenase of Paracoccidioides species for treatment of systemic fungal infections. Antimicrobial agents and chemotherapy, v. 61, n. 9, June, 2017. Disponível em: https://aac.asm.org/content/aac/61/9/e00165-17.full.pdf. Acesso em: 20 ago. 2020.

DELABARRE, Byron; THOMPSON, Paul R.; WRIGHT, Gerard D.; BERGHUIS, Albert M. Crystal structures of homoserine dehydrogenase suggest a novel catalytic mechanism for oxidoreductases. Nature Structural Biology, v. 7, n. 3, March, 2000. Disponível em: https://www.nature.com/articles/nsb0300_238. Acesso em: 28 ago. 2020.

SHIKANAI-YASUDA, Maria Aparecida et al. Consenso em paracoccidioidomicose. Revista da sociedade brasileira de medicina tropical. Mai-jun, 2006. Disponível em: https://www.scielo.br/pdf/rsbmt/v39n3/a17v39n3.pdf. Acesso em: 20 ago. 2020.

THOMAS, Dominique; BARBEY, Régine; SURDIN-KERJAN, Yolande. Evolutionary relationships between yeast and bacterial homoserine dehydrogenases. Federation of European Biochemical Societies, v. 323, n. 3, Jun, 1993. Disponível em: https://febs.onlinelibrary.wiley.com/doi/epdf/10.1016/0014-5793\%2893\%2981359-8. Acesso em: 19 ago. 2020. 


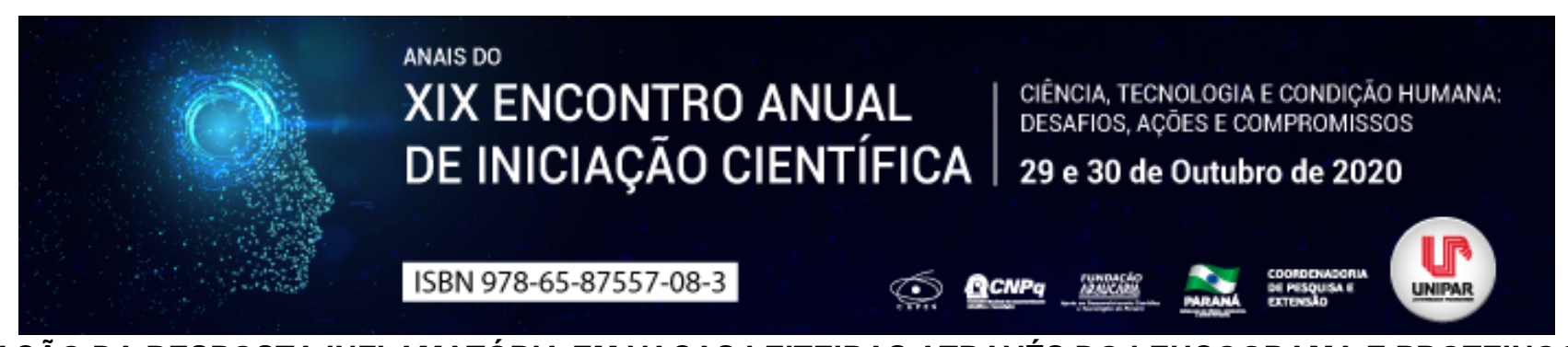

AVALIAÇÃO DA RESPOSTA INFLAMATÓRIA EM VACAS LEITEIRAS ATRAVÉS DO LEUCOGRAMA E PROTEINOGRAMA RELATO DE CASOS

\author{
${ }^{1}$ Felipe Eduardo Dal Más, ${ }^{2}$ GUSTAVO LUIS DAL MÁS, ${ }^{3}$ CAMILA NASCIMENTO OSBI, ${ }^{4}$ LARISSA YURIKA TANABE, \\ ${ }^{5}$ MARILENE MACHADO SILVA
}

\begin{abstract}
${ }^{1}$ Médico Veterinário Mestrando do Programa de Pós Graduação em Ciência Animal UFPR - Palotina
${ }^{1}$ Graduando do curso de Medicina Veterinária UFPR Palotina

${ }^{2}$ Médica Veterinária do Programa de Residência em Medicina Veterinária Câmpus Palotina, Área de concentração: Laboratório Clínico Veterinário

${ }^{3}$ Médica Veterinária do Programa de Residência em Medicina Veterinária Câmpus Palotina, Área de concentração: Laboratório Clínico Veterinário

${ }^{4}$ Professora Adjunto de Medicina Veterinária UFPR - Palotina
\end{abstract}

Introdução: A inflamação é uma resposta tecidual à alguma lesão, que pode ser causada por micro-organismos (ACKERMANN, 2013) e, em vacas leiteiras, doenças infecciosas no período de transição, como a mastite e a metrite são comuns (LEBLANC, 2010), e podem levar a alterações inflamatórias. Os leucócitos são células da função imune, e sua avaliação pelo leucograma permite a obtenção de informações que auxiliam no diagnóstico, monitoramento, na avaliação da terapêutica e do prognóstico (TORNQUIST; RIGAS, 2010; ROLAND et al., 2014), sendo que o leucograma de ruminantes apresenta diferenças em relação a outras espécies (TORNQUIST; RIGAS, 2010). A avaliação de proteínas de fase aguda (PFA), que tem suas concentrações alteradas pelo estímulo inflamatório, também é útil nos ruminantes, auxiliando na avaliação do estado de saúde e detecção de doenças (TOTHOVA et al., 2014). Assim, o objetivo deste trabalho foi relatar alterações no leucograma e proteínas sanguíneas de vacas com mastite e metrite, correlacionando com a gravidade e evolução, afim de elucidar melhor a interpretação e a utilidade destes testes nas doenças inflamatórias de bovinos.

Relato de Caso: Relata-se a avaliação do leucograma e proteinograma de cinco vacas com doenças inflamatórias e infecciosas, duas com mastite e três com metrite. Os exames foram realizados no Laboratório Clínico Veterinário HV-UFPR Palotina. Os resultados foram expressos em clls/uL para leucócitos totais (LT), neutrófilos segmentados (S), bastonetes (B), metamielócitos (Met), eosinófilos (E), linfócitos (L) e monócitos (Mo), em g/dL para albumina (Alb) e globulinas (Glo), e em mg/dL para fibrinogênio (Fib). A vaca 1 apresentou metrite aguda pós parto, com útero aumentado e corrimento amarronzado e fétido, LT: 4900, S: 1225, B: 0, E: 49, L: 3136, Mo: 490, Alb: 2,6, Glob: 4, Fib: 400. A vaca 2 teve metrite aguda grave, quatro dias após o parto, associada a retenção de placenta, apresentava febre e outras manifestações sistêmicas, LT: 7300, S: 584, B: 1533, Met: 511, E: 292, L: 3723, Mo: 657, Alb: 3, Glob: 3,7, Fib: 1000. A vaca 3 apresentava mastite grave, com evolução cerca de três dias, inicialmente leve com agravamento do quadro, apresentava-se febril, úbere com edema e secreção purulenta, LT: 10600, S: 4240, B: 1166, Met: 0, E: 2212, L: 4558, Mo: 424, Alb: 2,4, Glob: 7,15, Fib: 1200. A vaca 4 apresentava mastite moderada a grave, com evolução de quatro dias, quarto com edema e secreção catarral, LT:11900, S: 9044, B: 1547, Met: 0, L: 1309, Alb: 1,9, Glob: 5,5, Fib: 800. A vaca 5 apresentava metrite leve, com mais de uma semana de evolução, com conteúdo purulento, não fétido e útero pouco aumentado, LT: 10100, S: 2727, B: 0, E: 1515, L: 5454, Mo: 404, Alb: 2,7, Glob: 6,2, Fib: 800. Os valores foram comparados com parâmetros de referência para leucograma e proteínas (SMITH, 2015).

Discussão: A vaca 1 apresentou neutropenia, achado mais comum em quadros inflamatórios agudos e graves, ocorrendo nas primeiras 24 a 48h, devido a migração dos neutrófilos ao local inflamatório, com pequena reserva medular (JONES; ALLISON, 2007). Além disso, a resposta medular é lenta nos ruminantes, (WEISER, 2012), porém após 24h células imaturas começam a ser liberadas, havendo neutropenia com desvio à esquerda (DE), e depois de três a cinco dias, o número de neutrófilos começa a subir, apresentando segmentados normais com DE (TORNQUIST; RIGAS, 2010), o que ocorreu nas vacas 2 e 3, respectivamente. O DE ocorre de maneira ordenada, e a presença de metamielócitos, não somente bastonetes, indica um estímulo inflamatório mais intenso (WEISER, 2012), compatível com a gravidade da doença da vaca 2. Conforme a inflamação cronifica, os números de neutrófilos tendem a aumentar (WEISER, 2012), compatível com a neutrofilia associada ao DE da vaca 4, pelo maior tempo de evolução. Na inflamação mais crônica os neutrófilos podem estar dentro da normalidade, havendo somente aumento do fibrinogênio (TORNQUIST; RIGAS, 2010), compatível com a vaca 5, com metrite de evolução mais crônica. Assim, em alguns casos o aumento da concentração de fibrinogênio pode indicar inflamação na ausência de alterações no leucograma (JONES; ALLISON, 2007). O fibrinogênio eleva-se 24h após o estímulo inflamatório (MCSHERRY et al., 1970), justificando que apenas a vaca 1 não apresentou aumento, em momento mais inicial do quadro. O fibrinogênio aumentado também pode estar ligado à gravidade da enfermidade, indicando prognóstico (GARRY, 1984), sendo mais alto justamente nas 
vacas 2 e 3. A albumina é PFA negativa, reduzindo suas concentrações conforme o tempo da inflamação, e as globulinas elevam-se, uma vez que este grupo compreende PFA positivas e imunoglobulinas, que aumentam no quadro inflamatório, principalmente com mais tempo de evolução (SMITH, 2015), sendo que quatro vacas apresentaram hipoalbuminemia e todas hiperglobulinemia, que foi mais intensa nas vacas 3, 4 e 5, pelo maior tempo de evolução da doença.

Conclusão: O leucograma e o proteinograma são úteis na avaliação das doenças inflamatórias de vacas leiteiras, mostrando alterações que auxiliam no diagnóstico, na determinação da gravidade e da evolução do quadro.

\section{Referências}

ACKERMANN, Mark. A. Inflamação e cicatrização. In: MCGAVIN, M. Donald; ZACHARY, James. F. Bases da Patologia em Veterinária. 5. ed. Rio de Janeiro: Elsevier, 2013. p. 89-146.

GARRY, Franklyn B. Plasma fibrinogen measurement: prognostic value in calf bronchopneumonia?. Zentralblatt für Veterinärmedizin Reihe A, v. 31, n. 1-10, p. 361-369, fev. 1984.

JONES, Meredyth L.; ALLISON, Robin W. Evaluation of the ruminant complete blood cell count. Veterinary Clinics of North America: Food Animal Practice, v. 23, n. 3, p. 377-402, nov. 2007.

LEBLANC, Stephen. Monitoring Metabolic Health of Dairy Cattle in the Transition Period. Journal of Reproduction and Development, v. 56, Suppl, p. 29-35, jan. 2010.

MCSHERRY, B. J.; HORNEY, F. D.; DEGROOT, J. J. Plasma Fibrinogen Levels in Normal and Sick Cows. Canadian Journal of Comparative Medicine, v. 34, n. 3, p.191-197, jul. 1970.

ROLAND, Leonie; DRILLICH, Marc; IWERSEN, Michael. Hematology as a diagnostic tool in bovine medicine. Journal of Veterinary Diagnostic Investigation, v. 26, n. 5, p. 592-598, ago. 2014.

SMITH, Bradford. P. Large Animal Internal Medicine. 5. ed. St. Louis: Elsevier, 2015

TORNQUIST, Susan. J.; RIGAS, Johanna. Interpretation of Ruminant Leukocyte Responses. In: WEISS, Douglas. J.; WARDROP, K. Jane. Schalm's Veterinary Hematology 6. ed. Ames: Wiley-Blackwell, 2010. p. 307-313.

TOTHOVA, Csilla; NAGY, Oskar; KOVAC, Gabriel. Acute phase proteins and their use in the diagnosis of diseases in ruminants: a review. Veterinarni Medicina, v. 59, n. 4, p.163-180, 2014.

WEISER, Glade. Interpretation of Leukocyte Responses in Disease. In: THRALL, Mary Anna; WEISER, Glade; ALLISON, Robin. W.; CAMPBELL, Terry. W. Veterinary Hematology and Clinical Chemistry, 2. ed. Ames: John Wiley \& Sons, 2012. p. $127-139$. 


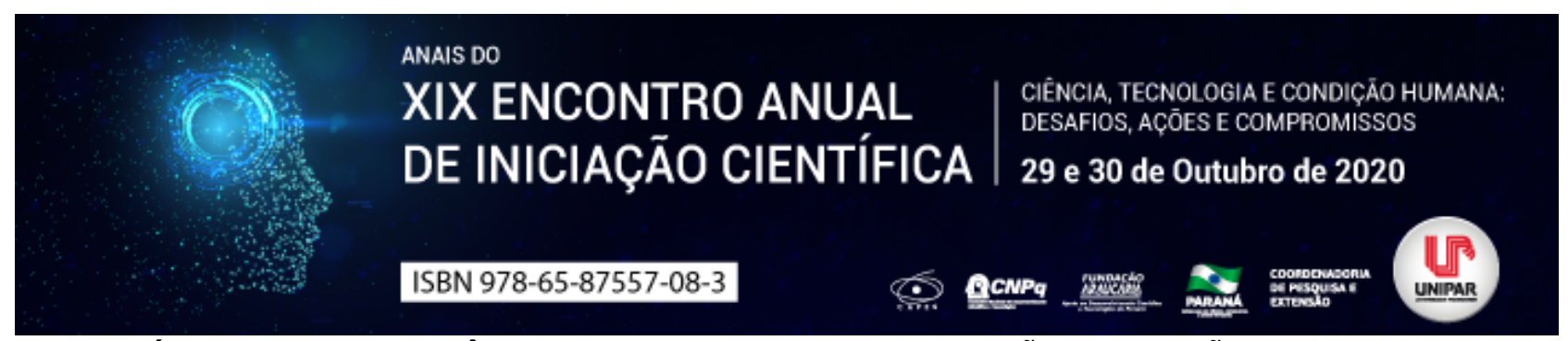

DIAGNÓSTICO DA PERSISTÊNCIA DO DUCTO ARTERIOSO EM CÃES - REVISÃO DE LITERATURA

\begin{abstract}
${ }^{1}$ Nathália Perugini, ${ }^{2}$ MATHIAS FUZETTE AMARAL, ${ }^{3}$ GABRIEL COELHO GIMENES
\end{abstract}
${ }^{1}$ Discente do curso de Medicina Veterinária - Universidade Estadual de Maringá UEM

${ }^{1}$ Discente do curso de Medicina Veterinária - Universidade Estadual de Maringá UEM

${ }^{2}$ Mestre em ciência animal - Universidade Paranaense UNIPAR

Introdução: A ocorrência de anormalidades entre a circulação sistêmica e pulmonar, habitualmente vistas nas cardiopatias, constitui uma das principais causas de morbidade e mortalidade em pequenos animais (NELSON E COUTO, 2010), dentre essas cardiopatias, a persistência do ducto arterioso é a cardiopatia que mais acomete cães (BONAGURA E KEENE, 2008). As artérias da circulação sistêmica transportam o sangue oxigenado do ventrículo esquerdo do coração para os órgãos e tecidos corporais. A circulação sistêmica se inicia com a aorta ascendente até alcançar a coluna vertebral na altura da sexta vértebra torácica e prosseguindo, desse ponto em diante, como aorta descendente, a qual se une à artéria pulmonar pelo ligamento arterioso, o resquício do ducto arterioso. (KONIG E LIEBICH, 2011). O ducto arterioso é um vaso sanguíneo fetal que tem como função desviar o sangue dos pulmões fetais colapsados para a aorta. Se após alguns dias de nascimento o animal ainda apresentar o ducto, é considerado persistência do ducto arterioso (PDA), também denominado de ducto arterioso patente ou persistente, e é uma das cardiopatias mais frequentes em cães (ORTON, 2003).

Objetivo: Objetiva-se com este trabalho revisar informações essenciais por meio da literatura disponível na forma impressa e/ou digital, para a compreensão do diagnóstico de uma das cardiopatias congênita que mais acomete cães.

Desenvolvimento: Quando há permanência do ducto arterioso, acarreta com maior frequência em um fluxo da aorta para a artéria pulmonar (fluxo da esquerda para a direita, contrário do fluxo feito no período fetal) (BELERENIAN et al., 2001; BUCHANAN, 2001), sendo esta a forma de PDA mais comum e também pode ser chamada de PDA clássica (PDAc). Com o passar do tempo, pode ocorrer o agravamento da PDAc, evoluindo para uma persistência do ducto arterioso reversa (PDAr), onde ocorre fluxo sanguíneo da direita para a esquerda, atingindo cerca de 15\% dos casos de PDA em cães (NELSON E COUTO, 2014). Para o correto diagnóstico de uma PDA, é de suma importância realizar o exame físico para seu diagnóstico inicial, já que um animal com esta condição não diagnosticada, tem expectativa de vida inferior a 1 ano por falha cardíaca progressiva (GÓMEZ et al., 2018). Para isso, inicia-se com a ausculta cardíaca de grande importância para reconhecer o sopro contínuo bem característico dessa cardiopatia e solicitar os exames necessários para o diagnóstico da doença (MILLER E GORDON, 2009). A auscultação deve ser realizada cranialmente, com foco na base esquerda do coração, facilitando, assim, o diagnóstico, mesmo que o diâmetro do ducto seja pequeno. O sopro pode vir associado a um pulso hipercinético, por isso é crucial analisar o pulso arterial, da mesma forma que as mucosas que, frequentemente apresentam uma cianose diferencial (SMITH JUNIOR et al., 2016). O hemograma e perfil bioquímico dos cães com PDA clássica possuem valores de referência dentro dos parâmetros considerados normais, já os casos de PDA reversa, podem revelar um hemograma com policitemia (hematócrito maior que 55\%) (TILLEY et al., 2016). Os achados significativos no eletrocardiograma de um animal com PDA são os de sobrecarga em átrio esquerdo e ventrículo esquerdo causados pela PDAc (HENIK, 2009) e em casos de PDAr, é observada uma sobrecarga do ventrículo direito, contudo, não são todas as vezes que o eletrocardiograma irá apresentar alterações (BELERENIAN et al., 2001). Nas radiografias torácicas, observam-se aumento no átrio e no ventrículo esquerdo, dilatação dos vasos pulmonares e ondulação da aorta na vista ventrodorsal (GÓMEZ et al., 2018). Quanto à angiocardiografia, a princípio, a cateterização e sua realização são dispensáveis no diagnóstico da PDA, por ser exame invasivo e necessitar de anestesia, ainda que seja pertinente utilizá-la quando os estudos ecocardiográficos com Doppler não são precisos ou quando há suspeita de outras malformações (GREEN E BONAGURA, 2008; OYAMA et al., 2010). A ecocardiografia confirma o diagnóstico de PDA ao mostrar dilatação e hipertrofia do ventrículo esquerdo, dilatação da artéria pulmonar, aumento de velocidade de ejeção da aorta e, com Doppler, se observa turbulência nas artérias pulmonares, sendo um método não invasivo que substitui as angiografias (GÓMEZ et al., 2018).

Conclusão: essa revisão de literatura apontou a importância do diagnóstico de uma persistência do ducto arterioso em cães, já que é uma das cardiopatias que mais acomete a espécie e apresenta alta taxa de mortalidade caso não seja diagnosticada de forma correta e precocemente. Com isso, podemos concluir que o exame preventivo de um animal jovem é de suma importância para evitar a subdiagnosticação de doenças como a PDA e aumentar a expectativa de vida desses animais.

\title{
Referências
}

BELERENIAN, G.C. Conducto Arterioso Persistente. In: BELERENIAN, G.C.; MUCHA, C.J.; CAMACHO, A.A. Afecciones Cardiovasculares en pequeños animales. Buenos Aires: Intermédica, p. 122-128, 2001. 
BONAGURA, J.D.; KEENE, B. Insuficiência cardíaca em cães. In: BIRCHARD, S.J.; SHERDING, R.G. Manual Saunders de clínica de pequenos animais. 3.ed. São Paulo: Roca, 2008. 2048p.

BUCHANAN, J.W. Patent Ductus Arteriosus Morphology, Pathogenesis, Types and Treatment. Journal of Veterinary Cardiology, v. 3, n. 1, p. 7-16, 2001.

GÓMEZ, J.R.; SAÑUDO, M.J.M.; MORALES, J.G. Cirurgia na clínica de pequenos animais. 1. ed. São Paulo: MedVet, 2018. 380p.

GREEN, W.H.; BONAGURA, J.D. Doença cardíaca congênita. In: BIRCHARD, S.J.; SHERDING, R.G. Manual Saunders de clínica de pequenos animais. 3.ed. São Paulo: Roca, p. 1623-1632, 2008, 2048p.

HENIK, R.A. Kirk's current veterinary therapy xiv. St. Louis: Elsevier, 2009.

KONIG, H.E; LIEBICH, H.G; Anatomia dos animais domésticos. 4.ed. Porto Alegre: Artmed, cap. 12, p.474-475, 2011.

MILLER, M.W.; GORDON, S.G. Kirk's current veterinary therapy xiv. St. Louis: Elsevier, 2009.

NELSON, R.W.; COUTO, C.G. Cardiopatia Congênita. In: NELSON, R.W.; COUTO, C.G. Medicina interna de pequenos animais. 4. ed. Rio de Janeiro: Elsevier, p. 95-112, 2010, 1468p.

NELSON, R.W.; COUTO, C.G. Medicina interna de pequenos animais. 5. ed. California: Elsevier, 2014.

ORTON, E.C. Cardiac Surgery. In: SLLATER, D. Textbook of Small Animal Surgery. Filadélfia: Elsevier Health Sciences / Saunders, p. 955-986, 2003.

OYAMA, M.A.; SISSON, D.D.; THOMAS, W.P.; BONAGURA, J.D. Congenital heart disease. In: ETTINGER, S.J.; FELDMAN, E.C. Textbook of veterinary internal medicine. 7.ed., Philadelphia: Saunders Elsevier, 2010, 2208p.

SMITH JUNIOR, F. W. K.; TILLEY; L. P.; OYAMA, M. A.; SLEEPER, M. M. Manual of canine and feline cardiology. St. Louis, Missouri: Elsevier, 2016. 473 p.

TILLEY, L.; SMITH, F.; OYAMA, M.; SLEEPER, M. Manual of Canine and Feline Cardiology. 5.ed. 2016.

Coordenadoria de Pesquisa e Extensão - COPEX

Departamento de Editoraçāo e Divulgaçāo Científica - DEDIC 


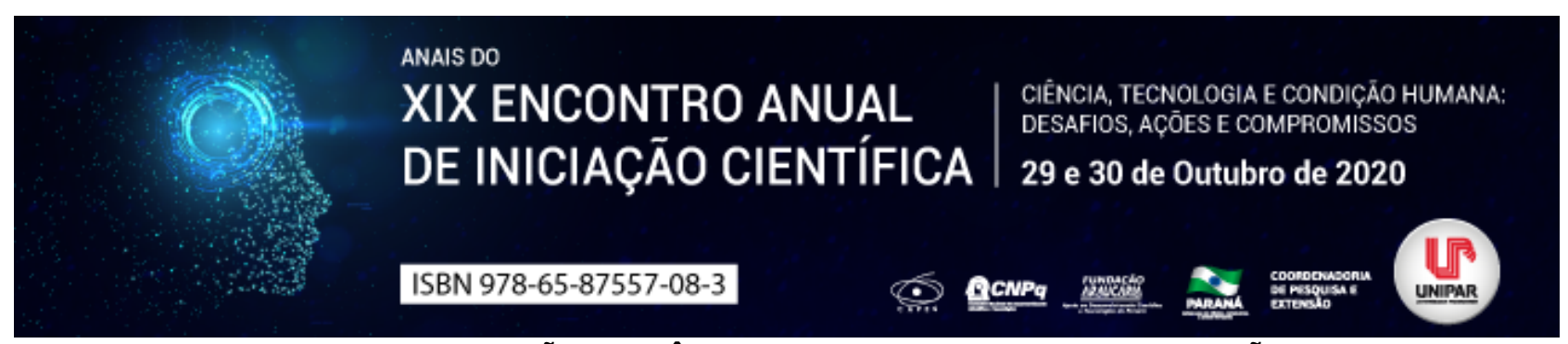

CRIOPRESERVAÇÃO DE SÊMEN EQUINO: AVANÇOS E APLICAÇÕES

\title{
${ }^{1}$ FERNANDA CORREA BIGATTAO, ${ }^{2}$ IZABELA DE OLIVEIRA BORGHI, ${ }^{3}$ DANIEL CAMPOS GIOSA , ${ }^{4}$ CARLOS RENATO DE FREITAS GUAITOLINI, ${ }^{5}$ AULY BEATRIZ TRINDADE, ${ }^{6}$ ROSIARA ROSARIA DIAS MAZIERO
}

\author{
${ }^{1}$ Acadêmico bolsista do PIBIC/UNIPAR \\ ${ }^{1}$ Acadêmica do Curso de Medicina Veterinária- bolsista PIBIC/UNIPAR \\ ${ }^{2}$ Discente do mestrado em ciência animal com ênfase em produtos bioativos-UNIPAR \\ ${ }^{3}$ Acadêmico do Curso de Programa Nacional de Pós-doutorado -PNPD/CAPES da UNIPAR \\ ${ }^{4}$ Acadêmica do Curso de Medicina Veterinária-Bolsista PEBIC/CNPQ \\ ${ }^{5}$ Docente da UNIPAR
}

Introdução: A criopreservação de sêmen equino tem se difundido cada vez mais em território nacional, entretanto, os processos de congelação e descongelação levam a efeitos deletérios sobre o espermatozoide, diminuindo sua cinética e viabilidade (OLIVEIRA,2013). Neste sentido, o sucesso desta biotécnica é muito variável em garanhões. Em particular as raças nacionais, Mangalarga e Mangalarga Marchador, são menos resistentes ao processo de congelação e isto está associado ao tipo de crioprotetor utilizado no processo. Assim, estudos recentes afirmam que a utilização acima de $3 \%$ de glicerol provoca acentuado decréscimo da fertilidade do sêmen fresco de garanhões, sendo recomendada a dimetilformamida (ALVARENGA et al., 2005).

Objetivo: Analisar métodos que possam melhorar a criopreservação de sêmen equino, visando a cinética, a viabilidade espermáticas e a fertilidade das fêmeas.

Desenvolvimento: $O$ equino é a espécie animal que maior número de empregos gera mundialmente, pela tecnificação de sua criação e pelo alto valor agregado de seus produtos. As recentes conquistas brasileiras em pistas internacionais, tanto de corridas como no salto, tornaram o cavalo um produto de exportação, gerando divisas para o nosso país. Neste sentido, a inseminação artificial (IA) é uma técnica largamente utilizada na reprodução equina. Sua utilização oferece várias vantagens sobre a monta natural, como a otimização do uso do garanhão por temporada de monta, aumento da sua eficiência reprodutiva, a diminuição dos riscos de acidentes durante a cobertura e a redução da transmissão de doenças venéreas (BUSTAMANTE FILHO, 2006). Na equinocultura mundial é cada vez maior a utilização do sêmen congelado devido a recente liberação do seu uso por grande parte das associações de criadores. Entretanto, a fertilidade do sêmen ainda é baixa e dificulta a sua utilização em larga escala (OLIVEIRA, 2011). O plasma seminal também pode alterar a resistência espermática a refrigeração, visto que altas concentrações de plasma seminal podem ser deletérias ao sêmen refrigerado, no entanto, a remoção total do plasma não resulta em maior longevidade seminal, embora possa contribuir para a estabilização da membrana e mostrar-se benéfica para garanhões subférteis (SAMPAIO E ZÚCCARI, 2016). A manutenção de uma pequena fração (5 a 20\%) do plasma seminal parece proteger a célula espermática contra os danos provocados pelas ROS, e sua função antioxidante pode ser ampliada pela interação com os componentes do diluidor (KANKOFER ET AL., 2005). Neste contexto, o uso de diluentes de sêmen é fundamental para prolongar a sobrevivência espermática, pois estabiliza a atividade enzimática, promovendo a manutenção da integridade de membrana, além de protegê-lo contra as condições desfavoráveis como o choque térmico, efeitos deletérios do plasma seminal, bem como produtos tóxicos derivados do metabolismo espermático e diminuindo a proliferação microbiana. Na maioria dos estudos realizados temos constatado que os crioprotetores a base de amidas (Dimethylformamida e Methylformamida) proporcionaram resultados superiores em relação ao glicerol no que se refere a motilidade espermática, integridade celular e fertilidade em diferentes raças equinas. Tendo sido mais expressiva a melhora da qualidade do sêmen quando da congelação de sêmen de garanhões Mangalarga Marchador, Mangalarga Paulista e Lusitanos os quais são sabidamente indivíduos que apresentam uma baixa resistência ao congelamento (ALVARENGA et al., 2005).

Conclusão: A criopreservação de sêmen equino é aplicada mundialmente, entretanto os resultados ainda são inferiores aos observados em bovinos. As metodologias devem ser aprimoradas para que os resultados sejam aplicáveis comercialmente, para a rápida difusão do material genético desta espécie.

\section{Referências}

ALVARENGA, M. A.; LEÃO, K. M.; PAPA, F. O.; LANDIM-ALVARENGA, F. C.; MEDEIROS, A. S. L.; GOMES, G. M. Amides as an alternative cryoprotectors for freezing stallion semen - A review. Animal Reproduction Science, v. 89, p. 1-4, 2005.

BUSTAMANTE FILHO, I. C. Estresse oxidativo na criopreservação do sêmen equino. Dissertação (Mestrado em Zootecnia). Universidade Federal do Rio Grande do Sul (UFRGS), 2006.

KANKOFER, M.; KOLM, G.; AURICH, J.; AURICH, C. Activity of glutathione peroxidase, superoxide dismutase and catalase and 
lipid peroxidation intensity in stallion sêmen during storage at $5^{\circ} \mathrm{C}$. Theriogenology, v. 63, p.1354-1365, 2005.

OLIVEIRA, R. A. Antioxidantes na viabilidade do sêmen equino congelado e resfriado.Tese (Doutorado em Ciências Agrárias). Escola de Veterinária e Zootecnia, Universidade Federal de Goiás (UFG), 2011.

OLIVEIRA, G. C.; OLIVEIRA, B. M. M.; CELEGHINI, E. C. C.; FERNANDES, C. B.; MATTOS, C. B. Criopreservação do sêmen equino: uma revisão. Revista Brasileira de Reprodução Animal, v. 37, n. 1, p. 23-28, 2013.

SAMPAIO, B. F. B.; ZÚCCARI, C. E. S. Adição de antioxidantes hidro e lipossolúveis ao diluidor de refrigeração de sêmen equino. Revista Eletrônica de Veterinária, v. 17, n. 11, p. 1-28, 2016.

Coordenadoria de Pesquisa e Extensão - COPEX

Departamento de Editoraçāo e Divulgaçāo Científica - DEDIC 


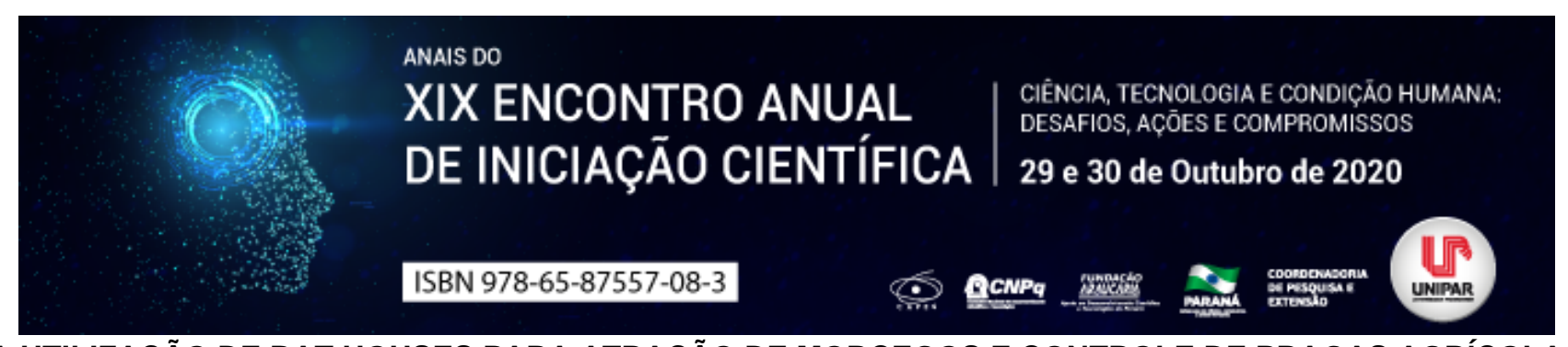

A UTILIZAÇÃO DE BAT HOUSES PARA ATRAÇÃO DE MORCEGOS E CONTROLE DE PRAGAS AGRÍCOLAS

\author{
${ }^{1}$ Gustavo Ferreira Manoel, ${ }^{2}$ MATHEUS HENRIQUE SOARES DE CAMARGO, ${ }^{3}$ DANIELE PINTO, ${ }^{4}$ MARCELO APARECIDO \\ MARQUES
}

${ }^{1}$ Acadêmico do curso de Engenharia Civil da Faculdade de Administração e Ciências Econômicas de Cianorte
${ }^{1}$ Acadêmico do curso de Engenharia Civil da Faculdade de Administração e Ciências Econômicas de Cianorte
${ }^{2}$ Docente da Faculdade de Administração e Ciências Econômicas de Cianorte
${ }^{3}$ Docente da Faculdade de Administração e Ciências Econômicas de Cianorte

Introdução: As bat houses são estruturas geralmente executadas em madeira, que tem por finalidade atuar como abrigos artificiais para quirópteros, assumindo um papel importante na preservação de espécies, que em alguns casos, estão ameaçadas e em perigo de extinção (TUTTLE; KISER; KISER, 2013). Estudos em campo apontam que predadores generalistas podem reduzir significativamente o número de pragas e, em alguns casos, diminuir ou prevenir danos causados às lavouras (SYMONDSON; SUNDERLAND; GREENSTONE, 2002). Muitos morcegos são importantes predadores generalistas de insetos voadores noturnos, realizando um importante trabalho na diminuição de pragas em áreas agrícolas (MCCRACKEN et al., 2012).

Objetivo: Uso de bat houses no auxílio ao combate de pragas insetívoras em lavouras.

Desenvolvimento: As bat houses podem assumir diversos modelos, desde pequenos, até grandes abrigos feitos para colônias que podem chegar a ocupação de 30000 morcegos. Recomenda-se o uso de madeira na execução dos abrigos, que devem ser feitos tomando os devidos cuidados para que sejam protegidos da chuva e do sol, mantendo uma temperatura agradável para garantir as chances de sucesso na colonização (TUTTLE; KISER; KISER, 2013). Empregando o uso das bat houses, com o intuito de atrair morcegos para as lavouras, podemos reduzir o número de pragas, resultando na diminuição do uso de inseticidas e atenuando os impactos econômicos (BROWN; BRAUN DE TORREZ; MCCRACKEN, 2015). O morcego-de-cauda-livre brasileiro (Tadarida brasiliensis) demonstra ter uma importância significativa em lavouras de algodão no centro sul do Texas, auxiliando no combate de pragas insetívoras como a lagarta-da-espiga ou lagarta do algodão (Helicoverpa zea), funcionando como controladores biológicos das pragas. Outro aspecto relevante é a redução de custos com o uso de pesticidas, trazendo benefícios econômicos e ambientais positivos para os agricultores e sociedade de modo geral (CLEVELAND et al., 2006). Na África do Sul a presença de morcegos em plantações de macadâmia, controla a população de percevejos refletindo em uma diminuição de 9 a 23\% dos danos causados por esses insetos. Esse fato tem impacto positivo na economia local onde o quiróptero corrobora diretamente a predação dos insetos e indiretamente, pois, com a diminuição da praga, diminui-se a aplicação de pesticidas (TAYLOR et al., 2018).

Conclusão: De acordo com os dados levantados, é evidente que o uso de abrigos artificiais para morcegos nas lavouras podem ser uma boa opção no auxílio ao combate de pragas insetívoras, podendo trazer diversos benefícios aos produtores e para a sociedade, como uma possível diminuição no uso de inseticidas e um possível aumento da produção. Contudo, são necessários estudos aprofundados sobre os aspectos positivos e negativos envolvendo a prática para confirmar sua eficácia.

\title{
Referências
}

BROWN, V. A.; BRAUN DE TORREZ, E.; MCCRACKEN, G. F. Crop pests eaten by bats in organic pecan orchards. Crop Protection, v. 67, p. 66 71, 2015.

CLEVELAND, C. J. et al. Economic value of the pest control service provided by Brazilian free-tailed bats in south-central Texas. Frontiers in Ecology and the Environment, v. 4, n. 5, p. 238 243, 2006.

MCCRACKEN, G. F. et al. Bats Track and Exploit Changes in Insect Pest Populations. PLoS ONE, v. 7, n. 8, 2012.

SYMONDSON, W. O. C.; SUNDERLAND, K. D.; GREENSTONE, M. H. D Iffusion of E Ffective B Ehavioral. Annual review Entomology, v. 47, p. 561 594, 2002.

TAYLOR, P. J. et al. Economic value of bat predation services A review and new estimates from macadamia orchards. Ecosystem Services, v. 30, p. 372 381, 2018.

TUTTLE, M. D.; KISER, M.; KISER, S. The House Builder's Handbook. $1^{\mathrm{a}}$ ed. Texas: University of Texas Press, 2013. 


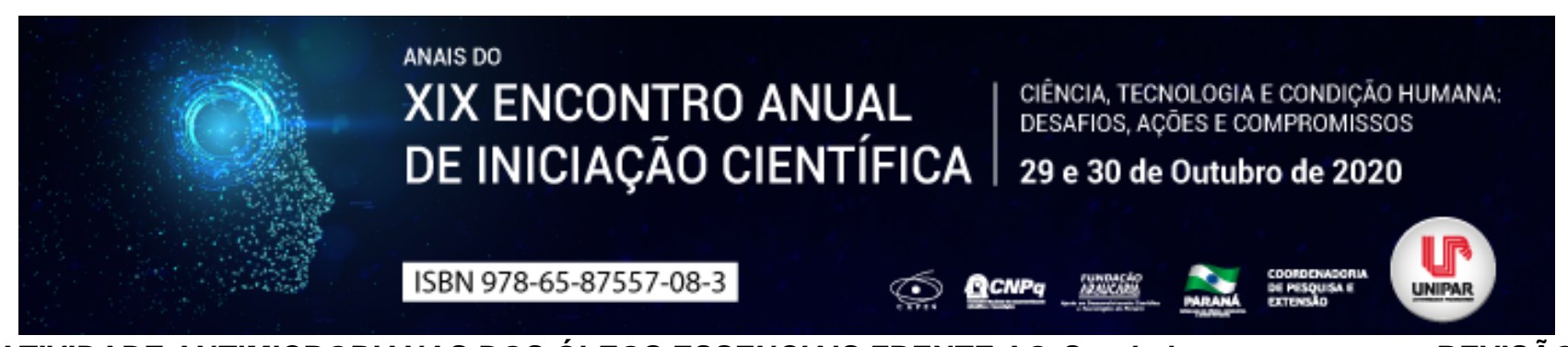

ATIVIDADE ANTIMICROBIANAS DOS ÓLEOS ESSENCIAIS FRENTE AO Staphylococcus aureus - REVISÃO

\author{
${ }^{1}$ VINICIUS AUGUSTO SILVA DIAS, ${ }^{2}$ DENISE MIYUKI KAWAMO, ${ }^{3}$ ANA KARLA FAVORETTO, ${ }^{4}$ JESSE LAHOS BORGES , \\ ${ }^{5}$ FILIPE CORREA PACHECO, ${ }^{6}$ RANULFO PIAU JUNIOR
}

\author{
${ }^{1}$ Acadêmico do curso de Medicina Veterinária da Unipar, bolsista PEBIC/Fundação Araucária \\ ${ }^{1}$ Acadêmica do Curso de Medicina Veterinária da UNIPAR \\ ${ }^{2}$ Acadêmica do Curso de Medicina Veterinária da UNIPAR \\ ${ }^{3}$ Acadêmico do Curso de Doutorado Em Ciência Animal com Enfase em Produtos Bioativos - UNIPAR \\ ${ }^{4}$ Mestrando do cursos de Pós-graduação em Ciência Animal com Ênfase em Produtos Bioativos-UNIPAR \\ ${ }^{5}$ Docente da UNIPAR
}

Introdução: Óleos essenciais são misturas complexas de compostos orgânicos voláteis, lipofílicas e odoríferas, apresentam inúmeros constituintes e podem ser extraídos dos vegetais de diversas formas. Nos últimos anos tem se observado um grande avanço científico envolvendo os estudos químicos e farmacológicos de plantas, buscando obter novos compostos com propriedades terapêuticas (CECHINEL FILHO; YUNES, 1997). Dentre as atividades farmacológicas, a antimicrobiana vem sendo estudada com mais intensidade, devido ao agravamento da resistência microbiana a antibióticos convencionais,. O interesse na busca por agentes antimicrobianos derivados de produtos naturais é justificável, uma vez que possuem uma diversidade molecular superior àquelas derivadas de produtos sintéticos (ANGÉLICO, 2011).

Objetivo: Analisar a atividade antimicrobiana dos óleos essenciais frente Staphylococcus aureus.

Desenvolvimento: A atividade antimicrobiana dos óleos essenciais estão relacionados com sua hidrofobicidade que os faz interagir com os lipídeos da parede, membrana celular e mitocôndria das células microbianas, alterando a permeabilidade e causando distúrbios nestas estruturas, resultando em fraturas grosseiras que provocam o vazamento de íons, moléculas e conteúdo celular, levando à morte ou inibição (BURT, 2004). O estudo realizado por Scherer et al. (2009) encontrou uma ação antimicrobiana de moderada a forte nas bactérias S. aureus, E. coli, P. aeruginosa, S. Thyphimurium e C. perfringens. Segundo Burt (2004), geralmente os óleos essenciais são mais ativos contra bactérias Gram-positivas do que contra bactérias Gramnegativas. De acordo com Menezes; Pinto; Cordeiro, (2008) o óleo essencial de romã (Punica granatum) se mostrou muito efetivo na inibição de bactérias gram-positivas, especificamente a S.aureus. Catão et al. (2006) realizou um estudo mostrando que as 17 cepas de S. aureus utilizadas mostraram sensibilidade ao extrato etanóico de romã. . Hussain et al. (2010) confirmaram a atividade inibitória do óleo essencial de alecrim sobre E. coli e S. aureus. A metodologia que foi empregada para a extração do óleo foi por hidrodestilação. Xu et al. (2016), confirmaram a ação inibitória do óleo essencial de cravo da índia sobre S. aureus.

Conclusão: Conclui-se mediante revisão que os óleos essenciais apresentam grande potencial contra diversas bactérias, dentre elas o S. aureus.

\footnotetext{
Referências

ANGÉLICO, Elissandra. Couras. Avaliação das atividades antibacteriana e antioxidante de Croton heliotropiifolius kunte e Croton blanchetianus Baill. 2011. 87p. Dissertação (Mestrado em Zootecnia), Universidade Federal de Campina Grande, Centro de Saúde Tecnologia Rural. Patos-PB. 2011.

BURT Sara. Essential oils: their antibacterial properties and potencial applications in foods - a review. International Journal of food microbiology. 94, p. 223- 253, ago-2004.

CATÃO, R. M. R. et al. Atividade antimicrobiana in vitro do extrato etanólico de Punica Granatum Linn. (romã) sobre isolados ambulatoriais de Staphylococcus aureus. Revista Brasileira de Análises Clínicas, Rio de Janeiro, v. 38, n. 2, p. 111-114, abrjun. 2006.

CECHINEL FILHO, Valdir; YUNES, Rosendo. Estratégias para a obtenção de compostos farmacologicamente ativos a partir de plantas medicinais. Conceitos sobre modificação estrutural para otimização da atividade. Química Nova, Santa Catarina, v. 21, n. 1, p. 99-105, 1998.

HUSSAIN, Abdullah ljaz et al. Rosmarinus officinalis essential oil: antiproliferative, antioxidant, and antibacterial activities. Brazilian Journal of Microbiology, v.41, n.4, p.1070-1078. Dez. 2010.

MENEZES, Silvana Magalhães Siqueira; PINTO, Diego Muniz; CORDEIRO, Luciana Nunes. Atividades biológicas in vitro e in
} 
vivo de Punica granatum L.(romã). RBM. Revista brasileira de medicina, v. 65, n. 11, p. 388-391, 2008

SCHERER, R. et al . Composição e atividades antioxidante e antimicrobiana dos óleos essenciais de cravo-da-índia, citronela e palmarosa. Rev. bras. plantas med., Botucatu, v. 11, n. 4, p. 442-449, 2009.

$\mathrm{XU}$, Jian-Guo et al. Chemical composition, antibacterial properties and mechanism of action of essential oil from clove buds against Staphylococcus aureus. Molecules, v. 21, n. 9, p. 1194, 2016.

Coordenadoria de Pesquisa e Extensão - COPEX

Departamento de Editoraçāo e Divulgaçāo Científica - DEDIC 


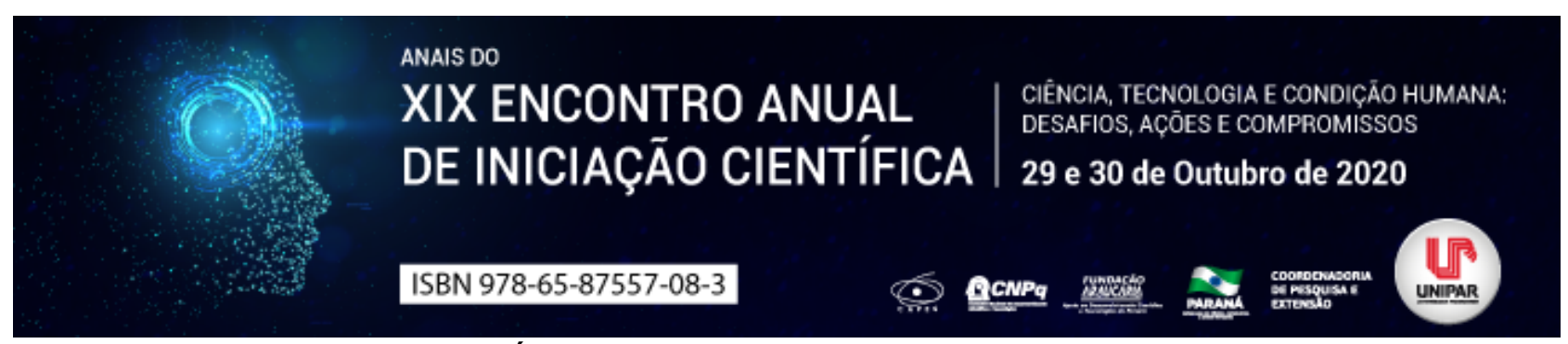

SINUSITE PRIMÁRIA BACTERIANA EM EQUINO - RELATO DE CASO

\begin{abstract}
${ }^{1}$ Mayara Nayane Sacoman Rocha Neves, ${ }^{2}$ DEREK WILLY GALDIOLI SILVEIRA, ${ }^{3}$ ARISLA VILLAS BOAS LIZZI, ${ }^{4}$ JEFERSON CARLOS GANDIN, ${ }^{5}$ DANTHYSE MIYOKO OHNO MULLER DE SOUS, ${ }^{6}$ MAX GIMENES RIBEIRO
\end{abstract}

$\begin{array}{ll}{ }^{1} \text { Discente do curso de Medicina Veterinária } & \text { UEM/Campus Regional de Umuarama-PR } \\ { }^{1} \text { Discente do curso de Medicina Veterinária } & \text { UEM/Campus Regional de Umuarama-PR } \\ { }^{2} \text { Discente do curso de Medicina Veterinária } & \text { UEM/Campus Regional de Umuarama-PR }\end{array}$

${ }^{3}$ Médico Veterinário Residente em Clínica Médica e Cirúrgica de Grandes Animais UEM/Campus Umuarama-PR

${ }^{4}$ Médico Veterinário Residente em Clínica Médica e Cirúrgica de Grandes Animais UEM/Campus Umuarama-PR

${ }^{5}$ Docente do curso de Medicina Veterinária-UEM/Campus Umuarama-PR

Introdução: A sinusite ou empiema primário é o acumulo de exsudato no lado interior das fossas sinusais, no qual acontece como resultante de infecções bacteriana primaria ou secundaria. Comumente a sinusite primaria recobre por inteira as cavidades dos seios paranasais, porem pode ser acercado aos seios conchais ventrais. A sinusite secundária em eqüinos esta relacionada a problemas na dentição do animal, como dentes lesionados, infundíbulos pérvios e periostalgia alveolar, em consequência da união entre o seio maxilar e as raízes da dentição. Tal erro nos dentes da cavidade oral faz com que abra acesso para a entrada de material orgânico ou bactérias até a raiz dos dentes e da cavidade sinusal (BELLIN; MELLO; ZAPPA, 2009). Equinos acometidos por sinusite primária apresentam sinais clínicos como, secreção nasal purulenta unilateral, com mau cheiro e em certos casos há alteração de volume facial, essencialmente quando abrange os seios frontais. Em caso de sinusite secundaria, é possível observar a presença de alterações na dentição e odor fétido ao inspecionar a cavidade oral. Para diagnóstico decisivo é importante discernir se a sinusite é primária ou secundária, portanto exames detalhados como avaliação da cavidade oral e exames radiográficos dos seios nasais são necessários (MACHADO; SILVA, 2016).

Objetivo: O objetivo do presente trabalho é relatar um caso de sinusite primária bacteriana, bem como, descrever os possíveis diagnósticos para tal lesão, cirúrgico e clinicamente.

Desenvolvimento: Um equino, fêmea, seis anos de idade, da raça Quarto de milha, $480 \mathrm{~kg}$, e gestação de aproximadamente seis meses, foi encaminhada ao setor de grandes animais do Hospital Veterinário (HV) da Universidade Estadual de MaringáUEM campus Umuarama. Durante a anamnese o proprietário relatou, que o animal havia passado por tratamento dentário a 6 meses, sem realização de extração e que há um ano o animal estava com seu rendimento reduzido durante os treinos, apresentava assimetria facial há cerca de duas semanas, com fístula do lado esquerdo, e havia sido medicado por outro médico veterinário com antibiótico sulfa+trimetropim, anti-inflamatório, flunexin meglumine e lavagem da fístula com iodo. No exame clínico específico o animal apresentava assimetria fácil bilateral com secreção purulenta nasal bilateral e sem fistula, para melhor diagnóstico foi realizado exame radiográfico que evidenciou presença de conteúdo nos seios nasais frontais e assim, encaminhada para tratamento na propriedade com flunexin meglumine e penicilina. Após 14 dias de tratamento o animal retornou ao Hospital Veterinário, por não apresentar uma melhora, foi sedada com $20 \mathrm{mg} / \mathrm{kg}$ de detomidina e avaliada a cavidade oral, onde constatou que a sinusite não era decorrente de um problema dentário, mas sim, um problema primário por contaminação bacteriana, no qual a origem do microorganismo é desconhecida. Ao exame físico, os parâmetros se encontravam dentro da normalidade. Deste modo, optou-se por um procedimento em estação, pois facilitaria o manejo durante a trepanação e evitaria o decúbito do animal gestante, foi realizada sedação do animal com detomidina a $20 \mathrm{mg} / \mathrm{kg}$ intravenosa, técnicas de anestesia regional com lidocaína á $2 \%$ para bloqueios bilaterais dos nervos infraorbitário (10ml) e infratroclear (2ml) e administração de detomidina a $20 \mathrm{mg} / \mathrm{kg}$ intramuscular após 20 minutos da administração intravenosa. A paciente foi submetida à trepanação dos dois seios nasais frontais (direito e esquerdo) para drenagem da secreção purulento, que durou em média 1 hora e 30 minutos. Feito o procedimento, manteram os seios nasais frontais com as fístulas abertas para a drenagem diária durante 10 dias. No pós operatório foi utilizado penicila $(15 \mathrm{ml})$ uma vez ao dia por 7 dias, flunexin $(10 \mathrm{ml})$ uma vez ao dia por cinco dias, fluidificante de secreção, solução fisiológica aquecida e permanganato de potássio (4 comp/l) para a limpeza dos seios nasais, feito três vezes ao dia durante 10 dias. Os curativos externos eram realizados com pomada alantol e uma adaptação de tecido para tampar os orifícios que eram usados para drenagem, colocando assim, uma mascara de proteção na cabeça do animal. Uma segunda trepanação foi realizada após cinco dias do primeiro processo apenas do lado direito para ajudar na melhora da drenagem, no qual foi realizado em estação e submetido aos mesmos procedimentos anestésicos citado anteriormente. Ressaltando que na utilização de detomidina a $20 \mathrm{mg} / \mathrm{kg}$ não foi usado administração pela via intramuscular, somente intravenosa. Os métodos de pós operatório foram desempenhados em um período de 15 dias, onde o animal foi liberado.

Discussão: Segundo PINTO (2016), é de extrema importância o exame clínico no animal, pois a idade, raça, as características 
da secreção, está associada ou não à intolerância ao exercício, a presença de ruídos respiratórios, tosse ou quaisquer outros sinais clínicos, é de suma utilidade na hora de concretizar e diferenciar os diagnósticos. Tais características encontradas no presente caso, exceto a presença de ruídos respiratórios e tosse, onde foi imprescindível para a avaliação do animal. Já de acordo com PAULO (2010), a presença de complicações em algum dos dentes molares ou pré-molares pode acarretar o aparecimento de infecção periapical com consequente sinusite bacteriana secundária. Característica não encontrada no animal citado, já que na inspeção da cavidade oral verificou-se que não havia problemas dentários. Habitualmente descobrir uma sinusite não é complicado, o difícil, muitas vezes é acertar a causa. Como neste relato de caso, uma vez que, não se sabe o que acarretou a sinusite primária por bactéria (PINTO, 2016).

Conclusão: Entende-se que o procedimento relatado obteve resultados satisfatórios, apresentando como principais vantagens a recuperação positiva do animal e procedimentos visando o bem estar da égua e do feto, no qual apesar dos métodos anestésicos e cirúrgicos o feto manteve-se estável e saudável.

\section{Referências}

Disponível em :< https://www.comprerural.com/wp-content/uploads/2016/08/ix_conf_08-Sinusite_sinoscopia_abraveq.pdf: acessado em 29/08/2020 às 20:30.

ESCODRO, PIERRE BARNABÉ; MARIZ, TOBYAS MAIA DE ALBUQUERQUE; JÚNIOR, JOSÉ VALMIR TENÓRIO FERREIRA; FONSECA, LUCAS SANTANA; BERNARDO, JULIANA DE OLIVEIRA; OLIVEIRA,CÍCERO FERREIRA. Revista científica eletrônica de medicina veterinária. Garça/sp: Faef, v. 12, jan. 2009. Semestral. Sinusite Eqüina.

GIBELLINI, CAIO CÉSAR; MELLO, DANIELA P; ZAPPA, VANESSA . Acta veterinaria brasilica. Mossoró/rn: Avb, v. 7, n. 1, 2013. Trimestral. Trepanação Óssea e Extração de Molares Com Equino em Posição Quadrupedal: Relato de Caso.Sinusite Crônica em eqüinos: auxílio diagnóstico e terapêutico da sinoscopia .

PAULO, DIANA LUÍSA DE OLIVEIRA MOREIRA. A importância da odontologia na prática clínica equina: the importance of odontology in equine clinical practice. 2010. 80 f. Dissertação (Mestrado) - Curso de Medicina Veterinária, Clínica Ambulatória de Equinos, Universidade Técnica de Lisboa, Lisboa, 2010.

PINTO, ANTÓNIO EDUARDO MIRA CRUZ MENDES. Clínica de Equinos: equine clinics. 2016. 107 f. Tese (Doutorado) - Curso de Medicina Veterinária, Escola de Ciências e Tecnologia, Universidade de Évora, Évora, 2016.

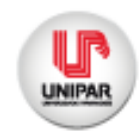




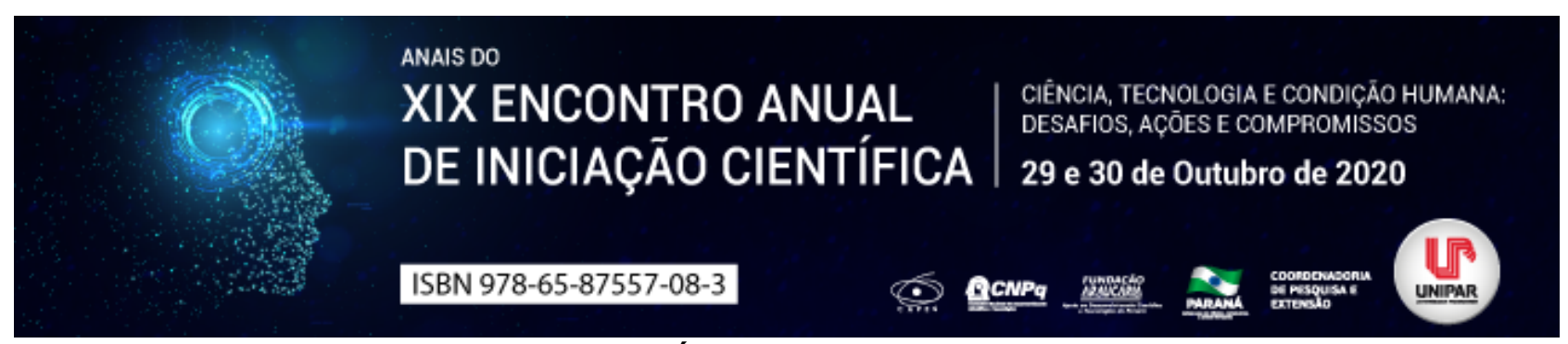

O USO DO MEL E DA PRÓPOLIS NO TRATAMENTO DE FERIDAS

\begin{abstract}
${ }^{1}$ Mayara Nayane Sacoman Rocha Neves, ${ }^{2}$ ARISLA VILLAS BOAS LIZZI, ${ }^{3}$ DIRCE CONSUELO CORONATO CORREIA, ${ }^{4}$ MAX GIMENES RIBEIRO
\end{abstract}

${ }^{1}$ Discente do curso de Medicina Veterinária UEM/Campus Regional de Umuarama-PR

${ }^{1}$ Discente do curso de Medicina Veterinária UEM/Campus Regional de Umuarama-PR

${ }^{2}$ Discente do curso de Medicina Veterinária UEM/Campus Regional de Umuarama-PR

${ }^{3}$ Docente do curso de Medicina Veterinária-UEM/Campus Umuarama-PR

Introdução: Uma vasta diversidade de produtos naturais tem sido usada no tratamento de feridas pela facilidade de utilização, inofensibilidade, baixo custo e poder bactericida ou bacteriostático. Entre eles destaca-se o mel e a própolis, no qual, é capaz de hidratar os tecidos, contrariando as injeções microbianas, tem o poder de acalmar a inflamação e evitar a adesão da gaze às feridas e tem ainda um efeito anticético e de regeneração tecidual.

Objetivo: Demonstrar a importância da utilização do mel (Apis melífera) e da própolis como alternativa natural no tratamento de feridas, utilizando-o assim, de forma coerente.

Desenvolvimento: Produzidos por abelhas (Apis melífera) os produtos, mel, própolis e a cera são conhecidos por suas propriedades medicinais, no entanto não são muito usados em tratamentos tópicos como coadjuvantes no tratamento de ferimentos (ARGENTINO; SANTOS; MARINHO, 2017). Porem antigamente o mel era aproveitado na medicina tradicional há cerca de 10.000 anos, segundo com as referências em textos Sumérios, Gregos, Romanos e também descobertos na Bíblia e no Alcorão (SANTOS, 2011). Já que a utilização do mel não seja algo de novo, o seu aproveitamento sempre foi baseado em princípios empíricos sem bases científicas concretas. Tal ocorrência, fez com que, o uso do mel na medicina fosse deixado de lado e colocado como medicina tradicional, tudo graças à descoberta dos antibióticos no início do século XX (SANTOS, 2011). Durante décadas, os antibióticos foram usados de forma errada por serem considerados como a cura para muitas doenças. Com o aumento indiscriminado do uso dos antibióticos, conseqüentemente, aumentou a ocorrência e número de bactérias que se tornaram resistentes a estes. Por isso, a comunhão médica e científica iniciou uma busca por potenciais a altura que pudesse substituir os antibióticos (SANTOS, 2011). O mel de abelhas, neste caso, é um produto usado como alimento e fabricado por abelhas meliponídeas, a partir do néctar das flores ou das eliminações vindas de partes vivas das plantas (SILVA, 2019). Na literatura médica do Egito, Grécia e nas culturas Ayurvédicas da Índia o uso do mel como cicatrizante de feridas é altamente mencionado. O mel reduz de forma rápida as infecções das lesões, edemas, dor e odor, no qual, os diversos constituintes do mel como as mais relevantes no tratamento de feridas são o debridamento, devido à capacidade de formar o peróxido de hidrogênio (SILVA, 2019), a construção do tecido de granulação e epitelização, pela formação de peróxido de hidrogênio e pelo pH ácido que proporciona a acidificação do meio, criando assim, a cicatrização ao aguçar a soltura de oxigênio na ferida, o efeito antiinflamatório em conjunto ao efeito antioxidante e o efeito antibacteriano associado a pouca presença de água livre (SANTOS et al., 2012). Deste modo, como a própolis também advinda das abelhas, demonstram desempenhos semelhantes aos produtos, como antimicrobiana, antioxidante, antiinflamatória e cicatrizante. Esses acontecimentos ocorrem pelo fato de sua composição química, tais como os flavonóides, tido como principal responsável pelo desempenho do fechamento da cicatriz (ARGENTINO; SANTOS; MARINHO, 2017). A própolis possui também uma grande complexidade química, e é tida como uma das fusões mais heterogêneas encontradas em fontes naturais, e é utilizada na medicina desde 300 a.C. estando em ênfase por causa de suas propriedades biológicas, atividade antimicrobiana, antiinflamatória, cicatrizante, anestésica, antiviral (SILVA, 2019). Este elemento natural vem sendo utilizado no combate de feridas pela destreza de utilização, inocuidade, custo baixo e poder contra as bactérias ou bacteriostático. Sendo assim, destaca-se o mel, cujos constituintes principais incluem $40 \%$ de glicose, $40 \%$ de frutose e $20 \%$ de água e o própolis, constituído basicamente de resinas e bálsamo, cera de abelha, óleos voláteis e pólen (RIBEIRO et al., 2013). Logo, as lesões tratadas com mel mostram pouca absorção neutrofílica e proliferação marcada de angioblastos e fibroblastos. No entanto, conforme a fonte da planta e processamento pode haver variação da atividade antibacteriana e no sucesso do tratamento medico (RIBEIRO et al., 2013).

Conclusão: Entende-se que com o aumento do uso de antibióticos, a ocorrência e número de bactérias que se tornaram resistentes também aumentou. Por este motivo, a comunidade médica e científica iniciou uma busca por possibilidades que possa combater os antibióticos. Estas buscas levaram à descoberta de alguns dos mecanismos e componentes do mel e da própolis que pode ser uma alternativa natural e útil para o tratamento de feridas e inflamação nas mesmas, já que a estudos comprovando sua eficácia em hidratar os tecidos, reduzir de forma rápida as inflamações e reconstituição dos ferimentos. 


\section{Referências}

ARGENTINO, Ícaro do Nascimento; Santos, Letícia Maria de Almeida; Marinho, Polyana Carolina. Manejo e Tratamento de Feridas em Equinos Com Produtos Fitoterápicos: Revisão de Literatura. Revista de Ciência Veterinária e Saúde Pública, Umuarama Pr, v. 4, n. 2, p.105-110, out. 2017.

RIBEIRO, G; Silva, M.A.G; Martins, C.B; Borges, V.P; Lacerda Neto, J.C. Associação fitoterápica no tratamento de feridas cutâneas induzidas em equinos. Arquivo Bresileiro de Medicina Veterinária e Zootecnia, Jaboticabal, v. 65, n. 5, p.1427-1433, 2013.

SANTOS, Ivan Felismino Charas; Cardoso, José Manuel da Mota; Oliveira, Karen Cardoso; Marujo, Renata Bezerra. Uso do mel no tratamento de ferida lacero contusa em um cão adulto - Relato de caso. Revista de Educação Continuada em Dermatologia e Alergologia Veterinária, Curitiba, Pr, v. 11, n. 1, p. 73-76, nov. 2011.

SANTOS, Ivan Felismino Charas; Grosso, Sara Luisa Sousa; Bambo, Otilia Bata; Nhambirre, André Paulo; Cardoso, José Manuel Mota; Schmidt, Elizabeth Moreira dos Santos; Marujo,Renata Bezerra. Mel e açúcar mascavo na cicatrização de feridas. Revista do Centro de Ciências Rurais, Santa Maria, v. 42, n. 12, p. 2219-2224, dez. 2012.

SILVA, Raquel de Alencar. Retração cicatricial de feridas cutâneas induzidas e posteriormente tratadas separadamente com mel, própolis e copaíba em bubalinos. 2019. TCC (Graduação em Medicina Veterinária) - Universidade Federal Rural da Amazônia, Belém, 2019. 


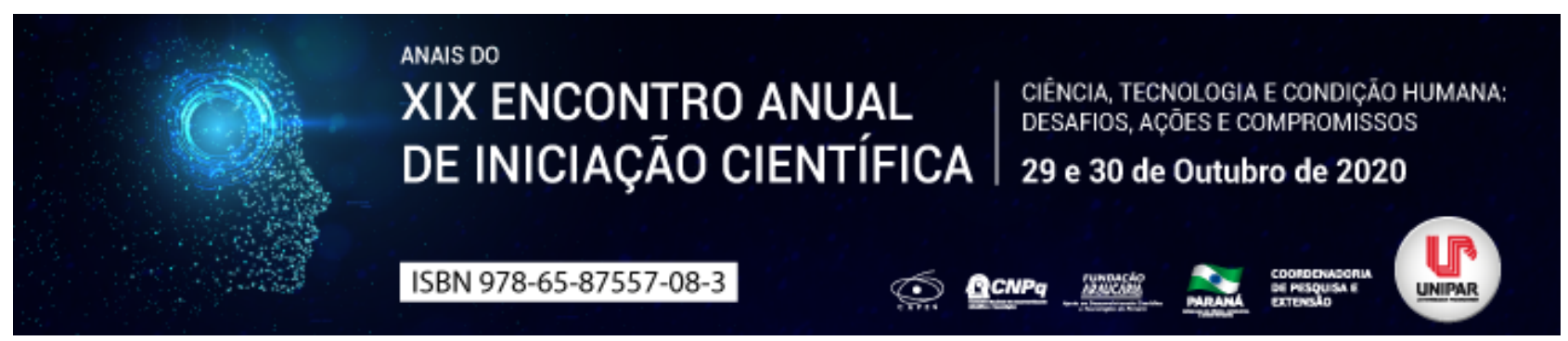

POTENCIAL ANTIMICROBIANO DE Alpinia purpurata (Vieill.) K. Schum. (Zingiberaceae). DE Alpinia Purpurata (Vieill.) K. Schum. (Zingiberaceae)

\title{
${ }^{1}$ RAFAELA GALVES FERREIRA, ${ }^{2}$ CAMILA DE CUFFA MATUSAIKI, ${ }^{3}$ FELIPE ANDRÉ PERREIRA RAMOS, ${ }^{4}$ LIDIANE NUNES BARBOSA, ${ }^{5}$ LUCIANA KAZUE OTUTUMI, ${ }^{6}$ ANDREIA ASSUNCAO SOARES
}

\author{
${ }^{1}$ Acadêmico bolsista do PEBIC / CNPQ \\ ${ }^{1}$ Acadêmico bolsista do PEBIC / CNPQ \\ ${ }^{2}$ Mestrando Profissional de Plantas Medicinais e Fitoterápicos na Atenção Básica/UNIPAR \\ ${ }^{3}$ Docentes Mestrado e Doutorado em Ciência Animal com Ênfase em Produtos Bioativos, UNIPAR \\ ${ }^{4}$ Docente do Mestrado e Doutorado em Ciência Animal com Ênfase em Produtos Bioativos, UNIPAR - Umuarama-PR. \\ ${ }^{5}$ Docente da UNIPAR
}

Introdução: A família Zingiberaceae tem recebido atenção especial, por produzir muitos compostos bioativos que são úteis em alimentos como ervas e especiarias; aromatizantes e temperos; nas indústrias farmacêutica e cosmética como agentes antioxidantes e antimicrobianos (CHEN et al., 2008; CHAN; WONG, 2015). Existem vários tipos de gengibres e estudos recentes reportam as propriedades medicinais, tais como, atividade antioxidante, antimicrobiana, anti-inflamatória e analgésica (VORAVUTHIKUNCHAI, 2007; HASAN, 2012). Dentre as espécies mais conhecida desta família destaca-se o Zingiber officinale Roscoe, conhecido popularmente como gengibre comestível, e amplamente cultivado para uso na forma de especiarias, condimentos e medicinal (SUHAD et al., 2012). Outras espécies de Zingiberaceae são amplamente cultivadas como ornamentais, destacando o gênero Alpinia, dentre elas a Alpinia purpurata (Vieill.) K. Schum. popularmente conhecida como gengibre-vermelho (CHAN; WONG, 2015. Diferentes extratos com folhas, rizomas e raízes do gengibre-vermelho demonstraram atividades antioxidante e antimicrobiana associados aos seus compostos bioativos (VILLAFLORES et al., 2010; RAJ et al., 2012; GHOSH; RANGAN, 2013; SAHOO; SINGHI; NAYAK, 2014; KONA; THOFEEQ; VENKATA, 2015). Essas informações sobre os gengibres são de grande importância, pois podem colaborar na compreensão dos mecanismos biológicos dos compostos bioativos e consequentemente, novas alternativas na produção de extratos e fármacos, (agentes terapêuticos) para a prevenção e tratamento de doenças (VORAVUTHIKUNCHAI, 2007; DAS; RAHMAN, 2012; GUPTA; SHARMA, 2014).

Objetivo: Avaliar o potencial antimicrobiano de Alpinia purpurata (Vieill.) K. Schum. (Zingiberaceae). de Alpinia Purpurata (Vieill.) K. Schum. (Zingiberaceae):

Desenvolvimento: Muitas plantas e especiarias possuem atividade antimicrobiana contra bactérias, fungos e leveduras, atuando provavelmente na desestabilização das paredes celulares e membranas celulares e subsequentemente na morte celular (DAVIDSON; PARISH 2001; TAJKARIMI; IBRAHIM; CLIVER, 2010). Essas informações disponíveis demonstram que diferentes antimicrobianos de origem vegetal podem efetivamente reduzir e ou inibir microrganismos patogênicos, e assim podem tornar-se uma boa alternativa aos antimicrobianos convencionais (NEGI, 2012). A qualidade antisséptica das plantas medicinais e seus extratos são bem reconhecidos, e estudos demonstram que os metabólitos secundários dessas plantas possuem potencial medicinal, farmacêutico e cosmético (RACHANA; VENUGOPALAN, 2014). A família Zingiberaceae tem recebido muita atenção, uma vez que diversas espécies produzem muitos compostos bioativos que são úteis em alimentos como ervas e especiarias; aromatizantes e temperos; nas indústrias farmacêuticas e de cosméticos como agentes antioxidantes e antimicrobianos (CHEN et al., 2008; CHAN; WONG, 2015). Dentre as espécies de Zingiberaceae, destacam-se os populares gengibres que são amplamente cultivados nos países tropicais e utilizados como especiarias na culinária e também como uso medicinal. Existem vários tipos de gengibres e estudos recentes reportam as propriedades medicinais, tais como, atividade antioxidante, atividade antimicrobiana, anti-inflamatória e analgésico (VORAVUTHIKUNCHAI, 2007; HASAN, 2012). Alpinia purpurata popularmente conhecida como gengibre vermelho, utilizada principalmente como planta ornamental, cujas flores, coloração vermelha, sendo bem atrativas, e os rizomas aromáticos (CHAN; WONG, 2015). O traço mais notável deste gênero é a beleza das inflorescências, o que explica o vasto uso ornamental através da comercialização de sementes e flores. Alpinia purpurata é conhecida no mundo todo e ocorre amplamente no Brasil, entretanto de uso medicinal pouco difundido (KOBAYASHI; MCEWEN; KAUFMAN, 2007; VICTÓRIO, 2011). Os extratos metanólicos das folhas, flores e rizomas, bem como do óleo essencial de várias espécies de Alpinia foram eficientes nas atividades antioxidante e antimicrobiana (SAHOO; SINGHI; NAYAK, 2014; WONG; LIM; OMAR, 2009).

Conclusão: Diferentes estudos têm demonstrado a atividade antimicrobiana dos compostos bioativos, porém ainda não estão totalmente esclarecidos os mecanismos de ação desses compostos isolados, sugerindo que diferentes pesquisas com ensaios microbiológicos e clínicos sejam realizadas afim de identificar as atividades destes compostos. Entretanto, são necessárias 
pesquisas in vitro e in vivo para avaliar a eficácia dos extratos do gengibre e compreender o seu papel na modulação das vias biológicas e moleculares, possibilitando assim, novas estratégias terapêuticas e a compreensão dos mecanismos biológicos dos compostos bioativos e consequentemente, novas alternativas de extratos e fármacos para prevenção e tratamento de doenças que acometem os indivíduos.

\section{Referências}

CHAN, E. W. C., WONG, S. K. Phytochemistry and pharmacology of ornamental gingers, Hedychium coronarium and Alpinia purpurata: a review. Journal of Integrative Medicine, v. 13, n.6, p. 368-379, 2015.

CHEN, I-N. et al. Antioxidant and Antimicrobial activity of Zingiberaceae plants in Taiwan. Plant Foods Human Nutrition, n. 63, p. 15-20, 2008.

DAVIDSON, P. M.; PARISH, M. E. Methods for testing the efficacy of food antimicrobials. Food Technology, v. 43, p. 148-155, 2001.

GHOSH, S.; RANGAN, L. Alpinia: the gold mine of future therapeutics. 3 Biotech, v. 3, n.3, p. 173-183, 2013.

GUPTA, S. K.; SHARMA, A. Medicinal properties of Zingiber officinale Roscoe - A review. Journal of Pharmacy and Biological Sciences, v. 9, n. 5, p. 124-129, 2014.

HASAN, H. A. et al. Chemical Composition and Antimicrobial Activity of the Crude Extracts isolated from Zingiber officinale by Different Solvents. Pharmaceut Anal Acta, v. 3, n. 9, p. 1-5, 2012.

KOBAYASH, K. D.; MCEWEN, j.; KAUFMAN, A. J. Ornamental Ginger, Red and Pink. Ornamentals and Flowers, v. 37, p.1-8, 2007.

KONA, L. A.; THOFEEQ, M. D.; VENKATA, R. In vitro Studies and Antibacterial Activity of Alpinia purpurata. Austin Journal of Biotechnology \& Bioengineering, v. 2, n. 4, p. 1-2, 2015.

NEGI, P. S. Plant extracts for the control of bacterial growth: Efficacy, stability and safety issues for food application. International Journal of Food Microbiology, v. 156, p. 1-17, 2012.

RACHANA, S.; VENUGOPALAN, P. Antioxidant and bactericidal activity of wild turmeric extracts. Journal of Pharmacognosy and Phytochemistry, v. 2, n. 6, p. 89-94, 2014.

RAHMANI, A. H.; SHABRMI, F. M. AL.; ALY, S. M. Active ingredients of ginger as potencial candidates in the prevention and treatment of diseases via modulation of biological activities. International Journal Pathophysiolol Pharmacol, v. 6, n. 2, p. 125136, 2014.

SAHOO, S.; SINGHI, S.; NAYAK, S. Chemical composition, antioxidant and antimicrobial activity of essential oil and extract of Alpinia malaccensis Roscoe (Zingiberaceae). International Journal of Pharmacy and Pharmaceutical Sciences, v. 6, n. 7, p. 183-188, 2014.

SUHAD, A. et al. Study the Antibacterial Activity of Zingiber officinale roots against some of pathogenic bacteria. Al-Mustansiriya Journal Sci, v. 23, n. 3, p.63-70, 2012.

TAJKARIMI, M. M.; IBRAHIM, S. A.; CLIVER, D. O. Antimicrobial herb and spice compounds in food. Food Control, v. 21, p. 1199-1218, 2010.

VICTÓRIO, C. P. Therapeutic value of the genus Alpinia Zingiberaceae. Brazilian Journal of Pharmacognosy, v. 21, n. 1, p. 194-201, 2011.

VILLAFOLRES, O. B.; MACABEO, A. P. G.; GEHLE, D.; KROHN, K.; FRANZBLAU, S. G.; AGUINALDO, A. M. Phytoconstituints from Alpinia purpurata and their in vitro inhibitory activity against Mycobacterium tuberculosis. Pharmacognosy Magazine, v. 6 , $\mathrm{n}$. 24, p. 339-344, 2011.

VORAVUTHIKUNCHAI, S. P. Family Zingiberaceae compounds as functional antimicrobials, antioxidants, and antiradicals. Food, v. 1, n. 2, p. 227-240, 2007.

WONG, L. F.; LIM, Y. Y.; OMAR, M. Antioxidant and Antimicrobial Activities of some Alpinia species. Journal of Food Biochemistry, v. 33, p. 835-851, 2009. 


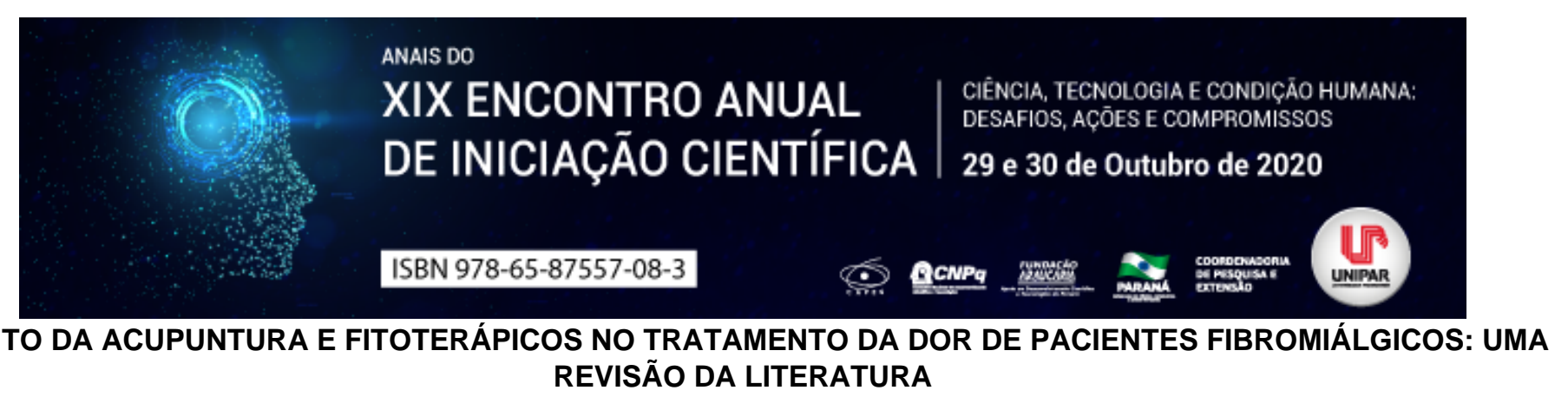

${ }^{1}$ ANA LUIZA REZENDE NABHAN, ${ }^{2}$ DANIELA DE CASSIA FAGLIONI B CERANTO

${ }^{1}$ Acadêmica do Mestrado em Plantas Medicinais e Fitoterápicos da UNIPAR
${ }^{1}$ Docente da UNIPAR

Introdução: A Fibromialgia, é uma síndrome dolorosa crônica, não inflamatória, de etiologia desconhecida, manifestada no sistema músculo-esquelético, podendo apresentar sintomas em outros sistemas. Com definição controvérsia, principalmente, pela ausência de substrato anatômico na sua fisiopatologia e por sintomas facilmente confundidos com a depressão e síndrome da fadiga crônica (PROVENÇA, 2004). Sua prevalência chega ser de 2 a $8 \%$ da população e sua etiologia é provavelmente multifatorial. O quadro clínico costuma ser constituído por um conjunto de sintomas e sinais, o que exige uma anamnese cuidadosa e detalhada do profissional, sendo a dor esquelética axial difusa e crônica uma queixa presente em todos os pacientes. Em geral, essa dor é de difícil localização, e por vezes são apontandos sítios peri-articulares, sem especificar se a origem é muscular, óssea ou articular. A medicina alternativa e complementar tem sido muito solicitada nos últimos anos, especialmente por pacientes fibromiálgicos, na qual a terapia convencional isolada tem mostrado benefícios limitados e que necessita de um tratamento multidisciplinar (BRAZ et al. 2011).Para Nascimento (2012), progressos recentes na terapêutica atual têm estimulado o uso de produtos naturais em todo o mundo, inclusive associando técnicas integrativas para o seu tratamento, em vista a melhorar a qualidade de vida dos pacientes.

Objetivo: Revisar a literatura sobre os efeitos da Acupuntura e de Fitoterápicos no tratamento da Fibromialgia.

Desenvolvimento: A Fibromialgia (FM) é uma doença crônica, que pode ser definida por dor nos tecidos fibrosos e musculares, que se caracteriza não somente pelo quadro álgico generalizado, como também por quadros associados de fadiga, depressão e distúrbios do sono (FERREIRA, 2015). Devido à ausência de substrato anatômico, a definição ou diagnóstico da FM acaba gerando controvérsias, visto que, alguns pacientes não apresentam alterações no estudo fisiopatológico que justifique os sintomas, sendo assim passam a não ser diagnosticados, mesmo apresentando quadros de dor músculo-esquelética importantes (MAGALHÃES E ROCHA, 2007). O Colégio Americano de Reumatologia, publicou em 1990, os critérios de classificação da FM e esses também foram validados para a população brasileira, sendo então a sensibilidade dolorosa em sítios anatômicos, denominado tender points, bem como a quantidade desses pontos, utilizado como um critério de avaliação e validação para o diagnóstico diferencial da FB (WOLF et al, 1990). A subjetividade dos sintomas e ausência de sinais juntamente com pontos dolorosos instáveis e inconstantes e a associação com distúrbios psiquiátricos, dificulta um diagnóstico isolado da doença. Cerca $2 \%$ da população geral apresenta um ou mais sintomas da FM, sendo esta patologia responsável por quase $15 \%$ das consultas registradas em ambulatórios de reumatologia e de 5\% a 10\% nos ambulatórios de clínica geral. Proporcionalmente atinge de 6 a 10:1 mais mulheres que homens, a maior prevalência dos casos está em indivíduos entre 30 e 50 anos (PROVENÇA et al 2004). Apesar de existirem inúmeros estudos sobre tratamentos de fibromialgia FERREIRA (2015), destaca que nada está ainda totalmente definido e evidenciado como sendo uma terapêutica específica e totalmente eficaz para cura dos sintomas. Dentre as possibilidades de tratamento estão o uso da Acupuntura e da Fitoterapia. A Acupuntura é uma técnica milenar que se baseia na estimulação de pontos específicos do corpo objetivando o efeito terapêutico ou homeostático. A escolha dos pontos de deve é baseada na classificação do desequilíbrio apresentado bem como a estimulação de um determinado ponto possui indicações específicas. Tradicionalmente, cada ponto de Acupuntura tem uma ou diversas ações, quando estimulado e quando usado em combinação com outros pontos os resultados são modificados, por isso a definição do tratamento também deve se basear nas categorias nas quais os pontos de divididos: efeitos locais, efeitos à distância ou objetivando efeitos sistêmicos (KIM, 2005). Nos últimos anos vários estudos tem demonstrado o efeito da acupuntura na melhora da qualidade de vida e na minimização das dores em pacientes fibromiálgicos (OLIVEIRA, et al 2014). Em 2013 OLIVEIRA et al fizeram uma revisão sistemática sobre os efeitos da acupuntura no tratamento da fibromialgia e os resultados demonstraram que vários estudos comprovam os benefícios da acupuntura como método analgésico na síndrome fibromiálgica. Pesquisas utilizando plantas medicinais vem recentemente apresentando atividades terapêuticas importantes no tratamento da Fibromialgia, com melhora significativa da dor, da insônia, da qualidade de vida e da ansiedade. Em um estudo realizado por EDDOUKS et al. (2012), foram encontradas: 01 patente na base do INPI, 28 patentes na base europeia Espacenet, 12 na DWPI, 11 na WIPO, totalizando 52 patentes. Desta forma, é grande a necessidade de descoberta de novas opções terapêuticas no tratamento da dor já que há uma lacuna tecnológica a ser preenchida, e um campo promissor para pesquisa e desenvolvimento de inovações tecnológicas (NASCIMENTO et al 2012).

Conclusão: A FM é caracterizada por um quadro clínico amplo, em que a dor é preponderante. Somente métodos farmacológicos não são totalmente eficazes para o tratamento, por isso, métodos alternativos de tratamento precisam ser 
investigados, dentre eles a acupuntura e a fitoterapia são técnicas promissoras neste contexto, inclusive a associação de ambas, poderia ser promissora para minimizar a dor de paciente fibromiálgicos.

\section{Referências}

BRAZ, Alessandra de Souza et at. Uso da Terapia não farmacólogica, medicina alternativa e complementar na fibromialgia. Rev.Bras.Reumatol. vol. 51 n03. São Paulo, 2001. Disponível em: https://www.scielo.br/scielo.php? script=sci_arttext\&pid=S0482-50042011000300008. Acesso: 23 de Julho de 2020.

KIM Yong-Suk et al.. The practice of Korean medicine: an overview of clinical trials in acupuncture. Evidence-Based Complementary and Alternative Medicine, v.2, n.3, p.325- 352, 2005.

EDDOUKS, Mohamed.; CHATTOPADHYAY, Debbrasad.; DE FEO, Vicenzo.; CHO, Willian.C. Medicinal Plants in the Prevention and Treatment of Chronic Diseases. Evidence-Based Complementary and Alternative Medicine, published online, September 18, 2012.

OLIVEIRA Rafaela Menezes; SOUSA Hugo Alves; GODOY José Roberto. Efeito da acupuntura na qualidade de vida e no tratamento da dor em pacientes com fibromialgia. Universitas: Ciências da Saúde, Brasília, v. 12, n. 1, p. 37-48, jan./jun. 2014. NASCIMENTO Simone Souza, et al. Utilização de plantas medicinais no tratamento da fibromialgia: uma prospecção tecnológica. Revista GEINTEC. v., n.1, p.68-75, 2012. D.0.I.:10.7198/S2237-0722201300010006.

PROVENÇA, José Roberto. et al..Fibromialgia. Rev. Bras. Reumatolol. Vol.44 n6. São Paulo Nov/Dez 2004. Disponível em:http://www.scielo.br/scielo.php?pid=S0482-50042004000600008\&script=sci_arttext\&tlng=pt. Acesso: 04 de Abril de 2020.

Coordenadoria de Pesquisa e Extensão - COPEX

Departamento de Editoraçāo e Divulgaçāo Científica - DEDIC 


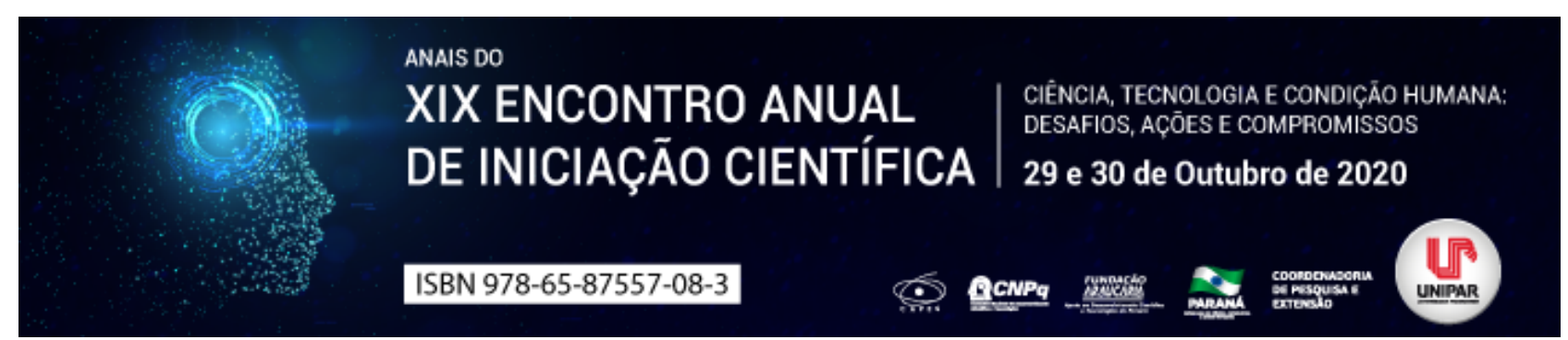

PERFIL HEPÁTICO DE TILÁPIAS DO NILO (Oreochromis Niloticus) EXPERIMENTALMENTE INFECTADAS POR Streptococcus Agalactiae

\begin{abstract}
${ }^{1}$ Julia Borasca, ${ }^{2}$ TAMIRES MARUITI SERRA, ${ }^{3}$ BRENO MANZANI, ${ }^{4}$ ANDRESSA CARDOSO INNOCENTE, ${ }^{5}$ ANDRÉ MARCOS SANTANA
\end{abstract}

${ }^{1}$ Discente do curso de Medicina Veterinária, Universidade Estadual de Maringá (UEM)

${ }^{1}$ Discente do curso de Medicina Veterinária, Universidade Estadual de Maringá (UEM)

${ }^{2}$ PREVET-Sanidade Aquícola, Jaboticabal - SP

${ }^{3}$ PREVET-Sanidade Aquícola, Jaboticabal - SP

${ }^{4}$ Docente do Departamento de Medicina Veterinária, Universidade Estadual de Maringá (UEM)

Introdução: A aquicultura em especial a piscicultura, é um dos setores de produção animal que mais vem se desenvolvendo ao longo dos anos no Brasil e nos países de todo o mundo (CONTE, 2004). A tilápia do Nilo é uma espécie benéfica para a economia brasileira por seu fácil manejo e qualidade no desempenho produtivo (TAVARES- DIAS et al., 2000). Na tilapicultura intensiva destaca-se, dentre os problemas sanitários mais importantes, a septicemia causada pela bactéria Streptococcus agalactiae (SALVADOR et al., 2005). Esse patógeno é capaz de causar altas taxas de morbidade e mortalidade, podendo atingir 90\% em um cultivo, sendo sua principal via de transmissão horizontal, pelo contato com peixes e ou alimentos contaminados e também pelo contato direto. (LIM \& WEBSTER, 2006). Essa bactéria possui características de aderência às superfícies epiteliais, invasão celular e injúria direta a tecidos (NIZET \& RUBENS, 2000). Os sinais clínicos são anorexia, escurecimento da pele, natação errática, letargia, curvatura do corpo, exoftalmia ocular, opacidade de córnea uni ou bilateral, sufusões no opérculo e base das nadadeiras, ulceração da epiderme e morte (TRABULSI \& ALTERTHUM, 2008); ainda há lesões internas, como congestão braquial, hepatomegalia associada à congestão, ascite, esplenomegalia e encefalomalácia (SALVADOR et al., 2003). Mediante o exposto é de suma importância a realização de estudos a respeito do perfil hepático das tilápias frente a essa infecção, identificando a suspeita das principais doenças e lesões hepáticas que esse patógeno pode causar, além de determinar a saúde do fígado e dos seus níveis de proteínas e enzimas no sangue.

Objetivo: Avaliar as alterações no perfil hepático de tilápias experimentalmente infectadas por Streptococcus agalactiae, de modo a melhor compreender a fisiopatologia dessa doença, alterações hepáticas e consequentemente adicionar informações auxiliares úteis para o diagnóstico e prognóstico dessa enfermidade, evitando disfunções graves e diminuição da taxa de crescimento e morte dos animais.

Material e Métodos: Foram inoculadas 150 tilápias, por via intraperitoneal, com uma cepa patogênica de Streptococcus agalactiae contendo $2 \times 10^{3}$ UFC. Os peixes foram acompanhados durante 7 dias pós-desafio, onde foram analisados a taxa de mortalidade. Para avaliação do perfil hepático, foram coletadas amostras de sangue de 12 peixes antes do desafio (M0), 7 dias pós (M1) e 14 dias pós (M2). Serão avaliadas as concentrações séricas de aspartato aminotransferase (AST) e de fosfatase alcalina (ALP). Os testes serão realizados utilizando-se conjuntos de reagentes de uso comercial. As leituras dos parâmetros serão realizadas em espectrofotômetro semi-automático.

Resultados: A taxa de mortalidade acumulada foi de: 0\% (dias 0 a 3 após a inoculação), 8\% (dia 4 após a inoculação), 14\% (dia 5 após a inoculação), 50\% (dia 6 após a inoculação), 80\% (dia 7 após a inoculação - M1), $90 \%$ (dia 8 a 10 após a inoculação), 93\% (Dia 11 a 13 após a inoculação) e 93\% (dia 14 após a inoculação - M2). Em relação ao perfil de resposta hepática,

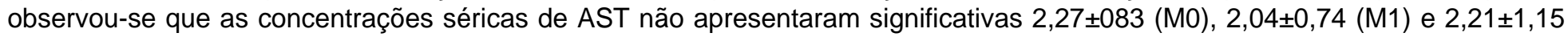

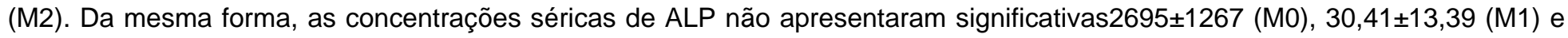
31,10 \pm 7,18 (M2)

Discussão: As altas taxa de mortalidade após a inoculação, no decorrer do experimento, confirmam que a inoculação experimental com $2 \times 10^{3}$ UFC foi capaz de induzir a doença nos peixes deste experimento, e corroboram com outro estudo que observou uma taxa de até $90 \%$ de mortalidade em tilápias infectadas por Streptococcus agalactiae (SALVADOR et al., 2005). Neste contexto, os valores de AST e ALP tem um potencial diagnóstico na toxicologia e patologia de peixes, sendo que a atividade sérica dessas enzimas pode trazer informações sobre danos celulares advindos de possível lesão no fígado, quando se apresentam aumentadas. No entanto, embora a literatura mostre que o Streptococcus agalactiae pode ocasionar hepatomegalia associada à congestão, entre outras alterações (SALVADOR et al., 2003), nosso trabalho não evidenciou alterações nas enzimas hepáticas estudadas, e assim não foi possível demostrar danos detectáveis nos hepatócitos.

Conclusão: As altas taxa de mortalidade, no decorrer do experimento, confirmaram que a inoculação experimental com 2x10 3 UFC foi capaz de induzir a doença nos peixes inoculados. No entanto, o estudo do perfil hepático de tilápias frente ao desafio, 
realizado pela análise das atividades séricas das enzimas hepáticas AST e ALP, não evidenciou alterações detectáveis nos hepatócitos.

\section{Referências}

CONTE, F. S. 2004. Stress and the welfare of cultured fish. In: Applied Animal Behavior Science. v.86: 205-223. ed.3, junho de 2004. Disponível em: https://www.sciencedirect.com/science/article/abs/pii/S01681591040004868159104000486. Acesso em 25 ago.2020.

LIM, C.; WEBSTER, C.D. 2006. Tilápia: biology, culture and nutrition. Haworth Press: New York. 678p. Disponível em: https://www.academia.edu/16673698/C_Lim_C_D_Webster_eds_Tilapia_Biology_Culture_and_Nutrition. Acesso em: 25 ago.2020.

NIZET V.; RUBENS C. 2000. Pathogenic mechanisms and virulence factors of Group B Streptococci. In: FISCHETTI V et al. (Eds.). Gram-positive pathogens. Washington: American Society for Microbiology. pp.125-135.

SALVADOR R.; DIAS, J. A.; FREITAS, J. C.; LEONHARDT, J. H.; MORENO, M . A.; MULLER, E. E.; PRETTO-GIORDANO, L. G.2003. Isolamento de Streptococcus spp. de tilápias do Nilo (Oreochromis niloticus) e qualidade da água de tanques rede na Região Norte do Estado do Paraná, Brasil. Semina: Ciências Agrárias 24: 35-42.

SALVADOR R.; MULLER, E. E.; FREITAS, J. C.; LEONHADT, J.H; PRETTO- GIORDANO, L. G.; DIAS, J. A. 2005. Isolation and characterization of Streptococcus spp. group B in Nile tilapias (Oreochromis niloticus) reared in hapas nets and earth nurseries in the northern region of Parana State, Brazil. Ciência Rural 35: 1374-1378.

TAVARES-DIAS M., SCHALCH S.H.C., MARTINS M.L.; MORAES F.R. 2000. Características hematológicas de Oreochromis niloticus (Osteichthyes: Cichlidae) cultivadas intensivamente em pesque-pague do município de Franca, São Paulo, Brasil. Ars Vet. 16:76-82.

TRABULSI, L. R.; ALTERTHUM, F. Microbiologia. 5.ed., São Paulo: Atheneu, 2008. 718p. 


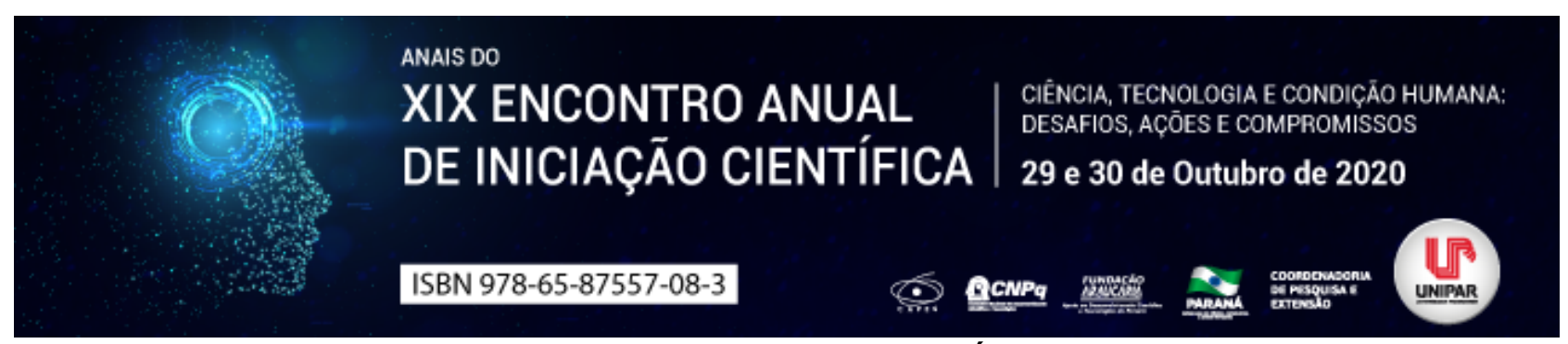

SARS-COV-2 E OS ANIMAIS DOMÉSTICOS

\begin{abstract}
${ }^{1}$ MARCIELY BRAGA CLAUDIANO, ${ }^{2}$ THAINA PIZANE DA SILVA, ${ }^{3}$ VINICIUS SILVEIRA DE QUEIROZ, ${ }^{4}$ ALYSSON RAMALHAIS, ${ }^{5}$ ANA MARIA QUESSADA
\end{abstract}

\author{
${ }^{1}$ Acadêmico Programa de Iniciação Cientifica PIC - Unipar \\ ${ }^{1}$ Acadêmica do Curso de Medicina Veterinária da UNIPAR \\ ${ }^{2}$ Acadêmico do Curso de Medicina Veterinária da UNIPAR \\ ${ }^{3}$ Acadêmico do Curso de Mestrado Em Ciencia Animal Com Enfase Em Produtos Bioativos - Turma Xv da UNIPAR \\ ${ }^{4}$ Docente da UNIPAR
}

Introdução: Recentemente um vírus se tornou o centro das atenções mundiais devido a sua alta taxa de contágio em humanos e sua agressividade em pessoas com comorbidade. O coronavírus é de uma a família viral e existem 4 gêneros pertencentes a família Coronaviridae, os Alphacoronavirus, Betacoronavirsus, Gammacoronavirus e os Deltacoronavirus, sendo que cada gênero pode levar a diferentes doenças, em diferentes espécies de animais (BOTTEON, 2020).

Objetivo: $O$ presente trabalho, tem por objetivo realizar revisão de literatura sobre a capacidade dos animais em contaminar ou transmitir o corona vírus no convívio doméstico.

Desenvolvimento: Por conhecimento científico sabemos que muitos dos vírus existentes na terra são de origem zoonótica, melhor dizendo, são doença infecciosa de animais e geralmente transmissível ao ser humano. Dentre estas, atualmente, o coronavírus do gênero Betacoronavirus, se tornou o centro das atenções devido à alta taxa de mortalidade, nível de contágio e falta de fármacos para tratamento e/ou prevenção. Os animais domésticos estão em contato direto com os humanos e, portanto, entender a fragilidade deles ao SARS-CoV-2, é importante para o controle de transmissão. Estudos recentes indicam que

houve menos de 25 relatos de todo o mundo de animais de estimação infectados com SARS-CoV-2 (AVMA, 2020). Há relatos nos Estados Unidos, China e Holanda de animais contaminados por funcionários e tutores que estavam com coronavírus. Em uma pesquisa chinesa foram infectados diversos animais, com o propósito de determinar o potencial de transmissão e evolução da doença, e a conclusão foi de que os felinos são mais susceptíveis ao contágio e sua resposta imunológica é mais fraca do que os demais animais testados. Pode-se comprovar a contaminação entre humanos e animais domésticos, porém, não está claro se os animais infectados podem transmitir o vírus para outras espécies ou a seres humanos (AVMA, 2020). Segundo Jianzhong et al. 2020, durante ensaio, o vírus foi isolado em cães infectados, e após convívio destes com outros cães não contaminados, nenhum dos animais desenvolveram sinais clínicos de doença respiratória. Assim, os animais foram liberados do estudo após 14 dias, resultando negativamente os testes RT-PCR realizados consecutivamente'. Já segundo Sit et al. 2020, em estudos de laboratório de infecção experimental com SARS-CoV-2, realizada em diversas espécies que podem ser mantidas como animais domésticos e se tornarem vetores de infecção humana, os cães, porcos, galinhas e patos demonstraram uma baixa probabilidade de armazenar e transmitir o vírus . Logo, são insuficientes as evidências de que os animais domésticos sejam infectados em condições naturais e, não há evidências da transmissão de contato do vírus em animais às pessoas. Posição esta diversa do estudo de sua disseminação de pessoa para pessoa.

Conclusão: Parece que o risco de disseminação do vírus pelos animais domésticos é muito baixo e improvável. O ideal é evitar o relacionamento com animais que possam estar contaminados, manter as vacinas dos animais em dia e buscar um profissional da área de medicina veterinária caso o animal apresente qualquer sinal de infecção, pois seu dono pode ser assintomático em conjectura diversa do animal.

\title{
Referências
}

AVMA. SARS-Cov-2 em animais. American Veterinary Medical Assoiaction. Disponível em: https://www.avma.org/resourcestools/animal-health-and-welfare/covid-19/sars-cov-2-animals-including-pets. Acesso em: 31 jun. 2020.

SIT, Thomas HC et al. Infecção de cães com Sars-Cov-2. NATURE. Disponível em: https://doi.org/10.1038/s41586-020-2334-5. Acesso em: 31 jun. 2020.

JIANZHONG, Shi et al. Suscetibilidade de furões, gatos, cães e outros animais domesticados ao SARS-coronavírus. SCIENCE. Disponível em: https://science.sciencemag.org/content/368/6494/1016.abstract. Acesso em: 19 jun. 2020.

KARINA BOTTEON. Coronavirus em humans e pets: entenda a diferença. Berinhringer Ingelheim. Disponível em: https://www.boehringer-ingelheim.com.br/quem-somos/conexao-com-executivos/coronavirus-em-humanos-e-pets-entendadiferencas. Acesso 31 jun 2020. 
Coordenadoria de Pesquisa e Extensão - COPEX

Departamento de Editoraçāo e Divulgaçāo Científica - DEDIC 


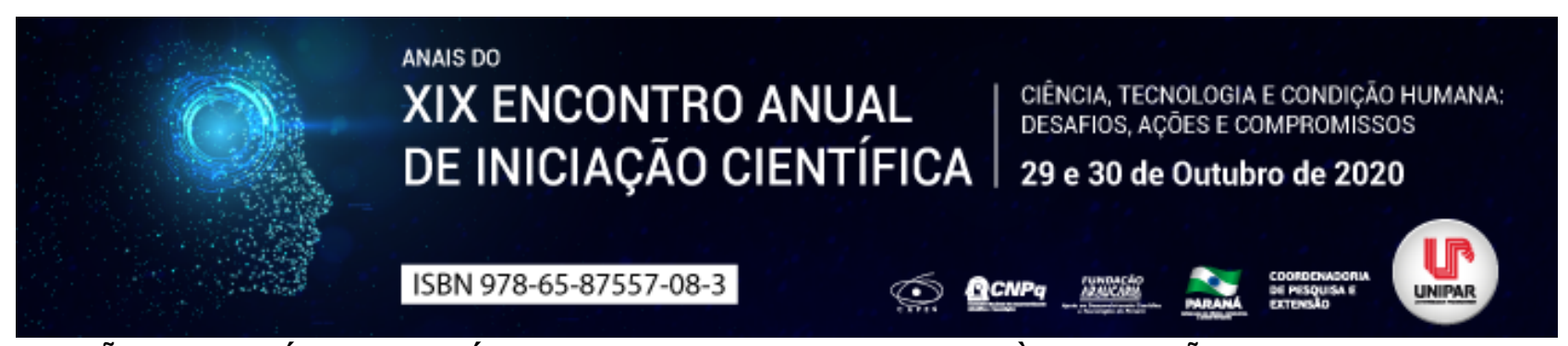

ALTERAÇÕES PATOLÓGICAS NO ÚTERO DE CADELAS SUBMETIDAS À APLICAÇÃO DE ANTICONCEPCIONAIS HORMONAIS

\author{
${ }^{1}$ RAFAEL MARTINS BASTOS, ${ }^{2}$ ANA CAROLINE SOARES CERANTO, ${ }^{3}$ ALYSSON RAMALHAIS, ${ }^{4}$ ANNA JULIA BARBOSA \\ SANT ANNA, ${ }^{5}$ CAROLINA AGUERA, ${ }^{6}$ ANA MARIA QUESSADA
}

\author{
${ }^{1}$ Acadêmico Bolsista do PEBIC/FUNDAÇÃO ARAUCÁRIA \\ ${ }^{1}$ Acadêmica Bolsista do PEBIC/CNPQ \\ ${ }^{2}$ Acadêmico do Curso de Mestrado Em Ciencia Animal Com Enfase Em Produtos Bioativos - Turma Xv da UNIPAR \\ ${ }^{3}$ Acadêmica PIBIC JUNIOR/CNPQ \\ ${ }^{4}$ Acadêmica PIBIC JUNIOR/CNPQ \\ ${ }^{5}$ Docente da UNIPAR
}

Introdução: A castração cirúrgica é o método mais seguro e efetivo para evitar a concepção em cadelas (CATAPAN et al., 2015), sendo importante para controle populacional de cães. Tal controle é necessário para que ocorra a diminuição de abandono e eutanásia destes animais, práticas comuns no Brasil, mas que são motivo de angústia para a sociedade e profissionais que trabalham na área. Além disso, o controle populacional de cães e gatos errantes é fundamental para o controle sanitário de zoonoses. Apesar das vantagens da castração cirúrgica, muitos tutores resistem a esse tipo de cirurgia, seja por medo, desconhecimento ou questões culturais (CATAPAN et al., 2015). Dessa maneira muitos tutores optam por administrar anticoncepcionais hormonais para evitar gestações indesejadas. Tais fármacos são fáceis de serem encontrados e são facilmente administrados. Contudo, tais medicamentos possuem uma série de efeitos colaterais como piometra (SILVEIRA et al., 2013; SOUZA et al., 2014; MOURA et al., 2016), tumores mamários, abortos, dermatoses (MOURA et al., 2016) e morte fetal (ARAÚJO et al., 2014). Às vezes as enfermidades em cadelas ocorrem com uma única aplicação (MOURA et al., 2016). No entanto, ainda não há estudos definitivos para relacionar a administração de anticoncepcionais hormonais a enfermidades reprodutivas. Desta forma, pretendeu-se estudar a ação que tais fármacos produzem nos ovários e útero de cadelas após a sua administração.

Objetivo: Acompanhar cadelas submetidas à administração de anticoncepcionais hormonais para registrar quaisquer alterações histopatológicas nos ovários e útero.

Metodologia: Sob supervisão médico-veterinária Foram selecionados 20 tutores que iriam administrar anticoncepcionais em cadelas pela primeira vez. Tais tutores foram selecionados entre clientes de 10 empresas que comercializam anticoncepcionais para fêmeas caninas na cidade de Umuarama (PR). Todos os tutores efetuaram a compra do anticoncepcional e foram abordados por estudantes de Medicina veterinária após a conclusão da compra para inclusão no projeto. Após concordarem com a participação, os tutores foram instruídos a não administrar o anticoncepcional e levar suas cadelas para exame e inclusão no projeto. Antes da aplicação do anticoncepcional, todas as cadelas foram examinadas clinicamente. Foram selecionadas apenas cadelas que não apresentaram alterações em todos os exames. Uma vez selecionadas, as cadelas foram submetidas à administração do anticoncepcional adquirido pelo tutor. Todos os fármacos eram injetáveis e foram aplicados por via subcutânea na região abdominal lateral direita. Noventa dias após a administração dos anticoncepcionais, todas as cadelas foram examinadas novamente. A seguir foram submetidas à ovariohisterectomia por método convencional (STONE, 2007). Os ovários e úteros removidos cirurgicamente foram examinados macroscopicamente e fotografados para detecção de quaisquer anormalidades. Os cornos uterinos foram abertos e identificados quanto ao lado. As peças foram, então, imersas em formol 10\% e encaminhadas ao Laboratório de Patologia Geral do Hospital Veterinário da Universidade Paranaense para serem processadas para exames histopatológicos. Todos os resultados obtidos foram anotados em fichas individuais.

Resultados e discussão: Todos os sistemas orgânicos foram examinados, mas o foco principal foi o sistema reprodutivo, uma vez que os efeitos adversos associados envolve o sistema reprodutor (SILVEIRA et al., 2013; ARAÚJO et al., 2014; SOUZA et al., 2014; MOURA et al., 2016). Entre efeitos adversos no sistema reprodutivo de cadelas submetidas à aplicação de anticoncepcionais estão piometra (SILVEIRA et al., 2013; SOUZA et al., 2014; MOURA et al., 2016; HONÓRIO et al., 2017), tumores mamários, abortos (MOURA et al., 2016; HONÓRIO et al., 2017) e morte fetal (ARAÚJO et al., 2014).Após a retirada do útero das cadelas constatou-se que em 18 cadelas (90\%; 18/20), o órgão apresentou alterações macroscópicas compatíveis com hiperplasia endometrial cística (HEC) e presença de pus associada à HEC caracterizando piometra (KEMPISTY et al., 2013). No exame microscópico, 19 cadelas (95\%; 19/20) apresentaram alterações uterinas que variaram de alterações circulatórias a hiperplasia endometrial cística grave.

Conclusão: Uma única aplicação de anticoncepcional injetável em cadelas foi capaz de causar alterações patológicas no 
sistema reprodutor destes animais, principalmente hiperplasia endometrial cística. Sugere-se que este fármaco seja aplicado sob estrita supervisão veterinária, sendo um item obrigatório na bula deste tipo de medicamento.

\section{Referências}

ARAÚJO, L.S. et al. Morte fetal em cadelas e gatas submetidas a tratamento com anticoncepcionais atendidas no Hospital Veterinário da Universidade Federal de Campina Grande. Acta Veterinaria Brasilica, v.8, Supl. 2, p. 193-194, 2014.

CATAPAN, D.C. et al. Estimativa populacional e programa de esterilização cirúrgica de cães e gatos. Acta Veterinaria Brasilica, v.9, n.3, p.259-273, 2015.

HONORIO, T.G.A.F. et al. Implicações patológicas após o uso de anticoncepcional, em cadelas situadas em Teresina

PI.

PUBVET. v. 11, n.2, p. 176-180, 2017.

KEMPSTY B. Endometritis and pyometra in bitches: a review. Veterinary Medicine, v. 58, n. 6, p.289-297, 2013.

MOURA R.B.R. et al. Estudo dos efeitos dos contraceptivos. 2016. Disponível em . Acesso 01 nov. 2019.

SILVEIRA, C.P.B.. Estudo retrospectivo de ovariossalpingo-histerectomia em cadelas e gatas atendidas em Hospital Veterinário Escola no período de um ano. Arquivo Brasilerio de Medicina Veterinária e Zootecnia, v.65, n.2, p.335-340, 2013.

SOUZA et al. Uso de contraceptivos de origem hormonal e quadro hematológico na incidência da piometra canina. Veterinária e Zootecnia, v.21, n.2, p.275-278, 2014.

STONE, E.A. Ovário e útero, In: SLATTER, DH (Ed), Manual de cirurgia de pequenos animais. 3a ed. . Manole: Barueri, 2007. p.1487-1502. 


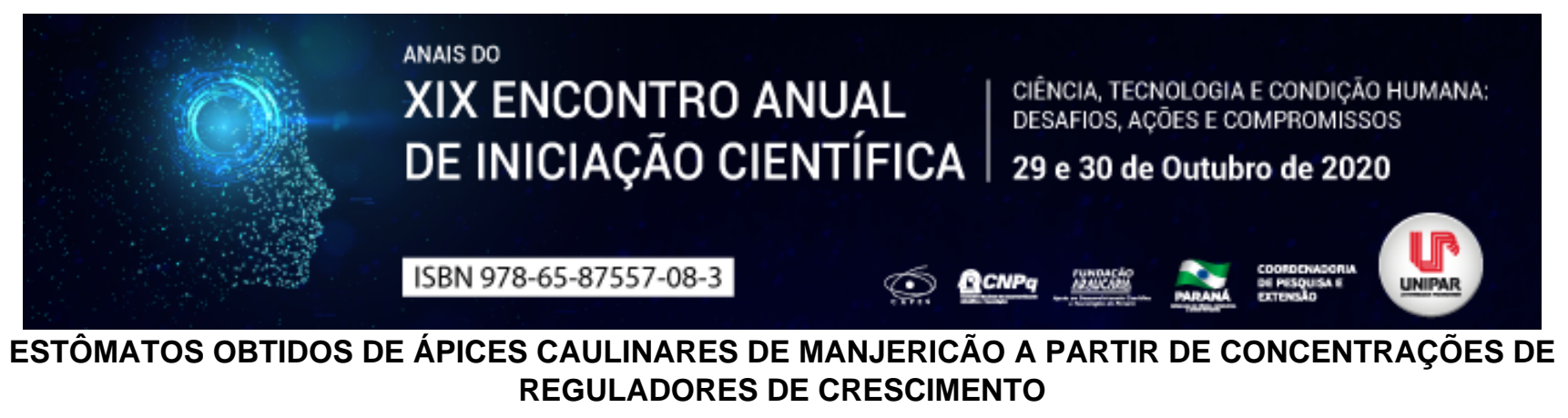

${ }^{1}$ SARAH DEMAY MARTINS GOES, ${ }^{2}$ GEYSIANE MOREIRA GEROTTI, ${ }^{3}$ FELIPE GORSKI, ${ }^{4}$ HELIDA MARA MAGALHAES

${ }^{1}$ Discente de Ciências Biológicas e Bolsista PEBIC-UNIPAR
${ }^{1}$ Discente de Medicina Veterinária e Bolsista PIBIC-UNIPAR
${ }^{2}$ Doutorando pelo Programa de Pós-Graduação em Biotecnologia Aplicada à Agricultura-UNIPAR
${ }^{3}$ Docente do Programa de Biotecnologia Aplicada à Agricultura-UNIPAR

Introdução: Ocimum basilicum L., popularmente conhecido como manjericão, pertence à família Lamiaceae (SAKKAS; PAPADOPOULOU, 2017). A micropropagação in vitro tem sido utilizada para multiplicação rápida e a obtenção de plântulas com uniformidade e qualidade fisiológica, produzindo mudas com as mesmas características produtivas da planta principal (MANAN et al., 2016). Os reguladores de crescimento são utilizados no cultivo in vitro porque sinalizam a expressão de genes do desenvolvimento das plantas. Sendo assim, uma importante etapa do processo é analisar a morfometria dos estômatos, os quais podem apresentar alterações em função das concentrações de reguladores de crescimento.

Objetivo: Avaliar a morfometria de estômatos a partir de ápices caulinares de manjericão em função de diferentes concentrações de reguladores de crescimento. Material e Métodos: Ápices caulinares de manjericão, obtidos a partir de sementes foram inoculados em meio de cultura MS (MURASHIGE; SKOOG, 1962), na concentração de total dos sais, suplementado com 30g.L-1 de sacarose, e 6,5g. L-1 de ágar com pH ajustado para 5,8. Os ápices foram inoculados em meio suplementado com 6 concentrações de reguladores; BAP e ANA (ST (sem tratamento) $0 ; 0 ; 1=0,05 ; 0,1 ; 2=0,1 ; 0,05 ; 3=0,1 ; 0,2 ; 4=0,5 ; 0,1 ; 5=1,0$; 0,5 ; BAP e ANA respectivamente). Após a inoculação dos explantes nos frascos estes foram fechados com tampas plásticas e vedados com parafilme. Os frascos foram mantidos em sala de crescimento com fotoperíodo de 24 horas luz fornecidas com o uso de lâmpadas light emitter diodes (LEDS) da marca Blumenau, LED T8 10W 6.000K, 100-240V-50/60Hz, fator de potência: $\geq 0,92$ (Alto FP), à temperatura de $25^{\circ} \mathrm{C} \pm 2{ }^{\circ} \mathrm{C}$ e intensidade luminosa de 2000 Lux. Ao final do experimento, foram coletadas folhas completamente expandidas do terço mediano da planta. Para a visualização dos estômatos, as lâminas foram montadas com a técnica de impressão, de acordo com Segatto et al. (2004), as análises foram realizadas na parte adaxial e abaxial das folhas. Para isso foram utilizadas três repetições com dez áreas de um $\mathrm{mm}^{2}$ para cada tratamento. Após a montagem das lâminas, estas foram fotografadas em microscópio Olympus BX-60 sendo as imagens capturadas por meio do software Motic Images Plus 3.0. As médias foram comparadas utilizando o teste de Tukey $(p<0,05)$. O software Sisvar ${ }^{\circledR}$, versão 5.6 (FERREIRA, 2011) foi utilizado em todas análises.

Resultado: A densidade estomática foi significativamente maior no tratamento 3 , tanto na epiderme adaxial (103,5 estômatos $/ \mathrm{mm} 2$ ) quanto na epiderme abaxial (169,56 estômatos $/ \mathrm{mm} 2$ ), sendo que para a epiderme abaxial foi maior quando avaliado somente este tratamento. O tratamento 3 obteve $20 \%$ mais estômatos que o tratamento 2 e $30 \%$ mais que SR na epiderme adaxial. Para a epiderme abaxial, foram $20 \%$ maior que o tratamento 2 e SR. Este resultado indica que a concentração de BAP e ANA empregada neste tratamento afetou o número de estômatos. O comprimento total dos estômatos na epiderme adaxial do tratamento SR $(129,21 \mu \mathrm{m})$ e do tratamento $2(125,96 \mu \mathrm{m})$ foram iguais estatisticamente, sendo $20 \%$ maiores que 0 tratamento $3(101,94 \mu \mathrm{m})$. O tratamento 2 também apresentou o maior comprimento para epiderme abaxial $(130,22 \mu \mathrm{m})$. Seguindo este padrão, o tratamento 2 apresentou a maior largura de célula guarda para epiderme adaxial $(90,67 \mu \mathrm{m}), 20 \%$ maior que o tratamento 3 , e abaxial $(121,33 \mu \mathrm{m}), 25 \%$ maior. A largura de célula subsidiária para epiderme adaxial foi $20 \%$ maior no tratamento $2(50,81 \mu \mathrm{m})$ que os demais tratamentos, já para a epiderme abaxial, SR $(30,91 \mu \mathrm{m})$, tratamento $2(31,14 \mu \mathrm{m})$ e tratamento $3(30,23 \mu \mathrm{m})$, não diferiram entre si $(p \leq 0,05)$. A abertura do poro foi maior no tratamento $\mathrm{SR}$, tanto na epiderme adaxial $(33,96 \mu \mathrm{m})$ e abaxial $(30,87 \mu \mathrm{m})$, sendo $40 \%$ maior que o tratamento 3 que foi a menor abertura $(21,9 \mu \mathrm{m}$ para adaxial e $19,45 \mu \mathrm{m}$ para abaxial).

Discussão: A citocinina pode aumentar a densidade estomática, reduzindo a resistência a água (FARBER et al., 2016). Estes podem estar causando uma espécie de estresse nas plantas. $O$ estresse já foi demonstrado como responsável por aumentar o número de estômatos por área de folha em O. basilicum (BARBIERI et al., 2012; JENSEN et al., 2018). Já foi sugerido que concentrações elevadas de diferentes fitormônios podem promover fechamento dos estômatos, para diminuir a perda de água (JANOWIAK et al. 2002). Além disso, auxinas endógenas normalmente regulam positivamente a abertura estomática, enquanto auxinas aplicadas a nível exógeno podem inibir a abertura estomática.

Conclusão: Para ápices caulinares, a densidade estomática foi maior no tratamento 3 (BAP 0,1 mg.L-1 e ANA 0,05 mg.L-1 ). A variação da densidade estomática foi influenciada pela concentração dos PGR exógenos. 


\section{Referências}

BARBIERI, G.; VALLONE, S.; ORSINI, F.; PARADISO, R.; DE PASCALE, S.; NEGRE-ZAKHAROV, F.; MAGGIO, A. Stomatal density and metabolic determinants mediate salt stress adaptation and water use efficiency in basil (Ocimum basilicum L.). Journal of Plant Physiology. v. 169, n. 17, p. 1737-1746, 2012. FARBER, M.; ATTIA, Z.; WEISS, D. Cytokinin activity increases stomatal density and transpiration rate in tomato. Journal of Experimental Botany, p. erw398, 2016. FERREIRA, D. F. Sisvar: a Guide for its Bootstrap procedures in multiple comparisons. Ciência Agrotecnologia. n. 2, v. 38, p. 109-112, 2017. JENSEN, N. B.; CLAUSEN, M. R.; KJAER, K. H. Spectral quality of supplemental LED grow light permanently alters stomatal functioning and chilling tolerance in basil (Ocimum basilicum L.). Scientia Horticulturae. v. 227, p. 38-47, 2018. MANAN, Aziemah Abdul et al. In vitro flowering, glandular trichomes ultrastructure, and essential oil accumulation in micropropagated Ocimum basilicum L. In Vitro Cellular \& Developmental Biology-Plant, v. 52, n. 3, p. 303-314, 2016. SAKKAS, H.; PAPADOPOULOU, C. Antimicrobial activity of basil, oregano, and thyme essential oils. Journal of Microbiological Biotechnology, n. 27, p. 429 438, 2017. JANOWIAK, Franciszek; MAAS, Britta; DÖRFFLING, Karl. Importance of abscisic acid for chilling tolerance of maize seedlings. Journal of Plant Physiology, v. 159, n. 6, p. 635-643, 2002. 
GRUPO 2: SAÚDE 


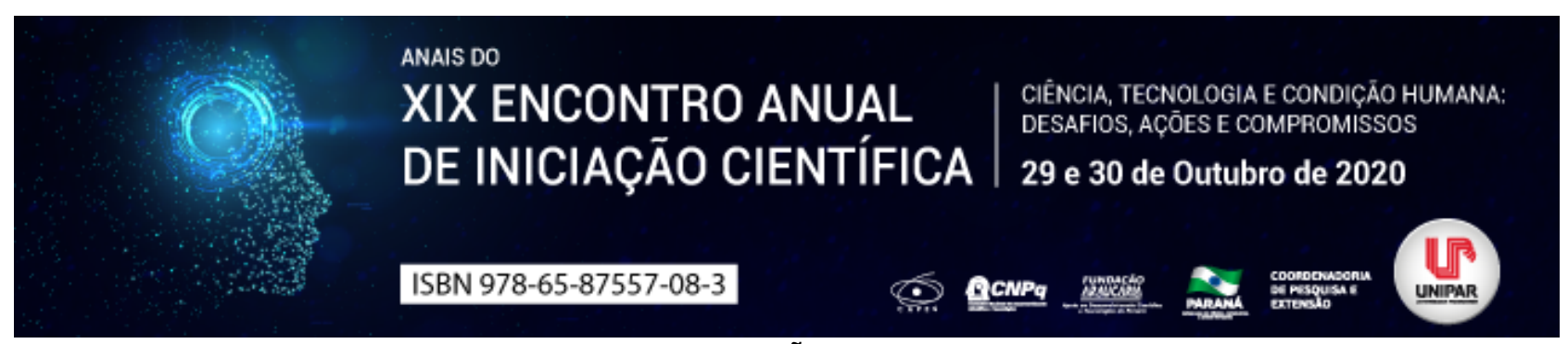

AYAHUASCA - REVISÃO DE LITERATURA

\title{
${ }^{1}$ FELIPE MARCHI, ${ }^{2}$ DANIELA DIB GONÇALVES
}

\author{
${ }^{1}$ Discente, Medicina PIC UNIPAR \\ ${ }^{1}$ Docente PPG em Ciência Animal, UNIPAR
}

Introdução: O Ayahuasca é um chá utilizado para fins religiosos por grupos indígenas e seculares localizado principalmente na região oeste da Amazônia, recebendo também os nomes de: natema, hoasca, daime, yagé, ou yajé conforme o grupo ou localidade (FRECSK, 2016). A substância possui forte poder alucinógeno devido a presença de alcaloides nas plantas que compõem o chá: as folhas do arbusto Psycotria viridis e o cipó Banisteriopis caapi especificamente (COSTA, 2005). O chá é preparado a partir de maceração em água fria ou através de decocção. Apenas homens manipulam o Banisteriopis caapi no preparo. O cipó é limpo e suas fibras maceradas são depositadas no fundo de uma panela com cerca de 40 litros. Posteriormente, separa-se uma serragem residual que é posta em camadas sucessivas, seguido pelas folhas da Chacrona (Psycotria viridis); essas folhas são colhidas e limpas exclusivamente por mulheres (GARRIDO, 2009).

A preparação da bebida é realizada em grandes fornalhas de alvenaria alimentadas por lenha. A quantidade de substrato e de água varia, esse fator constituirá a potência da bebida preparada, ou seja, o grau dos efeitos psicotrópicos. A potência é esolhida conforme a ocasião (GARRIDO, 2009). O Banisteriopis caapi contém derivados de $\beta$-carbolinas que são caracterizados como alcaloides maiores: harminina, tetrahidroharmina (THH) e a harmalina. Todos esses alcaloides são potentes inibidores da monoamino oxidase-A (CALLAWAY et al, 1996). Já as folhas do Psycotria viridis, contêm apenas um alcaloide, o N,Ndimetiltriptamina (DMT), um potente alucinógeno de curta duração (GABLE, 2007).

Objetivo: Relatar por meio de revisão de literatura a história, os contextos de utilização, os efeitos e os usos terapêticos do Ayahuasca.

Desenvolvimento: Acredita-se que o uso do Ayahuasca seja milenar; a utilização do Ayahuasca foi reprimida no período colonial pela Igreja Católica. Os participantes dos rituais eram punidos com torturas e até mesmo com a morte (LABATE e CAVNAR, 2014). Mesmo com toda a repressão, o alucinógeno continuou a ser utilizado em regiões remotas da floresta; sendo descrito cientificamente apenas na metade do século XIX, durante as excursões do botânico inglês Richard Spruce pela região (LABATE e CAVNAR, 2014). No início do século XX, cientistas isolaram os alcaloides ativos responsáveis pelos efeitos psicotrópicos do chá. Utilizando-se cipó Banisteriopsis, Louis Lewin identificou um composto que recebeu o nome de harmina. Por muitos anos a harmina foi um dos principais expoentes no tratamento contra a doença de Parkinson, caindo em desuso após a década de 1930, com a descoberta de novas formas de tratamento (LABATE e CAVNAR, 2014). No decorrer do século passado, foram sendo criadas diversas tradições Ayahuasqueiras no Brasil, com destaque para: Santo-Daime (1930), Barquinha (1945) e União do Vegetal (1960). Todas essas tradições, possuem um plano de fundo religioso que combina elementos do cristianismo, religiões ameríndias, espiritismo, religiões de matriz africana, budismo e esoterismo. (GARRIDO, 2009)

O período de latência da droga ocorre entre 35 a 40 minutos após a ingestão do chá, observando-se modificações no estado de consciência pelas próximas quatro horas. (FRECSK, 2016). Utilizando-se da técnica funcional de ressonância magnética ARAUJO et al. (2012) descobriram que a utilização do Ayahuasca induz a ativação das áreas occipital, temporal e frontal ao longo de um experimento com os olhos fechados. O consumo do chá ativou uma extensa rede no cérebro relacionada a percepção visual, memória e intenção (ARAUJO et al, 2012). O estímulo do Ayahuasca no córtex visual primário compara-se ao efeito de imagens naturais de olhos abertos. Assim, Araujo et al. (2012) concluíram que ao aumentar a intensidade da imaginação para o mesmo nível de percepção sensorial, o Ayahuasca confere um status de realidade para a experiências interiores. Os benefícios terapêuticos psicológicos, encontram-se na experiência de introspecção com características oníricas de visões e memórias autobiográficas que aumentam a capacidade atenção plena do usuário durante a experiência alucinógena (SOLER, et al 2015). Mas, o efeito psicoterapêutico não depende apenas da experiência de conteúdo ou profundidade do fenômeno - mas também do quanto as ideias adquiridas durante alucinação irão se integrar à vida cotidiana (FRECSK, 2016).

Além disso, constatou-se que o uso regular do chá a longo prazo realiza uma modulação do sistema de serotonina cerebral, mais especificamente no aumento da densidade de transportadores de serotonina nas plaquetas e no cérebro. Os Déficits serotoninérgicos possuem associação com várias desordens neurológicas ou psicológicas, dentre elas podemos citar: alcoolismo, depressão, autismo, esquizofrenia, TDAH e demências senis. (MCKENNA et al, 2004).

Conclusão: O Ayahuasca possui uma longa história, a ponto de fazer parte da cultura amazônica; muito vem se descobrindo a respeito deste chá nas últimas décadas, principalemten em relação a seus efeitos terapêuticos aplicados a psicologia, psiquiatria e neurológia. 


\section{Referências}

Callaway, James C. et al. Quantitation of $\mathrm{N}, \mathrm{N}$-dimethyltryptamine and harmala alkaloids in human plasma after oral dosing with Ayahuasca. J Anal Toxicol. 1996;20: 492-497.

COSTA, Maria Carolina Meres Costa; FIGUEIREDO, Mariana Cecchetto; CAZENAVE, Silvia de O. Ayahuasca: Uma abordagem toxicológica do uso ritualístico. Rev. Pisq. Clin. 32 (6); 310-318, 2005.

DE ARAUJO, Draulio B. et al. Seeing with the eyes shut: neural basis of enhanced imagery following ayahuasca ingestion. Hum. Brain Mapp. 33, 2550-2560. doi: 10.1002/hbm.21381, 2012.

FRECSKA, Ede; BOKOR, Petra; WINKELMAN, Michael. The Therapeutic Potentials of Ayahuasca: Possible Effects against Various Diseases of Civilization. Front. Pharmacol., 02 March, 2016.

GABLE, Robert S. Risk assessment of ritual use of dimethyltryptamine (DMT) and harmala alkaloids. Addiction.; 102: 24-34, 2007.

GARRIDO, Rodrigo Garrido; SABINO, Bruno Duarte. Ayahuasca: entre o legal e o cultural. Saúde, Ética e Justiça. 14(2): 44-53, 2009.

LABATE, Beatriz Caiuby; CAVNAR, Clancy. The Therapeutic Use of Ayahuasca. Heidelberg, New York, Dordrecht, London: Edit. Springer-verlag, 2014.

MCKENNA, Dennis J. Clinical investigations of the therapeutic potencial of ayahuasca: rationale and regulatory challenges. Pharmacology \& Therapeutics.102: 111-119, 2004.

SOLER, Joaquim. et al. Exploring the therapeutic potential of ayahuasca: acute intake increases mindfulness-related capacities. Psychopharmacology doi: 10.1007/s00213-015-4162-0, 2015. 


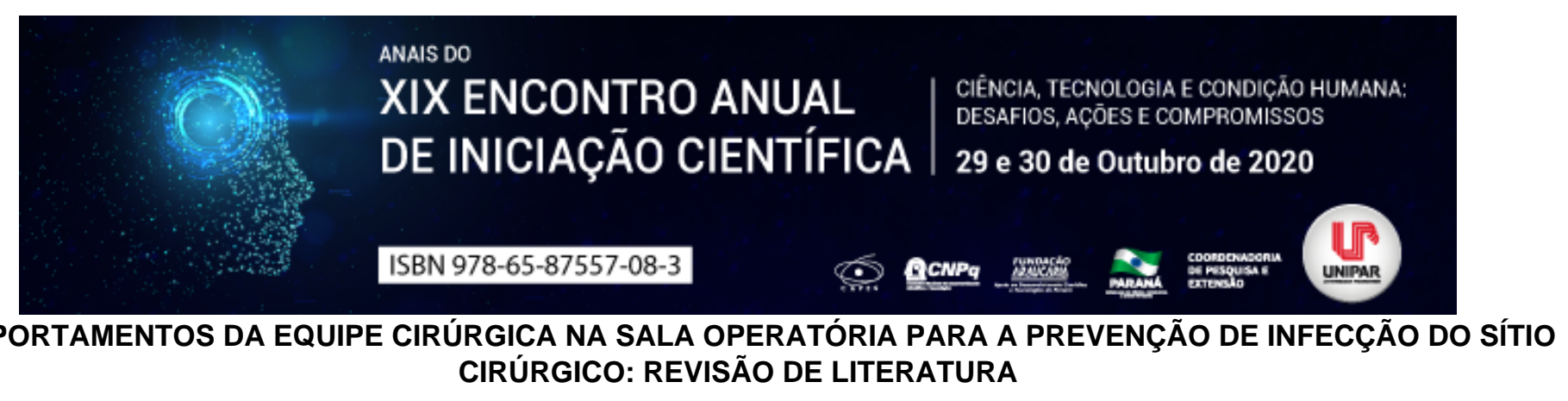

${ }^{1}$ Ana Beatriz Mucha Barros, ${ }^{2}$ CAMILA DALCÓL

${ }^{1}$ Acadêmica do curso de Enfermagem da UENP
${ }^{1}$ Docente da UENP

Introdução: Sabe-se que a infecções do sítio cirúrgico (ISC) é um problema de saúde pública a nível mundial, ocupando o terceiro lugar entre as infecções relacionadas à assistência à saúde (IRAS), estimando-se que $60 \%$ das ISC podem ser evitadas por meio de medidas de prevenção (ANVISA, 2009). As medidas de prevenção durante o período intraoperatório engloba estratégias relacionadas ao paciente, ao ambiente e à equipe cirúrgica. Os profissionais que atuam na sala operatória (SO) enfermeiros, técnicos de enfermagem, cirurgiões e anestesiologistas - devem realizar a antissepsia das mãos, antissepsia do local a ser operado, paramentação cirúrgica com avental e luvas estéreis, restrição de pessoas na sala de operação e na abertura de portas, controle da temperatura do ambiente, entre outros cuidados (WHO, 2018). Com isso, destaca-se a importância de boas práticas pela equipe cirúrgica na sala de operação a fim de evitar falhas que podem ocasionar a ISC.

Objetivo: Identificar o comportamento da equipe cirúrgica no período intraoperatório para a prevenção de ISC.

Desenvolvimento: Trata-se de uma revisão de literatura, realizada entre os meses de março e junho de 2020, nas bases de dados PubMed, Science Direct, Scielo e Biblioteca Virtual em Saúde com as palavras-chaves presentes no DeCS (Atitudes e práticas em saúde, Controle de infecção, Sala de operação e Segurança do paciente) e MeSH (Operating room, Behaviour, Patient care team e Surgical wound infection), utilizando os operadores booleanos AND e OR . Os critérios de inclusão foram: artigos disponíveis na íntegra, publicados entre os anos de 2011 e 2020, nas línguas portuguesa e inglesa. Critérios de exclusao: embasados no PRISMA e foram exluidos estudos que nao estavam relacionados aos profissionais de saúde, nao abordavam o periodo intraoperatório e nao se relacionavam a ISC, bem como, os trabalhos de conclusão de curso, dissertações e teses. Nas buscas foram encontrados 1.084 artigos, a partir da leitura do título foram excluídos 904 artigos, que não abordavam o tema da pesquisa, após a leitura do resumo foram selecionados 95 artigos, e a após a leitura dos artigos na íntegra, 10 artigos foram incluídos como amostra desta revisão de literatura. A maioria dos estudos foi publicado nos anos de 2013 (20\%), 2015 $(20 \%)$ e $2018(20 \%$, sendo $30 \%(n=3)$ realizados na Itália e 30\% $(n=3)$ publicados na revista American Journal of Infection. Quanto ao método, 60\% $(n=6)$ foram observacionais prospectivos, $20 \%(n=2)$ descritivos transversais, 10\% $(n=1)$ observacional transversal e $10 \%(n=1)$ transversal com utilização de questionário. Os profissionais abordados nos estudos foram em sua maioria enfermeiros (60\%), seguido de cirurgiões (50\%), Anestesistas (40\%), técnicos de Enfermagem (10\%), acadêmicos de medicina (10\%) e estudantes em treinamento (10\%). O número da amostra variou entre 9 e 890 profissionais e os principais desfechos analisados foram abertura de portas ( $40 \% ; n=4)$, número de pessoas na SO $(40 \% ; n=4)$, uso correto de luvas (40\%; $n=4)$, antissepsia do campo operatório $(30 \% ; n=3)$, paramentação cirúrgica $(30 \% ; n=3)$ e higiene das mãos $(20 \% ; n=2)$. A recomendação sobre abertura das portas da SO, é que seja o mínimo possível (SOBECC, 2017), e de acordo com os estudos está ocorrendo além do recomendado, e os motivos são a necessidade de suprimentos de fornecedores, necessidade de profissionais, aberturas sociais e/ou não essenciais (DURANTO et al., 2012). O número de profissionais na so deve ser de no máximo $9 \mathrm{em}$ procedimentos de alta complexidade, em estudo realizado com 74 profissionais da equipe cirúrgica, verificou-se que o número de pessoas presentes na SO variou de 6 a 12 (média=9), e em todos os casos houve um fluxo de tráfego de pessoas não relacionadas à operação (DALLOLIO et al., 2018). A higienização das mãos nem sempre é realizada, principalmente pelos anestesiologistas, estudo observou a inserção de quatro cateteres venosos e uma sonda nasogástrica, sendo que nenhum foi precedido ou seguido pela higiene das mãos, e não houve desinfecção das mãos em $43 \%$ dos procedimentos observados (OLIVEIRA, GAMA; 2015). Em relação a paramentação, o estudo de Lo Giudice e colaboradores (2019) mostrou que usaram luvas $100 \%$ dos cirurgiões, $13 \%$ dos anestesistas, $31 \%$ dos enfermeiros e $5 \%$ dos estudantes/residentes. Utilizaram máscara adequadamente $87 \%$ dos cirurgiões, $59 \%$ dos anestesistas, $66 \%$ dos enfermeiros e $80 \%$ dos estudantes/residentes. Outro estudo avaliou a antissepsia da área cirúrgica, sendo que de 717 procedimentos, a antissepsia foi realizada em $97,4 \%$ das vezes, sendo o principal antisséptico o iodofórmio (75,1\%) (DURANDO et al., 2012).

Conclusão: Foi possível identificar que o comportamento da equipe cirúrgica no período intraoperatório para a prevenção de ISC, é um assunto pouco estudado, e que as medidas de prevenção não estão sendo adotadas de forma correta em pelo menos metade das cirurgias, sendo de extrema importância a realização de treinamentos e educação continuada com a equipe cirúrgica. As lacunas identificadas foram a escassez de estudos nacionais e com a equipe cirúrgica completa, que apontam para possibilidades de estudos futuros. 


\section{Referências}

BRASIL. Ministério da Saúde; Agência Nacional de Vigilância Sanitária. Sítio Cirúrgico. Critérios Nacionais de Infecções relacionadas à assistência à saúde. Brasília: MS; 2009.

DALLOLIO, Laura; RAGGI, Alessandra; SANNA, Tiziana; MAZZETTI, Magda; ORSI, Alessandra; ZANNI, Angela; LEONI, Erica. Surveillance of Environmental and Procedural Measures of Infection Control in the Operating Theatre Setting. International Journal of Environmental,46(15),1-10, 2018. Disponivel em:https://www.mdpi.com/1660-4601/15/1/46. Acesso em: 24/06/2020.

DURANDO, Paolo; BASSETTI, Matteo; ORENGO, Giovanni; CRIMI, Paolo; BATTISTINI, Angela; BELLINA, Dorotea; ICARDI, Giancarlo. Adherence to international and national recommendations for the prevention of surgical site infections in Italy: Results from an observational prospective study in elective surgery. American Journal of Infection Control,40 (10), 969 972,2012. Disponivel em:https://www.ajicjournal.org/article/S0196-6553(11)01320-4/fulltext. Acesso em:24/06/2020.

LO GIUDICE, Daniela; TRIMARCHI, Gluseppe; LA FAUCI, Vicenza; SQUERI, Raffaele; CALIMERI, Sebastiano. Hospital Infection Control and Behaviour of Operating Room Staff. Cent Eur J Public Health, 27 (4), 292-295,2019. Disponivel em::https://cejph.szu.cz/artkey/cjp-201904-0005_hospital-infection-control-and-behaviour-of-operating-room-staff.php. Acesso em: 24/06/2020

OLIVEIRA, Adriana Cristina de; GAMA, Camila Sarmento. Evaluation of adherence to measures for the prevention of surgical site infections by the surgical team. Revista da Escola de Enfermagem da Usp, [s.I.], v.49, n.5,p. 767-774, out. 2015. Disponivel em: https://www.scielo.br/pdf/reeusp/v49n5/pt_0080-6234-reeusp-49-05-0767.pdf. Acesso em:25/06/2020

Global guidelines for the prevention of surgical site infection, second edition. Geneva:WORLD HEALTH ORGANIZATION;2018.. 


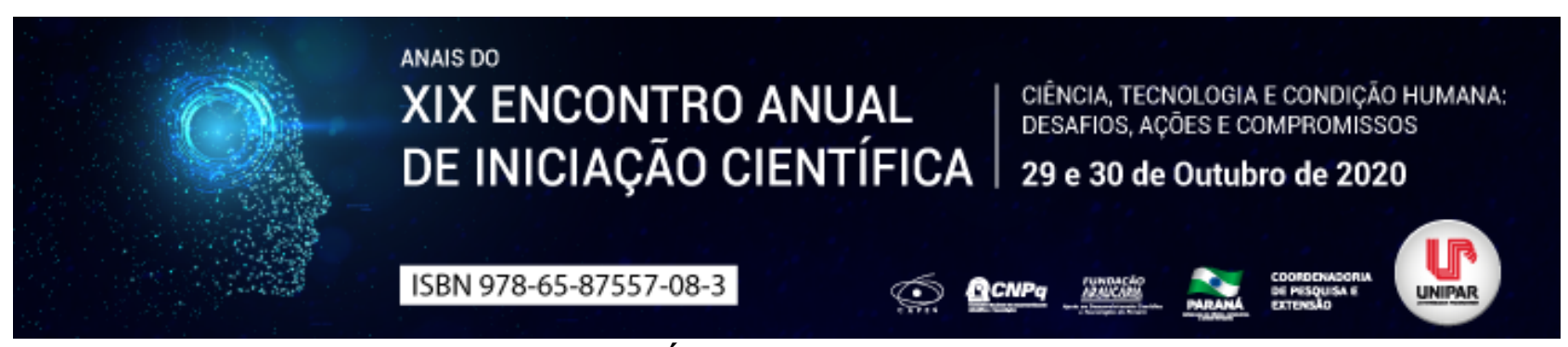

NOTIFICAÇOES DE CASOS DE INTERNAÇOES E ÓBITOS POR FEBRE AMARELA NO BRASIL DE JANEIRO DE 2015 A JANEIRO DE 2020

\author{
${ }^{1}$ ANA BEATRIZ PINHEIRO ZAUPA, ${ }^{2}$ ALINE REINERT DAZZI, ${ }^{3}$ BRUNA LUANA CHAPLA, ${ }^{4}$ GABRIELA CAROLINA \\ CREMONESE VON BORSTEL, ${ }^{5}$ ISABELA FARIAS MARQUES, ${ }^{6}$ ALTAIR DE SOUZA CARNEIRO
}

\begin{abstract}
${ }^{1}$ Acadêmica do Curso de Medicina da UNIPAR
${ }^{1}$ Acadêmica do Curso de Medicina da UNIPAR

${ }^{2}$ Acadêmica do Curso de Medicina da UNIPAR

${ }^{3}$ Acadêmica do Curso de Medicina da UNIPAR

${ }^{4}$ Acadêmica do Curso de Medicina da UNIPAR

${ }^{5}$ Docente da UNIPAR
\end{abstract}

Introdução: A febre amarela é considerada uma doença infecciosa febril aguda, causada por um vírus do gênero Flavivirus, família Flaviviridae, sendo transmitida por vetores, sendo eles os Aedes. A vacina contra a febre amarela foi desenvolvida em 1937, buscando combater o vetor e aumentar o número de pessoas imunizadas, e dessa maneira, na década seguinte conseguiu-se erradicar essa doença nas áreas urbanas do Brasil, porém, mesmo com a implementação da vacinação e tratamentos acessíveis nota-se um aumento de casos de internações e óbitos pelo Brasil (BRASIL, 2018).

Objetivo: Analisar casos de internações e óbito por febre amarela no Brasil de janeiro de 2015 à janeiro de 2020 , bem como o ciclo biológico da doença e a não adesão de sua profilaxia por meio de uma revisao de literatura.

Desenvolvimento: Por meio de uma revisao de literatura baseada em trabalhos relevantes sobre o assunto da febre amarela foi discutido nesse resumo acerca de seu ciclo e a nao adesao das medidas profiláticas que acarretam em um aumento de internacoes e óbitos da doenca no país. A febre amarela, segundo Secretaria da Saúde do Paraná (2004), é uma doença de uma duração curta e de intensidade variável causada por um vírus de ácido ribonocleico (RNA) arbovírus do gênero Flavivirus e família Flaviviridae.Conforme Henriques (2018) a origem dessa patologia se parte de evidências de que ela já ocorria na África antes da chegada dos europeus. Desse modo, depois que os invasores europeus chegaram no continente africano o mosquito Aedes aegypti chegou aos outros continentes a bordo dos navios que traficavam negros para serem vendidos como escravos. Portanto, a patologia foi se disseminando e se instalando nas regiões devido a condições favoráveis para o desenvolvimento dos vetores, aglomerações de indivíduos e condições precárias de higiene e saneamento básico.De acordo com Cavalcante (2017) a doença pode se manter em regiões endêmicas e enzoóticas por várias regiões tropicais dos continentes americanos e africanos, sendo a responsável por surtos em determinados períodos. As manifestações clínicas da forma grave se caracterizam por insuficiência renal e hepática, que podem acarretar ao óbito. Ainda não existe um tratamento específico para a febre amarela, sendo essencial que todos se vacinem.

Existem dois tipos de transmissão: a urbana e a silvestre, conforme explica Cavalcante (2017), no primeiro tipo de transmissão o agente transmissor é o Aedes aegypti e no segundo tipo os agentes transmissores são os mosquitos Haemagogus ( $H$. janthinomys e $H$. albomaculatus) e Sabethes (S. chloropteros) que acabam preferindo infectar animais silvestres, principalmente os macacos.Atualmente, a febre amarela silvestre (FA) é uma doença endêmica no Brasil (região amazônica). Na região extraamazônica, períodos epidêmicos são registrados ocasionalmente, caracterizando a reemergência do vírus no país. O padrão temporal de ocorrência é sazonal, com a maior parte dos casos incidindo entre dezembro e maio, e com surtos que ocorrem com periodicidade irregular, quando o vírus encontra condições favoráveis para a transmissão (elevadas temperatura e pluviosidade; alta densidade de vetores e hospedeiros primários; presença de indivíduos suscetíveis; baixas coberturas vacinais; e eventualmente, novas linhagens do vírus), podendo se dispersar para além dos limites da área endêmica e atingir estados das regiões Centro, segundo o Ministério da Saúde (2018). Apenas de janeiro a junho de 2019, forma notificados 1079 casos de febre amarela no Brasil, havendo 14 óbitos mostrando sua alta incidência, a qual poderia ocorrer se a população tivesse mais conhecimento sobre o assunto, bem como sua profilaxia e adesão da mesma (vacinação), de acordo com o Ministério da Saúde (2019). A queda nos índices de vacinação faz com que doenças já erradicadas ou controladas retornem e isso porque muitas pessoas acreditam que as vacinas não são mais necessitadas fazendo com que vírus, como o da febre amarela, e bactérias ressurjam trazendo consigo problemas e prejuízos para a população, conforme explica Brown (2018).

Conclusão: A febre amarela é uma doença de grande ocorrência na população brasileira, gerando muitas internações e óbitos. Um dos principais fatores desencadeadores desta situação é a não adesão de medidas profiláticas, como a vacinação pelos habitantes. Visando reduzir os casos de incidência e prevalência de febre amarela no Brasil, é necessário que a população se conscientize da importância de adotarem medidas de prevenção, principalmente a vacinação, além do uso de repelentes, telas 
em janelas e uso de roupas pretas e compridas.

\section{Referências}

CAVALCANTE, Karina Ribeiro Leite Jardim; TAUIL, Pedro Luiz. Risco de reintrodução de febre amarela urbana no Brasil. Epidemiol. Serv. Saúde, vol. 23, n.6, 2017. Disponível em https://www.scielosp.org/article/ress/2017.v26n3/617-620/es/. Acesso em: 26 jun. 2020

HENRIQUES, Cláudio Maierovitch Pessanha. A dupla epidemia: febre amarela e desinformação. Rev Eletron Comun Inf Inov Saúde. Brasília, v.12, n.1, p 1-5, 2018. Disponível em: https://www.arca.fiocruz.br/bitstream/icict/25772/2/3.pdf. Acesso em: 13 mai. 2020.

BRASIL, Ministério da Saúde. Febre amarela: guia para profissionais de saúde. Secretaria de Atenção à Saúde, 1ed, Brasília, p 1-72, 2018. Disponível em:https://portalarquivos2.saude.gov.br/images/pdf/2018/janeiro/18/Guia-febre-amarela-2018.pdf. Acesso em: 26 jun. 2020.

MIZUTA, Hayashida Mizuta et al. Percepções acerca da importância das vacinas e da recusa vacinal numa escola de medicina. Rev Paul Pediatr, vol. 37, n.1, p 34-40, 2019. Disponível em: http://www.scielo.br/pdf/rpp/v37n1/0103-0582-rpp-2019-37-100008.pdf. Acesso em: 27 jun. 2020.

BRASIL. Ministério da Saúde. Febre amarela: informações técnicas. Brasília, $2004 . \quad$ Disponível em: http://www.saude.pr.gov.br/modules/conteudo/conteudo.php?conteudo=381. Acesso em: 27 jun. 2020. 


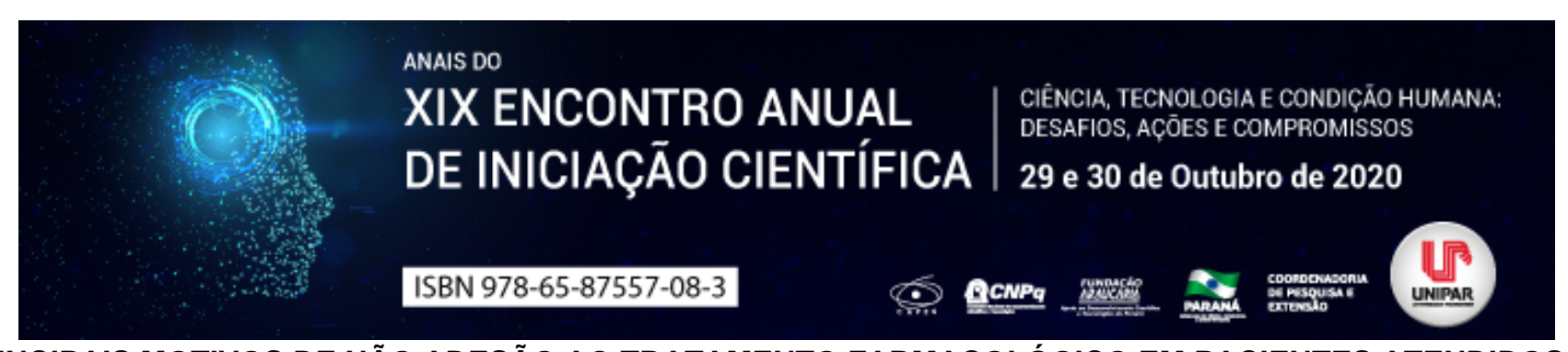

\section{PRINCIPAIS MOTIVOS DE NÃO ADESÃO AO TRATAMENTO FARMACOLÓGICO EM PACIENTES ATENDIDOS EM AMBULATÓRIO NUTRICIONAL RELATO DE EXPERIÊNCIA}

${ }^{1}$ Juliane Fernandes de Lima

${ }^{1}$ Mestranda em Ciências Farmacêuticas/ Unioeste

Introdução: A não adesão a farmacoterapia é um grave problema de saúde publica, devido aos riscos inerentes a falha terapêutica, e, portanto, torna-se essencial conhecer os fatores que podem influenciar o processo de adesão ao tratamento (BRASIL, 2016). A adesão pode ser definida como o grau de correspondência ou concordância entre o paciente e as recomendações propostas pelo profissional de saúde (CONTE et al., 2015). É considerado um tratamento exitoso aquele acima de $80 \%$ de utilização do tratamento prescrito (BRASIL, 2016). O objetivo deste relato foi descrever os principais motivos de não adesão ao tratamento farmacológico, com enfoque sobre a percepção do profissional nutricionista.

Relato de Caso: Trata-se de um estudo descritivo do tipo relato de experiência sobre a percepção de um nutricionista atuante no sistema único de saúde (SUS) sobre os motivos de não adesão ao tratamento farmacológico dos pacientes com doenças crônicas atendidos em ambulatório nutricional de um consórcio de saúde. Após 2 anos de observação, os principais motivos relatados de não adesão ao tratamento farmacológico foram: falta de renovação de receita; falta de medicamentos dispensados pelo SUS; efeitos colaterais indesejáveis; o custo financeiro de ter que arcar com parte do tratamento; resistência pessoal (não confiar ou não aceitar o diagnostico); opinião de terceiros (pessoas leigas); nível de percepção de saúde inversamente proporcional; falta de entendimento da própria doença e seu tratamento; problemas de visão; analfabetismo; isolamento social; questões psicológicas (depressão, desesperança); uso de múltiplas medicações. A maioria dos pacientes atendidos pelo ambulatório tem idade superior a 60 anos, fator este que também esta associado à baixa adesão ao tratamento farmacológico.

Discussão: Percebe-se que os motivos relatados podem ser agrupados em relações: sociais, culturais, financeiras, biológicas, psicológicas e institucionais, indo de encontro com o proposto pelo Ministério da Saúde (BRASIL, 2016). Os resultados aqui descritos encontram similaridade com os trabalhos de Pires e Freitas (2006), Girotto et al. (2013), Miasso et al. (2015) e Gewehr et al. (2018), quanto aos motivos que levam a não adesão da farmacoterapia. O sucesso do tratamento proposto envolve a educação em saúde, a humanização do atendimento com formação de vínculo, adoção do plano terapêutico singular, oferta de incentivo (financeiro) e auxilio na gestão de medicamentos (BRASIL, 2016).

Conclusão: Este relato vai de encontro com as motivações para não adesão ao tratamento farmacológico descritos na literatura, evidenciando a importância da educação em saúde e do maior envolvimento do profissional e do paciente no processo de cuidado.

\section{Referências}

BRASIL. Ministério da Saúde. Síntese de evidências para políticas de saúde: adesão ao tratamento medicamentoso por pacientes portadores de doenças crônicas. Secretaria de Ciência, Tecnologia e Insumos Estratégicos, Departamento de Ciência e Tecnologia. Brasília: Ministério da Saúde, 2016.

CONTE et al. Adesão ao tratamento: onde está o problema? Percepções a partir da vivência em equipe multidisciplinar hospitalar. Caderno pedagógico. V. $12, \quad$ n. $3, \quad$ p. $85-100,2015 . \quad$ Disponível em: http://www.univates.br/revistas/index.php/cadped/article/view/971. Acesso em: 19/06/2020

GEWEHR, D.M. et al. Adesão ao tratamento farmacológico da hipertensão arterial na Atenção Primária à Saúde. Saúde debate. V. 42, n.116, p. 179-190, 2018. Disponível em: https://www.scielo.br/scielo.php?pid=S0103$11042018000100179 \&$ script=sci_abstract\&tlng=pt. Acesso em: 22/06/20.

GIROTTO, E. et al. Adesão ao tratamento farmacológico e não farmacológico e fatores associados na atenção primária da hipertensão arterial. Ciência \& Saúde Coletiva. V.18, n. 6, p. 1763-1772, 2013. Disponível em: www.scielo.br/scielo.php? pid=S141381232013000600027\&script=sci_abstract\&tlng=pt. Acesso em: 22/06/20.

MIASSO, A.I et al.. Adesão, conhecimento e dificuldades relacionados ao tratamento farmacológico entre pessoas com esquizofrenia. Revista Eletrônica de Enfermagem. V. 17, n. 2, p. 186-95, 2015. Disponível em: https://revistas.ufg.br/index.php/fen/article/view/27636. Acesso em: 22/06/20.

PIRES, G.B; FREITAS, I.V. Prevalência de adesão ao tratamento farmacológico hipoglicemiante. Sitientibus. N.34, p.3745, 2006. 



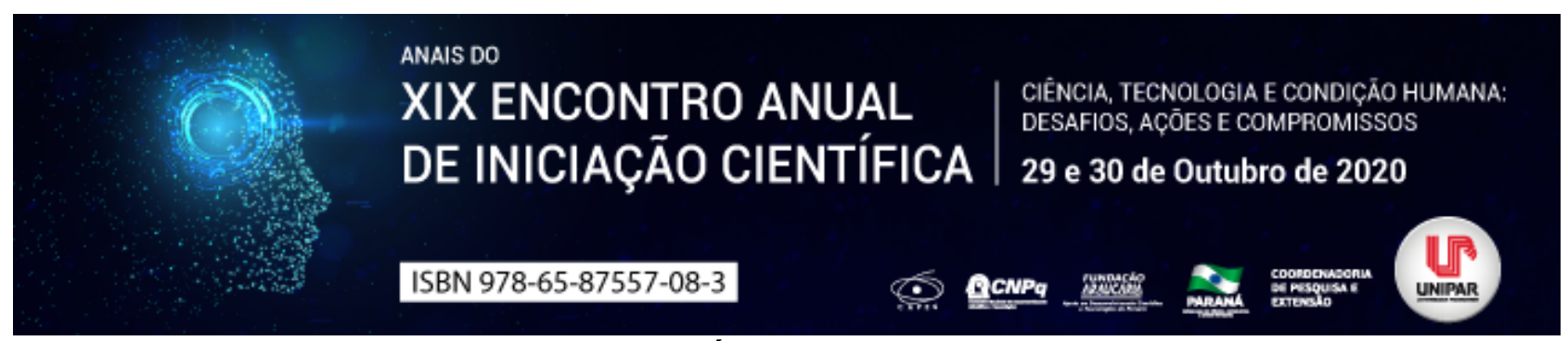

SAÚDE MENTAL

${ }^{1}$ Juliane Fernandes de Lima

${ }^{1}$ Nutricionista. Mestranda em Ciências Farmacêuticas - Unioeste

Introdução: O campo emergente da psiquiatria nutricional surge para elucidar as consequências e correlações entre o que comemos o que sentimos e a forma como nos comportamos. Estudos apontam que a alta prevalência e incidência de distúrbios mentais podem estar relacionadas à qualidade da dieta. Neste sentido, conhecer os mecanismos de ação de nutrientes-chave e a influencia do padrão dietético sobre a saúde mental torna-se essencial para a busca por novos tratamentos ou por complementar os já existentes (SARRIS et al., 2015).

Objetivos: O objetivo deste trabalho foi conceituar o termo, além de discutir suas aplicabilidades e potencialidades. Trata-se de uma revisão bibliográfica na base de dados da Biblioteca Virtual em Saúde (BVS), utilizando os descritores Nutritional psychiatry .

Desenvolvimento: O termo Nutritional psychiatry foi cunhado por um grupo de profissionais que posteriormente fundaram a International Society for Nutritional Psychiatry Research (Sociedade Internacional para a Pesquisa em Psiquiatria Nutricional) em 2013 para expressar um novo campo da medicina. Adaptado para nosso idioma, a psiquiatria nutricional tem como objetivo ampliar as pesquisas sobre causa e efeito entre o consumo alimentar o desenvolvimento/ progressão de doenças mentais. De forma geral, após vários estudos clínicos e revisões sistemáticas com meta-análise, o consumo de frutas, legumes, peixes e alimentos integrais, assim como o padrão alimentar mediterrâneo, são associados à diminuição de desenvolvimento de depressão. O consumo de nutrientes-chave também é muito discutido como possíveis estratégias de tratamento, na forma de nutracêuticos, sendo as proteínas, ferro, colina, folato, iodo, vitaminas A, D, B6 e B12 e ácidos graxos polinsaturados de cadeia longa, os nutrientes mais associados à manutenção da saúde mental. A relação cérebro-intestino também é explorada ao incluir estudos sobre o microbioma e sua influência na saúde mental (ADAN et al, 2020; CARNEGIE et al, 2020). O campo da psiquiatra nutricional é ainda pouco explorado apesar de apresentar grandes possibilidades de discussão. Como entraves a pesquisa, alguns autores citam as dificuldades metodológicas de estabelecer causa-efeito e de descrever os mecanismos biológicos envolvidos na saúde mental e cognição (SARRIS, 2019).

Conclusão: Apesar de ainda pouco difundido o campo da psiquiatria nutricional surge como uma possibilidade de tratamento menos agressiva, porém, eficiente às doenças mentais, principalmente àquelas relacionadas com depressão, ansiedade e transtornos de humor.

\section{Referências}

SARRIS, J. et al. Nutritional medicine as mainstream in psychiatry. The Lancet Psychiatry. Vol. 2, n. 3, pg. 271-274, 2015. ADAN, R.A.H et al. Nutritional psychiatry: Towards improving mental health by what you eat. European Neuropsychopharmacology. Vol. 29, n. 12, pg. 1321-1332, 2019.

CARNEGIE, R. et al. Mendelian randomisation for nutritional psychiatry. The Lancet Psychiatry. Vol. 7, n. 2, pg. 208-2016, 2020.

SARRIS, J. Nutritional Psychiatry: From Concept to the Clinic. Drugs. Vol. 79, n. 9, pg. 929-934, 2019. 


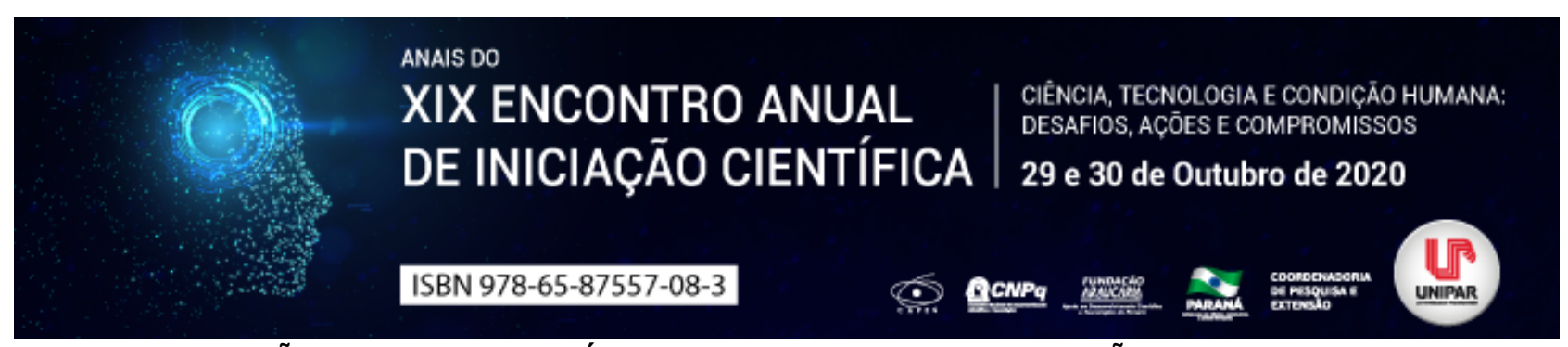

INFECÇÃO DO TRATO URINÁRIO EM GESTANTES: UMA REVISÃO DA LITERATURA

\begin{abstract}
${ }^{1}$ JESSICA ZANQUIS FERREIRA, ${ }^{2}$ CAMILA MARIA ESCARDILLE YOSHITANI, ${ }^{3}$ DAVI CORREA PEREIRA, ${ }^{4}$ ESTER PELEGRINI SILVA, ${ }^{5}$ FABIANE ANGELICA DE PAIVA PAULA, ${ }^{6}$ ELENIZA DE VICTOR ADAMOWSKI CHIQUETTI
\end{abstract}

\author{
${ }^{1}$ Acadêmica do Curso de Medicina da Universidade Paranaense - UNIPAR \\ ${ }^{1}$ Acadêmica do Curso de Medicina da UNIPAR \\ ${ }^{2}$ Acadêmico do Curso de Medicina da UNIPAR \\ ${ }^{3}$ Acadêmica do Curso de Medicina da UNIPAR \\ ${ }^{4}$ Acadêmica do Curso de Medicina da UNIPAR \\ ${ }^{5}$ Docente da UNIPAR
}

Introdução: A infecção do trato urinário (ITU) pode ser descrita como a presença e replicação de bactérias no trato urinário, ocasionando lesão de seus tecidos (PAGNOCELI; COLACITE, 2016). Podem ser classificadas de diferentes formas, levando em consideração a localização anatômica afetada e o sítio de proliferação bacteriana, sendo elas, bacteriúria assintomática (BA), cistite e pielonefrite (BAUMGARTEN et al.,2015). A BA é uma condição clínica, sem queixas urinárias, porém com exame de urocultura positivo, sendo mais de 100.000 colônias por $\mathrm{mL}$ de urina, este exame deve ser realizado no primeiro e no terceiro trimestre de gestação e se identificado a irregularidade, a BA deve ser tratada a fim de evitar o desenvolvimento de pielonefrite aguda (HEIN; BORTOLI; MASSAFERA, 2016). Algumas condições podem predispor a gestante ao desenvolvimento de BA como, aumento da idade, multiparidade, baixo nível socioeconômico e histórico de infecções do trato urinário na infância (BAUMGARTEN et al.,2015). Por sua vez, a cistite caracteriza-se pela aderência da bactéria á bexiga, também conhecida como infecção do trato urinário baixo, causando disúria, urgência miccional, polaciúria, dor suprapúbica ou dor abdominal, nictúria e normalmente é afebril (HEIN; BORTOLI; MASSAFERA, 2016). Neste caso, destacam-se os seguintes fatores de risco para o desenvolvimento de cistite, história pregressa de Chlamydia trachomatis, uso de drogas ilícitas e menos de 12 anos de escolaridade além das condições indicadas também para BA (BAUMGARTEN et al.,2015). Por fim, considerada a mais grave, podemos citar a pielonefrite, também conhecida como infecção do trato urinário alto, caracterizada pelo comprometimento de ureteres, pelve e parênquima renal, seus sintomas são: febre, taquicardia, náuseas, vômitos e dor lombar (HEIN; BORTOLI; MASSAFERA, 2016). Durante a gestação, a infecção do trato urinário deve ser considerada de grande importância devido a sua elevada incidência neste período da vida da mulher, é uma das intercorrências mais comuns durante a gestação, acometendo cerca de 10 a 12\% das mulheres grávidas (PIGOSSO; SILVA; PEDER, 2016).

Objetivo: Dessa forma, o presente estudo tem como objetivo apresentar a importância do diagnóstico e tratamento de infecções do trato urinário em gestantes.

Desenvolvimento: A gestação de forma individual não explica a maior ocorrência de ITU, porém as mudanças anatômicas e fisiológicas do trato urinário durante a gestação predispõe ao desenvolvimento de tais infecções (SANTOS; SILVA; PRADO, 2017). Nesse período ocorre dilatação dos ureteres e pelves renais, redução da atividade peristáltica ocasionada pelos níveis de progesterona que junto ao aumento do débito urinário, redução do tônus muscular vesical, ocasiona a estase urinária e ainda contribui para o refluxo vesico-ureteral evoluindo assim para um mal prognóstico da ITU nas gestantes (ANDRADE et al., 2016). Podemos citar algumas complicações maternas associadas a evolução da ITU durante a gestação, como, choque séptico, anemia, obstrução renal e abscesso renal ou perineal e até mesmo insuficiência renal, já ao se referir às complicações perinatais podemos destacar, a ruptura prematura de membranas amnióticas, restrição de crescimento intrauterino, trabalho de parto prematuro, baixo peso do recém nascido, paralisia cerebral, óbito perinatal e mortalidade fetal (SANTOS; SILVA; PRADO, 2017). Dessa forma é imprescindível a realização do diagnóstico precoce das ITU, que pode ser realizado clinicamente devido aos sintomas que a gestante pode apresentar, juntamente com o exame físico, sendo complementado por exames laboratoriais como, o parcial de urina e a urocultura que é considerada padrão ouro para o diagnóstico, pois indica qual agente etiológico é o causador da ITU, principalmente nos casos de bacteriúria assintomática, onde a falta de sintomas dificulta o diagnóstico clínico, e para um tratamento eficaz, é importante determinar a bactéria causadora da infecção, para selecionar o antibiótico a ser empregado (SILVA; SOUSA; VITORINO, 2019). Os principais agentes etiológicos responsáveis pela ITU são germes gramnegativos entéricos especialmente a Escherichia coli, seguida dos demais gram-negativos como Klebsiella e Proteus. Bactérias Gram positivas também causam ITU, porém de prevalência baixa, podemos citar o Staphylococcus saprophyticus e Streptococcus agalactiae (SILVA et al., 2017). Em relação ao tratamento, o fármaco de escolha é sempre de acordo com o perfil de sensibilidade dos microorganismos, observando o fato de terem inocuidade comprovada para o feto, os mais usados são: Cefalosporinas, Ampicilinas e Nitrofurantoínas (FERNANDES, et al., 2015). 
Conclusão: Portanto, podemos concluir que a infecção do trato urinário em gestante, nas suas diversas formas de classificação e manifestações clínicas, podem causar significativas complicações tanto para a mãe quanto para o bebê, fazendo-se importante o diagnóstico precoce e exato dessas infecções bem como a padronização do tratamento que deve ser apropriado e eficaz de acordo com o agente etiológico envolvido na infecção e seu risco de teratogenicidade, evitando assim danos as gestantes e ao feto.

\section{Referências}

ANDRADE, Luiz Felipe Felisberto et al. Infecção do Trato Urinário em Gestantes: Uma Revisão Literária: Brazilian Journal of Surgery and Clinical Research BJSCR, v.15, n.3, p.87-90, 2016.

BAUMGARTEN, Maria Cristina dos Santos et al. Infecção Urinária na Gestação: uma Revisão da Literatura. Journal of Health Sciences, 2015.

FERNANDES, Fabrícia Almeida et al. Relevância do diagnóstico e tratamento da infecção do trato urinário em gestantes: uma revisão da literatura. Ciência \& Desenvolvimento- Revista Eletrônica da Fainor, v. 8, n. 1, 2015.

HEIN, Safira; DE BORTOLI, Cleunir de Fátima Candido; MASSAFERA, Gisele Lopp. Fatores relacionados à infecção de trato urinário na gestação: revisão integrativa. Journal of Nursing and Health, v. 6, n. 1, p. 83-91, 2016.

PAGNONCELI, Juliana; COLACITE, Jean. Infecção urinária em gestantes: revisão de literatura. Revista Uningá Review, v. 26, n. 2, 2016.

PIGOSSO, Yaskara Gorczevski; DA SILVA, Claudinei Mesquita; DE PEDER, Leyde Daiane. Infecção do trato urinário em gestantes: incidência e perfil de suscetibilidade. Acta Biomedica Brasiliensia, v. 7, n. 1, p. 64-73, 2016.

SANTOS, Joyce Nascimento dos; SILVA, Raquel Prado da; PRADO, Lourivânia Oliveira Melo. Infecção do Trato Urinário na Gravidez: Complicações e Intervenções de Enfermagem. Congresso Internacional de Enfermagem. 2017.

SILVA, Bruno Nascimento da et al. Principais microrganismos causadores de infecção do trato urinário em gestantes Anais da Mostra de Biomedicina da Unicatólica, v.2, n.1, 2017.

SILVA, Raimunda de Abreu; SOUSA, Thainara Araújo; VITORINO, Keila de Assis. Infecção do Trato Urinário na Gestação: Diagnóstico e tratamento. Revista Científica da Faculdade de Educação e Meio Ambiente, v. 10, n. 1, p. 71-80, 2019. 


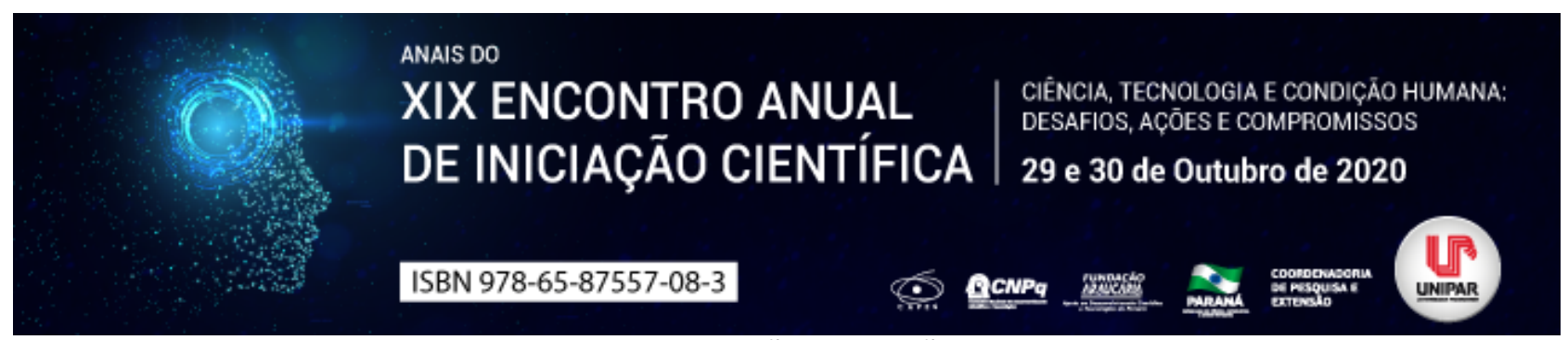

CUIDADOS PALIATIVOS: A RECUPERAÇÃO QUE NÃO PODE SER NEGLIGENCIADA

\begin{abstract}
${ }^{1}$ JESSICA ZANQUIS FERREIRA, ${ }^{2}$ CAMILA MARIA ESCARDILLE YOSHITANI, ${ }^{3}$ DAVI CORREA PEREIRA, ${ }^{4}$ ESTER PELEGRINI SILVA, ${ }^{5}$ GUILBERT CARLOS DE AZEVEDO DAVIZ, ${ }^{6}$ ALTAIR DE SOUZA CARNEIRO
\end{abstract}

\footnotetext{
${ }^{1}$ Acadêmica do Curso de Medicina da UNIPAR

${ }^{1}$ Acadêmica do Curso de Medicina da UNIPAR

${ }^{2}$ Acadêmico do Curso de Medicina da UNIPAR

${ }^{3}$ Acadêmica do Curso de Medicina da UNIPAR

${ }^{4}$ Acadêmico do Curso de Medicina da UNIPAR

${ }^{5}$ Docente da UNIPAR
}

Introdução: A Organização Mundial da Saúde define cuidados paliativos como assistências prestadas por uma equipe multidisciplinar com o objetivo de promover a qualidade de vida e prevenir ou aliviar o sofrimento físico, social, psicológico e espiritual do paciente doente com risco iminente de morte (GOMES; OTHERO, 2016). O termo paliativo tem origem do latim pallium, significando cobertor ou manta (MARTA et al., 2010). Essa especialidade diferencia-se fundamentalmente da medicina tradicional por focar no cuidado integral, através da prevenção e do controle de sintomas, para todos os pacientes que enfrentam doenças graves, assim como assistir a familiares, cuidadores, equipe de saúde e seu entorno, os quais adoecem e sofrem junto (GOMES; OTHERO, 2016). Em suma, o conceito morte é avaliado de diferentes maneiras na sociedade. Mesmo que em meio profissional de saúde, perder algum paciente é sinônimo de fracasso (HERMES; LAMARCA, 2013). Portanto, o presente artigo visa reconhecer a importância dos cuidados paliativos na promoção do bem estar dos pacientes, diferente de como é encarada socialmente, bem como avaliar seus efeitos como benefício psicológico, social e espiritual.

Objetivo: Comparar por meio da literatura científica a real expressão da atenção paliativa com os conceitos comumente atribuídos.

Desenvolvimento: A prática dos cuidados paliativos não exclui a possibilidades de tratamento, de maneira oposta, há bastante o que se fazer para cuidar do sofrimento dos pacientes que se apresentam em tal situação (ARANTES, 2016). Dados epidemiológicos evidenciam que aproximadamente 40 milhões/ano de pessoas no mundo precisam de cuidados paliativos (ACADEMIA NACIONAL DE CUIDADOS PALIATIVOS, 2009) e, por meio dessa especialidade, a medicina é capaz de fornecer melhorias na qualidade de vida do paciente, pois o processo da doença, além do acometimento físico, compromete psicologicamente, sendo esta incalculável e de viés subjetivo. Assim, cria-se um cenário doloroso, que torna a morte sombria tanto para aquele que se vê à beira da mesma quanto para os que participam do processo (GOMES; OTHERO, 2016). É imprescindível destacar, que o medo de morrer aflige, de certa forma, a todos, portanto é universal. É a resposta psicológica mais comumente presente, o medo do desconhecido, da solidão, da dor de perder um dos seus, até mesmo de seus sonhos serem interrompidos. Esse medo da morte evoca ansiedade e se faz difícil diferenciá-los em conceitos díspares. O que mais se teme ao se cogitar sobre morte, depende da época e da circunstância em que está sendo vivida (KOVÁCS, 1992). Por isso, o cuidado paliativo apresenta um tratamento físico, trabalha na minimização da dor e é capaz de oferecer cuidado emocional e psicossocial, estendendo-se ao indivíduo doente e a família (ARANTES, 2016). Todas essas situações são abordadas por uma equipe multidisciplinar (HERMES; LAMARCA, 2013). Dentre os princípios dos cuidados paliativos, destaca-se oferecer um sistema de suporte que possibilite o paciente viver tão ativamente quanto possível, até o momento da sua morte; e Melhorar a qualidade de vida e influenciar positivamente o curso da doença (ACADEMIA NACIONAL DE CUIDADOS PALIATIVOS, 2009). Destarte, o médico paliativista deve atuar para melhoria do conforto do paciente, redução do mal-estar causado pela doença ou pelo seu tratamento, e toda a equipe deve trabalhar para que os incômodos sejam atenuados para melhorias da qualidade de vida, dos familiares e de todos os acompanham o sofrimento (KÜRBER-ROSS, 2007).

Conclusão: Portanto, podemos concluir que, além dos cuidados da medicina tradicional, contamos ainda com a terapia dos cuidados paliativos para pacientes portadores de doenças crônicas que apresentam risco iminente de morte, terapia esta que não deve ser negligenciada, pois proporciona ao paciente, seus familiares e à todos que estão ao seu redor benefícios psicológico, social e espiritual frente as dificuldades da patologia enfrentada.

\title{
Referências
}

ACADEMIA NACIONAL DE CUIDADOS PALIATIVOS. Manual de cuidados paliativos. Rio de Janeiro: Diagraphic; 2009. Disponível em: https://paliativo.org.br/download/manual-de-cuidados-paliativos-ancp/. Acesso em: 25 mar. 2020.

ARANTES, Ana Cláudia. A morte é um dia que vale a pena viver. 1. ed. Portugal: Oficina do Livro, 2018. 
GOMES, Ana Luisa Zaniboni; OTHERO, Marília Bense. Cuidados paliativos. Estudos avançados. v. 30, n. 88, p. 155-166, 2016. Disponível em: . Acesso em: 25 mar. 2020.

HERMES, H. R.; LAMARCA, I. C. A.. Cuidados paliativos: uma abordagem a partir das categorias profissionais de saúde. Ciência \& Saúde Coletiva. v. 18, n. 9, p. 2577-2588, 2013. Disponível em: http://www.scielo.br/scielo.php? script=sci_arttext\&pid=S1413-81232013000900012\&lng=pt\&tlng=pt. Acesso em: 25 mar. 2020.

KOVÁCS, Maria Júlia. Morte e desenvolvimento humano. 1. ed. São Paulo: Casa do Psicólogo, 1992.

KÜBLER-ROSS, Elisabeth. Sobre a morte e o morrer: O que os doentes terminais têm para ensinar a médicos, enfermeiras, religiosos e aos seus próprios parentes. 9. ed. São Paulo: WWF Martins Fontes, 2017.

MARTA, Gustavo Nader; HANNA, Abdallah Samir; SILVA, João Luis Fernandes. Cuidados paliativos e ortotanásia. Diagn

Tratamento, v. 15, n. 2, p. 58-60, mar. 2010. Disponível em: . Acesso em: 25 mar. 2020.

Coordenadoria de Pesquisa e Extensão - COPEX

Departamento de Editoraçāo e Divulgaçāo Científica - DEDIC 


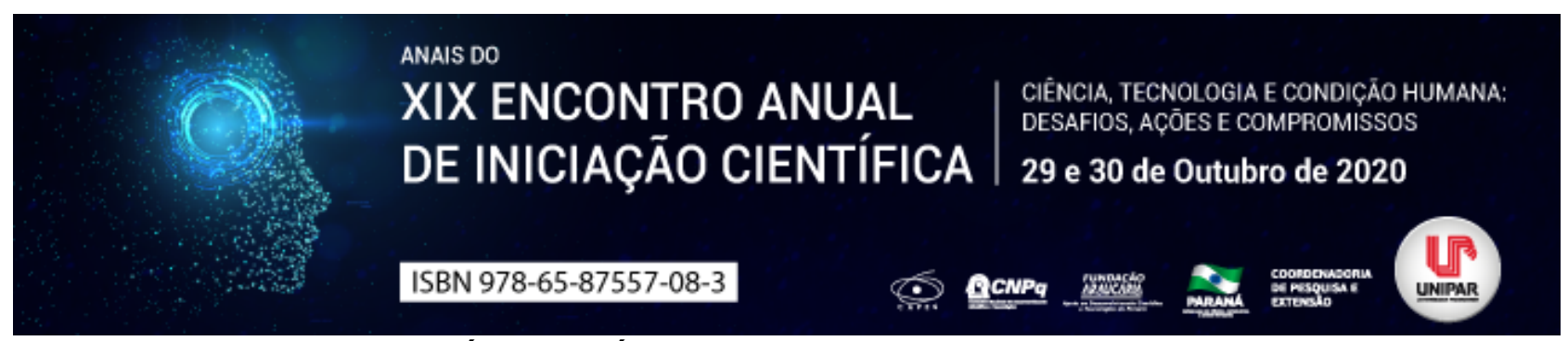

MEDULA ÓSSEA: PÓS-TRANSPLANTE E QUALIDADE DE VIDA

\title{
${ }^{1}$ MATHEUS DE SOUZA MARTINUCI, ${ }^{2}$ BEATRIZ CATHARINI CREVELARO, ${ }^{3}$ SUELLEN LAIS VICENTINO VIEIRA
}

\author{
${ }^{1}$ Discente do Curso de Farmácia, Ciências da Saúde, Universidade Paranaense - Umuarama-PR. \\ ${ }^{1}$ Discente do Curso de Farmácia, Ciências da Saúde, Universidade Paranaense - Umuarama-PR. \\ ${ }^{2}$ Docente do Curso de Farmácia, Ciências da Saúde, Universidade Paranaense - Umuarama-PR.
}

Introdução: O transplante de medula óssea é um procedimento de alta complexidade que vem se constituindo como uma alternativa terapêutica para diversos tipos de neoplasias sólidas, doenças hematológicas malignas ou não, doenças metabólicas e deficiências imunológicas (ANDRADE, et al., 2012). Nos últimos 20 anos, as pesquisas desenvolvidas no transplante de células-tronco hematopoiéticas permitiram melhor seleção de doadores, redução na toxicidade advinda do condicionamento, com desenvolvimento de regimes de intensidade reduzida e melhora no tratamento de suporte, com a diminuição das complicações pós-transplante, aumentando dessa forma, a sobrevida dos transplantados (PEREIRA, et al., 2020).

Objetivo: Realizar uma pesquisa bibliográfica sobre a qualidade de vida de pacientes submetidos ao transplante de medula óssea.

Desenvolvimento: $O$ transplante de Células-Tronco Hematopoiéticas é uma modalidade terapêutica utilizada de maneira crescente na oncologia e na hematologia. Trata-se de um tratamento complexo, em que a farmacoterapia representa um dos principais fatores para o sucesso. Mesmo após a alta hospitalar, os pacientes transplantados continuam sob risco de desenvolver sérias complicações (ZANETTI, et al., 2020). Atualmente, o transplante de medula óssea é considerado a terapia mais adequada e bem-sucedida no tratamento de doenças, que até há pouco tempo eram fatais, como a leucemia e outras neoplasias hematológicas. No entanto, é um extenso processo, agressivo e prolongado, de grande complexidade e passível de complicações que debilitam, deixam sequelas ou têm consequências fatais (CARDOSO, et al., 2018). A vida das pessoas submetidas ao transplante de medula óssea sofre modificações decorrentes, em parte, do longo processo vivenciado desde o diagnóstico até a alta hospitalar, o qual atua como um desencadeador de vivências de ansiedade que interferem em seu cotidiano de vida e de seus familiares. Acrescenta-se que, devido à complexidade do tratamento, elas apresentam longos períodos de hospitalização, caracterizando uma condição de isolamento social que gera mudanças existenciais, sinalizadoras da necessidade de adaptação a um novo estilo de vida (ANDRADE, et al., 2012). Em estudo realizado por BRAGA et.al (2017), sobre a qualidade de vida de pacientes submetidos ao transplante de medula óssea autólogo e alogênico em um Hospital Universitário do interior do Rio Grande do Sul obteve os seguintes resultados: a maioria dos indivíduos não se sente mais doente $(57,1 \%)$, e os efeitos colaterais do tratamento atualmente não os têm incomodado (35\%). Apesar de não haver um comprometimento significativo, a dor ainda está presente em suas vidas, sendo que $33,4 \%$ a descrevem como mais ou menos presente, e $23,8 \%$ muito presente. Sobre a capacidade de trabalhar (inclusive em casa), 76,2\% de indivíduos não se sentem aptos a realizar suas atividades nenhum pouco 14,3\%, um pouco $33,3 \%$ e mais ou menos $28,6 \%$. Apesar destes dados, mais de $50 \%$ indica que se sente realizado(a) com as atividades que ainda conseguem desempenhar. Em um outro estudo realizado por Cardoso et al. (2018), que teve como um de seus objetivos avaliar a qualidade de vida de crianças submetidas ao transplante de medula óssea que se encontravam na fase pós-alta hospitalar verificou na perspectiva das crianças ansiedade com tratamento, ansiedade com procedimento, náuseas, ausência de dores, problemas de comunicação, funções cognitivas afetadas, aparência e preocupações.

Conclusão: Pode- se concluir que o transplante de medula óssea utilizado de forma terapêutica é eficaz em grande parte dos indivíduos submetidos ao tratamento. Segundo os estudos os resultados demonstraram que os mesmos não se sentem mais doentes, mas a maioria não se sente apta para voltar ao mercado de trabalho, um número considerável de pacientes relatam sentir dor física constante em suas vidas. Para as crianças transplantadas em fase pós alta hospitalar os principais problemas relatados foram relacionados com a ansiedade, problemas de cognição e comunicação e como ponto positivo relataram a ausência de dores.

\section{Referências}

ANDRADE, Angélica Mônica; CASTRO, Edna Aparecida Barbosa de; SANTOS, Kelli Borges dos et. al. . A vida após o transplante de medula óssea: implicações para o cotidiano. Cogitare Enfermagem, v. 17, n. 2, p. 290-296, abr/jun 2012.

BRAGA, Marciele; CARDOSO, Andreza Lima; SCHIO, Bruna et.al.. Avaliação da qualidade de vida de pacientes submetidos ao transplante de células-tronco hematopoéticas. Saúde (Santa Maria), v. 43, n. 1, p. 233-243, jan/abr 2017.

CARDOSO, Érika Arantes de Oliveira; GARCIA, Juliana Tomé; GUIMARÃES, Ana Luisa Carvalho et al. . Qualidade de vida póstransplante de medula óssea: comparação entre avaliação das crianças e das mães. Revista Família, Ciclos de Vida e Saúde 
no Contexto Social, v. 6, n. 4, p. 686-693, nov 2018.

PEREIRA, Andréa; VIGORITO, Afonso Celso,; ALMEIDA, Alessandro de Moura; et. al. Consenso Brasileiro de Nutrição no Transplante de Células Tronco Hematopoiéticas: doença do enxerto contra o hospedeiro. Einstein (São Paulo), v. 18, p. 1-20, jan 2020. Disponível em < https://www.scielo.br/pdf/eins/v18/pt_2317-6385-eins-18-eAE4799.pdf>. Acesso em: 15 de jul. 2020.

ZANETTI, Maria Olívia Barboza; PEREIRA, Leonardo Régis Leira.. Uso de medicamentos após o Transplante de Células-Tronco Hematopoiéticas: produção de um manual educativo. Journal of Applied Pharmaceutical Sciences, v. 7, p. 82-87, jan 2020.

Coordenadoria de Pesquisa e Extensão - COPEX

Departamento de Editoraçāo e Divulgaçāo Científica - DEDIC 


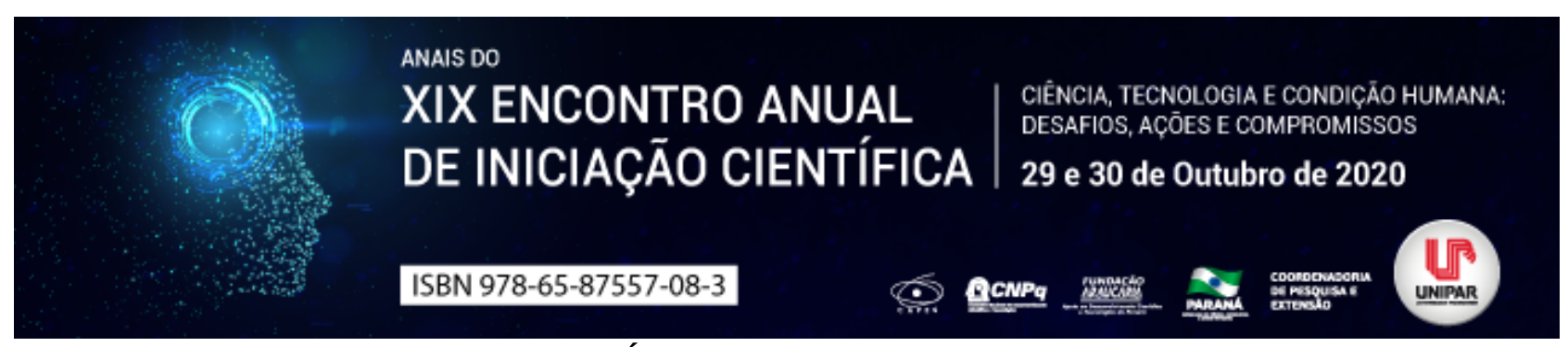

UM LEVANTAMENTO DOS SINAIS CLÍNICOS DA LOMBALGIA EM ESPORTISTAS DE CICLISMO

\author{
${ }^{1}$ MATHEUS RODRIGUES DA SILVA, ${ }^{2}$ DORA DE CASTRO AGULHON SEGURA
}

\author{
${ }^{1}$ Acadêmico do PIC/UNIPAR \\ ${ }^{1}$ Docente da UNIPAR
}

Introdução: Por se tratar de um esporte aeróbico e que trabalha a musculatura corporal de forma globalizada se faz necessário adotar medidas preventivas e cuidados para que em longo prazo essa prática não venha acarretar dores e disfunções indesejáveis, principalmente em nível de coluna lombar, onde está a maior incidência de lesões pelo uso da bicicleta (CLARSEN; KROSSHAUG; BAHR, 2010). O bom ajuste da bicicleta às características individuais do praticante favorecem à prevenção e amenização de dores relacionadas ao ciclismo, tendo sempre o parâmetro tanto da frequência com que se utiliza a bicicleta quanto do tempo em que se faz o uso, fatores estes determinantes para os praticantes, sejam eles profissionais ou amadores, alertando as posições corretas tanto do corpo, como o ajuste mais ergonômico da bicicleta às necessidades apresentadas pela prática.

Objetivo: Possibilitar o acesso a informações pertinentes ao uso mais coerente do ciclismo no dia a dia assim como esclarecer os agravos decorrentes do seu mau uso e os sinais apresentados pelo ciclista como consequência disto.

Desenvolvimento: As posições adotadas podem variar quando leva-se em conta ciclistas amadores em relação a atletas profissionais, para estes, posições que favoreçam a aerodinâmica são bem vindas, enquanto para aqueles, isso não confere nenhuma importância, contudo deve-se atentar que isso altera a forma como a coluna lombar trabalha bem como a propensão em sentir dores. Ciclistas amadores que adotam uma postura onde o tronco se apresenta de forma ereta, ou seja, próximo a postura fisiológica demonstram maior conforto e menos tendência à lombalgia (QUESADA et al., 2016). Diversos ajustes se mostraram eficientes na prevenção da dor lombar, um dos principais entre todos está a regulagem do banco para favorecer que a coluna lombar se posicione de forma mais próxima a anatomia natural, o que favorece uma redistribuição de peso mais igualitária entre as estruturas adjacentes sem sobrecarregar uma em detrimento de outra (SALAl et al., 1999). A regulagem da inclinação do banco anteriormente em aproximadamente $10-15^{\circ}$ favorece a redução da hiperextensão da coluna lombar e sua consequente flexão, essa posição quando adotada, apresenta grande eficácia no desaparecimento da lombalgia nos praticantes de ciclismo (SCHULTZ; GORDON, 2015). Complementando, Asplund e Ross (2010) mostram que, entretanto, apenas a combinação correta do ângulo do banco em relação à coluna pode não ser o suficiente no tratamento de lombalgias em ciclistas, um bom fortalecimento da musculatura global envolvida minam a prevalência ou não de dores relacionadas ao esporte (SCHULTZ; GORDON, 2015).

Conclusão: Sendo assim, a prática do ciclismo quando executada de forma descompromissada pode trazer agravos à saúde musculoesquelética que por vezes podem ser incapacitantes alterando a rotina diária do indivíduo. Desta forma se faz necessário um cuidado detalhado quanto ao seu uso, visando sempre a eliminação da possibilidade do aparecimento de lombalgias e como objetivo final possibilitar que a prática ciclística seja feita de forma satisfatória sem dores presentes.

\title{
Referências
}

ASPLUND, C.; ROSS, M. Core stability and bicycling. Current Sports Medicine Reports, Philadelphia, v. 9 n. 3 p. 155-160. Mai./Jun. 2010.

CLARSEN, B.; KROSSHAUG, T.; BAHR, R. Overuse injuries in professional road cyclists. The American Journal of Sports Medicine, California, v. 38, n. 12, p. 2494 2501. Dec. 2010.

SCHULTZ, S. J.; GORDON, S. J. Recreational cyclists: The relationship between low back pain and training characteristics. International Journal of Exercise Science, Bowling Green, v. 3 n. 3 p. 79 85. Jul. 2010.

QUESADA, J. I. P.; SORIANO, P. P.; CUEVAS, A. G.; PALMER, R. S.; DE ANDA, R. M. C. O. Effect of bike-fit in the perception of comfort, fatigue and pain. Journal of Sports Sciences, Londres, v. 35 n. 14 p. 1-7. Ago. 2016.

SALAI, M.; BROSH, T.; BLANKSTEIN, A.; ORAN, A.; CHECHICK, A.. Effect of changing the saddle angle on the incidence of low back pain in recreational bicyclists. British Journal of Sports Medicine, Londres, v. 33, n. 1, p. 398-400. Dec. 1999. 


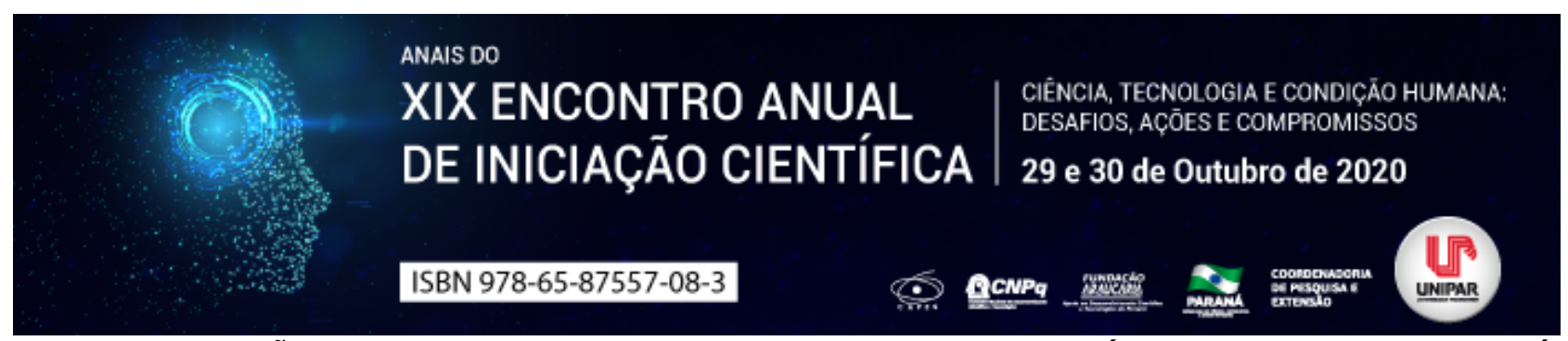

CARACTERIZAÇÃO DAS GESTANTES E DOS NASCIMENTOS NO MUNICÍPIO DE CASCAVEL, PARANÁ

\title{
${ }^{1}$ GABRIELA MARIA KEMFER, ${ }^{2}$ JULIANA CARISSIMI, ${ }^{3}$ DAISY CRISTINA RODRIGUES
}

\author{
${ }^{1}$ Acadêmica do Curso de Enfermagem da UNIPAR \\ ${ }^{1}$ Acadêmica do Curso de Enfermagem da UNIPAR \\ ${ }^{2}$ Docente da UNIPAR
}

Introdução: A atenção dos profissionais de saúde específica ao cuidado com a saúde do recém-nascido (RN) tem importância fundamental para a redução da morbidade e mortalidade infantil. A análise das condições de nascimento e caracterização das crianças com levantamento de perfil, são estratégias necessárias que auxiliam e orientam as ações dos serviços de saúde, proporcionando um planejamento efetivo e de qualidade. Além de permitir avaliação do atendimento prestado durante o pré-natal e parto (MENDES, 2020).

Objetivo: Identificar o perfil de recém nascidos do município Cascavel, no período de 2016 a 2018.

Metodologia: Trata-se estudo epidemiológico observacional, do tipo ecológico. A epidemiologia pode ser definida como forma de controlar problemas de saúde, estudando a distribuição, causas das doenças e condições de saúde da população (LIMACOSTA; BARRETO, 2003). O estudo foi fundamentado e construído com base de dados secundários eletrônicos do DATASUS, dentro da plataforma Tabnet. Para a busca dos dados foi acessado as estatísticas vitais, e selecionado a opção nascidos vivos, com abrangências geográficas no estado do Paraná entre os anos 2016 á 2018. As variáveis utilizadas durante a busca foram: idade gestacional, idade da mãe, tipo do parto, se foi realizado ou não pré-natal, número do Apgar no primeiro e quinto minuto.

Resultados e Discussões: A gravidez e a maternidade são normalmente descritas como uma das tarefas desenvolvidas mais significativas da idade adulta. Entretanto segundo as pesquisas percebemos que a gravidez também acontece com frequência na adolescência, de 10 a 14 anos tiveram 98 crianças nascidas. De acordo com Taborda (2014, pg. 20) a gravidez na adolescência é frequente e crescente no Paraná, e se caracteriza como um fator que aumenta a probabilidade de mortes relacionadas à gravidez ou parto. Percebe-se que, com o aumento da educação sexual, conscientização, diminuíram-se os casos de gravidez precoce, sendo eficaz, porém atualmente ainda é um número a se considerar. Também ocorrem números consideráveis de nascimentos entre 40 a 54 anos, nos três anos analisados, tiveram-se 594 casos. Com a idade avançada, acabam tornando-se gravidez de risco para a mãe e o bebê, podendo ocorrer pré-eclâmpsia e eclâmpsia, risco de aborto espontâneo e hipertensão. Nota-se o interesse e cuidado que as mães estão tendo em relação às consultas de pré-natal. As alternativas disponíveis de parto são normal e cesáreo, em Cascavel, ocorre-se prevalência do parto cesáreo. O parto saudável é um direito da mãe, porém ela precisa saber os riscos e benefícios para livremente optar. De acordo com Nascimento (2015, pg.122), O desejo da mulher por uma cesariana é sustentado pelo medo, pela conveniência e pela desinformação . Explicar o modo como o parto ocorre, é dever da equipe de saúde, a mãe necessita estar preparada para o momento. O parto cesáreo foi estabelecido como cultural, sendo preferido pelos médicos, entretanto não é o médico quem decide, aumento de casos de partos por cesárea ocorre por escolha da mãe, influência médica e casos em que a mãe apresente alguma DST's. Conforme, Oliveira (2012), a avaliação clínica do recém-nascido (RN) foi proposta por Virginia Apgar, que propõe analisar aspectos do recém-nascido no primeiro e quinto minuto com aplicação de escores. No exame de Apgar é avaliada aparência, pulso, gesticulação, atividade e respiração. Tem valiosa importância para o recém-nascido, com esse exame os profissionais saberão quais serão as necessidades do mesmo e auxilia na redução de mortes perinatais. Sendo uma escala de 0 a 10 pontos, avaliado no $1^{\circ}$ e $5^{\circ}$ minuto de vida. É importante ter o histórico de pré-natal, com intuito de saber como ocorreu a gestação, se houve algum problema e se a mãe recebeu devidos cuidados. Nota-se, que nas gestações de 37 a 41 semanas, o Apgar se torna mais alto, tanto no $1^{\circ}$ quanto no $5^{\circ}$ minuto de vida, em que podemos relacionar ao pré-natal e a uma gestação saudável. Já Apgar com numerações de 0 a 5, em menos de 36 semanas, no $1^{\circ}$ minuto, Cascavel teve 382 casos. No $5^{\circ}$ minuto, em mesma semana e numeração, houve 58 casos apenas. São avaliados, frequência cardíaca, a respiração com presença de choro, a flexibilidade e movimentações, reflexos e o tom da pele (rosada, pálida ou arroxeada). Cada qual possui uma nota de 0 a 3 pontos, a soma final, deverá mostrar o quão estável está o bebê (Oliveira, T. 2012).

Conclusão: Com a caracterização dos recém nascidos de Cascavel foi possível identificar que houve um número razoável de gravidez na adolescência, compreendemos que ainda é de extrema importância o diálogo dos pais com seus filhos referentes à maternidade e paternidade e suporte da redes de atenção básica. A idade de maternas que predominou em Cascavel, é de 25 a 29 anos, percebe-se que é uma faixa etária com boa fertilidade. Além disso, é essencial dar a decisão para a mãe no processo de pré-natal, parto e puerpério. E que RN de gestações saudáveis apresentam um melhor escore na avaliação do Apgar.

\section{Referências}


LIMA-COSTA, Maria; BARRETO, Sandhi. Tipos de estudos epidemiológicos: conceitos básicos e aplicações na área do envelhecimento, Minas Gerais, SCIELO, 2003. Disponível em: http://scielo.iec.gov.br/scielo.php?script=sci_arttext\&pid=S167949742003000400003 Acesso em: 28 mar. 2020.

NASCIMENTO, R. et al. Escolha do tipo de parto: fatores relatados por puérperas, Mato Grosso do Sul, 122 p. 2014.

Coordenadoria de Pesquisa e Extensão - COPEX

Departamento de Editoraçāo e Divulgaçāo Científica - DEDIC 


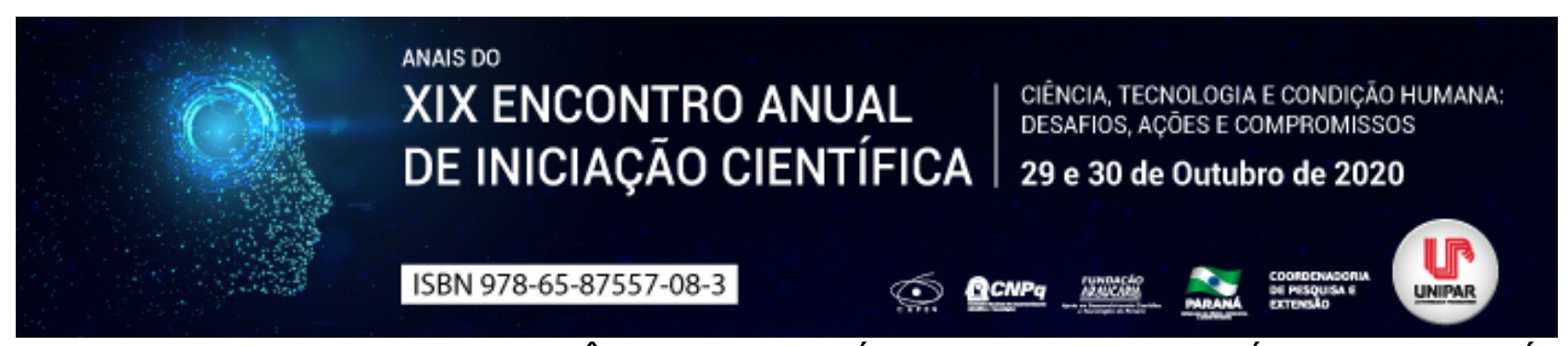

SÍFILIS ADQUIRIDA, EM GESTANTES E CONGÊNITA NO PARANÁ E UMUARAMA: UMA ANÁLISE EPIDEMIOLÓGICA DE 2010 A 2019

\title{
${ }^{1}$ VITOR ROQUE SAUER, ${ }^{2}$ NAIANY OLIVOTTO MARTINS, ${ }^{3}$ REINALDO HIGASHI YOSHII, ${ }^{4}$ MARINA GIMENES
}

\author{
${ }^{1}$ Acadêmico do PIC/UNIPAR \\ ${ }^{1}$ Acadêmica do Curso de Medicina da UNIPAR \\ ${ }^{2}$ Professor da disciplina de Epidemiologia e Saúde Coletiva do curso de Medicina da UNIPAR. \\ ${ }^{3}$ Professora Mestre, da disciplina de Epidemiologia e Saúde Coletiva do curso de Medicina da UNIPAR.
}

Introdução: De acordo com a Organização Mundial da Saúde (OMS) há mais de 5 milhões de infectados com sífilis anualmente (ORGANIZAÇÃO PAN-AMERICANA DE SAÚDE, 2019). Em relação à sífilis congênita, o número de casos de mortes evitáveis em fetos só é precedido pelos da malária (OPAS, 2019). A sífilis é uma IST (Infecção sexualmente transmissível) causada pela bactéria Treponema pallidum. Sua infecção ocorre por três vias: transmissão vertical, contato sexual ou transfusões sanguíneas. Sendo a primeira forma responsável pela sífilis congênita (AVELLEIRA e BOTTINO, 2016).

Objetivo: Realizar uma análise epidemiológica descritiva do número de casos de Sífilis adquirida, em gestantes e congênita entre os anos de 2010 e 2019 no estado do Paraná e no município de Umuarama.

Material e Métodos: Foi utilizado o banco de dados secundário, referente ao Sistema de Informação de Agravos de Notificação (SINAN), acessado via TabNet, disponibilizado pelo DATASUS. A coleta foi relacionada ao número de casos de Sífilis adquirida, em gestantes e congênita notificados no Estado do Paraná e no município de Umuarama. A coleta de dados foi realizada no período de 2010 até 2019. A incidência foi calculada para cada 100.000 habitantes, considerando a população estimada para 2019, segundo o IBGE.

Resultados: Com o levantamento de dados pelo DATASUS, no estado do Paraná, entre os anos de 2010 a 2019 , houve 37.381 casos de sífilis adquirida e sua incidência cresceu progressivamente, exceto em 2019. Considerando os anos de 2010 até 2019 a incidência foi de 327,80 casos para cada 100.000 habitantes por ano. No ano de 2010 foram notificados 77 casos; 436 em 2011 ; 807 casos em 2012; 1416 em 2013; 2337 em 2014; 4262 em 2015; 5513 em 2016; 7756 em 2017 ; em 2018 foram notificados 9928 casos; sendo esse o maior até então e por último em 2019 foram notificados 4949 casos. A incidência quando calculada para 100.000 hab variou de 0,67 em 2010 a 86,83 em 2018. Já na sífilis em gestantes no Paraná, em 2010 foram registrados 339 casos; 555 em 2011; no ano de 2012 foram 683; em 2013 foram 999; em 2014 foram 1324 casos; 1851 em 2015. Já nos anos de 2016, 2017, 2018 e 2019 foram registrados, respectivamente, 2269; 2572; 2836 e 1240 casos. A incidência variou de 2,96 em 2010 a 24,80 em 2018. Sobre a sífilis congênita no estado em 2010 foram registrados 147 casos; 215 em $2011 ; 304$ em 2012 ; 384 no ano de 2013; 468 em 2014 e 645 em 2015. Nos anos de 2016, 2017, 2018 e 2019 foram notificados 727; $865 ; 871$ e 414 casos, respectivamente e a incidëncia de 1,29 em 2010 a 12,84 em 2014. Sobre a sífilis adquirida no município de Umuarama, em 2010 não foram registrados casos, já em 2011 houve 1 caso notificado, seguido em 2012 por 11; 27 em 2013 ; 48 em 2014 ; 57 em 2015; 58 em 2016; 87 notificações em 2017; 66 em 2018 e por fim 42 casos no ano de 2019. A incidência da sífilis adquirida em Umuarama, entre 2010 e 2019 foi de 355,87, ou seja, 355,87 novos casos de sífilis adquirida para cada 100.000 hab/ano. E considerando ano a ano, a incidência aumentou, com queda nos anos de 2018 e 2019 . A variação da incidência foi de 0,90 em 2011 a 77,79 em 2017. Já a sífilis em gestantes na cidade, em 2010 foram registrados 3 casos; em 2011 não houve registro, em 2012 foram notificados 5; 2013 foram 7; em 2014 houve o registro de 6 casos; 2015 foram 9 casos. Em 2016 , 2017 , 2018, 2019 foram registrados 15, 17, 16 e 19 casos respectivamente. A maior incidência foi em 2019 com 17,03 casos para cada 100.000 hab. Quanto a sífilis congênita na cidade, no ano de 2010 não houve registro, em 2011 tiveram 2, em 2012 foi 1 caso. Nos anos de 2013, 2014, 2015 e 2016 não foram notificados casos. Em 2017, foi registrado 2 casos, 2018 não houve registro e em 2019 o número foi de 4 casos. A incidência chegou a 1,79 em 2011 e 2017, com aumento em 2019 para 3,59.

Discussão: Com base nos dados coletados, o estado do Paraná apresentou o mesmo comportamento que Umuarama em relação à incidência da sífilis adquirida, o município apresentou maior incidência entre os anos de 2012 a 2017 , excedendo o dobro em 2014, incidência de 20,43 no estado, enquanto Umuarama apresentou 43,03 para cada 100.000 hab. Referente à sífilis em gestantes, no Paraná de 2010 até 2018 houve um aumento gradativo e em 2019 uma queda brusca nos números. Diferentemente de Umuarama, que nos últimos 4 anos analisados teve o número de casos estáveis, porém no ano de 2019 a incidência de Umuarama foi maior que no Estado (17,03 e 10,84). Sobre o número de casos da sífilis congênita, há muitas discrepâncias entre Paraná e Umuarama, enquanto no primeiro houve o crescimento dos números de 2010 até 2018 e uma queda abrupta em 2019, no segundo, houve uma irregularidade. Em alguns anos, a cidade não registrou caso, mas de 2018 para 2019 houve $400 \%$ de aumento nos números. 
Conclusão: Com a análise de dados foi comprovado o aumento de sífilis no Paraná e em Umuarama na maioria dos anos observados. Pela gravidade da doença, deve-se investir em testes rápidos e no tratamento dos doentes e seus parceiros sexuais. Por fim, investir na prevenção é essencial, através da disseminação de informações, principalmente para as gestantes de Umuarama.

\section{Referências}

AVELLEIRA, João Carlos Regazzi; BOTTINO, Giuliana. Sífilis: diagnóstico, tratamento e controle. Anais Brasileiros de Dermatologia, [S.L.], v. 81, n. 2, p. 111-126, mar. 2006.

IBGE Instituto Brasileiro de Geografia e Estatística. Diretoria de Pesquisas, Coordenação de População e Indicadores Sociais, Estimativas da população residente com data de referência $1^{\circ}$ de julho de 2019. Rio de Janeiro, 2019. Disponível em: https://bityli.com/HErNz. Acesso em: 9 jul. 2020.

ORGANIZAÇÃO PAN-AMERICANA DE SAÚDE (OPAS). Organização Mundial da Saúde publica novas estimativas sobre sífilis congênita. Brasília, 28 fev. 2019. Disponível em: https://bit.ly/3fpZyXo. Acesso em: 9 jul. 2020.

Coordenadoria de Pesquisa e Extensão - COPEX

Departamento de Editoraçāo e Divulgaçāo Científica - DEDIC 


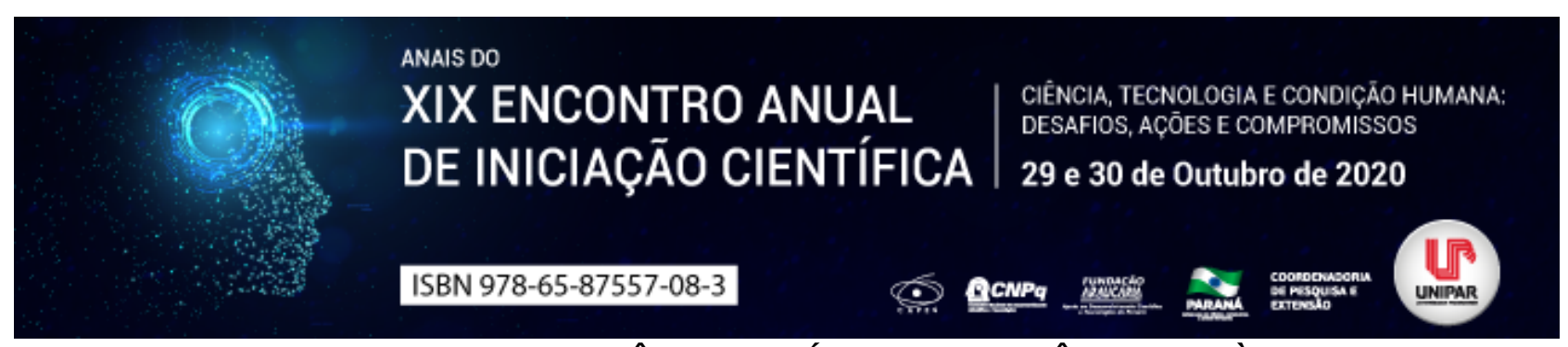

ENFERMAGEM NA ASSISTÊNCIA DE VÍTIMAS DA VIOLÊNCIA DOMÈSTICA

\title{
${ }^{1}$ VITOR UGO DIAS BARREIROS, ${ }^{2}$ NANCI VERGINIA KUSTER DE PAULA
}

\author{
${ }^{1}$ Docente do Curso de Enfermagem - UNIPAR \\ ${ }^{1}$ Docente do Curso de Enfermagem - UNIPAR
}

Introdução: A violência certamente sempre fez parte da vida humana, com grande impacto mundial. ela é um problema social e coletivo que atinge a todos, independente da sua classe social, religião, cultura,etnia, ou gênero, porém é importante ressaltar que cada grupo acima citado, tem sua específica vulnerabilidade, a questão aqui é que a violência tem grande impacto global, (MINAYO 2005). A violência doméstica é normalmente aquela que acontece nas casas, entre parceiros íntimos de forma intencional,(KRUG 2002).Os tipos de violência são: físicas, violência psicológica, a violência patrimonial, violência moral, e sexual,( SIGNORELLI 2013).

Objetivo: $O$ trabalho tem como objetivo esclarecer o papel do enfermeiro, na assistência prestada às vítimas de violência doméstica.

Desenvolvimento: Para saúde, a violência significa um grande desafio, pois ela atinge a saúde individual e coletiva, exigindo para sua prevenção e tratamento a criação de políticas públicas singulares, e um esquema especial nas práticas relacionada a esse setor, ( BRASIL 2005).

A mulher exposta a violência, está sujeita a vários problemas desde ansiedade, depressão, o abuso de substância psicoativas, transtornos de estresse pós traumáticos, e tentativas de suicídio recorrente,(BERNARDINO; et al 2011). Visto que o enfermeiro é o profissional linha de frente aos cuidados das vítimas, ele tem como função acolher e ouvir de forma atenciosa essa mulher, notificar a agressão sofrida, cuidar de forma holística, levando em conta os fatores psicológicos e espirituais encaminhá- la a outros serviços de saúde quando necessário, sempre promovendo segurança e respeito,( AGUIAR 2013). Destaca ainda o autor, que o cuidado também envolve intencionalidade, disponibilidade, receptividade, confiança e aceitação promovendo o crescimento de ambos, profissional e paciente. Acosta et al (2017) destaca que os profissionais de enfermagem precisam ser capacitados para atendimento de vítimas de violência doméstica, aprofundando conhecimento científico, aprendendo a cuidar nessa situação e notificando as violências domésticas ocorridas pelo sistema notificação de agravos.

Conclusão: $O$ cuidar exige do enfermeiro a utilização de ferramentas essenciais para o exercício profissional, para alcançar objetivos de um cuidado ideal, essas ferramentas envolvem a observação, o cuidado emocional, terapêutico, caráter humanitário, solidariedade, a sensibilidade, a técnica científica. A aplicação de tais ferramentas básicas de enfermagem estabelece uma relação de cuidado empático permitindo que a vítima se sinta cuidada e consiga expor seus anseios ao profissional, possibilitando um atendimento completo.

\section{Referências}

AGUIAR; Ricardo. Saraiva ; O CUIDADO DE ENFERMAGEM À MULHER VÍTIMA DE VIOLÊNCIA DOMÉSTICA, R. Enferm. Cent. O. Min. v. 3 n.2 p.723-731.2013. Disponível em: http://abre.ai/bvGmf .Acesso em:17 de agost. de 2020.

BERNARDINO, Ítalo Macedo et al. Violência interpessoal, circunstâncias das agressões e padrões dos traumas maxilofaciais na região metropolitana de Campina Grande, Paraíba, Brasil (2008-2011). Ciênc. saúde coletiva, vol.22, n.9, pp.3033-3044. 2017. Disponivel em: https://doi.org/10.1590/1413-81232017229.09852016. Acesso em : 23 de agost de 2020.

Brasil. Ministério da Saúde (MS). Impacto da violência na saúde dos brasileiros. Brasília: MS; 2005. Série B. Textos Básicos de Saúde. disponivel em: http://bvsms.saude.gov.br/bvs/publicacoes/impacto_violencia.pdf acesso em 17 de agosto 2020.

KRUG Etienne, et al World report on violence and health. 1. ed. Geneva: World Health Organization; 2002. Disponivel em : http://abre.ai/bvGr acesso em: 25 de agosto de 2020.

MINAYO, Maria Cecilia Souza. Violência: um problema para a saúde dos brasileiros Impactos da violência na saúde dos brasileiros. Brasília: Ministério da Saúde; 2005. Disponivel em: http://abre.ai/bvGt acesso em : 24 de agosto de 2020.

SIGNORELLI, Marcos Claudio, AUAD, Daniela, PEREIRA Pedro Paulo Gomes. Violência doméstica contra mulheres e a atuação profissional na atenção primária à saúde: um estudo etnográfico em Matinhos, Paraná, Brasil. Cad Saúde Pública, v. 6 n. 23 p.1230-40.2013 Disponível em : https://www.scielo.br/pdf/csp/v29n6/a19v29n6.pdf acesso em : 24 de agosto de 2020.

ACOSTA, Daniele Ferreira; GOMES, Vera Lúcia de Oliveira; OLIVEIRA, Denize Cristina , GOMES, Giovana Calcagno; FONSECA, Adriana Dora. Aspectos éticos e legais do cuidado de enfermagem às vítimas de violência doméstica ASPECTOS ÉTICOS E LEGAIS NO CUIDADO DE Texto Contexto Enferm, 2017; 26(3). Disponível em: https://www.scielo.br/pdf/tce/v26n3/0104-0707-tce-26-03-e6770015.pdf acesso em : 01/09/2020 
Coordenadoria de Pesquisa e Extensão - COPEX

Departamento de Editoraçāo e Divulgaçāo Científica - DEDIC 


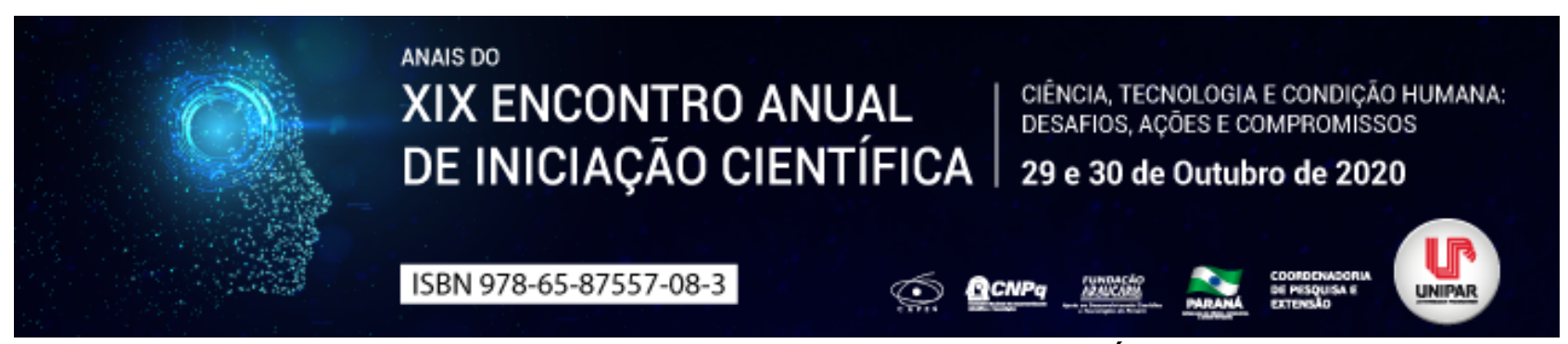

ALIMENTOS COM POTENCIAL EFEITO ANTIINFLAMÁTORIO

\section{${ }^{1}$ LARISSA GALANI BATISTELA, ${ }^{2}$ PAULA PEREIRA TORRES, ${ }^{3}$ LORENA NERIS BARBOZA}

$\begin{array}{llll}{ }^{1} \text { Discente do Curso de Nutrição } & \text { UNIPAR } & \text { Umuarama } & \text { PR } \\ { }^{1} \text { Discente do Curso de Nutrição } & \text { UNIPAR } & \text { Umuarama } & \text { PR } \\ { }^{2} \text { Docente do Curso de Nutrição } & \text { UNIPAR } & \text { Umuarama } & \text { PR }\end{array}$

Introdução: Os processos inflamatórios são reações decorrentes de respostas ao organismo afim de manter o equilíbrio homeostático frente aos estímulos agressivos e/ou injúrias que podem ser desencadeados por vários fatores como os biológicos, químicos e físicos. Durante o processo inflamatório são sintetizados, ativados e liberados diversas substâncias conhecidas como mediadores químicos, entre eles estão as moléculas citotóxicas, interleucinas pró-inflamatórias e espécies reativas de oxigênio e nitrogênio, tais substâncias contribuem para o desenvolvimento de várias doenças inflamatórias como a artrite, aterosclerose, diabetes, hepatite, obesidade, neurodegeneração e envelhecimento precoce. Além disso, sabe-se que determinados alimentos podem contribuir diretamente para o desenvolvimento do processo inflamatório ou mesmo pode ser um importante agente contra o desenvolvimento desse processo. É bem descrito na literatura que uma dieta rica em gordura hidrogenada, açúcar e pobre em frutas e hortaliças está relacionado com uma maior tendência na liberação de mediadores químicos. Ao passo que, uma alimentação saudável com fontes de fibras, vitaminas e minerais, podem apresentar potencial efeito anti-inflamatório e inibir os estágios da inflamação (BELLIK et al., 2012; SOARES et al., 2015).

Objetivo: Descrever com base em revisão de literatura quais são os alimentos que apresentam potencial efeito antiinflamatório.

Desenvolvimento: A alimentação é importante para a manutenção da saúde, pois fornecem metabólitos primários, minerais e vitaminas essenciais para as funções do organismo, além do que seus metabólitos também oferecem propriedades antiinflamatórias, analgésicas e curativas, podendo promover um equilíbrio entre inflamação e a anti-inflamação (CABALLEROGUTIERREZ et al., 2016). Uma alimentação regrada à frutas e vegetais garantem o consumo suficiente da maioria dos micronutrientes, como as fibras dietéticas, vitaminas e uma série de fitoquímicos com efeito antioxidante e anti-inflamatório, contribuindo assim para prevenção de doenças relacionadas aos processos inflamatórios (SOARES et al., 2015).

As vitaminas (E, D, e C) são conhecidas pelo seu potencial efeito anti-inflamatório e antioxidante inibindo as nitrosaminas produto cancerígeno decorrente de processos oxidativos (ZHANG et al., 2012). Os alimentos ricos em vitaminas compreendem os de origem vegetal como as sementes de oleaginosas, as frutas como o mamão, kiwi, laranja e alimentos de origem animal como ovos, carnes e queijos (SOARES et al., 2015). Ademais, estudos recentes revelaram importantes propriedades anti-inflamatórias de substâncias utilizadas como condimentos na preparação dos alimentos entre eles destacam-se o açafrão e a cebola. A Cúrcuma longa, importante fitoquímico, também conhecido como açafrão, apresentou a inibição do crescimento das células inflamatórias através da liberação do grupo tiol livre ativo no local alvo, neutralizando os radicais livres e ativando enzimas antioxidantes do próprio organismo. Muitos modelos de doenças inflamatórias crônicas estão sendo alvos de estudos utilizando a cúrcuma e tem-se verificado um efeito anti-inflamatório significativo por parte dessa substância (HE et al., 2017). O Allium cepa, popularmente conhecido como cebola, é um dos produtos mais utilizados na cozinha, é a fonte de uma vasta gama de fitoquímicos, como luteolina. Estudos determinaram que a luteolina induz inibição na produção de citocinas, através de alterações epigenéticas do fator nuclear B (FNB) reduzindo a expressão de citocinas, quimiocinas e enzimas pró-inflamatórias (TNF, IL-1, IL6, IL 8, COX 2, iNOS) (ZHANG Y et al., 2012; KIM et al., 2014). Outra substância com potencial efeito anti-inflamatório é a estévia, compreende um adoçante não calórico natural. A substância ativa é o esteviosídeo, um glicósido diterpeno que é modificado no nível intestinal ao esteviol, exerce um efeito anti-inflamatório, inibindo a ativação do fator nuclear kappa B obstruindo assim o processo transcricional e regulando a liberação das citocinas pró-inflamatórias, esses resultados corroboram para a substituição do açúcar pelo adoçante nas preparações alimentícias (FENGYANF et al., 2012).

Conclusão: A alimentação é extremamente importante para obtenção de substâncias que auxiliam na homeostase do organismo, além disso, os alimentos apresentam propriedades curativas com potencial efeito anti-inflamatório e antioxidante. Diversos alimentos possuem a capacidade de inibir a produção e liberação de mediadores químicos, impedindo assim o processo inflamatório, diante deste fato, o consumo dos alimentos como os vegetais, frutas, vitaminas e oleaginosas descritos neste trabalho devem ser considerados como uma estratégia dietética para prevenção e tratamento das doenças inflamatórias e consequente melhor qualidade de vida.

\section{Referências}

BELLIK, Y. HAMMOUDI, SM. ABDELLAH, F. IGUER-OUADA, M. BOUKRAÂ. L. Phytochemicals to prevent inflammation and allergy. Recent Pat Inflamm Allergy Drug Discov, v.2, p.147-58, 2012. 
CABALLERO-GUTIERREZ, Lidia. GONZALES, Gustavo. Alimentos con efecto anti-inflamatorio. Acta medica peruana v.33, n.1, p. 50-64, 2016. Disponível em http://www.scielo.org.pe/pdf/amp/v33n1/a09v33n1.pdf. Acesso em: 27 jul, 2020.

FENGYANG, L. YUNHE, F. BO, L. ZHICHENG, L. DEPENG L. DEJIE L. Stevioside suppressed inflammatory cytokine secretion by downregulation of NF-KB and MAPK signaling pathways in LPS stimulated RAW264.7 cells. Inflammation, v. 35, n. 5, p.166975, 2012.

HE, Y. YUE, Y.ZHENG, X. ZHANG, K. CHEN, S. DU, Z. Curcumin, inflammation, and chronic diseases: how are they linked? Molecules, v. 20, n. 5, p. 9183- 213, 2015.

$\mathrm{KIM}, \mathrm{HJ}$. LEE, W. YUN, JM. Luteolin inhibits hyperglycemia-induced proinflammatory cytokine production and its epigenetic mechanism in human monocytes. Phytotherapy Ressearch, v.28, n. 9, p.1383- 91, 2014.

SOARES, DJ. MOURA, LG. DAMACENO, MN. SOUZA, PA. BRAGA, RC. BRASIL, IM. Atividade anti-inflamatória de produtos de origem animal. Saúde em revista. Piracicaba, v.15, p. 39-45, 2015.

ZHANG, Yuesheng. The molecular basis that unifies the metabolism, cellular uptake and chemopreventive activities of dietary isothiocyanates. Carcinogenesis, v.33, n.1, p. 2-9, 2012. 


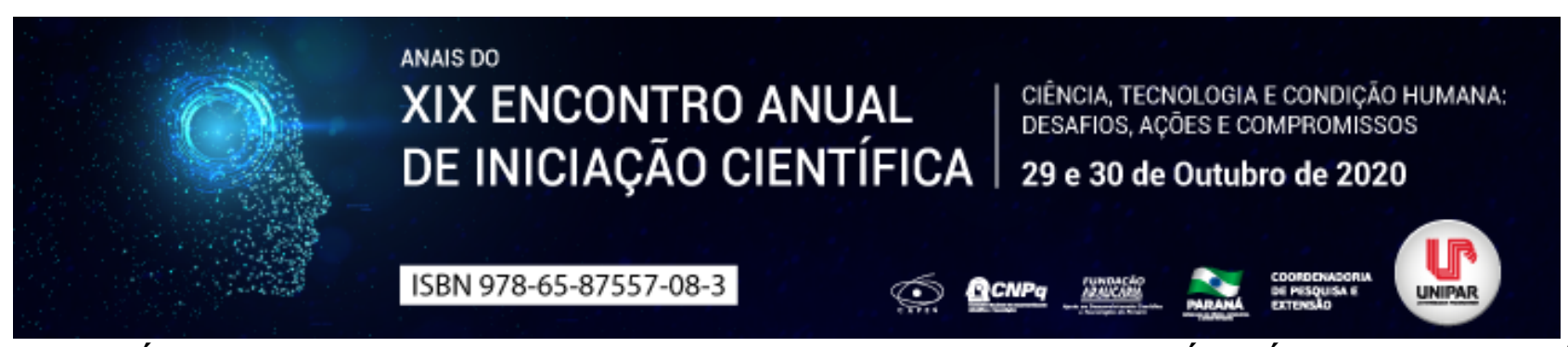

OBESIDADE X HÉRNIA DISCAL LOMBAR: UMA ANALISE DA QUALIDADE DE VIDA PRÉ E PÓS-CIRURGIA BARIÁTRICA

\author{
${ }^{1}$ DORA DE CASTRO AGULHON SEGURA, ${ }^{2}$ FABIANO CARLOS DO NASCIMENTO1, ${ }^{3}$ DJEICE DIANE HECK, ${ }^{4}$ MARIA \\ VICTORIA VECCHIETTI, ${ }^{5}$ LETICIA FLOIS FERREIRA
}

\author{
${ }^{1}$ Docente da Universidade Paranaense - Campus Toledo-PR \\ ${ }^{1}$ Docente da Universidade Paranaense - Campus Toledo-PR \\ ${ }^{2}$ Acadêmica do Curso de Fisioterapia da UNIPAR \\ ${ }^{3}$ Acadêmica do Curso de Fisioterapia da UNIPAR \\ ${ }^{4}$ Acadêmica do Curso de Fisioterapia da UNIPAR
}

Introdução: É notório o aumento de obesidade nos últimos 30 anos, visto o modo de viver da sociedade moderna, marcado por padrão alimentar inadequado e sedentarismo. O excesso de gordura corporal compromete a saúde, influenciando na qualidade de vida, gerando incapacidade e redução da longevidade (SEGURA et al., 2017). Diante dos resultados insatisfatórios do tratamento convencional, a cirurgia bariátrica compõe uma terapêutica eficaz, revertendo os principais problemas desencadeados pelo excesso de peso (SILVA-NETO et al., 2014). Entre as comorbidades mais comuns estão as alterações musculoesqueléticas, sobressaindo o diagnóstico de herniações discais, especialmente na coluna lombar, se repercutindo em dor e graves transtornos (GRANS et al., 2012). Silva et al. (2017) corroboram que as alterações musculoesqueléticas estão presentes em 18\% dos indivíduos submetidos à cirurgia bariátrica, porem é comprobatório que após o procedimento existe melhora das condições de saúde e aptidão física.

Objetivo: Analisar a qualidade de vida de indivíduos com diagnóstico de hérnia discal lombar pré e pós-cirurgia bariátrica.

Material e Métodos: Estudo prospectivo, envolvendo indivíduos de ambos os gêneros, idade superior a 18 anos, da cidade de Toledo-PR, pós-operados de cirurgia bariátrica pela técnica Fobi Capella com desvio de $\mathrm{Y}$ de Roux, com mais de 12 meses de cirurgia, e diagnóstico clínico de hérnia discal lombar comprovado por exame de imagem (TC/RNM). A avaliação compreendeu duas etapas, pré e pós-operatória, através da aplicação da Versão Brasileira do Questionário de Qualidade de Vida SF-36, sendo assinado pelos envolvidos o Termo de Consentimento Livre e Esclarecido após Aprovação do Comitê de Ética sob protocolo consubstanciado número 2.242.295. Foi realizado tratamento estatístico com cálculo de médias e análise percentual.

Resultados: Foram avaliados 32 indivíduos, 71,87\% mulheres, idade média de 36,6anos, média de tempo de pós-operatório de 32,4 meses, média de IMC pré-operatória de $46,4 \mathrm{~kg} / \mathrm{m}^{2}$ e pós-operatória de $29,1 \mathrm{~kg} / \mathrm{m}^{2}$. Os resultados do SF-36, comparando pré e pós-operatório apontaram significância nos itens capacidade funcional $(36,2-88,5)$, limitação por aspecto físico $(23,4-89,8)$ dor (31,5-91,6), estado geral de saúde $(39,6-87,9)$ e vitalidade $(33,2-85,7)$.

Discussão: Grans et al. (2012) ressaltam que a obesidade está fortemente relacionada à diversos problemas de saúde, entre eles, são comuns processos álgicos na coluna vertebral ocasionados por inúmeros fatores, sendo a perda de peso necessária e imprescindível para solução das comorbidades. Silva-Neto et al. (2014) agregam que a cirurgia bariátrica compõe uma terapêutica eficaz, sendo de solução mais rápida e duradoura, embora seja mais invasiva e possa ocasionar algumas deficiências nutricionais. O procedimento resolve problemas metabólicos que comprometem a longevidade e qualidade de vida do indivíduo, e a recuperação da saúde no pós-operatório se repercute em melhora da satisfação corporal, bem como do estado geral de saúde, resultados evidenciados no presente estudo, sobretudo através da melhora da mobilidade e diminuição da dor ocasionada pela presença da hérnia discal lombar. Um estudo comparativo entre indivíduos obesos, submetidos à cirurgia bariátrica, e indivíduos com peso em parâmetros de normalidade revelou que enquanto 58\% dos obesos relataram dor lombar, apenas $24 \%$ dos demais referiram a presença da algia, após um ano de cirurgia, a queixa reduziu significativamente, incidindo inclusive na melhora da capacidade funcional (JOAQUIM; HELVIE; PATEL, 2020).

Conclusões: A obesidade está fortemente relacionada aos problemas musculoesqueléticos, como herniações discais ocasionando quadros de lombalgia. A cirurgia bariátrica é uma alternativa eficaz para perda de peso, melhora das algias, se repercutindo em considerável melhora na qualidade de vida.

\title{
Referências
}

GRANS, R.; WARTH, C.F.; FARAH, J.F.M.; BASSITT, D.P. Qualidade de vida e prevalência de dor osteoarticular em pacientes submetidos à cirurgia bariátrica. Einstein, v. 10, n. 4, p. 415-21, 2012.

JOAQUIM, A.F.; HELVIE, P.; PATEL, A.A. Bariatric surgery and low back pain: A systematic literature review. Global Spine Journal, v. 10, n. 1, p. 102-110, 2020. 
SEGURA, D.C.A.; WOZNIAK, S.D.; ANDRADE, F.L.; MARRETO, T.M.; DAL PONTE, E. Deficiências nutricionais e suplementação em indivíduos submetidos à Gastroplastia Redutora do Tipo Y de Roux. Revista Brasileira de Obesidade, Nutrição e Emagrecimento, v. 11, n. 65, p. 338-47, 2017.

SILVA, C.D.A.; FIGUEIRA, M.A.; MACIEL, M.C.S.P.G.; GONÇALVES, R.L.; SANCHEZ, F.F. Perfil clínico de pacientes candidatos à cirurgia bariátrica. Revista Brasileira de Obesidade, Nutrição e Emagrecimento, v. 11, n. 64, p. 211-16, 2017.

SILVA-NETO, E.F.; VÁZQUEZ, C.M.P.; SOARES, F.M.; SILVA, D.G.; SOUZA, M.F.C.; BARBOSA, K.B.F. Cirurgia bariátrica reverte risco metabólico em pacientes assistidos em nível ambulatorial. Arquivo Brasileiro de Cirurgia Digestiva, v. 27, n. 1, p. 38-42, 2014.

Coordenadoria de Pesquisa e Extensão - COPEX

Departamento de Editoraçāo e Divulgaçāo Científica - DEDIC 


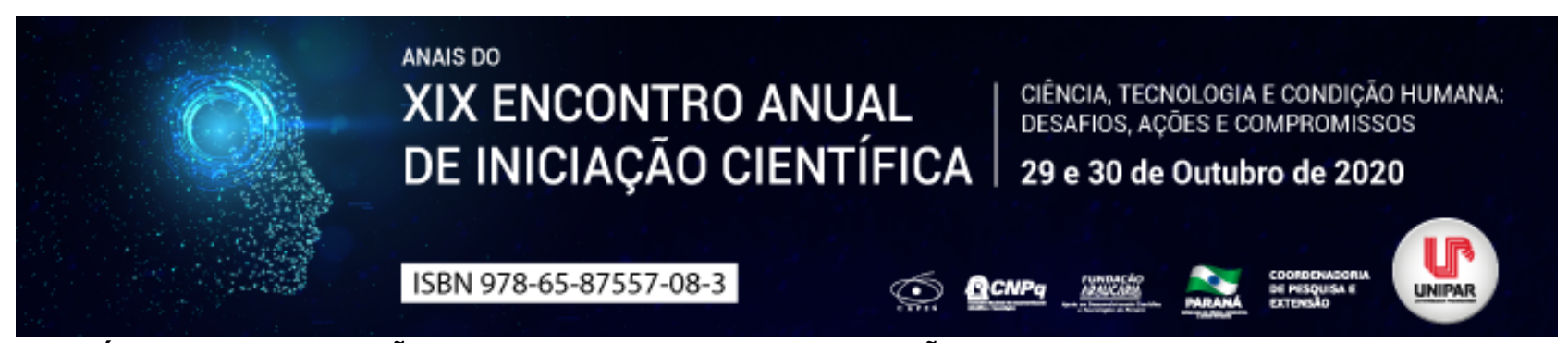

ANÁLISE DE ACEITAÇÃO DE QUEIJO FRESCO COM ADIÇÃO DE EXTRATO DE Origanum vulgare

\author{
${ }^{1}$ NATHALIA GOMES EKO LEGNANI, ${ }^{2}$ KAROLINY ABELHA DA SILVA, ${ }^{3}$ GEISIELE GOMES DA SILVA, ${ }^{4}$ MARCO AURÉLIO \\ CUNHA DEL VECHIO, ${ }^{5}$ LUCIANA KAZUE OTUTUMI , ${ }^{6}$ LIDIANE NUNES BARBOSA
}

\author{
${ }^{1}$ Discente em Nutrição, PIC - UNIPAR \\ 1 Nutricionista autônoma \\ ${ }^{2}$ Discente em Nutrição, PIC - UNIPAR \\ ${ }^{3}$ Mestrando PPG em Ciência Animal com Ênfase em Produtos Bioativos/Taxista - Prosup/CAPES \\ ${ }^{4}$ Docente - UNIPAR \\ ${ }^{5}$ Docente da UNIPAR
}

Introdução: Queijos frescos são obtidos a partir da coagulação enzimática do leite com o coalho e outras enzimas e, por possuírem acidez e umidade altas favorecem o crescimento de microrganismos envolvidos no seu processo de deterioração (DINIZ-SILVA et al., 2019). Por séculos, ervas e temperos têm sido utilizados não somente na culinária como também para fins medicinais. Com o aumento da procura de produtos mais saudáveis no mercado e da preocupação na redução do uso de substâncias que possam ter maior risco de efeito adverso, como conservantes sintéticos, o Origanum vulgare L. popularmente conhecido como orégano é muito utilizado na culinária brasileira e tem sido foco de estudo (YOUSSEF; EL-SAYED, 2019). Polifenóis, encontrados nele e em diversas ervas possuem propriedade antioxidante e antimicrobiana, tornando a sua aplicação interessante tanto para o uso na conservação do alimento quanto para o consumo (OPARA; CHOHAN, 2014).

Objetivo: Avaliar a aceitação do queijo fresco com extrato de orégano (Origanum vulgare L.) em diferentes concentrações utilizando uma escala hedônica.

Material e método: Foi utilizado para avaliação o teste de aceitação por escala hedônica de nove pontos com 60 avaliadores não treinados utilizando uma cabine de teste sensorial. O panelista (avaliador) expressou o grau de gostar ou de desgostar, de score 1 a 9, sendo 9 score máximo de aceitação, de forma globalizada. As amostras de queijo fresco com extrato em diferentes concentrações de orégano (controle C: $0 \mathrm{~g} / \mathrm{Kg}$; T1: 0,5 g/Kg; T2: $1 \mathrm{~g} / \mathrm{Kg}$ e T3: $3 \mathrm{~g} / \mathrm{Kg}$ ) foram codificadas com algarismos de três dígitos e aleatorizadas.

Resultados: Os resultados mostraram que não houve diferença de aceitação dos queijos entre os provadores homens, mas quando analisadas as respostas entre mulheres, observou-se que houve diferença entre o C e o T2; entre C e T1. Entre C e T3 não houve diferença. Ainda assim, foi possível observar que todos os tipos de queijo frescal produzidos foram bem aceitos (com ou sem o uso do extrato de orégano), variando as notas dependendo de sua concentração mas obtendo médias aritméticas que o classificaram entre gostei regularmente e gostei moderadamentel".

Discussão: No que tange o uso de condimentos naturais em preparações de alimentos da rotina alimentar, Costa et al. (2019) avaliaram em uma escala hedônica o uso de ervas aromáticas em substituição à temperos industrializados e não encontraram diferença estatística entre as amostras tratadas e o controle, demonstrando a viabilidade do uso de ervas aromáticas naturais ao paladar do brasileiro, tal como Angioletti et al. (2018), na elaboração de uma receita de pão de queijo funcional e do desenvolvimento de um produto que se assemelhasse ao tradicional mas que trouxesse também benefícios adicionais, formularam uma receita que adquiriu intenção de compra e grau de aceitação de 94\% utilizando alguns ingredientes como o orégano. Colaborando também com os achados no presente estudo, Presente et al. (2016) quando avaliaram a aceitação do queijo fresco com orégano (Origanum vulgare L.) não constataram diferenças estatisticamente significativas entre o grupo teste (óleo essencial de orégano) e o controle, demonstrando ainda boa intenção de compra. Em contrapartida, quando avaliou a aceitação e intenção de compra de queijos frescos com adição de um mix de óleos essenciais de orégano e gengibre (Zingiber officinale Roscoe), os autores relatam que a adição do óleo essencial de gengibre aos queijos na concentraçãa testada, afetou negativamente a qualidade sensorial dos queijos, principalmente com relação ao sabor. Diniz-Silva et al. (2019) avaliaram o uso combinado de óleos essenciais de orégano de mesma espécie e alecrim (Rosmarinus officinalis L.) em queijos frescos e enfatizaram que apesar de ser uma estratégia em preservar a qualidade do queijo refrigerado, ela deve ser cuidadosamente avaliada considerando as alterações de características adquiridas. Uma vez que o aumento da concentração de óleo essencial seja necessário, para prolongar o tempo de prateleira e compensar a interação deste veículo com a matriz do alimento, este pode exceder a tolerância ao aroma, impactando de forma negativa na avaliação sensorial (KHORSHIDIAN et al. 2018), desta forma, o extrato liofilizado tem potencial em ser uma alternativa ao óleo posto que mesmo na maior concentração (T3), o presente estudo mostrou a aceitação do queijo. Faz-se importante a aceitação do consumidor pelo produto e o interesse de mercado, uma vez que ultrapassar a tolerância ao sabor e ao odor, impacta negativamente em seu valor comercial (EL-SAYED, 
YOUSSEF, 2019; ROSSI et al. 2018).

Conclusão: $O$ paladar brasileiro já está habituado ao orégano, sendo esta uma erva aromática com propriedades antimicrobianas e antioxidantes. O extrato se apresenta como uma alternativa em potencial para ser usado como conservante natural devido a sua aceitação no queijo ser tão boa quanto o produto sem o condimento.

\section{Referências}

ANGIOLETTI, B. L. et al. Desenvolvimento de Pão de Queijo Funcional Visando Produção em Escala Industrial. XXII Congresso Brasileiro de Nutrologia. Anais... Thieme Revinter Publicações Ltda. v. 11, p. $290,2018$.

COSTA, C.A.C. et al. Queijo Tipo Minas Frescal com Colágeno Hidrolisado e Orégano: Tecnologia de Fabricação e Avaliação Sensorial. Congresso Nacional de Pesquisa e Ensino em Ciências - Anais... 2018.

COSTA, T.F.M. et al. Aceitabilidade de Temperos Instantâneos à Base de Ervas e Condimentos. Universidade Estadual do Ceará. Revista da Associação Brasileira de Nutrição, v. 10, n. 2, 2019.

DINIZ-SILVA. et al. A Synergistic Mixture of Origanum vulgare L. and Rosmarinus officinalis L. Essential Oils to Preserve Overall Quality and Control Escherichia coli O157: H7 in Fresh Cheese during storage. Elsevier, v. 112, 107781, 2019.

EL-SAYED, S. M.; YOUSSEF, A. M. Potential application of herbs and spices and their effects in functional dairy products. Elsevier - Heliyon, e01989, 2019.

KHORSHIDIAN, N. et al. Potential application of essential oils as antimicrobial preservatives in cheese. Innovative food science \& emerging technologies: IFSET: The Official Ccientific Journal of the European Federation of Food Science and Technology, v. 45, p. 62 72, 2018.

OPARA, E. I.; CHOHAN, M. Culinary Herbs and Spices: Their Bioactive Properties, the Contribution of Polyphenols and the Challenges in Deducing Their True Health Benefits. International Journal of Molecular Sciences, v. 15, n. 10, p. 1918319202 , 2014.

PRESENTE, J. G. et al. Aceitação e Conservação de Queijos Frescos Elaborados com Óleos Essenciais. Revista do Instituto de Laticínios Cândido Tostes, v. 71, n. 3, p. 153-165, 2016.

ROSSI, G. et al. Garlic (Allium sativum L.) fed to dairy cows does not modify the cheese-making properties of milk but affects the color, texture, and flavor of ripened cheese. Journal of Dairy Science, v. 101, n. 3, p. 2005-2015, 2018. 


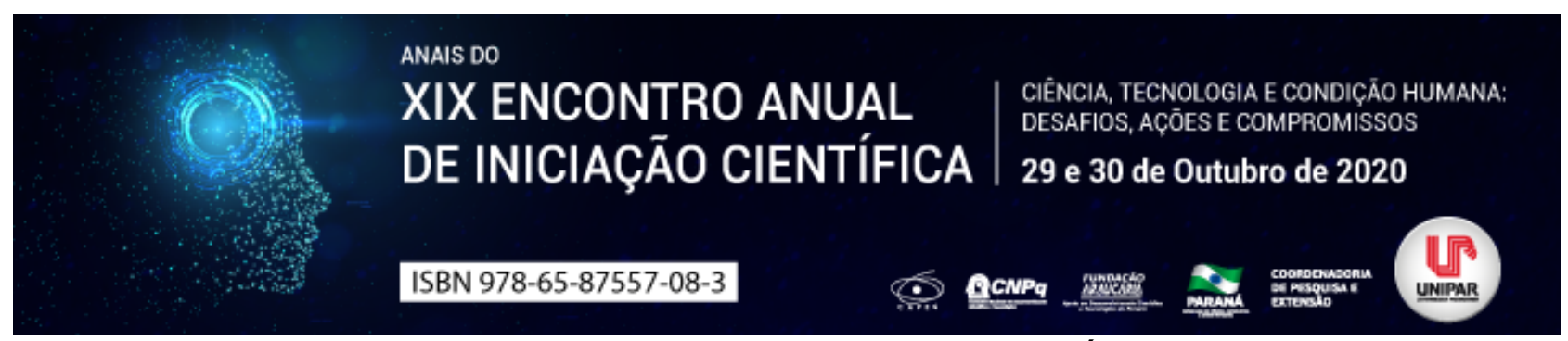

OBESIDADE E DOR LOMBAR: UMA ABORDAGEM DA CIRURGIA BARIÁTRICA COMO TRATAMENTO

\author{
${ }^{1}$ DJEICE DIANE HECK, ${ }^{2}$ LETICIA FLOIS FERREIRA, ${ }^{3}$ MARIA VICTORIA VECCHIETTI, ${ }^{4}$ POLYANA ALCANTARA DOS \\ SANTOS, ${ }^{5}$ DORA DE CASTRO AGULHON SEGURA
}

\author{
${ }^{1}$ Acadêmico de PIC/UNIPAR \\ ${ }^{1}$ Acadêmica do Curso de Fisioterapia da UNIPAR \\ ${ }^{2}$ Acadêmica do Curso de Fisioterapia da UNIPAR \\ ${ }^{3}$ Acadêmica do Curso de Fisioterapia da UNIPAR \\ ${ }^{4}$ Docente da UNIPAR
}

Introdução: Definida como excesso de gordura corporal que leva a uma predisposição à comorbidades crônicas, como hipertensão arterial, diabetes e doenças cardiovasculares e osteomusculares, a obesidade está relacionada a diversos riscos à saúde do indivíduo, abrangendo aspectos sociais, comportamentais e biológicos (PORTO et al., 2019). Conforme mais indivíduos se tornam ou permanecem obesos por períodos prolongados, maior e mais ampla é a ocorrência de déficit em estruturas e funções corporais (COSTA et al., 2018). Determinada como uma dor ou desconforto abaixo da última costela e acima da prega glútea inferior, a lombalgia pode apresentar ou não irradiação para membros inferiores, podendo ser classificada como crônica quando presente há mais de 3 meses. Pode gerar incapacidade total ou parcial devido aos desconfortos e limitações para as atividades diárias (BORTOLATTO et al., 2016). O tratamento para a obesidade envolve algumas ações terapêuticas como mudança de hábitos de vida, como inserção da prática de exercícios físicos e mudanças do comportamento alimentar, esse processo é contínuo e exige esforço do paciente. Porém, em casos extremos onde esse tratamento não gera um resultado eficaz, recomenda-se o tratamento cirúrgico através da cirurgia bariátrica ou gastroplastia (STIVAL et al., 2019).

Objetivo: Descrever como a cirurgia bariátria interfere no tratamento da dor lombar de indivíduos obesos.

Desenvolvimento: Em comparação com pessoas de boa nutrição os indivíduos obesos têm maiores queixas sobre as dores musculares, sendo resultado da sobrecarga de peso sobre as articulações. As maiores queixas envolvem osteoartrite nos joelhos, lombalgia e síndrome do túnel do carpo. Nestes casos a cirurgia bariátrica apresenta resultados excelentes na diminuição da dor devido à redução do peso (CORDEIRO; BERTO; TAGLIETTI, 2019). Uma análise de 20 pacientes com média de IMC de 49,4 kg/m 2 , sendo destes $80 \%$ mulheres, em período pré-operatório de cirurgia bariátrica, demonstrou que $95 \%$ dos envolvidos relataram algum tipo de dor em pelo menos uma parte do corpo, entre as mais citadas foram joelhos (36,8\%) e coluna lombar (26,3\%), a maioria dor crônica, com mais de um ano de presença sindrômica (63,1\%) e queixa diária (84,2\%), com intensidade de forte a pior possível (36,8\%). Esta dor correlaciona a obesidade com a alteração do centro de gravidade do indivíduo, sobrecarregando as articulações e gerando o incômodo (FERREIRA; PEDROSO; SOUSA, 2017). O estudo de Costa et al. (2018), com 150 indivíduos com obesidade grave, IMC médio de 46,12 kg/m 2 , sendo 85,33\% do gênero feminino, apontou que $72,67 \%$ queixavam-se de dor lombar. Aproximadamente 46,23\% eram obesos não praticantes de exercício físico. Em pesquisa com 50 pacientes obesos submetidos à cirurgia bariátrica e 50 pacientes não obesos, foram analisadas a incidência e a intensidade da dor lombar. Entre os pacientes obesos que passaram por cirurgia bariátrica o IMC médio antes do procedimento era de $46,7 \mathrm{~kg} / \mathrm{m} 2$ reduzindo pós-cirurgia para 33,6 kg/m 2 . Antes da cirurgia 29 pacientes obesos (58\%) apresentavam queixa de lombalgia, e 12 pacientes não obesos (24\%) relatavam a dor. Após um ano, somente 10 pacientes obesos apresentavam dor sendo menos frequente e exigindo menor consumo de medicamentos para a algia comparado ao período anterior da cirurgia (JOAQUIM; HELVIE; PATEL, 2020).

Conclusão: Através deste estudo foi possível correlacionar o excesso de peso às dores lombares, levando-se em conta o aumento da circunferência abdominal que altera o centro de gravidade do indivíduo e a sobrecarga sobre as articulações principalmente da coluna lombar e joelhos, gerando desconforto, dor e limitações físicas. Assim, foi possível concluir que a cirurgia bariátrica apresentou resultados importantes na redução do Índice de Massa Corporal e consequentemente no quadro clínico da lombalgia. Considerando os resultados, é importante ressaltar a quantidade restrita de estudos aplicados na variável associada entre obesidade, dor lombar e cirurgia bariátrica, destacando a importância da realização de pesquisas acerca da presença de dores osteomusculares nesse público.

\title{
Referências
}

BORTOLATTO, C. R.; OLIVEIRA, M. C. S.; FAJALLE, F. M.; SILVA, E. A. L. Análise do desempenho funcional e perfil sócio demográfico de uma população com queixa de lombalgia. Colloquium Vitae, v. 8, n. 2, p. 12-16, 2016.

CORDEIRO, J.; BERTO, N. R. T.; TAGLIETTI, M. Desordens musculoesqueléticas em obesos mórbidos no pré-operatório de 
cirurgia bariátrica. Revista Brasileira de Obesidade, Nutrição e Emagrecimento, v. 13, n. 80, p. 531-537, 2019.

COSTA, C. A.; LEAL, J. C.; SILVA, R. V.; PERNAMBUCO, A. P.; VASSIMON, H. S.; BRUNHEROTTI, M. A. A. Análise da situação de saúde apresentada por mulheres obesas de acordo com um core set resumido da CIF. Conexão Ciência, v. 13, n. 1, p. 7-17, 2018.

FERREIRA, J. D. C.; PEDROSO, C. F.; SOUSA, T. R. Perfil clínico e avaliação da dor em pacientes obesos no período préoperatório de cirurgia bariátrica. Revista Cien Escol Estad Saud Public Cândido Santiago, v. 3, n. 2, p. 82-96, 2017.

PORTO, T. N. R. S.; CARDOSO, C. L. R.; BALDOINO, L. S.; MARTINS, V. S.; ALCÂNTARA, S. M. L.; CARVALHO, D. P. Prevalência do excesso de peso e fatores de risco para a obesidade em adultos. Revista Eletrônica Acervo Saúde, v. 22, n. 1, p. 01-12, 2019.

JOAQUIM, A. F.; HELVIE, P.; PATEL, A. A. Bariatric surgery and low back pain: A systematic literature review. Global Spine Journal, v. 10, n. 1, p. 102-110, 2020.

STIVAL, N. L.; REIS, J. M.; CABRAL, J. F.; OLIVEIRA, J. M. Perspectiva da pessoa submetida à cirurgia bariátrica. Revista Brasileira de Obesidade, Nutrição e Emagrecimento, v. 13, n. 77, p. 79-89, 2019.

Coordenadoria de Pesquisa e Extensão - COPEX

Departamento de Editoraçāo e Divulgaçāo Científica - DEDIC 


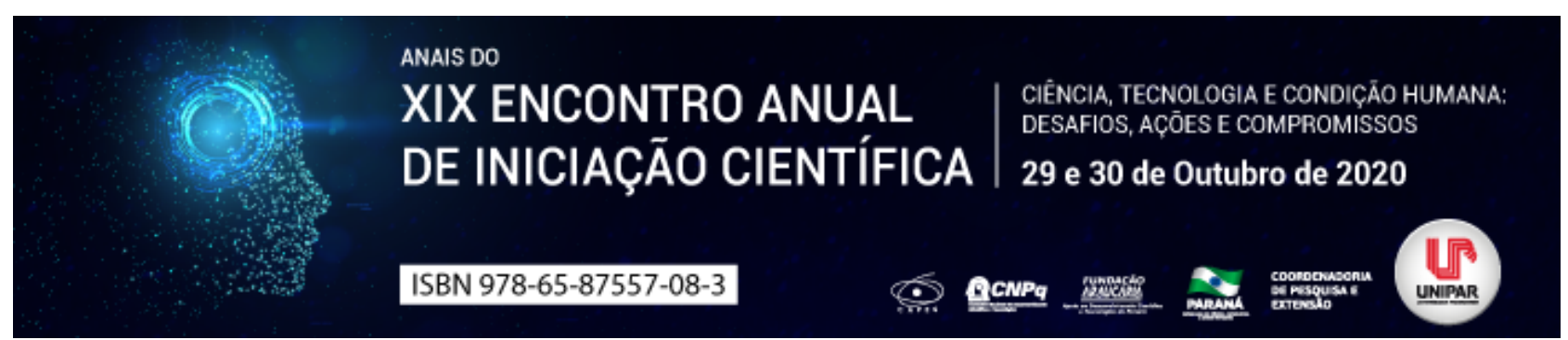

MANIFESTAÇÕES ORAIS SECUNDÁRIAS Á COVID-19: O QUE ESPERAR PÓS PANDEMIA?

\title{
${ }^{1}$ JENIFFER URBANO DEGASPERI, ${ }^{2}$ LETICIA DE FREITAS CUBA GUERRA
}

\author{
${ }^{1}$ Acadêmico do PIC/UNIPAR \\ ${ }^{1}$ Docente da UNIPAR
}

Introdução: No ultimo mês de 2019, na China, foram identificados 27 casos de pneumonia com etiologia desconhecida, a partir de então observaram que os pacientes estavam veiculados a um mercado atacadista de frutos do mar da cidade de Wuhan, e por meio de esfregaço na garganta dos contaminados o agente etiológico, um vírus, foi identificado e denominado SARS-CoV2 (GUO et al., 2020). Desde que a doença começou a acometer diversos países, pareceres acerca da biossegurança foram difundidos, e a busca por um tratamento foi instaurada. Uma vez que, ainda, não há remédio especifico para COVID-19 os fármacos utilizados incluem antivirais, corticosteroides, antimaláricos e antibióticos, popularmente conhecidos pelos profissionais da saúde, o que torna importante o estudo acerca desses fármacos e suas possíveis manifestações em cavidade oral visando o correto manejo das patologias orais (NICOLA et al., 2020).

Objetivo: Com base no exposto, a revisão de literatura buscará associações entre os fármacos utilizados para o tratamento da COVID-19 e manifestações secundárias a doença que acometem a cavidade oral, destacando como o cirurgião dentista pode tratar essas alterações.

Desenvolvimento: Á COVID-19 se instaurou e disseminou rapidamente, sem a preexistência de vacina e tratamento especifico para doença, portanto, os fármacos utilizados são prescritos com base na experiência medica e ensaios clínicos estão sendo realizados para verificar a segurança e eficácia de tais substâncias (PHUA et al., 2020). Os antivirais propostos para o tratamento da COVID-19 estão associados a complicações orais como parestesia peribucal, lipomatose da parótida, xerostomia, distúrbio do paladar e edema facial (SCULLY, 2009) para tratamento da parestesia indica-se vitamina B e C, anti-inflamatórios, estimulação elétrica, acupuntura e o LASER de baixa potencia, uma atualidade que vem sendo cada vez mais utilizada para manejo de parestesia (OLIVEIRA et al., 2015), sua indicação também é efetiva para disfunções em glândulas salivares, como xerostomia ou hipossalivação, outra manifestação decorrente do uso de antivirais (BARBIERI; COSTA; GUERRA, 2020). Quando se trata do uso de corticoides para manejo do paciente com COVID-19 a patologia oral mais associada a esse fármaco é a candidíase oral, o fungo Candida albicans encontra-se comensal na mucosa oral e em condições ideais torna-se patogênico, o corticoide influencia na imunidade do paciente, bem como na ecologia da microbiota, tornando-o propenso a desenvolver candidíase (PATIL et al., 2016), para tratamento de tal infecção os antifúngicos tópicos ou sistêmicos são utilizados, um exemplo é a nistatina (LYU et al., 2016). A azitromicina, um antibiótico usado para tratamento do paciente com COVID-19, pode gerar efeitos sistêmicos bem como em cavidade oral pode causar parestesia, descoloração da língua, candidíase, síndrome de Stevens Johnson, eritema multiforme e necrose epidérmica, para algumas dessas manifestações o tratamento foi proposto, quando se trata da síndrome de Stevens Johnson o tratamento mais indicado é o uso de glicocorticoides e ciclosporina (ZIMMERMANN et al.,2017) já o manejo do eritema multiforme deve objetivar a redução das lesões ou prevenção de sequelas, dentre os fármacos usados destaca-se 0 aciclovir, corticosteroides, antibióticos e imunossupressores (RISI-PUGLIESE et al., 2019). A ivermectina é um antiparasitário que foi amplamente usado para manejo do paciente infectado pelo SARS-CoV-2, manifestações secundarias a seu uso podem incluir linfadenopatia, inchaço e reação nas glândulas (SOLE et al., 1989). O ultimo fármaco de destaque é a hidroxicloroquina, essa induz a hiperpigmentação multifocal da mucosa oral, principalmente na região de palato, devido a produção estimulada de melanina e deposição de produtos metabólicos nos tecidos, seu manejo é baseado, principalmente, no ajuste da dose, com diminuição e descontinuidade do tratamento as lesões tendem a regredir (ANDRADE et al., 2013).

Conclusão: Os fármacos mais usados para tratamento da COVID-19 incluem antivirais, corticoides, azitromicina, ivermectina e hidroxicloroquina, todos esses medicamentos possuem manifestações orais associadas a seu uso, dentre essas destaca-se a parestesia, xerostomia, candidíase, síndrome de Stevens Johson, eritema multiforme e hiperpigmentação da mucosa, todas essas alterações devem ser tratadas pelo cirurgião dentista, portanto é necessário que esse profissional esteja habilitado e preparado para o tratamento de tais condições pós pandemia, visto que são consequências do tratamento usado no paciente que apresentou COVID-19.

\section{Referências}

ANDRADE, Bruno Augusto Benevenuto de. et al. Hard palate hyperpigmentation secondary to chronic chloroquine therapy: Report of five cases. Journal of Cutaneous Pathology, v. 40, n. 9, p. 833 838, 2013.

BARBIERI, Tainara; COSTA, Kiany Claudia da; GUERRA, Leticia de Freitas Cuba. Current alternatives in the prevention and treatment of xerostomia in cancer therapy. Revista Gaúcha de Odontologia, v. 68, p. 1 12, 2020. 
GUO, Yan-Rong. et al. The origin, transmission and clinical therapies on coronavirus disease 2019 (COVID-19) outbreak- A n update on the status. Military Medical Research, v. 7, n. 1, p. 1 10, 2020.

LYU, Xin. et al. Efficacy of nystatin for the treatment of oral candidiasis: a systematic review and meta-analysis. Drug Design, Development and Therapy, p. 1161 1171, 2016.

NICOLA, Maria. et al. Evidence Based Management Guideline for the COVID-19 Pandemic - Review article. International Journal of Surgery, 2020.

OLIVEIRA, Renata Ferreira de. et al. Laser Therapy in the Treatment of Paresthesia: A Retrospective Study of 125 Clinical Cases. v. 33, n. 8, p. 415 423, 2015.

PATIL, Archana. et al. Drug-induced oral candidiasis: a case report. IJSS Case Reports \& Reviews, v. 2, n. 12 , p. 14 , 2016.

PHUA, Jason. et al. Intensive care management of coronavirus disease 2019 (COVID-19): challenges and recommendations. The Lancet Respiratory Medicine, v. 8, n. 5, p. 506 517, 2020.

RISI-PUGLIESE, T de. et al. Interventions for erythema multiforme : a systematic review. J Eur Acad Dermatol Venereol, v. 33, n. 5, p. $842849,2019$.

SCULLY, Crispian. Medicina Oral e Maxilofacial. 2· ed. Rio de Janeiro: Elsevier, 2009

SOLE, G de. et al. Adverse reactions after large-scale treatment of onchocerciasis with ivermectin : combined results from eight community trials. 1989.

ZIMMERMANN, Stefanie. et al. Systemic Immunomodulating Therapies for Stevens-Johnson Syndrome and Toxic Epidermal Necrolysis A Systematic Review and Meta-analysis. JAMA dermatology, p. 1 9, 2017. 


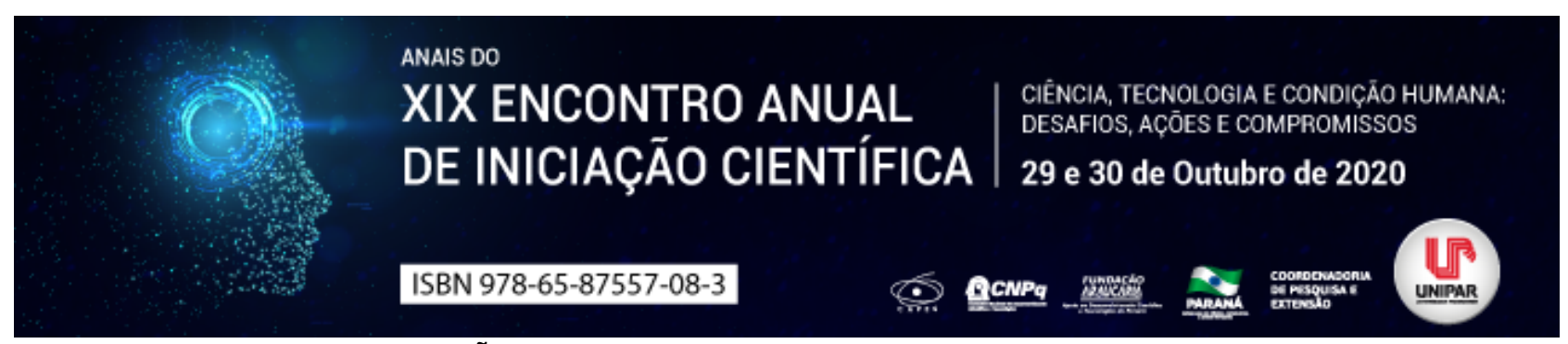

INTER RELAÇÃO DE EMPATIA ENTRE PACIENTE E FISIOTERAPEUTA

\begin{abstract}
${ }^{1}$ MILLENA ANGELI DOMINGUES PEREIRA, ${ }^{2}$ LORENA CASTAGNA ANGELIM COSTA, ${ }^{3}$ GABRIELE FERNANDA LOPES, ${ }^{4}$ GABRIELE FERNANDA LOPES, ${ }^{5}$ JEFFERSON J AMARAL DOS SANTOS
\end{abstract}

\author{
${ }^{1}$ Acadêmico bolsista do PIBIC/UNIPAR \\ ${ }^{1}$ Acadêmica do Curso de Fisioterapia da UNIPAR \\ ${ }^{2}$ Acadêmica do Curso de Fisioterapia da UNIPAR \\ ${ }^{3}$ Acadêmica do Curso de Fisioterapia da UNIPAR \\ ${ }^{4}$ Docente da UNIPAR
}

Introdução: Os serviços de saúde proporcionam a sociedade o envolvimento e o relacionamento entre os profissionais que atuam no atendimento e os pacientes que o recebem, devido as abordagens ligadas ao processo de comunicação estabelecido, durante o processo de adoecimento e tratamento. O vínculo do fisioterapeuta e do paciente mostra, a existência de diferentes possibilidades da relação entre a doença e ao tratamento, uma vivenciada pelo paciente, que envolve expectativas e medos baseados em diversos aspectos, sendo, sociais, culturais e emocionais ao momento de vida, e de outro lado o profissional da saúde, que possui preocupações ligadas ao caso clínico e em alcançar os objetivos, resultando em tensão, características das relações interpessoais baseadas no diálogo, conforme (MARKOVÁ, 1997).

Objetivo: Assim, o objetivo desse estudo é relatar a empatia entre a relação e comunicação através do meio de convivência pelo profissional fisioterapeuta e ao paciente em fase de reabilitação.

Desenvolvimento: Segundo Boesch (1977) para o fisioterapeuta, tratar o paciente consiste em uma rotina na qual o profissional já está habituado com as doenças, os seus sintomas, as diferentes reações de cada paciente e as restrições do tratamento, resultando apenas na precaução para solução da queixa física do mesmo. Diante das expectativas e emoções criadas no momento de limitação física e do próprio tratamento não são, normalmente, consideradas relevantes pelo profissional para o progresso da melhora. De acordo com Marinho Pem (2005) na área da fisioterapia, uma parte dos relatos sobre o relacionamento profissional e paciente, consiste que um dos princípios necessários para eficácia e ao processo de reabilitação é induzido a qualidade na relação criada do paciente e o fisioterapeuta. Subtil e Souza (2010) apontam que a medida que os pacientes vão se dedicar ao tratamento fisioterapêutico as relações interpessoais determinadas pela afetividade, se desenvolvem e podem afetar o curso e a eficiência da reabilitação. Marinho (1995) destaca ainda a importância na relação terapêutica estabelecida, além de proporcionar a criação de um espaço em que o paciente tem a liberdade de se expressar e ambos, dessa forma, têm a possibilidade de participar de fato ao processo de cura. O paciente nesse momento, pode sentir-se, então, aceito, compreendido, amado e sem culpa. Já a avaliação parcial desse paciente representa a fragilidade da relação terapêutica. Tomando as proposições de Boesch (1991) e Simão (2002), a empatia se torna uma necessidade importante entre o qualificado e o enfermo onde precisam ser capazes de observar as intenções, discernir sentimentos, compreender gestos e captar os significados manifestados na linguagem de ambos, a fim de avaliar seus objetivos, adiantando ações e reações. Ao entrar em contato com manifestações de algum sentimento experimentado pelo outro, o profissional e o paciente aprendem as razões dessas emoções ocorrer no outro e, em consequência, a implicação daquele sentimento para si próprio se expande (BOECH, 1991).

Conclusão: Com o presente trabalho pode-se concluir que a empatia do profissional com o paciente atua como uma ferramenta de auxílio, a qual proporciona uma estabilidade emocional e física ao paciente ajudando na conduta do tratamento e no processo de aceitação a doença. Tornando-se assim, também uma terapia alternativa no processo de reabilitação do mesmo.

\title{
Referências
}

BOESCH, E. E. (1991). Symbolic action theory and cultural psychology. Berlin: Springer Verlag.

BOESCH E. E. (1977). The medical interaction. A study in Thailand. The German Journal of Psychology, 1(1), $13-28$.

MARKOVÁ, I. (1997). On two concepts of interaction. In M. Grossen \& B. Py (Eds.), Pratiques sociales et mediations symboliques (pp. 23-44). Bern \& Berlin: Peter Lang

MARINHO, PEM. Escutar: aspecto relevante da relação fisioterapeuta-paciente na fisioterapia. Fisioter Mov. 1995;7(2):5962.

MARINHO, PEM. Refletindo sobre a expressividade da dor e a relação terapeuta-paciente. Fisioter Mov. 2005; $18(2): 73-9$. SUBTIL MML, SOUZA ML. Adesão ao tratamento fisioterapêutico: uma análise fenomenológico-semiótica da percepção de pacientes e terapeutas [dissertação]. Espírito Santo: Universidade Federal do Espírito Santo; 2010.

SIMÃO, L. M. (2002). O significado da interação verbal para os processos de construção de conhecimento: proposta a 
partir da ótica boeschiana. In S. A. S. Leite (Org.), Cultura, cognição e afetividade: a sociedade em movimento (pp. 85102). São Paulo: Casa do Psicólogo.

Coordenadoria de Pesquisa e Extensão - COPEX

Departamento de Editoraçāo e Divulgaçāo Científica - DEDIC 


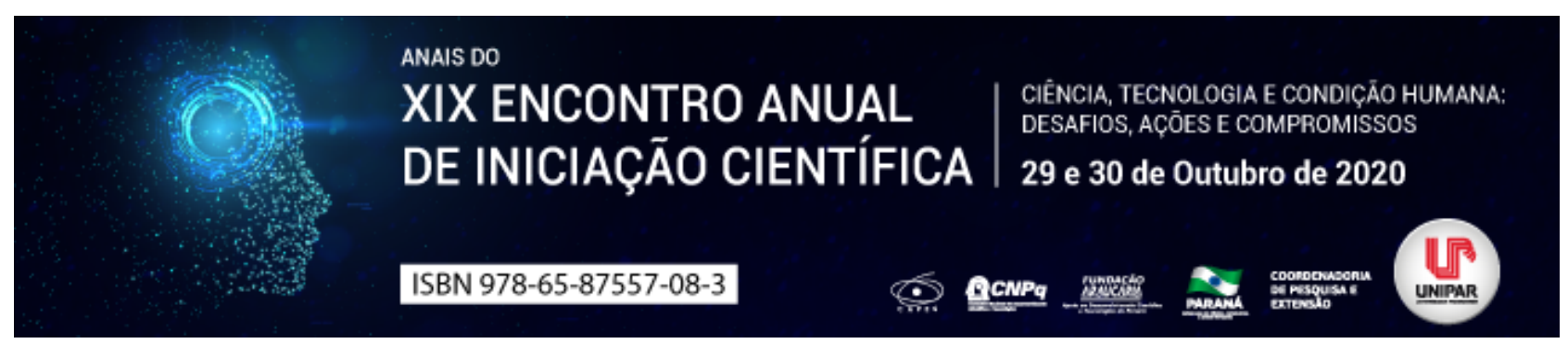

PROPRIEDADES DO POLIMETILMETACRILATO (PMMA) E SEU USO NA BIOPLASTIA

\title{
${ }^{1}$ BRENDA AYUMI TSUKAMOTO, ${ }^{2}$ JENIFFER VIEPRZ MORAIS, ${ }^{3}$ FRANCISLAINE APARECIDA DOS REIS LIVERO
}

\author{
${ }^{1}$ Acadêmico do Curso de Medicina da UNIPAR \\ ${ }^{1}$ Acadêmica do Curso de Medicina da UNIPAR \\ ${ }^{2}$ Docente da UNIPAR
}

Introdução: Grande parte das pessoas estão sempre à procura dos padrões de beleza idealizados e, para alcançar esse objetivo se rendem à procedimentos estéticos com o intuito de corrigir defeitos e reverter ou retardar os efeitos do envelhecimento. Atualmente, várias técnicas corretivas são encontradas, como cirurgia plástica, preenchimento facial e implantes (DOLGHI, 2014; RUBIN, HAGEMANN, 2018). A bioplastia, uma plástica sem cortes e sem cirurgia, é um exemplo de procedimento estético que utiliza implantes dérmicos de polimetilmetacrilato (PMMA) em técnicas de rejuvenescimento para preencher diversas partes do corpo (MENEZES, 2009; CRM-PR, 2010). Porém, os usos de PMMA podem provocar reações adversas, como deformações e até mesmo mutilações e necroses (RUBIN, HAGEMANN, 2018; CRM-PR, 2010).

Objetivo: Compreender as propriedades do PMMA e as consequências de seu uso em procedimentos estéticos.

Desenvolvimento: O PMMA é um polímero sintético amorfo, biocompatível derivado do plástico, formado por microesferas sintéticas suspensas em solução de colágeno bovino, carboximetilcelulose ou hidroxietilcelulose (CFM, 2013; DOLGHI, 2014). Além disso, essa substância é um termoplástico rígido, mais resistente que um vidro e resiste à várias condições ambientais, sendo usado na produção de lentes de contato, lentes intraoculares, implantes e próteses (DOLGHI, 2014; MENEZES, 2009; CRM-PR, 2010). Em procedimentos estéticos, pequenas quantidades desta substância são indicadas para correção volumétrica facial e corporal (MENEZES, 2009). Esse método é feito em ambiente ambulatorial com anestesia local, com recuperação rápida e resultados imediatos, sem necessidade de internamento (RUBIN, HAGEMANN, 2018). O PMMA precisa ser injetado entre a derme e o tecido subcutâneo ou plano subdérmico, caso contrário o efeito será menor. Após a administração dessa substância os macrófagos junto com os gigantócitos envolvem as esferas, as quais serão fixadas no tecido, resultando no surgimento de fibras elásticas e colágenas e aumentando o número de vasos sanguíneos, melhorando a textura da pele. São dois fatores principais que estão relacionados com o sucesso desse procedimento: biocompatibilidade do agente e a aplicação correta (DOLGHI, 2014). Entretanto, após a aplicação do PMMA, pode ocorrer reações adversas de curto prazo, como dor, edema, equimoses, alteração na pigmentação e elevação da pele (MENEZES, 2009). A aplicação $m$ regiões superficiais, como os lábios, deve ser evitado devido a maior probabilidade de acumular a PMMA, resultando em nódulos. (CHACUR, 2018). Apesar do PMMA ser considerado uma substância não absorvível, é possível constatar absorção pelo organismo e migração, resultando em formação de granuloma e reação alérgica tardia (CFM, 2013; RUBIN, HAGEMANN, 2018), principalmente quando aplicado um volume alto ou em local inadequado, que pode resultar em reações incuráveis e definitivas (nódulos e morte) (CFM, 2013). Outra consequência possível é a necrose induzida por PMMA, uma nova entidade clínica, com incidência desconhecida e fisiopatologia ainda em discussão. As complicações que acontecem estão associados ao uso indiscriminado do PMMA, em razão do seu baixo custo, e por não ter sua venda restrita, assim médicos incapacitados podem aplicar essa substância de forma errônea.

Conclusão: Tendo em vista os fatores analisados, o PMMA é uma substância formada por microesferas sintéticas, usada na bioplastia em pequenas doses para não ser absorvido pelo organismo. Caso esse produto seja administrado em uma grande quantidade ou em local inapropriado, geralmente por erro médico ou falta de ética, essa substância é absorvida, causando inflamações ou migração de PMMA no organismo, gerando consequências físicas. Dessa forma, o uso de PMMA adequado é de responsabilidade do médico, sendo necessário um planejamento cuidadoso do local, profundidade e a dose a ser aplicada, assim como o conhecimento das complicações que podem ocorrer.

\section{Referências}

CHACUR, Roberto. Ciência e arte do preenchimento. 1.ed. Porto Alegre, RS: AGE, 2018.

CONSELHO FEDERAL DE MEDICINA - CFM. Parecer CFM n. 5. Brasília, Conselho Federal de Medicina, 10 jan. 2013. Recomenda-se que o PMMA, quando utilizado, seja feito por médicos, em pequenas doses, pois o uso em grandes doses pode produzir resultados indesejáveis. Assunto: Uso indiscriminado do polimetilmetacrilato (PMMA). Disponível em: http://www.portalmedico.org.br/pareceres/cfm/2013/5_2013.pdf. Acesso em: 23 jun. 2020.

CONSELHO REGIONAL DE MEDICINA DO PARAÑ́́ - CRM-PR. Parecer CRM-PR n. 2238. Curitiba, Conselho Regional de Medicina do Paraná, 13 jul. 2010. Bioplastia - uso da substância polimetilmetacrilato (PMMA). Assunto: Procedimento de bioplastia de glúteo. Disponível em: https://sistemas.cfm.org.br/normas/arquivos/pareceres/PR/2010/2238_2010.pdf. Acesso em: 23 jun. 2020. 
DOLGHI, S. M. Avaliação de implantes de polimetilmetacrilato (PMMA) para procedimentos de bioplastia. $2014.48 \mathrm{f}$. Dissertação (Pós-Graduação em Ciência e Engenharia de Materiais) - Centro de ciência e tecnologia - Universidade Federal de Campina Grande, Campina Grande, 2014.

MENEZES, F. C. Estudo da reação tecidual à administração intraperitoneal de polimetilmetacrilato (PMMA) em ratos da linhagem Wistar. 2009. 136 f. Dissertação (Mestrado em Ciências da Saúde) - Universidade Federal de Uberlândia, Uberlândia, 2009.

RUBIN, L; HAGEMANN, C. A bioplastia e o uso do polimetilmetacrilato na estética. In: SEMINÁRIO INTERINSTITUCIONAL DE ENSINO, PESQUISA E EXTENSÃO, 23., 2018, Cruz Alta. Anais Cruz Alta: UNICRUZ, 2018. 4 p.

Coordenadoria de Pesquisa e Extensão - COPEX

Departamento de Editoraçāo e Divulgaçāo Científica - DEDIC 


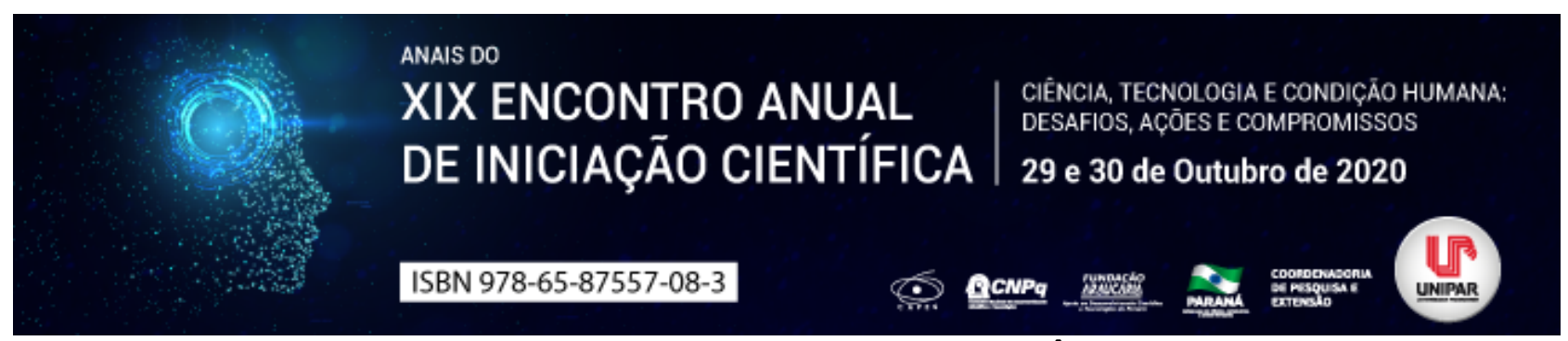

ASPECTOS E PARTICULARIDADES DOS SUBGRUPOS DA DEMÊNCIA FRONTOTEMPORAL

\title{
${ }^{1}$ BRENDA AYUMI TSUKAMOTO, ${ }^{2}$ MICHELI YURI OSHIAMA KIMURA, ${ }^{3}$ CAMILA RIGOBELLO
}

\author{
${ }^{1}$ Acadêmico do Curso de Medicina da UNIPAR \\ ${ }^{1}$ Acadêmica do Curso de Enfermagem da UNIPAR \\ ${ }^{2}$ Docente da UNIPAR
}

Introdução: A demência frontotemporal (DFT) é uma doença degenerativa do sistema nervoso central que provoca alterações neuropatológicas, principalmente relacionada à atrofia das regiões pré-frontais e temporais do encéfalo (CAIXETA; NITRINI, 1998; CAIXETA; NITRINI, 2001). É a segunda causa mais frequente de demência no período pré-senil, ou seja, entre 45 e 65 anos de idade (CAIXETA; NITRINI, 1998; TEIXEIRA-JR; SALGADO, 2006). Caracteriza-se por mudanças progressivas no comportamento, linguagem e personalidade, sendo essa progressão mais rápida ao comparar com outros quadros demenciais (RAMOS; HAMDAN, 2014; TEIXEIRA-JR; SALGADO, 2006). Há quatro subtipos clínico da DFT: variante frontal da DFT (vfDFT), Demência Semântica (DS), Afasia Progressiva não fluente (APnF) e DFT associada à doença do neurônio motor (DFT-SNM) (JOSVIAK et al., 2015). De acordo com o levantamento de dados pelo DATASUS, o Paraná registrou 390 internações no Sistema Único de Saúde relacionadas à quadros demenciais no período de janeiro/2015 a maio/2020 (BRASIL, 2020). Apesar de não apresentar os dados classificados por subgrupos, tais informações indicam a relevância do reconhecimento das diferentes manifestações clínicas para o adequado diagnóstico e escolha de condutas clínicas voltadas ao tratamento e reabilitação de tais pacientes.

Objetivo: Apresentar as particularidades dos diferentes subgrupos da DFT com foco nas manifestações clínicas.

Desenvolvimento: Há quatro fenótipos clínicos diferentes para a DFT, sendo uma delas rara. A mais comum é a variante frontal da DFT, também chamada de DFT comportamental, o qual o paciente tem os lóbulos frontal e temporal anterior afetados simetricamente. As alterações sutis de comportamento e de personalidade que se agravam progressivamente são observadas nesta patologia, tais como, redução da libido, mudança na alimentação ou nas preferências musicais, divertimentos infantis ou mudanças de trabalho, comportamento social anormal, comportamentos ritualizados e passam a ter dificuldade de seguir rotinas (JOSVIAK et al., 2015; RAMOS; HAMDAN, 2014). Nesse caso a linguagem, memória (relativa), funções corticais posteriores e habilidades visuo-espaciais são preservadas (RAMOS; HAMDAN, 2014). Na DS, o paciente apresenta atrofia bilateral no lóbulo temporal anterior, principalmente o esquerdo. Nesse caso há prejuízos na memória semântica e na compreensão da definição das palavras, tendo dificuldades para nomear objetos. Na maioria dos casos o indivíduo possui discurso fluente, porém com dificuldades para lembrar nomes e pouca precisão na utilização de termos adequados. Em casos mais graves, além da linguagem ser afetada, há também o comprometimento na capacidade de reconhecer faces (prosopagnosia) e objetos visuais (agnosia visual). Outras manifestações clínicas são erros fonêmicos ou articulatórios e agramatismo. Na APnF, ocorre a disfunção no lóbulo frontotemporal, com comprometimento da linguagem, como discurso lentificado, apraxia do discurso e agramatismo. Essa doença se progride em alguns anos para um quadro demencial global. Nesse subtipo, a semântica não é afetada, portanto, a compreensão do significado de palavras é preservada; e a parte comportamental não é prejudicada na fase inicial. (JOSVIAK et al., 2015; RAMOS; HAMDAN, 2014). O último subgrupo é a DFT-DNM, o mais raro de ocorrer, em torno de 10 a $15 \%$ dos pacientes com DNM cumprem os critérios para DFT. Nesse caso, o prejuízo cognitivo é presente em 20 a $25 \%$, alterações na linguagem e memória em 5 a 10\% e alterações no comportamento em até $75 \%$ dos pacientes com DNM. A DFTDNM progride rapidamente, mesmo antes do paciente apresentar manifestações motoras. O surgimento de doença do neurônio motor em pacientes com DFT costuma ocorrer entre 6 a 12 meses. Essa doença é caracterizada por uma atrofia cortical e degeneração da substância branca nos córtices pré-frontal dorsolateral e orbitofrontal e polo temporal (JOSVIAK et al., 2015; PEREIRA, 2018).

Conclusão: Tendo em vista os aspectos observados, a DFT é uma doença neurodegenerativa clínica e patológicas heterogêneas, acometendo maioria adultos no período pré-senil. As principais áreas afetadas por essa doença são a executiva e da linguagem, assim como suas subdivisões. Apesar da semelhança entre os subgrupos de DFT, há distinções nos mecanismos neurofisiológicos, que devem ser considerados no auxílio à intervenção e ao prognóstico da doença. Além disso, o entendimento dos critérios diagnósticos é fundamental para a identificação e tratamento adequado para cada subtipo de DFT.

\section{Referências}

BRASIL.MINISTÉRIO DA SAÚDE. DATASUS. Departamento de Informática do SUS- DATASUS. Disponível em <: http://tabnet.datasus.gov.br/cgi/tabcgi.exe?sih/cnv/nipr.def>. Acesso em: 06 maio 2020.

CAIXETA, L; NITRINI, R. Demência frontotemporal: estudo psicopatológico de 10 casos. Rev. psiquiatr. clín., São Paulo, v. 25, 
n.3, p. 132-4, maio-jun, 1998.

CAIXETA, L; NITRINI, R. Subtipos clínicos da demência frontotemporal. Arq. Neuropsiquiatr., v. 59, p. 3-A, 2001.

JOSVIACK, N. D., et al. Revisão dos principais genes e proteínas associadas à demência frontotemporal tau-positiva. Rev. Bras.

Geriatr. Gerontol., Rio de Janeiro, v. 18, n. 1, p. 201-211, 2015.

MENDES, R. B. Demência frontotemporal: evolução do conceito e desafios diagnósticos. 2015. 43 f. Dissertação (Mestrado em Medicina) - Ciências da Saúde - Universidade da Beira Interior, Covilhã, 2015.

PEREIRA, M. A. R. Demência frontotemporal em doenças do neurônio motor. 2018. Dissertação (Mestrado em Medicina) Ciências da Saúde - Universidade da Beira Interior, Covilhã, 2018.

RAMOS, A. A.; HAMDAM, A. C. Avaliação neurológica na doença alzheimer e demência frontotemporal: critérios nosológicos. Interação Psicol., Curitiba, v. 18, n. 3, p. 391-397, set./dez. 2014.

TEIXEIRA-JR, A. L.; SALGADO, J. V. Demência fronto-temporal: aspectos clínicos e terapêuticos. Rev. psiquiatr. Rio Gd. Sul, Porto Alegre, v. 28, n. 1, p. 69-76, Apr. 2006.

Coordenadoria de Pesquisa e Extensão - COPEX

Departamento de Editoraçāo e Divulgaçāo Científica - DEDIC 


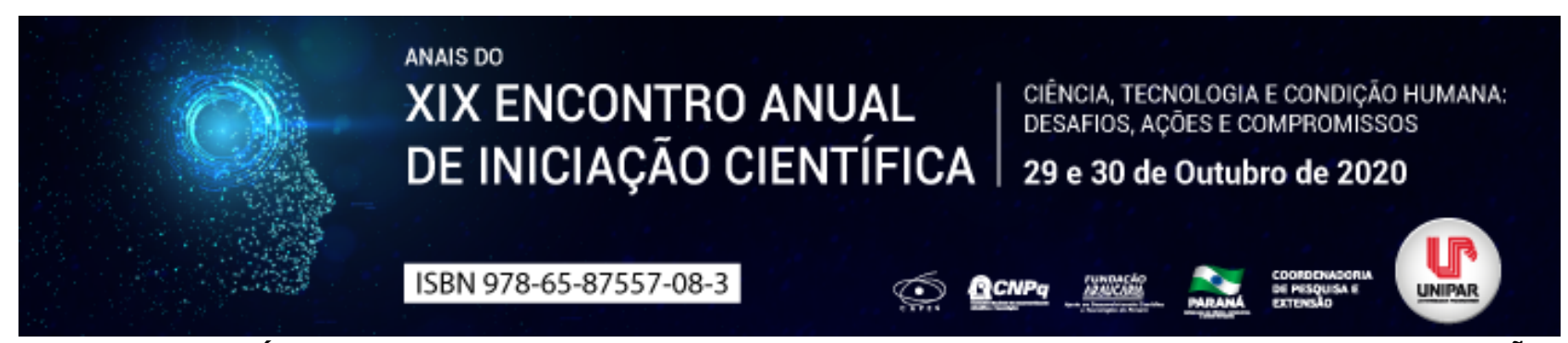

ASPECTOS FENOTÍPICOS DA OBESIDADE INFANTIL RELACIONADOS COM O GENE FTO: UMA REVISÃO DE LITERATURA

\author{
${ }^{1}$ NARA RUBIA GONCALVES, ${ }^{2}$ DANILLO PRECHLAK DE SOUZA, ${ }^{3}$ NELTON ANDERSON BESPALEZ CORREA, ${ }^{4}$ MARIA \\ ELENA MARTINS DIEGUES, ${ }^{5}$ LUCIANO SERAPHIM GASQUES
}

\author{
${ }^{1}$ Acadêmica do PIC/UNIPAR \\ ${ }^{1}$ Acadêmico do PIC/UNIPAR \\ ${ }^{2}$ Docente da UNIPAR \\ ${ }^{3}$ Docente da UNIPAR \\ ${ }^{4}$ Docente da UNIPAR
}

Introdução: A obesidade é definida como peso corporal desproporcional para a altura, com excessivo acúmulo de tecido adiposo. Esse problema de saúde pública atingiu proporções pandêmicas e traz impactos na saúde e economia mundial (LIMA, 2019). Consoante a Mărginean, Mărginean e Meliţ (2018), a prevalência mundial de obesidade é determinada por uma interação entre fatores ambientais e suscetibilidade genética individual. A herdabilidade desempenha um papel fundamental no desenvolvimento da obesidade infantil, com uma taxa de determinismo de até 70\%, e essa correlação parece ser maior em crianças do que em adultos. Reuter et al. (2016) citam que, entre os fatores ambientais, a forte influência do estilo de vida da família e da criança, onde as práticas de atividade física acompanhada da alimentação com baixo teor calórico atuam como fatores protetivos. Em relação a fatores hereditários, foi identificado que o gene FTO (fat mass and obesity associated) está relacionado com a obesidade e a adiposidade humana, principalmente o polimorfismo rs9939609 em relação a indivíduos de descendência europeia (PEREIRA et al., 2016).

Objetivo: Verificar a correlação entre a obesidade infantil e os aspectos fenotípicos com o gene FTO, especificamente o polimorfismo rs9939609, por meio de uma revisão de literatura.

Desenvolvimento: A predisposição genética para obesidade tem base poligênica, com um pequeno efeito no fenótipo, porém quando combinada aos fatores ambientais tem maior valor. Os critérios para estabelecer a obesidade infantil no Brasil são baseados nas curvas de crescimento e Índice de Massa Corporal (IMC) por idade da Organização Mundial da Saúde (OMS). Em crianças, a relação de gasto e consumo de calorias é crítica para o desenvolvimento da doença, onde hábitos alimentares tem impacto significativo e o perfil de adiposidade é mantido para a vida adulta (LIMA, 2019). Pereira et al. (2016) estudaram pacientes brasileiros, onde o grupo classificado como acima do peso e obesos tinha em média 11 anos e IMC médio de 26,7, enquanto o controle envolvia crianças com idade média de 11,9 anos e IMC médio de 17,9. Nesse estudo, foi possível detectar relação da obesidade com esse polimorfismo, levando a conclusão de que a miscigenação pode influenciar nos resultados, já que outros estudos com brasileiros não apresentaram resultados semelhantes. Todendi et al. (2018) colheram amostras em crianças e adolescentes de 6 a 17 anos, avaliando características fenotípicas como: cor da pele, textura e cor do cabelo e a forma do nariz e lábios, confirmando a descendência europeia dos participantes e sua relação com o polimorfismo. Reuter et al. (2016) estudaram crianças e adolescentes de 7 a 17 anos, avaliou-se o IMC e histórico familiar de obesidade. Foi perceptível a relação do alelo AA com maior risco para obesidade, onde os alunos apresentaram maior percentual de sobrepeso/obesidade $(57,4 \%)$ em comparação com genótipos AT $(28,9 \%)$ e TT $(33,1 \%)$, além de uma forte relação com a hereditariedade com o pai, avô materno e paterno. A mesma pesquisa com crianças chinesas não apresentou alterações até que as mesmas atingissem 12 a 14 anos, aumentando após essa faixa etária entre o gênero feminino. Mărginean, Mărginean e Meliţ (2018) revelam que, uma avaliação com 289 jovens de 6 a 19 anos, comprovou que o alelo A (genótipo AT ou AA) estava mais relacionado a preferência à alimentos com maior teor de gordura e maior ingestão dos mesmos.

Conclusão: Diante do exposto, é possível constatar que existe relações fenotípicas da obesidade infantil e o polimorfismo rs9939609 do gene FTO. O principal resultado abrange o alelo AA que apresentou maior risco para obesidade em relação à genótipos. Pode-se concluir também, que outras etnias podem apresentar resultados diferentes não sendo possível identificar alterações em todas etnias observadas. Tal informação demonstra que a grande miscigenação brasileira gera alterações fenotípicas em crianças mais próximas de raças caucasianas que aquelas com maiores influencias negras e indígenas.

\title{
Referências
}

LIMA, Rafael Silva. Avaliação e associação dos parâmetros metabólicos, inflamatórios e epigenéticos na obesidade infantil. Orientador: Juliana de Assis Silva Gomes Estanislau. 2019. 90 p. Dissertação (Pós-Graduação em Biologia Celular) Universidade Federal de Minas Gerais, Minas Gerais, 2019. 
MĂRGINEAN, Cristina Oana; MĂRGINEAN, Claudiu; MELIT, Lorena Elena. New Insights Regarding Genetic Aspects of Childhood Obesity: A Minireview. Front. Pediatr., v. 6, p. 271, 4 out. 2018.

PEREIRA, Patrícia de Araújo et al. Lack of association between genetic polymorphism of FTO, AKT1 and AKTIP in childhood overweight and obesity. Jornal de Pediatria (Versão em Português), v. 92, n. 5, p. 521-527, 2016.

REUTER, Cézane Priscila et al. Association between overweight and obesity in schoolchildren with rs9939609 polymorphism (FTO) and family history for obesity. Jornal de Pediatria (Versão em Português), v. 92, n. 5, p. 493-498, 2016.

TODENDI, Pâmela Ferreira et al. Genetic risk score based on fat mass and obesity-associated, transmembrane protein 18 and fibronectin type III domain containing 5 polymorphisms is associated with anthropometric characteristics in South Brazilian children and adolescents. British Journal of Nutrition, v. 121, n. 1, p. 93-99, 2018.

Coordenadoria de Pesquisa e Extensão - COPEX

Departamento de Editoraçāo e Divulgaçāo Científica - DEDIC 


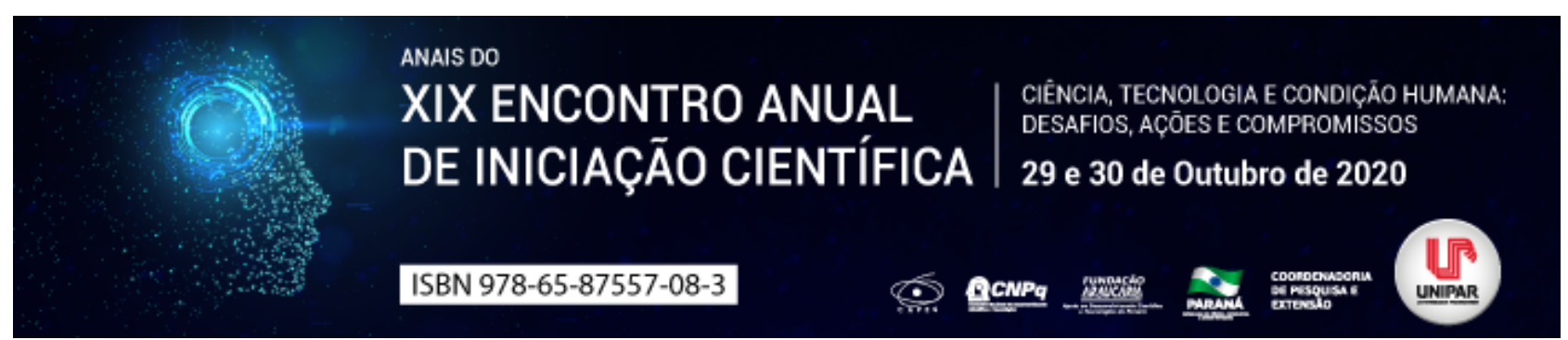

O USO DO MÉTODO THERASUIT NA REABILITAÇÃO EM CRIANÇA COM PARALISIA CEREBRAL

\title{
${ }^{1}$ MAIARA CRISTINA SALES, ${ }^{2}$ DORA DE CASTRO AGULHON SEGURA
}

\author{
${ }^{1}$ Acadêmica do curso de Fisioterapia da Unipar \\ ${ }^{1}$ Docente da UNIPAR
}

Introdução: A Paralisia Cerebral é uma lesão no Sistema Nervoso Central (SNC) que causa sequelas permanentes causadas pela má formação do encéfalo durante a gestação, nascimento ou primeiros anos de vida, dependendo do grau da lesão pode causar transtornos leves, moderados e graves dificultando o desenvolvimento motor e outras funções como postura, o equilíbrio e a coordenação (KOCH et al., 2014). Bailes, Greve e Schmitt (2010) corroboram que a lesão pode acontecer no período pré-natal, peri-natal ou pós-natal, determinando um distúrbio fixo não progressivo. A Paralisia Cerebral provoca diminuição variável na coordenação da ação muscular, decorrente da incapacidade que a criança apresenta em manter posturas funcionais e realizar movimentos. Segundo Santos, Santos e Martins (2017), a Paralisia Cerebral classifica os portadores nos ramos da hemiplegia, diplegia e quadriplegia, ambos distúrbios motores que necessitam de uma terapêutica específica. A técnica do Therasuit constitui um recurso de reabilitação com equipamentos e roupas especiais, contendo um colete, um short, joelheiras, capacete, e o tênis adaptado, que são interligados através de elásticos, conhecido como órtese dinâmica para alinhamento da postura e para dar apoio aos grupos musculares. Espera-se que esta técnica demonstre bons resultados em curto prazo de tratamento com melhora importante no desenvolvimento motor (NEVES et al., 2012).

Objetivo: Descrever, por meio de revisão literatura, os efeitos do Método Therasuit no desenvolvimento motor de crianças com Paralisia Cerebral.

Desenvolvimento: Em 1843 o cirurgião ortopedista inglês chamado Willian Jhon Little fez as primeiras descrições de uma desordem clínica que atinge o sistema nervoso central de crianças nos primeiros anos de vida. Observou-se, na época, que muitas dessas crianças nasciam após um parto prematuro ou complicado, e concluiu que a falta de oxigênio durante o parto era a principal causa do dano cerebral e consequente déficit no controle dos movimentos (ASSIS-MADEIRA; CARVALHO, 2009). Neves et al. (2012) e Myung-Sook et al. (2014) ressaltam que o Método TheraSuit foi criado por Izabela e Richard Koscielny, fisioterapeutas e pais de uma menina com Paralisia Cerebral. Trata-se de uma abordagem muito abrangente para aqueles que sofrem de distúrbios neurológicos, atrasos no desenvolvimento e lesões cerebrais traumáticas. Combina os melhores elementos de várias técnicas e métodos e possui uma lógica sólida baseada na fisiologia dos exercícios. É um programa de fortalecimento estabelecido para o participante com base em suas necessidades, pontos fortes e fracos. O método utiliza várias ferramentas e exercícios, uma delas é a órtese proprioceptiva dinâmica, que alinha o corpo o mais próximo possível do normal. 0 restabelecimento do alinhamento postural correto desempenha uma função crucial na normalização do tônus muscular, da função sensorial e vestibular.

Conclusão: Dessa forma, concluiu-se que o Método TheraSuit é uma técnica terapêutica inovadora, que ainda precisa ser amplamente estudada, porém que descreve benefícios diversos quanto ao ganho da independência funcional e consciência postural, estímulo do equilíbrio e coordenação, sendo muito eficaz para o tratamento de crianças com Paralisia Cerebral.

\section{Referências}

ASSIS-MADEIRA, E. A.; CARVALHO, S. G. Paralisia Cerebral e fatores de risco ao desenvolvimento motor: Uma revisão teórica. Cadernos de Pós-Graduação em Distúrbios do Desenvolvimento, v. 9, n. 1, p.142-163, 2009.

BAILES, A. M.; GREVE, K.; SCHMITT, L. C. Changes in two children with cerebral palsy after intensive suit therapy: A case report. Pediatric Physical Therapy, v. 22, n. 1, p. 76-85, 2010.

KOCH, H. G. B.; PEIXOTO, G. O.; LABRONICI, R. H. D. D.; SILVA, N. C. O. V. ALFIERI, F. M.; PORTES, L. A. Escalada terapêutica: Uma possibilidade de intervenção para crianças com Paralisia Cerebral. Acta Fisiátrica, v. 5 n. 22, p. 30-33, 2014.

MYUNG-SOOK, K.; JUNG-AH, L.; SUN YOUNG, K.; HYE-SEON, J. Effect of Adeli Suit treatment on gait in a child with cerebral palsy: A single-subject report. Physiother Theory Pract, v. 31, n. 4, p. 275-82, 2014.

NEVES, E. B.; SCHEEREN, E. M.; CHIARELLO, C. R.; COSTIN, A. C. M. S.; MASCARENHAS, L. P. G. PediaSuit na reabilitação da diplegia espástica: Um estudo de caso. Revista EFDeportes, n. 166, p. 01-08, 2012.

SANTOS, G. F. L.; SANTOS, F. F.; MARTINS, F. P. A. Atuação da fisioterapia na estimulação precoce em crianças com Paralisia Cerebral. DêCiência em Foco, v. 1, n. 2, p. 76-94, 2017. 



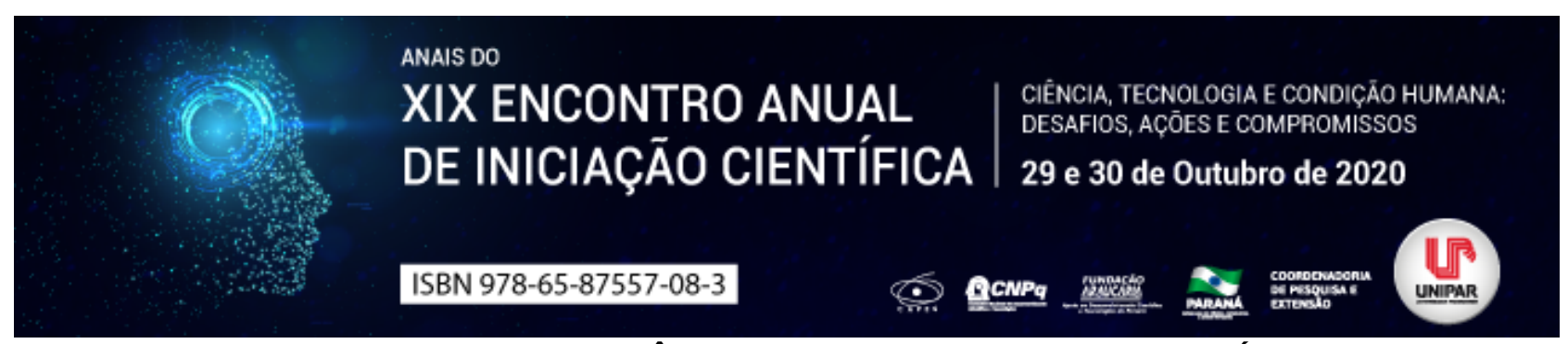

OSTEOPATIA COMO RECURSO TERAPÊUTICO PARA DOR LOMBAR EM INDIVÍDUOS ADULTOS

\title{
${ }^{1}$ DEBORA CRISTINA BORDIGNON, ${ }^{2}$ DORA DE CASTRO AGULHON SEGURA
}

\author{
${ }^{1}$ Acadêmico do curso de Fisioterapia da UNIPAR \\ ${ }^{1}$ Docente da UNIPAR
}

Introdução: De acordo com Koes, Van Tulder e Thomas (2006), a lombalgia tem como características dor, rigidez ou tensão muscular que afeta a região inferior da coluna vertebral, a região lombar. Os maiores índices de lombalgia são encontrados em indivíduos adultos, que estão em idade produtiva (BRIGANÓ; MACEDO, 2005). Dentro da fisioterapia existem diversas técnicas e recursos terapêuticos que possuem a finalidade de reduzir a dor do paciente e promover a sua reabilitação (CALONEGO; REBELATTO, 2002). Para Cupim et al. (2018) uma área da fisioterapia que contribui com técnicas para o tratamento das dores na coluna é a terapia manual. Franke, Frank e Fryer (2014) afirmam que o tratamento manipulativo osteopático (TMO), uma das técnicas encontradas na terapia manual, é capaz de tratar de forma eficaz as dores lombares.

Objetivo: Analisar quais são as alterações provocadas pela osteopatia em indivíduos adultos com lombalgia.

Desenvolvimento: Segundo Briganó e Macedo (2005), o tratamento manipulativo osteopático (TMO) visa, através do toque das mãos do terapeuta no corpo do paciente, promover o equilíbrio corporal, visceral e mental do doente. No estudo de Cabral et al. (2016), 17 pacientes adultos de ambos os gêneros, com dor lombar crônica, foram divididos em dois grupos, um grupo com 10 pacientes realizou o tratamento manipulativo osteopático (TMO) e o outro grupo com 7 pacientes praticaram exercícios terapêuticos. Após o período de tratamento, todos pacientes apresentaram redução da dor de forma significativa, em ambos os tratamentos. Cupim et al. (2018) realizaram um estudo com 15 adultos na faixa etária de 20 a 50 anos, os quais apresentavam lombalgia e realizaram o tratamento manipulativo osteopático (TMO), após o tratamento houve redução da dor e melhora da mobilidade corporal. No centro médico de Maine em Portland, um estudo avaliou 195 pacientes hospitalizados, submetidos às sessões de osteopatia. Posteriormente ao tratamento os pacientes obtiveram redução da dor, redução do uso de medicamentos para dor, redução da ansiedade e 98\% relataram sentir um maior nível de conforto (POMYKALA et al., 2008). Machado e Bittencourt (2011) avaliaram 20 pacientes adultos com dor lombar crônica, divididos em dois grupos. Um grupo realizou fisioterapia convencional e outro grupo realizou tratamento manipulativo osteopático (TMO). Após o tratamento, os pacientes do grupo de tratamento osteopático apresentaram uma intensa queda no quadro álgico, já o grupo da fisioterapia convencional obteve uma diminuição da dor menos expressiva. Os tratamentos manipulativos realizados na coluna vertebral promovem benefícios e não expõem riscos graves ao paciente (BRONFORT et al., 2008).

Conclusão: Desta forma, é evidente a necessidade de um tratamento eficaz para lombalgias, sendo que o tratamento manipulativo osteopático (TMO) compõe uma excelente alternativa dentre diversas técnicas fisioterapêuticas. A osteopatia é capaz de reduzir o quadro álgico de forma significativa, reduzindo também o uso de medicamentos para dor, além de melhorar a mobilidade corporal com um nível maior de conforto.

\section{Referências}

BRIGANÓ, J. U.; MACEDO, C. DE S. G. Análise da mobilidade lombar e influência da terapia manual e cinesioterapia na lombalgia. Revista Semina: Ciências Biológicas e da Saúde, v. 26, n. 2, p. 75-82, 2005.

BRONFORT, G.; HAAS, M.; EVANS, R.; KAWCHUK, G.; DAGENAIS, S. Evidence-informed management of chronic low back pain with spinal manipulation and mobilization. The Spine Journal, v. 8, n. 1, p. 213-225, 2008.

CABRAL, K. D. DE A.; MACIEL, R. P.; NASCIMENTO, L. S. G. DO.; FERREIRA, A. P. DE L.; ARAÚJO, M. DAS G. R. DE. Osteopatia x exercícios terapêuticos: efeitos do tratamento da dor e funcionalidades dos indivíduos com dor lombar crônica. XXI Congresso Brasileiro de Fisioterapia ética, evidências e funcionalidade. Anais do Congresso Brasileiro de Fisioterapia: Recife, 2016.

CALONEGo, C. A.; REBelATto, J. R. Comparação entre a aplicação do método Maitland e da terapia convencional no tratamento de lombalgia aguda. Revista Brasileira de Fisioterapia, São Carlos, v. 6, n. 2, p. 97-104, 2002.

CUPIM, T. S.; RIBEIRO, M. F.; ALMEIDA, B. M. S.; VIANA, F. C. Os Efeitos da Osteopatia no Tratamento de Disfunções na Coluna Vertebral. Revista Científica Multidisciplinar Núcleo do Conhecimento, v. 2, p. 42-54, 2018.

FRANKE, H.; FRANK, J. D.; FRYER, G. Osteophathic manipulative treatment for nonspecific low back pain: a systematic review and meta-analysis. BMC Muscoloskeletal Disorders, v. 15, n. 286, p. 1-18, 2014

KOES, B. W.; VAN TULDER, M. W.; THOMAS, S. Diagnosis and treatment of low back pain. British Medical Journal, v. 332 , n. 7555, p. 1430-1434, 2006.

MACHADO, V. C. V.; BITTENCOURT, D. C. DE. A conduta fisioterapêutica convencional e a osteopática no tratamento de 
pacientes com dor lombar crônica. Revista contexto e saúde, v. 10, n. 20, p. 551-558, 2011.

POMYKALA, M.; MCELHINNEY B.; BECK, B. L.; CARREIRO, J. E. Patient Perception of Osteopathic Manipulative Treatment in a Hospitalized Setting: A Survey-Based Study. Jornal da Associação Osteopática Americana, v. 108, n. 11, p. 665-668, 2008.

Coordenadoria de Pesquisa e Extensão - COPEX

Departamento de Editoraçāo e Divulgaçāo Científica - DEDIC 


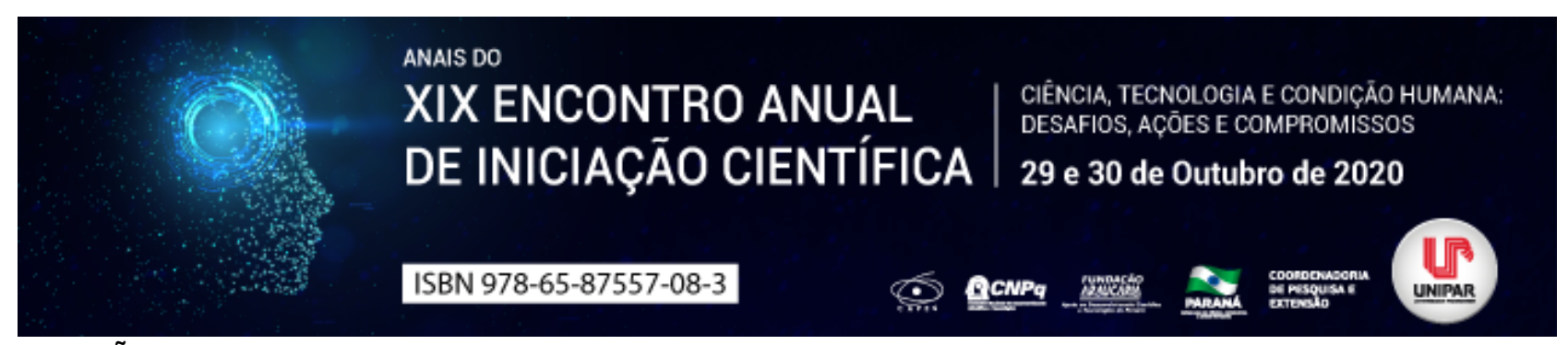

ATUAÇÃO DO FISIOTERAPEUTA EM EQUIPE MULTIDISCIPLINAR NA UNIDADE DE TERAPIA INTENSIVA

\author{
${ }^{1}$ PAOLA NATHALIA ZANETIN, ${ }^{2}$ LETICIA FLOIS FERREIRA, ${ }^{3}$ THAYNA PINTER MENDES CAMPOS, ${ }^{4}$ ANA PAULA CAMPOS \\ SANTANA, ${ }^{5}$ DORA DE CASTRO AGULHON SEGURA
}

\author{
${ }^{1}$ Acadêmico do curso de fisioterapia da UNIPAR \\ ${ }^{1}$ Acadêmica do Curso de Fisioterapia da UNIPAR \\ ${ }^{2}$ Acadêmica do Curso de Fisioterapia da UNIPAR \\ ${ }^{3}$ Acadêmica do Curso de Fisioterapia da UNIPAR \\ ${ }^{4}$ Docente da UNIPAR
}

Introdução: Segundo Santuzzi et al. (2013), a Unidade de Terapia Intensiva (UTI) é um espaço hospitalar que conta com o uso de aparelhos tecnológicos associados à experiência de múltiplos profissionais da saúde, com especialidades específicas, que buscam aumentar a expectativa e qualidade de vida do paciente, oferecendo suporte para os casos mais graves. A equipe multidisciplinar avalia os sinais e sintomas continuamente afim de minimizar as complicações que possam surgir em decorrência da permanência no leito. Um paciente é considerado crítico quando há riscos iminentes a manutenção da vida, necessitando de cuidados clínicos imediatos, na UTI, durante 24 horas por dia, são monitorados a hemodinâmica central, perfusão tecidual, temperatura corporal, ventilação e estado nutricional, sendo um dos setores de maior complexidade e tecnologia para oferecer o suporte adequado (FERMIANO et al., 2017). Alves et al. (2019) citam que por necessitar de cuidados de várias competências, e assistência contínua ao paciente, torna-se indispensável uma equipe multidisciplinar. A fisioterapia, como membro atuante, visa a preservação e recuperação precoce dos sistemas corporais, buscando promoção da independência funcional e consequentemente melhora da longevidade e qualidade de vida.

Objetivo: Avaliar a conduta fisioterapêutica em uma equipe multidisciplinar atuante na Unidade de Terapia Intensiva.

Desenvolvimento: Santana, Lopes e Queiroz (2014) descrevem que no ambiente hospitalar, sobretudo, em uma Unidade de Terapia Intensiva (UTI), torna-se necessário que a equipe multidisciplinar desenvolva e aprimore conhecimentos cognitivos, motores e de humanização do atendimento, deve contar com um grupo que possua formação diferenciada, com habilidades específicas de atendimento. Geralmente a equipe é composta por médicos, que assumem a função de líderes; enfermeiros, que dividem as tarefas dinâmicas de monitorar e atender as necessidades do paciente; técnicos de enfermagem, que coletam os exames laboratoriais e fazem a assepsia e aplicação dos medicamentos e o fisioterapeuta, que deve manter íntegra as funções cardiopulmonares e promover a recuperação funcional precocemente. Entre as técnicas fisioterapêuticas, a cinesioterapia motora, exercícios com cicloergômetro e posicionamento funcional, são de fácil aplicabilidade, baixo custo e risco nulo para o paciente. A mobilização precoce apresenta inúmeros benefícios como o aumento da força muscular periférica e da pressão inspiratória máxima, menor número de dias de internação, proporcionando melhor funcionalidade pós-alta (SILVA; OLIVEIRA, 2015). A fisioterapia faz o uso de exercícios de padrão respiratório, incitação da deambulação, mudança de posicionamento e estimulação da tosse, utilizam da terapia manual para melhora da circulação e quebra das aderências. Com a melhora do paciente e a recuperação da consciência começam a ser utilizados movimentos de cinesioterapia ativa, com ênfase em exercícios isométricos para evitar hipotrofismo muscular e exercícios isotônicos na busca pela força muscular. Tudo embasado na manutenção e evolução do paciente, desencadeando mobilidade, flexibilidade, coordenação motora e relaxamento corporal (SANTOS; BORGES, 2020). Rodrigues e Chiapeta (2017) destacam o quanto são importantes os cuidados na atuação do fisioterapeuta sobre os efeitos da inatividade do paciente acamado podendo contribuir com a redução de infecções, complicações pós-operatórias e no tempo de permanência do paciente no hospital. Moreira e Cassimiro (2019) relatam a utilização da percussão pulmonar, da tosse assistida, terapia expiratória forçada, estimulação do diafragma e musculatura costal e a drenagem postural em casos de insuficiência respiratória. Inclusive Guimarães (2020) evidência a importância do fisioterapeuta nas UTI submetidas aos pacientes afetados pelo SARS-CoV-2.

Conclusão: Assim sendo, pode-se concluir que os danos causados nos pacientes internados na Unidade de Terapia Intensiva por imobilidade e permanência no local podem ser prevenidos e minimizados com a presença de um fisioterapeuta, além de ser o profissional responsável pela ventilação mecânica. Assim sendo a fisioterapia se mostra de suma importância como membro de uma equipe multidisciplinar atuante na UTI, visando a recuperação mais rápida e promoção da qualidade de vida após a alta.

\title{
Referências
}

ALVES, L. C. B. E.; THOMMEN, L. P.; GOMES, C. M.; OLIVEIRA, V. R. C. Conhecimento de acadêmicos da saúde sobre a atuação do fisioterapeuta em unidades de terapia intensiva. Revista Brasileira Militar de Ciências, v.5, n.13, p.34-39, 2019. 
FERMIANO, N. T. C.; CAVENAGHI, O. M.; CORREIA, J. R.; BRITO, M. V. C.; FERREIRA, L. L. Avaliação dos níveis álgicos de pacientes críticos em terapia intensiva, antes, durante e após sessões de fisioterapia respiratória: Um estudo piloto. Scientia Médica, v.27, n.2, p.47-52, 2017.

GUIMARÃES, F. Atuação do fisioterapeuta em unidade de terapia intensiva no contexto da pandemia COVID-19. Fisioterapia em Movimento, v.33, e0033001, p.01-03, 2020.

MOREIRA, W. E. M.; CASSIMIRO, M. S. O papel do fisioterapeuta respiratório na abordagem do paciente com insuficiência respiratória: realidades da assistência domiciliar. Revista Saúde e Desenvolvimento, v.13, n.15, p.135-142, 2019.

RODRIGUES, F. R.; CHIAPETA, A. V. Atuação fisioterápica em pacientes adultos submetidos a unidades de terapia intensiva: Revisão de literatura. Revista Científica Univiçosa, v.9, n.1, p.245-250, 2017.

SANTANA, L. S.; LOPES, W. S.; QUEIROZ, V. A equipe multidisciplinar na atenção a pessoa em parada cardiorrespiratória: Uma revisão de literatura. Ciência Práxis, v.7, n.13, p.49-54, 2014.

SANTOS, J. S.; BORGES, A. R. A intervenção da fisioterapia na mobilização precoce em adultos dentro de uma unidade de terapia intensiva - UTI. Scientia Generalis, v.1, n.2, p.11-22, 2020.

SANTUZZI, C. H.; SCARDUA, M. J.; REETZ, J. B.; FIRME, K. S.; LIRA, N. O.; GONÇALVES, W. L. S. Aspectos éticos e humanitários da fisioterapia na UTI: Uma revisão sistemática. Fisioterapia em Movimento, v.26, n.2, p.415-422, 2013.

SILVA, I. T.; OLIVEIRA, A. A. Efeitos da mobilização precoce em pacientes críticos internados em UTI. Ciência \& Desenvolvimento Revista Eletrônica, v.8, n.2, p.01-06, 2015.

Coordenadoria de Pesquisa e Extensão - COPEX

Departamento de Editoraçāo e Divulgaçāo Científica - DEDIC 


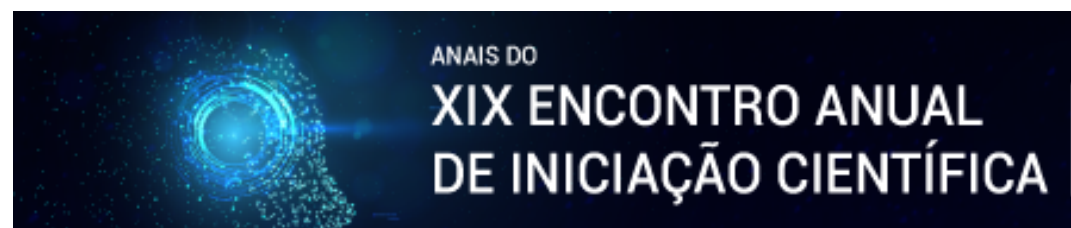

CIÊNCIA, TECNOLOGIA E CONDIÇĀOO HUMANA: DESAFIOS, AC̄ŌES E COMPROMISSOS

29 e 30 de Outubro de 2020

ISBN 978-65-87557-08-3

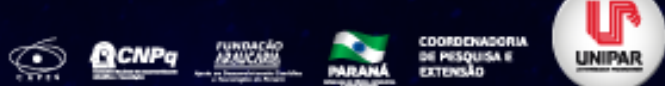

ationsion

AS RESINAS COMPOSTAS - REVISÃO DA LITERATURA

\begin{abstract}
${ }^{1}$ JENIFFER URBANO DEGASPERI, ${ }^{2}$ ALLAN FERREIRA DE LIMA ANTONELLI, ${ }^{3}$ GEOVANE CAPANA FIDELI, ${ }^{4}$ KAROLINA FERNANDA ABEGG QUEIROZ, ${ }^{5}$ RAYANE CRISTINA DE OLIVEIRA SOARES, ${ }^{6}$ WAGNER BASEGGIO
\end{abstract}

\author{
${ }^{1}$ Acadêmico do PIC/UNIPAR \\ ${ }^{1}$ Acadêmico do Curso de Odontologia da UNIPAR \\ ${ }^{2}$ Acadêmico do Curso de Odontologia da UNIPAR \\ ${ }^{3}$ Acadêmica do Curso de Auriculoterapia - Turma lii da UNIPAR \\ ${ }^{4}$ Acadêmica do Curso de Odontologia da UNIPAR \\ ${ }^{5}$ Docente da UNIPAR
}

Introdução: Na odontologia atual há uma constante renovação dos materiais empregados para os mais diversos procedimentos, principalmente mediante a necessidade estética, as restaurações que anteriormente eram realizadas com amalgama, são construídas com resina composta, comprovando que com o avanço do tempo os materiais restauradores evoluíram (CARVALHO, et al., 2018). Esse material possui excelentes propriedades, que incluem resistência, estética, boa adesão e bom tempo de trabalho, entretanto, como todo material possui suas limitacoes, a resina composta tem propriedades intrínsecas que a torna propensa ao manchamento, principalmente quando a etapa de acabamento e polimento é realizada incorretamente (SCHMITT, et al., 2011). Dos agentes exógenos que pigmentam a resina ao longo do tempo incluem as mais diversas bebidas, com destaque ao vinho, devido sua alta demanda e ingestão tanto em refeições quanto de maneira social, o que desperta a necessidade de avaliar a influencia do vinho nos compostos dentários, principalmente relacionado a maior rugosidade de superfície e consequente manchamento (TANTHANUCH; KUKIATTRALON, 2020).

Objetivo: Realizar uma revisão bibliográfica entre os anos 2010 a 2020 para avaliar, por meio da literatura existente, a influência do hábito de beber vinho no manchamento de restaurações em resina composta, pelo aumento da rugosidade de superfície, principalmente naquelas com acabamento e polimento insatisfatório.

Desenvolvimento: O vinho é uma bebida popular e dissipada em todo o mundo, no Brasil essa bebida é tradicional da região Sul, sendo consumida amplamente pela população ha muitos anos, nesse sentido, os pacientes que são submetidos a procedimentos odontológicos, como restaurações com resina composta, podem ter sua estabilidade de cor afetada pelos pigmentos contidos no vinho, pela acidez e pH diminuído dessa bebida alcoólica, que afetam a integridade estética da restauração, achados como esse foram propostos por Mezzomo (2019), por meio de uma pesquisa que avaliou, in vitro, as bebidas com alto teor de pigmentos consumidas no estado do Rio Grande do Sul, dentre as bebidas avaliadas, a conclusão foi de que o vinho tinto influenciou mais a estabilidade de cor da resina composta do que as demais bebidas, devido à degradação química do material restaurador que o torna propenso ao manchamento. Outro estudo, realizado por Tanthanuch; Kukiattralon (2020) avaliou o efeito do vinho tinto e vinho branco na dureza superficial da resina composta, a conclusão desse estudo atual indicou que a ação do vinho tinto foi diminuir os valores de microdureza significativamente, com isso, houve a produção de uma superfície áspera e porosa devido a acidez e baixo pH do álcool contido na bebida, principalmente, a superfície porosa permite que os pigmentos do vinho adentrem com maior efetividade a resina, produzindo o manchamento. Os fatores extrínsecos, dentre o qual destaca-se o consumo de bebidas com alto teor de pigmento, como o vinho, podem induzir no material restaurador o manchamento, entretanto, quando esse fator é somado a negligencia no procedimento de acabamento e polimento a estética da restauração se tornará insatisfatória e a capacidade de manchamento aumentará significativamente (AYKENT, et al., 2010). Após fotopolimerizada a resina composta ainda deve passar por mais etapas, a etapa de extrema importância é o acabamento e polimento, inicialmente, o acabamento visa a remoção grosseira do material, obtendo a forma anatômica desejada e que condiz com o elemento dental restaurado, posterior a essa etapa, o polimento deve minimizar a rugosidade de superfície para obter uma restauração lisa e brilhante (TAPIA, et al., 2012). O polimento correto é indispensável quando consideramos que a rugosidade de superfície pode ser o principal contribuinte para pigmentação extrínseca das restaurações em resina composta, exacerbado quando associado a hábitos alimentares, como o consumo de vinho (SILVA, 2015).

Conclusão: $O$ acabamento e polimento é uma etapa indispensável para o sucesso restaurador, negligência nessa etapa, principalmente se associado aos fatores extrínsecos, como o consumo de vinho, podem induzir ao manchamento, tanto pela acidez e diminuição do pH contida em bebidas com teor alcoólico, quanto pelo ineficaz polimento da superfície que aumenta a asperização e rugosidade, portanto, há necessidade do conhecimento acerca do acabamento e polimento para que haja sucesso nas restaurações, evitando manchamento 


\section{Referências}

AYKENT, Filiz, et al. Effect of different finishing techniques for restorative materials on surface roughness and bacterial adhesion. J Prosthet Dent, v. 103, n. 4, p. 221-7, abr. 2010.

CARVALHO, Anita Cruz, et al. Alteração de cor de resinas compostas imersas em diferentes bebidas. Journal of Health Sciences, v. 19, n.4, p. 221-227. 2018.

MEZZOMO, Fabiane. Avaliação da cor e da rugosidade superficial de resinas compostas após imersão em diferentes soluções alimentares relacionada a cultura da região da serra do Rio Grande do Sul. Orientadora: professora Laura Smidt Nunes. 2019. Trabalho de Conclusão de curso (aprovação na disciplina de TCC II do curso de odontologia) - Universidade de Caxias do Sul, Caxias do Sul, 2019.

SCHMITT, Vera Lucia. Effect of the polishing procedures on color stability and surface roughness of composite resins. ISRN dentistry, mai, 2011.

SILVA, Paula Barcellos da. Fatores que influenciam o manchamento marginal e superficial de restaurações de resina composta em dentes anteriores. 2015. Monografia (obtenção do grau de mestre em odontologia) - Universidade Federal de Pelotas, Pelotas, 2015.

TANTHANUCH, Saijai; KUKIATTRALON, Boonlert. Degradability of nanocomposites after cyclic immersion in red and white wines. Journal of Orofacial Sciences, v. 8, n.1. mai, 2020.

TAPIA, Larissa Rodriguez. Rugosidade de resinas compostas submetidas a diferentes métodos de acabamento e polimento. Revista de odontologia da UNESP, v. 41, n. 4, p. 254-259, mai./jun. 2010. 


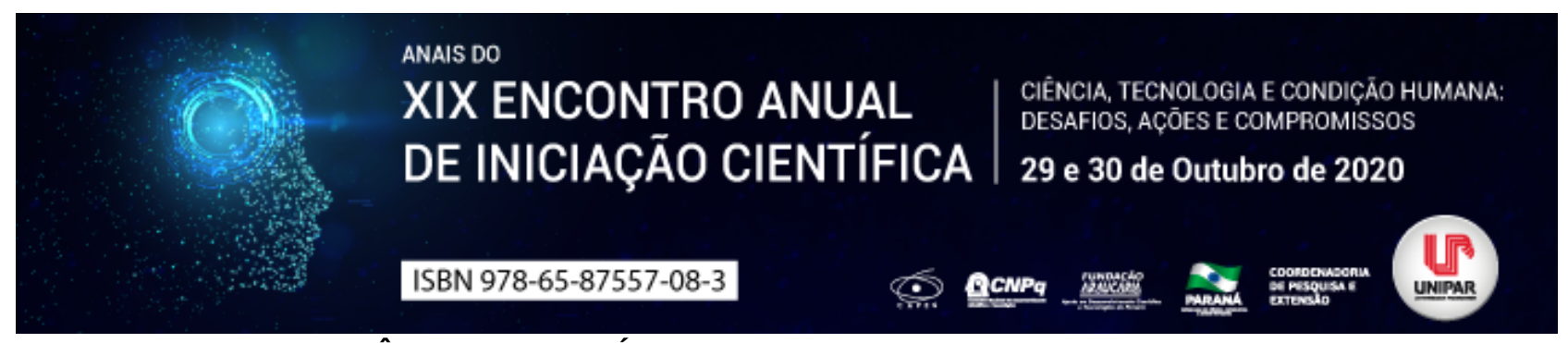

TRATAMENTO FISIOTERAPÊUTICO NO ESTÍMULO DA NEUROPLASTICIDADE EM CRIANÇAS COM PARALISIA CEREBRAL

\author{
${ }^{1}$ LETICIA FLOIS FERREIRA, ${ }^{2}$ PAOLA NATHALIA ZANETIN, ${ }^{3}$ ANA PAULA CAMPOS SANTANA, ${ }^{4}$ THAYNA PINTER MENDES \\ CAMPOS, ${ }^{5}$ DORA DE CASTRO AGULHON SEGURA
}

\author{
${ }^{1}$ Acadêmica do Curso de Fisioterapia da UNIPAR. \\ ${ }^{1}$ Acadêmica do Curso de Fisioterapia da UNIPAR \\ ${ }^{2}$ Acadêmica do Curso de Fisioterapia da UNIPAR \\ ${ }^{3}$ Acadêmica do Curso de Fisioterapia da UNIPAR \\ ${ }^{4}$ Docente da UNIPAR
}

Introdução: A encefalopatia crônica não-progressiva da infância, comumente chamada de Paralisia Cerebral, é consequente de um traumatismo estático que ocorre no período pré, peri ou pós-natal, afetando diretamente o sistema nervoso central na sua fase de crescimento estrutural e funcional. Por ser uma alteração sensório-motora acarreta em modificações musculares, posturais e de ordem voluntária, caracterizando-se pela carência de controle dos movimentos em decorrência das deformações osteomioarticulares (CARGNIN; MAZZITELLI, 2003). O diagnóstico precoce da lesão e a análise do desenvolvimento neurológico é imprescindível para escolha e início do tratamento eficaz. Dessa forma, a terapêutica deve ser iniciada dentro dos primeiros dois anos iniciais de vida, contribuindo com o aumento das expectativas de recuperação, visto que esse tempo é o período mais adequado partindo da neuroplasticidade, os sinais devem ser prontamente identificados nas avaliações e a incapacidade de desenvolvimento jamais deve ser minimizada ou negligenciada (PEREIRA, 2018). O fisioterapeuta possui uma importante função no contínuo tratamento das crianças com Paralisia Cerebral dispondo de diversas técnicas de reabilitação, tornando-se um integrante essencial tanto no acompanhamento de níveis sensoriais e motores, quanto no aconselhamento dos pais e/ou responsáveis quanto a continuidade do tratamento domiciliar (LUNA et al., 2018).

Objetivo: Dissertar acerca do tratamento fisioterapêutico no estímulo da neuroplasticidade em crianças portadoras de Paralisia Cerebral.

Desenvolvimento: Segundo Oliveira et al. (2013), o tratamento da Paralisia Cerebral é extraordinariamente individualizado, variando de paciente para paciente, sendo realizado o mais precoce possível visando não agravar problemas que prejudicam a mobilidade da criança, conquistando resultados mais pertinentes. O fisioterapeuta atua nessa condição com o objetivo de melhorar os recursos que a criança apresenta, partindo das suas particularidades e ajudando na realização de um movimento mais eficiente. A conduta motora vai ser alterada conforme o portador recebe um tratamento especializado pela equipe de reabilitação. Várias são as formas de tratamento fisioterapêutico, mas todas proporcionam uma visão acolhedora, não se concentrando apenas no quesito físico, mas contribuindo com o desenvolvimento de aspectos sociais, éticos e humanos (DOMENECH et al., 2016). O sistema motor experimenta alterações em decorrência do seu amadurecimento e interferência do meio em que se vive. Seguindo essa linha de pensamento, é fundamental que a plasticidade cerebral esteja presente no tratamento, acarretando em modificações estruturais e funcionais do sistema nervoso, buscando sempre um desenvolvimento adequado. A fisioterapia vai influenciar no tratamento e na reabilitação da criança, oportunizando o desenvolvimento de atividades motoras básicas e criando métodos que favoreçam a vivência de novas experiências (REITZ et al., 2018).

Conclusão: Diante do exposto, concluiu-se através deste estudo de revisão bibliográfica que a fisioterapia é extremamente oportuna para crianças com Paralisia Cerebral, enfatizando o diagnóstico precoce e início do processo de reabilitação, que através de diversas técnicas de estimulação promovem a neuroplasticidade assegurando uma melhora do desempenho funcional. Além disso, o apoio do fisioterapeuta ultrapassa as barreiras motoras, atuando como um apoio familiar, contribuindo com a evolução física, social e mental do paciente.

\title{
Referências
}

CARGNIN, A. P. M.; MAZZITELLI, C. Proposta de tratamento fisioterapêutico para crianças portadoras de Paralisia Cerebral espástica, com ênfase nas alterações musculoesqueléticas. Revista Neurociências, v. 11, n. 1, p. 34-39, 2003.

DOMENECH, A. C. P.; TAVARES, K. O.; RUEDELL, A. M.; NOBRE, J. R. S. Paralisia Cerebral: O significado da fisioterapia para as mães cuidadoras. Fisioterapia em Movimento, v. 29, n. 4, p. 757-766, 2016.

LUNA, M. M. A.; LUCENA, P. L; FARIAS, A. E. M; MELO, V. F. C. O acompanhamento fisioterapêutico de crianças com sequelas de Paralisia Cerebral atendidas no NASF do município de Alagoa Nova. Revista de Pesquisa: Cuidado é Fundamental Online, v. 10, p. 70-73, 2018. 
OliVEIRA, L. B.; DANTAS, A. C. L. M.; PAIVA, J. C.; LEITE, L. P.; FERREIRA, P. H. L.; ABREU, T. M. A. Recursos fisioterapêuticos na Paralisia Cerebral Pediátrica. Revista Científica da Escola da Saúde - CATUSSABA, v. 2, n. 2, p. 25-38, 2013.

PEREIRA, H. V. Paralisia Cerebral. Residência Pediátrica, v. 8, p. 01-09, 2018.

REITZ, G. S.; CHIROLLI, M. J.; ASSUNÇÃO, M. N.; DE SOUZA CRIPPA, P. V.; PEREIRA, S. M.; ROESLER, H. Influência do tratamento intensivo com suporte de peso corporal na função motora de crianças com Paralisia Cerebral. Acta Fisiátrica, v. 25, n. 4, p. 01-11, 2018.

Coordenadoria de Pesquisa e Extensão - COPEX

Departamento de Editoraçāo e Divulgaçāo Científica - DEDIC 


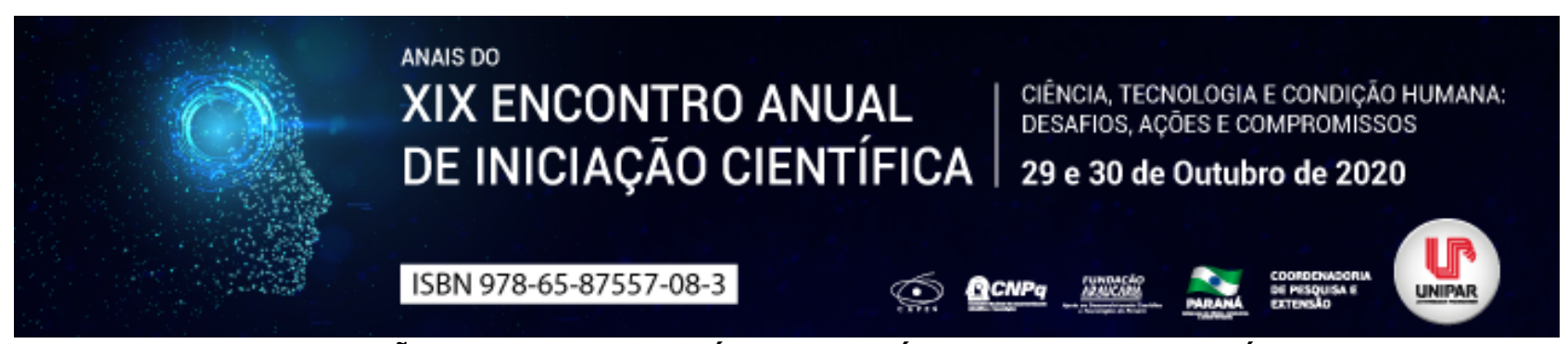

A APLICAÇÃO DO TAPING NO PÓS-OPERATÓRIO DE CIRURGIA PLÁSTICA

\title{
${ }^{1}$ AYESKA MYLLENA TEODORO PRAXEDES, ${ }^{2}$ DORA DE CASTRO AGULHON SEGURA
}

\author{
${ }^{1}$ Acadêmico do curso de Fisioterapia da UNIPAR \\ ${ }^{1}$ Docente da UNIPAR
}

Introdução: As últimas décadas, sobretudo no Brasil, foram marcadas por uma incessante procura por um corpo ideal. As cirurgias plásticas tem o potencial de proporcionar esta transição, conduzindo aqueles que a ela se submetem a recuperarem sua autoestima e bem-estar. É fato que há o risco de intercorrências, todavia enquanto cumpridos os cuidados necessários e recomendados, minimiza-se as chances de complicações e resultados adversos (PEREIRA; SANTOS, 2016). Entre as complicações pós-operatórias mais comuns ressalta-se edema, equimose, fibrose, gerando dor e limitação funcional. Assim, o acompanhamento de um profissional de fisioterapia neste período se faz imprescindível. Diversas são as técnicas pósoperatórias de cirurgias plásticas executadas por esse profissional, como uso de correntes de eletroestimulação, massagens drenantes e aplicação de taping (OLIVEIRA; CHI; LANGE, 2016; CHI et al., 2018). Pereira e Santos (2016) apontam que o taping é um artifício econômico de grande valia, fazendo uso de fitas elásticas aderentes, com intuito de restringir o papel da pele, agindo dentre outros benefícios, na atenuação álgica, bem como no decrescimento de outras intercorrências, facilitando os movimentos e otimizando o retorno precoce as atividades diárias.

Objetivo: Dissertar sobre os efeitos da aplicação do taping no pós-operatório de cirurgia plástica.

Desenvolvimento: O Brasil é segundo país que mais realiza procedimentos cirúrgicos de caráter estético. O procedimento mais procurado é o de prótese de silicone, seguido pela lipoaspiração, blefaroplastia, rinoplastia e abdominoplastia. Grande parte das cirurgias apresentam ocorrências no pós-operatório, como dor, equimoses, edemas e fibroses, provocando um vasto incomodo ao paciente (OLIVEIRA; CHI; LANGE, 2016). Quanto mais precoce se iniciar o tratamento para as complicações pós-operatórias mais rápida e efetiva será a recuperação, sendo também muito oportuno para um sucesso mais promissor do procedimento estético. A aplicação do taping no pós-operatório, algumas vezes já realizada no centro cirúrgico, previne a abertura de pontos cirúrgicos, impede o desenvolvimento do edema tecidual, bem como favorece a drenagem linfática e de possíveis hematomas por vasoplegia. A respeito das equimoses, a utilização do taping no pós-operatório facilita a filtração sanguínea dos tecidos, e ainda se apresenta de grande aplicabilidade em quadros de algia muscular resultante de determinados procedimentos (CHI et al., 2018; PEREIRA; SANTOS, 2016). Segundo Kase, Lemos e Dias (2013), a propriedade elástica do material promove trações e tensões superficiais, favorecendo a drenagem dos fluídos corporais. Através de sua aderência, age na abertura e fechamento dos vasos linfáticos e sanguíneos em virtude de suas inúmeras fibras que tem como finalidade reduzir o edema, abrandar a dor, e por conseguinte auxiliar no processo cicatricial, sendo se extrema valia na recuperação de diversos tipos de pós-operatório.

Conclusão: Assim sendo, pode-se concluir que o taping aplicado na prática clínica durante o pós-operatório de cirurgias plásticas reduz o edema, o desenvolvimento de equimose e sobretudo a formação de fibrose. Entretanto, embora sua utilização demonstre resultados consideráveis com potencial de recuperação, seus efeitos ainda possuem poucas evidências científicas, tornando necessário que sejam realizados mais estudos acerca do assunto a fim de otimizar sua aplicação.

\section{Referências}

CHI, A.; LANGE, A.; GUIMARÃES, M. V. T. N.; SANTOS, C. B. Prevenção e tratamento de equimose, edema e fibrose no pré, trans e pós-operatório de cirurgias plásticas. Revista Brasileira de Cirurgia Plástica, v.33, n.3, p.343-354, 2018.

KASE, K.; LEMOS, T. V.; DIAS, E. M. Kinesio Taping®. Introdução ao método e aplicações musculares. 2 ed. São Paulo: Andreoli, 2013.

OLIVEIRA, A. V. M.; CHI, A.; LANGE, A. O uso do taping no pós-operatório de cirurgia plástica. Revista Estética com Ciência, v. 1, n.2, p.62-64, 2016.

PEREIRA, M. S.; SANTOS, M. D. Efeitos da aplicação do linfotaping como técnica coadjuvante no pós-operatório cirurgias plásticas abdominais. Revista Visão Universitária, v.2, n.1, p.159-176, 2016. 


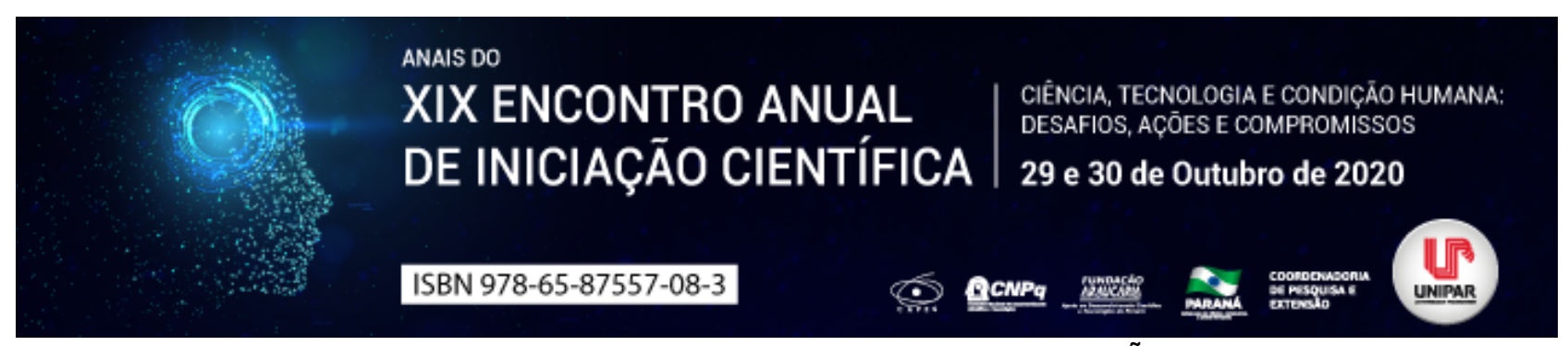

ATIVIDADE ANTIMICROBIANA DA CASEARIA SYLVESTRIS NA PREVENÇÃO DE PATOLOGIAS ORAIS

\author{
${ }^{1}$ ARGEMIRO RIBEIRO DE ALMEIDA NETO , ${ }^{2}$ ANA MARIA DA SILVA, ${ }^{3}$ GISELE APARECIDA SPADIM, ${ }^{4}$ HELOISA GARCIA \\ FRANCOZO, ${ }^{5}$ GIOVANA SOLER DOS SANTOS, ${ }^{6}$ DANIELA DE CASSIA FAGLIONI B CERANTO
}

\author{
${ }^{1}$ Acadêmico do PIC/UNIPAR \\ ${ }^{1}$ Acadêmico PIBIC/UNIPAR \\ ${ }^{2}$ Acadêmico PIC/UNIPAR \\ ${ }^{3}$ Acadêmico PIC/UNIPAR \\ ${ }^{4}$ Acadêmico PIC/UNIPAR \\ ${ }^{5}$ Docente da UNIPAR
}

Introdução: A Casearia syvestris possui capacidade antimicrobiana que, quando associada a métodos mecânicos de higienização oral, podem promover ação preventiva contra patologias orais.

Objetivo: Fazer uma revisão de literatura referente ao uso da planta Casearia sylvestris como agente antimicrobiano frente à patologias orais.

Desenvolvimento: A C . sylvestris, planta pertencente à família Flacortiaceae, é uma árvore que se apresenta com 4 a 6 m de altura, quando adulta, cultivada na América do Sul, é conhecida popularmente como Guaçatonga ou Chá de bugre (SCHNEIDER et al., 2006), possui propriedades terapêuticas, destacando-se a antimicrobiana (Arantes et al., 2005), destarte, com o intuito de usufruir destas propriedades podem ser desenvolvidos dentifrício, colutórios, pomadas ou outros produtos farmacêuticos utilizados para tratamentos odontológicos a fim de prevenir ou tratar patologias. Os resultados obtidos da atividade antimicrobiana do óleo da $\boldsymbol{C}$. sylvestris inibiu diversos microorganismos patogênicos, se demonstrando mais eficaz contra bactérias gram-positivas. O óleo extraído das folhas da planta apresentou atividade frente às bactérias como Enterococus faecalis, Escherichia coli, Micrococus e Staphylococus epidermitis que são bactérias responsáveis por endocardites, e podem, inclusive estar presentes na cavidade bucal, tornando-se uma alternativa contra esses microorganismos (SCHNEIDER et al. 2006). Em estudo publicado pelo Programa de Pós-Graduação em Ecologia, da Universidade Regional Integrada do Alto Uruguai e das Missões de Erechin, RS, concluiu-se que o óleo essencial de $\boldsymbol{C}$. sylvestris apresentou atividade antimicrobiana perante $70 \%$ das bactérias testadas, sendo a atividade antibacteriana maior sobre bactérias Gram-positivas em relação à Gram-negativas (Falcão et al., 2017).

As infecções que afetam a cavidade bucal são de origem polimicrobiana e na maioria dos casos apresentam um predomínio de microrganismos anaeróbios obrigatórios, e que juntamente com o desenvolvimento do biofilme dental, a virulência destas espécies envolvidas na etiologia desses processos infecciosos se manifesta em conjunto, desencadeando por exemplo doenças periodontais (Jardim Jr et al., 2020), que podem ser prevenidas através de rigorosa higiene oral realizada através de agentes de limpeza mecânico em conjunto com produtos farmacêuticos fitoterápicos, tais como o óleo da $\boldsymbol{C}$. sylvestris. O uso de agentes preventivos químicos direcionados à placa microbiana tem sido uma opção no tratamento da doença periodontal há quase um século, o consenso parece ser de que o uso de agentes preventivos deve ser um complemento e não um substituto para os métodos mecânicos mais convencionais e eficazes a limpeza da cavidade bucal. (Lindhe et al., 2005).

Conclusão: Logo, concluímos que o óleo da $\boldsymbol{C}$. sylvestris possui capacidade antimicrobiana comprovada, e se manipulado na forma de colutórios, dentifrícios, pomadas ou outros meios a serem utilizados em conjunto com os métodos de limpeza mecânicos tradicionais, como a escovação realizada em higienização oral, podem servir de métodos preventivos ao combate de patologias orais desencadeadas por microorganismos.

\title{
Referências
}

ARANTES, Angela Bonjorno. et al. Desenvolvimento de dentifrícios com extratos fluidos de Calendula Officinalis L. (Asteraceae) e Casearia Sylvestris Sw. (Flacourtiaceae) destinado ao combate da placa bacteriana. Rev. Bras. Farm. Universidade Federal do Paraná, v. 86, p. 61-64, 2005.

SCHNEIDER, Naira F. Z. et al. Composição química e atividade antimicrobiana do óleo volátil de Casearia sylvestris Swart. Revista Brasileira de Farmácia, v. 87, n. 4, p. 112-114, 2006.

FALCÃO, Leidiane. et. al. Ação antimicrobiana do óleo essencial de folhas de Casearia Sylvestris Swartz. Perspectiva, Erechim. v. 41, n.153, p. 115-123, 2017.

JARDIM JR., Elerson Gaetti. et al. Aspectos microbiológicos de infecções bucais: Relação ecológica e de virulência. 
Departamento de Microbiologia da Universidade de São Paulo. $2020 . \quad$ Disponível em: http://www.icb.usp.br/bmm/mariojac/index.php?option=com_content\&view=article\&id=48\&ltemid=58\&lang=br. Acesso em 02, de Junho de 2020.

LINDHE, Jan; KARRING, Thorkild e LANG, P. Niklaus. Tratado de Periodontia clínica e Implantologia Oral. $4^{a}$ Ed. Rio de Janeiro RJ. Editora Guanabara. p. 450, 2005.

Coordenadoria de Pesquisa e Extensão - COPEX

Departamento de Editoraçāo e Divulgaçāo Científica - DEDIC 


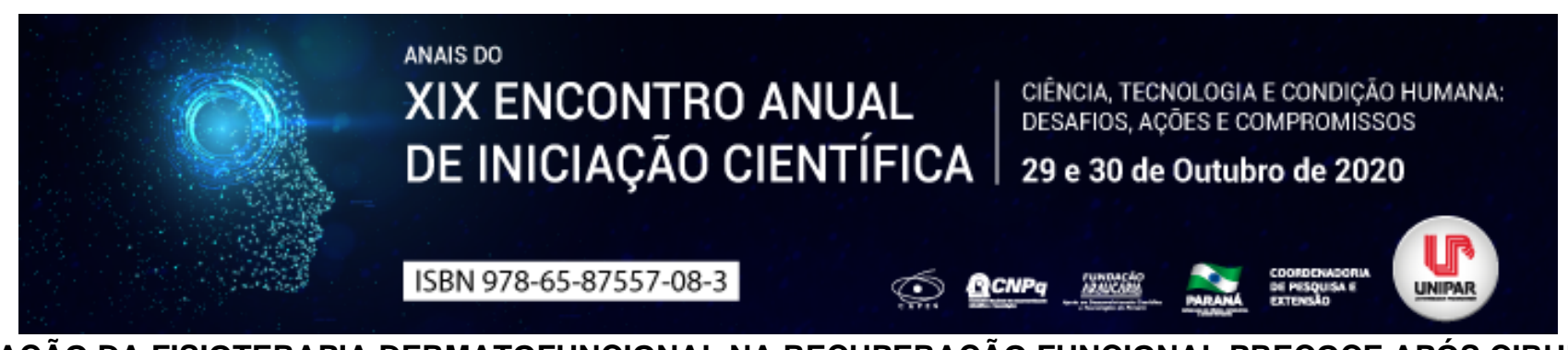

ATUAÇÃO DA FISIOTERAPIA DERMATOFUNCIONAL NA RECUPERAÇÃO FUNCIONAL PRECOCE APÓS CIRURGIA PLÁSTICA

\author{
${ }^{1}$ MAYARA JAKLINE RAMOS MATOS, ${ }^{2}$ DORA DE CASTRO AGULHON SEGURA
}

\author{
${ }^{1}$ ACADÊMICA DE FISIOTERAPIA- UNIPAR \\ ${ }^{1}$ Docente da UNIPAR
}

Introdução: A atuação do fisioterapeuta dermatofuncional na reabilitação de pacientes no pré e pós-operatório de cirurgia plástica se torna imprescindível a cada dia, devido à importância e reconhecimento dos resultados estéticos positivos apresentados, e principalmente pela melhora da funcionalidade do indivíduo. Os recursos fisioterapêuticos são utilizados na busca por um meio mais adequado para que ocorra a recuperação precoce do tecido lesionado após as intervenções cirúrgicas. Dentre os procedimentos cirúrgicos destacam-se a lipoaspiração, a abdominoplastia e os implantes de próteses de silicone, procedimentos invasivos, que por consequência acarretam em processos cicatriciais, os quais em alguns casos geram a formação de fibroses (PEREIRA et al., 2020). Cabe ao fisioterapeuta atuar com todos os recursos disponíveis para minimizar qualquer alteração funcional, aplicando a fisioterapia no pós-operatório, onde as técnicas permitem tratar os tecidos de forma imediata, promovendo uma cicatrização mais rápida e de melhor qualidade (MACEDO; OLIVEIRA, 2010).

Objetivo: Descrever sobre os efeitos da aplicação precoce da fisioterapia dermatofuncional na recuperação funcional de pacientes submetidos à cirurgia plástica.

Desenvolvimento: A fisioterapia busca manter o movimento dos seres humanos de todas as formas, porém a necessidade em ampliar seus objetivos e conhecimentos se faz necessário, criando novas perspectivas e áreas de atuação, como a fisioterapia dermatofuncional, que vem ganhando espaço na saúde, atuando na prevenção e melhora da qualidade de vida e bem-estar dos pacientes, possibilitando a atuação para uma melhor promoção de autoimagem e funcionalidade de pacientes submetidos aos procedimentos cirúrgicos (TACANI et al., 2013). Entre as práticas utilizadas na área da saúde estão as cirurgias plásticas, que podem ser classificadas como reparadoras ou estéticas, tendo por objetivo tratar deformidades, lesões, doenças em geral ou ainda por beleza física. Dentre os procedimentos cirúrgicos mais realizados destacam-se a lipoaspiração, a abdominoplastia e os implantes de próteses de silicone, as quais possibilitam reconstituir determinadas partes do corpo (PEREIRA et al., 2020). Porém, como toda técnica cirúrgica, as plásticas também acarretam em alguns tipos de complicações no pós-operatório, como cicatrizes hipertróficas e hipotróficas, hematomas, quelóides, aderências, fibroses, equimoses, infecções, perfurações abdominais, além de complicações vasculares como a trombose venosa profunda. Cada lesão envolve a redução da continuidade da pele, ocasionando danos da epiderme, derme, músculo ou até mesmo estruturas ósseas. Complicações derivadas de procedimentos cirúrgicos podem ser evitadas em muitos casos pela indicação precoce de atuação do fisioterapeuta, que buscará técnicas a serem realizadas tanto no pré, como no pós-operatório (SILVA; SANTOS, 2015). Cada paciente pode vir a apresentar tais distúrbios que provoquem dores, parestesias, limitações funcionais, edemas e infecções na cicatriz cirúrgica, além de alterações psicoemocionais. Portanto, a atuação precoce do fisioterapeuta, mesmo quando se trata de alterações estéticas, objetiva a reabilitação e retorno às atividades de vida diária o mais rápido possível (TACANI et al., 2013). Existem diversos recursos que possibilitam restabelecer a conformação dos tecidos e tratar com êxito as lesões causadas por cirurgias plásticas, principalmente fibroses e cicatrizes hipertróficas. Entre as técnicas disponíveis estão a Drenagem Linfática Manual e a Liberação Miofascial, métodos criados para promover a redução de edema nas estipuladas regiões corpóreas que estiverem com seus vasos e nervos modificados pela intervenção cirúrgica, assim como a mobilização dos tecidos, buscando melhorar tensões e rigidez (PEREIRA et al., 2020). Algumas consequências que podem se manifestar tardiamente também devem ser evitadas e tratadas, como a formação de aderência cicatriciais, flacidez e fraqueza muscular. Para isso recursos comuns da eletrotermofototerapia podem ser utilizados, como ultrassom, laser e crioterapia, vias fundamentais no processo de recuperação de quaisquer pacientes (SILVA; SANTOS, 2015).

Conclusão: Concluiu-se que, de modo geral, todos os pacientes submetidos precocemente a tratamentos fisioterapêuticos após a realização de cirurgias plásticas apresentam resultados satisfatórios em suas incisões e funcionalidade diária. Entretanto, é importe que o fisioterapeuta seja capacitado não apenas para realizar as técnicas do pós-operatório, mas também informar, prevenir e orientar o paciente sobre os cuidados indispensáveis neste período.

\title{
Referências
}

MACEDO, A. C. B.; OLIVEIRA, S. M. A atuação da fisioterapia no pré e pós-operatório de cirurgia plástica corporal: Uma revisão de literatura. Cadernos da Escola de Saúde, v. 1, n. 4, p. 185-201, 2010.

PEREIRA, D. S.; SÁ, M. L. A.; OLIVEIRA, J. G. O.; POLESE, J. C.; SILVA, F. S. Efeito da liberação miofascial em fibrose no pós- 
operatório de lipoaspiração em abdome: Um estudo piloto. Revista Interdisciplinar Ciências Médicas, v. 4, n. 1, p. 55-61, 2020. SILVA, C. M.; SANTOS, M. D. A atuação fisioterapêutica no pós-operatório imediato de abdominoplastia. Visão Universitária, v. 3, n. 1, p. 01-17, 2015.

TACANI, P. M.; ARCAS, C. S.; SILVA, F. F. D.; CARASCO, M.; MACHADO, A. F. P.; TACANI, R. E. Perfil dos pacientes atendidos em fisioterapia dermatofuncional. Fisioterapia Brasil, v. 14, n. 5, p. 351-356, 2013.

Coordenadoria de Pesquisa e Extensão - COPEX

Departamento de Editoraçāo e Divulgaçāo Científica - DEDIC 


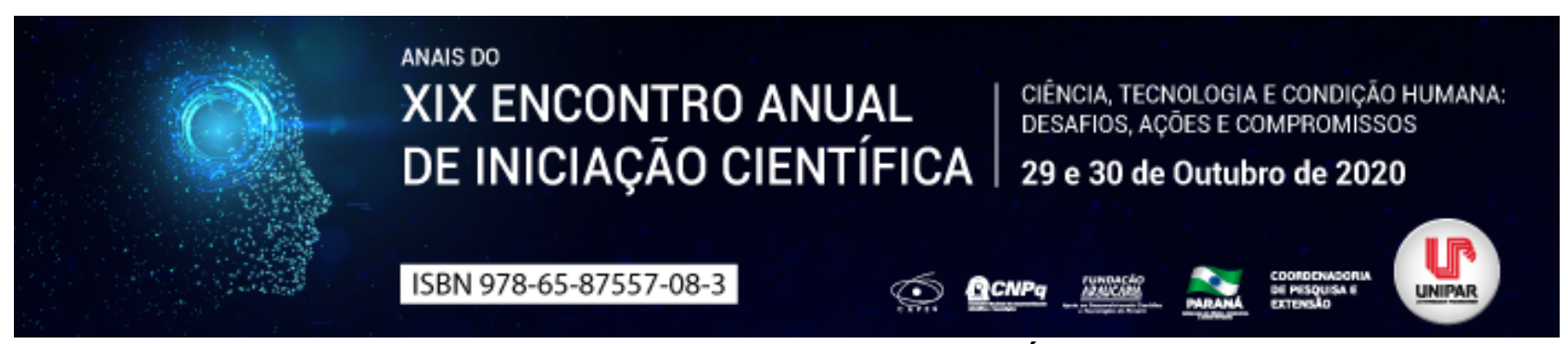

DOENÇA DE PARKINSON: OS EFEITOS NA SAÚDE DO IDOSO

\title{
${ }^{1}$ KAUAN APARECIDO DE CARVALHO, ${ }^{2}$ DEJANIRA ALVES RAPOSO DINELLY, ${ }^{3}$ DORA DE CASTRO AGULHON SEGURA
}

\author{
${ }^{1}$ Acadêmico Curso de farmácia Unipar \\ ${ }^{1}$ Acadêmica do Curso de Farmácia da UNIPAR \\ ${ }^{2}$ Docente da UNIPAR
}

Introdução: A Doença de Parkinson (DP) é uma afecção do sistema nervoso central, expressada de forma crônica e progressiva. O número de portadores da doença no mundo é estimado em mais de quatro milhões, atingindo cerca de $1 \%$ da população com mais de 65 anos, valor que tende a dobrar até o ano de 2030 (MENESES; TEIVE, 1996). As manifestações mais comuns envolvem tremor, rigidez e alterações posturais, causando no idoso dificuldade motora, da fala e deglutição, o que gera perda de peso, comprometendo o estado geral do indivíduo. Trata-se de uma enfermidade que atinge principalmente pessoas idosas e tem domínio direto sobre sua qualidade de vida. Não possui cura, é progessiva e de tratamento permanente e limitado (RODRIGUES; CENCHELLA, 2002).

Objetivo: Analisar os principais aspectos que afetam a saúde dos idosos que sofrem da Doença de Parkinson.

Desenvolvimento: Santos, Menezes e Souza (2009) esclarecem que envelhecer com a Doença de Parkinson implica em complicações degenerativas gradativas da capacidade funcional, que interferem na autonomia e independência funcional. Essa condição exige alterações no estilo de vida de portadores e cuidadores, podendo ocasionar diferentes significados, de acordo com as condições sociais, econômicas e culturais. A principal suspeita para causa da disfunção é a propensão genética, porém, a exposição a fontes tóxicas do meio ambiente teriam as circunstâncias essenciais para o desenvolvimento dos sintomas (WERNECK, 2010). Teive (2005) destaca que outro fator importante a ser considerado é o parkinsonismo precoce, antes dos 40 anos de idade, e o parkinsonismo juvenil, antes dos 21 anos de idade, fortemente relacionados à modificação genética. Existem diversos medicamentos utilizados para o tratamento da doença, entre eles sobressaem os agonistas dopaminérgicos. A prática da atividade física regular é imprescindível para manter as funções motoras por um período mais prolongado, assegurando ao portador maior independência. Bons hábitos como uma alimentação mais natural e balanceada, e o número adequado de horas de sono fazem com que a evolução dos sintomas ocorra mais lentamente (RODRIGUES; CECHELLA, 2002; FERRAZ, 2004).

Conclusão: Após o término do presente estudo concluiu-se que a Doença de Parkinson não afeta somente o portador, mas o conjunto familiar em decorrência das mudanças diárias necessárias para dar mais suporte de tratamento. É uma doença geralmente de propensão genética com complicações que vão se agravando diariamente. A disfunção vem acompanhada de diversas complicações, sendo psicológicas para aprender a conviver com a enfermidade, limitações físicas e dificuldades financeiras para assegurar o tratamento adequado. Para um tratamento mais eficiente, viu-se que a junção medicamentosa e de reabilitação física são de grande importância.

\section{Referências}

FERRAZ, H. B. Agonistas dopaminérgicos no tratamento da Doença de Parkinson. Revista de Neurociência, v. 12, n. 4, p. 192197, 2004.

MENESES, M. S.; TEIVE, H. A. G. Doença de Parkinson: Aspectos clínicos e cirúrgicos. Rio de Janeiro: Guanabara Koogan,1996.

RODRIGUES, A. R.; CECHELLA, M. A. A alimentação na Doença de Parkinson. Disciplinarum Scientia, v. 3, n. 1, p. 13-22, 2002.

SANTOS, I. S. C.; MENEZES, M. R.; SOUZA, A. S. Concepções de idoso sobre a vivência com a Doença de Parkinson. Revista de Enfermagem UERJ, v. 17, n. 1, p. 69-74, 2009.

TEIVE, H. A. Etiopatogenia da Doença de Parkinson. Revista de Neurociências, v. 13, n. 4, p. 201-214, 2005.

WERNECK, A. L. S. Doença de Parkinson: Etiopatogenia, clínica e terapêutica. Revista Hospital Universitário Pedro Ernesto, v. 9 , n. 1, p. $43-48,2010$. 


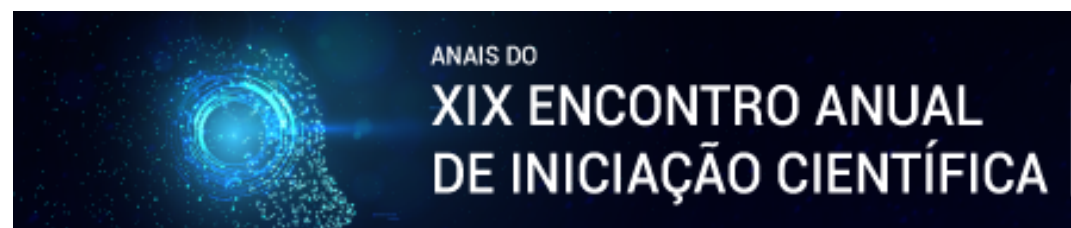

CIÊNCIA, TECNOLOGIA E CONDIÇĀO HUMANA: DESAFIOS, AC̄ŌES E COMPROMISSOS

29 e 30 de Outubro de 2020

ISBN 978-65-87557-08-3

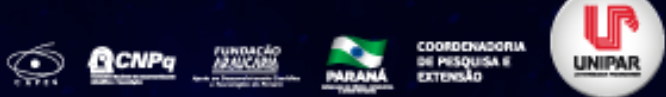

A DISBIOSE INTESTINAL COMO UM DISTÚRBIO DETERMINANTE NO DESENVOLVIMENTO DA DEPRESSÃO A PARTIR DO EIXO MICROBIOTA-INTESTINO-CÉREBRO

\author{
${ }^{1}$ ISADORA GIACOMINO ALVES, ${ }^{2}$ GABRIELA BEVILAQUA OKABAYASHI, ${ }^{3}$ CAROLINE VINTIGUERA PANCERA, ${ }^{4}$ ISABELLA \\ ACACIO FERREIRA DE SOUZA, ${ }^{5}$ FERNANDA KAYUMI YOSHIMURA, ${ }^{6}$ ALTAIR DE SOUZA CARNEIRO
}

\begin{abstract}
${ }^{1}$ Acadêmica do Curso de Medicina da UNIPAR
${ }^{1}$ Acadêmica do Curso de Medicina da UNIPAR

${ }^{2}$ Acadêmica do Curso de Medicina da UNIPAR

${ }^{3}$ Acadêmica do Curso de Medicina da UNIPAR

${ }^{4}$ Acadêmica do Curso de Medicina da UNIPAR

${ }^{5}$ Docente da UNIPAR
\end{abstract}

Introdução: O intestino humano apresenta um ecossistema de diversos microrganismos que compõem a microbiota normal. A alteração deste segmento do trato digestivo, caracterizando um predomínio de microrganismos maléficos, é chamada de disbiose intestinal. Assim, por meio do eixo intestino-cérebro, a desordem descrita pode provocar maior suscetibilidade para o desenvolvimento de algumas doenças psíquicas, como a depressão (SALGUEIRO, 2019; SILVA, 2019).

Objetivo: Analisar a relação entre transtorno depressivo e a disbiose intestinal.

Desenvolvimento: A microbiota humana é composta por vários microrganismos e estes podem ser permanentes ou transitórios (BEDANI; ROSSI, 2009). A disbiose intestinal é caracterizada pelo desequilíbrio da microbiota do intestino, no qual as bactérias patogênicas estão em maior quantidade comparando-se com as benéficas, provocando efeitos prejudiciais, como a digestão incorreta dos nutrientes e a formação de peptídeos nocivos pela combinação de toxinas com proteínas (ALMEIDA et al., 2018). Para que este cenário inconveniente não se manifeste, o eixo microbiota-intestino-cérebro mantém uma comunicação bidirecional e interativa, em que as vias neuro-endócrino-imunológicas estabelecem sinais reguladores entre o sistema nervoso central e o trato gastrointestinal (TGI). O hipotálamo comunica-se com a microbiota do TGI através do eixo hipotálamo-pituitária-adrenal, de forma que o intestino pode direcionar sinais ao cérebro. Atualmente, acredita-se que o principal canal desta sinalização é através das fibras do nervo vago aferente, onde cerca de $80 \%$ dessas retransmitem a informação sensorial das vísceras que inerva de volta ao cérebro, gerando respostas que auxiliam na manutenção da homeostase; e assim, a microbiota intestinal pode influenciar o cérebro através da modulação de substâncias neuroativas como a serotonina, noradrenalina e dopamina (WINTER et al., 2018). A partir dessas substâncias, a microbiota entérica induz o funcionamento fisiológico do cérebro, fazendo com que boa parte desses mecanismos necessitam de microrganismos e de seus metabólitos para que consigam adentrar no intestino e permitir a ativação de vários fatores, caracterizando um dos principais meios para a comunicação entre a microbiota e o eixo (SALGUEIRO, 2019). Conhecendo essa correlação, pode-se associar o tratamento da depressão com o da disbiose, a partir do uso de probióticos, que restauram o equilíbrio microbiano e regulam as suas funções, prevenindo assim, a colonização ou crescimento bacteriano patogênico e diminuindo processos inflamatórios (LIANG et al., 2019; SILVA et al., 2019).

Conclusão: A disbiose e o transtorno depressivo estão correlacionados por meio do eixo microbiota-intestino-cérebro, o qual atua de forma bidirecional. É possível identificar que, a partir de um desequilíbrio da microbiota intestinal, o quadro de depressão pode ser agravado através de respostas do nervo vago, e envolvendo sistemas como o nervoso, endócrino, imunológico, metabólico e de barreiras, como a barreira da mucosa intestinal e a hematoencefálica. Essa constatação indica que há relação entre disbiose e indivíduos depressivos, evidenciando-se, assim, ser benéfica a realização de terapias com suplementação de probióticos para alcançar o equilíbrio microbiano, levando à melhora das relações cognitivas e afetivas, e consequentemente aliviando os sintomas da depressão.

\title{
Referências
}

ALMEIDA, Luciana Barros et al. Disbiose intestinal. Revista Brasileira de Nutrição Clínica, v. 24, n. 1, p. 58-65, 2009. Disponível em: http://www.uece.br/nutrindo/index.php/arquivos/doc_download/143-disbiose-intestinal. Acesso em: 12 mai. 2020. BEDANI, Raquel; ROSSI, Elizeu Antonio. Microbiota intestinal e probióticos: implicações sobre o câncer de cólon. Jornal Português de gastrenterologia, v. 16, n. 1, p. 19-28, 2009. Disponível em: http://www.scielo.mec.pt/scielo.php? script=sci_arttext\&pid=S0872-81782009000100003. Acesso em: 12 mai. 2020.

LIANG, Ding; LONGGUI, Ning; GUOQIANG, Xu. Efficacy of different probiotic protocols in irritable bowel syndrome: A network meta-analysis. Medicine (Baltimore), v. 98, n. 27, jul. 2019. Disponível em: https://pubmed.ncbi.nlm.nih.gov/31277101/. Acesso em: 12 mai. 2020. 
SALGUEIRO, Carla Sofia Lopes. O segundo cérebro : da microbiota entérica à saúde cerebral. 2019. 58 f. Dissertação (Mestrado em Medicina) - Universidade da Beira Interior, Covilhã, 2019.

SILVA, Catarina Cruz Lourenço da. Depressão e interconexão microbioma-intestino-cérebro. Monografia (Mestrado em Ciências Farmacêuticas) - Universidade de Coimbra, Coimbra, 2019.

SILVA, Wenderson Costa da et al. A eficácia de agentes probióticos como terapia para a constipação intestinal na prática clínica: uma revisão integrativa. Unoesc \& Ciência-ACBS, v. 10, n. 1, p. 15-22, 2019. Disponível em: https://portalperiodicos.unoesc.edu.br/acbs/article/view/20077. Acesso em: 12 mai. 2020.

WINTER, Gal et al. Gut microbiome and depression: what we know and what we need to know. Reviews in the Neurosciences, v. 29, n. 6, p. 629-643, 2018. Disponível em: https://www.degruyter.com/view/journals/revneuro/29/6/article-p629.xml. Acesso em: 26 mai. 2020.

Coordenadoria de Pesquisa e Extensão - COPEX

Departamento de Editoraçāo e Divulgaçāo Científica - DEDIC 


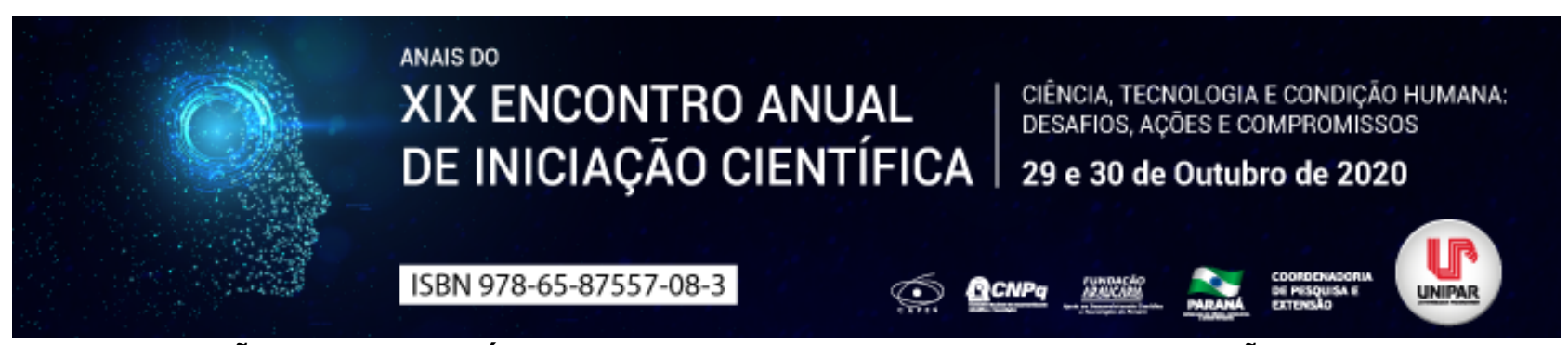

MANIFESTAÇÕES OFTALMOLÓGICAS RELACIONADOS AO SARS-COV-2: REVISÃO DA LITERATURA

\author{
${ }^{1}$ Ana Luiza Atoui Faria, ${ }^{2}$ TALITA COSTA BARBOSA, ${ }^{3}$ ELOISA CARVALHO DUZZI, ${ }^{4}$ MICHELLE NAVES DE DEUS, ${ }^{5}$ MILLENA \\ DA SILVA GONÇALVES, ${ }^{6}$ ELIZABETE SANTOS MELO
}

1Discente do curso de Medicina, Universidade Brasil, SP, Brasil
${ }^{1}$ Discente do curso de Medicina, Universidade Brasil, SP, Brasil
2Discente do curso de Medicina, Universidade Brasil, SP, Brasil
${ }^{3}$ Discente do curso de Medicina, Universidade Brasil, SP, Brasil
${ }^{4}$ Discente do curso de Medicina, Universidade Brasil, SP, Brasil
${ }^{5}$ Docente do curso de Medicina, Universidade Brasil, SP, Brasil

Introdução: As infecções pelos coronavírus são conhecidas desde os anos 60. Segundo Rafel et al. (2020), dentre os sete vírus principais, o SARS-CoV-2 é um dos três responsáveis por provocar síndromes respiratórias graves, sendo, atualmente, o causador de uma emergência de saúde pública que afetou a maioria dos países do globo. O aspecto clínico dessa doença é bastante amplo podendo assemelhar-se a um simples resfriado ou até à uma pneumonia. Por ser um caso ainda estudado, não se sabe ao certo quais sintomas estão realmente relacionados à COVID-19. No entanto, Zheng (2020) observou que além das manifestações respiratórias, também podem ocorrer alterações dermatológicas, gastrointestinais, neurológicas, oftalmológicas, entre outras. Com relação às manifestações oftalmológicas, estudos recentes mostraram que essa nova cepa de coronavírus pode produzir achados conjuntivais e ser detectada em lágrimas e secreções oculares. Embora esses achados não sejam considerados sintomas típicos da COVID-19, torna-se importante investiga-los, pois, a conjuntiva pode se tornar uma das rotas de transmissão dessa doença.

Objetivo: Identificar as evidências disponíveis na literatura sobre as manifestações oftalmológicas causadas pela COVID-19.

Método: foi realizado uma revisão da literatura nas bases de dados Pubmed, Scielo e LILACS com os descritores COVID-19 ,

SARS-CoV-2 e Manifestações Oftalmológicas. Foram encontrados artigos publicados no período de março a julho de 2020, e posteriormente, foram elencados segundo seu delineamento.

Desenvolvimento: No final de 2019, foram identificados vários casos de pneumonias cujo patógeno foi depois determinado como um novo betacoronavírus 2 de RNA chamado SARS-CoV-2. Desde então, o surto dessa doença expandiu-se rapidamente sendo declarada uma pandemia. O SARS-CoV-2 é um microrganismo emergente, que se espalha rapidamente e cuja entrada na célula alvo, depende da ligação de uma proteína S a um receptor celular do hospedeiro. Zhang et al. (2020) afirma que, assim como o SARS-CoV, o SARS-CoV-2 usa a enzima conversora da angiotensina 2, a ACE2, como receptor para a entrada no organismo. A ACE2 é encontrada em vários tipos de células epiteliais com maior expressão nas células caliciformes e células ciliadas do sistema respiratório, consistente com a patologia principal de COVID-19. No entanto, Zhou et al. (2020) observou que apesar de manifestações extrapulmonares ainda não serem totalmente claras, há evidências de que a superfície ocular possa servir como uma via de entrada para esses vírus já que o sistema nasolacrimal, fornece uma ponte entre tecidos oculares e respiratórios, facilitando a drenagem de fluido lacrimal contaminado da superfície ocular até o tecido do trato respiratório. Além disso, Chen et al. (2020) verificou a presença de manifestações oculares como conjuntivite em pacientes com a COVID-19. Isso se deve ao fato de células epiteliais conjuntivais, apresentarem grande expressão da enzima ACE2. Apesar de existirem poucos relatos sobre a associação de SARS-CoV-2 com manifestações oculares e essas, não terem sido descritas como uma característica clínica dessa doença, elas não podem ser excluídas, principalmente porque sabe-se que outros coronavírus podem causar conjuntivite. Os profissionais de saúde devem estar atentos dessa possibilidade para prevenir sequelas e identificar todas as manifestações clínicas dessa doença que vem afetando a população mundial.

Conclusão: A COVID-19 é transmitida principalmente através de gotículas respiratórias. No entanto, alguns estudos suspeitam que ela possa contaminar também outros epitélios que expressam a enzima ACE2 como o epitélio dos olhos. Apesar de o SARSCoV 2 ter sido detectado em algumas amostras oculares de pacientes com a COVID 19, e as manifestações de sintomas relacionado aos olhos terem prevalência relativamente baixa, vale a pena explorar o potencial de transmissão conjuntival desse vírus. Nesse ponto, são necessários estudos clínicos para investigar e fornecer mais informações sobre a real incidência de conjuntivite por SARS-CoV-2 e o papel da conjuntiva na via de transmissão.

\title{
Referências
}

CARVALHO, Arthur Ricardo Vilar Scavuzzi de et al . Epidemiology, diagnosis, treatment, and future perspectives concerning SARS-COV-2: a review article. Rev. Assoc. Med. Bras., São Paulo, v. 66, n. 3, p. 370-374, Mar. 2020.Disponível em: . Acesso 
em: 26 jul 2020.

CHEN L, Deng C, Chen X, et al. Ocular manifestations and clinical characteristics of 535 cases of COVID-19 in Wuhan, China: a cross-sectional study [published online ahead of print, 2020 May 18]. Acta Ophthalmol.Disponível em:< https://onlinelibrary. wiley.com/doi/full/10.1111/aos.14472>. Acesso em: 25 jul. 2020.

DOCKERY DM, Rowe SG, Murphy MA, Krzystolik MG. The Ocular Manifestations and Transmission of COVID-19: Recommendations for Prevention [published online ahead of print, 2020 May 8]. J Emerg Med. 2020;S0736-4679(20)30398-X. Disponível em:. Acesso em: 25 jul. 2020.

EMPARAN, Juan Pablo Olivares-de et al . COVID-19 and the eye: how much do we really know? A best evidence review. Arq. Bras. Oftalmol., São Paulo ,v. 83, n. 3, p. 250-261, June 2020.Disponível em:. Acesso em: 26 jul. 2020.

RAFAEL, Ricardo de Mattos Russo et al. Epidemiologia, políticas públicas e pandemia de Covid-19: o que esperar no Brasil? [Epidemiology, public policies and Covid-19 pandemics in Brazil: what can we expect?] [Epidemiologia, políticas públicas y la pandémia de Covid-19 en Brasil: que podemos esperar?]. Revista Enfermagem UERJ, [S.I.], v. 28, p. e49570, abr. 2020. ISSN 0104-3552. Disponível em: . Acesso em: 17 set. 2020.

ZHANG X, Chen X, Chen L, et al. The evidence of SARS-CoV-2 infection on ocular surface. Ocul Surf. 2020;18(3):360-362. Disponível em:< https://www.sciencedirect. com/science/article/pii/S15420124 20300653?via\%3Dihub>. Acesso em: 20 jul. 2020.

ZHOU Y, Duan C, Zeng Y, et al. Ocular Findings and Proportion with Conjunctival SARS-COV-2 in COVID-19 Patients. Ophthalmology. 2020;127(7):982-983. Disponível em:< https://www.aaojournal. org/article/S0161-6420(20)30405-X/pdf>. Acesso em: 25 jul. 2020 


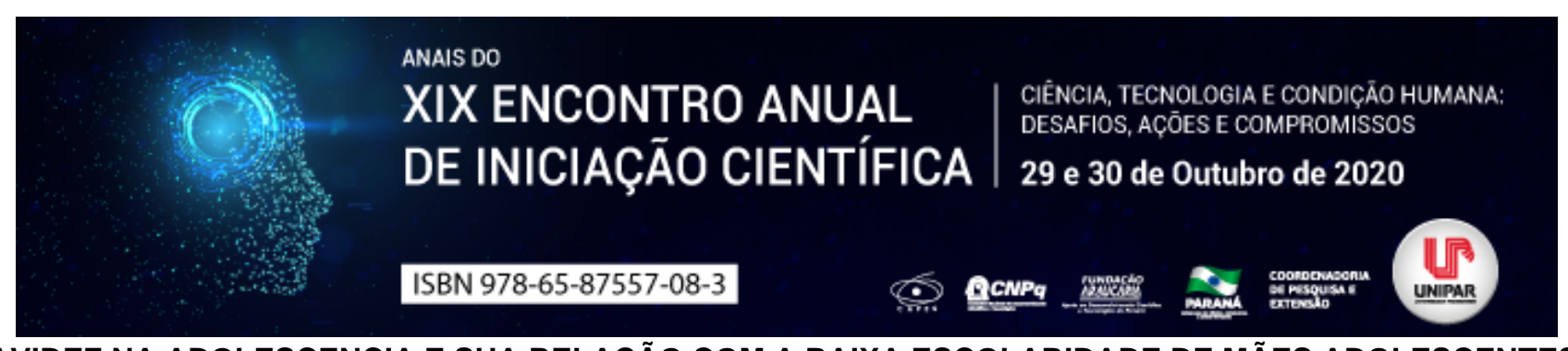

GRAVIDEZ NA ADOLESCENCIA E SUA RELAÇÃO COM A BAIXA ESCOLARIDADE DE MÃES ADOLESCENTES NA REGIÃO DO MUNICIPIO DE UMUARAMA - PR

\author{
${ }^{1}$ AMANDA STEFANI DA SILVA CRUZ, ${ }^{2}$ AMANDA NASCIMENTO VASQUES DE SOUZA, ${ }^{3}$ NANCI VERGINIA KUSTER DE \\ PAULA, ${ }^{4}$ RAFAELLA BUZINARO DA SILVA, ${ }^{5}$ ADALBERTO RAMON V. GERBASI
}

\author{
${ }^{1}$ Acadêmica bolsista do PIBIC/UNIPAR \\ ${ }^{1}$ Docente da UNIPAR \\ ${ }^{2}$ Docente da UNIPAR \\ ${ }^{3}$ Acadêmica do Curso de Enfermagem da UNIPAR \\ ${ }^{4}$ Docente da UNIPAR
}

Introdução: O período gestacional é um momento de muitas transformações para a gestante e sua família, uma experiência intensa, cheia de sentimentos às vezes negativos, momentos de incerteza, de anseios, principalmente por se tratar de adolescentes gestantes (BRASIL, 2016). Sendo a adolescência um período compreendido por indivíduos com idade entre 10 e 19 anos, estima-se que os mesmos representem de $20 \%$ a $30 \%$ da população mundial, no Brasil essa proporção pode chegar até 25\% (BOUZAS; CADER; LEÃO, 2014). Ressaltando-se, que uma gravidez não planejada na adolescência é um problema de desigualdade, que infelizmente afeta principalmente meninas em situação de vulnerabilidade, criando uma realidade capaz de retirar precocemente essas adolescentes do ambiente escolar, além de comprometer seus potenciais de bem-estar na vida adulta (UNFPA, 2016).

Objetivo: O objetivo do presente estudo foi analisar a escolaridade das mães adolescentes na região do município de Umuarama

PR e ações necessárias para a mudança do contexto atual.

Material e métodos: Pesquisa documental e quantitativa, realizada na Maternidade Regional, no município de Umuarama. Foram incluídas todas as fichas de gestantes adolescentes menores de 18 anos que deram entrada na maternidade no período de $1^{\circ}$ de janeiro 2016 a 31 de dezembro de 2016. Os dados foram coletados dos prontuários e livros de registros da Maternidade, nos meses de abril a junho de 2020, com auxílio de um formulário contendo dados socioeconômicos, como idade e escolaridade. A coleta de dados foi realizada após aprovação do Comitê de Ética em Pesquisa Envolvendo Seres Humanos, segundo a Resolução 466/2012 sendo aprovado com o parecer no 3.610.268.

Resultados: Foram analisados todos os prontuários de gestantes que deram entrada no serviço hospitalar no ano de 2016, a amostra foi composta por 145 adolescentes na faixa etária entre 12 a 17 anos e os resultados indicaram que, $3^{\circ}$ e no $4^{\circ}$ ano do Ensino Fundamental não houve registro de gravidez, contudo a maior quantidade de meninas grávidas encontra-se no $9^{\circ}$ ano com 27 casos $(45,8 \%)$ e de alunas do $8^{\circ}$ ano com 19 casos ou $32,2 \%$. A menor quantidade registrada foi de um (01) caso no $2^{\circ}$ ano ou 1,7\%. Já no Ensino Médio, a maior quantidade de adolescentes grávidas foi no $1^{\circ}$ Ano com 20 casos (45,5\%) e de alunas do $2^{\circ}$ ano com 15 casos $(34,1 \%)$ e a menor quantidade foi de alunas do $3^{\circ}$ ano com nove casos ou $20,5 \%$. Ressalta-se que das 61 adolescentes com 17 anos que já deveriam estar no ensino médio ou em fase de conclusão, 30 ainda encontravam-se terminando o ensino fundamental. Destacamos ainda que 9 encontravam-se no terceiro grau. Já 22 estavam com nível de escolaridade abaixo.

Discussão: O resultado sugere que há uma relação entre a gravidez na adolescência e a baixa escolaridade representada pelo grau de instrução apresentada pelas adolescentes do estudo. Dentre as justificativas que dificultaram a frequência escolar estão os sintomas gravídicos como: enjoos, sobrepeso, sonolência, mudanças de humor e as responsabilidades maternas com o bebê, principalmente a amamentação (SANTOS et al., 2018). A gravidez na adolescência é um dos fenômenos que mais possibilita a falta de oportunidade de emprego e situação de vida digna entre a população jovem, isto porque a maternidade precoce limita a escolaridade das mães e a oportunidade de concluir o ensino médio e ingressar em cursos técnicos ou graduações (SANTOS et al., 2018). Não existe idade para se estudar, porém no manual do MEC há tabela de equivalência quanto idade e provável série que poderia estar estudando e partindo desta, das adolescentes estudadas. O MEC em 2018 lançou um questionário e 91 mil gestores de escolas públicas e privadas responderam sobre adolescentes grávidas em idade escolar, o intuito era criar estratégias para redução de gravidez na adolescência e propostas de atendimento integral as jovens, reduzindo fragilidades na trajetória escolar. Ressalta-se que a maternidade precoce não se trata de um acontecimento igual para todas as adolescentes, e que está diretamente ligada ao contexto social no qual a adolescente está envolvida, percebe-se que nas classes sociais mais altas a vida escolar e profissional da adolescente não é tão prejudicada, já nas classes sociais mais baixas essas mães tem maiores dificuldades para conciliar a maternidade com os estudos, esse fato se explica por que muitas vezes essas meninas não recebem o apoio familiar e social necessário (NASCIMENTO; XAVIER; SÁ, 2011). 
Conclusão: Conclui-se que a gravidez na adolescência trata-se de um sério problema social, pois está diretamente ligada a baixa escolaridade de mães adolescentes. Assim torna-se importante ressaltar a necessidade de apoio a programas voltados para atenção a essas gestantes adolescentes, que as incentivem continuar no ambiente escolar e facilitem o acesso aos métodos contraceptivos e à educação sexual, além de reforçar que o apoio da sociedade e principalmente da família é essencial neste momento de fragilidade vivenciado por essas adolescentes.

\section{Referências}

BOUZAS, Isabel Cristina da Silva; CADER, Samara Ali; LEAO, Lenora. Gravidez na adolescência: uma revisão sistemática do impacto da idade materna nas complicações clinicas, obstétricas e neonatais na primeira fase da adolescência. Adolesc Saúde. Rio de Janeiro. v. 11, n. 3, p. 7-21, 2014. Disponível em: . Acesso em: 06 jun. 2020.

Fundo das Nações Unidas Para a População UNFPA. Maternidade: quase metade das gravidezes não é planejada, 2016. Disponível em: . Acesso em: 04 jun. 2020.

Ministério da Educação MEC. Gravidez na adolescência é tema de parceria entre ministérios, 2018. Disponível em: < http://portal.mec.gov.br/component/tags/tag/gravidez-na-adolescencia>. Acesso em: 23 ago. 2020.

NASCIMENTO, Mirlene Garcia; XAVIER, Patricia Ferreira; SA, Rafaella Domingos Passos. Adolescentes grávidas: a vivência no âmbito familiar e social. Adolesc Saúde. Rio de Janeiro. v. 8, n. 4, p. 41-47, 2011. Disponível: . Acesso em: 06 jun. 2020.

SANTOS, R.C.A.N. et al. Realidades e perspectivas de mães adolescentes acerca da primeira gravidez. Revista Brasileira de Enfermagem. v. 71, n. 1, p. 73-80, 2018. Disponível em: . Acesso em: 09 ago. 2020. 


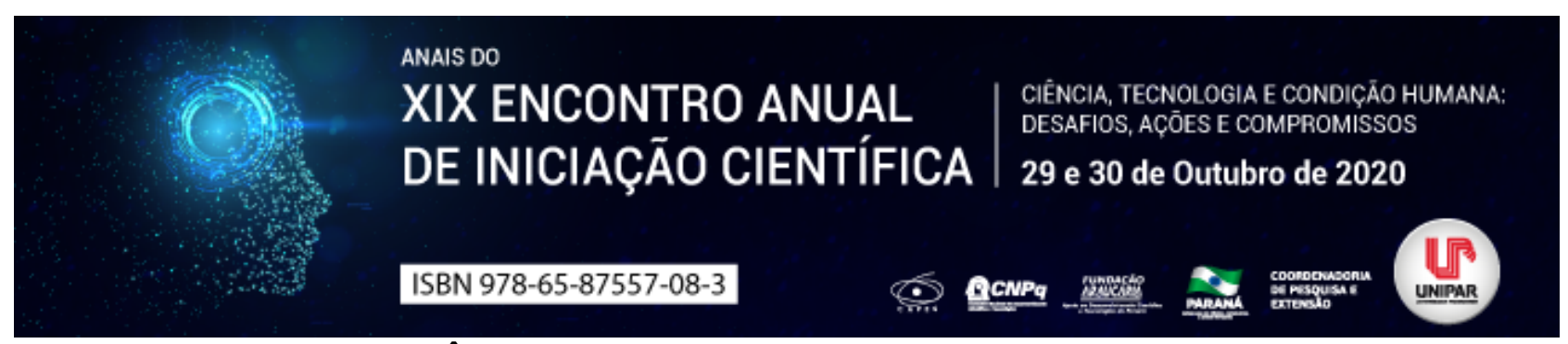

ASSISTÊNCIA DE ENFERMAGEM NO PARTO HUMANIZADO

\begin{abstract}
${ }^{1}$ AMANDA STEFANI DA SILVA CRUZ, ${ }^{2}$ CAMILA SANTANA DA COSTA, ${ }^{3}$ MIRELLA CARLOS SIQUEIRA, ${ }^{4}$ RAFAELLA BUZINARO DA SILVA, ${ }^{5}$ AMANDA NASCIMENTO VASQUES DE SOUZA
\end{abstract}

\footnotetext{
${ }^{1}$ Acadêmico do Curso de Enfermagem da UNIPAR

${ }^{1}$ Acadêmica do Curso de Enfermagem da UNIPAR

${ }^{2}$ Acadêmica do Curso de Enfermagem da UNIPAR

${ }^{3}$ Acadêmica do Curso de Enfermagem da UNIPAR

${ }^{4}$ Docente da UNIPAR
}

Introdução: A humanização no parto compreende um conjunto de técnicas embasadas em evidências cientificas e no cuidado qualificado e integral em saúde que tem por objetivo a prevenção da mortalidade materna e perinatal e a realização do parto e nascimento saudável (BELO HORIZONTE, 2015). Desta forma buscando um melhor atendimento e qualidade da assistência originou-se pela Organização Mundial da Saúde (OMS) o modelo de parto humanizado, sendo posteriormente adotado pelo Ministério da Saúde (MS), e referendado por meio da Portaria n 569 de 2000 (BRASIL, 2000). Porém no Brasil, o parto cesariano é o tipo de parto mais comum, segundo dados do DATASUS entre os anos de 2016 a 2018 foram realizados 4.857 .760 partos cesáreas e 3.861 .986 partos vaginais (DATASUS, 2020). Ressalta-se a atuação do Enfermeiro Obstetra contribuindo á parturiente, para que a mesma atue ativamente com conforto e segurança no seu processo de parturição, proporcionando assim a aplicação do modelo assistencial preconizado pelo Ministério da Saúde e Organização Mundial de Saúde (SIQUEIRA et al., 2019).

Objetivo: Compreender o papel do profissional enfermeiro junto à parturiente no cenário do parto humanizado.

Desenvolvimento: A Enfermagem é essencial na prática do parto humanizado, pois atua realizando ações direcionadas ao acolhimento, a criação de vínculo, esclarecimento de dúvidas e uso de técnicas não farmacológicas, tornando esse momento intenso e proporcionando a mulher o protagonismo dentro de seu parto (SOUZA et al.,2013). Destaca se que o parto humanizado traz inúmeros benefícios para mãe e o bebê, como: o protagonismo da mulher, o respeito ao tempo de nascimento de cada criança, tranquilidade e segurança durante a realização do parto, redução da dor e desconforto durante o parto, redução das complicações no pós-parto e da mortalidade materno-infantil (CORDEIRO et al.,2018). Considera-se que a conduta de enfermagem no cuidado com a parturiente tem grande relevância, podendo contribuir de forma decisiva para tornar o parto uma vivencia satisfatória ou frustrante para a mulher (SOUZA et al.,2013). Entretanto, a humanização no parto é permeada por várias dificuldades como, estruturas físicas inadequadas dentro das instituições, equipe de enfermagem reduzida, falta de materiais, excesso de pacientes para atendimento, falta de conhecimento e sensibilização dos trabalhadores e recusa das parturientes em cooperar em certas situações (CORDEIRO et al.,2018).

Conclusão: Este estudo permitiu ressaltar a importância do enfermeiro no cenário do parto humanizado, distinguindo que as técnicas e condutas utilizadas pela enfermagem durante o processo de parturição resultam em inúmeros benefícios para a mãe e o bebê, além de permitir que a mulher vivencie o protagonismo dentro do parto. Porém torna-se importante destacar que as práticas preconizadas para a realização de um parto humanizado e respeitoso ainda enfrentam muitas dificuldades para serem efetivadas nas instituições responsáveis pelo atendimento dessas mulheres.

\title{
Referências
}

BRASIL. Ministério da Saúde. Departamentos de dados do SUS (DATASUS). Disponível em: .Acesso em: 12 abril. 2020.

BRASIL. Lei no 569, de 1 de junho de 2000. Institui o Programa de Humanização no Pré-natal e Nascimento, no âmbito do Sistema Único de Saúde. Diário oficial da República Federativa do Brasil, Brasília, DF, 8 jun. 2000.

CORDEIRO, E. L. et al. A humanização na assistência ao parto e ao nascimento. Revista de enfermagem UFPE online, Recife, v. 12, n .8, p. 2154-2162, Agos. 2018.

SIQUEIRA, A. L. et al. O papel do enfermeiro obstetra no parto humanizado. Revista brasileira interdisciplinar de saúde, v. 1, n. 3, p. 1-5, 2019.

SOUZA, C. M. et al. Equipe de enfermagem e os dispositivos de cuidado no trabalho de parto: enfoque na humanização. Revista online de pesquisa cuidado é fundamental, v. 5, n. 4, p. 743-754, out/dez. 2013.

Prefeitura Belo Horizonte. Assistência ao Parto e Nascimento: Diretrizes para o cuidado multidisciplinar. 1. ed. Belo Horizonte, 2015. 
Coordenadoria de Pesquisa e Extensão - COPEX

Departamento de Editoraçāo e Divulgaçāo Científica - DEDIC 


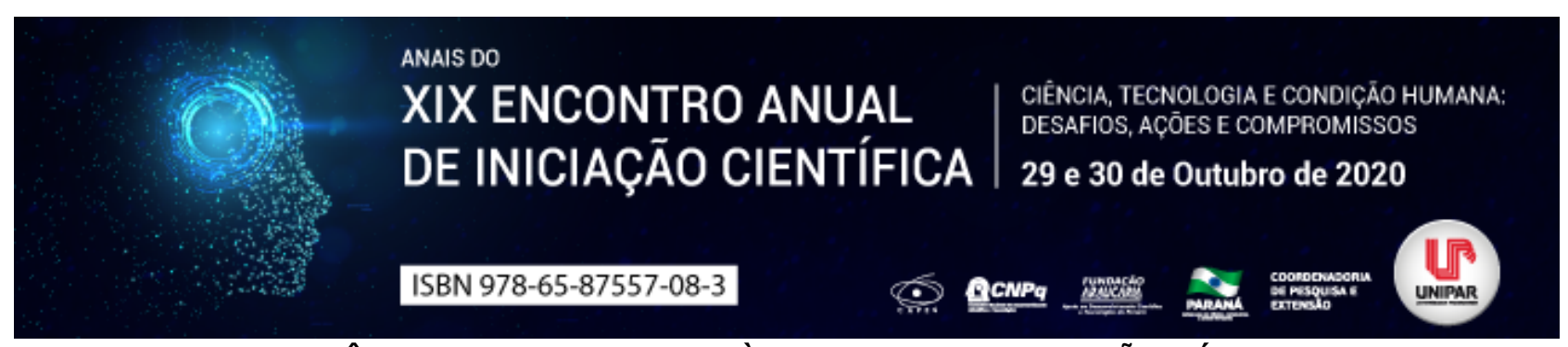

A ASSISTÊNCIA DE ENFERMAGEM À MULHER NA DEPRESSÃO PÓS-PARTO

\begin{abstract}
${ }^{1}$ MIRELLA CARLOS SIQUEIRA, ${ }^{2}$ AMANDA STEFANI DA SILVA CRUZ, ${ }^{3}$ CAMILA SANTANA DA COSTA, ${ }^{4}$ AMANDA NASCIMENTO VASQUES DE SOUZA
\end{abstract}

\footnotetext{
${ }^{1}$ Acadêmica do Curso de Enfermagem da UNIPAR

${ }^{1}$ Acadêmica do Curso de Enfermagem da UNIPAR

${ }^{2}$ Acadêmica do Curso de Enfermagem da UNIPAR

${ }^{3}$ Docente da UNIPAR
}

Introdução: A depressão pós-parto (DPP) é umas das alterações mais comuns no período pós-gestacional, acometendo de 10\% a 15\% das puérperas, sendo essa patologia caracterizada pela desordem do apetite, insônia ou hipersônia, declínio da energia, sentimento de desvalor ou culpa exagerada, pensamentos frequentes de morte, ideação suicida e repulsão ao bebê (BRASIL, 2010). Além da identificação de sinais e sintomas, devemos apontar os fatores de riscos que estão associados à depressão puerperal, como, histórias anteriores de depressão, dificuldades financeiras, baixa escolaridade, desemprego, ausência de suporte social, não aceitação da gravidez, violência domésticas, conflitos conjugais (ANDRADE et al, 2015). Ressalta-se que o principal papel do profissional enfermeiro é estabelecer uma relação terapêutica de confiança ao longo do ciclo gravídicopuerperal, assim, possui as competências necessárias para realizar orientações, visitas domiciliares, consultas de enfermagem e palestras para prevenção e redução dos riscos apresentados durante toda gravidez e puerpério (COELHO, 2014).

Objetivo: Destacar o papel do profissional enfermeiro na assistência a DPP frente os sinais e sintomas apresentados pelas puérperas.

Desenvolvimento: A DPP atinge mulheres no período de pós-parto, ocasionando alterações psíquicas, cognitivas, comportamentais e físicas que impossibilitam o estabelecimento de uma relação entre o binômio mãe-bebê (SOUZA et al, 2018). Os principais sinais que as puérperas apresentam são: aborrecimento com o choro da criança, dificuldade na amamentação, sentimento de culpa, se sente incapaz de cuidar do bebê e em situações mais graves acontece abandono da criança por parte da mãe e até agressão física. (ANDRADE et al, 2015). O diagnóstico precoce da DPP, realizado por intermédio do acompanhamento feito das gestantes no pré-natal, é de fundamental importância na prevenção ou reabilitação imediata. $O$ enfermeiro faz parte da equipe multiprofissional, onde possui o contato direto com a puérpera, sendo assim, é de extrema importância ter educação continuada em relação à DPP para facilitar o reconhecimento de traços depressivos e na aplicação de instrumentos de investigação no pós-parto imediato, como por exemplo, escalas para avaliação e rastreamento de fatores associados e sinais de depressão. (SOUZA et al, 2018). A equipe multiprofissional atua durante toda a gestação e pós-parto, proporcionando a puérpera o apoio necessário para enfrentar eventuais episódios de depressão,sendo necessário ser feito o devido acolhimento da mulher, para que ela se sinta segura para fazer suas queixas, temores e ansiedades, desta forma é possível tomar medidas preventivas precoces, ao qual traz grandes repercussões futuras (MEIRA et al, 2015). A assistência de enfermagem integral deve- se iniciar no pré-natal com a avaliação da autoestima da mulher e apoio psicossocial. A assistência individual quanto reuniões em grupos com gestantes e seus parceiros são essenciais nessa fase, pois, ocorre a troca de experiências, ansiedades e expectativas sobre a criança, amenizando a aflição e inseguranças relacionadas a esse período (COELHO, 2014).

Conclusão: É compreensível a importância do diagnóstico precoce da DPP, tanto para puérpera e familiares como para a criança. Sendo assim, é evidente que o principal modo de identificação da DPP é a realização das consultas de enfermagem no pré-natal e pós-parto, sendo diagnosticada e tratada rapidamente. Assim sendo necessária a atuação do profissional enfermeiro no reconhecimento de sinais indicativos de casos depressivos, com práticas acerca do tema, sendo possível organizar medidas de prevenção e promoção da saúde das mulheres com DPP ou daquelas que possuem fatores de risco para desenvolver a patologia.

\title{
Referências
}

ANDRADE, R.D. et al. Fatores relacionados à saúde da mulher no puerpério e repercussões na saúde da criança. Escola Anna Nery, Minas Gerais, v.19 n.1, p. 181-186, jan./dez. 2015.

BRASIL, Ministério da Saúde. Atenção a gestante e a puérpera no SUS-SP. Manual Técnico do Pré-natal e Puerpério. Secretaria de estado da saúde. São Paulo, p. 195-196, 2010.

COELHO, T. A.C. Determinantes das alterações psicoemocionais do puerpério: efeitos da autoestima. 2014. $137 \mathrm{f}$. Dissertação (Mestrado) Instituto Politécnico de Viseu, Escola Superior de Saúde de Viseu, Portugal, 2014. 
MEIRA, B.M. et al. Desafios para profissionais da atenção primária no cuidado à mulher com depressão pós-parto. Texto Contexto Enferm, Florianópolis, v.24 n.3, p. 706-712, jul./set. 2015.

SOUZA, K.L.C. et al. Conhecimento de enfermeiros da atenção básica acerca da depressão puerperal. Revista de Enfermagem UFPE Online,Recife, v.12 n.11, p. 2933-2943, nov. 2018.

Coordenadoria de Pesquisa e Extensão - COPEX

Departamento de Editoraçāo e Divulgaçāo Científica - DEDIC 


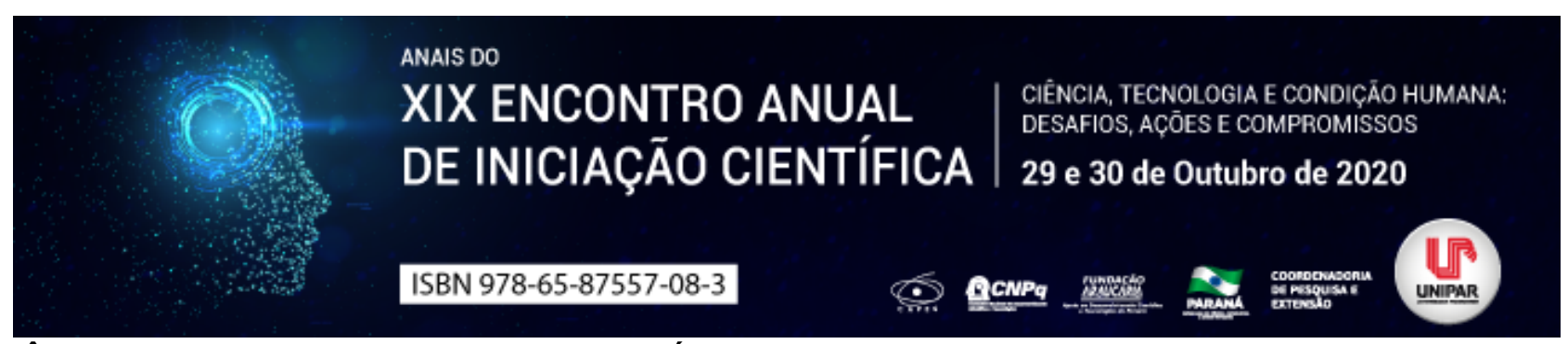

IMPORTÂNCIA DOS SINAIS DE ALERTA NO DIAGNÓSTICO PRECOCE DO TRANSTORNO DO ESPECTRO AUTISTA NO BRASIL

\author{
${ }^{1}$ ANA BEATRIZ PINHEIRO ZAUPA, ${ }^{2}$ GABRIEL HENRIQUE BELLATO PALIN, ${ }^{3}$ CARLOS EDUARDO RUZZENE RODRIGUES, \\ ${ }^{4}$ HIGOR DIAS DO PRADO, ${ }^{5}$ ALTAIR DE SOUZA CARNEIRO
}

\begin{abstract}
${ }^{1}$ Acadêmica do Curso de Medicina da UNIPAR
${ }^{1}$ Acadêmico do Curso de Medicina da UNIPAR

${ }^{2}$ Acadêmico do Curso de Medicina da UNIPAR

${ }^{3}$ Acadêmico do Curso de Medicina da UNIPAR

${ }^{4}$ Docente da UNIPAR
\end{abstract}

Introdução: De acordo com a Cartilha do Instituto Federal da Paraíba (2017), o Transtorno Espectro Autista (TEA), é uma perturbação que ocorre durante o desenvolvimento neurológico que acomete em sua maioria pacientes do sexo masculino, gerando comprometimentos de dois domínios centrais: primeiro a comunicação e interação social, seguido de padrões repetitivos e restritos de comportamento, interesses e o hiperfoco em atividade (ALMEIDA et al. 2018). Segundo Brites e Brites (2019) o diagnóstico precoce deve ser o principal foco objetivando remediar por completo ou evitar o máximo as consequências negativas no desenvolvimento infantil. Para que o diagnóstico seja considerado precoce deve ser feito antes dos três anos de idade e preferencialmente aos dois anos, de modo que apresenta sinais de alerta consideráveis.

Objetivo: Analisar os sinais precoces para um alerta de um possível diagnóstico do transtorno do espectro autista no Brasil através de uma revisao de literarutra.

Desenvolvimento: O TEA é considerado um distúrbio global do desenvolvimento humano, que envolve diversas alterações precoces na área de socialização, comunicação e cognição (FERNANDES, 2019) e através de uma revisao de literatura baseada em dados dos artigos mais relevantes foi feita uma análise da importância dos sinais de alerta no diagnóstico precoce do TEA no Brasil. Nesse sentido, o TEA provoca alterações na conectividade entre os hemisférios cerebrais, causando dificuldade de integridade das informações e na coordenação entre os diferentes sistemas neuronais do encéfalo. Além disso, pode-se dizer que a esquizofrenia está intimamente ligado às primeiras manifestações do TEA, visto que ela é responsável pela interrupção do equilíbrio de sinalização excitatória/inibitória no cérebro, especificamente no córtex pré frontal, onde é a área responsável pelo comportamento social do indivíduo (ALMEIDA et al. 2018). Ademais, É denominado ESPECTRO por haver uma gama de condições que englobam desde níveis mais leves até níveis mais profundos de comprometimento nestas conexões, resultando em diversos tipos de autistas, que podem diferir bastante de pessoa para pessoa (BRASIL, 2017). Sendo assim, o diagnóstico precoce é fundamental e deve ser realizado antes dos três anos de idade para que a criança tenha a chance de um bom desenvolvimento, a possibilidade de realizar terapias e métodos mais precocemente visando no futuro maiores condições de vencer os obstáculos da vida, além de reduzir danos às crianças, aos cuidadores, a família e a escola. (BRITES; BRITES, 2019). Os sinais de alerta já podem ser identificados no bebê que podem apresentar pouco ou nenhum contato visual, dificuldade de socialização e pouco interesse na voz humana. (TEIXEIRA, 2016). Antes dos dois anos de idade existem 12 sinais que mais se destacam, conforme explica Brites e Brites (2019), sendo eles pouco ou a ausência do contato visual; sentimento de indiferença ao colo dos pais ou preferem ficar soltos; não balbuciam até o sexto mês; tem nenhuma ou pouca resposta ao estímulo de outras pessoas ao seu redor; se irritam frequentemente; atraso em aprender gestos sociais; dificuldade na fala com atraso ou retrocesso; movimentos repetidos e sem intenção social; pouca ou nenhuma vontade de brincar com outras crianças; brincam de jeitos diferentes; focam excessivamente em cores das coisas, detalhes e formas; e não sentem prazer ou sentem sofrimento durante atividades sociais cotidianas. Caso apareçam pelo menos metade dos sinais de alerta deve haver uma preocupação havendo a necessidade de exames e encaminhamento para um especialista para que se confirme o transtorno do espectro autista. Ao iniciar a investigação podem ser usados, de início, três caminhos justapostos que são a escala de avaliação do desenvolvimento infantil, uma escala de triagem de autismo, como o M-CHAT para crianças entre 18 a 36 meses, e, por fim, saber os sinais precoces de risco para a possibilidade de autismo. (BRITES; BRITES, 2019).

Conclusão: O diagnóstico precoce deve ser feito o mais cedo possível para que as intervenções se iniciem, além disso, os tratamentos podem ser intensificados e direcionados para que os sintomas sejam reduzidos, a escola já fica ciente e capaz de trabalhar com a criança, de modo que consiga prevenir e proteger os alunos autistas de preconceitos e os incluam no processo de aprendizagem.

\title{
Referências
}


ALMEIDA, Simone Saraiva de Abreu et al. Transtorno do espectro autista. Residência Pediátrica, v.8, n.1, 2018. Disponível em: https://cdn.publisher.gn1.link/residenciapediatrica.com.br/pdf/v8s1a12.pdf. Acesso em: 21 jun. 2020.

BRITES, Luciana; BRITES, Dr Clay. Mentes Únicas. São Paulo: Editora Gente, 2019.

BRASIL. Instituto Federal da Paraíba. Conhecendo o transtorno do espectro autista. Cartilha Institucional. João Pessoa, 2017. Disponível em: https://estudante.ifpb.edu.br/static/files/cartilha_espectro_autista.pdf. Acesso em: 21 jul. 2020.

FERNANDES, Fernanda Dreux Miranda. Famílias com crianças autistas na literatura internacional. Revista da Sociedade Brasileira de Fonoaudiologia, v.14, n.3, 2009. Disponível em: https://www.scielo.br/scielo.php?script=sci_arttext\&pid=S151680342009000300022. Acesso em: 21 jul. 2020.

TEIXEIRA, Dr Augusto. Manual do autismo. Rio de Janeiro: Best Seller, 2016.

Coordenadoria de Pesquisa e Extensão - COPEX

Departamento de Editoraçāo e Divulgaçāo Científica - DEDIC 


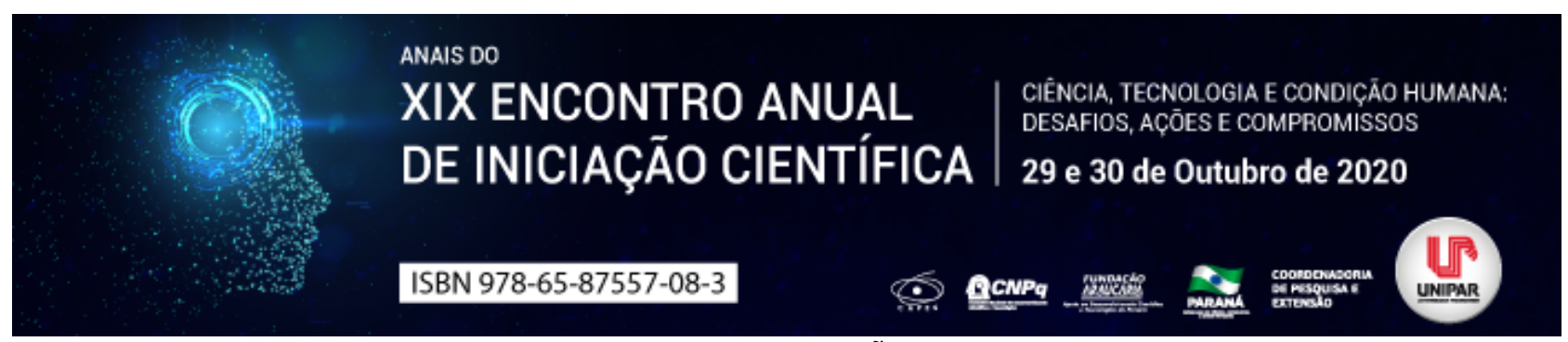

LEVANTAMENTO DOS FATORES DE RISCO E PREVENÇÃO DA DOENÇA DE ALZHEIMER NO BRASIL

\begin{abstract}
${ }^{1}$ GABRIEL HENRIQUE BELLATO PALIN, ${ }^{2}$ LARISSA LOYOLA BARBOSA, ${ }^{3}$ LUCAS ALEXANDRE GUBERT SCHIER, ${ }^{4}$ RAFAEL BEZERRA MARIM, ${ }^{5}$ SUELEN STEFANONI BRANDAO, ${ }^{6}$ ELENIZA DE VICTOR ADAMOWSKI CHIQUETTI
\end{abstract}

${ }^{1}$ Acadêmico do curso de Medicina da UNIPAR
${ }^{1}$ Acadêmica do Curso de Medicina da UNIPAR
${ }^{2}$ Acadêmico do Curso de Medicina da UNIPAR
${ }^{3}$ Acadêmico do Curso de Medicina da UNIPAR
${ }^{4}$ Acadêmica do Curso de Medicina da UNIPAR
${ }^{5}$ Docente do Curso de Medicina da UNIPAR

Introdução: A doença de Alzheimer (DA) é a patologia neurodegenerativa que pode estar associada à idade, cujas manifestações cognitivas e neuropsiquiátricas resultam em deficiência progressiva e incapacitação. Nesse sentido, é importante salientar que o sintoma inicial da doença é caracterizado pela perda progressiva da memória recente (SERENIKI; VITAL; 2008). Desse modo, com a evolução da patologia, outras alterações ocorrem na memória e na cognição, entre elas as deficiências de linguagem e nas funções vísuo-espaciais, haja vista que esses sintomas são frequentemente acompanhados por distúrbios comportamentais, incluindo agressividade, depressão e alucinações.

Objetivo: O objetivo deste trabalho é fazer um levantamento dos principais fatores de risco da doença de Alzheimer, além da prevenção direcionado à patologia no cenário brasileiro.

Desenvolvimento: A perda progressiva da autonomia, assim como a progressiva dependência e a necessidade de cuidados específicos, contribui para o aumento do risco de institucionalização. Por essas razões, o declínio cognitivo e as doenças mentais do idoso têm se tornado um grande problema de saúde pública (ZIDAN et al., 2012). Nesse sentido, no brasil, de acordo com os dados SciELO, a população que apresentavam a idade superior a 65 anos, foram o público pelo qual receberam o maior índice do diagnóstico positivo à doença de Alzheimer, sendo assim, transitando em uma porcentagem de 7,6\% para 7,9\% entre $2010 \mathrm{e}$ 2020, ou seja, 55.000 novos casos por ano. Desse modo, tem se que a idade é um dos principais fatores de risco da enfermidade, porém a predisposição genética além da mesma associada a exposição de agrotóxicos ambientais pode também justificar o desenvolvimento precoce ou tardio da (DA). Algumas discussões apontam que o grau de escolaridade pode ser significativo quando se fala no desenvolvimento do Alzheimer, visto que as pessoas que possuem um baixo nível de alfabetização são mais predispostos à doença, uma vez que há uma menor receptividade de sinapses cerebrais, diminuindo, desse modo, a sua reserva cognitiva cerebral e aumentando a vulnerabilidade à doença. Em contrapartida, de acordo com Lock (2005) o indivíduo que possui maior nível de instrução encontra-se mais disposto para se submeter aos testes de memória propostos pelos profissionais da saúde, podendo desse modo camuflar os primeiros sintomas da Doença de Alzheimer. Além disso a hipertensão e altos níveis plasmáticos de colesterol, à demência e o efeito benéfico das drogas redutoras do colesterol, como as estatinas, podem também ser considerados como fatores de risco. Ao mesmo tempo, é importante ressaltar que há pequenas médias que podem auxiliar na prevenção da doença de Alzheimer, como: atividades que estimulem a cognição, como leitura de jornais e livros, assistir TV, jogar cartas, palavras cruzadas e tocar instrumento musical foram associadas com a redução de risco para DA após 4 anos de seguimento. Além disso, as atividades físicas são essenciais para o ser humano, principalmente aos idosos, pois promove bem-estar, garantindo melhora na qualidade de vida, aumentando a autoestima, as capacidades físicas, motoras e sociais. Segundo Masumoto et. al. (2010), praticar exercícios pode aumentar os níveis de neurotransmissores, estimulando a atividade cognitiva em indivíduos com prejuízo mental. A ação da prática de atividades físicas também pode ser preventiva, pois auxilia no tratamento de danos traumáticos cerebrais, principalmente em doenças neurodegenerativas, como o Alzheimer, estimulando a processo de formação de novos neurônios no cérebro e a plasticidade cerebral.

Conclusão: À luz do exposto, se tem que o mal de Alzheimer pode ser considerada uma doença grave e que em maior ou menor grau, se faz presente em todas as regiões do país, visto que os mais atingidos por essa, são os familiares que por consequência presenciam a evolução gradativa da enfermidade no paciente, sabendo que este, não possui a total consciência da visão atual de sua própria saúde. Sendo assim, faz-se necessário a atuação efetiva do Ministério da Saúde a fim de criar mecanismo estatísticos e efetivos, com o propósito de informar a sociedade sobre as características, tratamentos e prevenção da patologia.

\title{
Referências
}


BRASIL, Ministério da Saúde. Alzheimer: o que é, causas, sintomas, tratamento, diagnóstico e prevenção. Disponível em: http://www.saude.gov.br/saude-de-a-z/alzheimer. Acesso em: 02 fev. 2020.

FERNANDES, Janaína da Silva Gonçalves; ANDRADE, Márcia Siqueira de. Revisão sobre a doença de alzheimer: diagnóstico, evolução e cuidados. Psicologia, Saúde \& Doenças, 2017.

FERREIRA, Dhuani Claro; MAINARDES, S. C. C. Doença de Alzheimer: como identificar, prevenir e tratar. VI Mostra Interna de Trabalhos de Iniciação Científica, 2012.

GUTIERREZ, Beatriz Aparecida Ozello et al. Impacto econômico da doença de Alzheimer no Brasil: é possível melhorar a assistência e reduzir custos?. Ciência \& Saúde Coletiva, 2014.

SERENIKI, Adriana; VITAL, Maria Aparecida Barbato Frazão. A doença de Alzheimer: aspectos fisiopatológicos e farmacológicos. Revista de psiquiatria do Rio Grande do Sul, 2008.

ZIDAN, Melissa et al. Alterações motoras e funcionais em diferentes estágios da doença de Alzheimer. Archives of Clinical Psychiatry (São Paulo), 2012.

Coordenadoria de Pesquisa e Extensão - COPEX

Departamento de Editoraçāo e Divulgaçāo Científica - DEDIC 


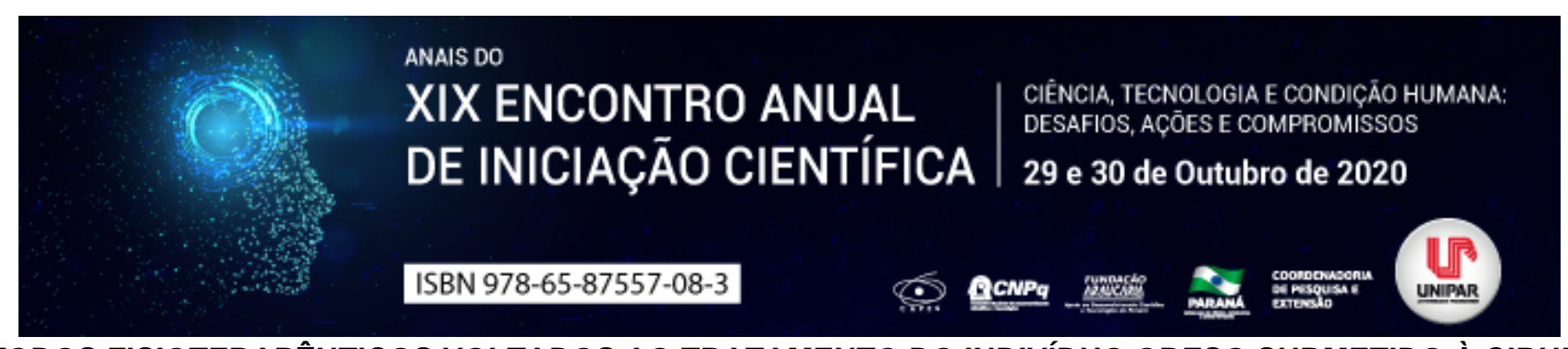

MÉTODOS FISIOTERAPÊUTICOS VOLTADOS AO TRATAMENTO DO INDIVÍDUO OBESO SUBMETIDO À CIRURGIA BARIÁTRICA

\author{
${ }^{1}$ LETICIA FLOIS FERREIRA, ${ }^{2}$ MARIA VICTORIA VECCHIETTI, ${ }^{3}$ DJEICE DIANE HECK, ${ }^{4}$ POLYANA ALCANTARA DOS \\ SANTOS, ${ }^{5}$ DORA DE CASTRO AGULHON SEGURA
}

\author{
${ }^{1}$ Acadêmica do PIC/UNIPAR \\ ${ }^{1}$ Acadêmica do PIC/UNIPAR \\ ${ }^{2}$ Acadêmica do PIC/UNIPAR \\ ${ }^{3}$ Acadêmica do PIC/UNIPAR \\ ${ }^{4}$ Docente da UNIPAR
}

Introdução: A obesidade é definida como um excedente de tecido adiposo corporal, considerada uma condição perigosa de numerosas doenças. É uma adversidade da saúde pública procedente de fatores genéticos e metabólicos, é acentuada devido a exibição a fatos ambientais, socioculturais e econômicos, correlacionados a princípios demográficos e ao sedentarismo (OLIVEIRA; FREITAS; ALMEIDA, 2016). Segundo Mattos e Luz (2009), a adoração do corpo magro converte a gordura em um atributo de fracasso moral e obeso. Muito mais que expor um fardo socialmente inaceitável, revela-se por transportar uma característica moral inconveniente, ou seja, um estigma. A descomunal fração de tecido adiposo no corpo, transfigura-se em uma desonra, um símbolo social e moral inoportuno que inabilita os seres em virtude da inadequação aos padrões de aparência. Em virtude de ser uma enfermidade correlacionada a inúmeros distúrbios e por ser diretamente associada à qualidade de vida, é imprescindível que a preparação do processo cirúrgico para tratamento do problema seja efetuado por uma equipe multidisciplinar, contribuindo para um resultado benéfico e bem sucedido. O fisioterapeuta, membro dessa equipe, atua no período pré e pós-operatório, tanto imediato quanto tardio. O seu objetivo fundamental é diminuir as taxas de complicações cardiopulmonares, musculoesqueléticas e metabólicas, requisitando avaliações e pareceres de todas as fases do tratamento (NASSIF et al., 2011).

Objetivo: Dissertar a cerca da atuação fisioterapêutica nas etapas do tratamento cirúrgico de indivíduos com obesidade.

Desenvolvimento: Segundo Magni et al. (2019), a obesidade acarreta em alterações de caráter respiratório, muito além dos funcionais, exigindo a utilização de um modelo de treinamento respiratório específico realizado pelos candidatos do processo cirúrgico. Dessa forma, a fisioterapia respiratória torna-se eficiente ao contribuir com o aumento da mobilidade do tórax e a força dos músculos acessórios da inspiração e expiração, destacando-se como um método de prevenção das complicações pósoperatórias. No pré-operatório é importantíssima a prática de atividade física, acarretando em vantagens como um menor tempo de operação, uma menor perda de sangue, poucas chances de complicações e uma redução mais considerável do peso corporal. Além do mais, é indicado que a prática de exercícios seja iniciada o mais precoce possível, associada a um acompanhamento e aconselhamento de profissionais capacitados da área (MOTTER et al., 2017). Além disso, a atividade física compõe uma estratégia importante no tratamento e na prevenção do retorno da obesidade, atuando lado a lado com a educação alimentar (ARAUJO et al., 2018). Segundo Taglietti e Bontempo (2017), o paciente que é submetido ao tratamento cirúrgico pode manifestar amplas sequelas físicas e psicológicas. Partindo desse ponto de vista, o enfraquecimento dessas implicações é encarado de forma positiva quando associada à qualidade de vida. Durante o pós-operatório são necessários cuidados que não se referem somente à doença, mas também às questões psicossociais, já que a ansiedade e o medo atuam de forma negativa no processo de recuperação. Sendo assim, é essencial que o atendimento seja de forma mais humanizada, tendo o fisioterapeuta atribuições que proporcionam ao paciente um estado de bem estar psico-funcional, diminuindo o tempo de recuperação e hospitalização.

Conclusão: Diante do exposto, concluiu-se através deste estudo que a fisioterapia é extremamente oportuna para pacientes com obesidade, atuando em todas as etapas do tratamento cirúrgico, contribuindo para uma melhor recuperação e qualidade de vida. Além disso, o apoio do fisioterapeuta ultrapassa as barreiras motoras, atuando no fator psicossocial durante o processo de aquisição do novo corpo.

\title{
Referências
}

ARAUJO, C. A. B.; QUEIROZ, L. F. H.; CAVALCANTE, A. S.; PONTES, R. B. Efeitos dos recursos da fisioterapia dermatofuncional sobre a perda de peso e sobre os marcadores de risco cardiovascular em pacientes obesos. Revista Brasileira de Fisiologia do Exercício, v. 17, n. 3, p. 156-164, 2018.

MAGNI, S. M. P.; BIANCHI, P. D. A.; STURMER, G.; NICOLODI, G. V.; KELLER, K. D. Efeitos de um treinamento fisioterapêutico 
respiratório em indivíduos candidatos à cirurgia bariátrica. Fisioterapia Brasil, v. 20, n. 2, p. 172-178, 2019.

MATTOS, R. S.; LUZ, M. T. Sobrevivendo ao estigma da gordura: Um estudo socioantropológico sobre obesidade. Physis: Revista de Saúde Coletiva, v. 19, n. 2, p. 489-507, 2009.

MOTTER, A. A.; GOMES, R. H. S.; VANHONI, P. S.; DA SILVA, L. A. F.; DOS SANTOS IVANSKI, M. B. Fisioterapia no préoperatório de cirurgia bariátrica: uma revisão integrativa. ASSOBRAFIR Ciência, v. 8, n. 2, p. 65-80, 2017.

NASSIF, D. S. B.; NASSIF, P. A. N.; LUCAS, R. W. C.; RIBAS-FILHO, J. M.; CZECZKO, N. G.; KALIL-FILHO, F. A.; FREITAS, A. C. T. Efeito da fisioterapia contra-resistida com relação à massa corporal magra em pacientes no pós-operatório de cirurgia bariátrica. Arquivos Brasileiros de Cirurgia Digestiva, v. 24, n. 3, p. 218-225, 2011.

OLIVEIRA, J. J. J.; FREITAS, A. C. T.; ALMEIDA, A. A. Efeito da fisioterapia ambulatorial pós-operatória sobre a capacidade funcional e a força muscular respiratória em pacientes submetidos à cirurgia bariátrica. Arquivos Brasileiros de Cirurgia Digestiva, v. 29, supl.1, p. 43-47, 2016.

TAGLIETTI, M.; BONTEMPO, B. G. Humanização da assistência de fisioterapia no pós-operatório de cirurgia bariátrica. Revista Brasileira de Obesidade, Nutrição e Emagrecimento, v. 11, n. 66, p. 479-485, 2017.

Coordenadoria de Pesquisa e Extensão - COPEX

Departamento de Editoraçāo e Divulgaçāo Científica - DEDIC 


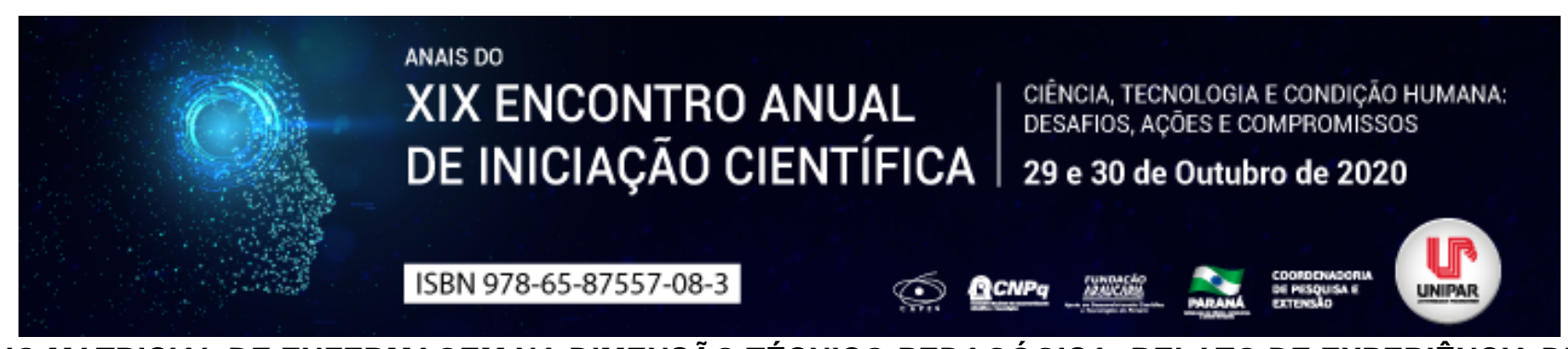

APOIO MATRICIAL DE ENFERMAGEM NA DIMENSÃO TÉCNICO-PEDAGÓGICA: RELATO DE EXPERIÊNCIA DE UM PROJETO DE EXTENSÃO

\begin{abstract}
${ }^{1}$ José Victor Soares da Silva, ${ }^{2}$ ISABELA DE SOUZA SANTANA, ${ }^{3}$ ANDERSON MOREIRA DE MELO, ${ }^{4}$ CRISTIANE CHAVES DE SOUZA
\end{abstract}

${ }^{1}$ Acadêmico do curso de Enfermagem da Universidade Federal de Viçosa

${ }^{1}$ Acadêmica do curso de Enfermagem da Universidade Federal de Viçosa

${ }^{2}$ Acadêmico do curso de Enfermagem da Universidade Federal de Viçosa

${ }^{3}$ Doutora em Enfermagem. Docente do curso de Enfermagem da Universidade Federal de Viçosa

Introdução: A Atenção Secundária é composta por serviços especializados prestados pela equipe interdisciplinar a nível ambulatorial, utilizando recursos tecnológicos de densidades intermediárias (ERDMANN et al., 2013). O enfermeiro é um dos integrantes dessa equipe interdisciplinar, e possui diversas atribuições na Atenção Secundária, com destaque para o serviço de apoio matricial. O apoio matricial em saúde é uma metodologia de trabalho especializada que se divide em duas dimensões: a assistencial, que tem como eixo norteador a Consulta de Enfermagem, e a técnico-pedagógica, que consiste no desenvolvimento da educação permanente junto às equipes, materializando o atendimento de profissionais de saúde, presencialmente ou via web, para orientação e apoio técnico na tomada de decisão acerca de planos de cuidados de áreas específicas da Enfermagem (BALLARIN, BLANES; FERIGATO, 2012). Na dimensão do apoio pedagógico as capacitações dos profissionais sobre o que a Enfermagem identifica, trata e avalia nos pacientes merece destaque, uma vez que visa transpor os muros do conhecimento produzido para sua aplicação no cuidado direto ao paciente. Este trabalho tem por objetivo relatar a experiência vivenciada por estudantes de Enfermagem na capacitação de profissionais de Enfermagem sobre a avaliação e tratamento de lesões cutâneas.

Relato: Trata-se de um relato de experiência, vivenciado por estudantes de Enfermagem de uma universidade pública federal durante as atividades de matriciamento na dimensão técnico-pedagógica. As atividades fazem parte de um projeto de extensão, desenvolvido em uma Unidade de Atendimento Especializado em Saúde. Os públicos alvos são profissionais de Enfermagem e pacientes de uma área adscrita de 11 municípios, totalizando uma população estimada de 120 mil pessoas. A atividade relatada refere-se a uma capacitação realizada com profissionais de Enfermagem, envolvendo a temática de avaliação e tratamento de lesões cutâneas. A atividade teve sua origem a partir do atendimento aos pacientes portadores de lesões cutâneas pela equipe do projeto. Estes eram referenciados pelas Unidades Básicas de Saúde. Durante os atendimentos, e no contra referenciamento dos pacientes, percebia-se uma lacuna no conhecimento dos profissionais, e por vezes, descontinuidade do plano terapêutico prescrito. A partir de então, tronou-se veemente a necessidade de capacitação dos profissionais na temática. A capacitação foi realizada por três graduandos de Enfermagem integrantes do projeto, supervisionados pelo docente coordenador. A capacitação aconteceu no Laboratório de Habilidades do Departamento de Medicina e Enfermagem da universidade, no período de 05 a 12 de novembro de 2019. Ao todo, participaram 16 integrantes de uma equipe de enfermagem da atenção primária integrante do projeto. O curso envolveu os seguintes momentos: 1. Estimulação dos participantes a explanarem suas vivências e experiências práticas e clínicas acerca da avaliação e tratamento das lesões cutâneas; 2. Apresentação teórica sobre a avaliação de feridas; 3. Apresentação teórica sobre a classificação das feridas e o estadiamento de lesões por pressão; 4. Apresentação teórica sobre as coberturas para o tratamento das lesões cutâneas; 5. Apresentação prática das coberturas para o tratamento de lesões cutâneas e seu manuseio; 6. Realização de um cenário simulado com manequim de média fidelidade, apresentando diversas lesões pelo corpo em diferentes estadiamentos para um momento de discussão e debate clínico abordando desde a avaliação da ferida até a prescrição de coberturas para o tratamento das lesões.

Discussão: O matriciamento permite melhorar o trabalho em equipe, fornece mais segurança e preparação para os profissionais resolverem os desafios do cotidiano (REIS, ROTILI, 2016). Neste sentido, a vivência relatada permitiu identificar, a partir dos relatos dos profissionais, fragilidades como o desconhecimento técnico-científico para a avaliação ao tratamento das lesões cutâneas, a falta de confiança e a insegurança de órgãos hierárquicos da saúde nos enfermeiros para disponibilizarem as coberturas de tratamento nas unidades básicas, o que culmina na desmotivação, no desinteresse pela capacitação profissional, na falta de autonomia, reconhecimento profissional dentro da equipe e perda da identidade profissional.

Conclusão: A vivência no apoio matricial é uma importante metodologia de trabalho, sendo suporte para os profissionais da saúde, capaz de produzir um espaço de ensino-aprendizagem compartilhado que estimule a corresponsabilização do aprendizado e do cuidado a ser prestado. A experiência relatada permitiu a atualização dos profissionais envolvidos, instigou-os a valorizarem o se trabalho profissional, bem como contribuiu para que o conhecimento produzido e ensinado na Universidade fizesse, de fato, diferença no cuidado prestado ao paciente. Foi percebido pelos extensionistas que, após o curso de atualização, 
os profissionais de enfermagem conseguiram identificar a importância de se apropriarem do conhecimento científico para consolidar a autonomia e a identidade profissional.

\section{Referências}

BALLARIN, Maria Luisa Gazabim Simões; BLANES, Lara de Sousa; FERIGATO, Sabrina Helena. Apoio matricial: Um estudo sobre a perspectiva de profissionais da saúde mental. Interface: Communicação, Saúde, Educação, v. 16, n. 42, p. 767-78, jul./set. 2012. Disponível em: https://www.scielo.br/scielo.php?pid=S1414-32832012000300014\&script=sci_arttext. Acesso em: 30 ago.2020.

ERDMANN, Alacoque Lorenzini et al. A atenção secundária em saúde: Melhores práticas na rede de serviços. Revista Latino Americana de Enfermagem, v. 21(spec):[08 telas], $\quad$ p. $131-39, \quad$ jan./fev. $2013 . \quad$ Disponível em: https://www.scielo.br/pdf/rlae/v21nspe/pt_17.pdf. Acesso em: 30 ago. 2020.

REIS, Cássia Barbosa; ROTILI, Monique. O apoio matricial como estratégia organizacional do trabalho em saúde na atenção primária. RealizAção - Revista on-line de Extensão e Cultura, v. 3, n. 6, p. $72-93 . \quad 2016 . \quad$ Disponível em: http://ojs.ufgd.edu.br/index.php/realizacao/article/view/6808/3822. Acesso em: 30 ago. 2020. 


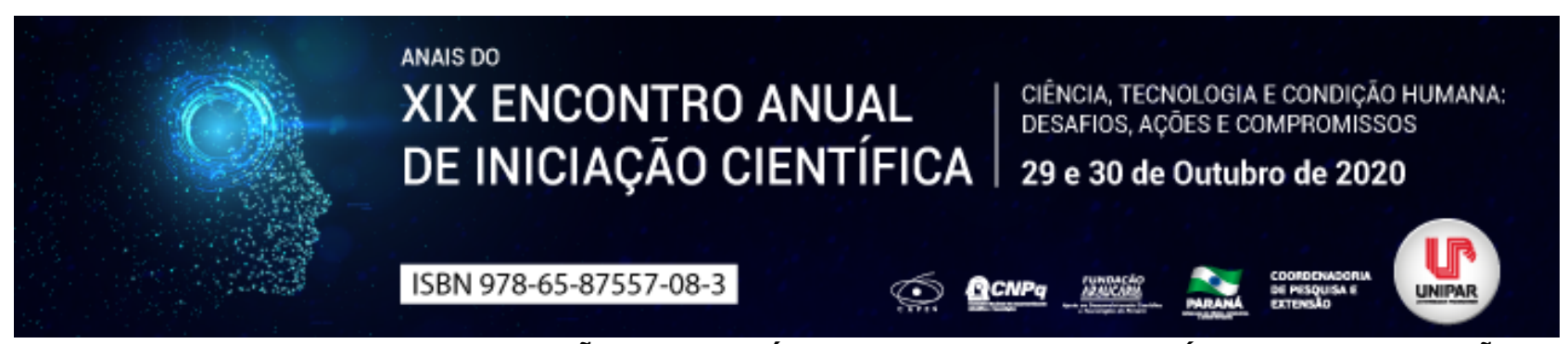

DOENÇAS QUE CAUSAM ALTERAÇÕES HISTOLÓGICAS EM VASOS SANGUÍNEOS: UMA REVISÃO

\begin{abstract}
${ }^{1}$ TAIS DA SILVA SCHMIDT, ${ }^{2}$ BEATRIZ MORETTO DE PAULA, ${ }^{3}$ MARIA EDUARDA PFAU, ${ }^{4}$ ELENIZA DE VICTOR ADAMOWSKI CHIQUETTI
\end{abstract}

${ }^{1}$ Discente do curso de medicina/ UNIPAR

${ }^{1}$ Discente do curso de medicina/ UNIPAR

${ }^{2}$ Discente do curso de medicina/ UNIPAR

${ }^{3}$ Docente do curso de medicina/ UNIPAR

Introdução: A patologia dos vasos sanguíneos está diretamente relacionada com doenças vasculares, as quais incluem: doença arterial obstrutiva periférica, aterosclerose e vasculite. Segundo Ferreira, Barroso e Duarte (2010) a doença arterial obstrutiva periférica relaciona-se intimamente com a aterosclerose, já a vasculite encaixa-se no panorama inflamatório desses vasos (GAUDIO; OCHTROP; BACCHIEGA, 2014). De maneira geral, tais alterações provocam ou são causas de estenoses, oclusões, rompimentos ou formação de trombos nos locais lesados (FERREIRA; BARROSO; DUARTE, 2010; GAUDIO; OCHTROP; BACCHIEGA, 2014).

Objetivo: Através da revisão de literatura compreender de que maneira a doença arterial obstrutiva crônica, a aterosclerose e a vasculite influenciam na histologia dos vasos sanguíneos e quais as suas manifestações provocadas no organismo acometido.

Desenvolvimento: Sabe-se que vasculite, Doença Arterial Obstrutiva Periférica e aterosclerose, são exemplos de distúrbios que podem gerar um grande impacto na qualidade dos pacientes, podendo levar a perda de membros ou até mesmo óbito (SILVA, 2015). De acordo com Ferreira, Barroso e Duarte (2010), a Doença Arterial Obstrutiva Periférica é causada por uma obstrução provocada, na maioria das vezes, por uma placa de ateroma encontrada na aorta e em seus ramos. De maneira generalizada, tal doença está intimamente relacionada com o desenvolvimento de estenoses e oclusões nos ramos aórticos que vão para os membros inferiores, tendo como consequência à manifestação clínica mais frequente a claudicação intermitente. Como dito, a DAOP é consequência de fenômenos ateroscleróticos sistêmicos capazes de provocar um risco elevado de morbidade e mortalidade cardiovascular, dessa forma é visto que a placa de ateroma se manifesta, inicialmente, infiltrando-se abaixo do endotélio por depósitos lipídicos determinando, por sua espessura, a intensidade da secção circular do vaso. Afirma-se que os locais de preferência de tal acúmulo lipídico, em relação aos membros inferiores, são nas ilíacas primitivas e bifurcações ilíacas, femorais e poplíteas, sendo mais comuns na origem ou bifurcações arteriais (FERREIRA; BARROSO; DUARTE, 2010; PICCINATO, 2013). A aterosclerose é uma doença inflamatória crônica com origem multifatorial, propiciada pelo acúmulo de colesterol na parede dos vasos, que obstrui a nutrição dos tecidos, causando danos cardíacos e cerebrais, comum em indivíduos sedentários com alimentação rica em colesterol, pessoas com histórico familiar, obesidade e diabetes mellitus. A fisiopatologia da aterosclerose acontece pelas moléculas de Lipoproteína de baixa densidade (LDL), que portam o colesterol e permeiam a parede dos vasos ativando o sistema imunológico, atraindo os macrófagos para a lesão, os quais fagocitam as lipoproteínas e formam as placas ateroscleróticas, que podem iniciar sua formação durante a infância e possui como principais fatores de risco a dislipidemia, hipertensão arterial, ou tabagismo e quando são instáveis podem romper, causando trombos, infarto agudo do miocárdio ou acidente vascular encefálico (AVE). As estrias gordurosas na aorta, que podem evoluir para as placas ateromatosas, podem começar a se formar durante a infância. As principais formas de prevenção são a mudança de estilo de vida, como a adoção de uma alimentação mais saudável e a prática de exercícios físicos regularmente, principalmente os exercícios aeróbios (SOUSA; RIBEIRO, 2019; OLIVEIRA et al., 2019). As vasculites são doenças sistêmicas resultantes de inflamações na parede dos vasos sanguíneos, podendo gerar rompimento, obstrução ou formação de trombos nos vasos (GONÇALVES, 2019). Dentre as principais consequências das vasculites estão: isquemia, necrose tecidual, trombose e aneurismas. A gravidade das vasculites varia de acordo com o tamanho, local e extensão do vaso (GAUDIO; OCHTROP; BACCHIEGA, 2014). Segundo Gonçalves (2019), na literatura não há pesquisas que definam com clareza a etiopatogenia dessas doenças, de modo que dificulta sua classificação. De início é necessário classificá-la em doença primária, no qual a inflamação vascular é considerada como a principal manifestação, ou secundária, onde tal inflamação é o sinal clínico gerado por outra doença preexistente. A classificação de Chapel Hill, no qual foi aprimorada em 2012, tem como principal meio de determinação das doenças o calibre dos vasos sanguíneos que foram acometidos, ela é categorizada em: vasculites de grandes vasos, vasculites de vasos de médio calibre, vasculites de pequenos vasos, vasculites de calibres variáveis, vasculites de órgão único, vasculites associadas à doença sistêmica e vasculites associadas a etiologias prováveis (GAUDIO; OCHTROP; BACCHIEGA, 2014).

Conclusão: As alterações histológicas nos vasos sanguíneos podem ser desencadeadas por várias doenças, inclusive as que 
foram abordadas. Além disso, tais mudanças influenciam em uma série de reações que alteram a homeostase do organismo gerando sinais e sintomas específicos para cada patologia. Dessa forma é dito que a maioria dessas lesões, geralmente, relacionam-se com formação de trombos, estenoses, oclusões e mudanças no epitélio vascular.

\section{Referências}

FERREIRA, Maria José; BARROSO, Pedro; DUARTE, Nádia. Doença arterial periférica. Revista Portuguesa de Medicina Geral e Familiar. v. 26, n.5, p. 502-509. 2010.

GAUDIO, Rodrigo C.; OCHTROP, Manuella Lima Gomes; BACCHIEGA, Ana Beatriz Santos. Classificação e clínica das vasculites pulmonares. Pulmão RJ. Rio de Janeiro, v. 23, n. 2, p. 9-14. 2014.

GONÇALVES, Mellina Silva. Vasculites: desafio diagnóstico e terapêutico. Arquivos Catarinenses de Medicina. Santa Catarina, v. 48, n. 4, p. 174-190. 2019.

OLIVEIRA, Gabriel Gaigher Pinaud de et al. Estilo de vida como fator de prevenção da aterosclerose. Cadernos da MedicinaUNIFESO. v. 2, n. 2. 2019.

PICCINATO, Carlos Eli. Doença Arterial Obstrutiva Periférica (DAOP). In: PICCINATO, Carlos Eli. Manual prático de angiologia e cirurgia vascular. São Paulo: Atheneu, 2013. p. 47-62.

SILVA, Silvio Alves da. Urgência e emergência em cirurgia vascular. 2015. Dissertação (Mestrado em Ciências da saúde) Universidade Federal do Tocantins. Palmas, 2015.

SOUSA, José Robson; RIBEIRO, Jannison Karlly Cavalcante. A Aterosclerose, suas Causas e a Importância da Adiponectina. Saúde e Desenvolvimento Humano. v. 7, n. 3, p. 49-55. 2019. 


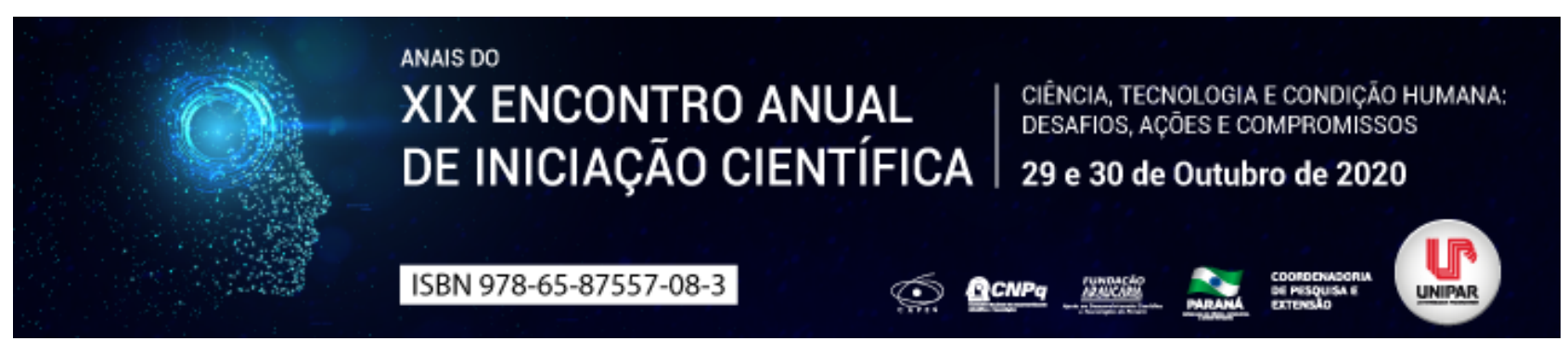

OS RISCOS DA POLIFARMÁCIA EM IDOSOS

\title{
${ }^{1}$ TAIS DA SILVA SCHMIDT, ${ }^{2}$ FERNANDA DE ABREU BRAGA, ${ }^{3}$ FRANCISLAINE APARECIDA DOS REIS LIVERO
}

\author{
${ }^{1}$ Acadêmica do Curso de Medicina da UNIPAR \\ ${ }^{1}$ Discente do curso de Medicina da Universidade Paranaense (UNIPAR) \\ ${ }^{2}$ Docente do Mestrado Profissional em Plantas Medicinais e Fitoterápicos e do PPG em Ciência Animal - UNIPAR
}

Introdução: A melhora na condição de vida que ocorreu a partir do século XX, aumentou a longevidade da população mundial, resultando no aumento das solicitações na área da saúde, o que gerou um maior custo com interações, equipamentos, tratamentos e esquemas terapêuticos complexos e prolongados (SAAD, 2016). A utilização de vários fármacos é realizada devido a fatores como as alterações epidemiológicas, o aumento da expectativa de vida, o processo de envelhecimento acelerado e a maior prevalência de doenças crônicas, é responsável pela elevação do consumo de medicamentos que pode se tornar a polifarmácia, cada vez mais comum na população idosa, sendo um desafio para os sistemas de saúde (CARNEIRO et al., 2018). Objetivo: Compreender como a prática da polifarmácia pode afetar a qualidade de vida da população idosa.

Desenvolvimento: Com o aumento da população com idade superior a 60 anos, ocorre uma mudança no perfil das doenças que acometem esses indivíduos, como as doenças crônicas não transmissíveis, que englobam a hipertensão arterial sistêmica, diabetes mellitus e a associação com outras comorbidades (MOURA; LOPES, 2020). A maior incidência de problemas de saúde entre idosos envolve problemas cardiovasculares como a hipertensão (63,5\%), cardíacos e circulatórios (44,2\%), endócrinos como o diabetes $(22,1 \%)$ e os do sistema nervoso central como a insônia (25,0\%) e depressão (17,3\%), (TOYODA, 2018). Logo, como essa população idosa apresenta comorbidades, por vezes é necessário o uso de vários medicamentos concomitantemente (TIAGO et al., 2020), em especial os que pertencem às classes de cardiovasculares, antidiabéticos, anti-inflamatórios não esteroides e psicofármacos como os antidepressivos e as benzodiazepinas (DA GAMA et al., 2019). A utilização de cinco ou mais medicamentos é definida como polifarmácia ou polimedicação e inclui o uso de medicação para corrigir o efeito adverso de outros fármacos, não sendo inclusos os medicamentos fitoterápicos, vitaminas e sais minerais (TIAGO et al., 2020). Além da associação da morbidades e do elevado número de fármacos prescritos, a falha na gestão da prática clínica, a fragmentação dos cuidados e a falta de envolvimento desses pacientes na decisão terapêutica, aumentam ainda mais o consumo de medicamentos, em que muitas vezes são desnecessários, causando a diminuição da qualidade de vida e o aumento dos custos com a saúde (DA GAMA et al., 2019). De acordo com a Organização Mundial da Saúde, mais de 50\% dos medicamentos são prescritos ou dispensados de uma forma inadequada e $50 \%$ dos pacientes idosos, tomam esses medicamentos de maneira incorreta, acarretando um aumento da ocorrência de morbidade e mortalidade nessa população (SALES; SALES; CASOTTI, 2014). Ademais, essas combinações farmacológicas podem elevar o risco de eventos adversos como quedas, reações adversas medicamentosas, déficits cognitivos e funcionais, (DA GAMA et al., 2019), iatrogenias, diminuição na adesão ao tratamento, toxicidade cumulativa, hospitalizações, óbito (MARQUES et al., 2019). Parte disso, se deve ao fato das variações fisiológicas relativas ao envelhecimento (PEREIRA et al., 2017), como a homeostase, o metabolismo, a perda de peso, a diminuição da massa magra, o aumento da massa gorda e a perda da capacidade funcional, propiciando uma mudança no perfil farmacocinético e farmacodinâmico dos medicamentos, acarretando o aumento da possibilidade de reações adversas e interações medicamentosas (TIAGO et al., 2020), pois o risco da ocorrência de reações adversas a medicamentos aumenta 13\% com a utilização de dois fármacos, $58 \%$ quando se utiliza cinco fármacos e $82 \%$ quando são utilizados sete ou mais fármacos (TOYODA, 2018). Para diminuir a polifarmácia inapropriada, foram criadas estratégias como a prescrição no meio hospitalar, eficaz na diminuição das prescrições e na utilização de medicações inadequadas; as Personal Drugs, que busca a redução da probabilidade de erro, devido a prescrição por fármacos utilizados com frequência pelo médico, os quais precisam ser eficazes, seguros, convenientes e possuir um custo acessível; a Medicines Appropriateness Index (MAl), que visa a identificação das medicações potencialmente inapropriadas de maneira individualizada para cada paciente. Por fim, foram criados dois critérios, que padronizam a prescrição: os Critérios de Beers, que englobam os fármacos inapropriados para prescrição nessa faixa etária, ao analisar a ineficácia e efeitos nocivos dos fármacos e os Critérios de STOP/START, que são compostos por medicações potencialmente inapropriadas e subutilizadas, auxiliando a prescrição e desprescrição de forma adequada (DA GAMA et al., 2019).

Conclusão: A polifarmácia é uma prática que deve ser utilizada com precauções, devido a riscos de interações medicamentosas e a sua aplicação inapropriada, que pode ser evitada pela utilização das estratégias criadas, como a prescrição hospitalar e os Critérios de Beer e STOPISTART.

\section{Referências}


CARNEIRO, Jair Almeida et al. Prevalência e fatores associados à polifarmácia em idosos comunitários. Medicina (Ribeirão Preto), v. 51, n. 4, p. 254-264, 2018.

GAMA, Maria Francisca Raposo da Oliveira et al. Polifarmácia no idoso-Consequências, desafios e estratégias de abordagem. Dissertação (Mestrado Integrado em Medicina) Universidade do Porto, Portugal, 2019

MARQUES, Priscila de Paula et al. Polifarmácia em idosos comunitários: resultados do estudo Fibra. Revista Brasileira de Geriatria e Gerontologia, v. 22, n. 5, 2019.

MOURA, Beatriz Vieira; LOPES, Guiomar Silva. Polifarmácia e os Problemas Relacionados aos Medicamentos no tratamento da hipertensão arterial de idosos acompanhados no ambulatório de Geriatria e Gerontologia da Unifesp. Almanaque Multidisciplinar de Pesquisa, v. 1, n. 1, 2020.

PEREIRA, Karine Gonçalves et al. Polifarmácia em idosos: um estudo de base populacional. Revista Brasileira de Epidemiologia, v. 20, p. 335-344, 2017.

SAAD, Paulo M. Envelhecimento populacional: demandas e possibilidades na área de saúde. Séries Demográficas, v. 3, p. 153166, 2016.

SALES, Alessandra Santos; SALES, Marta Gabriele Santos; CASOTTI, Cezar Augusto. Perfil farmacoterapêutico e fatores associados à polifarmácia entre idosos de Aiquara, Bahia, em 2014. Epidemiologia e Serviços de Saúde, v. 26, p. 121-132, 2017.

TIAGO, Daniela Cristina et al. A ocorrência de polifarmácia em idosos em hospital dia geriátrico. Revista Científica da Faculdade de Medicina de Campos, v. 15, n. 1, p. 18-24, 2020.

TOYODA, Márcio Jun. Polifarmácia em idosos: revisão dos últimos 10 anos. Tese (Doutorado em farmácia-Bioquímica) Universidade de São Paulo, 2018. 


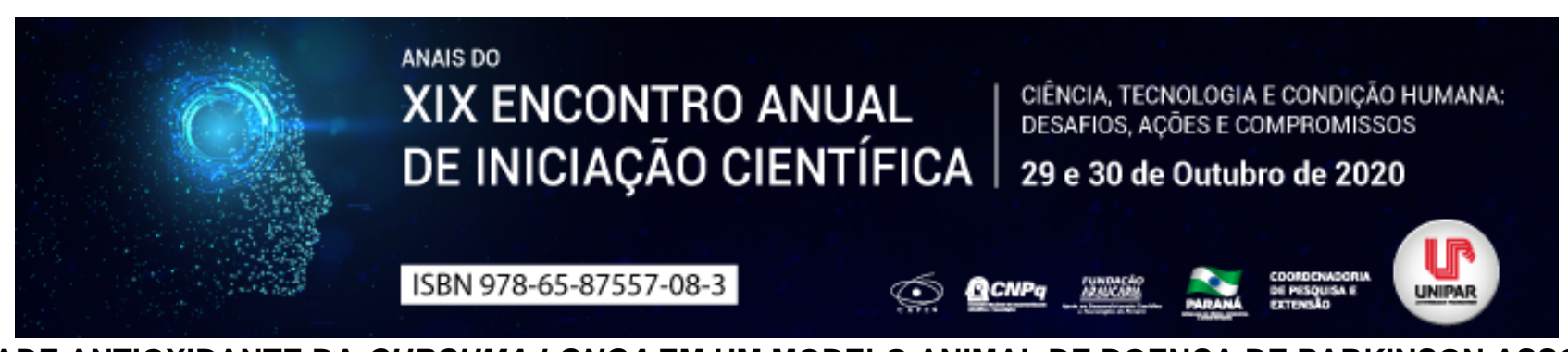

\title{
ATIVIDADE ANTIOXIDANTE DA CURCUMA LONGA EM UM MODELO ANIMAL DE DOENÇA DE PARKINSON ASSOCIADO À PERIODONTITE INDUZIDA
}

\author{
${ }^{1}$ CAROLINA SILVA TOPA, ${ }^{2}$ BEATRIZ AYUMI SHIOTANI, ${ }^{3}$ NAIANY OLIVOTTO MARTINS, ${ }^{4}$ LEONARDO DE SOUZA ARAUJO, \\ ${ }^{5}$ CINTIA DE SOUZA ALFERES ARAUJO , ${ }^{6}$ EVELLYN CLAUDIA WIETZIKOSKI LOVATO
}

\begin{abstract}
${ }^{1}$ Discente do curso de Odontologia - UNIPAR/Participante do Programa de Iniciação Científica - UNIPAR
${ }^{1}$ Discente do curso de Odontologia - UNIPAR/Participante do Programa de Iniciação Científica - UNIPAR

${ }^{2}$ Discente do curso de Medicina - UNIPAR/Participante do Programa de Iniciação Científica - UNIPAR

${ }^{3}$ Discente do curso de Odontologia - UNIPAR/Participante do Programa de Iniciação Científica - UNIPAR

${ }^{4}$ Docente do curso de Odontologia - UNIPAR

${ }^{5}$ Docente do curso de Medicina, Semipresencial - UNIPAR
\end{abstract}

Introdução: Evidências indicam que os antioxidantes contidos nas plantas podem tratar ou prevenir o desenvolvimento de várias doenças crônicas não transmissíveis, particularmente em condições neurológicas, bucais, cardiovasculares, entre outras. Alguns desses efeitos biológicos são atribuíveis aos metabólitos secundários das plantas, especialmente flavonóides e compostos fenólicos, que exercem efeitos antioxidantes in vitro e in vivo (MORETES; GERON, 2019). Na doença de Parkinson (DP) e na periodontite são descritas similaridades de respostas biológica imunoinflamatórias com produção de radicais livres que permitem hipotetizar uma interação entre ambas as patologias (CHEN et al., 2017), sendo de interesse clínico desenvolvimento de compostos com atividade antioxidante que possam ser empregados na terapêutica. Uma espécie com grande potencial antioxidante é a Curcuma longa ou seu principal componente, a curcumina.

Objetivo: Avaliar a atividade antioxidante do extrato hidroetanólico obtido do rizoma de $C$. Longa em modelo animal de DP induzido por 6-hidroxidopamina (6-OHDA) associado a periodontite experimental por ligadura.

Material e Métodos: Foram utilizados ratos Wistar machos, com 4 meses, pesando entre 280 e 315 gramas, divididos nos grupos: Sham e 6-hidroxidopamina (6-OHDA). O procedimento foi aprovado pelo Comitê de Ética de Pesquisa Envolvendo Uso de Animais da UNIPAR (protocolo 31166/2017). Para indução da DP, os ratos foram submetidos à cirurgia estereotáxica para infusão de 6-OHDA ou líquor cefalorraquidiano (grupo Sham), no feixe prosencefálico medial (DA CUNHA et al., 2008). Após 7 dias foi induzida a periodontite por ligadura de fio algodão no $1^{\circ}$ molar inferior esquerdo. Imediatamente após, iniciou o tratamento com veículo (água) ou extrato de $C$. longa nas concentrações de 5,50 e $500 \mathrm{mg} / \mathrm{kg}$ por 21 dias. Após o término, foi coletado o plasma para avaliação da atividade antioxidante total do tratamento com $C$. Longa pelo teste da capacidade de quelação de íons ferrosos (FRAP, BENZIE; STRAIN, 1996). As análises estatísticas foram feitas com o Software Statistica por ANOVA de uma via, seguido pelo pós teste de Tukey. Os dados foram expressos como média \pm desvio padrão da média e valores de $p \leq 0,05$ foram considerados significantes. As análises foram realizadas em quadriplicata.

Resultados: A determinação da capacidade de quelação de íons ferrosos pelo teste FRAP demonstrou diferença significativa entre os grupos de tratamento $(F 7,24=41,55, p<0,001)$. O grupo 6-OHDA (com DP e periodontite induzida) tratado com veículo apresentou menor capacidade de reduzir o íon ferro no organismo comparado ao grupo SHAM (somente com periodontite e tratado com veículo, $\mathrm{p}<0,001$ ), sugerindo que a DP associada a periodontite experimental pode aumentar a expressão de espécies reativas de oxigênio, saturando o sistema e agravando o quadro clínico. De forma interessante, observou-se que o tratamento dos animais 6 -OHDA com $5 \mathrm{mg} / \mathrm{Kg}$ do extrato hidroetanólico de $C$. Longa produziu maior capacidade antioxidante em comparação com os demais tratamentos $(p<0,05)$. O mesmo resultado não foi observado nos animais 6-OHDA tratados com 50 ou $500 \mathrm{mg} / \mathrm{Kg}(p>0,05)$. Em relação ao grupo SHAM que possui somente periodontite experimental não foram observadas diferenças significativas entre os tratamentos $(p>0,05)$.

Discussão: Na DP, o estresse oxidativo é decorrente principalmente da deficiência mitocondrial e do processo inflamatório crônico resultando na produção de espécies reativas de oxigênio (EROs), como o ferro que quando acumulado no cérebro ocasiona morte de neurônios dopaminérgicos na substância negra (PERFEITO et al., 2012). Na periodontite, o estresse oxidativo é responsável pelo dano tecidual periodontal favorecendo as interações microbianas decorrente do excesso de EROs ou da deficiência do status antioxidante (CHAPPLE et al., 2007). Considerando que o estresse oxidativo é a via similar de interação entre as duas patologias, é possível mensurar biomarcadores da capacidade antioxidante não enzimática em fluidos corporais de ratos objetivando a avaliação do status do estresse oxidativo e antioxidante. O FRAP é uma forma de detecção do estado oxidativo que mede principalmente a capacidade antioxidante total não proteica. $O$ ensaio FRAP também estima outros antioxidantes não enzimáticos como vitaminas C, E e bilirrubina, mas não pode detectar antioxidantes contendo proteínas e glutationa reduzida (GYURÁSZOVÁ et al., 2018). Pode ser utilizado para compreender a homeostase do ferro e sua relação com 
o estresse oxidativo relacionado a DP (MEDEIROS et al., 2016), assim como pode ser usado como um biomarcador local e sistêmico do estresse oxidativo na doença periodontal (BECERIK et al, 2017). Os resultados desta pesquisa demonstram diminuição da capacidade antioxidante nos animais com DP e periodontite sugerindo aumento do estresse oxidativo no plasma na associação das duas patologias. O tratamento subcrônico com $C$. Longa foi capaz de promover atividade antioxidante na dose de 5 mas não com 50 ou $500 \mathrm{mg} / \mathrm{Kg}$. Tal efeito pode estar relacionado com os metabólitos secundários produzidos pela planta e como eles interagem com os sistemas biológicos, porém outros estudos são necessários para entender estes mecanismos. Ainda, foi observado que o tratamento não reverte o estresse oxidativo ocasionado pela patologia periodontal sugerindo que o efeito da C. Longa pode estar relacionado a homeostasia do íon ferro, prevalente na DP.

Conclusão: A manifestação concomitante de DP e periodontite aumenta estresse oxidativo e pode ser revertido pelo tratamento subcrônico com C. Longa (5 mg/Kg). São necessários estudos complementares para entender os mecanismos envolvidos neste processo.

\section{Referências}

BECERIK, Sema. et al. Gingival crevicular fluid and plasma oxidative stress markers and TGM-2 levels in chronic periodontitis. Archives of Oral Biology, v. 83, p. 47-54, 2017.

BENZIE, Iris FF; STRAIN, John J. The ferric reducing ability of plasma (FRAP) as a measure of antioxidant power : the FRAP assay. Analytical biochemistry, v. 239, n. 1, p. 70-76, 1996.

CHAPPLE, I. L. C. et al. Compromised GCF total antioxidant capacity in periodontitis: cause or effect?. Journal of Clinical Periodontology, v. 34, n. 2, p. 103-110, 2007.

CHEN, Chang-Kai; WU, Yung-Tsan; CHANG, Yu-Chao. Association between chronic periodontitis and the risk of Alzheimer's disease: a retrospective, population-based, matched-cohort study. Alzheimer's Research \& Therapy, v. 9, n. 1, p. $56,2017$.

DA CUNHA, Claudio. et al. Hemiparkinsonian rats rotate toward the side with the weaker dopaminergic neurotransmission. Behavioural brain research, v. 189, n. 2, p. 364-372, 2008.

GYURÁSZOVÁ, Marianna. et al. Markers of oxidative stress and antioxidant status in the plasma, urine and saliva of healthy mice. Physiological Research, v. 67, n. 6, p. 921, 2018.

MEDEIROS, Marcio S. et al. Iron and oxidative stress in Parkinson's disease: an observational study of injury biomarkers. PLoS One, v. 11, n. 1, p. e0146129, 2016.

PERFEITO, Rita; CUNHA-OLIVEIRA, Teresa; REGO, Ana Cristina. Revisiting oxidative stress and mitochondrial dysfunction in the pathogenesis of Parkinson disease resemblance to the effect of amphetamine drugs of abuse. Free Radical Biology and Medicine, v. 53, n. 9, p. 1791-1806, 2012. 


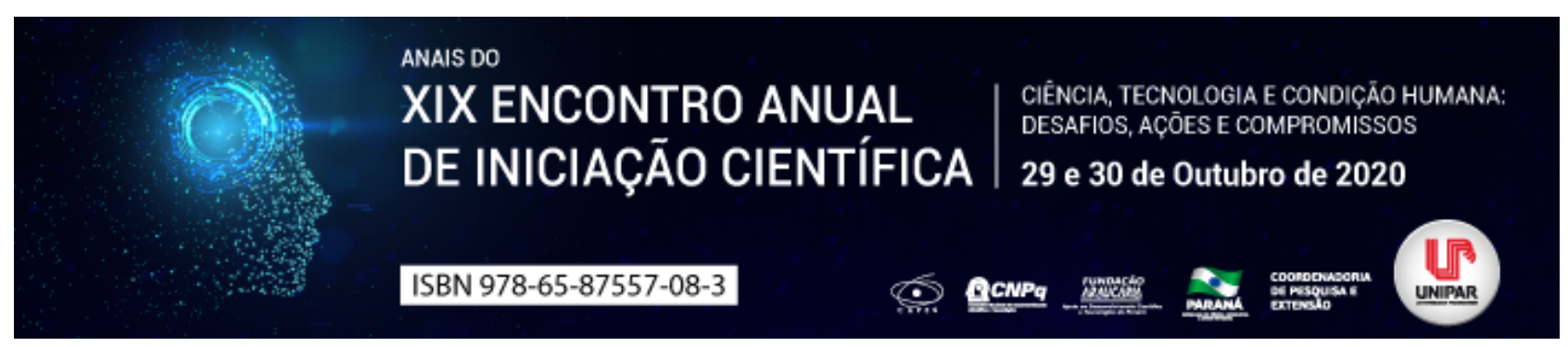

ATIVIDADE DO EXTRATO DE Origanum vulgare SOBRE COLIFORMES TERMOTOLERANTES ISOLADOS DE QUEIJO FRESCAL

\author{
${ }^{1}$ GEISIELE GOMES DA SILVA, ${ }^{2}$ NATHALIA GOMES EKO LEGNANI, ${ }^{3}$ ISABELA CARVALHO DOS SANTOS, ${ }^{4}$ MARCO \\ AURELIO CUNHA DEL VECHIO, ${ }^{5}$ MAYARA RODRIGUES DE OLIVEIRA, ${ }^{6}$ LIDIANE NUNES BARBOSA
}

\author{
${ }^{1}$ Discente de Nutrição, PIC, UNIPAR \\ ${ }^{1}$ Discente de Nutrição, PIC, UNIPAR \\ ${ }^{2}$ Doutoranda PPG em Ciência Animal com Ênfase em Produtos Bioativos/ Bolsista - Prosup/CAPES \\ ${ }^{3}$ Mestrando PPG em Ciência Animal com Ênfase em Produtos Bioativos/ Taxista - Prosup/CAPES \\ ${ }^{4}$ Nutricionista autônoma \\ ${ }^{5}$ Docente da UNIPAR
}

Introdução: O queijo tipo frescal é um produto lácteo típico do Brasil. É fabricado e comercializado fresco, sem maturação e por apresentar uma alta umidade (46 a 55\%), propicia condições favoráveis para o desenvolvimento de microrganismos patogênicos (DE CAMPOS et al., 2018). As legislações brasileiras definem padrões diferentes para os microrganismos indicadores, como coliformes totais e termotolerantes, a fim de verificar condições de higiene ao longo da produção ou pós processamento (MORAES et al., 2009). Origanum vulgare, conhecido como orégano, é uma planta muito utilizada como condimento em diferentes tipos de alimentos e seu sabor é de grande aceitação pelos consumidores em todo o mundo. Além disso, o orégano também é reconhecido por suas propriedades antioxidantes e antimicrobianas (YANISHLIEVA; MARINOVA; POKORNY, 2006).

Objetivo: O objetivo deste trabalho foi avaliar a atividade antibacteriana sobre coliformes termotolerantes isolados de queijo fresco adicionado de diferentes concentrações do extrato de O. vulgare.

Material e métodos: Para o preparo do extrato de O. vulgare, a planta foi cultivada no horto medicinal da Universidade Paranaense. Após obtenção do extrato alcoólico a $70^{\circ}$, o extrato foi liofilizado e conservado em freezer. 0 preparo do queijo frescal foi realizado em laticínio local de pequeno porte. Foram fabricados quatro tipos de amostras de queijo frescal sendo: queijo controle (sem adição de extrato), T1 (0,5 g de extrato de orégano/Kg), T2 (1g de extrato de orégano/Kg) e T3 (3g de extrato de orégano $\mathrm{Kg}$ ). Foram produzidas oito unidades de cada tipo de amostra e estas foram mantidas a temperatura de $4^{\circ} \mathrm{C}$. As análises microbiológicas foram realizadas nos dias 1 ( $1^{\circ}$ dia após a fabricação), 5 e 8 dia. Foram pesadas 25 gramas de amostra e homogeneizados em $225 \mathrm{~mL}$ de água tamponada estéril por dois minutos, e a partir desta diluição inicial $10^{-1}$, foi preparada uma série de diluições decimais. As análises foram realizadas em duplicatas. Para os coliformes termotolerantes foi realizada a técnica do Número Mais Provável (NMP) (FDA, 1992).

Resultados: Foi observado em T1 (0,5 g de extrato de orégano/Kg), uma redução de $46 \%$ de NMP/g de coliformes termotolerantes apenas no dia 1 , o T2 $(1 \mathrm{~g}$ de extrato de orégano/ $\mathrm{Kg})$, apresentou uma redução de $95 \%$ apenas no dia 8 , enquanto no T3 ( $3 \mathrm{~g}$ de extrato de orégano/ $\mathrm{Kg}$ ) nos dias 1 e 5 houve uma redução de $78 \%$ e no dia 8 obteve-se uma redução de $95 \%$, mostrando a atividade antibacteriana do orégano na maior concentração testada $(p<0,05)$ independentemente da quantidade de dias de armazenamento. Para todas as análises a quantidade de coliformes estava dentro dos limites aceitáveis conforme determina a ANVISA (BRASIL, 2001).

Discussão: A presença de altos níveis de coliformes no leite recém ordenhado para a fabricação de queijos podem trazer efeitos deletérios a sua produção, principalmente no desenvolvimento ácido pelas bactérias do ácido lático, além de defeitos nos queijos como o sopro e perdas na produção (FARKYE, 2000; LEDENBACH; MARSHALL, 2009). De acordo com Tayel et al. (2015), observaram o efeito do extrato de orégano, em meio de queijo diluído, contra a Escherichia coli O157:H7. O estudo mostrou a ação antibacteriana do extrato de orégano contra o patógeno, onde a concentração inibitória mínima foi de $975 \mu \mathrm{g} / \mathrm{mL}$ de extrato de orégano. Um estudo realizado por Cattelan (2012), demonstrou a redução da contagem de Escherichia coli em queijo minas frescal utilizando o óleo essencial de orégano em concentrações de $2 \%$ e 5\%, sendo que a maior concentração aplicada (5\%), permitiu a redução de cinco ciclos logaritmos durante o tempo de armazenamento. Outro estudo descrito por Govaris et al. (2011), relataram a diminuição na sobrevivência das cepas de Escherichia coli 0157:H7 no queijo feta com óleo essencial de orégano, onde na dose de $0,1 \mathrm{ml} / 100 \mathrm{~g}$, as cepas sobreviveram até 22 ou 18 dias de armazenamento, respectivamente, enquanto na dose de $0,2 \mathrm{ml} / 100 \mathrm{~g}$ até 16 ou 14 dias, respectivamente. Em geral, a literatura é escassa com relação a ação dos extratos sendo enfatizada a ação de óleos essenciais do orégano. Desta forma, os resultados acima corroboram com o presente estudo, que evidenciou a atividade antibacteriana do extrato de orégano com ênfase no T3, que teve melhor resultado na diminuição dos coliformes termotolerantes por ser o queijo com maior concentração de extrato testada. 
Conclusão: $O$ presente estudo teve resultados positivos sobre a atividade antibacteriana do extrato de orégano adicionado ao queijo frescal, dependendo apenas da concentração utilizada, quanto mais extrato melhor sua eficácia na redução dos coliformes termotolerantes, podendo assim, ser uma alternativa para conservação deste produto.

\section{Referências}

BRASIL. Agência Nacional de Vigilância Sanitária - Anvisa. Regulamento Técnico sobre Padrões Microbiológicos para Alimentos. Resolução-RDC no12, de 02 de janeiro de 2001, Diário Oficial [da] União, Brasília, no 7, 10 jan. 2001. Seção 1, p. 45-53.

CATTELAN, M. G. Atividade antibacteriana de óleos essenciais de especiarias em alimentos. 2012. $58 \mathrm{f}$. Dissertação (mestrado) - Universidade Estadual Paulista, Instituto de Biociências, Letras e Ciências Exatas, 2012.

DE CAMPOS, A. C. L. P. et al. Virulence Genes and Antimicrobial Resistance in Escherichia coli from Cheese Made from Unpasteurized Milk in Brazil. Foodborne Pathogens and Disease, Londrina, v. 15, n. 2, p. 94-100, 2018.

FDA. Bacteriological Analytical Manual for Foods. Food and Drug Administration, 7th ed. Arlington: AOAC International, 1992.

FARKYE, N. Y. Microbiology of cheese making and maturation. Encyclopedia of Food Microbiology, v. 1, p. 381-387, 2000.

GOVARIS, A. et al. Antibacterial activity of oregano and thyme essential oils against Listeria monocytogenes and Escherichia coli O157:H7 in feta cheese packaged under modified atmosphere. LWT - Food Science and Technology, v. 44, n. 4, p. 1240 1244, 2011.

LEDENBACH, L. H.; MARSHALL, R. T. Microbiological spoilage of dairy products. In: Compendium of the microbiological spoilage of foods and beverages. Springer, New York, p. 41-67, 2009.

MORAES, P. M. et al. Foodborne Pathogens and Microbiological Characteristics of Raw Milk Soft Cheese Produced and on Retail Sale in Brazil. Foodborne Pathogens and Disease, Viçosa, n. 6, v. 2, p. 245 249, 2009.

TAYEL, A. A. et al. Foodborne pathogens prevention and sensory attributes enhancement in processed cheese via flavoring with plant extracts. Journal of Food Science, Boston, v. 80, n. 12, p. M2886-M2891, 2015.

YANISHLIEVA, N. V., MARINOVA, E., POKORNY, J. Natural antioxidants from herbs and spices. European Journal of Lipid Science and Technology, v.108, n. 9, p. 776-793, 2006. 


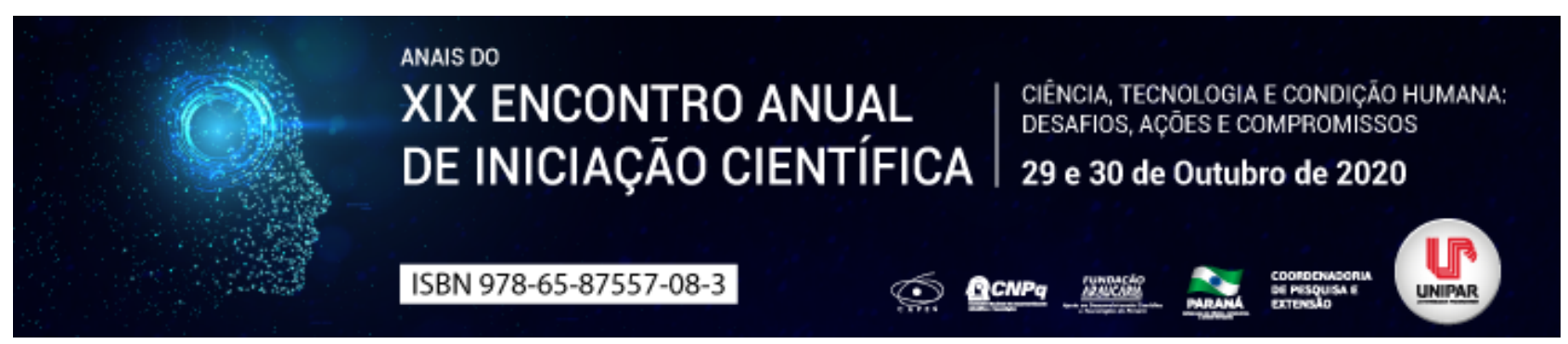

NARCOLEPSIA: DA FISIOPATOLOGIA AOS DESAFIOS DO TRATAMENTO

\title{
${ }^{1}$ GIOVANA TOLOTTI, ${ }^{2}$ KARINA DETOFOL, ${ }^{3}$ FRANCISLAINE APARECIDA DOS REIS LIVERO
}

\author{
${ }^{1}$ Discente Medicina UNIPAR \\ ${ }^{1}$ Discente Medicina UNIPAR \\ ${ }^{2}$ Docente Medicina UNIPAR
}

Introdução: A narcolepsia compreende uma condição neurológica crônica em que o principal sintoma caracteriza-se pela sonolência diurna excessiva associada a manifestações dissociativas do sono REM (do inglês: Movimento Rápido dos Olhos ), como cataplexia, paralisia do sono e alucinações hipnagógicas e hipnopômpicas (GONÇALVES, 2019). Conforme dados da Classificação Internacional dos Distúrbios do Sono (2014), esse distúrbio é dividido em dois grupos. A narcolepsia tipo 1 é caracterizada por níveis baixos de hipocretina-1 (neurotransmissor responsável por regular o ciclo sono-vigília) no líquido cefalorraquidiano, devido à perda de neurônios hipotalâmicos responsáveis pela sua produção; já na narcolepsia tipo 2, a cataplexia está ausente e os níveis de hipocretina-1 no líquor não se apresentam deficientes. Nesse contexto, de acordo com Rovere (2007), o paciente com narcolepsia possui dificuldade em manter a atenção e vigilância nas tarefas rotineiras, estando sujeito a acidentes, de modo a acarretar prejuízo social e impactar as relações de trabalho e sociofamiliares na percepção da qualidade de vida.

Objetivos: Divulgar a existência desse transtorno pouco conhecido e demonstrar os impactos psicossociais na vida dos portadores.

Desenvolvimento: A narcolepsia é uma patologia de natureza neurodegenerativa crônica, com início entre a primeira e segunda décadas de vida do indivíduo. Há envolvimento de fatores ambientais, os quais agem em uma plataforma genética autoimune específica com perda neuronal. Os sintomas essenciais consistem na cataplexia e sonolência excessiva (ALÓE et al., 2010). A cataplexia é definida como episódios súbitos, recorrentes e reversíveis de fraqueza da musculatura esquelética, desencadeados por situações de conteúdo emocional. Enquanto que, os sintomas acessórios são alucinações hipnagógicas e hipnopômpicas (de ocorrência ao adormecer e durante o despertar, respectivamente), paralisia do sono e sono fragmentado. Com efeito, a narcolepsia impõe aos portadores limites e restrições que exigem dos pacientes uma reorganização do cotidiano, de forma a comprometer a esfera psicossocial e trazer prejuízo a diversas áreas (RANGEL, 2019). Alterações no padrão normal do sono produzem consequências de ordens fisiológicas, emocionais e sociais, podendo desagregar as pessoas dos padrões culturais pré-estabelecidos (ROVERE, 2007). Nesse sentido, a sonolência diurna excessiva, marca registrada da narcolepsia, predispõe os pacientes a graves reduções de desempenho em múltiplas áreas de função. Existem inúmeros estudos os quais demonstram que existe uma maior prevalência de problemas psiquiátricos e neurocomportamentais em adultos (DIMITROVA, 2011). Para Shelton (2017), os sintomas de narcolepsia costumam ser mais graves em crianças do que em adultos. Em consequência do desafio diagnóstico e do baixo conhecimento da doença mesmo entre médicos, a narcolepsia na população pediátrica costuma ser confundida com epilepsia, déficit de atenção, depressão, psicose e outras complicações. Vale mencionar que esses distúrbios podem coexistir com a narcolepsia. Além disso, consoante a Dorris et al (2008), crianças com narcolepsia apresentam taxas mais altas de problemas comportamentais e educacionais. Ainda, segundo Inocente (2014), essas expressam sintomas depressivos juntamente com comportamento ansioso. Por conseguinte, concomitante à sintomatologia da doença, tem-se diminuição da concentração e do funcionamento executivo, de forma que crianças com narcolepsia apresentam sintomas de Transtorno do Déficit de Atenção com Hiperatividade (TDAH) clinicamente significativos. Para a realização do diagnóstico da narcolepsia recomenda-se a realização de polissonografia seguida do teste de latência múltipla do sono em um laboratório de sono para confirmação e diagnóstico de comorbidades. Quando não houver cataplexia, deve haver duas ou mais sonecas com sono REM no teste de latência múltipla do sono (ALÓE et al., 2010). Em relação ao tratamento para a narcolepsia, uma vez que não existe cura, esse é empregado com o fim de minimizar os sintomas apresentados. Assim, utilizam-se estimulantes do sistema nervoso central e antidepressivos, os quais evitam os ataques de cataplexia. Ademais, adotam-se medidas de higiene do sono, em que são respeitados os horários de descanso e aumentam-se as medidas comportamentais que promovem a vigília, por meio de exercício físico, exposição à luz solar e interação social (PERES, 2019). Logo, conhecer os aspectos gerais que norteiam a narcolepsia é de fundamental importância para assegurar menores impactos no cotidiano dos portadores da doença.

Conclusão: Percebe-se que a narcolepsia corresponde a uma doença potencialmente incapacitante. A patologia condiciona um decréscimo significativo na qualidade de vida, de maneira a acarretar problemas a nível de relações interpessoais e sociais, dificuldades de concentração e desempenho laboral, acadêmico e social, estando ainda associado a um risco aumentado para acidentes de trabalho. Enfim, o indivíduo pode sofrer uma grave disfunção psicossocial e física, de modo a ser indispensável a aderência ao tratamento, para que os portadores da narcolepsia possam desfrutar de uma maior comodidade. 


\section{Referências}

ALÓE, Flávio. et al. Diretrizes brasileiras para o diagnóstico da narcolepsia. Revista brasileira de psiquiatria, v. 32, n. 3, 294305, jun./set. 2010.

DALGALARRONDO, Paulo. Psicopatologia e semiologia dos transtornos mentais. 2. ed. Porto Alegre: Artmed, 2008.

DIMITROVA, Alexandra. et al. Comportamento de busca de recompensa na narcolepsia humana. Journal of Clinical Sleep Medicine, v. 7, jun. 2011. Disponível em: https://jcsm.aasm.org/doi/full/10.5664/JCSM.1076. Acesso em: 16 ago. 2020.

DORRIS, Liam. et al. Psychosocial and intellectual functioning in childhood narcolepsy. Developmental neurorehabilitation, $v$. 11, n. 3, p. 187-194, 2008.

GONÇALVES, Paulo Sérgio Pereira. The role of autoimmunity in narcolepsy. 2019. 22f. Dissertação (Mestrado em Ciências Médicas) Universidade da Beira Interior, Covilhã, 2019.

INOCENTE, Clara Odilia. et al. Depressive feelings in children with narcolepsy. Sleep medicine, v. 15, n. 3, p. 309-314, mar. 2014.

PERES, A. C. Narcolepsia: O relato de uma paciente que convive com um distúrbio do sono ainda pouco conhecido e muito desafiador. Radis, n. 198, mar. 2019. Disponível em: https://www.arca.fiocruz.br/bitstream/icict/32013/2/2019_Março_198.pdf. Acesso em: 16 ago. 2020.

RANGEL, Deborah Moreira. Alterações do sono em pacientes com doença de Niemann-pick tipo C. 2019. 158 f. Dissertação (Mestrado em Ciências Médicas) - Universidade Federal do Ceará, Fortaleza, 2019.

ROVERE, Heloisa Helena Dal. Narcolepsia: avaliação da qualidade de vida e impacto social. 2007. 101f. Dissertação (Mestrado em Ciências Médicas) Universidade de São Paulo, São Paulo, 2007.

SATEIA, Michael. International classification of sleep disorders. Chest, v. 146, n. 5, p. 1387-1394, 2014.

SHELTON, Althea Robinson. Correlaciona-se com comportamentos problemáticos na narcolepsia pediátrica: um estudo pilotovol. Journal of Clinical Sleep Medicine, v. 13, n. 12, p. 1435-1440, 2017.

Coordenadoria de Pesquisa e Extensão - COPEX

Departamento de Editoraçāo e Divulgaçāo Científica - DEDIC 


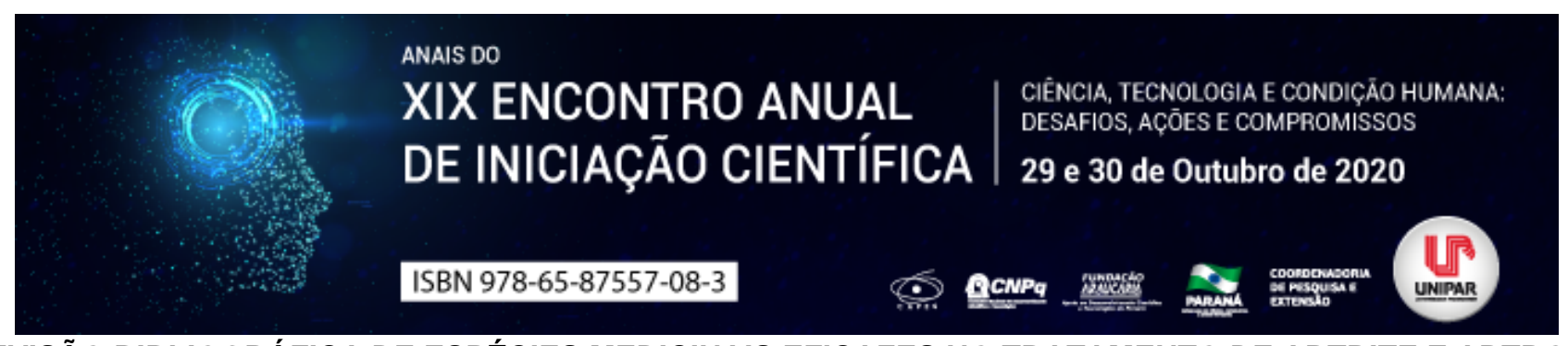

REVISÃO BIBLIOGRÁFICA DE ESPÉCIES MEDICINAIS EFICAZES NO TRATAMENTO DE ARTRITE E ARTROSE

\author{
${ }^{1}$ HERIS LORENZI DOS SANTOS, ${ }^{2}$ JOICE KARINA OTENIO, ${ }^{3}$ ROSSELYN GIMENES BAISCH, ${ }^{4}$ EMERSON LUIZ BOTELHO \\ LOURENÇO, ${ }^{5}$ EZILDA JACOMASSI
}

\footnotetext{
${ }^{1}$ Mestranda do Programa de Plantas Medicinais e Fitoterápicos na Atenção Básica/UNIPAR

${ }^{1}$ Mestranda do Programa de Plantas Medicinais e Fitoterápicos na Atenção Básica/UNIPAR

${ }^{2}$ Mestranda do Programa de Plantas Medicinais e Acadêmica do curso de Medicina - PIC/UNIPAR

$3^{3}$ Docente do Mestrado em Plantas Medicinais/ UNIPAR

${ }^{4}$ Docente do Mestrado em Plantas Medicinais/ UNIPAR
}

Introdução: As doenças inflamatórias articulares são acometidas especialmente por idosos. Sabe-se que a população idosa cresce anualmente e sofre muito com os desconfortos provocados pelos problemas articulares, como dores intensas, redução de mobilidade e consequentemente, com diminuição na qualidade de vida (NARCISO et al., 2016). Neste contexto, as plantas medicinais oferecem uma gama de aplicações para os mais variados tipos de doenças, se destacando aquelas usadas no tratamento e prevenção de inflamações articulares (SANTOS et al., 2020).

Objetivo: Realizar um levantamento, através de estudos registrados na literatura científica disponível, das espécies medicinais com ação contra as doenças articulares artrite e artrose.

Desenvolvimento: A população brasileira, em 2017, contava com 14,6\% de idosos, número que aumenta em 1 milhão de pessoas por ano (BRASIL, 2018). Nessa faixa etária as pessoas apresentam diversos problemas de saúde associados, por isso as plantas medicinais representam um recurso terapêutico importante, por não trazer muitos efeitos adversos, podendo ser utilizadas, como exemplo, no tratamento da Artrite Reumatoide (AR) e a Artrose (AO). O tratamento anti-inflamatório convencional para AR e AO pode causar vários efeitos colaterais indesejáveis, acometendo todos os órgãos internos, como o sistema gastrointestinal, cardiovascular, pulmonar, hepático, renal, hematológico e ainda desencadear reações na pele (MONTEIRO et al., 2008). De forma geral, a artrite é a inflamação das articulações, enquanto a artrose é a degeneração das articulações (COIMBRA et al., 2004). As principais espécies, levantadas na literatura para o tratamento de artrite foram a Curcuma longa e o Zingiber officinale (RAMADAN; AL-KAHTANI; EL-SAYED, 2011). As espécies medicinais, encontradas com estudos de eficácia no tratamento da artrose foram a Rosa canina (CHRISTENSEN et al., 2008) e o Harpagophytum procumbens (BRIEN; LEWITH; MCGREGOR, 2006). Essas espécies medicinais, podem ser futuramente utilizadas no tratamento da artrite e artrose, como adjunto ao tratamento convencional, visto que auxiliam na diminuição, prevenção, cura e minimização de sintomas. Além disso, representam baixo custo e colaboram para que os medicamentos químicos e sintéticos sejam utilizados em menor dose e administração, por apresentar mais efeitos colaterais. Outro fato importante, é que as plantas in natura ou produtos gerados a base delas possuem grande aceitação pela população.(SARAIVA et al., 2015).

Conclusão: Conclui-se, neste trabalho, que existe uma limitação de informações científicas, de pesquisas robustas com a utilização das plantas medicinais no tratamento da artrite e artrose, comparando-se a diversidade de plantas encontradas no Brasil.

\title{
Referências
}

BRASIL. Ministério da cidadania. Secretaria Especial do Desenvolvimento Social. Estratégia Brasil Amigo da Pessoa Idosa. 2018.

BRIEN, S.; LEWITH, G. T.; MCGREGOR, G. Devil's claw (Harpagophytum procumbens) as a treatment for osteoarthritis: a review of efficacy and safety. Journal Alternative Complementary Medicine, v. 12, n. 10, p. 981-993, 2006.

CHRISTENSEN, R. et al. Does the hip powder of Rosa canina (rosehip) reduce pain in osteoarthritis patients? a meta-analysis of randomized controlled trials. Osteoarthritis Cartilage v. 16, p. 965 972, 2008.

COIMBRA, I.B. et al. Osteoartrite (artrose): tratamento. Revista Brasileira de Reumatologia, v. 44, n. 6, 2004.

MONTEIRO, Elaine Cristina Almeida et al. Os antiinflamatórios não esteroidais (AINEs). Temas de reumatologia clínica, v. 9 , n. 2, p. 53-63, 2008.

NARCISO, Lurdes et al. Manual informativo para o doente com osteoartrose. 2016.

RAMADAN, Gamal; AL-KAHTANI, Mohamed Ali; EL-SAYED, Wael Mohamed. Anti-inflammatory and Anti-oxidant Properties of Curcuma longa (Turmeric) Versus Zingiber officinale (Ginger) Rhizomes in Rat Adjuvant-Induced Arthritis. Inflammation, v. 34, $\mathrm{n}$. 4, p. 291-301, 2011.

SANTOS, Maiara Gonçalves dos; DAMIANI, Pricila; MARCON, Ana Carolina Zappe; HAUPENTHAL, Alessandro. Osteoartrite de 
joelhos e funcionalidade, qualidade de vida e dor em idosas. Fisioterapia em movimento, Curitiba, 2020.

SARAIVA, Manuele Eufrasio et al. Plant species as a therapeutic resource in areas of the savanna in the state of Pernambuco, Northeast Brazil. Journal of Ethnopharmacology, v. 171, p. 141-153, 2015.

Coordenadoria de Pesquisa e Extensão - COPEX

Departamento de Editoraçāo e Divulgaçāo Científica - DEDIC 


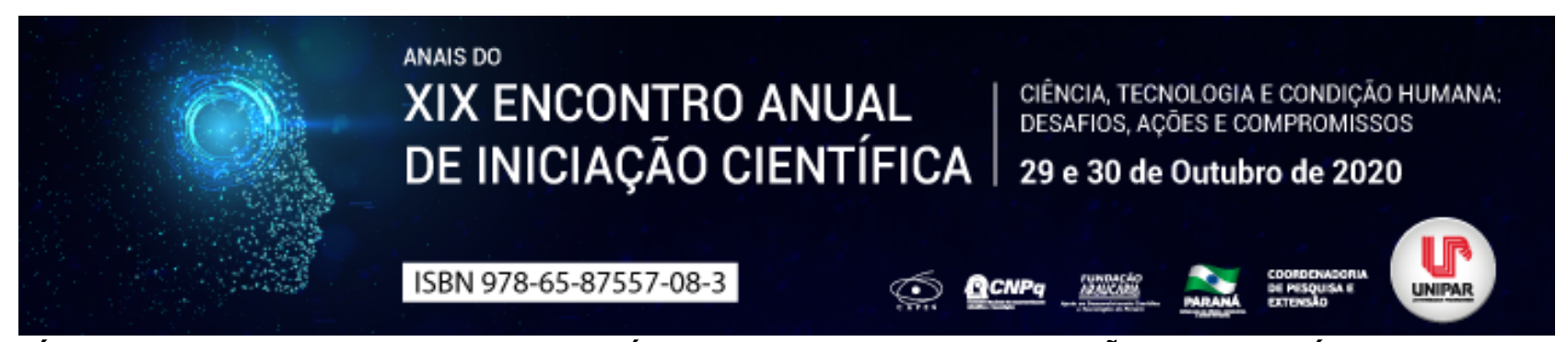

O LÚDICO ENTRE AS PROPOSTAS PEDAGÓGICAS NO ENSINO DA NATAÇÃO PARA O PÚBLICO INFANTIL

\author{
${ }^{1}$ GUILHERME VIEIRA ALFARO, ${ }^{2}$ GUILHERME DA SILVA DONADONI, ${ }^{3}$ KAMILLA RODRIGUES DE SOUZA, ${ }^{4}$ ANALIDES \\ FLAVIA CARUSO COSTA
}

\author{
${ }^{1}$ Acadêmico do curso de Educação Física da UNIPAR \\ ${ }^{1}$ Acadêmico do Curso de Educação Física da UNIPAR \\ ${ }^{2}$ Acadêmica do Curso de Pedagogia da UNIPAR \\ ${ }^{3}$ Docente da UNIPAR
}

Introdução: Desde as mais antigas civilizações, a natação é um dos esportes mais praticados e reconhecidos no mundo todo. Atendendo desde o público infantil até a terceira idade, sendo um esporte completo que proporciona aos seus praticantes não apenas a aprendizagem de técnicas de nado, mas também uma melhora na qualidade de vida de modo geral (OLIVEIRA, 2013). Diferenciando-se de outros esportes, a natação tem uma relação muito especial com o público infantil, pois a criança obteve uma vivência no meio líquido no ventre da mãe, o que pode facilitar sua aprendizagem e adaptação (SOUZA, 2004). Porém, segundo Fernandes (2006), os profissionais de educação física atuantes na área da natação, têm em sua grande maioria o foco somente no produto, através de uma sequência pedagógica sistematizada, deixando de lado os aspectos particulares de cada aluno, seus anseios, e limitando a sua aprendizagem apenas ao domínio técnico dos quatro estilos de nado. Procurando melhorar o ensino aprendizagem no período de iniciação do público infantil na natação, quebrando essa sequência pedagógica sistematizada que a anos se instalou na modalidade, segundo Saraiva (2018) vários profissionais estão implementando o uso do aspecto lúdico em suas aulas.

Objetivo: Identificar qual a importância da utilização de aspectos lúdicos entre as propostas pedagógicas no ensino da natação, para a iniciação do público infantil.

Desenvolvimento: Complicada para quem não domina, porém fascinante e muito simples para aqueles que a praticam, a natação pode ser vista como um notável exercício de promoção à saúde, com benefícios para todo o sistema muscular, respiratório e cardiovascular. Além disso, a natação pode ser usada no tratamento e prevenção de várias doenças, tornando-se também um mecanismo de defesa para o nosso corpo, prevenindo possíveis afogamentos (RODRIGUES, 2007). Neste contexto, segundo Zulietti (2002) a natação seria uma atividade de extrema importância para o público infantil, pois além de todos os atributos já citados que a prática pode propiciar ao indivíduo, ela ocasiona melhoras nos aspectos psicológicos e sociais, através da vivência e autonomia motora em um meio líquido. A natação, segundo Rodrigues (2007), quando aplicada ao público infantil não pode ocupar-se apenas ao fato de que a criança aprenda a nadar, ela também deve contribuir para ativar o processo evolutivo psicomorfológico, favorecendo assim o desenvolvimento de sua psicomotricidade. Tendo em vista o conhecimento da importância desta prática para o público infantil, segundo Oliveira (2013), tem ocorrido um considerável aumento na procura de aulas de natação para este público, e vários autores vêm pesquisando sobre a importância da ludicidade entre o processo pedagógico da natação, pois de acordo com Fernandes (2006), grande parte dos profissionais de educação física que atuam na área, têm tornado o processo de aprendizagem da modalidade em algo monótono e desinteressante, através de uma metodologia focada apenas no produto, ou seja, no domínio mecânico dos estilos de nado já consagrados, sem considerar os interesses e as possibilidades físicas particulares de cada aluno. Dentre alguns autores que estão realizando pesquisas sobre o tema, Gerster (2012), realizou uma pesquisa descritiva qualitativa em 3 escolas de natação, buscando analisar os diferentes procedimentos metodológicos de cada professor. Seus resultados revelaram a importância do lúdico nos procedimentos metodológicos, onde através dele os alunos se mostraram mais motivados e dispostos, a aprender os fundamentos de cada estilo na natação. Já Fernandes (2013), realizou um estudo de caso com crianças de 3 a 5 anos em uma escola de natação, com o objetivo de analisar as diferentes metodologias de ensino, onde para a coleta de dados foram feitas observações das aulas, e entrevistas semi estruturadas com os professores. A autora concluiu, que a utilização de técnicas alinhado a diferentes estímulos, respeitando as individualidades de cada aluno sempre através de uma perspectiva lúdica, pode ser considerada a maneira ideal de ensino da natação. Saraiva (2018) também através de uma pesquisa qualitativa em 26 turmas de natação, buscou analisar o uso dos aspectos lúdicos, constatando que algumas escolas através de suas metodologias de ensino, encaram a manifestação do caráter lúdico como sinônimo de perda de tempo, utilizando-o apenas nos minutos finais de suas aulas, dando assim pouca importância a sua potencialidade.

Conclusão: Pode-se concluir que, o caráter lúdico alinhado aos conteúdos técnicos na metodologia de ensino da natação, faz com que os conteúdos sejam absorvidos de melhor maneira pelas crianças, respeitando seus aspectos individuais, criando assim um clima cativante e harmonioso dentro do processo de ensino. Porém, é constatada a falta de materiais bibliográficos que 
apresentam a ludicidade entre as propostas pedagógicas do ensino da natação, fomentando os professores para um melhor ensino aprendizagem desse esporte.

\section{Referências}

FERNANDES, J.G. Natação para crianças de 3 a 5 anos: as prática de ensino-aprendizagem em um clube e em um academia de Porto Alegre. 2013. 51 f. (Conclusão do curso de Educação Física Licenciatura) - Universidade Federal do Rio Grande do Sul, Porto Alegre, 2013.

FERNANDES, J.; COSTA, P. Pedagogia da natação: um mergulho para além dos quatro estilos. Revista Brasileira de Educação Física e Esporte, São Paulo, v. 20, n. 1, p. 5-14, mar. 2006. Disponível em: https://tinyurl.com/y26sqg2x. Acesso em: 18/06/2020.

GESTER, G. Natação infantil, ludicidade e os aspectos metodológicos. In: SEMANA DE INICIAÇÃo CIENTíFICA DA UNICENTRO, XVII., 2012, Guarapuava. Disponível em: https://tinyurl.com/y3ewa92a. Acesso em: 18/06/2020.

OLIVEIRA, L. R. et al. Importância da natação para o desenvolvimento da criança e seus benefícios. @rgumentandum - Revista Eletrônica das Faculdades Sudamérica, Cataguases, v. 5, n. 5, p. 111-130, maio 2013 . Disponível em: https://tinyurl.com/yyr4waoe. Acesso em: 18/06/2020.

RODRIGUES, C. et al.. A prática da natação como melhora na socialização em crianças de 12 a 14 anos. Revista Meta Science. Rio de Janeiro. 2007. Disponível em: https://tinyurl.com/yxnz5v2y. Acesso em: 19/06/2020.

SARAIVA, S. B. F. et al. Conhecimentos Ludopedagógicos na Aprendizagem da Natação Infantil. Licere - Revista do Programa de Pós-graduação Interdisciplinar em Estudos do Lazer, Belo Horizonte, v. 21, n. 4, p. 429-449, dez. 2018. Disponível em: https://tinyurl.com/y4epwv8u. Acesso em: 19/06/2020.

SOUZA, Geane. Benefícios da utilização de materiais para o desenvolvimento psicomotor dentro do ensino da natação em crianças até 6 anos. Conclusão de Curso de Pós-Graduação Lato Sensu . Universidades Candido Mendes. Rio de Janeiro. 2004.

ZULIETTI, L. F; SOUZA, I. L. R. A aprendizagem da natação do nascimento aos 6 anos: Fases de desenvolvimento. Revista UniVap, São José dos Campos, v. 9, n. 17, p. 12-17, dez. 2002. Disponível: https://tinyurl.com/y525shnw. Acesso em: 20/06/2020. 


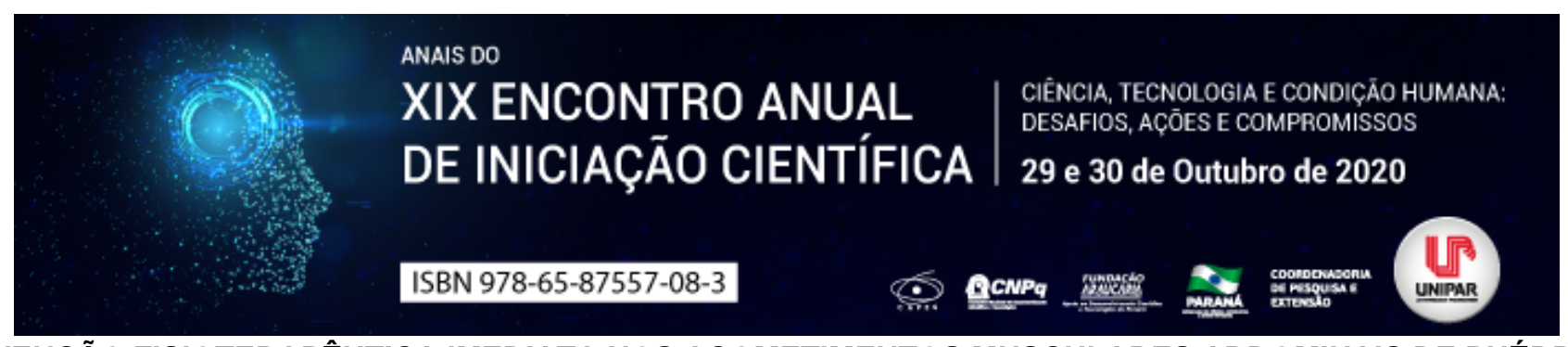

INTERVENÇÃO FISIOTERAPÊUTICA IMEDIATA NOS ACOMETIMENTOS MUSCULARES ABDOMINAIS DE PUÉRPERAS

\author{
${ }^{1}$ MAYARA JAKLINE RAMOS MATOS, ${ }^{2}$ DORA DE CASTRO AGULHON SEGURA
}

\author{
${ }^{1}$ ACADÊMICA DE FISIOTERAPIA- UNIPAR \\ ${ }^{1}$ Docente da UNIPAR
}

Introdução: O período gestacional refere-se a processos fisiológicos normais ocorridos na vida das mulheres, o qual acarreta inúmeras modificações hormonais, físicas, comportamentais e psíquicas, causadas principalmente pela ação de hormônios como, progesterona, estrogênio e relaxina (OLIVEIRA; SANTANA, 2019). Contudo, muitas mudanças mecânicas surgem no sistema musculoesquelético, como desconfortos gastrointestinais, algias e diástase do músculo reto abdominal. O propósito da fisioterapia no puerpério imediato é auxiliar através de técnicas, o retorno de atividades diárias, aliviando desconfortos, dores, disfunções musculares e reestabelecendo as funções fisiológicas alteradas pela gestação e parto (NUNES; GONÇALVES; LATORRE, 2019).

Objetivo: Descrever como o tratamento fisioterapêutico imediato se mostra importante para a regressão das modificações abdominais em puérperas.

Desenvolvimento: A fase pós-parto das gestantes é denominada puerpério, um período de retorno das alterações locais e sistêmicas do organismo feminino (SOUZA; NICIDA, 2019). Na biomecânica das gestantes ocorrem significativas modificações na parede abdominal, devido ao crescimento do feto no interior do útero, ocasionando estiramentos e afastamentos da musculatura, acarretando quadros clínicos como a diástase do músculo retoabdominal, dores lombares, flacidez e edemas abdominais. A atuação da fisioterapia no puerpério tem como objetivo o fortalecimento da musculatura abdominal, a estimulação do sistema circulatório, a analgesia da região perineal e a retomada do condicionamento cardiorrespiratório. Para tanto, são utilizados protocolos de atendimentos com exercícios dinâmicos e estáticos de contração abdominal, almejando a redução dos problemas abdominais de forma precoce, pois a fisioterapia precisa ser inserida de forma imediata no pós-gravídico, avaliando e recomendando exercícios de maneira segura e devidamente elaborados para cada puérpera (URBANO et al., 2019). Se faz necessário, ainda, salientar a existência de outras técnicas fisioterapêuticas particulares para o tratamento de algias locais, como eletroestimulação, liberação miofascial, drenagem linfática e outros métodos de massagens, que demonstram diferenças significativas nos indicadores do puerpério, principalmente na sensação de relaxamento, melhora dos sintomas físicos e disposição para atividades diárias. A atuação aplicada a parturiente permitirá boas condições para o sucesso físico e funcional, tanto para correção dos distúrbios posturais e musculares, quanto nas modificações estéticas do corpo (NUNES; GONÇALVES; LATORRE, 2019). Com base nas narrativas descritas pelas mulheres, o atendimento fisioterapêutico se mostra satisfatório, por incentivar a realização de atividades educativas, fomentar estratégias para a prevenção de intercorrências, e ainda minimizar a insegurança que pode estar presente durante o período gravídico-puerperal. Além disso, é possível ministrar atividades e intervenções de maneira simples e didática, ressaltando a importância da presença dos fisioterapeutas em maternidades (SILVA et al., 2019).

Conclusão: De acordo com a presente revisão sobre os acometimentos musculares abdominais e intervenções fisioterapêuticas no período de puerpério, concluiu-se que os problemas relacionados ao abdome após a gestação estão interligados, devido ao posicionamento de todos os tecidos envolvidos durante o ciclo da gravidez, e fica expresso que a fisioterapia imediata oferece grandes benefícios às puérperas, atuando na remediação e prevenção de complicações abdominais pós-gravídicas, por meio de exercícios musculares, massagens, eletroterapias e demais recursos disponíveis, mostrando grande satisfação por parte das parturientes, devendo ser implementada como rotina nas maternidades brasileiras.

\title{
Referências
}

NUNES, E. F. C.; GONÇALVES, B.; LATORRE, G. F. S. O papel da fisioterapia pélvica no puerpério imediato Uma revisão sistemática. Revista da AMRIGS, v. 63, n. 3, p. 344-348, 2019.

OLIVEIRA, A. C. M.; SANTANA, P.C. A importância da assistência fisioterapêutica prestada a parturiente durante o parto. Revista Científica da Faculdade de Educação e Meio Ambiente - FAEMA, v. 10, n. 1, p. 156-166, 2019.

SILVA, J. B.; DOI, G. E.; SILVA, L. C.; FELTRIN, M. I.; ZOTZ, T. G. G.; KORELO, R. I. G.; GALLO, R. B. S. Satisfação de puérperas após intervenção fisioterapêutica em educação em saúde. Saúde e Pesquisa, v. 12, n. 1, p. 141-150, 2019.

SOUZA, S. M.; NICIDA, D. P. A atuação da fisioterapia obstétrica: Revisão de literatura. Revista Saúde e Desenvolvimento, v. 13 , n. 15, p. 122-133, 2019.

URBANO, F. A.; BARBOSA, J. E. R.; FLAUSINO JUNIOR V. D.; MARTELLI, A.; DELBIM, A. Exercícios de fortalecimento para o músculo reto abdominal como tratamento da diástase pós-gestacional. Revista Ciência e Saúde, v. 4, n. 1, p. 10-16, 2019. 
Coordenadoria de Pesquisa e Extensão - COPEX

Departamento de Editoraçāo e Divulgaçāo Científica - DEDIC 


\title{
ANAIS DO XIX ENCONTRO ANUAL | CIĖNCIA, TECNOLOGIA E CONDIÇĀO HUMANA: DE INICIAÇÃO CIENTÍFICA DE INICIAÇĀO CIENTÍFICA 29 e 30 de Outubro de 2020 \\ ISBN 978-65-87557-08-3

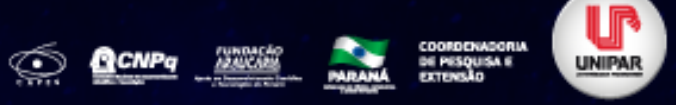 \\ DISTÂNCIA ENTRE A INCISURA E FORAME INFRA-ORBITAIS EM CRÂNIOS EDENTADOS PARA A ANESTESIA DO NERVO INFRA-ORBITAL
}

\begin{abstract}
${ }^{1}$ Caio Fossalussa da Silva, ${ }^{2}$ ANNY ISABELLY dOS SANTOS SOUZA, ${ }^{3}$ JOÃO CÉSAR GUIMARÃES HENRIQUES, ${ }^{4}$ GISELE RODRIGUES DA SILVA, ${ }^{5}$ FÁBIO FRANCESCHINI MITRI
\end{abstract}

\author{
${ }^{1}$ Faculdade de Odontologia da Universidade Federal de Uberlândia/Graduando \\ ${ }^{1}$ Faculdade de Odontologia da Universidade Federal de Uberlândia/Graduanda \\ ${ }^{2}$ Professor Doutor em Biopatologia Bucal, Universidade Federal de Uberlândia \\ ${ }^{3}$ Professora Doutora da Disciplina de Dentística, Universidade Federal de Uberlândia \\ ${ }^{4}$ Professor Doutor da Disciplina de Anatomia Humana, Universidade Federal de Uberlândia
}

Introdução: O nervo infraorbital (NIO) origina-se no interior da maxila, antes de emergir pelo forame, desse nervo se origina o nervo alveolar superior anterior (NASA), o qual supre a sensibilidade geral dos dentes anteriores superiores. Portanto, para o bloqueio anestésico do NASA, faz-se necessário anestesiar o NIO. Em média geral, o forame infraorbital (FIO) se localiza a 27 $\mathrm{mm}$ da margem do processo alveolar da maxila, região do primeiro pré-molar, e a 7,0 mm da margem infraorbital, em crânios dentados (CALDEIRA et al., 2008). Porém, esses valores devem ser investigados em pacientes edentados devido à severa reabsorção do processo alveolar nesses indivíduos e, consequente, diminuição da dimensão vertical de oclusão. Na idade senil, o envelhecimento ósseo resulta na diminuição da massa óssea dos ossos da face e consequentemente na diminuição das suas dimensões, o que leva a alterações importantes nas distâncias entre as estruturas anatômicas. Assim no idoso, a incisura infraorbital, na margem inferior da cavidade orbital, se localiza mais próxima do FIO.

Objetivo: O objetivo deste estudo foi avaliar a distância média entre a incisura infraorbital e o forame infraorbital em crânios dentados e edentados totais para que se tenha uma melhor referência na profundidade da penetração da agulha na técnica de anestesia do NIO.

Material e métodos: Foram utilizados 46 crânios adultos, sendo 23 crânios dentados e 23 edentados, sem consideração sobre gênero ou raça. Este estudo foi conduzido em acordo com a lei brasileira n 8.501 publicado em 1992 e a Declaração de Helsinki, a qual idealiza o uso de cadáveres ou peças anatômicas para o propósito de estudos ou pesquisas científicas. Estas peças constituem o material de estudo de graduação do acervo do laboratório de anatomia humana da Universidade Federal de Uberlândia. A mensuração da distância entre a incisura e o forame infraorbitais com um paquímetro digital milimetrado (Mitutoyo MTI Corporation, Crystal Lake, Illinois, USA). Os dados foram submetidos e aprovados em normalidade e homocedacidade no teste de Shapiro-Wilk e Levene e, em seguida, analisados estatisticamente utilizando-se a ANOVA two-way (2x2). Para a determinação de possíveis diferenças entre os grupos, maxila dentada e edentada total e antímeros direito e esquerdo, os dados foram submetidos ao teste de comparação múltipla, o teste de Tukey, com nível de $5 \%$ de significância $(p \leq 0,05)$.

Resultados: A distância média entre a incisura e o forame infraorbital das maxilas dentadas e edentadas totais, foi respectivamente de 9,34 e 7,50 $\mathrm{mm}$. Em cada maxila, a distância média foi de 9,34 $\mathrm{mm}$ em ambos os lados para as maxilas dentadas e 7,30 e 7,70 mm, respectivamente para as maxilas edentadas totais, lado direito e esquerdo. Em adição, as diferenças entre as distancias médias das maxilas dentadas e edentadas totais, considerando-se os antímeros direito e esquerdo, foram respectivamente de 2,04 e 1,64 mm. A análise estatística revelou diferença significativa entre as maxilas dentadas e edentadas totais, com menor distância entre os pontos anatômicos na maxila edentada total. Em contrapartida, a interação entre os antímeros nas respectivas maxilas não revelou diferença significativamente estatística

Discussão: A padronização de pontos anatômicos de referência palpáveis e a determinação de uma distância média relativa entre a incisura infraorbital ao forame infraorbital em diferentes maxilas (dentadas e edentadas), fornecerá parâmetros anatômicos e reais para o bloqueio anestésico seguro e efetivo do NIO. O presente estudo fornece importantes referências sobre as diferenças de distância entre pontos anatômicos palpáveis para a execução da complexa técnica de anestesia do NIO, muito utilizada nos procedimentos odontológicos, se estendendo também para a área da cirurgia bucomaxilofacial, nas reconstruções de assoalho de órbita e nos acessos de Caldwell-Luc (APINHASMIT et al., 2006; KHARB; PRAJNA; NIRUPMA, 2012), e para a área da cirurgia plástica, na qual já foi sugerido por Molliex et al o bloqueio do NIO prévio ao nervo nasociliar nas cirurgias de reconstrução nasal, facilitando assim o manuseio e a palpação destas estruturas para a correta execução da técnica anestésica. Variações na localização precisa do FIO são advindas de acordo com a população estudada, uma vez que podem haver diferenças no biótipo e na morfologia craniofacial (BERRY; BERRY, 1967). Os nossos resultados revelaram uma distância média da incisura infraorbital ao forame infraorbital de $9,34 \mathrm{~mm}$ na maxila dentada e uma distância de 7,50 mm na maxila edentada. 
Conclusão: $O$ conhecimento da anatomia da face e suas estruturas é fundamental para a execução de técnicas anestésicas odontológicas. A diminuição dessas distâncias entre a incisura e o FIO no edentado total é importante ferramenta de referência para o cirurgião dentista na execução da técnica de anestesia do NAI, resultando em um maior conforto para o paciente.

\section{Referências}

APINHASMIT W, CHOMPOOPONG S, METHATHRATHIP D, SANSUK R, PHETPHUNPHIPHAT W. Supraorbital notch/foramen, infraorbital foramen and mental foramen in thais: anthropometric measurements and surgical relevance. J Med Assoc Thai., v. 89, n. 5, p. 675 682, 2006.

BERRY AC, BERRY RJ. Epigenetic variation in the human cranium. J. Anat., v. 101, n. 2, p. 361 379, 1967.

CALDEIRA EJ, RANDI BA, FERRAGUTI JM, MINATEL E. Análise morfométrica da localização do forame infra-orbitário. Perspectivas Médicas., v. 19, n. 1, p. 17 19, 2008.

KHARB JP, PRAJNA S, NIRUPMA G. Morphometric analysis of infraorbital foramen in dry adult skulls and its surgical relevance. J Adv Res Biol Sci, v. 4, n. 2, p. 83 87, 2012.

Coordenadoria de Pesquisa e Extensão - COPEX

Departamento de Editoraçāo e Divulgaçāo Científica - DEDIC 


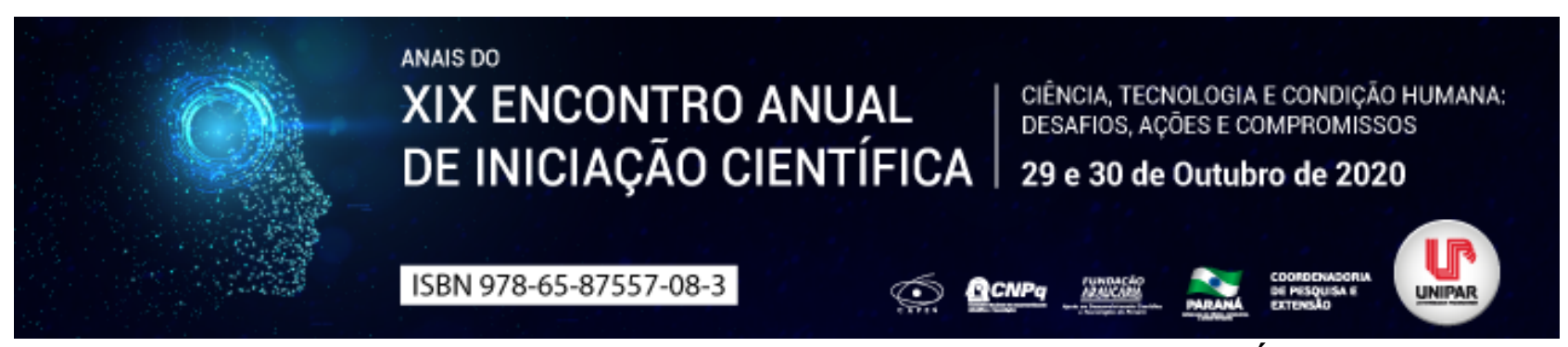

PRINCIPAIS TERAPIAS NO TRATAMENTO DA DERMATITE SEBORRÉICA

${ }^{1}$ Dyêggo Carvalho Amorim, ${ }^{2}$ MAGNA ALVES XAVIER, ${ }^{3}$ LUÍZA MARIA OLIVEIRA CAVALCANTE, ${ }^{4}$ LUCAS BARBOSA CAVALCANTE, ${ }^{5}$ BRUNO SAMPAIO GONÇALVES, ${ }^{6}$ LIDIA AUDREY ROCHA VALADAS MARQUES

\author{
${ }^{1}$ Unichristus \\ 1Unichristus \\ 2Unichristus \\ 3 Unichristus \\ 4 Unichristus \\ ${ }^{5}$ Pesquisadora (Pos-doutorado) da Universidade de Buenos Aires
}

Introdução: A Dermatite Seborréica (DS) é uma doença de pele, inflamatória e crônica que se manifesta na pele inicialmente com lesões eritematosas, bem delimitadas, cobertas por escamas gordurosas ou placas róseas e amareladas de formatos e tamanhos variados. Essa condição atinge 3 a 5\% da população, podendo acometer qualquer sexo idade. Essa condição também pode ocorrer em áreas oleosas de diferentes regiões do corpo, como rosto, peito e costas. Além de manchas descamativas e vermelhas na pele, a DC pode causar caspa. Ao longo dos anos, diversos tratamentos vem sendo propostos, especialmente os de uso tópico, pois normalmente essa condição é recorrente (STEFANAKI; KATSAMBAS, 2010; RODRIGUES NETO et al., 2013; FERRONATO, 2015).

Objetivo: Esse trabalho objetivou realizar uma revisão de literatura sobre os principais tratamentos para o controle da DS.

Desenvolvimento: Foi realizada uma revisão de literatura com pesquisa nos bancos de dados do Pubmed, Bireme, Lilacs e Scielo, sem delimitação de data, utilizando os descritores: Dermatite Seborréica, Inflamação e Tratamento Farmacológico. Resultados e discussão: A DS se caracterizada por ser uma inflamação cronica, sendo frequente a descamação independente da faixa etária. No manejo deve-se considerar o controle da inflamação, da proliferação fúngica e da oleosidade epidérmica. É notoriamente importante o papel do metabolismo de leveduras do gênero Malasseziana, assim, a utilização de agentes antifúngicos recebe destaque na abordagem terapêutica dessa condição (DEL ROSSO, 2011; RODRIGUES NETO et al., 2013) Ao realizar a seleção da farmacoterapia com agentes antifúngicos o profissional terá um amplo arsenal terapêutico, sendo viávela prescrição de uma variada gama de tratamentos tópicos. A literatura aponta que os corticosteróides tópicos, principalmente a Hidrocortisona, constituem a alternativa terapêutica mais viável, pois levam a uma melhora rápida dos principais sintomas, como eritema, descamação e prurido (GARY, 2011; RODRIGUES NETO et al., 2013). Porém, quando são interrompidos geram frequentes recidivas, devendo ser utilizados durante o menor tempo possível em virtudes dos efeitos colaterais que ocorrem com o uso prolongado. Outros agentes fungistáticos também vêm sido utilizados com sucesso em fórmulas de shampoos como piritionato de zinco e o sulfeto de selênio em concentrações que variam de 1 a 2,5\%, ambos apresentaram efeitos queratolítico que podem ter sua ação potenciada com a associação do ácido salicílico na formulação, facilitando, desse modo, a remoção das escamas e propiciando um efeito anti-inflamatório sobre as lesões. Os agentes antifúngicos azólicos se apresentam como outra opção terapêutica bastante útil, dentre eles destaca-se o cetoconazol, que apresenta também alguma atividade anti-inflamatória, possivelmente, por inibição da 5-Lipooxigenase, tendo repercussão na síntese de leucotrienos e outros derivados do ácido araquidônico (RODRIGUES NETO et al., 2013; MORENO-VÁZQUEZ; CALDERÓN; BONIFAZ, 2020).

Conclusão: A DS é doença muito comum e recorrente. Com a farmacoterapia e mudanças de hábitos é possível se obter um controle efetivo e um maior espaçamento na recorrência das crises da doença. Desse modo, somado como os esforços próprios do paciente, são possíveis de obter-se um controle efetivo e um maior espaçamento na recorrência das crises da doença.

\title{
Referências
}

FERRONATO, Beatriz Ana Zambon. Ideais dos pioneiros da educação nova: atualidade na educação contemporânea? Educere: Revista de Educação, Umuarama, v. 15, n. 2, p. 295-317, jul./dez. 2015.

DEL ROSSO, James Q. Adult seborrheic dermatitis: a status report on practical topical management. The Journal of clinical and aesthetic dermatology, v. 4, n. 5, p. 32, 2011.

GARY, Goldenberg. Optimizing treatment approaches in seborrheic dermatitis. The Journal of clinical and aesthetic dermatology, v. 6, n. 2, p. 44, 2013.

MORENO-VÁZQUEZ, Karla; CALDERÓN, Luz; BONIFAZ, Alexandro. Seborrheic dermatitis. An update. Dermatología Revista Mexicana, v. 64, n. 1, p. 39-49, 2020.

RODRIGUES NETO, Edilson Martins et al. Dermatite seborréica: abordagem Terapêutica no âmbito da clínica 
Farmacêutica. Revista Eletrônica de Farmácia, v. 10, n. 4, p. 11-11, 2013.

STEFANAKI, Irini; KATSAMBAS, Alexander. Therapeutic update on seborrheic dermatitis. Skin Therapy Lett, v. 15, n. 5, p. 1-4, 2010.

Coordenadoria de Pesquisa e Extensão - COPEX

Departamento de Editoraçāo e Divulgaçāo Científica - DEDIC 


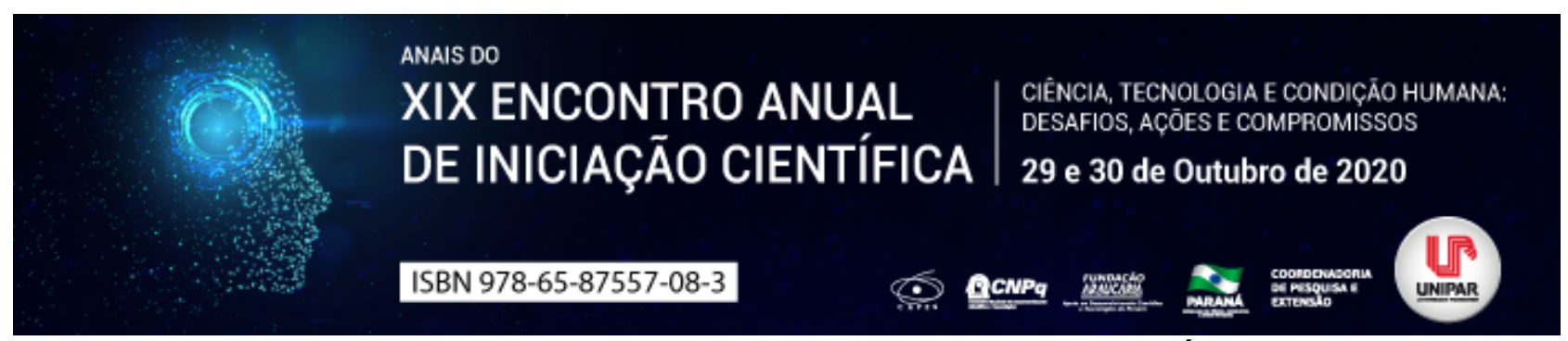

USO DA HIDROXIAPATITA COMO MATERIAL DE ENXERTIA ÓSSEA

1'LUÍZA MARIA OLIVEIRA CAVALCANTE, ${ }^{2}$ MAGNA ALVES XAVIER, ${ }^{3}$ DYÊGGO CARVALHO AMORIM, ${ }^{4}$ LUCAS BARBOSA CAVALCANTE, ${ }^{5}$ BRUNO SAMPAIO GONÇALVES, ${ }^{6}$ LIDIA AUDREY ROCHA VALADAS MARQUES

${ }^{1}$ Unichristus

1Unichristus

2Unichristus

3 Unichristus

${ }^{4}$ Unichristus

${ }^{5}$ Pesquisadora (Pos-doutorado) da Universidade de Buenos Aires

Introdução: O enxerto ósseo autógeno ainda é considerado o biomaterial padrão-ouro para enxerto ósseo, visto que apresenta melhores resultados devido as suas propriedades osteogênicas, osteocondutoras e osteoindutoras (KHORSAND et al., 2012; FARDIN et al., 2010; ESFAHANIZADEH et al., 2019). No entanto, cirurgias com enxertos ósseos autógenos acarretam a necessidade de um segundo sítio cirúrgico, o sítio doador, tornando o processo cirúrgico mais complexo, pode trazer sequelas ao paciente. Devido a isso são crescentes as pesquisas com biomateriais sintéticos, destacando-se a hidroxiapatita (HA).

Objetivo: Objetivou-se realizar uma revisão de literatura sobre o uso da HA para enxertia óssea nas áreas de saúde.

Desenvolvimento: Para isso foram buscados artigos nos bancos de dados PUBMED, LILACS e Web of Science. A HA é um importante composto inorgânico no tecido ósseo, sendo um complexo policristalino denso ou poroso, cuja composição varia com a idade, dieta e patologias associadas ao indivíduo. É composto principalmente de minerais como cálcio, fósforo e hidróxido de cálcio (FARDIN et al., 2010). A HA é a biocerâmica mais estudada atualmente para cirurgias de enxerto. A grande vantagem da utilização desse tipo de material para enxerto é que se dispensa o segundo sítio cirúrgico, o sítio doador quando se trabalha com enxerto autógeno, o que torna o procedimento reconstrutor mais rápido, seguro e menos complexo. Este material possui propriedades osteocondutoras e permite a conexão com o tecido conjuntivo que o circunda, facilitando a osseointegração. Outro motivo da ampla utilização desse material na área biomédica é a semelhança com o aspecto mecânico, químico e físico do tecido ósseo que também é constituído por HA, então a semelhança da HA sintética com o osso humano e suas propriedades osteocondutoras, garante sua compatibilidade e eficácia (FROUM et al., 2013; ESFAHANIZADEH et al., 2019; GIESENHAGEN et al., 2019).

Conclusão: Apesar das excelentes propriedades da HA, a mesma não possui resistência mecânica para grandes enxertos, sendo especialmente utilizada associada a placas de titânio, para assim suportar o peso e promover a osseointegração.

\section{Referências}

ESFAHANIZADEH, Nasrin et al. Histologic Evaluation of the Bone Regeneration Capacities of Bio-Oss and MinerOss X in Rabbit Calvarial Defects. Int J Periodontics Restorative Dent, v. 39, p. e219-e227, 2019.

FARDIN, Angélica Cristiane et al. Bone graft in dentistry: review of literature. Innovations Implant Journal, v. 5, n. 3, p. 48-52, 2010.

FROUM, Stuart J. et al. A histomorphometric comparison of Bio-Oss alone versus Bio-Oss and platelet-derived growth factor for sinus augmentation: a postsurgical assessment. International Journal of Periodontics \& Restorative Dentistry, v. 33, n. 3, p. 269-279, 2013.

GIESENHAGEN, Bernhard et al. Bone augmentation and simultaneous implant placement with allogenic bone rings and analysis of its purification success. Materials, v. 12, n. 8, p. 1291, 2019.

KHORSAND, A. et al. Histological evaluation of Accell Connexus ${ }^{\circledR}$ and Bio-Oss ${ }^{\circledR}$ on quality and rate of bone healing: a single blind experimental study on rabbit's calvarium. Journal of Dentistry (Tehran, Iran), v. 9, n. 2, p. $116,2012$.

Coordenadoria de Pesquisa e Extensão - COPEX

Departamento de Editoraçāo e Divulgaçāo Científica - DEDIC 


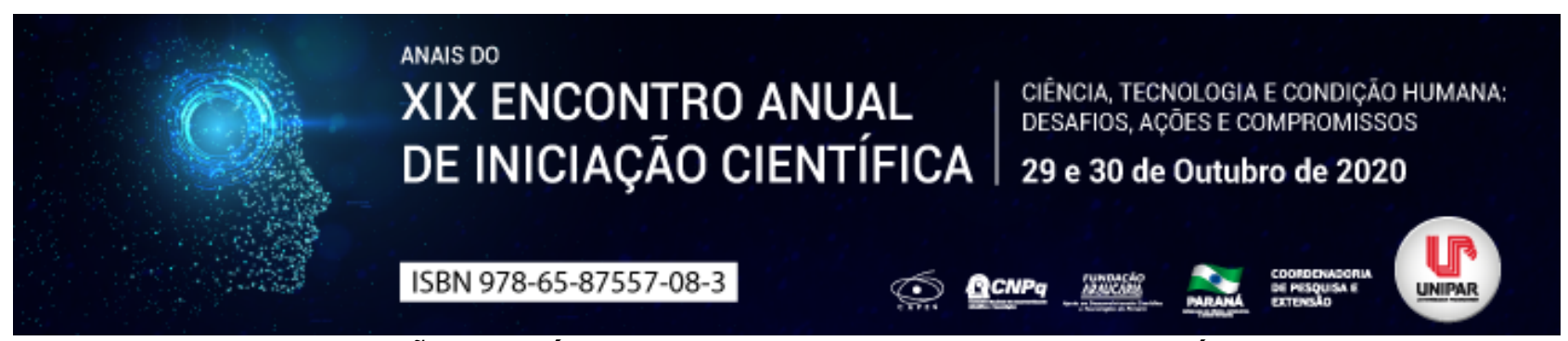

APLICAÇÃO BIOMÉDICA DE CERAMICAS DE FOSFATO DE CÁLCIO

1'LUÍZA MARIA OLIVEIRA CAVALCANTE, ${ }^{2}$ MAGNA ALVES XAVIER, ${ }^{3}$ DYÊGGO CARVALHO AMORIM, ${ }^{4}$ LUCAS BARBOSA CAVALCANTE, ${ }^{5}$ BRUNO SAMPAIO GONÇALVES, ${ }^{6}$ LIDIA AUDREY ROCHA VALADAS MARQUES

${ }^{1}$ Unichristus

${ }^{1}$ Unichristus

${ }^{2}$ Unichristus

${ }^{3}$ Unichristus

${ }^{4}$ Unichristus

${ }^{5}$ Pesquisadora (Pos-doutorado) da Universidade de Buenos Aires

Introdução: Os biomateriais são compostos que ao entrar em contato com o sistema biológico humano permitem substituir qualquer tecido, órgão e restituir sua função fisiológica. Na presença de reabsorções ósseas ou tumores, o cirurgião pode lançar mão de técnicas que visam promover o aumento de volume e qualidade óssea com os biomateriais (MARQUES et al., 2015). Entre os biomateriais se encontram as cerâmicas (biocerâmicas). Essas destacam-se pelas propriedades biológicas e osteoindutivas, além da capacidade de auto-adesão, e excelentes propriedades químicas e mecânicas, como excelente osteocondutividade, ótima resistência ao desgaste e biocompatibilidade (FARDIN et al., 2010).

Objetivo: $O$ objetivo do presente trabalho foi revisar na literatura as vantagens, desvantagens e os aspectos clínicos das biocerâmicas de fosfato de cálcio.

Desenvolvimento: Para isso, foram selecionados artigos no banco de dados Lilacs e PubMed. Atualmente a bioengenharia em ortopedia busca materiais com capacidade de osseointegração, sendo constante as pesquisas que avaliam a eficácia dos mesmos, de forma isolada e associada. Os fosfatos de cálcio são exemplos de biocerâmicas e fazem parte de um grupo de combinações que constituem a estrutura natural dos ossos e dentes humanos (ANDRADE; DOMINGUES, 2006). Desde 1980, pesquisas têm mostrado as vantagens da biocerâmica de fosfato de cálcio no campo biomédico. As principais cerâmicas relatadas na literatura são a hidroxiapatita e o trifosfato de cálcio (tcp alfa e beta). Existe uma variedade de biomateriais utilizados para enxertos, através dessa revisão de literatura sobre o assunto, pode se observar muitas informações contraditórias sobre cada material. Entretanto, o cruzamento de informações nos permite criar um panorama favorável para o da hidroxiapatita e do tcp-beta, devido sua atividade osteocondutora (MORAES et al., 2004). Além disso, a associação desses dois materiais vem indicando diversas aplicações na área médica. A principal razão dessa indicação é a facilidade de manejar esses materiais. Pesquisas atuais indicam que a associação do HA com o TCP- promove melhores resultados quanto à neoformação óssea. Essa associação tem mostrado resultados promissores na área biomédica e de biomateriais, na reposição de tecidos ósseos. A utilização dos dois biomateriais proporciona melhor característica de superfície de grãos e microporos, o que proporciona melhor controle de dissolução (ANDRADE; DOMINGUES, 2006); ZAFAR; ZHU; ZHANG, 2019).

Conclusão: A escolha de qual fonte de fatores de crescimento a ser utilizada cabe, portanto, ao profissional que deve observar atentamente as condições de obtenção, manipulação e também o custo do procedimento.

\section{Referências}

ANDRADE, Ângela Leão; DOMINGUES, Rosana Zacarias. Cerâmicas bioativas: estado da arte. Química Nova, v. 29, n. 1, p. 100-104, 2006.

FARDIN, Angélica Cristiane. et al. Enxerto ósseo em odontologia: revisão de literatura. Innovations Implant Journal, v. 5, n. 3, p. 48-52, 2010.

MARQUES, Lídia Audrey Rocha Valadas. et al. Application of BMP-2 for bone graft in Dentistry. RSBO Revista Sul-Brasileira de Odontologia, v. 12, n. 1, p. 88-93, 2015.

MORAES, Paola Castro et al. Biocompatibilidade do cimento de fosfato de cálcio implantado no rádio de coelhos. Acta Cirurgica Brasileira, v. 19, n. 4, p. 351-359, 2004.

ZAFAR, Muhammad Jamshaid; ZHU, Dongbin; ZHANG, Zhengyan. 3D Printing of Bioceramics for Bone Tissue Engineering. Materials, v. 12, n. 20, p. 3361, 2019. 


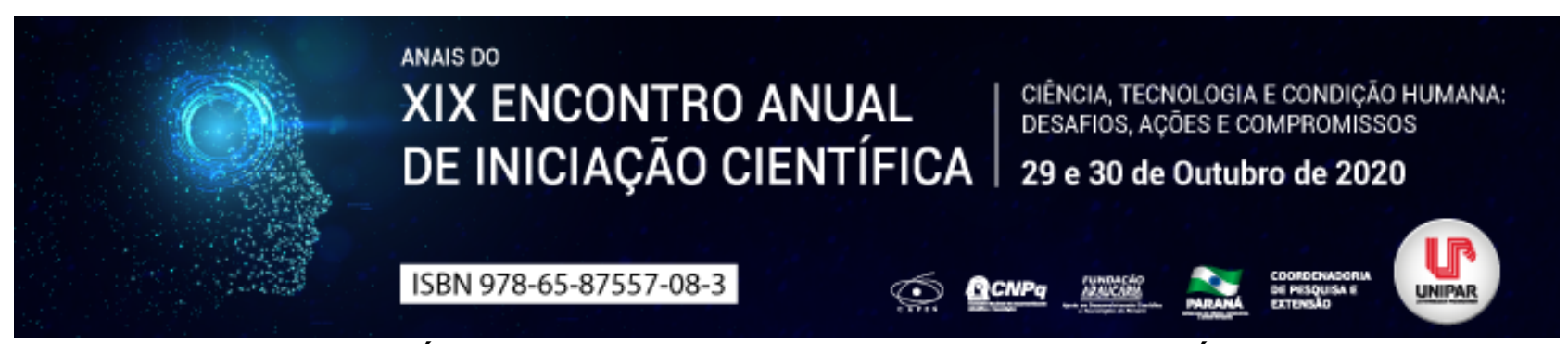

USO DA PRÓPOLIS EM PATENTES DE PRODUTOS DERMATOLÓGICOS

\begin{abstract}
1Jaciara Simões Benevides Sousa, ${ }^{2}$ DEUSIMAR ROMEU CAVALCANTE FILHO, ${ }^{3}$ LEONARDO JORGE ALVES BEZERRA, ${ }^{4}$ SANDRA MARA DA SILVA LIMA, ${ }^{5}$ FRANCISCO JOSIMAR GIRAO JUNIOR
\end{abstract}

\begin{abstract}
${ }^{1}$ Unichristus
1Unichristus

2Unichristus

${ }^{3}$ Estudante de Nutrição, Instituto Federal de Educação, Ciência e Tecnologia do Ceará.

${ }^{4}$ Docente da UNIQ
\end{abstract}

Introdução: Diversos compostos naturais com atividade biológica já tiveram suas propriedades e aplicabilidades em saúde avaliadas, dentre estes destaca-se a Própolis Vermelha Brasileira (PVB), um complexo resinoso com diversas atividades biológicas documentadas na literatura, tais como antimicrobiana, antisséptica, antifúngica, antioxidante, antitumoral, antiinflamatória, citotóxica, anti-úlcera, imunomodulatória e cardioprotetora (ABUBAKAR et al. 2014; AHMED et al., 2017; ALENCAR et al., 2007; DAUGSCH, 2007; DANTAS SILVA et al., 2017). Estudos de patentes são importantes, visto que sao indicadores de inovação e desenvolvimento científico tecnológico, assim como os artigos cientificos.

Objetivos: Objetivou-se realizar um estudo sobre as patentes de produtos dermatológicos com própolis em bancos de propriedade intelectual no Brasil e na Europa.

Material e Métodos: Trata-se de uma pesquisa documental de patentes referente à patentes com própolis e finalidades dermatologicas. Foram realizadas as buscas sobre essas patentes depositadas em dois bancos de referência de propriedade intelectual do mundo, o Instituto Nacional de Propriedade Industrial (INPI-Brasil) e o World Intellectual Property Organization (WIPO).

Resultados: Verificou-se que o World Intellectual Property Organization (WIPO) foi o banco com maior número de depósitos de patentes de produtos dermatológicos com própolis (97\%) quando comparado ao INPI (3\%).

Discussão: Diversos foram os tipos de produtos patenteados para uso dermatológico, como cremes, géis, loções, entre outros. Após a análise dos depósitos de patentes, percebe-se que a maioria está relacionada a produtos de uso pessoal e não profissional. A Europa, representada pelo World Intellectual Property Organization (WIPO), possui o maior número de pedidos de patentes, e percebe -se que no Brasil o interesse em relação à proteção da propriedade intelectual em produtos derivados da própolis ainda é pequeno (GIULIETTI et al., 2005). Apesar de terem ocorrido avanços significativos no campo de patentes com própolis, este campo ainda representa uma área em crescimento, sendo importante estimular a inovação e o desenvolvimento de novos produtos que incorporem a própolis, de maneira a aplicar o conhecimento de sua composição e propriedades terapêuticas (FURTADO JÚNIOR et al., 2018). Os dados obtidos se justificam pelo fato de países desenvolvidos investirem mais em desenvolvimento e inovação.

Conclusão: Apesar da riqueza em matérias primas de origem natural o Brasil ainda é muito pouco expressivo no que diz respeito à propriedade intelectual destas, visto que nos paises desenvolvidos o investimento é maior. O conhecimento acerca desse tema e as iniciativas de patenteamento ainda se apresentam bastante limitados dentro das universidades brasileiras.

\title{
Referências
}

ABUBAKAR, Murtala B.; ABDULLAH, Wan Zaidah; SULAIMAN, Siti Amrah et al. Polyphenols as Key Players for the Antileukaemic Effects of Propolis. Evidence-Based Complementary and Alternative Medicine, v. 2014 , p. 1 11, 2014.

AHMED, Romana; TANVIR, E. M.; HOSSEN, Md. Sakib et al. Antioxidant Properties and Cardioprotective Mechanism of Malaysian Propolis in Rats. Evidence-Based Complementary and Alternative Medicine, v. 2017, p. $111,2017$.

ALENCAR, Severino Matias; OLDONI, Tatiane L.C.; CASTRO, Mariana L. et al. Chemical composition and biological activity of a new type of Brazilian propolis: Red propolis. Journal of Ethnopharmacology, v. 113, n. 2, p. $278283,2007$.

DANTAS SILVA, Rejane Pina; MACHADO, Bruna Aparecida Souza; BARRETO, Gabriele de Abreu; et al. Antioxidant, antimicrobial, antiparasitic, and cytotoxic properties of various Brazilian propolis extracts. Plos One, v. 12, n. 3, p. e0172585, 2017.

DAUGSCH, Andreas. A Própolis Vermelha Do Nordeste Do Brasil E Suas Características Químicas E Biológicas. Orientador: Yong Kun Park. 2007. Tese (Doutorado em Ciência de Alimentos) Universidade Estadual De Campinas, Campinas, 2007.

GIULIETTI, Ana Maria; HARLEY, Raymond M.; DE QUEIROZ, Luciano Paganucci et al. Biodiversity and Conservation of Plants in 
Brazil. Conservation Biology, v. 19, n. 3, p. 632 639, 2005.

FURTADO JR, João Hildo de Carvalho; ROCHA VALADAS, Lídia Audrey; MENDONÇA, Keniesd Sampaio; et al. Propolis and its Dental Applications: A Technological Prospection. Recent Patents on Biotechnology, v. 12, n. 4, p. 288 296, 2018.

Coordenadoria de Pesquisa e Extensão - COPEX

Departamento de Editoraçāo e Divulgaçāo Científica - DEDIC 


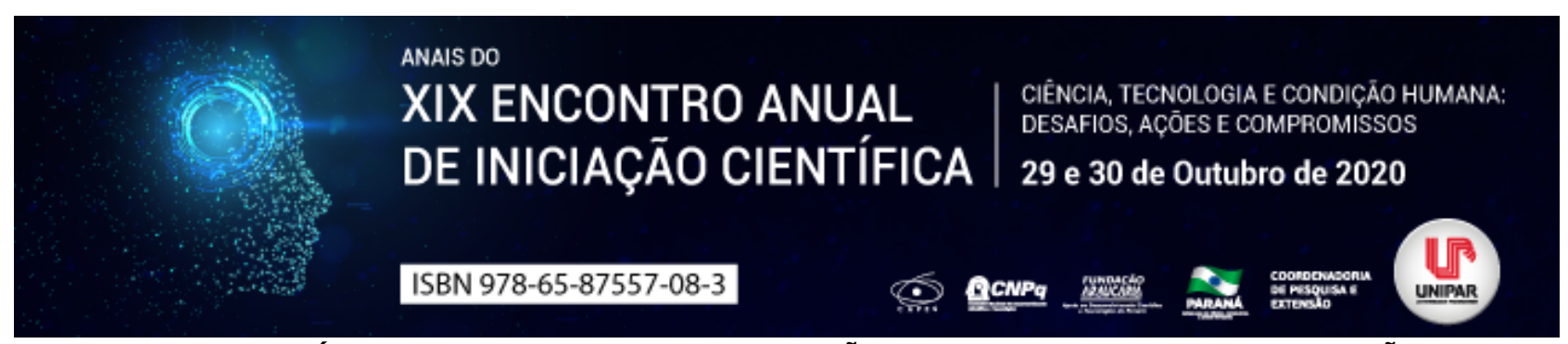

PAPILOMAVÍRUS HUMANO (HPV): TRANSMISSÃO, PATOGENICIDADE E PREVENÇÃO

\author{
${ }^{1}$ DAISI DE LIMA GEREVINI, ${ }^{2}$ BEATRIZ MANCHINI MARUJO, ${ }^{3}$ EDUARDA LUIZA MERTZ, ${ }^{4}$ NATALLY GABRIELLY MARTIN \\ FERNANDES, ${ }^{5}$ ELIZABETI DE MATOS MASSAMBANI
}

\begin{abstract}
${ }^{1}$ Acadêmica do Curso de Medicina da UNIPAR
${ }^{1}$ Acadêmica do Curso de Medicina da UNIPAR

${ }^{2}$ Acadêmica do Curso de Medicina da UNIPAR

${ }^{3}$ Acadêmica do Curso de Medicina da UNIPAR

${ }^{4}$ Docente da UNIPAR
\end{abstract}

Introdução: O HPV é um vírus capaz de causar infecções na pele e mucosa, como verrugas e lesões precursoras de câncer, sendo o câncer de colo de útero considerado o mais frequente. (SILVA, 2012). Este vírus é transmitido predominantemente por formas sexuais. (CARDOSO, 2012). A vacinação é um método de prevenção que está disponível tanto para homens quanto para mulheres, considerada eficaz, visto que estimula a produção de anticorpos específicos para cada tipo de HPV. (BRASIL, 2014).

Objetivo: Analisar os estudos relacionados ao HPV de acordo com sua transmissibilidade, patogenicidade, e medidas profiláticas.

Desenvolvimento: O Papilomavírus humano (HPV) é um vírus DNA pertencentes à família Papoviridae e o gênero Papillomavirus, e está associado com o câncer de colo uterino, o qual é no Brasil, considerado o segundo tumor com maior periodicidade e o quarto com maior causa de morte por câncer (FRIGATO; HOGA, 2003). O vírus apresenta altas taxas de contágio, sua contração pode ser a partir de exposição única. Sua principal forma de contágio é a via sexual, devendo ter contato direto com mucosa e pele infectadas. (BRASIL, 2014). A maioria das pessoas infectadas são assintomáticas (fator agravante para a transmissão), mas em casos mais graves, o vírus se multiplica, aparecendo lesões. Elas se dividem em clínicas (presença de verrugas na região genital e no ânus, normalmente causadas por tipos de HPV não cancerígenos) e subclínicas (apresentam muitas vezes nos mesmos locais das lesões clínicas e sem sinais e sintomas, podendo ser causadas por tipos de HPV de baixo e de alto risco para desenvolver câncer). (BRASIL, s.d.). O diagnóstico é realizado através de anamnese, exame físico, exame clínico urológico, ginecológico e dermatológico, além dos exames complementares (Papanicolau, inspenção com ácido acético a 5\%, colposcopia e peniscopia, biópsia, PCR e hibridização in situ). (NICOLAU, 2002). De acordo com o Ministério da Saúde, a profilaxia do contágio, pode ser obtida através do uso de vacinas; uso dos métodos de barreira em relações sexuais; realização da higiene pessoal e evitar grande quantidade de parceiros sexuais. Quanto a vacinação, existem duas formas, a profilática, que induz resposta humoral e a terapêutica, que atuam estimulando a resposta celular imunológica. Dentro da profilática, existem dois tipos, a bivalente que previne os tipos 16 e 18, indicada para homens e mulheres de 9 a 26 anos e a quadrivalente que previne contra infecção pelos tipos 6, 11, 16 e 18, indicada para mulheres de 10 a 25 anos. (ZARDO, et al., 2014). Em relação a prevenção contra o câncer cervical, são realizados exames de colpocitologia oncótica ou Papanicolau frequentemente. (Idem). 0 tratamento do HPV varia conforme a lesão que o indivíduo apresenta, sua localização e idade. São indicados o ácido tricloroacético de $50 \%$ a $90 \%$ (para mulheres gestantes por não possuírem efeitos adversos ao feto); 5 -fluoruracila em creme; e a podofilotoxina a 0,5\% em solução ou 0,15\% em creme (contraindicado em gestantes). (NICOLAU, 2002). Realiza-se também procedimentos cirúrgicos com índice de cura de $69 \%$ a $79 \%$. Além disso pode-se citar as imunoterapias, descritas em dois grupos, o interferon e o imiquimod. O primeiro é destinado para neoplasias geralmente, sendo classificado em alfa (quando há verrugas genitais), e em beta (casos neoplásicos intra-epitelial cervical, ou lesões genitais HPV). Já o imiquimod é administrado em forma de creme nas lesões cutâneas na vulva ou pênis. (Idem).

Conclusão: Conclui-se acerca da transmissão, patogenicidade e prevenção do Papilomavírus humano (HPV), em conformidade com a literatura analisada, que o patógeno apresenta elevada transmissibilidade, está associado com o câncer de colo uterino, porém, em contrapartida existe a vacinação, com a finalidade de combater o vírus e promover sua dissipação.

\title{
Referências
}

BRASIL. Ministério da Saúde. Guia prático sobre o HPV, guia de perguntas e respostas para profissional de saúde. 2014. BRASIL. Ministério da Saúde. HPV: o que é, causas, sintomas, tratamento, diagnóstico e prevenção. Disponível em: https://saude.gov.br/saude-de-a-z/hpv. Acesso em: 16 abr. 2020.

CARDOSO, Eugênia Márcia Moreira. Aspectos históricos, fisiopatológicos e preventivos da infecção por Papilomavírus Humano-HPV. Curso de especialização em atenção básica em saúde da família. Minas Gerais. 2012.

FRIGATO, Scheila.; HOGA, Luiza Akiko Komura. Assistência à mulher com câncer de colo uterino: o papel da enfermagem. 
Revista Brasileira de Cancerologia, Rio de Janeiro, v. 49, n. 4, p. 209-214, 2003.

NICOLAU, Sérgio Mancini. Papilomavírus humano (HPV): diagnóstico e tratamento. Brasília: Federação Brasileira das Sociedades de Ginecologia e Obstetrícia, 2002.

SILVA, Delane Cristina. Avaliação citológica do Papilomavírus Humano (HPV). 2012. Disponivel em: https://www.ccecursos.com.br/img/resumos/citologia/22.pdf. Acesso em: 26 mar. 2020.

ZARDO, Geisa Picksius et al. Vacina como agente de imunização contra o HPV. Ciência \& Saúde Coletiva, v. 19, p. 3799-3808, 2014.

Coordenadoria de Pesquisa e Extensão - COPEX

Departamento de Editoraçāo e Divulgaçāo Científica - DEDIC 


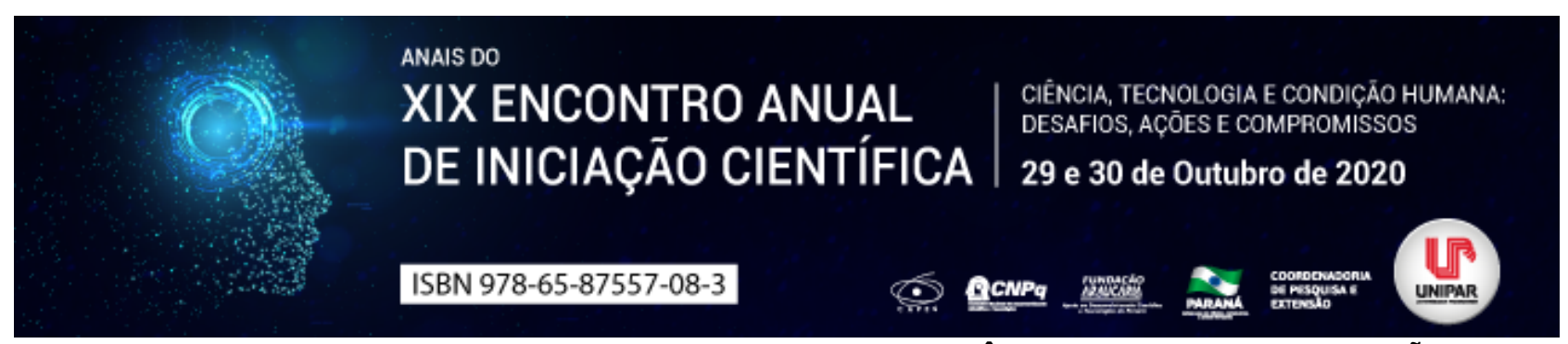

CAUSAS E TRATAMENTOS DA ESCOLIOSE NA ADOLESCÊNCIA ESTUDO DE REVISÃO

\begin{abstract}
${ }^{1}$ LARISSA LOYOLA BARBOSA, ${ }^{2}$ GABRIEL HENRIQUE BELLATO PALIN, ${ }^{3}$ LUCAS ALEXANDRE GUBERT SCHIER, ${ }^{4}$ SUELEN STEFANONI BRANDAO, ${ }^{5}$ RAFAEL BEZERRA MARIM, ${ }^{6}$ ELENIZA DE VICTOR ADAMOWSKI CHIQUETTI
\end{abstract}

\begin{abstract}
${ }^{1}$ Acadêmica do Curso de Medicina da UNIPAR
${ }^{1}$ Acadêmico do Curso de Medicina da UNIPAR

${ }^{2}$ Acadêmico do Curso de Medicina da UNIPAR

${ }^{3}$ Acadêmica do Curso de Medicina da UNIPAR

${ }^{4}$ Acadêmico do Curso de Medicina da UNIPAR

${ }^{5}$ Docente do Curso de Medicina da UNIPAR
\end{abstract}

Introdução: Escoliose idiopática em adolescentes (EIA) é uma curva lateral estruturada conhecida como uma deformação tridimensional na coluna vertebral, curvas no plano frontal, rotação das vértebras no plano transverso e a mudança do plano sagital, que ocorre entre 11 e 18 anos de idade mas, sua prevalência está na faixa de 11 a 16 anos (FERNANDES et al. 2012). Além disso, possui causa desconhecida, e o risco de progressão da curva está relacionado com o crescimento do paciente, idade, sexo e até mesmo problemas pulmonares. Portanto, quando está doença se intensifica a probabilidade de morte sobe, por tratar-se não apenas de problemas físicos mas também de problemas psicológicos. Contudo, a decisão de tratamento é difícil pois o mesmo altera a história premissa da doença, e para isso é necessário o envolvimento de um profissional que detenha grandes recursos (LIMA JUNIOR et al. 2011).

Objetivo: Conhecer por meio do estudo de revisão as fisiologias e patologias da escoliose idiopática em adolescentes como também a história das causas e a percepção em tratamentos.

Desenvolvimento: De acordo com Fernandes et al. (2012) escoliose idiopática em adolescentes (EIA) é assim chamada quando afeta indivíduos entre a faixa etária de 11 a 18 anos tendo a sua maior incidência no gênero feminino, e suas demais alterações podem causar complicações cardiorrespiratórias e dores na lombar, trazendo como consequência a baixa qualidade de vida dos adolescentes. Para que seja apresentada como escoliose idiopática é necessário um grau mínimo de abordagem, e segundo, Soliosis Research Society este grau deve superior a 10 sendo ele calculado pelo método de Cobb. Além da escoliose idiopática que atinge cerca 2 a $4 \%$ da população existe a escoliose secundária a qual fica relacionada com diversas doenças e síndromes. Para que haja um diagnóstico clínico fundamental é importante a realização do teste de Adams (inclinação do tronco para frente), sendo que seu tratamento varia desde a simples correção até a intervenção cirúrgica (OLIVEIRA, 2011). Dessa maneira, suas formas de tratamento são variadas (conservador ou cirúrgico) porém, até a década de 60 o método eficaz era a utilização de coletes gessados, atualmente, é utilizado o sistema criado em 1984 chamado de instrumentação segmentar que abrange a correção da coluna nos planos coronais e sagital como também no axial (AVANZI et al. 2008). Em conformidade com Rodrigues et al. (2009) é importante ressaltar que a cirurgia é recomendada quando a curvatura atinge os 50 graus de correção. Sendo a escoliose idiopática o desvio mais comum encontrado na região da coluna vertebral, os tratamentos e diagnósticos ocupam uma atenção especial no desenvolvimento da cirurgia ortopédica, caracterizando uma grande melhora na qualidade de vida dos adolescentes que em maioria das vezes sofrem para realização de exercícios físicos. Na cirurgia é proposto os resultados e diferenciações entre o uso de gancho e parafuso pediculado. Assim, o parafuso é o que apresenta maior custo e melhor correção da curva mas, entre eles não há diferença com os níveis de artrodese, sangramento e tempo cirúrgico (SOCIEDADE BRASILEIRA DE ORTOPEDIA E TRAUMATOLOGIA, 2008). Sua causa é proposta por teorias, as quais acreditam ser por meio de um distúrbio intrínseco da coluna (natureza genética, desenvolvimento anormal da coluna e dos discos vertebrais) e ainda outras alusões históricas prezam por distúrbios extrínsecos (anomalias do sistema nervoso, músculos paravertebrais e costelas). Ainda, é possível analisar a taxa de mortalidade de pacientes que possuem a EIA, e ela é comparada com a população geral, sendo assim os pacientes com a patologia apresentam maior índice de mortalidade do que adultos com idade superior a 40 anos (JUNIOR et al. 2011). Conforme, Oliveira (2011), é importante ressaltar que a coluna vertebral apresenta curvaturas fisiológicas, como a lordose cervical, cifose dorsal, lordose lombar e cifose sacrococcígea as quais são importantes para o ortostatismo e marcha humana. Contudo, são consideradas curvas patológicas as quais implicam em escoliose do plano frontal e hipercifose do plano sagital, ambas possuem seu diagnóstico clínico é feito completamente com exame radiográfico e seu tratamento é baseado na reeducação postural e reforço da musculatura.

Conclusão: A escoliose idiopática em adolescentes é uma patologia comum, atualmente, mesmo que existam diferentes maneiras de abordagem para tratamento de suas causas e complicações, ela se faz presente. Além disso, apresenta causa desconhecida e pode apresentar elevada causa de mortalidade na vida adulta. Em função de sua morbidade é necessário 
políticas públicas de tratamento para que haja uma diminuição nos problemas críticos de uma doença já existente.

\section{Referências}

AVANZI, Osmar et al. Escoliose idiopática do adolescente: correlação entre parâmetros radiográficos de correção e resultado clínico de tratamento. Coluna/Columna, v. 7, n. 3, p. 201-8, 2008.

FERNANDES, Laís et al. Qualidade de vida e funcionalidade em adolescentes com escoliose idiopática: estudo piloto. Fisioterapia em Movimento, v. 25, n. 1, p. 73-81, 2012.

LIMA JÚNIOR, Paulo Candido de et al. Escoliose idiopática do adolescente (eia): perfil clínico e radiográfico da lista de espera para tratamento cirúrgico em hospital terciário de alta complexidade do Sistema Público de Saúde Brasileiro. Coluna/Columna, v. 10, n. 2, p. 111-115, 2011.

OLIVEIRA, António. Deformidades da coluna no adolescente. Nascer e Crescer, v. 20, n. 3, p. 197-200, 2011.

RODRIGUES, Luciano Miller Reis et al. Escoliose idiopática do adolescente: análise do grau de correção obtido com o uso de parafusos pediculares. Arquivos Brasileiros de Ciências da Saúde, v. 35, n. 1, 2010.

SOCIEDADE BRASILEIRA DE ORTOPEDIA E TRAUMATOLOGIA. Escoliose Idiopática no Adolescente: Instrumentação Posterior. ASSOCIAÇÃO MÉDICA BRASILEIRA E CONSELHO FEDERAL DE MEDICINA. 2008. 3-6. 


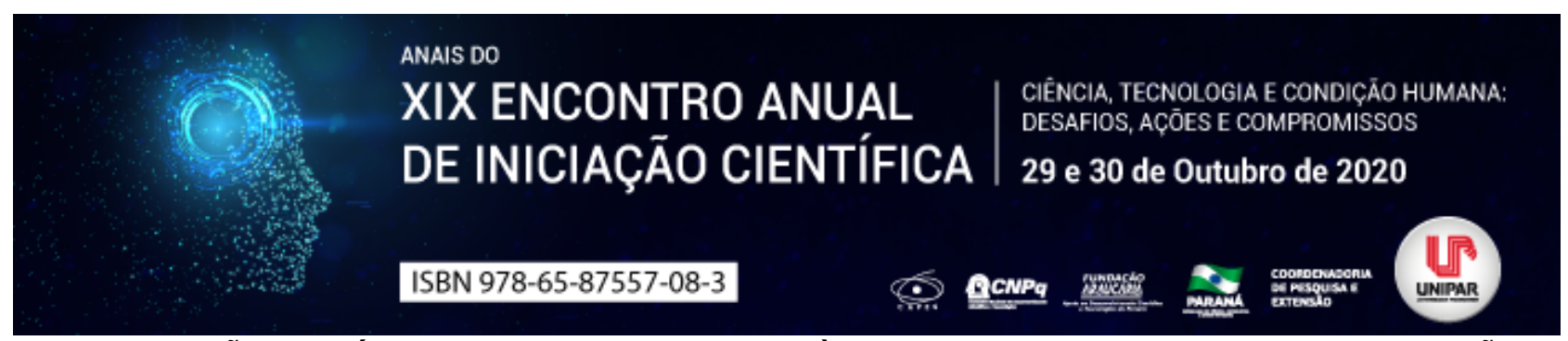

A APLICAÇÃO DA TÉCNICA DA PCR ASSOCIADA À MEDICINA FORENSE - ESTUDO DE REVISÃO

\author{
${ }^{1}$ LARISSA LOYOLA BARBOSA, ${ }^{2}$ LUIS FERNANDO DELAZARI VALERIO, ${ }^{3}$ RICARDO MARCELO ABRAO, ${ }^{4}$ LUCIANO \\ SERAPHIM GASQUES
}

${ }^{1}$ Acadêmica do Curso de Medicina da UNIPAR
${ }^{1}$ Acadêmico do Curso de Medicina da UNIPAR
${ }^{2}$ Docente da UNIPAR
${ }^{3}$ Docente da UNIPAR

Introdução: A medicina forense, também chamada de medicina legal, é uma ciência multidisciplinar que aplica seus conhecimentos médicos, biológicos, químicos, físicos, dentre outros, na resolução da gravidade dos interesses jurídicos (CROCE; JÚNIOR, 2017). Para a determinação de um perfil genético, como em casos de investigação de paternidade, identificação de corpos, violência sexual, a reação em cadeia da polimerase (PCR) é uma técnica muito utilizada, pois ela proporciona a amplificação in vitro de uma região específica do DNA. A técnica possui a capacidade de detectar em pequena quantidade de amostra biológica, ou até mesmo invisível ao olho nú, sequências específicas de ácidos nucleicos com alta sensibilidade e especificidade com grande confiabilidade. Por conta destas vantagens é um processo muito utilizado na medicina forense, onde o perito criminal trabalha em prol da justiça para encontrar a prova técnica mediante análise científica (HAAS; TORRES, 2016).

Objetivo: Compreender a relação entre a técnica de PCR com a medicina forense no desvendamento de casos e auxílio na parte jurídica.

Desenvolvimento: A coleta dos diferentes tipos de material biológico para a extração do DNA é um processo essencial para soluções de casos, e para isso é necessário cautela na identificação, preservação e registros dos materiais (LEITE et al. 2013). Mas, para cada tipo de material biológico é necessário um diferente tipo de coleta, com demasiados materiais (GAERTNER; BINSFELD, 2013). A PCR é uma técnica da Biologia Molecular que garantiu o rápido desenvolvimento dos estudos das sequências de ácidos nucléicos. A técnica é realizada em etapas com variação de temperaturas e tempo, que promovem duplicações sucessivas de cadeias de DNAs específicos in vitro. Cada ciclo da PCR envolve três fases, sendo elas: 1) a desnaturação da fita molde de DNA; 2) os pareamentos de dois iniciadores sintéticos (primers), os quais se ligam as regiões complementares flanqueadoras da sequência de DNA que sofrerá duplicação. São os primers os responsáveis pela identificação do local correto do material que sofrerá tal processo, já os dNTP's (desoxirribonucleotídeos fosfatados) são os cumpridores da criação de novas cópias de material; e 3) a amplificação por intermédio da enzima Taq polimerase, quando as novas fitas de DNA serão sintetizadas a partir de seus indicadores. Assim, em cada ciclo há uma duplicação do DNA alvo, e este procedimento é repetido cerca de 30 a 35 vezes ampliando assim a concentração do DNA de interesse (MARCON et al. 2011). Esta técnica pode ser aplicada em suas variações, e tipos, como a rt-PCR (Reverse Transcriptase Chain Reaction), onde ocorre a transcrição e a amplificação do material, partindo de um RNA que é convertido em cDNA (DNA complementar). Há também a multiplex PCR, Nested PCR e PCR competitiva. Porém, a principal diferença se encontra na PCR convencional e PCR em tempo real. A PCR convencional tem sua particularidade, a qual após a reação é necessário analisar seu resultado visualizando o produto da PCR em um gel de agarose ou poliacrilamida, enquanto na segunda, sua especificidade permite o monitoramento do progresso da reação, sendo possível a quantificação do material genético inicial (VIEIRA, 2011). A análise das regiões do DNA pela técnica de PCR, utilizando-se seus diversos marcadores ou primers, revela a alta variabilidade destas regiões do genoma, de maneira que seja improvável a existência de dois indivíduos com o mesmo perfil genético, a não ser no caso de gêmeos univitelinos (VALONES et al. 2009). O confronto entre o perfil genético da amostra e do suspeito tem sido amplamente utilizado em casos de investigação de paternidade/maternidade, em áreas criminais como a identificação de suspeitos em casos de crimes sexuais, identificação de cadáveres carbonizados ou em decomposição, de corpos mutilados, e o estabelecimento da ligação entre um suspeito a um local de crime (BONACCORSO, 2005).

Conclusão: A PCR é uma ferramenta muito útil na biologia molecular, por propiciar a amplificação de regiões específicas do material genético em situações onde a quantidade de DNA disponível, em quaisquer amostras biológicas, pode estar muito reduzida. Com a obtenção de um perfil genético pode-se então ser feita a identificação de suspeitos, exclusão de inocentes, investigação de paternidade ou maternidade, respondendo-se assim os interesses do poder judiciário. Atualmente, pode-se afirmar que a análise de polimorfismos do DNA está consolidada cientificamente, e não resta dúvidas de sua importância perante os tribunais. 


\section{Referências}

BONACCORSO, N. Aplicação do exame de DNA na elucidação de crimes. Tese de Doutorado. Universidade de São Paulo, 2005.

CROCE, D; JÚNIOR, D. Manual de medicina legal. Saraiva Educação SA, 2017.

GAERTNER, C; BINSFELD, P. Técnicas de Biologia Molecular aplicadas na Investigação Forense, 2013.

HAAS, D; TORRES, A. Aplicações das técnicas de PCR no diagnóstico de doenças infecciosas dos animais. Rev Científica de Medicina Veterinária. v. 14, n. 26, 2016.

LEITE, $\vee$ et al. Uso das técnicas de biologia molecular na genética forense. Derecho y Cambio Social. v. 10, n. 34, p. $21,2013$. MARCON, G et al. Detecção do DNA do Trypanosoma cruzi pela reação em cadeia da polimerase (PCR) em pacientes chagasicos cronicos. Dissertação de Mestrado. UNICAMP, 2001.

VALONES, $M$ et al. Principles and applications of polymerase chain reaction in medical diagnostic fields: a review. Brazilian Journal of Microbiology, v. 40, n. 1, p. 1-11, 2009.

VIEIRA, D. Técnicas de PCR: aplicações e padronização de reações. Saraiva Educação SA., 2011.

Coordenadoria de Pesquisa e Extensão - COPEX

Departamento de Editoraçāo e Divulgaçāo Científica - DEDIC 


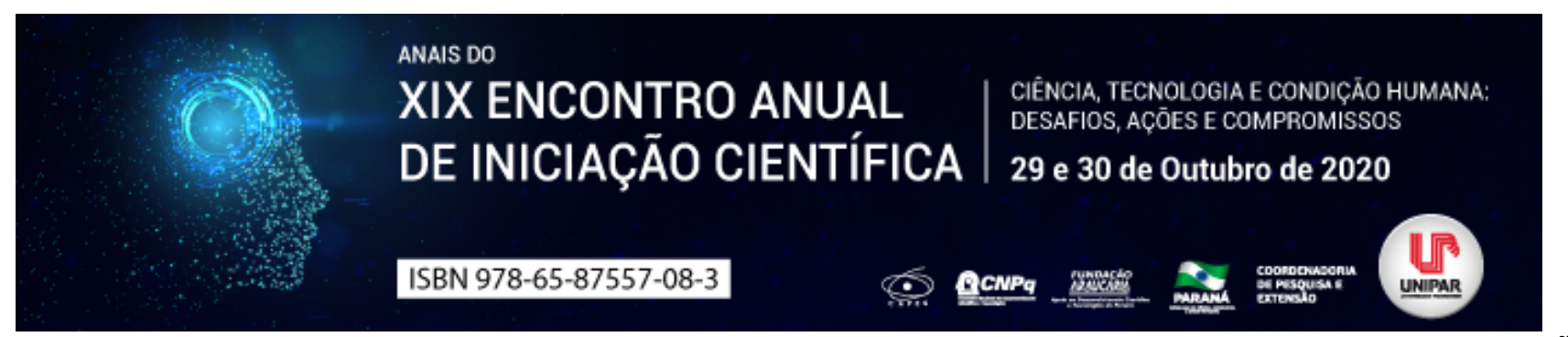

FATORES QUE CONTRIBUEM PARA O DESENVOLVIMENTO DA OBESIDADE INFANTIL ESTUDO DE REVISÃO

\author{
${ }^{1}$ LUIS FERNANDO DELAZARI VALERIO, ${ }^{2}$ LARISSA LOYOLA BARBOSA, ${ }^{3}$ LUCAS COSTA DE OLIVEIRA, ${ }^{4}$ VINICIUS PAIE \\ MARQUES DOS REIS, ${ }^{5}$ MICHEL ANDREW NOGARA
}

\author{
${ }^{1}$ Acadêmico do Curso de Medicina da UNIPAR \\ ${ }^{1}$ Acadêmica do Curso de Medicina da UNIPAR \\ ${ }^{2}$ Acadêmico do Curso de Medicina da UNIPAR \\ ${ }^{3}$ Acadêmico do Curso de Medicina da UNIPAR \\ ${ }^{4}$ Docente da UNIPAR
}

Introdução: O termo obesidade é definido como excesso de peso decorrente do acúmulo anormal de tecido adiposo no organismo, o diagnóstico é avaliado por meio do índice de massa corporal (IMC). A obesidade é reflexo de uma gama de fatores, com ênfase em um estilo de vida não saudável, predisposição genética, problemas na convivência familiar, influência dos pais e contribuição da mídia, perfil sociodemográfico, entre outros (DE CARVALHO, 2017). Além disso, observa-se que seu desenvolvimento está consoante com outras morbidades, como diabetes, hipertensão, doenças cardíacas precoces, malformações ósseas no crescimento, além de poder influenciar no desenvolvimento psicossocial. Destacando o acometimento de crianças, tem-se a obesidade infantil, com fatores peculiares à faixa etária, havendo uma estreita relação entre o desenvolvimento físico e psíquico do indivíduo, os quais necessitam de uma atenção especial quando comparados aos adultos (ENGLER, 2016). Dados que levam ao diagnóstico da obesidade nas crianças são preocupantes, e devem ser realizadas ações que busquem a atenuação ou a solução desse problema (COLLOCA; DUARTE, 2008).

Objetivo: Conhecer os fatores e associações que contribuem para o desenvolvimento e prevenção da obesidade infantil.

Desenvolvimento: A obesidade é designada como uma elevada quantidade de tecido adiposo comparado a massa magra do corpo, sendo considerada um grande problema da saúde pública, pois a doença é precursora de $72 \%$ das mortes que ocorrem no Brasil (ENGLER, 2016). A obesidade pode ser dividida em endógena e exógena, para tratamento da endógena deve ser identificado a doença a partir das mudanças de fatores hormonais e genéticos por meio de alterações metabólicas, já a exógena abrange um equilíbrio de ingestão e pouco gasto calórico (DE CARVALHO, 2017). As maiores influências que promovem o desenvolvimento da obesidade são expostos ao indivíduo na infância, mas as principais consequências são analisadas na vida adulta e por conta disso, deve ser realizadas estratégias de prevenção compreendo a autoestima, problemas emocionais, sociais e físicos de cada indivíduo (DE SÁ, 2017). Contudo, se tem dificuldades em designar a etiologia da doença associada à análise corporal, e por consequência é de íntegra necessidade educação de hábitos alimentares que possam promover sentimento de bem estar, com enfrentamento de barreiras como o bullying e a discriminação (PEREIRA; SANTOS; VIERA, 2017). Além disso, a vida moderna traz a rapidez como sinônimo e, consequentemente, quando o assunto é alimentação, a mesma demanda praticidade para este tipo de vida e assim a alimentação passa a ser mediada por produtos industrializados que apresentam alto índice calórico, sendo muitas vezes preferido pelas crianças, os quais são influenciados pela mídia e pelos pais (JARDIM, 2017). Em concordância, os pais ou responsáveis são as peças chaves para o progresso ou não da obesidade infantil, eles devem introduzir a educação alimentar saudável na vida das crianças, além de incentivar a prática de exercícios físicos. Dessa maneira, os exercícios físicos são os precursores para impedir o aparecimento de doenças crônicas e até mesmo problemas sociais, os quais no futuro podem progredir para crises de ansiedade e depressão (LINHARES, 2016). Outra questão, é o nível socioeconômico e de escolaridade dos pais, afetando na falta de atenção médica para com seus filhos, ou seja, o excesso de peso não se faz um problema para os mesmos pois, a grande maioria dos pais não apresenta conhecimento acerca do peso considerado padrão para cada idade e sexo (TENÓRIO, 2011). Por conseguinte, a obesidade infantil tem suas causas relacionadas a fatores endógenos, que representam cerca de 5\%, onde estão inseridos fatores genéticos, endócrinos e metabólicos, além disso, existem as causas exógenas, que simbolizam cerca de 95\% dos fatores, onde estão incluídos os de origem comportamental, dietética e/ou ambiente (COLLOCA; DUARTE, 2008). Por fim, a obesidade infantil é um fator expressivo para que haja mudanças no padrão de saúde mundial por mediações socioeconômicos, demográficas e relações familiares (SOUZA, 2019).

Considerações finais: A partir dos dados obtidos no estudo, pode-se observar os entraves que estimulam o desenvolvimento da obesidade infantil. Logo é possível formular estratégias de reeducação alimentar, começando pela conscientização dos pais, apontados como principais influenciadores da qualidade de alimentação dos filhos. Assim, poder-se-á atenuar a quantidade de crianças obesas e, por consequência, as inúmeras morbidades que decorrem da obesidade. 


\section{Referências}

DE CARVALHO, A. et al. Sobrepeso e obesidade em alunos de 6-10 anos de escola Estadual de Umuarama/PR. Arquivos de Ciências da Saúde da UNIPAR, v. 21, n. 1, 2017.

ENGLER, R. et al. Design e consumo: a influência da mídia sobre a obesidade infantil. Blucher Design Proc, v. 2, p. 5625-37, 2016.

DE SÁ, A. et al. Sobrepeso e obesidade entre crianças em idade escolar. Nutrición clínica y dietética hospitalaria, v. 37, n. 4, p. 167-171, 2017.

JARDIM, J. et al. Obesidade infantil no Brasil: uma revisão integrativa. JMPHC| Journal of Management \& Primary Health Care| ISSN 2179-6750, v. 8, n. 1, p. 66-90, 2017.

LINHARES, F. et al. Obesidade infantil: influência dos pais sobre a alimentação e estilo de vida dos filhos. Temas em saúde, v. 16, n. 2, p. 460-481, 2016.

PEREIRA, M; SANTOS, C; VIERA, C. A complexidade da determinação da obesidade infantil. Saúde em Revista, v. 17, n. 47, 2017. p. 51-61.

SOUZA, J. et al. Fatores que contribuem para o desenvolvimento da obesidade infantil: revisão integrativa. 2019. Disponível em: http://ri.ucsal.br:8080/jspui/handle/prefix/1427 Acesso em: 21 mai 2020.

COLLOCA, E; DUARTE, A. Obesidade infantil: etiologia e encaminhamentos, uma busca na literatura. II Seminário de Estudos em Educação Física Escolar, 2008. Disponível em: http://www.eefe.ufscar.br/pdf/2a/colloca.pdf Acesso em 21 mai 2020.

TENORIO, A. et al. Obesidade infantil na percepção dos pais. Revista paulista de pediatria, v. 29, n. 4, p. 634-639, 2011.

Coordenadoria de Pesquisa e Extensão - COPEX

Departamento de Editoraçāo e Divulgaçāo Científica - DEDIC 


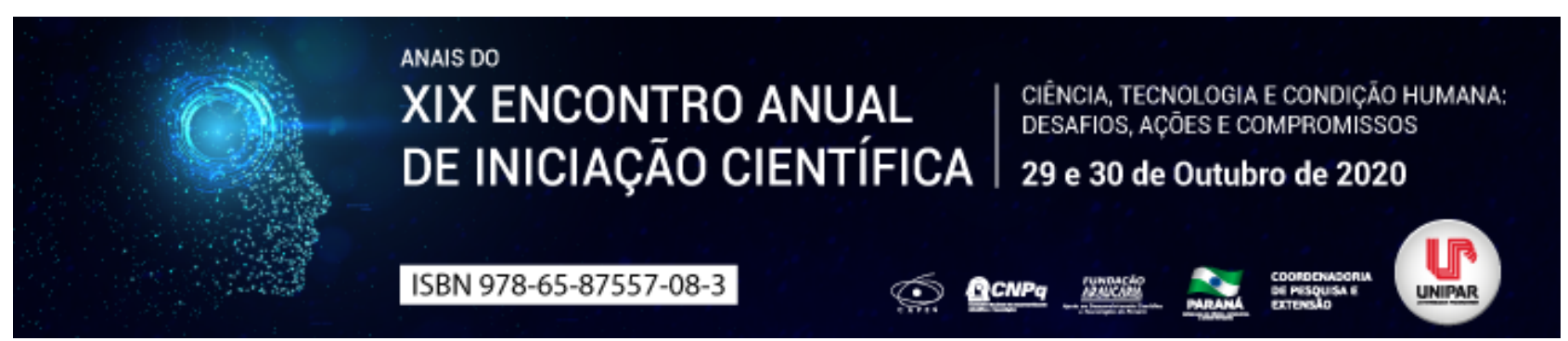

\title{
A ATUAÇÃO DO PROFISSIONAL DE EDUCAÇÃO FÍSICA EM UMA INSTITUIÇÃO DE LONGA PERMANÊNCIA PARA IDOSOS (ILPIS)
}

\author{
${ }^{1}$ Victor Matheus Lopes Martinez, ${ }^{2}$ SUZANA WUBNER WOLFF
}

\author{
${ }^{1}$ Universidade do Vale do Rio dos Sinos \\ ${ }^{1}$ Universidade do Vale do Rio dos Sinos
}

Introdução: Este artigo trata-se de um relato de experiência sobre a atuação do profissional de Educação Física em uma Instituição de Longa Permanência para Idosos (ILPIS) na cidade de Porto Alegre/RS. Para tanto, foi realizado um estágio de observação durante um (1) mês, sempre na parte da manhã.

Objetivo: o objetivo geral deste estudo foi identificar a práxis diária do profissional neste contexto geriátrico, oportunizando com esse relato a divulgação dessa área de atuação, pouco explorado pela área de Educação Física até o presente momento.

Desenvolvimento: A população senil por sua vez, vem crescendo de modo exponencial em nosso país, de modo que segundo o Instituto Brasileiro de Geografia e Estatística - IBGE (2018), por meio da Pesquisa Nacional por Amostra de Domicílios Contínua (PNAD), o Brasil ganhou cerca de 4,8 milhões de idoso desde 2012, havendo assim um crescimento de forma linear em todos os estados da nação, o que representa um aumento de $18 \%$ na totalidade dessa faixa etária, que com os estes dados agora soma $14,6 \%$ da população total de brasileiros. Cabe ainda ressaltar que o Rio Grande do Sul, em conjunto com o Rio de Janeiro, são os estados com maiores índices percentuais de pessoas com idade igual ou superior a 60 anos (18,6\%). Esta etapa que indubitavelmente a maioria dos que hoje são jovens passarão, a terceira idade , muitas vezes é algo temido, principalmente pelas doenças ocasionadas nesta etapa da vida, em especial as doenças neurodegenerativas que afetam o bem-estar do indivíduo, fazendo em muitos casos, o mesmo perder sua identidade pessoal, uma descaracterização de seus gostos, comportamento e hábitos próprios de maneira irreversível (FARRAN et al., 1991). Quanto a atuação do profissional de Educação Física, esta ocorre em conjunto com a equipe multidisciplinar em saúde da clínica estudada, sendo de suma importância para os benefícios mentais e físicos dos residentes do ILPI, pois muitos encontram-se severamente debilitados e o exercício físico de mobilidade e lazer é um excelente aliado na melhora clínica ou simplesmente em evitar que determinadas patologias decorrentes da senilidade se agravem nos idosos.

Conclusão: A observação junto com a literatura revelou que os idosos necessitam de um estímulo constante quanto às atividades físicas de modo a manterem sua mobilidade e saúde cognitiva. Conclui-se então que a atuação do profissional de Educação Física junto a uma equipe multiprofissional em saúde neste contexto é extremamente necessária e, portanto, esta deve ser explorada cada vez mais pelos profissionais da área e pelos ILPIS.

\section{Referências}

BRASIL. Secretaria de Vigilância em Saúde. Secretaria de Atenção à Saúde. Política Nacional de Promoção da Saúde. Brasília: Ministério da Saúde, 2006.

FARRAN, Carol. J.; KEANE-HAGERTY, Eleanora.; SALLOWAY, Stephen; KUPFERER, Sylvia. Finding meaning: an alternative paradigm for Alzheimer's disease family caregivers. Journal of Gerontology, vol. 31, n. 4, p. 483-489, 1991.

FARINATTI, Paulo de Tarso Veras. Envelhecimento, promoção da saúde e exercício: bases teóricas e metodológicas. ed. 1, Barueri, SP: Manole, 2008.

INSTITUTO BRASILEIRO DE GEOGRAFIA E ESTATíSTICA (IBGE). Pesquisa Nacional por Amostra de Domicílios Contínua (PNAD), 2020.

LIVINGSTON, Gill; HUNTLEY, Jonathan; SOMMERLAD, Andrew. The Lancet Comissions Dementia prevention, intervention, and care. The Lancet, vol. 390, p. 2673-2734, dezembro, 2017.

WOLFF, Suzana Hubner (Org). Vivendo e envelhecendo: Recortes de práticas sociais nos núcleos de vida saudável. São Leopoldo: Editora Unisinos, 2009. 


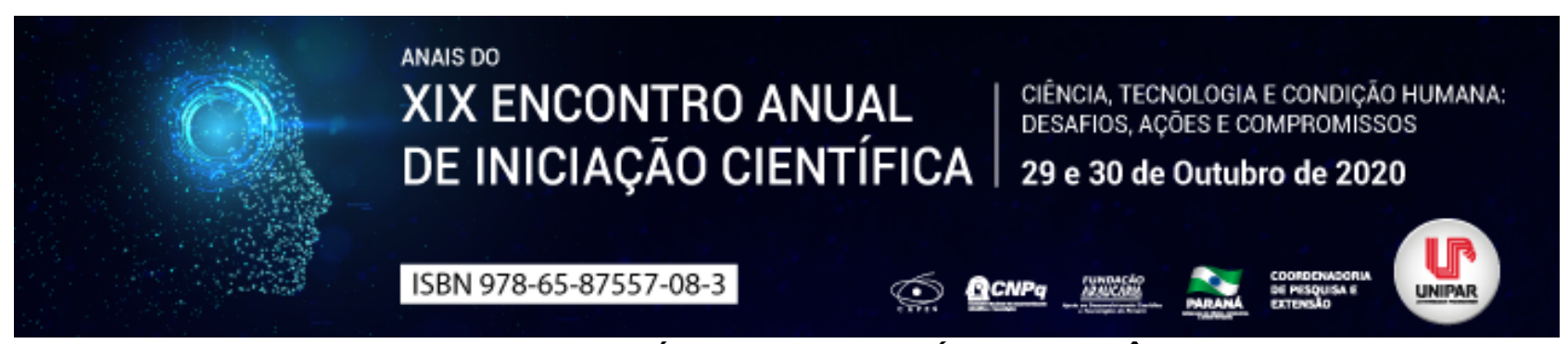

ESTUDO EPIDEMIOLÓGICO SOBRE A SÍFILIS CONGÊNITA

\title{
${ }^{1}$ DENISE APARECIDA MITRUT, ${ }^{2}$ MARIELLY MARIA VITÓRIA DUMKE, ${ }^{3}$ DAISY CRISTINA RODRIGUES
}

\author{
${ }^{1}$ Acadêmica do Curso de Enfermagem da UNIPAR \\ ${ }^{1}$ Acadêmica do Curso de Enfermagem da UNIPAR \\ ${ }^{2}$ Docente da UNIPAR
}

Introdução: Causada pela bactéria Treponema Pallidum, a sífilis é uma infecção sexualmente transmissível (IST) sendo curável, apresenta manifestações clínicas e estágios: primário, secundário e terciário com períodos latentes intercalados.A Organização Mundial da Saúde (OMS) estimou para 2016 cerca de 6,3 milhões de casos de contaminação de sífilis no mundo enquanto os dados do Ministério da Saúde (MS) no Brasil, publicado pelo Boletim Epidemiológico de Sífilis em novembro de 2018, mostram o alarmante número de 116.490 de infecções.

Objetivo: Identificar as bases de toda a população acometida, no grupo de gestante, nas contaminações natais por transmissão vertical e, finalmente, dos natimortos e mortes neonatais, além de ressaltar as vias de contágio.

Metodologia: Trata-se de um estudo epidemiológico observacional do tipo ecológico, é pautado na análise de fatos quantitativos extraídos do DATASUS, sistema de registro de dados médicos de diversas naturezas do Governo Federal do Brasil, e na organização dos mesmos junto à soma de elementos qualitativos em relação às populações infectadas nos anos de 2018, $2019 \mathrm{e}$ 2020.

Resultados: As contaminações em gestantes tem casos crescentes registrados desde 2005, o primeiro trimestre de gestação se mostra o mais frequente na deteç̧ão da doença $33,1 \%$ do total, onde a prevenção e cura são mais fáceis, o segundo trimestre revela uma acentuada queda nas constatações em apenas $28,8 \%$, perdendo para os $31,4 \%$ dos detectados, no terceiro trimestre é quando o tratamento se revela mais complicado devido a proximidade com o parto e assim acometendo a contaminação do feto. Metade dos casos de sífilis gestacional ocorre entre os 20 a 29 anos com expressivos $52,5 \%$ dos totais entre 10 à 40 anos ou mais de idade, revelando urgente necessidade de atenção a esta faixa etária, seja nos exames para a identificação e intervenção precoce, nas campanhas de conscientização sobre a enfermidade, mostra-se também que a condição no período gestacional está diretamente relacionado com baixa escolaridade, provável pela falta de informação, em $20 \%$ dos casos. Já em relação a cor (ou raça) com $48 \%$ de contaminação em mulheres pardas, que correspondem diretamente a maioria da população brasileira segundo os últimos censos (ou como as pessoas se identificam). Faz-se necessário a análise direta dos fatos em relação a etnia, dentro da idade média, pois a construção sociopolítica do país tende a prejudicar o desenvolvimento e o acesso a bens públicos para os indivíduos pobres e de cor. A sífilis congênita, é a que mais se quadruplicou na última década, em 94,5\% dos bebês são diagnosticados antes dos primeiros dias de vida, estando na fase recente da doença, os números referentes aos abortos e natimortos se totalizam em 7,2\% de infecção congênita, cerca de 12.500 crianças mortas precocemente nas últimas duas décadas, por algo que é facilmente tratável. Informações relacionados a realização de acompanhamento pré-natal, estimase que $78,2 \%$ das gestantes recebeu o acompanhamento, apesar de ser um número elevado $15,9 \%$ não recebeu o acompanhamento, o que representa grande risco para as gestantes e fetos, mais da metade destas mães, que totaliza $50,8 \%$ recebeu tratamento inadequado, enquanto os parceiros não foram tratados, em mais de $60 \%$ das situações. Discussões: A falta de atenção no tratamento das mães e parceiros traz grande impacto negativo à saúde pública. Já o tratamento é feito com penicilina, que desde sua descoberta tem se mostrado eficaz no combate a sífilis. Outras drogas estão em estudo para condições em que a penicilina não possa ser utilizada, porém nenhuma demonstrou eficácia semelhante a mesma.

Conclusões: A prevenção com uso de preservativos certamente permanece a maneira mais segura e de menor custo para o combate dessa doença que é sexualmente transmissível. É essencial que os profissionais da saúde sejam instruídos a identificar a fase da infecção para melhor identificação dos momentos críticos e médias referentes a busca por diagnósticos e métodos, sinalizando a ligação entre sintomas visíveis, como as feridas características esta da doença, e outros sintomas clínicos com o conhecimento geral e desenvolvimento da infecção na população.

\section{Referências}

REGAZZI, João Carlos; BOTTINO, Giuliana. SíFILIS, diagnóstico, tratamento e controle. Anais Brasileiros da Dermatologia. Rio de Janeiro RJ, 2006. Disponível em: https://www.scielo.br/scielo.php?script=sci_arttext\&pid=S0365-05962006000200002

OPAS Brasil, Organização Pan-Americana de Saúde. Organização mundial da saúde publica novas estimativas sobre a sífilis. Fevereiro de 2019. Disponível em: https://www.paho.org/bra/index.php?option=com_content\&view=article\&id=5879:organizacaomundial-da-saude-publica-novas-estimativas-sobre-sifilis-congenita\&ltemid=812. 
Coordenadoria de Pesquisa e Extensão - COPEX

Departamento de Editoraçāo e Divulgaçāo Científica - DEDIC 


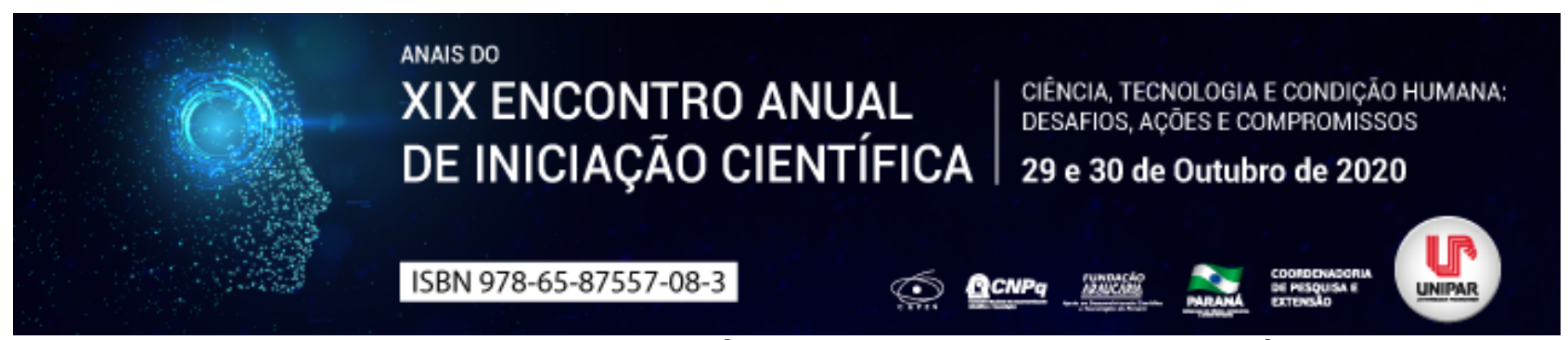

DIABETES MELLITUS: CARACTERÍSTICAS, EPIDEMIOLOGIA E DIAGNÓSTICO

\title{
${ }^{1}$ NATALLY GABRIELLY MARTIN FERNANDES, ${ }^{2}$ BEATRIZ MANCHINI MARUJO, ${ }^{3}$ DAISI DE LIMA GEREVINI, ${ }^{4}$ EDUARDA LUIZA MERTZ, ${ }^{5}$ LUCIANA VIEIRA PINTO RIBEIRO
}

\author{
${ }^{1}$ Acadêmica do Curso de Medicina da UNIPAR \\ ${ }^{1}$ Acadêmica do Curso de Medicina da UNIPAR \\ ${ }^{2}$ Acadêmica do Curso de Medicina da UNIPAR \\ ${ }^{3}$ Acadêmica do Curso de Medicina da UNIPAR \\ ${ }^{4}$ Docente da UNIPAR
}

Introdução: O diabetes, é resultado dos defeitos da secreção e ação da insulina no organismo, hormônio responsável pela lise da glicose, transformando-a em energia para o corpo. Pode se apresentar em diabetes tipo 1, tipo 2, latente e gestacional (BRASIL, s.d.). Para diagnosticar a enfermidade, faz-se análise de alterações da glicose plasmática de jejum, ou realiza um teste oral de tolerância à glicose (TOTG), este é feito após uma administração via oral de alta quantidade de glicose (GROSS et al., 2002). Esta doença, no ano de 2017 acometeu 12,5 milhões de indivíduos (SOCIEDADE BRASILEIRA DE DIABETES, 2019).

Objetivo: Averiguar os estudos relacionados ao diabetes mellitus incluindo a incidência desta patologia no Brasil e seu alarmante número.

Desenvolvimento: $O$ diabetes é uma doença que apresenta frequentemente como sintomatologia a poliúria, polidipsia, polifagia e perda ponderal (UFRGS, 2016). As principais complicações são: retinopatia, neuropatia, doença arterial periférica, doença coronariana, e doença cerebrovascular, podendo levar à morte (SOCIEDADE BRASILEIRA DE DIABETES, 2019). Ademais é caracterizada por uma deficiência na produção, liberação e atuação da insulina, ocasionando um acúmulo de glicose no sangue (BRASIL, s.d.). Os tipos de diabetes dividem-se em: diabetes tipo 1, tipo 2, latente autoimune do adulto (LADA) e gestacional. O tipo 1 está presente em cerca de 5 a 10\% das pessoas que apresentam esta doença crônica não transmissível genética, que normalmente tem início durante a infância ou adolescência. $O$ tipo 2 acomete $90 \%$ das pessoas que apresentam a doença, manifestando-se geralmente em adultos. Já a latente autoimune do adulto (LADA), agravante do tipo 2, acomete principalmente adultos. E por fim, a gestacional afeta até $4 \%$ das gestantes, podendo acometer qualquer mulher, geralmente assintomáticas, portanto, recomenda-se que todas as grávidas façam o exame de diabetes, regularmente, durante o prénatal (SOCIEDADE BRASILEIRA DE DIABETES, 2019); (BRASIL, 2019). No que tange ao diagnóstico da doença, torna-se positivo quando a glicemia fica acima de $200 \mathrm{mg} / \mathrm{dL}$ (em qualquer horário) e acima de $126 \mathrm{mg} / \mathrm{dL}$ (em jejum), sendo necessário repetir os testes no dia seguinte, para confirmação do diagnóstico. Também pode ser realizado, através da hemoglobina glicada, em que torna-se positivo com valor superior ou igual a 6,5\% (UFRGS, 2017). O diabetes é considerado uma epidemia mundial, por conta da rápida urbanização, sedentarismo, além do crescimento e envelhecimento populacional. Em 2017, conforme a Federação Internacional de Diabetes (International Diabetes Federation, IDF), 424,9 milhões de pessoas entre 20 a 79 anos no mundo todo apresentava diabetes. O Brasil, no mesmo ano, ocupava a quarta posição entre os dez países com maior número de indivíduos com diabetes, com 12,5 milhões de pessoas com o diagnóstico da doença. Além disso, o Brasil ocupa a terceira posição em número de crianças e adolescentes com diabetes tipo 1 . Um dos problemas alarmantes, é a estimativa de que $40 \%$ das pessoas que possuem a patologia, desconhecem a existência dela na América Latina. O diabetes apresenta uma alta taxa de mortalidade, com quatro milhões de mortes no ano de 2017. Uma das principais formas de se prevenir o diabetes, é através da alteração no estilo de vida, que reduz cerca de 58\% a incidência da doença (SOCIEDADE BRASILEIRA DE DIABETES, 2019).

Conclusão: Conclui-se a respeito das características, epidemiologia e diagnóstico da diabetes, que esta é uma patologia derivada de defeitos na elaboração e atuação da insulina, podendo ser facilmente diagnosticada, apesar de muitos não saberem que portam, estando presente em milhões de pessoas no Brasil, ocupando o ranking entre os dez países com o maior número de indivíduos com esta doença.

\section{Referências}

BRASIL. Ministério da Saúde. Diabetes (diabetes mellitus): sintomas, causas e tratamentos. Disponível em: http://www.saude.gov.br/saude-de-a-z/diabetes. Acesso em: 27 jul.2020.

BRASIL. Ministério da Saúde. Diabetes: o que é, tipos, sintomas e tratamento. 2019. Disponível em: https://saude.gov.br/component/content/article/746-saude-de-a-a-z/44609-diabetes-tipos-causas-sintomas-tratamento-e- 
prevencao. Acesso em: 27 jul.2020.

GROSS, Jorge L. et al. Diabetes melito: diagnóstico, classificação e avaliação do controle glicêmico. Arquivos Brasileiros de Endocrinologia \& Metabologia, v. 46, n. 1, p. 16-26, 2002.

SOCIEDADE BRASILEIRA DE DIABETES. DIRETRIZES. Sociedade Brasileira de Diabetes 2019-2020. S.L.: Clannad, 2019. Disponível em: https://www.diabetes.org.br/profissionais/images/DIRETRIZES-COMPLETA-2019-2020.pdf. Acesso em: 27 jun. 2020.

UFRGS. Critérios para o diagnóstico de diabetes. 2017. Disponível em: https://www.ufrgs.br/lidiadiabetes/2017/04/08/diagnostico-de-diabetes/. Acesso em: 27 jul. 2020.

UFRGS. Diabetes Mellitus. 2016. Disponível em:

https://www.ufrgs.br/telessauders/documentos/protocolos_resumos/endocrino_resumo_diabetes_TSRS_20160324.pdf. Acesso em: 27 jul.2020.

Coordenadoria de Pesquisa e Extensão - COPEX

Departamento de Editoraçāo e Divulgaçāo Científica - DEDIC 


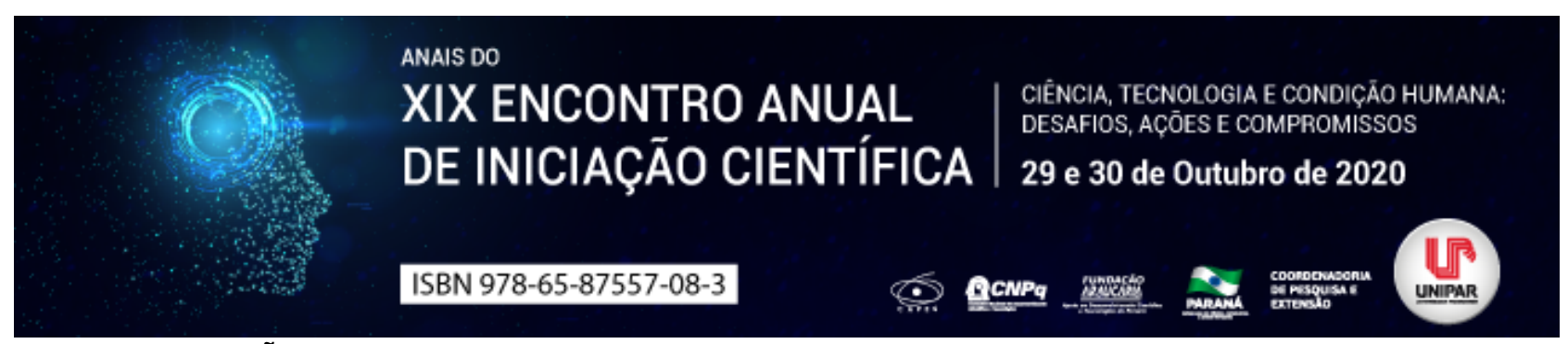

A MUTAÇÃO NO GENE MC4R E SUA INFLUENCIA SELETIVA NO CONSUMO ALIMENTAR

\title{
${ }^{1}$ VITOR ROQUE SAUER, ${ }^{2}$ LUCIANO SERAPHIM GASQUES, ${ }^{3}$ MARIA ELENA MARTINS DIEGUES, ${ }^{4}$ NELTON ANDERSON BESPALEZ CORREA, ${ }^{5}$ RICARDO MARCELO ABRAO
}

\author{
${ }^{1}$ Acadêmico do curso de Medicina e do PIC/UNIPAR \\ ${ }^{1}$ Professor Titular do Curso de Medicina da Universidade Paranaense - UNIPAR \\ ${ }^{2}$ Professora Titular do Curso de Medicina da Universidade Paranaense - UNIPAR \\ ${ }^{3}$ Professor Adjunto do Curso de Medicina da Universidade Paranaense - UNIPAR \\ ${ }^{4}$ Professor Titular do Curso de Medicina da Universidade Paranaense - UNIPAR
}

Introdução: Embora o consumo de alimentos humanos seja uma característica altamente hereditária ou psicológica, existem variações genéticas atualmente conhecidas por afetar formas comuns desses hábitos que explicam apenas uma proporção menor da influência genética (DOULLA et al., 2014). Na literatura, existem associações consistentes entre peso corporal e polimorfismos de nucleotídeo único (SNP) no gene associado à obesidade e com isso, estudos demonstram associações ao gene do receptor da melanocortina-4 (MC4R) (MUL et al., 2012). O MC4R está localizado no cromossomo 18 e é altamente expresso no hipotálamo, onde está relacionado com o controle central do equilíbrio alimentar e energético. Estudos de associação de obesidade em todo o genoma identificaram locais próximos ao gene MC4R que foram relacionados com à massa de gordura corporal (FAROOQI et al., 2003). O receptor de melanocortina 4 é um fator de controle hipotalâmico da homeostase energética de curto e longo prazo por sinais que são fornecidos pelo hormônio estimulador de a-melanócitos ( $\alpha-M S H)$, um agonista do MC4R que está relacionado ao neuropeptídeo agouti-related protein (AgRP), um antagonista do MC4R (PANARO; CONE, 2013). O sistema central de melanocortina contém circuitos neuronais, incluindo neurônios sensíveis à leptina que expressam AgRP no núcleo, e neurônios do tronco cerebral que expressam AgRP em alvos desses neurônios que expressam o MC4R sendo antagonista desses receptores (FAROOQI et al., 2003; DOULLA et al., 2014). Sabendo disso, a energia positiva está relacionada a sinalização da $\alpha-M S H$ fazendo com que a expressão de AgRP seja diminuída, aumentando os níveis de MC4R, assim os gastos de energia diminuem e a ingestão calórica aumenta (KLAAUW et al., 2016). Entretanto, existem estudos que descobrem que variações genéticas relacionadas a obesidade próximas ao gene MC4R não influenciam a ingestão alimentar em certos subgrupos. Porém grande parte dos estudos indicam que há a interrupção direcionada do MC4R em camundongos, resultando em aumento da ingestão de alimentos, peso corporal, comprimento, níveis séricos de hormônios, massa magra e níveis de tecido adiposo (KLAAUW et al., 2016).

Objetivo: O objetivo deste estudo foi realizar uma busca principal através dos autores, vindo a tratar sobre o referencial teórico do gene MC4R e sua influência no consumo alimentar.

Desenvolvimento: Panaro e Cone (2013) descrevem que estudos sugerem que a sinalização central da melanocortina pode regular especificamente o consumo de gorduras alimentares. Houve uma expressão ectópica em que a proteína bloqueia o receptor central de melanocortina-3 (MC3R) e MC4R, demonstrando preferência pelo consumo de gordura não observado em camundongos do tipo selvagem (PANARO; CONE, 2013). Klaauw et al. (2016), relata que o aumento no antagonista endógeno do MC4R, potencialmente, estimula a ingestão de alimentos, aumenta a preferência por gordura e reduz a ingestão de carboidratos quando administrado centralmente. Com esses resultados, a preferência por gordura, em relação aos carboidratos podem representar um comportamento vantajoso expresso em face de diminuição nutricional. Esse estudo comportamental e genético dos seres humanos com mutações naturais afetam áreas centrais específicas por vias de sinalização que fornecem uma ferramenta poderosa para conectar avanços no entendimento dos aspectos moleculares de controle energético aos alimentos pela preferência dos humanos (KLAAUW et al., 2016). Mul et al. (2012) relata que dados in vitro e in vivo mostram que a mutação do gene MC4R resulta em perda de função do gene. Foi observado que a mutação MC4R sob a localização correta da membrana in vitro, e que os ratos do estudo demonstraram ganho de peso, massa adiposa, níveis de hormônios plasmáticos, comprimento do corpo e ingestão basal de alimentos em combinação com diminuição da atividade (MUL et al., 2012). Os autores acreditam que o modelo de MC4R ainda contém um grande potencial para estudar a causa da obesidade monogênica humana, adicionando que o rato de estudo serviu para demonstrar a interferência do gene. Sendo assim, devido ao grande aumento e desempenho cognitivo do rato sendo expresso com o gene MC4R em comparação com os demais ratos, permitem cirurgias e experimentos comportamentais mais complexos, buscando entender melhor os mecanismos específicos que induzem a obesidade durante a perda da função do gene MC4R (MUL et al., 2012; PANARO; CONE, 2013; KLAAUW et al., 2016).

Conclusão: Sabendo dos resultados dos seguintes autores, atualmente, o MC4R é um alvo potencial de drogas para combater a obesidade. Tentativas anteriores de desenvolver agonistas do MC4R obtiveram falhas devido à ineficácia ou eventos adversos. 
Recentemente, uma nova geração de ligantes MC4R foi desenvolvida e com isso, novas pesquisas sobre o MC4R precisam ser elucidadas para melhor desenvolvimento de novas perspectivas para o tratamento da obesidade.

\section{Referências}

DOULLA, Manpreet et al. A novel MC4R mutation associated with childhood-onset obesity: a case report. Paediatrics \& Child Health, [S.L.], v. 19, n. 10, p. 515-518, dez. 2014.

FAROOQI, I. Sadaf et al. Clinical Spectrum of Obesity and Mutations in the Melanocortin 4 Receptor Gene. New England Journal Of Medicine, [S.L.], v. 348, n. 12, p. 1085-1095, 20 mar. 2003.

KLAAUW, Agatha Van Der et al. Divergent effects of central melanocortin signalling on fat and sucrose preference in humans. Nature Communications, [S.L.], v. 7, n. 1, p. 1-5, 4 out. 2016.

MUL, Joram et al. Melanocortin Receptor 4 Deficiency Affects Body Weight Regulation, Grooming Behavior, and Substrate Preference in the Rat. Obesity, [S.L.], v. 20, n. 3, p. 612-621, 28 abr. 2011.

PANARO, Brandon; CONE, Roger. Melanocortin-4 receptor mutations paradoxically reduce preference for palatable foods. Proceedings Of The National Academy Of Sciences, [S.L.], v. 110, n. 17, p. 7050-7055, 8 abr. 2013. 


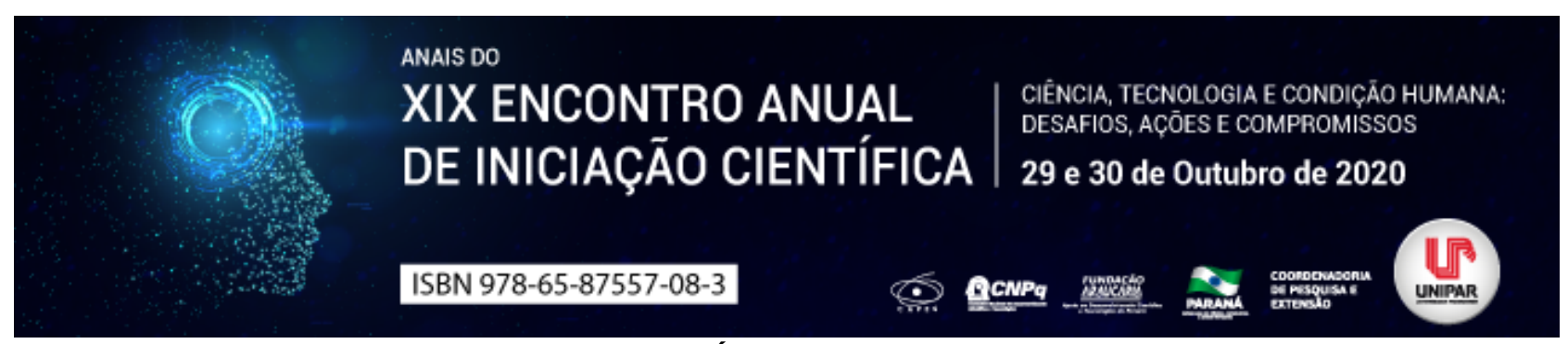

EFEITOS DOS EXERCÍCIOS RESISTIDOS EM IDOSOS

\title{
${ }^{1}$ REBECA EDUARDA DRISNER, ${ }^{2}$ THIAGO GABRIEL NERY DA SILVA, ${ }^{3}$ DORA DE CASTRO AGULHON SEGURA
}

\author{
${ }^{1}$ Acadêmica do curso de Educação Física - UNIPAR \\ ${ }^{1}$ Acadêmico do curso de Educação Física - UNIPAR \\ ${ }^{2}$ Docente - UNIPAR
}

Introdução: Segundo Moura (2019), a população brasileira é estimada em 210 milhões de habitantes, desse total, aproximadamente 28 milhões são idosos, ou seja, 13\% da população é constituída por pessoas acima de 60 anos. Perissé e Marli (2019) afirmam que para estes idosos terem qualidade de vida é preciso garantir direitos como saúde, assistência social, cultura, transporte, habitação e esporte. Moraes (2012) alega que para um idoso ser considerado saudável e hábil a exercer suas funções diárias, deve ser capaz de manter sua independência e autonomia e isto pode ser atingido por meio de atividades físicas direcionadas, que promovem o equilíbrio entre esses dois fatores. Conforme Santarém (2013), dentre as modalidades de atividades físicas existem os exercícios resistidos, mais conhecidos por exigir força muscular, caracterizados a partir do estreitamento das fibras musculares através da resistência sucessiva. Compõe uma alternativa eficaz de exercício voltado ao público idoso de acordo com as propriedades de treino postural, de coordenação e equilíbrio.

Objetivo: Dissertar sobre os efeitos dos exercícios resistidos em idosos.

Desenvolvimento: De acordo com Azevedo (2015), a população tem envelhecido de modo acelerado, e desde a década de 40 mudanças econômicas, culturais e sociais favoreceram o aumento da perspectiva de vida, apesar disso, o avanço da idade tende a intensificar os riscos de desenvolvimento de problemas de saúde. Aspectos orgânicos e biológicos influenciam fortemente sobre os fatores físicos e psicológicos do indivíduo, e vão se manifestando ao longo dos anos. Diversos são os problemas desencadeados com o envelhecimento, destacando a redução gradativa da força muscular, a dificuldade de coordenação motora e perda de equilíbrio (LOPES et al., 2015). Coelho e Natalli (2013) defendem o fato de que o envelhecimento de forma saudável retarda significativamente tais problemas funcionais e estruturais do sistema musculoesquelético, favorecendo uma melhor interação social e uma qualidade de vida mais desejável, contribuindo para o desempenho e capacidade funcional do idoso. Para Prado et al. (2010), a prática de exercícios físicos é um meio de prevenção fundamental, pois melhora o equilíbrio, a coordenação motora, a marcha, a força muscular, a sinestesia e a reação de tempo de resposta. Conforme Coelho e Natalli (2013), idosos que mantêm uma rotina de treinamento regular e adequado adquirem ótimos resultados para a saúde, mesmo os mais fracos apresentam melhorias com o treino resistido. Cerca de $70 \%$ das pessoas, acima de 60 anos, não praticam absolutamente nenhuma atividade física, o que se torna assustador se levado em conta o fato do sedentarismo aumentar as chances de uma comorbidade cardíaca ou neurológica. Lopes et al. (2015) consideram ainda que a prática de exercícios resistidos, como a musculação, é a mais apropriada a este público, pois diminui significativamente processos degenerativos e inflamatórios, tornando a pessoa idosa mais independente e confiante. Todavia, Coelho e Natalli (2013) ressaltam a importância do acompanhamento de um profissional qualificado e com profundo conhecimento das alterações fisiológicas que são associadas a idade.

Conclusão: O número de idosos tem crescido de forma significativa, assim como a expectativa de vida, porém, o avanço da idade traz consigo o declínio físico e psicológico, visto que é nesse período que ocorrem a redução expressiva da força muscular e a queda da capacidade funcional. Há eficácia gradual na existência de um programa de treinamento resistido para idosos, em decorrência de permitir melhor desempenho físico e possibilitar o retardo de doenças crônicas degenerativas.

\section{Referências}

AZEVEDO, L. S. A queda no idoso: Fatores de risco e prevenção. Dissertação (Mestrado Integrado em Medicina) - Faculdade de Medicina da Universidade de Coimbra, Coimbra, 2015.

COELHO, H. N.; NATALLI, B. V. A. Benefícios da musculação na terceira idade. Revista Digital EFDeportes, v. 15, n. 148, p.01-07, 2013.

LOPES, C. D. et al. Treinamento de força e terceira idade: Componentes básicos para autonomia. Trabalho de Conclusão de Curso (Graduação em Educação Física) Centro Universitário de Formiga-UNIFOR, Formiga, 2015.

MORAES, E. N. Atenção à saúde do idoso: Aspectos conceituais. Brasília: Organização Pan-Americana da Saúde, 2012.

MOURA, T. Estimativa da população do Brasil passa de 210 milhões. IBGE. 2019 . Disponível em:https://www.correiobraziliense.com.br/app/noticia/brasil/2019/08/28/internabrasil,779566/estimativa-da-populacao-do-brasil-

passa-de-210-milhoes-diz-ibge.shtml. Acesso em 31 mar. 2020.

PERISSÉ, C.; MARLI, M. Caminhos para uma melhor idade. Retratos: A Revista do IBGE, n. 16, p. 19-25, 2019. 
PRADO, R. A. et al. A influência dos exercícios resistidos no equilíbrio, mobilidade funcional e na qualidade de vida de idosas. 0 Mundo da Saúde, v.34, n. 2, p. 183-91, 2010.

SANTARÉM, J. M. Treinamento Resistido. 2013. Disponível em: http://treinamentoresistido.com.br/texto-basico/. Acesso em: 30 mar. 2020.

Coordenadoria de Pesquisa e Extensāo - COPEX

Departamento de Editoraçāo e Divulgaçāo Científica - DEDIC 


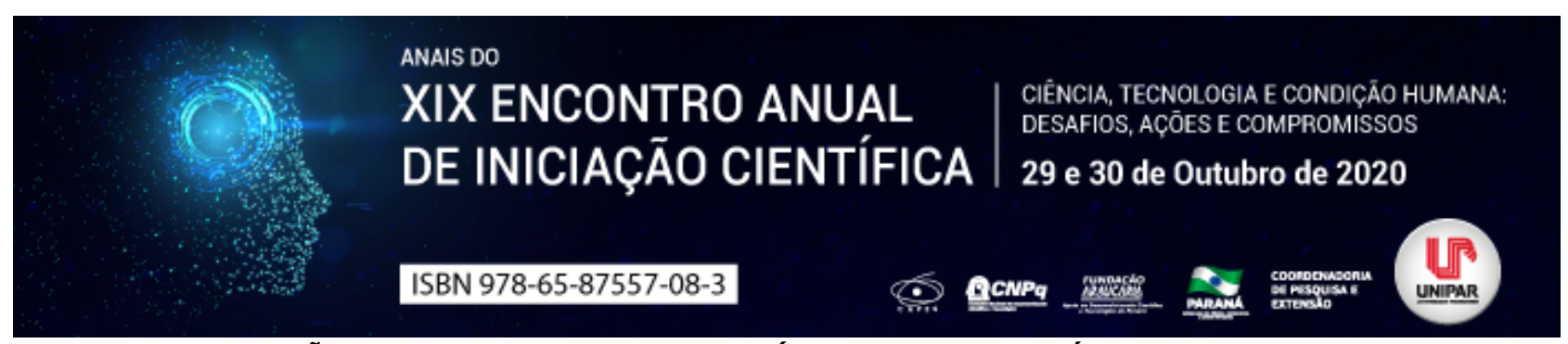

ALTERAÇÃO NODULAR EM DORSO DE LÍNGUA SEM DIAGNÓSTICO CONCLUSIVO

\author{
${ }^{1}$ GIULIA MARTINEZ MARTINS, ${ }^{2}$ JENIFFER URBANO DEGASPERI, ${ }^{3}$ ANA CLAUDIA POLETTO, ${ }^{4}$ LETICIA DE FREITAS CUBA \\ GUERRA
}

\author{
${ }^{1}$ Discente do curso de Odontologia da Universidade Paranaense / Campus Cascavel \\ ${ }^{1}$ Acadêmica do Curso de Odontologia da UNIPAR \\ ${ }^{2}$ Docente da UNIPAR \\ ${ }^{3}$ Docente da UNIPAR
}

Introdução: A língua como um órgão muscular revestida por mucosa, é passível de diversas alterações patológicas, como alterações da normalidade, infecciosas e até mesmo neoplásicas (MARCUCCI, 2014). Sendo o local de maior acometimento de câncer de cavidade oral no Brasil, e, uma das mais importantes ferramentas para o diagnóstico patológico (SUN et al., 2017; DE AQUINO et al., 2015). Diante disso, o objetivo deste trabalho é relatar a conduta adotada frente a uma lesão nodular em dorso de língua sem diagnóstico conclusivo, discutindo as possíveis hipóteses diagnósticas e investigadas.

Relato de caso: Paciente do gênero masculino, quinze anos, procurou atendimento odontológico referindo I"há mais de um ano aumento de volume na língual", sem sintomatologia dolorosa, somente desconforto. Durante anamnese relatou ser saudável, tendo onicofagia como hábito nocivo, faz uso de aparelho ortodôntico a menos de um ano e realizou diversos tratamentos sem sucesso. Ao exame físico, notou-se um aumento de volume nodular, medindo $3 \mathrm{~cm}$ de diâmetro, com a mesma coloração da mucosa, de consistência firme e localizado na linha média do dorso da língua. Observou-se também a presença de áreas atróficas compatíveis com glossite migratória benigna, além da língua fissurada e linfonodos impalpáveis. As hipóteses diagnósticas estabelecidas foram: depósitos amiloides, tumor de células granulares, Schwannoma e Linfangioma. Assim sendo, exames laboratoriais foram solicitados e apresentaram-se dentro dos parâmetros normais, além disso, foi realizada ultrassonografia que revelou imagem hipoecogênica sem presença de vascularização. Dessa forma, foi realizada biópsia incisional, que revelou presença de papilomatose. Diante disso, foi indicada remoção completa da lesão, em que, sua análise histológica revelou: projeções papilares em direção ao tecido epitelial exibindo infiltrado inflamatório até a região de submucosa, de formato irregular, superfície papilomatosa, coloração esbranquiçada com áreas pardacentas e consistência fibrosa, sendo o diagnóstico histopatológico dado como papilomatose e processo inflamatório crônico granulomatoso, não sendo identificado micro-organismos após análise para PAS e reação de Ziehl-Neelsen. Diante do laudo inconclusivo, o paciente será mantido em acompanhamento periódico e diante de qualquer recidiva ou outras alterações, novas investigações serão propostas.

Discussão: Inicialmente, diversas patologias foram consideradas, devido a gama de doenças que podem causar um nódulo no dorso da língua (MARCUCCI, 2014). Por não ter sido possível um diagnóstico através do laudo, o termo papilomatose foi empregado como um diagnóstico patológico representando a exacerbação das papilas do dorso da língua, devido a isso, pode ser viável solicitar ao patologista revisar as lâminas afim de encontrar área mais representativa da lesão (KIGNEL et al., 2003). Porém, o agente causador da lesão nodular é incerto, podendo ser derivado de hormônios da puberdade devido a idade do paciente, a diversos patógenos ou tumores. A remoção completa da lesão foi realizada devido a biópsia incisional descartar proliferação celular de origem neoplásica e as hipóteses diagnósticas anteriores ao procedimento. Entretanto, conforme o diagnóstico patológico de inflamação crônica granulomatosa, cabe a investigação sobre possíveis doenças infecciosas e granulomatosas. A tuberculose é uma doença bacteriana crônica, podendo ser considerada uma hipótese, visto que, em casos menos frequentes apresentam-se como nódulos, tendo predileção por língua, palato e lábios em fase secundária da doença. Apesar de ter dado negativo o resultado da coloração de Ziehl-Neelsen, há o conhecimento de insucesso de 40 a $73 \%$ dos casos com o teste, logo, não é descartada a possibilidade dessa patologia, sendo viável o questionamento de vacinação BCG ao paciente (NEVILLE et al., 2009). A sífilis é uma infecção bacteriana crônica, sexualmente transmissível, que possui diferentes quadros clínicos e fases, dificultando seu diagnóstico, porém, lesões nodulares já foram citadas durante a sífilis secundária, devido a isso, os exames de VDRL podem ser solicitados para descarte dessa doença (DE SOUZA, 2017). A paracoccidiodomicose é uma infecção fúngica, que poderia ser uma hipótese, mas foi descartada após laudo histopatológico. Entretanto, devido ao paciente ser adolescente, sem hábitos nocivos, região de difícil trauma, sem quadro compatível com neoplasia e do laudo histopatológico, nos leva a admitir que a biópsia excisional proporcionou um resultado satisfatório para a queixa principal do paciente, sendo essencial o acompanhamento periódico para possíveis recidivas e alterações, porém, cabe investigação mais detalhada do caso para conclusão do diagnóstico.

Conclusão: Diante do exposto, é necessário o conhecimento acerca da patogênese e estudo das diversas hipóteses diante de um quadro sem diagnóstico através da análise patológica e incomum, bem como, a importância da biópsia e dos exames 


\section{Referências}

DE AQUINO, Rodrigo Cézar Abreu. et al. Aspectos epidemiológicos da mortalidade por câncer de boca: conhecendo os riscos para possibilitar a detecção precoce das alterações na comunicação. Revista CEFAC, v. 17, n.4, p.1254-1261, jul/ago. 2015 DE SOUZA, Bárbara Capitanio. Manifestações clínicas orais da sífilis. Revista da Faculdade de Odontologia, Passo Fundo, v. 22, n.1, p. 82-85, jan/abr. 2017.

KIGNEL, Sergio. et al. Estomatologia - Bases do Diagnóstico para o Clínico Geral, 2. ed., São Paulo, Editora Santos, 2003. MARCUCCI, Gilberto. Estomatologia Fundamentos de Odontologia, 2. ed., Editora Santos, 2014.

NEVILLE, Brad W. et al. Patologia Oral e Maxilofacial, 3. ed., Rio de Janeiro: Elsevier, 2009.

SUN, Shipeng. et al. Biology of the tongue coating and its value in disease diagnosis. Complementary Medicine Research, v. 24, p. 1-7, set. 2017.

Coordenadoria de Pesquisa e Extensāo - COPEX

Departamento de Editoraçāo e Divulgaçāo Científica - DEDIC 


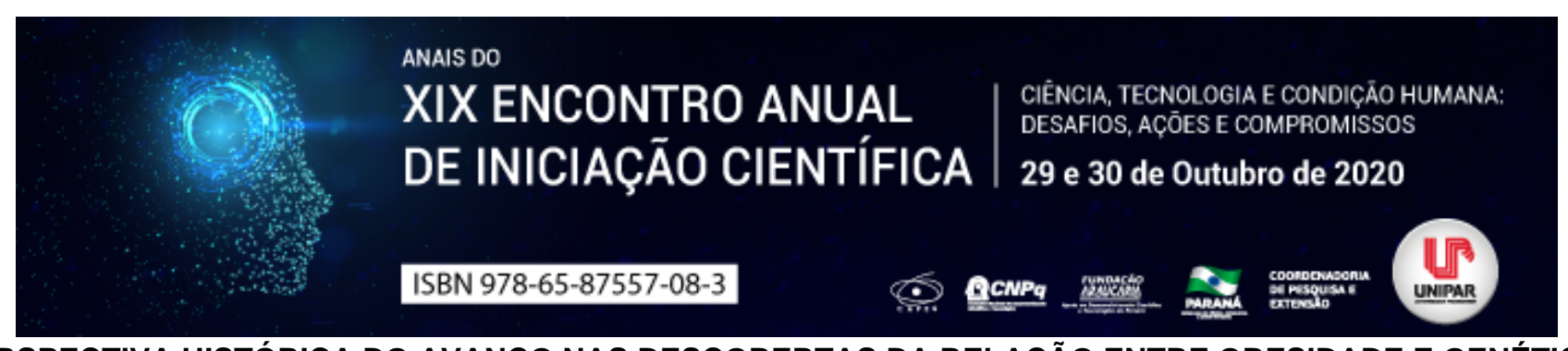

PERSPECTIVA HISTÓRICA DO AVANÇO NAS DESCOBERTAS DA RELAÇÃO ENTRE OBESIDADE E GENÉTICA

\title{
${ }^{1}$ LUCAS PINTO DE OLIVEIRA, ${ }^{2}$ MARIA ELENA MARTINS DIEGUES, ${ }^{3}$ LUCIANO SERAPHIM GASQUES
}

\author{
${ }^{1}$ Acadêmico do curso de Medicina e PIC/UNIPAR \\ ${ }^{1}$ Coordenadora do curso de Medicina da UNIPAR \\ ${ }^{2}$ Docente do curso de Medicina da UNIPAR
}

Introdução: Apesar de há mais de um século existirem propostas científicas quanto ao cunho genético da obesidade, ainda é muito persistente a visão da relação do excesso de peso como uma escolha pessoal/comportamental (JOU, 2014). Nesse sentido, destaca-se a importância da consciência quanto à etiologia da variabilidade do peso corporal, em que 20 a $25 \%$ tem contribuição genética (PEREIRA; RODRIGUES; CORTEZ, 2019). Assim, com o avanço da medicina personalizada, a disseminação e o aprofundamento na relevância da genética da obesidade é fundamental para o desenvolvimento de novas abordagens terapêuticas mais efetivas.

Objetivo: Compilar brevemente informações quanto a cronologia dos avanços e descobertas na relação entre a genética e a variação do peso corporal e as perspectivas futuras no tratamento personalizado da obesidade.

Desenvolvimento: Hoje, com a produção científica, estabeleceu-se uma base genética consistente para o entendimento da obesidade, adicional aos efeitos de estilo de vida, hábitos alimentares, ambientais e metabólicos, em três mecanismos de manutenção do peso corporal, atuando (1) na gerência de reguladores do apetite (peptídeos e monoaminas), (2) no efeito termogênico dos alimentos, na variação do metabolismo basal ou na atividade física espontânea e (3) na regulação metabólica dos nutrientes energéticos disponíveis (MARQUES-LOPES; et al., 2004). Entretanto, Jou (2014), em uma pesquisa feita nos Estados Unidos constatou que $61 \%$ dos entrevistados entendiam a obesidade estritamente como objeto de escolha pessoal quanto a alimentação e prática de exercícios físicos. Isso demonstra um grande desconhecimento científico acerca do tema, visto que em 1907, elaborado pelo patologista Carl von Noorden, já se delineavam os primeiros passos em direção a um entendimento mais profundo da relação genética da obesidade, estabelecendo-se o conceito de obesidade endógena e exógena, sendo a endógena derivada de um quadro de hipometabolismo e outras alterações tireoideas (PENNINGTON, 1953). Passando para a década 1950, relata-se que a pesquisadora Jules Hirsch, da Universidade Rockefeller, descobriu que, embora os obesos pudessem perder muito peso com uma dieta restritiva, suas taxas metabólicas cairiam em resposta à redução de calorias. Então, isso significaria que, por exemplo, se uma mulher obesa emagrecesse de $90 \mathrm{~kg}$ para $60 \mathrm{~kg}$, teria que consumir menos calorias para permanecer com esses $60 \mathrm{~kg}$ do que uma mulher com $60 \mathrm{~kg}$ cujo peso sempre se manteve estável (JOU, 2014). Na década de 1960, uma pesquisa com presidiários, feita pela Universidade de Vermont, verificou que uma dieta de mais de 10.000 kcal por dia, por 200 dias, 20 detentos ganharam em média de 9 a 11 kg. Entretanto, as taxas metabólicas desses indivíduos aumentaram juntamente com o aumento do consumo calórico, como se o corpo desses indivíduos estivessem defendendo os seus pesos inicias mais baixos. Assim, esses homens tiveram dificuldade de manter o ganho de peso e a maioria eliminou todo o peso ganho com relativa facilidade com a volta da ingestão calórica normal com exceção dois internos que ganharam peso rápido e, mesmo com o consumo calórico reduzido, tiveram muita dificuldade para perder o peso ganho. Ambos tinham histórico familiar positivo para obesidade (JACKS; KERNA, 2018). Outro marco para o conhecimento científico da obesidade, em 1983, Albert Stunkard, da Universidade da Pensilvânia, fez uma pesquisa com 540 adultos dinamarqueses que foram adotados antes de completarem 1 ano de idade traçando os dados de peso e altura dos pais biológicos e adotivos com essas pessoas, observaram que os resultados se aproximavam predominantemente do de seus pais biológicos, mesmo tendo ambiente compartilhado com os pais adotivos (STUNKARD, et al., 1986). Corroborando-se com este fato, Stunkard, em 1990, dirigiu um estudo feito com registros de gêmeos indênticos suecos, revelando que, indiferentemente, em casos que os irmãos foram criados juntos no mesmo ambiente ou completamente separados em ambientes distintos, os mesmo mantiveram virtualmente o mesmo peso (STUNKARD, et al., 1990). Finalmente, em 1994, Jeffrey Friedman e associados clonaram o gene ob que seria o responsável pela produção da leptina, considerada fundamental reguladora no balanço energético fisiológico (ZHANG, et al., 1994). Atualmente, a genética tem mostrado um papel considerável na modulação da susceptibilidade individual à obesidade, visto que estudos da obesidade monogênica fornecem evidências do papel da regulação do apetite e da sinalização neurológica na suscetibilidade à obesidade, com a via da leptina-melanocortina tendo um papel essencial na sinalização da saciedade (MOUSTAFA; FROGUEL, 2013).

Conclusão: A comunidade científica já vem percorrendo um longo caminho na busca da resolução dos porquês e comos da obesidade. No momento presente, baseados nessas descobertas, inúmeros estudos avançam em um maior aprofundamento genético da obesidade. Entretanto, de idônea importância, a sociedade deve ter acesso e conscientizar-se dessas facetas de uma mal tão presente em seu cotidiano, trazendo para sua realidade a visão da obesidade como algo muito além de uma escolha. 


\section{Referências}

JACKS, Denise G.; KERNA, Nicholas A. A Comprehensive Analysis of Obesity Part 1. Overview of Obesity. J Obes Nutr Disord: JOND-130. DOI, v. 10, p. 2577-2244.100030, $2018 . \quad$ Disponível em: www.nejm.org/doi/abs/10.1056/NEJM195306042482301. Acesso em: 05 ago. 2020.

JOU, Chin. The biology and genetics of obesity A century of inquiries. New England Journal of Medicine, v. 370 , n. 20, p. 1874-1877, 2014. Disponível em: https://www.nejm.org/doi/full/10.1056/NEJMp1400613. Acesso em: 05 ago. 2020.

MARQUES-LOPES, Iva et al. Aspectos genéticos da obesidade. Rev. Nutr, p. 327-338, 2004. Disponível em: https://www.scielo.br/scielo.php?pid=S1415-52732004000300006\&script=sci_abstract\&tlng=es. Acesso em: 05 ago. 2020.

MOUSTAFA, Julia S. El-Sayed; FROGUEL, Philippe. From obesity genetics to the future of personalized obesity therapy. Nature Reviews Endocrinology, v. 9, n. 7, p. 402, 2013. Disponível em: https://www.nature.com/articles/nrendo.2013.57.pdf? origin=ppub. Acesso em: 05 ago. 2020.

PENNINGTON, Alfred W. A reorientation on obesity. New England Journal of Medicine, v. 248, n. 23, p. 959-964, 1953. Disponível em: https://www.gavinpublishers.com/assets/articles_pdf/1540550450article_pdf52083722.pdf. Acesso em: 05 ago. 2020.

PEREIRA, Vanessa; RODRIGUES, Carina; CORTEZ, Filipa. Fatores genéticos, epigenómicos, metagenómicos e cronobiológicos da obesidade. Acta Portuguesa de Nutrição, n. 17, p. 22-26, 2019. Disponível em: http://www.scielo.mec.pt/scielo.php? pid=S2183-59852019000200004\&script=sci_arttext\&tlng=es. Acesso em: 05 ago. 2020.

STUNKARD, Albert J. et al. An adoption study of human obesity. New England Journal of Medicine, v. 314, n. 4, p. 193-198, 1986. Disponível em: https://www.nejm.org/doi/abs/10.1056/nejm198601233140401. Acesso em: 05 ago. 2020.

STUNKARD, Albert J. et al. The body-mass index of twins who have been reared apart. New England journal of medicine, v. 322, n. 21, p. 1483-1487, 1990. Disponível em: https://www.nejm.org/doi/full/10.1056/nejm199005243222102. Acesso em: 05 ago. 2020.

ZHANG, Yiying et al. Positional cloning of the mouse obese gene and its human homologue. Nature, v. 372, n. 6505, p. 425-432, 1994. Disponível em: https://link.springer.com/content/pdf/10.1038/372425a0.pdf. Acesso em: 05 ago. 2020. 


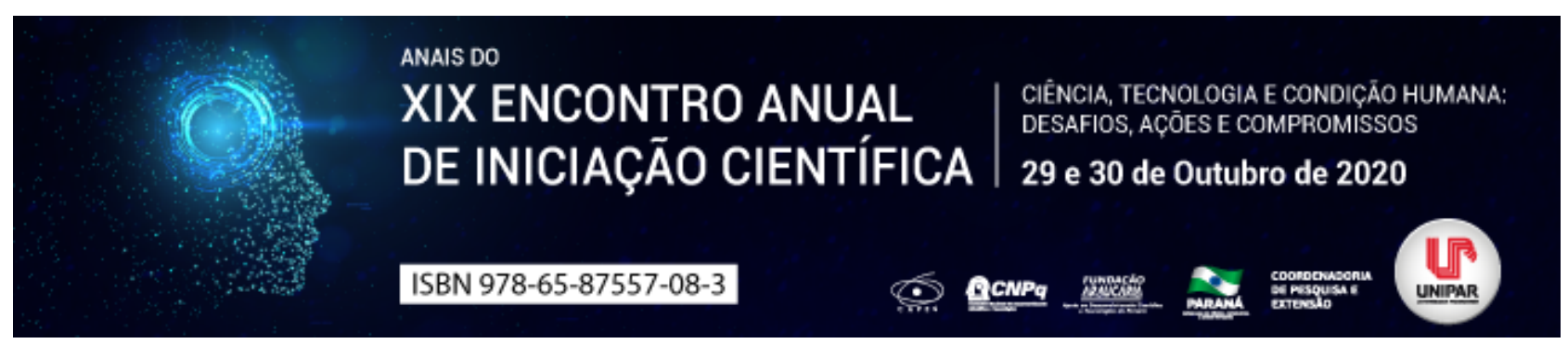

ANEMIA FALCIFORME E SUAS COMORBIDADES

\title{
${ }^{1}$ THAINARA KETLIN FERNANDES MARCHIORE, ${ }^{2}$ LETICIA PENTEADO DE ALBUQUERQUE, ${ }^{3}$ GRAZIELLE MECABO
}

\author{
${ }^{1}$ Acadêmica de Enfermagem - UNIPAR \\ ${ }^{1}$ Acadêmica de Enfermagem - UNIPAR \\ ${ }^{2}$ Docente - UNIPAR
}

Introdução: A anemia falciforme (AF) é uma doença hereditária, que foi descrita pela primeira vez em 1910 por Herrick, em uma ilha do Caribe, os eritrócitos cujo conteúdo predominante é a hemoglobina $\mathrm{S}(\mathrm{HbS})$, assumem, em condições de hipóxia, forma semelhante à de uma foice, por isso se dá o nome de AF. (BARNETT, 2017) A hidroxicarbamida (HU), utilizada no tratamento da AF, apresenta entre seus efeitos redução da hemólise. (TELEN, 2016) No entanto, pouco se sabe sobre a ação da HU nestes mecanismos; a desoxigenação da HbS e sua polimerização leva a rigidez, deformação e fragilidade do eritrócito e é considerado o mecanismo base da fisiopatologia da AF, sendo responsável por anemia hemolítica, fenômenos vaso oclusivos e asplenia funcional progressiva, característicos da doença.(KATO; PIEL; REID; GASTON et al., 2018) Os glóbulos vermelhos em forma de foice não circulam adequadamente na microcirculação, ficam mais rígidos e perdem a mobilidade, resultando tanto em obstrução do fluxo sanguíneo capilar como em sua própria destruição precoce. Esta doença acarreta graves manifestações clínicas, com maior frequência após os 3 meses de idade. Durante os 6 primeiros meses de vida, esses indivíduos são geralmente assintomáticos devido aos altos níveis de hemoglobina fetal (HbF).(TELEN, 2016; WILLIAMS; THEIN, 2018) As patologias causadas por uma alteração da hemoglobina, constituem uma das principais e mais frequentes doenças genéticas que acometem seres humanos, e dentre elas, a anemia, no Brasil, 5,6\%, sendo a raça negra a mais comum nessa condição. (CANCADO; JESUS, 2007)

Objetivo: Esta pesquisa foi realizada através de estudos bibliográficos e tem como objetivo explanar as cormobidades clinicas e tratamentos para a AF.

Desenvolvimento: Estudos populacionais têm demonstrado a crescente presença de $\mathrm{HbS}$ em indivíduos caucasoides. No Brasil, a principal causa dessa prevalência deve- se ao fato da alta taxa de miscigenação.(MECABO; YAMAMOTO; KIMURA; GUIRAO et al., 2014) A atual expectativa de vida para a população com AF é de 40 a 60 anos de idade. Embora muito superior há algumas décadas atrás, onde a expectativa de vida não passava dos 30 anos, está ainda se encontra muito inferior da expectativa de vida para a população geral, o que evidencia a necessidade de maiores investimentos no tratamento desses pacientes. O diagnóstico laboratorial da AF é feito a modo de identificar a $\mathrm{HbS}$ ou por eletroforese ou cromatografia líquida de alta performance, ou ainda, através da pesquisa do gene pela técnica de PCR. (KATO; PIEL; REID; GASTON et al., 2018) Na AF encontramos algumas manifestações clinicas, tais como, infecções graves por germes encapsulados, conhecidos como, Haemophilus influenzae, Strepcoccus pneumoniae, temos também a crise aplásica, sequestro esplênico, síndrome torácica aguda, priapismo e acidente vascular encefálico. Sendo que a maioria dos casos se manifesta na infância com crises álgicas. (KATO; PIEL; REID; GASTON et al., 2018) Sabe- se que a AF atinge com mais facilidade a população entre 40 a 60 anos de idade. O uso da HU tem mostrado ser benéfico na redução de hemólise e na maior sobrevida destes pacientes já que a única terapia curativa é o transplante de medula óssea. (PANEPINTO; KATO; SMITH, 2019) No entanto, nem todos os pacientes levam a sorte de serem compatíveis com o doador. Há mais de 25 anos utiliza-se a HU no tratamento da AF, sendo que a mesma contribui para diminuir os episódios de crise vaso oclusiva e também na síndrome torácica aguda. O uso de HU aumentava os níveis de HbF, o mesmo era um fator protetor da AF. Porém os benefícios da HU são outros, tais como aumento da oferta de óxido nítrico, diminuição de leucócitos e plaquetas. O HU é uma das drogas mais seguras tanto para adultos quanto para crianças, assim reduzindo a taxa de mortalidade. (NORONHA; SADREAMELI; STROUSE, 2016; STEINBERG; BARTON; CASTRO; PEGELOW et al., 2003) Na AF, pode-se ter complicações agudas, tais como, descompensação da função cardiorrespiratória, transformando a transfusão de hemácias em um recurso terapêutico. Sua utilização frequente desencadeia no excesso de ferro, sendo que não existe um mecanismo de ação que faça a excreção desse micronutrientes sua sobrecarga pode acarretar na disfunção de alguns órgãos como fígado, coração e órgãos endócrinos.(COATES; WOOD, 2017)

Conclusão: Os agravantes da AF nos pacientes e, as suas principais comorbidades implica no entendimento desta doença hereditária e quanto mais cedo o tratamento e aconselhamento iniciar, melhor o impacto na qualidade e sobrevida destes indivíduos. Além disso, é de suma importância a capacitação dos profissionais da área da saúde para um melhor compreendimento para o segmento dos portadores da AF.

\section{Referências}

BARNETT, R. Sickle cell anaemia. Lancet, 10073, 389, 2017. 
CANCADO, R. D.; JESUS, J. A. A doença falciforme no Brasil. Revista Brasileira de Hematologia e Hemoterapia. , 3, 29, p. 204-206, 2007.

COATES, T. D.; WOOD, J. C. How we manage iron overload in sickle cell patients. Brithish Journal of Haematology, 5, 177 , p. 703-716, 2017.

KATO, G. J.; PIEL, F. B.; REID, C. D.; GASTON, M. H. et al. Sickle cell disease. Nature Reviews Disease Primers, 4, p. 18010, Mar 152018.

MECABO, G.; YAMAMOTO, M.; KIMURA, E.; GUIRAO, F. et al. Hydroxycarbamide Is Related with Higher Expression of Band-3 and CD59 in Sickle Erythrocytes. Blood, 124, p. 4913-4913, 12/06 2014.

NORONHA, S. A.; SADREAMELI, S. C.; STROUSE, J. J. Management of Sickle Cell Disease in Children. South Med J, 109, n. 9, p. 495-502, Sep 2016.

PANEPINTO, J. A.; KATO, G. J.; SMITH, W. R. Health-related quality of life in sickle cell disease. Nature Reviews Disease Primers, 5, n. 1, p. 27, Apr 182019.

STEINBERG, M. H.; BARTON, F.; CASTRO, O.; PEGELOW, C. H. et al. Effect of hydroxyurea on mortality and morbidity in adult sickle cell anemia: risks and benefits up to 9 years of treatment. JAMA, 289, n. 13, p. 1645-1651, Apr 22003.

TELEN, M. J. Beyond hydroxyurea: new and old drugs in the pipeline for sickle cell disease. Blood, 127(7)810-819, 2016.

WILLIAMS, T. N.; THEIN, S. L. Sickle Cell Anemia and Its Phenotypes. Annual Review of Genomics and Human Genetics 19, p. 113-147, Aug 312018.

Coordenadoria de Pesquisa e Extensão - COPEX

Departamento de Editoraçāo e Divulgaçāo Científica - DEDIC 


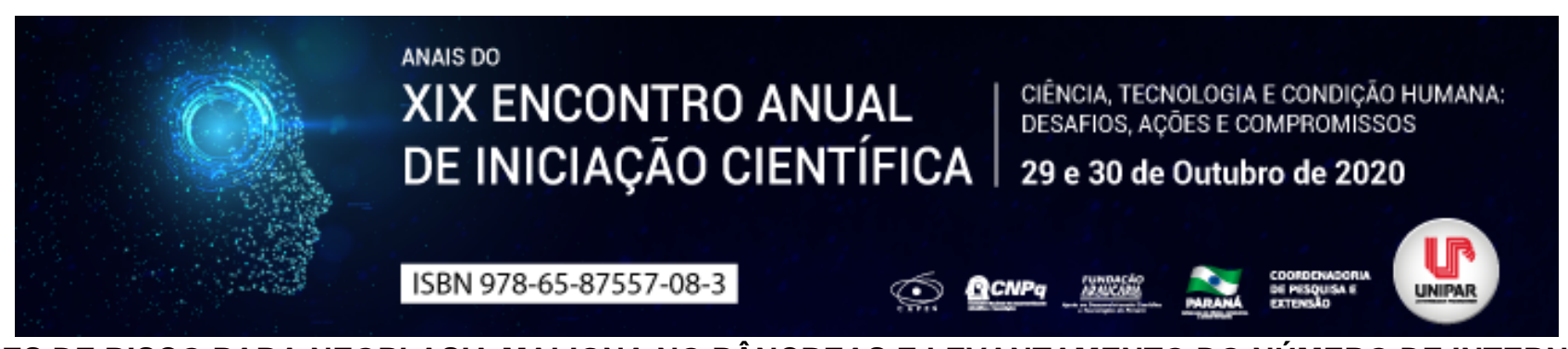

FATORES DE RISCO PARA NEOPLASIA MALIGNA NO PÂNCREAS E LEVANTAMENTO DO NÚMERO DE INTERNAÇÕES E ÓBITOS NO BRASIL ENTRE OS ANOS DE 2015 A 2018

\author{
${ }^{1}$ GABRIEL HENRIQUE BELLATO PALIN, ${ }^{2}$ ANA BEATRIZ PINHEIRO ZAUPA, ${ }^{3}$ GABRIELA CORREA ALBERTI, ${ }^{4}$ FABIANE \\ ANGELICA DE PAIVA PAULA, ${ }^{5}$ ISABELLA MORAIS TAVARES, ${ }^{6}$ MARINA GIMENES
}

\begin{abstract}
${ }^{1}$ Acadêmico do Curso de Medicina da UNIPAR
${ }^{1}$ Acadêmica do Curso de Medicina da UNIPAR

${ }^{2}$ Acadêmica do Curso de Medicina da UNIPAR

${ }^{3}$ Acadêmica do Curso de Medicina da UNIPAR

${ }^{4}$ Mestra, Médica Oncologista Clínica, Professora da disciplina de H.C. do Curso de Medicina da UNIPAR.

${ }^{5}$ Mestra, Professora da disciplina de Epidemiologia e Saúde Coletiva do curso de Medicina da UNIPAR.
\end{abstract}

Introdução: O câncer de pâncreas consiste em uma neoplasia maligna, cujo subtipo mais comum é o adenocarcinoma ductal (CASTILHO; JIMENEZ, 2020). O tumor se origina no tecido glandular (pâncreas exócrino) e atinge em sua maioria o lado direito do órgão, ou seja, a região da cabeça e corpo. Além de apresentar uma série de fatores que contribuem para o seu agravo, possui uma alta letalidade, com taxa de sobrevida global de aproximadamente $5 \%$ em cinco anos. A maioria dos diagnósticos são feitos de forma tardia após os 50 anos de idade, com pico de incidência em torno dos 70 aos 75 anos (SOLDAN, 2017), além de acometer predominantemente a população masculina. Ademais, apenas $15 \%$ a $20 \%$ dos pacientes são candidatos à pancreatectomia, que confere um prognóstico menos sombrio (STEER, 2009).

Objetivo: Descrever os fatores de risco associados a neoplasia maligna de câncer e analisar a morbidade hospitalar do SUS e óbitos no Brasil entre os anos de 2015 a 2018.

Material e Métodos: Foi realizado levantamento de morbidade e mortalidade hospitalar do SUS por neoplasia maligna do pâncreas no banco de dados do DATASUS no período de janeiro de 2015 a dezembro de 2018 no Brasil.

Resultados: Os dados obtidos no DATASUS mostram que houve, no período de janeiro de 2015 a dezembro de 2018 , um total de 39.480 internações de pacientes com câncer de pâncreas no Brasil, havendo uma maior concentração nos estados da Região Sudeste, com 19.154 casos (48,5\% do total de internações pela patologia). A região sul apresentou um montante de 10.328 internações, seguida pelo nordeste com 6.308, centro-oeste 2.416, e norte 1.274 internações, o que representa, respectivamente, $26,2 \% ; 15,9 \% ; 6,1 \%$ e $3,2 \%$ das hospitalizações no país. No ano de 2015 , foi apurado o número de 8.819 internações, enquanto que no ano de 2018 a soma de casos foi de 11.068, cujo aumento representou aproximadamente $20 \%$. Observou-se ainda, após análise dos dados, um total de 10.244 óbitos por neoplasia de pâncreas em todo o território nacional. O Sudeste foi a região detentora do maior índice, 5.083 óbitos, com destaque ao estado de São Paulo, ocupando a primeira posição no número de registros, 2.952 óbitos pela enfermidade. Por fim, houve um aumento de aproximadamente $18 \%$ na mortalidade comparando os anos de 2015 (2267 mortes) e 2018 (2785 mortes), sendo este fato mais pronunciado também na região Sudeste, cujos índices isolados consistem em cerca de 50\% (5.083 óbitos) do total de mortes no período no Brasil.

Discussão: Embora a neoplasia pancreática não esteja entre os dez principais tipos de câncer no Brasil, representa a oitava causa de morte por câncer, uma vez que grande parte dos pacientes são diagnosticados tardiamente (SOLDAN, 2017). Conforme dados do Instituto Nacional do Câncer, alguns fatores de risco podem levar ao surgimento da doença, cuja etiologia pode ser hereditária ou adquirida (INCA, 2018). Como condições adquiridas, pode-se citar: tabagismo, sedentarismo, dislipidemia, cirrose, dieta rica em gordura, baixo nível socioeconômico, pancreatite crônica, obesidade e diabetes mellitus (SOLDAN, 2017). Por outro lado, câncer de mama e ovário ligados aos genes BRCA1, BRCA2 e PALB2, síndrome de PeutzJeghers e síndrome de pancreatite hereditária consistem em fatores hereditários que podem desencadear a patologia em questão (SOLDAN, 2017). Outrossim, é importante ressaltar que alguns componentes químicos podem aumentar o risco de câncer de pâncreas, como: tetracloroetileno, estireno, cloreto de vinila, epicloridrina, HPA, agrotóxicos e solventes (INCA, 2018). O presente estudo demonstrou o aumento na incidência da neoplasia pancreática no período em questão. A ascensão dos casos pode estar associada ao envelhecimento populacional e ao aumento da prevalência dos fatores de risco para este tumor, como explicado por Davenport (2019). A avaliação acerca da elevação numérica de diagnósticos é importante devido aos fatores de risco detectáveis para esta doença (LOTUFO, 2019). Soldan (2017) ressalta que metade de todas as neoplasias são passíveis de prevenção em virtude de reduzir ou eliminar fatores de risco modificáveis e através de um diagnóstico precoce que possibilite o tratamento mais imediato e efetivo da doença. Em relação à mortalidade, o aumento observado pode estar relacionado ao diagnóstico tardio da doença conforme explicado pelo INCA (2018). Ainda, esta neoplasia tende a manifestar sintomas predominantemente em sua fase avançada, no entanto, quando ocorrem no início, se apresentam de forma inespecífica, 
dificultando o diagnóstico precoce. Por fim, a maior incidência desta condição ter se concentrado no Sudeste brasileiro se deve ao fato desta ser a região mais populosa do país e com maiores recursos na saúde, o que influencia diretamente no total de ocorrências e diagnósticos realizados.

Conclusão: A neoplasia pancreática apresenta alta taxa de letalidade e, em virtude de apresentar sintomatologia predominantemente na fase avançada, o atraso no diagnóstico, impossibilita instituir o tratamento oncológico específico, resultando nos altos índices de óbito. Uma das explicações possíveis para o justificar o aumento na incidência do câncer de pâncreas seria a maior exposição da população aos fatores de risco, no entanto, maiores estudos são necessários para precisar estas informações.

\section{Referências}

BRASIL. Portal de Saúde do SUS. DATASUS. Ministério da Saúde. Disponível em: http://tabnet.datasus.gov.br/cgi/tabcgi.exe? sih/cnv/nruf.def. Acesso em: 06 de jun de 2020.

CASTILHO, Carlos Fernandez-del; JIMENEZ, Ramon E. Overview of surgery in the treatment of exocrine pancreatic câncer and prognosis. Stanley W Ashley, MD, Kenneth K Tanabe, MD. Literature review current through: May 2020. Disponível em: https://www.uptodate.com/contents/overview-of-surgery-in-the-treatment-of-exocrine-pancreatic-cancer-and-prognosis?

search=Câncer\%20pâncreas\&source=search_result\&selectedTitle=2 150\&usage_type=default\&display_rank=2. Acesso em: 03 de jun. 2020.

CASTILHO, Carlos Fernandez-del; JIMENEZ, Ramon E. Epidemiology and nonfamilial risk factors for exocrine pancreatic cancer. Kenneth K Tanabe, MD. UpToDate. 2019. Disponível em: https://www.uptodate.com/contents/epidemiology-and-nonfamilial-riskfactors-for-exocrine-pancreatic-cancer" Acesso em: 06 jun. 2020.

DAVENPORT, Liam. Global Rise in Pancreatic Cancer Deaths Partly Preventable. Medscape. Oct 28, 2019. Disponível em: https://www.medscape.com/viewarticle/920459\#vp_3. Acesso em: 06 jun. 2020.

INCA. Instituto Nacional do Câncer. Câncer de pâncreas. 2018. Disponível em: https://www.inca.gov.br/tipos-de-cancer/cancerde-pancrea. Acesso em: 03 de jun de 2020.

LOTUFO, Paulo Andrade. A incidência e a mortalidade por câncer de pâncreas estão crescendo no Brasil. Diagn Tratamento, São Paulo, v. 24, n. 3, p. 84 -84, jul.-set., 2019.

SOLDAN, Mônica. Pancreatic cancer screening. Revista do Colégio Brasileiro de Cirurgiões, Rio de Janeiro, v. 44, n.2, p. 109111, Mar./Apr., 2017.

STEER, Michael L. Clinical manifestations, diagnosis, and surgical staging of exocrine pancreatic cancer. UpToDate, v. 17, 2009. 


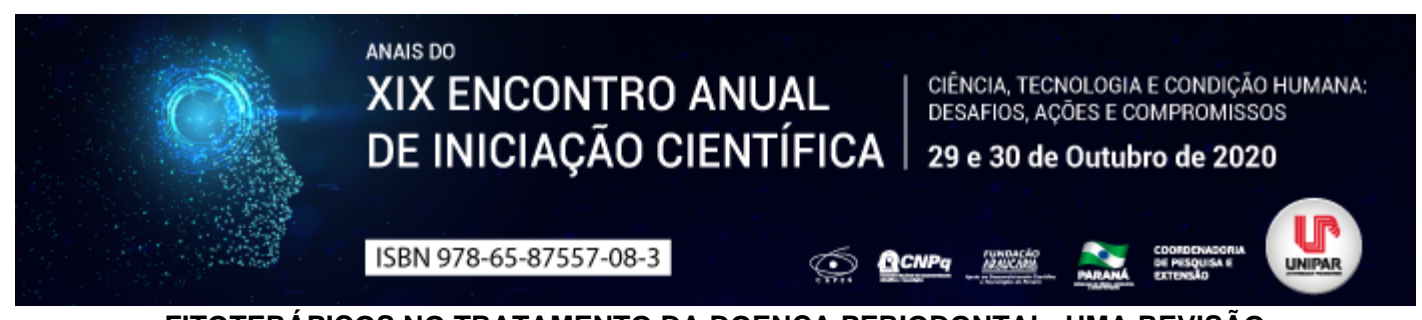

FITOTERÁPICOS NO TRATAMENTO DA DOENÇA PERIODONTAL: UMA REVISÃO

\author{
${ }^{1}$ JOAO MURILO GONCALVES GAZOLA, ${ }^{2}$ ANDRESSA ANDRADE NOVAES, ${ }^{3}$ GISELE APARECIDA SPADIM, ${ }^{4}$ HELOISA GARCIA FRANCOZO, \\ ${ }^{5}$ SUELEN STEFANONI BRANDAO, ${ }^{6}$ DANIELA DE CASSIA FAGLIONI B CERANTO
}

\begin{abstract}
${ }^{1}$ Discente do Curso de Odontologia PIBIC/UNIPAR
${ }^{1}$ Discente do Curso de Odontologia PIBIC/UNIPAR

${ }^{2}$ Discente do Curso de Odontologia PIC/UNIPAR

${ }^{3}$ Discente do Curso de Odontologia PIC/UNIPAR

${ }^{4}$ Discente do Curso de Medicina PIBIC/UNIPAR

${ }^{5}$ Docente da UNIPAR
\end{abstract}

Introdução: De acordo com Juiz et al. (2010) a doença periodontal (DP) é um conjunto de processos inflamatórios e infecciosos que agride os tecidos periodontais, de etiologia multifatorial e considerada pela Organização Mundial de Saúde como uma das duas principais doenças de risco para a saúde bucal. Higiene bucal e métodos farmacológicos são utilizados para controle da DP, mas a busca por métodos alternativos tem sido constante, através do uso de fitoterápicos que tenham atividade antimicrobiana.

Objetivo: O presente trabalho tem como objetivo realizar um levantamento bibliográfico sobre o uso de fitoterápicos no tratamento da DP.

Desenvolvimento: A etiologia da DP é basicamente a agressão por bactérias gram-negativas devido ao acúmulo de biofilme onde ocorre a colonização. Lindhe et al. (2018, p. 297) diz que de todos os ambientes do corpo humano, a cavidade oral fornece um ótimo habitat para o crescimento de bactérias: sua temperatura, umidade, abundante suprimento de nutrientes e, exclusivamente, as superfícies duras dos dentes. Os fitoterápicos podem atuar como uma substância adjuvante adicionada ao medicamento com a finalidade de prevenir alterações, corrigir e melhorar as características biofarmacotécnicas e tecnológicas do medicamento. Dias (2015) refere que a procura por produtos naturais com atividade semelhante à substâncias sintéticas vem aumentando, o objetivo das pesquisas voltadas às plantas medicinais é encontrar substâncias com menos efeitos adversos e com menor custo, conforme enfatiza Pinto et al. (2013). Na Odontologia, várias pesquisas estão sendo realizadas para melhorar o bem-estar do paciente e solucionar patologias, desta forma muitas visam descobrir materiais para o tratamento de diversas doenças orais, de forma alternativa. Um deles é o uso da aroeira como forma de tratamento da gengivite, segundo Dias (2015), ela possui ação antimicrobiana e anti-inflamatória, além de apresentar atividade bactericida e bacteriostática sobre Streptococus mutans, Streptococus mitis, Streptococus sobrinus, Streptococus sanguis, Lactobacillus casei. Segundo um estudo de Ribeiro et al. (2015) um grupo de animais tratados com a própolis teve resultados favoráveis radiograficamente, caracterizado pela redução do progresso da doença periodontal induzida por ligadura em ratos aos 7 e 21 dias, o que demonstrou a importância da utilização desse produto como substância auxiliar no tratamento e inibição da progressão da DP. O alho tem mostrado também atividades antifúngicas e antibacterianas, o extrato de alho inibiu o crescimento e também mostrou um efeito bactericida, sobre o organismo testado, isto mostra que esta planta é um importante coadjuvante no tratamento de pacientes portadores de periodontite, relatou Juiz (2010). Lobo et al. (2015) descreveu que a Lippia sidoides (alecrim-pimenta) e seus dois principais componentes timol e carvacrol apresentaram atividade antibacteriana e antifúngica relativamente fortes contra Streptococcus mutans e a Candida albicans, sendo a ação do carvacrol um pouco maior.

Conclusão: Diante dd acima citado, é explícito que o uso de fitoterápicos vem crescendo na odontologia, porém, ainda é algo novo, o que deve impulsionar o corpo docente e discente de pesquisa a investirem nessa área, para que os cirurgiões dentistas conheçam e adotem essas técnicas proporcionando melhor condição de saúde ao seu paciente.

\title{
Referências
}

DIAS, Joselúcia da Nóbrega; SILVA, Maria Priscilla Cibelle Ferreira; LIMA, Isabela Pinheiro Cavalcante. O uso de fitoterápicos à base de aroeira como coadjuvante no tratamento da gengivite: revisão sistemática. Revista Brasileira de Plantas Medicinais, Campinas, v. 17, n. 14, p. 1187-1191, junho, 2015. em: https://www.scielo.br/scielo.php?pid=S1516-

05722015000701187\&script=sci_abstract\&tIng=pt\#: :text=De\%20acordo\%20com\%20os\%20estudos,aroeira\%3B\%20gengivite\%3B\%20plantas20medicinais \%. Acesso em: 12 jul. 2020.

JUIZ, Paulo José Lima; ALVES, Reinaldo José Campos; BARROS, Tânia Fraga. Uso de produtos naturais como coadjuvante no tratamento da doença periodontal. Revista Brasileira de Farmacognosia, São Paulo, v. 20, n. 1, p. 134-139, jan/mar. 2010.

LINDHE, Jan; LANG, Niklaus Peter. Tratado de Periodontia Clínica e Implantologia Oral. 6. ed. Rio de Janeiro: Guanabara Koogan, 2018.

LOBO, Patrícia Leal Dantas et al. Atividade farmacológica do óleo essencial de lippia sidoides em odontologia: uma revisão de literatura. Revista Saúde e Pesquisa, Maringá, v. 8, n. 2, p. 373-378, maio/ago. 2015.

PINTO, Aryelle Thaysa Muniz et al. Atividade antimicrobiana de dentifrícios fitoterápicos contra streptococcus mutans e staphylococcus aureus. UNOPAR Cientifica Ciências Biológicas e da Saúde, Londrina, v. 15, n. 4, p. 259-263, jun/out. 2013.

RIBEIRO, Michael Ranniery Garcia et al. Resultados da aplicação tópica do extrato de própolis na redução da progressão da doença periodontal. Revista Brasileira de Plantas Medicinais, Campinas, v.17, n. 4, p. 915-921, março, 2015.

Coordenadoria de Pesquisa e Extensão - COPEX

Departamento de Editoraçāo e Divulgaçāo Científica - DEDIC 


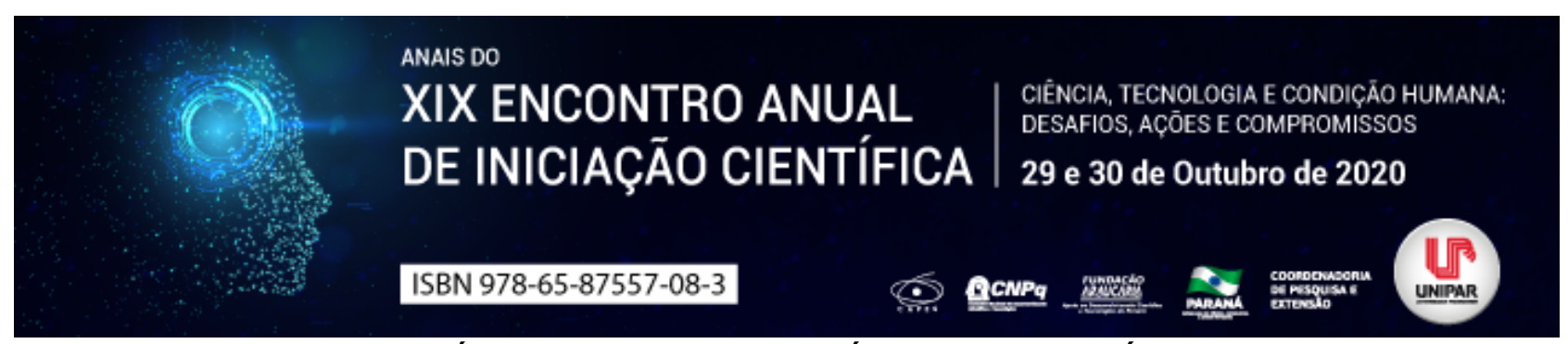

HEPATITE B NO PARANÁ E UMUARAMA: UMA ANÁLISE EPIDEMIOLÓGICA DE 2008 A 2018

\title{
${ }^{1}$ NAIANY OLIVOTTO MARTINS, ${ }^{2}$ VITOR ROQUE SAUER, ${ }^{3}$ MARINA GIMENES
}

\author{
${ }^{1}$ Acadêmico do Curso de Medicina da UNIPAR \\ ${ }^{1}$ Acadêmico do Curso de Medicina da UNIPAR \\ ${ }^{2}$ Docente da UNIPAR
}

Introdução: Segundo a Organização Mundial de Saúde (OMS, 2017), 325 milhões de pessoas são portadoras do vírus da Hepatite B (VHB) e é a responsável por ocasionar 4/5 dos casos de câncer de fígado primário, o mais mortal (Ott et al., 2012). Hepatite B é uma doença causada pelo vírus da família Hepadnaviridae e do gênero Ortohepadnavirus. Sua transmissão pode acontecer através de duas vias principais como a parenteral e sexual (DIAS; JÚNIOR; FALQUETO, 2014). O vírus da Hepatite B pode ocasionar hepatite crônica e se não for tratada, podendo evoluir para cirrose ou hepatite fulminante gerando uma necrose rígida do fígado (FERREIRA, 2000).

Objetivo: Realizar uma análise epidemiológica do número de casos de Hepatite B entre os anos de 2008 a 2018 no estado do Paraná e no município de Umuarama.

Material e métodos: Foi utilizado o Indicador e Dados Básicos das Hepatites nos Municípios Brasileiros, acessado por meio do TabNet, disponibilizado pelo DATASUS. A coletado foi relacionada com o número de casos de Hepatite B no Estado do Paraná e no Município de Umuarama. Os dados coletados foram entre os anos de 2008 até 2018. A incidência foi calculada para cada 100.000 habitantes com base nos dados populacionais do IBGE por ano de notificação.

Resultados: Com base no levantamento de dados pelo DATASUS, no estado do Paraná, entre 2008 e 2018, houve 20.026 casos com incidência mínima de 12,4 em 2008 e incidência máxima em 2011 de 21,4 casos para cada 100.000 habitantes e uma incidência total de 183,7 casos no período. No ano de 2008, foram registrados 1316 casos, em 2009 foram 1334 registros, no ano de 2010 houve 1563 notificações, em 2011 foram 2250. No ano de 2012, o Paraná contou com 2027 registrados, em 2013 com 2045 notificações, no ano de 2014 foram contabilizados 2139 casos. Já nos anos de 2015, 2016, 2017 e 2018 foram registrados 1926, 1913, 1739 e 1774 casos, respectivamente. Já no município de Umuarama, entre 2008 e 2018 houve 167 casos no total, com incidência mínima de 3,7 em 2016 e máxima em 2014 de 23,3 e uma incidência total de 160,1 casos para cada 100.000 habitantes no período. No ano de 2008, foram contabilizados 15 casos, em 2009 foram 18, no ano de 2010 foram 12 casos, em 2011 foram 18 novamente. Em 2012, 2013, 2014 e 2015, foram notificados 16, 23, 25 e 16 casos, respectivamente. No ano de 2016 foram 4 notificações, em 2017 foram registrados 12 e em 2018, 8 casos.

Discussão: Com base nos dados coletados o estado do Paraná na maioria dos anos teve seu número de casos diminuído, enquanto o município de Umuarama em geral teve aumento no número de casos de Hepatite B, exceto em 2017 e 2018 . Nos primeiros 2 anos da análise os números de casos aumentaram tanto no estado, como no município, e consequentemente as incidências. No ano de 2010, o município do Paraná continuou com as notificações aumentando da doença, ao contrário de Umuarama. Considerando o ano de 2011, Paraná e Umuarama aumentaram intensamente os números de casos, sendo que o estado obteve 687 casos a mais em relação ao ano interior e com a maior incidência registrada em 10 anos. Já no ano de 2012, os dois territórios analisados registraram baixa no número de casos e uma variação de incidência em relação ao ano anterior próxima, enquanto o estado variou sua incidência em 2,2, a da cidade variou 2. Em 2013, o número de casos do Paraná de hepatite B começou a baixar progressivamente até 2017, diferentemente do município, que em 2013 e 2014 apresentou os dois maiores registros no período de 10 anos, além das duas maiores incidências, 21,6 e 23,3, respectivamente. Em 2016, houve uma discrepância na incidência, sendo de Umuarama a menor do período analisado e aproximadamente 4,6 vezes menor que do Paraná. Nos últimos 2 anos da análise, cada local comportou-se de uma maneira. No Estado tanto as notificações de Hepatite $B$ quanto à incidência aumentaram. Enquanto o município apresentou diminuição dos casos e da incidência. É importante salientar, que por mais que o Paraná tenha apresentado na década, mais anos com diminuição do número de casos comparado com Umuarama, os números ainda são alarmantes, tendo em vista que a incidência total se mostrou maior no estado do que no município.

Conclusão: Com a análise feita entre os anos de 2008 a 2018 é possível observar que o comportamento do Paraná em relação à Umuarama foi discrepante, mas na maioria dos anos analisados a incidência foi grande dos dois locais analisados. Uma vez que a Hepatite B possui muitas formas de transmissão é importante investir em medidas de prevenção. Por meio de conscientização da população, incentivando o uso de preservativos durante as relações sexuais, não partilhamento de objetos e instrumentos perfurantes para injeção de drogas. Além de divulgar a importância de evitar contato com sangue contaminado e a esterilização correta de materiais cirúrgicos. Por fim, é essencial a vacinação das crianças e profissionais de saúde, já que este último é o mais vulnerável ao contágio devido a alta resistência ambiental do HBV e sua facilidade de transmissão. 


\section{Referências}

DIAS, Jerusa Araújo; CERUTTI JÚNIOR, Crispim; FALQUETO, Aloísio. Fatores associados à infecção pelo vírus da hepatite B: um estudo caso-controle no município de são mateus, espírito santo. Epidemiologia e Serviços de Saúde, [S.L.], v. 23, n. 4, p. 683-690, dez. 2014.

FERREIRA, Marcelo Simão. Diagnóstico e tratamento da hepatite B. Revista da Sociedade Brasileira de Medicina Tropical, [S.L.], v. 33, n. 4, p. 389-400, ago. 2000.

IBGE Instituto Brasileiro de Geografia e Estatística. Diretoria de Pesquisas, Coordenação de População e Indicadores Sociais, Estimativas da população residente com data de referência $1^{\circ}$ de julho de 2018. Rio de Janeiro, 2018. Disponível em: https://bityli.com/TdnP2. Acesso em: 02 ago. 2020.

ORGANIZAÇÃO PAN-AMERICANA DE SAÚDE (OPAS). Novos dados sobre hepatites destacam necessidade de uma resposta global urgente. Brasília, 28 abr. 2019. Disponível em: https://bityli.com/dcfGP. Acesso em: 02 ago. 2020.

OTT, Jördis J et al. Global epidemiology of hepatitis B virus infection: new estimates of age-specific HBsAg seroprevalence and endemicity. Vaccine, [S.L], v. 30, n. 12, p. 2212-2219, jan. 2012. 


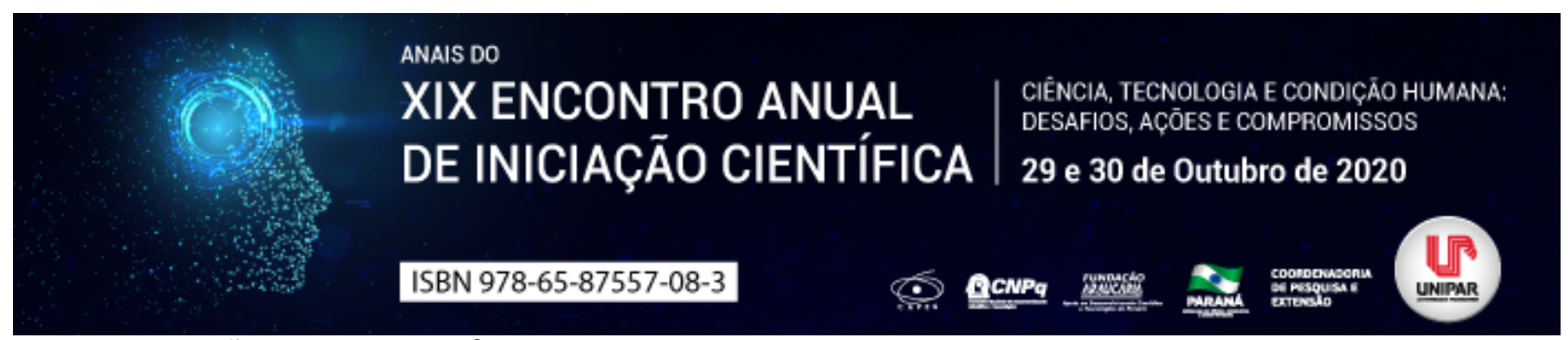

AÇÃO FISIOTERAPÊUTICA NO TRATAMENTO DE LOMBALGIAS EM GESTANTES

\author{
${ }^{1}$ ANA PAULA CAMPOS SANTANA, ${ }^{2}$ LETICIA FLOIS FERREIRA, ${ }^{3}$ PAOLA NATHALIA ZANETIN, ${ }^{4}$ THAYNA PINTER MENDES \\ CAMPOS, ${ }^{5}$ DORA DE CASTRO AGULHON SEGURA
}

\footnotetext{
${ }^{1}$ Acadêmica do Curso de Fisioterapia da UNIPAR

${ }^{1}$ Acadêmica do Curso de Fisioterapia da UNIPAR

${ }^{2}$ Acadêmica do Curso de Fisioterapia da UNIPAR

${ }^{3}$ Acadêmica do Curso de Fisioterapia da UNIPAR

${ }^{4}$ Docente da UNIPAR
}

Introdução: Diversas teorias foram criadas para identificar o motivo do aumento da incidência de lombalgia em gestantes, dentre elas incluem as alterações posturais devido ao crescimento do feto, influências hormonais que podem causam frouxidão das articulações, aumento do peso da gestante e alterações na água corpórea total. Durante a gravidez também ocorrem fatores endócrinos, fisiológicos e físicos que, de certa forma, contribuem para o acréscimo da carga imposta na coluna vertebral das grávidas (MANN et al., 2011). As dores nas costas durante a gestação ainda podem influenciar de modo negativo na qualidade do sono, devido o desconforto e frequência da dor. Estudos mostram que sem o tratamento adequado aproximadamente $20 \%$ das mulheres permanecem com algum quadro de algia mesmo após o parto e período de puerpério, sendo que a fisioterapia dispõe de diversas técnicas terapêuticas que corrigem a postura, promovem analgesia e melhora a funcionalidade corporal geral (NOREN et al., 2002).

Objetivo: Descrever sobre o tratamento fisioterapêutico para a lombalgia em gestantes.

Desenvolvimento: Gomes et al. (2013) relatam que o centro da mulher se modifica com a gestação, a região lombar acentua a curvatura como uma forma de equilíbrio para o centro gravitacional. A lombalgia é considerada um dos cinco sintomas mais comuns na gestação e cerca de 50 a 75\% das gestantes relatam casos de sintomas. Machado et al. (2008) demonstraram que através de séries variadas, o Método Pilates é indicado para o desenvolvimento de exercícios que promovem precisão e fluidez dos movimentos e melhora postural, além de minimizar as compensações típicas do período gestacional, estimula também a função respiratória, o relaxamento e a tranquilidade mental e corporal. Prevedel et al. (2003) citam que os benefícios da fisioterapia na água favorecem o retorno linfático venoso, melhora o tônus muscular, as funções intestinais e respiratórias e toda a reeducação postural, promovendo relaxamento na gestante. Martins (2002) avaliou o Método de Stretching Global e corrobora que a técnica foi eficaz no tratamento de lombalgia e dores pélvicas posteriores à gestação. Com o método de Reeducação Postural Global foi observada menor intensidade dos sintomas iniciais lombalgia e melhora das limitações funcionais resultantes da presença de dor (GIL; OSÍS; FAUNDES, 2011).

Conclusão: Através deste estudo foi possível concluir que todos os métodos avaliados, Pilates, Fisioterapia Aquática, Stretching Global e RPG, foram eficazes para o tratamento da lombalgia em gestantes. A ação fisioterapêutica aplicada de forma adequada é essencial para o fortalecimento e relaxamento dos músculos da mulher no período da gestação, além de proporcionar analgesia e melhora da mobilidade corporal, as técnicas utilizadas também descrevem benefícios na recuperação precoce durante o período do puerpério.

\title{
Referências
}

GIL, V. F. B.; OSIS, M. J. D.; FAÚNDES, A. Lombalgia durante a gestação: eficácia do tratamento com Reeducação Postural Global (RPG). Fisioterapia e Pesquisa, v. 18, n. 2, p.164-70, 2011.

GOMES, M. R. A. et al. Lombalgia gestacional: Prevalência e características clínicas em um grupo de gestantes. Revista Dor, v. 14, n. 2, p.114-117, 2013.

MACHADO, C. G. et al. O Método Pilates na diminuição da dor lombar em gestantes. Revista Eletrônica da Faculdade de Montes Belos, v. 3, n. 1, p. 01-07, 2008.

MANN, L. et al. Influência dos sistemas sensoriais na manutenção do equilíbrio em gestantes. Fisioterapia em Movimento, v. 24, n. 2, p. 315-325, 2011.

MARTINS, R. F. Algias posturais na gestação: Prevalência e tratamento. 122 f. Dissertação (Mestrado em Fisioterapia) Unicamp, Campinas-SP, 2002.

NOREN L. et al. Lumbar back and posterior pelvic pain during pregnancy: A 3-year follow-up. Eur J Spine, v. 11, p. 267-271, 2002.

PREVEDEL, T. T. S. et al. Repercussões maternas e perinatais da hidroterapia na gravidez. Revista Brasileira de Ginecologia 
e Obstetrícia, v. 25, n. 1, p. 53-59, 2003.

Coordenadoria de Pesquisa e Extensão - COPEX

Departamento de Editoraçāo e Divulgaçāo Científica - DEDIC 


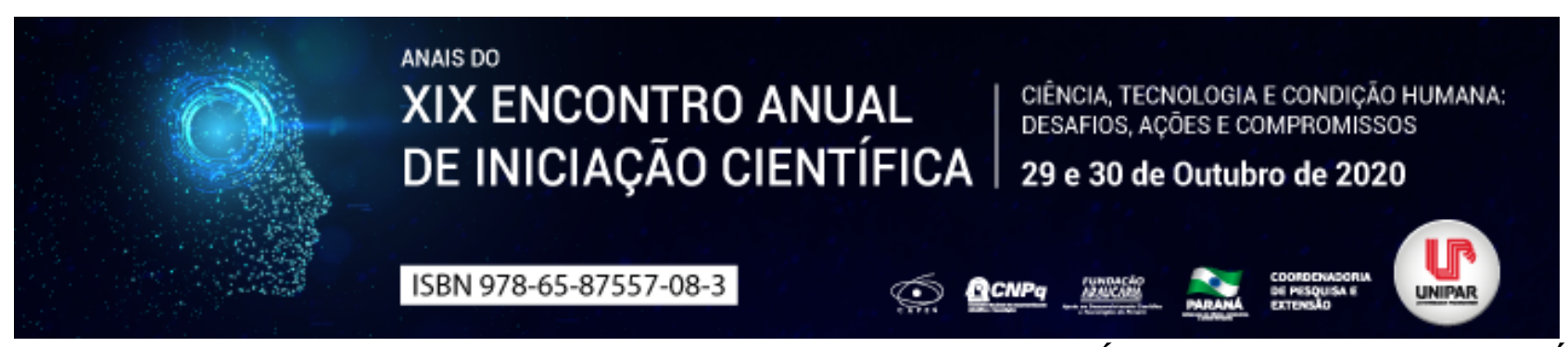

\title{
ESTABILIDADE DE COR DAS RESINAS COMPOSTAS: UM DESAFIO PARA DENTÍSTICA RESTAURADORA ESTÉTICA REVISÃO DE LITERATURA
}

\author{
${ }^{1}$ ALLAN FERREIRA DE LIMA ANTONELLI, ${ }^{2}$ GEOVANE CAPANA FIDELI, ${ }^{3}$ JENIFFER URBANO DEGASPERI, ${ }^{4}$ KAROLINA \\ FERNANDA ABEGG QUEIROZ, ${ }^{5}$ RAYANE CRISTINA DE OLIVEIRA SOARES, ${ }^{6}$ WAGNER BASEGGIO
}

$\begin{array}{lll}{ }^{1} \text { Discente do Curso de Odontologia } & \text { PIC } & \text { UNIPAR } \\ { }^{1} \text { Discente do Curso de Odontologia } & \text { PIC } & \text { UNIPAR } \\ { }^{2} \text { Discente do Curso de Odontologia } & \text { PIC } & \text { UNIPAR } \\ { }^{3} \text { Discente do Curso de Odontologia } & \text { PIC } & \text { UNIPAR } \\ { }^{4} \text { Discente do Curso de Odontologia } & \text { PIC } & \text { UNIPAR } \\ { }^{5} \text { Docente do Curso de Odontologia } & \text { PIC } & \text { UNIPAR }\end{array}$

Introdução: As resinas compostas são materiais restauradores que reproduzem as características dos tecidos dentais e amplamente usados na dentística restauradora. São materiais muitos versáteis e ocupam hoje uma parcela considerável do tempo clínico do operador. Entretanto, esses materiais apesar do avanço possuem algumas limitações e requerem alguns cuidados, uma delas é o manchamento do corpo, o que leva a degradação do material, ao comprometimento estético e, muitas vezes a necessidade de substituição da restauração (UCHIMURA et al., 2014). Dessa forma, para evitar esse manchamento, é fundamental que o profissional entenda quais recursos ele pode dispor.

Objetivo: O objetivo do estudo foi realizar uma revisão de literatura a respeito da etiologia das pigmentações em resina composta e expor alternativas clínicas e domiciliares para minimizar os efeitos na alteração de cor deste material odontológico estético.

Desenvolvimento: Com uma maior exigência da estética, por parte dos pacientes, o uso clínico de resinas compostas aumentou consideravelmente nos últimos anos. No entanto, este material ainda apresenta algumas limitações relacionada ao sucesso estético, uma delas é a instabilidade da cor quando expostas por um longo período de tempo na cavidade bucal (AL-NEGRISH, 2002). Segundo Hörsted-Binslev e Mjör (1988), a pigmentação ou alteração de cor dos compósitos podem ocorrer de três maneiras: (I) descoloração extrínseca, devido ao acúmulo de biofilme; (II) alterações de superfície ou subsuperfície com ligeira penetração e reação de agentes corantes na camada superficial da resina composta; (III) descoloração intrínseca devido a reações físico-químicas no interior do corpo da restauração. As resinas compostas são constituídas basicamente por uma matriz orgânica, cargas inorgânicas, agentes de união, iniciador de polimerização, pigmentos, aditivos, radiopacificadores e estabilizadores de cor (TUNCDEMIR; AYKENT, 2012). Dessa forma, caso a fotopolimerização não seja corretamente realizada, pode ainda haver a presença de monômeros que não foram reagidos e consequentemente facilitarão o fenômeno de sorção de água e absorção de agentes pigmentantes. A irregularidade da resina composta, também é um fator que influencia no manchamento desse material, visto que a superfície inadequada com presença de porosidades e/ou rugosidade potencializam a penetração de pigmentos, proporcionando também maior acúmulo de biofilme o que pode resultar na degradação da superfície desse material (ALANDIA-ROMAN et al, 2013; ARDU et al, 2010). Outros fatores extrínsecos mais relacionados as alterações de cor nos compósitos são: a higiene bucal e o consumo de bebida de coloração. Dentre as bebidas consumidas, o vinho tinto é o que mais se destaca no quesito manchamento, seguido pelo café e pelos chás.

Conclusão: Apesar da resina composta apresentar excelentes propriedades estéticas, ainda demandam de certa exigência para seu uso, tanto por parte do profissional quanto para o paciente, devido a instabilidade de cor que o material apresenta. Para minimizar esses efeitos indesejáveis, o profissional deve intervir na tanto prevenção desses manchamentos como também na redução, para isso, é essencial que se realize técnicas adequadas. A literatura nos mostra que, uma fotopolimerização bem feita, acabamento e polimento adequados são fatores que interferem diretamente no sucesso e longevidade do tratamento. É fundamental também, que o Cirurgião-Dentista entenda e explique para o paciente sobre as adversidades que podem ocorrer, bem como a importância da instrução para uma correta higiene oral e adequada dieta.

\section{Referências}

ALANDIA-ROMAN, Carla Cecília. et al. Effect of cigarette smoke on color stability and surface roughness of dental composites. Journal of dentistry, v. 41, p. e73-e79, 2013.

ALBUQUERQUE, Pedro Paulo AC et al. Color stability, conversion, water sorption and solubility of dental composites formulated with different photoinitiator systems. Journal of dentistry, v. 41, p. e67-e72, 2013.

AL-NEGRISH, Abdul Rhaman Salem. Composite resin restorations: a cross-sectional survey of placement and replacement in 
Jordan. International Dental Journal, v. 52, n. 6, p. 461-468, 2002.

ARDU, Stefano et al. A long-term laboratory test on staining susceptibility of esthetic composite resin materials. Quintessence International, v. 41, n. 8, 2010.

MATHIAS, Paula et al. Pigmentação de restaurações de resina composta: uma revisão de literatura. Revista de Odontologia de Araçatuba, v. 36, n. 2, p. 29-35, 2015.

SILVA, Juliana Cândido; SILVA, Diego Romário; DO NASCIMENTO BARBOSA, Danielle. Estabilidade de cor das resinas compostas: um desafio para a dentística restauradora. Archives of Health Investigation, v. 6, n. $10,2017$.

TUNCDEMIR, Ali Riza; AYKENT, Filiz. Effects of fibers on the color change and stability of resin composites after accelerated aging. Dental materials journal, v. 31, n. 5, p. 872-878, 2012.

UCHIMURA, Joana Yumi Teruya et al. Color stability over time of three resin-based restorative materials stored dry and in artificial saliva. Journal of Esthetic and Restorative Dentistry, v. 26, n. 4, p. 279-287, 2014.

Coordenadoria de Pesquisa e Extensão - COPEX

Departamento de Editoraçāo e Divulgaçāo Científica - DEDIC 


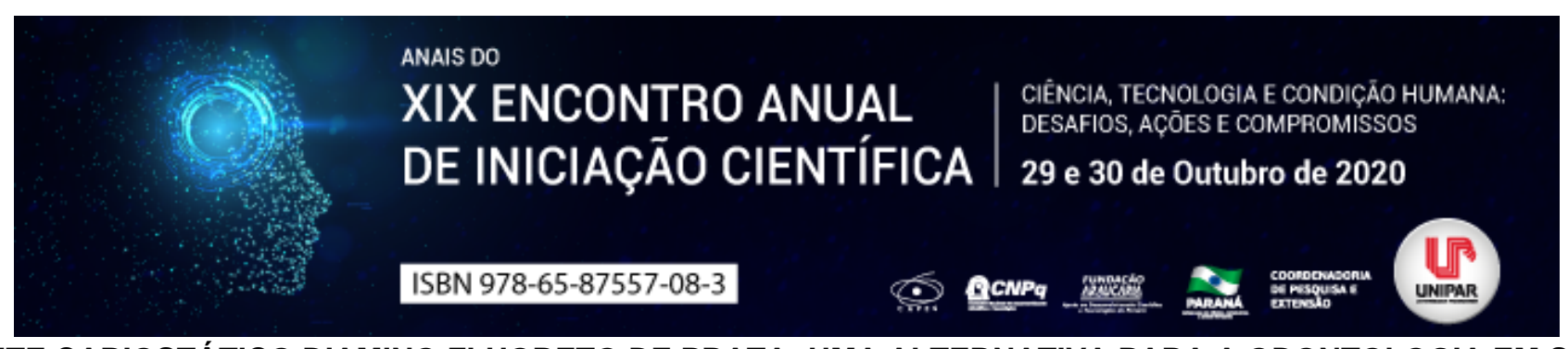

AGENTE CARIOSTÁTICO DIAMINO FLUORETO DE PRATA: UMA ALTERNATIVA PARA A ODONTOLOGIA EM SAÚDE PÚBLICA

\title{
${ }^{1}$ ANDRESSA VENTRAMELI DE ANDRADE, ${ }^{2}$ LAVINIA PRADO HERNANDES, ${ }^{3}$ ANA CAROLINA SOARES FRAGA ZAZE
}

\author{
${ }^{1}$ Acadêmica do Curso de Odontologia da - PIC - UNIPAR- Campus Umuarama-PR \\ ${ }^{1}$ Acadêmica do Curso de Odontologia da - PIC - UNIPAR- Campus Umuarama-PR \\ ${ }^{2}$ Docente da UNIPAR
}

Introdução: A doença cárie possui um caráter multifatorial que envolve fatores determinantes e modificadores. Afetando mais da metade das crianças no Brasil, a doença apresenta rápida evolução, podendo afetar diversos dentes e mais de $80 \%$ dos dentes decíduos que são atingidos são deixados sem tratamento. Observando que sua prevalência tem sido cada vez mais influenciada pelo contexto social, medidas de estratégia de saúde bucal têm sido promovidas, apresentando melhoras em resultados (JUNIOR et al., 2012). Nesse contexto o agente cariostático usado que tem se mostrado eficaz é o diamino fluoreto de prata (DFP), produto que tem notável capacidade de paralisar e prevenir a cárie. Suas principais características são: baixo custo, aplicação indolor e de técnica simples, seguro, dispensa a utilização de anestesia e brocas, não destrói a estrutura dentária e tem alta eficácia na paralisação da progressão da cárie, portanto, este agente pode ser utilizado em larga escala como boa opção para a Saúde Pública (TRICHES et al., 2009; SOUSA et al., 2016).

Objetivo: Fazer uma revisão bibliográfica sobre o diamino fluoreto de prata (DFP) ressaltando suas indicações, e limitações.

Desenvolvimento: A prevenção e o tratamento da doença cárie continuam sendo os maiores desafios da odontologia (DITTERICH et al., 2006). Principalmente na primeira infância, nota-se uma grande dificuldade na colaboração das crianças durante o tratamento odontológico, o que reforça a importância da prevenção. Assim, o diamino fluoreto de prata (DFP) tem sido apontado como uma alternativa, por ser um agente cariostático de propriedades preventivas, considerado como opção de tratamento, principalmente para crianças de pouca idade com dificuldades de colaboração durante o tratamento odontológico. Crianças que possuem uma predisposição à doença, juntamente com fatores externos envolvidos, terão cáries dentárias precocemente (JUNIOR et al., 2012). Tendo em vista estes aspectos, o diamino fluoreto de prata é uma boa opção, pois possui algumas propriedades vantajosas, como uma ação cariostática, anticariogênica, preventiva e dessensibilizante, e de acordo com essas propriedades, vão paralisar o desenvolvimento da doença cárie junto com a sua sintomatologia. Entretanto, mesmo com sua efetiva ação anticariogênica amplamente explorada pela literatura, os profissionais possuem receio na indicação de uso (TRICHES et al., 2009). Pelo fato do DFP causar um manchamento na superfície do esmalte dentário trazendo um aspecto de escurecimento para o dente, compromete o fator estético e pode ser considerado um limitador para o profissional fazer a indicação e gerar uma má aceitação por parte do responsável pela criança. Entretanto, como retratado no estudo de Delmaschi e colaboradores (2018), notou-se que a estética não foi um fator limitante e mostrou a aceitação dos responsáveis no uso do DFP, sendo considerado que a saúde vale mais que o fator estético, e que o mesmo, em um momento posterior, pode ser recuperado. Triches e colaboradores (2009) também afirmam que o fator estético não é decisivo na indicação do cariostático, segundo a percepção dos responsáveis. Cada vez mais a condição socioeconômica está ligada com a incidência de cárie dentária, portanto, o ideal seria um reforço na propagação da saúde bucal, mas tendo em vista as condições econômicas de determinadas regiões na saúde pública, onde não dispõem de muitos recursos, o uso do DFP pode ajudar a oferecer a proteção e o controle necessários. Tendo-se em conta que a maioria das vezes o contato do paciente com o cirurgião dentista é em função da presença da doença que já está instalada, o DFP mostrou eficácia nos programas comunitários devido seu baixo custo, fácil aplicação e colaboração do paciente com paralisação da lesão de cárie, em crianças de pouca idade, mas que já possuem lesões de cárie ( SANTOS et al., 2012). Portanto com base em uma busca minuciosa em banco de dados (pubmed, scielo, google acadêmico, biblioteca virtual em saúde) que trouxe artigos atuais se pode comprovar que o DFP pode ser um elemento de fator fundamental para o programa de prevenção e controle da doença cárie, sendo que seu uso poderia reduzir a necessidade de tratamento de urgência e diminuir a progressão, junto com o tratamento restaurador vicioso. Infelizmente é pouco utilizado na saúde pública, contudo, seu uso poderia se tornar uma boa opção, considerando a paralisação do processo carioso e também por ter uma abordagem minimamente invasiva, proporcionando conforto ao paciente, facilitando sua cooperação, com base em uma eficácia comprovada (SOUSA et al., 2016).

Conclusão: Com base nos estudos avaliados, conclui-se que o diamino fluoreto de prata é uma boa opção para uma abordagem minimamente invasiva, pois sua limitação sobre o fator estético parece não ser relevante por parte dos responsáveis. Portanto, deveria ser mais utilizado e explorado no setor da saúde pública, pelas propriedades favoráveis, especialmente na prevenção e paralisação da cárie dentária. 


\section{Referências}

DELMASCHI, Caroline Ramos; et al. Uso de diamino fluoreto de prata em crianças atendidas em uma unidade básica de saúde do norte do Paraná. Revista de Saúde Pública do Paraná, Ponta Grossa, v. 1, n. 1, p. 68 73, julho. 2018.

DITTERICH, Rafaela Gomes; ROMANELLI, Marissol Vasconcelos; RASTELLI, Maria Cristina; CZLUSNIAK, Gislaine Denise; WAMBIER, Denise Stadler . Diamino fluoreto de prata: Uma revisão de literatura. Publ. UEPG Ci. Biol. Saúde, Ponta Grossa, v. 12, n,2, p.45 52, jun. 2006.

SANTOS, Valdeci Elias Dos. et al.Efeitos adversos de técnicas provisórias em crianças: diamino fluoreto de prata $x$ tratamento restaurador provisório um estudo piloto. Revista Odonto Ciencia, Porto Alegre, v. 27, n. 1, p. 26 30, 2012.

JUNIOR, Valdeci Elias Dos Santos.; RODRIGUES DE SOUZA, Pollyana; ROSENBLATT, Aronita. Um recurso para paralisar e prevenir cárie em crianças: diamino fluoreto de prata. RFO, Passo Fundo, v. 17, n. 2, p. 228 233, maio/ago. 2012.

SOUSA, Fernanda Santos De Oliveira; et al. Prática odontopediátrica baseada em evidência científica ao alcance do clínico: o caso do efeito estético do uso tópico de diaminofluoreto de prata para o controle da cárie na dentição decídua. RGO, Campinas, v. 64, n. 4, p. 369 375, out./dez. 2016.

TRICHES, Thaisa Cezária; CORDEIRO, Mabel Mariela Rodríguez; SOUZA, Juliana Garcia Mugnai Vieira; SALTORI, Eduarda Karam; FRANÇA, Beatriz Helena Sottile. Aceitação dos pais quanto ao uso do diaminofluoreto de prata em crianças de 0 a 3 anos de Cascavel/PR. Pesqui. bras. odontopediatria clín. integr. João Pessoa, v.9, n.3, p. 265 69, set/dez. 2009. 


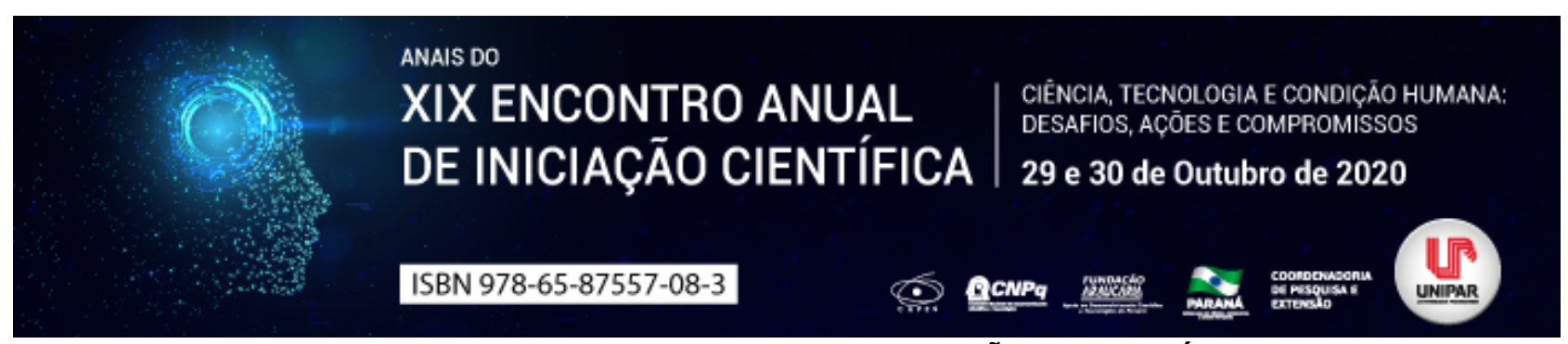

TRAUMA NA NEUROCIRURGIA E O DESENCADEAMENTO DE IMPLICAÇÕES PSICOLÓGICAS - ESTUDO DE REVISÃO

\title{
${ }^{1}$ LUIS FERNANDO DELAZARI VALERIO, ${ }^{2}$ LARISSA LOYOLA BARBOSA, ${ }^{3}$ MICHEL ANDREW NOGARA
}

\author{
${ }^{1}$ Acadêmico do Curso de Medicina da UNIPAR \\ ${ }^{1}$ Acadêmica do Curso de Medicina da UNIPAR \\ ${ }^{2}$ Docente da UNIPAR
}

Introdução: O trauma na neurocirurgia tem grande ligação com o trauma cranioencefálico (TCE), que é referenciado como qualquer dano ao cérebro causado por forças externas, diretas ou transmitidas, provocado por quedas, colisões de veículos motorizados, lesões esportivas, abuso / agressões ou explosões. Dessa maneira, no Brasil o TCE é considerado um problema da saúde pública com notória importância na mortalidade e morbidade (NAJEM, 2018). Há também o trauma raquimedular (TRM), o qual se define como agressões causados na medula espinhal, que provocam danos neurológicos, motores, sensitivos e autônomos. Esse tipo de trauma é causado, na maioria das vezes, por falta de cuidados no trânsito, configurando mais de 50\% das lesões, a outra parte do número de lesões se divide entre traumas que vão desde a prática de esportes até ferimentos causados por armas de fogo (DE SOUZA NETO, 2014). Como consequência desse trauma e de vários outros na neurocirurgia pode-se notar comprometimentos físicos, cognitivos, comportamentais e psicológicos, os quais geralmente levam a uma disfunção temporária ou permanente afetando a qualidade de vida (REIS, 2015).

Objetivo: Compreender os fatores psicológicos em indivíduos submetidos a neurocirurgia ligada a TCE e TRM.

Desenvolvimento: O trauma na neurocirurgia é evidenciado por complicações no crânio e na coluna sendo eles, o trauma cranioencefálico (TCE) e o trauma raquimedular (TRM), respectivamente. Assim, o TCE é um dano ao cérebro causado por diversas forças externas, abrangendo grande importância na morbidade e mortalidade, sendo 15\% a 20\% a causa das mortes de indivíduos com idade de 5 a 35 anos. O TCE apresenta dois mecanismos, sendo eles: lesão cerebral focal (causando contusão, laceração, hemorragia) e lesão cerebral difusa (causa aumento do tamanho do cérebro). Contudo, toda lesão é baseada na escala de Glasgow, onde um trauma grave apresenta escala de Glasgow de 3 a 8, trauma moderado de 9 a 12 e um trauma leve 13 a 15. Portanto, a escala é baseada em parâmetros como abertura ocular, resposta verbal e resposta motora (DE ALMEIDA, 2011). Já o TRM ocorre principalmente em homens de 18 a 40 anos. Esse dano à medula pode variar de uma lesão transitória, onde há a recuperação completa do paciente, até uma transecção completa do mesmo, que pode tornar o paciente paralisado abaixo do nível do local da lesão medular. Os maiores riscos desse tipo de lesão são quando há a agressão da parte neurológica (raízes nervosas, nervos periféricos e medula). As alterações fisiológicas que são notáveis nos pacientes são o choque medular, choque neurogênico, trombose venosa profunda, pneumonias, alterações psicossociais e infecções. A partir da avaliação do paciente podemos classificar o grau da lesão de acordo com a escala denominada ASIA (American Spine Injury Association), que apresenta uma escala que vai de $A$ (lesão completa, onde não há função motora e sensitiva nos segmentos sacrais) até $E$ (normal, quando há sensibilidade e força motora normal) (SOUZA, 2013). Há uma elevada relação entre o trauma na neurocirurgia e os fatores psicológicos, como as dúvidas, angústias, fantasias e temores, acarretando em perda de preservação e prevenção do estado emocional do indivíduo, sendo necessária. Sem embargo, o processo de hospitalização e intervenção cirúrgica provoca no paciente uma descaracterização do ambiente no qual está inserido, favorecendo uma despersonalização do mesmo, esse processo é decorrente de uma nova identidade, que é adquirida após o paciente ser tratado de acordo com a sua patologia, não como um indivíduo que apresenta singularidade e personalidade (BORGES, 2018).

Considerações finais: Deve ser realizada a preservação de danos emocionais e psicossociais, causados pelos traumas de neurocirurgias, sendo eles o Trauma crânio-encefálico (TCE) e Trauma raquimedular (TRM), pois, são esses, os que mais apresentam funções restritivas das partes cognitiva, motora e neurológica na área da medicina.

\section{Referências}

BORGES, E. A relevância da atuação do psicólogo face ao paciente crítico/cirúrgico e família. Psicologia, p. 1-15, 2018.

DE ALMEIDA. et al. Condutas no paciente com trauma crânio encefálico. Rev Bras Clin Med. São Paulo, v. 9, n. 1, p. 74-82, 2011.

DE SOUZA NETO. et al. Abordagem propedêuticas de enfermagem ao paciente com trauma raquimedular no pronto atendimento. Revista da Universidade Vale do Rio Verde, v. 12, n. 2, p. 716-724, 2014.

NAJEM, D. et al. Traumatic brain injury: classification, models, and markers. Biochemistry and cell biology, 2018 ; $96(4) 391$ 406.

REIS, C. et al. What's new in traumatic brain injury: update on tracking, monitoring and treatment. Int. J. Mol. Sci. 2 015 16(6):11903 11965. 
SOUSA, E. et al. Principais complicações do traumatismo raquimedular nos pacientes internados na unidade de neurocirurgia do Hospital de Base do Distrito Federal. Com. Ciências Saúde, v. 24, n. 4, p. 321-330, 2013.

Coordenadoria de Pesquisa e Extensão - COPEX

Departamento de Editoraçāo e Divulgaçāo Científica - DEDIC 


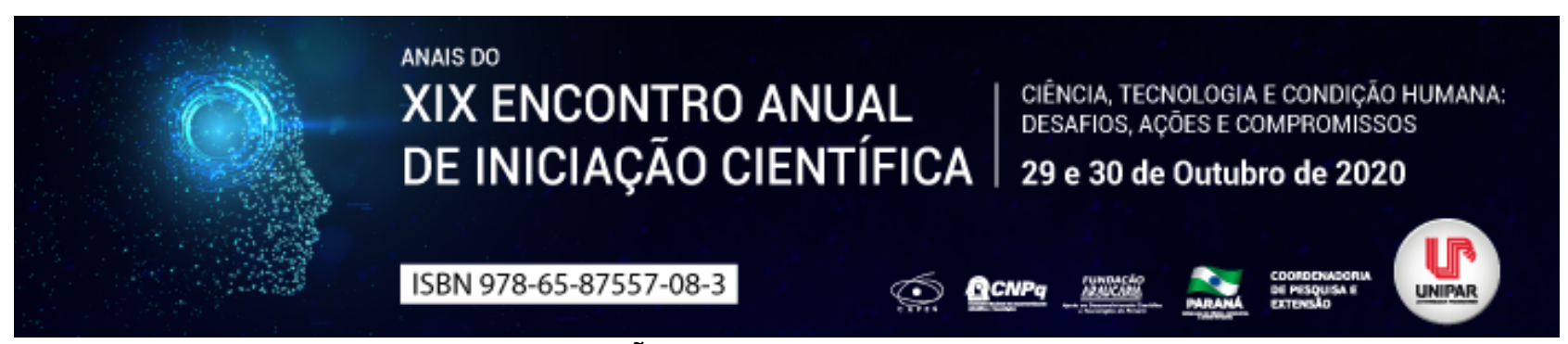

CURATIVO DE CVC: COMPARAÇÃO DE FILME TRANSPARENTE E GEL CLOREXIDINA

${ }^{1}$ Emilli Karine Marcomini

${ }^{1}$ Enfermeira. Mestranda do Programa de pós-graduação em Biotecnologia. Bolsista CAPES.

Introdução: O Cateter Venoso Central (CVC) é um dispositivo invasivo para acesso ao sistema intravascular, bastante empregado na Unidade de Terapia Intensiva (UTI), com a finalidade de administração de medicamentos, fluidos, eletrólitos e sangue, nutrição parenteral e monitorização hemodinâmica, no entanto, seu uso está relacionado a um grande potencial infeccioso, especialmente por estar em um vaso de maior calibre e de sua ponta estar localizada próximo ou dentro do átrio direito do coração. Uma vez que as infecções relacionadas ao cateter trazem danos e eventos indesejáveis ao paciente, medidas de prevenção e controle, como uso do curativo, foram adotadas para reduzir este índice (DOLCI; MARGATHO; SILVEIRA, 2017).

Objetivo: comparar a eficiência antimicrobiana do curativo gel de clorexidina e do curativo filme transparente de poliuretano em cateteres venosos centrais.

Desenvolvimento: O uso do CVC está associado a complicações infecciosas que podem aumentar os custos hospitalares, causar internações prolongada e elevar a mortalidade geral, no qual o principal mecanismo patogênico é decorrente da quebra da integridade cutânea causada pela inserção do cateter intravascular (DOLCl; MARGATHO; SILVEIRA, 2017). Atualmente, os curativos mais conhecidos e utilizados no mercado são o de gaze e fita adesiva, o filme transparente de poliuretano e o impregnado com clorexidina. O curativo simples com gaze estéril e esparadrapo, necessita troca em um período de 24 a 48 horas, o filme transparente e o gel clorexidina deve ser trocado entre três e sete dias ou a trocas não programadas por umidade, sujidade e descolamento. Ressalta-se que o curativo gel de clorexidina é composto também por um filme transparente de poliuretano, acrescido de um hidrogel que libera continuamente clorexidina a 2\% (ALMEIDA et al., 2018). A Clorexidina é um antisséptico bastante empregado na clínica, tendo três apresentações (aquosa, alcoólica e degermante), com concentrações que varia de 0,5 a 4\%, no qual seu uso provou ser eficaz na prevenção de infecções na microbiota da pele (VENDRUSCULO, 2016). É também considerada padrão ouro para preparações cutâneas de pele, antes da introdução de qualquer dispositivo (PEREIRA et al., 2020). Um ensaio clínico realizado no Hospital das Clínicas da Faculdade de Medicina Ribeirão Preto (SP), comparou a efetividade do curativo filme transparente de poliuretano com curativo gel de clorexidina, no qual observou que não houve diferenças na colonização da pele e da ponta do cateter com a clorexidina, sendo um resultado divergente da literatura internacional, que traz esta temática como uma benefício pra redução de IRAS e mortalidade (MARGATTO, 2016). Uma pesquisa realizada em um hospital universitário no interior do estado de São Paulo, no qual metade da amostra utilizou o curativo gel de clorexidina e o restante usou o filme transparente de poliuretano, obteve o resultado da cultura com crescimento de 13 colônias no primeiro grupo e no segundo, crescimento de 6 colônias, demonstrando maior crescimento bacteriano no sítio de inserção do cateter venoso central coberto pelo curativo gel de clorexidina (PEREIRA et al., 2020). Corroborando, Vendrusculo (2016) em sua dissertação não identificou diferenças significante nos dois grupos, afirmando ainda que os curativos são uma medida relevante para prevenir eventuais infecções da corrente sanguínea, mas não podem ser consideradas medidas isoladas. Divergindo destas pesquisas o estudo de Castanho et al. (2020), recomendam o uso do curativo gel de clorexidina para pacientes mais susceptíveis a complicações infecciosas, considerando ser uma alternativa eficaz para reduzir a ocorrência de infecções relacionadas ao cateter. Por fim, a baixa significância do curativo de gel com clorexidina traz a hipótese de resistência microbiana ao antisséptico, trazendo novas desafios para a prevenção de infecções relacionadas ao CVC (PEREIRA et al,.2020)

Conclusão: a comparação das duas formas de curativos empregados no sítio de inserção do CVC, identificou na maioria dos estudos que o curativo gel de clorexidina não têm sido uma medida eficaz na prevenção de infecções, trazendo uma preocupação relevante, visto a possibilidade de resistência microbiana a clorexidina. Um dado importante a ser considerado, é que não se deve considerar apenas o material do curativo em si, pois este é um procedimento cercado de técnicas, as quais podem implicar em desfechos finais desfavoráveis quando não seguidas as recomendações de segurança e prevenção de infecções. Ressalta-se a necessidade de realizar novos estudos envolvendo outros tipos de cobertura, em busca de encontrar qual seria o curativo antimicrobiano ideal para os pacientes que utilizam o CVC.

\section{Referências}

ALMEIDA, T. M. et al. Prevenção de infecções relacionadas ao cateter venoso central não implantado de curta permanência. Rev enferm UERJ, Rio de Janeiro, v.26, n. e31771, 2018.

CASTANHO, L. E. C. et al. Curativo gel de clorexidina no transplante de células-tronco hematopoéticas. Acta Paul.Enferm., São Paulo, v.33, eAPE20180307, 2020. 
DOLCI, M. E.; MARGATHO, A. S.; SILVEIRA, R. C. C. P. Tempo de permanência do curativo gel de clorexidina no cateter venoso central em paciente crítico. Esc. Anna Nery, Rio de Janeiro, v.21, n.4, e20170026, 2017.

MARGATTO, A. S. Ensaio clínico randomizado do uso do curativo gel de clorexidina para prevenção da colonização do cateter venoso central em pacientes adultos críticos. Tese (Doutorado em Ciências) Programa de Pós graduação enfermagem fundamental, 2016. 146 f. Universidade de São Paulo. Ribeirão preto, 2016.

PEREIRA, G. L. et al. Perfil microbiológico da colonização do sítio de inserção do cateter venoso central considerando dois curativos transparentes. Revista Faculdade de Medicina (Ribeirão Preto), v.53, n.2, p. 135-145, 2020.

VENDRUSCULO, T.M. Ocorrência de infecção da corrente sanguínea relacionada ao cateter venoso central no paciente adulto crítico utilizando no sítio de saída o curativo gel de clorexidina ou filme transparente de poliuretano. 2016. 101f. Dissertação (Mestrado em Ciências) Programa de pós graduação em tecnologia e inovação em enfermagem, Universidade de São Paulo, 2016. 


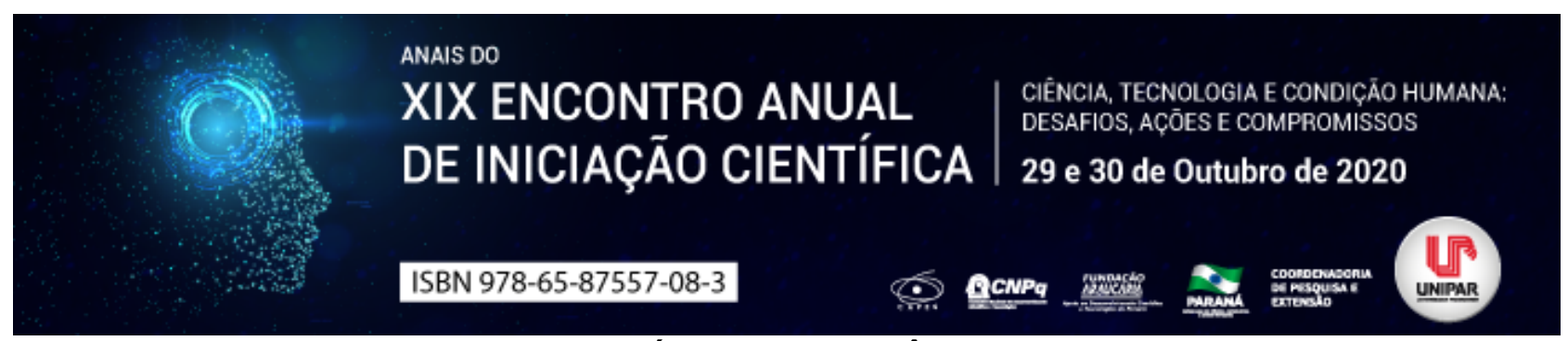

QUIROPRAXIA E VENTOSATERAPIA: O USO DE TÉCNICAS TERAPÊUTICAS INOVADORAS PARA O TRATAMENTO DA LOMBALGIA

\title{
${ }^{1}$ ANA PAULA DETTENBORN, ${ }^{2}$ DORA DE CASTRO AGULHON SEGURA
}

\author{
${ }^{1}$ Acadêmica do Curso de Fisioterapia da Unipar \\ ${ }^{1}$ Docente da UNIPAR
}

Introdução: Lombalgia são manifestações dolorosas localizadas na região lombar, provocando alterações musculoesqueléticas. É caracterizada por um quadro de desconforto e fadiga muscular (PEREIRA; FERREIRA; PEREIRA, 2010). Principal razão para pedidos de auxílio por invalidez e é a terceira causa mais comum de aposentadoria relacionada com a incapacidade no Brasil (FEITOSA et al., 2016). A quiropraxia atua no tratamento e prevenção de desordens musculoesqueléticas, onde são executadas manobras rápidas e precisas que favorecem o ajustamento articular, possibilitando a homeostasia corporal (BARBOSA; SOUZA, 2018). A ventosaterapia é uma técnica que utiliza a aplicação de copos de vidro que tem como objetivo ocasionar um vácuo e fazer uma sucção da pele, para estimular a circulação sanguínea, melhorar o metabolismo celular local e a eliminação de toxinas (OLIVEIRA; SILVA; PEREIRA, 2018; LAUCHE et al., 2016).

Objetivo: Apresentar os benefícios da ventosaterapia e quiropraxia para pessoas acometidas por lombalgia.

Desenvolvimento: Estima-se que $70 \%$ a $80 \%$ da população já vivenciaram um episódio de dor lombar na vida, sendo uma das situações mais dolorosas encontradas na prática fisioterapêutica. A quiropraxia é uma técnica da terapia manual que promove manipulações articulares transformando o funcionamento neurológico, vascular e bioquímico do tecido lesionado. Esta prática visa a restauração da funcionalidade do sistema musculoesquelético, melhorando a mobilidade articular em todos os planos anatômicos, bem como aumenta também a flexibilidade corporal global (BARBOSA; SOUZA, 2018). Tsuchida et al. (2010) avaliaram a dor de 19 cirurgiões-dentistas acometidos por lombalgia mecânica através da Escala Visual Analógica (EVA), e após 4 sessões de quiropraxia evidenciaram analgesia considerável e melhora da mobilidade corporal. A ventosaterapia atua na liberação de toxinas melhorando a circulação sanguínea e o metabolismo celular local, aliviando a dor, reduzindo edemas e tensões musculares (LAUCHE et al., 2016). Na pesquisa de Dorta et al. (2018) participaram 17 mulheres com dor lombar submetidas a técnica de ventosaterapia. Possibilitando verificar redução significativa da dor, porém sem melhora da funcionalidade corporal. No uso da ventosa está englobado o princípio ativo do uso da pressão negativa, o que torna um tratamento tanto curativo como preventivo para diversas comorbidades (CAMPOS; SANTOS, 2015).

Conclusão: Através do presente estudo foi possível concluir que o tratamento da lombalgia através da ventosaterapia e quiropraxia reduzem o limiar de dor e o desconforto muscular, proporcionando melhora da qualidade de vida do paciente, sendo importante enfatizar o aprofundamento de estudos acerca dessas técnicas que possuem baixo custo e fácil aplicação.

\section{Referências}

BARBOSA, A. C. C. T.; SOUZA, F. G. L. A. Quiropraxia no tratamento de lombalgia. Revisão Literária, v. 1, p. 01-10, 2018.

CAMPOS, G. H.; SANTOS, C. T. Tratamento de pontos-gatilhos (trigger points) por meio de terapia por ventosa. REVISA, v. 4, n. 2, p.146-54, 2015.

DORTA, G. A. et al. Efetividade da liberação miofascial por meio da ventosaterapia na dor, limitação de movimento e capacidade funcional de portadores de lombalgia. Revista Eletrônica de Trabalhos Acadêmicos, v. 3, n. 5, p. 01-06, 2018.

FEITOSA, A. S. A. et al. Estudo prospectivo de fatores prognósticos em lombalgia crônica tratados com fisioterapia: Papel do medo e dor extra espinhal. Revista Brasileira de Reumatologia, v. 56, n. 5, p. 384-390, 2016.

LAUCHE, R. et al. Efficacy of cupping therapy in patients with the fibromyalgia syndrome- arandomised placebo controlled trial. Scientific Reports, v. 6, p. 01-15, 2016.

OLIVEIRA, M. A. R.; SILVA, A. P.; PEREIRA, L. P. Ventosaterapia Revisão de Literatura. Revista Saúde em Foco, n. 10, p. 151-154, 2018.

PEREIRA, N. T.; FERREIRA, L. A. B.; PEREIRA, W. M. Efetividade de exercícios de estabilização segmentar sobre dor lombar crônica mecânico-postural. Fisioterapia e Movimento, v. 23, n. 4, p. 605-614, 2010.

TSUCHIDA, J. M. F. et al. Eficácia da terapia de manipulação articular quiroprática em odontólogos portadores de lombalgia mecânica. Revista Brasileira de Quiropraxia, v. 1, n.1, p. 61-67, 2010. 


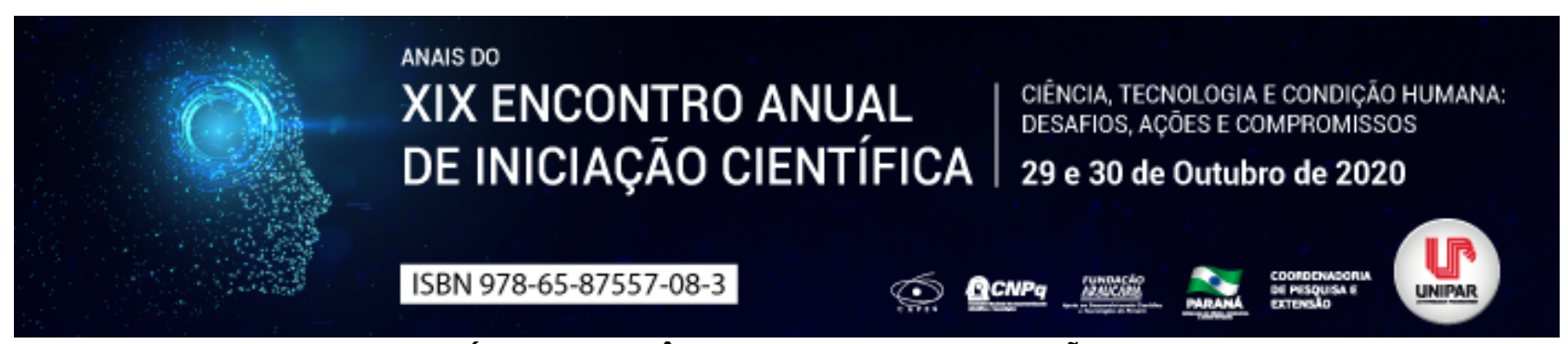

SÍFILIS CONGÊNITA: UMA BREVE REVISÃO

\title{
${ }^{1}$ BEATRIZ MORETTO DE PAULA, ${ }^{2}$ MARCELA MADRONA MORETTO DE PAULA
}

\author{
${ }^{1}$ Acadêmica do Curso de Medicina da UNIPAR \\ ${ }^{1}$ Docente da UNIPAR
}

Introdução: A sífilis congênita (SC) é uma doença infecto-contagiosa causada por uma bactéria conhecida como Treponema pallidum. Essa doença está entre as infecções perinatais mais frequentes no Brasil. É considerada um importante problema de saúde pública, apesar de seu fácil diagnóstico e de ser totalmente evitável quando o tratamento da gestante e de seu parceiro é realizado adequadamente. Em relação as suas formas de transmissão, sabe-se que, em sua maioria, a via sexual é a que gera maior número de casos, porém tal pesquisa abordará o tema relacionado com a transmissão vertical, em que a mãe infectada transmite essa doença para seu concepto durante a gestação. É possível também que ocorra transmissão direta no momento do parto, caso haja alguma lesão genital materna (AVELLEIRA; BOTTINO, 2006; BRASIL, 2006).

Objetivo: Realizar uma abordagem sobre a sífilis congênita e relacioná-la com a sua transmissão vertical, além de destacar sobre as suas principais manifestações clínicas e suas formas de prevenção.

Desenvolvimento: A sífilis é uma infecção sistêmica, de evolução crônica, com ampla variedade de manifestações clínicas e diferentes estágios: sífilis primária, sífilis secundária, latente recente e latente tardia, além de apresentar-se nas formas adquirida e congênita (AVELLEIRA, BOTTINO, 2006; COSTA et al., 2017). Segundo Avelleira e Bottino (2006), essa doença, na gestante, é dependente da mulher infectada não tratada ou tratada inadequadamente em que as fases iniciais, primária e secundária, são as que demonstram maior taxa de transmissão pela maior quantidade de bactérias na corrente sanguínea materna. É visto que a sífilis congênita (SC) é resultado da disseminação hematogênica do T. pallidum da gestante infectada para o feto por via transplacentária, em que as taxas de transmissão ao feto podem chegar a 100\% dependendo da doença materna e da fase da gestação. Como consequência da transmissão vertical, em $40 \%$ dos casos, pode ocorrer aborto precoce, óbito fetal ou neonatal, já em $60 \%$ dos casos dos recém-nascidos (RN) portadores de SC apresentam-se assintomáticos ou oligossintomáticos ao nascer, podendo desenvolver sintomas ao longo das semanas ou meses. De acordo com a Secretaria de Estado da Saúde de São Paulo (2008), a sífilis congênita se divide em dois períodos, sendo eles o precoce onde as manifestações clínicas iniciam até o segundo ano de vida, e o tardio onde o quadro é iniciado após o segundo ano de vida da criança. O primeiro período citado possui, na maior parte dos casos, características assintomáticas, porém o recém-nascido pode apresentar prematuridade, hepatomegalia, peso abaixo do normal, lesões de pele, esplenomegalia, leucocitose ou leucopenia, icterícia, anemia, entre outras disfunções. Por conseguinte, a sífilis congênita tardia tem como características: fronte olímpica, mandíbula curva, arco palatino elevado, tríade de Hutchinson, nariz em sela; tíbia em lâmina de sabre, surdez, retardo mental e hidrocefalia (SONDA et al., 2013). Os principais meios de prevenção à sífilis congênita estão intimamente ligados ao cuidado da mãe que possui sífilis gestacional, dessa forma é incluída como fator primordial na prudência de tal doença a assistência pré-natal, pois quando inadequada ou não realizada às chances do feto em adquirir este agravo são elevadas. A triagem sorológica no pré-natal é uma medida eficaz e o tratamento com penicilina é efetivo, barato e facilmente disponível. Cabe salientar que outras medidas como, orientações às grávidas sobre a gravidade, o modo de transmissão e suas consequências para o concepto são também importantes formas de prevenção para esse agravo. Dentre outros aspectos que estão envolvidos nesse panorama dessa doença, que são considerados fatores de riso são: pobreza, infecção pelo HIV, abuso de drogas, gestação na adolescência, baixa escolaridade, múltiplos parceiros sexuais, subutilização do sistema de saúde, entre outros (RODRIGUES, 2004 apud NONATO, 2015).

Conclusão: Vale a pena destacar a importância da sífilis como uma das doenças de maior prevalência de transmissão vertical, junto com uma variabilidade de apresentações clinicas. Sabendo-se que sífilis congênita é uma doença evitável, sua ocorrência representa uma falha do sistema público de saúde. Desta forma, as principais formas de prevenção dessa doença para se evitar a forma congênita, relacionam-se com os cuidados feitos pela gestante, sendo o pré-natal um dos principais focos de prevenir esse agravo.

\section{Referências}

AVELLEIRA, J. C. R.; BOtTINO, G. Sífilis: diagnóstico, tratamento e controle. Educação Médica Continuada. An. Bras. Dermatol., 81, 2, 111-26. 2006.

BRASIL. Ministério da Saúde. Diretrizes para o controle da sífilis congênita. Brasília, 2006.

COSTA, C. V. et al. Sífilis congênita: repercussões e desafios. Arq. Catarin. Med., 46, 3, 194-202, jul.-set. 2017. Disponível em: https://pesquisa.bvsalud.org/portal/resource/pt/biblio-849511. Acesso em: 01 09. 2020. 
NONATO, S. M.; MELO, A. P. S.; GUIMARÃES, M. D. C. Sífilis na gestação e fatores associados à sífilis congênita em Belo Horizonte-MG, 2010-2013. Epidemiol. Serv. Saúde, 24, 4, 681-694, 2015. Disponível em: http://scielo.iec.gov.br/scielo.php? script=sci_abstract\&pid=S1679-49742015000400010\&lng=pt\&nrm=iso. Acesso em: 01 09. 2020.

SECRETARIA DE ESTADO DE SAÚDE DE SÃO PAULO. Sífilis congênita e sífilis na gestação. Informes Técnicos Institucionais. Rev. Saúde Pública. 42, 4, 768-72. 2008.

SONDA , E. C. et al. Sífilis Congênita: uma revisão da literatura. Rev. Epidemiol. Control. Infect. 3, 1, 28-30, jan. 2013. Disponível em: file:///C:/Users/batto/Downloads/3022-15054-2-PB.pdf. Acesso em: 01 09. 2020.

Coordenadoria de Pesquisa e Extensão - COPEX

Departamento de Editoraçāo e Divulgaçāo Científica - DEDIC 


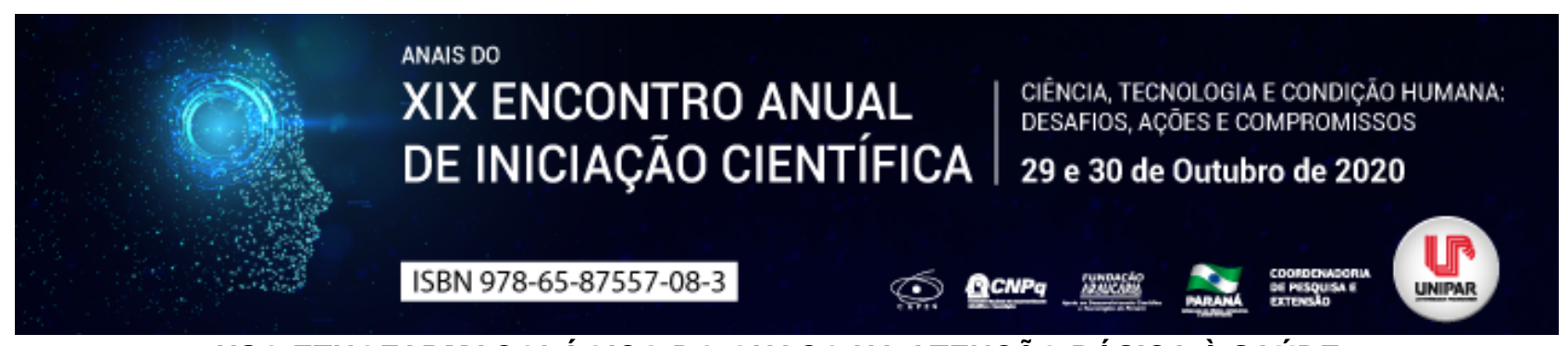

USO ETNOFARMACOLÓGICO DO GUACO NA ATENÇÃO BÁSICA À SAÚDE

\title{
${ }^{1}$ LETICIA RODRIGUES GENARIO, ${ }^{2}$ MARIANE DE ALMEIDA MACHADO, ${ }^{3}$ MONICA MICHELI ALEXANDRE , ${ }^{4}$ FABIOLA COSTA TAKAKUA, ${ }^{5}$ MARINA GIMENES
}

\author{
${ }^{1}$ Discente do curso de Farmácia, Participante do Programa de Iniciação Científica - PIC/UNIPAR. \\ ${ }^{1}$ Discente do curso de Farmácia, Participante do Programa de Iniciação Científica - PIC/UNIPAR. \\ ${ }^{2}$ Farmacêutica e discente do Curso de Medicina da Universidade Paranaense - UNIPAR. \\ ${ }^{3}$ Farmacêutica e discente do Curso de Medicina da Universidade Paranaense - UNIPAR. \\ ${ }^{4}$ Docente do curso de Farmácia, Medicina, Odontologia e Semipresencial Universidade Paranaense UNIPAR
}

Introdução: Mikania glomerata, ou conhecida popularmente como guaco, é uma planta que pertence à família Asteraceae. É um subarbusto silvestre, com folhagens densas e um caule ramificado. A mesma é nativa do Brasil, possuindo seu habitat em margens de rios, porém tem uma boa adaptação em cultivo doméstico. Já a propagação da espécie é realizada por sementes, ou plantio de estacas do caule, em terrenos arenosos e úmidos. É bastante procurada pelas abelhas melíferas durante a época da floração, quando exala um leve aroma de baunilha gerado pelo princípio ativo cumarina (MATHIAS, 2019). Mais comumente chamado de guaco, nas suas folhas se encontra a maior parte do seu princípio ativo, o qual é utilizado na fitoterapia, sendo este a cumarina. Vemos que as principais formas farmacêuticas, são os xaropes e tinturas, e o uso mais conhecido se aplica na ação expectorante, broncodilatador, em gripes e resfriados, tosse, e ainda em feridas e cortes, como anti-séptico e cicatrizante (COUTINHO; GONÇALVES e MARCUCCI, 2000). As folhas sempre foram utilizadas pelos indígenas brasileiros para combater os malefícios do veneno de serpentes, prática ainda hoje aplicada em algumas regiões do país. Também é conhecida por ervade-serpentes, cipó-caatinga ou erva-de-cobra (MATHIAS, 2019; COUTINHO; GONÇALVES e MARCUCCI, 2000).

Objetivo: Apresentar o uso etnofarmacológico do guaco na atenção básica de saúde, um fitoterápico disponível na Relação Nacional de Medicamentos Essenciais.

Desenvolvimento: A utilização de fitoterápicos é uma das mais antigas formas de prática medicinal da humanidade. O guaco, é um fitoterápico que está disponível na Relação Nacional de Medicamentos Essenciais, sendo bom, seguro e de baixo custo. Nos últimos anos, vários estudos na área científica permitiram a seguridade e eficácia das plantas medicinais o que provocou uma grande procura por terapias menos agressivas. O guaco, ou seja, a Mikania glomerata tem principal ação como broncodilatadora, antitussígena e expectorante, principal indicação pelo Sistema Único de Saúde (2011). Alguns estudos in vitro, testaram a atividades da Mikania glomerata como antibacteriana (PEREIRA, 2006) e frente a bactérias gram negativas e gram positivas, como, Streptococcus mutans, Streptococcus sobrinus, Staphylococcus aureus, Pseudomonas aeruginosa, Salmonella Typhimurium, Shigella sonnei, Klebsiella pneumoniae, Escherichia coli, entre outras. Foram encontrados estudos que avaliaram a atividade antidiarreica (SALGADO et al., 2005), antiviral (KAZIYAMA et al., 2012), anti-flamatória e antialérgica (FIERRO, 1999), e antitóxico no caso de picadas de cobra. A propriedade medicinal da erva está na cumarina, que relaxa a musculatura do trato respiratório, causando a melhora dos sintomas de asma e tosses. A cumarina e o ácido caurenóico são os principais metabólitos da planta, por terem ações anti-inflamatória e expectorante. Acredita-se que o ácido caurenóico tenha a propriedade de inibir o crescimento de Staphylococcus aureus e Candida albicans, podendo ser um dos responsáveis pela atividade antibiótica. Seus princípios ativos são taninos, resinas, saponinas, óleo essencial, açúcares, ácidos orgânicos e ácido caurenóico, substância amargas, guacina, pigmentos, heterosídeos, guacosídeo e cumarina. O extrato padronizado do guaco é equivalente a dose diária: 0,525 4,89 mg de cumarina (NICOLETTI, et al., 2007).

Devido ao potencial anticoagulante da cumarina, o uso do guaco é contraindicado para pessoas com alergia a esta planta, com doenças no fígado, que utilizam anticoagulantes, para crianças menores de 1 ano de idade e gestantes (COUTINHO, GONÇALVES e MARCUCCI, 2000). Além da interação com anticoagulantes, um estudo demonstrou que extratos secos de guaco poderão interagir, sinergicamente in vitro, com alguns antibióticos como tetraciclinas, cloranfenicol, gentamicina, vancomicina e penicilina, no entanto, o mecanismo de ação ainda é desconhecido (NICOLETTI, 2012).

Conclusão: Diante dos fatos analisados, conclui-se que o guaco (Mikania Glomerata) faz parte da RENAME (Relação Nacional de Medicamentos Essenciais), e como fitoterápico é uma ótima alternativa de tratamento, em doenças frequentes como: gripes, tosse, asma, entre outras. O guaco é um produto de uso tradicional utilizado pela população brasileira para tratamento de doenças do trato respiratório. Considerando a importância cultural do guaco, o consumo do xarope pela população brasileira, e o fato de o mesmo constar entre os fitoterápicos disponibilizados pelo Sistema Único de Saúde, é relevante que estudos sejam conduzidos visando demonstrar a sua eficácia e segurança. 


\section{Referências}

COUTINHO, Lucas; GONÇALVES, Carolina; MARCUCCI, Maria. Composição química, atividade biológica e segurança de uso de plantas do gênero Mikania. Revista Fitos, v. 14, n. 1, p. 118-144, 2020. Disponível em: https://revistafitos.far.fiocruz.br/index.php/revista-fitos/article/view/822. Acesso em: 25 ago. 2020.

FIERRO, Iolanda. et al. Studies on the anti-allergic activity of Mikania glomerata. Journal Ethnopharmacology, v.66, n.1, p. 1924, 1999. Disponível em: https://www.sciencedirect.com/science/article/abs/pii/S0378874198001512. Acesso em: 03 de ago. de 2020.

KAZIYAMA, V.M.; FERNANDES, M.J.B.; SIMONI, I.C. Atividade antiviral de extratos de plantas medicinais disponíveis comercialmente frente aos herpesvírus suíno e bovino. Revista brasileira de plantas medicinais, Botucatu, v. 14, n. 3 , p. $522-$ 528, 2012. Disponível em: http://www.scielo.br/scielo.php?script=sci_arttext\&pid=S1516-05722012000300015\&lng=en\&nrm=iso. Acesso em: 05 ago. 2020.

MATHIAS, João. Como plantar guaco. 2019. Disponível em: https://glo.bo/3gJ5AlJ. Acesso em 25 ago. 2020.

NICOLETTI, Maria. et. al. Fitoterápicos: principais interações medicamentosas. Revista Infarma, São Paulo v. 19, n. 1/2, p. 3240, 2007. Disponível em: http://www.revistas.cff.org.br/?journal=infarma\&page=article\&op=view\&path\%5B\%5D=222. Acesso em 30 jul. 2020.

PEREIRA, Aline. Purificação e caracterização de antibacterianos de plantas do município de Lavras, MG. 2006.206 p. Dissertação (Mestrado em Agrobioquímica) - Universidade Federal de Lavras, Lavras, 2006. Disponível em: http://repositorio.ufla.br/handle/1/1857. Acesso em: 05 ago. 2020.

SALGADO, Hérida; RONCARI, Ana Flávia; MOREIRA, Raquel. Efeitos antidiarréicos de Mikania glomerata Spreng. (Asteraceae). Revista brasileira de farmacognosia, João Pessoa, v. 15, n. 3, p. 205-208, setembro de 2005. Disponível em: http://www.scielo.br/scielo.php?script=sci_arttext\&pid=S0102-695X2005000300007\&lng=en\&nrm=iso. Acesso em: 05 de ago. de 2020. 


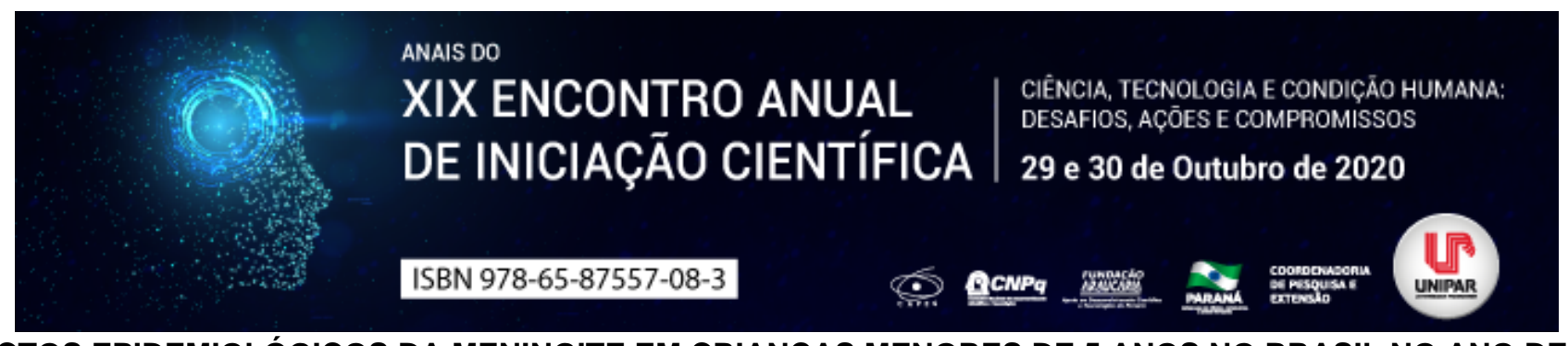

ASPECTOS EPIDEMIOLÓGICOS DA MENINGITE EM CRIANÇAS MENORES DE 5 ANOS NO BRASIL NO ANO DE 2019

\author{
${ }^{1}$ ISADORA GIACOMINO ALVES, ${ }^{2}$ FERNANDA SONZA, ${ }^{3}$ ISABELLA ACACIO FERREIRA DE SOUZA, ${ }^{4}$ MARCELA MADRONA \\ MORETTO DE PAULA
}

\author{
${ }^{1}$ Acadêmica do Curso de Medicina da UNIPAR \\ ${ }^{1}$ Acadêmica do Curso de Medicina da UNIPAR \\ ${ }^{2}$ Acadêmica do Curso de Medicina da UNIPAR \\ ${ }^{3}$ Docente da UNIPAR
}

Introdução: Meningite é um processo inflamatório que se instala nas meninges (SILVA; MEZAROBBA, 2018). A meningite de etiologia viral pode derivar de enterovírus, adenovírus, vírus do sarampo, e outros, enquanto a bacteriana, pode ser causada por Neisseria meningitidis, Haemophilus influenzae, Streptococcus pneumoniae, entre outros. Entre as etiologias citadas, a viral é a mais prevalente, porém a bacteriana apresenta maiores complicações e maior letalidade (TEIXEIRA et al., 2018).

Objetivo: Determinar o perfil epidemiológico dos casos confirmados de meningite em crianças menores de 5 anos no Brasil em 2019.

Material e Métodos: Estudo ecológico dos casos notificados de meningite em crianças menores de 5 anos no Brasil em 2019, a partir de dados obtidos do Departamento de Informática do Sistema Único de Saúde (DATASUS), através do SINAN (Sistema de Informação de Agravos de Notificação). Foram analisadas as seguintes variáveis: região de notificação, gênero, etiologia e evolução da doença.

Resultados: Em 2019 foram notificados 5.585 casos de meningite em crianças de 0-4 anos de idade no Brasil, representando $34,8 \%$ do total. Destes, 45,6\% foram em menores de 1 ano. A região sudeste apresentou o maior número de casos, com 59,2\%. Dos casos confirmados, 59,9\% ocorreram no gênero masculino. Quanto à etiologia, a meningite viral foi a mais frequente, perfazendo $63 \%$, seguida das bacterianas com $22,1 \%, 14 \%$ teve etiologia não especificada e $0,62 \%$ de outras etiologias. Em relação a evolução, 83,5\% receberam alta e 4,5\% evoluíram a óbito por meningite, sendo 63,6\% dos óbitos em menores de 1 ano.

Discussão: O elevado número de crianças com meningite encontrado neste estudo pode ser explicado por Maciel (2015), o qual afirma que menores de 5 anos são mais suscetíveis à meningite. Segundo Silva; Mezarobba (2018), isso ocorre por estarem expostas a mais microrganismos, pela imaturidade do sistema imune e pela ausência de anticorpos maternos. $\mathrm{O}$ acesso ao diagnóstico não é uma realidade em todo o país, isto pode ter interferido na maior notificação na região sudeste, juntamente com o fato de possuir a maior população. A doença atingiu mais homens, em conformidade com o estudo de Guimarães; Guimarães; Moreira (2014). A etiologia por agentes virais, neste estudo, foi a mais incidente, corroborando o estudo de Oliveira; Magnani (2011), este cenário ocorre pela fácil transmissão destes patógenos. Comparando-se com o mesmo estudo, em 2019 houve menor incidência de meningites por bactérias. A partir desta análise, conclui-se que a redução da etiologia bacteriana pode estar relacionada à incorporação da vacina meningocócica C conjugada (MenC) no calendário de vacinação no ano de 2010 (BRASIL, 2019). Em conformidade com Oliveira; Magnani (2011), este estudo revelou alto índice de cura. Quanto aos óbitos, a maioria ocorreu em menores de 1 ano, constituindo 1 morte a cada 16 crianças, demonstrando decréscimo se comparado ao estudo de Cohn (2010), que relatou 1 morte em cada 10 crianças.

Conclusão: Constatou-se que crianças do sexo masculino e menores de 1 ano foram mais acometidas por meningite. Houve diminuição da etiologia bacteriana, destacando o impacto positivo de imunizações, ainda que seja necessário melhora nas políticas públicas que visem a redução da incidência e maior alcance vacinal.

\title{
Referências
}

BRASIL. Ministério da Saúde. Secretaria de Vigilância em Saúde. Vigilância em saúde no Brasil 2003|2019: da criação da Secretaria de Vigilância em Saúde aos dias atuais. Boletim Epidemiológico, v. 50, n. esp., p. 1-154, 2019. Disponível em: https://portalarquivos2.saude.gov.br/images/pdf/2019/setembro/25/boletim-especial fbclid=IwAR3qTQYyo5tG7dYLNXWfj4ymtmIAoJtlolbTnwToAPConwrDnOVpv0kyzvo. Acesso em: 09 jul. 2020.

COHN, A. C. et al. Changes in Neisseria meningitidis disease epidemiology in the United States, 1998-2007: implications for prevention of meningococcal disease. Clinical Infectious Diseases, v. 50, n. 2, p. 184-191, 2010.

GUIMARÃES, I. L. B.; GUIMARÃES, M. L. B.; MOREIRA, A. C. A. Perfil epidemiológico da meningite em crianças. Revista Norte Mineira de Enfermagem, v. 3, n. 1, p. 1-7, 2014.

MACIEL, A. S. Avaliação do impacto da introdução da vacina na morbimortalidade por doença meningocócica na região 
Centro-Oeste do Brasil nos anos de 2007 a 2013. Monografia (Bacharelado em Saúde Coletiva) Universidade de Brasília, Brasília, v. 65, n. 5, 2015.

MINISTÉRIO DA SAÚDE/SVS - Sistema de Informação de Agravos de Notificação - Sinan Net. Disponível em: http://tabnet.datasus.gov.br/cgi/deftohtm.exe?sinannet/cnv/ meninbr.def. Acesso em: 09 jul. 2020.

OLIVEIRA, C. C. D.; MAGNANI, A. C. Incidência de meningite em crianças de 0-5 anos do município de Maringá-PR do ano de 2007 á 2009. Revista UNINGÁ, v. 30, n. 1, 2011.

SILVA, H. C. G.; MEZAROBBA, N. Meningite no Brasil em 2015: o panorama da atualidade. Arquivos Catarinenses de Medicina, v. 47, n. 1, p. 34-46, 2018.

TEIXEIRA, A. B. et al. Meningite bacteriana: uma atualização. Revista Brasileira de Análises Clínicas, v. 50, n. 4, p. 327-9, 2018. 


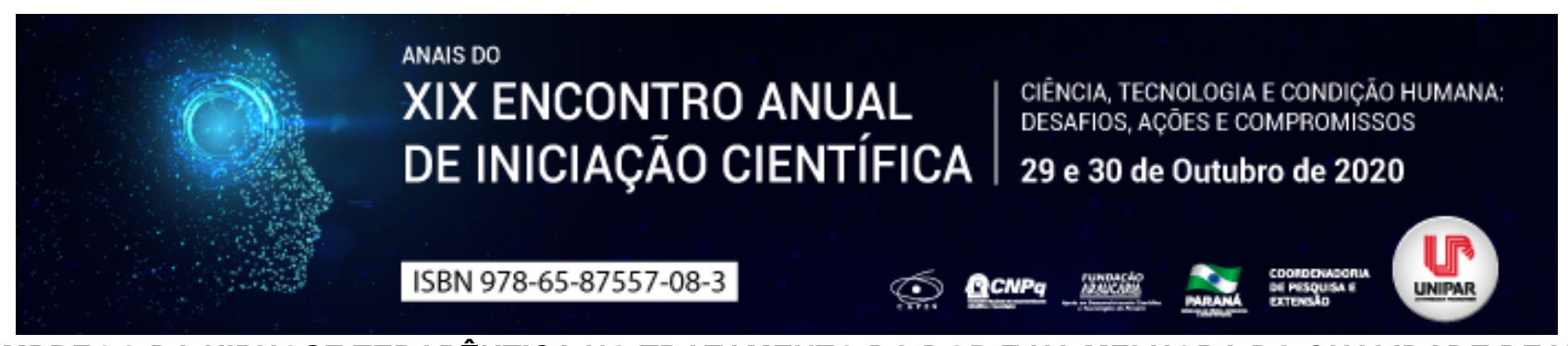

O EMPREGO DA HIPNOSE TERAPÊUTICA NO TRATAMENTO DA DOR E NA MELHORA DA QUALIDADE DE VIDA

\author{
${ }^{1}$ THAYNA PINTER MENDES CAMPOS, ${ }^{2}$ ANA PAULA CAMPOS SANTANA, ${ }^{3}$ LETICIA FLOIS FERREIRA, ${ }^{4}$ PAOLA NATHALIA \\ ZANETIN, ${ }^{5}$ DORA DE CASTRO AGULHON SEGURA
}

\footnotetext{
${ }^{1}$ Acadêmica do Curso de Fisioterapia da UNIPAR

${ }^{1}$ Acadêmica do Curso de Fisioterapia da UNIPAR

${ }^{2}$ Acadêmica do Curso de Fisioterapia da UNIPAR

${ }^{3}$ Acadêmica do Curso de Fisioterapia da UNIPAR

${ }^{4}$ Docente da UNIPAR
}

Introdução: A hipnoterapia visa ampliar a consciência do indivíduo através do relaxamento e da concentração focada, por meio de um conjunto de técnicas específicas de controle da atividade mental (GLASS; REALE, 2019). Liossi e Hatira (2003) evidenciam a eficiência da hipnose na diminuição da dor durante processos invasivos testados em crianças, porém citam que esse resultado positivo depende do paciente, nem todos aproveitam o processo terapêutico da mesma maneira. Além disso, por conta do período hipnótico resultar numa sugestionabilidade aumentada, essa se torna muito útil para fazer com que o paciente venha a aderir com maior facilidade uma dieta, bem como a prática de exercícios físicos, as horas necessárias de sono e mudanças em hábitos saudáveis, promovendo evoluções consideráveis que vão implicar em uma melhor qualidade de vida (PEREIRA, 2017). É de suma importância que a hipnoterapia seja desenvolvida de acordo com a singularidade de cada indivíduo, pois essa depende da compreensão do indivíduo como sujeito único, e suas experiências dolorosas e dificuldades não devem ser interpretadas a partir de escalas estatísticas ou teorias fechadas (MALLMANN, 2018).

Objetivo: Abordar a eficácia do tratamento com hipnose terapêutica nos mais diversos tipos de dores, bem como na melhora da qualidade de vida.

Desenvolvimento: Hodiernamente, há uma incansável busca por ferramentas para a auto cura dos desajustes internos, pois esses estão cada vez mais relacionados com os sintomas que o ser humano desencadeia e não são facilmente diagnosticados. Entre os mecanismos utilizados está a hipnoterapia (CAMPOS; OLIVEIRA, 2017). Nogueira, Lauretti e Costa (2005), através de um ensaio clínico feito com pacientes portadores de fibromialgia refratária, apontou uma diminuição significativa da dor diária após passarem por efetivas sessões de hipnoterapia, também foi constatada diminuição do uso de antidepressivos e antiinflamatórios. A hipnose vem se mostrando muito eficiente no tratamento de dores e também como um método complementar em diversas áreas da saúde física e mental, essa além de facilitar a mudança de hábitos, ainda ajuda a descobrir elementos psicológicos do subconsciente que podem estar envolvidos em diversas doenças, como na obesidade. Ademais, alinha diversos fatores relacionados a autoestima, confiança e motivação, o que influencia de forma muito positiva no processo da saúde (LAGUINHAS, 2017). Importantes são também as contribuições no campo odontológico, que além de tratar o medo e a ansiedade enfrentada por principalmente pacientes pediátricos, o estudo de Alóe et al. (2003) aponta a hipnoterapia como um dos tratamentos comportamentais no tratamento do bruxismo durante o sono, pois promove relaxamento, os músculos da mandíbula que se encontram hipertrofiados nessa afecção relaxam diminuindo a tensão entre os dentes e consequentemente os sintomas relatados.

Conclusão: Diante disso, foi possível concluir que a hipnoterapia se mostra eficaz no tratamento de afecções que acarretam dor e incômodos, bem como também é uma importante ferramenta para a promoção de uma melhor qualidade de vida.

\title{
Referências
}

ALÓE, F.; GONÇALVES, L. R.; AZEVEDO, A.; BARBOSA, R. C. Bruxismo durante o sono. Revista Neurociência, v. 11, n. 1, p. 04-17, 2003.

CAMPOS, J. F.; OLIVEIRA, A. O. Hipnose heriksoniana, aplicações na clínica psicológica. Revista Científica Univiçosa, v. 10, n. 1, p. 382-386, 2017.

GLASS, W. A.; REALE, E. A hipnose como aliada terapêutica. Revista Anais Eletrônico Cic., v. 17, p. 01-07, 2019.

LAGINHAS, A. C. T. P. Aplicação da hipnose clínica na obesidade. 2017. 31 f. Dissertação (Mestrado Integrado em Medicina) Universidade de Lisboa, Lisboa, 2017.

LIOSSI, C.; HATIRA, P. Clinical hypnosis in the alleviation of procedure-related pain in pediatric oncology patients. International Journal of Clinical and Experimental Hypnosis, v. 51, n. 1, p. 14-28, 2003.

MALLMANN, J. A. A. Hipnose, complexidade e dores crônicas: Um percurso teórico. Tese (Doutorado em Psicologia) Universidade de Brasília, Instituto de Psicologia, Programa de Pós-graduação em Psicologia Clínica e Cultura, Brasília-DF, 2018. 
NOGUEIRA, C. H.; LAURETTI, G. R.; COSTA, R. M. N. Avaliação duplamente encoberta da hipnose em fibromialgia. São Paulo Medical Jornal, v. 123, p. 14-18, 2005.

PEREIRA, M. G. Mudando a mente: Hipnose e diabetes. Revista Latino-Americana de Enfermagem, v. 25, e2868, p. 01-02, 2017.

Coordenadoria de Pesquisa e Extensão - COPEX

Departamento de Editoraçāo e Divulgaçāo Científica - DEDIC 


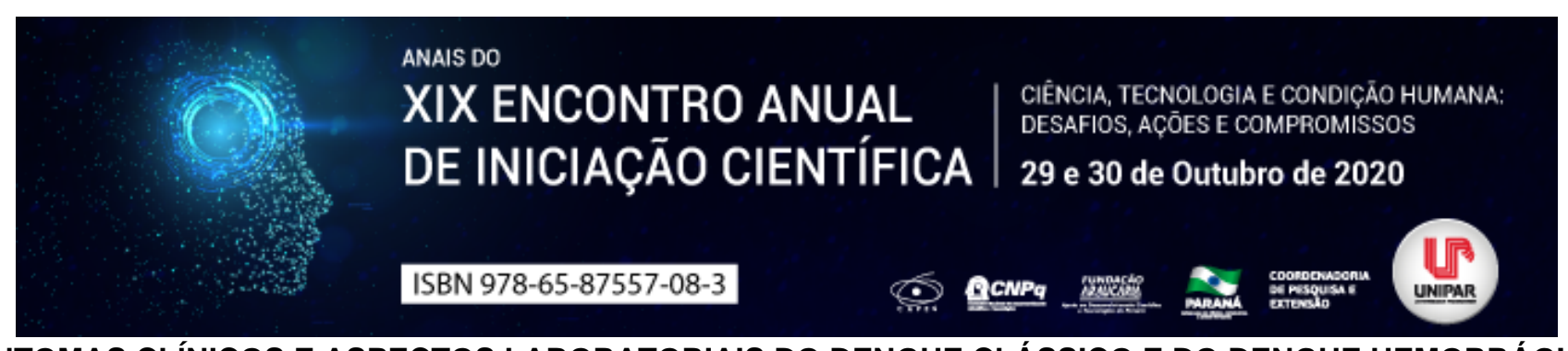

SINTOMAS CLÍNICOS E ASPECTOS LABORATORIAIS DO DENGUE CLÁSSICO E DO DENGUE HEMORRÁGICO

\author{
${ }^{1}$ ELIEZER FERREIRA DA SILVA, ${ }^{2}$ CAROLINA LUZIANA DE LIMA VALÉRIO, ${ }^{3}$ CRISTIANE CLAUDIA MEINERZS, ${ }^{4}$ MARIA \\ ELENA MARTINS DIEGUES, ${ }^{5}$ IRINEIA PAULINA BARRETA, ${ }^{6}$ ROSILEY BERTON PACHECO
}

\begin{abstract}
${ }^{1}$ Acadêmico do PIC/UNIPAR
${ }^{1}$ Acadêmico do PIC/UNIPAR

${ }^{2}$ Docente do Curso de Medicina da UNIPAR

${ }^{3}$ Docente do Curso de Medicina da UNIPAR

${ }^{4}$ Docente do Curso de Medicina da UNIPAR

${ }^{5}$ Docente da UNIPAR
\end{abstract}

Introdução: O dengue é uma enfermidade causada por um vírus pertencente ao gênero Flavivírus, da família Flaviridae, sendo caracterizado como uma doença febril de início abrupto, com duração de 5 a 7 dias. $O$ vírus do dengue apresenta quatro sorotipos: DEN-1, DEN-2, DEN-3 e DEN-4 (CASALI et al, 2004). Sua transmissão se dá a partir da picada da fêmea do mosquito Aedes aegypti contaminado; podendo ainda ocorrer transmissão vertical, ou seja, entre a mãe e o feto, fato esse raro (SINGHI; KISSOON; BANSAL, 2007). O vírus do dengue está presente em regiões tropicais e subtropicais e estima-se que aproximadamente três bilhões de pessoas estão susceptíveis a infecção pelo vírus do dengue (DALBEM et al, 2014). De acordo com a classificação clínica do dengue, ela pode ser definida como doença febril não-diferenciada ou síndrome viral; dengue e dengue hemorrágico $(\mathrm{DH})$ podendo esta ser $\mathrm{DH}$ sem choque ou podendo evoluir para síndrome do choque associada ao dengue (SCD) (SINGHI; KISSOON; BANSAL, 2007).

Objetivo: Avaliar manifestações clínicas do dengue clássico frente ao dengue hemorrágico, assim como aspectos laboratoriais.

Desenvolvimento: $O$ dengue clássico, inicia-se através de uma febre abrupta de $39^{\circ}$ a $40^{\circ}$, associado a dois dos seguintes sintomas pode-se chegar ao diagnóstico: cefaleia, dor retro-orbital, dor osteomioarticular, erupções, leucopenia ou sangramento. No caso do dengue hemorrágico, é necessário observar pelo menos quatro sintomas principais: febre, sangramento espontâneo, trombocitopenias e extravasamento do plasma, essa última condição se dá a partir do aumento do hematócrito de $20 \%$, ou a diminuição de $20 \%$ do hematócrito após a fase crítica da doença. É possível identificar o extravasamento do plasma através de exames de imagem, demonstrando derrame pleural, ascite ou derrame pericárdico (DALBEM et al, 2014). Em um estudo realizado por Casali et al, 2004, no município do RJ, os sintomas mais prevalentes em pacientes diagnosticados com DC foi: febre $(98,8 \%)$, cefaleia $(95,8 \%)$, mialgia $(92,4 \%)$, prostração $(90 \%)$, dor retro-orbitária $(82,5 \%)$, artralgia $(76,4 \%)$ e náusea $(70,8 \%)$, enquanto que os pacientes diagnosticados com dengue hemorrágico apresentaram febre $(99,2 \%)$, cefaleia $(94,7 \%)$, mialgia $(94,4 \%)$, prostração $(91,9 \%)$, dor retro-orbitária $(83,7 \%)$, náusea $(81,9 \%)$ e artralgia (76\%). Observou-se que manifestações hemorrágicas teve uma prevalência maior em pacientes diagnosticados com dengue hemorrágico. Dos pacientes com dengue hemorrágico, 55,4\% apresentaram dor abdominal, petéquias (51,6\%), hemorragia digestiva (37,6\%), gengivorragia $(34,6 \%)$, epistaxe $(34,1 \%)$, choque $(15,3 \%)$, hepatomegalia $(6,4 \%)$, ascite $(3,1 \%)$ e derrame pleural $(3,1 \%)$. Segundo um estudo conduzido por Oliveira et al, 2009, realizado com 543 pacientes, 90,2\% $(n=490)$ apresentaram dengue clássico e 9,8\% $(n=53)$ tiveram febre hemorrágica do dengue (FHD). Dos prontuários analisados, 68,5\% apresentaram plaquetas inferior a 150.000/mm ${ }^{3}$, em que os pacientes com DC apresentaram redução de plaquetas no $3^{\circ}$ dia, enquanto os pacientes com FHD apresentaram redução de plaquetas no $1^{\circ}$ e $2^{\circ}$ dias. Em relação ao número de leucócitos, $69,8 \%$ dos pacientes apresentaram leucócitos inferior à $4.000 / \mathrm{mm}^{3}$, onde os pacientes com FHD apresentaram redução já no $2^{\circ}$ dia de sintomas, enquanto que os pacientes com DC, observou-se redução dos leucócitos do $3^{\circ}$ ao $8^{\circ}$ dia de sintomatologia. Em relação a recuperação, tanto os pacientes com FHD, quanto os pacientes com DC, evoluíram para a recuperação a partir do $8^{\circ}$ dia. Observou-se que $67,8 \%$ dos pacientes apresentaram linfopenia, e um dado importante nesse trabalho foi a presença de linfócitos atípicos, onde 66,9\% dos pacientes apresentaram linfócitos atípicos que variaram de 1\% a 35\% (OLIVEIRA et al, 2009). A infecção do dengue pode se tornar mais grave, após o indivíduo ser novamente infectado, ou seja, uma infecção secundária, por um sorotipo diferente da qual foi infectado primariamente, essa condição pode ocorrer em 2-4\% dos indivíduos (SINGHI; KISSOON; BANSAL, 2007).

Conclusão: Observou-se no dengue clássico, febre de início abrupto e sintomas convencionais como cefaléia, mialgia, artralgia, dor retro-orbitária, dor abdominal entre outros. Em uma infecção secundária por um sorotipo diferente da infecção primária, aumenta a probabilidade para uma evolução ao dengue hemorrágico, que apresenta sintomas similares ao dengue clássico, entretanto, pode ocorrer manifestações hemorrágicas. Em exames laboratoratiais, observou-se em pacientes com DC a presença de leucopenia, plaquetopenia, linfopenia e a presença de linfócitos atípicos. No dengue hemorrágico, além dos achados 
laboratoriais citados acima, observou-se um aumento no hematócrito de $20 \%$, ou diminuição de $20 \%$ no hematócrito após a fase crítica, além de trombocitopenia e hemoconcentração, podendo ocorrer extravasamento do plasma através do aumento da permeabilidade vascular, e consequentemente gerando quados hemorrágicos. Portanto, é fundamental a relação médicopaciente, onde se faça uma anamnese adequada, assim como uma observação criteriosa do exame físico e laboratorial.

\section{Referências}

CASALI, Clarisse Guimarães et al. A epidemia de dengue/dengue hemorrágico no município do Rio de Janeiro, 2001/2002. Revista da Sociedade Brasileira de Medicina Tropical, Uberaba, v. 37, n. 4, p. 296-299, jul./ago. 2004.

DALBEM, Alexandre Garcia et al. Dengue clássica e febre hemorrágica da dengue: etiologia, fisiologia, epidemiologia e fatores de risco. Revista Ciência e Estudos Acadêmicos de Medicina, Cáceres, v. 1, p. 18-36, jan./jul. 2014.

OLIVEIRA, Éveny Cristine Luna et al. Alterações hematológicas em pacientes com dengue. Revista da Sociedade Brasileira de Medicina Tropical, Uberaba, v. 42, n. 6, p. 682-685, nov./dez. 2009.

SINGHI, Sunit; KISSOON, Niranjan; BANSAL, Arun. Dengue e dengue hemorrágico: aspectos do manejo na unidade de terapia intensiva. Jornal de Pediatria, Porto Alegre, v. 83, n. 2, supl. p. S22-S35, maio. 2007.

Coordenadoria de Pesquisa e Extensão - COPEX

Departamento de Editoraçāo e Divulgaçāo Científica - DEDIC 


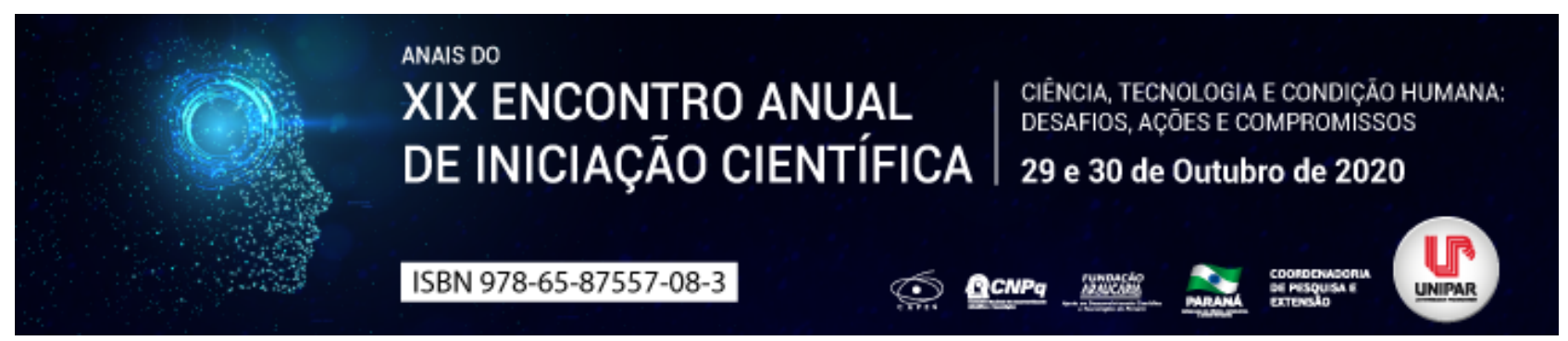

ANÁLISE DO GENE Fto RELACIONADO COM A MICROBIOTA INTESTINAL, TRANSTORNOS DE HUMOR E DEPRESSÃO: UMA REVISÃO

\author{
${ }^{1}$ LUIZ GUSTAVO MARTINS, ${ }^{2}$ FATIMA HASSAN SAFIEDDINE, ${ }^{3}$ MARIA ELENA MARTINS DIEGUES, ${ }^{4}$ RICARDO MARCELO \\ ABRAO, ${ }^{5}$ LUCIANO SERAPHIM GASQUES
}

\author{
${ }^{1}$ Acadêmico bolsista do PIBIC/UNIPAR \\ ${ }^{1}$ Acadêmica do Curso de Medicina da UNIPAR \\ ${ }^{2}$ Docente da UNIPAR \\ ${ }^{3}$ Docente da UNIPAR \\ ${ }^{4}$ Docente da UNIPAR
}

Introdução: Estudos indicam que o gene Fto (Fat mass and obesity) desempenha papéis fundamentais nos processos metabólicos relacionados com a obesidade, principalmente através da microbiota intestinal, desencadeando alterações comportamentais como transtornos de ansiedade e depressão (SUN et al., 2019). Dessa forma, há evidências epidemiológicas de associações entre depressão e obesidade que tendem a coocorrer, exibindo, assim, uma relação de forma bidirecional, onde possuir uma condição eleva o risco de desenvolver a outra (MILANESCHI et al., 2018). Essa correlação entre obesidade e depressão pode se reportar a microbiota intestinal, onde colônias de determinadas bactérias modulem alterações no do eixo HPA (hipotálamo-hipófise-adrenal) desencadeando transtornos de humor (BRAVO et al., 2011).

Objetivo: Verificar na literatura a relação existente entre expressão do gene Fto, os transtornos de humor e depressão a microbiota intestinal.

Desenvolvimento: Estudos indicam que o microbioma intestinal contribui para o fortalecimento e integridade do epitélio intestinal, auxilia na digestão, armazena energia, degrada xenobióticos e gera uma certa resistência à colonização de patógenos oportunistas, além de poder estar ligado ao desenvolvimento da obesidade por meio de culturas específicas de microrganismos (LÓPEZ E HERRERA, 2020). Segundo testes realizados por Sun et al. (2019), que observaram ratos com a expressão gene Fto e ratos knockout (sem a expressão do gene), submetidos a tratamento com antibióticos durante 6 semanas com o intuito de esgotar sua microbiota. Posteriormente, os ratos foram submetidos a testes de estresse crônico, concluindo-se que portadores do gene Fto possuíam uma hipersensibilidade a estímulo de ansiedade e depressão, principalmente por apresentarem uma menor abundância de espécie de bactérias Lactobacillus. Estudos em animais demonstraram que o gene Fto é amplamente expresso no cérebro através dos núcleos do hipotálamo, onde regula diversos processos metabólicos e cognitivos (RIVERA et al., 2012). Quando analisamos essa relação entre intestino e sistema nervoso central (SNC), notamos que os neurotransmissores GABA, principal inibidor do SNC, estão envolvidos diretamente em muitos processos fisiológicos e psicológicos, modulando ações que desencadeiam uma alteração na expressão do receptor GABA, implicando assim na patogênese da ansiedade e depressão (BRAVO et al., 2011). Luppino et al. (2010) descrevem que o excesso de tecido adiposo eleva a expressão do sistema inflamatório e, por consequência, de resistência à insulina, hiperlipidemia e síndrome metabólica. Quando há a ativação das vias inflamatórias nota-se uma relação direta com o ganho de peso e indução à ocorrência de estresse oxidativo e posterior degeneração neural. Somado a isso, a obesidade é um fator de risco para o desenvolvimento de doenças como o diabetes, onde favorecendo também a ocorrência de alterações cerebrovasculares e elevando o risco de propagação da depressão (HUBER, 2008). Outro ponto importante relacionado à obesidade e depressão é que o eixo HPA encontra-se em modo hiporresponsivo nos indivíduos obesos, assim há uma elevação dos níveis de hormônio liberador de corticotrofina no hipotálamo, responsável por alterações na inibição do feedback pelos glicocorticóides endógenos, acarretando prejuízo a saúde mental (JURUENA et al., 2004).

Conclusão: Os efeitos resultantes da expressão do gene Fto estão em grande evidência em pessoas obesas, principalmente por meio da microbiota intestinal que modula funções no SNC, desencadeando sintomas relacionados à ansiedade e transtornos depressivos. Desse modo, é válido ressaltar e avaliar as influências dessas alterações na vida do indivíduo, principalmente focando a sintomatologia da depressão.

\title{
Referências
}

HUBER, Jadson D. Diabetes, Cognitive Function, and the Blood-Brain Barrier. Current Pharmaceutical Design. v. 14, n. 16, p: 1594-1600, 2008.

JAVIER, A. Bravo; PAUL, Forsythe; MARIANNE, V. Chew; EMILY, Escaravage; HÉLÈNE, M. Savignac; TIMOTHY, G. Dinan; JOHN, Bienenstock; JOHN, F. Cryan. A ingestão da cepa de Lactobacillus regula o comportamento emocional e a expressão do 
receptor GABA central em um camundongo através do nervo vago. Anais da Academia Nacional de Ciências. v.108, n.38, p.16050-16055. 2011. Disponível em: https://www.pnas.org/content/108/38/16050. Acesso em 13/06/2020.

JURUENA, Mario F.; CLEARE, Anthony J.; PARIANTE, Carmine M. O eixo hipotálamo-pituitáriaadrenal, a função dos receptores de glicocorticóides e sua importância na depressão. Revista Brasileira Psiquiatria. v. 26, n.3, 2004.

LUPPINO, Floriana S; WIT, Leonore M.; BOUVY, Paul F. Overweight obesity and depression a systematic review and metaanalysis of longitudinal studies. Archives General Psychiatry. v. 67, n.3, p. 220- 229, 2010.

MILANESCHI, Y; SIMMONS, W. Kyle; ROSSUM, Elisabeth F. C. van; et al. Depressão e obesidade: evidência de mecanismos biológicos compartilhados. Mol Psychiatry v.24, p.18 33, 2019.

RIVERA, M; COHEN-WOODS, S; KAPUR, K. et al. O transtorno depressivo modera o efeito do gene FTO no índice de massa corporal. Mol Psychiatry. v.17, p. 604 611, 2012.

SUN, Llijuan; MA, Lanjing; ZHANG, Haohao. et al. A deficiência de Fto reduz comportamentos semelhantes à ansiedade e à depressão em ratos através de alterações na microbiota intestinal. Theranostics . v.9 n.3, p.721-733. 2019. Publicado em 24 de janeiro de 2019. Disponível em: https://www.ncbi.nlm.nih.gov/pmc/articles/PMC6376469/. Acesso em 12/05/2020. 


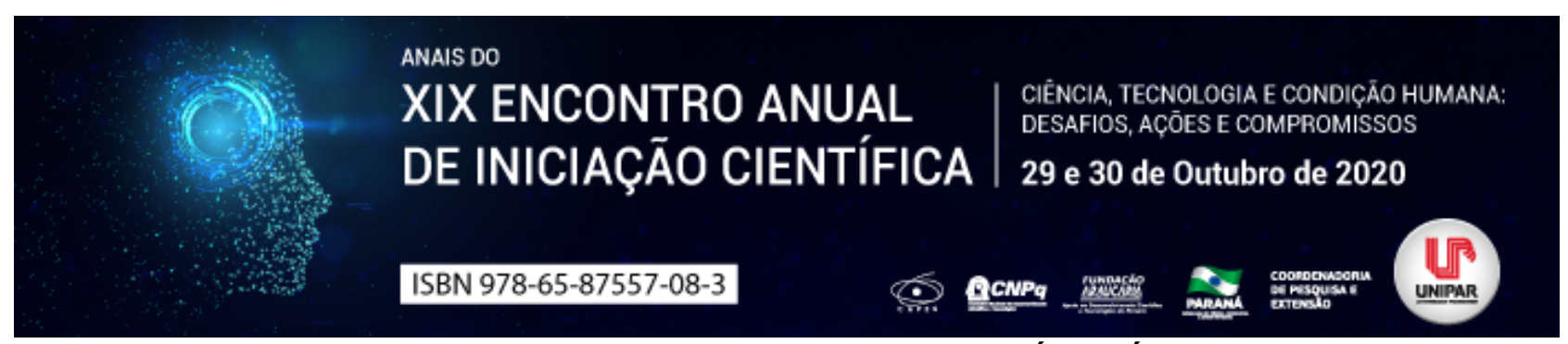

OBESIDADE INFANTIL, UM PROBLEMA DE SAÚDE PÚBLICA

\author{
${ }^{1}$ Emanuele Kelli Samaia Silva, ${ }^{2}$ ROSE MARY HELENA QUINT SILOCHI
}

\author{
${ }^{1}$ Discente do curso de Nutrição da Unioeste \\ ${ }^{1}$ Docente da Unioeste
}

Introdução: O Brasil tem apresentado um aumento significativo nos índices de sobrepeso e obesidade de sua população em todas as etapas da vida, sendo a infância a principal na construção de hábitos alimentares saudáveis para a vida adulta. A obesidade é uma doença crônica não transmissível (DCNT) caracterizada pelo acúmulo de gordura corporal sendo evidenciado por estudos nacionais e internacionais como um problema de saúde pública trazendo consigo complicações que permeiam até a vida adulta (ABESO, 2020). Nessa perspectiva, surge o contexto da obesidade infantil, as crianças tendem a ganhar peso com facilidade visto que, nessa faixa etária, fatores como alimentação inadequada, sedentarismo, genética e distúrbios psicológicos podem influenciar no ganho de peso (FIOCRUZ, 2020).

Objetivo: Sobre este assunto se propõe verificar a partir de revisão bibliográfica quais as principais causas e consequências da obesidade infantil apontadas por estudos nacionais a partir do ano de 2011 até meados de 2020 e as políticas públicas que contribuem para minimizar os impactos dessa doença e os possíveis agravos causados por ela.

Desenvolvimento: Segundo Marchi-Alves et al, (2011) a obesidade infantil trata-se de uma condição onde o excesso de gordura corporal afeta diretamente a saúde da criança, assim, inúmeros fatores podem influenciar no aparecimento dessa doença, dentre os quais destacam-se os aspectos genéticos, ambientais e sociais. Além disso, segundo estudos, os principais condicionantes da obesidade infantil estão relacionados com o alto consumo de ultra processados e atividade física insuficiente (HENRIQUES et al, 2018). Ainda, de acordo com Linhares et al (2016), pode-se destacar fatores relacionados ao âmbito familiar, genético, ambiental e social, necessitando de uma abordagem multidisciplinar e efetiva no controle da obesidade. Dados do Sistema de Vigilância Alimentar e Nutricional (SISVAN) no ano 2019, mostraram que, 16,33\% das crianças brasileiras na faixa etária de 5 a 10 anos se encontravam em sobrepeso, 9,38\% em obesidade e 5,22\% com obesidade grave. Já em relação aos adolescentes, $18 \%$ estavam na faixa de sobrepeso, 9,53\% obesidade e 3,98\% obesidade grave (SISVAN, 2019). Estes estudos apresentados pelo SISVAN demonstram que o período de vida mais vulnerável a obesidade infantil está relacionada a faixa etária da segunda infância a préadolescência. No Brasil, $38 \%$ das crianças do sexo masculino e $71 \%$ do sexo feminino realizam atividade física em quantidade inferior a 300 minutos por semana (CUREAU et al, 2016), isso pode ser explicado pelo aumento do tempo que as crianças passam utilizando meios eletrônicos, o que contribui para elevar as estatísticas do risco de obesidade infantil. A obesidade infantil traz grandes impactos, isso porque além de interferir no atual estado de saúde da criança, suas consequências podem chegar na fase adulta, o risco dessa progressão acontecer é de $25 \%$ e aumenta para $80 \%$ quando esse excesso de peso se faz presente na adolescência (MARCHI-ALVES et al, 2011). Dentre as consequências, estão as dislipidemias, diabetes, hipertensão arterial e problemas psicológicos (LINHARES et al, 2016). Nesse sentido, o governo brasileiro buscou soluções para minimizar a problemática, entre as ações destacam-se a criação da Promoção da Alimentação Adequada e Saudável (PAAS) que é parte fundamental da garantia da Segurança Alimentar e Nutricional, tornando a alimentação dos indivíduos adequada e sustentável (HENRIQUES, 2018; BRASIL, 2014). Há, ainda, a Política Nacional de Alimentação e Nutrição (PNAN) que estimula ações na busca pela garantia do acesso a alimentos em quantidade e qualidade adequadas, além de monitorar a situação nutricional da população beneficiada. E o Programa Nacional de Alimentação Escolar (PNAE) que também é uma ferramenta essencial na busca pela garantia da saúde da criança com o desenvolvimento de ações educativas e fornecimento de alimentos de qualidade no âmbito escolar (REIS et al, 2011). É de extrema relevância o acompanhamento nutricional das crianças desde a primeira semana de vida até, no mínimo, os dois anos de idade, a fim de que sejam garantidos o crescimento adequado e as intervenções necessárias para a saúde dos mesmos (DESIDERATA, 2019).

Conclusão: Para o enfrentamento desse cenário, de consumo alimentar da população e por consequência da alimentação infantil, é possível destacar a partir desse estudo que existe uma grande demanda por produtos industrializados em especial ultra processados, que possuem importante papel no aumento de casos de obesidade, trazendo como consequência a prevalência de agravos nutricionais. Para além do ato de se alimentar outras variáveis têm sido evidenciadas como por exemplo, o sedentarismo infantil, uso exagerado de mídias sociais, publicidade de alimentos aos quais apontam para a necessidade de políticas, projetos e ações de carácter multidisciplinar que tenha por objetivo maior qualidade de vida às crianças e uma educação nutricional a fim de mostrar a importância de hábitos de vida saudáveis na promoção do Direito Humano a Alimentação Adequada e de forma eficaz a Segurança Alimentar e Nutricional.

\title{
Referências
}


ABESO. Obesidade e sobrepeso. Disponível em: https://abeso.org.br/conceitos/obesidade-e-sobrepeso/ Acesso em: 03 ago. 2020

BRASIL. Ministério da Saúde. Portaria n².446, de 11 de nov. de 2014. Diário Oficial da União. Brasília, nov. 2014.

CUREAU, Felipe Vogt et al. ERICA: inatividade física no lazer em adolescentes brasileiros. Rev. Saúde Pública. v.50, n.1. feb.23, 2016. Disponível ht ems://www.scielo.br/scielo.php?script=sci_abstract\&pid=S0034$89102016000200304 \&$ Ing=en\&nrm=iso\&tlng=pt Acesso em 02 ago. 2020

DESIDERATA. Panorama da obesidade em crianças e adolescentes. Saúde em foco, Rio de Janeiro, v.1, n.1, p.2, out. 2019. FIOCRUZ. Obesidade infantil e na adolescência. Disponível em: http://www.fiocruz.br/biosseguranca/Bis/infantil/obesidadeinfantil.htm Acesso em: 03 ago. 2020

HENRIQUES, Patrícia et al. Políticas de Saúde e de Segurança Alimentar e Nutricional: desafios para o controle da obesidade infantil. Ciênc. saúde colet. Rio de Janeiro, v.23, n.12, p.4144-4147. dez. 2018. Disponível em: https://www.scielo.br/scielo.php?script=sci_arttext\&pid=S1413-81232018001204143\&lng=pt\&tlng=pt Acesso em: 25 jul. 2020

LINHARES, Francisca Michelli Medeiros. Obesidade infantil: influência dos pais sobre a alimentação e estilo de vida dos filhos. Temas em Saúde. João Pessoa, v.16, n.2, p.462-464. 2016.

MARCHI-ALVES, Leila Maria et al. Obesidade infantil ontem e hoje: Importância da avaliação antropométrica pelo enfermeiro. Escola Anna Nery Revista de enfermagem. Rio de Janeiro, v.15, n.2, p.238- 244, abril-jun. 2011.

REIS, Caio Eduardo et al. Políticas públicas de nutrição para o controle da obesidade infantil. Revista Paulista de Pediatria. São Paulo, v.29, n.4, p.626-627, dez. 2011. Disponível em: https://www.scielo.br/scielo.php?script=sci_arttext\&pid=S010305822011000400024 Acesso em: 21 jul. 2020

SISVAN, Sistema de Vigilância Alimentar e Nutricional. Estado nutricional. Disponível em: https://sisaps.saude.gov.br/sisvan/index Acesso em: 15 de julho de 2020 


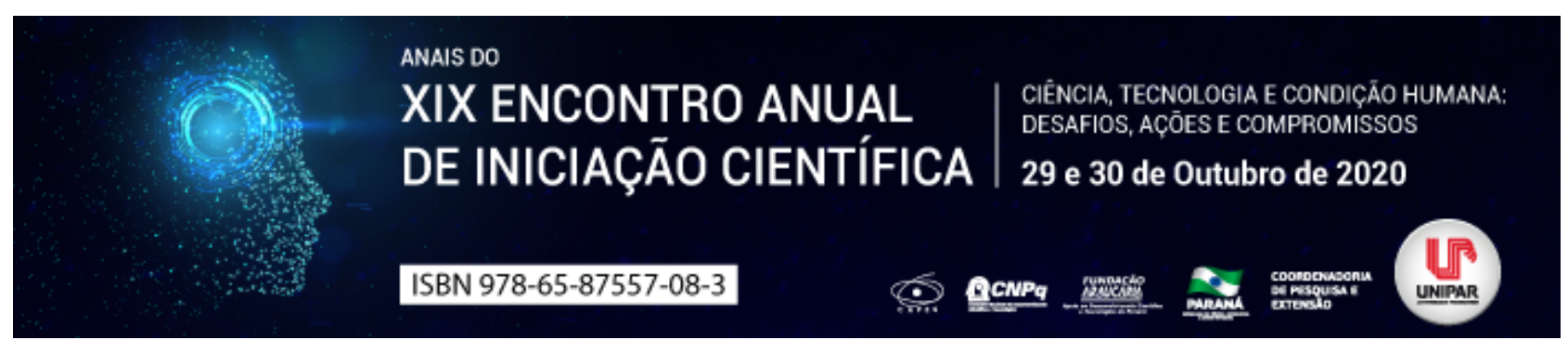

PERFIL EPIDEMIOLÓGICO DE SÍFILIS CONGÊNITA NO ESTADO DO PARANÁ - 2010 A 2019

\author{
${ }^{1}$ BEATRIZ PASCOALI CUNHA, ${ }^{2}$ CAROLINE VINTIGUERA PANCERA, ${ }^{3}$ JAINE THAIS GABRIEL, ${ }^{4}$ LUCIANA VIEIRA PINTO \\ RIBEIRO
}

${ }^{1}$ Acadêmica do Curso de Medicina da UNIPAR
${ }^{1}$ Acadêmica do Curso de Medicina da UNIPAR
${ }^{2}$ Acadêmica do Curso de Medicina da UNIPAR
${ }^{3}$ Docente da UNIPAR

Introdução: A sífilis congênita é uma doença hematogênica, ocasionada pela bactéria Treponema pallidum, com a disseminação entre a mãe não - tratada e o feto, pela via placentária, ou ainda, pelo canal do parto durante o nascimento (MURRAY, 2017). Essa contaminação pode ocorrer em qualquer fase gestacional, com uma probabilidade de $70 \%$ a $100 \%$ de ocorrer na sífilis primária e secundária (BRASIL, 2006). Além disso, a sífilis congênita pode ser caracterizada em dois estágios: precoce, que se manifesta até os dois anos de vida do feto e tardia, que surge após os dois anos de idade. Nesse sentido, quando a doença for sintomática no recém-nascido, esse pode apresentar lesões cutâneas, baixo-peso, prematuridade, morte fetal e neonatal, deficiência óssea, entre outras malformações congênitas. Assim, nota-se a importância da realização de um pré-natal adequado e um seguimento correto do tratamento quando necessário, para que os casos de sífilis congênita passem a diminuir.

Objetivos: Analisar as informações a respeito dos casos de Sífilis Congênita no estado do Paraná entre os anos de 2010 a 2019, utilizando os dados do DATASUS.

Desenvolvimento: A sífilis congênita é transmitida durante o período grávido puerperal, podendo trazer riscos ao feto (BRASIL, 2006). Nesse sentido, a maioria das transmissões de sífilis congênita acontecem na fase primária e secundária da sífilis, sendo ainda possível a transmissão pelo canal do parto, durante o nascimento (EPIDEMIOLÓGICA, 2008). De acordo com a análise de dados de sífilis congênita no Paraná, extraídos do Datasus, constatou-se que entre os anos de 2010 a 2019 o cenário das gestantes era de uma faixa etária entre 20-29 anos, de cor branca e nível de escolaridade médio completo. Em relação ao número de casos, teve-se um total de 5.040 casos de sífilis congênita durante os anos supracitados, sendo que os números vieram aumentando constantemente até o ano de 2018 (871 casos), sofrendo uma queda de aproximadamente 52\% no ano de 2019, com 414 casos. Dentre esses, quase em sua totalidade acometeu recém-nascidos com menos de 7 dias de vida. É válido ressaltar que o pré-natal é de extrema importância para a prevenção de doenças durante o período gestacional, sendo, nesse caso, realizado o diagnóstico de sífilis congênita para o combate da mesma. De acordo com o Datasus, das 5.052 gestantes entrevistadas com sífilis, cerca de 4.494 relataram ter realizado o pré-natal. Desse total, 3.607 tiveram o diagnóstico confirmado no pré-natal e 1.020 durante o parto/curetagem. Ademais, a realização do tratamento de forma eficaz é muito importante para que se tenha um controle da doença, o qual depende de quatro fatores, sendo eles: reconhecimento de sífilis na mãe, adaptação ao tratamento, aparecimento de evidências clínicas, laboratoriais e radiológicas no neonato e comparação da sorologia nãotreponêmica materna e do neonato. Assim, o tratamento é feito a base de Penicilina, podendo ser substituída por outros antibióticos (SONDA, 2013). Dessa forma, cerca de 58\% das gestantes tiveram um tratamento inadequado, $28,5 \%$ não realizaram, $7 \%$ ignoraram e apenas cerca de $6,31 \%$ realizaram de forma adequada. É considerável notar que entre os anos de 2018 e 2019 houve uma diminuição dos casos que não foram realizado tratamento, sendo de 16,9\% em 2018 caindo para 7,6\% em 2019. Esse decréscimo pode ser associado com a priorização da distribuição da penicilina no ano de 2018, via nota técnica № 02/2018 que recomenda o uso de penicilina exclusivamente para tratamento de sífilis (BRASIL, 2018a). Cumpre destacar também que o não tratamento dos parceiros foi um dos critérios para análise dos casos de sífilis congênita, nos anos supracitados, destacando que cerca de $85 \%$ dos parceiros não foram tratados (KOMKA, LAGO, 2007). Os dados do DATASUS, mostram que entre as gestantes com o diagnóstico de sífilis congênita no Paraná, apenas $9 \%$ dos casos tiveram seus parceiros tratados. Diante dos dados analisados, de acordo com Brasil (2018b), o Paraná ocupa o oitavo lugar no número de casos de sífilis no ano de 2018, em relação aos estados do Brasil.

Conclusão: Analisando os dados epidemiológicos da sífilis congênita, nos anos de 2010 a 2019, no estado do Paraná, constatou-se que muitas gestantes não procuraram tratamento ou o realizaram de forma inadequada, sendo que apenas em 2018 houve uma priorização da distribuição da penicilina. Além disso, 11\% não realizaram o pré natal, fato esse que pode estar relacionado com fatores socioeconômicos e culturais, gerando a falta de informação a respeito da importância do pré-natal e do tratamento adequado.

\title{
Referências
}


BRASIL. Ministério da Saúde. Cuidado integral à pessoa com sífilis: história natural da doença, prevenção, diagnóstico e tratamento. Natal- RN, 2018a. Disponível em: . Acesso em: 19 jun. 2020.

BRASIL. Ministério da Saúde. DATASUS: informações de saúde. Disponível em: Acesso em: 19 mai 2020.

BRASIL. Ministério da Saúde. Diretrizes para o controle da sífilis congênita. Manual de Bolso. Brasília - DF, 2006. Disponível em: Acesso em: 19 jun. 2020

BRASIL. Ministério da Saúde. Sífilis - 2018. Boletim Epidemiológico, Brasília, Out. 2018b. Disponível em: . Acesso em: 29 jul. 2020.

EPIDEMIOLÓGICA, Serviço de vigilância; et al. Sífilis congênita e sífilis na gestação. Revista Saúde Pública, São Paulo - SP, v. 42, n. 4, p. 768-772, 2008. Disponível em: Acesso em: 26 jun. 2020

MURRAY, Patrick R.; ROSENTHAL, Ken S.; PFALLER, Michael A. Microbiologia médica. 8. ed. Rio de Janeiro: Elsevier, 2017 SONDA, Eduardo Chaida et al. Sífilis Congênita: uma revisão da literatura. Rev Epidemiol Control Infect. v. 3, n. 1, p, 28-30, 2013. Disponível em: Acesso em: 26 jun. 2020

KOMKA, Maria Regina; LAGO, Eleonor Gastal. Sífilis congênita: notificação e realidade. Sci méd, v. 17, n. 4, p. 205-11, 2007. Disponível em: Acesso em: 26 jun. 2020. 


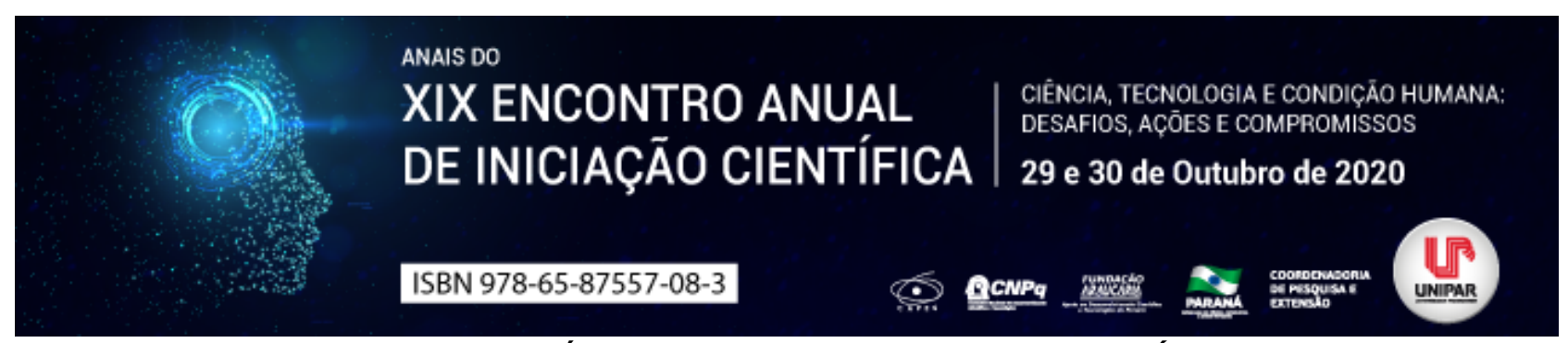

PANORAMA DOS CASOS PROVÁVEIS DE DENGUE NO BRASIL NO PERÍODO DE 2014 A 2017

\begin{abstract}
${ }^{1}$ JULIA BEATRIZ PINTO ARAUJO, ${ }^{2}$ ISABELlA ACACIO FERREIRA DE SOUZA, ${ }^{3}$ MARCELA MADRONA MORETTO DE PAULA
\end{abstract}

${ }^{1}$ Acadêmica do Curso de Medicina da UNIPAR

${ }^{1}$ Acadêmica do Curso de Medicina da UNIPAR

${ }^{2}$ Docente da UNIPAR

Introdução: A dengue é uma das principais arboviroses, sendo causada pelo vírus do gênero Flavivírus e da família Flaviviridae. Sua transmissão ocorre principalmente através da picada da fêmea do mosquito Aedes aegypti e apresenta quatro sorotipos distintos: DEN-1, DEN-2, DEN-3 e DEN-4. O quadro clínico pode variar desde a forma clássica benigna até a forma hemorrágica, podendo evoluir ao óbito (FURTADO et al., 2019). Segundo Viana e Ignotti (2013), a dengue é uma das doenças mais infecciosas do mundo e por isso se enquadra como um importante problema de saúde pública, posto que, é uma causa importante de morbidade e mortalidade. Em mais de 100 países a dengue é considerada endêmica e desde 2010 podem ser encontrados os quatros tipos de sorotipos simultaneamente no território nacional (GONÇALVES et al., 2015).

Objetivo: Realizar um levantamento de dados para avaliar o panorama dos prováveis de dengue nos estados brasileiros, contemplando o período de 2014 a 2017.

Material e métodos: Estudo epidemiológico descritivo e retrospectivo, realizado a partir de dados obtidos através do Banco de Dados Epidemiológicos (DataSUS) (https://datasus.saude.gov.br). Foram analisadas as variáveis: Regiões do Brasil, mês de notificação e zona de residência.

Resultados: No período de 2014 a 2017, foram totalizados 4.047 .182 casos prováveis de dengue no território brasileiro. Na região sudeste foi observado maior concentração de casos no período analisado, com $56,4 \%$, seguido da região nordeste com 20,5\% e centro-oeste 15,9\%. Já as regiões sul e norte foram as a que apresentaram menores quantidades de casos com 3,7\% e $3,5 \%$ respectivamente. Referente aos meses do ano, foi observado que $87 \%$ dos casos foram notificados no primeiro semestre, sendo que tais meses compreendem as estações de verão e outono. O maior pico registrado foi no mês de março e o valor mais baixo foi obtido no mês de setembro. Comparando às zonas de residência, foi observado que na zona urbana houve a maior concentração do número de casos em todas as regiões brasileiras, onde foi totalizado 85\%, enquanto que, na zona rural, os números de casos prováveis foram de $4,5 \%$ no referido período.

Discussão: Analisando o panorama da dengue no Brasil de 2014 a 2017, referente às regiões brasileiras, observou-se que foram notificados casos em todo território nacional, contudo, houve predomínio na região sudeste. Um estudo retrospectivo da dengue no Brasil realizado por Câmara et al. (2007) revelou um padrão muito semelhante da distribuição do número de casos prováveis de dengue nas regiões brasileiras, onde as regiões Nordeste e Sudeste detiveram o maior número de casos, posto que, são considerados polos atratores de trabalhadores e turistas que se expõem à infecção e levam o vírus para seus locais de origem. A dengue pode ser considerada um subproduto da urbanização acelerada e sem planejamento, característica dos centros urbanos de países em desenvolvimento. Através da análise dos dados, percebeu-se um padrão sazonal, tendo uma maior quantidade de casos nos primeiros seis meses do ano, com as estações mais quente e úmidas, típico dos climas tropicais. Tal informação foi corroborada através dos estudos elucidados por Barbosa e Lourenço (2010) e Costa e Calado (2016). As épocas de chuvas são responsáveis por contribuir para a maior incidência, uma vez que é possível obter condições ideais para a reprodução do vetor e proliferação da quantidade de casos. É notável uma menor incidência de chuva nos meses seguintes, com estações mais secas e de menor umidade. Entretanto, ainda assim, é verificada a presença do vetor e de quantidades menores de infecção. Consoante aos locais de habitação, a predominância dos casos na zona urbana pode estar relacionada com a alta densidade demográfica no ambiente urbano que associada às deficiências no abastecimento de água e limpeza e ineficiência do combate ao vetor, favorecem o número de casos nestes ambientes. Segundo Cunha et al. (2008), existem condições propícias para o surgimento e permanência dos focos. A associação entre moradias, o saneamento domiciliar realizado pelos moradores através de hábitos pessoais e culturais, e a inadequação de algumas habitações, são algumas condições capazes de favorecer o surgimento de criadouros e consequente aumento da quantidade de casos.

Conclusão: Foi evidenciado que existem diversas razões responsáveis pela disseminação da dengue, como alterações climáticas, rápida urbanização e crescimento populacional acelerado. Por ser uma das doenças mais infecciosas do mundo, é um grande problema de saúde pública. O Brasil possui condições meteorológicas bastante favoráveis à proliferação, por isso, faz-se ainda mais necessário que medidas de controle sejam aplicadas, sendo realizada principalmente a prevenção. Deve haver uma maior mobilização da população para a realização de medidas protetivas nos seus ambientes domiciliares e cabe aos órgãos públicos o investimento em saneamento básico e desenvolvimento de projetos de combate ao foco da doença. Com todas as 
medidas sendo aplicadas seria possível observar uma menor incidência e talvez, com sorte, o Brasil poderia sair da classificação de país endêmico.

\section{Referências}

BARBOSA, Gerson Laurindo; LOURENÇO, Roberto Wagner. Análise da distribuição espaço-temporal de dengue e da infestação larvária no município de Tupã, Estado de São Paulo. Rev. Soc. Bras. de Med., v.43, n.2, 2010. Disponível em: https://www.scielo.br/pdf/rsbmt/v43n2/08.pdf. Acesso em: 07 de jul. 2020.

CÂMARA, Fernando Portela. et al. Estudo retrospectivo (histórico) da dengue no Brasil: características regionais e dinâmicas. Rev. Soc. Bras. Med. Trop., v.40, n.2, 2007. Disponível em: https://www.scielo.br/pdf/rsbmt/v40n2/a09v40n2.pdf. Acesso em: 07 de jul. 2020.

COSTA, Isabelle Matos Pinheiro; CALADO, Daniela Cristina. Incidência dos casos de dengue (2007-2013) e distribuição sazonal de culicídeos (2012-2013) em Barreiras, Bahia. Epid. Serv. Saúde, v.25, n.4, 2016. Disponível em: https://www.scielosp.org/pdf/ress/2016.v25n4/735-744/pt. Acesso em: 07 de jul. 2020.

CUNHA, Maria da Consolação Magalhães. et al. Fatores associados à infecção pelo vírus do dengue no Município de Belo Horizonte, Estado de Minas Gerais, Brasil: características individuais e diferenças intra-urbanas. Epid. Serv. Saúde, v.17, n.3, 2008. Disponível em: http://scielo.iec.gov.br/pdf/ess/v17n3/v17n3a07.pdf. Acesso em: 16 de jul. 2020.

GONÇALVES, Ronaldo Pinheiro. et al. Contribuições recentes sobre conhecimentos, atitudes e práticas da população brasileira acerca da dengue. Saúde Soc. SP, v.24, n.2, $2015 . \quad$ Disponível em: https://www.scielosp.org/pdf/sausoc/2015.v24n2/578-593/pt. Acesso em: 01 de jul. 2020.

FURTADO, Amanda Naiala Ribeiro. et al. Dengue e seus avanços. Rev. Bras. de Anál. Clín., v.51, n.3, 2019. Disponível em: >. Acesso em: 01 de jul. de 2020.

VIANA, Dione Viero; IGNOTTI, Eliane. A ocorrência da dengue e variações meteorológicas no Brasil: revisão sistemática. Rev. Bras. Epid., v.16, n.2, 2013. Disponível em: https://www.scielosp.org/pdf/rbepid/2013.v16n2/240-256/pt. Acesso em: 01 de jul. 2020. 


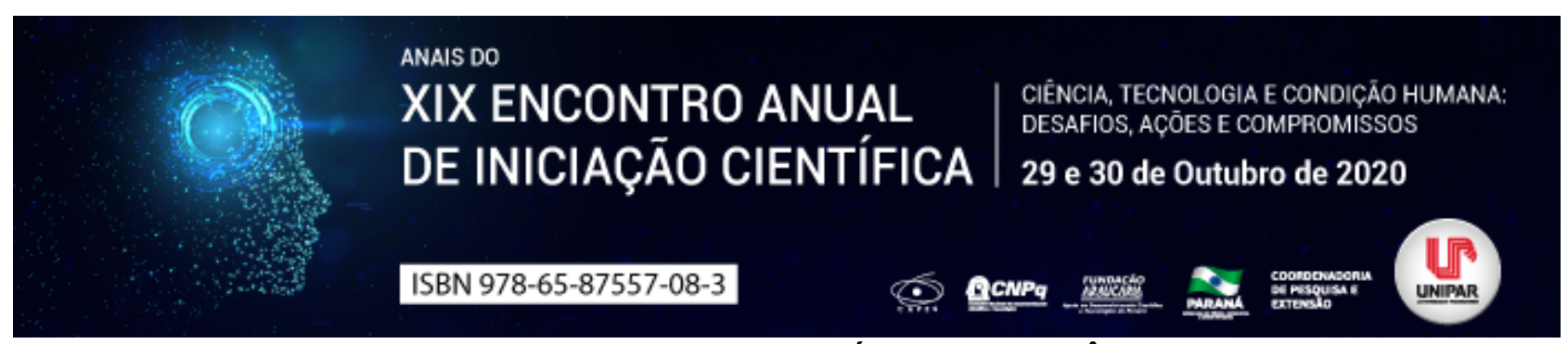

SARAMPO NO BRASIL: UM OLHAR ATRAVÉS DA DISSONÂNCIA COGNITIVA

\title{
${ }^{1}$ ANA MARIA MIYAWAKI PAULINO, ${ }^{2}$ ISABELA TONON LAINO, ${ }^{3}$ ALTAIR DE SOUZA CARNEIRO
}

\author{
${ }^{1}$ Acadêmica do Curso de Medicina da UNIPAR \\ ${ }^{1}$ Acadêmica do Curso de Medicina da UNIPAR \\ ${ }^{2}$ Docente da UNIPAR
}

Introdução: A dissonância cognitiva é chamada de "inconsistência de conhecimento". Ela é uma autoproteção em que a pessoa gera um conflito interno entre o que ela mesma acredita(crença) e algum fato(ciência). De acordo com (SCHOLTEN. et al., 2006, p. 167), "quando mais, ou maiores, forem as vantagens que têm de ser trocadas entre opções, maior é o conflito sentido pelo decisor". Isto posto, temos o ressurgimento do sarampo ligado a dissonância cognitiva, onde mesmo sabendo da sua necessidade por algum motivo a pessoa não o faz, através da não vacinação voluntária e individual.

Objetivo: Analisar o ressurgimento do sarampo no Brasil ligado a dissonância cognitiva.

Materiais e métodos: No artigo "Sarampo no Brasil: um olhar através da dissonância cognitiva", foi utilizado um compilado de artigos e fontes de pesquisas relacionados ao tema. Após isso, foi selecionado, de maneira grupal, as informações que para a pesquisa seria mais interessante, analisando cada literatura consultada.

Resultados: Os resultados mostraram que devido a dissonância cognitiva e outros fatores extrínsecos como a mídia e noticias falsas, muitas pessoas vem deixando de se vacinar e de vacinar seus filhos, causando novos surtos de sarampo no Brasil.

Discussão: O sarampo é uma doença causada por um vírus de RNA, de nível mundial, que acomete principalmente crianças imunodeprimidas, desnutridas e sem vacinação, com idade de até 15 anos. Seu maior grupo de risco são crianças com até 5 anos de idade, e sua transmissão acontece de pessoa para pessoa, através de gotículas respiratórias, decorrente de tosse ou espirro, podendo ser transmitida 4 a 6 dias antes da fase prodrômica e 4 dias após o surgimento da erupção(W.LEVINSON, 2014). É uma doença conhecida por causar erupção maculopapular com início na face, indo posteriormente para tronco e membros. Ademais, causa febre, conjuntivite, coriza, tosse seca, pneumonia e abortos ou bebês natimorto. O Brasil erradicou a transmissão do vírus do sarampo autóctone ganhando seu certificado em 2016, mas acabou perdendo ele no final de 2018(MEDEIROS, 2020). Diante disso, tem-se que o tipo que circula atualmente no país é o D8, vinda de turistas e migrantes que transmitiram para aqueles não vacinados, em estados com cobertura vacinal inferior a 95\%. Por ser altamente contagiosa uma pessoa infectada transmite para até 18 pessoas - é uma doença de notificação compulsória imediata, para que se realize medidas de prevenção de controle, como a vacina. Até outubro de 2019, já haviam sido confirmados 10.429 casos em todo o Brasil. (MEDEIROS, 2020). As campanhas de vacinação contra o sarampo no Brasil teve início nos anos de 1960, sendo constatado que a partir dela o número de óbitos caiu de 3.386/100.000 habitantes para 7 óbitos por 100.000 habitantes, além disto, a imunização preveniu mais de 20 milhões de mortes entre 2000 a 2015 no mundo, sendo uma das mais eficazes na saúde pública(OPAS). Contudo, ela ainda é uma doença que causa epidemias a cada 2 ou 3 anos. (DOMINGUES et al., 1997). As chamadas imunidade de rebanho é o meio mais eficaz de se combater o sarampo, onde se tem uma cobertura vacinal superior a 95\%(MEDEIROS, 2020). Contudo, devido políticas de saúde pública, meios de comunicação falsos, fatores intrínsecos ao indivíduo (conhecimento, experiências pessoais, importância e convicções morais e religiosas) e grupos anti-vacinas, as pessoas vem deixando de se vacinar e/ou vacinar seus filhos, devido a um conflito de pensamentos entre os prós e contras da vacinação, dando início a sua dissonância cognitiva. De acordo com Aps LRMM. et al. (2018), esses movimentos tem influenciado com estratégias de distorção e divulgação de informações falsas que, alegando uma base científica, questionam a eficácia e segurança de diversas vacinas. Ademais, a partir do momento em que pessoa se vê diante de um questionamento, ela começa a entrar em conflito pela escolha do que é certo e em dissonância quando dois elementos(conhecimento, mídia, religião) não concordam entre si, gerando um sentimento de frustração e/ou agressividade. A dissonância cognitiva tem como objetivo uma relação positiva entre o tamanho de troca(fatores positivos ao tomar uma decisão) e o conflito, entretanto, muitas vezes a pessoa com dissonância tende a se justificar, e quanto mais difícil é de achar argumentos, maior é o conflito sentido por ela (SCHOLTEN. et al, 2006). Face ao exposto, a pessoa com dissonância tenta reduzi-la, para não ter sentimentos de frustração através três possíveis mudanças, das quais: mudar seu comportamento e tomar a vacina; mudar o seu ambiente (a informação de que a vacina faz mal), com a intenção de acreditar que "existe uma conspiração mundial que quer destruir a vacina", e que ela, portando, não é maléfica e/ou abandonar a dissonância ou tentar reduzir sua importância. Dessa forma, a pessoa continua a não tomar vacina, com a justificativa de que não quer se aborrecer mais com esse assunto. Isso gera, consequentemente, um aumento de pessoas não vacinadas e um aumento de endemias.

Conclusão: A dissonância cognitiva tende a ser positiva quando se analisa os riscos/benefícios e/ou prós para uma tomada de decisão correta. Contudo, devido disseminação de notícias falsas, como a que as vacinas causam efeitos adversos maléficos, 
muitas são as pessoas tem entrado em conflito entre o que é dito e o que se acredita, deixando a vacinação de lado. As causas vão desde políticas mal administradas, locais com pouca informação e pessoas que não acreditam na sua vericidade, trazendo a tona doenças antes já erradicadas como o sarampo.

\section{Referências}

APS, Luana Raposo de Melo Moraes et al. Eventos adversos de vacinas e as consequências da não vacinação: uma análise crítica. Revista de Saúde Pública, v. 52, p. 40, 2018.

DOMINGUES, Carla Magda Allan S. et al . A evolução do sarampo no Brasil e a situação atual. Inf. Epidemiol. Sus, Brasília, v. 6, n. 1, p. 7-19, mar. 1997.

EPIDEMIOLÓGICA, Vigilância et al. Alerta de sarampo. Rev Saúde Pública, v. 40, n. 4, p. 751, 2006.

FESTINGER L. Cognitive dissonance. Sci Am 1962;207:93-102.

MEDEIROS, Eduardo Alexandrino Servolo. Entendendo o ressurgimento e o controle do sarampo no Brasil. Acta Paulista de Enfermagem, v. 33, 2020.

OPAS. Folha informativa-sarampo da Organização Pan-Americana de Saúde e Organização Mundial de Saúde. 19 de ago. 2019. Disponível em: https://www.paho.org/bra/index.php?option=com_content\&view=article\&id=5633:folha-informativasarampo\&ltemid=1060. Acesso em: 9 jun. 2020.

SCHOLTEN, Marc; CARRILHO, Joana Paixão. Festinger revisitado: Sacrifício e argumentação como fontes de conflito na tomada de decisão. Análise Psicológica, v. 24, n. 2, p. 167-177, 2006.

WARREN LEVINSON. Microbiologia médica e imunologia .12. ed. Porto Alegre : AMGH, 2014.

Coordenadoria de Pesquisa e Extensão - COPEX

Departamento de Editoraçāo e Divulgaçāo Científica - DEDIC 


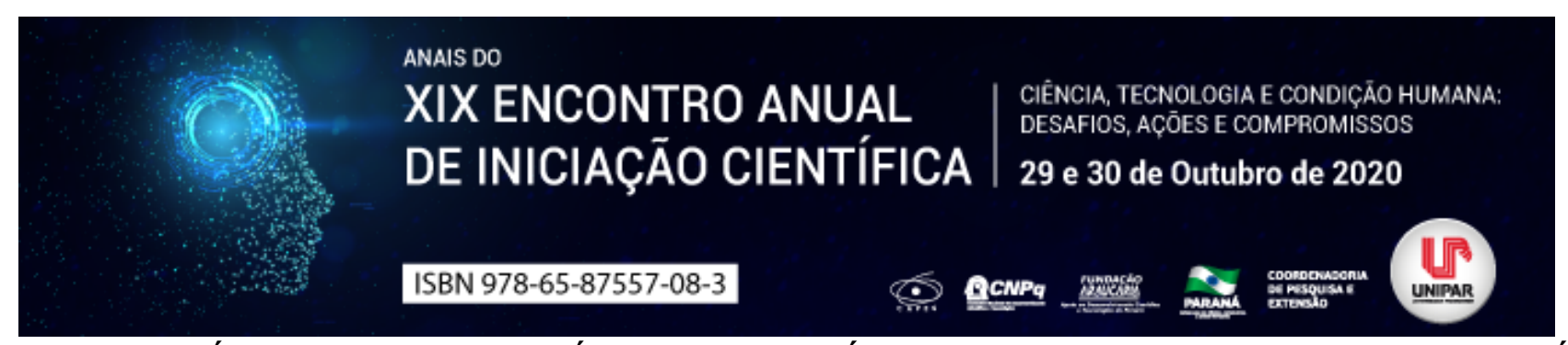

FEBRE REUMÁTICA AGUDA: UMA ANÁLISE EPIDEMIOLÓGICA DE 2010 A 2020 NO ESTADO DO PARANÁ

\begin{abstract}
${ }^{1}$ ROBERTO RONEY BICHERI FILHO, ${ }^{2}$ VITOR ROQUE SAUER, ${ }^{3}$ RAFAELA BEARZI RESTON, ${ }^{4}$ ROBERTO RONEY BICHERI, ${ }^{5}$ MARINA GIMENES
\end{abstract}

${ }^{1}$ Discente do Curso de Medicina da Universidade Paranaense - UNIPAR
${ }^{1}$ Discente do Curso de Medicina da Universidade Paranaense - UNIPAR
${ }^{2}$ Discente do Curso de Medicina da Universidade Paranaense - UNIPAR
${ }^{3}$ Médico Cardiologista, Perito Médico Federal e Médico do Trabalho - CRM/UF 16962/PR
${ }^{4}$ Professora Mestre, da disciplina de Epidemiologia e Saúde Coletiva do curso de Medicina da UNIPAR

Introdução: $A$ febre reumática (FR) é causada pela infecção da bactéria Streptococcus $\beta$-hemolítico do grupo A (PEREIRA; BELO; SILVA, 2017). Segundo Seckeler e Hoke (2011), uma pequena quantidade de casos de FR são desenvolvidas levando em consideração a alta prevalência de faringite e sendo a suscetibilidade da doença está relacionada com a genética. Pode estar relacionada com o aumento do número da doença reumática cardíaca, uma vez que após a $\mathrm{FR}, 65 \%$ dos paciente são observados clinicamente com sequelas da doença (KUMAR; TANDON, 2013). A sociedade Brasileira de Cardiologia (2019) estima no Brasil aproximadamente 10 milhões de faringoamigdalites estreptocócicas por ano, dos quais resultam em trinta mil novos casos de FR e dentre estes, 15 mil podem evoluir para um acometimento cardíaco. Com a faringoamigdalite instalada, a FR pode ser prevenida com o uso de penicilina, eleita de primeira escolha (PEREIRA; BELO; SILVA, 2017), e após 24h após início da medicação, o paciente torna-se minimamente contagiante, de acordo com a Sociedade Brasileira de Reumatologia (2009) estabelecido nas diretrizes sobre febre reumática.

Objetivo: Realizar uma análise de forma descritiva e epidemiológica sobre o número de internações da febre reumática aguda entre os anos de 2010 à 2020 no estado do Paraná e no município de Umuarama.

Material e Métodos: A coleta dos dados de internação da febre reumática foram realizados entre os períodos de 2010 até 2020 no banco de dados TabNet - DATASUS.

Resultados: No estado do Paraná entre os anos de 2010 a 2020, foram notificados 1.114 internações por FR, dentre os seus principais municípios destaca-se, respectivamente, Londrina (191), Prudentópolis (95) e Curitiba (58), e no município de Umuarama, 19 casos.

Discussão: Os dados encontrados mostram números baixos de internações relacionadas a FR, que podem estar relacionados de acordo com Mota (2014), a episódios agudos com sintomas cardíacos de leve intensidade que não são adequadamente reconhecidos ou não constituírem motivo para a procura de assistência médica. Desta forma, os dados coletados não revelam o total de casos de FR. Por outro lado, Silva, Silva e Silva (2010), em um estudo, notaram um declínio expressivo do número de hospitalizações por FR ao longo dos 20 anos, e sugerem que pode ser por conta de um perfil de menor gravidade dos casos. Outro fato pode estar vinculado a crescente marginalização dos setores mais pobres da sociedade, com hospitais não atendendo os mais afetados pela doença (KUMAR; TANDON, 2013). O município de Londrina apresentou o maior número de internações com 191 pacientes de febre reumática, embora seja o maior número, com certeza não representam o total de casos, considerando os pacientes menos graves que não foram computados e foram tratados e acompanhados ambulatorialmente. Como a Febre Reumática não é uma doença de notificação compulsória, 191 casos não representa a totalidade, no entanto apenas uma parte do alcance da doença, por isso alguns autores sugerem que o ideal seria uma base de dados específicas para essa patologia (FIGUEIREDO et al., 2019). Segundo as Diretrizes brasileiras para o diagnóstico, tratamento e prevenção da febre reumática (SBR, 2009) a FR é uma doença de diversos âmbitos, sejam eles socioeconômico ou de fator ambiental, atinge com grande frequência em crianças e adolescentes, os quais passam a desenvolver com facilidade a faringoamigdalite estreptocócica. Ainda conforme o no grau de desenvolvimento da FR, uma alimentação irregular, a falta de um amparo médico e moradias com certo nível de aglomeração, são fatores agravantes, e têm sido associado à recorrência da doença (SANTOS, 2013), além do mais, fatores genéticos também ganham luz no evoluir da FR, traz uma maior suscetibilidade aos portadores genéticos, com possibilidade de avançar ou progredir em sequelas (SBR, 2009). Segundo Figueiredo et al. (2019) pela magnitude do problema, com crescente taxas de mortalidade e comparação entre os custos totais e uso de penicilinas, o Brasil não conta com programas de controle e que essa estratégia de prevenção já foi aplicada em muitos países com respostas positivas.

Conclusão: A febre reumática, doença inflamatória causada por uma bactéria, possui baixa incidência de internações no estado do Paraná, prevalecendo em 3 cidade, mas esses números não refletem o número de casos da doença. Dessa forma, além do diagnóstico genético, é importante salientar as medidas preventivas. Para a prevenção primária é necessária a pronta 
identificação do paciente e a seleção adequada da terapia da faringite por estreptococos do grupo $A$, uma vez que essa é precursora da febre reumática. Com relação a prevenção, o uso de medicamentos seguros como a penicilina pode evitar a instalação da FR, mas levado em consideração os potenciais efeitos adversos e o custo. A doença pode vir se agravar quando não acompanhada corretamente, progredindo para um futuro quadro de complicações nas valvas cardíacas, como estenose, já que é responsável pela maioria das causas que levam à cirurgia cardíaca de próteses valvares.

\section{Referências}

FIGUEIREDO, Estevão Tavares de et al. Febre Reumática: Uma Doença sem Cor. Arquivo Brasileiro Cardiologia, São Paulo, v. 113, n. 3, p. 345-354, set. 2019.

KUMAR, Krishna; TANDON, Rajendra. Rheumatic fever \& rheumatic heart disease: the last 50 years. The Indian journal of medical research, v. 137, n. 4, p. 643, 2013.

MOTA, Cleonice de Carvalho Coelho. A febre reumática e suas complicações: impacto e desafios. Nascer e Crescer, v. 23, n. 3 , p. 121-123, set. 2014.

PEREIRA, Breno Álvares de Faria; BELO, Alinne Rodrigues; SILVA, Nilzio Antônio da. Febre reumática: atualização dos critérios de Jones à luz da revisão da American Heart Association-2015. Revista Brasileira de Reumatologia, v. 57, n. 4, p. 364-368, 2017.

SANTOS, Jessica Mendes. Recorrência de febre reumática numa população ambulatorial em Salvador (Bahia): associação com dados clínicos e epidemiológicos. 2013. 46 f. Monografia (Graduação em Medicina) Universidade Federal da Bahia, Faculdade de Medicina da Bahia. Salvador, 2013.

SECKELER, Michael; HOKE, Tracey. The worldwide epidemiology of acute rheumatic fever and rheumatic heart disease. Clinical Epidemiology, v. 3 p. 67-84, 22 fev. 2011.

SILVA, André Pacheco; SILVA, Maurício Laerte; SILVA, Denise Bousfield da. Frequência de internações por febre reumática em um hospital pediátrico de referência em um período de 20 anos. Revista Paulista de Pediatria, São Paulo, v. 28, n. 2, p. 141147, jun. 2010.

SOCIEDADE BRASILEIRA DE CARDIOLOGIA. Atualização da Diretriz de Prevenção Cardiovascular da Sociedade Brasileira de Cardiologia - 2019. Prevenção da Cardiopatia Reumática. Arquivo Brasileiro Cardiologia. Salvador-Bahia. v. 113, n.4, p. 194240 out. 2019.

SOCIEDADE BRASILEIRA DE REUMATOLOGIA. Diretrizes brasileiras para o diagnóstico, tratamento e prevenção da febre reumática. Arquivo Brasileiro Cardiologia, São Paulo, v. 93, n. 3, supl. 4, p. 3-18, set. 2009.

Coordenadoria de Pesquisa e Extensão - COPEX

Departamento de Editoraçāo e Divulgaçāo Científica - DEDIC 


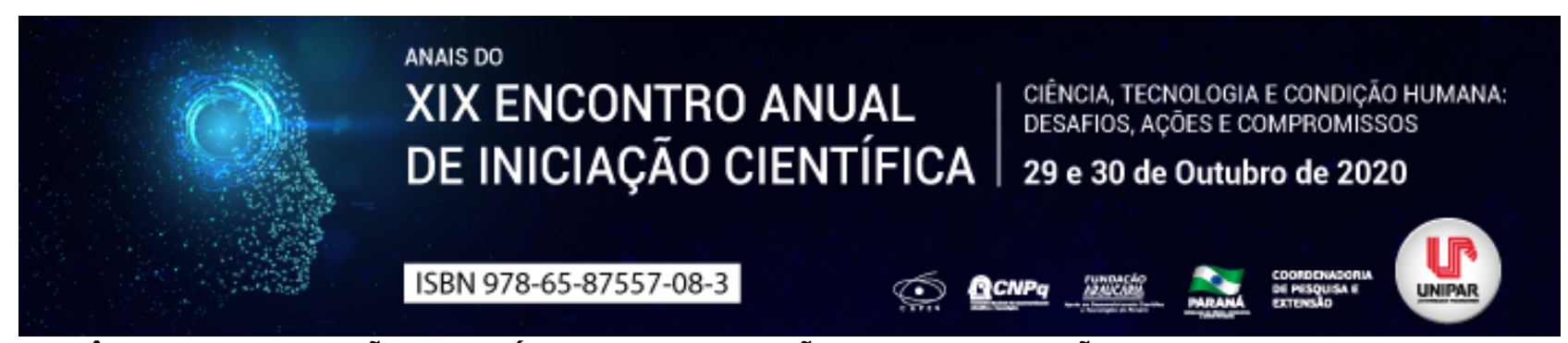

A IMPORTÂNCIA DA INICIAÇÃO CIENTÍFICA NA FORMAÇÃO E QUALIFICAÇÃO DO PROFISSIONAL ENFERMEIRO: REVISÃO DA LITERATURA

\author{
${ }^{1}$ Laís Sousa da Silva, ${ }^{2}$ DANIEL REIS CORREIA, ${ }^{3}$ JOSÉ VICTOR SOARES DA SILVA, ${ }^{4}$ ISABELA DE SOUZA SANTANA, \\ ${ }^{5}$ RENATA OLIVEIRA CAETANO, ${ }^{6}$ CRISTIANE CHAVES DE SOUZA
}

\begin{abstract}
${ }^{1}$ Acadêmica do Curso de Enfermagem da Universidade Federal de Viçosa
${ }^{1}$ Acadêmico do Curso de Enfermagem da Universidade Federal de Viçosa

${ }^{2}$ Acadêmico do Curso de Enfermagem da Universidade Federal de Viçosa

${ }^{3}$ Acadêmica do Curso de Enfermagem da Universidade Federal de Viçosa

${ }^{4}$ Acadêmica do Curso de Enfermagem da Universidade Federal de Viçosa

${ }^{5}$ Docente do Curso de Enfermagem da Universidade Federal de Viçosa
\end{abstract}

Introdução: O curso de graduação em Enfermagem tem como escopo a formação de enfermeiros generalistas capazes de desenvolver, participar e aplicar pesquisas que visem a qualificação do exercício profissional (AZEVEDO; AKERMAN, 2015). Para isso, a participação em atividades extracurriculares, durante a formação, compreende um importante fator para o alcance de conhecimentos e habilidades que favorecem a construção de um profissional apto para atuar em todas as áreas da enfermagem. Dentre estas atividades, destaca-se a Iniciação Científica (IC), caracterizada por inserir os discentes, desde o início do curso, em grupos e/ou projetos de pesquisa, capazes de possibilitar aquisição e produção científica de novos conhecimentos (FERNANDES et al., 2015). Além disso, a IC, por meio das pesquisas realizadas, corrobora para o desenvolvimento do raciocínio crítico, ético e profissional, a fim de maximizar a importância das evidências científicas para conduzir uma futura prática clínica qualificada (FARIAS et al., 2018). Outrossim, além de enriquecer a formação acadêmica do graduando, a IC desperta no indivíduo o interesse pela inserção em programas de pós-graduação (especialização, mestrado, doutorado), o que proporciona a continuidade da edificação do saber (FERNANDES et al., 2015).

Objetivo: Relatar o que a literatura aponta sobre a importância da iniciação científica durante e após a graduação para a qualificação do profissional enfermeiro.

Desenvolvimento: A compreensão do progresso científico como componente basilar da graduação em enfermagem, permite identificar a indissociabilidade entre a pesquisa e a formação profissional (AZEVEDO; AKERMAN, 2015). No entanto, para que todos os estudantes sejam capazes de desenvolver ciência, é de suma importância que as instituições de ensino e os docentes do curso promovam o incentivo a essa produção. No caso dos docentes, é sabido que a sua orientação é imprescindível para que os discentes progridam motivados e estimulados na área da pesquisa, uma vez que contribuem, significativamente, para o direcionamento de técnicas essenciais para a busca de dados e para o desenvolvimento da escrita científica, da interpretação dos resultados e da argumentação baseada em evidências científicas (PEDROSA et al., 2015). Além disso, o processo de iniciar na carreira científica concede aos acadêmicos maior autonomia para produção de conhecimentos, segurança para explanar a respeito dos assuntos pesquisados e amadurecimento científico para aplicação em sua prática clínica profissional. A IC tem a capacidade de aproximar o aluno da sua realidade social, engajando-o a desenvolver pesquisas que atenuem problemáticas encontradas na sociedade e que contribuam para a melhoria da assistência nas lacunas identificadas. Dessa forma, o aprendiz se torna construtor e reconstrutor do meio em vive (SANTOS; ANJOS; ALMEIDA, 2015). Ademais, a produção técnica-cientifica é de extrema relevância para a mudança do contexto social e assistencial, e, para isso, a mesma deve ser divulgada e disponibilizada, para que os enfermeiros e futuros enfermeiros tenham acesso e possam aplicá-las em suas atuações clínicas assistenciais. Diversas são as formas de divulgação das produções científicas, como apresentação de trabalhos em congressos, simpósios, publicação em periódicos indexados e em anais de eventos científicos, o que colabora para a construção e enriquecimento curricular, proporcionando a trajetória de inserção do estudante na pós-graduação, para dar continuidade no processo de aperfeiçoamento profissional (FERNANDES et al., 2015). Por fim, entendendo-se o que a pesquisa em ensino na enfermagem proporciona para a formação e qualificação do enfermeiro, tanto na academia quanto na assistência, é essencial que os discentes, enfermeiros e docentes desenvolvam, juntos, pesquisas científicas relacionadas à problemática do contexto assistencial, para que durante os estágios da graduação haja a integração entre a teoria aprendida e a prática executada (AZEVEDO; AKERMAN, 2015). Assim, para que a prática clínica seja exercida de maneira eficaz e atualizada, é importante realizar a educação continuada, a fim de capacitar os enfermeiros, por meio de novos estudos publicados, objetivando transpassar a dicotomia entre a pesquisa e o cuidar (PEDROSA et al., 2015).

Conclusão: A importância da iniciação científica, durante a graduação, está estritamente relacionada à qualidade da formação do acadêmico, da sua atuação como pesquisador e da sua prática assistencial. As pesquisas constituem um fator essencial para 
a construção do raciocínio clínico, crítico e reflexivo pelos alunos, para tomadas de decisões corretas e seguras, de acordo com cada situação. Assim, o estudante, como agente ativo da produção de conhecimento, colabora para o desenvolvimento de práticas inovadoras e para a valorização da sua futura profissão enquanto ciência.

\section{Referências}

AZEVEDO, Adriana Medeiros Sales de; AKERMAN, Marco. O ensino de Ciências Básicas na Enfermagem: um panorama desafiador de pesquisa em ensino. ABCS Health Sciences, [s.l], v. 40, n. 3, p. 306-311, out 2015.

FARIAS, Dilton Luis Soares de, et al. Ensino superior em enfermagem: processos e tendências de trabalho docente. Revista de Enfermagem UFPE On Line, Recife, v. 12, n. 12, p. 3368-3377, dez 2018.

FERNANDES, Josicélia Dumêt, et al. Modalidades de integração da pós-graduação com a graduação no ensino de enfermagem. Revista Baiana Enfermagem, Salvador, v. 29, n. 3, p. 192-200, set 2015.

PEDROSA, Karilena Karlla Amorim, et al. Enfermagem baseada em evidência: caracterização dos estudos no Brasil.Cogitare Enfermagem, [s.l], v. 20, n. 4, p. 733-741, out 2015.

SANTOS, Vanessa Cruz; ANJOS, Karla Ferraz dos; ALMEIDA, Obertal da Silva. Iniciação Científica a partir de Estudantes de Enfermagem. Revista Brasileira de Ciências da Saúde, Salvador, v. 19, n. 4, p. 255-260, 2015. 


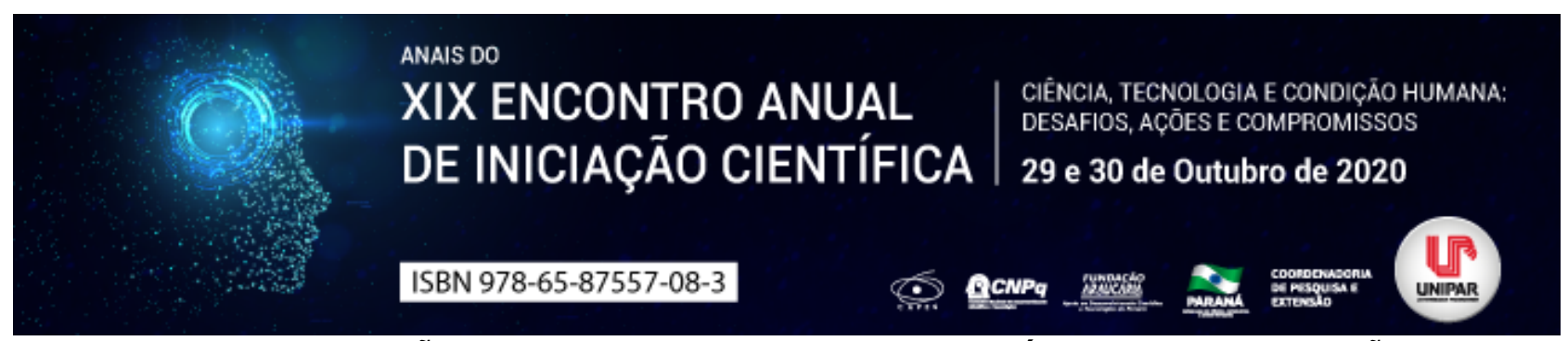

PRINCIPAIS LESÕES EM JOGADORES DE FUTEBOL E MÉTODOS DE PREVENÇÃO

\title{
${ }^{1}$ ALINE FREDO, ${ }^{2}$ DORA DE CASTRO AGULHON SEGURA
}

\author{
${ }^{1}$ Acadêmica do curso de Fisioterapia da Unipar \\ ${ }^{1}$ Docente da UNIPAR
}

Introdução: Os atletas profissionais estão sempre sujeitos às lesões, podendo ser um dos agentes causadores de afastamento da prática da modalidade esportiva. Esse desligamento pode gerar ao atleta prejuízos como perda do desempenho físico, além de trazer consequências ao fator psicológico, por muitas vezes em decorrência de uma recuperação demorada (ROSE; TADIELLO; ROSE, 2006). Fatores como idade, gênero e as regiões mais acometidas em cada modalidade contribuem para uma análise de comportamento da epidemiologia das lesões, sendo assim, de extrema importância o conhecimento para uma possível prevenção de lesão no esporte. O aumento considerável na incidência de lesões se deve a sobrecarga em alguns pontos do aparelho locomotor, bem como a busca pelo sucesso, se expondo a esforços físicos intensos próximos ao limite do sistema fisiológico (CARVALHO, 2013). Sendo o futebol considerado a modalidade esportiva mais popular do mundo, com praticantes de diferentes faixas etárias e gênero, é comum a alta incidência de lesões, em decorrência do grande contato físico, das diferentes mudanças de direções e dos movimentos de aceleração e desaceleração, curtos e rápidos. A atuação fisioterapêutica é de extrema importância para o atleta, não somente no tratamento de lesões, mas principalmente atuando com programas de prevenções e avaliações, buscando diminuir a incidência de complicações (AFONSO et al., 2020).

Objetivo: Desta forma, o objetivo desse estudo foi descrever sobre as lesões mais frequentes em atletas jogadores de futebol, bem como a sua possível prevenção.

Desenvolvimento: $O$ futebol é a modalidade esportiva mais conhecida mundialmente, pela sua beleza e principalmente pelo conjunto de ações corporais e capacidades biomotoras em apenas uma partida. Esporte que exige máximo condicionamento físico do atleta, impondo mudanças bruscas de direção, contato físico com outros jogadores, movimentos rápidos, dribles, giros e chutes, que muitas vezes acabam promovendo diversos tipos de lesões (AFONSO et al., 2020). Segundo Kryger et al. (2019), as lesões interferem diretamente na carreira do atleta, afetando a saúde física e metal, provocando distúrbios do sono, frustrações e até mesmo uma pausa precoce da atividade esportiva. As lesões musculoesqueléticas são as predominantes em relação ao contato direto. Ruptura ligamentar de joelho, estiramento muscular e entorses articulares estão entre as principais lesões na carreira de um atleta de futebol. A lesão de ligamento cruzado anterior compõe um preocupante e grave problema para jogadores, em virtude do prolongado tempo de recuperação, que podem evoluir, se não receber um tratamento adequado, para problemas em longo prazo como osteoartrite de início precoce (WALDÉN et al., 2016). A taxa de lesões do ligamento cruzado anterior é considerada alta em atletas jovens, com fatores de risco no gênero feminino. A ruptura total pode causar grandes instabilidades, limitando movimentos e a capacidade funcional, sendo necessário cirurgia para reconstrução (PIMENTA et al., 2012). Outra lesão comum em atletas é o estiramento muscular, considerado um excesso do alongamento das fibras musculares, caracterizando uma lesão indireta. Normalmente ocorre em músculos superficiais, como gastrocnêmio, semitendíneo e reto femoral, lesões que podem ser classificadas em grau I, II, e III de acordo com a intensidade (FERNANDES; PEDRINELLI; HERNANDEZ, 2011). As lesões musculares correspondem cerca de 30 a $50 \%$ das lesões no esporte, juntamente com a articulares, juntas fazem parte do grupo de lesões que podem ocorrer por métodos de treinos ineficazes, muitas vezes sem uma recuperação adequada (CARVALHO, 2013). Com todos os impactos negativos que as lesões causam aos atletas existe a importância da implantação de programas preventivos. Um avanço mais detalhado e direcionado, como fatores de ricos e lesões mais frequentes em jogadores de futebol, ajuda num direcionamento para a prevenção (RUIVO; PINHEIRO; RUIVO, 2018). Muitos desses programas podem ser realizados e incluídos na rotina de treinos e aquecimentos, assim como treinamentos de propriocepção e exercícios de condicionamento neuromuscular (BALDAÇO et al., 2010). Balk et al. (2019) evidenciam protocolos preventivos que melhoram na estabilização articular, controle da postura corporal, condicionamento físico, equilíbrio estático e dinâmico e principalmente fortalecimento muscular.

Conclusão: As principais lesões que acometem os jogadores de futebol são as ligamentares, musculares e articulares. Visto que os programas de prevenções tem sido uma boa saída para a diminuição do índice de lesões, porém não podem ser considerados como um método de melhora de performance para os atletas.

\section{Referências}

AFONSO, M. S.; BARROS, S.; KOTH, A. P.; RODRIGUES, V. L.; NEVES, F. B.; LOURENÇÃO, L. G. Fisioterapia desportiva no programa de prevenção de lesão no futebol profissional. Research, Society and Development, v.9, n.3, p.e72932434, 2020.

BALDAÇO, F. O.; CADÓ, V. P.; SOUZA, J. D.; MOTA, C. B.; LEMOS, J. C. Análise do treinamento proprioceptivo no equilíbrio de 
atletas de futsal feminino. Fisioterapia em Movimento, v.23, n.2, p.183-192, 2010.

BALK, R. S.; ESCOBAR, A. J.; LARA, S.; AZEVEDO, R.; CASTRO, A. M. Benefícios do treinamento funcional em conjunto com o Fifa 11+ no controle postural de atletas de basquetebol. Revista Brasileira de Ciências do Esporte, v.41, n.1, p.76-82, 2019.

CARVALHO, D. A. Lesões ortopédicas nas categorias de formação de um clube de futebol. Revista Brasileira de Ortopedia, V.48, n.1, p.41-45, 2013.

FERNANDES, T. L.; PEDRINELLI, A.; HERNANDEZ, A. J. Lesão muscular: Fisiopatologia, diagnóstico, tratamento e apresentação clínica. Revista Brasileira de Ortopedia, v.46, n.3, p.247-255, 2011.

KRYGER, K.; WIECZOREK, A.; WIECZOREK, J. The influence of functional movement screen results on the frequency of sports injuries in soccer players. Central European Journal of Sport Sciences and Medicine, v.27, n.3, p.41-53, 2019.

PIMENTA, T. S.; MEDEIROS, W. E.; CAMPOS, J. C.; COSTA, J. M. S.; FRANÇA, J. S. Protocolos de tratamento fisioterápico após cirurgia do ligamento cruzado anterior. Acta Biomédica Brasiliense, v.3, n.1, p.27-34, 2012.

ROSE, G.; TADIELLO, F.; ROSE, D. Lesões esportivas: Um estudo com atletas do basquetebol brasileiro. Revista Digital EFDesportes, v.10, p.94-99, 2006.

RUIVO, R.; PINHEIRO, V.; RUIVO, J. Prevenção de lesões no futebol: Bases científicas e aplicabilidade. Revista de Medicina Desportiva Informa, v.9, n.2, p.16-19, 2018.

WALDÉN, M.; HÄGGLUND, M.; MAGNUSSON, H. ACL injuries in men's professional football: A 15 year prospective study on time trends and return-to-play rates reveals only $65 \%$ of players still play at the top level 3 years after ACL rupture. British Journal of Sports Medicine, v.50, n.12, p.744-750, 2016. 


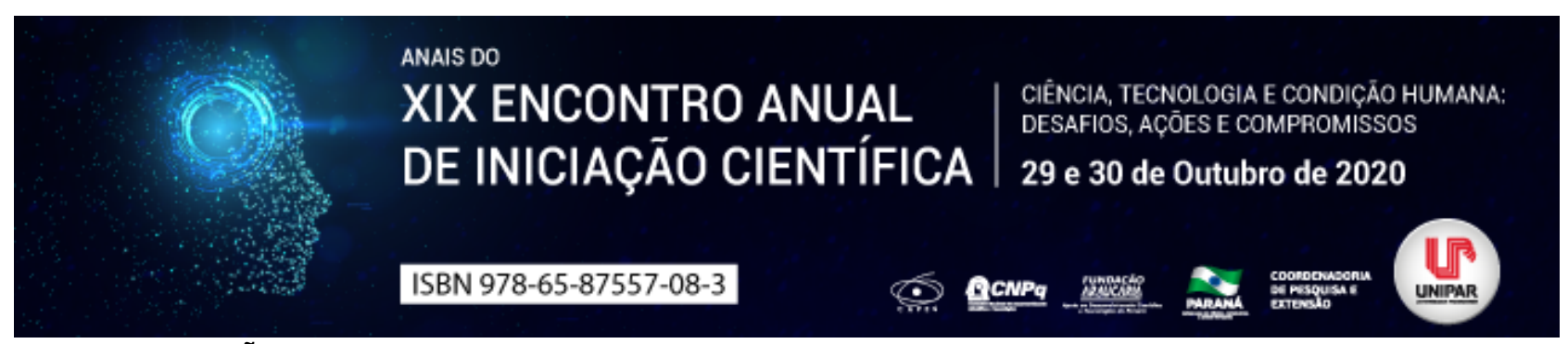

CAPIM LIMÃO (Cymbopogon citratus) COMO UM AGENTE ANTIBACTERIANO EM ALIMENTOS

\begin{abstract}
${ }^{1}$ MARIANA HACHICHO ALMEIDA, ${ }^{2}$ FERNANDA SANDRI, ${ }^{3}$ MARCO AURELIO CUNHA DEL VECHIO, ${ }^{4}$ KAROLAINE BEZERRA, ${ }^{5}$ DANIELA DIB GONÇALVES, ${ }^{6}$ LIDIANE NUNES BARBOSA
\end{abstract}

\author{
${ }^{1}$ Acadêmico Bolsista do PIBIC/ UNIPAR \\ ${ }^{1}$ Acadêmico Bolsista do PIBIC/ UNIPAR \\ ${ }^{2}$ Mestrando PPG em Ciência animal com Ênfase em Produtos Bioativos/ taxista - Prosup/CAPES. \\ ${ }^{3}$ Mestrando PPG em Ciência animal com Ênfase em Produtos Bioativos/ taxista - Prosup/CAPES \\ ${ }^{4}$ Docente UNIPAR \\ ${ }^{5}$ Docente da UNIPAR
}

Introdução: A planta Cymbopogon citratus é popularmente chamada de capim-limão no território brasileiro, principalmente no estado do Paraná dispõe de diversas utilidades medicinais, o seu óleo essencial é listado em muitos estudos por possuir capacidade antimicrobiana (ALMEIDA, 2016). Os óleos essenciais são renomados por apresentarem diversas propriedades, entre elas o efeito antimicrobiano, podendo agir frente a bactérias, vírus e fungos. São compostos do metabolismo secundário das plantas e no organismo vivo, defendem os vegetais de fitopatógenos (CONTRUCCl et al., 2019). O óleo de capim-limão apresenta diversos componentes, se dividindo em majoritários e minoritários, os majoritários são geranial, neral, mirceno e geraniol, sendo que o geranial e o neral apresentam o citral como seu isômero e, juntos constituem a maior parte do óleo essencial (ALMEIDA, 2016). A elevada procura por alimentos livres de substâncias químicas ou conservantes sintéticos, têm motivado a troca desses produtos por alternativas que sejam mais naturais, os óleos essenciais são uma opção interessante para esses produtos (POSSAS, 2015).

Objetivo: Realizar uma revisão bibliográfica sobre a atividade antimicrobiana do óleo essencial e do extrato de Cymbopogon citratus (DC.) Stapf, (Capim-Limão), relacionado a patógenos alimentares e conservação natural de alimentos.

Desenvolvimento: $O$ óleo de $C$. citratus apresentou capacidade de controle microbiano, para Listeria monocytogenes, Salmonella Typhimurium e Escherichia coli, podendo ser utilizado na redução bacteriana de hortaliça, como uma opção natural, sendo que o aumento da concentração de óleo essencial está relacionado com o aumento da ação do mesmo (MACHADO et al., 2016). Quando aplicando o óleo de C. citratus por difusão em placas, sobre as bactérias Staphylococcus aureus e E. coli, também ocorreu um resultado positivo para $S$. aureus, já para E. coli não apresentou os mesmos resultados, demonstrando ser resistente (ALMEIDA, 2016). Esses resultados corroboram com Machado et al. (2015) onde foi relatado que o óleo essencial de C. citratus teve efeito antimicrobiano frente patógenos alimentares e apresenta ação antimicrobiana para bactérias Grampositivas e Gram-negativas, possuindo menor eficácia contra as Gram-negativas, sendo que a bactéria inibida com menor concentração de produto foi o S. aureus. De acordo com Machado et al. (2015), ao relacionar a ação antimicrobiana de $C$. citratus, com componentes alimentares, notou-se que o óleo de folhas frescas possui um maior efeito, do que os derivados de folhas secas. A atividade antimicrobiana do óleo essencial de $C$. citratus demonstrou- se efetiva contra patógenos e bactérias alimentares, tendo maior ação na existência de proteínas, pH ácido e amido, em contrapartida para os lipídios os resultados foram diferentes pois, na sua presença diminuiu expressivamente a ação antimicrobiana do óleo (MACHADO et al, 2015). Segundo Contrucci et al. (2019), é possível a elaboração de agentes antimicrobianos, que contenham baixo custo e eficácia contra determinadas bactérias, através dos óleos essenciais com ação antimicrobiana. Boeira et al. (2018), relatou a atividade antimicrobiana de C. citratus in vitro, contra Salmonella sp., E. coli e S. aureus e avaliou o efeito que o extrato do C. citratus apresenta na linguiça frescal, mostrando que a eficácia do mesmo preservou o produto contra bactérias psicrotróficas por 42 dias de armazenamento e elevou o período de vida útil por 21 dias. Sendo assim, em virtude da sua grande disponibilidade e custo baixo, o C. citratus pode ser classificado como uma alternativa natural modificando o uso de substâncias sintéticas nas indústrias de alimentos (BOEIRA, et al 2018).

Conclusão: $O$ óleo essencial de $C$. citratus tem sua atividade antimicrobiana comprovada em diversos estudos e apresenta potencial para ser utilizado no controle de diversos microorganismos alimentares, principalmente para bacterias Gram-positivas. Possuem facilidade para serem adquiridos além de preços acessíveis. Dessa forma, seu uso como agente antimicrobiano na indústria de alimentos pode ser considerado uma fonte natural, para substituir conservantes sintéticos e substâncias químicas, tendo produtos finais mais naturais para o consumidor.

\title{
Referências
}

ALMEIDA, Mariana Fernandes de. Óleo essencial de Cymbopogon citratus: caracterização e avaliação das atividades 
antioxidante, antimicrobiana e citotóxica. Orientador: Alexandre Porte. 2016. Dissertação (Mestrado em Alimentos e Nutrição) Universidade Federal do estado do Rio de Janeiro, Rio de Janeiro, 2016.

BOEIRA, Caroline Pagnossim et al. Extração de compostos bioativos de capim-limão, atividade antioxidante e avaliação da atividade antimicrobiana em linguiça frescal de frango. Ciência Rural, v.48, n.11, p. 1-8, 2018.

CONTRUCCI, Bruno Antunes et al. Efeito de óleos essenciais sobre bactérias gram-negativas isoladas de alimentos. Ensaios e Ciência, v. 23, n. 3, p. 180-184, 2019.

MACHADO, Terezinha Feitosa et al. Atividade antimicrobiana do óleo essencial do capim limão (Cymbopogon citratus) e sua interação com os componentes dos alimentos. Embrapa Agroindústria Tropical, v.33, n.1, p.30-38, 2015.

CONGRESSO BRASILEIRO DE CIÊNCIA E TECNOLOGIA DE ALIMENTOS, 25, 2016. Gramado. Efeito antimicrobiano do óleo essencial do capim-limão sobre patógenos em repolho. Anais [...] Gramado: SBCTA-RS, 2016.

POSSAS, Arícia Mara Melo et al. Óleo essencial como antimicrobiano natural em produtos cárneos à base de peito de peru: estudo da transferência de Salmonella Enteritidis durante o fatiamento e do seu comportamento durante a vida útil dos produtos fatiados. Orientador: Marta Cristina Teixeira Duarte. 2015. Dissertação (Mestrado em Ciência de Alimentos) Universidade Estadual de Campinas, Faculdade de Engenharia de Alimentos, Campinas- SP, 2015.

Coordenadoria de Pesquisa e Extensão - COPEX

Departamento de Editoraçāo e Divulgaçāo Científica - DEDIC 


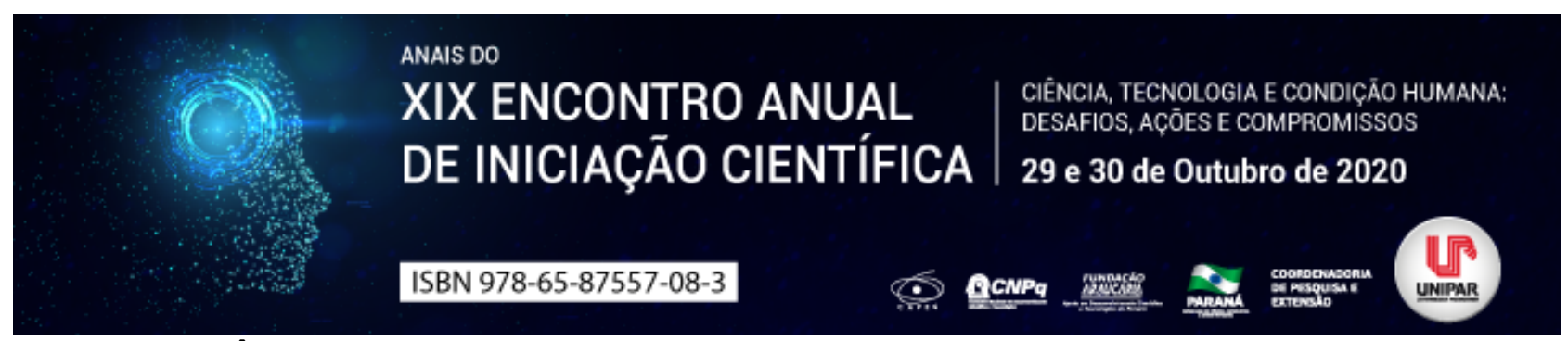

A INFLUÊNCIA DA ANSIEDADE NO DESEMPENHO ESPORTIVO DE ATLETAS DE FUTSAL

\title{
${ }^{1}$ LARISSA PEREIRA DA CRUZ, ${ }^{2}$ MARCELO FIGUEIRO BALDI
}

\author{
${ }^{1}$ Acadêmica do curso de Educação Física da UNIPAR \\ ${ }^{1}$ Docente da UNIPAR
}

Introdução: A ansiedade é considerada uma patologia pela Organização Mundial da Saúde (OMS), podendo desencadear alterações no âmbito cognitivo e motor. Geralmente acompanhada por sintomas de ativação fisiológica, como dificuldades para respirar, palpitações, tonturas, sensações térmicas, entre outros. Spielberger (1972) caracterizou a ansiedade como um sentimento subjetivo de tensão e apreensão, provocando inúmeras reações físicas, psicológicas, psicomotoras e sociais no indivíduo. Segundo Weinberg e Gould (2001) o atleta muito ansioso pode desencadear maior dispêndio de energia, mudanças na concentração, dificuldades na coordenação e estreitamento do campo de atenção. Esses fatores podem ser os responsáveis pela mínima diferença de desempenho e pela classificação final dos atletas na competição. Diante do exposto, o presente estudo procurou responder ao seguinte problema de pesquisa: qual a influência da ansiedade no desempenho esportivo de atletas de futsal?

Objetivo: analisar a influência da ansiedade no desempenho esportivo de atletas de futsal.

Desenvolvimento: O Futsal é uma das modalidades esportivas mais praticadas no mundo, onde várias habilidades psicológicas são essenciais para o rendimento dos atletas. Podemos definir habilidades psicológicas como habilidades que permitem ao atleta enfrentar determinadas situações com confiança e consciência de que o seu corpo e mente estão em conjunto para realizar a melhor performance (COX, 1994). Os estudos de Gonçalves e Belo (2007) constatam que os escores de auto confiança são mais elevados em esportes coletivos, pois a presença dos companheiros de equipe diminui a responsabilidade individual dos atletas, diminuindo assim os níveis de ansiedade. No entanto, polos negativos como inferioridade, desconfiança, vergonha e culpa são colocados à prova em treinamentos e principalmente nas competições, onde os fatores extrínsecos são mais marcantes, trazendo várias outras condutas negativas, embasando a ansiedade e influenciando diretamente em alterações nos aspectos físicos e psicológicos (PAIVA; SILVA, 2008). Em consequência disso, o atleta pode enfrentar dificuldades na tomada de decisões e inabilidade para se concentrar, devido à perda de controle do seu estado emocional. Outro fator enfrentado é a dificuldade na coordenação motora e encurtamento do seu campo de atenção, podendo também desencadear um maior dispêndio energético decorrente do aumento da tensão muscular (MORAES, 1990).

Conclusão: A presente pesquisa procurou evidenciar a relação entre ansiedade e desempenho esportivo de atletas de futsal e os diversos fatores que causam alterações nesse meio. Após a análise podemos concluir que os atletas que possuem maior controle emocional terão os melhores resultados, pois a performance vai além dos aspectos físicos. Portanto, conhecer como a ansiedade se expressa é de suma importância para que se criem estratégias de intervenção eficazes respeitando as condições e qualidade de vida dos atletas desde a iniciação.

\section{Referências}

COX, R. (1994). Sport Psychology: Concepts and Applications. (pp. 197 208). Third Edition. Columbia: Brown \& Benchmark Publishers.

GONÇALVES, M. P.; BELO, R. P. Ansiedade-traço competitiva: diferenças quanto ao gênero, faixa etária, experiência em competições e modalidade esportiva em jovens atletas. Psico USF, v.12, n.2, p.301-307, dez. 2007.

MORAES, L. C. Ansiedade e Desempenho no Esporte. Revista Brasileira de Ciência e Movimento, v. 4, n. 2, p. 51-56, 1990. PAIVA, R.; SILVA, T. Considerações a respeito da ansiedade em jovens atletas a partir dos estágios psicossociais do desenvolvimento. Psicologia em pesquisa UFJF, v. 01, n. 2, p.11-19, jan/jun, 2008.

SPIELBERGER, C. D. (1972). Anxiety: current trends in theory and research. New York: Academic Press.

WEINBERG, R. S.; GOULD, D. Fundamentos da psicologia do esporte e do exercício. 2. ed. Porto Alegre: Artmed, 2001. 


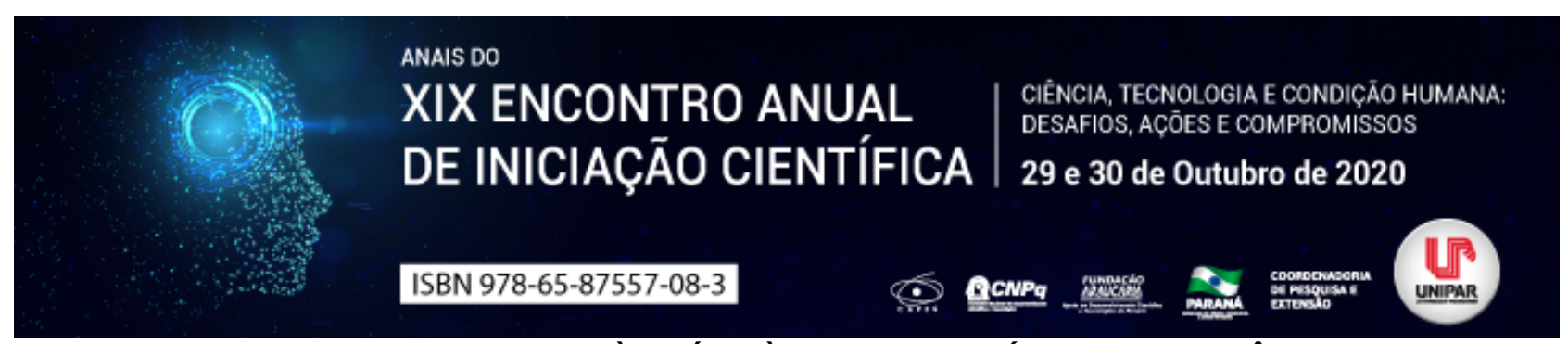

DESAFIOS DA LINHA DE CUIDADO À SAÚDE ÀS CRIANÇAS VÍTIMAS DE VIOLÊNCIA SEXUAL

\title{
${ }^{1}$ EDYANE SILVA DE LIMA
}

\author{
${ }^{1}$ Assistente Social na Prefeitura de Assis Chateaubriand/PR
}

Introdução: A Organização Mundial de Saúde (OMS) e a Organização Pan Americana de Saúde (OPAS), a partir da década de 1990, reconhecem oficialmente a violência como o maior problema de saúde pública no mundo. Fenômeno multilateral, demarcado por relações de domínio e submissão, que necessita ser enfrentada e superada. (CARVALHO, 2010) No caso da violência sexual contra a criança é compreendida (...) como qualquer conduta que constranja a criança ou o adolescente a praticar ou presenciar conjunção carnal ou qualquer outro ato libidinoso, inclusive exposição do corpo em foto ou vídeo por meio eletrônico ou não (...) (BRASIL, 2017, p. 1), desdobrando-se em: a) abuso sexual; b) exploração sexual comercial; e, c) tráfico de pessoas. Na política de saúde, desde 2001 temos a inserção de instrumentos normativos como Política Nacional de Redução da Morbimortalidade por Acidentes e Violência (PNRMAV, 2001), a Rede Nacional de Prevenção da Violência e Promoção da Saúde e os Núcleos de Prevenção de Violências e Promoção da Saúde em estados e municípios (2004), a Política Nacional de Atenção Básica (2006), o Sistema de Vigilância de Violências e Acidentes em Serviços Sentinela - VIVA (2006), as Diretrizes para organização de redes de atenção integral às urgências (2009), a Política Nacional de Atenção Integral à Saúde da Criança (PNAISC) de 2015, sendo que em 2010 a política de saúde legitima a atribuição de atendimento à violência sexual através do protocolo de atendimento Linha de cuidado para atenção integral à saúde de crianças, adolescentes e suas famílias em situação de violências - orientação para gestores e profissionais de saúde.

Objetivo: Refletir sobre os desafios que permeiam a linha de cuidados às crianças vítimas de violência sexual na atenção primária à saúde mediante estudo de revisão bibliográfica.

Desenvolvimento: A Atenção Primária à Saúde (APS) caracteriza-se como a porta de entrada as ações de saúde, abrangendo um conjunto de ações, e dentre estas, as de prevenção de agravos como a violência sexual. Nesse sentido, deve filtrar as demandas, das mais simples às complexas, organizando o fluxo dos serviços nas redes de saúde. Portanto, o atendimento da demanda de violência sexual contra criança na APS utiliza como instrumento a linha de cuidados para a atenção integral à saúde de crianças em situação de violências permite uma ação articulada com a rede de cuidado e de proteção social existente no território. Tem como dimensões de atuação: a) Acolhimento; b) Atendimento; c) Notificação; e, d) Seguimento na rede de cuidado e de proteção social. Embora estabeleça as dimensões do cuidado as vítimas de violência, cada unidade atua sob nuances particulares. O Brasil registrou 29.628 casos de violência sexual contra crianças e adolescentes em 2018 , destes, 12.522 são reincidentes. (BRASIL, 2018) No Estado do Paraná foram notificados entre 2011 e $2017,2.512$ casos de violência sexual contra criança e adolescente. (SINAN NET, 2019) Mesmo com significativa inserção da temática nos protocolos e fluxos da política de saúde, muitos estudos apontam sobre a fragilidade e ínfimo preparo dos profissionais para lidar com situações de violência. (MOREIRA et al, 2014) Há uma dissonância entre casos notificados e casos atendidos no fluxo da atenção básica. Embora o documento ofereça parâmetros para as intervenções de profissionais da saúde, não garante, por si só, um bom atendimento, sendo necessário outras estratégias intersetoriais e articuladas.

Conclusão: Por mais que haja legislações que coíbam a violação de direitos à criança no Brasil e protocolos norteadores das ações de enfrentamento e atendimento, há grandes desafios para enfraquecer os casos desta natureza. Que vão desde a identificação até a notificação dos casos. Devido os registros comprem a banco de dados isolados, tal fator pode refletir na reincidência dos episódios. Além disso, a insuficiência de investimento na política de atenção básica à saúde, sobretudo no programa Estratégia Saúde da Família, que remete ao empenho de uma equipe multidisciplinar, constitui dificuldade para o acesso e acompanhamento das vítimas/familiares, bem como a viabilização da linha de cuidado concernente. Culminando em ações pontuais e até mesmo no abandono ao acompanhamento profissional na atenção primária à saúde, podendo refletir em crescentes traumas com vieses complexos.

\section{Referências}

BRASIL. Ministério da Saúde. Sistema de Informação de Agravos de Notificação Sinan Net. Violência doméstica sexual elou outras violências - Paraná. Brasília, 2017. Disponível em: Acessado em: 22 Jul. 2019.

Ministério da Saúde. Secretaria de Atenção à Saúde. Departamento de Ações Programáticas Estratégicas. Linha de cuidado para a atenção integral à saúde de crianças, adolescentes e suas famílias em situação de violências: orientação para gestores e profissionais de saúde. Brasília: Ministério da Saúde, 2010. 104, p.

Ministério da Saúde. Secretaria de Vigilância em Saúde. Análise epidemiológica da violência sexual contra crianças e adolescentes no Brasil, 2011 a 2017. In: Boletim Epidemiológico. Volume 49, n. 27. Jun. 2018. 
Lei Federal 13.431 de 04 de Abril de 2017. Estabelece o sistema de garantia de direitos da criança e do adolescente vítima ou testemunha de violência e altera a Lei n 8.069, de 13 de julho de 1990 (Estatuto da Criança e do Adolescente). Brasília, 2017.

CARVALHO, Cláudia Maciel. Violência infanto-juvenil, uma triste herança. 30-43 pp. In: ALMEIDA, Maria da Graça Blaya (org.) A violência na sociedade contemporânea. Porto Alegre: EDIPUCRS, 2010. 161 p.

MOREIRA, Tatiana das Neves Fraga; MARTINS, Cleide Lavieri; FEUERWERKER, Laura Camargo Macruz; SCHAIBER, Lilia Blima; A construção do cuidado: o atendimento às situações de violência doméstica por equipes de Saúde da Família. In: Saúde Soc. São Paulo, v.23, n.3, p.814-827, 2014.

Coordenadoria de Pesquisa e Extensāo - COPEX

Departamento de Editoraçāo e Divulgaçāo Científica - DEDIC 


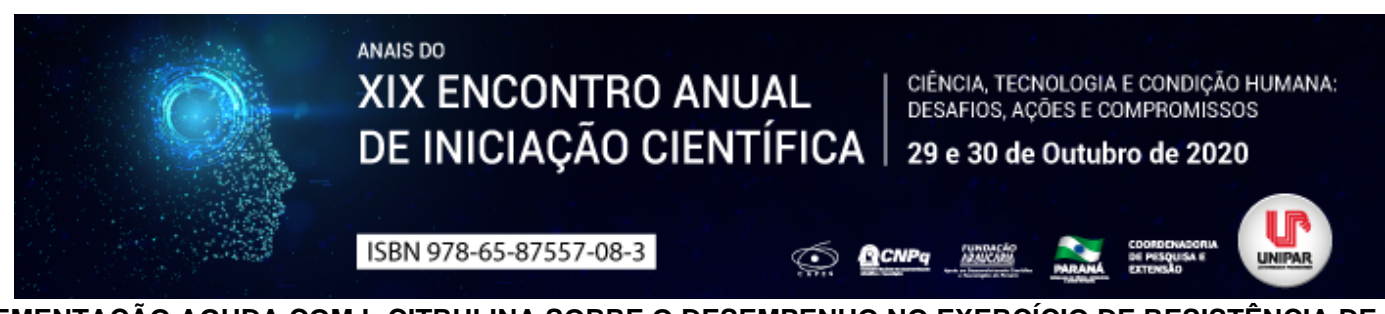

EFEITOS DA SUPLEMENTAÇÃO AGUDA COM L-CITRULINA SOBRE O DESEMPENHO NO EXERCÍCIO DE RESISTÊNCIA DE ALTA INTENSIDADE

\author{
${ }^{1}$ DANIEL ALBERTO DE OLIVEIRA CLAUS, ${ }^{2}$ FRANCIELE SANTANA DOS SANTOS, ${ }^{3}$ GABRIELA ALVES TRINDADE, ${ }^{4}$ GABRIEL REZENDE BULLA, ${ }^{5}$ JOAO \\ PAULO GUIAO, ${ }^{6}$ ALAN PABLO GRALA
}

\author{
${ }^{1}$ Acadêmico PIC-EAD do curso de Licenciatura em Educação Física EAD \\ ${ }^{1}$ Acadêmica do Curso de Educação Física da UNIPAR \\ ${ }^{2}$ Acadêmica do Curso de Educação Física da UNIPAR \\ ${ }^{3}$ Acadêmico do Curso de Educação Física da UNIPAR \\ ${ }^{4}$ Acadêmico PIC-EAD do curso de Licenciatura em Educação Física EAD \\ ${ }^{5}$ Docente do Curso de Educação Física - UNIPAR
}

Introdução: O aminoácido L-citrulina (L-CIT) é conhecido pelo seu potencial de elevar a disponibilidade de óxido nítrico (NO) no organismo (BAILEY et al., 2015; CUTRUFELLO; GADOMSKI; ZAVORSKY, 2014) e está presente em vários suplementos nutricionais destinados a aprimorar o desempenho físico. Àlvares et al. (2011) relatam que o NO é um potente vasodilatador endógeno responsável por alterações no fluxo sanguíneo durante o exercício dinâmico e na recuperação pós-exercício. Assim, tem sido sugerido que uma elevação na produção de NO poderia aumentar a entrega de oxigênio e nutrientes aos músculos ativos, aprimorando a tolerância ao exercício físico e os mecanismos de recuperação (BESCÓs et al., 2012). No exercício de resistência de alta intensidade, qualquer recurso que possa contribuir para aumentar a tolerância ao esforço ou protelar a fadiga pode ser determinante para alcançar os resultados almejados.

Objetivo: Analisar os efeitos da suplementação aguda com L-citrulina sobre o desempenho no exercício de resistência de alta intensidade.

Material e métodos: Para compor a amostra do estudo, foram selecionados 13 corredores amadores (Idade: $35,6 \pm 8,6$ anos). Os procedimentos envolvidos na pesquisa foram aprovados pelo Comitê Ética em Pesquisa envolvendo Seres Humanos (CEPEH) da Universidade Paranaense - Unipar sob parecer 2.778.511. Foram definidos 4 momentos distintos para a realização do estudo: momento inicial (MI), momento de familiarização (MF), momentos de testes 1 (M1) e 2 (M2). O MI envolveu os procedimentos de antropometria e anamnese dos participantes. 7 dias após o Ml, foi realizado o MF, onde foram realizados os processos de familiarização com os equipamentos e procedimentos da pesquisa, incluindo o teste incremental em esteira rolante (TIE). 7 dias após o MF, foi dado início as sessões de testes (M1 e M2). Tanto no M1 quanto no M2 os participantes receberam de forma randomizada, duplo-cego em crossover, 1 hora antes do início de cada sessão de teste, a suplementação de L-CIT (6g de I-citrulina $+6 \mathrm{~g}$ de dextrose) ou Placebo (12g de dextrose). Durante os momentos de testes (M1 e M2), 1 hora após consumirem os suplementos, os sujeitos realizaram o TIE. Este teste envolveu os seguintes procedimentos: 3 minutos de aquecimento à velocidade de $7 \mathrm{Km} / \mathrm{h}$ seguidos por um aumento de $1,2 \mathrm{Km} / \mathrm{h}$ a cada 3 minutos até o avaliado alcançar a exaustão ou relatar incapacidade de prosseguir por qualquer motivo. A esteira permaneceu o tempo todo com uma inclinação de 1\%. Foi recordado o tempo total para se alcançar a exaustão (TEx) em todos os momentos de testes. A frequência cardíaca foi monitorada durante todo o teste com o transmissor de frequência cardíaca Polar ${ }^{\circledR}$ H10. Esse equipamento foi utilizado para determinar tanto a frequência cardíaca média (FCméd) quanto a frequência cardíaca máxima (FCmax). Os procedimentos estatísticos utilizados envolveram a realização dos testes de Shapiro-Wilk e ANOVA unidirecional. O nível de significância adotado foi de $\mathrm{p}<0,05$.

Resultados: Para todas as variáveis analisadas durante o TIE (FCmed, FCmax e TEx) não foi observada nenhuma diferença significativa ( $p<0,05)$ favorável a suplementação com L-CIT em comparação com o placebo (FCmed: $p=0,804$; FCmax $p=0,671 ;$ TEx: $p=0,863$ ).

Discussão: A hipótese inicial do estudo era que a ingestão aguda de L-CIT poderia aprimorar o desempenho e/ou a tolerância ao esforço dos participantes no TIE pela redução da FCméd, FCmax e/ou aumento no TEx, indicando uma menor sobrecarga dos sistemas de fornecimento de energia. Entretanto, a ingestão aguda de $6 \mathrm{~g}$ de L-CIT não proporcionou nenhuma alteração benéfica sobre os parâmetros avaliados, assim, os resultados são contrários a algumas evidências encontradas na literatura. Como exemplo, Suzuki et al. (2016) observaram que a suplementação de $2.4 \mathrm{~g} / \mathrm{dia}$ de L-CIT por 7 dias reduziu em $1,5 \%$ o tempo para se completar um percurso de $4 \mathrm{~km}$ de ciclismo em comparação com o placebo. Além deste achado, foi constatado também uma redução na percepção subjetiva de esforço após o exercício no grupo suplementado com L-citrulina. Bailey et al. (2015) observaram que a suplementação crônica de L-CIT (7 dias) na quantidade de $6 \mathrm{~g} /$ dia proporcionou um aprimoramento na cinética do VO2 e no desempenho geral durante teste de alta intensidade no cicloergômetro. A quantidade de L-CIT administrada neste estudo foi superior a utilizada por Suzuki et al. (2016) e igual a de Bailey et al. (2015), entretanto, nestes dois estudos prévios a suplementação foi realizada por 7 dias, diferente do presente estudo em que a suplementação foi realizada de forma aguda. Este fator pode ter contribuído para a ausência de efeito no desempenho físico. Também é possível que a ingestão de uma dose maior de LCIT pudesse favorecer o desempenho, visto que, alguns estudos com ingestão aguda e doses superiores a $6 \mathrm{~g}$ observaram resultados positivos (PÉREZGUISADO; JAKEMAN, 2010).

Conclusão: Frente os resultados encontrados, é possível afirmar que a suplementação aguda com $6 \mathrm{~g}$ de L-CIT não foi capaz de aprimorar o desempenho ou a tolerância ao esforço de adultos saudáveis na corrida.

\title{
Referências
}

ALVARES, T. S.; CONTE, C. A.; PASCHOALIN, V. M.; SILVA, J. T.; MEIRELLES, C.; BHAMBHANI, Y. N.; GOMES, P. S. Acute L-arginine supplementation increases muscle blood volume but not strength performance. Appl Physiol Nutr Metab. v.37, n.1, p.115-126, Dec.2012. Disponível em: https://www.researchgate.net/publication/221753163_Acute_L arginine_supplementation_increases_muscle_blood_volume_but_not_strength_performance. Acesso em: 13/08/2020.

BAILEY, S. J.; BLACKWELL, J. R.; LORD, T.; VANHATALO, A.; WINYARD, P. G.; \& JONES, A. M. L-citrulline supplementation improves O2 uptake kinetics and high-intensity exercise performance in humans. J Appl Physiol. v.119, n.4, p.385-395, Aug. 2015.

BESCÓS, R.; SUREDA, A.; TUR, J. A.; PONS, A. The effect of nitric-oxide-related supplements on human performance. Sports Medicine. v.42, n.2, p.99-117, Feb.2012. Disponível em: https://www.researchgate.net/publication/221762106_The_Effect_of_Nitric-Oxide Related_Supplements_on_Human_Performance. Acesso em 13/08/2020.

CUTRUFELLO, P. T.; GADOMSKI, S. J.; ZAVORSKY, G. S. The effect of L-citrulline and watermelon juice supplementation on anaerobic and aerobic exercise performance. J Sports Sci. v.33, n.14, p.1459-1466, Dec. 2014.

PÉREZ-GUISADO, J.; JAKEMAN, P. M. Citrulline malate enhances athletic anaerobic performance and relieves muscle soreness. J Strength Cond Res. v.24, n.5, p.1215-1222, May 2010. 
SUZUKI, T.; MORITA, M.; KOBAYASHI, Y, KAMIMURA, A. Oral L-citrulline supplementation enhances cycling time trial performance in healthy trained men: double-blind randomized placebo-controlled 2-way crossover study. J Int Soc Sports Nutr. v.13, n.6, p.1-8, Feb.2016. Disponível em: https://jissn.biomedcentral.com/articles/10.1186/s12970-016-0117-z. Acesso em 13/08/2020.

Coordenadoria de Pesquisa e Extensão - COPEX

Departamento de Editoraçāo e Divulgaçāo Científica - DEDIC 


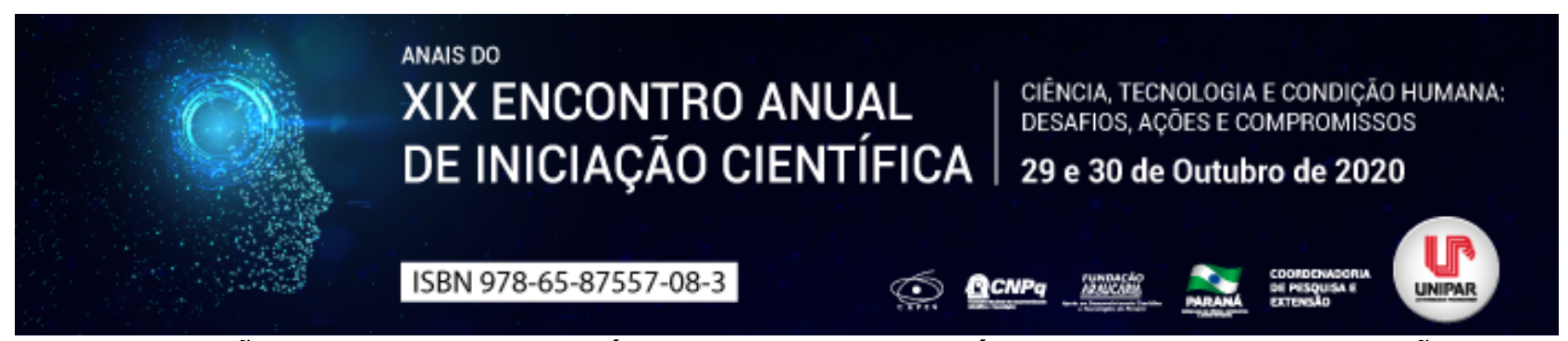

A ADESÃO DO EXAME CITOPATÓLOGICO DO COLO DO ÚTERO DURANTE A GESTAÇÃO

\title{
${ }^{1}$ THAMIRYS SIQUEIRA CARPEJANI, ${ }^{2}$ ANA CAROLINA DA SILVA, ${ }^{3}$ DAIANE CORTEZ RAIMONDI
}

\author{
${ }^{1}$ Discente do Curso de Medicina, participante do Programa de Iniciação Científica - PIC/UNIPAR \\ ${ }^{1}$ Discente do Curso de Enfermagem, participante do Programa de Iniciação Científica - PIC/ UNIPAR \\ ${ }^{2}$ Docente e Orientadora do Programa de Iniciação Científica PIC/da UNIPAR
}

Introdução: O câncer de colo do útero constitui um problema de saúde pública, no qual foi a causa de 6.385 óbitos de mulheres em 2018 (INCA, 2020). Diante da elevada morbimortalidade da doença, dá-se a importância de medidas preventivas, bem como o diagnóstico precoce realizado através do exame citopatológico do colo do útero (INCA, 2020), que consiste na coleta de células da ectocérvice e da endocérvice para análise. É válido mencionar a importância deste exame durante o pré-natal para o rastreamento de lesões precursoras, pois este câncer é comum na gravidez, provavelmente relacionado ao desequilíbrio na flora vaginal, que propicia o desenvolvimento de infecções sexualmente transmissíveis - IST's como o Papilomavírus Humano HPV que é responsável pelo câncer do colo do útero (SANTOS; LEÃO, 2011). É recomendado que as mulheres de 25 a 64 anos realizem o exame periodicamente, assim como as gestantes (XAVIER, 2017).

Objetivo: Identificar à adesão das gestantes ao exame citopatológico do colo do útero.

Metodologia: $O$ estudo apresenta dados preliminares de uma pesquisa descritiva, transversal de abordagem quantitativa realizada por acadêmicos participantes de um projeto de iniciação científica. A amostra do estudo foi composta por puérperas atendidas no mês de julho em uma Maternidade Regional do Noroeste do Paraná, no qual foi aplicado questionário semiestruturado contendo questões objetivas e subjetivas sobre a realização do exame citopatológico do colo uterino durante a gestação. Foram incluídas no presente estudo as puérperas residentes no município da Maternidade que realizaram ao menos uma consulta de pré-natal e tiveram o parto no mês de julho. A pesquisa cumpriu todas as exigências éticas, estabelecidas na Resolução CNS no. 466/2012, sendo aprovado pelo parecer CAAE: 22352919.3.0000.0109.

Resultados: Aceitaram participar do estudo 62 puérperas, no qual destas, $22(35,48 \%)$ realizaram a coleta de exame citopatológico do colo do útero durante a gestação. Em relação ao local, 17 (77\%) gestantes realizaram o exame na unidade básica de saúde UBS e 5 (23\%) em clínica particular, sendo que 18 (81,8\%) mulheres realizaram o pré-natal exclusivamente pelo Sistema Único de Saúde SUS e quatro $(18,2 \%)$ realizaram consultas pelo SUS e particular. Considerando todas as puérperas entrevistadas, quando questionadas sobre a importância do exame preventivo durante a gestação, 33 (53,22\%) informaram que foram orientadas durante o pré-natal, sendo que $23(69,7 \%)$ relataram terem sido orientadas pelo profissional enfermeiro, quatro (12,1\%) pelo médico; quatro (12,1\%) pelo enfermeiro e médico e $2(6,1 \%)$ receberam orientação pelo auxiliar ou técnico de enfermagem.

Discussão: Pode-se constatar baixa adesão das gestantes na realização do exame citopatológico do colo do útero durante a gestação, o que pode estar relacionada com a não realização de atividades de orientação em saúde pelos profissionais que realizam o pré-natal, visto que várias participantes do estudo relataram não terem sido orientadas sobre a importância do procedimento durante as consultas. Estes dados diferem do estudo realizado por Terlan e Cesar (2018) no qual constataram a adesão de $78,4 \%$ das gestantes ao exame preventivo; sobre a não adesão o estudo evidenciou relação com a baixa escolaridade e condição socioeconômica, além da baixa adesão às consultas de pré-natal. Oliveira, Fernandes e Galvão (2005) reforçam sobre a baixa adesão ao exame à falta de informações e baixa renda familiar. Frente à relação da baixa condição econômica com a maior incidência de câncer no Brasil, é importante salientar o dever do médico de explicar todo o acesso e direito que a gestante tem ao exame preventivo, além de incentivar a adesão da gestante ao exame, visto que este é disponibilizado gratuitamente nas unidades básicas de saúde brasileiras (CASARIN; PICCOLI, 2011). Cabe mencionar que a procura por cuidado está ligada com a maior adesão ao exame, assim quanto maior a frequência da gestante às consultas de pré-natal maior a chance de realização do exame, visto que a mesma estará sendo orientada frequentemente sobre os cuidados em saúde necessários durante esta fase. Cezario, et al (2014) consideram a necessidade de enfoque educativo direcionado às gestantes usuárias das unidades de saúde da atenção básica, com intuito de esclarecer sobre a realização do exame citopatológico e sua relação com a deteç̧ão precoce do câncer do colo do útero, pois o conhecimento deficiente interfere diretamente nas estatísticas de adesão ao exame, bem como nas estimativas anuais do câncer do colo do útero. É importante que informações sobre as diferentes vivências sejam trocadas entre as mulheres e os profissionais de saúde, sendo considerada a melhor forma de promover a compreensão do processo de gestação e adesão a prática do exame (NEME, 2000).

Conclusão: Verifica-se a necessidade de sensibilizar as gestantes para adesão ao exame citopatológico do colo uterino durante as consultas de pré-natal, para isto, é necessário à capacitação e educação permanente dos médicos e demais profissionais de saúde. Portanto, é de extrema importância enfatizar a promoção da saúde através de estratégias educativas. 


\section{Referências}

CASARIN, M.R.; PICCOLI, J.C.E. Educação em saúde para prevenção do câncer de colo do útero em mulheres do Município de Santo Anglo/RS. Ciênc Saúde Coletiva [periódico na Internet]. 2011 [acesso em 2015 Out 21];16(9): [aproximadamente 8 p.]. Disponível em: www.scielosp.org/pdf/csc/v16n9/a29v16n9.pdf. Acesso: 10 agosto 2020.

INSTITUTO NACIONAL DE CÂNCER JOSÉ ALENCAR GOMES DA SILVA. Tipos de câncer. Rio de Janeiro: INCA, 2020. Disponível em: https://www.inca.gov.br/tipos-de-cancer. Acesso em: 20 agosto 2020.

NEME, B. (Coord). Obstetrícia básica. 2 $2^{\mathrm{a}}$ ed. São Paulo: Sarvier, 2000.Disponível em: http://bvsms.saude.gov.br/bvs/publicacoes/pre-natal_puerperio_atencao_humanizada.pdf Acesso: 10 agosto 2020.

OLIVEIRA, M.S.; FERNANDES, A.F.; GALVÃO, M.T. Women living the experience of illness in the presence of cervical-uterine cancer. Acta Paul Enferm. 2005;18(2):150-5. Portuguese. Disponível em: https://www.scielo.br/pdf/ape/v25n6/v25n6a09.pdf Acesso: 11 agosto 2020.

SANTOS, L.A.; LEÃO, G. M. Percepção da cliente gestante sobre o exame preventivo de câncer cérvico-uterino. Saúde Coletiva, v. 27, n. 6, jan.-fev. 2011, p. 713. Disponível em: file:///C:/Users/55449/Downloads/581-3626-1-PB.pdf Acesso: 11 agosto 2020.

TERLAN, R.J.; CESAR J.A. Não realização de citopatológico de colo uterino entre gestantes no extremo sul do Brasil: prevalência e fatores associados. Ciência \& Saúde Coletiva, 23(11):3557-3566, 2018. Disponível em: https://www.scielo.br/scielo.php?script=sci_arttext\&pid=S1413-81232018001103557 Acesso: 21 de agosto 2020.

XAVIER, J. Prevenção ao câncer do colo do útero. 2017. Disponível em: https://portal.fiocruz.br/noticia/prevencao-ao-cancer-docolo-do-utero Acesso: 20 agosto 2020. 


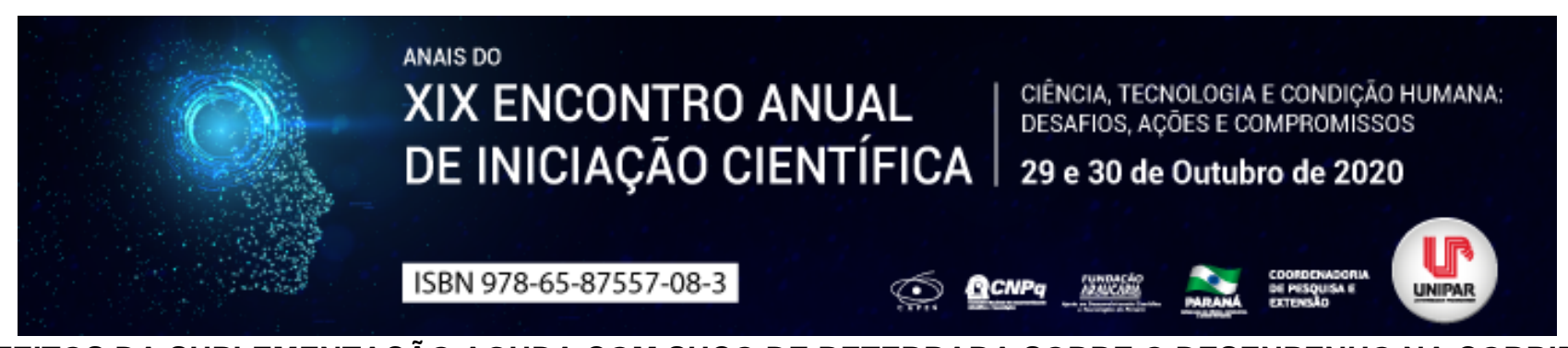

EFEITOS DA SUPLEMENTAÇÃO AGUDA COM SUCO DE BETERRABA SOBRE O DESENPENHO NA CORRIDA

\begin{abstract}
1JOAO PAULO GUIAO, ${ }^{2}$ DANIEL ALBERTO DE OLIVEIRA CLAUS, ${ }^{3}$ FRANCIELE SANTANA dOS SANTOS, ${ }^{4}$ GABRIEL REZENDE BULLA, ${ }^{5}$ GABRIELA ALVES TRINDADE, ${ }^{6}$ ALAN PABLO GRALA
\end{abstract}

\author{
${ }_{1}^{1}$ Acadêmico PIC-EAD do Curso de Educação Física UNIPAR \\ ${ }^{1}$ Acadêmico PIC-EAD do Curso de Educação Física UNIPAR \\ ${ }^{2}$ Acadêmica do Curso de Educaçãoo Física da UNIPAR \\ ${ }^{3}$ Acadêmico do Curso de Educação Física da UNIPAR \\ ${ }^{4}$ Acadêmica do Curso de Educação Física da UNIPAR \\ ${ }^{5}$ Docente do Curso de Educação Física UNIPAR EAD
}

Introdução: O nitrato inorgânico (NIT) está presente em muitos alimentos, sendo especialmente abundante em vegetais de folhas verdes e na beterraba. Após a ingestão, o NIT é convertido em nitrito e em condições com baixa disponibilidade de oxigênio, o nitrito pode ser convertido em óxido nítrico que, por sua vez, desempenha diversos papeis no controle vascular e metabólico (JONES, 2014). Também tem sido relatado que a suplementação com NIT pode reduzir o custo de oxigênio no exercício submáximo e aprimorar a tolerância ao exercício (LARSEN et al., 2007; SHANNON et al., 2016). A corrida de rua é uma atividade aeróbia comum, de baixo custo e que apresenta inúmeros benefícios para seus praticantes. Desta forma, qualquer recurso capaz de aprimorar o desempenho neste tipo de exercício, em especial a tolerância ao esforço, poderia estimular tanto atletas amadores quanto profissionais a buscar melhores resultados pessoais ou competitivos.

Objetivo: Identificar os benefícios da suplementação aguda com suco de beterraba sobre o desempenho na corrida.

Material e Métodos: Foram selecionados 13 corredores de rua amadores para compor a amostra do estudo (Idade: 35,6 $\pm 8,6$ anos). Os procedimentos envolvidos na pesquisa foram aprovados pelo Comitê Ética em Pesquisa envolvendo Seres Humanos (CEPEH) da Universidade Paranaense - Unipar, sob número do parecer 2.778.511. Foram definidos 4 momentos distintos para a realização do estudo: Momento inicial (MI), momento de familiarização (MF), momentos de testes 1 (M1) e 2 (M2). O MI envolveu os procedimentos de antropometria e anamnese dos participantes. Três dias após o Ml, foi realizado o MF, onde foram realizados os processos de familiarização com os equipamentos e procedimentos da pesquisa, incluindo o Teste de corrida estável de longa duração (TCLD). Sete dias após o MF, foi dado início as sessões de testes (M1 e M2). Tanto no M1 quanto no M2 os participantes receberam de forma randomizada, duplo-cego em crossover, 2 horas antes das sessões de testes, a suplementação de NIT na forma de suco de beterraba ( $150 \mathrm{~g}$ de beterraba in natura processada e misturada com $250 \mathrm{ml}$ de água e $30 \mathrm{ml}$ de groselha $=5 \mathrm{mmol} / 300 \mathrm{mg}$ de nitrato) ou placebo $(60 \mathrm{ml}$ de groselha $+250 \mathrm{ml}$ de água). Durante os momentos de testes (M1 e M2), 2 horas após consumirem os suplementos, os sujeitos realizaram o TCLD. Este teste consistiu em correr 45 minutos na esteira rolante na intensidade de $70-75 \%$ da frequência cardíaca máxima ( $F C_{\text {máx }}$. A esteira foi ajustada para 1 grau de inclinação em todos os momentos. Durante a realização do teste, foi posicionado na frente da esteira um quadro contendo a escala de Borg para determinação da percepção do esforço (PSE) a cada 5 minutos. A frequência cardíaca foi monitorada durante todo o teste com o transmissor de frequência cardíaca Polar ${ }^{\circledR} \mathrm{H} 10$ e o software de gravação e monitoramento Polar ${ }^{\circledR}$ Beat. Esse equipamento foi utilizado para determinar tanto a frequência cardíaca média $\left(F C_{\text {méd }}\right)$ quanto a frequência cardíaca máxima $\left(F C_{\max }\right)$. Os procedimentos estatísticos utilizados envolveram a realização dos testes de Shapiro-Wilk e teste ANOVA unidirecional. O nível de significância adotado foi de $p<0,05$.

Resultados: Para todas as variáveis analisadas durante o TCLD ( $F C_{m e d}, F_{\max }$ e PSE) não foi observada nenhuma diferença significativa $(p<0,05)$ favorável ao uso do suco de beterraba em comparação com o placebo ( $F C$ med: $p=0,909$; $F C$ max $p=0,838$; PSE: $p=0,822$ ).

Discussão: Acreditou-se inicialmente que a ingestão do suco de beterraba poderia aprimorar o desempenho e/ou a tolerância ao esforço dos participantes no TCLD pela redução de uma ou mais das seguintes variáveis: $\mathrm{FC}_{\text {méd }}$. FCmax e PSE. Nesta pesquisa, o NIT foi administrado na forma de suco de beterraba, na quantidade aproximada de 300mg de NIT /dose e sua ingestão não proporcionou nenhuma alteração benéfica sobre os parâmetros avaliados. Assim, os resultados são contrários a algumas evidências encontradas na literatura. Como exemplo, Larsen et al. (2007) observaram a redução do custo de oxigênio no exercício submáximo após a suplementação com NIT em comparação com o placebo e melhor tolerância ao esforço. Shannon et al. (2016) constataram que o consumo médio de oxigênio foi significativamente menor e a saturação de oxigênio maior após o consumo de suco de beterraba durante a corrida realizada em ambiente hipóxico. $O$ suco de beterraba também aprimorou o desempenho (aproximadamente 3,2\%) dos 12 participantes no desempenho do tiro de 1500 metros. A quantidade de NIT 
administrada neste estudo foi um pouco menor do que a quantidade utilizada por Larsen et al. (2007) e Shannon et al. (2016), além disso, Larsen et al. (2007) utilizou suplementação por três 3 dias consecutivos antes do teste, diferente da estratégia adotada neste estudo, que utilizou suplementação aguda. Estes fatores podem ter contribuído para a ausência de efeito no desempenho físico.

Conclusão: Frente os resultados encontrados, é possível afirmar que a suplementação aguda com suco de beterraba não foi capaz de aprimorar o desempenho ou a tolerância ao esforço de adultos saudáveis na corrida.

\section{Referências}

JONES, A. M. Dietary nitrate supplementation and exercise performance. Sports Med, v.44 (suppl. 1), p.35-45, may.2014.

LARSEN, F. J.; WEITZBERG, E.; LUNDBERG, J. O.; EKBLOM, B. Effects of dietary nitrate on oxygen cost during exercise. Acto

v.191,

n.1,

p.59-66,

sep.2007.

Disponível

em:

https://www.academia.edu/13719192/Effects_of_dietary_nitrate_on_oxygen_cost_during_exercise. Acesso em: 13/08/2020.

SHANNON, O. M.; DUCKWORTH, L.; BARLOW, M. J.; WOODS, D.; LARA, J.; SIERVO, M.; O`HARA, J. P. Dietary nitrate supplementation enhances high-intensity running performance in moderate normobaric hypoxia, independent of aerobic fitness. Nitric Oxide. $\quad$ v.59, p.63-70, sep.2016. https://www.researchgate.net/publication/313842912_Dietary_nitrate_supplementation_enhances_high-

intensity_running_performance_in_moderate_normobaric_hypoxia_independent_of_aerobic_fitness. Acesso em: 13/08/2020.

Coordenadoria de Pesquisa e Extensão - COPEX

Departamento de Editoraçāo e Divulgaçāo Científica - DEDIC 


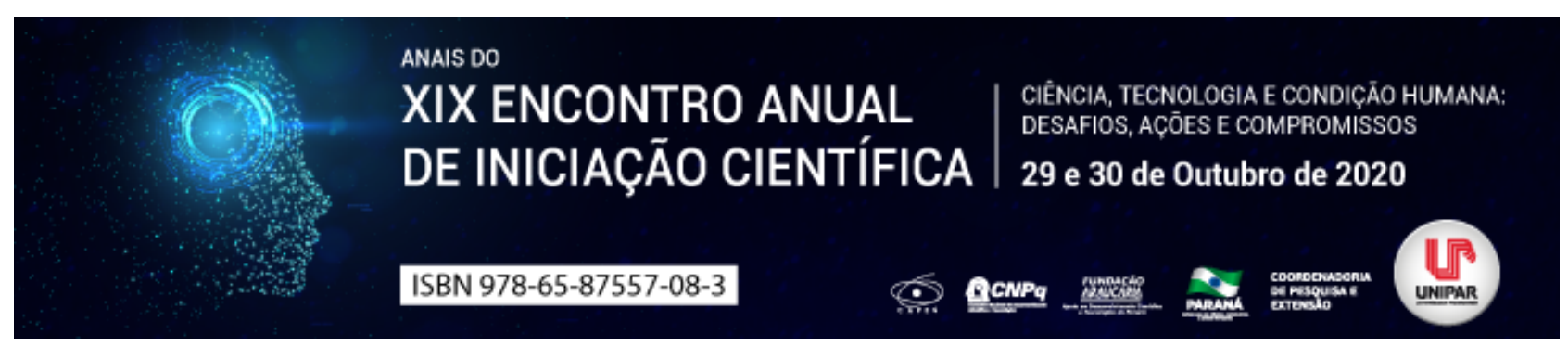

DESMINOPATIA NA MIOCARDIOPATIA RESTRITIVA

\begin{abstract}
${ }^{1}$ RAFAEL BEZERRA MARIM, ${ }^{2}$ SUELEN STEFANONI BRANDAO, ${ }^{3}$ LARISSA LOYOLA BARBOSA, ${ }^{4}$ LUCAS ALEXANDRE GUBERT SCHIER, ${ }^{5}$ GABRIEL HENRIQUE BELLATO PALIN, ${ }^{6}$ ELENIZA DE VICTOR ADAMOWSKI CHIQUETTI
\end{abstract}

\author{
${ }^{1}$ Acadêmico do Curso de Medicina da UNIPAR e Enfermeiro Especialista em Terapia Intensiva \\ ${ }^{1}$ Acadêmica do Curso de Medicina da UNIPAR \\ ${ }^{2}$ Acadêmica do Curso de Medicina da UNIPAR \\ ${ }^{3}$ Acadêmico do Curso de Medicina da UNIPAR \\ ${ }^{4}$ Acadêmico do Curso de Medicina da UNIPAR \\ ${ }^{5}$ Docente do Curso de Medicina UNIPAR
}

Introdução: De acordo com Clemen et al. (2013), desminopatia é uma condição rara do grupo de miopatias miofibrilares causada por mutação no gene humano da desmina. As miocardiopatias são um grupo de doenças em que apresenta comprometimento miocárdico. Para Almeida; Silveira e Brito (2011), a Miocardiopatia Restritiva é uma doença que causa rigidez e redução do relaxamento do músculo cardíaco comprometendo o enchimento ventricular, podendo afetar um ou os dois ventrículos, e pode ser uma doença primária ou secundária. Já para Silva et al. (2007), a miocardiopatia causada pelo depósito de desmina é comumente associada a distúrbios eletrofisiológicos e tem como características a falha no enchimento diastólico ventricular, diferentes graus de bloqueios atrioventriculares e taquicardias ventriculares.

Objetivo: Esse trabalho tem como objetivo fazer um breve apanhado da literatura sobre desminopatia, miopatias miofibrilares, cardiomiopatias com ênfase na miocardiopatia restritiva causada por desminopatia a partir do depósito dessa proteína. Esse estudo foi realizado através de análise de materiais publicados no período inicial de 2015 a 2020 , se extendendo ao período de 1997 a 2020 pela especificidade do tema e carência de materiais disponíveis, e presentes nos bancos de dados: SciElo e LILACS, dos quais foram extraídas as definições, condições e dados epidemiológicos de miocardiopatia e desminopatia.

Desenvolvimento: A desmina é classificada como uma proteína e é um filamento intermediário que atua como citoesqueleto conectando o sarcolema, disco Z e a membrana nuclear nos sarcômeros, conferindo a estrutura, bem como a integridade funcional das miofibrilas (SILVA et al., 2007). A desminopatia é uma condição rara do grupo de miopatias miofibrilares (CID 10: G71.2: miopatias congênitas) de prevalência desconhecida causada por mutação no gene humano da desmina no cromossomo 2 q35 de causa autossômica dominante, autossômica recessiva e com acentuada variabilidade fenotípica. É caracterizada pela agregação dessa proteína (desmina), com alterações degenerativas no aparato miofibrilar. A primeira descrição de miopatia miofibrilar causada por desmina aconteceu no ano de 1998 e, a partir daí, um crescente número de miopatias fibrilares foram identificadas. Estudos epidemiológicos detalhados, bem como a incidência e prevalência de desminopatia ainda não são claros. Com a interpretação dos estudos publicados, o acometimento dessa doença não afeta mais que 5 indivíduos a cada 10.000 (CLEMEN et al., 2013). As miocardiopatias (ou cardiomiopatias) são um grupo de doenças em que apresenta comprometimento miocárdico que, embora seja controverso, é classificado a partir da fisiopatologia dominante e, quando presentes, agentes etiológicos e patogênicos (MADY; FERNANDES, 1997; PORTO, 2019). A Organização Mundial da Saúde (OMS) classificou, em 1995, as miocardiopatias em: Miocardiopatia Dilatada, Miocardiopatia Hipertrófica, Miocardiopatia Restritiva, Miocardiopatia Arritmogênica do Ventrículo Direito, Miocardiopatias Específicas e Miocardiopatias Não Classificadas. Já uma comissão da American Heart Association (AHA), em 2006, definiu as miocardiopatias como sendo um I"grupo heterogêneo de doenças do miocárdio associadas com disfunção mecânica e/ou elétrica, e que usualmente (mas não invariavelmente) exibem dilatação ou hipertrofia ventriculares inapropriadas (ALBANESI, 1998; BRAGA et al., 2011). A Miocardiopatia Restritiva é uma doença que causa rigidez e redução do relaxamento do músculo cardíaco comprometendo o enchimento ventricular, podendo afetar um ou os dois ventrículos, e pode ser uma doença primária ou secundária. A maior parte das miocardiopatias restritivas é secundária e associada à amiloidose, hemocromatose, sarcoidose, esclerodermia, síndrome hipereosinofílica, endomiocardiofibrose e doenças de depósito. Os sinais e sintomas se parecem com os de Insuficiência Cardíaca Congestiva (ICC). O diagnóstico de tal patologia se dá por meio de história clínica, exame físico, ECG, RX de tórax, ECO, RNM, biópsia endomiocárdica e diagnóstico diferencial com pericardite constritiva (ALMEIDA; SILVEIRA e BRITO, 2011). Na desminopatia, o indivíduo apresenta, de acordo com Silva et al. (2007) e Arbustini et al. (1998), fraqueza muscular em tronco, região cervical e musculatura respiratória, doenças do sistema de condução, arritmias e morte súbita. Já na Miocardiopatia Restritiva causada por depósito de desmina, para Benvenuti et al. (2012), os distúrbios no sistema de condução, como o bloqueio atrioventricular total (BAVT) e outros distúrbios eletrofisiológicos, o comprometimento da musculatura esquelética são as principais manifestações. 
Considerações finais: A miocardiopatia causada pelo depósito de desmina é comumente associada a distúrbios eletrofisiológicos e tem como características a falha no enchimento diastólico ventricular, diferentes graus de bloqueios atrioventriculares e taquicardias ventriculares. Como as dificilmente observadas desminopatias não possuem tratamento específico, atingir o diagnóstico pouco influencia na conduta, entretanto há grande importância no rastreio e prevenção.

\section{Referências}

ALBANESI, Francisco Manes. Cardiomiopatias. Arq. Bras. Cardiol., Rio De Janeiro, v. 71, n. 2, 1998.

ALMEIDA, Dirceu Rodrigues; SILVEIRA, José Alexandre; BRITO, Flávio. Miocardiopatias restritivas. Rev. Soc.Cardiol., São Paulo, v. 21, n. 1, p. 14-20, 2011.

ARBUSTINI, Eloisa et al. Restrictive Cardiomyopathy, Atrioventricular Block and Mild to Subclinical Myopathy in Patients With Desmin-Immunoreactive Material Deposits. JACC, v. 31, n. 3, 1998.

BENVENUTI, Luiz Alberto et al. Patologia do bloqueio atrioventricular na cardiomiopatia por depósito de desmina. Arq. Bras. Cardiol., São Paulo, v. 98, n. 1, p. 3-6, 2012.

BRAGA, João Carlos Ferreira; GUIMARÃES FILHO, Fabio Villaça; RODRIGUES, Alexandre. Cardiomiopatias: conceito e classificação. Rev. Soc. Cardiol., São Paulo, v. 21, n. 1, p. 2-6, jan./mar, 2011.

CLEMEN, Christoph S. et al. Desminopathies: pathology and mechanisms. Acta Neuropathol, Switzerland, v. 125, p. 47-75, 2013.

MADY, Charles; FERNANDES, Fábio. Cardiomiopatias. Uma Visão Crítica do Conceito da Classificação. Arq. Bras. Cardiol., v. 69, n. 5, 1997.

PORTO, Celmo Celeno. Semiologia médica, 8.ed., Rio de Janeiro, Guanabara Koogan, 2019.

SILVA, Christiano Pereira et al. Cardiomiopatia restritiva por depósito de desmina. Arq. Bras. Cardiol., v. 89, n. 6, p. 165-168, 2007.

Coordenadoria de Pesquisa e Extensão - COPEX

Departamento de Editoraçāo e Divulgaçāo Científica - DEDIC 


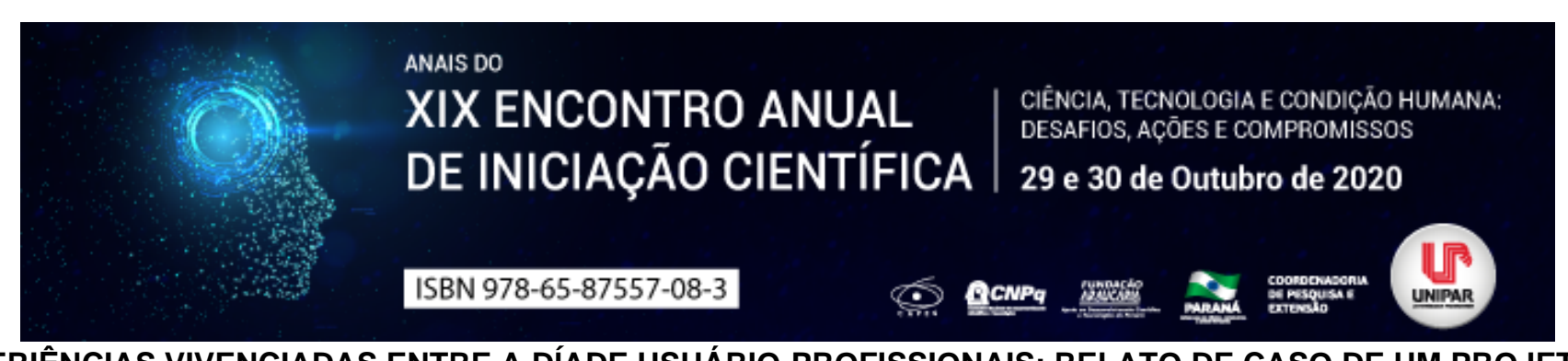

EXPERIÊNCIAS VIVENCIADAS ENTRE A DÍADE USUÁRIO-PROFISSIONAIS: RELATO DE CASO DE UM PROJETO DE EXTENSÃO

\begin{abstract}
${ }^{1}$ Isabela de Souza Santana, ${ }^{2}$ JOSÉ VICTOR SOARES DA SILVA, ${ }^{3}$ ANDERSON MOREIRA DE MELO, ${ }^{4}$ PEDRO PAULO DO PRADO JÚNIOR, ${ }^{5}$ CRISTIANE CHAVES DE SOUZA
\end{abstract}

\begin{abstract}
${ }^{1}$ Acadêmica do curso de Enfermagem da Universidade Federal de Viçosa
${ }^{1}$ Acadêmico do curso de Enfermagem da Universidade Federal de Viçosa

${ }^{2}$ Acadêmico do curso de Enfermagem da Universidade Federal de Viçosa

${ }^{3}$ Doutor em Ciências da Nutrição. Docente do curso de Enfermagem da Universidade Federal de Viçosa

${ }^{4}$ Doutora em Enfermagem. Docente do curso de Enfermagem da Universidade Federal de Viçosa
\end{abstract}

Introdução: O Sistema Único de Saúde (SUS) norteia o modelo de atenção à saúde por meio dos princípios doutrinários: universalidade, integralidade e equidade e dos organizativos: participação social, regionalização e hierarquização e descentralização (MATTOS, 2009). Nessa perspectiva, o Ministério da Saúde, em 2003, implementou a Política Nacional de Humanização (PNH) para reforçar a necessidade de uma visão ampliada do sistema de saúde, do sujeito e seu processo de saúde-doença. Essa política transversal às ações em saúde auxilia na compreensão de uma rede desaúde integrada por meio da gestão eficaz e de uma assistência que confirme a autonomia do profissional e do usuário, através da participação ativa do sujeito, trazendo-o a co-responsabilização no seu plano de cuidado (BRASIL, 2004). Dentro dessa rede de atenção à saúde, destaca-se o Apoio Matricial em Enfermagem, que atua como centro de referência e especialidade. Este por sua vez se divide em duas dimensões (assistencial e pedagógica), em especial, a assistencial que é realizada por meio das Consultas de Enfermagem realizadas na Atenção Secundária, sendo esta integrada à rede de saúde (BRASIL, 2004; BALLARIN, BLANES; FERIGATO, 2012). Este trabalho tem por objetivo descrever, através de um relato de caso, experiências clínicas assistenciais vivenciadas por estudantes de Enfermagem na Atenção Secundária na avaliação, tratamento e prescrição de coberturas para lesões cutâneas.

Relato de Caso: Trata-se de um relato de caso sobre as experiências de três discentes de enfermagem de uma universidade federal de Minas Gerais, que realizaram o acompanhamento de uma paciente com lesões cirúrgicas bilaterais em região inguinal na Unidade de Atenção Especializada em Saúde (UAES), por meio do projeto de extensão intitulado Implantação do ambulatório de apoio matricial de Enfermagem na Unidade de Atendimento Especializado sob supervisão do docente coordenador. O atendimento foi $100 \%$ pelo SUS. As consultas foram realizadas em consultórios individuais, sendo divididas em três momentos. 1. Histórico de Enfermagem e diagnósticos de enfermagem; 2. Avaliação da paciente e prescrição de cuidados no tratamento das lesões cutâneas, além da orientação sobre seu processo saúde-doença e o enfrentamento do mesmo na vida diária; 3. Planejamento do cuidado co-participativo e empoderamento sobre a situação clínica, além de formas de enfrentamento que contribuíram com as experiências positivas vivenciadas pelos alunos e na autonomia da cliente.

Discussão: O estudo de Chibante (2018) corrobora com as experiências vivenciadas neste relato pela díade usuárioprofissionais, no qual após as consultas de enfermagem para avaliação e prescrição de coberturas foram eficazes para o tratamento das lesões cutâneas, além de estimular a participação ativa da usuária em seu processo de saúde-doença. Nessa perspectiva, a paciente deste relato e do estudo supracitado trazem relatos semelhantes acerca dos cuidados prestados por outros profissionais da rede, como: essa tesoura não é aquela estéril , não escutavam minha opinião , pedi para não passarem aquela pomada. Estes relatos foram essenciais para demonstrar o empoderamento adquirido pela paciente a partir do conhecimento compartilhado entre a díade, evidenciando a importância do autocuidado como estratégia de enfrentamento (CHIBANTE, 2018). Além da abordagem das necessidades psicobiológicas, identifica-se questões psicológicas, como o medo da morte, ansiedade e perda da esperança. As consultas de enfermagem influenciaram positivamente na evolução das lesões, no seu bem-estar e também na redução das angústias. Diante disso, foi vivenciado e reafirmado pelos alunos sobre a importância tanto do cuidado holístico e integral na assistência, quanto da participação ativa da díade usuário-profissional, a partir da troca de experiências e conhecimentos, traçando um plano de tratamento compartilhado e corresponsável, tornando acessível essa clínica ampliada (BAADE, BUENO, 2016). Foi realizado o serviço de contra referência da usuária para a Unidade Básica de Saúde responsável, estimulando o fortalecimento e a responsabilidade dos serviços por meio de um cuidado baseado nos princípios do SUS. Logo, foi possível identificar uma experiência positiva dos graduandos, pois conseguiram entender a relevância de colocar em prática a teoria aprendida na universidade e alcançar resultados satisfatórios de melhoria do bem-estar da paciente.

Conclusão: Concluiu-se que os estudantes de enfermagem desfrutaram de uma experiência positiva durante a assistência prestada à paciente, baseando-se nos relatos de satisfação e do reconhecimento e valorização do enfermeiro referida pela 
cliente. As consultas permitiram aos discentes acompanharem a evolução clínica das lesões e o enfrentamento do processo saúde-doença pela paciente, o retorno da autoestima e a esperança pela vida. Ademais, os princípios preconizados pela PNH, no tangente ao Apoio Matricial, como o de participação ativa do usuário do sistema e a co-responsabilização no seu regime terapêutico foram possíveis de serem vivenciados pelos alunos na assistência baseada no cuidado holístico.

\section{Referências}

BAADE, Rosilei Teresinha Weiss; BUENO, Edison. Coconstrução da autonomia do cuidado da pessoa com diabetes, Interface (Botucatu), Botucatu, v. 20, n. 59, p. 941-51, out./dez., 2016. Disponível em: https://www.scielo.br/scielo.php? script=sci_arttext\&pid=S1414-32832016000400941\&lng=pt\&tlng=pt. Acesso em: 24 ago. 2020.

BALLARINN, Maria Luisa Gazabim Simões; BLANES, Lara de Sousa; FERIGATO, Sabrina Helena. Apoio matricial: um estudo sobre a perspectiva de profissionais da saúde mental. Interface (Botucatu), Botucatu, v. 16, n. 42, p. 767-778, Set. 2012. Disponível em: http://www.scielo.br/scielo.php?script=sci_arttext\&pid=S1414-32832012000300014\&lng=en\&nrm=iso. Acesso em: 24 ago.

BRASIL. Ministério da Saúde (MS). Secretaria de Atenção à Saúde. Núcleo Técnico da Política Nacional de Humanização. HumanizaSUS: Equipe de referência e Apoio Matricial. Brasília: Editora do Ministério da Saúde; 2004.

CHIBANTE, Carla Lube de Pinho. O paciente como protagonista do cuidado de enfermagem durante a hospitalização: subsídios para a autonomia no processo de viver com CNTS. Orientadora: Fátima Helena do Espírito Santo. 2018. p; 1-156. Tese (Doutorado em Ciências do Cuidado em Saúde) Escola de Enfermagem Aurora de Afonso Costa, Universidade Federal Fluminense, Niterói, 2018.

MATTOS, Ruben Araujo de. Princípios do Sistema Único de Saúde (SUS) e a humanização das práticas de saúde. Interface (Botucatu), Botucatu, v. 13, supl. 1, p. 771-780, 2009. Disponível em: http://www.scielo.br/scielo.php? script=sci_arttext\&pid=S1414-32832009000500028\&lng=en\&nrm=iso. Acesso em: 24 ago. 2020. 


\title{
ANAIS DO \\ XIX ENCONTRO ANUAL | CIÊNCIÁ, TECNOLOGIAE CONDIÇĀOHUMANA: DE INICIACÃO CESAFIOS, AÇŌES E COMPROMISSOS \\ DE INICIAÇÃO CIENTÍFICA 29 e 30 de Outubro de 2020 \\ ISBN 978-65-87557-08-3 \\ $\leftarrow$ PCMPG \\ AVALIAÇÃO DA EFICIÊNCIA DOS SERVIÇOS ONCOLÓGICOS DISPONÍVEIS NO SISTEMA ÚNICO DE SAÚDE ENTRE OS ESTADOS BRASILEIROS
}

\author{
${ }^{1}$ FERNANDA SONZA, ${ }^{2}$ ISABELLA ACACIO FERREIRA DE SOUZA, ${ }^{3}$ ISADORA GIACOMINO ALVES, ${ }^{4}$ FRANCISLAINE \\ APARECIDA DOS REIS LIVERO, ${ }^{5}$ LUIZ ANDRE NADLER LINS
}

\author{
${ }^{1}$ Acadêmica do curso de Medicina da UNIPAR \\ ${ }^{1}$ Acadêmica do curso de Medicina da UNIPAR \\ ${ }^{2}$ Acadêmica do curso de Medicina da UNIPAR \\ ${ }^{3}$ Docente da UNIPAR \\ ${ }^{4}$ Docente da UNIPAR
}

Introdução: O câncer se caracteriza pela perda de controle do crescimento celular e pela capacidade de invadir órgãos ou estruturas corporais. Tem início na incapacidade do sistema imunológico de identificar e eliminar células cancerosas recémformadas e em pequena quantidade (ROY; SAIKIA, 2016). É uma das principais causas de morte mundial, ficando atrás apenas de doenças cardiovasculares (WISEMAN, 2019). Em 2018, foi responsável por 9,6 milhões de mortes, das quais cerca de 70\% foram em países menos desenvolvidos (WORLD HEALTH ORGANIZATION, 2018). Diante da importância epidemiológica do câncer, o qual apresenta-se como um problema de saúde pública, é fundamental a integração dos serviços especializados para a assistência de alta complexidade em oncologia no Sistema Único de Saúde (SUS). Nesse sentido, entender a eficiência e a distribuição destes serviços nos estados brasileiros torna-se essencial para controlar e combater todo tipo de câncer e sua mortalidade.

Objetivo: Avaliar os índices de eficiência dos estabelecimentos de saúde de alta complexidade em oncologia no SUS em relação às taxas de incidência estimadas e número de mortes por essa causa nos estados do Brasil.

Material e Métodos: Foi realizada uma análise da eficiência a partir de dados coletados da Portaria $n^{\circ} 1399$, de 17 de dezembro de 2019 acerca do número de estabelecimentos de saúde de alta complexidade em oncologia no SUS habilitados para o tratamento de câncer de cada unidade federativa (como outputs), além das projeções demográficas para cada estado no ano de 2020 segundo o IBGE, estimativa de novos casos de neoplasias malignas para 2020 de acordo com o Ministério da Saúde e o número total de mortes pela patologia em 2018 segundo o INCA (como inputs). A avaliação da eficiência desses serviços foi feita por meio de análise de razão de performance.

Resultados: O Mato Grosso do Sul apresentou-se como estado referência de eficiência com valor 1 de benchmark na relação número de estabelecimentos/população estimada para 2020. Nesta mesma métrica, o estado do Pará exibiu a pior performance sendo 84\% menos eficiente. Além disso, observou-se que o Pará apresentou o maior número de mortes em relação à estimativa, com valor de 0,54 . Por outro lado, os estados de Santa Catarina e Tocantins apresentam os melhores resultados nesta relação, com valores de 0,27 . Em relação a análise do número de estabelecimentos/estimativa de novos casos de neoplasia malignas em 2020, Rondônia é o estado de referência com benchmark de valor 1 e Goiás, o de pior valor, sendo $82 \%$ menos efetivo. Não houve nenhum estado com $100 \%$ de eficiência em ambas dimensões aferidas.

Discussão: Ao analisar a relação entre o número de estabelecimentos/população e o número de mortes/estimativa verifica-se graficamente uma correlação linear negativa com baixo coeficiente de determinação. Com esses dados, identifica-se que o número de mortes por câncer diminui com o aumento de serviços de oncologia disponíveis, porém, a variabilidade de um é pouco explicada pela do outro, já que a diminuição da mortalidade por câncer não depende apenas do número de serviços, mas também da qualidade e do acesso aos serviços disponibilizados, medidas de prevenção primária, fatores de risco, faixa etária, padrão de nutrição e atividade física, além de outros fatores ambientais e econômicos (ALVES; MAGALHÃES; COELHO, 2017; WISEMAN, 2019). Este estudo se faz relevante para evidenciar os estados com pior eficiência nos serviços de saúde de alta complexidade em oncologia. Assim, poderá contribuir com as políticas públicas de saúde na elaboração de medidas mais eficazes para garantir a equidade na distribuição de tratamento e controle da doença, garantindo melhor acesso da população aos serviços de saúde.

Conclusão: Quanto maior a eficiência, em relação número de serviços/população, menor a mortalidade proporcional à estimativa, sendo que essa associação exibe um coeficiente de determinação baixo pois este fator desempenha certa influência, porém não isoladamente.

\section{Referências}

ALVES, Mônica Oliveira; MAGALHÃES, Sandra Célia Muniz; COELHO, Bertha Andrade. A regionalização da saúde e a 
assistência aos usuários com câncer de mama. Saúde e Sociedade São Paulo, v. 26, n. 1, p. 141-154, 2017.

ROY, Partha Sarathi; SAIKIA, Bhargab Jyoti. Câncer e cura: uma análise crítica. Indian Journal of Cancer, v. 53, n. 3, p. 441442, 2016.

WISEMAN, Martin. J. Nutrition and cancer: prevention and survival. British Journal of Nutrition, v. 122, n. 5, p. 481-487, 2019. WORLD HEALTH ORGANIZATION. Folha de dados do câncer da Organização Mundial da Saúde. 2018.

Coordenadoria de Pesquisa e Extensão - COPEX

Departamento de Editoraçāo e Divulgaçāo Científica - DEDIC 


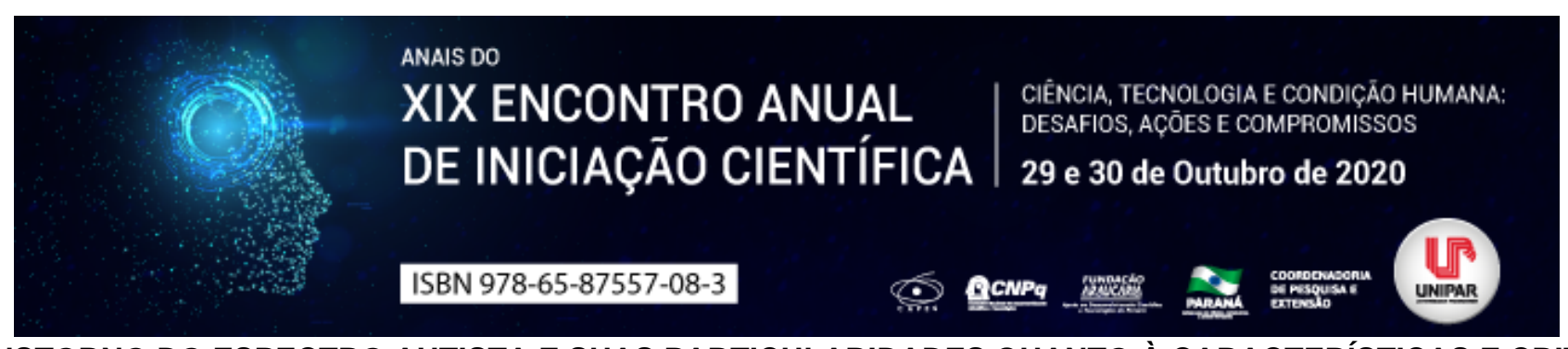

\title{
O TRANSTORNO DO ESPECTRO AUTISTA E SUAS PARTICULARIDADES QUANTO À CARACTERÍSTICAS E CRITÉRIOS DIAGNÓSTICOS
}

\author{
${ }^{1}$ KARINA FUMAGALI MILESKI, ${ }^{2}$ FERNANDA DE ABREU BRAGA, ${ }^{3}$ BRENDA AYUMI TSUKAMOTO, ${ }^{4}$ TAIS DA SILVA \\ SCHMIDT, ${ }^{5}$ SILVANA NUNES FERNANDES, ${ }^{6}$ MICHEL ANDREW NOGARA
}

\author{
${ }^{1}$ Acadêmica bolsista do PIBIC/UNIPAR \\ ${ }^{1}$ Acadêmica do Curso de Medicina da UNIPAR \\ ${ }^{2}$ Acadêmica do Curso de Medicina da UNIPAR \\ ${ }^{3}$ Acadêmica do Curso de Medicina da UNIPAR \\ ${ }^{4}$ Discente do curso de Medicina/UNIPAR \\ ${ }^{5}$ Docente da UNIPAR
}

Introdução: De acordo com Sociedade Brasileira de Pediatria (2019), o transtorno do espectro autista (TEA), é um distúrbio caracterizado pelo comprometimento precoce do desenvolvimento sociocomunicativo e pelo aparecimento de comportamentos repetitivos e estereotipados, possuindo comprometimentos variáveis. Essas características comportamentais podem ser identificadas ao longo da infância (ALMEIDA et al, 2019). Devido a grande complexidade desse distúrbio e variações, a identificação de sua origem é dificultada em cada indivíduo portador de TEA (GRIESI-OLIVEIRA; SERTIE, 2017). De acordo com a American Psychiatric Association (2014), essas manifestações podem variar de acordo com a gravidade da condição da criança autista, a idade da mesma e de acordo com o nível do transtorno diagnosticado.

Objetivo: Descrever os níveis de gravidade para o transtorno do espectro autista e as principais formas de diagnóstico por meio de revisão bibliográfica.

Desenvolvimento: Os artigos foram extraídos da base de dados portal de periódicos CAPES e Google Acadêmico, entre os anos de 2008 e 2020, sendo que para tal busca foram utilizados os descritores, autismo , níveis , manifestações , restando cinco artigos a serem analisados, após a exclusão dos que não se relacionavam com o objetivo do presente trabalho. No geral, a Associação Brasileira de Psiquiatria (2019) expõe que durante o primeiro ano de vida, será de suma importância a identificação de alguns sinais sugestivos para o Transtorno do espectro autista, como a perda de algumas habilidades adquiridas, baixo contato visual e incapacidade de olhar fixamente, dificuldade em alcançar objetos, a não aceitação ao toque ou a não responsividade ao nome, maior afeição a objetos do que à pessoas, ausência de sorriso social, e desprezo de ruídos, sons e vozes no ambiente. Isto posto, após a confirmação por diagnóstico médico, o TEA poderá ser caracterizado em três níveis de gravidade, seguindo o exposto pela American Psychiatric Association (2014). No Nível 1, será necessário apoio, pois, a comunicação social será dificultada, já que haverão falhas na tentativa de interações verbais e não verbais, assim como a dificuldade em criar vínculos em sociedade. Além disso, quanto aos comportamentos restritos e repetitivos, serão inflexíveis e apresentarão dificuldades em conviver com mudanças ou outros tipos de comportamentos, fazendo indivíduo passar por grande sofrimento e limitações quanto a mudança de foco ou ações. O Nível 2, exigirá apoio substancial, ou seja, o indivíduo dependerá de auxílio para o desempenho dos afazeres, apresentando déficits graves na comunicação verbal e não verbal, prejuízo social aparente, limitação em iniciar interações sociais ou a responder a elas. Suas ações serão inflexíveis, apresentando dificuldade em situações de mudanças e suas atitudes consideradas restritas e repetitivas. Já o Nível 3, exige elevado apoio substancial, manifestando déficits graves na comunicação verbal e não verbal, prejudicando e limitando as interações sociais, pois falam pouco, geralmente sendo iniciadas com abordagens incomuns. Ademais, seu comportamento é considerado inflexível, apresentando dificuldades em lidar com mudanças, já que a rotina apresenta grande importância em seu cotidiano. Já na esfera do diagnóstico e identificação dos níveis, pode ser realizado por diferentes técnicas, como a de Childhood Autism Rating Scale (CARS), o Social Communication Questionnaire (SCQ); o Screening Tool for Autism in Two Years Old (STAT); o Developmental Behaviour Checklist (DBC); o Checklist for Autism in Toddlers (CHAT) e o Modified Checklist for Autism in Toddlers (M-CHAT), as quais são aplicadas em forma de questionários. Dentre essa gama de diagnósticos, sabe-se que a técnica CARS é a mais aplicada, baseando-se em um questionário com 15 perguntas feitas aos pais ou responsáveis pelos autistas (LOSAPIO; PONDE, 2008).

Conclusão: Portanto, é evidente a complexidade do transtorno do espectro autista, já que, este será responsável por prejuízos na vida pessoal, social, acadêmica ou profissional do indivíduo. Dessa forma, será necessária uma análise precisa das diferentes manifestações e descrições dos níveis de gravidade do TEA apontadas pelo DSM-V, que mesmo mediante a descrição detalhada do portador, observa-se dificuldade na identificação da origem desse distúrbio e de modo particular, o diagnóstico de cada paciente. Tal fato ressalta a importância do desenvolvimento de técnicas de identificação e acompanhamento com portadores e 
seus familiares para um rastreamento detalhado acerca do desenvolvimento sócio comunicativo precoce da criança. Portanto a detecção de problemas no desenvolvimento social, é crucial para o diagnóstico do TEA, maximizando a probabilidade de a criança receber intervenção precoce em serviços especializados. Devido a diferenças clínicas entre a população autista, é necessária uma equipe multidisciplinar para uma avaliação formal. A análise precisa do diagnóstico fornece ferramentas para intervenções terapêuticas, assim como estabelecer formas adequadas de interação dos pais com os filhos autistas.

\section{Referências}

ALMEIDA, Pollyana Cecília Carvalho; MURTA, Júlia de Almeida Nunes; MENDES, Yasmin Teixeira. Identificação precoce do Transtorno do Espectro Autista. Simpósio de Otorrinopediatria do Norte de Minas e III Congresso Norte Mineiro de Saúde da Criança. 2019. Disponível em: https://acervomais.com.br/index.php/saude/article/download/3092/1836\#page=30. Acesso em: 09 de julho 2020.

AMERICAN PSYCHIATRIC ASSOCIATION. Manual diagnóstico e estatístico de transtornos mentais: DSM-5. 5 ed. Porto Alegre: Artmed, 2014.

LOSAPIO, Mirella Fiuza; PONDE, Milena Pereira. Tradução para o português da escala M-CHAT para rastreamento precoce de autismo. Revista Psiquiatria Rio Grande do Sul, Porto Alegre, v. 30, n. 3, p. 221-229, 2008.

GRIESI-OLIVEIRA, Karina; SERTIE, Andréa Laurato. Transtornos do espectro autista: um guia atualizado para aconselhamento genético. Einstein, São Paulo, v. 15, n. 2, p. 233-238, 2017.

SOCIEDADE BRASILEIRA DE PEDIATRIA. Manual de Orientação: Transtorno do Espectro do Autismo. n. 05, Abril, 2019. Disponível em: https://www.sbp.com.br/fileadmin/user_upload/Ped._Desenvolvimento_-_21775b-MO__Transtorno_do_Espectro_do_Autismo.pdf. Acesso em: 15 de junho de 2020. 


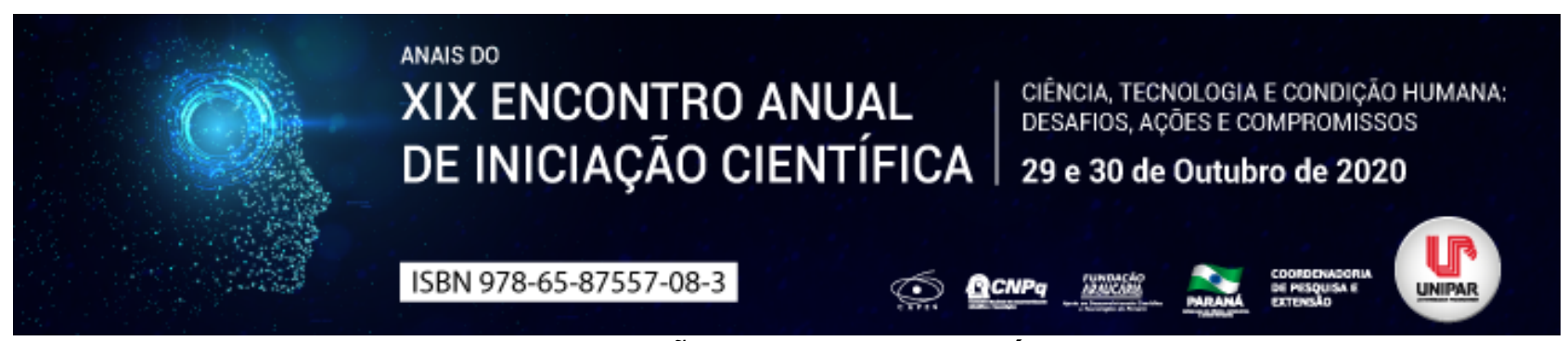

A FISIOTERAPIA NAS DISFUNÇÕES DO ASSOALHO PÉLVICO EM GESTANTES

\title{
${ }^{1}$ CRISLAINE SIVIERO DE PAULA, ${ }^{2}$ ELIGE VERANGELA SIMON, ${ }^{3}$ DORA DE CASTRO AGULHON SEGURA
}

\author{
${ }^{1}$ Acadêmica do Curso de Fisioterapia da UNIPAR \\ ${ }^{1}$ Acadêmica do Curso de Fisioterapia da UNIPAR \\ ${ }^{2}$ Docente da UNIPAR
}

Introdução: No período gestacional ocorrem modificações anatômicas, hormonais e mecânicas no corpo da mulher. Essas mudanças que fazem parte de um processo natural e fisiológico exigem diversas adaptações, sobretudo do sistema musculoesquelético. O constante crescimento do útero e o aumento do peso corporal exercem maior pressão aos músculos do assoalho pélvico acrescido da ativa atuação dos hormônios, levando ao enfraquecimento (PERUZZl; BATISTA, 2018). O enfraquecimento dos órgãos pélvicos resulta em afecções como incontinências urinárias, incontinência fecal, prolapsos, dor pélvica e disfunções sexuais. Essas alterações podem afetar negativamente na qualidade de vida das gestantes (VAZ et al., 2019). A fisioterapia dispõe de técnicas que auxiliam no recrutamento das fibras musculares assegurando maior força e tonicidade, sendo indicada como prevenção e reabilitação de distúrbios já instalados. Diversas são os métodos utilizados, como Cinesioterapia Convencional, Eletrotermofototerapia, Fisioterapia Aquática e o Método Pilates (SOUSA; SILVA; PEREIRA, 2018). Objetivo: Descrever, através de um estudo de revisão bibliográfica sobre o tratamento fisioterapêutico nas disfunções do assoalho pélvico em gestantes.

Desenvolvimento: Segundo Vaz et al. (2019), ao engravidar, a mulher vivencia mudanças hormonais que ocasionam em alterações dos tecidos conectivos influenciando no mecanismo de suporte e continência do assoalho pélvico. Somado a isso, os constantes aumentos da massa corporal materna e útero gravídico resultam em excesso de pressão e tensão na musculatura perineal. Como primeira linha eficaz na prevenção e tratamento das disfunções do assoalho pélvico durante a gravcidez, existe a técnica de treinamento da musculatura. No decorrer da gestação sua efetividade está relacionada à hipertrofia e ativação dos músculos pélvicos ao ser exposta ao aumento da pressão intra-abdominal prevenindo a descida perineal e a melhora do suporte estrutural das vísceras pélvicas (MACEDO; OGNIBENI, 2019; CASTRO; MACHADO; TRINDADE, 2019). Como benefícios do fortalecimento do assoalho pélvico se destacam taxas significativamente menores de episiotomia e traumatismo perineal grave. $O$ treinamento muscular também pode influenciar encurtando o primeiro e o segundo estágios do trabalho de parto nas primigestas (VAZ et al., 2019). Uma forma eficaz de fortalecimento da musculatura pélvica, é o Método Pilates, que através de movimentos resistidos e alongamentos associados com a respiração, melhora a percepção e consciência, privando de disfunções urinárias e auxilia no momento do parto (CORDEIRO; BRASIL; GONÇALVES, 2018). O assoalho pélvico proporciona sustentação aos órgãos pélvicos e mantem a continência urinária. A sobrecarga na musculatura pode desencadear quadros de incontinência urinária. Entre os principais tratamentos fisioterapêutico estão a Cinesioterapia Convencional, Exercícios de Kegel para o fortalecimento do assoalho pélvico e o Biofeedback que é um aparelho que facilita o reconhecimento da musculatura trabalhada (MARTINEZ; KRAIEVSKI, 2017). Segundo Sousa, Silva e Pereira (2018), a fisioterapia na assistência da mulher em trabalho de parto, vem aumentando cada vez mais. Por meio da cinesioterapia, as técnicas são ensinadas com o intuito de aumentar o relaxamento, permitindo que a gestante colabore durante todas as fases do parto. Nas condutas são realizados exercícios com bastão e bola, exercícios de anteversão e retroversão pélvica, exercícios ativos de membros superiores e inferiores. Como técnica de percepção respiratória, existe a respiração profunda ou abdominal, a parturiente realiza uma inspiração expandindo a parede abdominal descontraída, abaixando o diafragma, expira lentamente, contraindo os músculos abdominais, esse exercício controlada a velocidade da expiração, facilitando a contração dos músculos abdominais, e no período de expulsão do feto a parturiente respira fundo e realiza uma apneia, fazendo força para expulsar o bebê relaxando a musculatura perineal, promovendo um parto mais natural.

Conclusão: Concluiu-se através deste etudo que o período gestacional é demarcado por alterações musculares do assoalho pélvico favorecendo diversas desordens, sendo a fisioterapia extremamente indicada como tratamento preventivo e de reabilitação. Através de técnicas que objetivam o fortalecimento muscular as gestantes conseguem uma hipertrofia das fibras musculares evitando diagnósticos de incontinência urinária, parto prematuro, menores taxas de episiotomia, além de favorecer um melhor trabalho de parto.

\section{Referências}

CASTRO, L. A.; MACHADO, C. G.; TRINDADE, A. P. N. T. Fisioterapia em mulheres com incontinência urinária. Revista Uningá, v. 56, n. 4, p. 39-51, 2019.

CORDEIRO, C. C.; BRASIL, D. P.; GONÇALVES, D. C. Os benefícios do Método Pilates no período gestacional: Uma revisão 
bibliográfica. Scire Salutis, v. 8, n. 2, p. 98-103, 2018.

MACEDO, C. B.; OGNIBENI, L. C. R. Análise comparativa de protocolos de tratamento fisioterapêutico para fortalecimento do assoalho pélvico. Revista Uningá, v. 56, n. 4, p. 170- 181, 2019.

MARTINEZ, M. A.; KRAIEVSKI, E. S. O advento da fisioterapia no tratamento da incontinência urinária de esforço. Revista Conexão Eletrônica, v.14, n. 1, p. 01-08, 2017.

PERUZZI, J.; BATISTA, P. A. Fisioterapia nas disfunções do assoalho pélvico e na sexualidade durante o período gestacional. Fisioterapia Brasil, v. 2, n. 1, p. 177- 182, 2018.

SOUSA, C. B.; SILVA, I. M. A.; PEREIRA, V. S. S. Atuação da fisioterapia para a redução do tempo no trabalho de parto vaginal. Scire Salutis, v. 8, n. 2, p. 123-128, 2018.

VAZ, J. R.; ALMEIDA, C. A. P. L.; ARAÚJO, E. T. H.; MAGALHÃES, E. J. L. Treinamento da musculatura do assoalho pélvico no período gestcional. Brazilian Journal Health, v. 2, n. 2, p. 06-11, 2019.

Coordenadoria de Pesquisa e Extensão - COPEX

Departamento de Editoraçāo e Divulgaçāo Científica - DEDIC 


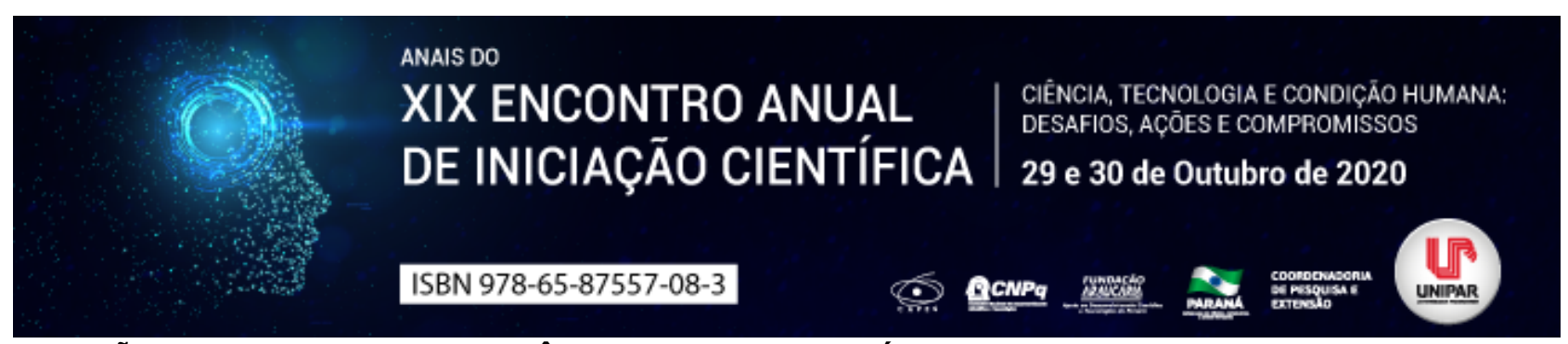

CONTRIBUIÇÃO DO MOSQUITO TRANSGÊNICO COMO ESTRATÉGIA DE CONTROLE DA DENGUE NO BRASIL: UMA REVISÃO DE LITERATURA

\author{
${ }^{1}$ MARIO MARQUES PEREIRA FILHO, ${ }^{2}$ EDINEU LOPES DOS SANTOS JUNIOR, ${ }^{3}$ CRISTIANE CLAUDIA MEINERZ , ${ }^{4}$ MARIA \\ ELENA MARTINS DIEGUES, ${ }^{5}$ IRINEIA PAULINA BARETTA, ${ }^{6}$ ROSILEY BERTON PACHECO
}

\author{
${ }^{1}$ Acadêmico bolsista do PIBIC/UNIPAR \\ ${ }^{1}$ Acadêmico do Curso de Medicina da UNIPAR \\ ${ }^{2}$ Docente da UNIPAR \\ ${ }^{3}$ Docente da UNIPAR \\ ${ }^{4}$ Docente da UNIPAR \\ ${ }^{5}$ Docente da UNIPAR
}

Introdução: A dengue é conceituada como uma arbovirose (doença causada por um vírus cujo agente transmissor é um artrópode), sendo caracterizada por sintomas comuns que incluem principalmente febre alta $\left(39^{\circ} \mathrm{C}\right.$ a $\left.40^{\circ} \mathrm{C}\right)$ de início abrupto, com duração média de três a cinco dias, associada a cefaleia intensa, mialgia, artralgia, prostração, dor retrorbital, anorexia, exantema, distúrbios gastrointestinais, prurido cutâneo e dor abdominal generalizada. A classificação da dengue a distingue em: dengue clássica, febre hemorrágica da dengue e dengue com complicações (CORREIA, 2019). O mosquito Aedes aegypti é o transmissor não somente dos quatro subtipos de dengue, mas também da febre amarela, da febre chikungunya e do zika vírus. Ademais, os países de clima tropical e subtropical, como o Brasil, apresentam condições climáticas favoráveis tanto ao seu desenvolvimento quanto a sua proliferação. Dessa forma, a multiplicação de casos ocorrentes no país reitera a necessidade de controle do vetor. Por tal motivo, surge a utilização do mosquito geneticamente modificado para a geração de descendentes inférteis, a qual constitui estratégia sofisticada de controle efetivo da transmissão. Entretanto, há alguns desafios face a sua implementação, principalmente no tocante a restrições metodológicas e éticas (WISE et al., 2018).

Objetivo: Analisar as variações de técnicas referentes à aplicação do Aedes aegypt transgênico e seu impacto na população selvagem a partir da geração de descendentes inférteis.

Desenvolvimento: É inegável que o controle do vetor associa-se não somente a partir das campanhas de saúde pública para combate ao desenvolvimento do mosquito em água parada com o respectivo apoio da população, mas também por meio de técnicas que inviabilizem a própria reprodução do Aedes aegypti. Nesse sentido, a Técnica do Inseto Estéril (Sterile Insect Technique SIT) consiste na criação voluptuosa, seguida pela esterilização utilizando radiação e posterior liberação de insetos machos em uma população selvagem e baseia-se principalmente em comprometer o potencial reprodutivo da espécie, uma vez que os machos liberados cruzarão com fêmeas selvagens, sendo que as gerações subsequentes sofrerão consequência desse processo: a grande quantidade de machos estéreis liberados ao longo do tempo torna a população-alvo suscetível ao colapso, ocorrendo, assim, a eliminação da espécie na área alvo (BERNATE; MEYER, 2017). As grandes vantagens da utilização da SIT consistem no fato de que a mesma não é danosa ao meio ambiente, ao passo que aproveita o comportamento do macho em localizar a fêmea para acasalar, porém, cabe salientar que, do ponto de vista ético e de biossegurança, a liberação de mosquitos machos estéreis somente deve acontecer caso não haja liberação concomitante de fêmeas, pois somente os machos não possuem hábitos hematófagos e, portanto, não transmitiriam patógenos. Desse modo, existe parcial inviabilidade do programa supracitado, pois a separação manual é dificultosa, apresentando alto índice de contaminação de fêmeas entre os machos estéreis na etapa de soltura. Além disso, outro impasse para a efetividade de implementação reside no fato de que a produção torna os machos irradiados menos competitivos em relação aos mosquitos selvagens para o acasalamento, além de um tempo de vida reduzido dos mosquitos transgênicos, em decorrência da etapa de esterilização por radiação em massa dos machos (BERNATE; MEYER, 2017). A liberação de insetos carregando um gene letal dominante (Release of Insect carrying a Dominant Lethal gene RIDL) consiste em uma técnica baseada no prejuízo à reprodução dos mosquitos selvagens de uma população-alvo, sendo que a aplicação da RIDL ocorre por meio do gene letal dominante associado a um promotor específico de fêmeas, em associação com a tetraciclina, a qual, por sua vez, funciona como um supressor, devido as baixas concentrações do fármaco promoverem a não ligação da proteína tTA ao DNA, prevenindo a expressão do gene letal, ou seja, a tetraciclina é utilizada para manter a colônia, pois funciona como mecanismo que desativa a expressão do gene letal dominante e, dessa maneira, evidentemente, o método diferencia-se da técnica anterior, porque, em vez de utilizar a separação manual de machos e fêmeas para posterior liberação, a simples remoção do repressor tetraciclina do sistema acaba por ocasionar a morte de todas as fêmeas, já que, em sua ausência, o gene letal dominante é ativado e, na etapa de cópula, os machos homozigotos para o gene letal, ao cruzarem com as fêmeas selvagens, produzem descendentes ou progênies heterozigotas, motivo pelo qual somente os 
machos sobrevivem (WILKE et al, 2009).

Conclusão: Constatam-se, assim, as vantagens da utilização da RIDL, comparativamente à SIT, nos fatores citados a seguir: danos ambientais inexistentes, quando não mínimos; insetos machos com maior capacidade de competição na etapa de cópula com a fêmea; ausência da radiação possibilitando que a acidental soltura de artrópodes não-irradiados não venha acontecer, além de poder-se aplicar em insetos que não toleram radiação; a liberação dos insetos é permitida em qualquer estágio de seu desenvolvimento. Pois, a aprimorada técnica de inserção de mosquitos transgênicos numa população selvagem é efetiva como modo de suprimir o vetor da doença, por meio da utilização da RIDL.

\section{Referências}

CORREIA, Tercio Cirqueira et al. Prevalência de dengue clássica e dengue hemorrágica no Brasil, entre 2011 e 2015 . Revista Eletrônica Acervo Saúde, n. 22, p. e753-e753, 2019.

BERNATE, Carmen; MEYER, João. Análise da distribuição espaço-tempo do mosquito Aedes aegypti geneticamente modificado. Proceeding Series of the Brazilian Society of Computational and Applied Mathematics, v. 5, n. 1, 2017.

WYSE, Ana Paula Pintado; ACEBAL, José Luiz; DE OLIVEIRA, Moisés Filgueira. Estudo do c omportamento antropofílico de mosquitos selvagens e transgênicos. In: Seminário de Discentes dos Programas de Pós-Graduação Stricto Sensu. 2018.

WILKE, André Barreto Bruno et al. Controle de vetores utilizando mosquitos geneticamente modificados. Revista de Saúde Pública, v. 43, p. 869-874, 2009. 


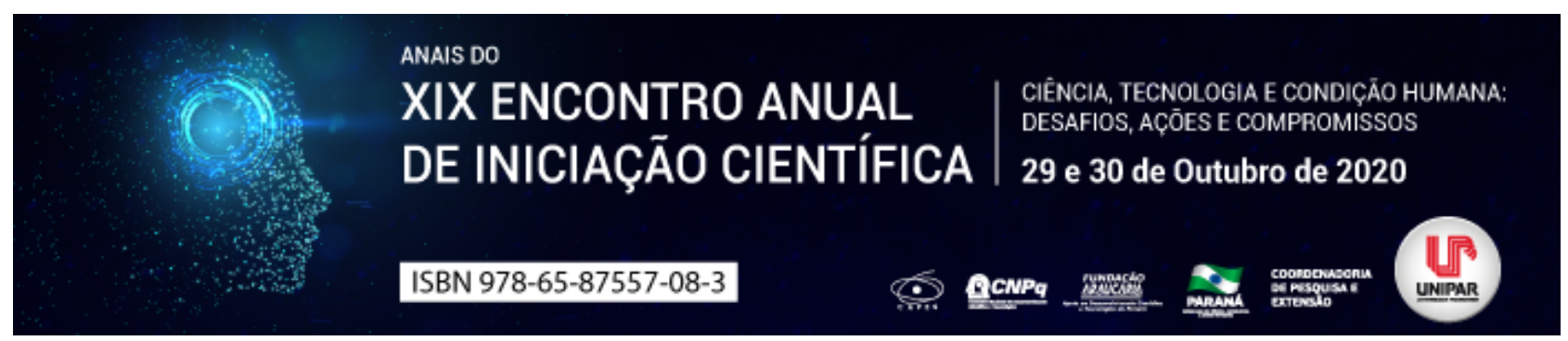

DISTÚRBIOS POSTURAIS DESENCADEADOS PELO USO INADEQUADO DOS APARELHOS DA TECNOLOGIA MODERNA

\section{${ }^{1}$ KARINE GREEF LAMB, ${ }^{2}$ DORA DE CASTRO AGULHON SEGURA}

${ }^{1}$ Acadêmico do curso de Fisioterapia UNIPAR

${ }^{1}$ Docente da UNIPAR

Introdução: O mundo moderno está caracterizado pelo uso muito comum dos recursos tecnológicos, como os dispositivos portáteis, nominados como smartphones, entretanto, a maioria das pessoas não se atenta para o uso responsável no quesito cuidar da saúde, mantendo a postura inadequada, mal posicionada, principalmente em região de coluna cervical, contribuindo para o desenvolvimento de sintomas osteomusculares e dor crônica (ABDELHAMEED; ABDELAZIEM, 2016). Sapziani et al. (2019) ressaltam que a postura atribuída ao corpo nas atividades rotineiras pode ser prejudicial, propiciando desgastes nas vértebras, discos e articulações vertebrais, sendo decorrente de posturas antálgicas e viciosas. Queiroz et al. (2018) evidenciaram que 60 (33\%) dos 183 adolescentes observados em um estudo pesquisando problemas relacionados ao uso inadequado do celular apresentaram mais de um tipo de síndrome álgica musculoesquelética, sendo que o músculo mais afetado foi o trapézio e grande parte dos adolescentes apresentaram além de dor, incapacidade física considerável.

Objetivo: Discorrer sobre como o uso dos aparelhos da tecnologia moderna influenciam na postura inadequada podendo causar desordens osteomusculares.

Desenvolvimento: Quando o pescoço é tracionado para frente, o peso da cabeça coloca uma pressão indevida nas vértebras da parte superior da coluna, contribuindo para uma possível doença degenerativa de disco e outros problemas articulares. Essa postura inadequada sobrecarrega músculos da parte superior do dorso para equilibrar a força da gravidade da cabeça. A posição geralmente possui ombros anteriorizados e um aumento da cifose torácica significativo causando dor severa e crônica (NEUPANE; ALI ITFHIKAR; MATHEW, 2017).Yong et al. (2011) apresentaram que o design e o ângulo de visão dos aparelhos celulares interferem no posicionamento da cabeça e do pescoço durante o uso, sobretudo, muito constante. Constataram que uma posição adequada para o uso de celulares, tablets, notbooks e computadores de uma forma geral, seria apoiado sobre uma mesa e não sobre o colo, ou em um ângulo de visão raso, o que propicia uma posição neutra do pescoço e da coluna, evitando não somente quadros dolorosos, mas também melhor performance corporal.

Conclusão: Tendo em vista a presença da tecnologia na atual sociedade, esse estudo buscou informar a população dos possíveis impactos osteomusculares causados pelo uso de aparelhos portáteis como smartphones, que geralmente se manifestam de forma negativa e como preveni-los. Levando a conclusão que a utilização dos equipamentos de forma apropriada assegura prevenção de dor e lesões, além da melhora da produtividade funcional corporal.

\section{Referências}

ABDELHAMEED, A. A.; ABDELAZIEM, A. M. R. Exercise training and postural correction improve upper extremity symptoms among touchscreen smartphone users. Hong Kong Physiotherapy Journal, v. 35, p. 37-44, 2016.

NEUPANE, S.; ALI ITFHIKAR, U.T.; MATHEW, A. Text neck syndrome - Systematic review. Imperial Journal of Interdisciplinary Research, v. 3, p. 01-08, 2017.

QUEIROZ, L. B.; LOURENÇO, B.; SILVA, L. E.; LOURENÇO, D. M.; SILVA, C. A. Musculoskeletal pain and musculoskeletal syndromes in adolescents are related to electronic devices. Jornal de Pediatria, v. 94, p. 673-679, 2018.

SAPZIANI, A. O.; MELKE, T. C.; SPAZIANI, L. C.; FRANQUEIRO, N. V. J.; AURELIANO, P. M. C.; RAMOS, R. R.; TALIARI, J. D. S. A frequência de distúrbios posturais na população jovem. Revista Científica Multidisciplinar Núcleo do Conhecimento, v. 7 , p. 70-78, 2019.

YONG, J. G.; TRUDEAU, M.; ODELL, D.; MARINELLI, K.; DENNEERLEIN, J. T. Touch-screen tablet user configurations and case-supported tilt affect head and neck flexion angles. Work (Reading Mass), v. 41, p. 81-91, 2011. 


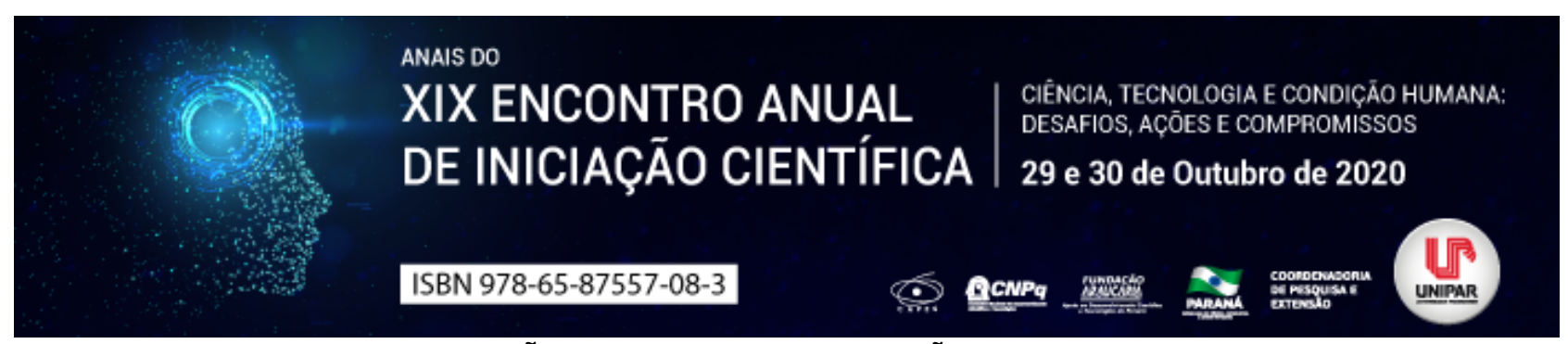

REABSORÇÕES RADICULARES:REVISÃO DE LITERATURA

\author{
${ }^{1}$ NATALIA LOPES HUNGARO, ${ }^{2}$ RAFAEL ANTONHOLI DA SILVA, ${ }^{3}$ TAIS LOPES NUNES, ${ }^{4}$ ANA CAROLINE DOS SANTOS \\ GRUNOW, ${ }^{5}$ LUIZ FERNANDO TOMAZINHO
}

\begin{abstract}
${ }^{1}$ Academica/UNIPAR
${ }^{1}$ Academico/UNIPAR

${ }^{2}$ Academica/UNIPAR

${ }^{3}$ Academica/UNIPAR

${ }^{4}$ Docente da UNIPAR
\end{abstract}

Introdução: O processo da reabsorção radicular é um processo tanto quanto frequente onde pode ser patológico e/ou fisiológico em que consiste na perda do tecido dentinário mineralizado bem como o cemento e dentina da superfície interna ou externa do dente em consequência da ação dos clastos. Na maioria dos casos é assintomático e acaba sendo descoberto em exames radiográficos de rotina. Pode comprometer as características anatômicas, funcionais e estéticas do dente (BRAMANTE et al.,2004). A reabsorção radicular fisiológica é um processo normal que ocorre em dentição decídua exceto nos casos em que ocorre prematuramente. Em relação à reabsorção patológica esta divide-se em inflamatória ou por substituição.

Objetivo: Este trabalho tem como objetivo realização de uma revisão de literatura sobre as reabsorções radiculares. Assim como sua etiologia, o diagnóstico, realçar as possíveis opções de tratamento, demonstrar a importância de efetuar um correto diagnóstico para posterior tratamento mais adequado.

Desenvolvimento: A reabsorção radicular interna também denominada de reabsorção intracanal, odontoblastoma, endodontoma ou granuloma interno, representa um processo patológico de ocorrência relativamente rara na qual ocorre reabsorção da face interna da cavidade pulpar. Sua etiologia não está totalmente estabelecida, sendo a maioria dos autores concordante de que o trauma é o principal agente etiológico (TROPE,1997; LOPES E SIQUEIRA JÚNIOR,1999; RUIZ et al.,2002; NEVILLE et al.,2005). Entretanto, pode estar relacionada a outros fatores, como cárie e restaurações profundas. Devido à ausência de sintomas a reabsorção radicular interna pode ser diagnosticada a partir da ocorrência de uma fratura ou ainda durante exames radiográficos de rotina (CONSOLARO,2005). A reabsorção externa é classificada de acordo com as características clínicas, em reabsorção superficial externa, reabsorção radicular externa inflamatória e reabsorção por substituição. A reabsorção radicular externa inflamatória é subdividida em reabsorção cervical e apical. Pode ocorrer como reação tardia pós-traumatismo dentário como conseqüência do movimento ortodôntico, cirurgia ortognática, tratamento periodontal, clareamento de dentes sem vitalidade pulpar, porém sua patogênese exata ainda é pouco conhecida (TRONSTAD,1991; HEIMISDOTTIR et al.,2005). No que diz respeito à reabsorção inflamatória esta ocorre quando algum fator causal atua no local onde se encontram os cementoblastos promovendo a sua remoção da superfície expondo desta forma a superfície radicular mineralizada aos osteoclastos promovendo a reabsorção radicular e a substituição por tecido de granulação inflamatório, mas temporariamente, uma vez que assim que seja removido o fator causal pode ser reparada.(CONSOLARO, 2011). Reabsorção Inflamatória Apical:Está estabelecida na região média ou apical da superfície radicular externa. A ruptura dos vasos sanguíneos do forame apical e consequentemente a necrose pulpar podem ocorrer após injurias como a avulsão e a luxação. Microorganismos chegarão ao canal radicular estabelecendo assim um processo de infecção endodôntica. Este tipo de reabsorção pode aparentar como uma flutuação ou fistula no exame clinico.(ANDREASEN, 1988) A reabsorção por substituição consiste em substituição do tecido radicular reabsorvido por osso levando a anquilose alveolodentária que é caracterizada por envolvimento de osteoblastos e cementoblastos que acabam por formar áreas de união do cemento com o osso. É considerada a reabsorção irreversível devido ao facto de que depois de remoção do fator causal não pode ser reparada. (CONSOLARO, 2011). As reabsorções dentárias inflamatórias têm como princípio terapêutico a eliminação da causa. Quando o processo inflamatório e o estresse celular cessam na área em reabsorção, as unidades osteorremodeladoras e seus clastos sofrem uma desmobilização e saem da superfície radicular: os mediadores desaparecem. $\mathrm{O} \mathrm{pH}$ da região volta ao estado de neutralidade e novos cementoblastos são formados, recolonizando a superfície radicular em alguns dias. Forma-se, em seguida, novo cemento, com reinserção das fibras colágenas no meio da nova camada cementoblástica.

Conclusão: As reabsorções tanto internas quanto externas caracterizam-se por um problema multifatorial e portanto a sua resolução clínica exige a necessidade de intervenção multiprofissional. O diagnóstico precoce por intermédio do controle e acompanhamento clínico-radiográfico dos pacientes com história de traumatismo dentário, constitui- se na melhor conduta para alcançar o sucesso no tratamento das reabsorções radiculares. O traumatismo dentoalveolar está entre os principais agentes etiológicos das reabsorções radiculares externas. Ainda existe uma grande variação quanto aos tratamentos, mas todos indicam 
uma limpeza do sistema de canais radiculares como forma de tentar a paralização do processo reabsortivo. O risco de recidiva do processo de reabsorção após o término do tratamento impõe o acompanhamento como forma imprescindível de controle e manutenção do sucesso clínico.

\section{Referências}

ANDREASEN, J. O.; ANDREASEN, F. M. Traumatismo dentário: soluçöes clínicas. In: Traumatismo dentário: soluçöes clínicas. 1991. p. 168-168.

BRAMANTE, Clovis Monteiro et al. Acidentes e complicações no tratamento endodôntico: soluções clínicas. Santos, 2003. CONSOLARO, Alberto. Reabsorções dentárias nas especialidades clínicas. In: Reabsorções dentárias nas especialidades clínicas. 2005. p. 616-616.

CONSOLARO, Alberto. O conceito de reabsorções dentárias ou As reabsorções dentárias não são multifatoriais, nem complexas, controvertidas ou polêmicas!. Dental Press Journal of Orthodontics, v. 16, n. 4, p. 19-24, 2011.

CONSOLARO, Alberto; FURQUIM, Laurindo Zanco. Extreme root resorption associated with induced tooth movement: a protocol for clinical management. Dental press journal of orthodontics, v. 19, n. 5, p. 19-26, 2014.

HEIMISDOTTIR, Kristin; BOSSHARDT, Dieter; RUF, Sabine. Can the severity of root resorption be accurately judged by means of radiographs? A case report with histology. American Journal of Orthodontics and Dentofacial Orthopedics, v. 128, n. 1, p. 106-109, 2005.

LOPES, Hélio Pereira; SIQUEIRA JUNIOR, José Freitas. Endodontia: biologia e técnica. In: Endodontia: biologia e técnica. 1999. p. 650-650.

NEVILLE, B.W., et al., (2005).Patologia oral e maxilofacial. Rio de Janeiro: Guanabara Koogan, 2005. 705 p.

NG, Lydia et al. Traumatic dental injuries presenting to a paediatric emergency department in a tertiary children's hospital, Adelaide, Australia. Dental traumatology, 2020.

RUIZ, P. A.; REZENDE, T. M. B.; COELHO, C. S. M. Reabsorção radicular interna: relato de três casos em um mesmo paciente. Bras Patol Oral, v. 1, n. 1, p. 47-50, 2002.

Coordenadoria de Pesquisa e Extensão - COPEX

Departamento de Editoraçāo e Divulgaçāo Científica - DEDIC 


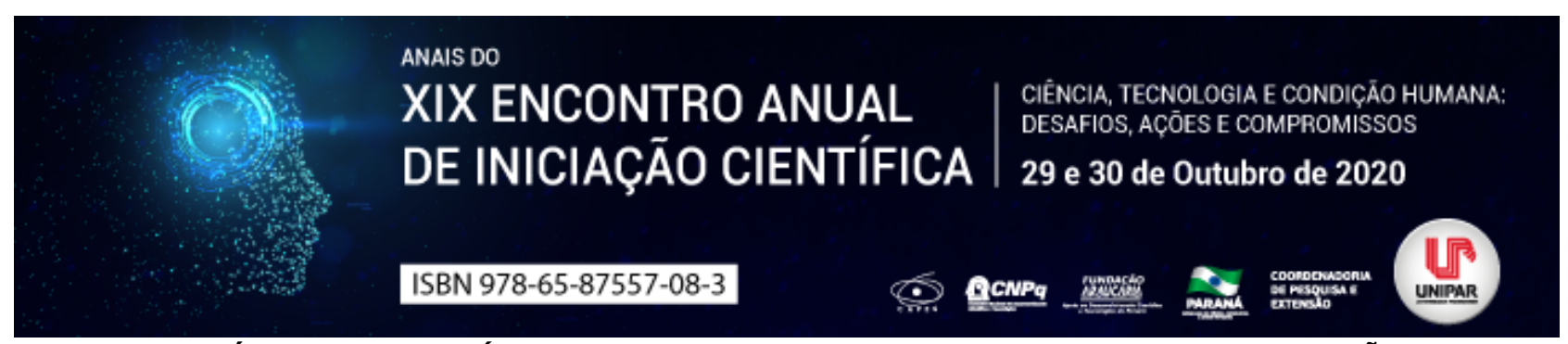

MIMÉTICOS DO DOMÍNIO BH3 NO TRATAMENTO DE NEOPLASIAS: UMA REVISÃO

\begin{abstract}
${ }^{1}$ CARLOS EDUARDO RUZZENE RODRIGUES, ${ }^{2}$ ANA BEATRIZ PINHEIRO ZAUPA, ${ }^{3}$ GABRIEL HENRIQUE BELLATO PALIN, ${ }^{4}$ HIGOR DIAS DO PRADO, ${ }^{5}$ ELIZABETI DE MATOS MASSAMBANI
\end{abstract}

\begin{abstract}
${ }^{1}$ Acadêmico do Curso de Medicina da UNIPAR
${ }^{1}$ Acadêmica do Curso de Medicina da UNIPAR

${ }^{2}$ Acadêmico do Curso de Medicina da UNIPAR

${ }^{3}$ Acadêmico do Curso de Medicina da UNIPAR

${ }^{4}$ Docente da UNIPAR
\end{abstract}

Introdução: Um tecido deve se manter em um tamanho ideal através da mesma taxa de morte e produção de células (ALBERTS, 2017). Em situações nas quais as células sofrem alterações neste equilíbrio, são acionados mecanismos que buscam mantê-lo, um deles é a apoptose. Assim, sinais apoptóticos ativam as caspases, enzimas proteolíticas que clivam proteínas específicas dentro da célula, culminando na morte celular. Vale lembrar que os fatores pró-apoptóticos precisam se desvencilhar dos fatores antiapoptóticos para que isso ocorra. Portanto, sob a ótica de Luchs (2010), as moléculas antiapoptóticas, quando em excesso, podem ser oncogênicas, haja visto que não ocorre o controle do tamanho tecidual. Ademais, a produção das moléculas pró-apoptóticas é controlada pela proteína p53, a qual se apresenta disfuncional em mais da metade dos cânceres. Felizmente, é possível encontrar hipóteses acerca da utilização de substâncias que mimetizam fatores próapoptóticos a fim de atenuar os danos causados por essas enfermidades.

Objetivo: Revisar estudos que utilizam moléculas similares a fatores pró-apoptóticos como forma de tratamento para neoplasias. Desenvolvimento: A princípio, as células do corpo vivem em harmonia umas com as outras, dividindo os substratos que chegam a elas, de forma a mantê-las vivas - como em um ecossistema, sem competição pela sobrevivência, apenas há a colaboração. Com o tempo, entretanto, essas células envelhecem e morrem, concluindo o ciclo celular ideal. Todavia, em alguns casos, uma mutação pode gerar células que consomem mais substrato, atrapalhando o bom convívio. Nesse contexto, esse evento pode comprometer o conjunto, em razão da falta de nutrientes para células sadias, mais fracas (ALBERTS, 2017). De forma geral, células descontroladas geneticamente convertem-se em cancerígenas. Dito isto, a apoptose é um dos processos fundamentais para a regressão tumoral e, portanto, a resistência aos seus mecanismos é uma das razões principais do surgimento de neoplasias (GASQUES et al, 2013). Segundo Brasileiro Filho (2016), as proteínas pró-apoptóticas, em especial a Bax e Bak, e antiapoptóticas, principalmente a Bcl-2 e Bcl-X, formam heterodímeros inibindo a função umas das outras. Com a inibição das proteínas pró-apoptóticas, devido às antiapoptóticas, a saída do citocromo $\mathrm{C}$ do interior das mitocôndrias é frustrado, obstando a ativação das caspases, responsáveis pelas mudanças morfológicas presentes na apoptose. Logo, é essencial que uma parcela das proteínas antiapoptóticas sejam inibidas para que ocorra o retrocesso do tamanho tecidual. As proteínas BH3- apenas realizam tal inibição, contudo, para que essas proteínas sejam expressadas, a molécula p53, um ativador de transcrição de sequências específicas precisa ser funcional. Em vista disso, a p53 ativa a transcrição das proteínas BH3, induzindo a apoptose, o problema encontra-se no fato de 70\% dos cânceres apresentarem mutações no gene que a dá origem (PIMENTA et al., 2013). Indubitavelmente, o acúmulo da proteína Bcl-2 ocorrerá e o processo supracitado não acontece (MONTOVANI, 2010). Desse modo, a simples restrição na atividade da Bcl-2 e Bcl-X é eficaz para que a célula inicie a morte celular programada (GASQUES; et al, 2013). É possível causar a inibição das moléculas antiapoptóticas através de moléculas que mimetizam o domínio BH3apenas, induzindo a regressão tumoral (TOGNON et al., 2013). Consequentemente, desenvolver medicamentos que aparentam proteínas BH3 amenizaria os danos causados por tecidos que crescem excessivamente (KUMAR, 2018). Por esse motivo, há estudos, em fase avançada, que analisam substâncias que se colocam no lugar inibitório dos fatores pró-apoptóticos, deixandoos livres para formação de poros na mitocôndria e, por resultado, o citocromo C livre no citoplasma. As estratégias para regular a hiperexpressão dos genes BCL-2 envolvem o Oblimersen sódico/G3139, oligonucleótidos anti-sense, droga capaz de perturbar o RNAm que sintetiza as proteínas em questão. Outrossim, os compostos miméticos BH3, por exemplo o ABT-737, mostram-se eficazes na apoptose de células cancerígenas (SILVA, 2014).

Conclusão: Conclui-se que a desfuncionalização dos fatores antiapoptóticos Bcl-2 e Bcl-X são suficientes para conduzir a célula a uma morte celular que não produz processos inflamatórios. Pensando nisso, cientistas buscam moléculas que sejam capazes de mimetizar o domínio BH3 de substâncias pró-apoptóticas, em falta nas células cancerígenas, muitas vezes, devido a mutação no gene produtor da proteína p53. Dessa forma, essas moléculas que possuem áreas similares ao domínio BH3 juntar-se-ão as proteínas antiapoptóticas, permitindo a ação das pró-apoptóticas. Destarte, espera-se que ocorra o retorno dos tecidos acometidos ao tamanho original, tornando provável a melhora do prognóstico em diversos casos. 


\section{Referências}

ALBERTS, Bruce. Biologia Molecular da Célula. 6. ed. São Paulo: Artmed, 2017.

BRASILEIRO FILHO, G. Bogliolo: Patologia. 9. ed. Rio de Janeiro: Guanabara Koogan, 2016.

GASQUES, Luciano Seraphim; GALVANINI, Paulo Alexandre; FAVARETTO, Fernando; SANTANA Tamara Francislaine; PAMPHILE, João Alencar. Independência ou morte: a apoptose como mecanismo de defesa. Arq. Ciênc. Saúde UNIPAR, Umuarama, v. 17, n. 1, p. 49-53, 2013.

KUMAR, Vinay; ABBAS, Abul; ASTER, Jon. C. Robbins: Patologia Básica. 10. ed. Rio de Janeiro: Elsevier, 2018.

LUCHS, Adriana; PANTALEAO, Cláudia. Apoptose e modelos in vivo para estudo das moléculas relacionadas a este fenômeno.

Einstein, São Paulo, v. 8, n. 4, p. 495-497, 2010.

MONTOVANI, Jair; SALES, Magaly; PARDINI, Maria Inês. Deteç̧ão do rearranjo da proteína BCL2/JH em carcinomas epidermoides de boca e faringe. Arquivos Int. Otorrin., São Paulo, v. 14, n. 3, p. 288-293, 2010.

PIMENTA, Vanessa Sousa Cruz; PRADO, Yandra Cassia Lobato; REZENDE E SILVA, Danilo; MACHADO, Patrícia Almeida; ARAÚJO, Eugênio Gonçalves. Papel da proteína p53 na proliferação neoplásica. Enciclopédia Biosfera, Centro Científico Conhecer, Goiânia, v. 9, n. 17, 2013. Disponível em: https://repositorio.bc.ufg.br/bitstream/ri/12588/5/.pdf. Acesso em: 16 jul. 2020.

SILVA, Ana Paula Silvério. Importância da apoptose nas neoplasias hematopoiéticas. Orientador: Leonor Correia. 2014.85 f. Dissertação (Mestrado em Análises Clínicas) - Universidade de Lisboa, Lisboa, 2014.

TOGNON, Raquel; NUNES, Natália Souza; CASTRO, Fabíola Attié. A. Desregulação da apoptose em neoplasias mieloproliferativas crônicas. Einstein, São Paulo, v. 11, n. 4, p. 540-544, 2013.

Coordenadoria de Pesquisa e Extensão - COPEX

Departamento de Editoraçāo e Divulgaçāo Científica - DEDIC 


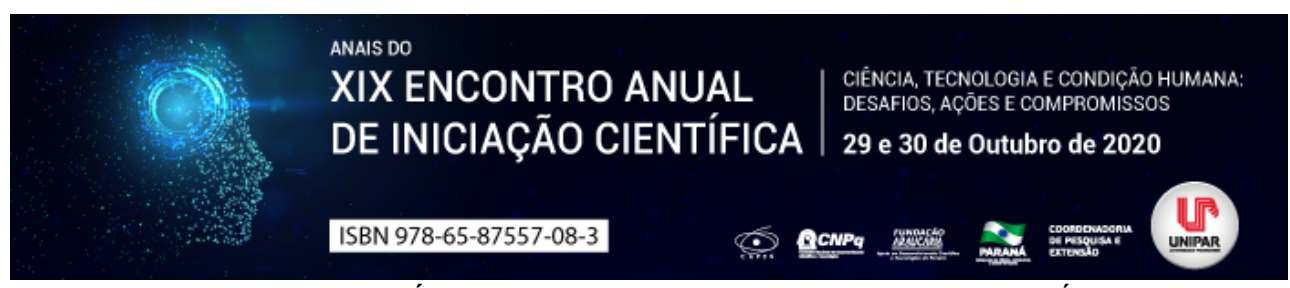

ANÁLISE COMPARATIVA ENTRE OS TRATAMENTOS CIRÚRGICOS PARA OBESIDADE, SLEEVE E BYBASS GÁSTRICO EM Y DE ROUX, EM RELAÇÃo ÀS CARÊNCIAS VITAMÍNICAS

\author{
${ }^{1}$ BRUNA LUANA CHAPLA, ${ }^{2}$ ANA BEATRIZ PINHEIRO ZAUPA, ${ }^{3}$ GABRIELA CAROLINA CREMONESE VON BORSTEL, ${ }^{4}$ PATRICIA RODRIGUES HAUCK PRANTE, \\ ${ }^{5}$ GUSTAVO MEIRELES COSTA, ${ }^{6}$ FABIO AUGUSTO DE CARVALHO
}

\author{
${ }^{1}$ Acadêmica do Curso de Medicina da UNIPAR \\ ${ }^{1}$ Acadêmica do Curso de Medicina da UNIPAR \\ ${ }^{2}$ Acadêmica do Curso de Medicina da UNIPAR \\ ${ }^{3}$ Docente da UNIPAR \\ ${ }^{4}$ Docente da UNIPAR \\ ${ }^{5}$ Docente da UNIPAR
}

Introdução: Conforme a OMS a obesidade pode ser definida como um acúmulo anormal ou excessivo de gordura corporal, que pode atingir graus capazes de afetar a saúde. Essa doença pode ser tratada com a cirurgia bariátrica, que consiste em um procedimento que modifica o trato gastrointestinal do paciente,visando uma diminuição da ingestão alimentar podendo estar associado ou não a hipo- absorção dos nutrientes (BAHIA e VIANNA, 2010).

Objetivo: Comparar, através de revisões de literatura, as duas técnicas mais frequentes de cirurgia bariátrica, bem como as alterações nutricionais geradas por elas.

Desenvolvimento: A obesidade é uma patologia de etiologia complexa e multifatorial, ocasionada pela interação de genes, ambiente, fatores emocionais, causas secundárias e estilo de vida. (BAHIA e VIANNA, 2010). Um dos métodos do tratamento são as cirurgias. Elas são classificadas em disabsortivas e/ou restritivas. As restritivas diminuem a capacidade de ingesta alimentar sendo exemplos a banda gástrica e a gastrectomia vertical ou sleeve. Já as cirurgias restritivas/disabsortivas acabam diminuindo a capacidade de absorção dos alimentos, bem como, a restrição alimentar. Os principais exemplos são o bypass gástrico em $Y$ de Roux e o duodenal Switch ou derivação bíleo-pancreática. (FANDINO et al, 2004). Dentre esses tipos de cirurgia bariátrica destacam-se o sleeve e o bypass gástrico em Y de Roux, como os procedimentos mais realizados. No procedimento sleeve ocorre uma restrição gástrica, com remoção de $70 \%$ a $80 \%$ do estômago, com retirada do corpo, fundo e parte do antro gástrico, levando a restrição alimentar e diminuição do hormônio grelina, responsável por ativar o centro da fome no hipotálamo. a. O bypass, além da restrição mecânica representada pela redução gástrica, ocorre hipoabsorção dos nutrientes e modifica a produção das incretinas, hormônios que modulam a fome e a saciedade (BAHIA e VIANNA, 2010). Em estudo feito por Ferraz et al (2018), comparando as técnicas sleeve e bypass gástrico com relação às deficiências nutricionais de hemoglobina, ferritina, ferro, zinco e da vitamina B12, tanto no pré operatório quanto em 3, 6, 12 e 24 meses após a realização da cirurgia, constata-se que os pacientes que realizaram a operação do tipo sleeve apresentaram níveis maiores de zinco e ferro do que pacientes que realizaram o bypass gástrico. Ademais, com relação aos demais nutrientes (hemoglobina, ferritina e vitamina B12), os resultados apresentados foram conflitantes.

Conclusão: Em revisão de literatura comparando as técnicas de sleeve e bypass gástrico para o tratamento da obesidade, em relação à deficiência de micronutrientes, os níveis de ferro e zinco encontram-se reduzidos em pacientes que realizaram o bypass gástrico, principalmente de zinco, com maior significância estatística. Com relação aos outros nutrientes, são necessários mais estudos com maior período de observação para uma conclusão definitiva.

\title{
Referências
}

BAHIA, Luciana.; VIANNA, Denizar. Cirurgia Bariátrica: Pareceres técnicos-científicos. Instituto de Estudos de Saúde Suplementar, UERJ, Rio de Janeiro, 2010, p. 184, v.1. Disponível em: https://www.tjrs.jus.br/export/poder_judiciario/tribunal_de_justica/centro_de_estudos/doutrina/doc/PARECER_CIENTIFICO_SOBRE_CIRURGIA_BARIATRICA.pdf. Acesso em: 19 ago 2020.

FANDINO, Julia et al. Cirurgia Bariátrica: aspectos clínico-cirúrgicos e psiquiátricos. R. Psiquiatr. RS, 2004, vol. 26. n.1, p. 47-51,. Disponível em: https://www.scielo.br/scielo.php?script=sci_arttext\&pid=S0101-81082004000100007. Acesso em: 19 ago. 2020.

FERRAZ, Álvaro Antonio Bandeira et al. Deficiências de micronutrientes após cirurgia bariátrica: análise comparativa entre gastrectomia vertical e derivação gástrica em Y de Roux. Revista do Colégio Brasileiro de Cirurgiões, 2018, vol.45, no.6, Rio de Janeiro. Disponível em: https://www.scielo.br/scielo.php? script=sci_arttext\&pid=S0100-69912018000600155. Acesso em 23 ago 2020. 


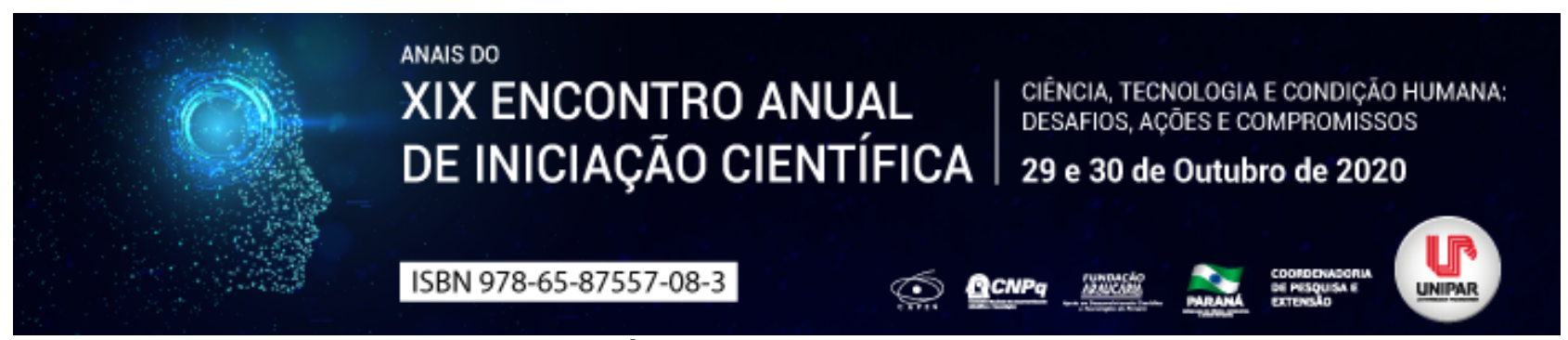

EFEITOS BIOLÓGICOS DA Croton urucurana BAILL

\begin{abstract}
${ }^{1}$ PRISCILA MEGDA JOAO JOB ZAGO, ${ }^{2}$ AMANDA NASCIMENTO VASQUES DE SOUZA, ${ }^{3}$ FRANCISLAINE APARECIDA DOS REIS LIVERO
\end{abstract}

\footnotetext{
${ }^{1}$ Mestranda em Plantas Medicinais e Fitoterápicos na Atenção Básica, Universidade Paranaense

${ }^{1}$ Mestranda em Plantas Medicinais e Fitoterápicos na Atenção Básica, Universidade Paranaense

${ }^{2}$ Docente do Mestrado Profissional em Plantas Medicinais e do PPGCA UNIPAR
}

Introdução: A Croton urucurana Baill, popularmente conhecida como sangra d'agua, pau-de-sangue ou sangue-de-dragão é uma árvore da família Euphorbiaceae, distribuída no Cerrado brasileiro, que pode atingir 6 a 8 metros de altura. Quando seu tronco é cortado ou ferido, libera uma seiva que em contato com o ar se torna resinosa e adquire a cor vermelha como sangue (LORENZI et al., 2002). Na medicina popular brasileira, preparados farmacológicos da casca das espécies de C. urucurana vêm sendo utilizado como analgésico, anti-inflamatório e anticancerígeno (RANDAU et al., 2002). Da casca da árvore, extrai-se um látex vermelho que é utilizado como cicatrizante, antibiótico, purgativo e curativo para micoses. Embora a eficácia e segurança do uso desta planta ainda precisem de maior comprovação, sua utilização popular é transmitida com base na tradição popular, que utiliza cascas da espécie, Ihe atribuindo propriedades anti-inflamatórias, antiulcerogênica, analgésica, antidiarreica e cicatrizante (SILVA et al., 1998; GURGEL et al., 2001; RAO et al., 2007; CORDEIRO et al., 2016; CANDIDO-BACANI et al., 2017).

Objetivo: Descrever as propriedades medicinais da Croton urucurana Baill.

Desenvolvimento: Os principais constituintes da C. urucurana são taninos, lignanas e taspina, um alcaloide. Os taninos são polifenóis com ação adstringente, sendo usados no tratamento de diarréia, hipertensão arterial, reumatismo, hemorragias, feridas, queimaduras, problemas estomacais e urinários (HASLAM, 1996). As lignanas são um tipo de fito-hormônios, com ação antimitótica, anticonvulsivante, depressora do sistema nervoso central, antibacteriana e analgésica (ALVES et al., 2003). A taspina tem ação anti-inflamatória e antioxidante (SILVA et al., 1998). O látex de C. urucurana já foi identificado como agente anticâncer devido a seus efeitos citotóxicos, induzindo apoptose com interrupção do ciclo celular em modelos com hepatocarcinoma (CANDIDO-BACANI et al., 2017). O extrato da casa da planta também mostrou ação citotóxica contra células leucêmicas in vitro (VIEIRA et al., 2017). Outro estudo com a espécie mostrou redução de edema e menor recrutamento leucocitário em cavidade peritoneal de camundongos, com atividade anti-inflamatória e antinociceptiva, relacionados a presença de alcalóides e flavonóides, corroborando seu efeito antiulcerogênico (CORDEIRO et al., 2016). Estudos in vitro também demonstram ação anti-fúngica contra 5 tipos de dermatófitos (GURGEL et al., 1997) e antibacteriana contra S. pyogenes, K. pneumoniae, P. aeruginosa, S. typhimurium, S. aureus, S. epidermidis, E. Faecalis e E. coli (OLIVEIRA et al., 2008). Também conhecida é a propriedade nociceptiva da C. urucana, com supressão de dor visceral, com possível mecanismo opióide, reforçando sua indicação como analgésico em condições gastrointestinais e patologias do trato urinário em modelo animal (RAO et al., 2007). Ainda, um estudo evidenciou efeito antidiarréico desta espécie em diarréia induzida por óleo de mamona em rato, com inibição do trânsito intestinal e potencial indicação no controle de enfermidades associadas à diarréia secretora (GURGEL et al., 2001).

Conclusão: Com a referente pesquisa, permitiu-se constatar a importância da Croton urucurana e seu grande potencial de utilização, contendo, principalmente, efeito anti-inflamatório, antiulcerogênico, antidiarreico e cicatrizante, com potencial para o desenvolvimento de medicamentos.

\title{
Referências
}

ALVES, D. L.; SILVA, C. R. Fitohormônios. Abordagem natural da terapia hormonal. São Paulo: Editora Atheneu, 2003.

CANDIDO-BACANI, P. M.; et al. [1 9-NaC]-crourorb A1 isolated from Croton urucurana latex induces G2/M cell cycle arrest and apoptosis in human hepatocarcinoma cells. Toxicology Letters, v. 273, p. 44 54, 2017.

CORDEIRO, K. W.; et al. Anti-inflammatory and antinociceptive activities of Croton urucurana Baillon bark. Journal of Ethnopharmacology, v. 183, p. 128-135, 2016.

GURGEL, L. A.; SIDRIMB, J. J. C.; MARTINS, D. T.; CHECHINEL FILHO, V.; RAO, V. S. In vitro antifungal activity of dragon's blood from Croton urucurana against dermatophytes. Journal of Ethnopharmacology, v. 97, p. $409412,2005$.

GURGEL, L. A.; et al. Studies on the antidiarrheal effect of dragon's blood from Croton urucuran. Phytotherapy Research, v. 15, p. 319-22, 2001.

HASLAN, E. Natural polyphenois (vegetables tanins) as drugs and medicines, possible modes of action. Journal of Natural Products, v. 59, p. 205-215, 1996.

LORENZI, H.; MATOS, F. J. A. Plantas medicinais no Brasil - Nativas e Exóticas. Nova Odessa: Instituto Plantarun, p. $512,2002$. 
RAO, V.S., et al. Dragon's blood from Croton urucurana (Baill.) attenuates visceral nociception in mice. Journal of Ethnopharmacology, v. 113, p. 357-60, 2007.

SILVA, G.A.; GONÇALVES, M. I. A.; BACCHI, E. M. Taspina, um alcalóide cicatrizante isolado do látex de Croton urucurana Baill. Revista de Farmácia e Bioquímica da Universidade de São Paulo, v. 34, p. 67, 1998.

VIEIRA, G. T.; OLIVEIRA, T. T.; MONTEIRO, L. P.; KANASHIRO, M. M.; COSTA, M. R.; PEREIRA, W. L. Atividade citotóxica do extrato de Croton urucurana Baill contra linhagens de células leucêmicas humanas U937 e THP1. Ciência e Natura, v. 39 , p. 512-519, 2017.

OLIVEIRA, I. S.; LIMA, J. C. S.; SILVA, R. M.; MARTINS, D. T. O. Triagem da atividade antibacteriana in vitro do látex e extratos de Croton urucurana Baillon. Revista Brasileira de Farmacognosia, v. 18, p. 587-593, 2008.

Coordenadoria de Pesquisa e Extensão - COPEX

Departamento de Editoraçāo e Divulgaçāo Científica - DEDIC 


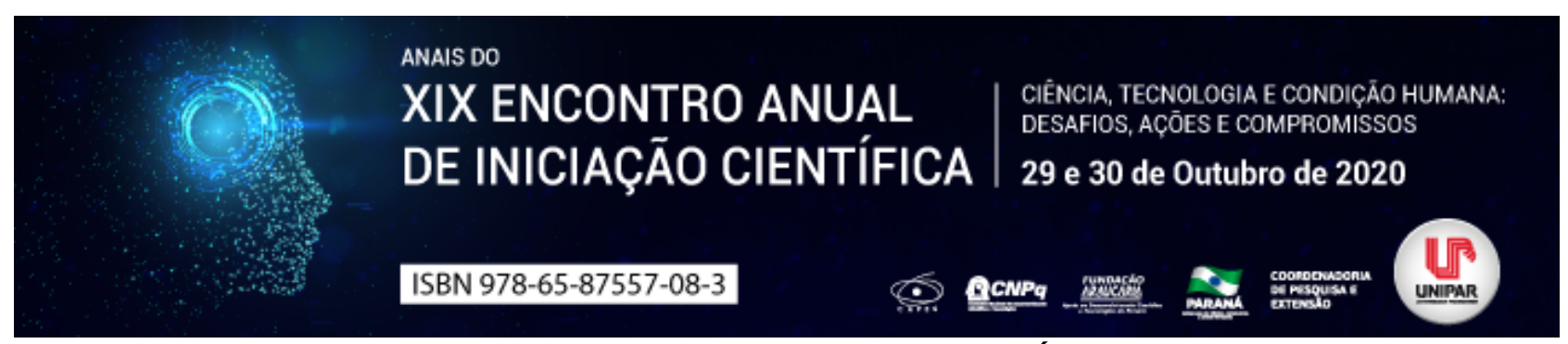

ENCARCERADAS: DEPRESSIVAS INVISÍVEIS

\title{
${ }^{1}$ NAIANY OLIVOTTO MARTINS, ${ }^{2}$ BRENDA PASSOS BESAGIO, ${ }^{3}$ ISABELLA ARANTES TOBBIN, ${ }^{4}$ TAMILA SIMINSKI
}

\author{
${ }^{1}$ Acadêmico do PIC/UNIPAR \\ ${ }^{1}$ Acadêmica do Curso de Medicina da UNIPAR \\ ${ }^{2}$ Acadêmica do Curso de Medicina da UNIPAR \\ ${ }^{3}$ Docente da UNIPAR
}

Introdução: A população carcerária feminina corresponde a 4,94\% do total de presos no Brasil (INFOPEN, 2019). O sistema carcerário brasileiro é considerado punitivo e incapaz de ressocializar o indivíduo, sendo de suma importância diante desse cenário destacar o processo de depressão em mulheres encarceradas em regime fechado (SILVA, 2016). Segundo a OMS (Organização Mundial da Saúde), cerca de 12 milhões de brasileiros sofrem com a depressão, esse número coloca o Brasil em segundo lugar das Américas, sendo ultrapassado apenas pelo Estados Unidos. Estima-se que no Brasil cerca de 25\% das pessoas teve ou terá em algum momento depressão, sendo as mulheres as mais afetadas, podendo nos piores casos levar ao suicídio.

Objetivo: Retratar a depressão em mulheres presas em regime fechado por meio de uma revisão de literatura. Desenvolvimento: A população carcerária possui uma propensão ao desenvolvimento de doenças mentais por viverem em confinamento e em condições insalubres (SILVA, 2016). Neste sentido destaca-se a depressão que é uma patologia caracterizada principalmente por um sentimento de tristeza permanente, desinteresse em atividades que antes eram prazerosas, insônia ou hipersônia, cansaço excessivo, aumento ou diminuição de apetite, humor depressivo, ansiedade e pensamentos suicidas (OPAS, 2017). Naturalmente, as mulheres são mais afetadas pela depressão quando comparadas aos homens, cerca de duas vezes mais (ZENDER; OLSHANSKY, 2009). Existem várias razões para isso acontecer, como a diferença anatômica entre os cérebros dos homens e mulheres, um exemplo disso é a região do lóbulo frontal, responsável pela produção de pensamentos, escolha de decisões e memórias laborais, sendo essa área maior em pessoas do sexo feminino (MARIEB; WILHELM; MALLAT, 2014; ZENDER; OLSHANSKY, 2009). Além disso, as mulheres passam por períodos pré-menstruais, gravidez e menopausa, que se caracterizam por mudanças hormonais. Por essas alterações as mulheres ficam mais vulneráveis à depressão, pela diferença de interação entre os hormônios e as redes neuronais (SOARES; PROUTY; POITRAS, 2002). São inúmeros os fatores que propiciam a depressão em presas, entre eles é possível destacar o isolamento social e consequentemente o distanciamento da família, uma vez que maioria das prisões femininas são localizadas nas grandes cidades, dificultando as visitas de familiares que residem nos interiores (SILVA, 2016). Um estudo realizado por Canazaro e Argimon (2010), com 287 mulheres na Penitenciária Feminina do Estado do Rio Grande do Sul, evidencia que aproximadamente $49 \%$ das presidiárias analisadas possuem sintomas depressivos, um pouco mais de $30 \%$ faz uso de medicamento psiquiátrico com prescrição médica e aproximadamente $17 \%$ usam medicamento psiquiátrico sem prescrição. Outro fator que chama a atenção, é a história patológica pregressa dessas mulheres, aproximadamente 32\% apresentam histórico familiar de depressão (CANAZARO; ARGIMON, 2010). Segundo o INFOPEN (2019) a taxa de suicídio em mulheres privadas de liberdade ultrapassada $23 \%$ e quando há depressão associada, o risco de suicídio aumenta 20 vezes (BOTEGA, et al., 2006). De acordo com Botega e colaboradores (2006) um dos fatores que também influenciam no desenvolvimento da depressão em presas, é a pouca assistência psicológica, aumentando dessa forma a vulnerabilidade dessas mulheres. A principal forma de diagnóstico da depressão é pela anamnese médica, que consiste em uma avaliação a partir do histórico de sintomas narrados pela paciente, mais precisamente por meio da história de doença atual. (PARK; ZARATE JUNIOR, 2019). Contudo no Brasil inteiro, existem apenas 235 psiquiatras e 1244 psicólogos para atender a uma demanda de 36.929 mulheres (INFOPEN, 2019). Além de poucos profissionais capacitados, é fundamental salientar a omissão do poder público em relação a saúde mental das mulheres encarceradas. Grande parte das casas de detenção não disponibilizam um tratamento adequado para depressão, tampouco há um local exclusivo para mulheres portadoras de doenças mentais morarem. Assim, essas mulheres são jogadas em selas comuns, onde sofrem agressões e são exploradas por outras detentas, sem nenhum tratamento correto para sua enfermidade (OEA, 2007).

Conclusão: A depressão é uma doença grave, omitida no sistema carcerário feminino, sendo um fator de risco à vida das detentas. Diante disso são necessárias medidas governamentais que amenize essa situação, como o aumento no número de profissionais da saúde nos presídios, de forma uniforme em todo país e protocolos adequados para cada patologia. Por fim, também é essencial a coleta de dados mais específicos sobre as depressões na população feminina encarcerada, já que existe uma carência dessas informações. 


\section{Referências}

BOTEGA, Neury José. et al. Prevenção do comportamento suicida. Psico,[S.L], v. 37, n. 3, p. 5, 2006.

BRASIL. Organização de Nações Unidas. Depressão é tema de campanha da OMS para Dia Mundial da Saúde de 2017. ONUBR 2016. Disponível em: encurtador.com.br/ahtX5. Acesso em: 08 de agos. 2020.

CANAZARO, Daniela; ARGIMON, Irani Iracema de Lima. Características, sintomas depressivos e fatores associados em mulheres encarceradas no Estado do Rio Grande do Sul, Brasil. Cad. Saúde Pública, Rio de Janeiro, v. 26, n.7, p.1323-1333, 2010.

Departamento Penitenciário Nacional. Levantamento Nacional de Informações Penitenciárias (INFOPEN). 2019.

DUARTE, Thais Lemos. Intimidade no cárcere: Perfil dos presos cadastrados para realizar visitas íntimas no Rio de Janeiro. Dilemas: Revista de Estudos de Conflito e Controle Social, [S.L], v. 7, n. 3, p. 607-640, set. 2014.

MARIEB, Elaine N.; WILHELM, Patricia Brady; MALLAT, Jon. Anatomia Humana. 7. ed. São Paulo: Pearson Education do Brasil, 2014.

ORGANIZAÇÃO DOS ESTADOS AMERICANOS (OEA). Relatório sobre mulheres encarceradas no Brasil. Documento apresentado à Corte Interamericana de Direitos Humanos. Fevereiro, 2007.

ORGANIZAÇÃO PAN-AMERICANA DE SAÚDE (OPAS). Depressão: o que você precisa saber. Brasília, 2017. Disponível em: encurtador.com.br/MNVZ1. Acesso em: 25 jul. 2020.

SILVA, Jeferson Barbosa. Mulheres invisíveis, mentes esquecidas: a saúde mental de mulheres sob privação de liberdade. 2016. 125 f. Dissertação (Mestrado)- Curso de Enfermagem, Universidade Federal da Paraíba, João Pessoa, 2016.

SOARES, Cláudio N; PROUTY, Jennifer; POITRAS, Jennifer. Ocorrência e tratamento de quadros depressivos por hormônios sexuais. Rev. Bras. Psiquiatr., São Paulo, v. 24, supl. 1, p. 48-54, Apr. 2002.

ZENDER, Robynn; OLSHANSKY, Ellen. Women's Mental Health: Depression and Anxiety. Nursing Clinics Of North America, California, v. 44, n. 3, p. 355-367, set. 2009. 


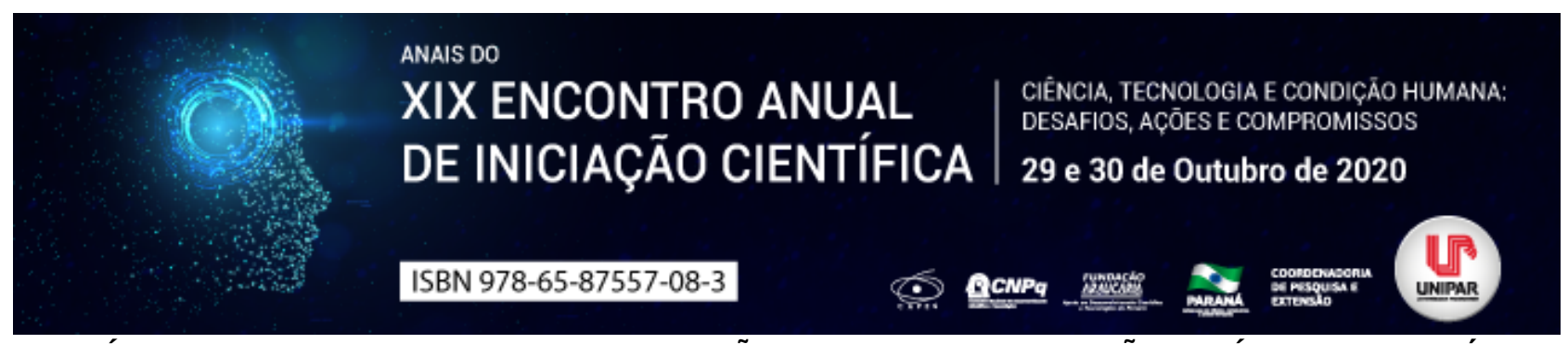

ASCARIDÍASE E SEUS ASPECTOS DE TRANSMISSÃO, CICLO, MANIFESTAÇÕES CLÍNICAS, DIAGNÓSTICO E PROFILAXIA

\author{
${ }^{1}$ RENAN CORADIN, ${ }^{2}$ GABRIELA BEVILAQUA OKABAYASHI, ${ }^{3}$ JENIFFER VIEPRZ MORAIS, ${ }^{4}$ ELENIZA DE VICTOR \\ ADAMOWSKI CHIQUETTI
}

${ }^{1}$ Acadêmico do curso de Medicina da UNIPAR
${ }^{1}$ Acadêmica do Curso de Medicina da UNIPAR
${ }^{2}$ Acadêmica do Curso de Medicina da UNIPAR
${ }^{3}$ Docente do Curso de Medicina da UNIPAR

Introdução: As infecções parasitárias intestinais afetam a maior parte da população mundial (PINHEIRO, 2011 apud MELO; BARROS, 2017). O enteroparasita mais comum encontrado é o nemalteminto Ascaris lumbricoides, causador da Ascaridíase, uma parasitose intestinal que acomete cerca de um bilhão de pessoas no mundo (ORGANIZAÇÃO MUNDIAL DA SAÚDE, 2011 apud MELO; BARROS, 2017). De acordo com Coelho et al., (2001 apud MENDES; et al 2016) as parasitoses representam um grave problema de saúde pública, visto que as suas formas de transmissão são consideradas indicadores de desenvolvimento socioeconômico de um país ou de uma região.

Objetivo: Abordagem revisional sobre as formas de transmissão da Ascaridíase, relacionando a infecção parasitária ao contexto ambiental e socioeconômico da população que favorecem a disseminação do parasita. Caracterizando a parasitose, suas manifestações clínicas, ciclo biológico, diagnóstico e prevenção.

Desenvolvimento: A ascaridíase costuma ser assintomática, porém em situações de carga parasitária moderada ou alta, pode resultar em manifestações clínicas como desnutrição, principalmente em crianças (MELO; BARROS, 2017). Essa doença é considerada a verminose mais comum em regiões pobres, caracterizando um grande problema para a saúde pública (LOPES, 2018). De acordo com NEVES, (2011 apud DIAS, 2018) o parasita causador da ascaridíase é o Ascaris lumbricoides, o qual é encontrado em todos os países do mundo, levando em conta fatores como clima, ambiente, e principalmente a condição socioeconômica da população. A transmissão costuma ocorrer pela via fecal-oral, onde há a ingestão de alimentos com a presença do parasita em sua forma infectante (ALVES, 2014 apud MELO; BARROS, 2017). Em relação ao seu ciclo biológico, este é simples e monoxênico, no qual se inicia com a ingestão das larvas L3 (forma infectante) que atravessam o trato gastrointestinal chegando ao intestino delgado, onde ocorre a eclosão das larvas com auxílio das condições do local. Após serem liberadas, as larvas alcançam o ceco e penetram na mucosa até caírem na circulação sanguínea e linfática, as quais proporcionam a chegada ao fígado. As larvas aumentam de tamanho e logo chegam ao átrio direito do coração e em seguida aos pulmões, sendo neste último onde ocorre o ciclo de Loss. Em seguida, as larvas mudam para o estágio L4, rompem os capilares e chegam aos alvéolos, onde chegam à fase L5. Sobem pela árvore brônquica até atingir a faringe, podendo ser expelidas ou deglutidas. Caso forem deglutidas, chegam ao intestino delgado e se tornam adultos, posteriormente se tornam maduros sexualmente e realizam cópula e oviposição, e os ovos formados são expelidos juntamente com as fezes (REY, 2011; KHUROO et al., 2016; SILVA; MASSARA, 2016; COOPER; HOLLINGSWORTH, 2018 apud LOPES, 2018). Ao chegarem ao ambiente exterior, os ovos são embrionados, formando consecutivamente L1, L2 e L3, até que o ciclo se repita com uma nova infecção (HALL; HOLLAND, 2000; SCOTT, 2008 apud LOPES, 2018). Em relação aos sinais e sintomas causados pelo Ascaris lumbricoides quando estão em migração nos pulmões são febre, tosse, respiração com sibilos e sangue no escarro. Mas, em pequenas quantidades no intestino não costuma apresentar sinais e sintomas, porém, em números elevados se manifesta com cólicas, enjoo, vômitos e distensão abdominal (MELO; BARROS, 2017). A forma de diagnóstico mais precisa é a laboratorial, no qual é realizada uma análise de amostra de fezes, sendo diagnosticada ao identificar ovos ou vermes na amostra fecal. Em algumas situações ainda, esses vermes podem estar saindo pelo nariz ou pela boca. De forma complementar, podem ser usados métodos como a tomografia computadorizada ou ultrassonografia (PATRIARCHA, 2012). Assim, a forma de profilaxia para essa verminose é a lavagem correta das mãos e dos alimentos a serem consumidos, possuir saneamento básico e a educação em saúde.

Conclusão: Tendo em vista a importância do controle da doença para a Saúde Pública, e do risco que esta ocasiona quando não diagnosticada e tratada precocemente, podendo levar a complicações maiores visto que o ciclo do parasita ocorre e se repete o interior do organismo, medidas de prevenção e controle de higiene são imprescindíveis e estas devem ser reforçadas principalmente as pessoas de maior vulnerabilidade à doença.

\title{
Referências
}


DIAS, J. S. Ascaridíase em meio ao cenário ambiental e socioeconômico de Santa Helena, Baixada Maranhense, Brasil. Universidade Federal do Maranhão. Pinheiro/MA, 2018.

LOPES, C. A. Imunodiagnóstico da ascaridíase humana: uma nova abordagem sorológica utilizando a tecnologia IgY. Universidade Federal de Uberlândia. Uberlândia, 2018.

MELO, Z. F. M.; BARROS, M. C. E. S. Complicações da Ascaridíase em crianças: Uma revisão literária. Centro Universitário de Brasília - UNICEUB. Brasília, 2017.

MENDES, A. N.; COSTA E SILVA, A. C.; KOPPE, E. C.; FILGUEIRAS, L. A. Incidência de ascaridíase em comunidade quilombola de Cachoeiro de Itapemirim, Espírito Santo, Brasil. Boletim Informativo Geum, v. 7, n. 1, p. 28-33, jan./mar. 2016.

PATRIARCHA, A. P. Parasitismo por Ascaris lumbricoides: abordagem teórica. Faculdade de Educação e Meio Ambiente FAEMA. Ariquemes/RO, 2012. Disponível em: Acesso em: 30 jun. 2020. 


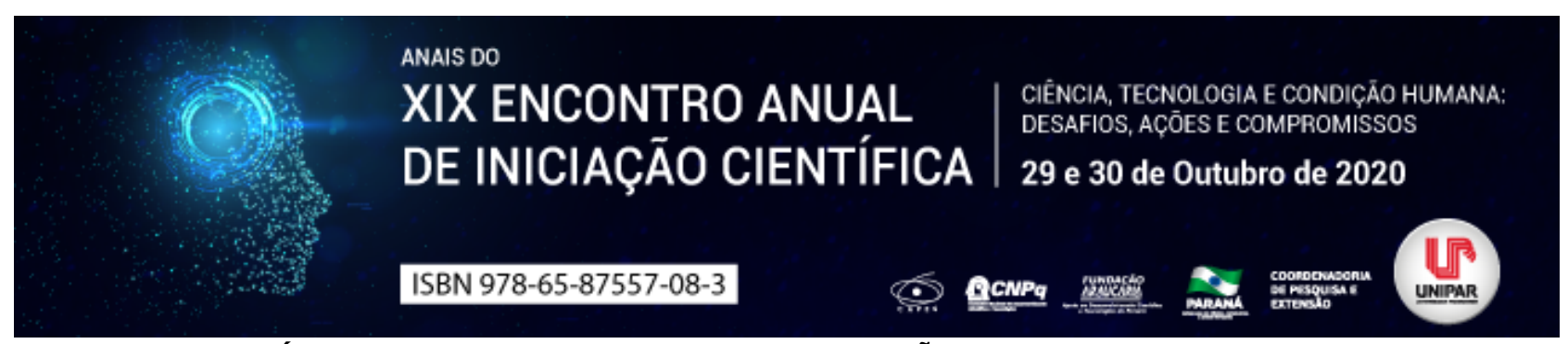

BENEFÍCIOS ERGOGENICOS DA SUPLEMENTAÇÃO COM SUCO DE BETERRABA

\begin{abstract}
${ }^{1}$ FRANCIELE SANTANA DOS SANTOS, ${ }^{2}$ DANIEL ALBERTO DE OLIVEIRA CLAUS, ${ }^{3}$ GABRIEL REZENDE BULLA, ${ }^{4}$ GABRIELA ALVES TRINDADE, ${ }^{5}$ JOAO PAULO GUIAO, ${ }^{6}$ ALAN PABLO GRALA
\end{abstract}

\author{
${ }^{1}$ Acadêmica do curso de Educação Física - PIC/UNIPAR \\ ${ }^{1}$ Acadêmico do curso de Educação Física - PIC-EAD/UNIPAR \\ ${ }^{2}$ Acadêmico do curso de Educação Física - PIC/UNIPAR \\ ${ }^{3}$ Acadêmica do curso de Educação Física - PIC/UNIPAR \\ ${ }^{4}$ Acadêmico do curso de Educação Física - PIC-EAD/UNIPAR \\ ${ }^{5}$ Docente do Curso de Educação Física - UNIPAR EAD
}

Introdução: No esporte competitivo, aumentos de 0,5\%

1,0\% no desempenho são considerados críticos para a vitória e qualquer recurso capaz de possibilitar esse ganho é extremamente relevante no contexto esportivo. Um dos recursos mais comuns utilizados para melhorar o desempenho físico são os suplementos dietéticos, frequentemente consumidos por atletas e praticantes de exercícios físicos para auxiliar no treinamento ou no alcance de objetivos pessoais. Recentemente, um grande corpo de evidências vem destacando o potencial ergogênico do suco de beterraba, rico em nitrato inorgânico. A suplementação com nitrato dietético pode favorecer o desempenho nos esportes e nos esforços de alta intensidade, e vem se tornando cada vez mais popular entre atletas competitivos e recreacionais (DOMINGUÉZ et al., 2017). O ciclismo é uma modalidade que requer tanto potência aeróbia quanto anaeróbia e exige do ciclista a habilidade de gerar muita potência por um curto espaço de tempo em momentos como a largada, subidas e sprints finais, sendo ainda necessário sustentar níveis de elevados de força por longos períodos (FARIA E; FARIA I; PARKER, 2005). Frente a essas características e necessidades do ciclismo, a suplementação com nitrato dietético, na forma de suco de beterraba, poderia ser uma estratégia efetiva para aprimorar o desempenho dos ciclistas.

Objetivo: Identificar por meio de uma revisão de literatura os benefícios da suplementação com suco de beterraba para o desempenho no ciclismo.

Desenvolvimento: $\mathrm{O}$ suco de beterraba é utilizado como suplemento devido a seu alto conteúdo de nitrato inorgânico $\left(\mathrm{NO}_{3}{ }^{-}\right)$, um composto encontrado naturalmente em vegetais e em alimentos processados, onde é utilizado como conservante. O nitrato é ingerido na dieta é convertido para óxido nítrico (NO) pela via nitrato-nitrito-NO, aumentando a disponibilidade de NO para os tecidos ativos (GONZALEZ et al., 2020). O NO provoca uma grande variedade de ações no corpo humano incluindo, vasodilatação, aprimoramento no uso do cálcio, respiração celular, biogênese mitocondrial e aumento da velocidade de contração muscular (JONES, 2014). Já foi demonstrado que o suco de beterraba pode modificar variáveis associadas ao desempenho de resistência (JONES 2014), assim como pode influenciar favoravelmente parâmetros cardiorrespiratórios como a captação máxima de oxigênio, a eficiência e economia do exercício e a cinética da captação de oxigênio pulmonar (DOMINGUÉZ et al., 2017). Com relação ao ciclismo, Wikerson et al. (2012) realizaram um estudo com ciclistas treinados e observaram que a suplementação com suco de beterraba $(500 \mathrm{ml}, 2.5 \mathrm{~h}$ antes do teste) melhorou o tempo para completar um teste de $80 \mathrm{~km}(50$ milhas) em $0.8 \%$. Lansley et al. (2011) constataram que a suplementação com suco de beterraba (500ml, $2.5 \mathrm{~h}$ antes do teste) melhorou o desempenho de ciclistas treinados, diminuindo o tempo para concluir testes de contrarrelógio de $16.1 \mathrm{~km}$ e $4 \mathrm{~km}$ em $2.8 \%$ e $2.7 \%$ respectivamente. Esse resultado foi associado com a melhora da relação potência/consumo de $\mathrm{O}_{2}\left(\mathrm{~W} / \mathrm{V}_{\mathrm{O} 2}\right)$ de $7 \%$ nos $16.1 \mathrm{~km}$ e $11 \%$ nos $4 \mathrm{~km}$. Por sua vez, Kelly et al. (2013) analisaram o efeito da suplementação com suco de beterraba (500ml, aproximadamente $8.2 \mathrm{mmol}$ de nitrato) sobre o tempo para exaustão no ciclismo. Os testes foram realizados em indivíduos ativos nas intensidades de $60 \%, 70 \%, 80 \%$ e $100 \%$ do pico de potência. Após a suplementação, a tolerância ao exercício foi aprimorada nas intensidades de $60 \%, 70 \%$ e $80 \%$ e houve uma tendência de aumento para 100\%. Os resultados podem indicar uma menor resposta no consumo de oxigênio em intensidades submáximas, o que poderia reduzir a elevação no componente lento do consumo de oxigênio, protelando o tempo para os atletas alcançarem o $\mathrm{VO}_{2 \max }$ e consequentemente entrarem em fadiga. Buscando analisar os efeitos da suplementação com suco de beterraba sobre parâmetros fisiológicos e cognitivos durante e após o exercício submáximo, Thompson et al. (2014) conduziram um estudo onde os participantes pedalaram por $20 \mathrm{~min}$ a $50 \% \mathrm{VO}_{2 \text { pico }}$ seguidos por $20 \mathrm{~min}$ a $70 \%$ do $\mathrm{VO}_{2 \text { pico }}$ e por fim, realizaram um estágio final a $90 \%$ do $\mathrm{VO}_{2 \text { pico }}$ até a exaustão. Foi constatado uma tendência de menor consumo de oxigênio e aumento na oxigenação dos tecidos após a suplementação com suco de beterraba em comparação ao placebo. Observou-se também o aumento de $16 \%$ no tempo para exaustão no estágio final do teste a $90 \%$ do $\mathrm{VO}_{2 \text { pico, }}$, porém, não houve melhora no desempenho cognitivo pós exercício. 
Conclusão: A princípio é possível afirmar que a suplementação aguda/crônica com suco de beterraba pode reduzir o consumo de oxigênio $\left(\mathrm{VO}_{2}\right)$ durante o exercício, enquanto aprimora a relação entre watts (potência) necessários e nível de $\mathrm{VO}_{2}$. Estes mecanismos tornam possível a melhora no tempo para exaustão e nos testes contrarrelógio do ciclismo.Esse é um dado interessante para atletas, pois a economia de $\mathrm{O}_{2}$ é um fator chave para aprimorar o desempenho cardiorrespiratório, possibilitando o aumento da eficiência energética nas modalidades esportivas de resistência como o ciclismo.

\section{Referências}

DOMÍNGUEZ, R.O.; CUENCA, E.; MATÉ-MUÑOZ, J.L.; GARCÍA-FERNÁNDEZ, P.; SERRA-PAYA, N.; ESTEVAN, M.C.; HERREROS, P.V.; GARNACHO-CASTAÑO, M.V. Effects of beetroot juice supplementation on cardiorespiratory endurance in athletes. A systematic review. Nutrients, Basel-Switzerland, v.9, n.1, p.01-18, jan. 2017.

FARIA, E. W.; PARKER, D. L.; FARIA, I. E. The science of cycling: physiology and training part 1. Sports Medicine, AucklandN.Z., v.35, n.4, p.285-312, 2005.

GONZALEZ, A.; CHURCH, D.; TOWNSEND, J. R.; BAGHERI, R. Emerging Nutritional Supplements for Strength and Hypertrophy: An Update of the Current Literature. Strength and Conditioning Journal, Colorado Springs-US, Volume published Ahead-of-Print, p.1-14, Abr.2020.

JONES, A. M. Dietary nitrate supplementation and exercise performance. Sports Medicine, Auckland-N.Z., v.44, supl.1, p.35-45, maio/2014.

KELLY, J.; VANHATALO, A.; WILKERSON, D. P.; WYLIE, L, J. Effects of nitrate on the power-duration relationship for severeintensity exercise. Medicine and Science in Sports and Exercise, Indianapolis-US, v.45, n.9, p.1798-1806, set.2013.

LANSLEY, K. E.; WINYARD, P. G.; BAILEY, S. J.; VANHATALO, A.; WILKERSON, D. P.; BLACKWELL, J. R.; GILCHRIST, M.; BENJAMIN, N. Acute dietary nitrate supplementation improves cycling time trial performance. Medicine and Science in Sports and Exercise, Indianapolis-US, v.43, n.6, p.1125-1131, jun.2011.

THOMPSON, K. G.; TURNER, L.; PRICHARD, J.; DODD, F.; KENNEDY, D. O.; HASKELL, C.; BLACKWELL, J. R. Influence of dietary nitrate supplementation on physiological and cognitive responses to incremental cycle exercise. Respiratory Physiology \& Neurobiology, Philadelphia-US, v.193, p.11-20, mar.2014.

WIKERSON, D. P.; HAYWARD, G. M.; BAILEY, S. J.; VANHATALO, A.; BLACKWELL, J. R.; JONES, A. M. Influence of acute dietary nitrate supplementation on 50-mile time trial performance in well-trained cyclists. European Journal of Applied Physiology, Cham-Switzerland, v.112, n.12, p.4127-4134, 2012. 


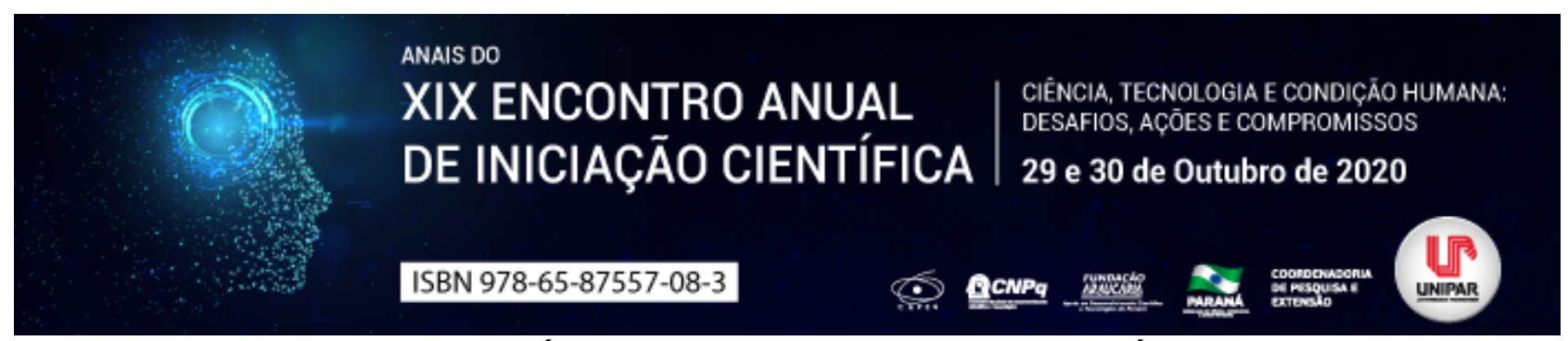

OS BENEFÍCIOS DA AROMATERAPIA PARA A SAÚDE

\author{
${ }^{1}$ MATHEUS DE SOUZA MARTINUCI, ${ }^{2}$ ZILDA CRISTIANI GAZIM
}

\author{
${ }^{1}$ Acadêmico do PIC/UNIPAR \\ ${ }^{1}$ Docente da Universidade Paranaense UNIPAR
}

Introdução: A medicina complementar e alternativa está evoluindo progressivamente nos países desenvolvidos e em desenvolvimento em todo o mundo. A aromaterapia é uma das terapias que mais tem crescido atualmente, utilizando óleos aromáticos na forma de massagens e inalação direta (HSU et al., 2019). Os óleos essenciais são substâncias voláteis, também denominadas de óleos etéreos, óleos aromáticos, extraídos das plantas pelas técnicas de destilação com água (hidrodestilação) ou vapor (arraste por vapor d'água), expressão mecânica ou enfloração (PEARSON et al., 2019).

Objetivos: O presente estudo consistiu em uma revisão sobre os benefícios da aromaterapia para a saúde.

Desenvolvimento: A utilização dos óleos essenciais como terapia complementar de baixo risco, utiliza essências naturais de plantas como lavanda, hortelã, hortelã-pimenta e cítricos para fins terapêuticos. Estas moléculas aromáticas podem fornecer uma opção de tratamento complementar podendo vir a substituir em alguns casos os medicamentos químicos sintéticos (JARUZEL et al., 2019). A forma de utilização destas moléculas ocorrem através das vias olfativas, oral e tópica, sendo que a via inalatória é a mais rápida, produzindo efeitos quase imediatos. As alterações causadas no corpo parecem livres de efeitos colaterais e podem ser sustentadas quando a inalação é repetida (SCHNEIDER et al., 2018). ÖZLÜ et al., (2017), realizaram um estudo experimental com 60 pacientes de uma unidade de terapia intensiva cirúrgica com quadro pós-operatório, e ausência de complicações; sendo estes divididos em dois grupos, em um grupo era realizada a aromaterapia e no outro o tratamento convencional. Os resultados do estudo mostraram que a massagem com óleos essenciais melhorou a qualidade do sono dos pacientes resultando em mudanças positivas em seus parâmetros fisiológicos. Em um outro estudo conduzido por REYES et al., (2020), 50 pacientes com doença renal crônica foram escolhidos aleatoriamente para utilizar o óleo essencial de laranja doce e o outro a técnica de respiração profunda em três centros ambulatoriais de hemodiálise nas Filipinas entre julho e agosto de 2015. Um questionário com perguntas específicas e com uma escala de classificação numérica foram utilizados para medir a dor e ansiedade nesses pacientes. Após a intervenção, os escores de dor e ansiedade foram significativamente menores nos pacientes que receberam o oléo de laranja doce quando comparado aos que realizaram a técnica de respiração profunda. Em um outro estudo realizado por RAMBOD, et. al., (2020), 100 pacientes com infarto agudo do miocárdio foram designados para os grupos intervenção receberam por inalação o óleo essencial de limão e como controle óleo mineral. A terapêutica foi realizada por três dias consecutivos, sendo avaliados a pressão arterial, alterações eletrocardiográficas e ansiedade. Observou-se diferença significativa entre os dois grupos em relação à pressão arterial sistólica e percentual de alterações do segmento ST e da onda T no eletrocardiograma no terceiro e quarto dias após a intervenção. Também foi encontrada diferença significativa entre os dois grupos em relação à freqüência cardíaca e ansiedade no $4^{\circ}$ dia após a intervenção. O estudo concluiu que o grupo que realizou a aromaterapia obteve a redução da pressão arterial sistólica, a ansiedade, a freqüência cardíaca e a porcentagem de alterações do segmento ST e da onda T no eletrocardiograma, sendo o uso da terapia sugerido nas unidades coronarianas.

Conclusão: Diante do exposto é possível concluir que o uso da aromaterapia mostrou-se eficaz e traz grande benefícios, sendo uma das terapias da medicina complementar que está em expansão e mostrando cada vez mais seus resultados benéficos.

\title{
Referências
}

HSU, Chia-hsien; CHI , Ching-Chi; CHEN, Pei-Shih; et al. The effects of aromatherapy massage on improvement of anxiety among patients receiving palliative care: A systematic review of randomized controlled trials. Medicine, v. 98, n. 9, p. 14720, mar 2019.

JARUZEL, Candace; GREGOSKI, Mathew; MUELLER, Martina; et al. Aromatherapy for preoperative anxiety: A pilot study. Journal of Perianesthesia Nursing, v. 34, n. 2, p. 259-264, abr 2019.

ÖZLÜ, Zeynep Karaman; BILICAN, Pınar. Effects of aromatherapy massage on the sleep quality and physiological parameters of patients in a surgical intensive care unit. African Journal of Traditional, Complementary and Alternative Medicines, v. 14, n. 3, p. 83-88, abr 2017.

PEARSON, Amy; CUTSHALL, Susanne; HOOTEN, Michael; et al. Perspectives on the use of aromatherapy from clinicians attending an integrative medicine continuing education event. BMC complementary and alternative medicine, v. 19, n. 1, p. 174, jul 2019.

RAMBOD, Masoume; RAKHSHAN, Mahnaz; TOHIDINIK, Sara; et al. The effect of lemon inhalation aromatherapy on blood pressure, electrocardiogram changes, and anxiety in acute myocardial infarction patients: A clinical, multi-centered, assessor- 
blinded trial design. Complementary Therapies in Clinical Practice, v. 39, n. 2, p. 101155, mai 2020.

REYES, Catherine Maria; REYES, Corrine Maria; RIBAY, Krystal., et al. Effects of sweet orange aromatherapy on pain and anxiety during needle insertion among patients undergoing hemodialysis: A quasi-experimental study. In Nursing Forum. mar 2020.

Disponível

em:

Coordenadoria de Pesquisa e Extensão - COPEX

Departamento de Editoraçāo e Divulgaçāo Científica - DEDIC 


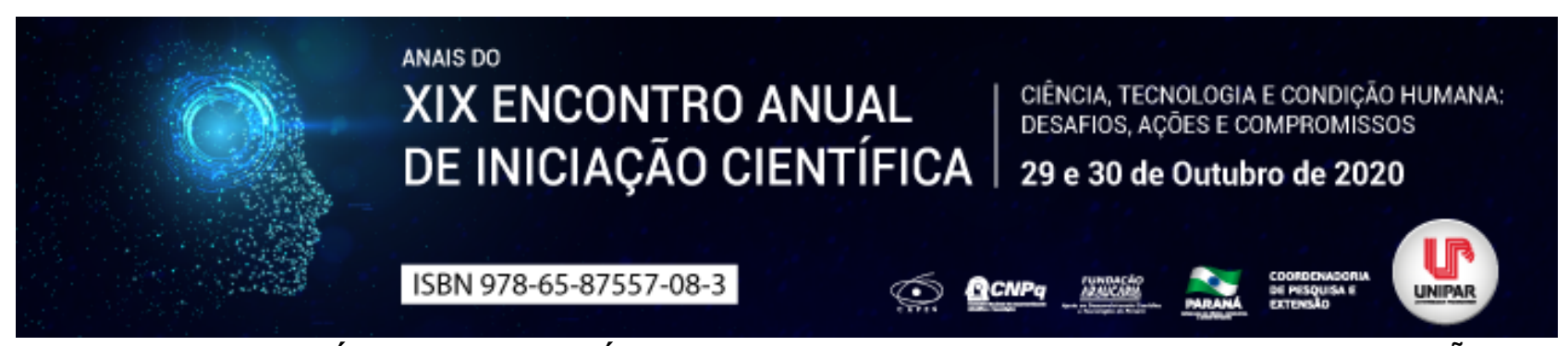

ABORDAGEM ODONTOLÓGICA NO DIAGNÓSTICO PRECOCE DA LEUCEMIA E SUAS MANIFESTAÇÕES ORAIS

\title{
${ }^{1}$ BRUNA DENZER THOLKEN, ${ }^{2}$ JENIFFER URBANO DEGASPERI, ${ }^{3}$ LETICIA NADAL
}

\author{
${ }^{1}$ Acadêmica do Curso de Odontologia da UNIPAR \\ ${ }^{1}$ Acadêmica do Curso de Odontologia da UNIPAR \\ ${ }^{2}$ Docente da UNIPAR
}

Introdução: As leucemias são desordens malignas causadas por modificações nas células-tronco hematopoiéticas, em que há diferenciação e produção de leucócitos nocivos à medula óssea, ocasionando a proliferação de células leucêmicas (ANTONINI; LEMES; MOZZINI, 2018). Essa doença acomete muitas pessoas em todo o mundo, especialmente crianças e adolescentes, podendo atingir todas as faixas etárias. As primeiras manifestações da leucemia podem surgir na cavidade oral, motivo este que leva muitas pessoas até o cirurgião dentista por acreditarem que seja uma patologia local (COSTA; SOUZA; COSTA, 2016). Dessa forma, torna-se essencial abordar o presente assunto, sendo de suma importância o cirurgião dentista saber interpretar esses sintomas para diagnosticar a doença em sua fase inicial, bem como tratar os sinais bucais advindos do tratamento da leucemia (MARCHÃO, 2016).

Objetivos: Revisar os dados da literatura a fim de apresentar a influência do cirurgião dentista no diagnóstico precoce da leucemia, identificando as principais manifestações orais da doença, e os sinais provenientes do tratamento antineoplásico.

Desenvolvimento: A leucemia é uma neoplasia maligna em que as células sanguíneas provenientes da medula óssea se multiplicam de modo irregular e exagerado, alterando as células hematopoiéticas e, conforme progridem, avançam para a corrente sanguínea, afetando também outros tecidos e órgãos por todo o organismo (MACEDO, et al., 2014). Essa doença possui uma etiologia incerta, porém alguns fatores externos podem estar associados, como exposição à radiação, produtos químicos, infecções virais, condições genéticas e socioeconômicas que deixam certos indivíduos mais suscetíveis para a doença (SANTOS, et al., 2019). As leucemias são classificadas em agudas e crônicas, e histologicamente em mielóide e linfóide. As leucemias agudas são mais agressivas e acometem principalmente crianças, se caracterizam pelo crescimento acelerado de células imaturas, que se destinam ao sangue periférico (COSTA; SOUZA; COSTA, 2016). Já as crônicas evoluem mais lentamente e acomete geralmente adultos; atingem células maduras, que se produzem excessivamente na circulação sanguínea (MARCHÃO, 2016). Em até 89\% das fases iniciais da leucemia aguda há manifestação de sinais da doença na cavidade oral, motivo este que reforça a importância do cirurgião dentista no diagnóstico precoce dessa doença. As principais manifestações orais encontradas são: hiperplasia gengival, úlceras, palidez da mucosa, petéquias e equimoses, observa-se aumento do volume gengival, sangramento gengival decorrente da trombocitopenia (baixo número de plaquetas) e maior suscetibilidade a infecções pelo baixo nível de neutrófilos (neutropenia) (MACEDO, et al., 2014). Nos pacientes com leucemia, é comum a formação de úlceras na mucosa oral, visto que a microbiota normal encontra-se alterada, contribuindo com o surgimento de infecções da mucosa gengival, que resulta em gengivites, infecções fúngicas ou evidências do Herpes Simples. Também nota-se áreas de sangramento em algumas regiões da cavidade oral, como gengiva, assoalho oral, língua e lábios (COSTA; SOUZA; COSTA, 2016). Além do diagnóstico precoce, o cirurgião-dentista compõem a equipe multidisciplinar que trata as consequências da doença e do próprio tratamento da leucemia. A quimioterapia, radioterapia ou cirurgia podem causar efeitos colaterais na cavidade oral e até mesmo piorar problemas já existentes. Algumas manifestações orais derivadas do tratamento incluem: mucosite oral, xerostomia, infecções oportunistas causadas por fungos, vírus ou bactérias, osteorradionecrose, cárie de radiação e sangramento gengival. Caso haja suspeita de leucemia durante a anamnese e exame clínico, o CD deve solicitar exames complementares, como o hemograma, e posteriormente realizar a leitura correta do mesmo para encaminhá-lo a um profissional especializado para diagnóstico e tratamento da doença (COSTA; SOUZA; COSTA, 2016). Porém, é de grande relevância que o dentista participe da equipe multidisciplinar responsável pelo tratamento do paciente, acompanhando-o em todas as etapas do processo, a fim de torná-lo menos invasivo, prevenindo o aparecimento de novas patologias na cavidade oral e tratando, de modo seguro as que já existem, respeitando o nível de saúde em que o paciente se encontra (MARCHÃO, 2016).

Conclusão: É imprescindível que o cirurgião-dentista saiba interpretar e acompanhar, desde as primeiras manifestações orais até o término do tratamento o paciente acometido pela leucemia, tendo em vista que são muitas as ocorrências de sinais na cavidade oral antes e depois do tratamento antineoplásico, podendo assim, evitar muitas complicações bucais além de melhorar a qualidade de vida desses indivíduos.

\section{Referências}

ANTONINI, Michele Formighieri; LEMES, Letícia Tainá de Oliveira; MOZZINI, Carolina Barreto. Manifestações Orais da Leucemia no Momento do Diagnóstico. Revista Brasileira de Cancerologia, v. 64, n. 2, p. 227-235, 2018. 
COSTA, Sueli de Sousa; SOUSA, Hiran Reis; COSTA, Izolda Souza. O papel do cirurgião-dentista no diagnóstico precoce da leucemia e sua responsabilidade ética e legal-revisão de literatura. RBOL-Revista Brasileira de Odontologia Legal, v. 4, n. 2, 2017.

MACEDO, Dhiancarlo Rocha et al. Manifestação oral da leucemia mielóide aguda como primeiro sinal para o diagnóstico. Revista Bahiana de Odontologia, v. 5, n. 2, p. 125-130, 2014.

MARCHÃO, Natália Sofia Rodrigues. Leucemia e saúde oral-o papel do médico dentista. 2016. Monografia (mestre em medicina dentária) - Universidade do Porto, Portugal, 2016.

SANTOS, Mirella Meireles Ferreira dos. et al. Leucemia mieloide, aguda e crônica: Diagnósticos e possíveis tratamentos. Revista Saúde em Foco Edição no 11 Ano: 2019, p. 279 294, 2019.

Coordenadoria de Pesquisa e Extensão - COPEX

Departamento de Editoraçāo e Divulgaçāo Científica - DEDIC 


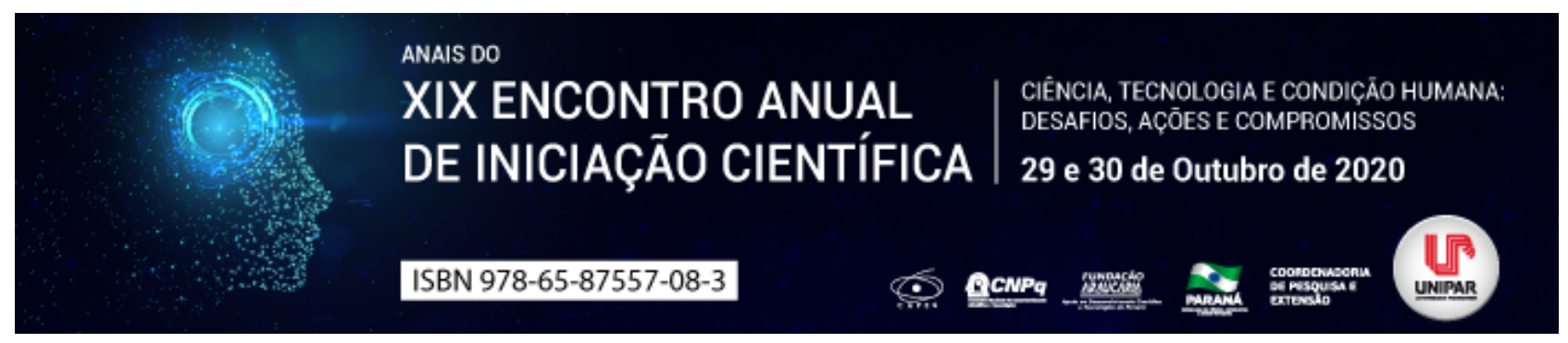

DIABETES MELLITUS EM IDOSOS: COMO O PROFISSIONAL DE ENFERMAGEM AUXILIA O IDOSO NO CUIDADO DA DOENÇA

\title{
${ }^{1}$ ISABELLA THAISSA FRANZOIA, ${ }^{2}$ GEOVANY BRANDO MOREIRA, ${ }^{3}$ LEILANE TALITA FATORETO SCHWIND, ${ }^{4}$ RODRIGO LEITE ARRIEIRA
}

\author{
${ }^{1}$ Acadêmica do curso de Enfermagem da UNIPAR \\ ${ }^{1}$ Acadêmico do curso de Enfermagem da UNIPAR \\ ${ }^{2}$ Professora colaboradora na Universidade Estadual de Maringá - UEM \\ 3 Professor titular na Universidade Paranaense - UNIPAR Umuarama
}

Introdução: A Diabetes Mellitus tipo II (DM II) é uma doença metabólica que atinge diversas pessoas no mundo todo, principalmente jovens e idosos. Na população idosa ocorre o maior risco de morte e, como qualquer doença metabólica, pode desencadear outras distúrbios metabólicas, como por exemplo: disfunções cardiovasculares e renais (MARQUES et al., 2019). Nesse sentido, é preciso a promoção à saúde e a prevenção de complicações, necessitando de intervenções educativas que favoreçam o empoderamento da pessoa com essa condição crônica e que facilite sua capacidade de formular e seguir a rotina de hábitos saudáveis, propostas pelos enfermeiros a fim de diminuir o risco de complicações da DM II.

Objetivo: Descrever como a promoção educativa da enfermagem pode contribuir para a melhoria do quadro da Diabetes Mellitus em idosos.

Desenvolvimento: Idosos apresentam uma rotina mais sedentária e, em muitos casos, além da DM II, apresentam doenças cardiovasculares como, por exemplo, hipertensão. Com o desenvolvimento da DM II pode haver outras complicações cardiovasculares e renais como a nefropatia diabética, que consiste na perda da função renal lentamente, diminuindo a expectativa de vida desses indivíduos (HAMMERSCHMIDT, 2007). Diante disso, é importante o autocuidado propiciado pelos enfermeiros (OLIVEIRA et al., 2016). O objetivo do processo de autocuidado é capacitar o indivíduo a entender os processos terapêuticos para melhoraria de sua saúde, uma vez que, aqueles que não o recebem, podem agravar seu quadro clínico. Nesse sentido, destaca-se que o autocuidado não é realizado sozinho, mas sim faz parte de um conjunto de fatores ambientais, sociais, econômicos, hereditários e relacionados aos serviços da saúde. Para auxiliar nesse processo, a Teoria do Déficit de Autocuidado de Orem consiste no cuidado que o enfermeiro tem com o paciente e é apontada como um guia para orientar o educador em diabetes (SÜRÜCÜ; KIZILCI, 2012). Essa teoria facilita para o uso da linguagem de enfermagem padronizada para a comunicação entre enfermeiros e pacientes, além de auxiliar na padronização de conhecimentos para a prática de enfermagem (OLIVEIRA et al., 2016). Nesse sentido, o enfermeiro deve conhecer o processo de cuidado e automonitorização da glicemia, além de reconhecer que a participação do paciente é imprescindível para o sucesso do autocuidado. Outro ponto essencial no processo de autocuidado é que o enfermeiro conheça a individualidade do seu paciente, a fim de trabalhar especificamente cada caso, minimizando os possíveis riscos e limitações que possa ter e, assim, iniciar o seu processo terapêutico, baseado em uma manutenção de hábitos saudáveis e no trabalho da autoconfiança (MARQUES et al., 2019). Dentre os processos de educação abordado pelo enfermeiro, considera-se a checagem da glicemia, aferição da pressão arterial, peso e IMC, bem como instruir os idosos a cuidarem dos seus pés, como se planejar para melhorar seu quadro e tirar dúvidas que o idoso possa apresentar. Vale ressaltar que, para eficácia do processo, é preciso que o acompanhamento seja de longa duração. Dessa forma, pode-se utilizar meios de comunicação, como ligações por telefone, vídeo chamadas ou até mesmo trocas de mensagens via whatsapp, para fazer o acompanhamento diário do paciente (BARBOSA et al., 2014). Esse contato promove a proximidade do paciente com a equipe de saúde e, consequentemente, auxilia na monitorização do processo de autocuidado do indivíduo, na alimentação, na checagem de glicemia e o cuidado com os pés (BATISTA et al., 2017). Outra maneira de intervir é realizando visitas ao domicílio e acompanhamento na atenção básica, para manter o monitoramento e o processo de autocuidado (LIMA et al., 2016).

Conclusão: A DM II é uma doença metabólica em que o seu tratamento, especialmente em idosos, deve assegurar o autocuidado e, por isso, é necessário que o enfermeiro conheça o histórico do paciente e observe os riscos que o mesmo pode correr caso não o realize. Além disso, deve-se elaborar um planejamento terapêutico a fim de ensinar como adequar a alimentação, buscar exercícios que melhore sua condição de vida, tirar possíveis dúvidas possíveis do paciente, realizar a checagem da glicemia, pressão arterial, peso e IMC. Todas essas medidas visam manter a diabetes mellitus do tipo II controlada, cabendo ao enfermeiro essa função, uma vez que a enfermagem busca a humanização do indivíduo e não cuida somente da doença, mas, também, atua na compreensão do paciente e como ajudá-lo. Diante disso, a enfermagem tem um papel fundamental em instruir e acompanhar os idosos que sofrem com a DM II. 


\section{Referências}

BARBOSA, Isadora Marques; LIMA, Francisca Elisângela Teixeira; MAGALHÃES, Fernanda Jorge; ALMEIDA, Paulo César. Influência da assistência de enfermagem por telefone na prática do autocuidado do usuário com Diabetes Mellitus. Revista Enfermagem UFPE On Line, v. 8, n. 11, p. 3874-3880, nov. 2014.

BATISTA, Jéssica Magalhães Felipe; TEIXEIRA, Carla Regina de Souza; BECKER, Tânia Alves Canata; ZANETTI, Maria Lúcia; ISTILLI, Plínio Tadeu; PACE, Ana Emília. Conhecimento e atividades de autocuidado de pessoas com Diabetes Mellitus submetidas a apoio telefônico. Revista Eletrônica de Enfermagem, p. 19-36, jan./dez. 2017.

HAMMERSCHMIDT, Karina Silveira de Almeida. O cuidado gerontológico de enfermagem subsidiando o empoderamento do idoso com Diabetes Mellitus. 2007. 185 f. Dissertação (Mestrado - Programa de Pós Graduação em Enfermagem. Área de Concentração: Prática Profissional de Enfermagem) - Universidade Federal do Paraná, Curitiba, 2007.

LIMA, Adilson Fernandes; MOREIRA, Andréa Carvalho Araújo; SILVA, Maria Josefina; MONTEIRO, Paula Andréia Araújo; TEIXEIRA, Priscila Gonçalves. A percepção do idoso com diabetes acerca de sua doença e o cuidado de enfermagem. Ciência, Cuidado e Saúde, v. 15, n. 3, p. 522-529, jul. 2016.

MARQUES, Marília Braga; COUTINHO, Janaína Fonseca Victor; MARTINS, Mariana Cavalcante; LOPES, Marcos Venícios de Oliveira; MAIA, Juliana Cunha; SILVA, Maria Josefina. Intervenção educativa para a promoção do autocuidado de idosos com Diabetes Mellitus. Revista da Escola Enfermagem da USP, v. 53, e3517, 2019.

OLIVEIRA, Glória Yanne Martins; ALMEIDA, Angélica Maria de Oliveira; GIRÃO, Ana Lívia Araújo; FREITAS, Consuelo Helena Aires. Intervenções de enfermagem para promoção do autocuidado de pessoas com Diabetes tipo 2: revisão integrativa. Revista Eletrônica de Enfermagem, v. 18, e1188, 2016.

SÜRÜCÜ, Hamdiye Arda; KIZILCI, Sevgi. Use of Orem's self-care Deficit Nursing Theory in the self management education of patient with type 2 diabetes: A case study. Self-care, Dependent-Care and Nursing, v. 19, n. 1, p. 53-59, 2012. 


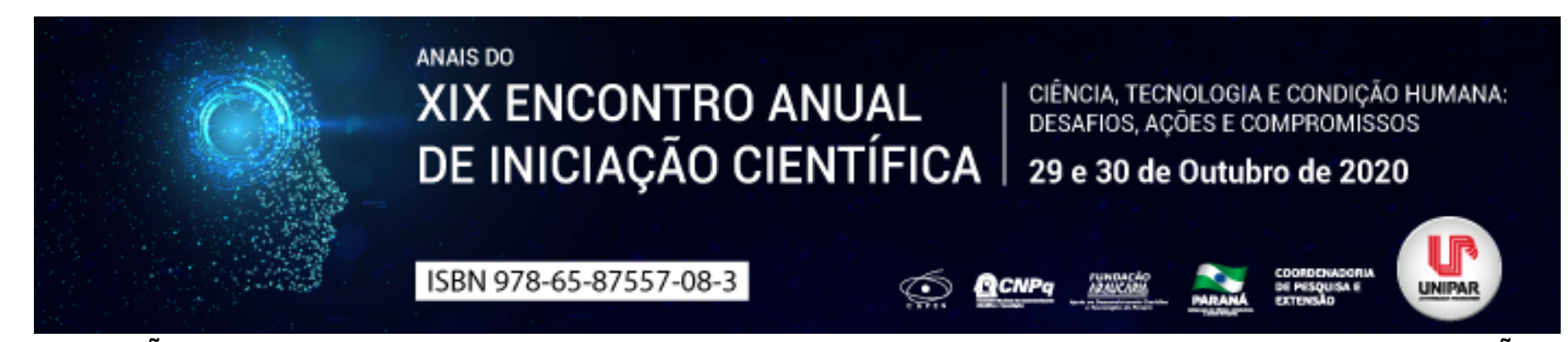

UTILIZAÇÃO DE PROTOTIPAGENS EM CIRURGIA E TRAUMATOLOGIA BUCOMAXILOFACIAL: REVISÃO DE LITERATURA

\begin{abstract}
${ }^{1}$ BEATRIZ AYUMI SHIOTANI, ${ }^{2}$ GABRIEL MACIEL DA SILVA, ${ }^{3}$ JOAO CARLOS RAFAEL JUNIOR , ${ }^{4}$ JULIA NICOLETTI LEITE, ${ }^{5}$ NATALIA COQUEIRO SIQUEIRA, ${ }^{6}$ GIORDANO BRUNO DE OLIVEIRA MARSON
\end{abstract}

\author{
${ }^{1}$ Acadêmica do PIC/UNIPAR \\ ${ }^{1}$ Acadêmico do PIBIC/UNIPAR \\ ${ }^{2}$ Acadêmico do CNPQ/UNIPAR \\ ${ }^{3}$ Acadêmica do Curso de Odontologia da UNIPAR \\ ${ }^{4}$ Acadêmica do Curso de Odontologia da UNIPAR \\ ${ }^{5}$ Docente da UNIPAR
}

Introdução: Prototipagem rápida é uma tecnologia de confecção aditiva onde através de uma sucessiva deposição de camadas sobrepostas, resultam em um modelo tridimensional. Protótipos tornaram-se uma ferramenta em avanço contínuo nos últimos anos dentro da odontologia, considerando o elevado número de casos com algum tipo de deformidade facial e/ou mutilação bucal no Brasil, e com o advento dos protótipos ou biomodelos, os profissionais da área odontológica obtém em suas mãos uma réplica de alta fidelidade das estruturas ósseas cranianas ou outras estruturas do paciente de interesse do profissional, apresentando diversas vantagens de uso como, diagnósticos com elevada precisão e menor agressividade, simplificação de casos considerados de elevada complexidade, redução no tempo de procedimento cirúrgico e diminuição nos períodos longos de morbidade pós-operatória (CARVALHO et al., 2007).

Objetivo: Realizar uma revisão de literatura sobre a prototipagem rápida, sua aplicabilidade dentro da área de Odontologia e suas contribuições clínicas e laboratoriais.

Desenvolvimento: A prototipagem rápida (PR) é o termo utilizado para fabricação de modelos físicos com elevada precisão anatômica, em uma escala real de 1:1. Sua confecção é obtida através dos dados de exames que geram imagens tridimensionais, sendo eles, os exames tomográficos, ressonâncias magnéticas e ultrassonografia (TENÓRIO et al., 2015), onde essas imagens são gravadas no computador ao formato DICOM (Digital Imaging and Communications in Medicine) e impressos no programa denominado CAD (computer aided design) que auxilia o profissional na criação de peças virtuais tridimensionais e em seguida, são enviados para as estações de PR, na qual, através do sistema CAM (Computer Aided Manufacturing), os protótipos são fabricados (MEURER et al., 2003; TENÓRIO et al.,2015). Para que seja possível a construção destes modelos, existem duas tecnologias: a subtrativa e a aditiva, onde no método subtrativo, utilizam-se de um bloco íntegro inicial e o projeto é esculpido nesse material, em contrapartida, o aditivo adiciona várias camadas do material, uma sobre a outra, através de uma máquina de acordo com o formato desejado, sendo a mais utilizada para fabricação de protótipos dentro área odontológica, a aditiva, devido a redução do material disperdiçado em relação a tecnologia subtrativa e sua alta fidelidade em reproduzir as devidas complexidades das estruturas anatômicas. Dentro da tecnologia aditiva, possuem as seguintes técnicas de reprodução: a FDM (fabricação por filamento fundido), na qual utiliza-se de filamentos como matéria-prima em um diâmetro constante de 1,75 $\mathrm{mm}$ ou 2,85 mm, sendo geralmente termoplásticos enrolados em uma bobina e durante o processo, esse filamento é extrusado por um bico aquecido e montado em um sistema de movimentos lineares que se move ao redor de uma área de impressão. Além dessa, a técnica SLA (estereolitografia), onde a construção do biomodelo ocorre a partir do uso de resina líquida fotopolimerizável como matéria-prima e por meio de uma reação de cura, cada camada desta resina é transformada para o estado sólido (COELHO et al.,2018), e por último, a SLS (sinterização seletiva a laser), que a partir do uso de material em pó como matéria prima, juntamente com um laser de alta potência, as pequenas partículas de material são combinadas para formar uma única camada horizontal de acordo com os dados do CAD (CARVALHO et al., 2007; SANTANA et al., 2015). Tais métodos possibilitaram o surgimento de biomodelos com elevada precisão das estruturas ósseas e espessuras milimétricas através dos cortes tomográficos, levando a uma maior fidelidade do biomodelo e consequentemente, tornando-se uma ótima ferramenta auxiliar para as equipe cirúrgica dentro da Odontologia. Visto que com o biomodelo impresso tridimensionalmente em mãos, ocorre a simplificação de casos com maior complexidade, obtendo-se como vantagem a disponibilidade do tempo para planejar antecipadamente a cirurgia, favorecendo ao profissional uma melhor elaboração de técnica, avaliação de detalhes, melhor precisão do diagnóstico, aperfeiçoamento do procedimento, tratamentos menos agressivos, além de antecipar as dificuldades e, principalmente, a solução para esta (MEURER et al., 2003). Outro benefício é a redução em $20 \%$ no tempo de cirurgia devido a redução no comprometimento dos tecidos, por conseguinte, uma diminuição de contágio das áreas cirúrgicas, proporcionando, assim, uma rápida cicatrização ao paciente, gerando melhores resultados e redução de custo do tratamento (SAMMARTINO et 
al., 2004). Segundo um caso descrito por Sugawara et al., 1997, a necessidade e o tamanho do enxerto puderam ser antecipados, sendo optado pelo mento como região doadora. Segundo o cirurgião, sem o planejamento com o biomodelo, seria realizado um enxerto de crista ilíaca. Logo, o biomodelo evitou o uso de um sítio doador de grande morbidade e os gastos com uma segunda equipe cirúrgica, melhorando o resultado final, além de minimizar o custo global do procedimento. Este caso encontra-se fundamentada na literatura que defende o uso destes biomodelos para avaliar a necessidade de enxertos e doador (MEURER et al., 2003). Sendo de suma importância ressaltar as vantagens obtidas com o auxilio dessa ferramenta na área de saúde, visto que em muitos casos, os profissionais da área precisam refazer a cirúrgia, o tratamento é agressivo e incerto, além de ter a possibilidade de resultados insatisfatórios e custos elevados.

Conclusão: Tendo em vista que o Biomodelo tornou-se um ótimo recurso dentro da área de Odontologia, auxiliando em planejamentos e procedimentos através da simulação de procedimentos no protético antecipadamente a cirúrgia, observamos a redução dos riscos e dinamizamos o tempo cirúrgico.

\section{Referências}

COELHO, Arthur Wilson Fonseca; ARAUJO, Anna Carla; THIRÉ, Rossana Mara da Silva Moreira. Manufatura aditiva por estereolitografia: análise da geometria da peça e da influência da posição e orientação de fabricação. Matéria (Rio de Janeiro), v. 23, n. 4, 2018.

DE CARVALHO, Eduardo Machado. Prototipagem na odontologia: obtenção e uso. 2007.

MEURER, Eduardo et al. Biomodelos de prototipagem rápida em CTBMF. RBC, Rev. Bras. Cir. Periodontia, p. 172-80, 2003.

SANTANA, Leonardo et al. Avaliação de uma impressora 3D baseada em projeto de código aberto na fabricação de peças em PLA. 2015.

SAMMARTINO, Gilberto et al. Stereolithography in oral implantology a comparison of surgical guides. Implant dentistry, v. $13, \mathrm{n}$. 2, p. 133-139, 2004.

SUGAWARA, Y. et al. Life-size, computer-generated skull replica to assist surgery of craniofacial fibrous dysplasia. Journal of Cranio-Maxillofacial Surgery, v. 25, n. 6, p. 294-300, 1997.TENÓRIO, Jefferson da Rocha et al. Prototipagem e cirurgia guiada em implantodontia: revisão de literatura. RFO UPF, v. 20, n. 1, p. 110-114, 2015. 


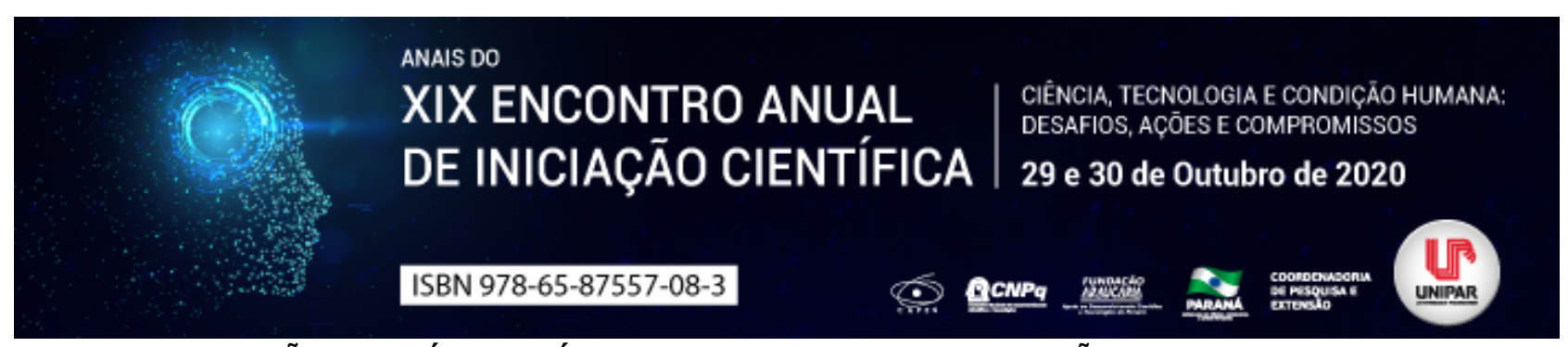

AVULSÃO DENTÁRIA APÓS TRAUMATISMO BUCAL: REVISÃO DE LITERATURA

\begin{abstract}
${ }^{1}$ BEATRIZ AYUMI SHIOTANI, ${ }^{2}$ CAROLINE DOMINGUES, ${ }^{3}$ GABRIEL MACIEL DA SILVA, ${ }^{4}$ GABRIELI JANKE RIGHEZ, ${ }^{5}$ SABRINA PAIXAO DOS SANTOS RODRIGUES, ${ }^{6}$ LUIZ FERNANDO TOMAZINHO
\end{abstract}

\author{
${ }^{1}$ Acadêmica PIC/UNIPAR \\ ${ }^{1}$ Acadêmica do Curso de Odontologia da UNIPAR \\ ${ }^{2}$ Acadêmico PIBIC/UNIPAR \\ ${ }^{3}$ Acadêmica do Curso de Odontologia da UNIPAR \\ ${ }^{4}$ Acadêmica do Curso de Odontologia da UNIPAR \\ ${ }^{5}$ Docente da UNIPAR
}

Introdução: A avulsão dentária consiste no total deslocamento do dente para fora do alvéolo de origem, afetando diversos tecidos circunvizinhos decorrente do rompimento total do feixe vásculo-nervoso apical pós traumático. (FRUJERI et al., 2006). Sendo um problema de saúde pública devido a sua alta prevalência, responsável pelo grande número de perdas dentárias e o acarretamento de um grande impacto emocional, estético, social, funcional e comportamental.

Objetivo: Realizar uma revisão de literatura sobre avulsão dentária, os protocolos de tratamento propostos e suas consequências, visando o conhecimento sobre a correta conduta a ser tomada para um prognóstico favorável.

Desenvolvimento: $O$ traumatismo dentário refere-se a um conjunto de impactos que afetam a estrutura dentária e seu suporte, podendo ser classificados segundo a Associação Internacional de Traumatologia Dentária, como: subluxação, concussão, extrusão, intrusão, avulsão, subluxação e fratura das estruturas dentárias. Dentre elas, sendo a lesão considerada mais grave, a avulsão, caracterizada pelo total deslocamento do dente para fora do seu alvéolo (MARQUES, 2015). O traumatismo dental acomete principalmente o incisivo central superior de ambas dentições, numa frequência de $1 \%$ a $16 \%$ em dentes permanentes, onde o fator predominante são as quedas, acidentes motociclísticos e automobilísticos, e em um número menor em decíduos, de 7\% a 13\% (JÚNIOR et al., 2015), em razão das atividades da infância, a menor quantidade de fibras do ligamento periodontal em dentes recém-erupcionado e da rizogênese incompleta (ANDREASEN et al., 2001, PRATA et al., 2000). Visto que nas últimas décadas foi notório perceber que o traumatismo alvéolo-dentário constitui-se como um fator etiológico responsável pela perda de grande número de dentes, além da possibilidade de gerar problemas emocionais, funcionais e estéticos, é necessário, portanto, tentar ao máximo manter o dente natural no arco até ser alcançado o crescimento ósseo total (AGGARWAL et al., 2010), possibilitando a prevenção da atrofia do rebordo e desprezando a necessidade de uma reabilitação protética (MARÃO et al., 2012). Diante de tal situação, é recomendado após a avulsão dentária, o reimplante imediato para a melhor recuperação de suas funções. Segundo Kinirons et al., (2000) o período que o dente permanece fora do alvéolo em um meio seco, está intrinsecamente ligado à possibilidade de cicatrização, sendo indicado reimplantar nos primeiros 15 a 20 minutos após avulsão e tornando-se inviável a partir dos 60 minutos, quando não possível o reimplante imediato, realizar o correto armazenamento em meio adequado. Vários são os meios citados nos estudos para o armazenamento do dente avulsionado, dentre eles: o leite, solução salina Balanceada de Hank`s, solução salina fisiológica, saliva ou água. Segundo Trope et al., (2002) os fibroblastos armazenados no leite permaneceram com vitalidade durante seis horas, porém sua morfologia sofrem alterações, enquanto o armazenamento em Solução de Hank's manteve 70\% dos fibroblastos vitais por 96 horas, sem alteração da morfologia(LEE et al. 2001, BLOMLÖF et al., 1983). Já a solução salina é um meio estéril, sendo aceitável para curtos períodos de armazenamento, sendo menos prejudicial que a saliva, visto que a saliva possui a presença de bactérias no meio que podem contaminar o dente, e como última alternativa, a água, sendo utilizadas apenas quando os outros meios citados estão inacessíveis (TROPE et al., 2000). O tratamento de terapia endodôntica depende do tempo decorrido fora do alvéolo e do estágio de desenvolvimento da porção radicular. Em dentes com rizogênese completa reimplantados, o tratamento endodôntico deve ser realizada entre 7-10 dias após o traumatismo, visando impedir reabsorção do tipo inflamatória e evitar novos danos ao ligamento periodontal. Recomenda-se a extirpação pulpar e uso da pasta de hidróxido de cálcio, sendo realizada a obturação com guta-percha apenas quando a lâmina dura intacta for detectada no exame radiográfico. Já em casos de dentes avulsionados com rizogênese completa fora do alvéolo em um tempo superior a 60 minutos e em meio seco, o tratamento sugerido é a retirada do ligamento periodontal e por meio de substâncias químicas, tratar a superfície radicular, antes do reimplante (MARQUES, 2015). Já em casos de dentes com rizogênese incompleta e dentro dos 60 minutos, há chances de revascularização pulpar, indicado imergir o dente em uma solução com doxiciclina para estimular o processo (TROPE et al., 2000). Ademais, após o reimplante do dente avulsionado, recomenda-se estabilizar o dente com o uso da esplintagem semirrígida em um período de 7-14 dias, utilizando como material o fio de nylon e resina composta ou outro similar, favorecendo assim, a cicatrização e estabilização do dente 
durante esse período de cicatrização. Sendo prescrito ao paciente pós operatório, o uso de antibiótico e antiinflamatório, além, de uma dieta leve por duas semanas e higienização local com escovas de cerdas macias e bochechos de clorexidina a $0.12 \%$ durante uma semana (American Association of Endodontics, 2004). E por último passo, a proservação com o auxílio do exame radiográfico, sendo realizada por no mínimo 5 anos, sendo de suma importância, esse passo, visto que o prognóstico de um dente com permanência extraoral superior a 60 minutos em meio seco, provavelmente será a anquilose e uma das sequelas mais graves e frequentes relacionadas ao dente avulsionado é a reabsorção radicular, sendo recomendado para esse caso, a remoção do ligamento periodontal e o tratamento radicular, imergindo o dente avulsionado em solução de fluoreto de sódio a $2.4 \%$ e pH de 5.5, por 20 minutos para retardar esse processo (MARQUES, 2015)

Conclusão: Durante e após o procedimento de reimplante, é imprescindível o manejo correto do periodonto e dentes envolvidos para um prognóstico favorável.

\section{Referências}

Andreasen JO, Andreasen, FM. Texto e atlas colorido de traumatismo dental. $3^{\mathrm{a}}$ ed. Porto Alegre: Artmed; 2001.

AGGARWAL, V.; SINGLA, M. Management of inflammatory root resorption using MTA obturation a four year follow up. British dental journal, v. 208, n. 7, p. 287-289, 2010.

BLOMLÖF, L. et al. Storage of experimentally avulsed teeth in milk prior to replantation. Journal of Dental Research, v. 62, n. 8 , p. 912-916, 1983.

FLORES, Marie Therese. et al. Guidelines for the management of traumatic dental injuries. I. Fractures and luxations of permanent teeth. Dental traumatology, v. 23, n. 2, p. 66-71, 2007.

FRUJERI, Maria de Lourdes Vieira. Avulsão dentária: efeito da informação na mudança de comportamento em diferentes grupos profissionais. 2006.

KINIRONS, M. J. et al. Variations in the presenting and treatment features in reimplanted permanent incisors in children and their effect on the prevalence of root resorption. British dental journal, v. 189, n. 5, p. 263-266, 2000.

LEE, Jessica Y.; VANN, William F.; SIGURDSSON, Asgeir. Management of avulsed permanent incisors: a decision analysis based on changing concepts. Pediatric dentistry, v. 23, n. 4, p. 357-360, 2001.

MARÃO, Heloisa Fonseca. et al. Periapical tissue reactions to calcium hydroxide and MTA after external root resorption as a sequela of delayed tooth replantation. Dental Traumatology, v. 28, n. 4, p. 306-313, 2012.

MARQUES, Mariana Marroni. Avulsão dentária: revisão de literatura. 2015.

TROPE, Martin. Clinical management of the avulsed tooth: present strategies and future directions. Dental Traumatology, v. 18 , n. 1, p. 1-11, 2002.

SILVA JÚNIOR, Edmilson Zacarias da. et al. Prognóstico e tratamento da avulsão dentária: relato de caso. Revista de Cirurgia e Traumatologia Buco-maxilo-facial, v. 15, n. 3, p. 39-42, 2015. 


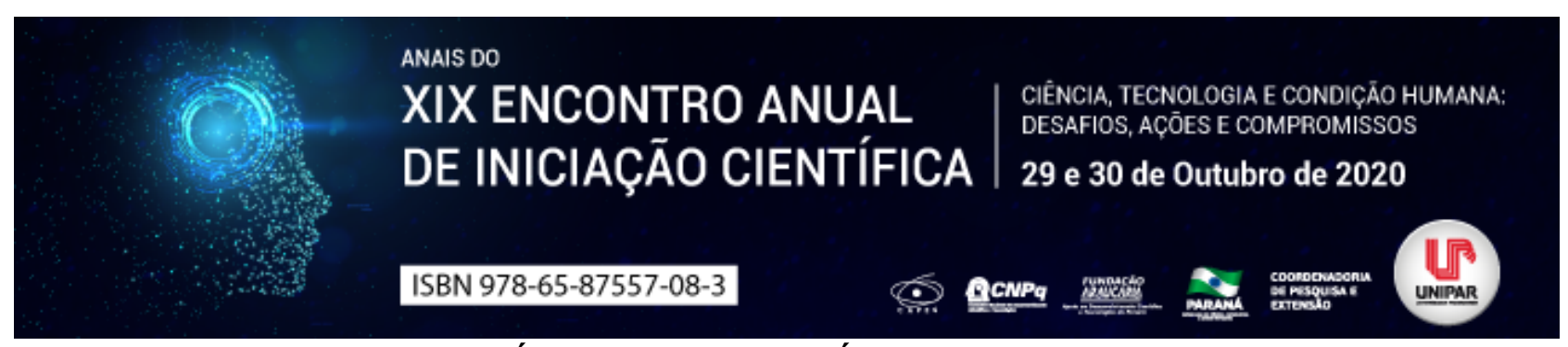

EXAME CITOPATOLÓGICO DO COLO DO ÚTERO: PERFIL DAS GESTANTES

\author{
${ }^{1}$ ANA CAROLINA DA SILVA, ${ }^{2}$ THAMIRYS SIQUEIRA CARPEJANI, ${ }^{3}$ DAIANE CORTEZ RAIMONDI
}

\author{
${ }^{1}$ Acadêmica do PIC/UNIPAR \\ ${ }^{1}$ Acadêmica do Curso de Medicina da UNIPAR \\ ${ }^{2}$ Docente da UNIPAR
}

Introdução: No Brasil, o câncer de colo uterino é a segunda neoplasia mais comum entre as mulheres, no qual estima-se para 2020 a ocorrência de 16,5 mil novos casos (INCA, 2020). Em relação aos fatores de risco, destaca-se a infecção pelo Papilomavírus Humano HPV como um fator necessário para o desenvolvimento da oncogênese do colo uterino, assim a prevenção da doença pode ser realizada pela imunização contra o HPV, mudanças de hábitos sexuais, bem como através do exame citopatológico do colo uterino (FIOCRUZ, 2017). Ressalta-se que a realização deste exame é a principal estratégia para detectar lesões precursoras e possibilitar o diagnóstico precoce da doença. O exame preventivo é disponibilizado nas unidades de saúde da rede pública para as mulheres de 25 a 64 anos que já iniciaram as atividades sexuais, sendo que a realização periódica permite reduzir a ocorrência e a mortalidade pela doença (INCA, 2020). Vale mencionar a importância da realização do exame citopatológico no período gestacional, visto que trata-se de uma oportunidade de realizar o rastreamento, além de ser a neoplasia maligna mais comumente diagnosticada na gestação, porém, verifica-se que neste período a recusa pelo procedimento tende a ser mais acentuada (CEZARIO; PIMENTEL; OLIVEIRA; OLIVEIRA, 2014).

Objetivo: Avaliar o perfil das gestantes que realizaram o exame citopatológico do colo uterino durante a gestação.

Metodologia: Trata-se de dados preliminares de um estudo descritivo, transversal, de abordagem quantitativa realizado com puérperas internadas no mês de julho na Maternidade Regional do Noroeste do Paraná. A pesquisa foi realizada por acadêmicas participantes de um programa de iniciação científica, com as puérperas residentes no município de localização da maternidade e que realizaram ao menos uma consulta de pré-natal. Foi aplicado um questionário semiestruturado contendo questões objetivas e subjetivas, sobre o conhecimento e adesão ao exame citopatológico do colo do útero durante a gestação. O estudo cumpriu as exigências éticas, estabelecidas na Resolução CNS no. 466/2012, sendo aprovado pelo parecer CAAE: 22352919.3.0000.0109.

Resultados: Participaram da pesquisa 62 puérperas, sendo que apenas $22(35,48 \%)$ relataram ter realizado o exame preventivo do câncer do colo do útero durante a gestação. Entre as puérperas que realizaram o exame durante o período gestacional, destaca-se que 12 (54,6\%) possuem de 26 a 39 anos. Em relação à raça $16(72,7 \%)$ se declararam pardas. Já os níveis de escolaridade variaram, sendo os mais prevalentes o ensino médio completo (40,9\%). Das participantes 10 (45,5\%) são amasiadas. Sobre a renda salarial, $11(50,0 \%)$ puérperas possuem entre um a dois salários mínimos. Sobre a via de parto, 50\% realizaram parto normal e 50\% cesárea. Das participantes 18 (81,8\%) realizaram o pré-natal no Sistema Único de Saúde- SUS; e quatro $(18,8 \%)$ intercalaram entre o SUS e particular. Em relação a quantidade de consultas no pré-natal, 11 (50\%) realizaram mais de dez consultas.

Discussão: De acordo com os resultados obtidos, a maioria das puérperas que realizaram o exame citopatológico do colo uterino são adultas jovens, pardas, com ensino médio completo ou incompleto, amasiadas com renda entre um a dois salários mínimos com mais de sete consultas de pré-natal realizado pelo SUS. A presença de companheiro e a escolaridade são fatores que podem intervir positivamente no cuidado à saúde, favorecendo a adesão das mulheres ao exame. Estes dados corroboram com o estudo de Yassoyama, Salomão e Vicentini (2006), no qual identificaram que as mulheres alfabetizadas e com união estável possuem mais conhecimento sobre o exame preventivo, e o acolhimento realizado pela unidade colabora para aceitação e adesão da mulher ao exame. Sobre a adesão ao exame, Rosa et al. (2018) constataram que as gestantes possuem pouco conhecimento sobre o exame preventivo, o que pode refletir na baixa adesão das mesmas ao procedimento, isto reflete a necessidade de sensibilizar as gestantes durante as consultas de pré-natal sobre a importância da realização do exame durante o período gestacional. Um estudo realizado em uma unidade de saúde do Ceará constatou que $82,9 \%$ das gestantes que participaram do estudo não haviam realizado o exame citopatológico do colo uterino durante o pré-natal corroborando com os dados do presente estudo, onde a adesão das gestantes ao exame foi baixa (PEIXOTO et al. 2012).

Conclusão: Pode-se concluir que as gestantes possuem individualidades que devem ser consideradas durante o pré-natal, pois conhecer as gestantes possibilita uma melhor abordagem para sensibilizar as mesmas sobre a importância da participação do pré-natal e realização de exames, como o citopatológico do colo uterino. Vale destacar ainda que a capacitação dos profissionais de saúde para uma assistência sistematizada, acolhimento e educação em saúde, podem ser fatores fundamentais para adesão das gestantes ao exame citopatológico do colo uterino, pois esta é de extrema importância para a redução da taxa de morbimortalidade feminina por câncer colo do útero. 


\section{Referências}

CEZARIO, K. G.; PIMENTEL, L.P.; OLIVEIRA, P.M.P.; OLIVEIRA, M. G. Conhecimento de gestantes sobre o exame citopatológico: um estudo na atenção básica em saúde. Rev enferm UFPE on line., Recife, 8(5):1171-7, maio., 2014.

INCA. Instituto Nacional de Câncer José Alencar Gomes da Silva. Câncer do Colo do útero. 2020. Disponível em: https://www.inca.gov.br/tipos-de-cancer/cancer-do-colo-do-utero. Acesso em: 04, agosto 2020.

ROSA, A. R. R. et al. Exame citopatólogico do colo do útero: investigação sobre conhecimento, atitude e prática de gestantes. Cogitare Enferm. (23)2: e52589, 2018. Disponível em: file:///C:/Users/CAROL/Downloads/52589-233964-1-PB.pdf. Acesso em: 20, agosto 2020.

PEIXOTO, C. R. et al. Perfil das gestantes atendidas no serviço de pré-natal das unidades básicas de saúde de Fortaleza-CE. Rev. Min. Enferm.;16(2): 171-177, abr./jun., 2012.

XAVIER, J.; Prevenção ao câncer do colo do útero. Fundação Oswaldo Cruz, 2017. Disponível em: https://portal.fiocruz.br/noticia/prevencao-ao-cancer-do-colo-do-utero. Acesso em: 04, agosto 2020.

YASSOYAMA, M. C. B. M.; SALOMÃO, M. L. M.; VICENTINI, M. E.; Características das mulheres que realizam exame preventivo do colo do útero durante a gestação: bases para estratégias do Programa de Saúde da Família (PSF). Arquivo Ciência Saúde, 2006. Disponível em: http://repositorio-racs.famerp.br/racs_ol/vol-12-4/02_ID150.pdf. Acesso em: 25, agosto 2020. 


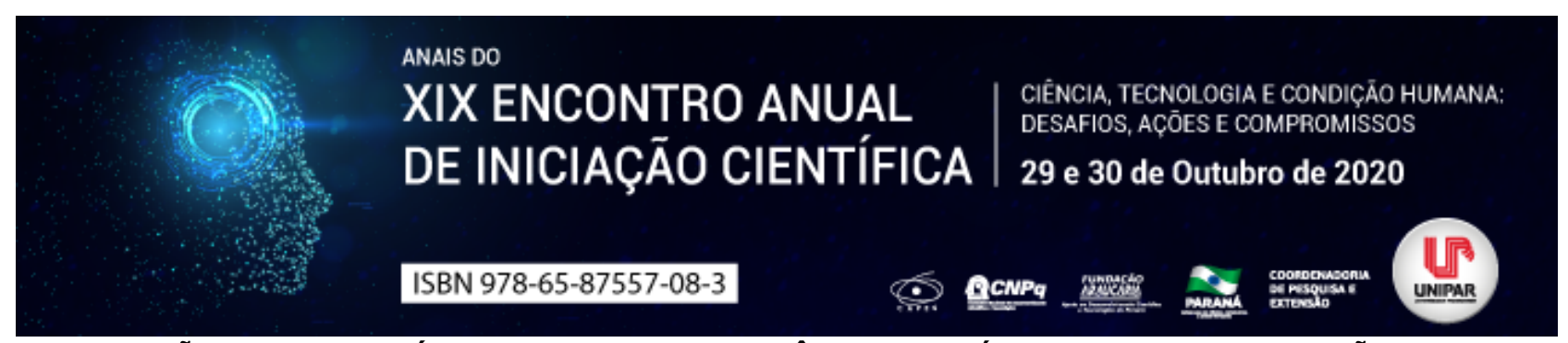

TRATAMENTOS NÃO FARMACOLÓGICOS PARA INCONTINÊNCIA URINÁRIA EM IDOSOS: REVISÃO INTEGRATIVA DA LITERATURA

\author{
${ }^{1}$ RAPHAELA BOLIGON, ${ }^{2}$ DIANE MIRELLY DICKEL, ${ }^{3}$ GABRIEL CAMINI, ${ }^{4}$ DIANDRA MICHELLY DICKEL, ${ }^{5}$ ALESSANDRO \\ RODRIGUES PERONDI
}

\author{
${ }^{1}$ Acadêmico do PIC/UNIPAR \\ ${ }^{1}$ Acadêmico do PIC/UNIPAR \\ ${ }^{2}$ Acadêmico do Curso de Enfermagem da UNIPAR \\ ${ }^{3}$ Acadêmica do Curso de Enfermagem da UNIPAR \\ ${ }^{4}$ Docente da UNIPAR
}

Introdução: A Incontinência Urinária (IU) pode ser definida como a perda involuntária de urina, ocorrida tanto em homens como em mulheres, trazendo um importante impacto negativo na vida dessas pessoas, comprometendo o convívio social causando vergonha, depressão e isolamento (RIBEIRO et al, 2020). Embora o envelhecimento aumente a probabilidade de IU, não é uma consequência inevitável do envelhecimento. A IU geralmente pode ser tratada, a chave para o tratamento é identificar suas causas (NAZARKO, 2013). Para isso, as IU são classificadas pelos sintomas ou pelas circunstâncias que ocorrem no momento da perda de urina (NAZARKO, 2018). Diversas formas de tratamento são descritas como eficazes para tratar IU, incluindo medicamentos, exercícios específicos, biofeedback, técnicas de estimulação elétrica ou magnética, dentre muitas outras (OLIVEIRA et al., 2007). Muitos desses métodos, ainda que antigos, permanecem controversos na literatura, visto que ainda existem dúvidas quanto aos reais benefícios e efeitos colaterais de suas utilizações.

Objetivo: O estudo teve como objetivo verificar, por meio de revisão integrativa da literatura, as intervenções não farmacológicas utilizadas para o tratamento da incontinência urinária em idosos.

Desenvolvimento: Realizou-se uma Revisão Integrativa (RI) orientada pela questão norteadora: Quais são as intervenções não farmacológicas utilizadas no tratamento da incontinência urinária no idoso publicados na literatura cientificas nos últimos 5 anos? . Efetuou-se a busca na Base de Dados da Biblioteca Virtual em Saúde (BVS Salud) utilizando-se os descritores e suas combinações nas línguas portuguesa e inglesa Idosos e Incontinência Urinária por Estresse e o operador booleano and e como critérios de busca publicações no formato de artigos científicos. Os critérios de inclusão definidos para a seleção dos artigos foram: artigos publicados em português, inglês e espanhol; artigos na íntegra que retratassem a temática, publicados nos últimos cinco anos (2015 a 2020). Na busca realizada foram encontrados 26 artigos, na sequência, realizou-se análise crítica que correspondeu à avaliação dos estudos e interpretação dos resultados. Nesta análise foram excluídos 19 artigos, destes 4 por se repetirem na base de dados e 15 por não responderem ao objetivo do estudo. Para melhor apresentação dos artigos que compuseram o escopo da RI, os estudos foram identificados com a letra $\mathrm{E}$, numerados sucessivamente. A amostra final foi composta por 7 artigos, todos enquadrados no nível 5 de evidência, por serem provenientes de relatos de caso ou de experiência. Destes 2 foram publicados em 2017, 3 em 2018 e 2 em 2019. Em um contexto geral, os estudos reunidos retratam o uso de tratamentos alternativos para a IU e a eficácia dos mesmos, que variam entre exercício de fortalecimento do assoalho pélvico, laser de érbio vaginal, bainhas penianas e balões intravesicais da Vesair. Os estudos E1, E2 e E3 apresentam algumas estratégias comportamentais no tratamento da IU. O E1, testou o processo de treinamento da musculatura pélvica (PFMT) e apontou como resultado que o PFMT impede o início da IU no final da gravidez e no pós-parto, já na prevenção da incontinência urinária tardiamente a pergunta continua em aberto. O estudo E2 realizou sessões de cinesioterapia para fortalecimento do assoalho pélvico e apontou que o tratamento foi capaz de proporcionar melhor fortalecimento do assoalho pélvico, maior controle sobre a perda de urina diária e alívio dos sinais e sintomas da IU. O E3 desenvolveu técnicas de ioga baseadas em Iyengar e demonstrou evidências preliminares de redução dos sintomas de IU (DORNOWSKI, 2018; SANTANA SILVA, 2017; HUANG, 2019). Os estudos E4, E5 e E6 trazem a utilização de dispositivos para o tratamento da IU, no E4 foi identificado melhora na qualidade de vida em homens com IU após a utilização das bainhas penianas. O ensaio E5 avaliou a incrustação em balões intravesicais da Vesair e apontou que a taxa de incrustação é baixa e não parece aumentar a taxa de resultados adversos ou reduzir a eficácia clínica. O E6 trata a complacência a longo prazo de pessários vaginais e evidenciou melhora significativa dos sintomas obstrutivos, em contrapartida, mulheres com IU grave, a condição pode piorar (NAZARKO, 2018; VAN KOEVERINGE, 2017; HSIEH, 2019). O E7 apresenta os efeitos a longo prazo do laser de érbio vaginal, demonstrando melhora da incontinência urinária de esforço leve a moderada, sem grandes efeitos colaterais (GAMBACCIANI et al., 2018).

Conclusão: O estudo colaborou para aprimorar o conhecimento sobre as intervenções não farmacológicas utilizadas no tratamento da IU. Para tanto, a escassez de estudos, bem como o baixo nível de evidencia dos mesmos, se apresentam como 
limitações desta pesquisa. Salientamos que novos estudos com abordagens mais amplas devem ser conduzidos, com vista a proporcionar melhor compreensão sobre essa modalidade de tratamento da IU no idoso.

\section{Referências}

DORNOWSKI, Marcin et al. Six-Week Pelvic Floor Muscle Activity (sEMG) Training in Pregnant Women as Prevention of Stress Urinary Incontinence. Med Sci Monit. Polônia, v. 24, p. 5653- 5659, Agosto. 2018.

SANTANA SILVA, Luzia Wilma et al. Fisioterapia na incontinência urinária: olhares sobre a qualidade de vida de mulheres idosas. Revista Kairós Gerontologia. São Paulo, v. 20, n. 1, p. 221-238, jan. 2017.

HUANG, Alison J. et al. A group-based yoga program for urinary incontinence in ambulatory women: feasibility, tolerability, and change in incontinence frequency over 3 months in a single-center randomized trial. American Journal of Obstetrics \& Gynecology. v. 220, n. 1, p. 87.E1-87.E13, January. 2019.

NAZARKO. Linda. Male urinary incontinence management: penile sheaths. Revista Br J Community Nurs. Europa, v. 23, n. 3, p. 110-116, mar. 2018.

VAN KOEVERINGE, Gommert A. et al. Minimal Device Encrustation on Vesair Intravesical Balloons in the Treatment of Stress Urinary Incontinence: Analysis of Balloons Removed from Women in the SOLECT Trial. Adv Ther. Europa, v. 34, p. 16861694 , June. 2017.

HSIEH, Ming Fang et al. Long-term compliance of vaginal pessaries Does stress urinary incontinence matter?. Revista Medicine. ed. 14, v. 98, p. 15063, abr, 2019.

GAMBACCIANI, Marco et al. Long-term effects of vaginal erbium laser in the treatment of genitourinary syndrome of menopause. Revista Climacteric. v. 21, n. 2, p. 148 -152, fev. 2018.

RIBEIRO, Daniel Carvalho et al. Incontinência dupla: fatores associados e impacto sobre a qualidade de vida em mulheres atendidas em serviço de referência. Revista brasileira Geriatria e Gerontologia. Rio de Janeiro, v. 22, n. 6, mar. 2020.

SOUZA, Luiz Manuel Mota et al. Metodologia de revisão integrativa da literatura em enfermagem. Revista investigação enfermagem. p. 17 26, nov. 2017. 


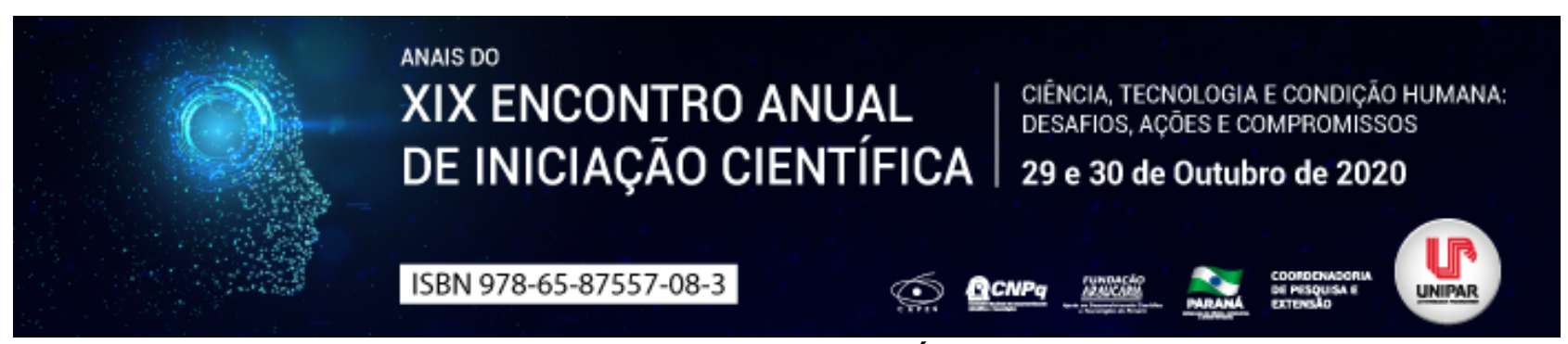

PARASITOSE EM CRIANÇAS NA FASE PRÉ-ESCOLAR NO BRASIL

\title{
${ }^{1}$ DANILO DA SILVA MUNARETO, ${ }^{2}$ ANA PAULA SOKOLOWSKI DE LIMA, ${ }^{3}$ SUELLEN LAIS VICENTINO VIEIRA
}

\begin{abstract}
${ }^{1}$ Discente do Curso de Farmácia, Ciências da Saúde, Universidade Paranaense - Umuarama-PR.
${ }^{1}$ Discente do Curso de Farmácia, Ciências da Saúde, Universidade Paranaense - Umuarama-PR.

${ }^{2}$ Docente do Curso de Farmácia, Ciências da Saúde, Universidade Paranaense - Umuarama-PR.
\end{abstract}

Introdução: As enteroparasitoses são infecções causadas por parasitos intestinais, sendo em sua maioria desencadeadas por protozoários e helmintos. A falta de saneamento básico e escassez de higiene, contribuem na manutenção do ciclo biológico e a disseminação dos parasitos (ASTUDILLO; BRAVA; 2017). Estima-se que 200 milhões de crianças na idade pré-escolar de todo o mundo sejam afetadas por enteroparasitos, devido à falta principalmente de estratégias de melhoramento do nível socioeconômico da população (ANTOLI et al., 2018). A faixa de idade mais propícia a contaminação com parasitoses está relacionada a crianças de 0 a 12 anos de idade, pois frequentam creches ou escolas, estando mais susceptíveis devido ao hábito de levar objetos à boca, como forma de exposição, bem como, a imaturidade de higiene, tendo os parasitas mais comum de ser encontrados no território Brasileiro são: Ascaris lumbricoides, Trichuris trichiura, Ancilostomideos, Entamoeba histolytica, Giardia lamblia, Endolimax nana e Entamoeba coli (CALDEIRA et al., 2019). O Brasil está entre os países com maior índice de parasitoses intestinais, sendo alta a prevalência em crianças de idade pré-escolares, devido aos hábitos inadequados, falta da conscientização dos pais e professores e a falha da prática de higiene (ANTOLI et al., 2018).

Objetivo: Realizar uma revisão de casos de parasitoses em crianças na fase pré-escolar no Brasil.

Desenvolvimento: As enteroparasitoses, são doenças cujo os agentes são helmintos ou protozoários causadores de alguns tipos de infecção no trato gastrointestinal, acometendo principalmente países em desenvolvimento, apresentam baixo nível de mortalidade, porém altas taxas de morbidades, principalmente em crianças, levando a desnutrição e prejudicando seu desenvolvimento cognitivo, sendo considerado um grande problema de saúde pública (ASTUDILLO; BRAVA; 2017). A prevalência das enteroparasitoses, está diretamente relacionada a um conjunto de fatores como saneamento básico, falta de educação sanitária, clima, hábitos de higiene pessoal e coletiva, como lavagem das mãos e alimentos irregulares, além de baixa condições socioeconômicas (ANTOLI et al., 2018). De acordo Wiebbelling et al. (2019), relata que 36\% da população brasileira apresentam algum tipo de parasitose intestinal, sendo as crianças mais susceptíveis, chegando a 55,3\% por falta de acesso básico como rede de esgoto, água tratada e conscientização dos pais sobre a higienização adequada. De acordo com uma análise integrativa de casos de parasitose no Brasil, os helmintos foram os mais prevalentes nas crianças estudadas de Seres (Goiás), sendo Ascaris lumbricoides (58,3\%) o mais predominante, tendo uma prevalência de até $70 \%$ de parasitoses em crianças de idade escolar, por outro lado, o protozoário mais relatado no estudo é a Giardia intestinalis com uma prevalência que varia de 4,9 a 96\%, apesar de ser parasitas comum na saúde do país torna-se negligenciado por falta de medidas de prevenção, passando despercebidas e tornando um grande problema de saúde pública (SOLANO-BARQUERO et al., 2018). Em estudo realizado por Siqueira e Tristão (2019), analisando a prevalência de contaminação de crianças de 0 a 12 anos, verificaram diagnóstico de Ascaris lumbricoides como o mais prevalente dentro da classe do helminto e entre os protozoários a Entamoeba histolytica e Giardia lamblia. O estudo ainda apontou que $47 \%$ das crianças de fase escolar, apresentam alguma forma de parasito podendo ser encontrados cistos, ovos ou larvas de alguma espécie. O diagnóstico de parasitose pode ser realizado pelo exame parasitológico de fezes feito em um laboratorio de analises clínicas, onde a coleta é realizada em um frasco estéril, de tampa larga e rosqueável com uma quantidade mínima de 5 gramas de fezes. As amostras são analisadas macroscopicamente observando a consistência, se apresenta característica diarreica, e microscopicamente por métodos direto em lâmina e outros métodos de concentração (CAVAGNOLLI et al., 2015). O tratamento das parasitoses baseia-se no uso de antiparasitário, que são fármacos que agem com o intuito de eliminar parasitas que estão localizado no trato gastrointestinal sendo ovo, cisto e protozoário que invadem o tecido, seu uso indiscriminado de anti-helmínticos sem diagnóstico laboratorial pode desenvolver resistência medicamentosa, além de trazer um problema secundário ou adverso devido a exposição desnecessária ao medicamento e através do exame parasitológico de fezes, que tem uma fundamental importância na identificação do parasita e também para o uso correto do medicamento sendo ele uma vez específico a cada parasita (FREITAS; TASCA; 2017).

Conclusão: A prevalência de enteroparasitos é um problema socioeconômico, principalmente em região subdesenvolvida e em desenvolvimento como no caso do Brasil. As crianças que frequentam creches são as mais prejudicadas, decorrente da falta de orientação sobre importância da higiene básica e saneamento, tendo assim a sua contaminação oral e fecal por ingestão de ovos e cisto. Os parasitos mais frequentes são o Ascaris lumbricoides, Entamoeba histolytica e Giardia sp. O diagnóstico por meios de exame parasitológico de fezes de rotina, ou em casos de sintomatologias características é essencial para a escolha adequada do agente antiparasitário. 


\section{Referências}

ANTOLI, Carla Muños et al. Enteroparasites in Preschool Children on the Pacific Region of Nicaragua. The American Journal of Tripical Medicine and Hygiene. v. 98, n. 2, p. 570-575, 2018.

ASTUDILLO, Osvaldo Germán; BRAVA, Amadeu Javier. Prevalencia de las parasitosis intestinales en el Hospital de Enfermedades Infecciosas Dr. Francisco Javier Muñiz . Lei latino-americana de bioquímica clínica. v.51, n.4, p.681-686, 2017.

CALDEIRA, Isabella Prates et al. Prevalência de parasitas em pacientes atendidos em laboratório de um centro universitário da cidade de Montes Claros, MG. Revista brasileira de analises clinica. v. 51, n. 3, p. 234-240, 2019.

FREITAS, Caroline Olmedo de; TASCA, Tiana. Análise comparativa do uso de medicamentos antiparasitários adquiridos na Unidade Básica de Saúde Santa Cecília Porto Alegre, RS versus drogarias. 2017. Trabalho de Conclusão de Curso (Bacharel em Farmácia) - Universidade Federal do Rio Grande do Sul - UFRS, 2017.

LINS, Isis Valeska Ferreira et al. Comparação entre o método da fita adesiva e o método de sedimentação espontânea para o diagnóstico de Enterobius vermicularis. Journal of Biology \& Pharmacy and Agricultu ral Managemen. v.12, n.4, p.11-18, 2016.

SIQUEIRA, Renata Lorrany Lima da Silva; TRISTÃO, Taliane Canto. Ocorrência e geolocalização de parasitos intestinais em laudos parasitológicos de fezes de crianças em um laboratório privado do município de Alto Paraíso/Ro nos anos de 2017-2018. 2019. Trabalho de Conclusão de Curso (Bacharel em Farmácia) - Faculdade de Educação e Meio Ambiente FAEMA, 2019.

SOLANO-BARQUERO, Melissa et al. Prevalencia de parasitosis en niños de 1 a 7 años en condición de vulnerabilidad en la Región Central Sur de Costa Rica. Ato médico da Costa Rica. v.60, n.2, p.19-29, 2018.

WIEBBELliNG, Adilia Maria Pereira et al. Prevalência e prevenção de parasitoses infantis em crianças de creches/escolas de Porto Alegre. Porto Alegre: UFCSPA. 2019. 


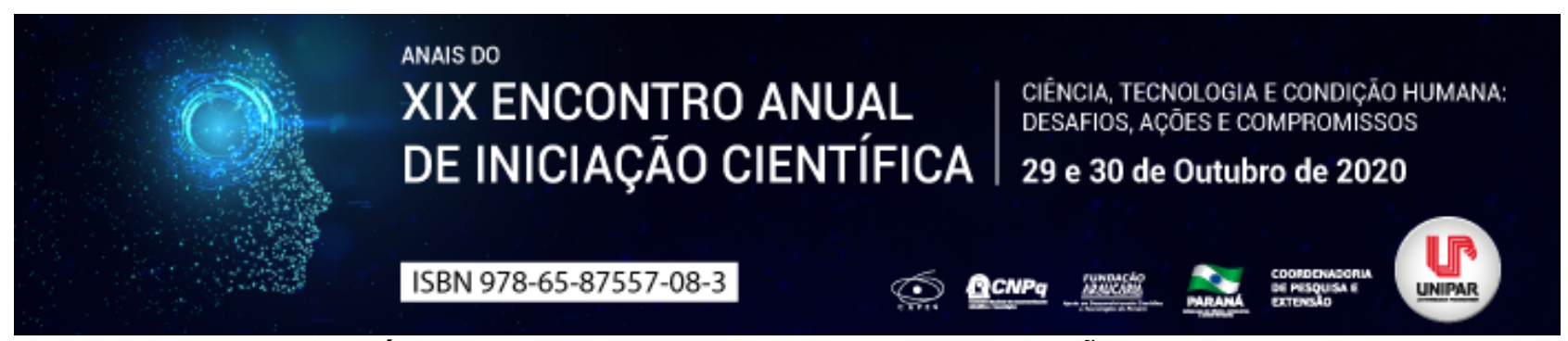

IMPACTO DOS HÁBITOS DE VIDA NO GENE FTO E SUA RELAÇÃO COM A OBESIDADE

\title{
${ }^{1}$ RAFAEL LEONARDI JANEIRO, ${ }^{2}$ MARIA ELENA MARTINS DIEGUES, ${ }^{3}$ LUCIANO SERAPHIM GASQUES
}

\author{
${ }^{1}$ Acadêmico bolsista do PIBIC/UNIPAR \\ ${ }^{1}$ Docente da UNIPAR \\ ${ }^{2}$ Docente da UNIPAR
}

Introdução: Segundo a Organização Mundial de Saúde, sobrepeso e obesidade são definidos como um acúmulo anormal de gordura em excesso que apresenta riscos à saúde. Em 2016, 650 milhões de adultos eram obesos e 340 milhões de crianças e adolescente estavam, ao menos, com sobrepeso (OMS, 2020). No ano de 2007, o gene fat mass and obesity-associated (FTO) se tornou o primeiro polimorfismo de nucleotídeo único (SNP) a ser associado ao aumento de massa corporal (FAWCETT; BARROSO, 2010). Dentre os estudos produzidos a partir desse tema, muitos retratam se há impacto dos hábitos de vida no gene.

Objetivo: Avaliar a influência de exercícios físicos sobre o gene FTO e descrever sua relação com o índice de massa corporal (IMC).

Desenvolvimento: Estudos associados ao genoma e ao fenótipo da obesidade de modelos de ratos transgênicos trouxeram uma compreensão sobre a exploração de novos genes obesogênicos. Alguns dos polimorfismos associados ao gene FTO codifica uma proteína associada a massa gorda. Os SNPs obesogênicos, em especial o rs9939609, são considerados os com a maior associação genética em relação à obesidade em várias populações de diferentes países (ZHAO et al., 2014). Além dos fatores genéticos, hábitos de vida, como dieta e sedentarismo, contribuem profundamente para o ganho de peso e obesidade. Por outro lado, o aumento do risco de obesidade devido a susceptibilidade genética pelas variantes do FTO, podem ser atenuadas através da atividade física (RAMPERSAUD et al., 2008). É importante salientar que indivíduos homozigotos (AA ou aa) para sobrepeso possuem 1,67 vezes mais chances de se tornarem obesos quando comparados a indivíduos heterozigotos (Aa). Todavia, o risco da obesidade pelo alelo pode ser diminuído quando associado a exercícios regulares, mesmo em indivíduos sedentários, afetando diretamente a gordura corporal (RANKINEN et al., 2010). Segundo Sonestedt et al. (2011), o FTO tem uma relação considerável não apenas com a massa gorda, mas também com a massa magra. Entretanto, o nível de atividade física e ingestão de gordura modifica apenas a associação com a massa gorda, sobretudo em indivíduos que possuem sobrepeso ou obesidade. Evidenciando que não importa a idade nem o sexo, Reinehr et al (2014) realizou uma intervenção no estilo de vida em crianças com sobrepeso, baseado em atividade física intensa, educação nutricional e terapia comportamental não somente a elas, como a suas famílias. Obteve-se, como resultado, que durante o período de intervenção (o primeiro ano da pesquisa), as crianças reduziram significativamente o IMC. Em contrapartida, no segundo ano da pesquisa, - apenas observacional -, houve um acréscimo notável no IMC. Além disso, Sonestedt et al. (2009), afirmou que a falta de regularidade de atividades físicas recreativas (futebol, corrida, ciclismo) resultou num acréscimo da susceptibilidade de um IMC mais alto pela variante do FTO.

Conclusão: A influência dos hábitos de vida, em especial da prática de exercícios físicos, são capazes de reduzir tanto a susceptibilidade genética para a obesidade e o sobrepeso, assim como o IMC em pessoas portadoras de SNPs obesogênicos no gene FTO.

\footnotetext{
Referências

FAWCETT, Katherine A.; BARROSO, Inês. The genetics of obesity: FTO leads the way. Trends in Genetics, v. 26, n. 6, p. 266274, 2010.

RAMPERSAUD, Evadnie. et al. Physical activity and the association of common FTO gene variants with body mass index and obesity. Archives of Internal Medicine, v. 168, n. 16, p. 1791-1797, 2008.

RANKINEN, Tuomo. et al. FTO genotype is associated with exercise training induced changes in body composition. Obesity, v. 18, n. 2, p. 322-326, 2010.

REINEHR, Thomas. et al. FTO gene: association to weight regain after lifestyle intervention in overweight children. Hormone Research in Paediatrics, v. 81, n. 6, p. 391-396, 2014.

SONESTEDT, Emily. et al. Association between fat intake, physical activity and mortality depending on genetic variation in FTO. International Journal of Obesity, v. 35, n. 8, p. 1041-1049, 2011.

SONESTEDT, Emily. et al. Fat and carbohydrate intake modify the association between genetic variation in the FTO genotype and obesity. The American Journal of Clinical Nutrition, v. 90, n. 5, p. 1418-1425, 2009.

ZHAO, Xu. et al. FTO and obesity: mechanisms of association. Current Diabetes Reports, v. 14, n. 5, p. 486, 2014.
} 
Coordenadoria de Pesquisa e Extensão - COPEX

Departamento de Editoraçāo e Divulgaçāo Científica - DEDIC 


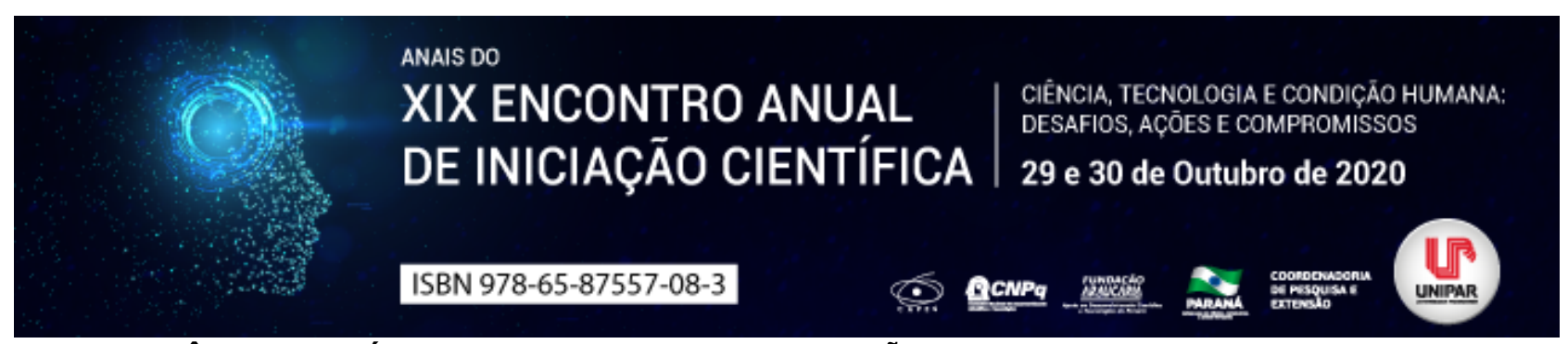

VIOLÊNCIA DOMÉSTICA CONTRA IDOSOS: ATUAÇÃO DO PROFISSIONAL ENFERMEIRO

\title{
${ }^{1}$ HELEN RODRIGUES DE OLIVEIRA, ${ }^{2}$ KATIA BIAGIO FONTES
}

\author{
${ }^{1}$ Discente do curso de Enfermagem - UNIPAR \\ ${ }^{1}$ Docente da UNIPAR
}

Introdução: A violência consiste em um problema social, que afeta toda uma população, porém as mulheres, crianças e idosos são os mais acometidos por ela. A violência doméstica é estabelecida como aquela que causa danos físicos, psicológicos, sexual e econômico dentro do âmbito intrafamiliar, e pode ser praticada por qualquer um que esteja em relação superior a vítima, sem necessariamente ter laços sanguíneos (DAY et al., 2003). A Organização Mundial da Saúde (OMS) descreve a violência contra o idoso como ação ou omissão proposital ou involuntária, podendo esta ser de natureza física e/ou psicológica, envolvendo maustratos (OMS, 2002).

Objetivo: Descrever o papel fundamental do enfermeiro (a) à idosos vítimas de violência doméstica.

Desenvolvimento: Estudo identificou que enfermeiros que atenderam idosos vítimas de violência, conseguiram identificar agressões através da anamnese e exame físico. Idosos, vítimas de violência apresentavam sinais de magreza e higiene pessoal prejudicada (MUSSE; RIOS, 2015). As consequências da violência, além de sinais físicos, incluem a depressão, o estresse póstraumático, o sentimento de vergonha e o sentimento de inutilidade (SANCHES; LEBRÃO; DUARTE, 2008). Estes dados evidenciam a importância da anamnese detalhada e exame físico completo, assim como um olhar clínico do profissional enfermeiro, como ferramentas fundamentais na identificação de idosos vítimas de violência. Resultados de estudo anterior demonstrou que, dos 307 idosos violentados, $57 \%$ dos agressores eram filhos e filhas (MINAYO, 2003). Quando se trata deste tipo de violência, a negligência e abandono são os tipos de violência mais sofridos pelos idosos (SHIMBO; LABRONICl; MANTOVANI, 2011). A enfermagem trabalha no suporte a família e, por conseguinte, o cuidado aos idosos, desta forma, faz-se necessário compreender todas as nuances dos maus-tratos provocados na esfera familiar, destacando assim a importância da visita domiciliar. É responsabilidade dos profissionais, favorecer uma atmosfera de confiança que favoreça o acolhimento e respeito às decisões do idoso (CAMACHO; ALVES, 2015). É dever dos profissionais de saúde de instituições públicas e privadas notificar compulsoriamente todos os casos de suspeita ou confirmação de violência à autoridade sanitária, assim como denúncia às autoridades legais competentes (BRASIL, 2013). Sendo assim, conhecer as leis que protegem a população idosa, torna-se de grande importância a fim de que esses profissionais se sintam respaldados frente a casos de denúncia.

Conclusão: Pode-se concluir que o papel da enfermagem na violência contra idosos contempla a importância da anamnese e exame físico, visto que essas ferramentas são fundamentais na identificação de idosos vítimas de violência. Envolve também o acompanhamento do idoso no âmbito doméstico, visto que normalmente as agressões são feitas pelos próprios cuidadores e familiares, destacando assim a necessidade de visitas domiciliar

frequentes. Fazem parte também da atuação do enfermeiro frente a idosos vítimas de violência a notificação e denúncia dos caso de suspeita e confirmação de violência.

\section{Referências}

BRASIL. Ministério da Saúde. Secretaria de Atenção à Saúde. Estatuto do Idoso 3. ed. Brasília, 2013.

CAMACHO, Alessandra Conceição Leite Funchal; ALVES, Rosemere Rosa. Maus tratos contra os idosos na perspectiva da enfermagem: revisão integrativa. Rev Enferm. UFPE online., v.9, n.2. p. 927-35, 2015. Disponível em: http://abre.ai/buDy Acesso em: 20 ag. 2020.

DAY, Vivian Peres. et al. Violência doméstica e suas diferentes manifestações. Revista de Psiquiatria do Rio Grande do Sul, v. 25, n. 1, p. 9-21, 2003. Disponível em: http://abre.ai/buDf. Acesso em: 20 ag. 2020.

MINAYO, Maria Cecília de Souza. Violência contra idosos no Brasil: Relevância para um velho problema. Cadernos de Saúde Pública, v. 19, n. 3, p. 783-91, 2003. Disponível em: https://cutt.ly/OffM17N Acesso em: 27 ag. 2020.

MUSSE, Juliana Oliveira; RIOS, Maria Helena Evangelista. Atuação do enfermeiro perante a violência doméstica sofrida pelo idoso, v. 20, n.2, p. 365-79, 2015. Disponível em: http://abre.ai/buDe. Acesso em: 20 ag. 2020.

ORGANIZAÇÃO MUNDIAL DA SAÚDE. Relatório mundial sobre violência e saúde. Geneva, 2002. Disponível em: https://www.cevs.rs.gov.br/ Acesso em: 20 ag. 2020.

SANCHES, Ana Paula R. Amadio; LEBRAO, Maria Lúcia; DUARTE, Yeda Aparecida de Oliveira. Violência contra idosos: uma questão nova? Saude soc., v.17, n.3, p.90-100, 2008. Disponível em: http://abre.ai/buDu Acesso em: 20 ag. 2020.

SÃO PAULO. Secretaria Municipal da Saúde. Coordenação de Desenvolvimento de Programas e Políticas de Saúde. Caderno de Violência contra a Pessoa Idosa: orientações gerais. São Paulo: SMS, 2007. 
SHIMBO, Adriano Yoshio; LABRONICI, Liliana Maria; MANTOVANI, Maria de Fátima. Reconhecimento da violência intrafamiliar contra idosos pela equipe da estratégia saúde da família. Escola Anna Nery, v. 13, n. 3, p. 506-10, 2011. Disponível em: http://abre.ai/bw87 Acesso em: 20 ag. 2020.

Coordenadoria de Pesquisa e Extensão - COPEX

Departamento de Editoraçāo e Divulgaçāo Científica - DEDIC 


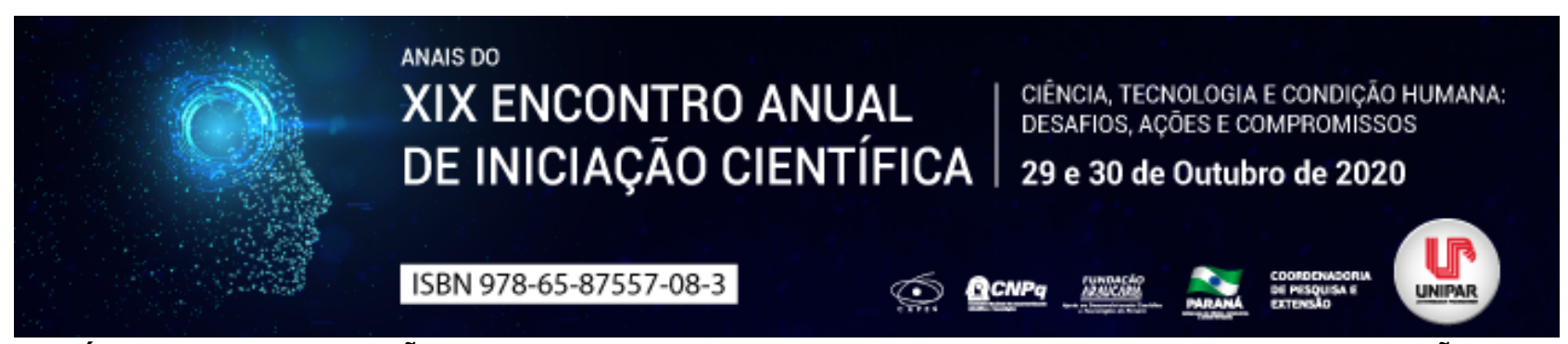

ÓBITOS POR INFECÇÃO HOSPITALAR NA UNIDADE DE TERAPIA INTENSIVA: UMA REVISÃO

\begin{abstract}
${ }^{1}$ ANA CAROLINA FURGHIERI ROSA, ${ }^{2}$ BEATRIZ MORETTO DE PAULA, ${ }^{3}$ GABRIELA ALVES DE OLIVEIRA, ${ }^{4}$ BRUNA MONTEIRO SANCHES, ${ }^{5}$ GABRIELA CORREA ALBERTI, ${ }^{6}$ ALTAIR DE SOUZA CARNEIRO
\end{abstract}

\begin{abstract}
${ }^{1}$ Acadêmica do Curso de Medicina da UNIPAR
${ }^{1}$ Acadêmica do Curso de Medicina da UNIPAR

${ }^{2}$ Acadêmica do Curso de Medicina da UNIPAR

${ }^{3}$ Acadêmica do Curso de Medicina da UNIPAR

${ }^{4}$ Acadêmica do Curso de Medicina da UNIPAR

${ }^{5}$ Docente da UNIPAR
\end{abstract}

Introdução: Infecções Hospitalares $(\mathrm{IH})$ são complicações que podem ocorrer após a realização de procedimentos relativos à assistência em saúde. São muitas as bactérias causadoras, se destacando as gram positivas. Tais infecções podem ser contraídas por meio de fatores endógenos e exógenos e também se manifestarem de forma mais grave em pessoas incluídas no grupo de risco (BRASIL, 2020; HORR, 2020). Por fim, é fundamental ressaltar que há formas de profilaxia eficientes para a prevenção dessas infecções evitando o número de óbitos.

Objetivo: Conhecer o que é infecção hospitalar, relacioná-la com suas formas de contração através da ala de Unidade de Terapia Intensiva (UTI) e apresentar medidas profiláticas que relacionem ao ao número de mortes por esse tipo de infecção nas instituições hospitalares.

Desenvolvimento: A infecção hospitalar $(\mathrm{IH})$ trata-se de qualquer infecção adquirida no ambiente hospitalar, podendo ocorrer após a alta. Pode ser desencadeada por diversos fatores, não necessariamente vinculados a má higiene, visto que alguns microrganismos naturais do organismo podem vir a causar problemas. Para fechar um diagnóstico relacionado a IH, é necessário que os profissionais de saúde investiguem o curso do paciente desde a sua chegada ao hospital, por meio de exames e acompanhamento clínico. As IH podem ser transmitidas através de objetos contaminados, de pessoa para pessoa ou até mesmo pelo ar. As pessoas mais suscetíveis a desenvolver as IH são idosos, portadores de doenças crônicas (hipertensão e diabetes), pacientes oncológicos, imunodeprimidos e transplantados. (HOSPITAL VIVALLE, 2016). Essas infecções estão mais presentes em alas das UTIs, por ser um ambiente mais propício para a colonização de bactérias especializadas. Além disso, esse tipo de patologia é responsável por um aumento significativo de doentes que vão à óbito dentro das instituições de saúde. Há muitas bactérias capazes de causar essa doença, e muitas delas se tornaram resistentes ao longo do tempo devido ao mal uso de medicamentos, implicando em procedimentos mais sofisticados no combate (SANTOS et al., 2016). A vulnerabilidade do paciente internado em UTI é um fator desencadeante para $\mathrm{IH}$, visto que patologias pregressas propiciam um desequilíbrio na microbiota normal e transitória, tida como um mecanismo de defesa, podendo implicar na prevalência de algum agente oportunista (SANTOS et al., 2016).

A ANVISA cita como infecções mais frequentes nas UTIs: pulmonares, principalmente associadas à ventilação mecânica, intraabdominais, infecções da corrente sanguínea primária, sendo a maioria relacionada a cateteres centrais, urinárias e àquelas de sítio cirúrgico. Observa-se que existem ainda as bactérias multirresistentes que perpetuam por meio de equipamentos não higienizados adequadamente e da equipe multiprofissional atuante, além de fungos em menor escala. De acordo com Da Mata Abbeg e Da Silva (2011), nenhum hospital é totalmente livre das IH, entretanto, é indispensável o uso de medidas de controle, para promover uma diminuição de casos e de possíveis agravos que possam acarretar piora do quadro clínico. Portanto, é fundamental a adoção de medidas conscientizadoras, a capacitação, o comprometimento e o cumprimento das normas de biossegurança estabelecidas por parte da equipe de saúde e colaboradores do hospital; o que envolve práticas corretas de higienização das mãos e do ambiente, uso de equipamentos de proteção individual (EPI), e vigilância epidemiológica. Além disso, segundo Lisboa et al. (2007), para a efetividade da prevenção das infecções nosocomiais, é imprescindível que os trabalhadores tenham um amplo conhecimento sobre as $\mathrm{IH}$, quais os tipos de infecções, os meios de infecção, as taxas de ocorrência e a relação entre elas. Por fim, o tratamento é feito por meio de antibióticos disponíveis, antifúngicos, drogas e outras medicações que controlam ou inibem a infecção instalada, além da conservação e limpeza adequada do ambiente hospitalar.

Conclusão: É visto que as infecções hospitalares podem variar de acordo com o local onde se manifestam no organismo sendo os micróbios mais comuns as bactérias gram positivas. Além do exposto afirma-se que as mortes por tais infecções podem relacionar-se diretamente com as medidas de prevenção colocadas em prática no dia-a-dia pelos profissionais de saúde que atuam nos hospitais em geral ou mais especificamente na ala de tratamento intensivo. Por fim, é dito que muitos óbitos poderiam ser evitados somente pelas práticas adequadas de medidas profiláticas para a infecção em questão, o que influenciaria 


\section{Referências}

BRASIL. Ministério da Saúde, 2020. Disponível em: . Acesso em: 26 mar., 2020.

CAMARGO, Luiz Fernando Aranha et al. Prevenção de infecções em unidade de terapia intensiva. Anvisa - Infecção relacionada à assistência à saúde. UNIFESP. São Paulo, 2004. Disponível em:

DA MATA ABEGG, Patricia Terron Ghezzi; DA SILVA, Ligiane de Lourdes. Controle de infecção hospitalar em unidade de terapia intensiva: estudo retrospectivo. Semina: Ciências Biológicas e da Saúde, v. 32, n. 1, p. 47-58, 2011.

HORR, Lidvina et al . Comissão de controle de infecção hospitalar.. Rev. Bras. Enferm., Brasília , v. 31, n. 2, p. 182-192, 1978. Disponível em: . Acesso em: 26 Mar. 2020.

LISBOA, Thiago et al. Prevalência de infecção nosocomial em Unidades de Terapia Intensiva do Rio Grande do Sul. Revista brasileira de terapia intensiva, v. 19, n. 4, p. 414-420, 2007.

SANTOS, Alice Veras et al. Perfil das infecções hospitalares nas unidades de terapia intensiva de um hospital de urgência. Revista de Enfermagem da UFPE, v. 10, n. Sup 1, p. 194-201, 2016.

Você sabe o que causa a Infecção Hospitalar? Hospital Vivalle, 2016. Disponível em: . Acesso em: 22, abril de 2010. 


\title{
ANAIS DO
}

XIX ENCONTRO ANUAL DE INICIAÇÃO CIENTÍFICA

CIÊNCIA, TECNOLOGIA E CONDIÇÃO HUMANA: DESAFIOS, AÇŌES E COMPROMISSOS

29 e 30 de Outubro de 2020

ISBN 978-65-87557-08-3

DOl: http://dx.doi.org/10.25110/xixeaic.2020

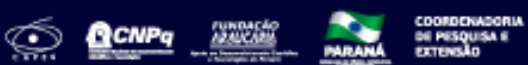

UNIPAR

CURCUMA LONGA PRODUZ AÇÃO ANTIPARKINSONIANA EM UM MODELO EXPERIMENTAL DE DOENÇA DE PARKINSON ASSOCIADO A PERIODONTITE INDUZIDA

\author{
${ }^{1}$ VITOR UGO DIAS BARREIROS, ${ }^{2}$ VITÓRIA BILANCHE, ${ }^{3}$ ORLETE MARIA POMPEU DE LIMA, ${ }^{4}$ JULIANA PELISSARI \\ MARCHI, ${ }^{5}$ CINTIA DE SOUZA ALFERES ARAUJO, ${ }^{6}$ EVELLYN CLAUDIA WIETZIKOSKI LOVATO
}

\author{
${ }^{1}$ Discente do curso de Enfermagem - UNIPAR/Participante do Programa Institucional de Bolsas de Iniciação Científica - \\ PIBIC/UNIPAR \\ ${ }^{2}$ Discente do Ensino Fundamental, Colégio Estadual Professor Paulo Alberto Tomazinho- CEPPAT Participante do \\ Programa Externo de Bolsas de \\ ${ }^{3}$ Docente da UNIPAR \\ ${ }^{4}$ Docente da UNIPAR \\ ${ }^{5}$ Docente da UNIPAR \\ ${ }^{6}$ Docente da UNIPAR
}

Introdução: A doença de Parkinson (DP) e a periodontite apresentam similaridades de respostas imuno-inflamatórias que podem influenciar a evolução de ambas patologias, ativando tanto o processo inflamatório que ocorre doença periodontal quanto a via da neurodegeneração da DP (KAMER et al., 2008). Neste projeto associou-se dois modelos consagrados [indução da DP pelo modelo da 6-hidroxidopamina (6-OHDA) e periodontite induzida por ligadura], em busca de um modelo para estudar substâncias para novas abordagens de tratamentos, como a Curcuma longa que possui compostos fenólicos que podem estar associado a efeitos dopaminérgicos.

Objetivo: Avaliar se o tratamento sistêmico com o extrato de $\mathrm{C}$. longa reverte o comportamento rotatório contralateral em animais com lesão unilateral por 6-OHDA e periodontite induzida desafiados com apomorfina.

Metodologia: Foram utilizados ratos Wistar machos, com 4 meses, pesando entre 280 e 315 gramas, divididos nos grupos: Sham e 6-hidroxidopamina (6-OHDA). O procedimento foi aprovado pelo Comitê de Ética de Pesquisa Envolvendo Uso de Animais da UNIPAR (protocolo 31166/2017). Para indução da DP, os ratos foram submetidos à cirurgia estereotáxica para infusão unilateral esquerda de 6-OHDA ou líquor cefalorraquidiano (Sham), no feixe prosencefálico medial (FPM, DA CUNHA et al., 2008). Após 7 dias foi realizado o teste de rotação com desafio de apomorfina $1 \mathrm{mg} / \mathrm{Kg}$, s.c. e induzida a periodontite por ligadura de fio algodão no $1^{\circ}$ molar inferior esquerdo, sendo o molar contralateral direito utilizado como controle intragrupo (SEMENOFF et al., 2008). Imediatamente após, iniciou o tratamento com veículo (água) ou extrato de C. longa nas concentrações de 5, 50 e $500 \mathrm{mg} / \mathrm{kg}$ por 21 dias. Após o término, os ratos foram avaliados novamente pelo comportamento rotatório. Neste teste foi analisado o número de rotações ipsilaterais (para o mesmo lado da lesão) e contralaterais (para o lado contrário da lesão) à lesão, por 1 hora. Após a análise comportamental os dados foram tabulados e analisados por ANOVA de medidas repetidas, seguido pelo post teste de Duncan quando necessário. Os dados foram expressos como média \pm erro padrão da média e valores de $p$ $\leq 0,05$ foram considerados significantes.

Resultados: Os resultados comportamentais demonstram que ratos com lesão no FPM por 6-OHDA apresentaram comportamento rotatório contralateral significante em relação ao grupo SHAM em todos os tratamentos (F7,57 = 14,89, $p$ $<0,001$, ANOVA de medidas repetidas; $p<0,001$, Duncan). Foi observada redução significativa do comportamento rotatório nos animais 6-OHDA tratados com C. longa na dose de $5 \mathrm{mg} / \mathrm{Kg}$ quando comparado ao grupo 6-OHDA tratados com água $(p<0,05)$. Entretanto, nenhuma diferença foi encontrada nos grupos 6 -OHDA tratados com $C$. longa nas doses de 50 e $500 \mathrm{mg} / \mathrm{Kg}$ comparado ao grupo 6-OHDA tratados com água ( $p>0,05)$.

Discussão: O modelo rotatório de roedores, produzido pela lesão unilateral da via nigroestriatal, é uma ferramenta útil para testar substâncias com ação dopaminérgica (DA CUNHA et al., 2008). Neste modelo, o animal apresenta comportamento motor assimétrico após a administração de drogas dopaminérgicas, devido a um desequilíbrio fisiológico entre o lado lesado e não-lesionado (BETARBET et al., 2002). Quando desafiados com apomorfina, apresentam comportamento rotatório contralateral que pode ser explicado pela hiperexpressão dos receptores dopaminérgicos na porção lesada do estriado (METZ; WHISHAW, 2002). Sabe-se que o número de rotações observadas após a administração de um agonista dopaminérgico pode distinguir entre uma lesão da substância negra parte compacta parcial e uma lesão próxima da desnervação completa (> 90\%). Porém, uma lesão menor de $50 \square 80 \%$ resulta em comportamento rotatório menos expressivo, que pode ser confirmado pela neuroquímica (YUAN, et al., 2005). Neste projeto foi utilizado o modelo animal de rotação para identificar os animais com neurodegeneração na via nigroestriatal, além de verificar a influência da

periodontite experimental sobre o comportamento do animal lesionado. Assim, os resultados confirmam que a cirurgia para indução da DP nos ratos foi adequada, com desnervação próximo da totalidade, uma vez que os ratos lesionados com 6-OHDA no FPM, quando desafiados com apomorfina apresentaram comportamento rotatório contralateral a lesão 
significativo comparado aos animais SHAM. Ainda, sabe-se que modelo da rotação pode ser usado como screening para substâncias com ação dopaminérgica (UNGERSTEDT; ARBUTHNOTT, 1970). Assim, em função de o extrato de C. longa possuir compostos fenólicos que podem estar associado a efeitos dopaminérgicos, testou-se a hipótese de que o tratamento sistêmico com o extrato desta planta reduziria as rotações contralaterais em animais com lesão unilateral por 6-OHDA desafiados com apomorfina. Após 21 dias de tratamento sistêmico observou-se redução do comportamento rotatório nos animais 6-OHDA tratados com C. longa na dose de $5 \mathrm{mg} / \mathrm{Kg}$ mas não foi observado o mesmo efeito nas doses de 50 e $500 \mathrm{mg} / \mathrm{Kg}$. Tal efeito pode estar relacionado com os metabólitos secundários produzidos pela planta e como eles interagem com os sistemas biológicos, porém outros estudos são necessários para entender estes mecanismos.

Conclusão: $\mathrm{O}$ extrato de $\mathrm{C}$. longa na dose de $5 \mathrm{mg} / \mathrm{Kg}$ reverte o comportamento rotatório contralateral em animais com lesão unilateral por 6-OHDA e periodontite induzida desafiados com apomorfina. Outras avaliações são necessários para verificar possíveis alterações específicas quando associadas a dois modelos experimentais consagrados, validando de fato, um modelo útil para o estudo de ambas as patologias, bem como o tratamento da C. longa na associação entre as duas patologias.

\section{Referências}

BETARBET, Ranjita; SHERER, Todd B.; GREENAMYRE, J. Timothy. Animal models of Parkinson's disease. Bioessays, v. 24, n. 4, p. 308-318, 2002. Disponível em: https://onlinelibrary.wiley.com/doi/abs/10.1002/bies.10067 acesso em 16 de junho 2020.

Da Cunha C, Wietzikoski EC, Ferro MM, et al. Hemiparkinsonian rats rotate toward the side with the weaker dopaminergic neurotransmission. Behavioural Brain Research. 2008 Jun;189(2):364-372. Disponível em: https://europepmc.org/article/MED/18328580 acesso em 28 de junho 2020.

HORNYKIEWICZ, Oleh. Biochemical aspects of Parkinson's disease. Neurology, v. 51, n. 2 Suppl 2, p. S2-S9, 1998. Disponível em: acesso em 28 de junho 2020.

KAMER, Angela R. et al. Inflammation and Alzheimer's disease: possible role of periodontal diseases. Alzheimer's \&

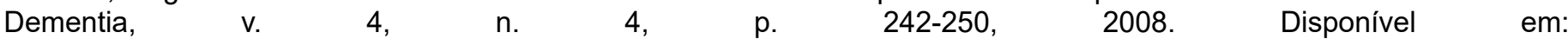
https://www.sciencedirect.com/science/article/abs/pii/S1552526007006218 acesso em 22 de junho 2020.

MORI, Fumiaki et al. Relationship among a-synuclein accumulation, dopamine synthesis, and neurodegeneration in Parkinson disease substantia nigra. Journal of Neuropathology \& Experimental Neurology, v. 65, n. 8, p. 808-815, 2006. Disponível em: https://academic.oup.com/jnen/article/65/8/808/2645296 acesso em 25 de junho 2020.

SEMENOFF, Gordon W.; SEMENOFF, V.; ZHOU, Fei. Domain walls in gapped graphene. Physical review letters, v. 101, n. 8, p. 087204, 2008. Disponível em: https://journals.aps.org/prl/abstract/10.1103/PhysRevLett.101.087204 acesso em 22 de junho 2020.

UNGERSTEDT U., G.W ARBUTHNOTT. Quantitative recording of rotational behavior in rats after 6-hydroxy-dopamine lesions of the nigrostriatal dopamine system, 1970 Dec 18;24(3):485-93. Disponível em: https://pubmed.ncbi.nlm.nih.gov/5494536/. acesso em 27 de junho 2020.

Coordenadoria de Pesquisa e Extensão - COPEX

Departamento de Editoraçāo e Divulgaçāo Científica - DEDIC 


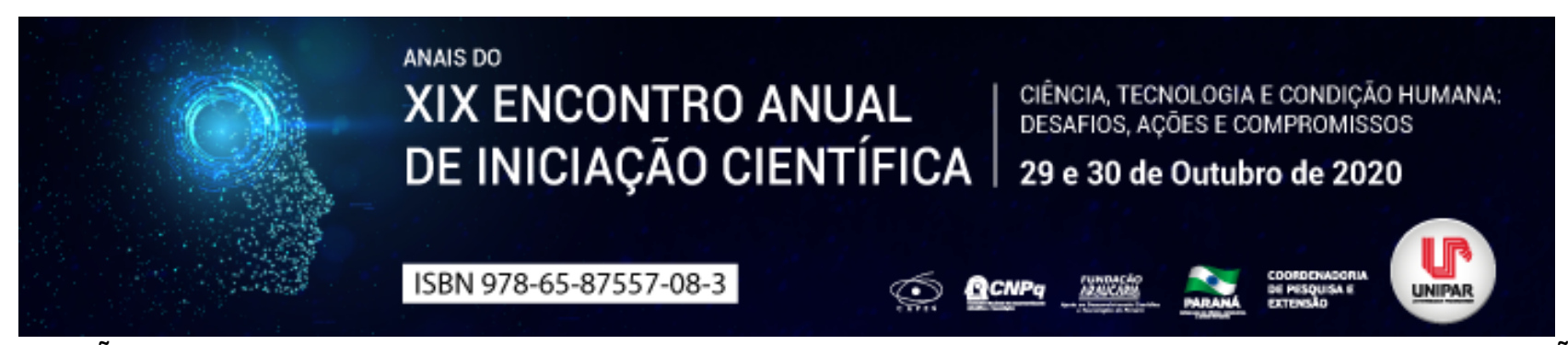

\title{
A UTILIZAÇÃO DO SETMELANOTIDEO (RM-493), NO TRATAMENTO DA OBESIDADE CAUSADA PELA MUTAÇÃO DO GENE MC4R
}

\section{${ }^{1}$ KARINA FUMAGALI MILESKI, ${ }^{2}$ LUCIANO SERAPHIM GASQUES, ${ }^{3}$ RICARDO MARCELO ABRAO}

\author{
${ }^{1}$ Acadêmica do PIBIC do Curso de Medicina da Universidade Paranaense UNIPAR. \\ ${ }^{1}$ Professor Titular do Curso de Medicina da Universidade Paranaense UNIPAR. \\ ${ }^{2}$ Professor Titular do Curso de Medicina da Universidade Paranaense UNIPAR.
}

Introdução: De acordo com Dubern (2015), a obesidade afeta grande parte da população mundial, apresentando relevância neste contexto os fatores genéticos, capazes de contribuir e acentuar tal problema. Logo, é de extrema importância destacar as alterações gênicas relacionadas com a melanocortina-4 receptor (MC4r), já que esta será responsável pela regulação do aporte alimentar, ao emitir sinais de saciedade via leptina/melanocortina. Esta via, se dará por uma cascata de reações, onde inicialmente a leptina, proveniente do tecido adiposo, se ligará ao receptor de leptina (LEPr) encontrado no núcleo arqueado do hipotálamo, permitindo a ativação dos neurônios anorexígenos Pró-opiomelanocortina (POMC), encontrados no mesmo local. Posteriormente será formado o hormônio estimulante alfa-melanócito (alfa-MSH), que por meio da rápida transmissão glutamaérgica se ligará e ativará o MC4r, localizado no núcleo paraventricular (PVN), provocando a diminuição da ingestão de alimentos. Logo, as mutações relacionadas com o gene MC4r serão capazes de provocar diversas alterações no indivíduo, sendo necessária uma intervenção medicamentosa, para correção de tais erros.

Objetivo: Analisar a atuação do RM-493 nas correções de mutações gênicas relacionadas com o gene MC4r e caracterizar os benefícios deste tratamento aos portadores de obesidade. Para tal, foi utilizado o método de revisão sistemática, com artigos extraídos da base de dados PubMed, Scielo, ScienceDirect e LILACS, publicados a partir de 2003, utilizando os descritores

Setmelanotídeo , MC4r , e Mutação resultando em 8 trabalhos analisados.

Desenvolvimento: Portanto, as mutações no gene MC4r, pode causar uma expressão anormal deste na membrana, mudanças na atividade basal no receptor, alteração no transporte intracelular de proteínas e ausência de estímulo à saciedade, podendo levar à obesidade grave (MOSCA et al., 2012). Neste caso, será observado de acordo com Rodrigues et al. (2003), severa hiperfagia, hiperinsulinemia, crescimento linear acelerado, aumento da densidade mineral óssea e aumento da massa magra e gorda. Desse modo, estuda-se a possibilidade de tratamento com o agonista sintético Setmelanotídeo (RM-493), o qual será responsável por ativar o receptor MC4r e restaurar seu correto funcionamento (COLLET et al., 2017). Este fármaco, conhecido anteriormente como BIM-22493, é caracterizado como um agonista peptídeo cíclico, de alta capacidade de ligação com o MC4r, ativando-o em concentrações nanomolares, sendo também cerca de quinhentas vezes mais eficiente que o hormônio estimulante natural alfa-MSH, tornando-o capaz de resgatar ou aumentar a sinalização dos MC4rs mutantes (COLLET et al., 2017). Estas variações gênicas, ocorrem na maioria dos casos devido a proteínas ubiquitinadas mal dobradas, as quais poderão ser adequadamente estabilizadas mediante o uso de RM-493 (RODRIGUES et al., 2003). Tal estabilização ocorrerá graças a estrutura cíclica deste composto, o qual fará uma ligação ortostérica (ativando o receptor) e outra alostérica, caracterizando um ligante bitópico não tradicional, que dispensa a utilização de vinculadores ou blocos de construção, já que o RM-493 é suficientemente grande e capaz de se ligar-se simultaneamente com ambos os locais. Este modelo bitópico , apresenta grande importância pois, ao estabilizar e ativar o MC4r na presença de polimorfismos, resultam em uma maior potência e eficácia durante o tratamento (FALLS; ZHANG, 2019). Dentre os resultados obtidos pela empresa Rhythm nos testes fase III, foram verificados benefícios, como a redução da hiperfagia, do peso corporal, da quantidade de insulina, colesterol ou gordura no sangue e da quantidade de gordura no fígado (KUMAR et al., 2009). Porém, Kievit et al. (2013), expõe que o tratamento com RM493, apresentou características transitórias quanto à ingestão de alimentos, já que nas oito primeiras semanas houve uma drástica redução da ingesta e após este período um aumento, não havendo no entanto, uma recuperação do peso anterior completo, assim como os níveis de insulina e tolerância à glicose, que normalizaram após 12 semanas. O benefício da utilização do RM-493, baseia-se no fato de que este fármaco, ao contrário de outros agonistas do MCR4r utilizados anteriormente, não provoca alterações na frequência cardíaca e pressão arterial, sendo seus efeitos adversos mínimos, podendo manifestar em alguns casos, dor geral e articulares, náuseas, sensibilidade genital feminina e ereção peniana, todos classificados como sintomas leves, transitórios e solucionados sem sequelas (CHEN, 2015).

Conclusão: Portanto, evidencia-se que o estudo sobre as mutações relacionadas com o gene MC4r e suas possíveis correções é um fator de extrema importância no combate à obesidade grave, já que estas alterações são ditas como principal causa deste problema. Nesse contexto, surge o RM-493, o qual será responsável por estabilizar o gene melanocortina-4 mutante e promover sua reativação, sendo notório que aprovação do tratamento com este fármaco, será de grande valia ao ser humano, já que o mesmo será capaz de restaurar uma via já pertencente ao indivíduo, sem que cause maiores danos. 


\section{Referências}

CHEN, Kong Y. et al. RM-493, a melanocortin-4 receptor (MC4R) agonist, increases resting energy expenditure in obese individuals. The Journal of Clinical Endocrinology and Metabolismo. v. 100, n. 4, p. 1639-45, 2005.

COLLET, Tinh-Hai. et al. Evaluation of a melanocortin-4 receptor (MC4R) agonist (Setmelanotide) in MC4R deficiency. Molecular Metabolism, v. 6, n. 10, p. 1321-1329, 2017.

DUBERN, Beatrice. Deficiência de Leptina. The ECOG's eBook on Child and Adolescent Obesity. 2015. Disponível em: https://ebook.ecog-obesity.eu/pt/clinicas-problemas-saude/deficiencia-leptina/. Acesso: 11 de Agosto 2020.

FALLS, Bethany A.; ZHANG, Yan. Insights into the allosteric mechanism of setmelanotide (RM-493) as a potent and first-in-class melanocortin-4 receptor (MC4R) agonist to treat rare genetic disorders of obesity through an in silico approach. ACS Chemical Neuroscience. v. 10, n. 3, p. 1055-1065, 2018.

KIEVIT, Paul. et al. Chronic treatment with a melanocortin-4 receptor agonist causes weight loss, reduces insulin resistance, and improves cardiovascular function in diet-induced obese rhesus macaques. Diabetes. v. 62, n. 2, p. 490-497, 2013.

KUMAR, Ganesh K.; et al. Analysis of the therapeutic functions of novel melanocortin receptor agonists in MC3R- and MC4Rdeficient C57BL/6J mice. Peptides. v. 30, n. 10, p. 1892 1900, 2009.

MOSCA, Paulo R. F. et al. Obesidade e genética. Clinical \& Biomedical Research. v. 32, n. 3, 2012.

RODRIGUES, Adriane M.; SUPLICY, Henrique L.; RADOMINSKI, Rosana B. Controle neuroendócrino do peso corporal: implicações na gênese da obesidade. Arquivos Brasileiros de Endocrinologia \& Metabologia. v. 47, n. 4, p. 398-409, 2003. 


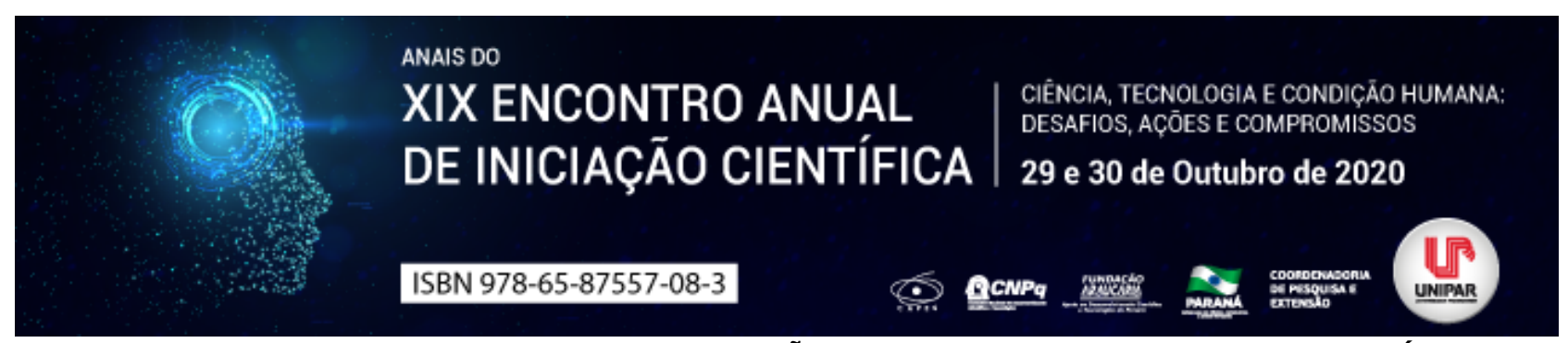

PANORAMA ATUAL SOBRE A SUPLEMENTAÇÃO COM BCAA PARA O DESEMPENHO FÍSICO

\title{
${ }^{1}$ GABRIEL REZENDE BULLA, ${ }^{2}$ DANIEL ALBERTO DE OLIVEIRA CLAUS, ${ }^{3}$ FRANCIELE SANTANA dOS SANTOS, ${ }^{4}$ JOAO PAULO GUIAO, ${ }^{5}$ GABRIELA ALVES TRINDADE, ${ }^{6}$ ALAN PABLO GRALA
}

\author{
${ }^{1}$ Acadêmico PIC do curso de Educação Física Unipar \\ ${ }^{1}$ Acadêmico PIC-EAD do curso de Educação Física Unipar \\ ${ }^{2}$ Acadêmico PIC do curso de Educação Física Unipar \\ ${ }^{3}$ Acadêmico PIC-EAD do curso de Educação Física Unipar \\ ${ }^{4}$ Acadêmico PIC do curso de Educação Física Unipar \\ ${ }^{5}$ Docente do Curso de Educação Física Unipar EAD
}

Introdução: Suplementos nutricionais contendo aminoácidos são usualmente utilizados por atletas e indivíduos envolvidos com a prática regular de exercícios físicos. Em especial, os aminoácidos de cadeia ramificada (valina, leucina e isoleucina), conhecidos como BCAAs, são amplamente populares e comercializados com a finalidade de aprimorar o desempenho físico (FOURÉ; BENDAHAN, 2017). De forma geral, é creditado a suplementação com BCAAs a capacidade de protelara fadiga central, aumentar a disponibilidade de energia para o exercício, reduzira dor e/ou percepção de esforço e a lesão muscular (MATSUMOTO et al., 2009; JACKMAN et al., 2010). Apesar de ser um produto comum e de fácil acesso, seus benefícios são questionados com frequência na literatura científica (KNECHTLE et al., 2012; SHEIKHOLESLAMI-VATANI; AHMADI, 2016). Desta forma, torna-se necessário reunir informações atuais sobre os reais benefícios da suplementação com BCAAs visando proporcionar uma atualização sobre suas recomendações auxiliar na prescrição adequada e segura destes aminoácidos.

Objetivo: Revisar a literatura atual buscando reunir informações atualizadas sobre os benefícios da suplementação de BCAA para o desempenho físico.

Desenvolvimento: Durante o exercício de resistência, os BCAAs são captados e oxidados pelos músculos esqueléticos causando o declínio de sua concentração plasmática. Além disso, quando o exercício promove a elevação dos níveis plasmáticos de ácidos graxos livres (AGL) a concentração de triptofano livre (TRIP-L) aumenta, pois ambos competem pelo mesmo sistema de transporte. Um aumento plasmático na relação TRIP-L/BCAAs vai favorecer o transporte de triptofano para o cérebro e a síntese, concentração e liberação de 5-hidroxitriptamina(5HT), o que pode ser responsável pela fadiga durante o exercício de resistência de longa duração (BLOMSTRAND, 2006). A ingestão de BCAAs pode ser capaz de reduzir a captação de TRIP-L pelo cérebro e a síntese de 5HT e consequentemente, retardar a ocorrência da fadiga central (BLOMSTRAND, 2006). Kim et al. (2013) relatam o BCAA como suplemento nutricional pode aprimorar as concentrações séricas de substâncias relacionadas a fadiga (lactato, amônia e 5HT), metabólitos energéticos (glicose e AGL) e substâncias relacionadas a dor e desconforto muscular, como as enzimas creatina quinase (CK) e lactato desidrogenase (LDH). Com relação a estes prováveis benefícios proporcionados pela suplementação com BCAAs, Hormoznejad; Javid; Mansoori, (2019) descrevem nos resultados de sua revisão sistemática e meta-análiseque a ingestão destes aminoácidos tem um efeito benéfico sobre as concentrações de lactato, AGL, glicose, amônia e CK, entretanto, efeitos positivos sobre a fadiga central e níveis de LDH não foram encontrados. Rahimi et al. (2017) realizaram uma revisão sistemática e meta-análise buscando especificar os efeitos da suplementação com BCAAs sobre a dor muscular e marcadores indiretos de lesão muscular. Em seus resultados, estes pesquisadores relatam que os BCAAs têm efeito positivo sobre a lesão muscular induzida pelo exercício. Os dados demonstraram que a suplementação administrada antes ou até 24 horas após o exercício reduz a CK por pelo menos 24 horas, mas não alivia os sintomas da dor muscular tardia e os níveis de LDH. Por sua vez, Fouré; Bendahan (2017) por meio de uma revisão sistemática da literatura, analisou os efeitos benéficos da suplementação com BCAAs no contexto da lesão muscular induzida pelo exercício. Como resultado, foi constatado que a suplementação com BCAAs pode aliviar as consequências da lesão muscular induzida pelo exercício em condições específicas. Por fim, estes pesquisadores explicam que os potenciais benefícios decorrentes da suplementação com BCAAs podem ser obtidos para lesões musculares induzidas pelo exercício de baixa a moderada magnitude e utilizando como estratégia de ingestão uma alta dose diária de BCAAs por um longo período de tempo (vários dias), especialmente antes do período de ocorrência da lesão.

Conclusão: Após a análise dos estudos, é possível afirmar que a suplementação com BCAAs tem potencial para melhorar alguns aspectos relacionados ao desempenho físico, principalmente com relação a lesão muscular induzida pelo exercício. Alguns benefícios comumente relatados como redução da fadiga central e da dor muscular tardia,não foramconfirmados pela bibliografia consultada, entretanto, foi constatado que a suplementação com BCAAs pode reduzir de forma eficaz a concentração 
de indicadores de lesão muscular (CK), mas para obter este benefício, é recomendando a ingestão crônica destes aminoácidos. De forma geral, é possível afirmar que a suplementação crônica com BCAAs pode reduzir a extensão da lesão muscular e acelerar o processo de recuperação, além disso, uma menor lesão também contribui para a manutenção da função muscular e menor perda de força e potência após o exercício.

\section{Referências}

BLOMSTRAND, E. A role for branched-chain amino acids in reducing central fatigue. The Journal of Nutrition,v.136, n.2, p.544547, feb.2006.Disponível em: https://academic.oup.com/jn/article/136/2/544S/4664405. Acesso em 11/08/2020.

FOURÉ, A.; BENDAHAN, D. Is Branched-Chain Amino Acids Supplementation an Efficient Nutritional Strategy to Alleviate Skeletal Muscle Damage? A Systematic Review. Nutrients, v.9, n.10, Set. 2017. Disponível em: https://www.ncbi.nlm.nih.gov/pmc/articles/PMC5691664/. Acesso em 12/08/2020.

HORMOZNEJAD, R.; ZARE JAVID, A.; MANSOORI, A. Effect of BCAA supplementation on central fatigue, energy metabolism substrate and muscle damage to the exercise: a systematic review with meta-analysis. Sport Sci Health, v.15, p.265 279 , mar.2019. Disponível em: https://link.springer.com/article/10.1007/s11332-019-00542-4. Acesso em: 11/08/2020.

JACKMAN, S. R.; WITARD,O. C.; JEUKENDRUP, A.E.; TIPTON, K. D. Branched-chain amino acid ingestion can ameliorate soreness from eccentric exercise. Med Sci Sports Exerc, v.42, n.5, p.962-970, may.2010.

KIM, D. H.; KIM, S. H.; JEONG, W. S.; LEE, H. Y. Effect of BCAA intake during endurance exercises on fatigue substances, muscle damage substances, and energy metabolism substances. J Exerc Nutr Biochem, v.17, n.4, p.169 180, dec.2013. Disponível em: https://www.ncbi.nlm.nih.gov/pmc/articles/PMC4241904/. Acesso em: 11/08/2020.

KNECHTLE, B.; MRAZEK, C.; WIRTH, A.; KNECHTLE, P.; RÜST, C.; SENN, O.; ROSEMANN, T.; IMOBERDORF, R.; BALLMER, P. Branched-chain amino acid supplementation during a 100-km ultra-marathon: a randomized controlled trial. J Nutr Sci Vitaminol., v.58, n.1, p.36-44, set.2012.

MATSUMOTO, K.; KOBA, T.; HAMADA, K.; SAKURI, M.; HIGUCHI, T.;MIYATA, H. Branched-chain amino acid supplementation attenuates muscle soreness, muscle damage and inflammation during an intensive training program. J Sports Med Phys Fitness, v.49, n.4, p.424-432, dez.2009.

RAHIMI, M. H.; SHAB-BIDAR, S.; MOLLAHOSSEINI, M.; DJAFARIAN, K. Branched-chain amino acid supplementation and exercise-induced muscle damage in exercise recovery: A meta-analysis of randomized clinical trials. Nutrition, v.42, p.30-36, oct, 2017. Disponível em: https://www.sciencedirect.com/science/article/pii/S0899900717300953?via\%3Dihub. Acesso em: $11 / 08 / 2020$.

SHEIKHOLESLAMI-VATANI, D.; AHMADI, S. Effect of Oral Branched-Chain Amino Acid Supplementation Prior to Resistance Exercise on Metabolic Hormones, Plasma Amino Acids, and Serum Indices of Muscle Damage in the Recovery Period. Topics in Clinical Nutrition. V.31, n.4, p.346-354, oct.2016. 


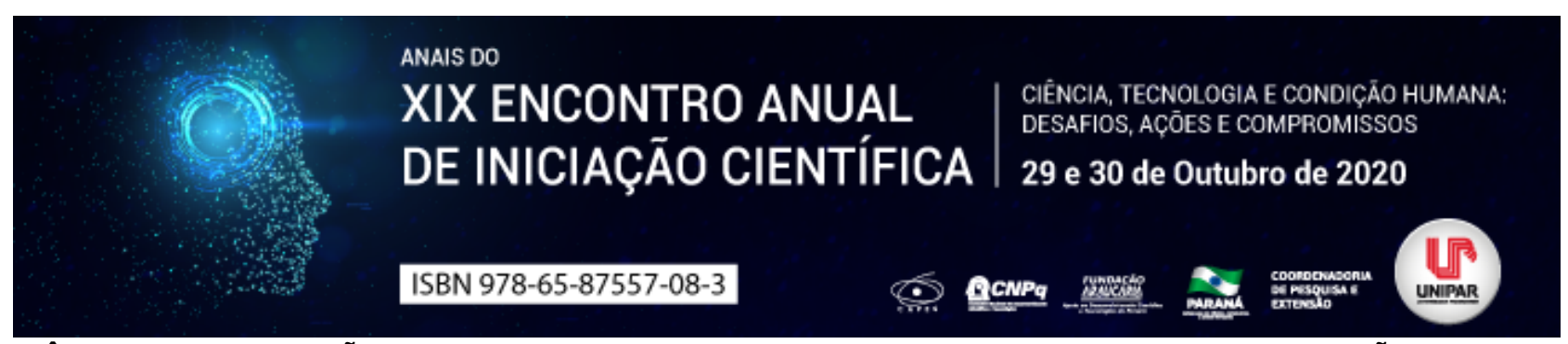

A IMPORTÂNCIA DO CIRURGIÃO DENTISTA EM UNIDADES DE TERAPIA INTENSIVA NA PREVENÇÃO DE PATOLOGIAS

\section{${ }^{1}$ IZADORA ACORDI LUPATELLI, ${ }^{2}$ JENIFFER URBANO DEGASPERI, ${ }^{3}$ LETICIA NADAL}

${ }^{1}$ Discente do Curso de Odontologia da Universidade Paranaense - UNIPAR / Campus Cascavel.

${ }^{1}$ Acadêmica do Curso de Odontologia da UNIPAR

${ }^{2}$ Docente da UNIPAR

Introdução: A saúde oral deve estar inserida no contexto da saúde sistêmica e geral, devido à integração da boca como parte do corpo humano, e em pacientes críticos em Unidades de Terapia Intensiva, os cuidados com a saúde bucal são essenciais. De acordo com o Manual da Odontologia Hospitalar (2012) a condição bucal do paciente é de extrema importância e se for desfavorável pode causar diversas complicações, piorando a saúde, a qual já se encontra debilitada (GUERRA; SANTOS, 2018). A permanência desses pacientes na UTI pode acarretar na piora de condições bucais preexistentes como cáries e doença periodontal, baixo fluxo salivar, e desenvolvimento de infecções oportunistas como candidíase e herpes (Batista et al., 2014), mas o que vem sendo destacado é que focos infeciosos em cavidade oral, falta de higienização e doença periodontal podem piorar o quadro de saúde geral do paciente, mostrando uma relação bidirecional.

Objetivo: Diante do exposto, há necessidade de revisar as bases bibliográficas, visando compreender o papel do cirurgião dentista na UTI para prevenção de diversas patologias e sua necessidade na equipe multidisciplinar hospitalar a fim de melhorar o tratamento integrado do paciente.

Desenvolvimento: Pacientes críticos em UTI's demandam cuidados multiprofissionais e o CD está cada mais vez mais inserido no processo. A higiene da cavidade oral durante esse período hospitalar fica muitas vezes a cargo dos técnicos de enfermagem e devido a sua sobrecarga de trabalho, acaba sendo negligenciada. A maior parte dos pacientes estão em ventilação mecânica, o que leva a diminuição do fluxo salivar e desequilíbrio da microbiota, sendo propensos a infecções por bactérias patogênica, tornando a cavidade bucal uma porta de entrada para infecções sistêmicas, as doenças orais como: cárie, gengivite, doença periodontal, candidíase, úlceras traumáticas e halitose podem ser frequentes caso não haja a higiene correta do paciente (BATISTA et al., 2014). Além disso, as bactérias presentes na cavidade oral, podem ser aspiradas e causar uma pneumonia por aspiração, essa infecção tem alta taxa de mortalidade, sendo que 20 a $50 \%$ dos pacientes afetados acabam falecendo. A presença do cirurgião dentista em âmbito hospitalar, visa dar suporte a diagnósticos relacionados a doenças bucais e orientar a correta higienização da cavidade oral dos acamados. Medidas como, realizar a remoção mecânica da placa duas vezes ao dia, umidificação da cavidade bucal, aplicação de digluconato de clorexidina $0,12 \%$ em tecidos moles e realizar uma profilaxia uma vez na semana, trouxeram resultados satisfatórios e redução da mortalidade em pacientes imunocomprometidos (GOMES, 2012). Devido o amplo estudo sobre patologias orais e higienização bucal, a presença de um cirurgião dentista na equipe multidisciplinar do hospital se faz necessária, visto que esses profissionais estão aptos a promover a saúde bucal de pacientes hospitalizados e fornecer informações e treinamento adequados a outros profissionais (BLUM et al., 2017). Inquestionavelmente, a falta de um cirurgião dentista na equipe pode acarretar na negligência da saúde bucal e consequentemente comprometer a saúde integral do paciente, dessa forma, o PROJETO DE LEI N. ${ }^{\circ} 2.776-\mathrm{B}$, de 2008, torna obrigatória a presença de profissionais da odontologia na equipe multiprofissional das unidades de terapia intensiva, visando manter a saúde do sistema estomatognático, além da saúde bucal.

Conclusão: Diante do exposto, fica evidente a necessidade do profissional de Odontologia em UTIs, tanto em tratamentos, urgências e traumas, quanto na prevenção de diversas patologias. Dessa maneira, o paciente será tratado integralmente, fornecendo a ele, melhor condição de vida, dignidade e recuperação.

\section{Referências}

BATISTA, S. A et al. Alterações orais em pacientes internados em unidades de terapia intensiva. Revista Brasileira de Odontologia, v. 71, n. 2, p. 156, 2015.

BLUM, Davi Francisco Casa et al. Influence of dentistry professionals and oral health assistance protocols on intensive care unit nursing staff. A survey study. Revista Brasileira de terapia intensiva, v. 29, n. 3, p. 391, 2017.

BRASIL, Câmara dos Deputados (2008). PROJETO DE LEI N. ${ }^{0}$ 2.776-B, DE 2008 (Do Sr. Neilton Mulim). 2008. Disponível em: http://www.camara.gov.br/proposicoesWeb/prop_mostrarintegra;jsessionid=ADE697BEAF7144851AE6AA567350FA0F.node2?

codteor=1077018\&filename=Avulso+-PL+2776/2008. Acesso em julho de 2020._

GOMES, S. F; ESTEVES, M. C. Atuação do cirurgião-dentista na UTI: um novo paradigma. Revista brasileira de odontologia, v. 69 , n. 1, p. $67,2012$. 
GUERRA, L. C; SANTOS, A. T. Perfil Odontológico De Pacientes Internados Na Unidade De Terapia Intensiva De Um Hospital Oncológico Do Sudoeste Do Paraná. Arquivos de Ciências da Saúde da UNIPAR, v. 22, p. 75-80, 2018

Coordenadoria de Pesquisa e Extensão - COPEX

Departamento de Editoraçāo e Divulgaçāo Científica - DEDIC 


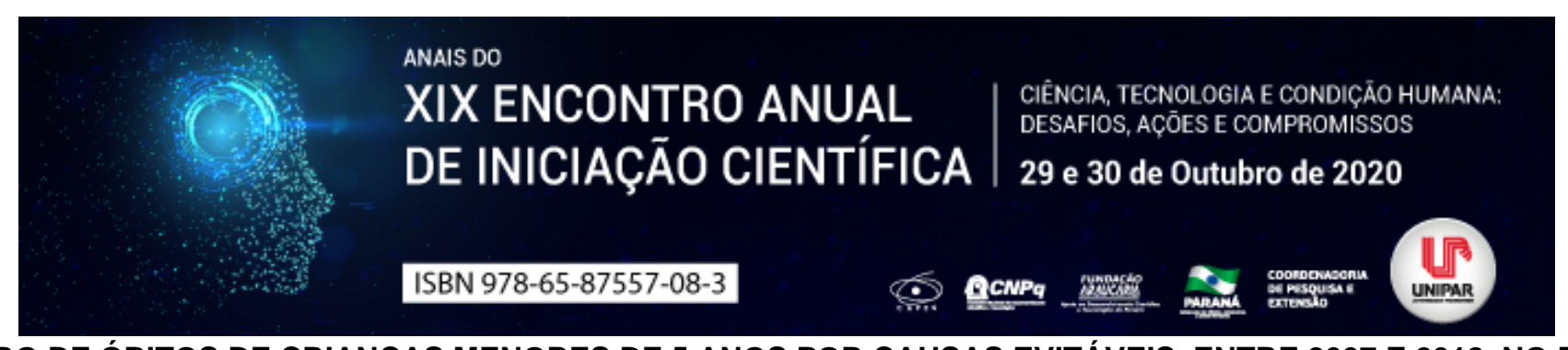

NÚMERO DE ÓBITOS DE CRIANÇAS MENORES DE 5 ANOS POR CAUSAS EVITÁVEIS, ENTRE 2007 E 2018, NO BRASIL

\author{
${ }^{1}$ LUCAS ALEXANDRE GUBERT SCHIER, ${ }^{2}$ LARISSA LOYOLA BARBOSA, ${ }^{3}$ GABRIEL HENRIQUE BELLATO PALIN, ${ }^{4}$ SUELEN \\ STEFANONI BRANDAO, ${ }^{5}$ RAFAEL BEZERRA MARIM, ${ }^{6}$ ELENIZA DE VICTOR ADAMOWSKI CHIQUETTI
}

${ }^{1}$ Acadêmica do Curso de Medicina da UNIPAR
${ }^{1}$ Acadêmica do Curso de Medicina da UNIPAR
${ }^{2}$ Acadêmico do Curso de Medicina da UNIPAR
${ }^{3}$ Acadêmica do Curso de Medicina da UNIPAR
${ }^{4}$ Acadêmico do Curso de Medicina da UNIPAR
${ }^{5}$ Docente do Curso de Medicina da UNIPAR

Introdução: Os dados quantitativos relacionados a mortes infantis em território nacional, abrangendo especificamente óbitos por causas evitáveis, servem como base para realização de análises, direcionando e amplificando a possibilidade do uso de estudos para criação de projetos e políticas públicas que visem a redução deste quadro. Considerando a base de dados do DATASUS (Departamento de Informática do SUS), alimentados pelo Ministério da Saúde, é possível desenvolver uma análise quantitativa apurada e confiável, utilizando como base a premissa do óbito por causas evitáveis, em crianças de até 5 anos. Os números permitem levantar possíveis causas, e por consequência possíveis soluções, para as ocorrências, como falta de políticas públicas, ou desigualdade social relacionada à atenção básica, conforme descrito por Garcia; Santana (2011). Dentre as causas elencadas pelo órgão citado, encontram-se óbitos provenientes de enfermidades que poderiam ser evitadas por ações relacionadas à atenção à gestante, atenção à mulher durante o parto, atenção ao recém-nascido, ações de imunização, diagnóstico e tratamento adequado, e ainda incluem causas mal definidas, ou não claramente evitáveis.

Objetivo: Apresentar informações quantitativas quanto aos dados relacionados a óbitos de crianças de 0 a 5 anos em território nacional, por causas evitáveis, no período de 2007 até 2018, com base nos dados obtidos através do DATASUS (Departamento de Informática do SUS).

Desenvolvimento: O presente estudo encontrou, através do DATASUS, um total de 553.090 mortes de crianças menores de 5 anos, em território Brasileiro, por causas evitáveis, entre os anos 2007 e 2018 sendo que, do total, 66,04\% poderiam ter sido totalmente evitadas, ou pelo menos reduzidas, por meio da utilização de medidas de promoção à saúde em algum âmbito, enquanto apenas $33,96 \%$ possuem razão mal definida, ou são provenientes de causas que não são claramente evitáveis. Os dados apontam uma quantidade decrescente de óbitos anuais, iniciando com 53.252 em 2007, e finalizando 2018 com 41.733 , apresentando uma redução de óbitos de $21,63 \%$ dentro do período, sugerindo um cenário positivo, mas ainda preocupante, para os próximos anos. A estatística aponta que um maior acúmulo dos óbitos se concentra nas regiões Nordeste e Sudeste (32,66\% e $35,40 \%$ dos casos, respectivamente), enquanto as regiões Norte, Sul e Centro-Oeste apresentam números mais baixos (13,62\%, 10,79\% e 7,94\% respectivamente). Reduzindo a análise ao Estado do Paraná, no mesmo período, houve 25.402 mortes de crianças com até 5 anos por causas evitáveis, das quais cerca de $47 \%$ poderiam ser reduzidos ou evitados por ações voltadas para atenção à gestante, durante o parto, e ao recém-nascido a exemplo da sífilis congênita e doenças geradas pelo vírus da imunodeficiência humana, enquanto há outros que seriam reduzidos com aplicação de ações devidas de promoção à saúde vinculadas à atenção básica em saúde, como as doenças infecciosas intestinais, representando 9\%, ou por Diagnóstico e Tratamento adequados (7\%). Ou seja, no Estado do Paraná, no período apurado, a soma das mortes evitáveis por ações de responsabilidade da Saúde Pública do Estado totaliza mais de 63\% (mais de 16.000 mortes). Uma análise feita por Oliveira; Costa; Mathias (2012), permite entender que $14,8 \%$ do total de internações em três municípios do Paraná acontecem por doenças infecciosas e parasitárias com causas evitáveis, e complementa que todas poderiam ser evitadas com a implementação de medidas assertivas na atenção primária à saúde. Além disso, outros estudos realizados no Brasil consideram as doenças infecciosas e parasitárias como as mais frequentes em relação a hospitalização. Ainda, a análise realizada por Jodas; et al (2013), na terceira maior cidade do Paraná, Maringá, aponta que a morte precoce apresenta relação direta com a qualidade de atenção ofertada à gestante e ao recém-nascido. Fato este que condiz com estudo realizado por Escuder; Venâncio; Pereira (2003), o qual salienta a necessidade de assistência à gestante e reforça que o apoio deve ocorrer também no sentido de estímulo à amamentação, uma vez que é uma ação relativamente simples que chega a reduzir entre 3,6\% e $13 \%$ os óbitos em crianças de até 04 anos, em 14 municípios da Grande São Paulo. Em outro viés, Garcia; Santana (2011), aponta a existência de uma linha tênue entre as desigualdades sociais e as doenças infecciosas e parasitárias em crianças, principalmente as que envolvem contaminação por falta de higiene adequada e saneamento básico, o que se relaciona diretamente com o estudo de França e Lansky (2003), que aponta a taxa de MI (Mortalidade Infantil) como sendo o resultado de uma série de fatores somados. 
De acordo com os autores, a combinação de fatores biológicos, sociais, culturais e de falhas no sistema de saúde colaboram diretamente para as variações na taxa. Ressalta-se, ainda, que na cartilha de atenção ao pré-natal de baixo risco, do Ministério da Saúde, há diversas medidas para a redução de tais mortes, sendo ações de imunização, atendimento à mulher em período de gravidez e parto, atenção aos recém-nascidos, entre outras estratégias de promoção à saúde.

Conclusão: Os números apontam para uma grande quantidade de óbitos que poderiam ser evitados, caso a saúde pública possuísse ações específicas. A partir dos dados obtidos, pode-se realizar análises que permitam formular estratégias que objetivem a criação e aplicação de ações e políticas públicas de saúde, visando especificamente a redução de óbitos infantis, abaixo de 5 anos, por causas evitáveis.

\section{Referências}

Brasil, Ministério da Saúde. Banco de dados do Sistema Único de Saúde - DATASUS: Informações de Saúde, Sistema de Informações sobre Mortalidade. Disponível em http://www2.datasus.gov.br/DATASUS, acesso em 31/07/2020

ESCUDER, Maria Mercedes; VENÂNCIO, Sonia Isoyama; PEREIRA, J. C. R. Estimativa de impacto da amamentação sobre a mortalidade infantil. Rev. Saúde Pública, São Paulo, v. 37, n.3, p.319-325, Junho 2003.

FRANÇA, Elisabeth; LANSKY, Sônia. Mortalidade infantil neonatal no Brasil: situação, tendências e perspectivas. Anais do XVI Encontro Nacional de Estudos Populacionais, p.1-29, 2016.

GARCIA, Leila Posenato; SANTANA, Lúcia Rolim; Evolução das desigualdades socioeconômicas na mortalidade infantil no Brasil, 1993-2008. Ciência \& Saúde Coletiva, v.16, p.3717-3728, 2011.

JODAS, Denise Albieri; SCOCHI, Maria José; VICENTE, Jéssica Batistela. Análise dos óbitos evitáveis de menores de cinco anos no município de Maringá-PR. Esc. Anna Nery, Rio de Janeiro, v.17, n.2, p. 263-270, 2013

OLIVEIRA, Rosana Rosseto.; COSTA, Joseane Rosenilda; MATHIAS, Thais Aidar de Freitas. Hospitalização de crianças menores de cinco anos devido a causas evitáveis. Rev. Latino-Am. Enfermagem. vol.20 no.1 Ribeirão Preto, 2012.

Coordenadoria de Pesquisa e Extensão - COPEX

Departamento de Editoraçāo e Divulgaçāo Científica - DEDIC 


\title{
ANAIS DO \\ XIX ENCONTRO ANUAL | CIÊNCIÁ, TECNOLOGIA E CONDIÇĀO HUMANA DE INICIAÇÃO CIENTÍFICA DESAFIOS, AC̣ŌES E COMPROMISSOS \\ DE INICIAÇĀO CIENTÍFICA 29 e 30 de Outubro de 2020 \\ ISBN 978-65-87557-08-3 \\ $\odot$ PCNPq \\ O USO DO ROLEPLAY NO DESENVOLVIMENTO DE COMPETÊNCIAS PARA A IDENTIFICAÇÃO DOS DETERMINANTES SOCIAIS DE SAÚDE: RELATO DE EXPERIÊNCIA
}

\author{
${ }^{1}$ Daniel Reis Correia, ${ }^{2}$ LAÍS SOUSA DA SILVA, ${ }^{3}$ LARA LELIS DIAS, ${ }^{4}$ THAÍS BITENCOURT FARIA, ${ }^{5}$ ANA CLARA REIS CRUZ, \\ ${ }^{6}$ BEATRIZ SANTANA CAÇADOR
}

\begin{abstract}
${ }^{1}$ Acadêmico do curso de Enfermagem pela Universidade Federal de Viçosa
${ }^{1}$ Acadêmica do curso de Enfermagem pela Universidade Federal de Viçosa

${ }^{2}$ Acadêmica do curso de Enfermagem pela Universidade Federal de Viçosa

${ }^{3}$ Acadêmica do curso de Enfermagem pela Universidade Federal de Viçosa

${ }^{4}$ Acadêmica do curso de Enfermagem pela Universidade Federal de Viçosa

${ }^{5}$ Docente do curso de Enfermagem pela Universidade Federal Viçosa
\end{abstract}

Introdução: O desafio das práticas em saúde é superar a lógica hegemônica de produção, na qual os atos em saúde estão comprometidos com a produção de procedimentos em detrimento da busca por produção de cuidado. Produzir cuidado implica em superar o reducionismo de técnicas que concebem o homem apenas em sua dimensão biológica, desconsiderando todo seu contexto material e existencial de vida (MERHY, 2004). A mudança das relações de cuidado constitui-se como um giro ético necessário para transformar as práticas em saúde (HADDAD; ZOBOLI, 2010). Dentro da prática profissional, que tem o cuidado como objetivo, os determinantes sociais da saúde (DSS) interferem diretamente no processo saúde-doença-cuidado sendo, concomitantemente, relacionadas às condições de vida de uma pessoa. Os fatores sociais, econômicos, políticos, culturais, espirituais, étnico-raciais, psicológicos e comportamentais influenciam na situação de saúde e devem ser identificados, a fim de possibilitar intervenções dentro de cada contexto, assegurando apoio e ampliação na capacidade de resolver problemas (SANTOS et al., 2015). Existe, pois, a necessidade de combater às desigualdades sociais e seus efeitos nas condições de saúde da população e, para isto, a identificação dos condicionantes de saúde constitui-se importante ferramenta na consulta de enfermagem, potencializando sua qualidade e oferecendo um plano de cuidado condizente com as particularidades de cada realidade avaliada (QUEVEDO et al., 2017). Diante do exposto, os discentes do curso de Enfermagem da Universidade Federal de Viçosa (UFV) tiveram a oportunidade de interpretar, tendo como referência as bases teóricas problematizadas em aula, situações cotidianas comuns em um ambiente de Unidade Básica de Saúde (UBS) e desenvolver competências que serão potencializadas durante a prática de enfermagem, tal como a identificação das vulnerabilidades (BROCH et al., 2020).

Relato do caso: Trata-se de relato de experiência de uma vivência ocorrida em 28 de junho de 2019, na disciplina de Enfermagem, Saúde e Sociedade I, com alunos do primeiro período do curso de Enfermagem da UFV. A turma foi dividida em cinco grupos, cada qual orientado por um professor. Todos os grupos basearam-se no mesmo caso e os papeis de cada um foram sorteados. Estes foram mantidos em sigilo e os estudantes foram convidados a assumir suas ações encenando em um laboratório conformado como um consultório de enfermagem. Após vivenciada a experiência, cada grupo teve que identificar as necessidades de saúde representadas pela família. O último momento da atividade foi um compartilhamento geral de todos os estudantes participantes e uma apresentação das necessidades identificadas em cada grupo. Na oportunidade, foram discutidas as interpretações das cenas que representavam desafios na prática do cuidado, na visão dos futuros profissionais, integrando os determinantes sociais a esses usuários e em como cada aluno acumulou experiências de formas completamente distintas, permitindo um feedback pelos professores presentes nas práticas.

Discussão: $O$ roleplay possibilitou o desenvolvimento da práxis em que os discentes foram convidados a contracenar, em sigilo, papeis específicos (PAULINO et al., 2019). Foram abordadas diferentes situações-problemas, como: alcoolismo; abuso sexual infantil; uso de opióides; gravidez não planejada; desejo por aborto; depressão; negacionismo aos tratamentos de saúde; abandono da vida religiosa. A abordagem despertou o interesse do estudante em produzir soluções partindo da problematização, além de observar e absorver as várias camadas que cada um dos personagens detinha nas suas vidas particulares e no meio da estrutura familiar. A prática se desenvolveu através do diálogo entre uma enfermeira e os cinco membros de um núcleo familiar, no qual a aluna responsável por interpretar a profissional, deveria ser capaz de reconhecer situações de risco referentes às questões micro e macrossociais e seus reflexos na saúde daquelas pessoas. Assim, conseguimos visualizar um dos temas mais importantes e complexos na rotina de um enfermeiro: estabelecer um vínculo com seus pacientes, de forma a conhecer e identificar todos os problemas e possibilitar novos caminhos para solucionar as lacunas na saúde do indivíduo (SOUSA et al., 2019). Vale ressaltar que, se na abordagem, não fossem considerados os DSS, a conduta da enfermeira estaria reduzida ao atendimento de uma queixa principal. Caso o modelo hegemônico de pensar o processo saúde-doença fosse perpetuado, o cuidado não seria produzido. 
Conclusão: A atividade possibilitou diversas análises de como o enfermeiro, no seu papel de agente transformador da realidade, é fundamental no reconhecimento dos DSS no processo saúde-doença-cuidado. Dessa forma, conseguimos desenvolver as cenas, ao inferir a formação de vínculos e demonstrar várias experiências pessoais, na visão de cada um dos personagens dentro do roleplay. Logo, desenvolver habilidades e competências para identificação de determinantes sociais é fundamental para transformar as práticas em saúde em cuidados efetivos.

\section{Referências}

BROCH, Daiane. et al. Social determinants of health and community health agent work. Revista da Escola de Enfermagem da Usp, [S.L.], v. 54, n. 03558, p. 1-8, jan. 2020.

HADDAD, Jerusa Gomes Vasconcellos; ZOBOLI, Elma Lourdes Campos Pavone. O Sistema Único de Saúde e o giro ético necessário na formação do enfermeiro. O Mundo da Saúde, São Paulo, v. 1, n. 34, p. 86-91, jan. 2010.

MERHY, Emerson Elias. O Ato de Cuidar: a Alma dos Serviços de Saúde. In: Brasil. Ministério da Saúde. Secretaria de Gestão do Trabalho e da Educação na Saúde. Departamento de Gestão da Educação na Saúde. Ver SUS Brasil: cadernos de textos. Brasília: Ministério da Saúde, 2004, p.108-137.

PAULINO, Danilo Borges. et al. Role-Play como Estratégia Pedagógica para Problematizar as Linhas de Cuidado Integral em Saúde aos Adolescentes e Jovens. Revista Brasileira de Educação Médica, Uberlândia, v. 43, n. 1, p. 662-671, jan. 2019.

SANTOS, Adriano Maia dos. et al. DESAFIOS À GESTÃO DO TRABALHO E EDUCAÇÃO PERMANENTE EM SAÚDE PARA A PRODUÇÃO DO CUIDADO NA ESTRATÉGIA SAÚDE DA FAMÍLIA. Rev. Aps, [S.I], v. 18, n. 1, p. 39-49, jan. 2015.

SOUSA, Izautina Vasconcelos de. et al. Enfrentamento de problemas que impactam na saúde de uma comunidade socialmente vulnerável sob a ótica dos moradores. Ciência \& Saúde Coletiva, [S.L.], v. 24, n. 5, p. 1647-1656, maio 2019.

QUEVEDO, André Luis Alves de et al. DETERMINANTES E CONDICIONANTES SOCIAIS: formas de utilização nos planos nacional e estaduais de saúde. Trabalho, Educação e Saúde, [S.L.], v. 3, n. 15, p. 823-842, dez. 2017.

Coordenadoria de Pesquisa e Extensão - COPEX

Departamento de Editoraçāo e Divulgaçāo Científica - DEDIC 


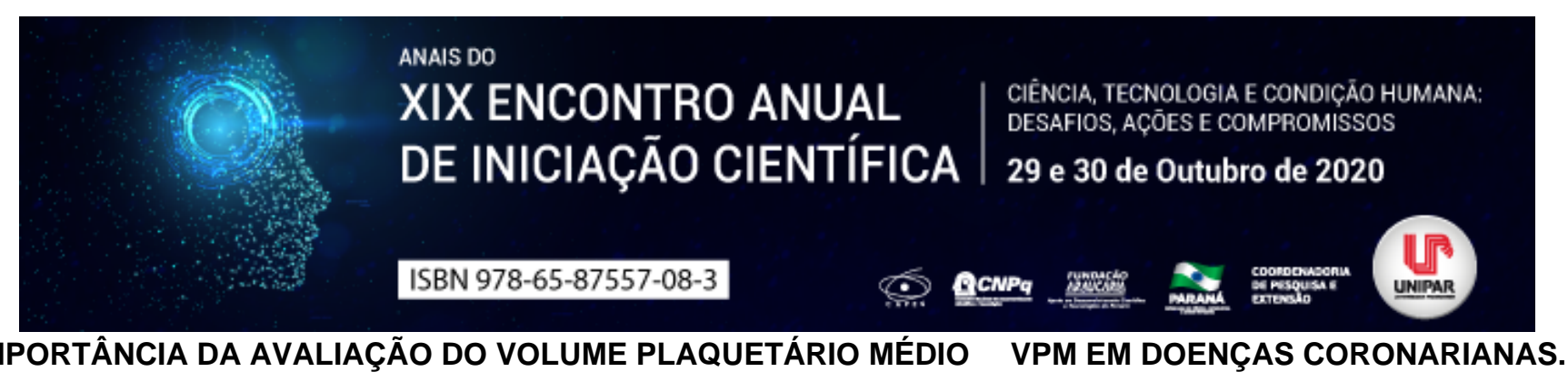

\title{
${ }^{1}$ SCHIRLEY CAROLAI DICKEL, ${ }^{2}$ ANDERSON FELIPE FERREIRA
}

\author{
${ }^{1}$ Acadêmica do curso de Biomedicina da UNIPAR. \\ ${ }^{1}$ Docente da UNIPAR
}

Introdução: As plaquetas são pequenos fragmentos citoplasmáticos de megacariócitos (células presentes na medula óssea) e são responsáveis pela hemostasia e coagulação. A trombopoietina atua nas células-tronco (Stem Cell) e promove a estimulação das unidades formadoras de colônias de megacariócitos (CFU-Meg) juntamente com ação de citocinas (IL-3, IL-6 e IL-11) para desencadear o processo de Plaquetogênese. O crescimento, maturação e regulação dos megacariócitos mostrou ser o maior agente de controle na regulação da produção plaquetária. Alguns anos atrás os estudos plaquetários buscavam se importar somente com a contagem de plaquetas e os aspectos morfológicos. Atualmente a determinação de novos parâmetros como o Volume Plaquetário Médio (VPM), passou a avaliar o tamanho e função das plaquetas, com isso é possível estabelecer prováveis relações entre desordens plaquetárias e doenças coronarianas (SANTOS, MEIRELLES, 2004).

Objetivo: Abordar através de um levantamento bibliográfico a importância da avaliação plaquetária de modo qualitativo e quantitativo e posteriormente estabelecer a relação entre o VPM e doença coronariana.

Desenvolvimento: A avaliação do tamanho e da morfologia das plaquetas tornou-se útil principalmente nos pacientes portadores de desordens coronarianas e sua possível relação com o desenvolvimento de episódios trombóticos, desta forma, o VPM é de grande importância, particularmente nas trombocitopenias e trombocitoses. Os valores de referência para VPM são variáveis entre laboratórios, sendo determinado de acordo com cada um, contudo a literatura mantém valores próximos, onde a média encontrada para o parâmetro foi de 10,3fL, variando de 8,8fL a 12,5fL (MONTEIRO, 2016). O diâmetro normal de uma plaqueta é de 2 a $3 \mu \mathrm{m}$, caracterizam-se como macroplaquetas aquelas com um diâmetro entre 4 a $7 \mu \mathrm{m}$, já as plaquetas gigantes são maiores que $7 \mu \mathrm{m}$, geralmente 10 a $20 \mu \mathrm{m}$ (WENDLAND, FARIAS, MANFROI (2009). Na composição plaquetária há expressão de proteínas de superfície pró coagulantes, como as glicoproteínas IIB, Illa e P-selectina e a presença de grânulos densos, nas macroplaquetas e plaquetas gigantes esses fatores de composição são metabolicamente e enzimaticamente mais ativos do que as plaquetas normais, conferindo-lhe às um maior potencial adesão e risco de desenvolvimento trombótico (CAMUR et al, 2005). Estudos apontam que as plaquetas influenciam na patogenia das síndromes coronarianas agudas (SCAs) como a Angina instável, infarto agudo do miocárdio (IAM) e morte súbita, pois desempenham uma importante função no desenvolvimento de trombo intravascular, a maior causa de SCA. Após erosão ou ruptura de uma placa aterosclerótica em uma artéria coronariana, a ativação plaquetária é crucial para o processo de coagulação fisiológico, porém a presença de macroplaquetas ou plaquetas gigantes podem ocasionar um quadro de IAM, devido a agregação plaquetária maciça e a possível formação de trombos. $O$ quadro hemolítico associado após a ruptura dos eritrócitos, faz com que seja liberado uma quantidade suficiente de difosfato de adenosina (ADP) para mobilizar a saída de íons de cálcio microtubulares e intensificar a adesão das plaquetas (RODRIGUES et al, 2013). Portanto, nota-se que o tamanho das plaquetas responde como um indicador sensível de sua reatividade, e seu tamanho determina a formação de trombos nas artérias coronárias no caso de ruptura da placa aterosclerótica. Considera-se que valores de VPM > 9fL esteja associado a elevação do risco para óbito, insuficiência cardíaca e incidentes isquêmicos após o Infarto agudo do miocárdio (WENDLAND, FARIAS, MANFROI (2009).

Conclusão: $O$ volume plaquetário médio é apontado em estudos como um importante indicador da atividade plaquetária. $O$ aumento do VPM pode ser justificado devido a liberação precoce dessas plaquetas da medula óssea por maior consumo durante a lesão coronariana após a ruptura da placa aterosclerótica, a presença de macroplaquetas e plaquetas gigantes acabam favorecendo eventos trombóticos devido a sua alta capacidade de adesão.

\section{Referências}

CAMUR, K. N; DEMIRTUNÇ, R; KONURALP, C; ESKISER, A; BASARAN, Y. Could mean platelet volume be a predictive marker for acute myocardial infarction? Revista Medical Science Monitor, v. 11, n. 8. p. 387, 2005.

MONTEIRO, L. Valores de referência dos índices plaquetários e construção de algoritmo para liberação do plaquetograma. Revista brasileira de análises clínicas - RBAC, 2016. Disponível em: Acesso em: 20. jul. 2020.

RODRIGUES, B. R; FRANÇA. H. H; MAIELLO, J. R; CLIQUET, M. G. Análise Do Volume Plaquetário Médio (VPM) Em Pacientes Com Doença Arterial Coronariana. Revista da Faculdade de Ciências Médicas Sorocaba, v. 15, n. 1, p. 192 - $197,2013$.

SANTOS, E. V; MEIRELLES, F. J. Plaquetograma em gestantes normais e com pré-eclâmpsia. Revista brasileira de Ginecologia e Obstetrícia - RBGO, v. 26, n. 3, p. 201- 206, 2004.

WENDLAND, A. E; FARIAS, M. G; MANFROI, W. C. Volume plaquetário médio e doença cardiovascular. Jornal Brasileiro de 
Patologia e Medicina Laboratorial, v.45, n.5, p.371-378, 2009

Coordenadoria de Pesquisa e Extensão - COPEX

Departamento de Editoraçāo e Divulgaçāo Científica - DEDIC 


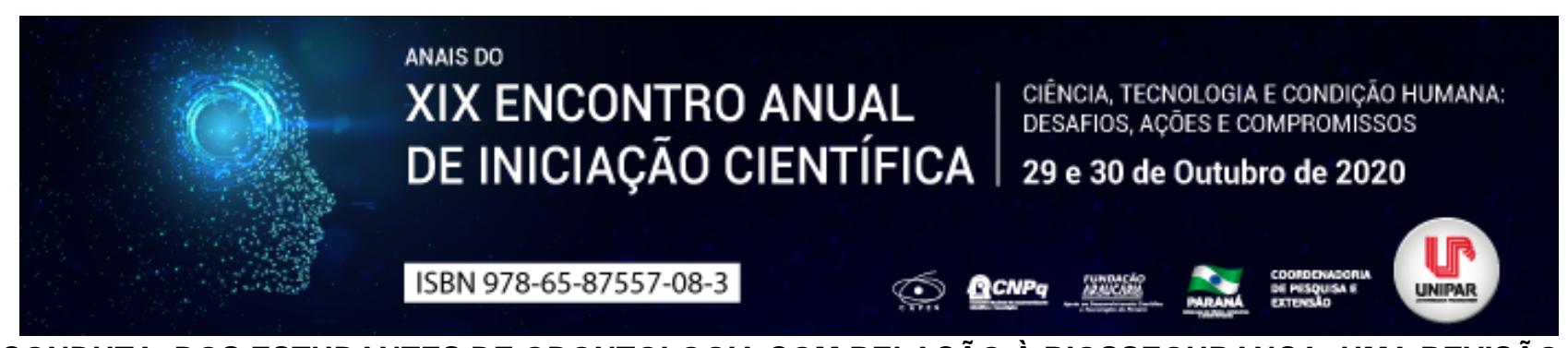

CONDUTA DOS ESTUDANTES DE ODONTOLOGIA COM RELAÇÃO À BIOSSEGURANÇA: UMA REVISÃO

\title{
${ }^{1}$ LAVINIA PRADO HERNANDES,${ }^{2}$ ANDRESSA VENTRAMELI DE ANDRADE, ${ }^{3}$ JENIFFER URBANO DEGASPERI, ${ }^{4}$ ISABELA ROCHA DE SOUZA, ${ }^{5}$ ANA CAROLINA SOARES FRAGA ZAZE
}

\author{
${ }^{1}$ Discente do Curso de Odontologia da Universidade Paranaense - PIC -UNIPAR Campus Umuarama-PR \\ ${ }^{1}$ Discente do Curso de Odontologia da Universidade Paranaense - PIC -UNIPAR Campus Umuarama-PR \\ ${ }^{2}$ Discente do Curso de Odontologia da Universidade Paranaense - PIC- UNIPAR Campus Cascavel-PR \\ ${ }^{3}$ Discente do Curso de Odontologia da Universidade Paranaense - UNIPAR Campus Umuarama-PR \\ ${ }^{4}$ Docente do Curso de Odontologia da Universidade Paranaense - Pesquisadora Institucional - UNIPAR Campus Umuarama-PR
}

Introdução: A biossegurança possui um papel importante na área da saúde, é um conjunto de ações que previnem, diminuem e eliminam riscos de contaminação no ambiente, fazendo uso de várias medidas para um bloqueio eficaz da transmissão e infecção cruzada, por isso é de extrema importância que as universidades sigam e ensinem todos os padrões à seus alunos, para a melhor execução das atividades clínicas com segurança. Contudo, no cenário atual, estudos mostraram que estudantes estão negligenciando os protocolos de biossegurança, aumentando os riscos já existentes (LOPES ET AL., 2019).

Objetivo: Realizar uma revisão bibliográfica sobre a conduta de futuros cirurgiões dentistas no âmbito da biossegurança e apresentar dados do cenário atual das universidades, buscando averiguar como está a postura dos estudantes na clínica odontológica.

Desenvolvimento: A biossegurança tem sido considerada um conjunto de ações voltadas para prevenção de patologias e infecção cruzada. Os trabalhadores da área de saúde e estudantes de odontologia estão constantemente expostos a riscos ocupacionais. No campo da odontologia, os acadêmicos são designados como um grupo essencial para a educação em biossegurança e controle de infecção cruzada para treinamento de rotina e conformidade adequada com o protocolo, segundo Lopes e colaboradores (2019) sua aplicação envolve conhecimento, responsabilidade, determinação, organização e disciplina. Analisando estudos realizados em algumas universidades por meio de pesquisas sobre comportamento dos alunos de Odontologia em relação ao controle de infecção cruzada, Pimentel e colaboradores, em 2012, obtiveram os seguintes resultados, em uma Universidade da Paraíba. Dados foram coletados por meio de questionários autoaplicáveis, contendo 19 questões objetivas abordando temas como: etapas dos processos de esterilização (desinfecção pré-lavagem, lavagem e esterilização), desinfecção de superfícies e utilização de barreira mecânica nessas superfícies. Foi encontrada falta de padronização nos procedimentos de biossegurança mostrando um grande déficit em medidas relacionadas com o controle da infecção cruzada. Outro estudo realizado por Lages e colaboradores (2015) foi relacionado à prevenção do acidente com exposição a material biológico. Os autores delinearam um estudo com estudantes do curso de odontologia de duas universidades distintas, em uma mesma cidade. Através da distribuição dos pesquisados por faixa etária, foi possível verificar que a maioria tinha entre 18 a 25 anos de idade em ambas as instituições. O questionário abordou: I - medidas de proteção, II - ocorrência de acidentes e conhecimento das condutas pós-acidente III - conhecimento, percepção do risco e esclarecimentos formalmente preconizados. O uso de EPIs em ambas as instituições apresentaram resultados positivos na utilização de jaleco, luvas, máscara e gorro, porém quanto à utilização de óculos de proteção, houve uma diferença significativa, sendo maior em uma das instituições, onde os acadêmicos relataram sempre utilizar, enquanto na outra, os relatos refletem que o uso não é tão frequente. Também em relação a higienização das mãos, com água e sabão ou preparação alcoólica, foram obtidos resultados alarmantes, sendo que a mesma instituição que apresentou resultados favoráveis em relação à frequência do uso de óculos de proteção, seguiu esta tendência, enquanto os acadêmicos da outra instituição não se preocupam muito com esta medida. O mesmo foi observado quanto a prática de higienização das mãos antes de calçar as luvas, apenas. Observou-se que a instituição que apresentou melhores resultados apresenta a característica de exigência maior e conscientização da importância do uso de EPI e biossegurança são mais enfatizados (LAGES ET AL., 2015). Nestes estudos foram encontrados falta de padronização e diversas negligências nos procedimentos de biossegurança, que influenciam de maneira direta na formação e manutenção de hábitos corretos durante a vida profissional. Além disso os estudantes de odontologia são considerados como os que apresentam um maior risco de sofrer uma exposição acidental com material biológico, quando comparado a outros estudantes da área da saúde, pois ainda estão em processo de aprendizagem e consequentemente possuem pouca destreza no manuseio dos instrumentais (ZHANG ET AL., 2008).

Conclusão: Com base nos estudos realizados, percebe-se que apesar de todas as informações serem apresentadas sobre biossegurança, parece não ser tão satisfatória a aplicação dos conceitos na prática clínica, pelos estudantes. Isso mostra a importância da abordagem e controle da efetividade da aplicação das normas e princípios de biossegurança nas universidades e 
cursos de Odontologia, para garantir a incorporação de todos os métodos desejados, cotidianamente, pelos estudantes, com o intuito de trazer segurança para toda a equipe profissional e pacientes.

\section{Referências}

LOPES, Amanda Lívia. et al. Biossegurança em Odontologia: conduta dos estudantes antes e após uma ação educativa. Revista da ABENO, v. 19, n. 2, p. 43 53, Abril/Junho, 2019.

PIMENTEL, Marcele Jardim .et al. Biossegurança: comportamento dos alunos de Odontologia em relação ao controle de infecção cruzada. Cad. Saúde Colet, v. 20, n. 4, p. 525 532, Novembro, 2012.

LAGES, Silvana Maria Ramos. et al. Formação em odontologia: O papel das instituições de ensino na prevenção do acidente com exposição a material biológico. Ciencia \& trabajo, v. 17, n. 54, p. 182 187, Setembro/Dezembro, 2015.

ZHANG, Zhuo. et al. Risk of sharps exposure among health science students in northeast China. BioScience Trends, v. 2, n. 3 , p. 105 111, June 12, 2008.

Coordenadoria de Pesquisa e Extensão - COPEX

Departamento de Editoraçāo e Divulgaçāo Científica - DEDIC 


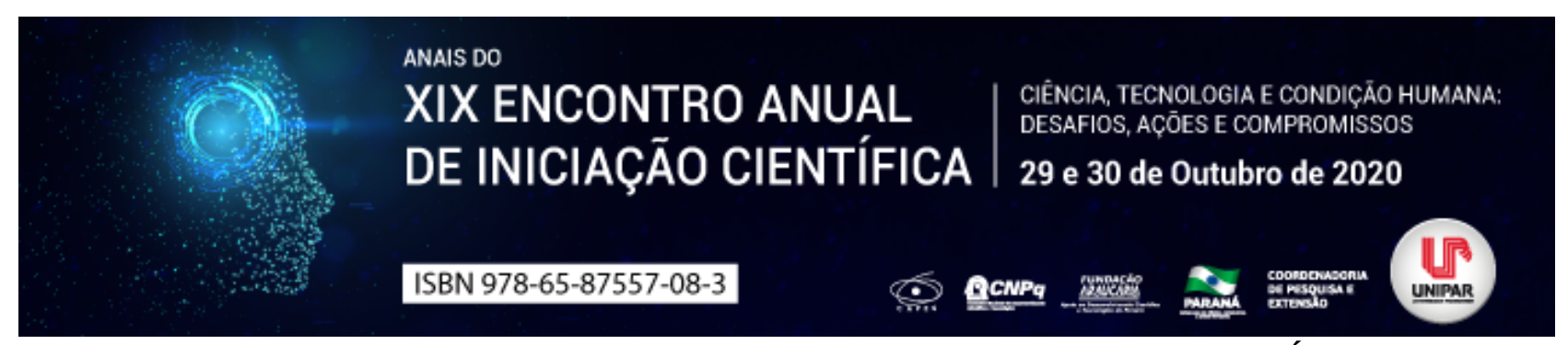

MASSACRE SILENCIOSO: MORTES NEGLIGENCIADAS POR TUBERCULOSE NOS PRESÍDIOS BRASILEIROS

\begin{abstract}
${ }^{1}$ ISABELLA ARANTES TOBBIN, ${ }^{2}$ NAIANY OLIVOTTO MARTINS, ${ }^{3}$ BRENDA PASSOS BESAGIO, ${ }^{4}$ LORENA DE FATIMA MORETTO, ${ }^{5}$ TAMILA SIMINSKI
\end{abstract}

\begin{abstract}
${ }^{1}$ Acadêmico bolsista do PIBIC/UNIPAR
${ }^{1}$ Acadêmica do Curso de Medicina da UNIPAR

${ }^{2}$ Acadêmica do Curso de Medicina da UNIPAR

${ }^{3}$ Acadêmica do Curso de Medicina da UNIPAR

${ }^{4}$ Docente da UNIPAR
\end{abstract}

Introdução: Nos últimos anos houve um aumento significativo de novos detentos no Brasil, superlotando as celas, acarretando em um ambiente com condições insalubres, propiciando o crescente número de novos casos de tuberculose. Segundo o Boletim Epidemiológico de Tuberculose do Ministério da Saúde (2020), o índice de infectados aumentou de 6,4\% para 11,1\%, no ano de 2019, entre as pessoas privadas de liberdade. A tuberculose (TB) é uma doença infectocontagiosa bacteriana, seu tratamento ininterrupto permite alto percentual de cura. No entanto, muitas vezes, é abandonado por sua duração e impressão de melhora rápida no início (SOUZA, 2018). Em relação às pessoas privadas de liberdade, os desafios são ainda maiores, como o diagnóstico tardio, o elevado índice de HIV (Vírus da Imunodeficiência Humana), além de outros agravos como o tabaco e o uso de drogas, tornando-os ainda mais vulneráveis à infecção por tuberculose (BALDAN; FERRAUDO; ANDRADE, 2017).

Objetivo: Analisar na literatura a incidência, vigilância e assistência à morbidade por tuberculose em presídios brasileiros.

Desenvolvimento: $O$ aumento da população carcerária e a consequente superlotação nas prisões, intensificou a situação precária de higiene já enfrentada. Em consequência disso, cresce também a mortalidade por doenças tratáveis como a tuberculose (SILVA, 2020). A TB é uma doença infecciosa causada pela bactéria Mycobacterium tuberculosis, podendo ser classificada como latente quando não manifesta sintomas e não é transmitida, ou ativa quando passa a apresentar manifestações como tosse crônica, febre vespertina, sudorese noturna, perda de peso e expulsão de escarros com sangue, podendo acometer outros órgãos além dos pulmões. A TB ativa possui uma taxa de $50 \%$ de morte sobre sua incidência quando não tratada, a transmissão ocorre por via aérea por meio de partículas em forma de aerossóis contendo bacilos. O diagnóstico é realizado principalmente pela baciloscopia, pelo Teste Rápido Molecular para Tuberculose (TRM-TB) e pela radiografia do tórax (PILLER, 2012). Segundo Valença (2016) a prevalência de TB entre os detentos chega a ser 50 vezes maior que a média da população brasileira. A maioria dos indivíduos aprisionados são do sexo masculino, com pouca escolaridade, vindos de comunidade desfavorecidas e que já possuem agravos como uso de drogas e tabaco. Ademais, grande parte dos encarcerados são portadores de doenças sexualmente transmissíveis (IST's) e a maioria, não tem conhecimento ou não realiza tratamento. A coinfecção por TB e HIV, apresenta riscos ainda maiores, uma vez que pode ocorrer falência na medicamentação pelo desenvolvimento de cepas multirresistentes (BALAN; FERRAUDO; ANDRADE, 2017). O descaso frente a essa situação se permeia desde ambientes com pouca ventilação, baixa incidência solar, excesso de umidade e a sobrelotação até ao diagnóstico tardio e a não continuidade ao tratamento, obtendo alto número de reincidência entre os aprisionados (VALENÇA et al., 2016). Segundo o INFOPEN (2017), a taxa de celas que apresentam superlotação é em média 171,62\% em relação ao esperado, se destacando também a grande quantidade de pessoas por celas nos presídios femininos. O tratamento da tuberculose é disponibilizado pelo SUS, sendo recomendado a estratégia através do Tratamento Diretamente Observado (TDO), que consiste no monitoramento diário da ingestão dos quatro fármacos que integram a medicamentação. Geralmente o tratamento tem duração de no mínimo 6 meses e logo no início a transmissão se reduz e os pacientes já apresentam sensação de melhora, o que causa grande abandono do tratamento e o desenvolvimento de cepas resistentes que ocasionam a reincidência da doença com agravo (SOUZA, 2018). De acordo com Alves (2020), a reincidência da TB se dá principalmente pelo abandono ou inadequação do tratamento, sendo $33 \%$ maior entre aprisionados com a coinfecção TB-HIV e de $22 \%$ entre indivíduos que não realizaram baciloscopia de acompanhamento. Outro fator agravante é a falta de estrutura para realizar as coletas de material biológico e diagnóstico. Segundo ALLGAYER (2019), 84\% das prisões no Rio Grande do Sul não apresentavam local para coleta de escarro e apenas 7\% possuíam radiógrafo e o TRM-TB. Nesse sentido, em 2004, foi criado o Programa Nacional de Controle da Tuberculose (PNCT) que atua em conjunto ao Plano Nacional de Saúde no Sistema Penitenciário (PNSSP) e tem por objetivo a descentralização das ações de controle da TB. No entanto, o acompanhamento ineficiente, a subvalorização dos sintomas destes pacientes e a naturalização da desassistência aos presos permitem o alto percentual de sua incidência e mortalidade. (NONATO et al., 2017).

Conclusão: $O$ crescente número de casos de tuberculose nas prisões evidencia que embora assegurados pela lei, o acesso a 
saúde é pouco legitimado e perpassa por desafios como a acomodação insalubre que aumenta a suscetibilidade à infecção e transmissão. Dessa forma se faz necessário um atendimento humanizado e especializado, visto que muitas mortes, reincidência e agravos poderiam ser evitadas se a população carcerária tivesse acesso a condições de acomodações mais humanas e acompanhamento clínico constante.

\section{Referências}

ALLGAYER, Manuela Filter et al. Tuberculose: vigilância e assistência à saúde em prisões. Revista Brasileira de Enfermagem, v. 72, n. 5, p. 1304-1310, 2019.

ALVES, Kelle Karolina Ariane Ferreira et al. Fatores associados à cura e ao abandono do tratamento da tuberculose na população privada de liberdade. Revista Brasileira de Epidemiologia, v. 23, p. e200079, 2020.

BALDAN, Sueli Santiago; FERRAUDO, Antonio Sergio; ANDRADE, Monica de. Características clínico-epidemiológicas da coinfecção por tuberculose e HIV e sua relação com o Índice de Desenvolvimento Humano no estado do Mato Grosso do Sul, Brasil. Revista Pan-Amazônica de Saúde, v. 8, n. 3, p. 59-67, 2017.

BRASIL, Ministério da Saúde. Boletim epidemiológico de tuberculose, março 2020.

SOUZA, Jhenifer et al. Incidência da tuberculose e a correlação entre a realização do tratamento e a cura. Revista de Enfermagem da UFSM, v. 8, n. 4, p. 637-648, 2018.

NONATO, Ruan Roberto Lima et al. Tuberculose e pessoas privadas de liberdade no Brasil: um estudo à luz da revisão integrativa. 2017.

PILLER, Raquel VB. Epidemiologia da tuberculose. Pulmão RJ, v. 21, n. 1, p. 4-9, 2012.

SILVA, Matheus de Souza Moura. Retrato do Sistema Penintenciário Brasileiro: O perfil dos encarcerados e a realidade dos presíddios. Repositório de Trabalhos de Conclusão de Curso, 2020.

VALENÇA, Mariana Soares et al. Tuberculose em presídios brasileiros: uma revisão integrativa da literatura. Ciência \& Saúde Coletiva, v. 21, p. 2147-2160, 2016.

BRASIL. Ministério da Justiça e Segurança Pública. Levantamento Nacional de Informações Penitenciárias - 2017. 


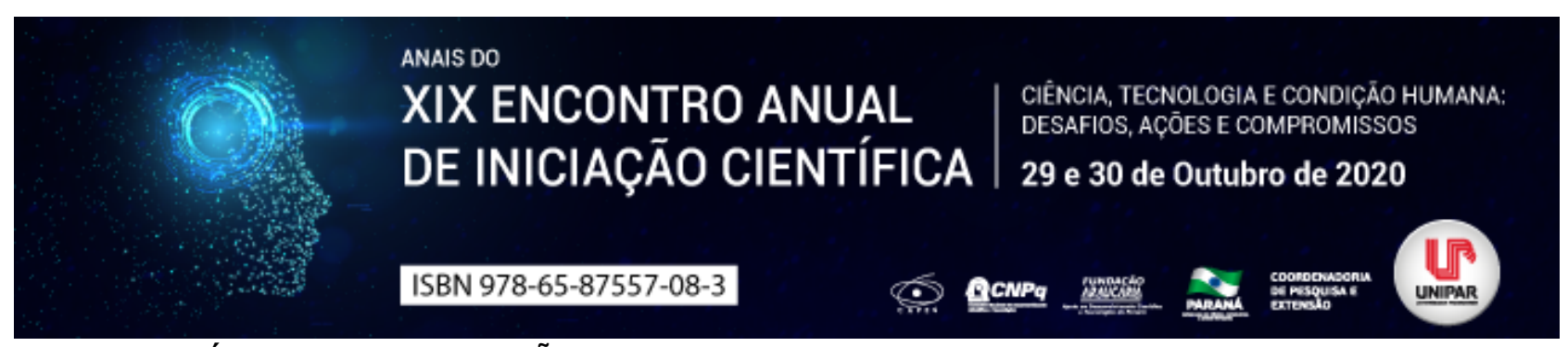

HORTAS COMUNITÁRIAS: CONSIDERAÇÕES GERAIS SOBRE QUALIDADE E SEGURANÇA DOS ALIMENTOS E DAS PLANTAS MEDICINAIS

\title{
${ }^{1}$ GRACIELE MOREIRA DO NASCIMENTO , ${ }^{2}$ LETICIA MARTINS HILDEBRAND, 3FELIPE ANDRÉ PEREIRA RAMOS, ${ }^{4}$ LAURIETI DE ALMEIDA, ${ }^{5}$ ANDREIA ASSUNCAO SOARES
}

\author{
${ }^{1}$ Acadêmico do Curso de Nutrição bolsista do PIBIC/UNIPAR \\ ${ }^{1}$ Acadêmica do Curso de Medicina Veterinária bolsista do PIBIC/UNIPAR \\ ${ }^{2}$ Mestrando Profissional de Plantas Medicinais e Fitoterápicos na Atenção Básica/UNIPAR \\ ${ }^{3}$ Acadêmica do Ensino Médio PEBIC EM-JR/CNPq/UNIPAR \\ ${ }^{4}$ Docente Mestrado Profissional de Plantas Medicinais e Fitoterápicos na Atenção Básica e Mestrado e Doutorado em Ciência \\ Animal da UNIPAR
}

Introdução: Seja nas pequenas cidades, ou grandes centros o estimulo por ações coletivas que melhorem a convivência e harmonia com o ambiente é cada vez maior. Segundo, Pessoa, et al. (2006) devido a esses estímulos, em todo mundo vem se observando um fenômeno crescente de residentes urbanos que se dedicam a atividades agrícolas, como as hortas comunitárias. O guia alimentar para população brasileira (2014) considera que as hortas comunitárias mesmo que pequenas, oferecem com baixo custo, quantidade razoável de alimentos in natura que garante variedade de frutas, legumes, dentre outras plantas, como as plantas com valor medicinal.

No entanto, por serem consumidas in natura, não passando por nenhum processamento pós-colheita, elas são consideradas um dos principais veículos de transmissão de doenças de origem alimentar (DTAs), sendo, portanto, necessário a avaliação das suas condições higiênicas e sanitárias (CARVALHO et al., 2019).

Essa avaliação visa verificar a contaminação microbiológica e parasitológica ao longo da cadeia produtiva que pode apresentar um impacto importante no estado de saúde do consumidor (SOUZA; LIONZO; PETROVICK, 2006).

Objetivo: O objetivo desse trabalho foi relatar algumas considerações gerais através de pesquisas bibliográfica sobre a qualidade e segurança dos alimentos e das plantas com potencial medicinal inseridas nas hortas comunitárias e seus indicadores de contaminação.

Desenvolvimento: Para que todo potencial terapêutico das plantas medicinais e nutricional das hortaliças sejam aproveitados é importante avaliar se sua produção é segura para o consumo humano.

Plantas medicinais e as hortaliças em geral, em razão da sua forma de cultivo, armazenamento e consumo, podem representar importantes veículos de transmissão de enteropatógenos para hospedeiros susceptíveis, podendo desencadear no consumidor desde infecções assintomáticas até quadros mais graves com síndrome da má absorção, emagrecimento, desenvolvimento de anemias, quadros de diarreia, oclusão, perfuração intestinal e dores abdominais (ANDRADE et al., 2010). Segundo Souza (2006), para considerar um produto seguro para o consumo, tanto os alimentos como as plantas medicinais, devem ter seus constituintes ou contaminantes que podem causar perigo à saúde, ausentes ou em concentrações abaixo do limite de risco. Os principais microrganismos contaminantes são Salmonella spp., Shigella spp., Escherichia coli, Vibrio cholerae, dentre outros. Conforme explica Souza et al. (2005) um alimento ou uma planta medicinal pode tornar-se de risco por razões como: i) manipulação inadequada; ii) uso de matérias primas contaminadas; iii) contaminação e/ou crescimento microbiano; iv) uso inadequado de aditivos químicos; v) adição acidental de produtos químicos; vi) poluição ambiental e degradação de nutrientes. Para avaliação da segurança de um alimento ou de uma planta medicinal para consumo utilizamos indicadores de contaminação, que são microrganismo cuja presença em alimentos, indica a possibilidade da existência de microrganismos produtores de toxinfecções alimentar, esses indicadores são considerados de grande importância na avaliação da segurança e qualidade microbiológica dos alimentos (HAYES, 1995). Microrganismos indicadores de contaminação higiênico-sanitária são de fundamental importância para: i) monitorar; ii) detectar mudanças de qualidade; iii) classificar; iv) restringir o uso de águas ou alimentos. Identificando estas situações torna-se possível tomar medidas de correção e mudanças para tornar o alimento seguro, ou ao menos evitar que ele chegue a mesa dos consumidores (SOUZA, 2006).

Conclusão: Conclui-se que avaliar possíveis contaminação presente nos alimentos é fundamental para garantir sua segurança e higiene, evitando doenças de origem alimentar. A identificação rápida dos indicadores de contaminação se faz necessário para que se possa tomar medidas e cuidados no manejo da horta a fim de diminuir a contaminação, orientar a higienização segura e em último caso evitar que o alimento chegue a mesa do consumidor. 
ANDRADE, Elisabeth Campos, et al. Parasitoses intestinais : uma revisão sobre seus aspectos sociais, clínicos e terapêuticos. Revista APS, v. 13, n. 2, p. 231 240, 2010.

BRASIL. MINISTÉRIO DA SAÚDE. Guia alimentar para população brasileira. 2ed. Brasília, 2014.

CARVALHO, Laiana Ferreira de; SANTOS, Gleyson Moura dos; CAMPOS, Clélia de Moura Fé. Qualidade microbiológica da cebolinha (Allium schoenoprasum L.) produzida em hortas comunitárias de Teresina-PI. Archives of health investigation, v. 8 , n. 6, 2019.

HAYES, Rutherford. Microbiological examining methods. In: Food microbiology and hygiene. Springer US, 1995. p.184-223. PESSOA, Cristiane Cardoso; SOUZA, Marcelino de; $\mathrm{SCHUCH}$, llaine. Agricultura urbana e Segurança Alimentar: estudo no município de Santa Maria RS. Segurança Alimentar e Nutricional, v. 13, n. 1, p. 23-27, 2006.

SOUSA, Cristina Paiva. Segurança alimentar e doenças veiculadas por alimentos: utilização do grupo coliforme como um dos indicadores de qualidade de alimentos. Revista APS, v. 9, n. 1, p. 83-88, 2006.

SOUZA, Evandro Leite; et al. Bacteriocins: molecules of fundamental impact on the microbial ecology and potential food biopreservatives. Brazilian Archives of Biology and Technology, v. 48, n. 4, p. 559-566, 2005.

SOUZA, Tatiane Pereira de; LIONZO, Maria Ismenia Zulion.; PETROVICK, Pedro Ros. Avaliação da redução da carga microbiana de droga vegetal através do processamento tecnológico: decocção e secagem por aspersão. Revista Brasileira de Farmacognosia, v. 16, n. 1, p. 94 98, 2006. 


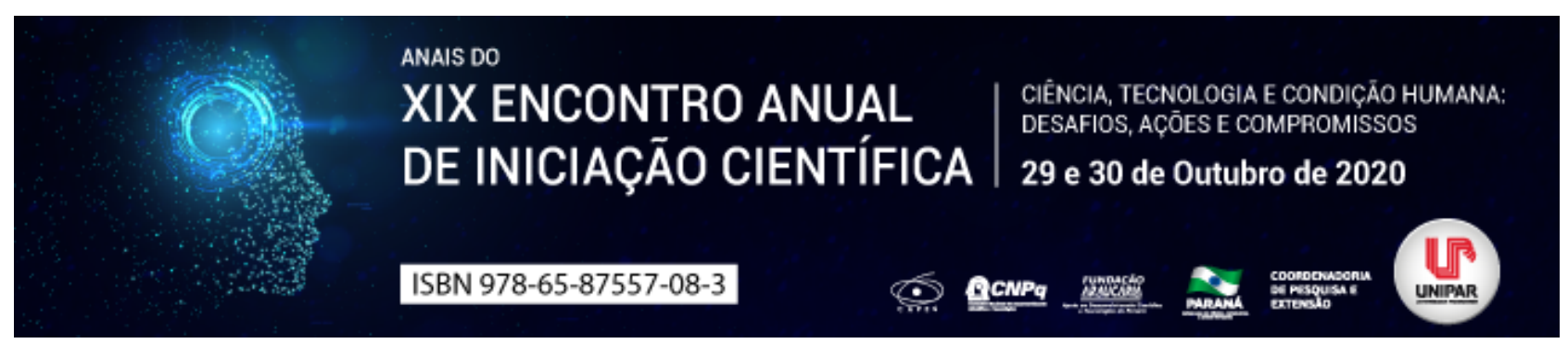

FISIOPATOLOGIA DA ANEMIA E EXAMES LABORATORIAIS

\begin{abstract}
${ }^{1}$ ISABELA RAMOS LESNIEWSKI, ${ }^{2}$ JENIFFER URBANO DEGASPERI, ${ }^{3}$ LETICIA DE FREITAS CUBA GUERRA, ${ }^{4}$ LETICIA NADAL
\end{abstract}

${ }^{1}$ Discente do curso de Odontologia da Universidade Paranaense - UNIPAR/ Campus Cascavel PR.

${ }^{1}$ Discente do curso de Odontologia da Universidade Paranaense - UNIPAR/ Campus Cascavel PR.

${ }^{2}$ Docente do curso de Odontologia da Universidade Paranaense - UNIPAR/ Campus Cascavel e Fco. Beltrão PR.

${ }^{3}$ Docente do curso de Odontologia da Universidade Paranaense - UNIPAR/ Campus Cascavel PR.

Introdução: Exames laboratoriais, quando bem indicados, colaboram para decidir condutas e determinar diagnósticos com segurança ao paciente (SILVEIRA, 2015). O hemograma é um exame complementar amplamente utilizado, pois fornece uma visão do sistema hematopoiético do indivíduo, examinando as células do sangue mediante a análise das séries vermelha, brancas e plaquetária (NAOUM; NAOUM, 2008).

Objetivo: Revisar a literatura a fim de destacar a importância da série vermelha do hemograma, bem como suas implicações de alterações das hemácias na odontologia.

Desenvolvimento: É indicado que um hemograma seja requerido previamente a procedimentos cirúrgicos de média ou grande complexidade ou quando um paciente apresenta sinais e sintomas que podem ser observados clinicamente, pois por meio deste exame complementar é possível verificar se o paciente apresenta anormalidades hematopoiéticas o que poderia contraindicar tal procedimento e exigir tratamento médico (SILVA et al., 2020; TOMMASI, 2014). Ao realizamos a interpretação da análise do sangue, nos deparamos com alguns conceitos, como a série vermelha, denominada eritrograma, que contempla a contagem de eritrócitos, hematócrito, dosagem de hemoglobina e índices hematimétricos (NAOUM; NAOUM, 2008). O termo contagem de eritrócitos $(\mathrm{Hm})$ é empregado para detectar a quantidade dessa célula presente no sangue. Quando seu número está abaixo do normal chama-se eritropenia, e acima eritrocitose. O hematócrito $(\mathrm{Ht})$ representa a proporção dos glóbulos vermelhos, correspondendo ao percentual do sangue que é composto por hemácias. No momento que esse parâmetro está abaixo do valor considerado normal, pode representar alterações na produção dos eritrócitos e consequentemente indica que o percentual de plasma está elevado, no entanto quando há muita concentração de hemácias pode representar um caso de desidratação devido ao plasma estar reduzido. (TOMMASI, 2014, TONANI; NETO, 2001). A concentração de hemoglobina (Hb) avalia a proteína que transporta o oxigênio, no caso, a hemoglobina, além disso, o teor total presente no sangue está interligado com o número de eritrócitos e quando o valor desse tópico está abaixo do considerado normal, o paciente está apresentando um caso de anemia. Por isso, este é o parâmetro laboratorial mais utilizado para definir um quadro anêmico, juntamente com o hematócrito (SANTIS, 2019). Já a Hemoglobina Corpuscular Média (HCM) é representada pela quantidade média de hemoglobina transportada pelos glóbulos vermelhos, correspondendo a proporção real de hemoglobina existente dentro da hemácia (TONANI; NETO, 2001). O volume corpuscular médio (VCM) avalia os tipos de anemia que se manifestam a partir das alterações no tamanho da hemácia, que pode ser macro (grande), micro (pequena) e normocíticas (tamanho normal) (SILVEIRA, 2015; TONANI; NETO, 2001; TOMMASI, 2014). Já a Concentração de Hemoglobina Corpuscular Média (CHCM) é determinada a partir do valor da hemoglobina por eritrócito, correspondendo a quantidade de hemoglobina média percentualmente que está contida em cada hemácia, avaliando a concentração que condiz com a coloração. Quando as hemácias têm pouca hemoglobina são definidas como hipocrômicas, em contrapartida se as hemácias têm muita hemoglobina, são classificadas como hipercrômica e em condições consideradas normais: normocrômicas. (TONANI; NETO, 2001). O coeficiente de variação de volume do glóbulo vermelho ao redor da média (RDW) avalia o grau de variação no tamanho das hemácias e auxilia no diagnóstico de problemas na morfologia, assim, podendo revelar uma anisocitose (excessiva variação de tamanho dos eritrócitos) (SILVEIRA, 2015). Observamos que uma das condições que podem ser diagnosticadas pela interpretação do hemograma é a anemia, que se caracteriza por uma situação onde ocorre a diminuição de hemoglobina e massa eritrocitária nos eritrócitos, fazendo com que o transporte de oxigênio se torne insuficiente. Há vários tipos de anemia e cada uma tem suas particularidades fisiopatológica. Clinicamente, o paciente, em geral encontra-se pálido, além de frequentes relatos de anorexias, fadiga e dispneia. Na cavidade oral pode-se observar despapilação da língua, mucosa pálida e atrófica (SANTIS, 2019; TONANI; NETO, 2001).

Conclusão: Diante disso, exames hematológicos não consistem somente em parâmetros laboratoriais, mas sim, são importantes ferramentas capazes de expressar as condições orgânicas do indivíduo num dado momento. Assim, deve ser solicitado regularmente e introduzido dentro da rotina diária da prática odontológica, uma vez que alterações hematopoiéticas podem apresentar suas manifestações clínicas primárias pela mucosa bucal e causar complicações em tratamentos odontológicos. 


\section{Referências}

NAOUM, Paulo Cesar; NAOUM, Flávio Augusto. Interpretação laboratorial do hemograma. São José do Rio Preto, Brazil, 2008. SANTIS, Gil Cunha de. Anemia: definição, epidemiologia, fisiopatologia, classificação e tratamento. Medicina (Ribeirão Preto), 2019.

SILVA, Kaohana Thais da. et al. Hemograma pré-cirúrgico: visão dos dentistas e pacientes. Brazilian Journal of Health Review, v. 3, n. 2, 2020.

SILVEIRA, Raquel Sousa. A compreensão do hemograma para profissionais não médicos. AC\&T - Academia de Ciência e Tecnologia. v. 15020, p. 130, 2015.

TOMMASI, Antonio Fernando. Diagnóstico em patologia bucal. 4. Ed. Rio de Janeiro: elsevier, 2014.

TONANI, Pedro Carlos Ferreira; NETO, Antônio Carrilho. Exames complementares laboratoriais de interesse para o cirurgião dentista, 2. ed: Curitiba: editora maio, 2001 


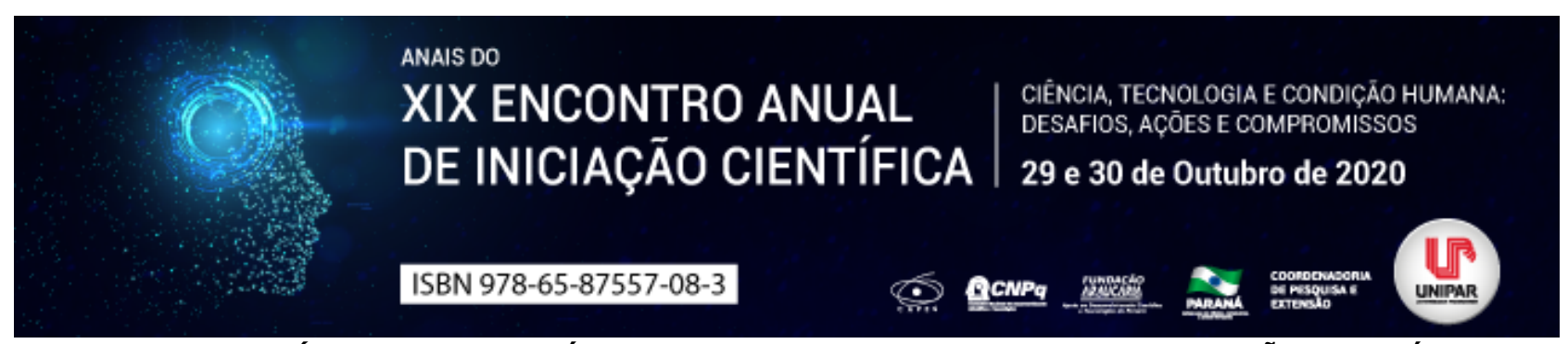

ASPECTOS CLÍNICOS E HISTOLÓGICOS DO REPARO ALVEOLAR: UMA REVISÃO LITERÁRIA

\begin{abstract}
${ }^{1}$ MAISA DA ROSA DE TONI, ${ }^{2}$ LISLENE CRISTINA FARIA DE OLIVEIRA, ${ }^{3}$ GUSTAVO BONNER CARRASCO OLIVEIRA, ${ }^{4}$ ISABELA RAMOS LESNIEWSKI, ${ }^{5}$ JENIFFER URBANO DEGASPERI, ${ }^{6}$ LETICIA NADAL
\end{abstract}

\footnotetext{
${ }^{1}$ Acadêmica do Curso de Odontologia - Unipar Cascavel

${ }^{1}$ Acadêmica do Curso de Odontologia da UNIPAR

${ }^{2}$ Acadêmico do Curso de Odontologia da UNIPAR

${ }^{3}$ Acadêmica do Curso de Odontologia da UNIPAR

${ }^{4}$ Acadêmica do Curso de Odontologia da UNIPAR

${ }^{5}$ Docente da UNIPAR
}

Introdução: O entendimento do processo de reparo após as exodontias dentárias é essencial na odontologia, especialmente na implantodontia, sendo relevante para o auxílio no atendimento pré e pós-operatório, garantindo o planejamento cirúrgico, evitando complicações ao paciente.

Objetivo: Tem como intuito descrever as etapas que compõe o processo biológico do reparo alveolar.

Desenvolvimento: Mesmo que medidas preventivas sejam empregadas pela odontologia, a exodontia dentária é rotina nos consultórios odontológicos, ocorrendo por diversos fatores, como: doenças periodontais severas, insucesso em tratamentos endodônticos, protéticos, indicações ortodônticas, traumas dentais, e outros. Após a exodontia dentária, o osso alveolar começa o processo de reparo, seguindo 3 fases: proliferativa, desenvolvimento do tecido conjuntivo, maturação do tecido conjuntivo, diferenciação óssea ou mineralização. A fase de proliferação celular inicia imediatamente após a formação do coágulo. Consiste na resposta imediata da lesão no processo das extrações dentárias, sendo que, os vasos que são lesionados geram um coágulo no alvéolo nas primeiras 24 horas. Ao final do primeiro dia verifica-se um alveólo totalmente preenchido por sangue, com borda separadas e edema, e histologicamente uma rede de fibrina recobre a superfície do coágulo. Entre o $2^{\circ}$ ao $5^{\circ}$ dia o coágulo é invadido por fibroblastos pré-existentes e frutos da diferenciação de células adventícias, além uma notório angiogênese. No $6^{\circ}$ dia o coágulo se transforma num tecido e granulação, sendo esta uma matriz que permite a formação do tecido ósseo. (CARDAROPOLI; ARAÚJO; LINDHE, 2003; KUBILIUS; KUBILIUS; GLEIZNYS, 2012). Após 7 dias, a fase é desenvolvimento do tecido conjuntivo, com tecido neoformado apresentando grande quantidade de fibroblastos e vasos sanguíneos, clinicamente verifica-se redução da hiperemia[LN1], edema e a proliferação tecidual sobre o coágulo torna-se mais evidente. A fase de maturação do tecido conjuntivo inicia-se no $14^{\circ}$ dia, perdurando por 4 semanas, sendo caracterizada por aumento das fibras colágenas, diminuição do número de células e vasos sanguíneos, início da deposição de matriz orgânica e formação de tecido osteóide, diferenciação dos fibroblastos e das células osteoprogenitoras em osteoblastos, osteoclastos e osteócitos e observa-se união epitelial sobre a superfície do coágulo sanguíneo. Clinicamente observa-se união das bordas gengivais, com traço linear no centro. Por fim, aproximadamente no $40^{\circ}$ dia no fundo do alvéolo há início da deposição de osteóide e calcificação, caracterizando a fase de diferenciação óssea. No $64^{\circ}$ dia as trabéculas ósseas apresentam-se neoformadas com características normais, havendo equilíbrio da atividade osteoclástica e osteoblástica. Clinicamente a mucosa apresenta cor e consistência normais. É importante destacar que radiograficamente verifica-se reabsorção quase em toda extensão do septo alveolar e da lâmina dura (CARDAROPOLI; ARAÚJO; LINDHE, 2003; KUBILIUS; KUBILIUS; GLEIZNYS, 2012).

Conclusão: Observa-se que o reparo alveolar adequada é um processo indispensável após uma exodontia, pois garante ao indivíduo um reparo ósseo efetivo. O procedimento possui complexidade em cada fase, sendo necessário que estas aconteçam corretamente, assim o conhecimento do odontólogo somado ao cuidado do paciente irá proporcionar um resultado satisfatório para ambos.

\title{
Referências
}

CARDAROPOLI, Giuseppe; ARAÚJO, Maurício; LINDHE, Jan. Dynamics of bone tissue formation in tooth extraction sites: An experimental study in dogs. Journal of Clinical Periodontology, v. 30, n. 9, p. 809 818, 2003.

KUBILIUS, Marius; KUBILIUS, Ricardas; GLEIZNYS, Alvydas. The preservation of alveolar bone ridge during tooth extraction.Odontologijos studija, v. 14, n. 1, p. 3 11, 2012. 


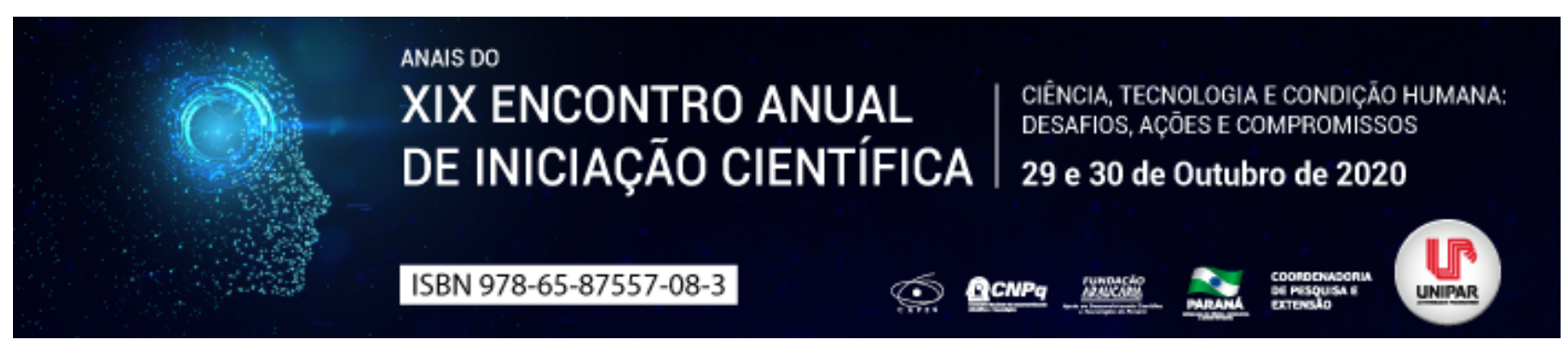

MATERNIDADE NO CÁRCERE PRIVADO

\title{
${ }^{1}$ BRENDA PASSOS BESAGIO, ${ }^{2}$ ISABELLA ARANTES TOBBIN, ${ }^{3}$ NAIANY OLIVOTTO MARTINS, ${ }^{4}$ TAMILA SIMINSKI
}

\author{
${ }^{1}$ Acadêmica do curso de Medicina da UNIPAR \\ ${ }^{1}$ Acadêmica PIBIC/UNIPAR \\ ${ }^{2}$ Acadêmica PIC/UNIPAR \\ ${ }^{3}$ Docente da UNIPAR
}

Introdução: Nas últimas décadas, ocorreu um crescimento do encarceramento feminino, o que vem tirando da invisibilidade questões referentes a vulnerabilidade das gestantes no sistema penitenciário (DIUANA, et al., 2017). Com esse crescimento, houve a necessidade da criação de regras específicas envolvendo a Organização das Nações Unidas e o Governo Brasileiro, a fim de garantir a integridade das detentas e principalmente das mães, no entanto, é possível observar que o Brasil carece de penitenciárias que respeitem plenamente as normas nacionais e internacionais referentes ao tratamento dado às mulheres privadas de liberdade (RONCHI, 2017).

Objetivo: Realizar um levantamento bibliográfico acerca da situação das maternidades nos presídios brasileiros, considerando a estrutura, acesso à saúde e os direitos das gestantes.

Desenvolvimento: O número de mulheres no sistema penitenciário passou de 5,6 mil para 37,2 mil entre os anos de 2000 e 2019 e, consequentemente, houve um aumento também no número de mães (INFOPEN, 2019). Tal crescimento fez com que houvesse a necessidade de normas com especificidade de gênero e, devido a isso, o Governo Brasileiro participou da Assembleia Geral das Organizações das Nações Unidas (ONU), a fim de elaborar um conjunto de regras para o tratamento dessas detentas, conhecidas como Regras de Bangkok (CONSELHO NACIONAL DE JUSTIÇA: REGRAS DE BANGKOK, 2016). Esse documento apresenta normas para o tratamento de gestantes, lactantes ou mulheres com filhos, que incluem instalações específicas e até mesmo penas não privativas de liberdade. No entanto, essas normas não são aplicadas de forma efetiva no Brasil, visto que várias penitenciárias apresentam estruturas precárias e as gestantes não possuem atendimento médico especial (RONCHI, 2017). Essas regras internacionais estão associadas ao art. 14, $\S 3^{\circ}$, da Lei de Execução Penal, que assegura acompanhamento médico à mulher, principalmente no pré-natal e no pós-parto. Nesse sentido, é importante salientar o perfil das mulheres apenadas, sendo elas predominantemente negras (62\%), em idade fértil e com o ensino fundamental incompleto. Além disso, de acordo com o Departamento Penitenciário Nacional, em março de 2020 foram contabilizadas 208 grávidas, 44 puérperas no sistema prisional brasileiro, das quais 77 grávidas e 20 puérperas são presas provisórias. Apesar desses números, no que se refere a infraestrutura, $84 \%$ das prisões não apresentam dormitório/cela adequado para gestantes, $86 \%$ não contam com berçário e/ou centro de referência materno-infantil. Somado a essa questão, mesmo que $84 \%$ das mulheres estejam em penitenciárias com módulos de saúde, esses módulos são mal distribuídos, tendo como exemplo os estados do Acre e do Rio de Janeiro, onde $70 \%$ das detentas não contam com essa estrutura. Corroborando ao déficit estrutural, existe a carência de profissionais da saúde para o atendimento dessas mães, visto que o país possui apenas 28 ginecologistas em atividade nos estabelecimentos penais (INFOPEN, 2018). Para exemplificar o tratamento dado às gestantes, foi realizado o estudo Saúde materno-infantil nas prisões , financiado pela Fundação Oswaldo Cruz e Ministério da Saúde. A pesquisa mostrou que 93\% das mulheres tiveram acesso ao pré-natal mas apenas $36 \%$ o classificaram como adequado, devido número baixo de consultas ou pelo início tardio desse acompanhamento (após a 16 ${ }^{\mathrm{a}}$ semana). Ademais, somente $3 \%$ tiveram a presença de um acompanhante de escolha no momento do parto, contrariando a Lei 11.108 que dá a gestante o direito de escolher quem irá acompanhá-la, e ainda foi relatado que algumas detentas foram algemadas durante o parto e sofreram violência verbal e psicológica (LEAL, et al., 2016). Isso deixa claro o preconceito velado sofrido por essas mulheres até mesmo no ambiente hospitalar, por profissionais que deveriam garantir o seu acolhimentos, mas que apenas atuam como um entrave na reintegração social das encarceradas (MATOS, 2019). Do mesmo modo, em uma pesquisa desenvolvida no Complexo Penal Feminino Dr. João Chaves, em Natal, Rio Grande do Norte, as detentas relataram a dificuldade no processo para conseguir agendar consultas pré-natais, assim como obter medicamentos adequados, tornando evidente a precariedade do sistema carcerário (GALVÃO, et al., 2013).

Conclusão: Ao observar a situação atual das gestantes no sistema penitenciário, fica evidente a necessidade de uma melhor infraestrutura assim como o aumento no número de médicos, a fim de garantir o acesso dessas mulheres a prevenção e promoção da saúde, além de um melhor acompanhamento pré-natal. Nesse sentido, urge uma melhor coleta de dados, para dar fim a invisibilidade que ainda permeia sobre essas mulheres e para que as leis de garantia de direitos sejam realmente aplicadas, de modo que as encarceradas sejam tratadas de maneira mais humana e sem preconceitos, com a finalidade de alcançar a reintegração social plena proposta inicialmente pelo Sistema Penitenciário. 


\section{Referências}

BRASIL. Conselho Nacional de Justiça-CNJ. Regras de Bangkok (2016). Regras das nações unidas para o tratamento de mulheres presas e medidas não privativas de liberdade para mulheres infratoras.

BRASIL. Lei de execução Penal. Lei n7210 de 11 de julho de 1984. A execução penal tem por objetivo efetivar as disposições de sentença ou decisão criminal e proporcionar condições para a harmônica integração social do condenado e do internado, Brasília, 1984.

BRASIL. Ministério da Justiça e Segurança Pública. Departamento penitenciário nacional divisão de atenção às mulheres e grupos específicos. INFORMAÇÃO No 63/2020/DIAMGE/CGCAP/DIRPP/DEPEN.

BRASIL. Ministério da Justiça e Segurança Pública. Levantamento Nacional de Informações Penitenciárias INFOPEN. 2019.

BRASIL. Ministério da Justiça e Segurança Pública. Levantamento Nacional de Informações Penitenciárias Infopen Mulheres 2edição. 2018.

DIUANA, Vilma; CORREA, Marilena C.D.V.; VENTURA, Miriam. Mulheres nas prisões brasileiras: tensões entre a ordem disciplinar punitiva e as prescrições da maternidade. Physis, Rio de Janeiro, vol. 27, núm. 3, Julho, 2017.

GALVÃO, Mayana Camila Barbosa; DAVIM, Rejane Marie Barbosa. Ausência de assistência à gestante em situação de cárcere penitenciário. Cogitare Enfermagem, vol. 18, núm. 3, Julho-Setembro, 2013.

LEAL, Maria do Carmo. et al. Nascer na prisão: gestação e parto atrás das grades no Brasil. Ciência \& Saúde Coletiva, vol.21 núm.7, julho. 2016.

MATOS, Khesia Kelly Cardoso. et al. Filhos do cárcere: representações sociais de mulheres sobre parir na prisão. InterfaceComunicação, Saúde, Educação, vol. 23, e180028, julho, 2019.

RONCHI, Isabela Zanette. A maternidade e o cárcere: uma análise de seus aspectos fundamentais. Porto Alegre. 2017. 


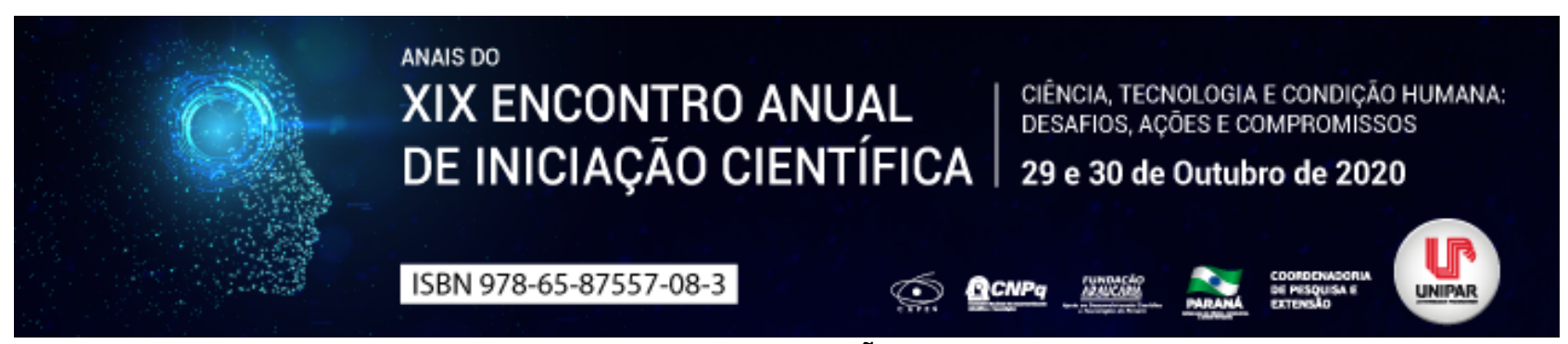

ESTUDO AVALIATIVO DOS PAIS SOBRE A ERUPÇÃO DO PRIMEIRO MOLAR PERMANENTE

\begin{abstract}
${ }^{1}$ ALICE DA ROSA TORMES, ${ }^{2}$ GABRIELI GUILHERME PSZEBISZESKI, ${ }^{3}$ GABRIELLY TIZOTTI KLEIN, ${ }^{4}$ JULIANA GARCIA MUGNAI VIEIRA SOUZA
\end{abstract}

\author{
${ }^{1}$ Acadêmico do PIC/UNIPAR - Campus Cascavel \\ ${ }^{1}$ Acadêmica do PIC/UNIPAR - Campus Cascavel \\ ${ }^{2}$ Acadêmica do PIC/UNIPAR - Campus Cascavel \\ ${ }^{3}$ Docente da UNIPAR - Campus Cascavel
}

Introdução: A atenção à saúde no contexto familiar é uma importante estratégia para a adequação do sistema de saúde vigente, em especial, no que tange ao fortalecimento da atenção básica e na melhoria da qualidade de vida. As crianças colocam o aprendizado em prática se este for relacionado com pessoas que tem um significado para elas. Assim, pais e responsáveis tornam-se referência de práticas relacionadas com a saúde. E no caso específico da promoção de saúde bucal, é imprescindível motivar os pais para que se conscientizem da real importância desta para a saúde geral de seus filhos (MASSONI et al., 2010). Para Martins et al. (2016) a atenção odontológica na infância é de suma importância para conscientização e instrução dos pais sobre a saúde bucal do bebê, destacando informações sobre higiene bucal e hábitos alimentares, entre outros aspectos como o desenvolvimento normal da dentição. Lopes et. al. (2011) é destaca a importância do primeiro molar permanente. Sua perda em uma criança pode acarretar alterações deletérias no arco dentário que podem causar conseqüências por toda a vida. Mostrando a necessidade de um diagnóstico precoce de lesões de cárie nestes dentes.

Objetivo: Avaliar o conhecimento dos pais sobre a erupção do primeiro molar permanente.

Material e métodos: $O$ trabalho realizado foi aprovado pelo comitê de ética em pesquisa envolvendo seres humanos (CEPEH) com o número de parecer 3.838.661. Devido a pandemia e as medidas de segurança necessárias, a pesquisa está sendo realizada de forma remota através de formulário online, e disponibilizado através de um link enviado aos pais e responsáveis. Esse contato se deu através de professores e diretores de colégios da região oeste do Paraná, envolvendo as cidades de Toledo, Cascavel, Guaíra. O público alvo é de 100 pais e responsáveis de crianças que estão matriculadas do $1^{\circ}$ ao $6^{\circ}$ ano do ensino fundamental, na faixa etária de 6 a 11 anos. Juntamente com o formulário foi enviado um áudio informativo, explicando o motivo da pesquisa o termo de consentimento livre e esclarecido. Neste estudo realizamos um questionário com perguntas objetivas sobre a erupção do primeiro molar permanente. Os resultados numéricos serão analisados estatisticamente e uma análise descritiva será realizada.

Resultados: A pesquisa está em andamento, portanto, os dados são parciais. Até o presente momento foram aplicados 38 questionários, no qual os resultados parciais obtidos foram: a idade dos responsáveis está em torno de 25 e 52 anos, que $50 \%$ das crianças eram do sexo masculino e 50\% eram do sexo feminino, 64,9\% com idade entre 6 a 8 anos, e 35,1\% de 9 a 11 anos. Dentre os resultados, sobre a quantidade de dentes decíduos que a criança apresenta na cavidade bucal 52,6\% afirmaram não saber e $47,4 \%$ responderam saber. Quando questionados sobre quais dentes permanentes irrompem primeiro na cavidade bucal, $92,1 \%$ responderam que os primeiros dentes que irrompem (nascem) são os anteriores e 7,9\% afirmaram ser os dentes posteriores. Das respostas obtidas 59,5\% afirmam saber diferenciar os dentes posteriores entre molares decíduos e molares permanentes, já 40,5\% afirmam não saber diferenciar. Grande parte $(55,3 \%)$ acredita que para irromper todos os dentes permanentes tem que esfoliar algum dente decíduo.

Discussão: A presente pesquisa mostrou que, quando os responsáveis foram questionados sobre a cronologia entre dentes anteriores e posteriores permanentes, a maioria (92,1\%) mostrou desconhecimento sobre essa informação, pois acreditam ser os dentes anteriores permanentes que erupcionam primeiro na boca, já 40,5\% não sabem diferenciar entre dentes decíduos e permanentes posteriores, e 44,7\% acreditam ser necessário esfoliar um elemento decíduo para erupcionar um permanente. Esse resultado foi semelhante ao trabalho de Massoni et. al (2010) que, verificou essa mesma situação, e afirmou que os pais e responsáveis desconhecem aspectos relacionados ao início da dentição permanente, o que mostra a necessidade da elaboração de ações de promoção de saúde bucal, que orientem quanto aos cuidados com o período de transição entre as dentições decídua e permanente, instruindo a respeito dos primeiros elementos permanentes a erupcionar, que são os primeiros molares, que irrompem na região posterior, em torno dos 6 anos de idade, dando início a dentição mista. Botelho et. al (2011) mostra que nas regiões onde existe um alto índice de cárie, os primeiros molares permanentes são os dentes mais afetados devido aos defeitos estruturais das cicatrículas e fissuras, menor densidade de cálcio na coroa e grande número de sulcos inacessíveis à limpeza, erupção assintomática e má higiene bucal.

Conclusão: Concluiu-se com os dados obtidos até o momento, que existe uma necessidade de maior esclarecimento sobre a 
importância do primeiro molar permanente, e sobre os tipos de danos que podem ser causados, caso ocorra uma perda precoce desse elemento. A partir disso observa-se a necessidade de uma campanha de informação e promoção de saúde.

\section{Referências}

BOTELHO, Kátia. et al. Condição clínica dos primeiros molares permanentes: de crianças entre 6 e 8 anos de idade. Odontol. Clín.-Cient., Recife, v. 10, n.2, p.167-171, abr./jun., 2011.

LOPES, Érika Fonseca.; POMARICO, Luciana.; SOARES, Lívia Ferreira. Condição do primeiro molar permanente: avaliação após 3 anos. Rev. Brás. Odontol., Rio de Janeiro, v.68, n.1, p.29-32, jan/jun. 2011.

MASSONI, Andreza Cristina de Lima. et al. Saúde bucal infantil: conhecimento e interesse de pais e responsáveis. Pesq Bras Odontoped Clin Integr, João Pessoa, 10(2):257-264, maio/ago. 2010.

MARTINS, Caroline Luana Costa.; JETELINA, Juliana de Camargo. Conhecimento dos pais sobre saúde bucal na infância e a relação com o motivo da consulta odontológica. Journal of Oral Investigations, Passo Fundo, v. 5, n. 1, p. 27-33, out. 2016.

SILVA, Alleson Jamesson. et al. Perda de primeiros molares permanentes em crianças e adolescentes atendidos na ClínicaEscola de Odontologia - UFPE. Revista Eletrônica Acervo Saúde, Recife, v.11, n.17, p. e1580, nov. 2019. 


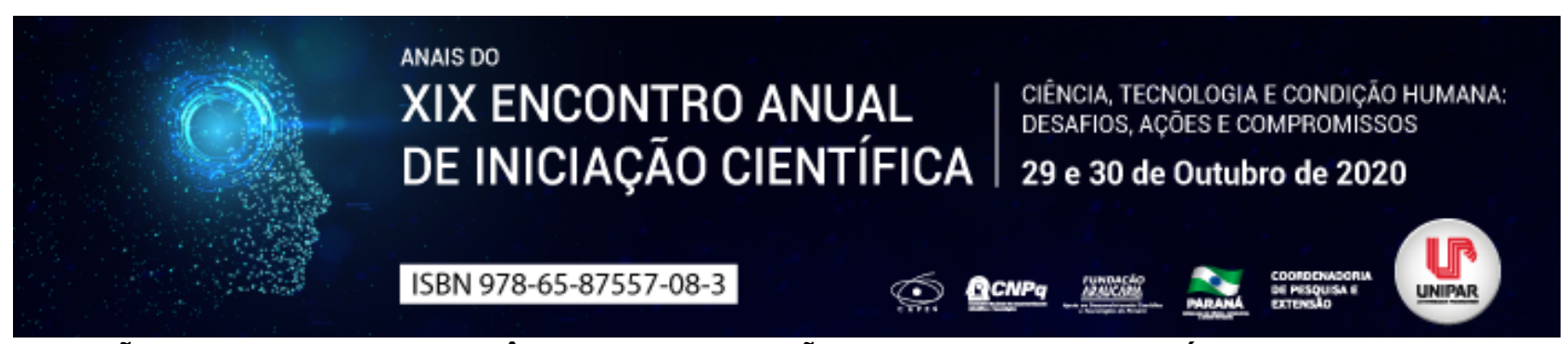

\title{
MANIFESTAÇÕES BUCAIS E A IMPORTÂNCIA DO CIRURGIÃO-DENTISTA NO DIAGNÓSTICO PRECOCE DO QUADRO BULÍMICO
}

\author{
${ }^{1}$ JENNIFER LORENSINI DOS SANTOS, ${ }^{2}$ ADRIELLY MEDEIROS, ${ }^{3}$ IZADORA FRANCESCHET, ${ }^{4}$ JENIFFER DEGASPERI, \\ ${ }^{5}$ LUANA VANZETTO, ${ }^{6}$ LETICIA NADAL
}

\begin{abstract}
${ }^{1}$ Discente do curso de Odontologia da Universidade Paranaense
UNIPAR / Campus Cascavel PR

${ }^{1}$ Discente do curso de Odontologia da Universidade Paranaense

UNIPAR / Campus Cascavel PR

${ }^{2}$ Discente do curso de Odontologia da Universidade Paranaense

UNIPAR / Campus Cascavel PR

${ }^{3}$ Discente do curso de Odontologia da Universidade Paranaense

UNIPAR / Campus Cascavel PR

${ }^{4}$ Discente do curso de Odontologia da Universidade Paranaense

UNIPAR / Campus Cascavel PR

${ }^{5}$ Docente do curso de Odontologia da Universidade Paranaense

UNIPAR / Campus Cascavel PR
\end{abstract}

Introdução: Os transtornos alimentares são uma preocupação séria no que diz respeito à saúde bucal dos pacientes. Eles representam um desafio clínico para profissionais de odontologia por causa de suas características psicológicas, médicas, nutricionais e padrões dentais, bem como suas características únicas (ARANHA et al., 2008). A Bulimia nervosa é uma doença caracterizada por perturbados padrões de comportamento alimentar, um controle patológico do peso corporal e perturbação na percepção da forma do corpo (ARANHA et al., 2008). Pacientes com o distúrbio da bulimia consomem deliberadamente alimentos de forma excessiva e posteriormente opta por meios compensatórios para eliminar peso, como o vômito posterior a refeições. Essa doença acarreta danos no organismo do paciente que dependendo do grau podem ser irreparáveis. Dentre todos os problemas que podem acometer o paciente portador de bulimia destacam-se os problemas da cavidade oral, que podem ser identicados pelo cirurgião-dentista no início da doença (POPOFF et al., 2010).

Objetivo: Assim sendo, essa revisão literária objetivou abordar como o distúrbio da bulimia interfere diretamente na saúde bucal. Desenvolvimento: Não existe uma exata etiologia para a bulimia, mas é comprovado que os indivíduos que as desenvolvem estão inseridos numa sociedade que prioriza a beleza, modismo e culto ao corpo além da aparência social (JUNIOR et al., 2012), tendo como uma de suas consequências distúrbios como a bulimia nervosa originadas na maioria das vezes por um conjunto de fatores como ansiedade, depressão e até mesmo dependência química (POPOFF et al., 2010). Independentemente dos fatores, ainda há uma falta de consciência sobre o papel indispensável do cirurgião dentista em um tratamento multidisciplinar de pacientes afetados (ARANHA et al., 2008). Pesquisas desenvolvidas por Junior, et al. (2012) mostraram que a doença atinge de $1 \%$ a $2 \%$ da população mundial, acometendo em sua maioria mulheres jovens. Os pacientes portadores dessa patologia apresentam diversas consequencias na saúde geral, e no quesito bucal, a erosão dental é a alteração mais encontrada (em 100\% dos pacientes), sendo acometida em sua maior parte no arco dentário superior e nos dentes anteriores, seguida de $54,1 \%$ de sensibilidade dental e um aumento do acometimento de cárie de até de 33,3\%. Estima-se que aproximadamente 6 meses após o início de ações como o vômito induzido constantemente podem já se observar as manifestações na boca. A erosão dental é um dos primeiros sintomas do quadro bulímico, podendo ser identificado e diagnosticado pelo cirurgião dentista, isso ocorre pelo fato da cavidade oral tornar-se um ambiente ácido que consequentemente irá descalcificar os dentes, esse desgaste é diferenciado dos demais porque geralmente acontece nas faces palatais e vestibulares dos dentes anteriores da arcada superior. Além da regurgitação rotineira fatores como a dieta e o fluxo salivar são determinantes no $\mathrm{pH}$ da cavidade oral, que quanto maior mais fácil de acontecer a desmineralização do esmalte dentário originando processos erosivos em pacientes bulímicos, ademais a higienização logo após a ação do vômito deixa o esmalte desorganizado o que facilita sua retirada através da abrasão na escovação. Devido ao alto desgaste dos elementos dentários, uma das consequências que os pacientes podem desenvolver é a hipersensibilidade, além disso consta que a dieta rica em açúcar e carboidratos juntamente com uma higiene oral deficitária aumenta a incidência de cárie nesses pacientes que apresentam quadro bulímico (JUNIOR et al., 2012). A equipe odontológica podem ser os primeiros profissionais de saúde a detectar, diagnosticar e levar o paciente ao tratamento médico, assim, fornecer tratamento multidisciplinar com um diagnóstico favorável (ARANHA et al., 2008).

Conclusão: A bulimia apresenta diversas alterações na cavidade oral, como erosão dentária, aumento da incidência de cárie, hipersensibilidade, entre outras, o cirurgião dentista sendo um dos primeiros profissionais a ter contato com essas manifestações na cavidade oral desempenha uma tarefa de extrema importância no diagnóstico precoce, pois somente assim poderá oferecer um tratamento odontológico adequado.

\section{Referências}


ARANHA ACC et al. Eating Disorders Part I: Psychiatric Diagnosis and Dental Implications. The Journal of Comtemporary Dental Practice. 2008; v. 9, n. 6, p. 1-11

JUNIOR, Rui Medeiros et al. Manifestações orais e maxilofaciais secundárias à bulimia nervosa: uma revisão sistemática. Pesquisa Brasileira em Odontopediatria e Clínica Integrada, v. 12, n. 2, p. 279-284, 2012

POPOFF, Daniela Araújo Veloso et al. Bulimia: manifestações bucais e atenção odontológica. RGO. Revista Gaúcha de Odontologia (Online), v. 58, n. 3, p. 381-385, 2010.

Coordenadoria de Pesquisa e Extensão - COPEX

Departamento de Editoraçāo e Divulgaçāo Científica - DEDIC 


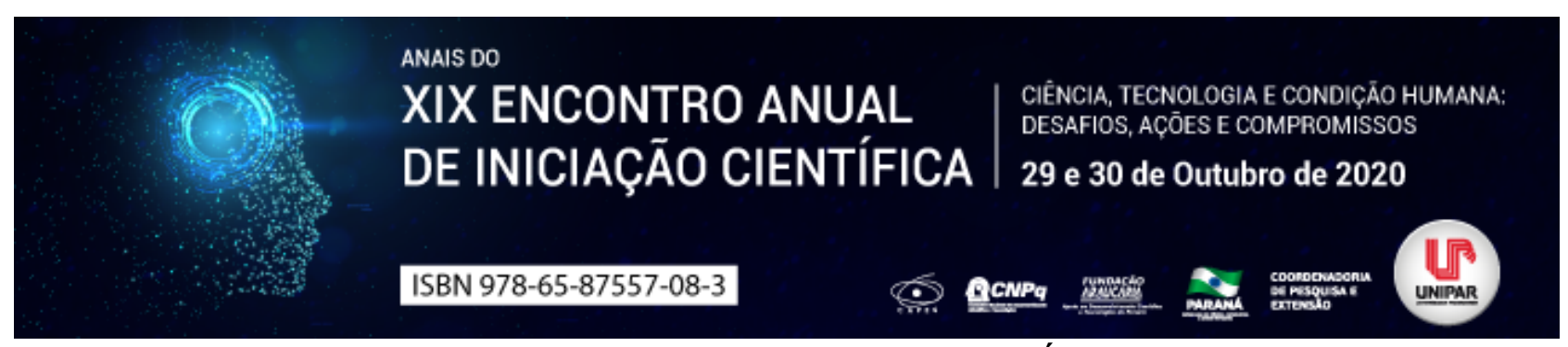

DESVIOS POSTURAIS EM BAILARINAS CLÁSSICAS

\title{
${ }^{1}$ AMANDA DIAS DE SOUZA, ${ }^{2}$ LUCYELENA AMARAL PICELLI
}

\author{
${ }^{1}$ Acadêmica do curso de Educação Fisica - Universidade Paranaense \\ ${ }^{1}$ Docente do curso de Educação Física - Universidade Paranaense
}

Introdução: $O$ início do balé clássico se deu originalmente na Itália no século $X V$, sendo denominado de 'balé de corte', porém foi a partir do século XVII na França que ele se desenvolveu (WOSNIAK, 2016). O primeiro ballet que aconteceu na corte de Médicis em Paris, foi o Ballet Comique de La Reine, onde reunia amadores e profissionais, entre eles rei Luiz XIV, conhecido também como 'Rei Sol', em um espetáculo que era apresentado como parte de divertimentos da corte. De acordo com Monteiro (1998) o balé é o oposto da dança mecânica que se contenta a agradar somente os olhos, é uma dança que apresenta significados e emociona, que se comunica com o público através da imitação da natureza.Transformando-se assim a dança de corte ao balé de ação, uma arte que no início teria sido praticada exclusivamente pela elite da corte da França. Deste modo a técnica do balé clássico busca trabalhar com a maior variedade de habilidades motoras e capacidades físicas utilizando também movimentos de grande amplitude articular e a postura ereta e alongada, podendo através dos diversos movimentos transmitir graça, energia e encanto aos olhos do público. O balé clássico está em constante evolução ao longo do tempo e se destaca como base inicial para várias outras modalidades de dança. Segundo Guimarães e Simas (2001) a dança é uma necessidade natural e involuntária do ser humano de exaurir pelo movimento seu estado reprimido.praticante compense em outras articulações e músculos, e até ocasionar anomalias posturais.

Objetivo: Identificar os desvios posturais mais acometidos em bailarinas clássicas através da revisão de literatura.

Desenvolvimento: A prática do Balé Clássico quando praticada corretamente resulta em vários benefícios para saúde como melhoria da socialização, desenvolvimento rítmico, aprimoramento do senso de confiança, aperfeiçoamento da memória, fortalecimento do condicionamento físico, aumento da flexibilidade. Estimula e contribui também para o autoconhecimento, desenvolve o equilíbrio, agilidade e a coordenação motora entre outros aspectos (SIMAS; MELO,2000). A prática quando feita em um período de no mínimo 5 anos com a média de 4 a 10 horas de treinamentos semanais, requer desempenho com perfeição técnica, que envolve extremas posições articulares e grande esforço muscular durante a rotação externa do quadril, além de hiperextensão do joelho e o extremo controle da articulação do tornozelo (PICON; FRANCHI, 2007). Por consequência, quando solicitados precocemente durante a infância de forma extrema as amplitudes das articulações, elas podem operar como patógeno de músculos, ossos, articulações e tendões. Desse modo, o balé clássico pode promover algumas modificações biomecânicas, anatômicas, morfológicas e físicas que podem até desestabilizar o equilibrio funcional dos praticantes (PICON et al., 2002). Segundo Meereis et al. (2011), a prática do balé clássico é capaz de ocasionar extensão de tronco e anteversão da pelve, e ao longo do tempo de prática a bailarina pode ainda adquirir tornozelos valgos e outros padrões posturais. Simas e Melo (2000) ressalta que as alterações posturais mais identificadas em bailarinas são, hiper lordose lombar, tronco inclinado para trás, pernas hiperestendidas, cifose cervical, joelhos varos, ombros desnivelados e tornozelos pronados. Esses autores apontam que um bom arranjo postural de uma bailarina está no encaixe de quadril, visto que a prática do balé intenciona rotacionar toda essa articulação, que quando não é realizada de forma correta pode prejudicar a postura da bailarina fazendo com que a praticante compense em outras articulações e músculos, e até ocasionar anomalias posturais.

Conclusão: Após verificar os principais desvios posturais mais incidentes em bailarinas clássicas, é possível constatar que o conhecimento dessas alterações no corpo das praticantes, se faz de grande importância para a consciência corporal de bailarinas, bem como assimetrias e restrições de movimentos e principalmente professores de balé clássico visando a prevenção de possíveis lesões secundárias. Tendo em vista, que a prática de movimentos repetitivos por no mínimo 5 anos dessa modalidade tem seu próprio conjunto de incidências de desvios posturais como comentados acima. Assim, concluímos que as alterações mais acometidas em bailarinas clássicas, são as articulações sendo frequentes nos tornozelos seguidas dos joelhos, pelve, coluna e ombros.

\section{Referências}

GUIMARÃES, A. C.A; SIMAS, J. P. N. Lesões no Ballet Clássico. Revista da Educação Física/UEM. Maringá, v.12, n. 2, p.8996. Sem. 2001. Disponível em: http://periodicos.uem.br/ojs/index.php/RevEducFis/article/view/3751 Acesso em: 19/06/2020.

MEEREIS, E. C. W. et al. Análise de Tendências Posturais em Praticantes de Balé Clássico. Revista da Educação Física. Maringá, v.22, n.1, p.27-35. 2011. Disponível em: http://periodicos.uem.br/ojs/index.php/RevEducFis/article/view/9130_Acesso em: 19/06/2020.

MONTEIRO, M. Noverre: Cartas sobre a Dança/ Mariana Monteiro; tradução e notas da autora

São Paulo: p.34, Editora da 
Universidade de São Paulo: FAPESP, 1998.

PICON, A. P.; FRANCHI, S. S.; Análise antropométrica dos pés de praticantes de balé clássico que utilizam sapatilha de ponta. Revista UNIARA, n. 20,2007. Disponível em: https://www.uniara.com.br/legado/revistauniara/pdf/20/RevUniara20_14.pdf Acesso em: 19/06/2020.

PICON,A. P.et al. A biomecânica e balé clássico : Uma avaliação de grandezas dinâmicas do sauté em sapatilhas de pontas. Revista Paulista de Educação Fisica, São Paulo, v.16, n.1, p. 53-60, janeiro/junho 2002. Disponível em: http://www.revistas.usp.br/rpef/article/view/138697 Acesso em: 19/06/2020.

SIMAS, J. P. N.; MELO, S. I.L. Padrão Postural de Bailarinas Clássicas. Revista da Educação Física/UEM. Maringá, v.11, n.1, p.51-57, 2000. Disponível em: http://www.periodicos.uem.br/ojs/index.php/RevEducFis/article/view/3791 Acesso em: 19/06/2020.

WOSNIAK, C. Contexto Histórico. In: KOTAKA, C. R. Balés Ilustrados: uma enciclopédia para Dança Clássica- V.1, 1 ed. p.25, Curitiba, Editora Regina Coeli Kotaka, 2016.

Coordenadoria de Pesquisa e Extensão - COPEX

Departamento de Editoraçāo e Divulgaçāo Científica - DEDIC 


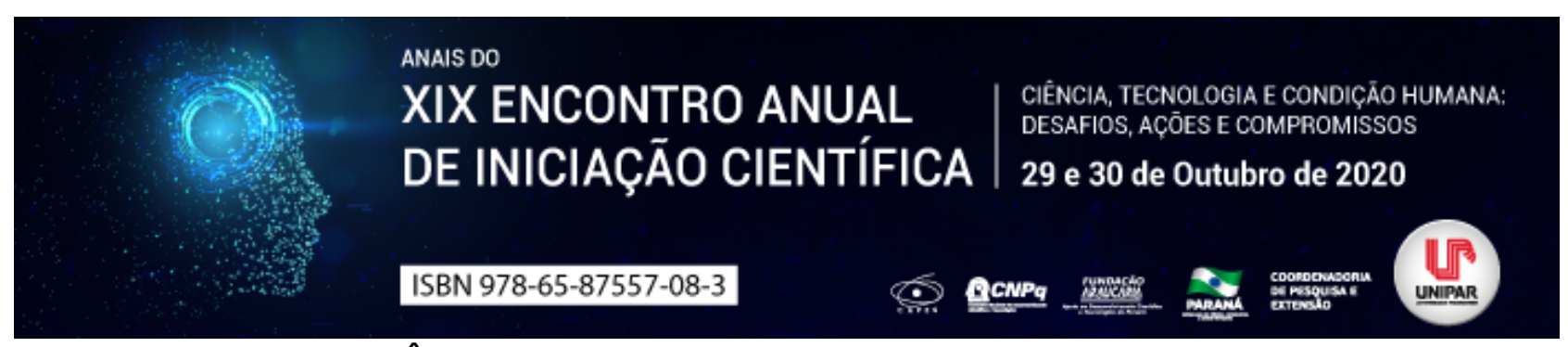

USO TERAPÊUTICO DO CANABIDIOL PARA TRATAMENTO DA EPILEPSIA

\begin{abstract}
${ }^{1}$ MATEUS ROVIERO DA SILVA, ${ }^{2}$ GABRIEL ALENCAR MANZOTTI, ${ }^{3}$ JOAO VITOR BARBOSA DO CARMO, ${ }^{4}$ LARISSA ANTONHOLI FELIX, ${ }^{5}$ LORENA NERIS BARBOZA
\end{abstract}

\begin{abstract}
${ }^{1}$ Discente do Curso de Farmácia UNIPAR Umuarama PR
${ }^{1}$ Discente do Curso de Farmácia UNIPAR Umuarama PR

${ }^{2}$ Discente do Curso de Farmácia UNIPAR Umuarama PR

${ }^{3}$ Discente do Curso de Farmácia UNIPAR Umuarama PR

${ }^{4}$ Docente do Curso de Farmácia UNIPAR Umuarama PR
\end{abstract}

Introdução: A epilepsia é uma doença neurológica crônica, podendo progredir em relação a desordem cognitiva, frequência e gravidade dos episódios críticos, sendo caracterizada por crises epiléticas recorrentes. A palavra epilepsia deriva do verbo grego ëpilamvanein, que significa convulsão, sendo essa a principal manifestação clínica da doença. Esse distúrbio é ocasionado por descargas neuronais excessivas e sincrônicas, podendo ter origem a partir de um ou dois pontos do hemisfério cerebral, gerando respectivamente, crises focais ou generalizadas. Essas descargas são provocadas por estímulos excitatórios mediados por glutamato ou pela falta de inibição mediada pelo ácido gama-aminobutírico (MARANHÃO; GOMES; CARVALHO, 2011). Ao decorrer da história, apesar do desenvolvimento de drogas antiepiléticas, iniciou-se a busca por terapias oriundas de compostos vegetais com propriedades farmacológicas evidenciadas pouco utilizados, pelo fato de sua eficácia ser considerada controversa, que é o caso da Cannabis sativa. Essa planta conta com diversos constituintes químicos e, segundo Brucki et al. (2015) os seus principais compostos são o $\Delta 9$-tetraidrocanabinol (THC) e o Canabidiol (CBD), que se difere do primeiro por não apresentar propriedades psicoativas.

Objetivo: Determinar com base em revisão de literatura a influência do canabidiol, bem como suas as propriedades terapêuticas como tratamento já descritos para epilepsia.

Desenvolvimento: Popularmente conhecida como maconha, a Cannabis sativa vem sendo utilizada para fins medicinais a milhares de anos, inicialmente em culturas asiáticas. No início do século XX, extratos da planta chegaram até a ser comercializados para tratamentos de distúrbios mentais. Porém, devido as suas propriedades alucinógenas, que a colocam em condição de droga ilícita, houve uma intensa diminuição do uso terapêutico da Cannabis no ramo da psiquiatria (CRIPPA; ZUARDI; HALLAK, 2010). A maconha só voltou em pauta na década de 60, quando o grupo do professor Raphael Mechoulam conseguiu definir as estruturas químicas dos principais compostos presentes na planta, bem como a descoberta dos receptores canabidioides. Crippa, Zuardi e Hallak (2010, p. 557) concordam que o reconhecimento do sistema endocanabinoide pode modular diversos processos fisiológicos e, possivelmente, patofisiológicos nos transtornos psiquiátricos . De acordo com Brucki et al. (2015) o efeito antiepilético do CBD é comprovado, entretanto, respaldado por mecanismos de ação, propriedades farmacocinéticas, segurança a longo prazo e interação com outros fármacos ainda mais incógnitos. Nesse ponto, os pacientes tratados com o CBD são aqueles cujo não obtiveram resposta a outros fármacos, ou seja, o composto vem sendo utilizado em casos de epilepsia mais graves, sendo visto como a última tentativa para possível melhora do quadro. Embora o mecanismo de ação do CBD não seja completamente conhecido, ele é capaz de facilitar a sinalização dos endocanabioides por meio da inibição da recaptação ou hidrólise enzimática da anandamida, sugerindo que o CBD aumente a disponibilidade de anandamida, que atua no controle das descargas de neurotransmissores nos neurônios pré-sinápticos, reduzindo as crises convulsivas (PEDRAZZI et al., 2014). Segundo estudo liderado por Devinsky et al. (2014) os ensaios clínicos com o CBD, desencadearam uma melhora de cerca $50 \%$ das crises convulsivas em $40 \%$ dos pacientes tratados, onde enquanto alguns obtiveram melhora total, não apresentando nenhuma convulsão, outros não mostraram sentir efeito algum ao tratamento, os resultados foram avaliados como pouco satisfatórios. Portanto, apesar de alguns resultados promissores, ainda são necessários estudos para validar toda farmacocinética e farmacodinâmica envolvida. Dentre os efeitos adversos mais comuns apresentados pelos pacientes inclui a diarreia, fadiga, perda ou ganho de peso, alteração no apetite e sonolência (BRUCKI et al., 2015).

Dessa mesma forma, em estudo promovido por Suraev et al. (2018) a fim de analisar a efetividade do CBD na infância, observouse a redução de convulsões em uma parcela das crianças, porém outras cursaram o caminho contrário, havendo o aumento no número de crises. É notório que o canabidiol vem sendo alvo de muitos estudos terapêuticos afim de desvendar melhor os mecanismos, efeitos adversos e possíveis interações tanto para o tratamento de epilepsia como em outras doenças neurológicas, porém muitas pesquisas ainda são necessárias para elucidar o uso terapêutico.

Conclusão: Na presente pesquisa pôde-se observar que o canabidiol exerce de fato efeitos antiepiléticos, no entanto, de acordo com os resultados dos ensaios realizados em estudos supracitados, sua efetividade não se difere da apresentada pelos outros 
fármacos antiepiléticos disponíveis no mercado. Portanto, é preciso que se explore melhor as propriedades farmacológicas desse composto, analisando como se ocasionam os efeitos adversos que ainda se mostram pouco elucidados, afim de reconhecer os limites terapêuticos da droga. Dessa forma, espera-se que o CBD desempenhe o seu grande potencial para se tornar umas das principais alternativas em tratamentos de epilepsia.

\section{Referências}

BRUCKI, Sonia M. D., et al. Canabinoides e seu uso em neurologia Academia Brasileira de Neurologia. Arq. Neuro-Psiquiatr., São Paulo, v. 73, n. 4, p. 371-374, abr. 2015. Disponível em: https://www.scielo.br/scielo.php?script=sci_arttext\&pid=S0004282X2015000400371. Acesso em: 19 jul. 2020.

CRIPPA, José Alexandre S.; ZUARDI, Antonio Waldo; HALLAK, Jaime E. C. Uso terapêutico dos canabinoides em psiquiatria. Rev. Bras. Psiquiatr., São Paulo, v. 32, supl. 1, p. 556-566, mai. 2010. Disponível em: https://www.scielo.br/scielo.php? script=sci_arttext\&pid=S1516-44462010000500009\&lng=pt\&tlng=pt. Acesso em: 12 jul. 2020.

DEVINSKY, Orrin et al. Cannabidiol: Pharmacology and potential therapeutic role in epilepsy and other neuropsychiatric disorders. Wiley Periodicals, v. 55, n. 6, p. 791-802, mai. 2014. Disponível em: https://onlinelibrary.wiley.com/doi/full/10.1111/epi.12631. Acesso em: 23 ago. 2020.

MARANHÃO, Marcius Vinícius Mulatinho, GOMES, Eni Araújo, CARVALHO, Priscila Evaristo de. Epilepsia e anestesia. Rev. Bras. Anestesiol., Campinas, v. 61, n. 2, p. 242-254, abr. 2011. Disponível em: https://www.scielo.br/scielo.php? script=sci_arttext\&pid=S0034-70942011000200013. Acesso em: 19 jul. 2020.

PEDRAZZ̄I, João Francisco Cordeiro, et al. Perfil antipsicótico do canabidiol. Medicina (Ribeirão Preto), v. 47, n. 2, p. 112-119, fev. 2014. Disponível em: http://www.revistas.usp.br/rmrp/article/view/84556. Acesso em: 14 jun. 2020.

SURAEV, Anastasia, et al. Composition and Use of Cannabis Extracts for Childhood Epilepsy in the Australian Community. Scientific Reports, 8, n. 10154, jul. 2018. Disponível em: https://www.nature.com/articles/s41598-018-28127-0. Acesso em: 23 ago. 2020.

Coordenadoria de Pesquisa e Extensão - COPEX

Departamento de Editoraçāo e Divulgaçāo Científica - DEDIC 


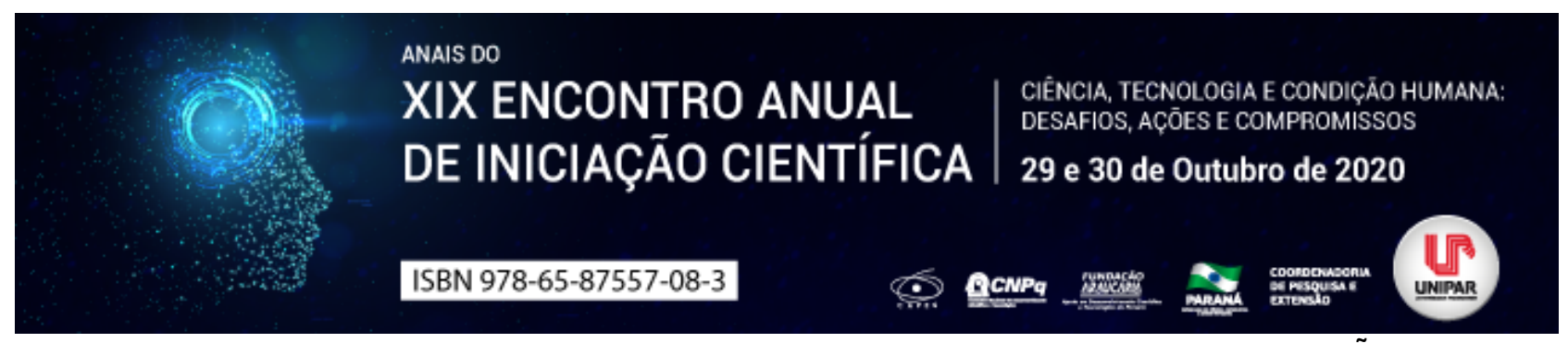

XEROSTOMIA EM PACIENTES SUBMETIDOS A RADIOTERAPIA DE CABEÇA E PESCOÇO: REVISÃO DA LITERATURA

\author{
${ }^{1}$ NATIELLE KUNZLER BIRCK, ${ }^{2}$ GIULIA MARTINEZ MARTINS, ${ }^{3}$ JENIFFER URBANO DEGASPERI, ${ }^{4}$ LETICIA SCHAVETOCK, \\ ${ }^{5}$ REBECCA FAVERO LEMKE, ${ }^{6}$ LETICIA DE FREITAS CUBA GUERRA
}

\author{
${ }^{1}$ ACADEMICO DO CURSO DE ODONTOLOGIA DA UNIPAR \\ ${ }^{1}$ Acadêmica do Curso de Odontologia da UNIPAR \\ ${ }^{2}$ Acadêmica do Curso de Odontologia da UNIPAR \\ ${ }^{3}$ Acadêmica do Curso de Odontologia da UNIPAR \\ ${ }^{4}$ Acadêmica do Curso de Odontologia da UNIPAR \\ ${ }^{5}$ Docente da UNIPAR
}

Introdução: A xerostomia pode ser causada pela radiação atuando sobre as glândulas salivares (CUNHA et al., 2011). Essa condição é uma das manifestações bucais frequentes em pacientes induzidos ao tratamento antineoplásico, e como consequência diversas manifestações orais podem se fazer presente. Dada a relevância clínica do presente assunto, é necessário que os cirurgiões dentistas e acadêmicos de odontologia entendam a necessidade do acompanhamento odontológico durante o tratamento radioterápico para auxiliar na diminuição dos efeitos da radiação, além de um acompanhamento regular pelo fato de apresentarem baixo fluxo salivar, resultando em um alto índice de risco de afecções bucais (FREITAS, et al., 2011).

Objetivo: Revisar a literatura a fim de abordar as implicações da xerostomia em pacientes submetidos a radioterapia na prática clínica odontológica e no acompanhamento durante o tratamento antineoplásico.

Desenvolvimento: A xerostomia, sem dúvidas, é a notável e indiscutível causa de doenças orais em pacientes submetidos a radioterapia e quimioterapia. Os pacientes que apresentam essa enfermidade produzem saliva insuficiente para manutenção da mucosa. Consequentemente, elas apresentam incômodo oral e dor aumentado grandemente a susceptibilidade para cáries dentárias, afecções bucais constantes e dificuldades na hora de falar, engolir e mastigar. A radioterapia lesa o parênquima das glândulas salivares conduzindo para fibrose e hipofunção secretora. As decorrências desse tratamento são referes às doses frequentes de radiação levando a condição conhecida por xerostomia pós-tratamento antineoplásico (FREITAS, et al., 2011). A terapia medicamentosa antineoplásica induz a morte de células tumorais, além de alterar as células íntegras, podendo afetar a renovação celular, alterando o potencial mitótico qualitativamente e quantitativamente (ARAÚJO et al., 2015). Essa condição leva o paciente a uma hipossalivação ou até xerostomia, aumentando a suscetibilidade de doenças bucais devido a baixa no fluxo salivar, além de que, muitas das alterações podem ser irreversíveis e leva o paciente a ter um odor fétido mesmo com uma boa higiene oral. Ademais, atualmente acredita-se que, medicamentos antineoplásicos atuam diretamente na mucosa oral, afetando sua renovação celular, sendo um fator determinante para a redução do fluxo salivar nesses pacientes. Diversas formas e técnicas são citadas na literatura para a prevenção e diminuição da xerostomia, dentre eles destaca-se a luz laser de baixa potência que tem demonstrado eficácia no tratamento de incontáveis complicações e doenças, por possibilitar a modulação genética do metabolismo da célula, além de gerar insensibilidade e ação anti-inflamatória, sem consequências mutagênicas e fototérmicas. $O$ laser se apresenta como uma técnica não agressiva, apresenta bom custo e benefício, além de ser fácil de aplicação e manipulação, podendo estar presente assim, na prática clínica de oncologia odontológica. Além disso, estimulantes e substituições salivares são usados como formas de controlar os sintomas xerostomia e sensação de boca seca (BARBIERI, COSTA, GUERRA, 2020).

Conclusão: A xerostomia provoca uma hipofunção salivar, tendo um impacto significativo no modo de vida do paciente, além de requerer planejamento e precauções com os dentes e com a cavidade bucal por parte do cirurgião-dentista. Através do presente trabalho é notório que o cirurgião dentista deve se fazer presente durante o tratamento radioterápico para uso de medicamentos anódinos, a fim de amenizar as consequências da radioterapia, possibilitando a indução do fluxo salivar assim, reduzindo o risco de afecções bucais, como ulcerações e cáries.

\title{
Referências
}

ARAUJO, Thyago Leite Campos de. et al. Manifestaciones orales en pacientes sometidos a quimioterapia. Revista Cubana de Estomatología, v. 52, n. 4, 2015.

BARBIERI, Tainara; COSTA, Kiany Claudia da; GUERRA, Letícia de Freitas Cuba. Current alternatives in the prevention and treatment of xerostomia in cancer therapy. RGO-Revista Gaúcha de Odontologia, v. 68, 2020.

CUNHA, Milene Alves da. et al. Laser terapêutico: opção viável no tratamento da mucosite oral e xerostomia em pacientes submetidos à radioterapia e quimioterapia. 2008. VII Encontro Latino Americano de Iniciação Científica e IV Encontro 
Americano de Pós-Graduação Universidade do Vale do Paraíba. Campos do Jordão.

FREITAS, Daniel Antunes. et al. A saúde oral e a radioterapia de cabeça e pescoço. The oral health and the head and neck radiotherapy. Arquivos Catarinenses de Medicina, v. 40, n. 3, 2011.

Coordenadoria de Pesquisa e Extensão - COPEX

Departamento de Editoraçāo e Divulgaçāo Científica - DEDIC 


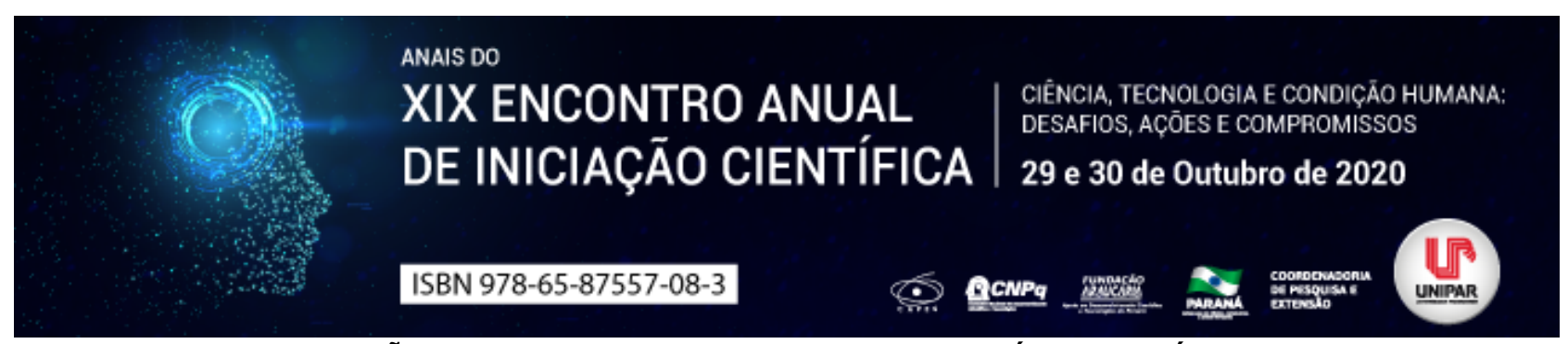

ATUAÇÃO DO ENFERMEIRO EM CASOS DE USUÁRIOS DE ÁLCOOL

\author{
${ }^{1}$ GEOVANY BRANDO MOREIRA, ${ }^{2}$ ISABELLA THAISSA FRANZOIA, ${ }^{3}$ LEILANE TALITA FATORETO SCHWIND, ${ }^{4}$ RODRIGO \\ LEITE ARRIEIRA
}

\author{
${ }^{1}$ Acadêmico do curso de Enfermagem - UNIPAR/Umuarama \\ ${ }^{1}$ Acadêmica do curso de Enfermagem - UNIPAR/Umuarama \\ ${ }^{2}$ Professora adjunta da Universidade Estadual de Maringá - UEM \\ ${ }^{3}$ Professor titular na UNIPAR/Umuarama
}

Introdução: O álcool é uma das drogas mais consumidas no país e no mundo e está associado a diversos danos para a saúde, acidentes e problemas sociais e psicológicos. Com isso, evidencia-se a prática dos profissionais da saúde em intervenções para o enfrentamento do abuso do álcool (GUIMARÃES; FERNANDES; PAGLIUCA, 2015). Nesse sentido, destaca-se o trabalho de profissionais de enfermagem para atuar no desenho e na implantação de programas e projetos de promoção de saúde, prevenção do uso e abuso de álcool (GONÇALVES; TAVARES, 2007).

Objetivo: Abordar as ações e encaminhamentos que o profissional de enfermagem pode realizar ao se deparar com um usuário de álcool.

Desenvolvimento: O enfermeiro é um dos profissionais de saúde capaz de identificar problemas associados ao uso do álcool e dar acolhimento com a finalidade de sensibilizar o usuário. Neste sentido, é fundamental a intervenção do mesmo, que auxilia tanto para a terapia medicamentosa e como nos cuidados gerais. Além disso, destaca-se a importância dos encaminhamentos e medidas para prosseguimento de tratamento por meio dos Centros de Atenção Psicossocial (CAPSad), que é um serviço de referência especializado para o acompanhamento e controle do problema. Entretanto, a internação não é considerada uma forma de tratamento, todavia, uma forma de enfrentamento do problema (BRANCO et al., 2013). O álcool causa vários efeitos negativos sobre o sistema nervoso central (SNC), que pode variar desde agitação até o coma. Além disso, outros sinais como euforia, flutuação de humor, midríase e taquicardia são reflexos da sua intoxicação. Quando as concentrações de álcool aumentam, o SNC fica em depressão e pode ser evidenciado retardo na frequência respiratória e cardíaca, hipotensão arterial e hiporreflexia como os sintomas mais comuns (HAES et al., 2010). Muitos usuários de álcool e, de outras drogas, mantêm-se distanciados da sociedade e consideram que não necessitam de nenhuma ajuda, por vergonha ou por acreditarem que possuem total domínio da situação em que se encontram. Entretanto, os enfermeiros não devem tirar a autonomia ou desejo do paciente, mas têm um papel fundamental na orientação do mesmo e, caso ocorra bem, posteriormente, o encaminhamento para o CAPSad pode ser de grande ajuda (SOUZA; PINTO, 2012). A Intervenção Breve (IB) cabe à vários profissionais que tenham sido treinados, podendo ser uma recomendação de limitação do consumo até recursos oferecidos como tratamento e, como a maioria dos dependentes de risco são cooperativos, a IB vai desencadear a decisão e o comprometimento com mudanças, minimizando a ingestão alcoólica (PEREIRA et al., 2013). Uma breve intervenção pode ser benéfica ao possibilitar que esses serviços complementem programas assistenciais e, assim, prevenir que os usuários desenvolvam problemas mais graves, como uma parada cardiorrespiratória. Entretanto, a capacitação das equipes de saúde da família, em especial dos enfermeiros, permite que seja realizada uma abordagem mais efetiva e o devido encaminhamento do usuário de álcool para os CAPSad (BRASIL, 2003).

Conclusão: A intervenção dos enfermeiros é indispensável na identificação, acolhimento e encaminhamento do usuário de álcool, sendo importante para que encontre ajuda e reduza os danos à sua saúde. Para isso, é necessário que esses profissionais estejam capacitados, para que possam abordar esse tema com calma, sutileza e compreensão. Dessa forma, essas ações serão capazes de fortalecer a atenção primária e, consequentemente, reduzir os possíveis danos que seriam causados.

\title{
Referências
}

BRANCO, Fernanda Matos Fernandes Castelo et al. Atuação da equipe de enfermagem na atenção ao usuário de crack, álcool e outras drogas. Journal of the Health Sciences Institute, v. 31, n. 2, p. 161-165, 2013. Disponível em: https://www.unip.br/presencial/comunicacao/publicacoes/ics/edicoes/2013/02_abr-jun/V31_n2_2013_p161a165.pdf. Acesso em: 31/07/2020.

BRASIL. Ministério da Saúde. A política do ministério da saúde para a atenção integral a usuários de álcool e outras drogas. $1^{\mathrm{a} e d .}$ Brasília - DF: Editora Ministério da Saúde, 2003 , 60. Disponível em: http://bvsms.saude.gov.br/bvs/publicacoes/politica_atencao_alcool_drogas.pdf. Acesso em: 01/08/2020.

GONÇALVES, Sonia Silva Paiva Mota; TAVARES, Claudia Mara de Melo. Atuação do enfermeiro na atenção ao usuário de álcool e outras drogas nos serviços extra-hospitalares. Escola Anna Nery Revista de Enfermagem. v. 11, n. 4, p. 586-592, 
2007. Disponível em: https://www.scielo.br/pdf/ean/v11n4/v11n4a05. Acesso em: 12/07/2020.

GUIMARÃES, Fernanda Jorge; FERNANDES, Ana Fátima Carvalho; PAGLIUCA, Lorita Marlena Freitag. Intervenções para enfrentamento do abuso de álcool: revisão integrativa. Revista Eletrônica de Enfermagem, v. 17, n. 3, p. 1-11, 2015. Disponível em: https://pesquisa.bvsalud.org/portal/resource/pt/biblio-832577. Acesso em: 22/07/2020.

HAES, Tissiane M. et al. Álcool e sistema nervoso central. Revista de Medicina, v. 43, n. 2, p. 153-163, 2010. Disponível em: http://www.revistas.usp.br/rmrp/article/view/173. Acesso em: 10/07/2020.

PEREIRA, Maria Odete et al. Efetividade da intervenção breve para o uso abusivo de álcool na atenção primária: revisão sistemática. Revista Brasileira de Enfermagem. Brasília. v. 66, n. 3, p. 420-428, 2013. Disponível em: https://www.scielo.br/pdf/reben/v66n3/a18v66n3.pdf. Acesso em: 22/07/2020.

SOUZA, Luccas Melo; PINTO, Maria Getúlio. Atuação do enfermeiro a usuários de álcool e de outras drogas na saúde da família.

Revista Eletrônica de Enfermagem, v. 14, n. 2, p. 384-394, 2012. Disponível em: http://www.fen.ufg.br/fen_revista/v14/n2/v14n2a18.htm. Acesso em: 1007/2020.

Coordenadoria de Pesquisa e Extensão - COPEX

Departamento de Editoraçāo e Divulgaçāo Científica - DEDIC 


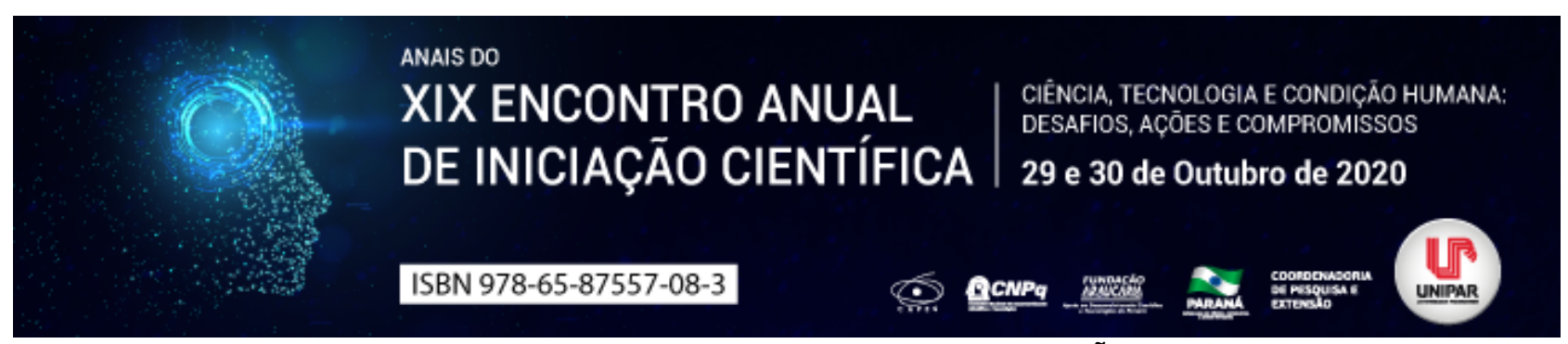

TRATAMENTO COM LIRAGLUTIDA PARA OBESIDADE CAUSADA PELA MUTAÇÃO DO GENE MC4R: UMA REVISÃO DA LITERATURA

\author{
${ }^{1}$ PAULA MOSCOVITS QUEIROZ, ${ }^{2}$ PATRICIA RODRIGUES HAUCK PRANTE, ${ }^{3}$ LUCIANO SERAPHIM GASQUES, ${ }^{4}$ RICARDO \\ MARCELO ABRAO
}

\author{
${ }^{1}$ Acadêmica do PIBIC do curso de Medicina UNIPAR \\ ${ }^{1}$ Professora Assistente do curso de Medicina UNIPAR \\ ${ }^{2}$ Professor Titular do curso de Medicina UNIPAR \\ ${ }^{3}$ Professor Titular do curso de Medicina UNIPAR
}

Introdução: De acordo com Fernandes (2014), a obesidade é uma desordem poligênica complexa com crescente prevalência mundial que pode acarretar diversas complicações ao indivíduo. A mutação no gene MC4R (melanocortin 4 receptor) representa a forma mais prevalente de obesidade monogênica fazendo-se necessário avançar sobre o conhecimento dessa área genética e terapêutica.

Objetivo: Revisar a literatura quanto ao uso de análogo sintético do GLP-1 (glucagon-like peptide 1) para o tratamento de obesidade genética causada pela mutação do gene MC4R.

Desenvolvimento: Na atualidade, a obesidade é um dos principais problemas de saúde pública, e é amplamente influenciada pela alimentação, prática de exercícios e por fatores genéticos (RODRIGUES; SUPLICY; RADOMINSKI, 2003). Associada à mutação no gene MC4R, Fernandes (2014) esclarece que esta costuma se manifestar por obesidade mórbida de início precoce, hiperfagia, hiperinsulinemia, hiperglicemia, aumento da massa magra e gordura corporal e aumento do crescimento linear na infância e idade óssea maior que a cronológica. Isso acontece pela influência do gene na homeostase energética. A via leptinamelanocortina, em situação de balanço positivo, com o aumento da leptina e insulina ocorre a estimulação dos neurônios da POMC (pro-opiomelanocortin) e do CART (cocaine and amphetamine regulated transcript) da via orexigênica e inibição da AgRP (agouti-related peptide) e NPY (neuropeptide $Y$ ) da via anoréxica. O inverso ocorre nas situações de balanço energético negativo, com o aumento da ghrelina. Nesse caso, em estado não alimentado, não há sinalização do gene MC4R e isso gera aumento do apetite, pois o a-MSH (alpha melanocyte-stimulating hormone), produto da POMC é agonista dos genes MC3R (melanocortin 3 receptor) e MC4R, já a AgRP é antagonista do MC4R e resulta na hiperfagia e redução de gasto calórico. O autor ainda explica que os números crescentes da epidemia da obesidade, leva-nos a buscar soluções terapêuticas para essa doença multifatorial, e quando causada pela mutação do gene MC4R, há ainda mais problemas para encontrar um tratamento medicamentoso adequado. A liraglutida, de acordo com Pajecki et al. (2012), é um análogo sintético do GLP-1, utilizado para tratamento de diabetes tipo II, mas que, por seu efeito sacietogênico (com ação sobre mecanismos de apetite e saciedade e sobre a adiposidade) já vem sendo utilizado como medicamento para obesidade. Para Kaineder et al. (2017), a estimulação da insulina e inibição do glucagon geradas pelo fármaco é responsável por reduzir os níveis de glicose e com tratamento de liraglutida central, a estimulação da termogênese em tecido adiposo marrom (MTD) e escurecimento do tecido adiposo branco (WAT) via proteína quinase hipotalâmica ativada por AMP gera a perda de peso. Também foi realizado um estudo com roedores que demonstrou que o tratamento central do fármaco gerou significante ativação do gene MC4R. Corroborando com a assertiva, Lepsen et al. (2018), fez um estudo com 14 indivíduos obesos com essa mutação patogênica e 28 participantes controle sem a mutação, para analisar o efeito do fármaco liraglutida por 16 semanas.

Conclusão: Constata que a liraglutida foi responsável não apenas pela perda de peso, como a diminuição da concentração de gordura total, circunferência abdominal, glicemia de jejum e pós-prandial. O que chama atenção também foi que o efeito do medicamento foi mais eficaz para o grupo que apresentava a mutação. Dessa forma conclui-se que a liraglutida é um tratamento eficaz para obesidade monogênica que, inclusive, já tem sido utilizada para tratamento no reganho de peso após a cirurgia bariátrica, que até então era um enorme desafio para os cirurgiões e endocrinologistas. A utilização desse fármaco trouxe enormes benefícios para a saúde do paciente e para a relação médico paciente por reduzir a sensação de frustração e medo desses pacientes e por diminuir os riscos do paciente de ter que passar por outra cirurgia de risco elevado.

\title{
Referências
}

FERNANDES, Ariana Ester. Efeito das variações alélicas no gene do receptor tipo 4 de melanocortina sobre o comportamento alimentar em crianças e adolescentes obesos. Orientador: Dr. Márcio Corrêa Mancini. 2014.95 f. Dissertação (Mestrado em Ciências Programa de Endocrinologia) Universidade de São Paulo, São Paulo, 2014.

KAINEDER, Katrin et al. Chronic intrahypothalamic rather than subcutaneous liraglutide treatment reduces body weight gain and 
stimulates the melanocortin receptor system. International Journal of Obesity. v. 41.p. 1263-1270, May. 2017.

LEPSEN, Eva W. et al. Patients with Obesity Caused by Melanocortin-4 Receptor Mutations Can Be Treated with a Glucagon-like Peptide-1 Receptor Agonist. Elsevier Inc: Cell Press. v. 28. n. 1, July, 2018. Disponível em: < https://www.sciencedirect.com/science/article/pii/S1550413118303152>. Acesso em: 12 jul. 2020.

PAJECKI, Denis et al. Tratamento de curto prazo com liraglutide no reganho de peso após cirurgia bariátrica. Relato de caso. Revista Colégio Brasileiro de Cirurgiões. v.40. n. 3, p. 191-195, set. 2012.

RODRIGUES, Adriane. M.; SUPLICY, Henrique L.; RADOMINSKI, Rosana B. Controle neuroendócrino do peso corporal: implicações na gênese da obesidade. Arquivos Brasileiros de Endocrinologia \& Metabologia. v. 47. n. 4, p. 398-409, ago. 2003.

Coordenadoria de Pesquisa e Extensāo - COPEX

Departamento de Editoraçāo e Divulgaçāo Científica - DEDIC 


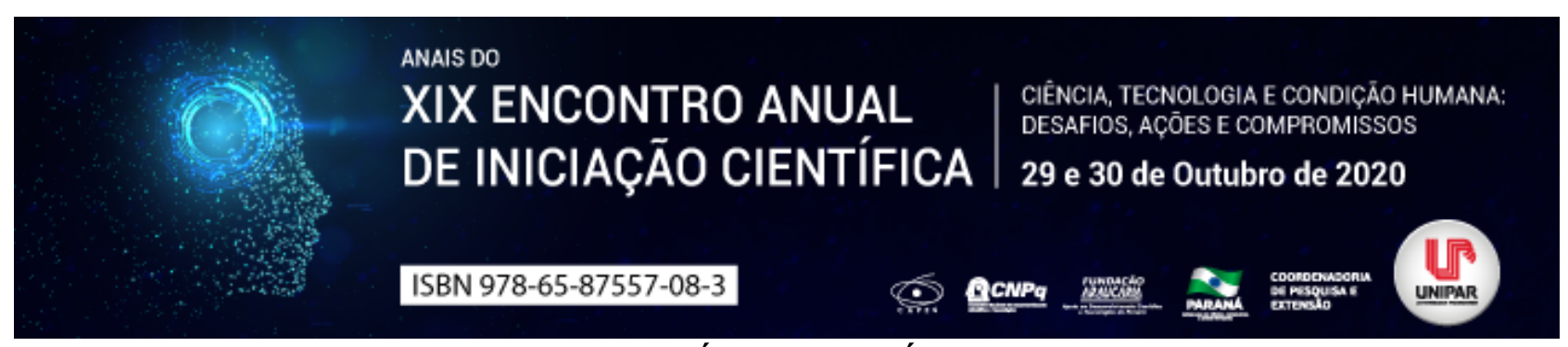

\title{
O USO DE MICROAGULHAMENTO ASSOCIADO AO ÁCIDO RETINÓICO NO TRATAMENTO DE REJUVENESCIMENTO FACIAL - ESTUDO DE CASO
}

\author{
${ }^{1}$ KARINA MARIA DE BARROS , ${ }^{2}$ LIDIA PRISCILA LONGO, ${ }^{3}$ GIOVANA MIOTO DE MOURA
}

\author{
${ }^{1}$ Tecnóloga em Estética e Cosmética - UNIPAR - Cianorte \\ ${ }^{1}$ Tecnóloga em Estética e Cosmética - UNIPAR - Cianorte \\ ${ }^{2}$ Docente - UNIPAR - Cianorte
}

Introdução: A senilidade é inevitável ao ser humano, com aparências inestéticas é possível observar o aparecimento de alterações como rugas, linhas de expressão, manchas e flacidez, provenientes das modificações celulares, que perdem ou diminuem a capacidade de absorção de nutrientes, duplicação do material genético e de reparo de lesões (BORGES \& SCORZA, 2016). Em razão disso, a procura por tratamentos estéticos tem aumentado, com objetivo de retardar o envelhecimento e manter a aparência da pele jovem por mais tempo, e este estudo de caso tem como propósito demonstrar a eficácia para rejuvenescimento através da associação do Microagulhamento e o Ácido Retinóico.

Relato de Caso: Voluntária do sexo feminino, 50 anos de idade, fototipo I, segundo a classificação dos tipos de pele de Fitzpatrick, presença de fotoenvelhecimento nível III avançado, seguindo a classificação de Glogau (MAIO, 2011), com rugas em repouso em orbicular do olho, rugas dinâmicas na testa e em orbicular da boca, flacidez tissular, manchas hipercrômicas, com coloração avermelhada na região de pescoço e colo devido à exposição solar prolongada de vários anos sem o uso de fotoproteção. O estudo proposto remete a realização de 4 sessões, sendo as ímpares, o uso de ácido retinóico $5 \%$, e as pares o uso de microagulhamento, com intervalo quinzenal entre as mesmas. O protocolo de ácido retinóico consiste em: higienização com sabonete neutro, esfoliante, com a pele seca e limpa, a aplicação do ácido em face, pescoço e colo, com ação por 6 horas, e orientação de lavagem após o tempo, com água corrente. O segundo protocolo foi realizado com aparelho de Derma Pen ${ }^{\circledR}$ de 12 agulhas de $0,5 \mathrm{~mm}$ de comprimento, iniciado a sessão com sabonete neutro, esfoliante, água thermal, aplicação do microagulhamento com movimentos circulares em sentido linear horizontal e vertical quatro vezes em toda face, e sobre as rítides pontual duas vezes; seguido da penetração de produto estéril que contém ativos como: fator de crescimento com Tecnologia Nanofactor (TGF- ß3), Ácido Hialurônico, Alantoína, Colágeno, Oligoelementos. Observando a presença de descamação cutânea após o procedimento, e com isso, a regeneração e a melhora da pele, tanto na elasticidade e na firmeza da pele, quanto nas linhas de expressão e rugas que diminuíram significativamente tornando os sulcos menos evidentes.

Discussão: O microagulhamento, conhecido como terapia de indução de colágeno, é a capacidade de ativar os fibroblastos para produção de novas fibras de colágeno e elastina (responsáveis pela firmeza e elasticidade cutânea), através de microlesões controladas causadas por microagulhas fixas em um rolo giratório (BORGES \& SCORZA, 2016). É uma técnica que tem como objetivo abrir caminho para penetração de ativos na pele de maneira mais rápida, eficaz, e sem alterar a estrutura dos ativos a serem permeados, esse mecanismo é chamado de Drug Delivery (PIATTI, 2017). Entre os equipamentos presentes para venda e uso, há agulha que varia de $0,25 \mathrm{~mm}$ à $3,0 \mathrm{~mm}$ (BORGES \& SCORZA, 2016). Logo, o comprimento da agulha é o que determina a profundidade das lesões, que se classifica como: leve até 0,5 mm; moderada 1,5 mm e profunda 2,5 mm (LIMA, et al., 2013). Já os peelings químicos são substâncias utilizadas para tratamento de alterações na pele, capaz de atingir a pele em diversas profundidades: superficial, atinge a epiderme até a derme papilar; médio, se estende da derme papilar até a parte superior da derme reticular; e o profundo, que chega até as camadas intermediárias da derme reticular (MAIO, 2011). A finalidade desse método é causar uma aceleração na renovação celular, bem como provocar uma descamação das camadas mais superficiais, eliminando a superfície danificada e envelhecida (PIMENTEL, 2012). O ácido retinóico também chamado de tretinoína, é considerado um peeling superficial, e tem como principal resultância o estímulo a proliferação e a diferenciação dos queratinócitos na camada basal ocasionando esfoliação e renovação da epiderme, consequentemente o aumento do colágeno da camada papilar e reorganização das fibras elásticas danificadas, a angiogênese, e o aumentando a vascularização dérmica (MAIO, 2011). Derivado da vitamina A, pode ser usado nos tratamentos de fotoenvelhecimento, acne, mancha e alterações superficiais da pele, através do contato com a pele em até 12 horas, sem causar Frost (PIMENTEL, 2012).

Conclusão: Conforme estudo apresentado, o microagulhamento associado ao ácido retinóico mostrou-se eficaz para o tratamento de rejuvenescimento facial, a pele da paciente apresentou maior firmeza e atenuação das rítides, melhorando em geral, o aspecto da pele, resultados comprovados por relato da voluntária e registros fotográficos. Contudo, o fotoenvelhecimento é uma disfunção complexa que demanda um tratamento longo, por isso para um resultado ainda melhor, é necessário dar continuidade ao tratamento e o uso dos cosméticos home care.

\section{Referências}


BORGES, F. S.; SCORZA, F. A. Terapêutica em estética: conceitos e técnicas. 1ed. São Paulo, Phorte, 2016.

LIMA, E. V.A; LIMA, M. A.; TAKANO, D. Microagulhamento: estudo experimental e classificação da injúria provocada

\& Cosmetic Dermatology. Volume 5. $n^{\circ} 2,2013$.

MAIO, M. Tratado de medicina estética. 2ed. São Paulo, Roca, 2011.

PIATTI, I. Microagulhamento + Fatores de crescimento. Revista vida estética - Especial microagulhamento, N¹69, página 1619, junho de 2017.

PIMENTEL, A. S. Peeling químico superficial e máscara facial: guia teórico e prático para esteticistas e

fisioterapeutas dermato funcionais. São Paulo, Livraria Médica Paulista, 2012.

Coordenadoria de Pesquisa e Extensão - COPEX

Departamento de Editoraçāo e Divulgaçāo Científica - DEDIC 


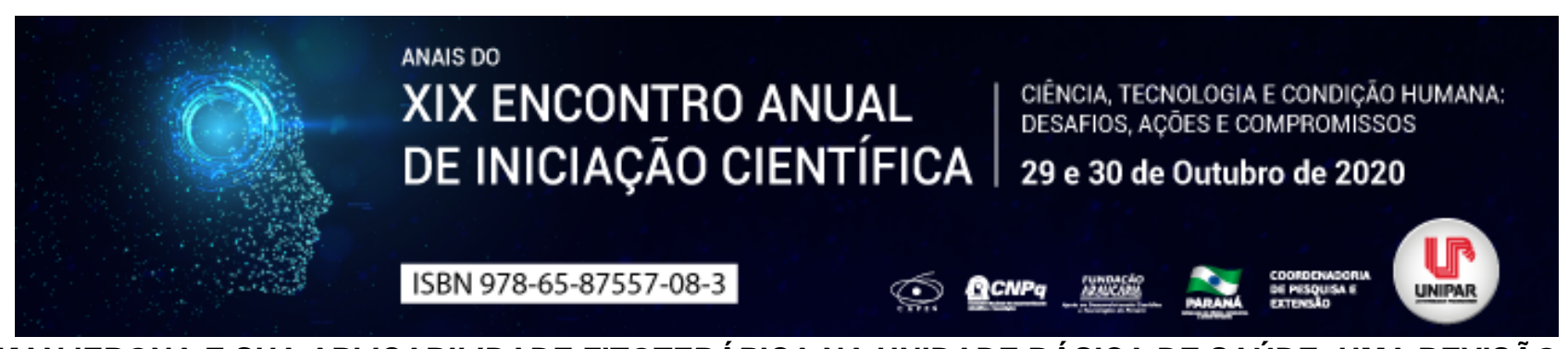

A MANJERONA E SUA APLICABILIDADE FITOTERÁPICA NA UNIDADE BÁSICA DE SAÚDE: UMA REVISÃO DE LITERATURA

\author{
${ }^{1}$ LUCIANA LOPES GUTIERREZ BARTOLLI, ${ }^{2}$ THAYNARA KNOPIK DECHECHI, ${ }^{3}$ IRINEIA PAULINA BARETTA
}

\author{
${ }^{1}$ Acadêmico de Medicina/bolsista PIBIC, Mestranda do Mestrado Profissional em Plantas Medicinais e Fitoterápicos na Atenção \\ Básica/UNIPAR \\ ${ }^{1}$ Acadêmica do Curso de Medicina da UNIPAR/ PIC \\ ${ }^{2}$ Docente da UNIPAR
}

Introdução: A sabedoria popular (conhecimento empírico) combinada aos conhecimentos científicos se torna uma aliada importante dos profissionais de saúde, principalmente aqueles que trabalham no Sistema Único de Saúde SUS. A Organização Mundial de Saúde OMS, incentiva a utilização de plantas medicinais (LEITE, 2012) e com esse apoio o Ministério da Saúde apresentou a Política Nacional de Práticas Integrativas e Complementares (PNPIC) no SUS, afim de ampliar as opções terapêuticas aos usuários do SUS. A manjerona (Origanum majorana L.) da família das Labiadas é uma planta de uso medicinal perene, aromática, utilizada na culinária, medicina popular e como óleo essencial. Proveniente da Turquia, África e sul da Europa, é uma planta mediterrânea. É composta principalmente por monoterpenos, compostos fenólicos e flavonóides, triacontano, sitosterol, ácidos oleanólico e rosmarínico, hidroquinonas, taninos, carvacrol, timol, mentona, acetato de linalina e 1,8-cineol (FELTROW; ÁVILA, 2000). Dentre as propriedades da manjerona estão atividades antimicrobiana, antioxidante e antifúngica (SILVA, 2011). Suas propriedades terapêuticas e medicinais incluem relaxamento, sedação, expectorante, estomáquico, analgésico e bactericida, usada para tensão nervosa, enxaquecas, depressão, angustia e insônia (PAGANINI; FLORES E SILVA, 2014).

Objetivos: O objetivo deste trabalho é verificar, através de estudos científicos, as propriedades terapêuticas da manjerona e seu emprego em UBS como coadjuvante em tratamentos convencionais.

Desenvolvimento: O uso de plantas medicinais sempre esteve presente no cotidiano da maioria das pessoas, pois seu uso vem sendo passado de geração em geração, assim como o estudo de suas propriedades farmacológicas. Diante das pesquisas científicas realizadas ao longo dos anos, podem-se averiguar as propriedades medicinais de diversas plantas, inclusive da manjerona e incluí-las nas Unidades Básicas de Saúde - UBS, pois possuem custo acessível à população e são fáceis de utilizar. Para isso a população precisa ser orientada sobre sua utilização evitando assim complicações à saúde, que podem depender da forma de uso, já que muitos acreditam que por ser de origem natural, não é prejudicial à saúde. Sua utilização exige cuidados iguais aos outros medicamentos: orientações com profissionais da saúde, comunicação ao médico e outros profissionais sobre a utilização de plantas medicinais e suas reações desagradáveis, cuidados com relação a gestação, mulheres que amamentam, crianças e idosos (ALMEIDA, 2011). Seu uso popular ocorre sob a forma de infuso, decocto, tintura, pó, xarope ou pomada, sendo indicado como tônico, digestivo, aromático, nas gripes de criança, expectorante, bronquite, asma, problemas de pele, estimulante de secreções estomacais, contra venenos, dores reumáticas e carminativa (GRANDI et al., 1989). A erva tem valor medicinal devido às suas propriedades estimulante e antiespasmódica. É também um bom tônico geral para o tratamento de várias doenças do sistema respiratório e digestivo. Promove a menstruação, então não se recomenda a mulheres grávidas, embora na culinária seja segura em pequenas quantidades. Outras propriedades reconhecidas: antisséptica, colagoga, diaforética, diurética, emenagoga, expectorante, estomáquica e levemente tônica. Toma-se internamente para o tratamento de reclamações dos brônquios, dores de cabeça tensionais, insônia, ansiedade, distúrbios digestivos menores e menstruação dolorosa. Externamente é utilizada para tratar a dor muscular, queixas brônquicas, artrite, entorses e articulações (SIGRIST, 2013). Segundo MAKRANE et al., 2018, a manjerona auxilia nos efeitos positivos dos mecanismos envolvidos na diarréia infecciosa aguda, principalmente em crianças. Assim como seu óleo essencial obteve efeitos inibitórios contra E. coli e $S$. aureus em culturas incubadas. Sendo também efetiva em testes de laboratório com culturas com fungos de $A$. flavus e $A$. parasiticus (FREIRE et al., 2011). Um estudo realizado no município de Galvão, SC em 2013, mostrou que 2,5\% dos entrevistados faziam uso do chá das folhas da manjerona no tratamento da ansiedade (BETT, 2013). O óleo essencial da manjerona foi testado para verificar sua eficácia na inibição do crescimento de cepas bacterianas isoladas de pacientes com conjuntivite, tendo sido comprovado seu intenso potencial antimicrobiano (OLIVEIRA et al., 2009). Vários estudos também relatam que o óleo essencial de manjerona não apresenta potencial tóxico e irritante, porém o seu uso deve ser evitado durante a gravidez, com isso foi avaliado o efeito do óleo essencial em cromossomos linfocitários humanos e verificou-se que ele induz uma instabilidade genômica in vitro em linfócitos humanos saudáveis a partir de $25 \mu \mathrm{g} / \mathrm{mL}$ (SOARES, 2019).

Conclusão: Diante do que foi exposto, a manjerona apesar de ter seu uso difundido de forma empírica ao longo dos anos, ainda não possui estudos científicos suficientes para comprovar todas as suas propriedades, sendo mais indicada como agente 
antimicrobiano, estimulante e antiespasmódico. Essas indicações já seriam suficientes para estimular o seu uso nas UBS, seja através de chás ou óleo essencial.

\section{Referências}

ALMEIDA, Eloisa de. Uso de plantas medicinais no dia a dia da população assistida pela estratégia saúde da família: uma revisão de literatura. Atenção Básica em Saúde da Família. UFMG. Conselheiro Lafaiete. 2011.

BETT, Marisa S. O uso popular de plantas medicinais utilizadas no tratamento da ansiedade no município de Galvão-SC. UFSC. Florianópolis. 2013.

FELTROW, Charles W.; ÁVILA, Juan R. Manual de Medicina Alternativa para o Profissional. 1. ed. Rio de Janeiro, Guanabara Koogan, 2000.

FREIRE, J. M. Óleo essencial de Origanum majorana L., Illicium verum Hook. f. e Cinnamomum zeylanicum Blume: caracterização química e antimicrobiana. Rev. bras. plantas med. Botucatu, v. 13, n. 2, p. 209-214, 2011.

GRANDI, Telma. Plantas medicinais de Minas Gerais, Brasil. Acta. Bot. Bras. v.3, n.2. 1989.

LEITE, Barbara L. S. Estudo das propriedades farmacológicas e toxicológicas do óleo essencial de Cymbopogon winterianus em roedores. UFS. Aracaju. 2012.

MAKRANE, Hanane. Origanum majorana L extract exhibit positive cooperative effects on the main mechanisms involved in acute infectious diarrhea, Journal of Ethnopharmacology. 2018.

OLIVEIRA, Jana de. Eficácia dos óleos essenciais de Origanum vulgare L. e Origanum majorana L. na inibição do crescimento de cepas bacterianas isoladas de pacientes com conjuntivite. Braz. arco. biol. technol. Curitiba, v. 52, n. 1, p. 45-50, fevereiro. 2009.

PAGANINI, Tatiane; FLORES e SILVA, Yolanda. O uso da aromaterapia no combate ao estresse. Arq. Ciênc. Saúde Unipar, Umuarama, v. 18 n. 1, p. 43-49, jan./abr. 2014.

SIGRIST, Sergio. Manjerona. Plantas Medicinais Aromáticas- Condimentares. 28/05/2013. Disponível em: http://www.ppmac.org/content/manjerona. Acesso em: 25/08/2020.

SILVA, Mayara Gobetti da. Atividade antioxidante e antimicrobiana in vitro de óleos essenciais e extratos hidroalcóolicos de manjerona (Origanum majorana I.) e manjericão (Ocimum basilicum I.). UTFPR. Pato Branco. 2011.

SOARES, Anelise; et al. Efeito do óleo de Origanum Majorana L. em cromossomos de linfócitos cultivados. Anais do Salão Internacional de Ensino, Pesquisa e Extensão, v. 11, n. 2, 30 mar. 2020.

Coordenadoria de Pesquisa e Extensão - COPEX

Departamento de Editoraçāo e Divulgaçāo Científica - DEDIC 


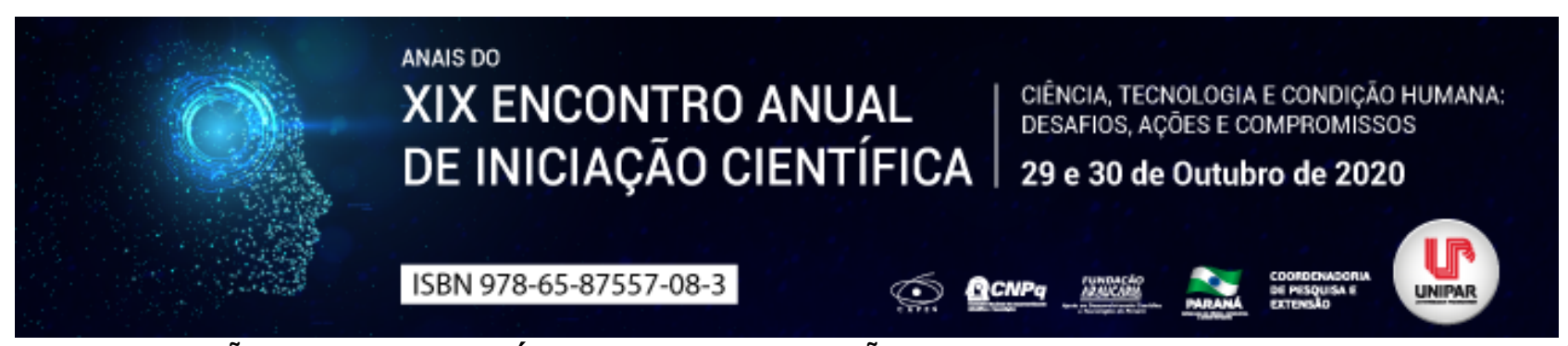

BIOTRANSFORMAÇÃO COMO ESTRATÉGIA PARA A PRODUÇÃO DE AROMAS E AROMATIZANTES ALIMENTÍCIOS NATURAIS

${ }^{1}$ DEBORA TIEMI IGARASHI DOS SANTOS, ${ }^{2}$ JULIANA SILVEIRA DO VALLE

\author{
${ }^{1}$ Acadêmica de Nutrição Bolsista PIBIC, UNIPAR \\ ${ }^{1}$ Docente de Nutrição e da Pós-Graduação em Biotecnologia Aplicada à Agricultura, UNIPAR
}

Introdução: Segundo a Agência Nacional de Vigilância Sanitária aromas ou aromatizantes, são substâncias ou misturas de substâncias com propriedades odoríferas e/ou sápida (com sabor), capazes de conferir ou intensificar sabor aos alimentos (ANVISA, 2007). Estes dividem-se em duas classes, podendo ser artificiais ou sintéticos, comumente usados por indústrias de alimentos por seu custo reduzido, carregam em sua composição substâncias que atribuem ao alimento, efeitos que despertam sensação de prazer, por meio do paladar e/ou olfato (CHIAPPINI, 2007), como também naturais, sendo definidos como compostos químicos com propriedades aromáticas, obtidos a partir da matéria-prima de caráter animal ou vegetal, assim como por métodos físicos, enzimáticos ou microbiológicos (VESPERMANN et al., 2017). Por serem de origem natural, atendem à demanda crescente da população que procura por aditivos mais saudáveis e isso tem feito a indústria buscar por formas alternativas de obter aromas orgânicos, por exemplo, em processos de biotransformação (SALES et al., 2018).

Objetivo: Realizar uma revisão da literatura sobre aromas ou aromatizantes produzidos por biotransformação.

Desenvolvimento: A revisão foi baseada em artigos obtidos por meio de busca utilizando-se diversas parlavras-chave e suas combinações no Google Acadêmico, PubMed e Science Direct. A biotransformação, também chamada de bioconversão, consiste na alteração química de moléculas precursoras por meio de reações químicas de óxido-redução, hidrólise ou adição, ou ainda por uma sequência destas reações (BIER; MEDEIROS; SOCCOL, 2017). Estas atividades químicas são catalisadas por sistemas biológicos como células ou enzimas (SALES et al., 2018). A utilização de microrganismos em processos de biotransformação é uma estratégia para a formação de aromas destinados à indústria de alimentos de forma ecológica (CHIAPPINI, 2007). Dentre as moléculas precursoras que podem ser usadas para gerar compostos de aroma por biotransformação estão o limoneno, $\alpha$ e $\beta$ pineno e o ácido ferúlico (VESPERMANN et al., 2017). Entre os compostos de aromas gerados por bioconversão mais relevantes estão a-terpineol, ácido perílico, limoneno-1,2-diol, vanilina, verbenol, verbenona, entre outros (SALES et al., 2018). O limoneno é um terpeno presente em óleos essenciais de frutas cítricas, como a casca da laranja, conferindo seus aromas característicos. É o terpeno mais abundante na natureza o que o torna interessante para utilização como substrato para a formação orgânica de essências, devido a sua alta disponibilidade e preço acessível (MOLINA, 2010). Bier; Medeiros; Soccol, (2017) cultivaram o fungo Phomopsis sp por meio de cultivo a base de resíduo da indústria de suco de laranja rico em limoneno e verificaram a produção de derivados deste como a-terpineol e principalmente o limoneno-1,2-diol (2,1 g/L). Pinenos são monoterpenos bicíclicos de baixo custo e comumente usados como substratos para o processo. Rottava et al., (2010) avaliaram o potencial de Aspergillus niger e Penicillium camembertii em converterem $\beta$-pineno em compostos aromáticos e relataram a produção de grande quantidade de $\alpha$-terpineol, um elemento de aroma floral muito usado comercialmente e cuja fragrância é similar ao da flor lilás (Syringa vulgaris). Vespermann et al., (2017) em um estudo de revisão, reportaram ao menos sete estudos diferentes que utilizaram espécies de fungos (Aspergillus sp. Penicillium sp, Chrysosporium sp) na bioconversão de a-pineno em verbenol e verbenona, compostos odoríferos presentes naturalmente no óleo essencial de plantas. O ácido ferúlico é um composto fenólico presente em coberturas externas de frutas, vegetais e grãos em geral associado a outras biomoléculas, como os polissacarídeos. O ácido ferúlico pode ser extraído de subprodutos agroindustriais e convertido em compostos de aroma como a vanilina, muito valorizada por conferir essência característica da baunilha. Upadhyay et al., (2019) relataram a obtenção de ácido ferúlico do farelo de milho e sua conversão em ácido vanílico, um precursor da vanilina, por uma cepa recombinante de Pseudomonas putida reduzindo custos de produção de vanilina.

Conclusão: com a mudança na perspectiva dos consumidores, que agora priorizam hábitos que melhorem sua qualidade de vida, a busca por aromas naturais ganha mais importância. O uso de microrganismos e de processos biotecnológicos para a produção de aromatizantes é uma alternativa que pode atender a essa necessidade.

\title{
Referências
}

AGÊNCIA NACIONAL DE VIGILÂNCIA SANITÁRIA - ANVISA. Informe técnico No 26, DE 14 de junho de 2007. Disponível em http://portal.anvisa.gov.br/. Acesso em: 24. ago. 2020.

BIER, Mário Cesar Jucoski; MEDEIROS, Adriane Bianchi Pedroni; SOCCOL, Carlos Ricardo. Biotransformation of limonene by an endophytic fungus using synthetic and orange residue-based media. Fungal Biol. v. 121, n. 2, p. 137-144, 2017.

CHIAPPINI, Claudete Corrêa de Jesus. Aromas naturais produzidos por microrganismos. Rev. Com Ciência, 2007. Disponível 
em http://www.comciencia.br/comciencia/index.php?section=8\&edicao=28\&id=325. Acesso: 24. ago. 2020.

MOLINA, Gustavo. Prospecção de processos biotecnológicos de interesse industrial. Campinas, 2010. 114 f. Dissertação (Mestrado em Engenharia de Alimentos) - Departamento de Ciência de Alimentos, Universidade Estadual de Campinas.

ROTTAVA, Ieda; TONIAZZO, Geciane; CORTINA, Priscila Fernanda; MARTELLO, Eduarda et al. Screening of microorganisms for bioconversion of (-) $\beta$-pinene and R-(+)-limonene to a-terpineol. LWT-Food Sci. Technol., v. 43, n. 7, p. 1128-1131, 2010.

SALES, Adones; PAULINO, Bruno Nicolau; PASTORE, Glaucia Maria; BICAS, Juliano Lemos. Biogeneration of aroma compounds. Curr. Opin. Food Sci., v. 19, p. 77-84, 2018.

UPADHYAY, Priya; SINGHA, Nitesh; TUPEA, Rasika; ODENATHA, Annamma et al. Biotransformation of corn bran derived ferulic acid to vanillic acid using engineered Pseudomonas putida KT2440. Prep. Biochem. Biotech., v. 50, n. 4, p. 341-348, 2020.

VESPERMANN, Kele; PAULINO, Bruno; BARCELOS, Mayara; PESSÔA, Marina et al. Biotransformation of $\alpha$-and $\beta$-pinene into flavor compounds. Appl. Microbiol. Biot., v. 101, n. 5, p. 1805-1817, 2017.

Coordenadoria de Pesquisa e Extensão - COPEX

Departamento de Editoraçāo e Divulgaçāo Científica - DEDIC 


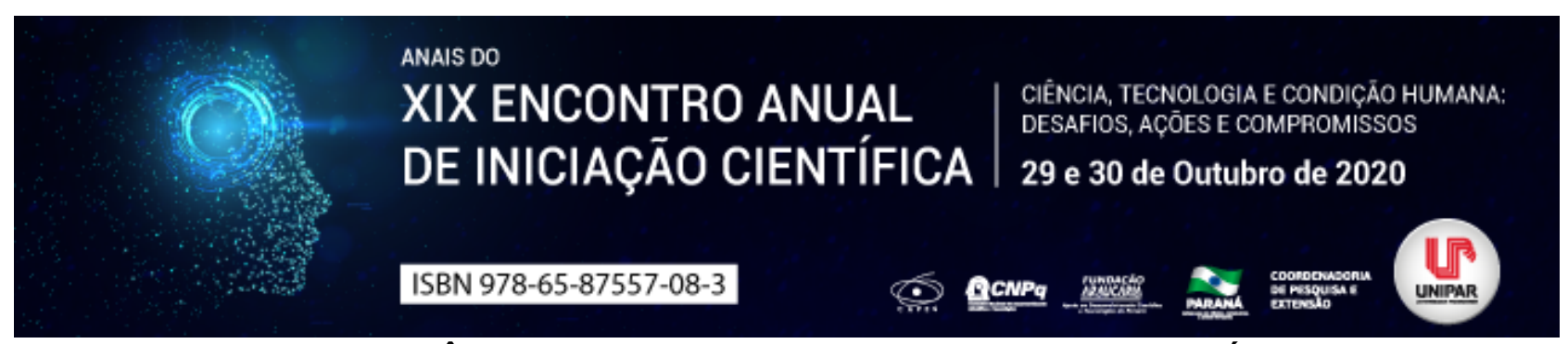

A IMPORTÂNCIA DA EMPATIA PARA O PROFISSIONAL DE SAÚDE

\begin{abstract}
${ }^{1}$ LORENA CASTAGNA ANGELIM COSTA, ${ }^{2}$ MILLENA ANGELI DOMINGUES PEREIRA, ${ }^{3}$ GABRIELE FERNANDA LOPES, ${ }^{4}$ JEFFERSON J AMARAL DOS SANTOS
\end{abstract}

\author{
${ }^{1}$ Acadêmico Bolsista PIBIC/UNIPAR \\ ${ }^{1}$ Acadêmica Bolsista PIBIC/UNIPAR \\ ${ }^{2}$ Acadêmica Bolsista PIBIC/UNIPAR \\ ${ }^{3}$ Docente da UNIPAR
}

Introdução: Segundo Terezam; Queiroz e Hoga (2017) empatia é a habilidade que deve ser desenvolvida pelo ser humano, para se colocar nas mesmas circunstâncias que se encontra outra pessoa, vivenciando suas experiências e seus problemas. 0 desenvolvimento da empatia é muito importante para fazer com que um relacionamento interpessoal seja saudável mentalmente e fisicamente. Ao longo dos anos a empatia vem sendo conceituada como um estado cognitivo ou emocional, podendo ser a combinação de ambos (LOUREIRO et al., 2011). O relacionamento interpessoal e a empatia vem sendo discutidos em diversas áreas na saúde e sendo assimilados ao ganho de qualidade no tratamento do paciente. Ratka (2018) relata que o cérebro já está pré-determinado a ser empático de forma que cada nível de empatia adquirida representa diferentes regiões cerebrais. A empatia tem sua importância no atendimento ao paciente, onde o profissional pode compreender melhor a história, os sintomas, os sentimentos, pode se comunicar de maneira mais acessível, ganhar confiança rapidamente, dessa forma pode aumentar a satisfação do paciente e melhor aceitação no tratamento, tornando uma melhoria potencial (COSTA; AZEVEDO, 2010).

Objetivo: Dissertar sobre a importância da empatia para os profissionais de saúde.

Desenvolvimento: De acordo com Barbosa et al. (2013), o treinamento da empatia iniciado na graduação tende a diminuir a ansiedade e melhorar a colaboração na equipe multidisciplinar. Em diversos estudos é relatado que os acadêmicos de medicina em seu primeiro ano possuem uma estimativa elevada da empatia, porém ao longo dos anos da graduação é observado uma diminuição deste nível (SHAPIRO, 2008; HOJAT et al., 2009). Para a empatia em nível terapêutico acontecer o profissional da saúde deve possuir bem estar físico e mental e maturidade, o paciente e o profissional devem estabelecer um respeito mútuo para que a empatia possa acontecer, esta pode ser a nível verbal e não verbal. Tornando assim o relacionamento profissional de saúde-paciente saudável e eficaz para o tratamento (TAKAKI; SANT' ANA, 2004). Além de ajudar no andamento do tratamento a relação empática profissional de saúde-paciente, também contribui na anamnese, de forma que o paciente se sente mais à vontade para disponibilizar dados com mais relevância ajudando na escolha do tratamento (LOUREIRO et al., 2011). A importância para esta área é que a empatia pode disponibilizar um tratamento mais humano e eficaz, traçando estratégias adquiridas com o relato do paciente, além do benefício para o paciente, tendo uma maior qualidade no atendimento e para o profissional evitando estresse e depressão (SAMPAIO; OLIVEIRA; PIRES, 2020). Terezam; Queiroz e Hoga (2017) dissertam que com base no relato de pacientes mesmo que os enfermeiros tenham capacidade e boas técnicas para realizar 0 procedimento, a falta da empatia causa uma diminuição na satisfação do atendimento. Já no estudo de Costa e Azevedo (2010) foi observado que os médicos detinham receio pela atitude pró-empática pela possibilidade de serem antiéticos, também foi relatado que a empatia dada pelo médico deve ser aceita pelo paciente fluir melhor esta relação. Nestes estudos a forma de pesquisa é através da Escala de Empatia de Jefferson (JSE) a qual foi utilizada inicialmente para medir a empatia em estudantes de medicina, posteriormente ela foi validada para uso e confiabilidade em outros profissionais da saúde, esta escala é autoaplicável, possui 20 questões, cada questão permite respostas na escala tipo Likert contendo sete opções desde discordo totalmente até concordo totalmente de acordo com a concordância do profissional com a frase. A JSE possui subescalas, sendo a primeira de acordo com a parte cognitiva denominada de Adopção de perspectiva, a segunda subescala envolve o emocional chamada de Cuidar com humanidade e a última trata da empatia em si denominada de Capacidade de se colocar-se na pele do doente. A pontuação funciona de forma que cada resposta tem um valor, quanto mais alto o valor adquirido no final, maior é o nível de empatia.

Conclusão: Assim concluísse que a empatia em nível terapêutico se mostrou eficaz tanto para o paciente enquanto em relação a satisfação do atendimento e a confiança dada para o profissional, quanto para o profissional da saúde que consegue obter um melhor tratamento, uma anamnese mais fidedigna e consequentemente diminuindo estresse e depressão ocasionados pelo trabalho.

\title{
Referências
}

BARBOSA, Peter; RAYMOND, Gaye; ZLOTNICK, Cheryl; WILK, James; TOOMEY, Robert; MITCHELL, James. O treinamento de 
redução do estresse baseado em mindfulness está associado a maior empatia e redução da ansiedade para estudantes de pósgraduação na área da saúde. Education for Health, Mumbai, v.26, n.1, p. 9-14, abr. 2013.

COSTA, Fabrício; AZEVEDO, Renata Cruz. Empatia, relação médico-paciente e formação em medicina: um olhar qualitativo. Revista brasileira de educação médica, Brasília, v.34, n.2, p.261-269, jun. 2010.

HOJAT, Mohammadreza; VERGARE, Michel; MAXWELL, Kaye; GEORGE, Brainard; HERRINE, Steven; ISENBERG, Gerald; VELOSKI, Jon; GONNELLA, Joseph. The devil is in the third year: a longitudinal study of erosion of empathy in medical school. Acad Med, Philadelphia, v.84, n.11, p. 1182-1191, nov.2009.

LOUREIRO, José; GONÇALVES, Manuel; TRANCAS, Bruno; CALDAS, Alexandre Castro. Empatia na relação médico-doente Evolução em Alunos do Primeiro Ano de Medicina e Contribuição para a Validação da Escala Jefferson em Portugal. Acta Médica Portuguesa, Lisboa, v. 24, n.2, p. 431-442, dez. 2011.

RATKA, Anna. Empathy and the Development of Affective Skills. Pharmaceutical education, Arlington, v.82, n.10, dez. 2018.

SAMPAIO, Leonardo; OLIVEIRA, Letícia; PIRES, Michelle. Empatía, depresión, ansiedad y estrés en Profesionales de la Salud Brasileños. Ciências Psicológicas, Montevideo, v. 14, n.2, p. 2125-2215, jun. 2020.

SHAPIRO, Johanna. Walking a mile in their patients' shoes: empathy and othering in medical students' education. Philos Ethics and Human in Medicine, v.3, n.10, mar. 2008.

TAKAKI, Maria; SANT'ANA, Débora. A empatia como essência no cuidado prestado ao cliente pela equipe de enfermagem de uma unidade básica de saúde. Cogitare Enfermagem, Curitiba, v.9, n.1, jun. 2004.

TEREZAM, Raquel; REIS, Jessica; HOGA, Luiza Komura. A importância da empatia na saúde e no cuidado de enfermagem. Revista Brasileira de Enfermagem, Brasília, v.70, n.3, p, 669-670, jun. 2017. 


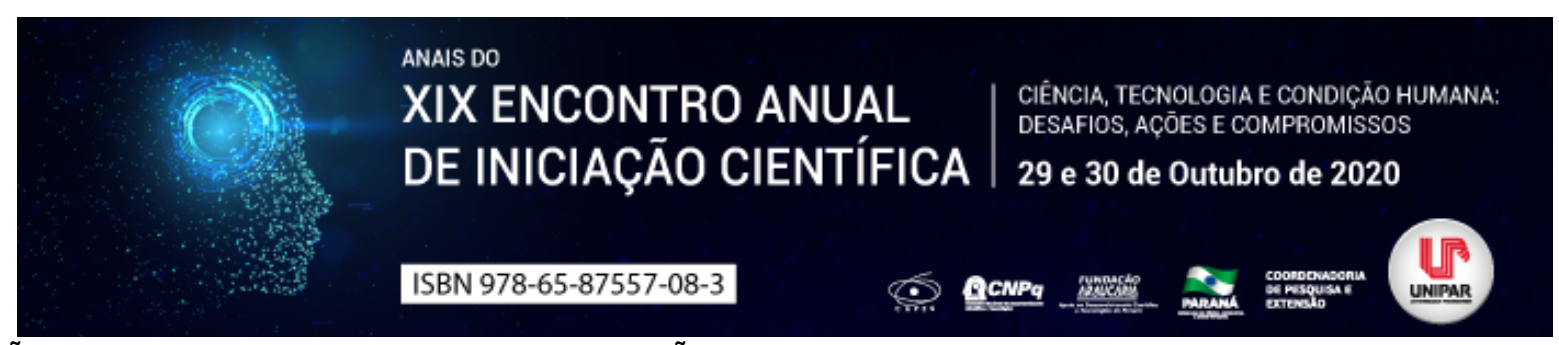

A UTILIZAÇÃO DO EXTRATO DE Punica granatum (ROMÃ) COMO AGENTE ANTIMICROBIANO NO BIOFILME DENTAL: REVISÃO DE LITERATURA

\author{
${ }^{1}$ BIANCA RAUANE RIBEIRO FAVARO, ${ }^{2}$ TAIS NUNES LOPES DA SILVA, ${ }^{3}$ KLISSIA ROMERO FELIZARDO
}

\author{
${ }^{1}$ Acadêmica do Curso de Odontologia da UNIPAR \\ ${ }^{1}$ Acadêmica do Curso de Odontologia da UNIPAR \\ ${ }^{2}$ Docente da UNIPAR
}

Introdução: Dentre as principais e mais comuns infecções orais estão a cárie dentária, a gengivite e a periodontite. Uma característica comum nessas patologias é a presença de microrganismos que estão diretamente relacionados com o desenvolvimento ou persistência dessas infecções. O controle ou a remoção desses microrganismos é realizado através da escovação dental, utilização de fio dental e enxaguatórios bucais, auxiliando no controle e prevenção dessas doenças (BATISTA, LINS et al., 2014). A clorexidina é o antisséptico mais utilizado para prevenir o acúmulo de biofilme. Porém pode causar gosto metálico na boca, provocar náuseas e vômitos, dores abdominais, hipersalivação e até mesmo genotoxicidade (ARGENTA et al., 2012). A remoção mecânica do biofilme dental é imprescindível para a prevenção da cárie, porém é considerada uma tarefa difícil e influenciada pela habilidade manual e motivação do indivíduo para a execução. Assim, em virtude dessas dificuldades, para assegurar um adequado controle de biofilme existe um grande interesse em se utilizar agentes antimicrobianos fitoterápicos que possam auxiliar na escovação dental deficiente (FRANCO et al., 2008; BHADBHADE, ACHARYA et al., 2011; AKCA et al., 2016).

Objetivo: O trabalho tem como objetivo relatar através de uma revisão bibliográfica nas bases de dados LILACS, BBO, PubMed e BIREME, a eficácia de agentes fitoterápicos com características antimicrobianas, extrato da Punica granatum (Romã) em enxaguatórios bucais, sobre os microrganismos que compõem o biofilme dental.

Desenvolvimento: A utilização de plantas medicinais e/ou fitoterápicos traz grandes vantagens no processo de promoção da saúde, pois são eficientes e de baixo custo. Essa prática é bastante usada em medicina, no entanto sua aplicabilidade na odontologia clínica ainda é considerada discreta, porém é sabido que a população frequentemente utiliza espécies vegetais, sob a forma de enxaguante bucal ou pomadas, para o tratamento de doenças bucais (OLIVEIRA, LEHN, 2015; MONTEIRO, FRAGA, 2015). A Punica granatum (Romã), é uma planta largamente utilizada na medicina popular para o tratamento de estomatites e inflamação da garganta. Sua utilização popular tem sido respaldada por estudos científicos sobre suas propriedades terapêuticas, principalmente antimicrobiana e anti-inflamatória. Estas propriedades têm sido estudadas em diferentes preparações desta planta, incluindo extratos e frações do fruto, flores e folhas; e parecem estar relacionadas ao alto teor de compostos fenólicos em suas composições (MONTEIRO, FRAGA, 2015). Os dados da literatura relatam que os extratos de casca de Punica granatum em diferentes concentrações foram eficazes contra diferentes espécies bacterianas, como S.aureus, E.coli, Salmonella enterica, Shigella sonnei, Enterococcus faecalis e Bacillus subtilis (PAGLIARULO et al., 2016; ROSASBURGOS et al., 2017). Li et al. (2005) relataram o poder inibitório in vitro de um extrato da flor do $P$. granatum sobre uma enzima bacteriana digestiva da sucrose que é considerado o fator responsável por despertar problemas orais, como a gengivite. Em outro estudo, a profilaxia da boca através de enxaguantes bucais com diferentes extratos removeu a placa bacteriana presente dos dentes (DI SILVESTRO, 2009) se mostrando eficaz no combate a bactérias gram-positivas e negativas que compõem o biofilme bucal. A romã é rica em taninos hidrolisáveis, estes compostos aumentam a lise bacteriana, bem como causam interferência no dispositivo de aderência bacteriana à superfície dos dentes, sendo ativo contra a formação da placa dental e considerado um inibidor do crescimento de linhagens de streptococcus acidogênicos e acidúricos. Acerca dos compostos responsáveis pela ação antimicrobiana dessa planta, encontra-se a punicalagina, um tanino elágico derivado do fruto da romã, como um dos principais constituintes antimicrobianos da fruta (MOORTHY et al., 2013).

Conclusão: Pode-se concluir que o uso de compostos de origem natural como os polifenóis extraídos da Punica granatum (Romã) em enxaguatórios bucais é seguro e eficaz na redução dos microrganismos que compõem o biofilme dental, comprovando a sua ação antimicrobiana.

\title{
Referências
}

DA SILVA OLIVEIRA, Fernanda Granja; LEHN, Carlos Rodrigo. Riscos e perspectivas na utilização de fitoterápicos no Brasil. Opará: Etnicidades, Movimentos Sociais e Educação, v. 3, n. 4, p. 35-44, 2015.

DE OLIVEIRA MOTA, Isabelly Bárbara et al. Fitoterapia na odontologia: levantamento dos principais produtos fitoterápicos usados para a saúde bucal. Psicologia e Saúde em debate, v. 4, n. Suppl1, p. 71-71, 2018.

FERNANDES, Gabriela Lopes. Extrato da casca de Punica granatum potencializa o efeito anti cárie de um enxaguatório bucal contendo trimetafosfato de sódio e flúor. 2020.

FRANCO NETO,

Carlos

Alfredo

et

al. Comparative analysis of the effect of two chlorhexidine mouthrinses on plaque accumulation and gingival bleeding. Brazilian oral research, v. 22, n. 2, p. 139-144, 2008.

JOÃO ANTÔNIO, Argenta. et al. Efeito do extrato de romã (Punica granatum) sobre bactérias cariogênicas: estudo in vitro e in vivo. Arquivos em Odontologia, v. 48, n. 4, p. 218-226, 2012.

JUNIOR, Jonas Ildefonso, MONTEIRO, Álefe Brito. Plantas medicinais e fitoterápicos úteis na odontologia clínica: uma revisão. Revista da 
Faculdade de Odontologia da UFBA, v. 50, n. 1, p. 47-56, 2020.

MONTEIRO, Maria Helena Durães Alves et al. Fitoterapia na odontologia: levantamento dos principais produtos de origem vegetal para saúde bucal. 2014.

MOORTHY, Kannaiyan et al. Antimicrobial activity and qualitative phytochemical analysis of Punica granatum Linn. (PERICARP). Journal of Medicinal Plants Research, v. 7, n. 9, p. 474-479, 2013.

SOUSA, Nágila Caroline Fialho et al. Propriedades farmacológicas de Punica granatum L (romã): uma revisão de literatura. Revista Ceuma Perspectivas, v. 31, n. 1, p. 57-67, 2018.

Coordenadoria de Pesquisa e Extensão - COPEX

Departamento de Editoraçāo e Divulgaçāo Científica - DEDIC 


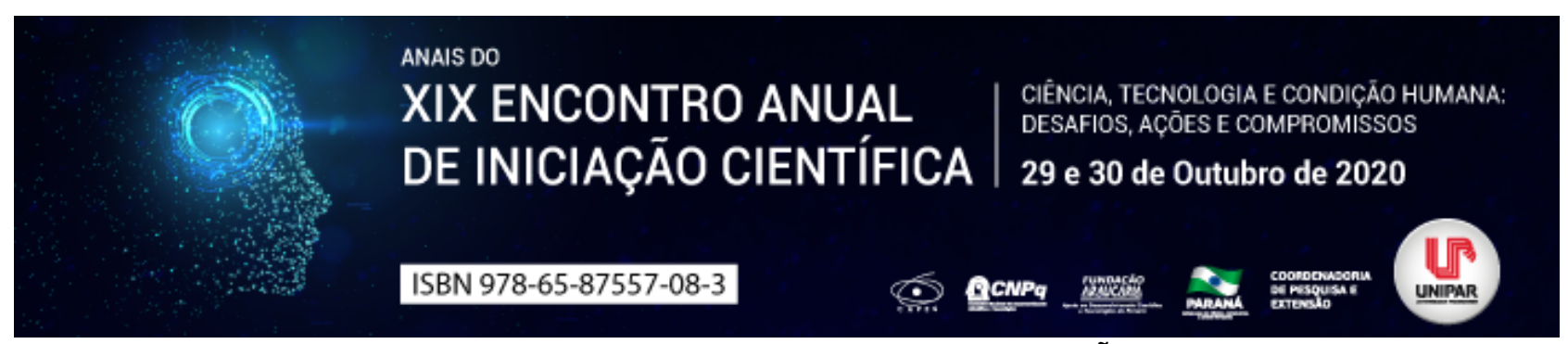

OS BENEFICIOS DO ALEITAMENTO MATERNO PARA A MÃE E A CRIANÇA

\title{
${ }^{1}$ ELIANE MACEDO LUZ, ${ }^{2}$ IRINEIA PAULINA BARETTA
}

\author{
${ }^{1}$ Discente do curso de Enfermagem - UNIPAR \\ ${ }^{1}$ Docente da UNIPAR
}

Introdução: Amamentação é nutrição de escolha, segundo a American Academy of Pediatrics (AAP) recomenda leite materno por, no mínimo, 6 meses e introdução de alimento sólido apropriado dos 6 meses a 1 ano. O aleitamento materno é fundamental para a saúde da criança (RAMOS, et al 2010). Proporciona saúde ao bebe, com vantagens nutricional e cognitiva e proteção contra infecções, alergias, obesidade, doença de Crohn e diabetes. É um método fácil, econômico, e promove o vínculo afetivo entre mãe e filho (BRASIL,2017). Em primíparas, a produção láctea é plenamente estabelecida em 72 a $96 \mathrm{~h}$, e em menos tempo nas multíparas. Ainda o aleitamento materno é um processo fisiológico que traz inúmeras vantagens bio-psico-social para as puérperas (MARITNS e SANTANA,2013). O conhecimento sobre os benefícios da amamentação para a saúde da criança são amplos porem para a saúde da mulher pouco se sabe ainda.

Objetivo: Esclarecer os benefícios que o aleitamento materno proporciona para o bebe.

Desenvolvimento: A amamentação exclusiva é a estratégia que mais previne mortes infantis (ALMEIDA, et al 2010). O leite materno pode garantir que as crianças se beneficiem no desenvolvimento e maturidade durante a adolescência e a vida. Por conter todos os nutrientes essenciais da vida, o leite materno pode prevenir doenças, reduzir mortalidade infantils, evitar infecções respiratórias e diarrérias, reduzir alergias, hipertensão, colesterol, diabetes e obesidade. Melhora a qualidade de vida e aumenta a conexão entre mãe e filho (VINAGRE, DINIZ, VAZ, 2001). Em revisão da literatura as evidências provam que os benefícios da amamentação são importantes para saúde da mulher, uma vez que reduz o risco de câncer de mama, tanto antes da menopausa como após. Também há evidências de que a amamentação proteja contra certos tipos de câncer, como o do epitélio ovariano (REA,2004). Para Marinho e Leal (2004) a prática do aleitamento materno relaciona-se profundamente a fatores de ordem física, psicológica e social, sendo reconhecida por todos os profissionais de saúde envolvidos neste processo. Para se ter sucesso no aleitamento materno é necessária a conjunção de vários fatores tais como, orientações prévias ao nascimento e no pós-parto, objetivando preparar a mãe para enfrentar e superar as dificuldades que possam surgir. Minimizar as preocupações, fortalecer a autoconfiança e instrui-la na superação dos obstáculos. Desta forma, entende-se a importância do papel do enfermeiro em todo esse processo, uma vez que é este profissional quem acompanha a mãe e identifica, durante o pré-natal, quais os conhecimentos que a mãe possui acerca do processo de aleitamento materno, que experiência prática ela já teve, que crenças possui acerca do assunto, qual sua vivência social e familiar no que tange ao aleitamento materno.

Conclusão: $O$ aleitamento materno, principalmente durante os seis meses de vida, promove saúde e previne doenças no bebe. O enfermeiro deve orientar e acompanhar a mãe desde o pré-natal ao pós parto, sobre a prática do aleitamento, bem como incentivar e esclarecer os benefícios que tal ação promove. Quando a mulher conhece as vantagens da amamentação ao seu filho favorece o aumento do tempo do aleitamento melhorando assim a relação afetiva mãefilho.

\section{Referências}

ALMEIDA, Nilza Alves Marque, FERNANDES Aline Garcia ,ARAUJO Cleide Gomes.Aleitamento Materno: uma abordagem sobre o papel do enfermeiro no pós parto. RevEletEnf,v.6 n.3 p. 358-367. 2004 Disponivel em: https://revistas.ufg.br/fen/article/view/835/982. Acesso em : 20 de agosto de 2020.

MARINHO Carla; LEAL, Isabel Pereira Os profissionais de saúde e o aleitamento materno: um estudo exploratório sobre as atitudes de médicos e enfermeiros. Psicologia, saúde \& doenças, Lisboa v. 5, n. 1, p. 93-105, jul. 2004. Disponível em: http://www.scielo.oces.mctes.pt/pdf/psd/v5n1/v5n1a07.pdf. Acesso em: 28 de agosto de 2020.

RAMOS, Carmen Viana, ALMEIDA,João Aprígio Guerra, SALDIVA Silvia Regina Dias Médici; PEREIRA Luciana Maria Ribeiro, ALBERTO Norma Sueli Marques da Costa. Prevalência do Aleitamento Materno Exclusivo e os fatores a ele associados em crianças nascidas nos Hospitais Amigos da Criança de Teresina Piauí. RevEpidemiolServ v.19 n.2 p.115-124. Disponível em: http://scielo.iec.gov.br/scielo.php?script=sci_arttext\&pid=S1679-49742010000200004 acesso em : 28 de agosto de 2020.

REA, Mariana. Os benefícios da amamentação para a saúde da mulher. Jornal de Pediatria, Rio de Janeiro, Vol. 80, №5(Supl), 2004, Disponível em :https://www.scielo.br/pdf/jped/v80n5s0/v80n5s0a05.pdf. Acesso em: 20 de agosto de 2020.

VINAGRE, et al. leite humano: um pouco de sua história. Pediatria, São Paulo, v.23, n.4, p. 340-345, 2001. Disponível em: https://revistas.ufg.br/fen/index. Acesso em: 20 de agosto de 2020. 
Coordenadoria de Pesquisa e Extensão - COPEX

Departamento de Editoraçāo e Divulgaçāo Científica - DEDIC 


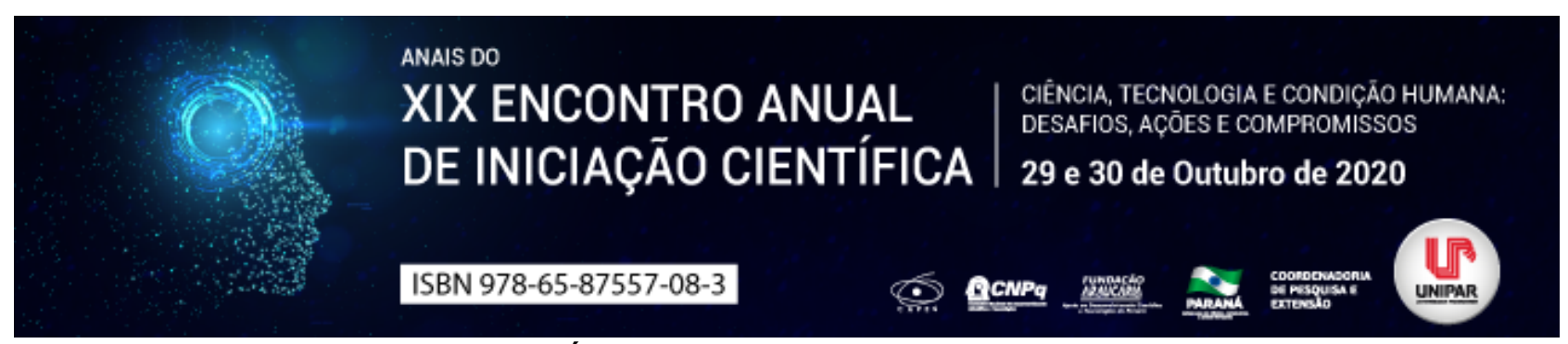

EFEITOS DA PRÁTICA DO ALONGAMENTO NA LOMBALGIA

\begin{abstract}
${ }^{1}$ THIAGO GABRIEL NERY DA SILVA, ${ }^{2}$ JESSICA FERNANDA SILVA TORRES, ${ }^{3}$ REBECA EDUARDA DRISNER, ${ }^{4}$ ANDRE GIOVANNI BOSCARDIM D STEFANI ALVES FERRO, ${ }^{5}$ DORA DE CASTRO AGULHON SEGURA
\end{abstract}

\footnotetext{
${ }^{1}$ Acadêmico do Curso de Educação Física da UNIPAR

${ }^{1}$ Acadêmica do Curso de Educação Física da UNIPAR

${ }^{2}$ Acadêmica do Curso de Educação Física da UNIPAR

${ }^{3}$ Acadêmico do Curso de Educação Física da UNIPAR

${ }^{4}$ Docente da UNIPAR
}

Introdução: A lombalgia é definida como a sensação dolorosa que ocorre, com ou sem rigidez, entre a prega glútea e o último arco costal, se estendendo para a região de todas as vértebras lombares (CECIN, 1997). De acordo com Siqueira et al. (2012), algumas das causas dessa algia estão relacionadas a curvatura vertebral diminuída, invertida ou aumentada, ou ainda, redução do espaço intervertebral, com pinçamento nervoso e até a possibilidade de protusões ou herniações discais. A incidência dos níveis de dor lombar está geralmente relacionada as alterações posturais, desequilibrando parâmetros de força, inferindo sobre a resistência e flexibilidade articular. Como a lombalgia é uma disfunção muito comum na sociedade torna-se necessária a realização de pesquisas que investiguem técnicas de tratamento, entre elas, destaca-se como recurso terapêutico a aplicação de exercícios de alongamento muscular (MACHADO; BIGOLIN, 2010).

Objetivo: Descrever quais alterações que a prática do alongamento muscular pode promover aos indivíduos que sofrem com lombalgia.

Desenvolvimento: Deyo et al. (1991) manifestam que uma dor na região da coluna lombar se torna uma doença crônica grave, e isso se afirma quando é reconhecido que a alteração da lordose lombar pode comprometer a função dos músculos tanto flexores do quadril quanto dos extensores lombares e do grupamento abdominal, além de também sobrecarregar o ligamento longitudinal anterior, afinar o forame intervertebral e estreitar o espaço discal posterior, comprimindo a dura-máter, vasos sanguíneos de raízes nervosas, aproximando as facetas articulares que podem passar a sustentar o peso, causando irritação sinovial, podendo chegar a uma inflamação severa articular (KISNER; COLBY, 2009). Segundo Alencar et al. (2015), há uma correlação forte e direta entre o depósito de gordura visceral, profundidade da lordose lombar e circunferência abdominal, de forma que quanto maior a for circunferência abdominal e gordura visceral, maior será a profundidade da coluna lombar, apontando que a protrusão abdominal é um fator associado ao aumento da lordose lombar, e que por fim causará lombalgia. Assim expressivamente, de acordo com Deyo et al. (1991), entre $70 \%$ a $80 \%$ dos indivíduos adultos decairão sobre o diagnóstico de dor lombar em algum período da vida, sendo as mulheres mais afetadas. A partir dessa perspectiva diversas técnicas de tratamento devem ser consideradas, entre elas o alongamento muscular promove ganho da elasticidade com promoção de analgesia e relaxamento muscular. Entretanto, a técnica deve ser aplicada gradativamente, respeitando as limitações individuais, sendo que as sessões devem ser mantidas por um período prolongado a fim de obter melhores resultados. A prática regular do alongamento além de diminuir a dor e melhorar a mobilidade, também corrige alterações posturais que são consideradas fatores causadores da disfunção (KLEINPAUL et al., 2008).

Conclusão: Levando em consideração os aspectos apresentados, o alongamento muscular promove elasticidade e flexibilidade dos músculos a partir da prática orientada e regrada, resultando em uma melhora significativa de casos de lombalgia. A técnica é eficaz na promoção de analgesia, melhora da funcionalidade e postura corporal.

\title{
Referências
}

ALENCAR, G. G.; ROCHA, M. B. N.; SILVA, L. R.; MOURA, M. C. G. G.; SILVA, G. A. P. Relação entre lordose lombar e depósito de gordura abdominal em adolescentes e adultos jovens. Revista Brasileira de Ciência e Movimento, v. 23, n. 2, p. 74-80, 2015.

CECIN, H. A. Proposição de uma reserva anatomofuncional, no canal raquidiano, como fator interferente na fisiopatologia das lombalgias e lombociatalgias mecânico-degenerativas. Revista da Associação Médica Brasileira, v. 43, n. 4, p. 295-310, 1997.

DEYO, R. A.; CHERKIN, D.; CONRAD, D.; VOLINN, E. Cost, Controversy, Crisis: Low back pain and the health of the public. Annu J Public Health, v. 12, p. 141-156, 1991.

KISNER C.; COLBY, L. Exercícios Terapêuticos. Fundamentos e Técnicas. 5. ed. São Paulo: Manole, 2009. p. $42-67$ KLEINPAUL, J. F.; MANN, L.; TEIXEIRA, C. S.; MORO, A. R. P. Dor lombar e exercício físico. Uma revisão. Revista Digital, v. 13, n. 127, p. 01-09, 2008. 
MACHADO, G. F.; BIGOLIN, S. E. Estudo comparativo de casos entre a mobilização neural e um programa de alongamento muscular em lombálgicos crônicos. Fisioterapia e Movimento, v. 23, n. 4, p. 545-554, 2010.

SIQUEIRA, G. R.; LEMOS, A. T.; SANTOS, F. R.; GAYA, A. C. A. Hiperlordose lombar em crianças e adolescentes de uma escola privada no Sul do Brasil: Ocorrência e fatores associados. Caderno de Saúde Pública, v. 28, n. 4, p. 781-788, 2012.

Coordenadoria de Pesquisa e Extensão - COPEX

Departamento de Editoraçāo e Divulgaçāo Científica - DEDIC 


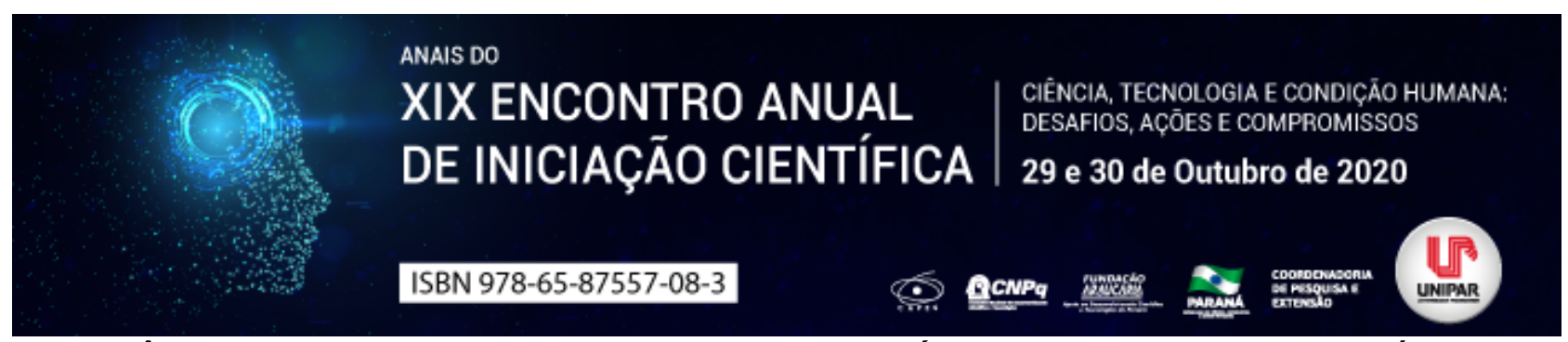

IMPORTÂNCIA DA DIETA LOW FODMAPs NOS CASOS DE SÍNDROME DO INTESTINO IRRITÁVEL (SII)

\begin{abstract}
${ }^{1}$ ESTER PELEGRINI SILVA, ${ }^{2}$ CAMILA MARIA ESCARDILLE YOSHITANI, ${ }^{3}$ FABIANE ANGELICA DE PAIVA PAULA, ${ }^{4}$ DAVI CORREA PEREIRA, ${ }^{5}$ JESSICA ZANQUIS FERREIRA, ${ }^{6}$ ELENIZA DE VICTOR ADAMOWSKI CHIQUETTI
\end{abstract}

\author{
${ }^{1}$ Acadêmica do Curso de Medicina participando do PIC/UNIPAR \\ ${ }^{1}$ Acadêmica do Curso de Medicina da UNIPAR, bolsista do PIBIC/UNIPAR \\ ${ }^{2}$ Acadêmica do Curso de Medicina da UNIPAR \\ ${ }^{3}$ Acadêmico do Curso de Medicina da UNIPAR, bolsista do PEBIC/CNPQ \\ ${ }^{4}$ Acadêmica do Curso de Medicina da UNIPAR \\ ${ }^{5}$ Docente do Curso de Medicina UNIPAR
}

Introdução: A Síndrome do Intestino Irritável (SII) é uma patologia crônica acometida no trato gastrointestinal, o qual é cada vez mais comum na prática clínica (MENDONÇA et al., 2018). Tal doença é responsável por alterar a rotina intestinal associada a um conjunto de sintomas, como: dor ou desconforto abdominal, constipação ou diarreia, inflamação, hipersensibilidade visceral, distensão abdominal, muco nas fezes, mudanças da consistência fecal, flatulência e urgência retal, e como consequência altera a microbiota intestinal (PASSOS, 2006; GOMES et al., 2019). A etiologia da SIl ainda não é totalmente elucidada, devido a multifatoriedade sintomatológica que acomete cada indivíduo (ANDRADE et al., 2015; GOMES et al., 2019). O tratamento desse transtorno consiste em mudanças no estilo de vida ou a utilização de medicamentos, sendo a primeira opção a terapia não farmacológica (ANDRADE et al., 2015).

Objetivo: Analisar a literatura referente a dieta low FODMAPs no tratamento da SII.

Desenvolvimento: A prevalência da SIl ocorre entre os 20 a 40 anos de idade, com maior prevalência em mulheres, e atinge cerca de 10 a $20 \%$ da população mundial, sendo mais incidente nos países desenvolvidos, o qual acredita-se relacionar com a rotina de vida, como nutrição e o grau de stress do indivíduo (LOPES et al., 2019; GOMES et al., 2019). A fisiopatologia desse transtorno consiste no aumento da motilidade de alguns órgãos do sistema digestório, principalmente no intestino. A principal forma de se obter o diagnóstico é através dos critérios de Rome IV e escala de Bristol, aplicados durante a anamnese, os quais são complementados com os exames físico e laboratoriais (ARAÚJO et al., 2016; GOMES et al., 2019). Devido às tais alterações viscerais em função da SII, pode ocorrer uma disbiose causada pela diminuição da diversidade da flora, possibilitando a proliferação de outras espécies que prejudiquem a função intestinal, o qual agrava ainda mais o estado de saúde do indivíduo. Assim, a microbiota exerce um papel fundamental na manutenção homeostática corporal, sendo que ela regula-se principalmente pelos hábitos alimentares (GOMES et al., 2019). Ainda não há um tratamento eficaz para a doença, porém estudos indicam melhoras na qualidade de vida com as modificações dietéticas, sendo essas: a dieta low FODMAPs, o consumo de probióticos, prebióticos, simbióticos e uma dieta restrita de certos alimentos e bebidas (ANDRADE et al., 2015; GOMES et al., 2019). No início do século XXI, os pesquisadores P. Gibson e S. Shepherd, criaram a dieta pobre em FODMAPs para pacientes com distúrbios gastrointestinais, trata-se de um acrônimo de fermentável, oligossacarídeos (fruto-oligossacarídeos, frutanos, galactoligossacarídeos, rafinose e inulina), dissacarídeos (lactose), monossacarídeos (frutose) e polióis (sorbitol, manitol, xilitol, polidextrose e isomaltose) (ANDRADE et al., 2015; LOPES et al., 2019; GOMES et al., 2019). Os alimentos FODMAPs ganharam destaque pois são compostos constituídos de moléculas mal absorvíveis no lúmen intestinal e possui fermentação rápida, o qual gera uma maior formação de gases que, por sua vez, contribuem ainda mais para o agravamento dos sintomas ao causarem uma pressão contra a parede intestinal (ANDRADE et al., 2015). Inicialmente, é recomendado que o paciente com SII realize a dieta low FODMAP's entre 6-8 semanas para verificar se houve melhorias significativas, visto que trata-se de uma restrição severa e necessita de um controle e uma supervisão, porém esse tratamento apresenta resultados significativos (ANDRADE et al., 2015; ARAÚJO et al., 2016; GOMES et al., 2019).

Conclusão: Portanto, conclui-se que a mudança nutricional é um fator válido tanto economicamente quanto fisiologicamente. Destarte, apesar de ser extremamente restritiva, é descrito pela literatura que a dieta low FODMAPs tem apresentado benefícios importantes para grande parte dos indivíduos portadores da Síndrome do Intestino Irritável. Desse modo, torna-se ainda mais providencial devido complexidade da patologia, visto que os sintomas são responsáveis por limitar a rotina dos pacientes, o qual afeta diretamente a sua qualidade de vida. É válido salientar a importância do tratamento dietético associado a uma equipe multidisciplinar, com o objetivo de monitorar o estado físico e psicológico do indivíduo.

\title{
Referências
}

ANDRADE, Vera Lucia Angelo et al. Dieta restrita de FODMEPs como opção terapêutica na síndrome do intestino irritável: 
revisão sistemática. Gastroenterologia Endoscopia Digestiva, São Paulo, v. 34, n. 1, jan./mar. 2015.

ARAÚJO, João Pedro da Cruz. Intestino irritável: abordagem diagnóstica e terapêutica. Orientador: Dr. Manuel Martins Alves. 2016. Tese (Doutorado) - Faculdade de Medicina da Universidade de Lisboa, Lisboa, 2016.

DE MENDONÇA, Ana Paula Monteiro et al. Estado nutricional, qualidade de vida e hábitos de vida em portadores da síndrome do intestino irritável: um estudo caso-controle. Revista dos Trabalhos de Iniciação Científica da UNICAMP, n. 26, dez. 2018.

GOMES, Cátia Sofia Pinheiro. Síndrome do intestino irritável e microbiota intestinal. Orientadora: Dra Cristina Maria Gil Trindade. 2019. Revisão Temática - Faculdade de Ciências da Nutrição e Alimentação da Universidade do Porto, Porto, 2019.

LOPES, Suzana Soares et al. Evaluation of carbohydrate and fiber consumption in patients with irritable bowel syndrome in outpatient treatment. Arquivos de Gastroenterologia, v. 56, n. 1, p. 3-9, mar. 2019.

Coordenadoria de Pesquisa e Extensão - COPEX

Departamento de Editoraçāo e Divulgaçāo Científica - DEDIC 


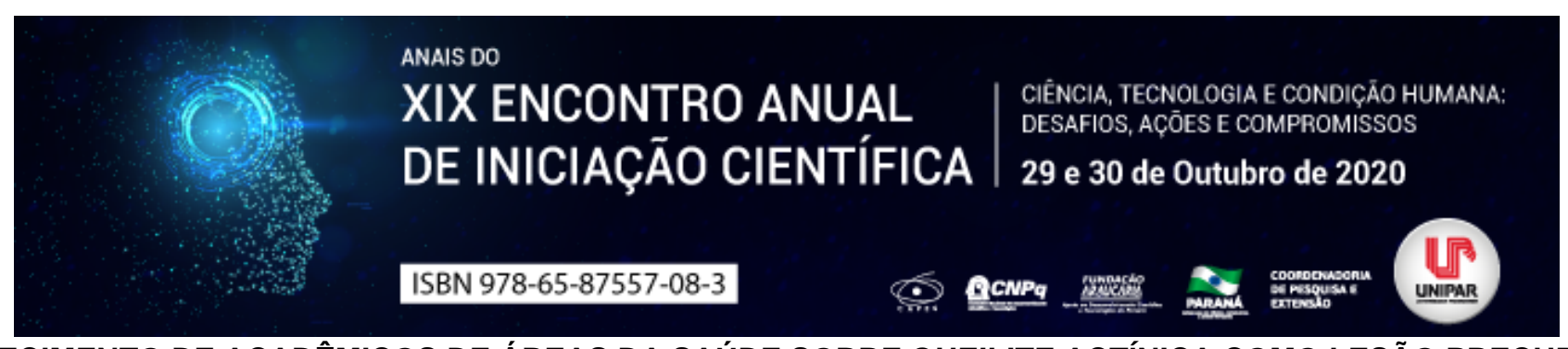

\title{
CONHECIMENTO DE ACADÊMICOS DE ÁREAS DA SAÚDE SOBRE QUEILITE ACTÍNICA COMO LESÃO PRECURSORA DO CÂNCER BUCAL
}

\author{
${ }^{1}$ MARIA RITA BARBOSA DE OLIVEIRA, ${ }^{2}$ JOAO CARLOS RAFAEL JUNIOR, ${ }^{3}$ NATALIA COQUEIRO SIQUEIRA, ${ }^{4}$ SABRINA \\ PAIXAO DOS SANTOS RODRIGUES, ${ }^{5}$ DUANI CRISTINA BAZZO, ${ }^{6}$ DANIELA DE CASSIA FAGLIONI B CERANTO
}

\author{
${ }^{1}$ Acadêmico Bolsista do PEBIC / CNPQ \\ ${ }^{1}$ Acadêmico Bolsista do PEBIC / CNPQ \\ ${ }^{2}$ Acadêmica do Curso de Odontologia da UNIPAR \\ ${ }^{3}$ Acadêmica do Curso de Odontologia da UNIPAR \\ ${ }^{4}$ Acadêmica do Curso de Odontologia da UNIPAR \\ ${ }^{5}$ Docente da UNIPAR
}

Introdução: Dentre as doenças mais letais no Brasil, o câncer encontra-se como uma das principais, podendo se desenvolver em diversas áreas, estando o câncer bucal dentre os mais prevalentes. Este fato pode ser justificado em decorrência do estilo de vida adotado por muitos, como tabagismo, alcoolismo, má alimentação e exposição excessiva ao sol, produzindo um aumento no número de casos progressivamente. Com relação à exposição ao sol, a queilite actínica, decorrente do excesso de radiação ultravioleta, é uma lesão cancerizável altamente prevalente em pessoas que estão propensas à exposição excessiva, sendo frequente em áreas cuja atividade econômica está pautada na agricultura, como o Noroeste do Paraná. Portanto, é essencial que todos os profissionais de saúde saibam reconhecer este como sendo um fator causador do câncer bucal e fiquem atentos à mudanças que ocorrem previamente à malignização, principalmente, lesões em lábios, onde a queilite manifesta-se. Logo, é importante que os profissionais saibam reconhecê-la precocemente, para que o paciente tenha um bom prognósticos, devendo assim, ser dada atenção ao assunto ainda durante a graduação (INCA, 2020).

Objetivo: $\mathrm{O}$ objetivo do presente trabalho foi avaliar o conhecimento de acadêmicos de diferentes áreas da saúde, sobre sinais e sintomas da queilite actínica, uma das lesões cancerizáveis mais importantes e prevalentes.

Material e Métodos: Inicialmente foi feito um levantamento da quantidade de alunos matriculados nos primeiros anos em 2020 dos cursos da área da saúde da Universidade Paranaense UNIPAR campus Umuarama. Os pesquisadores abordaram os alunos remotamente, com autorização dos coordenadores responsáveis por cada curso de graduação, sendo explicado o intuito da pesquisa, após a aprovação dos responsáveis os links do questionário foram enviados e os questionamentos foram respondidos pelos voluntários. Em seguida da coleta dos dados, foram realizadas análises descritivas para avaliar o conhecimento sobre Queilite Actínica e outros fatores, entre os estudantes.

Resultados: Acadêmicos de 7 cursos participaram. Destes 13,6\% $(n=15)$ estavam matriculados no curso de Enfermagem, 20\% $(n=22)$ no curso de Estética e Cosmética, 20\% ( $n=22)$ na Medicina, $19 \%(n=21)$ no curso de Psicologia, 18\% $(n=20)$ no curso de Odontologia, 5,4\% (n=6) em Nutrição e 3,6\% (n=4) em Farmácia, totalizando 110 voluntários.

Dentre os resultados mais relevantes encontrados pode-se citar a abordagem do questionamento sobre o conhecimento sobre lesões pré-malignas, sendo que $90 \%(n=99)$ responderam que não possuem conhecimento de quais são essas lesões e $10 \%$ $(n=11)$ responderam que sim. Outro dado que chama atenção, é referente à capacidade de reconhecer as características clínicas da Queilite Actínica. Neste quesito, 97,3\% ( $n=107)$ afirmaram que não conhecem enquanto apenas 2,7\% $(n=3)$ responderam que conseguiriam reconhecer casos de QA, com isso é notório a incapacidade de diagnosticar esta lesão. Sabendo que o diagnóstico precoce do câncer, é essencial para um bom prognóstico, os participantes foram questionados sobre o assunto. Neste aspecto, 87\% ( $n=96)$ relataram que o diagnóstico precoce é importante e 13\% $(n=14)$ disseram não haver importância.

Discussão: Relativo a trabalhos que abordam o conhecimento de acadêmicos sobre o câncer bucal e lesões pré-malignas, Basso et al., em sua pesquisa detectaram que a maioria dos estudantes não possuem conhecimento a respeito das lesões prémalignas, não sendo também capazes de diagnosticá-las. O mesmo questionamento foi feito por Lima et al., que obtiveram resultados semelhantes, constatando que a maioria não tinha o conhecimento sobre estas lesões. Estes dados corroboram os resultados do presente estudo, em que $90 \%$ dos avaliados relataram desconhecer a respeito. Ao se levar em consideração o diagnóstico precoce do câncer bucal, os resultados de Oliveira et al., mostraram que a maioria dos voluntários possuem conhecimento a cerca do assunto corroborando os achados no presente estudo.

Conclusão: Diante desses achados, esse trabalho constatou que grande fração dos estudantes universitários conhece a importância do diagnóstico precoce do câncer. Apesar disso praticamente desconhecem as lesões que podem preceder ao seu aparecimento, bem como suas características clínicas. Ressalta-se a importância da inclusão de temas como câncer bucal, fatores etiológicos, lesões precursoras e como proceder frente a uma suspeita, no primeiro ano de graduação, para que 
gradativamente, de acordo com o período cursado, eles possam aumentar sua destreza e estarem aptos a enfrentarem ocorrências semelhantes.

\section{Referências}

BRASIL. Ministério da Saúde. Instituto Nacional de Câncer [Internet]. Rio de Janeiro INCA; c1996-2020 [citado 2020 mai 20]. Disponível em: https://www.inca.gov.br/.

BASSO, Sabrina et al. Avaliação do Conhecimento de Universitários em relação ao Câncer Bucal. Odontologia Clínico Científica, v. 13, n. 3, p. 451-56, 2014.

LIMA, Antonio Adilson Soares et al. Conhecimento de Alunos Universitários sobre Câncer Bucal. Revista Brasileira de Cancerologia, v. 51, n. 4, p. 283-88, 2005.

OLIVEIRA, Jamile Marinho Bezerra et al. Câncer de Boca: Avaliação do Conhecimento de Acadêmicos de Odontologia e Enfermagem quanto aos Fatores de Risco e Procedimentos de Diagnóstico. Revista Brasileira de Cancerologia, v. 59, n. 2, p. 211-18.

Coordenadoria de Pesquisa e Extensão - COPEX

Departamento de Editoraçāo e Divulgaçāo Científica - DEDIC 


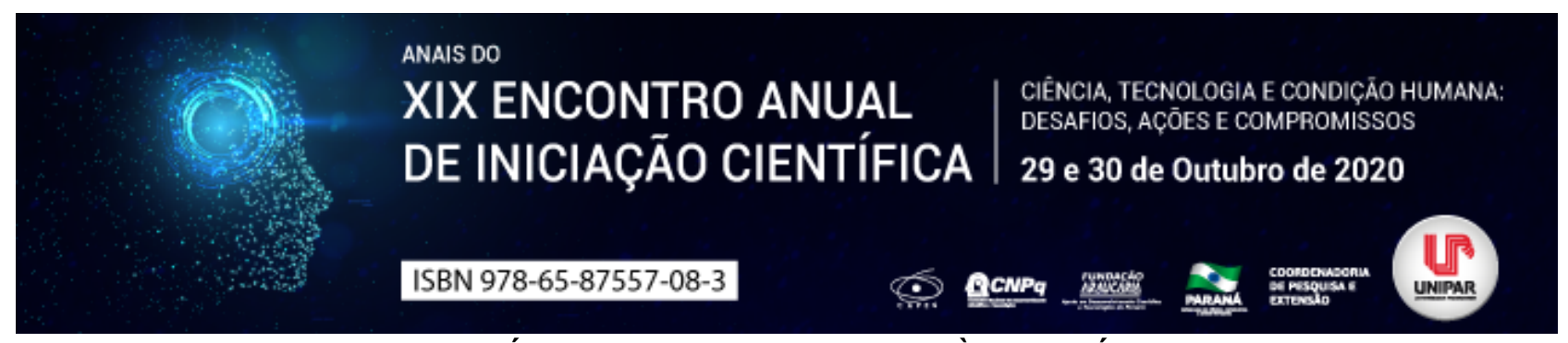

ATIVIDADE ANTIBACTERIANA DOS ÓLEOS ESSENCIAIS FRENTE ÀS BACTÉRIAS GRAM-POSITIVAS E GRAMNEGATIVAS

\author{
${ }^{1}$ CASSIANA ICZAK, ${ }^{2}$ BRUNO HENRIQUE NESI, ${ }^{3}$ YAGO EDUARDO PEREIRA DEOTTI, ${ }^{4}$ GIOVANA CRISTINA CICHOSKI \\ TONELLO, ${ }^{5}$ ALESSANDRO RODRIGUES PERONDI, ${ }^{6}$ FRANCIELE DO NASCIMENTO SANTOS ZONTA
}

\author{
${ }^{1}$ Acadêmica do Curso de Enfermagem - PIC/UNIPAR \\ ${ }^{1}$ Acadêmico do Curso de Enfermagem. PIC/UNIPAR \\ ${ }^{2}$ Acadêmico do Curso de Enfermagem. PIC/UNIPAR \\ ${ }^{3}$ Acadêmica do Curso de Enfermagem. PIC/UNIPAR \\ ${ }^{4}$ Docente da UNIPAR \\ ${ }^{5}$ Docente da UNIPAR
}

Introdução: Nos últimos anos surgiram estudos na área da fitoterapia, seja ela usada em forma de infusões ou óleos, extraídos de folhas ou ervas, para a cura ou alívio de inúmeras comorbidades (FIGUEIREDO, GURGEL, JUNIOR, 2015).

Objetivo: Descrever dados da literatura sobre a atividade antibacteriana dos óleos essenciais frente às bactérias gram-positivas e gram-negativas.

Desenvolvimento: Os Óleos Essenciais (OE) possuem princípios ativos naturais, sendo extraídos de diversas partes das plantas como sementes, caules, folhas, raízes e flores, e apresentam uma série de metabólitos que inibem, retardam e estabilizam a proliferação dos microrganismos. Alguns estudos voltados a esta temática propõem descrever a atividade inibitória e a sensibilidade dos mesmos frente aos agentes patógenos, como Staphylococcus aureus, Escherichia coli e Salmonellatyphimurium (SARTO, JUNIOR, 2014). Os serviços de saúde pública reconheceram óleos essenciais como substâncias seguras, que podem ser usados como aditivos antibacterianos e empregados contra infecções causadas por bactérias multirresistentes, além disso, utilizados como componentes de formulações para a higiene e desinfecção de ambientes (FIGUEIREDO, GURGEL, JUNIOR, 2015). Possuem uma composição química complexa que junto ao potencial antibacteriano faz com que ocorra a partição dos lipídios da membrana celular e mitocôndrias das bactérias, por conta da hidrofilidade, aumentando a permeabilidade da membrana, provocando o vazamento de moléculas essenciais à sua sobrevivência e levando as bactérias à morte, além disso, os componentes dos óleos essenciais podem também ligar-se a íons e moléculas transmutando algumas funções biológicas, ou seja, considerando o grande número de componentes químicos presentes, vale ressaltar que o efeito antibacteriano não pode ser atribuído a um mecanismo de ação específico (LıMA, et al, 2019). Na atividade antibacteriana, os óleos essenciais são utilizados na inibição do crescimento de agentes patológicos. De acordo com Foralosso (2018), o óleo essencial de laranja apresenta atividade fraca a moderada contra todas as espécies de bactérias testadas, destacando-se uma atividade moderada frente a Bacilluscereus, uma importante espécie patogênica em alimentos. Em uma pesquisa realizada por Pombo (2018) as bactérias gram-positivas Staphylococcus aureus e Bacilluscereus foram susceptíveis a ação antibacteriana quando comparadas às gram-negativas Escherichia coli e Salmonella entérica que tiveram um desempenho mais satisfatório, com maiores concentrações sobre os óleos essenciais de orégano e cravo. Em estudo feito por Araújo (2015) identificou-se que os óleos essenciais de orégano fruíram baixas concentrações inibitórias para Escherichia coli e Salmonellasp, evidenciando que o princípio ativo provoca distorção da estrutura célular, modificando sua permeabilidade e variações de ph. O óleo de eucalipto apresentou atividade antibacteriana em diversos fenótipos de resistência no ambiente hospitalar, especialmente entre as bactérias gram-negativas. Já nas gram-positivas como $S$. aureus, o óleo essencial de eucalipto apresentou menor concentração inibitória, inclusive frente ao isolado clínico multirresistente (CONTRUCCI et al., 2019). No tratamento de feridas os óleos essenciais vêm sendo estudados para uma intervenção terapêutica e de baixo custo, os óleos mais utilizados são, óleo de coco, copaíba, calêndula e de girassol, por apresentar componentes químicos com uma atividade antimicrobiana e anti-inflamatória, contribuindo para a cicatrização da lesão (SOUSA, 2018). No estudo de Ramalho (2020) sobre o óleo essencial de Eucalyptus citriodora, observou que o mesmo apresentou uma inibição contra a Klebsiella pneumoniae, a ação antibacteriana desse óleo trata-se da lipofilicidade que adentram a camada lipídica da membrana celular da bactéria, proporcionando a permeabilidade dessas estruturas, ocasionando o alastramento de íons e constituintes celulares provocando a ruptura da membrana plasmática.

Conclusão: Os óleos essenciais apresentam uma ampla ação antibacteriana e podem ser considerados como uma nova possibilidade terapêutica, especialmente em conservantes alimentícios, produtos para desinfecção de ambientes, tratamentos de feridas e infecções. 


\section{Referências}

ARAÚJO, Luana Silva; SERRA, Josilene, Lima; NASCIMENTO Adenilde, Ribeiro. Composição química e susceptibilidade do óleo essencial de orégano (Origanum Vulgare L, Família Lamiaceae) Frente às cepas de Escherichia Coli, Staphylococcus Aureus e Salmonella Choleraesuis. Boletim do Centro de Pesquisa de Processamento de Alimentos, v. 33, n. 1, jun, 2015.

CONTRUCCI, Bruno Antunes. et al. Efeito de óleos essenciais sobre bactérias gram-negativas isoladas de alimentos. Ensaios e Ciência, v. 23, n. 3, p. 180-184, 2019.

FIGUEREDO, Climério Avelino de. et al. A Política Nacional de Plantas Medicinais e Fitoterápicos: construção,perspectivas e desafios. Physis: Revista de Saúde Coletiva, v. 24, p. 381-400, 2015.

FORALOSSO, Fabiana Bortolini; ZAPPAROLI, Anaeli; BATISTEL, Paola Da Silva. Avaliação da atividade antibacteriana de óleos essenciais cítricos orgânicos frente a microrganismo de importância em alimentos. Anais da MICTI, v. 1, n. 1, p. 1-5, 2018.

LIMA, Carla Vanessa Ribeiro. et al. Ação antibacteriana do óleo essencial das folhas de aroeira frente a patógenos multirresistentes. Diversitas Journal, v. 4, n. 1, p. 242-252, 18 fev. 2019.

POMBO, Joseane Cristina Pinheiros. et al. Efeito antimicrobiano e sinergístico de óleos essenciais sobre bactérias contaminantes de alimentos. Segurança Alimentar E Nutricional, v. 25, n. 2, p. 108-117, maio/ago, 2018.

RAMALHO, Maria Auxiliadora da Silva. et al. Atividade antiaderente dos óleos essenciais de Eucalyptusglobulus e Eucalyptuscitriodora contra cepas de Klebsiellapneumoniae. Research, SocietyandDevelopment, v. 9, n. 7, p. e406974245e406974245, 2020.

SARTO, Marcella Paula Mansano; JUNIOR, Gerson Zanusso. Atividade antimicrobiana de óleos essenciais. Revista UNINGÁ Review, v. 20, n. 1, 2014.

SOUSA, Rafael Damiane Santos. Estudo de substâncias químicas em óleos de coco, copaíba, calêndula e girassol utilizados no tratamento de feridas: uma abordagemteórica. Orientador: Nestor Everton Mendes Filho. 2018. Trabalho de conclusão de curso.Química Industrial Universidade Federal Do Maranhão, São Luís, 2018. 


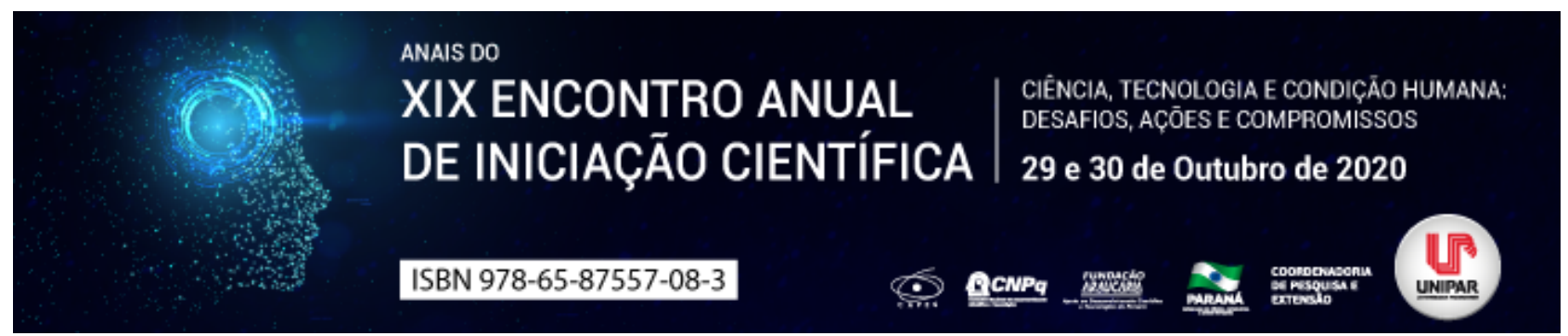

SÍFILIS GESTACIONAL: OCORRÊNCIA DE CASOS NO MUNICÍPIO DE UMUARAMA/PARANÁ

\author{
${ }^{1}$ ISABELLA ACACIO FERREIRA DE SOUZA, ${ }^{2}$ FERNANDA SONZA, ${ }^{3}$ ISADORA GIACOMINO ALVES, ${ }^{4}$ JULIA BEATRIZ PINTO \\ ARAUJO, ${ }^{5}$ TANIA HARUMI UCHIDA
}

\footnotetext{
${ }^{1}$ Acadêmica do curso de Medicina da UNIPAR

${ }^{1}$ Acadêmica do Curso de Medicina da UNIPAR

${ }^{2}$ Acadêmica do Curso de Medicina da UNIPAR

${ }^{3}$ Acadêmica do Curso de Medicina da UNIPAR

${ }^{4}$ Docente da UNIPAR
}

Introdução: A sífilis é uma doença infecciosa, de evolução crônica e por vezes assintomática, causada pela bactéria Treponema pallidum. A transmissão ocorre por via sexual, via vertical ou transfusão sanguínea contaminada (TABISZ et al., 2012). De acordo com a Organização Mundial da Saúde, 1,5 milhão de gestantes são diagnosticadas com sífilis anualmente (WHO, 2012). Embora os métodos de diagnóstico laboratorial e diretrizes de rastreamento pré-natal estejam amplamente disponíveis e o tratamento seja relativamente simples, a sífilis na gestação é um importante agravo de saúde pública, responsável por elevados índices de morbimortalidade intrauterina (MAGALHÃES et al., 2011).

Objetivo: Descrever a ocorrência da sífilis gestacional no município de Umuarama, no estado do Paraná, no período de 2010 a 2019.

Material e Métodos: Trata-se de um estudo transversal e ecológico dos casos de sífilis gestacional notificados no município de Umuarama/PR, no período de 2010 a 2019. Os dados foram obtidos no Sistema de Informação de Agravos de Notificação (SINAN). Foram analisadas as variáveis independentes: número de casos, faixa etária e idade gestacional.

Resultado: No período de 2010 a 2019, foram notificados no município de Umuarama/PR, 97 casos de sífilis em gestantes. Referente aos casos notificados por ano, verificou-se três casos em 2010, em 2011 não houve casos notificados, cinco em 2012, sete em 2013, seis em 2014, nove em 2015, quinze em 2016, dezessete em 2017, dezesseis em 2018 e dezenove em 2019. A faixa etária predominante foi de 20 a 29 anos, perfazendo $50,5 \%$ dos casos $(n=49), 39,2 \%$ das gestantes $(n=38)$ possuíam de 15 a 19 anos, e 10,3\% ( $n=10)$ foram de 30 a 39 anos. Quanto ao diagnóstico por idade gestacional, $56,7 \%(n=55)$ ocorreram no $1^{\circ}$ trimestre de gestação, $25,8 \%(n=25)$ no $2^{\circ}$ trimestre e $15,5 \%(n=15)$ no $3^{\circ}$ trimestre e dois casos com idade gestacional ignorada.

Discussão: A sífilis é uma doença de notificação compulsória nacional e obrigatória. No Brasil a sífilis em gestantes vem sendo notificada desde 2005 e em 2018 foram notificados no SINAN 62.599 casos (LIMA et al., 2013; BRASIL, 2019). No período analisado, o município de Umuarama/PR exibiu aumento no número de casos de sífilis gestacional notificados, esse crescimento pode estar associado à diversos fatores como, a diminuição das subnotificações, adesão das gestantes ao pré-natal e o diagnóstico efetivo da doença. Observou-se uma prevalência de mulheres com 20 a 29 anos $(50,5 \%)$, semelhante ao perfil brasileiro (BRASIL, 2019). Provavelmente essa faixa etária é a mais acometida por ser a fase de vida sexual mais intensa. Esses dados ressaltam a necessidade de ações de educação em saúde voltadas para a prática sexual protegida e de planejamento familiar. Além disso, pode-se verificar no município de Umuarama/PR, que 56,7\% dos diagnósticos ocorreram no $1^{\circ}$ trimestre de gestação, a detecção precoce e elevação da taxa de deteç̧ão da sífilis em gestantes se devem aos planos e estratégias desenvolvidos pelo Sistema Único de Saúde (SUS), como a Rede Cegonha e a implantação dos testes rápidos para a triagem da sífilis na Atenção Primária à Saúde. No entanto, em muitos municípios brasileiros a sífilis gestacional é predominantemente detectada durante $02^{\circ}$ e $3^{\circ}$ trimestres de gestação, demonstrando a importância de melhorias nas condutas que visam o diagnóstico precoce (CAVALCANTE; PEREIRA; CASTRO, 2017; MASCHIO-LIMA et al., 2019). Em Umuarama/PR, 25,8\% ( $n=$ 25) dos casos de sífilis gestacional foram diagnosticados no $2^{\circ}$ trimestre e $15,5 \%(n=15)$ no $3^{\circ}$ trimestre, esses números podem ser reflexo da adesão tardia ao pré-natal, indicando que apesar dos avanços das medidas implementadas pelo SUS, ainda há necessidade de práticas de educação em saúde direcionadas ao planejamento familiar e à adesão precoce ao pré-natal.

Conclusão: Sendo assim, verificou-se que houve aumento nos casos de sífilis gestacional no município de Umuarama/PR, a faixa etária acometida foi 20 a 29 anos e o diagnóstico ocorreu predominantemente no $1^{\circ}$ trimestre da gestação. Com esses resultados é notória a importância dos municípios conhecerem a realidade da doença na sua população para que ações de promoção e prevenção sejam implementadas.

\title{
Referências
}

BRASIL. Ministério da Saúde. Secretaria de Vigilância em Saúde. Boletim Epidemiológico de Sífilis. Brasília: Ministério da 
Saúde, 2019.

CAVALCANTE, Patrícia Alves de Mendonça; PEREIRA, Ruth Bernardes de Lima; CASTRO, José Gerley Diaz. Sífilis gestacional e congênita em Palmas, Tocantins, 2007-2014. Epidemiologia e Serviços de Saúde, Brasília v. 26, n. 2, p. 255264, 2017. Disponível em: https://www.scielo.br/scielo.php?script=sci_arttext\&pid=S2237-96222017000200255. Acesso em: 18 ago. 2020.

LIMA, Marina Guimarães et al. Incidência e fatores de risco para sífilis congênita em Belo Horizonte, Minas Gerais, 20012008. Ciência \& Saúde Coletiva. v. 18, n. 2, p. 499-506, 2013. Disponível em: https://www.scielo.br/scielo.php? script=sci_abstract\&pid=S1413-81232013000200021\&lng=pt\&nrm=iso\&tlng=pt. Acesso em: 18 ago. 2020.

MAGALHÃ̃ES, Daniela Mendes dos Santos et al. A sífilis na gestação e sua influência na morbimortalidade materno-infantil. Comunicação em Ciências da Saúde, v. 22, n. 1, p. 43-54, 2011. Disponível em: https://bvsms.saude.gov.br/bvs/artigos/sifilis_gestacao.pdf. Acesso em: 16 ago. 2020.

MASCHIO-LIMA, Taiza et al. Perfil epidemiológico de pacientes com sífilis congênita e gestacional em um município do Estado de São Paulo, Brasil. Revista Brasileira de Saúde Materna Infantil, v. 19, n. 4, p. 865-872, 2019. Disponível em: https://www.scielo.br/scielo.php?pid=S1519-38292019000400865\&script=sci_arttext\&tlng=pt. Acesso em: 20 ago. 2020.

TABISZ, Laiza et al. Sífilis, uma doença reemergente. Revista do Médico Residente, v. 14, n. 3, 2012. Disponível em: http://www.crmpr.org.br/publicacoes/cientificas/index.php/revista-do-medico-residente/article/view/263. Acesso em: 19 ago. 2020. WORLD HEALTH ORGANIZATION. Investment Case for Eliminating Mother-to-Child Transmission of Syphilis: Promoting Better Maternal and Child Health and Stronger Health Systems. Geneva: World Health Organization, 2012. Disponível em: https://www.who.int/reproductivehealth/publications/rtis/9789241504348/en/. Acesso em: 19 ago. 2020. 


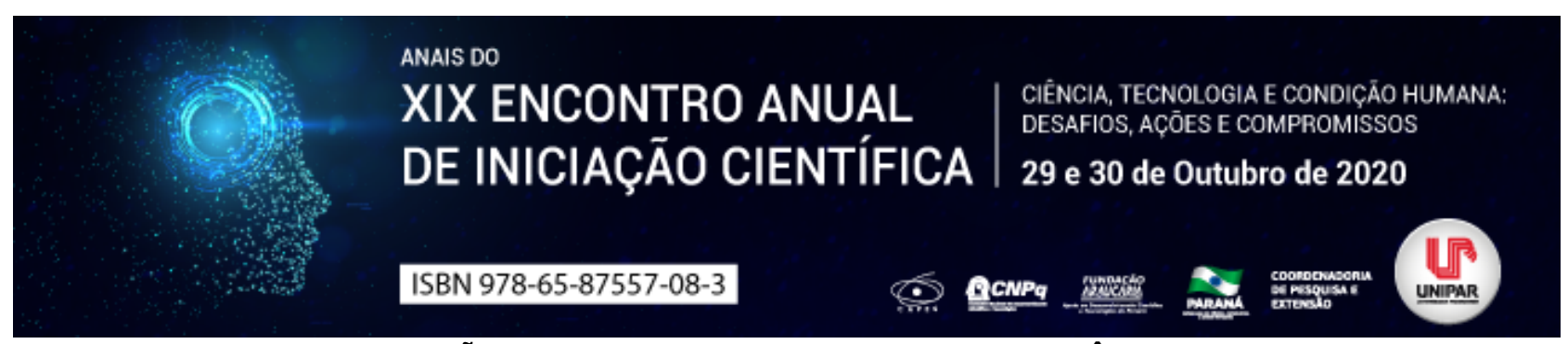

CORRELAÇÃO DA DOENÇA PERIODONTAL COM O CÂNCER ORAL

\title{
${ }^{1}$ GIULIA MARTINEZ MARTINS, ${ }^{2}$ JENIFFER URBANO DEGASPERI, ${ }^{3}$ NATIELLE KUNZLER BIRCK, ${ }^{4}$ LETICIA NADAL
}

\author{
${ }^{1}$ Discente do curso de Odontologia da Universidade Paranaense / Campus Cascavel \\ ${ }^{1}$ Acadêmica do Curso de Odontologia da UNIPAR \\ ${ }^{2}$ Acadêmico do Curso de Odontologia da UNIPAR \\ ${ }^{3}$ Docente da UNIPAR
}

Introdução: A doença periodontal (DP) é uma doença inflamatória que afeta os tecidos de suporte e revestimento dos dentes, isso é, o ligamento periodontal, osso alveolar e gengiva, podendo levar a formação de bolsas periodontais, recessão gengival, destruição dos tecidos e perda óssea, e até mesmo, a perda dentária (JAVED; WARNAKULASURIYA, 2015). Por outro lado, o câncer é, de forma genérica, o conjunto de doenças que se caracteriza pelo crescimento e proliferação descontrolada de células anormais (STUANI et al., 2016), sendo o principal problema de saúde pública no mundo. Dentre eles, o câncer bucal ocupa a sexta posição de tumores mais frequentes na Região Sul do Brasil em homens (INCA, 2019). Considerando que, pacientes com DP possuem em torno de 2 vezes mais risco de desenvolver câncer bucal é necessário o conhecimento acerca do tema, visto que ambas são comuns na rotina clínica (YAO et al., 2014).

Objetivo: Revisar as bases bibliográficas verificando a correlação entre a doença periodontal e o câncer bucal e definir se a DP como um fator de risco o desenvolvimento do câncer bucal.

Desenvolvimento: A DP é causada pela interação de um complexo de bactérias denominadas de periodontopatógenos específicos em que podem variar de acordo com a gravidade e tipo da doença, causando a liberação de mediadores inflamatórios, que leva a destruição dos tecidos de suporte dental, juntamente com a resposta inflamatória do hospedeiro (STUANI et al., 2016). Em contrapartida, ainda não está estabelecido todos os fatores relacionados ao surgimento do câncer, porém, sabe-se que cerca de quinze por cento dos tumores são desencadeados por um processo inflamatório. Isso quer dizer que, a presença de doenças inflamatórias como a DP, aumentam o risco de transformação maligna, além de, fornecerem um microambiente para diferenciação e proliferação de células cancerígenas (DE MORAES et al., 2016). Tanto a doença periodontal como o câncer, possuem fatores genéticos e ambientais que podem influenciar na sua progressão e desenvolvimento. Assim como, fatores de risco que podem desencadear ambas as doenças, como a má higiene, etilismo, tabagismo e o envelhecimento (ALVES et al., 2013). Diante da existência de processos semelhantes entre as duas patologias, nos permite avaliar essa correlação, não somente em câncer bucal, como em câncer colorretal, pancreático e pulmonar (CHUNG; YORK; MICHAUD, 2019). Porém, mesmo sem esses fatores, a DP é considerada um fator de risco independente para o câncer bucal (YAO et al., 2014). Os periodontopatógenos presentes nas bolsas periodontais são transportados pela saliva e sangue para demais regiões, podendo acarretar em desordens sistêmicas, bem como, a saliva possui um papel muito importante devido a metabolização do álcool, tabaco e alimentos (STUANI et al., 2016). Devido a isso, além do câncer, a doença periodontal vem sendo relacionada e estudada com diversas condições sistêmicas, como diabetes, doenças cardiovasculares, osteoporose e gravidez, e que, o tratamento periodontal contribui para reverter e prevenir quadros sistêmicos (YAO et al., 2014; AMAR; KIM, 2008). A microbiota oral é composta por diversos micro-organismos que variam de acordo com sua localidade e colonização dependente de fatores como higiene e composição salivar, mas que a maioria permanecem em equilíbrio, porém, quando ocorrem alterações podem causar doenças, (GERMANO et al., 2018). A cavidade oral, por ser de fácil acesso, pode armazenar diferentes patógenos e até mesmo agentes cancerígenos, que alteram a resposta imune do indivíduo pela sua disseminação, bem como a alta exposição desses agentes na boca podem levar a formação de uma lesão pré-neoplásica (STUANI et al., 2016). Sabe-se ainda que mediadores bacterianos podem alterar as células do nosso organismo, causando proliferação e mutagênese, e até mesmo inibindo a apoptose. Diante disso, estudos recentes buscam identificar a relação da periodontite com o $H$. pylori que possui potencial carcinogênico, bem como sua relação com o câncer bucal (IRANI; BARATI; BADIEI, 2020). Por outro lado, a P. gengivalis e F. nucleatum, são relacionados com o desenvolvimento do câncer bucal, podendo ser um detector de estágio inicial da doença ou até mesmo atuar na prevenção (BUI et al., 2019). Diante disso, estudos sugerem que há um aumento de duas a cinco vezes mais chances de desenvolvimento de câncer bucal em pacientes com DP, e ainda, há um risco de cinco vezes mais de desenvolver câncer de língua a cada milímetro de perda óssea alveolar (JAVED; WARNAKULASURIYA, 2015). Além disso, a perda óssea associada a doença periodontal é considerada um fator de risco para o câncer bucal (IRANI; BARATI; BADIEI, 2020).

Conclusão: Diante do exposto, é notória a existência de correlação entre as duas patologias, e que a doença periodontal pode aumentar o risco para o câncer bucal. Tanto o tratamento periodontal, como o controle de outros fatores de risco são 
recomendados para controle das duas patologias. Porém, ainda são necessários mais estudos e pesquisas acerca do tema para compreensão total dessa relação.

\section{Referências}

ALVES, Vanessa Tubero Euzebio et al. Aspectos relacionados ao câncer oral de interesse na periodontia. Brazilian Society of Periondotology, São Paulo, v. 23, n. 04, p. 31 37, dez. 2013.

AMAR, Jemin.; KIM, Salomon. Periodontal disease and systemic conditions: a bidirectional relationship. Odontology PMC, EUA, v. 94, n. 1, p. 10 21, jul. 2008.

BUI, Fiona Q. et al. Association between periodontal pathogens and systemic disease. Biomedical Journal, EUA, v. 42, n. 1, p. 27 35, mar. 2019.

CHUNG, Mei; YORK, Benjamin R.; MICHAUD, Dominique S. Oral Health and Cancer. Odontology PMC, EUA, v. 6, n.2, p. 130137, jun. 2019.

DE MORAES, Renata Costa et al. Association between chronic periodontitis and oral and/or oropharyngeal cancer. Brazilin Dental Journal, Brasil, v. 27. n.3, p.261-266, 2016.

GERMANO, Victória Escóssia et al. Microrganismos habitantes da cavidade oral e sua relação com patologias orais e sistêmicas: Revisão de Literatura. Revista de Ciências da Saúde Nova Esperança, Brasil, v. 16, n. 2, p. 91 99, out. 2018.

Instituto Nacional de Câncer José Alencar Gomes da Silva (INCA). Estimativa 2020 Incidência de Câncer no Brasil. Ministério da Saúde, Rio de Janeiro, 2019.

IRANI, Soussan.; BARATI, Iman.; BADIEI, Mohammadreza. Periodontitis and oral cancer - current concepts of the etiopathogenesis. Oncology Reviews, Italy v. 14, n. 1, p. 23-34, jan. 2020.

JAVED, Fawad.; WARNAKULASURIYA, Saman. Is there a relationship between periodontal disease and oral cancer? A systematic review of currently available evidence. Critical Reviews in Oncology/Hematology, EUA, v. 97, p. 197205 , ago. 2015.

STUANI, Vitor de Toledo et al. A relação entre doença periodontal e o câncer oral. Revista Brasileira de Odontologia, Rio de Janeiro, v. 73, n. 3, p. 218, jul/set. 2016.

YAO, Qi-Wei et al. Association of periodontal disease with oral cancer: A meta-analysis. Tumor Biology, China, v. 35, n. 7, p. 7073 7077, abr. 2014. 


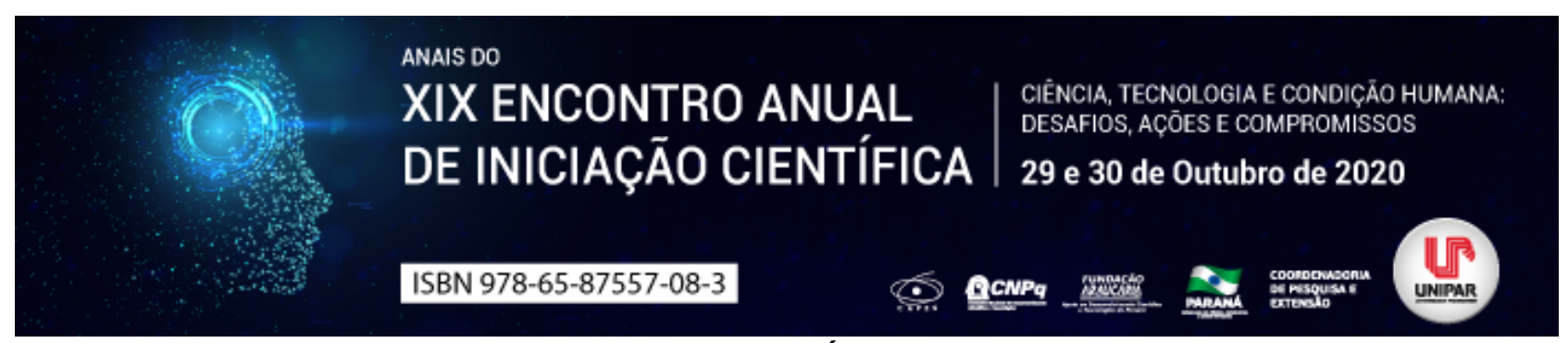

DISTANCIA DA MARGEM ANTERIOR DO RAMO DA MANDÍBULA AO FORAME MANDIBULAR EM DENTADOS E EDENTADOS TOTAIS: ANESTESIA PTERIGOMANDIBULAR

\author{
${ }^{1}$ Anny isabelly dos santos souza, ${ }^{2}$ VÍTOR LUÍS RIBEIRO, ${ }^{3}$ CAIO FOSSALUSSA DA SILVA, ${ }^{4}$ JOÃO CÉSAR GUIMARÃES \\ HENRIQUES, ${ }^{5}$ FABIO FRANCESCHINI MITRI
}

\begin{abstract}
${ }^{1}$ Graduando(a), Faculdade de Odontologia da Universidade Federal de Uberlândia (FOUFU). Uberlândia/MG.
${ }^{1}$ Cirurgião-Dentista, Graduado na Faculdade de Odontologia da Universidade Federal de Uberlândia (FOUFU). Uberlândia/MG.

${ }^{2}$ Graduando(a), Faculdade de Odontologia da Universidade Federal de Uberlândia (FOUFU). Uberlândia/MG

33Professor Doutor, Departamento de Diagnóstico Estomatológico, Faculdade de Odontologia da Universidade Federal de Uberlândia (FOUFU).

${ }^{4}$ Professor Doutor, Departamento de Anatomia Humana, Instituto de Ciências Biomédicas (ICBIM) da Universidade Federal de Uberlândia (UFU).
\end{abstract}

Introdução: A técnica de anestesia pterigomandibular é complexa, devido ao acesso e localização deste nervo na face medial do ramo da mandíbula (LIMA E CÉSPEDES, 2009). Uma das maiores dúvidas durante esta técnica anestésica é a profundidade de introdução da agulha para alcançar o forame da mandíbula e, consequentemente, promover o bloqueio do nervo alveolar inferior (NAI) e se há diferença em relação ao paciente edentado total (LIMA et al., 2011. O forame da mandíbula (FM) está localizado na face interna da parte média do ramo da mandíbula (RM), acima do plano oclusal dos dentes inferiores, entretanto, a sua localização pode variar de indivíduo para indivíduo, o que dificulta em alguns casos a anestesia do nervo alveolar inferior. Pelo FM penetram o nervo e os vasos alveolares inferiores no canal da mandíbula, que se estendem até o plano mediano. A taxa de sucesso do bloqueio do nervo alveolar inferior é menor do que a maioria dos outros bloqueios de nervos, devido à variação anatômica na altura do FM na face lingual do ramo e a maior profundidade da penetração necessária nos tecidos moles, sendo necessários estudos topográficos desta região e associação com outras estruturas anatômicas para maior índice de acertos (STRINI et al., 2006). O conhecimento topográfico e local da anatomia da mandíbula e do NAl é extremamente importante para o profissional da saúde.

Objetivo deste estudo é determinar a distância média da margem anterior do ramo da mandíbula, na região da fossa retromolar, até o centro do forame da mandíbula, como uma referência para a técnica de anestesia do nervo alveolar inferior nas mandíbulas dentadas e edentadas totais.

Material e Método: Este estudo foi conduzido em acordo com a Lei Brasileira n 8.501 publicado em 1992 e a Declaração de Helsinki, a qual idealiza o uso de cadáveres ou peças anatômicas para o propósito de estudos ou pesquisas científicas. Foram utilizadas 40 mandíbulas de indivíduos adultos, de ambos os sexos, sem consideração sobre gênero, raça ou idade, obtidas do acervo do material de estudo do Laboratório de Anatomia Humana da Universidade Federal de Uberlândia. Foram determinadas as distâncias médias entre a fossa retromolar e o centro do forame da mandíbula, dos lados direito e esquerdo. Foram estudadas 4 variáveis, mandíbula dentada e edentada total e antímeros direito e esquerdo de cada mandíbula, nos quais foram determinadas as distâncias médias, e suas interações, entre a distância da fossa retromolar (face medial do ramo da mandíbula, acima do trígono retromolar) até o centro do forame mandibular, com a unidade de medida em milímetros (mm).Os dados coletados foram submetidos ao teste de Shapiro-Wilk e igualdade de variância para determinação de normalidade e homocedacidade, nos quais foram aprovados. A seguir, os dados foram submetidos ao teste ANOVA two-way (2x2) de medidas repetidas seguido do teste de Tukey. Todos os testes foram realizados em nível de $5 \%$ de significância $(p \leq 0,05)$.

Resultados: Não apresentaram diferenças estatísticas e revelaram valores entre as mandíbulas dentadas e edentadas apresentaram diferenças médias de 0,7 $\mathrm{mm}$, antímero direito, e 0,3 $\mathrm{mm}$, antímero esquerdo. Nas mandíbulas dentadas, os antímeros entre si apresentaram diferença média de $0,3 \mathrm{~mm}$ e, nas mandíbulas edentadas, diferença média de $0,7 \mathrm{~mm}$. As médias entre esses valores podem ser consideradas de $0,5 \mathrm{~mm}$ entre as mandíbulas e 0,5 $\mathrm{mm}$ entre os antímeros.

Discussão: A mandíbula edentada total apresenta a estrutura geral alterada em relação à mandíbula dentada. Entre os ossos da face, a maxila e a mandíbula são os ossos que alcançam o pico de projeção na fase adulta (ENLOW, 1966). O avanço da idade causa alterações de posição da superfície externa dos ossos (MENDELSON; WONG 2012). A anestesia local é fundamental na prática odontológica e as falhas na execução da técnica podem ser causadas por falta de experiência e conhecimento anatômico (WILSON; JOHNS; FULLER, 1984; MADAN, 2002). A posição do forame da mandíbula também pode apresentar uma pequena variação de um indivíduo para outro, mas os trabalhos mostram que essa alteração não é significante (URBINA; MARCOS; NYdia, 1984). Não há relação entre a posição do forame mandibular e a quantidade de dentes ou da altura da mandíbula (ENNES; MEDEIROS, 2009), o que pode ser confirmado nesse estudo. Os lados, sexo e idade também não apresentam 
diferença, e também não ocorrem diferenças estatísticas entre as mandíbulas dentadas e edentados totais, diminuindo a preocupação do profissional para técnica anestésica, o que também foi confirmado nesse estudo.

Conclusões: Não há diferenças significativas nas distâncias dos pontos de referência anatômica para a técnica de anestesia pterigomandibular entre as mandíbulas dentadas e edentadas totais, e entre os seus antímeros. Desta forma, entre os pacientes dentados e edentados totais, não há variação significativa a ser considerada para a profundidade de introdução da agulha durante a realização da referida técnica anestésica.

\section{Referências}

ENLOW, DH. A morphogenetic analysis of facial growth. Am J Phys Anthropol. 52: 283-299, 1966.

MENDELSON, B; WONG C. Changes in the Facial Skeleton with Aging: Implications and Clinical Applications in Facial Rejevenation. Aesth Plast Surg. 36: 753-760, 2012.

LIMA, NA; CÉSPEDES, IC. Fatores que levam ao sucesso da anestesia Pterigomandibular. Revista Odontológica. 17(33): 7178, 2009.

LIMA, DSC; FIGUERÊD, AA; ROCHA, EA; COSTA, VHMV; CASTRO, MP; SILVA, RCP; CHAGAS, GL; ARAÚJO, P; MENDONÇA, VRR; GRAVINA, PR; MADAN, GA; MADAN, SG; MADAN, AD. Failure of inferior alveolar nerve block. J Am Dent Assoc. 133(7): 842-846, 2002.

ENNES, JP; MEDEIROS MR. Localization of Mandibular Foramen and Clinical Implications. Int. J. Morphol. 27(4): 1305-1311, 2009.

MENESES, JVL. Estudo anatômico do forame mandibular e suas relações com pontos de referência do ramo da mandíbula. Rev Bras Cir Craniomaxilofac. 14(2): 91-96, 2011.

MENDOZA, CC; VASCONCELOS, BCE; SAMPAIO, G; CAUÁS, M; BATISTA, JEM. Localização topográfica do forame mandibular: estudo comparativo em mandíbulas humanas secas. Rev Cir e Traum Buco-Maxilo-Facial. 4(2): 137-142, 2004.

STRINI, PJSA; SILVA, JÚNIOR W; RODRIGUES, DA; GUIMARÃES, EC; BERNARDINO, JÚNIO RR. Avaliação topográfica do forame mandibular em peças anatômicas maceradas parcialmente dentadas e edêntulas. Rev Fac Odontol Univ Passo Fundo. 11(2): 111-115, 2006.

URBINA, HO; MARCOS, GE; NYDIA, EAM. Medidas anatomicas de la mandíbula aplicadas a la técnica de Obwegeser-Dal Pont. An Anat Norm. 2(2): 34-36, 1984.

WILSON S, JOHNS P; FULLER, PM. The inferior alveolar and mylohyoid nerves: na anatomic study and relationship to local anesthesia of the anterior mandibular teeth. J Am Dent Assoc. 10(3): 350-352, 1984. 


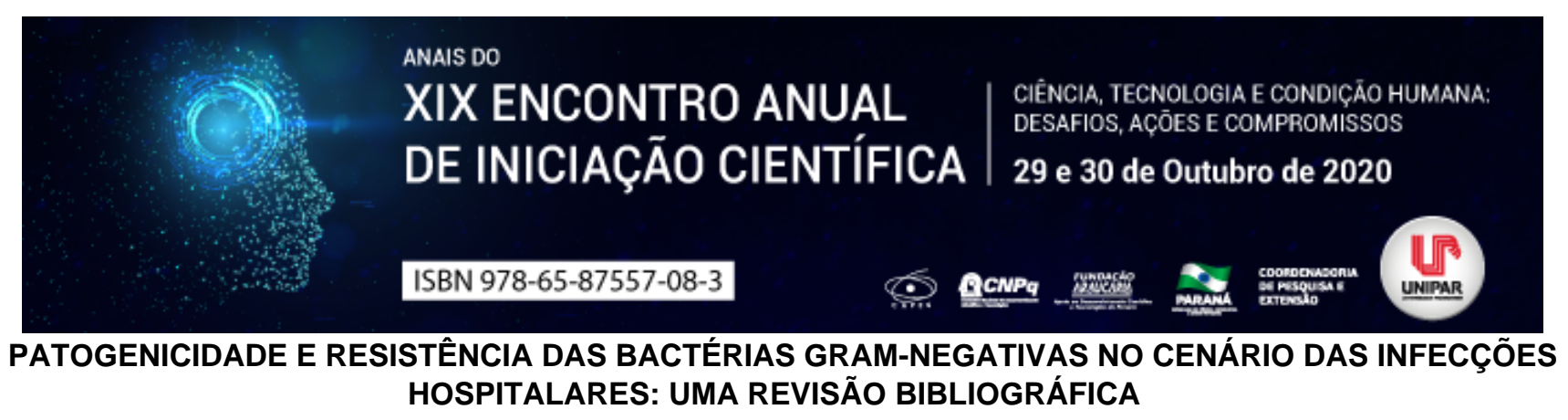

\author{
${ }^{1}$ AMANDA GABRIELI RITTER, ${ }^{2}$ JULIANA GOMES, ${ }^{3}$ LETICIA ALVES PEZZINI, ${ }^{4}$ CAROLINE MEOTTI, ${ }^{5}$ PATRICIA AMARAL \\ GURGEL VELASQUEZ, ${ }^{6}$ FRANCIELE DO NASCIMENTO SANTOS ZONTA
}

\author{
${ }^{1}$ Acadêmica do Curso de Enfermagem - PIC/UNIPAR \\ ${ }^{1}$ Acadêmica do Curso de Enfermagem - PIC/UNIPAR \\ ${ }^{2}$ Acadêmica do Curso de Enfermagem - PIC/UNIPAR \\ ${ }^{3}$ Acadêmica do Curso de Farmácia. PIC/UNIPAR \\ ${ }^{4}$ Docente da UNIPAR \\ ${ }^{5}$ Docente da UNIPAR
}

Introdução: As infecções bacterianas ocorrem principalmente em ambientes hospitalares, onde o hospedeiro desses microrganismos encontra-se vulnerável e suscetível a diversos procedimentos invasivos que facilitam sua adaptação e proliferação (MOTA, OLIVEIRA, SOUTO, 2018). A resistência bacteriana tem aumentado gradativamente nos últimos anos devido ao uso inadequado de antimicrobianos e a facilidade de mutação dos microrganismos em diversos ambientes (MACEDO, 2016).Segundo a Sociedade Brasileira de Microbiologia, cerca de 700 mil óbitos por bactérias multirresistentes são registrados anualmente, as estimativas são de que até 2050 ocorram em torno de 10 milhões de mortes por ano (SOUZA, 2019).

Objetivo: Descrever a patogenicidade de Bacilos Gram-negativos frente às infecções hospitalares, de acordo com dados da literatura.

Desenvolvimento:As infecções bacterianas ocorrem com alta frequência principalmente no âmbito hospitalar, local considerado uns dos principais reservatórios para as bactérias, entre os microorganismos patogênicos destacam-se os bacilos Gramnegativos (BNG) fermentadores (Klebsiellapneumoniae, Escherichia coli, Enterobacterspp) e bacilos Gram-negativos não fermentadores (Pseudomonas aeruginosa, Acinetobacterbaumannii e Stenotrophomonasspp) do grupo das Enterobacterias (TAFUR, TORRES, VILLEGAS, 2011).Os BGN não fermentadores são microrganismos frequentemente encontrados em infecções hospitalares, sendo consequência de sua capacidade de sobrevivência durante longos períodos em superfícies, de sua baixa necessidade nutricional e alta tolerância as variações ambientais, possuem mecanismos de escape da defesa do organismo hospedeiro o que aumenta sua capacidade de resistência aos antimicrobianos (MOTA, OLIVEIRA, SOUTO, 2018). Entre as principais infecções por BGN no ambiente hospitalar destacam-se, principalmente, as infecções do trato urinário, do trato respiratório, infecções de corrente sanguínea e feridas operatórias, consequente de uma maior necessidade de antibioticoterapia e procedimentos estéreis (BRASIL, 2013).Os BNG são, na maioria das vezes, os microrganismos que apresentam maior resistência aos antibióticos disponíveis, o que desencadeia consequências nocivas aos pacientes pela falta de opções terapêuticas em seus tratamentos (MOTA, OLIVEIRA, SOUTO, 2018). A Unidade de Terapia Intensiva (UTI) é um dos ambientes mais propícios ao desenvolvimento e proliferação dessas bactérias, a diversidade e disseminação desses microrganismos são consequências do intenso fluxo de pacientes imunologicamente críticos, procedimentos invasivos rotineiros e longos períodos de internação neste setor (MOTA, OLIVEIRA, SOUTO, 2018). A resistência aos antimicrobianos está intimamente relacionada ao uso indiscriminado e excessivo dos antibióticos, tornando este um dos principais problemas de saúde pública mundial, com grande impacto econômico e social, dentre as principais causas de mortalidade no mundo. A resistência bacteriana pode ocorrer por vários mecanismos, sejam eles intrínsecos ou adquiridos, a resistência intrínseca ocorre de forma natural, como parte de um processo de evolução bacteriana, já na resistência adquirida ocorre por meio da pressão seletiva exercida pelo uso indiscriminado de antimicrobianos, podendo ocorrer mutações genéticas, originando genes de resistência que podem ser transferidos entre as espécies bacterianas (MACEDO, 2016). As enterobactérias possuem características especificas e importantes, como sua simples necessidade nutricional, sua capacidade de reduzir nitrato a nitrito e de fermentar a glicose, elas não formam esporos e podem ser móveis ou imóveis, podem crescem em qualquer tipo de ambiente e são catalase-positiva e oxidase-negativa, o que constitui uma característica importante na diferenciação das enterobactérias de outros BGN (TAFUR, TORRES, VILLEGAS, 2011). Esses microrganismos são capazes de causar infecções em diversos órgãos do organismo humano, tornando-se assim, potenciais agentes de infecções hospitalares, as enterobactérias são capazes de adquirir e disseminar plasmídeos com genes de multirresistência múltiplos, o que dificulta o tratamento dessas infecções em ambiente hospitalar (MACEDO, 2016).

Conclusão: O confronto entre o surgimento de enzimas que inativam diversas classes de antibióticos amplamente utilizados para tratamento de infecções por BGN e a falta de novas opções terapêuticas para os mesmos vem sendo registrada por 
diversos anos, tendo como consequência, inúmeras cepas hospitalares cada vez mais resistentes entre patógenos comumente encontrados nesses ambientes e aumento gradativo da mortalidade por infecções hospitalares.

\section{Referências}

BRASIL. Agência Nacional de Vigilância Sanitária Microbiologia Clínica para o Controle de Infecção Relacionada à Assistência à Saúde. Módulo 6: Deteç̧ão e identificação de bactérias de importância médica IAgência Nacional de Vigilância Sanitária. Brasília: ANVISA, 2013.

MACEDO, Camila Avelino de. Estudo de vigilância em resistência bacteriana com ênfase em bacilos Gram negativos multirresistentes isolados de hospitais de referência no estado do Rio Grande do Norte. 2016. 60f. Trabalho de Conclusão de Curso. Universidade Federal do Rio Grande do Norte. Natal, Rio Grande do Norte, 2016.

MOTA, Fernanda Soares da; OLIVEIRA, Heloísa Aquino de; SOUTO, Renata Carneiro Ferreira. Perfil e prevalência de resistência aos antimicrobianos de bactérias Gram-negativas isoladas de pacientes de uma unidade de terapia intensiva. RBAC, v. 50, n. 3, p. 270-7, 2018.

SOUZA, Andressa Baiense. Detecção de biofilme em bactérias gram-negativas isoladas em uma Unidade de Terapia Intensiva Neonatal. 2019. 23f. Trabalho de Conclusão de Curso. Universidade Federal de Uberlândia. Curso de Biomedicina. Uberlândia, Minas Gerais, 2019.

TAFUR, José David; TORRES, Julián Andrés; VILLEGAS, Maria Virginia. Mecanismos de resistência a los antibióticos enbacterias Gram negativas. Infectio, v. 12, n. 3, 2011. 


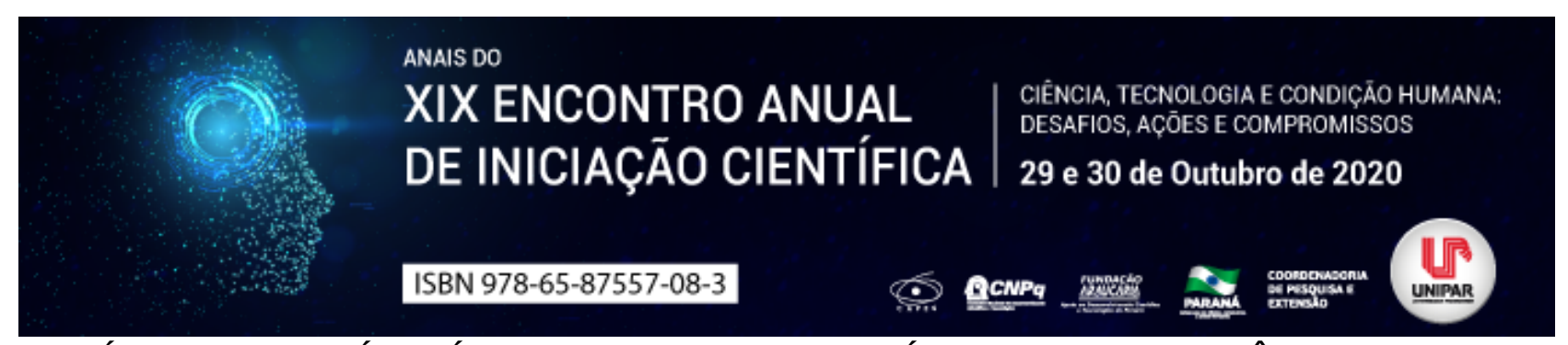

BENEFÍCIOS DO EXERCÍCIO FÍSICO EM PORTADORES DO VÍRUS DA IMUNODEFICIÊNCIA HUMANA (HIV)

\title{
${ }^{1}$ RENATA BATISTELLA, ${ }^{2}$ DURCELINA SCHIAVONI BORTOLOTI
}

\author{
${ }^{1}$ Discente do Curso de Educação Física Bacharelado / UNIPAR Francisco Beltrão \\ ${ }^{1}$ Docente do Curso de Educação Física Bacharelado / UNIPAR Francisco Beltrão
}

Introdução: O vírus da imunodeficiência humana (HIV), é uma doença que compromete o sistema imunológico e se não tratada, tem alta prevalência de mortalidade. A pessoa infectada pelo vírus, passa-se a ter o diagnóstico de AIDS (Síndrome da Imunodeficiência Adquirida) no estágio mais avançado da doença (CORDEIRO et al., 2018). Já na década de 80, estudos apresentaram as primeiras terapias antirretrovirais (TARV), que são soluções farmacológicas que impedem a proliferação do HIV no organismo, reprimindo o enfraquecimento do sistema imunológico. Entretanto, após alguns anos do uso desses medicamentos, verificou-se alterações metabólicas e de composição corporal, denominados síndrome da lipodistrofia e lipoatrofia do tecido adiposo subcutâneo, incluindo dislipidemia e/ou resistência à insulina e diabetes mellitus, facilitando o desenvolvimento de doenças cardiovasculares (COELHO; VASSIMON, 2015). Nesse sentido, estudos têm apontado que a inclusão de programas de exercício físico na rotina de tratamento destes pacientes, pode auxiliar na melhoria da composição corporal e prevenção de doenças cardiovasculares (TROMBETA, et al., 2013).

Objetivo: Verificar os benefícios do exercício físico em portadores do vírus da imunodeficiência humana - HIV.

Desenvolvimento: $O$ estudo foi conduzido por meio de uma revisão sistemática da literatura. Incluiu-se estudos indexados às seguintes bases de dados nacionais: BVS Biblioteca Virtual em Saúde, LILACS Literatura Latino-Americana e do Caribe em Ciências da Saúde; SCIELO Scientific Eletronic Library Online e na ferramenta de busca Google Acadêmico, publicados de 2010 até Julho de 2020. Os estudos deveriam ser compostos de indivíduos acima de 18 anos de ambos os sexos, portadores do HIV. Os descritores utilizados para as buscas foram: HIV, AIDS, anticorpos Anti-HIV, sorologia da AIDS, adulto, exercício físico, atividade física. Após as buscas foram encontrados apenas 8 artigos, sendo que destes, dois eram estudos de revisão (SOUZA et al., 2015; LAZZAROTTO, DERESZ, SPRINZ, 2010). Os programas de exercícios físicos relatados nos estudos, variaram de 12 semanas a 9 meses, com número total de participantes variando entre 1 e 216, e faixa etária entre 18 e 66 anos. Quanto ao tipo de exercício adotado para as intervenções houve predominância do treinamento físico resistido, sendo que dois estudos utilizaram o treinamento físico concorrente (LAZZAROTTO, DERESZ, SPRINZ, 2010; LAZZAROTTO, BAZZO, 2016), e outros dois realizaram o treinamento físico combinado (GARCIA et al., 2014; TROMBETA et al., 2013). Essa revisão sistemática se propôs a verificar os benefícios do Exercício Físico em portadores do vírus HIV. Com o avanço das pesquisas, verificou-se que embora a utilização da terapia antirretroviral (TARV) proporcione o aumento da vida útil do indivíduo portador de HIV, esta ocasiona diversos efeitos colaterais no organismo. Nesse sentido, a literatura passa a destacar a importância da prática de exercício físicos e controle nutricional como componentes importantes no auxílio do tratamento da AIDS. De acordo com o estudo de Zanetti, et al., (2016), 12 semanas de treinamento físico resistido periodizado em paciente portador de HIV, foram eficientes no combate aos efeitos adversos da TARV, além disso, verificou-se alterações antropométricas, como a diminuição das circunferências principalmente de abdômen, alterações no metabolismo lipídico, com aumento de HDL e diminuição de LDL e reduções de adipocinas no organismo. De acordo com estudo de Cordeiro, et al., (2018) pessoas recém-diagnosticadas com HIV que fazem atividade física de forma sistematizada apresentam progresso no diagnóstico tardio da AIDS e tem melhor aceitação da doença em relação a mesma população sedentária. Apesar do baixo número de estudos identificados nesta revisão, o treinamento físico resistido e o treinamento combinado, parecem ser métodos de treinamento eficazes para indivíduos portadores de HIV, visto que treinamento resistido parece promover melhora da força muscular, redução do percentual de gordura e aumento de massa muscular, além de melhora no perfil lipídico, sistema imunológico e metabolismo basal (ZANETTI et al., 2016). Já o treinamento físico combinado (treinamento resistido + aptidão cardiorrespiratória), apresentou-se efetivo no aumento significativo do VO2 e no número de linfócitos T-CD4+ (GARCIA et al., 2014).

Conclusão: Os programas de treinamento resistido, treinamento combinado e treinamento concorrente, com intensidade adequada, apresentaram benefícios significantes portadores do vírus HIV, com destaque para as melhorias em parâmetros metabólicos e inflamatórios, diminuição significativa na carga viral em alguns indivíduos, aumento da força muscular, diminuição nas regiões de lipodistrofia, melhoria no perfil lipídico, flexibilidade, composição corporal e VO2. Adicionalmente, parece minimizar os efeitos colaterais tratamento com TARV, permitindo a esse indivíduo melhor qualidade de vida.

\section{Referências}

COELHO, Isabela Borges Cristina; VASSIMON, Helena Siqueira. Excesso de peso em portadores do HIV assintomáticos: uma nova realidade e desafio, Revista Brasileira de Nutrição Clínica, v.30, n.2, p.111-5, 2015. 
CORDEIRO, Hygor. et al. Atividade física e indicadores de saúde em pessoas vivendo com HIV/aids, ABCS Health Sciences, v. 43, n. 3 2018, p. 130-135, 2018.

GARCIA, Alesandro, et al. Cinética de lactato de sujeitos com HIV após 20 semanas de treinamento físico combinado, Revista Brasileira de Atividade Física e Saúde, Pelotas/RS, v.19, n.3, p.382-389, mai/2014.

LAZZAROTTO, Alexandre Ramos, BAZZO, Karen Olivia. Treinamento concorrente na imunidade e aptidão física de pacientes HIVIAIDS, Revista Brasileira de Medicina do Esporte, v.22, n.2 , p. 153-156, mar/abr, 2016.

LAZZAROTTO, Alexandre Ramos, DERESZ, Luís Fernando, SPRINZ, Eduardo. HIVIAIDS e Treinamento Concorrente: a Revisão Sistemática, Revista Brasileira de Medicina do Esporte, v.16, n. 2, p. 149-154, mar/abr, 2010.

PEREIRA, Fábio Vilela Luis. Exercício Físico E Aids, Revista Plural da Onerai, p.1-25, 2010.

SILVA, Luiz Gouvêa Fernando. Programa de treinamento resistido ondulatório para pessoas infectadas pelo HIV: estudo de caso. Lecturas: Educación Física y Deportes, v. 24, n. 252, p.1-16, maio 2019.

SOUZA, Thiago de Paiva Siqueira, et al. Prescrição e efeitos do treinamento de força em pessoas vivendo com hiv/aids. Revista Baiana de Saúde Pública, v.39, n.3, p.655-667, jul/set 2015.

TROMBETA et al. Efeitos do Treinamento Físico Combinado Realizado na Intensidade do Limiar Anaeróbio Sobre a Composição Corporal e Sistema Imune de Sujeitos com HIV. Revista Brasileira de Ciência e Movimento, v 2, n.4, p.5-12, 2013.

ZANETTI, Hugo Ribeiro, et al. Efeito de 12 semanas de treinamento físico resistido periodizado em paciente vivendo com HIV e lipodistrófico: um estudo de caso. Revista Brasileira de Ciência e Movimento, v.24, n. 1, p. 86-93, 2016.

Coordenadoria de Pesquisa e Extensão - COPEX

Departamento de Editoraçāo e Divulgaçāo Científica - DEDIC 


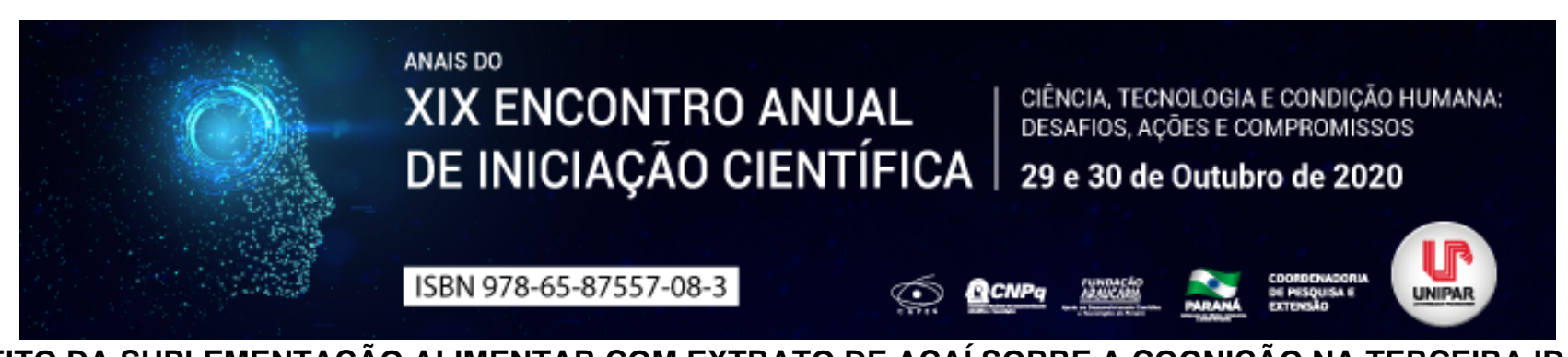

EFEITO DA SUPLEMENTAÇÃO ALIMENTAR COM EXTRATO DE AÇAÍ SOBRE A COGNIÇÃO NA TERCEIRA IDADE

\author{
${ }^{1}$ Alana Nogueira Augusto, ${ }^{2}$ CÉSAR AUGUSTO \\ ${ }^{1}$ Estudante Colégio Novomundo - Praia Grande - SP \\ ${ }^{1}$ SESAP Prefeitura Municipal de Praia Grande
}

Introdução: O Açaí (Euterpe olerácea) é um fruto cuja polpa é considerada pela ANVISA como alimento funcional (aquele que pode fazer parte da dieta sem seguimento clínico) além de ser nutracêutico (que apresenta propriedades nutritivas e terapêuticas) isso graças a sua grande quantidade de antioxidantes (flavonoides, antocianinas e compostos fenólicos). Vários trabalhos demonstraram ampla gama de seus benefícios que incluem redução da glicemia em diabéticos, controle de dislipidemias, prevenção de danos musculares, etc. Entre tantos processos salutares existem ainda evidências que seus compostos são capazes de retardar ou mesmo inibir o processo de degeneração de células cerebrais e de atuar melhorando o metabolismo cerebral. Além disso, um de seus compostos, a apigenina, tem sido apontada como tendo propriedades neuroprotetivas contra Alzheimer. Porém muitos dos trabalhos pertinentes a essa área envolvem o estudo destes compostos in vitro ou ensaios com animais. São ainda muito poucos os trabalhos dessa área envolvendo ensaios clínicos e o estudo científicos de seus efeitos em seres humanos.

Objetivo: Para avaliar o potencial benéfico da suplementação com extrato de Açaí sobre a cognição em pacientes da terceira idade foi idealizado este ensaio clínico randomizado com estudo duplo-cego.

Metodologia: Avaliação da cognição através do questionário MEEM (Mini Exame do Estado Mental) de uso consagrado como teste de rastreio cognitivo mais usado no mundo e de uso padrão pelo Ministério da Saúde. É um teste fácil de aplicar (com duração ao redor de 10 minutos), não necessita de material específico ou sala adaptada e cujas questões abrangem a avaliação de vários domínios como orientação espacial, temporal, memória imediata e de evocação, cálculo, linguagem-nomeação, repetição, compreensão, escrita e cópia de desenho (com pontuação que varia de 0 a 30 sendo os valores que tendem a 30 pontos indicadores de melhor cognição) e que foi aplicado em pacientes acima de 60 anos pertencentes a uma renomada Clínica Multidisciplinar de Especialidades Médicas (Traumaxxis) localizada no Município de Praia Grande após aval de sua Comissão de Ética (sob processo n. 001/2018) depois de ter sido preenchido o Termo de Consentimento Livre e Esclarecido (segundo a resolução 466/2012 do Conselho Nacional de Saúde) antes de sua participação. Os pacientes foram divididos em dois grupos: O primeiro ( $\mathrm{n} 1$, com 17 indivíduos) submetidos a suplementação de Açaí em cápsulas na dose recomendada pela literatura de 500 mg de 12 em 12 horas e o segundo, o grupo controle, (n2, com 15 indivíduos) que recebeu cápsulas placebo (contendo amido de milho). Os pacientes foram avaliados no início no estudo e após 4 e 8 semanas. Avaliou-se a normalidade e a homogeneidade dos resultados empregando o teste Shapiro-Wilk e Levene. Utilizou-se para calcular as diferenças entre grupos o teste ANOVA bidirecional, seguido do post hoc de Tukey. A significância adotada foi $p \leq 0,05$.

Resultados: A média etária foi de 67 anos (variando de 60 a 81 anos) com escolaridade média de 8 anos (variando de 4 a 19 anos). A média inicial do MEEM no grupo Açaí (n1) foi de $24,1 \pm 1,4$ e no grupo controle (n2) $24,2 \pm 1,5$, após 4 semanas verificou-

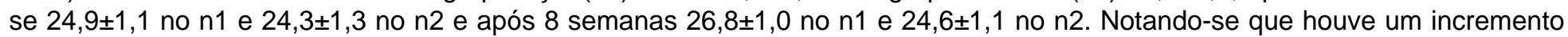
significativo $(p<0,05)$ na pontuação do MEEM, na avaliação da oitava semana de uso no grupo com suplementação de Açaí (n1). Conclusão: Os resultados demonstram o potencial benéfico do uso de Açaí na cognição de pacientes na terceira idade e que esse benefício resulta de seu uso continuado.

\title{
Referências
}

CANUTO, G.A.B; Xavier, A.A.O; Neves, L.C; Benassi, M.D.T. Caracterização físico-química de polpas de frutos da Amazônia e sua correlação com a atividade anti-radical livre. Revista Brasileira de Fruticultura, 32(4), 1196-1205, 2010. Disponível: .

FOLSTEIN, M.F; Folstein, S.E; McHugh, P.R. «l"Mini-mental statel". A practical method for grading the cognitive state of patients for the clinician». Journal of Psychiatric Research, 12 (3): 18998, 1975. Disponível: < https://pubmed.ncbi.nlm.nih.gov/1202204/>. LOBO, Ana Carolina Martini; Velasque, Leandra Fiori Lopes. Revisão de literatura sobre os efeitos terapêuticos do açaí e sua importância na alimentação. Biosaúde, Londrina, v. $18, \quad$ n.2, $2016 . \quad$ Disponível: < http://www.uel.br/revistas/uel/index.php/biosaude/article/view/27624>.

MACHADO, A.K; Andreazza, A.C; Silva, T.M. et al. Neuroprotective effects of açaí (Euterpe oleracea Mart.) against rotenone in vitro exposure. Oxid Med Cell Longev, 2016:1. Disponível:

MELO, Denise Mendonça de; BARBOSA, Altemir José Gonçalves. O uso do Mini-Exame do Estado Mental em pesquisas com idosos no Brasil: uma revisão sistemática. Ciências da saúde coletiva, vol.20, n.12, pp.3865-3876, 2015. Disponível:.

PORTINHO, J.A; Zimmermann, L.M; Bruck, M.R.. Efeitos benéficos do açaí. International Journal of Nutrology, $5(1), 2012$. 
Disponível: .

SEABRA, M.L.V; Concilio, G; Villares, J.B; Carlini, E.A. Avaliação do teste Mini-mental state em voluntários e pacientes brasileiros. Rev Bras Psiquiatr, 12 (1/4): 1-29, 1990. Disponível: .

Referências revisadas com acesso em: 16/08/2020.

Coordenadoria de Pesquisa e Extensão - COPEX

Departamento de Editoraçāo e Divulgaçāo Científica - DEDIC 


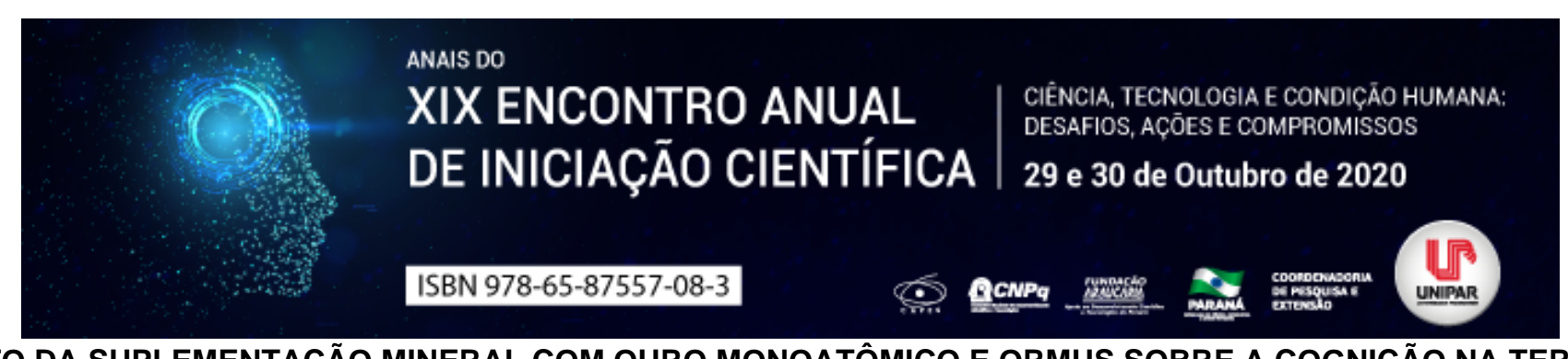

\section{EFEITO DA SUPLEMENTAÇÃO MINERAL COM OURO MONOATÔMICO E ORMUS SOBRE A COGNIÇÃO NA TERCEIRA IDADE}

${ }^{1}$ Alana Nogueira Augusto, ${ }^{2}$ CÉSAR AUGUSTO

${ }^{1}$ Estudante Colégio Novomundo - Praia Grande - SP
${ }^{1}$ SESAP Prefeitura Municipal de Praia Grande - SP

Introdução: O Ouro Monoatômico (ouro em suspenção coloidal na concentração de $1 \mathrm{mg} / \mathrm{L}$ de água destilada) e o ORMUS (cristais de Sal Marinho e Sal do Himalaia triturados, Carbonato de Sódio e água bidestilada deionizada e ozonizada na concentração de 7g/L) são classificados como suplementos minerais (ANVISA, RDC 240 26/07/2018). Admite-se que são ORMEs, Elementos Monoatômicos Orbitalmente Rearranjados, ou seja, elementos em m-sate um estado da matéria em que seus átomos não participam de ligações químicas e, portanto, com grande capacidade antioxidante. A literatura relacionada lista ampla gama de benefícios, entre eles a redução do estresse, rejuvenescimento celular e melhora da cognição. Seu uso tem sido defendido com base numa variedade de relatos pessoais e trabalhos com design sem rigor científico capazes de justificar seu uso.

Objetivo: Foi idealizado este ensaio clínico randomizado com estudo duplo-cego para preencher essa carência de estudos científicos que avaliem o potencial benéfico da suplementação com ORMUS e Ouro monoatômico sobre a cognição e o estresse em pacientes da terceira idade.

Metodologia: Avaliação da cognição através do questionário MEEM (Mini Exame do Estado Mental) de uso consagrado como teste de rastreio cognitivo mais usado no mundo e de uso padrão pelo Ministério da Saúde, cujas questões abrangem a avaliação de vários domínios como orientação espacial, temporal, memória imediata e de evocação, cálculo, linguagem-nomeação, repetição, compreensão, escrita e cópia de desenho (com pontuação que varia de 0 a 30 sendo os valores tendendo a 30 pontos indicadores de melhor cognição) e do estresse através da Escala de Estresse Percebido (EEP-10) composta de 10 questões fechadas cuja pontuação pode variar de 0 a 40 com as maiores pontuações indicando maior grau de estresse ( valores de 0 a 13 são considerados baixo grau de estresse, 14 a 26 moderado grau e acima de 27 alto grau de estresse). São testes fáceis de aplicar (com duração ao redor de 10 minutos cada), não necessitam de material específico ou de sala adaptada e foram aplicados em pacientes acima de 60 anos, pertencentes a uma renomada Clínica Multidisciplinar de Especialidades Médicas (Traumaxxis) localizada no Município de Praia Grande após aval de sua Comissão de Ética (sob processo n. 002/2018) depois de ter sido preenchido o Termo de Consentimento Livre e Esclarecido (segundo a resolução 466/2012 do Conselho Nacional de Saúde) antes de sua participação. Os pacientes foram divididos em três grupos. O primeiro, o grupo controle, ( $\mathrm{n}$, com 9 indivíduos) recebeu placebo composto por água destilada em dose de 30 gotas em 12/12horas, o segundo grupo (n2, com 10 indivíduos) recebeu Ouro Monoatômico na dose recomendada (conforme dose que a literatura pertinente relata obtenção dos efeitos desejados) fracionada em 30 gotas de 12/12 horas $(0,006 \mathrm{mg} /$ dia muito aquém da dose limite segura para ingestão diária de composto de ouro que seria de $50 \mathrm{mg} / \mathrm{dia}$, não devendo ultrapassar a dose acumulada de $3 \mathrm{~g}$ de ouro), por fim o terceiro grupo (n3, com 10 indivíduos), recebeu ORMUS também em dose utilizada pela literatura pertinente distribuídas em 30 gotas de 12/12 horas (0,042 $\mathrm{mg} / \mathrm{dia})$, também aquém do que recomenda a Organização Mundial da Saúde como seguro para evitar hipertensão arterial que seria $5 \mathrm{~g}$ sal/dia ou $2 \mathrm{~g}$ de sódio). Portando ambos os grupos receberam doses clinicamente seguras dos compostos. Os pacientes foram avaliados no início no estudo e após 4 e 8 semanas. Avaliou-se a normalidade e a homogeneidade dos resultados empregando o teste Shapiro-Wilk e Levene. Utilizou-se para calcular as diferenças entre grupos o teste ANOVA bidirecional, seguido do post hoc de Tukey. A significância adotada foi $p \leq 0,05$. Controle pressórico foi realizado em todos os pacientes durante o ensaio.

Resultado: A média etária foi de 64 anos (variando de 60 a 79 anos) com escolaridade média de 12 anos (variando de 4 a 20

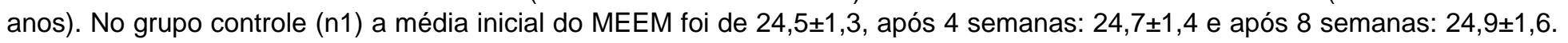
No grupo com Ouro monoatômico (n2) a média inicial do MEEM foi de $24,8 \pm 1,7$, após 4 semanas: $24,1 \pm 1,9$ e após 8 semanas: 24,6 $\pm 1,5$. No grupo com ORMUS (n3) a média inicial do MEEM foi de $24,2 \pm 1,6$, após 4 semanas: $24,4 \pm 1,6$ e após 8 semanas: $24,1 \pm 1,7$. Quanto ao score da EEP-10 no grupo n1 foi de $17,6 \pm 1,1$ no início, com 4 semanas: $17,8 \pm 1,0$ e após 8 semanas: $17,7 \pm 1,3$. No grupo $n 2$ o score inicial da EEP-10 foi de $18,2 \pm 0,9$, com 4 semanas: $17,2 \pm 1,1$ e com 8 semanas: $17,5 \pm 0,8$. No grupo

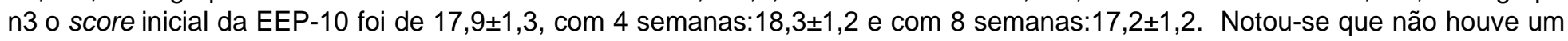
incremento significativo $(p<0,05)$ na pontuação do MEEM e tampouco redução do estresse percebido (score da EEP-10) no grupo submetido ao Ouro monoatômico ou no grupo com ORMUS, tanto nas avaliações da quarta semana, quanto nas avaliações da oitava semana do estudo. Não houve variação nos níveis pressóricos em pacientes de qualquer grupo durante o ensaio

Conclusão: Os resultados não sancionaram os benefícios alegados destas substâncias, portanto não validam o uso deste tipo 


\section{Referências}

Breve história dos usos medicinais do ouro (canal científico UNICAMP). Disponível em: .

CHRIS EMMONS, R.Ph. Ormus: modern day alchemy. Dreamgate Press 17601 Rainier Dr Santa Ana, CA 92705 EUA 2009. Disponível em: < https://www.amazon.com/Ormus-Modern-Day-Alchemy-Collection/dp/0981584012>.

COHEN, S.; Karmack, T.; Mermelsteinm, R. A global measure of perceived stress. J Health Soc Behav., 24 (4): 385-96, 1983. Disponível em: .

FOLSTEIN, M.F.; Folstein, S.E.; McHugh, P.R. «l"Mini-mental statel". A practical method for grading the cognitive state of patients for the clinician». Journal of Psychiatric Research, 12 (3): 18998, 1975. Disponível em: < https://pubmed.ncbi.nlm.nih.gov/1202204/ >.

LUFT, Caroline Di Bernardi et al. Versão brasileira da Escala de Estresse Percebido: tradução e validação para idosos. Rev. Saúde Pública, São Paulo, v. 41, n. 4, p. 606-615, 2007. Disponível em:

MELO, Denise Mendonça de; BARBOSA, Altemir José Gonçalves. O uso do Mini-Exame do Estado Mental em pesquisas com idosos no Brasil: uma revisão sistemática. Ciênc. Saúde coletiva, Rio de Janeiro, v. 20, n. 12, p. 3865-3876, Dez. 2015. Disponível em:

Sobre o ouro monoatômico? Disponível em: < http://bioquantica.weebly.com/ormus-histoacuteria-2.html>. What Are Monatomic Elements? The Science of Alchemy White Powder. Disponível em: . Todas referências revisadas com acesso em: 16/08/2020. 


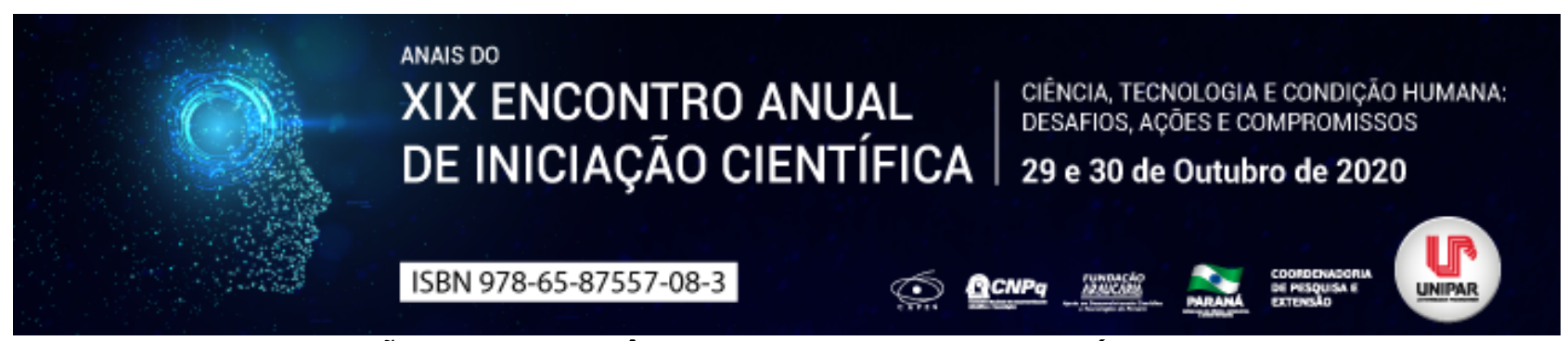

REABILITAÇÃO FISIOTERAPÊUTICA EM PACIENTES COM SÍNDROME DE RETT

\title{
${ }^{1}$ VANESSA GABRIELE ENDLER, ${ }^{2}$ JESSICA JUSSARA SCHENKNECHT, ${ }^{3}$ DORA DE CASTRO AGULHON SEGURA
}

\author{
${ }^{1}$ Acadêmica do Curso de Fisioterapia da UNIPAR \\ ${ }^{1}$ Acadêmica do Curso de Fisioterapia da UNIPAR \\ ${ }^{2}$ Docente da UNIPAR
}

Introdução: A Síndrome de Rett é uma enfermidade neurológica progressiva, que se manifesta principalmente em meninas, mas pode acometer também o gênero masculino (MOOG et al., 2003). A desordem afeta o gene do cromossomo $X$, sem a proteína produzida por este gene ocorre um mecanismo de repressão da transcrição, desligando assim outros genes. A doença compromete aproximadamente uma em cada 10.000 pessoas (SANTOS et al., 2018). Para Kaufmann et al. (2012), as crianças com Síndrome de Rett se isolam e podem apresentar um comportamento atípico decorrente do atraso mental. O quadro clínico é extenso e limita o desenvolvimento neuropsicomotor, promovendo respostas atrasadas ou ausentes aos estímulos interativos. As características são incuráveis e incapacitantes, atrapalham sumariamente o processo de reabilitação do paciente. As técnicas terapêuticas proporcionam benefício das funções cognitivas, motoras e a melhora na qualidade de vida, reduzindo as dificuldades, ajustando o portador ao convívio social. A fisioterapia é imprescindível e altamente importante no estímulo da aquisição das habilidades e na interação social (NEUL et al., 2010).

Objetivo: Abordar a atuação da reabilitação fisioterapêutica no tratamento da Síndrome de Rett.

Desenvolvimento: O pesquisador Andreas Rett, em 1954, identificou algumas características da Síndrome de Rett através de um estudo em meninas que manifestavam comportamento autista, de apraxia da marcha, perda de expressão facial e movimentos repetitivos das mãos (MONTEGGIA; KAVALI, 2010). As formas clínicas da Síndrome de Rett são descritas em três categorias: Primeira, clássica ou típica, que compõem cerca de $80-90 \%$ dos casos, como destaque a criança tem seu desenvolvimento considerado dentro do padrão entre os 6 a 18 meses de idade; Segunda, variante ou atípica, representando cerca de 40\% dos casos, esta possui 5 variedades; e Terceira, com leve dificuldade de aprendizado, descrita como rara (ARON et al., 2019). Para Santos et al. (2018), esta síndrome possui um alto grau de gravidade por considerar os danos cognitivos e motores, diante disto se faz necessário o uso de fisioterapia logo que diagnosticada, considerando a sua grande influência na postura e independência. A fisioterapia é muito eficaz no tratamento do quadro clínico, pois normaliza o tônus muscular, fortalece e alonga a musculatura, retarda a escoliose, e ajuda na estimulação dos membros e ajustamento do desenvolvimento motor (QUEIROZ; BARROS; CALLES, 2014). O tratamento se caracteriza por ser lento, com o objetivo de que o paciente continue se sentindo motivado em realizar as atividades diárias (SANTOS et al., 2018).

Conclusão: As técnicas promovidas pelo tratamento fisioterapêutico influenciam e trazem avanços no desenvolvimento neuromotor infantil de portadores de Síndrome de Rett, promovendo grande influência na melhora de controle de tronco, equilíbrio, fortalecimento muscular e independência funcional. Além disso, se destacam técnicas de estimulação social cognitiva, que são consideradas muito populares em outros transtornos neurológicos com características similares, imprescindíveis na socialização da criança.

\section{Referências}

ARON, W. C. et al. Síndrome de Rett: Analisis molecular del gen MECP2 en pacientes chilenas. Revista Chilena de Pediatría, v. 90, n. 2, p. 152-156, 2019.

KAUFMANN, W. E. et al. Social impairments in Rett Syndrome: Characteristics and relationship with clinical severity. J Intellect Disabil Res, v. 56, p. 233-47, 2012.

MONTEGGIA, L. M.; KAVALI, E. T. Rett Syndrome and the impact of MeCP2 associated transcriptional mechanisms on neurotransmission. Biol Psychiatry, v. 65, n. 3, p. 204-210, 2010.

MOOG, U. et al. Neurodevelopmental disorders in males related to the gene causing Rett Syndrome in females (MECP2). European Journal of Pediatric Neurology, p. 05-12, 2003.

NEUL, J. L. et al. Síndrome de Rett: Critérios de diagnóstico e nomenclatura revisados. Anais de Neurologia, v. 68, n. 6, p. $944-$ 950, 2010.

QUEIROZ, C. M. B.; BARROS, J. E. S. L.; CALLES, A. C. N. As características da Síndrome de Rett: Uma revisão de literatura. Ciências Biológicas e da Saúde, v. 2, n. 2, p. 43-54, 2014.

SANTOS, Y. K. S.; DIAS, N. R. D.; SOUZA, M. C. A.; SOUZA, S. S.; COUTINHO, B. G.; LIMA, W. J. M. Síndrome de Rett: Um olhar para a fisioterapia. Revista Campo do Saber, v. 4, n. 6, p. 48-50, 2018. 
Coordenadoria de Pesquisa e Extensão - COPEX

Departamento de Editoraçāo e Divulgaçāo Científica - DEDIC 


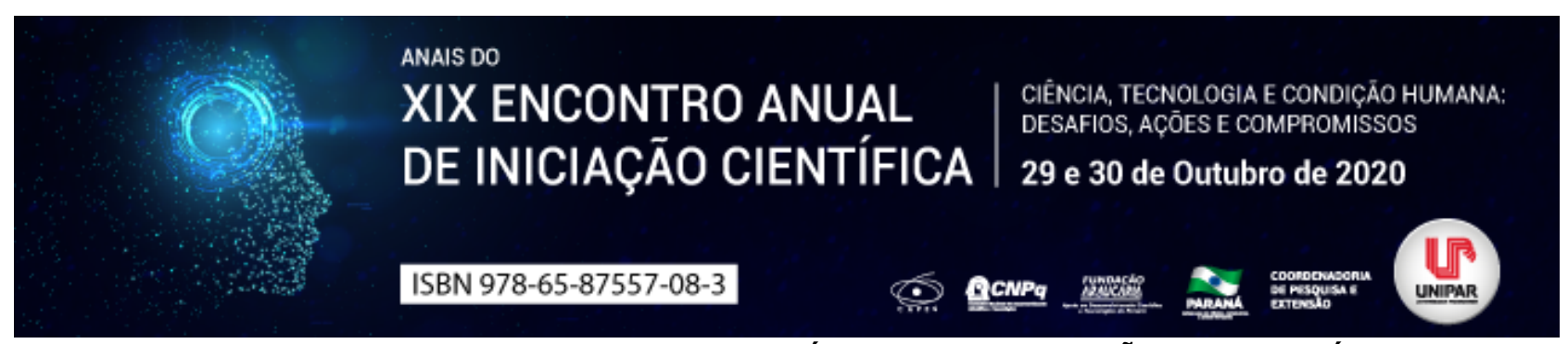

POTENCIAL ANTIBACTERIANO DE FITOTERÁPICOS: UMA REVISÃO BIBLIOGRÁFICA

\begin{abstract}
${ }^{1}$ BRUNO HENRIQUE NESI, ${ }^{2}$ ANA ALICE BERNARDI COZER, ${ }^{3}$ STEFANY DE OLIVEIRA, ${ }^{4}$ PATRICIA AMARAL GURGEL VELASQUEZ, ${ }^{5}$ ALESSANDRO RODRIGUES PERONDI, ${ }^{6}$ FRANCIELE DO NASCIMENTO SANTOS ZONTA
\end{abstract}

\author{
${ }^{1}$ Acadêmico do Curso de Enfermagem. PIC/UNIPAR \\ ${ }^{1}$ Acadêmica do Curso de Enfermagem - PIC/UNIPAR \\ ${ }^{2}$ Acadêmica do Curso de Enfermagem da UNIPAR \\ ${ }^{3}$ Docente da UNIPAR \\ ${ }^{4}$ Docente da UNIPAR \\ ${ }^{5}$ Docente da UNIPAR
}

Introdução: A comunidade científica tem buscado novas alternativas para que os índices e os custos de tratamento de quadros relacionados à resistência bacteriana diminuam, para tanto, pesquisas com fitoterápicos têm ganhando cada vez mais espaço, demonstrando que as plantas pesquisadas demonstram potencial inibitório contra as bactérias. Tais pesquisas com plantas são possíveis devido a implementação da Política Nacional de Práticas Integrativas e Complementares (PNPIC), através da PORTARIA No 971, DE 3 DE MAIO DE 2006 (SANTOS, 2017).

Objetivo: Descrever o potencial dos fitoterápicos como antimicrobianos através de uma revisão da literatura.

Desenvolvimento: A resistência bacteriana aos antibióticos é um dos problemas de saúde pública mais relevante, pois muitas bactérias, anteriormente suscetíveis aos antibióticos usualmente utilizados, deixaram de responder a esses fármacos. A resistência ocorre por vários fatores, entre eles o uso irracional do fármaco, a não adesão à terapêutica por parte dos pacientes, automedicação, a falta de conhecimento dos prescritores e da população (LOUREIRO, 2016). A resistência se dá por vários mecanismos, dentre eles, a alteração no DNA da bactéria, que pode ser uma resistência natural ou adquirida, além disso, mutação cromossômica; transferência (transformação, transdução, conjugação, transposição); inativação enzimática ( $\beta$ lactamase); alteração de permeabilidade do fármaco e alteração no sítio de ação do fármaco (RIBEIRO, 2016). Devido a isso, novas terapêuticas vêm sendo buscadas para o combate as bactérias, e sua resistência aos antibióticos, dentre elas cita-se a fagoterapia, onde fagos, um tipo de vírus que ataca as bactérias, matando-as, podendo ser classificadas conforme sua morfologia, propriedades físico-químicas e biológicas (MARCHIOTTI, 2016), além do uso dos fitoterápicos como terapia alternativa.Os fitoterápicos são divididos pela Agência Nacional de Vigilância Sanitária (ANVISA), conforme a Resolução da Diretoria Colegiada (RDC) $n^{\circ} 10$ de 2010, em duas subclasses: as plantas medicinais, que é toda a espécie vegetal, cultivada ou não, com o objetivo de tratar, aliviar ou curar doenças, baseando-se nos conhecimentos populares e culturais; e o medicamento fitoterápico, que é obtido através de parte de uma planta e passa por um processo industrial para obtenção de seu extrato, óleo, solução, dentre outras formas, devendo seguir controles de qualidade, embalagem e rotulação, conforme a RDC (MENDONÇA, 2018). No caso das plantas, surgem dos metabólitos secundários, que também servem para sobrevivência e defesa. Esses metabólitos dividem-se em três classes: os terpenóides (é a maior classe, são formados por unidades de isopropeno, destes ressalta-se os óleos essenciais), os alcalóides (compostos cíclicos em que seu anel possui ao menos um átomo de nitrogênio, tem efeito intenso no sistema nervoso, como morfina, cocaína e cafeína) e os compostos fenólicos (em seu anel aromático há uma hidroxila ligada, dentre estes estão os flavonoides responsáveis pela coloração, por exemplo, esta classe é subdividida em antocianinas, flavonas e flavonóis). Uma pesquisa realizada por SOUZA (2018) avaliou diversas espécies de plantas, entre elas as mais comuns, como o Alecrim (Rosmarinus officinalis), a Camomila (Matricaria chamomilla) e o Cravo-da-índia (Syzygium aromaticum), e conclui que todas as plantas testadas apresentaram atividade antibacteriana semelhante ou superior aos antibióticos, em diferentes concentrações testadas, comprovando a eficácia dos fitoterápicos. Em outras pesquisas realizadas, como a de SATO (2018), onde testou a Cerejeira do Mato (Eugenia involucrata), a mesma obteve inibição bacteriana para Staphylococcus aureus e Candida krusei, através do extrato da folha; JARDIM (2019) realizou testes com folhas de Gengibre (zingiber officinale roscoe), tendo efeito inibitório frente a isolados de Escherichia coli, sendo utilizado na forma de chá.O Brasil detém uma vasta diversidade em plantas, possibilitando que as mesmas sejam exploradas cientificamente, para que tenham sua eficácia comprovada. Entretanto, nota-se que falta incentivo da parte dos gestores de saúde e que ainda se faz necessário que os profissionais de saúde passem por mais capacitações referentes ao assunto, para que estes detenham o conhecimento acerca das plantas, para que saibam usá-las com segurança, unindo esse conhecimento ao conhecimento popular, tornando o uso dos fitoterápicos mais recorrente, principalmente no cenário microbiológico (SANTOS, 2017).

Conclusão: A utilização dos fitoterápicos como antibacterianos ainda é algo novo, mas que já demonstra sua eficácia diante das pesquisas realizadas. É necessária a promoção dessa prática, pois grande parte da população não tem conhecimento sobre sua 
utilização e eficácia. Eles apresentam-se com elevado potencial de uso, levando em consideração o aumento significativo da resistência bacteriana nos últimos anos, especialmente por tratar-se de um método mais acessível para a população e que poderá proporcionar redução de custos para instituições e gestores de saúde.

\section{Referências}

AGÊNCIA NACIONAL DE VIGILÂNCIA SANITÁRIA. Resolução RDC no 10, de 9 de março de 2010. Dispõe sobre a notificação de drogas vegetais junto à Agência Nacional de Vigilância Sanitária e dá outras providências. Diário Oficial da União, 2010.

JARDIM, Mauro Fernandes Aparecido et al. Atividade antibacteriana e antioxidante dos extratos aquosos das folhas e dos rizomas de zingiber officinale roscoe cultivadas no horto medicinal da unipar/Antibacterial and antioxidant activity of water extracts of zingiber officinale roscoe leaves and rhizomas cultivated in unipar's medical court. Brazilian Journal of Development, v. 5, n. 10, p. 18292-18309, 2019.

LOUREIRO, Rui João et al. O uso de antibióticos e as resistências bacterianas: breves notas sobre a sua evolução. Revista Portuguesa de saúde pública, v. 34, n. 1, p. 77-84, 2016.

MARCHIOTTI, MATHEUS CORDEIRO et al. FAGOTERAPIA: UMA ALTERNATIVA SIMPLES E BARATA PARA O TRATAMENTO DE INFECÇÕES BACTERIANAS RESISTENTES À ANTIBIOTICOTERAPIA. REVISTA UNINGÁ REVIEW, v. 26, n. 2, 2016.

MENDONÇA, Valéria Melo et al. Fitoterapia tradicional e práticas integrativas e complementares no sistema de saúde do Brasil. 2018.

RIBEIRO, M.; CORTINA, M. A. As principais bactérias de importância clínica e os mecanismos de resistência no contexto das Infecções Relacionadas à Assistência à Saúde (IRAS). Rev. Cien. UMC Mogi das Cruzes, v. 1, p. 1-1, 2016.

SANTOS, Valéria Pereira; TRINDADE, Luma Mota Palmeira. A enfermagem no uso das plantas medicinais e da fitoterapia com ênfase na saúde pública. Revista Científica FacMais, v. 8, n. 1, p. 16-34, 2017.

SATO, Tatiane Satie et al. Proposta de formulação contendo extrato de folhas de Eugenia involucrata e análise da atividade antimicrobiana. 2018.

SOUZA, Tainá AA; PESSOA, Flávia OA; PESSOA, Moisés S. Produtos naturais com atividade antimicrobiana frente a patógenos de interesse humano. Journal of Applied Pharmaceutical Sciences, v. 5, n. 3, p. 8-18. 


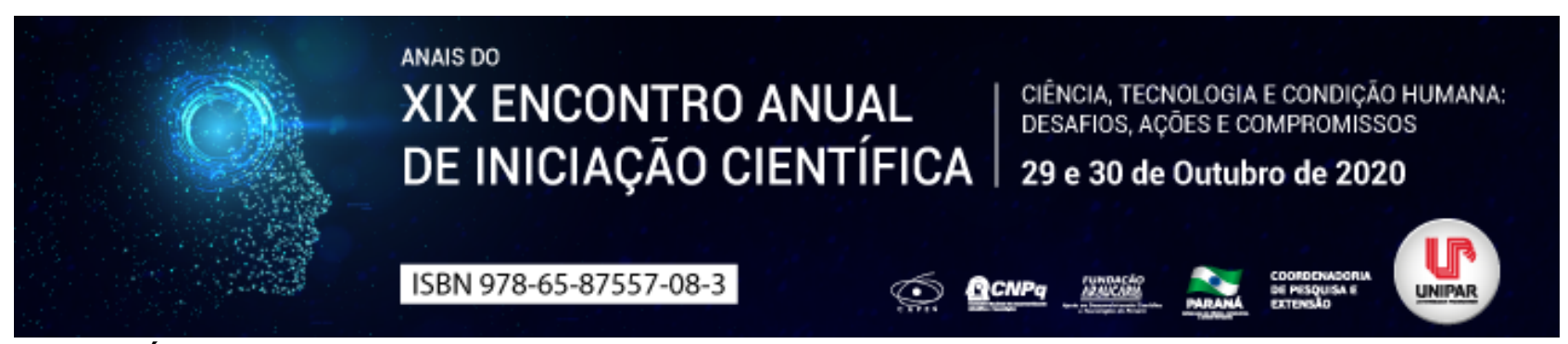

ANÁLISE SOBRE O IMPACTO NA QUALIDADE DE VIDA DOS PORTADORES DA EPILEPSIA

\begin{abstract}
${ }^{1}$ ESTER PELEGRINI SILVA, ${ }^{2}$ CAMILA MARIA ESCARDILLE YOSHITANI, ${ }^{3}$ DAVI CORREA PEREIRA, ${ }^{4}$ FABIANE ANGELICA DE PAIVA PAULA, ${ }^{5}$ JESSICA ZANQUIS FERREIRA , ${ }^{6}$ ELENIZA DE VICTOR ADAMOWSKI CHIQUETTI
\end{abstract}

\author{
${ }^{1}$ Acadêmica do Curso de Medicina participando do PIC/UNIPAR \\ ${ }^{1}$ Acadêmica do Curso de Medicina da UNIPAR, bolsista do PIBIC/UNIPAR \\ ${ }^{2}$ Acadêmico do Curso de Medicina da UNIPAR, bolsista do PEBIC/CNPQ \\ ${ }^{3}$ Acadêmica do Curso de Medicina da UNIPAR \\ ${ }^{4}$ Acadêmica do Curso de Medicina da UNIPAR \\ ${ }^{5}$ Docente do Curso de Medicina da UNIPAR
}

Introdução: O cérebro humano funciona como uma complexa máquina em constante ação. Esse importante órgão possui aproximadamente 100 bilhões de neurônios de formas e tamanhos diferentes, que realizam diversas conexões, as sinapses (MORA, 2016). Pessoas portadoras de epilepsia, possui uma desordem cerebral, caracterizada por interrupções no funcionamento normal do cérebro (FISHER et al., 2005). Para identificar a epilepsia é feito além do diagnóstico clínico, exames complementares como eletroencefalograma (EEG) que é uma maneira de se obter uma avaliação mais apurada (BATISTA et al., 2020). Crises epiléticas são imprevisíveis, o que diminui a autoconfiança, a autonomia e a sensação de liberdade do indivíduo, isso altera a individualidade do epilético, causando-lhe alterações psíquicas, o que dificulta o relacionamento consigo mesmo e com a sociedade, diminuindo sua qualidade de vida (CALAZANS; BELÉM 2019).

Objetivo: Analisar a literatura referente ao impacto que a epilepsia gera na qualidade de vida dos seus portadores.

Desenvolvimento: O cérebro é responsável por funções que ditam quem somos, o que fazemos e até o que sentimos, pois, atividades como vigília e sono, fome e saciedade, alegria e a tristeza, são alguns exemplos do que esse complexo órgão pode comandar (MORA, 2016). Sabendo que a epilepsia causa uma interrupção no funcionamento normal do cérebro, o seu diagnóstico é um desafio a ser enfrentado, visto que pode trazer um impacto negativo para a pessoa, sua família e na sociedade na qual está inserida (TEDRUS; PEREIRA; ZOPPI, 2018). Dentre as diversas causas dessa condição neurológica encontra -se traumas cranianos, danos cerebrais durante a gestação, herança genética (RIGATTI; TREVISOL-BITTENCOURT, 1999). Dentre os problemas que mais afetam a qualidade de vida dos portadores de epilepsia encontra-se comorbidades como depressão em ambos os sexos e psicose que é a de maior impacto negativo dentre elas. Essas são comorbidades psiquiátricas são comumente desenvolvidas em portadores dessa condição clínica, além de outros problemas como ansiedade, abuso de álcool e drogas. É importante, ainda, destacar a imprevisibilidade do momento em que a crise pode acontecer, gerando insegurança no portador (CALAZANS; BELÉM 2019). Esse distúrbio neurológico revela a dificuldade em lidar com as crises epiléticas, problemas comportamentais e até sociais, sendo evidente o impacto na integridade familiar do indivíduo (TISSER et al., 2016).

Conclusão: Foi observado que a pessoa portadora de epilepsia sofre grande impacto em sua qualidade de vida, visto que essa condição comumente desenvolve outras comorbidades psíquicas associadas. Outra situação é que o paciente vivencia a dificuldade na aceitação do diagnóstico, sente-se impotente, podendo ter alteração em sua individualidade. Foi analisado, ainda, que a depressão e a psicose é o que mais atinge negativamente a qualidade de vida da pessoa, dentre outros fatores como ansiedade, abuso de álcool e drogas. Destaca-se, então, que essa condição clínica carrega consigo, risco elevado de desenvolvimento de distúrbios psiquiátricos, afetando a qualidade de vida dos seus portadores.

\title{
Referências
}

BATISTA, Carla. et al. Impacto do EEG Ambulatório de 24 Horas na abordagem clínica a doentes com suspeita de Epilepsia. RevSALUS, p. 14, 2020. Disponível em: http://hdl.handle.net/10400.26/32554. Acesso em: 22 jun. 2020.

CALAZANS, Ana Bárbara dos Santos; BELÉM, Nathália Paraíso. Impacto das alterações psiquiátricas na qualidade de vida dos pacientes portadores de epilepsia: revisão integrativa da literatura. Centro Universitário Tiradentes - UNITIAL, 28, out. 2019. Disponível em: http://openrit.grupotiradentes.com:8080/xmlui/handle/set/2712. Acesso em: 02 fev. 2020.

FISHER, Robert S. et al.. Epileptic seizures and epilepsy: definitions proposed by the International League Against Epilepsy (ILAE) and the International Bureau for Epilepsy (IBE). Epilepsia, v. 46, n. 4, p. 470-472, 2005. Disponível em: https://doi.org/10.1111/j.0013-9580.2005.66104.x. Acesso em: 05 fev. 2020.

MORA, Francisco. Continuum: Como Funciona o Cérebro?. 1. ed. São Paulo: Artmed Editora, 2016.

RIGATTI, Marcelo; TREVISOL-BITTENCOURT, Paulo Cesar. Causas de epilepsia tardia em uma clínica de epilepsia do Estado de Santa Catarina. Arquivos de Neuro-Psiquiatria, v. 57, n. 3B, p. 787-792, 1999. Disponível em: https://doi.org/10.1590/S0004- 
282X1999000500009. Acesso em: 22 jun. 2020.

TEDRUS, Glória Maria Almeida Souza; PEREIRA, Renato Buarque; ZOPPI, Mariana. Epilepsy, stigma, and family. Epilepsy \& Behavior, v. 78, p. 265-268, 2018. Disponível em: https://doi.org/10.1016/j.yebeh.2017.08.007. Acesso em: 05 jul. 2020.

TISSER, Luciana Alves et al.. Influência do controle de crises no desenvolvimento de crianças com epilepsia: inteligência, comportamento, qualidade de vida e sono. Orientador: Magda Lahorgue Nunes. 2016. Tese (Pós-graduação em Medicina)

Pontifícia Universidade Católica do Rio Grande do Sul, 2016.

Coordenadoria de Pesquisa e Extensão - COPEX

Departamento de Editoraçāo e Divulgaçāo Científica - DEDIC 


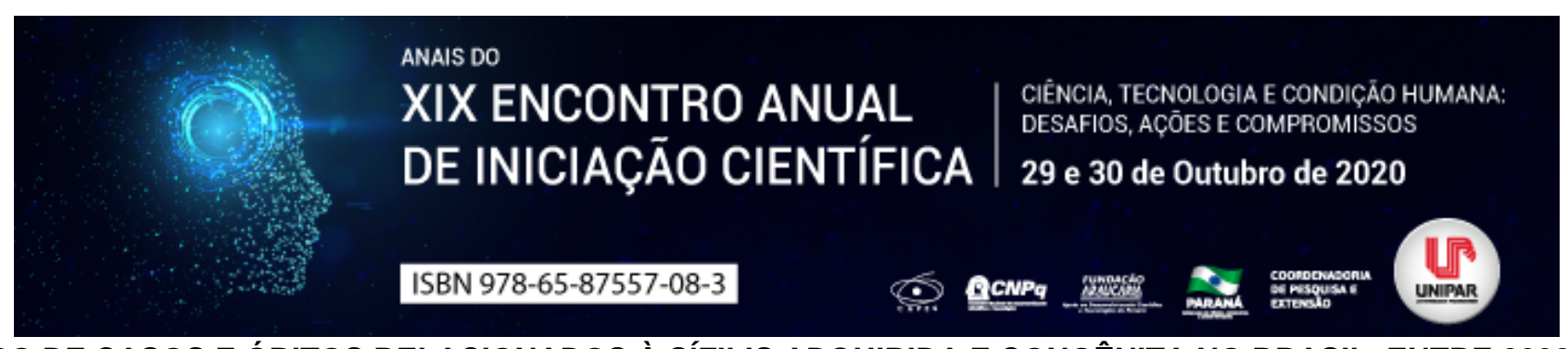

NÚMERO DE CASOS E ÓBITOS RELACIONADOS À SÍFILIS ADQUIRIDA E CONGÊNITA NO BRASIL, ENTRE 2008 E 2019

\author{
${ }^{1}$ MARIANA SAUSEN BASSO, ${ }^{2}$ LUCAS ALEXANDRE GUBERT SCHIER, ${ }^{3}$ LETICIA NOGUEIRA ALVES DA SILVA, ${ }^{4}$ YASMIN \\ NAVA SINHORIN, ${ }^{5}$ ELENIZA DE VICTOR ADAMOWSKI CHIQUETTI
}

${ }^{1}$ Discente do Curso de Medicina/UNIPAR
${ }^{1}$ Discente do Curso de Medicina/UNIPAR
${ }^{2}$ Discente do Curso de Medicina/UNIPAR
${ }^{3}$ Discente do Curso de Medicina/UNIPAR
${ }^{4}$ Docente do Curso de Medicina da UNIPAR

Introdução: A Sífilis é uma IST (infecção sexualmente transmissível), causada pela bactéria Treponema pallidum, que afeta apenas humanos, existente na forma Adquirida, transmitida por via sexual, ou Congênita, quando a doença é transmitida pela mãe ao feto, durante a gestação, ou no parto. Os dados levantados pelo Datasus (Departamento de Informática do SUS), apontam para o crescimento no número de casos, seguidos pelo número de óbitos por Sífilis no Brasil entre os anos de 2008 a 2019, apesar de se tratar de uma doença curável, e evitável. A Sífilis pode ser apresentar assintomática e, de acordo com Lago; Garcia (2000), tal fato colabora para a transmissão direta da doença. Por ser uma IST, as medidas profiláticas são relativamente simples, e acessíveis, sendo suficiente o uso de preservativos para prevenir o contágio da Sífilis Adquirida, enquanto que a Sífilis Congênita pode ser controlada quando o diagnóstico da gestante é feito de forma precoce. A falta de conhecimento de tais fatos, bem como da importância e seriedade da enfermidade, parece contribuir para o aumento do número de casos, de acordo com Figueiredo et al. (2020). O serviço de atenção à gestante do SUS preconiza exames e acompanhamento para tal doença, bem como oferece medicamentos do tipo Benzatina (Benzetacil), atualmente o tratamento mais indicado para a doença, com $98 \%$ de eficiência, de acordo com o Ministério da Saúde (2020). Sendo uma doença curável e evitável, levanta-se a questão do porquê os números vêm aumentando, principalmente considerando que anualmente o acesso à dados e informações se torna mais acessível.

Objetivo: Apresentar informações quantitativas quanto aos dados relacionados aos casos registrados de Sífilis Congênita e Adquirida, relacionando com o número de óbitos registrados, tendo como base os números publicados pelo Ministério da Saúde em Boletins Epidemiológicos, e também disponíveis pela plataforma do Datasus, com o intuito de angariar informações e relacionar dados, que corroboram para possíveis melhorias ou adaptações em Políticas Públicas que prezam prevenção e tratamento.

Desenvolvimento: Os números levantados pelo Ministério da Saúde explicitam a realidade do crescimento da quantidade de casos registrados, bem como de óbitos, relacionados com os vários tipos de Sífilis. Tal fato, já era previsto por Lago; Garcia (2000), em análise realizada antes mesmo do período apurado em estudo, que apontava um alto índice de não percepção de casos de Sìilis Congênita, ocasionando complicações pós-parto e, muitas vezes, situações emergenciais. A constatação de que $50 \%$ dos recém nascidos com tal condição se caracterizam por serem assintomáticos, causa dificuldade no diagnóstico quando não há desconfiança por parte do médico. Os autores afirmam que tal movimento colabora para o crescimento do número de casos no Brasil, fato que ocorreu nos anos seguintes, conforme discussão apontada por Brito (2020), em que o autor relata a fala do então Ministro da Saúde, Sr. Luiz Henrique Mandetta, que afirmara que a Sífilis se trata do maior problema quando abordado o assunto relacionado à IST (Infecções Sexualmente Transmissíveis), com 158.051 casos registrados apenas no ano de 2018. Tal questão chama atenção, uma vez que trata-se de uma doença que pode ser prevenida com cuidados e atenção básica em saúde, visando a interrupção da cadeia de transmissão conforme citado por Avelleira; Bottino (2006), quando colocado que a detecção precoce pode ser a chave para evitar a transmissão sexual no caso da Sífilis Adquirida, responsável por 95\% dos contágios, e também vertical no caso da Sífilis Congênita. Tal detecção poderia ser feita com aplicação de testes rápidos, ou com estratégia de prevenção primária através da informação à população. Em publicação recente, Figueiredo et al. (2020) aponta a existência de uma relação clara e direta entre a disponibilidade de acesso à métodos de detecção diagnóstica e métodos terapêuticos na atenção primária e o volume de transmissão vertical de Sífilis, sendo evidenciado que a maior atenção voltada à detecção primária resulta em uma menor incidência de transmissão.No que tange dados oficiais, o Boletim Epidemiológico de Outubro de 2019, publicado pelo Ministério da Saúde, aponta um aumento de 4.157\% no número de casos de Sífilis Adquirida e Congênita, quando comparados os anos de 2018 e 2010. Ainda no ano de 2018, o número de óbitos correspondeu à cerca de $1 \%$ do total de casos, mas a quantidade de casos representou mais de $25 \%$ de aumento em relação à 2017.

Conclusão: $\mathrm{A}$ análise dos dados e a apresentação do número de casos e óbitos relacionados à Sífilis, bem como a sua curva ascendente, servem como base para estudos relacionados à Políticas Públicas de Saúde que visem a prevenção e/ou a cura 
precoce da pessoa infectada. Tomando-se por base o aumento nos casos da doença, os números sugerem que as medidas tomadas pela população e pela rede pública de atenção à saúde não estão sendo suficientes para diminuir, ou sequer frear a disseminação de casos de Sífilis. Na condição de uma doença evitável e tratável, o aumento de casos deve ser estudado a fim de que ocorra a promoção de políticas de saúde, especialmente no que tange atenção primária, tanto à gestante, quanto visando a detecção precoce da doença.

\section{Referências}

AVELLEIRA, João Regazzi; BOTTINO, Giuliana; Sífilis: Diagnóstico, tratamento e controle - Anais Brasileiros de Dermatologia. vol.81 no.2 - Rio de Janeiro, 2006

BRASIL, Ministério da Saúde, Boletim Epidemiológico de 2019 - Secretaria de Vigilância em Saúde - Ministério da Saúde Outubro/2019. Disponível em https://g1.globo.com/ciencia-e-saude, acesso em 20/08/2020

BRITO, Carlos; Brasil tem 18 casos de Sífilis por hora Revista de Ciência e Saúde G1, 2020. Disponível em https://g1.globo.com/ciencia-e-saude, acesso em 20/08/2020

DATASUS: Informações de Saúde, Sistema de Informações sobre Mortalidade. Disponível em http://www2.datasus.gov.br/DATASUS, acesso em 31/07/2020

FIGUEIREDO, Daniela Cristina; et al - Relação entre oferta de diagnóstico e tratamento da sífilis na atenção básica sobre a incidência de sífilis gestacional e congênita - Cadernos de Saúde Pública - vol.36 no.3 Rio de Janeiro, 2020

LAGO, Eleonor; GARCIA, Pedro. Sífilis Congênita: uma emergência emergente também no Brasil - Jornal de Pediatria da

Sociedade Brasileira de Pediatria, 0021-7557/00/76-06/461, 2000 


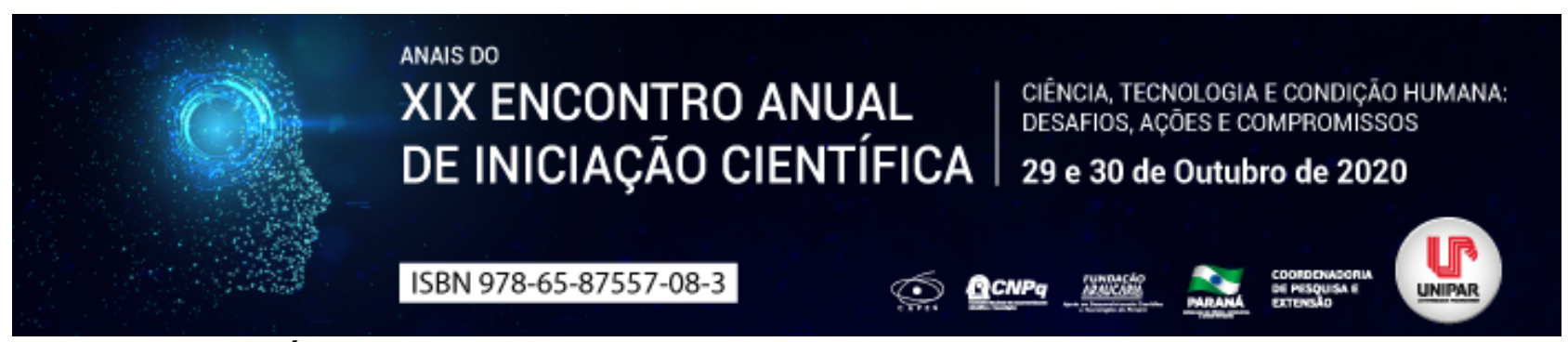

ABORDAGEM CIRÚRGICA DE FRATURA COMPLEXA DE FACE E SEUS DESAFIOS- RELATO DE CASO

\begin{abstract}
${ }^{1}$ Anny isabelly dos santos souza, ${ }^{2}$ CAIO FOSSALUSSA DA SILVA, ${ }^{3}$ IZABELLA SOL, ${ }^{4}$ CRISTÓVÃO MARCONDES DE CASTRO RODRIGUES, ${ }^{5}$ CLAUDIA JORDÃO, ${ }^{6}$ JONAS DANTAS BATISTA
\end{abstract}

\begin{abstract}
${ }^{1}$ Anny Isabelly dos Santos Souza
${ }^{1}$ Graduanda (o) da Faculdade de Odontologia da Universidade Federal de Uberlândia (FOUFU) Uberlândia-MG.

${ }^{2}$ Residente em Cirurgia e Traumatologia Buco-maxilo-facial no Hospital de Clínicas da Universidade Federal de Uberlândia

${ }^{3}$ Residente em Cirurgia e Traumatologia Buco-maxilo-facial no Hospital de Clínicas da Universidade Federal de Uberlândia

${ }^{4}$ Doutora em Odontologia pela Universidade Estadual de Campinas

${ }^{5}$ Doutor em Odontologia na área de concentraçaõ em Cirurgia e Traumatologia Buco-maxilo-facial pela Pontifícia Universidade Católica do Rio
\end{abstract}

Introdução: Acidentes automobilísticos são um dos principais fatores das causas de urgências e emergências nos hospitais. Nos quais, o trauma facial está presente na maioria dos casos. A literatura implica que a maior incidência de acidentes ocorre em pacientes jovens, sendo prevalente na faixa etária dos 21 a 30 anos. As lesões que acomete cabeça e pescoço podem proporcionar ao paciente um impacto funcional, como alterações de oclusão dentária ou da articulação temporomandibular (ATM), risco de via aérea e possível quadros infecciosos, além de danos estéticos (MONNAZZl et al., 2002). Por isso, é de grande importância o tratamento rápido e adequado. As fraturas no terço médio da face são comuns e podem ser classificadas em Le Fort I, Le Fort II e Le Fort III (SILVA J; CAUÁS M, 2004). Ademais, o osso mandibular também costuma ser de grande importância nos traumas faciais, visto que sua posição anatômica em relação ao esqueleto facial e também por ser o único osso móvel da face (SILVA et al., 2011). Os tratamentos dessas fraturas consistem na fixação interna rígida com placas e parafusos, esse método possibilita a melhor contenção dos fragmentos, a de redução aberta e fixação com placas tornaram-se um meio mais seguro e eficaz do tratamento (OLIVEIRA et al., 2013). Vale ressaltar, que para um diagnóstico preciso e precoce dessas fraturas é de grande valia o uso de exames complementares tais como radiografias extra-órais ou tomografia computadorizada helicoidal (GOTO et al., 2007).

Relato de caso: Relato de caso clínico do tratamento cirúrgico de uma paciente vítima de acidente motociclístico de alta energia (moto x carro), sem perda de consciência no local, com capacete aberto e trauma de face importante. Paciente encaminhado para o serviço de Cirurgia e Traumatologia da Universidade Federal de Uberlândia. No exame clínico apresentava vias aéreas com grande quantidade sangue e retroposição da musculatura lingual devido à fratura cominutiva de mandíbula, levando quadro de dificuldade respiratória, no qual foi realizado intubação oro-traqueal de emergência para manutenção de via aérea. No exame de imagem, de tomografia computadorizada, foi diagnosticada fratura cominutiva bilateral de parasinfise e também LEFORT II bilateral. O paciente foi encaminhado à unidade de terapia intensiva para acompanhamento até realização da cirurgia de estabilização das fraturas de face.

O tratamento utilizado foi a redução e fixação de face por meio de bloqueio maxilo mandibular (barra de Erich) + osteossíntese das fraturas, feito o acesso extra-oral e instalação de placa do tipo load bearing 2.4/2.7 na região mandibular e para fratura lefort II foi realizado o acesso subciliar bilateral e acesso intra-oral bilateral com instalações de mini-placas do sistema 1.5 e 2.0 respectivamente. Realizou-se sutura intra-oral com monocryl 4-0 a sutura muscular com vycril 3-0 e sutura de pele nylon 5-0. 0 paciente utilizou clindamicina $600 \mathrm{mg} 3 x$ ao dia e ceftriaxona $1000 \mathrm{mg} 2 x$ ao dia durante período de internação. Por fim, o paciente se manteve na UTI até extubação ocorrida 4 dias após a abordagem cirúrgica, encaminhando para enfermaria e após dois dias de alta hospitalar com retornos ambulatórias. Como prescrição domiciliar de amoxicilina $500 \mathrm{mg} 3 \mathrm{x}$ ao dia por sete dias, dexametasona $4 \mathrm{mg} 2 \mathrm{x}$ ao dia por três dias e dipirona sódica $500 \mathrm{mg} 4 \mathrm{x}$ ao dia por três dias. Ainda, com orientação oral rigorosa e higiene das feridas com agua e sabão e compressa de água morna de 4-4horas. O paciente apresentou com evolução satisfatória, sem alterações oclusais, ausência de deiscência ou infecções dos sítios cirúrgicos. Após acompanhamento ambulatorial de 45 dias, foi realizada a radiografia pós-operatória do paciente em seguida alta ambulatorial.

Discussão: Estudos demonstram que cresce constantemente o número de fraturas faciais devidos á violência interpessoal e ás agressões físicas, no entanto as fraturas que ocorrem com maior frequência são consequência de acidentes automobilísticos (HUPP et al., 2009). Esses acidentes causam com fraturas cominutivas, que podem apresentar um grande risco para manutenção de via aérea do paciente como exposto no caso apresentado (GOTO et al., 2007). Ademais, a complicações mais comuns são respectivamente são as cicatrizes, alterações oclusais, infecções, parestesias, anosmia e assimetria facial. Sendo de grande importância a experiência do cirurgião buco-maxilo-facial no manejo desses traumas complexos, pois mesmo nos dias atuais ainda se mostram grande desafio para a especialidade. 


\section{Referências}

GOTO, AAA; AGUIAR, AS; DENARDIN, OVP, RAPPORT A. Tratamento cirúrgico das fraturas subcondilares: avaliação da abordagem retromandibular de Hinds. Rev Col Bras Cir v. 34, n.5 p. 303-8,2007.

HUPP, JR; ELLIS, E; TUCKER, MR. Cirurgia Oral e Maxilofacial Contemporânea. Elsevier, 5ed. 2009.

MONNAZZI, MS; HOCHULI-VIEIRA, E; GABRIELLI, MAC; GABRIELLI, MFR; PEREIRA FILHO V. A avaliação de complicações tardias em fraturas maxilares do tipo le fort. Rev Fac Odontol Bauru: v. 10 n.4 p.257-62, 2002.

OLIVEIRA, CCMX; JÚNIOR, EZ; JÚNIOR, QB; ALVMEIDA, HCR; PACHECO, GM. Fratura de mandíbula durante exodontia de terceiro molar inferior incluso: relato de caso. Rev. Cir. Traumatol. Buco-Maxilo-Fac. Camaragibe v.13, n.4, p. 15-20 , out./dez. 2013.

SILVA, J; CAUÁS, M. Fratura de mandíbula decorrente de acidente automobilístico: relato de caso. Odontol Clín Cient: v.3 n.3, pag 199-207, 2004.

SILVA, JJL; LIMA, AAAS; DANTAS, TB; FROTA, MHA; PARENTE, RV; LUCENA, ALSPN. Fratura de mandíbula: estudo epidemiológico de 70 casos. Rev. Bras. Cir. Plást; v. 26, n.4, pag 645-8, 2011. 


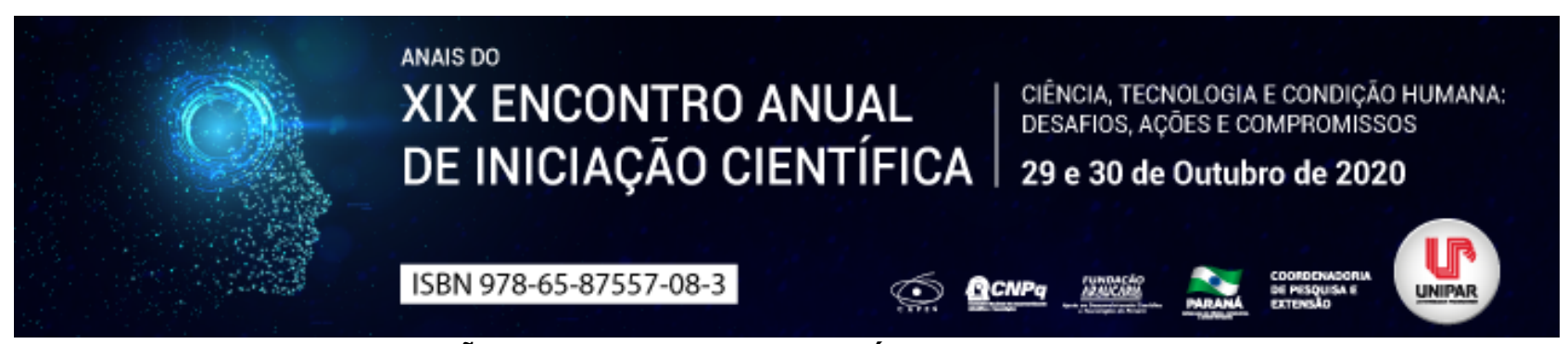

PERCEPÇÃO DOS PAIS SOBRE A SAÚDE BUCAL DOS FILHOS

${ }^{1}$ ANA KAROLYNA DAMASO TAVARES, ${ }^{2}$ MARCIEL SABATOVYTCH DE OLIVEIRA, ${ }^{3}$ LUANA CAMILA DE OLIVEIRA NIEHUES SABATOVYTCH, ${ }^{4}$ JULIANA GARCIA MUGNAI VIEIRA SOUZA

\author{
${ }^{1}$ Acadêmica do PIC/UNIPAR- Campus Cascavel \\ ${ }^{1}$ Acadêmico do PIC/UNIPAR- Campus Cascavel \\ ${ }^{2}$ Acadêmica do PIC/UNIPAR- Campus Cascavel \\ ${ }^{3}$ Docente do Curso de Odontologia UNIPAR- Campus Cascavel
}

Introdução: A abordagem familiar é indispensável para adequação e promoção do sistema de saúde. Pais e responsáveis tornam-se responsável e referência de práticas para as crianças (MASSONI et al., 2010). Considerando que a correta higiene, escovação ideal e uso do fio dental, eliminam bactérias causadoras da doença cárie, é de extrema importância que a criança tenha diariamente bons hábitos de higiene bucal (CASTILHO et al., 2013). Neste sentido, é imprescindível o conhecimento dos pais sobre a saúde bucal de seus filhos (MASSONI et al., 2010).

Objetivo: Avaliar a percepção dos pais/responsáveis sobre a saúde bucal dos filhos.

Material e método: $O$ trabalho realizado foi aprovado pelo comitê de ética em pesquisa envolvendo seres humanos (CEPEH) com o número de parecer 3.838.661. Devido a pandemia e as medidas de segurança necessárias, a pesquisa está sendo realizada de forma remota através de formulário online, e disponibilizado através de um link enviado aos pais e responsáveis. Esse contato se deu através de professores e diretores de colégios da região oeste do Paraná, envolvendo as cidades de Toledo, Cascavel e Guaíra. O público alvo é de 100 pais e responsáveis de crianças que estão matriculadas do $1^{\circ}$ ao $6^{\circ}$ ano do ensino fundamental, na faixa etária de 6 a 11 anos. Juntamente com o formulário foi enviado um áudio informativo, explicando o motivo da pesquisa o termo de consentimento livre e esclarecido. Neste estudo realizamos um questionário com perguntas objetivas sobre a erupção do primeiro molar permanente e saúde bucal. Os resultados numéricos serão analisados estatisticamente e uma análise descritiva será realizada.

Resultados: A pesquisa está em andamento, contudo, os dados são parciais. Até o presente momento foram aplicados 38 questionários, no qual os resultados parciais obtidos foram: $35,1 \%$ acreditam que a cárie dentária é transmissível; $76,3 \%$ dos pais relataram que os filhos escovam os dentes sozinhos; $42,1 \%$ considera a saúde bucal de seu filho regular; $21,1 \%$ consideram escovas com cerdas médias ideal para higienização dos dentes; $44,7 \%$ das crianças já tiveram cárie dentária; $40,5 \%$ dos pais não sabem diferenciar os dentes posteriores (molares) entre decíduos e permanentes; $92,1 \%$ julgam que os dentes anteriores são os primeiros permanentes a nascer; $52,6 \%$ não sabem quantos dentes decíduos a criança possui; $44,7 \%$ pensam que para irromper todos os dentes permanentes é necessário esfoliar algum dente decíduo previamente; $13,2 \%$ relataram ter levado o filho ao dentista a mais de 1 ano.

Discussão: Apesar dos visíveis avanços na área da saúde, a doença cárie ainda representa um grave problema bucal na infância e está fortemente ligada à influência de fatores comportamentais, com ênfase na higiene bucal (MARTINS e JETELINA, 2016). Embora seja multifatorial, diferente do que $35,1 \%$ dos pais questionados acreditam, a cárie dentária não é transmissível. A atenção à saúde no contexto familiar está tento cada vez mais visibilidade e, foi comprovada como um método muito relevante quando se pensa em adequação do sistema de saúde vigente, progredindo assim na qualidade de vida da população, pois se sabe que a família constitui o ambiente de criação de indivíduos instruindo sobre suas necessidades e aprendizados (GUIMARÃES et al., 2003). Os pais possuem um papel fundamental na abordagem educativa, na formação de valores, hábitos e comportamentos dos filhos, por esse motivo devem ter conhecimento para atuar na promoção de saúde e na supervisão da higienização bucal das crianças (MARTINS e JETELINA, 2016). De acordo com o questionário aplicado, 44,7\% dos pais julgam que para irromper os dentes permanentes é sempre necessário esfoliar um elemento decíduo previamente. Segundo Martins e Jetelina (2016), seus entrevistados também demonstraram pouco conhecimento em relação a esta mesma pergunta. Igualmente nos resultados de Massoni et al (2010), que 63,3\% tiveram o mesmo pensamento. Até o presente momento, também foi possível perceber que $92,1 \%$ dos entrevistados acreditam que os dentes anteriores são os primeiros permanentes a erupcionar, um número muito próximo do resultado de Massoni et al (2010), o qual foi 91,8\%. Quando questionados sobre o tipo de escova dental correta, $78,9 \%$ dos pais sabiam que uma boa escova de dente é aquela que possui cerdas macias. Entretanto, $42,1 \%$ avaliaram a saúde bucal do filho regular.

Conclusão: Com base nos dados já obtidos, pode-se concluir que os pais necessitam de mais informações sobre saúde bucal de seus filhos. É essencial que haja programas educativos a esse público sobre os devidos cuidados de higienização bucal para que não sejam desprezados. 


\section{Referências}

CASTILHO, Aline Rogéria Freire de et al . Influência do ambiente familiar sobre a saúde bucal de crianças: uma revisão sistemática. J. Pediatr. (Rio J.), Porto Alegre, v. 89, n. 2, p. 116-123, Apr. 2013.

COSTA MARTINS, Caroline Luana; JETELINA, Juliana de Camargo. Conhecimento dos pais sobre saúde bucal na infância e a relação com o motivo da consulta odontológica. Journal of Oral Investigations, Passo Fundo, v. 5, n. 1, p. 27-33, out. 2016. ISSN 2238-510X. Disponível em: https://seer.imed.edu.br/index.php/JOl/article/view/1024. Acesso em: 17 ago. 2020.

GUIMARÃES, Amanada Olivera et al. As origens, objetivos e razões de ser da odontologia para bebês. JBP $\mathbf{J}$ Bras Odontopediatr Odontol Bebê, Curitiba, v.6, n.29, p.83-86, 2003.

TEIXEIRA, Mayla Kezy et al. Primeiro molar permanente: estudo de prevalência de cárie em crianças. Int J Dent, Recife, v. 10, n. 4, p. 223-227, out./dez. 2011.

MASSONI Andreza Cristina de Lima Targino et al. Saúde Bucal Infantil: Conhecimento e Interesse de Pais e Responsáveis. Pesquisa Brasileira em Odontopediatria e Clínica Integrada, Universidade Federal da Paraíba, Brasil, v. 11, n. 2, p. 257-264, maio/agosto, 2010. Disponível em: https://www.redalyc.org/articulo.oa?id=63716962018

MOHEBBI, Simin Z et al. Mothers as facilitators of oral hygiene in early childhood. International Journal of Pediatric Dentistry, v. 18 , n. 1, p. 48-55, jan. 2018.

MOURA, Lúcia de Fátima Almeida de Deus; MOURA, Marcoeli Silva de; TOLEDO, Orlando Ayrton de. Conhecimentos e práticas em saúde bucal de mães que freqüentaram um programa odontológico de atenção materno-infantil. Ciênc. saúde coletiva, Rio de Janeiro, v. 12, n. 4, p. 1079-1086, Aug. 2007. 


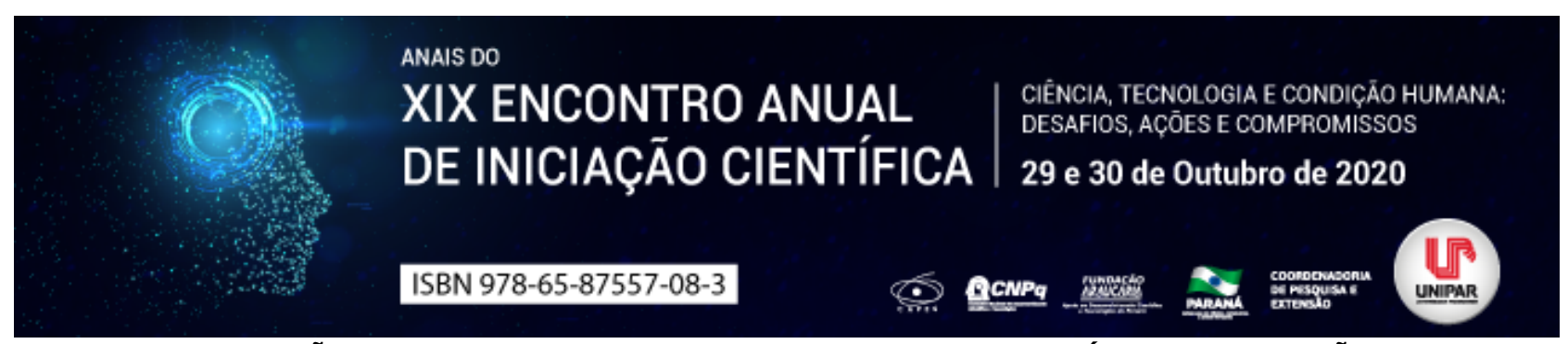

AVALIAÇÃO DA HIGIENE BUCAL DE ESCOLARES DO MUNICÍPIO DE UBIRATÃ-PR

\begin{abstract}
${ }^{1}$ ANA KAROLYNA DAMASO TAVARES, ${ }^{2}$ LUCAS GARCIA VIEIRA SOUZA, ${ }^{3}$ GEOVANE CAPANA FIDELI, ${ }^{4}$ HELEN CRISTINA LAZZARIN, ${ }^{5}$ JULIANA GARCIA MUGNAI VIEIRA SOUZA
\end{abstract}

\author{
${ }^{1}$ Acadêmica do Curso de Odontologia UNIPAR- Campus Cascavel \\ ${ }^{1}$ Acadêmico do Curso de Odontologia UNIPAR- Campus Cascavel \\ ${ }^{2}$ Acadêmico do Curso de Odontologia UNIPAR- Campus Cascavel \\ ${ }^{3}$ Docente do Curso de Odontologia UNIPAR- Campus Cascavel \\ ${ }^{4}$ Docente do Curso de Odontologia UNIPAR- Campus Cascavel
}

Introdução: A placa bacteriana é um conjunto organizado de microrganismos, a qual fica aderido nos dentes e superfície gengival, possui propriedades agressivas, podendo ser capaz de provocar uma inflamação (ALMEIDA, COUTO e GUSMÃO., 2001). Sabe-se que uma das principais medidas de promoção de saúde bucal é estimular o autocuidado por meio do controle de placa, assim, faz com que o paciente exerça seu papel na promoção da sua própria saúde como a desorganização da placa por meio do uso mecânico do fio dental e escovação (GOMES e SILVA, 2010).

Objetivo: Avaliar o índice de higiene bucal de crianças em escola urbana e rural da cidade de Ubiratã-PR.

Material e método: O presente trabalho foi aprovado pelo Comitê de ética em pesquisa envolvendo seres humanos (CEPEH) sob o parecer: 2.675.513. Foram avaliadas 57 crianças, da escola da área urbana $\mathrm{Dr}^{\circ}$ Gentil Toledo de Moraes Jr e da escola rural municipal Porto dos Santos. As séries avaliadas foram: primeiro ano, segundo ano, terceiro ano e quarto ano, com idades entre 6 e 9 anos. O exame optado para a pesquisa foi criado por Greene e Vermillion (1964), conhecido como Índice de Higiene Oral Simplificado (IHOS). Foram examinados os dentes: 16 face vestibular, 11 face vestibular, 26 face vestibular, 36 face lingual, 31 face vestibular e 46 face lingual. Este índice escolhido tem como propósito analisar a presença de biofilme nas superfícies dos elementos e concedendo assim um código de zero a três. A média individual soma os códigos de cada elemento e divide pelo total de dentes examinados. A codificação, segundo Antunes e Peres (2013), pode ser assim classificada: Zero: inexistência de placa. Um: placa cobrindo não mais de um terço da superfície dental. Dois: placa cobrindo mais de 1/3 da superfície, porém menos de 2/3. Três: placa cobrindo mais de 2/3 da superfície dentária. Após o resultado, classificamos o IHOS como: bom (0$0,6)$; regular $(0,7-1,8)$; fraco $(1,9-3,0)$. Primeiramente foi ensinado a realizar a técnica de escovação de Fones no macro modelo e em seguida realizado a escovação supervisionada das crianças. Foi realizada a parte educativa sobre promoção de saúde bucal.

Resultados: A primeira coleta foi realizada no mês de maio de 2018, obteve-se como resultado 40,35\% dos escolares com o IHOS fraco e 45,62\% tiveram resultado com índice regular. O exame foi refeito no mês de agosto, 2018, reavaliando todo o índice das crianças para ver se houve melhora. O IHOS foi $14,03 \%$ classificando assim fraco e o número de regular cresceu para $77,19 \%$.

Discussão: O biofilme é de caráter fundamental para o aparecimento da cárie, porém isso não significa que sua presença sempre resultará na progressão e aparecimento das lesões cariosas, para isso outros fatores precisam estar relacionados, como o tempo de exposição e dieta cariosa, o que deixará mais propício para tal acontecimento. O entendimento dos problemas bucais e de suas origens é de extrema relevância para saber as medidas corretas de prevenção, controle e tratamento destes. As utilizações de indicadores epidemiológicos como os índices de placa estão cada vez mais em uso, sendo muito significativo a determinação do poder discriminatório dos mesmos (SOUZA et al., 2016). Na primeira coleta o índice fraco foi bem alto, isso pode ter sido influenciado pela falta de instrução e condição socioeconômica. Segundo a pesquisa de Meneguin (2011), mostrou que a cárie tem sido relacionada a piores condições sociais, a renda familiar, o grau de instrução do pai e da mãe, moradia e classe socioeconômica propriamente dita; esses foram estaticamente significativas em relação a prevalência da doença. $\mathrm{Na}$ segunda coleta, o índice regular teve um aumento significativo tanto da escola rural e urbana. Assim como a pesquisa de Aquilante et. al. (2003), a qual mostrou uma melhora evidente na higiene bucal quando comparados os grupos experimental e controle do estudo. Souza et.al. (2016), mostra que houve melhores nos resultados do sexo feminino. Já neste trabalho, mostra melhores resultados no sexo masculino.

Conclusão: As ações educacionais, palestras e escovações dentárias supervisionadas proporcionaram o efeito esperado, visto que, relacionando os resultados iniciais e finais das crianças, em ambas as escolas, o índice IHOS prevalente nos resultados finais foi regular. Assim mostrou que houve uma grande influência positiva na melhora da higiene bucal destas crianças.

\title{
Referências
}

ALMEIDA, Jéssica Cristina de Siqueira; COUTO, Geraldo Bosco; GUSMÃO, Estla. Escovação no controle da placa: avaliação do 
ensino e motivação em escolares. Revista Gaúcha de Odontologia, Recife, v. 49, n. 3, p. 127-132, jul./ago./set., 2001.

ANTUNES, José Leopoldo Ferreira; PERES, Marco Aurélio. Epidemiologia da saúde bucal. 2 ed. São Paulo: Editora Santos, 2013.

GOMES, Viviane Elisângela; SILVA, Débora Dias; A importância do controle de placa dental na clínica odontológica. Arquivo em Odontologia, Cascavel/PR, v. 45, n. 1, p. 22-27, jan./mar. 2010.

LIMA, José Eduardo de Oliveira. Cárie dentária: um novo conceito. Revista Dental Press de Ortodontia e Ortopedia Facial, Maringá, v.12, n.6, p.119-130, nov/dez. 2007.

MENEGHIN, Marcelo de Castro et al. Impacto de programas educativos sobre condições bucais de escolares de 6 e 7 anos em duas escolas municipais do interior do Estado de São Paulo/ Brasil. Arquivos em Odontologia, Belo Horizonte, v. 48, n. 1, p. 4046, jan./mar. 2012.

OLIVEIRA, Eduardo José Pereira et al. Heróis da saúde bucal: Saúde bucal numa abordagem lúdico-recreativa. Revista Ciência em Extensão, Minas Gerais, v. 12, n. 3, p. 55-65, ago. 2016.

SOUZA, Juliana Garcia et al. Avaliação de higiene bucal de crianças atendidas na clínica odontológica da Universidade Paranaense- Campus Cascavel- PR, Brasil. Arquivos do Mudi, Cascavel/ PR, v. 20, n.1, p. 15-24, set. 2016. 


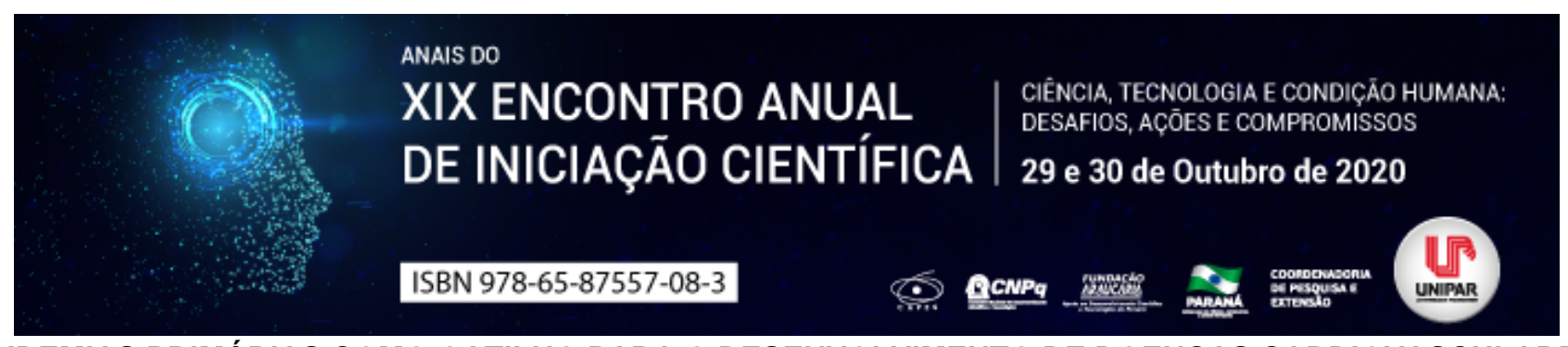

DISLIPIDEMIAS PRIMÁRIAS COMO GATILHO PARA O DESENVOLVIMENTO DE DOENÇAS CARDIOVASCULARES: UM ESTUDO DE REVISÃO

\author{
${ }^{1}$ YASMIN NAVA SINHORIN, ${ }^{2}$ BARBARA SILVA BRAVO, ${ }^{3}$ FERNANDA DE ABREU BRAGA, ${ }^{4}$ GUSTAVO RATTI DA SILVA , \\ ${ }^{5}$ FRANCISLAINE APARECIDA DOS REIS LIVERO
}

\author{
${ }^{1}$ Discente do Curso de Medicina - PIC/UNIPAR \\ ${ }^{1}$ Discente do Curso de Medicina/Bolsista - PIBIC/UNIPAR \\ ${ }^{2}$ Discente do Curso de Medicina/Bolsista - PEBIC/CNPq \\ ${ }^{3}$ Discente do PPG em Ciência Animal com Ênfase em Produtos Bioativos/Bolsista - Prosup/CAPES \\ ${ }^{4}$ Docente do Mestrado Profissional em Plantas Medicinais e do PPG em Ciência Animal - UNIPAR
}

Introdução: As dislipidemias, em geral, são uma desregulação nos níveis de lipídeos e/ou lipoproteínas plasmáticas, podendo ou não ter causas ambientais (MAGALHÃES et al., 2015). A Anvisa (2011) caracterizou as dislipidemias como uma desregulação nos níveis séricos de lipídeos na corrente sanguínea, podendo ser caracterizadas como aumento dos níveis de colesterol total (CT), triglicerídeos (TG) e de lipoproteína de baixa densidade colesterol (LDL-c) e diminuição dos níveis de lipoproteína de alta densidade colesterol (HDL-c) (ANVISA, 2011). As dislipidemias são classificadas em hipercolesterolemia isolada, HDL-c baixo, hipertrigliceridemia isolada e hiperlipidemia mista. A dislipidemia primária não contém uma causa precursora evidente, e acontece por uma mutação em um ou mais genes (XAVIER et al., 2013). Ainda, as dislipidemias estão relacionadas com o adoecimento do sistema cardiovascular devido ao acúmulo de lipídeos na túnica íntima das artérias, podendo desencadear infarto agudo do miocárdio e acidentes vasculares encefálicos (MAGALHÃES et al., 2015).

Objetivo: Compreender a íntima relação entre as dislipidemias primárias e o desenvolvimento de doenças cardiovasculares (DCV).

Desenvolvimento: As dislipidemias são apontadas como um dos maiores fatores de riscos para desenvolvimento de diversas doenças relacionadas ao sistema cardiovascular (OLIVEIRA, 2000; POZZAN et al., 2004; GAMA, 2007; FAULHABER et al., 2009; ANVISA, 2011; XAVIER et al., 2013; LOIO; MAIA, 2014; MAGALHÃES et al., 2015), devido ao acúmulo de lipídeos na parede das artérias (aterosclerose), formando placas e podendo comprometer a circulação sanguínea, o que acarreta em infarto agudo do miocárdio e doenças cardíacas isquêmicas (ANVISA, 2011). As dislipidemias secundárias são as mais comuns e são associadas a causas externas, entretanto, há grande importância nos casos de dislipidemias primárias, uma vez que, apesar de serem menos comuns que as secundárias, oferecem maior risco de desenvolvimento de DCV, visto que acompanham o paciente desde o seu nascimento (FALUDI et al., 2017). De fato, alguns estudos evidenciam que a aterosclerose e o infarto tem seu gatilho ainda na infância/adolescência sendo confirmado por necropsias e autópsias realizadas em jovens que já em sua maioria apresentavam lesões ateroscleróticas (OLIVEIRA, 2000). As dislipidemias primárias podem ser classificadas em poligênicas e monogênicas (XAVIER et al., 2013; FALUDI et al., 2017). As poligênicas não possuem grau de hereditariedade definido, são as mais comuns dentre as causas primárias, e são caracterizadas pelo efeito cumulativo de polimorfismos de um único gene no organismo (FALUDI et al., 2017). Os pacientes que possuem dislipidemia primária poligênica, quando expostos a fatores externos, terão agravo significativo no seu perfil lipídico, como o aumento do LDL-c, TG e CT, entretanto, com dieta regular e prática de exercícios físicos há diminuição do risco de desenvolvimento de dislipidemia. Já nos casos de dislipidemias monogênicas os pacientes apresentam seu perfil lipídico com maiores alterações (MADEIROS, 2013) bem como um histórico de casos familiares de aterosclerose precoce e/ou dislipidemias. Geralmente esses pacientes são identificados já na infância devido a alterações extremas e sem fatores externos aparentes (FALUDI et al., 2017). As dislipidemias primárias monogênicas podem ser subdivididas em grupos onde os principais são hipercolesterolemia familiar e hipercolesterolemia familiar heterozigótica (FALUDI et al., 2017).

Conclusão: A partir do exposto pode-se observar que as dislipidemias primárias têm grande importância no desenvolvimento de DCV devido ao acúmulo de lipídeos na parede das artérias. Ainda, necessita-se de uma atenção maior por não haver uma causa aparente e poder desenvolver DCV, o que pode ser agravado com fatores secundários. Entretanto, o quadro pode ser amenizado com dieta equilibrada e exercícios físicos.

\title{
Referências
}

ANVISA. Dislipidemias. Saúde e economia. Ano III - 6a ed. 2011.

FALUDI, André Arpad. et al. Atualização da Diretriz Brasileira de Dislipidemias e Prevenção da Aterosclerose. Arquivos Brasileiros de Cardiologia, Rio de Janeiro, v. 109, n. 2, supl. 1, p. 1-76. 2017. 
FAULHABER, Maria Cristina Brito. et al. Dislipidemias na Infância e na Adolescência: Um Caso de Saúde Pública? Revista de Pediatria da SOPERJ, Rio de Janeiro, v. 10, n. 1, Mai. 2009.

GAMA, Sueli Rosa. et al. Prevalência Em Crianças de Fatores de Risco Para as Doenças Cardiovasculares. Cadernos de Saúde Pública, Rio de Janeiro, v. 23 n. 9, set. 2007.

LOIO, Marisa. MAIA, Daniela de Andrade. Rastreio de Dislipidemias em Crianças e Adolescentes - A Evidência Que Sustenta as Recomendações. Revista Portuguesa de Medicina Geral e Familiar, Lisboa, v. 30 n. 4, ago. 2014.

MAGALHÃES, Taís Cristina Araújo. et al. Fatores Associados à Dislipidemia em Crianças De 4 a 7 Anos De Idade. Revista de Nutrição, Campinas, v. 28, n. 1, p. 17-28, jan./fev., 2015.

MEDEIROS, Ana Margarida et al. Dislipidemia e Risco Cardiovascular em Crianças: Identificação de Biomarcadores Para Uma Melhor Diferenciação Entre Uma Dislipidemia Monogénica e Uma Dislipidemia Poligénica/Externa. Instituto Nacional de Saúde Doutor Ricardo Jorge, Lisboa, v. 2, n. 2, Doenças Não Transmissíveis. 2013.

OLIVEIRA, Reynaldo Gomes. A Obesidade na Infância e Adolescência Como Fator de Risco Para Doenças Cardiovasculares do Adulto. Obesidade e Anemia Carencial na Adolescência: simpósio. - São Paulo : Instituto Danone, p.270. 2000.

POZZAN, Roselee. et al. Dislipidemia, Síndrome Metabólica e Risco Cardiovascular. Revista da SOCERJ - Rio de Janeiro, v. 17, n. 2, p. 97-104, Abr/Mai/Jun. 2004.

XAVIER, Hermes Toros. et al. V Diretriz Brasileira de Dislipidemias e Prevenção da Aterosclerose. Arquivos Brasileiros de Cardiologia, Rio de Janeiro, v. 101, n. 4, supl.1, Out. 2013.

Coordenadoria de Pesquisa e Extensão - COPEX

Departamento de Editoraçāo e Divulgaçāo Científica - DEDIC 


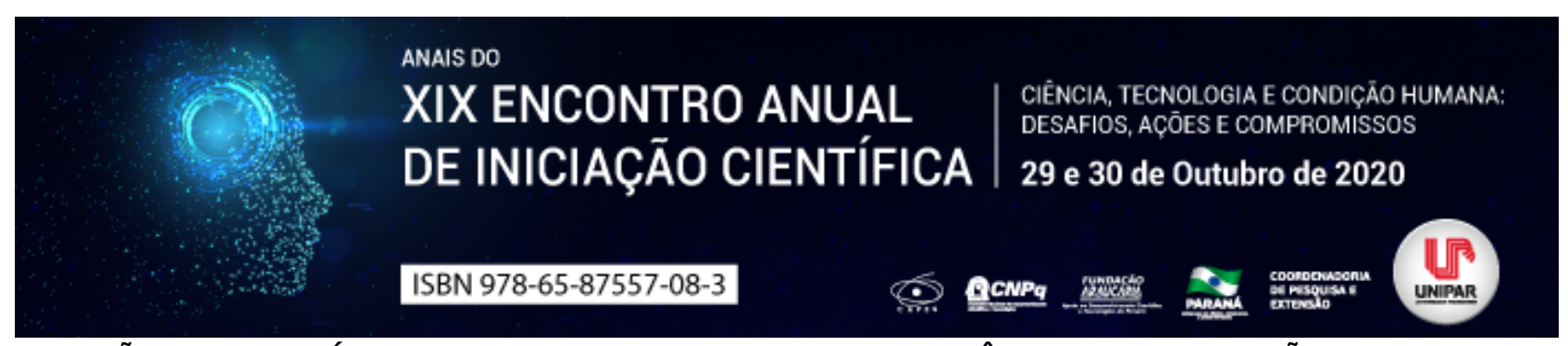

RELAÇÃO DA PROTEÍNA P53 COM O DESENVOLVIMENTO DO CÂNCER: UMA REVISÃO INTEGRATIVA

\title{
${ }^{1}$ IZABEL PUZISKI ROSSATO, ${ }^{2}$ ISADORA MARIAH MENOIA, ${ }^{3}$ MIGUEL FRANCISCO FERREIRA BATISTA, ${ }^{4}$ DENISE ALVES LOPES, ${ }^{5}$ MARIA ELENA MARTINS DIEGUES, ${ }^{6}$ RODRIGO LEITE ARRIEIRA
}

\author{
${ }^{1}$ Acadêmica do Curso de Medicina - UNIPAR \\ ${ }^{1}$ Acadêmica do Curso de Medicina - UNIPAR \\ ${ }^{2}$ Acadêmico do Curso de Medicina - UNIPAR \\ ${ }^{3}$ Docente na UNIPAR/Umuarama \\ ${ }^{4}$ Docente na UNIPAR/Umuarama \\ ${ }^{5}$ Docente na UNIPAR/Umuarama
}

Introdução: A p53 é uma Proteína Supressora de Tumor composta de 393 aminoácidos, é codificada pelo Gene Supresor de Tumor p53 que está situado no braço curto do cromossomo 17 (ARRUDA et al., 2008). No ciclo celular desempenha o papel de reguladora da transcrição na fase $\mathrm{G} 1$, pelo reparo de códons com falhas no pareamento ou indução à apoptose antes da replicação, a fim de evitar que esses erros se desenvolvam e estejam presentes nas células filhas de uma linhagem. Sua insuficiência ou ausência, causadas por mutações no gene, possui consequências, conduzindo a uma elevada taxa de mutações e produção de células possivelmente cancerosas (ALBERTS et al., 2017). De acordo com FÉLIX (2019), as células cancerígenas se multiplicam diversas vezes tomando o lugar das saudáveis e acumulando-se nos tecidos, culminando em câncer.

Objetivo: Descrever o papel da proteína p53 no controle do ciclo celular e no desenvolvimento de câncer.

Desenvolvimento: O processo que resulta no aparecimento de um câncer, chamado de carcinogênese, desencadeia a ação desordenada de funções celulares que antes encontravam-se em equilíbrio, causando, assim, a expressão exacerbada de determinadas proteínas como a p53, que leva esse nome devido ao seu peso que equivale a 53 Kda (CUNHA; BOURROUL; COTRIN, 2014; PINHO, 2000). Em 1979 ocorreu a sua primeira análise, na qual foi percebida como parte de um complexo de antígeno do vírus símio (PINHO, 2000; ARRUDA, 2008). Segundo Arruda et al. (2008), alguns anos depois em 1989, essa proteína foi descrita pela primeira vez como uma oncoproteína que, quando a p53 está saudável, apresenta uma meia vida de seis minutos e, em contrapartida, sua forma adoecida se acumula no núcleo. Essa proteína é conhecida como guardiã do genoma, pois em resposta aos danos celulares, o gene respectivo é ativado e induz o fator de transcrição a interagir com, pelo menos, outros seis genes diferentes, provocando a parada do ciclo celular, o que concede à proteína a chance de exercer sua função, que é manter a integridade das fitas. Na presença da p53 com mutação, um processo de seleção natural favorável desencadeia a transformação maligna das células com danos no DNA que escapam do reparo e desconstrução (FETT-CONTE; SALLES, 2002; PINHO, 2000). Segundo Cunha, Bourroul e Cotrin (2014), a decorrência da acetilação da p53 fomenta a acetilação de lisina 120, o qual é um sítio de repetição para a mutação da p53 no câncer, impedindo a sua função de interromper o crescimento celular. Ainda de acordo com as autoras, isto advém da resposta ao estresse ao qual o organismo está exposto, ocorrendo dentro do domínio de ligação ao DNA. Em geral, essas mutações promovem a perda de função pela interação do alelo mutante com o alelo saudável, assim os cromossomos homólogos não conseguem parear, gerando alterações genéticas e epigenéticas (FETT-CONTE; SALLES, 2002; CUNHA; BOURROUL; COTRIN, 2014). Desta forma, a p53 em seu estado mutado exerce efeitos anti-apoptóticos que contribuem na gênese de uma neoplasia maligna, pelo acúmulo de células nos tecidos (CUNHA; BOURROUL; COTRIN, 2014). Um exemplo disso é o câncer de pulmão, onde em cerca de $50 \%$ a $70 \%$ dos casos observam-se mutações em um alelo p53, os quais são mais resistentes à quimioterapia e radiação (VIKTORSSON; DE PETRIS; LEWENSOHN, 2005). Um fator que vem sendo estudado é a terapia gênica, considerada como uma alternativa e uma esperança para os pacientes com câncer. Os estudos acerca desta terapia buscam criar um fiscalizador da expressão de genes mutados, a partir de vetor adenoviral responsivo, que receba a introdução de um gene que funcione corretamente e, dessa forma, seja transportado ao gene selvagem e passe a trabalhar como regulado (CATANI, 2014). Dentre os vetores aprovados, o primeiro deles produzido pela China é um adenovírus portador do cDNA de p53 para a terapia do câncer, o qual, desde então, tem se mostrado muito eficaz no tratamento do câncer de cabeça e pescoço quando combinado com à quimioterapia, sem apresentar muitos efeitos colaterais e, quando esses estão presentes, são semelhantes à gripe. Contudo, os dados demonstraram que, mesmo com sua eficácia comprovada, essa terapia funciona com determinados tipos de câncer e que, devido a seu alto custo de produção, cerca de um milhão de reais por paciente, o tratamento gênico não é considerado uma opção viável (COSTANZISTRAUSS; STRAUSS, 2015).

Conclusão: Em face do exposto, pode-se concluir que a proteína p53 exerce funções importantes na regulação da transcrição e que o seu comprometimento está intimamente associado à não correção de falhas nos códons, resultando em mutações que se 
acumulam conforme as linhagens celulares seguintes e, consequentemente, sendo responsáveis pelo desenvolvimento do câncer. Evidencia-se, assim, a importância deste fator no diagnóstico, prognóstico e terapêutica, fazendo dele um alvo para estratégias de terapia gênica que, apesar de seu elevado custo, vem apresentando bons resultados no combate ao câncer.

\section{Referências}

ALBERTS, Bruce et al. Fundamentos da Biologia Celular. 4. ed. Porto Alegre: Artmed Editora, 2017.

ARRUDA, Jalsi Tacon et al. Proteína p53 e o Câncer: controvérsias e esperanças. Revista EVS-Revista de Ciências Ambientais e Saúde, v. 35, n. 1, p. 123-141, 2008.

CATANI, João Paulo Portela. Terapia gênica do câncer associando reparo da via p53 à imunoestimulação por IFN beta. 2014. 140 f. Tese (Doutorado - Faculdade de Medicina da Universidade de São Paulo. Programa de Oncologia) - Universidade de São Paulo, São Paulo, 2014.

COSTANZI-STRAUSS, Eugenia; STRAUSS, Bryan E. Perspectivas da terapia gênica. Revista de Medicina, v. 94, n. 4, p. 211 222, 2015.

CUNHA, Eliana de Araújo; BOURROUL, Selma; COTRIN, Simone Silva. Atividade da p53 no desenvolvimento do câncer. Atas de Ciências da Saúde, v. 2, n. 3, 2014.

FÉLIX, Ana Carla Pereira. Leucemia: etiologia e genética. São José do Rio Preto, 2019. Disponível em: http://www.ciencianews.com.br/arquivos/ACET/IMAGENS/biblioteca-

digital/hematologia/serie_branca/leucemias_linfomas_mieloma/leucemias/5-Leucemias-etiologia-e-genetica.pdf.

FETT-CONTE, Agnes Cristina; SALLES, Andréa B. Carvalho. A importância do gene p53 na carcinogênese humana. Revista Brasileira de Hematologia e Hemoterapia, v. 24, n. 2, p. 85-89, 2002.

PINHO, Mauro de Souza Leite. Proteína p53: algum valor clínico ou apenas pesquisa? Uma revisão da literatura. Revista Brasileira de Coloproctologia, v. 20, n. 4, 2000.

VIKTORSSON, Kristina; DE PETRIS, Luigi; LEWENSOHN, Rolf. The role of p53 in treatment responses of lung cancer. Biochemical and Biophysical Research Communications, v. 331, n. 3, p. 868-880, 2005. 


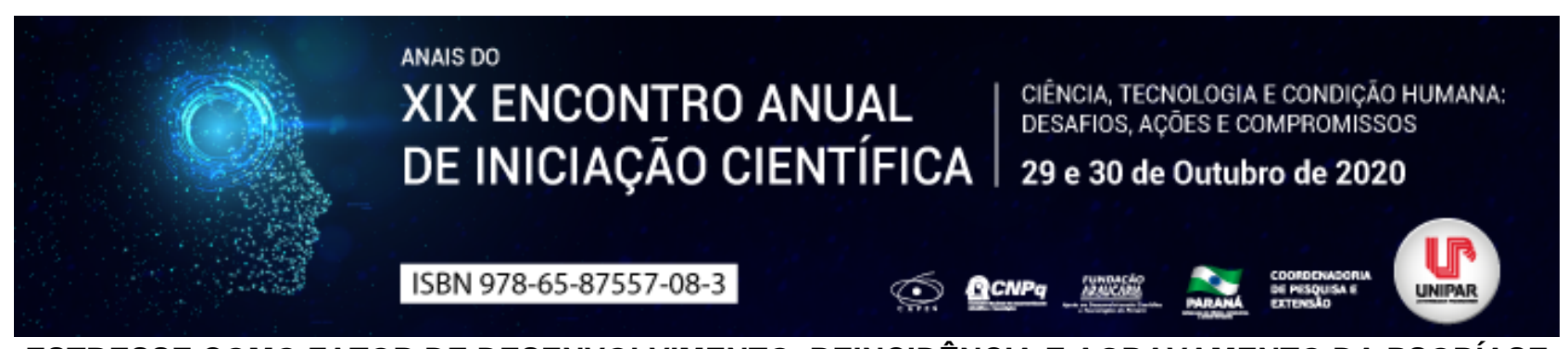

ESTRESSE COMO FATOR DE DESENVOLVIMENTO, REINCIDÊNCIA E AGRAVAMENTO DA PSORÍASE

\begin{abstract}
${ }^{1}$ DEBORAH TAVARES BIEZUS, ${ }^{2}$ MARIA EDUARDA PFAU, ${ }^{3}$ SUELEN STEFANONI BRANDAO, ${ }^{4} \mathrm{JESSICA}$ ZANQUIS FERREIRA, ${ }^{5}$ ELENIZA DE VICTOR ADAMOWSKI CHIQUETTI
\end{abstract}

\author{
${ }^{1}$ Acadêmica de Medicina/UNIPAR \\ ${ }^{1}$ Acadêmica do Curso de Medicina da UNIPAR \\ ${ }^{2}$ Acadêmica do Curso de Medicina da UNIPAR \\ ${ }^{3}$ Acadêmica do Curso de Medicina da UNIPAR \\ ${ }^{4}$ Docente da UNIPAR
}

Introdução: A psoríase é uma doença inflamatória crônica não contagiosa a qual acomete pele e articulações afetando 1 a 3\% da população mundial de 10 a 45 anos de idade. Essa disfunção resulta da proliferação de células de defesa pela epiderme, onde os linfócitos $T$ desencadeiam a produção anormal de componentes imunopatogênicos. Apresenta, de forma geral, sintomas comuns, além de placas, manchas e descamação cutânea, dor local, irritação, coceira e fadiga. Essa patologia não tem cura, sua principal causa ainda é o fator genético e não há exames de sangue que confirmem a presença da doença, ela é feita analisando o aspecto da pele, local da lesão e suas características, pode-se realizar uma biópsia para confirmação (MOSCARDI et al., 2017).

Objetivo: Realizar um levantamento bibliográfico sobre psoríase relacionando o estresse como fator de desenvolvimento ou agravamento da enfermidade.

Desenvolvimento: O estresse pode ser caracterizado como estado de alerta permanente, quando essa alteração não cessa ocorre um acúmulo de tensão, trazendo sinais de patologias, além do fato de que o estresse excessivo é apontado como o principal responsável pela suscetibilidade às doenças, contribuindo para seu aparecimento ou agravamento (SILVA et al., 2019). Segundo o Consenso Brasileiro de Psoríase e Guias de Tratamento (SOCIEDADE BRASILEIRA DE DERMATOLOGIA, 2005), inicialmente, pode-se citar a psoríase em placas, caracterizada por placas eritematosas, espessas, escamas no couro cabeludo e áreas de extensão que pode ser desencadeada por vários fatores como o estresse, infecção, trauma, medicações e xerose. Há também a psoríase pustulosa localizada, caracterizada por pápulas ou placas eritematosas, pústulas, usualmente nas palmas e plantas, geralmente é desencadeada por estresse, infecção e medicamentos, seu diagnóstico diferencial é erupção pustulosa por drogas, eczema disidrótico e dermatose pustulosa subcorneana. A psoríase gutata por sua vez caracteriza-se por pápulas eritematosas, descamativas, normalmente no tronco, é desencadeada por infecção estreptocócica na orofaringe, no seu diagnóstico deve ser eliminado a possibilidade de pitiríase rósea, sífilis secundária, erupção por drogas e pitiríase liquenóide. Por fim, a psoríase pustulosa generalizada e a psoríase eritrodérmica, que podem ser consideradas um tanto quanto mais invasivas, pois a psoríase pustulosa generalizada é caracterizada por pústulas isoladas ou sobre pápulas ou placas disseminadas e ainda pode estar associada a comprometimento sistêmico como febre, dor no corpo e diarreia, pode ser causada por estresse, infecção e medicamentos, conta com um diagnóstico diferencial de erupção pustulosa por drogas, dermatose pustulosa subcórnea e septicemia por gram negativos, a psoríase eritrodérmica conta com os mesmos fatores desencadeantes que a psoríase pustulosa generalizada, difere-se apenas pela caracterização devido a eritema intenso e escamas cobrindo todo o corpo, frequentemente também está associada a sintomas sistêmicos, seu diagnóstico diferencial é a erupção por drogas, dermatite eczematosa, micose fungóide, pitiríase rubra pilar e pênfigo foliáceo. Ao considerar-se o estresse como fator agravante da psoríase, é importante saber que esse estímulo afeta o organismo humano de diversas maneiras. Eventos ou estímulos estressores são aqueles que sobrecarregam ou excedem os recursos adaptativos de cada indivíduo. As reações fisiológicas as quais o organismo é submetido foi estudada e denominada por Salye em 1963 como Síndrome de Adaptação Geral (SAG). Essa síndrome consiste em três fases: alarme, resistência e exaustão (NODARI et al., 2014). Já em relação ao tratamento da psoríase, existem várias modalidades, como, agentes terapêuticos tópicos, sistêmicos e fitoterápicos, além de terapias alternativas e complementares, deverá ser considerado a extensão e severidade das lesões, sexo e idade do paciente, comprometimento da qualidade de vida, comorbidades e medicações associadas, acessibilidade e viabilidade econômica do tratamento, para que só então seja possível determinar a melhor modalidade de tratamento para cada paciente (PEDROSA, 2015).

Conclusão: Pode-se concluir que a psoríase é uma patologia causada por diferentes fatores etiológicos, bem como, genético, ambiental e auto-imune, se manifestando de várias formas em cada uma de suas classificações. Acredita-se que o estresse possa ser um fator responsável pelo desenvolvimento e reincidência da enfermidade. Sendo assim, ações integrativas na área da saúde tornam-se necessárias para a promoção da saúde e melhora no bem-estar. 


\section{Referências}

MOSCARDI, Evelyn Roberta; OGAVA, Suzana Ester nascimento. Psoríase: etiologia, diagnóstico e tratamento. Revista UNINGÁ Review. v. 29, n.9. 2017. Disponível em: https://www.mastereditora.com.br/periodico/20170204_1211532.pdf. Acesso em: 30 ago. 2020.

NODARI. Natália Lenzi. et al. Estresse, conceitos, manifestações e avaliação em saúde: revisão de literatura. Revista Saúde e Desenvolvimento Humano, $\mathrm{v}$. 2 , $\mathrm{n}$. 1 , 2014. Disponível em: https://revistas.unilasalle.edu.br/index.php/saude_desenvolvimento/article/view/1543. Acesso em: 30 ago. 2020 PEDROSA, Janaina Araujo Acupuntura no tratamento da psoríase. 2015. Orientador: Fábio Fonseca. Monografia. 2015 Escola de Medicina Chinesa - EBRAMEC.

Sociedade Brasileira de Dermatologia Consenso Brasileiro de Psoríase e guias de tratamento. Disponível em: http://formsus.datasus.gov.br/novoimgarq/24326/4118143_345331.pdf?ref=psoriase.com.br. Acessado em: 18 ago. 2020.

SILVA, Maria Aparecida do Nascimento; BARROS, Izabella Paiva Monteiro de; MERLETTI, Cristina Keiko Inafuku de Estresse: um fator (des)encadeante da psoríase. Acta Psicossomática, v. 2, n. 1, $2019 . \quad$ Disponível em: http://www.actapsicossomatica.com.br/ojs/index.php/acta/article/view/13. Acesso em: 18 ago. 2020. 


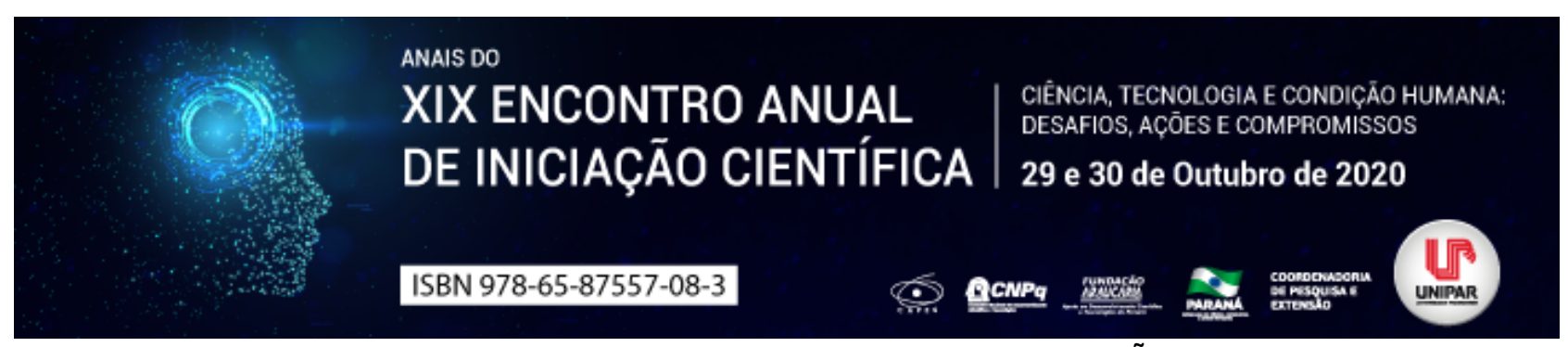

QUALIDADE DE VIDA EM IDOSOS INCONTINENTES: UMA REVISÃO INTEGRATIVA

\title{
${ }^{1}$ TAIS VIEIRA DOS REIS, ${ }^{2}$ KEROLI ISIDORIO, ${ }^{3}$ BRUNO HENRIQUE NESI, ${ }^{4}$ ANA MARIA BOHRER DE LIMA, ${ }^{5}$ ALESSANDRO RODRIGUES PERONDI
}

\author{
${ }^{1}$ Acadêmico do PIC/UNIPAR \\ ${ }^{1}$ Acadêmico do PIC/UNIPAR \\ ${ }^{2}$ Acadêmico do Curso de Enfermagem da UNIPAR \\ ${ }^{3}$ Acadêmica do Curso de Enfermagem da UNIPAR \\ ${ }^{4}$ Docente da UNIPAR
}

Introdução: O perfil da população mundial sofreu modificações nos últimos anos devido ao aumento da expectativa de vida, ocasionando grandes desafios para o sistema único de saúde (JORGE et al., 2019). Dentre as alterações que surgem no processo de envelhecimento destacam-se as fisiológicas, psicológicas e sociais, ao passo que todas resultam em transformações que afetam a qualidade de vida (QV) da pessoa idosa (MATOS et al., 2019). Bernardes et al., (2019) aponta que a qualidade de vida envolve âmbito familiar, bem-estar, satisfação pessoal, capacidade funcional, autoestima, valores éticos, culturais, atividades sociais, condições socioeconômicas e comorbidades que causam limitações no desenvolvimento de atividades diárias, dentre as quais, a Incontinência Urinária (IU) apresenta-se com grande prevalência. Segundo Ribeiro et al., (2019) a IU é definida como a perda involuntária da urina pela uretra; pode ser classificada em IU por esforço, IU de urgência e IU mista. Por conta da grande prevalência, a IU traz impactos diretos a qualidade de vida na população idosa, tornando-o mais vulnerável a fragilidades, em decorrência da diminuição da capacidade funcional e consequentemente limitando a participação social (SABOIA et al., 2017, WESCHENFELDER et al., 2016) levando a constrangimento, vergonha, estresse, diminuição da auto estima e disfunção sexual (PADILHA et al., 2018, SILVA et al., 2017). Diante desse cenário este estudo teve como objetivo verificar, por meio de revisão integrativa da literatura a repercussão da incontinência urinária na qualidade de vida de idosos

Metodologia: Trata-se de uma Revisão Integrativa (RI) orientada pela questão norteadora: Qual a repercussão da incontinência urinária na qualidade de vida de idosos na perspectiva das publicações científicas dos últimos 5 anos? . Efetuouse a busca na Base de Dados da Biblioteca Virtual em Saúde (BVS Salud) utilizando-se os descritores: Idoso; Incontinência urinária; Qualidade de vida, com o operador booleano and e tendo como critérios de busca publicações no formato de artigos científicos. Como intervalo de tempo utilizou-se os últimos cinco anos (2015 a 2020). Na busca realizada foram encontrados 16 artigos, na sequência, realizou-se análise crítica que correspondeu à avaliação dos estudos e interpretação dos resultados. Nesta análise foram excluídos 8 artigos, destes 5 por se repetirem na base de dados e 3 por não responderem ao objetivo do estudo. Para melhor apresentação dos manuscritos que compuseram o escopo da RI, os estudos foram identificados com a letra $\mathrm{E}$, numerados sucessivamente.

Resultados e Discussão: Os resultados obtidos da RI culminaram na seleção de 8 artigos, destes estudos foram 3 quantitativos, 1 qualitativo e 4 transversais. Em relação ao tipo de estudo, 4 foram artigos originais e 4 estudos clínicos. Quanto ao ano de publicação 1 foi publicado em 2016, 2 em 2017, 1 em 2018 e 4 em 2019. Em relação às populações/amostras, integralmente os estudos foram desenvolvidos com sujeitos de ambos os sexos, com idade igual ou superior a 60 anos. Os estudos E1, E2, E3 e E4, abrangeram apenas o sexo feminino com incontinência urinária, onde o E1 e E3 apresentaram dados negativos em relação a (QV) qualidade de vida das pacientes com esta condição, demonstrando que a IU ocasiona problemas físicos, emocionais, sociais, sexuais e socioeconômicos, sendo identificado no E3 piores resultados em mulheres com diagnóstico de incontinência urinária mista (SABOIA et al., 2017, PADILHA et al., 2018). O E2 avaliou a QV após realização de Fisioterapia para o problema em questão, obtendo dados satisfatórios, como bem-estar físico, emocional e fortalecimento pélvico (SILVA et al., 2017). Logo, o E4 constatou que a percepção geral de saúde em pacientes que possuem IMC mais elevado e outras comorbidades associadas culmina no agravamento do comprometimento da QV na presença de IU (RIBEIRO et al., 2019). Em relação ao estudo E5, foi possível identificar sentimentos de ansiedade, preocupação, baixa autoestima, devido a dificuldade de reconhecer a incontinência urinária como patologia causadora de isolamento social e problemas econômicos (MATOS et al., 2019). O E6 concluiu que a autopercepção de saúde em idosos influenciou em efeitos negativos para o desenvolvimento de depressão e IU (JORGE et al., 2019). O E7 avaliou a prevalência de IU em grupo rural e urbano, onde os resultados mostraram que o ambiente em que indivíduo está inserido não interfere no desenvolvimento da perda urinária (WESCHENFELDER et al., 2016). O E8 identificou o surgimento de IU em homens que realizaram prostatectomia radical, resultando em dificuldade na relação sexual, impactando diretamente na QV, no meio social e nas atividades físicas e diárias (BERNARDES et al., 2019).

Conclusão: Os resultados deste estudo confirmaram a hipótese de que a QV dos idosos é afetada pela presença de IU e 
reforçam a necessidade de pesquisa com maior abrangência nesta área. Considerando o alto índice, a prevalência cada vez maior e o envelhecimento da população brasileira, os resultados apontam para a necessidade de propagação dessas informações, fornecendo subsídios para que a população em geral aprimore o conhecimento acerca desta patologia, e assim desenvolvam a consciência de que uma assistência correta e de qualidade promove a melhoria da QV desses indivíduos.

\section{Referências}

BERNARDES, Mariana Ferreira Vaz Gontijo; et al. Impacto da incontinência urinária na qualidade de vida de indivíduos submetidos à prostatectomia radical. Rev. Latino-Am. Enfermagem, v. 27, p. 3131, 2019.

JORGE, Luisa Braga; et al. Impacto da autopercepção de saúde em longevos com incontinência urinária (Impact of self-perceived health on long-lived subjects with urinary incontinence). Sci Med, v. 29, n. 1, p. 32831. 2019.

MATOS, Mirelle Aires Botello; et al. As Repercussões Causadas pela Incontinência Urinária na Qualidade de Vida do Idoso. Rev Fund Care Online, v. 11, n. 3, p. 567-575. Abr/jun, 2019.

PADILHA, Juliana Falcão; et al. Investigação da qualidade de vida de mulheres com incontinência urinária. Arq. Cienc. Saúde UNIPAR, Umuarama, v. 22, n. 1, p. 43-48, jan./abr. 2018.

RIBEIRO, Daniel Carvalho; et al. Incontinência dupla: fatores associados e impacto sobre a qualidade de vida em mulheres atendidas em serviço de referência. Rev. Bras. Geriatr. Gerontol, v. 22, n. 9, p. 190216, 2019.

SABOIA, Dayana Maia; et al. Impacto dos tipos de incontinência urinária na qualidade de vida de mulheres. Rev Esc Enferm USP, v. 51, p. 03266. 2017.

SILVA, Luzia Wilma Santana; Fisioterapia na incontinência urinária: olhares sobre a qualidade de vida de mulheres idosas. Revista Kairós - Gerontologia, v. 20, n.1, p. 221-238, 2017.

WESCHENFELDER, Áureo Júnior; et al. Prevalência de incontinência urinária e seu impacto sobre a qualidade de vida de idosos: estudo comparativo entre meio urbano e meio rural. Revista Kairós Gerontologia, v. 19, n. 3, p. 67-77. 2016. 


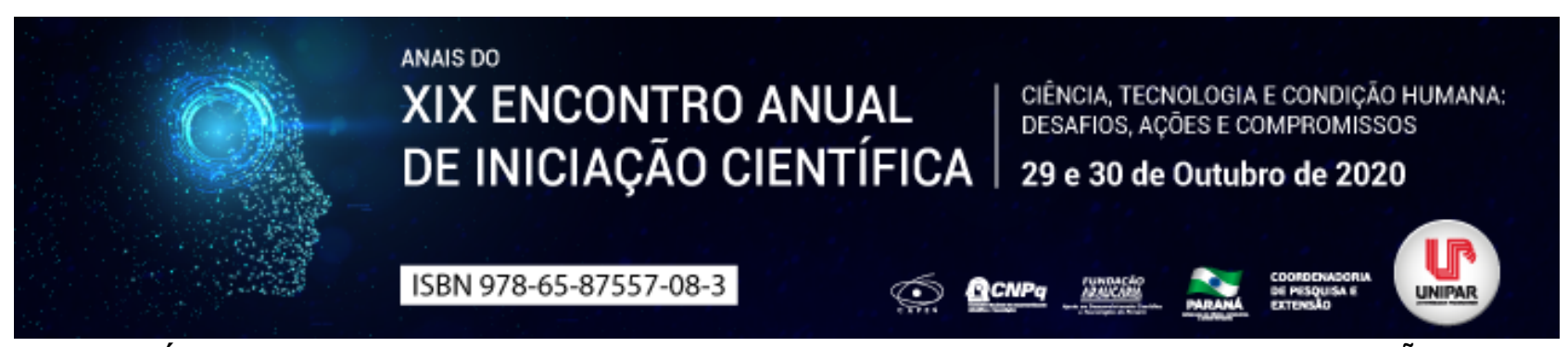

ANÁLISE DO MECANISMO DO GENE FTO RELACIONADO A OBESIDADE: UMA REVISÃO

\begin{abstract}
${ }^{1}$ CAMILA MARIA ESCARDILLE YOSHITANI, ${ }^{2}$ ESTER PELEGRINI SILVA, ${ }^{3}$ RICARDO MARCELO ABRAO, ${ }^{4}$ LUCIANO SERAPHIM GASQUES
\end{abstract}

${ }^{1}$ Acadêmica bolsista do PIBIC/UNIPAR

${ }^{1}$ Acadêmica do Curso de Medicina da UNIPAR

${ }^{2}$ Docente da UNIPAR

${ }^{3}$ Docente da UNIPAR

Introdução: Caracterizada como uma doença crônica, a obesidade se tornou um dos maiores problemas de saúde mundial, devido ao aumento acelerado do número de casos nos últimos anos (LIMA et al., 2010). Tal dado é alarmante, pois o excesso de adiposidade pode suscetibilizar diversos fatores de riscos e o desenvolvimento de patologias mais complexas (DENG et al., 2018). Outrossim, existem diversas etiologias para obesidade que favorecem o balanço energético positivo e o ganho de peso, entre as causas são possíveis elencar os fatores genéticos que podem estar relacionados com o controle da ingestão de alimentos (LIMA et al., 2010). Assim, múltiplos genes estão associados com maior variação do índice de massa corpórea (IMC), dentre os quais se destaca o gene FTO (Fat mass and obesity-associated gene) localizado no cromossomo 16. Alguns polimorfismos de nucleotídeo SNPs (Single Nucleotide Polymorphism) presentes nesse gene localizados no íntron 1 são responsáveis por predispor o indivíduo à obesidade, pois atua na regulação da massa gorda, adipogênese e peso corpóreo (DENG et al., 2018; MERKSTEIN, 2015).

Objetivo: Esta revisão busca analisar os mecanismos moleculares e fisiopatológicos por meio dos quais o gene FTO está envolvido com a obesidade.

Desenvolvimento: Identificado pelo GWAS (Genome-wide association study), o gene FTO foi um dos primeiros relacionados com a obesidade a ser identificado. Ele encontra-se localizado no cromossomo 16q12.2, no qual sua cadeia possui 9 éxons e 8 íntrons (CHEN, 2019; DENG et al., 2018). Normalmente, tal gene é responsável por codificar uma a desmetilase de ácido nucleico N6-metiladenosina (m6A) dependente de 2-oxiglutarato, um intermediário do Ciclo do Ácido Cítrico, o qual relaciona-se com o balanço energético. Essa enzima irá atuar como catalisadora na desmetilação do RNA e DNA (CHEN, 2019; SPEAKMAN, 2015; MERKSTEIN, 2015). Essas reações encontram-se em diversos tecidos sendo que é mais prevalente no hipotálamo, na região do núcleo arqueado, onde se localiza o centro de controle da fome (CHEN, 2019). Outros locais são os tecidos adiposos, pâncreas, fígado, músculos esqueléticos, rins e gônadas (LIMA et al., 2010). Acredita-se que expressão irregular desse gene afeta a modificação do m6A e pode ser causada por algumas mutações pontuais intrônicas, sendo que existem cerca de 2.348 SNPs presentes nesse gene, dos quais 26 polimorfismos são encontrados no íntron 1 e relacionam-se com o aumento da massa gorda no indivíduo. Existem estudos os quais sugerem que as alterações podem atuar no próprio gene FTO, tal situação presente no SNC interfere na ingestão de alimentos pela redução da saciedade pós-prandial, plenitude e aumento da fome, possivelmente relacionado aos níveis irregulares de leptina e grelina após a refeição (LIMA et al., 2010; SPEAKMAN, 2015; CHEN, 2019; DENG et al., 2018). Verificou-se que alguns alelos de risco estão ligados a baixos níveis séricos da leptina, diminuindo a saciedade, e elevação da expressão da grelina, influenciando o comportamento ingestivo (CHEN, 2019; DENG et al., 2018). Além disso, existem evidências os polimorfismos do FTO podem exercer influência sobre a expressão nos genes adjacentes, tanto a jusante quanto a montante, o IRX3, o IRX5 e o RPGRILP1 (DENG et al., 2018; SPEAKMAN, 2015). A forma co-regulada de atuação com o gene RPGRILP1 ocorre pela influência sofrida por um elemento regulador presente no gene FTO, o CUX1 (SPEAKMAN, 2015). Acredita-se o FTO pode também interagir com genes da família Iroquois Homeobox, como o IRX3, sugerindo uma alteração a nível do metabolismo dos adipócitos, em que os SNPs interagem com os promotores desse gene (DENG et al., 2018; MERKSTEIN, 2015; SPEAKMAN, 2015). Além disso, o gene FTO é responsável por interferir no processo de adipogênese, no início da expansão clonal mitótica. Isso ocorre por atingir o fator de transcrição RUNX1T1. Nesse caso, o aumento de adipócitos está relacionado com o gene regular de modo excessivo a expressão da isoforma S de RUNX1T1 (MERKSTEIN, 2015). Essas interações gene-gene indicam que os SNPs presentes no primeiro íntron podem atuar em alvos mais distantes, sendo o seu mecanismo ainda mais complexo por não se limitar a um único gene.

Conclusão: Portanto, foi possível verificar que o gene FTO pode ter seu funcionamento normal de codificação da desmetilase de ácido nucleico N6-metiladenosina $(\mathrm{m} 6 \mathrm{~A})$ dependente de 2-oxiglutarato alterado, por conta de possíveis SNPs presentes, desempenhando um papel desregulado, e como consequência, afetando a modificação do m6A que é considerado importante na homeostasia de células e tecidos. Dessa forma, há a desregulação dos níveis hormonais e hipertrofia de adipócitos, predispondo o indivíduo ao aumento de massa gorda. Foi possível compreender mais sobre a obesidade genética e os seus 
mecanismos o que é fundamental para desenvolver abordagens terapêuticas diferenciadas individualizadas, visando uma melhor adaptação ao paciente.

\section{Referências}

CHEN, JiaLing; DU, Bin. Novel positioning from obesity to cancer: FTO, an m6A RNA demethylase, regulates tumour progression. Journal of cancer research and clinical oncology, v. 145, n. 1, p. 19-29. 2019.

DENG, Xiaolan et al. Critical enzymatic functions of FTO in obesity and cancer. Frontiers in endocrinology, v. 9, p. $396,2018$. LIMA, William Alves; GLANER, Maria Fátima; TAYLOR, Aline Pic. Fenótipo da gordura, fatores associados e o polimorfismo rs9939609 do gene FTO. Rev. bras. cineantropom. desempenho hum., v. 12, n. 12, p. 164-172, 2010.

MERKESTEIN, Myrte et al. FTO influences adipogenesis by regulating mitotic clonal expansion. Nature communications, v. 6 , $\mathrm{n}$. 1, p. 1-9, 2015.

SPEAKMAN, John R. The 'Fat Mass and Obesity Related' (FTO) gene: Mechanisms of Impact on Obesity and Energy Balance. Current Obesity Reports, v. 4, n. 1, p. 73-91, 2015.

Coordenadoria de Pesquisa e Extensāo - COPEX

Departamento de Editoraçāo e Divulgaçāo Científica - DEDIC 


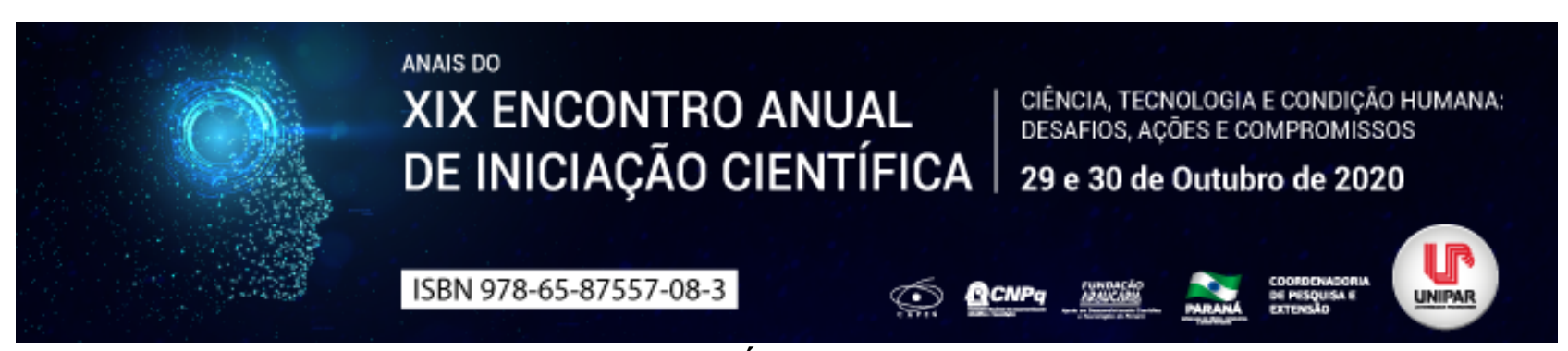

ATIVIDADE ANTIMICROBIANA DE DIFERENTES ESPÉCIES DE Eugenia sp. FRENTE AO Staphylococcus aureus

\title{
${ }^{1}$ MARIANA DALMAGRO, ${ }^{2}$ GUILHERME DONADEL, ${ }^{3}$ JAQUELINE HOSCHEID, ${ }^{4}$ EMERSON LUIZ BOTELHO LOURENCO
}

\author{
${ }^{1}$ Acadêmica do PIC-UNIPAR \\ ${ }^{1}$ Mestrando - UNIPAR \\ ${ }^{2}$ Docente da UNIPAR \\ ${ }^{3}$ Docente da UNIPAR
}

Introdução: A família Myrtaceae apresenta espécies com atividades antioxidante, hipoglicemiante, antireumática, sendo essas empregadas em distúrbios estomacais e também como anti-hipertensivas. Com alicerce na presença de substâncias polifenólicas, buscou-se estudar os efeitos ligados à atividade antioxidante e atividade antimicrobiana (AURICCHIO, et al., 2007). De acordo com Sato et al., (2018) extratos de diversas espécies do gênero Eugenia apresentam concentrações elevadas de compostos fenólicos, sendo que extratos obtidos com etanol acidificado concederam maior quantidade de extração dos compostos mencionados.

Objetivo: Identificar a espécie do gênero Eugenia, que obteve melhores resultados, frente ao Staphylococcus aereus.

Materiais e métodos: O teste de Concentração Inibitória Mínima (CIM) foi realizado frente aos microrganismos Staphylococcus aureus, seguindo metodologia previamente descrita (ANVISA, 2003). Foram adicionados $90 \mu \mathrm{L}$ de caldo BHI nos orifícios de microplacas contendo 96 poços e em seguida a partir da segunda coluna adicionou-se $90 \mu \mathrm{L}$ dos extratos preparados com etanol, nas concentrações de $1000 \mathrm{mg} / \mathrm{mL}$, homogeneizou-se três vezes, e em seguida transferiu-se $90 \mu \mathrm{L}$ para a terceira coluna e assim sucessivamente, até chegar na décima primeira coluna. Por último foi adicionado aos orifícios da microplaca, desde a primeira à décima primeira coluna, $10 \mu \mathrm{L}$ das suspensões bacterianas em água estéril na escala 0,5 de McFarland. Para o controle positivo foi utilizado a primeira coluna (caldo + bactéria), já para o controle negativo foi utilizada a décima segunda coluna (contendo apenas caldo). A incubação das microplacas em estufa bacteriológica ocorreu a $37^{\circ} \mathrm{C}$ durante 24 horas. Após esse período adicionou-se em todos os poços $20 \mu \mathrm{L}$ do revelador TTC (2,3,5 trifeniltetrazólio) a $2 \%$ e as mesmas foram incubadas novamente por 2 horas. Ao final da incubação, o aparecimento de cor avermelhada indicou a multiplicação bacteriana, enquanto que aqueles que permaneceram incolores demonstraram a sua ausência.

Resultados: Após realizar as análises descritas, observou-se que Eugenia involucrata e Eugenia myrcianthes apresentaram atividade antimicrobiana na concentração $62,50 \mathrm{mg} / \mathrm{mL}$, já o extrato etanólico de Eugenia uniflora mostrou-se efetivo com 15,62 $\mathrm{mg} / \mathrm{mL}$ e seu extrato aquoso com $10,46 \mathrm{mg} / \mathrm{mL}$.

Discussão: Não foram encontrados estudos específicos sobre a Eugenia myrcianthes, porém, de acordo com Sato et al., (2018) estudos descrevem, que esse gênero se destaca pelo potencial farmacológico. Extratos das folhas de diferentes espécies do gênero Eugenia, e também o óleo essencial extraído das folhas dessas, apresentaram atividades antifúngica e antibacteriana, ademais, o extrato bruto do caule e folhas do gênero Eugenia apresentou atividade antioxidante. Outras atividades caracterizadas na literatura, a partir de estudos com extratos, foi atividade diurética e anti-inflamatória. Segundo Gonçalves et al., (2005) o extrato de Eugenia uniflora é um dos que apresentam alta atividade antimicrobiana, que também é referido na literatura como tendo atividade contra Streptococcus, Escherichia coli, e Bacillus cereus. Os ensaios antimicrobianos, empregando os extratos desenvolvidos de Eugenia involucrata, demonstraram inibição das cepas de Staphylococcus aureus e Candida krusei nas concentrações de 3,0; 6,0 e 12,0 mg/mL (SATO, et al., 2018).

Conclusão: Dado o exposto, conclui-se que todas as espécies estudadas do gênero Eugenia sp. apresentaram atividade antimicrobiana significativa, contudo, o extrato seco de Eugenia unifora L. foi o que manifestou-se com melhores resultados frente ao Staphylococcus aereus.

\section{Referências}

ANVISA. Agência nacional de vigilância sanitária, v. 23, n. 1, 2003.

AURICCHIO, M. T. et al. Atividades Antimicrobiana e Antioxidante e Toxicidade de Eugenia uniflora. Latin American Journal of Pharmacy, v. 16, n. 1, p. 76-81, 2007.

GONÇALVES, A. L. et al. Estudo comparativo da atividade antimicrobiana de extratos de algumas árvores nativas. Arq. Inst. Biol., São Paulo, v. 72, n. 3, p.353-358, jul./set., 2005.

SATO, T. S. et al. Proposta de formulação contendo extrato de folhas de Eugenia involucrata e análise da atividade antimicrobiana. Revista Fitos, Rio de Janeiro, v. 12, n. 1, p. 68-82, 2018. 
Coordenadoria de Pesquisa e Extensão - COPEX

Departamento de Editoraçāo e Divulgaçāo Científica - DEDIC 


\title{
ANAIS DO \\ XIX ENCONTRO ANUAL | CIĖNCIA, TECNOLOGIA E CONDIÇĀO HUMANA: DE INICIAÇÃO CIENTÍ́FICA DESAFIOS, AÇŌES E COMPROMISSOS \\ DE INICIAÇĀO CIENTÍFICA 29 e 30 de Outubro de 2020 \\ ISBN 978-65-87557-08-3 \\ a \\ IMPORTÂNCIA DA VERIFICAÇÃO DA SOROCONVERSÃO DA VACINA CONTRA HEPATITE B EM PROFISSIONAIS DA ODONTOLOGIA
}

\author{
${ }^{1}$ GABRIELA ZANUto DE LIMA, ${ }^{2}$ JOAO MURILO GONCALVES GAZOLA, ${ }^{3}$ GABRIEL MACIEL DA SILVA, ${ }^{4}$ NATALIA \\ COQUEIRO SIQUEIRA, ${ }^{5}$ JEMIMA BATISTA DOS SANTOS, ${ }^{6}$ VERUSKA DE JOAO MALHEIROS PFAU
}

\author{
${ }^{1}$ Discente de Odontologia da Universidade Paranaense \\ ${ }^{1}$ Acadêmico do Curso de Odontologia da UNIPAR \\ ${ }^{2}$ Acadêmico do Curso de Cirurgia Periodontal e Introducao A Implantodontia - Turma Viii da UNIPAR \\ ${ }^{3}$ Acadêmica do Curso de Curso Avancado Em Cirurgias Bucais - Turma lii da UNIPAR \\ ${ }^{4}$ Acadêmica do Curso de Odontologia da UNIPAR \\ ${ }^{5}$ Docente da UNIPAR
}

Introdução: De acordo com o Ministério da Saúde a Hepatite B é uma doença infecciosa viral, possui como agente etiológico um hepatovirus da família hepadnaviridae. GARBIN, et al., 2020, cita os cirurgiões dentistas e auxiliares bucais como susceptíveis a contaminação pelo Vírus da Hepatite B (VHB), pela condição inerente a exposição ocupacional. Para prevenção, SOUZA et al., 2015, cita a vacinação como uma alternativa segura que auxilia na tentativa de controle da propagação do vírus. Mas além de simplesmente cumprir as etapas da vacinação, deve ser realizado o exame Anti-Hbs, para constatar a soroconversão e assim certificar-se da devida imunização. Estudos têm apontado índices baixos em relação à realização da comprovação sorológica por meio do exame, entre os acadêmicos e profissionais da Odontologia (FERREIRA, 2018; PINELLI, NELO, LOFFREDO, 2016; ANGELO, 2007). Sendo assim, torna-se necessário investigar sobre a imunização e soroconversão entre cirurgiões dentistas, além dos motivos que influenciam o descuido dos profissionais, frente a prevenção da Hepatite B.

Objetivo: Realizar um levantamento bibliográfico, sobre a verificação de soroconversão após vacina contra Hepatite B entre profissionais da Odontologia.

Desenvolvimento: No contexto Odontológico, a Hepatite B é considerada uma doença ocupacional devido ao alto grau de exposição dos profissionais e acadêmicos a instrumentos perfuro-cortantes, materiais biológicos contaminados (saliva, sangue e etc.) e pelos aerossóis produzidos durante os atendimentos, que podem ser facilmente absorvidos/inalados (PINELLI, NELO, LOFFREDO, 2016; NETO, et al., 2013; FREITAS, et al., 2011). Deste modo, inquéritos sorológicos demonstram uma maior prevalência desta infecção em dentistas do que na população geral, principalmente em especialidades cirúrgicas. O uso das barreiras de proteção, a fim de evitar contaminação, abrangem medidas de precauções fundamentais, como o uso de proteção individual, tanto do profissional, como de sua equipe, bem como a desinfecção e esterilização dos equipamentos, e manutenção da imunização ativa (FERREIRA, et al., 2018). Segundo SOUZA et al., 2015, o esquema vacinal completo consiste na administração de 3 doses da vacina contra VHB em um intervalo de zero, um e seis meses. O Ministério da Saúde indica aos profissionais da área da saúde a realização de exames sorológicos (anti-Hbs) após realização do ciclo vacinal, com objetivo de verificar a soroconversão, já que $10 \%$ dos adultos que recebem as 3 doses não soroconvertem. E mediante a casos assim, é necessário realizar nova administração de dose vacinal e posterior verificação sorológica. Somente $75 \%$ dos profissionais realizam o esquema vacinal completo e apenas 26\% realizam a verificação da imunização pós vacinação (COSTA, et al., 2017). Segundo GARBIN, et al., 2020, apesar da importância do exame anti-Hbs, essa medida ainda é pouco conhecida pelos profissionais da saúde. De encontro a essa perspectiva, SOUZA et al., 2015, associa o baixo índice da realização do exame antihbs, com a ilusão de considerar-se imune, pelo simples fato de ter recebido a vacina. A necessidade de maiores informações, foi apresentada como justificativa para a vacinação incompleta ou não realização do exame anti-hbs (CARNEIRO, CANGUSSU, 2009). Isto torna-se justificável, uma vez que, a autoproteção depende de fatores educacionais. A instabilidade com a profissão, pode interferir neste cuidado, pois a proporção de não-vacinados, entre os profissionais temporários foram 2,3 vezes maiores, se comparado aos profissionais permanentes (ASSUNÇÃO, et al., 2012). De acordo com COSTA, et al., 2017, a capacitação dos profissionais da área da saúde exerce grande influência na conscientização, pois trabalhadores que participam de capacitações apresentam maior prevalência de vacinação. Em relação aos acadêmicos. CARNEIRO, CANGUSSU, 2009, sugerem que a verificação da imunização deve ser realizada sete meses antes do contato inicial de alunos com pacientes para assim garantir a redução de infecção pelo Vírus da Hepatite B entre os alunos de Odontologia (FREITAS, et al., 2011).

Conclusão: A realização do exame anti-Hbs para constatar a soroconversão da hepatite B se mostra importante, já que a simples aplicação da vacina não é garantia de imunização. No campo da Odontologia, percebe-se um baixo índice de vacinação e verificação de soroconversão. A realização do exame de antiHbs durante a graduação, surge como uma alternativa eficaz na redução de contaminados pelo Vírus da Hepatite B. Assim, considera-se que projetos de educação em Saúde, com ênfase na 
prevenção da Hepatite B, devem ser desenvolvidos para proteção dos profissionais da saúde e acadêmicos, com finalidade de promover a prática do autocuidado.

\section{Referências}

ANGELO, Angelinne Ribeiro. et al. Hepatite B: Conhecimento e Prática dos Alunos de Odontologia da UFPB. Pesquisa Brasileira em Odontopediatria e Clínica Integrada, v. 7, n. 3, p. 211-216, set./dez. 2007.

ASSUNÇÃO, Ada Ávila. et al. Vacinação contra hepatite B e exposição ocupacional no setor saúde em Belo Horizonte, MG. Revista Saúde Pública, v. 46, n. 4, p. 665-673, 2012.

COSTA, Fernanda Marques. et al. Fatores associados à verificação da imunização pós-vacinação contra hepatite $B$ entre trabalhadores da Atenção Primária. Cadernos Saúde Coletiva, v. 25, n. 2, p. 192 200, 2017.

FERREIRA, Larissa Queiróz. et al. Hepatite B: conhecimento e atitudes de acadêmicos de Odontologia. Revista Archives of Health Investigation, v. 7, n. 7, p. 258-261, 2018.

FREITAS, Daniel Antunes. et al. Conhecimento de acadêmicos de odontologia sobre Hepatite B. Revista Brasileira de Cirurgia da Cabeça e Pescoço, v. 40, n. 1, p. 30-33, 2011.

GARBIN, Cléa Adas Saliba. et al. Imunização contra hepatite B em auxiliares em saúde bucal: estudo transversal no sistema público de saúde do estado de São Paulo, em 2018. Epidemiologia e servicos de saude: revista do Sistema Único de Saúde do Brasil, v. 29, n. 2, p. 1-8, 2020.

MINISTÉRIO DA SAÚDE. Boletim Epidemiológico - Hepatites Virais 2019. Volume 50, № 17, Julho 2019.

NETO, Epitácio Pessoa de Andrade. et al. Prevalência de acidentes ocupacionais e perfil de vacinação contra Hepatite $B$ entre estudantes e profissionais da odontologia: um estudo piloto. Arquivos em Odontologia, v. 49, n. 1, p. 32-38, jan/mar 2013.

PINELLI, Camila; NERI, Sabrina do Nascimento; LOFFREDO, Leonor de Castro Monteiro. Dental students' reports of occupational exposures to potentially infectious biological material in a Brazilian School of Dentistry. Cadernos Saúde Coletiva, v. 24, n. 2, p. 162-169, 2016.

SOUZA, Fernanda de Oliveira. et al. Vacinação contra hepatite B e Anti-HBS entre trabalhadores da saúde. Cadernos Saúde Coletiva, v. 23, n. 2, p. 172 179, 2015. 


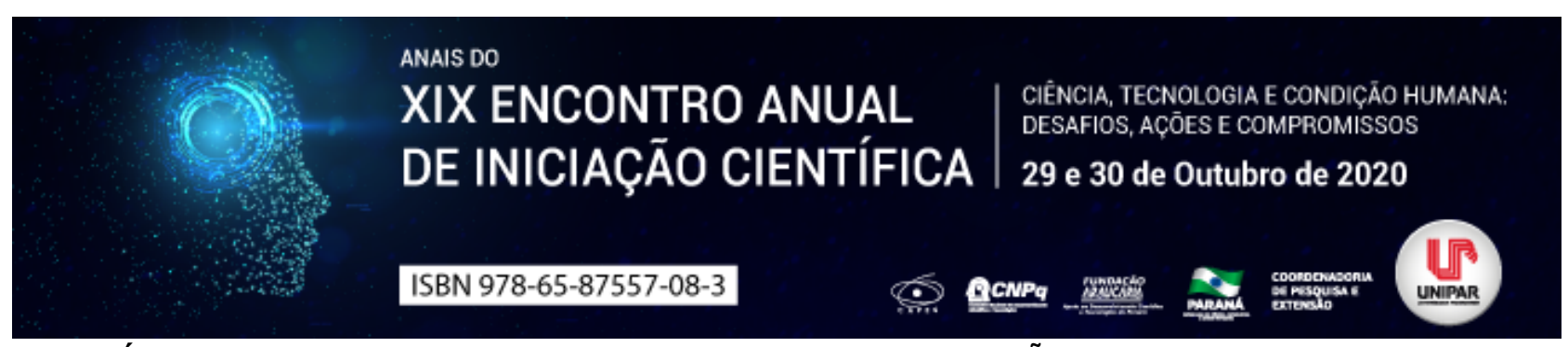

DIAGNÓSTICO DIFERENCIAL DE FLUOROSE E HIPOMINERALIZAÇÃO MOLAR-INCISIVO DO ESMALTE

\author{
${ }^{1}$ GABRIELA ZANUTO DE LIMA, ${ }^{2}$ SAMARA DE SOUZA RODRIGUES, ${ }^{3}$ FERNANDA FERREIRA MARQUES, ${ }^{4}$ ANA CAROLINA \\ SOARES FRAGA ZAZE
}

${ }^{1}$ Discente de Odontologia da Universidade Paranaense Campus Umuarama - PIC/UNIPAR

${ }^{1}$ Acadêmica do Curso de Odontologia da UNIPAR

${ }^{2}$ Cirurgiã Dentista - Egressa Unipar

3 Docente da UNIPAR

Introdução: A coroa dentária é recoberta por um tecido mineralizado, responsável por promover a proteção e revestimento, denominado esmalte dentário.. A Amelogênese (período de formação do esmalte dental) ocorre em três estágios: formação da matriz celular, calcificação e maturação. Esses processos podem ser facilmente afetados por alterações sistêmicas, locais ou hereditárias, acarretando a má formação do esmalte. As anomalias podem variar de acordo com sua pigmentação, translucidez e espessura do esmalte. (BARZOTTO; RIGO, 2018). Segundo Lima et al. em 2015, essas características são relevantes para a classificação. Apesar do índice de classificação estabelecido, o diagnóstico diferencial nem sempre é fácil de se realizar, devido a grande semelhança dessas lesões. Principalmente entre a hipomineralização e a fluorose já que suas manifestações clínicas, são parecidas. Tornando-se necessário

Objetivo: Apresentar evidências científicas que facilitem o diagnóstico diferencial entre as anomalias do esmalte dental, por meio de uma revisão de literatura, explicando as suas etiologias, aspectos clínicos e sistêmicos para o reconhecimento e diferenciação de hipomineralização e fluorose.

Desenvolvimento: O esmalte dentário, responsável pelo revestimento da coroa dentária, é um tecido acelular, rico em hidroxiapatita carbonatada, possui aspecto translúcido, alto índice de friabilidade e dureza, no entanto, não possui capacidade de regeneração. Segundo, Barzotto e Rigo em 2018, a amelogênese, é dividida em 3 estágios: o período de formação da matriz; o estágio de calcificação e o estágio de maturação. Essas etapas podem ser alteradas por fatores genéticos, sistêmicos e locais. Segundo Lima et al. (2015) quando a amelogênese é alterada na etapa de formação da matriz, o defeito do esmalte será quantitativo. Ao passo que, se a fase alterada for a de maturação, ocasionará defeitos qualitativos do esmalte. Para diagnóstico diferencial de Hipomineralização Molar-incisivo (HMI) e Fluorose, essas informações devem ser levadas em consideração. Santos, et al., (2014), apresentaram uma classificação, na qual, HMI e a Fluorose, são incluídas no grupo Hipomineralização (opacidades), por apresentarem características semelhantes. Ambos são defeitos qualitativos do esmalte, com alterações na microestrutura do esmalte durante a fase de maturação. A HMI, é uma displasia do esmalte, desencadeada por um distúrbio de ordem ameloblástica, que ocorre em uma fase precoce da fase de maturação. São opacidades demarcadas em coloração amarelo-acastanhado, com bordas claras e diferentes do esmalte normal. Em relação a sua etiologia, pode estar associada a fatores sistêmicos, doenças respiratórias e complicações perinatais (ARAÚJO; RESENDE; POSSEBON, 2020). De encontro a essa perspectiva, Silva; et al., 2020, indicam que distúrbios durante a gravidez, infecções graves, uso recorrente de antibióticos e fatores genéticos, podem estar associados a sua etiologia. Lina, et al., 2018, cita além complicações estéticas, o comprometimento funcional. As forças produzidas durante a mastigação podem ocasionar o desgaste e fraturas do dente, levando a exposição de dentina. Por conta da condição do esmalte, é observado maior susceptibilidade de desenvolvimento de lesões de cárie. A Fluorose Dentária é desencadeada por ingestão contínua de flúor, durante o período de formação dos dentes e maturação do esmalte. Os altos índices de fluoretos no período de mineralização do esmalte, inibe as proteínas enzimáticas, atrasando a degradação as proteínas da matriz durante a fase de maturação. (SHAHROOM; MANI; RAMAKRISHNAN, 2019). O flúor pode entrar no sistema humano por meio da ingestão de alimentos, água potável, inalação e até mesmo contato dérmico (BEYENE; ABEBE; MELESE, 2019). Segundo Bevilacqua, Sacramento e Felício, em 2010, clinicamente, apresenta-se como um esmalte opaco e com manchas que podem variar de branco a castanho-escuro, podendo apresentar áreas com erosão. A anamnese e o exame clínico se mostram fundamentais para o diagnóstico diferencial de Fluorose e Hipomineralização do Esmalte. O exame clínico possui algumas condições ideais para realização, a começar por uma iluminação adequada, profilaxia prévia do esmalte, bem como, secagem dos dentes (RIGO; LODI; GARBIN, 2015). Deste modo, Barzotto e Rigo, em 2018, ao compararem a Fluorose e a HMI, evidenciaram a importância da anamnese, em consonância com um exame clínico minucioso, já que a fluorose, além de ocorrer bilateralmente e de forma simétrica, está relacionada à ingestão de fluoretos, informação que pode ser coletada pela anamnese.

Conclusão: Com isso, para um diagnóstico eficaz de Fluorose e Hipomineralização Molar-Incisivo, deve haver uma anamnese criteriosa e um exame clínico minucioso dos elementos dentários. Mas é indispensável o conhecimento prévio de sua etiologia, 
características e apresentações clínicas. Ou seja, conhecimento e habilidade do cirurgião dentista, por meio de respaldo científico o que permite elaborar um prognóstico que atenda as necessidades do paciente, neutralizando os efeitos deletérios causados pelo defeito do esmalte.

\section{Referências}

ARAÚJO, Ana Maria Paixão; RESENDE, Nanashara da Silva; POSSEBON, lana Caroline A. Alves. Hipomineralização Molarincisivo: uma revisão de literatura. Revista Cathedral Saúde, v. 2, n. 1, 2020.

BARZOTTO, Izabel; RIGO, Lilian. Clinical decision making for diagnosis and treatment of dental enamel injuries. Journal of Human Growth and Development, v. 28, n. 2, p. 189-198, 2018.

BEVILACQUA, Flávia Magnani; SACRAMENTO, Tamires; FELÍCIO, Cristina Magnani. Amelogênese Imperfeita, Hipoplasia de Esmalte e Fluorose Dental - Revisão de Literatura. Revista Brasileira Multidisciplinar, v. 13, n. 2, p. 136-148, Jul. 2010.

BEYENE, Abebe; ZEWDU, Abebe; MELESE, Addisu. Concentração de fluoreto nas águas subterrâneas e prevalência de fluorose dentária no Vale do Rift etíope: revisão sistemática e metanálise. BMC Public Health, v. 19, n. 1298 p. 1-9, 2019.

LIMA, Gisele Quariguasi Tobias. et al., Manchas brancas em esmalte dentário: Cárie Dentária, Hipoplasia ou Fluorose? Uma abordagem Crítica. Revista de Pesquisa em Saúde, v. 16, n. 2, p. 112-118, mai/ago, 2015.

LINA, M. Gronelândia. et al., Oral health-related quality of life in Colombian children with Molar-Incisor Hypomineralization. Acta Odontológica Latinoamericana, v. 31, n. 1, p. 38-44, 2018.

RIBAS, Andrea de Oliveira; CZLUSNIAK, Gislaine Denise. Anomalias do Esmalte Dental: etiologia, diagnóstico e tratamento. Publicatio UEPG: Ciências Biológicas e da Saúde, Ponta Grossa, v. 10, n. 1, p. 23-26, Mar. 2004.

RIGO, Lilian; LODI, Leodinei; GARBIN, Raíssa Rigo. Diagnóstico diferencial de fluorose dentária por discentes de odontologia. Journal Einstein, v. 13, n. 4, p. 547-554, 2015.

SANTOS, Camila Thomaz. et al. Anomalias do esmalte dentário - revisão de literatura. Arch Health Invest, v. 3, n. 4, p. 74-81, 2014.

SHAHROOM, Nor Syakirah Binti; MANI, Geo; RAMAKRISHNAN, Mahesh. Interventions in management of dental fluorosis, an endemic disease: A systematic review. Journal of family medicine and primary care, v. 8, n. 10, p. 3108-3113, Oct. 2019.

SILVA, Fernanda Mafei Félix. et al. Defining the Prevalence of Molar Incisor Hypomineralization in Brazil. Pesquisa Brasileira em Odontopediatria e Clínica Integrada, v. 20, 2020. 


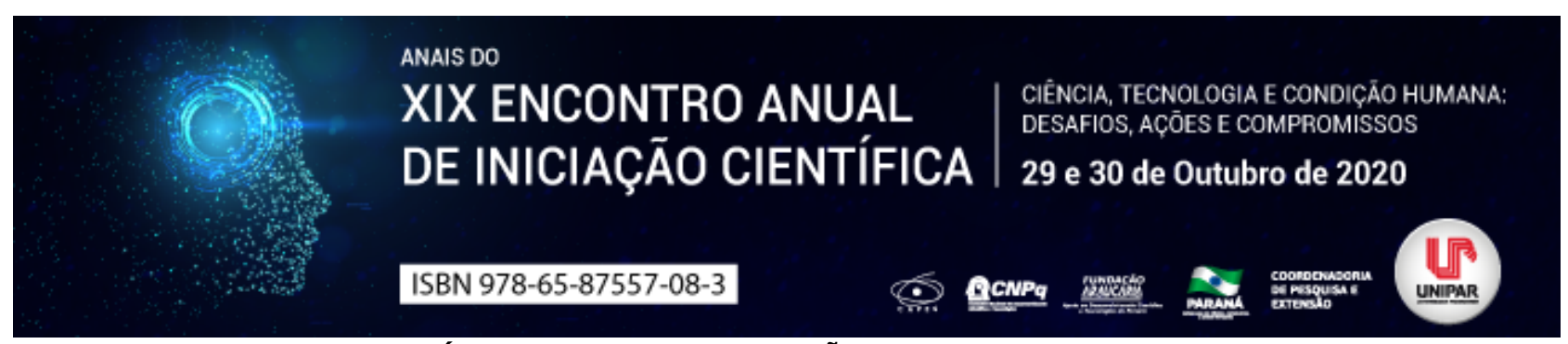

SÍFILIS ADQUIRIDA: ADESÃO AO TRATAMENTO

\begin{abstract}
${ }^{1}$ ANNE GABRIELLA PACITO MONTEIRO, ${ }^{2}$ ISABELA LUIZA DOSSO, ${ }^{3}$ LETICIA MARIA CAMPOS, ${ }^{4}$ AMANDA NASCIMENTO VASQUES DE SOUZA, ${ }^{5}$ ADALBERTO RAMON VALDERRAMA GERBASI, ${ }^{6}$ NANCI VERGINIA KUSTER DE PAULA
\end{abstract}

\author{
${ }^{1}$ Discente do Curso de Enfermagem, PIC/UNIPAR \\ ${ }^{1}$ Discente do Curso de Enfermagem, PIC/UNIPAR \\ ${ }^{2}$ Discente do Curso de Enfermagem, PIC/UNIPAR \\ ${ }^{3}$ Mestranda no Programa em Plantas Medicinais e Fitoterápicas na Atenção Básica, PIC/UNIPAR \\ ${ }^{4}$ Docente do Curso de Enfermagem da Universidade Paranaense/UNIPAR \\ ${ }^{5}$ Docente do Curso de Enfermagem da Universidade Paranaense/UNIPAR
}

Introdução: A sífilis é uma Infecção Sexualmente Transmissível (IST) ocasionada pela bactéria Treponema pallidum, sendo transmitida pela via congênita de mãe para filho (a) , transfusão sanguínea e principalmente pela via sexual (BRASIL, 2010). O Ministério da Saúde classifica a doença como sífilis adquirida, congênita e gestacional, que por sua evolução lenta, pode ou não apresentar sintomas, dificultando o tratamento precoce (BRASIL, 2010; BRASIL, 2016). Por sua vez, a sífilis adquirida é subdividida em primária, secundária, terciária e latente. Na primária, há a presença de feridas em região específica do corpo, normalmente é indolor, sem a presença de pus e sem ardência. Na sífilis secundária, os sinais só irão aparecer semanas após a ferida cicatrizar, podendo o paciente apresentar cefaléia, mal estar e pirexia (estado febril). A sífilis terciária, por sua vez, pode demorar até 40 anos após a primeira infecção, ocasionando problemas nos ossos, pele, coração e sistema nervoso, podendo levar a óbito. Já a sífilis latente, não apresenta sinais ou sintomas, visto que estes surgem da sífilis secundária ou terciária, não tendo uma duração específica, podendo também ser dividida em latente recente, quando a infecção tem menos de dois anos e latente tardia, quando a infecção já está instalada há mais de dois anos (BRASIL, 2019; DELBEN; VIANA, 2018). O Boletim Epidemiológico mostra que nos anos de 2010 a 2019 foram realizadas 650.258 notificações para sífilis adquirida, deste número, foram 158.051 casos somente no ano de 2018. Também ficou evidenciado que a doença ocorre em pessoas entre 20 e 29 anos, com seu maior índice na Região Sul e na Sudeste, com 71.842 e 36.808 notificações, respectivamente (BRASIL, 2019).

Objetivo: Verificar as dificuldades à adesão e à realização do tratamento para a sífilis.

Desenvolvimento: Para a sífilis e outras ISTs, a melhor forma de prevenção é o uso de preservativos, mas no caso de doença instalada o Sistema Único de Saúde (SUS) fornece tratamento gratuito e eficaz, quando realizado da maneira correta, porém mesmo assim há um grande aumento de casos nos últimos anos (BRASIL, 2010). O Ministério da Saúde disponibiliza ainda o teste rápido que deve ser a primeira escolha para a detecção da sífilis e em casos de testes reagentes (positivos), será encaminhada uma amostra sanguínea para o teste não treponêmico. O teste não treponêmico é dividido em quantitativo (determina os anticorpos que são reagentes na amostra e monitora a resposta ao tratamento) e o qualitativo (determina se a amostra é reagente ou não) detectando anticorpos presentes na sífilis, mas que não são específicos para o Treponema Pallidum, já o teste treponêmico, é realizado apenas na forma qualitativa, detectando anticorpos que são específicos para $T$. pallidum. $O$ tratamento para sífilis é realizado com penicilina benzatina, onde o mesmo segue um esquema terapêutico para cada estágio da doença, ressaltando ainda a necessidade da realização do tratamento em todos os parceiros sexuais (BRASIL, 2019). Neste sentido, é necessário que haja uma assistência de saúde de maneira integral e de qualidade para todos os pacientes, onde o enfermeiro desempenha um papel fundamental para esse processo tanto na prevenção quanto no tratamento (BRASIL, 2016; Rodrigues ARM, Silva MAM da, Cavalcante AES et al. 2016). Segundo uma pesquisa realizada no interior do Ceará com parceiros de gestantes diagnosticadas com sífilis, vários são os fatores para a não adesão ao tratamento, dentre eles o nível de escolaridade, não entendimento da real consequência da doença e dos possíveis conflitos originados da relação da doença com a infidelidade da esposa (FIGUEIREDO et al 2015). Outro problema citado pelos autores era o tratamento realizado em hospitais daquela região, pois a demora no atendimento dificultava o diagnóstico e o tratamento dos homens. Pesquisas também destacaram a dificuldade de identificar os parceiros sexuais, descaso ao uso de preservativos, difícil acesso e diagnóstico tardio pela falta de capacitação das equipes de saúde, além do uso de drogas pelos soropositivos (GONÇALVES et al, 2020).

Conclusão: A sífilis é uma patologia que pode gerar inúmeras consequências para a mulher, para seu parceiro e para o recémnascido quando não tratada da maneira correta. Dentre os impasses encontrados, fica evidenciado que a falta de adesão ao tratamento está relacionada à dificuldade de acesso ao serviço, grau de escolaridade, falta de treinamento com a equipe multidisciplinar para uma busca ativa e acompanhamento dos pacientes, bem como a dificuldade de tratar todos os parceiros sexuais, sendo assim, é de suma importância que a equipe de saúde realize orientações e educação em saúde, facilitando o diagnóstico e tratamento precoce da doença. 


\section{Referências}

BRASIL. Ministério da Saúde. Sífilis. Brasília - 2019. Disponível em: . Acesso em: 10 Ago. 2020.

BRASIL. Ministério da Saúde. Sífilis: Estratégias para Diagnóstico no Brasil. Brasília: Ministério da Saúde, Coordenação de Doenças Sexualmente Transmissíveis e Aids. 2010. 100 p. (Série TELELAB)

BRASIL. Ministério da Saúde. Manual Técnico para Diagnóstico da Sífilis. Brasília - 2016. Disponível em: . Acesso em: 11 Ago. 2020.

BRASIL. Ministério da Saúde. Boletim epidemiológico da Sífilis. Brasília - 2013. Disponível em: . Acesso em: 11 Ago. 2020.

BRASIL. Ministério da Saúde. Secretaria de Vigilância em Saúde Departamento de DST, Aids e Hepatites Virais. Protocolo clínico e diretrizes terapêuticas para prevenção da transmissão vertical de HIV, sífilis e hepatites virais. Brasília, DF; 2019. Disponível em: . Acesso em: 16 de Ago. 2020.

DELBEN, Thainara Victória Tondorf; VIANA, Tiago Rodrigues. Sífilis Características e nova abordagem. Saúde \& Conhecimento-Jornal de Medicina Univag, v. 1, 2018.

DE FIGUEIREDO, Mayanne Santana Nóbrega et al. Percepção de enfermeiros sobre a adesão ao tratamento dos parceiros de gestantes com sífilis. Rev da Rede de Enfermagem do Nordeste. 2015;16(3):345-54.

DA SILVA, Policardo Gonçalves et al. Sífilis adquirida: dificuldades para adesão ao tratamento. Rev. iberoam. Educ. investi. Enferm. 2020; 10(1):38-46. 


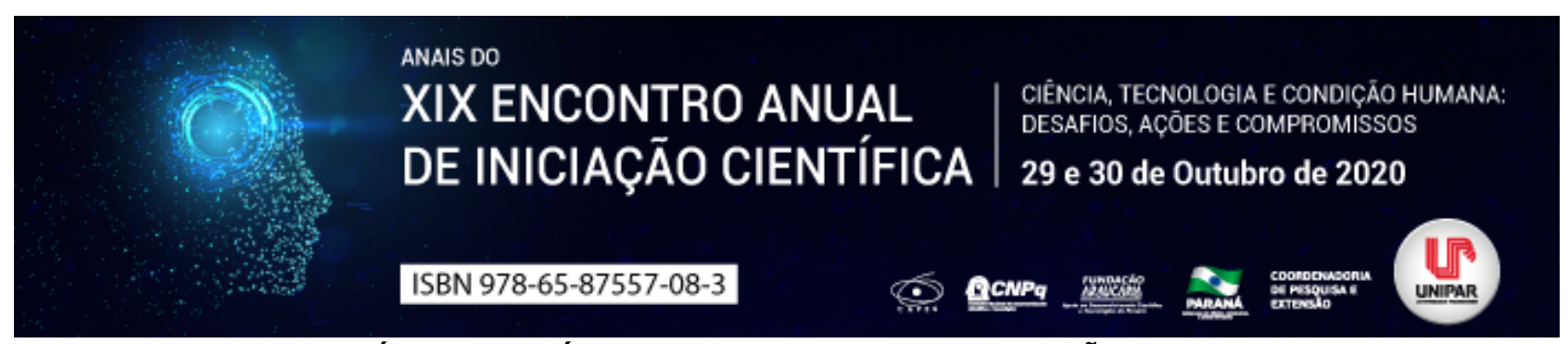

EFICÁCIA DA PRÓPOLIS NO TRATAMENTO DE LESÕES BUCAIS

\begin{abstract}
${ }^{1}$ GISELE APARECIDA SPADIM, ${ }^{2}$ ANA MARIA DA SILVA, ${ }^{3}$ GIOVANA SOLER DOS SANTOS, ${ }^{4}$ ELOISA PEREIRA DE SOUZA, ${ }^{5}$ ARGEMIRO RIBEIRO DE ALMEIDA NETO, ${ }^{6}$ DANIELA DE CASSIA FAGLIONI B CERANTO
\end{abstract}

\author{
${ }^{1}$ Acadêmica do Curso de Odontologia PIC/UNIPAR \\ ${ }^{1}$ Acadêmica do Curso de Odontologia PIBC/UNIPAR \\ ${ }^{2}$ Acadêmica do Curso de Odontologia PIC/UNIPAR \\ ${ }^{3}$ Acadêmica do Curso de Odontologia PIC/UNIPAR \\ ${ }^{4}$ Acadêmico do Curso de Odontologia PIC/UNIPAR \\ ${ }^{5}$ Docente da UNIPAR
}

Introdução: A própolis possui eficácia no tratamento de lesões bucais, tendo atividade antibacteriana, antifúngica e antimicrobiana sendo utilizada na odontologia devido tais propriedades (DE ALMEIDA et al., 2016).

Objetivo: Fazer uma revisão de literatura referente ao uso do própolis em algumas lesões bucais, que tenham como agentes etiológicos fungos e/ou bactérias.

Desenvolvimento: Há muito tempo a humanidade tem o hábito de utilizar produtos naturais para o tratamento de doenças, dentre estes produtos, a própolis é um dos que se destaca. A própolis é uma substância coletada pelas abelhas, resinosa e sem toxicidade tendo uma mistura de folhas, seiva e saliva de insetos (DE ALMEIDA et al., 2016). Ela é utilizada pelas abelhas para obstruir a colmeia e tem tonalidades que variam desde marrom ao amarelo esverdeado, com aparência grudenta (PENSIN et al., 2009). Na ação antibacteriana a própolis tem como ferramenta a inibição da divisão celular e da síntese proteica, bem como a ruptura da membrana (PETER, 2015). Assim seu uso em lesões aftosas teve grande eficácia, como em um estudo em que foi utilizada para a regressão da lesão, no qual os participantes utilizaram a própolis em orabase a $5 \%$ sobre as lesões por aproximadamente 3 meses de estudo. Após todo esse tempo utilizando a pomada, foi feito o uso de placebo pelo mesmo período para comparação, os resultados demonstraram que a pomada de própolis fez com que houvesse regressão da lesão e a aceleração de sua cicatrização, passando desta forma a cicatrizar em torno de 2 a 5 dias o que antes demorava em torno de 7 a 14 dias. Não obstante os pacientes relataram melhora em questão das dores sentidas (PENSIN et al., 2009). Em outro estudo os pacientes foram divididos de acordo com a ocorrência das lesões. Um grupo as lesões aconteciam em um intervalo de tempo entre 7 e 21 dias e o outro grupo com frequência de 30 a 90 dias. Foi aplicado uma solução de $5 \%$ de própolis em propilenoglicol, 3 vezes ao dia sobre as lesões. Como resultado obteve que a própolis diminui o número de ulcerações aftosas, a frequência e o tempo de duração. Concluindo assim que seu uso tem bastante eficácia no tratamento de aftas (LOTUFO et al., 2005). Já na atividade antifúngica o extrato da própolis da abelha Apis mellifera foi avaliado frente a diversas espécies do gênero Candida, estas apresentaram alta sensibilidade ao extrato da própolis e constataram ainda que quanto maior a sua concentração, melhores seriam os resultados frente a espécie do fungo (LONGHINI et al., 2007). Considerando ser a Candida spp um fungo comensal, mas que também é encontrada em lesões causadas pela prótese removível, ou até mesmo pode ser encontrado em indivíduos saudáveis, na cavidade oral, a própolis seria uma opção de tratamento quando houvesse um desequilíbrio e o fungo manifestasse doença (SALVATORI et al., 2016). Logo, a própolis tem sido testada no tratamento de estomatite protética, devido sua ação antifúngica sobre a Candida albicans (SCALERCIO et al., 2007). Portanto com o objetivo de avaliar sua eficácia,18 paciente foram diagnosticados com essa lesão, sendo instruídos a 4 vezes por dia aplicar o extrato da própolis durante uma semana. Por outro lado outros seis pacientes usaram a Nistatina na lesão, durante o mesmo tempo. Foi constatado que o extrato da própolis regrediu a lesão, assim como a nistatina, comprovando desse modo seu poder antifúngico na cavidade oral (SANTOS et al., 2005 ). A própolis também se mostrou eficaz no tratamento periodontal. Estudos demonstraram seu poder antibacteriano contra os patógenos periodontais (DODWAD; KUKREJA, 2011). Esperança (2007) mostrou em um estudo in vitro sua eficácia contra bactérias periodontopatogênicas, colocando a solução de própolis em culturas de bolsa periodontal, o que resultou em uma ação inibitória da própolis contra os microorganismos, comprovando assim sua ação antimicrobiana.

Conclusão: A revisão exposta, mostra a eficácia da própolis em algumas lesões bucais comprovando sua utilidade com a ação antifúngica, antibacteriana, antimicrobiana e seu poder no tratamento periodontal, assim como seu potencial de cicatrização, o que a torna promissora no controle de doenças bucais.

\title{
Referências
}

DE ALMEIDA, Débora Cristina et al. Própolis na odontologia: Uma abordagem de suas diversas aplicabilidades clínicas. Revista Fluminense de Odontologia, v. 2, n 46, p. 1-12, Jul/ Dez, 2016. 
DODWAD, Vidya; KUKREJA, Bhavna Jha. Propolis mouthwash: A new beginning. Journal of Indian Society of Periodontology, v. 5, n. 2, p.121-125, 2011.

LONGHINI, Renata et al. Obtenção de extratos de própolis sob diferentes condições e avaliação de sua atividade antifúngica. Brazilian Journal of Pharmacognosy, João Pessoa, v.17, n. 3, p. 388-395, Jul./Set, 2007.

LOTUFO, Mônica Andrade et al. Clinical evaluation of the topical use of propolis in recurrent minor aphthous ulceration. Cienc Odontol Bras, v. 8, n. 3, p. 6-9, 2005.

PENSIN, Nicolas Renan et al. Efeito de pomada de própolis em orabase para tratamento de ulcerações aftosas recorrentes um estudo piloto. Arq Ciênc Saúde UNIPAR, Umuarama, v. 13, n. 3, p. 199-204, Set/Dez.2009.

PETER, Cristina Mendes. Atividade antimicrobiana de extratos hidroalcoólicos de própolis marrom, verde e de abelhas jataí (Tetragonisca angustula) frente a microorganismos infecciosos de interesse em Medicina Veterinária e Humana. 2015. Dissertação (Mestrado) -Faculdade de veterinária,Programa de Pós-Graduação, Universidade Federal de Pelotas, Pelotas, 2015.

SALVATORI, Ornella et al . Imunidade inata e saliva em doenças orais medidas por Candida albicans. J Dent Res, v. 95, n. 4, p. 365-371, 2016.

SANTOS, Vagner Rodrigues et al. Oral candidiasis treatment with Brazilian ethanol propolis extract. Phytother Re, v. 19, n. 7, p. 652-654, 2005.

SCALERCIO, Michelle et al. Estomatite protética versus candidíase: diagnóstico e tratamento. Revista Gaúcha de Odontologia, Porto Alegre, v. 55, n. 4, p. 395-398, 2007.

SPERANÇA, Paulo Augusto et al. Verificação da atividade antimicrobiana de soluções à base de própolis sobre microbiota oriunda de bolsas periodontais estudo in vitro. Rev Periodontia, v. 17, n. 3, p. 54-59, 2007. 


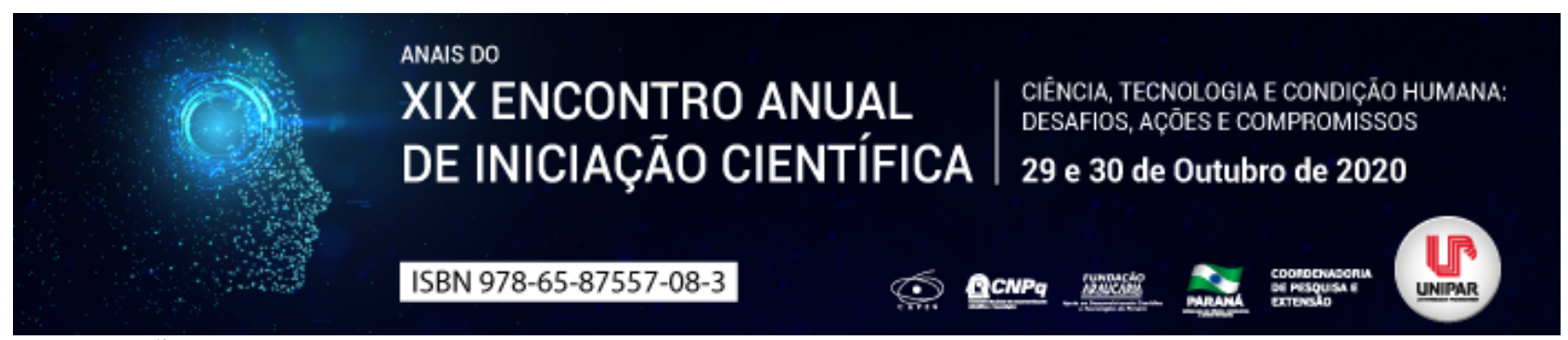

RELAÇÃO ENTRE A MICROBIOTA INTESTINAL E O TRANSTORNO DO ESPECTRO AUTISTA (TEA)

\begin{abstract}
1'LEANDRO MARTINS LIMA SOUZA, ${ }^{2}$ FERNANDA DE ABREU BRAGA, ${ }^{3}$ LORENA DE FATIMA MORETTO, ${ }^{4}$ LUCAS NOGUEIRA ANTUNES DE SOUZA, ${ }^{5}$ PAULA MONTANHINI FAVETTA
\end{abstract}

${ }^{1}$ Acadêmico do curso de Medicina da UNIPAR
${ }^{1}$ Acadêmica do Curso de Medicina da UNIPAR
${ }^{2}$ Acadêmica do Curso de Medicina da UNIPAR
${ }^{3}$ Acadêmico do curso de Medicina do Centro Universitário São Lucas
${ }^{4}$ Doutoranda no PPG em Ciência Animal com Ênfase em Produtos Bioativos, Bolsista PROSUP-CAPES UNIPAR

Introdução: O Transtorno do Espectro Autista (TEA) tem como característica central a disfunção comportamental social e/ou cognitivo do indivíduo, podendo este ter como base várias etiologias genéticas, como a relacionada à idade dos pais, ou do meio externo, ligado em sua maioria ao pré-natal (VÉRAS, NUNES, 2019). Por possuir padrões sociais e comportamentais repetitivos, pacientes com TEA, costumam apresentar hábitos de repetições diárias, sendo que muitas destas está diretamente ligada a alimentação. Diante disso, distúrbios patogênicos do sistema nervoso juntamente com o sistema digestório, e sobretudo a microbiota intestinal, têm demonstrado relação com os diagnósticos do TEA (DIAS, 2016).

Objetivo: Através de uma revisão bibliográfica analisar a relação entre a microbiota intestinal e o Transtorno do Espectro Autista (TEA).

Desenvolvimento: $O$ presente trabalho consiste numa revisão de literatura utilizando o banco de dados eletrônico Google Acadêmico , com as seguintes palavras-chave: autismo; microbiota intestinal no autismo; probióticos no tratamento do TEA; transtorno gastrointestinal no TEA. Foram selecionados sete artigos de 2015 a 2020, sendo excluídos os artigos que não estavam relacionados com a microbiota intestinal e o TEA. A relação cérebro-intestino-microbiota tem papel fundamental ao bom funcionamento do organismo e ao desenvolvimento adequado do indivíduo, sendo que sua disfunção tem refletido diretamente as comorbidades e tratamentos do TEA (SOARES, 2017). A microbiota intestinal infantil é constituída principalmente nos três primeiros anos de vida, sendo diretamente relacionada aos fatores genéticos, ao reflexo do parto, antibióticos, alimentação materna subsequente a amamentação e posteriormente outras formas de nutrição da criança, a qual está intimamente ligada a alteração da permeabilidade intestinal, produção de enzimas digestivas, inflamações nas mucosas enterogástricas e o desenvolvimento de alergias a diversos componentes (SOARES, 2017). Transtornos gastrointestinais são muito comuns em pacientes autistas, podendo atingir até $60 \%$ desta população, tendo por consequência dores abdominais, diarreia, constipação e, podendo ser desenvolvida, a síndrome do intestino irritável (VERAS, NUNES, 2019). Estas comorbidades são diretamente relacionadas a microbiota intestinal, a qual é responsável pela homeostase do trato digestivo, já que é composta por um conjunto de microorganismos, como por exemplo bactérias, fungos e vírus. A deficiência de aminoácidos precursores de neurotransmissores, como o triptofano e a tirosina é muito comum em crianças autistas, o que explica a relação do TEA com distúrbios ambientais, alterações gastrointestinais e as condições alimentares (DIAS, 2016). Somando-se ao exposto, crianças autistas possuem em quantidades excessivas bactérias patogênicas, como a Clostridium difficile, em sua microbiota intestinal, ocorrendo um processo de disbiose e, consequentemente, o desequilíbrio imunorregulatório, que juntamente com alterações ambientais e a permeabilidade da mucosa intestinal pode levar ao agravamento do comportamento autista (DIAS, 2016). Diante disso, muitas destas respostas podem ser classificadas como respostas imunes do trato gastrointestinal, onde as células epiteliais do intestino ficam mais permeáveis e suscetíveis a uma possível inflamação, concluindo, assim, uma relação entre a disfunção gastrointestinal e doenças autoimunes (DIAS, 2016; VERAS, NUNES, 2019). Isso é demonstrado, por exemplo, quando crianças autistas são expostas ao glúten, a caseína e aos peptídeos derivados destas proteínas, já que estas demonstraram causar maior permeabilidade intestinal nos indivíduos e respostas inflamatórias interrompendo a relação microbiota-intestino-cérebro (DIAS, 2016). Ademais, por não existir cura ao TEA, atribuem-se tratamentos aos sintomas adjacentes, como por exemplo à disfunção gastrointestinal, sendo que neste está sendo utilizado antimicrobianos, que têm auxiliando na resposta imune e nas habilidades cognitivas do paciente com autismo, além de melhora da função intestinal, aumento da secreção, vasodilatação, permeabilidade vascular e, consequentemente, liberação de serotonina, melhorando, assim, os sintomas do autismo em relação social (ROCHA, et al., 2020; DIAS, 2016). Nessa senda, a utilização de probióticos têm se tornado cada vez mais comum na terapia do TEA. A suplementação de Lactobacillus acidophilus, Lactobacillus rhamnosus e Bifidobacteria longum tem demonstrado resultados positivos e com significativa melhora dos pacientes em relação aos sintomas gastrointestinais e, logo, nos sintomas do autismo como um todo, podendo, assim, gerar uma melhora na gravidade do transtorno (ROCHA, et al., 2020). 
Conclusão: De acordo com as informações disponibilizadas na literatura, a regulação da microbiota intestinal está diretamente relacionada à disfunção gastrointestinal que consequentemente atinge as funções cognitivas cerebrais e, assim, podendo ser desenvolvido, a partir de então, o TEA. Conclui-se, também, que ainda se faz necessário novos estudos, de forma a explicar os mecanismos deste efeito da microbiota intestinal em relação ao autismo.

\section{Referências}

DIAS, B. P. Relação entre a microbiota intestinal e o autismo. Trabalho de Conclusão de Curso (Bacharelado em Biomedicina). Centro Universitário São Lucas. Porto Velho, 2016.

PINHO, M. A. Manifestações gastrointestinais em crianças com transtorno do espectro autista. 2015. Tese (doutorado) Universidade Federal da Bahia, Instituto de Ciências da Saúde, 2015.

PINTO, A. C. S. et. al. A disfunção da microbiota intestinal no transtorno do espectro do autismo: revisão integrativa de literatura. Anais do Primeiro Simpósio de Otorrinopediatria do norte de Minas Gerais e III Congresso Norte Mineiro de saúde da criança. Montes Claros MG, 2019.

ROCHA, G. S. S. et al. Terapias alternativas e complementares no tratamento de sintomas gastrointestinais em crianças com transtorno do espectro autista. Revista Eletrônica Acervo e Saúde. v.sup. n.52, 2020. Acesso em: 24 jul. 2020. Disponível em: https://doi.org/10.25248/reas.e3538.2020

SERAFIM, C. R., et. al. A influência da alimentação no comportamento da criança com transtorno do espectro autista. 2019. Centro Universitário Toledo, 2019.

SOARES, R. A. A influência da microbiota intestinal nas perturbações do espectro do autismo. 2017. Dissertação (Mestrado em Farmácia). Universidade de Coimbra, Portugal, 2017.

VERAS, R. S. C.; NUNES, C.P.; Conexão cérebro-intestino-microbiota no transtorno do espectro autista. Revista de medicina de família e saúde mental, v.1, n. 1, 2019. Acesso em: 24 jul. 2020 . Disponível em: http://www.revista.unifeso.edu.br/index.php/medicinafamiliasaudemental/article/view/1564.

Coordenadoria de Pesquisa e Extensão - COPEX

Departamento de Editoraçāo e Divulgaçāo Científica - DEDIC 


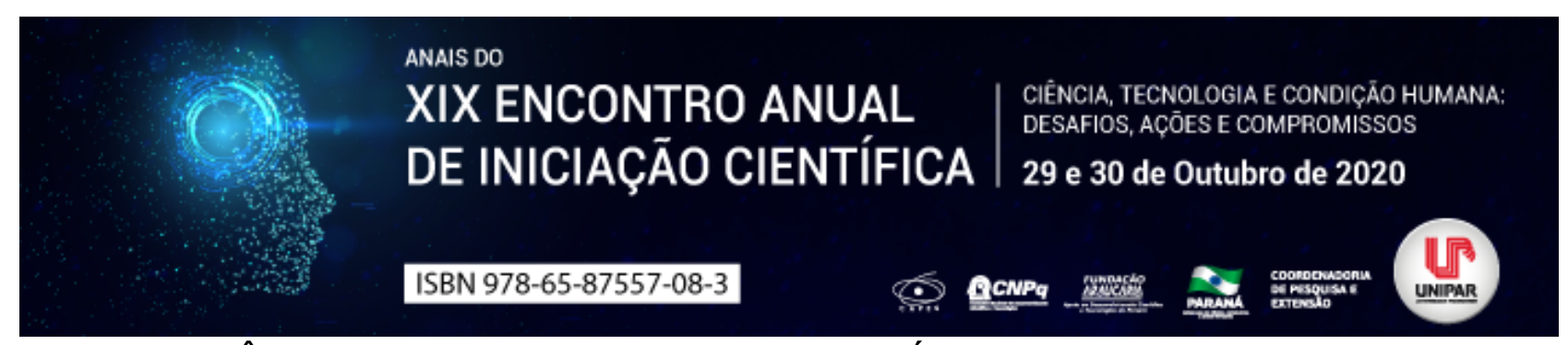

TERAPIA FOTODINÂMICA APLICADA A ATIVIDADE MICROBIOLÓGICA DO COMPOSTO FOTOSSENSIBILIZANTE HIPERICINA

\author{
${ }^{1}$ AMANDA CRISTINA DA ROCHA OLIVEIRA, ${ }^{2}$ BRUNA APARECIDA SOARES FAVARO, ${ }^{3}$ HELOISA MACHINESKI, \\ ${ }^{4}$ NATHIELLE MIRANDA
}

${ }^{1}$ Acadêmica do Curso de Farmacia da UNIPAR
${ }^{1}$ Acadêmica do Curso de Farmácia da UNIPAR
${ }^{2}$ Acadêmica do Curso de Farmácia da UNIPAR
${ }^{3}$ Docente da UNIPAR

Introdução: A resistência antibiótica entre bactérias patogênicas é iminente e se tornou um dos maiores problemas de saúde a nível global (LOUREIRO et al, 2016). Na esfera da saúde pública, ela configura um risco a qualidade de vida, danificando o orçamento dos sistemas de saúde, além de agravar as infecções hospitalares, podendo também comprometer a vida humana (COSTA; JUNIOR, 2017). A terapia fotodinâmica (TFD) é uma modalidade de tratamento alternativa que de forma isolada ou em combinação com tratamentos usuais resulta em melhores resultados clínicos, e vem sendo muito usada para tratar infecções bacterianas, fúngicas e virais (SCHERER et al, 2017). Fundamentalmente, a TFD é uma reação química ativada por luz para provocar a destruição seletiva de um tecido ou patógeno, e demanda de um agente fotossensibilizante no tecido-alvo, oxigênio e fonte de luz (ISSA; AZULAY, 2010).

Objetivo: $\mathrm{O}$ aumento da resistência das bactérias às drogas antibióticas leva a necessidade de desenvolver novos meios com ação terapêutica em indivíduos infectados. Assim sendo, o objetivo principal é uma revisão de literatura com a abordagem sistemática das questões referentes a atividade da Hipericina e sua aplicação como fármaco fotossensibilizador em terapia fotodinâmica antimicrobiana.

Desenvolvimento: Abrahamse e Hamblin (2016) caracterizam a TFD como uma técnica onde a luz é utilizada para ativar compostos químicos intitulados fotossensibilizadores, que interagem com o oxigênio presente na molécula produzindo espécies reativas de oxigênio (EROs), provocando danos oxidativos nos micro-organismos, expondo as bactérias à atividade de antibióticos e de outras substâncias com propriedades antimicrobianas. O composto fotossensível em questão, aplicável a TFD é a Hipericina, uma naftodiantrona presente nas plantas do gênero Hiperycum, sendo abundante principalmente em glândulas vermelhas das pétalas e estames das flores, local mais provável de sua biossíntese (ZOBAYED et al., 2006). A Hipericina é, certamente, o mais potente FS identificado na natureza e vem sendo pesquisada como uma nova geração de drogas para a terapia fotodinâmica antimicrobiana com resultados comprovados frente a algumas cepas bacterianas resistentes a antibióticos padrões (YOW et al., 2012). Outro interesse aplicável é a sua combinação com agentes fotossensibilizadores para maximizar seus efeitos. Seu baixo custo, efeitos colaterais mínimos, probabilidade de recorrência reduzida, além da simplicidade da técnica e o risco de resistência microbiana ainda não ter sido relatado, fazem com que seja uma importante modalidade de tratamento principal ou complementar (EDUARDO, 2015).

Conclusão: Diante do exposto, destaca-se o emprego da Terapia fotodinâmica antimicrobiana utilizando o composto fotossensibilizante Hipericina, como uma forma de reduzir a resistência através de danos oxidativos a estrutura de microorganismos, sendo mais vantajosa por seu custo acessível, além da possibilidade de novas abordagens de tratamentos e poucos efeitos colaterais.

\title{
Referências
}

ABRAHAMSE, Heidi; HAMBLIN, Michael. New photosensitizers for photodynamic therapy. Biochemical Journal, v.473, n.4, Feb, 2016. Disponível em: https://pubmed.ncbi.nlm.nih.gov/26862179/. Acesso em: 11 set. 2020.

COSTA, Anderson; JUNIOR, Antonio. Resistência bacteriana aos antibióticos e Saúde Pública: uma breve revisão de literatura.
Estação
científica
(UNIFAP),
v.7, $\quad$ n.2,
Mai/Ago,
2017.
Disponível
em:

https://periodicos.unifap.br/index.php/estacao/article/view/2555. Acesso em: 11 set. 2020.

EDUARDO, Carlos; BELLO-SILVA, Marina Stella; RAMALHO, Karen Muller; LEE, Ester; ARANHA, Ana Cecilia. A terapia fotodinâmica como benefício complementar na clínica odontológica. Revista da Associação Paulista dos Cirurgiões Dentistas, São Paulo, v.69, n.3, p.226-235, ago., 2015.

ISSA, Maria; AZULAY, Mônica. Terapia fotodinâmica: revisão da literatura e documentação iconográfica. Anais Brasileiros de Dermatologia, Rio de Janeiro, v.85, n.4, p.501-511, ago., 2010.

LOUREIRO, Rui João; ROQUE, Fátima; RODRIGUES, António; HERDEIRO, Maria Teresa; RAMALHEIRA, Elmano. O uso de 
antibióticos e as resistências bacterianas: breves notas sobre sua evolução. Revista Portuguesa de Saúde Pública, Portugal, v.34, n.1, p.77-84, jan./abr. 2016.

SCHERER, Kathrin; BISBY, Roger; BOTCHWAY, Stanley; PARKER, Anthony. New Approaches to Photodynamic Therapy from Types I, II and III to Type IV Using One or More Photons. Anti-Cancer Agents in Medicinal Chemistry, v.17, n.2, October, 2017. Disponível em: https://pubmed.ncbi.nlm.nih.gov/27173966/. Acesso em: 11 set. 2020.

YOW, Christine; TANG, Hi; CHU, Ellie; HUANG, Zheng. Hypericin-mediated photodynamic antimicrobial effect on clinically isolated pathogens. Photochem Photobiol, v.88, n.3, May.-Jun., $2012 . \quad$ Disponível em: https://pubmed.ncbi.nlm.nih.gov/22233203/. Acesso em: 11 set. 2020.

ZOBAYED, Sayed; AFREEN, Fawzia; GOTO, Eiji; KOZAI, Takashi. Plant-Environment Interactions: Accumulation of Hypericin in Dark Glands of Hypericum perforatum. Annals of Botany, Japan, v.98, n.4, p.793-804, ago. 2006.

Coordenadoria de Pesquisa e Extensão - COPEX

Departamento de Editoraçāo e Divulgaçāo Científica - DEDIC 


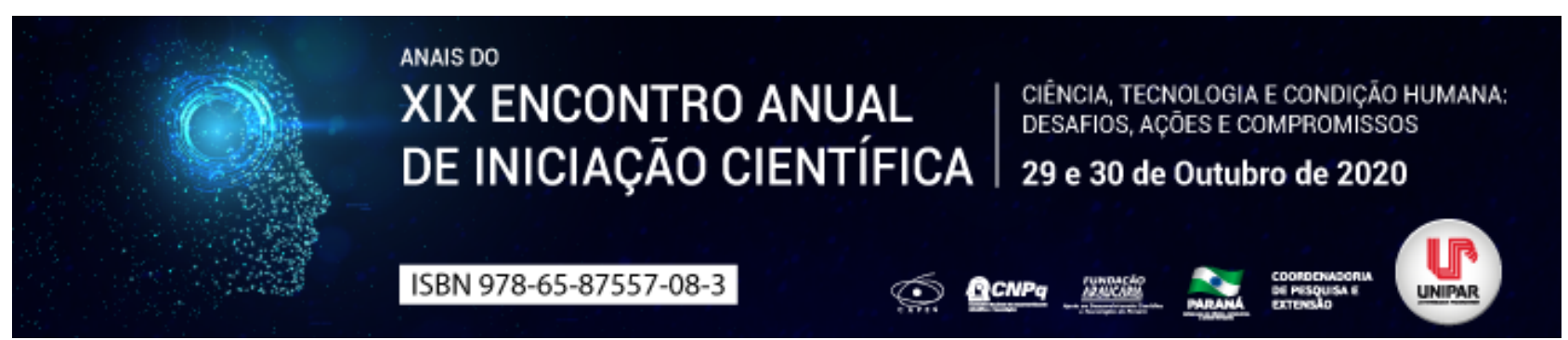

A CONTRIBUIÇÃO DA RADIOGRAFIA PERIAPICAL NO DIA A DIA CLÍNICO DO CIRURGIÃO DENTISTA

\author{
${ }^{1}$ NILO GUSTAVO COLERAUS SILVA, ${ }^{2}$ JENIFFER URBANO DEGASPERI, ${ }^{3}$ LUIZA HORTENCIA HAMERA ANDRUK, \\ ${ }^{4}$ KATLHEEN MAYARA DE SOUZA, ${ }^{5}$ LETICIA DE FREITAS CUBA GUERRA
}

\author{
${ }^{1}$ Acadêmico bolsista do PIBIM/UNIPAR \\ ${ }^{1}$ Acadêmica do Curso de Odontologia da UNIPAR \\ ${ }^{2}$ Acadêmica do Curso de Odontologia da UNIPAR \\ ${ }^{3}$ Acadêmica do Curso de Odontologia da UNIPAR \\ ${ }^{4}$ Docente da UNIPAR
}

Introdução: Os exames de imagem são frequentemente utilizados para complementar os diagnósticos e planejamentos na área da odontologia (FURQUIM; COSTA, 2009). É de suma importância que os exames sejam indicados com critério de acordo com cada situação clínica e, com técnica apurada para que a imagem obtida tenha uma excelente qualidade para que de fato cumpra os seus objetivos. Dentre os diferentes exames de imagem destaca-se a radiografia como parte do dia a dia do dentista em seu consultório. Considerando as diferentes técnicas radiográficas, a periapical é a mais amplamente empregada.

Objetivo: Revisar os dados da literatura com intuito de destacar a importância das radiografias periapicais no dia a dia clínico do cirurgião dentista.

Desenvolvimento: Os profissionais da saúde, como o cirurgião dentista, sempre estão atrás de aperfeiçoar seu diagnóstico, afinal, a partir de um diagnóstico correto, o profissional pode traçar seu plano de tratamento com uma maior segurança e é o exame de imagem que faz grande parte do papel facilitador no diagnóstico (VIEIRA et al., 2008). A radiografia, é um exame complementar que pode auxiliar no diagnóstico de algumas patologias, é muito eficaz quando associado a um exame clínico minucioso e uma anamnese detalhada, o radiográfico auxilia na hipótese diagnóstica de cárie, endodontia, periodontia, fraturas e em outras patologias (BOTELHO; MENDONÇA; CARDOSO, 2003). Para isso, é necessário que o profissional realize tomadas radiográficas com excelência para que, ao final do processo, ele obtenha uma imagem com boa qualidade. Com isso, é de suma importância que o cirurgião dentista submeta o seu paciente a um processo radiográfico de excelência, entendendo cada etapa a ser aplicada até a formação da imagem (FURQUIM; COSTA, 2009). Existem duas técnicas mais utilizadas que são a técnica da Bissetriz e a técnica do paralelismo, a primeira necessita que o ângulo do raio-X seja perpendicular a bissetriz do ângulo formado entre o filme radiográfico e a estrutura dental. Entretanto, os erros do operador são muito comuns nessa técnica, pode ocorrer desde erros na angulação, posicionamento inadequado da película radiográfica e até a movimentação do paciente na hora da tomada radiográfica. Contudo, a técnica do paralelismo consiste em utilizar posicionadores para que o filme fique paralelo ao longo do eixo do dente facilitando a tomada radiográfica e possibilitando uma imagem com menores distorções, que se assemelham mais ao real tamanho da estrutura dental, para que o cirurgião dentista possa avaliar melhor o seu paciente e chegar a um diagnóstico preciso (DELLAZZANA et al., 2010). Entretanto, é de suma importância que o profissional realize todas as etapas do processamento com excelência, já que qualquer descuido pode acarretar em problemas com a imagem final. Portanto, se deve realizar todos procedimentos com cautela para não submeter tanto o profissional quanto o paciente a doses de radiação desnecessárias (DELLAZZANA et al., 2010). Sob outro viés, com a evolução da tecnologia, temos a radiografia digital, onde se apresenta uma imagem com maior mais precisão e qualidade. Essa imagem digital, além de proporcionar uma melhor qualidade na imagem para realizar um diagnóstico, também traz consigo uma facilidade muito maior no armazenamento e processamento dessa imagem, facilitando ainda mais o dia a dia clínico do profissional dentista (BOTELHO; MENDONÇA; CARDOSO, 2003).

Conclusão: Mediante aos fatos expostos, nota- se que o exame de imagem é um aliado da odontologia no diagnóstico de diversas anormalidades que os pacientes venham a apresentar até um simples diagnóstico de uma cárie. E por isso, é de suma importância que o cirurgião dentista tenha capacidade de realizar uma tomada radiográfica de excelência e também tenha conhecimento para entender a indicação desse exame e tenha condições para interpretá-lo, a fim de facilitar sua hipótese diagnóstica.

\title{
Referências
}

BOTELHO, Tessa; MENDONÇA, Elismauro; CARDOSO, Lázara. Contribuição da Radiografia digital na Clínica Odontológica. 12. ed. Goiânia: Robrac, 2003.

DELLAZZANA, Fernando. et al. Uso de posicionadores radiográficos especiais em procedimentos endodônticos: relato de caso. 16. ed. Canoas, RS: Stomatos, 2010. 
FURQUIM, Tania; COSTA, Paulo., Garantia de qualidade em radiologia diagnóstica. 3. ed. São Paulo, SP: Revista brasileira de física médica, 2009.

VIEIRA, Evanice. et al. Inter-relação cirurgião dentista e radiologista: sucesso no diagnóstico odontológico. 16. ed. São Bernardo do Campo, SP: Journal Odonto, 2008.

Coordenadoria de Pesquisa e Extensão - COPEX

Departamento de Editoraçāo e Divulgaçāo Científica - DEDIC 


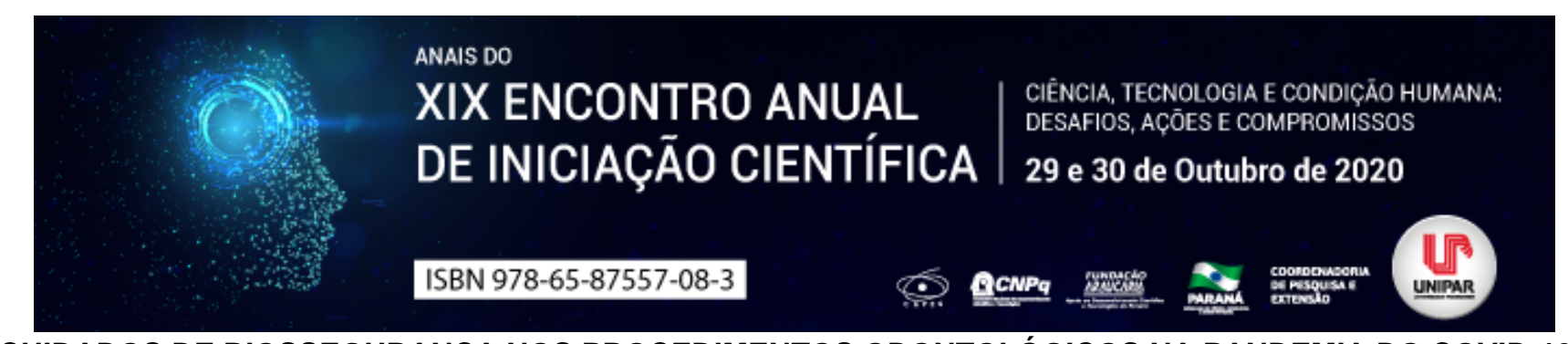

CUIDADOS DE BIOSSEGURANÇA NOS PROCEDIMENTOS ODONTOLÓGICOS NA PANDEMIA DO COVID-19

\author{
${ }^{1}$ NILO GUSTAVO COLERAUS SILVA, ${ }^{2}$ JENIFFER URBANO DEGASPERI, ${ }^{3}$ KATIA CRISTINA DE CARVALHO, ${ }^{4}$ LUIZA \\ SANZOVO, ${ }^{5}$ JULIANA GARCIA MUGNAI VIEIRA SOUZA, ${ }^{6}$ HELEN CRISTINA LAZZARIN
}

\author{
${ }^{1}$ Acadêmico bolsista do PIBIM/UNIPAR \\ ${ }^{1}$ Acadêmica do Curso de Odontologia da UNIPAR \\ ${ }^{2}$ Acadêmica do Curso de Odontologia da UNIPAR \\ ${ }^{3}$ Acadêmica do Curso de Odontologia da UNIPAR \\ ${ }^{4}$ Docente da UNIPAR \\ ${ }^{5}$ Docente da UNIPAR
}

Introdução: Segundo a Organização Mundial da Saúde (OMS), os surtos do novo coronavírus constituem uma emergência de saúde pública que atingem a população mundialmente (TUNÃS, 2020). Este acontecimento faz com que os profissionais da área da saúde acrescentem à rotina clínica alguns cuidados que visem diminuir a transmissão e contágio do vírus. Logo, os cirurgiões dentistas, por estarem expostos aos aerossóis gerados durante os procedimentos clínicos diários, encontram-se em uma situação de alto risco (OLIVEIRA et al., 2020). Portanto, é fundamental que haja trabalhos científicos e protocolos que ofereçam métodos a serem utilizados por esses indivíduos a fim de diminuir os impactos da pandemia (CAVALCANTI et al., 2020).

Objetivo: Realizar uma revisão de literatura com o intuito de descrever os cuidados em biossegurança durante os atendimentos odontológicos, principalmente na pandemia do COVID-19, ressaltando as vias de transmissão que podem ocorrer durante o atendimento.

Desenvolvimento: Desde que o vírus SARS-CoV2 se instalou em células humanas com potencial altamente transmissível, tornou-se necessário estudos acerca de sua patogenicidade e como o vírus é transmitido. Neste contexto, as vias de transmissão mais comuns, incluem as regiões anatômicas em mucosa oral e nasal, olhos e podem ocorrer por meio da tosse, gotículas de saliva contaminada, espirros e aerossóis gerados durante o atendimento odontológico pelo uso da caneta de alta rotação. É indiscutível que o odontólogo apresenta contato com essas áreas do paciente e com os fluidos corporais durante o atendimento, além do fato de utilizar instrumentos cortantes e instrumentos rotatórios que emitem produtos de aerossóis. Logo, torna-se essencial reduzir o número de atendimentos, e, nesse sentido, as recomendações limitam os atendimentos apenas para os serviços de emergência e urgência (FRANCO; CAMARGO e PERES, 2020). Outro aspecto a ser destacado, é que os sintomas do COVID-19 mais descritos pelos infectados são: febre, cefaleia, falta de ar, fadiga e perda do paladar (MENG; HUA e BIAN, 2020). Por esse motivo, a anamnese detalhada é imprescindível, uma vez que pode servir de auxílio para observar os sinais prodrômicos e a mesma pode ser feita por meio de uma conversa pelo telefone para possibilitar que o paciente fique o menor tempo possível em contato com o profissional e seus auxiliares clínicos. Para completar essa ação, o termômetro de testa é um ótimo instrumento que está sendo utilizado e possui bons resultados na percepção dos casos, pois, se o paciente possui febre no instante da consulta pode ser um indicativo da doença podendo impedir o atendimento odontológico no momento (FRANCO; CAMARGO e PERES, 2020). Outrossim, cabe ao auxiliar organizar o ambiente de trabalho de modo a deixar o mínimo possível de materiais em contato com o ar, realizar a desinfecção final e limpeza com álcool $70 \%$ ou hipoclorito de sódio não só dos instrumentais, mas de toda a clínica após o atendimento dos pacientes, independente de apresentarem sintomatologia ou não (PENG et al., 2020). Caso não seja possível adiar a consulta, o operador deve optar por manusear, preferencialmente, a caneta de baixa rotação sem spray de água, substituir a seringa tríplice por lavagem com seringa e soro fisiológico e aderir o isolamento absoluto sempre que possível. Também é proposto o emprego de outras barreiras de infecção, como a viseira facial de plástico, associada ao uso da máscara N95 e a cirúrgica, bem como a utilização do avental impermeável e descartável e ambos devem ser trocados a cada paciente. Isso ocorre, pois, apesar de nenhuma medida preventiva ser $100 \%$ eficaz, praticar todas elas em conjunto podem reduzir as chances de disseminação do vírus (ATHER et al., 2020). Ademais, é indispensável o uso dos outros EPI'S óculos de proteção, jaleco, gorro, luvas em todos os procedimentos. Por fim, o destino do lixo é de extrema relevância, pois dispõem de objetos infectados e por isso devem ser descartados em sacos plásticos identificados (FRANCO; CAMARGO e PERES, 2020).

Conclusão: A Odontologia é uma área da saúde que se encontra vulnerável aos riscos de contaminação pelo COVID-19 e por isso é de suma importância realizar algumas mudanças na rotina clínica, principalmente relacionadas à biossegurança. Deve-se buscar diminuir a transmissão e assim, reduzir os riscos de infeç̧ão cruzada, do paciente para o cirurgião dentista e auxiliar, ou desses para o paciente. 


\section{Referências}

ATHER, Amber et al. Coronavirus Disease 19 (COVID-19): Implications for Clinical Dental Care. Journal of Endodontics, v. 46, n. 5 , p. $584-595,2020$.

CAVALCANTI, Yuri Wanderley et al. Impacto econômico das novas recomendações de biossegurança para a prática clínica odontológica durante a pandemia da COVID-19. Pesquisa Brasileira em Odontopediatria e Clínica Integrada, p. 1 - 62, 2020.

FRANCO, Juliana Bertoldi; CAMARGO, Alessandra Rodrigues de; PERES, Maria Paula Siqueira de Melo. Cuidados Odontológicos na era do COVID-19: recomendações para procedimentos odontológicos e profissionais. Revista Associação Paulista de Cirurgiões Dentistas, v. 74, n. 1, p. 18 - 21, 2020.

OLIVEIRA, José Jhenikártery Maia de et al. O impacto do coronavírus (COVID-19) na prática odontológica: desafios e métodos de prevenção. Revista Eletrônica Acervo Saúde, v. esp. 46, p. 1 - 12, 2020.

PENG, Xian et al. Transmission routes of 2019-nCoV and controls in dental practice. International Journal of Oral Science, $v$. 12, n. 1, p. 1 - 6, 2020.

TUÑAS, Inger Teixeira de Campos de et al. Doença pelo Coronavírus 2019 (COVID-19): Uma Abordagem Preventiva para Odontologia. Revista Brasileira de Odontologia, v. 77, p. 10 16, 2020. 


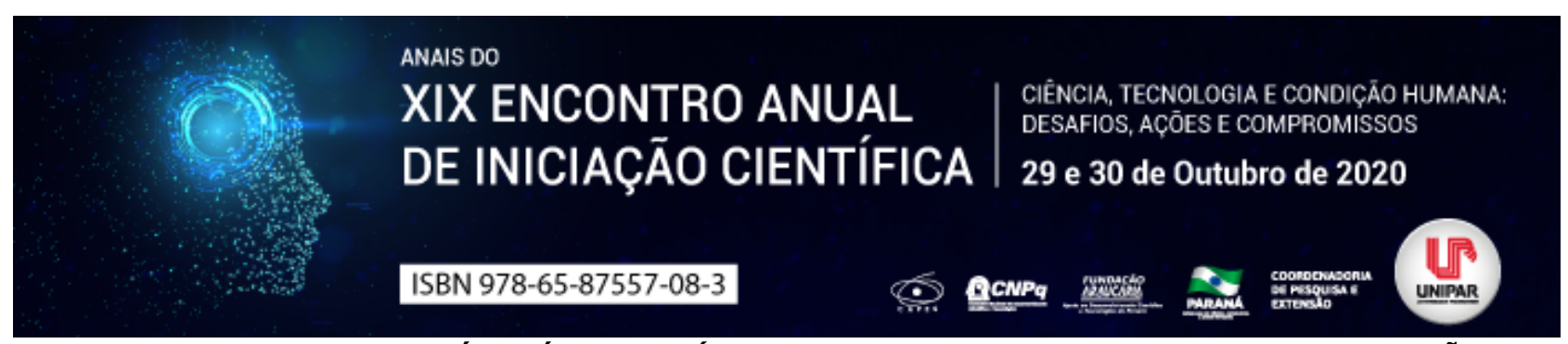

INFLUENCIA DO ALONGAMNETO PRÉ E PÓS EXERCíCIOS NO TREINAMENTO DE FORÇA E PREVENÇÃO DE LESÕES

\title{
${ }^{1}$ GIOVANA ORTEGA DEL MASSA, ${ }^{2}$ MARCIO APARECIDO RINALDO
}

\author{
${ }^{1}$ Acadêmica do Curso de Educação Física, Ciências da Saúde, Universidade Paranaense-UNIPAR \\ ${ }^{1}$ Docente da UNIPAR
}

Introdução: Exercícios de alongamento são constantemente executados nas rotinas de atletas e praticantes antes do início das atividades física e desportivas com o intuito de prevenir o risco de lesões, bem como aumentar a amplitude articular e diminuir os sintomas de dor muscular (BACURAU et al. 2009). Existem técnicas variadas de alongamentos, incluindo o alongamento dinâmico e o alongamento estático, sendo esse o mais utilizado por praticantes de atividade física. Segundo Camara et al. (2015) a execução do alongamento antes de exercícios de força pode ter impacto significativo no seu desempenho. Alguns estudos recentes apontam que a técnica de alongamento estático antes dos exercícios pode induzir perda de força máxima e potência dos grupos musculares alongados anteriormente (NETO.A. G, MANFFRA.E. F, 2008) Complementando Pereira et al. (2007) revela que o alongamento pré e/ou pós exercício ocasiona estresse mecânico no tecido muscular, gerando microtraumas.

Objetivo: Investigar atraves da literatura se a pratica do alongamento pré e pós exercício interfere no treinamento de força e auxilia na prevenção de lesões.

Desenvolvimento: De acordo com Camara et al. (2015) a pratica do alongamento imediatamente antes do exercício promove a flexibilidade muscular, reduzindo a rigidez do musculo preservando assim o indivíduo de uma possível lesão ao executar o movimento seguinte. Por outro lado, o estudo realizado por Bastos et al. (2014) atraves do alongamento estático durante 30 segundos anteriormente ao exercício, executado por 30 indivíduos do sexo masculino, revelou não haver influência significativa dos exercícios de alongamento em relação aos testes de forca de 1RM, entretanto houve uma diminuição do desenvolvimento de força máxima. O alongamento pré exercício pode ocasionar danos na musculatura como processos mecânicos ou mecanismos neurais podendo assim reduzir o rendimento de força (CAMARA et al. 2015), entretanto o estudo de Pereira et al. (2007) revelou que o alongamento pós exercício resistido demonstrou um efeito gerador de microtraumas principalmente em homens por razões de possuírem menor flexibilidade, considerando que o alongamento promove modificações na elasticidade muscular. A técnica de alongamento dinâmico aparenta aperfeiçoar o controle motor atraves de repetições de movimentos, fazendo com que aumente o fluxo sanguineo elevando a temperatura, gerando assim uma melhora no desempenho de força e velocidade (CAMARA et al. 2015). Para Neto. A.G, Manffra. E.F (2008) o alongamento pré exercicio dependente de força máxima muscular com volume total, igual ou superior a 360 segundos pode implicar no desempenho de atletas de alto rendimento. Nesse mesmo conceito Camara et al (2015) ressalta que o efeito negativo da pratica de alongamento está associado as atividades físicas que requerem movimentações com baixa velocidade.

Conclusão: Assim concluímos que tem se assegurado que as variadas técnicas de alongamento devem estar inclusas no planejamento de atividades físicas, mas ainda há muitas controvérsias nos presentes estudos sobre em que momento pré ou pós exercicio ela pode ser eficaz na prevenção de lesões, a maioria dos estudos apresentados mostraram não haver uma influência significativa na prevenção de lesões, porem em alguns estudos a prática do alongamento pré exercicio por determinados segundos pode gerar microtraumas no tecido muscular, podendo levar a implicações no desenvolvimento e rendimento do praticante, analisamos também que o alongamento dinâmico é a técnica mais eficaz em atividades que requer força e velocidade.

\section{Referências}

BACURAU.P. F et al. Efeito agudo de um exercício de alongamento balístico e estático na flexibilidade e força máxima. Journal of Strenght and Conditioning Research, v. 23, n. 1, p. 304-308, janeiro, 2009. Disponível em: https://journals.Iww.com/nscajscr/Fulltext/2009/01000/Acute_Effect_of_a_Ballistic_and_a_Static.43.aspx Acesso em: 22 jul. 2020

BASTOS. C.L.B et al. Influencia aguda do alongamento estático no comportamento da força muscular máxima, Motri, v.10, n.2, Vila Real, junho, 2014. Disponível em: http://www.scielo.mec.pt/scielo.php?pid=S1646107X2014000200010\&script=sci_arttext\&tlng=es Acesso em: 22 jul. 2020

CAMARA.F.M et al. O Mandamento do Alongamento: Evidencias e Propostas para Revisão. Revista Brasileira de Ciência e Movimento, v. 23, n.2, p. 148-155, 2015. Disponível em: https://portalrevistas.ucb.br/index.php/RBCM/article/view/5165 Acesso em: 22 jul. 2020

NETO.A.G, MANFFRA.E.F. Influência do volume de alongamento estático dos musculos isquiotibiais nas variáveis isocineticas. Revista Brasileira de Medicina do Esporte. 15, n.2, p.104-109, 2008. Disponível em: https://www.scielo.br/scielo.php? pid=S1517-86922009000200004\&script=sci_abstract\&tlng=pt Acesso em: 22 jul. 2020

PEREIRA.R et al. Efeito do alongamento pós exercicio na concentração sérica de creatina kinase (ck) de homens e 
mulheres. Motri, v.3, n.2, Santa Maria da Feira, abril, 2007 Disponível em: http://www.scielo.mec.pt/scielo.php? script=sci_arttext\&pid=S1646-107X2007000200015 Acesso em: 22 jul. 2020

Coordenadoria de Pesquisa e Extensão - COPEX

Departamento de Editoraçāo e Divulgaçāo Científica - DEDIC 


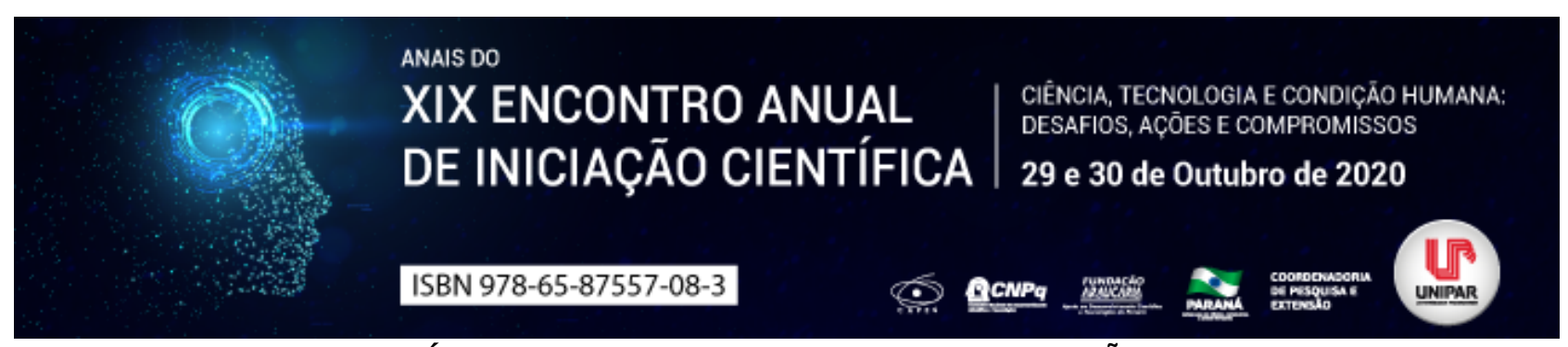

SÍNDROME DE EHLERS-DANLOS: UMA REVISÃO

${ }^{1}$ HIGOR DIAS DO PRADO, ${ }^{2}$ ANA BEATRIZ PINHEIRO ZAUPA, ${ }^{3}$ CARLOS EDUARDO RUZZENE RODRIGUES, ${ }^{4}$ FATIMA HASSAN SAFIEDDINE, ${ }^{5}$ GABRIEL HENRIQUE BELLATO PALIN, ${ }^{6}$ ELENIZA DE VICTOR ADAMOWSKI CHIQUETTI

\footnotetext{
${ }^{1}$ Acadêmico do Curso de Medicina da UNIPAR

${ }^{1}$ Acadêmica do Curso de Medicina da UNIPAR

${ }^{2}$ Acadêmico do Curso de Medicina da UNIPAR

${ }^{3}$ Acadêmica do Curso de Medicina da UNIPAR

${ }^{4}$ Acadêmico do Curso de Medicina da UNIPAR

${ }^{5}$ Docente da UNIPAR
}

Introdução: A Síndrome de Ehlers-Danlos (EDS) consiste numa desordem genética hereditária que afeta o tecido conjuntivo e causa uma série de alterações, afetando a pele, ligamentos, articulações, vasos sanguíneos e órgãos internos. Apesar de rara, a condição mostra-se um importante objetivo de estudo devido ao seu espectro clínico altamente variado, podendo comprometer severamente a qualidade de vida do portador ou até mesmo levá-lo a uma morte prematura (DE PAEPE, MALFAIT, et al; 2012).

Objetivo: Realizar uma análise, de forma geral, da síndrome de Ehlers-Danlos e de seus principais subtipos conhecidos atualmente.

Desenvolvimento: A EDS surge a partir de mutações existentes nos genes responsáveis por decodificar o colágeno fibrilar ou por alterações nas enzimas envolvidas na biossíntese do colágeno (DE PAEPE, MALFAIT, et al; 2012). Ao analisar fibroblastos de portadores da síndrome, percebe-se que a atividade das enzimas procolágeno peptidases, responsáveis pela conversão de procolágeno em colágeno, é reduzida, causando assim nos fibroblastos um aumento na taxa de síntese de colágeno e procolágeno devido à sua incapacidade de converter adequadamente o procolágeno em colágeno (LICHTENSTEIN, et al; 1973). Ao todo, hoje, conhece-se treze subtipos da síndrome, sendo que cada um surge a partir de uma mutação num gene específico diferente; todavia, seus principais tipos, sendo os mais conhecidos e estudados, ainda são os tipos I, II, III, IV e VII (PARAPIA, JACKSON; 2008). A EDS do tipo I e II, é conhecida como a EDS clássica e surge a partir de uma mutação nos genes COL5A1, COL5A2 ou COL5A1 promovendo a formação de um procolágeno tipo $\mathrm{V}$ ou I anormal e causando frouxidão na pele, hipermobilidade articular, hipotonia muscular e hérnias; o tipo III, por outro lado, é conhecida como o tipo EDS hipermobilidade e ainda não tem o gene responsável pela mutação e seu procolágeno afetado conhecidos, causa manifestações como hipermobilidade articular, frouxidão na pele, cria uma textura aveludada na pele do portador além de luxações recorrentes; já o tipo IV, o tipo vascular, é causado por uma mutação no COL1A2 provocando uma deficiência na cadeia $\alpha-2$ do colágeno tipo III e gera manifestações como ruptura arterial, hipermobilidade em pequenas articulações, hematomas frequentes e varicose; o tipo VII, é causada por deficiências em cadeias do procolágeno tipo I provocada por mutações nos genes COL1A1 e COL1A2 e tem como manifestações clínicas hipermobilidade articular, luxações recorrentes, frouxidão na pele, hipotonia muscular, hematomas frequentes e cifoescoliose (PARAPIA, JACKSON; 2008; DE PAEPE, MALFAIT, et al; 2012). Todavia, é notório que o tipo com maior complicação e que causa mais impacto na vida do portador seja o tipo vascular EDS tipo IV, pois os seus portadores sofrerão com complicações arteriais, intestinais e uterinas durante sua vida, sendo que, grande parte, experimentam suas primeiras complicações aos 20 anos de idade; além disso, a expectativa de vida dos portadores da EDS tipo IV é de apenas 48 anos (PEPIN; 2000). Vale salientar ainda que a EDS não possui tratamento específico ainda, sendo tratado apenas suas complicações secundárias que surgem ao decorrer da vida do portador (BERGQVIST, et al; 2013). Vale salientar ainda que o diagnóstico dos diferentes tipos de EDS é clínico, seguindo a história natural da doença do paciente, de seus familiares, analisando assim suas manifestações em seus diferentes sistemas e utilizando-se testes genéticos para complementar o diagnóstico (SHIRLEY, et al; 2012).

Conclusão: A Síndrome de Ehlers-Danlos mostra-se uma condição genética rara, ainda pouco conhecida e sem métodos de tratamento específico. Os portadores são acompanhados durante sua vida e recebem tratamentos apenas paliativos, isto é, apenas complicações da síndrome são tratadas a fim de melhorar a qualidade de vida do portador de maneira geral.

\section{Referências}

BERGQVIST, David; BJÖRCK, Martin; WANHAINEN, Anders. Treatment of vascular Ehlers-Danlos syndrome: a systematic review. Annals of surgery, v. 258, n. 2, p. 257-261, 2013.

DE PAEPE, Anne; MALFAIT, Fransiska. The Ehlers Danlos syndrome, a disorder with many faces. Clinical genetics, v. 82, n. 1 , p. 1-11, 2012. 
LICHTENSTEIN, Jack R. et al. Defect in conversion of procollagen to collagen in a form of Ehlers-Danlos syndrome. Science, v. 182, n. 4109, p. 298-300, 1973.

PARAPIA, Liakat A.; JACKSON, Carolyn. Ehlers-Danlos syndrome a historical review. British journal of haematology, v. 141, n. 1, p. 32-35, 2008.

PEPIN, Melanie et al. Clinical and genetic features of Ehlers Danlos syndrome type IV, the vascular type. New England Journal of Medicine, v. 342, n. 10, p. 673-680, 2000.

SHIRLEY, Eric D.; DEMAIO, Marlene; BODURTHA, Joanne. Ehlers-danlos syndrome in orthopaedics: etiology, diagnosis, and treatment implications. Sports health, v. 4, n. 5, p. 394-403, 2012.

Coordenadoria de Pesquisa e Extensão - COPEX

Departamento de Editoraçāo e Divulgaçāo Científica - DEDIC 


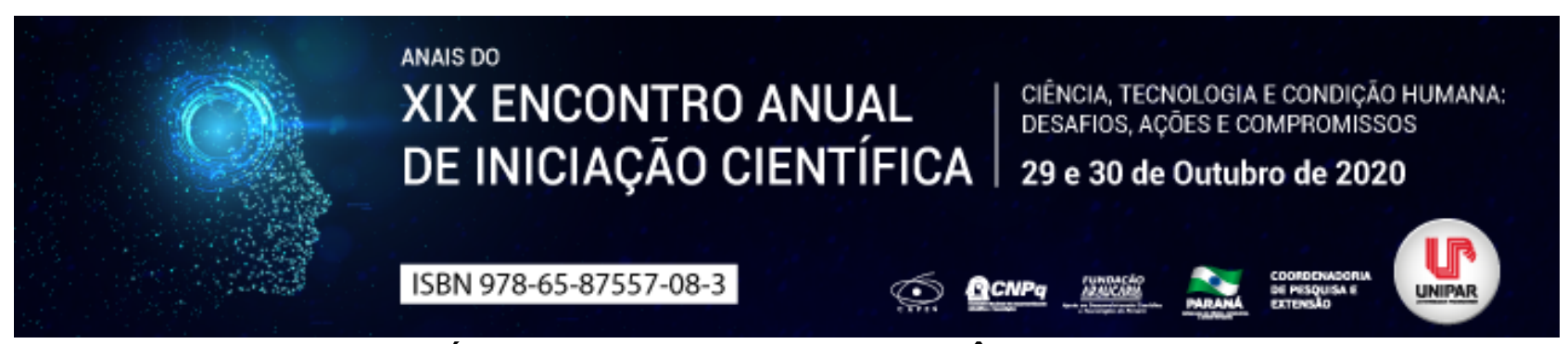

SAÚDE SEXUAL DE MULHERES CISGÊNERO LGBT

\title{
${ }^{1}$ DEBORAH TAVARES BIEZUS, ${ }^{2}$ ELENIZA DE VICTOR ADAMOWSKI CHIQUETTI
}

\author{
${ }^{1}$ Acadêmica de Medicina/UNIPAR \\ ${ }^{1}$ Docente da UNIPAR
}

Introdução: Ao analisarmos o processo de saúde-doença-cuidado, é importante levarmos em conta o conceito de saúde contemplado pela noção de Determinantes Sociais de Saúde (DSS), que abrange desde de acesso aos serviços de saúde, renda, educação, meio-ambiente, trabalho, habitação, condições de alimentação, etc (MOSCHETA; FÉBOLE; ANZOLIN, 2016). A partir disso, entramos na saúde pública no Brasil que, desde 1988, está consolidada no Sistema Único de Saúde (SUS). Esse sistema estabelece a saúde como direito universal, sendo o Estado o provedor do acesso para todos os cidadãos com seus princípios de universalidade, equidade e integralidade. Em contrapartida, reconhecermos que o acesso à saúde é desigual por diversas condições, sendo uma delas uma questão de diferença sexual (FERRAZ; KRAICZY, 2010) porque o preconceito sofrido por essa população os limita diante da possibilidade de ter vida considerada saudável. Buscando ajudar os profissionais da saúde a entender sobre os fatores de risco e contágio de infecções sexualmente transmissíveis (IST's), como gonorreia, clamídia, sífilis e HIV entre mulheres cisgênero LGBT, e compreender as especificidades necessárias para saúde sexual dessa comunidade e como elas podem se proteger durante suas relações sexuais, tendo em vista que algumas mulheres LGBT consideram não contrair nenhuma IST's por não terem relação sexual com homens.

Objetivo: Trata-se de uma revisão bibliográfica da literatura, com objetivo de aprofundar o conhecimento e ajudar os profissionais da saúde a ter uma convivência mais saudável com mulheres LGBT. Para isso, o levantamento foi realizado na Scientific Eletronic Library Online (Scielo) e Google Acadêmico, usando descrição de saúde sexual LGBT mulheres

lésbicas e bissexuais e utilizando apenas os referenciais entre os anos de 2010 a 2019.

Desenvolvimento: O direito constitucional começou a ser cobrado do Ministro da Saúde pela população Lésbica, Gay, Bissexual e Trans (LGBT) na década de 1980, à procura de enfrentamento da epidemia de HIVIAIDS entre a comunidade. O produto final após a reivindicação de tratamentos qualificados cumpriu seus objetivos, a garantia de seus direitos sexuais e reprodutivos das mulheres lésbicas e bissexuais no processo saúde-doença (LÚCIO, 2019). Como bem apontado no artigo de Ferraz; Kraiczyk, (2010) a pesquisa feita pela Fundação Perseu Abrama indicou que mais de $25 \%$ da população brasileira é homofóbica. Olhando sob essa realidade, muitos profissionais da saúde não sabem como agir diante da saúde sexual dessas mulheres que tem relação sexual com outras mulheres, o que leva a falta de informação, alusão de que mulheres LGBT não contraem Infecções Sexualmente Transmissíveis (IST) e, consequentemente, ao baixo número de mulheres LGBT que realizam exames preventivos e rotineiros, como prevenção de câncer de colo uterino e câncer de mama, Papanicolau e Mamografia, respectivamente (ALBUQUERQUE, 2013). Deveria ser dever de todos os profissionais da saúde entender que sexo entre mulheres é tão arriscado quanto relações heterossexuais, pois nele também há contato digital-vaginal ou digital-anal e compartilhamento de objetos para penetração (vibradores e dildos) de secreções (LÚCIO, 2019) e, algumas vezes, com sangue, por isso elas estão igualmente propensa à disseminar IST, como herpes, verruga genital, hepatites, sífilis, HIV, clamídia e gonorreia. Na tentativa de instruir essas mulheres, Riley (2011) explica em seu artigo alguns cuidados simples que podem ser feitos para se fazer sexo seguro, como lavar, ferver e limpar com álcool os objetos utilizados nas relações sexuais e também usá-los com camisinhas. Usar luva ou dedeira de látex para proteção dos dedos, as calcinhas de látex que conseguem manter a sensibilidade quanto para sexo oral quanto contato entre vulvas e o Dental Dam, uma folha de látex normalmente usada nos consultórios odontológicos pode ser utilizada no sexo oral. Nesse sentido os princípios de funcionamento do SUS de universalidade, integralidade e equidade expressados nas políticas públicas poderão enfrentar a homofobia e heteronormatividade compulsória das mulheres.

Conclusão: A homossexualidade é construída sob a discriminação e as políticas públicas que apesar de tentarem desconstruir esse obstáculo, ainda se percebe que profissionais da saúde não se encontram prontos para atender pacientes desse grupo de pessoas. Mais que isso, é importante salientar também a falta de pesquisas feitas na área, o que nos revela escassez de estudos e conhecimento para cuidado da saúde do grupo.

\section{Referências}

ALBUQUERQUE, Grayce Alencar et al. Homossexualidade e o direito à saúde: um desafio para as políticas públicas de saúde no Brasil. Saúde em debate, Rio de Janeiro, v. 37, n. 98, p. 516-524, setembro. 2013.

FERRAZ. D, KRAICZYK. J. Gênero e políticas de saúde - construindo respostas para o enfrentamento das desigualdades no âmbito do SUS. Revista de Psicologia da UNESP, v. 9, p. 70-82, 2010.

LÚCIO, F. P. da S.; ZERBINATI, J. P.; BRUNS, M. A. T.; SOUZA-LEITE, C. R. V. de. Saúde sexual da mulher lésbica e/ou 
bissexual: especificidades para o cuidado à saúde e educação sexual. Revista Ibero-Americana de Estudos em Educação, Araraquara, v. 14, n. esp. 2, p. 1465-1479, jul., 2019.

MARQUES, António Manuel; OLIVEIRA, João Manuel de; NOGUEIRA, Conceição. A população lésbica em estudos da saúde: contributos para uma reflexão crítica. Ciênc. saúde coletiva, Rio de Janeiro, v. 18, n. 7, p. 2037-2047, julho 2013

MOSCHETA, M. dos S.; FÉBOLE, D. da S.; ANZOLIN. B. Visibilidade seletiva: A influência da heterossexualidade compulsória nos cuidados em saúde de homens gays e mulheres lésbicas e bissexuais. Saúde \& Transformação Social, Florianópolis, v.7, n.3, p.71-83, 2016.

RIPLEY, Victoria. Promoting sexual health in women who have sex with women. Art and Science Sexual Health, v. 25, n. 25, p. 41-46, junho 2011. 


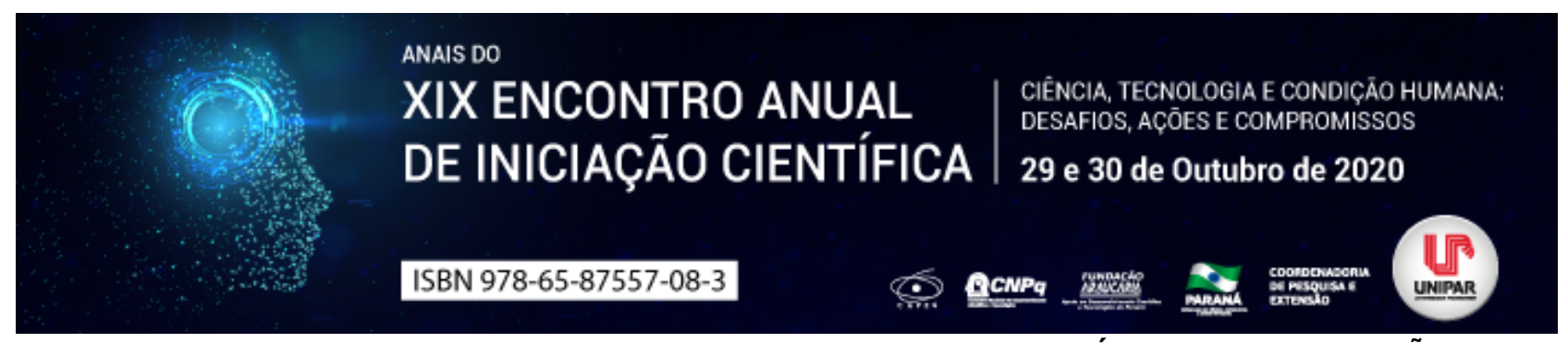

ALTERNATIVOS AO ENXERTO DE TECIDO MOLE PARA O TRATAMENTO CIRÚRGICO DE RECESSÃO GENGIVAL

\author{
${ }^{1}$ NATALIA COQUEIRO SIQUEIRA, ${ }^{2}$ JOAO CARLOS RAFAEL JUNIOR , ${ }^{3}$ ANA MARIA DA SILVA, ${ }^{4}$ ANA CAROLINE DOS \\ SANTOS GRUNOW, ${ }^{5}$ EDUARDO AUGUSTO PFAU
}

${ }^{1}$ Acadêmica do curso de Odontologia da UNIPAR
${ }^{1}$ Acadêmico bolsista do PEBIC/CNPQ
${ }^{2}$ Acadêmica bolsista do PIBIC/UNIPAR
${ }^{3}$ Acadêmica bolsista do PIBIC/UNIPAR
${ }^{4}$ Docente da UNIPAR

Introdução: Com os novos padrões de beleza, a busca pelo sorriso perfeito tem se intensificado e a procura por tratamentos odontológicos para correção de defeitos tem sido uma prática frequente. Sob este contexto, a recessão gengival é definida como migração apical da margem gengival que pode gerar defeitos estéticos e funcionais ao paciente (VENTURIM et al., 2011). O tratamento para as recessões gengivais, na maioria das vezes, é feito através de uma cirurgia de enxerto gengival, que tem como padrão ouro o uso de tecido conjuntivo removido de uma área doadora do próprio paciente (SCHMITT et al., 2016). Porém, algumas desvantagens estão relacionadas a técnica operatória usada para obtenção desse tipo de enxerto autógeno, e isso motiva o desenvolvimento de biomateriais alternativos, os quais oferecem a possibilidade de execução de um tratamento cirúrgico mais confortável e com menor morbidade ao paciente (PAULA et al., 2017). Diversos materiais têm sido descritos na literatura e demonstram resultados clínicos satisfatórios.

Objetivo: O objetivo do presente trabalho é apresentar, através de uma revisão de literatura, as aplicações clínicas, vantagens e desvantagens dos alternativos de tecido mole para enxerto gengival.

Desenvolvimento: A recessão gengival é definida como sendo a migração apical da margem da gengiva em sentido apical levando a exposição radicular, podendo gerar ao paciente portador danos estéticos e funcionais. Suas causas estão pautadas principalmente no acúmulo de biofilme e trauma de escovação, porém outros fatores podem contribuir para o seu desenvolvimento, como trauma oclusal, fenótipo periodontal fino, raízes proeminentes, pouca faixa ou ausência de gengiva aderida (VENTURIM et al., 2011). O tratamento mais usual para as recessões gengivais é a realização de cirurgia de enxerto, para isso, o padrão ouro é utilizar um enxerto de tecido conjuntivo autógeno, contudo algumas desvantagens estão relacionadas a esta técnica, dentre elas estão o desconforto maior proporcionado ao paciente, pois são necessários dois sítios cirúrgicos, limitação da área doadora, riscos de acidentes hemorrágicos aumentados no ato operatório, tempo cirúrgico maior, necessidade de habilidade técnica e conhecimento anatômico para remoção do enxerto (LIMA; DAMACENA, 2019; SANZ; SIMION, 2014).

Tudo isso justificou a necessidade de procura por substitutos de tecido mole, conhecidos como biomateriais que tendem a sanar diversas das desvantagens acima citadas. As diversas matrizes de colágeno existentes no mercado possuem diferentes composições e formulações, porém sempre com o intuito de otimizar o ato operatório ao operador e paciente, e a aplicabilidade destes materiais são variadas, recobrimento radicular, correção de defeitos peri-implantares e melhora na faixa de gengiva queratinizada (SANZ; SIMION, 2014; PAPI; POMPA, 2018).

A literatura ainda é escassa e não há um consenso a respeito do comportamento clínico e qualidade dos biomateriais. Schmitt et al. (2016) afirmaram que o ganho de espessura de tecido conjuntivo com a utilização de biomateriais pode chegar até a 1,16mm. Além disso, Zadeh (2011) afirma que os biomateriais reduzem consideravelmente o tempo operatório e o risco de complicações operatórias, bem como são bem eficazes no aumento da espessura de gengiva queratinizada, podendo ser observado no trabalho de Papi; Pompa (2018), que apresentaram um caso clínico onde o ganho de gengiva aderida ao redor de implantes foi considerável usando uma matriz xenogênica. O estudo de Suzuki et al. (2018) foi pautado na análise de 36 recessões gengivais, classificadas como sendo do tipo RT1, o estudo foi dividido e 18 recessões foram tratadas com um enxerto de tecido conjuntivo autógeno e outras 18 utilizando um biomaterial (o material de escolha foi o Mucoderm®). A avaliação após 6 meses mostrou que o biomaterial foi eficaz no recobrimento radicular, porém o grupo do tecido conjuntivo obteve resultados superiores. Isso mostra que ainda não há uma segurança completa na utilização destes novos materiais.

Conclusão: Em face do exposto, os biomateriais disponíveis no mercado podem ser considerados como boa alternativa para substituição dos enxertos de tecido mole, diminuindo tempo operatório e proporcionado mais conforto e segurança ao paciente durante o ato operatório e durante o período pós operatório também. Porém, são necessários mais estudos em relação a qualidade para recobrimento gengival, bem como o comportamento destes materiais com o passar do tempo, se proporcionará um efeito estável ou não. 


\section{Referências}

De LIMA, Marcos Dunshee de Abranches Acylino; DAMACENA, Lara Barros. Utilização de uma matriz de colágeno porcino como alternativa aos enxertos autógenos na terapia mucogengival: Revisão de Literatura. Rev. ACBO., v. 8, n. 3, p. 70-76, 2019.

De PAULA, Bruna Luisa et al. Biomateriais utilizados em substituição ao enxerto autógeno de gengiva. Braz. J. Periodontol., v. 27, n. 1, p. 27-33, mar. 2017.

PAPI, Piero; POMPA, Giorgio. The use of a novel porcine derived acellular dermal matrix (Mucoderm) in peri-implant soft tissue augmentation: Preliminary results of a prospective pilot cohort study. Biomed. Rest. Int., v. 2018, n.9, p. 640-651, jul. 2018.

SANZ, Mariano; SIMION, Massimo. Surgical techniques on periodontal plastic surgery and soft tissue regeneration: Consensus Report of group 3 of the 10th European workshop on periodontology. J. Clin. Periodontol., v. 41, n. 15, p. 92-97, 2014.

SCHMITT, Cristian et al. Soft tissue volume alterations after connective tissue grafting at teeth: The subepithelial autologous connective tissue graft versus a porcine collagen matrix- a pre-clinical volumetric analysis. J. Clin. Periodontol., v. 43, n. 7, p. 609-617, 2016.

SUZUKI, Kleber Tanaka. Comparação clínica entre a utilização do enxerto de tecido conjuntivo e matriz de colágeno suína (Mucoderm) para tratamento de retrações do tipo 1: estudo clínico controlado e aleatorizado. 2018. 55f. Dissertação (Mestrado em Periodontia) - Universidade de São Paulo, Ribeirão Preto, 2018.

VENTURIM, Rosalinda Tanuri Zanionotto et al. Técnicas cirúrgicas de enxerto de tecido conjuntivo para o tratamento da recessão gengival. Rev. Gaúcha Odontol., Porto Alegre, v. 59, n. 0, p. 147-152, jan.jjun. 2011.

ZADEH, Homayoun. Minimally invasive treatment of maxillary anterior gingival recession defects by vestibular incision subperiosteal tunnel access and platelet-derived growth factor BB. Int. J. Periodontics. Restorative Dent., v. 31, n. 6, p. 653660, 2011. 


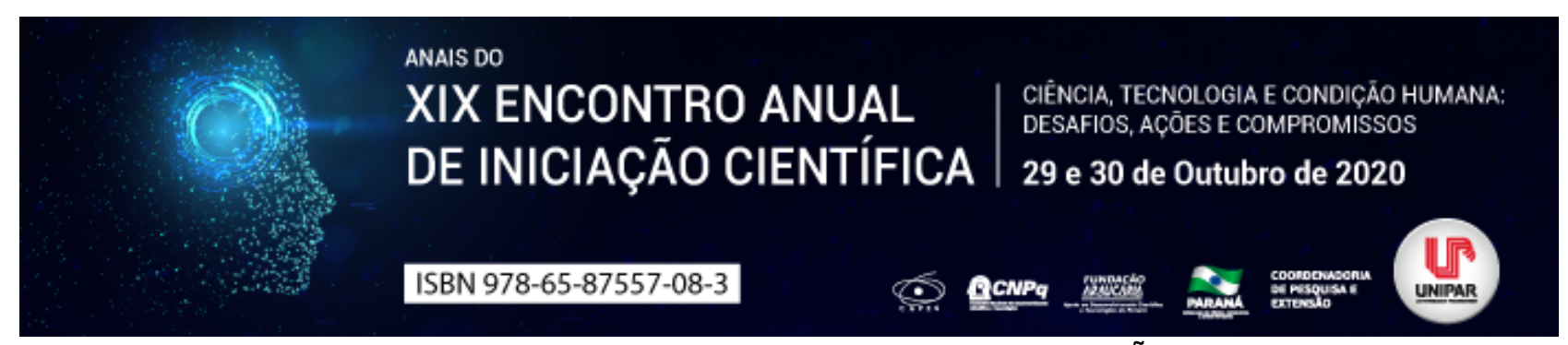

FATORES QUE AUMENTAM O RISCO DE MANCHAMENTO EM RESTAURAÇÕES EM RESINA COMPOSTA

\author{
${ }^{1}$ GEOVANE CAPANA FIDELI, ${ }^{2}$ KAROLINA FERNANDA ABEGG QUEIROZ, ${ }^{3}$ ALLAN FERREIRA DE LIMA ANTONELLI, \\ ${ }^{4}$ RAYANE CRISTINA DE OLIVEIRA SOARES, ${ }^{5}$ JENIFFER URBANO DEGASPERI, ${ }^{6}$ WAGNER BASEGGIO
}

\author{
${ }^{1}$ Acadêmico do PIC/UNIPAR \\ ${ }^{1}$ Acadêmico do PIC/UNIPAR \\ ${ }^{2}$ Acadêmico do PIC/UNIPAR \\ ${ }^{3}$ Acadêmico do PIC/UNIPAR \\ ${ }^{4}$ Acadêmico do PIC/UNIPAR \\ ${ }^{5}$ Professor titular do curso de odontologia da UNIPAR
}

Introdução: As resinas compostas passaram por muitos avanços ao longo dos anos, entretanto ainda existem problemas que afetam a sua durabilidade. O manchamento é um desses problemas, e é muito importante para o cirurgião dentista saber identifica-lo e preveni-lo, pois assim o tratamento será mais duradouro e esteticamente mais satisfatório.

Objetivo: Identificar, por meio de uma revisão de literatura, os principais fatores que aumentam o risco de manchamento em resinas compostas.

Desenvolvimento: As resina apresentam muitas vantagens em relação à outros materiais, entretanto pode sofrer com a retenção de corantes provenientes da alimentação (CAMPOS et al, 1999). Alguns fatores que facilitam o manchamento da resina composta podem ser divididos em fatores intrínsecos, como descoloração do próprio material tais como alteração da matriz resinosa ou da interface matriz/carga; e fatores extrínsecos que incluem o manchamento pela adsorção ou absorção de corantes resultante da contaminação por fontes exógenas como café, chá, nicotina e bebidas (UM; RUYTER; 1991). A porosidade da resina também interfere na sua estabilidade de cor, pois facilita a penetração de corantes e acúmulo de placa dental, a qual acelera a degradação do material (DOMINGUES et al, 2001). Dessa forma é importante que o paciente mantenha uma boa higienização para manter um ambiente propício, livre de biofilme, para a manutenção da resina composta, como também o uso de resinas menos porosas (BARATIERI; 1992). Powers, Dennison, Koran (1978) afirmam que a desidratação e a decomposição química dos componentes da resina composta são fatores que contribuem para a instabilidade da cor nas restaurações estéticas de resina composta. (ARAÚJO et al., 1996) Ressaltam que a baixa intensidade de luz dos aparelhos fotopolimerizadores influencia na sorção de água levando à menor resistência e ao maior manchamento da restauração. Além disso uma polimerização inadequada pode levar à instabilidade de cor, solubilidade e diminuição da dureza (MEDEIROS, NASCIMENTO; 2002). Para Vinha, Santos, Panzeri (1987) as faces restauradas tratadas com brocas multilaminadas e com pontas diamantadas, são mais susceptíveis a penetração de corantes, pois este acabamento superficial pode provocar desorganização na superfície das resinas compostas. De acordo com Maixner, Susin (2001) o tipo de resina composta utilizada, o grau de polimerização do material, a técnica de acabamento e polimento da restauração, o contato imediato do paciente com alimentos e o controle de placa são as principais causas da descoloração das resinas compostas. (HACHIYA et al., 1984) avaliaram a relação dos sistemas de acabamento e polimento com a descoloração da resina composta e concluíram que o polimento após 48 horas promove menos descoloração do que o produzido imediatamente.

Conclusão: Dessa forma algumas medidas podem ser utilizadas para evitar o manchamento das resinas compostas, como controle da placa, com boa higiene oral; controle da dieta, evitando ingestão de alimentos e substâncias corantes; um bom sistemas de acabamento e polimento, executado no momento certo e controle clínico do processo de fotopolimerização.

\title{
Referências
}

ARAÚJO, R. M.; ARAÚJO, M. A. M. de; MENDES, A. J. D. Influência da intensidade de luz de fotopolimerizadores na infiltração marginal. Rev. APCD, São Paulo, v.50, n.5, set./out., 1996.

BARATIERI, L. N.; RITTER, A. V.; ANDRADA, M. A. C. Como melhorar o desempenho das restaurações? In: FELLER, C.; BOTTINO, M. A. Atualização na Clínica Odontológica: a prática da clínica geral. 16. ed. São Paulo: Artes Médicas, 1994. p.33-60. CAMPOS, E. de. et al. Influência de corantes sobre a translucidez de resinas compostas. Rev. Fac. Ciênc. Odontol., Marília, ano 2, n., 1999. Disponível em: https://docplayer.com.br/49893303-Influencia-de-corantes-sobre-a-translucidez-de-resinascompostas.html. Acesso em: 14 jul. 2020

DOMINGUES, L. A. et al. A influência da intensidade da luz sobre o manchamento da resina. RGO, Porto Alegre, v.50, n.2, p.79-83, abr./maio/jun. 2002.

HACHIYA, Y. Relation of finish to discoloration of composite resins. J. Prosthet. Dent., v.52, n.6, p.811- 814, Dec. 1984. 
MAIXNER, A. O.; SUSIN, A. H. Avaliação da alteração de cor de resina composta submetida à ação de corantes de gêneros alimentícios. Rev Dentística on line, 2001.

MEDEIROS, E. B. de; NASCIMENTO, A. B. L. do. Causas e conseqüências da fotopolimerização inadequada da resina composta. RBO, v.59, n.6, nov./dez., 2002.

POWERS, J. M.; DENNISON, J. B.; KORAN, A. Color stability of restorative resins under accelerated aging. J Dent. Res., Washington, v.57, n.11-12, p.964- 970, Nov./Dec. 1978.

UM, C. M.; RUYTER, I. E. Staining of resin-based veneering materials with coffee and tea. Quintessence Int., Berlin, v.22, n.5, p.377-387, May 1991.

VINHA, D.; SANTOS, A.; PANZERI, H. Resinas Compostas; acabamento superficial X penetração de corantes. RGO, v. 35 , n.4, p.323-325, jul./ago. 1987.

Coordenadoria de Pesquisa e Extensão - COPEX

Departamento de Editoraçāo e Divulgaçāo Científica - DEDIC 


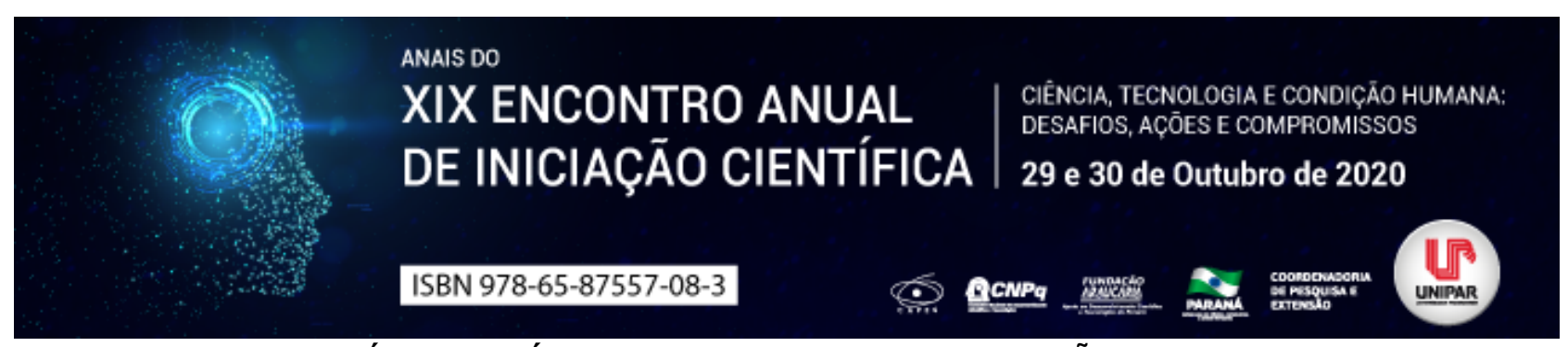

EFICÁCIA DA CÚRCUMA NO TRATAMENTO DE LESÕES BUCAIS

\begin{abstract}
${ }^{1}$ ANA MARIA DA SILVA, ${ }^{2}$ ARGEMIRO RIBEIRO DE ALMEIDA NETO, ${ }^{3}$ GIOVANA SOLER DOS SANTOS, ${ }^{4}$ GISELE APARECIDA SPADIM, ${ }^{5}$ HELOISA GARCIA FRANCOZO, ${ }^{6}$ DANIELA DE CASSIA FAGLIONI B CERANTO
\end{abstract}

${ }^{1}$ Acadêmica bolsista do PIBIC/UNIPAR
${ }^{1}$ Acadêmico do PIC/UNIPAR
${ }^{2}$ Acadêmica do PIC/UNIPAR
${ }^{3}$ Acadêmica do PIC/UNIPAR
${ }^{4}$ Acadêmica do PIC/UNIPAR
${ }^{5}$ Docente da UNIPAR

Introdução: O uso de fitoterápicos no reparo de lesões bucais vem sendo muito estudado. A biodiversidade nacional e a possibilidade de acesso com menor custo fazem dos produtos naturais uma importante alternativa terapêutica. Assim, a Curcuma longa $L$. com suas propriedades antioxidantes, anti-inflamatórias, anti-neoplásicas, antimicrobiana e cicatrizadoras vem ganhando espaço nesses estudos (SILVA, 2015; SCHMIDT, 2019; GONÇALVES, 2014).

Objetivo: Revisar a literatura quanto à eficiência da cúrcuma no tratamento de lesões bucais.

Desenvolvimento: A curcuma é um rizoma da família Zingiberaceae de nome científico Curcuma longa L. Composta por amido, proteínas, fibras, lipídios e oleoresinas, as quais apresentam os compostos curcuminóides, responsáveis pela cor, e os sesquiterpenos, responsáveis pelo aroma (MINISTÉRIO DA SAÚDE, 2015). O principal curcuminóide desse rizoma é a curcumina, um composto fenólico, evidenciado em vários estudos, com propriedades antioxidantes, anti-inflamatórias, antineoplásicas, antimicrobiana e cicatrizadoras (SILVA, 2015; SCHMIDT, 2019; GONÇALVES, 2014). Matos (2018), em um estudo que testou a capacidade anti-inflamatória da curcumina em diferentes doses via gavagem sobre mucosite oral induzida por 5fluorouracil em hamsters, mostrou que, em menores doses, os animais tratados com curcumina apresentaram menor severidade da lesão e capacidade de reparo tecidual semelhante ao grupo de animais que sofreram apenas trauma sem administração de 5fluorouracil, um dos principais quimioterápicos que afetam o epitélio bucal e que pode potencializar a mucosite (PATIL et al., 2015). Além disso, esses animais também apresentaram menor contagem global de leucócitos com níveis muito próximos ou dentro da média de referência, indicando que a curcumina em pequenas doses fez com que os animais melhorassem sua resposta imuno/inflamatória. Também Schmidt (2019) evidenciou que lesões de mucosite oral quimioinduzidas em hamsters tratadas com uso tópico de formulação mucoadesiva de Curcuma longa $L$. apresentaram efeito terapêutico acelerado com maior redução clínica da lesão, maior grau de reepitelização, menor processo inflamatório, menor angiogênese e marcação epitelial de TGF-B1 (fator de crescimento transformador). Da mesma forma, Patil e colaboradores (2015) avaliaram a eficácia da curcumina sobre a mucosite oral no uso clínico em pacientes com câncer submetidos ao tratamento por radio-quimioterapia. Após serem avaliados quanto aos sinais e sintomas da lesão, os pacientes foram divididos, randomicamente, em dois grupos e submetidos a três bochechos diários com clorexidina 0,2\% (grupo 1) e com curcumina a 0,004\% (grupo 2) durante 10 dias. Os resultados mostraram que o grupo que fez bochecho com a solução de curcumina apresentou cicatrização mais rápida e melhor adesão ao tratamento de radio-quimioterapia, não sendo observadas complicações orais e sistêmicas. A curcumina também foi testada para o tratamento de úlceras bucais por Silva (2015) que dividiu em dois grupos 30 ratos Wistar machos com lesões induzidas no dorso da língua e os tratou topicamente com oleoresina de cúrcuma contendo 5,5\% de curcumina (grupo experimental) e com solução salina $0,9 \%$ (grupo controle). O grupo tratado com oleoresina de cúrcuma teve significativa diminuição da quantidade de infiltrado inflamatório e aumento da quantidade de fibroblastos e da deposição de colágeno no processo de cicatrização tecidual, o que evidencia as propriedades anti-inflamatórias e cicatrizantes da curcumina. Da mesma forma, Danilevicz (2016) avaliou a ação tópica da formulação mucoadesiva com extrato de Curcuma longa $L$. no reparo de úlceras em mucosa bucal de ratos induzidas com instrumento de punch de $3 \mathrm{~mm}$, e os resultados mostraram que o grupo de animais tratados com o extrato de cúrcuma apresentaram redução do tempo de cicatrização das úlceras associado à aceleração do reparo epitelial, diminuição do infiltrado neutrofílico e aumento da inflamação crônica com proliferação de fibroblastos, evidenciando que o extrato de cúrcuma estimula o reparo tecidual em úlceras bucais. Outro trabalho realizado por Godoi (2020) avaliou clinicamente o potencial da aplicação tópica da curcumina nanoparticulada sobre a redução de sinais e sintomas do líquen plano oral, obtendo como resultados redução acentuada da sintomatologia dos pacientes em todos os períodos analisados durante o tratamento e demonstrou uma significativa redução das células $T$, o que sugere um potencial do composto no tratamento da doença. Demonstrando a capacidade anticancerígena da curcumina, Gonçalves (2014), em um estudo que avaliou o impacto do tratamento sistêmico da curcumina sobre os períodos iniciais da carcinogênese bucal induzida pelo 4-NQO em ratos, constatou 
que o curcuminóide pode modular a expressão de genes e proteínas indispensáveis à carcinogênese e, dessa forma, intervir e atenuar o desenvolvimento do processo carcinogênico.

Conclusão: A presente revisão ressalta a eficácia dos curcuminóides da Curcuma longa L. no tratamento de lesões orais, evidenciando suas propriedades antioxidantes, anti-inflamatórias, anti-neoplásicas e cicatrizadoras.

\section{Referências}

DANILEVICZ, Chris Krebs. Efeito da formulação mucoadesiva com extrato de Curcuma longa L. no reparo de úlceras em pele e em mucosa bucal de ratos. 2016. TCC (Graduação em Farrmácia) - Universidade Federal do Rio Grande do Sul, Porto Alegre, 2016.

GODOI, Mariely Araújo de. Impacto da aplicação tópica do curcumin nanoparticulado no tratamento de lesões de líquen plano oral (LPO). 2020. Dissertação (Mestrado em Odontologia) - Universidade Estadual Paulista, Araraquara, 2020.

GONÇALVES, Vinícius de Paiva. Ação do curcumin sobre os períodos iniciais da carcinogênese bucal induzida por 4-NQO em modelo murino. 2014. Dissertação (Mestrado em Odontologia) - Universidade Estadual Paulista, Araraquara, 2014.

MATOS, Iolanda Augusta Fernandes de. Efeito na fisiologia, e condições hepáticas da curcumina em modelo experimental de mucosite oral. 2018. TCC (Graduação em Odontologia) - Universidade Federal do Rio Grande do Norte, Natal, 2018.

MINISTÉRIO DA SAÚDE. Monografia da Espécie Curcuma longa L. (Curcuma). Brasília, 2015.

PATIL, Karthikeya. et al. Use of Curcumin Mouthrinse in Radio-Chemotherapy Induced Oral Mucositis Patients: a pilot study. Journal of Clinical And Diagnostic Research, v. 9, n. 8, p. 59-62, jan. 2015. Disponível em: https://www.ncbi.nlm.nih.gov/pmc/articles/PMC4576643/. Acesso em: 16 jul. 2020.

SCHMIDT, Tuany Rafaeli. Estudo do efeito da formulação mucoadesiva do extrato de curcuma longa L. na mucosite oral quimioinduzida em hamster. 2019. TCC (Graduação em odontologia) - Universidade Federal do Rio Grande do Sul, Porto Alegre, 2019.

SILVA, Juliana Barbosa da. Análise histopatológica do processo de reparo cicatricial de úlceras bucais tratadas com oleoresina de cúrcuma (Curcuma longa L.): estudo em ratos. 2015. TCC (Graduação em Nutrição) - Universidade Federal de Pernambuco, Vitória de Santo Antão, 2015. 


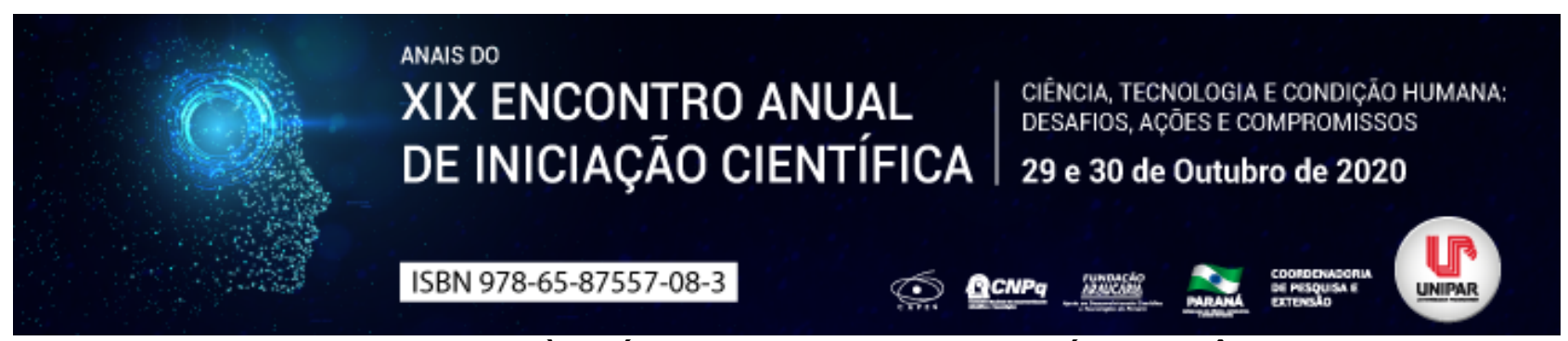

EFEITOS NOCIVOS À SAÚDE HUMANA DO USO DE FLÚOR SISTÊMICO

\begin{abstract}
${ }^{1}$ ANA MARIA DA SILVA, ${ }^{2}$ GISELE APARECIDA SPADIM, ${ }^{3}$ JOAO CARLOS RAFAEL JUNIOR , ${ }^{4}$ LEISLE VERONICA PRESTES, ${ }^{5}$ ANA CAROLINE DOS SANTOS GRUNOW, ${ }^{6}$ ANA CAROLINA SOARES FRAGA ZAZE
\end{abstract}

\author{
${ }^{1}$ Acadêmica bolsista do PIBIC/UNIPAR \\ ${ }^{1}$ Acadêmica do PIC/UNIPAR \\ ${ }^{2}$ Acadêmico bolsista do PEBIC/CNPQ \\ ${ }^{3}$ Acadêmica do Curso de Odontologia da UNIPAR \\ ${ }^{4}$ Acadêmica bolsista do PIBIC/UNIPAR \\ ${ }^{5}$ Docente da UNIPAR
}

Introdução: O uso de flúor na forma de fluoreto tem contribuído para uma significativa redução de prevalência e severidade da cárie dental em todo o mundo. São várias as formas de acesso existentes, sendo a fluoretação da água potável e os dentifrícios fluoretados as mais comuns. Contudo, sabe-se também que o flúor é um elemento tóxico e a sua ingestão diária pode causar efeitos nocivos à saúde humana, e, tendo em vista a suas variadas vias de exposição atualmente (ar, água, alimentos e produtos de higiene oral), o controle da dose consumida torna-se cada vez mais difícil e os riscos mais preocupantes (RAMIRES; BUZALAF, 2007).

Objetivo: Revisar a literatura quanto aos efeitos nocivos que o uso de flúor sistêmico pode causar na saúde humana.

Desenvolvimento: $O$ uso de flúor sistêmico, no Brasil, com a fluoretação da água potável, é efetivo e capaz de controlar a doença cárie, principalmente em populações com alto risco e sem acesso a outras fontes de flúor (RAMIRES; BUZALAF, 2007). São várias as suas vias de exposição, sendo difícil controlar a quantidade ingerida diariamente, em função das variações individuais, regionais e culturais, e embora o organismo tenha a capacidade de metabolizar o flúor, a sua presença constante causa efeito cumulativo, podendo resultar em efeitos secundários tóxicos crônicos (MAGALHÃES, 2018). A fluorose dental e a esquelética são as mais frequentes manifestações crônicas da excessiva ingestão de flúor, sendo a primeira caracterizada como a hipomineralização do esmalte dentário resultante da retenção de proteínas na matriz, relacionada à exposição de altas doses de fluoreto durante a amelogênese (DOMINGOS ET AL., 2018), e a segunda como doença metabólica crônica que afeta as estruturas ósseas e causa deformações, podendo levar a osteosclerose, calcificação de ligamentos, osteoporose, osteomalácia e osteopenia (MAGALHÃES, 2018). Além disso, Silva e colaboradores (2018), em um estudo com o objetivo de determinar os efeitos causados pelo flúor nos principais órgãos responsáveis pela sua digestão, constataram mudanças morfológicas no duodeno, rim e fígado de ratos submetidos à água fluoretada em diferente concentrações $(0,7 ; 1,2$ e 2,0 ppmF). O duodeno apresentou maior número de células caliciformes e glândulas de Brunner, que são responsáveis pela produção de muco na camada submucosa, já no fígado houve irregularidade nos sinusóides, os quais se apresentaram com espaço diminuído, provocando um enfartamento dos hepatócitos, e no formato da veia centrolobular, a qual se apresentou com maior quantidade de tecido conjuntivo ao seu redor, o que pode dificultar o deságue dos sinusóides, e nos rins houve um espessamento da cápsula de Bowman e irregularidade no corpúsculo renal. Também Kobayashi (2008) em seus estudos, observou mudanças estruturais em rins de animais com intoxicação crônica de flúor, como hemorragias, hiperemia glomerular e medular, alterações inflamatórias, destruição tubular e edema intersticial, além de glomerulonefrite subaguda, nefrite crônica e necrose. Da mesma forma, Chioca (2007) averiguou que a exposição excessiva ao flúor pode ocasionar efeitos tóxicos ao Sistema Nervoso Central (SNC), segundo ele a presença constante e em maiores quantidades de flúor torna a barreira hematoencefálica permeável ao mesmo. Num estudo que avaliou a memória de ratos submetidos a fluoreto de sódio (NaF) na água de beber, Chioca (2007) constatou que mesmo em concentrações de intoxicação moderadas de NaF (2.33 e $4.87 \mathrm{mg} / \mathrm{kgF}$ ) os ratos apresentaram prejuízo na habituação e redução no número de esquivas ativas, o que indica que o $\mathrm{NaF}$ tem potencial deletério sobre o aprendizado e memória. Além disso, Valdez-Jiménez e colaboradores (2010), afirmam que os efeitos associados à presença de flúor no cérebro, dependendo da dose administrada, idade e tempo de exposição, incluem danos no hipocampo, redução de receptores de acetilcolina nicotínicos e aumento de radicais livres no cérebro, o que desencadeia a ativação de vias metabólicas relacionadas à doença de Alzheimer. Ainda, segundo Domingos e colaboradores (2018), embora a maior parte do fluoreto seja absorvida pelos tecidos mineralizados, uma pequena parte atua nos tecidos moles podendo causar inibição de atividades enzimáticas e interagir com genes modulados pelo flúor relacionados a ciclo celulares, comunicação entre células, resposta ao stress, enzimas metabólicas e transdução de sinais. Ademais, Ge e colaboradores (2005), em um estudo que avaliou os efeitos do alto teor de flúor e baixo teor de iodo na função tireoidiana em ratos, demonstrou que a acumalção de fluoreto pode levar a disfunção na tireoide, especialmente quando existe em simultâneo a carência de iodo, uma vez que nestas condições houve elevado dano no DNA das 
células tireóideas.

Conclusão: Nota-se, portanto, que o uso sistêmico de flúor pode ocasionar efeitos nocivos à saúde humana de toxicidade crônica, levando a alterações morfológicas e estruturais em órgãos e sistemas do organismo. Este fato mostra a necessidade de um monitoramento rigoroso da fluoretação da água de abastecimento público e da conscientização sobre o uso e consumo de produtos fluoretados, pela população.

\section{Referências}

CHIOCA, Léa Rosa. Ingestão crônica de flúor induz prejuízo nos testes de habituação e esquiva ativa em ratos. 2007. Dissertação (Mestrado em Farmacologia) - Universidade Federal do Paraná , Curitiba, 2007.

DOMINGOS, Patricia Aleixo dos Santos et al. Riscos do uso do flúor sistêmico - revisão de literatura. Journal of Research In Dentistry, Palhoça, v. 6, n. 4, p. 86-90,jul. 2018.

GE, Ya-Ming; NING. et al. Effects of High Fluoride and Low lodine on Thyroid Function in Offspring Rats. Journal Of Integrative Agriculture, Beijing, v. 12, n. 3, p. 502-508, mar. 2013.

KOBAYASHI, Cláudia Ayumi Nakai. Análise proteômica em urina e rim de ratos submetidos a tratamento crônico com flúor. 2008. Dissertação (Mestrado em Odontologia) - Universidade de São Paulo, Bauru, 2008.

MAGALHÃES, Helena Isabel Couto. Efeitos do flúor na saúde humana. 2018. Dissertação (Mestrado em Farmácia) Universidade Fernando Pessoa, Porto, 2018.

RAMIRES, Irene; BUZALAF, Marília Afonso Rabelo. A fluoretação da água de abastecimento público e seus benefícios no controle da cárie dentária: cinqüenta anos no brasil. Ciência \& Saúde Coletiva, Rio de Janeiro, v. 12, n. 4, p. 1057-1065, ago. 2007.

SILVA, Alessandra Dutra da. et al. Efeitos da toxicidade sistêmica produzida pelo flúor: estudo em modelo animal. Stomatos, Canoas, v. 24, n. 47, jul/dez, 2018. Disponível em: http://www.periodicos.ulbra.br/index.php/stomatos/article/view/4110/3350. Acesso em: 16 ago. 2020.

VALDEZ-JIMÉNEZ, L. et al. Effects of the fluoride on the central nervous system. Neurología, Madrid, v. 26, n. 5, p. 297-300, 2011. 


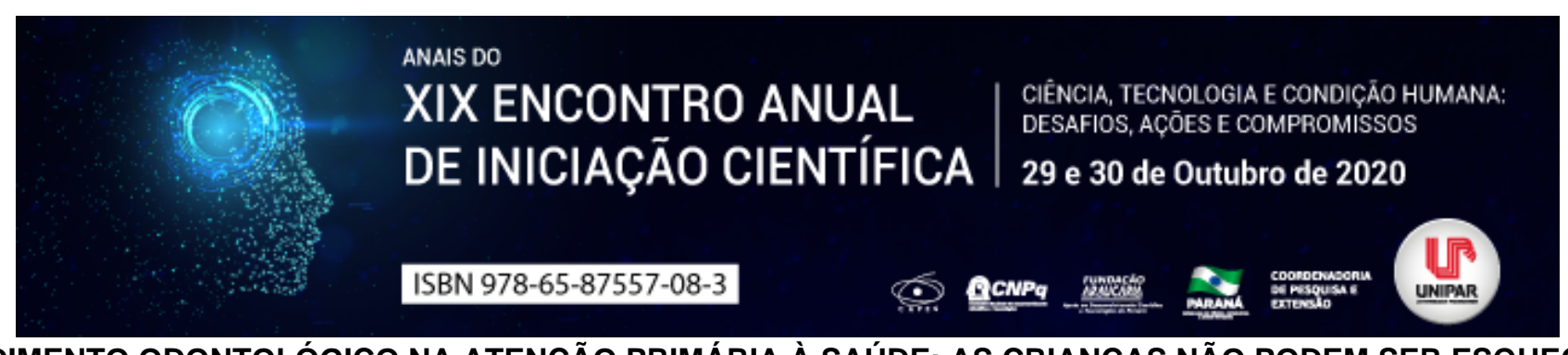

ATENDIMENTO ODONTOLÓGICO NA ATENÇÃO PRIMÁRIA À SAÚDE: AS CRIANÇAS NÃO PODEM SER ESQUECIDAS

\author{
${ }^{1}$ NATALIA COQUEIRO SIQUEIRA, ${ }^{2}$ JOAO CARLOS RAFAEL JUNIOR, ${ }^{3}$ MARIA RITA BARBOSA DE OLIVEIRA, ${ }^{4}$ GABRIELA \\ ZANUTO DE LIMA, ${ }^{5}$ BEATRIZ AYUMI SHIOTANI, ${ }^{6}$ WESLEY FERNANDO FERRARI
}

\author{
${ }^{1}$ Acadêmica do Curso de Odontologia da UNIPAR \\ ${ }^{1}$ Academico bolsista do PEBIC/CNPQ \\ ${ }^{2}$ Acadêmica bolsista do PEBIC/CNPQ \\ ${ }^{3}$ Acadêmica do Curso de Odontologia da UNIPAR \\ ${ }^{4}$ Acadêmica PIC/UNIPAR \\ ${ }^{5}$ Docente da UNIPAR
}

Introdução: É grande o número de famílias e/ou responsáveis que procuram atendimento odontológico na rede pública de saúde às crianças sob seus cuidados. Diante da não obrigatoriedade da oferta de atendimentos odontopediátricos nos Centros de Especialidades Odontológicas (CEOs), cabe à Atenção Primária à Saúde (APS) a resolutividade da maioria das doenças e agravos, uma vez que esta pode ser a única alternativa de atendimento para grande parte dos usuários do SUS (VICENTE et al., 2015).

Objetivo: Realizar uma reflexão a respeito da importância do atendimento odontológico integral ao paciente infantil no âmbito da APS, do reconhecimento e preparo da equipe frente aos desafios comportamentais inerentes a esta faixa etária e da capacidade de execução de um planejamento odontológico integral.

Desenvolvimento: Os pacientes infantis compõem uma parte significativa do público assistido pelas ESB na maioria dos territórios. A Linha Guia de Saúde Bucal do estado do Paraná aconselha que os cuidados com a saúde bucal se iniciem nos primeiros dias de vida. Além da consulta clínica para detecção de alguma alteração bucal no bebê, a mãe deve ser esclarecida quanto ao aleitamento, cárie da primeira infância e o uso de bicos e chupetas, pois tais medidas ocupam um papel decisivo na prevenção de problemas (SESA, 2016). O último levantamento epidemiológico brasileiro mostrou que a cárie dentária atinge aproximadamente $53,4 \%$ das crianças com cinco anos de idade (BRASIL, 2012), enquanto a Pesquisa Nacional por Amostra de Domicílios - PNAD 2008 apontou que 77,9\% das crianças de 0 a 4 anos nunca visitaram o dentista (IBGE, 2010). Sob a perspectiva profissional, um número alarmante: uma pesquisa com mais de 18.000 equipes de saúde bucal revelou que um quinto das unidades de saúde não realiza atendimento odontológico na primeira infância (ESSVEIN et al.,2019). É notório que uma grande parcela da população infantil não tem acesso aos cuidados profissionais desde cedo, o que deveria preocupar profissionais e gestores de saúde. Em muitos casos, o primeiro contato da criança com o cirurgião dentista ocorre em condições de estresse, nas consultas imediatas em caráter de urgência, o que impede a longitudinalidade do cuidado em saúde bucal (GOMES et al., 2013). O grande problema é que a procura por atendimento diante de situações de dor ou sofrimento pode ocorrer nos momentos em que tratamentos conservadores já não são indicados, o que poderia resultar até mesmo em extrações dentárias precoces (BAVARESCO et al., 2018). Nesta linha de pesquisa, Costa et al., (2014) salientam que o atendimento agendado, negligenciado por algumas equipes de saúde bucal, é preferível em relação às consultas de urgência, para que a atenção integral ao paciente infantil seja oferecida. Cabe ressaltar a importância de técnicas de condicionamento para controle da ansiedade e do medo durante as consultas odontológicas infantis, também praticáveis no atendimento público (GOMES et al., 2013; SOARES et al., 2015). Toda essa dinâmica de planejamento e engajamento com vistas ao atendimento infantil na APS deveria estar pautada na não obrigatoriedade de atendimento odontopediátrico nos CEOs (atenção especializada), ou seja, grande parte das crianças brasileiras tem na APS a oportunidade única de restabelecimento da saúde bucal.

Conclusões: Diante do exposto, fica clara a necessidade de que gestores de saúde apresentem todas as condições possíveis para que os profissionais de saúde bucal na esfera da APS ofereçam atendimento integral como resposta às necessidades odontológicas infantis. Pode-se pressupor também que o envolvimento das equipes de saúde bucal na tentativa de se contornar dificuldades inerentes ao atendimento à esta faixa etária é crucial para o sucesso no acolhimento dessas crianças.

\title{
Referências
}

BAVARESCO, Caren Serra et al. Pediatric dentistry in primary healthcare: Creation, development, and evaluation of a distance education course. Telemedicine and e-Health, v. 24, n. 8, p. 1-7, ago. 2018.

BRASIL. Ministério da Saúde, Secretaria de Atenção à Saúde, Departamento de Atenção Básica, Coordenação Nacional de Saúde Bucal. Pesquisa Nacional de Saúde Bucal: resultados principais. Brasília; 2012 . Disponível em: http://bvsms.saude.gov.br/bvs/publicacoes/pesquisa_nacional_saude_bucal.pdf. 
COSTA, Ana Maria Duarte Dias. et al. Ansiedade ao tratamento odontológico em escolares do ensino médio no município de Alfenas-MG. Braz. J. Periodontol., v. 24, n. 2, p. 13-18, jun. 2014.

ESSVEIN, Gustavo et al. Atendimento odontológico na primeira infância no Brasil: da política pública à evidência. Rev. de Saúde Pública, v. 53, n. 15, p. 1-12, 2019.

GOMES, Samara Santos Rodrigues. et al. Comportamento em crianças pré-escolares na primeira consulta odontológica: relação entre medidas objetivas e subjetivas. J. Manag. Prim. Health Care, v. 4, n. 2, p. 102-109, 2013.

IBGE. Instituto Brasileiro de Geografia e Estatística. Pesquisa Nacional por Amostra de Domicílios: um panorama da saúde no Brasil: acesso e utilização dos serviços, condições de saúde e fatores de risco e proteção à saúde 2008. Rio de Janeiro, 2010. MORETTO, Maria Lívia Tourinho; PRISZKULNIK, Léia. Sobre a inserção e o lugar do psicanalista na equipe de saúde. Tempo Psicanalítico, Rio de Janeiro, v. 46, n. 2, p. 287-298, 2014.

SESA. Secretaria do Estado da Saúde do Paraná. Superintendência de Atenção à Saúde. Linha guia rede de saúde bucal, Curitiba: SESA PR, 2016. 92p.

SOARES, Erika Fernandes. et al. Características ideais ao cirurgião-dentista na estratégia saúde da família. Trab. Educ. Saúde, Rio de Janeiro, v. 12, n. 2, p. 327-341, mai./ago. 2014.

VICENTE, Sonia Pineda. et al. A inclusão do odontopediatra nos centros de especialidades odontológicas. Rev. Uningá Review, Maringá, v. 24, n. 3, p. 113-117, out./dez. 2015. 


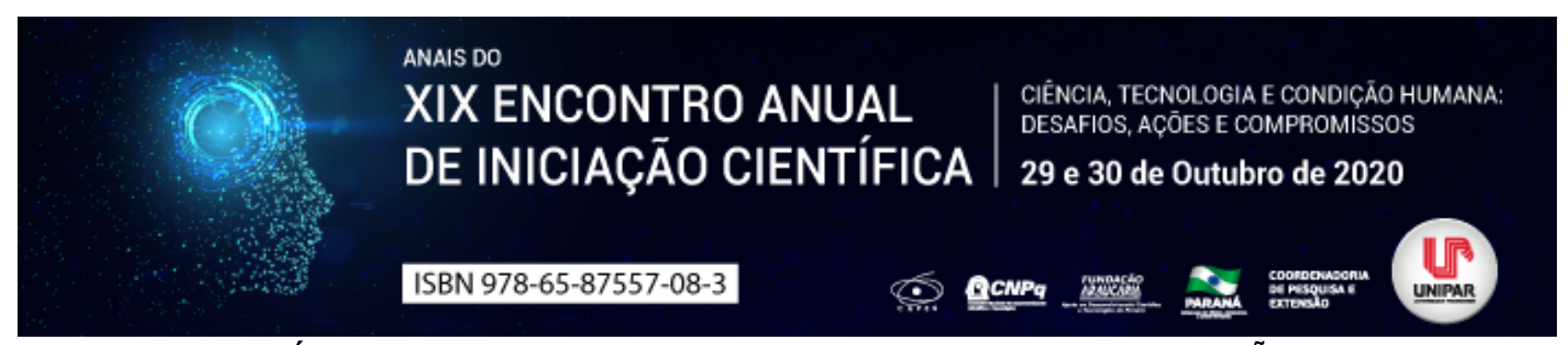

DESAFIOS PSICOLÓGICOS E SOCIAIS DE PORTADORES DE AIDS/HIV: UMA REVISÃO DE LITERATURA

\begin{abstract}
${ }^{1}$ GABRIEL HENRIQUE DO PRADO GONCALVES, ${ }^{2}$ NAIANY OLIVOTTO MARTINS, ${ }^{3}$ DENISE ALVES LOPES, ${ }^{4} \mathrm{MICHEL}$ ANDREW NOGARA
\end{abstract}

\author{
${ }^{1}$ Acadêmico do curso de Medicina da UNIPAR \\ ${ }^{1}$ Acadêmica do Curso de Medicina da UNIPAR \\ ${ }^{2}$ Docente da UNIPAR \\ ${ }^{3}$ Docente da UNIPAR
}

Introdução: A síndrome da imunodeficiência adquirida (AIDS) apresentou-se de forma agressiva na história. Somente no Brasil no ano de 2019, foi estimado que mais de 850.000 brasileiros convivem com AIDS (MINISTÉRIO DA SAÚDE, 2019). A causa da AIDS é a infecção do vírus da imunodeficiência humana (HIV), que afeta as células do sistema imunológico (MINISTÉRIO DA SAÚDE, 2019). Essa patologia trouxe à sociedade uma discussão acerca da diversidade no âmbito social, contribuindo para emergir temáticas consideradas tabus, como a sexualidade, o que a estigmatizou. Por isso, ao receber seu diagnóstico, o indivíduo encontra diversos fatores psicológicos que o fazem questionar sobre seu futuro, e, ao adentrar a nova realidade, tem seu modo de ser e de se relacionar consigo mesmo e com os outros transformados (LOBO; LEAL, 2019).

Objetivo: Relatar os principais desafios psicológicos e sociais de sujeitos portadores de AIDS.

Desenvolvimento: A AIDS é causada por um vírus e sua transmissão ocorre por meio da troca de flú́dos corporais, como na relação sexual sem preservativo, transfusão de sangue, compartilhamento de seringa e também por transmissão vertical (MINISTÉRIO DA SAÚDE, 2020). A causa dessa infecção é frequentemente e erroneamente associada à comportamentos socialmente vistos como imorais, como a promiscuidade, homossexualidade e uso de drogas, sendo seu diagnóstico motivo de medo do preconceito e rejeição perante familiares e sociedade em geral (MALISKA, 2009). Esse cenário gerou uma visão socialmente distorcida e estigmatizadora sobre a doença, dificultando a convivência social das pessoas com AIDS (LOBO; LEAL, 2019). Estudos indicam que os sujeitos soropositivos têm suas vidas alteradas a partir do diagnóstico, mesmo que assintomáticos, passando-se a se sentirem pessoas diferentes das demais, como se fossem ameaças (GONÇALVES; BANDEIRA; GARRAFA, 2011). Dentre diversos sentimentos, podem ser apresentados a surpresa, decepção, tristeza, desespero, medo do desconhecido e medo do futuro, podendo ser intensificados de acordo com crenças, valores e grupo social em que o indivíduo se insere (MALISKA, 2009). Muitos portadores da doença escondem-na de seus parceiros sexuais, familiares ou amigos por acreditarem que são os culpados por contraí-la, por medo da exclusão social e do preconceito (GOMES AMT et al., 2011). Uma vez que muitos são os avanços no tratamento e que em alguns casos o vírus nem se manifeste, a AIDS passou de uma doença letal para uma condição crônica, o que exige maior atenção na qualidade de vida do paciente diagnosticado (MALISKA, 2009). Os soropositivos apresentam dificuldades para satisfazerem sua qualidade de vida, visto que essa patologia pode levar a interrupção de relações interpessoais, isolamento social, dificuldades com a sexualidade e relações sociais, comprometendo negativamente sua saúde mental e física (JESUS et al., 2017). O convívio com essa doença exige muito além do tratamento, pois podem estar envolvidos diversos sintomas depressivos, estigma, discriminação e outros fatores (JESUS et al., 2017). Estando ligada ao comportamento sexual, a AIDS é vista no senso comum como vergonhosa, pois doenças ligadas a esse comportamento são moralmente repreendidas, culpando a vítima, principalmente, no caso das mulheres (GONÇALVES; BANDEIRA; GARRAFA, 2011). Conforme mostra um estudo realizado em um Serviço de Assistência Especializado de um Centro Integrado de Saúde no Estado do Piauí na região nordeste do Brasil com portadores de AIDS/HIV, mais que $70 \%$ dos entrevistados viviam com alguns sintomas psicossociais, como medo, ansiedade e depressão e um pouco mais de $61 \%$ relataram já terem sido vítimas de estigma ou preconceito (OLIVEIRA et al., 2015). Os portadores de AIDS ainda enfrentam dificuldade em atendimentos no Sistema Único de Saúde (SUS), no privado, sendo tratados de maneira distinta, visto que muitos trabalhadores da saúde ficam distante fisicamente dessas pessoas, aplicam ações de biossegurança desnecessárias e muitos quebram o sigilo entre profissional de saúde e paciente (GOMES HN et al., 2019). Nos atendimentos odontológicos, muitos profissionais recusam prestar atendimento ou aumentam o orçamento do serviço (DISCACCIATI; VILAÇA, 2001).

Conclusão: A AIDS configura-se como uma doença que traz consigo inúmeros desafios psicossociais para seus portadores, visto que, ainda hoje, são vítimas de uma visão estereotipada socialmente. A partir da descoberta da doença, e muitas vezes do preconceito e discriminação pelo enfermo, estes podem apresentar uma modificação em seu comportamento social e restrições em suas relações pessoais, podendo afetar o bem estar psicológico do indivíduo. Dessa forma, é importante que a sociedade se conscientize sobre os desafios vividos por soropositivos, para que os tratem de maneira igualitária e respeitosa, sem qualquer tipo de distinção. A AIDS demanda atenção integral da população desde sua prevenção até seu tratamento efetivo. 


\section{Referências}

CAMARGO, Luiza Adem. et al. Saúde mental, suporte familiar e adesão ao tratamento: associações no contexto HIV/Aids. Psico USF, 2014; v. 19, n. 2, p. 221-232, 2014.

DISCACCIATI, José Augusto César; VILAÇA, Ênio Lacerda. Atendimento odontológico ao portador do HIV: medo, preconceito e ética profissional. Revista Panamericana de Salud Pública, v. 9, p. 234-239, 2001.

GOMES, Antônio Marcos Tosoli. et al. Representações sociais da AIDS para pessoas que vivem com HIV e suas interfaces cotidianas. Revista Latino-americana de Enfermagem, v. 19, n. 3, p. 485-492, 2011.

GOMES, Hévila Nascimento. et al. Análise do atendimento nos serviços de saúde entre pessoas vivendo com HIVIAIDS. Journal of Health \& Biological Sciences, v. 7, n. 4, p. 387-394, 2019.

GONÇALVES, Erli Helena; BANDEIRA, Lourdes Maria; GARRAFA, Volnei. Ética e desconstrução do preconceito: doença e poluição no imaginário social sobre o HIV/Aids. Revista Bioética, v. 19, n. 1, p. 159 - 78, 2011.

JESUS, Giselle Juliana de. et al. Dificuldades do viver com HIVIAids: Entraves na qualidade de vida. Acta Paul Enferm., v. 30, n. 3, p. 301-307, Maio. 2017.

MALISKA, Isabel Cristina Alves. et al. Percepções e significados do diagnóstico e convívio com o HIV/aids. Revista Gaúcha de Enfermagem, v. 30, n. 1, p. 85, 2009.

BRASIL, MINISTÉRIO DA SAÚDE. Brasil mais do que dobra o tempo de sobrevida de pessoas com aids. 2019. Disponível em: encurtador.com.br/jkRSW. Acesso em: 28 ago. 2020.

BRASIL, MINISTÉRIO DA SAÚDE. Aids / HIV: o que é, causas, sintomas, diagnóstico, tratamento e prevenção. Disponível em: encurtador.com.br/rwEFT. Acesso em: 18 ago. 2020.

OLIVEIRA, Francisco Braz Milanez, et al. Qualidade de vida e fatores associados em pessoas vivendo com HIVIAIDS. Acta Paulista de Enfermagem, v. 28, n. 6, p. 510-516, 2015.

LOBO, Ângelo Souza; LEAL, Maria Alice Ferreira. Comunicação de más notícias: a revelação do diagnóstico de HIVIAids e seus impactos psicológicos. CIAIQ2019, v. 2, p. 549-558, 2019. 


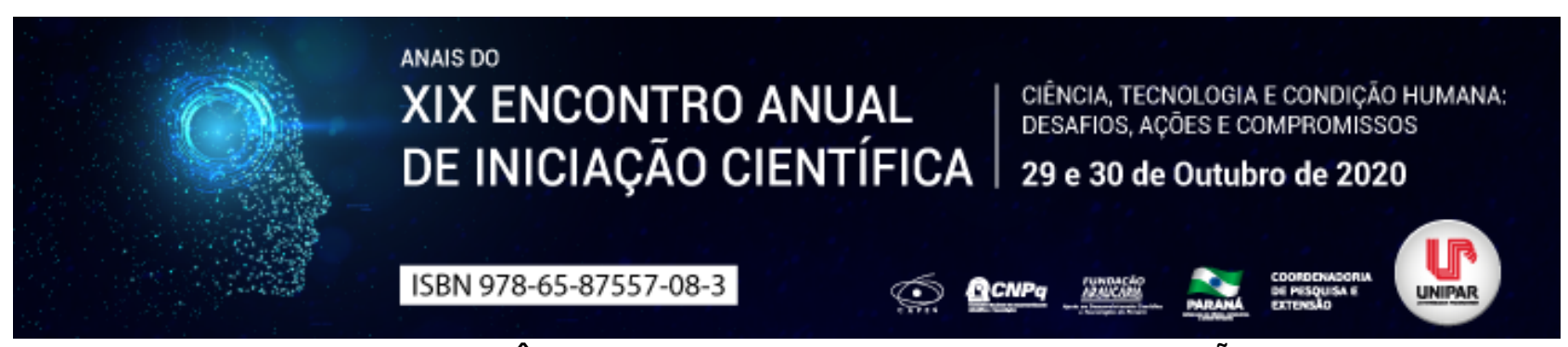

EFETIVIDADE DE IRRIGANTES ENDODÔNTICOS A BASE DE QUITOSANA NA REMOÇÃO DA SMEAR LAYER APÓS INSTRUMENTAÇÃO DO CANAL RADICULAR

\title{
${ }^{1}$ LAINARA ANGELO SANTOS, ${ }^{2}$ KLISSIA ROMERO FELIZARDO
}

\author{
${ }^{1}$ Acadêmica de Odontologia da Unipar \\ ${ }^{1}$ Docente da UNIPAR
}

Introdução: Várias técnicas têm sido sugeridas e empregadas na remoção do material obturador, como o uso de limas manuais ou rotatórias, associadas ou não à solventes endodônticos ou ao calor, e pontas de papel com produtos químicos (WILCOX et al., 1987). Nesta linha de pensamento, independentemente do tipo de instrumento e técnica utilizada, é inquestionável a formação de uma lama dentinária chamada smear layer durante o processo de retratamento. Esta apresenta-se com aspecto granular, amorfo e irregular sendo composta por matéria inorgânica (raspas de dentina), microrganismos e seus subprodutos, remanescentes de substâncias químicas (agentes irrigantes, solventes e medicação intracanal), guta percha e cimento endodôntico (KELES et al., 2016). A presença e/ou manutenção desta lama dentinária sobre as paredes do canal radicular tem resultado na adesão insatisfatória de materiais obturadores (TABRIZIZADEH et al., 2015) e pinos de fibra de vidro; à dentina radicular (OLIVEIRA et al., 2018). Algumas substâncias como o ácido etilenodiamino tetraacético (EDTA) e ácido cítrico, auxiliam na descalcificação e remoção da smear layer. O EDTA é o mais eficiente e mais utilizado na atualidade. Esta substância contribui para a remoção da porção inorgânica, seguido da irrigação com $\mathrm{NaOCl}$ que faz remoção da parte orgânica da smear layer (HAAPASALO et al., 2010). Outras substâncias têm sido testadas com o mesmo fim e apresentando potencial para a substituição ao EDTA (SHENOY et al., 2014).

Objetivo: Este trabalho tem por objetivo mostrar através de uma revisão da literatura, a efetividade de irrigantes endodônticos a base de quitosana na remoção da smear layer após instrumentação do canal radicular. Foram utilizados trabalhos coletados por meio das bases de dados BIREME, SCIELO, EBSCO e PubMed.

Desenvolvimento: Avanços em pesquisas com biomateriais no desenvolvimento de novas biomacromoléculas e materiais biocompatíveis para uso clínico odontológico (TARTARI et al., 2013) tem contribuído para a descoberta de substâncias alternativas ao EDTA. Neste sentido, a quitosana aparece como supridora do EDTA, uma vez que apresenta características antioxidantes, antimicrobianas, anti-inflamatórias, cicatrizante e de inibição da formação de biofilmes (GEETHAPRIYA et al., 2016). A quitosana é obtida a partir da desacetilação da quitina encontrada nos exoesqueletos de artrópodes (cascas de crustáceos e insetos), sendo um produto abundante na natureza e de baixo custo. Na endodontia a quitosana foi utilizada incorporada ao hidróxido de cálcio (GEETHAPRIYA et al., 2016). Neste trabalho foi possível observar que, além de impedir a formação do biofilme na interface cimento/dentina, houve liberação prolongada de íons cálcio, pelo hidróxido de cálcio. Também outros autores avaliaram a eficácia da quitosana, quitosana+EDTA e $\mathrm{NaOCl} 5,2 \%$ contra o Enterococcus faecalis. Os autores verificaram que a quitosana e a quitosana+EDTA reduziram a quantidade desta bactéria (GUIBAL et al., 2000). O tipo de interação desta solução com a smear layer pode estar relacionado à estrutura da quitosana e a seu pH (SILVA et al., 2013). De acordo com Silva et al. (2013), a solução de quitosana com concentração de 0,2\%, permanecendo por 3 min. dentro do canal radicular, apresenta a mesma efetividade que o EDTA neste mesmo tempo. Os pesquisadores avaliaram qualitativamente a remoção da smear layer por meio de $\mathrm{MEV}$ e quantitativamente a concentração de íons cálcio, após a irrigação, por espectrofotometria de absorção atômica. Foram usados quitosana 0,2\%, EDTA 15\%, ácido cítrico 10\% e ácido acético 1\%. A efetividade de todas as soluções nos terços médio e apical dos canais radiculares também foi observada, sendo o EDTA e a quitosana as soluções que apresentaram o melhor efeito na remoção da smear layer. Foi observada relação direta entre a maior capacidade de remoção da smear layer e as concentrações de íons cálcio.

Conclusão: Conclui-se que a smear layer deve ser removida para o sucesso do tratamento endodôntico, e a quitosana quanto ao efeito quelante tem merecido atenção dos pesquisadores por ser uma opção à substituição ao EDTA por conta de seus efeitos antimicrobianos.

\section{Referências}

GEETHAPRIYA, N.; SUBBIYA, A.; PADMAVATHY, K.; MAHALAKSHMI, K.; VIVEKANANDAN, P.; SUKUMARAN, V.G. Effect of chitosan-ethylenediamine tetraacetic acid on Enterococcus faecalis dentinal biofilm and smear layer removal. $\mathbf{J}$ Conserv Dent, v.19, n.5, p.472, 2016.

GUIBAL, E.; MILOT, C.; ROUSSY, J. Influence of hydrolysis mechanisms on molybdate sorption isotherms using chitosan. Separation Science and Technology, v.35, p.1020-38, 2000.

HAAPASALO, M.; SHEN, Y.; QIAN, W.; GAO, Y. Irrigation in endodontics. Dent Clin North AM, v.54, n.2, p.291-312, 2010. 
KELES, A.; KAMALAK, A.; KESKIN, C.; AKCAY, M.; UZUN, I. The efficacy of laser ultra sound and self-adjustable file in removing smear layer debris from oval root canals following retreatment: A scanning electron microscopy study. Aust Endod J, v.1, n.3, p.5-8, 2016.

OLIVEIRA, L.V. Importância da limpeza, método e momento de alívio do canal radicular para instalação do pino de fibra de vidro: revisão sistemática e estudo laboratorial. J Endod, 2018.

SHENOY, A.; AHMADUDDIN, B.; BOLLA, N.; RAJ, S.; MANDAVA, P.; NAYAK S. Effect of final irrigating solution on smear layer removal and penetrability of the root canal sealer. J Conserv Dent, 17:40-4, 2014.

SILVA, P.G.; NAKADI, F.V.; PÉCORA, J.D.; CRUZ-FILHO, A.M. Chitosan: a new solution for removal of smear layer after root canal instrumentation. Int Endod J, v.46, p.336-8, 2013.

TABRIZIZADEH, M.; SHAREGHI, A. The Effect of Preparation Size on Efficacy of smear layer Removal; A Scanning Electron Microscopic Study. Iran Endod J, v.10, n.3, p.169-73, 2015.

TARTARI, T.; JUNIOR, D.; PEREIRA, A.; JUNIOR, S.; CARRERA, J.O.; KLAUTAU, E.B. Etidronate from medicine to endodontics: effects of different irrigation regimes on root dentin roughness. J Appl Oral Sci, 21(5):409-15, 2013.

WILCOX, L.R.; KRELL, K.V.; MADISON, S.; RITTMAN, B. Endodontic retreatment: evaluation of gutta-percha and sealer removal and canal reinstrumentation. J Endod, v.13, n.9, p.453-7, sep., 1987. 


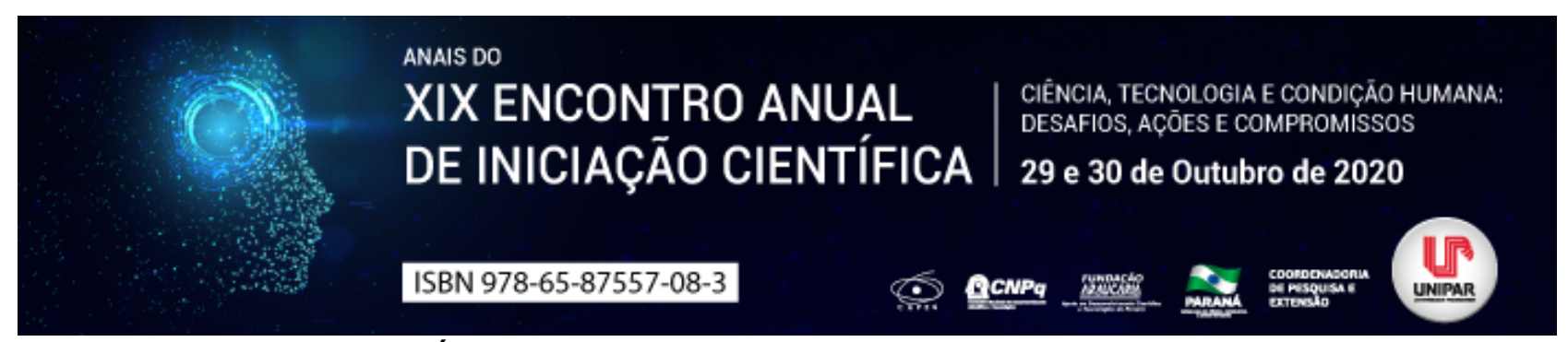

\title{
APLICABILIDADE DE FITOTERÁPICOS NO CONTROLE DO MEDO E ANSIEDADE DURANTE O ATENDIMENTO ODONTOLÓGICO REVISÃO DE LITERATURA
}

\author{
${ }^{1}$ ANDRESSA ANDRADE NOVAES, ${ }^{2}$ ANA MARIA DA SILVA, ${ }^{3}$ JOAO MURILO GONCALVES GAZOLA, ${ }^{4}$ SUELEN STEFANONI \\ BRANDAO, ${ }^{5}$ ELOISA PEREIRA DE SOUZA, ${ }^{6}$ DANIELA DE CASSIA FAGLIONI B CERANTO
}

\author{
${ }^{1}$ Acadêmica bolsista do PIBIC/UNIPAR \\ ${ }^{1}$ Acadêmica bolsista do PIBIC/UNIPAR \\ ${ }^{2}$ Acadêmico bolsista do PIBIC/UNIPAR \\ ${ }^{3}$ Acadêmica bolsista do PIBIC/UNIPAR \\ ${ }^{4}$ Acadêmica do PIC/UNIPAR \\ ${ }^{5}$ Docente da UNIPAR
}

Introdução: O medo e a ansiedade estão presentes na odontologia há décadas, reflexos de um histórico cruel e obtuso da prática odontológica, que interferem diretamente no manejo do profissional e na ida do paciente ao consultório. Ao se deparar rotineiramente com esses problemas, o cirurgião-dentista necessita lançar mão de alternativas que facilitem e tornem o atendimento odontológico agradável. Preconizando um tratamento de forma integrada e humanizada, os fitoterápicos são medidas assertivas, podendo ser utilizados com excelência na área odontológica, trazendo inúmeros benefícios tanto ao paciente, quanto ao profissional.

Objetivo: Avaliar a aplicabilidade de fitoterápicos no controle do medo e ansiedade durante o atendimento odontológico, através de uma revisão da literatura.

Desenvolvimento: A fitoterapia é uma técnica complementar que vem sendo muito utilizada atualmente, quando bem aplicada por um profissional capacitado, pode substituir as terapias medicamentosas com êxito, tendo em vista que possuem menores riscos de efeitos colaterais e baixo custo (DE FARIAS, 2019). De acordo com o estudo de Pinheiro et al (2003), a Valeriana officinalis apresenta um efeito ansiolítico similar ao grupo dos benzodiazepínicos, sem impactos adversos consideráveis, não potencializa os efeitos do álcool etílico, não causa dependências físicas e/ou psicológica, não impossibilita o uso de veículos e não necessita de acompanhante após o tratamento, ao contrário do que observamos com os benzodiazepínicos. O Passiflora incarnata, popularmente conhecido como maracujá , possui atividades sedativas, depurativas e anti-inflamatórias, atuam no nervosismo, ansiedade e insônia, agindo como depressor inespecífico do sistema nervoso central (LOPES, TIYO E ARANTES, 2017). O medo e a ansiedade estão inter relacionados, considerando um paciente que precisa de atendimento odontológico, mas possui medo, seja por experiências anteriormente vividas, por traumas impostos por vivências de familiares ou até mesmo pelo histórico da prática rude da odontologia, automaticamente esse paciente desenvolverá ansiedade ao atendimento, além de postergar a visita ao dentista, elevando as taxas de má saúde bucal, devido à ausência de visitas periódicas para avaliação bucal. Ao se deparar com opções de fitoterápicos para o manejo desses problemas, há predileção pelo cirurgião dentista por esse tratamento, tendo em vista seus benefícios, sua formulação natural e grande aceitabilidade do paciente.

Conclusão: Dado o exposto, os fitoterápicos Valeriana officinalis e Passiflora incarnata tem um efeito positivo quando aplicados para a intervenção do medo e ansiedade durante o atendimento odontológico, como alternativas ao uso de ansiolíticos. Isso porque possuem baixo custo e mínimo risco de efeitos colaterais, quando comparados ao grupo dos benzodiazepínicos. Os medicamentos à base de ervas estão sendo utilizados frequentemente, porém, é necessário que o cirurgião dentista esteja inteirado sobre tais informações, através da leitura de artigos recentes e cursos de atualização. Quando bem aplicado, este método de tratamento facilita a conduta profissional e o decorrer do atendimento, proporcionando o bem estar do paciente, a fim de que a condição de saúde bucal seja mantida.

\section{Referências}

DANTAS, Liliane-Pocone et al. Effects of passiflora incarnata and midazolam for control of anxiety in patients undergoing dental extraction. Medicina oral, patologia oral y cirugia bucal, v. 22, n. 1, p. e95, 2017. Disponível em: https://bit.ly/2QC4g9D. Acesso em: 26 ago. 2020.

DE FARIAS, Ana Clara Lima et al. O uso de fitoterápicos para o controle do medo e ansiedade no tratamento odontológico. Anais da Jornada Odontológica de Anápolis-JOA, 2019. Disponível em: https://bit.ly/2DetLec. Acesso em: 26 ago. 2020.

LOPES, Mayke Willian; TIYO, Rogerio; ARANTES, Vinicius Pereira. Utilização de Passiflora incarnata no tratamento da ansiedade. REVISTA UNINGÁ REVIEW, v. 29, n. 2, 2017. Disponível em: https://bit.ly/2Gb7VJG. Acesso em: 26 ago. 2020.

PINHEIRO, Marcos Luciano Pimenta et al. Avaliação dos efeitos da Valeriana officinalis $L$ no controle da ansiedade em 
pacientes submetidos a exodontias de terceiros molares mandibulares inclusos. 2003. Dissertação (Mestrado) Universidade Estadual de Campinas, Piracicaba, 2003. Disponível em: https://bit.ly/3jpfue4. Acesso em: 26 ago. 2020.

Coordenadoria de Pesquisa e Extensão - COPEX

Departamento de Editoraçāo e Divulgaçāo Científica - DEDIC 


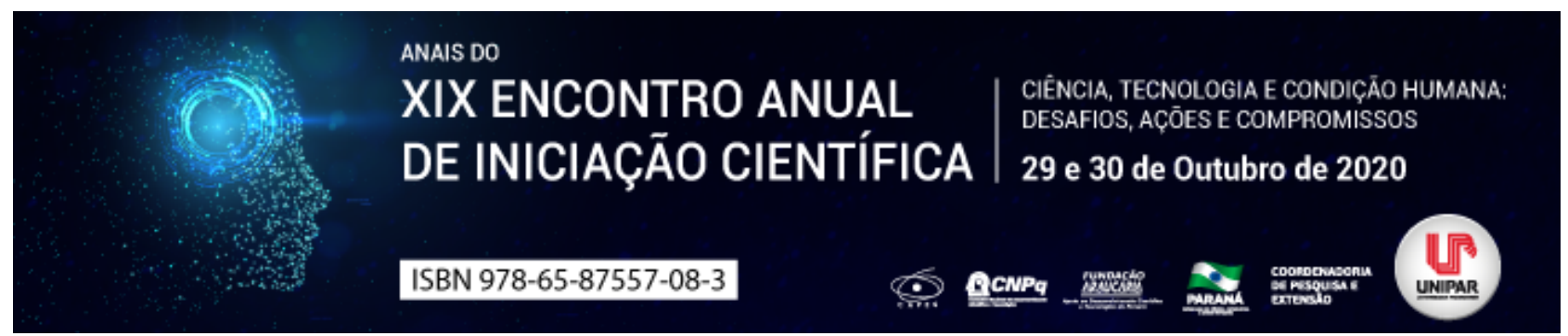

DESENVOLVIMENTO DA LATERALIDADE NA INICIAÇÃO AO FUTSAL: UM ESTUDO DE REVISÃO

\title{
${ }^{1}$ ELVIS HENRIQUE LIMA DE JESUS, ${ }^{2}$ JOAO VICTOR JOLO, ${ }^{3}$ LARISSA PEREIRA DA CRUZ, ${ }^{4}$ MARCELO FIGUEIRO BALDI
}

\author{
${ }^{1}$ Acadêmico do PIC/UNIPAR \\ ${ }^{1}$ Acadêmico do PIC/UNIPAR \\ ${ }^{2}$ Acadêmico do PIC/UNIPAR \\ ${ }^{3}$ Docente da UNIPAR
}

Introdução: A lateralidade é evidenciada tanto na preferência de utilização de uma das partes do corpo, como ao nível dos respectivos desempenhos na realização das tarefas descrito por Oliveira (2014). Tais assimetrias têm sido atribuídas à expressão de diferentes fatores, sendo esses genéticos, socioculturais e experiências vivenciadas, definida como a preferência de utilização de uma das partes simétricas do corpo relativamente à outra, nomeadamente, no que diz respeito aos pés, às mãos, aos olhos e aos ouvidos (OLIVEIRA, 2014). Que proporciona corroborar a proposição da lateralidade como um fator dinâmico da motricidade humana, em que a quantidade de experiências passadas assume um papel relevante da determinação nas assimetrias laterais, entre os membros homólogos (TEIXEIRA, 1998). Assim, um importante aspecto a ser investigado sobre a lateralidade humana, diz respeito a manifestação de assimetrias laterais em habilidades motoras determinadas culturalmente em função da quantidade de prática prévia (TEIXEIRA, 1998). De modo que essa quantidade de prática prévia já vivenciada, pode influenciar no desenvolvimento da iniciação de modalidades esportivas, que o referente estudo aborda a iniciação ao futsal. Diante do exposto, o presente estudo procurou responder ao seguinte problema de pesquisa: como desenvolver a lateralidade na iniciação ao futsal?

Objetivo: Analisar através de um estudo de revisão o desenvolvimento da lateralidade na iniciação ao futsal.

Desenvolvimento: A lateralidade é de suma importância nas modalidades esportivas onde utiliza-se a predominância de um lado do corpo, principalmente nos aspectos táticos e técnicos. Quando não está bem definida, ocorrem dificuldades na orientação espacial e na diferenciação entre o lado dominante e não-dominante, além de desconhecimentos de direita-esquerda (MEINEL, 1984). Autores como Negrine (1986) e Romero (1988) ressaltam que o desenvolvimento do domínio corporal é um dos fatores fundamentais no processo de aprendizagem do ser humano.

A dominância cerebral - existência de um hemisfério cerebral dominante para determinadas funções gera assimetrias na capacidade de desempenho entre os dois lados do corpo. A diferenciação funcional dos hemisférios cerebrais parece ser uma das genitoras das diferenças entre o membro dominante e o membro não dominante. Esta diferenciação advém de fatores genéticos devido às distinções estruturais no sistema nervoso central (Bryden, 1990; Kandel, Schwartz \& Jessell, 1991). O hemisfério cerebral esquerdo é especializado em funções de linguagem, pensamento analítico, processamento seriado e controle sequenciado de atos motores. Já o hemisfério cerebral direito é adaptado para pensamento integrativo, processamento paralelo e análise de relações espaciais (Kandel, Schwartz \& Jessell, 1991). Para pessoas destras, o principal responsável por processamento paralelo e percepção de aspectos espaciais do ambiente é o hemisfério cerebral direito, enquanto o hemisfério esquerdo desempenha o papel principal no sequenciamento e temporização dos movimentos (Goodale, 1990). Este formato de controle cerebral faz com que ambos os hemisférios estejam ativos durante o planejamento e a execução do movimento. Além de aspectos genéticos, fatores ambientais também podem influenciar na preferência por um dos membros. (BARBIERI,2009, p. 3435). Neste mesmo contexto, levando em concepção ao trabalho na iniciação do futsal afirma Vayner (1985) que uma educação dirigida ao corpo inteiro é a única forma de afinar a lateralidade completa. Assim em concordância com Cambão (2014) que para desenvolver essas habilidades cognitivas sob a lateralidade dos pés, é preciso avaliar possíveis assimetrias de modo a objetivar e prescrever o treinamento enfatizando membro menos dominante. No intuito de avaliar a lateralidade, Cambão (2014), Oliveira, Graça e Garganta (2012) propõem métodos de situações de jogos onde analisam todos os movimentos bimotores dos jogadores e suas frequências de dominância de membros inferiores. Isto para auxiliar no processo de ensino aprendizagem e treinamento da modalidade. Por outro lado, Moraes (2016) propõe a utilização de testes funcionais de sprints em W, box run e teste de salto de única perna para avaliar estes aspectos. Já em contra partida Souza (2014) utiliza de um único teste de chute frontal ao gol, porém de uma forma adaptada, cujo não há a utilização do gol convencional. Estes estudos avaliaram crianças de 9 à 14 anos, de uma escolinha de futsal, em que os resultados dos testes constataram que as crianças de 11 a 14 anos, obtiveram resultados positivos com a dominância do 'pé não preferido', em relação a crianças abaixo dos 11 anos de idade, pelo fato de que as mesmas ainda não conseguem compreender o domínio motor da lateralidade, em comparativo com as acima dos 11 anos de idade, já com um certo grau de treinamento já adquirido. Por essa razão, devemos possibilitar todas as experimentações corporais possíveis, de forma que o indivíduo descubra o movimento como elemento mediador nas construções sobre ele 
mesmo, sobre o outro e sobre o mundo.

Conclusão: Conclui-se que através dos resusltados obtidos, considerável positivo, no que se diz respeito a faixa etária das crianças na iniciação esportiva do futsal na predominancia do membro não dominante em que estão em pleno desenvolvimento, principalmente nas habilidades motoras fundamentais, e que cabe ao profissional de Educação Física planejar, prescrever e verificar se o treinamento em foco no membro menos utilizado, pode influenciar na melhora do desempenho dos membros inferiores para um equilíbrio da lateralidade na modalidade.

\section{Referências}

BARBIERI, F. A. Assimetrias laterais no movimento de chute e rendimento no futebol e no futsal. Motricidade. v.5 n.2 Vila Real mar. 2009

CAMBÃO, E. L. F. O efeito do treino técnico sobre o pé não preferido na redução das assimetrias funcionais dos membros inferiores em jovens futebolistas. Orientador: Professor José Guilherme de Oliveira. 2014. Dissertação - Faculdade de Desporto da Universidade do Porto, Porto, 2014.

MEINEL, Kurt. Teoria da Motricidade Esportiva sob o Aspecto Pedagógico. Rio de Janeiro: Ao Livro Técnico, 1984.

MORAES, D. Performance funcional dos membros inferiores de escolares do ensino fundamental e praticantes de escolinhas de futsal. Revista Brasileira de Futsal e Futebol, Edição Especial: Pedagogia do Esporte, São Paulo. v.8. n.31. p.319-325. Jan./dez. 2016.

NEGRINE, A. Educação psicomotora: a lateralidade e a orientação espacial. Porto Alegre: Palloti, 1986.

OLIVEIRA, J. G. G. A influência do treino técnico sobre o pé não-preferido na redução da assimetria funcional dos membros inferiores em jovens jogadores de futebol. Faculdade de Desporto da Universidade do Porto, Porto. 2014.

ROMERO, Eliane. Lateralidade e rendimento escolar. Revista Sprint, vol. 6, 1988.

SOUZA, S. J. Transferência bilateral de aprendizagem nos fundamentos do futsal em um projeto municipal da cidade de Sombrio - SC. Orientador: Graça Romulo Luiz da. 2014. Monografia - Universidade do Extremo Sul Catarinense, UNESC, 2014. TEIXEIRA, A. L. et al. Assimetria laterais no desempenho de habilidades relacionadas ao futebol. KINESIS. Santa Maria. N. 20. P. 77-92. 1998.

VAYER, P. Linguagem corporal: a estrutura e a sociologia da ação. Porto Alegre: Artes Médicas, 1985. 


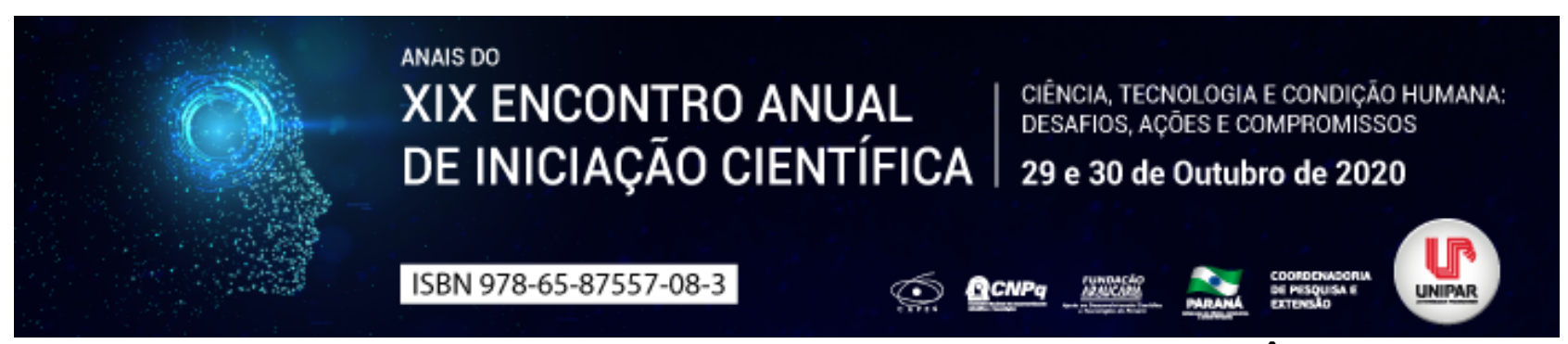

RUPTURA PREMATURA DE MEMBRANA OVULARES E SUAS CONSEQUÊNCIAS

\author{
${ }^{1}$ RAFAELLA BUZINARO DA SILVA, ${ }^{2}$ AMANDA STEFANI DA SILVA CRUZ, ${ }^{3}$ NANCI VERGINIA KUSTER DE PAULA, ${ }^{4}$ AMANDA \\ NASCIMENTO VASQUES DE SOUZA
}

\author{
${ }^{1}$ Acadêmica do curso de Enfermagem da UNIPAR \\ ${ }^{1}$ Acadêmica do Curso de Enfermagem da UNIPAR \\ ${ }^{2}$ Docente da UNIPAR \\ ${ }^{3}$ Docente da UNIPAR
}

Introdução: A Ruptura prematura das membranas (RPM) também conhecida amniorrexe prematura, é definida pela ruptura espontânea das membranas uterinas antes do trabalho de parto (ANDERS et al; 2013). Define-se como amniorrexe pré-termo quando ocorrido até 37 semanas de gestação, e termo acima de 37 semanas de gestação (BRASIL, 2010). O período entre a ruptura das membranas ao início do trabalho de parto é definido como latência, a qualidade da assistência realizada durante este período pode trazer benefícios ou danos ao bebê e a mãe (FEBRASGO, 2011). Segundo o Ministério da Saúde (MS) a RPM é responsável por $1 / 3$ dos casos de mortalidade fetal e materna (BRASIL, 2013). A amniorrexe pré termo é incidente em 3\% das gestações, no entanto, é causador de $1 / 3$ dos partos prematuros e $20 \%$ das mortes em recém nato neste período, nas gestações pré-termo 63\% das mulheres entrarão em trabalho de parto em até uma semana, já nas a termo 95\% apresentará trabalho de parto em até 7 dias (LIMA et al; 2017).

Objetivo: Destacar as principais complicações ameaçadoras de vida do recém nato e da parturiente frente à Ruptura Prematura de Membranas.

Desenvolvimento: Estudos mostram que os principais fatores de risco para a amniorrexe prematura é apontado como, histórico de parto pré-termo, feto anterior com peso menor de $2.500 \mathrm{~g}$, tabagismo, consumo de bebidas alcoólicas, hemorragia pré-parto, insuficiência cervical, infecção no trato urinário, vaginose bacteriana, classe social baixa, magreza materna e desnutrição. (SCANDIUZZI;2014). As principais complicações maternas da amniorrexe pré-termo se apresentam como, endometrite e a corioamnionite, principalmente devido ao longo período de latência. Já as perinatais apresentam como consequências, prematuridade, pneumonia, infecção neonatal, oligoidrâmnio, prolapso de cordão, mudança na contração uterina, distócias, síndrome do desconforto respiratório, hipoplasia pulmonar, hemorragia intraventricular, mortalidade perinatal (SCANDIUZZI et al, 2014). Portanto diante da saúde pública que vivenciamos onde é realizado esse acompanhamento do pré natal, a principal ação preventiva está na atenção primária, com uma assistência qualificada e integral no pré-natal podendo evitar riscos preveníveis da gestação, parto e puerpério, é de extrema importância a atuação do enfermeiro da rede básica durante as consultas de pré-natal, o profissional deve compreender a relevância de uma assistência humanizada, de qualidade e contínua, para orientações e tomada de decisões favoráveis durante a gestação, uma vez que é o profissional de enfermagem que tem maior vínculo com a gestante e a família, garantindo um bem estar materno infantil (BRAZ; OLIVEIRA; ALMEIDA; 2016).

Conclusão: Com este estudo observou se que a enfermagem mediante as necessidades, proporciona a educação continuada incentivando e buscando um pré-natal de qualidade na saúde pública, com plano de cuidados humanizados visando a eficiência de acordo com as necessidades da gestante, para a prevenção de complicações em cada período gestacional, principalmente de patologias como a RPM, objetivando o bem estar materno fetal.

\title{
Referências
}

ANDERS, Jane Cristina; MONTEIRO, Juliana Cristina dos Santos; Carvalho, Maria Cândida et al. Curso de especialização linhas do cuidado em enfermagem, saúde materna, neonatal e do lactente. Universidade Federal a Santa Catarina. p.113. 2013.

BRASIL. Ministério da Saúde. Manual Técnico Gestação de Alto Risco. 2010

BRAZ, Juliana de Vasconcelos Cerqueira; OLIVEIRA, Cristiane Mota; ALMEIDA, Isabella Barros et al. Incidência de gestante admitidas com ruptura prematura de membranas em uma maternidade de alto risco no município de Aracaju-Sergipe. Revista Barriguda. v. 6. n. 3. Dezembro, 2016

FEBRASGO. Manual Gestação de Alto Risco. 2011.

LIMA, Simone Santos; COSTA, Lorena Silva; MENEZES, Max Oliveira. Ruptura prematura de membranas ovulares e alteração do líquido amniótico: Assistência de enfermagem. Universidade Tiradentes. Maio, 2017.

SCANDIUZZI, Maissa marçola; PINHEIRO, Thiago Cerizza; RODRIGUES, André Afonso Nimtz et al. Resultados maternos e perinatais na ruptura prematura de membranas. Revista da faculdade de ciências médicas de Sorocaba. v. 16. n. 4. p.178181. Novembro, 2014. 
Coordenadoria de Pesquisa e Extensão - COPEX

Departamento de Editoraçāo e Divulgaçāo Científica - DEDIC 


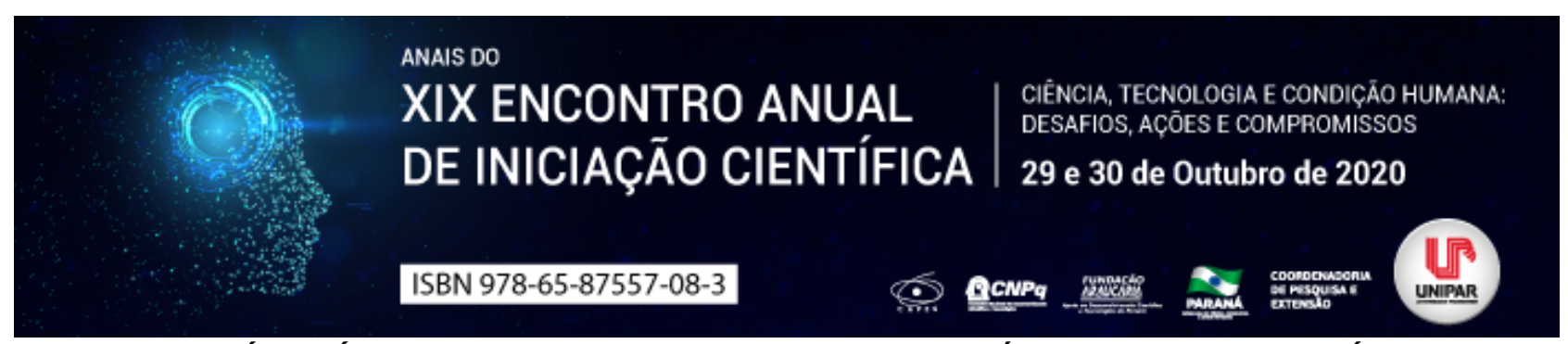

EXERCÍCIO FÍSICO E AUTISMO: POSSIBILIDADES DE PRÁTICAS E SEUS BENEFíCIOS

\begin{abstract}
${ }^{1}$ DANIEL SANTOS EVANGELISTA, ${ }^{2}$ GUILHERME SANTOS GONZALES, ${ }^{3}$ VIVYANNE MARIA MARYNOWSKI CONTI, ${ }^{4}$ FERNANDO SERAFIM DA SILVA, ${ }^{5}$ ALISSON FELIPE RIBEIRO DOS SANTOS, ${ }^{6}$ MARIA GABRIELLA GIROTO
\end{abstract}

\begin{abstract}
${ }^{1}$ Discente do curso de Educação Física, Ciências da Saúde, Universidade Paranaense - UNIPAR
${ }^{1}$ Discente do curso de Educação Física, Ciências da Saúde, Universidade Paranaense - UNIPAR

${ }^{2}$ Discente do curso de Educação Física, Ciências da Saúde, Universidade Paranaense - UNIPAR

${ }^{3}$ Discente do curso de Educação Física, Ciências da Saúde, Universidade Paranaense - UNIPAR

${ }^{4}$ Discente do curso de Educação Física, Ciências da Saúde, Universidade Paranaense - UNIPAR

${ }^{5}$ Docente do curso de Educação Física, Ciências da Saúde, Universidade Paranaense - UNIPAR.
\end{abstract}

Introdução: Estima-se que uma a cada 160 crianças no mundo tem transtorno do espectro autista, e que esta prevalência esta aumentando. O TEA se refere a uma série de condições caracterizadas por algum grau de comprometimento no comportamento social, na comunicação e na linguagem, por uma gama estreita de interesse e atividades que são únicas para o individuo e realizadas de forma repetitiva (OPAS/OMS, 2020). De acordo com Schmidt (2014) o termo autista foi utilizado por Eugene Bleuler em 1916 pela primeira vez para se referir aos sintomas negativos da esquizofrenia. Ricco (2017) comenta que um indivíduo com autismo apresenta diversos sinais como a fixação em um objeto especifico, tem atraso no desenvolvimento da coordenação motora fina e comprometimentos no desenvolvimento motor. Baseando-se nisso, o presente estudo indaga quais são as principais indicações de exercício físico para indivíduos com autismo?

Objetivo: Investigar na literatura as recomendações de práticas de exercício físico para indivíduos com autismo e seus possíveis efeitos.

Desenvolvimento: De acordo com Silva et al (2018) a prática de exercício físico promove a aprendizagem dos indivíduos favorecendo o desempenho educacional e motor da criança. Nesse contexto Lourenço et al (2015) expõem que a prática de atividade física para indivíduos autistas é bastante relevante pois traz benefícios nos diferentes domínios, pois auxilia na melhora da condição física e no desenvolvimento motor. As variedades de exercício físico como recreação, lutas, danças, esporte, entre outras atividades, são ferramentas que auxiliam o desenvolvimento global de indivíduos com TEA por estimular tanto o desenvolvimento como a interação social. Nesse entendimento, Cruz e Praxedes (2018), relatam que na natação, atividades de adaptação no meio líquido, deslocamentos e exercícios de respiração e flutuação na água, trazem grandes benefícios para pessoa com autismo, pois melhoram o repertório motor e a convivência com colegas e professores. Aguiar, Baumar e Pereira (2017) ressaltam que a pratica de artes marciais podem ser uteis no desenvolvimento dos indivíduos autistas onde os mesmo apresentam melhora na comunicação e com o grupo. De acordo com Russo (2020) a inclusão no esporte, exercício e outras atividades podem ser considerados um complemento terapêutico tradicional estabelecido por apresentarem impacto na melhora de sintomas, comportamento e qualidade de vida. É muito importante que o profissional de educação física trabalhe com ferramentas que possam auxiliar no desenvolvimento de indivíduos com TEA, na prescrição de atividades que atendam as carências do desenvolvimento e que proporcionem a aprendizagem de habilidades. Assim o profissional de educação física, independente da área de atuação, tem um importante papel tanto na identificação das alterações motoras características do TEA, como também na prescrição de exercício físicos adequando como estratégia de promoção da qualidade de vida e desenvolvimento motor, cognitivo e social dessas criança (PENIDO et al, 2016).

Conclusão: Através da literatura pesquisada é possível constatar a importância das práticas de exercício físico para aspectos fundamentais do desenvolvimento de indivíduos com o Transtorno do Espectro Autista, que é o desenvolvimento motor, comunicação e a integração social. A realização de práticas como a recreação, natação, lutas, entre outros esportes podem contribuir para um bom estimulo da coordenação motora e de habilidades motoras, estimulam a comunicação e interação com outras pessoas, bem como auxiliam no convívio social. E para o alcance destes benefícios é fundamental o preparo do profissional na construção de planejamentos que consideram e respeitam a individualidade, suprindo as carências do desenvolvimento e estimulando a comunicação e interação social.

\title{
Referências
}

AGUIAR, Renata Pereira; BAUMAN, Claudia Donato; PEREIRA, Fabiane Silva. Importância da prática de atividade física para as pessoas com autismo. J. Health Biol. Sci. 2017; 5(2): 178-183. Disponível em: https://periodicos.unichristus.edu.br/jhbs/article/view/1147/428. Acesso em: 10 abril. 2020.

CRUZ, Matheus Ramos da; PRAXEDES, Jomilto. A importância da educação física para o desenvolvimento motor de crianças e 
jovens com transtornos do espectro autista. E- Mosaicos Revista Multidiciplinar de Ensino, Pesquisa Extensão e Cultura do Instituto de Aplicação Fernando Rodrigues da Silveira (CAp-UERJ) v7 N. 14 ABRIL 2018 ISSN: 2316-9303. Disponível em: https://www.e-publicacoes.uerj.br/index.php/e-mosaicos/article/view/33622/24231. Acesso em: 19 jul. 2019.

LOURENÇO, Carla Cristina Vierira; et al. Avaliação dos efeitos de programas de intervenção de atividade física em indivíduos om transtorno do espectro do autismo. Rev. Bras. Ed. Esp., Marilia, v. 21, n. 2, p. 310-328, Abr.-Jun., 2015. Disponível em: https://www.scielo.br/pdf/rbee/v21n2/1413-6538-rbee-21-02-00319.pdf. Acesso em: 20 abr. 2020.

OPAS/OMS BRASIL. Folha informativa: transtorno do espectro autista. 2017. Disponível em: https://www.paho.org/bra/index.php?Itemid=1098. Acesso em: 10 jul. 2020.

PEDINO, Lívia Alípio; et al. Conhecimento de graduados e graduandos em educação física sobre o autismo. Revista da Sobama, Marília, v. 17, n. 2 p. 37-42, Jul./Dez., 2016. Disponível em file:///D:/Downloads/6829-Texto\%20do\%20artigo-22053-310-20170331.pdf.

RICCO, Ana Claudia. Efeitos da atividade física no autismo. Trabalho de Conclusão de Curso. Graduação (Educação Física). Universidade Estadual Paulista. Instituto de Biociências de Rio Claro. Rio Claro SP, 2017. Disponível em: https://repositorio.unesp.br/bitstream/handle/11449/156379/000897264.pdf?sequence=1\&isAllowed=y. Acesso em: 25 jun. 2020 RUSSO, Fabiele. Benefício do exercício físico no desenvolvimento cognitivo do autismo. Neuro conecta. Fev. 2020. Disponível em: https://neuroconecta.com.br/beneficios-do-exercicio-fisico-no-desenvolvimento-cognitivo-do-autista/. Acesso em: 25 jun. 2020.

SHMIDT, Carlo. (org.) Autismo, Educação e Transdisciplinaridade. [livro eletrônico] Campinas, SP: Papirus, 2014. Disponível em: https://plataforma.bvirtual.com.br/Acervo/Publicacao/5649. Acesso em: 14 jun. 2020.

SILVA, Simone Gama da. et al. Os benefícios da atividade física para pessoas com autismo. Revista Diálogos em Saúde. v. 1 , n. 1, Cabedelo-PB. Jan/Jun de 2018. Disponível em: file://ID:/Downloads/204-640-1-PB\%20(4).pdf. Acesso em: 25 mai. 2020. 


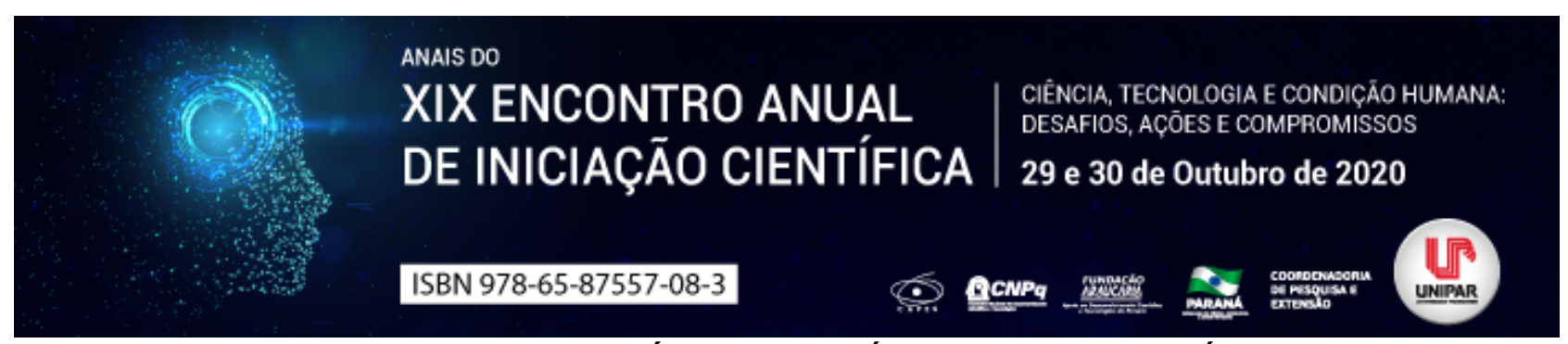

ABCD DO MELANOMA: MÉTODO CONFIÁVEL OU INSATISFATÓRIO?

\author{
${ }^{1}$ DIOGO CHUEIRI ESCHHOLZ, ${ }^{2}$ GABRIELA DOS ANJOS SANTOS, ${ }^{3}$ HAYUMI NATALIA YAMAMOTO HIGASHI, ${ }^{4}$ ISADORA \\ VAROTTO FELTRIN, ${ }^{5}$ ELENIZA DE VICTOR ADAMOWSKI CHIQUETTI
}

\author{
${ }^{1}$ Acadêmica do Curso de Medicina da UNIPAR \\ ${ }^{1}$ Acadêmica do Curso de Medicina da UNIPAR \\ ${ }^{2}$ Acadêmica do Curso de Medicina da UNIPAR \\ ${ }^{3}$ Acadêmica do Curso de Medicina da UNIPAR \\ ${ }^{4}$ Docente da UNIPAR
}

Introdução: As neoplasias podem ser classificadas como benignas ou malignas, sendo as benignas compostas por células bem diferenciadas que se assemelham estreitamente a suas contrapartes normais, sendo suas mitoses raras e sua configuração normal. Neoplasias malignas caracterizam-se por ampla gama de diferenciações celulares parenquimatosas, desde as bem diferenciadas até as completamente indiferenciadas (ROBBINS, 2013). Melanomas são neoplasias malignas originárias de melanócitos. Embora a maioria deles se originem na pele, podem ter início na cavidade oral, esôfago, ânus, conjuntiva ou no trato genital feminino, sendo divididos em vulvar, vaginal, ovariano ou cervical (NAl et al, 2018).

Objetivo: Esse artigo tem como objetivo apresentar fatores indicativos do melanoma que é uma neoplasia maligna muito presente no mundo atual, possuindo uma alta taxa de incidência.

Desenvolvimento: O melanoma é classificado em extensivo superficial, nodular, acrolentiginoso e lentigo maligno melanoma, podendo ocorrer outras apresentações e diferenças entre faixas etárias, sendo a $19^{\circ}$ neoplasia mais frequente no mundo com taxa de incidência de 3,3 por 100 mil habitantes. Em particular, o melanoma também é a forma mais comum de câncer para adultos jovens (25 a 29 anos) e a segunda forma mais comum de câncer para jovens (15 a 29 anos) (MENDES et al, 2016). Entre todos os cânceres de pele, o melanoma é uma das formas mais mortais da doença (MENDES et al, 2016). No Brasil, em 2017, foram 2.920 novos casos da doença em homens e 3.340 mulheres. (PURIM et al, 2020). A cirurgia de excisão local com ampliação das margens é o principal tratamento na fase inicial. Para grupos de alta taxa de recorrência é indicada terapia adjuvante - quimioterapia sistêmica, interferon alfa, bioquimioterapia, agentes de ação autoimune, agentes hormonais e vacinas. Todavia, as terapias adjuvantes não são ainda as mais efetivas para o tratamento do melanoma (PURIM et al, 2020). Outro tipo de tratamento utilizado desde os anos 90 é a dermatoscopia que segue o padrão de crescimento e taxa de crescimento da lesão, sendo um dos sinais mais valiosos de malignidade, e pode ser estudado através de modelos matemáticos que quantificam e classificam o padrão de crescimento (MENDES et al, 2016). Durante o exame físico inicialmente são notados sinais sugestivos de um tumor do tipo melanoma como, a presença de assimetria (A), bordos irregulares e mal definidos (B), alterações de cor (C), diâmetro maior que $6 \mathrm{~mm}(\mathrm{D})$; constituindo o método "ABCD", usado para o diagnóstico do melanoma, que deve ser confirmado por análise histopatológica da lesão (PURIM et al, 2020). A partir disso usaram critérios como sexo, idade, diâmetro máximo da lesão, subtipo histopatológico, sítio primário, espessura microscópica, índice mitótico, ulceração, fase de crescimento e regressão para criar uma análise estatística. Dessa forma foram utilizados dois grupos para os testes, um com pessoas que possuem melanoma $>6 \mathrm{~mm}$ de diâmetro e o outro com $6 \mathrm{~mm}$. Deve ser levado em consideração o número de casos de MC com diâmetro $<6 \mathrm{~mm}$. Portanto, lesões pigmentadas que apresentam Diâmetro $<6 \mathrm{~mm}$ não devem ser excluídas da suspeita de melanoma, mostrando assim, que a regra atual do ABCD é falha na variável diâmetro (FILHO et al, 2015) e por conta dessa variável, o número de melanomas malignos aumentou sua incidência em todo o mundo. Contudo um sintoma muito comum em pacientes com câncer é a dor, que é complexa, multifatorial e interfere diretamente na qualidade de vida dos pacientes (PARREIRAS, et al, 2016). Em uma pesquisa realizada em 306 pacientes portadores de melanoma, mostrou que $38,2 \%$ havia prevalência de dor. Dentre os que se queixavam de dor, sua localização era a mesma da lesão em $20,5 \%$ dos casos, em $8 \%$ dos casos ela era no mesmo local das metástases do melanoma maligno e 55,8\% responderam que a dor relacionava-se com a linfadenectomia. Dentre esses pacientes, $70 \%$ receberam tratamento para o controle da dor, $2 \%$ foram encaminhados para tratamento especializado e $75 \%$ relataram incapacidade relacionada à dor (PARREIRAS et al, 2016).

Conclusão: Embora muito utilizado, o modelo $A B C D$ se mostrou falho, apresentando uma variável pouco funcional, sendo o diagnóstico precoce a melhor medida profilática. Além disso é importante investir no ensino da oncologia cutânea, desde a graduação, para que assim possa melhorar a prevenção, detecção, atenção e gestão da doença para a população.

\title{
Referências
}

MENDES, Ana Isabel. et al. On the geometric modulation of skin lesion growth: a mathematical model for melanoma. Res. 
Biomed. Eng., Rio de Janeiro, v. 32, n. 1, p. 44-54, Mar. 2016.

NAI, Gisele Alborghetti. et al. Postpartum Genital Melanoma - A Case Report. Rev. Bras. Ginecol. Obstet., Rio de Janeiro, v. 40, n. 3, p. 163-167, Mar. 2018.

OLIVEIRA FILHO, Renato Santos de. et al. Considerar diâmetro apenas maior que $6 \mathrm{~mm}$ como suspeita de malignidade de melanoma pode prejudicar pacientes. Einstein (São Paulo), São Paulo, v. 13, n. 4, p. 506-509, Dec. 2015.

PARREIRAS, Fernanda Cardoso. et al. Prevalência de dor em pacientes com melanoma. Rev. dor, São Paulo, v. 17, n. 1, p. 3942, mar. 2016.

PURIM, Kátia Sheylla Malta. et al. Característica do melanoma em idosos. Rev. Col. Bras. Cir, vol. 47, Rio de Janeiro, 2020 Epub June 15, 2020.

KUMAR, Vinay. et al. Robbins, patologia básica; 9º edição. [tradução de Claudia Coana. et al.]. - Rio de Janeiro : Elsevier, 2013

Coordenadoria de Pesquisa e Extensão - COPEX

Departamento de Editoraçāo e Divulgaçāo Científica - DEDIC 


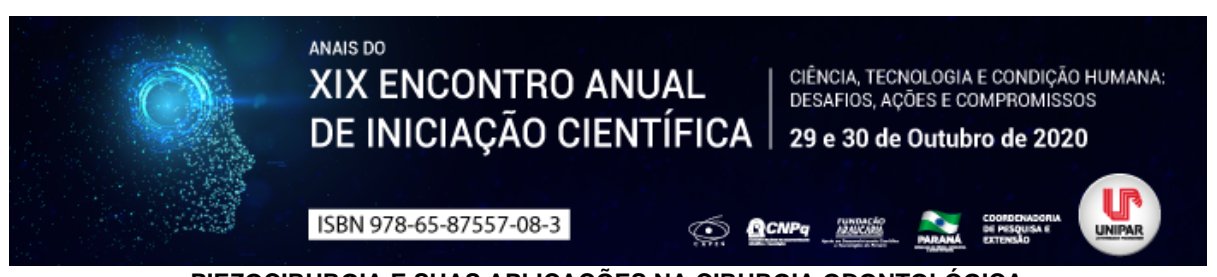

PIEZOCIRURGIA E SUAS APLICAÇÕES NA CIRURGIA ODONTOLÓGICA

${ }^{1}$ Isabela Trarbach Gomes, ${ }^{2}$ CLARA MIOTTO SILVA, ${ }^{3}$ KARINE SANTOS ALMEIDA, ${ }^{4}$ PRISCYLA VITORINO SOARES, ${ }^{5}$ MARTHA ALAYDE ALCANTARA SALIM

\begin{abstract}
${ }^{1}$ Acadêmica Curso de Odontologia, Universidade Federal do Espírito Santo, UFES, Vitória, Brasil
${ }^{1}$ Acadêmica Curso de Odontologia, Universidade Federal do Espírito Santo, UFES, Vitória, Brasil

${ }^{2}$ Acadêmica Curso de Odontologia, Universidade Federal do Espírito Santo, UFES, Vitória, Brasil

${ }^{3}$ Acadêmica Curso de Odontologia, Universidade Federal do Espírito Santo, UFES, Vitória, Brasil

${ }^{4}$ Docente do Departamento de Clínica Odontológica, Universidade Federal do Espírito Santo
\end{abstract}

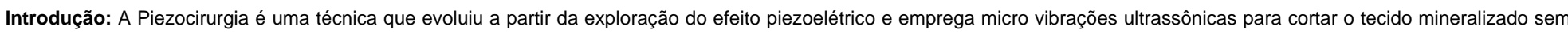

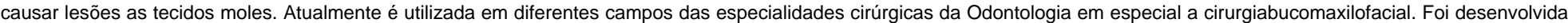

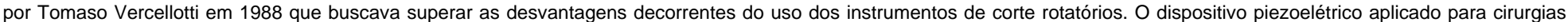

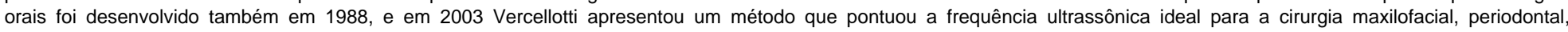

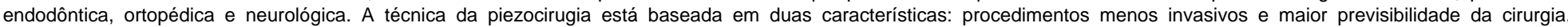

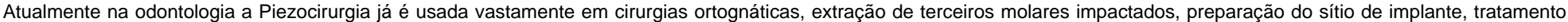
das desordens temporomandibulares e enucleação de cistos, tumores, entre outros.

Objetivos: Demonstrar as aplicações da Piezocirurgia na Odontologia, assim como, expor as vantagens e desvantagens dessa técnica.

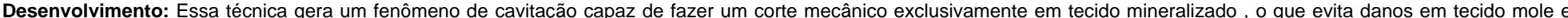

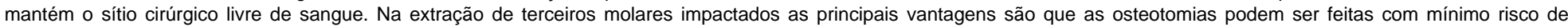

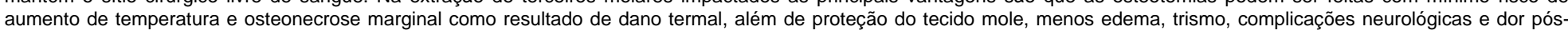

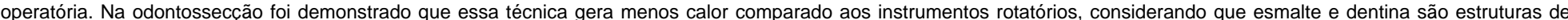

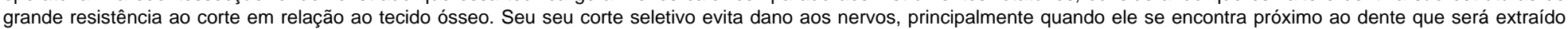

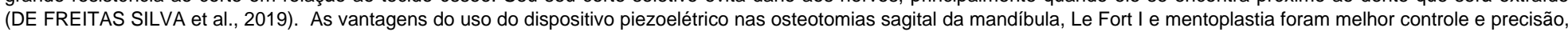

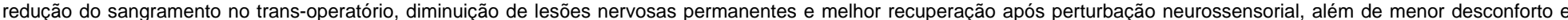

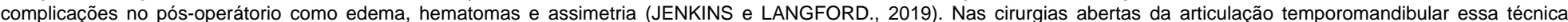

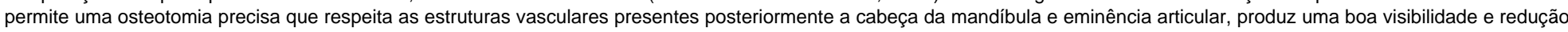

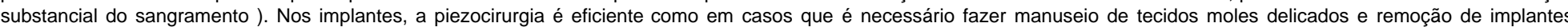

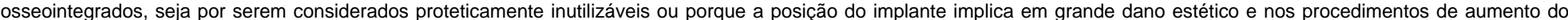

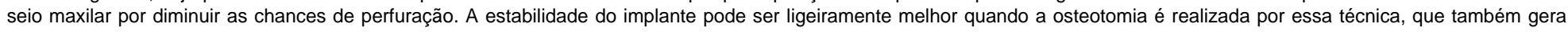

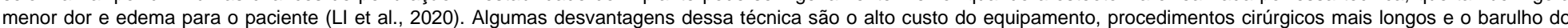

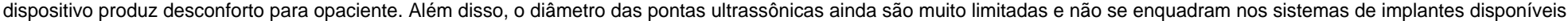
comercialmente.

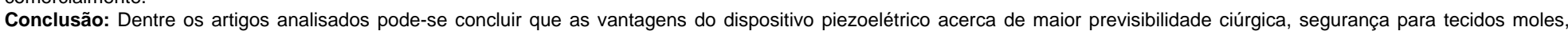

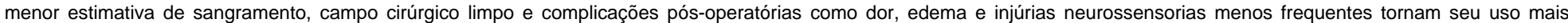
benéfico mesmo com as desvantagens.

\title{
Referências
}

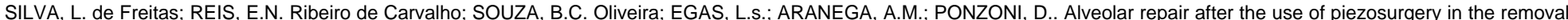

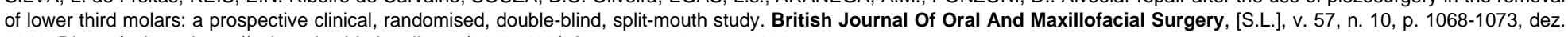
2019. Disponível em: https://pubmed.ncbi.nlm.nih.gov/31607400/. Acesso em: 27 ago. 2020.

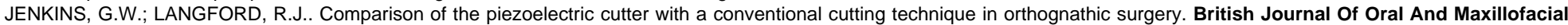

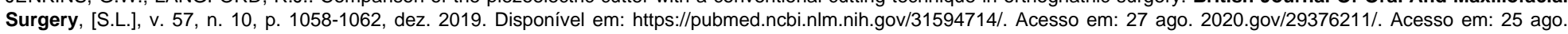
2020.

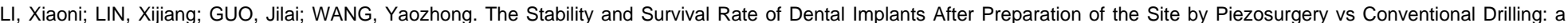

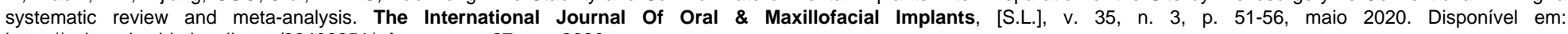
https://pubmed.ncbi.nlm.nih.gov/32406651/. Acesso em: 27 ago. 2020.

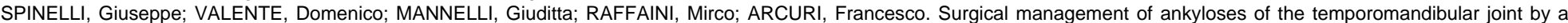

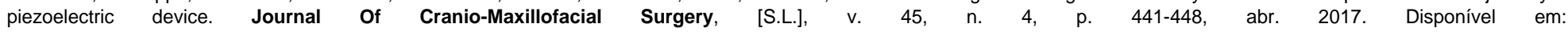

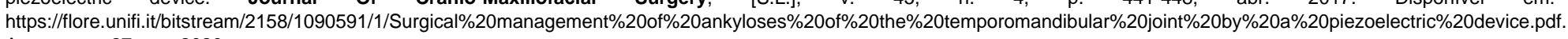
Acesso em: 27 ago. 2020. 


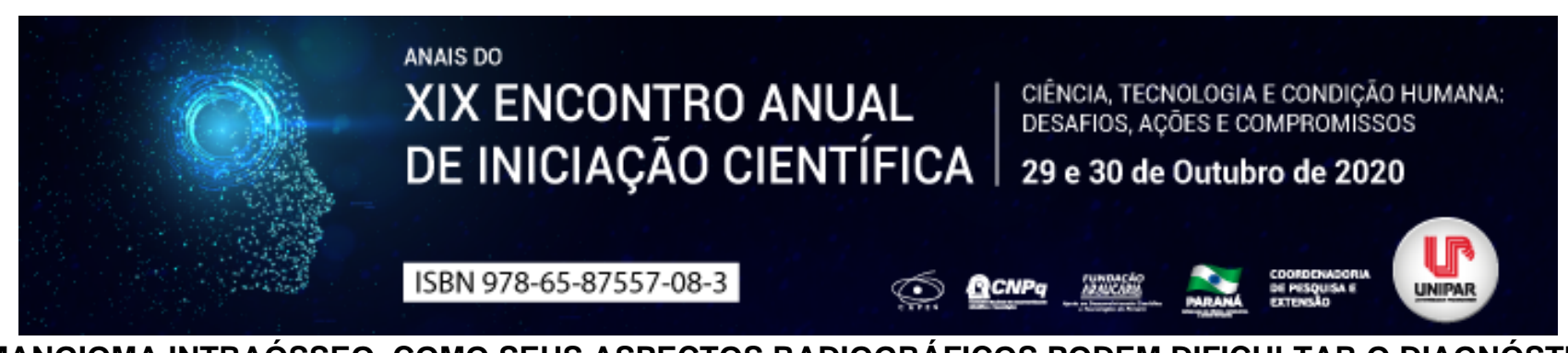

HEMANGIOMA INTRAÓSSEO, COMO SEUS ASPECTOS RADIOGRÁFICOS PODEM DIFICULTAR O DIAGNÓSTICO

\begin{abstract}
${ }^{1}$ Karine Santos Almeida, ${ }^{2}$ CLARA MIOTTO SILVA , ${ }^{3}$ ISABELA TRARBACH GOMES, ${ }^{4}$ PRISCYLA VITORINO SOARES , ${ }^{5}$ LILIANA APARECIDA PIMENTA DE BARROS, ${ }^{6}$ TERESA CRISTINA RANGEL PEREIRA
\end{abstract}

\author{
${ }^{1}$ Acadêmica Curso de Odontologia, Universidade Federal do Espírito Santo, UFES, Vitória, Brasil \\ ${ }^{1}$ Acadêmica Curso de Odontologia, Universidade Federal do Espírito Santo, UFES, Vitória, Brasil \\ ${ }^{2}$ Acadêmica Curso de Odontologia, Universidade Federal do Espírito Santo, UFES, Vitória, Brasil \\ ${ }^{3}$ Acadêmica Curso de Odontologia, Universidade Federal do Espírito Santo, UFES, Vitória, Brasil \\ ${ }^{4}$ Professora Associada, Universidade Federal do Espírito Santo, UFES, Vitória, Brasil \\ ${ }^{5}$ Professora Associada, Universidade Federal do Espírito Santo, UFES, Vitória, Brasil
}

Introdução: Hemangiomas são classificados, atualmente, como tumores vasculares benignos causados por um crescimento anormal de vasos sanguíneos de origem endotelial. Os hemangiomas podem ocorrer em qualquer lugar do corpo, o tipo central (intraósseo) é um achado raro, compreendendo de 0,5 a 1\% de todos os tumores intraósseos (KUMAR et al., 2015), com pico de incidência na puberdade, sem regressão espontânea (PIGOSSI et al., 2013). A ocorrência nos ossos da mandíbula e da maxila são raros (BALAN et al., 2014). A mandíbula é mais envolvida que a maxila e, em ambas, a região posterior é a mais afetada (ZLOTOGORSKI et al., 2005), sendo mais comum nas mulheres. O diagnóstico do hemangioma central na região da cabeça é um desafio, dificultado pelo aspecto radiográfico variável simulando outras patologias, sendo considerado um ótimo imitador (NAGPAL et al, 2005).

Objetivo: Caracterizar as várias manifestações que o hemangioma intraósseo pode apresentar, e associar com os possíveis diagnósticos diferenciais, a fim de contribuir para o correto processo diagnóstico e, consequentemente, no estabelecimento do tratamento adequado.

Desenvolvimento: Foi realizado um estudo descritivo a partir da revisão de literatura de 9 artigos, com pesquisa no banco de dados do PubMed, Scielo, Google Acadêmico e 2 Livros de Radiologia. Clinicamente o hemangioma intraósseo possui certas características, como ser mais prevalente em mulheres na proporção de 2:1. O crescimento é lento, variando de meses a anos, produzindo uma expansão óssea, podendo ou não gerar assimetria facial podendo ou não ser dolorosa e, algumas vezes, associada com uma pulsação na região. Alguns sinais e sintomas descritos são reabsorção óssea e radicular, migração e perda dentária e hemorragias espontâneas provenientes do sulco gengival. É crucial salientar que pacientes podem ou não apresentar tais sinais e sintomas. Radiograficamente, sua imagem é variada e possui diversas representações registradas na literatura, ressaltando que na fase inicial, as lesões podem não ser visíveis em radiografias. Em alguns casos, a lesão pode apresentar alteração no padrão trabecular que pode ser fina ou não ser nítida em algumas áreas, em relação a sua borda, ela pode variar de bem definida a difusa. Imagens multiloculares são mais comumente encontradas, no entanto, casos de lesões uniloculares são reportadas. O padrão mais documentado é a representação de favos de mel, porém o aspecto de bolhas de sabão e raquete de tênis são mais incomuns. Devido à grande variedade de representações radiográficas, alguns diagnósticos diferenciais podem ser apresentados como: ameloblastoma, lesão de células gigantes, mixoma, cisto dentígero, displasia fibrosa, osteossarcoma, cisto ósseo aneurismático e granuloma, além da osteoporose e a osteopenia. O desconhecimento ou a pouca investigação do quadro clínico-radiográfico, assim como os possíveis diagnósticos diferenciais do hemangioma central pelo cirurgião dentista pode gerar riscos ao paciente, como realização de extração simples na região ou a realização de biópsia da área, possibilitando uma hemorragia, com intercorrências mais graves, como a morte. O cirurgião dentista pode lançar mão de modernas técnicas radiográficas e imagem, como tomografia computadorizada, ressonância magnética, além da ultrassonografia. Uma abordagem mais cuidadosa, com procedimentos menos invasivos como a punção antes de uma intervenção cirúrgica em regiões suspeitas desempenha um papel importante no auxílio do diagnóstico correto, garantindo a segurança de uma conduta clínica segura e tratamento correto para o paciente.

Conclusão: Embora, o hemangioma intraósseo (central), na região de mandíbula e maxila, seja raro, o cirurgião dentista deve se atentar a suas variações imaginológicas e peculiaridades para que a vida do paciente não seja colocada em risco. $O$ proceder adequado na condução diagnóstica deve ser feito após uma análise meticulosa da anamnese e exame físico, juntamente com a avaliação das imagens.

\title{
Referências
}

BALAN, P.; GOGINENI, S.; SHETTY, S.; AREEKAT, F. Radiologic features of intraosseous hemangioma: a diagnostic challenge. Archives of Medicine and Health Sciences, Karnataka, v. 2, n. 1, p. 67-70, 4 jun. 2014. Disponível em: 
http://www.amhsjournal.org/text.asp?2014/2/1/67/133823. Acesso em: 17 jul. 2020.

DHIMAN, N.; JAISWARA, C.; KUMAR, N.; PATNE, S.; PANDEY, A.; VERMA, V. Central cavernous hemangioma of mandible: case report and review of literature. National Journal of Maxillofacial Surgery, Varanasi, v. 6, n. 2, p. 209-213, 10 jun. 2015. Disponível em: http://www.njms.in/text.asp?2015/6/2/209/183866. Acesso em: 03 ago. 2020.

ELIOT, C.; CASTLE, J. Intraosseous Hemangioma of the Anterior Mandible. Head and Neck Pathology, Maryland, v. 4, n. 2, p. 123-125, 4 mar. 2010.

KIM, J-E; YI, W-J; HEO, M-S; LEE, S-S; CHOI, S-C; HUH, K-H. An unusual case of intraosseous vascular malformation of the maxilla mimicking fibrous dysplasia: a case report and literature review on imaging features of intraosseous vascular anomalies of the jaw. Dentomaxillofacial Radiology, Seoul, v. 43, n. 7, p. 20130400, 17 jun. 2014.

NAGPAL, A.; SUHAS, S.; AHSAN, A.; PAI, K.; RAO, N. Central haemangioma: variance in radiographic appearance. Dentomaxillofacial Radiology, Karnataka, v. 34, n. 2, p. 120-125, mar. 2005

NAIKMASUR, V.; SATTUR, A.; BURDE, K.; NANDIMATH, K.; THAKUR, A.. Central hemangioma of the mandible: role of imaging in evaluation. Oral Radiology, Karnataka, v. 26, n. 1, p. 46-51, 11 mar. 2010

OKURA, S. et al. A case of venous malformation of the mandible. Oral Radiology, Yokohama, v. 35, n. 5, p. 194-197, Abr. 2018.

PIGOSSI, S. C. et al. Tratamento conservativo de hemangioma intra-ósseo na mandíbula: relato de caso com 17 anos de acompanhamento. Revista de Odontologia da UNESP, São Paulo, v. 42, n. 130, p. 1-1, jun. 2013. Disponível em: https://www.revodontolunesp.com.br/article/588019857f8c9d0a098b51bf. Acesso em: 03 ago. 2020

SOCIEDADE JAPONESA DE RADIOLOGIA ORAL E MAXILOFACIAL. Atlas de Diagnóstico Oral por Imagens. 1. ed. Rio de Janeiro: Elsevier, 2013.

WHITE, S. C.; PHAROAH, M. Radiologia Oral: fundamentos e interpretação. 5. ed. Rio de Janeiro: Elsevier, 2007.

ZLOTOGORSKI, A.; BUCHNER, A.; KAFFE, I.; SCHWARTZ-ARAD, D. Radiological features of central haemangioma of the jaws. Dentomaxillofacial Radiology, Tel Aviv, v. 34, n. 5, p. 292-296, 24 abr. 2005.

Coordenadoria de Pesquisa e Extensão - COPEX

Departamento de Editoraçāo e Divulgaçāo Científica - DEDIC 


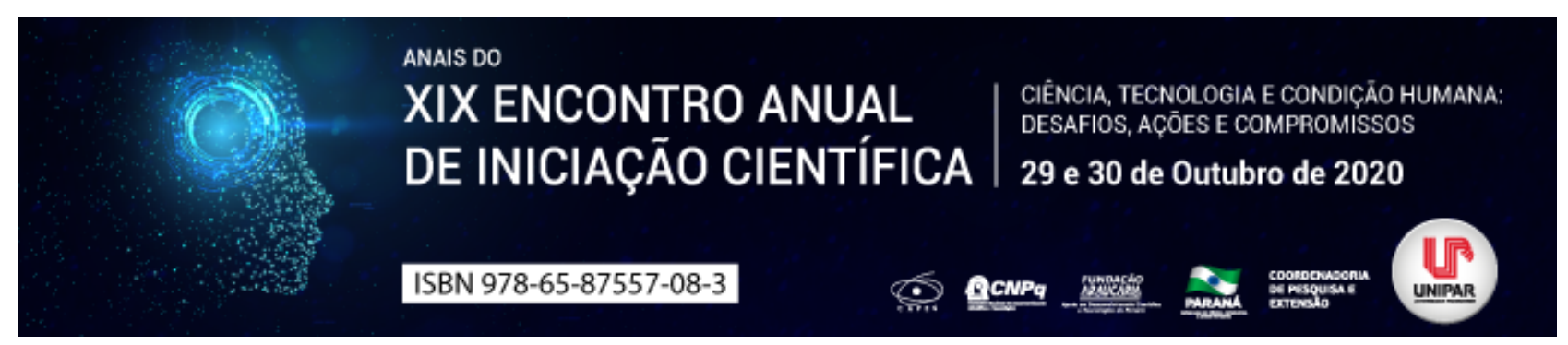

MANEJO DO PACIENTE SOB USO DE ANTICOAGULANTES ORAIS DIRETOS E CIRURGIA ORAL MENOR

\begin{abstract}
${ }^{1}$ Isabela Trarbach Gomes, ${ }^{2}$ CLARA MIOTTO SILVA, ${ }^{3}$ KARINE SANTOS ALMEIDA, ${ }^{4}$ PRISCYLA VITORINO SOARES, ${ }^{5}$ GABRIELA MAYRINK GONÇALVES
\end{abstract}

\begin{abstract}
${ }^{1}$ Acadêmica Curso de Odontologia, Universidade Federal do Espírito Santo, UFES, Vitória, Brasil
${ }^{1}$ Acadêmica Curso de Odontologia, Universidade Federal do Espírito Santo, UFES, Vitória, Brasil

${ }^{2}$ Acadêmica Curso de Odontologia, Universidade Federal do Espírito Santo, UFES, Vitória, Brasil

${ }^{3}$ Acadêmica Curso de Odontologia, Universidade Federal do Espírito Santo, UFES, Vitória, Brasil

${ }^{4}$ Discente do Centro Universitário FAESA
\end{abstract}

Introdução: Desde 2010, quatro drogas chamadas de anticoagulantes orais diretos (ACOD), que são, dabigatrana, rivaroxabana, apixabana e edoxabana foram aprovadas pela Food and Drug Administration Os ACOD são usados para a prevenção de acidente vascular cerebral, embolia sistêmica em pacientes com fibrilação atrial não valvar e tratamento e prevenção de tromboembolismo venoso (BRENNAN et al., 2020; MILLER; MILLER, 2018). Essa nova geração de anticoagulantes foi desenvolvida para fornecer uma saída às desvantagens percebidas na varfarina, por ter farmacocinética e farmacodinâmica previsíveis e menos interações medicamentosas, o que melhora a qualidade de vida do paciente por conta de ajustes de dosagem e monitoramento menos frequentes (ELAD et al., 2016; LABABIDI et al., 2018; SCHMITT et al., 2020). Sua principal complicação é o aumento do sangramento em cirurgias, o que torna o paciente que faz uso crônico desses medicamentos um desafio para os dentistas.

Objetivos: Fazer uma revisão integrativa da literatura, para avaliar a segurança da continuação da terapia anticoagulante com ACDO caso o paciente seja submetido a uma cirurgia oral menor e analisar o risco de sangramento no pós-operatório. Desenvolvimento: Os ACOD são divididos em dois subgrupos que incluem o inibidor direto da trombina representado pelo dabigatrana e os inibidores do fator Xa que são a rivaroxabana, apixabana e edoxabana (YOSHIKAWA et al., 2019; SCHMITT et al., 2020). As vantagens dos ACDOs sobre os inibidores da vitamina $K$ são eficácia rápida, meia-vida curta e efeito anticoagulante mais previsível, pois interferem diretamente na cascata da coagulação.(BERTON et al., 2019; SCHMITT et al., 2020; YOSHIKAWA et al., 2019). A concentração plasmática máxima de ACOD é atingida rapidamente, por isso o efeito terapêutico do ACOD é rápido e o risco de sangramento é quase imediato. O metabolismo acontece principalmente no fígado, por isso deve-se atentar a maior estimativa de sangramento em pacientes com problemas hepáticos (ELAD et al., 2016; PATEL et al., 2017). ACOD são muito usados pela população mais velha normalmente mais atingida por comorbidades e essas drogas ainda não possuem um método de monitoramento rápido e específico como a Razão Normalizada Internacional, sendo assim, o manejo adequado desses pacientes é imprecindível.(BERTON et al., 2019; YOSHIKAWA et al., 2019). Quando os procedimentos odontológicos são realizados sem a retirada do medicamento, o sangramento é administrável com medidas hemostáticas convencionais. A ponte de heparina não é recomendada, porque essas mudanças no tratamento podem aumentar o sangramento pós-operatório. Em pacientes com características clínicas que predispõem ao sangramento e em procedimentos cirúrgicos complexos e invasivos é necessária uma abordagem individualizada com o consenso entre o dentista e o médico responsável do paciente, a fim de minimizar riscos e possíveis complicações (LANAU et al., 2017). O planejamento do tratamento odontológico de pacientes em uso de ACOD, deve avaliar doenças existentes, histórico médico e lista de medicamentos. A avaliação do dentista deve se atentar nos fatores que podem aumentar o sangramento (insuficiência renal, uso de outras medicações que aumentam o sangramento como antiagregantes plaquetários) ou complicações tromboembólicas. Deve-se considerar qual é o procedimento odontológico, sua extensão, intensidade de sangramento estimada no trans e pós-operatório, risco de tromboembolismo caso o medicamento seja descontinuado e a disponibilidade de medidas hemostáticas locais e sistêmicas (BERTON et al., 2019; JOHNSTON, 2016; LABABIDI et al., 2018; MAUPRIVEZ et al., 2016; MILLER; MILLER, 2018). Recomenda-se que a exodontia ocorra 6 horas após a última dose de ACOD para aproveitar o nível plasmático mais baixo. Em administração de uma vez ao dia, sendo tomado a tarde ou noite, a cirurgia deve ocorrer na manhã seguinte, com a concentração sanguínea da droga mais baixa. O procedimento deve ser o mais atraumático possível e medidas adicionais de hemostasia local devem ser feitas antes da próxima dose como suturas com esponjas de gelatina ou celulose e compressão da ferida com gaze para reduzir o risco de sangramento pós-operatório. (MILLER; MILLER, 2018; YOSHIKAWA et al., 2019). No estudo de MAUPRIVEZ et al., 2016 foi comparada a incidência de sangramento pós-operatório nas extrações dentárias entre pacientes tratados com ACODs e pacientes tratados com antagonistas da vitamina $\mathrm{K}$ sem suspensão do tratamento anticoagulante. Os eventos de sangramento que ocorreram foram leves e facilmente controlados e foi concluído que as extrações dentárias podem ser realizadas com segurança em pacientes tratados com ACODs sem interromper ou modificar a dose. 
Conclusão: Pacientes sob uso crônico de ACOD não devem ter sua medicação descontinuada para evitar complicações tromboembólicas. Deve-se levar em consideração as comorbidades do paciente antes do procedimento, principalmente alterações renais e hepáticas. As exodontias podem ser realizadas de forma segura se for levado em consideração o horário das doses do medicamento e usar medidas locais de hemostasia.

\section{Referências}

BERTON, Federico. et al. Should we fear direct oral anticoagulants more than vitamin $\mathrm{K}$ antagonists in simple single tooth extraction? A prospective comparative study. Clinical Oral Investigations, v. 23, n. 8, p. 3183 3192, 2019. Disponível em: https://www.ncbi.nlm.nih.gov/pmc/articles/PMC7040537/ Acesso: 29 ago. 2020

BRENNAN, Yvonne. et al. Dental extractions on direct oral anticoagulants vs. warfarin: The DENTST study. Research and Practice in Thrombosis and Haemostasis, v. 4, n. 2, p. 278 284, 2020. Disponível em: https://www.ncbi.nlm.nih.gov/pmc/articles/PMC7040537/ Acesso: 29 ago. 2020

ELAD, S. et al. Novel anticoagulants: General overview and practical considerations for dental practitioners. Oral Diseases, v. 22 , n. 1, p. 23 32, 2016. Disponível em: https://pubmed.ncbi.nlm.nih.gov/26386350/. Acesso: 29 ago. 2020

JOHNSTON, S. An evidence summary of the management of patients taking direct oral anticoagulants (DOACs) undergoing dental surgery. International Journal of Oral and Maxillofacial Surgery, v. 45, n. 5, p. 618 630, 2016. Disponível em: https://pubmed.ncbi.nlm.nih.gov/26774397/. Acesso: 29 ago. 2020

LABABIDI, E. et al. Assessing an oral surgery specific protocol for patients on direct oral anticoagulants: a retrospective controlled cohort study. International Journal of Oral and Maxillofacial Surgery, v. 47, n. 7, p. 940 946, 2018. Disponível em: https://pubmed.ncbi.nlm.nih.gov/29653869/. Acesso: 29 ago. 2020

LANAU, Neus. et al. Direct oral anticoagulants and its implications in dentistry. A review of literature. J Clin Exp Dent, v. 9, n. 11, p. 1346-54, 2017. Acesso em: https://www.ncbi.nlm.nih.gov/pmc/articles/PMC5741849/ 24 ago. 2020.

MAUPRIVEZ, Cédric. et al. Management of dental extraction in patients undergoing anticoagulant oral direct treatment: a pilot study. Oral Surgery, Oral Medicine, Oral Pathology and Oral Radiology, v. 122, n. 5, p. e146-e155, 2016. Disponível em: https://pubmed.ncbi.nlm.nih.gov/27554378/. Acesso: 29 ago. 2020

MILLER, S. G.; MILLER, C. S. Direct oral anticoagulants: A retrospective study of bleeding, behavior, and documentation. Oral Diseases, v. 24, n. 1-2, p. 243-248, 2018. Disponível em: https://onlinelibrary.wiley.com/doi/abs/10.1111/odi.12698. Acesso: 29 ago. 2020

PATEL, J. P. et al. Managing direct oral anticoagulants in patients undergoing dentoalveolar surgery. British Dental Journal, v. 222, n. 4, p. 245-249, 2017. Disponível em: Acesso: https://pubmed.ncbi.nlm.nih.gov/28232717/. 29 ago. 2020

SCHMITT, Cm. et al. Management of anticoagulated patients in dentoalveolar surgery: a clinical comparative study. Clinical Oral Investigations, v. 24, n. 8, p. 2653-2662, 2020. Disponível em: https://pubmed.ncbi.nlm.nih.gov/31713746/. Acesso: 29 ago. 2020

YOSHIKAWA, $\mathrm{H}$. et al. Safety of tooth extraction in patients receiving direct oral anticoagulant treatment versus warfarin: a prospective observation study. International Journal of Oral and Maxillofacial Surgery, v. 48, n. 8, p. 1102-1108, 2019. Disponível em: https://pubmed.ncbi.nlm.nih.gov/30745243/. Acesso: 29 ago. 


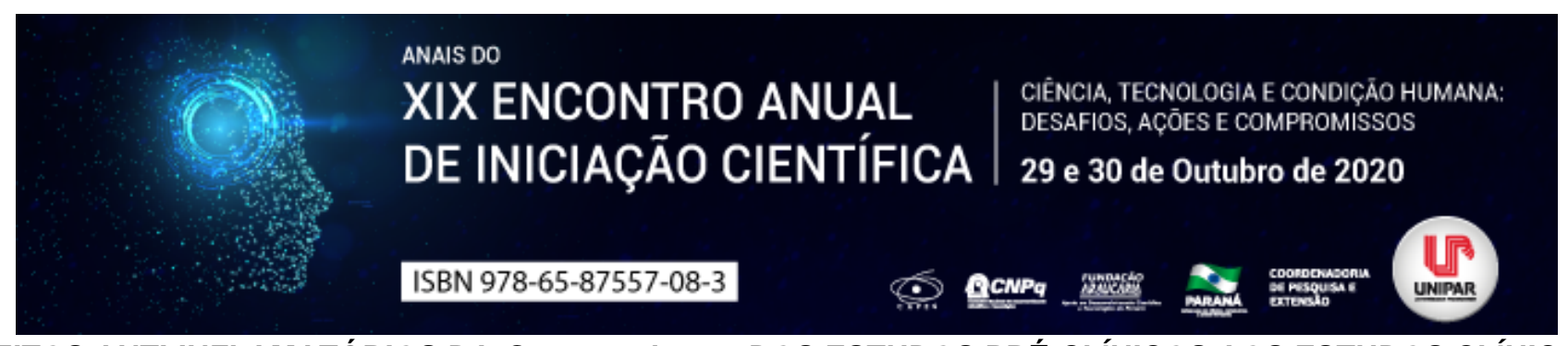

EFEITOS ANTI-INFLAMATÓRIOS DA Curcuma longa: DOS ESTUDOS PRÉ-CLÍNICOS AOS ESTUDOS CLÍNICOS

\begin{abstract}
${ }^{1}$ BARBARA SILVA BRAVO, ${ }^{2}$ FERNANDA DE ABREU BRAGA, ${ }^{3}$ YASMIN NAVA SINHORIN, ${ }^{4}$ GUSTAVO RATTI DA SILVA , ${ }^{5}$ FRANCISLAINE APARECIDA DOS REIS LIVERO
\end{abstract}

\author{
${ }^{1}$ Discente do Curso de Medicina/Bolsista - PIBIC/UNIPAR \\ ${ }^{1}$ Acadêmica do Curso de Medicina da UNIPAR \\ ${ }^{2}$ Acadêmica do Curso de Medicina da UNIPAR \\ ${ }^{3}$ Acadêmico do Curso de Biomedicina da UNIPAR \\ ${ }^{4}$ Docente da UNIPAR
}

Introdução: A Curcuma longa é uma planta herbácea da família Zingiberaceae de cor vermelha alaranjada, originária da Índia, nativa de regiões asiáticas. De acordo com Grasso, Aoyama e Furlan (2017), é conhecida como açafrão-da-terra, cúrcumaturmérico, açafrão-da-índia e gengibre-amarelo, podendo ser cultivada em regiões tropicais e subtropicais. Seu pó, que é amplamente consumido na culinária por possuir aroma e sabor marcantes, vem dos rizomas maduros da planta e a cor vermelha alaranjada é proveniente dos curcuminoides polifenólicos. Esta planta possui atividade anti-inflamatória comprovada devido a presença dos curcuminoides, em especial a curcumina, principal metabólito, que está associada ao potencial terapêutico desta planta, a qual pode ser uma alternativa promissora para a prevenção e/ou tratamento de diversas inflamações (DELFANTE, 2020).

Objetivo: Avaliar a eficácia e os efeitos da Curcuma longa no tratamento de inflamações.

Desenvolvimento: A inflamação é uma resposta adaptativa provocada por estímulos e condições nocivos, como infecção e lesão tecidual. É um processo fisiológico complexo, regulado por várias vias de sinalização, requerendo a interação de tipos diferentes de células, fazendo a modulação de uma extensa gama de respostas celulares, incluindo maturação e função das células imunes, além da homeostase dos tecidos (MEDZHITOV, 2008). Segundo Gené et al. (2009), grande parte dos medicamentos anti-inflamatórios agem sobre vias do ácido araquidônico através da inibição de cicloxigenase (COX) envolvida nos mecanismos patogênicos da dor e inflamação. De fato, a curcumina, principal componente do açafrão, está associada ao potencial terapêutico dessa planta, haja visto sua ação anti-inflamatória, ela inibe diferentes moléculas envolvidas na inflamação, como a fosfolipase A2, lipoxigenases, COX-2, leucotrienos, tromboxanos, prostaglandinas e fator de necrose tumoral $\alpha$ (TNF- $\alpha$ ), além de ativar células do sistema imune (CHAINANI-WU et al, 2003; GRASSO; AOYAMA; FURLAN, 2017). Portanto, o uso da C. longa tem sido uma alternativa promissora, uma vez que esta espécie apresenta ação anti-inflamatória potente através de distintos efeitos sobre a cascata do ácido araquidônico (MARCHI et al., 2016). Além disso, as propriedades anti-inflamatórias atribuídas à $C$. longa podem ser comparadas à eficácia dos glicocorticóides, hormônios produzidos pelas glândulas supra-renais que possuem potente ação anti-inflamatória, pois melhora a interação glicocorticóide/receptor, sem desencadear, entretanto, os efeitos secundários dos mesmos (PERES, 2015). Vários estudos pré-clínicos foram realizados para investigar os efeitos antiinflamatórios da curcumina (JURENKA, 2009). Em um ensaio com camundongos knockout, utilizando ração padrão enriquecida com $0,2 \%$ de curcumina durante duas semanas ocorreu a redução da inflamação do cólon por meio da pontuação da gravidade da lesão histológica. A diminuição da inflamação se deu através da redução da migração de neutrófilos mediada pela inibição do complexo fosfoinositídeo 3-quinase e MAP quinase p38, além do aumento da remodelação das uniões da aderência do epitélio e reparo da barreira celular endotelial (COONEY et al., 2016). No estudo de Funk et al. (2006) os efeitos anti-inflamatórios da C. longa foram avaliados em ratos tratados com o bioativo $(23 \mathrm{mg} / \mathrm{kg}, 4$ dias) e submetidos à um modelo de inflamação induzido por parede celular estreptocócica. Ocorreu inibição de $64 \%$ dos processos inflamatórios agudos e $74 \%$ dos processos inflamatórios crônicos. No entanto, nos testes em que o tratamento foi iniciado após a resolução da fase aguda não observou-se efeito clinicamente significativo. No estudo clínico conduzido por Madhu et al. (2013) foram investigados pacientes com osteoartrite no joelho. Destes, 30 foram tratados com placebo, 30 foram tratados com extrato de curcumina (1 $/ \mathrm{g} / \mathrm{dia})$ e 60 foram tratados com sulfato de glucosamina isolado ou associado à curcumina $(750 \mathrm{mg} / \mathrm{dia})$ durante 42 dias. Após o período de tratamento, foi possível observar, nos grupos controle, diminuição significativa na dor, em relação ao grupo placebo, diminuição no uso de medicamentos para alívio da dor, além de melhora clínica. Esse estudo mostrou segurança e eficácia, além de ser uma opção viável de tratamento para pacientes portadores de osteoartrite de joelho.

Conclusão: A C. longa se mostrou eficaz em diversos estudos. A curcumina é a substância fundamental na ação antiinflamatória da $C$. longa e sua ação envolve a inibição de vias pró-inflamatórias, apontando desfechos promissores para o tratamento de inflamações. 


\section{Referências}

CHAINANI-WU, Nita. et al. Safety and anti-inflammatory activity of curcumin: a component of tumeric (Curcuma longa). The Journal of Alternative and Complementary Medicine, São Francisco, Califórnia, v. 9, n. 1, p. 161 168, 2003.

COONEY, Janine Margaret. et al. A combined omics approach to evaluate the effects of dietary curcumin on colon inflammation in the Mdr1a-l- mouse model of inflammatory bowel disease. The Journal Of Nutritional Biochemistry, v. 27, p. 181-192, jan. 2016.

DELFANTE, Ana Carolina Vieira. et al. Farmácia e promoção da saúde. Atena Editora, Ponta Grossa, v. 1, p. 177-180, E-Book, 2020. ISBN 978-65-81740-26-9.

FUNK, Janet L. et al. Turmeric extracts containing curcuminoids prevent experimental rheumatoid arthritis. Journal of Natural Products, p. 351 355, abr. 2006.

GENE, Emili. et al. Recommendations for the use of anti-inflammatory drugs and indications for gastrointestinal protection in emergency departments. Emergencias, Barcelona, Espanha, v. 21, p. 295-300, out. 2009.

GRASSO, Eliane da Costa.; AOYAMA, Elisa Mitsuko.; FURLAN, Marcos Roberto. Ação anti-inflamatória da Curcuma longa L. (ZINGIBERACEAE). Revista Eletrônica Thesis, São Paulo, v. 14, n. 28, p. 117-129, 2017.

JURENKA, Julie S. Anti-inflammatory properties of curcumin, a major constituent of Curcuma longa: a review of preclinical and clinical research. Alternative Medicine Review, v. 14, n. 2, 2009.

MADHU, Krishna.; CHANDA, Pranab K.; SAJI, M. J. Safety and efficacy of Curcuma longa extract in the treatment of painful knee osteoarthritis: a randomized placebo-controlled trial. Inflammopharmacology, Bangalore, v. 21, n. 2, p. 129 136, nov. 2012.

MARCHI, Juliana Pelissari. et al. Curcuma longa L., o açafrão da terra, e seus benefícios medicinais. Arquivos de Ciências da Saúde UNIPAR, Umuarama, v. 20, n. 3, p, 189-194, set./dez. 2016.

MEDZHITOV, Ruslan. Origin and physiological roles of inflammation. Nature. New Haven, Connecticut. v. 454, p. 428435 , jul. 2008.

PERES, Anne Seliprandy.; VARGAS, E. G. A.; SOUZA, V. R. S. Propriedades funcionais da cúrcuma na suplementação nutricional. Revista Interdisciplinar do Pensamento Científico, v. 1, n. 15, jul/dez. 2015. 


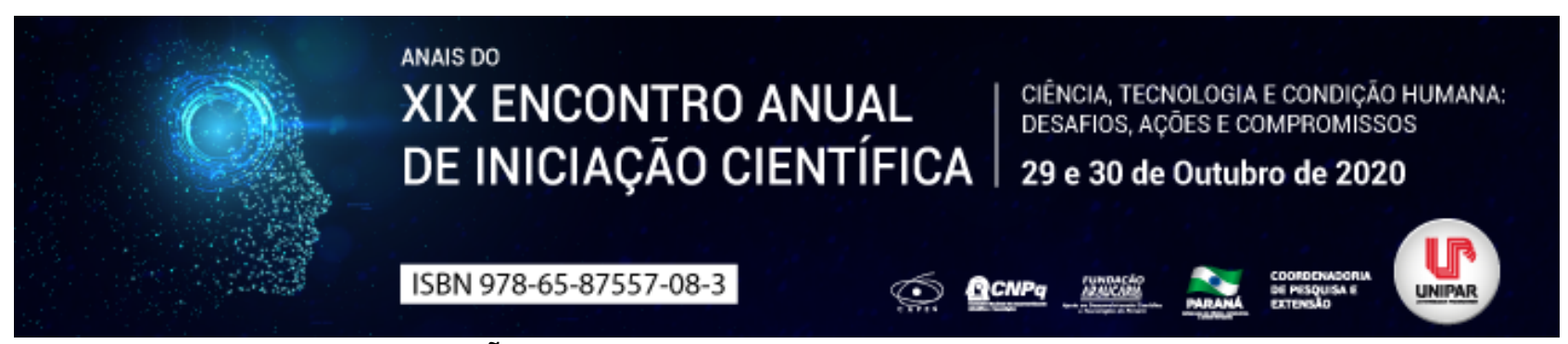

MANIFESTAÇÕES ORAIS DA COVID-19: FATO OU CASUALIDADE?

\begin{abstract}
${ }^{1}$ Karine Santos Almeida, ${ }^{2}$ CLARA MIOTTO SILVA, ${ }^{3}$ ISABELA TRARBACH GOMES, ${ }^{4}$ PRISCYLA VITORINO SOARES, ${ }^{5}$ TÂNIA REGINA GRÃO-VELLOSO
\end{abstract}

\begin{abstract}
${ }^{1}$ Acadêmica Curso de Odontologia, Universidade Federal do Espírito Santo, UFES, Vitória, Brasil
${ }^{1}$ Acadêmica Curso de Odontologia, Universidade Federal do Espírito Santo, UFES, Vitória, Brasil

${ }^{2}$ Acadêmica Curso de Odontologia, Universidade Federal do Espírito Santo, UFES, Vitória, Brasil

${ }^{3}$ Acadêmica Curso de Odontologia, Universidade Federal do Espírito Santo, UFES, Vitória, Brasil

${ }^{4}$ Professora Associada, Universidade Federal do Espírito Santo, UFES, Vitória, Brasil
\end{abstract}

Introdução: A pandemia de COVID-19, iniciada no ano de 2019 na China, revelou a necessidade de uma rápida reestruturação no sistema de saúde no mundo todo. Alguns sintomas foram logo relatados com maior frequência, como febre, fadiga e tosse seca. (WANG et al., 2020). Também foram descritos problemas gustatórios e olfativos como sinal para presença da doença. (DE MARIA et al., 2020). Recentemente, artigos abordando manifestações orais como uma das possíveis formas de apresentação da COVID-19 suscitou uma nova discussão sobre serem ou não sintomas da doença, sendo necessária uma melhor análise dos casos. (CARRERAS-PRESAS et al., 2020; CHAUX-BODARD et al., 2020; SOARES et al., 2020).

Objetivo: Compreender as manifestações orais em pacientes com COVID-19 descritas na literatura, para melhor orientação dos profissionais de saúde, assim como maior inclusão do cirurgião-dentista (CD) no processo de diagnóstico.

Desenvolvimento: Foi realizado levantamento bibliográfico no banco de dados do PubMed, palavras chaves: COVID-19, symptons, oral lesion, oral mucosa. Foram avaliados 13 artigos, dentre eles 4 artigos eram relatos de caso referente a um total de seis pacientes com COVID-19 e lesões orais. Os 13 artigos foram provenientes de diversos países como a China (4), França (1), Brasil (2), Alemanha (1), Espanha (2), EUA (1), Itália (1), Reino Unido (1). O número total de casos avaliados foi de 2878, sendo 1455 homens e 1423 mulheres. As idades em geral eram médias dos casos avaliados, variaram entre maiores de 60 anos (959) e menores de 60 anos (1919). Pacientes com uma ou mais comorbidades foram 1046. O diagnóstico pela técnica de RT-PCR foi realizado em 2621 pacientes. Apenas três artigos não informaram este dado. Os sinais e sintomas descritos foram, febre (1847), tosse (1570), fadiga (799), vômito (176), dor de cabeça (294), dor de garganta (208), diarreia (481), anosmia (58), ageusia (61). Os sinais e sintomas mais comuns foram febre, tosse e fadiga. Em 8 artigos foram contabilizados aproximadamente 445 pacientes com uso de oxigênio ou ventilação mecânica. Nos artigos referentes a levantamento epidemiológico não foram descritas lesões orais. Nos artigos relatos de caso de pacientes com manifestação oral as lesões eram em lábios, palato duro e língua, com maior ocorrência em língua. A COVID-19 foi classificada quanto ao grau de severidade em apenas 6 artigos, sendo encontrados aproximadamente 817 pacientes com a forma leve e em 67 pacientes a severa. A presença de lesões orais como sinal ou sintoma da COVID-19 foi retratada recentemente na literatura, representando nesta revisão $0,2 \%$ dos casos. Grande parte dos pacientes apresentava comorbidades como hipertensão, diabetes e obesidade. Nos casos com lesão oral um paciente não possuía comorbidades, não fez uso de medicação sistêmica e foi classificado como forma leve. Nos demais casos, em 4 não foi informado a forma da COVID-19 e 1 caso foi classificada como severa. Também foi observado nestes pacientes uma ou mais comorbidades, sendo a hipertensão e diabetes mais comuns, além do uso de uma ou mais medicações sistêmicas. As lesões orais variavam de máculas eritematosas, placas brancas, bolhas e úlceras. Esta última observada em 5 pacientes. O diagnóstico por RT-PCR foi informado apenas para 3 pacientes com lesão oral, sendo os demais tratados como COVID devido a apresentarem sintomas e terem tido contato com familiares positivos. O COVID-19 ainda é uma doença em processo de conhecimento com muitas lacunas a serem preenchidas. A baixa incidência de lesões orais em pacientes com COVID-19 descrita na literatura (0,2\% nesta revisão) pode ser devido a não especificidade das lesões com a COVID-19, ou mesmo a ausência do CD na equipe da linha de frente com mais experiência na identificação de alterações da mucosa oral. Nos relatos de caso de pacientes com lesões orais o CD apenas foi solicitado para parecer devido a queixa do paciente de desconforto oral.

Conclusão: Embora, 6 pacientes tenham sido identificados, ainda é prematuro afirmar que lesões orais sejam sinal da doença. Seria necessário o exame bucal fazer parte de protocolo de atendimento ao paciente com COVID-19, bem como ser realizado por CD da equipe hospitalar.

\title{
Referências
}

ALBARELLO, F. et al. 2019-novel Coronavirus severe adult respiratory distress syndrome in two cases in Italy: an uncommon radiological presentation. International Journal of Infectious Diseases, Rome, v. 93, p. 192-197, Apr. 2020.

CHAUX-BODARD, A. et al. Oral manifestation of Covid-19 as an inaugural symptom? Journal of Oral Medicine and Oral 
Surgery, Lyon, $\quad$ v. $26, \quad$ n. $\quad 2, \quad$ p. $18, \quad 30 \quad$ abr. $2020 . \quad$ Disponível https://www.jomos.org/articles/mbcb/full_html/2020/02/mbcb200030/mbcb200030.html. Acesso em: 28 jul. 2020.

HAMER, O. et al. CT morphology of COVID-19: case report and review of literature. Röfo - Fortschritte Auf Dem Gebiet Der Röntgenstrahlen und Der Bildgebenden Verfahren, Regensburg, v. 192, n. 05, p. 386-392, 26 mar. 2020. Disponível em: https://www.thieme-connect.com/products/ejournals/html/10.1055/a-1142-4094?articleLanguage=en. Acesso em: 28 jul. 2020.

HAN, C. et al. Digestive Symptoms in COVID-19 Patients With Mild Disease Severity. American Journal of Gastroenterology, Philadelphia, v. 115, n. 6, p. 916-923, Jun. 2020.

$\mathrm{HU}$, Z. et al. Clinical characteristics of 24 asymptomatic infections with COVID-19 screened among close contacts in Nanjing, China. Science China Life Sciences, Nanjing, v. 63, n. 5, p. 706-711, Mar. 2020.

JAIN, V. et al. Predictive symptoms and comorbidities for severe COVID-19 and intensive care unit admission: a systematic review and meta-analysis. International Journal of Public Health. London, v. 65, n. 5, p. 533-546, May 2020.

JIN, X. et al. Epidemiological, clinical and virological characteristics of 74 cases of coronavirus-infected disease 2019 (COVID-19) with gastrointestinal symptoms. International Jornal of Gastroenterology and Hepatology, Zhejiang, v. 69, n. 6, p. 1002-1009, Mar. 2020.

MARTíN, C. et al. Oral vesiculobullous lesions associated with SARS-CoV-2 infection Oral Diseases: Leading in Oral, Maxilofacial, Head and Neck Medicine, Madrid, v. 26, n. 5, p. 1-3, May. 2020.

MARTÍN-SÁNCHEZ, F. et al. Clinical presentation and outcome across age categories among patients with COVID-19 admitted to a Spanish Emergency Department. European Geriatric Medicine, Madrid, p. 1-13, Jul, 2020.

SANTOS, J. et al. Oral mucosal lesions in a COVID-19 patient: new signs or secondary manifestations? International Journal of Infectious Diseases, Rome, v. 97, p. 326-328, Ago. 2020.

SOARES, C. et al. Letter to Editor: oral lesions in a patient with covid-19. Medicina Oral Patología Oral y Cirugia Bucal, São Paulo, p. 563-564, 2020. Disponível em: http://www.medicinaoral.com/medoralfree01/aop/24044.pdf. Acesso em: 28 jul. 2020.

SULEYMAN, G. et al. Clinical Characteristics and Morbidity Associated With Coronavirus Disease 2019 in a Series of Patients in Metropolitan Detroit JAMA network open. New York, vol. 3, n. 6, p.1-12, Jun. 2020.

ZHOU, Z. et al. Effect of Gastrointestinal Symptoms in Patients With COVID-19. Gastroenterology, New York, v. 158, n. 8, p. 2294-2297, Jun. 2020. 


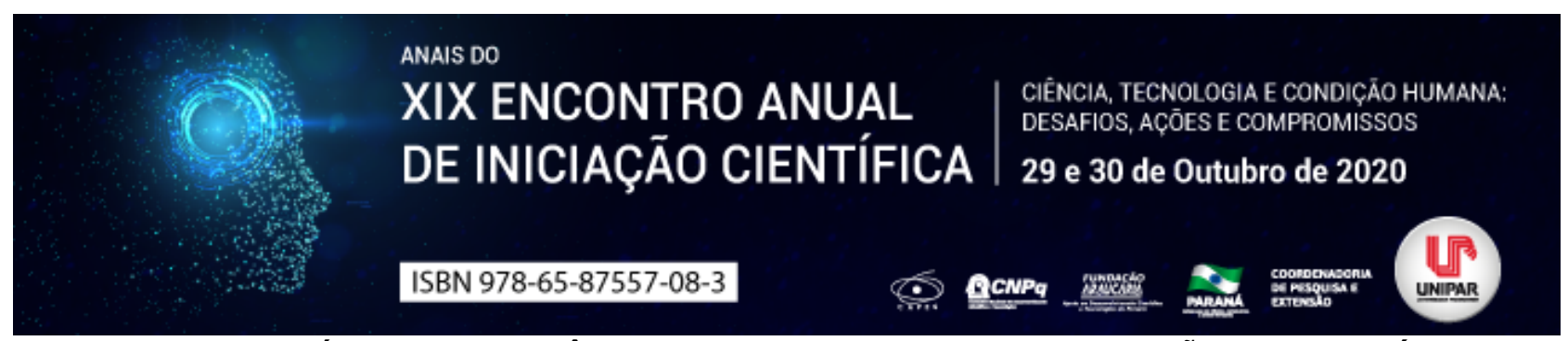

FLUOROSE DENTÁRIA: A IMPORTÂNCIA DA ANAMNESE NA DETERMINAÇÃO DO DIAGNÓSTICO

\title{
${ }^{1}$ ANDRESSA VENTRAMELI DE ANDRADE, ${ }^{2}$ LAVINIA PRADO HERNANDES,${ }^{3}$ ANA CAROLINA SOARES FRAGA ZAZE
}

\author{
${ }^{1}$ Acadêmica do Curso de Odontologia da -PIC - UNIPAR- Campus Umuarama-PR \\ ${ }^{1}$ Acadêmica do Curso de Odontologia-PIC-Unipar \\ ${ }^{2}$ Docente da UNIPAR
}

Introdução: A implementação de fluoretos em rede de saneamento básico, tem promovido melhorias na saúde bucal da população, trouxe um grande declínio da cárie dentária, entretanto tem sido acompanhada de uma grande preocupação com o aumento da prevalência de fluorose na dentição permanente. Sendo a mesma uma alteração na mineralização dos dentes em formação devido à presença de Flúor e está relacionada à ingestão crônica deste elemento, sua severidade dependente da dose de exposição (LIMA-ARSATI ET AL., 2018). Com base no descrito, o objetivo é relatar o caso de fluorose dentária observado em adolescente, cuja a história direcionada na anamnese e aspectos clínicos foram o diferencial para o diagnóstico da fluorose e definição do tratamento.

Relato de caso: Paciente feminino, feoderma, 12 anos de idade, procurou atendimento na clínica odontológica da Unipar referindo ter uma sensibilidade nos dentes durante a escovação e ao beber água, sendo gelada ou não. A mãe relatou ter observado que os dentes da criança, logo após o irrompimento, apresentavam manchas e que já havia procurado atendimento na rede pública e privada, contudo nunca recebeu uma explicação para a causa da alteração. No exame clínico, observou-se manchas esbranquiçadas, acometendo grande parte da superfície das coroas dentárias e pequenas áreas de depressões arredondadas, onde se observou ausência de esmalte dentário. Os dentes que possuíam um maior número de depressões apresentaram sensibilidade a estímulos térmicos principalmente ao frio. Durante anamnese direcionada à detecção de fluorose, a mãe relatou que sua família morou em Bombinhas (SC), quando a criança tinha por volta de 2 a 6 anos. Os autores não tiveram acesso ao controle da fluoretação da água de abastecimento público, quando entraram em contato com o departamento de saneamento básico, porém a água tratada era apenas utilizada para preparo de alimentos. Foi citado que a criança teve suspeita de doença celíaca por volta dos 3 anos, contudo o diagnóstico da referida doença não foi conclusivo, segundo biópsia intestinal realizada. A mãe recebeu orientações sobre possíveis causas de fluorose, quando a adolescente comentou sobre o fato de que a ingeria dentifrício fluoretado na concentração de 1100ppm, durante a escovação, durante sua infância. Com base na descrição do índice de TF, foi feita a classificação do grau de fluorose, identificando como grau 6. Foi indicada a realização de restaurações oclusais para suprir a perda de estrutura dental, favorecendo a diminuição da sensibilidade devido ao fato de proteger a dentina exposta ao meio bucal. Em seguida, para ao menos melhorar a condição estética dos dentes anteriores, foi indicada a técnica de microabrasão do esmalte, com o intuito de melhorar o grau de satisfação da paciente com relação ao seu sorriso, o que interferia no seu relacionamento social, pelo fato de ter vergonha de sua aparência..

Discussão: A fluorose dentária é uma alteração provocada por exposição prolongada do germe dentário ao flúor durante sua formação (FORTUNATO, 2012). Porém sua etiologia certeira vai muito além, um dos aspectos que vem trazendo uma preocupação e sendo uma explicação para o aumento de fluorose dentária e a associação do dentifrício a água fluoretada, sendo que são muitos os fatores que interferem na severidade desta condição, como por exemplo, a dose ingerida pela criança, baixo peso, insuficiência renal crônica ou, até mesmo, estado nutricional precário (COELHO et al., 2017). No caso em estudo, o relato de ingestão de dentifrício fluoretado leva à suspeita de que esta seja a causa da alteração na formação do esmalte, como também a suspeita de doença celíaca que decorreu um quadro de desnutrição. Mesmo o resultado da biópsia não sendo conclusivo, mostra que o estado nutricional, confirmado por exames laboratoriais, foi um fator importante para o desenvolvimento da fluorose, pois como relatado por Moura e colaboradores, (2016) a severidade da fluorose está associada ao fator nutricional, idade e peso da criança, sendo que a forma de tratamento será determinada por um adequado diagnóstico e permitirá a determinação de um prognóstico mais favorável (RIGO; LODI; GARBIN, 2015). Diversas alternativas de tratamento são preconizadas para a fluorose dental e elas devem ser determinadas de acordo com a classificação do grau da fluorose. Como no presente caso foi classificado como grau 6, optou-se por uma abordagem conservadora, evitando desgastes dentários excessivos.

Conclusão: O diagnóstico da fluorose dentária deve estar relacionado à uma minuciosa anamnese, com o intuito de verificar diferentes fontes de utilização de Flúor e demais fatores relacionados ao grau de severidade. É necessário que sejam instituídas atividades de educação em saúde relacionadas à prevenção da fluorose, divulgando os fatores que causam a alteração, bem como medidas que evitem o consumo excessivo do flúor e distúrbios sistêmicos que predispõem os indivíduos ao desenvolvimento da fluorose dentária. 


\section{Referências}

COELHO, Ana Flavia Romualdo. et al. Fluorose dentária: relato de caso com abordagem terapêutica. Arquivo Brasileiro de Odontologia, Minas Gerais, v. 12, n. 2, p. 7 12, maio. 2017.

FORTUNATO, Gabriela Eugênia De Souza. et al. Percepção da fluorose dentária e avaliação da concordância entre pais e filhos: validação de um instrumento. Cadernos de Saúde Pública, Rio de Janeiro, v. 28, n. 8, p. 1493 1505, Agosto.2012.

LIMA-ARSATI, Ynara Bosco. De Oliveira. et al.Exposição a fluoreto por crianças na faixa etária crítica para fluorose dentária, residentes no semiárido brasileiro. Ciencia e Saude Coletiva, Rio de Janeiro, v. 23, n. 4, p. 1045 1054, abril. 2018.

MOURA, Marcoeli Silva De. et al. Vigilância epidemiológica da fluorose dentária em município de clima tropical com água de abastecimento público fluoretada. Ciencia e Saude Coletiva, Rio de Janeiro, v. 21, n. 4, p. 1247 1254, abril. 2016.

RIGO, Lilian.; LODI, Leodinei.; GARBIN, Raissa Rigo. Diagnóstico diferencial de fluorose dentária por discentes de odontologia. Einstein (São Paulo, Brazil), São Paulo, v. 13, n. 4, p. 547 554, dezembro. 2015.

Coordenadoria de Pesquisa e Extensão - COPEX

Departamento de Editoraçāo e Divulgaçāo Científica - DEDIC 


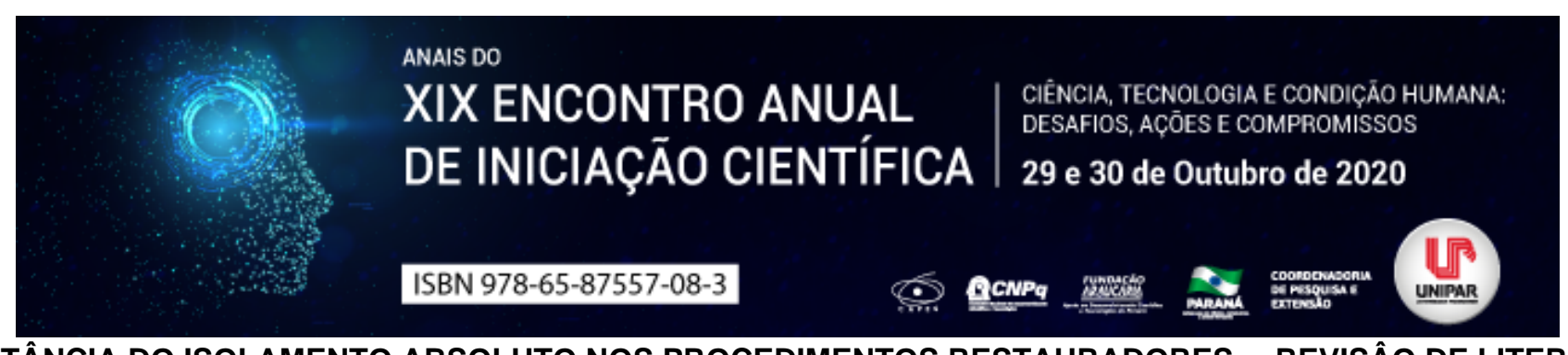

IMPORTÂNCIA DO ISOLAMENTO ABSOLUTO NOS PROCEDIMENTOS RESTAURADORES

REVISÂO DE LITERATURA

\begin{abstract}
${ }^{1}$ GUSTAVO BONNER CARRASCO OLIVEIRA, ${ }^{2}$ MAISA DA ROSA DE TONI, ${ }^{3}$ JENIFFER URBANO DEGASPERI, ${ }^{4}$ WAGNER BASEGGIO
\end{abstract}

${ }^{1}$ Acadêmico do Curso de Odontologia UNIPAR

${ }^{1}$ Acadêmica do Curso de Odontologia da UNIPAR

${ }^{2}$ Acadêmica do Curso de Odontologia da UNIPAR

${ }^{3}$ Docente da UNIPAR

Introdução: O isolamento absoluto é um procedimento que visa eliminar a umidade do campo operatório, fator que interfere diretamente na adesão do material restaurador, consequentemente, sua longevidade. Apenas 44\% dos dentistas utilizam o isolamento absoluto em todos esses procedimentos, e 24\% usam dependendo de variáveis.(ANABTAWI et al., 2013) Dada a informação estatística, se faz necessário que os profissionais e acadêmicos da área, considerem o significante uso desse método.

Objetivo: Mostrar a importância do isolamento absoluto nos procedimentos restauradores, com intuito de destacar a relevância que esse método traz tanto para qualidade quanto para durabilidade do material na cavidade oral.

Desenvolvimento: O isolamento é um método realmente efetivo e recomendado para todos os tipos de restaurações, pois cria diversas vantagens para o profissional, como a melhor visão do campo operatório, promove um melhor controle de umidade, retração do tecido gengival, protege o paciente para que ele não aspire algum instrumento ou material e um dos mais importantes, garante o aumento da longevidade das restaurações.(AHMAD, 2009) Por mais que em variadas situações clínicas, o uso do isolamento possa parecer difícil, talvez por complicações em técnica ou aceitação do paciente, é confirmado que, com esse procedimento haverá menores chances de falhas, já que o controle de umidade que ele proporciona, acarreta em uma maior segurança e taxa de sucesso durante o procedimento adesivo para que haja uma melhor adesão do material restaurador à superfície dentária, consequentemente, eleva a taxa de tempo de sobrevivência da restauração. (WANG et al., 2016) Além de todas as complicações que podem surgir durante a realização do isolamento absoluto, fatores extrínsecos como a umidade do ar e a temperatura do ambiente também são levados em conta já que podem ter importante influência sobre a adesão dentária, pois quando não utilizado o dique de borracha, a umidade intrabucal pode ser encontrada entre 78 a $94 \%$ e a temperatura aparece entre 26 a $29^{\circ} \mathrm{C}$, quando realizado o isolamento corretamente, a umidade cai em até $40 \%$ enquanto a temperatura se ameniza ligeiramente. (SARAIVA, 2008) O isolamento também possui sua importância em procedimentos endodônticos, onde controla a umidade, não só aumentando a qualidade das restaurações feitas nos dentes tratados de forma endodôntica, como também evita que a estrutura receba contato da saliva, que por sua vez também pode transportar microrganismos patogênicos, o que leva a contaminação dentro da câmera pulpar, onde as bactérias se alojariam nessa região prejudicando o resultado do procedimento, podendo acarretar, além da contaminação da região, em uma infiltração coronária. (GOLFEIN et al., 2013)

Conclusão: O isolamento é um processo indispensável em restaurações diretas e também de devida importância no tratamento endodôntico, pois promove um melhor acesso para o profissional, melhor visibilidade do campo de operação, protege o paciente de possíveis acidentes como a aspiração de algum material, defende a estrutura dentária de saliva e sangue, que podem por sua vez trazer microrganismos indesejáveis para o local e é um fator indispensável que garantirá uma maior longevidade e qualidade da restauração. Portanto, é importante que cada vez mais profissionais da área, considerem esse método para sua rotina.

\title{
Referências
}

AHMAD, Ibrahim. Ali. Rubber dam usage for endodontic treatment: A review. International Endodontic Journal, v. 42, n. 11, p. 963 972, 2009.

ANABTAWI, Mona. et al. Rubber dam use during root canal treatment: Findings from the Dental Practice-Based Research Network. Journal of the American Dental Association, v. 144, n. 2, p. 179 186, 2013.

GOLDFEIN Joshua et al. Rubber dam use during post placement influences the success of root canal-treated teeth. $\mathbf{J}$ Endod. $\mathbf{v}$. 39, n 12, p.1481-1484, 2013.

SARAIVA, Letícia. O. Influência da umidade e temperatura intrabucais na resistência de união de sistemas adesivos convencionais de dois passos - estudo in situ. Universidade Federal da Bahia, p. 74, 2008.

WANG, Yan. et al. Rubber dam isolation for restorative treatment in dental patients. Cochrane Database of Systematic Reviews, v. 2016, n. 9, 2016. 
Coordenadoria de Pesquisa e Extensão - COPEX

Departamento de Editoraçāo e Divulgaçāo Científica - DEDIC 


\title{
ANAIS DO \\ XIX ENCONTRO ANUAL | CIÊNCIA, TECNOLOGIA E CONDIC̄ÃO HUMANA: DE INICIAÇÃO CIENTÍFICA \\ DE INICIAÇÃO CIENTÍFICA 29 e 30 de Outubro de 2020 \\ ISBN 978-65-87557-08-3 \\ 0 \\ EFETIVIDADE DE MEDICAÇÕES INTRACANAIS COMPOSTOS POR PRODUTOS FITOTERÁPICOS NO COMBATE À BACTÉRIA Enterococcus Faecalis: REVISÃO DE LITERATURA
}

\author{
${ }^{1}$ RAFAELLA BRITO CARBELIM, ${ }^{2}$ ISABELLE VENCIGUERRA ALMEIDA, ${ }^{3}$ GABRIELI JANKE RIGHEZ, ${ }^{4}$ CAROLINE \\ DOMINGUES, ${ }^{5}$ JULIA NICOLETTI LEITE, ${ }^{6}$ KLISSIA ROMERO FELIZARDO
}

\author{
${ }^{1}$ Acadêmica de Odontologia Unipar \\ ${ }^{1}$ Acadêmica do Curso de Odontologia da UNIPAR \\ ${ }^{2}$ Acadêmica do Curso de Odontologia da UNIPAR \\ ${ }^{3}$ Acadêmica do Curso de Odontologia da UNIPAR \\ ${ }^{4}$ Acadêmica do Curso de Odontologia da UNIPAR \\ ${ }^{5}$ Docente da UNIPAR
}

Introdução: As patologias que envolvem a polpa e tecidos peri-radiculares são causadas pelas bactérias e seus produtos, sendo que a via de acesso para os canais radiculares é pelos túbulos dentinários, a exposição pulpar e o periodonto (GONÇALVES, 2017). Existem três tipos de infecções - a primária, a secundária e a persistente. A infecção primária acontece em dentes sem tratamento endodôntico e com necrose pulpar, predominando bactérias gram negativas. Já a infecção secundária acontece depois do insucesso do tratamento endodôntico, com a contaminação do canal radicular durante ou após o tratamento. E a infecção persistente é aquela que se manteve depois de feitos os procedimentos de desinfecção e consiste na resistência dos microrganismos ao tratamento endodôntico, como é o caso do E. faecalis. Sua causa está associada tanto aos microrganismos da infecção primária quanto aos da infecção secundária (LACERDA et al., 2016). O hidróxido de cálcio é a medicação mais utilizada como curativo de demora no tratamento dos sistemas de canais. A ação antimicrobiana do hidróxido de cálcio está associada à liberação de íons de hidroxila no meio aquoso, sendo que o seu efeito letal sobre as bactérias estaria relacionado aos seguintes mecanismos: danos à membrana citoplasmática das bactérias, desnaturação proteica e danos no DNA bacteriano. Porém, o Enterococcus faecalis utiliza a bomba de prótons para manter resistência sobre o hidróxido de cálcio, pois assim mantém o pH ácido no interior da célula bacteriana, evitando a sua alcalinização (SOUSA, 2017). Diante de tais limitações, substâncias com potencial antimicrobiano têm sido pesquisadas para serem utilizadas na terapia endodôntica em conjunto com o hidróxido de cálcio; entre essas substâncias pode-se citar os produtos fitoterápicos (MAEKAVA et al., 2013).

Objetivo: Este trabalho tem como objetivo mostrar através de levantamento bibliográfico nas bases de dados Lilacs, MedLine, PubMed e BVS, a eficácia de curativos intracanal compostos por produtos fitoterápicos no combate a bactérias Enterococcus faecalis.

Desenvolvimento: Na odontologia, a própolis tem sido sugerida como medicação alternativa contra o $E$. faecalis pelo fato de pesquisas apresentarem eficácia contra esse microrganismo (ESMERALDO, 2016), sendo uma substância que apresenta menos citotoxicidade. As atividades biológicas e as ações antimicrobianas da própolis estão relacionadas principalmente com a presença de fenóis e polifenóis, que são substâncias aromáticas que deriva de flavonas, flavonóides e flavonóis e são ativo contra a parede celular bacteriana (PIMENTA et al., 2015). Revati et al. (2015) avaliaram através de um estudo in vitro a ação antibacteriana de 7 extratos etanólicos de especiarias contra o Enterococcus: cominho (Zingiber officinale), feno grego ou alforva (Trigonella foemum-graceum), cravo (Syzgium aromaticum), cardamomo (Elettoria cardamoun) e pimenta preta (Piper nigurm). Apenas a canela e o gengibre demonstraram atividade contra todos os isolados bacterianos, enquanto o cominho e o cravo tiveram um efeito variável sobre as cepas. O feno grego, pimenta preta e o cardamomo não mostraram efeito sobre o microrganismo. Ghonmode et al. (2013) investigaram a eficácia antimicrobiana do extrato de folhas de neem e extrato de semente de uva (GSE) na desinfecção do sistema de canais radiculares. Ambos mostraram zonas de inibição sugerindo que eles tinham propriedades antimicrobianas, demonstrando a possibilidade de uso como medicação intracanal. Valera et al. (2013), pesquisaram a atividade antimicrobiana de extratos naturais de gengibre (GE) glicólicos sobre C. albicans e E. faecalis inoculados por 21 dias em 72 canais radiculares de dentes humanos extraídos. O extrato de gengibre reduziu significantemente 0 número das UFC/ml.

Conclusão: De acordo com os resultados apresentados na literatura, pode-se concluir que o uso das medicações intracanais à base de produtos fitoterápicos são alternativas no combate a bactérias Enterococcus faecalis.

\section{Referências}

ESMERALDO, M. R. A.; COSTA, E. M. M. B.; ESMERALDO, C. A. Extrato de própolis verde e associações medicamentosas: análise antimicrobiana contra o Enterococcus faecalis. Con. Cien. Tecnol. v. 10, n. 3, p. 85-94, 2016. 
GUIMARÃES JR, J. Biossegurança e controle de infecção cruzada em consultórios odontológicos. São Paulo: Ed. Santos, p.536, 2001.

GHONMODE, W. N. et al. Comparison of the antibacterial efficiency of neem leaf extracts, grape seed extracts and $3 \%$ sodium hypochlorite against E. feacalis - An in vitro study. J. Int. Oral Health, v.5, n.6, p.-61-66, 2013.

GONÇALVES, Manuela Colbeck; MALIZIA, Claudio; DA ROCHA, Luiz Eduardo Monteiro Dias. Lesões endodôntico-periodontais: do diagnóstico ao tratamento. Braz J Periodontol-March, v. 27, n. 01, 2017.

LACERDA, M. F. L. S. et al. Infecção secundária e persistente e sua relação com o fracasso do tratamento endodôntico. Rev. Bras. Odontol. v. 73, n. 3, p. 212, 2016.

MAEKAWA L. E. et al. Effect of Zingiber officinale and propolis on microorganisms and endotoxins in root canals. J. Appl. Oral Sci. vol.21, n.1, p. 25-31, 2013.

PIMENTA, H. C. et al. In vitro effectiveness of Brazilian brown propolis against Enterococcus faecalis. Brazilian oral research. São Paulo, v. 29, n. 1, p. 1-6, 2015.

SOUSA, M. N.; MACEDO, A. T.; SANTOS, J. R. A. Inter-relação entre Enterococcus faecalis, Candida albicans e os tratamentos endodônticos. Rev. Invest. Biomed. São Luiz, v. 9, n. 1, p. 49-57, 2017.

VALERA, M. C. et al. In vitro antimicrobial activity of auxiliary chemical substances and natural extracts on Candida albicans and Enterococcus faecalis in root canals. J. Appl. Oral Sci, n.2, p.118-123, 2013.

Coordenadoria de Pesquisa e Extensão - COPEX

Departamento de Editoraçāo e Divulgaçāo Científica - DEDIC 


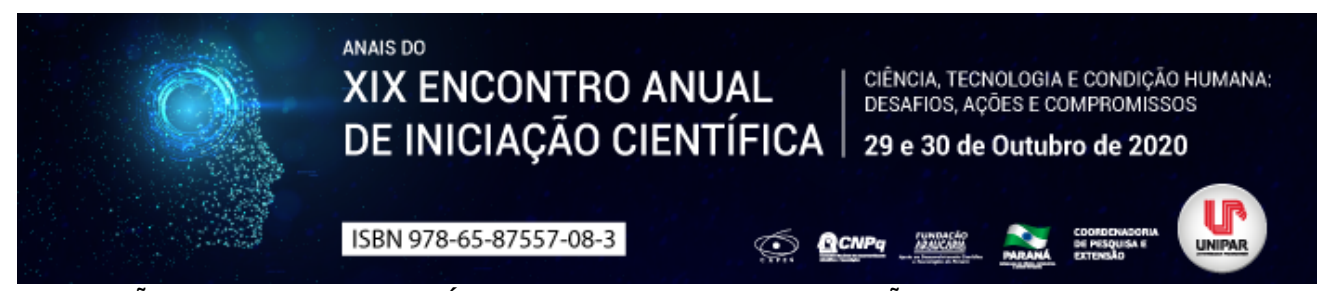

AVALIAÇÃO DO USO DE DENTIFRÍCIOS CLAREADORES E DO CARVÃO ATIVADO NA ODONTOLOGIA

\title{
${ }^{1}$ JULIA NICOLETTI LEITE, ${ }^{2}$ BEATRIZ AYUMI SHIOTANI, ${ }^{3}$ RAFAELLA BRITO CARBELIM, ${ }^{4} \mathrm{KLISSIA} \mathrm{ROMERO} \mathrm{FELIZARDO}$
}

\author{
${ }^{1}$ Acadêmica do Curso de Odontologia da UNIPAR \\ ${ }^{1}$ Acadêmica do Curso de Cirurgia Periodontal e Introdução a Implantodontia - Turma VIII da UNIPAR \\ ${ }^{2}$ Acadêmica do Curso de Odontologia da UNIPAR \\ ${ }^{3}$ Docente da UNIPAR
}

Introdução: Nos dias atuais, o clareamento dental se tornou um dos procedimentos mais procurados na odontologia, já que a busca por dentes mais brancos se tornou um padrão de beleza na sociedade, oferecendo não apenas estética, como também um efeito positivo ao paciente, influenciando diretamente sua autoestima e qualidade de vida (JUREMA, 2016). Com o intuito de satisfazer as necessidades dos consumidores, o mercado passou a oferecer dentifrícios cada vez mais especializados prometendo um rápido e efetivo efeito clareador por meio de ação mecânica simples e em um curto período de tempo (BERNARDINO et al., 2016). Entretanto, muitos dentifrícios contêm somente abrasivos para remoção de manchas extrínsecas, enquanto poucos apresentam em sua composição agentes realmente clareadores, como o peróxido de hidrogênio, parecendo então apresentar eficiência limitada (SILVA et. al., 2011). O carvão ativado entrou atualmente no mercado como um produto atrativo ao consumidor, pois promete clarear os dentes mais rapidamente além de ser antimicrobiano (THAMKE et al., 2018; LEE et al., 2017). Contudo, existem estudos indicando que há presença de remoção de manchas extrínsecas da superfície de esmalte por abrasão, a qual não se restringe às sujidades, podendo atingir o esmalte e causar aumento na rugosidade superficial, desgaste irreversível do tecido e hipersensibilidade (GREENWALL, GREENWALLCOHEN, WILSON, 2019; VAZ et al., 2019).

Objetivo: Este trabalho tem como objetivo relatar a efetividade de dentifrícios clareadores e carvão ativado através de levantamento bibliográfico nas bases de dados LILACS, BBO, BIREME e PubMed.

Desenvolvimento: Vários estudos vêm sendo publicados com o intuito de medir o potencial clareador com o uso dos dentifrícios, e muitos resultados indicam que sua utilização pode fazer a remoção e prevenção de manchas extrínsecas. Todavia, o agente clareador não está presente na maioria das vezes e não ocorre o clareamento dental. Ele contém abrasivos, como a alumina, fosfato dicálcio dihidrato e sílica, sendo responsáveis por remover apenas manchas superficiais, proporcionando um clareamento aparente dos dentes. Quando os dentifrícios apresentam maior abrasão, possibilitam um desgaste da estrutura dental que podem levar a hipersensibilidade dentinária e até tornar os dentes mais escuros pela diminuição da espessura de esmalte e exposição de dentina (SILVA et. al., 2011). Muitos produtos over-the-counter , (produtos clareadores que não necessitam de receita ou supervisão profissional), indicam que seu uso frequente levará ao clareamento dental como também benefícios a gengiva. Entretanto, um grande período é necessário para que realmente ocorra mudança na cor, já que a concentração de agentes clareadores é muito pequena. Ademais, o seu uso frequente ocasionará efeitos colaterais, como alterações na morfologia do esmalte, mudança na textura e rugosidades, como aponta vários estudos (PINTO et al., 2004). Além disso, durante a higienização, a fricção no periodonto pode favorecer o desnudamento do epitélio, ocasionando dor e favorecendo a entrada de infecções oportunistas, além de poder ficar com pequenas partículas acumuladas no sulco gengival ou em bolsas préexistentes, levando a doenças gengivais (BOOKS, BASHIRELAHI, REYNOLDS, 2017).

Conclusão: Através dessa revisão de literatura, pode-se constatar que os produtos over-the-counter (OTC) promovem bons resultados aparentes, porém podem apresentar riscos e possíveis efeitos colaterais a longo prazo, principalmente quanto ao uso do carvão ativado. Portanto, o consumidor deve estar atento de que eles podem trazer prejuízos à saúde, buscando sempre produtos confiáveis, como também orientações e acompanhamento de um profissional habilitado.

\section{Referências}

BERNARDINO, R. M. P. et al. Efetividade de dentifrícios clareadores sobre esmalte de dentes bovinos. Rev Salusvita, v. 35, n. 3, p. 475-89, 2016.

BROOKS, J. K.; BASHIRELAHI, N.; REYNOLDS, M. A. Charcoal and charcoal-based dentifrices: A literature review. J Am Dent Assoc, v. 148, p. $661-670,2017$. Disponível em: https://www.ncbi.nlm.nih.gov/pubmed/28599961.

GREENWALL, L. H.; GREENWALL-COHEN, J.; WILSON, N. H. F. Charcoal-containing Dentifrices, v. 226, n. 9, p. 697-700, 2019. Disponível em: https://www.nature.com/articles/s41415-019-0232-8.

JUREMA, A. L. B. Eficácia de agentes clareadores de venda livre associados ou não ao clareamento com peroxido de carbamida a $10 \%$. 2016.84 pp. Universidade Estadual Paulista Júlio de Mesquita Filho , São José dos Campos, 2016.

LEE, J. et al. Comparison of bacterial contamination in bristles of charcoal toothbrushes versus non-charcoal toothbrushes, 2017. Disponível em: https://www.researchgate.net/publication/317616560_Comparison_of_bacterial_contamination_in_bristles_of_charcoal_toothbrushes_versus_noncharcoal_toothbrushes.

PINTO, C. F. et al. Peroxide bleaching agent effects on enamel surface microhardness, roughness and morphology. Brazilian Oral Research, v. 18, n. 4, p. 306-311, 2004.

SILVA, J. P. F. L. Avaliação da eficácia de cremes dentais clareadores com o uso associado ou não de escova dental especial. Rev Fac Odontol Lins, v. 21, n. 2, p. 31-39, 2011.

THAMKE, M. V. et al. Comparison of Bacterial Contamination and Antibacterial Efficacy in Bristles of Charcoal Toothbrushes versus Noncharcoal Toothbrushes: A Microbiological Study. Contemp Clin Dent, v. 9, n. 3, p. 463-467, jul./sep. 2018. Disponível em: http://www.contempclindent.org/article.asp?issn=09 76237X; year=2018; volume $=9$;issue $=3 ;$ spage $=463$; epage $=4$ 67; aulast $=$ Thamke. .

VAZ, V. T. P. et al. Whitening toothpaste containing activated charcoal, blue covarine, hydrogen peroxide or microbeads: which one is the most effective? 2019. Disponível em: http://www.scielo.br/scielo.php?script=sci_arttext\&p id=S1678-77572019000100429. 


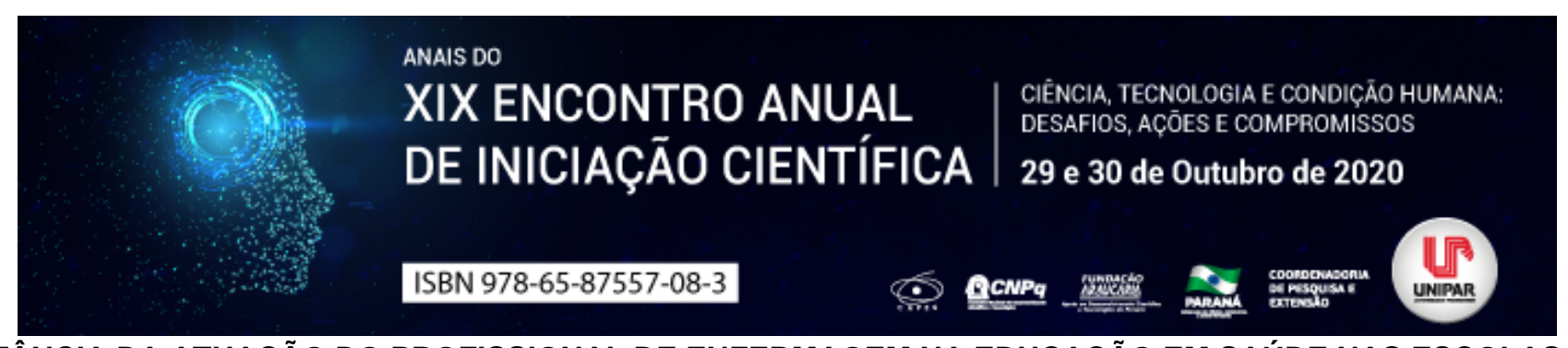

\title{
IMPORTÂNCIA DA ATUAÇÃO DO PROFISSIONAL DE ENFERMAGEM NA EDUCAÇÃO EM SAÚDE NAS ESCOLAS E SUAS POSSIBILIDADES NA PRÁTICA
}

\author{
${ }^{1}$ GABRIELLE DANTAS COSTA, ${ }^{2}$ KATIA BIAGIO FONTES
}

\author{
1 1Discente do Curso de Enfermagem/UNIPAR \\ ${ }^{1}$ Docente da UNIPAR
}

Introdução: As práticas de educação em saúde vêm sendo implantadas no ambiente escolar já tem alguns anos, porém, sustentadas por uma base tradicional de ensino em saúde escolar, por meio de ações como: palestras dos profissionais da saúde, atendimento odontológico, entre outras atividades (CAVALCANTE, 2016). A educação em saúde é um processo que educa e constrói conhecimentos relacionados à saúde do indivíduo, porém, necessita ter a participação ativa da comunidade, para que the possa ser proporcionado informações e conjuntos de práticas que colaboram com o aumento da sua autonomia no autocuidado, visando a prevenção e minimização de agravos à saúde (MINISTÉRIO DA SAÚDE, 2007).

Objetivo: Identificar na literatura científica os principais métodos de abordagem, temas e estratégias de educação em saúde produzidos por acadêmicos e profissionais de enfermagem.

Desenvolvimento: A escola é um espaço de grande importância para um maior desenvolvimento de senso crítico, hábitos básicos de vida e construção de valores, (GUBERT, 2009), neste contexto, o profissional enfermeiro como educador em saúde pode atuar nesse espaço na transmissão de saberes e informações, disseminando boas práticas em saúde e compartilhamento de experiências. Para Alvarenga et al., (2012), a implementação das ações em saúde no âmbito escolar pode sensibilizar os escolares gerando impactos nos seus hábitos de vida que também irão repercutir em todo ambiente familiar. Com este propósito, diferentes iniciativas têm sido desenvolvidas no Brasil, como projetos por meio de atividades extraclasse via Instituições de Ensino Superior Privadas, em parceria com escolas públicas (FONSECA et al., 2019) e ações exercidas por Instituições Públicas de Ensino Superior com o Programa de Extensão Universitária (ProExt), programa este criado em 2003 pelo Ministério da Educação, com a finalidade de amparar instituições públicas de ensino superior na implementação de políticas públicas (MEC, 2003). Também têm sido realizadas ações mediante o Programa Saúde na Escola (PSE), instituído em 2007, pelos Ministérios da Saúde e da Educação desenvolvido por profissionais das áreas da educação e da saúde, a fim de auxiliar no desenvolvimento integral dos estudantes da rede pública através de atividades promotoras de saúde, prevenção e assistência (BRASIL, 2007). O PSE, segundo registros analisados por Assis (2015) tem desenvolvido como proposta, o uso de metodologias ativas, por meio de estratégias como rodas de conversas voltadas à reflexão para promoção da saúde e prevenção de agravos. Através de perguntas que norteiam as dinâmicas, o mediador conduz desde a reflexão sobre o papel da escola, o seu objetivo e o que crianças e adolescentes podem fazer em relação à saúde da comunidade em que vivem e da escola. Rosa et al., (2017), têm identificado também como estratégias de educação em saúde, a capacitação de professores por meio de profissionais enfermeiros, para abordar temas relacionados à saúde em sala de aula, como: promoção do autocuidado, prevenção de comportamentos de riscos, participação de projetos de educação em saúde, serviços de orientação sexual, prevenção do uso de drogas, educação alimentar. Ações como, consultas de enfermagem, avaliação de deficiências auditivas, visuais, cognitivas, distúrbios de fala, controle de doenças crônicas, bem como o encaminhamento aos serviços de saúde e assistência apropriado em casos emergentes, têm sido realizadas por enfermeiros. Alvarenga et al., (2012) destacam que, além da avaliação das condições de saúde dos escolares que possibilitam identificar os principais problemas encontrados nas crianças e traçar a métodos de ensino, as condutas e orientações educativas devem ser desempenhadas não só com as crianças, mas também com seus pais, com o propósito de promover saúde e evitar doenças e agravos.

Conclusão: Pode-se concluir que o enfermeiro em parceria com profissionais da educação podem desenvolver diferentes ações de educação em saúde no ambiente escolar. Suas ações vão desde a capacitação de professores e prevenção de doenças e agravos em estudantes na abordagem de diferentes temas. Quanto aos métodos de ensino, as metodologias ativas por meio da participação ativa dos alunos, têm sido sugeridas por estudiosos. A extensão da educação em saúde à família dos alunos também tem sido apresentada como estratégia de promoção à saúde, podendo assim gerar impactos positivos na vida dos escolares e seus familiares.

\section{Referências}

ALVARENGA, Willyane de Andrade et al. Ações de educação em saúde realizadas por enfermeiros na escola: percepção de pais. Rev. Mineira de enfermagem. v.16, n.4, 2012. Disponível em: Acesso em: 20 Ago. 2020.

ASSIS, Sheila Soares; JORGE, Tania Cremonini de Araujo. Ações intersetoriais para o controle das doenças negligenciadas e promoção da saúde: uma análise do Programa Saúde na Escola (PSE) e suas contribuições para o Ensino de Ciências. In: Anais 
do X Encontro Nacional de Pesquisa em Educação em Ciências. Águas de Lindóia: Educação em Saúde e Educação em Ciências. 2015.

BRASIL. Lei no 6.286, de 5 de dezembro de 2007. Institui o Programa Saúde na Escola - PSE e dá outras providências. Diário oficial da República Federativa do Brasil, Brasília, DF.

BRASIL, Ministério da Saúde, Caderno de Educação Popular em Saúde, 2007. Brasília, DF.

BRASIL, Ministério da Educação, Programa de Extensão Universitária (ProExt), 2003.

CAVALCANTI, Patrícia Barreto; LUCENA, Carla Mousinho Ferreira. O uso da promoção da saúde e a intersetorialidade: Tentativas históricas de integrar as políticas de saúde e educação. Rev. eletrônica Polêm!ca, v.16, n.1, p. 24-41, 2016. Disponível em: https://cutt.ly/HfjSvAJ. Acesso em: 22 Ago. 2020.

FONSECA, Ana Eliza de Carvalho. et al. A educação em saúde como estratégia de prevenção de agravos e doenças no ambiente escolar. Interfaces - Revista de Extensão da UFMG, v. 7, n. 1, p. 1-591, 2019. Disponível em: Acesso em: 07 Ago. 2020.

GUBERT, Fabiane do Amaral. et al. Tecnologias educativas no contexto escolar: estratégia de educação em saúde em escola pública de Fortaleza-CE. Rev. eletrônica de enfermagem UFG, v. 11, n. 1, p. 165-72, 2009. Disponível em: https://cutt.ly/NfjSQz4. Acesso em: 07 Ago. 2020.

ROSA, Élida Ferreira Torga. et al. Considerações sobre a enfermagem na saúde escolar e suas práticas educativas. HOLOS, v.5, p. 360-69, nov. 2017. Disponível em: . Acesso em: 17 ago. 2020.

Coordenadoria de Pesquisa e Extensão - COPEX

Departamento de Editoraçāo e Divulgaçāo Científica - DEDIC 


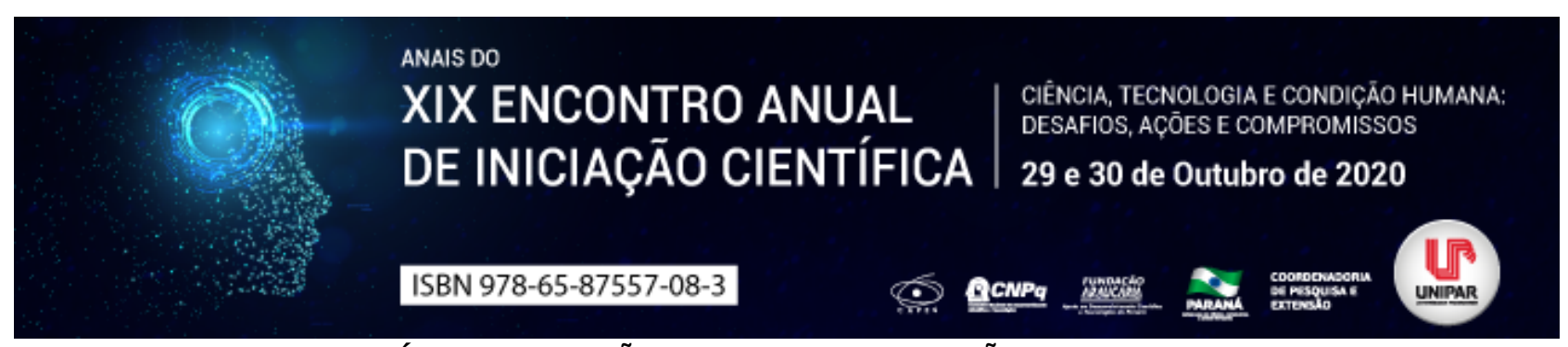

HANSENÍASE EM REGIÃO OROFACIAL - REVISÃO DE LITERATURA

\begin{abstract}
${ }^{1}$ JEMIMA BATISTA DOS SANTOS, ${ }^{2}$ TAIS YUKARI YAMAMOTO, ${ }^{3}$ NATÁLIA CABRAL DE ALEXANDRINO, ${ }^{4}$ GABRIELA ZANUTO DE LIMA, ${ }^{5}$ GABRIEL MACIEL DA SILVA, ${ }^{6}$ DANIELA DE CASSIA FAGLIONI B CERANTO
\end{abstract}

${ }^{1}$ Acadêmica do Curso de Odontologia da UNIPAR
${ }^{1}$ Acadêmica do Curso de Odontologia da UNIPAR
${ }^{2}$ Acadêmica do Curso de Odontologia da UNIPAR
${ }^{3}$ Acadêmica do Curso de Odontologia da UNIPAR
${ }^{4}$ Acadêmico do Curso de Cirurgia Periodontal e Introdução A Implantodontia - Turma VII da UNIPAR
${ }^{5}$ Docente da UNIPAR

Introdução: A hanseníase é uma doença bacteriana crônica, de alta infectividade e baixa patogenicidade, na qual o agente etiológico é o Mycobacterium leprae, também chamado de bacilo de Hansen. Um parasita intracelular obrigatório que se acumula principalmente na pele, nos nervos periféricos e pares cranianos, levando à diversas lesões cutâneas, à perda da condução neural e, consequentemente, à severas alterações anatômicas e funcionais nas extremidades do corpo, membros e região orofacial (NEVES, 1997). De acordo com a Associação Brasileira de Dermatologia, a hanseníase só pode ser transmitida por meio de convivência muito próxima e prolongada com o doente da forma transmissora, chamada multibacilar, que não se encontra em tratamento, por contato com gotículas de saliva ou secreções do nariz, tocar a pele do paciente não transmite a hanseníase.

Objetivo: O objetivo deste trabalho é fazer uma revisão da literatura sobre a hanseníase com manifestações na região orofacial visto que esse assunto não é muito discutido em nosso meio, bem como descrever e comentar sobre a importância de identificar essa patologia em seu estado inicial.

Desenvolvimento: A hanseníase é uma doença crônica infecciosa granulomatosa causada por um bacilo álcool-ácido resistente, Mycobacterium leprae, de evolução lenta que apresenta um tropismo peculiar para pele, nervos periféricos e mucosas, em especial ao trato respiratório, podendo afetar outros órgãos como o fígado, os testículos, os olhos e a cavidade bucal (VILHENA et al., 2019). De acordo com Sousa et al (2018), a hanseníase é uma doença de evolução prolongada com grande potencial incapacitante e é considerada um importante problema de saúde pública. A via inicial de contágio é respiratória ou gastrointestinal (KUMAR et al., 2006). As manifestações clínicas da hanseníase dependem mais da resposta imunocelular do hospedeiro ao Mycobacterium leprae e da capacidade de multiplicação bacilar. São precedidas por período de incubação longo, entre 2 e 10 anos (RODRIGUES, LOCKWOOD, 2011). Nery e seus colaboradores (2013), referem que, devido à destruição das terminações nervosas livres, a sensibilidade altera-se nas lesões, primeiramente a térmica, seguida da dolorosa e tátil. Para um exame mais detalhado os nervos devem ser palpados, pesquisando-se dor, espessamento e aderência aos planos adjacentes. Sendo que os mais frequentemente comprometidos são: radial, ulnar, mediano, fibular comum, tibial posterior, grande auricular, facial e trigêmeo. O exame histopatológico é realizado pelas colorações de hematoxilina-eosina e Faraco-Fite, que evidencia bacilos álcool-ácido-resistentes. No grupo indeterminado, observa-se infiltrado inflamatório inespecífico, com predomínio de linfócitos, perianexial e perineural, bacilos ausentes ou raros (LASTÓRIA, ABREU, 2012). As reações hansênicas resultam de alterações agudas no balanço imunológico entre hospedeiro e Mycobacterium leprae. Eles afetam, principalmente, pele e nervos, sendo causa de morbidade e incapacidade de ações. Geralmente ocorrem no curso da doença e durante ou após tratamento, podendo ser classificadas em dois tipos: tipo 1 e tipo 2 (DA COSTA NERY et al., 2006). Reação tipo 1 ocorre em dimorfos. Relaciona-se à resposta imunocelular, para melhora (reação reversa) ou piora (reação de degradação). As lesões tornam-se hiperestésicas, eritêmato-edematosas, descamam e, às vezes, ulceram. Geralmente, há edema das extremidades e neurite, com mínimas manifestações sistêmicas nos indivíduos próximos ao pólo tuberculóide, mas importantes nos próximos ao pólo virchowiano (RODRIGUES, LOCKWOOD, 2011). Reação tipo 2 (eritema nodoso hansênico) relaciona-se à imunidade humoral a antígenos bacilares, com deposição de imunocomplexos nos tecidos. Aparece subitamente, especialmente durante 0 tratamento, nos virchowianos e dimorfo-virchowianos. Surgem nódulos inflamatórios subcutâneos simétricos, em qualquer região, às vezes com necrose por obliteração vascular (eritema nodoso necrótico), e sintomas gerais, como febre, mal-estar, mialgias, edema e artralgias, podendo ocorrer comprometimento hepatorrenal (CUEVAS et al., 2007).

Conclusão: Conclui-se que o reconhecimento precoce da Hanseníase e o tratamento oportuno são elementos chaves para cessar a transmissão, prevenindo incapacidades. Nesse contexto, o cirurgião dentista atua em ações de promoção e prevenção de saúde bucal tendo como competência prestar assistência odontológica realizando a avaliação diagnóstica, tratamento, reabilitação e prevenção para o rápido diagnóstico desta patologia. 


\section{Referências}

CUEVAS, Jesús. et al. Erythema nodosum leprosum: reactional leprosy. In: Seminars in cutaneous medicine and surgery. 2007. p. 126-130.

DA COSTA NERY, José Augusto. et al. Contribution to diagnosis and management of reactional states: a practical approach Contribuição ao diagnóstico e manejo dos estados reacionais. Uma abordagem prática. An Bras Dermatol, v. 81, n. 4, p. 367-75, 2006.

KUMAR, Sudhir. et al. Cranial nerve involvement in patients with leprous neuropathy. Neurology India, v. 54, n. 3, p. $283,2006$. NERY, José Augusto da Costa et al. Compreendendo o estado reacional tipo 1 para diagnóstico e tratamento precoce: uma forma de evitar incapacidades na hanseníase. Anais brasileiros de dermatologia, v. 88, n. 5, pág. 787-792, 2013.

NEVES, RG Talharis. Dermatologia Tropical: Hanseníase. Editora Tropical, Manaus, 1997.

RODRIGUES, Laura C.; LOCKWOOD, Diana NJ. Leprosy now: epidemiology, progress, challenges, and research gaps. The Lancet infectious diseases, v. 11, n. 6, p. 464-470, 2011.

SOUSA, Ihales Michel Carvalho Brandão; CARVALHO, Vânia Elizabeth Castelo Branco; FERRAZ, Pablo Rodrigo Rocha. Reabilitação fonoaudiológica da disfagia orofaríngea após acidente vascular encefálico: revisão de literatura. Journal of Specialist, v. 1, n. 1, 2018.

VILHENA, Amujacy Tavares. et al. Atenção odontológica à pacientes portadores de hanseníase: uma revisão integrativa. Revista Eletrônica Acervo Saúde, n. 18, p. e137-e137, 2019. 


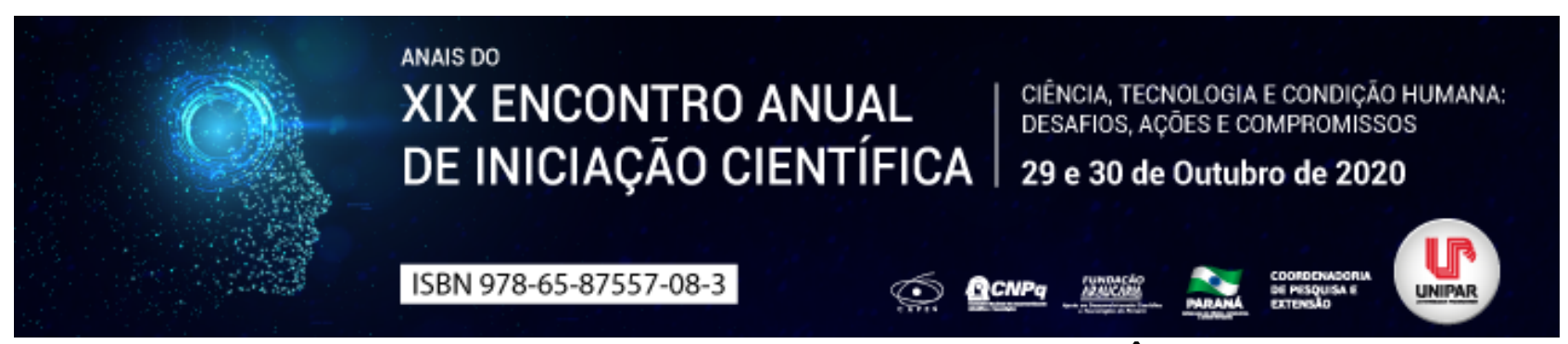

REABILITAR COM FACETAS EM RESINA OU EM CERÂMICA?

\begin{abstract}
${ }^{1}$ GEOVANE CAPANA FIDELI, ${ }^{2}$ MARCELO WELINGTHON DE OLIVEIRA GRACIA, ${ }^{3}$ ANA KAROLYNA DAMASO TAVARES, ${ }^{4}$ BRUNA CAMILA WEBER, ${ }^{5}$ WAGNER BASEGGIO
\end{abstract}

\author{
${ }^{1}$ Acadêmico do PIC/UNIPAR \\ ${ }^{1}$ Acadêmico do Curso de Odontologia da UNIPAR \\ ${ }^{2}$ Acadêmica do Curso de Odontologia da UNIPAR \\ ${ }^{3}$ Acadêmica do Curso de Odontologia da UNIPAR \\ ${ }^{4}$ Professor titular do curso de odontologia da UNIPAR
}

Introdução: Atualmente, há um aumento na quantidade de tratamentos envolvendo facetas, isso se dá por conta da sua estética favorável e da evolução dos materiais utilizados, o que permite mimetizar a face vestibular dos elementos dentários com eficiência. Esse tratamento pode ser realizado utilizando resinas compostas ou cerâmicas, permitindo uma disponibilidade muito grande de matérias, sendo assim necessário conhecer esses materiais e saber eleger qual é mais indicada para cada paciente, afim de proporcionar mais coerência na reabilitação.

Objetivo: Identificar a melhor indicação para o uso de facetas em resina e em cerâmica.

Desenvolvimento: A faceta é o recobrimento da face vestibular do esmalte dental por um material restaurador, fortemente unido ao elemento dentário por meio de sistemas adesivos (CARDOSO et al, 2011). Algumas situações clínicas são consideradas indicações para facetas: hipoplasia de esmalte; manchas e ranhuras de esmalte; alterações cromáticas causadas pela fluorose; substituição de restaurações de resina composta superficiais esteticamente insatisfatórias; fraturas coronárias; anomalias de forma e volume; dentes com diastemas; dentes desalinhados; reparo de coroa metalocerâmica; perda de estrutura dos dentes devido a doença ou trauma (RADZ, 2011). As facetas em resina composta podem ser confeccionadas em uma única sessão clínica, de forma direta pelo cirurgião dentista, permitindo menor custo, diminuição de etapas de laboratório, em algumas técnicas, podem dispensar provisório e moldagem, como também apresentam maior conservação da estrutura dental comparado a restaurações em cerâmica. Além disso, possuem menor potencial de fratura e não causam desgaste abrasivo da dentição oposta, permitindo inclusive reversibilidade do tratamento (KU; PARK; YANG, 2002; MAGNE; BELSER, 2003). Porém, as facetas de resina composta direta possuem algumas desvantagens, incluindo a instabilidade de cor, possível necessidade de várias substituições durante o tempo de vida do paciente, contração de polimerização, baixa resistência à abrasão e acúmulo de placa. Outra limitação é a incapacidade de alguns profissionais na manipulação do material (FELIPPE; BARATIERI, 2000; BAGIS, B.; AYDOĞAN; BAGIS, Y., 2008). Além disso, técnicas indiretas, mais utilizada para cerâmicas, permitem ao cirurgião-dentista superar algumas das limitações das restaurações diretas de resina composta, como o controle do ajuste marginal, contatos proximais, forma anatômica e a estratificação de cores. No entanto, a técnica indireta requer maior número de sessões clínicas, necessita ser confeccionada em laboratório, requer moldagem e provisório, além do maior risco de fraturas (BAGIS et al, 2008). As restaurações indiretas são claramente superiores em casos complexos, onde é difícil recriar forma e cor de maneira harmoniosa (MANGANI, 2007). Por outro lado, resinas compostas possuem maior módulo de elasticidade que cerâmicas, sendo mais elásticas e menos afetadas por microfraturas, assim seu uso é especialmente recomendado em pacientes com hábitos parafuncionais (MANGANI, 2007). As cerâmicas possuem excelentes propriedades, como a biocompatibilidade, estabilidade de cor, longevidade, aparência semelhante à dos dentes e previsibilidade de resultado (PAGANI; BOTTINO, 2003). Além dessas propriedades, a cerâmica minimiza a adesão ou a retenção de placa bacteriana ao longo do tempo, devido à conservação de sua lisura superficial (PAGANI et al, 2003). São compatíveis com o periodonto, possuem alta resistência, estabilidade de cor, coeficiente de expansão térmica semelhante ao esmalte e conservam uma proporção significativa de esmalte natural (TOUATI et al, 2000). O emprego de facetas de porcelana com o intuito de modificação de cor, forma, textura da superfície, comprimento e alinhamento de um ou vários dentes, redução de diastemas e outros problemas de ordem estética são frequente e com uma alta taxa de sucesso (MASSING et al, 2006). Outra indicação seria a alteração e correção de relações oclusais como mudança da guia e dimensão vertical (SOBRINHO et al, 2004). Apesar das várias indicações para facetas, existem casos em que não há necessidade de realizar esse procedimento, como em dentes que podem estabelecer sua estética com clareamento, dentes severamente mau posicionados, oclusão topo a topo, entre outros.

Conclusão: A resina composta é mais indicada para pacientes com hábitos parafuncionais, já a cerâmica permite um tratamento mais previsível e com uma estabilidade melhor a longo prazo. Entretanto, cabe também ao cirurgião dentista avaliar qual o material será eleito para confecção da faceta de acordo com suas habilidades clínicas e características do paciente, buscando identificar, através da comunicação, os anseios do paciente. 


\section{Referências}

BAGIS, B.; AYDOĞAN, E.; BAGIS, Y. H. Direct Restorative Treatment of Missing Maxillary Laterals with Composite Laminate Veneer: A Case Report. Open Dent J., v. 2, p. 93-95, 2008.

CARDOSO, P.C. et al. Restabelecimento estético funcional com laminados cerâmicos. ROBRAC, Goiânia v. 20, n. 52. p. 8893, 2011.

CONCEIÇÃO, E. N. et al. Laminados Cerâmicos. In: Dentistica: Saúde e Estetica.2 ed. Porto Alegre :Artmed, p. 478- 501, 2007.

FELIPPE, L. A.; BARATIERI, L.N. Direct resin composite veneers: masking the dark prepared enamel surface. Quintessence Int., Illinois, v.31, n.8, p.557-562, 2000.

$\mathrm{KU}, \mathrm{C}$. W.; PARK, S. W.; YANG, H. S. Comparison of the fracture strengths of metal-ceramic crowns and three ceromer crowns. J Prosthet Dent., v.88, p. 170-175, 2002.

MANGANI, F.; CERUTTI, A.; PUTIGNANO, A.; BOLLERO, R.; MADINI, L. Clinical approach to anterior adhesive restorations 57 using resin composite veneers. Eur J Esthet Dent., v. 2, n. 2, p. 188- 209, 2007.

MASSING, N.G.; BELLATO L.B.; MAGAGNIN, C.; SILVA, S.B.A.; BUSATO, A. L.S.; BARBOSA, A.N. Facetas Estéticas em Porcelana. Revista Ibero- americana de Odontologia Estética \& Dentística, v. 5, n.18, p.136-141, 2006.

PAGANI C., BOTTINO, M. C. Proporção áurea e a Odontologia estética. J Bras Dent Estet, Curitiba, v.2, n.5, p.80-85, jan./ mar, 2003.

RADZ, G. M. Minimumthickness anterior porcelainrestorations. Dent Clin North Am., v. 55, n. 5, p. 353-370, 2011.

SOBRINHO, L.C.; BORGES, G.A.; SINHORETI, M.A.C.; CONSANI, S. Materiais cerâmicos. In: MIYASHITA,E.; FONSECA,A.S. Odontologia Estética: o estado da arte. São Paulo: Artes Médicas, cap. 6, p. 708- 800, 2004.

TOUATI, B. et al. Sistemas Cerâmicos Atuais. In: Odontologia Estética e Restaurações Cerâmicas. 1. ed. São Paulo.Ed. Santos, p. 293-313, 2000. 


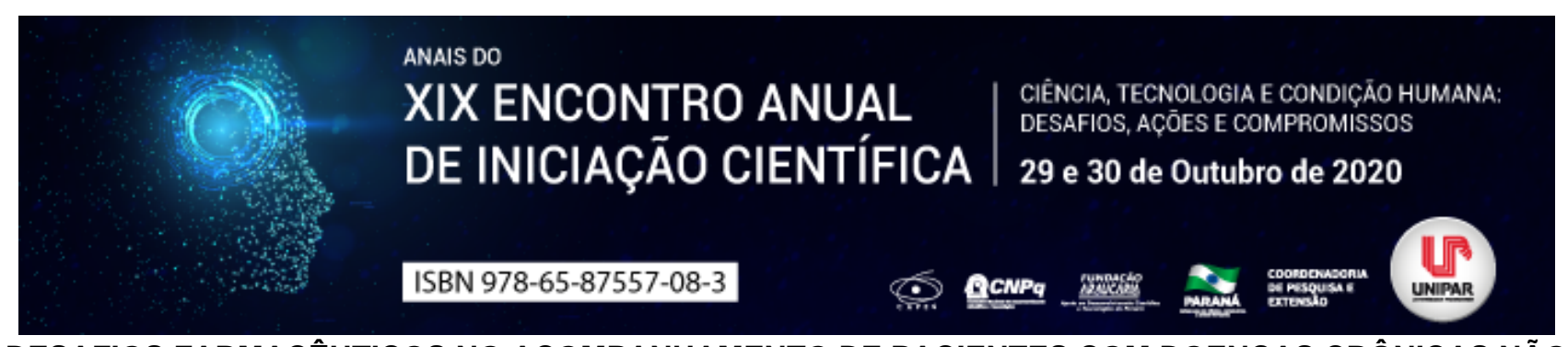

DESAFIOS FARMACÊUTICOS NO ACOMPANHAMENTO DE PACIENTES COM DOENÇAS CRÔNICAS NÃO TRANSMISSÍVEIS

\title{
${ }^{1}$ CARINE PAULA FLOREK PASTRO, ${ }^{2}$ SUELLEN LAIS VICENTINO VIEIRA
}

\author{
${ }^{1}$ Acadêmica do curso de Farmácia da UNIPAR \\ ${ }^{1}$ Docente da UNIPAR
}

Introdução: Muito se discute a respeito dos novos desafios farmacêuticos no acompanhamento de pacientes com doenças crônicas não transmissíveis (DCNT). Afinal, ao dar início a um tratamento, é na farmácia que o paciente estará todo mês buscando seus medicamentos. O papel do farmacêutico é prestar atendimento especializado embasado na assistência e atenção farmacêutica. As DCNT, como hipertensão arterial sistêmica, diabetes, entre outras, apresentam aumentos alarmantes na população, sendo este um público constante nas farmácias, para a aquisição de medicamentos de uso continuo. O Ministério da Saúde (2013) coloca-nos que é essencial que o farmacêutico conheça as DCNT, seus agravantes clínicos, métodos preventivos e tratamentos, para melhor atendimento e acompanhamento dos pacientes.

Objetivo: Levantar informações acerca dos desafios farmacêuticos no acompanhamento de pacientes com doenças crônicas não transmissíveis.

Desenvolvimento: As DCNT são uma série de patologias que acometem os seres humanos em diversas etapas da vida. Elas não possuem transmissão, ou seja, incidem apenas ao paciente e limitam a atividade do dia-a-dia (ALBUQUERQUE, 2019, p.03). As DCNT podem ter causa genética, hereditária ou oriunda de maus hábitos de saúde. São responsáveis por uma parcela significativa de recursos financeiros destinados a saúde nos municípios. Estão geralmente associadas a órgãos estruturais do corpo humano, como por exemplo, os rins, o coração e os vasos sanguíneos. Em geral começam assintomáticas, o que gera um diagnóstico tardio. Para o Ministério da Saúde, as DCNT possuem fatores de risco como idade, herança genética, tabagismo, alimentação, inatividade física e alcoolismo (MINISTÉRIO DA SAÚDE, 2008, p.09). Vale destacar que, estes são amplificados por aspectos condicionantes da sociedade, como problemas culturais, ambientais e econômicos. O Banco Mundial (2005) destaca que o reconhecimento destes agravantes é primordial para frearmos o aumento destas doenças, além, da conscientização da população como método preventivo. No ambiente farmacêutico, o acompanhamento é realizado com a finalidade de alinhar o tratamento com o auxílio constante de um profissional qualificado para suprir quaisquer necessidades do paciente. A farmácia clínica muda o papel do farmacêutico que, de um profissional que lida apenas com medicamentos, passa a ser um membro da equipe multiprofissional de saúde, interagindo com os demais e relacionando-se com as pessoas usuárias . (BRANDÃO, 2018, p.09). Contato que se estende até o acolhimento da família, gerando um gesto de humanização da prática farmacêutica. Vale destacar que trabalhar com a farmácia clínica, impõem ao profissional uma visão mais ampla, abordagem integral ao paciente e a sua família. São processos gerais que visam exclusivamente o bem-estar do doente, e desta forma a conduta do farmacêutico é voltada para o cuidado, e não ao produto que ele vende.

Conclusão: A quantidade de trabalhos sobre o tema é escassa, fato este instiga a pesquisa. Na maioria das vezes a prevenção contra as DCNT são deixadas de lado, o que causa sobrecarga ao sistema único de saúde e altos custos aos cofres públicos, além do agravamento do quadro clínico, em decorrência de um diagnóstico tardio. Conclui-se que, os desafios farmacêuticos são enormes, porém, este profissional precisa estar preparado para o enfrentamento destas enfermidades, além de ser capaz de ajudar os pacientes a terem uma vida mais saudável, seja ela através da cura ou controle da doença.

\section{Referências}

ALBUQUERQUE, Suely Miya Shiraishi Rollemberg. Protocolo das Linhas de Cuidado das Doenças Crônicas não Transmissíveis: Área técnica das Doenças Crônicas não Transmissíveis da Atenção Básica do Município de São Paulo. São Paulo. Instituto Tellus. 2019

BANCO MUNDIAL. Brasil: Enfrentando o Desafio das Doenças Não Transmissíveis no Brasil. Relatório No. 32576-BR. Organização Pan-Americana da Saúde. 2005. Disponível em https://www.paho.org/bra/. Acesso em 25 de fevereiro de 2020.

BRANDÃO, Aloísio. Os novos desafios dos farmacêuticos Revista Pharmacia Brasileira n 89. Conselho Federal de Farmácia. Brasília. 2018. Disponível em http://www.cff.org.br/sistemas/geral/ revista/pdf/141/pb89_julho2018.pdf. Acesso em 16 de janeiro de 2020

BRASIL. Ministério da Saúde. Diretrizes para o cuidado das pessoas com doenças crônicas nas redes de atenção à saúde e nas linhas de cuidado prioritárias. Brasília. 2013.

BRASIL. Ministério da Saúde. Diretrizes e recomendações. Cuidado Integral de Doenças Crônicas não Transmissíveis. Secretaria de Atenção à Saúde. Brasília. Ministério da Saúde, 2008. 
Coordenadoria de Pesquisa e Extensão - COPEX

Departamento de Editoraçāo e Divulgaçāo Científica - DEDIC 


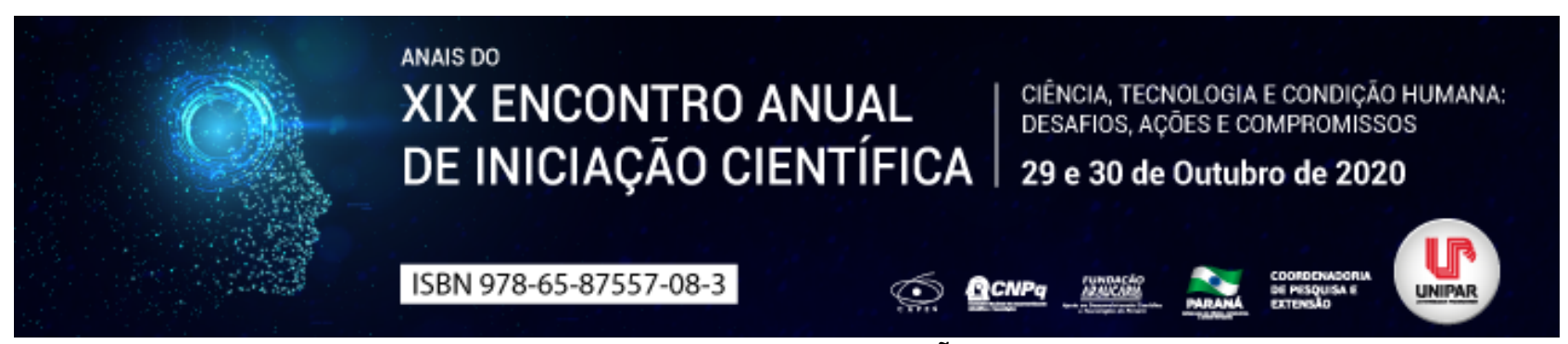

DISOSTOSE CLEIDOCRANIANA - REVISÃO DE LITERATURA

\begin{abstract}
${ }^{1}$ MILENA PIZZI, ${ }^{2}$ MARIANE EDUARDA RECALCATTI, ${ }^{3}$ EDUARDA OLIVEIRA SEVERGNINI, ${ }^{4}$ LETICIA DE FREITAS CUBA GUERRA, ${ }^{5}$ ANA CLAUDIA POLETTO
\end{abstract}

\author{
${ }^{1}$ Discente de Odontologia UNIPAR \\ ${ }^{1}$ Discente de Odontologia UNIPAR \\ ${ }^{2}$ Discente de Odontologia UNIPAR \\ ${ }^{3}$ Docente da UNIPAR \\ ${ }^{4}$ Docente da UNIPAR
}

Introdução: A disostose cleidocraniana (DCC) é uma desordem óssea congênita rara (LI et al., 2016). A prevalência é de um por milhão (MARUSSI et al, 2008). Não possui predileção por sexo ou raça (FARRONATO et al., 2008). É causada por mutações do gene de transmissão RUNX2, localizado no cromossomo 6p21 (ZHANG et al., 2015). A grande maioria dos pacientes apresentam uma tríade patognomônica de lesões: múltiplos dentes supranumerários, hipoplasia ou ausência das clavículas e suturas sagitais e fontanelas abertas. Quando uma das características da síndrome não está presente, é necessário o diagnóstico diferencial com outras condições, como a hidrocefalia, osteogênese imperfeita, a osteopetrose e a picnodisostose (SANTOS et al., 2016). As anormalidades bucodentais frequentemente encontradas além dos múltiplos supranumerários são: retenção na dentição decídua, impactação e atraso na erupção dos dentes permanentes, palato estreito, arqueado e fundo, dentes ectópicos e hipoplasia de esmalte e, em alguns casos a anadontia parcial pode estar presente (DANTAS et al., 2017). A DCC é uma condição rara e desafiante que requer uma atenção multidisciplinar, principalmente dos cirurgiões dentistas.

Objetivo: O objetivo deste trabalho foi realizar uma revisão de literatura sobre a Disostose Cleidocraniana, com ênfase nas manifestações bucais e papel do cirurgião-dentista no cuidado com os pacientes portadores dessa patologia.

Desenvolvimento: A DCC não costuma ser identificada em idades mais tenras pelo fato de que a hipoplasia do terço médio da face costuma ficar mais evidente somente durante a puberdade, além de que há uma relativa falta de complicações médicas em relação a outras displasias esqueléticas, sendo comum que a doença seja desconhecida pelo paciente até que algum profissional a identifique (MACHADO et al., 2010). Segundo Park, Vargervik e Oberol (2013), o cirurgião-dentista tem participação crucial no cuidado com os portadores de disostose cleidocraniana, pois o RUNX2 atua no desenvolvimento ósseo e dentário mediando interações entre células epiteliais e mesenquimais durante a morfogênese. É muito importante, a utilização dos exames radiográficos, tais como panorâmicas, radiografia cefalométrica e radiografias simples de tórax, abdômen, clavícula, mãos e pés (NIU et al., 2016). Na DCC, os dentes decíduos erupcionam normalmente, entretanto, apesar da presença dos germes dos dentes permanentes, eles se mantêm retidos. Além da retenção prolongada dos dentes decíduos, há uma grande quantidade de dentes supranumerários, principalmente na mandíbula. Os molares permanentes que não têm antecessores decíduos geralmente erupcionam em suas posições normais, embora essa erupção seja retardada (SERRATINE et al, 2007). O manejo odontológico para pacientes com DCC é desafiador, e envolve tratamentos ortodônticos e cirúrgicos abrangentes. As abordagens terapêuticas principais publicadas na literatura são os métodos Toronto-Melbourne, Belfast-Hamburg, e o de Jerusalém. No método TorontoMelbourne, a extração dos dentes decíduos e supranumerários é realizada dependendo do estágio em que as raízes dos permanentes estejam se desenvolvendo, portanto, para esta abordagem, o melhor período é a fase inicial. Na abordagem de Belfast-Hamburg, a cirurgia extensiva é realizada em um único episódio sob anestesia geral, e apresenta como o objetivo a extração dos dentes decíduos e supranumerários e a exposição dos dentes permanentes, onde serão colados brackets ortodônticos para tracionamento. Já na técnica de Jerusalém, o método é baseado em duas intervenções cirúrgicas, dependendo do desenvolvimento radicular dos dentes permanentes (ROCHA et al, 2014).

Conclusão: Tendo em vista que a Displasia Cleidocraniana (DCC) se trata de uma anomalia hereditária rara, quanto mais cedo o reconhecimento dessa patologia, mais eficaz será o tratamento e acompanhamento da equipe multidisciplinar no atendimento das necessidades do paciente e familiares, visando à adaptação funcional do indivíduo e uma melhor qualidade de vida.

\title{
Referências
}

BECKER, A., Lustmann J, Shteyer A. Cleidocranial dysplasia: Part 1- General principle of the orthodontic and surgical treatment modality. American jornal of orthodontics and dentofacial orthopedics. 1997; 111.

BELLEMO, Bianca Sobral; HUNGARO, Thiago Alves; KURIHARA, Ana Carolina Zanin Sacoman. Displasia cleidocraniana: um estudo de caso. Revista Eletrônica Acervo Saúde/Electronic Journal Collection Health ISSN 2178-2091. Publicado 4/2020.

DANTAS, Andrêssa GuimarãeS; LIMA, Raquel Amaral Souza; FERREIRA, Mariana de Matos; LELES, Gustavo Vieira; VIANNA, 
Alexandre Costa Ferreira. Displasia Cleidocraniana: Diagnóstico através de exames de imagens e clínico. 2017.

MACHADO, Cíntia de Vasconcellos; PASTOR, landira Maria Oliveira e ROCHA, Maria Celina Barreiros Siquara da.Características clínicas e radiográficas da displasia cleidocraniana: relato de caso. RFO UPF [online]. 2010, vol.15, n.3, pp. 302-306. ISSN 1413-4012.

MARCON, Tayane Vicenço. DISOSTOSE CLEIDOCRANIANA: RELATO DE CASO. 2017.

MARUSSI, Victor Hugo Rocha et al. Disostose Cleidocraniana: relado de caso. 2008;30(2) : 79-82. MENDOZA-Londono R, Lee B. Cleidocranial Dysplasia. 2006 Jan 3 [Updated 2013 Aug 29]. In: Pagon RA, Adam MP, Ardinger HH, et al., editors. Gene Reviews ${ }^{\circledR}$

PORCIUNCULA, Ricardo Ferreira de Lira; SOARES, Maria Lúcia Lima; ARAÚJO, Diego Lisboa; MOTA, Lucas Rocha; LIRA, Larine Ferreira. Disostose cleidocraniana: relato de dois casos familiares. 2013.

ROCHA, R., Zasso MB, Floriano G, Derech C, Ribeiro GU, Locks A. Orthodontic traction in a patient with cleidocranial dysplasia: 3 years of follow- up. American Journal Of Orthodontics and Dentofacial Orthopedics. 2014; 146: 1.

SANTOS, Rennan Luiz Oliveira dos et al. Abordagem cirúrgica em paciente portador da disostose cleidocraniana. Rev. cir. traumatol. buco-maxilo-fac. [online]. 2016, vol.16, n.3, pp. 40-43. ISSN 1808-5210. SERRATINE, Ana Claudina Prudêncio; ROCHA, Roberto. Displasia cleidocraniana - apresentação de um caso clínico. Arquivos Catarinenses de Medicina Vol. 36, no . 1, de 2007.

SERRATINE, Ana Claudina Prudêncio et al. Displasia Cleidocraniana apresentação de um caso clínico. Arquivos Catarinenses de Medicina. 2007, 36(1).

PETROPOULOS, Vicki C., DMD ,MS, Treatment of a Patient with Cleidocranial Dysplasia Using Osseointegrated Implants : A Patient Report. 2009, 14(2). 


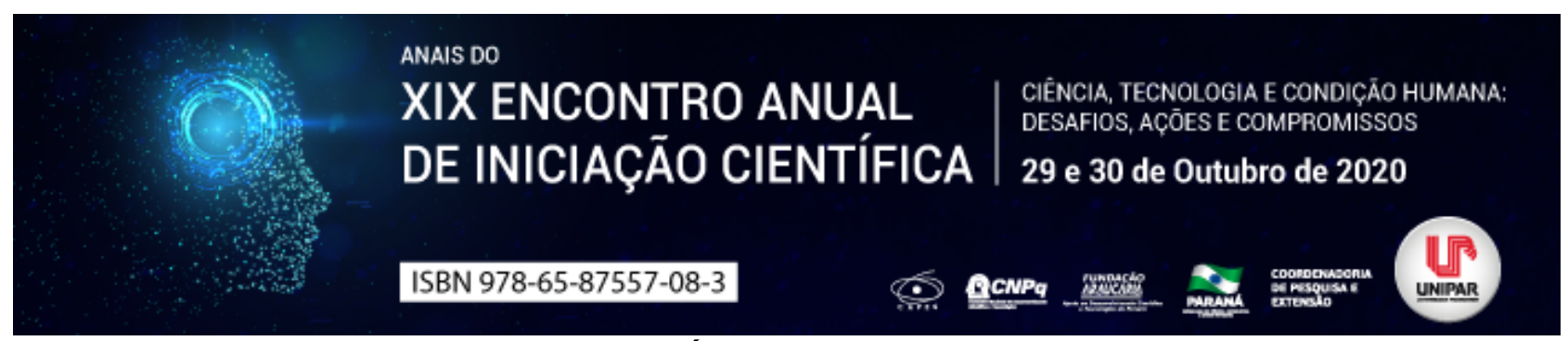

TRATAMENTO DE HEMANGIOMA EM LÍNGUA COM ESCLEROTERAPIA: RELATO DE CASO

\begin{abstract}
${ }^{1}$ GABRIELI JANKE RIGHEZ, ${ }^{2}$ BEATRIZ AYUMI SHIOTANI, ${ }^{3}$ CAROLINE DOMINGUES, ${ }^{4}$ GABRIEL MACIEL DA SILVA, ${ }^{5}$ RAFAELLA BRITO CARBELIM, ${ }^{6}$ CINTIA DE SOUZA ALFERES ARAUJO
\end{abstract}

\author{
${ }^{1}$ Acadêmico do PIC/UNIPAR \\ ${ }^{1}$ Acadêmica do Curso de Cirurgia Periodontal e Introducao A Implantodontia - Turma Viii da UNIPAR \\ ${ }^{2}$ Acadêmica do Curso de Odontologia da UNIPAR \\ ${ }^{3}$ Acadêmico do Curso de Cirurgia Periodontal e Introducao A Implantodontia - Turma Viii da UNIPAR \\ ${ }^{4}$ Acadêmica do Curso de Odontologia da UNIPAR \\ ${ }^{5}$ Docente da UNIPAR
}

Introdução: O hemangioma é considerado como uma neoplasia vascular benigna, caracterizado por uma fase de crescimento rápido, com proliferação de células endoteliais (MANDU, 2013). Clinicamente apresenta-se como aumento de volume de conteúdo sanguíneo ou por manchas de cor vermelha ou azulada, quando presente na região oral e perioral, pode causar prejuízo estético e funcional (QUEIROZ, 2016). A conduta terapêutica frente aos casos de hemangioma pode ser de diversas formas, como por meio de crioterapia, agentes esclerosantes, aplicação de corticoides, excisão cirúrgica, aplicação de laser ou de interferon alfa (MANDU, 2013).

Objetivo: Este trabalho tem como objetivo relatar um caso de hemangiona em língua tratado com esclerose terapêutica com oleato de monoetanolamina (Ethamolin $\left.{ }^{\circledR}\right)$.

Relato de caso: Paciente gênero feminino, 47 anos, faioderma, apresentou-se na Clínica Odontológica da Unipar com queixa principal de um crescimento na língua presente há dois anos. No exame intraoral constatou-se lesão resistente a palpação, indolor, de coloração arroxeada de implantação séssil, presente em borda anterior da língua. Realizou-se vitropressão e ocorreu esmaecimento da lesão sugerindo hipótese de diagnóstico de hemangioma. A via terapêutica escolhida foi a de injeções de agente esclerosante com anestésico local, proporção de 2:1 respectivamente, as aplicações foram realizadas no centro da lesão e ao redor da mesma, com penetração da agulha em poucos milimetros, foi associada a aplicação de laser para diminuição da resposta sintomatológica que poderia vir a ocorrer. Foi prescrito Dipirona sódica $500 \mathrm{mg}$ em caso de dor. Após 21 dias da primeira aplicação a paciente retornou apresentando melhora clínica significativa e negando resposta inflamatória grave na região. Foi realizada uma segunda aplicação seguindo os mesmos procedimentos descritos de também associando a aplicação de laser. Após 30 dias a paciente apresentou completa recidiva da lesão.

Discussão: A literatura apresenta casos de hemangioma comuns em cabeça e pescoço, sendo dificilmente encontrado em região oral, quando apresentados nesses casos se encontram em língua, lábio e mucosa bucal (QUEIROZ, 2016). É ocasionado por proliferação de vasos sanguíneos, pode surgir na infância ou na vida adulta com etiologia ligada à genética ou trauma local, pode apresentar tamanho variável gerando até assimetria facial (MANDU, 2013). A principal queixa dos pacientes portadores de hemangiomas é o distúrbio estético (MANDU, 2013). No caso relatado a lesão encontra-se em região de língua, com aumento de volume e coloração arroxeada. A escleroterapia é um dos métodos mais seguros e de baixo custo que promove ótimos resultados, como a recidiva parcial ou total da lesão (PALMA, 2016). O tratamento para hemangiomas é controverso e depende da experiência, disponibilidade de recursos, localização da lesão, tamanho da lesão, duração da lesão e idade do paciente (MANDU, 2013).

Conclusão: Até o presente momento a aplicação de Ethamolin® manifesta resultados positivos na diminuição da lesão, a escleroterapia é considerada uma técnica prática, segura, não cirúrgica que promove a involução da lesão, porém a literatura apresenta casos de recidiva em lesões benignas como o hemangioma.

\footnotetext{
Referências

MANDU, Angélica Lopes Cordeiro, et al. Escleroterapia de hemangioma: relato de caso. Rev. cir. traumatol. buco-maxilofac., Camaragibe, vol.13, n.1, jan./mar. 2013.

MIRANDA, Elise ALves de, et al. Uso de oleato de monoetanolamina para esclerose química em paciente com hemangioma intraoral: relato de caso. Rev. Dens., vol.19, n. 2, 2011.

PALMA, Fabiano Rodrigues et al. Escleroterapia de hemangioma oral. Relato de caso. SALUSVITA, Bauru, v. 35, n. 1, p. 85-93, 2016.

QUEIROZ, Salomão Israel Monteiro Lourenço et al. Tratamento do hemangioma oral com escleroterapia: relato de caso. J. vasc. bras., Porto Alegre, v. 13, n. 3, p. 249-253, set. 2014. Disponível em: . Acesso em: 05 ago. 2020.
} 
SILVA, Jonathan Ribeito da, et al. O uso de oleato de monoetanolamina no tratamento de hemangioma em lábio inferior: relato de caso. Odontol. Clín.-Cient. (Online), Recife, vol.15, n. 2, abr./jun, 2016.

Coordenadoria de Pesquisa e Extensão - COPEX

Departamento de Editoraçāo e Divulgaçāo Científica - DEDIC 


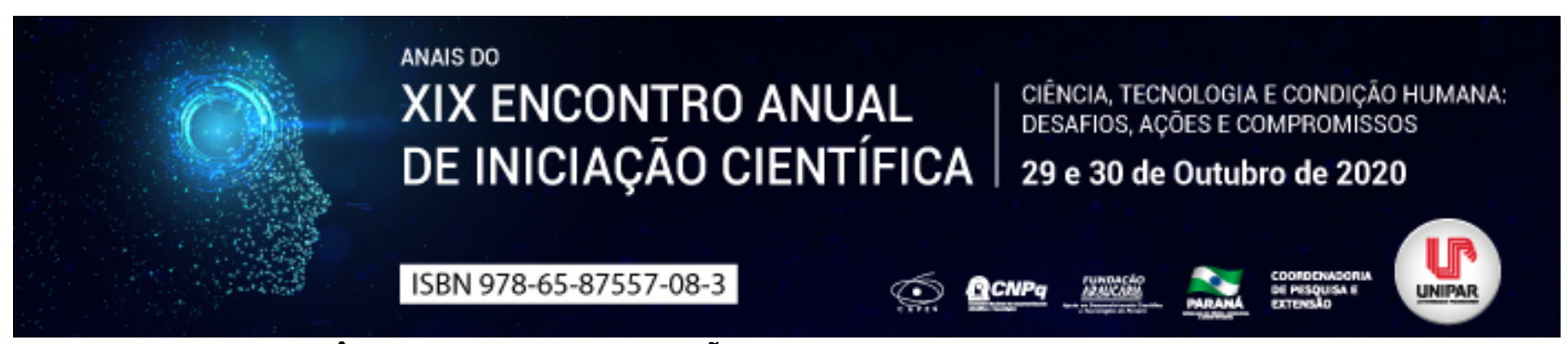

A IMPORTÂNCIA NA PADRONIZAÇÃO DE MEDIDAS CASEIRAS DOS ALIMENTOS

\title{
${ }^{1}$ KEILA MARIA MOREIRA, ${ }^{2}$ INDIOMARA BARATTO
}

\author{
${ }^{1}$ Discente do Curso de Nutrição - UNIPAR \\ ${ }^{1}$ Docente da UNIPAR
}

Introdução: Medidas caseiras são instrumentos utilizados para medir as quantidades dos alimentos, servem para ajudar na execução de formulações. Os alimentos são matérias primas primordiais para a elaboração de uma preparação que pode ser realizada por meio de diversas técnicas e métodos (ARAÚJO et al., 2016). Muitas vezes torna-se difícil orientar os pacientes ou funcionários utilizando-se apenas o peso (gramas, $\mathrm{kg}, \mathrm{mg}$ ), por isso torna-se importante determinar medidas caseiras dos alimentos, sendo assim, mais fácil o entendimento. As medidas caseiras são ferramentas de trabalho diário na profissão do nutricionista, são utilizadas para elaboração de fichas técnicas e planejamentos alimentares, proporcionando um trabalho mais bem elaborado e ágil, além de melhor entendimento por parte dos pacientes e/ou clientes (RETAMOSO et al., 2009). Podemos considerar medidas caseiras como instrumentos úteis para medir quantidades de alimentos que serão utilizadas para preparar e também servir refeições. Para realizar a medida adequada a melhor maneira é utilizar balança de precisão para obtenção dos pesos, prática está muito eficiente, exigindo um tempo maior para realização do trabalho (RETAMOSO et al., 2009). Entende-se que medidas caseiras são realizadas com a utilização de utensílios destinados a medir as quantidades de determinados alimentos que serão utilizados para preparar e servir refeições. No Brasil a RDC 359 de 23 de dezembro de 2003 define que medida caseira é determinada com o auxílio de utensílios comumente utilizados pelo consumidor para medir alimentos e estabelece medidas caseiras e suas relações com as porções correspondentes em gramas e mililitros, detalhando-se os utensílios geralmente utilizados, suas capacidades e dimensões (ARAÚJO et al., 2016).

Objetivo: Determinar medidas caseiras em grupos alimentares (cereais, pães, raízes e tubérculos, hortaliças, frutas, carnes e ovos, leguminosas, leite e derivados, óleos e gorduras, açúcares e doces e alguns produtos industrializados).

Métodos: O presente estudo foi desenvolvido no laboratório de dietética da UNIPAR, Unidade de Francisco Beltrão, sendo realizado estudo descritivo com coleta de dados. Os gêneros alimentícios foram previamente selecionados de acordo com a disponibilidade local e sazonalidade. Para determinar medida caseira, ou seja, porções dos grupos alimentares (tubérculos e açúcares), foram utilizados alimentos in natura. Para aferir o peso dos alimentos utilizou-se balança digital com precisão de $0,1 \mathrm{~g}$, da marca ÚTIL e utensílios do laboratório de dietética. Para determinar medidas caseiras, utilizou-se balança de precisão e padronizou-se os alimentos por tamanho e unidade. Após a tabulação dos dados foi elaborada uma tabela, na qual os alimentos estão classificados de acordo com os gêneros já citados.

Resultados: Analisou-se até este momento dois grupos alimentares (resultado parcial). Determinou-se medidas caseiras de algumas raízes e tubérculos, classificados de acordo com seu tamanho (pequeno, médio, grande). Ao analisar a batata doce verificou-se os seguintes dados: $145 \mathrm{~g}$ (unidade pequena), $170 \mathrm{~g}$ (unidade média) e $195 \mathrm{~g}$ (unidade grande), batata inglesa $85 \mathrm{~g}$ (unidade pequena), $130 \mathrm{~g}$ (unidade média) e $165 \mathrm{~g}$ (unidade grande) e batata salsa, $50 \mathrm{~g}$ (unidade pequena), $86 \mathrm{~g}$ (unidade média) e $108 \mathrm{~g}$ (unidade grande). Outro grupo analisado foi de açúcares, sendo que para este grupo utilizou-se medidas caseiras através de colheres (sopa, sobremesa, chá, café), para açúcar cristal verificou-se 20,1g para colher de sopa, 14,8g para colher de 10g para colher de sobremesa, $3 \mathrm{~g}$ para colher de chá e $1 \mathrm{~g}$ para colher de café, e para açúcar refinado 19,8g para colher de sopa, $16 \mathrm{~g}$ para colher de sobremesa, $5 \mathrm{~g}$ para colher de chá e $3 \mathrm{~g}$ para colher de café.

Discussão: Em estudo realizado com grupos alimentares, verificou-se resultados muito semelhantes aos encontrados em nossa pesquisa (RETAMOSO et al., 2009). As medidas caseiras são instrumentos utilizados para medir as quantidades dos alimentos, que servem para ajudar na execução de formulações e na orientação nutricional de pacientes, a forma mais simples para a medição de ingredientes é a utilização de xícaras, colheres, copos e pires. Esses instrumentos de uso culinário são amplamente usados em cozinhas residenciais como também em Unidades de Alimentação e Nutrição (UAN's) (PHILLIPI, 2014). No laboratório de alimentos, a experimentação consiste em controlar as possíveis variações, nas quais permitam conhecer suas diferenças e posteriormente adequá-las. Por isso, deve-se ter cuidado na pesagem da maior parte dos ingredientes, pois a importância para a preparação dos alimentos é que tenham dados concretos da relação peso/medida caseira, bem como a sua adequação quanto aos utensílios a serem utilizados (CUNHA et al., 2008). Verificou-se que existem poucas pesquisas realizadas especificamente com medidas caseiras, sendo necessário abranger mais este assunto para evitar carência de informações, pois estas são muito utilizadas por profissionais da área de Nutrição.

Conclusão: Entende-se que medidas caseiras são úteis para a elaboração de preparações e de orientações nutricionais, pois facilitam a compreensão das quantidades estabelecidas. Sugere-se que este trabalho mesmo após sua finalização tenha continuidade, tendo em vista o aprimoramento, cada vez maior, de uma tabela de pesos e medidas para ser utilizada no 
laboratório de dietética da UNIPAR. Durante a realização desta pesquisa ficou evidente o diferencial entre pesos nos grupos de tubérculos e açúcares, o que deixa claro a importância da realização de estudos neste formato.

\section{Referências}

ARAÚJO, Wilma; MONTEBELLO, Nancy di Pilla Montebello; BORGO, Luiz Antônio. Alquimia dos alimentos. 3. ed. Distrito Federal: Senac, 2016.

CUNHA, Alessandra Danielle da Silva; DANTAS, Ana Paula da Rocha; ALVEZ, Paula Viana; GONÇALVEZ, Maria da Conceição Rodrigues. Medidas Caseiras no preparo de alimentos: um instrumento facilitador. $X$ encontro de iniciação a docência. Paraíba: Universidade Federal da Paraíba, 2008.

PHILLIPI, Sônia Tucunduva. Nutrição e técnica dietética. 3. ed. Barueri: Manole, 2014.

REMATOSO, Vanessa; MESQUITA, Marizete de; OLIVEIRA, Viviani Ruffo de. Padronização de medidas caseiras como instrumento facilitador para discentes e docentes do curso de nutrição, Santa Maria, v. 10, n. 1, 2009. Disponível em: https://periodicos.ufn.edu.br/index.php/disciplinarumS/article/view/957/900. Acesso em: 25 ago. 2020.

Coordenadoria de Pesquisa e Extensão - COPEX

Departamento de Editoraçāo e Divulgaçāo Científica - DEDIC 


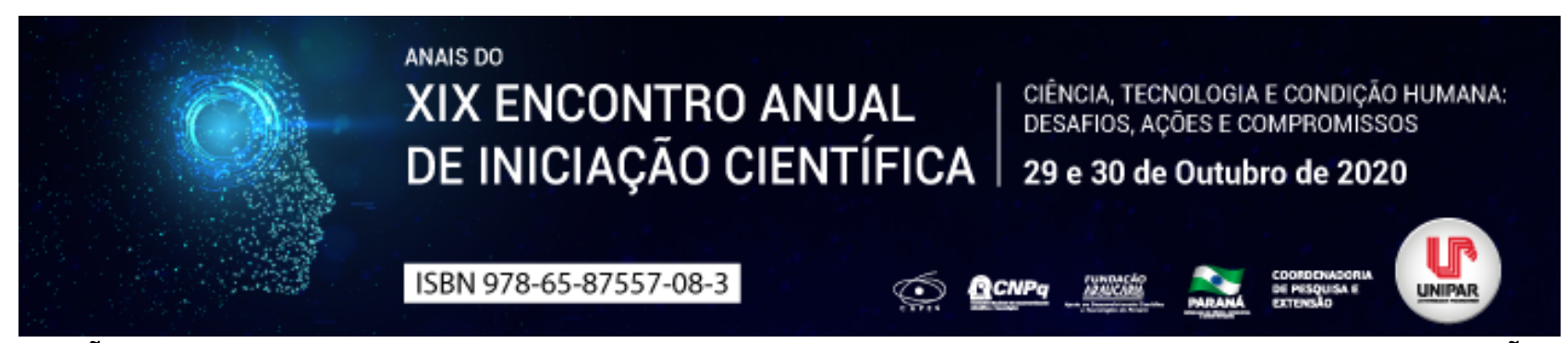

RELAÇÃO DE MEDICAMENTOS NA OSTEONECROSE DO COMPLEXO MAXILO-MANDIBULAR - REVISÃO DA LITERATURA

\author{
${ }^{1}$ GABRIEL MACIEL DA SILVA, ${ }^{2}$ ANA CAROLINE DOS SANTOS GRUNOW, ${ }^{3}$ CAROLINE DOMINGUES, ${ }^{4}$ BEATRIZ AYUMI \\ SHIOTANI, ${ }^{5}$ GABRIELA ZANUTO DE LIMA, ${ }^{6}$ DANIELA DE CASSIA FAGLIONI B CERANTO
}

\author{
${ }^{1}$ Acadêmico PIBIC/UNIPAR \\ ${ }^{1}$ Acadêmica PIBIC/UNIPAR \\ ${ }^{2}$ Acadêmica PIC/UNIPAR \\ ${ }^{3}$ Acadêmica PIC/UNIPAR \\ ${ }^{4}$ Acadêmica do Curso de Odontologia da UNIPAR \\ ${ }^{5}$ Docente da UNIPAR
}

Introdução: Os bifosfonatos são fármacos amplamente utilizados no tratamento de doenças relacionadas à perda de mineral ósseo devido ao aumento da reabsorção óssea. São utilizados particularmente na osteoporose pós-menopáusica, enquanto que por via intravenosa utilizam-se especialmente como coadjuvantes em alguns tipos de cancro (MENDES, 2017). A osteonecrose associada aos bifosfonatos é caracterizada por uma área de exposição óssea na maxila e mandíbula de difícil reparo, acometendo pacientes que mantenham uso contínuo ou nos quais foram administrados bisfosfonatos, sem terem sido submetidos à irradiação do complexo maxilo-mandibular.

Objetivo: Fazer uma revisão da literatura relacionando os bisfosfonatos e osteonecrose na cavidade bucal. Utilizamos da base de dados do PubMed, Scielo e Google Acadêmico.

Desenvolvimento: Os bifosfonatos (BFs), são uma classe de fármacos derivados do pirofosfato inorgânico comumente utilizados para o tratamento de doenças nas quais há uma reabsorção óssea. Os BFs têm a capacidade de atingir uma concentração favorável nos osteoclastos, justificando o seu uso no tratamento de osteoporose pós-menopáusica. (MENDES, 2017). Eles diminuem a reabsorção óssea porque induzem apoptose osteoclástica e com isso acabam inibindo os osteoclastos maduros (CHIANESI, 2018). O metabolismo ósseo possui duas atividades: deposição e reabsorção. Na deposição, os osteoblastos sintetizam uma matriz que sofre mineralização primária e um longo processo de mineralização secundária, que vem logo em seguida. Já a reabsorção óssea, é realizada pelos osteoclastos que consiste na dissolução mineral óssea e no catabolismo dos componentes da matriz óssea (OLIVEIRA et al., 2014). Devido à dinâmica do tecido ósseo, este é continuamente reabsorvido pela atividade osteoclástica e substituído pela atividade osteoblástica, ambas reguladas por fatores sistêmicos e locais (CASTRO et al., 2004). A osteonecrose associada aos bifosfonatos (OAB) é caracterizada por uma área de exposição óssea na maxila e/ou mandíbula de difícil reparo, acometendo pacientes que mantenham uso contínuo ou nos quais foram administrados bisfosfonatos (BFs), sem terem sido submetidos à irradiação do complexo maxilo-mandibular (JúNIOR et al., 2017). A diminuição do processo de reabsorção óssea pelos BFs pode ser explicada considerando-se que os metabólitos dos compostos não nitrogenados são tóxicos aos osteoclastos, levando-os à morte. Os compostos nitrogenados, por sua vez, bloqueiam a diferenciação dos osteoclastos e estimulam os osteoblastos a produzir fator de inibição dos osteoclastos, acarretando em diminuição na reabsorção óssea. Como o processo de metabolismo ósseo está baseado nos processos de reabsorção e deposição, a remodelação óssea fica comprometida. Contudo, o tecido ósseo continua a mineralizar, podendo tornar-se frágil, quebradiço e menos elástico (RUGGIERO, 2008). A boca é colonizada por um grande número de bactérias, e os ossos maxilares frequentemente estão envolvidos em processos sépticos de origem periodontal ou pulpar (YONEDA, 2010). Quando ocorre um acúmulo de BF capaz de diminuir o metabolismo ósseo, a reparação tecidual após um trauma, induzido ou fisiológico, não ocorre adequadamente, levando à exposição de uma área de osso necrótico ao meio bucal (RUGGIERO, 2008). A predileção pelos maxilares também não está totalmente elucidada, mas há indícios de que a microbiota oral, juntamente com o estresse mecânico a que são submetidos os ossos gnáticos durante a função, fazem com que micro danos fisiológicos ocorram na cavidade oral. Alguma alteração no processo de remodelação óssea acontece por intermédio dos bisfosfonatos, fazendo com que não ocorra reparação óssea satisfatória (BROZOSKI et al., 2012; FLIEFEL et al., 2015).

Conclusão: Conclui-se que os bifosfonatos e a osteonecrose possuem uma correlação muito próxima, pois, é explícito na literatura que esta composição traz muitos malefícios ao complexo maxilo-mandibular, em uma relação dose-tempo de administração, portanto, é importante que o cirurgião-dentista esteja atento e sempre questione sobre o uso atual ou pregresso de medicamentos desta classe antes de intervenções invasivas, para evitar o desenvolvimento de osteonecrose associada à medicamentos. 


\section{Referências}

BROZOSKI, Mariana Aparecida et al. Osteonecrose maxilar associada ao uso de bisfosfonatos. Revista Brasileira de Reumatologia, v. 52, n. 2, p. 265-270, 2012.

CASTRO, Lúcia Fioravanti et al. Bifosfonatos (BFs) como transportadores osteotrópicos no planejamento de fármacos dirigidos. Química Nova, v. 27, n. 3, p. 456-460, 2004.

JÚNIOR, Aécio Abner Campos Pinto. Osteonecrose dos maxilares associada ao uso de bisfosfonatos. CEP, v. 31, p. $400,2017$. FLIEFEL, R. et al. Treatment strategies and outcomes of bisphosphonate-related osteonecrosis of the jaw (BRONJ) with characterization of patients: a systematic review. International journal of oral and maxillofacial surgery, v. 44, n. 5, p. 568-585, 2015.

OLIVEIRA, M. A.; et al. Osteonecrose induzida por bisfosfonatos: relato de caso clínico e protocolo de atendimento. Arq. Med. Hosp. Fac. Cienc. Med. Santa Casa São Paulo, v. 59, n. 1, p. 43-48, 2014.

RUGGIERO, Salvatore L.; WOO, Sook-Bin. Biophosphonate-related osteonecrosis of the jaws. Dental Clinics of North America, v. 52, n. 1, p. 111-128, 2008.

YONEDA, Toshiyuki et al. Osteonecrose da mandíbula relacionada ao bisfosfonato: documento de posição do comitê da forçatarefa aliada da sociedade japonesa para pesquisa óssea e mineral, sociedade japonesa de osteoporose, sociedade japonesa de periodontologia, sociedade japonesa para radiologia oral e maxilofacial e sociedade japonesa de cirurgiões bucomaxilofaciais. Journal of bone and mineral metabolism, v. 28, n. 4, pág. 365-383, 2010.

Coordenadoria de Pesquisa e Extensão - COPEX

Departamento de Editoraçāo e Divulgaçāo Científica - DEDIC 


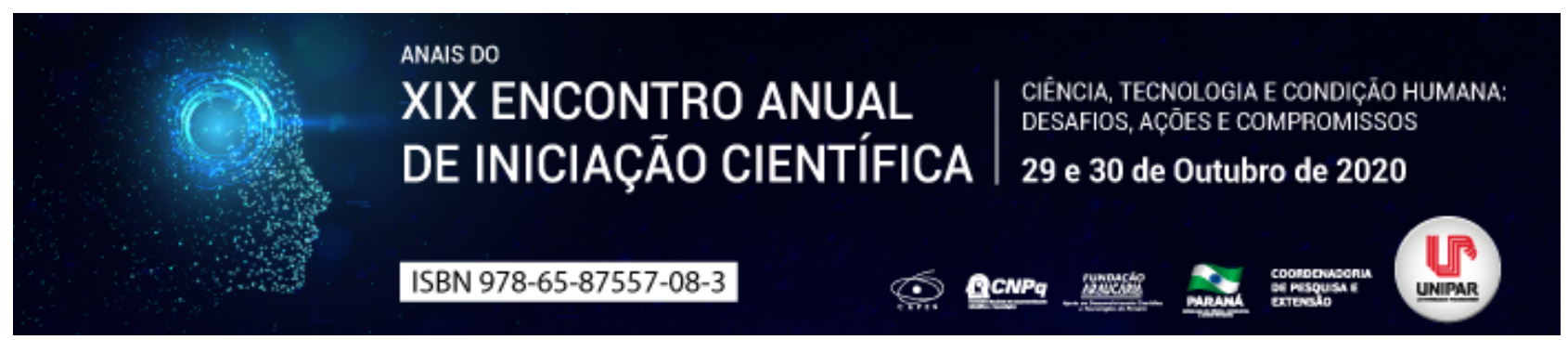

ATIVIDADE ANTIMICROBIANA DO EXTRATO DE FOLHAS DE Protium heptaphyllum, FRENTE A Escherichia coli E Staphylococcus aureus

\author{
${ }^{1}$ HELOISA MACHINESKI, ${ }^{2}$ BRUNA APARECIDA SOARES FAVARO, ${ }^{3}$ AMANDA CRISTINA DA ROCHA OLIVEIRA, \\ ${ }^{4}$ JAQUELINE HOSCHEID
}

${ }^{1}$ Acadêmica do Curso de Farmácia da UNIPAR
${ }^{1}$ Acadêmica do Curso de Farmácia da UNIPAR
${ }^{2}$ Acadêmica do Curso de Farmácia da UNIPAR
${ }^{3}$ Docente da UNIPAR

Introdução: Doenças infecciosas são a segunda maior causa de mortalidade do mundo, e a consequência também das altas taxas de resistência microbiana principalmente em hospitais, essas entre outras razões justificam a necessidade da busca por novos antibióticos que atuem por mecanismos de ações diferentes dos que já existem, pois ocorre um decréscimo constante de novos agentes antimicrobianos aprovados pelo FDA. No Brasil há uma ampla biodiversidade, arsenal para a descoberta de novos compostos microbicidas (GUIMARÃES; MOMESSO; PUPO, 2010), Protium heptaphyllum conhecido popularmente como Breu branco, é empregado no tratamento de feridas, como anti-inflamatório e cicatrizante, analgésico, expectorante, repelente de insetos, incensos em situações religiosas (MARQUESI et al., 2010), gastroprotetor, hepatoprotetor, ansiolítico, antidepressivo e antineoplásico. Além de ser utilizado na medicina popular, é usado também na indústria de verniz em calafetagem de embarcações (BANDEIRA et al., 2002).

Objetivo: O objetivo deste trabalho foi avaliar os efeitos antimicrobiano e a concentração inibitória mínima do extrato etanólico das folhas de $P$. heptaphyllum frente à Escherichia coli e Staphylococcus aureus.

Material e Métodos: O trabalho foi executado nos laboratórios de Microbiologia da Universidade Paranaense UNIPAR, campus Toledo, no mês de agosto de 2020. Os extratos foram obtidos, preparados e cedidos pela Universidade Estadual do Oeste do Paraná Unioeste para realização das análises. Foram preparados pelo emprego dos métodos extrativos de Soxhlet e ultrassom utilizando o etanol como solvente extrator. Em ambos os métodos a proporção droga:solvente foi de 1:10 (p/v). Os extratos foram evaporados até resíduo em evaporador rotativo e foram armazenados sob refrigeração em vidro âmbar. A atividade antimicrobiana e a Concentração Inibitória Mínima (CIM) frente à Staphylococcus aureus e Escherichia coli, foi determinada utilizado microdiluição seriada em placas de 96 poços, em triplicata, seguindo a metodologia da ANVISA (2003). Aos 96 poços foram adicionados $90 \mu \mathrm{L}$ de caldo infusão cérebro coração (BHI), em seguida à segunda coluna foram adicionados 90 $\mu \mathrm{L}$ dos extratos na concentração de $1000 \mathrm{mg} / \mathrm{mL}$. Após homogeneizar três vezes, $90 \mu \mathrm{L}$ foram transferidos para a terceira coluna, e assim sucessivamente até chegar à décima primeira coluna. Posteriormente foi adicionado aos orifícios da microplaca $10 \mu \mathrm{L}$ das suspensões bacterianas em água estéril, na escala 0,5 de McFarland. Para o controle negativo foi utilizado a décima segunda coluna contendo apenas caldo e $10 \mu \mathrm{L}$ do veículo de solubilização dos extratos, já para o controle positivo foi utilizado a primeira coluna contendo caldo e bactéria. As microplacas foram incubadas em estuda bacteriológica a $37^{\circ} \mathrm{C}$ por 24 horas. Ao final da incubação, o aparecimento de turvação indicou a multiplicação bacteriana, enquanto que aqueles poços que permaneceram translúcidos indicaram a ausência de multiplicação.

Resultados: Não foi observada atividade antimicrobiana dos extratos etanólicos preparados com folhas de $P$. heptaphyllum frente à Escherichia coli e Staphylococcus aureus na concentração avaliadas.

Discussão: Apesar de não ter sido observada atividade antibacteriana frente aos microrganismos testados nas concentrações e metodologias avaliadas, trabalhos anteriores comprovam a presença de compostos triterpênicos e as atividades gastroprotetora e anti-inflamatória para a resina natural coletada do tronco (OLIVEIRA et al., 2004) bem como para extratos obtidos a partir das folhas de $P$. heptaphyllum (SIANI et al., 1999). Assim, este estudo encoraja a pesquisa de novas atividades farmacológicas envolvendo extratos de $P$. heptaphyllum.

Conclusão: $O$ extrato etanólico de folhas de $P$. heptaphyllum não apresenta atividade antimicrobiana frente à Staphylococcus aureus e Escherichia coli em concentrações inferiores à $500 \mathrm{mg} / \mathrm{mL}$.

\title{
Referências
}

ANVISA. Metodologia dos Testes de Sensibilidade a Agentes Antimicrobianos por Diluição para Bactéria de Crescimento Aeróbico: Norma Aprovada - Sexta Edição. ANVISA. v. 23, n. 2, p. m7- a6, 2003.

BANDEIRA, Paulo Nogueira; PESSOA, Otília Deusdênia Loiola; TREVISAN, Maria Teresa Salles; LEMOS, Telma Leda Gomes. METABÓLITOS SECUNDÁRIOS DE Protium heptaphyllum MARCH. Revista Química Nova, São Paulo, v. 25, n. 6, p. 1078- 
1080, nov./dez. 2002.

GUIMARÃES, Denise Oliveira; MOMESSO, Luciano Silva; PUPO, Mônica Tallarico. Antibióticos: importância terapêutica e perspectivas para a descoberta e desenvolvimento de novos agentes. Revista Química Nova, São Paulo, v. 33, n. 3, p. 667-679, jun. 2010.

OLIVEIRA, Francisco; VIEIRA Júnior Geraldo; CHAVES, Mariana; ALMEIRA, Fernanda; FLORÊNCIO, Mariana; LIMA, Júnior Roberto; SILVA, Regilane; SANTOS Flávia; RAO, Vietla. Gastroprotective and anti-inflammatory effects of resin from Protium heptaphyllum in mice and rats. Pharmacological Research, Rio de Janeiro, v. 49, n. 2, p. 105-111, fev. 2004.

SIANI, Antonio; RAMOS, Mônica Freiman; MENEZES, Octávio Lima; RIBEIRO, Ricardo; FERNANDEZ, Ferreira; SOARES, Renata Oliveira; ROSAS, Elaine Cruz; SUSUNAGA, Glória; GUIMARÃES, Anderson; ZOGHBI, Maria Graças; HERIQUES, Maria. Evaluation of anti-inflammatory-related activity of essential oils from the leaves and resin of species of Protium. Journal of Ethnopharmacology, Rio de Janeiro, v. 66, n. 1, p. 57-68, jul. 1999.

TENOVER, Fred. Mechanisms of Antimicrobial Resistance in Bacteria. The American Journal of Medicine, Atlanta, v. 119, n. 6, p. 3-10, jun. 2006.

Coordenadoria de Pesquisa e Extensão - COPEX

Departamento de Editoraçāo e Divulgaçāo Científica - DEDIC 


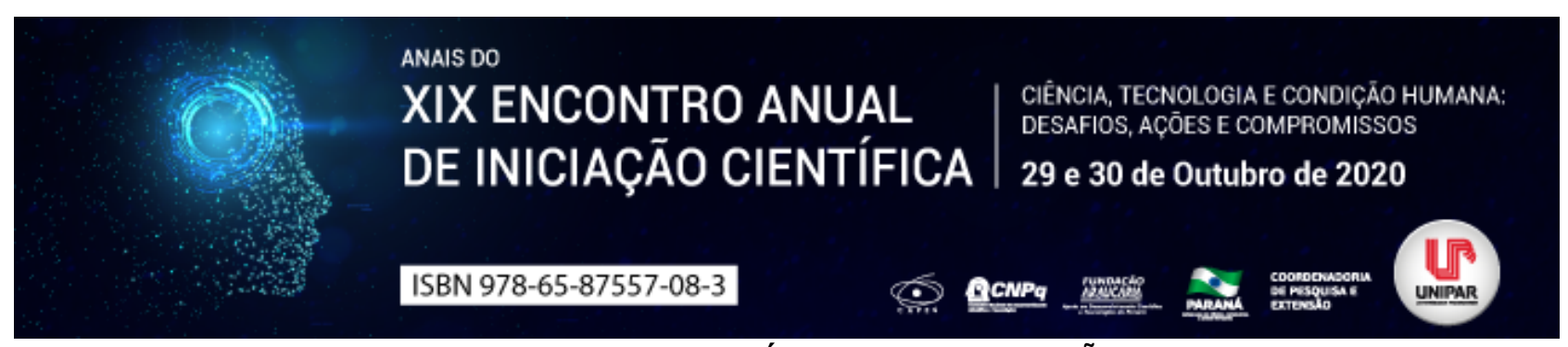

DENGUE NO PARANÁ-ESTUDO DE REVISÃO

\begin{abstract}
${ }^{1}$ NATALIA FERNANDES DA SILVA, ${ }^{2}$ NATHALIA PONTES DE MELO VASCONCELOS, ${ }^{3}$ LETICIA VITORIA CAMARGO DE MACEDO, ${ }^{4}$ LUIZA LOPES DA ROSA, ${ }^{5}$ JULY NAMIE KIKUTI SOUZA, ${ }^{6}$ ELENIZA DE VICTOR ADAMOWSKI CHIQUETTI
\end{abstract}

\begin{abstract}
${ }^{1}$ Acadêmica do Curso de Medicina da UNIPAR
${ }^{1}$ Acadêmica do Curso de Medicina da UNIPAR

${ }^{2}$ Acadêmica do Curso de Medicina da UNIPAR

${ }^{3}$ Acadêmica do Curso de Medicina da UNIPAR

${ }^{4}$ Acadêmico do Curso de Medicina da UNIPAR

${ }^{5}$ Docente da UNIPAR
\end{abstract}

Introdução: A dengue é uma doença viral aguda, de rápida disseminação e notificação compulsória. É capaz de causar desde infecções assintomáticas a óbitos (GOTO et al., 2016). A ocorrência de dengue tem sido registrada de forma ininterrupta no Brasil desde o ano de 1986, quando uma grande epidemia atingiu a região metropolitana do Rio de Janeiro (JONNY et al., 2010). Conforme Singhi; kissoon; Bassan (2007) e Frantchez et al. (2016) a dengue é uma doença causada pelo vírus do gênero Flavivirus pertencente à família Flaviviridae, sendo descritas quatro espécies, denominadas de sorotipos: den-1, den-2, den-3 e den-4. Atualmente, não há medicação ou vacina específica disponível para combater o vírus do dengue. Seu controle depende basicamente do controle do vetor.

Objetivo: Fazer um levantamento bibliográfico sobre a Dengue no Estado do Paraná nos períodos de 1995 a 2007 e entre 2011/2012 e 2012/2013.

Desenvolvimento: Em conformidade com Jonny et al. (2010) foram confirmados 51.924 casos da dengue no Estado do Paraná entre 1995 e 2007, desses, 49.043 casos foram autóctones (94,4\%) e 2.884 casos importados (5,6\%). O número total de casos notificados no Brasil, no mesmo período de tempo foi 4.182.249, sendo que a porcentagem que corresponde ao Paraná foi $1,2 \%$. Dos 399 municípios paranaenses, 279 (70\%) notificaram um ou mais casos da dengue no período estudado. Na análise de dispersão no período 1995-2007, se observa um padrão de comportamento em cada onda epidêmica, como exemplo: período 1995-1997, após o evento epidêmico, a distribuição dos casos se retraiu significativamente. Logo começa o mesmo padrão, iniciando com um declínio no número de casos até chegar numa ampla distribuição dos casos que evolui novamente em epidemia, como em 1998-2003, este comportamento se repete no período 2004-2007 (JONNY et al., 2010) . Desta forma, a distribuição dos casos está relacionada à inserção de pelo menos um sorotipo do vírus na sociedade, embora a taxa de mortalidade seja baixa, isso acaba ocasionando um desgaste na saúde das pessoas com a doença. Considerando os municípios com maior taxa de incidência, pode-se observar que estes não são os considerados como principais pólos turísticos ou econômicos do Estado. As cidades de Londrina, Maringá e Foz do Iguaçu contribuíram no total com 40\% de casos no período 1995-2007 e com 36,38\% dos casos no período entre 2006 e 2007. Este quadro permite indicar a tendência de três localidades de grande ocorrência da dengue no Paraná que se integram com o anel rodoviário do Estado (JONNY et al., 2010). Para, além disso, de acordo com Goto et al. (2016), das 132.979 notificações de dengue registradas no período de 2011/2012 e 2012/2013, observou-se que no último período houve um aumento de quase $400 \%$ em relação ao anterior (23.400 e 109.579 casos, respectivamente). No primeiro período a Macro-Norte apresentou $54 \%$ dos casos notificados (12.549), número que, no segundo período e na Macro-Noroeste, alcançou 61\% (66.441 casos). A Macro-Leste foi a que apresentou a menor proporção de casos notificados nos dois períodos - respectivamente, 2,5\% (574 de 23.400) e 1,2\% (1.323 de 109.579). Conforme Teixeira et al. (1999), por não se dispor de vacina, a prevenção primária do dengue é efetivada quando a vigilância entomológica ou o combate ao vetor antecede a introdução do vírus. Ou seja, o combate ao Aedes aegypti está centrada em duas estratégias: controle ou erradicação, nas quais se fazem presentes três componentes básicos: saneamento do meio ambiente; ações de educação, comunicação e informação (IEC); e combate direto ao vetor (químico, físico e biológico).

Conclusão: Em suma, tem-se que a Dengue se apresenta como uma problemática ainda a ser enfrentada no Estado do Paraná, devido ao aumento considerável do número de casos, de acordo com os dados expostos neste estudo de revisão, observando que no ano de 1995 a 2007 houve um aumento significante do número de dengue e já entre os anos de 2011/2012 e 2012/2013 no último período, ocorreu um aumento de $400 \%$ em relação ao anterior.

\title{
Referências
}

FRANTCHEZ, D.; et al. Dengue en adultos: diagnóstico, tratamiento y abordaje de situaciones especiales. Rev. Méd. Urug. v.32, 
n.1, Montevideo, abr 2016.

GOTO, D.; et al. Avaliação da oportunidade de notificação da dengue no Estado do Paraná. Acta paul. enferm. v.29, n.3, São Paulo mai./June 2016.

JONNY, L.; et al. Dengue no Estado do Paraná, Brasil: distribuição temporal e espacial no período 1995-2007. Rev. Univ. Ind. Santander. Salud. v.42, n.2, Bucaramanga May/Aug. 2010.

SINGHI, S.; KISSOON, N.; BANSAL, A. Dengue e dengue hemorrágico: aspectos do manejo na unidade de terapia intensiva. J. Pediatr. v.83 n.2, suppl.0, Porto Alegre May 2007.

TEIXEIRA, M.; BARRETO, M.; GUERRA, Z. Epidemiologia e medidas de prevenção do Dengue. Inf. Epidemiol. Sus v.8 n.4, Brasília dez. 1999.

Coordenadoria de Pesquisa e Extensão - COPEX

Departamento de Editoraçāo e Divulgaçāo Científica - DEDIC 


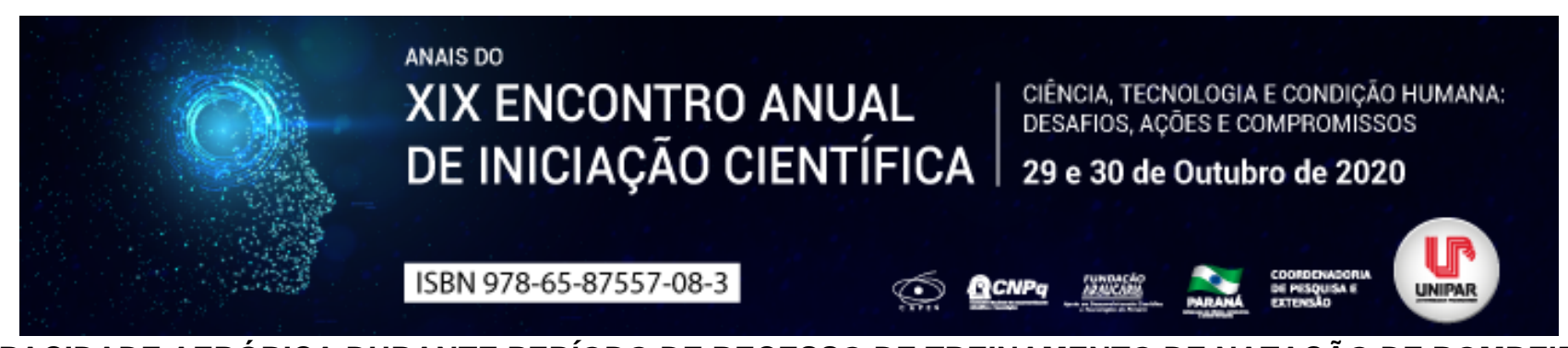

CAPACIDADE AERÓBICA DURANTE PERÍODO DE RECESSO DE TREINAMENTO DE NATAÇÃO DE BOMBEIROS PARTICIPANTES DA OPERAÇÃO VERÃO - TEMPORADA 2019/2020

\title{
${ }^{1}$ ISABELLA BALBINOT, ${ }^{2}$ DURCELINA SCHIAVONI BORTOLOTI
}

\author{
${ }^{1}$ Discente do Curso de Educação Física Bacharelado / UNIPAR Francisco Beltrão \\ ${ }^{1}$ Docente do Curso de Educação Física Bacharelado / UNIPAR Francisco Beltrão
}

Introdução: O profissional bombeiro tem como objetivo na execução de sua função, colocar sua vida em risco para salvar a vida de terceiros. A Operação Verão é uma mobilização que acontece durante a temporada de veraneio para guarnecer os balneários do Paraná, principalmente o litoral. Por se tratar de uma modalidade esportiva que absorve o impacto dos movimentos com a água, a natação oferece pouco risco de lesão. A modalidade trabalha toda a musculatura do corpo, além de fortalecer o sistema cardíaco e respiratório, melhorando o condicionamento físico (RODRIGUES, 2014). A natação é a atividade laboral majoritária dos bombeiros guarda-vidas, assim exige condicionamento físico específico das capacidades físicas usada para realizar os salvamentos e resgates aquáticos. Segundo a United Station Lifesaving Association, as chances de uma pessoa se afogar em praias protegidas por guarda-vidas são de 1 em 18 milhões.

Objetivo: Verificar a capacidade aeróbica de Bombeiros de um município do Sudoeste do Paraná participantes da Operação Verão na temporada 2019/2020 durante período de recesso condicional de treinamento de natação.

Métodos: A amostra foi composta por 9 bombeiros do sexo masculino que estiveram na Operação Verão 2019/2020, com idades entre 28 e 45 anos. Os bombeiros estavam em recesso condicional de treinamento de natação devido a pandemia da Covid-19. Para as coletas dos dados, seguiu-se todos os protocolos de segurança estabelecidos pela Unipar. Foram realizadas avaliações físicas antropométricas de peso, estatura, circunferência de cintura (CC) e cálculo do índice de Massa Corporal (IMC) e questionário sobre dados de treinamento atual. A frequência cardíaca de repouso, durante e após o teste, foram medidas por meio de um frequencímetro cardíaco. Para avaliar a capacidade aeróbia na piscina, foi realizado o teste de 12 minutos de Cooper para natação (T12). Para cálculo do VO2máx, utilizou-se a equação prescrita por Reis et al. (2018) e para categorização dos valores adequados e inadequado empregou-se tabela normativa adaptada de Bonacella (1996) e do American Heart Association (AHA) (1972) apud Herdy e Caixeta (2016). Para o tratamento dos dados utilizou-se estatística descrita para caracterização da amostra e para verificar as prevalências de classificação por faixa de idade e dados antropométricos de acordo com as tabelas normativas.

Resultados: Valores médios de distância encontrados no T12 foram de 547,11 \pm 88,71 (metros) e de VO2máx foram de 47,13 \pm $9,46$ ( $\mathrm{ml} / \mathrm{kg} / \mathrm{min})$. Os indivíduos tiveram classificação diferente em relação as duas tabelas normativas utilizadas. Na específica, ficaram como 'ótimos'( $n=2)$, 'bons' $(n=3)$ e 'regulares' $(n=4)$. Já na tabela do AHA ficaram, como 'muito elevados'( $n=3)$, 'elevados' $(n=4)$ e 'intermediários'( $n=2)$. Ainda, o IMC de sete avaliados estava a cima do recomendado (WHO,1995), enquanto CC estava dentro dos limites estabelecidos pela literatura (WHO, 2008). Em relação ao treinamento não específico durante o recesso, seis dos nove participantes, mantiveram-se fisicamente ativos em programas de treinamento resistido e/ou corrida.

Discussão: De acordo com Reis et al. (2018), o desempenho inferior de nadadores mais velhos nem sempre está relacionado, exclusivamente com o fator idade, mas sim, com possivelmente, tempo e frequência de treinamento na água. Segundo Prestes et al. (2006) apud Rosa e Zanetti (2017), um maior percentual de gordura corporal, pode acometer maior flutuação na água, o que acarretará num menor gasto energético na mecânica de nado. Os resultados do presente estudo, mostraram que os seis bombeiros militares que se mantiveram fisicamente ativos durante a pandemia, tiveram melhor desempenho do que os três bombeiros que não fizeram nenhum tipo de exercício físico durante esse período. Os achados deste estudo corroboram ainda com os dados de Júnior et al. (2018) que encontrou valores médios de distância de 516,0 \pm 83,0 (metros) em bombeiros de Minas Gerais. Analisando todos os aspectos, e levando em consideração a profissão dos avaliados, que podem ser chamados a qualquer momento para alguma operação de resgate, podemos inferir que, os resultados apesar de apresentaram-se dentro do esperado para a idade, podem em parte serem superestimados em tabelas normativas generalistas.

Conclusão: Conclui-se que, mesmo os resultados serem superestimados, os bombeiros estão com aptidão cardiorrespiratória dentro do ideal, de acordo com as tabelas normativas. Também concluímos que, mesmo não sendo exercício físico específico, nesse caso a natação, bombeiros que tiveram algum tipo de treinamento durante o recesso, tiveram melhor desempenho no T12 na piscina e consequentemente, melhor VO2máx. Além disso, a continuidade do treinamento e a especificidade devem ser mantidas durante o ano todo, para melhoria e manutenção dos níveis de VO2máx, bem como melhores dados antropométricos principalmente relativos a distribuição de gordura abdominal.

\section{Referências}


RODRIGUES, F. J. Proposta da inclusão da natação no teste de aptidão física do CBMGO. 2014. 45f. Monografia - Curso de Formação de Oficiais. 2014.

USLA'S top ten beach and water safety tips. United States Lifesaving Association. Disponível em: https://www.usla.org/page/SAFETYTIPS. Acesso em: 10 de abr. de 2020.

ROSA, A. P.; ZANETTI, H. R. Perfil antropométrico e aptidão cardiorrespiratória de atletas adolescentes de natação da cidade de Araguari-MG. Revista Brasileira de Prescrição e Fisiologia do Exercício. São Paulo. v. 11, n. 65, p. 254-260, 2017.

REIS, D. F. et al. Capacidades aeróbia, anaeróbia e parâmetros biomecânicos de nadadores de academia. Revista Brasileira de Prescrição e Fisiologia do Exercício, v. 12, n. 74, p. 325-332. São Paulo, 2018.

JÚNIOR, A. C. M. O. et al. Padrões de aptidão física e qualidade de vida de bombeiros militares. Revista da Educação Física, v. 87, n. 1, p. 260-270, 2018.

HERDY, A. H.; CAIXETA, A. Brazilian Cardiorespiratory Fitness Classification Based on Maximum Oxygen Consumption. Arquivos Brasileiros de Cardiologia, v. 106, n. 5, p. 389 95, 2016.

World Health Organization (WHO). Waist circumference and waist-hip ratio. Geneva: World Health Organization; 2008.

World Health Organization (WHO). Physical status: the use and interpretation of anthropometry. Geneva: World Health Organization; 1995. (WHO - Technical Report Series, 854).

BONACELLA, P. N. O teste de 12 minutos em natação. Disponível em: https://www.youtube.com/watch? $v=T 3 Y U H M G K v Y w \& t=768 s$. Acesso em: $18 \mathrm{de} \mathrm{fev}$. de 2020. 


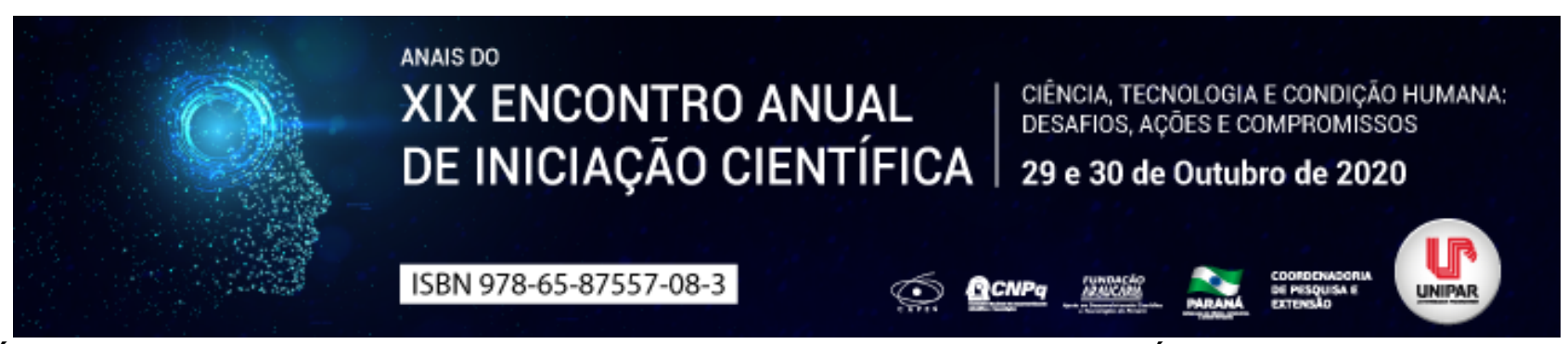

DIAGNÓSTICO E ACOMPANHAMENTO DE UM PACIENTE COM LEUCOPLASIA EM LÁBIO INFERIOR: RELATO DE CASO

\author{
${ }^{1}$ LETICIA SCHAVETOCK, ${ }^{2}$ JENIFFER URBANO DEGASPERI, ${ }^{3}$ NATIELLE KUNZLER BIRCK, ${ }^{4}$ REBECCA FAVERO LEMKE, \\ ${ }^{5}$ ANA CLAUDIA POLETTO, ${ }^{6}$ LETICIA DE FREITAS CUBA GUERRA
}

\author{
${ }^{1}$ Acadêmico do Curso de Odontologia da UNIPAR \\ ${ }^{1}$ Acadêmica do Curso de Odontologia da UNIPAR \\ ${ }^{2}$ Acadêmico do Curso de Odontologia da UNIPAR \\ ${ }^{3}$ Acadêmica do Curso de Odontologia da UNIPAR \\ ${ }^{4}$ Docente da UNIPAR \\ ${ }^{5}$ Docente da UNIPAR
}

Introdução: A leucoplasia é definida como mancha branca ou placa não removível por raspagem que pode ocorrer na mucosa bucal, faringe ou laringe (FARINELLI; VILARDI, 2015). Para ser classificada como leucoplasia oral (LO), a Organização mundial da saúde (OMS) sugere que a lesão não deve apresentar características clínicas ou patológicas de outra doença e apresentar distúrbio potencialmente maligno, sendo a lesão cancerizável mais frequente na cavidade bucal (NEVILLE, 2016). Com base no descrito, o objetivo é relatar o caso de um paciente com LO em lábio inferior.

Relato de caso: Paciente do sexo masculino, 47 anos, tabagista, procurou atendimento devido a uma sensibilidade dolorosa no dente 37 e por questões estéticas dos dentes anteriores. Segundo o paciente sua última visita ao dentista aconteceu há 20 anos, e sua queixa principal foi l"sentir gosto ruim na boca, mau hálito e dentes moles . No exame físico intraoral, além de alterações periodontais e dentárias, observou-se placa branca no lábio inferior medindo $7 \mathrm{~mm}$ no maior diâmetro. Diante do quadro clínico, a hipótese diagnóstica foi de LO, após 6 meses a lesão ainda não havia regredido, somente nesse momento a biopsia foi recomendada. Foram solicitados exames complementares (hemograma, plaquetas, glicemia TP, TTPA, VSG), programada uma biópsia incisional e o paciente foi orientado quanto a hidratação dos lábios e uso de protetor solar labial. O exame microscópico revelou fragmento de mucosa revestida por tecido epitelial pavimentoso estratificado ortoqueratinizado exibindo hiperqueratose, e focos de duplicação e polarização reversa da camada basal. Na lâmina própria observou-se discreto infiltrado inflamatório crônico de permeio às fibras colágenas. Com base nas características clínicas a lesão foi diagnosticada como hiperqueratose com discreta atipia epitelial. O paciente, foi orientado a cessar o tabagismo, manter rígidos cuidados de hidratação em proteção dos lábios e está em acompanhamento periódico preventivo. Diante de qualquer alteração no aspecto da lesão, nova biópsia deverá ser indicada.

Discussão: Estudos demonstram que a LO desenvolve-se em qualquer região, mas a mucosa jugal, o lábio inferior e a língua tem sido as áreas mais afetadas, a LO tem predileção por homens, com idade acima dos 40 anos. Pode ser relacionada ao tabagismo, etilismo, papilomavírus (HPV) e também a radiação. (RODRIGUES et al. 2000). O caso aqui relatado corrobora com os dados da literatura referentes a predileção dá LO por homens, tendo em vista que a lesão acomete um indivíduo do gênero masculino, fumante e pertencente a faixa etária na qual a lesão mencionada é mais comumente diagnosticada. Pode-se sugerir que qualquer lesão cuja história clínica e aspecto não permitam a elaboração do diagnóstico e que esteja presente por um período de dez dias sem nítida regressão (relatadas pelo paciente ou observadas pelo profissional) devem ser imediatamente submetidas à biópsia. (TOMMASI, et al. 2013). No caso relatado, o paciente teve a lesão descoberta e após 6 meses a lesão ainda não havia regredido, somente nesse momento a biópsia foi realizada. A técnica de biópsia incisional é a mais indicada, pois a partir do conhecimento da existência ou não e do grau de displasia da lesão é que o tratamento pode ser estabelecido. Por apresentar um grau leve de atipias celulares, a excisão completa da lesão não é necessária, porém, por ser considerada uma lesão com potencial de transformação maligna para carcinoma epidermóide, é importante o acompanhamento periódico (MARCUCCl; SILVA, 2005).

Conclusão: A LO é considerada uma das lesões orais potencialmente malignas mais frequente, por isso é de suma importância conhecer as características clínicas e os sintomas da LO, como também é necessário conhecer a sua patologênese para poder fazer a indicação adequada dos exames complementares, buscando um diagnóstico correto e um tratamento satisfatório.

\title{
Referências
}

FARINELLI, Lucas; VILARDI, Bruna Maria Rodrigues. Leucoplasia Oral: Qual a Melhor Conduta Clínica? Revista da Faculdade de Odontologia de Lins, Piracicaba. v. 25, n. 1, p. 85 86, 2015MARCUCCI, Gilberto; SILVA, Sergio Spinelli. Fundamentos de Odontologia, Estomatologia; Rio de Janeiro: Guanabara Koogan. 2005

NEVILLE, Brad. Patologia oral e maxilofacial. 3. ed. Rio de Janeiro: Elsevier, 2016 
RODRIGUES, Tânia Lemos Coelho; COSTA, Lino João; SAMPAIO, Maria Carmeli Correia, et al. Leucoplasias bucais: relação clínico-histopatológica, Pesquisa Odontológica Brasileira, São Paulo, out/dez, v 14, ed 4, p 357-361, 2000.

TOMMASI, Maria Helena. Diagnóstico em Patologia Bucal. 4 ed. Rio de Janeiro: Elsevier, 2013

World Health Organization; Collaborating Centre for Oral Precancerous lesions. Definition of leukoplakia and related lesions: an aid to studies on oral precancer. Oral Surg Oral Med Oral Pathol. 46:518-39. 1978.

Coordenadoria de Pesquisa e Extensão - COPEX

Departamento de Editoraçāo e Divulgaçāo Científica - DEDIC 


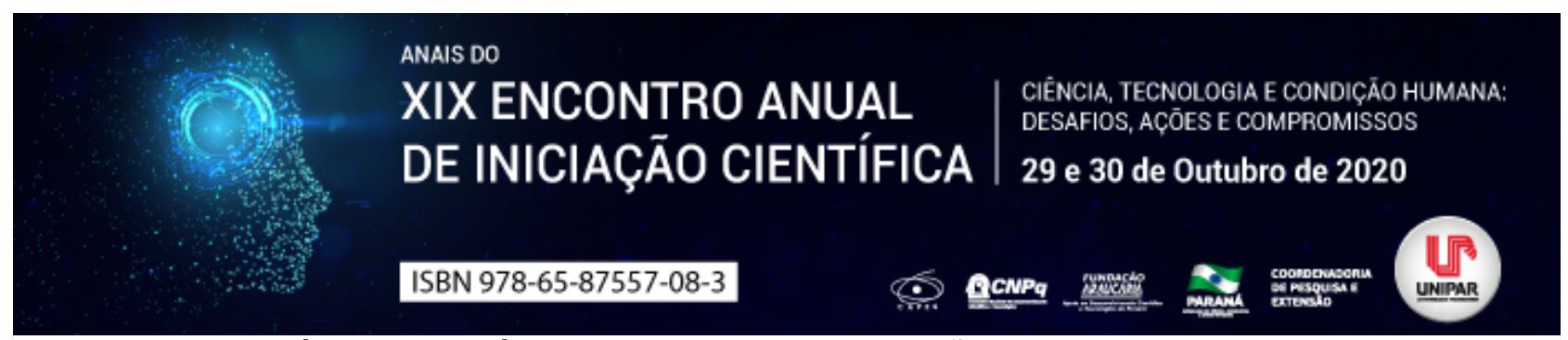

OS BENEFÍCIOS DA PRÓPOLIS SOBRE AS ULCERAÇÕES AFTOSAS RECORRENTES

\begin{abstract}
${ }^{1}$ SABRINA MARQUES BARROSO, ${ }^{2}$ CAROLINE DOMINGUES, ${ }^{3}$ MORGANA THAIS GREMASCHI, ${ }^{4}$ DANIELA DE CASSIA FAGLIONI B CERANTO
\end{abstract}

${ }^{1}$ Acadêmica do Curso de Odontologia da UNIPAR
${ }^{1}$ Acadêmica do Curso de Odontologia da UNIPAR
${ }^{2}$ Acadêmica do Curso de odontologia da UNIPAR
${ }^{3}$ Docente da UNIPAR

Introdução: As ulcerações aftosas recorrentes (UAR) que são comumente conhecidas pela maioria das pessoas como aftas, são muito prevalentes nos consultórios odontológicos, tornando de extrema importância que o cirurgiões-dentistas possuam conhecimento sobre o seu diagnóstico e tratamento (PENSIN et al.,2009). De acordo com Pereira (2006), a forma mais frequente de aparecimento de UARs são geralmente as aftas menores cujo tamanho pode chegar até $1 \mathrm{~cm}$ de diâmetro, podendo ter formatos variados, sendo também caracterizada por possuir uma pseudomembrana esbranquiçada no seu interior e circundada por um halo eritematoso, geralmente com intensidade de dor variada para cada indivíduo. Costa e Castro (2013) relatam que umas das formas de tratamento para diminuir os sintomas da dor das ulcerações aftosas recorrentes seria através do uso de produtos de origem natural, como a própolis que auxilia na melhora dos sintomas. De acordo com Oliveira, Siqueira e Murgo (1999), própolis é um termo genérico que indica uma substância resinosa natural que é produzida pelas abelhas, encontradas no interior das colmeias, sendo utilizadas como formas de tratamento diante de algumas lesões.

Objetivo: O objetivo deste trabalho é, através de uma revisão da literatura, relatar os benefícios que os produtos naturais a base de própolis apresentam no auxílio da recuperação e diminuição dos sintomas das ulcerações aftosas recorrentes, assim como melhora a qualidade de vida de seus portadores.

Desenvolvimento: A própolis começou a ter uma alta valorização após descobertos os benefícios e os seus efeitos vantajosos que ela causava principalmente quando usada topicamente em forma de pomada na cavidade oral (OLIVEIRA, SIQUEIRA e MURGO, 1999). Dentre as suas propriedades químicas possui capacidade anti-viral, anti-inflamatório, ação curativa, antibacteriana, cicatrizante, reparo tecidual, anestésico local (BENTO et al., 2019). Também apresenta característica de induzir a neoformação vascular, formação epitelial e fibroblástica, fazendo com que a aplicação tópica de uma pomada a base de própolis sobre as ulcerações aftosas recorrentes promova a formação de tecido conjuntivo e epitelização, auxiliando para o reparo tecidual (ALMEIDA et al., 2016). Na composição química da própolis um dos fatores mais importantes para a cicatrização de úlceras e feridas na cavidade oral é o seu aspecto antioxidante, ou seja quando ocorre o aparecimento de uma úlcera na região de mucosa jugal, são liberados radicais livres que impedem que ocorra a cicatrização do tecido, fazendo com que demore mais tempo a lesão na cavidade oral, ao usar uma pomada a base de própolis, os flavonóides contidos em sua composição removem esses radicais livres e permitem que o tecido se regenere e tenha um tempo reparo mais rápido (MENEZES, 2005).

Pensin et al., (2009) realizaram um estudo piloto e comprovaram que o uso da pomada a base de própolis a $5 \%$ em orabase em ulcerações aftosas recorrentes auxilia no processo de reparo tecidual, e torna a cicatrização mais rápida, além de que os sintomas de dor causadas pelas aftas diminuem, por causa do efeito anestésico da própolis, consequentemente por esse fator anestésico auxilia a melhora da qualidade de vida das pessoas, outro fator importante é a diminuição do tempo de cicatrização que normalmente é de 7 a 14 dias, mas com o uso da pomada de própolis caiu para 2 a 5 dias. Também observaram que o tempo entre as recorrências aumentou, o que é extremamente favorável.

Conclusão: Diante da revisão de literatura sob os benefícios da própolis sob as ulcerações aftosas recorrentes, pode se afirmar que a própolis possui um campo de aplicabilidade muito grande, por ser natural, atóxica e ainda ser de baixo custo, podendo alcançar um número maior de pessoas por ser mais acessível, assim como habilidades terapêuticas auxiliam de forma significativa nas cicatrizações e reparos teciduais dessas lesões, além de diminuir a dor e o desconforto e, consequentemente, melhorar a qualidade de vida dessas pessoas.

\title{
Referências
}

MENEZES, Hermes. Própolis: uma revisão dos recentes estudos de suas propriedades farmacológicas. Arq. Inst. Biol., v. 72, n. 3, p. 405-411, jul./set., 2005. Disponível em: http://www.biologico.sp.gov.br/uploads/docs/arq/V72_3/menezes.PDF. Acesso em: 22 de agosto de 2020.

PENSIN, Nícolas Renan, et al. Efeito de pomada de própolis em orabase para tratamento de ulcerações aftosas recorrentes um estudo piloto. Arq. ciências saúde UNIPAR, v. 13, n. 3, p. 199-204, set./dez. 2009. Disponível em: 
https://revistas.unipar.br/index.php/saude/article/view/3199/2237. Acesso em: 22 de agosto de 2020.

OLIVEIRA, A.C; SIQUEIRA, S; MURGO, D.O.A. Estudo da aplicação da própolis na odontologia (revisão de literatura). X Encontro Latino Americano de Iniciação Científica e VI Encontro Latino Americano de Pós-Graduação Universidade do Vale do Paraíba, p. 737-740. Disponível em: http://www.inicepg.univap.br/cd/INIC_2006/inic/inic/03/INIC0001241ok.pdf. Acesso em: 22 de agosto de 2020.

PEREIRA, Karuza Maria Alves et al. Ulceração aftosa recorrente: revisão dos conceitos atuais. Rev. odontol. UNESP, v. 35, n. 1 , p. 61-67, 2006. Disponível em: https://www.revodontolunesp.com.br/article/588017d67f8c9d0a098b492b/pdf/rou-35-1-61.pdf. Acesso em: 22 de agosto de 2020.

COSTA, Giliane B.F; CASTRO, Jurema, F.L. Etiologia e tratamento da estomatite aftosa recorrente- revisão de literatura. Rev. USP, v. 46, n. 1, 2013. Disponível em: http://www.revistas.usp.br/rmrp/article/view/62322/65127. Acesso em: 22 de agosto de 2020.

ALMEIDA, Débora Cristina, et al. Própolis na odontologia:Uma abordagem de suas diversas aplicabilidades clínicas. Rev. flum. odonto, n. 46, jul./dez. 2016. Disponível em: https://periodicos.uff.br/ijosd/article/view/30489/17722. Acesso em: 25 de agosto de 2020.

BENTO, Lidelci Figueredo et al. Comportamento cicatricial pós indução de diferentes formatos de feridas tratadas por segunda intenção com extrato de própolis. Orientadora: Rosa Maria Barilli Nogueira. 2019. Tese (pós graduação) Universidade do Oeste Paulista, Presidente Prudente - SP, 2019.

Coordenadoria de Pesquisa e Extensão - COPEX

Departamento de Editoraçāo e Divulgaçāo Científica - DEDIC 


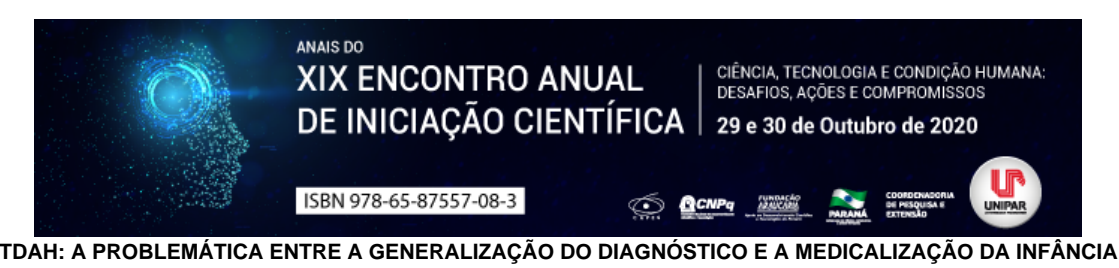

${ }^{1}$ LORENA DE FATIMA MORETTO, ${ }^{2}$ CAMILA MARIA ESCARDILLE YOSHITANI, ${ }^{3}$ LEANDRO MARTINS LIMA SOUZA, ${ }^{4}$ ISABELLA ARANTES TOBBIN, ${ }^{5}$ TAMILA SIMINSKI

${ }^{1}$ Acadêmico do Curso de Medicina da UNIPAR ${ }^{1}$ Acadêmica do Curso de Medicina da UNIPAR ${ }^{2}$ Acadêmico do Curso de Medicina da UNIPAR ${ }^{3}$ Acadêmica do Curso de Medicina da UNIPAR ${ }^{4}$ Docente da UNIPAR

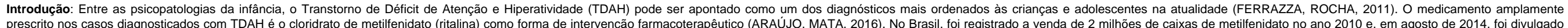

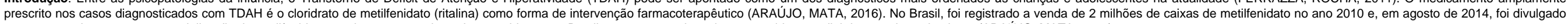
um aumento de $775 \%$ na comercialização de metifenidato em dez anos, sendo assim, considera-se o Brasil como o segundo maior consumidor mundial desse psicoestimulante (ARAÚJO, MATA, 2016).

Objetivo: Realizar uma revisão literária sobre a forma generalizada de diagnosticar o TDAH e a medicalização da infância.

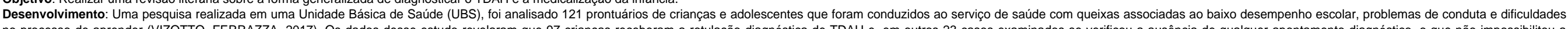

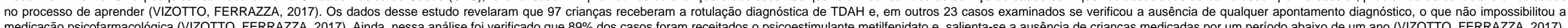

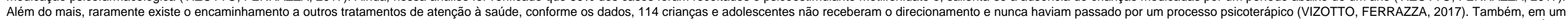

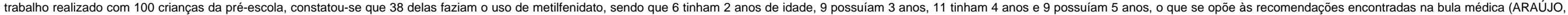

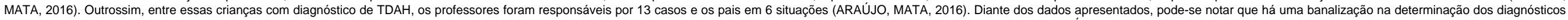

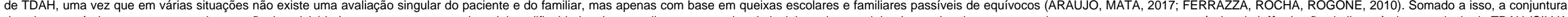

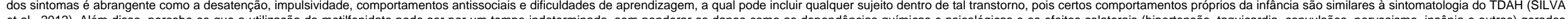

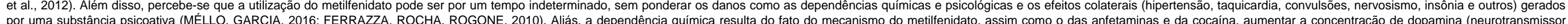

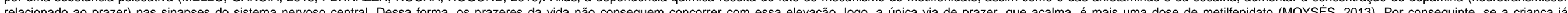

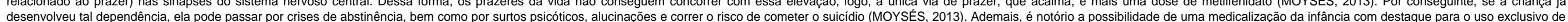

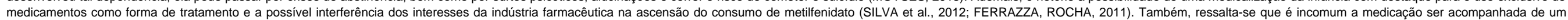

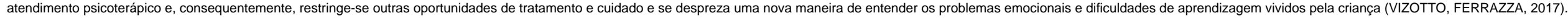

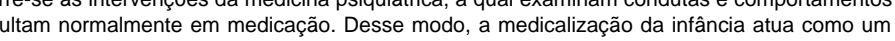
mecanismo normatizador que se agrava decorrente dos efeitos colterais que o dilta

\section{Referências}

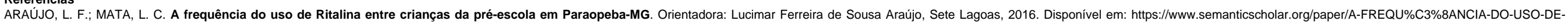
RITALINA-ENTRE-CRIAN\%C3\%87AS-DA-Ara\%C3\%BAjo-Mata/4e9bd76cd72e755bb206f44846a2ab631206d7f6?p2df. Acesso em: 05 ago. 2020

FERRAZZA, D. A.; ROCHA, L. R.; ROGONE, H. M. A prescrição banalizada de psicofarrmacos na infancia. Revista de Psicologia da UNESP, v. 9, n. 1, São Paulo, 2010.

FERRAZZA, D. A.; ROCHA, L. R. A psicopatologização da infância no contemporâneo: um estudo sobre a expansão do diagnóstico de Transtorno de Déficit de Atenção e Hiperatividade . INTERthesis, v. 8, n. 2, p. 237-251, Florianópolis, 2011.

SILVA, A. C. P. et al. A explosão do consumo de ritalina. Revista de Psicologia da UNESP, v. 11, n. 2, São Paulo, 2012

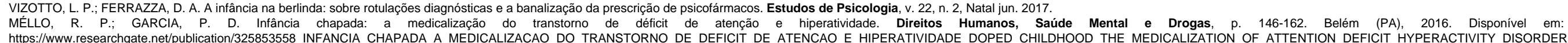
Acesso em 01 ago. 2020

MOYSÉS, M. A. A ritalina e os riscos de um genocídio do futuro . Disponível em: http://www.unicamp.br/unicamp/noticias/2013/08/05/ritalina-e-os-riscos-de-um-genocidio-do-futuro. São Paulo, 2013.

Coordenadoria de Pesquisa e Extensão - COPEX

Departamento de Editoraçāo e Divivilgaçăo Cientifica - DEDIC 


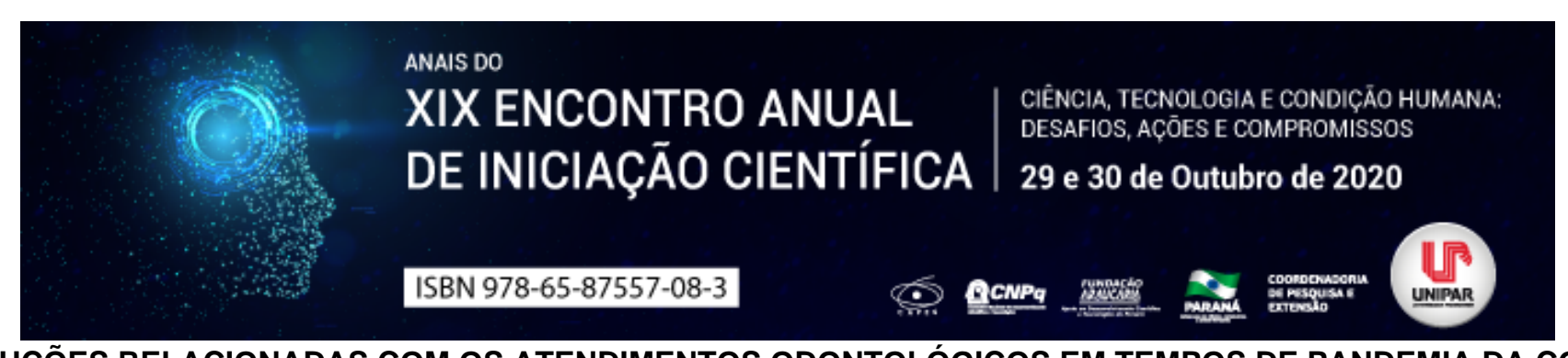

PRECAUÇÕES RELACIONADAS COM OS ATENDIMENTOS ODONTOLÓGICOS EM TEMPOS DE PANDEMIA DA COVID19

\title{
${ }^{1}$ LEISLE VERONICA PRESTES, ${ }^{2}$ ANA MARIA DA SILVA, ${ }^{3}$ ANA CAROLINE DOS SANTOS GRUNOW, ${ }^{4}$ GISELE APARECIDA SPADIM, ${ }^{5}$ EDUARDO AUGUSTO PFAU, ${ }^{6}$ VERUSKA DE JOAO MALHEIROS PFAU
}

\author{
${ }^{1}$ Acadêmica do Curso de Odontologia da Universidade Paranaense \\ ${ }^{1}$ Acadêmica PIBIC do Curso de Odontologia da Universidade Paranaense \\ ${ }^{2}$ Acadêmica PIBIC do Curso de Odontologia da Universidade Paranaense \\ ${ }^{3}$ Acadêmica PIC do Curso de Odontologia da Universidade Paranaense \\ ${ }^{4}$ Docente da Universidade Paranaense \\ ${ }^{5}$ Docente da Universidade Paranaense
}

Introdução: Em dezembro de 2019, na China, uma nova cepa de Coronavírus ocasionou um surto de pneumonia que se espalhou rapidamente para outros países (COOK, 2020). Devido a rápida disseminação geográfica, a Organização Mundial de Saúde (OMS) elevou, em 11 de março de 2020, o estado de contaminação à Pandemia de Covid-19. Considerando a forma de transmissão do vírus, que segundo Cook (2020) é predominantemente transmitido por contato ou transmissão de gotículas e a área de atuação do Cirurgião Dentista (CD), pode-se considerar que o potencial de disseminação desse vírus pode ser maior em ambiente odontológico. De acordo com Giordano, et al. (2020) a área de atuação do CD corresponde a uma distância de cerca de $30 \mathrm{~cm}$ da via aérea do paciente, o que propicia maior exposição do profissional à contaminação de doenças infectocontagiosas. Em procedimentos clínicos odontológicos, é comum a utilização de instrumentos como peças de mão, seringa tríplice, ultrassom e jato de bicarbonato de sódio, os quais são capazes de produzir aerossóis, ou seja, partículas com potencial de disseminação por todo o ambiente. Neste momento de pandemia por um vírus respiratório, esse potencial de disseminação tornou-se um desafio sanitário para a odontologia, assim a utilização correta dos equipamentos de proteção individual (EPI), bem como, a inserção ou alteração de dispositivos de segurança se fizeram necessários para tornar mais seguro 0 atendimento odontológico.

Objetivo: Avaliar, através de uma revisão de literatura, os riscos e medidas preventivas no consultório odontológico diante da pandemia do novo Coronavírus.

Desenvolvimento: Partículas líquidas e/ou sólidas em suspensão no ar é a definição de aerossol, que por sua vez pode conter microrganismos patogênicos, advindos eventualmente de sangue e saliva de pacientes em atendimento odontológico. No consultório odontológico, as partículas de aerossóis advêm de instrumentos rotatórios, além de ultrassom e jatos abrasivos comumente utilizados na rotina odontológica, podendo ser considerado como vetores de transmissão de diversos vírus, incluindo o COVID-19 que é a doença infectocontagiosa em evidência. Bardal et al. (2007) atestam que a área contaminada a partir da boca do paciente, quando da utilização desses instrumentos, corresponde a 100\% até um metro de distância e, 50\% até dois metros. Deste modo, medidas preventivas são necessárias a fim de evitar que as partículas virais aerossolizadas se propaguem. A Agência Nacional de Vigilância Sanitária (ANVISA), juntamente com o Conselho Federal de Odontologia (CFO), atualizou a Nota Técnica que diz respeito a orientação sobre medidas de prevenção e controle que devem ser adotadas diante do Coronavírus, incluindo o atendimento odontológico (ANVISA, 2020). De acordo com Russo et al. (2000), alguns procedimentos como recobrimento de superfícies por filmes plásticos, bochecho com solução aquosa de clorexidina a 0,12\%, esterilização do instrumental e desinfecção de superfícies e equipamentos, são indicados para evitar a contaminação do consultório. Cuidados estes que já faziam parte das orientações para o atendimento odontológico. A fim de evitar a contaminação cruzada, os motores com válvulas de anti retração ou antirrefluxo são as mais recomendadas, além de ser de extrema importância a autoclavagem das peças de mão após cada atendimento. Ademais, é de suma importância manter o controle microbiológico da qualidade da água do equipo odontológico utilizada nos aparelhos de ultrassom (TUÑAS, I. T. D. C, et al. 2020). Em pacientes com sintomas suspeitos ou com doença confirmada, deve-se realizar apenas atendimentos de urgência e emergência, os quais não podem ser adiados. Segundo a American Dental Association (ADA), os procedimentos a serem realizados pelo CD em pacientes com COVID-19 são abscessos (dentário ou periodontal) ou infecção bacteriana, resultando em dor localizada e edema, além de indicar-se a utilização de curetas para remoção de placa bacteriana, evitando a utilização do jato e do ultrassom (ANVISA, 2020). Medidas, além das já citadas acima, são da mesma forma importantes, dentre as quais se destacam a disponibilização de EPIs para os pacientes e devida paramentação e desparamentação do profissional e equipe. Franco et al.(2020) sugerem que quanto aos EPIs já utilizados diariamente na clínica odontológica (gorro, óculos, jaleco e luvas), é prudente o uso concomitante de máscara N95/PFF2, protetor facial (Face Shield) e avental impermeável descartáveis. Estes novos EPIs devem a partir de agora fazer parte da nova rotina do atendimento odontológico. 
Conclusão: O ambiente odontológico é um potencial gerador de aerossóis, devido ao conjunto de instrumentos utilizados. Desta forma, os cuidados com a biossegurança tornaram-se ainda mais indispensáveis. O cirurgião dentista deve estar atento para evitar a disseminação desse vírus pandêmico, e de outros micro-organismos patogênicos, de forma a minimizar a contaminação entre pacientes, profissionais e equipe. Diante do exposto, é crucial que os cirurgiões dentistas, intensifiquem as medidas preventivas de acordo com a necessidade do momento, principalmente em tempos de pandemia de COVID-19.

\section{Referências}

AGÊNCIA NACIONAL DE VIGILÂNCIA SANITÁRIA. Nota Técnica GVIMS/GGTESI ANVISA N 04/2020: Orientações para serviços de saúde: medidas de prevenção e controle que devem ser adotadas durante a assistência aos casos suspeitos ou confirmados de infecção pelo novo coronavírus (SARS-CoV-2). Brasília, 30 jan. 2020. Disponível em: >http://portal.anvisa.gov.br/documents/33852/271858/Nota+T\%C3\%A9cnica+n+04-2020+GVIMS-GGTES-ANVISA/ab598660-

3de4-4f14-8e6f-b9341c196b28> Acesso em: 18 de jul. de 2020.

BARDAL P. M.; JORGE A. O. C.; SANTOS S.S.F. Avaliação da contaminação de aventais após procedimento odontológico. Rev. APCD, v. 61, n. 4, p. 308-314, jul./ago. 2007.

COOK, T. M. Personal protective equipment during the coronavirus disease (COVID) 2019 pandemic

a narrative review. Anaesthesia, v. 75, p. 920-927, abr. 2020.

FRANCO J. B.; CAMARGO A. R.; PERES M. P. S. M. Cuidados odontológicos na era do COVID-19: recomendações para procedimentos odontológicos e profissionais. Rev. Assoc. Paul Cir. Dent.., v. 74, n. 1, p. 18-21, 2020.

GIORDANO, C. et al. Sedação inalatória com óxido nitroso para assistência odontológica durante a pandemia de covid-19 -teste de segurança no uso da técnica. Revista FAIPE, v. 10, n. 1, p. 69-84, jan./jun. 2020.

RUSSO, E. M. A. et al. Avaliação da intensidade da contaminação de pontas de seringa tríplice. Pesqui. Odontol. Bras., v. 14, n. 3, p. 243-247, jul./set. 2000.

TUÑAS, I. T. D. C; et al. Doença pelo Coronavírus 2019 (COVID-19): Uma Abordagem Preventiva para Odontologia. Revista Brasileira de Odontologia, v. 77, 2020. 


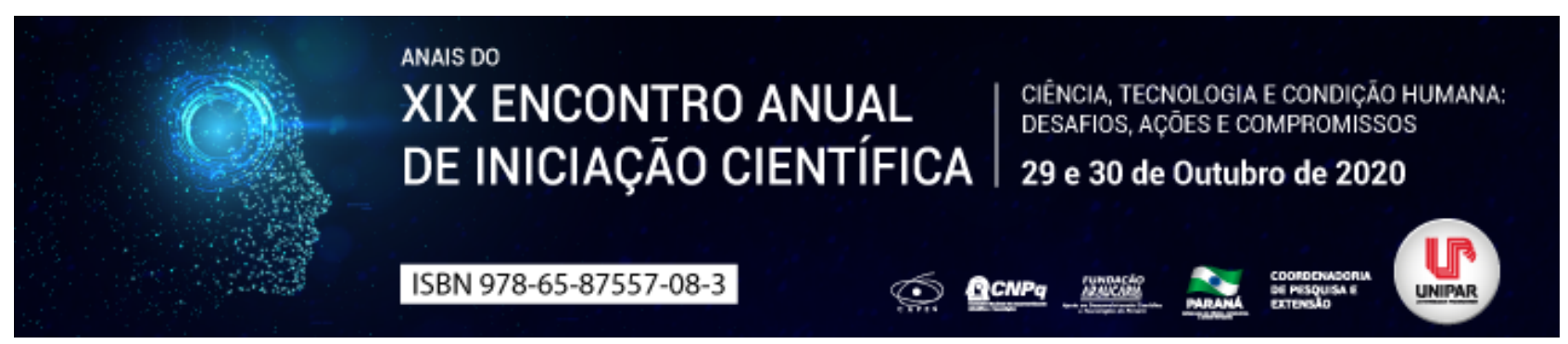

HIGIENE BUCAL DE PESSOAS PORTADORAS DE NECESSIDADES ESPECIAIS

\author{
${ }^{1}$ VERONICA DE MORAES, ${ }^{2}$ BRUNA CAMILA WEBER, ${ }^{3}$ FERNANDA LIMA, ${ }^{4}$ JULIANA GARCIA MUGNAI VIEIRA SOUZA, \\ ${ }^{5}$ HELEN CRISTINA LAZZARIN
}

\author{
${ }^{1}$ Acadêmico do curso de Odontologia da UNIPAR \\ ${ }^{1}$ Acadêmica do Curso de Endodontia de Molares - Turma Vii da UNIPAR \\ ${ }^{2}$ Acadêmica do Curso de Odontologia da UNIPAR \\ ${ }^{3}$ Docente da UNIPAR \\ ${ }^{4}$ Docente da UNIPAR
}

Introdução: Portador de Necessidade Especial (PNE) é todo indivíduo que apresenta uma variação física ou mental, e necessita de atenção especial por um determinado período ou pela vida toda. Esse auxílio pode ser fundamental, dependendo da limitação do PNE, como: dificuldade de comunicação e compreensão, limitação física, dificuldade socioeconômica, até mesmo incapacidade da família ou de cuidadores em conseguir ajudar (CALDAS Jr e MACHIAVELLI, 2013). Estes pacientes apresentam condição de saúde bucal ruim, apresentando um maior índice de lesões cariosas, doenças periodontais e dentes perdidos. A formação de biofilme pode decorrer da ingestão frequente de medicações ricas em açúcares que servem, por exemplo, para disfarçar o gosto amargo, como também, da ausência de escovação dental (ROMANELLI, 2006). A escovação é fundamental para a prevenção dessas doenças, uma vez que desorganiza a placa bacteriana, impedindo o processo de desmineralização da estrutura dental e inflamação dos tecidos de suporte, garantindo uma boa higiene bucal, fator que interfere consideravelmente na qualidade de vida desses pacientes (LIMA, 2007). Segundo a Organização Mundial da Saúde (OMS), o percentual de indivíduos com necessidades especiais, no Brasil, é equivalente a 15\% da população. De acordo com o Instituto Brasileiro de Geografia e Estatística (IBGE), a cada 10\% de PNE, apenas 3\% têm acesso ao serviço de saúde bucal. Diante da preocupação em se atender esses pacientes, o Conselho Federal de Odontologia criou, em 2002, uma especialidade voltada ao atendimento para este público. O tratamento para estes pacientes necessita uma atenção multiprofissional e familiar (SANTOS e HORA, 2012).

Objetivo: O objetivo dessa pesquisa foi avaliar a higiene bucal de pessoas portadoras de necessidades especiais.

Metodologia: Neste estudo transversal foram avaliados 30 pacientes da APAE (Associação de Pais e Amigos dos Excepcionais) do município de Braganey PR, tendo por objetivo avaliar a saúde bucal das pessoas portadoras de necessidades especiais, com termo de consentimento Livre e Esclarecido assinado pelos responsáveis. Esta pesquisa foi realizada em 2 etapas e aprovada pelo Comitê de Ética em Pesquisa Envolvendo Seres Humanos (CEPEH) sob o parecer 2.675.596. No primeiro momento foi coletado o IHOS (Índice de Higiene Oral Simplificado), sem instrução de higiene oral prévia, logo em seguida foi realizado orientações de técnicas de escovação aos funcionários e professores. No segundo momento, após um período de 30 dias, foi aplicado novamente o índice. No índice IHOS, a cada superfície avaliada, é atribuído um código que varia de zero a três. Após o resultado do índice médio individual, os índices são classificados como bom (resultados entre 0 e 0,6), regular (resultados entre 0,7 e 1,8) e fraco (resultados entre 1,9 e 3,0) em ambas as etapas da pesquisa.

Resultados: Os dados coletados na amostra durante o primeiro momento da pesquisa revelaram a prevalência de IHOS regular, composto por 16 alunos (53,33\%), seguido de IHOS fraco formado por 13 alunos (43,33\%) dos alunos examinados e apenas 1 aluno (3,33\%) da amostra total apresentava um índice de IHOS bom. Após a primeira coleta de dados, foram passadas orientações de higiene bucal e demonstração da técnica de escovação de Fones aos alunos e funcionários da APAE de Braganey PR. Essa técnica foi escolhida devido à falta de coordenação motora dos alunos. Para verificar a eficácia das instruções de higiene bucal, foi retornado à instituição após um intervalo de 30 dias, sendo realizado um novo exame IHOS, onde foi possível observar a redução do IHOS fraco em 36,67\% e do regular em 3,33\%. O IHOS bom aumentou em $40 \%$.

Discussão: Os PNE apresentam alto índice de desordens bucais, tais como, cárie dental, doença periodontal e dentes perdidos. Tais doenças podem estar relacionadas à condição socioeconômica destes pacientes, suas limitações físicas ao realizar a higiene bucal de forma adequada, à dieta cariogênica e a escassez de profissionais qualificados, além do alto custo no atendimento a estes pacientes. Sendo de extrema importância a realização de um programa de controle da placa bacteriana voltado ao PNE (JORGE et al., 2017). Uma pesquisa realizada com PNE e o estudo em questão mostra que o IHOS fraco é mais predominante inicialmente quando há dificuldade motora em realizar a higiene bucal, à falta de informações, a limitação intelectual em compreender a importância da escovação dental e ao consumo frequente de medicamentos contendo açúcares, por isso se deve a importância da motivação (QUEIROZ et al., 2014; OLIVEIRA, 2019). A pesquisa em questão apresentou resultados significativos frente à diminuição do IHOS fraco em 36,67\% e o aumento do índice bom em 40\%, enfatizando assim a importância da promoção de saúde voltada a este público. 
Conclusão: A pesquisa apresentou resultados significativos frente à diminuição do $\mathrm{IHOS}$ fraco e o aumento do índice bom. Evidenciou a necessidade de uma maior atenção a esses pacientes, pois, quando bem instruídos sobre a importância da higiene bucal podem apresentar uma melhora significativa.

\section{Referências}

CALDAS Jr., Arnaldo de França; MACHIAVELLI, Josiane Lemos. Atenção e cuidado da saúde bucal da pessoa com deficiência: Introdução ao estudo. Recife: Ed. Universitária da UFPE, 2013. 70 p.

JORGE, Kelly Oliva, et al. Atendimento odontológico às crianças com necessidades especiais: uma revisão da literatura. Revista da Universidade do Rio Verde. Três Corações, v.15, n. 2, p. 54-64, ago./dez. 2017.

LIMA, José Eduardo de Oliveira. Cárie dentária: um novo conceito. Rev. Dent. Press Ortodon. Ortop. Facial, Maringá, v. 12, n. 6, p. 119-130, nov./dez. 2007.

OLIVEIRA, Mariana Souza Fidelis de. Percepção dos cuidadores de pessoas com deficiência sobre a saúde bucal. 2019. 43 f. Trabalho de Conclusão de Curso (Graduação em Odontologia) - Universidade de Brasília, Brasília, 2019.

QUEIROZ, Faldryene de Souza et al. Avaliação das condições de saúde bucal de Portadores de Necessidades Especiais. Rev. Odontol UNESP, v. 43, n. 6, p. 396-401, 2014.

ROMANELLI, Marissol Cristina Maria de Oliveira Vasconcellos. Levantamento epidemiológico das doenças cárie e periodontal em alunos com necessidades especiais das APAE na região metropolitana de Curitiba Paraná. 2006.105 f. Dissertação (Mestrado em Clínica Integrada, Dentística Restauradora e Periodontia) Universidade Estadual de Ponta Grossa, Ponta Grossa, 2006.

SANTOS, Marcela F. Souza. HORA, Ignez A. dos Anjos. Atenção odontológica a pacientes especiais: atitudes e percepções de acadêmicos de odontologia. Revista da Abeno, v. 12, n. 2, p. 207-12, 2012. 


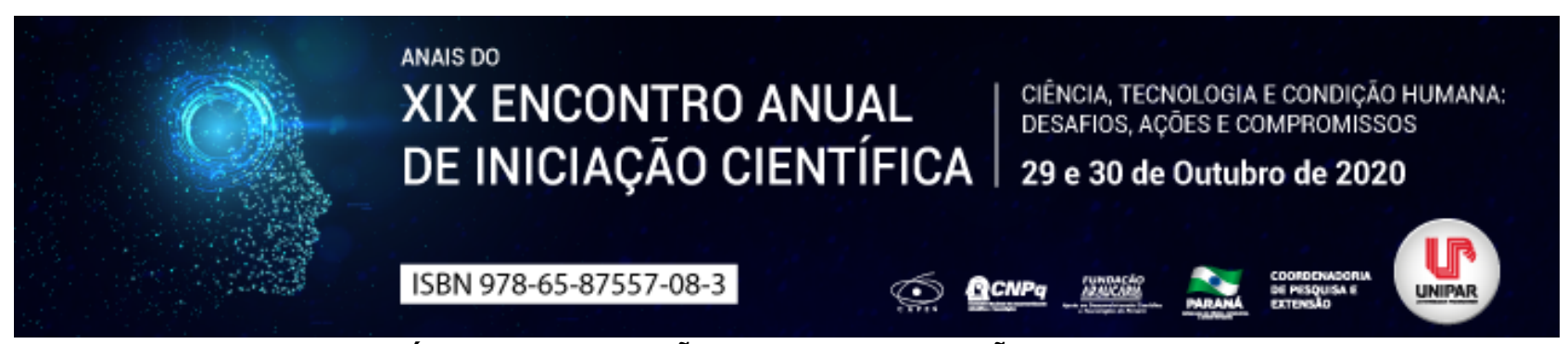

EFEITOS DA PRÁTICA DA NATAÇÃO NA COORDENAÇÃO MOTORA DE CRIANÇAS

\author{
${ }^{1}$ RENAN CARLOS BIGAS, ${ }^{2}$ MARIA GABRIELLA GIROTO
}

${ }^{1}$ Discente do curso de Educação Física, Ciências da Saúde, Universidade Paranaense - UNIPAR

${ }^{1}$ Docente do curso de Educação Física, Ciências da Saúde, Universidade Paranaense - UNIPAR

Introdução: A natação é conhecida como um dos esportes mais praticados no mundo desde a antiguidade, sendo um dos mais completos pois a partir das prática do mesmo se desenvolve várias capacidades físicas e nos trás vários benefícios como a melhoria da saúde do praticante. Com a prática da natação pode-se adquirir várias melhorias na qualidade de vida do indivíduo tais como o desenvolvimento físico, melhora a coordenação motora, diminui o stress, eleva a auto estima, além de prevenir doenças e melhorar a saúde (OLIVEIRA et al, 2013).

Objetivo: Verificar através da literatura quais são os efeitos da prática da natação na coordenação motora de crianças.

Desenvolvimento: De acordo com Oliveira et al (2013, p.111) l"a natação é um dos desportos mais praticados no mundo desde tempos remotos, sendo um dos mais completos e que mais desenvolve capacidades físicas e movimenta todo o corpo de forma harmônica oferecendo também uma série de benefíciosl". Os praticantes geralmente não buscam somente a aprendizagem dos nados, mas também a qualidade de vida. Onde vários benefícios como a melhoria na coordenação motora, desenvolvimento físico, auto estima, diminuição de estresse, prevenção de doenças e melhora na saúde (OLIVEIRA et al, 2013). Cassimiro e Corrêa (2015) expõem que o aprendizado da natação, proporciona um aumento da maturação neurológica, além do aumento do equilíbrio nas primeiras etapas do desenvolvimento infantil e do desenvolvimento da habilidade sensório motora. Sendo assim, esta prática converte num meio ação para alto potencial educativo para o desenvolvimento motor do indivíduo. Através de pesquisas Souza et al (2018) apontam que o desenvolvimento motor em crianças praticantes da natação é mais avançado que $o$ de crianças que não praticam a modalidade, e adquirem uma melhor performance nas variáveis de motricidade global, equilíbrio e organização espacial. A natação concede aos seus praticantes um ambiente abonado de estímulos efetivos que nos concede um melhor desenvolvimento motor e um repertório motor mais amplo, fazendo com que a coordenação motora das crianças que a praticam seja superior aos não praticantes (SOUZA et al, 2018). Segundo Lopes e Pereira (2004) fora os benefícios relacionados a habilidade motora, favorece a integração entre crianças, melhorando o desenvolvimento harmonioso do corpo e da agilidade mental. Desta forma, a natação pode-se ser uma atividade física de que contribui não apenas para a melhoria de capacidades motoras como a coordenação, mas também no desenvolvimento de habilidades, e contribui para o desenvolvimento social e afetivo.

Conclusão: Conclui-se que crianças que praticam a natação, além de melhorar sua coordenação motora, desenvolvem todo o conjunto de capacidades e habilidades motoras, contribuindo assim para o desenvolvimento motor, além de ser uma aliada para a qualidade de vida, como a prevenção de doenças, diminuição do estresse, melhora na saúde, auto estima e socialização do praticante.

\title{
Referências
}

CASSIMIRO, T.; CORRÊA, V. J. As variáveis da prática da natação na coordenação motora de crianças de dez e onze anos de idade. 2015. Trabalho de Conclusão de Curso (Licenciatura em Educação Física) Faculdade Calafiori, São Sebastião do Paraíso/MG. 2015.

LOPES, M.G.O.; PEREIRA, J.S. A Influência da natação sobre o equilíbrio em crianças. Fitness \& Performance Journal, v.3, n.4, p.201-206,2004.

Disponível

em:

file:///home/chronos/u76fda0bd434db9582ec484c25ea4e9e78bb6cf1c/MyFiles/Downloads/Dialnet-

AlnfluenciaDaNatacaoSobreOEquilibrioEmCriancas-2956331.pdf. Acesso em: 09 jul. 2020.

OLIVEIRA, L. R. de. et al. Importância da natação para o desenvolvimento da criança e seus benefícios. Revista Argumentandum Faculdade Sudamérica. vol 5, p. 111-130, 2013. Disponível em: http://sudamerica.edu.br/argumentandum/artigos/argumentandum_volume_5/Texto_5_Larice.pdf. Acesso em: 09 jul. 2020.

SOUZA,W. M et al. Análise de desenvolvimento motor em crianças de 5 anos praticantes de natação. Revista Científica UMC: Edição Especial PIBIC, Mogi das Cruzes. Outubro, 2018. ISSN 2525-5250. Disponível em: file:///home/chronos/u76fda0bd434db9582ec484c25ea4e9e78bb6cf1c/MyFiles/Downloads/581-2202-1-PB.pdf. Acesso em: 09 jul. 2020. 


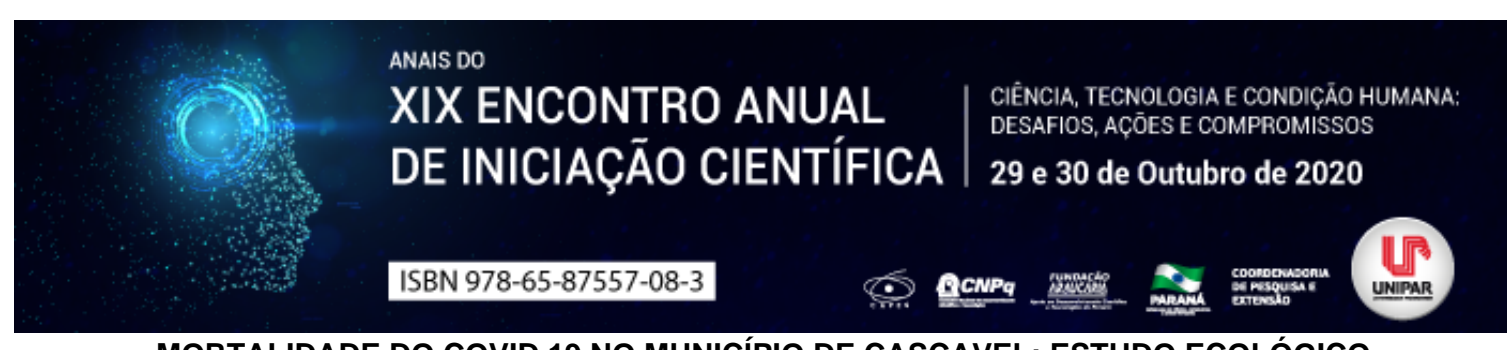

MORTALIDADE DO COVID 19 NO MUNICÍPIO DE CASCAVEL: ESTUDO ECOLÓGICO

${ }^{1}$ DANIELI DAMASCENO SOARES, ${ }^{2}$ BRUNA KAUYNE PEREIRA PLACK, ${ }^{3}$ MARCOS ANTONIO DA SILVA LIMA, ${ }^{4}$ DAISY CRISTINA RODRIGUES

${ }^{1}$ Discente do $5^{\circ}$ ano Enfermagem da Universidade Paranaense (UNIPAR), campus Cascavel/PR

${ }^{1}$ Acadêmica do Curso de Enfermagem da UNIPAR

${ }^{2}$ Acadêmico do Curso de Enfermagem da UNIPAR

${ }^{3}$ Docente da UNIPAR

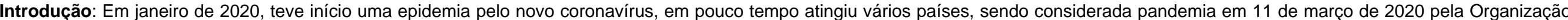

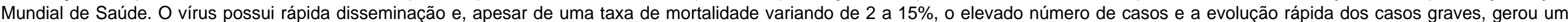

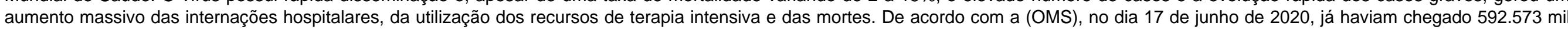

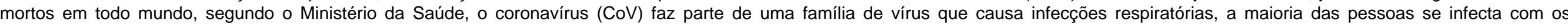

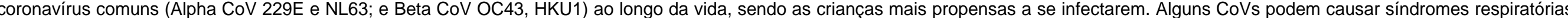

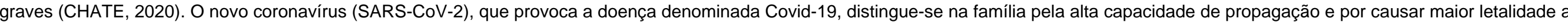
pessoas acima dos 60 anos, e com problemas respiratórios crônicos, dentre outros (MOREIRA, 2020).

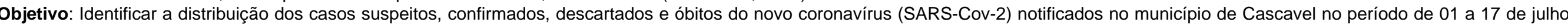
de 2020.

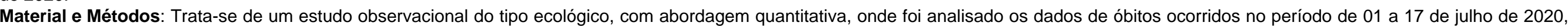
registrados no sistema de informação que é o painel Coronavírus (https://covid.saude.gov.br/), elaborado pelo Ministério de Saúde do Brasil.

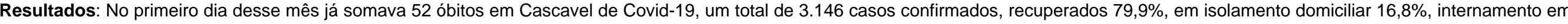

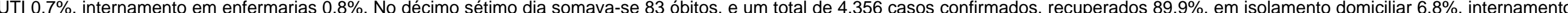

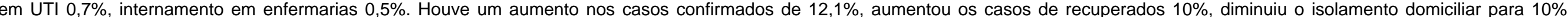
internamento em UTI permaneceu a mesma porcentagem, diminuiu o internamento em enfermarias para $0,3 \%$, aumentou o número de óbitos para $0,3 \%$.

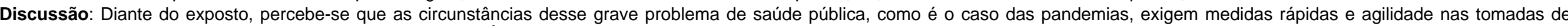

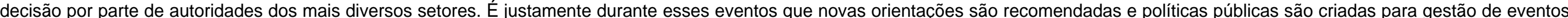

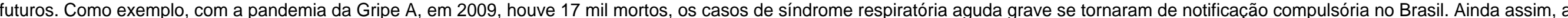

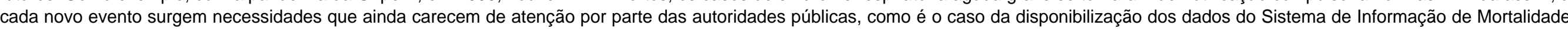

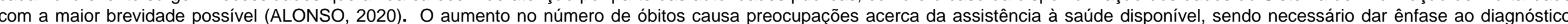

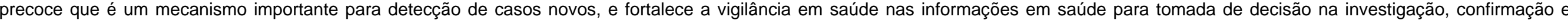
descartes de casos (LANA, et al. 2020).

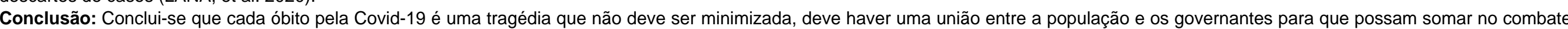
a este desafio sanitário global.

Referências

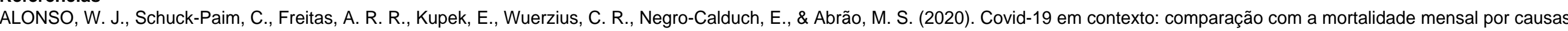

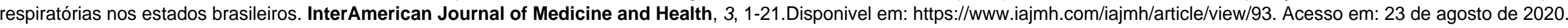

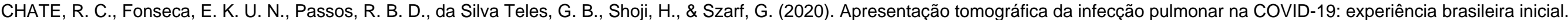

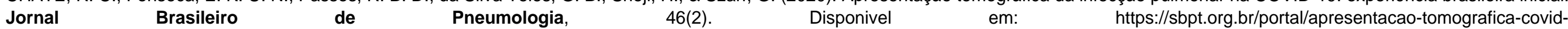

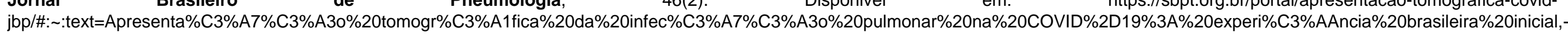

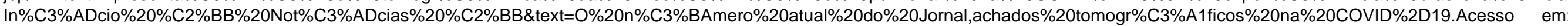




\section{3 de agosto de 2020}

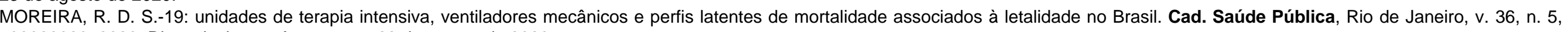
e00080020, 2020. Disponivel em: . Acesso em: 23 de agosto de 2020.

ORGANIZACÃ̃ MUNDIAL DA SAÚDE. Doença de coronavírus 2019 (COVID-19): relatório da situação, 72. 2020.

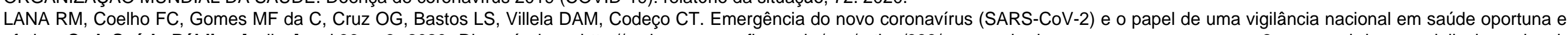

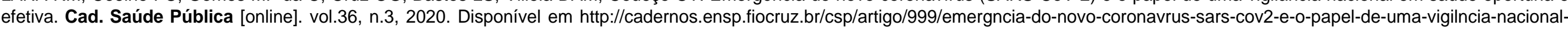
em-sade-oportuna-e-efetiva. ISSN 1678-4464. http://dx.doi.org/10.1590/0102-311X00019620.

Coordenadoria de Pesquisa e Extensão - COPEX

Departamento de Editoração e Divulgaçāo Científica - DEDIC 


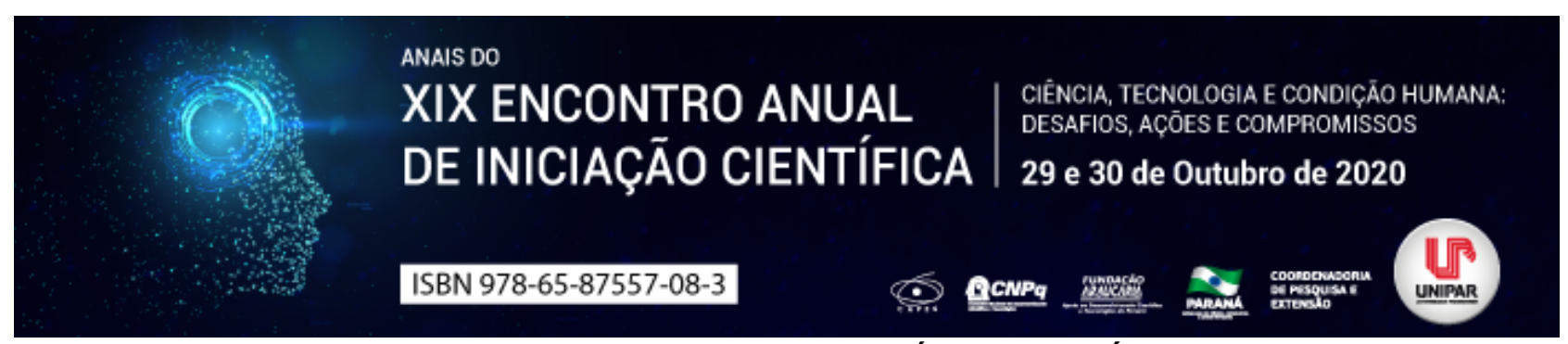

\title{
O SIGNIFICADO DA EMPATIA NA ÁREA DA SAÚDE
}

\author{
${ }^{1}$ GABRIELE FERNANDA LOPES, ${ }^{2}$ LORENA CASTAGNA ANGELIM COSTA, ${ }^{3}$ MILLENA ANGELI DOMINGUES PEREIRA, \\ ${ }^{4}$ JEFFERSON J AMARAL DOS SANTOS
}

\author{
${ }^{1}$ Acadêmica bolsista do PIBIC/UNIPAR \\ ${ }^{1}$ Acadêmica do Curso de Fisioterapia da UNIPAR \\ ${ }^{2}$ Acadêmica do Curso de Fisioterapia da UNIPAR \\ ${ }^{3}$ Docente da UNIPAR
}

Introdução: O termo empatia possui várias vertentes e traduções, atualmente com tantos usos diferenciados a sua definição se torna difícil, porém mesmo isso acontecendo o seu emprego continua com grande importância na relação terapeuta e paciente (SOUZA; HOKAMA; HOKAMA, 2020). Hipóteses são criadas associando a empatia com uma habilidade para manejo dos sentimentos pessoais negativos advindos da observação do sofrimento alheio, essa evidência é baseada por demonstração dos componentes cognitivos e afetivos da empatia sendo essencial a compreensão da emoção de outrem. Os elementos comportamentais da empatia favorecem ao indivíduo a atuação mais eficaz nos fatores que desencadeiam sofrimento em outras pessoas o que é fundamental para profissionais na área da saúde (SAMPAIO; OLIVEIRA; PIRES, 2020).

Objetivo: Relatar a importância da empatia em algumas áreas da saúde.

Desenvolvimento: A palavra empatia foi utilizada pela primeira vez no fim do século XIX pelo filósofo alemão Robert Vischer, ele tentava retratar sentimentos advindos da observação de uma obra de arte, especialmente quando o espectador se sentia ligado a esta, passando a ser empregado para retratar sentimentos de conexão com a natureza. Apenas no século XX o termo foi utilizado para relações humanas por Sigmund Freud no sentido de colocar-se na posição de outra pessoa . Entretanto foi em 1909 que o psicólogo Edward Tichener a utilizou com o significado de atualmente: ato de entender a perspectiva do outro (SOUZA; HOKAMA; HOKAMA, 2020). Pesquisas mais atuais destacam que a empatia envolve componentes cognitivos, afetivos e comportamentais. No componente cognitivo a empatia se define como a capacidade de entender cuidadosamente os sentimentos e pensamentos de alguém. Sobre o componente afetivo é envolto de interesse genuíno no bem-estar do outro. Já no componente comportamental é uma demonstração explícita de compreensão pelo outro tanto em comunicação verbal quanto não verbal, esse é o componente principal que indica à outra pessoa que essa está sendo compreendida (MARTINS et al., 2018). Segundo Luchini Junior, Biesek e Friestino (2019) no campo da medicina, principalmente na área da Atenção Básica em saúde que é a porta de entrada do SUS (Sistema Único de Saúde), dentre as habilidades necessárias se ressalta a empatia, pois, por meio desta se configura uma ligação entre o médico e o paciente que tem como função melhorar todo o processo de cuidado e tratamento. Na psicoterapia a empatia é mais uma vez considerada uma habilidade essencial já que o comportamento empático proveniente do terapeuta propicia um fortalecimento do vínculo terapêutico e por consequência uma maior adesão do tratamento pelo paciente (MARTINS et al., 2018). Entretanto na enfermagem a dimensão privilegiada ao tratamento é a física pelos procedimentos técnicos, porém em um tratamento mais avançado a enfermagem é capaz de acessar as emoções subjetivas atingindo a transpessoalidade, por meio de comunicação e empatia, assim desenvolvendo a harmonia e confiança necessária para o processo de recuperação e tratamento (LEÃO; SAVIETO, 2016). Todavia no início das carreiras dos profissionais da saúde o nível de empatia é alto, porém este é reduzido pelo estresse cotidiano causado pela exposição ao sofrimento de pacientes, isso pode ser denominado como compaixão fadigada, ou seja, a perda gradativa da empatia. Não se importar com outras pessoas, exaustão emocional, raiva, distúrbios do sono são os sintomas principais e mais evidentes desse trauma. Quando isso ocorre é necessário que os terapeutas procurem se reconhecer como pessoas que se encontram vulneráveis e perdoem a si mesmos (HOGA; REIS-QUEIROZ; TEREZAM, 2016).

Conclusão: Conclui-se que a empatia é um constructo essencial para a área da saúde nos tratamentos e nas ligações entre terapeutas e pacientes, desenvolvendo grande importância para que ambos se empenhem na continuidade dos cuidados.

\section{Referências}

SAMPAIO, L. R.; OLIVEIRA, L. C. de.; PIRES, M. F. D. N. Empatía, depresión, ansiedad y estrés en Profesionales de la Salud Brasileños. Ciencias Psicológicas, [S. I.], v. 14, n. 2, p. e-2215, 2020.

MARTINS, J. S.; OLIVEIRA, L. S.; VASCONCELOS, R. C. C.; CARVALHO, A. L. N. Empatia e relação terapêutica na psicoterapia cognitiva: uma revisão sistemática. Rev. Brasileira de Terapia Cognitiva., Rio de Janeiro, v. 14, n. 1, p. 50-56, jun. 2018.

TEREZAM, R.; REIS-QUEIROZ, J.; HOGA, L. A. K. A importância da empatia no cuidado em saúde e enfermagem. Rev. Brasileira de Enfermagem, Brasília, v. 70, n. 3, p. 669-670, jun. 2017. 
SAVIETO, R. M.; LEAO, E. R. Assistência em Enfermagem e Jean Watson: Uma reflexão sobre a empatia. Esc. Anna Nery, Rio de Janeiro, v. 20, n. 1, p. 198-202, mar. 2016.

SOUZA, L.; HOKAMA, P.; HOKAMA, N. A empatia como instrumento para a humanização na saúde: concepções para a prática profissional. Revista de Educação da Universidade Federal do Vale do São Francisco (REVASF), Petrolina, v.10, n.21, mai. 2020.

LUCHINI JUNIOR, D.; BIESEK, L. L.; FRIESTINO, J. K. O. Empatia médica e o sofrimento mental: uma abordagem na atenção básica. Repositório Digital., Chapecó, 2019. Disponível em: https://rd.uffs.edu.br/handle/prefix/3691.

Coordenadoria de Pesquisa e Extensão - COPEX

Departamento de Editoraçāo e Divulgaçāo Científica - DEDIC 


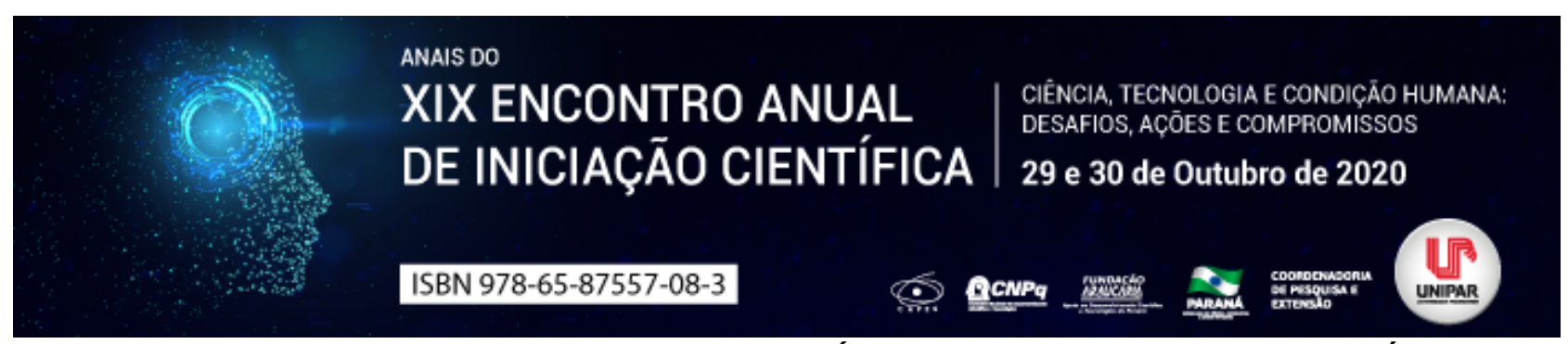

MORTALIDADE NEONATAL PRECOCE NO MUNICÍPIO DE CASCAVEL: ESTUDO ECOLÓGICO

\title{
${ }^{1}$ DANIELI DAMASCENO SOARES, ${ }^{2}$ BRUNA KAUYNE PEREIRA PLACK, ${ }^{3}$ DAISY CRISTINA RODRIGUES
}

\author{
${ }^{1}$ Discente do $5^{\circ}$ ano Enfermagem da Universidade Paranaense (UNIPAR), campus Cascavel/PR \\ ${ }^{1}$ Discente do $5^{\circ}$ ano Enfermagem da Universidade Paranaense (UNIPAR), campus Cascavel/PR \\ ${ }^{2}$ Docente da UNIPAR
}

Introdução: De acordo com a Organização Mundial de Saúde (OMS), morrem, no mundo, a cada ano, 7,1 milhões de crianças no primeiro ano de vida. Metade dessas mortes ocorre no período neonatal, ou seja, antes dos primeiros 28 dias de vida cerca de $75 \%$ na primeira semana, isto é, no período neonatal precoce (até o sétimo dia de vida) e $40 \%$ nas primeiras horas de vida (SOARES, 2010). Estudos no Brasil também evidenciam uma maior concentração dos óbitos neonatais nas primeiras horas e dias (ALMEIDA,2020). Em 2004 a mortalidade neonatal precoce atingiu 11,5 óbitos por mil nascidos vivos. Esses estudos têm demonstrado a importância de intervenções na redução da mortalidade infantil em todo o país, com destaque especial para as ações dos serviços de saúde (TEIXEIRA, 2016).

Objetivo: Identificar a mortalidade neonatal precoce no município de Cascavel, e explorar sua associação com fatores socioeconômicos e biológicos registrados nos sistemas de informação em saúde.

Material e Métodos: Trata-se de um estudo observacional do tipo ecológico, com abordagem quantitativa, foi analisado os dados de óbitos infantis ocorridos no período de 2018, registrados no Sistema de informação de mortalidade (SIM) e Sistema de informação de nascidos vivos (SINASC).

Resultados: Com a análise da associação das variáveis socioeconômicas, a idade materna apontou para maior chance do óbito neonatal precoce entre as mães adolescentes e as que apresentavam 25 a 29 anos, quando comparadas às mães de 30 a 34 anos de idade. A escolaridade, das mães dos neonatos que foram a óbito antes de completarem uma semana de vida, foi de 8 a 11 anos, ou seja ensino fundamental e médio. Relativo à raça/cor materna, houve diferença com $85 \%$ de brancas, para o óbito neonatal precoce entre as variáveis obstétricas, destacou-se: maior chance para a ocorrência do óbito neonatal precoce para as mulheres com gestação única ou dupla e que apresentaram perda fetal anterior. Na abordagem das variáveis do recém-nascido, se verificou maior chance de óbito neonatal precoce para: o sexo masculino, baixo peso ao nascer, prematuros, com sinal de asfixia de acordo com Apgar no quinto minuto de vida, e os que apresentavam anomalia congênita ao nascimento; com maior risco para os de extremo baixo peso ao nascer $(<1.000 \mathrm{~g})$ e os prematuros extremos ( $<32$ semanas). Conforme as variáveis assistenciais observa-se maior chance de óbito neonatal precoce em filhos de mulheres que realizaram até seis consultas, quando comparadas as que realizaram sete ou mais. Destaca-se que o parto cirúrgico se apresentou como $64 \%$.

Discussão: Diante do exposto encontrados nos dados do Ministério da Saúde no departamento de informática do Sistema Único de Saúde (DATASUS), 2016, percebe-se que a situação de mortalidade neonatal precoce não difere do cenário nacional. A maior causa de óbito registrada é a hipóxia, causalidade relacionada com a assistência ao parto, e também envolvida com a qualidade do desfecho da gestação. Portanto intervenções se fazem necessárias, no que diz respeito às melhorias na rede hospitalar de assistência ao parto de baixo risco e também no de alto risco, tanto no âmbito da estrutura física e recursos tecnológicos, como na capacitação de profissionais para acolhimento humanizado ao parto e puerpério imediato, ressaltando a importância da adoção do parto vaginal, não só por ser uma prática preconizada pelo Ministério da Saúde, mas também por contribuir na redução desses óbitos. No que tange as ações a serem desenvolvidas na atenção primária para minimização essas mortes engloba uma implementação integrada para se obter um efeito positivo, direcionando uma assistência materno-infantil de qualidade. Para isso, utilizar de intervenções baseadas nas evidencias encontradas, afim de assegurar uma gestação saudável e garantir um nascimento seguro, além de desenvolver ações voltadas para saúde reprodutiva. Estruturação de equipes multiprofissionais, capacitação e qualificação para vigilância dos óbitos, manutenção da regulação das parturientes em tempo oportuno, são medidas importantes no combate a complicações ocorridas durante o trabalho de parto e ou relacionadas ao parto. Brasil. Ministério da Saúde. Departamento de Informática do Sistema Único de Saúde (DATASUS). 2016

Conclusão: É importante estimular a utilização dos dados gerados pelos sistemas de informações de base epidemiológica no planejamento das ações de saúde. A redução da mortalidade neonatal precoce está ligada ao reconhecimento da sua importância pelos gestores do sistema de saúde. Conferir visibilidade a esta situação é a primeira tarefa para a tomada de decisões. As características sócio demográficas maternas, reprodutivas, assistenciais e do recém-nascido são importantes indicadores que podem ser utilizados como condições de alerta para monitoramento deste componente da mortalidade infantil.

\section{Referências}

Almeida, M. C. S., Gomes, C. M. S., \& Nascimento, L. F. C. Análise espacial da mortalidade neonatal no estado de São Paulo, 
2006 2010. Revista Paulista de Pediatria, v. 32, n. 4, p. 374-380, 2014. Disponível em:< https://www.scielo.br/scielo.php? pid=S0103-05822014000400374\&script=sci_arttext\&tIng=pt >acesso em: 13 de agosto de 2020.

ANDRADE, S. M. de et al. Condições de vida e mortalidade infantil no Estado do Paraná, Brasil, 1997/2001. Cadernos de Saúde Pública, v. 22, n. 1, p. 181-189, 2006.ARAÚJO, B. F.; BOZZETTI, M. C.; TANAKA, A. C. Mortalidade neonatal precoce no município de Caxias do Sul: um estudo de coorte. J Pediatr (Rio J), v. 76, n. 3, p. 200-6, 2000. Disponível em: Acesso em: 13 de agosto de 2020.

BERCINI, L. O. Mortalidade neonatal de residentes em localidade urbana da região sul do Brasil. Revista de Saúde Pública, v. 28, p. 38-45, 1994. Disponível em: Acesso em: 14 de agosto de 2020.

Brasil. Ministério da Saúde. Departamento de Informática do Sistema Único de Saúde (DATASUS). Estatísticas Vitais [Internet]. 2016 [cited 2017 Aug 02]. Disponivel em: Acesso em: 14 de agosto de 2020.

LEAL, M. do C.; SZWARCWALD, C. L. Evolução da mortalidade neonatal no Estado do Rio de Janeiro, Brasil (1979-1993): análise por causa segundo grupo de idade e região de residência. Cadernos de Saúde Pública, v. 12, p. 243-252, 1996. Disponível em: Acesso em: 14 de agosto de 2020. 


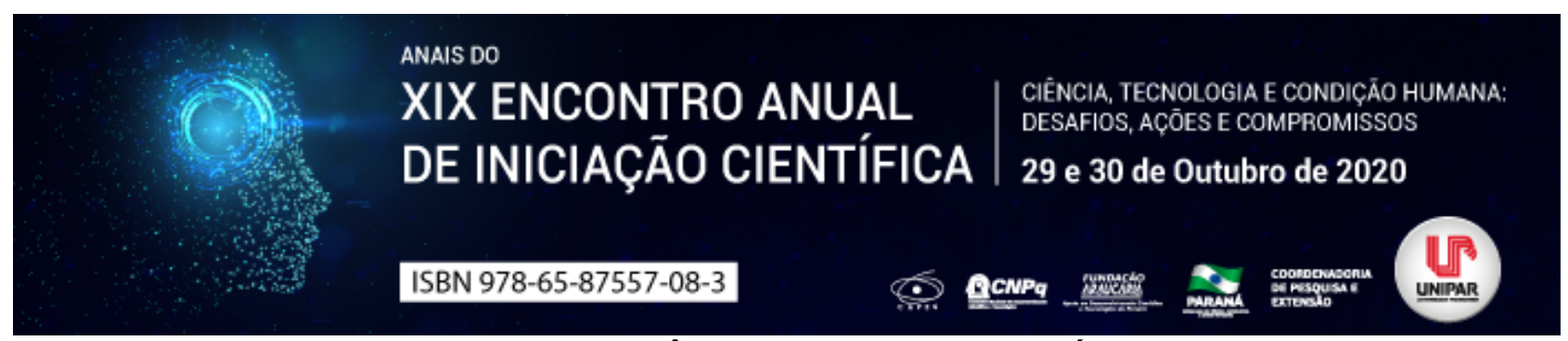

\title{
UMA ABORDAGEM DO TRATAMENTO FISIOTERAPÊUTICO PRECOCE NO ESTÍMULO DO DESENVOLVIMENTO MOTOR DE CRIANÇAS COM SÍNDROME DE DOWN
}

${ }^{1}$ LAURA HEIS OLIVO, ${ }^{2}$ DORA DE CASTRO AGULHON SEGURA

\author{
${ }^{1}$ Acadêmica do curso de Fisioterapia da UNIPAR \\ ${ }^{1}$ Docente da UNIPAR
}

Introdução: Segundo Ferrarini (2016), a Síndrome de Down é uma anomalia genética caracterizada pela trissomia do cromossomo 21, que desencadeia uma série de características comuns e atraso no desenvolvimento de diversas habilidades físicas e cognitivas. Devido ao desenvolvimento mais lento, se estimuladas as ações motoras e intelectuais mais precocemente os portadores poderão se desenvolver com o máximo de normalidade dentro de suas limitações. Quanto antes começar o tratamento fisioterapêutico objetivando a aquisição das funções normais melhor será o prognóstico do indivíduo em fase adulta (HALLAL; MARQUES; BRACCIALLI, 2008; HINTZ, 2017).

Objetivo: Descrever sobre a abordagem fisioterapêutica precoce em portadores de Síndrome de Down.

Desenvolvimento: Um dos problemas neuromusculares mais comuns em crianças com Síndrome de Down é a hipotonia muscular, que retarda o desenvolvimento motor e pode gerar lesões. Apesar da doença não ter cura, se exercitado o quadro disfuncional através de manipulações terapêuticas ofertadas por profissionais da fisioterapia pode haver uma melhora extremamente significativa das alterações (MARINHO, 2018). Simeonsson, Cooper e Sheiner (1982) destacam como forma terapêutica o estímulo precoce com objetivo de facilitar o desenvolvimento motor e cognitivo dos portadores. Além disso, a intervenção precoce previne instabilidades articulares e deformidades ósseas, contribuindo para a aquisição de habilidades funcionais na área da mobilidade corporal. A equoterapia compõe um método terapêutico educacional que busca o desenvolvimento biopsicossocial. A técnica utiliza o cavalo que conforme a movimentação estimula terminações neuromusculares, fortalecendo habilidades motoras e facilitando a independência funcional (BRILINGER, 2005). Ainda, a fisioterapia aquática como método fisioterapêutico permite a normalização do tônus muscular, possibilitando maior funcionalidade corporal. Além disso, promove maior amplitude de movimento, melhorando a força muscular, equilíbrio, locomoção e coordenação, capacita o condicionamento respiratório e a circulação sanguínea (PRADO, 2019).

Conclusão: Assim sendo, diante das dificuldades dos portadores de Síndrome de Down a fisioterapia é importante e necessária para o desenvolvimento precoce neuropsicomotor. Conforme apresentado, concluiu-se que alguns métodos da fisioterapia convencional, voltados para a cinesioterapia clássica, bem como através de técnicas diferenciadas como a equoterapia e a fisioterapia aquática, são capazes de promover normalização do tônus, estímulo da motricidade normal e avanços em demais habilidades físicas e cognitivas.

\section{Referências}

BRILINGER, C. O. A influência da equoterapia no desenvolvimento motor do portador de Síndrome de Down: Estudo de um caso. 2005. 110 f. Trabalho de Conclusão de Curso (Graduação em Fisioterapia) - Universidade do Sul de Santa Catarina, Tubarão-SC, 2005.

FERRARINI, A. C. A criança com Síndrome de Down na educação infantil: Uma pesquisa bibliográfica. 2016.46 f. Trabalho de Conclusão de Curso (Graduação em Pedagogia) - Centro de Educação, Comunicação e Artes da Universidade Estadual de Londrina, Londrina-PR, 2016.

HALLAL, C. Z.; MARQUES, N. R.; BRACCIALLI, L. M. P. Aquisição de habilidades funcionais na área de mobilidade em crianças atendidas em um programa de estimulação precoce. Revista Brasileira de Crescimento e Desenvolvimento Humano, v. 1, n. 18, p. 27-34, 2008.

HINTZ, T. F. A Equoterapia no desenvolvimento do sujeito com Síndrome de Down - Um estudo de caso em Santa MariaRS. 2017. 45 f. Trabalho de Conclusão de Curso (Graduação em Educação Especial) - Universidade Federal de Santa Maria, Santa Maria-RS, 2017.

MARINHO, M. F. S. A intervenção fisi9terapêutica no tratamento motor da Síndrome de Down: Uma revisão bibliográfica. Revista Campo do Saber, v. 4, n. 1, p. 2447-50, 2018.

PRADO, C. E. S. Efeitos da fisioterapia aquática em pacientes portadores de Síndrome de Down. $2019.31 \mathrm{f}$. Trabalho de Conclusão de Curso (Graduação em Fisioterapia) Universidade Federal de Uberlândia, Uberlândia-MG, 2019.

SIMEONSSON, R. J.; COOPER, D. H.; SHEINER, A. P. A review and a analysis of the effectiveness of early intervention programs. Pediatric, v. 69, p. 635-40, 1982. 
Coordenadoria de Pesquisa e Extensão - COPEX

Departamento de Editoraçāo e Divulgaçāo Científica - DEDIC 


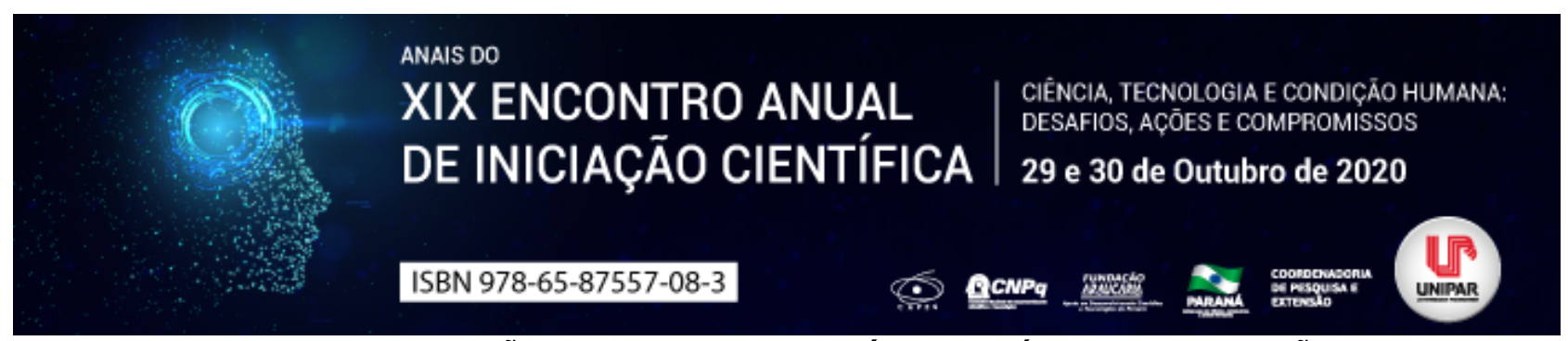

INSTRUMENTOS DE AVALIAÇÃO DO DESEMPENHO TÉCNICO-TÁTICO NA INICIAÇÃO AO FUTSAL

\author{
${ }^{1}$ GUILHERME SANTOS GONZALES, ${ }^{2}$ MURILO ACACIO MACHADO DE OLIVEIRA, ${ }^{3}$ GLEIBY REGINA MARTINS GOMES, \\ ${ }^{4}$ MARCELO FIGUEIRO BALDI
}

\author{
${ }^{1}$ Acadêmico do PIC/UNIPAR \\ ${ }^{1}$ Acadêmico do Curso de Educação Física da UNIPAR \\ ${ }^{2}$ Acadêmica do Curso de Educação Física da UNIPAR \\ ${ }^{3}$ Docente da UNIPAR
}

Introdução: O treinamento de futsal exige dos alunos muitas habilidades em diferentes áreas e uma delas é o desempenho técnico-tático. O desempenho técnico-tático é de suma importância, pois é através dele que se avalia a adaptação, tomada de decisão e eficácia durante a partida, permitindo aprimorar o planejamento, controle dos treinos e obter mais informações sobre o rendimento individual dos atleta (SALLES; COLLET; NASCIMENTO, 2012). Para a avaliação do desempenho técnico-tático os profissionais de Educação Física contam com os seguintes instrumentos: GPAl (Game Performance Assessment Instrument), TSAP (Team Sport Assessment Procedure) (SANTOS et al.,2016), FUT-SAT (Sistema de Avaliação Tática no Futebol) (SAAD, 2012). No entanto, a aplicação de tais instrumentos pode gerar dúvida em função do desconhecimento acerca dos mesmos. Diante do exposto, o presente estudo procurou responder ao seguinte problema de pesquisa: como avaliar o desempenho técnico-tático na iniciação ao futsal?

Objetivo: Analisar os instrumentos de avaliação do desempenho técnico-tático na iniciação ao futsal.

Desenvolvimento: A evolução das pesquisas em esportes coletivos, indicou a necessidade do desenvolvimento conjunto dos aspectos técnicos-táticos. Sendo assim fez-se necessário o uso de instrumentos de avaliação técnico-tática, onde se avalia a eficiência, eficácia e adaptação, em outras palavras como fazer e como utilizar (SAAD, 2012).O treinador utiliza dessas informações para que possa ter um processo eficaz de ensino-aprendizagem-treinamento, compreendendo as particularidades do treino (SAAD, 2015). Existem na literatura testes como GPAI (Game Performance Assessment Instrument), onde se avalia o desempenho do jogo em uma visão tática, através de como o jogador resolve problemas táticos em contexto ecológico. Pode ser realizado em observação direta ou filmagem, sua desvantagem é que não há parâmetros de comparação, permitindo apenas comparação entre atletas, ou o TSAP (Team Sport Assessment Procedure) que classifica a situação de cada jogador em relação a componentes técnicos e táticos em situação de jogo, sua abordagem é realizada de forma holística, sua desvantagem é que sua visão holística é sobre o desempenho da equipe (SANTOS et al.,2016). Também há instrumentos como FUT-SAT que avaliam em situações reduzidas de jogo como goleiro mais três jogadores, em busca de um método que avalia todos os componentes de desempenho Saad (2012) se baseou em instrumentos já existentes para a construção de uma nova avaliação, fazendo com que esse novo instrumento avalie os seguintes componentes de desempenho: a adaptação, a tomada de decisão e a eficácia de forma mais específicas, onde um avalia aspectos técnicos, outro tático e por fim se avalia o desempenho técnico de forma individual (SAAD; COLLET; NASCIMENTO, 2019). Em seu estudo Saad et al. (2014) aplicou o teste em 5 grupos, onde um focava na unidimensionalidade técnica, duas em atividades de jogo e outras duas em atividades técnico-tático, as equipes do técnico-tático tiveram melhores resultados sobre adaptação, tomada de decisão e eficácia.

Conclusão: É possível concluir, que o uso de instrumentos de avaliação do desempenho técnico-tático é de extrema importância, e quanto mais eficiente e mais completo for o teste mais eficaz será a análise, para que o profissional consiga acompanhar as falhas e habilidades da equipe, para que o mesmo saiba em quais atividades investir mais tempo, e em que fase competitiva incluir atividades de jogo, técnicas e táticas.

\title{
Referências
}

SAAD, M. A; COLLET, C; NASCIMENTO, J. V. Construção e validação preliminar do instrumento de avaliação do desempenho técnico-tático no futsal. Revista Brasileira Educação Física Esporte, São Paulo, v.4, n.33, p.597-609, out.-dez. 2019.

SANTOS et al. Avaliação de performance em jogos-desportivos: GPAI e TSAP. Conexões, Campinas, v.14, n.2, p.137-157, abr./jun. 2016.

SALLES, W. N; COLLET, C; NASCIMENTO, J. V. Avaliação do desempenho técnico-tático entre atletas de voleibol feminino infantil. EFDeportes.com, Buenos Aires, v.17, n.168, mai. 2012.

SAAD, M. A; NASCIMENTO, J. V; MILISTETD, M. Nível de desenvolvimento técnico-tático de jovens jogadores de futsal, considerando a experiência esportiva. Revista da Educação Física/UEM, v. 24, n. 4, p. 535-544, out. 2013.

SAAD, M. A. et al. Estrutura das sessoẽs de treinamento técnico - tático de equipes de futsal sub-13 e sub-15 ao longo da 
temporada. Revista Brasileira de Futsal e Futebol, São Paulo, v. 7, n. 25, p. 360-365. ago. 2015.

SAAD, M. A. et al. Impacto das metodologias empregadas pelos treinadores no desenvolvimento técnico-tático individual dos jogadores de futsal das categorias sub-13 e sub-15. Revista Brasileira de Ciência e Movimento. v. 22, n. 2, p. 96-105. jun. 2014.

SAAD, M. A. A formação técnico-tática de jogadores de futsal nas categorias sub-13 e sub-15: Análise do processo de ensino-aprendizagem-treinamento. Orientador: Prof. Dr. Juarez Vieira do Nascimento. 2012. 164 p. Tese (Doutorado em Educação Física) - Universidade Federal de Santa Catarina, Florianópolis, 2012.

Coordenadoria de Pesquisa e Extensão - COPEX

Departamento de Editoraçāo e Divulgaçāo Científica - DEDIC 


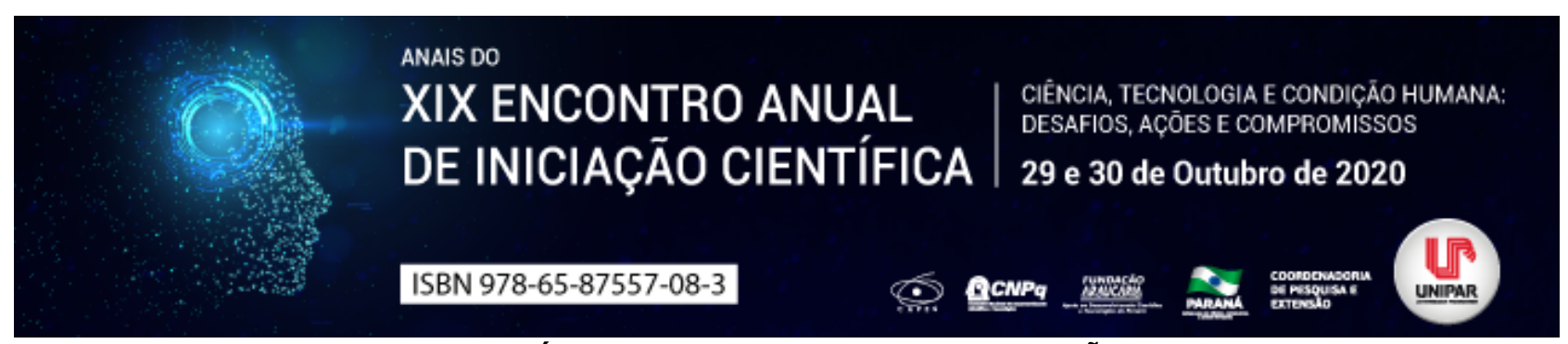

ASPECTOS FISIOLÓGICO DA SENSIBILIDADE NA REGIÃO OROFACIAL

\title{
${ }^{1}$ ISABELLA CARDOSO MARTINS, ${ }^{2}$ JENIFFER URBANO DEGASPERI, ${ }^{3}$ DANIELA DE CASSIA FAGLIONI B CERANTO
}

\author{
${ }^{1}$ Acadêmico do Curso de Odontologia UNIPAR \\ ${ }^{1}$ Acadêmica do Curso de Odontologia da UNIPAR \\ ${ }^{2}$ Docente da UNIPAR
}

Introdução: A região orofacial é considerada uma das mais sensíveis do corpo humano, isso se deve à presença de campos receptivos pequenos, porém, em grandes quantidades, o que causa uma maior sensibilidade em relação às outras regiões corporais. O aumento da sensibilidade é delicado, pode estar relacionado à sensibilização periférica, quando há inflamação local ou à sensibilização central, nestes casos, altera a funcionalidade dos neurônios e em vias nociceptivas que são as responsáveis pela transdução de informações dolorosas, provocados pela maior excitabilidade da membrana (ASHMAVI, et al., 2016). Os estímulos podem ser reconhecidos de diferentes formas, e em cada região ele terá uma incidência, com isso tem-se o mapeamento do córtex, chamado de homúnculo, com figuras distorcidas em que as maiores áreas corticais refletem uma maior sensibilidade, o que acontece na região orofacial (SILVA, et al., 2013). Nesse sentido, se trata de um tema extremamente importante pois está ligado à dor orofacial, que é bastante prevalente, e qualquer alteração nesse nível poderia gerar um desequilíbrio na região e até mesmo no sistema. Portanto, é necessário que o cirurgião dentista e também os estudantes de odontologia compreendam o assunto e sua relevância pois está diretamente relacionado com a sua área de atuação.

Objetivo: Revisar a literatura sobre a importância da sensibilização central no estudo da fisiologia humana como um avanço para a abordagem da dor e fenômenos que podem alterar a homeostasia através da sensibilidade na região orofacial.

Desenvolvimento: A sensibilidade é a responsável por garantir a captação de informações do meio, interpretá-las e consequentemente dar uma resposta, com isso tem-se a sensibilização central que traz os potenciais de ação com informações dos estímulos, sendo eles gerados na periferia e levados até o córtex cerebral, e então à consciência (FREIRE, et al., 2016). A sensibilização central é o fenômeno que apresenta as alterações que ocorrem no sistema nervoso central, trazendo grandes consequências ao paciente, como dores que afetam diversas regiões, na orofacial têm-se as dores de origem dentoalveolar, de origem musculoesquelética, dores da mucosa bucal, dores neuropáticas da boca e face e dores que não são de origem odontogênica (ASHMAVI, et al., 2016). As informações sensoriais da região orofacial, inclusive a dor, são transmitidas pelo nervo trigêmeo. As informações nociceptivas, captadas pelos nociceptores localizados em toda a cavidade oral, são enviadas via fibras A delta e C, por vias distintas até o sistema nervoso, onde são codificadas e refletem em respostas conscientes e comportamentais frente ao estímulo (BALDO; REGATÃO, 2013). Na região orofacial estão presente os receptores táteis, sendo o de maior sensibilidade o corpúsculo de Meissner, uma terminação nervosa de fibra sensorial mielinizada, encontrado nos lábios e em outras regiões, eles são sensíveis aos movimentos na superfície da pele, o que garante a essa região uma maior sensibilidade (GUYTON; HALL, 2011). As sensações somestésicas, captadas por receptores sensoriais de todas as partes do corpo entram no sistema nervoso pelas raízes dorsais da medula espinal, e ascendem por meio de um dos dois sistemas: o lemniscal ou o anterolateral. A cognição relacionada às sensibilidades dolorosas são encaminhadas pelo anterolateral, que também garante a modulação da sensibilidade dolorosa (BALDO; REGATÃO, 2013).

Conclusão: A sensibilidade na região orofacial, quando excessiva, causa a dor, sua mensuração pode mostrar como é o equilíbrio dessa região. A dor por tempo prolongado altera morfofisiologicamente os receptores centrais o que pode levar à sensibilização, ao ponto de condições dolorosas serem mantidas mesmo sem estímulos clinicamente identificáveis, o que dificulta o diagnóstico e, consequentemente, o tratamento. Por isso, é essencial que os cirurgiões dentistas explorarem não só a anatomia mas principalmente a fisiologia da região e dor.

\section{Referências}

ASHMAVI, Hazem Adel; FREIRE, George Miguel Goés. Sensibilização periférica e central. Revista Dor, São Paulo, v. 17, n. 1, p. 31-34, outubro. 2016.

BALDO, Marcus Vinícius C; REGATÃO, Milene Camargo. Fisiologia Oral. São Paulo: Santos Editora, 2013.

FREIRE, George Miguel Goés; ASHMAVI, Hazem Adel. Sensibilização periférica e central. Revista Dor, São Paulo, v. 17, n. 1, p. 31-34, outubro. 2016.

GUYTON, Arthur; HALL, Jhon Edward. Tratado de fisiologia médica. 12. ed. Rio de Janeiro: Elsevier, 2011.

SILVA, Sergio Gomes. A gênese cerebral da imagem corporal: algumas considerações sobre o fenômeno dos membros fantasmas em Ramachandran. Revista de Saúde Coletiva, Rio de Janeiro, v. 23, n.1, p. 167-195, janeiro. 2013. 
Coordenadoria de Pesquisa e Extensão - COPEX

Departamento de Editoraçāo e Divulgaçāo Científica - DEDIC 


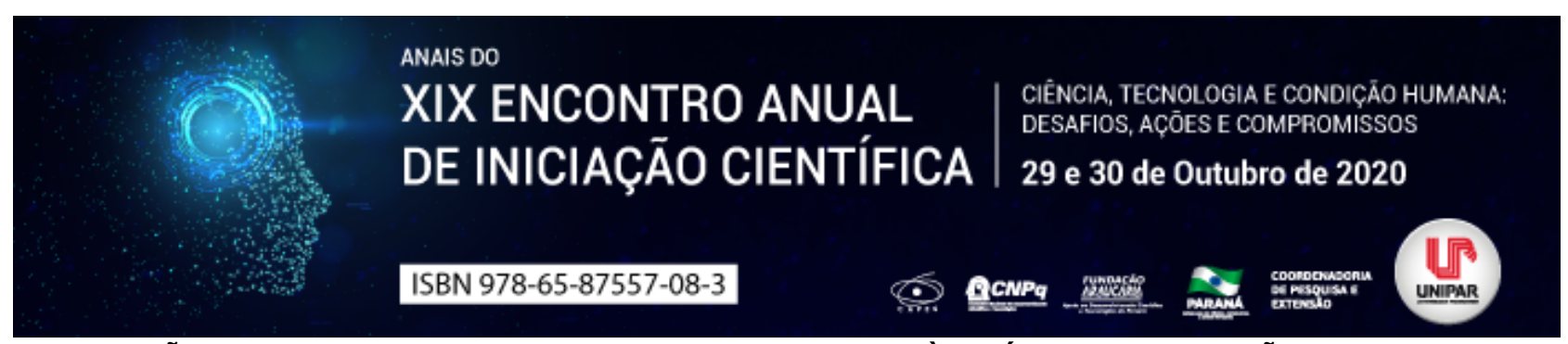

POPULAÇÃO LGBTQIA+ E O MITO DO ACESSO UNIVERSAL À SAÚDE: UMA REVISÃO DE LITERATURA

\title{
${ }^{1}$ GUSTAVO HENRIQUE ISTOSKI HEINZ, ${ }^{2}$ ANA CAROLINA SOARES FRAGA ZAZE
}

\author{
${ }^{1}$ Acadêmico do PIBIC/Unipar \\ ${ }^{1}$ Docente da UNIPAR/Umuarama
}

Introdução: O movimento LGBTQIA+ (lésbicas, gays, bissexuais, travestis, transexuais, transgêneros, queers, intersex, agêneros, assexuados e mais) teve sua eclosão no final da década de 70 , todavia tomando força no século XXI, segundo Bortoletto (2019). Conforme publicação de Russel e More em 2016 (apud SCHENEL, 2018), a população LGBTQIA+ tem um acesso reduzido aos serviços de saúde, mesmo tal área tendo como obrigação oferecer amparo de maneira afável e decisiva. $O$ que pode ser apontado como justificativa é a formação acadêmica de profissionais inseridos em uma estrutura curricular heteronormativa, não sabendo lidar com diferentes orientações sexuais e identidades de gênero, questão discutida durante a $2^{\mathrm{a}}$ Semana de Combate às Fobias de Gênero na Saúde da Universidade Federal de Santa Catarina.

Objetivo: Realizar uma revisão bibliográfica acerca do acesso, contato e manejo clínico comportamental da população LGBTQIA+ aos serviços de saúde.

Desenvolvimento: Cardoso e Ferro (2012) definiram que a população LGBT é aquela não conformada com a identidade sexual heterenormativa ou do sexo biológico para com o gênero, assim, tendo seus direitos humanos básicos feridos e possivelmente firmada em uma situação de vulnerabilidade. Um dos principais problemas enfrentados por LGBTs, de acordo com Carvalho e Philippi (2012), está na recepção acolhedora e no manejo dos estabelecimentos de serviço de saúde perante à comunidade. Segundo publicação de Miller (2002 apud CARDOSO; FERRO, 2012), a abreviatura LGBT deve ser entendida de forma diferenciada, separando identidade de genêro ( $T$ de transsexuais e travestis) e sexualidade ( $L$ de lésbicas, $G$ de gays e $B$ de bissexuais), porque os diferentes grupos sofrem uma caminhada de adoecimento divergentes e consequentemente necessitarão de tratamento e ajuda profissional distintas. Um levantamento realizado no Distrito Federal por Carvalho e Phillippi (2012) mostrou que há diversas dificuldades encontradas por lésbicas, gays, bissexuais, transgêneros ao buscarem os serviços de saúde, tanto em rede privada quanto pública. Entre esses desconcertos apresenta-se piadas de mau gosto, deboche, falta de instrução dos profissionais da saúde para esclarecimento de questões pertinentes da comunidade. Estatisticamente a pesquisa mostrou o seguinte: $56,6 \%$ dos entrevistados acham necessário um conhecimento prévio e básicos dos servidores da saúde sobre assuntos específicos da comunidade e também a diminuição do preconceito, visto que $43,3 \%$ já afirmaram ter sofrido alguma discriminação advinda de um ambiente de saúde (público ou privado). Sendo assim, a população LGBT não tem suas necessidades de saúde contempladas por estar subordinada à homofobia, ou seja, à rejeição ou à intolerância irracional à homossexualidade. (ARAUJO et al, 2006 apud ALBUQUERQUE et al, 2013, p. 521). Quanto a instrução dos profissionais para lidar com a comunidade, Schenel em 2018, publicou que tal problema pode ser consequência da falta de conteúdos e disciplinas disponibilizadas aos estudantes durante o período de graduação. Além disso, Madhan (2011 apud SCHENEL, 2018) destacou uma baixa empatia dos estudantes universitários para com a comunidade LGBTQIA+ quando posta lado a lado com outras populações estigmatizadas (portadores de HIV, doentes mentais, narcóticos). Os discentes manifestaram menor relevância de cuidado e preocupação aos LGBTs. Em 2013, Albuquerque e colaboradores relataram um pequeno resultado de pesquisa científica mostrando dados e a condição de atendimento, comportamento e conhecimento dos profissionais da saúde em relação ao grupo. Os autores recomendaram o estímulo de pesquisas multidisciplinares e focadas também em especialidades para gerar resultados científicos que possam nortear políticas e aproximação de pessoas LGBTQIA+ para o ambiente de saúde e informar aos profissionais a necessidade de manifestar uma relação coesa com o grupo.

Conclusão: É, portanto, notória a dificuldade de assistência à saúde encontrada por pessoas LGBTQIA+. A homofobia por parte dos profissionais de saúde, total ou parcial desconhecimento das particularidades da comunidade manifestadas por colaboradores da saúde são paradigmas que precisam ser vencidos para toda população receber um auxílio integral. Além do mais, as instituições de ensino superior são ativas na produção da ciência. Alunos, professores e pesquisadores trabalham para realizar uma formação crítica e sempre buscando construir uma sociedade democrática e integra. Deste modo, uma das soluções plausíveis é o desenvolvimento de estudos científicos voltados às minorias em questão. Também deve existir uma maior inclusão de disciplinas e conteúdos a serem ministrados durante o período de graduação abordando tal tema e suas particularidades de atendimento.

\section{Referências}

$2^{\mathrm{a}}$ Semana de Combate às Fobias de Gênero na Saúde. 2016. Disponível em: http://saudepublica.ufsc.br/wpcontent/uploads/2017/05/1a Carta enfrentamento as fobias de genero na saúde.pdf . Acesso em: 18 jul. 2020. 
ALBUQUERQUE, Grayce Alencar et al. Homossexualidade e o direito à saúde: um desafio para as políticas públicas de saúde no Brasil. Saúde debate, Rio de Janeiro, v. 37, n. 98, p. 516-524, Set. 2013. Dispoível em: http://www.scielo.br/scielo.php? script=sci_arttext\&pid=S0103-11042013000300015\&Ing=en\&nrm=iso. Acesso em: 18 jul. 2020.

BORTOLETTO, Guilherme Engelman. LGBTQIA+: identidade e alteridade na comunidade. Orientador: Emerson Nascimento. 2019. Monografia (Especialista em Gestão de Produção Cultural) - Universidade de São Paulo, São Paulo, 2019. Disponível em: http://celacc.eca.usp.br/?q=pt-br/tcc_celacc/lgbtqia-identidade-alteridade-comunidade

CARDOSO, Michelle Rodrigues; FERRO, Luís Felipe. Saúde e população LGBT: demandas e especificidades em questão. Psicol. cienc. prof., Brasília, v. 32, n. 3, p. 552-563, 2012. Disponível em: http://www.scielo.br/scielo.php? script=sci_arttext\&pid=S1414-98932012000300003\&lng=en\&nrm=iso. Acesso em: 18 jul. 2020.

CARVALHO, Laudenize Souza; PHILIPPI, Miriam May. Percepção de lésbicas, gays e bissexuais em relação aos serviços de saúde. Universitas: Ciências da Saúde, Brasília, v. 11, n. 2, p. 83-92, jul./dez. 2013. Disponível em: https://www.publicacoesacademicas.uniceub.br/cienciasaude/article/view/1837/2286. Acesso em: 18 jul. 2020.

SCHENAL, Tainá Alexandra. A temática LGBT na formação em Odontologia: uma revisão de literatura. Orientador: Mirelle Finkler. 2018. Monografia (Bacharelado em Odontologia) - Universidade Federal de Santa Catarina, Florianópolis, 2018. Disponível em: https://repositorio.ufsc.br/handle/123456789/191207?show=full 


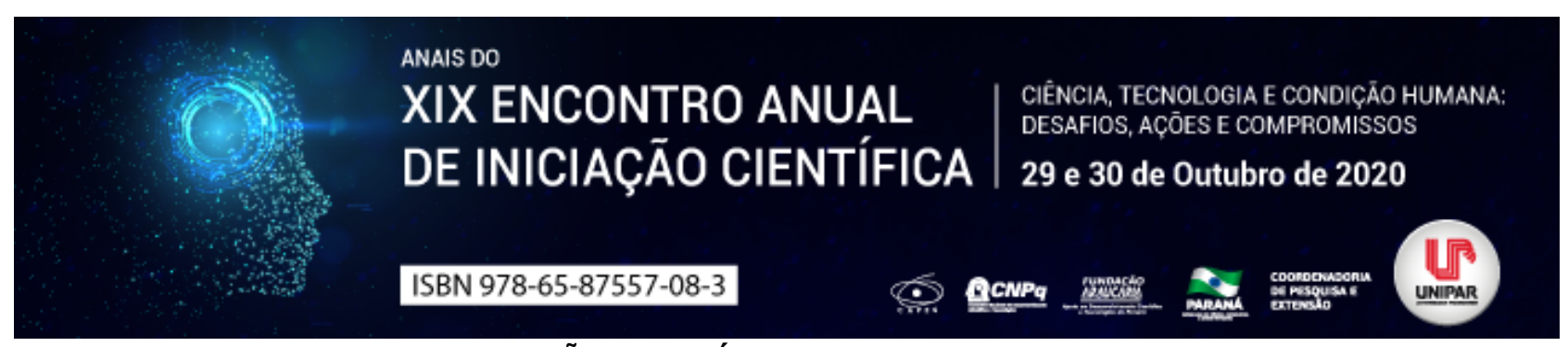

AVALIAÇÃO DE SAÚDE BUCAL DE ESCOLARES

\begin{abstract}
${ }^{1}$ BRUNA CAMILA WEBER, ${ }^{2}$ VERONICA DE MORAES, ${ }^{3}$ FERNANDA LIMA, ${ }^{4}$ GEOVANE CAPANA FIDELI, ${ }^{5}$ JULIANA GARCIA MUGNAI VIEIRA SOUZA, ${ }^{6}$ HELEN CRISTINA LAZZARIN
\end{abstract}

\author{
${ }^{1}$ Acadêmico do Curso de Odontologia da UNIPAR \\ ${ }^{1}$ Acadêmica do Curso de Odontologia da UNIPAR \\ ${ }^{2}$ Acadêmica do Curso de Odontologia da UNIPAR \\ ${ }^{3}$ Acadêmico do Curso de Odontologia da UNIPAR \\ ${ }^{4}$ Docente da UNIPAR \\ ${ }^{5}$ Docente da UNIPAR
}

Introdução: O Brasil é um dos países que apresenta, para todas as idades, um dos maiores índices de cárie dentária e periodontopatias. Entretanto, a prática odontológica ainda concentra suas ações no campo da assistência individual consistindo, tecnicamente, em procedimentos cirúrgico-restauradores e as poucas ações de promoção de saúde bucal coletiva são desenvolvidas, em sua maioria pelo poder público (CASTRO et al., 2012). O Programa Saúde na Escola (PSE) é uma política intersetorial do Ministério da Saúde e do Ministério da Educação, instituído em 2007. O programa tem como objetivo contribuir para a formação integral dos estudantes da rede pública por meio de ações de promoção, prevenção e atenção à saúde (BRASIL, 2009). Quando considerado os cuidados odontológicos, dentro do PSE é realizado o levantamento, tratamento e monitoramento das necessidades de saúde bucal identificadas e a inserção de ações de promoção da saúde nas escolas (BRASIL, 2009).

Objetivo: Avaliar a saúde bucal de crianças atendidas no Programa Saúde na Escola (PSE), no bairro Santa Cruz, município de Cascavel PR, e verificar se a inserção deste programa surtiu alguma melhoria na saúde bucal desses escolares.

Material e Métodos: Foram avaliados dados secundários de 717 estudantes da escola municipal Edson Pietrobelli CAIC II (Centro de Atenção Integral a Criança e ao Adolescente) e da escola Ademir Correa na faixa etária de 5 a 6 anos e de 9 a 10 anos. Estes exames foram realizados pelos cirurgiões dentistas da atenção básica responsáveis pelos atendimentos da clínica odontológica do CAIC II, no bairro Santa Cruz, do município de Cascavel PR nos anos de 2016 e 2018. Os exames odontológicos dos escolares já previamente realizados consistem em dividir as alterações bucais por riscos. O risco 1 indica presença de cárie, mancha branca, alteração gengival e dente com indicação de extração; o risco 2 indica placa bacteriana e dente fraturado; e o risco 3 a presença de restauração e outros problemas como ortodontia. A pesquisa foi aprovada pelo Comitê de Ética em Pesquisa Envolvendo Seres Humanos (CEPEH) sob o parecer número 4.054.272.

Resultados: Participaram da pesquisa 717 estudantes sendo 458 alunos de 5 a 6 anos (63,87\%). Já no grupo de 9 a 10 anos, foram usados dados de 259 alunos (36,12\%). Em 2016, os alunos de 9 a 10 anos apresentaram uma maior porcentagem de casos referentes ao risco 1 (74,40\%), do que os de 5 a 6 anos (64,45\%). Entretanto, no total do risco 2, quem prevaleceu foram as crianças de 5 a 6 anos (43,79\%). Já no risco 3 a idade de 9 a 10 anos apresentou quase o dobro de casos (30,52\%), comparado com os menores (16,10\%). Já em 2018 os alunos de 9 a 10 anos apresentaram um maior número de casos (59,99\%) referentes ao risco 1, quando comparado às crianças de 5 a 6 anos, que tiveram uma porcentagem de $35,44 \%$. No risco 2 , os alunos de 9 a 10 anos apresentaram 17,69\% de casos e os de 5 a 6 anos 8,33\%. O resultado também foi maior para o grupo de 9 a 10 anos no total de risco 3, pois apresentaram 33,06\% de casos, e os de 5 a 6 anos totalizaram 15,27\%. Comparando os resultados dos alunos de 5 a 6 anos, no período de 2016, o total do risco 1 foi de $64,45 \%$, o risco 2 totalizou $43,79 \%$ de casos, e o risco 3 deu um resultado de 16,10\%. Já no ano de 2018 o resultado para risco 1 foi de 35,64\%, para o risco 2 foi de 8,33\% e a soma dos casos de risco 3 resultou em 15,27\%. Para os alunos de 9 a 10 anos, no risco 1, o total de casos em 2016 foi de 74,40\% e em 2018 de 59,99\%. O risco 2 esteve presente em 27,13\% dos alunos em 2016 e em 17,69\% deles em 2018. Em 2016 30,52\% dos avaliados apresentaram risco 3, já em 2018 esse resultado aumentou para 33,06\%.

Discussão: Segundo Pesquisa Nacional de Saúde Bucal aos 5 anos de idade 46,6\% das crianças brasileiras estão livres de cárie na dentição decídua e aos 12 anos 43,5\% apresentam a mesma condição na dentição permanente (BRASIL, 2011). Tais dados corroboram com os encontrados em Cascavel PR de 2018 em que 49,53\% das crianças de 5 a 6 anos e 31,53\% das crianças de 9 a 10 anos não apresentaram alterações bucais. Outro estudo semelhante realizado na cidade de Água Santa RS com escolares de 12 anos de escolas públicas revelou que 50,5\% consideravam necessitar de algum tipo de tratamento odontológico (MORO et al., 2009) que está de acordo com as pesquisas já citadas. É valido ressaltar que a pesquisa foi realizada em crianças de apenas um bairro de Cascavel PR, e mesmo a literatura mostrando evidências similares, o bairro em questão é de classe econômica mais baixa, podendo influenciar nos resultados obtidos. 
Conclusão: Diante da pesquisa realizada, foi possível observar que o Programa Saúde na Escola vem sendo eficaz com relação à saúde bucal visto que os índices de alterações bucais diminuíram de 2016 para 2018. É importante ressaltar que a promoção de saúde depende também do engajamento e compromisso dos profissionais de saúde e com a eficácia e eficiência deste projeto é possível reduzir os problemas bucais.

\section{Referências}

BRASIL. Ministério da Saúde. Secretaria de Atenção à Saúde. Departamento de Atenção Básica. Saúde na Escola - Caderno de Atenção Básica 24/ Ministério da Saúde, Secretaria de Atenção à Saúde, Departamento de Atenção Básica. Brasília : Ministério da Saúde, 2009. 96 p. Disponível em: . Acesso em: 18 de ago. de 2020.

BRASIL. Ministério da Saúde. Projeto SB Brasil 2010: pesquisa nacional de saúde bucal 2010: resultados principais / Ministério da Saúde, Secretaria de Atenção à Saúde, Departamento de Atenção Básica. Brasília: Ministério da Saúde, 2011. Disponível em: . Acesso em: 18 de ago. de 2020.

CASTRO, Christina Oliveira de et. al.Programas de educação e prevenção em saúde bucal nas escolas: análise crítica de publicações nacionais. Odontologia Clínico Científica., Recife, v. 11, n. 1, p. 51-56, jan./mar., 2012. Disponível em: . Acesso em: 18 de ago. de 2020.

MORO, Leonardo et al. Condições de saúde bucal de escolares de 12 anos de idade, município de Água Santa, Rio Grande do Sul, Brasil. Revista da Faculdade de Odontologia de Porto Alegre, Porto Alegre, v. 50, n. 2, p. 12-17, mai./ago. 2009. Disponível em: . Acesso em: 18 de ago. de 2020. 


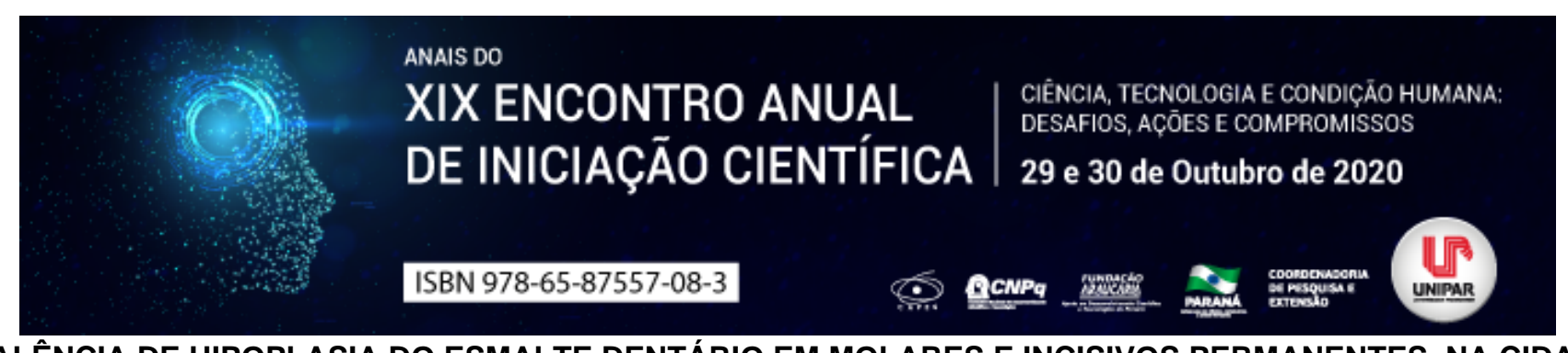

PREVALÊNCIA DE HIPOPLASIA DO ESMALTE DENTÁRIO EM MOLARES E INCISIVOS PERMANENTES, NA CIDADE DE CRUZEIRO DO OESTE, PR - BR: RESULTADOS PARCIAIS

\author{
${ }^{1}$ GUSTAVO HENRIQUE ISTOSKI HEINZ, ${ }^{2}$ CAMILA SESTITO FRANCISCATO, ${ }^{3}$ MARIANA CAPARROZ ALENCAR, ${ }^{4}$ NATHALIA \\ VOLPATTO FERREIRA, ${ }^{5}$ THALIA HAMURA, ${ }^{6}$ ANA CAROLINA SOARES FRAGA ZAZE
}

\begin{abstract}
${ }^{1}$ Acadêmico Bolsista do PIBIC/Unipar
${ }^{1}$ Acadêmica do PIC/UNIPAR

${ }^{2}$ Acadêmica do Curso de Odontologia da UNIPAR

${ }^{3}$ Egressa do curso de Odontologia da UNIPAR-Umuarama

${ }^{4}$ Egressa do curso de Odontologia da UNIPAR/Umuarama

${ }^{5}$ Docente da UNIPAR/Umuarama
\end{abstract}

Introdução: Com função de proteger e revestir o elemento dentário, o esmalte dental pode sofrer alterações em sua formação mineral. Durante os inúmeros processos da amelogênese é possível que ocorram anomalias, seja hipoplasias e hipomineralização, segundo publicação de Santos e colaboradores em 2014.

Hoffmann, Sousa e Cypriano (2007) definiram que a hipoplasia do esmalte é uma deficiência de esmalte advinda de alterações de desenvolvimento. Ela pode se manifestar na forma de fissuras, fóssulas e perdas de grandes áreas minerais.

Objetivo: O presente trabalho busca mostrar, de forma parcial, os resultados obtidos pelo levantamento epidemiológico da hipoplasia do esmalte dentário em molares e incisivos permanentes, em escolares de 8 a 10 anos de idade do município paranaense de Cruzeiro do Oeste.

Material e método: A pesquisa foi desenvolvida visando levantar dados de forma epidemiológica de casos de hipoplasia dentária em crianças matriculadas na rede pública de ensino na cidade de Cruzeiro do Oeste- PR. Tal projeto foi aprovado pelo Comitê de Ética em Pesquisa envolvendo Seres Humanos da UNIPAR (CAAE 07675619.0.0000.0109). Foram convidados a participar alunos com idade entre 8 e 10 anos mediante assinatura do termo de consentimento pelos responsáveis. Os voluntários foram avaliados no ambiente escolar por três avaliadores calibrados, com ajuda de anotadores. Antes das análises dentais, as crianças realizaram a higiene bucal (escovação dentária com técnica de escovação supervisionada). Para avaliar os defeitos de desenvolvimento do esmalte, o índice escolhido foi o modificado e proposto na metodologia apresentada pela OMS. Todas as faces dos elementos 11, 12, 16, 21, 22, 26, 31, 32, 36, 41, 42 e 46 foram submetidas ao exame clínico e as devidas condições anotadas em fichas individuais. Posteriormente os dados foram tabulados em planilhas do Excel.

Resultados: A pesquisa foi encerrada em dezembro de 2019 e retomada em 2020. Até o último mês de 2019,214 crianças foram avaliadas e 88,3\% apresentaram algum nível de alteração em esmalte dentário ao menos em um elemento avaliado. Números obtidos após análise voluntários de cinco escolas de diferentes regiões da cidade. Escola 1 (84\% dos avaliados apresentaram graus de hipoplasia), Escola 2 (94\%), Escola 3 (86\%), Escola 4 (92\%) e Escola 5 (85,7\%). Futuramente novas análises serão realizadas para identificar os dentes mais afetados e a os graus de hipoplasia mais comuns. Autoridades responsáveis pela saúde bucal da cidade foram procuradas para obter informações e possíveis explicações para os resultados obtidos nos grupos estudados. Uma das hipóteses apresentadas foi os diferentes pontos de coleta e distribuição do sistema de água municipal. Portanto, será primordial um estudo detalhado do abastecimento hídrico público.

Discussão: Galassi em 2002 (apud LEÃO, 2010) publicou que a odontogênese começa durante a $11^{\circ}$ semana gestacional, o processo é iniciado com a formação da lâmina dentária envolvendo os germes dentários. O desenvolvimento comum do esmalte passa por três fases. Na primeira, secretora, ocorre a deposição da matriz orgânica. Na segunda, transição, observa-se a calcificação/mineralização da matriz secretada anteriormente. Na última fase, maturação, os cristais são complementados e expandidos. Por outro lado, Nishio, em 2008 afirmou que o esmalte dentário é formado por duas fases: secreção e maturação. O que regula todo processo de formação são os ameloblastos. Assim, durante o estágio de secreção, os ameloblastos sintetizam e secretam proteínas da matriz do esmalte, tais como amelogenina, ameloblastina e enamelina; e da enzima enamelisina . Também identificou que na ausência ou déficit de alguma proteína/enzima existem chances de ocorrer graus de hipoplasia do esmalte. Os defeitos de esmalte dental são comuns, com sua incidência variando entre as populações. A hipoplasia de esmalte é o defeito mais frequente, podendo acometer ambas as dentições (BEILACQUA; SACRAMENTO; FELÍCIO, 2010, p. 139). Em 2009, Souza e colaboradores publicaram que a hipoplasia dentária podem ser consequência de diversos meios. Cita-se origem hereditária, sistêmica ou local. Além disso, é díficil ter sua causa definida porque muitos pais ou responsáveis não são capazes de pontuar todos os problemas, traumas e acidentes que a criança foi vítima. Passos e coadjutores submeteram um artigo em 2007 que apontava a necessidade de existir um certo cuidado e critério ao diagnosticar lesões de hipoplasia do esmalte dental 
porque há riscos de serem confundidas com cáries dentárias incipientes.

Conclusão: Observa-se a necessidade de aprofundamento dos estudos acerca da hipoplasia dental visto que as causas podem ser diversas e consequentemente difíceis de serem encontradas. Sobre os resultados obtidos no projeto de pesquisa até o momento, foi observado que $88,3 \%$ da amostra apresentou defeitos na estrutura do esmalte dentário. Desta forma, o projeto irá se estender para tentar localizar os motivos que apresentam esse elevado número.

\section{Referências}

BEVILACQUA, Flávia Magnani; SACRAMENTO, Tamires; FELíCIO, Cristina Magnani. Amelogênese Imperfeita, hipoplasia de esmalte e fluorose dental - revisão de literatura. Revista Uniara, Araraquara, v. 13, n. 2, p. 136-148, 2010. Disponível em: https://www.uniara.com.br/legado/revistauniara/pdf/25/livia_artigo10.pdf. Acesso em: 7 ago. 2020.

HOFFMANN, Rosana H. Schlittler; SOUSA, Maria da Luz R. de; CYPRIANO, Silvia. Prevalência de defeitos de esmalte e sua relação com cárie dentária nas dentições decídua e permanente, Indaiatuba, São Paulo, Brasil. Cad. Saúde Pública, Rio de Janeiro, v. 23 , n. 2, p. 435-444, 2007. Disponível em: http://www.scielo.br/scielo.php?script=sci_arttext\&pid=S0102311X2007000200020\&lng=en\&nrm=iso. Acesso em: 08 ago. 2020.

LEÃO, Maria Antonieta Carneiro. Defeitos de desenvolvimento do esmalte dentário em crianças nascidas com baixo peso. Orientador: Pedro Israel Cabral de Lira. 2010. Dissertação (Mestrado em Odontologia) - Universidade Federal de Pernambuco, Recife, 2010.

NISHIO, Clarice. Formação do esmalte dentário, novas descobertas, novos horizontes. Rev. Dent. Press Ortodon. Ortop. Facial, Maringá, v. 13, n. 4, p. 17-18, 2008. Disponível em: http://www.scielo.br/scielo.php?script=sci_arttext\&pid=S141554192008000400002\&lng=en\&nrm=iso. Acesso em: 16 jul. 2020.

PASSOS, Isabela Albuquerque et al. Defeitos do esmalte: etiologia, características clínicas e diagnóstico diferencial. Rev Inst Ciênc Saúde, São Paulo, v. 25, n. 2, p. 187-192, 2007. Disponível em: https://www.unip.br/presencial/comunicacao/publicacoes/ics/edicoes/2007/02_abr_jun/V25_N2_2007_p187-192.pdf. Acesso em: 18 jul. 2020.

SANTOS, Camila Thomaz dos et al. Anomalias do esmalte dentário- revisão de literatura. Arch Health Invest, v. 3 n.4, p. 74-81, 2014. Disponível em: http://www.archhealthinvestigation.com.br/ArcHI/article/view/694/1067. Acesso em: 20 ago. 2020. 


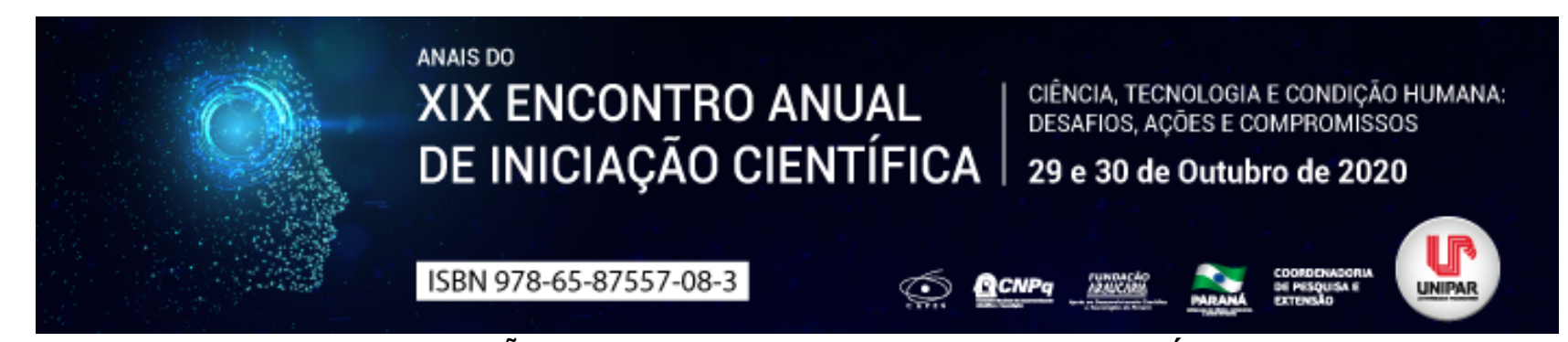

CAPACIDADE DE BIOACUMULAÇÃO DE METAIS DE INTERESSES FARMACOLÓGICO E NUTRICIONAL POR BASIDIOMICETOS

\author{
${ }^{1}$ ELOIZI MACRI, ${ }^{2}$ ALLANA VILAS BOAS DE OLIVEIRA, ${ }^{3}$ MARIA CAROLINA SCUIZATO HIDALGO, ${ }^{4}$ BRENDA APARECIDA \\ CHRISTOFOLE, ${ }^{5}$ GIANI ANDREA LINDE COLAUTO, ${ }^{6}$ MARIA GRACIELA IECHER FARIA NUNES
}

\author{
${ }^{1}$ Acadêmico bolsista do PIBIC/UNIPAR \\ ${ }^{1}$ Acadêmica do Curso de Farm $\tilde{A}_{j}$ cia da UNIPAR \\ ${ }^{2}$ Acadêmica do Curso de FarmÃ $\tilde{A}_{i}$ cia da UNIPAR \\ ${ }^{3}$ Acadêmica do Curso de Farm $\tilde{A}_{i}$ cia da UNIPAR \\ ${ }^{4}$ Docente da UNIPAR \\ ${ }^{5}$ Docente da UNIPAR
}

Introdução: Basidiomicetos são conhecidos popularmente como cogumelos e orelhas de pau, representam aproximadamente 12.000 espécies dentro do reino Fungi. Na sua maioria são comestíveis sendo fontes de proteínas e sais minerais, apresentam atividades antitumoral (WASSER, 2017), antimicrobiana (ABATE; ABRAHAM, 1994), antioxidante (UMEO, et al.,2015) podendo ser considerado um alimento não convencional. Além disso tem capacidade de bioacumular metais, característica observada na natureza e na biorremediação (VAISHALY et al., 2015), despertando o interesse para a bioacumulação in vitro de metais de interesse nutricional e farmacológico na sua forma vegetativa e reprodutiva (SILVA et al., 2012; MARCANTE et al., 2014).

Objetivo: Realizar um levantamento bibliográfico sobre a capacidade de basidiomicetos bioacumular metais de interesse farmacológico e nutricional.

Desenvolvolvimento: Os basidiomicetos apresentam em sua composição, em média, $90 \%$ de água e 10\% de massa seca. Na porção de biomassa seca encontramos como principais constituintes carboidratos e proteínas. Estes são fungos são comestíveis, em sua maioria. Suas características químicas são atrativo do ponto de vista nutricional, além de capacidade de degradar substratos ligninocelulósicos devido a presença de um aparato enzimático capaz de bioconversão de resíduos lignocelulósicos, sendo de interesse industrial (AIDA et al., 2009). Possuem substâncias bioativas: polissacarídeos, proteínas, ergosterol, triterpenóides, destacando-se as $\beta$-D-glucanas que estimulam produção de anticorpos, C3 (complemento), macrófago, neutrófilos (AINDA et al., 2009). Outros compostos, como sesquiterpenóides, hidroquinonas e ergosterol apresentando atividades antitumoral (WASSER, 2017), antimicrobiana (ABATE; ABRAHAM, 1994), antioxidante (UMEO, et al.,2015), além disso tem capacidade de bioacumular metais de interesse nutricional e farmacológico na sua forma vegetativa e reprodutiva (SILVA et al., 2012; MARCANTE et al., 2014). Os métodos de biorremediação usam microrganismos de ocorrência natural para desintoxicar poluentes produzidos pelo homem, de forma que eles transformem os poluentes em produtos inócuos, uma das formas é quando o fungo bioacumula o composto eliminando-o da natureza (VAISHALY et al., 2015). Desta forma descobriu-se que os basidiomicetos eram capazes de biocumular metais, podendo ser utilizados para bioacumulação in vitro, em um ambiente controlado. A concentração dos elementos bioacumulados são geralmente dependentes da espécie e composição do meio de cultivo utilizado (COCCHI et al., 2006). Nem todos os fungos têm a mesma capacidade de bioacumulação (SILVA et al., 2012; ASSUNÇÃO et al., 2012). Estas características de bioacumulação foram observadas durante o cultivo de cogumelos em substrato enriquecido com selênio, lítio, ferro e zinco (ASSUNÇÃO et al., 2012; SILVA et al., 2012; VIEIRA et al., 2013). Além de zinco, ferro e lítio em micélio (MARCANTE et al., 2014; ALMEIDA et al., 2014; FARIA et al., 2018, FARIA et al., 2019, UMEO et al., 2019, ZIEBA et al., 2020). Pleurotus ostreatus tem capacidade de bioacumular ferro, sendo um possível suplemento alimentar para pacientes com anemia (ALMEIDA, et al., 2015, UMEO et al., 2019). Lítio também é um metal que pode ser bioacumulado, já se observou a capacidade de $P$. ostreatus (ASSUNÇÃO et al., 2012; NUNES, et al., 2014; FARIA, et al., 2018), Lentinus crinitus (FARIA, et al., 2019). A produção de micélio de basidiomicetos bioacumulado com lítio pode representar uma melhoria na eficácia do tratamento utilizado para transtorno de humor bipolar, além disso, o lítio foi investigado em associação com suicídio, demência e agressividade. (MIURA, et al. 2014). Basidiomicetos também tem capacidade de bioacumular zinco: Agaricus subrufescens (MARCANTE, et al., 2014; UMEO, et al., 2019), P. ostreatus (VIEIRA, et al., 2013; UMEO, et al., 2020). O zinco está envolvido na síntese de proteínas e ainda como cofator de inúmeras enzimas metabólicas. O zinco participa ainda da regulação da atividade sináptica e dos processos neuronais e tem papel crítico na regulação da transcrição de genes e na síntese e no crescimento neuronal (ANDERSON; ERICKSON, 2009). Também existem relatos sobre a biaocumulação de selênio: Pleurotus ostreatus (SILVA, et al., 2012; MILOVANOVIC, et al., 2013), Pleurotus eryngii (ZIEBA, et al., 2020). É recomendado a ingestão de 55 $\mu$ g por dia, os basidiomicetos podem ser bioacumulados com selênio e se tornar um alimento enriquecido (MILOVANOVIC, et al., 2013). 
Conclusão: Estudos sobre a bioacumulação metais em basidiomicetos permitem desenvolver medicamento e/ou um suplemento alimentar de alto valor agregado como alternativas de entrega de lítio e eventuais outros sais de uso nutricional e farmacológico.

\section{Referências}

ABATE, D.; ABRAHAM, W.R. Antimicrobial metabolites from Lentinus crinitus. J Antibiot Res, v. 47, n. 11, p. 1348 1350, 1994. AIDA F.M.N.A. et al. Mushroom as a potential source of prebiotics: a review. Trends in Food Sci Technol. v. 20, p. 567-575, 2009.

ALMEIDA S. M. et al. Iron bioaccumulation in mycelium of Pleurotus ostreatus. Braz J Microbiol. v. 46, n.1, p. 195-200, 2015.

ASSUNÇÃO L. S., et al.: Enrichment of mushrooms: An interesting strategy for the acquisition of lithium. Food Chem. v. 134 p. 1123 1127, 2012.

COCCHI, L. et al. Heavy metals in edible mushrooms in Italy. Food Chem, v. 98, n. 2, p. 277-284, 2006.

FARIA, M. G. I. et al. Bioaccumulation of Lithium (Li2CO3) in Mycelia of the Culinary-Medicinal Oyster Mushroom, Pleurotus ostreatus (Agaricomycetes). Int J Med Mushrooms, v. 20, n. 9, p. 901-907, 2018.

FARIA, M. G. I. et al. Lithium bioaccumulation in Lentinus crinitus mycelial biomass as a potential functional food. Chemosphere, v. 235, p. 538-542, 2019.

MILOVANOVIC, I. et al. Potential Enrichment of Medicinal Mushrooms with Selenium to Obtain New Dietary Supplements. Int $\mathbf{J}$ Med Mushrooms, v. 15, n. 5, p. 449-455, 2013.

MIURA T, et al. (2014) Comparative Efficacy and tolerability of pharmacological treatments in the maintenance treatment of bipolar disorder: a systematic review and network meta-analysis. Lancet n.1 p. 351-359, 2014.

MARCANTE, C. R.;et al. Bioacumulação de zinco em micélio de Agaricus subrufescens.Arq ciênc vet zool UNIPAR. v. 17, n. 4, p. 249-252, 2014.

NUNES M. D.et al. Lithium chloride affects mycelial growth of White rot fungi: Fungal screening for Li-enrichment. Afr J Microbiol Res. v. 21 p. 2111-2123. 2014.

SILVA, M. C. D. et al. Enrichment of Pleurotus ostreatus mushrooms with selenium in coffee husks. Food Chem, v. 131, n. 2, p. 558 563, 2012.

UMEO, S.H. et al.Iron Or Zinc Bioaccumulated In Mycelial Biomass of Edible Basidiomycetes. An Braz Acad Sci, v. 92, n.2, p. e20191350, 2020.

UMEO, S. H. et al. Iron and zinc mycelial bioaccumulation in Agaricus subrufescens strains. Semina: Ciênc, v. 40, n. 6, p. 2513 , 2019.

UMEO, S. et al. Short Communication Screening of basidiomycetes in submerged cultivation based on antioxidant activity. Genet Mol Res, v. 14, n. 3, p. 9907 9914, 2015.

VIEIRA, P. A., et al. Antioxidant activities, total phenolics and metal contents in Pleurotus ostreatus mushrooms enriched with iron, zinc or lithium. Food Sci Technol. v. 54, p. 421- 425. 2013.

VAISHALY A.G; Mathew, Blessy \& Beeregowda, Krishnamurthy \& Krishnamurthy, T. (2015). Bioaccumulation of Heavy metals by fungi. Int J Environ An Ch n. 1. p. 15-21. 2015.

WASSER, S. P. Medicinal Mushrooms in Human Clinical Studies. Part I. Anticancer, Oncoimmunological, and Immunomodulatory Activities: A Review. Int J Med Mushrooms, v. 19, n. 4, p. 279 317, 2017.

ZIĘBA, P. et al. Selenium and Zinc Biofortification of Pleurotus eryngii Mycelium and Fruiting Bodies as a Tool for Controlling Their Biological Activity. Molecules, v. 25, n. 4, p. 889, 2020. 


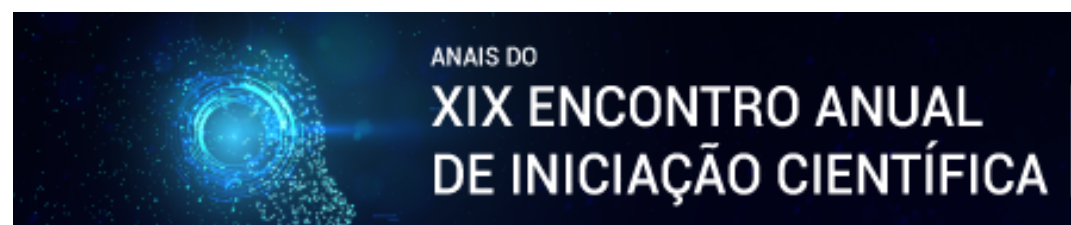

CIÊNCIA, TECNOLOGIA E CONDIÇĀO HUMANA: DESAFIOS, AC̄ŌES E COMPROMISSOS

29 e 30 de Outubro de 2020

ISBN 978-65-87557-08-3
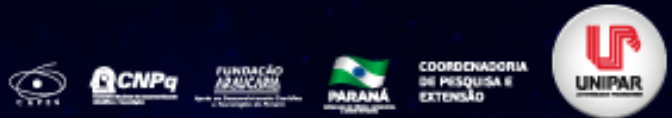

BENEFÍCIOS DA CIRURGIA ORTOGNÁTICA PARA O TRATAMENTO DA SÍNDROME DA APNEIA E HIPOAPNEIA OBSTRUTIVA DO SONO: UMA REVISÃO DE LITERATURA

\begin{abstract}
${ }^{1}$ PRISCYLA VITORINO SOARES, ${ }^{2}$ CLARA MIOTTO SILVA, ${ }^{3}$ KARINE SANTOS ALMEIDA, ${ }^{4}$ ISABELA TRARBACH GOMES, ${ }^{5}$ MARTHA ALAYDE ALCANTARA SALIM VENANCIO
\end{abstract}

\footnotetext{
${ }^{1}$ Acadêmica do curso de Odontologia da Universidade Federal do Espírito Santo

${ }^{1}$ Acadêmica do curso de Odontologia da Universidade Federal do Espírito Santo

${ }^{2}$ Acadêmica do curso de Odontologia da Universidade Federal do Espírito Santo

${ }^{3}$ Acadêmica do curso de Odontologia da Universidade Federal do Espírito Santo

${ }^{4}$ Docente da Universidade Federal do Espírito Santo
}

Introdução: A Síndrome da Apneia e Hipoapneia Obstrutiva do Sono (SAHOS) é caracterizada pela obstrução parcial (hipoapneia) ou total (apneia) das vias aéreas durante a inspiração, podendo ser acompanhada de episódios de despertar, causando aumento do risco de desenvolvimento de doenças cardiovasculares, hipoxemia intermitente, sonolência diurna e fadiga (HADDAD et al., 2017).

Objetivo: O objetivo dessa revisão é demonstrar o benefício da cirurgia ortognática como método de tratamento da SAHOS buscando melhora na qualidade de vida do paciente.

Desenvolvimento: Segundo Haddad et al., 2017, a SAHOS é quatro vezes mais comum em homens de maior idade, podendo acometer jovens e crianças. Alguns fatores estão associados à predisposição à SAHOS como anormalidades craniofaciais, aumento dos tecidos linfóides, diminuição da ação dos músculos dilatadores da faringe, obesidade e consumo de álcool e tabaco (HADDAD et al., 2017; RODRIGUES et al., 2019). Os sinais e sintomas mais comuns são ronco alto e perturbador, interrupção do sono, hipersonolência diurna, déficit cognitivo, irritabilidade, ansiedade, hipoxemia, hipercapnia, flutuações na pressão intratorácica, fadiga e excesso de peso (RODRIGUES et al., 2019). O padrão ouro para diagnóstico da SAHOS consiste no exame polissonográfico que registra a atividade cerebral, respiração, frequência cardíaca, atividade muscular, ronco, níveis de oxigênio no sangue e episódios de obstrução das vias aéreas durante o sono, medidos pelo índice de apneia e hipoapneia (IAH). O IAH é considerado leve quando até 5 a 15 eventos de apneia ocorrem por hora durante o sono, moderado de 15 a 29 eventos/hora e grave acima de 30 eventos/hora. Alguns tratamentos alternativos podem ser propostos para os pacientes com a finalidade de diminuir o IAH e a sintomatologia, além da necessidade de perda de peso e mudança de postura durante o sono (NOLLER et al., 2017; RODRIGUES et al., 2019). Dentre eles, as cirurgias de tecidos moles como remoção das adenoides, uvulopalatofaringoplastia, correção de desvio de septo e a turbinectomia são atualmente os mais indicados (RODRIGUES et al., 2019). O tratamento mais indicado consiste na realização de pressão positiva contínua nas vias aéreas (CPAP), principalmente em casos graves (HADDAD et al., 2017). O grande problema é que, além de não ser um tratamento curativo, é necessária à adesão do paciente, uma vez que o CPAP deve ser usado mais de 4 horas em $70 \%$ das noites dormidas, não sendo tolerado pela grande maioria. Em pacientes intolerantes ao CPAP, o aparelho intraoral (AIO) pode ser indicado, pois, além de ser fabricado individualmente de acordo com as impressões dentárias do paciente, tem a finalidade aumentar o volume das vias aéreas pela movimentação anterior dos músculos genioglosso, gênio-hioideo, milo-hioideo e digástrico, com objetivo de reduzir a obstrução orofaríngea (HADDAD et al., 2017). Atualmente, muito se tem discutido sobre a indicação da cirurgia ortognática de avanço maxilo-mandibular para pacientes com SAHOS grave, que têm mostrado resultados promissores com diminuição significativa do IAH e da sintomatologia. Na revisão sistemática de Noller et al., 2017, foi possível concluir que o avanço mandibular demonstrou melhora significativa da SAHOS com diminuição do IAH de 46 para 6 eventos por hora em pacientes adultos com retrognatia mandibular, além de melhora na dessaturação de oxigênio de 72\% para 89\% (NOLLER et al., 2017). A cirurgia combinada de avanço maxilar e mandibular consegue expandir as vias aéreas pela alteração da estrutura esquelética através de osteotomias, como Le Fort I, e aumento da tensão nos tecidos moles da faringe, alterando as dimensões médio-lateral e ântero-posterior das vias aéreas superiores (ZANGUI et al., 2016). No entanto, por se tratar de uma cirurgia para pacientes com deformidades esqueléticas e que muitas vezes é indicada como tratamento da SAHOS em pacientes que possuem padrão esquelético normal, o avanço maxilomandibular é limitado, sendo a rotação do plano oclusal no sentido anti-horário realizada auxiliando no aumento do espaço posterior das vias aéreas em casos selecionados, principalmente, àqueles que requerem avanços mandibulares na ausência de um defeito maxilar anteroposterior (BREVI et al., 2011; RODRIGUES et al., 2019).

Conclusão: A cirurgia ortognática, principalmente, o avanço maxilomandibular, atualmente, têm demonstrado ótimos resultados para a SAHOS. O planejamento e o conhecimento prévio dos fatores de risco da doença são primordiais para garantir o sucesso do tratamento. 


\section{Referências}

BREVI, Bruno Carlo; TOMA, Livia; PAU, Mauro; SESENNA, Enrico. Counterclockwise Rotation of the Occlusal Plane in the Treatment of Obstructive Sleep Apnea Syndrome. Journal Of Oral And Maxillofacial Surgery, [S.L.], v. 69, n. 3, p. 917-923, mar. 2011. Elsevier BV. http://dx.doi.org/10.1016/j.joms.2010.06.189. Acesso em: 02 ago. 2020.

HADDAD, Fernanda Louise Martinho; GREGÓRIO, Luis Carlos. Manual do residente: medicina do sono. Barueri, São Paulo: Manole, 2017.

NOLLER, Michael W.; GUILLEMINAULT, Christian; GOUVEIA, Christopher J.; MACK, Douglas; VIVIAN, Charles; ABDULLATIF, Jose; MANGILI, Stefano; LIU, Stanley Yung; ZAGHI, Soroush; CAMACHO, Macario. Mandibular advancement for adult obstructive sleep apnea: a systematic review and meta-analysis. Journal Of Cranio-Maxillofacial Surgery, [S.L.], v. 45, n. 12, p. 2035-2040, dez. 2017. Elsevier BV. http://dx.doi.org/10.1016/j.jcms.2017.10.006. Acesso em: 12 ago. 2020.

RODRIGUES, Willian Caetano; GABRIELLI, Mário Francisco Real; OLIVEIRA, Marina Reis; PIVETA, Ana Cláudia Gabrielli; GABRIELLI, Marisa Aparecida Cabrini. Orthodontic-surgical treatment of a patient with Marfan Syndrome and Obstructive Sleep Apnea Syndrome: a case report with a 9-year follow-up. Rgo - Revista Gaúcha de Odontologia, [S.L.], v. 67, n. 50, p. 1-9, fev. 2019. FapUNIFESP (SciELO). Disponível em: http://dx.doi.org/10.1590/1981-863720190005020180013. Acesso em: 13 de ago. 2020.

ZAGHI, Soroush; HOLTY, Jon Erik C.; Victor Certal; ABDULLATIF, Jose; BIOL, Christian Guilleminault; POWELL, Nelson B.; RILEY, Robert W.; CAMACHO, Macario. Maxillomandibular Advancement for Treatment of Obstructive Sleep Apnea A Metaanalysis. JAMA Otolaryngol Head Neck Surgery, Los Angeles, CA, v. 142, n. 1, p. 58-66, 25 nov. 2015. Disponível em: http://dx.doi:10.1001/jamaoto.2015.2678. Acesso em: 21 ago. 2020.

Coordenadoria de Pesquisa e Extensão - COPEX

Departamento de Editoraçāo e Divulgaçāo Científica - DEDIC 


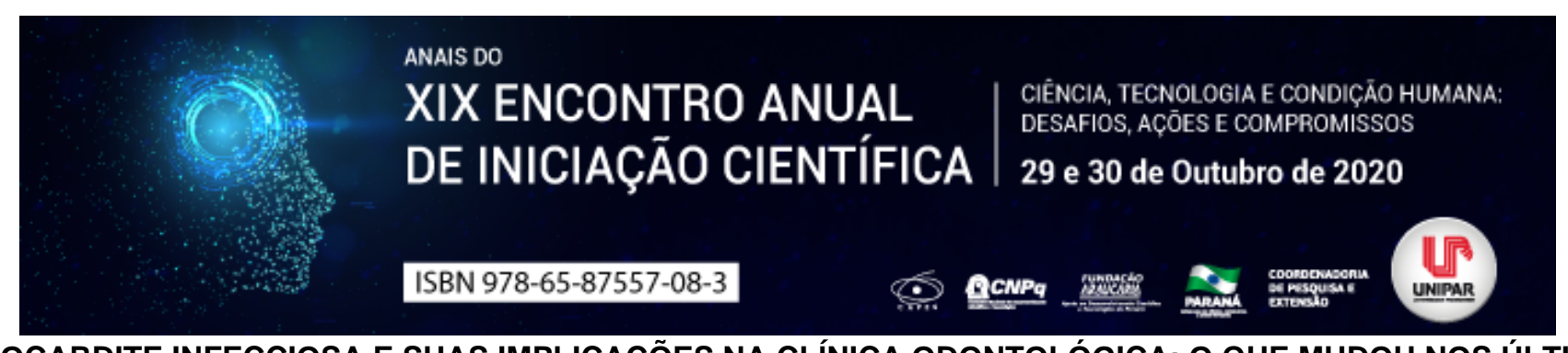

ENDOCARDITE INFECCIOSA E SUAS IMPLICAÇÕES NA CLÍNICA ODONTOLÓGICA: O QUE MUDOU NOS ÚLTIMOS ANOS

\author{
${ }^{1}$ Clara Miotto Silva, ${ }^{2}$ ISABELA TRARBACH GOMES, ${ }^{3}$ KARINE SANTOS ALMEIDA, ${ }^{4}$ PRISCYLA VITORINO SOARES, \\ ${ }^{5}$ RENATA PITTELA CANÇADO, ${ }^{6}$ ANDRÉ ALBERTO CÂMARA PUPPIN
}

\begin{abstract}
${ }^{1}$ Acadêmica em Odontologia, Universidade Federal do Espírito Santo
${ }^{1}$ Acadêmica em Odontologia, Universidade Federal do Espírito Santo

${ }^{2}$ Acadêmica em Odontologia, Universidade Federal do Espírito Santo

${ }^{3}$ Acadêmica em Odontologia, Universidade Federal do Espírito Santo

${ }^{4}$ Docente do Departamento de Clínica Odontológica, Universidade Federal do Espírito Santo

${ }^{5}$ Docente do Departamento de Clínica Odontológica, Universidade Federal do Espírito Santo
\end{abstract}

Introdução: A endocardite infecciosa é uma inflamação que afeta as estruturas internas do coração, como válvulas e endocárdio. Deve-se à presença de bactérias ou fungos que chegam ao coração através da circulação sanguínea. As recomendações para a profilaxia antibiótica da endocardite têm sido alvo de várias atualizações nos últimos anos com a tendência para simplificá-la e para restringir o número total de doentes elegíveis.

Objetivo: Realizar uma revisão de literatura visando definir as atuais condutas da clínica odontológica frente à Endocardite infecciosa (EI), indicação e avaliação de pacientes de risco relacionando ao tipo de procedimento a ser realizado, bem como a prevenção de El e alerta ao uso indiscriminado de antimicrobianos.

Desenvolvimento: Foi realizado um estudo descritivo a partir da revisão de literatura de sete artigos, com pesquisa no banco de dados Scielo, PubMed e Google Acadêmico nos idiomas português e inglês com as palavras-chave: Endocardite infecciosa, profilaxia antibiótica. Ao longo dos anos tem-se observado um padrão de constante evolução no que diz respeito a El. Alterações e melhorias na terapêutica antimicrobiana, no tratamento de complicações que possam estar envolvidas, assim como no reconhecimento do envolvimento de novos microrganismos, contribuíram para esta evolução observada (SANTOS, 2018). Os agentes etiológicos com maior relevância para o desenvolvimento da El são: Streptococcus viridans, Staphylococcus aureus, Chlamídias e fungos (COSTA e FERREIRA, 2011). De acordo com a gravidade, a endocardite classifica-se em aguda e subaguda. A El aguda é caracterizada por lesão invasiva, ulcerativa e necrosante, de difícil cura, com indicação de intervenção cirúrgica e tratamento antimicrobiano. A subaguda possui menor virulência, geralmente faz parte da microbiota normal oral e ataca principalmente valvas anormais de forma insidiosa e melhora com o uso apenas de antibióticos, levando a um processo de fibrose e cicatrização (ROCHA; ROCHA; SPROVIERI, 2009). As características clínicas mais observadas da El são: Febre alta, perda de peso, letargia, dificuldade respiratória, sopros cardíacos novos, fenômenos imunológicos, manifestações cutâneas como os nódulos de Osler e as lesões de Janeway (ARAÚJO-JÚNIOR; MAGALHÃES; MELO-SILVA; MIRANDA; GONÇALVES; DIASRIBEIRO; PAIVA, 2019). Entre as principais complicações estão incluídas sepse, acidente vascular cerebral e insuficiência cardíaca por disfunção valvar. A finalidade da profilaxia com antibióticos é a de prevenir processos infecciosos, sejam eles locais ou sistêmicos, preservando a saúde e o bem estar geral do paciente. Este procedimento tem dois objetivos: evitar contaminação no local que será exposto após cirurgia, nominada profilaxia antibiótica; e precaver contaminação a distância, assim como na EI (MOREIRA e ANDRADE, 2011). As intervenções odontológicas constituem umas das principais causas de bacteremia transitória, e assim as bactérias podem colonizar tecidos cardíacos que estão previamente comprometidos, causando uma grande infecção local e assim levar a endocardite infecciosa (NASCIMENTO et al., 2011). A American Heart Association (AHA2017) alterou suas recomendações de profilaxia antibiótica de endocardite, reduzindo o número de indicações e restringindo-as a pacientes com condições cardíacas. De acordo com as novas diretrizes, a profilaxia para El é indicada para pacientes portadores de condições cardíacas de alto risco tais como endocardite bacteriana prévia, paciente portador de valvas cardíacas protéticas, disfunção da válvula cardíaca após transplante de coração, portadores de cardiopatia congênita e doença cardíaca congênita cianótica não-reparada em procedimentos que implicam manipulação do tecido da gengiva ou da região periapical dos dentes ou perfuração da mucosa oral, como implantes e extrações dentais. Em procedimentos menos invasivos como remoção de suturas, dentística restauradora, não é indicada a profilaxia. O protocolo padrão e alternativo para prevenção de El: Amoxicilina $2 \mathrm{~g}$ (adulto) ou $50 \mathrm{mg} / \mathrm{kg}$ (criança) via oral. Para pacientes alérgicos à Penicilina, o protocolo é através da administração de Clindamicina $600 \mathrm{mg}$ (adulto) ou $20 \mathrm{mg} / \mathrm{kg}$ (criança) via oral. Em caso de impossibilidade de administração via oral, o protocolo alternativo é através da administração endovenosa (EV) ou intramuscular (IM): Ampicilina $2 \mathrm{~g}$ (adulto) ou 50mg/kg (criança). Pacientes alérgicos à Penicilina: Clindamicina 600 mg (adulto) ou $20 \mathrm{mg} / \mathrm{kg}$ (criança). A escolha da profilaxia antibiótica deve levar em conta os aspectos atuais de nossa população, bem como a classificação de risco para endocardite e a evolução clínica de 
cada paciente na prática diária, para uma correta indicação do antibiótico e melhora de seu custo efetividade.

Conclusão: Mediante à revisão de literatura realizada, pode-se concluir que a melhor maneira de se prevenir uma El é conhecendo o paciente através de uma anamnese criteriosa, constando toda a história médica odontológica pregressa do paciente, afim de identificar de forma individualizada os pacientes de risco, evitando o uso indiscriminado de antimicrobianos e posterior favorecimento da resistência bacteriana dos microorganismos associados a etiopatologia da endocardite bacteriana.

\section{Referências}

DA SILVA ROCHA, Cynthia Aparecida; DA SILVA ROCHA, Mauricio; SPROVIERI, Sandra Regina Schwarzwälder. O que há de novo na profilaxia da endocardite bacteriana. Deve-se mudar a conduta atual?. Rev Bras Clin Med, v. 7, p. 418-421, 2009. Disponível em:

http://bases.bireme.br/cgibin/wxislind.exe/iah/online/?

IsisScript=iah/iah.xis\&src=google\&base=LILACS\&lang=p\&nextAction=Ink\&exprSearch=533123\&indexSearch=ID. Acesso em: 16 set. 2020.

DE ARAÚJO-JÚNIOR, Júlio Leite et al. Associação entre endocardite bacteriana e procedimento de cirurgia e traumatologia bucomaxilofacial. ARCHIVES OF HEALTH INVESTIGATION, v. 8, n. 3, 2019. Disponível em: http://archhealthinvestigation.emnuvens.com.br/ArcHI/article/view/3177. Acesso em: 16 set. 2020.

DE ASSIS COSTA, Aline; FERREIRA, Adriane Cristina Richa. Evolução do Protocolo Padrão de Profilaxia Antibiótica à Endocardite Bacteriana. Disponível em: http://editora.universidadedevassouras.edu.br/index.php/RPU/article/view/327. Acesso em: 16 set. 2020.

DO NASCIMENTO, Erica Manuela et al. Abordagem odontológica de pacientes com risco de endocardite: um estudo de intervenção. Odonto, v. 19, n. 37, p. 107-116, 2011. Disponível em: https://www.metodista.br/revistas/revistasmetodista/index.php/Odonto/article/view/2067. Acesso em 16 set. 2020.

DOS SANTOS, Manuela Alexandra Pereira. Profilaxia da endocardite bacteriana nos procedimentos dentários: necessidade ou incerteza. 2018. Disponível em: http://docplayer.com.br/122814681-Profilaxia-da-endocardite-bacteriana-nos-procedimentosdentarios-necessidade-ou-incerteza-manuela-alexandra-pereira-dos-santos.html. Acesso em: 16 set. 2020.

MOREIRA, Alcides; DE ANDRADE, Eduardo Dias. Prospective study of the incidence of infection in impacted third molar surgery: the role of antibiotic pro phylaxis. RGO: Revista Gaúcha de Odontologia, v. 59, n. 3, 2011. Disponível em: http://revodonto.bvsalud.org/scielo.php?script=sci_arttext\&pid=S1981-86372011000400002\&lng=es\&nrm=iso. Acesso em: 16 set. 2020.

Coordenadoria de Pesquisa e Extensão - COPEX

Departamento de Editoraçāo e Divulgaçāo Científica - DEDIC 


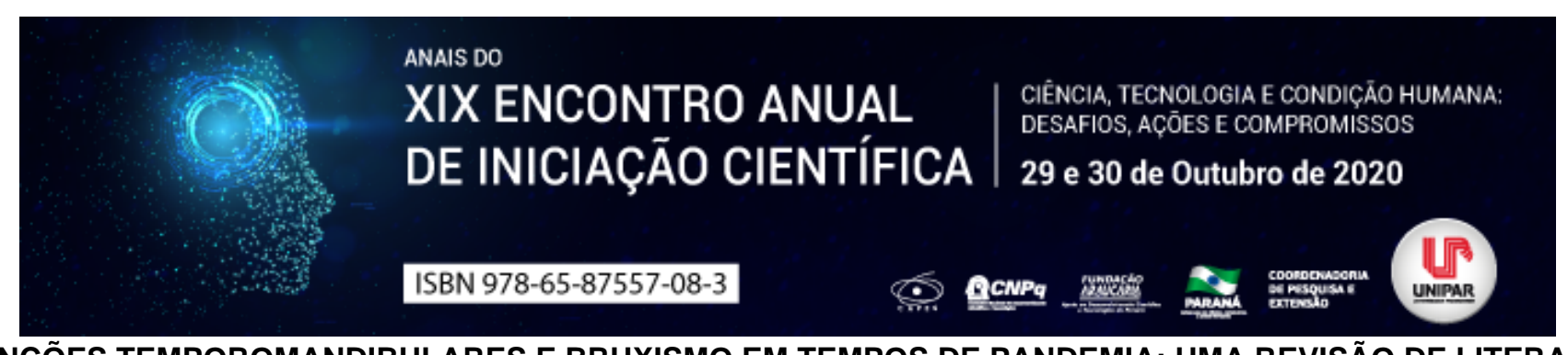

DISFUNÇÕES TEMPOROMANDIBULARES E BRUXISMO EM TEMPOS DE PANDEMIA: UMA REVISÃO DE LITERATURA

\begin{abstract}
${ }^{1}$ PRISCYLA VITORINO SOARES, ${ }^{2}$ CLARA MIOTTO SILVA, ${ }^{3}$ KARINE SANTOS ALMEIDA, ${ }^{4}$ ISABELA TRARBACH GOMES, ${ }^{5}$ MARTHA ALAYDE ALCANTARA SALIM VENANCIO
\end{abstract}

\begin{abstract}
${ }^{1}$ Acadêmica do curso de Odontologia da Universidade Federal do Espírito Santo
${ }^{1}$ Acadêmica do curso de Odontologia da Universidade Federal do Espírito Santo

${ }^{2}$ Acadêmica do curso de Odontologia da Universidade Federal do Espírito Santo

${ }^{3}$ Acadêmica do curso de Odontologia da Universidade Federal do Espírito Santo

${ }^{4}$ Docente da Universidade Federal do Espírito Santo
\end{abstract}

Introdução: O novo corona vírus foi inicialmente detectado na cidade de Wuhan, na China, e declarado no dia 11 de março de 2020 pela Organização Mundial da Saúde (OMS) como uma pandemia (AHMED et al., 2020). Segundo dados da OMS, atualmente, a COVID-19 já atinge a marca de mais de 20 milhões de casos e 750 mil mortes em todo o mundo. As desordens temporomandibulares (DTM's) podem ser musculares ou articulares e são diretamente influenciadas por fatores psicológicos do indivíduo como o estresse e ansiedade vividos em tempos de incertezas e emergências na saúde pública (ALEMIDA-LEITE et al., 2020). Objetivo: O objetivo desta revisão é mostrar como o medo, estresse e ansiedade gerados em tempos de pandemia, atualmente, a COVID-19, principalmente pela necessidade de isolamento social para conter a disseminação da doença, podem exacerbar distúrbios somáticos como as disfunções temporomandibulares e o bruxismo. Como se trata de um novo vírus ainda com pesquisas em andamento, as informações são passíveis de atualização.

Desenvolvimento: O vírus SARS-COV-2 foi inicialmente detectado em Wuhan, na China e se espalhou por todo o mundo. A infecção pode ser transmitida de pessoa para pessoa seja por gotículas respiratórias, saliva, pelas mãos ou superfícies contaminadas pelo vírus. Atualmente, sabe-se que o período de incubação do vírus dura cerca de quatro a quatorze dias, sendo necessário que os indivíduos contaminados ou que possuam algum tipo de sintoma permaneçam em quarentena (AHMED et al., 2020). Os sinais e sintomas vão desde a uma dor de cabeça, febre alta, tosse seca e dispneia, no entanto, algumas pessoas são contaminadas e permanecem assintomáticas. Portanto, é recomendado que a população faça a higienização das mãos com água corrente e sabão, utilize álcool em gel, máscaras e mantenha-se em isolamento social e, caso seja necessário sair de casa para atividades essenciais, manter distanciamento social de pelos menos 1,5 metro, diminuindo a disseminação e contágio do vírus o que pode causar ou agravar problemas psicológicos. Segundo OLIVEIRA et al., 2020, os pacientes que apresentam distúrbios somáticos, são diretamente influenciados por alterações psicossociais (OLIVEIRA et al., 2020). De acordo com AHMED et al., 2020 e ALMEIDA-LEITE et al., 2020, o estresse e a ansiedade são respostas naturais de defesa do indivíduo, porém, nessas situações, são exacerbados se relacionando com distúrbios do sono, bruxismo em vigília e as DTM's, principalmente, musculares (AHMED et al., 2020; ALMEIDA-LEITE et al., 2020). Segundo ALMEIDA-LEITE et al., 2020, DTM, ansiedade e depressão possuem uma relação significativa. O estresse leva a uma cadeia de eventos que aumentam os níveis de atividade parassimpática e liberação de adrenocorticoides que estimulam a vasoconstrição muscular e aumento da resistência vascular periférica (ALMEIDA-LEITE et al., 2020). A ansiedade é regulada a níveis de SNC e envolve interações entre o córtex pré-frontal, sistema límbico, estruturas paralímbicas e regiões motoras do tronco cerebral que levam a respostas motoras e fisiológicas (ALMEIDA-LEITE et al., 2020; OLIVEIRA et al., 2020). A sobrecarga desse sistema pode resultar em pacientes com DTM, principalmente, musculares, distúrbios do sono, perpetuação da dor crônica e com o bruxismo, principalmente, em vigília. $O$ aumento da contração muscular em pacientes submetidos a estresse pode aumentar em até seis vezes a probabilidade do paciente em realizar bruxismo em vigília, uma vez que essa ação muscular faz parte da reação de defesa do organismo submetido a situações de medo e insegurança vividas atualmente (ALMEIDA-LEITE et al., 2020; OLIVEIRA et al., 2020). Diversos tratamentos são propostos para pacientes que sofrem desses problemas. Em tempos de isolamento social, terapias que auxiliam na diminuição do estresse e ansiedade são primordiais, além de possuírem baixo custo e fácil aplicação via videoconferências (BEHAN, 2020). A prática de meditação pode auxiliar o indivíduo a tomar ciência do que está acontecendo consigo mesmo e reagir a qualquer situação que surja em seu dia-a-dia de forma mais calma e equânime. Além disso, a meditação pode atuar diretamente no córtex pré-frontal mostrando melhora significativa na regulação emocional (BEAHN, 2020). Conclusão: A necessidade em manter-se em isolamento social somada à grande carga de informações, desinformação e incerteza do futuro agrava o estresse, medo e ansiedade vividos pela população. Além das DTM's musculares, dos distúrbios do sono e do bruxismo em vigília, outros problemas de saúde geral podem sofrer grande impacto com a pandemia, sendo necessário informar os pacientes sobre a necessidade em buscar tratamentos cada vez mais multiprofissionais que auxiliem no controle do estresse e da ansiedade garantindo maior qualidade de vida. 


\section{Referências}

AHMED, Muhammad Adeel; JOUHAR, Rizwan; AHMED, Naseer; ADNAN, Samira; AFTAB, Marziya; ZAFAR, Muhammad Sohail; KHURSHID, Zohaib. Fear and Practice Modifications among Dentists to Combat Novel Coronavirus Disease (COVID-19) Outbreak. International Journal Of Environmental Research And Public Health, [S.L.], v. 17, n. 8, p. 2821, 19 abr. 2020. MDPI AG. http://dx.doi.org/10.3390/ijerph17082821. Acesso em: 01 de agosto de 2020

ALMEIDA-LEITE, Camila Megale; STUGINSKI-BARBOSA, Juliana; CONTI, Paulo César Rodrigues. How psychosocial and economic impacts of COVID-19 pandemic can interfere on bruxism and temporomandibular disorders? Journal Of Applied Oral Science, [S.L.], v. 28, n. 1, p. 1-3, 2020. FapUNIFESP (SciELO). http://dx.doi.org/10.1590/1678-7757-2020-0263. Acesso em: 04 de agosto de 2020

BEHAN, C. The benefits of meditation and mindfulness practices during times of crisis such as COVID-19. Irish Journal Of Psychological Medicine, [S.L.], p. 1-3, 14 maio 2020. Cambridge University Press (CUP). http://dx.doi.org/10.1017/ipm.2020.38. Acesso em: 10 de agosto de 2020.

OLIVEIRA, Simone Saldanha Ignacio de; GONÇALVEZ, Sergio Luiz Melo; WEIG, Karin de Mello; MAGALHÃES FILHO, Thales Ribeiro; MARTINEZ, Omar Efrain Roque; KALIL, Maria Theresa Alves da Cunha; BOGGISS, George Patrick; MANDARINO, Denise; TANGANELI, João Paulo Colesanti; ALMADA, Thiago Sousa. Temporomandibular disorders: guidelines and self-care for patients during covid-19 pandemic. Brazilian Dental Science, [S.L.], v. 23, n. 2, p. 1-8, 12 jun. 2020. Lepidus Tecnologia. http://dx.doi.org/10.14295/bds.2020.v23i2.2255. Acesso em: 22 de agosto de 2020. 


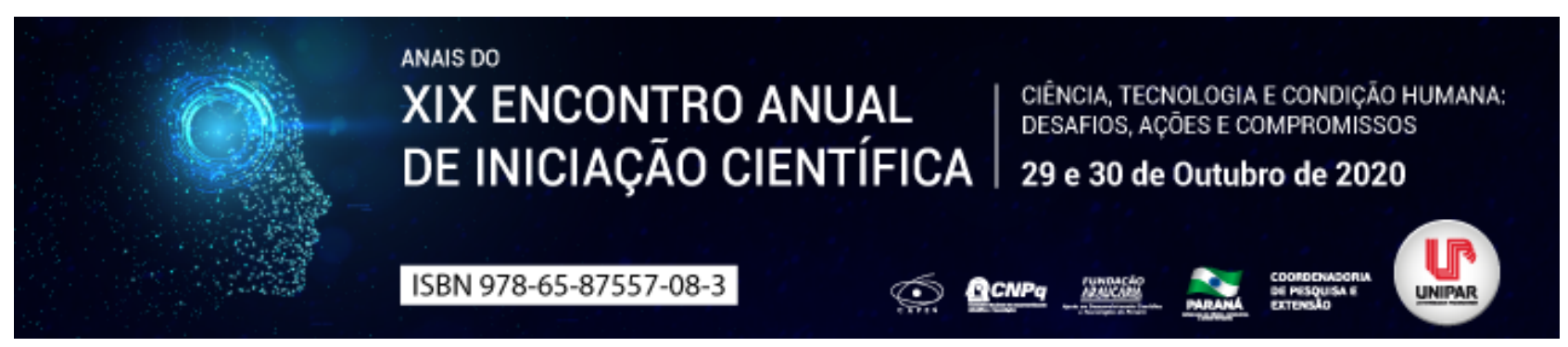

ODONTOLOGIA MINIMAMENTE INVASIVA

\title{
${ }^{1}$ DUANI CRISTINA BAZZO, ${ }^{2}$ SABRINA PAIXAO DOS SANTOS RODRIGUES, ${ }^{3}$ MARIA RITA BARBOSA DE OLIVEIRA, ${ }^{4}$ ANA CAROLINA SOARES FRAGA ZAZE
}

\author{
${ }^{1}$ Discente do curso de Odontologia - Unipar, Campus Umuarama \\ ${ }^{1}$ Discente do curso de Odontologia - UNIPAR, Campus Umuarama \\ ${ }^{2}$ Discenge do curso de Odontologia e aluna do Programa de Iniciação Científica (PEGIC) - UNIPAR, Campus Umuarama \\ ${ }^{3}$ Docente do curso de Odontologia - Pesquisadora institucional - UNIPAR, Campus Umuarama
}

Introdução: A Odontologia Minimamente Invasiva (OMI) aplica estratégias de prevenção e manutenção da saúde bucal, baseada em um correto diagnóstico, acompanhamento e instrução ao paciente (instruções de dieta, higiene oral) e a mínima intervenção, se a mesma se apresentar necessária (TUMENAS et al., 2014). Com essa técnica conservadora, as restaurações e preparos cavitários devem ser adiados e evitados ao máximo. Os materiais utilizados vêm sendo aprimorados constantemente, com o intuito de trazer maior conforto ao paciente e preservação de estrutura dental, sendo muito indicada na odontopediatria (FRANKEN, 2015). Com a busca por técnicas mais atuais e menos invasivas, a remoção parcial do tecido cariado tem sido estudada atualmente, em busca da preservação da estrutura dentária. Diante disso, após a remoção parcial desse tecido é feito o selamento da cavidade, evitando que a lesão de cárie progrida, paralisando a doença (MELO, 2019).

Objetivo: O objetivo deste trabalho é apresentar uma revisão de literatura, sobre a Odontologia Minimamente Invasiva, com o intuito de mostrar a importância sobre o conhecimento e aplicação da técnica.

Desenvolvimento: Após a realização da primeira restauração, existe uma tendencia do dente entrar no ciclo restaurador repetitivo, que leva a uma lenta e progressiva destruição do elemento dentário, podendo desencadear na perda do elemento dental. Quando o tratamento convencional é realizado, remove-se totalmente o esmalte e a dentina cariados, levando à uma chance de promover uma expansão desnecessária da cavidade, o que em alguns casos, pode levar à exposição do tecido pulpar (ARAÚJO et al., 2010). Além de ser demorado, pode gerar custos adicionais, necessitar de um maior número de sessões, cria a possibilidade do paciente não retornar nas consultas subsequentes ou até mesmo que a restauração provisória feita na primeira sessão apresente diversos tipos de falhas, gerando um incômodo maior (MALTZ, 2014). Pesquisas mostram que a remoção parcial do tecido cariado, seguida pelo selamento da cavidade associada à utilização de material forrador fazem com que a dentina fique mais clara e endurecida, comparada a cor e textura do início do tratamento (MERTZ et al., 2002). Em casos feitos selando a cavidade com resina flow e acompanhamento, sem remoção de tecido cariado previamente, houve paralisação da lesão de cárie (PONTE et al., 2017). A remoção parcial do tecido cariado em uma sessão apresenta resultados superiores à remoção total do tecido cariado, devido a não ter a necessidade de fazer mais de uma sessão e abertura da cavidade para remover dentina afetada, independente do material restaurador utilizado. É uma possibilidade que deve ser considerada para o controle de lesões agudas e profundas, promovendo a manutenção da integridade do órgão pulpar (ARAÙJO et al., 2017). Comprovada a efetividade na diminuição da incidência de futuros tratamentos restauradores e lesões de cárie oclusais, por meio da técnica minimamente invasiva, a (ABO) Associação Brasileira de Odontopediatria indica a aplicação de selantes em fóssulas e fissuras para crianças e adolescentes com alto risco de cárie (OTA et al., 2015). Para lesões de manchas brancas inativas que apresentam um comprometimento estético, a técnica de microabrasão apresenta um resultado satisfatório na devolução da estética e preservação do elemento dental, sendo uma técnica minimamente invasiva e deve ser a técnica de primeira escolha (OLIVEIRA et al., 2016). Se a técnica de Mínima Intervenção for escolhida, o paciente deve ser sempre monitorado e receber frequentes instruções de higiene oral e de dieta, para que a mudança de hábitos seja efetiva no controle do risco de desenvolvimento da doença cárie (TUMENAS et al., 2014).

Conclusão: Com base na literatura estudada, concluímos que a técnica de mínima intervenção na odontologia tem apresentado bons resultados, desde que a mesma seja bem indicada e que o paciente seja acompanhado pelo cirurgião dentista, a fim de provocar a mudança de hábitos que resultará no sucesso do tratamento e controle da doença cárie.

\section{Referências}

ARAÚJO, Natália Costa et al. Considerações sobre a Remoção Parcial do Tecido Cariado. Int J Dent. Recife, v. 9, n. 4, p. 202209. 2010.

ARAÚJO, Joyce Figueira de et al. Remoção parcial do tecido cariado em dentes permanentes: uma revisão integrativa da literatura. Rev. Bras. Odontol., Rio de Janeiro, v. 74, n. 1, p. 31-5, jan./mar. 2017.

MALTZ, Marisa et al. A clinical, microbiologic, and radiographic study of deep caries lesions after incomplete caries removal. 
Quintessence international. Berlin, Germany, v. 33, n. 2, p. 151-9. 2002.

MALTZ, Marisa; JARDIM, Juliana Jobim. Como as pesquisas de excelência em remoção parcial de tecido cariado podem contribuir para a prática clínica? Rev Assoc Paul Cir Dent. São Paulo, v. 68, n. 4, p. 326-7, 2014.

MELO, Marcello Barrico Cabral de. Remoção parcial e selamento de tecido cariado: revisão de literatura. Orientador: Lucilei Lopes Bonato. 2019. (Monografia) - Universidade de Taubaté, Taubaté, 2019.

OTA, Caroline Miki et al. Selamento de lesão de cárie em metade externa de dentina em molar decíduo relato de caso clínico com proservação de 12 meses. ConScientiae Saúde. São Paulo, v. 14, n. 2, p. 314-320. 2015.

OLIVEIRA, Layrlla Kateriny Moura et al. Microabrasão na estética dentária: sucesso com procedimento minimamente invasivo. Revista Ciência Plural, Natal, v. 1, n. 3, p. 76-84, fev. 2016.

PONTE, Yohana de Oliveira et al. Selamento de lesões de cárie oclusais em molares decíduos: relato de dois casos clínicos. RFO, Passo Fundo, v. 22, n. 3, p. 362-67, set./dez. 2017.

TUMENAS, Isabel et al. Odontologia Minimamente Invasiva. Rev Assoc Paul Cir Dent. São Paulo, v. 68, n. 4, p. 283-95. 2014.

FRANKEN, Monique Ananda. Medicina Dentária Minimamente Invasiva: opções de tratamento em Odontopediatria. orientadora: Rita Rodrigues. 2015. (Tese -Mestrado) - Universidade Fernando Pessoa, Porto, 2015. 


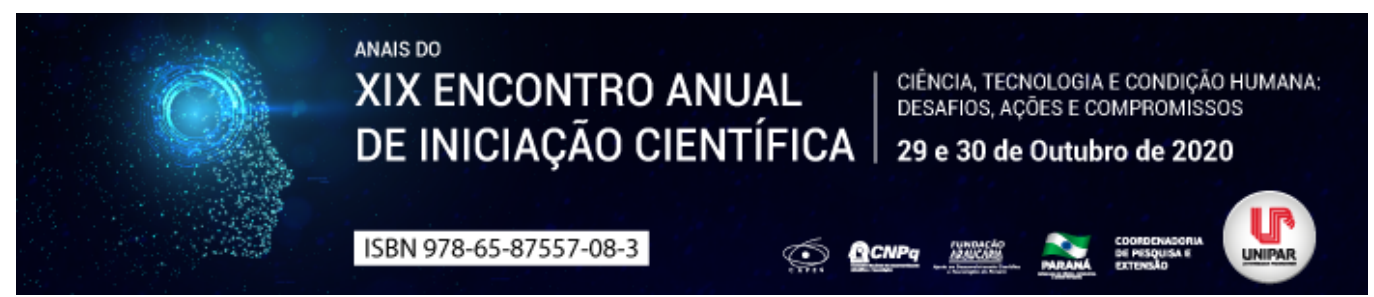

DOR NEUROPÁTICA PÓS IMPLANTE DENTÁRIO

${ }^{1}$ Clara Miotto Silva, ${ }^{2}$ ISABELA TRARBACH GOMES, ${ }^{3}$ KARINE SANTOS ALMEIDA, ${ }^{4}$ PRISCYLA VITORINO SOARES, ${ }^{5}$ ANA LUIZA LEAL BARBOSA

${ }^{1}$ Acadêmica em Odontologia, Universidade Federal do Espírito Santo.
${ }^{1}$ Acadêmica em Odontologia, Universidade Federal do Espírito Santo.
${ }^{2}$ Acadêmica em Odontologia, Universidade Federal do Espírito Santo.
${ }^{3}$ Acadêmica em Odontologia, Universidade Federal do Espírito Santo.
${ }^{4}$ Corpo Docente da Universidade Vila Velha - Disciplina de Cirurgia e Traumatologia Bucomaxilofacial

Introdução: A Dor neuropática orofacial é definida como dor iniciada ou causada por lesão primária ou disfunção no sistema nervoso nas vias aferentes da face e cavidade oral. A incidência de lesão nervosa após procedimentos cirúrgicos odontológicos, incluindo extrações de terceiros molares e instalação de implantes, é maior do que comumente se acredita. Atualmente a literatura especializada é vasta sobre prevalência de anormalidades sensitivas e lesão nervosa periférica após procedimentos odontológicos. Essas informações sugerem conduta que inclua exame minucioso, interconsultas e adoção de medidas preventivas, curativas ou paliativas para o tratamento da dor (SIQUEIRA et al., 2011).

Objetivo: O objetivo desta revisão é discorrer sobre as neuropatias após a instalação de implantes, formas de prevenção e medidas terapêuticas.

Desenvolvimento: As dores neuropáticas são oriundas do Sistema Nervoso Central ou Periférico, sendo classificadas em episódicas e contínuas. O termo

Neuropatia Trigeminal Dolorosa Periférica Traumática (PPTTN) foi proposto para dor neuropática que ocorre dentro de três meses após procedimentos odontológicos, sejam eles invasivos ou não (DELCANHO et al., 2014). É importante por parte do cirurgião dentista (CD), saber diferenciar a dor persistente da dor pós-operatória relacionada à inflamação. Esta é maior no início e diminui com a cicatrização dos tecidos e pode ser bem controlada por métodos farmacológicos e não farmacológicos. Por outro lado, a dor crônica ou persistente, pode surgir de imediato ou algum tempo após a cirurgia, quando já houve a cicatrização tecidual. A dor crônica ocorre entre $10 \%$ e $50 \%$ dos pacientes com dor pós-cirúrgica. Na área de inervação trigeminal, cerca de $10 \%$ de pacientes submetidos à cirurgia desenvolvem dor persistente neuropática (SIQUEIRA et al., 2010). O nervo alveolar inferior (NAI) apresenta maior risco de lesão em relação ao nervo lingual (NL), por estar contido em um canal ósseo, predispondo ao trauma isquêmico e maior incidência de danos permanentes. Possíveis lesões, têm um efeito significativo na qualidade de vida do paciente e a iatrogênese dessas lesões pode levar a outros efeitos psicológicos significativos. Visto que os meios para o correto diagnóstico das neuropatias pós-implante não são amplos e definidos, o ideal é preveni-la, com a utilização de meios de diagnóstico por imagem que determinem, de forma exata e segura, o ideal posicionamento tridimensional do implante em relação aos ramos nervosos. Os sinais ou sintomas somatossensoriais podem ser negativos (hipoestesia e/ou hipoalgesia) e/ou positivos (hiperalgesia e/ou alodinia). Quando o nervo é lesionado, recomenda-se a remoção imediata dos implantes, sugerindo que sejam reimplantados alguns dias depois. A remoção precoce em casos de dano direto ao nervo pode diminuir a neuropatia e até recuperar totalmente as funções sensoriais (NEVES, 2017). A terapêutica medicamentosa é um tratamento adjunto que pode favorecer o prognóstico, devendo ser baseada no nível de severidade da lesão. Quando leve, altas doses de anti-inflamatórios não-esteroidais é indicado. Em casos de injúria moderada a severa, deve-se administrar esteróides orais e, em casos mais complicados, outros agentes farmacológicos, como antidepressivos e anticonvulsivantes, devem ser utilizados (JUODZBALYS et al., 2013). Atualmente, não há um protocolo bem definido para o tratamento das neuropatias pós-implante, porém quanto mais rápido inicia-se o tratamento, mais favorável se torna o prognóstico de recuperação funcional do paciente.

Conclusão: A neuropatia trigeminal dolorosa periférica traumática é uma dor orofacial que acomete pacientes pós procedimentos cirúrgicos onde ocorre a lesão de um nervo com danos passageiros ou por vezes permanentes. O cirurgião dentista deve ser capaz de diferenciar a dor persistente da dor inflamatória póscirúrgica através dos sinais e sintomas. O diagnóstico e o tratamento precoce da lesão de nervo e da dor neuropática após a instalação de implantes são benéficos ao paciente e têm importantes implicações éticas e legais.

\section{Referências}

DELCANHO, Robert; MONCADA, Elizabeth. Persistent pain after dental implant placement: a case of implant-related nerve injury. The Journal of the American Dental Association, v. 145, n. 12, p. 1268-1271, 2014. Disponível em: https://jada.ada.org/article/S0002-8177(14)60300-7/abstract. Acesso em: 03 set. 2020. JUODZBALYS, Gintaras et al. Inferior alveolar nerve injury associated with implant surgery. Clinical oral implants research, v. 24, n. 2, p. $183-190,2013$. Disponível em: https://onlinelibrary.wiley.com/doi/abs/10.1111/j.1600-0501.2011.02314.x. Acesso em: 03 set. 2020.

NEVES, Rodrigo Anselmo et al. Dor neuropática orofacial como consequência da instalação de implantes. Odontologia-Tubarão, 2017.Disponível em: https://www.riuni.unisul.br/handle/12345/5874\#: :text=Com\%20isso\%20queremos\%20elucidar\%20o,sistema\%20nervoso\%20central\%20ou\%20perif\%C3\%A9rico. Acesso em: 03 set. 2020.

PARK, Yong-Tae; KIM, Seong-Gon; MOON, Seong-Yong. Indirect compressive injury to the inferior alveolar nerve caused by dental implant placement. Journal of Oral and Maxillofacial Surgery, v. 70, n. 4, p. e258-e259, $2012 . \quad$ Disponível em: https://www.academia.edu/21543114/Indirect_Compressive_Injury_to_the_Inferior_Alveolar_Nerve_Caused_by_Dental_Implant_Placement. Acesso em: 03 set. 2020.

SIQUEIRA, José Tadeu Tesseroli de; SIQUEIRA, Silvia Regina Dowgan Tesseroli de. Dor persistente, anormalidades sensitivas, lesão de nervo e perda do implante após cirurgia com implantes dentais: sugestão de abordagem clínica. Revista Dor, v. 12, n. 2, p. 172-181, 2011. Disponível em: https://www.scielo.br/scielo.php?pid=S1806-00132011000200015\&script=sci_abstract\&tlng=es. Acesso em: 03 set. 2020.

SIQUEIRA, José Tadeu Tesseroli de; SIQUEIRA, Silvia Regina Dowgan Tesseroli de. Dor orofacial pós-operatória persistente: o risco de iatrogenia: relato de caso. Revista Dor, São Paulo, v. 11, n. 2, p. 180-184, 2010. Disponível em: https://repositorio.usp.br/item/002161865. Acesso em: 03 set. 2020.

Coordenadoria de Pesquisa e Extensão - COPEX

Departamento de Editoração e Divulgaçāo Científica - DEDIC 


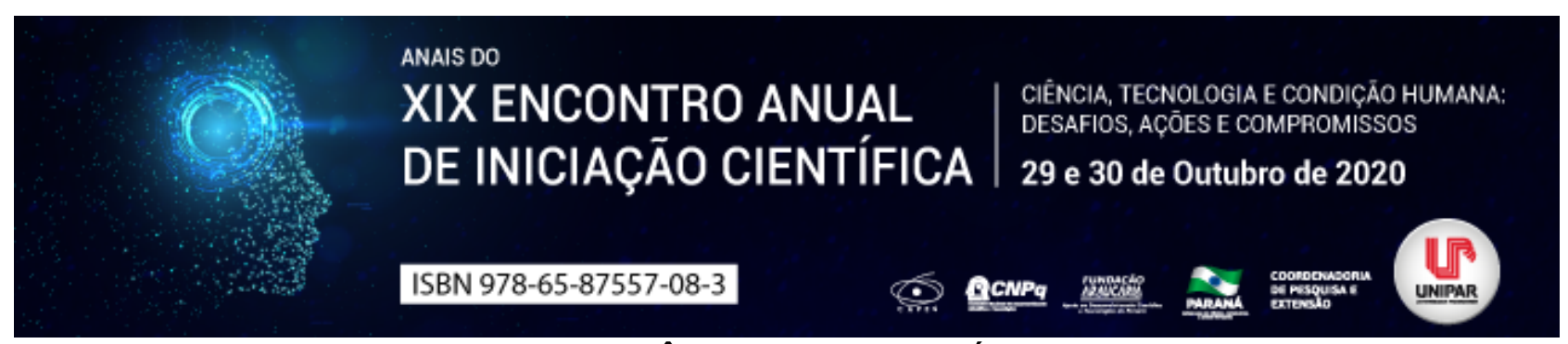

GRAVIDEZ NA ADOLESCÊNCIA: PARTO CESÁREA OU NORMAL?

\author{
${ }^{1}$ RAFAELLA BUZINARO DA SILVA, ${ }^{2}$ AMANDA STEFANI DA SILVA CRUZ, ${ }^{3}$ AMANDA NASCIMENTO VASQUES DE SOUZA, \\ ${ }^{4}$ ADALBERTO RAMON V. GERBASI, ${ }^{5}$ NANCI VERGINIA KUSTER DE PAULA
}

\begin{abstract}
${ }^{1}$ Acadêmica do curso de Enfermagem da Unipar - PIC
${ }^{1}$ Acadêmica do Curso de Enfermagem da UNIPAR - PIBIC

${ }^{2}$ Docente da UNIPAR

${ }^{3}$ Docente da UNIPAR

${ }^{4}$ Docente da UNIPAR
\end{abstract}

Introdução: A adolescência é definida como a fase entre a infância e a vida adulta, marcada por um conjunto de impulsos e desenvolvimento físico, mental e social (BRASIL, 2007). Em 2019 através da Lei 13.798, foi acrescentado ao ECA em seu artigo $8^{\circ}$ a Semana Nacional de Prevenção da Gravidez na Adolescência , com objetivo de divulgar ações de prevenção e educação para redução da gravidez, pois 18\% das crianças nascidas no Brasil são de mães adolescentes (BRASIL, 2019). A idade fértil na adolescente é caracterizada principalmente pela menarca, a primeira menstruação da menina, que acontece por volta dos 12 anos de idade (EISENSTEIN, 2005). A falta de planejamento familiar, deficiência da educação sexual no lar e no âmbito escolar favorece a gestação na adolescência e como consequência abandono dos estudos. O baixo nível escolar e a falta de qualificação limita a adolescente a trabalhos domésticos (SOUZA; ANDRADE; SOUSA, 2013) . A gravidez na adolescência eleva a possibilidade de complicações para a mãe e para o feto, aumenta o risco de parto prematuro, baixo peso ao nascer e óbito fetal, também ocorre um maior índice de anemia e de hipertensão específica da gravidez, do que em mulheres adultas (BOUZAS et al, 2014). Destacam ainda os autores um agravamento da situação socioeconômica da família da adolescente com a chegada de mais um ser, pois ela depende deles, principalmente quando a família possui baixa renda e a adolescente tem baixo nível de escolaridade.

Objetivo:O estudo tem por objetivo identificar a via de nascimento que mais se destaca em gestantes adolescentes.

Metodologia: Trata-se de uma pesquisa documental de natureza quantitativa, retrospectiva, realizada na Maternidade Regional de um município da Região Noroeste do Paraná, que avaliou os registros de tipo de parto no período de $1^{\circ}$ de janeiro 2016 a 31 de dezembro de 2016 de gestantes menores de 18 anos. Essa pesquisa faz parte de um projeto do PIBIC/PIC e os dados foram coletados dos prontuários e livros de registros da Maternidade, no mês de julho de 2020, com auxílio de um formulário contendo dados referentes a tipos de partos . A coleta de dados foi realizada após aprovação do Comitê de Ética em Pesquisa Envolvendo Seres Humanos, segundo a Resolução 466/2012, sob o parecer 3.610.268.

Resultados: Foram avaliados todos os registros de gestantes adolescentes que deram entrada na maternidade no ano de 2016, em uma população de 164 adolescentes, dessas 85 (51,8\%) realizaram parto normal (PN) e 79 (48,2\%) partos por cesárea (PC). Não houve nenhum registro de PN em adolescentes com 12 anos e apenas um registro de cesárea nessa idade. Aos 13 anos seis casos de adolescentes grávidas sendo dois PN e quatro PC. Aos 14 anos foram 13 casos, sete casos de PN e seis de PC. A partir dos 15 anos houve um aumento dos casos com 18 casos de parto normal e oito cesáreas, seguido por adolescentes de 16 anos com 32 PN para 23 PC. Já aos 17 anos houve um predomínio para PC com 37 casos e 26 PN.

Discussão: De acordo com os resultados da pesquisa houve um aumento dos casos de gravidez a partir dos 15 anos, com um total de com 136 casos e um equilíbrio entre os casos de parto normal e cesárea. Silveira (2004) relata que a adolescente possui maior predisposição a ter um parto normal quando comparadas com mulheres adultas, em razão de melhor função do miométrio que é a camada mais grossa da parede uterina, ressaltando que há grande relutância por parte dos obstetras para realizar cesarianas em adolescentes (BOUZAS et al, 2014). Silveira (2004) acrescenta que a cesárea é mais comum em mulheres maiores de 18 anos, comparando ao nosso estudo que foi evidenciado já a partir dos 17 anos de idade. Matos et al (2018) destaca em sua pesquisa que o tipo de parto realizados está intimamente ligado a adolescente ter ou não informações e conhecimento sobre parto normal ou cesárea, além da dificuldade e conhecimento de ser protagonista de suas escolhas Atualmente a legislação vem colaborar ao processos de escolha de via de parto o que empodera a mulher em poder decidir sobre tipo de parto a ser realizado. A preocupação pelo parto cesariano se deve a preocupação aliada aos riscos que toda cirurgia oferece. Segundo Schiller (2015), no Brasil o parto não somente é realizado exclusivamente em hospitais, e a cesárea sendo a tipo de parto mais realizado entre obstetras, mesmo existindo um risco maior a saúde materno fetal devido ao procedimento cirúrgico, risco de infecção o que requer maior cuidado no pós parto, riscos de doenças respiratórias no recém nato. No Brasil apesar da busca por uma assistência humanizada dentro dos hospitais, visando bem estar a parturiente e ao recém nato, o medo da dor, da tensão, impede o processo fisiológico do parto normal, o que leva a práticas e intervenções que 
poderiam ser evitadas (MOURA et al; 2007).

Conclusão: Conclui - se desta pesquisa que a gravidez está presente e continua nas adolescentes, sendo a via de nascimento predominante parto normal, de forma pouca significativa, relacionada principalmente pela idade materna apresentada.

\section{Referências}

BOUZAS, Isabel; CADER, Samaria; LEÃO, Lenora. Gravidez na adolescência: uma revisão sistemática do impacto da idade materna nas complicações clínicas, obstétricas e neonatais na primeira fase da adolescência. Adolesc Saúde, v. 11, n. 3, p. 721, Set, 2014

BRASIL. Marco Legal, saúde um direito de adolescentes. 1 ed. Brasília, 2007.

EISENSTEIN, Evelyn. Adolescência: definições, conceitos e critérios. Revista oficial do núcleo de estudos da saúde do adolescente/UERJ. v. 2, n. 2, Junho, 2005

MATOS, Greice Carvalho; ESCOBAL, Ana Paula de Lima; PALMA, Josiane Santos et al. Parto normal ou cesárea na adolescencia: de quem é a decisão?. Rev enferm UFPE online., Recife, 12(6):1681-7, jun., 2018

MOURA, Fernanda Maria de Jesus S. Pires et al. A humanização e a assistência de enfermagem ao parto normal. Rev. bras.enferm., Brasília, v. 60, n. 4, p. 452-455, Aug. 2007.

SILVEIRA, Isolda Pereira; OLIVEIRA, Veríssimo et al. Perfil obstétrico de adolescente de uma maternidade pública no Ceara. Escola Anna Nery Revista de Enfermagem. v.8. n² 2. p. 205-210. Agosto, 2004.

SOUZA AS DE, ANDRADE AN; SOUSA HGL et al. Revista de enfermagem UFPE online - Complicações obstétricas em adolescentes de uma maternidade. Recife. 7(4):1167-73, abr., 2013.

SCHILLHER, Esther Ferreira. A Relação entre perfis de parturientes e vias de parto no Brasil. Universidade de Brasília. Brasília. Dezembro, 2015. 


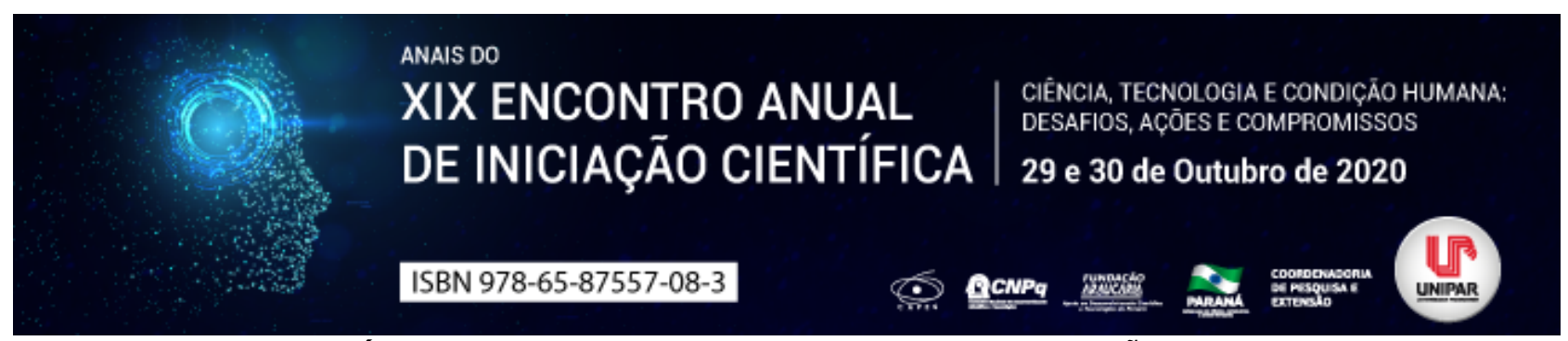

QUEILITE ACTÍNICA EM TRABALHADORES RURAIS: UMA REVISÃO DE LITERATURA

\begin{abstract}
1JOAO CARLOS RAFAEL JUNIOR , ${ }^{2}$ MARIA RITA BARBOSA DE OLIVEIRA, ${ }^{3}$ NATALIA COQUEIRO SIQUEIRA, ${ }^{4}$ BEATRIZ AYUMI SHIOTANI, ${ }^{5}$ GABRIEL MACIEL DA SILVA, ${ }^{6}$ DANIELA DE CASSIA FAGLIONI B CERANTO
\end{abstract}

\author{
${ }^{1}$ Acadêmico Bolsista do PEBIC/CNPQ \\ ${ }^{1}$ Acadêmica Bolsista do PEBIC/CNPQ \\ ${ }^{2}$ Acadêmica do Curso de Odontologia da UNIPAR \\ ${ }^{3}$ Acadêmica do PIC/UNIPAR \\ ${ }^{4}$ Acadêmico Bolsista do PIBIC/UNIPAR \\ ${ }^{5}$ Docente da UNIPAR
}

Introdução: Entre as doenças que possuem maior prevalência na população brasileira, o câncer pode ser citado como sendo uma das principais. Dentre eles, destaca-se o câncer bucal que, segundo estimativas do Instituto Nacional do Câncer (INCA), no ano de 2020 tenha 15.192 mil novos casos no Brasil. Sob esse contexto, alguns sinais e sintomas podem preceder ao desenvolvimento do câncer bucal, são as chamadas lesões pré-malignas, destacando-se a leucoplasia, eritroplasia e a queilite actínica (ARNAUD et al., 2014). A queilite actínica é uma lesão pré-maligna que ocorre nos lábios devido a uma exposição frequente aos raios solares sem a utilização de fatores de proteção, desse modo, destaca-se a manifestação em trabalhadores rurais, os quais estão expostos diariamente ao sol, sendo então essencial que medidas de proteção e prevenção sejam traçadas voltadas para esse público (ARAUJO et al., 2012).

Objetivo: O presente trabalho objetiva, através de uma revisão de literatura, expor a relação entre queilite actínica e trabalhadores rurais, abordando dados de prevalência e uso de métodos de proteção.

Desenvolvimento: $O$ câncer bucal é o quinto tipo de câncer mais prevalente em homens e o sétimo em mulheres e segundo dados do INCA para o ano de 2020, estima-se 15.190 novos casos de câncer bucal (INCA, 2020). O câncer surge devido a uma mutação genética do DNA de uma célula, gerando então um processo de malignização nesta célula, a qual passará a ter um crescimento exagerado e desordenado (NEVILLE, 2009). Alguns sinais e sintomas podem preceder ao surgimento do câncer bucal, são as chamadas lesões pré-malignas, definidas como sendo um tecido morfologicamente alterado, no qual é mais possível a ocorrência do câncer, nota-se que não há relação de obrigatoriedade entre possuir uma lesão pré-maligna e ter câncer (LUCIO; BARRETO, 2012). No âmbito destas lesões, enquadra-se a queilite actínica, sendo causada pela exposição crônica à radiação ultravioleta sem a utilização de fatores de proteção, é definida como sendo uma condição degenerativa do epitélio de revestimento, o que leva a uma elastose solar e afeta a região de vermelhão do lábio inferior (CINTRA et al., 2013). Sua maior prevalência está situada em indivíduos do sexo masculino, acima de 40 anos e leucodermas, expostos frequentemente à radiação solar como os trabalhadores rurais (ARAUJO et al., 2012). A principal característica clínica da QA é a perda da elasticidade e formato do contorno labial, o qual apresenta-se com um aspecto enrijecido, além disso podem ser encontradas áreas escamosas, esbranquiçadas, fissuras, ulcerações, sangramento, desenvolvimento de pelos, podendo ser encontradas áreas leucoplásicas associada. Histologicamente encontra-se um epitélio atrófico, hiperqueratose em semimucosa labial com elastose solar, ainda pode ser encontrado um infiltrado inflamatório crônico no local (ARNAUD et al., 2014). O melhor tratamento para a QA é a prevenção, utilização de fatores de proteção labial, conscientização e autocuidado. Porém, em alguns casos de lesões já instaladas pode-se realizar ablação com CO2 ou até mesmo a cirurgia de vermelhectomia (VÉO et al., 2010). A literatura ressalta que dentre os indivíduos que trabalham expostos ao sol, a prevalência de queilite actínica pode chegar a 43,2\% (SARMENTO et al., 2014). Em relação aos trabalhadores rurais, os achados de Filho (2010) ao estudar uma população de 240 trabalhadores rurais no Sergipe, obteve que cerca de 16,7\% possuíam QA, além disso mostrou uma predileção por indivíduos do sexo masculino, acima de 50 anos, leucodermas e tabagistas. Ferreira et al. (2016) ao analisar a prevalência de lesões prémalignas em uma população de 1.385 fazendeiros obtiveram a queilite actínica como lesão mais frequente acometendo cerca de $28,4 \%$, em segundo lugar estava a leucoplasia em 2,3\% dos participantes. Nota-se um grande destaque para a QA, sendo a mais prevalente em relação a todas as outras lesões cancerizáveis. Dados importantes foram obtidos nos estudos de Teixeira et al. (2019), que analisaram 223 trabalhadores rurais na Bahia e destes, cerca de 31,8\% apresentavam graus variados de QA, além disso, nenhum dos pesquisados usavam protetor labial. Isso expõe claramente a falta de informações por parte dos trabalhadores rurais acerca da importância de proteção e autocuidado.

Conclusão: Em face do exposto, a literatura mostra que os dados de prevalência de queilite actínica em trabalhadores rurais são altos, concluindo que se trata de uma parcela da população mais susceptível, além disso, a falta de uso de fatores de proteção demonstra uma falta de conscientização sobre a importância do autocuidado na prevenção desta lesão, visto que a prevenção é 
pautada como o melhor tratamento. Os dados são preocupantes, pois a QA é um grande vetor para o desenvolvimento do Carcinoma de Células Escamosas.

\section{Referências}

ARAÚJO, Caliandra Pinto et al. Queilite actínica: um estudo de 35 casos com destaque para os aspectos morfológicos. RPG Revista de Pós-Graduação, v.9, n. 6, p. 21-27, 2012.

ARNAUD, Rachel Reinaldo. Queilite actínica: avaliação histopatológico de 44 casos. Rev. Odontol. UNESP, v.43, n.6, p.384389, nov./dez. 2014.

BRASIL. Ministério da Saúde. Instituto Nacional de Câncer INCA. Rio de Janeiro, c1996-2020. Disponível em: https://www.inca.gov.br/. Acesso em: 14 ago. 2020.

CINTRA, José Silvino. Queilite actínica: estudo epidemiológico entre trabalhadores rurais do município de Piracicaba- SP. Rev. Assoc. Paul. Cir. Dent., São Paulo, v.67, n.2, p. 118-121, 2013.

FERREIRA, Antonio. Prevalence and factors associated with oral potentially malignant disorders in Brazil's rural workers. J. Comum. Dis., v. 22, n. 6, p. 536-542, 2016.

FILHO, Paulo Ricardo Martins. Levantamento epidemiológico da queilite actínica em trabalhadores rurais da microrregião sergipana do sertão do São Franciso. 2010. 68f. Dissertação (Mestrado em Ciências da Saúde) - Universidade Federal de Sergipe, Sergipe, 2010.

LUCIO, Priscilla Suassuna; BARRETO, Rosimar de Castro. Queilite actínica-perfil da produção científica em odontologia no Brasil nos últimos dez anos. Rev. Cubana Estomatol., Ciudad de La Habana, v.49, n.4, p.276-285, 2012.

NEVILLE, Brad. Patologia oral \& Maxilofacial. $3^{\mathrm{a}}$ ed. Rio de Janeiro: Elsevier, 2009.

SARMENTO, Dmitry José de Santana et al. Actinic Cheilitis: clinicopathologic profile and association with degree of dysplasia. Int. J. Dermatol., v. 53, n. 1, p. 466-472, 2014.

TEIXEIRA, Ana Conceição de Oliveira Cravo et al. Presença de queilite actínica em trabalhadores da zona rural de Governador Mangabeira atendidos nas unidades básicas de saúde. Textura, v. 13, n. 22, p. 176-189, 2019.

VÉO, Paulo César Rodrigues et al. Tratamento cirúrgico da queilose actínica. Revista Gaúcha Odontologia, v. 58, n. 3, p. 393397, 2010. 


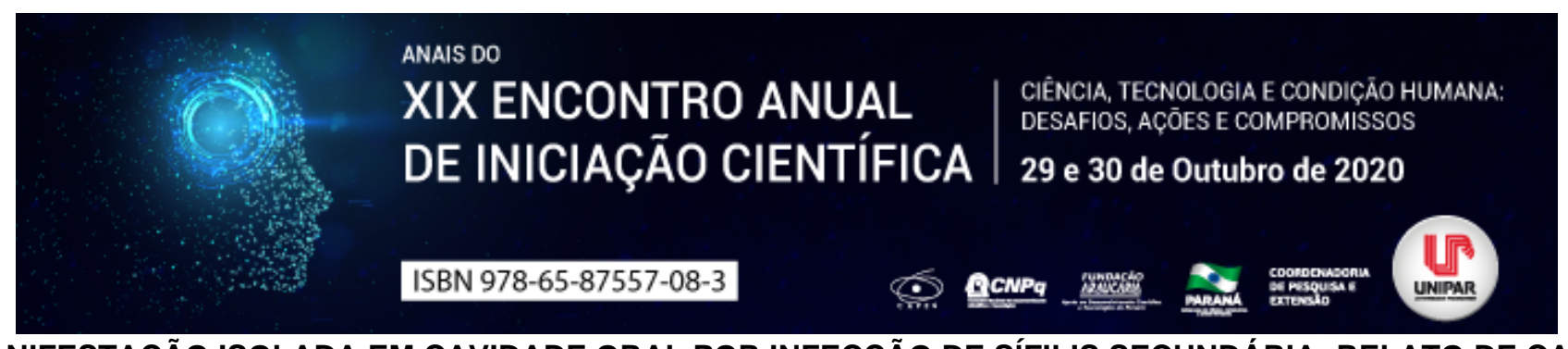

MANIFESTAÇÃO ISOLADA EM CAVIDADE ORAL POR INFECÇÃO DE SÍFILIS SECUNDÁRIA: RELATO DE CASO

\author{
${ }^{1}$ HELENA CAROLINE DA SILVA, ${ }^{2}$ ALINE TESKER VALDAMERI, ${ }^{3}$ JENIFFER URBANO DEGASPERI, ${ }^{4}$ ANA CLAUDIA \\ POLETTO, ${ }^{5}$ LETICIA DE FREITAS CUBA GUERRA
}

\author{
${ }^{1}$ Acadêmica do Curso de Odontologia da UNIPAR \\ ${ }^{1}$ Acadêmica do Curso de Odontologia da UNIPAR \\ ${ }^{2}$ Acadêmica do Curso de Odontologia da UNIPAR \\ ${ }^{3}$ Docente da UNIPAR \\ ${ }^{4}$ Docente da UNIPAR
}

Introdução: A sífilis é uma infecção sexualmente transmissível (IST) causada pela bactéria Treponema pallidium, que tem como único hospedeiro o ser humano, caso não seja tratada pode se apresentar três fases: primária, secundária e terciária. As manifestações variam em cada fase e podem ser sistêmicas, cutâneas e também orais que são, geralmente, sintomas iniciais e podem guiar o diagnóstico precoce, o qual representa grande influência sobre o tratamento nesta situação (ANDRADE et al., 2018). Diante do descrito, o objetivo é relatar um caso de sífilis secundária em cavidade oral, cujo exame clínico e exames complementares foram decisivos para o diagnóstico.

Relato de caso: Paciente do gênero feminino, 55 anos, compareceu na clínica odontológica da Universidade Paranaense UNIPAR do campus de Francisco Beltrão com queixa de dor nos dentes posteriores e sensibilidade a bebidas ácidas, contou que sua última consulta odontológica foi a cerca de três anos e já sentia dor. Relata ter fumado durante 30 anos tendo cessado o uso 6 meses antes da consulta e não fazer consumo de bebidas alcoólicas. No exame físico intraoral, observou-se alterações compatíveis com grânulos de Fordyce na região anterior do lábio inferior, estomatite nicotínica em terço médio do palato duro, varicosidade lingual e melanose reacional. Além disso, observou-se placas branco/acinzentadas em dorso de língua, mucosa labial inferior, mucosa jugal bilateral e no rebordo inferior dos dentes 36, 37 e 16. Diante disso, foram solicitados exames complementares (hemograma, glicemia, ferro sérico, ácido fólico, vitamina B12, VSG, anti- HIV, VDRL, FTA-ABS, HBS, VSH, PTH). Após 14 dias, confirmou-se o diagnóstico de sífilis com resultado positivo para VDRL e FTA-ABS. Foram receitadas três doses de penicilina benzatina, sendo uma dose por semana. No retorno, 34 dias depois, a avaliação intra oral apresentou leve remissão das lesões com áreas esbranquiçadas ainda persistindo em mucosa labial inferior e dorso da língua, mediante nova queixa da paciente foi solicitado uma titulação de VDRL e novo retorno da paciente, entretanto, até o presente momento o mesmo não ocorreu, o quadro seguirá em acompanhamento.

Discussão: A sífilis é uma doença infecciosa transmitida em casos de relações sexuais e sexo oral, realizadas sem o uso de preservativos. É causada pela bactéria Treponema Pallidum e acomete mais o gênero masculino, apresentando três estágios clínicos: primária, secundária e terciária. A forma mais comum utilizada para o diagnóstico da sífilis, segundo o Ministério da Saúde, é a realização do teste rápido (TR) , no entanto também podem ser indicados testes sorológicos, como o VDRL e o FTA-ABS, que possuem alta eficiência. A fase secundária, que é o foco deste relato, pode surgir entre a $6^{\circ}$ e $8^{\circ}$ semana depois das lesões primárias (MARI et al., 2019), sendo considerada, juntamente com o primário, o estágio mais contagioso da doença. Tem como principais características sintomas sistêmicos como fadiga, mal-estar, febre, dor de garganta, perda de peso, dor de cabeça e linfadenomegalia reativa (SANTOS; SÁ; LAMARCK, 2019), também pode apresentar rosácea por todo o corpo e, aliado a esses fatores, é comum o aparecimento de lesões orais. Sobre as lesões orais, as placas mucosas são a manifestação clínica mais comum nesta fase e estão preferencialmente localizados nos lábios, língua, mucosa bucal e palato. Nesta fase, é comum o aparecimento de manchas ou placas mucosas ligeiramente elevadas e coberto por pseudo-membranas brancas ou acinzentadas (ANDRADE et al., 2018). No caso relatado, a paciente não apresentava nenhum sinal e sintoma sistêmico, como febre ou dores de cabeça, que pudessem indicar uma infecção por sífilis. No entanto, as lesões de placa branca presentes em mucosa oral são manifestações comuns no segundo estágio clínico dessa doença e foram então consideradas como um possível diagnóstico mesmo sendo muito incomuns quando isoladas, sem outros indicadores. Os testes sorológicos realizados, VDRL e FTA-ABS, confirmaram o diagnóstico e após aplicações de penicilina benzatina, medicamento muito utilizado para o tratamento dessa infecção, as lesões regrediram. A titulação de VDRL após o tratamento poderia indicar se as demais lesões persistentes na cavidade bucal possuíam ou não relação com esse diagnóstico, e se necessário, mais um curso de penicilina poderia ser indicado, no entanto, como a paciente abandonou o tratamento, o caso segue em aberto.

Conclusão: É de extrema importância a orientação para a população sobre o uso de preservativos na prevenção de IST. Também, é necessário que o cirurgião-dentista esteja capacitado, possuindo amplo conhecimento a respeito das doenças e suas 
manifestações bucais para realizar um diagnóstico com características diferenciais das que comumente são observadas como, por exemplo, na infecção por sífilis secundária e deve ter domínio sobre a indicação dos exames complementares para que, assim, possa diagnosticar e tratar corretamente seu paciente.

\section{Referências}

ANDRADE, Rodrigo Soares. et al. Oral findings in secondary syphilis. Medicina Oral Patologia Oral y Cirugia Bucal, v. 23, n. 2, p. e138 e143, 2018.

MARI, Elena. et al. Beyond appearance: an unusual manifestation of isolated oral secondary syphilis. International Journal of Immunopathology and Pharmacology, v. 33, p. 1 4, 2019.

Ministério da Saúde (BR). Sífilis: o que é, causas, sintomas, tratamento, diagnóstico e prevenção. https://saude.gov.br/saude-dea-z/sifilis acesso em: 01 de agosto, 2020.

SANTOS, Erison Santana dos; SÁ, Jamile de Oliveira; LAMARCK, Rachel. Manifestações orais da sífilis: revisão sistematizada de literatura. Archives of Health Investigation, v. 8, n. 8, p. 413 416, 2019.

Coordenadoria de Pesquisa e Extensão - COPEX

Departamento de Editoraçāo e Divulgaçāo Científica - DEDIC 


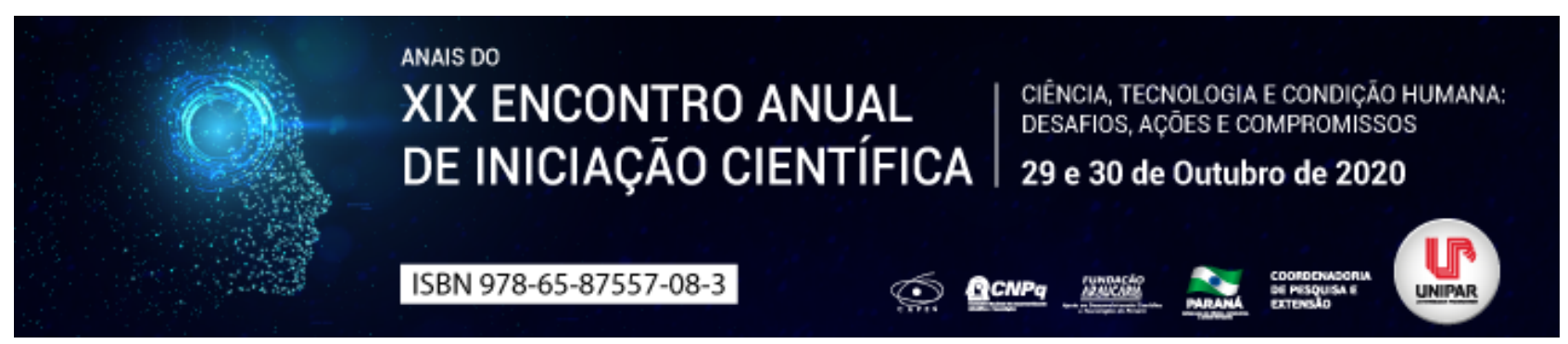

RISCOS PSICOSSOCIAIS NO TRABALHO: PERSPECTIVAS DA EQUIPE DE ENFERMAGEM

\title{
${ }^{1}$ EDUARDA dOS SANTOS AMARAL, ${ }^{2}$ EDUARDA DUARTE DE CASTRO, ${ }^{3}$ SALUHU IBRAHIM, ${ }^{4}$ FRANCIELE ANI CAOVILLA FOLLADOR, ${ }^{5}$ JOLANA CRISTINA CAVALHEIRI
}

\author{
${ }^{1}$ Acadêmico do Curso de Enfermagem da UNIPAR \\ ${ }^{1}$ Acadêmica do Curso de Enfermagem da UNIPAR \\ ${ }^{2}$ Acadêmico do Curso de Enfermagem da UNIPAR \\ ${ }^{3}$ Docente do curso de Nutrição da Universidade Estadual do Oeste do Paraná. Unidade de Francisco Beltrão. \\ ${ }^{4}$ Docente da UNIPAR
}

Introdução: Estudos têm demonstrado que a saúde mental dos profissionais está diretamente associada ao local de trabalho, visto que esta atividade ocupa a maior parte do dia dos trabalhadores (FERNANDES et al., 2018; MORENO et al., 2018). Entre as situações expostas no ambiente de trabalho, têm-se os riscos psicossociais, que são definidos como contextos negativos que ocorrem por condições e pelo conteúdo da atividade laboral (RODRIGUES; FAIAD, 2019). Os profissionais de enfermagem estão expostos aos fatores psicossociais devido a jornadas extensas, sobrecarga de trabalho, remuneração salarial insuficiente, desvalorização profissional, desgaste físico e mental resultante do cuidado direto com os pacientes e seus familiares, o que desencadeia sobrecarga psíquica, esgotamento profissional, absenteísmo e adoecimento (SILVA et al., 2017).

Objetivo: Vislumbrar na perspectiva do profissional de enfermagem os riscos psicossociais identificados no ambiente de trabalho.

Metodologia: Pesquisa descritiva, exploratória, transversal e quantitativa desenvolvida com trabalhadores de enfermagem de uma instituição hospitalar pública e outra mista do município de Francisco Beltrão-Paraná. A amostragem ocorreu por conveniência. A coleta de dados ocorreu de fevereiro a agosto de 2018, por meio de um questionário confeccionado pelos pesquisadores conforme a literatura, com diferentes situações do ambiente de trabalho no qual os profissionais estão expostos. A análise dos dados ocorreu por frequência descritiva e relativa. A pesquisa foi aprovada pelo Comitê de Ética da Universidade Estadual do Oeste do Paraná, pelo protocolo n².415.008, em 2017.

Resultado: Participaram do estudo 198 profissionais, no qual o risco psicossocial foi identificado por $67,3 \%$, sendo que as situações estressantes (63,3\%), sobrecarga de trabalho (51,5\%), agressões verbais, físicas e comportamentais (48,0\%), postura arrogante de pacientes e familiares (32,1\%), falta de segurança (13,8\%), desvio de função (12,8\%), diversidade de diagnósticos médicos $(11,2 \%)$, convívio entre colegas (2,6\%), assédio de chefes e profissionais médicos (1,5\%) e a desvalorização profissional (0,5\%), foram as cargas psíquicas referidas pelos profissionais de enfermagem.

Discussão: Neste estudo $67,3 \%$ dos profissionais relataram a presença do risco psicossocial no ambiente de trabalho, o que ocorre pelo aumento da cobrança por produtividade, a insegurança no ambiente trabalhista e a deterioração das condições laborais (OROZCO-VÁSQUEZ; ZULUAGA-RAMÍREZ; PULIDO-BELLO, 2019). Estudo desenvolvido com enfermeiros atuantes na região nordeste do Brasil obteve a alusão aos riscos psicossociais no ambiente de trabalho (LIMA et al., 2018), da mesma forma que pesquisa realizada com a equipe de enfermagem atuante em cuidados diretos a pacientes críticos em Portugal (MEIRA; COELHO, 2019), demonstrando que os riscos psicossociais estão presentes nas diversas especialidades e localidades. As situações estressantes do ambiente de trabalho foram citadas como fator psicossocial, assim como estudo realizado com profissionais de enfermagem da Bahia (NETO; XAVIER; ARAÚJO, 2019) e de Maceió (MOURA., et al, 2019). Nota-se que o estresse ocupacional resulta em impactos sociais, econômicos e pessoais e é deletério para a saúde do trabalhador e para a atividade, sendo necessário realizar intervenções para redução dos indicadores. A sobrecarga de trabalho foi referida como risco psicossocial, o que vai ao encontro de estudo desenvolvido com profissionais atuantes no serviço de emergência o qual identificaram o excesso de tarefas como fator de risco (SANTOS et al., 2020), e que pode acarretar exaustão física e mental, insatisfação, absenteísmo e desencadear uma assistência errônea, deixando os usuários e equipe desgostosas (OLIVEIRA et al., 2017).Também verificou-se que os profissionais aludiram as agressões verbais, físicas e comportamentais, postura arrogante de pacientes e familiares e assédio de chefes e profissionais médicos, dados que corroboram com estudo realizado com trabalhadores da enfermagem na Região Sul do Brasil, onde os diferentes tipos de agressões foram provocadas por chefes, superiores, além de pacientes e seus familiares (TSUKAMOTO., et al, 2019), sendo o assédio pouco aludido por medo de perder o vínculo empregatício, vergonha ou perseguição. Por fim em menor frequência observou-se a falta de segurança, desvio de função, diversidade de diagnósticos médicos, convívio entre colegas. Dessa forma, salienta-se a importância do reconhecimento dos riscos psicossociais por parte dos profissionais de enfermagem, bem como pela instituição, visto que a saúde do trabalhador reflete na assistência prestada, desencadeando riscos para os pacientes e para o profissional. É necessário ressaltar a 
importância da educação continuada da equipe, reorganização do trabalho, assim como a implementação de estratégias para que a prevalência das cargas psíquicas seja reduzida.

Conclusão: As ocorrências consideradas riscos psicossociais pelos profissionais de enfermagem foram as situações estressantes, a sobrecarga laboral e a exposição a violência, assemelhando-se as pesquisas brasileiras sobre a temática.

\section{Referências}

FERNANDES, Márcia Astrês et al. Fatores psicossociais e o trabalho com o dependente químico na concepção da enfermagem. Revista Brasileira de Medicina do Trabalho, v. 16, n. 3, p. 297-304, Set.2018.

LIMA, Sónia Maria Silvestre de; AGOSTINHO, Marcia; MOTA, Liliana. Percepção dos profissionais de saúde das limitações à notificação do erro/evento adverso. Revista de Enfermagem Referência, v.4. n. 19, p. 99-106, Out.2018.

MEIRA, Hugo Alexandre Neves Fortes Guimarães; COELHO, Sílvia Patrícia Fernandes. Riscos psicossociais dos enfermeiros que prestam assistência ao doente crítico. Revista de Enfermagem Referência, 4. n. 22, p. 127-138, Jun.2019.

MORENO, Juliany Kelly et al. Síndrome de Burnout e fatores de estresse em enfermeiros nefrologistas. Rev enferm UFPE on line., v.12, n. 4, p.865-71, abr. 2018.

MOURA, Reinaldo dos Santos et al. Níveis de estresse da enfermagem nas Unidades de Terapia Intensiva. Rev. enferm. UFPE on line, v.13 n.3 p. 569-577, mar. 2019.

NETO, Eduardo Moreira; XAVIER, Aline Silva Gomes; ARAÚJO, Tânia Maria de. Fatores associados ao estresse ocupacional entre profissionais de enfermagem em serviços de saúde de média complexidade. Revista Brasileira de Enfermagem, v. 73, n.1 p.1-9, Ago. 2020.

OLIVEIRA, Jacqueline Flores de et al. Satisfação profissional e sobrecarga de trabalho de enfermeiros da área de saúde mental. Ciência \& Saúde Coletiva, v. 24, n.7 p. 2593-2599, Out. 2019.

OZOZCO-VÁSQUEZ, Margarita-María; ZALUAGA-RAMÍREZ, Yury-Carolina; PULIDO-BELLO, Geraldine. Fatores de risco psicossociais que afetam os profissionais de enfermagem. Revista Colombiana de Enfermagem, v. 14, n. 18, pág. 5, Abr. 2019.

RODRIGUES, Carlos Manoel Lopes; FAIAD, Cristiane. Pesquisa sobre riscos psicossociais no trabalho: Estudo bibliométrico da produção nacional de 2008 a 2017. Revista Psicologia Organizações e Trabalho, v. 19, n. 1, p. 571-579, Jul. 2019.

SANTOS, Katerine Moraes et al., Perfil da equipe de enfermagem de unidades ambulatoriais universitárias: considerações para a saúde do trabalhador. Esc Anna Nery. v. 24, n. 2, e20190192. Fev. 2020.

SILVA, Jorge Luiz Lima et al. Riscos psicossociais em enfermagem de terapia intensiva: reflexão sobre possíveis soluções. Revista de Enfermagem da UFSM, v. 7, n. 4, p. 736-745, Ago. 2017.

TSUKAMOTO, Sirlene Aparecida Scarpin et al. Violência ocupacional na equipe de enfermagem: prevalência e fatores associados. Acta Paulista de Enfermagem, v. 32, n. 4, p. 425-432, Abr. 2019. 


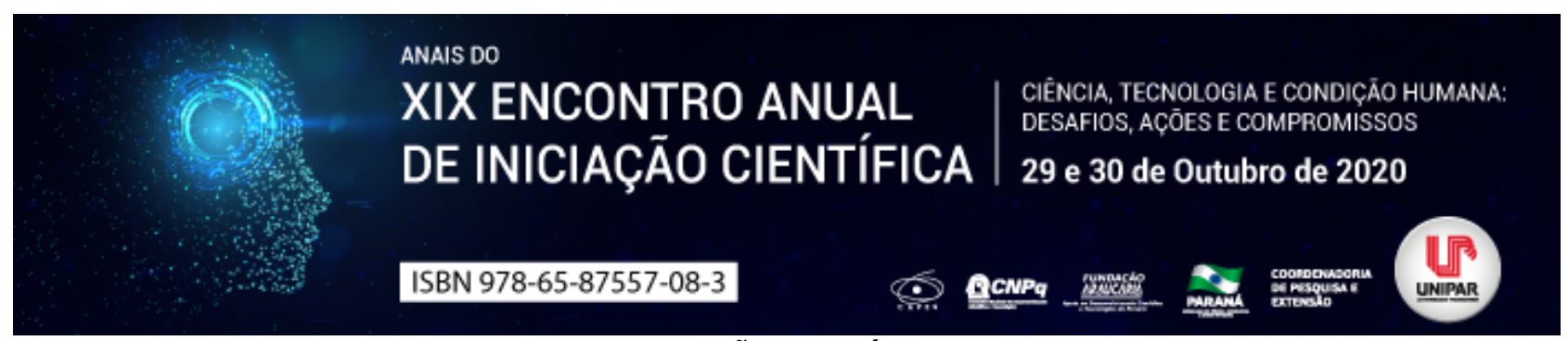

MEDIDAS PREVENTIVAS CONTRA INFECÇÃO URINÁRIA ASSOCIADA A CATETER VESICAL

\author{
${ }^{1}$ Emilli Karine Marcomini, ${ }^{2}$ JULIANA BERNARDI WENZEL
}

${ }^{1}$ Enfermeira. Mestranda do Programa de pós-graduação em Biotecnologia. Bolsista CAPES.

${ }^{1}$ Licenciada e Bacharel em Ciências Biológicas com Ênfase em Biotecnologia-UNIPAR. Mestre e Doutora em Biologia Comparada-UEM.

Introdução: A Infecção de Trato Urinário (ITU) associada ao Cateter Vesical de Demora (CVD), é uma das infecções mais incidentes no ambiente de terapia intensiva, que eleva consideravelmente as taxas de morbidade, mortalidade e custos gerais, além de representar cerca de $40 \%$ das notificações de infecções nosocomiais (AMANDO, 2018). Entre os microrganismos causadores, destacam-se a espécie fúngica Candida albicans e bacteriana Escherichia coli, a qual é bastante evidente nas ITUs, por conter genes associadas a aderência às células uroepiteliais e aos próprios cateteres, com formação de biofilmes (Fímbria tipo 1 e tipo P), além da motilidade, que facilita a ascensão por via intra ou extraluminal (CAVALCANTE; BRAQUEHAIS; ALBUQUERQUE, 2017; MOTA; OLIVEIRA, 2019). Grande parte dos microrganismos responsáveis pela ITU habitam o trato gastrointestinal ou fazem parte da microbiota orgânica, ocasionando a infecção em razão do desequilíbrio homeostático, da susceptibilidade do hospedeiro e de fatores que potencializam a patogenicidade (FREITAS et al., 2016).

Objetivo: Analisar estudos que abordem medidas de controle de infecção urinária associada a cateterização vesical.

Desenvolvimento: Apesar de ser considerada uma infecção com alto potencial preventivo, os índices de ITU têm sido comumente crescentes no ambiente de hospitalar, especialmente no âmbito da unidade de terapia intensiva, demonstrando haver falhas no processo de controle e prevenção (DORESTE et al., 2019). Cuidados com a inserção, manipulação e retirada de um CVD são primordiais são prevenir as ITU, visto a existência de fatores que podem elevar significativamente a ocorrência da infecção, como o tempo de permanência, colonização microbiana, alterações orgânicas e condições clínicas do paciente (TAVARES et al., 2020). Tais fatores reforçam a necessidade de um diagnóstico clínico precoce e uma terapêutica adequada a patogenicidade do paciente, as quais estão cada vez mais limitadas pela resistência bacteriana, responsável pela evolução clínica desfavorável e por linhagens resistentes de bactérias e fungos causadores de ITU (FREITAS et al., 2016). O grande aumento da resistência bacteriana, aliado as ausências de realização de antibiogramas e diagnósticos precoces, possibilitou que os microrganismos exercessem a capacidade de modificar seu próprio DNA, ampliando a capacidade de multiplicação e adaptação, adquirindo assim, genes resistentes a inúmeros antimicrobianos (COSTA; CUNHA, 2019; SILVA et al., 2017). Algumas diretrizes consideram a impregnação ou o revestimento de CVD com compostos antimicrobianos, uma excelente alternativa para controle de ITU, no qual o estudo in vitro de Amando (2018) comprovou a eficiência do método para prevenção da formação de biofilmes, sem causar qualquer toxicidade ao tecido, além de inibir o crescimento de cepas resistentes. Outra alternativa de controle se refere ao tipo do material do cateter, no qual cateteres hidrofílicos são considerados menos susceptíveis a desenvolver ITU, pois reduzem o atrito, o trauma uretral e mantém a lubrificação natural, diminuindo consideravelmente a manipulação do profissional com o dispositivo (ALMEIDA; LINDOSO; PESSOA, 2016).

Conclusão: Os elevados índices de ITU associadas a CVD e o aumento de linhagens resistentes fazem com que essas infecções se tornem relevantes para o âmbito da saúde pública e da assistência hospitalar. As recomendações de controle de ITU, estão relacionadas aos cuidados na inserção, manutenção e no controle do tempo de permanência. A questão da resistência microbiana traz a necessidade de desenvolver novos agente antimicrobianos, capazes de atuarem com eficiência sobre biofilmes e cepas gerais. Desta forma, um controle bem-sucedido da ITU depende da eficácia de compostos antimicrobianas e do cuidado profissional, principalmente do enfermeiro, que é o protagonista na inserção, manutenção e avaliação de resultados.

\title{
Referências
}

ALMEIDA, M. M.; LINDOSO, A. M.; PESSOA, R. M. C. Evidence in practice urinary catheterization. ReonFacema, v. 2, n. 2 , p.196-201, 2016.

AMANDO, B.R. Impregnação de cateteres urinários com moduladores de quorum sensing e inibidor de bombas de efluxo para inibição de biofilmes bacterianos associados a infecção do trato urinário. 2018. 88f. Dissertação (Mestrado em Microbiologia Médica) - Programa de Pós-Graduação em Microbiologia Médica, Universidade Federal do Ceará. Fortaleza-CE, 2018.

CAVALCANTE, T. M. C.; BRAQUEHAIS, A. R.; ALBUQUERQUE P. R. G. B. Bladder catheter delay: perfil epidemiological urinary infection in intensive therapy center. Rev. Tendên. da Enferm. Profis., v.9, n.2, p.2164-2169, 2017.

COSTA, D. R.; CUNHA, L.T. Levantamento da suscetibilidade de Escherichia coli em infecções do trato urinário no laboratório 
São Geraldo em Varginha, Minas Gerais. Acta Biomedica Brasiliensia, v.10, n.1, p.1-5, 2019.

DORESTE, F. et al. Segurança do Paciente e Medidas de Prevenção de Infecção do Trato Urinário Relacionados ao Cateterismo Vesical de Demora. Revista Enfermagem Atual In Derme, v. 89, n. 27, 25 set. 2019.

FREITAS, R. B. Infecções do trato urinário de origem hospitalar e comunitária: revisão dos principais micro-organismos causadores e perfil de susceptibilidade. Revista Científica Fagoc Saúde, v.1, n.1, 2016.

MOTA, É. C.; OLIVEIRA, A. C. Infecção do trato urinário associada a cateter vesical: por que não controlamos esse evento adverso? Rev. esc. enferm. USP, São Paulo, v.53, e03452, 2019.

SILVA, A. S. et al. Identificação e prevalência de bactérias causadoras de infecções urinárias em nível ambulatorial. Rev. Bras. Pesq. Saúde, Vitória, v.19, n.3, p.69-75, 2017.

TAVARES J. M. M. et al. Incidência de infecção urinária em pacientes hospitalizados em uso de cateter vesical de demora. Revista Eletrônica Acervo Saúde, v. 12, n.8, e3497, 2020. 


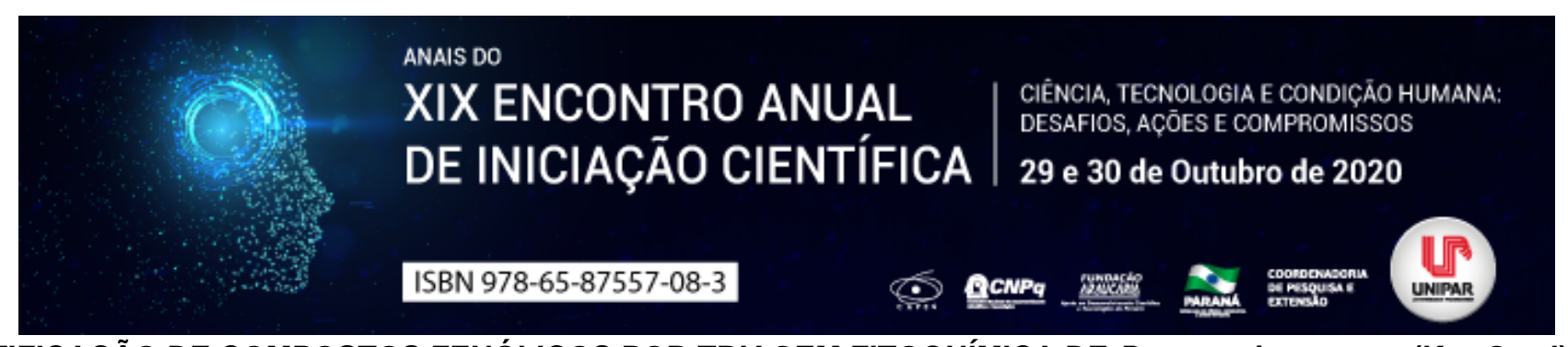

IDENTIFICAÇÃO DE COMPOSTOS FENÓLICOS POR TRIAGEM FITOQUÍMICA DE Pyrostegia venusta (Ker-Gawl) Miers

\author{
${ }^{1}$ Thiago Pinheiro de Moura, ${ }^{2}$ MAGDA MIRANDA SCHMITZ, ${ }^{3}$ DEYSIANE LIMA SALVADOR
}

\begin{abstract}
${ }^{1}$ Acadêmico do Curso de Biomedicina do Centro Técnico-Educacional Superior do Oeste Paranaense UNIMEO/CTESOP
${ }^{1}$ Acadêmica do Curso de Biomedicina do Centro Técnico-Educacional Superior do Oeste Paranaense UNIMEO/CTESOP

${ }^{2}$ Docente do Curso de Biomedicina do Centro Técnico-Educacional Superior do Oeste Paranaense UNIMEO/CTESOP
\end{abstract}

Introdução: Pyrostegia venusta (Ker-Gawl) Miers ( $P$. Venusta), é uma espécie vegetal pertencente à família Bignoniaceae popularmente conhecida como flor-de-São-João ou cipó-de-São-João e está amplamente disseminada em todo o Continente americano, sendo utilizada pela população Brasileira como fitoterápico. $P$. venusta é utilizada para combater diversas doenças, dentre elas a candidíase (doença infecciosa causada por fungos que acomete milhares de pessoas pelo mundo) (PEREIRA et al., 2014). Estudos mostram diversos compostos fenólicos obtidos do extrato vegetal das partes aéreas, raízes e flores de P. Venusta (FERREIRA e ALVARES, 2000; VIEL et al., 2019). Mekan e colaboradores (2019) revelaram que os compostos fenólicos da espécie vegetal Euphorbia hirta foram eficientes inibidores do crescimento de Alternaria solani, um fungo causador de doenças fitopatogênicas. Doenças causadas por fungos tem resultado em grandes problemas em várias culturas vegetais ao redor do mundo. Dados revelam que de 20 a $40 \%$ das perdas no rendimento das colheitas são causados por fitopatógenos e consequentemente, isso aumenta os custos de produção (RAMIREZ et al., 2020). Muitas plantações são perdidas devido aos estragos causados pela presença de fungos. A população que consome esses alimentos com histórico de contaminação tornam-se suscetíveis a desenvolverem doenças devido a presença de fungos fitopatogênicos (LIBERTO et al., 2019). Para o combate desses fungos, a utilização de agrotóxicos é realizada intensivamente. Entretanto, o uso excessivo e sem controle provoca consequentemente resistência por parte dos microrganismos fitopatogênicos. Dessa forma, a busca por alternativas menos nocivas para o combate de fungos fitopatogênicos tem sido alvo de grandes pesquisas, pois o uso indiscriminado de fungicidas trazem sérios problemas, tanto para as plantas quanto para os seres humanos (SILVA et al., 2005). Com base nessas informações sobre compostos fenólicos, e a importância para o combate de fungos fitopatogênicos, surge o interesse em investigar plantas que sejam ricas em compostos fenólicos.

Objetivo: Realizar uma triagem fitoquímica de $P$. venusta para identificar a presença de compostos fenólicos no extrato bruto vegetal das partes aéreas e flores da planta.

Material e Métodos: A espécie $P$. venusta foi coletada às margens da rodovia entre as cidades de Assis Chateaubriand e Toledo, no Paraná. As partes aéreas e flores da planta foram separadas e secas em estufa com circulação de ar a $35^{\circ} \mathrm{C}$, e posteriormente trituradas com o auxílio de um moinho de facas. O material vegetal seco e moído foi pesado, obtendo-se $56,3 \mathrm{~g}$ das partes aéreas e 16,4g das flores, sendo submetidos à extração com etanol P.A., por maceração exaustiva, sob temperatura ambiente em frasco de vidro de 3,0 L. O solvente foi removido por destilação simples, obtendo-se aproximadamente 5,0g e 3,0g das partes aéreas e flores, respectivamente. Os extratos alcoólicos foram submetidos a testes fitoquímicos para verificar a presença de compostos fenólicos segundo a metodologia descrita por Matos (1997).

Resultados: A partir da triagem fitoquímica dos extratos alcoólicos das partes aéreas e flores de $P$. venusta, foi possível realizar a identificação de cinco subclasses de metabólitos secundários: flavonóides, flavonóis, flavanonas, catequinas e depsídeos e depsidonas. Todas essas subclasses corroboram com dados encontrados na literatura (ALTOÉ, 2014; COIMBRA et al., 2019).

Discussão: A classe de metabólitos secundário composta por compostos fenólicos possuem inúmeras aplicações, sendo uma delas, atribuída à inibição de fungos fitopatogênicos (MEKAN et al., 2009). No que se refere ao uso da espécie $P$. venusta, não são encontrados dados na literatura que revele seu estudo envolvendo fungos causadores de doenças em plantas. Entretanto, em humanos, já é conhecido sua propriedade antifúngica, onde há estudos que trazem como uma forte opção no combate à candidíase (PEREIRA et al., 2014). No presente trabalho, pela triagem fitoquímica de compostos fenólicos, foi identificado cinco subclasses desses compostos (flavonóides, flavonóis, flavanonas, catequinas e depsídeos e depsidonas), tanto das partes aéreas da planta quanto das flores. Essa classe de compostos fenólicos é responsável pela excelente atividade antioxidante, no qual, estudos sugerem que $P$. venusta é uma fonte natural de antioxidantes, visto que vários compostos isolados tem essa atividade, tanto provenientes das flores quanto das raízes. No entanto, as folhas são descritas possuindo um teor total baixo de flavonóides e fenóis, que são os metabólitos em parte responsáveis por tal atividade (ALTOÉ, 2014). Dessa forma, o resultado da investigação fitoquímica foi importante para revelar a existência de compostos fenólicos promovendo um elevado grau de interesse em estudos posteriores envolvendo o uso dos extratos de $P$. venusta na inibição de fungos fitopatogênicos.

Conclusão: O presente estudo revelou a presença de compostos fenólicos nas partes aéreas e folhas de $P$. venusta, o que torna os extratos dessa planta promissores para realização de ensaios microbiológicos contra fungos fitopatogênicos. 


\section{Referências}

ALTOÉ, Thales Del Puppo. Estudo Químico-Biológico de Pyrostegia venusta (Ker Gawl.) Miers (Bignoniaceae). Dissertação (Mestrado em Química) Universidade Federal do Espírito Santo, Vitória, 2014.

COIMBRA, M. C. et al. Growth, morphology and bioactive phenolic compounds production in Pyrostegia venusta calli. Biocatalysis and Agricultural Biotechnology, v. 18, p. 1-8, 2019.

FERREIRA, D. T.; ALVARES, P. S. M. Constituintes químicos das raízes de Pyrostegia venusta e considerações sobre sua importância medicinal. Química Nova, v. 23, n. 1, p. 42-46, 2000.

LIBERTO, M. G. D. et al. Evaluation of Argentinean medicinal plants and isolation of their bioactive compounds as an alternative for the control of post harvest fruits phytopathogenic fungi. Brazilian Journal of Pharmacognosy, 2019.

MATOS, F. J. A. Introdução à fitoquímica experimental. 2.ed. Fortaleza: Edições UFC, 1997.

MEKAM, P. N. et al. Phenolic compounds profile of water and ethanol extracts of Euphorbia hirta L. leaves showing antioxidant and antifungal properties. South African Journal of Botany, v. 127, p. 319-332, 2019.

PEREIRA, A. M. S. et al. Evaluation of anticandidal and antioxidant activities of phenolic compounds from Pyrostegia venusta (Ker Gawl.) Miers. Chemico-biological interactions, v. 224, p. 136-141, 2014.

RAMIREZ, B. C. et al. Inhibition of Rhizoctonia solani RhCh-14 and Pythium ultimum PyFr-14 by Paenibacillus polymyxa NMA1017 and Burkholderia cenocepacia CACua-24: A proposal for biocontrol of phytopathogenic fungi. Microbiological Research, v. 230, 2019.

SILVA, I. D. et al. Efeito do extrato de sucupira (pterodon emarginatus vog.) sobre o desenvolvimento de fungos e bactérias fitopatogênicos. Pesquisa Agropecuária Tropical, v. 35, n. 2, p. 109-115, 2005.

VIEL, A. M. et al. Toxicological, genotoxic and antioxidant potential of Pyrostegia venusta. Bioscience Journal, v. 35, n. 2, 2019. 


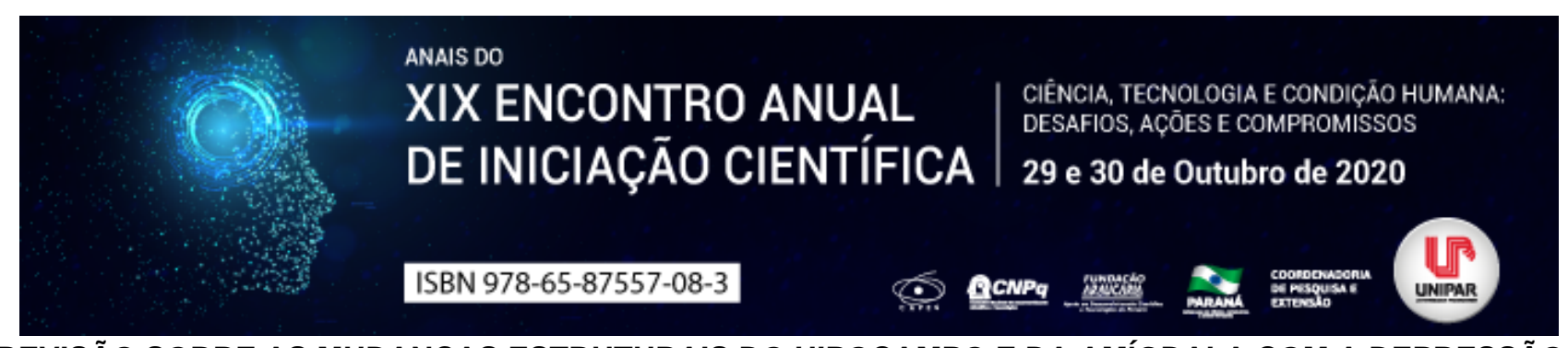

REVISÃO SOBRE AS MUDANÇAS ESTRUTURAIS DO HIPOCAMPO E DA AMÍGDALA COM A DEPRESSÃO

\author{
${ }^{1}$ ALLAN CHENU ROMANO, ${ }^{2}$ IZABEL PUZISKI ROSSATO, ${ }^{3}$ MICHEL ANDREW NOGARA, ${ }^{4}$ CAMILA RIGOBELLO
}

\author{
${ }^{1}$ Acadêmico do curso de Medicina da UNIPAR \\ ${ }^{1}$ Acadêmica do Curso de Medicina da UNIPAR \\ ${ }^{2}$ Docente da UNIPAR \\ ${ }^{3}$ Docente da UNIPAR
}

Introdução: As amígdalas, são o centro emocional cerebral com a capacidade de condicionar um reforço com valor emocional e responder a reflexos simpáticos e parassimpáticos, já o hipocampo, é responsável pelo armazenamento da memória remota relacionada à identidade e ao aprendizado. Esses são dois componentes do sistema límbico, que se caracteriza por coordenar as atividades sociais e possibilitar a criação de sensações, a partir dos sentimentos e emoções (ALBUQUERQUE, 2010). Estas estruturas podem apresentar alterações em sujeitos que sofrem de quadros clínicos no âmbito dos transtornos depressivos, que em sua maioria se caracterizam pela presença de humor deprimido, vazio e irritável, seguido de alterações somáticas e cognitivas que afetam significativamente suas vidas (APA, 2014).

Objetivo: Relacionar as alterações morfofuncionais das amígdalas e do hipocampo com a depressão.

Desenvolvimento: O sistema límbico é um grupo de estruturas envolvidas no processamento e na regulação das emoções, da memória e do interesse sexual. Primeiramente observado por James Papez, em 1937, era denominado como I"circuito de Papezl" e composto pelo hipocampo, fórnice, corpos mamilares, núcleo anterior do tálamo e giro do cíngulo, e tempo depois foi adicionado a amígdala, a área fronto-basal anterior e o córtex orbitofrontal (KAPCZINSKI et al., 2011). Segundo Liu (2017) e Albuquerque (2010), em diversos estudos foram percebidos que mudanças morfofuncionais das amígdalas e do hipocampo estão associadas a depressão, o primeiro, se caracteriza como estruturas esféricas localizadas no ventrículo lateral do lobo temporal, organizadas em um complexo de núcleos neuronais, sendo o basolateral mais relacionado a essa doença, a qual gera um aumento na flexibilidade sináptica das amígdalas, interrompe a sinalização do glutamato, ocasiona variações de volume conforme a gravidade da doença, e além disso, perturbações negativas nesta estrutura desencadeia um fator de predisposição para a depressão. Ainda para Liu (2017) o hipocampo, que é uma estrutura do prosencéfalo localizada na porção medial do lobo temporal, apresenta a formação de conexões de fibras nervosas com regiões cerebrais que estão ligadas às emoções como o córtex pré-frontal, essa estrutura pode apresentar redução volumétrica em pacientes depressivos que podem desencadear processos neurodegenerativos pela adição de glicocorticóides, os quais em grande quantidade reduzem a conectividade cerebral. Em estudos nota-se que há uma próxima relação funcional e topográfica entre amígdala e o hipocampo, os vinculando ao processo de armazenar as memórias e conferir emoções à elas (BARRETO, 2009). Contudo para Albuquerque 2010, o estudo de Erk mostra que esse reforço emocional é relacionado com conteúdos negativos, que são evocados com mais frequência em pacientes deprimidos. Desse modo, pacientes sem a região paralímbica afetada apresentam uma melhor capacidade de compreender situações ideativas mórbidas com respostas não-delirantes e auto-referentes (ROZENTHAL, 2004).

Conclusão: É possível concluir que as amígdalas e o hipocampo estão diretamente relacionadas ao armazenamento de memórias e aos valores emocionais a elas conferidos, os quais são retomados ao longo da vida, entretanto em pacientes com depressão há uma maior evocação dos conteúdos negativos. Também foi evidenciado que essas estruturas sofrem alterações volumétricas e fisiológicas em pacientes com essa doença e que essas mudanças paralímbicas neurodesenvolvimentais os deixam mais vulneráveis ao desenvolvimento de psicoses no quadro depressivo. Conhecer as alterações morfofuncionais dessas estruturas límbicas podem auxiliar para o diagnóstico, até então clínico, e na busca de novas alternativas terapêuticas.

\title{
Referências
}

ALBUQUERQUE, Fabíola da Silva; SILVA, Regina Helena. A amígdala e a tênue fronteira entre memória e emoção. Revista de Psiquiatria do Rio Grande do Sul, v. 31, n. 3, 2009. Disponível em: https://www.scielo.br/scielo.php?pid=S0101$81082009000400004 \&$ script=sci_arttext\&tlng=pt. Acesso em: 12/08/2020.

APA. AMERICAN PSYCHIATRIC ASSOCIATION, et al. DSM-5: Manual diagnóstico e estatístico de transtornos mentais. 5. ed. Porto Alegre: Artmed Editora, 2014. p. 189-190.

BARRETO, João Erivan Façanha et al. Sistema límbico e as emoções. Revista neurociências, v. 18, n. 3, p. 386-394, 2010. Disponível em: https://periodicos.unifesp.br/index.php/neurociencias/article/view/8466. Acesso em: 12/08/2020.

JOCA, Sâmia Regiane L.; PADOVAN, Cláudia Maria; GUIMARÃES, Francisco Silveira. Estresse, depressão e hipocampo. Brazilian Journal of Psychiatry, v. 25, p. 46-51, 2003. Disponível em: https://www.scielo.br/scielo.php?pid=S1516- 
44462003000600011\&script=sci_arttext\&tlng=pt. Acesso em: 12/08/2020.

KAPCZINSKI, Flávio; IZQUIERDO, Iván; QUEVEDO, João. Bases biológicas dos transtornos psiquiátricos: uma abordagem translacional. 3. ed. Porto Alegre: Artmed Editora, 2009.

LIU, Wei; GE, T.; LENG, Y.; PAN, Z.; FAN, J.; YANG, W.; CUI, R. The role of neural plasticity in depression: from hippocampus to prefrontal cortex. Neural Plasticity, 2017. Disponível em: https://pubmed.ncbi.nlm.nih.gov/28246558/. Acesso em: 15/08/2020.

ROZENTHAL, Marcia; LAKS, Jerson; ENGELHARDT, Eliasz. Aspectos neuropsicológicos da depressão. Revista de Psiquiatria do Rio Grande do sul, v. 26, n. 2, p. 204-212, 2004. Disponível em: https://www.scielo.br/scielo.php?pid=S0101$81082004000200010 \&$ script=sci_abstract\&ting=es. Acesso em: 12/08/2020.

VISMARI, Luciana. Neuroanatomia dos transtornos de humor. ConScientiae Saúde, n. 3, p. 95-102, 2004. Disponível em: https://www.redalyc.org/pdf/929/92900311.pdf. Acesso em: 13/08/2020.

Coordenadoria de Pesquisa e Extensão - COPEX

Departamento de Editoração e Divulgaçāo Científica - DEDIC 


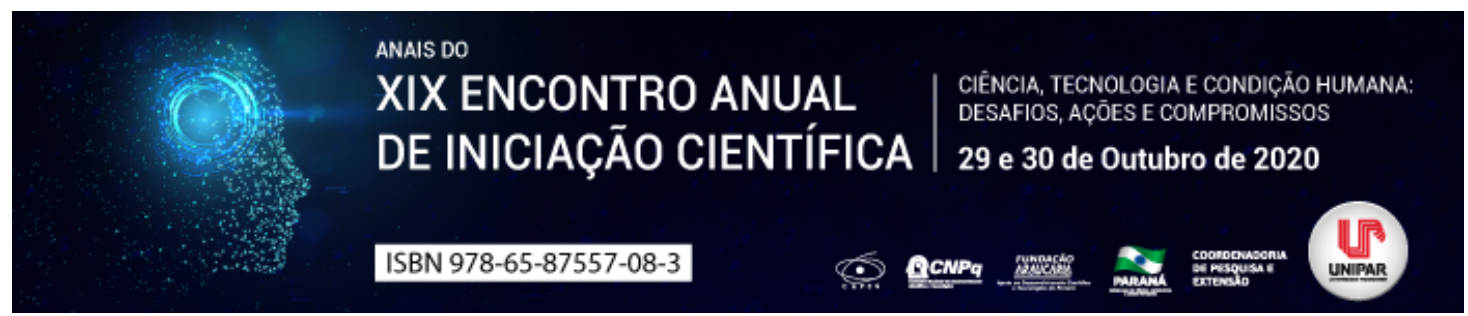

EDUCAÇÃO EM SAUDE PARA VITIMAS DE ACIDENTE DE TRANSITO POR MOTOCICLETAS

\author{
${ }^{1}$ VINICIUS ANTONIO GROTTO VELHO, ${ }^{2}$ IRINEIA PAULINA BARETTA
}

\author{
${ }^{1}$ Discente do Curso de Enfermagem/UNIPAR \\ ${ }^{1}$ Docente da UNIPAR
}

Introdução: Motoristas tem preferido cada vez mais as motocicletas devido a agilidade que a mesma proporciona ao usuário e também pelo seu custo benefício, impulsionado pelo aumento da população e frota em grandes centros urbanos (Machado, Lindau, \& Obelheiro, 2014). Este crescimento em conjunto com o aumento de profissões que utilizam desse meio para trabalhar, podem estar relacionados ao elevado número de acidentes no trânsito, apoiando os altos índices de lesões, de diversos tipos e gravidade causando muitas vezes, incapacitações físicas e elevados índices de mortalidade (Miziara, Miziara, \& Rocha, 2014). O processo de educação em saúde visa à apropriação temática pela população em um conjunto de práticas do setor que contribui para aumentar a autonomia das pessoas no seu cuidado e no debate com os profissionais e os gestores a fim de alcançar uma atenção de saúde de acordo com suas necessidades. (Falkenberg, Mendes, Moraes, \& Souza, 2014)

Objetivo: Contextualizar a importância da realização de medidas educativas em saúde para vítimas de acidente de transito por motocicletas.

Desenvolvimento: As práticas de educação em saúde envolvem três segmentos de atores prioritários: os profissionais de saúde que valorizem a prevenção e a promoção tanto quanto as práticas curativas; os gestores que apoiem esses profissionais; e a população que necessita construir seus conhecimentos e aumentar sua autonomia nos cuidados, individual e coletivamente. Muitas práticas educativas nos serviços de saúde ainda são feitas com esta visão, apesar da participação comunitária estar presente na retórica de muitos gestores, profissionais de saúde e educadores são preconizados nos princípios e diretrizes do SUS. (Falkenberg, Mendes, Moraes, \& Souza, 2014) Dada relevância a Organização das Nações Unidas (ONU) lançou o desafio para a Década de Ações pela Segurança no Trânsito 20112020 e com isso em resposta a esse desafio o Projeto Vida no Trânsito (PVT) é uma iniciativa brasileira voltada para a vigilância e prevenção de lesões e mortes no trânsito e promoção da saúde que traz como foco das ações a intervenção em dois fatores de risco priorizados no Brasil: Dirigir após o consumo de bebida alcoólica e velocidade excessiva e/ou inadequada, além de outros fatores ou grupos de vítimas identificados localmente a partir das análises dos dados, notadamente acidentes de transporte terrestre envolvendo motociclistas. (Saúde, 2017) Dentro desse contexto encontra-se a enfermagem a qual constitui um componente formado por saberes científico e técnicos próprios, que são reproduzidos por diversas práticas (ensino, assistência e/ou pesquisa), sejam elas no contexto social, ético ou político. Esse conjunto de conhecimentos é aplicado por meio de prestação de serviços à pessoa, à família ou à coletividade, tendo como base o contexto de vida dessas pessoas. Nesse sentido, a enfermagem constitui uma profissão que visa à qualidade de vida e saúde, atuando na educação, promoção, prevenção, recuperação e reabilitação do estado de saúde. (COFEN, 2017)

Conclusão: A educação popular em saúde continua sendo hoje um desafio aos gestores e profissionais na busca por práticas integrais, mais voltadas às reais necessidades das populações e considerando, como suporte para essas práticas, tanto processos de informação e comunicação como de participação popular e participação social. Para promover a educação em saúde, também é necessário que ocorra a educação voltada para os profissionais de saúde.

\title{
Referências
}

COFEN. (18 de Julho de 2017). Código de Ética dos profissionais de Enfermagem. Fonte: Conselho Federal de Enfermagem: https://portal.corensp.gov.br/codigo-de-etica-dos-profissionais-de-enfermagem/

Falkenberg, e. B., Mendes, 1. d., Moraes, 1. P., \& Souza, E. M. (2014). Educação em saúde e educação na saúde:conceitos e implicações para a saúde coletiva. Researchgate, 847-852. Acesso em 23 de Setembro de 2020, disponível em https://www.researchgate.net/publication/275606740_Educacao_em_saude_e_educacao_na_saude_conceitos_e_implicacoes_para_a_saude_coletiva

Machado, R. C., Lindau, L. A., \& Obelheiro, M. (2014). Caracterização do uso de motocicletas como meio de transporte urbano em Porto Alegre. Lume repositorio digital, 1-15. Acesso em 23 de setembro de 2020, disponível em https://www.lume.ufrgs.br/bitstream/handle/10183/103757/000937343.pdf?sequence=1

Miziara, I. D., Miziara, C. S., \& Rocha, L. E. (2014). Acidentes de Motocicletas e sua relação com o trabalho: revisão da literatura. 19 , 52-9. Acesso em 23 de setembro de 2020, disponível em www.revistas.usp.br/sej/article/download/100092/98769

Saúde, M. d. (20 de Novembro de 2017). Projeto Vida No Trânsito. Acesso em 23 de setembro de 2020, disponível em Ministerio da Saúde: https://www.saude.gov.br/saude-de-a-z/acidentes-e-violencias/41896-projeto-vida-no-transito 


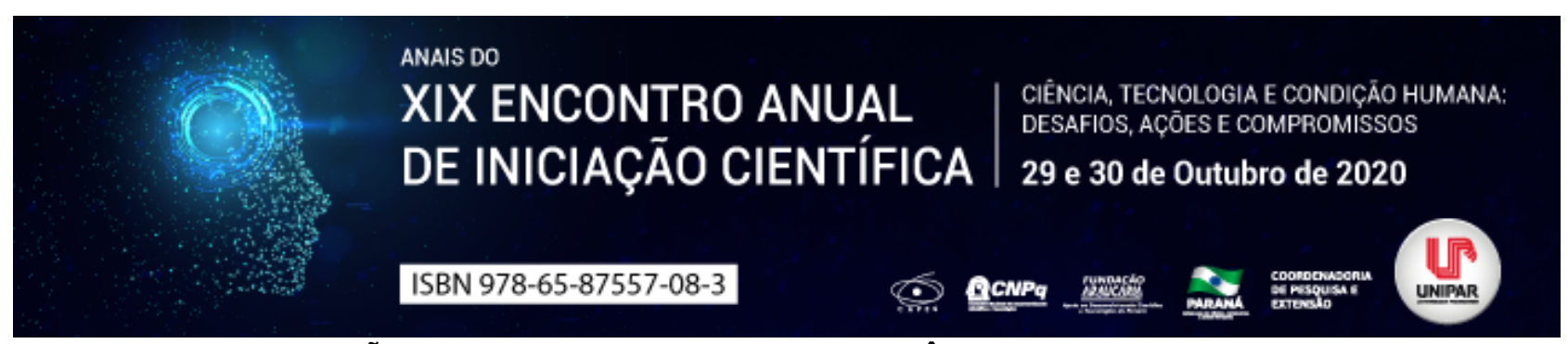

ATUAÇÃO DA ENFERMAGEM FRENTE AO CÂNCER INFANTO JUVENIL

\title{
${ }^{1}$ TAYNARA GONCALVES, ${ }^{2}$ STEFANY DE OLIVEIRA, ${ }^{3}$ JOLANA CRISTINA CAVALHEIRI
}

\author{
${ }^{1}$ ACADÊMICA DE ENFERMAGEM/UNIPAR \\ ${ }^{1}$ Acadêmica do Curso de Enfermagem da UNIPAR \\ ${ }^{2}$ Docente da UNIPAR
}

Introdução: Nas últimas décadas foram obtidos muitos avanços, no tratamento e diagnóstico do câncer infanto-juvenil, resultando em um maior percentual de cura, chegando a $70 \%$ dos doentes, quando diagnosticado precocemente em centros de oncologia. Entretanto em adolescentes de 1 a 19 anos ainda é a segunda morbidade que causa mais mortes (COSTA; CEOLIN, 2010). O Instituto Nacional do Câncer (INCA) indica que a maior incidência deste tipo de patologia é entre crianças de 5 anos de idade (39,5\%), a maioria do sexo masculino (64\%). Logo, o diagnóstico se torna mais difícil, tendo que encaminhar essa criança, para outros centros de atendimento mais especializados (FREIRE et al., 2019). O câncer causa várias mudanças físicas, decorrente dos procedimientos invasivos, como a radioterapia e quimioterapia, dolorosos e as vezes seguidos de internação. $O$ tratamento, é considerado uma fase crônica, que varia de acordo com o grau que a doença se encontra, podendo ser curta ou longa, de acordo com a evolução da patologia (BRUM; DE AQUINO, 2016). Quanto aos cuidados de enfermagem, envolvem técnicas relacionadas a higiene, coleta de exames, medicamentos e alimentação. Infelizmente, estes cuidados físicos, não são suficientes, sendo que a maior parte dos profissionais não se atenta às condições ambientais, econômicas, culturais e familiares, em que esta criança, ou adolescente está inserida (VIEIRA CASTRO; COUTINHO, 2016). Diante deste problema, uma ferramenta muito válida é inclusão do lúdico,que busca diminuir os impactos da descoberta da doença, da hospitalização e auxilia na adaptação da criança à nova realidade, tornando o tratamento mais agradável, tirando o foco do agravo, proporcionando alegria e leveza, além de melhorar a relação entre a equipe de enfermagem e o paciente, trazendo confiança para passar por esse doloroso processo (MARQUES et al., 2016).

Objetivo: Realizar uma revisão de literatura para compreender a atuação da enfermagem frente ao câncer infanto-juvenil. Desenvolvimento: Em razão do diagnóstico, à criança oncológica, sofre mudanças bruscas em sua vida. Por não possuir maturidade suficiente para entender a situação, logo, imagina que algo horrível está acontecendo, o que por sua vez, pode levar ao interrompimento dos laços familiares, angústias, pois se trata de um ambiente hospitalizado, com pessoas que não fazem parte do seu convívio (DELFINO et al., 2018). A equipe de enfermagem, faz parte de todo o processo de tratamento dessa criança/jovem, atuando de forma ativa. Em virtude disso, é importante que a equipe consiga compreender os sentimentos, tanto do paciente quanto da família no cuidado. Além disso, deve ter conhecimento técnico sobre a doença e sobre a fase de vida em que a criança se encontra (SILVA et al., 2018) Ademais, a equipe de enfermagem exerce um papel fundamental na assistência de quem irá cuidar de uma criança, realiza o acolhimento e pode instigar o surgimento de estratégias e adaptações para melhorar o resultado do tratamento. Dessa forma, é papel do enfermeiro buscar um método humanizado e um planejamento integral com a equipe, para acolher os parentescos do paciente e diminuir o sofrimento do tratamento (GAMA et al., 2018). A vulnerabilidade psíquica na família é muito presente, em todo o processo desde o descobrimento da neoplasia e no decorrer do tratamento, além disso, podem ocorrer crises entre os cuidadores. Além disso, mesmo que a criança consiga sobreviver a enfermidade, as sequelas podem permanecer o resto da vida, interferindo na fase de crescimento e desenvolvimento e aumentando os receios e preocupações da família (LIVINALLI, 2015) No âmbito do cuidado paliativo, a Organização Mundial de Saúde defende que a morte é um processo natural e inevitável, o profissional de enfermagem neste aspecto, deve atuar no alívio da dor, integrando o cuidado físico e psicológico, tornando esse momento menos aflitivo, nunca adiando ou antecipando este processo. Além de ofertar apoio à família para enfrentamento da doença e de uma possível morte, cabe ao profissional, conhecer o paciente terminal integralmente, sua vida, experiências e sua expectativa. retomando sua dignidade na ameaça da morte (TUROLLA, DE SOUZA 2015).

Conclusão: Portanto observa-se que a enfermagem exerce um papel de suma importância na assistência oncológica infantil, atuando desde o tratamento do paciente, com a higiene do até a administração de medicamentos e no cuidado paliativo. Além disso, o câncer é uma doença muito agressiva com reflexos na criança e família, dessa forma, a equipe de enfermagem deve proporcionar um acolhimento adequado, a integralidade do cuidado, observando a família e o lúdico no plano de cuidados.

\section{Referências}

BRUM, Monize Viana; DE AQUINO, Giselle Braga. Estudo do impacto do tratamento do câncer infantil nos aspectos emocionais dos cuidadores de crianças com diagnóstico da doença. Revista Científica Da Faminas, v. 10, n. 2, 2016.

COSTA, Thailly Faria da; CEOLIM, Maria Filomena. A enfermagem nos cuidados paliativos à criança e adolescente com câncer: 
revisão integrativa da literatura. Revista Gaúcha de Enfermagem, v. 31, n. 4, p.776-784, 2010.

DELFINO, Cintia da Trindade Azevedo. et al. Câncer infantil: Atribuições da enfermagem em cuidado paliativo. Revista Saúde e Desenvolvimento, v. 12, n. 10, p. 18-40, 2018.

FREIRE, Mariana Duarte. et al. A IMPORTÂNCIA DO DIAGNÓSTICO PRECOCE NO CÂNCER INFANTO-JUVENIL. ID on line Revista de Psicologia, v. 13, n. 46, p. 44-45, 2019.

GAMA, Jéssica dos Reis, e Isabela Caires Soares. I"Estratégias de adaptação psicológica e de saúde dos cuidados diante do diagnóstico de câncer infantil.I" (2018).

MARQUES, Elisandra Paula. et al. Lúdico no cuidado à criança e ao adolescente com câncer: perspectivas da equipe de de enfermagem. Escola Anna Nery, v. 20, n. 3, 2016.

SILVA, Camila Morena Margato. et al. Significado do cuidar e seus sentimentos para equipe de enfermagem diante da criança em tratamento oncológico. Revista de Enfermagem e Atenção à Saúde, v. 7, n. 2, 2018.

TUROLLA, Kelly Regina; DE SOUZA, Mariana Castro. Enfermagem Pediátrica Oncológica: Assistência na Fase de Terminalidade. Ensaios e Ciência, v. 19, n. 1, 2015.

Coordenadoria de Pesquisa e Extensão - COPEX

Departamento de Editoraçāo e Divulgaçāo Científica - DEDIC 


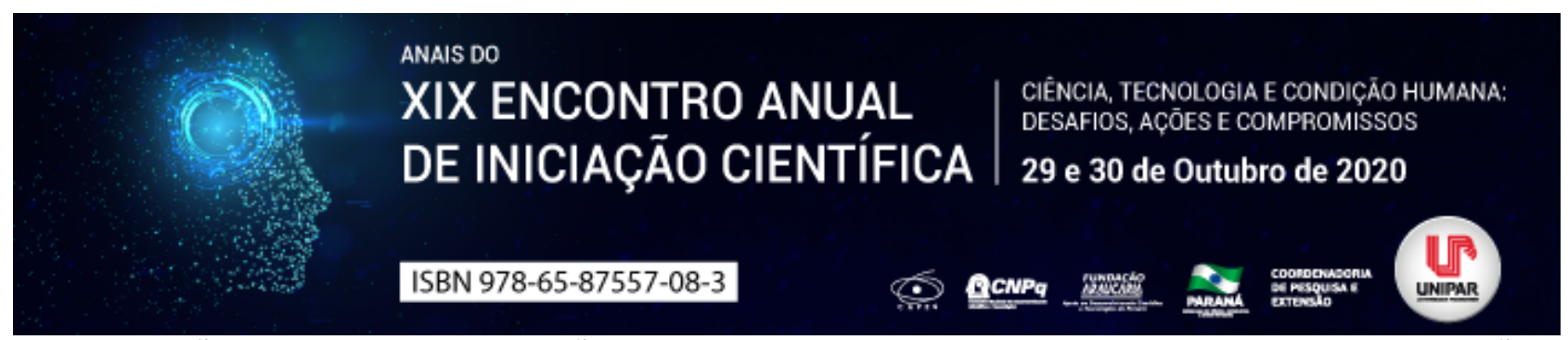

A UTILIZAÇÃO DA BIORREMEDICAÇÃO EM SOLO CONTAMINADO POR HAPS: ESTUDO DE REVISÃO

\author{
${ }^{1}$ Magda Miranda Schmitz, ${ }^{2}$ THIAGO PINHEIRO DE MOURA, ${ }^{3}$ DEYSIANE LIMA SALVADOR
}

\begin{abstract}
${ }^{1}$ Acadêmica do curso de Biomedicina do Centro Técnico-Educacional Superior do Oeste Paranaense - UNIMEO/CTESOP
${ }^{1}$ Acadêmico do curso de Biomedicina do Centro Técnico-Educacional Superior do Oeste Paranaense - UNIMEO/CTESOP

${ }^{2}$ Docente do curso de Biomedicina do Centro Técnico-Educacional Superior do Oeste Paranaense - UNIMEO/CTESOP
\end{abstract}

Introdução: Os problemas de poluição e degradação ambiental agravaram-se com o aumento das práticas industriais que ocorreram após a Revolução Industrial (SOUSA, 2016). Com a industrialização em ritmo acelerado, os problemas ambientais começaram a surgir devido à liberação de poluentes prejudiciais ao meio ambiente e aos seres vivos (SOUSA, 2016; BILAL e IQBAL, 2020). Dessa forma, a busca por alternativas capazes de reduzir os danos causados pelos poluentes lançados de forma irregular, tem se tornado uma necessidade imediata para favorecer um ambiente mais saudável e sustentável (BILAL e IQBAL, 2020). Muitos dos contaminantes ambientais e/ou seus produtos de degradação resultam em efeitos nocivos e/ou mutagênicos aos organismos vivos, podendo acarretar modificações na estrutura ecológica e funcional da comunidade biológica e por esta razão houve a preocupação em desenvolver biotecnologias sustentáveis para descontaminar ambientes poluídos (JACQUES, 2007). Nesse contexto, os processos de remediação têm sido utilizados contra vários contaminantes tóxicos, diminuindo as agressões realizadas pela população aos recursos naturais (BILAL e IQBAL, 2020). A biorremediação é uma técnica utilizada que consiste na transformação ou degradação de contaminantes em substâncias não tóxicas ou menos tóxicas que a molécula original. Podem ser utilizados diversos organismos para essa técnica, como plantas, algas, fungos e bactérias (JACQUES, 2007). De forma mais simples, a biorremediação pode ser definida como um modo da natureza se limpar, expondo o local contaminado a um exército de microrganismos que transformam o contaminante em uma substância segura, recorrendo ao uso de atividade biológica natural (JACQUES, 2007).

Objetivos: Realizar uma abordagem sobre os problemas ambientais causados pela contaminação por HAPs, bem como, mostrar a importância da biorremediação em solos para degradação desses contaminantes.

Desenvolvimento: Os hidrocarbonetos aromáticos policíclicos (HAPs) são formados por carbono e hidrogênio cuja estrutura consiste de pelo menos dois anéis aromáticos. Existem 16 tipos de HAPs considerados importantes no monitoramento ambiental de poluentes orgânicos, como por exemplo, o fenantreno e o pireno (WALLACE, 2020). Os HAPs são substâncias semivoláteis, geralmente formadas a partir da queima de combustíveis fósseis, madeira ou processos que utilizam derivados de petróleo (JAQUES, 2007; PIRACELLI, 2020). O uso improdutivo do solo juntamente com o risco elevado de entrada de diferentes poluentes nos ecossistemas causado pelo aumento da demanda e desenvolvimento de infraestruturas são um dos fatores preocupantes associados à degradação do solo. Estudos recentes revelam que vapores asfálticos gerados por simulação em laboratório, evidenciaram que ratos expostos a esses vapores que são compostos por uma ampla classe de HAPs, apresentaram efeito mutagênico causando câncer de pele. Desse modo, pode-se concluir que há risco de trabalhadores da área adquirirem câncer de pulmão, estômago, pele e leucemia (PIRACELLI, 2020). Para reduzir a contaminação por esses poluentes pode ser realizada a biorremediação que consiste em um processo biotecnológico baseado no uso de agentes biológicos com a finalidade de eliminar poluentes ambientais ou reduzi-los a compostos de baixa toxicidade (LACERDA et al., 2019). Para que a biorremediação seja efetiva, o solo deve possuir populações microbianas pré existentes que favoreça a biorremediação ou deve ocorrer a introdução de microrganismos que sejam capazes de degradar os HAPs. Nos casos em que os solos possuem uma população microbiana baixa que impossibilita uma degradação efetiva dos contaminantes (HAPs), é realizada uma melhoria da qualidade do solo, com um controle e monitoramento dos teores de umidade, nutrientes e pH de forma a otimizar o processo de degradação e oxidação das populações microbianas existentes (BERTOLUCI, 2019). Nos casos em que o solo não possui os microrganismos capazes de realizar a biodegração, os mesmos são introduzidos por um processo conhecido como consórcio microbiano (LACERDA et al., 2019). Um estudo realizado por Boonchan et al. (2000) mostrou que a degradação do pireno foi possível a partir do consórcio microbiano composto pela bactéria Stenotrophomonas maltophilia e pelo fungo Penicillium janthinellum incubados por 30 dias com $250 \mathrm{mg} \mathrm{L}^{-1}$ de pireno, observando degradações próximas a 100\%. Outro estudo realizado por Liu et al. (2004) mostrou que a degradação de fenantreno e pireno ocorreu com a utilização da bactéria Sphingomona após 5 dias de incubação com $2000 \mathrm{mg} \mathrm{L}^{-1}$ de fenantreno e $100 \mathrm{mg} \mathrm{L}^{-1}$ de pireno, obtendo uma degradação de 60 e 40\%, respectivamente. A utilização de Paracoccus é efetiva para degradação de fenantreno ou pireno, numa contração de 100 $\mathrm{mg} \mathrm{L}^{-1}$, chegando a degradar $100 \%$ desses HAPs (ZHANG et al., 2004).

Conclusão: O processo de biorremediação é uma alternativa efetiva para degradação de substâncias tóxicas, transformando-as em substâncias seguras. No entanto, é necessário um estudo para escolha do microrganismo que seja mais eficiente no 
tratamento.

\section{Referências}

BERTOLUCI, Vitor Joaquim Morreira. Biorremediação de solos contaminados com PAH (hidrocarbonetos aromáticos policíclicos - pireno e fenantreno). Dissertação (Mestrado em Gestão Ambiental) - Universidade do Minho, Braga, 2020.

BILAL, M.; IQBAL, H. M. N. Microbial bioremediation as a robust process to mitigate pollutants of environmental concern. Case Studies in Chemical and Everinmental Engineering, 2020, https://doi.org/10.1016/j.cscee.2020.100011.

BOONCHAN, S. et al. Degradation and mineralization of high-molecular-weight polycyclic aromatic hydrocarbons by defined fungal-bacterial cocultures. Applied and Environmental Microbiology, v. 66, n. 3, p. 1007-1019, 2000.

JACQUES, R. J. S. et al. Biorremediação de solos contaminados com hidrocarbonetos aromáticos policíclicos. Revista Ciência Rural, v. 37, n. 4, p. 1192-1201, 2007.

LACERDA, F. et al. Biorremediação: Educação em saúde e alternativas à poluição ambiental. 1 Ed. Editora IFRN: Natal, 2019.

LIU, Y. et al. Isolation and characterization of polycyclic aromatic hydrocarbons-degrading Sphingomonas sp. strain ZL5. Biodegration, v. 15, n. 2, p. 205-212, 2004.

PIRACELLI, V. P. et al. Emissões de poluentes atmosféricos em condições reais de pavimentação asfáltica: material particulado, black carbon e hidrocarbonetos policíclicos aromáticos. Revista Química Nova, v. 43, n. 4, 2020.

SOUSA, K. C. et al. Biorremediação de Solos Contaminado por Hidrocarbonetos Utilizando Fungos. Revista da Universidade Vale do Rio Verde, Três Corações, vol. 14, n. 2, p. 43-52, 2016.

WALLACE, M. A. G. et al. Dataset of polycyclic aromatic hydrocarbon recoveries from a selection of sorbent tubes for termal desorption-gas chromatography/massa spectrometry analysis. Data in brief, v. 29, 2020.

ZHANG. H. et al. Isolation and characterization of novel bactéria degrading polycyclic aromatic hydrocarbons from polluted Greek soils. Applied Microbiology and Biotechnology, v. 65, n. 1, p. 124-131, 2004.

Coordenadoria de Pesquisa e Extensāo - COPEX

Departamento de Editoraçāo e Divulgaçāo Científica - DEDIC 


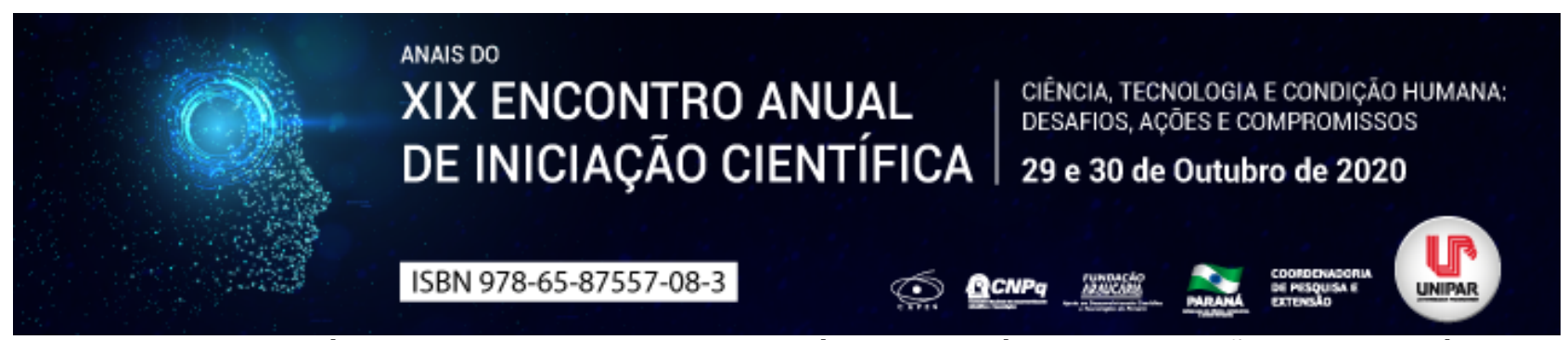

FARMACORRESISTÊNCIA BACTERIANA NA ASSISTÊNCIA PEDIÁTRICA: REVISÃO BIBLIOGRÁFICA

\title{
${ }^{1}$ GABRIELA FAVERO ESPOLADOR, ${ }^{2}$ KAROLAINE BEZERRA, ${ }^{3}$ MARCO AURELIO CUNHA DEL VECHIO, ${ }^{4}$ ISABELA CARVALHO DOS SANTOS, ${ }^{5}$ DANIELA DIB GONÇALVES, ${ }^{6}$ LIDIANE NUNES BARBOSA
}

\author{
${ }^{1}$ Mestranda PGG Ciência Animal com Ênfase em Produtos Bioativos. \\ ${ }^{1}$ Mestranda PPG em Ciência Animal com Ênfase em Produtos Bioativos/ Taxista - Prosup/CAPES \\ ${ }^{2}$ Mestrando PPG em Ciência Animal com Ênfase em Produtos Bioativos/ Taxista - Prosup/CAPES \\ ${ }^{3}$ Doutoranda PPG em Ciência Animal com Ênfase em Produtos Bioativos/ Bolsista - Prosup/CAPES \\ ${ }^{4}$ Docente- UNIPAR \\ ${ }^{5}$ Docente da UNIPAR
}

Introdução: O uso irracional dos antimicrobianos muitos micro-organismos desenvolvem uma certa resistência ao medicamento, assim ocasionando a troca do remédio para outros de largo espectro (WANNMACHER, 2004). Na perspectiva pediátrica surge a preocupação com as cepas multirresistentes, cujo submete a criança a utilizar diversos antimicrobianos considerados fortes , que podem prejudicar a funcionalidade do organismo (BOTE; FIGUEIREDO, 2017). Assim, ao verificar que a prescrição dessas drogas, no setor pediátrico, nota-se que muitas vezes a prescrição é de forma empírica, e como consequência tal medicamento pode não conter uma ação específica ao patógeno que se prolifera na criança, podendo assim fortalecer e impulsionar esse micro-organismo (MARKS et al., 2020). Portanto muitos pontos devem ser levados em consideração quando há a prescrição seguindo o pressuposto de farmacovigilância, a qual tem por objetivo prevenir efeitos adversos dos fármacos, visto que os antibióticos estão no topo dos mais prescritos no presente século (BOTE; FIGUEIREDO, 2017).

Objetivo: Demonstrar a resistência antimicrobiana desenvolvida em crianças, por meio de uma revisão bibliográfica.

Desenvolvimento: Ao decorrer dos anos os micro-organismos desenvolveram diversos mecanismos que ocasionam sua resistência, associando a causalidade com uso indevido e/ou exagerado dos antimicrobianos pelas pessoas (OLIVEIRA; AIRES, 2016). Sabe-se que o organismo da criança é mais vulnerável, devido a imaturidade do seu sistema de defesa, deste modo resultando em diversos infecções ao passar pela infância, apontando as patologias mais comuns, muitas já possuem protocolo de prescrição empiricamente de antibióticos (BOTE; FIGUEIREDO, 2017). Estudos revelam que a prescrição empírica dos antibióticos se vem de pesquisas que exibem os sítios de infecções mais frequentes e seus agentes agressores, deste modo apontando os medicamentos que agem contra os determinados invasores (BRíGIDO et al., 2020). No topo das infecções que mais acometem a pediatria verifica-se a Infecção de Trato Urinário (ITU), onde diversos estudos já focam nessa patologia específica associada a farmacorresistência, devido a utilização exagerada de certos medicamentos ofertado pelos pais, ou seja, automedicação, ou pelo uso de fármacos que não atuam contra o agente causador devido a prescrição sem resultado de exames (ABREU, et al., 2016). Na ITU se utiliza como diagnóstico o quadro clínico juntamente com exames de urina mais urocultura, a qual demora alguns dias para chegar ao resultado devido a necessidade de verificação dos organismos que surgiram na análise do material, perante essa demora os médicos precocemente prescrevem medicamentos contra a doença para alívio dos pais, sem levar em consideração alguns pontos importantes como: uso de microbianos prévio, hospitalização prévia, história clínica ou até mesmo área geográfica (MARKS et al., 2020). O desfecho dos casos de ITU muitas vezes é positivo com os medicamentos prescritos empiricamente, entretanto muitos casos não obtém o sucesso ansiado, assim resultando em hospitalização devido a cepas multirresistentes, sendo necessário a utilização dos antibióticos de última geração (BOTE; FIGUEIREDO, 2017). Levado em consideração a utilização dos antimicrobianos em grande escala, ainda há a necessidade de estudos que demonstram a padronização da assistência prestada a diversas patologias que necessitam de uso de antimicrobianos, deste modo dando atenção a diversos aspectos pertinentes mediante as doenças, como coleta de uma boa história clínica da criança juntamente com verificação de condição de saúde e diagnóstico precoce, para que seja possível uma prescrição mais precisa do medicamento (BRÍGIDO et al., 2020). Abreu e colaboradores (2016), demonstrou a preocupação da farmacorresistência na idade pediátrica, devido à escassez de pesquisas para novos antimicrobianos, portanto futuramente algumas infecções consideradas simples podem conter possíveis complicações devido à falta de fármacos que atuam contra as cepas então resistentes, muitas vezes causadas pelo uso indevido das medicações. Procura-se trabalhar com o diagnóstico precoce das patologias apresentadas na pediatria, para que assim consiga-se prescrever a droga exata para ação contra o agente agressor, resultando em um menor tempo de tratamento devido não haver a necessidade de troca de medicamentos, bem como um tratamento eficaz (BOTE; FIGUEIREDO, 2017).

Conclusão: Notoriamente os organismos resistentes não são apenas resultantes da mutação dos mesmos, mas também do uso irracional dos antimicrobianos. Verifica-se como ponto chave a farmacovigilância, a qual profissionais de saúde devem utilizar 
como prioridade frente a prescrição de antimicrobianos, pois infelizmente a questão das mudanças internas próprias do organismo não podemos evitar. Assim aponta-se também a educação dos cuidadores/pais/familiares das crianças, o qual devem saber que automedicação de primeiro momento não é a melhor opção, devido as inúmeras consequências que podem resultar.

\section{Referências}

ABREU, Marlene et al. Infecções por bactérias multirresistentes em idade pediátrica: estudo retrospectivo de sete anos de um hospital de nível I. Acta Pediátrica Portuguesa, v. 47, p. 130-138, 2016.

BOTE, Cássia Galavotti; FIGUEIREDO, Angélica Brino. Resistência bacteriana a antimicrobianos em pacientes pediátricos e a enfermagem: uma revisão crítica. Monografia apresentada à banca da Faculdade Inesp. São Paulo, 2017.

BRÍGIDO, Heliton Patrick Cordovil et al. Perfil de resistência de agentes de infecção urinária em crianças internadas em um hospital de pediatria em Belém do Pará. Brazilian Journal of Health Review. v. 3, n. 4, p. 9808-9818. Curitiba, 2020.

MARKS, Fernanda Ossani et al. Infecção do trato urinário: etiologia, perfil de sensibilidade e resistência aos antimicrobianos em hospital pediátrico. Research, Society and Development, v. 9, n.8. p. e677985807-e677985807, 2020.

OLIVEIRA, Rita; AIRES, Teresa. .Resistência aos antibacterianos. Gazeta Médica, v. 3, n. 2, p. $22,2016$.

WANNMACHER, Lenita. Uso indiscriminado de antibióticos e resistência microbiana: uma guerra perdida. Uso racional de medicamentos: temas selecionados, v. 1, n. 4, p. 1-6, 2004. 


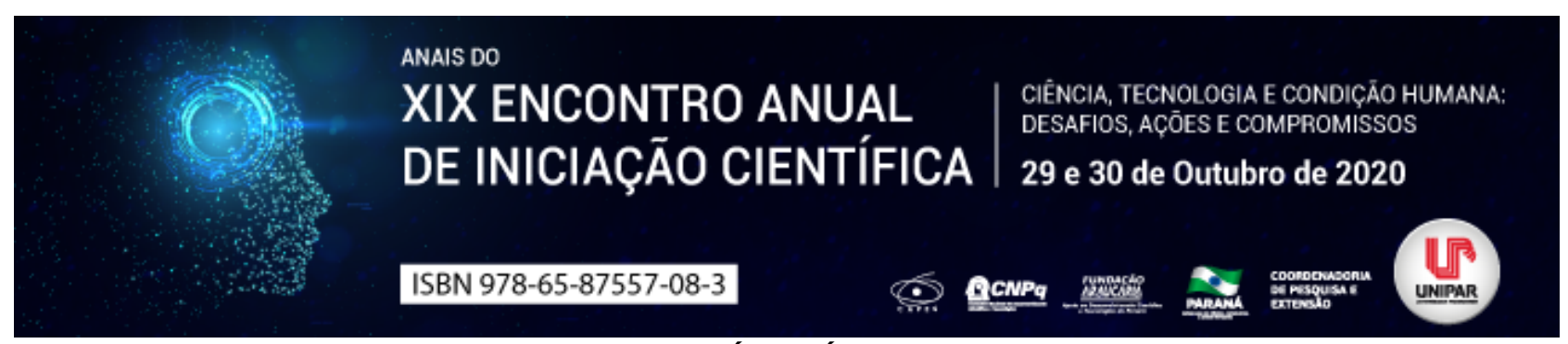

OS EFEITOS DA PRATICA DE EXERCíCIO FÍSICO EM PESSOAS COM ANSIEDADE

\author{
${ }^{1}$ THAIS KAROLYNE VIEIRA CANUTO, ${ }^{2}$ SILVIA REGINA NISHIYAMA SUCUPIRA SARTO
}

\author{
${ }^{1}$ Acadêmica do curso de Educação Física da UNIPAR \\ ${ }^{1}$ Docente da UNIPAR
}

Introdução: A ansiedade é uma emoção que está presente na vida de todo ser humano e ela geralmente aparece quando o indivíduo passa por momentos de tensão ou exaustão. Ela pode ser benéfica para as pessoas em momentos que nos faz sentir medos e ajuda a prevenir alguns tipos de riscos, mas quando ela ultrapassa um limite tornando-se ansiedade excessiva, ela é considerada uma doença, o que acarretaria em malefícios para saúde do homem. Desse modo, o presente estudo visa analisar quais são os efeitos da prática de exercício físico em pessoa com ansiedade.

Objetivo: Investigar através de revisão bibliográfica quais são efeitos da prática de exercício físico em uma pessoa ansiosa.

Desenvolvimento: De acordo com Silva (2017 p. 84) a ansiedade é definida como sensação de receio e de apreensão, sem causa evidente . Já Silva (2010) diz que ansiedade caracteriza-se por um estado subjetivo desagradável de inquietação, tensão e apreensão. Nos tempos atuais, pode-se perceber que a ansiedade está presente em níveis elevados nas crianças, pois essa ansiedade é nutrida pelas expectativas culturais que o meio lhes proporciona, e podemos notar também, que em adultos ela se manifesta devido ao acúmulo de funções e do modo materialista (SILVA, 2017). Em sua pesquisa, Fernandes (2018) traz que

os sintomas de ansiedade e depressão mais relatados foram nervosismo, sensação de estar assustado, indigestão ou desconforto abdominal, medo de que aconteça o pior, fadiga e irritabilidade . O exercício físico pode ajudar na melhora da ansiedade e da saúde psicológica das pessoas, porém, para obter bons resultados, é preciso definir algumas variáveis como níveis de atividade física, frequência e intensidade dos exercícios (LAUX, 2018). Vários tipos de exercícios podem ser realizados para controlar os sintomas de ansiedade, como caminhadas, corridas, danças, ioga, treinamentos resistidos, entre outros. Importante destacar que o tipo de exercício, como por exemplo o aeróbio é mais eficaz na redução de tais sintomas, enquanto que o anaeróbio deve ser evitado uma vez que seus resultados não são apropriados para diminuir essa emoção/sensação, pois ele produz lactato que poderia trazer alguns desconfortos para o indivíduo (ARAÚJO, 2007). O exercício físico vem como um tratamento alternativo não farmacológico para a melhora da ansiedade, onde auxilia na diminuição de sentimentos negativos e tem uma influência benéfica no humor (FULK, 2004).

Conclusão: Esse estudo permitiu verificar que o exercício pode ser uma forma de tratamento não farmacológico que auxilia a diminuir os sintomas de ansiedade e também influencia beneficamente no humor do indivíduo. A prática do exercício físico faz com que durante e pós exercício a pessoa libere uma substancia chamada endorfina que atua no cérebro como m analgésico onde ajuda na redução do estresse e da ansiedade do indivíduo e também a deixa com uma sensação de prazer e bem-estar.

\title{
Referências
}

ARAÚJO, Sônia R. C. de, .Transtornos de ansiedade e exercício físico. Rev Bras Psiquiatr. Vol. , p. 164-171. 2007. Disponível em: https://www.scielo.br/pdf/rbp/v29n2/a15v29n2.pdf.Acesso em: 15 jul. 2020.

FERNANDES, Márcia Astrês, et al. Prevalência de sintomas ansiosos e depressivos em universitários de uma instituição pública. Rev. Bras. Enferm. vol.71, p. 2298-2304. Out/Mar 2018. Disponível em: https://www.scielo.br/scielo.php? script=sci_arttext\&pid=S0034-71672018001102169\&lng=pt\&nrm=iso\&tlng=pt\#TFN09. Acesso em: 16 jun. 2020.

FULK LJ, et al. Chronic physical exercise reduces anxiety-like behavior in rats. Int J Sports Med. p.78-82. 2004. Disponível em: https://pubmed.ncbi.nlm.nih.gov/14750018/. Acesso em: 14 jul. 2020.

LAUX, Rafael, et al. Efecto de um Programa de Ejercicio Físico en el Medio Ambiente de Trabajo Sobre la Ansiedad. Cienc Trab. Vol.62, p. 80-83. 2018. Disponível em: https://scielo.conicyt.cl/pdf/cyt/v20n62/0718-2449-cyt-20-62-00080.pdf. Acesso em: 15 jul. 2020.

SILVA, Ana Beatriz Barbosa. Mentes ansiosas: medo e ansiedade nosso de cada dia. 2. ed. São Paulo: Principium, 2017. SILVA, André Liuz Picolli da. O Tratamento da Ansiedade por Intermédio da Acupuntura: Um Estudo de Caso. PSICOLOGIA CIÊNCIA E PROFISSÃO. p. 200-211. Nov/Sept. 2010. Disponível em: https://www.scielo.br/pdf/pcp/v30n1/v30n1a15.pdf. Acesso em: 16 jun. 2020. 


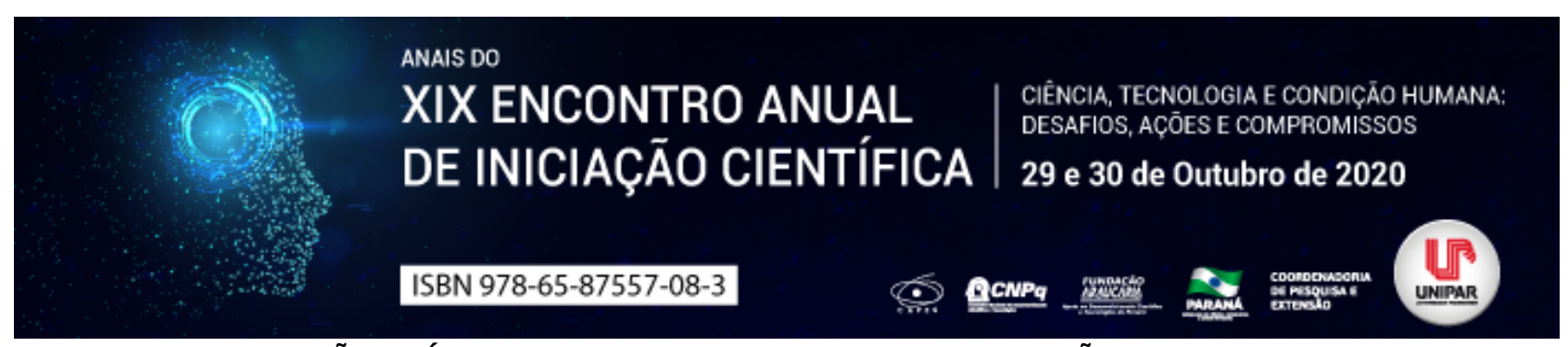

AVALIAÇÃO CLÍNICA DOS ADESIVOS UNIVERSAIS: REVISÃO DE LITERATURA

\section{${ }^{1}$ EVERTON JOSE FELIX, ${ }^{2}$ MILENA GEMELLI, ${ }^{3}$ JENIFFER URBANO DEGASPERI, ${ }^{4}$ EVELINE CLAUDIA MARTINI}

${ }^{1}$ Acadêmico do curso de odontologia da UNIPAR de Francisco Beltrão

${ }^{1}$ Acadêmica do Curso de Odontologia da UNIPAR

${ }^{2}$ Acadêmica do Curso de Odontologia da UNIPAR

${ }^{3}$ Docente da UNIPAR

Introdução: O avanço na odontologia vêm sendo cada vez mais promissor para agilizar e facilitar a vida clínica do cirurgiãodentista (CD), especialmente no protocolo adesivo. Por isso, nos últimos anos, foi disponibilizado no mercado um novo tipo de sistema adesivo, chamado de universal ou multimodal. De acordo com os fabricantes, podem ser aplicados sobre a estrutura dental pela técnica convencional ou autocondicionante, fazendo o condicionamento ácido seletivo do esmalte na técnica autocondicionante, porém, condicionamento na dentina ainda é controverso na literatura (MEERBEEK et al., 2020; TASCHNER, et al., 2010; VAN LANDUYT, et al., 2006). Devido a relevância do tema abordado, é importante que acadêmicos de odontologia e CD conheçam o material e entendam sua correta utilização, bem como suas variações.

Objetivo: Com base em estudos clínico encontrados na literatura existente, será realizado uma revisão da literatura para compreender a efetividade e a longevidade do adesivo universal na união com os substratos dentais.

Desenvolvimento: Uma inovação na odontologia são os adesivos universais, que permitem uma aplicação segura e em diversos procedimentos, não sendo restrito somente em esmalte ou em dentina (MEERBEEK et al., 2020; MUÑOZ, et al., 2013; ROSA; PIVA; SILVA, 2015). Antes do surgimento desses, tínhamos dados de que os adesivos autocondicionantes fortes em dentina mostravam-se menos eficazes em esmalte, exceto os suaves e muito suaves que mostraram resultados satisfatórios (ROSA; PIVA; SILVA, 2015; PERDIGÃO; SWIFT, 2015), por isso a dificuldade em se usar um único tipo de sistema adesivo em diferentes substratos, vantagem que os universais trouxeram. $\mathrm{O}$ pH da maior parte dos adesivos universais é 2 ou próximo desse valor, semelhante aos adesivos autocondicionantes suaves e muito suaves. Sendo assim, os adesivos universais aplicados nas estruturas dentais com a técnica autocondicionante em dentina é promissor (ARINELLI, et al., 2016). O sistema adesivo autocondicionante não possui capacidade de adesão em esmalte, sendo necessário um condicionamento prévio com ácido fosfórico, deixando a superfície do esmalte mais poroso aumentando a adesividade (KASE, et al., 2013; KALAVRACHARLA, et al. 2015; MEERBEEK et al., 2020). Essa versatilidade do sistema adesivo Universal, aumenta a facilidade na aplicação e diminui a probabilidade de erros e de insucesso, uma vez que pode ser utilizado com ou sem o ácido fosfórico. Com um único material o CD pode decidir qual técnica utilizar de acordo com cada caso e principalmente, com cada substrato (KOSE, et al., 2013).

Conclusão: Após uma revisão detalhada da literatura, conclui-se que o sistema adesivo universal mostrou-se satisfatório na maioria dos estudos realizados, tanto na técnica convencional ou na autocondicionante, porém com condicionamento prévio seletivo de esmalte houve melhores resultados. Entretanto, por ser um produto considerado novo no mercado odontológico, não tem como afirmar com propriedade sua efetividade a longo prazo e devemos acompanhar a elaboração de mais estudo clínicos com períodos de tempo de avaliação maiores para uma conclusão mais segura.

\section{Referências}

ARINELLI Angela Marta Dib, et al. Sistemas adesivos atuais. Rev. bras. odontol., Rio de Janeiro, v. 73, n. 3, p. 242-46, 2016

MUÑOZ, Miguel Angel, et al. Immediate bonding properties of universal adhesives to dentine. J Dent, v. 41, n. 4, p. 404-11, 2013.

PERDIGÃO Jorge, SWIFT Edward Junior. Universal Adhesives. J Esthet Restor Dent. v. 27 n. 6 p. 331-4. iew and metaanalysis. J Dent, v. 43 n. 7 p. 765-76, 2015

ROSA Wellington Luiz de Oliveira, PIVA Evandro, SILVA Adriana Fernandes. Bond strength of universal adhesives: asystematic review and meta-analysis. J Dent, v. 43, n. 7, p. 765-76, 2015.

MEERBEEK Bart Van, et al. From Buonocore's Pioneering Acid-Etch Technique to Self-Adhering Restoratives. A Status Perspective of Rapidly Advancing Dental Adhesive Technology. J Adhes Dent. v. 22 n. 1 p. 7-34, 2020 


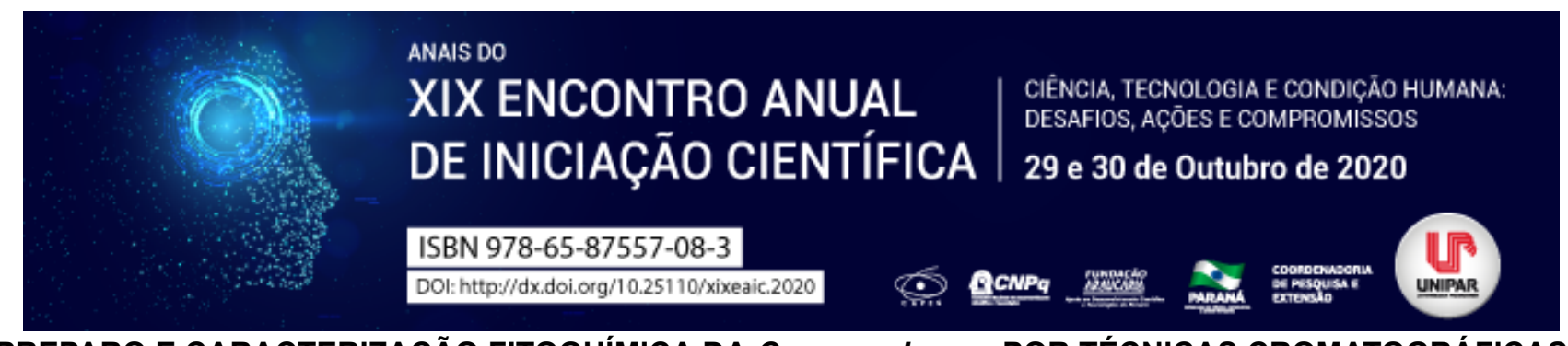

PREPARO E CARACTERIZAÇÃO FITOQUÍMICA DA Curcuma Longa POR TÉCNICAS CROMATOGRÁFICAS

\author{
${ }^{1}$ CAMILA MORENO GIAROLA, ${ }^{2}$ JULIANA PELISSARI MARCHI, ${ }^{3}$ SAMANTHA WIETZIKOSKI SATO, ${ }^{4}$ CINTIA DE \\ SOUZA ALFERES ARAUJO, ${ }^{5}$ EVELLYN CLAUDIA WIETZIKOSKI LOVATO
}

\author{
${ }^{1}$ Acadêmico Bolsista do PEBIC/CNPQ \\ 2Docente da UNIPAR \\ ${ }^{3}$ Docente da UNIPAR \\ ${ }^{4}$ Docente da UNIPAR \\ ${ }^{5}$ Docente da UNIPAR
}

Introdução: O açafrão (Curcuma longa) é uma planta com uma ampla descrição de seus aspectos etnobotânicos e usos etnofarmacológicos diretamente relacionados aos seus constituintes químicos. São descritos diversas propriedades farmacológicas: anti-inflamatória, antibacteriana, antiimuno-deficiência viral humana e efeitos antioxidantes (ARAÚJO; LEON, 2001), que dependem da composição química do extrato e da técnica de extração. Para o estudo dos compostos bioativos da $C$. longa, um estudo fitoquímico deve ser realizado, sendo utilizados os métodos cromatográficos como a cromatografia gasosa (CG) e a cromatografia líquida de alta eficiência (CLAE).

Objetivo: Avaliar a composição química do extrato hidroetanólico obtido do rizoma de C. longa por exaustão.

Metodologia: Os rizomas de C. longa foram coletados no horto de Plantas Medicinais da UNIPAR entre junho e julho de 2016. Foram lavados e secos em estufas a $50^{\circ} \mathrm{C}$ por 6 dias. A preparação do extrato hidroetanólico foi obtido por exaustão, um processo que acontece na capela de exaustão, um equipamento de proteção coletiva (EPC) em todos os laboratórios que tenham algum tipo de trabalho com manipulações de produtos químicos, voláteis, partículas ou líquidos. Realiza a transferência de calor entre o ar e o material vegetal que restou da última extração e, por meio da evaporação, tem o intuito de exaurir por completo o resíduo do solvente. O material foi pulverizado até granulometria de $850 \mu \mathrm{m}$. $\mathrm{O}$ pó foi submetido a maceração com renovação de solvente usando etanol: água. O filtrado foi concentrado a $20 \%$ até a obtenção do extrato. A quantidade de rizoma utilizado no processo de extração foi $1: 3$, e o rendimento foi $18,41 \%$. Amostras de solo foram coletadas a $20 \mathrm{~cm}$ de profundidade. A análise do solo é de extrema importância para a obtenção do extrato, uma vez que suas características fisicoquímicas interferem na qualidade do extrato. Para a análise do solo foram quantificados seus nutrientes (ARRUDA et al., 2014). A análise fitoquímica foi realizada usando um cromatógrafo a gás (Agilent 7890 B) acoplado a um espectrômetro de massa (Agilent 5977ª - CG-MS) com uma coluna capilar Agilent $\mathrm{HP}-5 \mathrm{MS}$ com temperatura de $280^{\circ} \mathrm{C}$, volume de $2 \mu \mathrm{L}$ na proporção de 1:20 e hélio como transportador gás. Os compostos foram identificados comparando seus espectros de massa com os espectros de massa na biblioteca NIST 11.0 e Adams (2017). A quantificação de curcumina e curcuminoides foi realizada por CLAE (Varian 920 LC) em fase reversa, utilizando uma coluna $\mathrm{C} 18$. A curva de calibração foi gerado com um padrão autêntico de curcumina, preparado a 1, 5, 10, 15, 20 e $30 \mu \mathrm{g} / \mathrm{ml}$ em metanol. As amostras foram preparadas a $500 \mu \mathrm{g} / \mathrm{ml}$ com injeções de $10 \mu \mathrm{l}$. A detecção foi realizada com um detector de matriz de fotodíodos, e os curcuminóides foram monitorados a $425 \mathrm{~nm}$.

Resultados: A textura do solo foi de: $91,25 \%$ de areia, 3,75\% de silte e 5,0\% de argila. O pH mostrou-se ácido (pH $3,70)$, teor de matéria orgânica de $13,55 \mathrm{~g} / \mathrm{dm}^{3}$ e saturação para bases (15,79\%). A composição química do extrato bruto foi obtida pelo processo de maceração dinâmica com esgotamento de solvente e analisado por CG-MS. No total foram identificados 117 compostos, representando $99,43 \%$ dos componentes voláteis. Os sesquiterpenos oxigenados foram os compostos dominantes, compreendendo $60,5 \%$, seguido pelos sesquiterpenos hidrocarbonetos com $22,22 \%$. As substâncias majoritárias identificadas foram ar-turmerone $(9,70 \%), \gamma$-curcumene $(8,55 \%), \alpha$-turmerone $(7,30 \%)$ e $\beta$ sesquiphellandrene $(6,78 \%)$. A CLAE indicou a presença de três picos consistentes com os curcuminóides, observados em 7,08, 8,44 e 10,05 min. Esses picos apresentaram espectros de absorvância semelhantes com Imax a 418-426 nm. Os perfis de eluição dos curcuminóides sugerem a presença de bisdemetoxicurcumina (BDM), desmetoxicurcumina (DMC) e curcumina (pico principal). O padrão utilizado para quantificação apresentou um pico único aos 10,05 min. Assim, a quantificação dos curcuminóides foi baseada na curva de calibração obtida de curcumina, que deu um coeficiente de correlação de 0,995.

Discussão: Neste estudo, a análise do solo indicou baixos níveis de cálcio, magnésio, alumínio, carbono, matéria orgânica, soma de bases e saturação de bases. Foram observados níveis médios de potássio e ferro, com altos níveis de hidrogênio + alumínio e saturação de alumínio, manganês, cobre e zinco. Presume-se que o nível médio de potássio não interfira com o número de rizomas, apenas o número de folhas (MAY et al., 2005). O potássio pode aumentar o crescimento das folhas na planta mãe. Os níveis combinados de nitrogênio, fósforo e potássio podem estar relacionados à cor do pigmento nos rizomas de C. longa e no desenvolvimento das plantas (CECILIO-FILHO et al., 2000). Outro fator que interfere diretamente na composição das plantas é o $\mathrm{pH}$ do solo. Neste estudo, o pH foi de 3,7. Após a avaliação da composição química por GC-MS foi possível observar baixa expressão de curcuminóides ( $\gamma$-curcumene - 8,55\%). A 
análise por CLAE indicou baixas concentrações totais de curcuminóides na amostra. Uma explicação pode estar relacionada ao $\mathrm{pH}$ que interfere com os níveis de curcumina, uma vez que a maior estabilidade da molécula de curcumina é encontrada entre o pH 4,0 e 7,0 (RUSIG; MARTINS, 1992), pH inferior a 4,0 e superior a 7,0 torna a curcumina instável, aumentando a velocidade de degradação da molécula (RUSIG; MARTINS, 1992).

Conclusão: Observou-se baixa expressão de curcumina e curcuminóides, principal composto da C. longa. Assim, tornase necessário outros estudos afim de correlacionar atividade biológica com os constituintes encontrados nos estudos fitoquímicos.

\section{Referências}

ARAÚJO, C. A. C.; LEON, L. L. Biological activities of Curcuma Longa L. Memórias do Instituto Oswaldo Cruz, Rio de Janeiro, v. 96, n. 5, p. 723-728, jul. 2001.

ARRUDA, M. R.; MOREIRA, A.; PEREIRA, J. C. R. Soil Sampling and Care for Fertility Purposes [Amostragem e Cuidados na Coleta de Solo para Fins de Fertilidade]. Embrapa Amazônia Ocidental 2014; 115:1 $\square 20$.

ADAMS, R. P: Identification of essential oils components by gas chromatography/ mass spectroscopy. fourth one ed. Allured, Carol Stream, 2017, pp. 804.

MAY, A.; CECILIO FILHO, A. B.; CAVARIANNI, R. L.; BARBOSA, J. C. Turmeric (Curcuma longa L.) development and dutivity in function at nitrogen and potassium doses. Revista Brasileira de Plantas Medicinais, v. 7, p. $72 \square 78,2005$.

CECILIO-FILHO, A. B.; SOUZA, R. J; BRAZ, L. T; TAVARES, M. Curcuma: medicinal, spice and of other potential use plant. Ciência Rural, v. 30, p. 171 $\square 175,2000$.

RUSIG, O.; MARTINS, M. C. Effect of temperature, pH and light on turmeric (Curcuma longa L.) and curcumin oleoresin extracts. Revista Brasileira de Corantes Naturais, v. 158 $\square$ 164. 1992.

Coordenadoria de Pesquisa e Extensão - COPEX

Departamento de Editoraçāo e Divulgaçāo Científica - DEDIC 


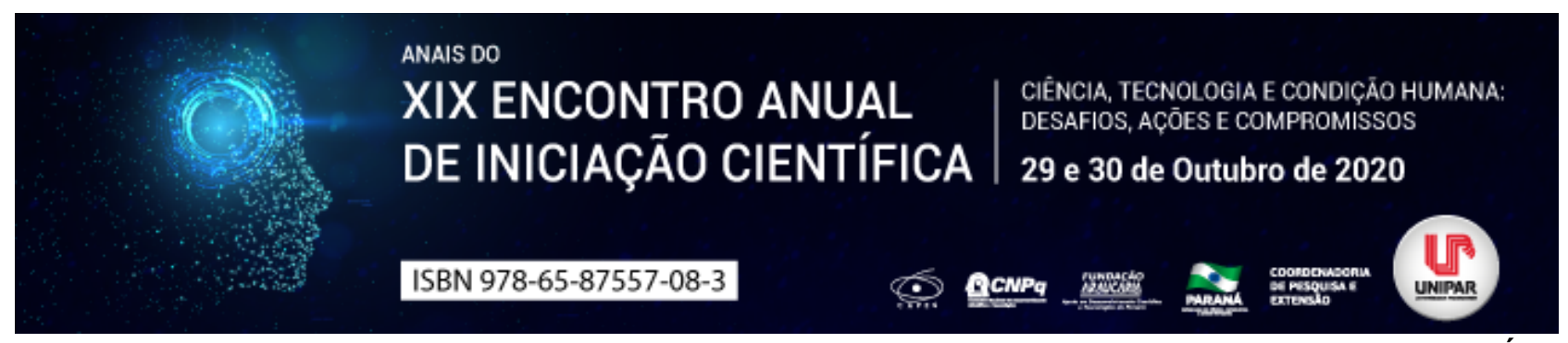

OESTEONECROSE DOS MAXILARES INDUZIDA PELO USO DE BISFOSFONATOS - MANEJO ODONTOLÓGICO

\begin{abstract}
${ }^{1}$ CAROLINE DOMINGUES, ${ }^{2}$ GABRIEL MACIEL DA SILVA, ${ }^{3}$ GUSTAVO BARBOSA CORREA DE MORAIS, ${ }^{4}$ ANA CAROLINE DOS SANTOS GRUNOW, ${ }^{5}$ QUEREN ALVES DE PAULA , ${ }^{6}$ DANIELA DE CASSIA FAGLIONI B CERANTO
\end{abstract}

\author{
${ }^{1}$ Acadêmica do curso de Odontologia da Universidade Paranaense \\ ${ }^{1}$ Acadêmico PIBIC do Curso de Odontologia da UNIPAR \\ ${ }^{2}$ Acadêmico PIC do Curso de Odontologia da UNIPAR \\ ${ }^{3}$ Acadêmica PIBIC do Curso de Odontologia da UNIPAR \\ ${ }^{4}$ Acadêmica PIC do Curso de Odontologia da UNIPAR \\ ${ }^{5}$ Docente do curso de Odontologia da UNIPAR
}

Introdução: De acordo com Passeri, Bèrtolo, Abuabara (2011) os bisfosfonatos inibem a ação dos osteoclastos por meio da inibição da enzima farnesil difosfato sintase, o que causa as diversas alterações citoesqueléticas, diminuindo a ação de reabsorção óssea dos osteoclastos e induzindo a apoptose celular. Consequentemente paralisam a reabsorção, aumentam a massa e a mineralização óssea, reduzindo o risco de fraturas e diminuindo a sintomatologia dolorosa. Apesar dos inúmeros benefícios e melhora na qualidade de vida dos pacientes esses medicamentos foram relacionados com a osteonecrose dos maxilares em alguns casos. A osteonecrose dos maxilares é caracterizada pela exposição de tecido ósseo necrosado ou pela presença de fístula oroantral na cavidade bucal do paciente. Essa patologia é recorrente em pacientes que utilizam bisfosfonatos, sua etiologia é variada, porém, alguns estudos mostram que interferências odontológicas como exodontias ou cirurgias envolvendo tecido ósseo, além do contato constante com a microbiota bucal, podem desencadear o processo de osteonecrose (DOTTO, 2011; MORAIS, 2016).

Objetivo: O objetivo deste trabalho é realizar um levantamento bibliográfico a respeito da osteonecrose induzida pelo uso de bifosfonatos, suas causas, sintomas, tratamentos e cuidados ao atender paciente sob uso desses medicamentos.

Desenvolvimento: De acordo com a Associação Americana de Cirurgiões Bucomaxilofaciais (AAOMS) para ser diagnosticado com osteonecrose dos maxilares o paciente deve apresentar três características principais: 1) ter realizado tratamento anterior com bisfosfonatos; 2) Ter osso necrótico exposto na cavidade oral por tempo superior a 8 semanas; 3) Não ter realizado tratamento de radioterapia na região. Segundo Passeri, Bèrtolo, Abuabara (2011) é evidente a relação dos bisfosfonatos com a osteonecrose dos maxilares, porém, a probabilidade de desenvolvimento dessa doença é maior em pacientes que utilizam por períodos maiores que 3 anos estes medicamentos e por via intravenosa, esses casos são comuns no tratamento de tumores malignos, metástases ósseas de câncer de mama, pulmão e próstata, e também de doenças osteolíticas. Para esses casos o medicamento de escolha é o zoledronato (que apresenta potência dez vezes maior que os bisfosfonatos usados no tratamento de osteoporose) por isso, a atenção deve ser maior ao atender pacientes sob uso deste medicamento.

Ao iniciar a terapia com bisfosfonatos é de extrema importância a realização de avaliação odontológica, para remover possíveis focos infecciosos, realizar tratamentos necessários e instruir o paciente quanto a higiene oral que deverá ser realizada com maior dedicação durante o uso do medicamento, para prevenir a ocorrência da osteonecrose dos maxilares. Nos casos em que a prevenção não foi eficaz e a doença se instalou é importante realizar o correto diagnóstico e tratamento adequado (Caminha et al., 2019). O protocolo de tratamento para a osteonecrose dos maxilares segundo a AAOMS é diferente em cada fase da doença, e classifica-se conforme o estágio: Categoria de risco - Não há presença de osso necrótico, paciente sob uso de bisfosfonato oral ou endovenoso. Neste estágio não há indicação de tratamento, apenas instruções de higiene e cuidados orais ao paciente. Estágio 1 - Osso necrótico exposto, porém, o paciente não apresenta sintomatologia e não há evidência de infecção. 0 tratamento para esses casos consiste na administração de enxaguatórios bucais com ação antibacteriana, acompanhamento clínico do paciente com frequência trimestral, instrução ao paciente e revisão junto a equipe médica sobre a necessidade de continuação do uso do medicamento. Estágio 2 - Osso necrótico exposto com associação de infecção, que é caracterizada por dor e edema da região, pode ou não ocorrer secreção purulenta. Para tratar esses pacientes utiliza-se a terapia antibiótica com penicilina, cefalexina, clindamicina ou fluoroquinolona de primeira geração, a escolha deve ser feita de acordo com as necessidades do paciente; a terapia antibiótica é associada a enxaguatórios antibacterianos, medicamentos para controle da dor e debridamentos superficiais podem ser realizados para aliviar a irritação dos tecidos. Estágio 3 - Osso necrótico exposto, com infecção e associação de fratura patológica, fístula extra oral ou osteólise. O tratamento indicado nesses casos consiste na administração de terapia antibiótica e controle da dor, enxaguatórios antibióticos e procedimento cirúrgico para controle da doença e infecção do local a longo prazo.

Conclusão: A partir da revisão de literatura realizada é possível afirmar que existe íntima relação entre o uso de bisfosfonatos e 
a osteonecrose dos maxilares, e que essa relação depende de fatores associados como a condição sistêmica do paciente e a dose e duração da terapia medicamentosa. A partir disso, fica clara a necessidade de acompanhamento odontológico a pacientes sob uso de bisfosfonatos a fim de evitar a ocorrência da osteonecrose dos maxilares, doença que debilita e prejudica a qualidade de vida dos acometidos.

\section{Referências}

CAMINHA, Raquel D. et al. Perfil de risco para osteonecrose dos maxilares associada a agentes antiangiogênicos. Einstein (Sao Paulo). v. 17, n. 3, p. -, 2019. Disponível em: https://journal.einstein.br/pt-br/article/perfil-de-risco-para-osteonecrose-dosmaxilares-associada-a-agentes-antia ngiogenicos/. Acesso em: 13 jul 2020.

DOTTO, Anderson Cesar; DOTTO, Marcelo Luis. Osteonecrose dos maxilares induzida por bisfosfonatos revisão de literatura e relato de caso. Revista da Faculdade de Odontologia-UPF, v. 16, n. 2, 2011. Disponível em: http://seer.upf.br/index.php/rfo/article/view/962/1368. Acesso em: 13 jul 2020.

MORAIS, Everton Freitas et al. Osteonecrose dos maxilares associado ao uso de alendronato oral em paciente sob tratamento de osteoporose. CATUSSABA-ISSN 2237-3608, v. 5, n. 1, p. 21-29, 2016 . Disponível em: https://repositorio.unp.br/index.php/catussaba/article/view/1222. Acesso em: 13 jul 2020.

PASSERI, Luis Augusto et al. Osteonecrose dos maxilares associada ao uso de bisfosfonatos. Rev Bras Reumatol, v. 51, n. 4, p. 401-7, 2011.Disponível em: https://www.scielo.br/pdf/rbr/v51n4/v51n4a12. Acesso em: 13 jul 2020.

Coordenadoria de Pesquisa e Extensão - COPEX

Departamento de Editoraçāo e Divulgaçāo Científica - DEDIC 


\title{
-

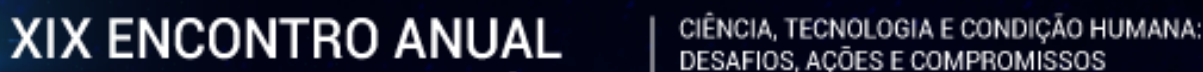 DE INICIAÇÃO CIENTÍFICA DESAFIOS, ACOESE E COMPROMISSOS DE INICIAÇAOO CIENTIFICA 29 e 30 de Outubro de 2020 \\ ISBN 978-65-87557-08-3

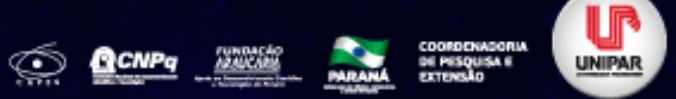 \\ INCIDÊNCIA DA DENGUE NA 12 a REGIONAL DE SAÚDE-UMUARAMA PR ENTRE OS ANOS DE 2015 A 2020 COM RELAÇÃO A DETERMINADOS PERÍODOS DO ANO
}

\author{
${ }^{1}$ Julia Oliveira Fabretti, ${ }^{2}$ CAROLINE DE OLIVEIRA, ${ }^{3}$ CAROLINA MAJONI DE OLIVEIRA, ${ }^{4}$ LUCIANA VIEIRA PINTO RIBEIRO
}

\author{
${ }^{1}$ Universidade de Marília (UNIMAR), acadêmico do Curso de Medicina \\ ${ }^{1}$ Universidade de Marília (UNIMAR) \\ ${ }^{2}$ Universidade de Marília (UNIMAR) \\ ${ }^{3}$ Docente da UNIPAR
}

Introdução: A dengue é uma doença que encontra-se em transmissão há 3 séculos pelo vetor Aedes aegypti pertencente ao gênero Flavivirus e a família Flaviviridae, sendo o mesmo constituído de um filamento único de RNA, envelopado, e possui quatro sorotipos, sendo eles DENV-1,DENV-2,DENV-3,DENV-4.O transmissor é originário da Áfritca Subsaariana, antropofílico, o qual a medida que o tempo passa observa-se uma espécie cosmotropical (HALSTEAD,2019; TEIXEIRA et al., 1999). O vírus é adquirido pela fêmea do mosquito a partir do momento em que se alimenta do sangue de um doente em sua fase de viremia, depositando-se na saliva e fazendo com que o artrópode se torne infectante por toda a sua vida, assim como também há uma transmissão de forma transovariana para sua prole (DIAS et al.,2010). A priori, as condições climáticas são apontadas como condicionantes das apresentações epidemiológicas e clínicas da dengue, sendo considerado um dos maiores fatores que modulam a transmissão e circulação do vírus. (BARRETO et al.,2008).

Objetivo: O objetivo deste trabalho é analisar a incidência da dengue na $12^{\mathrm{a}}$ Regional de Saúde Umuarama, PR em 5 anos (2015-2020) e se existe correlação entre os surtos do vetor com determinados meses ou períodos do ano, e com tais informações e consequente conclusão é passível de um sistema de alerta precoce para meios de prevenção por parte da gestão municipal.

Desenvolvimento: A incidência da dengue encontra-se inconstante, de modo que houve um aumento significativo de $1325 \%$, comparando-se o ano de 2015 em relação à 2020 (SESA, 2020). Analisando mensalmente verifica-se que no ano de 2015 os meses de abril, maio, junho, julho e agosto foram marcados por incidência maior ou igual a 300 casos/100.000 habitantes no município, ou seja, encontrava-se em surto, onde o maior índice ocorreu no mês de julho (1215,67\%); no ano de 2016 o surto se fez presente nos meses de abril, maio, junho e julho, onde a maior incidência foi em junho (533,15\%); em 2017 o município não constatou surto, porém os meses de maior incidência foram em março, maio e julho (10,85\%); em 2018 assim como em 2017, não foi verificado surto, mas os meses de maior incidência foram em maio e julho (12,65\%); em 2019, o surto esteve presente nos meses de maio, junho e julho, e neste por último avaliou-se a maior incidência $(1370,21 \%)$ e em 2020 , o surto esteve presente nos meses de fevereiro, março, abril, maio, junho, tendo este a maior incidência $(16383,35 \%)$ e julho. Todos estes meses ao longo desses cinco anos de maior evidência epidemiológica, se enquadrariam nas estações de verão (primeiras três semanas de março), outono (toda a sua periodicidade) e inverno (respectivos aos meses de junho, a partir de sua terceira semana e julho em toda a sua periodicidade). O verão paranaense é historicamente uma estação chuvosa por todo o estado e as temperaturas apresentam aumento em seus valores médios à medida que a estação transcorre, com exceção de março, sendo considerado pelos estudiosos o período mais propício ao vetor. O outono no estado caracteriza-se pela grande variabilidade das chuvas, devido a passagens de frentes frias, e as temperaturas, normalmente apresentam grande amplitude térmica diária. As características do Inverno são pautadas nos menores valores de precipitação acumulada, sendo que nos meses de julho e agosto ocorrem os mais secos do ano no Paraná, além disso, é a estação mais fria do ano. Ademais, ao observarmos o índice pluvial, não é possível agrupar ou definir períodos ou estações específicas aonde haja uma elevação em mm significativo (SIMEPAR, 2020). O risco climático é um sistema de alerta disponível nos boletins da dengue no site da secretaria da saúde do Paraná, desenvolvido pelo LABOCLIMA (Laboratório de Climatologia) da UFPR (Universidade Federal do Paraná), com o apoio do SIMEPAR (Instituto Tecnológico do Paraná) e da SESA/PR (Secretaria de Saúde do Estado), que diz respeito ao monitoramento das condições de risco climático no estado, permitindo identificar a formação de situações meteorológicas favoráveis à reprodução e atuação do Aedes aegypti. Ao avaliar estes dados, os meses de maior risco nos anos de 2015 a 2019 se enquadrariam entre janeiro a abril, e no ano de 2020 entre janeiro a março.

Conclusão: Ao averiguar, organizar e interpretar todos os dados acima apresentados, conclui-se que os meses de maior incidência do Aedes aegypti entre anos de 2015 a 2020 na 12ª Regional de Saúde-Umuarama-Pr, foram no período de março a julho (não condizendo fielmente aos meses indicados pelos boletins de risco climáticos), pelos os quais a gestão municipal devese atentar em relação a medidas preventivas contra o vetor, que corresponde não só uma estação, mas sim três (verão, outono e inverno), cada uma com suas características específicas, desmitificando-se que apenas climas com chuvas abundantes, umidade 
e o calor típicos do verão são propícios para a reprodução e proliferação do mosquito, ou seja as estações se tornaram atípicas e com chuvas mais espalhadas durante o ano todo como já citado acima, assim constatando que o vetor se adaptou ás condições climáticas adversas para a sua sobrevivência e proliferação.

\section{Referências}

HALSTEAD, Scott. Avanços recentes no entendimento da dengue. F1000Research , v. 8, 2019.

RODENHUIS-ZYBERT, Izabela A.; WILSCHUT, Jan; SMIT, Jolanda M. Dengue virus life cycle: viral and host factors modulating infectivity. Cellular and molecular life sciences, v. 67, n. 16, p. 2773-2786, 2010.

STOLERMAN, Lucas M.; MAIA, Pedro D.; KUTZ, J. Nathan. Forecasting dengue fever in Brazil: An assessment of climate conditions. PloS one, v. 14, n. 8, p. e0220106, 2019.

ISLAM, Rashedul et al. Dengue epidemiology and pathogenesis: images of the future viewed through a mirror of the past. Virologica Sinica, v. 30, n. 5, p. 326-343, 2015.

CARRINGTON, Lauren B.; SIMMONS, Cameron P. Human to mosquito transmission of dengue viruses. Frontiers in immunology, v. 5, p. 290, 2014.

VIANA, Dione Viero; IGNOTTI, Eliane. The ocurrence of dengue and weather changes in Brazil: a systematic review. Revista brasileira de epidemiologia= Brazilian journal of epidemiology, v. 16, n. 2, p. 240-256, 2013.

TEIXEIRA, M. d G.; BARRETO, MAURÍCIO LIMA; GUERRA, Z. Epidemiology and preventive measures of dengue. Informe Epidemiológico do SUS, v. 8, n. 4, p. 5-33, 1999.

DIAS, Larissa BA et al. Dengue: transmissão, aspectos clínicos, diagnóstico e tratamento. Medicina (Ribeirão Preto Online) , v. 43, n. 2, pág. 143-152, 2010.

BARRETO, Maurício L.; TEIXEIRA, Maria Glória. Dengue no Brasil: situação epidemiológica e contribuições para uma agenda de pesquisa. Estudos avançados, v. 22, n. 64, p. 53-72, 2008.

SEDEST.Simepar,2020.Sistema de tecnologia e monitoramento ambiental do Paraná. Disponível em: . Acesso em: 25 de ago. de 2020.

CELEPAR.Secretária de saúde do Paraná,2020.Boletim da dengue. Disponível em : < http://www.dengue.pr.gov.br/modules/conteudo/conteudo.php?conteudo=28>. Acesso em: 25 de ago.de 2020 . 


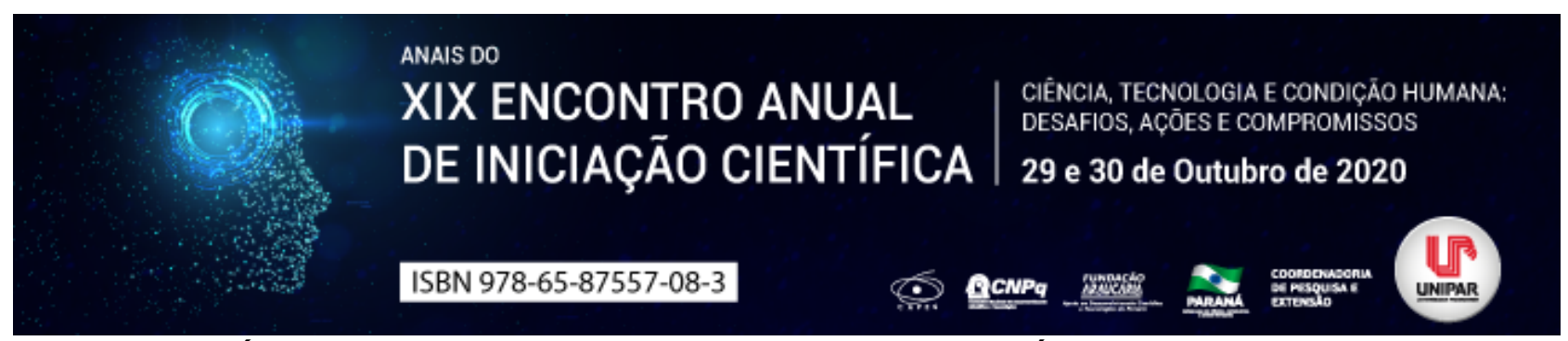

NÍVEIS DE FERRITINA COMO MARCADOR DE PROGNÓSTICO NA COVID-19

${ }^{1}$ DANIELA CRISTINA PERIN, ${ }^{2}$ PATRICIA AMARAL GURGEL VELASQUEZ

${ }^{1}$ Acadêmico do PIC/UNIPAR

${ }^{1}$ Docente da UNIPAR

Introdução: O primeiro relato de COVID-19, doença associada ao novo coronavírus SARS-CoV-2 (síndrome respiratória aguda grave do coronavírus 2), ocorreu em Wuhan, China, em dezembro de 2019, espalhando-se rapidamente por todo o mundo (NI et al., 2020). Em março de 2020, a Organização Mundial de Saúde (OMS) declarou a COVID-19 uma pandemia (COLAFRANCESCO et al., 2020). Segundo Taneri e col. (2020) a infecção por SARS-CoV-2 frequentemente resulta em COVID19, e Ni e col. (2020) complementa afirmando que é o terceiro coronavírus altamente patogênico a surgir, seguindo o SARS-CoV e a síndrome respiratória do Oriente Médio-CoV..De acordo com a OMS, a classificação de gravidade da COVID-19 é: Doença Leve, quando o paciente não apresenta evidências de hipóxia ou pneumonia; Doença Moderada, quando o paciente apresenta sinais de pneumonia com saturação de oxigênio $\left(\mathrm{SpO}_{2}\right)^{3} 90 \%$; Doença Grave, quando há sinais clínicos de pneumonia e a $\mathrm{SpO}_{2}$ é < $90 \%$ e Doença Crítica, quando há presença de Síndrome do Desconforto Respiratório Agudo (SDRA), sepse ou choque séptico (WHO, 2020). Estudos indicam que SDRA é a principal causa de mortalidade na COVID-19, sugerindo que a hiperinflamação causada pelo vírus pode ser a responsável por esses dados. Observaram que nesses pacientes alguns marcadores como hiperferritinemia e valores elevados de Interleucina-6 poderiam predizer o desfecho negativo (RUAN et al, 2020). De acordo com Li (2020), em comparação com os casos não graves de COVID - 19, os níveis de marcadores relacionados à inflamação, dentre eles a ferritina, foram significativamente maiores nos casos graves. A ferritina é um indicador muito precoce de inflamação e é um dos sistemas mais ancestrais de proteção do hospedeiro contra infecções por patógenos. Sua dosagem precoce em pacientes sintomáticos domiciliares pode ser extremamente útil (BOLONDI et al., 2020).

Objetivos: Avaliar a relação entre os níveis de ferritina sérica e casos graves de COVID-19 e sua utilização como prognóstico para a doença, por meio de uma revisão bibliográfica.

Desenvolvimento: De acordo com Bolondi et al. (2020), os primeiros relatórios da província chinesa de Hubei descreveram alguns biomarcadores preditivos para a evolução clínica de pacientes hospitalizados, dentre eles a ferritina, e complementar a isso, Taneri et al. (2020) declarou que os pacientes com COVID-19 tendem a apresentar níveis patologicamente aumentados de ferritina. Velavan e Meyer (2020) também expuseram que pacientes com COVID-19 admitidos em UTIs têm concentrações mais altas de citocinas pró-inflamatórias e que o tratamento para reduzir os danos pulmonares relacionados a inflamação é fundamental. Acrescentam, ainda, que níveis elevados de ferritina e síndrome de tempestade de citocinas foram relatados em pacientes com COVID-19 grave, afirmando que os níveis séricos de ferritina podem ser usados na estratificação de risco para prever COVID-19 grave e fatal em pacientes hospitalizados. A ferritina é um mediador chave da desregulação imunológica, especialmente sob hiperferritinemia extrema, por meio de efeitos imunossupressores e pró-inflamatórios diretos, contribuindo para a tempestade de citocinas (VARGAS, ROJO, 2020). Um estudo realizado por Ni e cols. (2020), realizado com 27 pacientes confirmados para COVID-19 grave, na China, mostrou que a ferritina sérica estava significativamente elevada em todos os pacientes. Observaram ainda em seu estudo que a diferença no nível de fatores de inflamação entre os pacientes com COVID-19 leve e grave era significativa e que os achados sugeriram que estes níveis podem ser um indicador mais objetivo para distinguir pacientes leves e graves com a doença. Segundo Taneri e cols. (2020), em 5.700 pacientes hospitalizados por COVID-19 em Nova York, os níveis de ferritina estavam patologicamente elevados e esses níveis aumentados podem ser indicativos de uma forte reação inflamatória no COVID-19 ou relacionados à entrada viral no corpo humano e seu impacto no metabolismo do ferro.

Conclusão: A maioria dos pacientes confirmados com COVID-19 apresentam níveis elevados de ferritina sérica. Desses, os pacientes muito graves apresentaram níveis superiores de ferritina sérica em relação aos pacientes graves. Sendo assim, o estudo infere que o acompanhamento dos níveis de ferritina sérica pode ser uma ferramenta útil como marcador de prognóstico de COVID-19, especialmente para casos muito graves.

\section{Referências}

BOLONDI, Giuliano et al. Iron metabolism and Iymphocyte characterisation during COVID-19 infection in ICU patients: na observational cohort study. World Journal of Emergency Sugery. Vol 15,1 41. Jun 2020.

COLAFRANCESCO, Serena et al. COVID-19 gone bad: A new character in the spectrum of the hyperferritinemic syndrome? Autoimmunity reviews, Vol 19,7. Jul 2020.

$\mathrm{LI}$, Xiaochen et al. Risk factors for severity and mortality in adult COVID-19 inpatients in Wuhan. The Journal of allergy and clinical immunology. Vol 146,1. Jul 2020. 
$\mathrm{NI}$, Ming et al. Characteristics of inflammatory factors and lymphocyte subsets in patients with severe COVID-19. Journal of medical virology. Vol 92, e9. May 2020.

RUAN Q, YANG K, WANG W, JIANG L, SONG J. Clinical predictors of mortality due to COVID-19 based on an analysis of data of 150 patients from Wuhan, China. Intensive Care Med 2020; published online March 3. DOI:10.1007/s00134-020-05991-X

TANERI, Petek Eylul et al. Anemia and iron metabolism in COVID-19: a systematic review and meta-analysis. European Journal of epidemiololgy. 10 Aug. 2020.

VARGAS, Manuel Vargas, ROJO, Christian Cortés. Ferritin levels and COVID-19. Revista Panamericana de salúd publica. Vol 44 e72. Jun 2020.

VELAVAN, Thirumalaisamy P, MEYER, Christian G. Mild versus severe COVID-19: Laboratory markers. International Journal of Infectious Diseases. Vol 95. Jun 2020.

WHO, World Health Organization. Clinical management of COVID-19: interim guidance. 2020. Disponível em Acesso em 28 de agosto de 2020.

Coordenadoria de Pesquisa e Extensão - COPEX

Departamento de Editoraçāo e Divulgaçāo Científica - DEDIC 


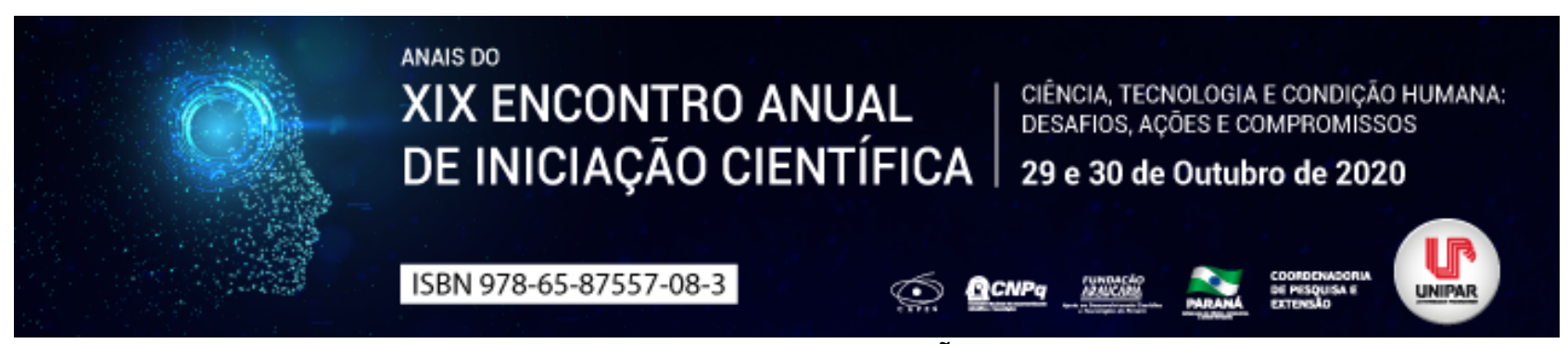

ESTUDO DO EFEITO DA Plinia cauliflora NA PREVENÇÃO DE OSTEOPOROSE EM RATAS

\begin{abstract}
${ }^{1}$ ANA CAROLINE DOS SANTOS GRUNOW, ${ }^{2}$ GABRIEL MACIEL DA SILVA, ${ }^{3}$ AMANDA CHIULO GIROTTO, ${ }^{4}$ QUEREN ALVES DE PAULA, ${ }^{5}$ GUSTAVO BARBOSA CORREA DE MORAIS, ${ }^{6}$ DANIELA DE CASSIA FAGLIONI B CERANTO
\end{abstract}

\author{
${ }^{1}$ Acadêmica bolsista do PIBIC/UNIPAR \\ ${ }^{1}$ Acadêmico do Curso de Cirurgia Periodontal e Introdução A Implantodontia - Turma VIII da UNIPAR \\ ${ }^{2}$ Acadêmica do Curso de Odontologia da UNIPAR \\ ${ }^{3}$ Acadêmica do Curso de Odontologia da UNIPAR \\ ${ }^{4}$ Acadêmico do Curso de Odontologia da UNIPAR \\ ${ }^{5}$ Docente da UNIPAR
}

Introdução: A osteoporose (OSP) é uma patologia esquelética sistêmica, osteometabólica, que induz a deterioração da microarquitetura e causa diminuição da Densidade Mineral Óssea (DMO), devido ao aumento da reabsorção e redução da formação óssea, o osso cortical fica mais poroso e frágil, sendo mais suscetíveis às fraturas. As alterações ósseas causadas pela OSP não são observadas somente em ossos longos e vértebras, mas também, nas estruturas ósseas do sistema estomatognático (NAVES et al., 2015). A doença tem origem multifatorial e é classificada em tipos I (pós menopausa) afetando principalmente o osso trabecular e II (senil) minimizando a formação óssea e afetando o osso cortical e trabecular (VARGAS et al., 2018). Considerando os danos das drogas convencionais utilizadas no tratamento da OSP, como é o caso dos bifosfonatos que causam a osteonecrose dos maxilares, a busca por métodos integrativos e complementares, que sejam tão eficazes, quanto seguros e econômicos, para a prevenção e contenção da doença, vem aumentando e muitos estudos têm sido realizados para analisar os efeitos de plantas medicinais e medicamentos fitoterápicos no tratamento da OSP (MARQUES et al., 2016).

Objetivo: Uma das plantas que chama atenção principalmente por sua ação antioxidante sendo uma ótima candidata para a prevenção da osteoporose é a Plinia cauliflora, assim, este estudo tem por objetivo avaliar o efeito terapêutico de extratos aquosos de Plinia cauliflora na perda óssea induzida por ovariectomia (OVX).

Material e Métodos: Estão sendo utilizadas Ratas Wistar fêmeas, com 90 dias de idade, pesando entre 230-250g. Os procedimentos foram aprovados pelo Comitê de Ética de Pesquisa Envolvendo o Uso de Animais da UNIPAR. Primeiramente trinta animais foram submetidos à ovariectomia (OVX) bilateral (grupos OVX). Dez animais foram submetidos à sham OVX para simular estresse cirúrgico (grupo sham). Trinta dias após a cirurgia, os animais foram divididos em 5 grupos ( $\mathrm{n}=06 / \mathrm{grupo}$ ). Sendo um grupo de falso operado e um controle. O extrato da Plinia Cauliflora foi padronizado e obtido utilizando a casca do fruto (jabuticaba), que após seca e moída é submetida por ao processo de extração por infusão e passado por um longo processo laboratorial. Os animais nos grupos controle e sham OVX receberam veículo (água filtrada) diariamente em um volume de $5 \mathrm{~mL}$ / kg. E no outro grupo as doses de Plinia cauliflora foram divididas respectivamente: $37,5 \mathrm{mg} / \mathrm{Kg}$ (dose 1), 75mg/kg (dose 2) e $150 \mathrm{mg} / \mathrm{kg}$ (dose 3) estão sendo administrados por via oral aos diferentes grupos de ratas uma vez por dia durante 45 dias. Os animais estão sendo pesados semanalmente para ajustes de dose regulares.

Resultados: Ao final dos 45 dias, as ratas foram submetidas à densitometria e a eutanásia por decapitação, foi realizada a coleta total do soro, remoção da tíbia e dos maxilares para análise mineral óssea da densidade e dosagem de hormônios como Estradiol, Testosterona, Osteocalcina (estudo em andamento).

Discussão: De acordo com Marques e seus colaboradores (2019), a prevalência da osteoporose vem aumentando com o envelhecimento populacional, sua etiologia é multifatorial e inclui sedentarismo, hábitos alimentares além de alterações hormonais, que são os fatores mais comuns e prevalentes, porque elas ocasionam redução de massa óssea. Por ser multifatorial, o seu tratamento é dificultado, até que a causa seja definida. A diminuição da massa óssea após a menopausa apresenta relação primária com o funcionamento ovariano devido o mesmo ser a principal fonte de estrogênio circulante. Esta regressão é causada porque os hormônios sexuais, principalmente os femininos, se encontram alteradas. A redução dos níveis de estrogênio provoca uma ativação na remodelação óssea, com um domínio na fase de reabsorção em relação à formação, devido ao acréscimo de osteoclasto nas superfícies dos ossos trabeculares, e no final da fase de reabsorção há uma redução nas taxas de apoptose, devido os osteoclastos serem mais ativos, isso provoca grandes cavidades que são parcialmente reparadas pelas atividades osteoblásticas. A Plinia cauliflora é uma árvore nativa do Brasil, especificamente de Minas Gerais em regiões montanhosas da Mata Atlântica e além de suas características fitoterápicas, tem um alto potencial econômico. Uma das suas principais ações é sua função antioxidante natural, devido às antocianinas do grupo dos flavonóides que inibe a oxidação dos radicais livres nas células osteoblásticas permitindo a formação da matriz óssea, protege e estimula os tecidos ricos em colágeno, além disso possui ação na regulação hormonal através da sua ligação a esteróides (KNEKT et al., 2000). A maior 
concentração destas antocianinas é na casca do fruto (REZENDE., 2010).

Conclusão: Os procedimentos experimentais com o tratamento das ratas com o extrato já foram realizados. O trabalho está na fase de análise histológica e bioquímica, para verificar a eficácia ou não da Plinia cauliflora na prevenção da osteoporose. Ao final do estudo, os resultados serão submetidos à análises estatísticas realizadas utilizando análise de variância unidirecional seguida do teste de Dunett, os valores de $p<0,05$ serão considerados significativos.

\section{Referências}

KNEKT P. et al. Quercetin intake and the incidence of cerebrovascular disease. Eur. J. Clin. Nutr., v. 54, n. 5, pp. 415-417. May. 2000.

MARQUES, M. A. A. et al Caracterização das plantas medicinais e medicamentos fitoterápicos para tratamento da osteoporose utilizados no Brasil. Arq. Ciênc. Saúde UNIPAR, Umuarama, v. 20, n. 3, p. 183-188, set./dez., 2016.

MARQUES, M. A. A. et al Osteoprotective Effects of Tribulus terrestris L.: Relationship Between Dehydroepiandrosterone Levels and Ca2+-Sparing Effect. J Med Food. v.22, n.3, p.241 247, 2019.

NAVES, R. C et al A osteoporose pode agravar a doença periodontal? Uma revisão de literatura. Revista Bahiana de Odontologia. v. 6, n. 2, p. 102-112, agosto, 2015.

REZENDE, L.C. Avaliação da atividade antioxidante e composição química de seis frutas tropicais consumidas na Bahia. Tese (Doutorado em Química) - Universidade Federal da Bahia, Programa de Pós-Graduação em Química, Salvador, 2010.

VARGAS, R. M. et al The effects of osteoporosis in the oral cavity and the contribution of the dentist surgery: literature review. Revista das Ciências da Saúde do Oeste Baiano Higia. v. 3, n. 1, p. 14-27, 2018. 


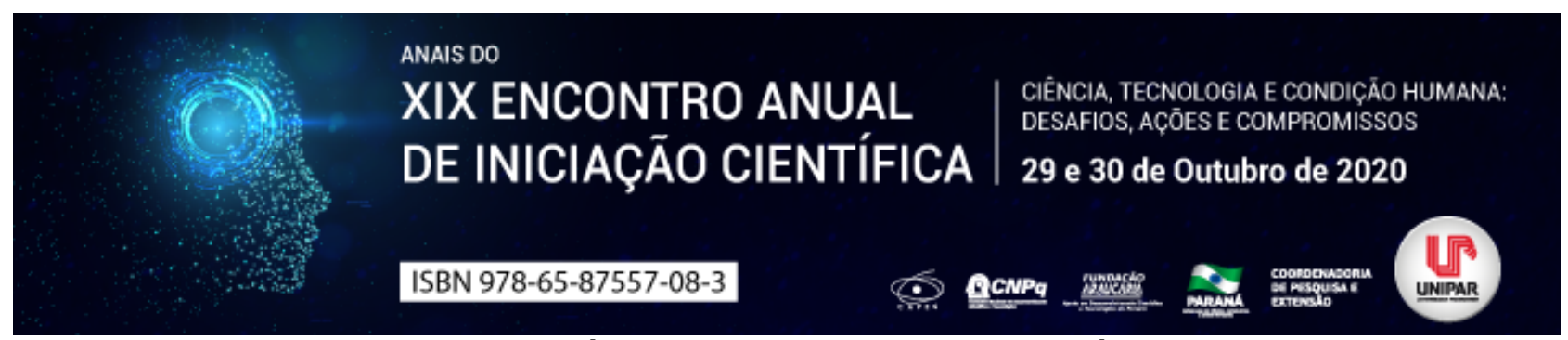

ASPECTOS CLÍNICOS DA ESTOMATITE SOB PRÓTESE

${ }^{1}$ GIOVANA SOLER DOS SANTOS, ${ }^{2}$ ANDRESSA ANDRADE NOVAES, ${ }^{3}$ ELOISA PEREIRA DE SOUZA, ${ }^{4}$ JOAO MURILO GONCALVES GAZOLA, ${ }^{5}$ SUELEN STEFANONI BRANDAO, ${ }^{6}$ DANIELA DE CASSIA FAGLIONI B CERANTO

\author{
${ }^{1}$ Acadêmico do PIC/UNIPAR \\ ${ }^{1}$ Acadêmica do Curso de Tecnicas Cirurgicas Periodontais e Introducao A Implantodontia - Turma I da UNIPAR \\ ${ }^{2}$ Acadêmica do Curso de Odontologia da UNIPAR \\ ${ }^{3}$ Acadêmico do Curso de Odontologia da UNIPAR \\ ${ }^{4}$ Acadêmica do Curso de Medicina da UNIPAR \\ ${ }^{5}$ Docente da UNIPAR
}

Introdução: A estomatite sob prótese ou estomatite protética é uma lesão frequenete, relacionada ao uso de próteses mucossuportadas. É definida como uma inflamação da mucosa subjacente à prótese removível, mais frequentemente associada à região do palato (DELGADO, et al 2016); dificilmente aparece sob prótese inferior. Por ser a estomatite protética a lesão mais encontrada, mesmo que haja variados tipos de lesões que potencialmente aparecem na mucosa associados ao uso de próteses bucais nota-se a importância de se conhecer essa patologia a fim de diagnosticá-la de maneira precisa.

Objetivo: Essa revisão da literatura objetiva identificar a estomatite sob prótese e seus aspectos.

Desenvolvimento: A estomatite protética (EP), é uma patologia que apresenta etiologia multifatorial, sendo ela uma reação inflamatória da mucosa bucal. Fatores como problemas locais microbianos, acúmulo de placa bacteriana, colonização de fungos, problemas mecânicos como porosidade na resina da prótese, relacionado a traumas causados pelo uso e deficiente higienização da prótese, favorecem a susceptibilidade à infecção por microrganismos da mucosa subjacente a prótese. Tais condições favorecem a colonização de bactérias e fungos o que pode causar infecções, a infecção mais comum é a infecção fúngica causada pela Candida albicans, entretanto, outras espécies de Candida spp também são causadoras. As leveduras do genero Candida fazem parte da microflora oral, esse fungo apresenta dimorfismo de maneira que pode apresentar-se na forma de levedura quando é inócuo, e é capaz de se diferenciar dessa forma para forma de hifa quando é patogênico. Existem outros fatores que influenciam como: distúrbios endócrinos, antibioticoterapia, corticoterapia, imunossupressão e psicofármacos, consumo excessivo de açúcar, radiação da cabeça e pescoço, idade, neoplasias, xerostomia, tabagismo, diabetes, material e idade da prótese, assim como uso contínuo e mal adaptação da prótese. Regularmente a EP é assintomática, porém, pode apresentar sintomatologia rara, sendo os sintomas: dor, halitose, prurido e queimação. Em relação aos sinais se destacam alteração na cor e textura da mucosa, de acordo com Neves (2015) a classificação mais utilizada na literatura é a de Newton, dividida em 3 tipos, sendo: Tipo I Hiperemia punctiforme - Presença de petéquias e inflamação de pequenas áreas delimitadas, com poucas áreas de hiperemia, limitada aos ductos das glândulas salivares palatinas menores principalmente posterior do palato; Tipo II Hiperemia difusa - Superfície com áreas eritematosas difusas, a mucosa apresenta-se atrófica com textura lisa; Tipo III Hiperemia granular - Mucosa com hiperplasia granular hiperémica que pode estar sob toda a região coberta pela prótese. Esta baseia-se em critérios clínicos que, por vezes, surgem associados dificultando a sua classificação. O diagnóstico dessa patologia é quase sempre é baseado em sintomas e sinais clínicos, demonstrando a relevância de conhecê-los. A presença da prótese é o fator dominante para a ocorrência da estomatite protética e a fim de preveni-la é importante a manutenção e utilização apropriadas da prótese, tanto quanto uma correta higienização oral e higienização da prótese, assim como a remoção da prótese durante o sono; para isso a orientação do uso e o acompanhamento periódico são essenciais. Dessa maneira é possível sustentar condições funcionais, evitando prejuízo aos tecidos de suporte.

Conclusão: A associação da estomatite protética a um fator de causa particular não é permissível, já que um fator tido separadamente não é considerável válido para seu surgimento. Devido a essa premissa, todos fatores etiológicos predisponentes da estomatite protética precisam ser contidos, a fim de garantir condições de higidez aos pacientes.

\title{
Referências
}

SOARES, Diana Gabriela de Souza. CARVALHO, Maria de Fátima Farias Peixoto. PADILHA, Wilton Wilney Nascimento. Estudo Clínico e Micológico em Portadores de Estomatite Protética. Revista Brasileira de Ciências da Saúde, v. 12, n. 2, p. 169-180, 2008.

SCALERCIO, Michelle. VALENTE, Tatiane. ISRAEL, Mônica Simões. RAMOS, Maria Eliza. Estomatite protética versus candidíase: diagnóstico e tratamento. RGO, Porto Alegre, v. 55, n. 4, p. 395-398, out/dez.2007.

DELGADO, António. VITORINO, Lucia. CARVALHO, Joana. FÉLIX, Sérgio. Estomatite Protética: uma visão atual. Journal 
Dentistry, p. 38-40, dez.2016.

SESMA, Newton. MORIMOTO, Suzana. Estomatite protética: etiologia, tratamento e aspectos clínicos. Journal of Biodentistry and Biomaterials, São Paulo, n. 2, p. 24-29, set./fev.2011.

CARVALHO de OLIVEIRA, Terezinha Rezende. FRIGERIO, Maria Luiza Moreira Arantes. YAMADA, Maria Cecília Miluzzi. BIRMAN, Esther Goldenberg. Avaliação da estomatite protética em portadores de próteses totais. Pesqui Odontol Bras, v. 14, n. 3, p. 219-224, jul./set.2000.

NEVES, Ivone Maria dos Santos Mota. Abordagem do paciente com estomatite protética. Porto, p. 1-76, 2015.

Coordenadoria de Pesquisa e Extensão - COPEX

Departamento de Editoraçāo e Divulgaçāo Científica - DEDIC 


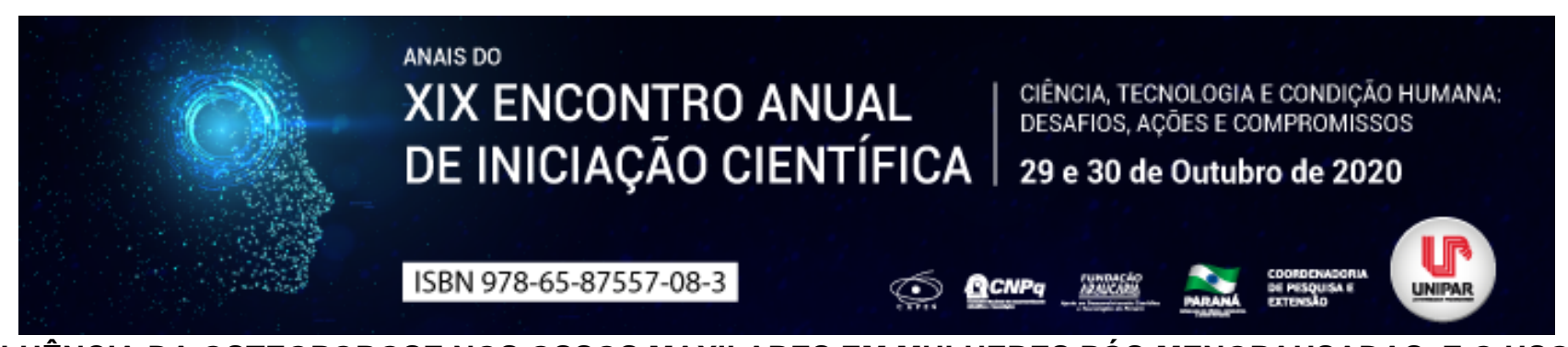

INFLUÊNCIA DA OSTEOPOROSE NOS OSSOS MAXILARES EM MULHERES PÓS-MENOPAUSADAS E O USO DE FITOTERÁPICOS

\begin{abstract}
${ }^{1}$ CARLA ROSEANE ZANFRILLI PAGANINI, ${ }^{2}$ EMERSON LUIZ BOTELHO LOURENÇO, ${ }^{3}$ DANIELA DE CASSIA FAGLIONI BOLETA CERANTO

${ }^{1}$ Acadêmica no Mestrado Profissional em Plantas Medicinais e Fitoterápicos na Atenção Básica. UNIPAR Umuarama/PR. ${ }^{1}$ Docentes no Mestrado Profissional em Plantas Medicinais e Fitoterápicos na Atenção Básica. UNIPAR Umuarama/PR ${ }^{2}$ docente do Mestrado Profissional em Plantas Medicinais e Fitoterápicos na Atenção Básica. UNIPAR Umuarama/PR
\end{abstract}

Introdução: A osteoporose (OSP) é uma doença óssea progressiva ocasionada por diminuição da massa óssea, levando a uma maior fragilidade e um maior risco de fraturas (MARQUES et al, 2019). Sendo caracterizada como uma doença silenciosa e diagnóstico tardio, o que tem provocado uma aumento no número de pessoas afetadas no Brasil de 7,5 milhões em 1980 para 15 milhões no ano 2000, chegando a acometer 35 a 52\% das mulheres com mais de cinquenta anos e uma proporção de 19 a $39 \%$ dos homens (DOURADO, et al. 2012). Como ocorre com várias outras doenças, consequentemente, o agravamento da patologia faz com que ocorram elevados custos dispendidos para o tratamento que impactam muito na saúde pública. Considerando não apenas o fator financeiro, mas também o bem estar do paciente que, muitas vezes apresenta diversos efeitos colaterais com o uso de tratamentos convencionais, o que tem ocasionado osteonecrose dos maxilares após o uso de alguns medicamentos como é o caso dos bisfosfonatos. A busca por terapias naturais e complementares deve ser uma constante. Dentre os métodos naturais de tratamento, os fitoterápicos se destacam com resultados bastante promissores.

Objetivo: O presente trabalho pretende abordar, em formato de revisão da literatura, os conhecimentos atuais sobre a possível influência da osteoporose nos ossos maxilares de mulheres pós-menopausadas, bem como o uso de fitoterápicos e possíveis efeitos da Plinia cauliflora para prevenção e tratamento da osteoporose.

Desenvolvimento: Devido ao envelhecimento populacional, a necessidade de métodos preventivos para a osteoporose vem aumentando (MARQUES et al, 2019). Segundo a Associação Brasileira de Avaliação Óssea e Osteometabolismo (ABRASSO), cerca de 200 milhões de mulheres sofrem com a doença no mundo, de acordo com International Osteoporosis Foundation (IOF) e no Brasil, são 10 milhões de pessoas atingidas por esse problema (dados ABRASSO 2017). Levando em conta que o país tinha 28 milhões de idosos em 2016, ou 13,5\% do total da população, e que em dez anos, chegará a 38,5 milhões, 17,4\% do total de habitantes, segundo o Instituto Brasileiro de Geografia e Estatística (IBGE), focar no esclarecimento público sobre a osteoporose é urgente e essencial. A diminuição da massa óssea após a menopausa apresenta relação primária com o funcionamento ovariano devido o mesmo ser a principal fonte de estrogênio circulante. A densidade mineral óssea (DMO), em homens e mulheres diminui gradualmente na faixa etária acima de 35 anos, ocorre mais rapidamente em mulheres, especialmente após a menopausa, sendo considerada três vezes mais comum entre mulheres do que homens (MENEZES; DE PAULA; PEREIRA, 2020). Esta regressão é causada porque os hormônios sexuais, principalmente os femininos, se encontram alterados. A redução dos níveis de estrogênio provoca uma ativação na remodelação óssea, com um domínio na fase de reabsorção em relação à formação, devido ao acréscimo de osteoclasto nas superfícies dos ossos trabeculares, e no final da fase de reabsorção há uma redução nas taxas de apoptose, devido os osteoclastos serem mais ativos, isso provoca grandes cavidades que são parcialmente reparadas pelas atividades osteoblásticas. A perda da matriz óssea decorrente da menopausa apresenta como característica a excessiva atividade dos osteoclastos (KEATING et al, 2000). Em vista do caráter multifatorial da OSP, é necessário que os profissionais que se disponham ao tratamento, avaliem e considerem todos os fatores envolvidos. Através de maiores investimentos, bem como o crescimento de pesquisas realizadas com plantas medicinais, a fim de desenvolver medicamentos através de seus princípios ativos, podem ser um caminho para alternativas eficazes e viáveis ao tratamento de várias doenças epidemiologicamente relevantes na população (CURY, 2005). Dentre as alternativas fitoterápicas encontramos a Jabuticaba (Plinia cauliflora Berg), que além de apresentar características medicinais, têm um alto potencial econômico. Dentre as espécies nativas, a Plinia cauliflora é uma árvore originária do Brasil, mais especificamente de Minas Gerais, em regiões montanhosas da Mata Atlântica (https://www.criasaude.com.br/fitoterapia/jabuticaba.html 2018). Os flavonoides estão presentes na maioria dos tecidos vegetais. Estes grupos dão cor às folhas, flores e frutos e desempenham funções de defesa, protegendo contra irradiação UV, dentre outras (LAGE et al, 2014). Estudos constataram que a casca da Plinia cauliflora possui maior concentração de antocianinas, que tem uma alta potencialização na ação antioxidativa (REZENDE, 2010), sendo uma candidata com potencial à prevenção da osteoporose.

Conclusão: $O$ extratos de $P$. cauliflora, de acordo com a fitoquímica que o integra, apresenta fortes indícios de melhora na prevenção da osteoporose e melhora na qualidade de ossos com osteoporose propriamente dita, trazendo assim para a população uma alternativa para o combate a uma doença que apresenta crescimento ascendente, principalmente na população 
de maior idade, o quese pretende comprovar com os resultados do projeto que está em andamento.

\section{Referências}

Associação Brasileira de Avaliação Óssea e Osteometabolismo - ABRASSO. Disponível em: . Acesso em: 30 ago. 2020. CURY, Viviane Goreth. Eficácia terapêutica da Casearia sylvestris sobre herpes labial e perspectiva de uso em saúde coletiva. Orientador: Prof. Dr.Francisco Carlos Groppo. Tese (Mestre em Odontologia em Saúde Coletiva). Universidade Estadual de Campinas, Piracicaba SP , 2005.

DOURADO, Caroline Marangon et al. Densidade mineral óssea em idosos e presença de fatores de risco nutricionais para osteoporose.111 f. Dissertação (Mestrado em Gerontologia Biomédica) - Pontifícia Universidade Católica do Rio Grande do Sul, Porto Alegre, 2012.

KEATING, Manassiev. Estrogens and Osteoporosis, menopause Biology and Pathobiology. Rev, Academic Press. p.509-33. 2000.

LAGE, Fabiola Fonseca. Casca de jabuticaba: inibição de enzimas digestivas, antioxidante, efeitos biológicos sobre o fígado e perfil lipídico. Tese (Doutorado em Agroquímica) - Universidade Federal de Lavras. Lavras MG. Feb. 2014.

MARQUES, Marcia Alessandra Marques. Osteoprotective Effects of Tribulus terrestris L.: Relationship Between Dehydroepiandrosterone Levels and Ca2+ -Sparing Effect. J Med Food. v. 22, n.3, p.241 247, março. 2019.

MENEZES, Rodrigo Coelho Bezerra; DE PAULA, Bruna Balbino; PEREIRA, Yamba Carla Lara. Medição da cortical óssea através de radiografia panorâmica para diagnóstico de osteopenia e osteoporose em mulheres. Medicina (Ribeirão Preto), v. 53, n. 1, p. 9-13, 2020.

REZENDE, Larissa Cavalcante. Avaliação da atividade antioxidante e composição química de seis frutas tropicais consumidas na Bahia. Tese (Doutorado em Química) - Universidade Federal da Bahia, Programa de Pós-Graduação em Química, Salvador, 2010. 


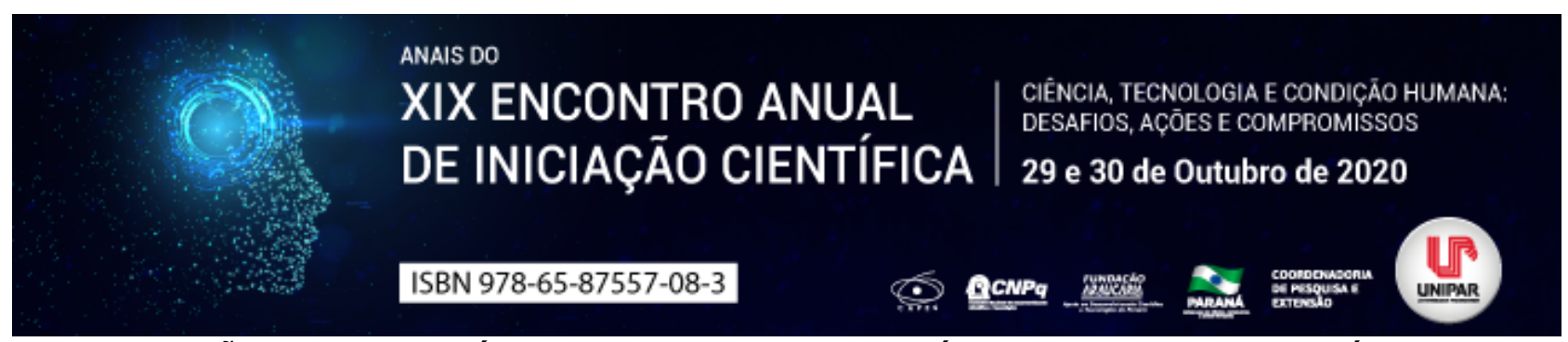

INTERVENÇÕES FARMACOLÓGICAS NA OSTEOPOROSE PÓS-MENOPAUSA: O QUE HÁ DE NOVO?

\begin{abstract}
${ }^{1}$ Alice Pereira de Siqueira Nascimento, ${ }^{2}$ ANDREW PEREIRA DA SILVA, ${ }^{3}$ GABRIEL VÍTOR LIMA DE ANDRADE, ${ }^{4}$ LUAN NOVAES LEITE, ${ }^{5}$ PEDRO ÉRICO ALVES DE SOUZA, ${ }^{6}$ FABRICIO OLIVEIRA SOUTO
\end{abstract}

${ }^{1}$ Acadêmica do curso de Medicina da UFPE - CAA
${ }^{1}$ Acadêmico do curso de Medicina da UFPE - CAA
${ }^{2}$ Acadêmico do curso de Medicina da UFPE - CAA
${ }^{3}$ Acadêmico do curso de Medicina da UFPE - CAA
${ }^{4}$ Acadêmico do curso de Medicina da UFPE - CAA
${ }^{5}$ Docente do curso de Medicina da UFPE - CAA

Introdução: A osteoporose caracteriza-se pela deterioração microarquitetural do tecido ósseo, resultando em fragilidade deste tecido. Assim, há um maior risco de fraturas, principalmente nas vértebras, rádio distal e fêmur proximal. Tais casos estão relacionados com a menor qualidade e expectativa de vida, sendo considerados de relevante questão de saúde pública. Grande parte desses pacientes é representada pelas mulheres na pós-menopausa, devido à redução da produção ovariana de estrogênios, a qual desequilibra negativamente os processos de formação e remodelação ósseas (EASTELL, et al. 2016; RADOMINSKI, et al. 2017). Nesse sentido, o uso de intervenções farmacológicas nessas pacientes é de extrema importância para evitar a osteoporose.

Objetivo: Reconhecer novidades farmacológicas na terapêutica da osteoporose pós-menopausa, enfatizando sua aplicabilidade clínica.

Desenvolvimento: Inicialmente, deve-se destacar que a estratégia de decisão medicamentosa depende do risco estimado para fraturas em cada paciente. Para isso, utilizam-se ferramentas de avaliação, como o FRAX, que a partir de alguns fatores de risco,- idade, sexo, tabagismo, alcoolismo, índice de massa corporal, dentre outros -, é calculada a probabilidade em 10 anos de fraturas osteoporóticas maiores (KANIS, et al. 2017). Desse modo, as medicações visam a redução desse risco de fraturas ósseas. As principais opções farmacológicas utilizadas atualmente são os bisfosfonatos orais e injetáveis, denosumabe, estrogênios e teriparatida (TU, et al. 2018). Porém, este trabalho propõe-se a analisar as inovações terapêuticas referentes ao tema, evidenciando os seguintes fármacos: romosozumabe, abaloparatida e odanacatibe. O romosozumabe é um anticorpo monoclonal com atividade anti-esclerostina que age inibindo essa proteína, induzindo o aumento da formação e a diminuição da reabsorção óssea, sendo demonstrado no exame de densitometria mineral óssea (DMO) (COSMAN, et al. 2016). Além disso, reduz o risco de fraturas principalmente vertebrais, mas com ação também em ossos não vertebrais e no quadril (SAAG, et al. 2017). Adicionalmente, seu uso mostrou-se um risco para pacientes com alto risco cardiovascular ou com infarto agudo do miocárdio ou acidente vascular encefálico prévio (SHOBACK, et al. 2020). Já a Abaloparatida é um peptídeo anabólico análogo da proteína relacionada ao receptor 1 do Paratormônio, que tem atividade de redução do risco de fraturas lombares, do colo femoral e de quadril, tendo sido demonstrado maior resposta a esse peptídeo quando comparado ao teriparatida, um anabólico já usado (MILLER, et al. 2019). A abaloparatida, segundo Hernandez e colaboradores (2019) diminui de forma relevante os riscos de fraturas vertebrais e não vertebrais. Além disso, aumentou marcadores associados a formação e remodelação óssea (propeptídeo aminoterminal do procolágeno tipo 1 e telopeptídeo C-terminal do colágeno tipo 1). Ainda segundo Hernandez e colaboradores (2019), o romosozumabe é o mais eficaz em aumentar o valor da DMO entre abaloparatida e teriparatida. O odanacatibe, por sua vez, é um inibidor seletivo e reversível da catepsina K, a principal enzima degradadora de colágeno ósseo. Nesse sentido, tal medicamento promove reduções na reabsorção óssea e no consequente risco de fraturas, sem afetar significativamente a formação desse tecido, aumentando a densidade mineral (STONE, et. al. 2019). Porém, sua utilização foi associada a um maior risco cardiovascular em mulheres pós-menopausa, destacando-se a incidência de casos de derrame e episódios de fibrilação e flutter atrial (MCCLUNG, et al. 2019).

Conclusão: No presente estudo, foram encontradas três principais novidades farmacológicas na terapêutica de osteoporose em mulheres na pós-menopausa. Dentre estas, dois fármacos (abaloparatida e romosozumabe) apresentaram bons resultados comparando-se às intervenções já estabelecidas. Porém, o romosozumabe demonstrou efeitos colaterais cardiovasculares relevantes, sendo contra-indicado para pessoas com comorbidades desse tipo. O odanacatibe foi relacionado a riscos maiores que benefícios. Nesse último caso, devido aos eventos cardiovasculares associados, como derrames. Em suma, as duas primeiras drogas citadas são promissoras, configurando-se como ferramentas novas e adequadas para individualizar 0 tratamento dessa população. Deve-se ainda realizar mais estudos acerca de tais medicamentos, buscando o aprofundamento e comprovação de novos resultados. 


\section{Referências}

COSMAN, F. et al. Romosozumab Treatment in Postmenopausal Women with Osteoporosis. N. Engl. J. Med., [s.I.], v. 375, n. 16, p. 1532-1543, out. 2016.

EASTELL, R. et al. Postmenopausal Osteoporosis. Nat. Rev. Dis. Primers, Londres, v. 2, n. 1, p. 1-16, set. 2016.

HERNANDEZ, A. D. et al. Comparative efficacy of bone anabolic therapies in women with postmenopausal osteoporosis: A systematic review and network meta-analysis of randomized controlled trials. Maturitas, [s.l.], v. 129, n. 1, p. 12-22, nov. 2019.

MCCLUNG, M. R. et al. Odanacatib for the treatment of postmenopausal osteoporosis: results of the LOFT multicentre, randomised, double-blind, placebo-controlled trial and LOFT Extension study. Lancet Diabetes Endocrinol., Londres, v. 7, n. 12, p. 899-911, dez. 2019.

KANIS, J. A. et al. FRAX Update. J. Clin. Densitom., [s.I.], v. 20, n. 4, p. 360-367, jul./set. 2017.

MILLER, P. D. et al. Bone mineral density response rates are greater in patients treated with abaloparatide compared with those treated with placebo or teriparatide: Results from the ACTIVE phase 3 trial. Bone, Londres, v. 120, n. 1, p. 137-140, mar. 2019.

RADOMINSKI, S. C. et al. Diretrizes brasileiras para o diagnóstico e tratamento da osteoporose em mulheres na pós-menopausa. Rev. Bras. Reumatol., São Paulo, v. 57, supl. 2, p. 452-466, jun. 2017.

SAAG, K. G. et al. Romosozumab or Alendronate for Fracture Prevention in Women with Osteoporosis. N. Engl. J. Med., [s.I.], v. 377, n. 15, p. 1417-1427, out. 2017.

SHOBACK, D. et al. Pharmacological Management of Osteoporosis in Postmenopausal Women: An Endocrine Society Guideline Update. J. Clin. Endocr. Metab., [s.I.], v. 105, n. 3, p. 587 594, mar. 2020.

STONE, J. A. Clinical and translational pharmacology of the cathepsin $\mathrm{K}$ inhibitor odanacatib studied for osteoporosis. Br. J. Clin. Pharmacol., Londres, v. 85, n. 6, p. 1072-1083, jun. 2019.

TU, K. N. et al. Osteoporosis: A Review of Treatment Options. Pharm. Ther., [s.I.], v. 43, n. 2, p. 92-104, fev. 2018. 


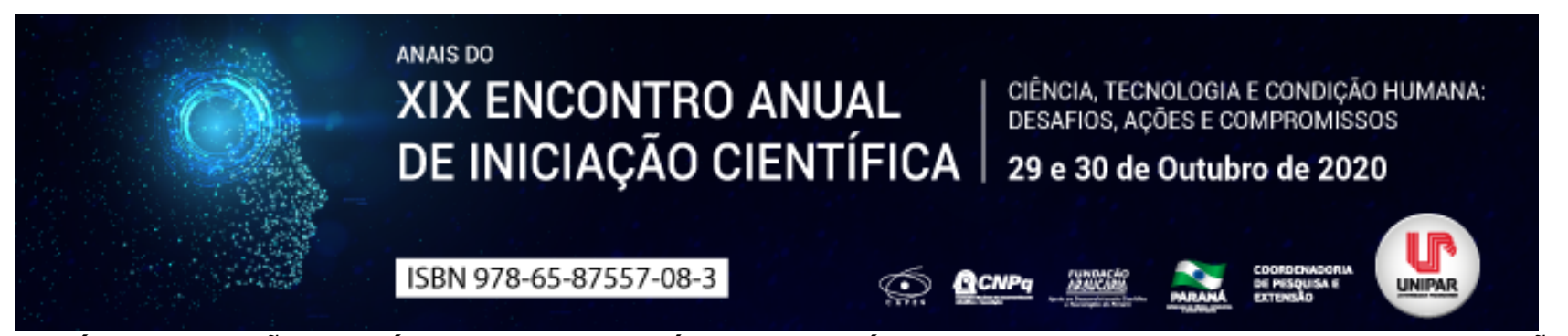

A POSSÍVEL RELAÇÃO DA SÍNDROME DOS OVÁRIOS POLICíSTICOS E O GENE FTO - ESTUDO DE REVISÃO

\author{
${ }^{1}$ VITORIA MARIA RAUBER MARCELINO, ${ }^{2}$ MARIA ELENA MARTINS DIEGUES, ${ }^{3}$ RICARDO MARCELO ABRAO, ${ }^{4}$ LUCIANO \\ SERAPHIM GASQUES
}

${ }^{1}$ Acadêmica do curso de Medicina/UNIPAR

${ }^{1}$ Docente da UNIPAR

${ }^{2}$ Docente da UNIPAR

${ }^{3}$ Docente da UNIPAR

Introdução: A síndrome dos ovários policísticos (SOP) é uma doença endócrina que afeta uma em cada 15 mulheres em idade reprodutiva, caracterizada por um aumento na produção dos hormônios masculinos, onde, dentre seus sintomas, destacam-se a anovulação crônica e as manifestações de hiperandrogenismo, aliados a distúrbios reprodutivos (ANDRADE et al., 2016). Com relação a sua patogênese, está associada a susceptibilidade ambiental e a fatores genéticos. Nesse contexto se insere o gene FTO (fat mass and obesity associated), cujos portadores apresentam, assim como na SOP, resistência à insulina e predisposição a obesidade (RAMOS, 2014).

Objetivo: Verificar a relação do gene FTO com a síndrome dos ovários policísticos por meio de revisão de literatura.

Desenvolvimento: A SOP tem sua prevalência variável, a depender dos critérios que são utilizados para o diagnóstico, quando utilizado os critérios do National Institutes of Health $(\mathrm{NIH})$ sua prevalência é de $9 \%$, porém, se utilizados os critérios de Rotterdam, essa prevalência pode chegar a até 18\% (RAMOS, 2014). Nessas pacientes são observados os sintomas clínicos da doença, como a anovulação crônica e as manifestações de hiperandrogenismo, assim como alterações metabólicas, além de resistência à insulina, culminando em maiores índices de obesidade. Nos pacientes portadores de variantes específicas do FTO foram observados aumento da massa gorda, resistência insulínica e anormalidades metabólicas (JUHÁSZ, 2019). As semelhanças observadas entre as apresentações clínicas de polimorfismos específicos do gene FTO e a SOP originaram a hipótese de que guardassem uma relação, podendo estas variações do FTO estar diretamente associadas à susceptibilidade de SOP. Porém ainda são poucos os estudos que objetivam fazer essa relação, havendo controvérsias sobre a influência do gene FTO na síndrome dos ovários policísticos. Sendo assim, sugere-se que o gene FTO atue em conjunto com outros fatores, como mecanismos epigenéticos que modulam a expressão gênica, a idade da paciente e os hábitos adotados pela mesma, devendo-se levar em conta, nesta análise, que a SOP é multifatorial, o que dificulta inferir uma relação estrita com um único fator, como no caso do gene FTO (RIBEIRO, 2019).

Conclusão: A relação entre o gene FTO e a síndrome dos ovários policísticos ainda é controversa, uma vez que a SOP é uma patologia multifatorial, podendo haver diferenças na análise das diferentes etnias. Entretanto, pacientes que apresentaram a SOP em conjunto com variações específicas do gene FTO tiveram um aumento nas taxas de desenvolvimento do sobrepeso e diabetes como resultado da resistência à insulina.

\title{
Referências
}

ANDRADE, Victor Hugo Lopes de. et al. Aspectos atuais da síndrome do ovário policístico: uma revisão da literatura. Rev. Assoc. Med. Bras. [online]. 2016, vol.62, n.9, pp.867-871. Disponível em: https://doi.org/10.1590/1806-9282.62.09.867. Acesso em: 03 ago 2020.

JUHÁSZ, Paulo Henrique Silva Brandão. Epigenética e genética da obesidade: uma análise do gene FTO, sua prevalência e relação gene nutriente. Orientadora: Maria Daniela de Araújo Medeiros Dias. 2019. Trabalho de conclusão de curso (Graduação em Nutrição) - Faculdade de Ciências da Educação e Saúde, Centro Universitário de Brasília, Brasília, 2019.

RAMOS, Ramon Bossardi. Avaliação de polimorfismos em genes relacionados à obesidade e diabetes em mulheres com a síndrome dos ovários policísticos e associação com variáveis metabólicas e hormonais. Orientadora: Poli Mara Spritzer. 2014. 79 f. Tese (Doutorado em Ciências Médicas) Universidade Federal do Rio Grande do Sul, Porto Alegre, 2014.

RIBEIRO, Camila Toffoli. Perfil de metilação dos genes POMC e FTO em pacientes portadoras da Síndrome dos Ovários Policísticos: um estudo caso-controle. Orientadora: Ana Carolina Japur de Sá Rosa e Silva. 2019. Tese (Doutorado em Ciências Médicas) Faculdade de Medicina de Ribeirão Preto, Ribeirão Preto, 2019. 


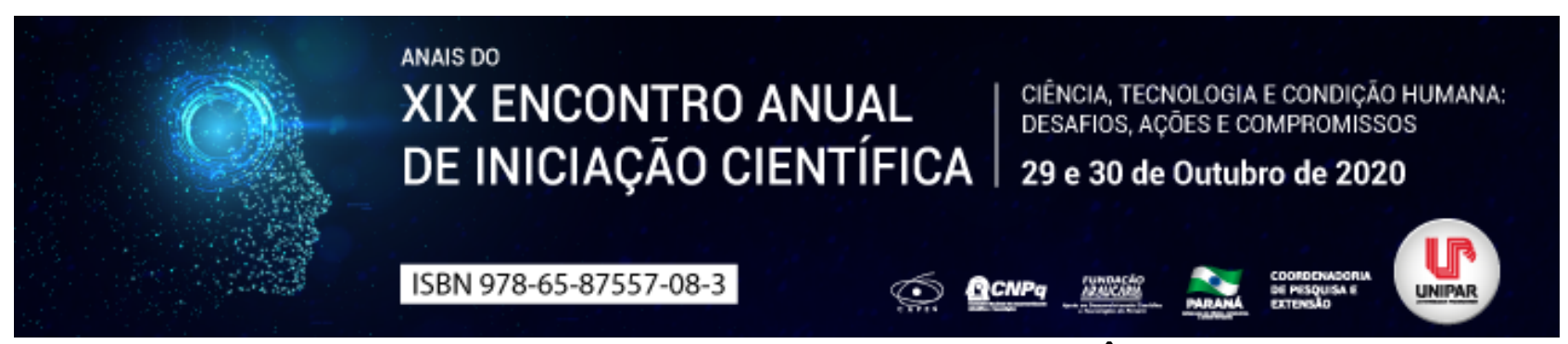

FATORES DE RISCO PARA O DESENVOLVIMENTO DO CÂNCER BUCAL

\begin{abstract}
${ }^{1}$ GISELE APARECIDA SPADIM, ${ }^{2}$ ANA MARIA DA SILVA, ${ }^{3}$ LEISLE VERONICA PRESTES, ${ }^{4}$ GABRIEL MACIEL DA SILVA, ${ }^{5}$ BEATRIZ AYUMI SHIOTANI, ${ }^{6}$ DANIELA DE CASSIA FAGLIONI B CERANTO
\end{abstract}

\author{
${ }^{1}$ Acadêmica do Curso de Odontologia PIC/UNIPAR \\ ${ }^{1}$ Acadêmica do Curso de Odontologia PIBIC/UNIPAR \\ ${ }^{2}$ Acadêmica do Curso de Odontologia da UNIPAR \\ ${ }^{3}$ Acadêmico do Curso de Odontologia PIBIC/UNIPAR \\ ${ }^{4}$ Acadêmica do Curso de Odontologia PIC/UNIPAR \\ ${ }^{5}$ Docente da UNIPAR
}

Introdução: A taxa de prevalência de câncer bucal (CB) no Brasil aponta este tumor como o quinto mais frequente entre os homens, e o sétimo entre as mulheres de acordo com estimativa realizada pelo Instituto Nacional de Câncer (INCA-2020). A etiologia do câncer de boca é multifatorial, sendo o tabaco e o álcool os fatores de risco mais importantes. Além destes, a exposição solar excessiva sem a devida proteção ao longo dos anos constitui-se em um considerável fator de risco para o câncer de boca, especialmente o de lábio. Outros fatores, como papilomavírus humano (HPV), dieta e ocupação, vêm sendo estudados com o intuito de investigar sua implicação na carcinogênese bucal. Os resultados apontam para uma associação entre tais fatores e o câncer de boca (ANDRADE et al., 2015). Esse tipo de câncer pode ser detectado simplesmente com visualização da cavidade oral em busca de lesões, sendo um método de baixo custo e que pode ser feito pelo próprio indivíduo. Apesar disso, a maior parte dessas neoplasias é diagnosticada nas fases mais avançadas da doença (estágios III e IV) (DE SOUZA TORRES et al., 2016).

Objetivo: Fazer uma revisão da literatura sobre os principais fatores de risco para o desenvolvimento do câncer bucal, bem como descrever e comentar sobre a importância de identificar essa patologia em seu estado de início.

Desenvolvimento: $O$ câncer pode ser definido como a multiplicação desordenada de células defeituosas ou atípicas, que não conseguem ser debeladas, totalmente, pelo sistema imunológico, por razão ainda desconhecida. Esse crescimento celular descontrolado pode vir a comprometer tecidos e órgãos. A incidência de câncer de boca e de faringe tem aumentado no mundo nas últimas décadas, acompanhando o aumento do consumo de tabaco e de bebidas alcoólicas. Apesar do sexo masculino ser o mais acometido pela doença, afirma-se que as mulheres estão cada vez mais expostas a essa lesão por estarem fumando e fazendo uso de bebidas alcoólicas no mesmo nível que os homens (DOS SANTOS DOMINGOS et al., 2017). O cigarro representa o maior risco para o desenvolvimento dessa doença, sendo que seu risco varia de acordo com o consumo, ou seja, quanto mais frequente for o ato de fumar, maiores as chances de desenvolver câncer de boca. $O$ risco de câncer aumenta de acordo com o início precoce do tabagismo, a quantidade de cigarros fumados e o número de anos que a pessoa fuma. Assim, o tabaco, além de ser um fator de risco para o câncer, é também um importante fator que dificulta o tratamento e o controle das neoplasias em geral. A luz ultravioleta representa um importante fator de risco para o desenvolvimento de câncer de lábio, já que a incidência aumenta principalmente nas pessoas de pele clara, com ocupações externas e que residam ou trabalhem em áreas rurais (DE SOUZA TORRES et al., 2016). O álcool está associado com o aumento da proliferação celular. O consumo de álcool, especialmente o etanol, interfere no reparo do DNA e pode ter um efeito imunossupressor. Por um mecanismo ainda desconhecido, o álcool é capaz de impossibilitar que as células epiteliais organizem a barreira de permeabilidade, que é fundamentalmente composta por lipídios e que possui a função de impedir a desidratação e a penetração de agentes externos. $O$ processo se dá pela conversão do álcool pela enzima álcool desidrogenase (ADH) em acetaldeído, e este em acetato, pela enzima aldeído desidrogenase (ALDH). O acetato alcança diferentes partes do organismo, podendo ser utilizado na produção de energia ou de outras moléculas, pela rota de degradação semelhante à da glicose. No entanto, como a atividade da ALDH é baixa na cavidade oral, pode haver acúmulo de acetaldeído no epitélio bucal. (CARRARD et al., 2008)

Conclusão: Conclui-se que o tabaco, o álcool e os fatores genéticos, são sim grandes predisponentes para o desenvolvimento do câncer bucal. Nesse sentido, o cirurgião dentista deve estar preparado para realizar um minucioso exame intra-oral e extraoral, avaliando sempre a presença de lesões pré-cancerígenas, que uma vez diagnosticadas e tratadas no seu estágio inicial, pode impedir a progressão da lesão.

\title{
Referências
}

ANDRADE, Jarielle Oliveira Mascarenhas et al. Fatores associados ao câncer de boca: um estudo de caso-controle em uma população do Nordeste do Brasil. Revista Brasileira de epidemiologia, v. 18, p. 894-905, 2015. 
CARRARD, Vinícius Coelho et al. Álcool e câncer bucal: considerações sobre os mecanismos relacionados. Revista brasileira de cancerologia, v. 54, n. 1, p. 49-56, 2008.

DE SOUZA TORRES, Stella Vidal et al. A importância do diagnóstico precoce de câncer bucal em idosos. Rev Soc Bras Clin Med, v. 14, n. 1, p. 57-62, 2016.

DOS SANTOS DOMINGOS, Patricia Aleixo et al. Câncer bucal: um problema de saúde pública. Revista de Odontologia da Universidade Cidade de São Paulo, v. 26, n. 1, p. 46-52, 2017.

Coordenadoria de Pesquisa e Extensão - COPEX

Departamento de Editoraçāo e Divulgaçāo Científica - DEDIC 


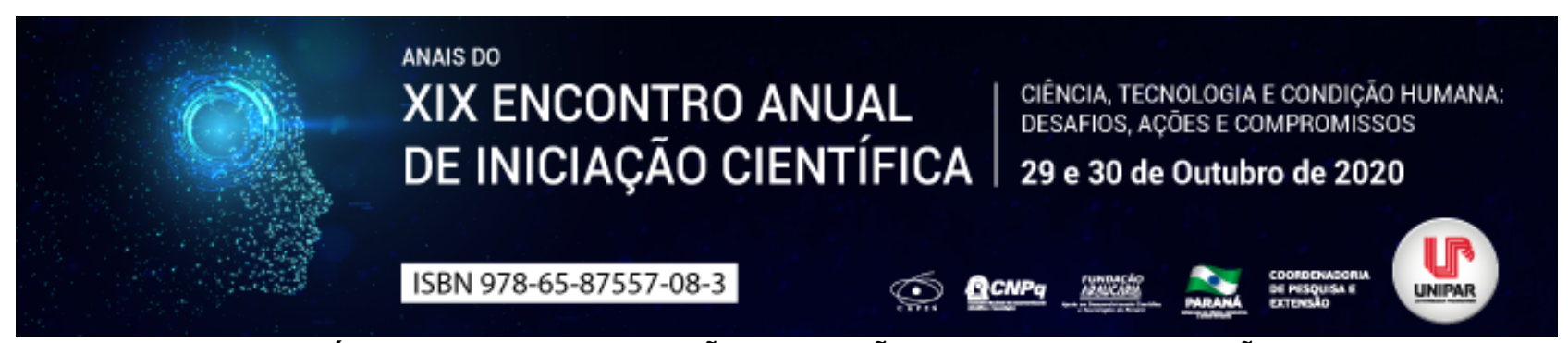

O USO DE FITOTERÁPICOS NA CICATRIZAÇÃO DE LESÕES ORAIS: UMA REVISÃO DE LITERATURA

\begin{abstract}
${ }^{1}$ HELOISA GARCIA FRANCOZO, ${ }^{2}$ ANDRESSA ANDRADE NOVAES, ${ }^{3}$ GISELE APARECIDA SPADIM, ${ }^{4}$ ARGEMIRO RIBEIRO DE ALMEIDA NETO, ${ }^{5}$ JOAO MURILO GONCALVES GAZOLA, ${ }^{6}$ DANIELA DE CASSIA FAGLIONI B CERANTO
\end{abstract}

${ }^{1}$ Discente PIC do Curso de Odontologia/UNIPAR
${ }^{1}$ Discente PIBIC do Curso de Odontologia/UNIPAR
${ }^{2}$ Discente PIC do Curso de Odontologia/UNIPAR
${ }^{3}$ Discente PIC do Curso de Odontologia /UNIPAR
${ }^{4}$ Discente PIBIC do Curso de Odontologia/UNIPAR
${ }^{5}$ Docente do Curso de Odontologia e Medicina/UNIPAR

Introdução: Os medicamentos fitoterápicos são obtidos a partir de plantas, podendo ser utilizados em forma de chás, soluções, comprimidos, pomadas, dentre outros modos. As afecções bucais mais comuns são a cárie, a gengivite, a periodontite, estomatite aftosa, herpes simples e problemas de cicatrização na mucosa bucal, diante disso a fitoterapia pode ser utilizada para o tratamento destas patologias (BOHNEBERGER, et al, 2019)

Objetivo: O presente trabalho tem como objetivo revisar a literatura sobre os diferentes fitoterápicos que podem ser utilizados, na Odontologia, para favorecer e ajudar na cicatrização de lesões bucais em geral.

Desenvolvimento: Os medicamentos fitoterápicos são obtidos a partir de plantas, podendo ser utilizados em forma de chás, soluções, comprimidos, pomadas, dentre outros modos. As afecções bucais mais comuns são a cárie, a gengivite, a periodontite, a estomatite aftosa, o herpes simples e problemas de cicatrização na mucosa bucal (BOHNEBERGER, et al 2019), de certa forma, todas tendo o envolvimento de agentes infecciosos. As plantas que são usadas com ação terapêutica possuem diversas propriedades entre elas: ação antimicrobianas, anti-inflamatórias, cicatrizantes e analgésicas (ALELUIA, et al, 2015), portanto, podem ser efetivas no tratamento de doenças bucais, o que desperta interesse entre os pesquisadores para associar a ação dos princípios ativos das plantas ao tramentos destas patologias. Bohneberger, et al, (2019) estudaram o princípio ativo da aloé vera, no preparo de enxaguatórios bucais e géis dentários, com a função de eliminar bactérias pelas suas propriedades antimicrobianas e antisépticas, com resultados positivos. O mesmo agente ativo pode ainda ser usado após cirurgias periodontais e de exodontia, nos casos de gengiva traumatizada e de mucosite por ter propriedades cicatrizantes e regenerativas. $\mathrm{O}$ uso tópico de Calêndula é aceito para tratamento de estomatites aftosas e após extrações dentárias pelo seu efeito antisséptico, além disso promove hemostasia prevenindo inflamações e favorecendo a cicatrização (BOHNEBERGER, et al, 2019). A papaína é uma enzima proteolítica complexa de origem vegetal extraída do látex do mamão (carica papaya), é utilizada a partir da forma bruta como liofilizada, para o auxílio dos processos de cicatrização tecidual, em função do seu poder acelerador de crescimento tecidual, bactericida, bacteriostático e debridante de tecidos necrosados, desvitalizados e infectados. A indicação da utilização de soluções de papaína é realizada em várias concentrações, durante todas as fases do processo de cicatrização de feridas, entretanto, é dependente das características de cada fase em que se encontra a lesão (BRITO JUNIOR; FERREIRA, 2015). O Própolis possui propriedades de regeneração teciduais como cicatrização de úlceras e feridas, relacionadas com sua atividade antioxidante (MENEZES, 2005). Ele atua na redução da resposta inflamatória por meio da promoção da atividade fagocítica, auxiliando no sistema imunológico. É indicado em diversas ocasiões entre elas na terapêutica pós-operatória e também no tratamento de doenças periodontais (BOHNEBERGER, et al, 2019) e ulcerações aftosas recorrentes (PENSIN, 2008).

Conclusão: Os fitoterápicos, na maioria das vezes, têm a função de auxiliar no processo de cicatrização das lesões orais, visto que cada planta possui duas ou mais propriedades válidas nos tratamentos de lesões. Dito isso, as propriedades se complementam e só assim conseguem facilitar a cicatrização e a cura dessas diversas lesões presentes na cavidade oral dos indivíduos.

\title{
Referências
}

BOHNEBERGER, Gabriela; et al; Fitoterápicos na Odontologia, quando podemos utilizá-los?. Brazilian Journal of health Review, Curitiba, $\quad$ v. $2, \quad \mathrm{n} \quad 4, \quad \mathrm{p} \quad 3504-3517, \quad 2019 . \quad$ Disponível el em: https://www.brazilianjournals.com/index.php/BJHR/article/view/2448/2481.Acesso em: 24/08/2020.

ALELUIA, Camila de Melo; et al; Fitoterápicos na Odontologia. Revista de Odontologia da Universidade Cidade de São Paulo,

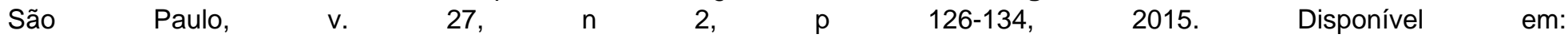
http://publicacoes.unicid.edu.br/index.php/revistadaodontologia/article/view/263/160. Acesso dia: 24/08/2020.

BRITO JUNIOR, Lacy Cardos de; FERREIRA, Pollyana de Lucena. Cicatrização de feridas contaminadas tratadas com papaína. 
Medicina (Ribeirão Preto), v. 48, n 2, p. 168-174. 2015. Disponível em: http://www.revistas.usp.br/rmrp/article/view/99751/98171. Acesso em: 24/08/2020. Periódico sediado em: Ribeirão Preto-SP.

MENEZES, H. Própolis: uma revisão dos recentes estudos de suas propriedades farmacológicas. Arq. Inst. Biol, São Paulo, v. 72, n 3, p 405-411, 2005. Disponível em: https://pdfs.semanticscholar.org/c874/20358851158c7e19464162f01e8bff9980b2.pdf. Acesso em: 24/08/2020.

PENSIN NR, PENSIN C, MIURA CSN, BOLETA-CERANTO DC. Efeito de pomada de própolis em orabase para tratamento de ulcerações aftosas recorrentes um estudo piloto. Arq Ciênc Saúde UNIPAR. Umuarama, v.13, n.3, p.199-204, 2009.

Coordenadoria de Pesquisa e Extensão - COPEX

Departamento de Editoraçāo e Divulgaçāo Científica - DEDIC 


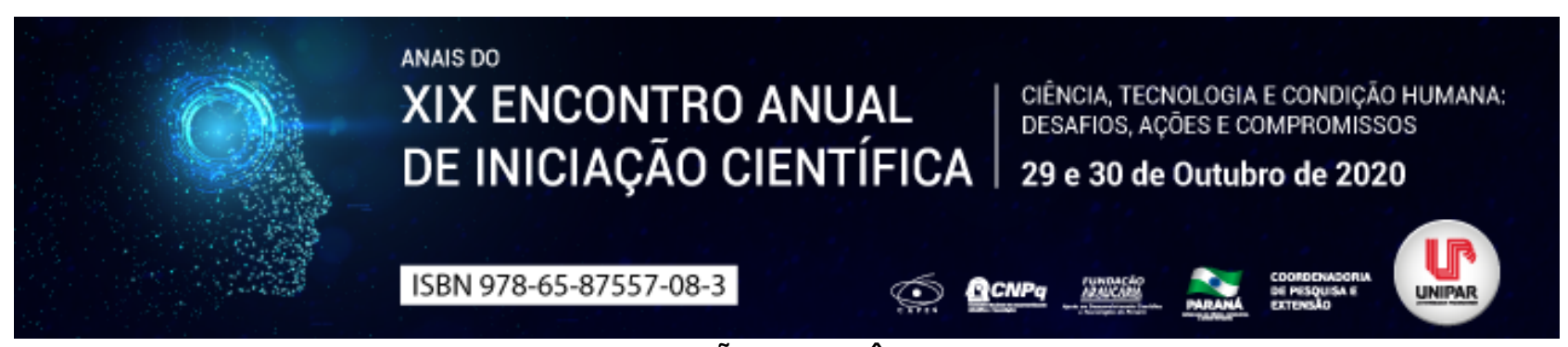

OBESIDADE E SUAS IMPLICAÇÕES NO CÂNCER DE MAMA NO BRASIL

\begin{abstract}
${ }^{1}$ Gustavo Sousa Oliveira, ${ }^{2}$ VIRGÍNIA BRAZ DA SILVA VAZ, ${ }^{3}$ GABRIELA OLIVEIRA DE MOURA RIGONATO, ${ }^{4}$ CRISTIANE ANGELICA DE PAIVA PAULA
\end{abstract}

\begin{abstract}
${ }^{1}$ Acadêmico do curso de Medicina do Centro Universitário Instituto Master de Ensino Presidente Antônio Carlos
${ }^{1}$ Acadêmico do curso de Medicina do Centro Universitário Instituto Master de Ensino Presidente Antônio Carlos

${ }^{2}$ Acadêmico do curso de Medicina do Centro Universitário Instituto Master de Ensino Presidente Antônio Carlos

${ }^{3}$ Orientadora, Mestre em direito e docente na Universidade Presidente Antônio Carlos
\end{abstract}

Introdução: Segundo a Vigilância de Fatores de Risco e Proteção para Doenças Crônicas por Inquérito Telefônico (VIGITEL) a obesidade aumentou em 67,8\% em 13 anos saindo de uma prevalência de 11,8\%, em 2006, para 19,8\% em 2018. No que se refere ao sobrepeso, o público feminino corresponde a $20,7 \%$ com crescimento de $40 \%$. Contata-se, diante dos dados, que as mulheres têm, gradativamente, aumentado o seu peso, sendo esse dado muito importante, pois o excesso de peso predispõe esse público a doenças crônicas não transmissíveis e, também, é um fator de risco para o desenvolvimento de treze tipos de câncer (VIGITEL, 2019). Ainda dentro desse contexto, o câncer de mama, de acordo com a OMS (2018), é o que mais incide em mulheres no mundo com prevalência de $24,2 \%$ sendo a quinta causa de morte por câncer em geral e a causa de morte por câncer mais freqüente em mulheres. E essa situação, com exceção dos tumores de pele não melanoma, se replica no Brasil como o câncer que mais acomete as mulheres, sendo a estimativa de 66.280 casos novos para o ano de 2020 , o que equivale a dizer que 43,74 casos de câncer de mama incidem a cada 100.000 mulheres. Diante dessa perspectiva, é importante discutir como o excesso de peso pode aumentar, ainda mais, o acometimento de câncer em mulheres (OMS, 2018; INCA, 2019).

Objetivo: Sendo assim, o trabalho objetiva, utilizando-se de revisão bibliográfica de artigos encontrados na base de dados Scientific Electronic Library, INCA e OMS, correlacionar as causas e consequências da presença da obesidade em mulheres portadoras de câncer de mama.

Desenvolvimento: Os estudos têm indicado alto grau de associação entre obesidade e câncer de mama em mulheres. E os fatores de maior relevância na bibliografia são a composição corporal e o desequilíbrio hormonal causado pela obesidade (SIQUEIRA, 2014). No que concerne a distribuição corporal, o tecido adiposo branco é subdividido em visceral e subcutâneo que se diferenciam em alguns aspectos: sendo o primeiro composto por células grandes resistentes a insulina o que faz com que haja liberação de ácidos graxos livres amplificando, ainda mais, a resistência a insulina. E o segundo por células pequenas e mais sensíveis a insulina implicando em menor lipólise e maior lipogênese. Ambos produzem hormônios e citocinas inflamatórias, no entanto, o tecido visceral tem maior contribuição por ser altamente ativo (SALES, HALPERN e CERCATO, 2018). A quantidade de gordura no corpo e a sua distribuição corporal estão altamente interligadas com maior ou menor nível inflamatório, no caso de pacientes obesas, com aumento da gordura visceral, isso pode indicar inflamação crônica pelo excesso de liberação de citocinas inflamatórias. Em mulheres obesas o nível de IL-6 está 35\% maior do que em pacientes magras (DAVOODI, 2013). Em um ambiente com liberação crônica de diversas citocinas como TNF-alfa, IL-1, IL-6, inibidor primário do ativador do plasminogênio 1, proteína 1 e IL-8 há proliferação celular e angiogênese o que está altamente intrincado com a maneira que o câncer se desenvolve (PINHEIRO et. al., 2015). No que se refere ao desarranjo hormonal, causado pelo excesso de peso, a literatura aponta que há, em mulheres acima do peso na pós-menopausa, conversão e produção periférica de androstenediona em estrona excessivamente, com concomitante redução dos níveis de globulinas transportadoras de hormônios sexuais (SHBGs) o que implica em altos níveis de estrogênio que, notadamente, é conhecido por ser um hormônio que induz proliferação cooperando para a carcinogênese (PINHEIRO et. al., 2015). É importante ressaltar que há divergências sobre a associação da obesidade com o câncer de mama na pré-menopausa, alguns estudos afirmam que a obesidade está associada negativamente com o câncer de mama em mulheres jovens e a justificativa se baseia na maior propensão de ciclos menstruais anovulatórios e mais longos que acarretam em uma baixa exposição ao estrogênio e menor tempo na fase lútea que é o período responsável por mitose das células mamárias (VASCONCELOS, MENDONCA e SICHIERI, 2001). Vale ressaltar, que os prováveis desdobramentos no que tange ao prognóstico da paciente com neoplasia de mama e a possível recidiva podem ter influência do seu peso. Estudos sugerem que pacientes obesas sofrem com dois agravantes da doença: a demora no diagnóstico de câncer mamário (epud Carmichael, 2006) e a redução da dose feita empiricamente pelo oncologista. Apesar de a literatura divergir, em relação a como deve ser feito o cálculo, a redução da dose pelo médico, por medo de toxidade, pode fazer com que o tratamento não seja tão efetivo como deveria o que prejudica a paciente (KIRJNER e PINHEIRO, 2016).

Conclusão: Diante do exposto, a conciliação de informações de como a obesidade pode afetar o câncer de mama e as possíveis implicações do excesso de peso durante o tratamento quimioterápico são de extrema importância. Pois, com base nesse saber, a 


\section{Referências}

CARMICHAEL, A. R. Obesity and prognosis of breast cancer. Obesity Reviews, v.7, n.4, 2006. Disponível em: http:/l search.ebscohost.com/login.aspx?direct=true\&db=a9h\&AN=22657009\&lang=pt-br\&site=ehost-live. Acesso em: 16 ago. 2020.

DAVOODI, Sayed Hossain et al. A obesidade é um importante fator de risco para certos tipos de câncer. Jornal iraniano de prevenção do câncer , v. 6, n. 4, p. 186, 2013.

ENDOGENOUS HORMONES BREAST CANCER COLLABORATIVE GROUP. Body mass index, serum sex hormones, and breast cancer risk in postmenopausal women. Journal of the National Cancer Institute, v. 95, n. 16, p. 1218-1226, 2003. INSTITUTO NACIONAL DE CÂNCER. Estimativa 2020: Incidência do Câncer no Brasil. Rio de Janeiro: INCA, 2019.

KIRJNER, Aline; PINHEIRO, Rosilene de Lima. Interferência da obesidade no tratamento quimioterápico em mulheres com câncer de mama. Rev Bras Cancerol, v. 53, n. 3, p. 345-354, 2007.

OMS.Folha informativa Câncer. Disponível em: https://www.paho.org/bra/index.php? option=com_content\&view=article\&id=5588:folha-informativa-cancer\&ltemid=1094 . Acesso em: 29 de ago. 2020.

PINHEIRO, Aline Barros et al. Associação entre índice de massa corpórea e câncer de mama em pacientes de Salvador, Bahia. Rev Bras Mastologia, v. 24, n. 3, p. 76-81, 2014.

SALES, Patrícia, HALPERN, Alfredo e CERCATO, Cintia. Biologia do tecido adiposo. O Essencial em endocrinologia. 1. ed. Rio de Janeiro: Roca, 2018. p. 479 - 482

SIQUEIRA, Luciana Teixeira. Associação entre obesidade e câncer: análise proteômica. Orientador: Álvaro Antônio Bandeira Ferraz. 2014. 121f. Tese (Doutorado em cirurgia) Universidade Federal de Pernambuco, Recife, 2014.

VASCONCELOS, Anelise Bezerra de; MENDONCA, Gulnar Azevedo e Silva; SICHIERI, Rosely. Altura, peso, mudança de peso e risco de câncer de mama no Rio de Janeiro, Brasil. São Paulo Med. J. v. 119, n. 2 , Março de 2001. Disponível em . Acesso em: 16 de agosto de 2020.

Brasil. Ministério da Saúde. Secretaria de Vigilância em Saúde. Departamento de Análise em Saúde e Vigilância de Doenças não Transmissíveis. Vigitel Brasil 2018: vigilância de fatores de risco e proteção para doenças crônicas por inquérito telefônico: estimativas sobre frequência e distribuição sociodemográfica de fatores de risco e proteção para doenças crônicas nas capitais dos 26 estados brasileiros e no Distrito Federal em 2018 / Ministério da Saúde, Secretaria de Vigilância em Saúde, Departamento de Análise em Saúde e Vigilância de Doenças não Transmissíveis. Brasília: Ministério da Saúde, 2019. 


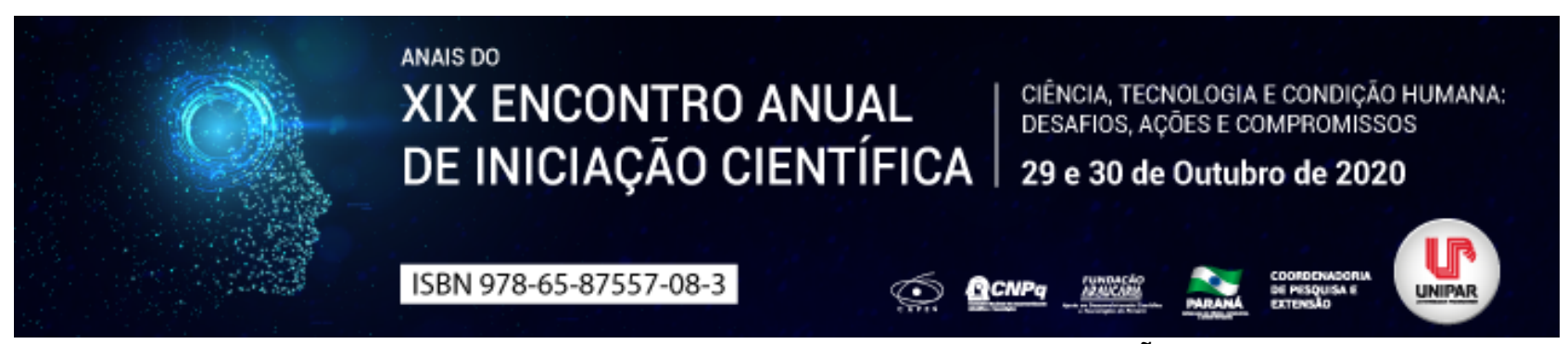

IMPACTOS BUCAIS CAUSADOS PELA OSTEOPOROSE: UMA REVISÃO DE LITERATURA

\begin{abstract}
${ }^{1}$ ANA CAROLINE DOS SANTOS GRUNOW, ${ }^{2}$ LEISLE VERONICA PRESTES, ${ }^{3}$ NATALIA COQUEIRO SIQUEIRA, ${ }^{4}$ ANA MARIA DA SILVA, ${ }^{5}$ NATALIA LOPES HUNGARO, ${ }^{6}$ DANIELA DE CASSIA FAGLIONI B CERANTO
\end{abstract}

\author{
${ }^{1}$ Acadêmica bolsista do PIBIC/UNIPAR \\ ${ }^{1}$ Acadêmica do Curso de Odontologia da UNIPAR \\ ${ }^{2}$ Acadêmica do Curso de Curso Avancado Em Cirurgias Bucais - Turma lii da UNIPAR \\ ${ }^{3}$ Acadêmica do Curso de Odontologia da UNIPAR \\ ${ }^{4}$ Acadêmica do Curso de Odontologia da UNIPAR \\ ${ }^{5}$ Docente da UNIPAR
}

Introdução: Com o aumento do envelhecimento populacional, cresce o número de casos de pessoas acometidas pela osteoporose a cada ano, se tornando um grande problema de saúde pública. A doença é caracterizada pela redução da massa óssea e pela deterioração de sua microarquitetura, tem origem multifatorial e é classificada como primária, subdividida em tipos I (pós menopausa) e II (senil), e secundária que pode ser causada por processos inflamatórios, uso de drogas, entre outras causas. Importantes sinais indicadores da doença podem ocorrer na cavidade bucal, principalmente em maxila, podendo interferir na conduta do cirurgião dentista, sendo primordial que este esteja bem preparado para lidar com o caso e suas implicâncias na cavidade oral, que são representados pela doença periodontal, redução do rebordo alveolar, diminuição da massa e densidade óssea maxilar e edentulismo. São também relatadas diminuição da espessura óssea cortical, representada pelo aumento da porosidade cortical da mandíbula, a medida que aumenta a idade (VARGAS, 2016).

Objetivo: Visto a possibilidade da perda óssea no esqueleto da face causar desordens crânio-mandibulares, esta revisão tem o objetivo de avaliar os impactos bucais causados pela osteoporose e assim, possibilitar o aumento do conhecimento sobre esta doença, que acomete grande parte da população, para contribuir com a atuação profissional dos cirurgiões dentistas.

Desenvolvimento: O envelhecimento populacional é um fenômeno mundial caracterizado pela redução da taxa de fertilidade e um aumento da expectativa de vida da população. Devido ao envelhecimento, ocorre um declínio progressivo de todos os processos fisiológicos do corpo humano sendo marcado pelo aumento das doenças crônico-degenerativas, como a osteoporose, esta, representa uma das maiores doenças não transmissíveis da atualidade (FRAZÃO, 2006). No Brasil, de acordo com dados do Ministério da Saúde, 10 milhões de brasileiros são afetados pela doença. A osteoporose é definida como uma desordem esquelética sistêmica caracterizada pela baixa densidade mineral óssea e pela degeneração de sua microarquitetura e da resistência óssea, causando aumento da fragilidade e maior risco de fraturas (RODRIGUES, 2016). A população feminina é mais acometida pela doença, afetando mais de 200 milhões de mulheres no mundo todo, pelo fato desta apresentar um menor pico de massa óssea e também pelas consequências da menopausa, onde a redução de estrogênio ativam os ciclos de remodelação óssea causando uma perda massiva e acelerada de massa óssea (VARGAS, 2016; RODRIGUES, 2016). A perda óssea bucal pode estar ligada à perda óssea sistêmica, por isso, a qualidade e a quantidade do osso da mandíbula e da maxila têm sido foco da atenção dos odontólogos. A perda dos dentes naturais e dores na gengiva podem ser sintomas de osteoporose, o cirurgião dentista deve estar atento aos sintomas, pois a doença dificilmente é diagnosticada sem que haja uma fratura, para isso é importante avaliar a utilização da radiografia panorâmica no rastreamento de pessoas com baixa mineral óssea, a título de instrumento auxiliar no encaminhamento de pacientes para realização de densitometria óssea (VARGAS, 2016). Essa perda óssea bucal, torna a mandíbula mais sujeita à reabsorção óssea alveolar, comprometendo a densidade tecidual e massa óssea da mandíbula e maxila e em portadores de osteoporose podem causar aumento significativo na taxa de perda óssea no osso que envolve os dentes, o osso alveolar. Pode interferir na espessura da cortical óssea e na velocidade de reabsorção alveolar residual após extrações dentárias, na altura dos ossos maxilares e mandibulares em edêntulos dificultando a reabilitação por próteses e em caso de implantes deve ser avaliado individualmente a condição sistêmica do paciente (CHAIM, 2016). Ainda que a osteoporose não inicie a doença periodontal ela pode afetar o curso da doença, pela redução da densidade mineral óssea e massa do trabeculado ósseo, facilitando a reabsorção do osso alveolar causando a doença periodontal e podendo irreversivelmente destruir os tecidos de suporte dentário levando ao edentulismo, assim a associação entre ambas está relacionada ao fato de serem condições patológicas que causam reabsorção óssea. Elas possuem também fatores de risco em comum, como o aumento da prevalência com a idade, fumo, certas doenças e alguns medicamentos (PENONI et al., 2017).

Conclusão: A perda de tecido ósseo da maxila e da mandíbula, influencia diretamente na fixação dos dentes, de maneira que um grau severo de perda na densidade óssea pode levar a perda de dentes naturais e ainda dificultar a fixação de próteses e implantes. Se a osteoporose for associada à doença periodontal, observa-se agravamento do 
quadro que pode potencializar a perda do dente. Assim, é dever do cirurgião dentista saber da condição sistêmica do seu paciente e também conhecer sobre a doença osteoporose, para minimizar danos e também estar atento para o diagnóstico precoce.

\section{Referências}

CHAIM, Asiz. et al. Alterações no complexo Maxilo-Mandibular na osteoporose: revisão de literatura. Revista UNINGÁ. MaringáPR. vol. 49, pp. 79-84, Jul-Set. 2016.

FRAZÃO, Paulo; NAVEIRA, Miguel. Prevalência de osteoporose: uma revisão crítica. Revista Brasileira de Epidemiologia, [S.L.], v. 9, n. 2, p. 206-214, jun. 2006. FapUNIFESP (SciELO).

RODRIGUES, lara Guimarães; BARROS, Marilisa Berti de Azevedo. Osteoporose autorreferida em população idosa: pesquisa de base populacional no município de campinas, são paulo. Revista Brasileira de Epidemiologia, [S.L.], v. 19, n. 2, p. 294-306, jun. 2016. FapUNIFESP (SciELO).

SOUZA, Edilane Santos de; SANTOS, Juliete de Jesus; SANTANA, Lourenço Luis Botelho de. Impactos associados ao uso prolongado de bisfosfonatos no tratamento da osteoporose em idosos. Textura, [S.L.], v. 12, n. 20, p. 151-161, 20 fev. 2019. Textura. http://dx.doi.org/10.22479/desenreg2018v12n20p151-161.

VARGAS, Renato Magalhães; SCHMITT, Eduardo Augusto. Os efeitos da osteoporose na cavidade bucal e a contribuição do cirurgião dentista: revisão de literatura. Orientador: Jorge Abel Flores. 30f. 2016. Trabalho de Conclusão de Curso (graduação em Odontologia), Universidade Federal de Santa Maria (UFSM, RS), 2016.

PENONI, Daniela Cia; LEÃO, Anna Thereza Thomé; FERNANDES, Tatiana Melo; TORRES, Sandra Regina. Possible links between osteoporosis and periodontal disease. Revista Brasileira de Reumatologia (English Edition), [S.L.], v. 57, n. 3, p. 270273, maio 2017. Elsevier BV. http://dx.doi.org/10.1016/j.rbre.2016.03.004. 


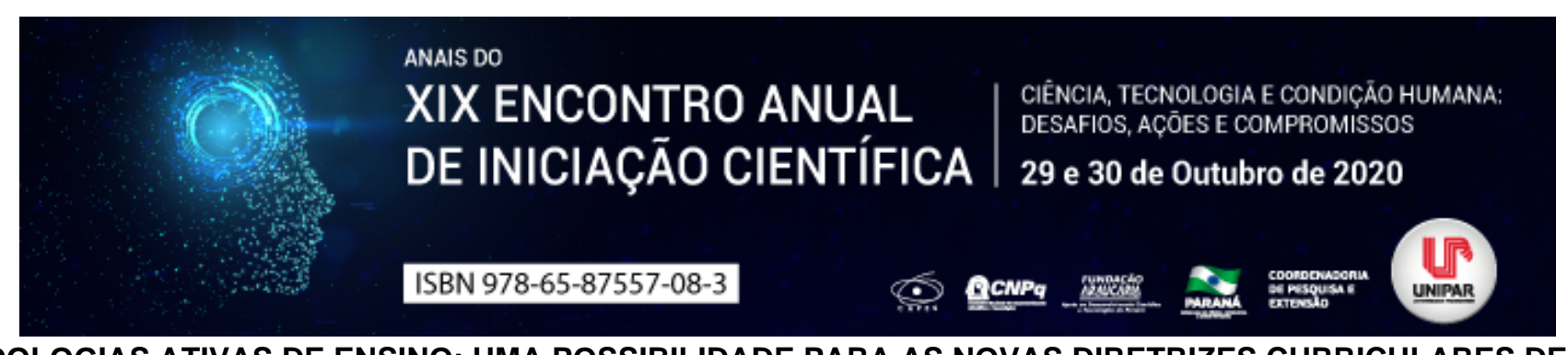

METODOLOGIAS ATIVAS DE ENSINO: UMA POSSIBILIDADE PARA AS NOVAS DIRETRIZES CURRICULARES DE 2014?

\begin{abstract}
${ }^{1}$ Gustavo Sousa Oliveira, ${ }^{2}$ GABRIELA OLIVEIRA DE MOURA RIGONATO, ${ }^{3}$ VIRGÍNIA BRAZ DA SILVA VAZ, ${ }^{4}$ CRISTIANE ANGELICA DE PAIVA PAULA
\end{abstract}

${ }^{1}$ Acadêmico do curso de Medicina do Centro Universitário Instituto Master de Ensino Presidente Antônio Carlos

${ }^{1}$ Acadêmico do curso de Medicina do Centro Universitário Instituto Master de Ensino Presidente Antônio Carlos

${ }^{2}$ Acadêmico do curso de Medicina do Centro Universitário Instituto Master de Ensino Presidente Antônio Carlos

${ }^{3}$ Orientadora, Mestre em direito e docente na Universidade Presidente Antônio Carlos

Introdução: Estando a medicina no epicentro de constantes mudanças, readaptações para melhor atender a população são feitas constantemente, tendo em vista a incessante revolução de informações. Entretanto, os debates sobre como correlacionar, de forma consistente, políticas públicas integrais de saúde e profissionais com destreza, se perduraram por muito tempo, e somente no século XX, por meio das Diretrizes Curriculares Nacionais do Curso de Graduação em Medicina de 2001 (DCN), foi definido o perfil do egresso da formação médica [...] generalista, humanista, crítica e reflexiva, capacitado a atuar, pautado em princípios éticos [...] (CONSELHO NACIONAL DE EDUCAÇÃO, 2001, p. 38). E em 2014, foram tomadas novas providências em relação à resolução da DCN estabelecendo competências e habilidades que devem ser desenvolvidas utilizando-se de métodos ativos de aprendizagem (CONSELHO NACIONAL DE EDUCAÇÃO, 2014). Nesse sentido, a discussão sobre o ensino médico é necessária. O embate mais atual sobre o tema tem versado sobre a implementação de metodologias ativas de ensino. No entanto, somente uma análise casuística, que compara novos métodos de ensino com a metodologia tradicional e analisa os desafios intrínsecos de transições metodológicas, pode sanar dúvidas a respeito de como se posicionar em um cenário de quebras de paradigmas (GOMES e REGO, 2011).

Objetivo: O presente trabalho objetiva, utilizando-se de revisão bibliográfica de artigos encontrados na base de dados Scientific Electronic Library, analisar quais os desdobramentos da implementação de novas metodologias de ensino comparando-as ao método tradicional.

Desenvolvimento: No Brasil, devido a DCN, as escolas médicas vêm aplicando métodos de ensino ativo, com ênfase na aprendizagem baseada em problema. Nessa perspectiva, questiona-se qual a real contribuição da metodologia de ensino ativa para as escolas médicas brasileiras. Em um estudo de revisão científica internacional, com busca sobre o tema nos últimos 20 anos, demonstrou-se que a literatura diverge amplamente sobre os ganhos cognitivos da aprendizagem baseada em problemas e conclui que não há comprovação de ganhos de conhecimentos superiores quando comparado ao método tradicional. E ainda, questiona qual a eficácia da mudança metodológica, por si só, na modificação da postura do egresso. Estando isso atrelado ao fato de que, normalmente, as escolas médicas internacionais, que optaram por mudanças nos seus métodos de ensino, associavam isso a outras adaptações (GOMES e REGO, 2011). Ainda nesse sentido, outra revisão bibliográfica internacional, que compara artigos publicados entre 1998 a 2008, afirma que as competências em áreas sociais foram mais bem contempladas quando foi utilizada a aprendizagem baseada em problemas (ABP) e ratifica que são necessários mais estudos qualitativos que acompanhem o cotidiano dos discentes que participam dos diferentes métodos. $E$ também, esclarece que a execução e o entendimento do método ABP varia nas diversas instituições e isso influi diretamente no estudo (GOMES et. al., 2009). No que concerne a implantação de métodos ativos, a literatura esclarece que muitas vezes por erros pedagógicos o instrumento aplicado é visto, pelos alunos, como ineficaz. Em uma pesquisa, os dados obtidos a respeito da visão dos alunos são de que as aulas, que utilizam recursos de aprendizagem ativa, tornam-se mais interessantes. Não só, como também criam o hábito de estudo, geram autonomia, permitem trabalhar com problemas reais e desenvolvem habilidades relacionadas à pesquisa. Apesar de que quando questionados sobre as limitações do método a unanimidade de estudantes afirmou que a metodologia ativa de ensino não foi capaz de explanar todo o conteúdo e que o método tradicional seria mais proveitoso. Sendo uma das justificativas sobre a insuficiência a de que houve desconhecimento dos professores a respeito de como aplicar o método de ensino ativo, falta de orientação aos alunos a respeito de até onde se aprofundar nos temas, excesso de trabalhos e a falta de participação dos docentes durante a tutoria (RIBEIRO, ALBUQUERQUE e RESENDE, 2020). Sobre os docentes, um outro estudo revela que $60 \%$ gostariam de usar outros recursos metodológicos, no entanto, o empecilho mais comum relatado, por $28 \%$, foi a falta de experiência e capacitação (CRUZ et al., 2019).

Conclusão: Com isso, o desenvolvimento de competências, no que concerne a uma postura mais ativa ante ao aprendizado, capacidade de buscar conhecimento e a integração deste é de suma importância para os dias atuais e pode ser aprendido com o uso da metodologia ativa. No entanto, as instituições de ensino precisam entender que a pura implantação de novos métodos pedagógicos por si só não são suficientes, sendo necessário um apoio de mudanças na atitude dos profissionais e também na 
dos alunos. (TORRES, SAMPAIO e CALDEIRA, 2019). E tudo isso deve ser aplicado com concomitância de constantes pesquisas de desempenho dos instrumentos formativos para que as possíveis contradições venham ser sanadas (MARIN et. al., 2010).

\section{Referências}

CONSELHO NACIONAL DE EDUCAÇÃO. Resolução n³ de 20 de junho de 2014. Institui Diretrizes Curriculares Nacionais do Curso de Graduação em Medicina e dá outras providências. Diário Oficial [da] República Federativa do Brasil: seção 1. Brasília, jun. 2014, pp. 8-11.

CONSELHO NACIONAL DE EDUCAÇÃO. Resolução n 4 de 7 de novembro de 2001. Institui Diretrizes Curriculares Nacionais do Curso de Graduação em Medicina. Diário Oficial [da] República Federativa do Brasil: seção 1. Brasília, nov. 2001, p. 38.

CRUZ, Poliana Oliveira da et al . Percepção da Efetividade dos Métodos de Ensino Utilizados em um Curso de Medicina do Nordeste do Brasil. Rev. Bras. de Educ. Méd., Brasília, v. 43, n. 2, p. 40-47, jun. 2019.

GOMES, Andréia Patrícia; REGO, Sergio. Transformação da educação médica: é possível formar um novo médico a partir de mudanças no método de ensino-aprendizagem?. Rev. Bras. de Educ. Méd., Rio de Janeiro, v. 35, n. 4, p. 557-566, Dez. 2011.

GOMES, Romeu et al. Aprendizagem Baseada em Problemas na formação médica e o currículo tradicional de Medicina: uma revisão bibliográfica. Rev. Bras. de Educ. Méd., Rio de Janeiro, v. 33, n. 3, p. 433-440, Set. 2009.

MARIN, Maria José Sanches et al. Aspectos das fortalezas e fragilidades no uso das metodologias ativas de aprendizagem. Rev.

Bras. de Educ. Méd., Rio de Janeiro, v. 34, n. 1, p. 13-20, Mar. 2010.

RIBEIRO, Juliana Terra; ALBUQUERQUE, Natália Mariana Diógenes Silva de; RESENDE, Tania Inessa Martins de. Potencialidades e desafios da metodologia ativa na perspectiva dos graduandos de Medicina. Revista Docência do Ensino Superior, Belo Horizonte, v. 10, e019233, p. 1-19, 2020.

TORRES, Vânia; SAMPAIO, Cristina Andrade; CALDEIRA, Antônio Prates. Ingressantes de cursos médicos e a percepção sobre a transição para uma aprendizagem ativa. Interface, Botucatu, v. 23, 2019. Disponível em: Acesso em: 28 Ago. 2020. 


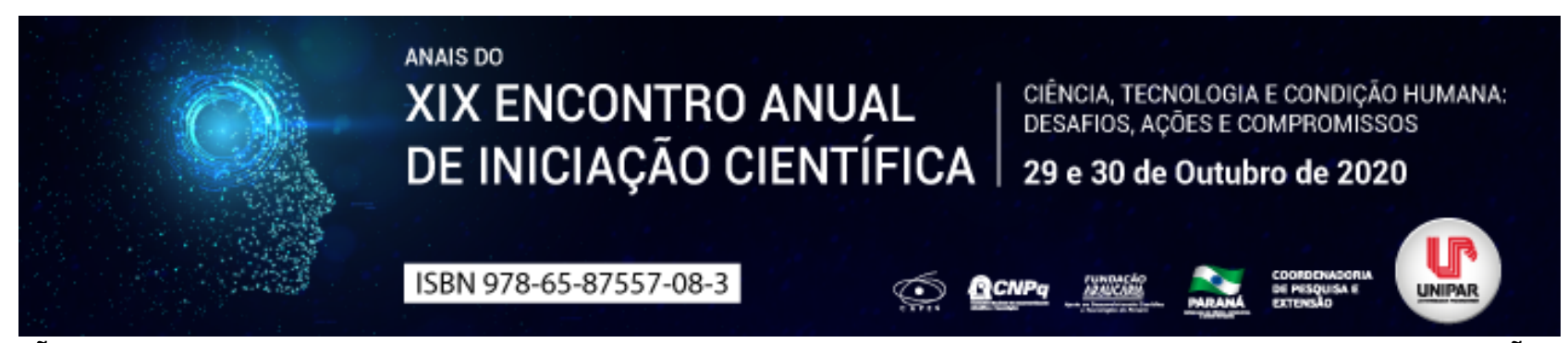

\title{
AVALIAÇÃO NUTRICIONAL E HORMONAL EM MULHERES DE 25 A 35 ANOS PRATICANTES DE MUSCULAÇÃO EM UMA ACADEMIA DE FRANCISCO BELTRÃO - PR
}

${ }^{1}$ JOSE DOMINGOS PAEZ, ${ }^{2}$ INDIOMARA BARATTO

\author{
${ }^{1}$ Acadêmico do Curso de Nutrição da Unipar \\ ${ }^{1}$ Docente da UNIPAR
}

Introdução: Impulsionadas pela idolatria ao corpo, algumas mulheres idealizam para si corpos magros e com uma quantidade aumentada de músculos como uma forma de se sentirem bonitas e encaixar-se nos padrões de beleza atuais. Os androgênios são os esteróides sexuais quantitativamente predominantes na mulher, sendo o sulfato de dehidroepiandrosterona (SDHEA) o mais abundante e a testosterona $(T)$ o de maior importância por sua potência biológica (LONGCOPE, 1986). A adesão a um plano nutricional, associada a prática de exercícios de musculação é altamente recomendada para ganhar massa muscular (WILLIANS, 2002), considerando que o desenvolvimento da força é uma resposta adaptativa do sistema neuromuscular frente á sobrecarga aplicada (WEINECK, 1999). Sabemos que a testosterona é um hormônio altamente anabólico e capaz de promover a síntese proteica ativando o sistema IGF-1 intra-muscular (URBAN, et al., 1995), logo, a quantidade de androgênios circulantes é fator determinante no aumento na quantidade de tecido muscular (DUARTE, et al., 2004). A síndrome da insuficiência androgênica na mulher constitui-se num conjunto de sintomas clínicos na presença de biodisponibilidade diminuída de testosterona e níveis normais de estrogênios (BACHMANN et al., 2002). Além de um bom programa de exercícios e uma dieta adequada, uma boa saúde hormonal pode ser fator crucial na obtenção de bons resultados, quando o ganho de tecido muscular é um objetivo.

Objetivo: Determinar o estado nutricional e os níveis de testosterona em mulheres de 25 a 35 anos praticantes de musculação em uma academia na cidade de Francisco Beltrão-PR.

Métodos: Este estudo foi realizado com mulheres que praticam musculação em uma academia na cidade de Francisco Beltrão PR. As participantes deste estudo foram encaminhadas a um laboratório de análises clínicas da cidade de Francisco Beltrão PR, onde foi colhida uma amostra sanguínea para realização dos exames de testosterona livre e total. As mesmas também foram submetidas a uma avaliação de composição corporal por adipometria usando o protocolo de 7 dobras de Pollock e responderam a um questionário com perguntas sócio econômicas. Este trabalho foi avaliado e aprovado pelo comitê de ética em pesquisa sob o parecer de número 4.137.391.

Resultados: Os resultados aqui apresentados são parciais, contudo o estudo identificou dados sobre as características antropométricas e dietéticas de 15 mulheres praticantes de musculação de uma academia localizada na cidade de Francisco Beltrão. Destas, 14 apresentaram IMC de eutrofia, nenhuma apresentou IMC de sobrepeso e apenas 01 apresentou IMC de obesidade. Como o IMC não revela a composição de massa gorda e não é o mais recomendado para quem faz atividades físicas realizamos a adipometria usando o protocolo de 7 dobras de Pollock (POLLOCK \& WILMORE,1993) para tal. Verificou-se que 01 mulher apresenta percentual de gordura excelente (14-16\%), 07 mulheres apresentam percentual de gordura bom (18-20\%), 03 apresentam \% de gordura acima da média (21-23\%), 04 apresentam \% de gordura média (24-29\%).

Discussão: Da população avaliada, apenas uma mulher apresentou estado nutricional obesidade ou altamente inadequado. Como o restante das mulheres apresentaram estado nutricional adequado é um dado excelente, já que a obesidade tem sido associada a vários fatores de risco e tem mais predominância em mulheres em todo o mundo (POPKIN \& DOACK, 1998) corroborando a premissa de que para alcançar, de forma saudável, resultados estéticos é necessária a prática de exercício físico junto à nutrição, favorecendo a redução de peso, do percentual de gordura, aumentando a massa muscular e prevenindo ou melhorando quadros de doenças crônico-degenerativas (BIESKI e Colaboradores, 2005).

Conclusão: A busca por profissionais que auxiliem de forma correta as mulheres a ganharem massa muscular e reduzir seus percentuais de gordura vem aumentando gradativamente e faz-se necessário cada vez mais o conhecimento das variáveis que implicam nesses resultados por meio dos profissionais. A conclusão deste trabalho terá um melhor desfecho quando avaliarmos os níveis de testosterona das mesmas. Notamos que de uma maneira geral a maioria das participantes avaliadas mostraram valores de IMC e de percentual de gordura dentro dos níveis adequados.

\section{Referências}

BACHMANN, Gloria MD.; BANCROFT, Jonh MD.; BRAUNSTEIN, Gleen MD. et al. - Female androgen insufficiency: the Princeton consensus statement on definition, classification, and assessment. Fertil Steril 77: 660-665, 2002.

BIESEK, Simone; ALVES, Letícia.Azen; GUERRA, Isabela. Estratégias de nutrição e suplementação no esporte. Barueri, SP: Manole, 2005. 
DUARTE, Mônica P.C. LEAO; Lenora M.C.S.M. e FARIAS, Maria Lucia F.. Insuficiência androgênica na mulher e potenciais riscos da reposição terapêutica. Arq Bras Endocrinol Metab [online]. 2005, vol.49, n.2

LONGCOPE, Christopher. Adrenal and gonadal androgen secretion in normal females. J Clin Endocrinol Metab 1986;15:213-28 POLLOCK, Michael Patrick.; WILMORE, Jack. Exercícios na saúde e na doença: avaliação e prescrição para prevenção e reabilitação. São Paulo. Médica e Científica. 1993.

POPKIN, Barry; DOACK, Colleen. The obesity Epidemic Is a Worldwide Phenomenon. Nutr Rev 1998; 56(6): 106-14. URBAN, Randall; Bodenburg Yvonne; Gilkison Charles; Foxworth Judy; Coggan Andrew R., Wolfe Robert, et al. Testosterone administration to elderly man increases skeletal muscle strength and protein synthesis. Am J Physiol 1995;269:820-6. WEINECK, Jurgen. Manual do Treinamento Esportivo. $2^{a}$ ed. São Paulo: Manole, 1999.

WILLIAMS, Melvin. Nutrição e saúde, condicionamento \& desempenho esportivo. 1ª ed. São Paulo, Manole, 2002. 


\title{
- tramem DE INICIACÃO CIENTÍFICA DESAFIOS, ACOÖES E COMPROMISSOS DE INICIAÇĀO CIENTÍFICA 29 e 30 de Outubro de 2020 \\ ISBN 978-65-87557-08-3 \\ 6 ockpg 20

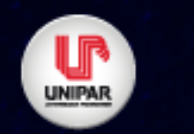 \\ DIFICULDADES DO ACESSO À SAÚDE BUCAL POR PACIENTES COM NECESSIDADES ESPECIAIS - O PAPEL DO SISTEMA ÚNICO DE SAÚDE
}

\author{
${ }^{1}$ CAROLINE DOMINGUES, ${ }^{2}$ BEATRIZ AYUMI SHIOTANI, ${ }^{3}$ GABRIEL MACIEL DA SILVA, ${ }^{4}$ GABRIELI JANKE RIGHEZ, \\ ${ }^{5}$ RAFAELLA BRITO CARBELIM, ${ }^{6}$ PATRICIA GIZELI BRASSALLI DE MELO
}

\author{
${ }^{1}$ Acadêmica de Odontologia, Universidade Paranaense \\ ${ }^{1}$ Acadêmica de Odontologia, Universidade Paranaense \\ ${ }^{2}$ Acadêmico de Odontologia, Universidade Paranaense \\ ${ }^{3}$ Acadêmica do Curso de Odontologia, UNIPAR \\ ${ }^{4}$ Acadêmica do Curso de Odontologia, UNIPAR \\ ${ }^{5}$ Docente do curso de Odontologia, UNIPAR
}

Introdução: A Lei ${ }^{\circ} 8.080$ de 19 de Setembro de 1990 garante que a saúde é um direito de todos os cidadãos e um dever do Estado. Apesar de ser garantida pela legislação, muitos pacientes com necessidades especiais enfrentam dificuldades no acesso à assistência odontológica no Brasil. Pacientes com necessidades especiais (PNE) são caracterizados como pacientes que possuam qualquer condição ou alteração que possa interferir na realização de tratamentos odontológicos, requerendo atendimento especializado e multidisciplinar (CAMPOS et al., 2009). Grande parte desses pacientes apresentam maior quantidade de doenças bucais como cárie, doença periodontal, hábitos parafuncionais, má oclusões e até mesmo perdas dentárias. A maior predisposição à doenças bucais advém principalmente, da dificuldade motora na realização da higiene oral, da dieta rica em carboidratos e também da grande quantidade de medicamentos ingeridos, estando alguns desses, diretamente relacionados com doenças e complicações orais (LUCENA; LOPES; BATISTA, 2018). Mesmo sabendo da necessidade e da importância do atendimento para esses pacientes, muitos profissionais da odontologia não se sentem confiantes em prestar atendimento, seja por falta de conhecimentos ou falta de treinamento, além da baixa remuneração e da crença inadequada de que são necessários recursos e equipamentos especiais (MARTA., 2011).

Objetivo: Realizar uma revisão de literatura abordando as dificuldades no acesso à saúde bucal por pacientes com necessidades especiais na saúde pública.

Desenvolvimento: Em sua maioria os PNE podem e devem ser atendidos na Unidade Básica de Saúde, e somente em casos mais graves, que necessitem de atendimento especializado, deverá ser encaminhado para a atenção secundária. Na atenção primária o atendimento deve abranger temas como a instrução de higiene oral para o responsável ou cuidador em casos de pacientes que não tenham autonomia para realizá-la, além da realização de procedimentos básicos (LUCENA; LOPES; BATISTA, 2018). A disciplina de atendimento a pacientes especiais não é obrigatória no Brasil e muitas universidades optam por não ministrá-la, formando profissionais inexperientes na área (SPEZZIA; BERTOLINI, 2017). Além da falta de profissionais qualificados, os PNE enfrentam a baixa procura da família por atendimento odontológico preventivo, a maioria desses pacientes são dependentes da família e de cuidadores que acabam negligenciando a saúde bucal, dando maior ênfase a outras especialidades e outros tratamentos que já são realizados com alta frequência (ARAGÃO et al., 2011). No caso de pacientes com deficiência mental e intelectual, é comum o uso de medicamentos como antidepressivos e anticonvulsivantes, que frequentemente causam quadros de hiperplasia gengival, xerostomia, aumento da ocorrência de úlceras, candidíase, estomatite e glossite, fatores estes, que dificultam a higienização bucal, o tratamento odontológico, com prejuízos na qualidade de vida desses pacientes (JÜNIOR; ROSA; FELIPE; CONCEIÇÃO.,2020). No caso da xerostomia, a propensão à cárie aumenta consideravelmente. A hipossalivação altera a composição orgânica e eletrolítica da saliva, com redução da capacidade tampão e consequentemente, interferência no processo de remineralização dentária, o que favorece a instalação de processos cariosos (MOURA et al.,2020). Em associação a esses fatores, deve-se considerar também, a falta de cooperação de alguns desses pacientes, seja ela motivada por traumas passados, estímulo doloroso ou devido a condição psicológica e comportamental do paciente. Essas características demandam maior tempo clínico e experiência do profissional, motivos estes que levam muitos profissionais e familiares a optarem pelo tratamento hospitalar, sob anestesia geral (DALL'MAGRO, A. DALL'MAGRO, E. KUHN, 2010). Tais situações ainda sofrem influência da ansiedade e medo demonstrados pelos pais dos pacientes, que devido a baixa prioridade à saúde bucal acabam não se adaptando aos tratamentos. Todavia, fatores como dificuldade de comunicação com deficientes mais graves que não conseguem expressar os problemas dentários e a falta de transporte e consultórios adaptados a receber esses pacientes também precisam ser considerados (MARTA., 2011). Para proporcionar educação em saúde bucal, é necessário que a partir do nascimento o paciente já tenha contato com o Cirurgião Dentista, que auxiliará o cuidador ou responsável na higienização, além de criar um vínculo com a criança, de modo a facilitar possíveis tratamentos futuros e 
prevenindo o aparecimento de patologias orais, ademais, o tratamento odontológico desses pacientes é mais complexo e pode gerar traumas (DALL'MAGRO, A. DALL'MAGRO, E. KUHN, 2010).

Conclusão: Diante desses apontamentos, foi possível perceber que os motivos que levam a falta de atendimento a pacientes com necessidades especiais são muitos, estando entre os principais, a falta de capacitação dos profissionais e falta de conscientização dos cuidadores a respeito da importância da saúde bucal. Dessa forma, é essencial que mais pesquisas e trabalhos sejam realizados na área, visando difundir informações, instruções e orientações tanto para profissionais da odontologia como para pais e responsáveis, a fim de desmistificar o atendimento a esses pacientes especiais, com impacto positivo na sua qualidade de vida.

\section{Referências}

BRASIL, Casa Civil. Lei no 8.080, de 19 de setembro de 1990. Diário Oficial da união, v. 20, 1990.

CAMPOS, Cerise de Castro et al. Manual prático para o atendimento odontológico de pacientes com necessidades especiais. Goiânia: Universidade Federal de Goiás, 2009. https://files.cercomp.ufg.br/weby/up/133/o/Manual_corrigido-.pdf

DE ARAGÃO, Ana Karla Ramalho et al. Acessibilidade da criança e do adolescente com deficiência na atenção básica de saúde bucal no serviço público: estudo piloto. Pesquisa Brasileira em Odontopediatria e Clínica Integrada, v. 11, n. 2, p. 159-164, 2011. https://www.redalyc.org/pdf/637/63721615002.pdf

DE ALMEIDA JÚNIOR, Eduardo Rodrigues et al. Atendimento odontológico em pacientes com epilepsia e suas intercorrências. Facit Business and Technology Journal, v. 1, n. 16, 2020. https://jnt1.websiteseguro.com/index.php/JNT/article/view/582/440 MARTA, Sara Nader. Programa de assistência odontológica ao paciente especial: uma experiência de 13 anos. RGo. Revista Gaúcha de Odontologia (Online), v. 59, n. 3, p. 379-385, 2011. http://revodonto.bvsalud.org/pdf/rgo/v59n3/a05v59n3.pdf MOURA, Ana Beatriz Rodrigues et al. Atendimento odontológico para pacientes com necessidades especiais: uma revisão de literatura. Research, Society and Development, v. 9, n. 8, p. e288985405-e288985405, 2020. https://rsdjournal.org/index.php/rsd/article/view/5405/4819

SPEZZIA, Sérgio; BERTOLINI, Silvia Regina. Ensino odontológico para pacientes especiais e gestão em saúde. Journal of Oral Investigations, v. 6, n. 1, p. 85-98, 2017. https://seer.imed.edu.br/index.php/JOI/article/view/1815/pdf

KUHN-DALL'MAGRO, Alessandra; DALL'MAGRO, Eduardo; KUHN, Giana Flávia. Perfil clínico dos pacientes especiais tratados sob anestesia geral no Hospital São Vicente de Paulo de Passo Fundo entre os anos de 2005 e 2010. Revista da Faculdade de Odontologia-UPF, v. 15, n. 3, 2010. http://seer.upf.br/index.php/rfo/article/view/1668/1111 


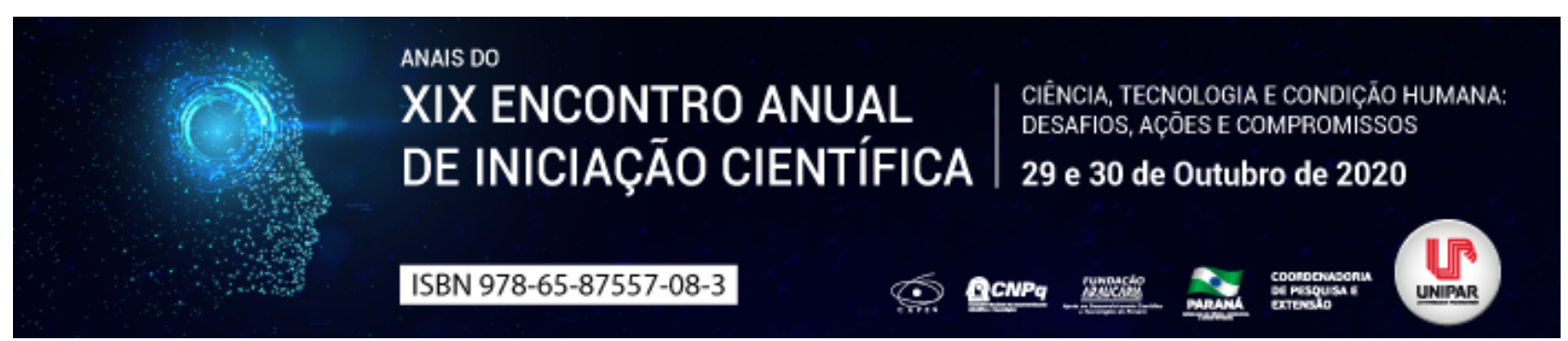

PERCEPÇÃO DA IMAGEM CORPORAL E FATORES ASSOCIADOS EM UNIVERSITÁRIOS

\title{
${ }^{1}$ EMANUELLY SHAYENE GARBOZZA, ${ }^{2}$ MIRIAN COZER
}

\author{
${ }^{1}$ Discente do curso de Nutrição/UNIPAR \\ ${ }^{1}$ Docente da UNIPAR
}

Introdução: A imagem corporal corresponde a diversos fatores cognitivos e multissensoriais, onde experiências existenciais e individuais irão compor a imagem, é uma representação mental de todas as maneiras de percepção do corpo seguida por uma auto avaliação da imagem percebida pelo indivíduo (MACEDO et al, 2019).

Objetivo: Avaliar a associação da imagem corporal, alimentação emocional e estado nutricional em universitários de áreas distintas da Universidade Paranaense UNIPAR no município de Francisco Beltrão/PR.

Material e Métodos: Trata-se de um estudo de caráter transversal, descritivo, qualitativo e quantitativo. A pesquisa foi aprovada pela Comissão de Ética da Universidade Paranaense UNIPAR, sob o número do parecer consubstanciado 31704920.4.0000.0109. Participaram do estudo acadêmicos dos cursos de nutrição, farmácia, engenharia civil e arquitetura e urbanismo, perfazendo assim a amostra dos alunos da área da saúde e das exatas, respectivamente. Totalizou uma amostra de 390 estudantes. Os quais foram convidados a participar da pesquisa via mensagem eletrônica, recebendo o resumo do projeto e o endereço eletrônico para acesso ao formulário que foi desenvolvido através da ferramenta online Google Forms. Utilizou como instrumentos dessa pesquisa quatro questionários validados pela literatura, sendo: Questionário de Imagem Corporal (Body Shape Questionnaire BSQ); Questionário de três fatores (The Three Factor Eating Questionnaire TFEQ-21); Escala de Silhuetas; e Questionário elaborado com base no questionário de atividade física habitual. O estado nutricional foi classificado por meio do Índice de Massa Corporal, através de dados auto referidos pelos participantes. A coleta dos dados deu-se durante a primeira quinzena do mês de agosto do corrente ano. Os dados foram submetidos ao tratamento estatístico por meio do Software Statistical Package for Social Science (SPSS ${ }^{\circledR}$ ), versão 18. Os resultados foram considerados estatisticamente significativos ao nível de $p<0,05$, com nível de significância de $95 \%$.

Resultados: Foram analisados até o momento 110 questionários, desses, 61,8\% possuem idade entre 18 a 21 anos, 10,9\% são do sexo masculino e $89,1 \%$ do feminino. A maioria dos respondentes $(36,4 \%)$ encontram-se no 1 ano. O estado civil predominante entre os avaliados foi solteiro perfazendo $76,4 \%$. Para análise dos instrumentos aplicados a amostra dessa pesquisa foi dividida entre universitários da área da saúde e área das exatas conforme descrito na metodologia. Sendo assim, $25 \%$ dos estudantes dos cursos de exatas encontram-se em obesidade segundo a classificação do IMC. Quanto ao BSQ 3,7\% indicavam insatisfação grave em relação a imagem corporal e 74,7\% apresentaram-se satisfeitos nesse quesito. Ao analisar a escala de silhuetas $77,7 \%$ encontram-se classificados com insatisfação e com desejo de diminuir a silhueta. $81,4 \%$ relatam fazer atividades físicas. Ao analisar o questionário TFEQ-21 na dimensão de descontrole alimentar $11,1 \%$ dos alunos classificaram elevada o quesito descontrole alimentar, na dimensão alimentação emocional $37 \%$ elevada restrição e 44,4\% elevada restrição na dimensão de restrição cognitiva. $44,44 \%$ dessa amostra consideraram sua saúde boa. Ao analisar os formulários provenientes dos cursos da área da saúde, $67,4 \%$ encontram-se em eutrofia segundo a classificação do IMC. 8,43\% classificaram-se em insatisfação grave, enquanto $73,4 \%$ estavam satisfeitos segundo a classificação do BSQ. $71,08 \%$ possuem insatisfação e desejam diminuir a sua silhueta, enquanto $14,45 \%$ desejam aumentar. $80,7 \%$ relataram realizar atividades, sendo a musculação $(39,7 \%)$ predominante. Classificaram-se com restrição elevada na dimensão restrição cognitiva $25,3 \%, 34,9 \%$ na dimensão alimentação emocional e $24,1 \%$ na dimensão descontrole alimentar. 38,5\% dos participantes consideraram sua saúde muito boa. Discussão: A insatisfação corporal pode ser definida como uma avaliação negativa auto percebida (ADAMI et al, 2008), ou seja, desenvolve-se a partir de uma desaprovação da imagem corporal construída (HERON et al, 2013).). O bem-estar psicológico inclui a ausência de emoç̃̃es negativas, contudo a imagem corporal vai corresponder à percepção que o sujeito tem de si e do seu corpo, esta imagem vai ser afetada pela sociedade em que o indivíduo se insere e pelos padrões de beleza da mesma, provocando sentimento de rejeição no sujeito perante tais ideais (SILVA et al, 2019).

Conclusão: Diante do exposto, verificou-se que nos cursos de exatas o sobrepeso esteve presente em maior proporção do que na área da saúde, nos quesitos de imagem corporal nota-se que os acadêmicos de exatas possuem maior insatisfação com a imagem corporal, e com restrição elevada nas dimensões alimentação emocional e restrição cognitiva, enquanto os acadêmicos da área da saúde, encontram-se apenas com restrição elevada na dimensão de descontrole alimentar. Portanto, infere-se, com bases nesses resultados, que a insatisfação corporal foi maior na área de exatas do que na área da saúde.

\section{Referências}

ADAMI, Fernando. et al . Insatisfação corporal e atividade física em adolescentes da região continental de Florianópolis. Psic.: 
Teor. e Pesq., Brasília, v. 24, n. 2, p. 143-149, Junho, 2008.

HERON, Kristin. E.; Smyth, Joshua. M.; Akano, Esther.; Wonderlich, Stephen. A. Assessing Body Image in Young Children: A Preliminary Study of Racial and Developmental Differences. SAGE Open. V. 3. N.1. p. 1, 2013.

MACEDO, J. L., Oliveira, A. S. S., Reis, E. R., \& Assunção, M. de J. S. M. (2019). Prevalência de insatisfação corporal em praticantes de atividade física. RBNE - Revista Brasileira De Nutrição Esportiva, 13(81), 617-623.

SILVA, Laleska Pâmela Rodrigues da et al. Insatisfação da imagem corporal e fatores associados: um estudo em jovens estudantes universitários. Einstein (São Paulo), São Paulo, v. 17, n. 4, 2019.

Coordenadoria de Pesquisa e Extensão - COPEX

Departamento de Editoraçāo e Divulgaçāo Científica - DEDIC 


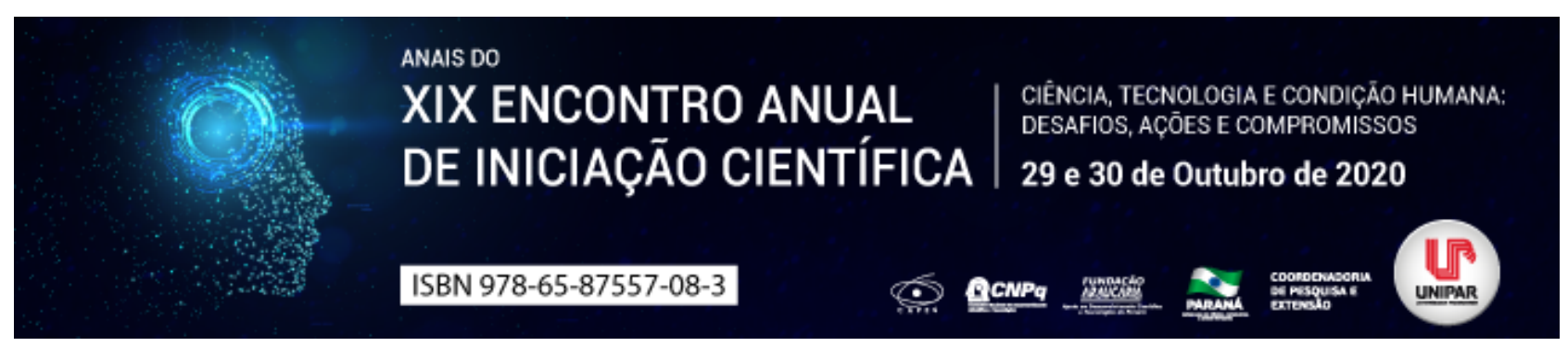

OSTEOPOROSE NA ODONTOLOGIA

\begin{abstract}
${ }^{1}$ QUEREN ALVES DE PAULA, ${ }^{2}$ GABRIEL MACIEL DA SILVA, ${ }^{3}$ GUSTAVO BARBOSA CORREA DE MORAIS, ${ }^{4}$ AMANDA CHIULO GIROTTO, ${ }^{5}$ CAROLINE DOMINGUES, ${ }^{6}$ DANIELA DE CASSIA FAGLIONI B CERANTO
\end{abstract}

\author{
${ }^{1}$ Acadêmica do Curso de Odontologia da UNIPAR \\ ${ }^{1}$ Acadêmico do Curso de Cirurgia Periodontal e Introdução A Implantodontia - Turma VIII da UNIPAR \\ ${ }^{2}$ Acadêmico do Curso de Odontologia da UNIPAR \\ ${ }^{3}$ Acadêmica do Curso de Odontologia da UNIPAR \\ ${ }^{4}$ Acadêmica do Curso de Odontologia da UNIPAR \\ ${ }^{5}$ Docente da UNIPAR
}

Introdução: A osteoporose é uma doença osteometabólica caracterizada por perda de massa óssea e deterioração da microarquitetura do tecido ósseo, como consequência ocorre a fragilidade óssea e maior suscetibilidade à fraturas. Muitas vezes o paciente desconhece a existência da doença, e é o Cirurgião-Dentista (CD) que ao intervir, realizando sua conduta clínica, levanta a suspeita. Reconhecida a doença pelo $C D$, deve ser feito o encaminhamento para tratamento médico numa fase em que não exista muita perda óssea, para que se tenha menos repercussões ou sequelas nos ossos do complexo maxilofacial, reduzindo-se eventuais complicações que poderiam interferir desfavoravelmente nas condutas clínicas odontológicas. Assim se torna de grande importância que o CD esteja atento à doença (SPEZZIA, 2009).

Objetivo: O objetivo desse trabalho é, através de uma revisão da literatura, salientar a importância do cirurgião dentista para identificar todas as manifestações clínicas provocadas pela osteoporose, principalmente as manifestações orais no quadro clínico de cada paciente.

Desenvolvimento: A osteoporose também se manifesta na cavidade bucal, partindo de um quadro sistêmico de comprometimento do paciente. A perda óssea bucal pode estar relacionada com a perda óssea sistêmica e o osso acometido por osteoporose pode influenciar procedimentos odontológicos, como o tratamento utilizando-se implantes osseointegrados, levando em conta que a osseointegração pode ser prejudicada, já que refere a uma deficiência do metabolismo ósseo, causando comprometimento à neoformação e reparação óssea ao redor de implantes (SPEZZIA, 2009). A osteoporose sistêmica, o baixo teor de cálcio dietético e os baixos níveis de vitamina $\mathrm{D}$ podem influenciar a condição periodontal e podem estar associados à perda do dente. Relatou-se que a doença periodontal é mais comum em mulheres com osteoporose e está associada a um menor nível de vitamina D. Por conseguinte, o conhecimento da condição óssea sistêmica de um paciente odontológico juntamente com o conhecimento da ingestão de cálcio e vitamina $D$ do paciente, pode ser importante para compreender a sua condição periodontal e melhorar sua saúde bucal (PENONI et al, 2015). A osteoporose também é um fator de risco para o paciente em reabsorção óssea alveolar pós uma exodontia, a osteoporose pode causar alterações periodontais ou o agravamento de problemas periodontais preexistentes, podendo levar ao aparecimento de mobilidade dentária e até mesmo perdas dentárias (SPEZZIA, 2009). Assim torna-se importante que o Cirurgião-Dentista permaneça atento no ato da terapia e da instrumentação periodontal. Existem evidências de que a forma e a espessura da cortical mandibular em radiografias panorâmicas podem ser usadas como ferramentas para detectar baixa densidade óssea mineral, não com a finalidade de diagnóstico, e sim para identificar o risco e encaminhar adequadamente a paciente para investigação por densitometria, permitindo interceptar o progresso da doença, por isso é importante que o cirurgião-dentista esteja atento à alterações radiográficas (MAH et al, 2008). O osso osteoporótico tem uma característica de ser mais poroso do que o osso normal, resultado do processo aumentado de reabsorção óssea, que é proveniente de atividade predominantemente osteoclástica e ocorrem modificações na arquitetura trabecular óssea. A doença causa redução do trabeculado ósseo e do osso cortical, fato que pode ser visualizado pelo exame radiográfico. Geralmente emprega-se a radiografia panorâmica para tal, já que o trabeculado ósseo é facilmente visualizado nessas radiografias (SPEZZIA, 2009).A anamnese bem conduzida, seguindo critérios médicos e odontológicos, funciona como um instrumento importante, eficiente e imprescindível, norteando e organizando dados, sinais e sintomas de grande significado e fornecendo informações que contribuem para a identificação de eventuais enfermidades e/ou alterações sistêmicas ou locais, ainda que pareçam dissociadas da queixa principal do paciente (OURIQUE et al, 2005).

Conclusão: $O$ diagnóstico precoce que pode ser realizado pleo $C D$ é fundamental para que o tratamento necessário seja instituído. Neste quesito o trabalho do CD é imprescindível porque além de orientar e fornecer melhora na qualidade de vida do paciente, também pode instruir a higiene bucal e necessidade de acompanhamento periódico, para evitar agravos da osteoporose no ossos do complexo maxilo-mandibular. 


\section{Referências}

MAHL, Celia Regina Winck; LICKS, Renata; FONTANELLA, Vania Regina Camargo. Comparação de índices morfométricos obtidos na radiografia odontológica panorâmica na identificação de indivíduos com osteoporose/ osteopenia. Radiol. Bras., São Paulo, v.41, n.3, p.183-187, 2008.

OURIQUE, Sérgio A. M.; ITO, André, Yasumoto; SUAREZ, Omar F. Osteoporose em Implantodontia: o Estado Atual da Questão, RBP Revista Brasileira de Implantodontia \& Prótese sobre Implantes. v.12, n. 47/48, p:237-45. 2005.

PENONI,Daniela.Cia et al.Possíveis ligações entre a osteoporose e a doença periodontal.Rev. Bras. Reumatol. vol.57 no.3 São Paulo May/June 2017.

SPEZZIA, Sérgio. O papel da osteoporose na Odontologia, Rev. Assoc. Paul. Cir. Dent. v.68, n.4, p.366-367. Sao Paulo Out./Dez. 2014. 


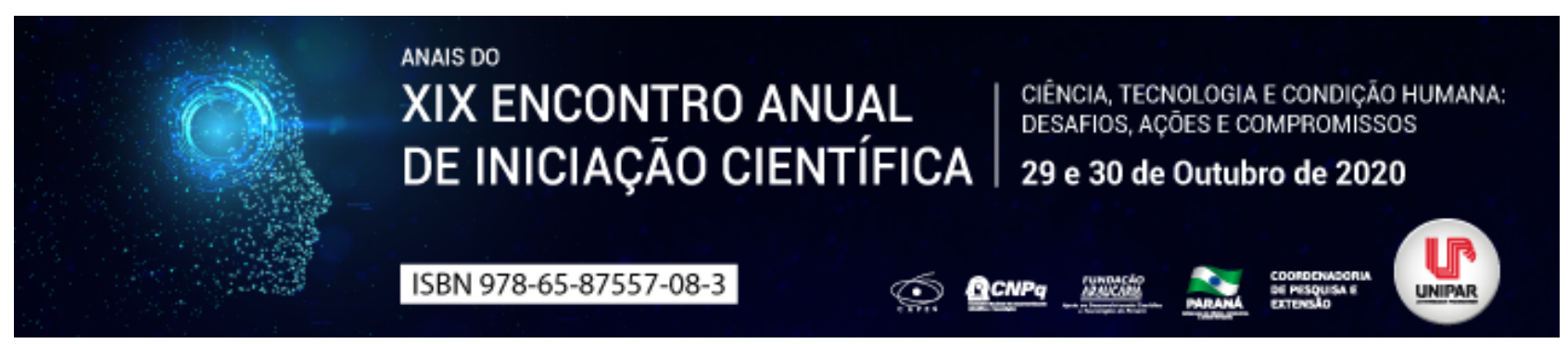

ATIVIDADE ANTI HIPERTENSIVA DO Cymbopogon citratus

${ }^{1}$ FERNANDA SANDRI, ${ }^{2}$ MARIANA HACHICHO ALMEIDA, ${ }^{3}$ MARCO AURELIO CUNHA DEL VECHIO, ${ }^{4}$ KAROLAINE BEZERRA, ${ }^{5}$ ISABELA CARVALHO DOS SANTOS, ${ }^{6}$ LIDIANE NUNES BARBOSA

\author{
${ }^{1}$ Acadêmico bolsista PIBIC/UNIPAR \\ ${ }^{1}$ Acadêmico bolsista PIBIC/UNIPAR \\ ${ }^{2}$ Mestrando PPG em Ciência Animal com Ênfase em Produtos Bioativos/ Taxista - Prosup/CAPES \\ ${ }^{3}$ Mestranda PPG em Ciência Animal com Ênfase em Produtos Bioativos/ Taxista - Prosup/CAPES \\ ${ }^{4}$ Doutoranda PPG em Ciência Animal com Ênfase em Produtos Bioativos/ Bolsista - Prosup/CAPES \\ ${ }^{5}$ Docente da UNIPAR
}

Introdução: A Cymbopogon citratus é uma erva, popularmente conhecida no Brasil como capim-limão, geralmente utilizada na forma de chás ou óleos e possui diversos efeitos medicinais, como ação antibacteriana, antifúngica, antiinflamatória, hipoglicêmica, hipotensora entre outros (SHAH et al., 2011). A hipertensão arterial sistêmica (HAS) é uma doença de alta prevalência no Brasil, onde, em cerca de $40 \%$ dos adultos acima de 25 anos de idade no país sofrem de HAS, e sendo esta a responsável por 12,8\% das mortes no Brasil em 2008 (LOBO et al., 2017). Desde o princípio da humanidade a natureza é utilizada em favor à saúde. Com o aumento das indústrias e da tecnologia os fármacos químicos passaram a ser mais utilizados, porém, com estudos científicos desmistificando lendas e comprovando a funcionalidade de plantas fitoterápicas. Outro fator que contribui para o maior interesse nos produtos naturais é a crise financeira vivida por muitos povos, onde vêm-se resgatando o uso da medicina natural principalmente para doenças de alta prevalência, como a HAS (FARIAS, 2016). Dentro desse cenário, o capim-limão é cotado para a prevenção e tratamento de hipertensão arterial.

Objetivo: O presente estudo tem como objetivo avaliar a ação anti hipertensiva do Cymbopogon citratus através de revisão bibliográfica.

Desenvolvimento: Para o presente estudo, 8 artigos foram analisanos e 5 usados diretamente para a produção do mesmo. As palavras-chave pesquisadas foram: Hiper tensão arterial, cymbopogon citratus, e plantas medicinais. Farias (2016) fez uma revisão bibliográfica sobre plantas medicinais e seus usos e, dos 62 artigos utilizados, 13 tinham relação com pressão arterial, alguns apenas com relatos populares sobre tais efeitos e outros com estudos in vitro, in vivo e em humanos; o artigo relata o uso das folhas, raízes e rizoma do Cymbopogon citratus e diz que a erva reduz a resistência vascular, ou seja, diminui a vasoconstrição, por bloqueio de canais de cálcio. Em um estudo com 30 ratos normotensos, não só o impedimento da vasoconstrição, mas o efeito vasodilatador, pode ser comprovado e, este variou de acordo com a dose de Cymbopogon citratus, administrado na forma de extrato metanólico das folhas por via intravenosa (LIMA MELO, 2016). Oliveira e Rocha (2016) nos mostram que muitos cidadãos na cidade de Caxias-MA fazem chás com as folhas do capim-limão para combater a HAS e que a mesma possui também efeito diurético, que é complementar ao tratamento anti hipertensivo, tal artigo não traz dados científicos que comprovem esses efeitos, apenas relatos populares. Facilmente percebemos que, apesar de conclusões distintas, todos os autores citados concordam na existência e eficácia da ação anti hipertensiva da erva estudada, no entanto, os resultados não são conclusivos sobre a melhor forma de uso para obtenção do efeito terapêutico .

Conclusão: Os dados mostram um indicativo das potencialidades anti hipertensivas do Cymbopogon citratus mas, outros estudos se fazem necessários para ver sua eficiência e segurança em humanos.

\title{
Referências
}

FARIAS, Daíse. Uso de plantas medicinais e fitoterápicos como forma complementar no controle da hipertensão arterial. Journal of Biology \& Pharmacy and Agricultural Management. , v. 12, n. 3, p.1-13, 2016.

LIMA MELO, Jeancarlo. Efecto hipotensor e inhibidor de la vasoconstricción por bloqueo de canales de calcio del extracto metanólico de hojas hierba luisa (Cymbopogon Citratus) en ratas normotensas y anillos vasculares aórticos de rata. Repositorio Institucional UNSA, p.1-2, 2016.

LOBO, Larissa Aline Carneiro et al. Tendência temporal da prevalência de hipertensão arterial sistêmica no Brasil. Cadernos de Saúde Pública, v. 33, p. e00035316, 2017.

OLIVEIRA, Vilma Bragas de; ROCHA, Marcia Cristina Alves da. Levantamento das plantas utilizadas como medicinais na cidade de Caxias-MA: uma perspectiva etnofarmacológica. Revista Interdisciplinar, v. 9, n. 4, p. 43-52, out. nov. dez. 2016.

$\mathrm{SHAH}$, Gagan et al. Base científica para o uso terapêutico de Cymbopogon citratus, stapf (capim-limão). Jornal de Tecnologia e Pesquisa Farmacêutica Avançada, v. 2, n. 1, p. 3, 2011. 
Coordenadoria de Pesquisa e Extensão - COPEX

Departamento de Editoraçāo e Divulgaçāo Científica - DEDIC 


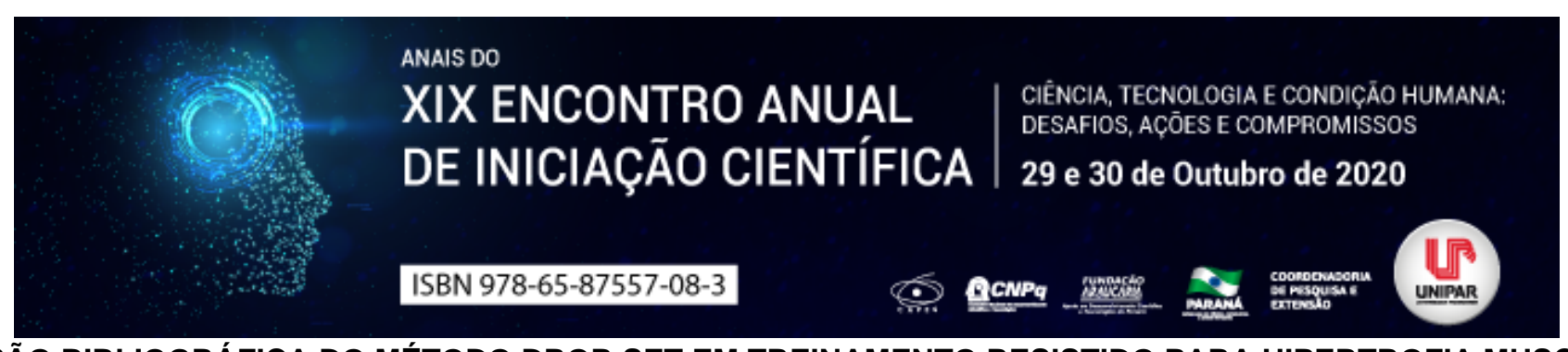

REVISÃO BIBLIOGRÁFICA DO MÉTODO DROP-SET EM TREINAMENTO RESISTIDO PARA HIPERTROFIA MUSCULAR

\author{
${ }^{1}$ FELIPE ELIAS GAVENDA, ${ }^{2}$ FERNANDO HENRIQUE PAVAO
}

\author{
${ }^{1}$ Acadêmico do PIC/UNIPAR \\ ${ }^{1}$ Docente da UNIPAR
}

Introdução: Atualmente o treinamento resistido possui muitos praticantes ao redor do mundo devido aos seus diversos benefícios, como: melhora da saúde, qualidade de vida, lazer, condicionamento e construção de uma melhor estética corporal por meio da hipertrofia muscular (GENTIL, 2005). Para alcançar melhores resultados foram desenvolvidas maneiras de manipular os estímulos por meio dos métodos de treinamento de força (MTF), os quais fornecem estímulos mecânicos diferentes do treinamento usual para buscar melhor desempenho e desenvolvimento muscular (GENTIL, 2006). Um dos mais conhecidos métodos de treinamento é o Drop-Set, também considerado o mais utilizado nos treinamentos de força devido ao trabalho neural e melhor hipertrofia pelo maior tempo de estresse mantendo boa execução da técnica. Esse método é formado por séries descendentes e repetições até a falha concêntrica, com diminuição da carga e continuidade do exercício até uma nova falha muscular. Dessa forma, causa um estímulo tensional e um estímulo metabólico, envolvendo duas das principais variáveis para a hipertrofia muscular (GIANOLLA, 2003).

Objetivo: O objetivo do presente estudo é revisar a literatura sobre a eficácia do método de treinamento de força Drop-set para ganhos de massa muscular em praticantes de treinamento resistido assim como comparar os efeitos do MTF Drop-set em relação ao método tradicional de treinamento de força sobre a hipertrofia muscular.

Desenvolvimento: O treinamento resistido é influenciado por estímulos mecânicos e metabólicos, sendo que o estímulo mecânico depende do volume de treinamento (séries e repetições) e da carga levantada. Acredita-se que esses fatores determinantes sejam os mais importantes para o desenvolvimento da força e hipertrofia muscular (GENTIL, 2006). O músculo esquelético possui ótima capacidade adaptativa aos estímulos realizados em treinamentos. Essas adaptações podem causar aumento no tamanho das fibras musculares e alterações na capacidade metabólica (FIGUEREDO; NARESI, 2010). O MTF Dropset é caracterizado pela execução de três séries de um exercício com repetições máximas e técnica adequada até a falha concêntrica do movimento. O exercício possui intensidade alta e a primeira série se inicia com sobrecarga acima de $75 \%$ de 1 $\mathrm{RM}$, ao atingir a falha concêntrica do músculo alvo há uma redução da carga em $20 \%$ para que o indivíduo consiga prosseguir com a execução. Após ocorrer uma nova falha concêntrica é reduzido novamente a sobrecarga em, aproximadamente, $20 \%$ para que o praticante execute e atinja a terceira falha concêntrica. Esse método é realizado sem intervalos (TOGASHI, 2009; SALLES E SIMÃO, 2014). Um estudo feito por Angleri et. al (2017) comparou efeitos do método Drop-set com treinamento de força tradicional. Foram presentes no estudo 32 homens com idades de 27士3,9 anos com experiência em treinamento de 6,4 $\pm 2,0$ anos. Após realizada uma familiarização, teste de 1RM e medidas antropométricas foram aplicadas 12 semanas de treinamento físico com duas sessões semanais, nas quais 16 dos indivíduos fizeram treinamento de força tradicional (TRAD), 8 fizeram sistema de pirâmide e 8 Drop-set, todos com volumes finais iguais. Segundo Angleri a área de secção transversa do músculo treinado aumentou 7,6\% para o TRAD, 7,5\% para o sistema de pirâmide e 7,8\% para o sistema Drop-set. Portanto, concluiu que o método não promove maiores aumentos de massa muscular comparado ao treinamento de força tradicional com intensidade e volume constante. Já o estudo de Gentil et. al (2006) comparou respostas metabólicas agudas por meio do lactato sanguíneo e mecânicas entre métodos de treinamento. Foram avaliados 7 homens treinados, onde foram aplicados em um aparelho de extensão de joelho os métodos: 10 repetições máximas, métodos 6 repetições máximas, método de séries descendentes (Dropset), método de repetições forçadas, método de isometria funcional, oclusão vascular e método superlento. Gentil concluiu que todos os métodos parecem apresentar um estímulo metabólico semelhante, porém o método de séries descendentes (Drop-set) produziu cargas mais altas, induziu maior stress mecânico e constatou que torna atraente a especulação de que este MTF é particularmente eficiente na indução de ganhos no tamanho do músculo e força.

Conclusão: O presente estudo conclui que a hipertrofia muscular ocorre devido a diversos estímulos metabólicos, mecânicos e tensionais oriundos do exercício físico. Porém o método de treinamento Drop-set não se apresenta mais eficiente para hipertrofia muscular comparado ao treinamento de força tradicional quando a intensidade e o volume final são o mesmo. Ainda assim, se mostra como uma boa opção para uma periodização de treinamento resistido, já que apresenta maiores cargas finais, tendências positivas para hipertrofia muscular, maior frequência cardíaca e maior stress mecânico com relação ao treinamento de força tradicional.

\title{
Referências
}

BOMPA, T; CORNACCHIA, L. S. Treinamento de Força Levado a Sério. 2. ed. Editora Manole, 2004. 
BROWN, Lee. E.I CHANDLER, T. Jeff. Treinamento de Força Para o Desempenho Humano. 1. ed. Porto Alegre: Editora Artmed, 2009.

CARVALHO, M. L.; BRUN, G.; CHUPEL, M. U.; SOUZA, W. C. DE; SOUZA, W. B. DE; GRZELCZAK, M. T.; MASCARENHAS, L. P. G. Eficácia do método de musculação Drop-Set relacionando força e composição corporal. Saúde e meio ambiente: revista interdisciplinar, v. 3, n. 2, p. 35-43, 2015.

CEOLA, M. H. J; TUMELERO, S. Grau de hipertrofia muscular em resposta a três métodos de treinamento de força muscular. Lecturas: Educación física y deportes, n.121, p. 19, 2008.

DE ARRUDA, D. P. et al. Relação entre treinamento de força e redução do peso corporal. Revista Brasileira de Prescrição e Fisiologia do Exercício, v. 4, n. 24, p. 10, 2010.

GENTIL, Paulo et al . Efeitos agudos de vários métodos de treinamento de força no lactato sanguíneo e características de cargas em homens treinados recreacionalmente. Rev Bras Med Esporte, Niterói , v. 12, n. 6, p. 303-307, 2006 . Disponível em: http://dx.doi.org/10.1590/S1517-86922006000600001. Acesso em: 20 Ago. 2020.

GIANOLLA, F. Musculação: conceitos básicos. Barueri: Manole 2003.

8. MARCHAND, E. Melhoras na força e hipertrofia muscular, provenientes dos exercícios resistidos. Lecturas: Educación Física y Deportes, Buenos Aires, v. 8, n. 57, 2003. Disponível em: http://www.efdeportes.com. Acesso em: 20 Ago. 2020.

TOGASHI, G.B. Dano muscular induzido pelo sistema de treinamento de cargas descendentes em exercícios resistidos. 2009. Dissertação de Mestrado. Universidade Federal de São Carlos. São Carlos. 2009.

WEINECK, J. Treinamento Ideal. 9. ed. São Paulo: Manole, 2003.

Coordenadoria de Pesquisa e Extensão - COPEX

Departamento de Editoraçāo e Divulgaçāo Científica - DEDIC 


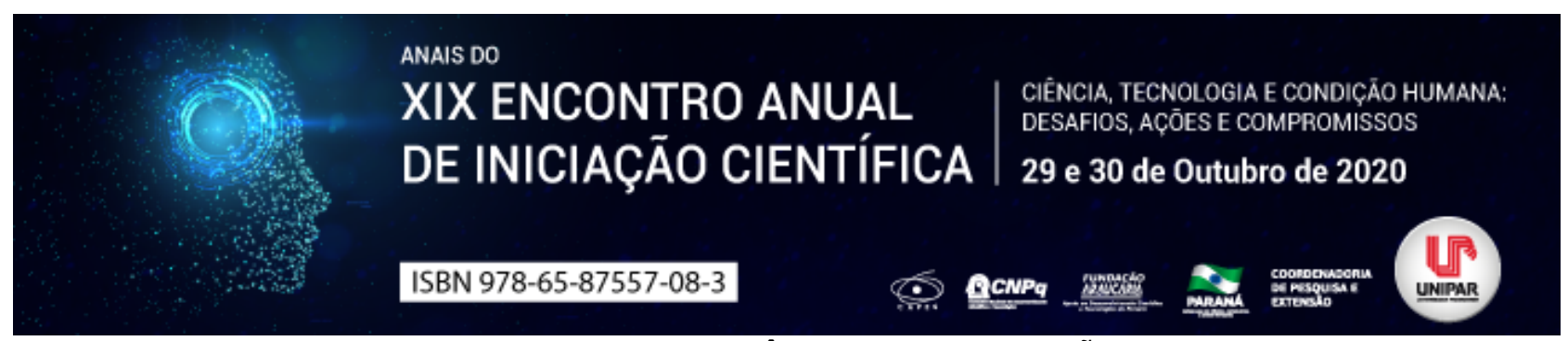

PATOLOGIAS DO ESTÔMAGO: UMA REVISÃO

\begin{abstract}
1 BARBARA HELENA SIOLARI DE MICO ROBERTO, ${ }^{2}$ BRUNA FAVRETTO DA SILVA, ${ }^{3}$ FERNANDA YUKARI TANAKA DE MELO, ${ }^{4}$ LAIS TEODORO LOPES, ${ }^{5}$ ELENIZA DE VICTOR ADAMOWSKI CHIQUETTI
\end{abstract}

\author{
${ }^{1}$ Discente do curso de medicina da Unipar \\ ${ }^{1}$ Acadêmica do Curso de Medicina da UNIPAR \\ ${ }^{2}$ Acadêmico do Curso de Medicina da UNIPAR \\ ${ }^{3}$ Acadêmica do Curso de Medicina da UNIPAR \\ ${ }^{4}$ Docente da UNIPAR
}

Introdução: As doenças encontradas no estômago podem ser lesões inflamatórias, majoritariamente desencadeadas pela presença da bactéria Helicobacter pylori, ou neoplasias (FILHO, 2016). Em um adulto, o estômago pode conter de 1.200 a 1.500 $\mathrm{mL}$, é dividido em três regiões e possui a função de decomposição dos alimentos. Nele estão contidas células parietais, responsáveis por secretar ácido clorídrico, o fator intrínseco, glicoproteína necessária para a absorção intestinal da vitamina B12 e as células principais, também chamadas de células zimogênicas, secretoras de pepsinogênio (FILHO, 2016).

Objetivo: Este estudo de revisão tem por objetivo retratar algumas das patologias do estômago, por meio de seus sintomas e predisposições, com ressalva em seus diagnósticos precoces.

Desenvolvimento: As doenças do estômago possuem alguns desconfortos semelhantes entre si, sendo eles episódios de vômitos, náuseas, dor epigástrica e desconforto abdominal (VINAY et al., 2013). Dentre as principais doenças estão o adenocarcinoma gástrico, a estenose hipertrófica do piloro, o linfoma não Hodgkin, o tumor carcinóide e a úlcera péptica. O adenocarcinoma gástrico é uma doença neoplásica maligna, abrangendo mais de $90 \%$ dos cânceres gástricos. Seus sintomas envolvem dispepsia, disfagia, náuseas, perda de peso, anorexia, hábitos intestinais alterados, anemia e hemorragia, sendo mais frequente em homens. É estimado que a sua taxa de sobrevida seja de $20 \%$ após 5 anos da doença. Os fatores de risco contemplam consumo de álcool; consumo excessivo de sal; tabagismo e histórico de câncer na família (GARCIA e VIOLA, 2018). A estenose hipertrófica de piloro é caracterizada pela hipertrofia do músculo circular na menor extensão da camada muscular longitudinal, acarretando no estreitamento do lúmen pilórico. Sua etiologia ainda não contempla estudos concretos, porém observa-se que pode estar conexo a fatores como a predisposição genética ligada ao gênero masculino que é 4 vezes mais incidente do que em meninas, sendo a principal causa cirúrgica após o nascimento (lactente); fatores extrínsecos, como a dieta com base na amamentação e tabagismo da mãe; fatores hormonais, visto que o esfíncter pilórico está sobre controle da gastrina, e a elevação deste hormônio pode provocar várias contrações podendo levar a hipertrofia compensatória por trabalho excessivo da atividade de contração (BOLAÑOS e AYMERICH, 2014). Há 2 grupos de linfoma: o linfoma de Hodgkin (LH) e o não Hodgkin, que se dá pela estimulação do antígeno da $H$. pylori, podendo desenvolver neoplasias malignas no estômago. Seus sintomas abrangem: febre, suores noturnos, perda de peso, prurido, astenia e dor epigástrica em $70 \%$ dos casos. Os fatores de risco são: sistema imune comprometido; portadores dos vírus Epstein-Barr e HTLV1 e da bactéria $H$. pylori; exposição frequente a substâncias químicas; exposição a altas doses de radiação; trabalhadores rurais expostos a múltiplos agentes (MONTEIRO et al., 2016). O tumor Carcinóide é um tumor neuroendócrino que ocorre $65 \%$ das vezes no trato gastrointestinal e $25 \%$ nos pulmões. Apresenta um crescimento mais lento do que os carcinomas e sua ocorrência mais comum é na faixa etária dos 60 anos. Seus fatores de riscos são consumo de álcool, excesso de peso, obesidade, consumo excessivo de sal, tabagismo, ingestão de água com alta concentração de nitrato, exposição frequente a compostos químicos, histórico em parentes com o tumor (BLASCO et al., 2016). A úlcera péptica está associada a infecção por $H$. pylori ou ainda pelo consumo excessivo de medicamentos antiinflamatórios ou anti-agregantes plaquetários, como é o caso da aspirina. Essa doença pode ocorrer em todo o trato gastrointestinal exposto a sucos gástricos ácidos, porém é mais comum no antro gástrico e na primeira porção do duodeno, podendo ocorrer também no esôfago. Seus sintomas envolvem dor intensa no abdomem e em alguns relatos tem-se quadros de náuseas, vômitos, perda de apetite e fezes com sangue. Os fatores de risco são o uso excessivo de anti-inflamatórios ou ácido acetilsalicílico, predisposição genética; presença de $H$. pylori que ataca o estômago deixando-o mais suscetível; fatores emocionais ligados ao estresse (CALDERÓN et al., 2018). A visita frequente ao médico para realizar exames de rotina é crucial para um diagnóstico precoce, conexo a gravidade da maioria das patologias estomacais, que desenvolvem neoplasias, benignas ou malignas, assim se descoberto precocemente o tratamento pode ser feito de forma mais eficiente, com resultados promíscuos, aumentando a taxa de sobrevida.

Conclusão: Dado os fatos, fica evidente que as doenças que afetam o estômago possuem incidência consideravelmente alta, podendo originar neoplasias ou não, apresentando sintomas comuns como desconforto abdominal, náuseas e dor epigástrica. 
Mostra-se também, que quando diagnosticadas precocemente essas doenças possuem tratamentos promíscuos, sendo possível concluir exames periódicos para esses diagnósticos, e ocasionando maior chance de cura em casos graves através de tratamentos eficazes que variam conforme o grau em que a doença se encontra, quanto antes descoberta maior será a expectativa de vida.

\section{Referências}

BLASCO, Maria del Carmen et al. Tumor carcinóide do trato gastrointestinal: cerca de dois casos clínicos. Revista gastroenterologia, Perú, vol.36 n.3, jul./set., 2016. Disponível em: http://www.scielo.org.pe/scielo.php? script=sci_arttext\&pid=S1022-51292016000300014 .Acesso em: 12, junho. 2020.

BOLAÑ $\bar{S}$, Aymerich Oscar. Estenosis hipertrófica pilórica infantil. Revista Medicina legal de Costa Rica, vol.31, n.1 , Jan./Mar., 2014. Disponível em: https://www.scielo.sa.cr/scielo.php?script= sci_arttext\&pid=S140900152014000100007\&lang=en. Acesso em: 13, junho. 2020

BRASILEIRO FILHO, Geraldo. Bogliolo Patologia. 9. ed Rio de Janeiro: Guanabara Koogan, 2016. 1.006-1033.

CALDERÓN, G. E. Gerly et al. Reexame de úlcera péptica em pacientes com e sem doença renal crônica. Revista Horizonte Medico, Vol.18, Peru, Lima, 2018. Disponível em: http://www.scielo.org.pe/scielo.php?pid=S1727558X2018000400003\&script=sci_arttext .Acesso em: 14, junho.2020.

MONTEIRO, Talita et al. Linfoma de Hodgkin: aspectos epidemiológicos e subtipos diagnosticados em um hospital de referência no Estado do Pará, Brasil. Revista Pan-Amazonica de Saude, v.7, n.1, mar., 2016. Disponível em: http://scielo.iec.gov.br/scielo.php?script=sci_arttext\&pid=S2176-62232016000100003.Acesso em:13, junho. 2020.

TONETO, Marcelo Garcia; VIOLA, Luciana. Estado atual do tratamento multidisciplinar do adenocarcinoma gástrico, Revista ABCD, Arquivo Brasileiro Cirurgia Digestiva, 2018. Disponível em:https://www.scielo.br/pdf/abcd/v31n2/pt_0102-6720-abcd-3102-e1373.pdf . Acesso em: 16, junho. 2020.

KUMAR, Vinay et al. Robbins Patologia Básica. 9. ed. Rio de Janeiro: Saunders Elsevier, 2013.

Coordenadoria de Pesquisa e Extensão - COPEX

Departamento de Editoraçāo e Divulgaçāo Científica - DEDIC 


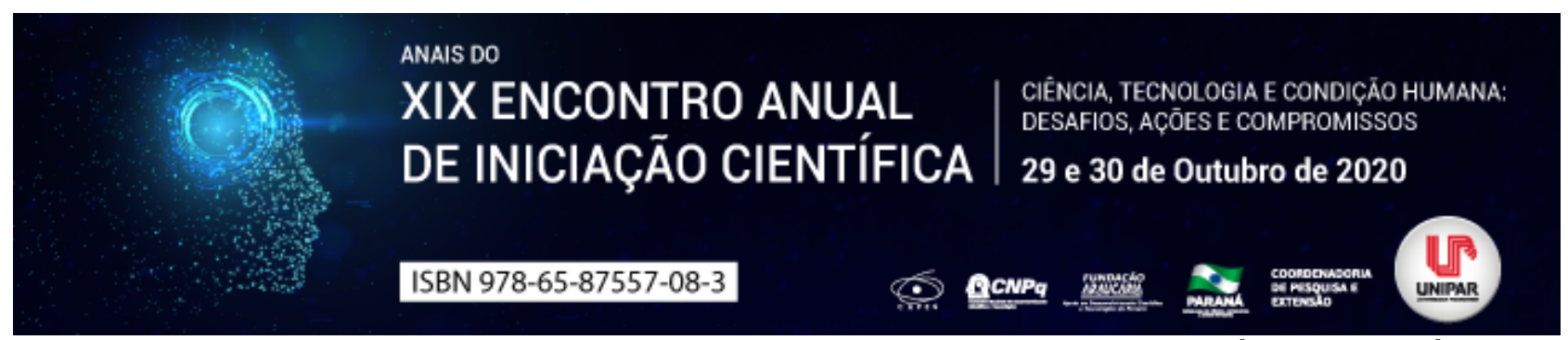

ORTOREXIA NERVOSA: ALERTA PARA ESTUDANTES E PROFISSIONAIS DA ÁREA DA SAÚDE

\title{
${ }^{1}$ ALINE DE SOUZA, ${ }^{2}$ JANAINA STRAPAZZON RAFAGNIN
}

\author{
${ }^{1}$ Acadêmico do curso de Nutrição da UNIPAR \\ ${ }^{1}$ Docente da UNIPAR
}

Introdução: Embora não tenha sido reconhecida como um transtorno alimentar, a Ortorexia Nervosa (ON) vem crescendo na sociedade e se tornando preocupante. É certo que a pessoa acometida deve ter um conhecimento sobre alimentação saudável, sendo assim o grupo mais suscetível a esse comportamento seriam os estudantes de nutrição, nutricionistas e proficionais da area da saúde em geral, podendo haver uma pressão a terem um alimentação exemplo (PENAFORTE, et al., 2018). Os transtornos alimentares (TA's) são doenças graves de ordem psiquiátrica, gerado pelo culto à imagem corporal e atingem principalmente adolescentes do sexo feminino (ABREU, CANGELLI FILHO, 2004). Os principais TA's descritos pela literatura são: a Anorexia Nervosa (AN), Bulimia Nervosa (BN), Transtorno de Compulsão Alimentar Periódica (TCAP) e Vigorexia ou Transtorno Dismórfico Corporal (TDC) (NASCIMENTO, et al., 2012).

Objetivo: Com base na literatura caracterizar a ON como alerta para os estudantes e profissionais da área da saúde, com o intuito de prevenção.

Desenvolvimento:A ON é descrita como um comportamento obsessivo patológico por alimentos saudáveis. É caracterizado pela obsessão em uma dieta composta exclusivamente por alimentos saudáveis e puros . Foi descrita pela primeira vez em 1997, pelo médico Steve Bratman que cunhou o termo ortorexia, do grego orto que significa correto e rexia apetite, alimentação correta. Bratman e Knight eram médicos conhecedores das práticas alimentares alternativas, conviviam com adeptos ao vegetarianismo e dietas macrobióticas. Escreveram um livro chamado Health Food Junkie Viciado em comida saudável em tradução livre - (BRATMAN, KNIGHT, 2000), onde expuseram seus estudos e informações sobre esse comportamento obsessivo. Diferente de outros transtornos como $\mathrm{AN}$ e BN, na ON o indivíduo não se preocupa com a quantidade ingerida do alimento, nem necessariamente tem o desejo de emagrecer, mas sim com a qualidade do alimento (PONTES, MONTAGNER, MONTAGNER, 2014). Excluem de sua dieta alimentos que não sejam saudáveis , que contenham pesticidas, herbicidas, conservantes e corantes, que sejam geneticamente modificados, possuam muito sal ou muito açúcar, que passem por algum processo de industrialização onde percam seus nutrientes. Também preocupam-se com a forma de armazenamento do alimento, o tempo entre a colheita, exposição e em alguns casos, na forma de preparo, com o material dos utensílios usados. Com essa preocupação exacerbada o indivíduo pode levar até mais de três horas por dia investigando e planejando sua alimentação (PONTES, 2012; MARTINS, et al., 2011). Um comportamento que também pode ser identificado em pessoas que possuem ON é o afastamento do convívio social, a preferência por fazer suas refeições sozinhas, evitando o questionamento referente às suas escolhas e hábitos alimentares. É comum haver um desprezo por pessoas que não sigam os mesmos padrões, uma auto-imposição para explicar a sua ideologia de alimentação correta, saudável. O seu objetivo é uma alimentação que contribua para o funcionamento do organismo e de alguma maneira liberte seu corpo e mente de impurezas (MARTINS, et al., 2011).Por se tratar de um comportamento onde a uma busca por alimentos saudáveis, a ON pode ter um diagnostico muito tardio. Uma boa alimentação é vista como sinônimo de saúde, é indicado por muitos profissionais, o indivíduo também parece sentir orgulho de sua rotina, de seus hábitos, tornando mais difícil a aceitação do problema, que pode estar trazendo prejuízo à saúde (PONTES, 2012). No primeiro momento a ON parece não ser prejudicial à saúde, pois que mal pode haver em comer apenas alimentos saudáveis? O comportamento, com o passar do tempo, vai se tornando mais seletivo, excluindo alimentos que possuem nutrientes essenciais para a saúde, tendo condutas alimentares cada vez mais restritivas, o que pode levar a desnutrição, anemia, hipovitaminose (falta de algumas vitaminas no organismo), hipervitaminose (excesso de algumas vitaminas), osteoporose, deficiência de oligoelementos, hipotensão, pode também levar a depressão, ansiedade e hipocondria (JEREZ F, et al., 2015). Esse comportamento tem prevalência em pessoas que possuem conhecimento sobre o assunto, profissionais que em algum momento da formação estudaram a matéria de nutrição, ou adeptos de modismos alimentares, que precisam de uma dieta restritiva de algum grupo alimentar, atletas que se dedicam ao esporte. Requer autodisciplina, controle para seguir uma dieta. Uma limitação pode ser o poder aquisitivo do indivíduo, muitos dos alimentos classificados como saudáveis tem um custo mais elevado (PONTES, 2012).

Conclusão:O fato de estudantes e profissionais da saúde ser o grupo mais acometido, torna a situação ainda mais preocupante, visto que esses profissionais precisam mudar vidas, passar orientações saudávies, promover saúde. O comportamento obsessivo compulsivo, gerado pela ON pode trazer prejuízo para a saúde da pessoa, como incentivar a reprodução do comportamento. São necessárias ações de concientização em toda a sociedade e principalmente nos estudantes e profissionais da área da saúde. 


\section{Referências}

JEREZ F, Tatiana. et al. Prevalência de comportamento ortorexico em estudantes do ensino médio de Temuco. Revista Chilena de nutrition., Santiago, v. 42, n. 1, p. 41-44, março de 2015.

Disponível em https://scielo.conicyt.cl/scielo.php?script=sci_arttext\&pid=S0717-75182015000100005\&lng=es\&nrm=iso.

MARTINS, Márcia Cristina Teixeira et al . Ortorexia nervosa: reflexões sobre um novo conceito. Revista de Nutrição., Campinas, v. 24, n. 2, p. 345357, Abr. 2011.

NASCIMENTO, Antonio Leandro; APPOLINARIO, José Carlos; FONTENELLE, Leonardo Franklin. Comorbidade entre transtorno dismórfico corporal e bulimia nervosa. Revista psiquiatria Clinica., São Paulo, v. 39, n. 1, pág. 40-42, 2012.

PENAFORTE, Fernanda R. O. et al. Ortorexia nervosa em estudantes de nutrição: associações com o estado nutricional, satisfação corporal e período cursado. Jornal brasileiro de Psiquiatria., Rio de Janeiro, v. 67, n. 1, p. 18-24, Mar. 2018.

PONTES, Jackeline B. Montagner, Maria I, Montagner, Maria A. Ortorexia nervosa: adaptação cultural do orto-15. Demetra: Alimentação, nutrição \& saúde., v. 9. n. 2. p. 533-548. 2014.

PONTES, Jackeline B. Ortorexia em estudantes de nutrição: a hiper correlação incorporada ao habitus profissional? Dissertação de Mestrado. Brasília-DF. Universidade de Brasília. Faculdade de Ciências da Saúde. Programa de Pós-Graduação em Ciências da Saúde. 2012. 


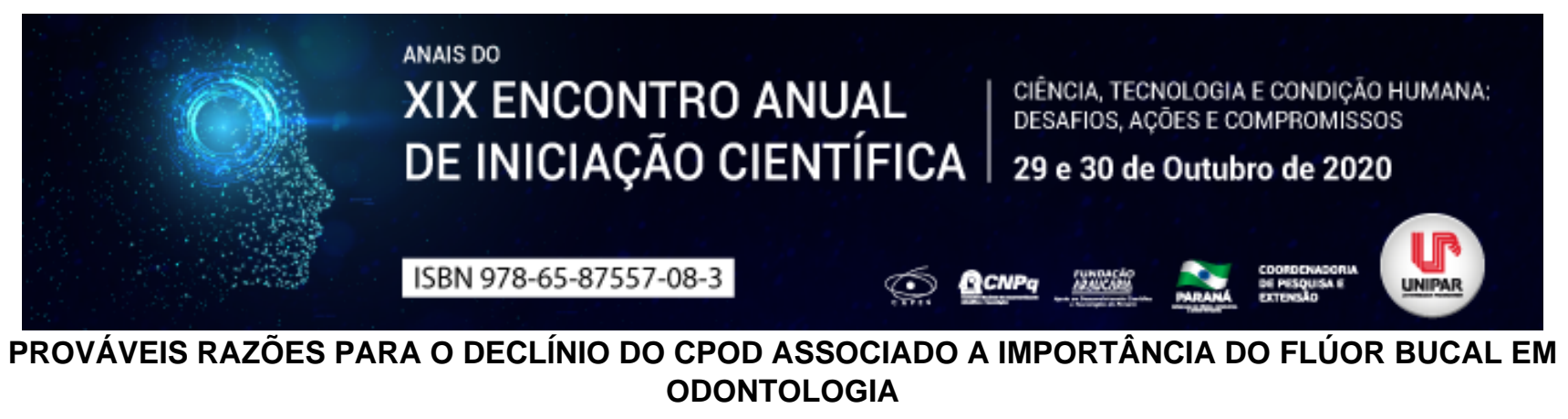

\begin{abstract}
${ }^{1}$ IZADORA FRANCESCHET FARIAS, ${ }^{2}$ JENNIFER LORENSINI DOS SANTOS, ${ }^{3}$ LUANA VANZETTO, ${ }^{4}$ JENIFFER URBANO DEGASPERI, ${ }^{5}$ JULIANA GARCIA MUGNAI VIEIRA SOUZA
\end{abstract}

\begin{abstract}
${ }^{1}$ Acadêmico do Curso de Odontologia da UNIPAR
${ }^{1}$ Acadêmica do Curso de Odontologia da UNIPAR

${ }^{2}$ Acadêmica do Curso de Odontologia da UNIPAR

${ }^{3}$ Acadêmica do Curso de Odontologia da UNIPAR

${ }^{4}$ Docente da UNIPAR-Campus Cascavel
\end{abstract}

Introdução: O efeito benéfico do flúor no controle da cárie dentária foi descoberto eventualmente no início da primeira década do século XX e desde então, vem sendo um grande aliado na prevenção desta doença (DOMINGOS et al., 2018). O flúor é uma substância farmacologicamente ativa, importantíssimo na atualidade como meio complementar para a melhoria na saúde bucal e qualidade de vida, assim reduzindo os índices de cárie junto com o controle de placa bacteriana e uma dieta saudável. A descoberta do efeito preventivo o transformou, ao longo do século, no principal agente utilizado no enfrentamento da doença cárie em todo o mundo (NARVAI, 2000). Os fluoretos estão disponíveis em vários tipos, formas de aplicação e concentrações para utilização em odontologia, inúmeros estudos têm relatado a sua eficácia na prevenção da cárie, apesar do declínio significativo na prevalência em muitas populações entre todas as idades, continua sendo um vasto problema de saúde pública, deste modo, o flúor age como uma estratégia eficaz para ajudar na remineralização dos dentes, e é considerado de alto padrão para a prevenção da lesão cariosa (MARIA et al., 2019).

Objetivos: Este estudo tem como objetivo abordar alguns dos motivos que levaram ao declínio do índice de cariados, perdidos e obturados por dente (CPOD) com relação a importância da fluoretação, utilizando como método a revisão de literatura.

Desenvolvimento: Estudos apontam que a concentração correta de flúor na água chega a reduzir aproximadamente 60\% da prevalência da cárie dentária, a Organização Mundial da Saúde (OMS), em 1958, reconheceu a fluoretação das águas como uma solene medida de saúde pública, criando um programa para fomentar este método com aprovação unânime dos países membros, em 1975 (ARANHA ROSSI et al., 2020). Este é um método de prevenção que pode atingir diversas classes socioeconômicas, por ser uma ação governamental restrita e de uso coletivo, em 2010, o CPOD após a Pesquisa Nacional de Saúde Bucal foi 2,1, o que pôs o Brasil no grupo de países com baixa prevalência de cárie, houve uma redução de $25 \%$ no valor do CPOD, em relação ao levantamento anterior (AGNELLI, 2016). Outro imprescindível elemento foi o uso de gel ou verniz aplicado pelo cirurgião dentista no consultório odontológico, que é amplamente utilizado em nosso país, o gel é mesclado de flúor-fosfato-acidulado, com uma concentração de 1,23\% de flúor, liberando uma vasta quantidade para os dentes no momento da aplicação, os vernizes são compostos de fluoreto de sódio ( $\mathrm{NaF}$ ) a $5 \%$, aderem à superfície dos dentes durante um tempo mais prolongado do que o gel, levando horas para serem completamente removidos, e liberam lentamente o flúor para os dentes neste período (AGNELLI, 2016). Lembrando que o flúor em gel é eficiente na prevenção e remineralização de lesões de cariosas incipientes, um fato é a diferença de preço entre os produtos fluoretados, onde o verniz chega a ser até mesmo 4 vezes mais caro que o gel, conclui-se que o gel neutro e o verniz fluoretado apresentam bom comportamento no tratamento de lesões de mancha branca, sempre feitas por um profissional de odontologia, há também os dentifrícios fluoretados que são frequentemente encontrados no aspecto de pasta, sendo usado durante a escovação, o flúor presente nos dentifrícios é responsável por aproximadamente $25 \%$ da redução da cárie dentária, é importante cuidar da boca desde o nascimento, entretanto o uso de dentifrício se deve após a erupção do primeiro dente decíduo, para que desde já haja o hábito da escovação, quando a criança tem menos de 3 anos, limita-se a quantidade de creme dental a um esfregaço, ou seja, equivalente à um grão de arroz, já crianças com mais de 3 anos a quantidade recomendada é do tamanho de uma ervilha, lembrando que é recomendado realizar a escovação sem enxaguar com água, pois o instinto da criança é de engolir, e consequentemente torna-se susceptível à fluorose (MARIA et al., 2019). Dentre todas as estratégias preventivas elaboradas até o momento para prevenir os problemas bucais, a escovação dentária com dentifrícios é considerada a de melhor impacto, uma vez que remove ou desorganiza a biofilme responsável tanto pela desmineralização dos tecidos dentários como pela destruição dos tecidos de sustentação (PAZ; SILVA, 2018).

Conclusão: Conclui-se que a utilização do flúor contribuiu para o declínio do CPOD no mundo todo. Os dentifrícios são considerados o meio mais racional de uso de fluoretos, pois participam da desorganização do biofilme dentário na escovação dentária. Houve também uma redução significativa da doença cárie dentária em áreas que fazem uso de água fluoretada. 


\section{Referências}

AGNELLI, Patricia Bolzan. Variação do índice CPOD do Brasil no período de 1980 a 2010. Revista Brasileira de Odontologia, v. 72, n. 1/2, p. 10, 2016.

ARANHA ROSSI, Thais Regis; PASSOS MOREIRA, Luiz Gaudencio; DE BARROS, Sandra Garrido. History of fluoridation policies as a strategy by the Brazilian Legislative Branch to fight dental caries, 1963 to 2019. Cadernos de Saude Publica, v. 36, n. 4, 2020.

DOMINGOS, Patricia Aleixo dos Santos; RICCI-DONATO, Hércia Adad Russi; DECARO, Ana Karla Ferreira. Riscos do uso do flúor sistêmico - revisão de literatura. Journal of Research in Dentistry, v. 6, n. 4, p. 86, 2018.

MARIA, Patrícia; TEIXEIRA, Barbosa. GASPAR, Silveira; CARLOS, Roberto; PINHO, Mourão. Scientific-Clinical Odontology. v. 18, 2019.

NARVAI, Paulo Capel. Cárie dentária e flúor: uma relação do século XX. Ciência \& Saúde Coletiva, v. 5, n. 2, p. $381392,2000$.

PAZ, Ruth da Silva. RUTH PAZ DA SILVA DENTIFRÍCIOS: COMPOSIÇÃO, INDICAÇÃO, TIPOS Porto velho/RO 2018. 2018.

Coordenadoria de Pesquisa e Extensão - COPEX

Departamento de Editoraçāo e Divulgaçāo Científica - DEDIC 


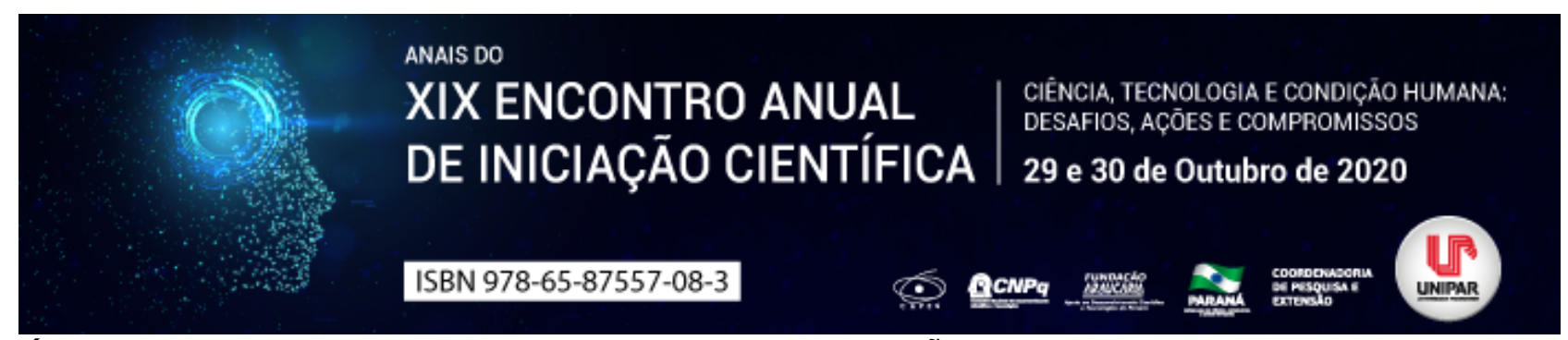

A SÍFILIS NA ODONTOLOGIA: SUAS PRINCIPAIS MANIFESTAÇÕES NA CAVIDADE ORAL, UMA REVISAO DE LITERATURA

\begin{abstract}
${ }^{1}$ KATIA CRISTINA DE CARVALHO, ${ }^{2}$ JENIFFER URBANO DEGASPERI, ${ }^{3}$ LUIZA SANZOVO, ${ }^{4}$ LETICIA DE FREITAS CUBA GUERRA
\end{abstract}

${ }^{1}$ Acadêmica do Curso de Odontologia UNIPAR

${ }^{1}$ Acadêmica do Curso de Odontologia da UNIPAR

${ }^{2}$ Acadêmica do Curso de Odontologia da UNIPAR

${ }^{3}$ Docente da UNIPAR

Introdução: A sífilis é uma infecção causada pela bactéria Treponema pallidum,sua transmissão pode ser vertical ou sexualmente transmitida, é dividida em três fases sendo elas: primária, que representa o estágio inicial da doença onde há presença de um único cancro na área de inoculação; secundária, onde surgem sinais, sintomas importantes e erupções cutâneas maculopapulares pelo corpo. Já na terciária fase, é possívelobservar lesões crônicas destrutivas e também podem ocorrer manifestações em todos os tecidos ou órgãos. Nota-se que essas fases sediferenciam clinicamente e apresentam uma serie de manifestações bucaisrelevantes. Portanto, é indispensável ter conhecimento sobre o caso citado afim de realizar um diagnóstico diferencial e proporcionar tratamento de qualidade na odontologia (NEVILLE,2016).

Objetivo: Revisar os dados da literatura com o objetivo de entender a doença e os mecanismos que causam a sífilis classificando as suas principais manifestações bucais auxiliando no diagnóstico da doença.

Desenvolvimento: A sífilis é uma doença sexualmente transmissível causada por infecção bacteriana crônica devido aoTreponema pallidum. As principais vias de transmissão são sexuais e também pode ser vertical (na gestação).A sífilis é dividida em três estágios, com manifestações clinicas e patológicas distintas (ROBBINS; COTRAN, 2010). Desse modo, a sífilis primária apresenta cancro, lesão vermelha, única, firme e indolor,se desenvolve na área de inoculação, tornam-se visíveis de três a noventa dias após o contato inicial. Na mucosa oral o local mais afetado é o lábio, porém, a língua, o palato, a gengiva e as amígdalas podem ser acometidas. Ademais, a lesão oral apresenta-se como uma úlcera de base clara e indolor e ainda pode ocorrer linfadenopatia regional, pois, nessa fase, a bactéria está sendo disseminada pelo organismo através de vasos linfáticos e as lesões mesmo não tratadas cicatrizam de três a oito semanas (NEVILLE, 2016).Outrossim, a sífilis secundária pode ser identificada clinicamente de quatro à dez semanas e pode ocorrer antes da resolução da lesão inicial. Nessa fase, percebem-se sinais e sintomas como linfadenopatia, cefaléia, dor de garganta, mal-estar e febre. Diferente da sífilis primária, a secundária possui múltiplas lesões desde, erupção cutânea maculopapular pelo corpo e cavidade oral, onde se manifestam como placas mucosas e esbranquiçadas que se fundem com placas adjacentes formando o aspecto caminho de caracol . Após essa formação podem ser evidenciados necrose superficial e descamação do tecido expondo tecido conjuntivo. Destaca-se que lesões são frequentes em superfície da mucosa e lábio, mas podem acometer também mucosa jugal e palato. Quando em região de comissura labial recebem o nome de pápula fendida e as lesões não tratadas tem resolução de três a doze semanas. Após a sífilis secundária os portadores entram em um período de latência que pode durar de um a trinta anos -cerca de $30 \%$ dos portadores entram na fase terciária(NEVILLE, 2016).Na sífilis terciária as lesões apresentam-se crônico destrutivas, são chamadas de gomas sifilíticas e possuem coloração branca acinzentadas. Outro ponto é que as mesmas podem ser únicas ou múltiplas variando de tamanho. Um fator significativo é a incidência em indivíduos não tratados e imunosuprimidos. Sendo assim há possibilidade de desencadear manifestações cardiovasculares e nervosas (TOMASSI, 2013). Suas manifestações bucais apresentam-se como lesão endurecida, nodular ou ulcerada que pode causar extensa destruição tecidual, geralmente acometem palato e língua. Quando há o envolvimento do palato a ulceração pode perfurar em direção a cavidade nasal. Já a língua apresenta um aumento de tamanho, formato irregular e padrão lobular conhecido como glossite intersticial. Além disso, a atrofia e perda das papilas produz uma condição de glossite luética (NEVILLE, 2016). A sífilis congênita, transmitida via placentária ou contato direto com a mãe portadora leva a três achados conhecidoscomo: tríade de Hutchinson que incluí aceratite ocular intersticial, surdez associada ao comprometimento do oitavo par de nervos cranianos e dentes de hutchison, conhecido na Odontologia devido ao crescimento de incisivos pequenos em forma de chave de fenda e com fendas em esmalte ou molares de Mulberry que são dentes em forma de amora(ROBBINS; COTRAN, 2010). O diagnóstico pode ser dado e confirmado através de da visualização de microorganismos espiralados no exame de campo escuro de um esfregaço do exudatode uma lesão ou, mais frequentemente, através de exames laboratoriais como VDRL e FTA-ABS. O tratamento é realizado com penicilina de posologia individualizada (AVELLEIRA; BOTTINO, 2006).

Conclusão: A sífilis é uma doença transmitida por via sexual ou genéticade origem bacteriana através do Treponema 
pallidum.Por fim, a mesma é dividida em três estágios sendo eles classificados como primário secundário e terciário. Logo, é de extrema importância que o cirurgião dentista conheça a fundo as características clinicas e as manifestações da sífilis para proporcionar ao paciente um tratamento adequado e eficaz evitando complicações clinicas.

\section{Referências}

AVELLEIRA, J. C. R.; BOTTINO, G. Sífilis: diagnóstico, tratamento e controle. Anais Brasileiros de Dermatologia, v. 81, n. 2, p. 111 126, 2006.

MARUCCI, Guilberto. Fundamentos de odontologia estomatologia.Rio de Janeiro: Guanabara Koogan, 2005. NEVILLE, Brad. Patologia oral \&maxilofacial. 4. ed. Rio de Janeiro: Elsevier, 2016.

ROBBINS, Stanley; COTRAN, Ramzi S. Bases patológicas das doenças. 8. ed. Rio de janeiro: Elsevier, 2010. TOMASSI, Maria Helena. Diagnóstico em patologia bucal. 4. ed. Rio de Janeiro: Elsevier, 2013.

Coordenadoria de Pesquisa e Extensão - COPEX

Departamento de Editoração e Divulgaçāo Científica - DEDIC 


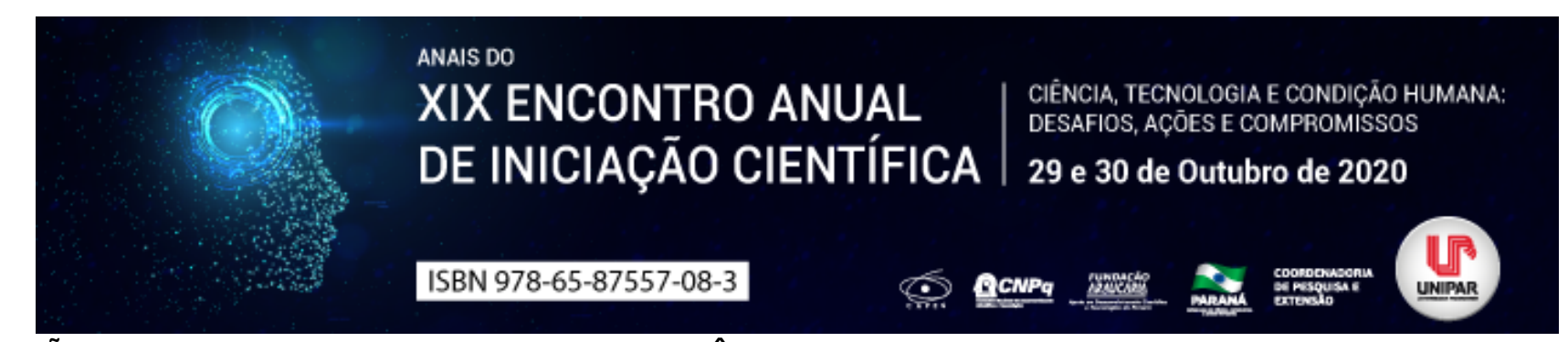

\title{
APLICAÇÃO DA TERAPIA COM LASER DE BAIXA POTÊNCIA COMO TRATAMENTO DA MUCOSITE ORAL INDUZIDA POR RADIOTERAPIA
}

\author{
${ }^{1}$ LUIZA SANZOVO, ${ }^{2}$ JENIFFER URBANO DEGASPERI, ${ }^{3}$ KATIA CRISTINA DE CARVALHO, ${ }^{4}$ LETICIA DE FREITAS CUBA \\ GUERRA
}

\author{
${ }^{1}$ Acadêmica do Curso de Odontologia da UNIPAR \\ ${ }^{1}$ Acadêmica do Curso de Odontologia da UNIPAR \\ ${ }^{2}$ Acadêmica do Curso de Odontologia da UNIPAR \\ ${ }^{3}$ Docente da UNIPAR
}

Introdução: A Mucosite Oral (MO) é uma das complicações mais comuns induzida em pacientes que são submetidos a tratamento antineoplásico com radioterapia na região de cabeça e pescoço (RAMPINI et al., 2009). Uma alteração marcante dessa patologia é apresentar eritemas, atrofia e/ou ulcerações na mucosa oral, além de causar diversas outras disfunções que alteram o bem-estar das pessoas sujeitas a esse tratamento. Apesar da alta taxa de incidência do câncer bucal, poucos estudos abordam métodos que visam diminuir os efeitos adversos gerados por esse motivo (DAUGĖLAITĖ et al., 2019). Portanto, tornase essencial discutir a temática a fim de melhorar a qualidade de vida desses indivíduos. Nesse sentido, a utilização da laserterapia merece destaque, uma vez que não é traumático, possui baixo custo e bons resultados (RAMPINI et al.,2009).

Objetivo: Revisar os dados da literatura com o intuito de descrever as complicações induzidas pelo tratamento antineoplásico, como a mucosite oral, e uma alternativa para seu tratamento, como uso do LASER de baixa potência (LBP), para auxiliar na redução das lesões e seu aparecimento.

Desenvolvimento: Segundo o Instituto Nacional do Câncer (INCA), para cada ano do triênio de 2020 a 2022, estima-se 15.190 novos casos de câncer de lábio e cavidade oral. Logo, muitos indivíduos serão expostos aos efeitos colaterais da radioterapia, sendo que o mais agudo é a MO, que tem grande impacto no modo de vida do paciente durante o tratamento e, em muitos casos, isso pode levar à sua interrupção. Essa patologia, caracteriza-se por apresentar sensação dolorosa, disfagia, alterações no paladar e risco de infecção secundária, bem como suas lesões fundamentais que incluem: atrofia e/ou ulcerações. Como as consequências citadas são extremamente prejudiciais, torna-se fundamental apresentar meios de prevenção e tratamento (OTTAVIANI, et al., 2013). Devido ao fato da mucosa encontrar-se sensível já que a proliferação das células epiteliais foi afetada, faz-se necessário adotar recursos que minimizem o sofrimento gerado durante a intervenção oncológica. Para isso, um ótimo recurso é optar pelo LBP, haja vista que possibilita a bioestimulação do tecido lesado, promove a cicatrização da ferida, reduzindo a dor e a inflamação (LOPES; MAS; ZÂNGARO, 2006). Ademais, a luz interage com as células, linfócitos, mastócitos e resulta em aumento na produção de ATP mitocondrial. Outro aspecto a ser destacado é que o LBP, quando utilizado para reparação tecidual, promove formação de novos vasos sanguíneos, proliferação dos fibroblastos e aumento na produção de colágeno. Desse modo, deve ser aplicado diariamente para reduzir o incômodo do paciente submetido ao tratamento antineoplásico com radioterapia de cabeça e pescoço. Outrossim, é necessário a manutenção da higiene bucal e recomenda-se o uso de bochechos, antibióticos, antifúngico e analgésicos como coadjuvantes no tratamento (DAUGĖLAITĖ et al., 2019).

Conclusão: Mediante o exposto, é possível observar que a laserterapia é uma alternativa viável dado que auxilia na redução da dor, conservação da mucosa, redução da inflamação e melhora da cicatrização, ações que estabelecem maior comodidade aos pacientes com mucosite oral pós radiação.

\author{
Referências \\ DAUGĖLAITÉ, GODA. et al. Prevention and treatment of chemotherapy and radiotherapy induced oral mucositis. Medicina \\ (Lithuania), v. 55, n. 2, p. 1 14, 2019. \\ DE OLIVEIRA LOPES, Carlos.; MAS, Josepa Rigau. I.; ZÂNGARO, Renato Amaro. Prevenção da xerostomia e da mucosite oral \\ induzidas por radioterapia com uso do laser de baixa potência. Radiologia Brasileira, v. 39, n. 2, p. 131 136, 2006. \\ OTTAVIANI, Giulia. et al. Effect of class IV laser therapy on chemotherapy-induced oral mucositis: A clinical and experimental \\ study. American Journal of Pathology, v. 183, n. 6, p. 1747 1757, 2013. \\ RAMPINI, Mariana, Pereira; et al. Utilização da Terapia com Laser de Baixa Potência para Prevenção de Mucosite Oral : Revisão \\ de Literatura. Revista Brasileira de Cancerologia, v. 55, n. 1, p. 59 68, 2009. \\ Relatório sobre o cenário assistencial e epidemiológico do câncer de lábio e cavidade oral no Brasil. Instituto Nacional do Câncer, \\ 2020. Disponível em: https://www.inca.gov.br/publicacoes/relatorios/relatorio-sobre-o-cenario-assistencial-e-epidemiologico-do-
}


cancer-de-labio-e. Acesso em: 20 de julho de 2020.

Coordenadoria de Pesquisa e Extensão - COPEX

Departamento de Editoraçāo e Divulgaçāo Científica - DEDIC 


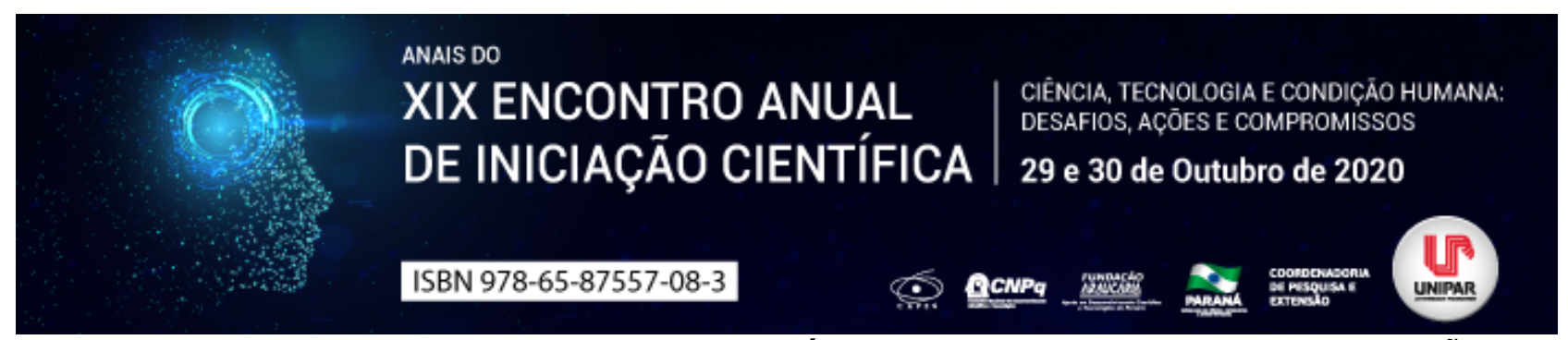

CANDIDOSE: UMA DOENÇA INFECCIOSA DE ORIGEM FÚNGICA - SUAS PRINCIPAIS MANIFESTAÇÕES ORAIS

\author{
${ }^{1}$ KATIA CRISTINA DE CARVALHO, ${ }^{2}$ JENIFFER URBANO DEGASPERI, ${ }^{3}$ LUIZA SANZOVO, ${ }^{4}$ LETICIA DE FREITAS CUBA \\ GUERRA
}

${ }^{1}$ Acadêmica do Curso de Odontologia da UNIPAR

${ }^{1}$ Acadêmica do Curso de Odontologia da UNIPAR

${ }^{2}$ Acadêmica do Curso de Odontologia da UNIPAR

${ }^{3}$ Docente da UNIPAR

Introdução: A candidíase é uma doença infecciosa e oportunista de origem fúngica. Dos fungos patógenos aos humanos, os integrantes do gênero Candida são os mais frequentes, nesse grupo incluem-se mais de 350 espécies. A Candida albicans faz parte da microflora de indivíduos saudáveis, porém e em condições especiais, se torna patológica (ROBBINS; COTRAN, 2010). A Candida apresenta dimorfismo, caracterizado pela alteração da morfologia de levedura para hifa, o que justifica sua presença na microbiota normal e sua capacidade de tornar-se patológica, assim provoca uma série de infecções e manifestações bucais com diferentes características clínicas no indivíduo hospedeiro havendo fatores locais e sistêmicos que aumentam a predisposição a essa patologia (TOMMASI, 2013).

Objetivo: Revisar os dados da literatura com o objetivo de entender os mecanismos que causam a candidíase e as suas principais manifestações bucais auxiliando no diagnóstico da doença.

Desenvolvimento: A candidose é uma doença oportunista que causa uma infecção predisposta principalmente nos indivíduos com sistema imune debilitado ou imaturo, ou em condições de alteração de microbiota local, como uso de próteses, corticoides, antibióticos de amplo espectro, entre outras. O gênero Candida é amplo e possui diversas espécies, em humanos a espécie Candida albicans é a que possui maior incidência, sendo responsável pelas manifestações em cavidade oral. Uma característica marcante desse patógeno é o dimorfismo, caracterizado pela alteração da forma de levedura, que é comensal em mucosa oral, para hifa com capacidade patogênica, na última forma o fungo se adere mais facilmente danificando as células do hospedeiro, causando a candidose a maior parte das infecções se dá superficialmente, afetando mucosas úmidas, como a cavidade oral (TOMMASI, 2013). A Candidose pode estar presente de várias formas, sendo elas: superficial, encontrada na superfície de mucosas da cavidade oral, esofágica comumente encontrada em paciente imunodeprimidos, vaginal que é uma forma comum de infecção em mulheres, cutânea e candidíase invasiva, causada pela disseminação hematogênica do organismo em tecidos e órgãos (ROBBINS; COTRAN, 2010). A Candidose bucal está presente em tecidos bucais e peribucais e pode apresentar-se em diferentes aspectos. Pseudomembranosa: comum em bebês é conhecida também como sapinho , pode ser vista em crianças e idosos debilitados formando pseudomembrana esbranquiçada de fácil remoção, normalmente são indolores, porém, alguns pacientes relatam ardência e gosto amargo. Eritematosa: desenvolve-se após redução do componente bacteriano, formando uma mancha vermelha, e pode estar presente em mucosa jugal, palato e dorso de língua, o paciente pode queixar-se de ardência.Hiperplásica: placas brancas, densas e rugosas, não destacáveis, acometendo a região de mucosa jugal anterior, principalmente. Outras formas de apresentação da candidose oral incluem a estomatite protética (mancha vermelha e assintomática, localizada na superfície da mucosa do palato que suporta a prótese), queilite angular (fissuras eritematosas, descamativas e dolorosas no ângulo da boca), glossite rômbica (áreas eritematosas delimitadas, localizadas posteriormente na linha média do dorso da língua) (NEVILLE, 2016). O diagnóstico da candidose bucal é realizado através dos sinais e sintomas clínicos, alguns métodos podem auxiliar no diagnóstico tais como a citologia esfoliativa, cultura e biópsia quando se trata de candidíase leucoplasia. Seu tratamento é baseado na severidade da lesão, antifúngicos tópicos e sistêmicos estão entre as recomendações, a orientação para o paciente em relação mudança de hábitos e higiene bucal também é muito importante em especial para pacientes que fazem uso de prótese dentária a higienização deve ser realizada de forma mecânica, três vezes ao dia, e química onde a prótese deverá ficar imersa em solução de hipoclorito de sódio 0,5\% ou gluconato de clorexidina 0,12 \% por 10 minutos uma vez na semana (VALENTINI-MIOSO et al., 2019).

Conclusão: A Candidose é uma doença oportunista que se manifesta principalmente em pacientes imunodeprimidos, a doença apresenta manifestações sistêmicas e um grande número de manifestações bucais que podem ser consideradas como diagnósticos diferenciais de outras patologias, se faz necessário o diagnóstico correto da doença visando o conforto e a saúde bucal do paciente, para o tratamento é necessário um rigoroso cuidado com a higiene bucal sendo de extrema importância que o cirurgião dentista saiba manejar o paciente com candidíase, desde seu diagnóstico, tratamento e instrução de higiene bucal e protética. 


\section{Referências}

TOMMASI, Maria Helena. Diagnóstico em patologia bucal. 4. ed. Rio de Janeiro: Elsevier, 2013.

ROBBINS, Stanley; COTRAN, Ramzi S. Bases patológicas das doenças. 8. ed. Rio de janeiro: Elsevier, 2010.

NEVILLE, Brad. Patologia oral \&maxilofacial. 4. ed. Rio de Janeiro: Elsevier, 2016.

VALENTINI-MIOSO, Fernanda. et al. Chemical hygiene protocols for complete dentures: A crossover randomized clinical trial. Journal of Prosthetic Dentistry, v. 121, n. 1, p. 83 89, 2019.

Coordenadoria de Pesquisa e Extensão - COPEX

Departamento de Editoraçāo e Divulgaçāo Científica - DEDIC 


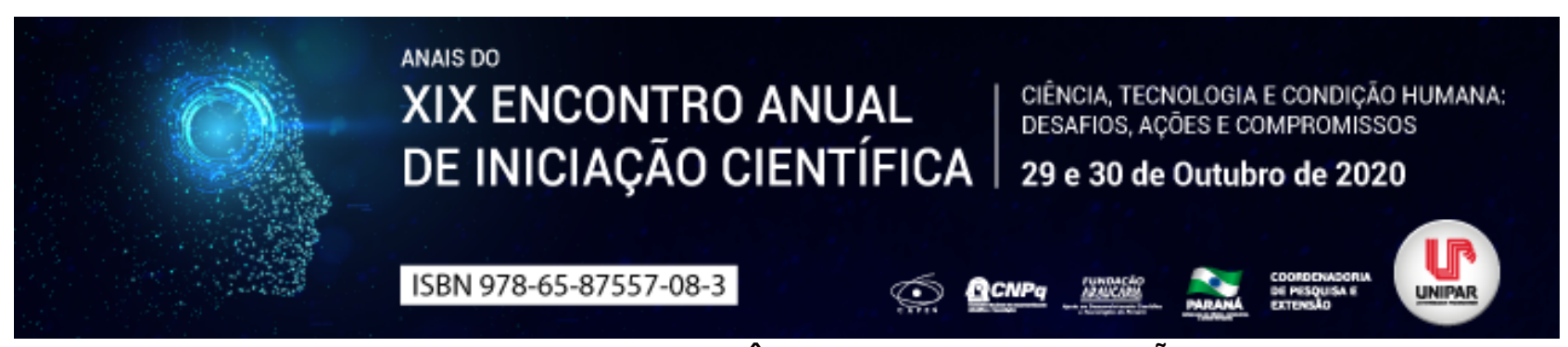

TOXOPLASMOSE CONGÊNITA: UMA BREVE REVISÃO

\begin{abstract}
${ }^{1}$ FABIANE ANGELICA DE PAIVA PAULA, ${ }^{2}$ BERNARDO MUNHOZ LIMA, ${ }^{3}$ BRENDA AYUMI TSUKAMOTO, ${ }^{4}$ CARLOS ALBERTO TANAKA, ${ }^{5}$ GABRIELA BEVILAQUA OKABAYASHI, ${ }^{6}$ MARCELA MADRONA MORETTO DE PAULA
\end{abstract}

\begin{abstract}
${ }^{1}$ Acadêmico do Curso de Medicina da UNIPAR
${ }^{1}$ Acadêmico do Curso de Medicina da UNIPAR

${ }^{2}$ Acadêmico do Curso de Medicina da UNIPAR

${ }^{3}$ Acadêmico do Curso de Medicina da UNIPAR

${ }^{4}$ Acadêmico do Curso de Medicina da UNIPAR

${ }^{5}$ Docente do Curso de Medicina da UNIPAR
\end{abstract}

Introdução: A toxoplasmose é causada pelo protozoário intracelular obrigatório Toxoplasma gondii cujo os seres humanos são hospedeiros intermediários enquanto que os felídeos são os hospedeiros definitivos (GONÇALVES et al., 2019). Possui elevada soroprevalência no Brasil, podendo variar de $64,9 \%$ a 91,6\% dependendo da região (BRASIL, 2019). A toxoplasmose pode ser adquirida, quando ocorre a ingestão via oral de cistos ou oocistos do parasita (BRASIL, 2019) ou congênita, quando ocorre a transmissão vertical de mãe para concepto (ALMEIDA, 2017). Neste caso, a doença pode afetar o neonato, desenvolvendo alterações tanto discretas como mais severas, conforme a fase gestacional em que a criança foi infectada, virulência do parasita e capacidade de resposta imunológica da gestante (BRASIL, 2019).

Objetivo: Realizar uma abordagem revisional da toxoplasmose congênita, suas consequências e importância da prevenção, utilizando artigos extraídos da base de dados da Scielo, Google Acadêmico, Biblioteca Virtual em Saúde e Arca, publicados desde 2012, usando descritores toxoplasmose congênita, pré-natal e Toxoplasma gondii . Após a exclusão de artigos que não estavam relacionados com o objetivo considerado, restaram-se 9 artigos a serem analisados.

Desenvolvimento: A toxoplasmose congênita (TC) ocorre quando a gestante se infecta com o protozoário Toxoplasma gondii, e os taquizoítos são transmitidos por via transplacentária da mãe para o filho durante a gestação (ALMEIDA, 2017). A transferência transplacentária do $T$. gondii ocorre principalmente em casos de infecção aguda, ou seja, de uma infecção primária da mãe durante a gestação ou, raramente, em casos de reagudizações (reinfecção ou reativação do protozoário em mulheres imunodeprimidas) (GONÇALVES et al., 2019). As gestantes normalmente são assintomáticas, porém as formas mais graves da doença para o feto surgem quando a infecção ocorre no início da gestação (SILVA et al.,2019), principalmente quando as gestantes não são diagnosticadas e tratadas adequadamente (MOURA, 2016). Quando a infecção materna ocorre no primeiro trimestre de gravidez, a chance de transmissão ao feto é cerca de $25 \%$, no segundo, $54 \%$ e no terceiro de $65 \%$, porém, as alterações no feto são inversamente proporcionais ao período de gestação, o que evidencia a importância da realização da sorologia para toxoplasmose durante o período gestacional (GONÇALVES et al., 2019). Em relação às manifestações clínicas, quando a transmissão vertical ocorre no primeiro trimestre da gravidez, geralmente ocorre o aborto; no segundo trimestre pode causar aborto ou nascimento prematuro e também há chance da criança nascer normal ou com anomalias graves; no terceiro trimestre a criança pode nascer normal e apresentar manifestações da doença após dias, semanas ou meses do nascimento (BRASIL, 2019). Desta forma, os sinais e sintomas que podem estar presentes na TC são: lesões oculares, comprometimento ganglionar total, anemia, síndrome de Sabin, que inclui coriorretinite, calcificações cerebrais, perturbações neurológicas e alteração no volume craniano (SPANHOL et al.; NEVES, 2012; 2016). Dada a importância das manifestações clínicas da toxoplasmose congênita, o acompanhamento pré-natal torna-se uma das principais medidas profiláticas a serem adotadas, uma vez que quando o diagnóstico é feito em tempo hábil, é possível diminuir a gravidade das sequelas, tratando-se adequadamente a gestante (CAPOBIANGO et al., 2016). Neste caso, a sorologia deve ser realizada no 10 e 30 trimestre da gestação, com o intuito de detectar possíveis infecções e evitar a transmissão vertical (GONÇALVES et al, 2019). O Ministério da Saúde recomenda que seja realizado pelo menos três testes sorológicos sendo o primeiro na primeira consulta de pré-natal e, em casos de gestantes suscetíveis e em regiões de alta endemicidade o rastreamento deve ser realizado pela pesquisa de anticorpos (IgM e IgG) a cada dois ou três meses (BRASIL, 2019). Caso o resultado seja positivo para IgG e negativo para IgM, significa que a infecção ocorreu no passado, não apresentando risco ao feto. O diagnóstico da doença aguda é realizado pelo perfil sorológico, que exibe positividade tanto para anticorpos da classe $\lg$ M quanto para IgG, onde é produzida primeiramente a imunoglobulina $\mathrm{M}$ ( $\operatorname{lgM})$, seguida da produção de imunoglobulina G (IgG). Porém, sabe-se que a presença desses anticorpos não significa, obrigatoriamente, a fase aguda da infecção, visto que são detectados em até 18 meses após a primoinfecção. Sendo assim, para diferenciar a infecção aguda da crônica, deve-se utilizar outros métodos diagnósticos como PCR e o teste de avidez de anticorpos IgG. O teste de avidez de IgG é importante para determinar a época da infecção pelo toxoplasma na gestante sendo 
importante destacar que, na gestante, a associação entre baixa avidez de IgG e títulos elevados de IgM e IgG são fortemente sugestivos de infecção aguda adquirida na gestação. Dentre as demais medidas profiláticas destacam-se ainda a necessidade de se evitar a contaminação pelo parasita, principalmente por gestantes, por meio da higienização frequente das mãos e alimentos, comer carnes e ovos bem cozidos, beber água filtrada e utilizar luvas para manusear jardins e alimentos (BRASIL, 2019).

Conclusão: A toxoplasmose congênita é uma patologia de grande interesse na saúde pública em razão de sua alta prevalência. Para que seja evitada, o pré-natal é fundamental, visto que nele é realizada a triagem sorológica materna para a detecção da toxoplasmose. Com o diagnóstico e tratamento precoce da doença, é possível diminuir a gravidade dos danos ao desenvolvimento fetal ou até mesmo evitar a transmissão vertical.

\section{Referências}

ALMEIDA, M. I. B. Associação das manifestações da toxoplasmose congênita em recém-nascidos e lactentes com a história gestacional e tratamento materno. 2017. Dissertação (Mestrado em Ciências) - Instituto Nacional de Saúde da Mulher, da Criança e do Adolescente. Rio de Janeiro, 2017.

BRASIL. Ministério da Saúde. Ampliação do uso do teste do pezinho para a detecção da toxoplasmose congênita. Brasília, 2019. Disponível em: . Acesso em: 20 jul. 2020.

CAPOBIANGO, J. D. et al. Toxoplasmose adquirida na gestação e toxoplasmose congênita: uma abordagem prática na notificação da doença. Epidemiologia e Serviços de Saúde, v. 25, p. 187-194, 2016.

CARVALHO, A. G. M. A. et al. Diagnóstico laboratorial da toxoplasmose congênita. Revista De Ciências Da Saúde, Nova Esperança, v. 12, p. 90-97, 2014.

GONCALVES, D. D. et al. Toxoplasmose congênita: estratégias de controle durante o pré-natal. Cadernos da MedicinaUNIFESO, v. 2, n. 1, 2019.

MOURA, F. L. et al. Fatores associados ao conhecimento sobre a toxoplasmose entre gestantes atendidas na rede pública doe saúde do município de Niterói, Rio de Janeiro, 2013-2015. Epidemiologia e Serviços de Saúde, v. 25, p. 655-661, 2016.

MOURA, I. P. S. et al. Conhecimento e comportamento preventivo de gestantes sobre Toxoplasmose no município de Imperatriz, Maranhão, Brasil. Ciência \& Saúde Coletiva, v. 24, p. 3933-3946, 2019.

NEVES, D. P. Parasitologia humana. 13.ed. São Paulo: Editora Atheneu, 2016.

SPANHOL, M. R. et al. Toxoplasmose na gestação. Revista Conhecimento Online. Novo Hamburgo, v. $2,2012$.

TAVARES, G. E. B.; TRICHES, D. L. G. F. Toxoplasmose: uma breve revisão. Revista Panorâmica Online, v. 1, p. 129 141, 2019.

WALCHER, D. L; COMPARSI, B; PEDROSO, D. Toxoplasmose gestacional: uma revisão. Rev. bras. anal. clin., Santo Ângelo, v. 49, n. 4 , p. 323-327, 2017. 


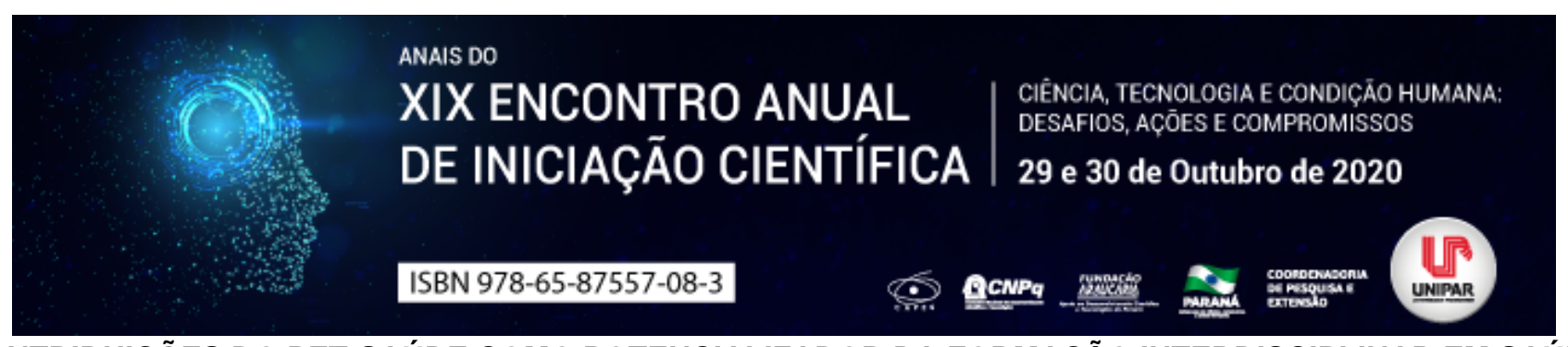

CONTRIBUIÇÕES DO PET-SAÚDE COMO POTENCIALIZADOR DA FORMAÇÃO INTERDISCIPLINAR EM SAÚDE

\begin{abstract}
${ }^{1}$ Andrew Pereira da Silva, ${ }^{2}$ ALICE PEREIRA DE SIQUEIRA NASCIMENTO, ${ }^{3}$ GABRIEL VÍTOR LIMA DE ANDRADE, ${ }^{4}$ LUAN NOVAES LEITE, ${ }^{5}$ PEDRO ÉRICO ALVES DE SOUZA, ${ }^{6}$ AMANDA SOARES DE VASCONCELOS
\end{abstract}

\begin{abstract}
${ }^{1}$ Acadêmico de Medicina na Universidade Federal de Pernambuco - Caruaru-PE
${ }^{1}$ Acadêmico de Medicina na Universidade Federal de Pernambuco - Caruaru-PE

${ }^{2}$ Acadêmico de Medicina na Universidade Federal de Pernambuco - Caruaru-PE

${ }^{3}$ Acadêmico de Medicina na Universidade Federal de Pernambuco - Caruaru-PE

${ }^{4}$ Acadêmico de Medicina na Universidade Federal de Pernambuco - Caruaru-PE

${ }^{5}$ Docente do Núcleo de Ciências da Vida na Universidade Federal de Pernambuco - Caruaru-PE
\end{abstract}

Introdução: O Programa de Educação pelo Trabalho para a Saúde (PET-Saúde) é um programa instituído pelo Ministério da Saúde com o intuito de fomentar a formação de grupos de aprendizagem tutorial em áreas estratégicas do Sistema Único de Saúde (SUS) (FARIAS-SANTOS; NORO, 2017; GRZYBOWSKI; LEVANDOWSKI; COSTA, 2017). O PET-Saúde permite a qualificação dos profissionais da saúde ao mesmo tempo em que oportuniza a iniciação aos trabalhos e vivências para os estudantes dos cursos dentro dessa área, tendo como pressupostos a educação pelo trabalho pautada na integração ensinoserviço-comunidade e existindo como uma das ações intersetoriais envolvidas no fortalecimento do SUS, a partir de seus princípios e de suas necessidades. (FRANÇA et al., 2018; ALMEIDA; TESTON; MEDEIROS, 2019). Nesse sentido, é de fundamental importância a atuação do programa no contexto da formação interdisciplinar e do trabalho em equipe colaborativo, o qual tem mostrado crescente desenvolvimento desde a sua criação, perpassando por desafios e consequentes avanços no âmbito da construção da educação interprofissional como fundamento de suas atividades (BATISTA et al., 2015; SANTOS; BATISTA, 2018).

Objetivo: Evidenciar, com base na literatura científica, o papel potencializador do PET-Saúde na formação interdisciplinar em saúde dos discentes e docentes participantes do programa.

Desenvolvimento: Trata-se de uma pesquisa de revisão integrativa realizada no mês de agosto de 2020 por meio de uma busca avançada nas bases de dados SciELO, PubMed, LILACS e BVS, com seleção dos artigos feita com os seguintes descritores:

PET-Saúde e Formação em Saúde , relacionados por meio do operador booleano AND . Em seguida, foram aplicados os critérios de inclusão: artigos publicados nos últimos cinco anos; que possuíam texto completo disponível; nos idiomas português, inglês ou espanhol e que abordassem o Programa de Educação pelo Trabalho para a Saúde (PET-Saúde) com foco na formação profissional. Foram excluídos artigos de revisão da literatura, artigos incompletos ou em duplicidade. A busca inicial nas bases de dados bibliográficas resultou em 375 documentos. Após o processo de seleção dos documentos seguindo da aplicação dos critérios de inclusão e exclusão, 361 trabalhos foram excluídos e a amostra final desta revisão integrativa foi constituída por 14 artigos científicos, selecionados pelos critérios de inclusão previamente estabelecidos. Foi identificado que o PET-Saúde, realizado no Território Nacional em consonância com as Diretrizes Nacionais Curriculares (DCN), as quais fundamentam uma aprendizagem ativa pelo estudante, dada a resolução de novas metodologias de construção do conhecimento, fortalece a Educação Interprofissional em Saúde (EIP) e auxilia na implementação do Programa Nacional de Educação Permanente em Saúde (PNEPS), formando profissionais qualificados para atuarem na rede do SUS com perfil adequado às necessidades em saúde do País. Isso se dá ao passo que o PET-Saúde transforma o processo de formação dos participantes do projeto, como o monitor estudante e os preceptores em serviço, ressignificando a prática docente do tutor envolvido (OLIVEIRA et al., 2018; SANTOS; BATISTA, 2018; NORO; MOYA, 2019). Ademais, a formação em saúde é influenciada pela inserção dos estudantes nos diversos espaços e cenários de atuação do SUS, como a Atenção Primária nesse contexto do programa. Tal oportunidade favorece a interação efetiva com os serviços e os diversos profissionais da rede de saúde (SANTOS et al., 2015; DA SILVA FILHO et al., 2018). Dessa maneira, o PET-Saúde colabora com a ampliação do olhar do participante por meio da construção de vínculos e compartilhamentos de conhecimentos no âmbito do sistema de saúde e com relação aos processos de interdisciplinaridade no trabalho, possibilitando uma visão crítica para sua formação. Entretanto, as fragilidades existem quanto à aplicabilidade efetiva do PET-Saúde para a formação interdisciplinar, evidenciando-se casos de hipervalorização da pesquisa no campo das atividades do programa, um processo de secundarização do trabalho do docente, políticas indutoras que se mostram descontínuas e, ainda, o subfinanciamento da educação, que ratifica as lacunas existentes na atuação do PET-Saúde (SANTOS; LIMA, 2018; ALMEIDA; TESTON; MEDEIROS, 2019).

Conclusão: É evidente a contribuição oportuna do PET-Saúde na formação interdisciplinar dos discentes e docentes envolvidos com o programa, com uma construção crítico-reflexiva e dialógica do conhecimento em saúde, contribuindo para a formação de 
profissionais qualificados a atuarem em prol da consolidação do SUS. Ressalta-se a importância das colaborações de incentivo para os programas de educação permanente em saúde, sendo imprescindível a valorização no campo da docência, no financiamento dos projetos e nas políticas de fortalecimento do SUS em consonância com os campos de desenvolvimento do PET-Saúde.

\section{Referências}

ALMEIDA, R. G. S.; TESTON, E. F.; MEDEIROS, A. A. A interface entre o PET-Saúde/Interprofissionalidade e a Política Nacional de Educação Permanente em Saúde. Saúde em Debate, v. 43, n. 1, p. 97-105, 2019.

BATISTA, S. H. S. et al. Formação em Saúde: reflexões a partir dos Programas Pró-Saúde e PET-Saúde. Interface Comunicação, Saúde e Educação, v. 19, supl. 1, p. 743-752, 2015.

CRUZ, K. T. et al. PET-Saúde: micropolítica, formação e o trabalho em saúde. Interface - Comunicação, Saúde e Educação, v. 19, supl. 1, p. 721-730, 2015.

DA SILVA FILHO, C. C. et al. Refletindo sobre o Pet-Saúde/Gradua-SUS no contexto da trajetória do pró-saúde: onde avançamos e onde precisamos avançar?. Seminário de Políticas Públicas e Sociais, v. 1, n. 1, p. 34-35, 2018.

FARIA, L. et al. Integração ensino-serviço-comunidade nos cenários de práticas na formação interdisciplinar em saúde: uma experiência do Programa de Educação pelo Trabalho para a Saúde (PET-Saúde) no sul da Bahia, Brasil. Interface Comunicação, Saúde e Educação, v. 22, n. 67, p. 1257-1266, 2018.

FARIAS-SANTOS, B. C. S.; NORO, L. R. A. PET-Saúde como indutor da formação profissional para o Sistema Único de Saúde. Ciência \& Saúde Coletiva, v. 22, n. 3, p. 997-1004, 2017.

FRANÇA, T. et al. PET-Saúde/GraduaSUS: retrospectiva, diferenciais e panorama de distribuição dos projetos. Saúde em Debate, v. 42, n. 2, p. 286-301, 2018.

GRZYBOWSKI, L. S.; LEVANDOWSKI, D. C.; COSTA, E. L. N. O que aprendi com o PET? Repercussões da inserção no SUS para a formação profissional. Revista Brasileira de Educação Médica, v. 41, n. 4, p. 505-514, 2017.

OLIVEIRA, L. C. et al. Trilhas mossoroenses: caminhos do PET-saúde na integração ensino-serviço. Revista de Enfermagem UFPE Online, V. 12, N. 2, p. 577-581, 2018.

NORO, L. R. A.; MOYA, J. L. M. O PET-saúde como norteador da formação em enfermagem para o sistema único de saúde. Trabalho, Educação e Saúde, v. 17, n. 1, p. 1-15, 2019.

SANTOS, M. M. et al. PET-Saúde: uma experiência potencialmente transformadora no ensino de graduação. Interface Comunicação, Saúde e Educação, v. 19, supl. 1, p. 893-901, 2015.

SANTOS, G. M.; BATISTA, S. H. S. Docência, Pró-Saúde e PET-Saúde: narrativas de um fazer interprofissional. Interface Comunicação, Saúde e Educação, v. 22, supl. 2, p. 1589-1600, 2018.

SANTOS, T. S.; LIMA, A. C. F. Desafios da interdisciplinaridade no PET-redes de atenção psicossocial e atuação da enfermagem. Revista de Enfermagem UFPE Online, v. 12, n. 5, p. 1493-1499, 2018.

SILVA, A. L. F. da et al. Saúde e educação pelo trabalho: reflexões acerca do PET-Saúde como proposta de formação para o Sistema Único de Saúde. Interface - Comunicação, Saúde e Educação, v. 19, supl. 1, p. 975-984, 2015. 


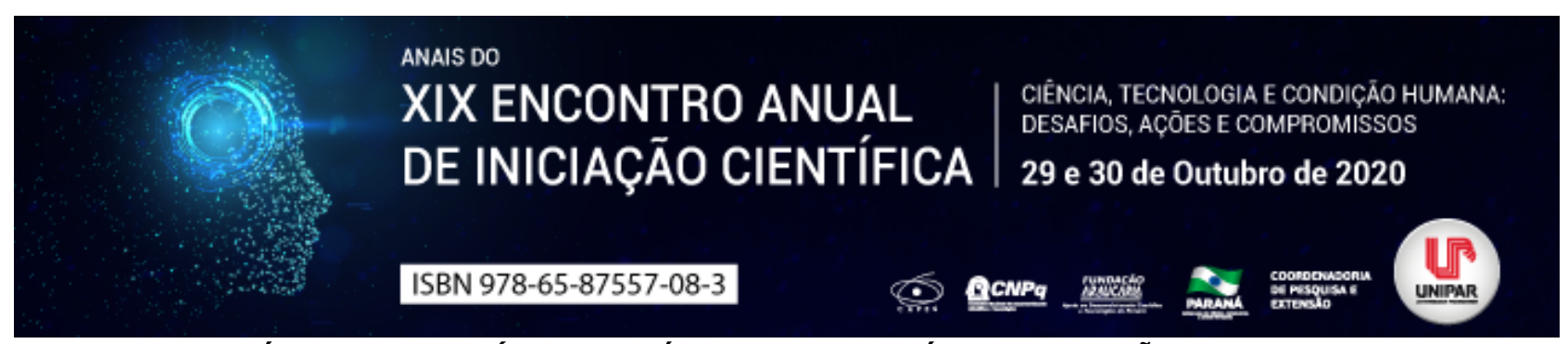

USO DO ÓLEO DE COPAÍBA NA PRÁTICA ODONTOLÓGICA: REVISÃO DE LITERATURA

\begin{abstract}
${ }^{1}$ TAIS NUNES LOPES DA SILVA, ${ }^{2}$ BIANCA RAUANE RIBEIRO FAVARO, ${ }^{3}$ NATALIA LOPES HUNGARO, ${ }^{4} \mathrm{KLISSIA}$ ROMERO FELIZARDO
\end{abstract}

${ }^{1}$ Discente de Odontologia/UNIPAR

${ }^{1}$ Discente de Odontologia/UNIPAR

${ }^{2}$ Discente de Odontologia/UNIPAR

${ }^{3}$ Docente de Odontologia/UNIPAR

Introdução: A presença de biofilme bacteriano é uma das causas do início do processo de cárie, levando à destruição de tecido sadio e consequentemente falha no tratamento odontológico, quer seja preventivo ou restaurador (GONZÁLEZ-CABEZAS, 2010). A composição do biofilme cariogênico consiste principalmente de Streptococcus mutans e Lactobacilli, localizadas predominantemente nas superfícies proximais e cervicais, regiões de fácil depósito de biofilme e difícil higienização (MJOR, 1985). Apesar da causalidade multifatorial da doença cárie o aperfeiçoamento de técnicas e materiais odontológicos, com a formulação de polímeros anti-cariogênicos tem sido objeto de estudos (HUANG et al., 2016), proporcionando aos materiais características antimicrobianas, seja para colaborar na prevenção da cárie ou impedir a recidiva na superfície já restaurada (PENMETSA et al., 2014).

Objetivo: Este trabalho tem como objetivo fazer um levantamento bibliográfico através das bases de dados LILACS, PubMed, BBO e Google Acadêmico, sobre a ação terapêutica do óleo de copaíba na prática odontológica.

Desenvolvimento: Estudos in vitro têm produzido evidências científicas que extratos e óleos naturais possuem atividade antimicrobiana frente a microrganismos patogênicos presentes na cavidade oral (CHANDRA et al., 2015). O óleo de copaíba apresenta tal propriedade, sendo uma das plantas com uso medicinal mais conhecida e utilizada no Brasil. Quimicamente, é uma solução de ácidos diterpênicos, em um óleo essencial constituído por sesquiterpenos. O composto sesquiterpeno é dividido em oxigenados e hidrocarbonetos (PIERI, MUSSI, MOREIRA, 2009). Os principais sesquiterpenos são o beta-cariofileno com ação anti-inflamatória, antibacteriana, antifúngica e antiedêmica, e o beta-bisaboleno, analgésico e anti-inflamatório (PIERI, MUSSI, MOREIRA, 2009). Segundo o estudo de Pieri et al. (2010) o óleo de copaíba apresentou resultados positivos para a inibição da formação do biofilme dental em cães, dificultando o aparecimento de bactérias resistentes. O Streptococcus mutans é a principal bactéria causadora da cárie dental e apresenta cepas resistentes, que são minimizadas com o uso do óleo causando um efeito bacteriostático sobre ele, sendo preferível usá-lo ao invés da clorexidina para controle microbiano (BARI et al., 2016). Além de sua eficácia contra S. mutans, o óleo puro de copaíba mostrou eficácia contra Streptococcus sanguinis; Porphyromonas gingivalis (MORAES et al., 2016) e Streptococcus sobrinus. Pode ser encontrado na forma farmacêutica de pomadas, óleos in natura, cápsulas, emulsões, gel de limpeza de cavidade, cimento odontológico (VASCONCELOS et al., 2008), cimento endodôntico experimental e uma resina adesiva experimental (AUGUSTO, 2019). As emulsões contendo diferentes concentrações de óleo de copaíba foram avaliadas quanto à atividade antimicrobiana (S. mutans, S. oralis, S. salivarius e L. casei) com resultados positivos nestes ensaios. A atividade antimicrobiana do gel à base de óleo de copaíba apresentou resultados favoráveis frente ao $S$. mutans e o S. salivarius. No caso do cimento odontológico associado ao óxido de zinco e hidróxido de cálcio apresentou atividade antibacteriana frente a $S$. mutans e $S$. sanguinis, indicando ser um material promissor. No caso da resina adesiva experimental, o óleo de copaíba foi adicionado a uma resina contendo Bis-GMA e HEMA, sendo avaliadas doze amostras de quatro espécies de copaíba (C. multijuga, C. langsdorffii, C. guianensis e C. reticulata), sendo 9 óleos, 2 óleos essenciais e 1 resíduo da destilação. Com a determinação da CIM, a composição química dos óleos com menores valores foi determinada, cujo resultado foi compatível com estudos prévios de análise fitoquímica das espécies multijuga e reticulata (VEIGA JUNIOR et al., 2007). A amostra que apresentou maior concentração de $\beta$-cariofileno e ácido copálico foi escolhida para formulação das resinas adesivas. A resina adesiva contendo $15 \%$ de óleo de copaíba apresentou diminuição na formação do biofilme e redução da viabilidade celular do S. mutans. A incorporação de um material de caráter untuoso e hidrófobo a uma mistura monomérica foi possível e mesmo após a polimerização apresentou atividade antibacteriana. Além disso, não apresentou alteração no grau de conversão, ângulo de contato e resistência de união imediata.

Conclusão: De acordo com os dados apresentados, o óleo de copaíba apresenta-se como alternativa viável para adição como agente antimicrobiano em materiais dentários.

\title{
Referências
}

AUGUSTO, C.R. Incorporação de óleo de copaíba (copaifera multijuga) em resina adesiva experimental. Orientador: 
Fabrício Mezzomo Collares. 2019. Tese (Doutorado em Odontologia) - Universidade do Rio Grande do Sul, Porto Alegre, 2019. CHANDRA SHEKAR, B. R. et al. Herbal extracts in oral health care - a review of the current scenario and its future needs. Pharmacogn. Rev.; v. 9, n. 18, p. 87-92, Jul-Dec. 2015.

GONZÁLEZ-CABEZAS, C. The chemistry of caries: remineralization and demineralization events with direct clinical relevance. Dent. Clin. North Am., v. 54, n. 3, p. 469-478, Jul. 2010.

HUANG, K. S. et al. Recent advances in antimicrobial polymers: a mini-review. Int. J. Mol. Sci., v. 17, n. 9, Sep. 2016.

MJOR, I. A. Frequency of secondary caries at various anatomical locations. Oper. Dent., v. 10, n. 3, p. 88-92, Summer. 1985.

MO, S. S. et al. The microflora analysis of secondary caries biofilm around Class I and Class II composite and amalgam fillings. BMC Infect. Dis., v. 17, n. 10, p. 241, Aug. 2010.

MORAES,T.S. et al. In vitro evaluation of Copaifera oblongifolia oleoresin against bacteria causing oral infections and assessment of its cytotoxic potential. Curr. Pharm. Biotechnol., v. 17, n. 10, p. 894-904, Aug. 2016.

PENMETSA, R. K. et al. An In vitro evaluation of antibacterial properties of self-etching dental adhesive systems. J. Clin. Diagn. Res., v. 8, n. 7, p. ZC01-ZC05, Jul. 2014.

PIERI, F. A.; MUSSI, M. C. M.; MOREIRA, M. A. S. Óleo de copaíba (Copaifera sp.): histórico, extração, aplicações industriais e propriedades medicinais. Rev. Bras. Plant. Med., v. 11, p. 465-472, 2009.

PIERI, Fábio Alessandro. et al. Efeito bacteriostático do óleo de copaíba (Copaifera officinalis) contra Streptococcus mutans. Braz. Dent. J. , Ribeirão Preto, v. 23, n. 1, p. 36-38, out. 2012. Disponível em: . Acesso em 26 de agosto de 2020.

VASCONCELOS, K. R. F. et al. Avaliação in vitro da atividade antibacteriana de um cimento odontológico à base de óleo-resina de Copaifera multijuga Hayne. Rev. Bras. Farmacogn., v. 18, p. 733-738, Dez. 2008.

VEIGA JUNIOR, Valdir F.; PINTO, Angelo C. O gênero Copaifera L. Quím. Nova, Rio de Janeiro, v. 25, n. 2, p. 273-286, set. 2002. Disponível em: https://www.scielo.br/pdf/qn/v25n2/10455.pdf. Acesso em: 24 de agosto de 2020. 


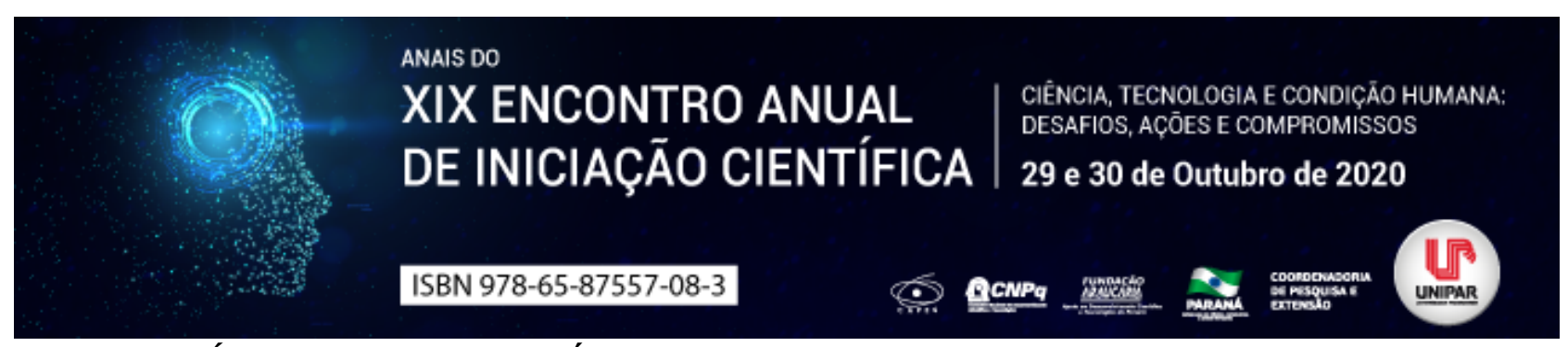

SÍNDROME DA MORTE SÚBITA INFANTIL NO BRASIL NOS ANOS DE 2008-2018

\author{
${ }^{1}$ FABIANE ANGELICA DE PAIVA PAULA, ${ }^{2}$ CAMILA MARIA ESCARDILLE YOSHITANI, ${ }^{3}$ DAVI CORREA PEREIRA, ${ }^{4}$ ESTER \\ PELEGRINI SILVA, ${ }^{5}$ JÉSSICA ZANQUIS FERREIRA, ${ }^{6}$ ELENIZA DE VICTOR ADAMOWSKI CHIQUETTI
}

\begin{abstract}
${ }^{1}$ Acadêmica do Curso de Medicina da UNIPAR
${ }^{1}$ Acadêmica do Curso de Medicina da UNIPAR

${ }^{2}$ Acadêmico do Curso de Medicina da UNIPAR

${ }^{3}$ Acadêmica do Curso de Medicina da UNIPAR

${ }^{4}$ Acadêmica do Curso de Medicina da UNIPAR

${ }^{5}$ Docente da UNIPAR
\end{abstract}

Introdução: A mortalidade infantil representa um importante indicador da saúde geral do país e da assistência à saúde da criança, pois reflete a saúde global da sociedade abrangendo condições sociais, econômicas e ambientais (MINISTÉRIO DA SAÚDE, 2018). Segundo Bezerra et al. (2015), a síndrome da morte súbita infantil (SMSI) está entre as principais causas de morte em menores de 1 ano no continente americano e europeu, apresentando uma incidência de 0,45 por mil nascidos vivos na Inglaterra no período de 2003 - 2006 e 55,3 por 100.000 nascidos vivos nos EUA no ano de 2008. Esta síndrome corresponde à morte repentina e abrupta do recém nascido durante o sono, sem explicação após investigação e necropsia do corpo (SANTOS et al. 2019). Acomete em média crianças de até 1 ano de vida e representa a primeira causa de morte pós-neonatal na atualidade sendo considerada a oitava enfermidade que mais causa mortalidade infantil (MARTINS et al. 2018).

Objetivo: Analisar a ocorrência de óbitos infantis (até 1 ano de idade) em decorrência da Sindrime da Morte Súbita Infantil no Brasil nos anos 20082018.

Material e Métodos: Foi realizado levantamento das notificações de óbitos em decorrência da SMSI no banco de dados do Departamento de Informática do Sistema Único de Saúde do Brasil (DATASUS) no período de 2008 a 2018 no Brasil. Representa um estudo observacional, retrospectivo e descritivo.

Resultados: As notificações no DATASUS mostram um total de 1.718 óbitos por SMSI no Brasil no período de 2008 à 2018 . A ocorrência de SMSI apresenta-se estável durante este período sendo representadas por 142 , 170 e 137 mortes, respectivamente, nos anos de 2008, 2013 e 2018. Em relação às regiões do Brasil, a região sudeste, nordeste, sul, norte e centro-oeste tiveram um total de 591, 483, 316, 188 e 140 óbitos, respectivamente.

Discussão: Os fatores associados à ocorrência da SMSI ainda não são claros e vários mecanismos fisiopatológicos têm sido propostos como causa (BEZERRA et al. 2015). No entanto, o modelo do Triplo Risco, proposto pela primeira vez por Filiano e Kinney (1994), tem sido fortemente relacionado à patogênese e consiste na ocorrência conjunta de fatores que envolvem: $1^{\circ}$ vulnerabilidade do lactente (prematuridade, mães fumantes, défices no neurodesenvolvimento, polimorfismos genéticos); $2^{\circ}$ período crítico no desenvolvimento (primeiros 6 meses de vida, particularmente entre 2 e 4 meses) e $3^{\circ}$ fatores de stress exógenos (decúbito ventral, presença de roupa de cama ou de outros objetos que possam cobrir a cabeça do lactente, o sobreaquecimento ou uma infecção recente) (GRANADO, 2015). Frente a isso,a estabilidade dos dados levantados no presente estudo indicam a necessidade de medidas educativas quanto a esta patologia uma vez que boa parte da patogênese da doença relaciona-se com comportamentos que podem ser evitados e, segundo Bezerra et al. (2015) a SMSI é considerada como abalo prevenível pelo Sistema Único de Saúde (SUS) quando há ações adequadas de promoção à saúde. Apesar da redução da mortalidade infantil dos anos 1990 para 2015 (BRASIL, 2017) a estabilidade destes dados fornecem evidências de que é preciso uma grande melhora na assistência à saúde, principalmente no que tange a assistência primária, uma vez que a redução da mortalidade infantil é fruto de melhorias na assistência médica do país (MARTINS et al. 2018; BRASIL, 2017) e que cerca de 52\% das mortes em menores de um ano estão relacionadas ao agrupamento fatores maternos e perinatais (BRASIL, 2017). Em relação às diferenças encontradas entre as regiões do Brasil, esta justifica-se pela distribuição populacional brasileira e pelas diferenças socioeconômicas encontradas nas diferentes regiões, uma vez que estudos têm demonstrado que o baixo nível socioeconômico é um fator de risco para todas as causas de mortalidade infantil (SANTOS et al. 2019). A SMSI trata-se de uma patologia de difícil determinação causal, e por isso, em seus estudos devem ser consideradas algumas limitações. Segundo Lorea et al. (2017), pelo fato de necropsias não ser uma conduta obrigatória no Brasil, o coeficiente de mortalidade por SMSI pode subestimar ou superestimar tais valores uma vez que o diagnóstico fica à mercê dos médicos e das informações obtidas através dos pais.

Conclusão: A baixa oscilação ao decorrer dos anos analisados indica a necessidade de medidas socioeducativas em relação a patologia e mostra um cenário que carece de melhoria na atenção à saúde da mulher e do recém nascido. A divulgação dos 
fatores de risco das formas prevenção, principalmente em relação o posicionamento da criança ao dormir é essencial para a compreensão da SMSI. As variações encontradas entre as regiões fornecem subsídio para elaboração e mensuração da saúde materna infantil.

\section{Referências}

BEZERRA, Marina A. de Lima et al. Fatores associados ao conhecimento das mães sobre a Síndrome da Morte Súbita do Lactente. Esc. Anna Nery, Rio de Janeiro, v.19, n.2, p.303-309, Junho 2015. Disponível em: http://www.scielo.br/scielo.php? script=sci_arttext\&pid=S1414-81452015000200303\&lng=en\&nrm=iso. Acesso em: Ago 2020.

BRASIL. Ministério da Saúde. Departamento de Vigilância de Doenças e Agravos não Transmissíveis e Promoção da Saúde. Saúde Brasil 2017: uma análise da situação de saúde e os desafios para o alcance dos objetivos de desenvolvimento sustentável. Brasília: Ministério da Saúde, 2018, 426p.

BRASIL. Ministério da Saúde (MS). Departamento de Vigilância de Doenças e Agravos Não Transmissíveis e Promoção da Saúde. Saúde Brasil 2015/2016: uma análise da situação de saúde e da epidemia pelo vírus Zika e por outras doenças transmitidas pelo Aedes aegypti. Brasília: MS, 2017.

GRANADO, Maria C. Milheiro. Síndrome da morte súbita do lactente: conceitos e realidade. Orientador: Cristina M. G. Cordeiro. 2015. 56f. Trabalho de conclusão de curso (Bacharel em medicina) - Universidade de Coimbra, Portugal, 2015.

LOREA, Rafaella de Lima et al.Síndrome da morte súbita infantil em Pelotas de 2006 a 2013: uma análise descritiva. Revista de Medicina, v. 96, n. 1, p. 27-31, 2017. Disponível em: https://www.revistas.usp.br/revistadc/article/view/125595/125354. Acesso em: 07 ago 2020.

MARTINS, Maria E. Pierre. et al. Síndrome da Morte Súbita Infantil: aspectos acerca das principais causas e as formas de prevenção. Revista de Psicologia, v. 12, n. 41, p. 192-205, 2018. Disponível em: https://idonline.emnuvens.com.br/id/article/view/1208/1766. Acesso em: 07 ago 2020.

SANTOS, Márcio Souza. et al. Caracterização dos óbitos infantis por broncoaspiração, sufocação e síndrome da morte súbita. Semina: Ciências Biológicas e da Saúde, v. 40, n. 1, p. 91-108, 2019. Disponível em: http://www.uel.br/revistas/uel/index.php/seminabio/article/view/34822/26018. Acesso em: 07 ago 2020. 


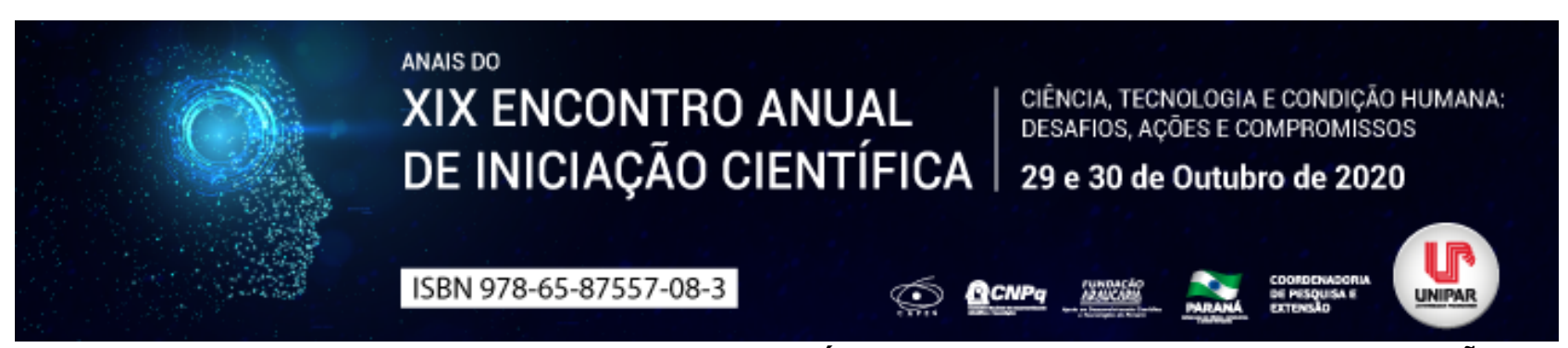

\title{
EFEITO DA QUALIDADE DO OPONENTE E DESEMPENHO PRÉVIO SOBRE O ESTRESSE E RECUPERAÇÃO ANTES DE JOGOS OFICIAIS DE FUTSAL
}

\author{
${ }^{1}$ MARCIO APARECIDO RINALDO, ${ }^{2}$ SOLANGE DE PAULA RAMOS, ${ }^{3}$ KARINA ALVES SILVA, ${ }^{4}$ EDIRLEY GUIMARÃES DE \\ SOUZA, ${ }^{5}$ VINÍCIUS FLÁVIO MILANEZ.
}

\author{
${ }^{1}$ Professor - Unipar \\ ${ }^{1}$ Universidade Estadual de Londrina - UEL \\ 2Universidade Estadual do Oeste do Paraná UNIOESTE \\ ${ }^{3}$ Universidade Filadélfia de Londrina \\ ${ }^{4}$ Universidade do Oeste Paulista de Presidente Prudente
}

Introdução: O futsal é uma modalidade esportiva indoor com características intermitentes e de alta intensidade (NASER et al. 2017), sendo que aproximadamente $22,6 \%$ da distância total média percorrida pelos jogadores em jogo (4313 $\pm 2139 \mathrm{~m})$ são deslocamentos em alta $(>15 \mathrm{~km} / \mathrm{h})$ e máxima $(>25 \mathrm{~km} / \mathrm{h}$ ) velocidade (BARBERO-ALVAREZ et al. 2008). Durante jogos oficiais, atletas profissionais passam cerca de 58 a 83\% do tempo em quadra em frequência cardíaca (FC) acima de $85 \%$ da FC máxima Barbero-Alvarez et al. (2008).

Objetivo: avaliar a associação de fontes de estresse relacionadas com o nível do adversário e deslocamentos em estrada para jogos de futsal sobre a percepção de recuperação e bem-estar de atletas de futsal em jogos realizados como mandatários.

Materiais e Métodos: 22 jogadores de futsal profissionais responderam a escala de qualidade total de recuperação (QTR) e o índice de Hooper $(\mathrm{IH})$ duas horas antes de 5 jogos de um campeonato estadual e 6 jogos da liga nacional. Foram coletados dados sobre a idade, dificuldade predita de jogo, distância $(\mathrm{Km})$ do jogo anterior, intervalo de tempo entre o jogo anterior (dias) classificação do time e oponente no momento do jogo, desfecho do jogo anterior do time e do adversário (derrota/empate/vitória). Diferenças entre o IH e QTR em diferentes jogos e desfechos de jogos foram avaliados com teste one-way ANOVA e Tukey. Diferenças entre campeonatos foram avaliados com teste T de Student. A associação das variáveis com a IH e TQR foram determinadas com Análise de Regressão Linear multivariada e teste de correlação de Spearman.

Resultados: A idade $(r=-0,20, p<0.01), \mathrm{IH}(r=0,58, p<0,001)$, fadiga $(r=-0,53, p<0,0001)$ e dor muscular $(r=-0,39, p<0,001)$ apresentaram correlação com a QTR. O IH foi maior nos jogos da Liga Nacional ( $p<0,005$, teste t de Student) e apresentou correlação fraca com a dificuldade predita de jogo $(r=0,18, p=0,02)$. O QRT pré-jogo foi maior após jogos antecedidos por derrota $(15,4 \pm 1,6$ u.a.) em relação ao empate $(14,6 \pm 1,8$ u.a., $p<0.05)$ e vitória $(14,7 \pm 1,7$ u.a., $p<0,05)$. A QTR foi menor nos jogos com vitória (14,3 $\pm 1,8$ u.a.) em relação aos jogos com empate $(15,4 \pm 1,7$ u.a., $p<0.01)$ e derrota $(15,1 \pm 1,6$ u.a., $p<0.05)$. A derrota do adversário no jogo anterior aumentou o estresse percebido $(2,1 \pm 0,8$ u.a.) em relação a vitória $(1,9 \pm 0,9$ u.a., $P<0,05)$. Discussão: Diversos fatores reportados na literatura interferem com a percepção de bem estar e recuperação de atletas, incluindo viagens entre jogos (LASTELLA et al. 2019), qualidade do oponente, intervalo e qualidade de recuperação entre sessões de treinos e fase da competição (CLEMENTE et al. 2020). O IH e QTR são escalas utilizadas para avaliar o estado de estresse (bem-estar) e recuperação de atletas, e a hipótese do estudo era que estes índices poderiam ser influenciados por fatores que causam estresse associados às condições em confrontos enfrentadas por atletas contra adversários de diferentes níveis de campeonato.

Conclusão: Os resultados sugerem que a percepção do balanço de recuperação e estresse reportado antes de jogos está correlacionado com a idade e qualidade do oponente.

\footnotetext{
Referências

BARBERO-ALVAREZ, J. C. et al. Match analysis and rate of futsal players during competition. J Sposts Sci, v. 26, n 1, p. 63-73, jan 12008

CLEMENTE, F. M. et al. Training load and well-being status variations of elite futsal players across a full season: Comparisons between normal and congested weeks. Physiol Behav, v. 201, p. 123-129, Mar 152019.

LASTELLA, M.; ROACH, G. D.; SARGENT, C. Travel fatigue and sleep/ wake behaviors of professional soccer palyers during international competition. Sleep Health, v. 5, n. 2. p. 141-147, Apr 2019.

NASER, N.; ALI, A.; MACADAM, P. Physical and physiological demands of futsal. J Exerc Sci Fit, v. 15, n. 2, p. 76-80, Dec 2017
} 



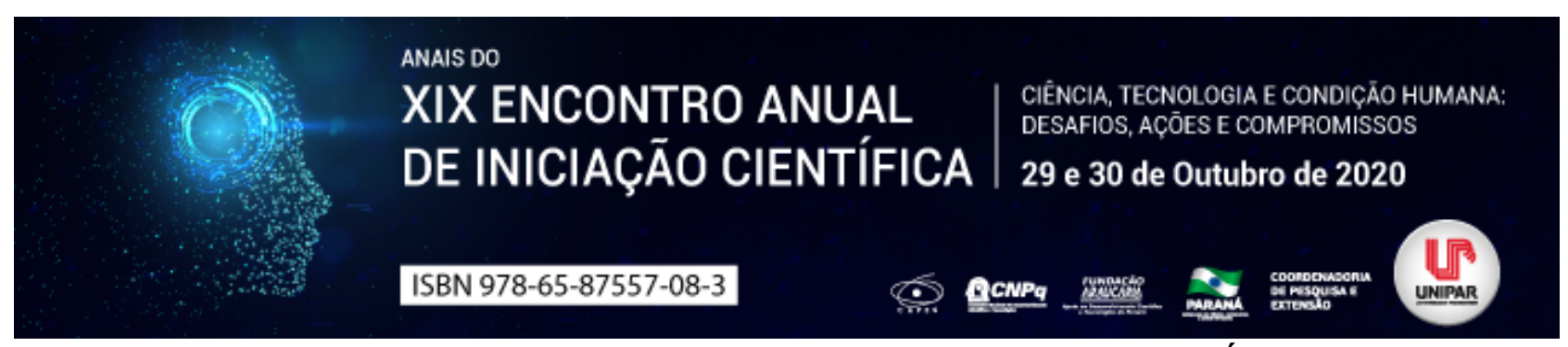

EFEITOS DOS IMUNOMODULADORES PARA O SISTEMA IMUNOLÓGICO

\title{
${ }^{1}$ LETICIA RODRIGUES GENARIO, ${ }^{2}$ MARIANE DE ALMEIDA MACHADO, ${ }^{3}$ SUELLEN LAIS VICENTINO VIEIRA
}

\author{
${ }^{1}$ Acadêmica do curso de Farmácia da Unipar \\ ${ }^{1}$ Acadêmica do curso de Farmácia da Unipar \\ ${ }^{2}$ Docente da UNIPAR
}

Introdução: O sistema imunológico é um conjunto complexo composto por células, órgãos, moléculas e citocinas. As citocinas se formam em cascata, na qual estimula-se suas células-alvo para produzir outras citocinas, podendo assim, aumentar ou diminuir a resposta imune, sendo o principal mecanismo de sinalização para defender o organismo de patógenos (ABBAS, LICHTMAN, PILLAI, 2013). Normalmente o combate das infecções ocorre através da utilização de antibioticoterapia, só que o emprego de imunomoduladores também tem sido introduzido na prática clínica, pois estes agem realizando a imunoestimulação, que conduz o aumento da imunidade inata e adaptativa (LIMA, 2007), melhorando a resposta contra agentes infecciosos.

Objetivo: Apresentar os principais efeitos dos imunomoduladores utilizados na atualidade.

Desenvolvimento: A função do sistema imunológico é oferecer a proteção necessária para que não haja invasões de microrganismos, este sistema é amplo e envolve principalmente dois tipos de defesa: imunidade inata que já é presente desde o nascimento, protegendo de forma rápida contra invasores, com elementos como citocinas, monócitos, macrófagos ou linfócitos natural killer, por exemplo. A segunda linha de defesa, é a imunidade adaptativa caracterizada por aprender e desenvolver memória imunológica, na qual destaca-se os linfócitos T e B e os anticorpos. Uma resposta imune adequada é essencial para proteger contra agentes invasores, e segundo Machado et al. (2004), os principais aspectos patológicos das infecções não estão relacionados com uma ação direta do agente patogênico, mas sim com uma resposta imune anormal. Sendo assim, pacientes com deficiência imunológica, ou uma resposta exagerada, se tornam mais suscetíveis. Os imunomoduladores, possuem mecanismos que vão interferir e modificar uma resposta imunológica, para que o indivíduo consiga enfrentar a doença. Fazer a imunoestimulação aumentando a função dos componentes da resposta imune, que podemos citar os interferons do tipo I que são produzidos por células infectadas por um vírus e, ao ter contato com uma célula saudável não infectada, ele consegue protegê-la contra a infecção (MACHADO et al., 2004), interleucina-2 que estimula o crescimento e a proliferação de linfócitos-T e B e de citocinas, que ajuda na propagação de respostas imunológicas específicas do antígeno, e dos anticorpos que identificam os antígenos (DE OLIVEIRA et al., 2011). O Imunoglucan DS, que possui Vitamina C, zinco e a beta-glucana que é um ativador do sistema imunológico por estimular os macrófagos, a fagocitose de patógenos, e as citocinas, ajudando nas resistências, como na infecção é um exemplo de imunomodulador presente me farmácias. Os imunomoduladores também realizam a imunossupressão, que reduz a atividade do sistema imune, que pode ser por uma doença autoimune ou ser intencional, no caso de alguns tratamentos, como para evitar rejeição de um transplante. A azatioprina, foi a primeira droga imunossupressora utilizada para transplante, mas tem seus efeitos adversos como supressão da medula óssea e hepatotoxicidade, seu princípio ativo é a 6tioguanina, análogo da purina, incorporada no DNA e RNA, o que interrompe a divisão celular, faz a supressão da função da célula T e da produção de anticorpos pelas células B (BRESSAN et al., 2010). O Metotrexato tem valor no tratamento da psoríase, análogo do ácido fólico que inibe a enzima diidrofolato redutase, e consequentemente tendo ação nos linfócitos circulantes (BRESSAN et al., 2010). A ciclofosfamida usada na artrite reumatoide, suprimi os linfócitos B, afeta intensamente células T supressoras CD8 (BRESSAN et al., 2010). A ciclosporina previne a rejeição de transplantes, agindo como uma pródroga (pois fica inativa até se ligar ao seu receptor, a ciclofilina), e dentro das células $T$ inibe a liberação de citocinas e de mediadores de mastócitos, a ativação de linfócitos (BRESSAN et al., 2010). Uma outra forma de modular a respostas é através da alimentação, a imunonutrição é definida como a habilidade dos nutrientes de influenciar na atividade das células constituintes do sistema imunológico, por meio da suplementação de nutrientes específicos ou combinados (CARMO, FORTES, 2019). Essa alimentação é enriquecida com nutrientes imunomoduladores como a L-arginina que atua na multiplicação e maturação dos linfócitos $\mathrm{T}$, a glutamina que faz a síntese de nucleotídeos, proteínas, citocinas, e proliferação das células imunológicas, ou por exemplos os ácidos graxos poli-insaturados e ômega-3 que são anti-inflamatório aumentando a produção de citocinas (CARMO, FORTES, 2019).

Conclusão: Através do referencial científico utilizado pode-se observar a variedade de tratamentos e efeitos dos imunomoduladores, estes têm potencial de modular o sistema imunológico, podendo aumentar ou diminuir a resposta contra agentes invasores, visando a defesa do organismo. Seus efeitos são observados tanto em tratamentos medicamentosos, quanto em alimentícios.

\section{Referências}


ABBAS, Abul, LICHTMAN, Andrew, PILLAI, Shiv. Imunologia básica. Rio de Janeiro: Elsevier, 2013. 336p.

BRESSAN, Aline Lopes et al. Imunossupressores na Dermatologia. Anais Brasileiro de Dermatologia. v.85, n.1, p.9-22, 2010. Disponível em: http://www.scielo.br/scielo.php?script=sci_arttext\&pid=S0365-05962010000100002\&lng=en\&nrm=iso. Acesso em: 15 ago. 2020.

CARMO, Simone Gonzaga do, FORTES, Renata Costa. Efeitos do uso de fórmulas imunomoduladoras em pacientes cirúrgicos portadores de câncer do trato gastrointestinal. Revista Cientifica Sena Aires. v. 8, n. 21, p. 96-111, 2019 Disponível em: http://revistafacesa.senaaires.com.br/index.php/revisa/article/viewFile/350/255. Acesso em: 12 ago. 2020.

DE OLIVEIRA, Caio Marcio Barros de et al. Citocinas e dor. Revista Brasileira de Anestesiologia, v.61, n.2, p.260-265, 2011. Disponível em: http://www.scielo.br/scielo.php?script=sci_arttext\&pid=S0034-70942011000200014\&lng=en\&nrm=iso. Acesso em: 20 jul. 2020.

LIMA, Hermênio Cavalcante. Dados e mitos sobre imunomoduladores. Anais Brasileiro de Dermatologia. v.82, n. 3, p. 207-221, 2007. Disponível em: http://www.scielo.br/scielo.php?script=sci_arttext\&pid=S0365-05962007000300002\&lng=en\&nrm=iso. Acesso em: 20 jul. 2020.

MACHADO, Paulo R.L. et al. Mecanismos de resposta imune às infecções. Anais Brasileiro de Dermatologia. v. 79, n. 6, p. 647-662, 2004. Disponível em: http://www.scielo.br/scielo.php?script=sci_arttext\&pid=S0365$05962004000600002 \&$ lng=en\&nrm=iso. Acesso em: 20 jul. 2020.

Coordenadoria de Pesquisa e Extensão - COPEX

Departamento de Editoraçāo e Divulgaçāo Científica - DEDIC 


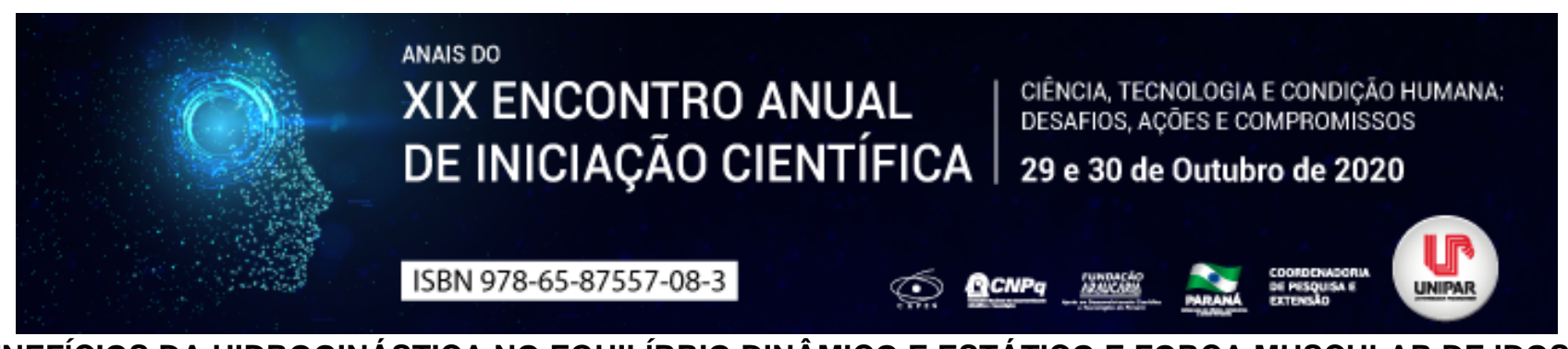

BENEFÍCIOS DA HIDROGINÁSTICA NO EQUILÍBRIO DINÂMICO E ESTÁTICO E FORÇA MUSCULAR DE IDOSOS

\author{
${ }^{1}$ NATHALIE CRISTINA ZANATA, ${ }^{2}$ DURCELINA SCHIAVONI BORTOLOTI
}

${ }^{1}$ Discente do Curso de Educação Física Bacharelado / UNIPAR Francisco Beltrão

${ }^{1}$ Docente do Curso de Educação Física Bacharelado / UNIPAR Francisco Beltrão

Introdução: O processo de envelhecimento promove modificações na aptidão física e composição corporal, com importantes reduções na força muscular e no equilíbrio. Nos idosos, as alterações nestas capacidades físicas, interferem diretamente na marcha, aumentando significativamente o risco de quedas. Vale ressaltar, que a perda do equilíbrio pode acometer os idosos independente do nível de atividade física habitual (SANTOS; SASSAKI, 2018). Entretanto, a prática de exercício físico sistematizado, contribui de maneira significativa para a manutenção ou redução da velocidade do declínio da aptidão física relacionada à saúde e das capacidades funcionais do idoso. Assim, o tipo de exercício físico deve considerar às modificações fisiológicas impostas pelo processo de envelhecimento (ALVES, 2004). Nesse sentido, a prática da Hidroginástica parece ser uma estratégia importante para o equilíbrio e a força de idosos, pois os movimentos próprios dessa atividade proporcionam a busca constante do equilíbrio e estabilidade corporal no meio aquoso (REICHERT et al., 2015).

Objetivo: Verificar os benefícios da Hidroginástica sobre o equilíbrio dinâmico e estático, bem como da força muscular de idosos a partir de uma revisão sistemática da literatura.

Desenvolvimento: $O$ estudo foi conduzido por meio de uma revisão sistemática da literatura. Incluiu-se estudos indexados às seguintes bases de dados nacionais: LILACS Literatura Latino-Americana e do Caribe em Ciências da Saúde; SCIELO

Scientific Eletronic Library Online e na ferramenta de busca Google Acadêmico, no período de 2000 até Julho de 2020. Os descritores utilizados foram: equilíbrio, idosos, hidroginástica, teste de força, teste de equilíbrio e teste do flamingo. Após a busca e análise dos artigos, apenas oito artigos foram selecionados para análise final desta revisão. Em relação ao local de publicação, dois foram conduzidos em Santa Maria RS, dois em São Paulo, dois em Pelotas - RS, um em Maringá - PR e um em Caxias do Sul - RS. Quanto ao tipo de exercício adotado para a intervenção houve predominância nos exercícios da Hidroginástica, sendo aplicados testes para equilíbrio e força antes e depois das aulas ou dos programas de hidroginástica (ALVES et al., 2004; TEIXEIRA et al., 2007; ALMEIDA et al., 2010; PUPO et al., 2010; STREIT et al., 2011; REICHERT et al. 2015; SOUZA JUNIOR et al., 2017). Apenas um estudo utilizou atividades de musculação relacionado com Hidroginástica (SOUZA et al., 2014). O estudo de Pupo et al., (2010), verificou que idosos praticantes de Hidroginástica apresentaram melhores resultados para o teste de equilíbrio quando comparados a grupo de idosos sedentários. Vale destacar que, não são recentes as informações da literatura científica, sobre os exercícios físicos regulares como estratégias fundamentais na prevenção de quedas e no controle postural de idosos (LORD et al., 2001; TEIXEIRA; PEREIRA, 2007). Alves et al., (2004) avaliam o efeito da Hidroginástica, e também encontram melhoras no equilíbrio dinâmico de idosas. Em estudo mais recente sobre essa temática conduzido em idosos previamente sedentários, observou-se efeito benéfico da prática de Hidroginástica sobre o tempo necessário para completar os testes foot up and go e timed up and go, testes que visam avaliar o equilíbrio dinâmico e a agilidade (REICHERT et al. 2015). Por outro lado, o estudo de Souza et al., (2014) apresentou maior força e menor tempo de execução no teste timed up and em idosos praticantes de musculação quando comparados aos praticantes de Hidroginástica, porém sem diferenças significantes entre os grupos para o risco de quedas avaliado por meio de Escala de Equilíbrio de Berg. Apesar do baixo número de estudo identificados sobre a temática na literatura nacional, a Hidroginástica foi descrita na maioria dos estudos desta revisão, como um importante tipo de exercício físico para a população idosa, possibilitando inúmeros benefícios, dentre eles destaca-se a melhora nas capacidades físicas associadas ao equilíbrio, força, coordenação motora, agilidade, esquema corporal e velocidade de ação e reação.

Conclusão: De forma geral, a prática da Hidroginástica parece ser uma importante indicação de atividade física sistematizada para o indivíduo idoso, uma vez que a literatura destaca efeitos benéficos relacionados tanto a melhoria do equilíbrio e da força, quanto de outros componentes da capacidade física e funcional promovendo assim autonomia para as atividades cotidianas, de lazer, e ocupacionais dos idosos.

\title{
Referências
}

ALMEIDA, Ana Paula Pessoa Veloso de; VERAS, Renato Peixoto; DOIMO, Leonice Aparecida. Avaliação do equilíbrio estático e dinâmico de idosas praticantes de hidroginástica e ginástica. Rev. Bras. Cineantropom. Desempenho Hum., Florianópolis, v. 12, n. 1, p. 55-61, Fev. 2010.

ALVES, Roseane Victor, et al. Aptidão física relacionada à saúde de idosos: influência da hidroginástica. Rev Bras Med Esporte, Niterói , v. 10, n. 1, p. 31-37, Fev. 2004. 
PUPO, Ana Carolina; ZOMIGNANI, Andrea Peterson; SILVA, Grace Larissa Oliveira. Comparação entre o equilíbrio de idosos praticantes de hidroginástica e idosos sedentários. Rev. Multidisciplinar da Saúde, v. 2, n. 4, p. 2-10, 497 -504, 2010.

REICHERT, Thaís et al., Efeitos da hidroginástica sobre a capacidade funcional de idosos: metanálise de estudos randomizados. Rev. Bras. Ativ. Fis. Saúde. Pelotas/RS, v.20,n. 5,p. 447- 457, Set. 2015.

SANTOS. Janete Cirinalva; SASSAKI. Laís de Melo. Diferença do equilíbrio corporal entre idosos praticantes de atividade física com idosos sedentários: Uma revisão de literatura. Pesquisa em Ação, v. 4, n.3, p. 1-10, Nov, 2018.

SOUZA, Lucas Kuser et al., Comparação dos níveis de força e equilíbrio entre idosos praticantes de musculação e de hidroginástica. Revista Brasileira Atividade Física e Saúde, Pelotas/RS, v. 19, n.5, p. 647-655, Set. 2014.

SOUZA JUNIOR, Roberto Otheniel et at., Efeitos da hidroginástica com exercícios dinâmicos em deslocamento sobre o equilíbrio corporal de idosos. Fisioter Pesqui., Maringá /PR, v. 24, n. 3, p. 303-3010, 2017.

STREIT, Inês Amanda; RIBEIRO, Contreira Andressa; CORAZZA, Sara Teresinha. Efeitos de um programa de hidroginástica no equilíbrio de idosos. ConScientia e Saúde, v. 10, n. 2, p.339-345, 2011.

TEIXEIRA, Clarissa Stefani; PEREIRA. Érico Felden; ROSSI. Angela Garcia. A hidroginástica como meio para manutenção de qualidade de vida e saúde do idoso. Acta Fisiatr., v.14, n.4, p. 226-232, Jul. 2007; 


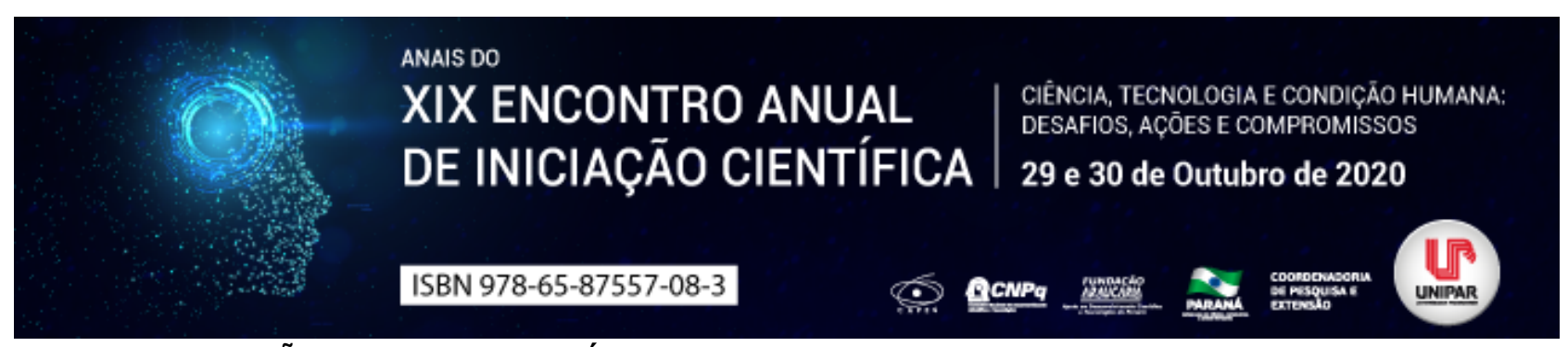

INFECÇÃO DO TRATO URINÁRIO ASSOCIADA AO CATETER VESICAL DE DEMORA

\author{
${ }^{1}$ ALESSANDRA LOTICI, ${ }^{2}$ GISELE LOTICI, ${ }^{3} \mathrm{CHARLES} \mathrm{DEIVID} \mathrm{COSTA} \mathrm{CRAVCZYK,}{ }^{4}$ ALINE APARECIDA BARTNISKI, ${ }^{5}$ PAULA \\ EDUARDA GOETERT, ${ }^{6}$ FRANCIELE DO NASCIMENTO SANTOS ZONTA
}

\author{
${ }^{1}$ Acadêmica do Curso de Enfermagem. PIC/UNIPAR \\ ${ }^{1}$ Acadêmica do Curso de Enfermagem da UNIPAR \\ ${ }^{2}$ Acadêmico do Curso de Enfermagem da UNIPAR \\ ${ }^{3}$ Acadêmica do Curso de Enfermagem. PIC/ UNIPAR \\ ${ }^{4}$ Acadêmica do Curso de Enfermagem. PIC/UNIPAR \\ ${ }^{5}$ Docente da UNIPAR
}

Introdução: A Infecção do Trato Urinário (ITU) relacionado ao uso de Sondagem Vesical de Demora (SVD) está entre as principais Infecções Relacionadas à Assistência em Saúde (IRAS) adquirida durante o internamento em Unidade de Terapia Intensiva (UTI).I"No Brasil, as ITU-SVD são responsáveis por 35 a 45\% de todas as infecções hospitalares. Segundo a Agência Nacional de Vigilância Sanitária (ANVISA) a incidência de ITU oscila entre 3,1 a 7,4 por 1000 cateteres/dial" (TAVARES et al. 2020).

Objetivo: Identificar o índice de ITU em pacientes internados em uma UTI de um hospital misto do Paraná, submetidos ao uso da SVD.

Materiais e métodos: Pesquisa de campo, retrospectiva de caráter descritiva e documental, com abordagem quantitativa, realizada por meio de dados coletados em fichas de notificação da Comissão de controle de infecção hospitalar de um hospital misto do Paraná. Foram incluídos todos os prontuários de pacientes internados durante o período de janeiro de 2018 a dezembro de 2018, que desenvolveram ITU relacionada ao uso do cateter vesical de demora na UTI. Foi realizada uma análise descritiva com apoio do programa Software StatisticalPackageof Social Sciences for Windows (SPSS). O estudo foi aprovado pelo Comitê de Ética em Pesquisa da Universidade Paranaense sob protocolo (1.993.266/2017).

Resultados: De um total de 104 pacientes internadosno período supracitado, 18 (17,3\%) desenvolveram ITU. Dentre eles, 50\% eram do sexo masculino e $50 \%$ do sexo feminino. Houve predominância de pacientes com faixa etária elevada, sendo $55,6 \%$ acima de 70 anos, seguido de $33,3 \%$ de 51 a 70 anos, e $11,2 \%$ de 21 a 40 anos. Quanto a origem das internações a maioria foi de origem clínica $72,2 \%$, seguido de cirúrgico $16,7 \%$ e trauma com $11,1 \%$. Em relação a doenças crônicas associadas, observouse a Hipertensão Arterial Sistêmica (HAS) com 22,2\%, Diabetes Mellitus(DM) com 5,6\%, e HAS e DM com 11,1\%. Destes pacientes, a maioria (55,6\%)evoluiu a óbito e $44,4 \%$ tiveram alta.

Discussão: Um total de $17,3 \%$ pacientes desenvolveu ITU associada ao uso da SVD nessa pesquisa. No estudo de Farias, Nascimento e Souza (2019) evidenciou-se que no Brasil de 20 a 30\% das IRAS que ocorrem, 10 a 30\% dos pacientes desenvolvem ITU-SVD. Referenteao sexo dos pacientes estudados verificou-se um equilíbrio. Obteve-se valor de $50 \%$ em ambos os gêneros, mesmo que a literatura traga as mulheres como mais suscetíveis a estas infecções. Em uma análise de Tavares et al (2020), o alto índice de casos de ITU's em pacientes do sexo feminino, justifica-sepela susceptibilidade de infecções recorrentes, anatomia da uretra feminina que possibilitafácil acesso dos microrganismos devido aproximidade com aorifício anal, facilitando a proliferação de bactérias. Ao avaliar a idade dos pacientes, observou-se uma prevalência em idosos acima de 70 anos. Em uma pesquisa realizada para avaliar o perfil da ITU em pacientes internados em uma UTI de um hospital de Cuiabá-MT evidenciou-se índices semelhantes, com prevalência de ITU em idosos acima de 61 anos (43,75\%). Essas proporções são verificadas pela imunossenescência,pela vulnerabilidade das condições de saúde, pelo aumento das comorbidades, e pela diminuição da motilidade da bexigaresultantede lesões celulares característicos do processo de envelhecimento (MENOTTI et al. 2019). Quanto a origem do internamento, prevaleceu os pacientes admitidos por motivos clínicos, correspondendo a (72,2\%), essa taxa elevada é devido aos internamentos relacionados a patologias crônicas, doenças de base, alterações cardiovasculares, faixa etária mais propicia para complicações clínicas como acidente vascular encefálico (AVE), síndromes metabólicas, extremos de idade, e outras comorbidades. Em relação às doenças crônicas, destacou-se a HAS com 22,2 \%. Em um estudo realizado com 30 pacientes $26,7 \%$ apresentaram como comorbidades a hipertensão, o Diabetes Mellitus (DM) e outras patologias. Diante das comorbidades associadas a ITU, a HAS é a mais encontrada com estimativa de 41,7\%, seguida de DM com $8,3 \%$, e HAS e diabetes com $8.3 \%$ dos casos (MOTA,OLIVEIRA, 2019). A presença de comorbidades associadas como o DM e a HAS aumentam substancialmente o risco de ocorrência de ITU por CVD (TAVARES et al. 2020). Além disso, o tempo de permanência, a colonização, as alterações no sistema imunológico, a nutrição, bem como os cuidados na manipulação e instalação do CVD podem contribuir para o desenvolvimento da infecção (FERREIRA, BARROS, BRAGA, 2016). Diante do exposto, o desfecho 
clínico dos pacientes abrangidos pela presente pesquisa, resultou em $55,6 \%$ em óbitos, tais índices são validados pela presença de doenças prévias, intercorrências ocasionadas durante o internamento, alusivo a vulnerabilidade do paciente na UTI e alterações fisiológicas, impedindo que o corpo atue contra os microrganismos que colonizam o local.

Conclusão: Observou-se que a incidência da ITU foi 17,3\%, valor inferior quando comparada a média nacional. Entretanto, vale ressaltar que, os pacientes inseridos no estudo a maioria foram a óbito. Houve predominância de idosos acima de 70 anos, com comorbidades. A ITU é uma infecção muito comum na UTI, necessitando de diversos cuidados.

\section{Referências}

FARIAS, Regiane Camarão; NASCIMENTO, Camila Cristina Lisboa; SOUZA, Marcelo Williams Oliveira. Infecção do trato urinário relacionada ao cateter vesical de demora: elaboração de Bundle. Revista Eletrônica Acervo Saúde, v. 11, n. 11, p. 510-510, mai., 2019.

FERREIRA, Renata Carneiro; BARROS, Caroline Espíndola; BRAGA, Ariane Leal. Perfil de infecção urinária associada à taxa de glicemia alterada. Revista Brasileira de Análises Clínicas, Rio de Janeiro, v. 48, n. 4, p. 346-351, 2016.

MENOTTI, Anna FláviaScalla, et al. Prevalência de Microrganismos em Infecções de Trato Urinário na Unidade de Terapia Intensiva Adulto em um Hospital de Médio Porte. Caderno de Publicações Univag. Várzea Grande, Mato Grosso n.10, 2019.

MOTA, Écila Campos; OLIVEIRA, Adriana Cristina. cRevista da Escola de Enfermagem da USP, São Paulo,v. 53, mai., 2019.

TAVARES, Jéssica Mayara de Medeiros. et al. Incidência de infecção urinária em pacientes hospitalizados em uso de cateter vesical de demora. Revista Eletrônica Acervo Saúde, v. 12, n. 8, jun., 2020. 


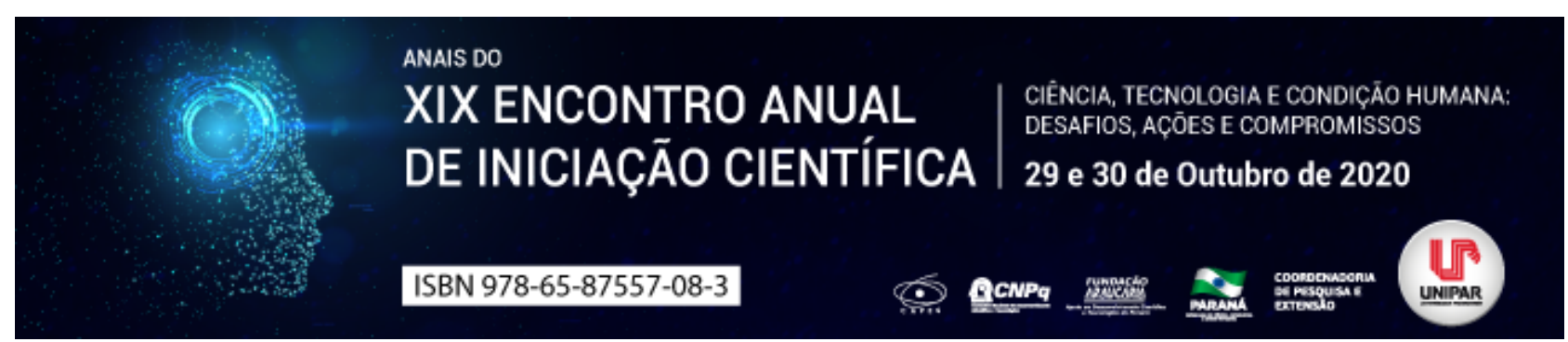

ATRIBUIÇÕES DA ENFERMAGEM FRENTE À SEGURANÇA DO PACIENTE NOS SERVIÇOS DE SAÚDE

\title{
${ }^{1}$ ALESSANDRA LOTICI, ${ }^{2}$ GISELE LOTICI, ${ }^{3}$ FRANCIELE DO NASCIMENTO SANTOS ZONTA
}

\author{
${ }^{1}$ Acadêmica do Curso de Enfermagem. PIC/UNIPAR \\ ${ }^{1}$ Acadêmica do Curso de Enfermagem da UNIPAR \\ ${ }^{2}$ Docente da UNIPAR
}

Introdução: Frente ao desenvolvimento de novas tecnologias, os serviços de saúde caminham em busca de melhorias e avanços em seus atendimentos, destacando-se a Segurança do Paciente (SP) como tema atual e de grande relevância mundial. No entanto, há vários fatores que contribuem para a exposição de riscos em pacientes, através da assistência prestada pela equipe multiprofissional de saúde, principalmente em ambiente hospitalar, com destaque para a Unidade de Terapia Intensiva (UTI). Segundo Silva et al 2016 apud Organização Mundial da Saúde (OMS) I"um a cada dez pacientes hospitalizados sofre pelos eventos adversos (EA) causados pelo processo de cuidarl". A OMS caracteriza a SP como a diminuição dos riscos e danos, que podem ser evitados através do atendimento dos profissionais de saúde ao paciente, e EA como dano não intencional causado pela assistência prestada sem relação com a doença (GOMES et al., 2018). A enfermagem está em constante contato com os pacientes, e assim, desenvolver ações positivas para sua segurança, podendo identificar fragilidades do cuidado, possíveis erros no processo de trabalho, utilizar de ferramentas e protocolos para melhorar o cuidado (COSTA et al., 2016).

Objetivo: Descrever as atribuições do enfermeiro frente à segurança do paciente nos serviços de saúde,de acordo com dados publicados na literatura.

Desenvolvimento: As publicações em torno da SP vêm ganhando destaque no século, desde que a OMS em 2004 criou a Aliança Mundial para a SP, e em 2013 o Ministério da Saúde (MS) criou o Programa Nacional de Segurança do Paciente (PNSP) no Brasil (MINUZZI et al., 2016). Em 2000, o Instituteof Medicine (IOM) após sua publicação Errar é Humano: Construindo um Sistema de Saúde Mais Seguro recomendou o desenvolvimento de uma cultura de segurança positiva para ajudar as instituições de saúde a melhorar a segurança de seus pacientes. A cultura de segurança de uma instituição é o compartilhamento de valores e conhecimentos sobre tudo que é mais importante, sobre o funcionamento da organização, interação e trabalho em equipe, o sistema organizacional, a aprendizagem através de erros e a boa comunicaçãoentre os profissionais (MELLO, BARBOSA, 2017). A segurança do cuidado prestado ao paciente é um importante indicador com alto impacto na qualidade da assistência em saúde. Em busca de melhorias no cuidado em saúde ofertado, a RDC n ${ }^{0} 36$ do MS instituiu ações para a promoção da segurança do paciente e melhoria da qualidade nos serviços de saúde, desenvolveu a obrigatoriedade do Núcleo de Segurança do Paciente (NSP) e do Plano de Segurança do Paciente em Serviços de Saúde (PSP)(COSTA et al., 2016). Surgiram 6 protocolos prioritários do MS, através da portaria $n^{\circ} 529$ de $1^{\circ}$ de abril de 2013, que são: prevenção de quedas, identificação do paciente com uso de pulseiras, segurança na prescrição, uso e administração de medicamentos, cirurgia segura, higiene das mãos e úlcera por pressão (GOMES et al., 2018). Segundo Silva et al (2016) dentre as situações que prejudicam a saúde brasileira estão: alta rotatividade e a falta de profissionais, falha na comunicação, registros de enfermagem incompletos, sobrecarga e estresse no trabalho, falta de gerenciamento e gestão do serviço, falhas na estrutura física, faltade materiais e equipamentos, falta de conhecimento e notificação inadequada dos EA. Cerca de $70 \%$ dos EA trazem consequências pequenas, como gastos desnecessários, e os outros 30\% trazem consequências mais significativas (MELLO, BARBOSA, 2017). A enfermagem deve amparar-se segundo seu Código de Ética e oferecer um cuidado livre de danos e EA, com compromisso e dedicação aos pacientes no ambiente de saúde. O cuidado deve ser por meio de estratégias e intervenções que facilitem a forma de cuidar, reconhecendo erros para posteriormente notificá-los e resolvê-los. Ter como rotina a utilização da Sistematização da Assistência de Enfermagem (SAE), cheklists, higiene rigorosa das mãos, gerenciamento do serviço, liderança de equipe e ampliação de conhecimentos (COSTA et al., 2016). O enfermeiro deve capacitar e treinar adequadamente sua equipe, realizar a educação continuada, para que assim o atendimento rotineiro não seja realizado de modo automático, sem ao menos observar atentamente os sinais e sintomas que o paciente apresenta. Também, encorajar a equipea adotar como forma de trabalho a utilização dos protocolos, para que as chances de erros por falta de conhecimentoda rotina do serviço não aconteçam. Também deve encorajar a equipe a notificar os erros cometidos, desmistificar a cultura negativa e punitiva. Assim, a equipe deixa o medo das punições, das críticas de lado, para realizara notificação adequada dos EA (MINUZZI et al., 2016).

Conclusão: $O$ grande desafio nos serviços de saúde para a SP é construir uma cultura de segurança positiva e de qualidade. $O$ enfermeiro tem um papel de suma importância, o qual deve liderar e treinar sua equipe para identificar, reconhecer e notificar os erros, a fim de resolvê-los de forma adequada. Transmitir conhecimento e segurança no serviço, para que assim a equipe sintase confiante em desenvolver suas funções adequadamente. 


\section{Referências}

COSTA, Theo Duarte. et al. Percepção de profissionais de enfermagem acerca de segurança do paciente em unidades de terapia intensiva. Rev. Gaúcha Enferm, Porto Alegre, v. 37, n. 3, set., 2016.

GOMES, Renara Meira. et al. Limites e desafios da comunicação efetiva para a segurança do paciente: um discurso coletivo. Rev. Eletr. Acer. da Saúde, Campinas, v. 10, n. 1, p. 2006-2012., 2018.

MELLO, Janeide Freitas; BARBOSA, Sayonara Fátima Faria. Cultura de segurança do paciente em unidade de terapia intensiva: perspectiva da equipe de enfermagem. Rev. Eletr. Enf, Goiânia, v. 19, 2017.

MINUZZI, Ana Paula. et al. Contribuições da equipe de saúde visando à promoção da segurança do paciente no cuidado intensivo. Esc. Anna Nery Rev. Enferm, Rio de Janeiro, v. 20, n. 1, p. 121-129, jan./mar., 2016.

SILVA, Aline Teixeira. et al. Assistência de enfermagem e o enfoque da segurança do paciente no cenário brasileiro. Saúde Debate, Rio de Janeiro, v. 40, n. 111, p. 292-301, out/dez. 2016. 


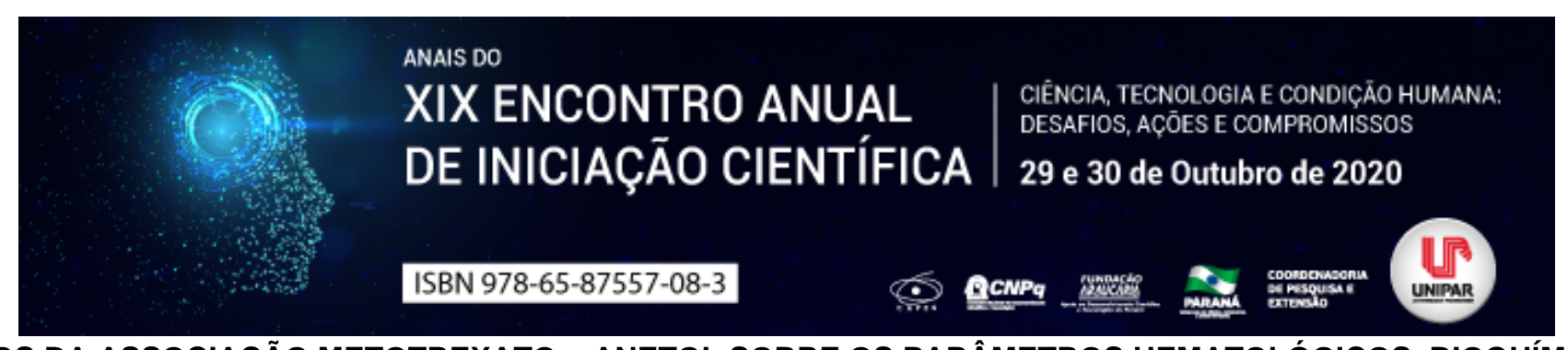

\title{
EFEITOS DA ASSOCIAÇÃO METOTREXATO + ANETOL SOBRE OS PARÂMETROS HEMATOLÓGICOS, BIOQUÍMICOS E O ESTRESSE OXIDATIVO PLASMÁTICO DE RATOS ARTRÍTICOS
}

\author{
${ }^{1}$ Carla Indianara Bonetti, ${ }^{2}$ JACKELINE JOYCE DA SILVA MOREIRA, ${ }^{3}$ EDVALKIA MAGNA TEOBALDO DA ROCHA, \\ ${ }^{4}$ ANACHARIS BABETO DE SÁ-NAKANISHI, ${ }^{5}$ CIOMAR APARECIDA BERSANI AMADO , ${ }^{6}$ LIVIA BRACHT
}

\begin{abstract}
${ }^{1}$ Acadêmica de Pós-Graduação (Mestrado) em Ciências Farmacêuticas, Laboratório de Metabolismo Hepático da Universidade Estadual de Maringá

${ }^{1}$ Acadêmica de Pós-Graduação (Mestrado) em Ciências Farmacêuticas, Laboratório de Metabolismo Hepático da Universidade Estadual de Maringá

${ }^{2}$ Mestranda em Ciências Farmacêuticas - UEM

${ }^{3}$ Docente Departamento de Bioquímica, Laboratório de Metabolismo Hepático da Universidade Estadual de Maringá.

${ }^{4}$ Docente Departamento de Farmacologia, Laboratório de Inflamação da Universidade Estadual de Maringá.

${ }^{5}$ Docente Departamento de Bioquímica, Laboratório de Metabolismo Hepático da Universidade Estadual de Maringá.
\end{abstract}

Introdução: A artrite reumatoide (AR) é uma doença multissistêmica crônica, cuja principal característica é a sinovite inflamatória persistente (FIRESTEIN, 2003). O metotrexato (MTX) é considerado a droga de escolha para o tratamento da AR, mas sua principal limitação é o aparecimento de efeitos adversos (O’DELL, 2004). O anetol (AN), constituinte do óleo essencial do anis estrelado, é capaz de atenuar a resposta inflamatória causada pela doença (RITTER et al., 2017). Todavia, não existem estudos que tenham investigado o uso destas substâncias associadas.

Objetivo: Avaliar os efeitos do tratamento com o AN, com o MTX e com a associação AN + MTX sobre os parâmetros hematológicos, bioquímicos e o estresse oxidativo plasmático em ratos artríticos.

Materiais e Métodos: Foram utilizados ratos Holtzman machos (180 a $220 \mathrm{~g}$ ). Todos os procedimentos foram aprovados pelo comitê de ética da UEM (CEUA no. 9937300419). A artrite (AIA) foi induzida por injeção intradérmica do adjuvante completo de Freund na superfície plantar da pata esquerda. Os animais foram tratados diariamente com AN (p.o.) nas doses de 62,5 e 250 $\mathrm{mg} / \mathrm{kg}$; MTX, uma vez por semana (i.p., 6, 12 e $24 \mathrm{mg} / \mathrm{kg}$ ) ou a combinação AN + MTX (62,5 + $6 \mathrm{mg} / \mathrm{kg}$, respectivamente). Os tratamentos começaram no dia da indução da AIA e continuaram por 21 dias. Os animais foram então eutanasiados com tiopental sódico $(50 \mathrm{mg} / \mathrm{Kg})$ e o sangue foi coletado da através de punção da veia cava. O sangue total foi utilizado para quantificação de leucócitos totais e hemácias, realizada por métodos a fresco. O plasma foi utilizado para determinação do estresse oxidativo e para determinação das atividades das transaminases plasmáticas alanina aminotransferase (ALT) e aspartato aminotransferase (AST), da enzima fosfatase alcalina (ALP) e das concentrações de ureia e creatinina. Os dados foram analisados por ANOVA seguido de pós-teste de Tukey $(p<0,05)$.

Resultados: Observou-se que houve aumento de $54 \%$ no número de leucócitos totais em ratos artríticos controle. Os tratamentos com anetol na dose de 62,5 e $250 \mathrm{mg} / \mathrm{Kg}$ não foram capazes de diminuir o número aumentado de leucócitos. O tratamento com MTX nas doses de 6,12 e $24 \mathrm{mg} / \mathrm{Kg}$ reduziram o número de leucócitos em $44 \%, 45 \%$ e $56 \%$, respectivamente. O tratamento com a associação AN + MTX reduziu em $27 \%$ o número de leucócitos totais, quando comparado ao grupo artrítico controle. Houve diminuição do número total de hemácias nos animais artríticos controle e nos tratados com AN e MTX em monoterapia, quando comparados aos animais normais. O tratamento com a associação AN + MTX não provocou redução do número total de hemácias. Foi observado que os tratamentos com AN na dose de $250 \mathrm{mg} / \mathrm{Kg}$ e MTX nas doses de 6,12 e 24 $\mathrm{mg} / \mathrm{kg}$ reduziram significativamente a atividade da mieloperoxidase (MPO) em 49\%, 62\%, 54\% e 63\% respectivamente. O tratamento com a associação AN + MTX se mostrou mais eficaz apresentando uma redução de $69 \%$ quando comparado com os animais artríticos controle. O conteúdo de proteína carbonilada no plasma aumentou em $34 \%$ nos animais artríticos não tratados, em relação aos animais normais. Os tratamentos com MTX na dose de $24 \mathrm{mg} / \mathrm{Kg}$ e com a associação se mostraram efetivos, reduzindo este parâmetro em $30 \%$ e $34 \%$. A capacidade antioxidante do plasma estava expressivamente reduzida em animais artríticos, como demonstrado pela diminuição dos parâmetros TAC (capacidade antioxidante total) e FRAP (capacidade antioxidante de redução de íons férrico) e também pela redução da quantidade de grupos tióis totais, em comparação com animais normais. Em animais artríticos, ocorre também uma redução significativa da concentração de albumina plasmática. A associação AN + MTX foi capaz restaurar a capacidade antioxidante total (TAC) e a concentração de tióis totais no plasma, para valores semelhantes aos de animais normais. Todavia, nenhum tratamento modificou o parâmetro FRAP, nem a concentração de albumina. Não houve diferença significativa da atividade plasmática de AST, ALT, fosfatase alcalina e creatinina entre os grupos. Em contrapartida, o tratamento com MTX 24mg/Kg aumentou a concentração plasmática de ureia.

Discussão: Os resultados do presente trabalho demonstram que os tratamentos com AN e com o MTX em monoterapia ou em 
associação foram eficazes em reduzir a leucocitose em animais artríticos. Estes efeitos são condizentes com a ação imunomoduladora e anti-inflamatória destes compostos (MOTA, 2012; AMES ET AL., 2020). A menor atividade da MPO no plasma de animais tratados com AN, MTX e AN + MTX reflete o menor número de células inflamatórias. Adicionalmente, o tratamento com AN e MTX reduziu o estresse oxidativo plasmático, como demonstrado pela redução da carbonilação de proteínas, um importante marcador de danos oxidativos. A associação do AN com o MTX em baixas doses apresentou vantagens em relação ao tratamento em monoterapia, já que foi o tratamento que provocou maior redução da atividade da MPO plasmática, foi o único tratamento capaz de aumentar significativamente a capacidade antioxidante total do plasma e o número de hemácias.

Conclusão: O presente estudo demonstra que a administração de AN potencializa os efeitos anti-artríticos do MTX. Portanto, a combinação AN + MTX pode representar uma estratégia nova e altamente eficaz para o tratamento da AR.

\section{Referências}

AMES, F. Q. et al. Anti-inflammatory Effect of Low-Dose Anethole and Ibuprofen Combination Is Accompanied by Partial Prevention of Hepatic Metabolic Changes in Arthritic Rats. Inflammation (2020). https://doi.org/10.1007/s10753-020-01241-w FIRESTEIN G. S. Evolving concepts of rheumatoid arthritis. Nature, 423:356 361, 2004.

MOTA, L. M. H. et al. Consenso 2012 da Sociedade Brasileira de Reumatologia para o tratamento da artrite reumatoide. Revista Brasileira de Reumatologia, v. 52, n. 2 p. 135-174, 2012.

O'DELL, J. R. Therapeutic Strategies for Rheumatoid Arthritis. New England Journal of Medicine, 350:25:2591 2602. 2004.

RITTER, A. M. V. et al. Anethole reduces inflammation and joint damage in rats with adjuvant- induced arthritis. Inflammation Research, 66: 725 737, 2017. 


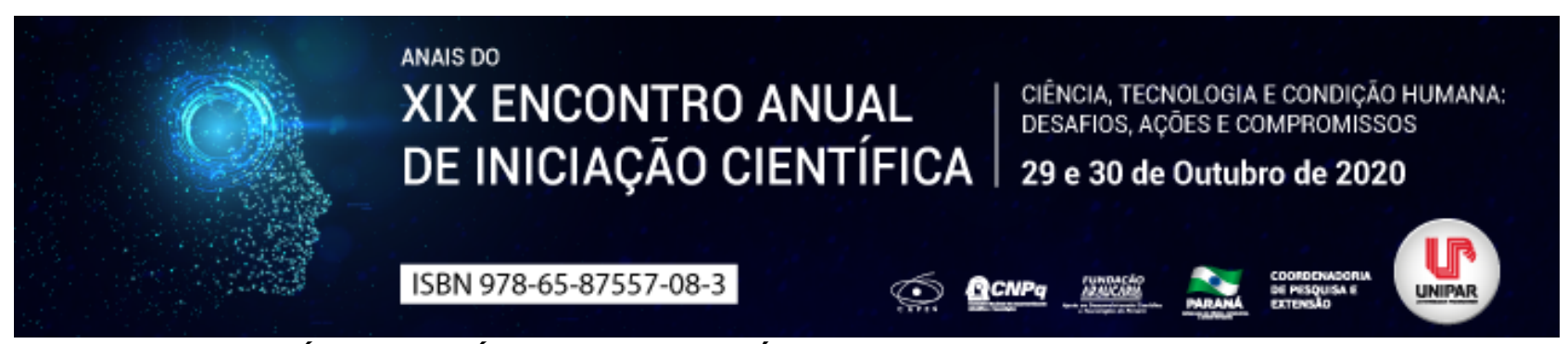

CARACTERÍSTICAS CLÍNICAS DAS BACTÉRIAS PERTENCENTES AO GRUPO ESKAPE

\begin{abstract}
${ }^{1}$ GISELE LOTICI, ${ }^{2}$ CHARLES DEIVID COSTA CRAVCZYK, ${ }^{3}$ ALESSANDRA LOTICI, ${ }^{4}$ PAULA EDUARDA GOETERT, ${ }^{5}$ ALINE APARECIDA BARTNISKI, ${ }^{6}$ FRANCIELE DO NASCIMENTO SANTOS ZONTA
\end{abstract}

\footnotetext{
${ }^{1}$ Acadêmica do Curso de Enfermagem. PIC/UNIPAR

${ }^{1}$ Acadêmico do Curso de Enfermagem. PIC/UNIPAR

${ }^{2}$ Acadêmica do Curso de Enfermagem da UNIPAR

${ }^{3}$ Acadêmica do Curso de Enfermagem da UNIPAR

${ }^{4}$ Acadêmica do Curso de Enfermagem da UNIPAR

${ }^{5}$ Docente da UNIPAR
}

Introdução: As bactérias estão entre os principais agentes envolvidos nas Infecções Relacionadas à Assistência à Saúde (IRAS) (COSTA, 2019). As IRAS são um grande problema de saúde pública, com altas taxas de morbidade, mortalidade e consequentemente altos custos de tratamento, especialmente no ambiente hospitalar. Dentre os problemas enfrentados atualmente, destaca-se o desenvolvimento de resistência das bactérias aos antimicrobianos(ZONTA et al. 2020). Os antimicrobianos foram desenvolvidos para resolver as infecções que no passado eram fatais, mas seu uso abusivo prejudicou o tratamento de várias enfermidades, a qual os patógenos estão tornando-se resistentes. Diante do exposto, ressalta-se o grupo ESKAPE, atualmente considerado o acrônimo que remete aosprincipais microrganismos relacionados as infecções, o qual fazem parte: Enterococcusfaecium, Staphylococcus aureus, bactérias gram-positivas e Klebsiellapneumoniae, Acinetobacterbaumanni, Pseudomonas aeruginosas eEnterobactersppbactérias gram-negativas(RIBEIRO et al. 2016).

Objetivo: Analisar as principais características clínicas das bactérias do grupo ESKAPE.

Desenvolvimento: O principal grupo populacional atingido por esses agentes patogênicos são pacientes imunocomprometidos, geralmente internados em Unidade de Terapia Intensiva (UTI). No ambiente hospitalar, a principal forma de disseminação do grupo ESKAPE e das infecções nosocomiais é através das mãos dos profissionais de saúde, pela falta de higiene. Proporcionando um ambiente propício para o desenvolvimento de infecções oportunistas(SILVA, VELASQUEZ, 2017). AEnterococcusfaecium pode ser encontrada no trato gastrointestinal, na vagina e na uretra masculina. São patógenos oportunistas, que podem provocar infecções urinárias e endocardites. Possuem alta capacidade de formar biofilme, fatores de virulência e resistência (COSTA, 2019).OStaphylococcus aureus possui em sua membrana externa, uma cápsula de polissacarídeo, que facilita inibição da fagocitose, juntamente com a presença de adesinas, as quais permitem aderência na superfície das células epiteliais (LIMA et al, 2015). Alusivo à isso, tem-se maior incidência em sítios como pele, ferida cirúrgica e sangue ocasionando endocardites, pneumonias e septicemias(RIBEIRO et al, 2016).A Klebsiellapneumoniaepode ser encontradaprincipalmente no trato urinário, mas também em tecidos moles, podendo ocasionar pneumonias e sepse.Pertence à família das Enterobacterias, é produtora da enzima carbapenemase, denominadaKPC. Por isso é considerada um microrganismo com alto poder de proliferação e difícil controle(SILVA, VELASQUEZ, 2017). Existem diversos mecanismos de virulência que facilitam a disseminação do patógeno, dentre eles destacam-se: à presença de cápsula, lipopolissacarídeos e adesinas, que contribuem para aderir às mucosas e a produção de sideróforos(COSTA, 2019). OAcinetobacter baumannii atinge em especial o trato respiratório inferior com $(17,7 \%)$, seguido por uma taxa de $(9,9 \%)$ em pele (queimados) e tecidos moles (sitio cirúrgico) (VIEIRA, PICOLI, 2015). Esse microrganismo mostra variados mecanismos de resistência a antimicrobianos, dentre eles destacase a formação de enzimas em seu interior, a qual irá realizar a degradação dos medicamentos, substituição da área em que o fármaco proporcionaria seu efeito e modificação na permeabilidade da membrana celular externa(COSTA, 2019). Já a Pseudomonas aeruginosa pode infectar partes distintas do corpo, principalmente imunocomprometidos (MANUAL MSD, 2018). Este microrganismo é considerado um patógeno de difícil tratamento, por ter uma limitada sensibilidade a agentes antimicrobianos(SILVA, 2016).Essa bactéria está presente no solo, água, palha, animais. As principais infecções ocasionadas por esta bactéria são: otites, infecções ósseas, articulares, infecções de pele, ITU e infecções do trato respiratório(MANUAL MSD, 2018). Por fim, aEnterobactersppencontra-se predominantemente na microbiota e intestinal dos seres humanos. Introduzida no grupo de bactérias multirresistentes, principalmente, através da produção da enzima beta-lactamase. As cepas Enterobactercloacae e Enterobacteraerogenes, apresentam-se comumente ligadas a quadros de meningites, infecções de pele, urinárias e respiratórias (COSTA et al, 2019). No estudo de Zonta et al (2020) dos 102paciente avaliados admitidos na UTI, 57 (55,8\%)estavam colonizados por microrganismos patogênicos.No estudo de Silva (2016)foram analisadas 577 cepas e identificou-se que o microrganismo mais prevalente foi Klebsiellapneumoniae (41\%), seguido de Staphylococcus aureus (22\%), Pseudomonas aeruginosa $14 \%$. 
Conclusão: Destaca-se a importância do grupo ESKAPES na ocorrência de variadas infecções em diferentes estruturas do corpo, ocorrendo em maior número em pacientes internados em UTIs. Salienta-se que tais bactérias apresentam mecanismos de multirresistência aos antimicrobianos disponíveis, o que se tornou um problema mundial de saúde. Fazem-se necessárias novas pesquisas na área, devido à limitação de estudos nacionais sobre o grupo ESKAPE, a fim de minimizar e controlar os índices de morbimortalidade.

\section{Referências}

COSTA, Beatriz Sabbo. et al. Superbactérias e o desenvolvimento de mecanismos e resistência a antimicrobianos. Orientador:Profa. Dra . leda YurikoSonehara, 2019. 57f. Trabalho de Conclusão de Curso (Graduação em Farmácia) Universidade Presbiteriana Mackenzie, São Paulo, 2019.

LIMA, Maíra Ferreira Pinto. et al. Staphylococcus aureus e as infecçõeshospitalares revisão deliteratura. Revista UNINGÁ Review. v.21, n.1, p. 32-39, jan./mar. 2015.

MANUAL MSD. Pseudomonas e infecções relacionadas. 2018. Disponível em: https://www.msdmanuals.com/ptpt/profissional/doen\%C3\%A7as-infecciosas/bacilos-gram-negativos/pseudomonas-e-infec\%C3\%A7\%C3\%B5es-relacionadas.

Acesso em: 11/08/2020

RIBEIRO, Marcelo. et al. As principais bactérias de importância clínica e os mecanismos de resistência no contexto das Infecções Relacionadas à Assistência a Saúde (IRAS). Revista Científica UMG; Mogi das Cruzes, v. 1, n.1, agost. 2016.

SILVA, Ana Carolina Pereira; VELASQUEZ, Patrícia Amaral Gurgel. Perfil de resistência de Klebsiellapneumoniae isoladas de pacientes da unidade de terapia intensiva de um hospital no Sudoeste do Paraná. DisciplinarumSciential Saúde, Santa Maria, v. 18, n. 2, p. 259-270, 2017.

SILVA, Daniely Martins. Perfil de susceptibilidade e prevalência de bactérias do grupo ESKAPE em um hospital público do Distrito Federal. Orientador: Profa. Dra. Thaís Alves da Costa Lamounier. 2016. 56f . Trabalho de Conclusão de Curso (Graduação em Farmácia) Universidade de Brasília, Ceilândia, 2016.

VIEIRA, PRISCILA BRAGA; PICOLI, Simone Ulrich. Acinetobacter Baumannii multirresistente: aspectos clínicos e epidemiológicos. Rev. BrasCiênc Saúde, v. 19, n. 2, p. 151-6, 2015.

ZONTA, Franciele do Nascimento Santos. et al. Colonização por ESKAPES e características clínicas de pacientes críticos. Enfermería Global, Múrcia, v. 19, n. 3, p. 214-254, 2020. 


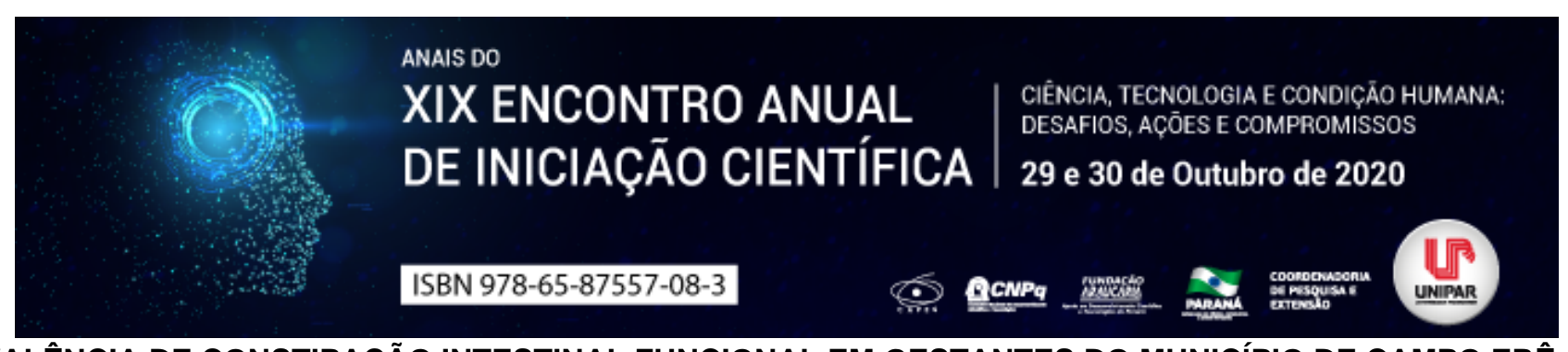

PREVALÊNCIA DE CONSTIPAÇÃO INTESTINAL FUNCIONAL EM GESTANTES DO MUNICÍPIO DE CAMPO ERÊ

\title{
${ }^{1}$ EDUARDA ORBACH DE ALMEIDA, ${ }^{2}$ INDIOMARA BARATTO
}

\author{
${ }^{1}$ Discente do curso de Nutrição/UNIPAR \\ ${ }^{1}$ Docente da UNIPAR
}

Introdução: A gestação é um período de vulnerabilidade na vida da mulher que provoca modificações fisiológicas, metabólicas e nutricionais em seu organismo (SILVA et al., 2018). A saúde da mãe e o desenvolvimento do feto requerem hábitos saudáveis para uma gestação adequada. Já nas primeiras semanas gestacionais, uma das alterações fisiológicas que ocorre é a redução da motilidade gastrintestinal, que é responsável também pelo sintoma de constipação intestinal. Esse é um sintoma muito comum na gravidez e está presente em cerca de $35-40 \%$ das mulheres grávidas (TEIXEIRA et al., 2015). A cronicidade desses sintomas e o uso abusivo de laxantes podem acarretar outros problemas como desequilíbrio da flora e inflamação intestinal, diminuição da absorção de água e nutrientes, dentre outros (COLLETE; ARAÚJO; MADRUGA, 2010). Na gestação, as condições associadas à constipação estão relacionadas com premissas dietéticas, ou seja, dieta, depleção de líquidos, baixo consumo de fibras, anorexia, demência e depressão, além disso, fatores como inatividade física, baixa ingestão calórica, baixa renda e sexo feminino podem aumentar o risco de constipação (LINDBERG et al., 2010). Uma alimentação equilibrada, uma ingestão hídrica correta, o consumo adequado de fibras e atividade física são essenciais para evitar e regular o sintoma de constipação intestinal. Objetivo: Identificar a presença de constipação intestinal funcional em mulheres grávidas no Município de Campo Erê SC. Métodos: Este estudo será realizado no município de Campo Erê e contará com uma amostra de gestantes que realizam o prénatal pelo Sistema Único de Saúde. Será aplicado um questionário, com questões abertas e fechadas, contendo os dados pessoais, história clínica e aspectos nutricionais, dentre eles será coletado o dia habitual para a contagem de fibras ( $\mathrm{g} / \mathrm{dia}$ ) da dieta e realizado cálculo e diagnóstico do Índice de Massa Corporal pré gestacional e atual, a partir da classificação do Institute of Medicine e Ministério da Saúde, consequentemente. Para o diagnóstico será avaliada a consistência das fezes a partir da Escala de Bristol e a presença de constipação intestinal através dos Critérios de Roma III. Este estudo foi aprovado pelo Comitê de Ética da nossa instituição sob o parecer 4.056.596.

Resultados: Os resultados ainda não foram concluídos. Pode-se afirmar que em torno de $60 \%$ das gestantes já foram diagnosticadas com constipação a partir dos Critérios de Roma III. Antes do período gestacional a maioria das mulheres estavam eutróficas (59\%), 23,4\% com excesso de peso (sobrepeso ou obesidade) e 17,6\% com baixo peso. Durante o período gravídico, $60 \%$ classificaram-se eutróficas, 35\% com excesso de peso e 5\% com baixo peso. Quanto ao consumo de fibras diárias, 94,2\% das gestantes tiveram um consumo $<28 \mathrm{~g}$ de fibras e 5,8\% apresentaram consumo $>28 \mathrm{~g}$ de fibras/dia. $11,7 \%$ das gestantes já haviam feito o uso de laxante natural conhecido como Cáscara Sagrada. Das 17 gestantes avaliadas, 76,4\% apresentam ingesta hídrica < 2litros de água/dia.

Discussão: Sabe-se que para uma gestação saudável e tranquila são necessários fatores como alimentação equilibrada, atividade física, sono adequado e estado nutricional de eutrofia (FREITAS, et al 2010). A obesidade materna pode desencadear um sistema de cascata em que os níveis de glicose aumentados estimulam a produção de insulina pelo feto, na qual proporciona um aumento indesejado da lipogênese fetal. No entanto, a desnutrição ou o ganho de peso insuficiente na gestação também podem ocasionar um transporte diminuído de nutrientes ao feto. Outro fator que influencia na saúde da mulher é a produção de hormônios durante a gravidez sendo a progesterona relacionada ao trato gastrointestinal. Ela é responsável pela redução da concentração plasmática da motilina, um polipeptídio intestinal que estimula a concentração de fibras lisas do intestino. Com a motilidade gastrointestinal reduzida há a presença de constipação (FREITAS, et al 2010). Muitas gestantes não alcançam as recomendações nutricionais apenas com a dieta, partindo para o uso de suplementos alimentares. SILVA, et al (2018) afirmam que o uso de sulfato ferroso pode causar complicações gastrointestinais e causar também o sintoma de constipação intestinal. Define-se a constipação funcional como um transtorno caracterizado por uma dificuldade persistente para evacuar ou uma sensação de evacuação incompleta e/ou movimentos intestinais infrequentes (WHO, 2006). A partir disso, há muitos indivíduos que abusam de substâncias laxativas que podem causar diarréia com perda intensa de eletrólitos e água (PINHEIRO, et al 2018). Vale destacar que para o manejo geral da constipação, segundo Programa Nacional Promoção da Alimentação Saudável (2015), indica-se beber bastante líquidos, normalmente água (2L por dia), aumentar a ingestão de alimentos ricos em fibras e realizar a prática regular de atividade física.

Conclusão: A conclusão deste trabalho acontecerá depois da análise estatística dos dados coletados. Por conseguinte, observase a prevalência de constipação intestinal funcional em gestantes do município de Campo Erê SC. 
COLLETE, V. L.; ARAÚJO, C. L.; MADRUGA, S. W. Prevalência e fatores associados à constipação intestinal: um estudo com base populacional em Pelotas, Rio Grande do Sul, 2007. Cad. Saúde Pública, Rio de Janeiro, 26(7):1391-1402, jul, 2010.

DIREÇÃO GERAL DA SAÚDE. Alimentação e nutrição na gravidez. Programa Nacional para a Promoção da Alimentação Saudável Alimentação e Nutrição na Gravidez, 2015

FREITAS, E. S; DAL BOSCO, S. M.; SIPPEL, C. A.; LAZZARETTI, R. K. Recomendações nutricionais na gestação. REVISTA DESTAQUES ACADÊMICOS, ANO 2, N. 3, 2010 - CCBS/UNIVATES.

LINDBERG, G., HAMID, S., MALFERTHEINER, P., THOMSEN, O., FERNANDEZ, L. B., GARISCH, J., THOMSON, A., GOH, K. L., TANDON, R., FEDAIL, S., WONG, B., KHAN, A., KRABSHUIS, J., MAIR, A. L. Constipação: uma perspectiva mundial. World Gastroenterology Organisation Practice Guidelines. Novembro de 2010. Disponível em: https://www.worldgastroenterology.org/.

PINHEIRO, A.K.; GOMES GERON, V.L.M.; TERRA JUNIOR, A.T.; SILVA NUNES, J.; BRONDANI, F.M.M. Constipação intestinal: tratamento com fitoterápicos. Revista Científica FAEMA. Faculdade de Educação e Meio Ambiente.DOI: http://dx.doi.org/10.31072.ISSN: 2179-4200

SILVA, C.F.; SILVA, G.F.; SCHAFASCHEK, H.S.; GUIMBALA, M.A.B.; ALMEIDA, S.; SILVA, J.C. Suplementação de sulfato ferroso na gestação e anemia gestacional: uma revisão da literatura. Arq. Catarin Med. 2018 jan-mar; 47(1):198-206

SILVA, M. G.; HOLANDA, V. R.; LIMA, L. S. V.; MELO, G. P. Estado Nutricional e Hábitos Alimentares de Gestantes Atendidas na Atenção Primária de Saúde. Revista Brasileira de Ciências da Saúde. Volume 24 Número 4 Páginas 349-356 2018.

TEIXEIRA, D., PESTANA, D., CALHAU, C., VICENTE, L., GRAÇA, P. Alimentação e nutrição na gravidez. Programa Nacional da Alimentação Adequada e Saudável. Direção Geral de Saúde, 2015.

WORLD GASTROENTEROLOGY ORGANISATION PRACTICE GUIDELINES. Constipação: uma perspectiva mundial. Novembro de 2010.

Coordenadoria de Pesquisa e Extensão - COPEX

Departamento de Editoraçāo e Divulgaçāo Científica - DEDIC 


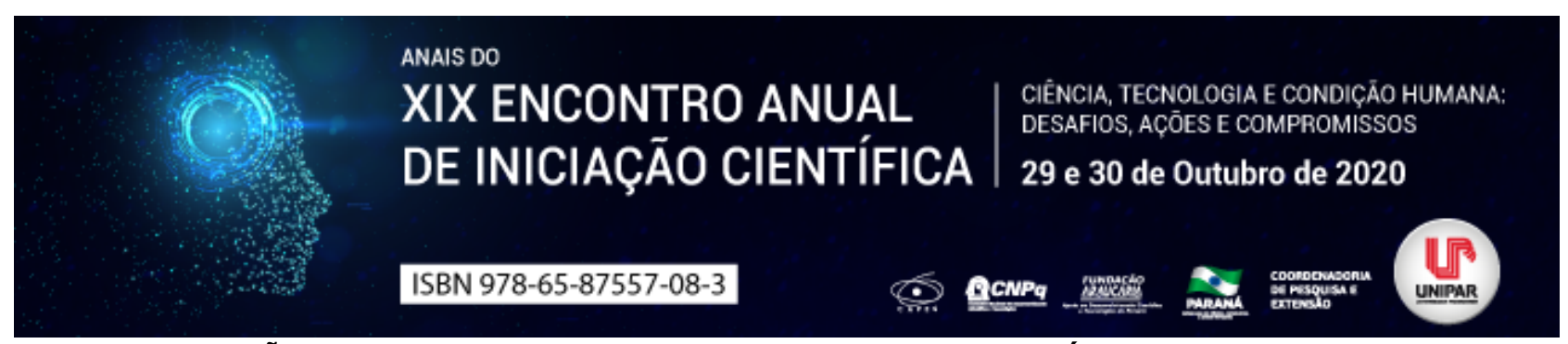

MODULAÇÃO CARDIOVASCULAR PROMOVIDA PELO NARGUILÉ EM UM MODELO ANIMAL

\begin{abstract}
${ }^{1}$ FERNANDA DE ABREU BRAGA, ${ }^{2}$ BARBARA SILVA BRAVO, ${ }^{3}$ YASMIN NAVA SINHORIN, ${ }^{4}$ EDUARDA CAROLINA AMARAL, ${ }^{5}$ FRANCISLAINE APARECIDA DOS REIS LIVERO
\end{abstract}

\author{
${ }^{1}$ Acadêmica do Curso de Medicina e bolsista do PEBIC/CNPq \\ ${ }^{1}$ Acadêmica do Curso de Medicina da UNIPAR \\ ${ }^{2}$ Acadêmica do Curso de Medicina da UNIPAR \\ ${ }^{3}$ Acadêmica do Curso de EstÃ@tica e CosmÃ@tica da UNIPAR \\ ${ }^{4}$ Docente da UNIPAR
}

Introdução: As doenças cardiovasculares (DCV) são responsáveis pela elevada morbimortalidade mundial, sendo a principal causa de morte no mundo (KOENE et al., 2016). Este fato pode ser explicado por uma série de fatores de risco modificáveis, aos quais a população está exposta, como o tabagismo (APPELMAN et al., 2015). Um método tradicional utilizado para fumar o tabaco é o narguilé, com substâncias capazes de provocar alterações sobre o organismo (MORRIS et al., 2015). Entretanto, mesmo com o conhecimento do risco cardiovascular bem estabelecido e das políticas públicas para a cessação do tabagismo, o fumo de narguilé é uma prática crescente entre a população e poucos estudos investigam os efeitos cardiotóxicos desta substância (GATRAD; GATRAD; SHEIKH, 2007). Dessa forma, modelos animais que investiguem este fator de risco e os mecanismos patofisiológicos da enfermidade, são necessários.

Objetivo: Avaliar os efeitos da exposição à fumaça do narguilé sobre a pressão arterial e peso dos órgãos de ratos.

Material e Métodos: Durante dez semanas, ratos Wistar machos $(n=8)$, com dois meses de idade, receberam dieta comercial padrão, água filtrada ad libitum e foram expostos à fumaça de narguilé 1 hora/dia, cinco dias/semana. Um grupo de animais não exposto ao fator de risco foi acompanhado paralelamente (grupo controle negativo). O peso dos animais foi acompanhado semanalmente e ao final do experimento, a pressão arterial sistólica, diastólica, média, frequência cardíaca e peso do coração, pulmões, rins, fígado e baço foram mensuradas. Para análise estatística foi utilizado o programa Graphpad Prism versão 5.0. Os dados foram previamente analisados quanto à homogeneidade da variância e à normalidade da distribuição. Utilizou-se o teste $t$ de Student, seguido pelo pós-teste de Mann Whitney. O nível de significância adotado foi de $95 \%(p<0,05)$. Todo o protocolo experimental foi aprovado pelo Comitê de Ética no Uso de Animais (CEUA) da UNIPAR (número 36948/2020).

Resultados: Em relação do peso dos animais, não observou-se diferença estatística entre os grupos no início e ao término das 10 semanas experimentais. Da mesma forma, não ocorreram alterações significativas em relação ao peso relativo do coração, pulmões, rins, fígado e baço em ambos os grupos. Ademais, após a avaliação dos parâmetros cardiovasculares, observou-se uma diminuição na frequência cardíaca, pressão arterial sistólica, diastólica e média nos animais do grupo Narguilé em relação aos animais do grupo basal.

Discussão: Este estudo avaliou o efeito do fumo de narguilé como fator de risco no desenvolvimento de doenças cardiovasculares, em ratos. Apesar do risco cardiovascular bem estabelecido e das políticas públicas para a cessação do tabagismo, o fumo de narguilé é uma prática crescente entre a população. Na última década, testemunhou-se um aumento constante no consumo de narguilé, especialmente entre as faixas etárias mais jovens (AKL et al., 2011; SIBAI et al., 2014). Considerando a relevância e a quantidade de estudos que descrevem a toxicidade cardiovascular associada ao tabaco, os relatos sobre o impacto do uso do narguilé no organismo são limitados (NEMMAR et al., 2016). O tabagismo, fator de risco bem estabelecido, afeta tanto a incidência quanto a mortalidade das DCV, por meio de vários mecanismos. A nicotina é um potente vasoconstritor, desencadeia aumento da frequência cardíaca e vasoconstrição elevando-se a pressão arterial devido à liberação de vasopressina e outros hormônios (ROSEMBERG, 2003). Em relação ao narguilé, estudos revelam a presença de diversos componentes tóxicos no plasma de indivíduos após o consumo dessa substância, como nicotina, monóxido de carbono, alcatrão e metais pesados (NEMMAR et al., 2013; INCA, 2017). Estes componentes são responsáveis por efeitos adversos sobre muitos órgãos, especialmente dos sistemas cardiovascular, onde há relatos de doença arterial coronariana (EL-ZAATAR; CHAMI; ZAATARI, 2015). No presente estudo, a inalação da fumaça do narguilé provocou efeito contrário dos relatados na literatura, mostrando que as ações do narguilé no sistema cardiovascular devem ser investigados mais detalhadamente. Frente ao exposto, esta pesquisa abre um horizonte para investigações sobre os efeitos do narguilé no sistema cardiovascular, que apontam importantes efeitos do uso deste fumígeno nesse sistema.

Conclusão: Os resultados desta pesquisa promovem abertura para um horizonte de investigações mais aprofundadas sobre os efeitos do narguilé no sistema cardiovascular. 


\section{Referências}

AKL, Elie et al. The prevalence of waterpipe tobacco smoking among the general and specific populations: a systematic review.

BMC Public Health, v. 11, n. 1, p. 244. 2011.

APPELMAN, Yolande et al. Sex differences in cardiovascular risk factors and disease prevention. Atherosclerosis, v. 241, n. 1, p. 211 218. 2015.

EL-ZAATARI, Ziad; CHAMI, Hassan A.; ZAATARI, Ghazi S. Health effects associated with waterpipe smoking. Tobacco Control, v. 24, n. Suppl 1, p. i31-i43. 2015.

GATRAD, Rashid; GATRAD, Adam; SHEIKH, Aziz. Hookah smoking. British Medical Journal, v. 335, n. 7609, p. $20-20.2007$.

INCA. Nota técnica: Uso de narguilé: efeitos sobre a saúde, necessidades de pesquisa e ações recomendadas para legisladores I Instituto Nacional de Câncer José Alencar Gomes da Silva ～2. ed. Rio de Janeiro. 49 p. 2017.

KOENE, Ryan J. et al. Shared risk factors in cardiovascular disease and cancer. Circulation, v. 133, n. 11, p. 1104-1114. 2016.

MORRIS, Pamela B. et al. Cardiovascular effects of exposure to cigarette smoke and electronic cigarettes: clinical perspectives from the Prevention of Cardiovascular Disease Section Leadership Council and Early Career Councils of the American College of Cardiology. Journal of the American College of Cardiology, v. 66, n. 12, p. 1378-1391. 2015.

NEMMAR, Abderrahim et al. Cardiovascular effects of nose-only water-pipe smoking exposure in mice. American Journal of Physiology-Heart and Circulatory Physiology, v. 305, n. 5, p. H740-H746. 2013.

NEMMAR, Abderrahim et al. Chronic exposure to water-pipe smoke induces cardiovascular dysfunction in mice. American Journal of Physiology-Heart and Circulatory Physiology, v. 312, n. 2, p. H329-H339. 2016.

ROSEMBERG, José. Nicotina: droga universal. São Paulo: Secretaria de Estado da Saúde - SES/CVE; 2003.

SIBAI, Abla Mehio et al. Lifetime cumulative exposure to waterpipe smoking is associated with coronary artery disease. Atherosclerosis, v. 234, n. 2, p. 454-460. 2014. 


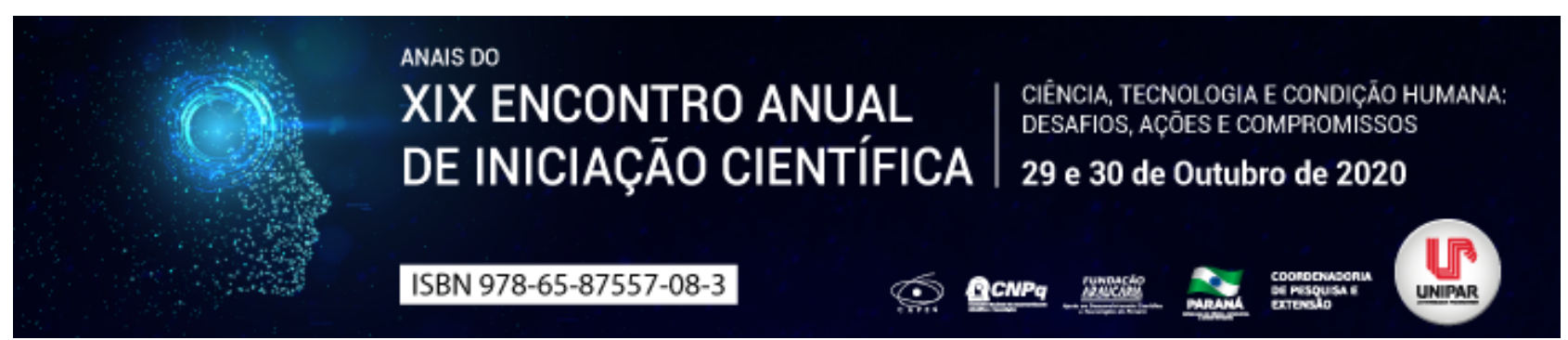

CALCIFICAÇÃO PULPAR: UMA REVISÃO DE LITERATURA

\begin{abstract}
${ }^{1}$ ISABELLE VENCIGUERRA ALMEIDA, ${ }^{2}$ LUDMYLLA APARECIDA DIAS CINQUINI, ${ }^{3}$ LARA YUKARI LENZONI TAKAHASHI, ${ }^{4}$ LUIZ FERNANDO TOMAZINHO
\end{abstract}

\author{
${ }^{1}$ Acadêmica do Curso de Odontologia da UNIPAR \\ ${ }^{1}$ Acadêmica do Curso de Odontologia da UNIPAR \\ ${ }^{2}$ Acadêmica do Curso de Odontologia da UNIPAR \\ ${ }^{3}$ Docente da UNIPAR
}

Introdução: A calcificação pulpar é caracterizada pela deposição de tecido duro dentro do espaço do canal radicular. Esta condição se caracteriza por uma coloração amarelada, perda de translucidez e tonalidade mais escurecida da coroa do dente (AMIR, GUTMANN, 2001; PATERSSON, MITCHELL, 1965). O aparecimento de áreas mineralizadas no tecido pulpar é um fenômeno relativamente comum na polpa madura, relacionadas ao processo de envelhecimento pulpar. Embora por si só não representem um processo patológico, sua ocorrência é fortemente relacionada a agressões do complexo dentino-pulpar em dentes expostos a cáries e traumatismos. (LUUKKO et al., 2011). Uma agressão por trauma pode originar uma resposta isquêmica, que por sua vez pode diminuir o suprimento neurovascular da polpa, ocasionando aumento de deposição de dentina mineralizada dentro da cavidade pulpar (ZUOLO et al., 2010; LOPES, SIQUEIRA, 2015). A obliteração parcial ou total da cavidade pulpar por tecido mineralizado, genericamente denominada de calcificação, representa um desafio para o clínico no âmbito de localizar e trabalhar nos canais (ZUOLO et al., 2010).

Objetivo: O objetivo deste trabalho é fazer um levantamento bibliográfico sobre a calcificação pulpar, e identificar à histopatologia, aspectos clínicos e radiográficos e possíveis tratamentos.

Desenvolvimento: As principais causas da calcificação pulpar são maioritariamente desconhecidas, mas sabe-se que podem desenvolver-se devido a cárie, medicações intracanalares, traumas (extrusão, luxação lateral) e envelhecimento (DEVA et al., 2006; LOPES, SIQUEIRA, 2015). As calcificações também são consequências comuns após traumas oclusais, em alguns tipos de cirurgia maxilar, e certos tratamentos ortodônticos (SARDHARA et al., 2016). Após estas lesões os dentes afetados nem sempre reagem aos testes de sensibilidade. Esta situação pode ser reversível, sendo possível que, depois de algumas semanas, o teste de sensibilidade volte a ser positivo (ANDREASEN, 1970; DE CLEEN, 2002). Em alguns pacientes a calcificação pulpar se apresenta sem sintomatologia. Por isso, na maioria dos casos essa alteração dental é diagnosticada acidentalmente com investigações clínicas ou radiográficas. As calcificações pulpares podem ser encontradas como calcificações discretas, que aparecem como dentículos, nódulos e pedras geralmente na polpa coronária ou como calcificações difusas que são áreas de calcificação irregular, paralelas aos vasos, sendo mais frequentes na polpa radicular (PIATTELLE, 1992). A necrose pulpar ocorre em 20\% dos dentes detectados radiograficamente com calcificação (SARDHARA et al., 2016). MCCABE, DUMMER (2012) concluíram em sua revisão que até $75 \%$ dos dentes com obliteração do canal pulpar estão livres de sintomas e não requerem tratamento além do monitoramento radiográfico, testes de sensibilidade pulpar de rotina não são confiáveis na presença de obliteração do canal pulpar, e dentes com obliteração do canal da polpa com necessidade de tratamento do canal radicular constituem um desafio de diagnóstico e tratamento. Nos casos de necrose pulpar, o tratamento endodôntico deve ser realizado, porém a calcificação pulpar e/ou obliteração pulpar impõe dificuldades, podendo resultar perfurações coronais e/ou radiculares afetando negativamente o prognóstico do tratamento (ESTRELA et al., 2018). O profissional deve ter atenção redobrada ao tomar a decisão do tratamento mais indicado, fazendo associação das respostas de achados clínicos radiográficos e sintomas do paciente (LUUKKO et al., 2011).

Conclusão: Através desta revisão de literatura, foi comprovado que a calcificação pulpar é um desafio clínico no consultório e cabe ao cirurgião-dentista avaliar e diagnosticar esta alteração, bem como, apresentar um plano de tratamento ideal para cada caso visando a funcionalidade e bem estar do paciente.

\title{
Referências
}

AMIR, Faisal A.; GUTMANN, James L.; WITHERSPOON, David E. Calcific metamorphosis: a challenge in endodontic diagnosis and treatment. Quintessence Int., Berlin, v.32, n.6, p.447-455, 2001.

ANDREASEN, Jean O. Luxation of permanent teeth due to trauma. A clinical and radiographic follow-up study of 189 injured teeth. Scandinavian Journal of Dental Research, v.78, n.3, p.273-86, 1970.

DE CLEEN, Michiel. Obliteration of pulp canal space after concussion and subluxation: Endodontic considerations. Quintes sence Int, v.33, n. 9, p. 661-669, Oct. 2002. 
DEVA, Virgil., et al., Radiological and microscopic aspects of the denticles. Romanian Journal of Morphology and Embryology, v.47, n.3, p.263 268, Fev. 2006.

ESTRELA Carlos., et al. Root perforations: a review of diagnosis, prognosis and materials. Braz Oral Res. v.32. e.0073, Out. 2018.

LOPES, Helio Pereira., SIQUEIRA, José Freitas. Endodontia: Biologia e Técnica. 4ª edição. Rio de Janeiro. Guanabara Koogan, 2015.

LUUKKO, Keijo., et al., Estrutura e Funções do Complexo Dentino-Pulpar. In: COHEN. Caminhos da Polpa. 10a ed. Rio de Janeiro: Elsevier, 2011 p. 418-463.

MCCABE, P.S.; DUMMER, P.M.H. Pulp canal obliteration: an endodontic diagnosis and treatment challenge. International Endodontic Journal, v.45, p.177 197, 2012.

PATERSSON, Samuel S; MITCHELL, David F. Calcific metamorphosis of the dental pulp. Oral Surg Oral Med Oral Pathol, v.20, p.94-101, 1965.

PIATTELLI, Adriano. Symmetrical pulp obliteration in mandibular first molars. J Endod, v.18, n.10, p. 515-516, 1992.

SARDHARA Yagnesh., et al. (2016). Management of Maxillary Central Incisor with Calcified Canal: Case Report. Journal of Dental and Medical Science, v.15, n.1, p. 24-41.

ZUOLO, Mário Luis., et al., Localização de canais calcificados com auxílio do microscópio clínico operatório - Série de casos. Revista da Associação Paulista de Cirurgiões Dentistas, v.64, n.1, p. 28-34, Fev 2010.

Coordenadoria de Pesquisa e Extensão - COPEX

Departamento de Editoraçāo e Divulgaçāo Científica - DEDIC 


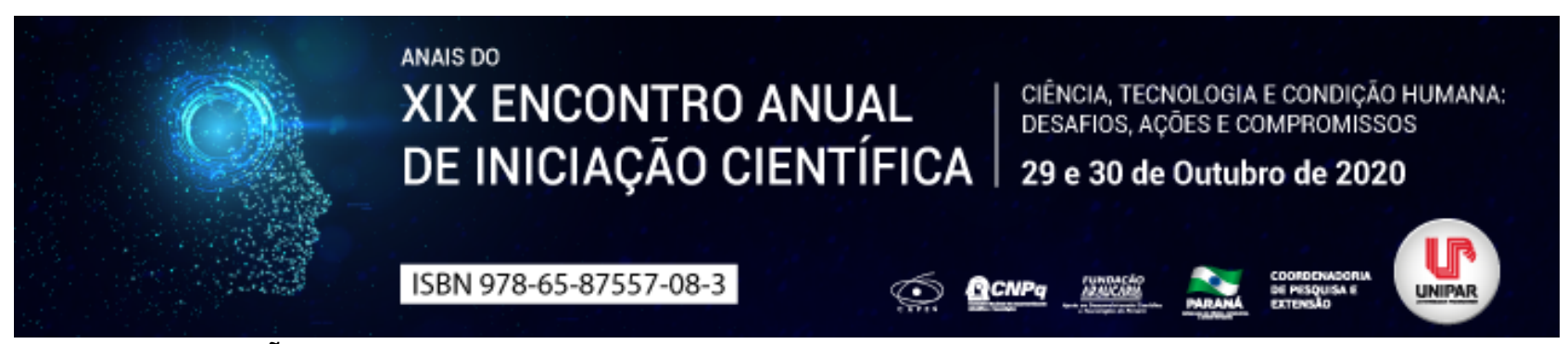

A APLICAÇÃO DE ARGILOTERAPIA EM OLEOSIDADE E ACNE FACIAL - ESTUDO DE CASO

\title{
${ }^{1}$ LIDIA PRISCILA LONGO, ${ }^{2}$ KARINA MARIA DE BARROS,${ }^{3}$ GIOVANA MIOTO DE MOURA
}

\author{
${ }^{1}$ Tecnóloga em Estética e Cosmética - UNIPAR - Cianorte \\ ${ }^{1}$ Tecnóloga em Estética e Cosmética - UNIPAR - Cianorte \\ ${ }^{2}$ Docente - UNIPAR - Cianorte
}

Introdução: A pele é constituída por pêlos, unhas, glândulas sudoríparas e sebáceas responsáveis pela junção de suor, sebo e água conferindo uma camada protetora e hidratante natural (OLIVEIRA, et al., 2014). Quando há uma elevação na produção de sebo pelas glândulas sebáceas, ocorre a oleosidade no sistema tegumentar, deixando a pele iluminada, sensível, e ha dilatação dos poros (KEDE; SEBATOVICH, 2004). Este processo em exagero evolui para uma patologia do folículo pilossebáceo, a acne, com efeitos de alta produção de queratina e sebo, bloqueio do folículo pilossebáceo, seguido do crescimento bacteriano, e inflamação (PIMENTEL, 2008). Para tratar a acne e a oleosidade recomenda-se a associação de técnicas como, a argiloterapia, um ativo natural com o pH próximo da pele com ação na redução da inflamação (SOUZA, 2009). Aliado a eletroterapia, com o uso de alta-frequência, pela ação bactericida e antisséptica; e o vapor de ozônio com efeito de emoliência, dilatação dos vasos e abertura dos poros (HERNANDEZ, 1999).

Relato de Caso: O objetivo do estudo é oferecer ao paciente uma melhora fisiológica cutânea, com diminuição no processo inflamatório, nas marcas e manchas de acne provocadas provavelmente pela somatória de alterações locais, e promoção de auto-estima com os bons resultados através de uma pele lisa, sedosa e jovial. O tratamento buscou tratar oleosidade e acne facial de uma voluntária com idade 15 anos (com termo de consentimento livre esclarecido e autorização por escrito e acompanhamento do pai), fototipo II (OLIVEIRA, et al., 2014), acometida com acne grau II, presença de pápulas, pústulas em processo inflamatório em zona $\mathrm{T}$ da face e com sensibilidade local. Para esse estudo de caso o tratamento proposto baseou-se em um encontro semanal durante 7 semanas usando o protocolo de argiloterapia, com vapor de ozônio e alta frequência, no qual foi positivo sua aplicação. Sendo as sessões ímpares contempladas com o uso de argila verde, e as pares com a argila branca. $O$ passo a passo da sessão resume-se em: higienização com gel de limpeza (Adcos), sabonete neutro (Adcos), esfoliante (Vitaderm), aplicação da máscara de argila (Vitaderm/lazlo) + água destilada e aplicação simultânea do vapor de ozônio por 15 minutos, lavagem do local com água, aplicação do alta frequência com intensidade média por 5 minutos, tonificação da pele (Samana) e filtro solar 60 (Adcos).

Discussão: A acne é uma dermatose multifatorial, trata-se de um processo inflamatório do folículo pilossebáceo com maior incidência em adolescentes, devido aos níveis elevados de hormônios sexuais, causando uma hiperplasia sebácea associada a hiperqueratose, obstruindo o orifício folicular e criando um cenário ideal para a colonização e proliferação da bactéria Propionibacterium acne (MAIO, 2011). Pode ser classificada em: Grau I comedogênica, com comedão aberto ou fechado sem inflamação; Grau II com pápulas e pústulas com inflamação; Grau III nódulos e cisto junto a inflamação; e Grau IV presença de nódulos, cisto e cicatrizes somados ao maior processo inflamatório (OLIVEIRA, et al., 2014). A argila é um produto natural utilizado para tratamentos estéticos, considerada grão de terra que transporta água para tecido tegumentar, de diferentes cores e com minerais distintos que determinam a ação do produto sobre a pele, como por exemplo a argila branca rica em silício, indicado para peles sensíveis, irritadas, em processo inflamatório; a verde, tem na sua composição o mineral montmorilonita utilizados nos casos de oleosidade, acne, seborreia, e manchas com ação calmante (AMARAL, 2015). Considerado aparelho essencial na estética, o alta frequência possui efeito de dilatador dos vasos, o aumento da oxigenação, ação bactericida e antisséptico, esse resultado acontece através da aproximação de alguns tipos de gases com oxigênio do ar, por isso sua alta indicação no tratamento de acne, alteração cutânea como seborréia (OLIVEIRA, et al., 2014). O Vapor de Ozônio é um equipamento conhecido por lançar vapor de água com moléculas de ozônio, na qual, são produzidas por uma reação entre oxigênio e uma lâmpada ultravioleta acoplada estrategicamente; possui principalmente ação bactericida e anti-séptica e indicado para procedimentos como limpeza de pele, emoliência, dilatação dos vasos e abertura dos poros em peles oleosas (HERNANDEZ, 1999). De acordo com estudo feito por Silva (2018), com 5 sessões semanais para tratar acne, usando máscara de argila da Medicatriz ${ }^{\circledR}$ (marca responsável pela elaboração do protocolo), aliado a alta frequência e vapor de ozônio em 5 mulheres com acne vulgar, com idade média de 21 anos, obtiveram resultados significativos no processo inflamatório, melhora da textura e diminuição da oleosidade.

Conclusão: A associação de técnicas como argiloterapia, alta frequência e vapor de ozônio mostrou-se eficaz no tratamento facial de oleosidade e acne, através da ação anti-inflamatória, secativa, hidratante, calmante, e clareadora com relato e diagnóstico visual e fotográfico comprobatórios da melhora na textura da pele, redução de oleosidade e sensibilidade dolorosa, diminuição da acne e aspecto secativo das mesmas. 


\section{Referências}

AMARAL, Fernando. Técnicas de aplicação de óleos essenciais: Terapias de saúde e beleza, São Paulo, Editora Cengage Learning, 2015.

HERNANDEZ, Micheline; MERCIER-FRESNEL, Marie-Madeleine. Manual de cosmetologia, 3. ed. Rio de Janeiro: Revinter, 1999.

KEDE, Maria Paulina Villarejo; SABATOVICH, Oleg. Dermatologia estética, São Paulo; Rios de Janeiro; Ribeirão Preto; Belo Horizonte, Editora Atheneu, 2004.

MAIO, Maurício. Tratado de medicina estética, 2. ed. São Paulo, Editora Roca LTDA, 2011.

OLIVEIRA, Andrea Lourenço. et al. Curso didático de estética. 2. ed. São Caetano do Sul: Yendis, 2014.

PIMENTEL, Arthur dos Santos. Peeling, máscara e acne: seus tipos e passos a passo do tratamento estético, São Paulo, Editora Livraria Médica Paulista, 2008.

SILVA, Jéssica Aparecida de Carvalho; PEREIRA, Pâmela Camila. Avaliação e tratamento estético da acne vulgar Evaluation and aesthetic treatment of acne vulgar. Revista Científica Universitas, Itajubá v. 5, n. 1, p.114-123 Jan-Jul. 2018 ISSN Eletrônico: 2175-4020. Disponível em: http://revista.fepi.br/revista/index.php/revista/article/view/581/pdf_33 Acesso em: 17. ago. 2019.

SOUZA, Valéria Maria de; JÚNIOR, Daniel Antunes. Ativos dermatológicos: Guia de ativos dermatológicos utilizados na farmácia de manipulação para médicos e farmacêuticos, São Paulo: Pharmabooks, 2009.

Coordenadoria de Pesquisa e Extensāo - COPEX

Departamento de Editoraçāo e Divulgaçāo Científica - DEDIC 


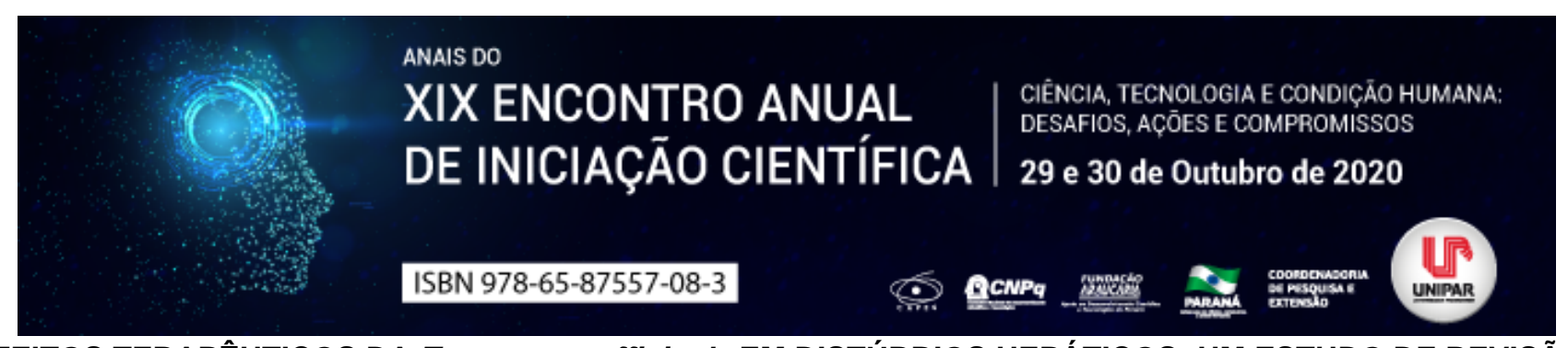

EFEITOS TERAPÊUTICOS DA Taraxacum officinale EM DISTÚRBIOS HEPÁTICOS: UM ESTUDO DE REVISÃO

\title{
${ }^{1}$ EDHILA ASSUNCAO PINHEIRO, ${ }^{2}$ EDUARDA CAROLINA AMARAL, ${ }^{3}$ FRANCISLAINE APARECIDA DOS REIS LIVERO
}

\author{
${ }^{1}$ Discente do Curso de Medicina/PIBIC-UNIPAR \\ ${ }^{1}$ Discente do Mestrado Profissional em Plantas Medicinais e Fitoterápicos na Atenção Básica, Bolsista PIT \\ ${ }^{2}$ Docente do Mestrado Profissional em Plantas Medicinais e Fitoterápicos na Atenção Básica e do PPG em Ciência Animal - \\ UNIPAR
}

Introdução: A Taraxacum officinale, popularmente nomeada dente-de-leão, é uma planta que faz parte da família Asteraceae, sendo uma espécie de alta incidência em várias regiões do Brasil (RIBEIRO, 2004). Essa planta possui uma raiz profunda e grossa com interior branco e exterior marrom, além de um caule oco e avermelhado e suas folhas são lisas e dentadas (ÁVILA, 2008). De acordo com Oliveira (2018) essa espécie possui grande relevância no cenário médico por suas diversas propriedades medicinais anti-inflamatórias, podendo ser utilizada no tratamento de doenças hepáticas, biliares, em astenias e distúrbios digestivos, além de ser rica em vitaminas e sais minerais, o que a torna um bom alimento.

Objetivo: Fornecer uma revisão de literatura sobre os efeitos terapêuticos do T. officinale em distúrbios hepáticos.

Desenvolvimento: A T. officinale pode ser consumida cru ou seca, tanto em forma de saladas quanto na preparação de infusões ou ainda sendo cozida (MARTINEZ et al., 2015). A T. officinale se destaca por ser rica em ferro, cobre, potássio, zinco além de conter mais vitaminas B1, B3, D, A e C que a maioria dos outros vegetais. Os componentes de maior importância para os efeitos hepáticos da T. officinale são as taraxacinas, que aumentam a função biliar, promovendo a degradação de ácidos graxos e consequentemente diminuindo o risco de desenvolvimento de esteatose hepática. A espécie apresenta ainda lactonas sesquiterpênicas do tipo eudesmanolida e germacranolida, que possuem importante propriedade anti-inflamatória (GUIRAROCHA, 2014). Por sua abundante concentração de zinco, a T. officinale tem efeito antioxidante hepático sobre as espécies reativas ao oxigênio (ERO), átomos ou moléculas extremamente reativos deletérios que possuem alta capacidade de produzir outros radicais livres citotóxicos e reativos (FERREIRA, 1997; RIBEIRO, 2004). Oliveira et al. (2018) confirmou o efeito antioxidante da dente-de-leão pela inibição dos danos oxidativos devido às vitaminas $\mathrm{A}$ e $\mathrm{C}$ presente, as quais além de proteger $\mathrm{O}$ organismo dos radicais, reduzem o nível intracelular de ERO. Para determinar sua capacidade antioxidante, foi utilizado o método de mecanismo de captura orgânica do radical livre estável DPPH, comprovando sua potencialidade maior com o extrato da planta obtido pelo procedimento a quente, através do extrato etanólico. O Rigoberto (2017), comparou o efeito hepatoprotetor do extrato etanólico do dente-de-leão e da silimarina, famoso composto extraído do fruto da Silybum marianum, em animais que foram submetidos a um modelo de hepatotoxicidade induzida pelo tetracloreto de carbono (CCl4), o evidenciando maior eficácia para a $T$. officinale em relação a silimarina. Segundo Jeon et al. (2010) o extrato etanólico de T. officinale reduziu a lesão hepática induzida por álcool em camundongos, aumentou a atividade antioxidante hepática e reduziu os níveis das enzimas aspartato aminotransferase (AST) e alanina aminotransferase (ALT). Ainda, em um estudo realizado por pesquisadores venezuelanos, a T. officinale foi considerada promissora contra os sintomas da malária, doença parasitária na qual o fígado é afetado, acredita-se na melhora por essa ter alta quantidade de flavonóides, reforçando seu caráter hepatoprotetor (CARABALLO, 2004). Por fim, foi realizado um estudo em ratos com o infuso da raiz da planta ( $1 \mathrm{~g} / \mathrm{kg}$ de peso corporal/dia) sobre o efeito protetor contra os lesões hepáticas ocasionadas pelo álcool. Observou-se redução nos níveis da alanina aminotransferase, lactato, AST e fosfatase alcalina, concomitante ao aumento do potencial antioxidante e diminuição da peroxidação lipídica (YOU et al., 2010).

Conclusão: Os estudos sobre os efeitos hepatoprotetores da T. officinale são promissores, principalmente por existirem vários indícios de sua capacidade de fornecer proteção aos hepatócitos diante dos radicais livres e seus efeitos degenerativos.

\section{Referências}

ÁVILA, Luís Carlos; LIMA, Angela. Indice terapêutico fitoterápico erva medicinais. Editora EPUB (Edições de Publicações Biomédicas Ltda). 1 ed. Petrópolis, RJ. p 143.2008.

FERREIRA, Ana Lucia Anjos.; M., L. S. Radicais livres: conceitos, doenças relacionadas, sistema de defesa e estresse oxidativo. Revista da Associação Médica Brasileira, v. 43, n. 1, p. 61-68, 1997.

CARABALLO, Alejandro. et al. Avaliação preliminar de plantas medicinais usadas como antimaláricos no sudeste amazônico venezuelano. Revista da Sociedade Brasileira de Medicina Tropical, v. 37, n. 2, p.186 188,2004.

GUIRACOCHA, Jenny Carolina Muñoz. Estudio Bibliográfico de las propiedades medicinales y nutricionales del Diente de León. 2014, p. 34-42, (Trabalho de Conclusão de Curso na área de Engenharia Química) - Universidade católica de Cuenca), Cuenca, 2014.

JEON, Hye-Jin. et al. Anti-inflammatory activity of Taraxacum officinale. Journal of ethnopharmacology, v. 115, n. 1, p. 82-88, 
2008.

MARTINEZ, Mario. et al. Taraxacum officinale and related species An ethnopharmacological review and its potential as a commercial medicinal plant. Journal of Ethnopharmacology, v. 169, p. 244 262, 2015.

OLIVEIRA, Bruna Pinto; SANTOS, Juliana Ferreira. Estudo das propriedades da taraxacum officinale (Dente de Leão), Universidade do Vale do Paraíba, São José dos Campos, 2018. p. 29-31.

OLIVEIRA, Gabriela Mota Silva; BRITO, Bruna da Silva; GASPI, Fernanda Oliveira Gaspari. Usos tradicionais e propriedades fitoterápicas do dente-de-leão (Taraxacum officinale FH Wigg.). Revista Eletrônica Acervo Saúde, n. 39, p. e-2121-e-2121, 2020.

RIBEIRO, Marilena. et al. Taraxacum officinale (Dente-de-leão). Uma revisão das propriedades e potencialidades medicinais. Arquivos do Museu Dinâmico Interdisciplinar, v. 8, n. 2, p. 46-49, 2004.

RIGOBERTO, Jácome Vargas Hernán. Efecto del extracto de Diente de León (Taraxacum officinale), sobre el comportamiento productivo y enzimas hepáticas séricas en pollos de engorde, p. 58, (trabalho de conclusão de curso na área de zootecnia) Universidad Técnica de Ambato, Ambato, 2017.

RUFINO, Maria do Socorro Moura. et al. Metodologia Científica: Determinação da atividade antioxidante total em frutas pela captura do radical livre DPPH. Embrapa Agroindústria Tropical-Comunicado Técnico (INFOTECA-E), 2007.

YOU, Yanghee. et al. In vitro and in vivo hepatoprotective effects of the aqueous extract from Taraxacum officinale (dandelion) root against alcohol-induced oxidative stress. Food and Chemical Toxicology. v. 48, n. 6, p. 1632-1637, 2010.

Coordenadoria de Pesquisa e Extensão - COPEX

Departamento de Editoração e Divulgaçāo Científica - DEDIC 


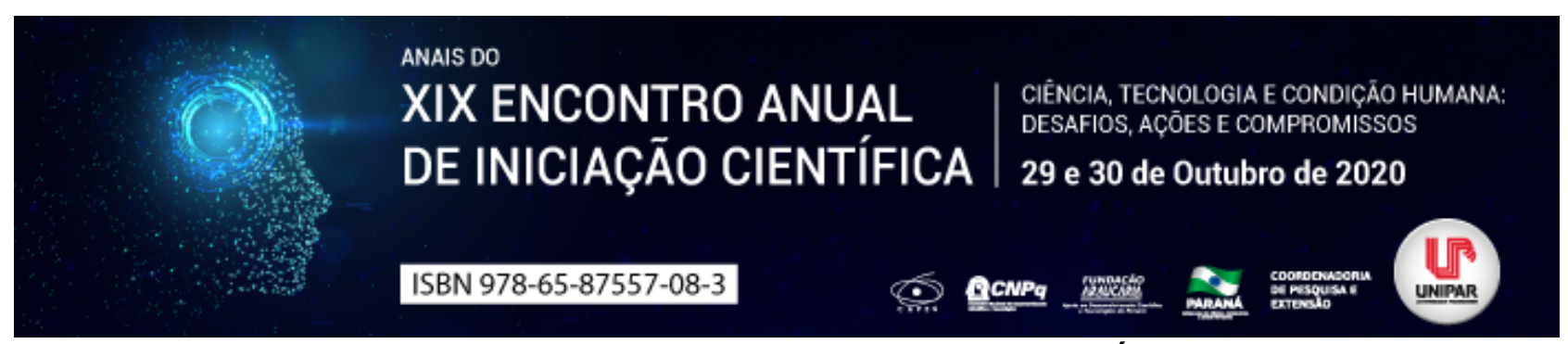

DISBIOSE INTESTINAL COMO FATOR RELACIONADO A RINITE ALÉRGICA EM ADULTOS

\author{
${ }^{1}$ CRISTIANE DIAS MARTINS, ${ }^{2}$ JANAINA STRAPAZZON RAFAGNIN
}

\author{
${ }^{1}$ Acadêmica UNIPAR \\ ${ }^{1}$ Docente da UNIPAR
}

Introdução: Em um indivíduo adulto cerca de $80 \%$ das células produtoras de anticorpos encontram-se associadas a mucosa do intestino delgado. Assim o desenvolvimento e progressão das respostas imunológicas neste local devem ser regulados a fim de se manter a auto tolerância, ou também conhecido como tolerância imunológica (GONÇALVES, et al., 2016). A microbiota intestinal compreende uma comunidade complexa de microrganismos comensais que vivem em simbiose no trato gastrointestinal humano. Eles formam uma barreira biológica (biofilme) contra a invasão de patógenos e contribuem para a modulação do sistema imune (TOMASELLO, et al., 2016; PETERSON, et al., 2007). Uma disfunção colônica devido a alterações da microbiota, na qual ocorre o predomínio de bactérias patogênicas sobre as bactérias benéficas, modifica a mucosa intestinal que se torna mais fina e mais permeável. Essa alteração é conhecida por disbiose intestinal (ALMEIDA, et al.,2009). A rinite alérgica (RA) é definida como uma inflamação da mucosa nasal, induzida pela exposição a alérgenos que, após sensibilização, desencadeiam uma resposta inflamatória mediada por imunoglobulinas $E$ (IgE). A RA é capaz de alterar de forma marcante a qualidade de vida das pessoas, causando morbidades e incapacidades (BEDOLLA-BARAJAS, et al., 2017; BROZEK, et al., 2017; BROSSEAU, et al., 2019;). Assim, torna-se necessário uma maior compreensão da relação entre microbiota intestinal e RA. Uma microbiota intestinal saudável tende a minimizar a automedicação e uso de medicamentos para rinite alérgica, e consequentemente redução do impacto econômico e na melhoria da qualidade de vida dos indivíduos acometidos por essa condição, fatos que justificam esta pesquisa.

Objetivo: Identificar a presença de disbiose intestinal em pacientes com rinite alérgica.

Materiais e métodos: Foram convidados a participar da pesquisa pacientes que realizaram o teste cutâneo para detecção de alergia (Prick Test ${ }^{\circledR}$ ) e se enquadravam nos critérios de inclusão de idade (18 a 59 anos) e diagnosticados pelo mesmo médico otorrinolaringologista. Após obtenção com conscentimento, os participantes preencheram os questionários de Rastreamento Metabólico e Hipersensibilidade Intestinal do Centro Brasileiro de Nutrição Funcional, que consistem em questões fechadas, com relação a sinais e sintomas sobre: a cabeça, os olhos, ouvidos, nariz, boca/garganta, pele, coração, pulmões, trato digestivo, articulações/músculos energia/atividade, mente e emoções. Os resultados foram interpretados por uma escala de pontuação de 0 a 4, na qual 0 nunca ou quase nunca teve sintomas e a pontuação 4 teve sintomas frequentes e severos. Esta pesquisa foi aprovada pelo comitê de ética em pesquisa com seres humanos da Unipar, sob o protocolo 4.053.784.

Resultados: Os dados foram coletados entre os meses de maio e agosto de 2020. Participaram da pesquisa 30 indivíduos com idade entre 20 e 58 anos, sendo $56,6 \%(n=17)$ do sexo feminino e $43,3 \%(n=13)$ do sexo masculino. Observou-se, por meio da análise do questionário de rastreamento metabólico que apenas 6,6\% $(n=2)$ dos participantes pontuaram abaixo de 20 pontos, indicando serem pessoas mais saudáveis. Do total de participantes, $13,3 \%(n=4)$ pontuaram entre 30 e 40 pontos, significando um indicativo para a disbiose. A maioria dos participantes, 66,6\% $(n=20)$ somaram mais de 40 pontos indicando absoluta certeza de hipersensibilidades alimentar e/ou ambientais e disbiose intestinal, dentre estes, $50 \%$ ( $n=10)$ são do sexo feminino e $50 \%$ $(n=10)$ do sexo masculino. $E 13,3 \%(n=4)$ somaram mais que 100 pontos referindo saúde muito ruim.

Discussão: De acordo com os resultados, sinais e sintomas de hipersensibilidades alimentar e/ou ambientais e disbiose intestinal estão presentes em $80 \%$ dos pacientes, sendo que apenas $6,6 \%$ dos pacientes apresentam chances remotas de apresentarem hipersensibilidade intestinal e disbiose. Segundo Nogueira e Gonçalves (2010), em paciente com RA, uma melhora na qualidade da microbiota, promove resposta satisfatória aos controles dos sintomas na qualidade de vida e nos marcadores laboratoriais. O estudo de Schaefer e Enk (2019) demonstrou que pacientes com alergias apresentam níveis baixos de lactobacilos e bacteroides, e que o uso de suplementação probiótica na RA pode ser benéfica. Sugerem, ainda, que uma microbiota mais equilibrada pode levar a reações menos graves aos alérgenos. Os autores Wise e colaboradores (2018) citam vários estudos que relacionam uma microbiota disbiótica com alergias e outras doenças, porém sugerem que mais pesquisas futuras forneçam uma compreensão maior de como o microbioma humano afeta a RA. Os resultados sugerem que é alta a prevalência de sinais e sintomas de disbiose em pacientes adultos com doenças alergênicas.

Conclusão: Os dados obtidos neste estudo apontam para uma forte associação entre a presença de sinais e sintomas de disbiose intestinal como fator associado a rinite alérgica em adultos.

\title{
Referências
}

ALMEIDA, Luciana Barros, et al. Disbiose intestinal. Revista Brasileira de Nutrição Clínica, 2009, 24.1: 58-65. 
BEDOLLA-BARAJAS, M.; MORALES-ROMERO, J.; PULIDO-GUILLÉN, N. A.; ROBLES-FIGUEROA, M. et al. Rhinitis as an associated factor for anxiety and depression amongst adults. Braz J Otorhinolaryngol, 83, n. 4, p. 432-438, 2017 Jul - Aug 2017. BROSSEAU, C.; SELLE, A.; PALMER, D. J.; PRESCOTT, S. L. et al. Prebiotics: Mechanisms and Preventive Effects in Allergy. Nutrients, 11, n. 8, Aug 2019.

BROŻEK, Jan L., et al. Diretrizes para rinite alérgica e seu impacto na asma (ARIA) - revisão de 2016. Jornal de Alergia e Imunologia Clínica , 2017, 140.4: 950-958.

GONÇALVES, J. L., YAOCHITE, J. N. U., de QUEIROZ, C. D. A. A., CÂMARA, C. C., \& ORIÁ, R. B. (2016). Bases do sistema imunológico associado à mucosa intestinal. ORIÁ, Reinaldo $B$ et al. Fisiologia das secreções salivares e gastrointestianis. São Paulo: Edgard Blucher, 369-388.

NOGUEIRA, J. C.; GONÇALVES, M. A. C. [Probiotics in allergic rhinitis]. Braz J Otorhinolaryngol, 77, n. 1, p. 129-134, 2011 Jan-Feb 2011.

PETERSON, D. A.; MCNULTY, N. P.; GURUGE, J. L.; GORDON, J. I. IgA response to symbiotic bacteria as a mediator of gut homeostasis. Cell Host Microbe, 2, n. 5, p. 328-339, Nov 2007.

SCHAEFER, M.; ENCK, P. Effects of a probiotic treatment (BMJ Open, 9, n. 10, p. e031339, 102019.

TOMASELLO, G.; MAZZOLA, M.; LEONE, A.; SINAGRA, E. et al. Nutrition, oxidative stress and intestinal dysbiosis: Influence of diet on gut microbiota in inflammatory bowel diseases. Biomed Pap Med Fac Univ Palacky Olomouc Czech Repub, 160, n. 4, p. 461-466, Dec 2016.

WISE, S. K.; LIN, S. Y.; TOSKALA, E.; ORLANDI, R. R. et al. International Consensus Statement on Allergy and Rhinology: Allergic Rhinitis. Int Forum Allergy Rhinol, 8, n. 2, p. 108-352, 022018. 


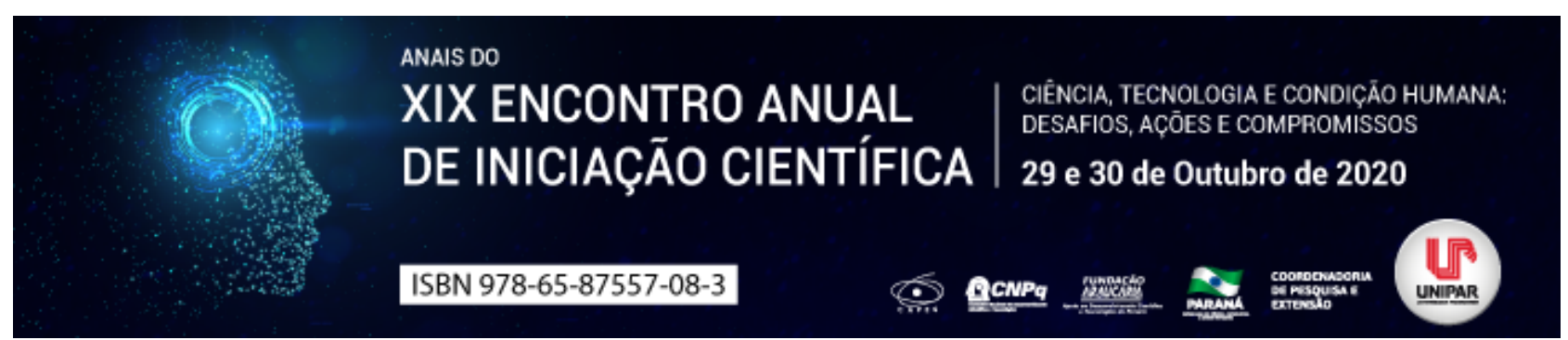

PATOLOGIAS DO FÍGADO - REVISÃO DE LITERATURA

\begin{abstract}
${ }^{1}$ GABRIELA KAROLAINE TEIXEIRA, ${ }^{2}$ GIULIA WICHOSKI CAMPIOL, ${ }^{3} \mathrm{HELOISA} \mathrm{GOMES} \mathrm{MANZZANO,}{ }^{4} \mathrm{HENRY}$ SATO GOYA, ${ }^{5}$ ELENIZA DE VICTOR ADAMOWSKI CHIQUETTI
\end{abstract}

\author{
${ }^{1}$ Discente do curso de Medicina \\ ${ }^{1}$ Acadêmica do Curso de Medicina da UNIPAR \\ ${ }^{2}$ Acadêmica do Curso de Medicina da UNIPAR \\ ${ }^{3}$ Acadêmico do Curso de Medicina da UNIPAR \\ ${ }^{4}$ Docente da UNIPAR
}

Introdução: O fígado possui papel fundamental na fisiologia normal do corpo. Isso inclui o processamento de aminoácidos, carboidratos, lipídios e vitaminas da dieta, e a síntese de muitas proteínas plasmáticas e a detoxificação e excreção para a bile de produtos de eliminação endógenos e xenobióticos. Assim, não é surpreendente que o fígado seja vulnerável a ampla variedade de insultos metabólicos, tóxicos, microbianos e circulatórios. (ROBBINS, 2016). O diagnóstico acurado e precoce do acometimento hepático é desejável por proporcionar melhor resposta terapêutica dos pacientes na fase inicial da doença. Para isso, existem diversos métodos que permitem analisar o fígado (SILVA et al; 2019).

Objetivo: Esta revisão de literatura tem como objetivo apresentar as principais patologias do fígado, bem como suas causas e consequências ao enfermo, reforçando a necessidade de um diagnóstico precoce para que aumente sua chance de sobrevida por meio do auxílio de tratamentos.

Desenvolvimento: Localizado no cruzamento entre o trato digestório e o restante do corpo, o fígado exerce o crítico trabalho de manter a homeostasia metabólica do corpo (ROBBINS, 2016). Sendo assim, as principais patologias do fígados abordados nessa revisão de literatura são: Hepatite autoimune, Esteatose Hepática, Hepatite B e C e Cirrose. A hepatite autoimune se caracteriza por conta de achados clínicos e laboratoriais específicos como níveis elevados de anticorpos, hipergamaglobulinemia e alterações hepáticas microscópicas, como hepatite de interface, infiltrado plasmocitário e células hepáticas regenerativas em roseta. Hepatite autoimune é usualmente uma doença crônica, mas a apresentação clínica pode variar desde alterações assintomáticas nas provas de função hepática até insuficiência hepática aguda (FILHO et al; 2017). A esteatose hepática ocorre em consequência de acúmulo de lipídios, microvesicular ou macrovesicular, nos hepatócitos, acima de $5 \%$ do peso do fígado, mais comumente por deposição de triglicérides. Essa condição tem como principal fator de risco doenças responsáveis por distúrbios metabólicos, como obesidade, diabetes mellitus tipo II e hiperlipidemias, e outras comorbidades que lesem os hepatócitos, como hepatite $C$ e uso de drogas e álcool. Além disso, sua cronificação cursa com inflamação lobular e evolui com fibrose hepática, cirrose e carcinoma hepatocelular (SILVA et al; 2019). As hepatites B e C são doenças infecciosas cujos agentes etiológicos são os vírus HBV e HCV, respectivamente. A transmissão dessas doenças pode ocorrer por vias horizontais e verticais, sendo que o HBV é transmitido, principalmente, por vias parenteral e sexual, enquanto o HCV, por transfusão sanguínea, uso de drogas injetáveis e terapias invasivas com equipamentos contaminados. Atualmente, essas doenças são prioridades em políticas públicas de saúde, por serem consideradas um grande problema no Brasil, uma vez que estão associadas às hepatopatias crônicas e à realização de transplantes de fígado (GONÇALVES et al; 2019). Entre os agravos atribuídos ao consumo de álcool, a cirrose hepática merece destaque como uma importante morbidade crônica fatal. Por sua vez, o câncer hepático é uma neoplasia na qual o consumo de álcool é uma importante causa componente (MELO et al; 2015). No Brasil, a incidência estimada de carcinoma hepatocelular (CHC) em 2016 foi de 10.000 casos, com taxa bruta de mortalidade de 5,1/100.000 indivíduos, sendo o sexto câncer com maior mortalidade. Os principais fatores de risco para CHC são infecção pelo vírus da hepatite B (VHB) e cirrose hepática, que está presente em até $90 \%$ dos pacientes com $\mathrm{CHC}$. As principais causas de cirrose hepática são hepatites virais crônicas pelo VHB e pelo vírus da hepatite C (VHC), cirrose alcoólica e doença hepática gordurosa não alcoólica (PEREIRA et al; 2020). O diagnóstico precoce do acometimento hepático é desejável em razão da melhor resposta terapêutica dos pacientes na fase inicial da doença. O exame físico nas fases iniciais da doença não apresenta alterações. (SILVA et al; 2019).

Conclusão: É importante que as patologias do fígado sejam diagnosticadas o mais cedo possível, visto que, as condições apresentadas são responsáveis por uma elevada taxa de mortalidade. Porém, com um diagnóstico precoce poderão ser feitos os devidos tratamentos e cuidados, a fim de reduzir os impactos e consequências de tais patologias.

\title{
Referências
}

ASTER, C. J.; ABBAS, K. A.; KUMAR, V. Robbins Patologia Básica. 9º edição. Rio de Janeiro, 2013 Ed: Elsevier. Acesso em: 
14 de junho de 2020.

FILHO, E. M. R.; FERNANDES, R.; SUSIN, R.; FIOR, B. Síndrome inflamatória de reconstituição imune como causa de hepatite autoimune e insuficiência hepática aguda. Rev. bras. ter. intensiva. vol.29 no.3 São Paulo 2017.

GONÇALVES, V. N.; MIRANDA, C. S. C.; GUEDES, A. J.; SILVA, T. C. L.; BARROS, M. E.; TAVARES, M. G. C.; PALÁCIOS, M. C. R. V.; COSTA, N. B. S.; OLIVEIRA C. H.; XAVIER, B. M. Hepatite B e C nas áreas de três Centros Regionais de Saúde do Estado do Pará, Brasil: uma análise espacial, epidemiológica e socioeconômica. Cad. saúde col. vol.27 no.1 Rio de Janeiro, 2019. Epub, 2019. Acesso em: 29 de junho de 2020.

MELO, A. P. S.; FRANÇA, E. B. S.; MALTA, D. C.; GARCIA, L. P.; MOONEY, M.; NAGHAVI, M.:Mortalidade por cirrose, câncer hepático e transtornos devidos ao uso de álcool: Carga Global de Doenças no Brasil, 1990 e 2015. Rev Bras Epidemiol. 2017. Epub maio 2017. Acesso em: 27 de junho de 2020.

PEREIRA, R. C. R.; HEMING, M. A. C.; TEJO, R. T.; OLIVEIRA, L. C. T.; SILVA, U. S. R.; PARENTE, B. D. Uso da classificação LI-RADS em pacientes com cirrose devido a infecção por hepatite B, C ou D ou infectados com hepatite B e D. Radiol Bras vol.53 no.1. São Paulo, 2020. Epub 20 dez 2019. Acesso em: 27 de junho de 2020.

SILVA, L. C. M.; OLIVEIRA, J. T.; TOCHETTO, S.; OLIVEIRA, C. P. M. S.; ROSA, R.; CHAMMAS, M. C. Análise da elastografia por ultrassonografia em pacientes com esteatose hepática. Radiol Bras vol.53 no.1 São Paulo 2020.

Coordenadoria de Pesquisa e Extensão - COPEX

Departamento de Editoraçāo e Divulgaçāo Científica - DEDIC 


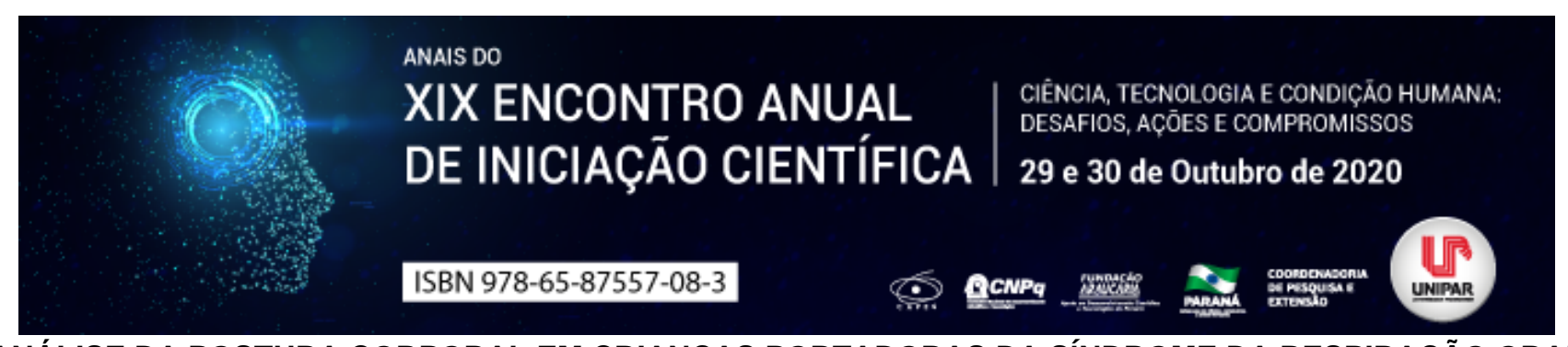

ANÁLISE DA POSTURA CORPORAL EM CRIANÇAS PORTADORAS DA SÍNDROME DA RESPIRAÇÃO ORAL

\author{
${ }^{1}$ ANA PAULA BORTOLOTO SANTOS, ${ }^{2}$ DORA DE CASTRO AGULHON SEGURA
}

\author{
${ }^{1}$ Acadêmica do Curso de Fisioterapia da UNIPAR \\ ${ }^{1}$ Docente da UNIPAR
}

Introdução: A síndrome da respiração oral caracteriza-se como um desvio adquirido, podendo ser causada por razões multifatoriais que podem levar o indivíduo a uma série de alterações faciais e corporais, limitando não só a capacidade vital, mas também a qualidade de vida, o que faz com que o paciente seja classificado como portador de uma doença, uma desordem. A síndrome da respiração oral tem sido considerada um preocupante problema de saúde pública, devido sua elevada prevalência, sobretudo, em crianças na fase de desenvolvimento (MENEZES; TAVARES; GARCIA, 2016).

Objetivo: Analisar a influência da respiração oral nas alterações posturais de crianças.

Desenvolvimento: Ao nascer, o bebê deve ser um respirador nasal obrigatório, devido ao ato de respirar pelo nariz que é essencial aos seres humanos. Para que a respiração nasal aconteça é imprescindível que as vias aéreas estejam íntegras tanto anatomicamente quanto funcionalmente. As respirações oral e mista, também são consideradas como tipos de respirações, porém, são vistas como formas atípicas que acontecem com o auxílio da boca, de maneira total ou parcial, simultaneamente (MENEZES; TAVARES; GARCIA, 2016). Meeires et al. (2011) classificam como portadores da síndrome da respiração oral os indivíduos que possuem mais de uma sintomatologia, entre elas, boca frequentemente aberta, palato duro alto e estreito, mal oclusão dentária, cefaleia, enurese, cansaço frequente, sonolência diurna, agitação noturna, bruxismo, olheiras profundas, face sonolenta, lábios e línguas hipotônicos, lábios ressecados, hiperatividade, dificuldades de desenvolvimento escolar e alterações músculo esqueléticas. Conti et al. (2011) evidenciam que na respiração oral crônica, o ar chega aos pulmões por um caminho mais curto e mais fácil. Como consequência, pode ocorrer mudança no ritmo respiratório, com deglutição de ar, causando flacidez e distensão abdominal, prejuízo da expansão torácica e da ventilação pulmonar. $O$ ato de respirar pela boca frequentemente faz com que ocorra uma protrusão da cabeça, para que haja uma compensação e facilite na respiração. Quando ocorre este processo de anteriorização da coluna cervical alta automaticamente os ombros rotacionam-se para frente gerando uma sobrecarga no tórax, alterando a frequência e a capacidade respiratória da criança, devido à forma mais comprimida e fora de sincronia em que o diafragma trabalha. A partir disso, a criança passa a ter o ciclo respiratório rápido e curto com níveis de oxigênio diminuídos. Devido a essas compensações a criança irá apresentar aumento na cifose torácica, aumento da lordose lombar, escápulas aladas, escoliose, depressão submamária, abdômen proeminente, assimetria de cintura pélvica, joelhos recurvados e valgos, arco plantar desabado, hálux valgo, além de ser notória a diminuição de força muscular (FELCAR et al., 2010). Morimoto e Karolczak (2017) apontam que é de grande importância uma abordagem correta para que se descubra origem do padrão respiratório alterado, e a partir daí é necessário que haja a intervenção precoce de uma equipe interdisciplinar, com ação de um fisioterapeuta no tratamento do padrão respiratório e nas alterações posturais, tornando o prognóstico mais favorável.

Conclusão: A compreensão e identificação dos efeitos da má postura nas crianças portadoras da síndrome respiratória oral precisam acontecer precocemente para que logo se possa direcionar a terapêutica interdisciplinar a fim de reduzir os sintomas e minimizar os custos gerados por esse distúrbio.

\title{
Referências
}

CONTI, P. B. M. et al . Avaliação da postura corporal em crianças e adolescentes respiradores orais. Jornal de Pediatria, $v$. 87, n. 4, p. 357-363, 2011.

MENEZES, V. A.; TAVARES, R. L. O.; GARCIA, A. F. G. Síndrome da respiração oral: Alterações clínicas e comportamentais. Arquivos em Odontologia, v. 45, n. 3, 43-47, 2016.

FELCAR, J. M. et al . Prevalência de respiradores bucais em crianças de idade escolar. Ciências e Saúde Coletiva, v. 15, n. 2, p. 427-435, 2010 .

MEEREIS, E. C. W. et al. Influência da respiração oral na postura corporal. Atividade física, lazer \& qualidade de vida: Revista de Educação Física, v. 2, n. 1, p. 01-10, 2011.

MORIMOTO, T.; KAROLCZAK, A. P. B. Associação entre as alterações posturais e a respiração bucal em crianças. Fisioterapia em Movimento, v. 25, n. 2, 68-73, 2017. 



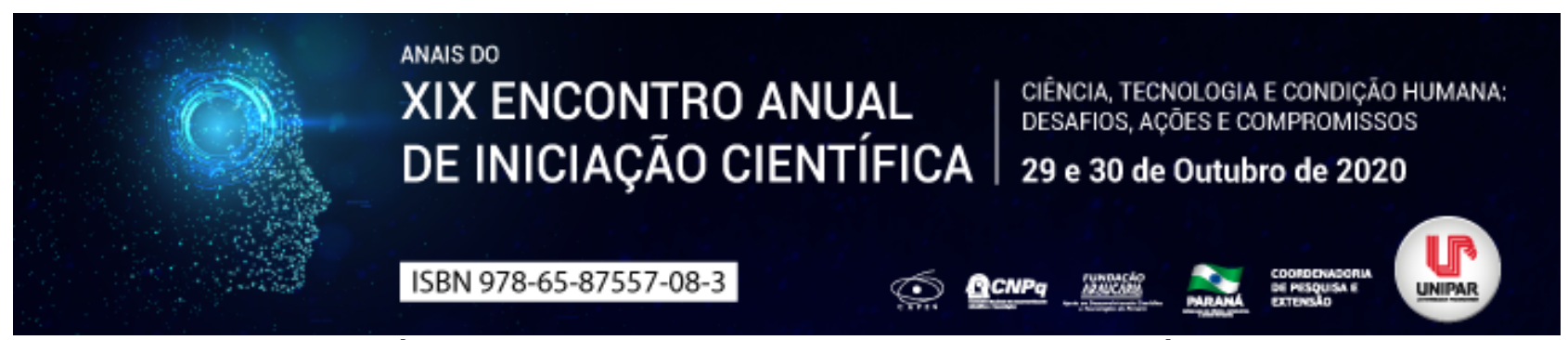

EFICÁCIA DO Ginkgo biloba NO TRATAMENTO DA DEMÊNCIA

\author{
${ }^{1}$ MONICA MICHELI ALEXANDRE , ${ }^{2}$ FABIOLA COSTA TAKAKUA , ${ }^{3}$ LETICIA RODRIGUES GENARIO, ${ }^{4}$ MARIANE DE ALMEIDA \\ MACHADO, ${ }^{5}$ MARINA GIMENES
}

\author{
${ }^{1}$ Acadêmica do PIC/UNIPAR \\ ${ }^{1}$ Acadêmica do Curso de Medicina da UNIPAR \\ ${ }^{2}$ Acadêmica do Curso de Farmácia da UNIPAR \\ ${ }^{3}$ Acadêmica do Curso de Farmácia da UNIPAR \\ ${ }^{4}$ Docente da UNIPAR
}

Introdução: Atualmente é perceptível que a expectativa de vida se elevou, porém, o aumento é proporcional ao aumento doenças crônicas que podem ser apresentadas ao longo do tempo. Tendo como exemplo demências, as quais têm sido muito frequentes relatadas. Dentre os tipos de demência, podemos citar a doença de Alzheimer (DA), sendo a enfermidade mais relatada e responsável pela maior porcentagem de óbitos em países desenvolvidos. Na américa do Sul, em especial no Brasil, estima-se que aproximadamente 2 milhões de pessoas de algum tipo de demência e dessas 40-60\% seja DA (CARDOSO; PAIVA, 2017; LOPES et al., 2020). Falco et al., (2016), mostram que as causas ainda não são totalmente esclarecidas, porém já se descobriu que os fatores genéticos e ambientais interferem na evolução e progressão da enfermidade e o tratamento farmacológico realizado para demências é sintomático. Mesmo não possuindo cura para a DA, a busca pela terapêutica alternativa, produtos naturais, torna-se cada vez maior, para tanto por exemplificar os estudos com a Ginkgo biloba (Gb). Por ser uma planta dotada de propriedades anti-inflamatórias, antioxidantes e antiplaquetárias, está entre as mais usuais, uma vez que estas propriedades, podem ser significativas no tratamento de patologias do foro cognitivo (MONTEIRO et al., 2019).

Objetivo: Avaliar a eficácia do Ginkgo biloba no tratamento das demências.

Desenvolvimento: $O$ extrato de Gb, denominado de EGb761, apresenta quantidades específicas de glicosídeos de ginkgoflavonas e terpenóides, e entre estes últimos, se tem os bilobalídeos e os ginkgolídeos A, B, C, M e J. Devido a ação de diversos princípios ativos os quais estão presentes no extrato, ocorre uma melhora do suprimento sanguíneo cerebral, devido a vasodilatação, e com isso a redução da viscosidade do sangue. (FORLENZA, 2003). Por possuir propriedades farmacológicas que culminam em melhoras nos casos de demências e consequentemente melhora na qualidade de vida desses pacientes com comprometimento cognitivo, o Gb se tornou o produto fitoterápico mais usual no mundo, do grupo de farmacoterapêutico de fármacos anti-demência. Porém para ter os resultados de melhora da perfusão cerebral, tem que ser administrada a Gb em uma dose única diária de $240 \mathrm{mg}$ do extrato de folhas secas da planta (DIAS et al., 2019). MONTEIRO et al. (2019), mostram que quando utilizado o extrato EGb 761, este apresentou resultados que foram controversos. Esse resultado foi obtido quando foram analisados em modelos in vivo face aos modelos in vitro, pois como a DA é multifatorial e ser dividida em vários estágios, e ainda há uma idiossincrasia muito alta, esses fatores levam ao insucesso dos estudos. Portanto ainda é necessário desenvolver novos estudos para afirmar a efetividade e eficácia em ensaios clínicos para as demências.

Conclusão: Apesar do desenvolvimento da medicina, vemos que a prevalência de demências tem crescido mundialmente. Devido a isso, as terapias alternativas como os fitoterápicos tem sido de grande ajuda, na prevenção do DA. Apesar de ainda não possuir estudos concretos da eficácia do Gb, ele possui resultados positivos, mas não há evidências suficientes para se indicar o uso da droga com a finalidade de tratar e/ou prevenir distúrbios de memória. Com isso, o ideal seria realizar a prevenção das demências, através dos profissionais da saúde, informando a população por meio de estratégias preventivas, alertando sobre os fatores de risco, mostrando que estes podem ser amenizados através de alterações no estilo de vida.

\title{
Referências
}

CARDOSO, Sofia Alves; PAIVA, Isabel. Nutrição e Alimentação na prevenção e terapêutica da Demência. Acta Portuguesa de Nutrição, n. 11, p. 30-34, 2017.

DIAS, Bruna Micaela Magalhães. Relatório de Estágio e Monografia intituladal" FITOTERAPIA NO CANSAÇO, DEMÊNCIA E PERDA DE MEMÓRIAl". Orientador: Dr. Carlos Rafael Pereira. 2019. 54f. Dissertação (Mestrado em Ciências Farmacêuticas). Universidade de Coimbra. Coimbra, 2019.

FALCO, Anna De et al. Doença de Alzheimer: hipóteses etiológicas e perspectivas de tratamento. Quím. Nova, São Paulo, v. 39, n. 1, p. 63-80, 2016.

FORLENZA, Orestes V. Ginkgo biloba e memória: mito ou realidade? Archives of Clinical Psychiatry (São Paulo), v. 30, n. 6, p. 218-220, 2003. 
LOPES, Lívia Cláudia Ferraro et al. Doença de Alzheimer e Ginkgo biloba. International Journal of Health Management Review, v. 6, n. 2, 2020.

MONTEIRO, Ana Catarina Lourenço. Mecanismo de ação e principais limitações da terapêutica das demências. Orientadora: Dra. Maria Lídia Palma. 2019. 97f. Dissertação de Mestrado. Universidade Lusófona de Humanidades e Tecnologias, Lisboa, 2019.

Coordenadoria de Pesquisa e Extensão - COPEX

Departamento de Editoraçāo e Divulgaçāo Científica - DEDIC 


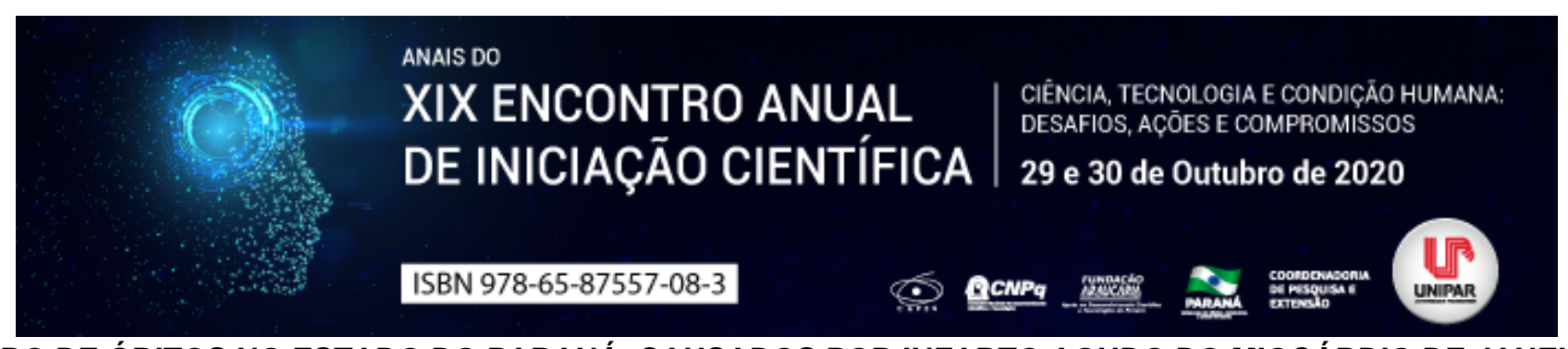

\title{
NÚMERO DE ÓBITOS NO ESTADO DO PARANÁ, CAUSADOS POR INFARTO AGUDO DO MIOCÁRDIO DE JANEIRO DE 2015 A NOVEMBRO DE 2019: UMA REVISÃO
}

\author{
${ }^{1}$ THAYNARA KNOPIK DECHECHI, ${ }^{2}$ LUCIANA LOPES GUTIERREZ BARTOLLI, ${ }^{3}$ TAMILYS EMANOELLY DE LIMA, ${ }^{4}$ ELENIZA \\ DE VICTOR ADAMOWSKI
}

${ }^{1}$ Discente do curso de Medicina/UNIPAR

${ }^{1}$ Discente do curso de Medicina/UNIPAR

${ }^{2}$ Discente do curso de Medicina/UNIPAR

${ }^{3}$ Docente do curso de Medicina/UNIPAR

Introdução: A cardiopatia isquêmica é a causa líder de óbitos não só no Brasil, mas também mundialmente. Em mais de $40 \%$ dos casos há morte súbita como primeira manifestação, sendo que, quando se trata de internamento em unidade hospitalar, mais de $50 \%$ dos casos não chegam a ser internados (SANTOS; BIANCO, 2018). Dentre as cardiopatias isquêmicas, enquadra-se o Infarto Agudo do Miocárdio (IAM). Consoante com Magalhães (2018), o Infarto Agudo do Miocárdio, comumente chamado de ataque cardíaco, consiste em um processo fisiológico, o qual pode levar a uma necrose de parte do músculo cardíaco, pelo motivo de faltar oxigênio e nutrientes, ocasionados pelo menor fluxo sanguíneo coronariano. Majoritariamente, uma oclusão na artéria forma um coágulo sobre uma região anteriormente lesionada pela aterosclerose, o que acarreta um menor fluxo e, posteriormente, um IAM.

Objetivo: Fazer um levantamento dos dados sobre o número de óbitos causados por Infarto Agudo do Miocárdio, distinguindo-os por sexo, no estado do Paraná, de janeiro de 2015 a novembro de 2019, utilizando os dados do DATASUS.

Desenvolvimento: Como explicado por Borba et al. (2016), para que a morbimortalidade por Infarto Agudo do Miocárdio diminua é necessário que haja um adequado cuidado do paciente ao chegar à emergência com suspeita de IAM, bem como é fundamental que os profissionais de saúde estejam capacitados para tal situação, também, para que o tratamento funcione é necessário que os cuidados desses pacientes baseiem-se na interrupção do mecanismo de lesão, de modo que o fluxo sanguíneo seja reestabelecido ao tecido isquêmico. Diante disso e do que expôs Costa et al. (2018), sabe-se que o IAM pode acarretar em óbito se não diagnosticado e tratado em tempo hábil, sendo necessário reconhecer os sintomas, diagnosticar e já iniciar um manejo ideal. De acordo com o levantamento de dados no DATASUS, verificam-se 22.142 casos de óbitos por IAM no período total analisado (janeiro de 2015 a novembro de 2019), tanto no sexo feminino, quanto no masculino. No decorrer desses anos o sexo masculino foi o que apresentou maior quantidade de casos de óbitos, 13.621, enquanto o feminino apresentou 8.521 casos de óbitos no mesmo período, sendo que ambos apresentaram uma queda na quantidade. A quantidade de casos de óbitos no sexo feminino reduziu para aproximadamente $48,62 \%$ do valor inicial (1987 casos em 2015 para 966 casos até novembro de 2019), já o número de casos de óbitos no sexo masculino reduziu para cerca de 51,19\% do valor inicial (3137 casos em 2015 para 1606 casos até novembro de 2019), com queda consecutiva nos números de casos de óbitos para ambos os sexos no decorrer do período analisado. Fazendo uma comparação entre os sexos no período total observado, além de o sexo feminino apresentar uma quantidade menor de casos de óbitos, com diferença de 5.100 casos, a queda também foi maior, com diferença aproximada de $2,57 \%$. Fato esse que demonstra que indivíduos do sexo feminino buscam mais atendimento na rede de serviços de saúde, reduzindo a morbimortalidade, em comparação aos do sexo masculino (ASSIS; JESUS, 2012).

Conclusão: Abstraídos os dados e analisado o número de óbitos por sexo no estado do Paraná, causados por Infarto Agudo do Miocárdio de janeiro de 2015 a novembro de 2019, foi possível notar que as pessoas do sexo masculino apresentaram uma quantidade maior de casos de óbitos e uma diminuição menor em comparação às do sexo feminino, destacando-se que apesar de os números estarem diminuindo, eles continuam altos e precisam ser reduzidos cada vez mais. Isso pode ser alcançado através de campanhas nas Unidades Básicas de Saúde, por marketing nas redes sociais, para que a população tenha conhecimento desde os sintomas iniciais e saibam da importância de procurar atendimento, principalmente os pacientes do sexo masculino, podendo, dessa forma, serem diagnosticados e tratados em um tempo mais adequado, visando um melhor prognóstico, do mesmo modo que elaborar mais projetos de capacitação voltados aos profissionais de saúde.

\section{Referências}

ASSIS, Marluce Maria Araújo; JESUS, Washington Luiz Abreu de. Acesso aos serviços de saúde: abordagens, conceitos, políticas e modelo de análise. Ciência \& Saúde Coletiva, v. 17, n. 11, 2012.

BORBA, Laura Pletsch, et al. Infarto Agudo Do Miocárdio. Revista Acta Méd., Porto Alegre, v. 37, n. 8, 2016.

BRASIL. MINISTÉRIO DA SAÚDE. Departamento de Informática do Sistema Único de Saúde - SUS (DATASUS). Disponível 
em: http://datasus.saude.gov.br. Acesso em: 18 dez. 2019.

COSTA, Francisco Ariel Santos da, et al. Perfil Demográfico De Pacientes Com Infarto Agudo Do Miocárdio No Brasil: Revisão Integrativa. SANARE, Sobral, v. 17, n. 2, jul./dez., 2018.

MAGALHÃES, Bruna. Infarto Agudo do Miocárdio (IAM). Editorial CENTERLAB Central de Artigos Para Laboratórios LTDA, n. 104, 2018.

SANTOS, Edmar Batista dos; BIANCO, Henrique Tria. Atualizações em doença cardíaca isquêmica aguda e crônica. Revista Sociedade Brasileira de Clínica Médica, v. 16, n. 1, jan./mar., 2018.

Coordenadoria de Pesquisa e Extensão - COPEX

Departamento de Editoraçāo e Divulgaçāo Científica - DEDIC 


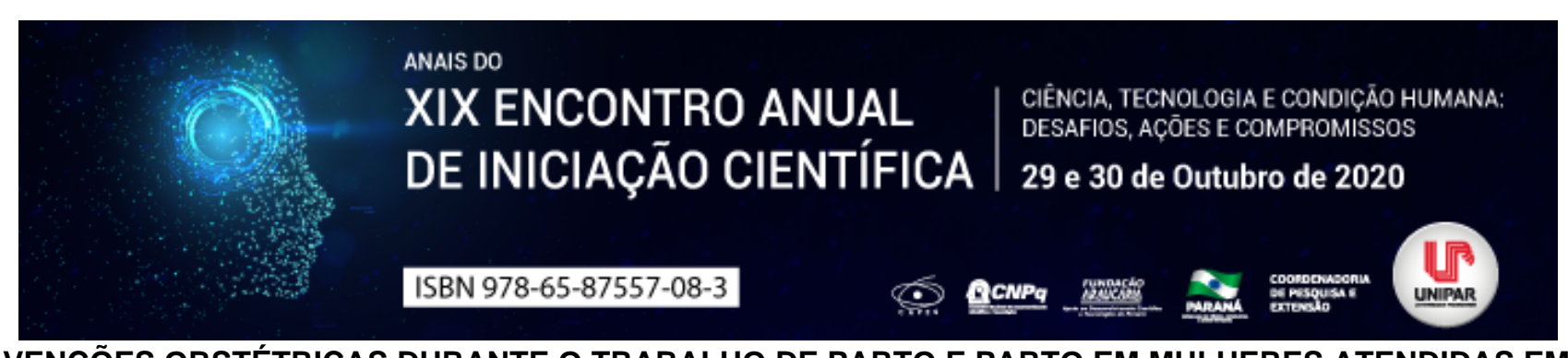

\title{
INTERVENÇÕES OBSTÉTRICAS DURANTE O TRABALHO DE PARTO E PARTO EM MULHERES ATENDIDAS EM DUAS MATERNIDADES
}

\author{
1 JOAO FERNANDO DOS SANTOS HOBOLD, ${ }^{2}$ CAROLINE MARIA DA SILVA, ${ }^{3}$ LETICIA WELTER, ${ }^{4}$ JOLANA CRISTINA \\ CAVALHEIRI, ${ }^{5}$ LEDIANA DALLA COSTA
}

\author{
${ }^{1}$ Acadêmico do PIC/UNIPAR \\ ${ }^{1}$ Acadêmica do Curso de Enfermagem da UNIPAR \\ ${ }^{2}$ Acadêmica do Curso de Enfermagem da UNIPAR \\ ${ }^{3}$ Docente da UNIPAR \\ ${ }^{4}$ Docente da UNIPAR
}

Introdução: Durante o trabalho de parto a gestante encontra-se vulnerável a diversas alterações e intercorrências, portanto, algumas recomendações e práticas baseadas em evidências científicas buscam amenizar o sofrimento nesse momento e melhorar a qualidade do cuidado, tais como, o alívio da dor, preferencialmente, utilizando-se de técnicas não farmacológicos como banhos terapêuticos e relaxantes, a aromaterapia, exercícios em bola suíça e a presença de um acompanhante para amenizar sinais de estresse, depressão e ansiedade na gestante e no recém-nascido (VIEIRA et al., 2019). O parto e o puerpério são fenômenos naturais que devem ser respeitados pelos profissionais de saúde, evitando-se intervenções desnecessárias e a violência obstétrica (MARQUES, 2020).

Objetivo: Identificar as intervenções obstétricas realizadas pelos profissionais de saúde durante o trabalho de parto e parto de mulheres atendidas em duas maternidades do interior do Paraná.

Metodologia: Estudo quantitativo, documental, de campo e descritivo realizado em duas maternidades de referência de Francisco Beltrão- PR. Uma delas destina-se ao atendimento de gestantes de risco habitual e outra, para os riscos intermediário e alto. Participaram da pesquisa, as puérperas internadas no período de junho a agosto de 2019, no qual a amostragem ocorreu por conveniência. Os dados foram coletados por meio de um questionário elaborado pelos autores, com base na literatura e na avaliação dos respectivos prontuários. Estes foram submetidos à análise descritiva, no programa Statistical Package for the Social Science, versão 25.0, com avaliação de frequências absolutas e relativas. A pesquisa foi aprovada pelo Comitê de Ética da Universidade Paranaense, sob o parecer $\mathrm{n}^{\circ} 3.364 .970 / 2019$.

Resultados: Participaram da pesquisa 207 puérperas. Quanto às intervenções utilizadas durante o trabalho de parto e parto, $30,7 \%$ das participantes evoluíram para parto normal e afirmaram ter realizado a tricotomia em casa. $O$ enema não foi aplicado para $26,7 \%$ das parturientes, $26,3 \%$ delas receberam algum tipo de hidratação venosa e 50,8\% receberam ocitocina durante 0 trabalho de parto. Sobre a realização de toques vaginais por mais de um profissional, $41,4 \%$ foram submetidas a essa técnica e a amniotomia foi utilizada em $90,15 \%$ das participantes. No que tange a cesariana, em relação à posição adotada no momento do parto, $98,7 \%$ assinalou posição supina . Durante o parto normal, a episiotomia e a laceração ocorreram em $92,3 \%$ e $88,5 \%$ dos partos, respectivamente.

Discussão: Quando observado as intervenções verificou-se que a tricotomia foi realizada pelas participantes em domicílio, o que diverge da pesquisa realizada em Caruaru- $\mathrm{PE}$, no qual $6,7 \%$ das puérperas relataram a tricotomia como orientação realizada durante o pré-natal (ALBUQUERQUE; LIMA; ALBUQUERQUE, 2020). Esta não é recomendada pela Organização Mundial da Saúde, uma vez que não demonstrou benefícios para parturiente (RITTER; GONÇALVES; GOUVEIA, 2020). Quanto ao enema, a literatura revela que não apresenta relevância na melhora da dor, na diminuição do risco de infecção, menor duração do trabalho de parto e na evacuação no momento expulsivo, como é justificado pelas maternidades (POSSATI et al., 2017). Referente ao uso de hidratação venosa, estudo no Nordeste do Brasil, obteve $59,4 \%$ das mulheres submetidas ao procedimento durante o trabalho de parto vaginal e 49,5\% em cesárea, sendo que não observou-se melhora na oferta de líquido e ainda dificulta a movimentação/deambulação da paciente (D'ORSI et al, 2005). Quanto a ocitocina e a amniotomia, dados inferiores a presente pesquisa foram observados em Belo Horizonte, no qual 41,7\% e 67,1\% utilizaram destes procedimentos, respectivamente (SOUSA et al., 2016). Ressalta-se que a Organização Mundial da Saúde preconiza o uso dessas práticas somente em intercorrências, como a falha na dilatação/contração uterina (PEREIRA et al., 2019). Em relação a posição supina na cesariana, pesquisa realizada em Uberlândia, obteve $84,78 \%$ das participantes nesta posição durante o procedimento, observando-se a não adesão ao preenchimento do partograma e variação nas posições durante os partos (MARTINS, 2018). Quanto ao toque vaginal, estudo realizado em Porto Alegre, obteve $76,8 \%$ das mulheres submetidas a essa prática, aumentando o risco de desenvolver infecções, tanto materna como no neonato (LOPES et al., 2019), o que vai ao encontro dos dados apresentados. No que diz respeito ao uso da episiotomia, estudo realizado em Pernambuco (LOPES et al., 2019), demonstrou a 
ocorrência do procedimento em $72,7 \%$ de forma rotineira, já em pesquisa realizada em São Paulo, 17,6\% das pacientes foram submetidas a episiotomia (SANCHES et al., 2019), dados ainda inferiores ao presente estudo, demonstrando a necessidade de avaliar a assistência ofertada.

Conclusão: As principais intervenções realizadas no trabalho de parto e parto foram a episiotomia, amniotomia, o toque vaginal e a administração de ocitocina, assemelhando-se ao cenário brasileiro quanto as práticas desenvolvidas neste período.

\section{Referências}

ALBUQUERQUE, Erick Alves; LIMA, Maria Bárbara Ramos De Barros; ALBUQUERQUE, Thaíse Torres. Implementação das práticas obstétricas preconizadas pelo programa de humanização no pré natal e nascimento em uma maternidade de risco habitual do interior de PE. Brazilian Journal of Health Review, v. 3, n. 2, p. 1422-1436, mar/abr. 2020.

D’ORSI, Eleonora et al. Qualidade da atenção ao parto em maternidades do Rio de Janeiro. Revista de saúde pública, v. 39, n.4 p. 645-654, ago. 2005.

LOPES, Giovanna De Carli et al. Atenção ao parto e nascimento em hospital universitário: comparação de práticas desenvolvidas após Rede Cegonha. Revista Latino-Americana de Enfermagem, v. 27, e3139, jan. 2019.

MARQUES, Silvia Badim. Violência obstétrica no Brasil: um conceito em construção para a garantia do direito integral à saúde das mulheres. Caderno ibero-americanos de direito sanitário, v. 9, n. 1, p. 97-119, abr. 2020.

MARTINS, Andressa Paula de Castro et al. Aspectos que influenciam a tomada de decisão da mulher sobre o tipo de parto. Revista Baiana de Enfermagem, v. 32, e25025, abr. 2018.

PEREIRA, Luana Rocha et al. Parto normal e intervenções ocorridas em uma maternidade pública. Revista Baiana de Enfermagem, v. 33, e32631, jan. 2019.

POSSATI, Andrêssa Batista et al. Humanização do parto: significados e percepções de enfermeiras. Escola Anna Nery Revista de Enfermagem, v. 21, n. 4, p. 1-6, jun. 2017.

RITTER, Simone Konzen; GONÇALVES, Annelise de Carvalho; GOUVEIA, Helga Geremias. Práticas assistenciais em partos de risco habitual assistidos por enfermeiras obstétricas. Acta Paulista de Enfermagem, v. 33, p.1-8, set. 2020.

SOUSA, Ana Maria Magalhães et al., Práticas na assistência ao parto em maternidades com inserção de enfermeiras obstétricas, em Belo Horizonte, Minas Gerais. Esc Anna Nery, v. 20, n.2, p. 324-33, 2016.

VIEIRA, Bianca da Costa et al. Boas práticas aplicadas às parturientes no centro obstétrico. Revista Brasileira de Enfermagem, v. 72, p. 191-196, set. 2019. 


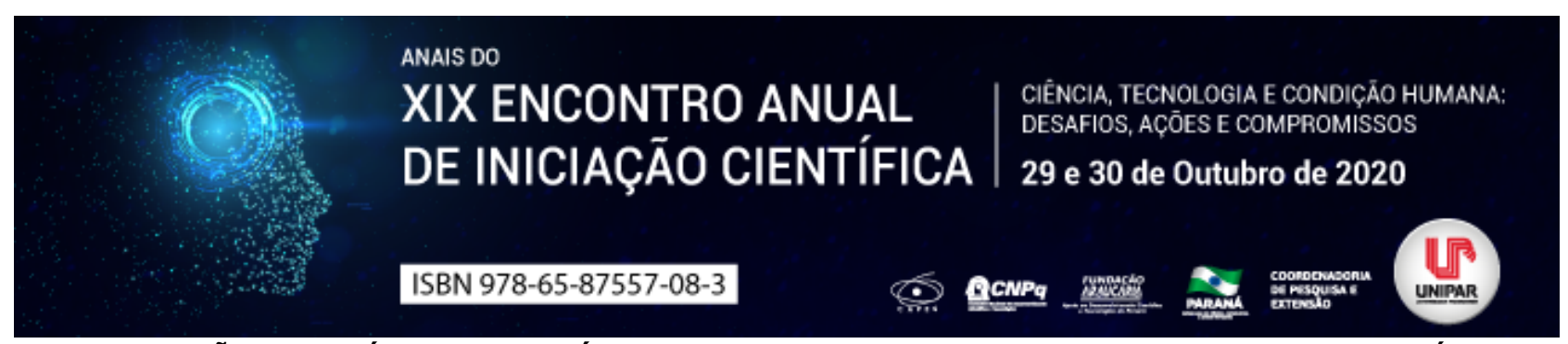

ADESÃO AS PRÁTICAS OBSTÉTRICAS EM MATERNIDADES DO INTERIOR DO PARANÁ

\author{
${ }^{1}$ MARLI OLIVEIRA DE PAULA, ${ }^{2}$ NATANIELLI APARECIDA BAGGIO, ${ }^{3}$ THALIA CAROLINE LEANDRO PASQUALOTTO, \\ ${ }^{4}$ JOLANA CRISTINA CAVALHEIRI, ${ }^{5}$ LEDIANA DALLA COSTA
}

\author{
${ }^{1}$ Acadêmica do PIC/UNIPAR \\ ${ }^{1}$ Acadêmica do Curso de Enfermagem da UNIPAR \\ ${ }^{2}$ Acadêmica do Curso de Enfermagem da UNIPAR \\ ${ }^{3}$ Docente da UNIPAR \\ ${ }^{4}$ Docente da UNIPAR
}

Introdução: As boas práticas obstétricas são condutas que devem ser incentivadas durante o trabalho de parto e incluem o alívio da dor de forma não farmacológica, o uso de massagens no corpo, banho no chuveiro, a escolha da posição para parir e via de parto, o uso da bola suíça e aromaterapia, entre outras. Estas buscam a humanização utilizando de empatia, conhecimento, experiência profissional, orientação, escuta ativa e um olhar totalmente voltado para as necessidades da parturiente (POSSATI et al., 2017). Diante do exposto, faz se necessário a elaboração de um plano de parto individual, uma das principais ferramentas para o empoderamento da mulher no processo de gestar-parir, tornando-a protagonista, bem como auxilia nas condutas da equipe de saúde podendo através dele realizar as boas práticas na assistência obstétrica (SILVA et al., 2017; SANTANA et al., 2019).

Objetivo: Conhecer a adesão dos profissionais de saúde às boas práticas obstétricas durante o trabalho de parto e parto em duas maternidades do interior do Paraná.

Metodologia: Estudo quantitativo, documental, de campo e descritivo realizado em duas maternidades de referência do Sudoeste do Paraná. Uma delas destina-se ao atendimento de gestantes de risco habitual e outra, para os riscos intermediário e alto. Participaram da pesquisa, as puérperas internadas no período de junho a agosto de 2019, no qual a amostragem ocorreu por conveniência. Os dados foram coletados por meio de um questionário elaborado pelos autores, com base na literatura e na avaliação dos respectivos prontuários. Estes foram submetidos à análise descritiva, no programa Statistical Package for the Social Science, versão 25.0, com avaliação de frequências absolutas e relativas. A pesquisa foi aprovada pelo Comitê de Ética da Universidade Paranaense, sob o parecer nº 3.364.970/2019.

Resultados: Participaram da pesquisa 207 puérperas as quais relataram que referente ao parto vaginal, 56,2\% das pacientes receberam orientações sobre formas de relaxamento para alívio da dor e 66,7\% delas usufruíram de técnicas não farmacológicas; $53,3 \%$ das puérperas não permaneceram a maior parte do tempo no leito durante o trabalho de parto e 59,2\% foram estimuladas a deambular e mudar de posição. No parto cesárea, o contato pele a pele logo na primeira meia hora de vida foi fornecido a $67,8 \%$ das parturientes. Em relação às técnicas para alívio da dor e auxílio no parto normal, 56,8\% foram orientadas a fazer exercícios e/ou agachamentos, a bola suíça foi utilizada por 67,9\% das parturientes, 54,8\% receberam massagens para alívio da dor, 80\% deambularam na maior parte do período de trabalho de parto, 70\% tomaram banho quente e $40 \%$ receberam orientações relacionadas às técnicas de respiração.

Discussão: Em relação ao alívio da dor durante o parto vaginal as participantes referiram receber orientação quanto às técnicas de relaxamento, inclusive de forma não farmacológica, semelhante a estudo desenvolvido em maternidade no Ceará, no qual $87,2 \%$ das participantes relataram utilizar de métodos não convencionais, sendo que o banho no chuveiro (77,2\%) foi a principal conduta utilizada pela equipe (AZEVEDO et al., 2019). Já quanto a não permanecer no leito e deambular, as participantes relataram que foram orientadas pela equipe, da mesma forma que pesquisa em Rio Branco, no Acre, no qual $81,3 \%$ das participantes disseram ter recebido esta orientação, as quais melhoram o fluxo sanguíneo no útero e placenta, a oxigenação fetal e a contração uterina, diminuem a percepção da dor e do tempo do trabalho de parto (LIMA et al., 2018). Com relação a estimulação do contato pele com pele, a Organização Mundial da Saúde sugere que o mesmo seja realizado logo após o nascimento, ou no prazo de cinco minutos e durar no mínimo uma hora. Pesquisa realizada no Hospital Universitário de Porto Alegre, a taxa de contato pele com pele foi de 60,1\%, (LOPES et al., 2019), índice que se apresenta inferior ao presente estudo. Em relação às técnicas e intervenções utilizadas no parto normal, pesquisa em Centro de Parto Normal no estado de São Paulo obteve a alusão aos agachamentos em apenas 14\% da amostra, as massagens em 11,3\% e a bola suíça em 10,7\%. A massagem diminui o estresse causado pelo trabalho de parto e auxilia no alívio da dor, já a bola suíça trabalha vários músculos e torna as contrações mais eficazes ajudando na descida do feto, enquanto o agachamento auxilia a aumentar a saída da pélvis (ALVES, 2019). Em relação a deambular e banho quente, pesquisa na maternidade pública de Rio Branco, Acre refere que apesar de ser estimulada por $81,3 \%$ dos profissionais, apenas $43,7 \%$ das mulheres aderiram a essa prática, além disso, $63 \%$ das 
participantes relataram tomar banho de água quente (LIMA et al., 2018). Em maternidade pública referência para risco habitual de Curitiba-PR, de 60 parturientes, apenas 21 mulheres relataram que fizeram técnicas de respiração durante o trabalho de parto, o que corresponde a 35\% (APOLINÁRIO et al., 2016), dado que assemelha-se ao presente estudo.

Conclusão: Entre as boas práticas orientadas observa-se as técnicas não farmacológicas para alívio da dor e de estimulação ao parto normal.

\section{Referências}

ALVES, Inglid Gleici Ferreira. Terapias alternativas e complementares utilizadas por enfermeiras obstetras em um centro de parto normal. Revista Saúde-UNG-Ser, v. 12, n. 3/4, p. 32-39, 2019.

APOLINÁRIO, Débora et al. Práticas na atenção ao parto e nascimento sob a perspectiva das puérperas. Revista da Rede de Enfermagem do Nordeste, v. 17, n. 1, p. 20-28, 2016.

AZEVEDO, Andressa Soares et al. Percepção de puérperas quanto as boas práticas de assistência ao trabalho de parto e parto. Red Med UFC, v.60, n.1, p. 28-34, 2020.

LIMA, Sheley Borges Gadelha et al. Práticas obstétricas de uma maternidade pública em Rio Branco-AC. Cogitare Enfermagem, v. 23, n. 4, [F.I], 2018.

LOPES, Giovanna De Carli et al. Atenção ao parto e nascimento em hospital universitário: comparação de práticas desenvolvidas após Rede Cegonha. Revista Latino-Americana de Enfermagem, v. 27, [F.I], 2019.

POSSATI, Andrêssa Batista et al. Humanização do parto: significados e percepções de enfermeiras. Escola Anna Nery Revista de Enfermagem, v. 21, n. 4, p.1-6, Ago. 2017.

SANTANA, Wanessa Nathally et al. Plano de parto como instrumento das boas práticas no parto e nascimento: revisão integrativa. Revista Baiana de Enfermagem, v. 33, [F.I], 2019.

SILVA, Adaiele Lucia Nogueira Vieira et al. Plano de parto: ferramenta para o empoderamento de mulheres durante a assistência de enfermagem. Revista de Enfermagem da UFSM, v. 7, n. 1, p. 144-151, jan/fev 2017.

Coordenadoria de Pesquisa e Extensão - COPEX

Departamento de Editoraçāo e Divulgaçāo Científica - DEDIC 


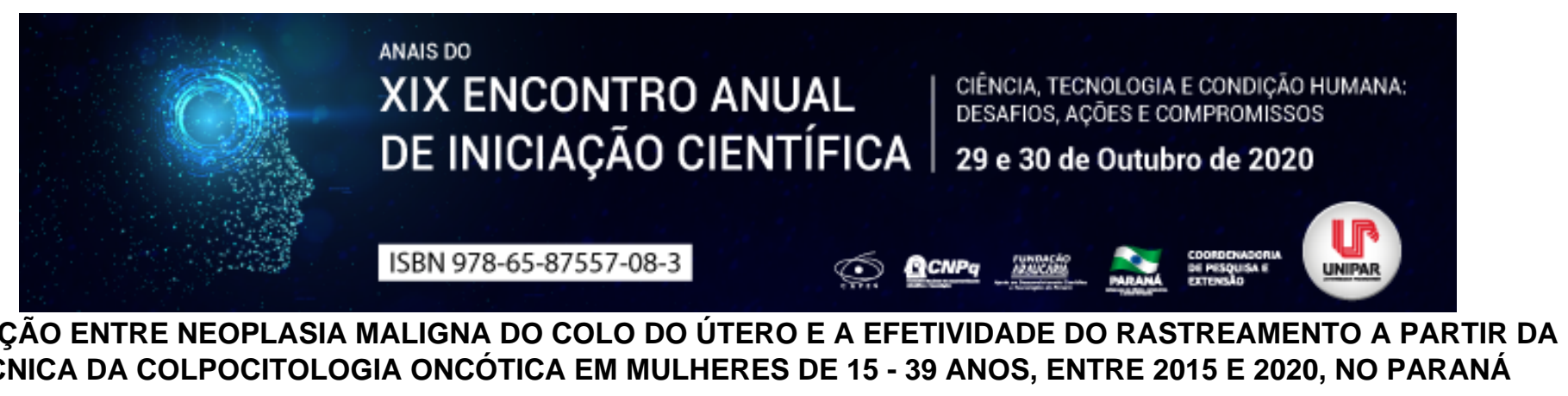

RELAÇÃO ENTRE NEOPLASIA MALIGNA DO COLO DO ÚTERO E A EFETIVIDADE DO RASTREAMENTO A PARTIR DA
TÉCNICA DA COLPOCITOLOGIA ONCÓTICA EM MULHERES DE 15 - 39 ANOS, ENTRE 2015 E 2020, NO PARANÁ

${ }^{1}$ VINICIUS PAIE MARQUES DOS REIS, ${ }^{2}$ KAREN RAMOS MARIN, ${ }^{3}$ THAYNE ZIMERMANN DURIGON, ${ }^{4}$ RODRIGO JACHIMOWSKI BARBOSA

\author{
${ }^{1}$ Acadêmico do curso de Medicina da UNIPAR \\ ${ }^{1}$ Acadêmica do Curso de Medicina da UNIPAR \\ ${ }^{2}$ Acadêmica do Curso de Medicina da UNIPAR \\ ${ }^{3}$ Docente da UNIPAR
}

Introdução: A análise de dados sobre os casos de neoplasia maligna do colo do útero deve ser realizada para a definição de políticas de prevenção mais assertivas. A incidência deste câncer está associada com a efetividade do rastreamento, uma vez que esta é a única neoplasia passível de ser detectada em fases pré-clínicas, além de possuir evolução lenta. Ademais, de acordo com Soares et al. (2010), o câncer de colo uterino possui prevenção relativamente barata e com os potenciais mais altos de cura, caso o diagnóstico ocorra precocemente. Ressalta-se que, conforme aponta Bim et al. (2010), comparando com países desenvolvidos, a mortalidade por esta neoplasia é elevada no Brasil, sendo que tal fato se deve ao diagnóstico realizado em estadiamento avançado. Desse modo, observa-se a íntima relação entre a instauração do câncer de colo do útero com a efetividade do rastreamento pela colpocitologia oncológica, também chamado exame de Papanicolau.

Objetivo: Analisar os dados acerca do número de casos da neoplasia maligna do colo uterino no Paraná, em mulheres de 15 à 39 anos, entre janeiro de 2015 e junho de 2020, relacionando com o percentual da população em questão a realizar a colpocitologia oncótica, com base nos dados obtidos no Departamento de Informática do SUS (DATASUS).

Desenvolvimento: No período de 2015 a 2020, no Paraná, foram diagnosticados 1.203 casos de neoplasia maligna do colo do útero, sendo que, dos casos já com estadiados, o maior percentual $(20,44 \%)$ se encontra em estádio III, fato que corrobora com o exposto por Bim et al. (2010), quando retrata que a maior parte dos casos possui diagnóstico tardio. Vale ressaltar que aproximadamente $40 \%$ da população considerada no período nunca realizou a colpocitologia oncótica. Tal fato é consoante com o indicado em Vidal et al. (2016), o qual retrata que em uma parcela relevante do público alvo não é realizado o exame preventivo. Além disso, do grupo analisado, a maior prevalência está na faixa etária de 30 à 39 anos, com 44,1\% dos casos, o que coincide com o grupo que mais realizou o exame de Papanicolau no período, $34,07 \%$ de todos os exames realizados, mesmo não sendo o grupo etário mais populoso. Fato que difere da população dos 20 aos 29 anos, uma vez que este grupo é mais populoso que o anterior, mas possui menor percentual de aderência à realização do exame de Papanicolau. Desse modo, pode-se salientar a relação entre a realização do exame preventivo e a assertividade diagnóstica, possibilitando o tratamento adequado. Outro ponto observado é que a faixa etária com menor quantidade de exames preventivos realizados é a de 15 a 19 anos, resultado análogo ao fato de ser a população com menor probabilidade de contato com o Papilomavírus humano - HPV, visto que a fisiopatologia do câncer de colo de útero está relacionada com a exposição a este vírus. Diante desses fatores, se estabelece a importância do papel educacional na prevenção, o que é destacado por Pinho; França (2003), de modo que um dos motivos para elevadas taxas de incidência do câncer de colo de útero seja o déficit na conscientização populacional. Aliado aos níveis educacionais estão as condições socioeconômicas, estas são apontadas por Barbosa et al. (2016) como o motivo pelo qual os estratos sociais mais desfavorecidos possuem projeção de aumento da mortalidade por neoplasia maligna do colo uterino nos próximos dez anos. Fato coincidente com Bim et al. (2010), onde foi realizado uma pesquisa em um município do Paraná, Guarapuava, denotando o nível socioeconômico como influente no acesso à consulta ginecológica. Ainda, entrevistando mulheres diagnosticadas com câncer de colo de útero, Vidal et al. (2016) aponta uma desorganização parcial no fluxo de pacientes entre os níveis de atenção em saúde como um dos entraves que ocasionam menos adesão ao exame preventivo, havendo como consequência, o tratamento não iniciar precocemente. Assim, ocorrendo um descompasso com o exposto nas Diretrizes brasileiras para o rastreamento do câncer do colo do útero (INCA, 2016), o qual expõe os protocolos de realização dos exames e estabelece organizacionalmente o fluxo dos pacientes.

Considerações finais: A partir da análise crítica dos dados obtidos, pode-se observar as populações com maior prevalência da neoplasia maligna de colo de útero e os motivos pelos quais isso se estabelece. Desse modo, deve-se formular estratégias que visem a conscientização da população sobre a importância em aderir ao exame de colpocitologia oncológica, o qual possui vantagens por ser de fácil realização e estar disponível na atenção básica, sendo o único capaz de detectar estágios pré-clínicos das lesões, evitando facilmente o estabelecimento do câncer. Assim, poder-se-á atenuar a situação, reduzindo a incidência da neoplasia maligna do colo do útero por meio do diagnóstico precoce. 


\section{Referências}

BARBOSA, Isabelle Ribeiro. et al. Desigualdades regionais na mortalidade por câncer de colo de útero no Brasil: tendências e projeções até o ano 2030. Ciência \& Saúde Coletiva, v. 21, p. 253-262, 2016.

BIM, Cíntia Raquel. et al. Diagnóstico precoce do câncer de mama e colo uterino em mulheres do município de Guarapuava, PR, Brasil. Revista da Escola de Enfermagem da USP, v. 44, n. 4, p. 940-946, 2010.

Diretrizes brasileiras para o rastreamento do câncer do colo do útero / Instituto Nacional de Câncer José Alencar Gomes da Silva. Coordenação de Prevenção e Vigilância. Divisão de Detecção Precoce e Apoio à Organização de Rede. 2. ed. rev. atual. Rio de Janeiro: INCA, 2016.

PINHO, Adriana de Araújo; FRANÇA-JUNIOR, Ivan. Prevenção do câncer de colo do útero: um modelo teórico para analisar o acesso e a utilização do teste de Papanicolaou. Revista Brasileira de Saúde Materno Infantil, v. 3, n. 1, p. 95-112, 2003.

SOARES, Marilu Correa. et al. Câncer de colo uterino: caracterização das mulheres em um município do sul do Brasil. Escola Anna Nery, v. 14, n. 1, p. 90-96, 2010.

VIDAL, Maria Luiza Bernardo. et al. Acesso ao tratamento de neoplasia maligna do colo do útero no SUS. 2017. Tese de Doutorado. Rio de Janeiro: INCA, 2016.

Coordenadoria de Pesquisa e Extensão - COPEX

Departamento de Editoraçāo e Divulgaçāo Científica - DEDIC 


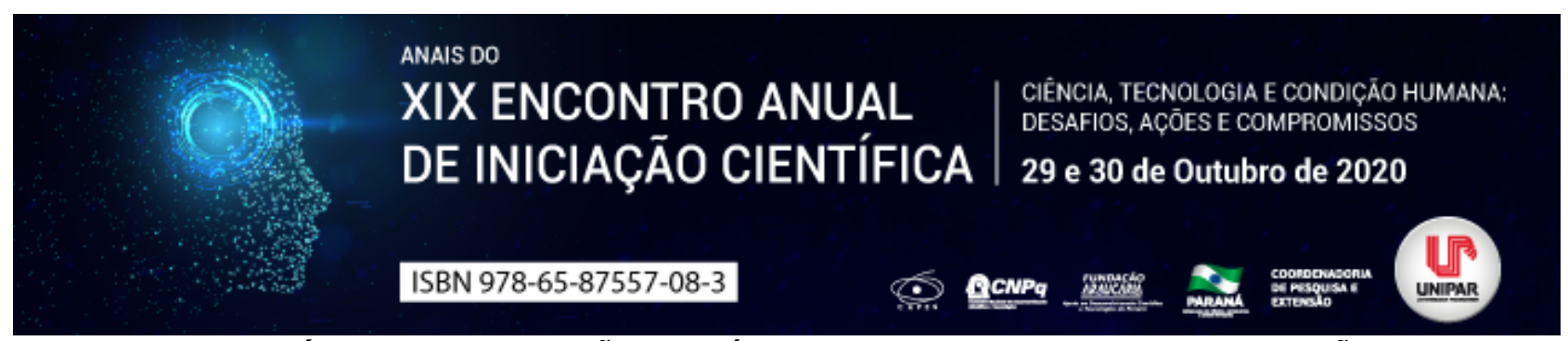

BENEFÍCIOS DA UTILIZAÇÃO DA SÁLVIA NA AROMATERAPIA: UMA REVISÃO

\title{
${ }^{1}$ THAYNARA KNOPIK DECHECHI, ${ }^{2}$ IRINEIA PAULINA BARETTA
}

\author{
${ }^{1}$ Discente do curso de Medicina/UNIPAR e Discente do PIC/UNIPAR \\ ${ }^{1}$ Docente da UNIPAR e Orientadora PIC/UNIPAR
}

Introdução: Consoante com Machado e Fernandes Junior (2011), a aromaterapia consiste na terapia que usa os óleos essenciais, os quais se enquadram no grupo de produtos naturais utilizados em abordagens terapêuticas e possuem potencial terapêutico e farmacológico alto, com a finalidade de promover e manter a saúde. Um dos produtos naturais empregados na aromaterapia é a sálvia, sendo seu gênero no sul da América representante de diversas espécies, dentre elas, 62 são encontradas no Brasil, além disso, sua família é a Lamiaceae, antigamente denominada Labiatae, que abrange 236 gêneros e 7173 espécies, as quais formam muitos compostos secundários, estes, por sua vez, são lembrados por seus óleos essenciais, originados em tricomas glandulares na superfície das folhas e inflorescências (SILVA; SANTOS; PENTEADO; 2011).

Objetivo: Fazer um levantamento sobre os benefícios da utilização da sálvia na aromaterapia, por meio de artigos científicos.

Desenvolvimento: Conforme Gnatta et al. (2016), o termo aromaterapia foi introduzido na França em 1928 por René Maurice de Gattefossé, um perfumista francês, esse termo surgiu após ele sofrer uma queimadura nas mãos e utilizar óleo essencial de lavanda, curando sua ferida, quase sem visualizar marcas, com cicatrização e alívio da dor rápidos. Segundo Ferreira (2014), a aromaterapia é usada principalmente na atenção primária, como medicina complementar, coexistindo com a forma de terapia considerada clássica, além de ser natural e não invasiva, visa tratar a saúde como um todo, em uma visão holística, sendo seus óleos essenciais usados como terapia para a promoção e manutenção do bem-estar do ser humano, desde o tratamento e prevenção de patologias até o tratamento de alterações de âmbito emocional, mantendo a homeostasia natural. Ainda, sobre a saúde emocional, em vários grupos sociais, as terapias com óleos essenciais tem permitido alcançar uma diminuição dos níveis de estresse e ansiedade (LYRA; NAKAl; MARQUES; 2010). Diante disso e do que expôs Malaquias et al. (2014), a sálvia apresenta, na medicina popular, algumas propriedades quando usada nas concentrações e modos ideais, dentre elas, a redução da ansiedade, da irritabilidade, da lactação, também utilizada para dispepsia, para resolver problemas hepáticos, digestivos, de úlceras, aftas e dores de dente, atuando como antiglicemiante, antimicrobiana, na higiene bucal, contra leucorréias, na cicatrização de feridas, como emenagoga, possuindo elevado potencial anti-inflamatório, antiproliferativo e neuroprotetor as células de roedores e humanos, com potencial antimicrobiano e ação contra cepas de Escherichia coli L., Salmonella typhi L., Salmonella enteritidis $L$. e Shigella sonei $L$., ademais foi percebido potencial cicatrizante do ácido oleanólico em ratos com úlceras provocadas por ácido acético, da mesma forma que foi verificada a atuação em células de roedores de modo direto em agentes pró-inflamatórios, realizando inibição de células polimorfonucleares (PLM), bem como a produção de leucotrienos, tal como foi notado efeito hipoglicemiante em ratos diabéticos impulsionados por estreptozotocina. O Programa Nacional de Plantas Medicinais e Fitoterápicos é uma iniciativa do governo brasileiro, tendo os fundamentos da Política Nacional de Plantas Medicinais e Fitoterápicos como base e como princípios orientadores o aumento das opções de terapia e melhoria da atenção à saúde aos usuários do Sistema Único de Saúde - SUS, tal qual utilizar a biodiversidade de modo sustentável, valorizar e preservar o conhecimento tradicional das comunidades e povos tradicionais, entre outros, visando o uso de produtos naturais pelas pessoas nos cuidados primários de saúde (MACHADO; FERNANDES JUNIOR, 2011).

Conclusão: Dessa forma, pode-se observar que a utilização da sálvia na aromaterapia possui diversos benefícios quando utilizada de maneira correta e adequada, manifestando efeitos que abordam o paciente em sua integralidade, desde aspectos físicos, atuando contra patologias, até mentais e sociais, como seu uso contra ansiedade, transtorno muito presente atualmente, o qual atrapalha não somente o próprio indivíduo, mas também suas relações interpessoais, corroborando ainda, para que as formas de medicina sejam complementares, formando uma medicina integrativa, a qual aborda o paciente de modo pleno.

\section{Referências}

FERREIRA, Ana Rita Alves. Uso de óleos essenciais como agentes terapêuticos. 2014. Trabalho apresentado à Universidade Fernando Pessoa como parte dos requisitos para a obtenção do grau de Mestre em Ciências Farmacêuticas - Universidade Fernando Pessoa Faculdade de Ciências da Saúde, Porto, 2014.

GNATTA, Juliana Rizzo, et al. Aromaterapia e enfermagem: concepção histórico-teórica. Revista da Escola de Enfermagem da USP, São Paulo, v. 50, n. 1, 2016.

LYRA, Cassandra Santantonio de; NAKAI, Larissa Sayuri; MARQUES, Amélia Pasqual. Eficácia da Aromaterapia na Redução de Níveis de Estresse e Ansiedade em Alunos de Graduação da Área da Saúde: Estudo Preliminar. Fisioterapia e Pesquisa, São Paulo, v. 17, n. 1, jan./mar., 2010. 
MACHADO, Bruna Fernanda Murbach Teles; FERNANDES JUNIOR, Ary. Óleos Essenciais: Aspectos Gerais e Usos em Terapias Naturais. Cadernos Acadêmicos Universidade do Sul de Santa Catarina, Tubarão, Santa Catarina, v. 3, n. $2,2011$. MALAQUIAS, Geiz, et al. Utilização na medicina popular, potencial terapêutico e toxicidade em nível celular das plantas Rosmarinus officinalis L., Salvia officinalis L. e Mentha piperita L. (Família Lamiaceae). RevInter Revista Intertox de Toxicologia, Risco Ambiental e Sociedade, v. 7, n. 3, out., 2014.

SILVA, Alice Freitas da; SANTOS, Élide Pereira dos; PENTEADO, Patrícia Teixeira Padilha da Silva. Análise Sensorial de Salvia officinalis L.. Visão Acadêmica, Curitiba, v. 12, n. 1, jan./jun., 2011.

Coordenadoria de Pesquisa e Extensão - COPEX

Departamento de Editoraçāo e Divulgaçāo Científica - DEDIC 


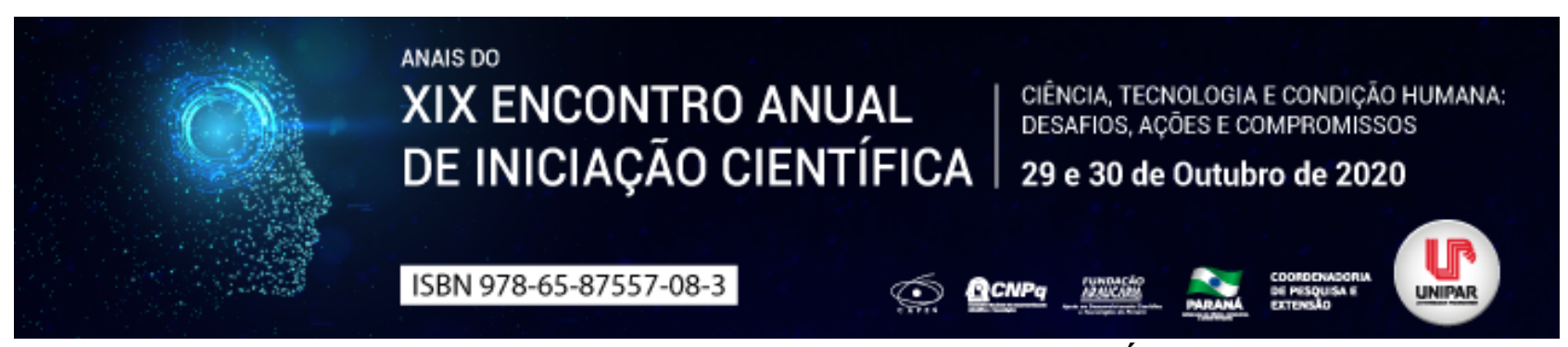

TECNOLOGIAS E SEUS AVANÇOS NO VOLEIBOL: O USO DO MÉTODO "DESAFIO"

\begin{abstract}
${ }^{1}$ BEATRIZ PIRES VIEIRA, ${ }^{2}$ BEATRIZ PIRES VIEIRA, ${ }^{3}$ MOISES HENRIQUE DE SOUZA SILVA, ${ }^{4}$ ARNALDO GOMES DO AMARAL
\end{abstract}

${ }^{1}$ Acadêmicos do Curso de Educação Física da UNIPAR

${ }^{1}$ Acadêmica do Curso de Educação Física da UNIPAR

${ }^{2}$ Acadêmica do Curso de Educação Física da UNIPAR

${ }^{3}$ Docente da UNIPAR

Introdução: Diversas modalidades fizeram a parceria com a tecnologia, porém a mais viável que há de muito tempos é o Voleibol, como alguns outros esportes ele também entrou no mundo da tecnologia. Atualmente grandes equipes de voleibol estão sob a orientação de profissionais treinados, e cada vez mais utilizam recursos técnicos, no entanto as dúvidas arbitrais acabam deixando de ser e tomando decisões exatas, este método é conhecido como DESAFIO. Para Federação Internacional de Vôlei FIVB A entidade anunciou que contará com o árbitro de vídeo (também conhecido como desafio, VAR, challenge ou vídeocheck) em todas as principais competições. (WEB VÔLEI, 2019, online)

Objetivo: Apresentar o método tecnológico do desafio, onde vamos mostrar sua funcionalidade e seus benefícios e como ajudam os árbitros e as comissões em um momento de dúvida na hora de um jogo.

Desenvolvimento: O voleibol é um esporte com uma história de mais de 100 anos e é atualizado periodicamente. Com a evolução das equipes e as táticas usadas para cada situação de jogo. Diante dessa evolução, com a ajuda a tecnologia para auxiliar cada lance com uma visão mais detalhada, utilizando diversas formas como a porcentagem das estatísticas da partida e também o auxílio de filmagem que são mais que importantes (SERAPIÃO, 2015). A utilização desses novos critérios tem uma relevância mais centrada na área de estatísticas no voleibol, com isso a junta de todas essas ferramentas vem a ser utilizada na forma tanto nas técnicas como as táticas. Com a filmagem e dados retirados nas partidas, tem como adquirir informações mais avançadas em seus atletas, mas também para o estudo do seu adversário, tais como jogos que já disputaram e entre outras maneiras para estudar o seu oponente (CALIXTO, 2015). A tecnologia não alcançou só a modalidade voleibol, mas cada temporada que passa a maioria dos esportes vem adquirindo para a facilidade de uma opinião exata. O futebol já adquiriu também arbitro de vídeo mais conhecido como VAR (Video Assistant Referee) as ações são para certificar se a bola foi dentro ou fora e também a validação do gol, diante disso acabam com as dúvidas tanto na parte da arbitragem como do atleta (SERAPIÃO, 2015). As utilizações dessa tecnologia nos esportes deram se o início nos Jogos Olímpico na edição de 1984, com método de estatísticas e também as atualizações tecnológicas na área esportiva. Em um jogo de voleibol os desafios são divididos em três tipos, cada um dos quais com uma das seguintes condições: confirmar se a bola está dentro ou fora, confirmar se há falta no saque ou confirmar se há invasão. E em 2019 uma nova decisão foi anunciada por Ary Graça, presidente da FIVB, em que o método do desafio aumentara mais uma tecnologia, onde além de todas essas que citamos acima, irá mostrar também se o jogador ocasionou os dois toques. Segundo Ottoni (2020), entrevistando Graça diz que I"Investimos em tecnologia todo o tempo, dentro e fora de quadra. A tecnologia não se limita ao desafio, usamos em muitas outras coisas. Mas o próprio desafio pode evoluir. Agora mesmo ele vai ganhar mais uma função, vai passar a ser usado para a marcação de dois toques na bola , Quando à o pedido, o segundo árbitro assisti ao replay e informa ao primeiro árbitro que assim ele é o responsável pela decisão. A equipe tem o direito de fazer dois pedidos de desafio para cada grupo. Se o vídeo solicitar que o árbitro faça alterações, o número de solicitações disponíveis permanece o mesmo. Caso contrário, a equipe perderá o desafio. $O$ árbitro de desafio informa o primeiro árbitro sobre a natureza da falta. No entanto, o primeiro árbitro deve tomar a decisão final com base na imagem Presente (COBRAV, 2018). Se o primeiro árbitro discordar, ele deve mudar O juiz julgou que a linha de serviço está faltando ou a linha está faltando ataque. Somente quando o árbitro de Desafio tem absoluta certeza sobre a situação, ele anuncia a decisão. Quaisquer dúvidas devem ser interpretadas em favor da decisão anterior (COBRAV, 2018).

Conclusão: Diante dos argumentos supracitados, concluímos que a tecnologia vem tomando conta em todas as áreas, e com isso seus benefícios são extremamente importantes. No esporte isso tem sido bem evidente como a tecnologia vem melhorando cada vez mais, no voleibol por exemplo tem bolas que podem passar de $120 \mathrm{~km}$ por hora, onde acaba não sendo evidente e com isso dificultando o trabalho do arbitro em decidir os pontos, entretanto vemos que o desafio tem sido muito importante neste esporte e em muitos outros também como no futebol que é conhecido como var , etc. Assim tiramos a conclusão de como o arbitro de desafio é importante, ele veio para acabar com as indecisões e com as penalidades marcadas erradas, não deixando nenhuma equipe sair prejudicada. 


\section{Referências}

SERAPIÃO, A. B. S.; CALIXTO, J. Tecnologias: as Aplicações e o Desenvolvimento na Modalidade Voleibol. IX Congresso Internacional de Educação Física e Motricidade Humana XV Simpósio Paulista de Educação Física Disponível em.

http://cev.org.br/biblioteca/tecnologias-as-aplicacoes-e-o-desenvolvimento-na-modalidade-voleibol/. Acesso em 15 ago 2020.

OTTONI, Daniel Ottoni. Tecnologia do vôlei vai detectar lances de dois toques durante as partidas. 2019. Disponível em: $\quad$ https://www.otempo.com.br/superfc/volei/tecnologia-do-volei-vai-detectar-lances-de-dois-toques-durante-as-partidas1.2207461 . Acesso em 15 ago 2020.

COMISSÃO BRASILEIRA DE ARBITRAGEM DE VOLEIBOLGUIA DE ARBITRAGEM. 2018. Disponível em: https://cbv.com.br/pdf/regulamento/quadra/guia-de-arbitragem-2018.pdf. Acesso em 15 ago 2020.

Coordenadoria de Pesquisa e Extensāo - COPEX

Departamento de Editoraçāo e Divulgaçāo Científica - DEDIC 


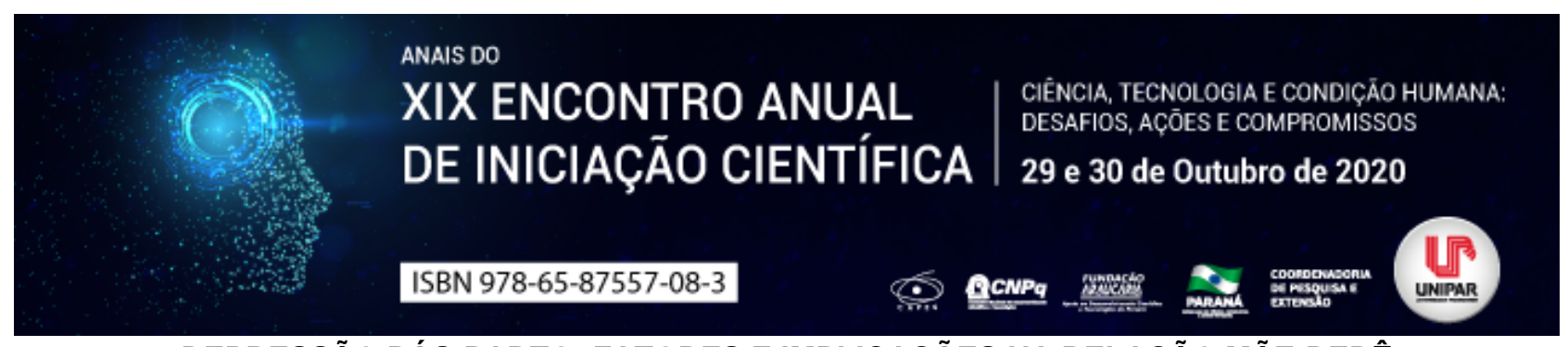

DEPRESSÃO PÓS-PARTO: FATORES E IMPLICAÇÕES NA RELAÇÃO MÃE-BEBÊ

\begin{abstract}
${ }^{1}$ RAFAELA BEARZI RESTON, ${ }^{2}$ ROBERTO RONEY BICHERI FILHO, ${ }^{3}$ VITOR ROQUE SAUER, ${ }^{4}$ FLÁVIA APARECIDA SACOMANI CARNELOS, ${ }^{5}$ ELIZABETI DE MATOS MASSAMBANI
\end{abstract}

\author{
${ }^{1}$ Acadêmica do Curso de Medicina da UNIPAR \\ ${ }^{1}$ Acadêmico do Curso de Medicina da UNIPAR \\ ${ }^{2}$ Acadêmico do Curso de Morfofisiologia Humana I da UNIPAR \\ ${ }^{3}$ Médica Ginecologista e Médica Obstretra - CRM: 27625-PR \\ ${ }^{4}$ Docente da UNIPAR
}

Introdução: A depressão pós parto (DPP) é definida como um quadro clínico severo e agudo, que requer acompanhamento psicológico e psiquiátrico (IACONELLI, 2005), atingindo de 10 a 15\% das mulheres no puerpério. A terminologia DPP foi alterada para periparto depressão ou com início periparto em 2014, posto que o início dessa perturbação do humor ocorre ainda durante a gravidez, no seu último mês até cinco meses após o parto, pois, cerca de $50 \%$ dos casos de depressão maior no pósparto começam antes do nascimento (ARRAIS, 2017). Por ocasionar alterações hormonais e emocionais na mulher, é considerado um sério problema de saúde materna, além de interferir diretamente na vida da criança (FERNANDES e COTRIN, 2013). Consequentemente a DDP, pode potencializar algumas desordens na criança, como desordens linguísticas, comportamentais, afetivas, cognitivas e sociais (SILVEIRA et.al., 2018).

Objetivo: Realizar uma revisão apresentando os fatores e implicações da depressão pós-parto na relação mãe-bebê.

Desenvolvimento: Transtornos de conduta, comprometimento da saúde física, ligações inseguras e episódios depressivos são associados no desenvolvimento da criança (KLAUS et al., 2000). Esses sintomas estão relacionados nas relações interpessoais, principalmente na interação mãe-bebê. Ao comparar a relação das mães que apresentam DPP com as que não apresentam, mostra a existência de um afeto de forma mais negativa bem como um menor envolvimento emocional com o bebê. Além disso, as crianças apresentam-se menos sorridentes, com menor interação corporal, alimentação irregular e complicações com o sono (RIGHETTI, CONNE-PERREARD, BOUSQUET \& MANZANO, 2002). Segundo Stern (1997), as influências patogênicas apenas são transmitidas para o filho quando ultrapassam pela relação entre mãe-bebê. Ainda de acordo com este mesmo autor, quando a mãe da criança está deprimida, ela interrompe o contato visual com o bebê e tem a tendência de não retomá-lo e dessa forma sua animação e tonicidade desaparecem. Os fatores de depressão relacionados ao bebê estão ligados com a genética e com fatores sociais, ainda conta com fatores físicos relacionados à mãe, tais como modificações hormonais e psicopatológicos prévio. No entanto, um estudo de depressão materna necessita de uma análise do meio externo do indivíduo apontando fatores socioculturais, sendo eles a morte de familiares, decepções na vida pessoal/profissional, volta a atividade profissional ou situações social de solidão (MAZET e STOLERU, 1990, apud SCHMIDT, 2005). Baixa auto-estima, complicações conjugais e socioeconômicos, e gravidez não planejada ou não desejada, podem ser apontados como fatores influenciadores na depressão pós-parto (BECK, 2002 apud SCHWENGBER, 2003). De outro lado, a participação de algum programa de pré-natal com base numa abordagem psicológica, ter uma relação saudável com suas próprias mães, ter suporte social na gestação e no puerpério e manter relações sociais positivas podem proteger a gestante contra a DPP e minimizar o impacto dos fatores de risco que causariam no puerpério (ARRAIS, 2017). É necessário distinguir dois termos dessemelhantes que acometem o puerpério, a DPP e a Tristeza Materna, sendo o principal fator a gravidade do quadro e o que ele tem de incapacitante, pois afeta a funcionalidade da mãe e põe em perigo o bem estar de ambos, mãe e bebê (IACONELLI, 2005). A tristeza materna, por sua vez, acomete por volta de $80 \%$ das mulheres, caracterizando-se por um estado de humor depressivo, acontecendo geralmente a partir da primeira semana pós parto. Este quadro é benigno e regride gradativamente após o primeiro mês. Como sintomas, apresentam irritabilidade, mudanças bruscas de humor, indisposição, tristeza, insegurança, baixa auto-estima, sensação de incapacidade de cuidar do bebê e outros (IACONELLI, 2005).

Conclusão: A família apresenta um fator essencial no auxílio dos sintomas da DPP, pois a mãe precisa se sentir especial e além de tudo saber que não há nada de errado acontecendo. No tocante, a mídia tende a glorificar o ato de ser mãe como um momento único, feliz e completo, caracterizando a DDP como patológico. Sendo assim, no âmbito profissional, é necessário compreender as diferenças entre a DPP e a Tristeza materna e também os fatores de risco que aumentam a probabilidade de uma DPP. E dessa forma, intervir de forma correta e precoce, facilitando o prognóstico de forma a não acarretar desordens e comprometer ou interferir no desenvolvimento do bebê.

\title{
Referências
}


ARRAIS, Alessandra da Rocha; ARAUJO, Tereza Cristina Cavalcanti Ferreira. Depressão pós-parto: uma revisão sobre fatores de risco e de proteção. Psic., Saúde \& Doenças, Lisboa, v. 18, n. 3, p. 828-845, dez. 2017.

FERNANDES, Francielle Caroline; COTRIN, Jane Teresinha Domingues. Depressão pós-parto e suas implicações no desenvolvimento infantil. Revista Panorâmica On-Line. Barra do Garças MT, v. 14, p. 15 34, jul. 2013.

IACONELLI, Vera. Depressão pós-parto, psicose pós-parto e tristeza materna. Revista Pediatria Moderna, Julho-Agosto, v. 41, n. 4, 2005.

KLAUS, M. H., KENNEL, J. H. \& KLAUS, P. H. Vínculo Construindo as bases para um apego seguro e para a independência. Porto Alegre: ArtMed, 2000.

RIGHETTI-VELTEMA, Marion; CONNE-PERRÉARD, Elisabeth; BOUSQUET, Arnaud; MANZANO, Juan. Postpartum depression and mother infant relationship at 3 months old. Journal Of Affective Disorders, v. 70, n. 3, p. 291-306, ago. 2002.

SCHMIDT, Eluisa Bordin; PICCOLOTO, Neri Maurício; MULLER, Marisa Campio. Depressão pós-parto: fatores de risco e repercussões no desenvolvimento infantil. Psico-USF, v. 10, n. 1, p. 61-68, jan./jun. 2005. Porto Alegre.

SCHWENGBER, Daniela Delias Sousa; PICCININI, Cesar Augusto. O impacto da depressão pós-parto para a interação mãebebê. Estudos de Psicologia, v. 8, n.3, p. 403-411, 2003. Rio Grande do Sul.

SILVEIRA, Mônica Silva; GURGEL, Ricardo Queiroz; BARRETO, Íkaro Daniel de Carvalho; TRINDADE, Leda Maria Delmondes Freitas. A depressão pós-parto em mulheres que sobreviveram à morbidade materna grave. Cadernos Saúde Coletiva, v. 26, n. 4, p. 378-383, dez. 2018. 


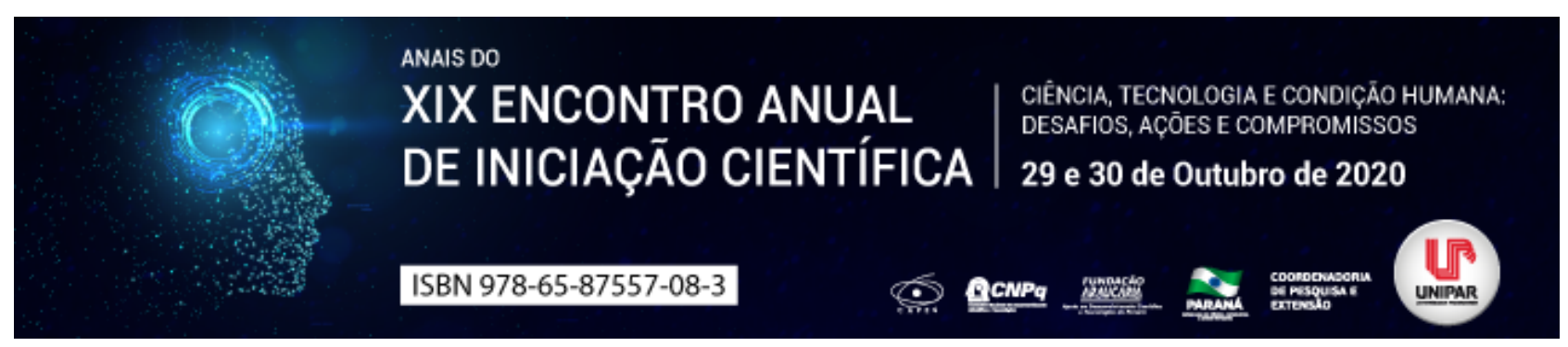

DIABETES MELLITUS TIPO 1 E A QUALIDADE DE VIDA EM ADOLESCENTES

\begin{abstract}
${ }^{1}$ ANA JULIA RAMALHO VIANA DE ALMEIDA, ${ }^{2}$ JULIA WAGNER KLEIN, ${ }^{3}$ TANIELLY CELLI JULIAO, ${ }^{4}$ THALITA ETIENE WILLEMANN DE CASTRO, ${ }^{5}$ FRANCISLAINE APARECIDA DOS REIS LIVERO, ${ }^{6}$ RODRIGO LEITE ARRIEIRA
\end{abstract}

\author{
${ }^{1}$ Acadêmica do Curso de Medicina - UNIPAR/Umuarama \\ ${ }^{1}$ Acadêmica do Curso de Medicina - UNIPAR/Umuarama \\ ${ }^{2}$ Acadêmica do Curso de Medicina - UNIPAR/Umuarama \\ ${ }^{3}$ Acadêmica do Curso de Medicina - UNIPAR/Umuarama \\ ${ }^{4}$ Docente da UNIPAR/Umuarama \\ ${ }^{5}$ Docente da UNIPAR/Umuarama
}

Introdução: $O$ diabetes mellitus tipo 1 (DM1) é definido como um processo autoimune de destruição das células beta pancreáticas com decorrente deficiência de insulina (DIB; TSCHIEDEL; NERY, 2008). Além disso, por ser uma doença crônica, o DM1 interfere diretamente na qualidade de vida, principalmente quando afeta adolescentes, devido a necessidade de fazer mudanças radicais em seu estilo de vida e de sua família. Isso porque requer mudanças na dieta, prática de atividade física, além de injeções diárias de insulina e consultas ao endocrinologista para ajustar as doses do medicamento. Em decorrência dessas mudanças diárias, o adolescente se sente diferente dos demais, pois eles precisam conviver com as limitações que a doença proporciona, o que desencadeia ansiedade, frustração e tristeza (PEREZ, 2013).

Objetivo: Identificar na literatura brasileira a qualidade de vida dos adolescentes portadores da patologia diabetes mellitus tipo 1.

Desenvolvimento: O processo fisiológico do DM1 acontece pela incapacidade de produção de insulina, já que as células beta pancreáticas, em um processo autoimune são destruídas. Sob esse ângulo, as células pancreáticas não conseguem sintetizar a insulina e, com a falta desse hormônio, não ocorre a absorção de glicose, que acumula-se no sangue (LUCENA, 2007). No Brasil, o DM1 apresenta aproximadamente 1 novo caso a cada 200.000 habitantes por ano, com um pico de incidência na adolescência (SBD, 2015). Ademais, é importante ressaltar que as doenças crônicas são as que mais corrompem a qualidade de vida do indivíduo, porque envolvem, de maneira definitiva, seu modo de viver e criam barreiras na sua capacidade produtiva e sua visão de mundo (CRUZ; COLLET; NÓBREGA; 2018). Fato que é mais intenso em adolescentes, devido a pouca maturidade e por estarem passando por um processo de transição. Por conseguinte, a família, a equipe de saúde e amigos possuem grande importância no ajustamento psicossocial e por consequência na melhora do controle metabólico, isso porque o suporte social contribui para a menor incidência de sintomas depressivos e melhor adaptação às limitações que a doença proporciona (PEREZ, 2013). Nessa perspectiva, o tratamento do DM1 é essencial à sobrevida do paciente, pode diminuir o risco cardiovascular e prevenir as complicações da enfermidade (SALES-PERES et al., 2016). O tratamento do DM1 possui um melhor resultado quando existe uma relação de troca entre a equipe multiprofissional e o paciente, pois se esses profissionais verem o paciente como um todo e não somente como uma doença, há uma maior probabilidade de sucesso no tratamento (JÚNIOR; CUNHA; CASTRO, 2008). Vale ressaltar, que essa patologia exige maior dedicação com o paciente, necessitando que o médico desempenhe um relacionamento social, humano e econômico, além de relacionar-se com a família, os temores, frustrações, desejos e valores dos portadores desta doença. Dessa forma, os médicos devem priorizar atitudes para a melhoria da relação com os adolescentes, como aconselhamento, tirar dúvidas e oferecer suporte emocional, para manter a doença controlada (FRAGOSO et al., 2010).

Conclusão: A qualidade de vida dos adolescentes com diabetes mellitus tipo I é diretamente afetada, pois em virtude da pouca maturidade, frequentemente, o autocuidado e a autodisciplina, que são extremamente necessários para minimizar as complicações dessa doença, não são totalmente concretizados. Nesse sentido, destaca-se a importância do acompanhamento, tratamento e melhoria da qualidade de vida dos adolescentes acometidos com DM1.

\title{
Referências
}

CRUZ, Déa Silvia Moura; COLLET, Neusa; NOBREGA, Vanessa Medeiros. Qualidade de vida relacionada à saúde de adolescentes com dm1- revisão integrativa. Ciência e Saúde Coletiva, v. 23, n. 3, p. 973-989, mar. 2018.

DIB, Sergio; TSCHIEDEL, Balduino; NERY, Marcia. Diabetes melito tipo 1: da pesquisa à clínica. Arquivos Brasileiros de Endocrinologia e Metabologia, v. 52, n. 2, p. 143-145, mar. 2008.

FRAGOSO, Luciana et al. Vivências cotidianas de adolescentes com diabetes mellitus tipo 1. Texto e Contexto Enfermagem, v. 19, n. 3, 443-451, julho/set. 2010.

JÚNIOR, Marcos de Souza Alvarenga; CUNHA, Cristiane de Freitas; CASTRO, Thalita Figueiredo Silva. A adolescencia e sua 
interferen̂ncia no controle do diabetes mellitus: dificuldades e propostas a partir de uma revisāo da literatura. Revista Médica de Minas Gerais, v. 18, n. Supl 1, S161- S166, 2008.

LUCENA, Joana Bezerra da Silva. Diabetes Mellitus Tipo 1 e Tipo 2. 2007. 74 f. Monografia (Curso de graduação em Farmácia) - Centro Universitário das Faculdades Metropolitanas Unidas, São Paulo, 2007.

PEREZ, Luciana. Adolescentes com diabetes melito tipo I: resiliência, qualidade de vida e suporte social. 2013 . 125 f. Dissertação (Programa de Pós-Graduação em Psicologia) - Universidade Federal do Rio Grande do Sul, Porto Alegre, 2013.

SALES-PERES, Silvia, et al. Estilo de vida em pacientes portadores de diabetes mellitus tipo 1: uma revisão sistemática. Ciência e Saúde Coletiva, v. 21, n. 4, p. 1197-1206, abr. 2016.

SBD. SOCIEDADE BRASILEIRA DE DIABETES. Diretrizes da Sociedade Brasileira de diabetes: $2014-2015$ - Tratamento de crianças e adolescentes com diabetes mellitus tipo 1. São Paulo, 2015.

Coordenadoria de Pesquisa e Extensão - COPEX

Departamento de Editoraçāo e Divulgaçāo Científica - DEDIC 


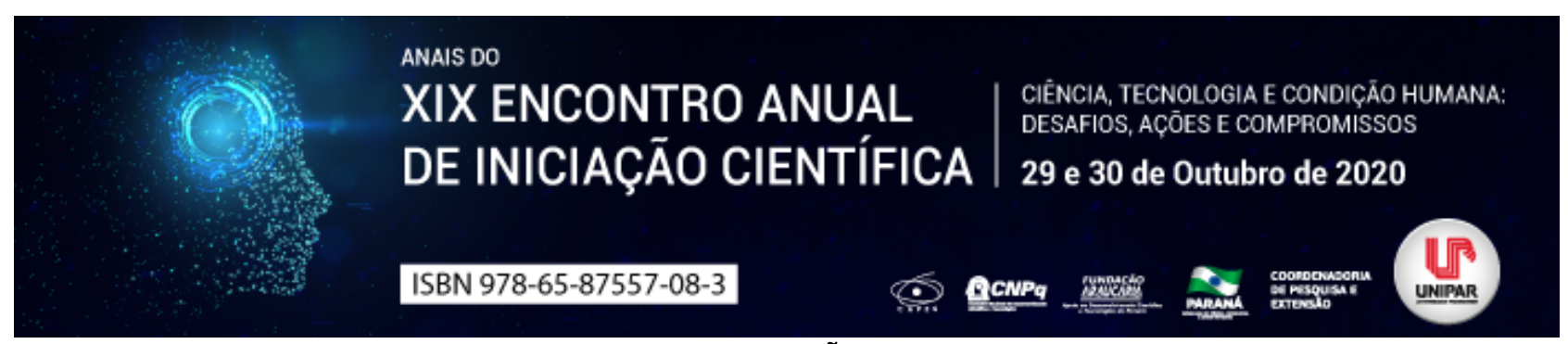

O QUE SABEMOS SOBRE A GESTAÇÃO E A PANDEMIA DA COVID-19

\begin{abstract}
${ }^{1}$ Gabriela Oliveira de Moura Rigonato, ${ }^{2}$ GUSTAVo SOUSA OLIVEIRA, ${ }^{3}$ VIRGÍNIA BRAZ DA SILVA VAZ, ${ }^{4}$ CRISTIANE ANGÉLICA DE PAIVA PAULA
\end{abstract}

\begin{abstract}
${ }^{1}$ Acadêmico de Medicina no Centro Universitário Instituto Master de Ensino Presidente Antônio Carlos
${ }^{1}$ Acadêmico de Medicina no Centro Universitário Instituto Master de Ensino Presidente Antônio Carlos

${ }^{2}$ Acadêmico de Medicina no Centro Universitário Instituto Master de Ensino Presidente Antônio Carlos

${ }^{3}$ Mestre em direito e docente na Universidade Presidente Antônio Carlos
\end{abstract}

Introdução: O novo coronavírus, conhecido como SARS-CoV-2, é causador da doença respiratória COVID-19, foi identificado pela primeira vez na China em dezembro de 2019 e se disseminou pelo mundo de maneira exponencial, então foi possível conhecer a gravidade da doença e seu potencial para causar extensos danos pulmonares e a síndrome respiratória aguda grave, esse cenário levou a Organização Mundial da Saúde a declara-la uma pandemia mundial. (MOREIRA, 2020). Desde então a comunidade científica tem unido forças para entender a evolução e as implicações do COVID-19 no organismo, principalmente em indivíduos mais vulneráveis, como as gestantes. Os dados são escassos, porém, a partir do que já é onhecido sobre os danos potenciais de vírus Coronavidae e outras infecções virais, sabe-se que podem ocasionar complicações na gravidez (RAMALHO, 2020). Com a falta de estudos que comprovem os reais danos desse novo vírus ao binômio mãe-filho e da frágil situação epidemiológica mundial, é fundamental o levantamento do máximo de informações a fim de enriquecer os dados sobre esta doença emergente.

Objetivo: Esse trabalho tem como objetivo investigar o que se conhece sobre os impactos da COVID-19 na gestação através de uma revisão bibliográfica de artigos e publicações encontrados nas bases de dados Medline, PubMed e Scielo para colaborar com a construção do conhecimento científico a respeito desse tema.

Desenvolvimento: As gestantes sofrem alterações fisiológicas únicas, especialmente imunológicas e cardiopulmonares, por esse motivo, estão expostas a um maior risco de complicações respiratórias e sistêmicas nas infecções virais, como nas causadas pelo vírus influenza A e nas epidemias de SARS-CoV e MERS-CoV, que levam ao aborto, parto prematuro, restrição do crescimento intra-uterino e morte materna (MINISTÉRIO DA SAÚDE, 2020). Para o COVID-19, não há comprovação de que mulheres grávidas sejam mais afetadas ou apresentem maior número de complicações que mulheres não grávidas (RAMALHO, 2020). Em comparação com as demais infecções virais por SARS-CoV e MERS-CoV durante a gravidez, as infecções com SARS-CoV2 parecem ter menor seriedade por apresentarem quadro clinico semelhante ao de mulheres não grávidas (SACCONE, CARBONE e ZULLO, 2020), apesar das preocupações com partos prematuros e baixo peso ao nascimento ainda permanecerem (CHERUIYOT, HENRY e LIPPI, 2020). Diante da frágil condição fisiológica e do risco elevado de morbimortalidade dessas pacientes, profissionais em todo o mundo estão atentos aos achados científicos que surgem a cada novo estudo, por esse motivo a Organização Mundial da Saúde classificou as gestantes como grupo de risco para a COVID-19 (ESTRELA et. al. 2020). Apesar de conhecidas as formas de transmissão do coronavírus, através de gotículas respiratórias de pessoas contaminadas ou pelo contato com objetos e superficies contaminados (MINISTÉRIO DA SAÚDE, 2020), uma das grandes preocupações e incógnitas da comunidade científica é quanto a transmissão vertical, que pode ocorrer durante a gravidez, no parto ou pela amamentação (MOREIRA, 2020). Até o momento não existem evidências claras quanto a essa forma de transmissão (GATTA et. al. 2020), porém teoricamente esse risco existe, assim como o observado nas infecções SARS-CoV, principalmente devido a presença, na placenta, da proteína conversora de angiotensina 2, que exerce papel de receptor canônico para a entrada do SARS-CoV2 nas células, e está presente em células de vários tecidos importantes, especialmente nos pulmões. Existem casos de neonatos que testaram positivo para o novo coronavírus logo após o parto, a transmissão vertical não foi excluída, mas não foram obtidos dados específicos que pudessem comprovar essa forma de transmissão (MOREIRA, 2020; DASHRAATH et. al. 2020). Existem vários estudos de casos de infecções maternas que se manifestaram no terceiro trimestre de gestação, porém não foram evidenciados casos de infecções durante o primeiro e segundo trimestres (CASTRO et. al. 2020). Nota-se uma preferência pelos parto cesárea, frequentemente antes do termo, por motivos não muito claros, que variam entre casos onde a paciente estava em oxigenoterapia para tratamento da síndrome respiratória, até mesmo em casos onde a decisão do tipo de parto foi influenciada pela ansiedade relacionada as potenciais consequências de uma infecção viral emergente cujas repercussões obstétricas são pouco conhecidas. Segundo artigos analisados, os sintomas mais comuns nas pacientes grávidas infectadas pelo SARS-CoV2 foram febre, em segundo lugar tosse, seguida pela dor de garganta, dispneia e diarréia. Todas as pacientes apresentaram sinais de infecção pulmonar em tomografia computadorizada. Apesar desses estudos, não existem dados conclusivos sobre as implicações clínicas para a mãe e o neonatal (GATTA et. al. 2020; CASTRO et. al. 2020). 
Conclusão: Estudos que apontam dados conclusivos sobre as implicações e evolução da COVID-19 em gestantes são escassos, insuficientes para confirmar sua transmissão vertical, sendo essencial o acompanhamento atento de pacientes que apresentarem diagnóstico ou suspeita, antecipando o agravamento e possibilitando melhor assistência à saúde do binômio.

\section{Referências}

CASTRO, Pedro et. al. Covid-19 and Pregnancy: An Overview. Revista Brasileira de Ginecologia e Obstetrícia, v. 42, n.7, pp 420-426, ago. 2020.

CHERUIYOT, Isaac; HENRY, Brandon Michael; LIPPI, Giuseppe. Is there evidence of intra-uterine vertical transmission potential of COVID-19 infection in samples tested by quantitative RT-PCR? European Journal of Obstetrics \& Gynecology and Reproductive Biology, Elsevier, v. 249, pp 100-101, jun. 2020.

DASHRAATH, Pradip et. al. Coronavirus disease 2019 (COVID-19) pandemic and pregnancy. American Journal of Obstetrics \& Gynecologyst, jun. 2020.

ESTRELA, Fernanda Matheus et. al. Gestantes no contexto da pandemia da Covid-19: reflexões e desafios. Physis: Revista de Saúde Coletiva, Rio de Janeiro, v. 30 (2), e300215, 2020.

GATTA, Anna Nunzia Della et. al. Coronavirus disease 2019 during pregnancy: a systematic review of reported cases. American Journal of Obstetrics \& Gynecologist, v. 223, i. 1, pp 36-41, jul 2020.

MINISTÉRIO DA SAÚDE. Diretrizes para Diagnóstico e Tratamento da Covid19 Atualizado em 07 de maio de 2020, Ministério da Saúde, 2020. Disponível em: < https://portalarquivos.saude.gov.br/images/pdf/2020/May/08/Diretriz-Covid19-v4-0705.20h05m.pdf>. Acesso em: 10 ago, 2020.

MOREIRA, Augusta Maria de Assumpção. Atualização da Transmissão Vertical da COVID-19. SGORJ Associação de Ginecologia e Obstetrícia do Estado do Rio de Janeiro, 01 jul. 2020. Disponível em: . Acesso em: 10 ago, 2020.

RAMALHO, Carla. COVID-19 na gravidez, o que sabemos? Acta Obstétrica e Ginecológica Portuguesa, Coimbra, v. 14, n 1, pp. 6-7, mar. 2020.

SACCONE, Gabriele; CARBONE, Floriana IIma; ZULLO, Fulvio. The novel coronavirus (2019-nCoV) in pregnancy: What we need to know. European Journal of Obstetrics \& Gynecology and Reproductive Biology, Elsevier, v. 249, pp. 92-93, abr. 2020. 


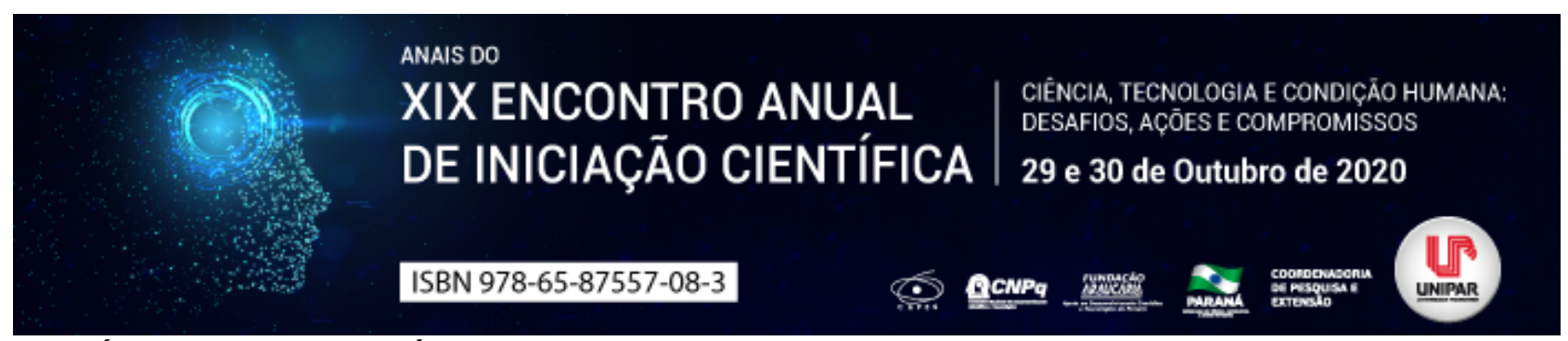

CARACTERÍSTICAS EPIDEMIOLÓGICA DA MORTALIDADE NEONATAL E INFANTIL EM UMA REGIONAL DE SAÚDE

\title{
${ }^{1}$ LUCIMARA DE MACEDO BORGES, ${ }^{2}$ MARCELA GONCALVES TREVISAN, ${ }^{3}$ LEDIANA DALLA COSTA
}

\author{
${ }^{1}$ Acadêmica do PIC/UNIPAR \\ ${ }^{1}$ Docente da UNIPAR \\ ${ }^{2}$ Docente da UNIPAR
}

Introdução: A mortalidade neonatal é determinada pelo óbito ocorrido entre 0 e 27 dias após o nascimento, já a mortalidade infantil decorre no período pós-natal, entre 28 dias até um ano de vida (SILVA et al., 2019). A mortalidade neonatal e infantil constitui-se como um problema crítico na área da saúde pública no Brasil e no mundo. Diante da visível queda na taxa de mortalidade em menores de um ano no país nas últimas duas décadas a situação ainda merece atenção especial. Essa taxa configura-se como um indicador que norteia o desenvolvimento social, econômico e a assistência à saúde da população (DEMITTO et al., 2017). De acordo com Kropiwiec, Franco e Amaral (2017), a redução epidemiológica da mortalidade infantil no Brasil e no mundo resulta de uma melhoria na organização da assistência no âmbito das Estratégias de Saúde da Família (ESF), principalmente aos progressos na qualidade da atenção à saúde das crianças, na qual se tem a maior abrangência do saneamento básico e campanhas de vacinação.

Objetivo: Analisar o perfil epidemiológico e as causas da mortalidade neonatal e infantil em uma Regional de Saúde entre os anos de 2018 a agosto de 2020.

Material e Métodos: Pesquisa exploratória, descritiva, documental, de caráter transversal e retrospectivo, com abordagem quantitativa, sendo os dados fornecidos por uma Regional de Saúde, responsável por abranger 27 municípios, pertencentes à região Sudoeste do Paraná. A amostra foi composta por 113 declarações de óbitos ocorridos nos primeiros 12 meses de vida, do recorte histórico entre os anos de 2018, 2019 a agosto de 2020. Não foram incluídos nas análises os óbitos sem os registros de informações referentes às variáveis do estudo. Empregou-se a análise estatística descritiva por meio do programa SPSS 25.0. O estudo foi submetido a avaliação do comitê de ética e aprovado sob o parecer $n^{\circ} 4.055 .493$, respeitando-se todos os preceitos éticos.

Resultados: A pesquisa foi composta por 113 declarações de óbitos, sendo a maioria, 56,6\%, do sexo masculino, 87,6\% de raça branca e prematuros $(62,0 \%)$, com predominância de $26,5 \%$ com peso entre $501 \mathrm{~g}$ a $1 \mathrm{~kg}$. Em relação aos óbitos, $66,4 \%$ foram neonatais. No que tange a causa base do óbito, 12,4\% foram decorrentes de septicemia bacteriana seguida de hipoplasia e displasia do pulmão (7,1 \%). Quanto aos dados maternos, 45,1\% das mães tinham entre 21 a 30 anos de idade e $84,1 \%$ tiveram gestação única. No quesito escolaridade, 31,0\% tinham apenas o ensino médio. Acerca da vida de parto, houve predomínio do cesariano em 64,6 \% dos casos. Destes, 48,7\% ocorreram no ano de 2018.

Discussão: Constatou-se predomínio de óbitos no sexo masculino, com baixo peso ao nascer e prematuridade. Esse perfil é similar ao estudo de Araújo Filho e colaboradores (2017) que apontam o sexo masculino vulnerável a ocorrência de complicações, pois o amadurecimento do sistema respiratório ocorre de forma mais tardia quando comparado com o sexo feminino. De acordo com Souza et al (2018) o baixo peso ao nascer é o fator de risco independente mais importante para o óbito. Ao analisarmos a raça, podemos observar a predominância na cor branca, o que contradiz o achado de Teixeira et al (2016). Esse achado está relacionado à disposição geográfica, pois segundo muitos estudos da literatura a raça branca não é classificada como fator de risco para óbito. De acordo com Alves et al (2018) a mortalidade neonatal está relacionada a vulnerabilidade do recém-nascido, devido a prematuridade, malformações congênitas e afecções neonatais, contribuindo assim para o agravamento do quadro clínico, ocasionando a sepse e consequentemente o óbito. Ao analisarmos a idade materna, existe uma contradição com a literatura, cujo principal fator de risco para óbito é a gestação na adolescência ou idade superior a 35 anos (ARAUJO FILHO et al., 2017). A escolaridade materna é sem dúvida outro fator contribuinte para a sobrevida infantil e indicador da condição socioeconômica. Dados similares ao estudo de Souza et al (2018) que evidenciam a baixa instrução materna, indicando que sejam mães adolescentes e que, consequentemente, devem receber uma atenção especial durante a realização do pré-natal. A gestação única não é caracterizada como risco. Segundo Demitto et al (2017) a gestação múltipla representa maior risco e prematuridade, junto a gemelaridade. O parto cesariano é predominante em muitos estudos, segundo Souza et al (2018) grande parte dos partos não necessitariam de procedimentos operatórios, pois esse ato traz mais risco para a mãe e para o bebê. Por fim, observou-se que houve uma redução no número de casos nos anos subsequentes a 2018, esse dado também pode ser constatado em estudos de recorte histórico quando, Souza et al (2018) revelam que, essa redução está associada a melhoria no estilo de vida, políticas públicas e programas de atenção à saúde.

Conclusão: Analisar os aspectos da mortalidade neonatal e infantil possibilita o planejamento e a readequação de ações no atendimento à saúde durante o período mais vulnerável e mais crítico dessas crianças, contribuindo assim, para a redução do 
número de óbitos.

\section{Referências}

ALVES, Jakeline Barbara et al. Sepse Neonatal: Mortalidade em município do sul do Brasil, 2000 a 2013. Rev Paulista de Pediatria. São Paulo. v. 2, n. 36, p. 132- 140, 2018. Disponível em: http://dx.doi.org/10.1590/1984-0462/;2018;36;2;00001. Acesso em: 01/03/2020.

ARAUJO FILHO, Augusto Cezar Antunes de et al. Aspectos epidemiológicos da mortalidade neonatal em uma capital do nordeste do Brasil. Revista Cuidarte. Bucaramanga, Colombia. v. 3, n. 8, p. 1767-1776, 2017. Disponível em: https://doi.org/10.15649/cuidarte.v8i3.417. Acesso em: 20/08/2020.

DEMITTO, Marcela de Oliveira et al. High neonatal death. Rev Esc Enferm USP, São Paulo, v. 51, 2017. Disponível em: http://dx.doi.org/10.1590/S1980-220X2016014703208. Acesso em: 14/03/2020.

KROPIWIEC, Maria Volpato; FRANCO, Selma Cristina; AMARAL, Augusto Randüz. Fatores associados à mortalidade infantil em município com índice de desenvolvimento humano elevado. Rev Paulista de Pediatria. São Paulo. v. 35, n. 4, p. 391-398, 2017. Disponível em: https://doi.org/10.1590/1984-0462/;2017;35;4;00006. Acesso em: 03/03/2020.

SILVA, Ana Cristina Farah Abdon et al. Índice De Morte Neonatal Precoce: Uma Análise Do Perfil Materno. Rev Eletrônica Acervo Saúde, n. 26, p. 690, jul. 2019. Disponível em: https://acervomais.com.br/index.php/saude/article/view/690. Acesso em 24/03/2020.

SOUZA, Ana Mayara Gomes et al. Perfil epidemiológico da mortalidade neonatal no Rio Grande do Norte-Brasil: Um estudo de base secundária. Rev Ciência Plural, Lagoa Nova, Natal, v. 4, n. 2, p. 115-127, fev. 2019. Disponível em: https://periodicos.ufrn.br/rcp/article/view/16844. Acesso em:03/08/2020.

TEIXEIRA, Gracimary Alves et al. Fatores de risco para a mortalidade neonatal na primeira semana de vida. Rev de Pesquisa Cuidado e Fundamental Online. Rio de Janeiro. v. 1, n. 8, p. 4036-4046. jan./ mar. 2016. Disponível em:https://10.9789/21755361. 2016.v8i1.4036-4046. Acesso em: 23/05/2020.

Coordenadoria de Pesquisa e Extensāo - COPEX

Departamento de Editoraçāo e Divulgaçāo Científica - DEDIC 


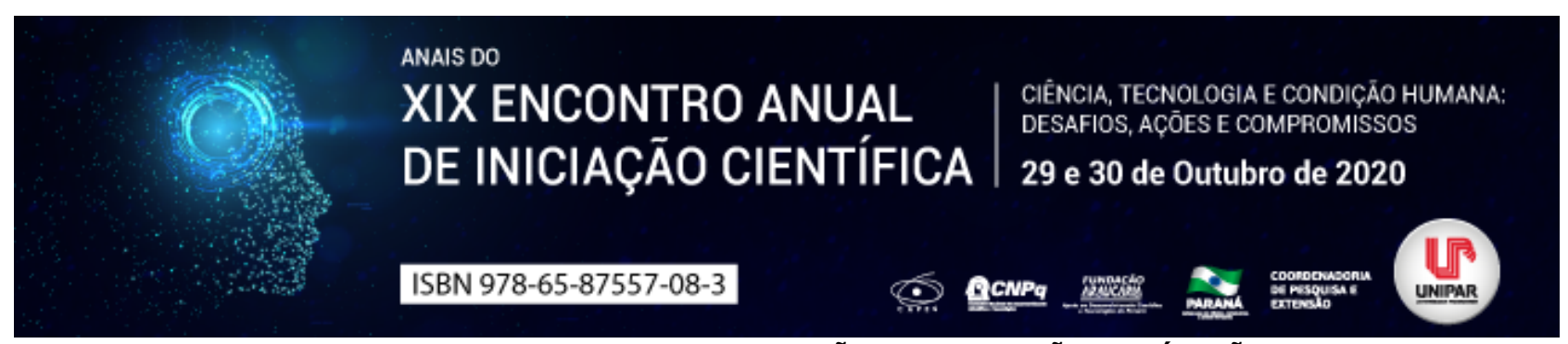

O PAPEL DO ENFERMEIRO NA DOAÇÃO E CAPTAÇÃO DE ÓRGÃOS

\section{${ }^{1}$ JOCIMARA SANDRINI DOS SANTOS, ${ }^{2}$ KATIA BIAGIO FONTES}

$11_{1}$ Discente do curso de Enfermagem - UNIPAR

${ }^{1}$ Docente da UNIPAR

Introdução: O método de doação de órgãos e tecidos dispõe de conhecimentos para salvar inúmeras vidas (COELHO et al., 2007). Contudo, dados recentes no país, evidenciaram que em março de 2020, a lista de espera para receber um órgão chegou a 46.002 candidatos. No estado do Paraná, dados entre os anos de 2013 a 2018, demonstraram que os números de entrevistas a familiares de concessores chegaram a 3.090, porém, apenas 1.947 se tornaram doadores efetivos (BRASIL, 2020). Para Rossato et al., (2017) o processo de doação de órgãos envolve sucessões de elementos que podem encaminhar ao êxito ou a reprovação, sendo a atuação do enfermeiro essencial em qualquer parte do processo.

Objetivo: O objetivo deste estudo foi investigar na literatura científica o papel do enfermeiro durante o processo de doação e captação de órgãos.

Desenvolvimento: A morte encefálica (ME) é a interrupção efetiva das funções cerebrais, identificado com o coma, o distanciamento de reações do tronco encefálico e parada respiratória. Depois da constatação de ME o órgão responsável por notificar, e distribuir os órgãos devem ser comunicados, independente do quadro clínico do doador e aceitação familiar para a doação de órgão (WESTPHAL et al., 2016). No Brasil a investigação de ME é validada por duas analises clinicas e um exame adicional, em clientes com indícios de óbito cerebral, faz parte também deste processo o papel de colaboração realizado junto ao paciente e sua família (SCHEIN et al., 2008). Diante disso, o enfermeiro tem como função orientar a equipe de saúde sobre a necessidade de esclarecer aos familiares do possível doador, sobre os procedimentos de ME, sendo essa atitude de grande importância uma vez que os familiares têm dificuldade na aceitação do diagnóstico de $\mathrm{ME}$, consequentemente, dificultando o processo da doação (BOUSSO, 2008). De acordo com a Resolução $n^{\circ}$ 292/2004, do Conselho Federal de Enfermagem (COFEN), é dever do enfermeiro planejar e executar procedimentos de coordenação, monitoramento e avaliação dos serviços de enfermagem para doadores de órgãos e tecidos. Os enfermeiros responsáveis por esses serviços devem não apenas ter conhecimento e treinamento suficientes, mas também fornecer as informações necessárias aos familiares, como também identificar possíveis doadores (CONSELHO FEDERAL DE ENFERMAGEM, 2004). Em suas atividades, o enfermeiro e sua equipe são responsáveis pela execução, manutenção, controle e registro de todos os parâmetros hemodinâmicos de potenciais doadores, ou seja, alterações de mudanças térmicas instantâneas, vasodilatação extrema, como síndromes típicas associadas à incapacidade de tremer para gerar calor, além de injetar uma grande quantidade de fluidos (GUIMARÃES et al., 2012). Devem também consentir que os familiares fiquem o máximo de tempo permitido ao lado do ente querido, favorecendo para a contribuição da doação. Ambos os familiares, como também concessor e receptor carecem de ser atendidos nas suas particularidades. Os familiares de concessores mortos precisam ser respeitados em seu sofrimento e o laço com a equipe garante compreensão e sensibilização sobre ME e doação de órgãos (MORAES et al., 2014). Sendo assim é essencial que o profissional enfermeiro e equipe envolvida tenham conhecimento técnico, científico em relação $\mathrm{ME}$, a fim de oferecer uma assistência eficaz (FREIRE et al., 2014).

Conclusão: Através da investigação dos estudos analisados pode-se concluir que o papel do enfermeiro no processo de doação e captação de órgãos envolve a identificação de um possível doador, a organização e execução dos protocolos e registro. Faz-se necessário que o profissional tenha conhecimento técnico científico, e que o responsável por esse setor também seja empático e tenha um bom diálogo com a família do possível doador a fim de tranquilizar e confortar os envolvidos no processo.

\section{Referências}

BOUSSO, Regina Szylit. The family decision-making process concerning consent for donating their child's organs: a substantive theory. Texto contexto - enferm. [online], v.1 n.1, p.45-54, 2008. Disponível em: http://abre.ai/bvkD . Acesso em: 28 ag. 2020. BRASIL. Ministério da Saúde. Doação de Órgãos: transplantes, lista de espera e como ser doador. Disponível em: http://abre.ai/bvkN Acesso em: 30 ag. 2020.

CONSELHO FEDERAL DE ENFERMAGEM. Resolução no 292/2004. Normatiza à atuação do Enfermeiro na Captação e Transplante de órgãos e Tecidos. Rio de Janeiro, 07 de junho de 2004. Disponível em: http://abre.ai/bvkE . Acesso em: 28 ag. 2020.

COELHO, Júlio Cezar Uili. et al. Opinião e conhecimento da população da cidade de Curitiba sobre doação e transplante de órgãos. Rev Assoc Med Bras, v.5, n.1, p. 421-5, 2007. Disponível em: http://abre.ai/bvkM Acesso em: 30 ag. 2020.

FREIRE, Izaura Luiza Silvério. et al. Compreensão da equipe de enfermagem sobre morte encefálica e a doação de órgãos. 
Revista Eletrônica Trimestral de Enfermeira, v.8, n.36, p.70-78, 2014. Disponível em: http://abre.ai/bvkF Acesso em: 28 ag. 2020.

GUIMARÃES, Jussara Borges. et al. Conhecimento dos enfermeiros sobre condutas na prevenção, manutenção e no controle da temperatura de potenciais doadores de órgãos. Hospital das Clínicas da Universidade Federal de Goiás, v.4, n.30, p.365-368, 2012. Disponível em: http://abre.ai/bvkK Acesso em: 28 ag. 2020.

MORAES, Edvaldo leal de. et al. Vivência de enfermeiros no processo de doação de órgãos e tecidos para transplante, v.2, n.22, p.226-33, 2014. Disponível em : http://abre.ai/bvkH Acesso em: 28 ag. 2020.

ROSSATO, Gabriela Camponogara. et al. Doar ou não doar: Visão de familiares frente a doação de órgãos. REME Rev Min

Enferm, v. 21, n.1, p.1-8, 2017. Disponível em: http://abre.ai/bvkJ Acesso em: 30 ag. 2020.

Coordenadoria de Pesquisa e Extensão - COPEX

Departamento de Editoraçāo e Divulgaçāo Científica - DEDIC 


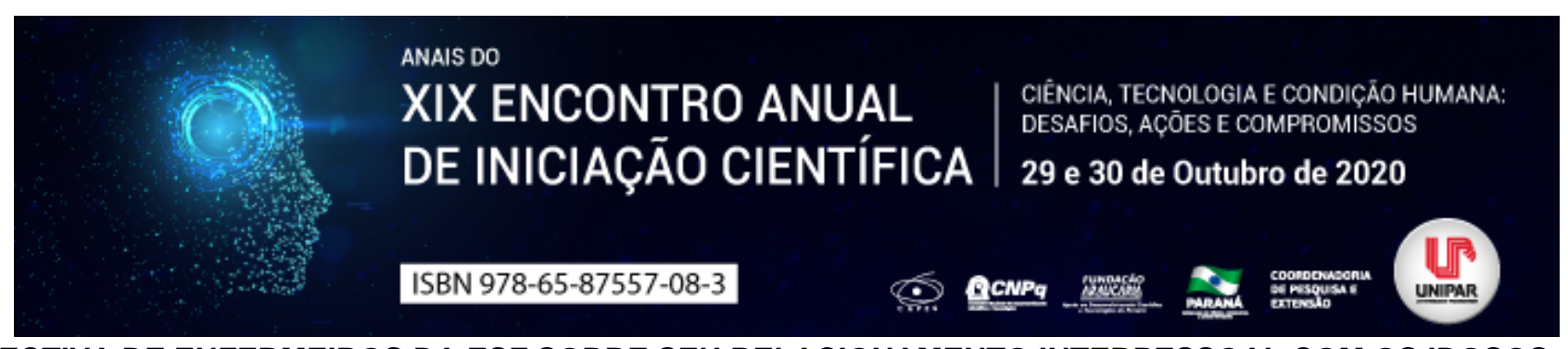

PERSPECTIVA DE ENFERMEIROS DA ESF SOBRE SEU RELACIONAMENTO INTERPESSOAL COM OS IDOSOS: DADOS PRELIMINARES

\author{
${ }^{1}$ Eduarda Rodrigues Ferreira, ${ }^{2}$ FRANCIELE RAIMUNDO DA SILVA, ${ }^{3}$ JENNIFER LORENA DE SOUZA DA SILVA, ${ }^{4}$ GABRIELLA \\ MICHEL DOS SANTOS BENEDETTI, ${ }^{5}$ MARIA ANTÔNIA RAMOS COSTA, ${ }^{6}$ HELLEN EMILIA PERUZZO
}

${ }^{1}$ Estudante de Enfermagem, Universidade Estadual do Paraná
UNESPAR
${ }^{1}$ Estudante de Enfermagem, Universidade Estadual do Paraná
UNESPAR.
${ }^{2}$ Estudante de Enfermagem, Universidade Estadual do Paraná $\quad$ UNESPAR
${ }^{3}$ Mestre em Enfermagem, docente da Universidade Estadual do Paraná UNESPAR.
${ }^{4}$ Doutora em Enfermagem, docente da Universidade Estadual do Paraná UNESPAR
${ }^{5}$ Doutora em Enfermagem, docente da Universidade Estadual do Paraná UNESPAR

Introdução: A complexidade da relação interpessoal, do encontro e diálogo é fundamental para a atribuição de significados das demandas de cuidado requeridas pelos pacientes e cobram especial relevância nos contextos clínicos de Atenção Primária à Saúde (APS) (BORGES, 2019). A população idosa corresponde ao maior número de atendimentos realizados pela APS e uma das grandes dificuldades enfrentadas no seu atendimento é o fato de grande parte possuírem dificuldades relacionadas às habilidades de linguagem, audição, fonação e mastigação. (SANTIAGO, 2016).

Objetivo: Compreender a percepção de enfermeiros da ESF sobre o relacionamento interpessoal com pacientes idosos no cuidado em saúde da atenção primária.

Materiais e métodos: Tratam-se de resultados preliminares de um estudo descritivo exploratório com abordagem qualitativa que está sendo realizado junto a enfermeiros atuantes em equipes da ESF de Unidades Básicas de Saúde (UBS) de um município de médio porte do noroeste do Paraná. O convite para participação está sendo encaminhado para todos os enfermeiros atuantes nas UBS do município, via e-mail particular. A coleta de dados está sendo realizada por meio de questionário estruturado e online, confeccionado a partir do Google Forms. Esta estratégia foi escolhida mediante ao cenário atual de enfrentamento do novo Covid-19. Visando o não contágio e disseminação da doença. O instrumento de pesquisa está norteado pelas questões:

Como é o seu relacionamento com os pacientes idosos no cuidado em saúde dentro da UBS?; Você enfrenta dificuldade em relacionar com esta população?; Você acredita que se faz ser compreendido pelo idosos na maioria das vezes?; e Quais ferramentas você acredita que podem ser utilizadas no enfrentamento das dificuldades neste relacionamento? . Os discursos estão sendo analisados por meio da análise de conteúdo temático (Bardin, 2016).

Resultados: Até o momento, participaram da pesquisa seis participantes. Da análise dos dados preliminares emergiram duas categorias temáticas. Na primeira categoria, Barreiras na comunicação e na gestão do tempo dificultam o relacionamento interpessoal , foram abordadas as barreiras encontradas referente ao relacionamento interpessoal entre enfermeiros da APS e os idosos, principalmente no tocante a dificuldade em serem compreendidos e ao fluxo de atendimento acelerado, eles descrevem o tempo como fator decisivo para um entendimento de qualidade aos idosos, o que consequentemente contribui para a falta de entendimento e dificuldade na comunicação. Já a segunda categoria, Estratégias para melhorar o relacionamento interpessoal entre enfermeiros e idosos, foram abordadas as estratégias que podem ser implementadas para promover um melhor relacionamento interpessoal entre enfermeiros e pacientes idosos, como oferecer um atendimento humanizado e integral para a criação de vínculo. Os participantes ainda citaram a escuta ativa como uma forma de compreender as necessidades desse público e também de fazer com que eles se sintam acolhidos, além de atendimento em horários diferenciados, como alternativa para compensar a escassez de tempo.

Discussão: Dentre as principais fragilidades no atendimento ao idoso, destacam-se as barreiras na linguagem, como as dificuldades na audição e fonação (SANTIAGO, 2016), tal como identificado nos resultados preliminares do presente estudo. A assistência prestada pelo enfermeiro ao paciente idoso na ESF ocorre de acordo com a demanda espontânea e é direcionada às patologias e não para as peculiaridades e especificidades do idoso (FRANCO et al., 2020). Os serviços de saúde devem estar organizados para atender amplamente as necessidades de saúde da sua população e promover uma assistência totalizadora do cuidado. Nesse sentido, os profissionais de saúde precisam adaptar-se para que as barreiras existentes sejam ultrapassadas (MATTOS, 2001). As equipes de saúde devem se desprender do modelo de atenção biomédico e buscar a integralidade das ações (COSTA; FRACOLLI, 2007). Acredita-se que a ESF é capaz de proporcionar a atenção integral à saúde dos idosos, entretanto é preciso que os profissionais que compõem a equipe sejam resolutivos e supram as necessidades desta população (COSTA; CIOSAK, 2010).

Conclusão: Os enfermeiros que participaram da pesquisa reconheceram as barreiras no atendimento aos idosos e 
apresentaram estratégias para melhorar a qualidade no atendimento ao paciente, como o atendimento integral e medidas de aproximação do usuário ao serviço de saúde. No entanto, além da forma de abordagem, deve-se haver a manutenção do vínculo entre profissional e paciente, o que contribui para a confiança e o idoso se sinta seguro.

\section{Referências}

BARDIN, L. Analise de Conteúdo. [S. I.]: Edições 70, 2016.

BORGES, Jose Wicto Pereira; MOREIRA, Thereza Maria Magalhães; MENEZES, Anaíze Viana Bezerra; LOUREIRO, Aline Maria Oliveira; CARVALHO, Irialda Saboia; FLORÊNCIO, Raquel Sampaio. Compreensão da relação interpessoal enfermeiro-paciente em uma unidade de atenção primária fundamentada em imogene king, Minas Gerais, v. 9, n. 3011, fev. 2019, Recom- Revista de Enfermagem do Centro-Oeste Mineiro, 2019.2 Disponível em: http://www.seer.ufsj.edu.br/index.php/recom/article/view/3011/2139. Acesso em: 11 ago. 2020.

COSTA, Maria Fernanda Baeta Neves Alonso; CIOSAK, Suely Itsuko. Atenção integral na saúde do idoso no Programa Saúde da Família: visão dos profissionais de saúde, Santos, v. 44, n. 2 Rev. Esc Enferm USP, 2010. Disponível em: https://www.revistas.usp.br/reeusp/article/view/40559/43688. Acesso em: 11 ago. 2020.

FRANCO, Patrícia da Costa; ESTEVES, Arinete Veras Fontes; OLIVEIRA, Ana Paula Pessoa; SAMPAIO, Sara Nogueira ; LIMA, Eurides Souza. Cotidiano do enfermeiro no atendimento ao idoso na estratégia saúde da família em Manacapuru-Amazonas, Amazonas, v. 25 Rev. Cogitare Enferm., 2020. Disponível em: https://revistas.ufpr.br/cogitare/article/view/68253/pdf. Acesso em: 11 ago. 2020.

MATTOS, RUBEN ARAUJO. Os sentidos da integralidade: algumas reflexões acerca dos valores que merecem ser defendidos. In: PINHEIRO, R; MATTOS, RA, editores. Os sentidos da integralidade na atenção e no cuidado à saúde. Rio de Janeiro: IMS/ABRASCO, 2001, p. 39-64.

SANTIAGO, Lívia Maria; GRAÇA, Cláudia Maria de Lima; RODRIGUES, Monique Coelho de Oliveira; SANTOS, Gislene Barbosa. Caracterização da saúde de idosos numa perspectiva fonoaudiológica, São Paulo, v. 18 n. 5, Revista CEFAC, 2016. Disponível em: http://ref.scielo.org/qbvvpp. Acesso em: 11 ago. 2020. 


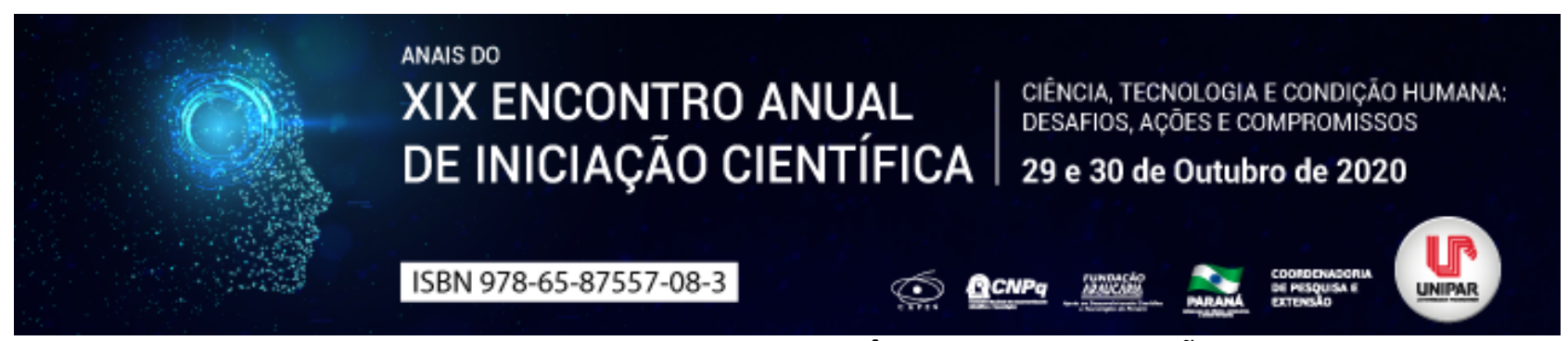

TOXOPLASMOSE E AS CONSEQUÊNCIAS NA GESTAÇÃO

\begin{abstract}
${ }^{1}$ BRUNA APARECIDA SOARES FAVARO, ${ }^{2}$ AMANDA CRISTINA DA ROCHA OLIVEIRA, ${ }^{3}$ HELOISA MACHINESKI,
${ }^{4}$ NATHIELLE MIRANDA
\end{abstract}

${ }^{1}$ Acadêmica do Curso de Farmácia e de Iniciação Científica da UNIPAR
${ }^{1}$ Acadêmica do Curso de Farmácia da UNIPAR
${ }^{2}$ Acadêmica do Curso de Farmácia da UNIPAR
${ }^{3}$ Docente da UNIPAR

Introdução: A toxoplasmose é uma doença parasitária encontrada principalmente nos países tropicais. Sua infecção não apresenta sintomas na grande maioria dos casos, porém está associada a grande morbidade durante a gestação. Seu agente etiológico, o protozoário Toxoplasma gondii, é um parasita com ciclo biológico de duplo hospedeiro. No gato ocorre o ciclo reprodutivo, sendo desta maneira o hospedeiro definitivo (Ministério da Saúde, 2013). O homem, hospedeiro intermediário, se infecta com T. gondii ingerindo alimentos crus, bebidas e águas contaminadas com oocistos presentes nas fezes dos felinos (Lélu et al., 2011).

Objetivo: O objetivo deste trabalho é ressaltar a importância e os cuidados com a toxoplasmose em gestantes.

Desenvolvimento: A transmissão vertical ou transplacentária é caracterizada por uma infecção do feto, ainda no útero, a partir da mãe com infecção primária, ou seja, ocorre quando a gestante tem seu primeiro contanto e adquire a toxoplasmose nesse período. Diante disso assume-se uma enorme importância quando acomete a gestante, pois além do risco da transmissão para o feto, pode também causar sequelas imediatas ou tardias ao mesmo (Pinard JÁ et al., 2003). A severidade e a ocorrência da infecção fetal dependem do período gestacional no qual ocorreu a contaminação. A probabilidade de haver infecção fetal aumenta com o avançar da idade gestacional, mas a gravidade das lesões cerebrais e das sequelas diminui conforme o período da gestação, sendo, portanto, os fetos mais afetados aqueles foram infectados mais precocemente. Portanto a maioria das crianças infectadas no período pré-natal nem sempre apresentam sintomas ao nascimento, mas tem grandes probabilidades de apresentarem sequelas no futuro, e assim sendo o diagnóstico depende muito dos métodos sorológicos utilizados (Jones et al., 2001). Portanto a infecção é geralmente assintomática na gestante, apresentando sintomas em apenas $10 \%$ dos casos, e estes geralmente inespecíficos, consequentemente, o diagnóstico da infecção materna se baseia principalmente nos testes sorológicos, pesquisando os anticorpos contra o parasita. Em indivíduos imunocompetentes os testes sorológicos com pesquisa de IgG e IgM são suficientes para o diagnóstico, por serem sensíveis, específicos e de fácil execução (Lappalainen et al., 2004). O teste de avidez do anticorpo IgG aparece mais tarde, indicando que o paciente já foi exposto ao parasita, assim o risco de transmissão para o feto é mínimo quando a soro-positividade ocorre antes da gestação (Figueró-Filho et al, 2005). Se nesse caso a mãe não apresentar nenhum dos marcadores IgG ou IgM os cuidados devem ser redobrados, significando que a mãe nunca teve contato com o parasito, e se vir a adquirir durante a gravidez, o parasito pode alcançar o feto e trazer complicações, causando danos neurológicos tais como hidrocefalia ou microcefalia, um certo déficit neuropsicomotor e epilepsia, ou o déficit visual progressivo e irreversível em qualquer época da vida. Sendo assim as gestantes devem evitar carnes cruas, não devem limpar caixa de areia de gato, e as mesmas não devem ter contato, portanto a triagem dessas gestantes soro-negativas e o seu seguimento sorológico durante a gravidez para a detecção precoce de soroconversão devem ser feitos (Prado et al., 2011). Além disso, por ser uma doença negligenciada e de pouco interesse às pesquisas, por apresentar altas taxas de mortalidade e por ser de grande importância epidemiológica, estudos devem ser feitos com o objetivo de demonstrar a importância dessa patologia (Higa et al., 2010).

Conclusão: Diante do exposto, destaca-se a prevenção dessa doença em gestantes por serem do grupo de risco, e da importância do mesmo a ser estudo e pesquisado, pois trâs muitos danos também ao feto.

\footnotetext{
Referências

Barbosa BF, Gomes AO Ferro EA, Napolitano DR, Mineo JR, Silva NM. Enrofloxacin is able to control Toxoplasma gondii infection in both in vitro and in vivo experimental models. Vet Parasitol. 2012 Jun 8;187(1-2):44-52.

Figueiró-Filho EA, Lopes AH, Senefonte FR, Souza Júnior VG, Botelho CA, Figueiredo MS. Toxoplasmose aguda: estudo da frequência, taxa de transmissão vertical e relação entre os testes diagnósticos materno-fetais em gestantes em estado da Região Centro-Oeste do Brasil. Rev. Bras. Ginecol. Obstet. 2005; 27(1):442-9.

HIGA, L. T. et al. Relato de dois casos de toxoplasmose em gestantes atendidas no noroeste do Paraná, Brasil. Scientia Medica, Porto Alegre, v. 20, n.1, p. 99-102, 2010.
} 
JONES, J. L.; LOPEZ, A.; WILSON, M.; SCHULKIN, J.; GIBBS, R. Congenital toxoplasmosis: a review. Obstetrics and Gynecology, n.56, p.296-305, 2001.

Lélu M, Gilot-Fromont E, Aubert D, Richaume A, Afonso E, Dupuis E, et al. Development of a sensitive method for Toxoplasma gondii oocyst extraction in soil. Vet Parasitol. 2011 Dec 29;183 (1-2):59-67.

Ministério da Saúde. Gestação de Alto Risco: Manual Técnico. 5a ed. Brasília, 2012. 301 p.

Lappalainen M, Hedman K. Serodiagnosis of toxoplasmosis. The impact of measurement of IgG avidity. Ann Ist Super Sanità. 2004; 40:81-8.

Prado AAF, Almeida GF, Gontijo LS, Torres MLT. Toxoplasmose: O que o Profissional da Saúde deve saber. Tese de Mestrado da Faculdade de Medicina Veterinária e Zootecnia da Universidade de São Paulo, Enciclopédia Biosfera, Centro Científico Conhecer. 2011; 7 (12)

Pinard JA, Leslie NS, Irvine PJ. Maternal serologic screening for toxoplasmosis. J Midwifery Womens Health. 2003;48:308-16.

Coordenadoria de Pesquisa e Extensão - COPEX

Departamento de Editoração e Divulgaçāo Científica - DEDIC 


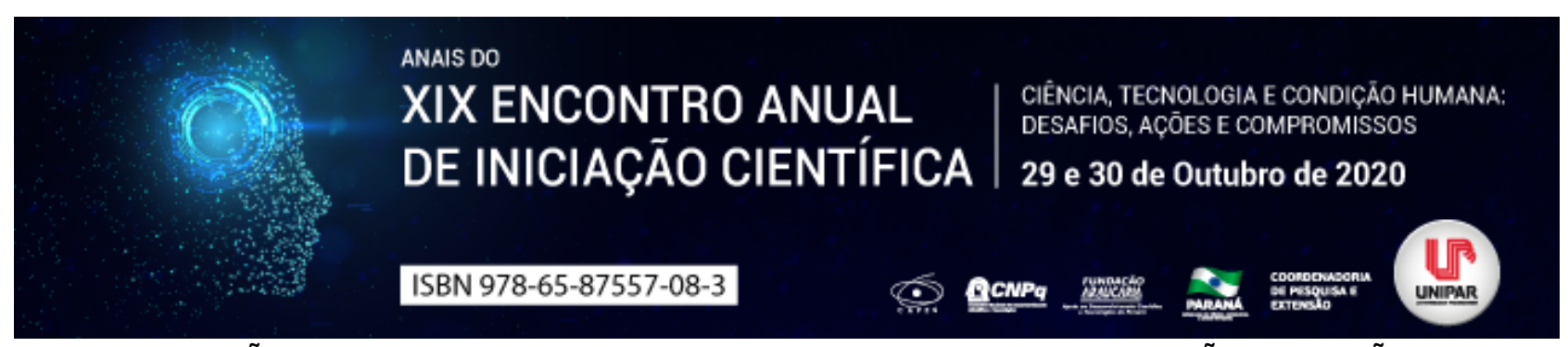

NÍVEL DE INSATISFAÇÃO DA IMAGEM CORPORAL EM PRATICANTES DE MUSCULAÇÃO - REVISÃO BIBLIOGRÁFICA

\title{
${ }^{1}$ ANDRE LUIZ DALANHOL TRES, ${ }^{2}$ DEBORA MARINA BANDEIRA, ${ }^{3}$ FERNANDO HENRIQUE PAVAO
}

\author{
${ }^{1}$ Acadêmico do curso de Educação Física da UNIPAR \\ ${ }^{1}$ Mestranda do Programa de Pós-Graduação Stricto Sensu em Conservação e Manejo de Recursos Naturais da UNIOESTE \\ ${ }^{2}$ Docente do curso de Educação Física da UNIPAR
}

Introdução: A história da imagem corporal se iniciou no século XVI, na França, com o médico cirurgião Ambroise Paré, mas somente, a partir do século XX, o tema foi abordado de forma expressiva por pesquisadores, o que resultou numa rede de opções metodológicas para a avaliação da imagem corporal. Entende-se por imagem corporal a figuração do nosso corpo formado em nossa mente, ou seja, o modo pelo qual o corpo se apresenta para nós, relacionando tamanho, imagem, formas do seu corpo e dos sentimentos criados a ela (SLADE, 1988; SCHILDER, 1999; MORGADO, 2009). Na sociedade pós-moderna, o ideal cultural de corpo é aquele musculoso, magro e belo. Vive-se numa busca incessante por um corpo dito perfeito, influenciada por padrões de beleza estabelecidos pela mídia (DAMASCENO et. al, 2006). Assim, as academias assumem um papel de destaque na sociedade com o treinamento de musculação, sendo praticado por muitas pessoas com objetivos distintos, como saúde, aumento de massa muscular, melhora da condição física geral, da potência ou da resistência muscular (UCHIDA, NAVARRO, PONTES, 2013). Desta forma, o levantamento, a investigação e a possível confirmação que o nível de insatisfação com a própria imagem e/ou saúde, é o principal motivo para o início de um programa de exercício físico (DAMASCENO et. al, 2005; KAKESHITA e ALMEIDA, 2006; FERMINO, PEZZINI e REIS, 2010).

Objetivo: Revisar a literatura científica sobre o nível de insatisfação da imagem corporal, baseados nos métodos BSQ (Body Shape Questionnaire) e Escala de Stunkard em praticantes de academia.

Desenvolvimento: Foram pesquisados artigos científicos publicados nos últimos 12 anos, utilizando os seguintes termos para pesquisa: Insatisfação da Imagem Corporal , Imagem Corporal Academia . A pesquisa foi realizada nas bases de dados científicas: Scielo , Pubmed e Google acadêmico , incluindo artigos originais publicados em três idiomas português, inglês e espanhol entre os anos de 2008 a 2020, que avaliassem autopercepção corporal em praticantes de academia de ambos os sexos e em qualquer modalidade. Foram excluídos tese, dissertações, relatos de casos e artigos de revisão. Em um primeiro momento foram selecionados 70 artigos, após a leitura dos títulos e resumos foram excluídos 60 artigos que não se encaixavam com o objetivo do estudo, restando 10 que preencheram os critérios de inclusão, foram analisados e incluídos no estudo. A amostra dos estudos variou entre 31-836 indivíduos, onde apenas dois artigos não tiveram amostra mista, os demais oito artigos avaliaram praticantes de academias de ambos os sexos. Dentre os artigos selecionados, oito artigos utilizaram o questionário BSQ e dois a escala Stunkard (FIRMINO et. al, 2010; DAMASCENO et al, 2011) para avaliar os indivíduos dos estudos. A prevalência de insatisfação corporal variou entre $7,8 \%$ a $98,8 \%$, avaliando tanto homens, quanto mulheres. Na maioria dos artigos selecionados indicam uma maior distorção da imagem corporal entre as mulheres em relação aos homens. A possível explicação para tal achado é que homens apresentam maior insatisfação por serem magros e os métodos de avaliação da insatisfação corporal avaliam apenas insatisfação por excesso de peso, o que poderia influenciar nos resultados encontrados. Para praticantes de academia não existe um método estabelecido para avaliação de insatisfação corporal especificamente destes indivíduos. Ressaltando que as escalas de silhuetas utilizadas para avaliar a insatisfação corporal em praticantes de academia são insuficientes. Os métodos de que normalmente são utilizados nestes estudos, na realidade, são mais adequadas para avaliação de distúrbios alimentares relacionados à imagem corporal. A insatisfação pode ser associada a fatores psicológicos, gerando preocupação excessiva com o corpo pode levar o indivíduo a ter um reflexo negativo da sua imagem corporal, gerando um desequilíbrio, diminuindo a autoestima e afetando diretamente sua vida pessoal e social. Com a ligação de bem estar físico e mental estão associados intimamente a autoestima, o exercício físico contribui para a melhora da autoestima, pois contribui na modulação das formas corporais. Este sentimento de insatisfação vem da crença de estar sobrepesado, apesar de o indivíduo estar com o peso adequado, e esta distorção, na maioria das vezes, está associada a distúrbios alimentares, prejudicando a saúde dos mesmos.

Conclusão: Pode-se concluir que a insatisfação corporal ocorre em ambos os sexos em praticantes em frequentadores de academias de ginástica, com maior insatisfação para as mulheres. Indivíduos insatisfeitos com seu corpo correm o risco de auto avaliação negativa quando expostos a imagens idealizadas, sendo que uma percepção errônea da imagem corporal pode comprometer a saúde física e mental do indivíduo. Esse estudo deixa lacunas importantes sobre a adequação de uma escala de silhuetas para praticantes de exercícios físicos em academias de ginástica.

\section{Referências}


DAMASCENO, V. O. et. al. Tipo físico ideal e satisfação com a imagem corporal de praticantes de caminhada. Revista Brasileira de Medicina do Esporte, v. 11, n. 3, 2005.

DAMASCENO, V. O. et. al. Imagem corporal e corpo ideal. Revista Brasileira de Ciência e Movimento, v. 14, n. 2, p. 81-94, 2006.

DAMASCENO, V. O. et. al. Relationship between anthropometric variables and body image dissatisfaction among fitness center users. Revista de Psicología del deporte, n.20, v.2, p.367-82, 2011.

FERMINO, R. C; PEZZINI, M. R; REIS, R. S; Motivos para prática de atividade física e imagem corporal em frequentadores de academia. Revista Brasileira Medicina Esporte, v. 16, n. 1, 2010.

KAKESHITA, I. S; ALMEIDA, S. S; Relação entre índice de massa corporal e a percepção da autoimagem em universitários. Revista Saúde Pública, v. 40, n. 3 p. 497-504, 2006.

MORGADO, F. F. R. et. al. Análise dos Instrumentos de Avaliação da Imagem Corporal. Journal Fitness Performance. v. 8, n. 3, p. 204-11, 2009.

SCHILDER, P. A imagem do corpo: as energias construtivas da psique. 3ed. São Paulo: Martins Fontes; 1999.

SLADE, P. D. Body image in anorexia nervosa. The British journal of psychiatry, v. 2, p. 20-22, 1988.

UCHIDA, M. C. et. al. Manual de musculação: uma abordagem teórico-prática do treinamento de força. São Paulo: Phorte, 2013, 296. 


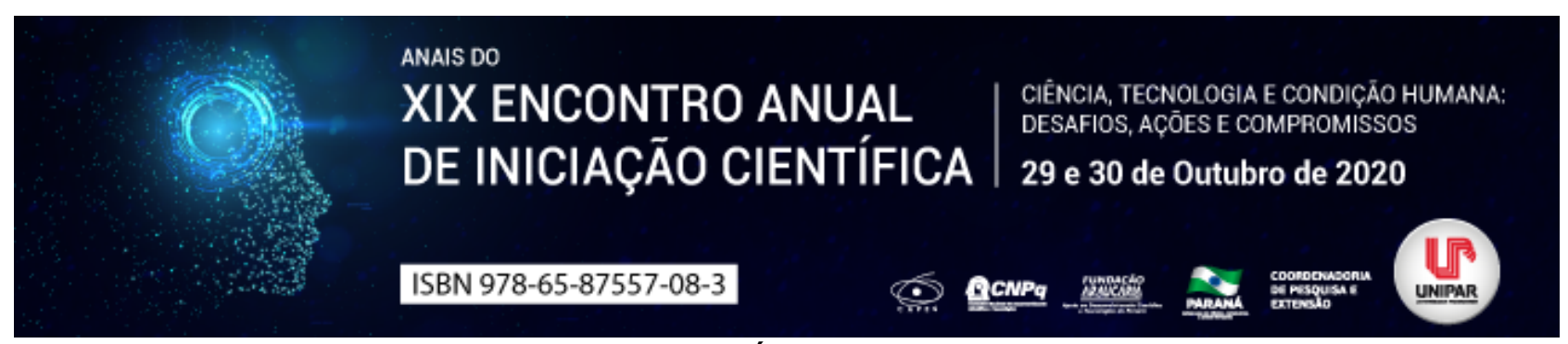

A VIABILIDADE DO AMÁLGAMA NOS DIAS ATUAIS

\title{
${ }^{1}$ YURI DE CARVALHO OLIVEIRA, ${ }^{2}$ ISABELA OUCHITA, ${ }^{3}$ KLISSIA ROMERO FELIZARDO
}

\author{
${ }^{1}$ Acadêmico do Curso de Odontologia da UNIPAR \\ ${ }^{1}$ Acadêmico do Curso de Odontologia da UNIPAR \\ ${ }^{2}$ Docente da UNIPAR
}

Introdução: O amálgama tem sido utilizado como material restaurador na odontologia há mais de 160 anos. Sua composição básica e as técnicas para a aplicação foram cientificamente definidas por Black em 1895. Este material sofreu algumas modificações, com melhorias nas suas propriedades físicas e mecânicas, aumentando a sua durabilidade e êxito nas restaurações. Segundo Burke et al. (2003) a idade média das restaurações com amálgama varia entre 10 a 12 anos, mesmo dependendo de fatores como, higiene oral, suscetibilidade do paciente à cárie, habilidade do clínico e qualidade do material utilizado. O debate sobre a segurança e eficácia do amálgama acontece há muito tempo, mesmo sendo um material que apresenta suas vantagens, que a restauração dura muito mais e que tem um custo significativamente inferior ao das resinas, além disso o potencial de contaminação de pacientes com restaurações de amálgama não chega a 1\%, mas a estética deficiente e sua toxicidade são fatores que fazem com que este material seja cada vez menos utilizado (CESAR, 2014). Tal fato se baseia, principalmente, no risco em potencial do amálgama contaminar o meio ambiente, devido ao seu descarte inadequado.

Objetivo: Este trabalho tem como objetivo relatar por meio de levantamento bibliográfico nas bases de dados LILACS, BIREME, BBO, PubMed e Google Acadêmico, sobre a viabilidade do amálgama atualmente.

Desenvolvimento: Em 1956, foi divulgado o Desastre de Minamata : o despejo criminoso de 27 toneladas de mercúrio na Baía de Minamata, ocasionando a morte de 900 pessoas e lesões graves em outras 2200. A partir deste acontecimento, começou-se um movimento mundial para banir o uso do mercúrio no mundo (NAVARRO, 2015). Em 2013, os representantes de mais de 140 países assinaram a Convenção de Minamata que estabelece: Até 2020 a eliminação do mercúrio em vários materiais (sabonetes, termômetros, medidores de pressão sanguínea, e lâmpadas fluorescentes). As restaurações de amálgama não foram atingidas pela proibição, no entanto, o tratado sugeriu algumas disposições relativas à diminuição gradual de uso na odontologia (NAVARRO, 2015), bem como a orientação correta quanto ao descarte dos resíduos que contêm mercúrio. Os mesmos devem ser recolhidos em recipientes abertos; pequenas quantidades de mercúrio derramadas devem ser recolhidas imediatamente com fita crepe; os recipientes de vidro só devem ser usados para armazenar pequenas quantidades que serão posteriormente transferidas para frascos de plástico rígido com tampa e boa vedação contendo solução à base de água e enxofre, e posteriormente enviado para reciclagem. A preocupação é evitar que o mercúrio impregnado em restaurações seja descartado no meio ambiente (ALCÂNTARA et al., 2015). O problema é que a logística reversa, que obriga o fabricante a coletar e descartar corretamente o material, ainda é incipiente (REZENDE; ROSSI; CLARO,2008) (ALCÂNTARA et al., 2015). Embora exista tecnologia disponível para a reciclagem do amálgama, esta depende do interesse da indústria (SANTOS; DIAS; DOS SANTOS, 2016). Incidentes de alergia verdadeira ao mercúrio são raros e tentativas de vincular seu uso a doenças não foram significativamente comprovadas segundo Shenoy (2008). Halbach et al. (2008) avaliaram a exposição interna ao mercúrio relacionado ao amálgama e estimaram a dose absorvida. O mercúrio integrado absorvido pelas restaurações de amálgama foi estimado em até $3 \mu \mathrm{g}$ por dia para um número médio de restaurações e $7,4 \mu \mathrm{g}$ por dia para uma alta carga de amálgama. Os autores concluíram que essas estimativas estão abaixo da dose tolerável de $30 \mu \mathrm{g}$ por dia estabelecida pela OMS, concluindo que mesmo um paciente com uma alta carga de restaurações de amálgama fica bem abaixo da dose tolerável absorvida. Hoje, apenas $60 \%$ da população mundial tem acesso ao que há de melhor na odontologia (CESAR, 2014). Partindo desse princípio, acredita-se que as restaurações de amálgama continuarão nos próximos anos, principalmente onde a odontologia de qualidade ainda não é realidade, e quando a estética não for uma preocupação (BHARTI et al., 2010).

Conclusão: A continuidade do uso do amálgama acaba sendo um assunto extremamente controverso quando se refere à toxicidade dele, porém no que diz respeito às qualidades clínicas do amálgama, a restauração dura muito mais e tem um custo significativamente inferior ao das resinas, o que facilita o acesso ao tratamento odontológico. O desafio, portanto, é avançar no desenvolvimento de novos materiais restauradores e, também, garantir que eles estejam ao alcance de toda a população, até lá acredita-se que as restaurações de amálgama continuarão nos próximos anos.

\section{Referências}

ALCÂNTARA, lara Cristine Gaspar et al. O futuro do amálgama na prática odontológica: o que o clínico precisa saber. TECNOLOGIA \& INFORMAÇÃO-ISSN 2318-9622, v. 2, n. 2, p. 32-41, 2015.

BHARTI, Ramesh et al. Dental amalgam: An update. Journal of conservative dentistry: JCD, v. 13, n. 4, p. 204, 2010. 
BURKE, Join Trevor. 'Stabilization of ceramic crowns against fracture', AADR 32nd Annual Meeting San Antonio, USA, abstract 1651, 2003.

CESAR, Paulo Francisco. Uso do amálgama no mundo. São Paulo: Usp, p. 5,2014.

NAVARRO, Maria Fidela de Lima. Devemos continuar ensinando amálgama dental? . Responsabilidade pela informação: Grupo Brasileiro de Professores de Dentística, 2015 Disponível em:. Acesso em: 31agosto 2020.

REZENDE, Maria Cristina Rosifini Alves; ROSSI, Ana Cláudia; CLARO, Ana Paula Rosifini Alves. Amálgama dentário: Controle dos fatores de risco à exposição mercurial. Rev. Odontol. Araçatuba, v. 29, n. 2, p.09-13, jul. 2008.

SANTOS, Danielle Tiburcio; DIAS, Katia Regina Hostilio Cervantes; DOS SANTOS, Márcia P. Alves. Amálgama dental e seu papel na Odontologia atual. Revista Brasileira de Odontologia, v. 73, n. 1, p. 64, 2016.

SHENOY, Arvind. Is it the end of the road for dental amalgam? A critical review. Journal of Conservative Dentistry: JCD, v. 11, n. 3, p. 99, 2008.

HALBACH, S. et al. Blood and urine mercury levels in adult amalgam patients of a randomized controlled trial: interaction of Hg species in erythrocytes. Environmental research, v. 107, n. 1, p. 69-78, 2008.

Coordenadoria de Pesquisa e Extensão - COPEX

Departamento de Editoraçāo e Divulgaçāo Científica - DEDIC 


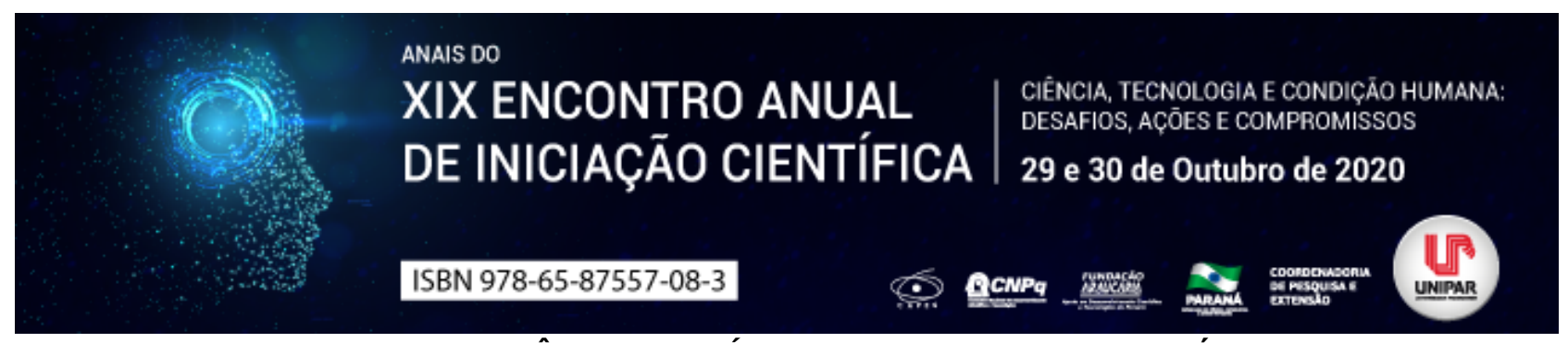

O USO DA VARIABILIDADE DA FREQUÊNCIA CARDÍACA COMO FERRAMENTA PRÉ-INDICATIVA DE DOENÇAS

\author{
${ }^{1}$ MARCELO SERENINI JUNIOR, ${ }^{2}$ ALAN PABLO GRALA, ${ }^{3}$ VITOR HUGO RAMOS MACHADO
}

\author{
${ }^{1}$ Acadêmico do PIC-PÓS/UNIPAR \\ ${ }^{1}$ Docente da UNIPAR \\ ${ }^{2}$ Docente da UNIPAR
}

Introdução: O Sistema Nervoso Autônomo (SNA) possui total influência no equilíbrio fisiológico do corpo humano, mantendo o funcionamento de diversos órgãos, aparelhos e sistemas, permitindo que o mesmo mantenha interação com o meio ambiente. Qualquer ação que estimule o desequilíbrio gera respostas orgânicas involuntárias que visam automaticamente restabelecer o equilíbrio funcional. Essas ações reguladoras automáticas são chamadas de respostas autonômicas, pois é executado pelo SNA através de suas 2 subdivisões o sistema nervoso simpático (SNS) e o sistema nervoso parassimpático (SNP). Praticamente todos os órgãos são controlados pelo SNA para que trabalhem na máxima sintonia possível (PASCHOAL et al., 2006). Algumas técnicas são utilizadas para a avaliação do SNA, a variabilidade da frequência cardíaca (VFC) é uma delas e tem sido muito utilizada devido a sua baixa complexidade, por ser uma medida simples e não invasiva dos impulsos autonômicos, sendo um marcador promissor do balanço autonômico. É uma medida que pode ser utilizada para avaliar o comportamento do SNA em condições diferentes, tais como sono, exercício físico, e também condições patológicas. As alterações nos valores da VFC são indicadores antecipados de comprometimentos a saúde (VANDERLEl et al., 2009).

Objetivo: Descrever a utilização da variabilidade da frequência cardíaca como uma ferramenta indicadora de riscos a doenças resultantes do mau funcionamento do sistema nervoso autônomo.

Desenvolvimento: A variabilidade da frequência cardíaca é caracterizada pelos intervalos entre os batimentos cardíacos, que mostram as mudanças ocasionadas da atuação do sistema nervoso autônomo em relação ao comportamento da frequência. Devido a sua facilidade de utilização e por não ser um método invasivo, a VFC se difundiu, porém o seu entendimento mostrouse mais complexo do que aparenta. Depois de ser padronizada tornou-se uma opção com alto grau de eficiência na mensuração da função autonômica cardíaca em todo tipo de população, desde atletas, indivíduos saudáveis, até portadores de alguma patologia. Alguns dispositivos são necessários para realizar o procedimento de análise da VFC, tais como o eletrocardiograma (ECG), conversores analógicos e cardiofrequêncímetros. O cardiofrequêncímetro vem se destacando devido a sua fácil utilização, baixo custo de manuseio, não invasivo e também por ser de fácil aplicação em estudos de campo, por não necessitar de um ambiente laboratorial para realizar a análise (LOPES et al., 2013). O interesse pela atuação do SNA vem crescendo, pois, vários estudos mostram que alterações autonômicas crônicas possuem ligação com o desenvolvimento de patologias cardiovasculares e aumento do risco de mortalidade (LUNZ et al., 2013). Alguns estudos demonstraram que o ajuste autonômico cardiovascular se mostra alterado em várias doenças que prejudicam o coração. Esse tipo de alteração contribui para o aparecimento de arritmias, tendo um importante papel na morbimortalidade das patologias decorrentes das alterações no sistema simpático-vagal (FILHO; BARBOSA; CORDOVIL, 2002). A capacidade de alterar a frequência dos batimentos cardíacos possui relação com a adaptação momento a momento do sistema cardiovascular quando submetido as mais diversas atividades cotidianas, desde o sono até o exercício (KAWAGUCHI et al., 2007). Uma alta variabilidade é um sinal de que o indivíduo se encontra saudável e possui uma boa capacidade de adaptação, com mecanismos autonômicos eficientes. Uma baixa variabilidade é um indicativo de pouca adaptação autonômica do SNA e mau funcionamento fisiológico do indivíduo (VANDERLEI et al., 2009).

Conclusão: Segundo estudos citados no trabalho, a VFC é uma ferramenta muito utilizada com o intuito de analisar a situação atual do SNA e, consequentemente, obter nortes a respeito da condição patológica do indivíduo. As pesquisas mostram o quanto é importante o papel da VFC no funcionamento do organismo. As respostas obtidas através da análise podem apresentar resultados concretos em relação a saúde cardiovascular de qualquer indivíduo, utilizando ferramentas de menor complexidade.

\title{
Referências
}

FILHO, J. B; BARBOSA, P. R. B; CORDOVIL, I. Modulação autonômica do coração na Hipertensão arterial sistêmica. Arquivos Brasileiros de Cardiologia, v.78, n.2, p.181-188, 2002.

KAWAGUCHI, L. Y. A., et al. Caracterização da variabilidade da frequência cardíaca e sensibilidade do barorreflexo em indivíduos sedentários e atletas do sexo masculino. Revista brasileira de medicina do esporte, v.13, n.4, p.231-236, 2007. LOPES, P. F. F., et al. Aplicabilidade clínica da variabilidade da frequência cardíaca. Revista de Neurociencia, v.21, n.4, p.600$603,2013$.

LUNZ, W., et al. Comparação da resposta autonômica cardiovascular de praticantes de musculação, corredores de longa 
distância e não praticantes de exercício. Revista brasileira de educação física e esporte, São Paulo, v.27, n.4, p.531-541, 2013.

PASCHOAL, M. A., et al. Variabilidade da Frequência Cardiaca em diferentes faixas etárias. Revista Brasileira de Fisioterapia, São Carlos, v.10, n.4, p.413-419, 2006.

VANDERLEI, L. C. M., et al. Noções básicas de variabilidade da frequência cardíaca e sua aplicabilidade clínica. Revista Brasileira de cirurgia cardiovascular, v.24, n.2, p.205-217, 2009.

Coordenadoria de Pesquisa e Extensão - COPEX

Departamento de Editoraçāo e Divulgaçāo Científica - DEDIC 


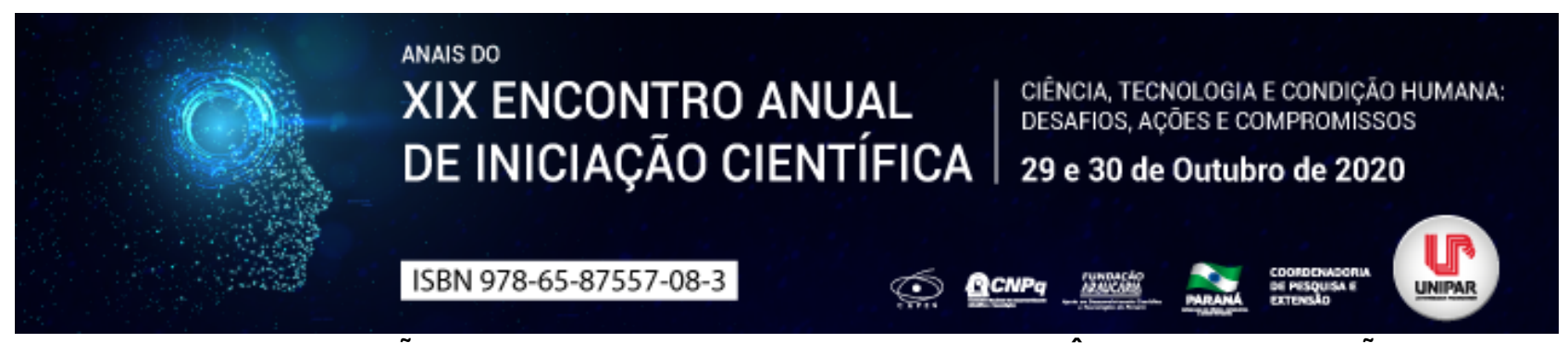

Staphylococcus aureus INFECÇÃO E GENE Mec A COMO FATOR DE RESISTÊNCIA: UMA REVISÃO DE LITERATURA

\author{
${ }^{1}$ ISABELA LINO FERREIRA DA SILVA DIAS, ${ }^{2}$ CAROLINE PINTO ZANI, ${ }^{3}$ ALINE PINTO ZANI, ${ }^{4}$ EDUARDA MARTINS DARMIN, \\ ${ }^{5}$ VINICIUS PEREIRA ARANTES
}

\author{
${ }^{1}$ Acadêmica bolsista PIBIC/UNIPAR \\ ${ }^{1}$ Acadêmica do Curso de Farmácia da UNIPAR \\ ${ }^{2}$ Acadêmica do Curso de Farmácia da UNIPAR \\ ${ }^{3}$ Acadêmica do Curso de Farmácia da UNIPAR \\ ${ }^{4}$ Docente da UNIPAR
}

Introdução: Staphylococus aureus possui visibilidade no âmbito das infecções em detrimento de sua elevada capacidade em obter resistência aos antimicrobianos (MOREIRA, 2013). A espécie que possui maior atenção médica, essencialmente em âmbito nasocomial é S.aureus, essa está diretamente relacionada a inúmeras infecções em seres humanos (SANTOS, 2007). A resistência aos antibióticos trata se de um problema de saúde pública que causa grande preocupação, estando em nível mundial como um dos mais relevantes, esse fator fornece resultados econômicos e clínicos que geram desassossego da parte dos profissionais de saúde e dos líderes políticos. Vale ressaltar que o uso inadequado de antibióticos é uma das principais causas da resistência bacteriana, que vem crescendo de maneira acentuada, estando dentre as bactérias Gram positivas que apresentam maior resistência as antibióticos a espécie S. aureus (LOUREIRO et al., 2016). A metodologia do presente estudo é a pesquisa de revisão e referencial bibliográfico, com abordagem qualitativa com a reunião de materiais acerca do tema.

Objetivo: Analisar o contexto do perfil de resistência de $S$. aureus frente aos antibióticos, por meio de um estudo de revisão bibliográfica com a reunião de materiais levantados em documentos científicos e periódicos.

Desenvolvimento: S.aureus é tido como um patógeno que busca oportunidades e está frequentemente relacionada a infecções que são desenvolvidas no âmbito hospitalar. Comumente tal gênero está intrínseco a microbiota da pele humana, assim como demais sítios anatômicos. A cada novo antibiótico introduzido no tratamento de patologias causadas pela bactéria, tem se o surgimento de cepas de S. aureus resistentes. Vale salientar que a resistência a antibióticos é responsável por problemas econômicos e clínicos, o que está diretamente ligado com a elevação da morbilidade e mortalidade, por conta da tardia administração de tratamentos que são eficazes frente as infecções geradas por bactérias resistentes, como S. aureus. Um longo período de hospitalização e a utilização de divergentes antibióticos elevam fortemente o custo com os cuidados. Questão que também deve ser levada em consideração, por conta da finidade dos recursos do sistema de saúde (LOUREIRO et al., 2016). Assim como a erronea administração de antibioticos e o não cumprimento da posologia receitada, da parte da população que contribuem para o aumento da resistência bacteriana.

Conclusão: Conclui se que o desenvolvimento de resistência frente aos antibióticos expresso por S.aureus está ligado aos métodos abordados na sua antibioticoterapia. Por sua vez, ao compreender o funcionamento patógeno desse agente infeccioso os profissionais da área da saúde são mais bem orientados para administrar sua antibioticoterapia, o que minimiza as oportunidades de seleção de cepas com características resistentes e multirresistentes aos antimicrobianos.

\title{
Referências
}

MOREIRA, Ana; SANTOS, Rosiane; BEDENDO, João. Prevalência e perfil de sensibilidade de sthaphylococus aureus isolados em pacientes e equipe de enfermagem. Cienc Cuid Saude 2013 Jul/Set; 12 (3) 572-579. DOI: 10.4025/cienccuidsaude.v12i3.17609.

LOUREIRO, Rui João et al. O uso de antibióticos e as resistências bacterianas: breves notas sobre a sua evolução. Rev. Port. Sau. Pub. [online]. 2016, vol.34, n.1, pp.77-84. ISSN 0870-9025. Disponível em: http://dx.doi.org/10.1016/j.rpsp.2015.11.003. Acesso em: 12, agosto de 2020.

SANTOS, André; SANTOS, Dilvani; FREITAS, Cícero; FERREIRA, Bruno; AFONSO, Ilídio; RODRIGUES, Calos; CASTRO, Helena. Staphylococcus aureus: visitando uma cepa de importância hospitalar. J Bras Patol Med Lab v. 43 n. 6. p. $413-423$. Dezembro 2007. Disponível em: https://www.scielo.br/pdf/jbpml/v43n6/v43n6a05.pdf. Acesso em: 10, agosto de 2020. 


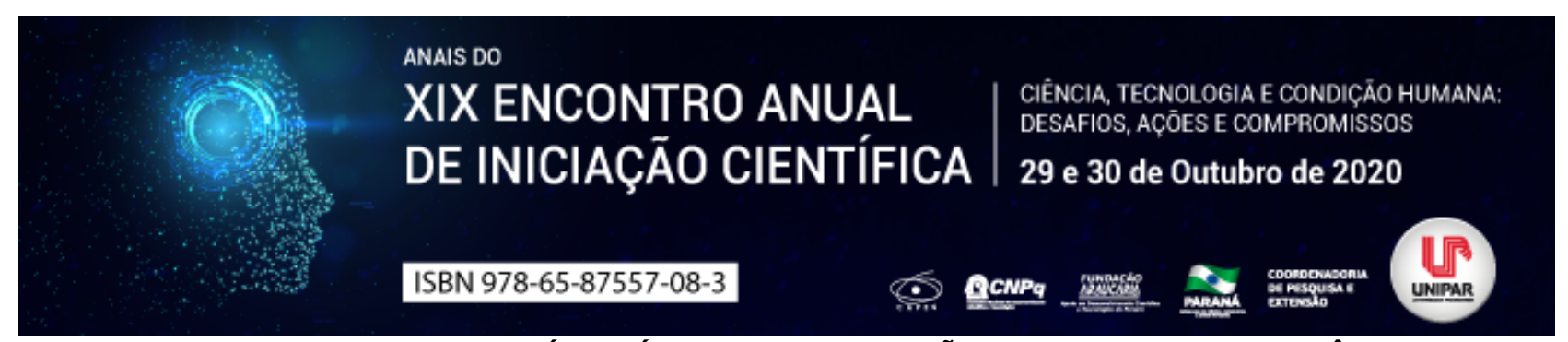

EFEITOS DE PROGRAMAS DE EXERCíCIO FÍSICO NA PREVENÇÃO E TRATAMENTO DO CÂNCER DE MAMA

\begin{abstract}
1JOSE PEDRO PAES DALAZOANA, ${ }^{2}$ MARIA IDALINA CLEMENTE MARQUES CASSIDORI, ${ }^{3}$ CARLOS BARKLEY DA SILVA PEREIRA, ${ }^{4}$ VITOR HUGO RAMOS MACHADO
\end{abstract}

\author{
${ }^{1}$ Acadêmico do PIC/UNIPAR \\ ${ }^{1}$ Acadêmica do Curso de Educação Física da UNIPAR \\ ${ }^{2}$ Acadêmico do Curso de Educação Física da UNIPAR \\ ${ }^{3}$ Docente da UNIPAR
}

Introdução: $O$ câncer é o nome atribuído a um conjunto de centenas doenças que têm em comum as células crescendo desordenadamente, que invadem nosso organismo. Em uma forma muito agressiva invadem nosso organismo podendo desenvolver tumores (INCA, 2020). A partir de uma mutação genética o câncer se desenvolve, e as células que compõe nosso organismo começam a receber informações erradas. No início dessa mutação provocando as primeiras modificações dos genes não é possível identificar clinicamente, só quando ela está bem proliferada é possível detectá-la (INCA, 2020). Existem vários tipos de câncer que podem se desenvolver por toda parte do nosso corpo mais ou menos agressivos, alguns malignos e outros, com uma identificação precoce, podem ser tratados (OMS, 2020). Quanto ao câncer de mama, desde a década de 70 a medicina tem se dedicado mais ao impacto psicossocial da doença. Estudos dessa época delinearam que as mulheres sofrem desconforto psicológico como depressão e raiva, mudanças de padrão de vida, relacionados ao casamento, vida sexual e atividades no trabalho e ainda medos, preocupações concernentes à mastectomia, recorrência da doença e morte (MEYEROWITZ, 1980). O câncer de mama acontece por conta de uma desordem nas células da mama, que evoluem de diferentes formas, alguns crescem mais rapidamente e outros mais lentamente (INCA, 2020). É estimado que para cada ano até 2022, sejam diagnosticados mais de 66 mil novos casos de câncer de mama no Brasil (INCA, 2020). O sedentarismo pode estimular o desenvolvimento do câncer e como pode ser um inimigo no tratamento. Tendo isso podemos entender assim que o exercício físico pode ser um grande auxílio para prevenção e auxílio para o tratamento (NASCIMENTO; LEITE; PRESTES, 2011).

Objetivo: Essa pesquisa tem como objetivo, investigar os efeitos de programas de exercício físico na prevenção e tratamento de mulheres portadoras do câncer de mama.

Desenvolvimento: Uma a cada 6 mortes do mundo é relacionada ao câncer, sendo assim a segunda maior causa de morte no mundo atualmente. Aproximadamente um terço dessas mortes estão relacionada ao alto índice de massa corporal, baixo consumo de frutas e vegetais, falta de atividade física e uso de álcool e tabaco (OPAS/OMS, 2020). Os exercícios durante o tratamento oncológico para pacientes com câncer de mama, apresentam uma tendência mais favorável para o alívio dos déficits na capacidade funcional, níveis de fadiga e depressão, e também suportam melhor as prescrições de exercícios comparado com aqueles que não se exercitam (SILVA et.al.,2018). Tendo isso as atividades físicas são aconselhadas para esses pacientes, os oncologistas estão em posição fundamental para oferecer essas atividades (FISHER et.al., 2015). Nos últimos 20 anos, houve um crescimento de estudos na comunidade científica, em busca de entender os efeitos dos programas de exercícios físicos durante e após o tratamento de câncer obtendo respostas em direção ao melhoramento do condicionamento físico, manutenção da aptidão cardiorrespiratória, fadiga e força (BUFFART et al., 2018). Uma revisão sistemática demonstrou que a realização do treinamento anaeróbio combinado com treinamento aeróbico, duas a três vezes por semana é seguro e benéfico para mulheres com câncer de mama, resulta em melhoras funcionais, psicológicas e clínicas (CHEEMA et al., 2007) . Dietrich e Miranda(2005) apontaram revisão efetuada por Courneya et al.(2002), esses resultados coletados em mais de 40 estudos, que investigaram a prática da atividade física e a qualidade de vida dos sobreviventes ao câncer e mostraram que a atividade física tanto durante a quimioterapia e radioterapia, quanto no pós tratamento, apontou benefícios positivos na qualidade de vida com melhorias na aptidão, melhorias na composição corporal e redução da fadiga, bem como melhorias do estado de humor, tais como depressão e ansiedade, entre outros,. Destaca-se que o exercício físico no período do tratamento, pode auxiliar na ativação de mecanismos biológicos, aumentar enzimas atuantes nos radicais livres e nas células Natural Killer, as quais podem dificultar a formação de tumor. A ativação do sistema imunológico consequentemente fará com que o organismo se torne menos vulnerável a outras doenças, o que fatalmente implicará seu quadro clínico (PEDROSO et al., 2005). Segundo o estudo de SIMÕES (2019) apesar da baixa adesão das mulheres com câncer de mama à atividade física, elas têm uma boa percepção sobre a importância de se realizar atividade física para o tratamento do câncer de mama. Confirmando com a ideia de que uma intervenção por meio de uma atividade física além de segura, é também benéfica às mulheres acometidas por câncer de mama.

Conclusão: Os resultados do presente estudo apontaram efeitos positivos quanto ao tratamento com exercícios físicos em mulheres com câncer de mama durante e após o tratamento. Entretanto é necessário estabelecer qual o melhor tipo de exercício, 
respeitando-se os princípios como: individualidade, tipo, intensidade, frequência e duração do exercício. Conforme o presente estudo, treinamentos combinados de força e aeróbio foram bem tolerados pelos pacientes, melhorando seu condicionamento físico, fadiga, força, flexibilidade, além de ter contribuído também na melhora do aspecto psicológico.

\section{Referências}

BATTAGLINI, C. et al. Atividade física e níveis de fadiga em pacientes portadores de câncer. Revista Brasileira de Medicina do Esporte, São Paulo, v. 10,n. 2, p. 98-104, 2004.

BRASIL. INSTITUTO NACIONAL DO CÂNCER. . Como surge o câncer? 2019. Disponível em: https://www.inca.gov.br/comosurge-o-cancer. Acesso em: 06 jun. 2020.

BRASIL. INSTITUTO NACIONAL DO CÂNCER. . O que é câncer? 2019. Disponível em: https://www.inca.gov.br/o-que-e-cancer. Acesso em: 06 jun. 2020.

BRASIL. INSTITUTO NACIONAL DO CÂNCER. . Tipos de câncer: câncer de mama. Câncer de mama. 2020. Disponível em: https://www.inca.gov.br/tipos-de-cancer/cancer-de-mama. Acesso em: 25 jul. 2020.

BRASIL. MINISTÉRIO DA SAðDE. . Câncer: sintomas, causas, tipos e tratamentos. Disponível em: http://www.saude.gov.br/saude-de-a-z/cancer. Acesso em: 10 jun. 2020.

BUFFART, Laurien M, et al. Targeting Exercise Interventions to Patients With Cancer in Need: Na Individual Patient Data MetaAnalysis. JNCl: Journal of the National Cancer Institute. v. 110, n.11, p.1190-1200, Nov 2018. Disponível em: https://doi.org/10.1093/jnci/djy161. Acesso em: 10 nov. 2018.

CHEEMA, B. et al. Progressive resistance training in breast cancer: a systematic review of clinical trials. Breast Cancer Research and Treatment, Secaucus, v. 109, no.1, p. 9-26, 2007.

DE BACKER, I. et al. High-intensity strength training improves quality of life in cancer survivors. Acta Oncologica, Stockholm, v. 46, no. 8, p. 1143-1151, 2007.

DE BACKER, I. et al. High-intensity strength training improves quality of life in cancer survivors. Acta Oncologica, Stockholm, v. 46, no. 8, p. 1143-1151, 2007.

Diettrich SHC, Miranda CRR. Atividade física e os efeitos colaterais de tratamento do câncer. Revista Agora 2005;01(4), Disponível em: Acesso em: 04 agosto 2011. Dimeo F, Schwartz S, Fietz

FISHER, A.; et al. Recall of physical activity advice was associated with higher levels of physical activity in colorectal cancer patients. BMJ Open, v. 5, n . 4, 2015.Disponível em: 10.1136/bmjopen-2014-006853. Acesso em: 15 ago. 2018.

Pedroso W, Araújo MB, Stevanato E. Atividade física na prevenção e na reabilitação do câncer. Motriz 2005;11(3):155---60.

SILVA, D. A.; et al. Mortality and years of life lost due to breast cancer attributable to physical inactivity in the Brazilian female population (1990 2015). Scientific Reports, v.8, jul. 2018. Disponível em: https://www.nature.com/articles/s41598-018-29467-7. Acesso em: 15 ago. 2020.

SIMÕES, A. et al. Revista Brasileira de Prescrição e Fisiologia do Exercício, São Paulo. v.1 3 . n. 8 7 . p. 1292-1298. Suplementar 1.2019.ISSN 1981-9900 


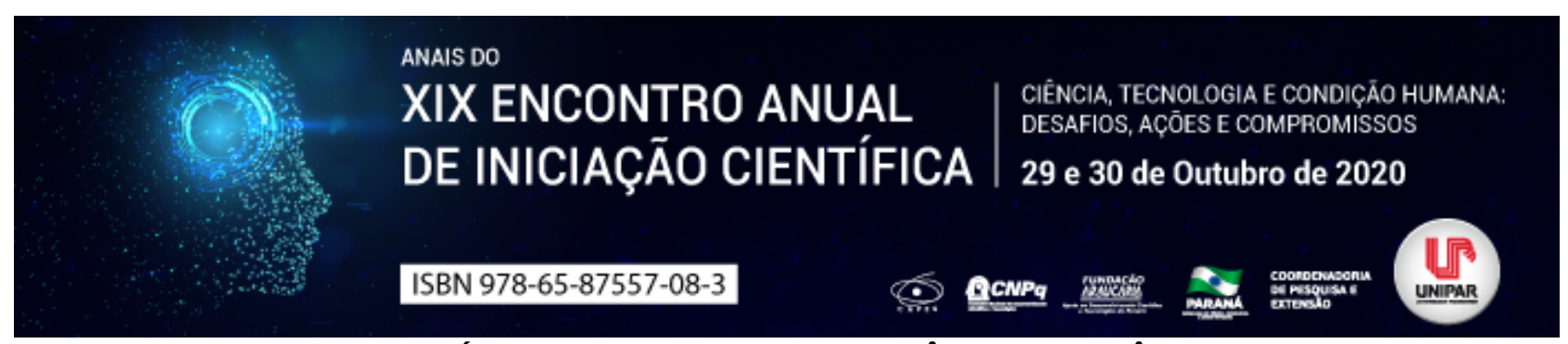

ESTUDO DA PROTEÍNA TCTP COMO ALVO TERAPÊUTICO EM CÂNCER DE MAMA

\section{${ }^{1}$ Antonielle Beatriz Baldissera, ${ }^{2}$ JEAN SILVA DE SOUZA, ${ }^{3}$ MAURO ANTÔNIO ALVES CASTRO, ${ }^{4}$ ANDREA SENFF RIBEIRO}

${ }^{1}$ Doutoranda Programa de pós graduação em Biologia Celular e Molecular- bolsista CAPES

${ }^{1}$ Mestrando Programa de pós graduação em Bioinformática- bolsista

${ }^{2}$ Docente do Programa de Pós graduação em Bioinformática- UFPR

${ }^{3}$ Docente do Programa de Pós graduação em Biologia Celular e Molecular- UFPR

Introdução: A proteína Translationally controlled tumor protein (TCTP) apresenta diversas funções celulares, está associada ao processo de reversão tumoral e é considerada como alvo molecular no câncer (TUYNDER et al., 2002). A TCTP apresenta-se altamente expressa nas células tumorais quando comparada com tecidos normais. Sertralina é um antidepressivo amplamente utilizado, destaca-se pela capacidade de diminuir a expressão da TCTP, e por estar relacionada com atividade antiproliferativa in vitro em células de tumor de mama (MDA-MB-231) (TUYNDER et al., 2004). O câncer de mama é destacado pela alta incidência entre mulheres no mundo (STEWARD; WILD,. 2014). Estes tumores são altamente heterogêneos e são subdivididos em subtipos, dos quais sobressaem o luminal A, luminal B, HER2+, triplo negativos (TNBC, triple negative breast cancer) e os normal-like. Neste trabalho, aprofundamos a compreensão do papel biológico da TCTP em diferentes subtipos de tumores de mama. O entendimento da resposta das linhagens celulares frente ao tratamento com sertralina, pode gerar novas perspectivas sobre o comportamento desses tumores, além de avaliar a droga como possível estratégia terapêutica em tumores de mama.

Objetivo: O objetivo do trabalho foi aprofundar a compreensão do papel biológico da TCTP em diferentes subtipos de tumor de mama.

Material e Métodos: Cultivamos as linhagens de mama MCF7 (luminal A), PMC42 (normal-like), SKBR3 (HER2+) e MDA-MB231 e MDA-MB-436 (triplo negativas) utilizando meio de cultura RPMI suplementadas com $10 \%$ de soro fetal bovino. Para realização dos experimentos, tratamos as células com sertralina $(0.1 \mu \mathrm{M}, 1 \mu \mathrm{M}, 5 \mu \mathrm{M}$ e $10 \mu \mathrm{M})$ e para o controle utilizamos somente meio de cultivo e DMSO. Determinamos o nível da proteína TCTP através da imunodetecção (western-blotting). Avaliamos a viabilidade celular através de luminescência (cell titer glo) e fizemos o ensaio de clonogenicidade em meio semisólido. Para avaliar a capacidade de migração das linhagens, fizemos o ensaio de migração celular, através do método scratch. Fizemos o download das contagens normalizadas em FPKM e dados clínicos das amostras de câncer de mama do projeto TCGA.

Resultados: A sertralina diminuiu os níveis de TCTP e apresentou efeitos antitumorais em todas as linhagens estudadas. As linhagens MCF7 e PMC42 foram bastante sensíveis ao tratamento, com grande diminuição das características fenotípicas tumorais. A linhagem SKBR-3 apresentou redução significativa na viabilidade celular e nos níveis de TCTP. Observamos uma significante diminuição da migração e da clonogenicidade celular para as linhagens MDA-MB231 e MDA-MB-436, representantes do subtipo triplo negativo. As análises mostraram maior expressão do gene que codifica a proteína TCTP, tpt1, nos subtipos luminal $A$ e normal-like e menor expressão no subtipo luminal B.

Discussão: Tuynder et. al. (2004) já havia demonstrado a ação da sertralina na diminuição dos níveis de TCTP em linhagens celulares, como de mama (MDA-MB-231) e em leucemia monocítica (U937). Nosso trabalho, mostrou que todas as linhagens apresentaram diminuição nas características de malignidade e nos níveis da proteína. Destacamos os resultados obtidos com o tratamento com sertralina da linhagem PMC42, que apresenta características de célula tronco tumoral. As linhagens do subtipo basal, que apresentam fenótipo agressivo e são pouco responsivas aos tratamentos disponíveis, também demonstraram diminuição nas características tumorais, apesar de serem menos sensíveis ao tratamento com sertralina quando comparado com as outras linhagens. Além disso, a expressão da TCTP em 508 biópsias de mama já foi correlacionada com parâmetros clínicos e patológicos de doença agressiva nos tumores de mama (AMSON et al., 2012). Portanto, os resultados obtidos evidenciam os efeitos da sertralina e da inibição da proteína TCTP nas diferentes linhagens de tumor de mama. Portanto, sugere-se que o uso da sertralina, combinada com as estratégias terapêuticas atuais em câncer de mama, é uma possibilidade terapêutica promissora. Especialmente naqueles subtipos menos responsivos clinicamente e com grande chance de resistência, como os triplo-negativos.

Conclusão: Os resultados obtidos no trabalho corroboram com dados da literatura que apontam a TCTP como alvo terapêutico e a sertralina como estratégia clínica possível e interessante para superar as dificuldades de resistência clínica. Em todas as linhagens tratadas observa-se o nítido efeito do tratamento de sertralina sobre as células, indicando que o uso desta, junto com quimioterápicos específicos, pode ser de grande auxílio no tratamento do câncer. 


\section{Referências}

Amson, R.; Pece, S.; Lespagnol, A.; Vyas, R.; Mazzarol, G.; Tosoni, D.; Colaluca, I.; Viale, G.; Rodrigues-Ferreira, S.; Wynendaele, J.; Chaloin, O.; Hoebeke, J.; Marine, J.C.; Di Fiore, P.P.; Telerman, A. Reciprocal repression between P53 and TCTP. Nature medicine, v. 18, p.91 99. 2012.

Steward, B. W.; Wild, C. P. (Ed.) World Cancer Report. Lyon: International Agency for Research on Cancer; Geneva: World Health Organization, 2014.

Tuynder, M.; Susini, L.; Prieur, S.; Besse, S.; Fiucci, G.; Amson, R.; Telerman, A. Biological models and genes of tumor reversion: Cellular reprogramming through tpt1/TCTP and SIAH-1. Proceedings of the National Academy of Sciences, v. 99, p. 1497614981. 2002.

Tuynder, M.; Fiucci, G.; Prieur, S.; Lespagnol, A.; G'eant, A.; Beaucourt, S.; Duflaut, D.; Besse, S.; Susini, L.; Cavarelli, J.; Moras, D.; Amson, R.; Telerman, A. Translationally controlled tumor protein is a target of tumor reversion. Proceedings of the National Academy of Sciences, v. 101. n. 43. 2004.

Coordenadoria de Pesquisa e Extensão - COPEX

Departamento de Editoraçāo e Divulgaçāo Científica - DEDIC 


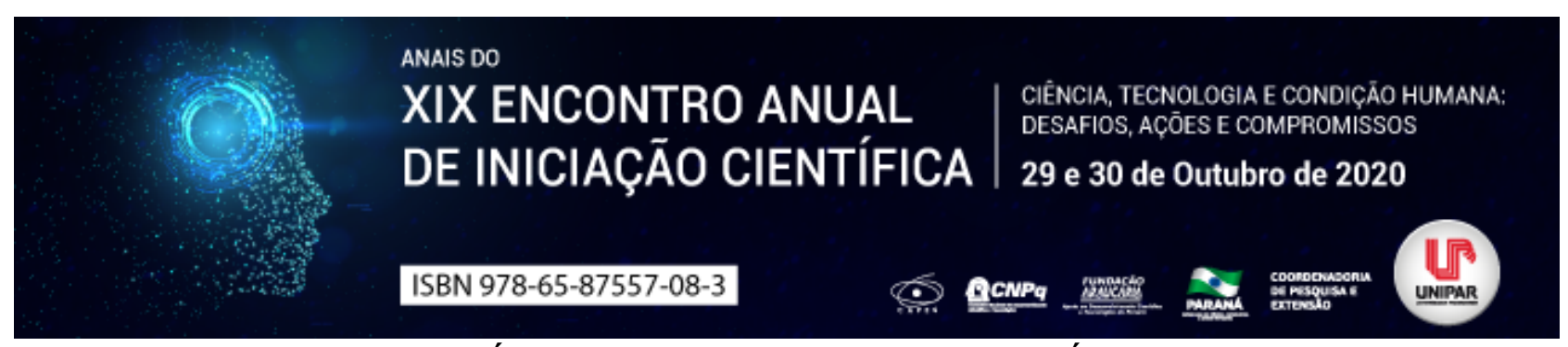

MEMÓRIA DE RNA: APANHADO BIBLIOGRÁFICO

\title{
${ }^{1}$ JULIANA JURUMENHA BARRETO, ${ }^{2}$ ANDERSON FELIPE FERREIRA
}

\author{
${ }^{1}$ Acadêmico da UNIPAR \\ ${ }^{1}$ Docente da UNIPAR
}

Introdução: As hipóteses sobre o armazenamento da memória angariaram novas teorias, a partir de experimentos, trabalhando com possibilidade de que o RNA do cérebro e a síntese de proteínas, estarem diretamente envolvidas no estabelecimento da memória de longo prazo, tendo em vista a alta capacidade de integração multidisciplinar envolvida no tema da memória, atrelada a diversas áreas do conhecimento. Tendo como objetivo entender a identificação da célula Engrama, célula responsável pela memória de longo prazo, em uma primeira tentativa científica, os pesquisadores afirmam ter transferido memórias entre caracóis do mar, injetando RNA de um caracol treinado em um que não tenha sido treinado - e observando a resposta no segundo caracol (CARNEY, 2018).

Objetivo: Apresentar novos conhecimentos a respeito da transmissão de memória por RNA, explorados em estudos recentes com caracóis marinhos, por meio de pesquisas bibliográfica em revistas acadêmicas científicas disponíveis on-line, com o uso das palavras-chave: RNA, Memória, síntese proteica na formação da memória.

Desenvolvimento: Se faz continuo a busca para entender como funciona a manutenção de memória nos seres vivos. Após diversos estudos, pesquisadores chegaram a um consenso de que os Engramas (unidade de informação cognitiva dentro do cérebro, o qual preserva lembranças) tem papel fundamental nos estudos realizados acerca do tema (TONEGAWA et al, 2015). Desde meados de 1920 até o presente, os experimentos ligados às pesquisas são subdivididos em categorias distintas, sendo: experimentos observacionais estudos analíticos têm mostrado que existe uma similitude entre certas atividades da amostra de células estudada e a expressão de conduta de memórias específicas -, de perda de função - Inquirições sobre perda de função mostraram que uma determinada população de neurônios é crucial para a expressão comportamental de memórias específicas

(TONEGAWA et al, 2015) e de ganho de função pesquisas sobre aprimoramento funcional mostram que a ativação de uma determinada população de neurônios é suficiente para expressar a memória comportamental (LASHLEY, 1950). O papel do RNA sob a memória já é discutido a algum tempo, sendo questionado a sua relevância em mamíferos (ALBERT, 1966). Recentemente, os pesquisadores aplicaram leves choques elétricos nas caudas de uma espécie de caracol marinho da espécie chamada Aplysia (BÉDÉCARRATS et al, 2018). Neste experimento o intuito era avaliar a relação da memória a longo prazo com a sinapse, pois, em pretérito era sabido da sua relação. Assim, após os traumas aferidos aos caracóis, poderia ser avaliado a fonte da memória de longo prazo. Os caramujos receberam cinco choques na cauda, um a cada 20 minutos, e depois mais cinco, 24 horas depois. Os choques aumentam o reflexo de retirada defensiva do caracol, uma resposta que ele exibe para proteção contra possíveis danos. Quando os pesquisadores subsequentemente tocaram os caracóis, eles descobriram que aqueles que sofreram os choques, exibiram uma contração defensiva que durou cerca de 50 segundos, enquanto aqueles que não receberam os choques, contraíram apenas cerca de um segundo. Os caracóis chocados tinham sido l"sensibilizadosl" para o estímulo. Após isso, os caracóis que receberam a transfusão de RNA, demostraram tempo de reação similar aos caracóis que haviam sofrido traumas. Essa espécie específica foi escolhida pelo número de neurônios ser limitado a 20.000, tornando o mapeamento e controle do mapa neural mais fácil. Tais pesquisas sugerem que, é possível que essas mudanças representem apenas uma produção aumentada de macromoléculas constitutivas em resposta a um aumento no metabolismo cerebral durante o treinamento, em vez de mudanças moleculares que estão diretamente envolvidas na modificação da conectividade sináptica (RAINBOW, 1979). As memórias são fortemente influenciadas por apelo sinestésico, experiências físicas e até mesmo, conforme no experimento, traumas (NAINAR et al, 2016). O conceito de armazenamento de memória no núcleo é altamente controverso para a hipótese dominante de longa data do armazenamento de memória sináptica. Contudo, conhecer o substrato neural é crucial para aplicações terapêuticas da manipulação da memória em doenças como Alzheimer, por exemplo. Se a hipótese de CARNEY (CARNEY, 2018) de que o RNA poderia ter impacto no armazenamento de memória em humanos for confirmada, isso poderia representar um tremendo potencial para tratamentos para combater a perda de memória ou aumentar a supressão de memória (KONTOYIANNIS,2018).

Conclusão: Com esses estudos, ganha-se um suspiro em relação as capacidades de controle das doenças neurodegenerativas, além das possibilidades de refinar a qualidade da melhora, não só para fins farmacológicos, mas também em matéria de ensino e pesquisa de traumas psicológicos. Sendo assim, a dimensão de tal hipótese ainda não pode ser mensurada, de modo que, se torna inevitável, a indagação de o quão longe o controle de memórias poderia impactar, não somente as vidas de acometidos por doenças, mas também, no trato de traumas, e a partir de uma ótica genética, a possibilidade de memórias serem passadas de pais para filhos. 


\section{Referências}

ALBERT, D. J. Memory in mammals: Evidence for a system involving nuclear ribonucleic acid. Revista Neuropsychologia, 4, $\mathrm{n}$. 1, p. 79-92, 1966.

BÉDÉCARRATS, A.; CHEN, S.; PEARCE, K.; CAI, D. et al. RNA from Trained Aplysia Can Induce an Epigenetic Engram for Long-Term Sensitization in Untrained Aplysia. Revista eNeuro, 5, n. 3, p. 18-38, 2018.

CARNEY, R. S. An Emerging Role for RNA in a Memory-Like Behavioral Effect in Aplysia. Revista eNeuro, 5, n. 3, May-Jun, 2018.

KONTOYIANNIS, D. L. An RNA checkpoint that keeps immunological memory at bay. Revista Nature Immunology, 19, n. 8, p. 795-797, 2018.

LASHLEY, K. S. In search of the engram. In: Physiological mechanisms in animal behavior. (Society's Symposium IV.). Revista American Psychological Association, n. 4, p. 454-482, 1950.

NAINAR, S.; MARSHALL, P. R.; TYLER, C. R.; SPITALE, R. C. et al. Evolving insights into RNA modifications and their functional diversity in the brain. Revista Nature Neuroscience, 19, n. 10, p. 1292-1298, Sep 27, 2016.

RAINBOW, T. C. Role of RNA and protein synthesis in memory formation. Revista Neurochemical Research, 4, n. 3, p. 297312, Jun, 1979.

TONEGAWA, S.; MORRISSEY, M. D.; KITAMURA, T. The role of engram cells in the systems consolidation of memory. Revista Nature Reviews Neuroscience, 19, n. 8, p. 485-498, 2018.

TONEGAWA, S.; LIU, X.; RAMIREZ, S.; REDONDO, R. Memory Engram Cells Have Come of Age. Revista Neurochemical Research, 87, n. 5, p. 918-931, 2015. 


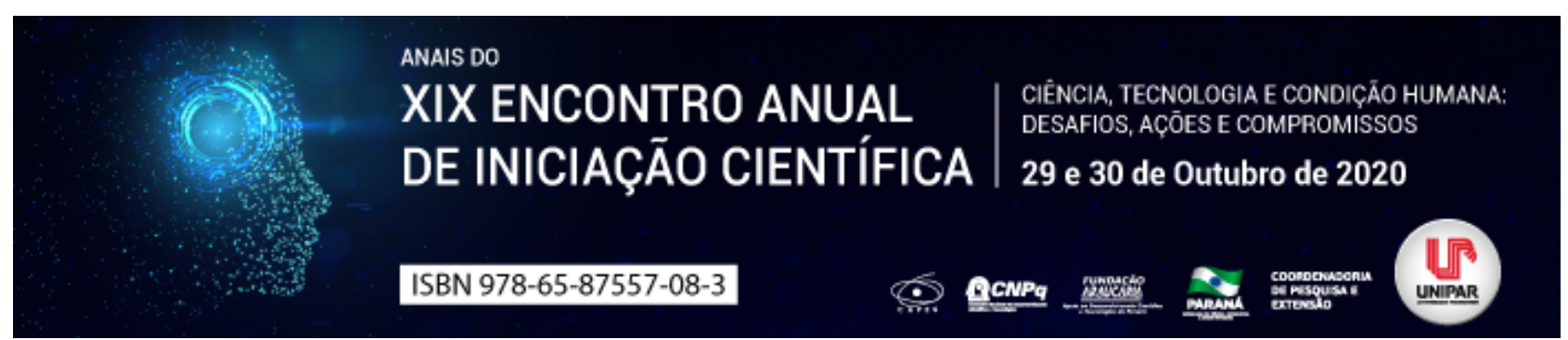

A HIDROTERAPIA NA RECUPERAÇÃO DO EQUILÍBRIO E PREVENÇÃO DE QUEDAS EM IDOSOS

\title{
${ }^{1}$ GABRIEL LUIZ DA SILVA, ${ }^{2}$ THIAGO ARTONI SERRATO, ${ }^{3}$ VITOR HUGO RAMOS MACHADO
}

\author{
${ }^{1}$ Acadêmico do Curso de Educação Física da UNIPAR \\ ${ }^{1}$ Acadêmico do Curso de Educação Física da UNIPAR \\ ${ }^{2}$ Docente da UNIPAR
}

Introdução: Nos primórdios, a hidroterapia era vista como um meio de relaxamento, alívio de estresse etc., mas com o passar dos anos essa técnica foi se aperfeiçoando e tendo suas inúmeras possibilidades de tratamento de lesões. A hidroterapia veio para mostrar o quão importante a água ajuda no tratamento das lesões, por não ter impactos auxilia na regeneração e recuperação dos movimentos (CAROMANO, NOWOTNY, 2002). Existem diversas formas de se usar a água como elemento terapêutico. O termo hidroterapia engloba todas elas, mas podem ser diferenciadas algumas formas distintas de utilização da água em processos profiláticos ou terapêuticos, tais como: Hidroterapia por via oral; Balneoterapia; Duchas quentes, frias ou mornas; Compressas úmidas; Crioterapia; Talassoterapia; Fangoterapia; Crenoterapia; Saunas (BIASOLI, et al, 2006). A hidroterapia não só proporciona relaxamento, auxilia no fortalecimento muscular, proporciona liberdade de movimentos e assim melhora o desenvolvimento muscular. Embora a hidroterapia não fosse considerada tão importante, hoje em dia vemos que as propriedades que a água proporciona ao indivíduo, tem nos mostrados resultados excelentes não só no tratamento de lesões, mas sim no bem estar que ela vem nos proporcionar (CAROMANO, NOWOTNY, 2002).

Objetivo: Investigar a influência da hidroterapia na recuperação do equilíbrio e prevenção de quedas em idosos.

Desenvolvimento: $\mathrm{Na}$ atualidade, as quedas se tornaram um dos maiores problemas de saúde pública em idosos, devido ao aumento da morbidade, mortalidade e custos para a família e a sociedade. Os principais fatores de risco para quedas nessa população estão relacionados à limitação funcional, história de quedas, aumento da idade, fraqueza muscular, uso de medicamentos psicotrópicos, riscos ambientais e sexo feminino (RESENDE, et al, 2008). Fatores que aumentam o risco de quedas na velhice podem ser vários, como a perda de massa muscular, artrite, problemas de visão, pressão arterial, diminuição do equilíbrio, dentre outros. Os perigos no entorno como iluminação inadequada, tapetes soltos, pisos escorregadios, móveis e objetos pelo caminho, calçadas desniveladas são condições que aumentam probabilidade de quedas, sendo que a maior parte delas ocorre dentro das casas (BOLONEZI, 2018). Os exercícios de fortalecimento com paciente submerso estão fundamentados nos princípios físicos da hidrostática, que permitem gerar resistência multidimensional constante aos movimentos. Essa resistência aumenta proporcionalmente à medida que a força é exercida contra ela, gerando uma sobrecarga mínima nas articulações (SILVA, SILVA, 2015). Após um tombo, lesões leves, fraturas, perda de consciência, traumatismo crânio encefálico, necessidade de hospitalização e aumento da incidência de complicações e morte são passíveis de acontecer (SERRA, 2013). Devido ao grande aumento de lesões, ressalta-se a relevância de assegurar aos idosos não somente longevidade, mas também uma boa qualidade de vida (QV). Para isso, deve realizar atividades que mantenham em funcionamento o seu sistema neuromotor, tais como mobilidade, alimentação, vestuário e atividade física, mantendo-se uma pessoa independente e autônoma (SALICIO, et al, 2018). A multiplicidade de sintomas como dor, fraqueza muscular, déficit de equilíbrio, obesidade, doenças articulares, desordens na marcha, dentre outras, dificultam a realização dos exercícios em solo por idosos, ao contrário dos exercícios realizados no meio aquático, onde há diminuição da sobrecarga articular, menor risco de quedas e de lesões (RESENDE, et, al, 2008). As mulheres caem mais que os homens, no entanto, as possíveis causas para explicar esse fenômeno permanecem pouco esclarecidas e controversas. Sugere-se, como causa, a maior fragilidade das mulheres em relação aos homens, assim como a maior prevalência de doenças crônicas. Suspeita-se ainda que pode estar relacionado à maior exposição às atividades domésticas pelas mulheres, ao contrário dos homens, resultando em um comportamento de maior risco. Para Fried et al, (2001), o sexo feminino poderia conferir um risco maior de fragilidade pelo fato da quantidade de massa magra e força muscular ser menor que nos homens da mesma idade (RESENDE, 2007). Diante disso atividades aquáticas auxiliam na melhora osteomuscular auxiliando na recuperação de idosos com déficit de equilíbrio, devido às características da água como viscosidade, temperatura, pressão hidrostática e a flutuabilidade que desaceleraram os movimentos, aumentando a confiança do indivíduo a se desafiar além de seus limites (SALICIO, et al, 2018).

Conclusão: Diante disso concluímos que a prática da hidroterapia resulta em uma melhora significativa no que se diz respeito ao equilíbrio e ao fortalecimento muscular para idosos trazendo assim mais segurança, confiança em si mesmo e em seus movimentos, diminuindo muito a gravidade de uma lesão causada por uma perda de equilíbrio por exemplo.

\section{Referências}

BIASOLI, Hidroterapia: aplicabilidades clínicas, Disponível em: Acesso em 22 junho, 2020. 
BOLONEZI, J. Quedas em idosos: um problema de saúde pública. Disponível em: Acesso em: 24, agosto. 2020.

CAROMANO, NOWOTNY, Princípios Físicos que fundamentam a hidroterapia, Disponível em: > Acesso em: 23 agosto, 2020.

RESENDE, hidroterapia na recuperação do equilíbrio em idosos, Disponível em: Revista Brasileira de Ciência e Movimento, Acesso em: 24, agosto 2020.

RESENDE, Novo protocolo de hidroterapia na recuperação do equilíbrio e prevenção de quedas em idosas, Disponível em Acesso em: 26, agosto 2020.

REZENDE SM, efeitos da hidroterapia na recuperação do equilíbrio e prevenção de quedas em idosas. Disponível em: Revista Brasileira de Fisioterapia, Acesso em: 25, agosto 2020.

SALICIO, et, al, hidroterapia como recurso para melhora da qualidade de vida de idosos, Disponível em: , Revista Inspirar edição 48, Acesso em: 24, agosto 2020.

SERRA, J.N. Quedas de idosos representam um grave problema de saúde pública. Disponível em:. Acesso em: 20 agosto, 2020. 


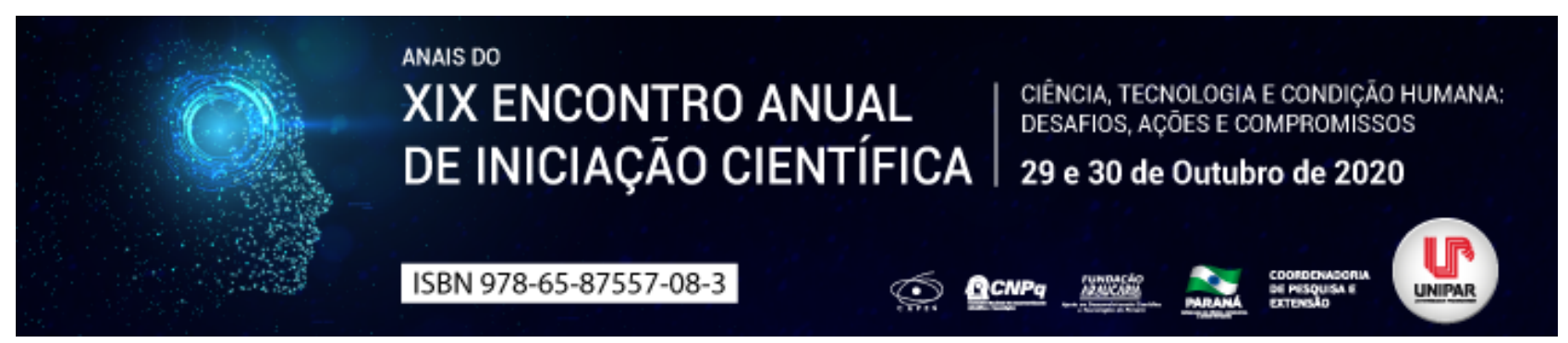

PERFIL DE SENSIBILIDADE DE ISOLADOS AMBIENTAIS DE Staphylococcus aureus FRENTE A ANTIMICROBIANOS DE USO PADRÃO

${ }^{1}$ ISABELA LINO FERREIRA DA SILVA DIAS, ${ }^{2}$ ALINE PINTO ZANI, ${ }^{3}$ CAROLINE PINTO ZANI, ${ }^{4}$ EDUARDA MARTINS DARMIN, ${ }^{5}$ VINICIUS PEREIRA ARANTES

\author{
${ }^{1}$ Acadêmica bolsista PIBIC/UNIPAR \\ ${ }^{1}$ Acadêmica do Curso de Farmácia da UNIPAR \\ ${ }^{2}$ Acadêmica do Curso de Farmácia da UNIPAR \\ ${ }^{3}$ Acadêmica do Curso de Farmácia da UNIPAR \\ ${ }^{4}$ Docente da UNIPAR
}

Introdução: Staphylococcus aureus tem ocupado lugar de destaque na etiologia das infecções em humanos e principalmente quando tratamos da alta versatilidade em adquirir resistência aos antimicrobianos. O fator resistência aos Staphylococcus aureus coexiste desde os primeiros casos de resistência às penicilinas e mais recentemente à meticilina. A ocorrência de $S$. aureus com perfil de multirresistência é definida como a condição igual ou maior que três classes de antimicrobianos rotineiramente empregados para seu tratamento.

Objetivo: Isolar Staphylococcus aureus ambientais e traçar o perfil de sensibilidade dos mesmos quando expostos aos antimicrobianos de uso comum na prática médica.

Material e Método: As amostras são provenientes de ambientes de elevado convívio e fluxo intenso, delineando como elegíveis os caixas eletrônicos, corrimão, bebedouros e carrinho de supermercado. As amostras foram obtidas empregando Swab estéril esterilizado e transferido para tubo contendo Tripticase Soy Broth (TSB) acrescido de 6,5\% de NaCl. Após $24 \mathrm{~h}$ de crescimento em estufa bacteriológica, a $37^{\circ} \mathrm{C}$, foi semeado em Agar manitol salgado, acrescido de $6,5 \%$ de $\mathrm{NaCl}$. As amostras suspeitas para S.aureus foram identificadas empregando os testes de catalase e coagulase. Para as amostras positivas para S.aureus, realizouse os testes de sensibilidade, empregando o método da difusão em discos frente a: penicilina G (PN) (10UI), gentamicina (GN) $(10 \mu \mathrm{g})$, eritromicina $(\mathrm{ERI})(15 \mu \mathrm{g})$, tetraciclina (TET) $(30 \mu \mathrm{g})$, sulfasotrin $(\mathrm{SF})(25 \mu \mathrm{g})$, oxacilina $(\mathrm{OXA})(1 \mu \mathrm{g})$, cefalotina $(\mathrm{CF})(30 \mu \mathrm{g})$ e vancomicina (VC) $(30 \mu \mathrm{g})$.

Resultados: Foram analisadas 113 amostras identificadas como Staphylococcus aureus, avaliou-se: Resistência à penicilina em $100 \%$ das amostras em teste, Gentamicina (30\%), Eritromicina (60\%), Tetraciclina (60\%), Sulfasotrin (20\%), Oxacilina (30\%),Vancomicina (0\%). Desta forma, identificamos 04 amostras com fator de multirresistência, onde três antimicrobianos apresentaram incapazes de eliminar o agente isolado.

Discussão: Superfícies ambientais contaminadas que são comumente manipuladas por pacientes e/ou profissionais podem atuar como fontes pela transferência de microrganismos pelas mãos. Em estudo realizado por Moreira et al (2013) em isolamento de S.aureus de vestíbulo nasal, observou-se que das 61 amostras dos pacientes, 39 (63,93\%) apresentaram resistência à OXA e $42(68,85 \%)$ também se mostraram resistentes pelo método de disco difusão.

Conclusão: O estudo revelou o conhecimento sobre cepas resistentes a Penicilina, Eritromicina, Tetraciclina, Oxacilina e outros agentes comumente empregados na prática médica. Destacamos a necessidade de futuros estudos sobre o assunto.

\title{
Referências
}

BRAZILIAN COMMITTEE ON ANTIMICROBIAL SUSCEPTIBILITY TESTING-BRCAST ( Método de difusão de disco-difusão do Eucast para teste de sensibilidade aos antimicrobianos). BRCAST,2015.

Ferreira et al. Methicillin resistant Staphylococcus aureus on surfaces of an intensive care unit. Acta paul. enferm. V.24,n.4,p.453-458, 2011.

MOREIRA,Ana Candida Martins Grossi; SANTOS,Rosiane Ribeiro dos;BEDENDO,João. Prevalência e Perfil de Sensibilidade de Staphylococcus aureus Isolados em pacientes e equipe de enfermagem.Ciência Cuid Saúde,V.12,N.3,p.572-579,2013.

VILARINHO,Lilian Machado; VILARINHO,Maria Luci Costa Machado; SILVA,Francsico Laurindo da Silva;GUIMARÃES,Maria do Socorro Oliveira Guimarães.;LEAL,Adnaide Cristina Almondes de Moura. Isolamento de Staphylococcus aureus em mãos de profissionais de unidades de terapia intensiva. Rev.Pre.Infec e saúde,.v.1,n.1,p.10-18,2015. 


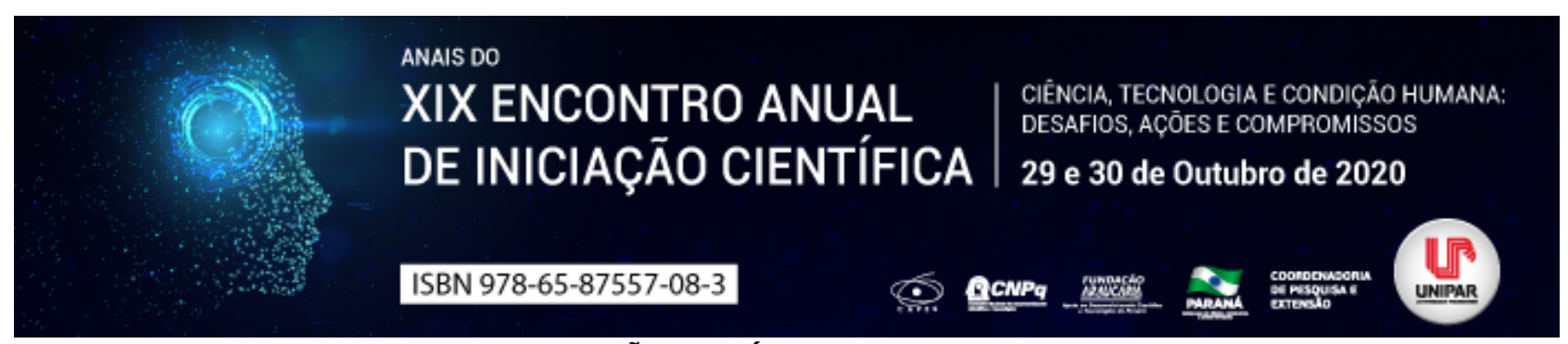

BIOACUMULAÇÃO DE LÍTIO POR BASIDIOMICETOS

\author{
${ }^{1}$ ALLANA VILAS BOAS DE OLIVEIRA, ${ }^{2}$ ELOIZI MACRI, ${ }^{3}$ MARIA CAROLINA SCUIZATO HIDALGO, ${ }^{4}$ BRENDA APARECIDA \\ CHRISTOFOLE, ${ }^{5}$ SUELEN PEREIRA RUIZ HERRIG, ${ }^{6}$ MARIA GRACIELA IECHER FARIA NUNES
}

\author{
${ }^{1}$ Acadêmico bolsista do PIBIC/UNIPAR \\ ${ }^{1}$ Acadêmica do Curso de Farmácia da UNIPAR \\ ${ }^{2}$ Acadêmica do Curso de Farmácia da UNIPAR \\ ${ }^{3}$ Acadêmica do Curso de Farmácia da UNIPAR \\ ${ }^{4}$ Docente da UNIPAR \\ ${ }^{5}$ Docente da UNIPAR
}

Introdução: O lítio (Li), na forma de carbonato de lítio, é utilizado como estabilizador de humor em casos de transtorno bipolar, também podendo ser utilizado como um neuroprotetor contra o Alzheimer (BSCHOR, 2014). Basidiomicetos são conhecidos popularmente como cogumelos e orelhas de pau, e descritos como fontes de proteínas e sais minerais com diversas atividades biológicas já relatada (SILVA-NETO, et al., 2019). A biomassa micelial bioacumulada com lítio pode ser considerada um alimento nutracêutico podendo ser uma suplementação ao tratamento contra os distúrbios de humor bipolar, ou um preventivo ao suicídio e até mesmo ao Alzheimer.

Objetivo: Realizar um levantamento bibliográfico sobre a bioacumulação de lítio por basidiomicetos

Desenvolvimento: $\mathrm{O}$ lítio, desde meados da década de 40, é utilizado na psiquiatria como estabilizador de humor em casos de transtorno bipolar (BSCHOR, 2014). Tendo indícios de ele possa agir como um neuroprotetor contra o Alzheimer e também preventivo contra suicídios(LIAUGAUDAITE, et al. 2017). O transtorno afetivo bipolar é caracterizado por episódios recorrentes de distúrbios na função psicossocial. É uma doença comum, grave, crônica acometendo em torno de 0,5 a $1 \%$ da população mundial (BSCHOR, 2014). Vários sais de lítio já foram utilizados, mas o carbonato de lítio tem sido a primeira escolha de tratamento desta doença psiquiátrica. Ele é absorvido no trato gastrointestinal e excretado pelos rins. A concentração de tratamento pode variar de $0,5 \quad 1,2 \mathrm{mmol} \mathrm{L}^{-1}$, mas a sua estreita janela terapêutica pode ser um problema (BSCHOR, 2014). A ingestão de subdoses de lítio pode prevenir o suicídio. Em países com suplementação da água com lítio de 0,07 a $0,170 \mathrm{mg} \mathrm{L}^{-1}$ houve uma redução da criminalidade e suicídio (LIAUGAUDAITE, et al. 2017). Os basidiomicetos pertencem taxonomicamente no Filo Basidiomycota do Reino Fungi. Produzem uma ampla variedade de produtos naturais que variam de componentes estruturais a compostos com atividades biológicas, como antitumoral, antioxidante, antimicrobiana, e capacidade de bioacumular metais (UMEO, et al.,2015; WASSER, 2017; FARIA, et al.,2018). Estas características de bioacumulação foram observadas durante o cultivo de cogumelos em substrato enriquecido com selênio, lítio, ferro e zinco (ASSUNÇÃO et al., 2012; SILVA et al., 2012). Além de zinco, ferro e lítio em micélio (MARCANTE et al., 2014; ALMEIDA et al., 2014; FARIA et al., 2018, FARIA et al., 2019). A concentração dos elementos bioacumulados são geralmente dependentes da espécie e composição do meio de cultivo utilizado. Nunes et al., (2014) realizaram um screening do crescimento micelial de várias espécies de basidiomicetos crescendo na presença de $\mathrm{LiCl}$, verificando que $P$. ostreatus foi a espécie mais tolerante a presença de $\mathrm{LiCl}$ sendo uma candidata a bioacumulação de Li. Nunes et al. (2015) observaram que os sais menos tóxicos para o crescimento de Ganoderma subamboinense, Grifola frondosa, Hericium erinaceus, Lentinula edodes, Pleurotus eryngii, Pleurotus ostreatus, Pleurotus djamor e Pholiota nameko foram o sulfato de lítio e cloreto de lítio. Assunção et al. (2012) verificaram que na presença de LiCl o basidiocarpo de $P$. ostreatus bioacumulou aproximadamente $200 \mu \mathrm{g} \mathrm{g}^{-1}$ de lítio. Mleczek et al. (2016) estudou basidiocarpos de $P$. ostreatus e Ganoderma lucidum enriquecidos com lítio proveniente de $\mathrm{Li}_{2} \mathrm{CO}_{3}$ e $\mathrm{CH}_{3} \mathrm{COOLi}$ para produção de alimentos biofortificados e observou que $G$. lucidum apresentou melhor resultados tanto para produção de cogumelos quanto para bioacumulação, bioacumulando no basidiocarpo $70 \mathrm{mg} \mathrm{kg}^{-1}$ de Li proveniente $\mathrm{Li}_{2} \mathrm{CO}_{3}$ e $25 \mathrm{mg} \mathrm{kg}^{-1}$ de Li proveniente de $\mathrm{CH}_{3} \mathrm{COOLi}$. A biomassa micelial de Pleurotus ostreatus e Lentinus crinitus apresenta alta capacidade de bioacumular Li proveniente de $\mathrm{Li}_{2} \mathrm{CO}_{3}, 1575,29$ e $574,72 \mathrm{\mu g} \mathrm{g}^{-1}$, respectivamente, maior concentração do que quando na presença de $\mathrm{LiCl}$, onde $P$. ostreatus bioacumulou $549.63 \mu \mathrm{g} \mathrm{g}^{-1} \mathrm{e} \mathrm{L}$. crinitus $267 \mu \mathrm{g} \mathrm{g}{ }^{-1}$ (FARIA, et al., 2018; FARIA, et al., 2019).

Conclusão: A bioacumulação de lítio pode ser uma estratégia interessante para controlar a solubilidade e disponibilidade do metal. Também observa-se que maiores bioacumulações acontecem em biomassa micelial e que o carbonato de lítio seria uma melhor opção para bioacumulação de lítio em basidiomicetos pois já é utilizado para o tratamento do transtorno afetivo bipolar. Assim a biomassa micelial bioacumulada com lítio pode ser considerada um alimento nutracêutico podendo ser uma 
suplementação ao tratamento contra os distúrbios de humor bipolar, ou um preventivo ao suicídio e até mesmo ao Alzheimer.

\section{Referências}

ASSUNÇÃO, L. S. D. et al. Enrichment of mushrooms: An interesting strategy for the acquisition of lithium. Food Chemistry, v. 134, n. 2, p. 1123 1127, 2012.

ALMEIDA S. M., UMEO S. H., MARCANTE R.C., YOKOTA M. E., VALLE J. S., DRAGUNSKI D. C., COLAUTO N. B., LINDE G. A. Iron bioaccumulation in mycelium of Pleurotus ostreatus. Braz. J. Microbiol. 2015. 46(1): 195-200

ASSUNÇÃO L. S., LUZ J. M.R., SILVA M. C. S., VIEIRA P. A. F., BAZZOLLI D. M. S., VANETTI M. C. D., KASUYA M. C. M.: Enrichment of mushrooms: An interesting strategy for the acquisition of lithium. Food Chemistry. $2012.134: 11231127$.

BSCHOR, T. Lithium in the Treatment of Major Depressive Disorder. Drugs, v. 74, n. 8, p. $855862,2014$.

FARIA, M. G. I. et al. Bioaccumulation of Lithium (Li2CO3) in Mycelia of the Culinary-Medicinal Oyster Mushroom, Pleurotus ostreatus (Agaricomycetes). International Journal of Medicinal Mushrooms, v. 20, n. 9, p. $901907,2018$.

FARIA, M. G. I. et al. Lithium bioaccumulation in Lentinus crinitus mycelial biomass as a potential functional food. Chemosphere, v. 235, p. $538542,2019$.

LIAUGAUDAITE, V. et al. Lithium levels in the public drinking water supply and risk of suicide: A pilot study. Journal of Trace Elements in Medicine and Biology, v. 43, p. 197 201, 2017.

MARCANTE, C. R.; MENIQUETTI, A.; PASCOTTO, C. R.; GAZIN, Z. C.; MAGALHÃES, H. M.; COLAUTO, N. B.; LINDE, G. A. Bioacumulação de zinco em micélio de Agaricus subrufescens. Arquivos de Ciências Veterinária. Zoologia Unipar. v. 17, n. 4, p. 249-252, 2014.

MLECZEK, M.; SIWULSKI, M.; RZYMSKI, P.; BUDZYNSKA, S.; GASECKA, M.; KALAC, P.; NIEDZIELSKI5, P. Cultivation of mushrooms for production of food biofortified with lithium. Eur Food Res Technol, p. 1-8, 2016.

NUNES M. D., CARDOSO W. L., LUZ J. M. R., KASUYA M.C.M. Lithium chloride affects mycelial growth of White rot fungi: Fungal screening for Li-enrichment. Afr. J. Microbiol. Res. 2014. 8(21): 2111-2123.

NUNES, M.D.; CARDOSO, W. L.; LUZ, J. M. R.; KASUYA, M. C. M. Effects of lithium compounds on the growth of white- rot fungi. Afr J Microbiol Res., v. 9, n. 34, p. 1954-1959, 2015.

SILVA, M. C. D. et al. Enrichment of Pleurotus ostreatus mushrooms with selenium in coffee husks. Food Chemistry, v. 131, n. 2, p. 558 563, 2012.

SILVA-NETO et al. Bromatological aspects of Lentinus crinitus mushroom (Basidiomycota: Polyporaceae) in agroforestry in the Cerrado. Food Science and Technology, 2019.

UMEO, S. et al. Short Communication Screening of basidiomycetes in submerged cultivation based on antioxidant activity. Genetics and Molecular Research, v. 14, n. 3, p. 9907 9914, 2015.

WASSER, S. P. Medicinal Mushrooms in Human Clinical Studies. Part I. Anticancer, Oncoimmunological, and Immunomodulatory Activities: A Review. International Journal of Medicinal Mushrooms, v. 19, n. 4, p. 279 317, 2017. 


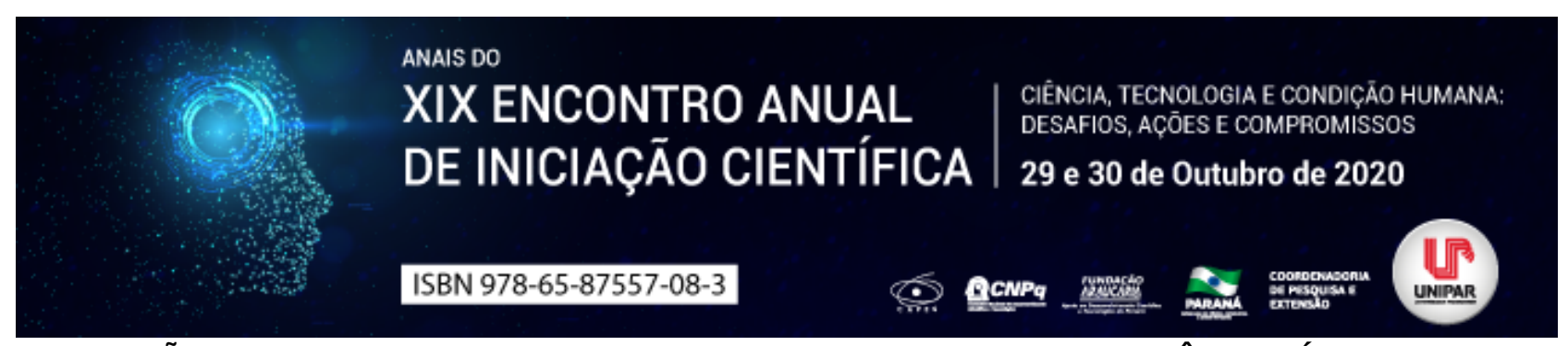

CONDIÇÕES DAS ACADEMIAS NO ATENDIMENTO A PESSOAS COM DEFICIÊNCIA FÍSICA E VISUAL

\title{
${ }^{1}$ GABRIEL FRANCISCO ROCHA, ${ }^{2}$ ISABELLE GUERRA WERLE, ${ }^{3}$ VITOR HUGO RAMOS MACHADO
}

\author{
${ }^{1}$ Acadêmico do Curso de Educação Física da UNIPAR \\ ${ }^{1}$ Acadêmica do Curso de Educação Física da UNIPAR \\ ${ }^{2}$ Docente da UNIPAR
}

Introdução: As atividades desportivas fazem parte da nossa vida a muito tempo. Segundo Noce (2008) somente após a segunda guerra mundial teve maior avanço na prática esportiva por pessoas com deficiência ( $P C D)$, no contexto de prevenção e reabilitação física, social e psíquica. É de conhecimento geral que a prática de atividade física regular tem inúmeros benefícios, porém a participação de $\mathrm{PcD}$ ainda é consideravelmente pequena. Isso está relacionado a várias barreiras que essas pessoas enfrentam e segundo Rimmer (2004), algumas delas são questões psicológicas, falta de aparelhos apropriados, treinamento dos profissionais, etc. Mas afinal, o que é acessibilidade e como isso se relaciona a pessoas com deficiência? De acordo com a Lei № 13.146, de 6 de julho de 2015, acessibilidade é a condição de uso de equipamentos, espaços, transportes, entre outros serviços oferecidos, públicos ou privados, para pessoas com deficiência ou mobilidade afetada (BRASIL, 2015). Segundo dados obtidos pelo Instituto Brasileiro de Geografia e Estatística (IBGE) no censo de 2010, quase 23,9\% da população brasileira possuía algum tipo de deficiência, cerca de 45.606 .048 pessoas. No ano de 2018 , foi lançado uma nota técnica corrigindo alguns dados do Censo de 2010, segundo recomendações do Grupo de Washington, a fim de padronizar e garantir as comparações entre países. Sendo assim, os números do censo foram atualizados, ficando dessa forma: 12.748 .663 pessoas possuíam algum tipo de deficiência, cerca de $6,7 \%$ da população brasileira. Desses valores, $3,4 \%$ são de deficiência visual, $2,3 \%$ motora, $1,4 \%$ mental e $1,1 \%$ auditiva.

Objetivo: Investigar, através de uma revisão bibliográfica, se as academias possuem uma infraestrutura adequada e profissionais capacitados para atender pessoas com deficiência física e visual.

Desenvolvimento: De acordo com o decreto federal $n^{\circ}$ 3.298, de 20 de dezembro de 1999, Art. 4o, a deficiência física é caracterizada como um comprometimento de um ou mais segmentos do corpo humano, resultando em alterações das funções físicas (BRASIL, 1999). Ainda segundo essa lei, a deficiência visual é caracterizada como cegueira, baixa visão, somatória menor ou igual a $60^{\circ}$ da medida do campo visual dos dois olhos ou a ocorrência simultânea das condições anteriores (BRASIL, 1999). Analisamos, por meio de revisões bibliográficas, três pesquisas, a primeira feita em Cascavel - PR em 2014 (SBARDELOTTO, MACADAR e MOREIRA, 2014), obteve o resultado de que os proprietários acreditavam possuir uma academia com adaptações que a tornava acessível a PCD, entretanto, não levaram em conta aspectos como altura do balcão de atendimento, altura do espelho e espaço para circulação de cadeira de rodas. Carvalho (2014), fez sua pesquisa em Caruaru - PE, e obteve resultados parecidos, nos quais as academias visitadas não possuíam equipamentos e placas de sinalização em braile, piso tátil direcional, local apropriado para deficientes visuais guardarem seus pertences e pouco espaço entre os equipamentos, dificultando a passagem de cadeira de rodas e de pessoas com muletas. Em uma cidade do norte paulista, uma pesquisa realizada por Rufini e Arroyo (2013) em dezembro de 2013, trouxe alguns dados sobre proprietários de academias e a infraestrutura que eles ofereciam. Durante a pesquisa, um questionário com 13 questões foi aplicado a eles, abordando temas como acessibilidade, atendimento e formação profissional. Em uma das questões, todos os participantes afirmaram possuir profissionais capacitados para atender pessoas com deficiência física, porém não deixaram claro qual tipo de preparação era essa. Em outra questão, foi abordado o tipo de formação dos profissionais que trabalhavam nas academias. Um desses locais possuía profissionais sem graduação, apenas com a capacitação do CREF para atuar em uma determinada modalidade. Já em outra, havia um profissional da área da Licenciatura trabalhando na área do Bacharelado (RUFINI e ARROYO 2013). Ainda em relação ao questionário de Rufini e Arroyo (2013), sobre a infraestrutura de acessibilidade para o deficiente, $80 \%$ dos participantes disseram que as academias possuem parte das adaptações arquitetônicas necessárias e $20 \%$ das academias possuíam todas as adaptações exigidas para o acesso desse público. Contudo, apenas uma das academias observadas possuía quase todas as adaptações necessárias, e mesmo assim, não possuía acesso com rampas para a sala de musculação no piso superior. O restante das academias possuía apenas rampas na entrada e alguns espaços livres de locomoção.

Conclusão: Após analisar os dados obtidos, foi possível observar que algumas academias possuem sim a capacidade para atender pessoas com deficiência física e visual, entretanto, grande parte dos estabelecimentos observados não possuem estrutura adequada para trabalhar com esse público, tanto na parte de formação profissional, quanto na parte de acessibilidade estrutural. Com isso, concluímos que, mesmo após tantos anos de luta pela inclusão dessas pessoas nos espaços de treinamento, fica evidente que a maior barreira a ser derrubada ainda é a má formação profissional e a negligência arquitetônica apresentada pelos estabelecimentos. 


\section{Referências}

BRASIL. Decreto n 3.298, de 20 de dezembro de 1999. Dispõe sobre a Política Nacional para a Integração da Pessoa Portadora de Deficiência, consolida as normas de proteção e dá outras providências. Diário Oficial da União, Brasília, p. 10, col. 1, 21 dez. 1999.

BRASIL. Lei no 13.146, de 6 de julho de 2015. Institui a lei brasileira de inclusão da pessoa com deficiência (estatuto da pessoa com deficiência). Diário Oficial da União, Brasília, p. 2, col. 2, 07 jul. 2015.

CARVALHO, Brenda Egito de. Recomendações para adaptação de academias de ginásticas à pessoa com deficiência visual. Orientador: Débora Tatiana Ferro Ramos. 2014. 81f. Monografia (Trabalho de Conclusão de Curso em Design) UFPE, CAA, Caruaru, 2014.

Censo Demográfico 2010: Características Gerais da População, Religião e Pessoas com Deficiência. Rio de Janeiro, 2012.

MARMELEIRA, J. F. F. et al. Barreiras para a prática de atividade física em pessoas com deficiência visual. Rev. Br. de Ciência do esp. v. 40, n. 2, p. 197-204 abril./junho. 2018.

NOCE, Franco; SIMIM, Mário Antônio de Moura; MELLO Marco Túlio de. A Percepção de Qualidade de Vida de Pessoas Portadoras de Deficiência Física Pode ser Influenciada Pela Prática de Atividade Física? Rev. Br. Med. Esp. São Paulo. v. 15, n. 3, p. 174 - 178, Mai./Jun. 2009.

REIS, Sophia Amadeu. Acessibilidade para pessoas com deficiência e mobilidade reduzida nas academias de Natal/RN. Orientador: Mônica Maria Fernandes de Lima. 2018. 173 f. Monografia (Graduação em Arquitetura e Urbanismo) - UFRN, Natal, 2018.

RUFINI, Letieri Helena; ARROYO, Claudia Teixeira-, Atividade física para pessoas com deficiência motora em uma cidade do norte paulista. Rev. Ed. F. UNIFAFIBE. São Paulo. a. II, n. 2, p. 99-111, dezembro. 2013.

SBARDELOTTO, Dirleia Aparecida; MACADAR, Marie Anne; MOREIRA Vitor Cesar, Inclusão de pessoas com necessidades especiais em academias de ginástica na perspectiva da teoria da ecologia organizacional. Anais do III SINGEP e II S2IS, São Paulo. 2014. 


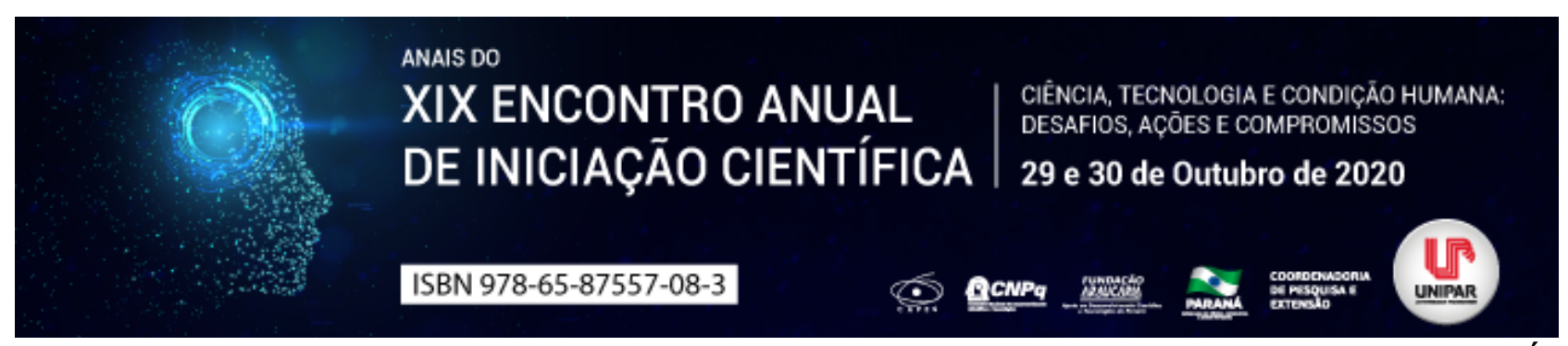

EFEITO DE DIFERENTES DESSENSIBILIZANTES PARA O CONTROLE DA HIPERSENSIBILIDADE DENTINÁRIA

\begin{abstract}
${ }^{1}$ Poliana Maria de Faveri Cardoso, ${ }^{2}$ ANNA CAROLINY DETOGNI, ${ }^{3}$ LEONARDO JOSÉ DE MEDEIROS PIVA, ${ }^{4}$ MÁRCIO JOSÉ MENDONÇA, ${ }^{5}$ VERIDIANA CAMILOTTI
\end{abstract}

${ }^{1}$ Discente do curso de Odontologia da UNIOESTE
${ }^{1}$ Discente do curso de Odontologia da UNIOESTE
${ }^{2}$ Discente do curso de Odontologia da UNIOESTE
${ }^{3}$ Docente da UNIOESTE
${ }^{4}$ Docente da UNIOESTE

Introdução: O desconforto causado pela hipersensibilidade dentinária (SD) é uma das queixas dentárias mais comuns nos consultórios odontológicos. Sendo descrito como resposta exagerada à aplicação de um estímulo na dentina exposta, especialmente na região cervical vestibular (CANALI et al., 2017). Apesar da rápida redução da SD, utilizando dessensibilizantes, a duração desses efeitos ainda é um fator crítico, principalmente, por não apresentarem adesão adequada à superfície dentinária (MADRUGA et al., 2017).

Objetivos: Avaliar diferentes materiais para o controle da hipersensibilidade dentinária cervical através de um estudo in vivo e constatar a influência dessa condição na qualidade de vida dos pacientes.

Materiais e métodos: Este estudo foi realizado na clínica de Odontologia da UNIOESTE após a aprovação do projeto pelo comitê de ética e pesquisa em seres humanos (número do parecer 2.443.042). Os pacientes foram selecionados a partir do exame clínico com sondagem e aplicação de jato de ar e foram selecionados 22 pacientes totalizando 116 dentes, 29 por grupo. Os dentes foram distribuídos em quatro grupos de acordo com o agente dessensibilizante: GD - Gluma Desensitizer® (Heraeus Kulzer, Hanau, Alemanha); CV Clinpro White Varnish ${ }^{\circledR}$ (3M ESPE, Minnesota, EUA); SB Single Bond Universal ${ }^{\circledR}$ (3M ESPE, St.Paul, EUA) AS: AdheSE ${ }^{\circledR}$ (Ivoclar Vivadent, Schaan, Liechtenstein). Foi utilizada a Escala Visual Analógica (EVA) com medidas de 0 a $10 \mathrm{~cm}$ na qual o voluntário indica a sua dor. Utilizou-se também jato de ar frio da seringa tríplice e estímulos táteis realizados com o auxílio de uma sonda exploradora $\mathrm{n}^{\circ} 5$. Um único valor EVA foi marcado pelo paciente referente aos estímulos térmico e tátil de cada dente avaliado. Imediatamente após a aplicação, os pacientes foram submetidos novamente a um teste de sensibilidade e a sensibilidade dentinária novamente quantificada através da escala EVA. As reavaliações foram realizadas em 7 , 30 e 60 dias. Os voluntários responderam a versão brasileira reduzida do questionário sobre o impacto da condição de saúde oral na qualidade de vida dos brasileiros (OHIP 14) durante a avaliação inicial e após a última reavaliação.

Resultados: Na comparação intragrupos foi possível observar uma diminuição estatisticamente significante $(p<0.05)$ do período inicial para todos os outros períodos para todos os tratamentos. Em relação à comparação intergrupos, observou-se diferença estatisticamente significativa $(p<0.05)$ entre os diferentes agentes dessensibilizantes somente no período de 7 dias para o SB. Quanto ao questionário de qualidade de vida, foi possível observar diminuição significativa da sensibilidade dolorosa bucal e dentária dos pacientes avaliados, percebeu-se que houve menor incômodo ao ingerir alimentos, redução do stress e preocupações e diminuição da dificuldade para relaxar $(p<0.05)$.

Discussão: Constatou-se que o efeito dessensibilizante mais significativo ocorreu no período de sete dias para o grupo o qual foi aplicado o adesivo Universal Single Bond. Talvez isso tenha ocorrido por este material apresentar ácido polialquenóico, composto base dos ionômeros de vidro Vitremer e Vitrebond. Acredita-se que a presença desse copolímero forme complexos dentro dos túbulos dentinários, desempenhando um efeito de relaxamento das tensões (KOSE et al., 2013). Em contrapartida, no estudo clínico de Patil et al., 2015, o adesivo Single Bond Universal se mostrou inferior ao Gluma no tratamento da hipersensibilidade dentinária. Essa diferença pode ter ocorrido devido ao número de elementos dentais com hipersensibilidade inseridos em sua pesquisa ter sido menor ao deste estudo, sendo 18 por grupo comparado aos 29 aqui utilizados. Além disso, constatou-se no estudo piloto realizado previamente a esse estudo que a dupla aplicação do adesivo Single Bond Universal se mostrou mais efetivo na redução da sensibilidade dentinária, o autor pode ter aplicado uma única camada do material, gerando diferença nos resultados. Quanto ao dessensibilizante Gluma, o fabricante sugere que fique em contato com a superfície dentária de 30 a 60 segundos, o autor e seus colaboradores deixaram por 30 segundos, e nessa pesquisa clínica o material permaneceu por 60 segundos, podendo ser o motivo para resposta divergente. Ao avaliar o impacto das condições de saúde oral no bem estar e autoestima é possível melhorar as intervenções clínicas e a qualidade de vida dos pacientes. O Perfil de Impacto da Saúde Oral é um dos indicadores mais utilizados internacionalmente para esse fim (AFONSO et al., 2017). Através do questionário OHIP-14 aplicado nesse estudo antes e após o tratamento com os agentes dessensibilizantes, foi constatado uma melhora na qualidade de vida dos voluntários. Houve diferença significativa na diminuição da dor, stress e preocupações. Além disso, ao ingerir 
alimentos doces e ácidos rotineiramente os pacientes relataram não sentir o desconforto causado pela SD.

Conclusão: Todos os agentes dessensibilizantes testados foram efetivos na diminuição da hipersensibilidade dentinária cervical. Além disso, houve uma melhora na qualidade de vida dos voluntários, constatado por meio do questionário aplicado.

\section{Referências}

AFONSO, Andreia, SILVA, Isabel, MENESES, Rute, FRIAS-BULHOSA, José. Qualidade de vida relacionada com a saúde oral: Validação portuguesa de OHIP-14. Psicologia, saúde \& doenças, v.18, n.2, p.374-388, 2017. Disponível em: http://www.scielo.mec.pt/scielo.php?script=sci_abstract\&pid=S1645-00862017000200008\&lng=pt\&nrm=iso Acesso em: 22 ago. 2020.

CANALI, Gabriela, RACHED, Rodrigo, MAZUR, Rui, SOUZA, Evelise. Effect of erosion/ abrasion challenge on the Dentin Tubule Occlusion Using Different Desensitizing Agents. Brazilian Dental Journal, v.28, n.2, p.216-224, mar/abr. 2017. Disponível em: https://pubmed.ncbi.nlm.nih.gov/28492753/ Acesso em: 22 ago. 2020.

KOSE, Carlos, PAULA, Eloisa Andrade, SERRANO, Alexandra Patricia Mena, TAY, Lidia, REIS, Alessandra, LOGUERCIO, Alessandro Dourado, PERDIGÃO, Jorge. Aplicação de um novo sistema adesivo universal: relato de caso. Revista Associação Paulista de Cirurgiões Dentistas, v.67, n.3, p.202-206, jun. 2013. Disponível em: http://revodonto.bvsalud.org/pdf/apcd/v67n3/a06v67n3.pdf Acesso em: 22 ago. 2020.

MADRUGA, Marina de Matos, SILVA, Adriana Fernandes, ROSA, Wellington Luiz de Oliveira, PIVA, Evandro, LUND, Rafael Guerra. Evaluation of dentin hypersensitivity treatment with glass ionomer cements: A randomized clinical trial. Brazilian Oral Research, v.31, nov. 2017. Disponível em: https://www.scielo.br/scielo.php?script=sci_arttext\&pid=S180683242017000100203\&lng=pt\&nrm=iso Acesso em: 22 ago. 2020.

PATIL, Shruti, NAIK, Balaram, SUMA, R. Evaluation of three different agents for in-office treatment of dentinal hypersensitivity: A controlled clinical study. Indian Journal Dental Research, v.26, p.38-42, 2015. Disponível em: http://www.ijdr.in/article.asp? issn=0970-9290; year=2015; volume=26;issue=1; spage=38;epage=42; aulast=Patil Acesso em: 22 ago. 2020.

Coordenadoria de Pesquisa e Extensão - COPEX

Departamento de Editoração e Divulgaçāo Científica - DEDIC 


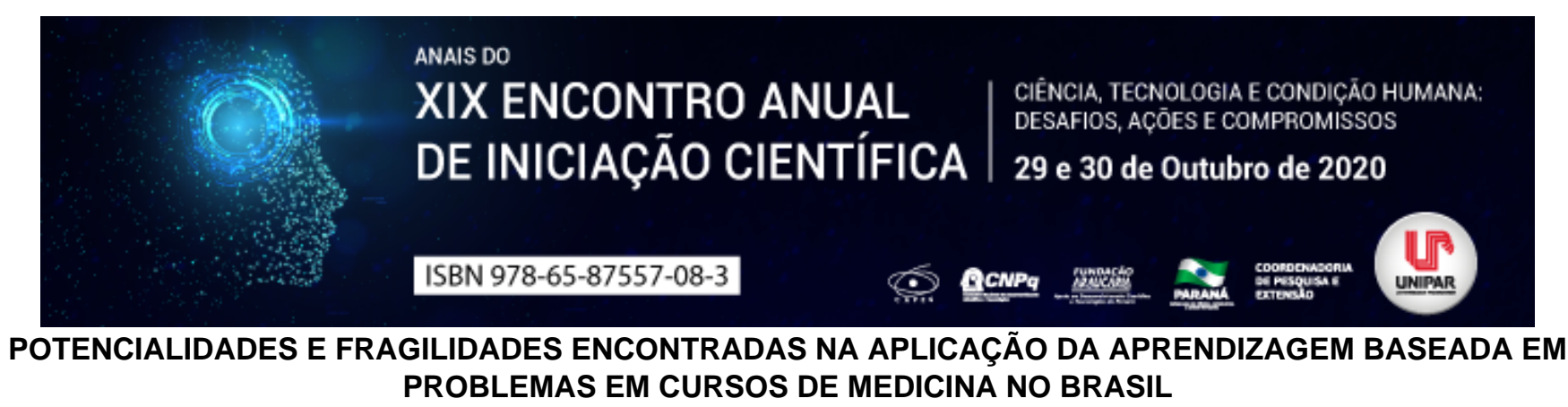

\begin{abstract}
${ }^{1}$ Gabriel Vítor Lima de Andrade, ${ }^{2}$ ALICE PEREIRA DE SIQUEIRA NASCIMENTO, ${ }^{3}$ ANDREW PEREIRA DA SILVA, ${ }^{4}$ LUAN NOVAES LEITE, ${ }^{5}$ PEDRO ÉRICO ALVES DE SOUZA, ${ }^{6}$ VITOR CAIAFFO BRITO
\end{abstract}

\begin{abstract}
${ }^{1}$ Acadêmico da Universidade Federal de Pernambuco - Centro Acadêmico do Agreste
${ }^{1}$ Acadêmica da Universidade Federal de Pernambuco - Centro Acadêmico do Agreste

${ }^{2}$ Acadêmico da Universidade Federal de Pernambuco - Centro Acadêmico do Agreste

${ }^{3}$ Acadêmico da Universidade Federal de Pernambuco - Centro Acadêmico do Agreste

${ }^{4}$ Acadêmico da Universidade Federal de Pernambuco - Centro Acadêmico do Agreste

${ }^{5}$ Docente da Universidade Federal de Pernambuco - Centro Acadêmico do Agreste
\end{abstract}

Introdução: As Diretrizes Curriculares Nacionais (DCNs) do curso de medicina surgiram em 2001 com o objetivo de guiar a criação do Projeto Pedagógico Curricular (PPC) dos cursos. Em 2014, as DCNs passaram a ter peso de lei e a embasar a acreditação e o reconhecimento dos cursos (OLIVEIRA et al., 2019). No âmbito dessas, está o uso de metodologias ativas de ensino-aprendizagem, como a Aprendizagem Baseada em Problemas (ABP), na graduação para que os futuros médicos desenvolvam habilidades além da retenção de conhecimentos teóricos (CUSTÓDIO; VIEIRA; FRANCISCHETTI, 2019).

Objetivo: Apresentar as principais potencialidades e fragilidades do uso da Aprendizagem Baseada em Problemas em cursos de graduação em medicina no Brasil.

Desenvolvimento: Essa revisão integrativa de literatura foi feita a partir da seleção de 9 artigos brasileiros encontrados na base de dados Scientific Electronic Library Online (SciELO), publicados entre 2019 e 2020, resultantes da busca com os descritores Aprendizagem Baseada em Problemas e Educação médica, e o operador booleano E . O uso da metodologia ABP em cursos médicos objetiva a criação de habilidades como comunicação e trabalho em equipe, a valorização do conhecimento prévio e vivências do aluno e o aumento da iniciativa e autonomia para ampliar o aprendizado (PAVAN; SENGER; MARQUES, 2019). A percepção dos alunos sobre a ABP é que a visão multidisciplinar facilita o aprendizado do conteúdo abordado e áreas associadas. Além disso, as habilidades de estudo tendem a ser ampliadas ao longo do curso, o que favorece - por exemplo - o acesso à informação acadêmica, primordial tanto na graduação como na prática profissional. Outrossim, os alunos sentem que a articulação teórico-prática deve ser melhorada com maior diálogo e objetivos mais claros, dada a importância para a profissão (BARRETO et al., 2019; DIAS; PIO, 2019). A visão dos professores sobre a metodologia é que ela privilegia a aprendizagem significativa, já que o aprendizado passa a ter um valor psicológico. Nesse método, o docente deve criar situações para construção do aprendizado, experimentar isso e corrigir falhas ao longo do caminho, para que o conhecimento seja obtido. Professores que passaram pela transição entre o método tradicional e o ABP relatam aumento na interação discente-docente e que os alunos realmente passam a ter mais autonomia e iniciativa. Quanto às principais fragilidades, os docentes afirmam que as universidades não oferecem treinamentos contínuos e que, muitas vezes, eles o fazem por conta própria; o que dificulta principalmente a forma de avaliar o estudantes que passa a não ser uniforme entre diferentes grupos de trabalho (PAVAN; SENGER; MARQUES, 2019). Em relação ao aprendizado teórico, estudantes que cursaram graduações com o ABP têm algumas vantagens. Discentes citaram que a falta de intencionalidade no ensino de alguns conceitos pode atrapalhar o entendimento de alguns deles, mas que isso pode ser superado quando o mesmo conceito é aliado a atividades práticas. Apesar disso, eles ainda sentem diferenças quando se compara o nível de conhecimento entre diferentes grupos, semelhante ao que foi dito por docentes quando perguntados sobre as principais dificuldades encontradas no método. Entre alunos do internato médico, foi notada uma vantagem dos alunos do ABP sobre os alunos do método tradicional no conhecimento de pancreatite aguda. Mesmo com esse dado, os resultados obtidos em prova comuns no fim do curso (como concursos para as residências) não mostram diferenças significativas entre alunos expostos a metodologias de ensino-aprendizagem diferentes. Entretanto, à aplicação de testes em médicos após um ano de formação, foi notado que aqueles que cursaram graduações com ABP tiveram maior retenção de conhecimentos, ou seja, o método proporcionou uma vantagem no âmbito do conhecimento necessário na prática profissional (MARINZECK et al., 2019; NONATO et al., 2020). Dados mostram que estudantes universitários são um grupo social com maior taxa de sintomas de ansiedade e depressão e, entre esses, os estudantes do curso de medicina apresentam taxas ainda maiores. Foi encontrado algum nível de ansiedade em quase todos os estudantes e metade desses relata comprometimento acadêmico. No âmbito do ABP, o método sugere que os estudantes matriculados tendem a ter menores níveis de depressão e ansiedade; porém, um estudo em universidade no Brasil mostra que mesmo assim a prevalência ainda é alta. Um fator comum encontrado entre os que apresentavam poucos ou nenhum sintoma foi a prática esportiva (MAIA et al., 2020; RODRIGUES et al., 
2019).

Conclusão: O uso da metodologia ativa de ensino-aprendizagem ABP no Brasil está em consonância com as DCNs. Como potencialidades, foram encontradas principalmente o treinamento de habilidades práticas, o maior envolvimento e interesse do discente com o próprio aprendizado e a tendência a ter menos sintomas de saúde mental ao longo da graduação. Entre as fragilidades, se destacam a ausência de capacitação longitudinal dos docentes, a falta de intencionalidade clara no ensino de alguns conceitos e a não uniformidade nas avaliações.

\section{Referências}

BARRETO, I. D. P.; et. al. Avaliação das Estratégias de Autoaprendizagem em Alunos de um Curso de Medicina em Belém Pará. Revista Brasileira de Educação Médica, [s.l.], v. 43, n. 4, p. 36-46, 2019.

CUSTÓDIO, L. A. F.; VIEIRA, C. M.; FRANCISCHETTI, I. A dimensão social na formação médica: o contexto de vida na aprendizagem baseada em problemas. Trabalho, Educação e Saúde, [s.l.], v. 18, n. 3, p. 1-20, 2020.

DIAS, N. V.; PIO, D. A. M. Percepção dos Estudantes de Medicina sobre Comunicação de Más Notícias na Formação Médica. Revista Brasileira de Educação Médica, [s.I.], v. 43, n. 1, p. 254-264, 2019. Supl 1.

MAIA, H. A. A. S.; et. al. Prevalência de Sintomas Depressivos em Estudantes de Medicina com Currículo de Aprendizagem Baseada em Problemas. Revista Brasileira de Educação Médica, [s.I.], v. 44, n. 3, p. e105, 2020.

MARINZECK, L. C.; et. al. Avaliação do Conhecimento de Alunos do Internato Médico sobre Pancreatite Aguda Utilizando a Aprendizagem Baseada em Problemas. Revista Brasileira de Educação Médica, [s.l.], v. 43, n. 1, p. 157-162, 2019.

NONATO, A. C.; et. al. Apprehension and Understanding of the Health Needs Concept for Students of an Active Curriculum. Revista Brasileira de Educação Médica, [s.I.], v. 44, n. 2, p. e070, 2020.

OLIVEIRA, C. A.; et. al. Alinhamento de Diferentes Projetos Pedagógicos de Cursos de Medicina com as Diretrizes Curriculares Nacionais. Revista Brasileira de Educação Médica, [s.I.], v. 43, n. 2, p. 143-151, 2019.

PAVAN, M. V.; SENGER, M. H.; MARQUES, W. Assessment of the Curricular Reform of a Medical Course from the Faculty's Perspective. Revista Brasileira de Educação Médica, [s.I.], v. 43, n. 1, p. 135-145, 2019. Supl 1.

RODRIGUES, M. D. S.; et. al. Transtorno de Ansiedade Social no Contexto da Aprendizagem Baseada em Problemas. Revista Brasileira de Educação Médica, [s.I.], v. 43, n. 1, p. 65-71, 2019. 


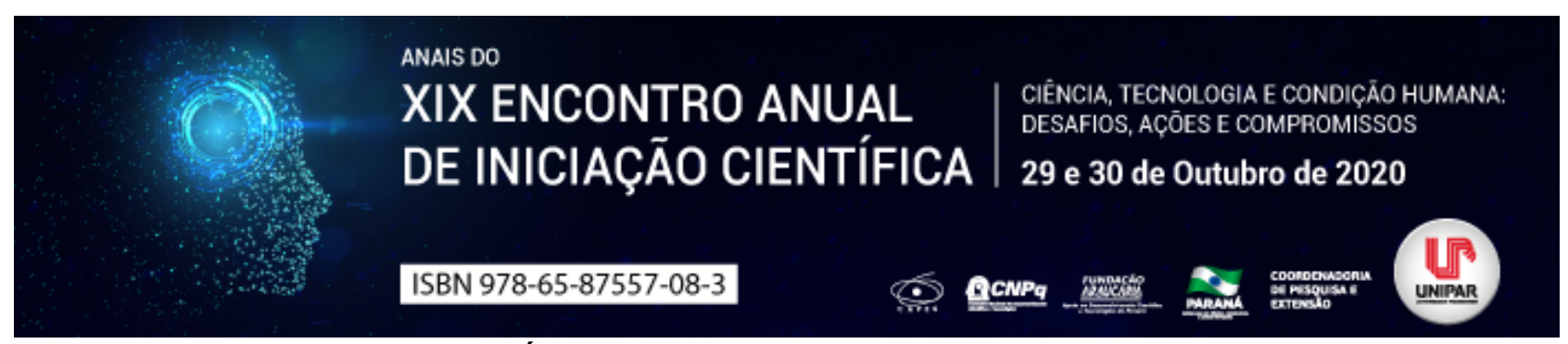

USO DE FITOTERÁPICOS NO TRATAMENTO DE PATOLOGIAS BUCAIS

\author{
${ }^{1}$ SUELEN STEFANONI BRANDAO, ${ }^{2}$ ANDRESSA ANDRADE NOVAES, ${ }^{3}$ JOAO MURILO GONCALVES GAZOLA, ${ }^{4}$ ANA MARIA \\ DA SILVA, ${ }^{5}$ DANIELA DE CASSIA FAGLIONI B CERANTO
}

\author{
${ }^{1}$ Acadêmica bolsista PIBIC/UNIPAR \\ ${ }^{1}$ Acadêmica do Curso de Tecnicas Cirurgicas Periodontais e Introducao A Implantodontia - Turma I da UNIPAR \\ ${ }^{2}$ Acadêmico do Curso de Odontologia da UNIPAR \\ ${ }^{3}$ Acadêmica do Curso de Odontologia da UNIPAR \\ ${ }^{4}$ Docente da UNIPAR
}

Introdução: Fitoterápicos são substâncias obtidas a partir de plantas que podem ser utilizadas como remédios naturais/artesanais. Os conhecimentos de seus efeitos foram passados pelas gerações, tendo um importante papel científico e histórico, colaborando inclusive no desenvolvimento de algumas nações (FRANCISCO, et al. 2010). Os medicamentos seguem com preparações vegetais padronizadas que consistem em uma mistura complexa de uma ou mais substâncias presentes na planta que são preparados adequadamente e posteriormente prescritos em obediência à legislação vigente (MACHADO, et al. 2014). Segundo Francisco et al. (2010) pesquisas com produtos naturais no meio odontológico têm buscado por novos produtos com maior atividade terapêutica, com menor toxicidade e melhor biocompatibilidade. A aceitação popular da fitoterapia leva a boas perspectivas no mercado de produtos odontológicos que contém substâncias naturais.

Objetivo: Revisar a literatura sobre o uso de medicamentos fitoterápicos no tratamento de patologias bucais, acrescido das ervas mais utilizadas.

Desenvolvimento: O emprego das plantas medicinais pela população é seguido da crença de que os medicamentos provenientes de extratos naturais têm menor probabilidade de causar efeitos colaterais além de serem mais baratos. Todavia, sabe-se que os fitoterápicos também acarretam efeitos colaterais e possuem contraindicações, sendo extremamente necessário conhecer seus princípios ativos, procedência, qualidade, para que possam ser usados com segurança (FRANCISCO, et al. 2010). A abrangência da utilização de fitoterápicos e de plantas medicinais é vasta e engloba fins variados, incluindo prevenção e tratamento da doença periodontal (BARBOSA, 2013). Segundo Evangelista (2013) somente em 1978, a Organização Mundial da Saúde (OMS) reconheceu os medicamentos de origem vegetal como recurso terapêutico. No Brasil, apenas em 2006 que se estabeleceu a política para o uso de plantas medicinais, aprovou-se a Política Nacional de Práticas Integrativas e Complementares (PNPIC) no SUS. Apesar do uso da fitoterapia ser milenar, sendo que O Papiro de Ebers (1500 a.C.) é considerado o primeiro manuscrito sobre o assunto, na Odontologia a utilização de plantas medicinais para tratar doenças bucais ou para tratar doenças sistêmicas com manifestações bucais ainda é pouco explorada (MACHADO, et al. 2014). Segundo Mota et al. (2018) compostos fitoterápicos podem ser utilizados nas mais variadas fórmulas, como: cápsulas, comprimidos, géis, pomadas, soluções aquosas, soluções hidro alcoólicas e infusões, que são conhecidas como chás, e acrescido de grandes vantagens como: custo acessível, fácil manuseio, menos efeitos colaterais se comparados a medicamentos não fitoterápicos e com atividades anti-inflamatória, antimicrobiana, ansiolítica, cicatrizante dentre outras. Segundo Machado et al. (2014) estudos com chás mostram que as infusões podem ser utilizadas para inibir o crescimento bacteriano e a aderência nas superfícies dentais e redução na produção de ácidos e polissacarídeos extracelulares. Espécies como Cravo da Índia, Romã, Malva, Tanchagem, Amoreira, Sálvia, Camomila, entre outras, são indicadas nos casos de gengivite, abscesso na boca, inflamação e aftas. Essas plantas têm apresentado ação bactericida e bacteriostática sobre bactérias Gram-positivas e Gram-negativas constituintes do biofilme dental. Outras plantas também apresentam grandes benefícios para uso odontológico como é o caso da babatenon (Pithecelobium avaremotemo Mart.), seguida da aroeira (Schinus terebinthifolius Raddi), cajueiro roxo (Anacardium occidentale L.) e quixaba (Bumelia sartorum Mart.). A mais indicada para halitose e dor de dente costuma ser o cravo (Syzygium aromaticum L.); para afta ou ferida na boca pedra ume (Myrcia salicifolia DC); e para sangramento gengival: babatenon, juá (Zizyphus joazeiro Mart.) e pedra ume (SANTOS et al. 2009). A Salvia officinalis (Salvia) é conhecida por suas propriedades antisépticas, cicatrizante, bactericida, antioxidante e antifúngica; a Punica granatum L. (Romã) se mostrou eficiente contra o Staphylococcus aureus; a Matricaria recutita L. (Camomila) possui atividade anti-inflamatória devido à presença de óleos essenciais, ricos em azuleno, matricina e alfa bisabolol, sendo muito utilizada em estomatites, gengivites, aftas e halitose (BARBOSA, 2011). O alho (Allium sativum) possui propriedade antibacteriana, antifungica e antiviral e é um importante coasdjuvante no tratamento de pacientes portadores de periodontite (SOUZA, et al. 2017).

Conclusão: Vários indícios demonstram que a prática da fitoterapia é muito antiga e que apresenta bons resultados. Todavia, ainda ocorre um preconceito velado por alguns profissionais e pacientes sobre seus efeitos o que se recomenda maior 
investimento por parte das autoridades de saúde em campanhas para incentivar o uso discriminado de tais medicamentos. Na área odontológica vários extratos têm se mostrado eficazes no tratamento de patologias, incluindo alguns pontos positivos como: fácil acesso, baixo custo e efeitos adversos menores o que o torna uma boa opção para tratamento de doenças diversas.

\section{Referências}

BARBOSA, Daniele do Nascimento. Análise clínica do efeito de fitoterápicos na redução do biofilme dental e sangramento gengival na doença periodontal. Orientador: Ruthinéia Diógenes Alves Uchoa Lins. 2011. Tese em Odontologia. Universidade Estadual da Paraíba. 2011.

FRANCISCO, Kleryson Martins Soares. Fitoterapia: uma opção para o tratamento odontológico. Revista Saúde, v. 4, n. 1, p. 1824, 2010.

MACHADO, Alessandra. Cury.; OLIVEIRA, Rodrigo. Cardoso. Medicamentos Fitoterápicos na odontologia: evidências e perspectivas sobre o uso da aroeira-do-sertão (Myracrodruon urundeuva Allemão). Revista Brasileira de Plantas Medicinais, v. 16, n. 2, p. 283-289, 2014.

MOTA, Isabelly Barbara de Oliveira, CUNHA, Larissa Souza, BRAGA, Laura Luiza Amâncio, LIMA, Caroline Caixeta, DIETRICH, Lia. Fitoterapia na odontologia: levantamento dos principais produtos fitoterápicos usados para a saúde bucal. I Fórum de Iniciação Cientifica da faculdade Patos de Minas. Novembro, 2018; Vol. 4(Supl1):71-71.

SANTOS, Esther Bandeira et al. Estudo etnobotânico de plantas medicinais para problemas bucais no município de João Pessoa, Brasil. Revista brasileira de farmacologia, João Pessoa, v. 19, n. 1b, p. 321-324, Mar. 2009.

SOUZA, Daniele Patricia Monteiro da Silva, GALDINO, Osvaldo Rufino. Uso de fitoterapicos no tratamento da doença periodontal. Orientadora: Daniela Siqueira Lopes. Trabalho de conclusao de curso em Odontologia. Faculdade Integrada de Pernambuco - FACIPE. 2017. 


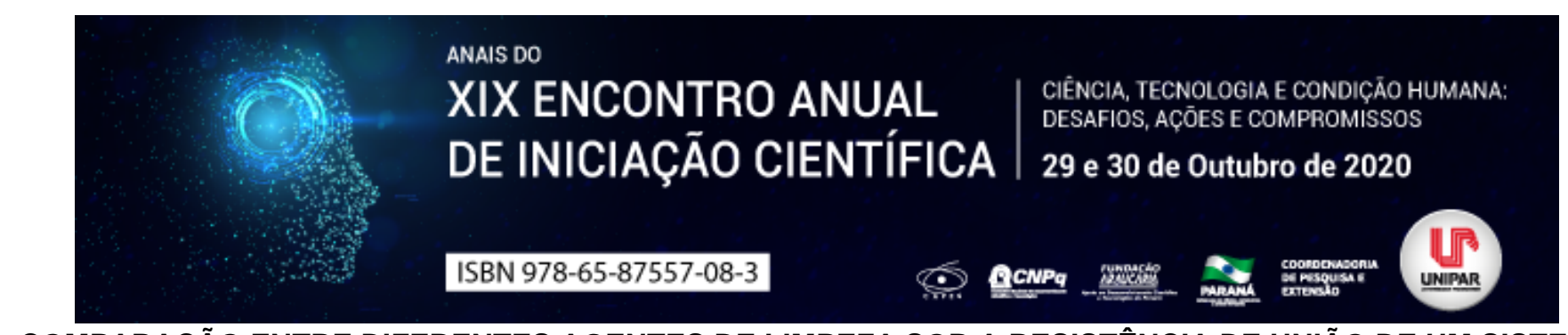

COMPARAÇÃO ENTRE DIFERENTES AGENTES DE LIMPEZA SOB A RESISTÊNCIA DE UNIÃO DE UM SISTEMA ADESIVO

\author{
${ }^{1}$ Poliana Maria de Faveri Cardoso, ${ }^{2}$ ANNA CAROLINY DETOGNI, ${ }^{3}$ LEONARDO JOSÉ DE MEDEIROS PIVA, ${ }^{4}$ MÁRCIO JOSÉ \\ MENDONÇA, ${ }^{5}$ VERIDIANA CAMILOTTI
}

${ }^{1}$ Discente do curso de Odontologia da UNIOESTE

${ }^{1}$ Discente do curso de Odontologia da UNIOESTE

${ }^{2}$ Discente do curso de Odontologia da UNIOESTE

${ }^{3}$ Docente da UNIOESTE

${ }^{4}$ Docente da UNIOESTE

Introdução: A contaminação do substrato dentinário pode interferir na qualidade de união entre materiais adesivos e o dente. Para aumentar a resistência de união do sistema adesivo e o material restaurador com a superfície dental, é importante realizar uma adequada limpeza da cavidade dental após o preparo cavitário (SILVA et al., 2015). Diante desse contexto, tem sido recomendado o uso de um agente antimicrobiano, na desinfecção das cavidades contaminadas, ou o uso de materiais restauradores capazes de inativar estas bactérias, tal procedimento evitaria a recidiva de cáries e melhoraria a retenção dos materiais restauradores às estruturas dentais, diminuindo a microinfiltração nas restaurações. Os agentes de limpeza comumente utilizados para este fim na odontologia são a clorexidina 2\%, o EDTA e o soro fisiológico (MONTAGNER et al., 2015).

Objetivo: Avaliar a influência de diferentes soluções de limpeza na resistência de união de um sistema adesivo e a resina composta a partir de um estudo in vitro.

Materiais e métodos: Foram selecionadas 40 coroas dentais bovinas, divididas em quatro grupos: $\mathrm{G} 0=$ soro; $\mathrm{G} 1=$ clorexidina 2\%; G2 = EDTA; G3 = água ozonizada (4ppm).Foi realizado o desgaste do esmalte dental na face vestibular e polimento com discos de lixas (TDV) da granulação mais grossa até a mais fina em baixa rotação com movimentos intermitentes em seguida os elementos foram armazenados em umidade relativa até o momento de seu uso. Em seguida, foram confeccionados cilindros de resina composta utilizando-se uma matriz de Tygon com diâmetro interno de $1 \mathrm{~mm}$ e $2 \mathrm{~mm}$ de altura . A fotoativação foi realizada por aparelho de luz LED com $1200 \mathrm{~mW} / \mathrm{cm} 2$ por 40 segundos. Foram confeccionados três cilindros de cimento resinoso para cada coroa bovina, para que seja feito um teste em triplicata, eliminando qualquer viés. Os CP foram armazenados por 30 dias em umidade relativa e acondicionados em estufa a $37^{\circ} \mathrm{C}$. As amostras foram submetidas ao teste de microcisalhamento em uma máquina universal de ensaios (EMIC) e a interface de resina dentina fraturada foram analisadas em uma lupa estereoscópica com aumento de 100x (Olympus SZ40, Japão). Os tipos de falha foram classificados como adesiva (A), mista (M), coesiva em resina composta $(C C)$ e coesiva em dentina $(C D)$. Os dados obtidos foram submetidos à análise estatística de Kruskall Wallis, seguido do teste de Tukey, $p<0,05$.

Resultados: Não houve diferenças estatisticamente significativas entre as soluções em relação a resistência de união no teste de microcisalhamento e houve predominância de fratura adesiva para todas as soluções.

Discussão: Os resultados apresentados neste trabalho mostram que não houve diferenças estatisticamente significativas entre as soluções de soro fisiológico, clorexidina 2\% e EDTA. Este resultado corrobora com estudo de Camilotti et al. (2013) e Pelegrine et al. (2010). Em seu estudo Carrilho et al. (2007) o uso da clorexidina não alterou os valores de resistência de união o que coincide com o presente estudo. A solução de água ozonizada obteve resultados similares às demais que concorda com a pesquisa realizada por Pithon \& Santos (2010). Com relação ao uso de ácido etilenodiaminotetracético (EDTA), o presente estudo corrobora com os achados de Sauro et al. (2010), que esta solução atua como as demais quando é utilizada com sistema adesivo. Santos et al. (2009) em seus estudos também concluiu que as soluções de limpeza não afetam a resistência de união. $O$ presente trabalho avalia a o desempenho da água ozonizada em comparação às soluções de limpeza já utilizadas na odontologia. Podemos observar que a solução da água ozonizada obteve desempenho similar às demais soluções em relação à união de resistência no sistema adesivo. Diante do contexto atual, na odontologia, o ozônio tem sido proposto como uma alternativa antisséptica, graças à potente ação antimicrobiana e alta biocompatilibilidade. A água ozonizada tem mostrado, por meio das pesquisas, incrível aplicabilidade com resultados realmente promissores (CAMILOTTI et al, 2013). Diante da literatura científica apresentada pode-se concluir que a ozonioterapia pode ser uma novas estratégia terapêutica na área da odontologia devido a sua atividade antimicrobiana, biocompatibilidade e boa resposta imunológica dos indivíduos frente a essa solução.

Conclusão: Dentro das limitações deste estudo in vitro, pode-se concluir que a água ozonizada teve desempenho satisfatório como as demais soluções de limpeza testadas quanto à resistência de união entre o substrato dentário e o cimento resinoso no teste de microcisalhamento. 


\section{Referências}

CAMILOTTI, Veridiana, IORIS, Matheus Dalmédico, BUSATO, Priscilla do Monte Ribeiro, UEDA, Julio Katuhide. Avaliação da influência da solução de irrigação na resistência adesiva de um cimento resinoso. Revista de Odontologia UNESP, v.42, n.2, p.83-88, mar./apr. 2013.

CARRILHO, Marcela Rocha de Oliveira, REIS, Alessandra, LOGUERCIO, Alessandro Dourado. Resistência de união à dentina de quatro sistemas adesivos. Pesquisa Odontológica Brasileira, vol.16, n.3, p.251-256, 2002.

MONTAGNER, Anelise Fernandes, PERRONI, Ana Paula, CORREA, Marcos Brito. Effect of pre-treatment with chlorhexidine on the retention of restorations: a randomized controlled trial. Brazilian Dental Journal, Ribeirão Preto, vol.26, n.3, mai./jun. 2015.

PELEGRINE, Rina Andréa, MARTIN, Alexandre Sigrist, CUNHA, Rodrigo Sanches, PELEGRINE, André Antonio, BUENO, Carlos Eduardo da Silveira. Influence of chemical irrigants on the tensile bond strength of an adhesive system used to cement glass fiber posts to root dentin. Oral Surgery, Oral Medicine and Oral Pathology, v. 110, p.73-6, ago. 2010.

PITHON, Matheus Melo, SANTOS, Rogério Lacerda. Does ozone water affect the bond strengths of orthodontic brackets? Australian Orthodontic Journal, v.26, p.73-77, may. 2010.

SAURO, Salvatore, TOLEDANO, Manuel, AGUILERA, Fátima Sánchez, MANNOCCl, Francesco. Resin dentin bonds to EDTAtreated vs. acid-etched dentin using ethanol wet-bonding. Dental Materials, v.26, n.4, p.368-79, jan. 2010.

SILVA, Enio Marcos, GLIW, Daniel, GILL, Alana. Effect of Chlorhexidine on Dentin Bond Strength of Two Adhesive Systems after Storage in Different Media. Brazilian Dental Journal, Ribeirão Preto, v.26, n.6, p.642-647, nov./dez. 2015. 


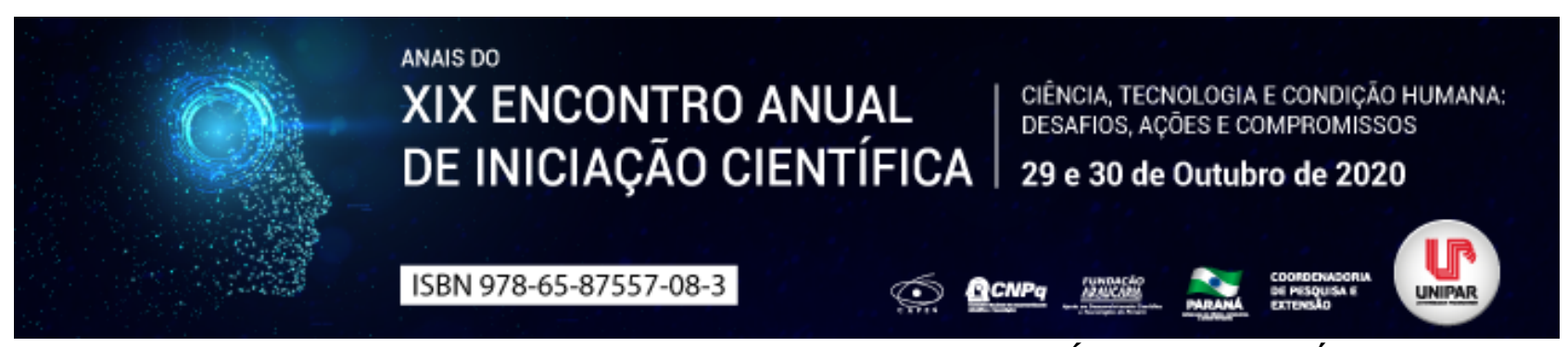

EPIDEMIOLOGIA DO HIV EM GESTANTES DE UM MUNICÍPIO DO PARANÁ

\author{
${ }^{1}$ TAINARA NOTH JOB DA SILVA, ${ }^{2}$ LEDIANA DALLA COSTA
}

\author{
${ }^{1}$ Acadêmica do PIC/UNIPAR \\ ${ }^{1}$ Docente da UNIPAR
}

Introdução: A síndrome da imunodeficiência adquirida (AIDS) é causada pela exacerbação do vírus da imunodeficiência humana (HIV) e com o passar dos anos leva ao portador um comprometimento imunológico importante, quando na gestação pode ocorrer a transmissão vertical da mãe ao feto (DANIELLE. et al, 2020). A infecção pelo HIV desde 2006 é considerada uma doença de notificação compulsória, apresentando as maiores taxas da infecção nas gestantes da região norte e nordeste entre os anos de 2006 a 2015, a nível nacional estima-se que a incidência dos casos chega a 11.070 por ano no Brasil (DOMINGUES; SARACENI; LEAL, 2018).

Objetivo: Identificar o perfil epidemiológico das gestantes com HIV presentes durante os anos de 2015 a 2019.

Metodologia: Trata-se de uma pesquisa de campo, exploratória, transversal, documental, retrospectiva de caráter quantitativo, desenvolvida com as fichas de notificação compulsórias através de um questionário confeccionado pelas pesquisadoras conforme literatura e fichas de notificação. A análise estatística descritiva foi realizada pelo programa estatístico SPSS 25.0. O projeto foi aprovado pelo Comitê de Ética sob o parecer 4.001.021, aprovado em 30/04/2020.

Resultados: A pesquisa foi constituída de 14 fichas de notificação de HIV na gestação, observou-se que 42,9\% dos casos foram notificados em 2015, sendo identificadas no primeiro trimestre de gestação $57,1 \%$ dos casos, com idade entre 17 e 35 anos, houve coincidência em mulheres de raça branca e parda, em sua maioria possuíam ensino fundamental completo, 57,1\% eram donas de casa, todavia 50\% tinham conhecimento do diagnóstico positivo, $71,4 \%$ realizaram a cesárea eletiva, sendo que $78,6 \%$ utilizaram a profilaxia antirretroviral durante o parto, contudo $71,4 \%$ foram nascidos vivos.

Discussão: O presente estudo evidenciou que $42,9 \%$ das notificações pelo HIV ocorreram no ano de 2015 , dados encontrados assemelham-se ao de Domingues; Saraceni e Leal (2015), que prevaleceu a maior taxa de detecção de HIV no sul do país, equivalente 2,2 vezes maior que a detecção brasileira em 2015. Houve prevalência da identificação no primeiro trimestre gestacional, visto que segundo a Portaria MS/GM no 77, de 12 de janeiro de 2012, que preconiza a testagem durante o pré-natal para redução da transmissão vertical, com relação a idade predominou-se mulheres com idade maior que 17 anos, sendo que $50 \%$ das parturientes se autodeclararam de raça branca e parda, sendo divergentes aos dados ponderados por Teixeira e seus colaboradores (2020), que ao analisar o perfil das gestantes HIV positivas, evidenciaram que a idade era superior a 20 anos e se autodeclaram pardas nos registros. Quanto ao grau de escolaridade, $64,3 \%$ possuíam ensino fundamental completo, igualandose aos dados evidenciados por Danielle e colaboradores (2020). Com relação a profissão, 57,1 \% declararam ser donas de casa, e 50\% das gestantes tinham conhecimento sobre o diagnóstico positivo anteriormente, estando em discordância com os resultados apresentados por Teixeira e colaboradores (2020), apresentaram a evidência laboratorial do HIV durante o pré-natal, $78,6 \%$ utilizaram a profilaxia antirretroviral durante o parto e houve prevalência da cesárea eletiva, similar ao estudo realizado por Silva e colaboradores (2017) que utilizou a terapia antirretroviral a fim de diminuir a transmissão, trazendo a cesárea eletiva como indicação para paciente HIV por ser realizada fora do trabalho de parto, com as membranas íntegras, diminuindo a infecção; por fim $71,4 \%$ foram nascidos vivos.

Conclusão: Observou-se uma queda expressiva no decorrer dos anos quando comparado ao ano de 2015 com índices elevados. É válido destacar, a importância do profissional de enfermagem no acompanhamento gestacional e manejo adequado da parturiente de alto risco, cabe a este o dever de informar, tranquilizar e humanizar a assistência prestada.

\title{
Referências
}

DOMINGUES, R. M. S. M; SARACENI, V; LEAL, M. C. Notificação da infecção pelo HIV em gestantes: estimativas a partir de um estudo nacional. Revista de Saúde Publica, p. 52-43,2018.

SILVA, C. M. et al. Panorama epidemiológico do HIV/Aids em gestantes de um estado do Nordeste brasileiro. Revista Brasileira de Enfermagem, p. 613-21, 2018.

GOMES, O. J. et al. Perfil sociodemográfico e clínico de mortalidade materna. Revista de enfermagem UFPE on line, Recife, v.12, n.12, p.3165-71, 2018.

TEIXEIRA, S. P. et al. Perfil epidemiológico de gestantes com HIV admitidas em uma maternidade de referência do Amapá. Revista eletrônica acervo saúde, v.12, n.2, p. 1-9, 2020.

DANIELLE, P. C. et al. Perfil clínico e epidemiológico de gestantes com HIV positivo atendidas em um hospital municipal de Niterói. Revista saúde coletiva, v.10, n.52, p.2280-2287, 2020. 
BRASIL. Ministério da saúde. PORTARIA № 77, DE 12 DE JANEIRO DE 2012. Dispõe sobre a realização de testes rápidos, na atenção básica, para a detecção de HIV e sífilis, assim como testes rápidos para outros agravos, no âmbito da atenção pré-natal para gestantes e suas parcerias sexuais. Diário oficial da união, Brasília, DF, 2012.

Coordenadoria de Pesquisa e Extensão - COPEX

Departamento de Editoraçāo e Divulgaçāo Científica - DEDIC 


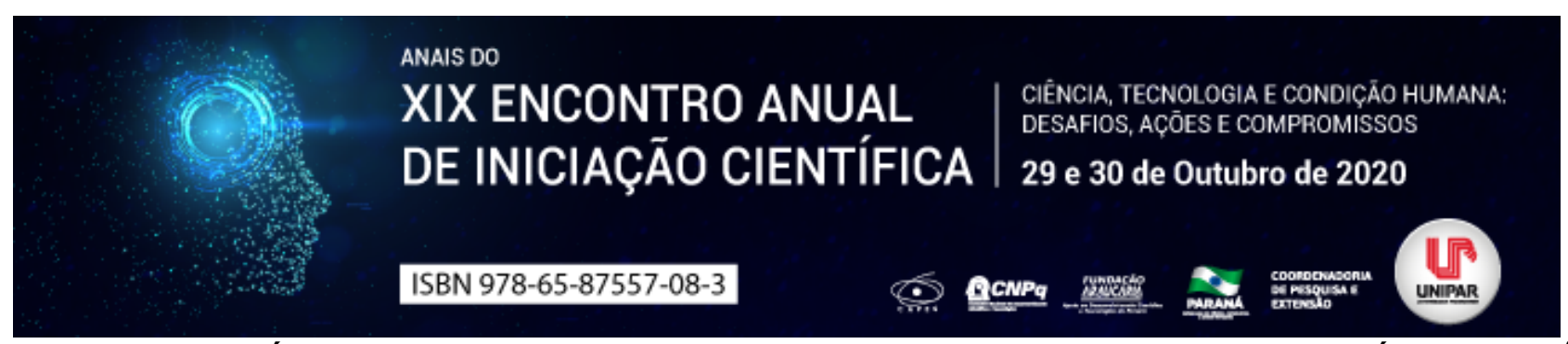

\title{
NÍVEIS DE FERRITINA SÉRICA EM PACIENTES DO SEXO MASCULINO ATENDIDOS NO LABORATÓRIO DE ANÁLISES CLÍNICAS DA UNIPAR
}

\author{
${ }^{1}$ DAIANA PIERINA FOPPA, ${ }^{2}$ LEIDI COMERLATO, ${ }^{3}$ ANA CAROLINA PEREIRA DA SILVA, ${ }^{4}$ PATRICIA AMARAL GURGEL \\ VELASQUEZ
}

${ }^{1}$ Discente do Curso de Farmácia e do Programa de Iniciação Científica da UNIPAR

${ }^{1}$ Discente do Curso de Farmácia e do Programa de Iniciação Científica da UNIPAR

Francisco Beltrão PR

${ }^{2}$ Farmacêutica do Curso de Farmácia da UNIPAR Francisco Beltrão PR

${ }^{3}$ Docente do Curso de Farmácia da UNIPAR Francisco Beltrão PR

Introdução: A ferritina é uma proteína presente em órgãos como fígado, baço, medula óssea e rim, cuja função primária é acumular o ferro intracelular, protegendo a célula dos efeitos tóxicos do metal livre. Porém, a ferritina pode sofrer alterações devido a sua capacidade de defesa celular contra estresse oxidativo e processos inflamatórios, apresentando elevação durante processos inflamatórios, infecciosos e neoplásicos, e também no alcoolismo, doenças hepáticas e neurodegenerativas (RAMAKRISHNAN et al., 2002; CHANG et al., 2013). Essa condição é avaliada através de exames laboratoriais como a dosagem de ferritina sérica e quando detectado hiperferritinemia, realiza-se a saturação de transferrina. Estima-se que apenas $10 \%$ dos casos de ferritina acima dos limites de normalidade são devidos a sobrecarga de ferro, por isso é necessário avaliar os fatores que possam elevar a ferritina (FLEMING, PONKA, 2012; GOOT et al. 2012). O tratamento pode ser realizado através de quelantes de ferro ou, embora controversa, o tratamento através da realização de sangria tem mostrado bons resultados (ESPER, 2015).

Objetivo: Avaliar o perfil de ferritina sérica e índices hematimétricos de pacientes do sexo masculino atendidos no Laboratório de Análises Clínicas da UNIPAR de Francisco Beltrão - PR.

Material e Métodos: Após aprovação pelo comitê de ética, foi realizado um levantamento de dados no período de janeiro a dezembro de 2019, dos pacientes do sexo masculino atendidos no Laboratório de Análises Clínicas da UNIPAR de Francisco Beltrão PR que realizaram o exame de ferritina. Os parâmetros avaliados foram faixa etária, valores de ferritina, hemoglobina e volume corpuscular médio (VCM).

Resultados: Ao analisar os valores de ferritina das amostras de 391 pacientes do sexo masculino, observou-se que, 4,1\% (16) apresentaram resultados abaixo do valor de referência, enquanto 55,5\% (217) estavam dentro da normalidade e 40,4\% (158) apresentaram elevados níveis de ferritina. Dos que apresentaram ferritina elevada, a faixa etária mais frequente foi a de 46 a 60 anos com $55,1 \%$ dos casos, seguida da faixa etária de 31 a 45 anos (21,51\%) e 61 a 75 anos (19,6\%). O hemograma foi realizado em 321 pacientes onde 44,5\% tiveram hemoglobina normal, 4,6\% baixa e 33,0\% apresentaram hemoglobina aumentada. Dos pacientes com a hemoglobina aumentada, 34,9\% também apresentam valores elevados no exame de ferritina. Já para o VCM, 74,4\% foram normais e 7,4\% apresentaram microcitose.

Discussão: $O$ significado clínico da hiperferritinemia ainda não está totalmente elucidado, no entanto sabe-se que ela está associada ao aumento da gravidade e morbimortalidade de diversas patologias (BAHR, 2019). No presente estudo, 40,4\% dos pacientes analisados apresentaram elevação da ferritina sérica, esse achado está de acordo com outras pesquisas presentes na literatura, como no estudo de Brito (2019), onde 49,6\% apresentaram a mesma alteração. Em relação a faixa etária, Boeira e Cunha (2018) avaliaram os níveis de ferritina em diferentes idades e constataram que a média com maior frequência de hiperferritinemia foi a de 56,4 anos, dado que corrobora com o presente estudo, onde a faixa etária de maior frequência foi a de 46 a 60 anos. Não se pode afirmar o motivo exato do elevado índice de ferritina sérica ser mais frequente em homens acima de 46 anos de idade, a literatura traz como uma das possíveis causas a síndrome metabólica, que envolve aumento do perímetro abdominal, pressão alta, diminuição do colesterol HDL e elevação dos triglicerídeos séricos. Nestes casos a detecção de índices elevados de ferritina poderia auxiliar no diagnóstico da síndrome metabólica (BOEIRA, CUNHA, 2018). Como a maior parte do ferro no organismo está associada à molécula de hemoglobina, a fagocitose e degradação de hemácias senescentes representa uma fonte importante de ferro. Essa quantidade de ferro reciclado é suficiente para manter a necessidade diária de ferro para a eritropoiese. Em situações em que a ferritina se apresenta elevada e a hemoglobina baixa entende-se que a causa da hiperferritinemia não se deve ao ferro, mas sim a um problema secundário (ESTEVÃO, 2010).

Conclusão: $O$ aumento da ferritina sérica pode ser entendido como um alerta do organismo que algo não está funcionando bem, pois às vezes ela é um sintoma secundário a alguma doença, como hepatopatias, anemia, patologias graves, doenças inflamatórias, doenças infecciosas e síndromes metabólicas. Portanto destaca-se a importância de incluir a dosagem de ferritina nos exames de rotina, para acelerar o diagnóstico e o tratamento que são essenciais para a melhor qualidade de vida e evitar o 


\section{Referências}

BAHR, Timothy M et al. Ferritin in serum and urine: a pilot study. Blood Cells, Mol and Dis. v.76, n. 1, p.59-62, 2019.

BOEIRA, Luana; CUNHA, Gladis Franck. Estudo exploratório de pacientes com índices elevados de ferritina (hiperferritinemia) atendidos em serviços de saúde no município de Bento Gonçalves RS. Rev. Interdisciplinar de Ciência Aplicada, v. 3, n. 6, p.10-15, 2018.

BRITTO, Gabriela Marcon. O perfil epidemiológico de pacientes com hiperferritinemia e análise do subdiagnóstico de linfohistiocitose hemofagocítica. 2019. 58 f. Trabalho de conclusão de curso (Graduação em Medicina) Universidade Federal da Fronteira Sul, Passo Fundo RS, 2019.

CHANG, Jung-Su et al. Serum ferritin and risk of the metabolic syndrome: a population-based study. Asia Pac J Clin Nutr. v.22, n.3, p. 400-407, 2013.

ESTEVÃO, Isabeth F et al. Valores de ferritina sérica em beta talassemia heterozigota. Rev. Bras. Hematol. Hemoter. v.32, n. 2, p.171-172, 2010.

FLEMING, Robert E; PONKA, Prem. Iron Overload in human disease. N Engl J Med. v.366, n.4, p.348-359, 2012.

GOOT, Katie et al. Elevated sérum ferritin what should GPs Know? Aust Fam Physician. v. 41, n. 12, p. 945-949, 2012.

RAMAKRISHNAN, Usha; KUKLINA, Elena; STEIN, Aryeh D. Iron stores and cardiovascular disease risk factors in women of reproductive age in the United States. The American Journal of Clinical Nutrition. v.76, n.6, p.1256-1260, 2002. 


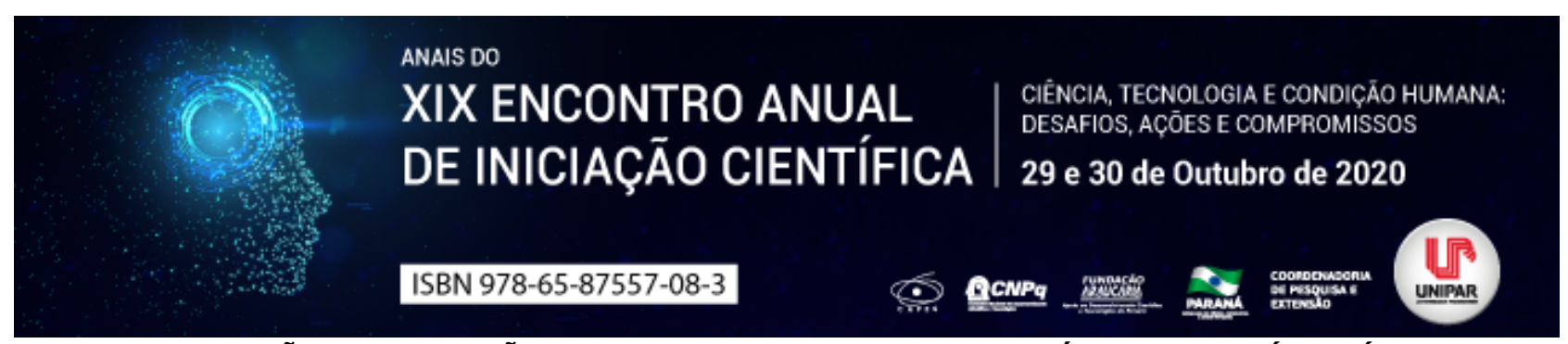

PREVENÇÃO E CORREÇÃO DE DESVIOS POSTURAIS ATRAVÉS DO EXERCíCIO FíSICO

\title{
1JOAO VICTOR JOLO, ${ }^{2}$ MARCELO FIGUEIRÓ BALDI
}

\author{
${ }^{1}$ Acadêmico do PIC/unipar \\ ${ }^{1}$ Docente da UNIPAR
}

Introdução: Diferentes programas de exercícios, surgiram ao longo do tempo com o intuito de aprimorar e eventualmente até corrigir padrões posturais que diferem da normalidade (VANICOLA et al., 2007). Entre essas práticas de exercícios atuais estão Pilates, RPG (reeducação postural global), alongamentos, musculação e natação. Uma educação postural regrada protege o indivíduo de lesões, considerando a biomecânica da coluna vertebral e as influências que o meio ambiente exerce nas atitudes e hábitos desenvolvidos e adotados pelos indivíduos (BRACCIALLI; VILARTA, 2000). Sendo assim, desenvolvidos dentre diferentes tipos de desvios como escoliose, hipercifose e hiperlordose que são anormalidade causadas por irregularidade e movimentos incorretos da coluna vertebral.

objetivo: Analisar as recomendações da literatura científica em relação à prevenção e correção dos desvios posturais através de exercícios físicos.

Desenvolvimento: Existem vários componentes da postura corporal, são eles: o aspecto evolutivo da postura ereta, a força gravitacional e muscular, o sistema endócrino, o equilíbrio, o reflexo, a imagem corporal, a atitude, a personalidade, a profissão, a hereditariedade e a influência social (SALVE; BANKOFF, 2003). Ainda segundo Salve e Bankoff (2003) retrata que a manifestação corporal está implicada a personalidade, e a maneira de posicionar-se diante das diversas situações, refletindo a trajetória de vida sendo o resultado de vários sistemas que atuam no organismo. Diante dos diferentes estímulos, os indivíduos podem adotar uma postura adequada ou inadequada, ou seja, com uma postura inadequada, o mínimo de atividade física que eleva o comprometimento e a compressão da coluna vertebral, se torna eficaz para prevenir certos desvios. O hábito da postura inadequada, leva o indivíduo a ter problemas no corpo interno e externo, por esse modo o alongamento, junto ao fortalecimento são exercícios essenciais para autocorreção da postura e prevenção de lesões segundo Braccialli e Vilarta (2000). O alongamento está representado também juntamente ao Pilates sendo um programa de exercícios que tem sido amplamente utilizado para reeducação postural e reabilitação geral, também reivindicada para melhorar a postura, reforçando a consciência corporal, com o uso de aparelhos ou até mesmo com alongamentos no solo (SCHOPPPEN, 2016). Outro método utilizado como correção postural é o método de Reeducação Postural Global (RPG), o qual tem por objetivo a prevenção e recuperação de disfunções musculoesqueléticas (SCHOPPPEN, 2016). Atualmente a musculação se destaca, sendo uma das modalidades de exercício mais praticadas em todo mundo, não somente os jovens são adeptos desta modalidade, pois tem sido reconhecida a sua importância para idosos, cardiopatas e até para crianças, podendo ser usada para melhora de aspectos funcionais e patológicos, como os desvios posturais citado por Schopppen (2016). Além desses exercícios tem-se dado um enfoque corretivo e postural para a prática de natação, especialmente para o nado de costas, sendo considerado um ótimo exercício para correção da cifose torácica, isso porque enfatiza o fortalecimento dos músculos dorsais (SCHOPPPEN, 2016). É importante lembrar que, estes exercícios devem ser selecionados de acordo com as alterações posturais que cada indivíduo apresenta, sendo diferentes níveis de desvios posturais desde leve, moderado e até intenso entre os mesmos torácicos, toraco-lombar e lombar, cujo diferentes tipos de autocorreção podem ser adaptados durante a realização de tarefas cotidianas considerada por Vinicola et al. (2007).

Conclusão: Conclui-se que, para a prevenção e melhora da postura corporal os exercícios físicos de alongamentos corporais e fortalecimento muscular sob as orientações de um profissional de Educação Física colaboram na reeducação postural do indivíduo com o intuito de obter resultados positivos diante de hábitos irregulares no cotidiano.

\section{Referências}

BRACCIALLI, Lígia. M. P.; VILARTA, Roberto. Aspectos a serem considerados na elaboração de programas de prevenção e orientação de problemas posturais, Revista Paulo educação física, São Paulo, p. 159-71, jul./dez. 2000. Acesso em: 19 jul. 2020.

BUENO, Rita. C. S.; RECH, Ricardo. R. D. Desvios posturais em escolares de uma cidade do Sul do Brasil. Revista Paulo Pediatria, v. 31, n. 2, jun. 2013. Acesso em: 19 jul. 2020.

PORTO, Flávia. et al. O Exercício físico influencia a postura corporal de idosos?. Revista educação física, v. 18, n. 3, July/sept. 2012. Acesso em: 19 jul. 2020.

SALVE, Mariângela. G. C.; BANKOFF, Antonia, D, P. Postura corporal - um problema que aflige os trabalhadores. Revista brasileira saúde ocupacional, v. 28, p. 105-106, São Paulo. 2003. Acesso em: 19 jul. 2020. 
VANICOLA, Maria. C. et al. Reeducação da postura corporal. Revista Rio Claro, v. 13, n. 4, p. 305-311, out./dez. 2007. Acesso em: 19 jul. 2020.

Coordenadoria de Pesquisa e Extensão - COPEX

Departamento de Editoraçāo e Divulgaçāo Científica - DEDIC 


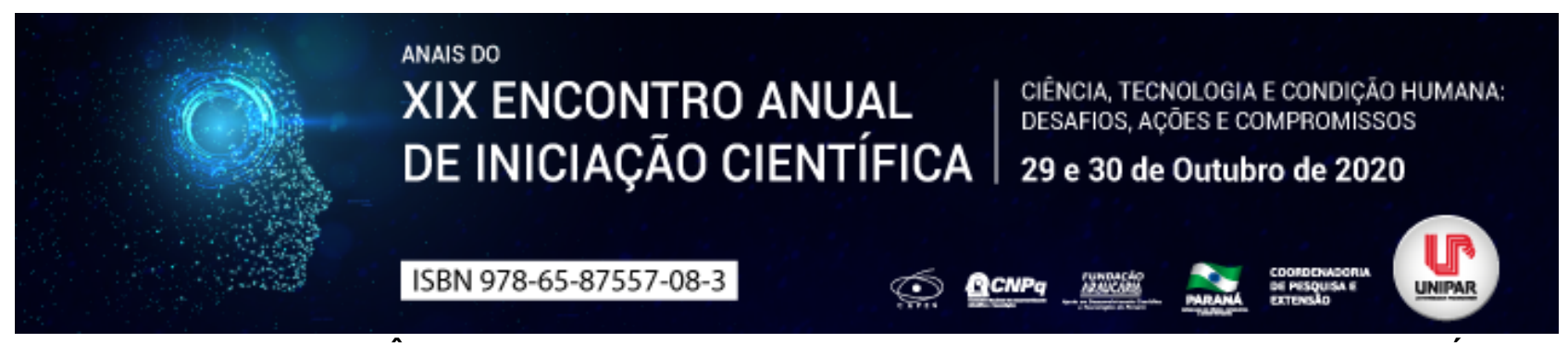

APLICABILIDADE TERAPÊUTICA DO GEL DE AROEIRA (Schinus terebinthifolius raddi) EM DISTÚRBIOS GINECOLÓGICOS

\author{
${ }^{1}$ FABIOLA COSTA TAKAKUA,${ }^{2}$ MONICA MICHELI ALEXANDRE,${ }^{3}$ LETICIA RODRIGUES GENARIO, ${ }^{4}$ MARIANE DE ALMEIDA \\ MACHADO, ${ }^{5}$ MARINA GIMENES
}

\author{
1acadêmico PIC- Unipar \\ ${ }^{1}$ Acadêmica do Curso de Medicina da UNIPAR \\ ${ }^{2}$ Acadêmica do Curso de Farmácia da UNIPAR \\ ${ }^{3}$ Acadêmica do Curso de Farmácia da UNIPAR \\ ${ }^{4}$ Docente da UNIPAR
}

Introdução: Utilizando as bases de dados Scielo e PubMed foi realizado a busca de dados terapêuticos para afecções ginecológicas sobre a Schinus terebinthifolius raddi vulgarmente nomeada de aroeira, é uma espécie brasileira encontrada desde o nordeste até o sul do país, contudo, amplamente distribuída aos arredores da América do Sul (NEVES et al., 2016). Constituída por árvores de médio a grande porte, possui cascas escamosas e afiladas, já o aspecto foliáceo apresenta formato de lança. As pequenas flores distribuídas nos pedúnculos variam da coloração branca ao amarelo esverdeado e os frutos carnosos avermelhados são do tipo drupa a qual exala odor similar a pimenta (DEGÁSPARI; WASZCZYNSKYJ; PRADO; 2005). Pertencente à família Anacardiaceae possui propriedades antiinflamatória, antimicrobiana, antialérgica e cicatrizante, sendo aplicada em distúrbios gastrointestinais, neuralgias e tradicionalmente em afecções ginecológicas, e, possui ação adstringente e tônica. Como via oral, a extração da porção do fruto é empregado na indústria alimentícia na forma de condimento (FALCÃo et al., 2015). Popularmente é denominada de aroeira vermelha, aroeira pimenteira, pimenta brasileira, isso se dá pela atribuição das características do fruto semelhante a uma pequena pimenta de coloração vermelha-rosácea. (LENZI; ORTH; 2004).

Objetivo: . Buscar na bibliografia as atividades terapêuticas da aroeira contra afeccções ginecológicas.

Desenvolvimento: Historicamente, teve seu primeiro registro na Farmacopeia Brasileira no ano de 1926, e faz parte da relação de Fitoterápicos do Sistema Único de Saúde (SUS), listada pela RENAME, e aprovada como droga fitoterápica pela Agência Nacional de vigilância à saúde (ANVISA), sob a forma de apresentação gel ginecológica e óvulos vaginais, e em 1999 o medicamento foi comercializado em gel, Kronel ${ }^{\circledR}$ (AMORIM; SANTOS, 2003). Em 1920, foi usada o extrato da planta para edema de membros inferiores e sintomas reumáticos (GILBERT; FAVORETO, 2011). Segundo a Farmacopéia brasileira, as propriedades terapêuticas estão contidas nas cascas do caule, entretanto, também encontra distribuídas aos frutos, folhas e raízes onde são usados popularmente na medicina. Os compostos químicos identificados estão atribuídos aos diversos polifenóis como os flavonoides, cumarinas, iridóides, taninos, metilxantinas, alcaloides, monoterpenos, sesquiterpenos, e saponinas (CARVALHO et al., 2013). Exibindo atividade antibacteriana contra Candida albicans, Escherichia coli,Staphylococcus álbuns, Staphylococcus aureus, Shigella dysenteriae, Bacillus subtilis (CARVALHO et al., 2013; SILVA et al., 2010). A aroeira revela uma alta diversidade ao tratamento de variadas patologias, pois possuem propriedades medicinais de grande interesse clínico. $\mathrm{O}$ primeiro estudo clínico referente a ação ginecológica da aroeira, foi no ano de 1974, onde o extrato da planta foi aplicado em 100 mulheres apresentando colpite e vaginite. Segundo Wanick (1974), acreditavam que os resultados citológicos seriam satisfatórios, porém como não foram demonstrados os achados citológicos antes do uso da aroeira, não houve possibilidade de comprovar sua efetividade. Dificilmente é observado inflamação ou alteração no sistema genital das mulheres que utilizam a aroeira nas consultas rotineiras ao ginecologista, pois demonstram fortalecimento no equilíbrio da flora vaginal, assim como uma diminuição contra invasão de patógenos. De acordo com Amorim (2003), publicaram o primeiro estudo do gel de aroeira clínico randomizado no mundo para tratar vaginose, controlado por placebo, foi testado em 48 mulheres sintomáticas e os resultados mostraram a cura em $84 \%$ contra $47,8 \%$ respectivamente. Além do mais, não houveram queixas de efeitos adversos e a presença de lactobacilos no esfregaço cervicovaginal aumentou em relação às usuárias do placebo. Ainda nesse contexto, os autores relatam que esse é o primeiro estudo do gel de aroeira clínico randomizado publicado no mundo para tratar vaginose. Essa ocorrência pode ser talvez pela consequência da utilização tradicional e consagrada da aroeira pela população em que poucas pesquisas clínicas têm sido aplicadas em seres humanos. No entanto, é evidente que o processo de cozimento (decocto) do caule da aroeira é comumente usados pelas mulheres nordestinas com a finalidade de tratar corrimentos e cervicites. Portanto, com base na tradição popular, é feito principalmente em banhos de assento após o parto, como ação anti-inflamatória e cicatrizante, ou como medicamento caseiro para o tratamento de doenças do sistema geniturinário (LORENZI; MATOS, 2002).

Conclusão: O gel de aroeira pode ser aplicado ao tratamento contra vaginose bacteriana assim representado no estudo em que houve $84 \%$ de mulheres curadas. Proporciona uma melhora no equilíbrio da flora vaginal com provável redução de recidivas. 
Considerando a alta disponibilidade de matéria prima e a necessidade de medidas a fim de minimizar a resistência bacteriana, a aroeira pode ser uma alternativa futura para tratamentos ginecológicos, entretanto, existe a necessidade de mais pesquisas e estudos clínicos detalhados.

\section{Referências}

AMORIM, Melania Maria Ramos de; SANTOS, Luiz Carlos. Tratamento da vaginose bacteriana com gel vaginal de Aroeira (Schinus terebinthifolius Raddi): ensaio clínico randomizado. Rev. Bras. Ginecol. Obstet., Rio de Janeiro , v. 25, n. 2, p. 95102, mar. 2003.

CARVALHO, Maria Graça; et al. Schinus terebinthifolius Raddi: composição química, propriedades biológicas e toxicidade. Revista brasileira de plantas medicinais, Botucatu, v. 15, n. 1, p. 158-169, 2013.

DEGÁSPARI, Cláudia Helena; WASZCZYNSKYJ, Nina; PRADO, Maria Rosa Machado. Atividade antimicrobiana de Schinus terebenthifolius Raddi. Ciênc. Agrotec., Lavras, v. 29, n. 3, p. 617-622, maio/jun., 2005.

FALCÃO, Maria Priscila Mendes Muniz et. al. Schinus terebinthifolius Raddi (Aroeira) e suas propriedades na Medicina Popular. Revista Verde, Paraíba, v. 10, n. 5, p. 23 - 27, dez. 20

GILBERT, Benjamin; FAVORETO, Rita. Schinus terebinthifolius Raddi, Revista Fitos, Rio de Janeiro, v. 6, n. 1, p. 43-56, 2011.

LENZI, Maurício; ORTH, Afonso Inácio. Characterization of the functional reproductive system of the pink-pepper (Schinus terebinthifolius Raddi). Revista Brasileira de Fruticultura, Jaboticabal, v.26, n.2, p.198-201, 2004.

LORENZI, Harri; MATOS, Francisco José de Abreu. Plantas medicinais no Brasil: nativas e exóticas. Instituto Plantarum, Nova Odessa, 512p. 2002. ISBN 8586714186.

NEVES, Edinelson José Maciel, et. al., Cultivo da aroeira-vermelha (Schinus terebinthifolius Raddi) para produção de pimenta-rosa. Embrapa Florestas, Colombo, 27 p., set. 2016.

SILVA, A.B. et al . Antibacterial activity, chemical composition, and cytotoxicity of leaf's essential oil from Brazilian pepper tree (Schinus terebinthifolius, Raddi). Braz. J. Microbiol., São Paulo , v. 41, n. 1, p. 158-163, mar. 2010.

Coordenadoria de Pesquisa e Extensão - COPEX

Departamento de Editoraçāo e Divulgaçāo Científica - DEDIC 


\title{
ANAIS DO \\ XIX ENCONTRO ANUAL | CIÊNCIA, TECNOLOGIA E CONDIÇÃO HUMANA: DE INICIAÇÃO CIENTÍ́FICA \\ DE INICIAÇÃO CIENTÍFICA 29 e 30 de Outubro de 2020 \\ ISBN 978-65-87557-08-3 \\ $\cos =1$ \\ USO DA LASERTERAPIA PARA TRATAMENTO DE MUCOSITE ORAL EM PACIENTE SUBMETIDA À TRATAMENTO ONCOLÓGICO - RELATO DE CASO
}

\author{
${ }^{1}$ GABRIEL MACIEL DA SILVA, ${ }^{2}$ BEATRIZ AYUMI SHIOTANI, ${ }^{3}$ GABRIELI JANKE RIGHEZ, ${ }^{4}$ JOAO CARLOS RAFAEL JUNIOR , \\ ${ }^{5}$ SABRINA PAIXAO DOS SANTOS RODRIGUES, ${ }^{6}$ CÍNTIA DE SOUZA ALFERES ARAÚJO
}

\author{
${ }^{1}$ Acadêmico PIBIC/UNIPAR \\ ${ }^{1}$ Acadêmica PIC/UNIPAR \\ ${ }^{2}$ Acadêmica PIC/UNIPAR \\ ${ }^{3}$ Acadêmico Bolsista PEBIC - CNPq UNIPAR \\ ${ }^{4}$ Acadêmica do Curso de Odontologia da UNIPAR \\ ${ }^{5}$ Docente da UNIPAR
}

Introdução: Tratamentos oncológicos, como a quimioterapia, têm como objetivo principal destruir as células cancerosas. No entanto, a maioria dos agentes quimioterápicos não atua de forma seletiva, danificando tanto as células malignas quanto as normais, particularmente as de crescimento rápido como as gastrointestinais, as capilares e as imunológicas (KWON, 2016). Os principais tipos de tratamentos do câncer são cirurgias, radioterapia e quimioterapia. As duas últimas modalidades, por não diferenciarem células neoplásicas de células sadias, a exemplo das células da mucosa bucal, frequentemente produzem vários efeitos colaterais como mucosite, cáries, xerostomia, ageusia e disgeusia, infecções secundárias, osteorradionecrose e trismo, sendo a mucosite oral um dos efeitos mais comuns do tratamento antineoplásico (MORAIS et al., 2015).

Objetivo: Relatar um caso clínico sobre mucosite oral durante o tratamento oncológico, bem como descrever e comentar sobre a importância de identificar essa patologia em seu estado de início.

Relato de Caso: Paciente do gênero feminino 72 anos, diagnosticada com carcinoma espinocelular localizado na região de pilar amigadaliano, tendo sido submetida a tratamento quimioterápico e radioterápico, compareceu a Clínica Odontológica da UNIPAR - Umuarama queixando-se de lesões ulceradas, dolorosas que surgiram em toda mucosa bucal após o término da radioterapia sendo assim, diagnosticada como mucosite, sendo classificada inicialmente com grau 2. Optou-se pela fotobioestimulação diária por dez dias, com laser de baixa potência LLLT, InGaAIP (Therapy XT, DMC) 600nm 2J/cm e $100 \mathrm{~mW}$ no local das lesões e em outras regiões da mucosa de forma a prevenir surgimento de outras lesões. A fotoestimulação promovia alívio sintomático, entretanto as lesões persistiam, chegando a um grau 3, o que a levou a internamento hospitalar. Após diversas sessões e associação com outras terapias, o quadro clínico mostrou melhora. A paciente continua em atendimento.

Discussão: A mucosite oral (MO) é um importante efeito adverso observado em pacientes oncológicos submetidos ao tratamento com quimioterapia e/ou radioterapia para cabeça e pescoço. Esta doença se manifesta clinicamente como lesões erosivas e/ou ulcerativas, que podem causar dor leve a grave. Estas lesões geralmente levam à diminuição significativa da qualidade de vida, uma vez que podem prolongar o tempo de internação hospitalar, influenciar no estado nutricional do paciente, aumentar o risco de infecções e aumentar a prescrição de opioides (CURRA et al., 2018). A mucosite oral é uma sequela comum do tratamento quimioterápico e/ou radioterápico ocorrendo em $40 \%$ a $100 \%$ das inflamações da mucosa oral. A classificação de mucosite oral, determinada pela Organização Mundial de Saúde (OMS) é: grau 0 - ausente; grau 1 - eritematosa; grau 2 eritematosa e ulcerada (indivíduo tolera sólidos); grau 3 - eritematosa e ulcerada (indivíduo aceita apenas líquidos); grau 4 eritematosa e ulcerada (alimentação impossibilitada do indivíduo) (REOLON et al., 2017). Ela é caracterizada como uma inflamação e ulceração da mucosa oral com formação de pseudomembranas que se constitui a fonte potencial de infecções com risco de morte. Este efeito se dá, principalmente, em pacientes submetidos ao tratamento oncológico para os diversos tipos de tumores do trato gastrointestinal, leucemias e àqueles submetidos a transplante de medula óssea (MORAIS et al., 2015). A laserterapia em pacientes oncológicos com mucosite oral tem conhecida habilidade de provocar efeitos biológicos por meio de processos fotofísicos e bioquímicos, aumentando o metabolismo celular. À medida que estimula a atividade mitocondrial, o laser atua como anti-inflamatório, analgésico e cicatrizador das lesões na mucosa. Toda a energia emanada do laser é absorvida por uma fina camada de tecido adjacente e também do ponto atingido pela radiação, desencadeando a proliferação epitelial e de fibroblastos, assim como alterações celulares e vasculares. Também se verifica a ocorrência de produção de colágeno e elastina, contração da ferida, aumento da fagocitose pelos macrófagos e da proliferação e ativação dos linfócitos, além da força de tensão que consequentemente acelera a cicatrização. O laser atua na prevenção e tratamento da mucosite oral para que haja manutenção da integridade da mucosa (REOLON et al., 2017).

Conclusão: Conclui-se que o laser de baixa potência é bem tolerado pelos pacientes e mostrou efeitos benéficos durante a abordagem da mucosite oral, melhorando a qualidade de vida dos pacientes durante o tratamento oncológico. 


\section{Referências}

CURRA, Marina. et al. Chemotherapy protocols and incidence of oral mucositis. An integrative review. Einstein (São Paulo), v. 16, n. 1, 2018.

KWON, Youngjoo. Manejo baseado em mecanismo para mucosite: opção para tratar os efeitos colaterais sem comprometer a eficácia da terapia do câncer. OncoTargets e terapia, v. 9, p. 2007, 2016.

MORAIS, Jaylinne Ribeiro. et al. Caracterização do paciente com mucosite oral induzida por quimioterapia / Caracterização do paciente com mucosite oral induzida por quimioterapia / Caracterização do paciente com mucosite oral induzida por quimioterapia. Revista de Enfermagem da UFPI, v. 4, n. 1, pág. 26-32, 2015.

REOLON, Luiza Zanette. et al. Impacto da laserterapia na qualidade de vida de pacientes oncológicos portadores de mucosite oral. Revista de Odontologia da UNESP, v. 46, n. 1, p. 19-27, 2017.

Coordenadoria de Pesquisa e Extensão - COPEX

Departamento de Editoração e Divulgação Científica - DEDIC 


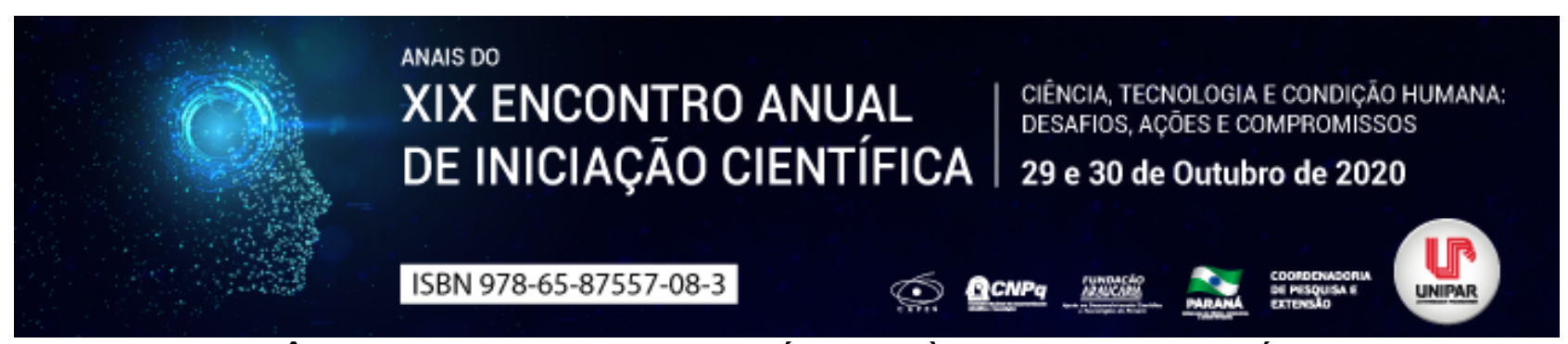

ASSISTÊNCIA DE ENFERMAGEM NO PRÉ-NATAL ÀS GESTANTES EM CÁRCERE

\author{
${ }^{1}$ CAMILA SANTANA DA COSTA, ${ }^{2}$ AMANDA STEFANI DA SILVA CRUZ, ${ }^{3}$ MIRELLA CARLOS SIQUEIRA, ${ }^{4}$ AMANDA \\ NASCIMENTO VASQUES DE SOUZA
}

\author{
${ }^{1}$ Acadêmica do Curso de Enfermagem da UNIPAR \\ ${ }^{1}$ Acadêmica do Curso de Enfermagem da UNIPAR \\ ${ }^{2}$ Acadêmica do Curso de Enfermagem da UNIPAR \\ ${ }^{3}$ Docente da UNIPAR
}

Introdução: Segundo os dados a população carcerária em 2014 é de aproximadamente 579.781 presos, sendo que 37.380 são mulheres. A maioria se destaca por serem jovens com faixa etária de 18 a 29 anos (50\%), negra (62\%), solteira (62\%), multigestas (74\%), com escolaridade incompleta (85\%), e a maioria delas está envolvida com tráfico de drogas, transporte ou comercialização de entorpecentes (BRASIL, 2014; BRASIL, 2018). No Brasil, a população carcerária feminina chegou a 42.000 , tendo um aumento significativo, colocando o país no quarto lugar do ranking dos países com maiores populações carcerárias femininas do mundo (BRASIL, 2018). Apesar de viver um momento único que é a gestação, as mulheres encarceradas sofrem com a assistência de saúde prestada nos presídios do Brasil, a implementação falha do acompanhamento da Rede Cegonha, que pode influenciar em complicações obstétricas (ANDRADE; GONÇALVES, 2018).

Objetivo: Destacar as dificuldades que as gestantes reclusas encontram e a importância da assistência de enfermagem ao prénatal das gestantes encarceradas.

Desenvolvimento: As mulheres em cárcere relatam a demora no agendamento das consultas, e a falta de profissionais capacitados para prestar esse cuidado, visto que é preconizado pelo Ministério da Saúde (MS), o direito á assistência completa do acompanhamento (ANDRADE; SANTOS; DUARTE, 2019). São evidentes que as prisões brasileiras existem muitos empecilhos que atrapalham o cuidado das gestantes, como por exemplo, a estrutura, instalações com o numero superior ao preconizado, condições inadequadas de iluminação, ventilação e higiene (BRASIL, 2018). Portanto uma das principais dificuldades das reclusas são as condições de isolamento que impede de forma integral e efetiva o acesso aos serviços de saúde, portanto o MS elaborou a Política Nacional de Atenção Integral à Saúde das Pessoas Privadas de Liberdade no Sistema Prisional, onde visa o acesso a rede pública universal, promovendo autonomia para a equipe de saúde durante o cuidado prestado e o acesso ao Sistema Único de Saúde (BRASIL, 2014). A Lei de Execução Penal no 7.210/1984, foi criada com o intuito de promover a separação prisional de acordo com o gênero, na tentativa de proporcionar uma situação harmônica, com o objetivo preventivo e curativo, condições físicas necessárias para promover a assistência de saúde adequada, a lei também traz que caso a assistência á saúde da mulher não seja realizada na penitenciária a mesma tem o direito de ser transferida para unidade de saúde mais próxima, onde ela terá o atendimento integral e respeitado (BRASIL, 1984). Como é preconizada pela Organização Mundial de Saúde (OMS), a importância do acompanhamento da equipe de saúde ao pré-natal, puerpério, e até o recém nascido (RN), conforme previsto na lei 11.942/2009 é estruturado que o estabelecimento penitenciário tenha condições físicas e de saúde, como berçário, onde as mulheres possam prestar os cuidados ao RN e alimentá-los (BRASIL, 2009). Conforme descrito nas regras das Nações Unidas para o tratamento de mulheres presas e medidas não privativas de liberdade para mulheres infratoras regra de Bangkok, onde apresentam um olhar individualizado para as características de gênero nas penitenciárias femininas na tentativa de haver locais reservados para que as reclusas gestantes ou em trabalho de parto, dar preferência de que o parto seja em hospitais e se não for possível e o RN vir a nascer no sistema penitenciário essa informação não deverá constar no seu registro de nascimento (BRASIL, 2016a). Visto que nos casos onde não houve crime grave, ou que não ofereça ameaça a reclusa poderá ser encaminhada para cumprir sua pena em prisão domiciliar dando preferência para o bem estar da gestante e visando uma gravidez humanizada (BRASIL, 2016b). Portanto as atribuições dos serviços de saúde no sistema carcerário visam à proteção, prevenção de agravos, o diagnóstico, tratamento, reabilitação e redução de danos, sendo que os profissionais participantes da equipe multiprofissional de saúde são compostos por médico, enfermeiro, psicólogo, farmacêutico, cirurgião dentista, técnico de enfermagem, assistente social, técnico em saúde bucal e terapeuta ocupacional (BRASIL, 2016a). Assim o enfermeiro pode atuar realizando testes rápidos, consultas de enfermagem, solicitar exames do pré natal, educação em saúde para as gestantes ofertar educação permanente para os funcionários da equipe de enfermagem (BRASIL, 2016b).

Conclusão: É evidente o atual cenário dos presídios femininos e a dificuldade que a gestante encontra em ter acessoà equipe de saúde, dessa forma, destaca se a importância em manter a interação dos órgãos de saúde com o sistema carcerário visando prestarum atendimento qualificado as gestantes encarceradas. O enfermeiro tem um papel relevante para garantir à continuidade 
nas consultas do pré natal, visando à proteção e prevenção da assistência a saúde, com um potencial de identificar os possíveis agravos que podem ocorrer durantea gestação oferecendo a essa mulher em cárcere o respeito adequado.

\section{Referências}

ANDRADE, A. B. C. A.; GONÇALVES, M. J. F. Maternidade em regime prisional: desfechos maternos e neonatais. Rev Enfermagem UFPE Online, Recife, v. 12, n. 6, p. 1763-1771, jun. 2018.

ANDRADE, U. V.; SANTOS, J. B.; DUARTE, C. A percepção da gestante sobre a qualidade do atendimento pré-natal em UBS, Campo Grande, MS. Rev Psicologia e Saúde, Campo Grande, v. 11 n. 1, p. 53-61, jan./abr. 2019.

BRASIL, Conselho Nacional da Justiça. Regras das Nações Unidas para tratamento de mulheres presas e medidas não privativas de liberdade para mulheres infratoras. Regras de Bangkok, Brasília, p. 21-68, 2016.

BRASIL, Ministério da Justiça, Levantamento nacional de informações penitenciárias infopen junho 2014, Departamento Penitenciário Nacional, Brasília, p. 5-27, 2014.

BRASIL, Ministério Da Justiça, Levantamento nacional de informações penitenciárias infopen mulheres, Departamento Penitenciário Nacional, Brasília, p. 13-54, 2018.

BRASIL, Portaria Interministerial $n^{\circ} 1$, de 02 de Janeiro de 2014. Institui a política nacional de atenção integral à saúde das pessoas privadas de liberdade no sistema prisional e no âmbito do Sistema Único de Saúde. Publicado no Diário Oficial da União.

BRASIL. Resolução $n^{\circ}$ 3, de 7 Junho de 2018. Conselho nacional de política criminal e penitenciária. Publicado no Diário Oficial da União, 13 junho de 2018, ISSN 1677-7042.

BRASIL, Lei $\mathrm{n}^{\circ}$ 11.942, de 28 de Maio de 2009. Institui as mães presas e aos recém - nascidos as condições mínimas de assistência. Publicado no Diário Oficial da União.

BRASIL. Lei n. 7.210, de 11 de Julho de 1984. Institui a Lei de execução penal. Publicado no Diário Oficial da União.

BRASIL, Secretaria De Estado Da Saúde, Atribuições da equipe de saúde no sistema prisional, Manual de Atribuições do Serviços de Saúde às Pessoas Privadas de Liberdade no Sistema Prisional, Santa Catarina, p. 10-22, 2016. 


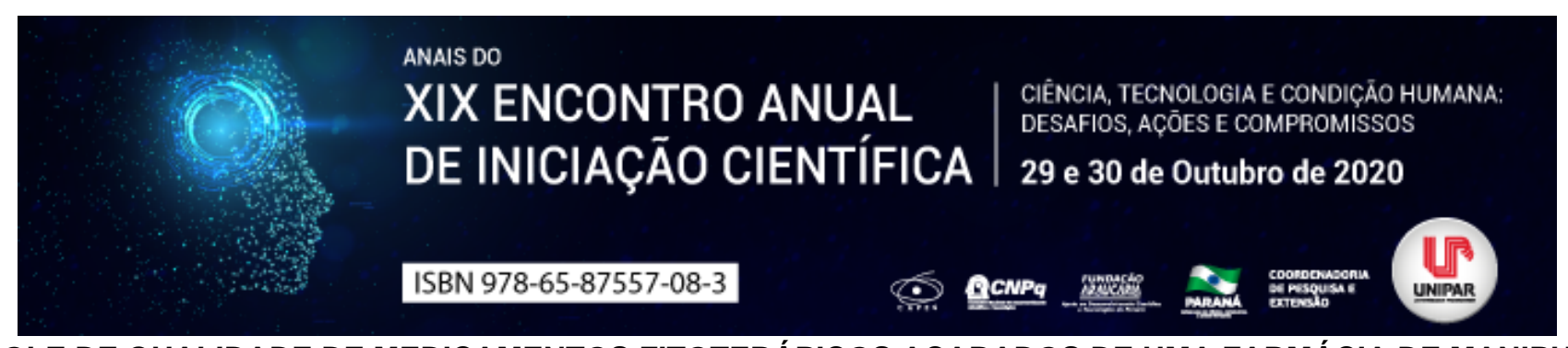

\title{
CONTROLE DE QUALIDADE DE MEDICAMENTOS FITOTERÁPICOS ACABADOS DE UMA FARMÁCIA DE MANIPULAÇÃO DE UM MUNICÍPIO DO SUDOESTE DO PARANÁ
}

\author{
${ }^{1}$ FABIANE LUCILA MEOTTI, ${ }^{2}$ MARIANE PAVANI GUMY, ${ }^{3}$ VANEZA PAULA POPLAWSKI CARNEIRO, ${ }^{4}$ JULIA COMACHIO \\ FAVRETTO, ${ }^{5}$ LEONARDO GARCIA VELASQUEZ
}

\author{
${ }^{1}$ Discente do Programa de Mestrado Profissional em Plantas Medicinais e Fitoterápicos na Atenção Básica/UNIPAR \\ ${ }^{1}$ Mestre em Plantas Medicinais e Fitoterápicos na Atenção Básica/UNIPAR \\ ${ }^{2}$ Mestre em Plantas Medicinais e Fitoterápicos na Atenção Básica/UNIPAR \\ ${ }^{3}$ Discente do curso de Farmácia/UNIPAR \\ ${ }^{4}$ Docente do Programa de Mestrado Profissional em Plantas Medicinais e Fitoterápicos na Atenção Básica/UNIPAR
}

Introdução: O uso de plantas para fins medicinais data do início da civilização, sendo esse recurso por muito tempo imprescindível para a prevenção de doenças, promoção, proteção e recuperação da saúde (FREGNANI; SALVI JUNIOR, 2020). A aprovação de políticas públicas para inclusão de plantas medicinais na Atenção Básica (BRASIL, 2016) permitiu o resgate da fitoterapia, após séculos de domínio da alopatia. O controle do processo executado da produção ao produto final, assegura a segurança e eficácia da terapêutica ao paciente.

Objetivo: Avaliar a qualidade de cápsulas manipuladas com extratos secos de fitoterápicos em uma farmácia de manipulação de um município do Sudoeste do Paraná.

Materiais e Métodos: O estudo foi realizado em uma farmácia de manipulação de um município do Sudoeste do Paraná. Tratase de uma pesquisa quantitativa do tipo descritiva. Os dados foram coletados em registros eletrônicos no período de 27/07/2020 a 14/08/2020, através da análise das fichas de produção e tabulados no software Microsoft Office Excel. Foram selecionados os quatro extratos mais prescritos no período (Passiflora incarnata, Curcuma longa, Melissa officinalis e Aesculus hippocastanum), na forma de cápsulas. Os testes realizados foram: peso médio, peso teórico, desvio padrão e desvio padrão relativo do produto acabado, obtidos através do Processador Estatítico SP 5000 da Gehaka, com metologia da Farmacopéia Brasileira $5^{a}$ edição (2010).

Resultados: No período de 27/07 a 14/08 de 2020 foram manipuladas 3.570 cápsulas de extrato seco de $P$. incarnata, prescritas em 68 receitas, representando $40,5 \%$ do total. O peso médio das cápsulas foi de 0,396 , desvio padrão 0,002737313 e desvio padrão relativo $0,46 \%$. As cápsulas de extrato seco de $C$. longa foram prescritas em 15 receitas (8,92\% do total) com 960 cápsulas manipuladas, apresentando peso médio 0,387, desvio padrão 0,003846154 e desvio padrão relativo $0,92 \%$. A terceira planta (10 receitas), 5,95\% do total foi a Castanha da Índia, da qual foram manipuladas 450 cápsulas com peso médio de 0,387 , desvio padrão 0,003846154 e desvio padrão relativo $0,92 \%$. A $M$. officinalis representou $7,73 \%$ das receitas (13 receitas), com 540 cápsulas manipuladas e peso médio 0,209 , desvio padrão 0,00178333 e desvio padrão relativo $1 \%$.

Discussão: Com o projeto Inserção de Plantas Medicinais na Atenção Básica do Ministério da Saúde, através de uma parceria entre a Prefeitura Municipal de Francisco Beltrão e a Universidade Paranaense UNIPAR, são disponibilizados para a população medicamentos fitoterápicos em cápsulas de Passiflora incarnata, Melissa officinalis, Curcuma longa, Aesculus hippocastanum, Cymbopogon citratus, Echinodorus grandiflorus, Equisetum arvense, Baccharis trimera, Piper methysticum e Ginkgo biloba. Dentre essas, os quatro fitoterápicos mais prescritos são a Passiflora incarnata L. (família Passifloraceae) com ações sedativa e ansiolítica (SILVA, 2018); a Melissa officinalis L. (família Lamiaceae), popularmente conhecida como ervacidreira, na qual os altos teores de ácidos fenólicos estão associados a capacidade antioxidante (DUTRA, 2019), além das propriedades antiespasmódica, ansiolítica e sedativa, descritas na Farmacopeia Brasileira (BRASIL, 2011); o Aesculus hippocastanum L. (família Sapindaceae), conhecida como Castanha da Índia, utilizada para o tratamento da insuficiência venosa e fragilidade capilar (BRASIL, 2016) e a Curcuma longa L. (família Zingiberaceae), denominada no Brasil popularmente como açafrão, com poderosas propriedades antioxidantes e anti-inflamatórias (BRASIL, 2015). Segundo a RDC no 67/2007, o cálculo do peso médio e o desvio padrão das cápsulas para avaliar a qualidade do produto acabado, seguindo as orientações da Farmacopeia Brasileira ou outro Compêndio Oficial reconhecido pela ANVISA é obrigatório (BRASIL, 2007). De acordo com Silva e Silva (2014), a determinação dele visa informar a homogeneidade por unidade do lote, indicando a eficiência do processo de pesagem e enchimento. Ele é determinado pela diferença dos valores individuais obtidos entre a cápsula cheia e vazia. A variação de peso aceitável para cápsula de gelatina dura apresentando peso médio igual ou superior a 300mg é de $\pm 7,5 \%$ e cápsulas com peso médio menor que 300mg não podem ter uma variação de peso maior que $10,0 \%$, determinando desvio padrão relativo das cápsulas (BRASIL, 2010). A não conformidade deste parâmetro constitui critério de reprovação do produto. $O$ Formulário Nacional da Farmacopeia Brasileira (2011) ressalta a necessidade de medir a variação e a extensão dos desvios em 
relação à média. No peso médio é possível a tolerância de duas cápsulas fora dos limites especificados, entretanto, nenhuma das cápsulas pode estar acima ou abaixo do dobro das porcentagens indicadas. O Formulário também destaca o cálculo do Desvio Padrão Relativo (DPR) ou coeficiente de variação (CV). Na segunda revisão da segunda edição do Formulário Nacional é enfatizado que o desvio padrão é relativo e é dado em porcentagem, não podendo ultrapassar $4 \%$.

Conclusão: Os medicamentos manipulados na farmácia de manipulação atendem as especificações de qualidade, estando assim, aprovados para a dispensação para a população.

\section{Referências}

BRASIL. Ministério da Saúde. Agência Nacional de Vigilância Sanitária. Resolução de Diretoria Colegiada no 67 de 08 de outubro de 2007. Dispõe sobre boas práticas de manipulação de preparações magistrais e oficinais para uso humano em farmácias. Diário Oficial da União, Brasília/DF, 09 out. 2007.

BRASIL. Ministério da Saúde. Agência Nacional de Vigilância Sanitária. Farmacopéia Brasileira, 5. ed. Brasília: ANVISA, 2010. BRASIL. Ministério da Saúde. Agência Nacional de Vigilância Sanitária. Formulário Nacional da Farmacopeia Brasileira. 2. ed. Brasília: ANVISA, 2011.

Brasil. Ministério da Saúde. Agência Nacional de Vigilância Sanitária. Formulário Nacional da Farmacopeia Brasileira 2.ed. 2. rev. Brasília: ANVISA, 2012.

BRASIL. Ministério da Saúde. Agência Nacional de Vigilância Sanitária. Monografia da espécie: Curcuma longa L. (Curcuma). Brasília: ANVISA, 2015.

BRASIL. Ministério da Saúde. Agência Nacional de Vigilância Sanitária. Memento Fitoterápico da Farmacopéia Brasileira, 1. ed. Brasília: ANVISA, 2016.

DUTRA, Jean Carlos Vencioneck. Caracterização fisiológica, fitoquímica e de atividades biológicas de plantas medicinais com potencial para produção de fitoterápicos. Tese (Doutorado em Biologia Vegetal) - Centro de Ciências Humanas e Naturais da Universidade Federal do Espírito Santo, Vitória, 2019.

FREGNANI, Joice; SALVI JUNIOR, Ademir. Perfil dos fitoterápicos dispensados em uma farmácia magistral do município de Jacutinga/MG. Revista Fitos, Rio de Janeiro, 2020.

SILVA, Rosemeire Lima; SILVA, Leandro de Oliveira. Controle de qualidade quanto à determinação de peso nas cápsulas manipuladas em farmácias da cidade de Mogi Guaçu, SP. Foco, ano 5, n. 7, jul./dez 2014.

SILVA, Fernando Eduardo Pereira. Avaliação de parâmetros físico-químicos de qualidade de medicamentos fitoterápicos à base de Passiflora spp Trabalho de Conclusão de Curso (Bacharel em Farmácia) - Universidade Federal de Campina Grande, Cuité/PB, 2018. 


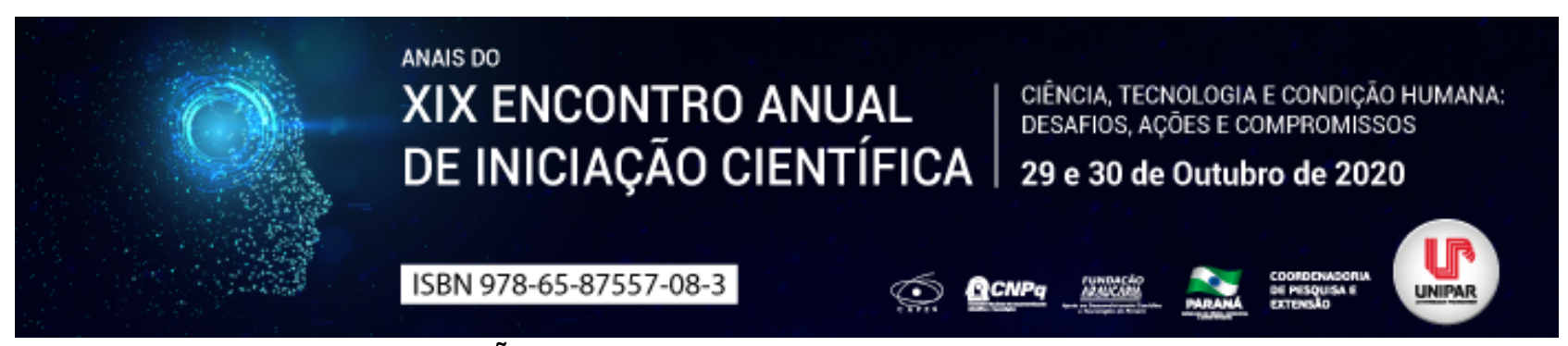

\title{
PERFIL DOS PROGRAMAS DE INICIAÇÃO ESPORTIVA ADOTADOS PELAS SECRETARIAS MUNICIPAIS DE ESPORTE DA MICRORREGIÃO DE CIANORTE
}

${ }^{1}$ MARCELO DE JESUS COSTA, ${ }^{2}$ VITOR HUGO RAMOS MACHADO

\author{
${ }^{1}$ Acadêmico do PIC-PÓS/UNIPAR \\ ${ }^{1}$ Docente da UNIPAR
}

Introdução: A iniciação esportiva é o período no qual a criança começa a aprender, de forma específica, a prática de esportes, sendo marcada pela prática regular e orientada de uma ou mais modalidades esportivas, e o objetivo imediato é dar continuidade ao desenvolvimento da criança de forma integral, não implicando em competições regulares. Será de grande importância a aplicação sistemática, planejada e consciente de um determinado método de ensino-aprendizagem-treinamento para o êxito e evolução do nível de desempenho do praticante.

Objetivo: O presente trabalho teve como objetivo avaliar o perfil dos programas de iniciação esportiva adotados pelas secretarias municipais de esporte da microrregião de Cianorte.

Material e Métodos: A presente pesquisa foi submetida e aprovada pelo CEPEH da Universidade Paranaense - Unipar sob o parecer 1.002.678. A amostra foi constituída por meio das Secretarias Municipais de Esporte que desenvolvam um projeto de iniciação esportiva, da microrregião geográfica de Cianorte, a qual é composta por 11 entidades esportivas. Para a coleta dos dados a serem analisados foram aplicadas pessoalmente entrevistas semiestruturadas, ao gestor esportivo responsável pelo programa de iniciação.

Resultados: Os resultados mostraram que todos defendem que o principal objetivo das entidades que representam é a metodologia da Iniciação Poliesportiva, porém nenhum deles possuiu tal método na prática em seus municípios, sendo utilizado em grande maioria a metodologia da Iniciação Esportiva Específica. Os critérios adotados pelas entidades avaliadas para o estabelecimento das idades na iniciação das crianças em seus programas esportivos foram 36,6\% para Fundamentação Teórica da Área e 63,64\% para Determinação Administrativa das gerências esportivas vigentes. Dos 48 programas esportivos ofertados nos 11 municípios avaliados, $13(27 \%)$ são individuais contra $35(73 \%)$ coletivos. Também as secretarias de esporte responderam que seu intuito principal quanto a competir ou participar, estaria vinculado aos dois, sendo assim, $82 \%$ dos gestores acreditam que suas modalidades devam participar e competir, mesmo em faixas etárias que estímulos competitivos em excesso não são adequados nos primeiros anos de vida. Além disso, as secretarias de esporte que incentivam a competição nas faixas etárias introdutórias, investem $9 \%$ em competições a nível municipal, 55\% em nível municipal e regional, 36\% em nível municipal, regional e estadual. Também modalidades com caraterísticas gerais como Ginástica e Atletismo são pouco estimuladas.

Discussão: Um programa de Iniciação Poliesportiva deve oferecer escolas de esportes gerais ou centros educacionais de atividades poliesportiva, desenvolvendo habilidades motoras gerais, respeitando a faixa etária e o desenvolvimento motor da criança, não exigindo participação em competições (ARENA; BOHME, 2004). Alguns pesquisadores consideram a faixa etária de 12-14 anos como a mais indicada para que a criança comece a participar de eventos competitivos, a criança até os 12 anos não deve participar de atividades esportivas específicas e de competições formais, por não possuir maturidade suficiente para compreender e assimilar tudo o que está envolvido em um processo competitivo. Alguns autores advertem que as competições e o treinamento dos jovens não devem ser dimensionados com base apenas na idade cronológica da criança, mas nas características físicas, emocionais e maturacionais, para que a prática esportiva não se torne uma obrigação, e sim um aspecto favorável no seu desenvolvimento (ARENA; BOHME, 2004; GRECO; BENDA, 1998; SOARES, 2009). Certas modalidades esportivas individuais com tendências a altos resultados em idades mais baixas, justificam uma precocidade no fato destes esportes estarem relacionados a fatores como a especialização que tradicionalmente começa mais cedo, o que pode provocar no organismo infantil possíveis danos físicos. (GRECO; BENDA, 1998; ARENA; BOHME, 2004). As modalidades coletivas são ofertadas em quase todos os municípios, bem diferente que as individuais. Nos programas de iniciação esportiva desenvolvidos pelas secretarias municipais, as idades variam de 5-13 anos de idade (início) a 14-18 anos de idade (final). Desde modo, comparando-se com a recomendação da literatura, sugere que a especialização precoce de uma única modalidade visando treinamento para competições, metodologia adotada pelos programas da microrregião embora o objetivo defendido pelos gestores fosse de iniciação poliesportiva, deve ocorrer por volta dos 12-13 anos dependendo da modalidade e tradições existentes (BOMPA, 1999; GRECO; BENDA, 1998; SOARES, 2009; RAMOS; NEVES, 2008).

Conclusão: Concluiu-se que a iniciação esportiva é um fenômeno complexo, onde é indispensável a formação adequada dos gestores, sendo necessariamente exigente por interferir diretamente no desenvolvimento motor, cognitivo, social e afetivo completo das crianças e adolescentes que estão sendo iniciadas. Para adequações dos programas esportivos se faz importante respeitar suas fases de desenvolvimento, visando um treinamento a longo prazo para que não ocorra uma especialização 
esportiva precoce.

\section{Referências}

ARENA, S. S.; BÖHME, M. T. S. Federações esportivas e organização de competições para jovens. Revista Brasileira de Ciência e Movimento, v. 12, n. 4, p. 45-50, 2004.

BOMPA, J. O. Periodization theory and methodology of training. Chaimpaign, Human Kinetics, 1999.

GRECO, P. J.; BENDA, R. N. (Org.). Iniciação Esportiva Universal: 2 - Metodologia da iniciação esportiva na escola e no clube. Belo Horizonte: Ufmg, 1998.

RAMOS, A. M.; NEVES, R. L. R. A iniciação esportiva e a especialização precoce à luz da teoria da complexidade - notas introdutórias. Pensar a prática, v. 11, n. 1, p. 1-8, 2008.

SOARES, I. A. Estudos sobre Iniciação Esportiva: Revisão de Literatura sobre Métodos e Fases de Ensino. Monografia (Bacharel em Educação Física) Universidade Estadual de Campinas, Campinas, 2009.

Coordenadoria de Pesquisa e Extensão - COPEX

Departamento de Editoraçāo e Divulgaçāo Científica - DEDIC 


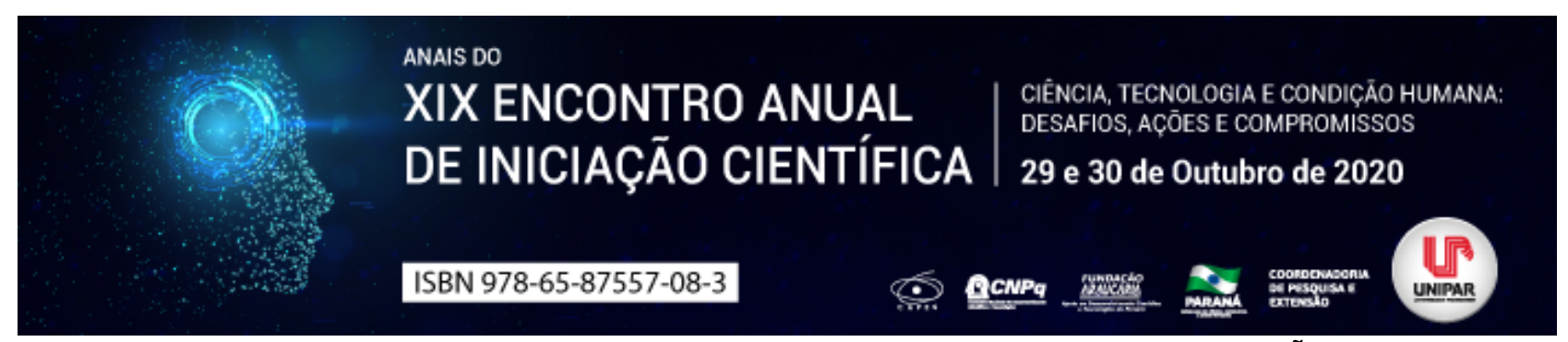

IMPACTO DO ENVELHECIMENTO SOBRE A SEXUALIDADE DOS IDOSOS: UMA REVISÃO INTEGRATIVA

\section{${ }^{1}$ SALUHU IBRAHIM, ${ }^{2}$ EDUARDA DOS SANTOS AMARAL, ${ }^{3}$ ALESSANDRO RODRIGUES PERONDI}

${ }^{1}$ Discente do curso de enfermagem da Universidade Paranaense UNIPAR/Francisco Beltrão-PR

${ }^{1}$ Acadêmica do Curso de Enfermagem da UNIPAR

${ }^{2}$ Docente da UNIPAR

Introdução: O processo de envelhecimento é uma reação natural de todos seres vivos. É um processo contínuo que traz consigo muitas mudanças na vida da pessoa idosa. Todavia, esse processo pode ocorrer de duas formas; pela senescência (envelhecimento usual sem complicações alheias) ou pela senilidade (presença de traumas ou doenças que desviam a curva de capacidade para baixo). Embora, hoje em dia, com a avançar da medicina, nota-se que a senescência representa a forma de envelhecimento mais prevalente no mundo, onde as populações idosas encontram-se mais saudáveis, mesmo com uma idade bem avançada e, em consequência, aumentando a capacidade de realização das suas sexualidades (VIEIRA; COUTINHO; SARAIVA, 2016). A prática sexual é uma das mais relevantes necessidades humanas básicas, no entanto, a sua manutenção deve ser aprimorada, indiferentemente da idade em que a pessoa se encontra (EVANGELISTA et al, 2019). Todos os seres humanos carregam consigo alguma personalidade da sexualidade e, encontra-se diretamente relacionado com a qualidade de vida. Percebe-se na nossa sociedade, preconceitos contra idosos que demonstram ser sexualmente ativos. Vale ressaltar que a sexualidade não se limita apenas a ocorrência de orgasmo, é muito mais que isso, é o espírito que move o indivíduo a encontrar amor, e demonstrar na forma de sentir, movimentar-se, tocar e ser tocado, promovendo intimidade, pensamentos e sentimentos saudáveis, assim, refletindo em saúde física e mental (OLIVEIRA; NEVES; SILVA, 2018).

Objetivo: Norteado por essas premissas, o objetivo deste estudo foi avaliar como as publicações cientificas dos últimos cinco anos abordam a sexualidade nos idosos.

Metodologia: Trata-se de uma Revisão Integrativa (RI) orientada pela questão norteadora: Qual a percepção dos idosos frente a sexualidade apontadas nas publicações científicas dos últimos 5 anos? . Efetuou-se a busca na Base de Dados da Biblioteca Virtual em Saúde (BVS Salud) utilizando-se os descritores: Idoso; Envelhecimento; Sexualidade, com o operador booleano and e tendo como critérios de busca publicações no formato de artigos científicos, no idioma português; publicados nos últimos 5 anos, disponíveis com texto completo. Na busca realizada foram encontrados 28 artigos, na sequência, realizou-se análise crítica que correspondeu à avaliação dos estudos e interpretação dos resultados. Nesta análise crítica, foram excluídos 19 artigos, destes, 6 por se repetirem nas bases de dados e 13 por não responderem ao objetivo do estudo. Para melhor apresentação dos manuscritos que compuseram o escopo da RI, os estudos foram identificados com a letra S, numerados sucessivamente.

Resultados e Discussão: Os resultados obtidos da RI culminaram na seleção de 9 artigos, destes 5 estudos foram quantitativos e 4 qualitativos. Em relação ao ano de publicação 2 foram publicados em 2016, 2 em 2017, 4 em 2018 e 1 em 2020 . Em relação as populações/amostras, integralmente os estudos foram desenvolvidos com idosos acima de 60 anos, 4 abordando ambos os sexos e 5 apenas mulheres. Os estudos S1, S7, S8 e S9, abrangeram ambos os sexos e S2, S3, S4, S5 e S6 abordaram apenas o sexo feminino, onde o S7 enfatizou mais as patologias que possuem impactos sobre a sexualidade dos idosos, citando o diabetes mellitus (DM) como uma das principais protagonistas de repercussões negativas. Em relação a compreensão da sexualidade, percebeu-se nos estudos S1, S8 e S9 que os idosos apresentaram pouco conhecimento sobre esta temática, compreendendo como a prática de atividade sexual propriamente dito, demonstrando a sexualidade ainda como um assunto complexo, controvertido e de conceituação difícil, alvo de muitos tabus, repressões, distorções e tentativas de reduzi-la a sinônimo de genitalidade e de reprodução. O artigo S4 concentrou mais na questão da influência que um hábito de vida saudável, principalmente exercício físico tem sobre a sexualidade do idoso. Com isso, revelou-se que os idosos que praticam a atividade física regularmente apresenta-se mais sexualmente ativos em comparação a demais. No que concerne os desejos sexual na terceira idade, os participantes do estudo S5 tiveram opiniões distintas, algumas relatam que praticam o ato sexual somente para satisfazer os seus companheiros, enquanto as outras realizam porque gostam mesmo de sexo. O estudo S6 desvendou que o maior problema que os idosos enfrentam, e que impedem a manifestação da sua sexualidade são as modificações físicas, emocionais, dificuldades sociais e culturais. Tais achados demonstram a necessidade de compreender a sexualidade para além da satisfação física, reafirmando a identidade de cada parceiro, demonstrando que cada pessoa pode ser valiosa para a outra. Junto ao sexo, também estão valores muito importantes na terceira idade: a intimidade, a sensação de aconchego, o afeto, o carinho e o amor.

Conclusão: Em um contexto geral os estudos selecionados demonstraram baixo impacto do envelhecimento sobre a sexualidade. Contudo, novos estudos com abordagens mais amplas devem ser conduzidos, ampliando as bases de dados analisados, com vistas a proporcionar maiores esclarecimentos dessa temática. 


\section{Referências}

EVANGELISTA. et al. Sexualidade de idosos: conhecimento/atitude de enfermeiros da Estratégia Saúde da Família. Rev Esc Enferm USP. 2019.

OLIVEIRA; NEVES; SILVA. Sentidos de Sexualidade entre Mulheres Idosas: Relações de gênero, ideologias mecanicistas e subversão: Psicologia \& Sociedade, Manaus. 2018.

VIERA; COUTINHO; SARAIVA. A Sexualidade Na Velhice: Representações Sociais De Idosos Frequentadores de Um Grupo de Convivência. Psicologia, ciência e profissão, Vol.36 nº 1, 196-209. Jan/mar. 2016.

AGUIAR, LEAL, MARQUES. Conhecimento e atitudes sobre sexualidade em pessoas idosas com HIV. Ciência \& Saúde Coletiva, Recife/PE. 2020.

SANTOS. et al. Concepção de mulheres idosas sobre a sexualidade na velhice. Rev enferm UFPE online. 2019.

RODRIGUES. et al. Análise do comportamento sexual de idosas atendidas em um ambulatório de ginecologia. Rev. Bras. Geriatr. Gerontol, Rio de Janeiro. 2018.

WITKPF et al. Estudo da função sexual e da aptidão funcional em mulheres idosas. Arq. Ciênc. Saúde. 2018.

NASCIMENTO. et al. Vivência da sexualidade por mulheres idosas. Rev enferm UERJ, Rio de Janeiro, 2017.

SCARDOELLI; FIGUEIREDO; PIMENTEL. Mudanças advindas do envelhecimento: sexualidade de idosos com complicações da diabetes mellitus. Rev enferm UFPE online. Recife, jul. 2017.

UCHÔA. et al. Sexualidade Sob Olhar da Pessoa Idosa. Rev. Bras. Geriatr. Gerontol., Rio de Janeiro, 2016.

ALENCAR et al. Exercício da sexualidade em pessoas idosas e os fatores relacionados. Rev. Bras. Geriatr. Gerontol., Rio de Janeiro, 2016. 


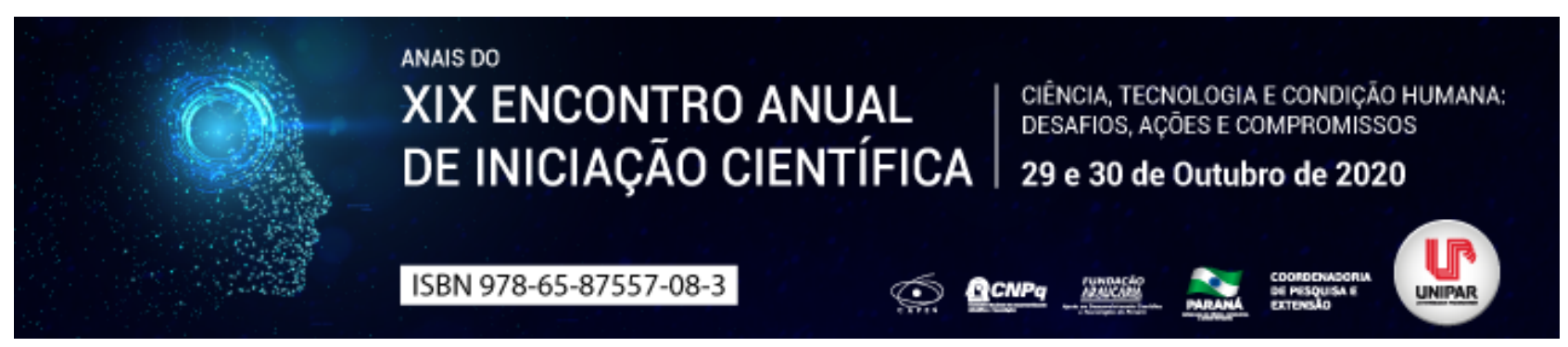

MENINGITE: ASPECTOS GERAIS

\begin{abstract}
${ }^{1}$ SUELEN STEFANONI BRANDAO, ${ }^{2}$ LARISSA LOYOLA BARBOSA, ${ }^{3}$ GABRIEL HENRIQUE BELLATO PALIN, ${ }^{4}$ LUCAS ALEXANDRE GUBERT SCHIER, ${ }^{5}$ RAFAEL BEZERRA MARIM, ${ }^{6}$ ELENIZA DE VICTOR ADAMOWSKI CHIQUETTI
\end{abstract}

\author{
${ }^{1}$ Acadêmico bolsista do PIBIC/UNIPAR \\ ${ }^{1}$ Acadêmica do Curso de Medicina da UNIPAR \\ ${ }^{2}$ Acadêmico do Curso de Medicina da UNIPAR \\ ${ }^{3}$ Acadêmico do Curso de Medicina da UNIPAR \\ ${ }^{4}$ Acadêmico do Curso de Medicina da UNIPAR \\ ${ }^{5}$ Docente da UNIPAR
}

Introdução: A meningite é uma doença infectocontagiosa caracterizada pela inflamação das meninges, possui diversos fatores que podem desencadeá-la podendo ser infecciosos ou não. As principais causas infecciosas são de etiologia bacteriana, viral, porém, fungos, protozoários e helmintos podem atuar como agentes menos recorrentes, a forma viral é a mais frequente e a bacteriana está associada a importante causa de mortalidade; tumores intracerebrais, doenças inflamatórias também podem desencadear a enfermidade como forma não infecciosa, trata-se de uma doença de grande relevância social (DIAS et al, 2017). Segundo Porto (2019) a doença pode ter instalação rápida, como ocorre nas infecções por vírus e bacterias, o processo progride lentamente quando o agente é o bacilo de Koch e fungos, e mais vagaroso ainda na sifilis.

Objetivo: $O$ presente artigo tem por objetivo revisar a literatura sobre Meningite relacionando sintomas, tipos, transmissão, tratamento e profilaxia.

Desenvolvimento: A meningite chegou ao Brasil devido a um navio que trazia imigrantes de Portugal e Espanha, no ano de 1906. Após desembarcarem no porto de Santos, foi constatado que haviam passageiros contaminados pela doença (RODRIGUES, 2015). Os sintomas costumam ser parecidos com o de uma gripe comum, como febre, náusea e dor de cabeça. Com a evolução da doença, novos sintomas podem surgir, como: rigidez no pescoço, sensibilidade à luz e manchas na pele (PELTON, 2010). Confusão mental pode seguir com agitação psicomotora e evoluir para coma, as convulsões são frequentes, especialmente em crianças (PORTO, 2019). Guia de vigilância epidemiológica (2009), as Meningites de origem infecciosa, principalmente as causadas por bactérias e vírus, são as mais importantes do ponto de vista da saúde pública, pela magnitude de sua ocorrência e potencial de produzir surtos. Dentre os agente etiológicos, destacam-se nas meningites bacterianas a Neisseria meningitidis (Meningococo), Streptococcus pneumoniae, Mycobacterium tuberculosis, Haemophilus influenzae, enquanto que nas meningites virais são mais recorrentes a causada pelos Enterovirus. Comumente, a transmissão se da de pessoa a pessoa, através das vias respiratórias, por secreções da nasofaringe e gotículas, a transmissão fecal-oral é de grande importância em infecções por enterovírus (RODRIGUES, 2015). Segundo Morais (2017), alterações climáticas influenciam a agilidade da transmissão da doença, ocorrendo predominância dessa disseminação em regiões temperadas no inverno ou regiões tropicais em épocas secas, no Brasil, a doença possui surtos ocasionais, principalmente no inverno. Para a correta identificação do agente etiológico da Meningite a análise do líquor se faz necessária. Habitualmente realiza-se a cultura bacteriana, fúngica, de tuberculose e teste VDRL, para excluir a possibilidade de uma Meningite Sifilítica, a PCR (Reação de polimerase em cadeia) também pode ter um papel importante se o teste inicial se mostrar inconclusivo (SILVA et al, 2018). O tratamento para a enfermidade deve ser o mais rápido possível, porém, mesmo com o tratamento a doença pode deixar sequelas ou causar a morte, antibioticoterapia é a base da intervenção incluindo controle hemodinâmico, glicêmico, coagulação, perfusão da pele e membros (PELTON, 2010). Como medida de prevenção e de controle da doença são realizadas a vacinação e a quimioprofilaxia com antibióticos. Sendo a vacina a forma mais eficaz de prevenção. No ano de 2010 houve a circulação da meningite do sorogrupo $\mathrm{C}$ e por isso a incorporação da vacina meningocócica $\mathrm{C}$ conjugada ao Programa Nacional de Imunização (PNI). A vacina é administrada em crianças, sendo feita duas doses: uma dose aos 3 meses e outra aos 5 meses, além de um reforço aos 12 meses (ANDRADE et al, 2020).

Conclusão: A meningite é uma enfermidade que ainda provoca alta letalidade tendo a intervenção através da antibioticoterapia como uma forma de tratamento, o prognostico da meningite está associado ao diagnóstico e tratamento da enfermidade. Algumas estratégias de prevenção e controle devem ser tomadas para tentar manter o equilíbrio da mesma, como: manter cobertura vacinal, orientar a população sobre a higiene corporal e ambiental, notificar os casos suspeitos e investigar todos os notificados, realizar capacitações dos profissionais envolvidos na atenção primaria afim de obter diagnósticos com maior precisão e agilidade. 


\section{Referências}

ANDRADE, Carla Hineida da Silva et al. Análise da incidência de Meningite Meningocócica em todas as faixas etárias antes e após a implantação da vacina meningocócica C (conjugada) no estado do Pará. Brazilian Journal of Health Review, v. 3, n. 4, p. 8650-8662, 2020.

DIAS, Fellipe Camargo Ferreira et al. Meningite: aspectos epidemiológicos da doença na região norte do Brasil. Revista de Patologia do Tocantins, v. 4, n. 2, p. 46-49, 2017.

GUIA DE VIGILANCIA EPIDEMIOLÓGICA, 7a edição, Série A, Ministério da saúde. Brasília/DF, 2009.

MORAIS, Joice Mariana Rodrigues et al. Retrato da Meningite em Salvador BA: Análise do período entre 2011- 2015. Ciência \& Desenvolvimento-Revista Eletrônica da FAINOR, v. 10, n. 1, 2017.

PELTON, S.I. Meningococcal disease awareness: clinical and epidemiological factors affecting prevention and management in adolescents. Journal of Adolescent Health. New York, v. 46, p. S9-S15, jun, 2010.

PORTO, Celmo Celeno. Semiologia Médica, 8. Ed., Rio de Janeiro, Guanabara Koogan, 2019.

RODRIGUES, Erick Miranda Bento. Meningite: Perfil epidemiológico da doença no Brasil nos anos de 2007 a 2013. Orientador: Bruno Silva Milagres. 2015. Trabalho de conclusão de curso em Biomedicina. Centro Universitário de Brasília. 2015. SILVA, Helena Caetano Gonçalves et al. Meningite no Brasil em 2015: O panorama da atualidade. Arquivos Catarinenses de Medicina, v. 47, n. 1, p. 34-46, 2018. 


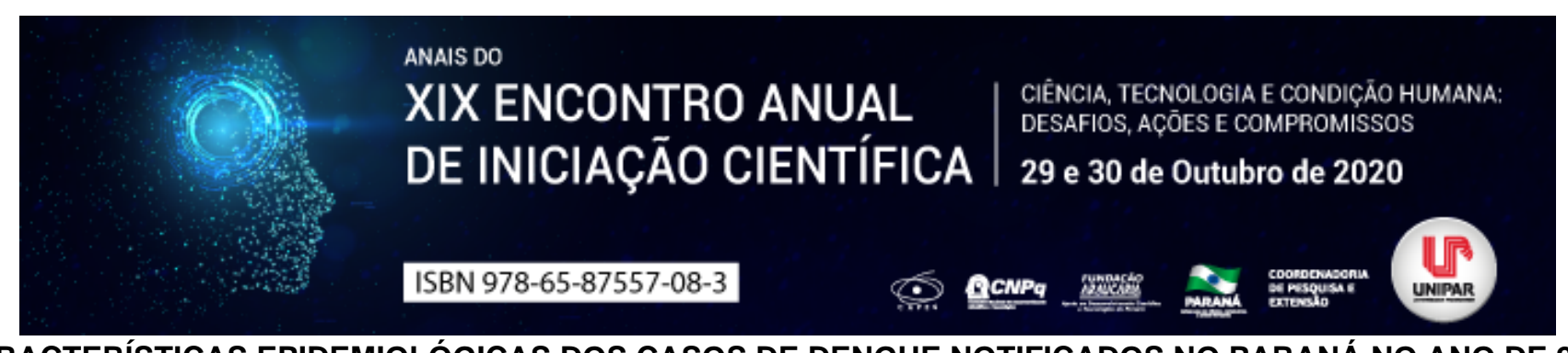

CARACTERÍSTICAS EPIDEMIOLÓGICAS DOS CASOS DE DENGUE NOTIFICADOS NO PARANÁ NO ANO DE 2019

\author{
${ }^{1}$ RAFAELA THAIS ZANCHET, ${ }^{2}$ JULIA COMACHIO FAVRETTO, ${ }^{3}$ AMANDA DE SOUZA, ${ }^{4}$ PATRICIA AMARAL GURGEL \\ VELASQUEZ
}

${ }^{1}$ Acadêmica do Curso de Farmácia da UNIPAR de Francisco Beltrão - PR / Participante do PIC

${ }^{1}$ Acadêmica do Curso de Farmácia da UNIPAR de Francisco Beltrão - PR / Participante do PIC

${ }^{2}$ Acadêmica do Curso de Farmácia da UNIPAR de Francisco Beltrão - PR / Participante do PIC

${ }^{3}$ Docente do Curso de Farmácia da UNIPAR de Francisco Beltrão - PR

Introdução: O vírus da dengue (DENV), um arbovírus da família Flaviviridae, é o agente etiológico da dengue, uma doença infecciosa transmitida pela fêmea do mosquito do gênero Aedes, sendo a espécie $A$. aegypti a mais importante. Atualmente esta doença é considerada um grande problema de saúde em países com clima tropical e subtropical, fator imprescindível para a proliferação do vetor (BARBOSA, CALDEIRA-JUNIOR, 2018; CAVALLI et.al., 2019).

Objetivo: Realizar um levantamento sobre as características epidemiológicas dos casos de dengue notificados no Paraná no ano de 2019.

Materiais e métodos: Os dados foram obtidos através do banco de dados do Sistema Nacional de Notificação (SINAN) online do DATASUS. A coleta dos dados ocorreu durante o mês de Agosto de 2020, quando foram verificados os casos de dengue ocorridos durante o ano de 2019 no Paraná. Para melhor visualização, construíram-se tabelas no Microsoft Excel com cabeçalho referente aos dados do estudo em questão. As variáveis levantadas e analisadas foram: os meses do ano, sexo, faixa etária e regional de saúde. Para análise dos dados, foi utilizado o método de análise descritiva simples.

Resultados: Durante todo o ano de 2019 foram totalizados 45.916 casos de dengue no Paraná, com uma média de 3.826 casos por mês. O mês de maio teve a maior incidência, 12.567 (27,36\%) casos, seguido por abril, 9.336 (20,33\%) casos e dezembro, $6.252(13,61 \%)$ casos de dengue. Os meses com menor incidência foram setembro, janeiro e agosto, com 504 (1,09\%), 522 $(1,13 \%)$ e $572(1,24 \%)$ casos, respectivamente. Notou-se também que houve maior prevalência de casos no sexo feminino, $55,02 \%$ dos casos.As faixas etárias mais atingidas foram dos 20 aos 39 anos com16.192 (35,26\%), seguido da faixa de 40 a 59 anos com $13.094(28,51 \%)$ casos. As faixas etárias menos acometidas foram crianças com menos de um ano, 496 (1,08\%) casos, e idosos com 80 anos ou mais, 487 (1,06\%) casos. Ao avaliar o número de casos por Regional de Saúde, foi possível identificar que a $17^{\mathrm{a}}$ Regional, localizada na região de Londrina, teve o maior número de casos, 11.789 (25,67\%), seguida pela $14^{a}$ Regional, região de Paranavaí, e pela 15a Regional, região de Maringá, com 6.203 (13,51\%) e 6.177 (13,45\%) casos, respectivamente. A $6^{\mathrm{a}}$ Regional, de União da Vitória teve o menor número de casos, apenas sete.

Discussão: No ano de 2018 foram notificados 265.934 casos prováveis de dengue no Brasil (incidência de 114,8/100 mil hab), dos quais, 2.299 foram no Paraná (20,3/100 mil hab). Já no ano de 2019 observou-se um aumento significativo nesses casos, pois a incidência passou para 735,2 casos/100 mil habitantes no país e no Paraná para 397,8, o que corresponde a um aumento de quase $2.000 \%$ no número de casos prováveis notificados no estado. Estudos apontam serem as mulheres as mais acometidas pela dengue, conforme observado no estado do Paraná no ano de 2019, talvez pelo fato delas buscarem o serviço de saúde com mais frequência que os homens (LEITE, 2015, DUTRA, COSTA, SAMPAIO, 2016). Dutra e cols (2016) também observaram o maior acometimento de pessoas na faixa etária dos 20 aos 39 anos, o que aumenta o ônus do problema, pois esse grupo está dentro da faixa das pessoas economicamente ativas que muitas vezes precisará se afastar do trabalho por conta da doença. Mesmo com as campanhas de combate à dengue, observa-se a expansão da doença no país. Alguns fatores podem explicar esse avanço nos números como maior nível de precipitação, aumento das temperaturas médias, crescimento das periferias urbanas e baixa renda (BHATT et al, 2013). As estratégias de combate ao vetor utilizadas pelo Ministério da Saúde no Brasil se dão através dos Agentes Comunitários de Saúde e Agentes de Combate a Endemias, em parceria com a população, os quais são responsáveis por promover o controle mecânico e químico do vetor, além de ações educativas durante a visita domiciliar pelos Agentes Comunitários (BRASIL, 2009). No entanto os números mostram a necessidade de se buscar novas medidas de combate ao vetor.

Conclusão: Os dados descritos no presente trabalho permitiram concluir que os números de casos de dengue no Paraná em 2019 são preocupantes, pois houve um aumento significativo comparado aos anos anteriores, já que de 2018 a 2019 houve um aumento de, aproximadamente, $2.000 \%$ nos casos. Observou-se que a situação das 14a, 15a e 17a Regionais de Saúde são alarmantes, pois juntas detêm 52,63\% dos casos do Paraná. Tendo em vista que a dengue é um grande problema de saúde pública, vale ressaltar que há a necessidade de ampliação das campanhas de combate ao vetor. Além disso, destaca-se a importância do incentivo à novas pesquisas relacionadas ao controle da doença 


\section{Referências}

BARBOSA, BFS.; CALDEIRA-JUNIOR, AM. Leucopenia e trombocitopenia no diagnóstico da dengue. Revista Cient. Sena Aires. Goiás, v. 7, n. 3, p. 171-181, 2018.

BHATT, S. et al. The global distribution and burden of dengue. Nature. n.10.103, v. 496, p. 504 507, Abril, 2013. Disponível em: https://doi.org/10.1038/nature12060. Acesso em: 24 Ago. 2020.

BRASIL, Ministério da Saúde. Secretaria de Vigilância em Saúde. Departamento de Vigilância Epidemiológica. Diretrizes nacionais para a prevenção e controle de epidemias de dengue. Brasília: Ministério da Saúde; 2009. (Série A. Normas e Manuais Técnicos.)

CAVALLI, FS. et. al. Controle do Vetor Aedes Aegypti e Manejo dos Pacientes com Dengue. Rev Fund Care Online. Rio de Janeiro, v. 11, n. 5, p. 1333-1339. 2019.

DUTRA, FCMS, COSTA, LC, SAMPAIO, RF. A influência do afastamento do trabalho na percepção de saúde e qualidade de vida de indivíduos adultos. Fisioterapia e Pesquisa, São Paulo, v.23, n.1, p.98-104, Mar.2016.

Coordenadoria de Pesquisa e Extensão - COPEX

Departamento de Editoraçāo e Divulgaçāo Científica - DEDIC 


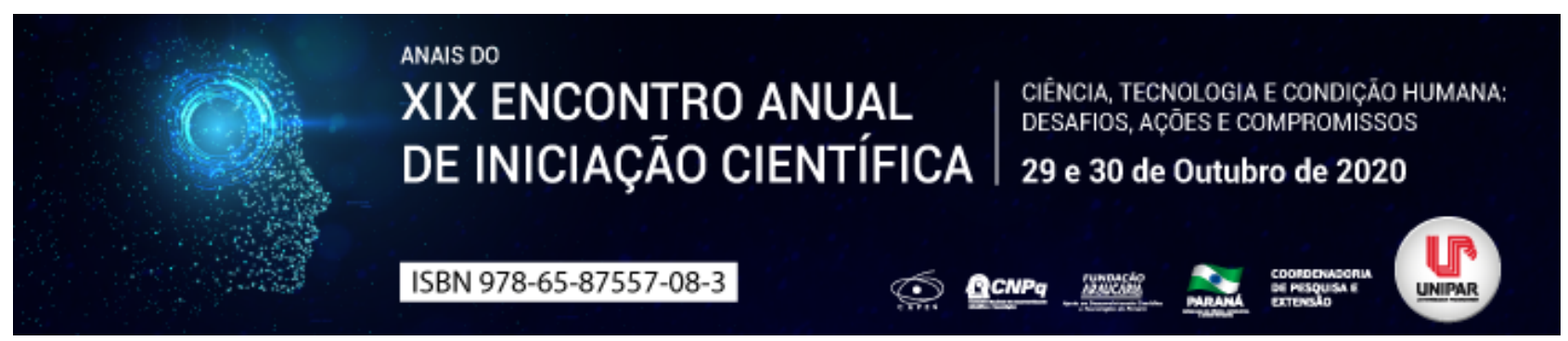

TREINAMENTO RESISTIDO PARA IDOSOS HIPERTENSOS

${ }^{1}$ KLAUS KENZO KIYOHARA AGAWA, ${ }^{2}$ JULIO CESAR MARTINS DA ROCHA, ${ }^{3}$ GLEICY KELLY THIEMY SATO, ${ }^{4}$ VIVYANNE MARIA MARYNOWSKI CONTI, ${ }^{5}$ FERNANDO SERAFIM DA SILVA, ${ }^{6}$ JAYME RODRIGUES DIAS JUNIOR

\footnotetext{
${ }^{1}$ Académico do curso de Educação Física

${ }^{1}$ Acadêmico do Curso de Educação Física da UNIPAR

${ }^{2}$ Acadêmica do Curso de Educação Física da UNIPAR

${ }^{3}$ Acadêmica do Curso de Educação Física da UNIPAR

${ }^{4}$ Acadêmico do Curso de Educação Física da UNIPAR

${ }^{5}$ Docente da UNIPAR
}

Introdução: A hipertensão arterial sistêmica é uma condição multifatorial caracterizada por níveis elevados e sustendos da pressão arterial $\geq 140 / 90 \mathrm{mmHg}$, se não controlada pode influenciar no desenvolvimento de outras comorbidades como doenças renais, infarto agudo do miocárdio e acidente vascular encefálico, a hipertensão acomente aproximadamente 60\% dos idosos, sendo necessário o desenvolvimento de intervenções que controlem os níveis pressóricos desses indivíduos (SOCIEDADE BRASILEIRA DE CARDIOLOGIA, 2010),

Objetivo: Analisar os benefícios do treinamento resistido para idosos hipertensos.

Desenvolvimento: 0 envelhecimento ocasiona alterações cardiovasculares, que podem resultar em aumento nos níveis de pressão arterial de repouso, sendo importante analisar os efeitos do exercício resistido sobre a pressão arterial de indivíduos idosos. O número de pessoas idosos diagnosticadas com hipertensão arterial sistêmica (HAS), tem aumentado devido diversos fatores, entre eles, a falta de exercício físico regularmente, levando ao acúmulo em excesso de gordura e uma alimentação inadequada (PINTO et al., 2007). Diante disso, diversos estudos tem mostrado que a prática de exercício físico pode contribuir de forma significativa para o controle da pressão arterial e entre os tipos de exercício, o treinamento resistido tem beneficiado e sendo indicado para estes indivíduos. pois promove a manutenção da força, aumento da massa muscular, melhora da autonomia da pessoa idosa, favorecendo o desenvolvimento das atividades cotidianas. Além desses benefícios, uma única sessão de treinamento resistido pode promover uma rdução da pressão arterial no idoso, tal resposta é conhecido como efeito hipotensor do exercicio (FAGARD et al., 2006). Moraes (2012) observou reduções significativas na pressão arterial de homens mais velhos após uma sessão de exercício resistido, o efeito hipotensor aparece logo após a realização da essão de exercicio. De acordo com Faria et al. (2008, p.302) tem sido sugerido que a redução de apenas $5 \mathrm{mmHg}$ na pressão arterial diminui em $40 \%$ o risco de acidentes vasculares cerebrais e em 15\% o risco de infarto agudo do miocárdio. Devido às adaptações fisiológicas que os exercícios trazem para o corpo. Com intensidade e cargas controladas a pressão arterial desses idosos reduz melhorando em curto e longo prazo.

Conclusão: O treinamento resistido para idosos hipertensos, com o acompanhamento e periodização ideal, geram níveis de hipotensão pós-exercício, diminuindo a pressão arterial de repouso, pressão arterial sistólica, pressão arterial média. Sendo utilizado como um tratamento não farmacológico.

\section{Referências}

FARIA, D. T. et al. Redução da pressão arterial e do duplo produto de repouso após treinamento resistido em idosas hipertensas. Arq. Bras. Cardiol. vol.91 no.5 São Paulo Nov. 2008.

PINTO, E. Blood pressure and ageing. Pós Med. v.83, n. 976, p. 109-114, 2007.

FAGARD, R. H. Exercise is good for your blood pressure: effects of endurance training and resistance training. Clin Exp Pharmacol Physiol. v.33, p.853 6, 2006.

Sociedade Brasileira de Cardiologia / Sociedade Brasileira de Hipertensão / Sociedade Brasileira de Nefrologia. VI Diretrizes Brasileiras de Hipertensão. Arq Bras Cardiol 2010; 95(1 supl.1): 1-51. 


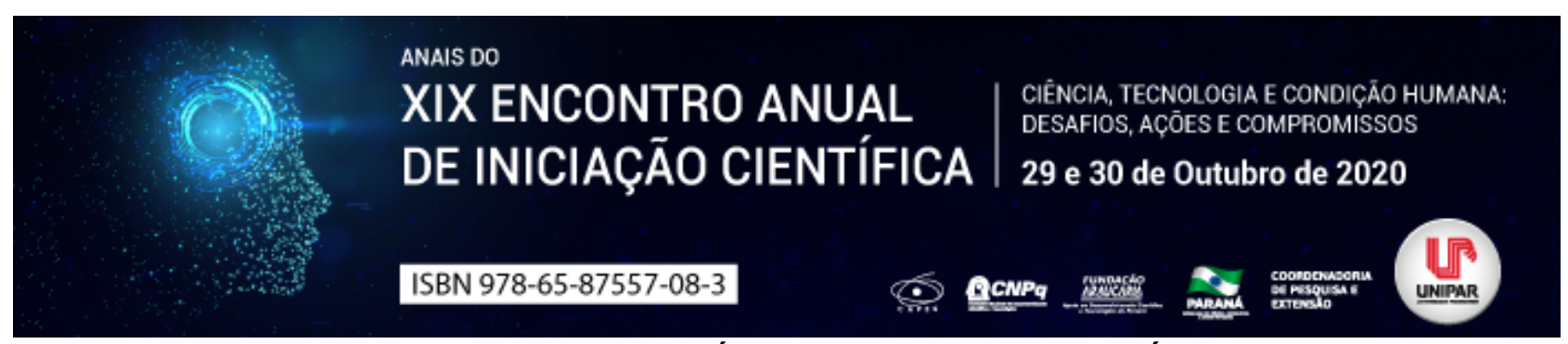

ATENDIMENTO ODONTOLÓGICO EM PACIENTES DIABÉTICOS

\title{
${ }^{1}$ FERNANDA LIMA, ${ }^{2}$ VERONICA DE MORAES, ${ }^{3}$ BRUNA CAMILA WEBER, ${ }^{4}$ LETICIA NADAL
}

\author{
${ }^{1}$ Academica do Curso de Odontologia UNIPAR \\ ${ }^{1}$ Acadêmica do Curso de Odontologia da UNIPAR \\ ${ }^{2}$ Acadêmica do Curso de Endodontia de Molares - Turma VII da UNIPAR \\ ${ }^{3}$ Docente da UNIPAR
}

Introdução: A Diabetes Mellitus (DM) é uma doença crônica causada por deficiência herdada ou adquirida na produção de insulina pelo pâncreas. A insulina é um hormônio que regula a glicose no sangue numa concentração normal entre 70 a 110 $\mathrm{mg} / \mathrm{dL}$ (NETO, J. N et al., 2011). A alta e baixa concentração sérica de glicose, é um efeito comum da diabetes descontrolado e ao longo do tempo leva a sérios danos a muitos dos sistemas do corpo, especialmente os nervos e vasos sanguíneos. $O$ Diabetes Mellitus é um dos mais importantes problemas de saúde, tanto em número de pessoas afetadas, incapacitações físicas e motoras, mortalidade prematura, como dos custos envolvidos no seu controle e tratamento de suas complicações. A saúde oral deve estar inserida no contexto da saúde sistêmica e geral, devido à integração da boca como parte do corpo humano, assim o conhecimento das manifestações orais do DM e os cuidados durante o atendimento odontológicos é essencial ao cirurgiãodentista (CD).

Objetivo: O objetivo dessa revisão de literatura é avaliar quais cuidados devem ser tomados pelo cirurgião-dentista durante o tratamento odontológico em pessoas portadoras da DM.

Desenvolvimento: O Diabetes Mellitus consiste em um grupo de doenças metabólicas caracterizadas, pelo aumento excessivo da quantidade de glicose no sangue (hiperglicemia). Existem 57 etiologias diferentes para a mesma. Entre elas são: Diabetes Mellitus Tipo I (DM1) quando o pâncreas não consegue produzir insulina essencial, Diabetes Mellitus Tipo II (DM2): inabilidade de responder a ação da insulina, Diabetes Mellitus Gestacional (DMG): diagnóstico de hiperglicemia na gravidez. Os fatores de risco mais importantes da DM2 são hereditariedade, sobrepeso, idade avançada, hipertensão arterial, estresse, sedentarismo, obesidade central. O DM2 é a manifestação mais comum da doença e, ocorre em pessoas que apresentam fatores de risco, com mais de 45 anos, com antecedente familiar. Os pacientes diabéticos apresentam as manifestações clínicas e a sintomatologia bucal de acordo com o estágio clínico da doença. A identificação ou suspeita do DM em pacientes no consultório é comum nos atendimentos odontológicos, pois, aproximadamente, 3 a $4 \%$ dos pacientes adultos que se submetem a tratamento odontológico são diabéticos. Cada paciente deve ser assistido de forma peculiar, pois, características da doença assumem forma mais marcante do que outras, em cada indivíduo (NETO, J. N et al., 2011). Entre as manifestações bucais apresentadas pelo paciente portador de DM estão: a doença periodontal, sendo considerada a sexta complicação crônica da doença, a candidíase bucal e xerostomia são achados comuns. Outras manifestações menos comuns são: abscessos recorrentes, hipoplasia ou hipocalcificação do esmalte, varicosidade lingual, úlcera traumática e hiperplasia gengival. Em relação ao atendimento odontológico é crucial o CD saiba como se encontra o controle glicêmico do paciente, podendo lançar mão de dois exames laboratoriais, a glicemia em jejum (normal 70-99 mg/dL, DM acima de $126 \mathrm{mg} / \mathrm{dL}$ ) e a hemoglobina glicada (normal é de 6\%). Paciente com valores alterados devem ser encaminhados ao endocrinologista para tratamento antes da realização de procedimentos odontológicos invasivos. Em relação ao atendimento odontológico, alguns cuidados devem ser tomados. $O$ primeiro deles é certificar-se de que o paciente alimentou-se adequadamente antes do procedimento, e caso o procedimento seja longo, verificar ajuste da dosagem da insulina, afim evitar hipoglicemia. O controle da ansiedade deve ser instituído para pacientes ansiosos, visto que a ativação do sistema simpático e liberação maciça de adrenalina aumentam a taxa de glicose sanguínea, esse controle pode ser realizado por meio da prescrição de ansiolíticos previamente a consulta. Em relação ao uso de fármacos, a adrenalina presente nos anestésicos locais apresenta um efeito farmacológico oposto ao da insulina sendo possível o paciente diabético descompensado ou instável estar vulnerável aos efeitos desse hormônio. Portanto, o uso de vasoconstritores do grupo das catecolaminas, deve ser evitado nesse tipo de paciente até que haja o controle da glicemia. Em pacientes com foco de infecção, é recomendado o emprego de solução anestésica que contenha felipressina, como a prilocaína. Os anti-inflamatórios não esteroidais devem ser usados com cautela, visto que podem interagir com hipoglicemiantes orais podendo acentuar seus efeitos levando a quadros de hipoglicemia. Uma das maiores discussões na literatura é em relação a profilaxia antibiótica, visto que os pacientes com DM são mais susceptíveis a infecções. Paciente controlados não precisam de medidas profiláticas, porém, em atendimentos de urgência em pacientes descompensados indica-se a utilização previa de amoxicilina (1g) ou clindamicina (600mg) $1 \mathrm{~h}$ antes do atendimento cirúrgico, para evitar-se complicações. Pacientes que apresentam infecções instaladas devem receber tratamento rigoroso, visto que o DM torna mais difícil o controle da doença 
(ANDRADE et al., 2014).

Conclusão: Devido à alta incidência relativa da doença Diabetes Mellitus e suas complicações para o paciente, bem como taxa de morbimortalidade considerável, verifica-se a importância do conhecimento dos cirurgiões-dentistas a respeito dos aspectos etiológicos, patogênicos, epidemiológicos e clínicos da doença, a fim de adotar uma conduta clínica adequada às condições peculiares do diabético durante a consulta odontológica em comunicação com o médico assistente, promovendo bem-estar e melhores condições de saúde ao mesmo.

\section{Referências}

ANDRADE, E. D. Terapêutica Medicamentosa Em Odontologia. $3^{a}$ Ed. São Paulo: Ed Artes Médicas, 2014

NETO, J. N et al. O paciente diabético e suas implicações para conduta odontológica. Revista Dentística Online, v.11, n 23 , ISSN 1518-4889, 2011.

TERRA, B. G.; GOULART, R. R.; BAVARESCO, C. S. O cuidado odontológico do paciente portador de Diabetes Mellitus tipo 1 e 2 na atenção primária à saúde. Revista Atenção Primária À Saúde, v. 14, n 2, p. 149-61, abr/jun 2011.

Coordenadoria de Pesquisa e Extensão - COPEX

Departamento de Editoraçāo e Divulgaçāo Científica - DEDIC 


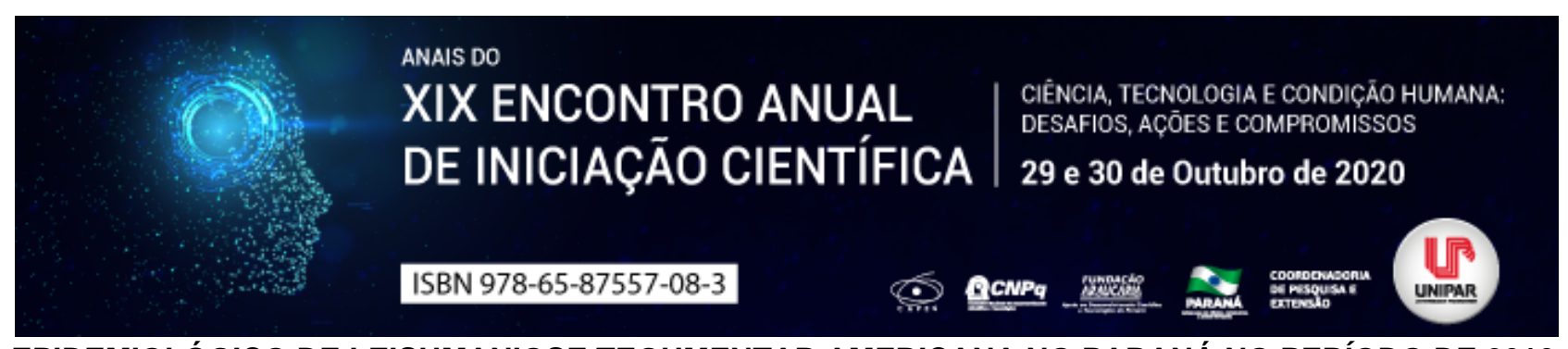

PERFIL EPIDEMIOLÓGICO DE LEISHMANIOSE TEGUMENTAR AMERICANA NO PARANÁ NO PERÍODO DE 2010 A 2018

\section{${ }^{1}$ LEONARDO LUAN PERICO, ${ }^{2}$ SSABELA PAOLA DALLA LONGA SALLES, ${ }^{3}$ LEONARDO GARCIA VELASQUEZ}

${ }^{1}$ Discente do curso de Farmácia, PIBIC - UNIPAR Unidade de Francisco Beltrão

${ }^{1}$ Discente do curso de Farmácia, PIC - UNIPAR Unidade de Francisco Beltrão

${ }^{2}$ Docente do Programa de Mestrado Profissional em Plantas Medicinais e Fitoterápicos na Atenção Básica/UNIPAR

Introdução: A leishmaniose representa uma zoonose causada por várias espécies de parasitas do gênero Leishmania, a qual apresenta um ciclo biológico que necessita de hospedeiros vertebrados e invertebrados (flebotomíneos) para completa evolução. As formas clínicas da doença são distintas, às quais são caracterizadas pela espécie de Leishmania e pela forma de transmissão em que a doença foi adquirida pelo hospedeiro. O parasita apresenta em seu ciclo evolutivo duas formas, denominadas amastigota e promastigota. Amastigota é a forma que atinge o SFM (Sistema Fagocítico Mononuclear) de hospedeiros vertebrado como humanos e animais silvestres e domésticos. Já a forma promastigota, é considerada a forma infectante, pois está presente no sistema digestório do hospedeiro invertebrado, o qual inocula o parasita no hospedeiro vertebrado durante o repasto sanguíneo, causando a infecção (GONTIJO et al.,2003).

Objetivo: Avaliar o perfil epidemiológico da Leishmaniose Tegumentar Americana no estado do Paraná no período de 2010 a 2018.

Material e métodos: Trata-se de um estudo retrospectivo, descritivo, bibliográfico, quali-quantitativo, que será realizado através da análise dos dados obtidos no DATASUS/TabNet (Serviço de Informação do SUS).

Resultados: Foram analisados os dados obtidos no sistema DATASUS/TabNet, os quais apontam 3.053 casos confirmados de Leishmaniose Tegumentar Americana, sendo 2.610 (85,48\%) na forma cutânea e 443 (14,51\%) na forma mucosa. Em relação aos dados sociodemográficos, foram notificados 2.259 (73,99\%) casos de pacientes do sexo masculino e 794 (26,01\%) casos de pacientes do sexo feminino. Dentre os pacientes do sexo masculino, 1.924 (85,17\%) foram na forma cutânea e 335 (14,64\%) na forma mucosa. Já no sexo feminino, 699 (88,04\%) foram na forma cutânea e 95 (11,96\%) na forma mucosa. A faixa etária com maior número de casos notificados ficou entre 20 e 59 anos independendo o sexo, sendo notificados 2.044 casos, e, dentre eles, 1.795 (87,82\%) foram na forma cutânea e 249 (12,18\%) na forma mucosa.

Discussão: A leishmaniose está presente em todo o mundo. Em 2018, foram notificados 251.553 casos em todo o mundo (RUIZPOSTIGO et al., 2020). Pesquisas através de estudos longitudinais permitem identificar padrões epidemiológicos de infecções como a leishmaniose, podendo assim detectar áreas endêmicas. No Brasil, é comum ocorrer surtos epidêmicos com a derrubada de matas para construção de estradas e extração de madeira (BARRETO et al., 1981; BASANO et al., 2004). Entre 1980 e 2013, foram identificados no Brasil 789.278 casos de leishmaniose tegumentar americana. Nesse período, 17.494 (2,2\%) foram notificados na região Sul, dos quais 16.700 (95,5\%) ocorreram no Paraná, representando quase que uma totalidade dos casos notificados em toda a região Sul do país (OLIVEIRA et al., 2016). Segundo dados coletados no DATASUS/TabNet, é evidenciado a prevalência da doença em questão sobre o sexo masculino, com 73,99\% dos casos confirmados, e $26,01 \%$ no sexo feminino. Os dados demonstram também a prevalência da forma clínica que mais acomete a população, tanto no sexo masculino quanto no feminino entre os anos de 2010 e 2018. A leishmaniose cutânea abrange cerca de 85,48\%, enquanto a leishmaniose na forma mucosa somente $14,51 \%$ dos casos notificados neste período. A faixa etária mais acometida pela leishmaniose é de 20 a 59 anos. Isso se dá devido a essa ser a idade ativa, ou seja, a idade mais ligada a atividades de exploração da floresta e derrubada de matas para construção de estradas, extração de madeira, moradias e indústrias (BRASIL, 2007). Os dados sociodemográficos encontrados neste estudo foram concordantes com outros estudos da literatura (SILVEIRA et al., 1996; MONTEIRO et al., 2008). Neste sentido, o Paraná apresenta números elevados de casos da doença pois o desenvolvimento da atividade agrícola é intenso, sendo uma das principais atividades econômicas exercidas no estado (SILVEIRA et al., 1996).

Conclusão: Diante dos trabalhos realizados sobre leishmaniose nos últimos anos, é evidenciado a natureza endêmica da doença em questão no estado do Paraná. Com isso, deve-se salientar a importância dos estudos dessa endemia para que sejam criadas ações de políticas públicas voltadas ao controle da leishmaniose (MONTEIRO et al., 2008). Os resultados encontrados comprovam a situação endêmica em que o Paraná se encontra, sendo responsável por cerca de $99 \%$ dos casos notificados no Sul do país (MONTEIRO et al., 2009).

\section{Referências}

BARRETO, Air C. et al. Características epidemiológicas da leishmaniose tegumentar americana em uma região endêmica do estado da Bahia, Brasil. I. Leishmaniose humana. Boletín de la Oficina Sanitaria Panamericana, v.90, n.5, p.415-24, maio 1981. 
BASANO, Sergio de Almeida. et al. Leishmaniose tegumentar americana: histórico, epidemiologia e perspectivas de controle. Rev. Bras. Epidemiol, Brasil, v. 7, n. 3, p. 328-337, 2004.

BRASIL. Ministério da Saúde. Secretaria de Vigilância em Saúde. Departamento de Vigilância Epidemiológica. Manual de Vigilância da Leishmaniose Tegumentar Americana / Ministério da Saúde, Secretaria de Vigilância em Saúde, Departamento de Vigilância Epidemiológica. $\quad$ 2. ed. Brasília: Editora do Ministério da Saúde, 2007.

DEPARTAMENTO DE INFORMÁTICA DO SUS - DATASUS. Informações de Saúde, Epidemiológicas e Morbidade: banco de dados. Disponível em: http://tabnet.datasus.gov.br/cgi/deftohtm.exe?sinannet/cnv/ltapr.def Acesso em: 23/08/2019.

GONTIJO, Bernardo, et al. Leishmaniose tegumentar americana. Rev. Soc. Med. Trop., v.36, n.1, p.71-80, fevereiro 2003.

MONTEIRO, Wuelton Marcelo. et al. Distribuição geográfica e características epidemiológicas da leishmaniose tegumentar americana em áreas de colonização antiga do Estado do Paraná, Sul do Brasil. Cad. Saúde Pública, Rio de Janeiro, v.24, n.6, p. 1291-1303, junho 2008.

MONTEIRO, Wuelton Marcelo. et al. Pólos de produção de leishmaniose tegumentar americana no norte do Estado do Paraná, Brasil. Cad. Saúde Pública, Rio de Janeiro, v.25 n.5, p.1083-92, maio 2009.

OLIVEIRA, Rosangela Ziggiotti de. et al. Leishmaniose tegumentar americana no município de Jussara, estado do Paraná, Brasil: série histórica de 21 anos. Rev. Saúde Pública Paraná, v.17, n.2, p.59-65, dezembro 2016.

RUIZ-POSTIGO, José Antonio. et al. Weekly Epidemiological Record. World Health Organization, v.95, n.25, p.265-280, 2020. SILVEIRA, Thaís Gomes Verzignassi, et al. Aspectos epidemiológicos da leishmaniose tegumentar em área endêmica do Estado do Paraná, Brasil. Cad. Saúde Pública, Rio de Janeiro, v.12, n.2, p.141-147, Junho 1996. 


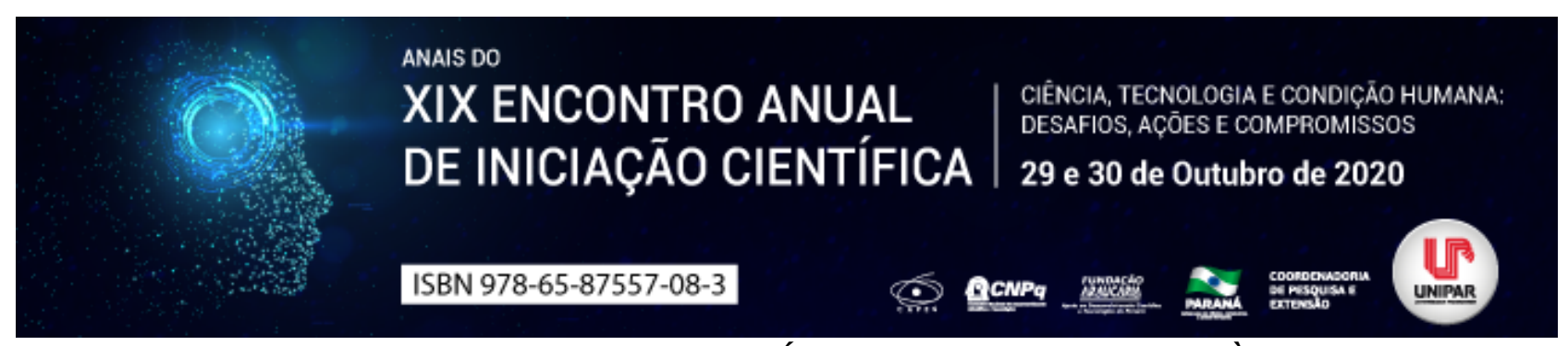

A VULNERABILIDADE E OS DESAFIOS DOS POVOS INDÍGENAS DO BRASIL FRENTE À PANDEMIA DA COVID-19

\begin{abstract}
${ }^{1}$ Pedro Érico Alves de Souza, ${ }^{2}$ ALICE PEREIRA DE SIQUEIRA NASCIMENTO, ${ }^{3}$ ANDREW PEREIRA DA SILVA, ${ }^{4}$ GABRIEL VITOR LIMA DE ANDRADE, ${ }^{5}$ LUAN NOVAES LEITE, ${ }^{6}$ SAULO FERREIRA FEITOSA
\end{abstract}

${ }^{1}$ Acadêmico de Medicina da Universidade Federal de Pernambuco
${ }^{1}$ Acadêmica de Medicina da Universidade Federal de Pernambuco
${ }^{2}$ Acadêmico de Medicina da Universidade Federal de Pernambuco
${ }^{3}$ Acadêmico de Medicina da Universidade Federal de Pernambuco
${ }^{4}$ Acadêmico de Medicina da Universidade Federal de Pernambuco
${ }^{5}$ Docente do curso de Medicina da Universidade Federal de Pernambuco, Campus Agreste.

Introdução: Originada de Wuhan, China, a pandemia do novo coronavírus Sars-CoV-2 se espalhou globalmente com milhões de infectados, com taxa de mortalidade geral variando entre 5,5\% e 5,9\% (EADES, et al., 2020; DE LEÓN-MARTíNEZ et al., 2020). No Brasil, o número de casos da COVID-19 cresce diariamente, e até o dia 29 de agosto de 2020 as Secretarias Estaduais de Saúde contabilizavam 3.804.803 de casos confirmados e 119.504 óbitos (SVS, 2020). Com os leitos de UTI e respiradores concentrados nas capitais da região sudeste, populações afastadas dos grandes centros urbanos são menos assistidas pelos serviços de saúde no combate ao novo coronavírus (MARSON; ORTEGA, 2020). A população indígena no Brasil totaliza 896,9 mil pessoas, com a sua maior parte vivendo na zona rural e distribuída em sua maioria nas regiões norte e nordeste (IBGE, 2010), evidenciando a situação de vulnerabilidade limitante do acesso aos cuidados de saúde para esses povos, o que dificulta o combate ao vírus nessas localidades.

Objetivo: Destacar, a partir da literatura científica, aspectos que abordam a vulnerabilidade e os desafios das populações indígenas do Brasil frente à pandemia da COVID-19.

Desenvolvimento: Historicamente, os patógenos foram um dos agentes mais fortes para dizimar os povos indígenas na América do Sul (HECK; PRÉZIA, 2001). Esse fato costuma vir relacionado com a ideia de que as populações indígenas são de alguma forma biologicamente inferiores e mais vulneráveis à uma doença nova, que é um mito, dado que não existe embasamento científico para apontar isso. Sempre que um novo vírus entra em contato com uma população imunologicamente ingênua, seja indígena ou não, ele se espalha rapidamente (AMIGO, 2020). O que viria a conferir vulnerabilidade para esses povos frente à esse vírus seriam fatores médicos, sociais e ambientais que variam desde a incidência de outras doenças (malária, sarampo, gripe e até doenças crônicas), a falta de serviços médicos próximos à essas localidades (leitos de terapia intensiva e respiradores necessários para tratar casos graves da COVID-19), até problemas de invasão e não demarcação de territórios visto que o governo federal, responsável pela atenção à saúde desses povos exclui de seus relatórios as pessoas que vivem em terras ainda não demarcadas e aquelas que habitam nos centros urbanos (MARSON; ORTEGA, 2020; MENESES- NAVARRO, et al., 2020). Essa vulnerabilidade é encontrada em dados da Articulação dos povos Indígenas do Brasil (APIB), que no dia 28 de agosto, notificou que a Covid-19 já havia alcançado 156 povos indígenas, havendo um total de 28744 casos confirmados e 757 óbitos. O povo Kokama, localizado no estado do Amazonas é o mais atingido, chegando a 58 óbitos, somados os casos confirmados e suspeitos (APIB, 2020). Além disso, em estudo recente, a Fundação Oswaldo Cruz constatou que 48\% das mortes pela covid-19, em pacientes internados, corresponde a pessoas indígenas, representando a maior taxa entre os grupos ètnicos do país. Dessa forma, mesmo quando os seus direitos são garantidos por lei ou acordos internacionais firmados há anos, esses povos encontram hoje uma realidade de negligência e marginalização pelos governos, o que denota a existência de desafios a serem enfrentados por essas comunidades. Um desses desafios seria a omissão das autoridades, que, ao se aliarem à desinformação e aos rumores e informações falsas, banalizam a gravidade de uma pandemia, culminando na descrença nos profissionais de saúde, responsáveis por conterem o avanço da doença. Também, com a falta de proteção financeira, agravada pelo desemprego generalizado produzido pela pandemia, medidas de isolamento são ignoradas com a migração desses povos para os centros urbanos, seja em busca de emprego, seja para receber o auxílio emergencial aprovado pelo Congresso Brasileiro, que só pode ser coletado nas cidades (MARSON; ORTEGA, 2020; MENESES- NAVARRO, et al., 2020; CURTICE; CHOO; 2020). NesSa realidade, medidas preventivas de isolamento social como as da Terra Indígena Uru-Eu-Wau-Wau, em Rondônia, se tornam de grande importância, dado que além dos residentes serem incentivados a permanecer nas aldeias, apenas um número limitado dos representantes dos serviços de saúde pode entrar (AMIGO, 2020).. Outra forma de enfrentar os desafios mencionados seria a criação de políticas concebidas e administradas pelas próprias comunidades indígenas, baseadas em evidências científicas, e com a gestão dos recursos relacionados com a COVID-19 pelas próprias comunidades, dentro de uma estrutura de respeito pela visão de mundo indígena, tendo em vista que historicamente soluções lideradas pelo governo não foram adequadas (MENESES- 
NAVARRO, et al., 2020; CURTICE; CHOO; 2020). Ademais, outra medida seria a criação de planos específicos que assegurem acesso a serviços de diagnóstico e atendimento hospitalar onde for necessário, com o auxílio de transporte e acesso a medicamentos e equipamento médico, que contém leitos de terapia intensiva e respiradores (BANNING, 2020; MENESESNAVARRO, et al., 2020);

Conclusão: A COVID-19 avança sobre a população indígena que se encontra em situação de vulnerabilidade em decorrência de desafios de ordem médica, social e ambiental constituídos ao longo da história, limitando acesso a cuidados de saúde que evidenciam um racismo sistêmico e uma discriminação contra os povos indígenas do país (AMIGO, 2020; EADES, et al., 2020; DE LEÓN-MARTÍNEZ et al., 2020; FERRANTE; FEARNSIDE, 2020).

\section{Referências}

AMIGO, Ignacio. Indigenous communities in Brazil fear pandemic's impact. Science. vol. 368, p. 6489, 2020.

APIB Articulação dos povos Indígenas do Brasil. Panorama Geral da COVID-19. 2020. Disponível em: Acesso em: 29/08/2020. BANNING, Jolene. How Indigenous people are coping with COVID-19. CMAJ : Canadian Medical Association journal, vol. 192, E787-E788, 2020.

CURTICE, Kaitlin; CHOO, Esther. Indigenous populations: left behind in the COVID-19 response. The Lancet, v. 395, n. 10239, p. $1753,2020$.

EADES, Sandra et al. Australia's First Nations' response to the COVID-19 pandemic. The Lancet, v. 396, n. 10246, p. 237-238, 2020.

DE LEÓN-MARTíNEZ, Lorena Díaz et al. Critical review of social, environmental and health risk factors in the Mexican indigenous population and their capacity to respond to the COVID-19. Science of The Total Environment, p. 139357, 2020.

Secretaria de Vigilância em Saúde (SVS): Guia de Vigiläncia Epidemiológica do COVID-19. Painel Coronavírus Brasília: Ministério da Saúde, 2020. Disponível em: . Acesso em: 29/08/2020.

FERRANTE, Lucas; FEARNSIDE, Philip M. Protect Indigenous peoples from COVID-19. Science, v. 368, n. 6488, p. 251-251, 2020.

IBGE Instituto Brasileiro de Geografia e Estatística. Censo Demográfico. 2010. Disponível em: . Acesso em: 29/08/2020.

HECK, Egon. PRÉZIA, Benedito (Orgs.) . Outros 500: Construindo uma Nova História. 1. ed. São Paulo: Editora Salesiana, 2001.

MARSON, Fernando Augusto Lima; ORTEGA, Manoela Marques. COVID-19 in Brazil. Pulmonology, v. 26, n. 4, p. 241-244, 2020. MENESES-NAVARRO, Sergio et al. The challenges facing indigenous communities in Latin America as they confront the COVID19 pandemic. International Journal for Equity in Health, v. 19, p. 1-3, 2020. 


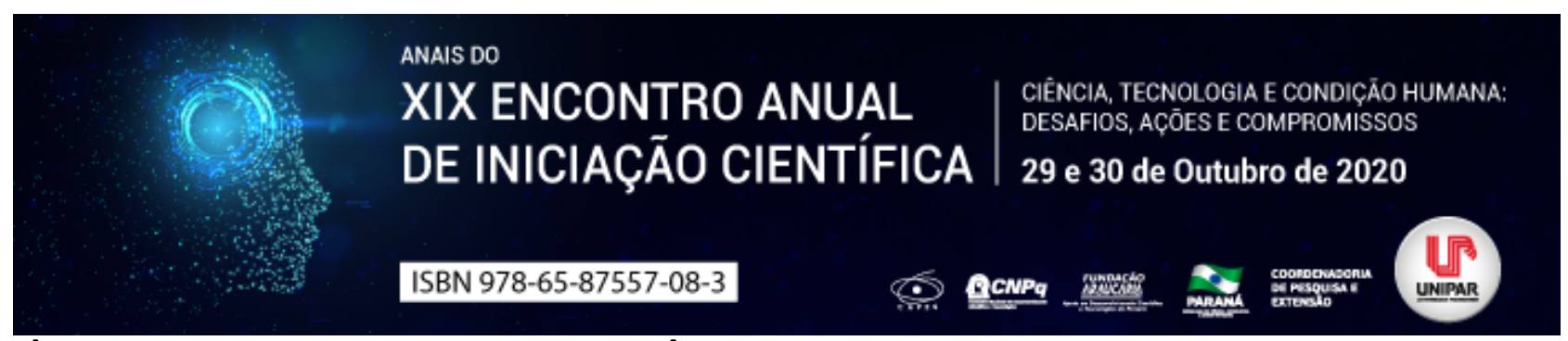

IMPORTÂNCIA DE NOVOS TRATAMENTOS TERAPÊUTICOS COMO ALTERNATIVA PARA TOXOPLASMOSE: REVISÃO BIBLIOGRÁFICA

\author{
${ }^{1}$ YURI PELICANO DOMINGUES, ${ }^{2}$ JOAO ANTONIO BERTA DE OLIVEIRA, ${ }^{3}$ MARIA DAMARIS RIBEIRO CAVALCANTE, ${ }^{4}$ ALAN \\ DA SILVA LISBOA, ${ }^{5}$ GUILHERME DONADEL, ${ }^{6}$ EMERSON LUIZ BOTELHO LOURENCO
}

\author{
${ }^{1}$ Acadêmico bolsista do PIBIC/UNIPAR \\ ${ }^{1}$ Acadêmico do Curso de Medicina Veterinária da UNIPAR \\ ${ }^{2}$ Acadêmica do Curso de Medicina Veterinária da UNIPAR \\ ${ }^{3}$ Acadêmico do Curso de Medicina Veterinária da UNIPAR \\ ${ }^{4}$ Discente do Mestrado em Ciência Animal e Produtos Bioativos \\ ${ }^{5}$ Docente da UNIPAR
}

Introdução: Toxoplasmose é uma doença causada pelo parasito T. gondii, que infecta entre 5-80\% da população humana ao redor do mundo (PITTMAN, 2015). A infecção aguda pela toxoplasmose em indivíduos adultos imunocompetentes normalmente é sem sintomas. Quando há manifestação de sintomas, o indivíduo sente dores de cabeça e mal estar, além de febre baixa e linfadenopatia cervical. Em indivíduos imunocomprometidos, como portadores de HIV ou câncer, a toxoplasmose pode levar até a morte. Isso acontece pois nesses pacientes a doença se manifesta de forma severa, causando manifestações graves, como: encefalites, miocardites e pneumonia (IDDAWELA, 2017).

Objetivo: Relatar através de revisão bibliográfica a importância da descoberta de novas alternativas terapêuticas contra a toxoplasmose.

Desenvolvimento:O protocolo de tratamento da toxoplasmose é baseado no uso concomitante da Pirimetamina para a inibição da dihidrofolato redutase (DHFR) e a sulfadiazina para a inibição da diidropteroato sintase (DHPS). Essa forma de tratamento vem sendo utilizado há muito tempo, porém o uso prolongado de antibióticos pode levar a resistência desses microrganismos, uma vez que estudos mostraram que a sensibilidade da pirimetamina pode variar significativamente entre as diferentes cepas de T. gondii (REYNOLDS, 2001). Alguns pesquisadores já descreveram a resistência a pirimetamina e outras drogas usadas no tratamento da toxoplasmose (REYNOLDS, 2001). Diante deste cenário, é muito importante que sejam desenvolvidos estudos que busquem outras formas de tratamento eficaz contra a toxoplasmose uma delas, pode ser através do uso de plantas medicinais e extratos vegetais. Uma planta medicinal que vêm sendo estudada como opção de tratamento de algumas doenças, é a Echinacea purpúrea. Essa planta é rica em vários fitoquímicos, incluindo derivados de ácido cafeico, alcamidas e polissacarídeos, e ainda possui propriedades imunomoduladoras e anti-inflamatórias (SAEIDNIA, 2015). A E.purpurea aumenta a função imunológica de ratos imunossupressores induzidos pelo estresse, podendo ainda promover a proliferação de esplenócitos, acelerar a atividade nas células natural killer do baço, e regula os linfócitos T e os níveis de citoquinas no sangue (PARK, 2017). Outra planta a ser mencionada é Annona muricata L onde estudo realizados por Miranda et al. 2018 comprovou que o trabalho in vitro com o extrato etanólico de $A$. muricata foi capaz de controlar o crescimento do parasita em várias concentrações e no estudo in vivo o tratamento com extrato de A.muricata prolongou a sobrevivência, controlou a proliferação do parasita no intestino delgado, pulmão e no cérebro após o período de infecção, portanto o extrato de $A$. muricata pode ser uma boa alternativa também no tratamento do toxoplasma gondii.

Conclusão: Diante disso, concluímos que é de extrema importância que sejam estudadas novas alternativas terapêuticas para a toxoplasmose, como é o caso do E.purpúrea e A. muricata pois apresentaram eficácia nos tratamentos realizados dessa doença que acomete grande parte da população ao redor do mundo.

\title{
Referências
}

IDDAWELA, D. VITHANA, S. RATNAYAKE, C. Seroprevalence of toxoplasmosis and risk factors of Toxoplasma gondii infection among pregnant women in Sri Lanka: a cross sectional study. BMC Public Health, v. 17, n. 1, p. 1-6, March 2017.

MIRANDA, N. C. et al. Efeito do extrato bruto etanólico da planta Annona muricata L. (graviola) e suas frações no controle da infecção in vitro e in vivo por Toxoplasma gondii. 2018. Tese (Doutorado) - Universidade Federal de Uberlândia, Programa de Pós-Graduação em Imunologia e Parasitologia Aplicadas. 2018.

PARK, S. et al. Echinacea purpurea Protects Against Restraint Stress-Induced Immunosuppression in BALB/c Mice. Journ of Medic Food, v. 21, n. 3, p. 261-268, Feb 2018.

PITTMAN, K.; KNOLL, L. Long-Term Relationships: the Complicated Interplay between the Host and the Developmental Stages of Toxoplasma gondii during Acute and Chronic Infections, Microb. Mol. Biol. Rev., v. 79, p. 387401, June 2015. 
REYNOLDS, M. OH, J. ROOS, D. In vitro generation of novel pyrimethamine resistance mutations in the Toxoplasma gondii dihydrofolate reductase. Antim Agents Chemother, v. 45, n. 4, p. 1271-1277, Febu 2001.

SAEIDNIA, S.; MANAYI, A.; VAZIRIAN, M. Echinacea purpurea: Pharmacology, phytochemistry and analysis methods. Pharmaco Reviews, v. 9, n. 17, p. 63, January 2015.

Coordenadoria de Pesquisa e Extensão - COPEX

Departamento de Editoraçāo e Divulgaçāo Científica - DEDIC 


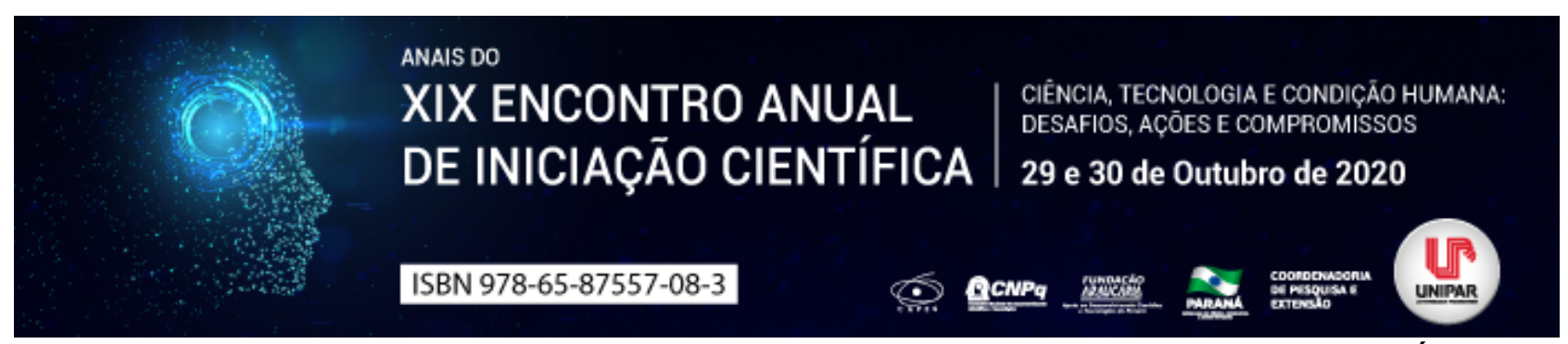

MONITORAMENTO DE PESSOAS VIVENDO COM HIVIAIDS NO SUDOESTE DO PARANÁ

\begin{abstract}
${ }^{1}$ ANA FRIDA DUARTE, ${ }^{2}$ MONISE CAROLINE CAPELIN, ${ }^{3}$ CAMILLE BENEDETE DOS SANTOS, ${ }^{4}$ ISABELA DA SILVA HISTER, ${ }^{5}$ LIRANE ELIZE DEFANTE FERRETO, ${ }^{6}$ VOLMIR PITT BENEDETTI
\end{abstract}

\begin{abstract}
${ }^{1}$ Discente de Farmácia, PIBIC/UNIPAR, Universidade Paranaense, Francisco Beltrão - PR
${ }^{1}$ Discente de Farmácia, PIC/UNIPAR, Universidade Paranaense, Francisco Beltrão - PR

${ }^{2}$ Discente de Farmácia, PIC/UNIPAR, Universidade Paranaense, Francisco Beltrão - PR

${ }^{3}$ Discente de Farmácia, PIC/UNIPAR, Universidade Paranaense, Francisco Beltrão - PR

${ }^{4}$ Docente UNIOESTE, Universidade do Oeste do Paraná, Francisco Beltrão - PR

${ }^{5}$ Docente UNIPAR, Universidade Paranaense, Francisco Beltrão PR
\end{abstract}

Introdução: A Síndrome da Imunodeficiência Adquirida (AIDS), causada pelo vírus da imunodeficiência humana (HIV), corresponde a uma doença crônica infecciosa, transmitida pelas vias sexual, parenteral ou vertical. Essa doença é caracterizada por um processo contínuo de supressão profunda do sistema imunológico mediada por linfócitos TCD 4+, tornando os indivíduos infectados suscetíveis a infecções oportunistas ou malignidades (GOULART et al., 2018). Dentre as principais infecções oportunistas registradas nesse grupo, destaca-se a candidíase oral. Para tanto, a avaliação de alterações registradas na cavidade oral destes indivíduos colabora para o monitoramento da progressão da doença. (GANNEPALLI et al., 2020).

Objetivo: Analisar e descrever a saúde bucal de pacientes vivendo com HIVIAIDS, atendidos no Serviço de Assistência Especializada e Centro de Triagem e Aconselhamento SAE/CTA, da secretaria de saúde do município de Francisco BeltrãoPR.

Material e métodos: Inicialmente os participantes foram encaminhados para uma consulta odontológica onde se se realizou uma entrevista, com preenchimento de uma ficha epidemiológica, sobre dados socioeconômicos, comportamentais e clínicos, bem como a avaliação da condição oral dos pacientes. Ao fim da consulta coletou-se o material biológico (saliva) com o auxilio de um swab estéril, o qual foi depositado em um tubo de ensaio contendo água peptonada $0,1 \%$ (estéril). A amostra coletada foi encaminhada para o Laboratório de Biotecnologia de Microrganismos da Unipar, onde foi semeado cada amostra em meio de cultura seletivo diferencial CHROMagar ${ }^{\mathrm{TM}}$ (Becton Dickinson) e incubado a $35^{\circ} \mathrm{C}$ por 48 horas para a identificação presuntiva de leveduras, seguindo a metodologia preconizada por Koneman et al. (2008). Este projeto de pesquisa foi submetido e aprovado pelo Conselho de Ética Envolvendo Seres Humanos CEPEH da UNIPAR, e estando registrado sob protocolo 3667278.

Resultados: Dos 27 pacientes que participaram do estudo, 55,6\% (15) são do sexo feminino e 44,4\% (12) masculino, apresentando idade média de 42,7 anos. Quanto ao seu estado civil, 48,2\% (13) estão casados 33,3\% (9) solteiros, 11,1\% (3) viúvos e 7,4\% (2) divorciados. Em complemento, 74,1\% (20) dessas pessoas vivem com familiares, $11,1 \%$ (3) com o parceiro, $11,1 \%$ (3) sozinhos e 3,7\% (1) com amigos. Ainda, 70,4\% (19) possuem filhos e 29,6\% (8) não têm. Com relação à renda familiar, para 55,6\% (15) esta é de 1 a 2 salários mínimos, 29,6\% (8) é de 2,1 a 4 salários mínimos, para 11,1\% (3) é superior a 4, contudo, 3,7\% (1) dos pacientes investigados não revelaram sua renda. No item que questionava a orientação e atividade sexual dos pacientes, observou-se que $81,5 \%$ (22) eram heterossexuais e $18,5 \%$ (5) homossexuais, ainda verificou-se que $85,2 \%(23)$ possuem vida sexual ativa e 14,8\% (4) não possuem. Destes, 59,3\% (16) fazem uso de preservativo, 40,7\% (11) não usam. Quanto aos hábitos dos pacientes, 51,9\% (14) relataram que são fumantes, 74,1\% (20) fazem uso de bebida alcoólica e 7,4\% (2) são usuários de drogas. No quesito que investigava a presença de alterações orais dos pacientes, $11,1 \%$ (3) apresentavam eritema gengival linear, $7,4 \%$ (2) quelite angular, 7,4\% (2) úlceras aftosas recorrentes, 3,7\% (1) gengivite necrosante e 3,7\% (1) herpes simples. Com relação à cultura de leveduras, foram analisadas 27 amostras sendo que 44,4\% (12) apresentaram crescimento e $55,6 \%$ (15) foram negativas. Dentre os isolados, $91,7 \%$ (11) correspondiam a leveduras da espécie Candida albicans e 8,3\% (1) Candida parapsilosis.

Discussão: Segundo observado nesse estudo, houve um predomínio do sexo feminino, sendo registrada entre os pacientes uma idade média de 42,7 anos, estes achados se assemelham com o que Goulart et al.(2018) encontrou em seu estudo. Suryana, Suharsono e Antara (2020) comentam que o baixo número de células T-CD4, o tabagismo, o alcoolismo, a idade, o sexo, a xerostomia bem como o uso de antibióticos são fatores que contribuem para o surgimento de distúrbios na mucosa oral de pessoas vivendo com HIVIAIDS. De acordo com Castro, Álvarez e Martínez (2015), a colonização da cavidade oral por leveduras do gênero Candida pode ser considerada um fator predisponente para o desenvolvimento de candidíase orofaríngea. Ainda os achados dos autores se assemelham aos obtidos nesta pesquisa, pois em ambos apontam Candida albicans como a espécie mais frequente na cavidade oral de indivíduos infectados pelo HIV. Já com relação às alterações na cavidade oral, Gannepalli et 
al. (2020) também identificou o eritema gengival linear como uma das manifestações orais mais frequentes.

Conclusão: Neste estudo observou-se que a maior parte dos indivíduos vivendo com HIVIAIDS, entre o grupo analisado são mulheres, com idade média de 42,7 anos. A maioria dos participantes vive com familiares, tem filhos e possuem uma renda familiar de 1 a 2 salários mínimos. Mais da metade dos entrevistados são heterossexuais, possuem vida sexual ativa e usam preservativos, atenta-se ainda para o tabagismo. Por fim, o eritema gengival linear foi a alteração mais comum e dentre as leveduras isoladas, a espécie mais frequente foi a Candida albicans.

\section{Referências}

CASTRO, Luz Ángela; ALVAREZ, María Inés; MARTINEZ, Ernesto. Candida en la cavidad oral de pacientes con VIH en Cali, Colombia: determinación de especies y sensibilidad al fluconazol. Latreia, Medellín, v. 28, n. 4, p. 368-377, dez. 2015.

GANNEPALLI, Ashalata et al. Oral Manifestations in HIV-TB Co- infected Patients and Their Correlation with CD4 Count in Telangana State, India. J Int Soc Prev Community Dent. Telanga, v. 10, n. 1, p. 21-35, jan. 2020.

GOULART, Letícia Silveira et al. Oral colonization by Candida species in HIV-positive patients: association and antifungal susceptibility study. Einstein (São Paulo). São Paulo, v. 16, n. 3, ago. 2018.

KONEMAN, Elmer et al. Diagnóstico microbiológico - texto e atlas colorido. 6.ed. Guanabara Koogan. Rio de Janeiro, 2008 SURYANA, Ketut; SUHARSONO, Hamong; ANTARA, I. Gede Putu Jarwa. Factors Associated with Oral Candidiasis in People Living with HIVIAIDS: A Case Control Study. Hivlaids (Auckland, NZ), v. 12, p. 33, 2020. 


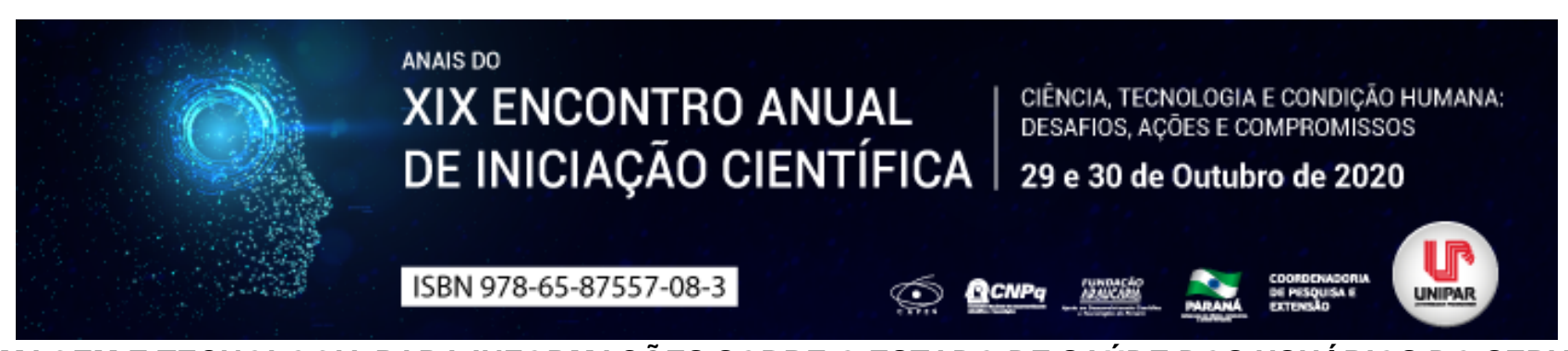

\title{
ENFERMAGEM E TECNOLOGIA PARA INFORMAÇÕES SOBRE O ESTADO DE SAÚDE DOS USUÁRIOS DO SERVIÇO EM SAÚDE
}

\author{
${ }^{1}$ JESSICA MARIANE DUTRA DA SILVA, ${ }^{2}$ ANNA PAULA HADAS ALVES,${ }^{3}$ ARNALDO GOMES DO AMARAL
}

\author{
${ }^{1}$ Acadêmica do Curso de Enfermagem da UNIPAR \\ ${ }^{1}$ Acadêmica do Curso de Enfermagem da UNIPAR \\ ${ }^{2}$ Docente da UNIPAR
}

Introdução: A evolução tecnológica é de suma importância para o desenvolvimento da sociedade e aprimoramento em diversas áreas. No âmbito das ciências da saúde a tecnologia é uma aliada indispensável, tanto para os tratamentos, como para a gestão e comunicação de dados referentes aos pacientes. Por meio de aplicativos e/ou banco de dados compartilhados, os profissionais da área têm acesso a uma gama de informações sobre um paciente específico e seu quadro, bem como aperfeiçoam o serviço prestado.

Objetivo: Discorrer sobre como a tecnologia auxilia no monitoramento e zelo de pacientes do Sistema de Saúde.

Desenvolvimento: $O$ acesso à saúde se trata de um direito inerente à pessoa humana, conforme aduz a Carta Magna Constitucional. Na mesma Lei tem-se o Direito fundamental à informação em saúde, o qual é definido no artigo $5^{\circ}$, inciso XIV da CRFB/88 (BRASIL, 1988), essa normativa garante a todos o direito à informação, resguardando o sigilo quando necessário. Assim, o usuário do serviço público tem garantia constitucional de ser informado sobre todos os âmbitos que abrangem sua saúde e serviços que possibilitem o devido acesso ao seu direito. Partindo desta premissa, podemos relacionar que o avanço tecnológico está diretamente ligado ao preceito ora mencionado na Carta Constitucional. A unificação de informações por meio de banco de dados tem facilitado e melhorado o modo que os profissionais da saúde lidam com os casos específicos de cada paciente. Por conseguinte os usuários também são beneficiados por meio de aplicativos e serviços que possibilitam uma compreensão panorâmica sobre diversas peculiaridades em caráter municipal, estadual e nacional. Na esfera nacional contamos com o Sistema de Informação em Saúde (SIS), que se trata de um processo de coleta, análise e transmissão de informações (BRASIL, 2009) Assim, os gestores da saúde no Brasil podem avaliar, monitorar e controlar as atividades desenvolvidas pelos prestadores de serviços através de indicadores locais, facilitando a formulação e avaliação de políticas, planos e programas de saúde (GUIMARÃES; ÉVORA, 2004). Atualmente existem cinco principais SIS ligados ao Ministério da Saúde: Sistema de Informações sobre Mortalidade (SIM), Sistema de Informações sobre Nascidos Vivos (SINASC), Sistema de Informação de Agravos de Notificação (SINAN), Sistema de Informações Hospitalares do SUS (SIH-SUS) e Sistema de Informações Ambulatoriais do SUS (SIA-SUS) (BARBOSA, 2006). Ademais, é notória a benevolência do uso da tecnologia no campo da Saúde, pois os sistemas com dados compilados auxiliam no tratamento de um paciente específico, com sua história clínica, desde o nascimento até o momento em que aquele necessita de um tratamento. Ainda, as informações podem ser guardadas e acessadas de maneira simples, otimizando o labor dos profissionais da área.

Conclusão: $O$ uso da tecnologia e sistemas de informação contribuiu significativamente com a saúde da população, pois possibilita a comunicação mais ampla entre profissional e maior entendimento aos pacientes, muitas vezes leigos no assunto. Além disso, os SIS vinculados ao Ministério da Saúde abrangem informações em diversas pastas da saúde, ajudando no combate e prevenção de epidemias, desnutrição, entre outras comodidades que afetam o usuário do Sistema em Saúde.

\author{
Referências \\ BARBOSA, D. C. M. Sistemas de informação em saúde: a percepção e a avaliação dos profissionais diretamente envolvidos na \\ atenção básica de Ribeirão Preto / SP. 2006. 17100 f. Dissertação (Mestrado) -Departamento de Medicina Social, USP, Ribeirão \\ Preto, 2006. \\ BRASIL. Constituição (1988). Constituição da República Federativa do Brasil: promulgada em 5 de outubro de 1988. 21. ed. \\ São Paulo: Revista Saraiva, 2016. \\ BRASIL. Ministério da Saúde. A experiência brasileira em sistemas de informação em saúde/ Ministério da Saúde, \\ Organização Pan-Americana da Saúde,Fundação Oswaldo Cruz. Brasília: Editora do Ministério da Saúde,v. 2, 2009. \\ GUIMARÃES, E. M. P.; ÉVORA, Y. D. M. Sistema de informação: instrumento para tomada de decisão no exercício da \\ gerência. Ciência da Informação, Brasília, v. 33, n. 1, p.72-80, 2004. Disponível em: https://www.scielo.br/scielo.php?pid=S0100-
}


19652004000100009\&script=sci_arttext\&tlng=pt. Acesso em: 10 de agosto, 2020.

Coordenadoria de Pesquisa e Extensão - COPEX

Departamento de Editoraçāo e Divulgaçāo Científica - DEDIC 


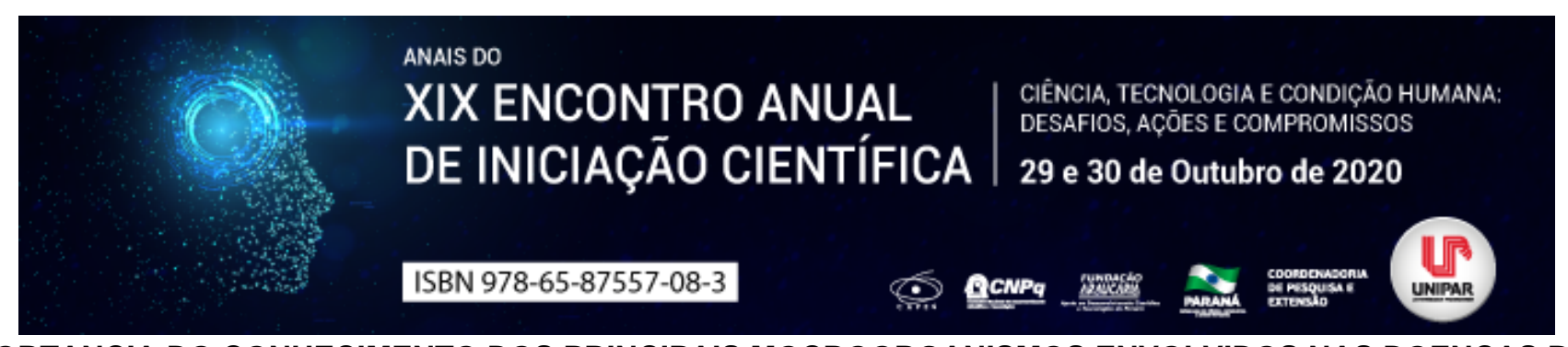

\title{
A IMPORTANCIA DO CONHECIMENTO DOS PRINCIPAIS MOCROORGANISMOS ENVOLVIDOS NAS DOENÇAS BUCAIS MAIS COMUNS DE ORIGEM INFECCIOSA
}

\author{
${ }^{1}$ CARLOS DANIEL DE SIQUEIRA CORADETTE, ${ }^{2}$ LEONARDO GARCIA VELASQUEZ
}

\author{
${ }^{1}$ Discente do curso de Mestrado Profissional em Plantas Medicinais e Fitoterápicos na Atenção Básica \\ ${ }^{1}$ Docente da UNIPAR
}

Introdução: A cárie dentaria e a doença periodontal estão entre as doenças infecciosas mais comuns que acometem a cavidade oral (Foschi et al. 2006). O controle e combate a estas doenças tem sido exaustivamente pesquisado ao longo dos anos, e o conhecimento destes microorganismos é de extrema importância para que se possa buscar alternativas eficazes para o tratamento, controle e prevenção das doenças por eles causadas (PASTER et al. 2006).

Objetivo: Buscar na literatura as os principais microorganismos responsáveis pelas infecções mais comuns na cavidade oral.

Desenvolvimento: A cárie dentária está entre as patologias infecciosas mais comuns da cavidade bucal e sua patogenicidade está intimamente relacionada ao metabolismo microbiano altamente fermentativo, destacando os estreptococos do grupo mutans, particularmente, Streptococcus mutans junto com Lactobacillus spp., e quando alcança a dentina, Actinomyces spp. (FOSCHI et al. 2006). Para Hamada et al. (1984), os estreptococos do grupo mutans considerados cariogênicos, são os que mais se destacam pela sua capacidade de colonizar precocemente a superfície dental, por sintetizar grandes quantidades de polímeros de carboidratos extra e intracelulares, que estabilizam a adesão bacteriana e funcionam como fontes de reservas nutritivas. Bactérias produtoras de ácido láctico, como Lactobacillus spp. aparecem mais relevantes após o início do processo carioso seguido da contínua dissolução mineral do dente. Em caso de cárie de dentina, na região cervical ou quando a cárie coronária ultrapassa em profundidade o esmalte dental, observa-se uma população microbiana mais complexa, com a presença de bactérias com grande atividade proteolítica, como Actinomyces spp. (ZAMBON \& KASPRZAK, 1995). Dentre as principais doenças que afetam a cavidade oral, destaca-se a doença periodontal. Esta, de acordo com Miranda et al. (2020), caracteriza-se por uma infecção mista ocasionada por especies bacterianas organizadas em um biofilme que colonizam as superfícies dos dentes, induzindo assim uma resposta inflamatória do hospedeiro. Isto leva a uma destruição dos tecidos de suporte do dente e pode até provocar a perda do elemento. Loberto et al. (2004) destaca como principal fator etiológico da doença periodontal o biofilime subgengival. Quando acontece a retenção do biofilme microbiano à margem gengival ocorre a quebra do equilíbrio da relação microbiota-hospedeiro e isso faz com que se inicie uma reação inflamatória que afeta os tecidos de revestimento do periodonto. Apesar da participação de alguns microrganismos como Actinomyces spp. e Prevotella intermedia na patogenicidade da gengivite, outros microrganismos podem também induzir a reação inflamatória, como o fazem os próprios estreptococos bucais (MIRA et al. 2017). Ledder et al. (2007) aponta diversos microrganismos como Aggregatibacter actinomycetemcomitans, Dialister pneumosintes, Porphyromonas gingivalis, Prevotella intermedia, P. nigrescens, Fusobacterium nucleatum, Tannerella forsythia e $T$. denticola particularmente implicados na etiologia destas doenças, as vezes associadas a outros microrganismos Gram-negativos e Gram-positivos, principalmente, anaeróbios estritos. Apesar da grande importância desempenhada pelos cocos Gram-positivos facultativos em abscessos em outras partes do corpo e na mucosa oral. Latimer et al. (2015) relata que a maior parte deles pertence aos gêneros Peptococcus e Peptostreptococcusao lado dos gêneros Prevotella, Porphyromonas, Campylobacter e Fusobacterium. Assim, o emprego de antimicrobianos por parte do paciente ou por indicação inadequada do profissional, nas infecções periapicais e periodontais laterais, pode levar a uma seleção biológica que terminará com a predominância de microrganismos resistentes ou tolerantes aos antimicrobianos (SILVA et al. 2009).

Conclusão: Tendo em vista a importância do controle das doenças bucais de origem infecciosa, e devido a resistência bacteriana aos antibióticos atuais, novas formas de tratamento são buscadas, e para isto, o conhecimento dos microorganismos que causam essas doenças é de extrema relevância para produção de medicamentos eficazes e seguros.

\section{Referências}

FOSCHI, F. et al. Treponema denticola in disseminating endodontic infections. J. Dent Res. v. 85, n. 8, p. 761-765, 2006.

HAMADA, S. et al. Virulence factors of Streptococcus mutans and dental caries prevention. J. Dent. Res. n. 63, p. 407-411, 1984. LATIMER J. et al. Antibacterial and anti-biofilm activity of mouthrinses containing cetylpyridinium chloride and sodium fluoride. BMC microbiology. n. 15, p. 169, 2015.

LEDDER, R. G. et al. Molecular analysis of the subgingival microbiota in health and disease. Appl. Environ. Microbiol., n. 73, p. 516-523, 2007.

LOBERTO, J. C. S. et al . Staphylococcus spp. in the oral cavity and periodontal pockets of chronic periodontitis patients. Braz. J. Microbiol., São Paulo , v. 35, n. 1-2, p. 64-68, 2004 
MIRA, A. et al. Role of microbial communities in the pathogenesis of periodontal diseases and caries. J Clin Periodontol.v. 44, n. 18, p. 23-38, 2017.

MIRANDA, S. L. F. et al . In Vitro Antimicrobial Effect of Cetylpyridinium Chloride on Complex Multispecies Subgingival Biofilm. Braz. Dent. J., Ribeirão Preto , v. 31, n. 2, p. 103-108, 2020.

PASTER, B. J. et al. The breadth of the bacterial diversity in the human periodontal pocket and other oral sites. Periodontology, v. 2000 n. 2, p. 80-87, 2006.

SILVA M. F. et al. A clinical investigation of the efficacy of a commercial mouthrinse containing $0.05 \%$ cetylpyridinium chloride to control established dental plaque and gingivitis. J Clin Dent, n. 20, p. 55-61, 2009.

ZAMBON, J. J.; KASPRZAK, S. A. The microbiology and histopathology of human root caries. Am. J. Dent. v. 8, n. 6, p. 323-328, 1995.

Coordenadoria de Pesquisa e Extensāo - COPEX

Departamento de Editoraçāo e Divulgaçāo Científica - DEDIC 


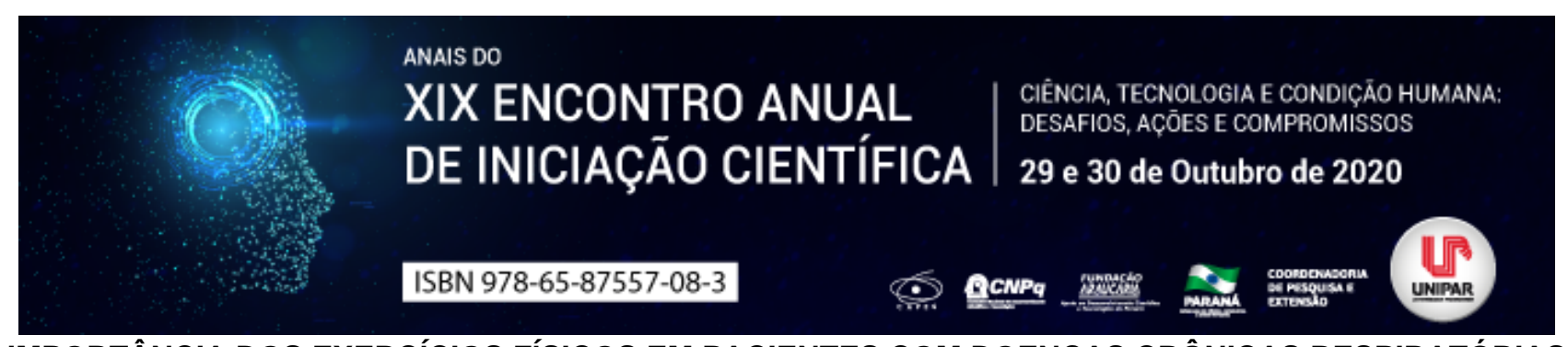

IMPORTÂNCIA DOS EXERCÍCIOS FÍSICOS EM PACIENTES COM DOENÇAS CRÔNICAS RESPIRATÓRIAS

\section{${ }^{1}$ EMERSON DE OLIVEIRA BOGALHO JUNIOR}

\section{${ }^{1}$ Acadêmico do PIC/UNIPAR}

Introdução: Doenças crônicas respiratórias são comuns em nosso País e também fora dele. As Doenças Respiratórias Crônicas (DRC) estão aumentando sua prevalência particularmente entre as crianças, afetando a qualidade de vida e provocando incapacidade nos indivíduos afetados, causando grande impacto econômico e social (CAMARGOS; KHALTAEV, 2006; GARD, 2008). A importância do exercício físico para a população está fundamentada na manutenção, melhoria e recuperação do estado de saúde, que pode sofrer interferências de fatores múltiplos, sendo que o exercício físico regular traz, para a maioria dos indivíduos, benefícios em várias funções fisiológicas, incluindo a função cardiorrespiratória, podendo beneficiar pessoas com problemas respiratórios (BARBOSA et. al, 2000; ZAGO et. al, 2000). Objetivo: Verificar na literatura os benefícios dos exercícios aeróbios em pessoas portadores de doenças respiratórias crônicas (DRC).

Desenvolvimento: $\mathrm{O}$ estudo foi conduzido por meio de uma revisão bibliográfica da literatura. Foram inclusos estudos indexados às seguintes bases de dados nacionais: Ciências da Saúde; SCIELO Scientific Eletronic Library Online e na ferramenta de busca Google Acadêmico, no período de 1993 até agosto de 2020. Os descritores utilizados foram: doenças respiratórias, asma, bronquite e exercício físico. Após buscas de análises dos artigos, nove estudos foram selecionados para compor esta revisão. Já no início deste século ocorriam cerca de 350.000 internações por asma no Brasil anualmente, constituindo-se a quarta causa de hospitalizações pelo Sistema Único de Saúde (2,3\% do total) e sendo a terceira causa entre crianças e adultos jovens (BRASIL, 2005). O sistema respiratório é composto por nariz, cavidade nasal, faringe, laringe, traqueia, brônquios e pulmões. Este sistema de órgãos é responsável pela troca gasosa do corpo humano através da hematose pulmonar possibilitando, assim, a respiração celular, através do fornecimento de oxigênio e remoção de gás carbônico do organismo (FONSECA et. al, 2011). O principal músculo da respiração é o diafragma que separa o tórax do abdômen, o diafragma se contrai quando se inspira, aumentando o vácuo dentro do tórax e faz com que o ar entre dentro dos pulmões. Quando o diafragma relaxa, o ar sai para fora dos pulmões (expiração). Ainda existem outros músculos auxiliares como os músculos intercostais (entre as costelas) e cervicais (do pescoço) que ajudam na respiração. Com isto, os músculos da caixa torácica movimentam-se para o seu interior, visando a total ventilação das partes média e superior dos pulmões. Para (NIETO, 2013), os objetivos mais importantes da natação são vistos sob três aspectos: físico, orgânico e psicológico. O primeiro visando o desenvolvimento das qualidades físicas, relaxamento, controle respiratório e corporal e as habilidades aquáticas. O segundo, o desenvolvimento da resistência do sistema muscular, resistência do sistema cardiovascular, respiratório e expansão pulmonar. E o terceiro, desenvolvimento da autoconfiança e criatividade, equilíbrio emocional e consciência corporal. Para (TEIXEIRA et. al,1993), a natação contribui para fortalecer todos os músculos respiratórios, especialmente o diafragma e os músculos respiratórios auxiliares. A caminhada também demanda uma grande quantidade de oxigênio, aumentando a frequência cardíaca e respiratória, favorecendo o fortalecimento do sistema cardiorrespiratório. Por conta desses benefícios é um exercício que pode ajudar no quadro clínico de portadores de DRC (LEVANDOSKI et. al, 2003).

Conclusão: Os exercícios de natação e caminhada realizados regularmente ajudam a aumentar a força e a função dos músculos respiratórios, tornando-os mais eficientes. Os seus músculos necessitarão de menos oxigênio para se moverem e produzirão menos dióxido de carbono, reduzindo a quantidade de ar que tem de inspirar e expirar nas atividades diárias e nos exercícios físicos. O treinamento também melhora a circulação e fortalece o coração, contribuindo com a saúde e qualidade de vida de portadores de DRC.

\section{Referências}

AGK, VASCONCELOS AMN, ALY CMC, RABELLO NETO DL, Porto DL, OLIVEIRA H, et al. Como morrem os brasileiros: caracterização e distribuição geográfica dos óbitos no Brasil, 2000, 2005 e 2009. In: Ministério da Saúde (BR). Secretaria de Vigilância em Saúde. Departamento de Análise de Situação em Saúde. Saúde Brasil 2010: uma análise da situação de saúde e de evidências selecionadas de impacto de ações de vigilância em saúde. Brasília: Ministério da Saúde; 2011. p. 51-78. Disponível em https://repositorio.unb.br/. Acesso em: 11 dez 2019.

BARBOSA A R, SANTARÉM J M, FILHO W J e MARUCCI M F N. Efeitos de um programa de treinamento contra resistência sobre a força muscular de mulheres idosas. Revista Brasileira de Atividade Física e Saúde. 2000, 3:12- 20; disponível em rbafs.emnuvens.com.br. Acesso em: 13 de jun de 2020.

CHATKIN, J. M.; BARRETO, S. M. Asma: liberdade para respirar. Guia de orientação para pais e pacientes. Porto Alegre: Artes Médicas, 1996. Disponível em www.prac.ufpb.br. Acesso em:10 de jun de 2020. 
FONSECA, K. Sistema Respiratório. Disponível em www.scielo.br. Acesso em: 13 de jun de 2020.

GUALDI, F. R. Asma e os benefícios da atividade física. Revista Digital, ano 10, n.72, maio 2004. Disponível em http://www.efdeportes.com. Acesso em 16 de jul:2020.

KERBEJ, F. C. Natação: algo mais que 4 nados. São Pulo: Manole, 2002. Disponível em https://jornada.ifsuldeminas.edu.br/. Acesso em:10 de jun de 2020.

OLIVEIRA PR, SERRANO DZ: Natação terapêutica para pneumopatas. São Paulo, Panamed, 1984. Disponível em www.bibliotecadigital.unicamp.br. Acesso em:10 de jun de 2020.

PAULINE, E. ET AL. Efeitos de Exercícios Físicos Direcionado ao Aumento de Mobilidade Torácica em Pacientes Portadores de Doença Pulmonar Obstrutiva Crônica. Jornal de pneumologia, 29 (5), set-out 2003.Disponível em www.lume.ufrgs.br. Acesso em:10 de jun de 2020.

Coordenadoria de Pesquisa e Extensão - COPEX

Departamento de Editoraçāo e Divulgaçāo Científica - DEDIC 


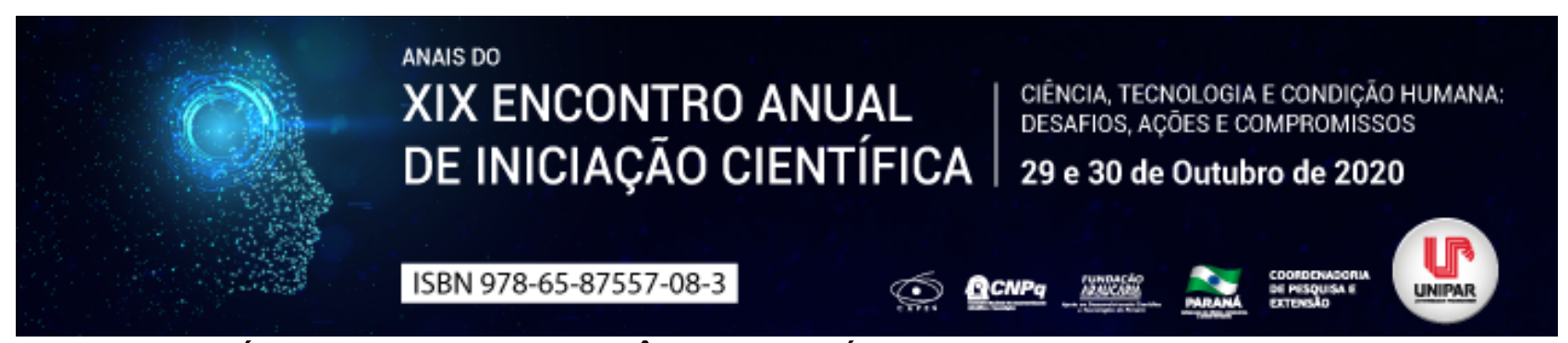

\title{
ANÁLISE MICROBIOLÓGICA E QUALIDADE HIGIÊNICO-SANITÁRIA DA GRANOLA COMERCIALIZADA A GRANEL NA REGIÃO NOROESTE DO PARANÁ
}

\author{
${ }^{1}$ ALINE PINTO ZANI, ${ }^{2}$ CAROLINE PINTO ZANI, ${ }^{3}$ VINICIUS PEREIRA ARANTES, ${ }^{4}$ LUANA MAGRI TUNIN
}

\author{
${ }^{1}$ Acadêmica bolsista PIBIC/UNIPAR

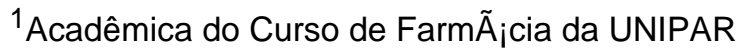 \\ ${ }^{2}$ Docente da UNIPAR \\ ${ }^{3}$ Docente da UNIPAR
}

Introdução: Nos últimos tempos vem aumentando o interesse de pessoas de diferentes classes sociais em consumir uma alimentação mais saudável e natural, dentro desse aspecto os alimentos funcionais estão em evidencia devido seu efeito benéfico ao organismo e por proporcionar um estilo de vida mais saudável. Sendo a granola um dos produtos que se destaca por ser bastante aceito pela população, esse é um alimento rico em fibras que favorece o equilíbrio da microbiota intestinal auxiliando os sintomas da constipação intestinal, além de auxiliar na diminuição dos riscos de doenças cardiovasculares (ALBUQUERQUE et al., 2019, p. 5).

Objetivo: avaliar a qualidade microbiológica da granola e também a qualidade higiênico sanitária dos estabelecimentos que comercializam este produto a granel na região noroeste do Paraná.

Material e Método: Para análise , foram adquiridas 10 amostras da granola coletadas nos comércios a granel da região Noroeste do Paraná em que avaliou a qualidade microbiológica através da técnica de contagem de Staphylococcus aureus, as amostras foram preparadas com 25 gramas da granola coletado e pesada, adicionou-se $225 \mathrm{~mL}$ de Solução salina $0,85 \%$, previamente esterilizada, homogeneizou por dois minutos, constituindo a diluição $10^{-1}$ realizadas diluições seriadas até $10^{-5}$, semeou-se as amostras em placas de Petri contendo Ágar Baird Parker e para as colônias suspeitas foram analisadas pela prova da catalase e coagulase. E a técnica do Número Mais Provável (NMP) para a determinação de coliformes foram pesadas $25 \mathrm{~g}$ de granola e colocadas em um Erlenmeyer com $225 \mathrm{~mL}$ de solução salina estéril, homogeneizando-a por 2 minutos. A determinação presuntiva do (NMP) foi realizada a partir de diluições seriadas de 0,1, 0,01 e 0,001mL da amostra, no Caldo Lauril Sulfato Triptose (LST). Os tubos foram incubados na estufa com $35^{\circ} \mathrm{C}$ por 48 horas. A partir dos tubos com leitura positiva, foram realizados os testes confirmativos para coliformes totais em Caldo Lactose Bile Verde Brilhante a $35^{\circ} \mathrm{C}$ por 24 horas, e coliformes termotolerantes em Caldo Escherichia coli a $45^{\circ} \mathrm{C}$ por 24 horas. Todas as amostras analisadas, foram inoculadas no tubo de ensaio com tubo Durhan invertido. Classificou-se como positivas, a presença de turvação e formação de gás averiguando sua conformidade segundo a RDC $n^{\circ} 12$ de 12 de janeiro de 2002, e aplicou-se um check list observacional adaptado da RDC $n^{\circ} 216$ de 15 de novembro de 2004 para avaliar a qualidade higiênico sanitária dos estabelecimentos que foram obtidas as amostras de granola a granel, (JUNQUEIRA et al., 2017, p. 118-155).

Resultados: Verificou-se que os estabelecimentos apresentam-se fora dos padrões estabelecidos pela legislação vigente RDC $n$ - 216 de 15 de novembro de 2004, foi avaliado como irregular o item manipulação com 53,3 \% de não conformidades, sendo esse o quesito mais crítico. Foram analisadas ausência de Staphylococcus aureus em sete amostras, e três amostras revelou presença, no entanto abaixo do limite padrão que é de $5 \times 10^{2}$, com relação ao Número Mais Provável (NMP) de coliformes totais e fecais, quatro amostras apresentaram-se fora dos padrões estabelecidos. Encontram-se com seus valores acima daqueles permitidos pela legislação vigente, que estabelece níveis máximos de $5 \times 10^{2} \mathrm{NMP} \mathrm{g}$, ou seja, o produto é inaceitável para o consumo.

Discussão: Estes resultados assemelharam-se aos descritos por (GRANADA et al., 2003, p.87-91), em que as análises microbiológicas das amostras de granolas envasadas e a granel não atenderam a legislação vigente. Em pesquisa Mendoza et al (2016), avaliando a qualidade microbiológica da mistura da granola, verificou que houve presença de coliformes totais e termotolerantes no entanto foi inferiores a 3 NMP. g-1, atendendo a legislação vigente.

Conclusão: As granolas comercializadas a granel se mantiveram dentro dos limites máximos permitidos para Staphylococcus aureus, atendendo o estabelecido pela legislação $n^{\circ} 12$ de janeiro de 2012, no entanto os coliformes totais e fecais apresentaram-se fora do limite com 4 amostras não satisfatória para o consumo, e as condições higiênicas sanitárias dos estabelecimentos também, apresentaram-se fora dos padrões exigidos, considerado como irregular. De maneira geral foram encontradas não conformidades nos itens área física e utensílios. Sendo então importante essa determinação da contaminação microbiológica, pois está diretamente ligada a qualidade do produto a ser ofertado no mercado consumidor.

\section{Referências}


ALBUQUERQUE, Marie Claire Carneiro; AZEVEDO, Larissa Negromonte Arruda; SANTOS, Emília Mendes da Silva; CUNHA, Ivana Gláucia Barroso. Análises microbiológicas de granolas comercializadas no Bairro São José na cidade de Recife-PE. Braz. J. Hea. Rev., Curitiba, v. 2, n. 3, p. 1743-1753, mar/abr. 2019.

BRASIL. Ministério da Saúde. Secretaria de Vigilância Sanitária. Resolução. RDC n 12, de 12 de janeiro de 2001 . Regulamento técnico sobre os padrões microbiológicos para alimentos. n. 7-E, p. 45-53, 10. Brasília: Diário Oficial da União, 2001.

BRASIL. Ministério da Saúde. Agência Nacional de Vigilância Sanitária. RDC n 216 de 15 de setembro de 2004 . Regulamento Técnico de Boas Práticas para Serviços de Alimentação. Brasília: Diário Oficial da União, 2004.

GRANADA Graziele, ROSA Vaness, ZAMBIAZI Rui, KOETZ Paulo. Caracterização de granolas comerciais. Ciênc. Tecnol. Aliment., Campinas, p.87-91, Jan./abr. 2003.

JUNQUEIRA, Valéria Christina Amstalden.; SILVA, Neusely.; SILVEIRA, Neliane Ferraz de Arruda. Manual de métodos de análise microbiológica de alimentos e água. $5^{\mathrm{a}}$ Ed. São Paulo: Editora Blucher, 2017. p. 535.

MENDOZA, Viviane da Silva.; DOS SANTOS, Luana de Leon.; SANJINEZ-ARGADOÑA, Eliana Janet. Elaboração de granola com adição de polpa e castanha de Bacuri para consumo com iogurte. Evidência-Ciência e Biotecnologia, v. 16, n. 2, p. 83100, 2017. 


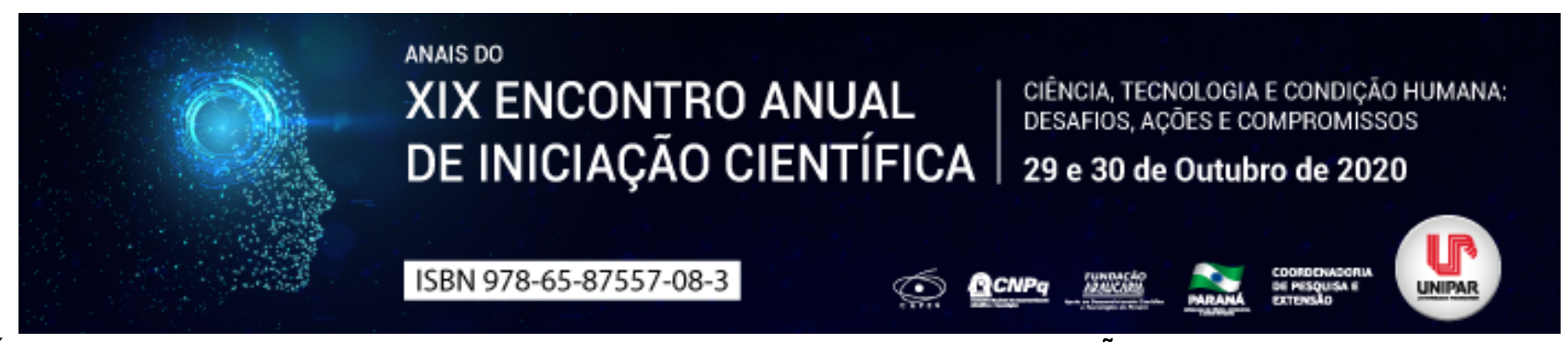

MALÁRIA- CASOS CONFIRMADOS NOTIFICADOS NO SISTEMA DE INFORMAÇÃO DE AGRAVOS DE NOTIFICAÇÃO BRASIL CASOS CONFIRMADOS POR GESTANTE SEGUNDO MUNICÍPIO DE INFECÇÃO PERÍODO: 2012 A 2016

\author{
${ }^{1}$ IARA HENRIQUE ROCHA, ${ }^{2}$ ISABELA TONON LAINO, ${ }^{3}$ ANA MARIA MIYAWAKI PAULINO, ${ }^{4}$ LUCIANA VIEIRA PINTO \\ RIBEIRO
}

${ }^{1}$ Discente do Curso de Medicina/UNIPAR

${ }^{1}$ Acadêmica do Curso de Medicina da UNIPAR

${ }^{2}$ Acadêmica do Curso de Medicina da UNIPAR

${ }^{3}$ Docente da UNIPAR

Introdução: Estima-se que, a cada ano, aproximadamente 50 milhões de mulheres residentes em países endêmicos para malária engravidem e enfrentam, consequentemente, um risco aumentado de adquirir malária e suas complicações. (CHAGAS et al. 2009). No Paraná, a maioria dos casos de malária em gestantes aconteceram na cidade de São Miguel do Iguaçu, onde as condições ecológicas e os fenômenos ambientais favorecem os criadouros naturais do anofelino, favorecendo assim a transmissão. Decorrente disso, nota-se diversos riscos fetais e maternos que a infecção malárica pode oferecer.

Objetivo: Analisar os casos de confirmados de malária que acometeram mulheres gestantes no Brasil no ano de 2012 a 2016 , por meio de uma analise quantitativa de informações utilizando uma base de dados online. Além disso, excluem-se as categorias I"idade gestacional ignoradal", I"não se aplicaml", I"ignorado/brancol" e I"nãol" da pesquisa realizada por meio do DATASUS.

Desenvolvimento: A malária é uma doença de caráter infeccioso transmitida por parasitos que pertencem ao filo Apicomplexa, família Plasmodidae e gênero Plasmodium. O período de incubação de malária varia de acordo com a espécie de plasmódio, sendo de 9-14 dias para o P. falciparum, 12-17 dias para o P. vivax, 18-40 para o P. malariae e 16-18 dias para o $P$. ovale. (NEVES, 2016). Ademais, a sintomatologia clínica da malária inclui calafrios, febre e sudorese, cuja manifestação é de caráter agudo e evolução crônica. Contudo, a gravidade da doença varia de acordo com a espécie de Plasmodium juntamente com o fator imunológico pessoal. Em gestantes, a real frequência da malária ainda é desconhecida, tanto no Brasil como em toda a região das Américas. (CHAGAS, 2009). A malária durante a gravidez constitui risco substancial para a mãe, o feto e o recémnascido. Em geral, mulheres grávidas no segundo e terceiro trimestres são mais suscetíveis aos quadros graves e complicados da malária causada pelo $P$. falciparum, o que pode resultar em aborto espontâneo, prematuridade, baixo peso ao nascer e morte materna. (NEVES, 2016). A característica clínica da malária durante a gravidez varia de acordo com o grau de imunidade que a mulher adquiriu durante a vida até o início da gravidez e conforme sua situação epidemiológica. Poucas infecções em adultos saudáveis que vivem em áreas de alta transmissão de malária resultam em febre. O mesmo se aplica para mulheres grávidas semi imunes, sendo comum que a maioria das grávidas com parasitemia apresentam poucos (CHAGAS, 2009). O tratamento da malária para gestantes infectadas pelo $P$. vivax deve ser tratada somente com a cloroquina, pois é a droga segura durante 0 período gestacional. Em casos de malária por $P$. falciparum, a gestante deverá ser tratada somente com quinina em monoterapia ou associada à clindamicina. Perante análise de dados disponível no DATASUS, nota-se que no período em questão (2012 a 2016). Houve um total de 3.358 casos de malária durante o período gestacional. Sete desses casos foram observados no primeiro trimestre de gestação, dez casos foram observados no segundo trimestre e sete casos ocorreram no terceiro trimestre de gravidez. Porto velho está liderando o ranking de casos de malária notificados durante a gravidez com o total 352 casos. Em segundo lugar se encaixa Manaus, com 145 casos no total notificados no banco de dados e em terceiro lugar está a cidade de Itaituba com 85 casos no total notificados.

Conclusão: Nota-se que por conta das regiões endêmicas de malária, há números maiores dos acometimentos em grávidas, visto que sua imunidade pode vir a ser um tanto quanto inferior à dos indivíduos não gestantes. Com isso, temos um maior número de casos na região norte do Brasil. O risco de apresentar alterações no curso da gestação na vigência de um episódio de malária parece ser semelhante independentemente da idade, paridade ou antecedentes de malária. Portanto, pode-se considerar que todas as gestantes devem ser alvo das ações de prevenção e controle da malária (CHAGAS, 2009).

\title{
Referências
}

CHAGAS, Edna Cristina da Silva et al. Malária durante a gravidez: efeito sobre o curso da gestação na região amazônica. Revista Panam Salud Publica, v. 26 (03), p.08-203, 2009

DEPARTAMENTO DE INFORMÁTICA DO SUS - DATASUS. Informações de Saúde, Epidemiológicas e Morbidade: banco de dados. Disponível em: http://tabnet.datasus.gov.br/cgi/tabcgi.exe?sinannet/cnv/malapr.def. Acesso em 6 jun. 2020

MELO, DÉBORA PRESTES DA SILVA, Partos de mulheres com Maléria: Estudo retrospectivo no hospital da mulher mãe 
Luzia no Amapá. Orientadora: Dr Rosemary Ferreira de Andrade. Dissertação (Pós-graduação) Universidade Federal do Amapá, Macapá, 2018.

NEVES, David Pereira. Parasitologia Humana. 13. ed. São Paulo, Editora Atheneu, 2016

Coordenadoria de Pesquisa e Extensão - COPEX

Departamento de Editoraçāo e Divulgaçāo Científica - DEDIC 


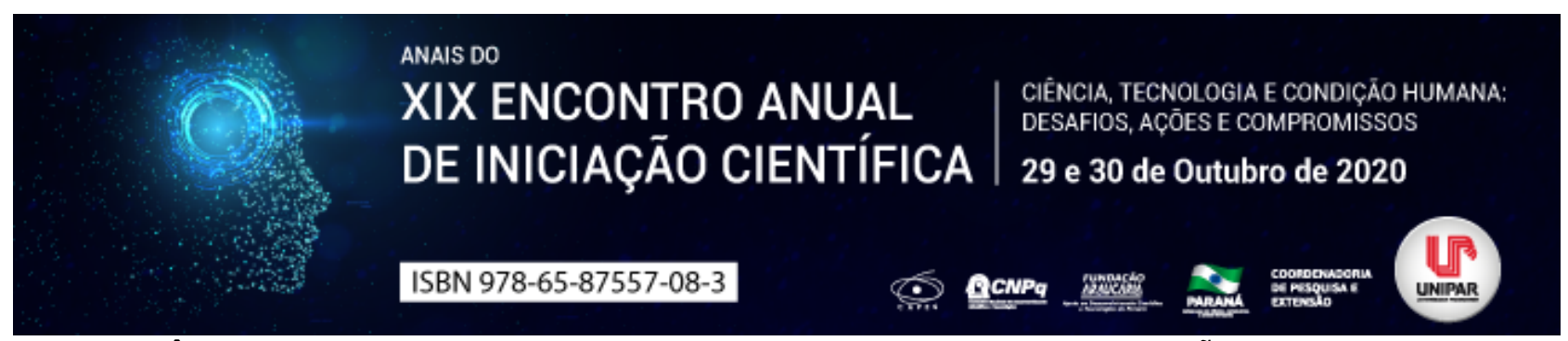

RESISTÊNCIA BACTERIANA FRENTE AOS ANTIMICROBIANOS: UMA REVISÃO DE LITERATURA

\begin{abstract}
${ }^{1}$ CAROLINE PINTO ZANI, ${ }^{2}$ ALINE PINTO ZANI, ${ }^{3}$ ISABELA LINO FERREIRA DA SILVA DIAS, ${ }^{4}$ EDUARDA MARTINS DARMIN, ${ }^{5}$ VINICIUS PEREIRA ARANTES
\end{abstract}

\author{
${ }^{1}$ Acadêmica bolsista PIBIC/UNIPAR

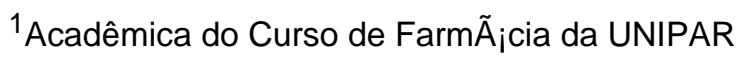 \\ ${ }^{2}$ Acadêmica do Curso de FarmÃ $\tilde{A}_{i}$ ia da UNIPAR

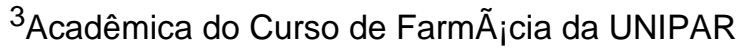 \\ ${ }^{4}$ Docente da UNIPAR
}

Introdução: A resistência bacteriana aos antibióticos e antimicrobianos é atualmente um dos problemas de saúde pública mais relevantes a nível global, dado que apresenta consequências clínicas e económicas preocupantes, estando associada ao uso inadequado de antibióticos, falta de informações, assistência farmacêutica falha durante a dispensa do medicamento levando ao aumento da morbidade e mortalidade devido também aos atrasos na administração de medicamentos, abandonos de tratamentos logo depois de uma significativa melhora do paciente, tornando os tratamentos eficazes contra as infeções causadas por bactérias microbiológicas resistentes. (LOUREIRO et al, 2016, p.78). Os antibióticos são uma classe de fármacos utilizados para o tratamento de doenças infecciosas, que diferem uns dos outros quanto as suas propriedades físicas, químicas, farmacológicas, no espectro e mecanismo de ação são obtidos não naturalmente, apresentando compostos químicos sintéticos e semi-sintéticos. Já os antimicrobianos são substâncias de origem natural ou sintética que agem sobre os microrganismos inibindo seu crescimento ou causando sua destruição, sendo utilizados de modo profilático e/ou terapêutico, constituindo um avanço farmacológico de suma importância e larga utilização. O uso indiscriminado de antimicrobianos contribui para o desenvolvimento de resistência bacteriana. Além disso, o uso abusivo desses fármacos pode originar bactérias multirresistentes, definidas como aquelas não suscetíveis a, pelo menos, um agente em três ou mais categorias de antimicrobiano (FURTADO et al, 2019, p.2).

Objetivos: Avaliação da resistência bacteriana e de antimicrobianos realizada por meio de um estudo de revisão, na qual os dados foram obtidos por meio de um levantamento com base em documentos científicos, e periódicos.

Desenvolvimento: A origem da resistência pode ser genética ou não e independente de qual seja a forma de maior importância neste processo, é de fato o número de novas bactérias resistentes e patogênicas tanto para os animais quanto para os humanos cresce mais rápido do que a capacidade dos laboratórios e indústrias tem de produzirem novas drogas (ORTEGA,2019). Dessa maneira a resistência de certo microrganismo à determinada droga pode ser classificada inicialmente como intrínseca ou adquirida A resistência intrínseca é aquela que faz parte das características naturais, fenotípicas do microrganismo, transmitida apenas verticalmente à prole, faz parte da herança genética do microrganismo. Já a resistência adquirida é muito importante do ponto de vista clínico, pois ocorre devido à modificação da carga genética da bactéria e pode aparecer por mutação cromossômica ou por mecanismos de transferência genética. Diante do fenômeno da resistência antimicrobiana nos indicadores de saúde e dos custos, é necessário modificar as práticas de tratamento, procurando o uso racional dos antimicrobianos e de estratégias que ajudem a preservar-Ihe a eficácia. Uma das recomendações é que os antibióticos devem ser diferenciados segundo seu uso em profiláticos, empíricos e específicos (terapêuticos).Pois de acordo com alguns artigos a decisão de usar antibióticos é tomada com frequência sem considerar o microrganismo, a seletividade, a resistência e a relação custo-benefício ao selecionar um antibiótico, possibilitando, dessa forma, ao cliente desenvolver resistência ao antimicrobiano utilizado (ORTEGA,2019).

Conclusão: Concluímos então que a utilização correta dos antimicrobianos, produzidos com qualidade e indicados para condições clínicas bem estabelecidas, pode prolongar sua vida útil, retardando o desenvolvimento da resistência bacteriana. A prescrição de antibióticos seja com finalidade profilática ou terapêutica, deve ser pautada pelo conhecimento dos conceitos básicos de antibioticoterapia e pelo conhecimento dos processos infecciosos. Devemos então deixar de acreditar nas abordagens empíricas e buscar conhecimento em estudos clínicos controlados que devem dirigir a nossa prática nas prescrições de antibióticos. Essas orientações devem ser reforçadas com base em estudos que abordem os efeitos dos antibióticos no local de interesse, efeitos adversos associados ao uso de antibióticos, o desenvolvimento da resistência aos antibióticos, as implicações de custos e questões de qualidade de vida. Se realizado todo esse planejamento é possível que haja uma significativa diminuição na resistência bacteriana e microbiológica.

\title{
Referências
}

ORTEGA, L. L. Resistência bacteriana: aquisição, mecanismos e prevenção. Universidade federal de santa catarina centro 
de ciências da saúde departamento de odontologia curso de graduação em odontologia. Florianópolis. Outubro-2019, p. 12-36. LOUREIRO, R. J.; ROQUE, F.; RODRIGUES, A. T.; HERDEIRO, T. M.; ROMALHEIRA, E. O uso de antibióticos e as resistências bacterianas: breves notas sobre a sua evolução. Revista Portuguesa de Saúde Pública $\vee 34$, edição 1 , Janeiro 2016, p.77-84.

FURTADO, D. M. F.; SILVEIRA, V. S.; FURTADO, D. M. F.; KILISHEK, M. P. Consumo de antimicrobianos e o impacto na resistência bacteriana em um hospital público do estado do Pará, Brasil, dos anos de 2012 a 2016. Revista Pan-Amazônica de Saude vol.10 Ananindeua Março. 2019 Epub 16-Set-2019, p. 2-8.

Coordenadoria de Pesquisa e Extensão - COPEX

Departamento de Editoraçāo e Divulgaçāo Científica - DEDIC 


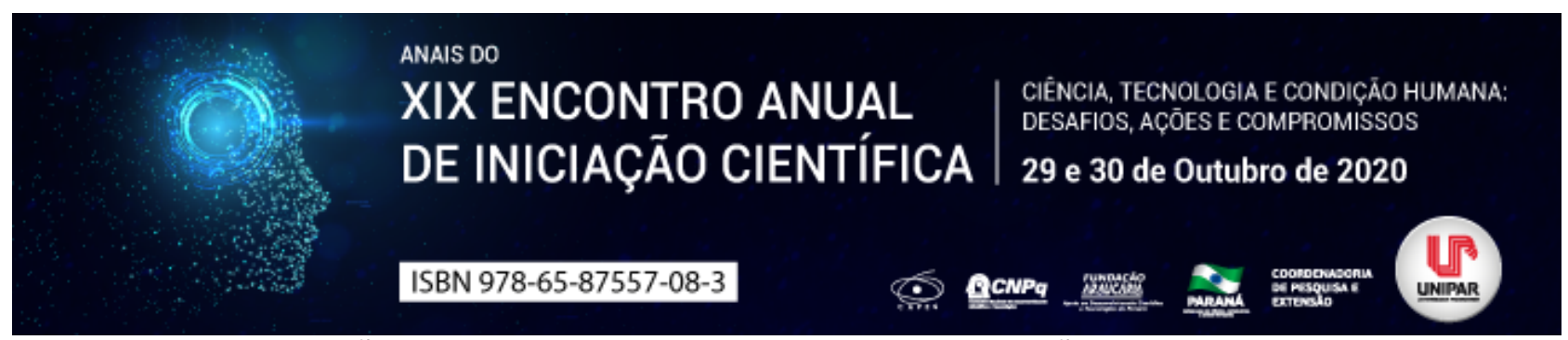

DISFUNÇÕES TEMPOROMANDIBULARES (DTM): REVISÃO DE LITERATURA

\author{
${ }^{1}$ SABRINA PAIXAO DOS SANTOS RODRIGUES, ${ }^{2}$ DUANI CRISTINA BAZZO, ${ }^{3}$ GABRIEL MACIEL DA SILVA, ${ }^{4}$ MARIA RITA \\ BARBOSA DE OLIVEIRA, ${ }^{5}$ BEATRIZ AYUMI SHIOTANI, ${ }^{6}$ CESAR AURELIO ZAZE
}

\author{
${ }^{1}$ Acadêmica do Curso de Odontologia da UNIPAR \\ ${ }^{1}$ Acadêmica do Curso de Diagnostico Bucal - Turma I da UNIPAR \\ ${ }^{2}$ Acadêmico do Curso de Cirurgia Periodontal e Introducao A Implantodontia - Turma Viii da UNIPAR \\ ${ }^{3}$ Acadêmica do Curso de Curso Avancado Em Cirurgias Bucais - Turma lii da UNIPAR \\ ${ }^{4}$ Acadêmica do Curso de Cirurgia Periodontal e Introducao A Implantodontia - Turma Viii da UNIPAR \\ ${ }^{5}$ Docente da UNIPAR
}

Introdução: A disfunção temporomandibular (DTM) está relacionado a doenças que irão acometer os músculos mastigatórios, ATM e estruturas adjacentes (AMANTÉA; NOVAES; CAMPOLONGO; BARROS., 2004). As DTMs são classificadas em dois subgrupos as de origem articular, onde seus sinais e sintomas estão relacionados à ATM; e as de origem muscular onde seus sinais e sintomas estarão relacionadas a musculatura estomatognática (BRANCO; BRANCO; TESCH; RAPOPORT., 2008).

Objetivos: Este trabalho tem como objetivo apresentar causas da disfunção temporomandibular (DTM).

Desenvolvimento: A etiologia da disfunção temporomandibular (DTM) é multifatorial (QUINTO., 2000) sua relação está voltado para fatores estruturais, neuromusculares, oclusais como perdas dentárias, desgaste dental, próteses mal adaptadas, cáries, restaurações inadequadas entre outras, fatores psicológicos relacionado a uma tensão aumentando a atividade muscular gerando espasmo e fadiga, hábitos parafuncionais (bruxismo, onicofagia, apoio de mão na mandíbula, sucção digital ou de chupeta) e lesões traumáticas ou degenerativas da ATM (PEREIRA; ANDRADE; COSTA; PORTAL., 2005). As dores da DTM é um sintomas mais comum é caracterizada nas regiões da articulações temporomandibulares e nos músculos mastigatórios, alguns estudos apresentam que as mulheres são mais afetadas que os homens (ZANETTINI et al., 1999). São realizadas diversas pesquisas sobre tratamento da DTM, entretanto ainda não existe oficialmente a escolha da melhor técnica em si terapêutica e o benefício de cada uma delas, tendo diversidades no protocolo de atendimento. A área da Fonoaudiologia pode ajudar na redução da dor, enfatiza a necessidade da reabilitação das funções orofaciais, aspecto diferencial com relação aos demais tratamentos. O protocolo pode ser relacionado a variação de várias técnicas trabalhadas juntas durante o tratamento como a terapia com exercícios miofuncionais orofaciais associada à laserterapia, ou a associação do uso da placa de oclusão aos exercícios miofuncionais orofaciais, evidenciam melhores resultados do que tratamentos isolados. No estudo realizado SASSI, Fernanda Chiarion. et al. relataram que o uso do laser isolado não apresentou melhores resultados que o tratamento miofuncional realizado de forma completa. Essas combinações de técnicas promovem melhoras, tanto relacionadas aos aspectos da mobilidade mandibular e redução da dor orofacial, quanto à melhora da funcionalidade do sistema miofuncional orofacial, como um todo.

Conclusão: A disfunção temporomandibular (DTM) pode ser desenvolvida no dia a dia devido a diversos fatores, como psicológicos causando uma tensão muscular, o tratamento ainda é incerto entretanto com estudos científicos diversas técnicas realizadas de forma conjunta obtém melhores resultados em redução da dor e qualidade ao paciente em comparação a técnicas isoladas.

\title{
Referências
}

AMANTÉA, Daniela Vieira; NOVAES, Ana Paula; CAMPOLONGO, Gabriel Denser; BARROS, Tarley Pessoa de. A importância da avaliação postural no paciente com disfunção temporomandibular. Acta Ortop. Bras. v. 12, n. 3, p. 155-9. 2004.

BRANCO, Raquel Stumpf; BRANCO, Carla Stumpf; TESCH, Ricardo de souza; RAPOPORT, Abrão. Freqüência de relatos de parafunções nos subgrupos diagnósticos de DTM de acordo com os critérios diagnósticos para pesquisa em disfunções temporomandibulares (RDC/TMD). Rev. Dent. Press Ortodon. Ortop. Facial Maringá, v.13, n. 2, Mar/Apr. 2008.

PEREIRA, Kelli Nogueira Ferraz; ANDRADE, Leilane Lima Sena de; COSTA, Maria Lúcia Gurgel da; PORTAL, Tatiane Fernandes. Sinais e sintomas de pacientes com disfunção temporomandibular. Rev CEFAC. v. 7, n. 2, p. 221-8. 2005.

QUINTO, Carla Azevedo. Classificação e tratamento das disfunções temporomandibulares: qual o papel do fonoaudiólogo no tratamento dessas disfunções?. Rev CEFAC. v. 2, n. 2, p. 15-22. 2000.

SASSI, Fernanda Chiarion. et al. Tratamento para disfunções temporomandibulares: uma revisão sistemática. Audiol Commun Res. 23:e1871. 2018.

ZANETTINI I; ZANETTINI UM. Disfunções temporomandibulares: estudo retrospectivo de 150 pacientes. Rev Cient AMECS. v. 8, 
n. 1, p. 9-15. 1999.

Coordenadoria de Pesquisa e Extensāo - COPEX

Departamento de Editoraçāo e Divulgaçāo Científica - DEDIC 


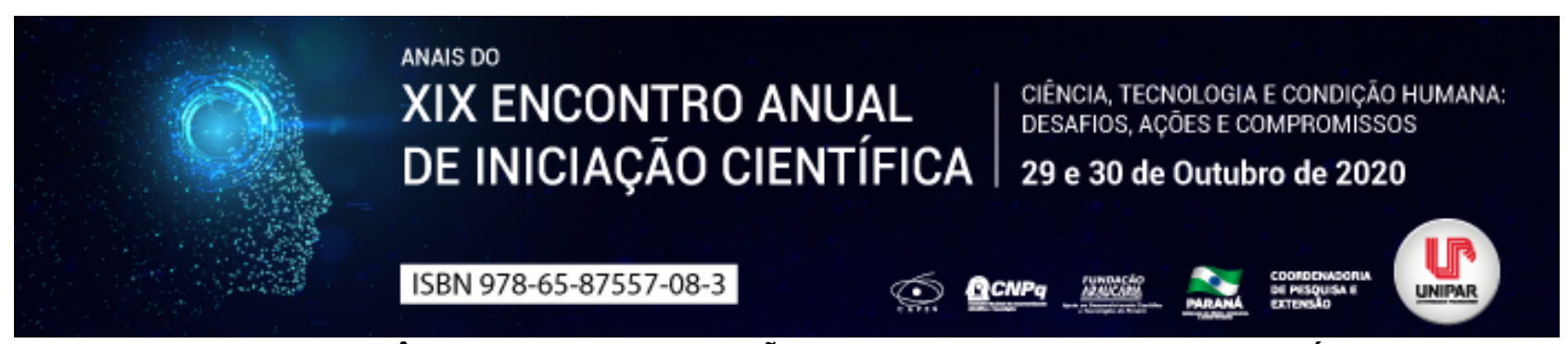

CASOS DE VIOLÊNCIA INFATIL NA REGIÃO SUL DO BRASIL: ESTUDO ECOLÓGICO

\title{
${ }^{1}$ MARIELLY MARIA VITORIA DUMKE, ${ }^{2}$ DENISE APARECIDA MITRUT, ${ }^{3}$ DAISY CRISTINA RODRIGUES
}

\author{
${ }^{1}$ Acadêmica do Curso de Enfermagem da UNIPAR \\ ${ }^{1}$ Acadêmica do Curso de Enfermagem da UNIPAR \\ ${ }^{2}$ Docente da UNIPAR
}

Introdução: Não existe uma definição única para descrever a violência infantil, no entanto, ela engloba toda situação que comprometa a saúde física e emocional da criança, como por exemplo: maltrato físico, negligência, maltrato psicológico ou abuso sexual infantil e entre outros, essas ações podem ser cometidas por pessoas, instituições e também pela própria sociedade. De acordo com a Organização Mundial da Saúde (OMS), cerca de 30\% dos menores de 18 anos são vítimas de violência física. Ao contrário do esperado essa violência vem aumentando a cada ano, e muitas vezes, os olhos são fechados para esse comportamento, muitos acreditam que esse é um problema que foi enfrentado em um passado distante, porém, na contemporaneidade os números continuam crescendo.

Objetivo: Identificar os dados da violência contra a criança na região sul brasileira, juntamente com suas possíveis causas.

Metodologia: Trata-se de um estudo epidemiológico observacional do tipo ecológico que é pautado nos dados quantitativos apresentados no Departamento De Informática Do Sistema Único de Saúde do Brasil (DATASUS), que se trata de um departamento que tem a responsabilidade de coletar, processar e disseminar informações sobre a saúde. Neste estudo é proporcionado a soma de dados em relação a violência contra crianças que estão entre um a ano anos de idade, na Região Sul do Brasil, dividida em Paraná, Santa Catarina e Rio Grande do Sul, nos anos de 2015, 2016 e 2017.

Resultados: Os dados do DATASUS demonstram um aumento no número de casos de violência infantil entre crianças de um a nove anos de idade no decorrer do tempo, exceto pelo estado do Rio Grande do Sul que teve uma baixa no total de casos no ano de 2016, porém, em 2017 teve um novo aumento mas esse não ultrapassou o de 2015. A cobertura do sistema DATASUS no demonstra que os maiores números de violência infantil são registrados no estado do Paraná por negligencia e abandono com o total de 7.143 casos, segundo lugar também é ocupado pela negligencia e abandono só que pelo Rio Grande do Sul com 4.809. Os números mais baixos registrados são sobre trabalho infantil tendo Santa Catarina com 11 registros, Rio Grande do Sul com 33 e Paraná com 167. O Abuso sexual infantil também é preocupante se repararmos que esse tipo de violência ocupa o terceiro lugar em números de registros, que são 2.978 no Paraná, 1.106 em Santa Catarina e 2.094 no Rio Grande Do Sul. É perceptível que diferente de algumas outras violências os números de abuso sexual cresceram ano após ano. Em 2017 além de acontecer um aumento nos acontecimentos, o número de crianças entre um e nove anos que passaram por alguma situação de violência foi o maior registrado, subindo aproximadamente 1000 casos em um ano, o Estado de Santa Catarina foi o que entre os três apresentou os números mais baixos, sendo assim o estado do Paraná tem a liderança no número de casos de violência infantil na Região Sul Brasileira. O estado do Paraná com 12.159 casos, Rio Grande do Sul com 7.981 e Santa Catarina com 3.990, todos com exceção de Santa Catarina com grandes aumentos ano após ano.

Discussões: Ao ser estudada, a violência infantil é direcionada a certos modelos e assim a possíveis causas, entre esses modelos é possível citar o Modelo Sociológico que considera a violência que pode ser consequência da carência econômica, a pobreza pode levar a criança a passar por maltrato e negligencias. Também há o Modelo Cognitivo onde o maltrato é uma situação de esperanças e percepções impróprias dos cuidadores em relação a criança em seus cuidados, já o Modelo Psiquiátrico para alguns pesquisadores é quando a violência infantil é vista como uma consequência da existência de doenças psicológica nos pais ou cuidadores. Este estudo aborda todos os tipos de violência direcionadas a crianças, porém podemos distinguir algumas delas em: negligencia e o abandono; a violência psicológica e moral; o abuso sexual infantil e o trabalho infantil: Qualquer forma de trabalho realizado por crianças abaixo da idade permitida na Lei Brasileira que possa priva-las de sua infância e interfira na realização de seus direitos.

Conclusão: É necessário ressaltar que o estudo realizado apresenta alguns obstáculos, em consequência de se fundamentar em dados preexistentes, presentes no DATASUS, que não dependem da possibilidade de controle por parte do pesquisador. Os resultados apresentados podem ser considerados hipóteses e poderão servir para propor ações e medidas de prevenção. Outra limitação é que pode ter ocorrido o preenchimento inadequado da ficha de cadastro; erros de digitação, uma baixa cobertura do sistema e também a não notificação do profissional da saúde. Ao observar os dados apresentados pelo sistema do DATASUS foi possível notar que as crianças não estão seguras e o risco de sofrerem de algum tipo de violência é alto, não sendo uma doença crônica e impossível de cortar a sua ocorrência com vacinas e medicações é de extrema importância que prestamos mais atenção a esse tipo de doença que afeta a nossa sociedade. 


\section{Referências}

CRUZ, Fernanda, Brasil é líder no ranking de violência contra a criança na AL, São Paulo, Abril, 2018. Disponível em: https://agenciabrasil.ebc.com.br/geral/noticia/2018-04/pesquisa-diz-que-brasil-e-lider-no-ranking-de-violencia-contra-crianca-na-al . Acesso em: 20 abr. 2020.

MINISTÉRIO DA SAÚDE, Violência Contra A Criança E O Adolescente, Proposta Preliminar De Prevenção E Assistência À Violência Doméstica - Brasília, 1997. Disponível em: http://bvsms.saude.gov.br/bvs/publicacoes/0220violencia.pdf. Acesso em: 20 abr. 2020.

RIBEIRO, Maiara, Negligência É A Forma De Violência Mais Comum Contra Crianças E Adolescente. Disponível em: https://drauziovarella.uol.com.br/pediatria/negligencia-e-a-forma-de-violencia-mais-comum-contra-criancas-e-adolescentes/.

Acesso em: 22 abr. 2020.

MALTA, D.C; BERNAL, R. T. I; TEIXEIRA, B. S, et al. Fatores associados a violências contra crianças em Serviços Sentinela de Urgência nas capitais brasileiras. Ciênc. Saúde Colet. Vol. 22, n.9, 2017.

Coordenadoria de Pesquisa e Extensão - COPEX

Departamento de Editoraçāo e Divulgaçāo Científica - DEDIC 


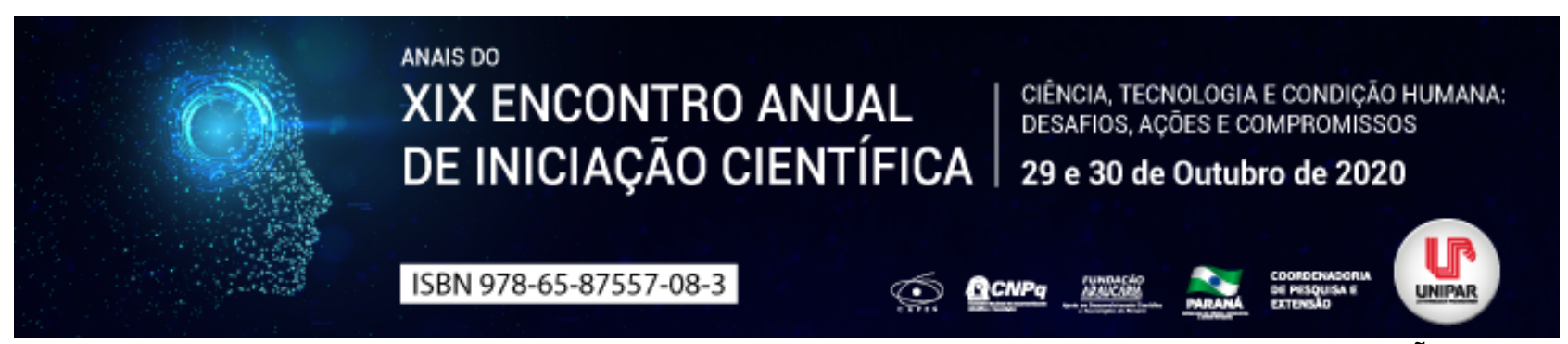

OSTEONECROSE ASSOCIADA AOS BIFOSFONATOS NA ODONTOLOGIA: UMA REVISÃO

\title{
1 JOAO MURILO GONCALVES GAZOLA, ${ }^{2}$ GABRIELA ZANUTO DE LIMA, ${ }^{3}$ VANESSA RODRIGUES DO NASCIMENTO
}

\author{
${ }^{1}$ Discente do Curso de Odontologia PIBIC/UNIPAR \\ ${ }^{1}$ Discente do Curso de Odontologia PIC/UNIPAR \\ ${ }^{2}$ Docente da UNIPAR
}

Introdução: Bifosfonatos são fármacos utilizados para tratamento de várias doenças ósseas, tais como osteoporose, neoplasias malignas com metástase óssea, hipercalcemia maligna e mieloma múltiplo (IZQUIERDO et al, 2011). Dentre os efeitos adversos dessa terapêutica, a osteonecrose dos maxilares associado à bifosfonatos (ONMAB) representa uma preocupante manifestação ao cirurgião dentista, comprometendo os ossos maxilares (SALES e CONCEIÇÃO, 2020).

Objetivo: Realizar um levantamento bibliográfico sobre a osteonecrose associada aos bifosfonatos na odontologia.

Desenvolvimento: A osteonecrose como um efeito colateral da terapia com bifosfonato vem sendo relatado desde 2003 (BARIN et al, 2016). Embora o uso da droga gere efeitos benéficos, a literatura aponta que existe um efeito colateral referente ao uso crônico dos bifosfonatos. A osteonecrose apresenta comportamento indolente e de difícil controle, definida pela exposição óssea espontânea ou por feridas não cicatrizantes, tal manifestação associada aos BFs (bifosfonatos) passou a estar localizada quase exclusivamente nos maxilares, sendo então denominada osteonecrose dos maxilares associada ao bifosfonatos relata Longo et al. (2014). Os BFs uma vez depositados na matriz óssea mineralizada se tornam capazes de diminuir o metabolismo ósseo, segundo Forte e Frascino (2016), acarretando em uma reparação e remodelação de feridas, após eventos traumáticos, tanto fisiológicos quanto induzidos, o que leva à exposição de um osso necrótico na região da maxila e/ou mandíbula. De acordo com Cordeiro e Gottardo (2018) para o diagnóstico, pode-se lançar mão de alguns exames de imagem e laboratoriais. Por exemplo, a Densitometria Óssea que também é utilizado em casos de osteoporose, também a radiografia panorâmica ou tomografias computadorizadas que são exames que mostram uma visão dos ossos da face, o que torna perceptível outras alterações neste osso. Já como exame laboratorial é usado o Telopeptídeo-C terminal (CTX) que é um exame que reconhece a reabsorção óssea através do colágeno degradado durante o processo, sendo um exame com alta sensibilidade, mas não muito específico, pois pode reconhecer outras patologias. Ruggiero et al. (2014) cunhou um protocolo de atendimento odontológico e manejo das situações que podem resultar nessa complicação para orientar os pacientes sobre os possíveis riscos a que esta sendo submetido. Para tratamento em pacientes com osteoporose, foi estabelecido que extrações e procedimentos mais invasivos não são contraindicados e no caso de implantes dentários, o paciente deverá assinar um termo de consentimento livre e esclarecido, que informando os possíveis riscos de falha do implante a longo prazo e do risco de desenvolvimento da osteonecrose dos maxilares, mesmo que baixo. Relata Cordeiro e Gottardo (2018) que a American Dental Association (2008) disponibilizou recomendações para realização de cirurgias nos pacientes com a doença estabelecida, que consiste na realização das cirurgias de modo a acometer um dente por vez, se assim for possível, prosseguindo então o tratamento para as próximas áreas depois do acompanhamento durante dois meses da primeira cirurgia. O protocolo seguro para um plano de tratamento correto a pacientes afetados pela doença, com a utilização de agentes antimicrobianos e antibióticos, e até mesmo algumas cirurgias ressectivas, no intuito de preservar a integridade do tecido gengival, vem a ser o meio de ação, até então, mais eficiente na manipulação desses casos (SOUZA, 2018). De acordo com Carvalho et al. (2010) o uso dos bifosfonatos tem sido relacionado com o desenvolvimento de necrose óssea tanto em maxila quanto em mandíbula, sendo essa a mais afetada, porém sua ação sobre a atividade dos osteoclastos vem sendo estudada com o intuito de proporcionar melhores resultados em procedimentos cirúrgicos, porém os protocolos para a indicação clínica dessa terapêutica ainda não estão estabelecidos. Devem ser realizados novos estudos para adequação da prescrição e dosagem dessas drogas para sua utilização efetiva como coadjuvantes nos tratamentos cirúrgicos maxilofaciais.

Conclusão: É de extrema importância que o cirurgião-dentista entenda sobre a terapêutica medicamentosa, para poder compreender possíveis restrições dos pacientes que fazem terapia com bifosfonatos perante a realização de procedimentos odontológicos, além do risco da osteonecrose dos maxilares.

\section{Referências}

BARIN, Luisa Machado et al. Osteonecrose dos maxilares associada ao uso de bifosfonatos: uma revisão de literatura. Revista de Odontologia da Universidade Cidade de São Paulo , v. 28, n. 2, p. 126-134, 2016.

CORDEIRO, Fernanda Lariny de Lara; GOTTARDO, Vilmar Divanir. Bifosfonatos na odontologia. Brazilian Journal of Surgery and Clinical Research, v. 25, n.1, p .44-48, 2018.

DE CARVALHO, Paulo Sérgio Perri et al. Principais aspectos da cirurgia bucomaxilofacial no paciente sob terapia com 
bifosfonatos. Revista da Faculdade de Odontologia-UPF , v. 15, n. 2, 2010.

DE SOUSA, Amanda Soares et al. Protocolo de atendimento odontológico de pacientes em tratamento com bifosfonatos. Revista Saúde-UNG-Ser, v. 12, n. 1/2, p. 54-61, 2019.

FRASCINO, Alexandre Viana; FORTE, Anne Caroline Corbalan Barbosa. Interação dos bisfosfonatos na cirurgia odontológica. Atas de Ciências da Saúde (ISSN 2448-3753), v. 4, n. 1, p. 12-22, 2016.

IZQUIERDO, Cristina de Moraes; DE OLIVEIRA, Marília Gerhardt; WEBER, João Batista Blessmann. Terapêutica com bisfosfonatos: implicações no paciente odontológico: revisão de literatura. Revista da Faculdade de Odontologia (Universidade de Passo Fundo), v.16, n. 3, p. 347-352, 2011.

LONGO, Francesco et al. Platelet rich plasma in the treatment of bisphosphonate-related osteonecrosis of the jaw: personal experience and review of the literature. International Journal of Dentistry. v. 2014, n. 1, p. 1-7, 2014.

RUGGIERO, Salvatore Louis et al. American Association of Oral and Maxillofacial Surgeons position paper on medication-related osteonecrosis of the jaw - 2014 update. Journal of oral and maxillofacial surgery. v. 72, n. 10, p. 1938-1956, 2014.

SALES, Kauanna Oliveira; DA CONCEIÇÃO, Leandro Silva. A atuação do cirurgião-dentista frente à osteonecrose dos maxilares associada ao uso de bisfosfonatos: uma revisão de literatura. Facit Business and Technology Journal. v. 1, n. $14,2020$. 


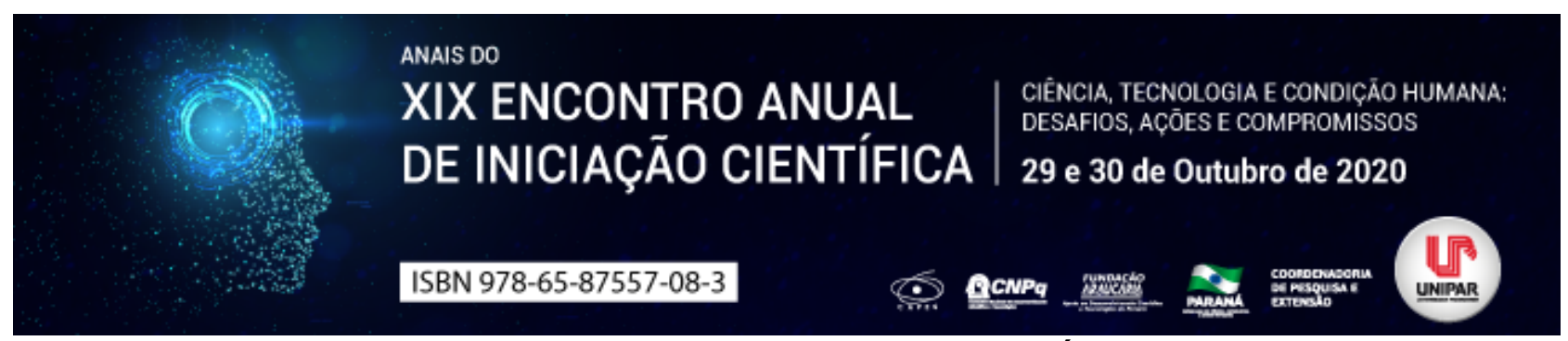

TREINAMENTO FUNCIONAL PARA PESSOAS COM HÉRNIA DE DISCO

\begin{abstract}
${ }^{1}$ VIVYANNE MARIA MARYNOWSKI CONTI, ${ }^{2}$ DANIEL SANTOS EVANGELISTA, ${ }^{3}$ GLEICY KELLY THIEMY SATO, ${ }^{4} \mathrm{KLAUS}$ KENZO KIYOHARA AGAWA, ${ }^{5}$ MARIA GABRIELLA GIROTO
\end{abstract}

\begin{abstract}
${ }^{1}$ Discente do curso de Educação Física, Ciências da Saúde, Universidade Paranaense UNIPAR
${ }^{1}$ Discente do curso de Educação Física, Ciências da Saúde, Universidade Paranaense - UNIPAR

${ }^{2}$ Discente do curso de Educação Física, Ciências da Saúde, Universidade Paranaense - UNIPAR

${ }^{3}$ Discente do curso de Educação Física, Ciências da Saúde, Universidade Paranaense - UNIPAR

${ }^{4}$ Docente do curso de Educação Física, Ciências da Saúde, Universidade Paranaense - UNIPAR
\end{abstract}

Introdução: O exercício físico auxilia na qualidade de vida de seus praticantes e ajuda no tratamento de diversas doenças dentre elas a hérnia de disco (VARELLA, 2015). Neste contexto o treinamento funcional pode ser uma alternativa de prática de exercício físico, porque fortalece a musculatura que auxilia no controle postural e desenvolve as capacidades fisiológicas e motoras através de movimentos funcionais que são facilmente realizados, pois são utilizados no dia a dia (MONTEIRO; EVANGELISTA, 2015). A hérnia de disco, por se tratar de uma doença que causa dor, deve ser trabalhada com muita atenção e cuidado pelo profissional para que não agrave mais o quadro, por tanto essa pesquisa se torna necessária para ajudar com informações relevantes para trabalhar com esse público.

Objetivo: Analisar através da literatura a prática do treinamento funcional como alternativa de exercício físico para pessoas com hérnia de disco e seus efeitos.

Desenvolvimento: A coluna vertebral é composta por diversas vertebras e cada uma com uma função, como: sustentação, distribuição das cargas corporais, entre outros. Por ser muito utilizada no dia a dia para todos os movimentos do corpo humano, Varella (2015) diz que: Os discos intervertebrais desgastam-se com o tempo e o uso repetitivo, o que facilita a formação de hérnias de disco, ou seja, parte deles sai da posição normal e comprime as raízes nervosas que emergem da coluna . O surgimento desta patologia se dá por diversos motivos, segundo Varella (2015) os mais reincidentes são: o tabagismo, o sedentarismo, genética, sobrepeso e envelhecimento. De acordo com Dias, Aires e Weidebach (2001) alguns sintomas podem ser bem característicos da patologia como as dores e formigamentos. Neste contexto, é necessária a utilização de algum meio para que reduza a possibilidade do aparecimento da hérnia de disco, podendo ser o treinamento funcional. Segundo Monteiro e Evangelista (2015) o treinamento funcional beneficia diversas capacidades do indivíduo, melhorando o desempenho das atividades realizadas no cotidiano e até mesmo no desempenho esportivo. Deste modo, sendo o sedentarismo um dos fatores mais relevantes para o desenvolvimento da hérnia de disco, o treinamento funcional poderá evitar que o surgimento aconteça e ajuda na redução do sobrepeso que também é outro fator de risco (VARELLA, 2015). Ademais, segundo Alcantra (2019) os músculos do core tem o objetivo de estabilizar coluna vertebral, porém, quando esses músculos não são desenvolvidos e estimulados acabam enfraquecendo-se e deixar a coluna suscetível a desgastes desnecessários e desenvolvendo a hérnia de disco. Estes exercícios conseguem auxiliar no carregamento do oxigênio e a nutrição necessária para a hérnia de disco auxiliando no alivio das dores originadas (WETHER; ROCHA; BARROS, 2004). E de acordo com Dacca e Furlan (2000) neste contexto, o atendimento personalizado busca um melhor atendimento para seu aluno, além de exercícios individualizados para melhorar a postura do aluno, o condicionamento físico, alongamento dos músculos, reduzir o peso corporal e reduzir as dores em alunos que possuem hérnia de disco e assim reduzir as chances de uma possível cirurgia como tratamento. Sendo assim o treinamento funcional poderá ajudar nas dores originadas da hérnia de disco com exercícios de alongamento, fortalecimento e até com atividades aeróbicas desde que bem orientada e respeitando as diferenças de cada aluno (ALCANTRA, 2019). Porém para um resultado positivo é necessário que o profissional faça um treinamento individualizado e de acordo com a dificuldade e peculiaridade da patologia do aluno (DACCA; FURLAN, 2000), e Reis et al (2017) afirma que o profissional que irá trabalhar com o aluno portador da hérnia de disco deverá saber manipular as variáveis para cada aluno respeitando os limites tanto do aluno como também da doença existente para a prática ser benéfica.

Conclusão: $O$ treinamento funcional pode ser utilizado como alternativa de exercício físico para indivíduos com hérnia de disco, onde sua prescrição pelo Profissional de Educação Física é direcionada considerando as características individuais e patologia, sendo desenvolvido através de exercícios de fácil execução, com dosagem de sobrecarga e intensidade controladas, fazendo fortalecimento, alongamento e compensação de grupos musculares que auxiliam na manutenção da postura, minimizando quadros de dor e prevenindo agravamentos da patologia. Uma vez que quando bem prescrito, orientado e acompanhado pode melhorar o fortalecimento muscular, as capacidades motoras, o controle postural, a mobilidade, reduzir o sobrepeso, combater o sedentarismo e desenvolver um estilo de vida ativo. 


\section{Referências}

ALCANTRA, M. F. S. A contribuição da atividade física no quadro patológico da hérnia de disco: uma revisão bibliográfica. ago. 2019. Trabalho de conclusão de curso- Universidade Estadual da Paraíba. Disponível em: http://dspace.bc.uepb.edu.br/jspui/handle/123456789/20969. Acesso em: 26 jun. 2020.

DACCA, E. R. G. S; FURLAN, M. M. D. P. Abordagem fitoterápica associada ao sistema de personal trainer no tratamento da hérnia de disco lombar: relato de caso. Arquivo de Ciência da Saúde da Unipar. Umuarama. v, 4, n. 2, maio/ago. 2000. Disponível em: https://www.revistas.unipar.br/index.php/saude/article/view/1022/886. Acesso em: 11 jun. 2020.

DIAS, C. L; AIRES, J. M; WEIDEBACH, W. A clínica e o tratamento fisioterápico da hérnia discal lombar. Revista Coluna Fisioterápica. Rio de Janeiro, v. 1, n. 1, set. 2001. Disponível em: http://www.luzimarteixeira.com.br/wpcontent/uploads/2011/04/revista-escoliose.pdf\#page=12. Acesso em: 10 jun. 2020.

MONTEIRO, A. G; EVANGELISTA, A. L. Treinamento funcional: uma abordagem prática. São Paulo: Phorte, 2015.

REIS, E. D. et al. Benefícios da musculação para portadores de hérnia de disco. Revista lbirapuera. São Paulo, n. 13, jan/jun. 2017. Disponível em: http://seer.unib.br/index.php/rev/article/view/109. Acesso em: 25 jun. 2020.

VARELLA, D. Hérnia de disco. Ministério da saúde. Brasília, 04 set. 2015. Disponível em: http://bvsms.saude.gov.br/dicas-emsaude/2043-hernia-de-disco. Acesso em: 09 jun. 2020.

WETHER, E. C. B; ROCHA, V. A; BARROS, J. F. O tratamento conservador através da atividade física na hérnia de disco lombar. Revista digital: efdeportes. Buenos Aires, n. 70, mar. 2004. Disponível em: https://www.efdeportes.com/efd70/hernia.htm. Acesso em: 26 jun. 2020. 


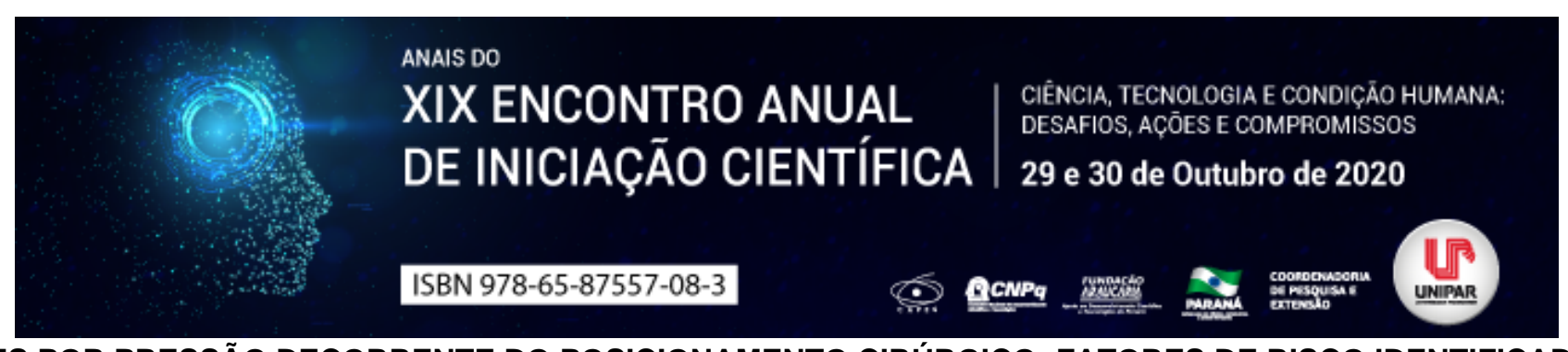

LESÕES POR PRESSÃO DECORRENTE DO POSICIONAMENTO CIRÚRGICO: FATORES DE RISCO IDENTIFICADOS NA LITERATURA

\title{
${ }^{1}$ EDUARDA DUARTE DE CASTRO, ${ }^{2}$ EDUARDA DOS SANTOS AMARAL, ${ }^{3}$ JOLANA CRISTINA CAVALHEIRI
}

\author{
${ }^{1}$ Acadêmico do curso de Enfermagem da Universidade Paranaense. Unidade de Francisco Beltrão \\ ${ }^{1}$ Acadêmica do curso de Enfermagem da UNIPAR \\ ${ }^{2}$ Docente da UNIPAR
}

Introdução: O centro cirúrgico é uma das unidades mais complexa da instituição hospitalar, por ser composta de Recuperação pós-anestésica (RPA) e pela Central de Material de Esterilização (CME), sendo estes serviços direcionados ao tratamento cirúrgico. Todo paciente submetido a procedimentos cirúrgicos está exposto a diferentes riscos associados a equipe de enfermagem, médica, a estrutura da unidade, anestesia e a própria cirurgia (CAPELA; GUIMARÃES, 2009). Neste sentido, é necessário otimizar a segurança do cliente, a partir da identificação correta ao adentrar ao centro cirúrgico, boa comunicação, atentar-se a vigilância de medicamentos que possam interferir no processo de recuperação e conter o risco de infecções associadas ao cuidado. Além disso, denota-se a necessidade de um posicionamento adequado no momento da cirurgia para evitar o desenvolvimento de lesões por pressões, que não estão diretamente associadas ao porte da cirurgia, mas sim como a forma que o paciente será posicionado em todo o período intraoperatório (BERWANGER et al., 2018). O posicionamento cirúrgico tem por objetivo possibilitar uma boa visualização do sítio cirúrgico, priorizando a segurança do paciente, sendo assim exige competência, conhecimento e habilidade, prevenindo os eventos adversos (LOPES; GALVÃO, 2010). Dessa forma, os enfermeiros e demais profissionais que atuam no setor, devem possuir conhecimento sobre os fatores de risco, escalas utilizadas e cuidados implantados para evitar o surgimento de lesão por pressão (CAPELA; GUIMARÃES, 2009), uma vez que este é um fator indispensável para o desempenho de um procedimento seguro e efetivo (LIMA et al.,2015).

Objetivo: Realizar uma revisão de literatura sobre os fatores de risco que contribuem para lesão por pressão por posicionamento no centro cirúrgico.

Desenvolvimento: O método de checklist vendo sendo proposto pelo Ministério da Saúde para garantir a segurança do paciente no centro cirúrgico. Este é um instrumento usado no período pré, trans e pós-operatório, sendo que o enfermeiro é um dos profissionais apropriados para realizar a checagem dos dados clínicos do paciente e com base nessas informações pode-se evitar complicações durante o procedimento (PAIVA et al., 2015), que podem variar da dor musculoesquelético, deslocamento de articulação, danos em nervos periféricos, lesões de pele, comprometimento cardiovascular e pulmonar. As lesões por pressão são eventos adversos que podem desenvolver-se no centro cirúrgico e variam de queimaduras mais sérias, pelo uso do bisturi elétrico, ou mesmo lesões por fricção e cisalhamento, em consequência da exposição cirúrgica sem ter os devidos cuidados no momento do posicionamento do paciente na mesa cirúrgica (BEZERRA et al., 2019). Os fatores de risco para lesões por pressão no centro cirúrgico são o comprometimento da mobilidade do paciente, perfusão tecidual, umidade da pele, idade, nutrição, o estado geral de saúde do paciente e a presença de lesões prévias (CEDRAZ et al.,2018). Além disso, pesquisa que avaliou o perfil epidemiológico de pacientes que realizaram procedimentos cirúrgicos, demonstrou fragilidades no cuidado, especialmente no surgimentos de lesão por pressão decorrentes do posicionamento, já que indivíduos acima de 50 anos e que realizaram anestesia peridural apresentaram $68 \%$ de chances de desenvolver comprometimento tegumentar. Em contrapartida, pacientes que foram induzidos a anestesia geral apresentam $20 \%$ de probabilidade. A sedação no paciente anula a capacidade de sentir desconforto, bloqueando a sensibilidade do corpo e consequentemente não se observam os primeiros sinais de lesão (OLIVEIRA et al,.2019). Diante destes fatores de risco e considerando que todos os pacientes que são submetidos algum tipo de cirurgia apresentam esta possibilidade de alteração tegumentar, os clientes devem ser meticulosamente avaliados no decorrer do período perioperatório em relação aos fatores de risco, medidas preventivas e consequentemente a implementação das mesmas durante o cuidado ofertado em ambiente cirúrgico (SCARLATTI et al., 2011). Dessa forma, deve-se desenvolver educação continuada permanente aos profissionais de enfermagem, para que tenham capacidade de analisar e intervir em que podem levar ao desenvolvimento de lesão pelo posicionamento cirúrgico (MENDONÇA et al.,2018), bem como evidencia-se a necessidade de o enfermeiro desenvolver a sistematização da assistência de enfermagem (SAE) e protocolos que buscam também qualificar a equipe, para prevenção, identificação e tratamento de lesões (BARBOSA; OLIVA; NETO, 2011, MIRANDA et al., 2016).

Conclusão: As lesões por pressão no ambiente cirúrgico ocorrem especialmente pelo posicionamento cirúrgico, sendo que a mobilidade do paciente, o tipo de anestesia, a presença de doenças que afetam a perfusão, a idade, umidade da pele e comprometimento prévio do tegumentos podem aumentar a chance de desenvolver lesões. Dessa forma, cabe ao enfermeiro e sua equipe proporcionar uma assistência livre de eventos adversos, zelando pelo paciente, enquanto este encontra-se vulnerável. 


\section{Referências}

BARBOSA, Maria Helena; OLIVA Artemis Maria Braz; NETO, Adriana Lemos de Sousa. Ocorrência de lesões perioperatórias por posicionamento cirúrgico. Rev. cuba. enferm, p. 31-41. v. 1, n. 27, p. 31-41 Nov. 2011.

BERWANGER, Djulia Camila et al. Ligações entre diagnósticos, resultados e intervenções de enfermagem para Pacientes no período transoperatório. Revista SOBECC, v. 23, nov. 4, p. 195-204, Nov. 2018.

BEZERRA, Mayara Beatriz Gonçalo et al. Fatores associados a lesões de pele decorrentes do período intraoperatório. Revista SOBECC, v. 24, n. 2, p. 76-84, Jan . 2019.

CAPELA, Cássia Fossá; GUIMARÃES, Solange Posicionamento cirúrgico e as complicações transoperatórias: recomendações de cuidados intraoperatórios. Revista SOBECC, v. 14, n. 1, p. 51-61, Jan. 2009.

CEDRAZ, Rayane Oliveira et al. Gerenciamento de riscos em ambiente hospitalar: incidência e fatores de riscos associados à queda e lesão por pressão em unidade clínica. Escola Anna Nery, v. 22, n. 1, P. 5 Nov. 2018.

DE MORAES Lopes, Camila Mendonça; GALVÃO, Cristina Maria. Posicionamento cirúrgico: evidências para o cuidado de enfermagem. Revista Latino-Americana de Enfermagem, v. 18, n. 2, p. 155-162, Ago. 2010.

PAIVA, Ana Clara Rodrigues et al. Checklist de cirurgia segura: análise do preenchimento da ficha de verificação no pré, trans e pós-operatório. Enfermagem Revista, v. 18, n. 2, p. 62-80, Mar. 2015.

MIRANDA, Amanda Braz et al. Posicionamento cirúrgico: cuidados de enfermagem no transoperatório. Revista SOBECC, v. 21, n. 1, p. 52-58, Mar. 2016.

LIMA, Antônio Fernandes Costa et al. Custos da implantação de um protocolo de prevenção de úlceras por pressão em um hospital universitário. Revista Eletrônica de Enfermagem, v. 17, n. 4, P. 3, Set. 2015.

OLIVEIRA, Haglaia Moira Brito de Sena et al. Avaliação do risco para o desenvolvimento de lesões perioperatórias decorrentes do posicionamento cirúrgico. Revista Gaúcha de Enfermagem, v. 40, Nov. 2019.

SCARLATTI, Kelly Cristina et al. Úlcera por pressão em pacientes submetidos à cirurgia: incidência e fatores associados. Revista da Escola de Enfermagem da USP, v. 45, n. 6, p. 1372-1379, Jun. 2011. 


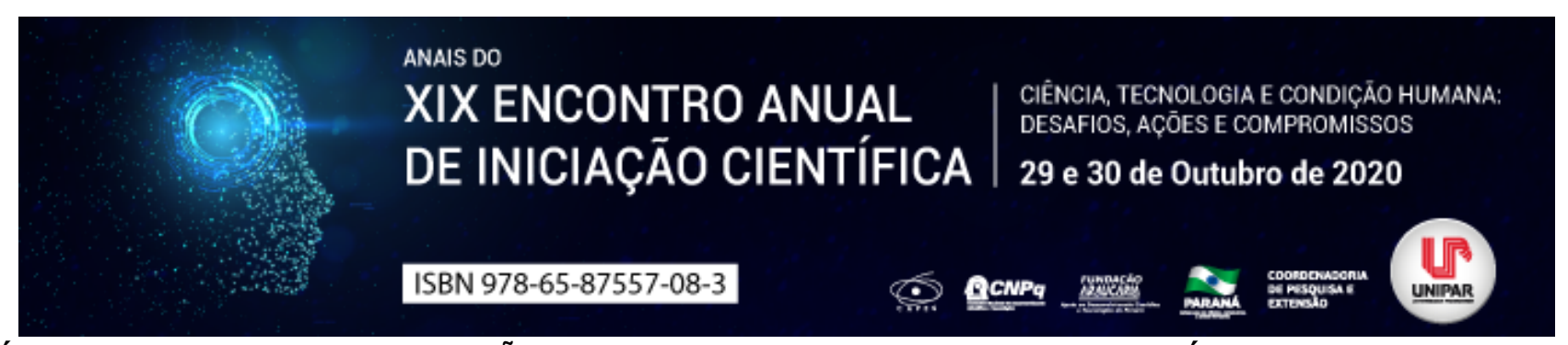

PÓS BICHECTOMIA COM APLICAÇÃO DE TAPING PELO PROFISSIONAL EM ESTÉTICA - RELATO DE CASO

\author{
${ }^{1}$ SEPHORA SERRANO BALDISERA, ${ }^{2}$ LIDIA PRISCILA LONGO, ${ }^{3}$ KARINA MARIA DE BARROS,${ }^{4}$ GIOVANA MIOTO DE \\ MOURA
}

${ }^{1}$ Docente - UNIPAR - Cianorte

${ }^{1}$ Tecnóloga em Estética e Cosmética - UNIPAR - Cianorte

${ }^{2}$ Tecnóloga em Estética e Cosmética - UNIPAR - Cianorte

${ }^{3}$ Docente - UNIPAR - Cianorte

Introdução: Intitula-se harmonização facial, os cuidados estéticos cirúrgicos ou não capazes de aguçar a beleza da face. Entre estes, a bichectomia que vem se destacando pelos resultados satisfatórios que os profissionais odontológicos, autorizados mediante resolução CFO-198/2019 (Conselho Federal Odontologia, 2019), vêm apresentando. Por se tratar de um procedimento invasivo, com cortes, possíveis extravasamentos de sangue e posterior edema, os cuidados pós cirúrgicos por meio de técnicas que promovam o conforto e o breve retorno do paciente às suas atividades cotidianas são necessários e comumente indicados por cirurgiões (BORGES, 2006). A drenagem linfática manual é a primeira aliada na readequação do paciente por reduzir o edema provocado pelo extravasamento de proteínas e hematomas devido ao rompimento de vasos (TACANI; TACANI; LIBERANO, 2011). Respeitando a conduta de drenar, estratégias surgiram a fim de complementar este processo, uma destas a Kinesio Taping ${ }^{\circledR}$. O taping, comumente chamado, é uma técnica desenvolvida pelo quiroprático Kenzo Kase na década de 70 , utilizada principalmente por fisioterapeuta e ortopedista para reabilitação dos movimentos de membros (PYSZORA; KRAJNIK, 2010). Consiste em uma fita de cotton fina, elástica, porosa, adesiva, hipoalergênica e sem princípios ativos que pode permanecer na pele por vários dias sem que seja removida ou provoque incômodo com a finalidade de tensionar, fortalecer ou drenar a região (FU et al., 2008). Dessa maneira, o presente relato de caso tem como objetivo elucidar a relevância do esteticista em pós-operatórios estéticos amparados pela regulamentação da profissão, projeto de lei no 959 de 2003 formulado por Alves (2003), que tem como finalidade promover a qualidade de vida e o breve retorno do cotidiano ao paciente.

Relato de Caso: $O$ trabalho baseia-se na aplicação de Kinesio Taping® e drenagem linfática manual no pós cirurgia de Bichectomia. A voluntária de 20 anos realizou o procedimento com o profissional cirurgião buco-maxilo-facial e recebeu a bandagem ainda na sala cirúrgica pelo tecnólogo em estética. O taping foi aplicado em duas técnicas: uma polvo , com 10\% de tensão da fita, com base em sentido as laterais da face, e as âncoras em região medial; e outra em I , com aplicação no sentido da lateral dos olhos até a região central do mento com média de $25 \%$ de tensão, sendo ambas as técnicas aplicadas nas duas laterais, direita e esquerda, e mantida por sete dias. Decorridas 48 horas do procedimento cirúrgico, o tecnólogo em estética iniciou o tratamento de drenagem linfática manual, constituído por quatro sessões com 48 horas de intervalo entre elas, sem a remoção das bandagens. Em sete dias de tratamento pós-operatório foi observada a melhora do edema, a reabsorção de equimose e a resolução do quadro álgico favorecendo o retorno da paciente para suas atividades diárias sem desconforto facial, enquanto que, como relatado pelo cirurgião, este mesmo procedimento sem qualquer intervenção pós cirúrgica comumente apresenta este comportamento a partir do $15^{\circ}$ dia.

Discussão: A investigação científica quanto a aplicação de Kinesio Taping® em pós-operatório de cirurgia plástica ainda é escassa, no entanto, Chy et al (2016) constataram que, a drenagem linfática manual associada ao taping reverteu a fibrose abdominal em pós-abdominoplastia e lipoaspiração e ainda relacionaram este resultado com a drenagem constante que as fitas de cotton estimulam na região. Além disso, Finnerty e Thomason (2010) observaram resultados satisfatórios com o taping em $70 \%$ das pacientes de câncer de mama acometidas pelo linfedema e demonstraram que este método pode vir a substituir as convencionais mangas de compressão. Aliás, corroborando este pensamento, Tsay et al (2009) já sugeriram que o taping poderia ser uma alternativa à bandagem de curto estiramento para pacientes com linfedema provocado pelo câncer de mama.

Conclusão: O Kinesio Taping $®$ associado a drenagem linfática manual demonstra efetividade em pós-operatório de Bichectomia elucidando a relevância profissional estética na concretização de excelência dos procedimentos de harmonização facial.

\title{
Referências
}

ALVES, H.E. Consulta tramitação das proposições: projeto de lei - 959/2003. Disponível em: . Acesso em 28 agosto de 2020. BORGES, F. dos S. Dermato Funcional - Modalidade Terapêuticas nas Disfunções Estéticas. 2ed. São Paulo: Phorte, 2006. Conselho Federal Odontologia. Resolução 198/2019: reconhece a harmonização orofacial como especialidade odontológica, e dá outras providências. Brasília: Conselho Federal de Odontologia; 2019. Disponível em: http://sistemas.cfo.org.br/visualizar/atos/RESOLU\%C3\%87\%C3\%83O/SEC/2019/198. Acesso em: 25 ago,2020. 
CHI, A.; OLIVEIRA, A.V.M.; RUH, A.C.; SCHLEDER, J.C. O uso de linfotaping, terapia combinada e drenagem linfática manual sobre a fibrose no pós-operatório de cirurgia plástica de abdome. Fisioter Bras. v. 17, n. 3, p.197-203, 2016.

FINNERTY, S; THOMASON, S; WOODS, M. Audit of the use of kinesiology tape for breast oedema. J Lymphoedema.v. 5, n. 1, p. 38-44, 2010.

FU, T.C.; WONG, A.M.K.; PEI, Y.C.; WU, K.P.; CHOU, S.W.; LIN, Y.C. Effect of Kinesio taping on muscle strength in athletes - A pilot study. J Sci Med Sport. v. 11, n. 11, p. 198-200, 2008.

HAN-JU, T.; HSIU-CHUAN, H.; JING-LAN, Y.; CHIUN-SHENG, H.; JAU-YIH, T. Could Kinesio tape replace the bandage in decongestive lymphatic therapy for breast-cancer-related lymphedema? A pilot study. Supportive Care in Cancer. v. 17, n. 1353, 2009.

PYSZORA, A; KRAJNIK, M. Is Kinesio Taping useful for advanced cancer lymphoedema treatment? A case report. J Palliat Med. v. 9, n.1, p. 141-144, 2010.

TACANI, R.E.; TACANI, O.M.; LIEBANO, R.E. Intervenção fisioterapêutica nas sequelas de drenagem linfática manual iatrogênica: relato de caso. Fisioter Pesq. v. 18, n. 2, p. 188-194, 2011.

Coordenadoria de Pesquisa e Extensão - COPEX

Departamento de Editoraçāo e Divulgaçāo Científica - DEDIC 


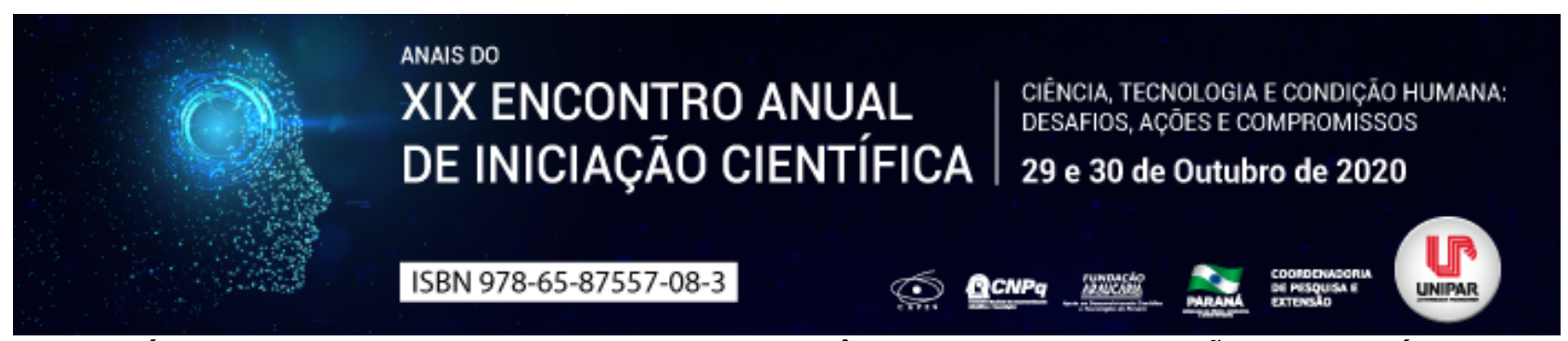

PRÓTESES BUCOMAXILOFACIAIS E SUA RELEVÂNCIA NA REINTEGRAÇÃO DO INDIVÍDUO

\title{
${ }^{1}$ KAROLINA FERNANDA ABEGG QUEIROZ, ${ }^{2}$ LETICIA NADAL
}

\author{
${ }^{1}$ Acadêmico do PIC/Unipar \\ ${ }^{1}$ Docente da UNIPAR
}

Introdução: Prótese, substituição artificial de uma parte perdida do organismo. A reabilitação de pacientes com alguma deformidade, independe da causa, que englobem cabeça, pescoço e partes constituintes do sistema estomatognático, desde 0 restabelecimento estético, de autoestima e reabilitações funcionais são dadas por próteses intra ou extra-orais, fixas ou móveis, pela especialidade de prótese bucomaxilofaciais. Entre os diversos aspectos envolvidos na reabilitação, os conhecimentos anatômicos orofaciais, a consideração dos aspectos psicológicos do indivíduo e o atendimento integrado multiprofissional devem ser desenvolvidos no decorrer de todos os planejamentos.

Objetivo: O objetivo desta revisão de literatura é exaltar a importância, vantagens e os benefícios das reabilitações bucomaxilofacias através das próteses.

Desenvolvimento: A face é o espelho da alma, sendo assim ultrapassa a questão humana do belo e do feio, e consoa com a concentração de funções atribuídas pela face, como a reflexão das emoções e todas os pontos funcionais (respiração, dicção, alimentação, audição, visão...). A necessidade de reabilitação por próteses bucomaxilosfaciais, independente se o fator etiológico deriva de traumas, más formações congênitas, excisão cirúrgica, tem significativo impacto na qualidade de vida dos pacientes (DIAS, 2016). Destes, além de limitações funcionais e/ou estéticas, muitos apresentam limitações de convívio social, afetivo, introspecção e outras condições de comorbidades psicológicas em decorrência da deformidade facial (SIMON, 2019). A tentativa de reestabelecer estruturas perdidas, por meios protéticos, mesmo que rudimentares, tem seus primeiros registros 2000 a.C., e grandes evoluções no decorrer das décadas, desde os materiais utilizados, as técnicas e variedades de próteses (GRAZIANI, 1982, SIMÕES, 2009). Rezende e Simões citam que houve expansão da área durante a Primeira Guerra Mundial, devido ao grande número de indivíduos mutilados, e os trabalhos no Brasil, iniciaram com Monteiro de Barros, após uma viagem para França, publicou Alta Prótese, o primeiro trabalho nacional nessa área. A reabilitação protética, vem se aperfeiçoando, visando maior biocompatibilidade e a maior naturalidade estética, para isso a associação de procedimentos cirúrgicos, técnicas de harmonização, osteointegração, e evolução no desenvolvimento de materiais como silicones e outros, tragam esperança os pacientes reabilitados. Como citado por Graziani e Simões, a gama de próteses gira de acordo com a extensão da área a ser reabilitada, modo de suporte/fixação, se são perdas intra orais ou externas, ósseas e/ou de tecido mole, dentre elas próteses de maxilas substituindo não somente os dentes também a parte óssea e gerando sustentação para os tecidos moles, as próteses obturadoras de fendas e comunicações, comumente associadas a maxila e as comunicações nasais e sinusais, as oculares, que visam substituir o globo ocular perdido, as auriculares que substituem o pavilhão auricular, as nasais que criam a substituição nasal após a rinectomia ou outra etiologia que causa a ausência do mesmo, entre outras próteses. Os processos para confecção das próteses são minuciosos e complexos, vão desde a avaliação criteriosa da condição da área a ser reabilitada, a real necessidade e impacto da reabilitação, exames complementares, condição psicológica, física e financeira, seleção da técnica de reabilitação, escolha do material, individualização dos processos de moldagem e produção, laboratório de escolha, montagem da equipe multidisciplinar que auxiliará o paciente (fonoaudiólogos, fisioterapeutas, médicos, dentistas) ao nível de satisfação e expectativas com o procedimento (GRAZIANI, 1982).

Conclusão: A importância de reabilitar o paciente como um todo, tendo uma visão multidisciplinar, traz consigo benefícios funcionais e melhora significativa na qualidade de vida desses pacientes. Reabilitando não só o estético, mas o funcional, devolvendo a sociedade um paciente com uma melhor autoestima e confiança. Assim a disseminação das próteses bucomaxilofaciais tendem a aumentar o conhecimento sobre as mesmas, tanto por profissionais da área da saúde, quanto por pacientes, assim popularizando/simplificando seu acesso. Mesmo sendo um desafio aos cirurgiões-dentistas, é um segmento que ressalta a evolução da ciência em prol do cuidar do próximo.

\section{Referências}

DIAS, Reinaldo Brito e; HERRERA, Luis Pablo; REIS, Ricardo César dos e COTO, Neide Pena. Contribuição da Prótese Bucomaxilofacial na internacionalização da Odontologia. Rev. Assoc. Paul. Cir. Dent. [online]. 2016, vol.70, n.2, pp. 122-125. ISSN 0004-5276.

GRAZIANI, Mario. Prótese Maxilo-facial. 3 ed. Rio de Janeiro, Guanabara Koogan, 1982.

RESENDE, José Roberto Vidulich de. Fundamentos da prótese buco-maxilo-facial. São Paulo: Sarvier, 1997.

SIMÕES, Fabiano Geronasso; REIS, Ricardo Cesar dos; BRITO e DIAS, Reinaldo de. A especialidade de prótese 
bucomaxilofacial e sua atuação na Odontologia RSBO. Revista Sul-Brasileira de Odontologia, Vol. 6, Núm. 3, septiembre, 2009, pp. 327-331

SIMON, Ingrid Gomes, BRUNEL, Luana Coelho. A reintegração psicossocial do paciente postador de prótese bucomaxilofacial. Tese (graduação) Cirurgião Dentista no curso de Odontologia da Universidade do Extremo Sul Catarinense UNESC Julho de 2019.

Coordenadoria de Pesquisa e Extensão - COPEX

Departamento de Editoraçāo e Divulgaçāo Científica - DEDIC 


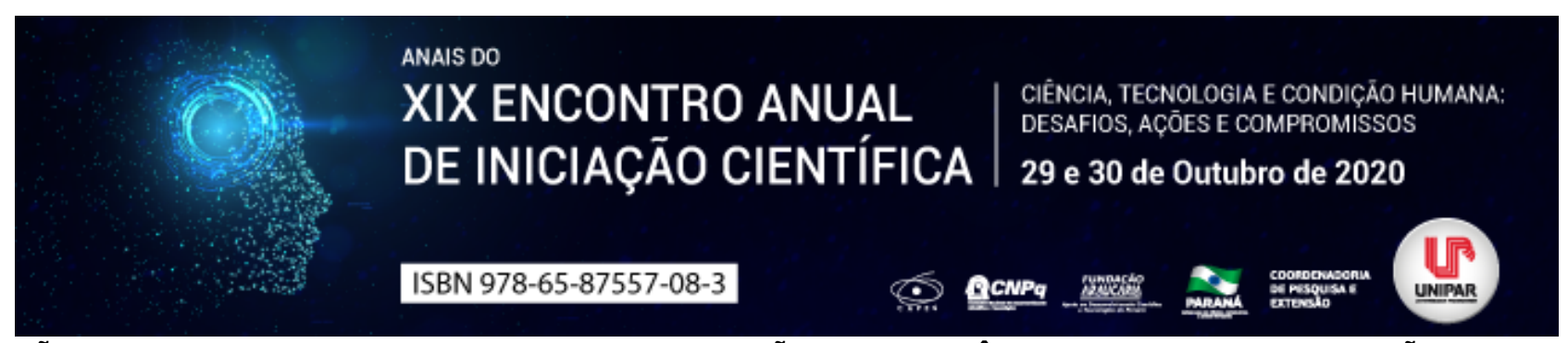

\title{
UTILIZAÇÃO DAS LIMAS XP-ENDO FINISHER E A IRRIGAÇÃO ULTRASSÔNICA PASSIVA NA REMOÇÃO DE HIDRÓXIDO DE CÁLCIO EM DENTES COM REABSORÇÃO RADICULAR INTERNA - ESTUDO DE REVISÃO
}

\author{
${ }^{1}$ SILVIA XAVIER GROSHEVIS, ${ }^{2}$ ELOISA MARIA ZANFRILLI, ${ }^{3}$ GABRIELI JANKE RIGHEZ, ${ }^{4}$ IGOR BUDI FERNANDES, ${ }^{5}$ TAIS \\ NUNES LOPES DA SILVA, ${ }^{6}$ SERGIO HENRIQUE STAUT BRUNINI
}

\author{
${ }^{1}$ Acadêmica do Curso de Odontologia da UNIPAR \\ ${ }^{1}$ Acadêmica do Curso de Odontologia da UNIPAR \\ ${ }^{2}$ Acadêmica do Curso de Odontologia da UNIPAR \\ ${ }^{3}$ Acadêmico do Curso de Odontologia da UNIPAR \\ ${ }^{4}$ Acadêmica do Curso de Odontologia da UNIPAR \\ ${ }^{5}$ Docente da UNIPAR
}

Introdução: A reabsorção radicular interna é tida como uma patologia, sua ocorrência se dá pela ação das células de degradação de tecido, conhecidas como células clásticas. Embora tenha etiologia controversa, o trauma dentário é o principal fator causal (PORTO e BARBOSA, 2018). O tratamento desta patologia é realizado com instrumentação endodôntica, e aplicação de um material que induz formação de tecidos mineralizados. O Hidróxido de cálcio é a medicação intracanal mais utilizada devido a sua ação antimicrobiana e capacidade de induzir formação de tecidos duros, no qual há dissociação química em íons de cálcio e hidroxila estimulando a mineralização e a elevação do pH (ZAND et al., 2017). No entanto, a remoção do hidróxido de cálcio do interior do canal é um desafio para os profissionais da odontologia, principalmente em áreas de irregularidades (ESTEVES, 2017). Para a remoção é envolvido vários tipos de irrigantes associados a instrumentação com limas endodônticas, porém as cavidades de reabsorção podem ser inacessíveis as instrumentações e irrigantes convencionais, e diferentes técnicas têm sido propostas para melhorar a capacidade de remover o hidróxido de cálcio de regiões mecanicamente inacessíveis dos canais radiculares com reabsorção interna (KÜÇÜKKAYA EREN et al., 2017). Dentre as varias técnicas, são empregadas as limas XP-Endo Finisher e a irrigação ultrassônica passiva para melhor acesso e remoção do hidróxido de cálcio do interior do canal radicular.

Objetivo: Discutir a eficácia de instrumentais utilizados na remoção de hidróxido de cálcio do interior do canal radicular em dentes com reabsorção interna.

Desenvolvimento: Quando a reabsorção interna é diagnosticada precocemente, o tratamento geralmente é bem-sucedido e o prognóstico a longo prazo é favorável (TOPÇUOĞLU et al., 2015). O principal objetivo do tratamento endodôntico é a eliminação dos microrganismos presentes no sistema de canais radiculares, através da limpeza e desinfecção química e mecânica dos mesmos, e posterior obturação com um material inerte (QUINTO, 2016). O medicamento intracanal que tem sido mais utilizado é o hidróxido de cálcio, devido a sua ampla finalidade como, estimular a apicificação, reparar perfurações, e prevenir reabsorções radiculares interna e externa, interrompendo o processo inflamatório, aumentando o pH do local e estimulando a mineralização (ZAND et al., 2017). Durante o tratamento das reabsorções radiculares internas, a irregularidade da cavidade cria desafios para a limpeza e obturação eficaz do espaço pulpar, desta forma, vários instrumentos e técnicas de ativação de irrigação foram desenvolvidos para remover hidróxido de cálcio do sistema de canais radiculares. (TOPÇUOĞLU et al., 2015; LAMBRIANIDIS et al., 2006). São vários os instrumentos utilizados, dentre eles está a lima XP-Endo Finisher produzidas com uma liga de níquel de titânio (NiTi). As limas de NiTi possui capacidade de expansão ao entrar em contato com a temperatura do canal radicular, são utilizadas após o preparo biomecânico, atuando como uma etapa final no protocolo de desinfecção dos canais, promovendo a agitação da solução irrigadora, aumentando seu poder de limpeza, remoção de raspas de dentina, e microrganismos em regiões onde o instrumental não consegue tocar. A irrigação ultrassônica passiva tem sido descrita como um excelente auxiliar no processo de limpeza final de canais radiculares, aumentando a eficiência de soluções irrigantes na remoção de debris, microrganismos e smear layer, melhorando a efetividade da limpeza do canal, favorecendo áreas que não foram limpas mecanicamente como é o caso das reabsorções radiculares internas(GALVANI, 2018).

Conclusão: Concluímos que o tratamento endodôntico de dentes com reabsorção radicular interna é de extrema complexidade, assim como a remoção de hidróxido de cálcio dos mesmos, e alguns métodos de irrigação devem fazer parte da rotina odontológica para a limpeza eficaz do canal promovendo sucesso no tratamento endodôntico.

\section{Referências}

GALVANI, Lucas David. Efeito da agitação mecânica do hipoclorito de sódio sobre a interface de adesão /do cimento endodôntico na dentina radicular. 2018. Dissertação (Mestrado em Odontologia) Faculdade de Odontologia de Araraquara da 
Universidade Estadual Paulista, Araraquara, 2018. Disponivel em: http://hdl.handle.net/11449/153771. Acesso em: 27 ago.2020. KÜÇÜKKAYA EREN, Selen; AKSEL, Hacer; PARASHOS, Peter. A novel model for testing the efficiency of removal of calcium hydroxide from complex root canal anatomies. Aust Endod J, v. 43, n. 1, p. 5-10, April, 2017. Disponível em: https://doi.org/10.1111/aej.12189. Acesso em: 27 ago. 2020.

LAMBRIANIDIS, T; KOSTI, E; BOUTSIOUKIS, C; MAZINIS, M. Removal efficacy of various calcium hydroxide/chlorhexidine medicaments from the root canal. Int Endod J, v. 39, n. 1, p. 55-61, Jan, 2006. DOI: 10.1111 / j.1365-2591.2005.01049.x. Disponível em: https://pubmed.ncbi.nlm.nih.gov/16409329/. Acesso em 27 ago. 2020.

PORTO, Elaine Lopes; BARBOSA, José Felinto. Reabsorção dentária: revisão de literatura. Revista Uningá Review, v. 24, n. 2, Jan., 2018. Disponível em: . Acesso em: 27 ago. 2020.

QUINTO, Inês Filipa Santos. Influência da lima XP-endo Finisher na remoção de resíduos e consequente selagem da obturação dos canais. 2016. Dissertação (Mestrado Integrado em Medicina Dentária) Faculdade de Medicina da Universidade de Coimbra, Coibra, 2016. Disponível em: http://hdl.handle.net/10316/35456. Acesso em: 27 ago.2020

TOPÇUOĞLU, HS; DÜZGÜN, S; SEYHANLI, KT; AKTI, A; PALA, K; KESIM, B. Efficacy of different irrigation techniques in the removal of calcium hydroxide from a simulated internal root resorption cavity. Int Endod J, v. 48, n. 4, p. 309-316, April, 2015.Doi: 10.1111 / iej.12316. Disponível em: https://pubmed.ncbi.nlm.nih.gov/24860966/. Acesso em: 27 ago.2020

ZAND, Vahid; MOKHTARI, Hadi; HASANI, Aila; JABBARI, Golchin. Comparison of the Penetration Depth of Conventional and Nano-Particle Calcium Hydroxide into Dentinal Tubules. Iran Endod J, v. 12, n. 3, p. 366, Summer, 2017. DOI: 10.22037 I iej.v12i3.16421. Disponível em: https://pubmed.ncbi.nlm.nih.gov/28808467/. Acesso em: 27 ago.2020. 


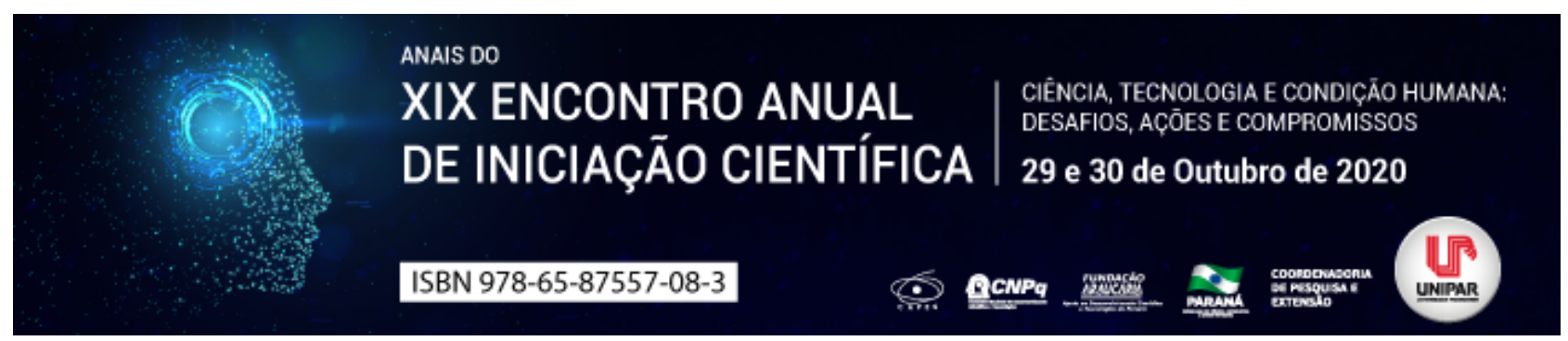

EFEITOS DO TREINAMENTO PARA A AMPLITUDE DE MOVIMENTO

\author{
${ }^{1}$ GLEICY KELLY THIEMY SATO, ${ }^{2}$ KLAUS KENZO KIYOHARA AGAWA, ${ }^{3}$ VIVYANNE MARIA MARYNOWSKI CONTI, ${ }^{4} \mathrm{JULIO}$ \\ CESAR MARTINS DA ROCHA, ${ }^{5}$ FERNANDO SERAFIM DA SILVA, ${ }^{6}$ MARCELO FIGUEIRO BALDI
}

\footnotetext{
${ }^{1}$ Acadêmico do Curso de Educação Física da UNIPAR

${ }^{1}$ Acadêmico do Curso de Educação Física da UNIPAR

${ }^{2}$ Acadêmica do Curso de Educação Física da UNIPAR

${ }^{3}$ Acadêmico do Curso de Educação Física da UNIPAR

${ }^{4}$ Acadêmico do Curso de Educação Física da UNIPAR

${ }^{5}$ Docente da UNIPAR
}

Introdução: O treino para amplitude de movimento é utilizado em modalidades que visam um melhor desempenho físico, neste contexto compreendemos a flexibilidade como um produto final que deve ser o resultado de treinos que aprimora a habilidade para mover uma ou mais articulações através de uma amplitude de movimento sem que haja dor muscular (COELHO, 2006). O alongamento pode reparar a musculatura e oferecer recuperação, atuando na prevenção de possíveis problemas posturais e tendinosos (HOULLIER; DAMIANO, 2001).

Objetivo: Discorrer sobre o alongamento e seus métodos, como parte do treinamento em todas as modalidades que visam um desempenho físico.

Desenvolvimento: De acordo Houllier e Damiano (2001) o alongamento é utilizado com o objetivos de ganho de amplitude de movimento articular, na evolução da cicatrização após uma lesão e no desempenho motor. Na fisiologia, ações excêntricas como os alongamentos em indivíduos não praticantes ou afastados dos exercícios provocam desconfortos, induzindo ao dano muscular e dor. Em um estudo indivíduos classificaram a dor muscular de 24 a $72 \mathrm{~h}$ depois do treino, a dor ocorria em virtude de exercícios excêntricos como o alongamento feito repetitivamente, a dor não se relacionava ao acúmulo de lactato e sim a dor muscular de início tardio a dor muscular neste sentido é beneficiada com o processo adaptativo que torna o músculo mais resistente (MCARDLE et al., 2017. p 547). O primeiro componente a ser alongado é o músculo, onde o alongamento pode ser classificado como passivo, levando a um relaxamento muscular, ativo dinâmico que é onde se utiliza a dinâmica de alongar e contrair e ativo passivo que representa um esgotamento do tecido muscular permitindo uma deformidade plástica nas miofibrilas. Durante o alongamento são utilizados também alguns componentes como o feixe conectivo, tendão, articulação, vasos sanguíneos e nervos. O material de Coelho (2006) relata ainda o que não deve ser feito como por exemplo, exercícios de alongamento sem o devido aquecimento, trações bruscas, rotações da coluna cervical, e exercícios de alongamento extremo que pode acarretar uma reação de defesa no corpo, alongar se antes de um exercício intenso (sprint, aceleração) pode tornar o treino menos eficaz, devido a tensão passiva no músculo. Sobre a organização cronológica do treinamento o preparo cardiorespiratório vem em $1^{\circ}$, exercício dinâmico em $2^{\circ}$ e o alongamento ativo em $3^{\circ}$ lugar e após isso as sessões específicas. Não só no treino o alongamento também é utilizado na manutenção de doenças como a fibromialgia que em um estudo, observou se que houve melhora na rigidez muscular e o sono (BRESSAN et al., 2008). Já na paralisia cerebral os exercícios de alongamento são utilizados para reabilitação no período de 2 vezes por dia para a melhora em aspectos como a higiene pessoal postura e alimentação (INTO, 2016).

Conclusão: Concluímos assim que o alongamento está diretamente ligado ao funcionamento morfológico ideal para a qualidade de vida, tanto na reabilitação quando no preparo físico de alto rendimento. Entender como o treino pode ser alocado, torna eficiente o seu propósito e pode atuar beneficamente com a manutenção e qualidade de vida.

\author{
Referências \\ MCARDLE, William D; KATCH, Frank L; KATCH, Victor L. Fisiologia Do Exercício Nutrição, Energia e Desempenho Humano. \\ Rio de Janeiro: Guanabara Koogan LTDA, 2017. \\ GEOFFROY, Chistophe; HOULLIER, G; FERRET, J. M. Alongamento para todos: Quando? Como? Por Quê? Rio de Janeiro: \\ Manole 2001. \\ COELHO, Luís Felipe Dos Santos. O TREINO DA FLEXIBILIDADE MUSCULAR E O AUMENTO DA AMPLITUDE DE \\ MOVIMENTO: UMA REVISÃO CRÍTICA DA LITERATURA. Revista de Desporto e Saúde da Fundação Técnica e Científica \\ do Desporto, Lisboa Portugal, julho. 2006. \\ BRESSAN LR, MATSUTANI LA, ASSUMPÇÃO A, MARQUES AP, CABRAL CMN. Efeitos do alongamento muscular e \\ condicionamento físico no tratamento fisioterápico de pacientes com fibromialgia. Rev Bras Fisioter, São Carlos, v. 12, n. 2, p.
}


88-93, mar./abr. 2008.

BRASIL, Rio de Janeiro. MANUAL DE ORIENTAÇÃO. Instituto Nacional de Traumatologia e Ortopedia. Edição 3, Maio de 2016.

Coordenadoria de Pesquisa e Extensão - COPEX

Departamento de Editoraçāo e Divulgaçāo Científica - DEDIC 


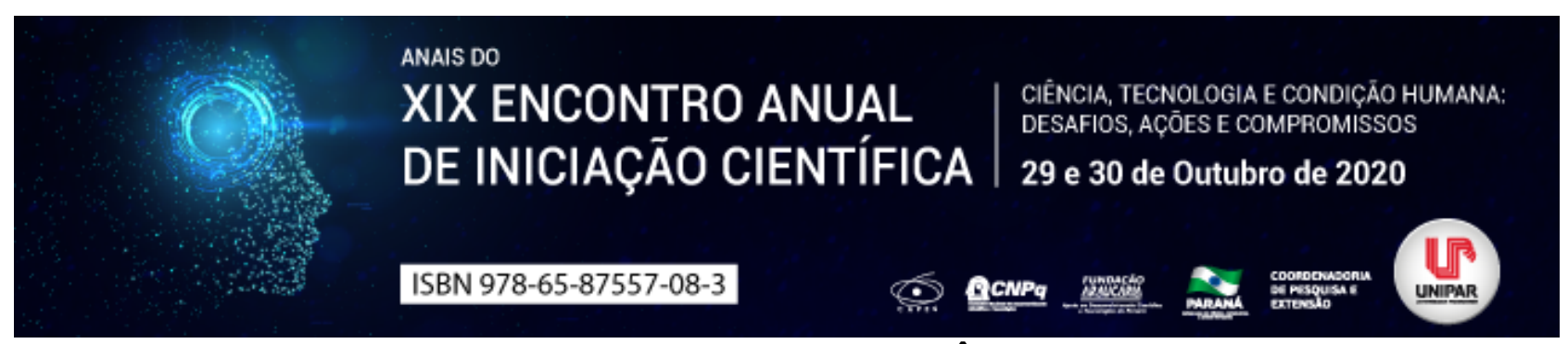

CAMOMILA E SEU USO TERAPÊUTICO

\author{
${ }^{1}$ MONICA MICHELI ALEXANDRE , ${ }^{2}$ FABIOLA COSTA TAKAKUA , ${ }^{3}$ LETICIA RODRIGUES GENARIO, ${ }^{4}$ MARIANE DE ALMEIDA \\ MACHADO, ${ }^{5}$ MARINA GIMENES
}

\author{
${ }^{1}$ Acadêmica do Curso de Medicina da UNIPAR \\ ${ }^{1}$ Acadêmica do Curso de Medicina da UNIPAR \\ ${ }^{2}$ Acadêmica do Curso de FarmÃ $\tilde{A}_{i}$ ia da UNIPAR

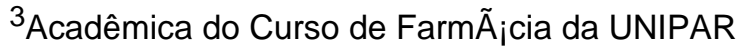 \\ ${ }^{4}$ Docente da UNIPAR
}

Introdução: As inflorescências secas da Matricaria recutita L., conhecida como Camomila está presente na maioria das casas, sendo usada suas flores em infusões, porém não só essas partes são utilizadas. Temos o extrato para tinturas as quais são de um vasto uso, sendo tradicional para fins medicinais. Seus efeitos curativos historicamente, são reconhecidos pela humanidade há mais de 2500 anos (ALMEIDA, 2011). Ainda na cosmética, ela pode ser utilizada como componente em xampus para clareamento dos cabelos. (ARRUDA et al., 2013). A Anvisa reconhece a camomila como medicamento e está incluída na lista de registro simplificado de fitoterápicos, ela possui duas formas farmacêuticas padronizadas as quais são: tintura (uso tópico), indicada como antiinflamatório, e o extrato (uso oral), indicado como antiespasmódico, em distúrbios digestivos e insônia leve (BRASIL, 2004).

Objetivo: Buscar na literatura estudos que mostram que a camomila está indicada nos distúrbios leves do sono.

Desenvolvimento: Usualmente, os medicamentos hipnóticos, em particular agonistas do receptor de benzodiazepínicos e terapia cognitivo-comportamental, são tratamentos de primeira linha para insônia crônica, os quais se incluem vários compostos fenólicos, principalmente os flavonóides apigenina, quercetina, patuletina, luteolina e seus glicosídeos (MCKAY; BLUMBERG, 2006). Um estudo foi realizado com idosos em Isfahan no Irã, no ano de 2014 com a camomila buscando efeitos de sedação, onde está mostrou-se ser eficaz na melhoria da qualidade do sono em idosos. Foi utilizado o extrato da camomila na qualidade do sono em idosos internados em casas de repouso, usando $400 \mathrm{mg}$ em cápsulas orais duas vezes ao dia, após o almoço e o jantar por 4 semanas, onde concluiu-se que a administração têm efeitos sedativos na qualidade do sono (MEHRDAD; SAYED, 2014). De acordo com Keefe et al. (2016), um estudo revela que $58,1 \%$ dos pacientes em tratamento da ansiedade com a camomila demonstrou uma boa aceitação, além de apresentar mínimos efeitos colaterais correspondente a dose total de 1500 mg/dia por um período de 8 semanas. Em 2002, uma entrevista feita pela Pesquisa Nacional de Entrevistas em Saúde dos Estados Unidos (National Health Interview Survey) relatou que 2,9\% de pacientes portadores de insônia equivalente a 1,05 milhões de pessoas, se beneficiam de terapias complementares, englobando o tratamento com plantas medicinais (LEACH; PAGE, 2015). Desse modo, podemos ver que a utilização de $1100 \mathrm{mg}$ diário de extrato de camomila oral em um estudo randomizado, duplo-cego, controlado por placebo na terapêutica ao transtorno de ansiedade generalizada denota ser uma alternativa a pacientes intolerantes ao tratamento convencional, revelando efeito sedativo razoável e uma melhor tolerância da camomila nos pacientes que apresentam alterações de ansiedade generalizada leve (AMSTERDAM et. al., 2009).

Conclusão: Embora os estudos da Camomila ainda sejam incipientes relacionados a qualidade do sono. Sabe-se que atualmente tem um número elevado de queixas de insônia, os quais relatam o uso de medicamentos controlados e pouco se ouve sobre a terapêutica com fitoterápicos para esses casos. Devido ao fato da insônia ser muito prevalente nos cuidados de saúde primários, e como a sociedade ainda é medicalizada, a busca pelos medicamentos alopáticos, inclusive sugerindo ao profissional a sua prescrição é uma constante nos consultórios médicos. Desta forma é de extrema relevância que se reconheça a importância dos fitoterápicos e que em especial a camomila possa fazer parte do arsenal inicial de insônias leves.

\title{
Referências
}

ALMEIDA, Mara Zélia de. Plantas medicinais / Mara Zélia de Almeida. - 3. ed. - Salvador: EDUFBA, 2011. 221 p.

AMSTERDAM, Jay. et.al. A randomized, double-blind, placebo-controlled trial of oral matricaria recutita (chamomile) extract therapy for generalized anxiety disorder. Journal of Clinical Psychopharmacology, v29, n.4, p. 378-382, ago. 2009. Disponível em: http://doi:10.1097/JCP.0b013e3181ac935c. Acesso em: 24 jul. 2020.

ARRUDA, Jalsi Tacon et al. Efeito do extrato aquoso de camomila (Chamomilla recutita L.) na prenhez de ratas e no desenvolvimento dos filhotes. Rev. Bras. Plantas Med., Botucatu, v.15, n.1, p. 66-71, 2013.

BRASIL. Ministério da Saúde. Agência Nacional de Vigilância Sanitária. Resolução (RE) n. ${ }^{\circ}$ 89, de 16 de março de 2004. Determina a publicação da Lista de Registro Simplificado de Fitoterápicos junto ao Sistema de Vigilância Sanitária. Diário Oficial 
da União, Brasília, mar. 2004. Seção 1.

KEEFE, Jonh. R., et al. Short-term open-label chamomile (Matricaria chamomilla L.) therapy of moderate to severe generalized anxiety disorder. Phytomedicine, v.23, n.14, p.1699 1705, dez. 2016.

LEACH, Matthew; PAGE, Amy. Herbal medicine for insomnia: A systematic review and meta-analysis Sleep Medicine Reviews. v.24, p. 01-12, dez. 2015. Disponível em: doi: 10.1016/j.smrv.2014.12.003. Acesso em: 24 jul. 2020.

MEHRDAD, Abdullahzadeh, SAYED, Ali Naji. The Effect of Matricaria Chamomilla on Sleep Quality of Elderly People Admitted to Nursing Homes. Iran Journal of Nursing.Iran, v.27, n.89, p. 69-79, agost. 2014. Disponível em: http://ijn.iums.ac.ir/article-1-1857en.html. Acesso em: 06 jul. 2020.

MCKAY, Diane L.; BLUMBERG, Jeffrey B. A review of the bioactivity and potential health benefits of chamomile tea (Matricaria recutita L.). Phytotherapy Research: An International Journal Devoted to Pharmacological and Toxicological Evaluation of Natural Product Derivatives, v. 20, n. 7, p. 519-530, 2006.

Coordenadoria de Pesquisa e Extensão - COPEX

Departamento de Editoraçāo e Divulgaçāo Científica - DEDIC 


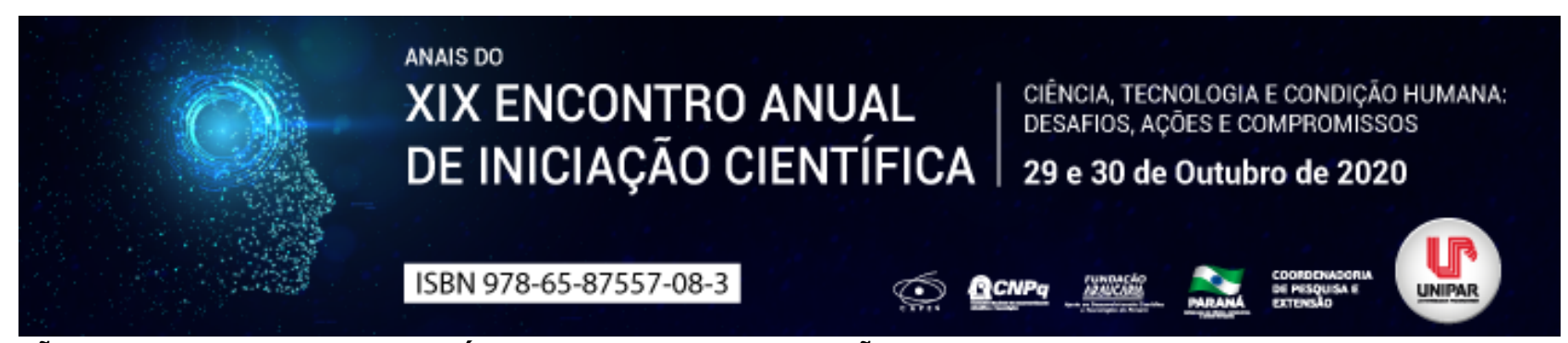

\title{
APLICAÇÃO DE RECURSOS TECNOLÓGICOS NA CLASSIFICAÇÃO DE PACIENTES E NO USO DOS PROFISSIONAIS DE ENFERMAGEM NAS UNIDADES
}

\section{${ }^{1}$ VITORIA TODERO ULIANA, ${ }^{2}$ RAFAELA DE OLIVEIRA FIRMINO, ${ }^{3}$ ARNALDO GOMES DO AMARAL}

\author{
${ }^{1}$ Acadêmica do curso de Enfermagem da Unipar \\ ${ }^{1}$ Acadêmica do Curso de Enfermagem da UNIPAR \\ ${ }^{2}$ Docente da UNIPAR
}

Introdução: Entre as áreas de atendimento no cuidado do paciente nas unidades de saúde, o serviço de urgência e emergência destaca-se como espaço particularmente importante e complexo, em conjunto com o avanço tecnológico a classificação e o tempo de espera do paciente foram reduzidos por meio da triagem e a classificação de risco. E assim determina a gravidade do quadro clínico do paciente. Antes deste avanço, os prontuários eram feitos em papéis nos quais algumas vantagens que se sobrepõem ao eletrônico, mas ainda sim contendo desvantagens. Com o avanço e a inserção da tecnologia na sociedade foi necessário a criação do prontuário eletrônico do paciente (PEP), para a agilidade, facilidade na prescrição médica, faturamento e estoque.

Objetivo: Apresentar aplicações de recursos tecnológicos na classificação e prontuários eletrônicos dos pacientes.

Desenvolvimento: Com os avanços tecnológicos na saúde, é possível fazer o Sistema de Triagem Manchester (STM), que é metodologia científica que tem por objetivo organizar a demanda de pacientes e colocar as urgências em primeiro lugar da fila de análise identificando as prioridades clínicas antes da avaliação médica. (MASSAD; MARIN; AZEVEDO NETO, 2003). Os objetivos da triagem ou da classificação de risco são: Identificar rapidamente os pacientes em situação de risco de morte, informar aos pacientes e famílias o tipo de serviço de que necessita e o tempo estimado de espera, reduzir o congestionamento nas áreas de tratamento do serviço de emergência, para melhoria do fluxo de pacientes. (COUTINHO; CECÍLIO; MOTA, 2012). Já há alguns anos, o prontuário eletrônico também tem ajudado profissionais da saúde e pacientes a compartilhar e gerenciar as informações em tempo real. (FIGUEROA, 2018). O prontuário do paciente foi desenvolvido por médicos e enfermeiros para garantir que se lembrassem de forma sistemática dos fatos eventos clínicos sobre cada indivíduo de forma que todos os demais profissionais envolvidos no processo de atenção de saúde poderiam também ter as mesma informações (SLEE, SLEE e SCHMIDT, 2000 apud PELISARIA; PALHARES, 2015). Desde de o atendimento ao diagnóstico, um dos pontos fortes de sua utilização é o fornecimento de laudos online. E a cada consulta, as informações se tornam um agrupamento, onde a disponibilidade do acesso ao (PEP), se tornou fundamental pois sempre à disposição dos profissionais de saúde, para facilitar a organização destes dados e integrá-los a gestão das unidades que utilizam, existem softwares de prontuário eletrônico que fornecem dados como o número de consultas realizadas, exames entre outras opções da instituição.

Conclusão: Com a adoção de protocolos é capaz de priorizar os atendimentos, diminuindo o tempo de espera e, consequentemente, o risco de deterioração dos pacientes. Dentre os protocolos de classificação de risco existentes destaca-se o Sistema de Triagem de Manchester (STM) (COMO FUNCIONA, 2020), que é um sistema de gerenciamento de risco clínico implementado em todo o mundo para gerenciar fluxo de paciente com segurança, quando a necessidade exceder a capacidade. E junto com a informatização dos prontuários eletrônicos, podemos acessar informações fundamentais dos atendimentos anteriores, e este benefício permite que o usuário acompanhe todas as ações que envolvem o doente e faz com que as tarefas sejam distribuídas automaticamente, como, consulta aos dados dos pacientes e interação entre as equipes com eficiência no atendimento de urgência.

\section{Referências}

FIGUEROA, Rafael. Avanços tecnológicos na saúde: quais soluções aplicar. Portal Telemedicina. 2018. Disponível em: http://gg.gg/lgern. Acesso em 14/07/2020.

como funciona o Sistema de Triagem de Manchester na Emergência?. 2020. Disponível em: https://www.accamargo.org.br/pacientes-acompanhantes/como-funciona-o-siste ma-de-triagem-de-manchester-na-emergencia. Acesso em 14/07/2020.

COUTINHO, Ana Augusta Pires; CECÍLIO, Luiz Carlos de Oliveira; MOTA, Joaquim Antônio César. Classificação de risco em serviços de emergência: uma discussão da literatura sobre o Sistema de Triagem de Manchester. Revista Medica de Minas

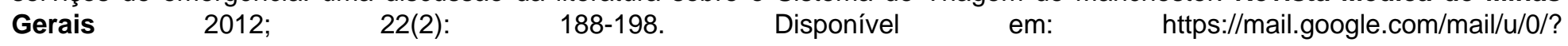
tab=rm\&ogbl\#inbox/FMfcgxwJXLfpcSKVMHzzxVLXCIPmWPId?projector=1\&messagePartld=0.2. Acesso em 14 ago 2020.

COSTA, Claudio Giulliano Alves da. Desenvolvimento e Avaliação Tecnológica de um Sistema de Prontuário Eletrônico do Paciente, Baseado nos Paradigmas da World Wide Web e da Engenharia de Software. Dissertação de Mestrado em 
Engenharia Elétrica. Faculdade de Engenharia Elétrica e de Computação da Universidade Estadual de Campina. 2001. Campinas. São Paulo. Disponível em: https://mail.google.com/mail/u/0/?tab=wm\&ogbl\#inbox/FMfcgxwJXLfpcSKVMHzzxvL XCIPmWPId?projector=1\&messagePartld=0.3. Acesso em 14 ago 2020.

EMPREGO DO SISTEMA DE TRIAGEM DE MANCHESTER NA ESTRATIFICAÇÃO DE RISCO: REVISÃO DE LITERATURA: Disponível em: https://mail.google.com/mail/u/0/?tab=rm\&ogbl\#inbox/FMfcgxwJXLfpcSKVMHzzXVLX ClPmWPId? projector=1\&messagePartld=0.1. Acesso em 14 ago 2020.

MASSAD, Eduardo; MARIN, Heimar de Fátima; AZEVEDO NETO, Raymundo Soares de [ed]. O Prontuário Eletrônico Do Paciente Na Assistência, Informação E Conhecimento Médico. São Paulo: H. de F. Marin, 2003. Disponível em: http://www.sbis.org.br/biblioteca_virtual/prontuario.pdf. Acesso em 14 ago 2020.

PELISARIA, Débora Cristina; PALHARES, Marina Silveira. 0 registro da intervenção no prontuário pelo terapeuta ocupacional em um ambulatório infantojuvenil. Associação de Capacitação, Orientação e Desenvolvimento do Excepcional ACORDE, São Carlos, SP, Brasil. Universidade Federal de São Carlos - UFSCar, São Carlos, SP, Brasil. 2015. Disponível em: http://doi.editoracubo.com.br/10.4322/0104-4931.ctoAO0497.Acesso em 14 ago 2020. 


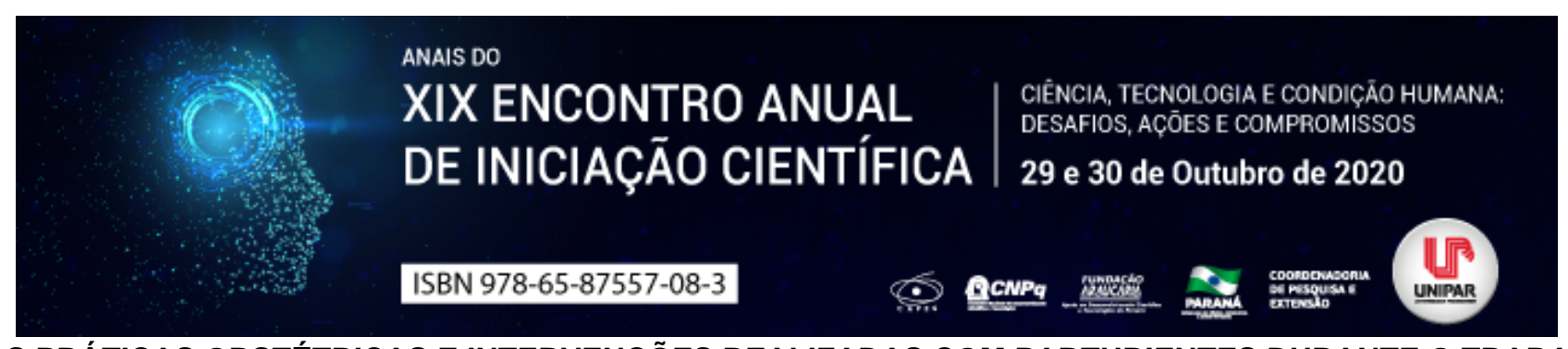

\title{
AS BOAS PRÁTICAS OBSTÉTRICAS E INTERVENÇÕES REALIZADAS COM PARTURIENTES DURANTE O TRABALHO DE PARTO
}

\author{
${ }^{1}$ KETLIN MARGARIDA WARMLING, ${ }^{2}$ THALIA DAL CERO, ${ }^{3}$ FRANCIELE DO NASCIMENTO SANTOS ZONTA, ${ }^{4}$ JOLANA \\ CRISTINA CAVALHEIRI, ${ }^{5}$ LEDIANA DALLA COSTA
}

\author{
${ }^{1}$ Acadêmica do PIC/UNIPAR \\ ${ }^{1}$ Acadêmica do Curso de Enfermagem da UNIPAR \\ ${ }^{2}$ Docente da UNIPAR \\ ${ }^{3}$ Docente da UNIPAR \\ ${ }^{4}$ Docente da UNIPAR
}

Introdução: O parto hospitalar, atualmente, configura-se pelo uso de técnicas e mecanismos que visam maior segurança ao atendimento prestado. É evidente que a evolução da obstetrícia no cenário brasileiro contribuiu positivamente com os índices de morbimortalidade materna e perinatal (BRASIL, 2017). Dessa forma, destaca-se o papel dos enfermeiros obstetras que aderem e disseminam as boas práticas, para maior qualidade e efetividade da assistência, e ainda buscam reduzir significativamente 0 número de cesarianas e intervenções realizadas (FEIJÃO; BOECKMANN; MELO, 2017).

Objetivo: Analisar as intervenções e adesão às boas práticas obstétricas no parto vaginal e parto cesárea.

Material e Métodos: Trata-se de uma pesquisa descritiva, com abordagem quantitativa de caráter transversal. Obtida através de entrevistas utilizando questionário. A amostra foi constituída por 207 puérperas que tiveram o desfecho do parto em duas maternidades referências do Paraná. As participantes assinaram o termo de consentimento livre e esclarecido (TCLE). Os dados coletados foram transferidos para uma planilha do Excel, e posteriormente submetidos à análise estatística descritiva. A pesquisa foi aprovada pelo Comitê de Ética em Pesquisas Envolvendo Seres Humanos da Universidade Paranaense sob o parecer $\mathrm{n}^{\circ}$ 3.364.970/2019.

Resultados: Observou-se que as boas práticas obstétricas foram adotas pelos profissionais significativamente no parto vaginal, sendo que $71,9 \%$ das pacientes receberam orientações sobre formas de relaxamento para alívio da dor, $73,7 \%$ delas usufruíram de técnicas não farmacológicas para alívio da dor e 70,2\% delas não permaneceu a maior parte do tempo no leito durante o trabalho de parto. Entre as participantes, $78,9 \%$ foram estimuladas a deambular e mudar de posição. Entretanto, quanto às técnicas e intervenções para alívio da dor e auxilio na estimulação ao parto normal, 59,6\% destas mulheres não receberam massagens para alívio da dor, $78,9 \%$ não deambularam na maior parte do período de trabalho de parto e apenas $75,4 \%$ tomaram banho quente. Já nos casos de parto cesárea, $78,7 \%$ das pacientes não receberam orientações sobre formas de relaxamento para alívio da dor, $86,0 \%$ delas não obtiveram técnicas não farmacológicas para alívio da dor e $76,7 \%$ delas permaneceram a maior parte do tempo no leito durante o trabalho de parto. Entre as participantes, $79,3 \%$ não foram estimuladas a deambular e mudar de posição. Em relação às técnicas e intervenções para alívio da dor e auxilio na estimulação ao parto normal, $87,3 \%$ destas mulheres não receberam massagens para alívio da dor, 98,0\% não deambularam na maior parte do período de trabalho de parto e $96,0 \%$ tomaram banho quente.

Discussão: Neste estudo, destaca-se que as boas práticas obstétricas de um modo geral foram mais empregadas no parto normal, conforme as recomendações atuais do Ministério da Saúde que preconiza a utilização de técnicas baseadas em evidências científicas, pois as mesmas melhoram a qualidade da assistência durante o parto, com a utilização de práticas para alívio à dor, métodos não farmacológicos e procedimentos de massagens relaxantes, além de banhos terapêuticos, áudioanalgesia e aromaterapia (MS, 2017). Diante do exposto, no presente estudo evidencia-se que as mulheres que realizaram parto vaginal foram mais orientadas sobre formas de relaxamento para alívio da dor representando $71,9 \%$, em contrapartida no parto cesariano 78,7\% não receberam orientações sobre a técnica, sendo assim, Rocha et al., 2015 salienta que para a realização de uma assistência de forma humanizada, os enfermeiros devem valorizar a mulher, estimulando o protagonismo das gestantes, dando apoio, respeitando crenças e valores, com compreensão e boa comunicação. Sobre as técnicas não farmacológicas, houve predominância no parto vaginal apresentando 73,7\%, corroborando com as Diretrizes Nacionais de Assistência ao Parto Normal que destaca que sempre que possível devem ser oferecido à mulher técnicas não farmacológicas para o alivio da dor, como imersão em água e massagem. Ainda, verificasse que durante o trabalho de parto permaneceu maior tempo no leito $76,7 \%$, sem caminhar e mudar de posição $73,3 \%$ das gestantes que realizaram parto cesariano, ao contrario do parto normal que $70,2 \%$ não foram mantidas no leito e $78,9 \%$ encorajadas a caminhar e mudar de posição, corroborando com o estudo de Sousa et al., 2016 que afirma que durante o período de expulsão as mulheres devem ter liberdade de posição e movimentação, com presença de acompanhante. Cabe ressaltar ainda, que em ambos os partos, as gestantes não foram submetidas a práticas como 
massagem, caminhada e chuveiro, confrontando com as Diretrizes, que destaca que toda gestante tem direito de um parto humanizado e de qualidade, o qual incentive suas decisões e escolhas (MS, 2017).

Conclusão: Portanto, tornasse fundamental, melhorar a qualidade da assistência ao parto e nascimento, incentivando a equipe multidisciplinar sobre a importância do uso de práticas evidenciadas em bases científicas, além disso, estimular o protagonismo das gestantes, para buscarem seus desejos e suas decisões.

\section{Referências}

BRASIL. Ministério da Saúde. Secretária de Ciência, Tecnologia e Insumos Estratégicos, Departamento de Gestão e Incorporação de Tecnologias em Saúde. Diretrizes Nacionais de Assistência ao Parto Normal. Brasília: Ministério da Saúde; 2017. Disponível em: http://bvsms.saude.gov.br/bvs/publicacoes/diretrizes_nacionais_assistencia_parto_normal.pdf. Acesso em: 18 agost. 2020.

FEIJÃO, L. B. V.; BOECKMANN, L. M. M.; MELO, M. C. Conhecimento de enfermeiras residentes acerca das boas práticas na atenção ao parto. Rev Enferm Foco, v.8, n.3, p.35-9, 2017.

MS - Ministério da Saúde (BR). Secretaria de Ciência, Tecnologia e Insumos Estratégicos. Departamento de Gestão e Incorporação de Tecnologias em Saúde. Diretrizes nacionais de assistência ao parto normal. Brasília. 2017.

ROCHA, F. A. A. et al. Cuidado no parto e nascimento: percepção de puérperas. Rev. Rene, v.16, n.6, 2015.

SOUSA, A. M. M.; SOUZA, K. V.; REZENDE, E. M. et al. Práticas na assistência ao parto em maternidades com inserção de enfermeiras obstétricas, em Belo Horizonte, Minas Gerais. Esc. Anna Nery, v.20, n.2, p.324-331, 2016. 


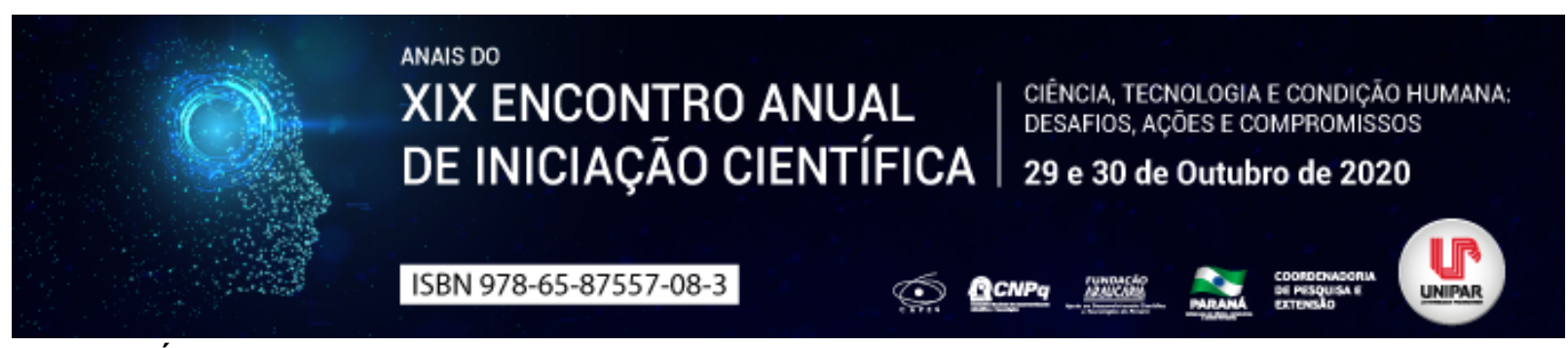

\title{
ANÁLISE DO CARÁTER DE ATENDIMENTO POR TRANSTORNOS MENTAIS E COMPORTAMENTAIS DEVIDO AO USO DE ÁLCOOL NAS REGIÕES DO BRASIL
}

\author{
${ }^{1}$ Denise Tiemi Uchida, ${ }^{2}$ TANIA HARUMI UCHIDA, ${ }^{3}$ MIGUEL MACHINSKI JUNIOR \\ ${ }^{1}$ Discente (mestrado) de Pós Graduação em Ciências da Saúde, UEM, Maringá - Paraná \\ ${ }^{1}$ Docente da UNIPAR \\ 2Docente Associado da Universidade Estadual de Maringá, UEM, Maringá - Paraná
}

Introdução: O relatório divulgado pela Organização das Nações Unidas evidenciou aumento no consumo de álcool e que seu consumo abusivo está diretamente ligado a metade dos casos de violência doméstica no mundo, além de casos de violência física, depressão, ao uso de outras drogas e está ligado a 15\% das mortes no trânsito no mundo inteiro (WHO, 2014). Em 2016, o brasileiro chegou a um consumo de 8,9 litros de álcool per capita, superando o consumo per capita da média mundial (WHO, 2018; BRASIL, 2017).

Objetivo: Analisar o caráter de atendimento por transtornos mentais e comportamentais devido ao uso de álcool nas regiões do Brasil, no período de 2015 a 2019.

Material e Métodos: Trata-se de um estudo transversal e ecológico. Os dados secundários foram obtidos no Sistema de Informações Hospitalares do Sistema Único de Saúde (SIH-SUS) fornecida no sítio eletrônico do Departamento de Informática do SUS (DATASUS), no período de 2015 a 2019. Foram analisados os dados referentes à lista de morbidade CID-10: transtorno mental e comportamental devido ao uso de álcool e como variável independente foi utilizado o caráter do atendimento por regiões do Brasil. Neste estudo foram excluídos os dados de paciente com idade menor ou igual a 15 anos. Para a análise dos dados foram calculadas as taxas de incidência por 100.000 habitantes e o tamanho da população residente usado no calculo da taxa de incidência foi aquele informado no sítio eletrônico do DATASUS, proveniente do Censo realizado pelo Instituto Brasileiro de Geografia e Estatística (IBGE).

Resultados: Ao analisar o banco de dados no período de 2015 a 2019 observamos que em todas as regiões do Brasil o caráter de atendimento por transtornos mentais e comportamentais devido ao uso de álcool foram na forma eletiva ou de urgência. Comparando todas as regiões do Brasil, o atendimento de urgência apresentou as maiores taxas de incidência e as regiões sul (45,44) e centrooeste $(17,93)$ foram as que mais apresentaram esse tipo de atendimento, sendo importante ressaltar, que no período de 2015 a 2019 , a região sul apresentou uma taxa de atendimento de urgência decrescente, com valores de 52,51 (2015); 47,6 (2016); 46,41 (2017); 43,18 (2018) e 37,48 (2019). Quanto as regiões que apresentaram as menores taxas no atendimento de urgência, as regiões sudeste, nordeste e norte apresentaram de 11,57; 8,88 e 1,94, respectivamente.

Discussão: A implantação de centros de atenção psicossocial (CAPS) foi uma grande conquista para população, no entanto a consolidação desta rede apresenta alguns desafios como dificuldade de acesso, falta de estabelecimento de políticas e práticas intersetoriais e a inconsistência da integralidade do cuidado que pode estar associado com as baixas taxas no atendimento de urgência nas regiões norte e nordeste (ALMEIDA; FUREGATO, 2015). Os resultados mostram que as taxas de atendimento de urgência teve caráter decrescente em todas as regiões do país, indicando o efeito positivo da reforma psiquiátrica impulsionada por diversas legislações que apoiaram o fechamento de grandes hospitais psiquiátricos e sua substituição por leitos hospitalares gerais, redirecionando os investimentos feitos pelo Sistema Único de Saúde (SUS) para serviços extra hospitalares voltadas para comunidade (DUARTE; GARCIA, 2013). No entanto, considerando que o álcool é a droga mais utilizada e que seu uso concomitante com outras drogas é comum e cada vez mais precoce na população, como demonstra estudos feitos por Garcia; Freitas (2013) e Silva et al. (2017), destacamos o viés da subnotificação, uma vez que o caráter do atendimento por transtorno mental e comportamental devido ao uso de álcool pode ter sido notificado para outro tipo de transtorno mental e comportamental.

Conclusão: No período analisado o atendimento por transtornos mentais e comportamentais mais prevalente devido ao uso de álcool foi o de caráter de urgência.

\section{Referências}

ALMEIDA, Aline Siqueira; FUREGATO, Antonia Regina Ferreira. Papéis e perfil dos profissionais que atuam nos serviços de saúde mental. Revista de Enfermagem e Atenção Saúde, v. 4, n.1, p. 79-88, jan/jun 2015.

BRASIL. Ministério da Saúde. Fundação Oswaldo Cruz. (2017). III Levantamento nacional sobre uso de drogas pela população brasileira. Rio de Janeiro: Fundação Oswaldo Cruz.

DUARTE, Silvia Louzada; GARCIA, Maria Lucia Teixeira. Reforma psiquiátrica: trajetória de redução dos leitos psiquiátricos no Brasil. Emancipação, v. 13, n. 1, p. 39-54, 2013.

GARCIA, Leila Posenato; FREITAS, Lucia Rolim Santana. Consumo abusivo de álcool no Brasil: resultados da pesquisa nacional de saúde. Epidemiologia e Serviços da Saúde [online], v. 24, n.2, p. 227-237, 2013. Disponível em: http://scielo.iec.gov.br/scielo.php? script=sci_abstract\&pid=S1679-49742015000200005\&lng=pt\&nrm=iso

SILVA, Daniela Luciana Silva; TORREZAN, Maira Bianquin; COSTA, Jonathan Vinicius; GARCIA, Ana Paula Rigon Francischetti; TOLEDO, Vanessa Pellegrino. Perfil sóciodemográfico e epidemiológico dos usuários de um centro de atenção psicossocial álcool e drogas. Revista de Enfermagem e Atenção Saúde [Online], v.6, n. 1, p. 67-79, Jan/Jun $2017 . \quad$ Disponível em: 
http://seer.uftm.edu.br/revistaeletronica/index.php/enfer/article/view/1659

World Health Organization (WHO). Global status report on alcohol and health 2014ed. Geneva: WHO; 2014 [acessado em 20 de agosto de 2020].

Disponível

em: https://apps.who.int/iris/bitstream/handle/10665/112736/9789240692763_eng.pdf;jsessionid=3CF819AE2C7603F76AA6A56854F0CAE8? sequence=1

World Health Organization (WHO). Global status report on alcohol and health 2018ed. Geneva: WHO; 2018 [acessado em 20 de agosto de 2020]. Disponível em: https://www.who.int/substance_abuse/publications/global_alcohol_report/en/

Coordenadoria de Pesquisa e Extensão - COPEX

Departamento de Editoraçāo e Divulgaçāo Científica - DEDIC 


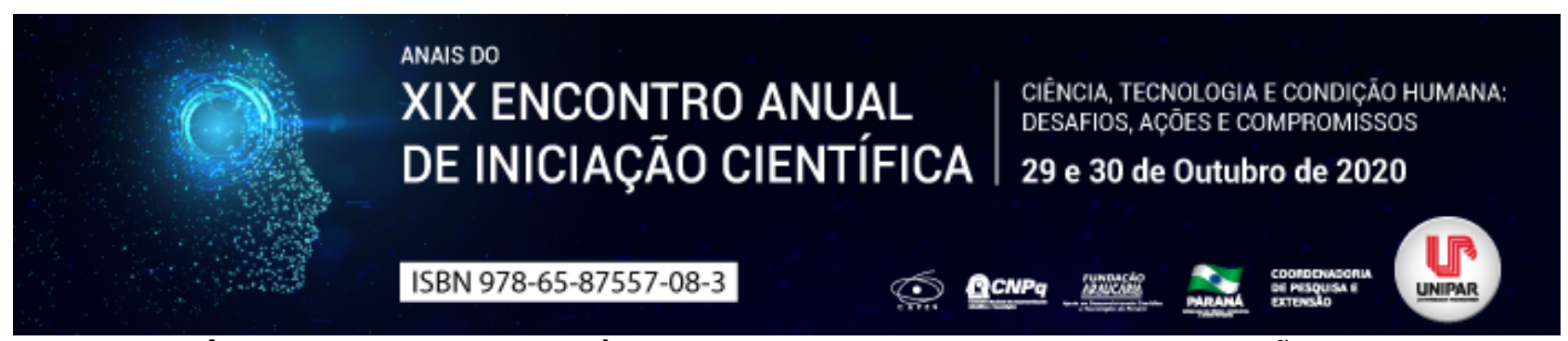

ASSISTÊNCIA DE ENFERMAGEM À GESTANTES PORTADORA DE HIPERTENSÃO ARTERIAL

\author{
${ }^{1}$ MARIA LUIZA CAVAZANI, ${ }^{2}$ DAIANE CORTEZ RAIMONDI
}

${ }^{1}$ Acadêmica do curso de Enfermagem - UNIPAR

${ }^{1}$ Docente da UNIPAR

Introdução: A hipertensão arterial (HA) durante a gestação é uma das principais causas de mortalidade materna no Brasil, tornando-se um grave problema de saúde pública (BRASIL, 2020), é caracterizada pela pressão arterial $\geq 140 \times 90 \mathrm{mmHg}$, sendo a aferição realizada com a gestante sentada ou em decúbito horizontal após repouso de ao menos cinco minutos (PARANÁ, 2018). Cabe mencionar que a doença hipertensiva específica da gravidez (DHEG) é definida pela presença de hipertensão arterial, proteinúria significante e/ou edema de face e mãos após a 20a semana gestacional, podendo ser classificada em préeclâmpsia leve, grave e eclampsia (PARANÁ, 2018). No Paraná foi implantado o Programa Rede Mãe Paranaense a fim de organizar a assistência materno-infantil reduzindo as taxas de morbimortalidade materna e neonatal, assim atualmente é realizado a estratificação de risco das gestantes em todas as consultas de pré-natal, no qual o diagnóstico de HA ou DHEG classifica a gestante como de alto risco, sendo necessário a realização concomitante do pré-natal na unidade de saúde e no centro de referência materno infantil a fim de ofertar uma assistência integral e de qualidade, visando um desfecho favorável a mãe e ao bebê (PARANÁ, 2017). Nesse contexto, vale mencionar a assistência de enfermagem como essencial no cuidado integral a gestante, sensibilizando sobre a importância da adesão a consulta de pré-natal, realização de exames, bem como hábitos de vida saudáveis (DIAS et al, 2018).

Objetivo: Descrever sobre a importância da assistência de enfermagem à gestante portadora de hipertensão arterial e/ou doença hipertensiva específica da gravidez.

Desenvolvimento: Visto que a DHEG e as hemorragias são as principais causas de mortalidade materna (PARANÁ, 2017) e considerando que a ocorrência de descolamento de placenta, edema cerebral e pulmonar, parto prematuro, baixo peso ao nascer, crise hipertensiva, retardo de crescimento intra-útero entre outras são complicações advindas da DHEG, é fundamental que os profissionais de saúde, como o enfermeiro estejam capacitados para realizar assistência integral e de qualidade, baseada nas evidências científicas, visando a promoção da saúde da mãe e do bebê e consequentemente reduzindo as taxas de morbimortalidade (SANTOS; NETO, 2016). O papel do enfermeiro é fazer intervenções em nível primário, secundário e terciário, desde a prevenção e identificação precoce da hipertensão durante a gravidez, como a realização de intervenções adequadas que possam reduzir complicações (LOPES et al 2013). Para isto, é de suma importância que o enfermeiro crie vínculo com a gestante e acolha a mesma nas consultas de pré-natal, favorecendo assim a construção do conhecimento e a sensibilização da gestante ao cuidado, realização de exames e comparecimento às consultas (DIAS et al, 2018). Cabe ao enfermeiro realizar a estratificação de risco desde a primeira consulta de pré-natal, observar e identificar possíveis fatores de risco e intervir positivamente para reduzir estes fatores e minimizar possíveis complicações, realizar os encaminhamentos necessários e orientar a gestante sobre a rotina de pré-natal para uma gravidez e parto saudáveis (SANTOS; NETO, 2016). Quando diagnosticada com HA e/ou DHEG cabe ao profissional enfermeiro elaborar plano de cuidados e sensibilizar a gestante sobre a necessidade de mudança de hábitos, como alimentação adequada com baixa ingesta de sódio, aumento da ingesta hídrica, realização de atividades físicas, São inúmeros os cuidados de enfermagem que devem ser prestados a essas gestantes, entre eles a identificação do nível de ansiedade, aferição da pressão arterial, orientações, avaliação e estabilização antes do parto estabelecendo um quadro clínico materno fetal estável (SAMPAIO et al 2013). Constata-se que a enfermagem possui um papel importante e fundamental na prevenção e controle dos sintomas no período gestacional, contribuindo juntamente com a equipe multidisciplinar ao equilíbrio e o bem estar materno e fetal (LOPES et al 2013).

Conclusão: Constata-se que os enfermeiros possuem competência e habilidade para atuar efetivamente no pré-natal de gestantes diagnosticadas com HA e/ou DHEG, identificando precocemente os riscos e intervindo positivamente na saúde do binômio mãe-bebê. Assim, reforça-se que este é um profissional essencial para promoção de um ciclo gravídico-puerperal saudável.

\title{
Referências
}

BRASIL. DATASUS Departamento de Informática do Sistema Único de Saúde. Óbitos maternos segundo categoria CID 10. 2020. Disponível em: http://tabnet.datasus.gov.br/cgi/tabcgi.exe?sim/cnv/mat10uf.def. Acesso em 16 agos. 2020.

DIAS, E. G. et al. Ações do enfermeiro no pré-natal e a importância atribuída pelas gestantes. Revista SUSTINERE, Rio de Janeiro, v.6, n.1, p. 52-62, jan-jun 2018.

LOPES, G.T et al. Hipertensão gestacional e síndrome de hellp: ênfase nos cuidados de enfermagem. Revista Augustus v.18, 
n.36, p.77-89, jul./dez. 2013.

PARANÁ. Secretaria Estadual de Saúde SESA PR. Linha Guia Rede Mãe Paranaense. Curitiba: 2017.

PARANÁ. Secretaria Estadual de Saúde SESA PR. Caderno de atenção ao pré-natal de alto risco. Curitiba: 2018.

SANTOS, J. O. S.; NETO, T. P. A. Atuação do enfermeiro na redução da ocorrência da pré-eclâmpsia: Uma revisão integrativa. Revista Científica da FASETE, v.1, 166-188, 2016.

SAMPAIO T. A. F. et al. Cuidados de enfermagem prestados a mulheres com hipertensão gestacional e pré-eclâmpsia. Revista saúde e física e mental UNIABE, v.2 n.1 Janeiro - Julho 2013.

Coordenadoria de Pesquisa e Extensão - COPEX

Departamento de Editoraçāo e Divulgaçāo Científica - DEDIC 


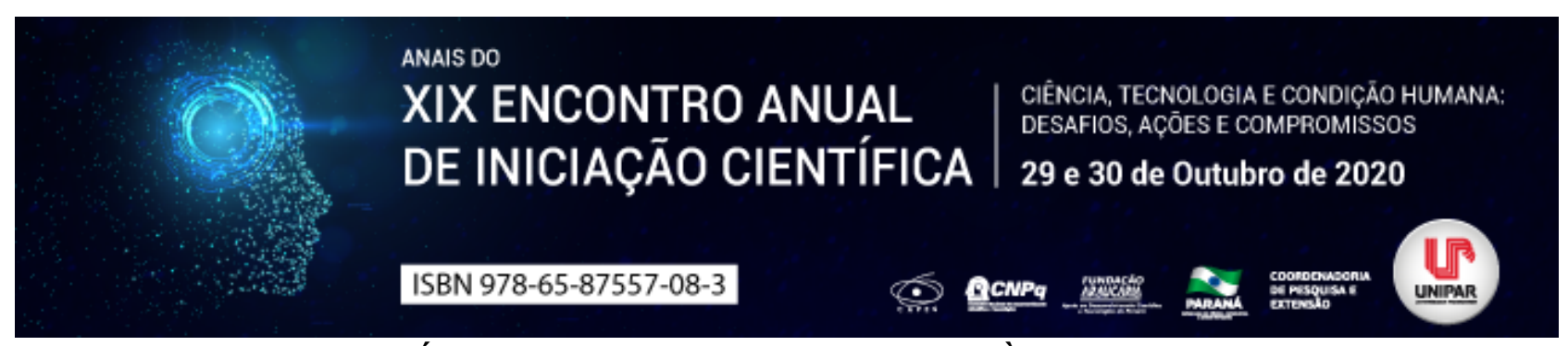

CUIDADOS ODONTOLÓGICOS EM PACIENTES PROPENSOS À ENDOCARDITE BACTERIANA

\begin{abstract}
${ }^{1}$ ADRIELLY SANTOS MEDEIROS, ${ }^{2}$ JENNIFER LORENSINI DOS SANTOS, ${ }^{3}$ JENIFFER URBANO DEGASPERI, ${ }^{4}$ KATYELI REGINA BOUFLEUHER FOLTZ, ${ }^{5}$ LETICIA NADAL
\end{abstract}

\author{
${ }^{1}$ Acadêmica do Curso de Odontologia da UNIPAR \\ ${ }^{1}$ Acadêmica do Curso de Odontologia da UNIPAR \\ ${ }^{2}$ Acadêmica do Curso de Odontologia da UNIPAR \\ ${ }^{3}$ Acadêmica do Curso de Odontologia da UNIPAR \\ ${ }^{4}$ Docente da UNIPAR
}

Introdução: A Endocardite Bacteriana (EB) é uma doença considerada rara e de morbimortalidade alta, decorrente da invasão de agentes infecciosos nas superfícies endocárdicas e valvulares. Normalmente, o revestimento epitelial do endocárdio é resistente a lesões infecciosas, porém, quando ocorre exposição do tecido conjuntivo, fungos e bactérias têm sua adesão facilitada (ROSSINI, 2016). A relação entre EB e a odontologia se dá pela incidência de bacteremias transitórias de origem bucal, que podem ocorrer a partir de procedimentos odontológicos causadores de sangramentos, e até mesmo em hábitos diários, como a escovação. Desde 1955 a American Heart Association (AHA) recomenda a profilaxia antibiótica (PA) para pacientes com cardiopatias antes de procedimentos odontológicos, porém, devido às crescentes pesquisas colocando em questão os malefícios da PA, em 2007 a AHA atualizou as suas recomendações (JUNIOR, 2010). Dada a relevância do presente assunto para a odontologia, é de suma importância que o cirurgião dentista (CD) esteja constantemente informado sobre as atuais recomendações acerca da EB.

Objetivo: Revisar a literatura atual, buscando analisar as novas perspectivas a respeito da EB, com ênfase nas suas causas e no uso da PA.

Desenvolvimento: A Endocardite Infecciosa (EI) de origem bacteriana provoca a inflamação e a destruição do endocárdio, é uma doença rara, de difícil diagnóstico e tratamento, considerada grave por possuir uma elevada taxa de mortalidade (DUARTE; BARBIAN, 2017). A sintomatologia da EB é variável, a febre costuma aparecer na maior parte dos casos, mas outros sintomas também são possíveis, e as consequências geradas por essa doença são graves, como acidente vascular cerebral e parada cardíaca. Em condições normais, o revestimento epitelial do endocárdio é resistente a lesões infecciosas (ROSSINI, 2016), porém, quando ocorre um desgaste desse revestimento, o corpo inicia uma resposta imunológica, que resulta em um tecido cicatricial propício à colonização de bactérias, tornando esses pacientes mais vulneráveis à EB. Sua etiologia advém maioritariamente das espécies de Estafilococos e Estreptococos, em especial os Estreptococos do grupo viridans, encontrados abundantemente na cavidade oral (DUARTE; BARBIAN, 2017). Estima-se que aproximadamente $10 \%$ a $20 \%$ dos casos de EB possuam relação com focos infecciosos de origem bucal, com ênfase na periodontite, por ser uma doença infecciosa e multifatorial, que acomete os tecidos de suporte do dente, os quais possuem alta vascularização, facilitando o contato do biofilme microbiano com a circulação sanguínea. As bactérias presentes na cavidade oral podem gerar uma bacteremia e chegar ao endocárdio, o risco de isso acontecer está relacionado com a gravidade da doença inflamatória local preexistente e a extensão do traumatismo aos tecidos moles (PINHEIRO et al., 2020). Essa relação entre as bactérias da cavidade bucal e o desenvolvimento da EB foi sugerida há mais de 100 anos, tendo como fontes de infecção a falta de higiene oral (SILVA, 2019). Com base nisso, em 1955 a AHA publicou o primeiro protocolo para prevenção da endocardite associado ao tratamento odontológico, recomendando o uso da PA (JUNIOR, 2010). A PA é a aplicação de antibióticos em pacientes que não possuem infecção, e tem por objetivo evitar a contaminação do local que será exposto pelo procedimento odontológico, assim como evitar a contaminação à distância (DUARTE; BARBIAN, 2017). Em contrariedade ao uso da PA, segundo Pinheiro, et al (2010)

quanto maior a frequência de utilização dos antibióticos, maiores serão os riscos de as reações adversas a esses medicamentos excederem a possibilidade da ocorrência de endocardites, os microrganismos patogênicos relacionados à $E B$ apresentaram altas taxas de resistência aos antibióticos mais usados para a profilaxia na odontologia, além disso, o risco de reação anafilática fatal à penicilina também é preocupante. Em decorrência disso, em 2007 a AHA atualizou suas diretrizes, passando a recomendar o uso da PA somente para pacientes de alto risco cardíaco em todos os procedimentos que envolvam manipulação do tecido gengival ou região periapical de dentes ou perfuração da mucosa bucal (JUNIOR, 2010). Outro aspecto de extrema relevância, é que, de acordo com Andrade et al. (2014), o risco de contrair EB é maior em bacteremias decorrentes de hábitos diários do que em procedimentos odontológicos, portanto, pacientes com predisposição à EB devem ter uma ótima higiene oral.

Conclusão: Tendo em vista a íntima relação entre a saúde oral e a saúde do coração é indispensável que o CD esteja 
constantemente atento a essa patologia, realizando cautelosamente a anamnese e dialogando com o cardiologista dos cardiopatas, com o intuito de reconhecer os pacientes de alto risco cardíaco, pois de acordo com a AHA estes necessitam da profilaxia antibiótica, dentre eles estão os usuários de prótese cardíaca valvar, os que possuem histórico prévio de El, e portadores de cardiopatia congênita cianótica não corrigida; cabe ressaltar também a importância do cirurgião dentista atuar na promoção de saúde, já que a bacteremia também pode ocorrer em hábitos diários.

\section{Referências}

ANDRADE, Eduardo Dias de. et al. Terapêutica medicamentosa em odontologia. 3. ed. São Paulo: Artes Médicas Ltda, 2014. DUARTE, Aline Mio; BARBIAN, Poliane. Quando realizar a profilaxia antibiótica em pacientes com alto risco para desenvolver endocardite infecciosa? 2017. Dissertação para TCC - Universidade de Uberaba, Uberaba - MG, 2017.

JUNIOR, Orlando Cavezzi. Endocardite infecciosa e profilaxia antibiótica: um assunto que permanece controverso para a Odontologia. Rev Sul-Bras Odontol, v. 7, n. 3, p. 372 376, jul-sep. 2010.

PINHEIRO, Juliana Campos. et al. Tratamento odontológico em pacientes endocardite bacteriana: Revisão de literatura. RvACBO, v. 9, n. 1, p. 20 25, 2020.

ROSSINI, Rafael. Endocardite infecciosa: a profilaxia antibiótica ainda é necessária? - Revisão de literatura. IOSR Journal of Economics and Finance, v. 3, n. 1, p. 56, 2016.

SILVA, Ana Maria Miguez. Uso racional de profilaxia para endocardite infecciosa na odontologia. 2019. Dissertação para TCC - Escola Bahiana de Medicina e Saúde Pública, Salvador, 2019.

Coordenadoria de Pesquisa e Extensāo - COPEX

Departamento de Editoraçāo e Divulgaçāo Científica - DEDIC 


\title{
-

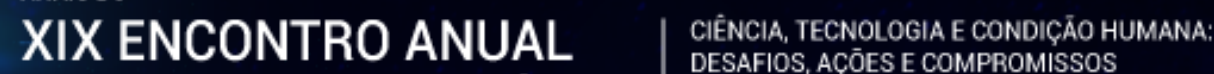 DE INICIACÃO CIENTÍFICA DESAFIOS, AQQOESE COMPROMISSOS DE INICIAÇAOO CIENTIFICA 29 e 30 de Outubro de 2020 \\ ISBN 978-65-87557-08-3

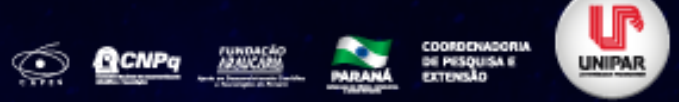 \\ EFETIVIDADE DO LASER TERAPÊUTICO NO TRATAMENTO DA SENSIBILIDADE DENTINÁRIA DECORRENTE DO CLAREAMENTO DENTAL: REVISÃO DE LITERATURA
}

\author{
${ }^{1}$ STEFANIA GASPARI, ${ }^{2}$ KLISSIA ROMERO FELIZARDO
}

\begin{abstract}
${ }^{1}$ Discente do Curso de Odontologia - UNIPAR/Participante do Programa Institucional de Bolsas de Iniciação Científica PIBIC/UNIPAR

${ }^{1}$ Docente do Curso de Odontologia UNIPAR
\end{abstract}

Introdução: A sensibilidade dolorosa é um dos efeitos adversos do clareamento dental, tanto durante quanto após o tratamento (BERNADON et al., 2010). Esse fator está diretamente vinculado às altas concentrações de peróxido de hidrogênio e ao tempo de exposição (sessões), segundo Calheiros et al (2017). Dentre as teorias que justificam a sensibilidade pós-clareamento a mais aceita é a de Brännström (1986), conhecida como Teoria Hidrodinâmica da Dor , a qual afirma que quando um estímulo é aplicado na dentina ocorre o deslocamento de fluído dentro dos túbulos. O movimento do fluído dentinário, em direção à polpa ou em sentido contrário, promove uma deformação mecânica das fibras nervosas que se encontram no interior dos túbulos ou na interface polpa/dentina, que é transmitida como uma sensação dolorosa. Em 2010, Markowitz propôs uma nova hipótese para explicar a sensibilidade causada pelo clareamento. Segundo este autor, existem grandes diferenças entre a dor causada pelo clareamento e a hipersensibilidade dentinária. Embora a dor do clareamento possa ser causada por estímulos térmicos, a maioria dos pacientes sentem uma dor como uma pontada ou um choque, sem nenhum estímulo. O autor sugere que os agentes oxidantes estimulam aferentes nociceptivos levando a dor e inflamação. Esta teoria tem sido complementada por outros estudos (COLDEBELLA et al., 2009) mostrando a penetração do peróxido de hidrogênio através do esmalte e dentina até o tecido pulpar onde, possivelmente, irrita os nervos e produz uma pulpite reversível e sensibilidade térmica temporária. A maioria dos tratamentos para hipersensibilidade dentinária está diretamente relacionada com a interrupção da transmissão do estímulo para as terminações nervosas dos processos odontoblásticos, reduzindo o movimento do fluído no interior dos canalículos através da oclusão dos túbulos dentinários pelos oxalatos, soluções fluoretadas, materiais restauradores adesivos, e aplicação de laser (KIMURA et al., 2000).

Objetivo: O objetivo do trabalho é apresentar através de uma revisão de literatura a efetividade do laser terapêutico no tratamento da hipersensibilidade dentinária decorrente do tratamento clareador de consultório.

Desenvolvimento: Foi efetuada uma pesquisa bibliográfica nas bases de dados PubMed/Medline, BIREME, Scielo, com as palavras-chave: Dentin Sensitivity ; treatment , hypersensitivity . Os critérios de inclusão foram artigos que referenciam os tratamentos da sensibilidade dentinária envolvendo o laser terapêutico. Os lasers utilizados no tratamento de hipersensibilidade dentinária podem ser divididos em dois grupos. Os lasers de baixa intensidade: Hélio-Neônio (He-Ne) e Arseneto de Gálio e Alumínio (AsGaAl) e os de alta intensidade: laser de Neodímio Ytrio Alumínio Granado (Nd:YAG) e o de dióxido de carbono (CO2). Os lasers de baixa intensidade ou soft lasers atuam com baixo comprimento de onda e geram um aumento de temperatura inferior a $0,1^{\circ} \mathrm{C}$. Estes comprimentos de onda estimulam a circulação e a atividade celular, atuam na bioestimulação devido ao aumento da produção de ATP mitocondrial e acarretam um aumento do limiar de excitabilidade das terminações nervosas livres que resulta em ação analgésica (DANTAS, 2013). Segundo Kimura et al. (2000) a ação do laser de baixa potência parece relacionar-se com o selamento dos túbulos dentinários e analgesia, sendo que o efeito é duradouro no primeiro caso. Portanto, recorrências de sensibilidade dentinária variam conforme o laser. De acordo com Reyto (1998), a sensibilidade suave a moderada está presente em aproximadamente $30 \%$ dos pacientes. No caso do clareamento dental com laser, em torno de $70 \%$ dos pacientes não apresentam sensibilidade, ou caso venham a apresentar relatam uma sensibilidade nível 1-2, considerada como leve ou suave. Moosavi et al. (2016) indicam o uso do laser de baixa potência infravermelho 3J como estratégia na redução da sensibilidade. Assim como nos estudos realizados por Santiago et al. (2020) realizado no estudo foi possível notar uma melhora no quadro de dor imediata após o uso do laser. Por outro lado, Calheiros et al. (2017) e Lima et al. (2014) atestam que não obtiveram resultados eficientemente satisfatórios no uso do laser de baixa potência no controle da sensibilidade pós clareamento, porém acredita que seja necessário ensaios clínicos com maior tamanho de amostra e diferentes configurações a laser para avaliar o melhor parâmetro de eficiência da técnica.

Conclusão: A utilização da laserterapia de baixa intensidade vem tendo cada vez mais sucesso e tornando-se um tratamento promissor no tratamento da hipersensibilidade dentinária.

\section{Referências}

BERNADON, Jussara et al. Clinical performance of vital bleaching techniques. Oper. Dent. v. 35, n.1, p. 3-10, 2010.

BRÄNNSTRÖM, M. The Hydrodynamic Theory of Dentinal Pain: Sensation in Preparations, Caries, and the Dentinal Crack 
Syndrome. Journal of Endodontics. v. 12, n. 10, p. 453-457, 1986.

CALHEIROS, Andrea Paiva Corsetti et al. Photobiomodulation in the prevention of tooth sensitivity caused by in-office dental bleaching. A randomized placebo preliminary study. Photomedicine and Laser Surgery. v. 35, n.8, p. 415-420, 2017.

COLDEBELLA, Cármem Regina et al. Indirect Cytotoxicity of a 35\% Hydrogen Peroxide Bleaching Gel on Cultured Odontoblast Like Cells. Braz Dent Journal. v. 20, n. 4, p. 267-274, 2009.

DANTAS, Euler Maciel et al. Tratamento da hipersensibilidade dentinária cervical com laser de baixa potência revisão de literatura. Odontol. Clín.-Cient. v. 12, n. 1, Recife, p. 07-11, 2013.

KIMURA Yuichi ET AL. Treatment of hipersensitiviy by lasers; a review. J Clin Periodontol. v. 27, n. 10, p. 715-721, 2000.

LIMA, Adriano et al. Effects of laser irradiation on pulp cells exposed to bleaching agents. Photochemistry and Photobiology. v. 90, p. 201-206, 2014.

MARKOWITZ, Kenneth. Pretty painful: why does tooth bleaching hurt? Med Hypotheses. v. 74, n. 5, p. 835-840, 2010.

MOOSAVI, Horieh. et al. Effect of low-level laser therapy on tooth sensitivity induced by in-office bleaching. Lasers Med Sci. V. 31, n. 4, p. 713-719, 2016.

REYTO, Robert. Laser tooth whitening, Esthetic Dentistry. v. 42, n. 4, p. 755-762, 1998.

SANTIAGO, Sabrina Reis et al. Efeitos do uso de flúor tópico e laser de baixa potência pós-clareamento no controle da sensibilidade imediata. Revista de odontologia contemporânea. v.4, p.56-63, 2020.

Coordenadoria de Pesquisa e Extensão - COPEX

Departamento de Editoraçāo e Divulgaçāo Científica - DEDIC 


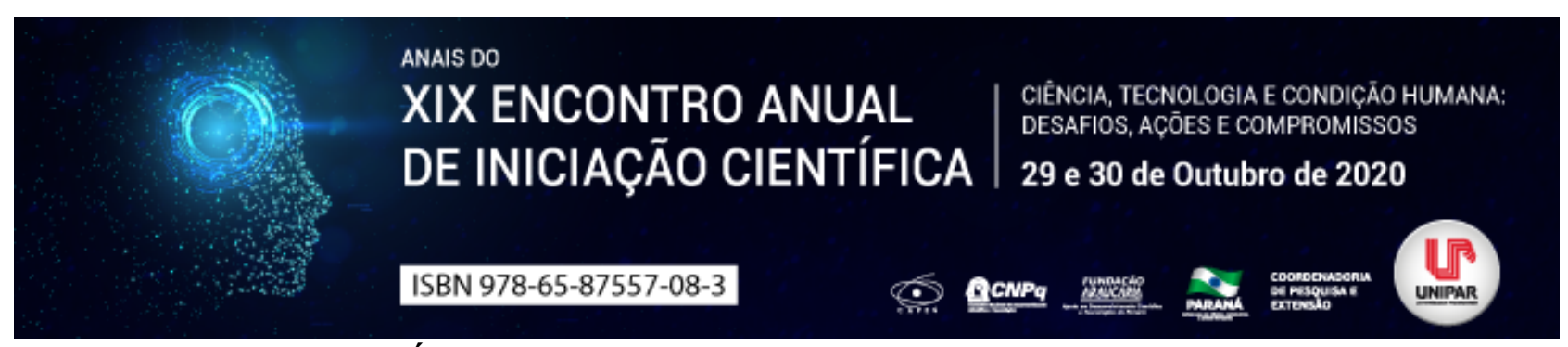

PERFIL TOXICOLÓGICO DO PARAQUAT: UM AGRAVO AO HOMEM E AO AMBIENTE

\title{
${ }^{1}$ BARBARA DE SOUZA CAMARGO SPADA, ${ }^{2}$ ANDERSON FELIPE FERREIRA
}

\author{
${ }^{1}$ Acadêmica do Curso de Biomedicina - UNIPAR \\ ${ }^{1}$ Docente da UNIPAR
}

Introdução: O Paraquat é um agrotóxico da classe herbicida, considerado extremamente tóxico, tinha seu uso autorizado para aplicações em pós-emergência de plantas infestantes em culturas como abacate, milho, soja, entre outros. Estudos realizados pelo GGTOX (Gerencia Geral de Toxicologia) em 2017 revelaram que ha casos de intoxicação grave aguda por trabalhadores expostos, geralmente por descuido e uso incorreto do produto, no Brasil os casos de óbito por intoxicação por Paraquat são principalmente devido a tentativas de suicidio ou acidentais. Em fevereiro de 2008 a Agência Nacional de Vigilância Sanitária (ANVISA) determinou a reavaliação toxicologica do Paraquat devido a esses estudos que evidenciaram casos de intoxicação aguda e crônica (ANVISA, 2017). O Paraquat pode provocar intoxicação por ingestão, inalação ou contato dérmico, a intoxicação aguda consecutiva à ingestão de uma dose grande, é seguida de edema pulmonar agudo, oligúria, insuficiência hepato-celular e supra renal e alterações bioquímicas (SERRA et al, 2003).

Objetivo: Abordar através de um levantamento bibliográfico em artigos, site da ANVISA, documentos oficiais e bulas, os aspectos que levaram a proibição do uso do Paraquat no Brasil, a fim de compreender melhor os efeitos tóxicos deste produto no organismo humano e também ao meio ambiente.

Desenvolvimento: O Paraquat é um herbicida de uso agrícola pertencente ao grupo dos Bipiridilo, utilizado para aplicações em pós-emergência das plantas infestantes, sua ação agronômica é através de ação não sistêmica, não seletivo de espécies. De acordo com os dados de reclassificações dos agrotóxicos realizados pela ANVISA (2017) o Paraquat foi reavaliado a partir das diversas possibilidades de manifestações tóxicas, desta forma, a reclassificação toxicologia foi pautada de acordo com a DL50 (Dose letal 50\%), que corresponde a dose necessária de uma substância para matar 50\% dos animais expostos ao produto (LARINI, 1997). Desta forma, a reclassificação foi: para exposição por via oral é de categoria 4 (nocivo se ingerido), para via cutânea foi considerado categoria 5 (pode ser perigoso em contato com a pele), a classificação toxicológica inalatória é de categoria 1 (fatal se inalado), em via dermica é classificado como categoria 2 (capaz de provocar irritação à pele), em via ocular categoria 1 (provoca lesões oculares graves), com teste de AMES e de Micronúcleo negativos. Em um levantamento realizado por SANTOS e colaboradores (2020), o Centro de Informação e Assistência Toxicológica de Santa Catarina (CIATox) registrou 58.927 casos de intoxicação por diversos agentes entre os anos de 2015 e 2019, onde 3.124 casos foram intoxicações por agrotóxicos, e destes, 181 casos foram por intoxicação de Paraquat (SANTOS et al, 2020). O teste de AMES utiliza-se culturas microcobiológicas com linhagens de Salmonella, especialmente desenvolvidas para detectar mutações ou substituição de pares do DNA que podem ser ocasionados devido a compostos com capacidade mutagênica (CETESB, 2013). O teste do Micronúcleo também avalia probabilidade de ocorrrência de mutagênese, onde quando positivo, observa-se um núcleo acessório, que surge a partir de fragmentos de cromossomos ou cromossomos inteiros que não são incluídos no núcleo principal durante a mitose devido alterações genéticas espontâneas ou mutações induzidas por agentes tóxicos (CARRARD, 2007). Os sintomas classicos dos quadros de intoxicação incluem: vômitos, lesões orais e faringeas, diminuição de potássio, aumento das aminotranferases, bilirrubina, amilase e creatinoquinase, insuficiência renal e respiratória. Na presença de oxigênio há um ciclo de oxidações e reduções com produção contínua de um íon superoxido, nos pulmões ocorre um processo que gera ao final fibrose pulmonar devido a lesão de pneumócitos e migração de macrófagos (SERRA et al, 2003; Pinheiro, 2002). Devido sua alta toxicidade ao homem e ao meio ambiente, foi determinada a proibição do produto no Brasil, levando-se em consideração os seguintes motivos: gravidade dos casos de intoxicação acidentais e ocupacionais (ANVISA, 2017). De acordo com Vaccari (2017), o uso de EPIs que não garantem proteção eficiente contra o produto; a existência de evidências que provam a relação de toxicidade com o desenvolvimento da doença de Parkinson e também seu potencial mutagênico. A GGTOX indicou a proíbição da produção, exportação, importação, comercialização e utilização de produtos que contenham Paraquat, visto que há evidências de o agrotoxico ser mutagênico, pois estudos mostram efeitos de induzir aberrações cromossomicas em celulas somáticas in vitro e in vivo em diferentes espécies além de ser um fator de risco para desencadear a Doença de Parkinson (ANVISA, 2017).

Conclusão: A intoxicação por Paraquat é perigosa e de mau prognóstico para o paciente, a exposição crônica pode trazer consequências sérias como desencadeamento da doença de Parkinson e mutações em celulas somáticas. A proibição no Brasil foi determinada para 22 de setembro de 2020 e possui grande significado, visto que os riscos são reais de problemas após exposição, devido ao grande risco de toxicidade para pessoas que se expõe cronicamente ao produto, aplicando de maneira inadequada nas plantações, e também nos casos de intoxicações agudas e propositais provindas de tentativas de suicídio. 


\section{Referências}

AGENCIA NACIONAL DE VIGILÂNCIA SANITÁRIA, VOTO N 056/2017/DIREGIANVISA, 19 de setembro de 2017, Proibição do Paraquate no Brasil. DIREG - Diretoria de Regulação Sanitárias. Disponível e: Acesso em: 20. Ago. 2020.

CARRARD, V. C; COSTA, C. H; FERREIRA, L. A; LAUXEN, I. S; RADOS, P. V. Teste dos Micronúcleos Um Biomarcador de Dano Genotóxico em Células Descamadas da Mucosa Bucal. Revista Faculdade Odontologia de Porto Alegre, v. 48, n. 1/3, p. 77-81, jan./dez. 2007.

COMPANHIA AMBIENTAL DO ESTADO DE SÃO PAULO CETESB, Ensaios de Genotoxicidade, 2013. Disponível em: Acesso em: 28. Ago. 2020.

LARINI, L. TOXICOLOGIA. 1. ed. São Paulo : Manole, 1997

PINHEIRO, I. Intoxicação por paraquat Revisão bibliográfica. Sociedade Portuguesa de Medicina Interna. Hospital Santa Maria, Lisboa 2002. Disponível em: Acesso em: 18. Ago. 2020.

RICKETTS, D. The microbial degradation of paraquat in soil. Revista Pest Management Science, n. 55, p. 596-598, 1999.

SANTOS, Claudia Regina dos et al. Avaliação da exposição a agrotóxicos: cinco anos de análises toxicológicas. Extensio: Revista Eletrônica de Extensão, Florianópolis, v. 17, n. 35, p. 162-176, abr. 2020.

SERRA, A; DOMINGOS, F; PRATA M. M. Intoxicação Por Paraquat. Revista Acta Médica Portuguesa, n. 16, p. 25-32, 2003.

VACCARI, C. Paraquat e a Doença de Parkinson: Revisão Sistemática e Metanálise de Estudos Observacionais. Orientador: João Lauro Viana de Camargo. 2017. Dissertação (Mestrado em Patologia) - Universidade Estadual Paulista I"Júlio de Mesquita Filhol", Botucatu - São Paulo, 2017.

Coordenadoria de Pesquisa e Extensão - COPEX

Departamento de Editoraçāo e Divulgaçāo Científica - DEDIC 


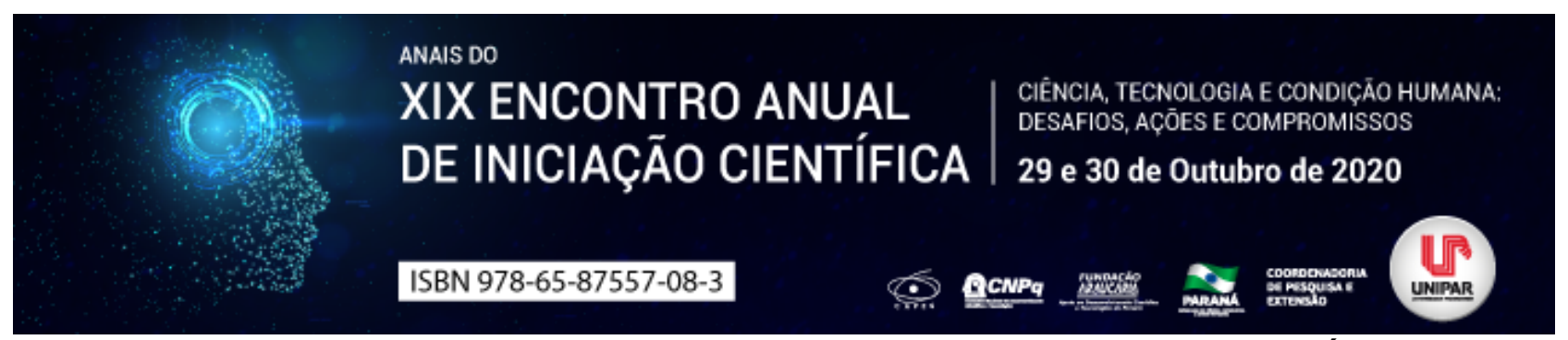

DETERMINANTES PARA NEAR MISS MATERNO NOTIFICADOS EM UMA REGIONAL DE SAÚDE DO PARANÁ

\author{
${ }^{1}$ ANA PAULA JAQUELINE CRESTANI, ${ }^{2}$ LEDIANA DALLA COSTA
}

\author{
${ }^{1}$ Acadêmica do PIC/UNIPAR \\ ${ }^{1}$ Docente da UNIPAR
}

Introdução: Um dos problemas mais desafiadores do mundo é a mortalidade materna (MM), que por longo período manteve constância em seus números de casos, tornando-se uma preocupação de nível global (ONU, 2019). No Brasil, entre o ano de 2004 a 2014, foram registrados pelo sistema de informação de mortalidade (SIM) 18.364 óbitos maternos (OM) (BARRETO et al., 2018). Porém, mesmo com tal magnitude as pesquisas representam a MM apenas como a ponta do iceberg , visto que, somente na América Latina a cada mulher que morre por complicações relacionadas à gravidez, outras 15 passam por Condições Ameaçadoras da Vida (CAV) também denominada de Near Miss Materno (NMM) (BRILHANTE et al., 2017). Segundo a Organização Mundial de Saúde (OMS), um caso de Near Miss Materno é definido como uma mulher que quase morreu, mas sobreviveu a uma complicação grave, ocorrida durante a gravidez, o parto ou em até 42 dias após o término da gravidez , (WHO, 2014).

Objetivo: Analisar os principais determinantes e fatores de risco para ocorrência de Near Miss Materno notificados em uma Regional de Saúde no Sudoeste do Paraná.

Metodologia: O presente estudo trata-se de uma pesquisa exploratória, descritiva, documental, transversal, retrospectiva e de caráter quantitativo, a ser desenvolvida em uma Regional de Saúde (RS) do Sudoeste do Paraná. Participaram do estudo todas as mulheres que passaram por Near Miss Materno, que foram notificadas para RS no período de Janeiro de 2018 a Agosto de 2020. A análise estatística foi realizada pelo programa estatístico SPSS 25.0 para análise de frequência, após a aprovação do Comitê de Ética em Pesquisas Envolvendo Seres Humanos (CEPEH) na data do dia 28 de maio de 2020, sob o protocolo 4.053.778, respeitando todos os preceitos éticos de acordo com a Resolução no 466/12 do Conselho Nacional de Saúde (CNS).

Resultado: Entre o período de Janeiro de 2018 à Agosto de 2020 foram registrados 4.251 internamentos obstétricos, destes, resultaram em 40 casos de Near Miss Materno, sendo a maioria de raça branca (45,0\%), com a média de idade de 29 anos, estratificada como risco habitual durante o pré-natal (52,5\%), porém durante a internação a estratificação foi alterada como alto risco em $72,5 \%$ dos casos. As principais condições pré-existentes foram cesárea anterior (27,5\%), assim como nos casos das multíparas com cesárea prévia (22,5\%), mas, em contra partida, $22,5 \%$ das mulheres não apresentaram alterações préexistentes. No que tange às principais Complicações Graves e ameaçadoras da vida é valido destacar a Hemorragia (35,0\%), Síndrome HELLP (hemólise, enzimas hepáticas elevadas, baixa contagem de plaquetas) (17,5\%), Síndrome hipertensiva relacionada à gestação, pré-eclâmpsia, eclâmpsia (15,0\%) condições estas, presentes na chegada ou dentro de 12 horas da chegada ao hospital em $67,5 \%$ das hospitalizações, resultando em cesárea de emergência em $47,5 \%$ dos desfechos dos partos. Discussão: O presente estudo evidenciou a Razão de Near Miss Materno (RNMM) de 9,4/1.000 mulheres, porcentagem similar a uma pesquisa realizada em um hospital no Estado do Piauí, no qual a RNMM ocorreu em 9,6/1.000 nascidos vivos (BRILHANTE et al.,2017). Em relação à etnia predominou a raça branca, com média de idade de 29 anos, dados que divergem da pesquisa de Silva e colaboradores (2016), onde apontou que 88,6\% dos casos de NMM ocorrem em mulheres com a cor de pele não branca e nos extremos das idades. No que se refere ao pré-natal (PN) a maior parte delas eram classificadas como risco habitual, alterando abruptamente para alto risco na avaliação da admissão hospitalar, à vista disso, outro estudo realizado no Estado do Paraná verificou predomínio de $66,7 \%$ de gestantes estratificadas como risco habitual, depois de corrigida a classificação houve a diminuição de $60 \%$ que deveriam ser sinalizadas como risco intermediário e alto risco (AMARI et al., 2020). Neste contexto, assim como toda assistência prestada, a atenção ao PN qualificada é fundamental quando se trata de redução dos índices de MM e perinatal (BARRETO et al.2018), sendo que, segundo o Decreto $n^{\circ} 94.406$ de 08 de Junho de 1987, dispõe que o Enfermeiro possui conhecimentos teóricos-científicos para realizar consultas de PN de baixo risco, assim como, direcionar a reavaliação da estratificação e vincular ao serviço especializado de referência (ROCHA et al., 2018). Quando avaliadas as condições pré-existente, destacaram-se histórico de cesarianas anteriores e cesáreas prévias, corroborando com estudo no mesmo Estado, onde $97 \%$ das mulheres tiveram alguma intervenção durante o parto sendo uma delas em $57 \%$ a cesariana, resultando em uma elevada prevalência de complicações puerperais, características de uma assistência obstétrica voltada ao modelo medicalizado (MONTESCHIO et al., 2020).No quesito das principais complicações que levaram ao Near Miss se faz pertinente destacar a hemorragia (35\%), Síndrome HELLP (17,5\%), pré-eclâmpsia e eclâmpsia (15\%), equivalente aos resultados de Silva et al. (2018), que destacou a doença hipertensiva é a principal causa de NMM em $45 \%$, seguido por hemorragia com 40,5\%, tais alterações que podem acarretar a interrupção da gestação, o que evidência a alta taxa de cesáreas de emergência do presente estudo (47,5\%), assumindo concordância com a pesquisa de Arrantes e colaboradores (2020) realizado no Sudeste 
do Brasil, no qual constatou que $55 \%$ de cesarianas no parto atual.

Conclusão: Ratificou-se a importância de estudar e avaliar os casos de NMM, pois tratasse de um evento mais frequente, que fornece valiosas informações dos principais determinantes, fatores de riscos e CAV, principalmente em nível local, tornando-se um indicador mais sensível para analisar a qualidade da assistência dos profissionais e situação de saúde durante a gestação, parto e puerpério.

\section{Referências}

AMARI, M. N. et al.Internações em Unidade de Terapia Intensiva Neonatal e a Estratificação de Risco Gestacional do Programa Rede Mãe Paranaense. Braz. J. of Develop., Curitiba, v. 6, n. 7, pp. 42365-42377, Jul. 2020.

ARRANTES, B. M. et al. Fatores associados ao near miss materno em um hospital universitário. REFACS (online), v. 8, n. 3 , Jul/Set 2020.

BARRETO, E. S. et. al. Redução da mortalidade materna e atuação do enfermeiro. Rev. Enferm. Contemp., Salvador, vol. 7, $\mathrm{n}$. 1, pag. 20-26, Abril, 2018.

BRILHANTE, V. M. et. al. Near Miss Materno como indicador de atenção à saúde: Uma revisão integrativa. Rev. Bras. Promoç. Saúde, Fortaleza, vol. 30, n. 4, pag. 1-9, Out./Dez. 2017.

MONTESCHIO, L. V. C. et al.Complicações puerperais em um modelo medicalizado de assistência ao parto. Rev Min Enferm. v. 24, e-1319, 2020.

ONU. Organização das Nações Unidas. Unicef e OMS dizem que taxas de mortalidade materno-infantil nunca foram tão baixas. 19 Set. 2019.

ROCHA, R. R. M. et. al. Conhecimento e Perspectiva de Enfermeiros na Rede de Atenção Materna e Infantil do Paraná. Cienc Cuid Saude, vol. 17, n. 1 Jan/Mar. 2018.

SILVA, J. M. P. et.al., Conceitos, prevalência e características da morbidade materna grave, near miss, no Brasil: revisão sistemática. Rev. Bras. Saude Mater. Infant. Recife, vol.18, n.1, Jan./Mar. 2018.

SILVA, T. C. et al.Morbidade materna grave identificada no Sistema de Informações Hospitalares do Sistema Único de Saúde, no estado do Paraná, 2010*. Epidemiol. Serv. Saúde, Brasília, vol. 25, n. 3, pp. 617-628, Jul/Set. 2016.

WHO; PAHO. Organização Mundial de Saúde. Avaliação da qualidade da assistência para complicações graves da gestação: uma abordagem para near miss da OMS para a saúde materna. 25 Set. 2014. 


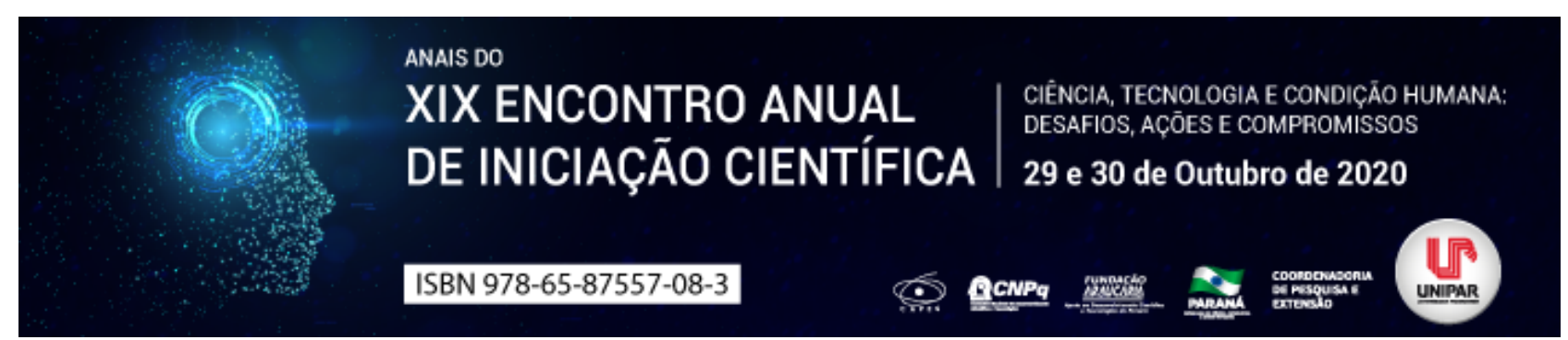

\title{
AVALIAÇÃO DA ATIVIDADE ANTIMICROBIANA DE ÓLEO ESSENCIAL DE CURCUMA ZEDOARIA EM EQUIPAMENTOS E MATERIAIS ESTÉTICOS
}

\author{
${ }^{1}$ MARIA EDUARDA PARRA VALHEJO, ${ }^{2}$ RAFAELLA PAIAO DE OLIVEIRA, ${ }^{3}$ POLIANA PRIETO MANTOVANI, ${ }^{4}$ LETICIA DE \\ MORAES MARGATTO, ${ }^{5}$ CAROLINE STEFANY MANZOLI BARBOSA, ${ }^{6}$ ELIZABETI DE MATOS MASSAMBANI
}

\begin{abstract}
${ }^{1}$ Discente do Curso de Tecnologia em Estética e Cosmética/UNIPAR/Acadêmica PIC
${ }^{1}$ Discente do Curso de Tecnologia em Estética e Cosmética/UNIPAR/Acadêmica PIC

${ }^{2}$ Discente do Curso de Tecnologia em Estética e Cosmética/UNIPAR/Acadêmica PIC

${ }^{3}$ Discente do Curso de Tecnologia em Estética e Cosmética/UNIPAR/Acadêmica PIC

${ }^{4}$ Discente do Curso de Tecnologia em Estética e Cosmética/UNIPAR/Acadêmica PIC

${ }^{5}$ Docente do Curso de Tecnologia em Estética e Cosmética e Medicina/UNIPAR
\end{abstract}

Introdução: Durante os procedimentos estéticos, tanto o cliente quanto o profissional correm riscos biológicos quando há contaminação microbiana das superfícies e das mãos, pois os micro-organismos estão cada dia mais presentes no cotidiano, contudo os estudos avançam para que na mesma proporção que nos afeta deve-se ter instrumentos e meios que ajudem a combatê-los ou ao menos preveni-los; dentre esses meios de combate aos riscos biológicos, os óleos essenciais além de serem uma forma acessível, natural e muito benéfica, vem sendo motivo de estudo pois alguns deles possuem ótimos efeitos antibacterianos e antifúngicos (FURLAN et al, 2018). Os procedimentos capilares manuais ou com equipamentos podem ser disseminadores de micro-organismos, mesmo os que sejam participantes da microbiota da pele e mucosas como leveduras do tipo Candida sp, e causadores de processos inflamatórios ocasionando a queda de cabelo e caspas devido a proliferação de fungos do tipo Trichophyton mentagrophytes. O uso da Curcurma zedoria (açafrão-da-terra) vem crescendo no meio alimentício, cosmético e farmacêutico por possuir ação anti-inflamatória e antimicrobiana que está relacionada a sua capacidade antioxidante, tornando-se assim uma possível alternativa de tratamento a micoses superficiais e patologia dolorosa como artrite crônica (NICOLETTI, 2003); sendo que a parte mais utilizada da planta é o rizoma que após a secagem e pulverização, encontra-se comercialmente disponível sob as formas de pó, cápsula ou extrato fluido, os quais podem ser empregados na forma de infuso, decocto, tintura, pó ou pedaços mastigáveis (FARINA, 2007). Ainda de acordo com este mesmo autor, os rizomas têm de 1,5 a $5 \%$ de óleo essencial, o qual é constituído principalmente por pineno, canfeno, cineol, cânfora e borneol.

Objetivo: Avaliar a atividade antimicrobiana do óleo essencial de Curcuma zedoaria em equipamentos e materiais estéticos.

Material e Métodos: Esta pesquisa, devidamente aprovada faz parte do Programa de Iniciação Científica da UNIPAR. O material vegetal obtido é de cultivo em Umuarama, PR, Brasil. O óleo essencial do rizoma de Curcuma zedoaria será obtido por hidrodestilação de 3 horas com o aparelho de Clevenger Modificado. A atividade antimicrobiana dos óleos essenciais será determinada pelo Método de Microdiluição em Caldo. Os micro-organismos utilizados para os ensaios serão coletados no Centro de Estética e Cosmética da Unipar Umuarama dos equipamentos para uso capilar como Alta frequência, Analisador capilar marca Castellus, Dermatoscópio capilar marca Estek e em unidades de materiais como escovas, pentes e pincéis antes de serem utilizados no cliente. Para as coletas serão utilizados swabs estéreis e o material coletado será semeado em ASD (Ágar Sabouraud Dextrose) inclinado (MERCK®) para crescimento de fungos. Será avaliada a atividade antimicrobiana em Trichophyton mentagrophytes obtido de isolado clínico e cepa padrão de Candida albicans.

Resultados: Os resultados do óleo essencial de Curcuma zedoaria para testar o potencial antimicrobiano sobre a levedura Candida albicans que possa estar presente nos equipamentos estéticos e materiais de uso capilar do Centro de Estética e Cosmética, e também com cepa padrão de Candida albicans, e com Trichophyton mentagrophytes obtido de isolado clínico, serão divulgados após a realização dos testes.

Discussão: Através de pesquisa realizada por Nicoletti (2003) para aplicação da planta Curcuma zedoaria como antifúngico nos fungos Candida albicans, Trichophyton mentagrophytes e Aspergillus niger, pode-se obter resultado através da concentração inibitória mínima (CIM) de 20mg/ml, desta forma é uma possibilidade terapêutica de uso tópico para estes micro-organismos. Em estudo de Sacchetti et al. (2005), o óleo essencial de cúrcuma apresentou valores de CIM de 0,36 mg/dL para C.albicans. Os resultados de pesquisa para avaliação antimicrobiana em crescimento planctônico e em biofilme demonstraram que óleo essencial de $C$. zedoaria apresentou atividade microbiostática e microbicida em todas as cepas analisadas, sendo a cepa mais sensível em relação a concentração microbicida mínima do óleo essencial de Curcuma zedoaria foi Candida albicans e a mais resistente foi Streptococcus mutans, uma vez que o óleo de C. zedoaria na concentração de 3,12\% produziu efeito fungicida em 70\% das cepas de C. albicans (ALMEIDA, 2010).

Conclusão: $\mathrm{Na}$ revisão bibliográfica desta pesquisa, o óleo essencial de Curcuma zedoaria vem sendo estudada e investigada 
devido a sua grande potencialidade terapêutica e ação farmacológica diversa, exibindo atividade antibacteriana e antifúngica. A conclusão dos resultados experimentais desta pesquisa será após a realização dos testes. Os óleos essenciais apresentam função contra diversos micro-organismos, e devido ao grande número de clientes na área capilar faz-se importante conhecer e evitar a proliferação de fungos e bactérias por estarem envolvidos em processos de lesões. Os óleos podem ser usados na indústria farmacêutica e de cosméticos como alternativa de tratamento e prevenção aos antimicrobianos convencionais, para ser coadjuvante na promoção da saúde.

\section{Referências}

ALMEIDA, Rosilene Batista de Aguiar. Avaliação da atividade dos óleos essenciais de Cymbopogon citratus (d.c.) stapf, Tagetes minuta I. e Curcuma zedoaria Roscoe frente aos microrganismos Candida spp., Staphylococcus spp. e Streptococcus mutans. Orientador: Antonio Olavo Cardoso Jorge. Tese (Doutorado em Biopatologia Bucal) - Universidade Estadual Paulista, São José dos Campos, 2010.

FARINA, Vitor Hugo. Efeito das plantas medicinais Curcuma Zedoaria e Camellia Sinensis no controle da halitose. Orientadora: Adriana Aigotti Haberbeck Brandão. 2007. 100 f. Dissertação (Mestrado em Biopatologia Bucal) - Universidade Estadual Paulista, São José dos Campos, 2007.

FURLAN, Maria Heloise Pascoin; TIETZ, Anelise Martins; OKABAYASHI, Cláudia Mika; MASSAMBANI, Elizabeti de Matos. Avaliação da atividade antimicrobiana do óleo essencial de Baccharis dracunculifolia dc. e de Schinus terebinthifolius raddi em micro-organismos presentes em equipamentos estéticos. In: III Congresso Internacional de Ciência, Tecnologia e Inovação e XVII Encontro Anual de Iniciação Científica da UNIPAR, v. 3, 2018. ISSN 2525-5967. Umuarama. Anais eletrônicos... Umuarama: UNIPAR, 2018. Disponível em: http://cicti.unipar.br/. Acesso em: 29 jun. 2020.

NICOLETTI, Maria Aparecida; BUGNO, Ariana; ORSINE, Elaine Maria de Almeida \& ZENEBON, Odair. Estudo da atividade antimicrobiana do extrato fluido da Curcuma zedoaria (Christm.) Roscoe na determinação da concentração mínima inibitória. Rev. Bras. Farm., v. 84, n. 2, p. 39-41, 2003. Disponível em: http://rbfarma.org.br/files/pag_39a41.pdf. Acesso em: 04 jul. 22020. SACCHETTI, Gianni; MAIETTI, Sílvia; MUZZOLI, Maria Vitoria; SCAGLIANTI, Martina; MANFREDINI, Stefano; RADICE, Mateo; BRUNI, Renato. Comparative evaluation of 11 essential oils of different origin as functional antioxidants, anti radicals and antimicrobials in foods. Food Chemistry, v. 91, p. 621-632, 2005. 


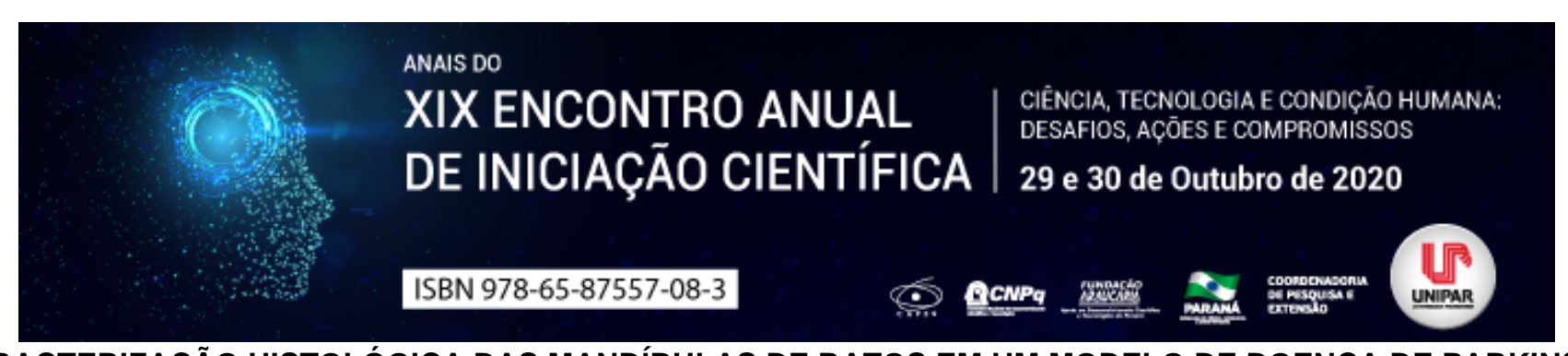

\title{
CARACTERIZAÇÃO HISTOLÓGICA DAS MANDÍBULAS DE RATOS EM UM MODELO DE DOENÇA DE PARKINSON ASSOCIADO A PERIODONTITE INDUZIDA
}

\author{
${ }^{1}$ Stefania GASPARI, ${ }^{2}$ EDUARdo AUgUSto PFAU, ${ }^{3}$ VANESSA RODRIGUES DO NASCIMENTO, ${ }^{4}$ CINTIA DE SOUZA \\ ALFERES ARAUJO, ${ }^{5}$ FRANCISLAINE APARECIDA DOS REIS LIVERO, ${ }^{6}$ EVELLYN CLAUDIA WIETZIKOSKI LOVATO
}

${ }^{1}$ Discente do Curso de Odontologia - UNIPAR/Participante do Programa Institucional de Bolsas de Iniciação Científica PIBIC/UNIPAR

${ }^{1}$ Docente do curso de Odontologia UNIPAR

${ }^{2}$ Docente do curso de Odontologia UNIPAR

${ }^{3}$ Docente do curso de Odontologia UNIPAR

${ }^{4}$ Docente do curso de Medicina, Medicina Veterinária - UNIPAR

${ }^{5}$ Docente do curso de Medicina, Semipresencial - UNIPAR

Introdução: Devido aos prejuízos motores, pacientes com doença de Parkinson (DP) apresentam dificuldades para realizar os cuidados com a higiene oral diária, favorecendo este grupo para o desenvolvimento da doença periodontal (KAUR et al., 2015; ZLOTNIK et al., 2015). Estudos prévios em pacientes parkinsonianos demonstram aumento da incidência e severidade de bolsas periodontais, mobilidade dental resultando em perdas dentárias comparado a grupos de pacientes não portadores da doença (PRADEEP et al., 2013; SCHWARZ et al., 2005). Apesar disto, tais estudo não descrevem as características biológicas ou verificam se a manifestação da DP é fator determinante para o agravamento do quadro periodontal e há escassez de um modelo animal que avalie as características biológicas na presença das duas doenças. Assim, esta pesquisa propõe a associação de dois modelos consagrados [indução da DP pelo modelo da 6-hidroxidopamina (6-OHDA) e periodontite induzida por ligadura], validando um modelo para estudo de substâncias de interesse para novas abordagens de tratamentos.

Objetivo: Avaliar as características histológicas das mandíbulas de ratos submetidos a indução da DP pelo modelo da 6-OHDA associada a periodontite induzida por ligadura.

Material e Métodos: Foram utilizados ratos Wistar machos, com 4 meses, pesando entre 250 e 315 gramas. O procedimento foi aprovado pelo Comitê de Ética de Pesquisa Envolvendo Uso de Animais da UNIPAR (protocolo 31166/2017). Para indução da $\mathrm{DP}$, os ratos foram submetidos à cirurgia estereotáxica para infusão de 6-OHDA $(n=7)$ ou líquor cefalorraquidiano (grupo Sham, $\mathrm{n}=10$ ), no feixe prosencefálico medial (DA CUNHA et al., 2008). Após 7 dias foi induzida a periodontite por ligadura de fio algodão no $1^{\circ}$ molar inferior esquerdo (periodontite induzida PI). No lado direito da mandíbula não foi induzida periodontite (sem periodontite induzida SPI) (SEMENOFF et al., 2008). Após 21 dias os animais foram mortos, as mandíbulas foram removidas e hemi-seccionadas em sua sínfise. Após processamento, foram realizadas secções longitudinais mésio-distais de $6 \mu \mathrm{m}$ e os tecidos foram corados com hematoxilina e eosina para avaliação histopatológica e da reabsorção óssea inter-radicular através da delimitação da área de tecido conjuntivo presente na região utilizando o software Image- ${ }^{\circledR}$. A atividade dos osteoclastos foi avaliada através de análise histoquímica usando o método de fosfatase ácida resistente ao tartarato (TRAP; WU et al., 2018).

Resultados: $\mathrm{Na}$ avaliação histopatológica das mandíbulas SPI do grupo Sham não foram observados infiltrado inflamatório ou alterações no osso alveolar, no epitélio marginal e no tecido conjuntivo. Já o grupo 6-OHDA SPI observou-se a presença de alterações teciduais, com ligeira reabsorção no tecido ósseo e leve infiltrado inflamatório crônico. Em relação as mandíbulas PI, foram observadas características histopatológicas semelhantes entre os grupos Sham e 6-OHDA, validando o modelo de periodontite induzida por ligadura. Entretanto, no grupo 6-OHDA foi observado intenso infiltrado inflamatório crônico no tecido conjuntivo da furca e aumento da distância do espaço entre o teto da furca e a crista óssea alveolar. A avaliação da reabsorção óssea foi quantificada pela extensão da área perdida de tecido conjuntivo na região inter-radicular. Foi observada diferenças significativas quando comparado o lado das mandíbulas (SPI e PI, $F(1,29)=158,45, p<0,0001$ ) dos grupos Sham e 6-OHDA. Ainda, considerando a mandíbula $\mathrm{PI}$, houve diferença significativa entre os grupos $(F(1,29)=158,45, p<0,0001)$, revelando perda óssea superior no grupo 6-OHDA comparado ao Sham $(p<0,001)$. Nenhuma diferença estatística foi observada entre os grupos quando comparadas as mandíbulas SPI $(p>0,05)$. A atividade dos osteoclastos foi quantificada pelo número de células TRAP positivas $/ \mathrm{mm}^{2}$. Nas mandíbulas $\mathrm{PI}$ foi observado maior número de células TRAP-positivas no grupo 6-OHDA em relação ao grupo Sham $(p<0,001)$. Entretanto, não houve diferença significativa quanto ao número de células TRAP positivas/mm quando comparado os grupos SPI.

Discussão: Os eventos fisiopatológicos similares entre a periodontite e a DP, tais como os eventos imuno-inflamatórios e oxidativos, suas características crônicas e maior susceptibilidade com idade mais avançada são bem descritos na literatura 
(CHEN et al., 2017). Essa similaridade sugere que os mediadores químicos produzidos por ambas doenças podem desempenhar um papel duplo, ativando tanto o processo que ocorre na inflamação periodontal quanto a via da neurodegeneração da DP potencializando a severidade de ambas (KAMER et al., 2008). De fato, os resultados apresentados apontam que os animais com DP e periodontite associadas apresentam maior reabsorção óssea com características histológicas mais severas comparado aos animais controle que possuem somente a periodontite. Tais resultados contribuem para aprofundar estudos em busca de agentes terapêuticos que possam ser empregados no tratamento desta população.

Conclusão: A DP exerce influência na severidade da manifestação da doença periodontal observado pelo aumento da reabsorção óssea e alterações histológicas.

\section{Referências}

CHEN, Chang-Kai; WU, Yung-Tsan; CHANG, Yu-Chao. Association between chronic periodontitis and the risk of Alzheimer's disease: a retrospective, population-based, matched-cohort study. Alzheimer's research \& therapy. v. 9, n. 1, p. $56,2017$.

DA CUNHA, Claudio. et al. Hemiparkinsonian rats rotate toward the side with the weaker dopaminergic neurotransmission. Behavioural Brain Research. v. 189, p. 364-372, 2008.

KAMER, Angela. et al. Alzheimer's disease and peripheral infections: the possible contribution from periodontal infections, model and hypothesis. J Alzheimers Dis. v. 13, n. 4, p. 437-439, 2008.

KAUR, Tejaswani Kaur; UPPOOR, Ashita; NAIK, Dilip. Parkinson's disease and periodontitis - the missing link? A review. Gerodontology. v. 33, n. 4, p. 434-438, 2016.

LINDEN, Gerry J.; HERZBERG Mark C.; Working group 4 of joint EFPIAAP workshop. Periodontitis and systemic diseases: a record of discussions of working group 4 of the Joint EFPIAAP Workshop on Periodontitis and Systemic Diseases. J Periodontol. v. 84, n. 4 Suppl, p. 20- 23, 2013.

PRADEEP, Raju Avani. Clinical evaluation of the periodontal health condition and oral health awareness in Parkinson's disease patients. Gerodontology. v. 32, n. 2, 2013.

SEMENOFF, Tereza Aparecida Delle Vedove. et al. Histometric analysis of ligature-induced periodontitis in rats: a comparison of histological section planes. J Appl Oral Sci. v. 16, n. 4, p. 251-256, 2008.

SCHWARZ, Johannes; HEIMHILGER, Engelbert; STORCH, Alexander. Increased periodontal pathology in Parkinson's disease. J. Neurol. v. 253, p. 608-611, 2005.

$\mathrm{WU}, \mathrm{Ya}$-Hsin. et al. Effects of theaflavins on tissue inflammation and bone resorption on experimental periodontitis in rats. $\mathbf{J}$ Periodontal Res. v. 53, n. 6, p. 1009-1019, 2018.

ZLOTNIK, Yair. et al. Disorders of the oral cavity in Parkinson's disease and parkinsonian syndromes. Parkinsons Dis. Hindawi. v. 2015, p. 379-482, 2015. 


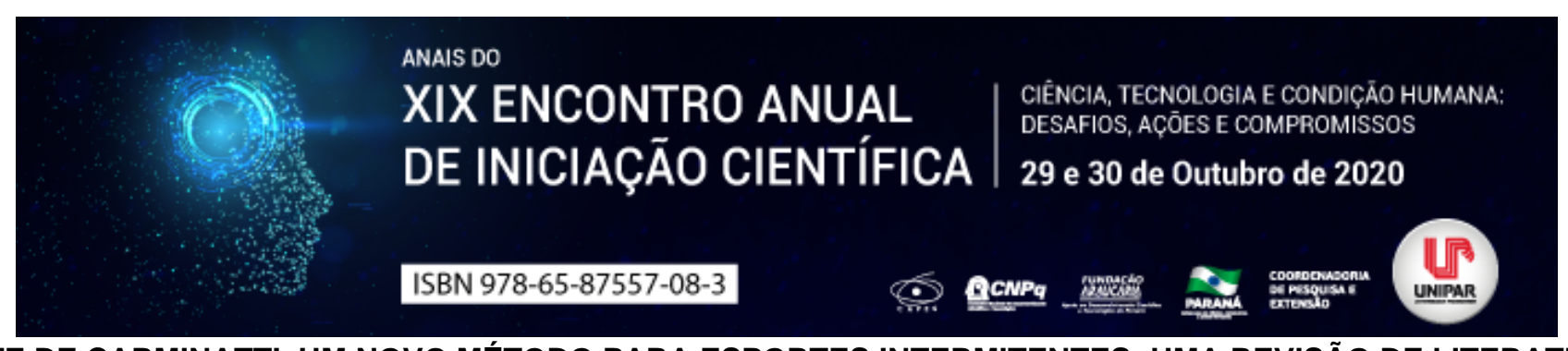

TESTE DE CARMINATTI, UM NOVO MÉTODO PARA ESPORTES INTERMITENTES: UMA REVISÃO DE LITERATURA

\author{
${ }^{1}$ GUILHERME DA SILVA DONADONI, ${ }^{2}$ GUILHERME VIEIRA ALFARO, ${ }^{3}$ HENRICH HYORDAN RODRIGUES DUTRA, \\ ${ }^{4}$ MARCELO FIGUEIRO BALDI
}

${ }^{1}$ Acadêmico do curso de Educação Física da Unipar
${ }^{1}$ Acadêmico do curso de Educação Física da Unipar
${ }^{2}$ Acadêmico do curso de Educação Física da Unipar
${ }^{3}$ Docente da UNIPAR

Introdução: Uma das principais preocupações de técnicos, preparadores físicos e fisiologistas é o planejamento e treinamento da preparação física, que objetiva-se em alcançar o maior índice possível de condicionamento de seus atletas, que a posteriori se converterá no desempenho físico individual de cada um, seja em uma única partida ou durante todo o calendário competitivo (ARRUDA et al., 1999). Para atingir os índices de condicionamento desejado o programa de preparação física deve ser revisado e reavaliado constantemente através de variáveis fisiológicas, a fim de verificar sua efetividade. Uma das variáveis mais citadas na literatura é o VO²máx, que apesar de ser utilizado frequentemente como forma de revisar e reavaliar um programa de treinamento (BASSETT; HOWLEY, 2000), apresenta falhas descritivas ao ser associado a esportes intermitentes, por ter seus dados coletados na maioria das vezes em laboratórios, resultando na falta de especificidade (FERNANDES DA SILVA, 2011). Diante o exposto, o presente estudo procurou responder o seguinte problema de pesquisa: quais as vantagens e a validade do Teste de Carminatti?

Objetivo: Analisar as vantagens e a validade do Teste de Carminatti (TCAR).

Desenvolvimento: O Teste de Carminatti (TCAR) é um teste de campo que opõe-se aos testes laboratoriais realizados de forma linear ou em bicicletas, trazendo como principal característica a especificidade dos movimentos realizados durante os jogos e sessões de treino de esportes intermitentes. Os estágios mais avançados do teste, atingem distâncias consideráveis, permitindo uma maior aceleração em comparação a outros testes, tanto os laboratoriais bem como outros protocolos de campo (DITTRICH et al., 2011). Ainda segundo Dittrich et al. (2011), o TCAR pode mensurar com maior propriedade as respostas fisiológicas de um atleta durante a prática de um esporte com característica intermitente e diversas trocas de direção, pois possui um alto grau de especificidade. O TCAR trata-se de um teste intermitente, do tipo incremental máximo, a partir de uma corrida em vai e vem, com multi estágios escalonados que aumentam a distância e a velocidade percorrida, gradativamente, até a exaustão (CARMINATTI, 2006), com o objetivo de determinar as variáveis fisiológicas pico de velocidade (PV) e ponto de deflexão da frequência cardíaca (PDFC) (CARMINATTI, 2004). O teste inicia-se com uma corrida de 15 metros, à um ritmo de $9 \mathrm{~km} / \mathrm{h}$ que é ditado por um sinal sonoro (bip), emitido a cada 6 segundos, sendo 12 segundos de corrida (6 na ida e 6 na volta) e mais 6 segundos de um descanso ativo de caminhada em uma área de aproximadamente 5 metros delimitada junto a marcação da linha de saída. Cada estágio possui 90 segundos, divididos em 5 corridas de 12 segundos ou 5 voltas, somados aos 6 segundos de descanso após cada corrida, quando completados os 90 segundos completa-se um estágio, é acrescido então ao teste 1 metro na distância percorrida e $0,6 \mathrm{~km} / \mathrm{h}$ na velocidade. Esse aumento da distância e da velocidade ocorre sempre ao término de cada estágio, de maneira gradual até o fim do teste, que se dá por duas chegadas consecutivas em atraso na linha que determina o fim da corrida ou pela exaustão voluntária (CARMINATTI, 2006). Em um estudo proposto por Dittrich et al. (2011), atletas de modalidades intermitentes foram testados com protocolos laboratoriais e com o TCAR, onde os resultados encontrados mostraram-se associáveis e os dados obtidos através do TCAR não expuseram discrepâncias, as diferenças encontradas são apenas reflexos da especificidade promovida pelo Teste de Carminatti e indicam uma comprovação de sua validade e eficácia.

Conclusão: Baseado no presente trabalho e na bibliografia utilizada para compor o mesmo, podemos concluir que o TCAR apresenta vantagens significativas caracterizadas por sua especificidade na simulação dos movimentos utilizados nos esportes intermitentes, tanto nas mudanças de direção como no espaço utilizado pelo mesmo, que permite ao corpo lidar de fato com o ambiente em que suas ações de jogo serão realizadas, culminando em respostas e ações fisiológicas mais precisas e coerentes, o que comprova ainda a validade do teste.

\title{
Referências
}

ARRUDA, M. et al. Futebol: uma nova abordagem de preparação física e sua influência na dinâmica da alteração dos índices de força rápida e resistência de força em um macrociclo. Revista treinamento desportivo, São Paulo, v. 4, n. 1. 1999.

BASSETT, D. R; HOWLEY, E. T. Limiting factors for maximum oxygem uptake and determinants of endurance performance. Medicine \& Sports in Sports \& Exercise, Tennesse - TN, v. 32, p. 70-84, 2000. 
CARMINATTI, L. J. Validade de limiares anaeróbicos derivados do teste incremental de corrida intermitente (TCAR) como preditores do máximo steady-state de lactato em jogadores de futsal. 2006. 105f. Dissertação (Mestrado em Ciências do Movimento Humano) - Universidade do Estado de Santa Catarina, Florianópolis, 2006.

CARMINATTI, L. J.; LIMA SILVA, A. E.; DE OLIVEIRA, F. R. Aptidão aeróbia em esportes intermitentes - Evidências de validade de constructo e resultados em teste progressivo com pausas. Revista brasileira de fisiologia do exercício. Rio de Janeiro - RJ, v. 3, n. 1, p. 120, Mar. 2004.

DA SILVA, J. F. et al. Validity and reliability of a new field test (Carminatti's test) for soccer players compared with laboratiry based measures. Journal of sports sciences, v. 29, n. 15, p. 1621-1628, 2011.

DITTRICH, N. et al. Validity of Carminatti's Test to determine physiological indices of aerobic power and capacity in soccer and futsal players. Journal of Strength and condition research. v. 25, n. 11, p. 3099-3016, Nov. 2011.

Coordenadoria de Pesquisa e Extensão - COPEX

Departamento de Editoraçāo e Divulgaçāo Científica - DEDIC 


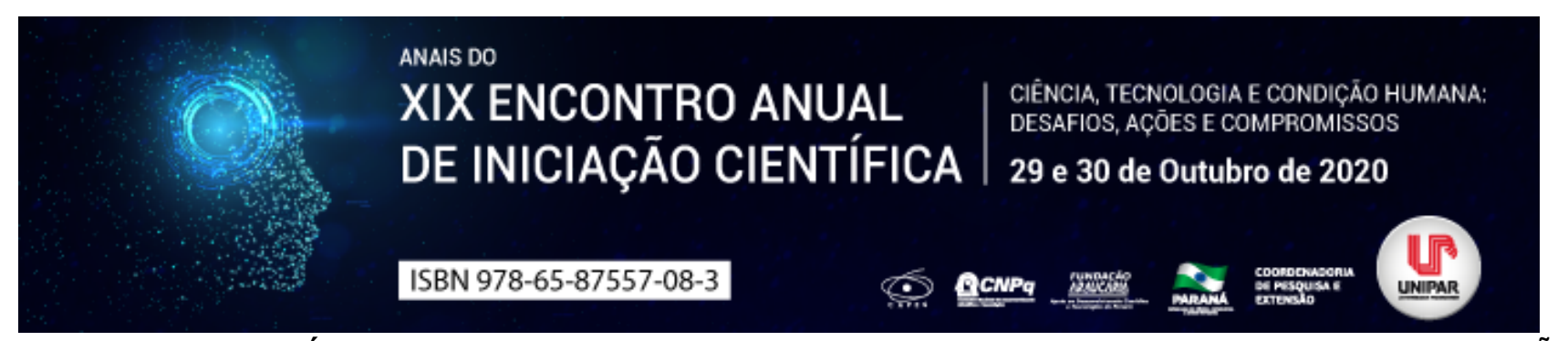

CIGARRO E NARGUILÉ ASSOCIADOS AO DESENVOLVIMENTO DA DOENÇA PERIODONTAL: UMA REVISÃO

\begin{abstract}
${ }^{1}$ LETICIA NAVAQUI ROCHA, ${ }^{2}$ ANDRESSA VENTRAMELI DE ANDRADE, ${ }^{3}$ CARINE CRISCIELE FORMAGGI SALES, ${ }^{4}$ JOAO MURILO GONCALVES GAZOLA, ${ }^{5}$ MARIA EDUARDA AKI OBO, ${ }^{6}$ CINTIA DE SOUZA ALFERES ARAUJO
\end{abstract}

\footnotetext{
${ }^{1}$ Acadêmica do curso de Odontologia UNIPAR

${ }^{1}$ Acadêmica do Curso de Odontologia da UNIPAR

${ }^{2}$ Acadêmica do Curso de Odontologia da UNIPAR

${ }^{3}$ Acadêmico do Curso de Odontologia da UNIPAR

${ }^{4}$ Acadêmica do Curso de Odontologia da UNIPAR

${ }^{5}$ Docente da UNIPAR
}

Introdução: É notável que o impacto sobre a saúde decorrente do uso do tabaco é latente e, neste contexto, vê-se que o consumo de cigarros está entre um dos principais fatores de risco para câncer de pulmão e muitas outras doenças, a exemplo da periodontite (AL HARTHI et al, 2013). De acordo com Souza et al (2006) as doenças periodontais são infecções crônicas associadas a microrganismos anaeróbicos que resultam em aprofundamento patológico do sulco gengival por meio de migração apical do epitélio juncional, destruição do ligamento periodontal e osso alveolar.

Objetivo: Realizar um levantamento bibliográfico sobre os malefícios do cigarro e do narguilé relacionados à doença periodontal. Desenvolvimento: A nicotina é uma das drogas mais antigas e mais usadas na atualidade, na forma de cigarro, além de ser considerada a maior causa de morte mundo. A nicotina age diminuindo a resposta imunológica dos usuários, causando imunossupressão, o que torna os pacientes mais propensos aos desenvolvimentos de doenças bucais e sistêmicas (MARQUES et al., 2016). Existem diferentes formas de preparar o tabaco com objetivo de alterar principalmente seu sabor e cheiro. Porém, todas suas formas de utilização têm em comum a liberação de nicotina no nosso organismo. $O$ tabaco pode ser queimado em forma de cigarro, cachimbo, charuto e o que é um dos mais populares, principalmente entre os jovens, o narguilé (VIEGAS, 2008). A associação entre tabagismo e periodontite é existente, de acordo com Leite et al (2018). Os autores pesquisaram estudos que abordam a associação entre tabagismo e a incidência e progressão da periodontite. As vias pelas quais o tabaco afeta a incidência e a progressão da doença permanecem incertas, porém, surgiu a hipótese de alguns mecanismos, sendo eles o efeito do tabagismo sobre a composição da microbiota, além da resposta imune e capacidade de cura do periodonto. O uso de várias formas de tabaco é um dos mais importantes fatores de risco evitáveis para a incidência e progressão da doença periodontal. $\mathrm{O}$ uso de tabaco afeta negativamente os resultados do tratamento tanto para doenças e condições periodontais como para implantes dentários (RYDER et al. 2018). Segundo Da Rocha et al (2019) o uso do tabaco, independentemente de sua forma de apresentação, está relacionado com o desenvolvimento e progressão da doença periodontal, sabendo que o número dos usuários de narguilé entre adolescentes, jovens e adultos vem crescendo drasticamente nos últimos anos, faz com que ocorra a necessidade de novas políticas de regulamentação para uso e venda desses produtos.

Conclusão: Perante o que foi citado acima, é de extrema importância que o cirurgião-dentista esteja atento aos sinais e manifestações de doenças decorrente do uso do tabaco, e saiba os malefícios que essa droga pode causar na saúde bucal.

\title{
Referências
}

AL HARTHI, Lena, et al. The impact of periodontitis on oral health-related quality of life: A review of the evidence from observational studies. Aust Dent, v. 58, n. 384, p. 274-7, 2013.

DA ROCHA, Evandro Franco, et al. O cigarro, o narguilé e a doença periodontal. Revista Eletrônica Acervo Saúde, n. 28, p. e784-e784, 2019.

LEITE, Fabio Renato Manzolli, et al. Effect of smoking on periodontitis: a systematic review and meta-regression. American Journal of Preventive Medicine, v. 54, n. 6, p. 831-841, 2018.

MARQUES, Lídia Audrey Rocha Valadas, et al. Abuso de drogas e suas consequências na saúde bucal: uma revisão de literatura. Faculdade de Odontologia de Lins/Unimep. v.26, n.1, p. 29-35. Jan-Jun.2016.

RYDER, Mark; $\mathrm{COUCH}$, Elizabeth; CHAFFEE, Benjamin. Personalized periodontal treatment for the tobacco-and alcohol-using patient. Periodontology 2000, v. 78, n. 1, p. 30-46, 2018.

SOUZA, Emmanuel, et al. A doença periodontal como fator de risco para as doenças cardiovasculares. IJD. International Journal of Dentistry, v. 5, n. 1, 2006.

VIEGAS, Carlos Alberto de Assis. Formas não habituais de uso do tabaco. Jornal Brasileiro de Pneumologia, v. 34, n. 12, p. 
1069-1073, 2008.

Coordenadoria de Pesquisa e Extensāo - COPEX

Departamento de Editoraçāo e Divulgaçāo Científica - DEDIC 


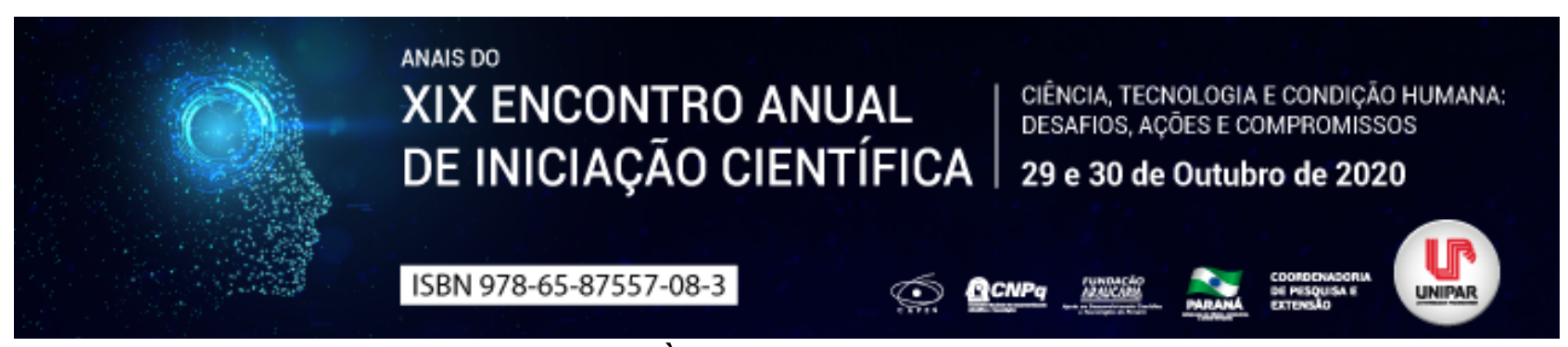

FATORES RELACIONADOS ÀS DORES NA COLUNA AO LONGO DA VIDA

\title{
${ }^{1}$ ANTONIO DONIZETE GONCALVES JUNIOR, ${ }^{2}$ VITOR HUGO RAMOS MACHADO
}

\author{
${ }^{1}$ Acadêmico do Curso de Educação Física da UNIPAR \\ ${ }^{1}$ Docente da UNIPAR
}

Introdução: A postura do homem tem sua origem nos primórdios da espécie humana, tendo o início de seu desenvolvimento na fase embrionária e seu término quando o indivíduo morre. E, é por meio das posturas adquiridas ao longo da vida que será moldado o formato da coluna vertebral (DO VALLE; NOLL; CANDOTTI, 2016). No século XVII, com o avanço da física e da medicina, a simetria e a retitude corporal passam a ser vistas como uma questão de saúde física (SOUZA 2002) .Na década de 1930, afirmava-se que: Talvez não exista 'maneira natural' no adulto . Os hábitos posturais são, segundo o autor, de alguma maneira moldados pela educação e pela cultura. (MAUSS 1930, apud SOUZA; VIEIRA, 2002). Na segunda metade do século XVIII, surge no exército a utilização de exercícios físicos para modelar o corpo. No século XIX, a utilização de exercícios para reforço muscular e correção postural extravasou o campo militar e passou a ser recomendada a toda a sociedade (SOUZA; VIEIRA, 2002). Mesmo com bases históricas fundamentadas em ciência os problemas crônicos relacionados à coluna representam importantes agravos pertencentes à saúde pública, de acordo com a Pesquisa Nacional de Saúde (PNS, 2013), $45 \%$ da população adulta do Brasil relatou ter dores de coluna. (CORREIA; CÂMARA, 2019). Dentre as causas mais comuns relacionadas a problemas de coluna estão: raça, idade, sexo, escolaridade, fatores comportamentais, fumo, baixa atividade física, trabalho físico extenuante, posturas viciosas, movimentos repetitivos, sedentarismo e obesidade (OLIVEIRA; BRAZ, 2016). As alterações posturais podem ser consideradas normais até aos oito anos; após essa idade o corpo adapta-se e realinha, repondo a postura corporal. (SOUZA; PAÇO; PINHO, 2017). Portanto, deve-se priorizar a verticalidade da postura das crianças ainda em fase escolar para evitar futuras complicações.

Objetivo: Elencar os fatores relacionados às dores na coluna ao longo da vida.

Desenvolvimento: Segundo o estudo realizado por Souza, Paço e Pinho (2017), foram estabelecidas associações estatisticamente significativas entre o padrão de respiração e o alinhamento horizontal dos acrômios, bem como com o alinhamento horizontal e vertical da cabeça; entre o padrão de respiração e deglutição com as relações oclusais ântero-posterior e oclusal vertical e ainda entre padrão de respiração e deglutição com hábitos de sucção digital e uso de chupeta. No estudo de Sedrez et. al (2015) foi encontrada associação entre cifose torácica e sexo feminino, prática de exercício físico uma ou duas vezes na semana, tempo de sono superior a 10 horas, posturas inadequadas para sentar para escrever e o meio de transporte do material escolar, quando assimétrico este também está relacionado a lordose lombar. Houve associação entre a presença de escoliose com a prática de esporte competitivo. Existem também estudos que evidenciam a alta prevalência de dores nas costas entre os escolares associada com; tempo ao assistir televisão, horas de sono por noite e postura utilizada ao sentar-se em um banco (VALLE et al 2016). O estudo de BORTOLINI, (2016) buscou verificar se existe associação entre dores nas costas, baixa força/resistência abdominal e pouca flexibilidade. Entretanto, o relato de dores nas costas não parece estar associado a uma baixa força/resistência abdominal e a uma baixa flexibilidade. Dentre as diversas causas que proporcionam problemas posturais, encontram-se a utilização de mochilas pesadas, assentos desproporcionais, exercícios inadequados ou mal executados pelas crianças. As principais patologias em escolares são hipercifose torácica, escoliose, joelho valgo e hiperlordose lombar, e a mais frequente o desnível de ombros (MENOTTI et al, 2018). Problemas posturais entre crianças e adolescentes fazem com que se tornem cada vez menos produtivos em suas atividades, pois sentem dores constantes. Devido a isso, se torna importante uma linha de comunicação entre pais, educadores e profissionais da área da saúde para que possam ser abordados os problemas e dificuldades das crianças e adolescentes de forma que possam ser criadas as melhores formas de preveni-los ou contorná-los (PEIXOTO, 2018). Diante disso, a proposta foi da construção da Agenda Auxiliar de Saúde Postural (ASP). O projeto será uma tentativa de facilitar a comunicação entre pais, professores e profissionais da saúde, e criar uma ferramenta capaz de auxiliar na melhora e na manutenção da condição de saúde de alunos, trazendo consigo todas as informações do aluno, junto com um relatório informando sobre a saúde funcional do mesmo. Dessa forma, a ASP pode evitar que crianças se tornem adultos com patologias irreversíveis (PEIXOTO et al 2018). A Ginástica Laboral é uma atividade física realizada nas empresas com seus funcionários que visa melhorar a qualidade de vida. Os resultados indicam que o programa de Ginástica Laboral contribui para melhorar as dores musculares e altera positivamente o fisiológico e o psicológico dos indivíduos praticantes. Conclui-se que a Ginástica Laboral contribuiu positivamente na qualidade de vida e na saúde dos funcionários (NORO 2017).

Conclusão: Portanto, fica evidente a comprovação de que o acompanhamento à postura de crianças e adultos realizado por profissionais deve ser feito de maneira periódica ao longo de toda a vida. Tanto nas escolas como nas empresas deve-se adotar programas com métodos, como a ginástica laboral, que promovam melhoramento e manutenção postural. Para tal, se faz 
necessário a implantação de políticas públicas que fiscalizem e incentivem esses programas. Além disso, é comprovado que alunos e trabalhadores acompanhados por tais métodos se apresentam com melhor saúde postural e tendem a render mais em suas funções por mais variadas que sejam.

\section{Referências}

BASSO DBA, SOUZA JA, PASINATO F,CORREAA ECR, DA SILVA MT. Study of the body posture in children with predominant oral breathing and school-age children in general. Saúde (Santa Maria) 2009; 25: 21-7.

CANDOTTI CT, MACEDO CH, NOLL M, FREITAS K. Escola postural: uma metodologia adaptada para crianças. Rev. Arquivos Mov. 2009;5(2):34-49.

CANDOTTI CT, NOLL M, CRUZ M. Prevalência de dor lombar e os desequilíbrios musculares em manicures. Rev. Arquivos Mov. 2010;6(1):125-40.

CANDOTTI CT, NUNES SE, NOLL M, FREITAS K, MACEDO CH. Efeitos de um programa de educação postural para crianças e adolescentes após oito meses do seu término.

CORREIA, Déborah Carolinne do Nascimento Câmara. Perfil epidemiológico dos pacientes com disfunção da coluna vertebral atendidos na unidade de reabilitação músculo-esquelética da UFRN. 2019. 33f. Trabalho de Conclusão de Curso (Graduação em Fisioterapia) - Departamento de Fisioterapia, Universidade Federal do Rio Grande do Norte, Natal, 2019

CUNHA CP. Dificuldade para pronunciar e a relação com a avaliação miofuncional em usuários de prótese total. [monografia na internet], Ribeirão Preto; 2004 [acesso em 12 mar 2015].

DUARTE, L. F. D. Da vida nervosa nas classes trabalhadoras urbanas. Rio de Janeiro, Graal, .1986.

FELÍCIO CM, CUNHA CC. Relações entre Condições Miofuncionais Orais e Adaptação de Próteses Totais. Revista Iberoamericana de Prótese Clínica e Laboratorial; 2005 [acesso em 10 mar 2015] 7(36): [p.195-202]

HANNA, T. What is somatics? Somatics: Magazine-Journal of the Bodily Arts and Sciences, v. 5, n. 4, p. 4-8, 1986.

HERTZ, R. A preeminência da mão direita: Um estudo sobre a polaridade religiosa. Religião e Sociedade, n. 6, p. 99-128, 1980.

KNOPLICH, J. Viva bem com a coluna que você tem. 25. ed. São Paulo: Ibrasa, 1996

OLIVEIRA, Vinicius Cunha. BICALHO, Leandro Inacio. SOARES, Thiago Barbabela, DORNELLAS, Rafael Silva. Estabilidade articular da coluna vertebral; teorias contemporâneas e novos paradigmas. Fisioterapia Brasil, v. 10, n. 4, julho/agosto de 2009. PENHA P, AMADO JOÃO SM. Avaliação da flexibilidade muscular entre meninos e meninas de $\mathbf{7}$ e 8 anos. Fisioter e Pesq 2008; 15(4):387-91. doi: 10.1590/S1809-29502008000400012.

PERES MA, BARBATO PR, REIS SCGB, FREITAS CHSM, ANTUNES JLF. Perdas dentárias no Brasil: análise da Pesquisa Nacional de Saúde Bucal 2010. Rev Saúde Pública; 2013 [acesso em 04 nov 2015]

Rev Paul Pediatr. 2011;29(4):577-583. doi:10.1590/S0103-05822011000400017. 


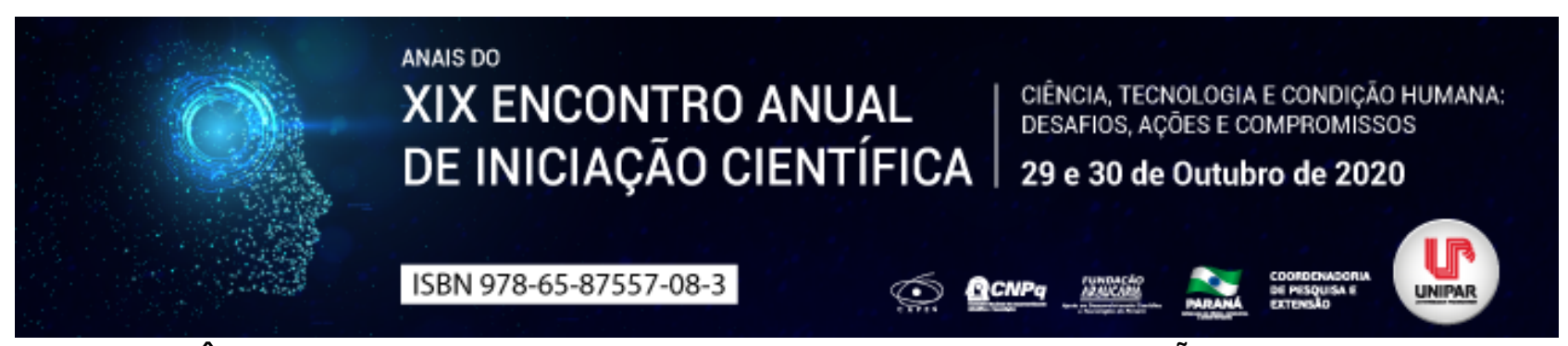

ANÁLISE DA FREQUÊNCIA NO CONSUMO DE FRUTAS E HORTALIÇAS NA POPULAÇÃO DAS CAPITAIS BRASILEIRAS

\author{
${ }^{1}$ Denise Tiemi Uchida, ${ }^{2}$ NANCY SAYURI UCHIDA
}

\author{
${ }^{1}$ Mestranda, Programa de Pós Graduação em Ciências da Saúde, Universidade Estadual Maringá, Maringá - Paraná \\ ${ }^{1}$ Docente, Departamento de Nutrição, Universidade Estadual Centro-Oeste, Guarapuava - Paraná
}

Introdução: As doenças crônicas não transmissíveis (DCNT) são consideradas umas das principais causas de morte (cerca de 70\%) e incapacidade no mundo, entre elas estão à obesidade, diabetes, doenças cardiovasculares e cânceres (WHO, 2011; WHO, 2013). Uma alimentação não saudável e a prática insuficiente de exercício físico representam um dos principais fatores de risco as DCNT, que é agravada em razão do crescente aumento no consumo de alimentos ultraprocessados e redução dos alimentos in natura (LOUZADA et al., 2015). Dados sobre alimentação da população, bem como as políticas públicas para promoção da alimentação saudável que incentivem o consumo regular de frutas, legumes e verduras são importantes no campo da saúde pública, para promoção da alimentação saudável, qualidade de vida e cidadania.

Objetivo: Analisar a frequência do consumo regular de frutas e hortaliças (FH) em homens e mulheres adultas nas capitais brasileiras, no ano de 2019.

Material e Métodos: Trata-se de um estudo transversal, de caráter descritivo e de base populacional, cujos dados secundários foram obtidos no Sistema de Vigilância de Fatores de Risco e Proteção para Doenças Crônicas por Inquérito Telefônico (VIGITEL), realizado em 2019. A população pesquisada compreende homens e mulheres adultas ( $\geq 18$ anos), moradores das 26 capitais dos estados brasileiros e o distrito federal e que possuíam em sua residência um número de telefone fixo. As características do padrão de alimentação foram obtidas por meio de um questionário onde foram considerados marcadores de padrões saudáveis de alimentação (frutas e hortaliças) e marcadores de padrões não saudáveis de alimentação (refrigerantes e alimentos ultraprocessados). Considerou-se regular o consumo de $\mathrm{FH}$ quando consumidos em cinco ou mais dias da semana. $\mathrm{O}$ consumo desses alimentos foi estimado a partir de respostas às questões realizadas por ligações telefônicas: Em quantos dias da semana o(a) Sr.(a) costuma comer frutas? , Em quantos dias da semana o(a) Sr.(a) costuma tomar suco de frutas natural? e Em quantos dias da semana o(a) Sr.(a) costuma comer pelo menos um tipo de verdura ou legume (alface, tomate, couve, cenoura, chuchu, berinjela, abobrinha não vale batata, mandioca ou inhame)? O percentual dos adultos que consomem $\mathrm{FH}$ regularmente foi obtido calculando o número de indivíduos que consomem estes alimentos em cinco ou mais dias da semana/ número de indivíduos entrevistados. O intervalo de confiança foi de $95 \%$.

Resultados: A frequência de adultos que consomem FH de forma regular nas capitais brasileiras e Distrito Federal foram de 25,2\% (São Luís) e 44,6\% (Belo Horizonte). No sexo feminino o consumo variou entre 28,3\% (São Luís) e 53,1\% (Distrito Federal) e no sexo masculino a variação ocorreu entre 17,7\% (Porto Velho) e 36,5\% (Belo Horizonte).

Discussão: Os resultados demostram diferenças no consumo de alimentos $\mathrm{FH}$ entre homens e mulheres e em todas as capitais brasileiras. O sexo feminino obteve o maior consumo regular de $\mathrm{FH}$, os maiores consumos ocorreram no Distrito Federal (53,1\%), Florianópolis (51,9\%) e Belo Horizonte (51,5\%), que concordam com outros estudos que apontam que mulheres tendem a consumir mais frutas e hortaliças do que homens (GOMES; CASTANHEIRA; PEREIRA, 2017; DAMIANI; PEREIRA; FERREIRA, 2017). O consumo maior de $\mathrm{FH}$ entre as mulheres pode estar relacionado à melhor percepção delas em relação aos benefícios do consumo para a saúde e/ou para prevenção/controle de doenças e à associação com uma alimentação mais saudável (DURANTE et al., 2017). Ao analisar o menor consumo FH entre as regiões do Brasil, as regiões Norte e Nordeste revelaram os menores índices no consumo em ambos os sexos. Entre os homens a menor frequência no consumo de $\mathrm{FH}$ ocorreram nas capitais de Porto Velho (17,7\%) e Rio Branco (19,3\%) e entre as mulheres a menor frequência foi em São Luís (28,3\%) e Belém $(29,9 \%)$. Outros estudos com dados da Pesquisa Nacional de Saúde, também identificou consumo menos prevalente de marcadores de consumo alimentar não saudável nas regiões Norte e Nordeste, em relação às demais (GABE; JAIME, 2020). Alimentos ricos em gorduras e açúcares estão inversamente relacionados ao consumo de frutas, legumes e verduras, tão logo, o consumo inadequado desses alimentos, está relacionado com o aumento do peso corporal e deve ser encorajado para melhoria da qualidade alimentar e nutricional da população (DAMIANI; PEREIRA; FERREIRA, 2017; LOPEZ; MENEZES; ARAÚJO, 2017). Em 2014, o Ministério da Saúde, publicou o Guia Alimentar para a População Brasileira que possui recomendações resumidas sobre a escolha de alimentos in natura ou minimamente processados e preparações culinárias, ao invés de alimentos ultraprocessados (GABE; JAIME, 2020). Apesar desse guia ressaltar a importância do consumo de FH para a saúde, é necessário ações no incentivo do consumo de frutas e hortaliças para população.

Conclusão: A frequência do consumo regular de frutas e hortaliças foi maior no sexo feminino e as menores frequências ocorrem nas regiões Norte e Nordeste, sugerindo a necessidade de ações e estratégias para a promoção do consumo de alimentos saudáveis na população. 


\section{Referências}

DAMIANI, Thaís Fernanda; PEREIRA, Lidia Pitaluga; FERREIRA, Márcia Gonçalves. Consumption of fruit, greens and vegetables in the Midwest region of Brazil: prevalence and associated factors. Revista Ciências \& Saúde Coletiva, v. 22, n. 2, p. 369-82, 2017.

DURANTE, Gabriela Dalcin et al. Differences in food consumption between men and women interviewed by vigitel telephone survey. Revista Brasileira em Promoção da saúde, Fortaleza, v. 30, n.3, p.1-12, jul./set., 2017.

GABE, Kamila Tiemann; JAIME, Patricia Constante. Dietary practices in relation to the Dietary guidelines for the brazilian population: associated factors among Brazilian adults, 2018. Revista Epidemiologia e Serviços de Saúde, Brasília, v. 29, n.1, março. 2020. Disponível em: https://www.scielo.br/scielo.php?pid=S2237-96222020000100309\&script=sci_arttext\&tlng=en

GOMES, Ana Paula Fernandes; CASTANHEIRA, Marcelo; PEREIRA, Sandra. Profile of fruit and vegetable consumption of elderly women in a health program for healthy aging in Rio de Janeiro. Nutrición clínica y dietética hospitalaria , v. 37, n.4, p. 160-166, 2017.

LOUZADA, Maria Laura da Costa et al. Ultra-processed foods and the nutritional dietary profile in Brazil. Revista de Saúde Pública, São Paulo, v. 49, p. 3, julho. 2015.

LOPES, Aline Cristine Souza; MENEZES, Mariana Carvalho; ARAUJO, Melissa Luciana. Food environment and access to fruits and vegetables: A metropolis into perspective . Revista Saúde e Sociedade, São Paulo, v.26, n.3, p.764-773, 2017.

World Health Organization. Global status report on noncommunicable diseases 2010. Geneva: WHO; 2011 [acessado em 20 de agosto de 2020]. Disponível em: http://www.who.int/nmh/publications/ncd_report2010/en/

World Health Organization. Global action plan for the prevention and control of NCDs 2013-2020 [Internet]. Genebra: World Health Organization; 2013 [acessado em 20 de agosto de 2020]. Disponível em: http://apps.who.int/iris/bitstream/10665/94384/1/9789241506236_eng.pdf?ua=1 


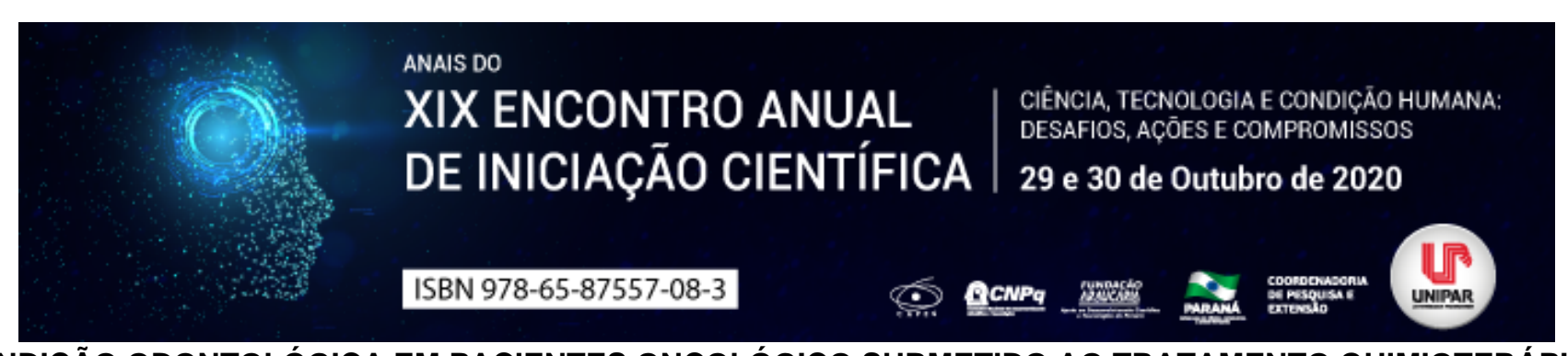

\title{
CONDIÇÃO ODONTOLÓGICA EM PACIENTES ONCOLÓGICO SUBMETIDO AO TRATAMENTO QUIMIOTERÁPICO: ACOMPANHAMENTO DE DOIS ANOS PÓS-TRATAMENTO
}

\author{
${ }^{1}$ BRUNA LUISA KOCH MONTEIRO, ${ }^{2}$ VALESCA ZELIK, ${ }^{3}$ JOAO VICTOR LOSS, ${ }^{4}$ FABRICIO ABEL PAGANINI, ${ }^{5}$ VOLMIR PITT \\ BENEDETTI
}

${ }^{1}$ acadêmico bolsista do PIBIC/UNIPAR

${ }^{1}$ Acadêmica do Curso de Odontologia da UNIPAR

${ }^{2}$ Acadêmico do Curso de Odontologia da UNIPAR

${ }^{3}$ Docente da UNIPAR

${ }^{4}$ Docente da UNIPAR

Introdução: Segundo a OMS existem 14 milhões de pessoas no mundo diagnosticadas com câncer e, de acordo com a organização, até 2030 a estimativa é que esse número irá aumentar para 21 milhões de casos (ROTTINI, 2019). Não obstante é a segunda patologia que mais causa mortes no mundo (JESUS et al., 2016). Existem diferentes abordagens de tratamento para as neoplasias, contudo as terapias mais comumente usadas são a quimioterapia, cirurgia e radioterapia, já a quimioterapia é empregada de forma isolada ou associada a outros fármacos ou modalidades terapêuticas (MORAIS et al., 2017). Os efeitos adversos desse tratamento são inúmeros e um dos principais são as manifestações orais, que têm correlação direta com o tipo de quimioterápico empregado, tempo de administração, dose, sexo, idade, qualidade da higiene oral e trauma local, ainda estudos afirmam que as alterações orais causadas por esses fármacos acometem $40 \%$ dos pacientes

(JESUS et al. 2016).

Objetivo: Analisar as alterações orais atuais, causadas em decorrência da quimioterapia, de pacientes em tratamento oncológico que foram submetidos ao fármaco entre os anos de 2017 e 2019 e que continuam com a terapia.

Metodologia: Para isto investigou 133 pacientes oncológicos sob tratamento quimioterápico no centro de oncologia de Francisco Beltrão - CEONC, em Francisco Beltrão, Paraná. Realizou-se a anamnese com

preenchimento de ficha epidemiológica, abordando questões referentes ao nome, idade, gênero, tipo de câncer, forma de tratamento, dentre outras perguntas. Seguiu-se com o exame clínico da cavidade bucal objetivando o diagnóstico das alterações orais, em seguida coletou-se cerca de $1 \mathrm{ml}$ de saliva do paciente. Na quantificação e identificação das leveduras oriundas da saliva, utilizou-se o meio cromógeno CHROMagar $®$ - Candida. Analisou-se os dados no Microsoft Office Excel e SPSS statistics nestas análises estatísticas utilizou-se o método de análise de variância (ANOVA), comparando as médias pelo teste de Tukey. Neste trabalho foram seguidos os trâmites éticos legais (29674620.1.0000.0109).

Resultados: Dos pacientes avaliados 99,2\% (132) exibiam ao menos uma alteração oral, sendo a candidíase a mais prevalente acometendo $72,1 \%$ (96) dos casos, seguida de xerostomia 69,9\% (93) e subsequente doenças gengivais $66,1 \%$ (88). Quando relacionado às manifestações orais com os sexos, não houve diferença significativa $(P>0,05)$, mas foi analisado que nos homens as alterações mais encontradas foram candidíase $81,4 \%$ (44) e doenças gengivais $77,7 \%$ (42), enquanto que nas mulheres foi xerostomia 74,6\% (59) e candidíase 65,8\% (52). Quando verificada a associação entre as alterações orais e faixa etária, não foi encontrada diferença significativa $(P>0,05)$. Entretanto, na correlação entre as alterações orais e o tipo de quimioterápico, a maior ocorrência das alterações estava presente nos pacientes que faziam uso o esquema terapêutico não baseado em antimetabólitos, alquilantes e antibióticos citotóxicos $(P<0,05) 18,9 \%(25)$. As patologias predominantes encontradas nesse grupo foram xerostomia $80 \%$ (20) e candidíase $76 \%$ (19). Das espécies de leveduas isoladas da saliva, a maior frequência de isolamento foi da Candida Albicans 62,1\% e C. glabrata 17,1\% ( $p<0,0001)$.

Discussão: Dos pacientes que utilizam como tratamento a quimioterapia, $40 \%$ deles são acometidos por patologias da cavidade oral durante a terapia. Freire et al. (2017) analisou em seu estudo que $56 \%$ dos pacientes avaliados manifestaram alguma alteração oral, com prevalência maior de patologias no sexo feminino. Estes dados não se assemelham os da presente trabalho. Segundo a análise de Hespanhol et al. (2010), dos pacientes avaliados em sua pesquisa, as alterações mais encontradas foram mucosite, lesões aftosas, candidíase e xerostomia. No estudo de Freire et al. (2017), as patologias mais recorrentes foram xerostomia, periodontite e gengivite. Estes dados corroboram aos desta pesquisa. Ainda segundo Hespanhol et al. (2010), a neutropenia advinda da quimioterapia causa imunossupressão, levando ao aparecimento de infecções oportunistas como a candidíase. De acordo com Jesus et al. (2016), os fármacos que ocasionam as lesões bucais são os 5-FU, metotrexato, cisplatina e ciclofosfamida. Para Borges et al. (2018), o acompanhamento e tratamento das patologias orais é imprescindível para diminuir a morbidade e remover focos infecciosos que podem levar a sepsis e interromper o tratamento antiblástico.

Conclusão: Nesta pesquisa observou-se que as alterações orais mais frequentes foram candidíase, seguida de xerostomia e 
doenças gengivais, independentemente de sexo e da idade. Quando analisado o esquema quimioterápico, os fármacos mais associados ao aparecimento das lesões foram aqueles no qual o esquema terapêutico não era baseado na utilização dos antimetabólitos, alquilantes e antibióticos citotóxicos. As leveduras mais encontradas na saliva foram a Candida albicans seguida de C. glabrata.

\section{Referências}

BORGES, Bianca Segantini et al. Atendimento odontológico de paciente submetido à radioterapia em região de cabeça e pescoço: relato de caso clínico. Revista de Odontologia da Universidade Cidade de São Paulo, v. 30, n. 3, p. 332-40, São Paulo, 2019.

FREIRE, Antônio Arlen et al. Manifestações bucais em pacientes submetidos a tratamento quimioterápico no hospital de câncer do Acre. Journal of Amazon Health Science, v. 2, n. 1, Acre, 2017.

HESPANHOL, Fernando Luiz, et al. Manifestações bucais em pacientes submetidos à quimioterapia. Ciência \& Saúde Coletiva. v.15, p.1085-1094, Rio de Janeiro, 2010.

JESUS, Leila Guerreiro, et al. Repercussões orais de drogas antineoplásicas: uma revisão de literatura - Oral effects of anticancer drugs: a literature review. RFO. v. 21, n. 1, p. 130-135, Passo Fundo, 2016.

MORAIS, Ângela Maria Dias, et al. Estudo das manifestações bucais de pacientes tratados com quimioterapia. $\mathbf{J}$ Orofac Invest. v. 4, n.1, p.49, Tocantins, 2017.

ROTTINI, Bruna Kamila, LIMA, Tainá Antunes de and GUERRA, Leticia de Freitas Cuba. Percepção Dos Pacientes Oncológicos, Sob Quimioterapia, Quanto Às Complicações Orais Advindas Do Tratamento Antineoplásico Em Um Hospital Do Sudoeste Paranaense. Revista Uningá, v. 56, n. S5, p. 23-36, Maringá, 2019. 


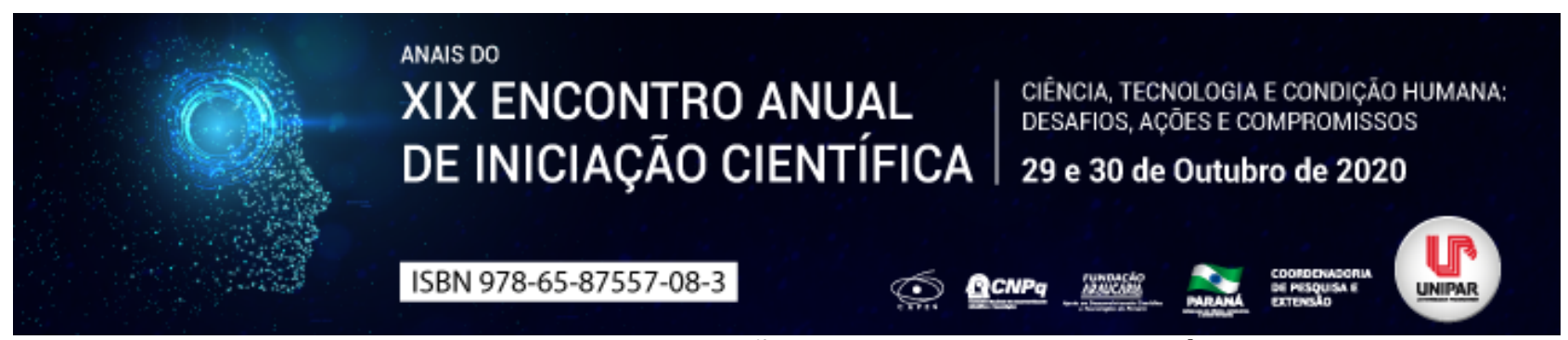

\title{
ANÁLISE DO TEOR DE CLORO ATIVO E PH DE SOLUÇÕES DE HIPOCLORITO DE SÓDIO UTILIZADAS DURANTE O TRATAMENTO ENDODÔNTICO
}

\author{
${ }^{1}$ ELOISA MARIA ZANFRILLI, ${ }^{2}$ SILVIA XAVIER GROSHEVIS, ${ }^{3}$ TAIS NUNES LOPES DA SILVA, ${ }^{4}$ GABRIELI JANKE RIGHEZ, \\ ${ }^{5}$ IGOR BUDI FERNANDES, ${ }^{6}$ SERGIO HENRIQUE STAUT BRUNINI
}

\author{
${ }^{1}$ Acadêmico do PIC/UNIPAR \\ ${ }^{1}$ Acadêmica do Curso de Cirurgia Periodontal e Introducao A Implantodontia - Turma Viii da UNIPAR \\ ${ }^{2}$ Acadêmica do Curso de Odontologia da UNIPAR \\ ${ }^{3}$ Acadêmica do Curso de Odontologia da UNIPAR \\ ${ }^{4}$ Acadêmico do Curso de Odontologia da UNIPAR \\ ${ }^{5}$ Docente da UNIPAR
}

Introdução: A presença de microrganismos no interior do canal radicular representa um fator preponderante no sucesso ou fracasso do tratamento endodôntico, sendo o preparo químico-mecânico a alternativa de controle desta contaminação. Neste binômio é notório que a ação mecânica dos instrumentos não é plenamente efetiva, sendo fundamental o auxílio químico proporcionado pela solução irrigadora. O hipoclorito de sódio constitui na principal substância utilizada com este propósito, fundamentada na capacidade antimicrobiana promovida pela liberação dos íons cloro. Contudo, as soluções de hipoclorito de sódio mostram-se instáveis, sofrendo alterações proporcionadas pela sua exposição ao sol, pelo local de armazenamento e até pelo frasco em que são acondicionadas, de modo que o profissional precisa manter-se atento a estas transformações que podem diminuir a efetividade do produto, tornando-o menos concentrado. Sendo assim, a avaliação da concentração de cloro ativo nas soluções de hipoclorito de sódio representa um controle essencial visando um melhor índice de sucesso para a terapia endodôntica.

Objetivo: Comparar resultados da concentração de cloro ativo de soluções de hipoclorito de sódio, assim como do pH das mesmas adquiridas no comércio local ou em casas especializadas em produtos odontológicos.

Material e Método: Foram utilizadas 4 (quatro) soluções comerciais de hipoclorito de sódio com rótulo indicando concentração de cloro livre entre 2 e 2,5\%, sendo uma adquirida através de distribuidor de material de limpeza e as demais em estabelecimento comercial de varejo. Além destas soluções, outras duas foram testadas, ambas na concentração de $1 \%$, sendo uma adquirida em casa de artigos odontológicos e outra proveniente da clínica de Odontologia da Unipar, campus Umurama diluídas pelo laboratório da instituição. O lacre dos frascos das soluções foi rompido e as embalagens permaneceram armazenadas em armários da Clínica Odontológica da Unipar a temperatura ambiente, por 120 dias simulando a utilização das mesmas no cotidiano das atividades práticas desenvolvidas na Clínica. Decorrido este prazo foram realizadas as avaliações do teor de cloro livre das soluções em triplicatas pelo método da iodometria, sendo utilizadas como resultado final a médias aritméticas das medidas obtidas. Para a determinação do pH das soluções, foi utilizado um aparelho digital peagâmetro, devidamente calibrado em temperatura ambiente com solução tampão.

Resultado: Solução de Milton (Asfer) teve média de concentração de cloro ativo 1,41 e pH 11,6; Solução de Milton (UNIPAR) teve média de concentração de cloro ativo 1,03 e pH 11,7; Água Sanitária (Q-Boa) teve média de concentração de cloro ativo 2,64 e pH 11,6; Água Sanitária (Candura) teve média de concentração de cloro ativo 2,64 e pH 11,6; Água Sanitária (Ypê) teve média de concentração de cloro ativo 2,66 e pH 12,1; Água Sanitária (Sol) teve média de concentração de cloro ativo 2,76 e pH 12.

Discussão: O hipoclorito de sódio representa a solução mais utilizada mundialmente como substância auxiliar durante o preparo biomecânico dos canais radiculares em virtude das suas propriedades, tais como: baixa tensão superficial, desodorizante, clareadora, lubrificante, detergente, bactericida, solvente de matéria orgânica e pH alcalino. (Batista et al, 2014). Contudo é uma substância bastante instável, apresentando perda de cloro, o que segundo Borin et al. (2008) compromete sua efetividade como substância química auxiliar, podendo ser considerado o motivo de insucessos do tratamento endodôntico. Borin et al. (2008) avaliaram a estabilidade do teor de cloro da solução de hipoclorito de sódio variando-se o local de armazenamento, a embalagem e a quantidade de substância presente no frasco por um período de 70 dias, podendo constatar de que a única variável que produziu uma diferença significativa foi o conteúdo dos frascos, sendo que a presença de uma menor quantidade na embalagem levou a uma maior perda de cloro ativo. Batista et al. (2014) avaliaram o teor de cloro ativo e o pH de seis soluções de hipoclorito de sódio em concentrações de 2-2,5\% durante 90 dias. Ao final deste período foi possível observar que todas as soluções apresentaram diminuição do teor de cloro ativo. Quanto ao pH todas as soluções mantiveram-se alcalinas. A pesquisa realizada neste trabalho constou teor de concentração de cloro ativo maior do que as disponibilizadas pelos fabricantes, as variações não 
chegaram à 0,5. Em relação ao pH todos se apresentaram alcalinos.

Conclusão: Todas as soluções avaliadas apresentaram teor de cloro ativo com concentrações próximos das especificações do fabricante, tornando seguro o emprego de substâncias adquiridas em estabelecimentos comerciais de varejo no processo de desinfecção dos canais radiculares.

\section{Referências}

ÁVILA, Leandro Marques; SANTOS, Marcelo; SIQUEIRA, Evandro Luiz; et al. Análise das soluções de hipoclorito de sódio utilizadas por endodontistas. RSBO. Joinville. v. 7, n. 4, p. 396-400, Out-Dez, 2010. Disponível em: http://revodonto.bvsalud.org/scielo.php?pid=S1984-56852010000400004\&script=sci_arttext. Acesso em: 28/08/2020.

BATISTA, Breno de Araújo; CARDOSO, Juliana Cordeiro; ARAÚJO, Cristina Reiss. Endodontia: Teor de cloro livre e Ph em soluções comerciais de hipoclorito de sódio utilizados em consultórios. Interfaces Científicas - Saúde e Ambiente. v. 3, n. 1, p. 47-56, Out., 2014. DOI: https://doi.org/10.17564/2316-3798.2014v3n1p47-56. Disponível em: https://periodicos.set.edu.br/saude/article/view/1912. Acesso em: 28/08/2020.

BORIN, Graziele; MELO, Tiago André Fontoura; OLIVEIRA, Elias Pandonor Motcy. Análise da estabilidade química da solução de hipoclorito de sódio a $1 \%$ levando-se em consideração o local de armazenamento e a quantidade de solução presente no frasco. RSBO. $\quad$ v. $5, \quad$ n. $3, \quad$ p. $07-12, \quad$ jun-ago $2008 . \quad$ Disponível em: file:///C:/Users/Usuario/Downloads/1_estabilidadequimica_BORIN.pdf . Acesso em: 28/08/2020. 


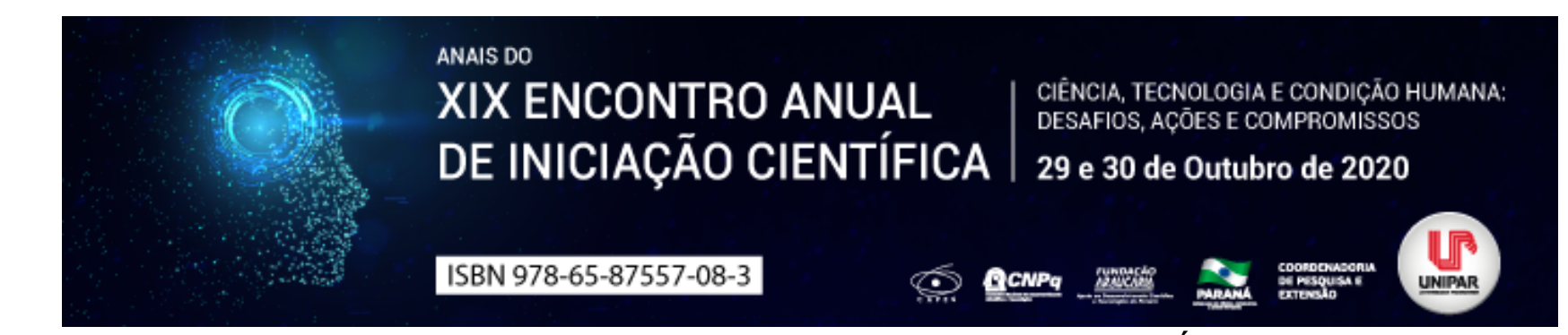

\title{
EXCESSO DE PESO CORPORAL EM CRIANÇAS DE DOIS A DEZ ANOS: UMA ANÁLISE A PARTIR DO SISTEMA INTEGRADO DE GESTÃO DE SERVIÇOS DE SAÚDE
}

\author{
${ }^{1}$ JESIEL DE SOUZA SOARES, ${ }^{2}$ ANDRE FERNANDO PASSOS DE OLIVEIRA,${ }^{3}$ ANA PAULA ZORZI PEREIRA , ${ }^{4}$ DURCELINA \\ SCHIAVONI BORTOLOTI
}

\author{
${ }^{1}$ Discente do Curso de Enfermagem PIC/UNIPAR Francisco Beltrão \\ ${ }^{1}$ Discente do Curso de Nutrição PIC/UNIPAR Cascavel
}

${ }^{2}$ Discente do Curso de Nutrição PIC/UNIPAR Francisco Beltrão

${ }^{3}$ Docente do Curso de Educação Física Bacharelado PIC/UNIPAR Francisco Beltrão

Introdução: Considerado como um dos principais problemas de saúde públicas na atualidade, a obesidade infantil vem aumentando gradativamente com o passar dos anos, independentemente da classe social, sexo ou faixa etária. De acordo com Freitas et al (2019), nos anos de 2008-2009, 33,5\% das crianças entre cinco e nove anos de idade estavam a cima do peso, e $14,3 \%$ eram obesas, o que possivelmente incidirá no futuro problemas como pressão alta, diabetes tipo II e doenças cardiovasculares, tornando-os adultos com várias comorbidades associadas e com alto índice de morbimortalidade. Recentemente a literatura tem apresentado vários estudos de prevalência de sobrepeso ou obesidade em crianças, como por exemplo o estudo de Moreira et al (2020), onde foram avaliadas 57 crianças e identificou que $40,4 \%$ apresentaram excesso de peso (sobrepeso, obesidade e obesidade grave). Uma estratégia para diagnóstico em grande escala da obesidade nesta faixa de idade é a avaliação do peso corporal pela idade. Trata-se de um método simples de fácil aplicabilidade e pode ser realizado no contexto escolar ou em unidades de saúde durante consulta pediátrica.

Objetivo: Verificar a prevalência de obesidade em crianças por meio do peso corporal para idade, de acordo com sexo em municípios brasileiros a partir de dados extraídos no Sistema Integrado de Gestão de Serviços de Saúde SIGSS.

Materiais e Métodos: Conduziu-se coleta de dados dos registros da variável de peso corporal de crianças de dois a 10 anos constantes no SIGSS utilizados pelos municípios brasileiros. Para tanto, foram coletados os dados abastecidos pelos municípios no SIGSS no período de janeiro de 2019 a julho de 2020. Tais registros foram inseridos pelos profissionais Nutricionistas e Agentes Comunitários de Saúde (ACS), seguindo os preceitos destacados nas regras do SUS - Sistema Único e Saúde (DATASUS, 2019). Os dados extraídos foram transportados para uma planilha do Microsoft ${ }^{\circledR}$ Office Excel, e posteriormente analisados por meio de estatística descritiva no programa SPSS 25,0 . A análise dos dados foi realizada com base nas tabelas de curvas de crescimento propostas pela OMS (2006) de acordo com sexo e idade, sendo considerado maior que dois escores $(>+2$ escor) o peso acima para idade.

Resultados: Das 40 declarações de permissão para utilização de dados solicitadas aos gestores municipais, foram recebidas até a finalização deste estudo, apenas quatro municípios (Capanema PR; Guaíra - PR; Gaspar - SC; Chapadão do Céu - GO), contudo, devido a pandemia do Covid-19, apenas o município de Guaíra realizou avaliações tanto em 2019 quanto em 2020, os demais apresentaram dados apenas do ano de 2019. Foram verificados para este estudo, 1647 registros válidos de peso corporal de crianças de dois a 10 anos de idade no SIGSS. A característica geral de peso corporal dos registros analisados foi de $25,792 \pm 10,133 \mathrm{Kg}$, estatura de 1,20 $\pm 0,16$ metros e índice de Massa Corporal de $17,11 \pm 3,14 \mathrm{Kg} / \mathrm{m}^{2}$. Os valores médios do peso corporal variaram entre 13,708 $\pm 2,682 \mathrm{Kg}$ à $38,300 \pm 11,521 \mathrm{Kg}$ para meninas e 14,828 $\pm 3,004 \mathrm{Kg}$ e 37,137 $\pm 9,139 \mathrm{Kg}$ para meninos. Ao analisar a classificação do peso corporal de acordo com a idade e o sexo, verificou-se a classificação de possivelmente inadequado (acima para idade) os seguintes percentuais: dois anos 48,2\% ( $n=112)$; três anos $34,1 \%(n=176)$; quatro anos 29,4\% ( $n=252)$; cinco anos $22,2 \%(n=185)$; seis anos $35,1 \%(n=154)$; sete anos $25,7 \%(n=179)$; oito anos $25,5 \%$ $(n=208)$; nove anos $16,6 \%(n=223)$; dez anos 16,2\% $(n=167)$.

Discussão: Este estudo apresentou uma variação importante nos dados de peso corporal de crianças de ambos os sexos dos municípios investigados. Vale destacar que, todos os municípios apresentam índice de Desenvolvimento Humano (IDH) classificados como elevado (IBGE, 2010), fator relevante, dentro das pesquisas epidemiológicas sobre estado nutricional de populações pediátricas. Contudo, os dados deste estudo demonstraram percentual preocupante quanto aos dados de excesso de peso corporal. Nesse sentido, a literatura tem destacado que, aparentemente o maior nível socioeconômico da população não incide diretamente na melhoria do estado nutricional, pois em geral observa-se um alto consumo de alimentos menos saudáveis (DA COSTA LOUZADA et al., 2015; LIMA et al., 2015). Com isso, no aspecto do estado de nutrição, principalmente nas crianças brasileiras, se observa uma tendência de aumento do excesso de peso, que pode levar ao estado de obesidade, em ritmo semelhante àquele observado entre a população adulta (CONDE et al., 2018). Vale destacar que, a obesidade é considerada, atualmente, um problema mundial de saúde pública, visto que predispõe ao surgimento ou agravo de doenças crônicas não 
transmissíveis. A Organização Mundial da Saúde estima que o número de crianças e adolescentes com excesso de peso é alto, com estimativas superiores a 340 milhões (WHO, 2019).

Conclusão: Verificou-se uma prevalência preocupante de crianças com peso corporal acima para a idade, com variação de $16,2 \%$ a 48,2\%. Indicando assim, que há necessidade de intensificação no acompanhamento na atenção primária nas crianças destes municípios, afim de evitar o estado de obesidade precoce nesta população.

\section{Referências}

CONDE, Wolney Lisbôa. et. al. Estado nutricional de escolares adolescentes no Brasil: a Pesquisa Nacional de Saúde dos Escolares 2015. Revista Brasileira de Epidemiologia, v. 21, p. e180008, 2018.

DA COSTA LOUZADA, Maria Laura. et. al. Alimentos ultraprocessados e perfil nutricional da dieta no Brasil. Revista de Saúde Pública, v. 49, p. 00-00, 2015.

FREITAS, Alex Sander. et al. Novos parâmetros de referência do índice de massa corpórea para crianças de seis a dez anos. Revista Paulista de Pediatria, v. 39, e2019129, 2021. Disponível em: http://www.scielo.br/scielo.php? script=sci_arttext\&pid=S0103-05822021000100408\&lng=en\&nrm=iso. Acesso em: 20 d Agosto. 2020.

LIMA, Niedja Maria da Silva. et. al. Excesso de peso em adolescentes e estado nutricional dos pais: uma revisão sistemática. Ciência \& Saúde Coletiva, v. 22, p. 627-636, 2017.

MOREIRA, Natália Boia Soares. et al. Prevalência de sobrepeso e obesidade em crianças de uma escola da rede privada na cidade de Teresópolis, Rio de janeiro. Revista da Jopic. v. 3, n. 6, p. 49-54, 2020

WHO. World Health Organization. Obesity and overweight $2019 . \quad$ Disponível em: http://www.who.int/mediacentre/factsheets/fs311/en/. Acesso em: 18 agosto. 2020 


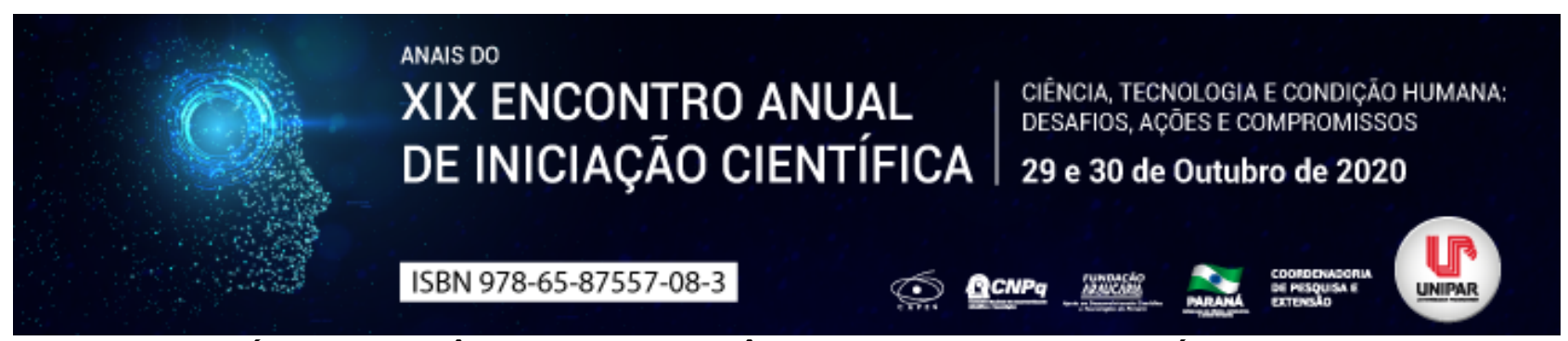

ATIVIDADE FÍSICA NA INFÂNCIA E ADOLESCÊNCIA: PROMOVENDO A SAÚDE NA FASE ADULTA

\begin{abstract}
${ }^{1}$ MATEUS DA SILVA MARQUES, ${ }^{2}$ ALISSON APARECIDO RODRIGUES SILVA, ${ }^{3}$ WILLIAN FERNANDO MARTINS PEREIRA, ${ }^{4}$ VITOR HUGO RAMOS MACHADO
\end{abstract}

\author{
${ }^{1}$ Acadêmico do Curso de Educação Física da UNIPAR \\ ${ }^{1}$ Acadêmico do Curso de Educação Física da UNIPAR \\ ${ }^{2}$ Acadêmico do Curso de Educação Física da UNIPAR \\ ${ }^{3}$ Docente da UNIPAR
}

Introdução: Atividade física tem sido enaltecida e propagada há séculos como um potente fator de promoção à saúde. A Sócrates, por exemplo, credita-se a seguinte afirmação: I"Na música, a simplicidade torna a alma sábia; na ginástica, dá saúde ao corpol" (GUALANO; TINUCCI, 2011). As grandes tecnologias que ultimamente avançaram vêm trazendo problemas para as crianças, pois elas escolhem ficar dentro de suas residências vendo televisão ou até mesmo em jogos em computadores e celulares, assim deixando as brincadeiras nas ruas. Crianças mais esportivas potencializam uma vida adulta melhor, diminuindo a taxa de mortalidade causadas pelo sedentarismo e suas comorbidades. Agregado a uma vida ativa, devemos sempre manter uma alimentação saudável e balanceada (BRAY; POPKIN, 1998). Os riscos associados gerados pela falta de atividade física são doenças metabólicas, diabetes, hipertensão, obesidade, problemas cardíacos (MENEZES et al., 2011). Má alimentação e uma diminuição das práticas de atividades físicas são umas das principais causas do sobrepeso e da obesidade em crianças, deixando de lado e não tratando corretamente no futuro quando chegarem a sua fase adulta poderá acarretar patologias. Programas de Exercícios e adequação na dieta são úteis para a diminuição das doenças na fase adulta (MARTINS et al., 2008).

Objetivo: Destacar a importância da atividade física na infância e adolescência.

Desenvolvimento: A atividade física é um fator importante para o desenvolvimento infantil, porém, isso trata das oportunidades de espaço, tempo e estruturação para que essas crianças possam realizar seus movimentos. Observa-se um comportamento de conhecimento por falta dos pais e seus professores a orientar de forma correta e adequada a vivência de movimentos diversos para crianças (BARROS et al. 2012; BARBOSA et al. 2016). As crianças e adolescentes no tempo atual ficam muito mais tempo em frente na televisão ou outros equipamentos tecnológicos como celulares e vídeo games, o que resulta na diminuição da prática de exercícios físicos e também resultando no acúmulo de te tecido adiposo corporal (AMARAL; PALMA, 2001; MOTA et al., 2015). Estudos do IBGE indicam que 54\% das crianças sofrem com a obesidade entre 6 a 11 anos, sendo estimado um número aproximado de 5 milhões de crianças obesas (IBGE,2014). Um estudo praticado e realizado em cidades do Vale do Taquari/RS, região onde foi identificada uma porcentagem muita alta de $46 \%$ com crianças entre 6 a 10 anos com sobrepeso acima do normal (BUENO et al., 2015). Dentre os vários agravos que a obesidade pode causar, podemos citar a dificuldade na capacidade cardiorrespiratória, depreciação da própria imagem e atrasos nas atividades motoras e físicas das crianças. Além dos impactos que a obesidade infantil pode criar durante a infância, suas consequências podem permanecer na fase adulta, pois sabe se que é muito uma criança chega na fase adulta sem sobrepeso (BERLEZE; HAEFFNER; VALENTINI, 2007). A atividade física desempenha um papel importante na condição física da criança, psicológica e mental, a prática pode aumentar a sua autoestima e a sensação do bem estar (BOIS et al.2005). Vários benefícios comprovam que a prática da atividade física, a diminuição dos sintomas de depressão e ansiedade, as doenças cardiovasculares e doenças degenerativas (STEIN, et al.,1999). O desenvolvimento geral está relacionado com o comportamento da genética, nutrição e o ambiente, contribuindo para o potencial do crescimento (Sociedade Brasileira de Pediatria, 2008). A prática da atividade física durante a infância na qual a criança está em estado de evolução é essencial para que ela tenha o desenvolvimento adequado. Pesquisas apontam que atualmente crianças entre 5 e 17 anos de idade devem realizar atividades físicas moderadas e vigorosas pelos menos 5 dias por semana no mínimo 60 minutos por dia (JANSSEN; ALLANA, 2010; STRONG et al., 2005; OMS, 2018). As atividades físicas jogos e brincadeiras têm uma participação importante para o desenvolvimento das crianças, pois realizando essas funções a criança explora o ambiente, interagem com os demais, expressam sentimentos e executam os movimentos (COOLKENS et al. 2018; ROLIM; GUERRA; TASSIGNY, 2008).

Conclusão: A prática de atividade física na infância e até mesmo na adolescência é importante pois ela ajuda no desenvolvimento motor e no sistema óssea, ajuda também nas prevenções de doenças patológicas como hipertensão, doenças cardiovasculares, entre outras.

\title{
Referências
}

AMARAL, A.P.A; PALMA, A.P. Perfil epidemiológico da obesidade em crianças: Relação entre televisão, atividade física e 
obesidade. Revista Brasileira de Ciências do Movimento. v.4, n.9, p. 19-24, 2001.

BARBOSA, S. C. et al. Ambiente escolar, comportamento sedentário e atividade física em pré-escolares. Revista Paulista de Pediatria. v. 34, n.1, p. 1-8, 2016.

BERLEZE, A.; HAEFFNER, L. S. B.; VALENTINI, N. C. Desempenho motor de crianças obesas: uma investigação do processo e produto de habilidades motoras fundamentais. Rev. Bras. Cineantropom. Desempenho Hum. v. 9, n. 2,2007.

COOLKENS, Rosalie et al. The Effect of Organized Versus Supervised Recesson ElementarySchool Children's Participation, Physical Activity, Play, and Social Behavior: A Cluster Randomized Controlled Trial. Journal Of Physical Activity And Health, Champaign, v. 15, n. 10, out. 2018.

GUALANO, B.; Tinucci, T. Sedentarismo, exercício físico e doenças crônicas. Rev. bras. educ. fís. esporte vol.25 no.spe São Paulo Dec. 2011.

JANSSEN, Ian; LEBLANC, Allana G. Systematic review of the health benefits of physical activity and fitness in schoolagedchildrenandyouth. International Journal Of Behavioral Nutrition And Physical Activity, London, v. 7, 11 maio 2010.

MARTINS, R. M.. Atividade física e alimentação saudável dentro da escola: critérios básicos para a diminuição da obesidade entre os adolescentes. Boletim Brasileiro de Educação Física (Brasília), v. 13, p. 1-1, 2008.

STEIN,R. Atividade física e saúde pública. Revista Brasileira de Medicina do Esporte, Niterói, Vol 5, ago 1999. 


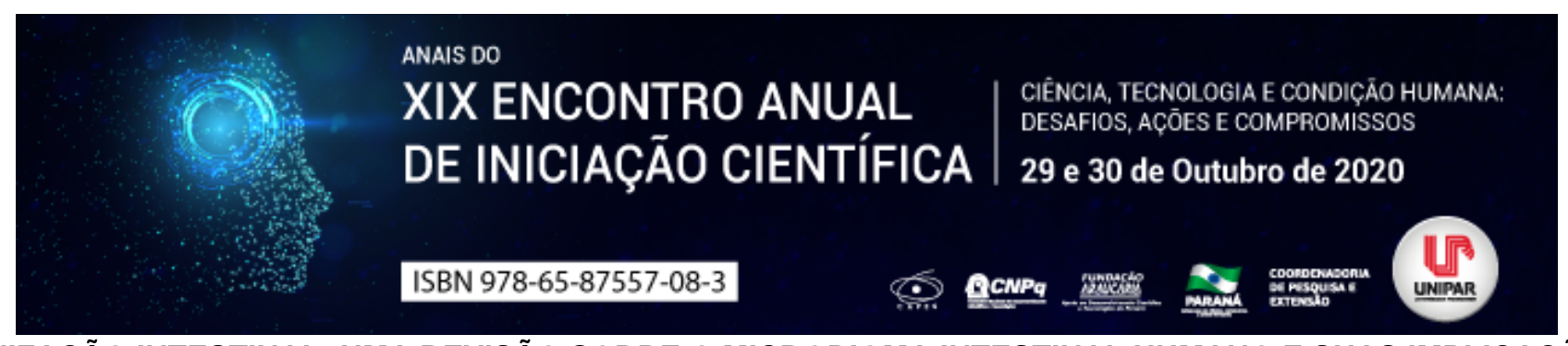

COLONIZAÇÃO INTESTINAL: UMA REVISÃO SOBRE O MICROBIOMA INTESTINAL HUMANO E SUAS IMPLICAÇÕES NA SAÚDE

\begin{abstract}
${ }^{1}$ DAVI CORREA PEREIRA, ${ }^{2}$ CAMILA MARIA ESCARDILLE YOSHITANI, ${ }^{3}$ ESTER PELEGRINI SILVA, ${ }^{4}$ FABIANE ANGELICA DE PAIVA PAULA, ${ }^{5}$ JESSICA ZANQUIS FERREIRA , ${ }^{6}$ ELENIZA DE VICTOR ADAMOWSKI CHIQUETTI
\end{abstract}

\begin{abstract}
${ }^{1}$ Acadêmico do Curso de Medicina da UNIPAR
${ }^{1}$ Acadêmica do Curso de Medicina da UNIPAR

${ }^{2}$ Acadêmica do Curso de Medicina da UNIPAR

${ }^{3}$ Acadêmica do Curso de Medicina da UNIPAR

${ }^{4}$ Acadêmica do Curso de Medicina da UNIPAR

${ }^{5}$ Docente da UNIPAR
\end{abstract}

Introdução: Os microrganismos que residem no ambiente intestinal (microbiota intestinal) compõem um diversificado e dinâmico sistema, sob influência de uma diversidade de fatores (CARDOSO, 2015). Incluem vírus, bactérias, protozoários, fungos e arqueobactérias (BARKO et al., 2018). São naturalmente causadores de infecções oportunistas e contribuintes para o desenvolvimento de patologias. Porém, não são apenas negativos seus efeitos, já que apresentam também grande potencial benéfico na promoção da saúde humana (CRESCl; BAWDEN, 2015).

Objetivo: Analisar os conhecimentos que sustentam a formação da microbiota intestinal, bem como influências que possuam implicações na saúde e na doença humana.

Desenvolvimento: $O$ primeiro estudo científico que apontou a possibilidade de modificação da microbiota intestinal visando repercussões na saúde foi realizado no início do século XX pelo russo Eli Metchnikoff (CRESCE; BAWDEN, 2015). Os microorganismos intestinais são contribuintes para formação de produtos carcinogênicos, no desenvolvimento de gastrite e de úlceras estomacais. Contudo, apresentam também uma ampla gama de benefícios, que incluem a síntese de vitaminas, a fermentação de carboidratos não digeríveis em fonte de energia, a facilitação da absorção de água e de sódio, e a competição com organismos patógenos (CARDOSO, 2015). Estudos apontam para o primeiro contato do ambiente intestinal com a microbiota durante o parto (PAIXÃO; CASTRO, 2016). Porém, já é sabida a presença de microorganismos desde o ventre materno. No útero, foi demonstrada a presença de microrganismos na placenta, líquido amniótico e cordão umbilical, destacando a importância da saúde intestinal materna. Ainda, a ausência de colonização intestinal durante o desenvolvimento fetal foi associada a patologias como enterocolite necrosante, sendo a suplementação com probióticos eficiente como meio profilático. Durante o parto, o bebê têm contato com microorganismos diferentes dos quais seu ambiente intestinal comporta, incluindo a variação bacteriana de acordo com o tipo do procedimento (parto normal ou cesária) (CRESCl; BAWDEN, 2015). Apesar da colonização ser instigada diariamente com a ingestão de alimentos e de água, a população diversa da microbiota gastrointestinal permanece relativamente constante com o decorrer da vida do hospedeiro (MURRAY; ROSENTHAL; PFALLER; 2014). Durante a amamentação, o bebê pode receber até 600 espécies diferentes de microorganismos, além dos demais componentes nutricionais necessários e prebióticos seletivos especialmente para espécies do gênero Bifidobacterium, tendo estas funções importantes na manutenção da mucosa intestinal e de produção de imunoglobulina $A$, o que aponta para o benefício da alimentação materna frente ao uso de fórmulas. A partir dos 3 anos, a microbiota intestinal de uma criança é semelhante ao de um adulto normal (CRESCI; BAWDEN, 2015). Variações neste período podem comprometer as funções imunológicas do indivíduo (HOLD; HANSEN, 2019). Com o envelhecimento, nota-se mudanças no microambiente intestinal relacionadas supostamente ao declínio na dentição, função salivar, digestão e trânsito intestinal. Estudos também apontaram para a redução da variedade microbiana intestinal com cuidados residenciais, pouca diversidade alimentar, aumento de marcadores inflamatórios e aumento da fragilidade do idoso. Além da idade, outras importantes influências da composição do microbioma intestinal humano incluem a localização geográfica e etnia, alterações dietéticas, a liberação de neuromediadores do estresse, a prática de exercícios físicos de alta intensidade, a presença de doenças críticas ou de disfunções do trato gastrointestinal, fatores psicológicos e efeitos farmacológicos. Avanços tecnológicos permitiram a expansão da ciência no âmbito microbiológico intestinal, de maneira que a compreensão das influências sobre a microbiota intestinal pode basear o tratamento de diversas patologias e a compreensão de doenças (CRESCl; BAWDEN, 2015).

Conclusão: O microbioma intestinal tem seu início de formação no período uterino, sofrendo maiores influências até o terceiro ano de vida, onde apresenta composição relativamente estável até a idade adulta, sendo significativamente afetado com a senescência. As principais influências na variabilidade e número de microorganismos incluem fatores físicos, ambientais e psicológicos, e constituem um importante marcador de desenvolvimento ou prevenção de doenças. $O$ avanço científico- 
tecnológico nessa área é capaz de possibilitar um melhor entendimento sobre diversas patologias, e de fornecer insights sobre o seu tratamento. Novas pesquisas nesta área devem possibilitar a identificação da microbiota intestinal como biomarcador de dieta nutricional e do desenvolvimento de doenças.

\section{Referências}

BARKO, P. C. et al.. The Gastrointestinal Microbiome. Journal of Veterinary Internal Medicine, v. 32, n. 1, 2018. Disponível em: https://www.ncbi.nlm.nih.gov/pmc/articles/PMC5787212/. Acesso em: 30 ago. 2020.

CARDOSO, Vanesa Marques. O Microbioma Humano. Orientador: José Cabeda, 2015. Tese (Mestrado em Ciências Farmacêuticas) - Universidade Fernando Pessoa, Porto, 2015.

CRESCI, Gail A.; BAWDEN, Emmy. The Gut Microbiome: What we do and don't know. HHS Public Acess Pubmed, vol. 30, n. 6, out. 2015. Disponível em: https://www.ncbi.nlm.nih.gov/pmc/articles/PMC4838018/. Acesso em: 30 ago. 2020.

HOLD, Georgina L.; HANSEN, Richard. Impact of The Gastrointestinal Microbiome in Health and Disease: Co-evolution with the Host Immune System. Current Topics in Microbiology and Immunology, 2019. Disponível em: https://link.springer.com/chapter/10.1007\%2F978-3-030-15138-6_12. Acesso em jul. 2020.

MURRAY, Patrick R.; ROSENTHAL, Ken S.; PFALLER, Michael A.. Microbiologia Médica. 7. ed. Rio de Janeiro: Elsevier, 2014.

PAIXÃO, Ludmilla Araújo; CASTRO, Fabiola Fernandes dos Santos. Colonização da Microbiota Intestinal e sua Influência na Saúde do Hospedeiro. Universitas: Ciências da Saúde, v. 14, n. 1, p. 85-96, 2016. Disponível em: https://www.publicacoesacademicas.uniceub.br/cienciasaude/article/view/3629. Acesso em: 30 ago. 2020. 


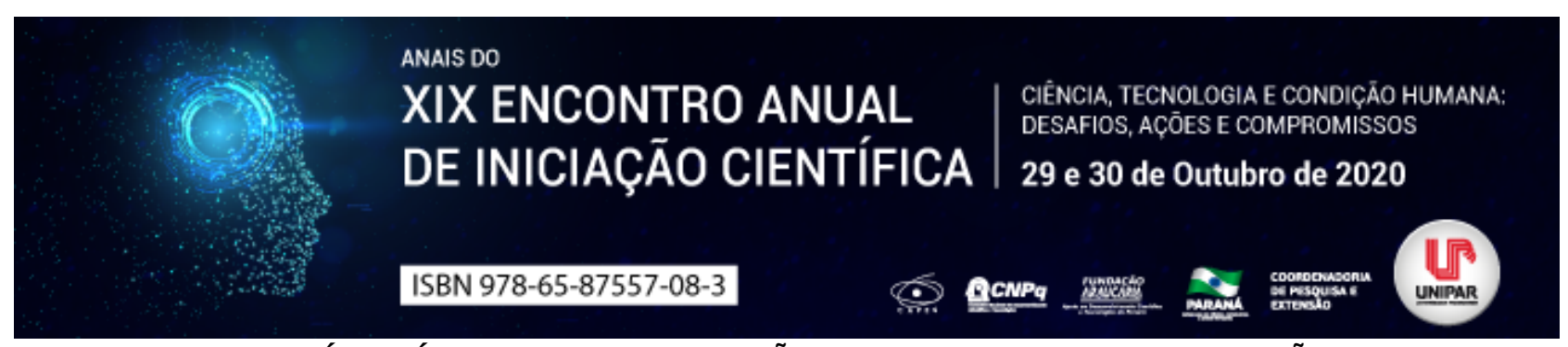

EXECÍCIO FÍSICO COMO PREVENÇÃO E TRATAMENTO DA DEPRESSÃO

\author{
${ }^{1}$ RIAN RIAD RIBEIRO, ${ }^{2}$ SILVIA REGINA NISHIYAMA SUCUPIRA SARTO
}

${ }^{1}$ Acadêmico do Curso de Educação Física da UNIPAR

${ }^{1}$ Docente da UNIPAR

Introdução: A depressão caracteriza-se por: tristeza, perda de interesse ou prazer, sentimentos de culpa ou baixo auto-estima, sono ou apetite perturbados, sentimentos de cansaço e falta de concentração (WORLD HEALTH ORGANIZATION, 2017, p. 7). Tal doença afeta mais de 300 milhões de pessoas em escala mundial, sendo a principal causadora da incapacidade, levando, em casos mais graves, ao suicídio (ORGANIZAÇÃO PAN-AMERICANA de SAÚDE, 2018). Dessa forma, torna-se necessário desvendar todas as formas possíveis, de combater tal implicação, que aterroriza a vida de diversos indivíduos, levando muitas vezes a morte do indivíduo. Assim dito, a prática do exercício físico vem tomando importância no que se refere à melhoria do estado psicológico em indivíduos depressivos, como também age como prevenção da depressão (VASCONCELOS-RAPOSO et al., 2009).

Objetivo: Analisar na literatura qual a eficácia da prática de exercício físico na prevenção e tratamento da depressão.

Desenvolvimento: Um estudo feito em Lisboa, Portugal, com 72 idosos de ambos os sexos, buscou comparar os níveis de ansiedade e depressão em pessoas da terceira idades ativas fisicamente e sedentárias, que não faziam uso de fármacos antidepressivos; tal estudo constatou que os idosos sedentários têm até 38 vezes de desenvolver ansiedade e/ou depressão que idosos ativos (MINGHELLI et al., 2013). Outro estudo, também de Portugal, agora com jovens de ambos os gêneros, de idades entre 18 a 27 anos, onde procurou saber a relação entre depressão, exercício físico e índice de massa corporal (IMC); constatou que ao passo que se aumenta a prática de exercício físico, os sintomas depressivos tendem a diminuir, todavia não se pode perceber relação significativa entre depressão e IMC; e concluiu que a prática de exercício físico pode ter caráter positivo tanto na redução quanto na prevenção da depressão em adultos (VASCONCELOS-RAPOSO et al., 2009). De forma similar, uma pesquisa feita em Maringá, Brasil, concluiu que o exercício físico, além de melhorar o condicionamento físico, traz benefícios psicofisiológicos, já de curto prazo, em tratamento de depressão moderada; todavia a prática do exercício deve ser mantida, pois, no devido estudo constatou que: um grupo de 9 mulheres depressivas, ao longo de 12 semanas em um programa de hidroginástica tiveram uma melhora significativa em seus quadros depressivos, porém, ao passo de 6 meses do fim do programa de treinos, notificou a regressão de seus números, voltando aos valores anteriores à rotina de treinos (VIEIRA; PORCU; ROCHA, 2007).

Conclusão: Visto as informações referentes aos diversos artigos sobre tal tema, pode aferir que a prática do exercício físico tem eficácia ao tratamento da depressão, assim como sua prevenção, independente da idade ou gênero, aliado ou não com fármacos; mas mostra-se necessário a continuidade do exercício, visto que sua interrupção cessa seus efeitos positivos.

\title{
Referências
}

MINGHELLI, Beatriz. et al. Comparação dos níveis de ansiedade e depressão entre idosos ativos e sedentários, Rev. psiquiatr. Clín, v. 40, n. 2, 15, fevereiro, 2013. Disponível em: https://www.scielo.br/pdf/rpc/v40n2/en_v40n2a04.pdf. Acesso em 22 jul. 2020.

ORGANIZAÇÃO PAN-AMERICANA de SAÚDE. Folha informativa: Depressão, março, 2018 Brasília, DF. Disponível em: https://www.paho.org/bra/index.php?option=com_content\&view=article\&id=5635:folha-informativa-depressao\&ltemid=1095.

Acesso em 28 jul. 2020.

VASCONCELOS-RAPOSO, José. et al. Relação entre exercício físico, depressão e índice de massa corporal, Fundação Técnica e Científica do Desporto, v. 5, n. 1, janeiro, 2009. Disponível em: http://www.scielo.mec.pt/pdf/mot/v5n1/v5n1a03.pdf. Acesso em 22 jul. 2020.

VIEIRA, José Luiz Lopes; PORCU, Mouro; ROCHA, Priscila Garcia Marques da. A prática de exercícios físicos regulares como terapia complementar ao tratamento de mulheres com depressão, Jornal Brasileiro de Psiquiatria, v. 56, n 1, 28, janeiro, 2007. Disponível em: https://doi.org/10.1590/S0047-20852007000100007. Acesso em 22 jul. 2020.

WORLD HEALTH ORGANIZATION.. Depression and other common mental disorders: global health estimates, fevereiro, 2017. Disponível em: https://apps.who.int/iris/bitstream/handle/10665/254610/WHO-MSD-MER-2017.2-eng.pdf?. Acesso em 22 jul. 2020. 



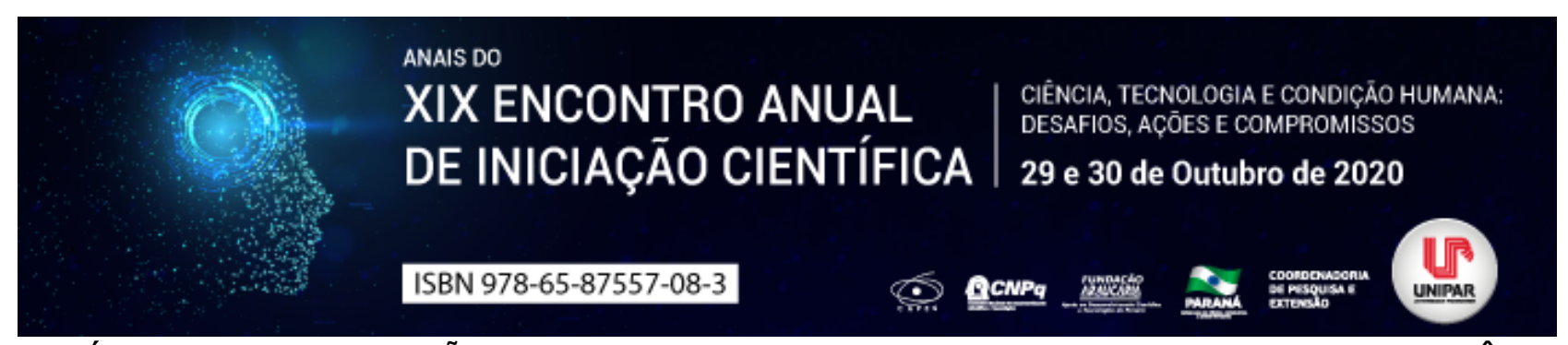

A EFICÁCIA DA ADMINISTRAÇÃO LOCAL DE ESTATINAS NO TRATAMENTO DA PERIODONTITE CRÔNICA

\author{
${ }^{1}$ Caroline Rodrigues Thomes, ${ }^{2}$ ROBERTA DEL PIERO TEIXEIRA, ${ }^{3}$ LARA VICTÓRIA DITTZ DE ABREU COSTA, ${ }^{4}$ ALFREDO \\ CARLOS RODRIGUES FEITOSA
}

${ }^{1}$ Acadêmica da Universidade Federal do Espírito Santo
${ }^{1}$ Acadêmica da Universidade Federal do Espírito Santo
${ }^{2}$ Acadêmica da Universidade Federal do Espírito Santo
${ }^{3}$ Docente da Universidade Federal do Espírito Santo

Introdução: A periodontite crônica é uma doença inflamatória de origem infecciosa caracterizada pela destruição progressiva dos tecidos moles e duros periodontais podendo levar à perda do dente. Os sintomas mais comumente encontrados são a presença de inflamação gengival, formação de bolsas periodontal, perda óssea alveolar, abscesso ou mobilidade dentária (PETIT, 2019). A patogênese da periodontite envolve uma complexa interação de cascatas imunológicas e inflamatórias ativadas por bactérias do biofilme dental (ESTANISLAU, 2015). A inflamação persistente associada à disbiose agravam os danos aos tecidos periodontais e, além disso, a própria resposta imune do hospedeiro desempenha um papel vital nesse fenômeno, contribuindo também com a destruição dos tecidos (PETIT, 2019). Assim, várias terapias adjuvantes têm sido utilizadas no tratamento da periodontite crônica para reduzir a destruição do tecido e aumentar os processos reparativos periodontais, incluindo estatinas (CAO, 2019). As estatinas são medicamentos inibidores do 3-hidroxi-3-metilglutaril coenzima A redutase (HMG-CoA redutase), amplamente empregadas na redução dos níveis sanguíneos de colesterol pela sua excelente propriedade de tolerabilidade, baixo custo e segurança (MUNIZ, 2018). O uso de estatinas é uma terapia estabelecida para hiperlipidemia e arteriosclerose, principalmente devido à redução da lipoproteína de baixa densidade. Além disso, tem sido investigado o seu uso em diversas especialidades odontológicas devido às suas propriedades terapêuticas no tecido ósseo e outros efeitos pleiotrópicos, como efeitos antiinflamatórios e imunomoduladores (ESTANISLAU, 2015).

Objetivo: Analisar a eficácia da administração local de estatinas no tratamento da periodontite crônica por meio de uma revisão de literatura narrativa dos últimos cinco anos.

Desenvolvimento: A identificação dos estudos foi realizada por meio de uma busca bibliográfica no portal eletrônico PubMed utilizando os MeSH terms Periodontal Therapy e Statins . Após a aplicação dos critérios de elegibilidade, de um total inicial de 70 estudos, foram selecionados 10, publicados no período de 2015 a 2020. Os critérios de inclusão foram revisões sistemáticas e não sistemáticas e ensaios clínicos randomizados. Os critérios de exclusão foram estudos prospectivos, estudos retrospectivos, relatos de casos, estudos in vitro, estudos com animais e àqueles fora do período e da temática investigada. As evidências analisadas demonstraram que as estatinas têm importantes efeitos anti-inflamatórios e relacionados ao sistema imune, reduzindo os níveis de proteína $C$ reativa e metaloproteinases de matriz, além de serem capazes de inibir a adesão e extravasamento de leucócitos, que bloqueiam a co-estimulação de células T. Ainda, reduzem a reabsorção óssea ao inibir a formação de osteoclastos e favorecem o aumento da apoptose dessas células (ESTANISLAU, 2015). A administração local de estatinas geralmente em forma de gel e de dentifrício é eficaz e promissora no tratamento adjuvante da periodontite crônica. Os resultados obtidos demonstraram que esses medicamentos promovem melhorias significativas em relação aos parâmetros clínicos e radiográficos da doença, ou seja, reduções do índice de placa e das perdas ósseas, além de um aumento do nível de inserção clínica (AKRAM, 2017; ALJUDAIBI, 2019; CAO, 2019; MUNIZ, 2018).

Conclusão: As estatinas são agentes eficazes no tratamento da periodontite crônica de forma adjuvante a terapia periodontal básica quando administrados de forma local por meio da indução de formação óssea, diminuição da inflamação e da imunomodulação. No entanto, são necessários mais estudos que direcionem uma aplicação clínica segura e com uma concentração/dose padronizada desses medicamentos, buscando investigar o seu potencial terapêutico em longo prazo. Além disso, nem todas as estatinas disponíveis foram testadas.

\title{
Referências
}

AKRAM, Zohaib; VOHRA, Fahim; JAVED, Fawad. Efficacy of statin delivery as an adjunct to scaling and root planing in the treatment of chronic periodontitis: A meta-analysis. Journal of Investigative and Clinical Dentistry, USA, v. 9, ed. 2, p. 1-12, 2017. Disponível em: https://pubmed.ncbi.nlm.nih.gov/29119729/. Acesso em: 16 ago. 2020.

ALJUDAIBI, Suha; DUANE, Brett. Do adjuvant statins improve the results of periodontal treatment in patients with chronic periodontitis?. Evidence Based Dentistry, [s. I.], v. 20, p. 18-19, 2019. Disponível em: https://www.nature.com/articles/s41432019-0009-6\#citeas. Acesso em: 18 ago. 2020. 
CAO, Ruoyan et al. Efficacy of locally-delivered statins adjunct to non-surgical periodontal therapy for chronic periodontitis: a Bayesian network analysis. BMC Oral Health, China, v. 19, ed. 105, p. 1-10, 2019 . Disponível em: https://bmcoralhealth.biomedcentral.com/articles/10.1186/s12903-019-0789-2. Acesso em: 18 ago. 2020.

ESTANISLAU, Ilanna Mara Gomes et al. Pleiotropic effects of statins on the treatment of chronic periodontitis a systematic review. British Journal of Clinical Pharmacology, Brasil, v. 79, ed. 6, p. 877 885, 2015. Disponível em: https://www.ncbi.nlm.nih.gov/pmc/articles/PMC4456120/pdf/bcp0079-0877.pdf. Acesso em: 15 ago. 2020.

MUNIZ, Francisco Wilker Mustafa Gomes et al. The effect of statins on periodontal treatment a systematic review with metaanalyses and meta-regression. Clinical Oral Investigations, Germany, v. 22, ed. 2, p. 671-687, 2018. Disponível em: https://link.springer.com/article/10.1007\%2Fs00784-018-2354-9. Acesso em: 17 ago.2020.

PETIT, Catherine et al. Contribution of Statins towards Periodontal Treatment: A Review. Mediators of Inflammation, France, p. 1-33, 2019. Disponível em: https://www.hindawi.com/journals/mi/2019/6367402/. Acesso em: 19 ago. 2020.

Coordenadoria de Pesquisa e Extensão - COPEX

Departamento de Editoração e Divulgaçāo Científica - DEDIC 


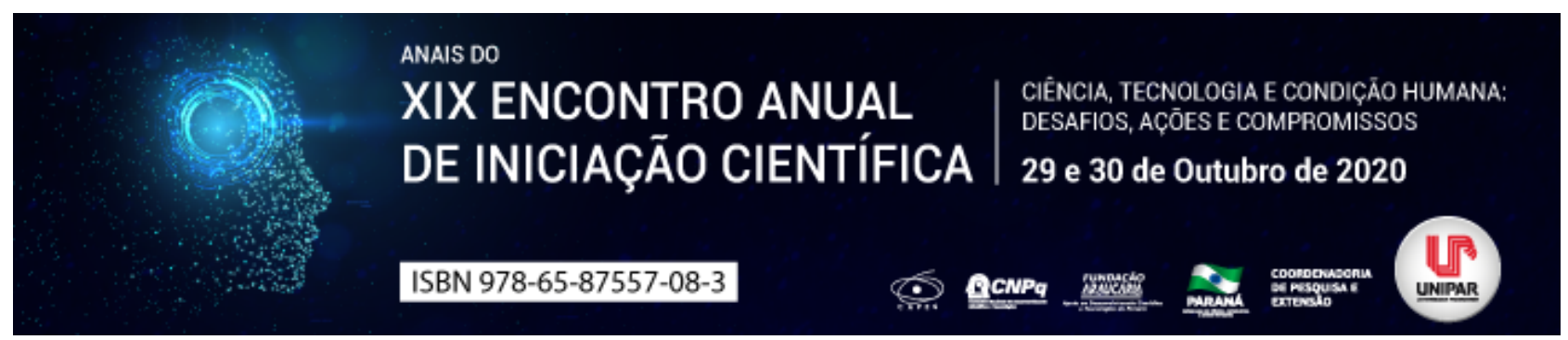

OBESIDADE COMO FATOR DETERMINANTE PARA DOENÇAS CARDIOVASCULARES

\author{
${ }^{1}$ POLYANA ALCANTARA DOS SANTOS, ${ }^{2}$ DJEICE DIANE HECK, ${ }^{3}$ LETICIA FLOIS FERREIRA, ${ }^{4}$ MARIA VICTORIA \\ VECCHIETTI, ${ }^{5}$ DORA DE CASTRO AGULHON SEGURA
}

\author{
${ }^{1}$ Acadêmico do PIC/UNIPAR \\ ${ }^{1}$ Acadêmica do Curso de Fisioterapia da UNIPAR \\ ${ }^{2}$ Acadêmica do Curso de Fisioterapia da UNIPAR \\ ${ }^{3}$ Acadêmica do Curso de Fisioterapia da UNIPAR \\ ${ }^{4}$ Docente da UNIPAR
}

Introdução: A obesidade é diagnosticada pelo cálculo do índice de massa corporal, adquirido através de variáveis como o peso e a altura, que em valores considerados acima do normal incidem no desenvolvimento de doenças crônicas graves como a diabetes tipo 2, diversas alterações cardiovasculares e alguns tipos de câncer. Possui como principal causa a ingestão exacerbada de alimentos calóricos associada ao sedentarismo, sendo relevantes outros aspectos como a genética e fatores ambientais. É mais comum em indivíduos que moram em perímetro urbano, sem distinção de raça, gênero e idade, se tornando um grave problema pandêmico (TENÓRIO et al., 2016). Segundo Wannmacher (2016), a obesidade possui relação considerável com o desencadeamento de inúmeras doenças cardiovasculares em decorrência da aterosclerose, sendo causa de morte em aproximadamente $20 \%$ da população mundial. A aterosclerose é definida como uma doença inflamatória, que gera o acúmulo de placas trombóticas e de ácidos graxos nas paredes dos vasos sanguíneos, podendo causar o infarto agudo do miocárdio ou um acidente vascular encefálico isquêmico (ROSS, 1999).

Objetivo: Dissertar sobre a obesidade como fator predisponente de doenças cardiovasculares.

Desenvolvimento: De acordo com Souza (2010), a família brasileira mudou drasticamente seus hábitos alimentares principalmente após a virada do século, como fator determinante da inserção da mulher no mercado de trabalho. A troca de alimentos complexos como proteínas, frutas, verduras e legumes por ácidos graxos e açucares causou uma grande mudança no biótipo dos indivíduos gerando ganho excessivo de peso, consequentemente a prevalência da obesidade e o aumento da incidência de doenças secundárias como as comorbidades cardiovasculares (ESCODA, 2002). O tecido adiposo deixou de ser somente um componente corporal para ser estoque demasiado de energia, que se não consumido se acumula na forma de gordura, causando a obesidade. Geralmente a terapêutica convencional, que associa dietoterapia, farmacoterapia e a prática regular de atividade física, promove grandes resultados, porém, em casos de insucesso, pode ser indicado o tratamento cirúrgico, nominado como gastroplastia. É necessário o acompanhamento de uma equipe multidisciplinar, enfatizando que a obesidade é uma doença grave, crônica e um forte marcador do desenvolvimento de outras desordens fatais que incluem os distúrbios cardiovasculares, que geralmente se iniciam com o aparecimento de sinais como a hipertensão arterial (TENÓRIO et al., 2016).

Conclusão: Concluiu-se, através deste estudo de revisão bibliográfica, que a obesidade é um forte fator desencadeante de doenças cardiovasculares graves, como o infarto agudo do miocárdio e o acidente vascular encefálico, sendo o tratamento um grande desafio da saúde pública.

\title{
Referências
}

ESCODA, M.S.Q. Para a crítica da transição nutricional. Revista de Ciência e Saúde Coletiva, Rio de Janeiro, v. 7, n. 2, p. 219226, abril 2002.

ROOS, R. Atherosclerosis - An inflammatory disease. The New England Journal of Medicine, Boston, v. 340, n. 2, p.115126, june 1999.

SOUZA, E. B. Transição nutricional no Brasil: Análise dos principais fatores. Caderno UniFOA, Volta Redonda, v. 5, n.13, p. 4448, agosto 2010.

TENÓRIO, M. C. C.; FRAGA, A. S.; SÁ, C. K. C.; LADEIA, A. M. T .Inflamação subclínica e doença cardiovascular na obesidade: O papel do exercicio físico contínuo e intervalado como tratamento. Revista Brasileira de Prescrição e Fisiologia do Exercício, São Paulo, v. 10, n. 61, p. 692-704, set./out. 2016.

WANNMACHER, L. Obesidade como fator de risco para morbidade e mortalidade: Evidências sobre o manejo com medidas não medicamentosas. Caderno da Organização Pan-Americana de Saúde e Organização Mundial da Saúde, Brasília, v. 1, n. 7 , p. 01-10, maio 2016. 
Coordenadoria de Pesquisa e Extensão - COPEX

Departamento de Editoraçāo e Divulgaçāo Científica - DEDIC 


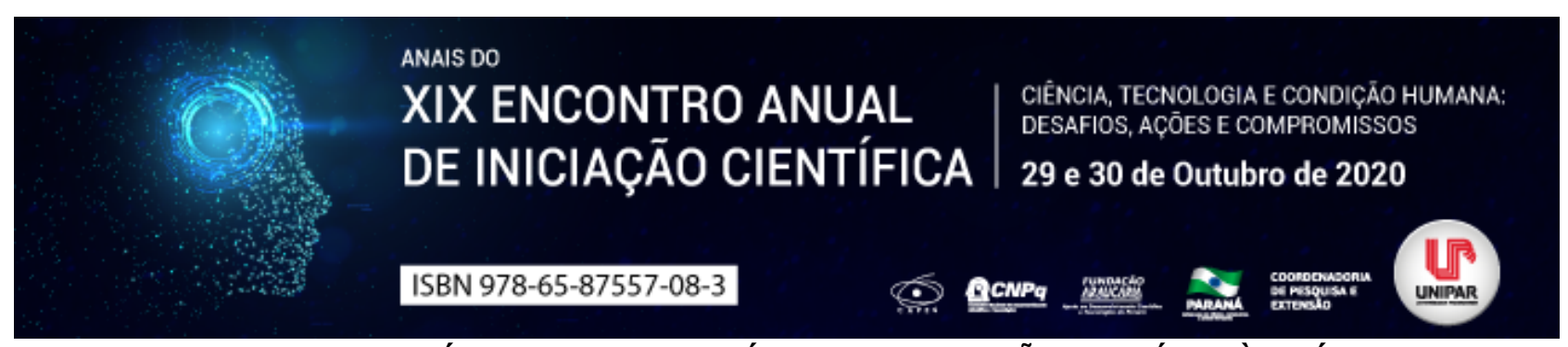

ACESSO AO PRÉ NATAL ODONTOLÓGICO NA ATENÇÃO PRIMÁRIA À SAÚDE

\author{
${ }^{1}$ JULIANA AUACHE, ${ }^{2}$ RENATA CORDEIRO RAMALHO, ${ }^{3}$ HELENA CAROLINE DA SILVA, ${ }^{4}$ EDUARDO KOERICH KOCH, \\ ${ }^{5}$ MARIANE EDUARDA RECALCATTI, ${ }^{6}$ FLAVIA RUIZ BARBOSA PAGANINI
}

\author{
1 acadêmico do PIC/UNIPAR \\ ${ }^{1}$ Acadêmica PIC/UNIPAR \\ ${ }^{2}$ Acadêmica PIC/UNIPAR \\ 3 acadêmico do PIC/UNIPAR \\ ${ }^{4}$ Acadêmica PIC/UNIPAR \\ ${ }^{5}$ Docente da UNIPAR
}

Introdução: O pré-natal de qualidade é capaz de diminuir a morbidade e a mortalidade materno-infantil, uma vez que a identificação do risco gestacional pelo profissional permite a orientação e os encaminhamentos adequados em cada momento da gravidez. (TOMASI et al., 2017; BOTELHO et al., 2019). O pré-natal odontológico consiste na prevenção de doenças e agravos, eliminação de focos de infecção que causem danos à saúde da mãe e do bebê, como prematuridade, baixo peso ao nascer e pré-eclâmpsia. Além de desconstruir alguns mitos sobre atendimento odontológico em gestante. (FAGUNDES et al., 2017; FIGUEIREDO et al., 2017). Em 2011 o MS implantou o PMAQ-AB com o objetivo de ampliar o acesso e melhorar a qualidade da atenção básica, com um padrão de qualidade comparável de modo nacional, regional e local (BRASIL, 2011). Em 2019 o Previne Brasil foi criado com intuito de alterar o método do financiamento da APS no SUS (HARZHEIM, 2020). Os indicadores avaliam o desempenho das equipes em relação ao acesso das gestantes aos cuidados bucais, auxiliam no planejamento, gestão e avaliação da assistência ao pré-natal.

Objetivo: Esta pesquisa, avalia o acesso das gestantes ao atendimento odontológico na atenção primária do SUS através da análise dos Indicadores CPCOPG do PMAQ-AB e PGPAO, do Previne Brasil.

Metodologia: Trata-se de estudo descritivo, utilizando fonte de dados dos sistemas de informação em saúde de base nacional do MS (DATASUS), nos períodos de 2018 a 2020 (primeiro quadrimestre), comparando-se os dados entre Brasil, regiões e estados. Os resultados para os indicadores foram obtidos no Sistema de informação em saúde para a Atenção Básica através do link https://sisab.saude.gov.br/ e selecionado na coluna à esquerda a opção indicadores de desempenho. O indicador escolhido foi proporção de gestantes com atendimento odontológico realizado, em nível nacional, regional e estadual. Com a mudança do sistema de financiamento em 2019 com o Previne Brasil o indicador de CPCOG passou a ser PGAO. O cálculo para o Indicador PGAO adotado pelo MS e constante em Nota Técnica é obtido pelo cálculo do número de gestantes no período, cadastradas, identificadas e que realizaram uma consulta pré-natal e um atendimento odontológico individual, ambos na AB. Dividido por uma estimativa utilizando o SINASC, sendo corrigido pelo potencial de atendidos por cada equipe ou no município. É considerado a mensuração que obtiver o maior resultado.Os dados foram coletados, organizados em planilhas do Excel, gráficos e aplicada a análise descritiva dos mesmos.

Resultado: Os resultados na proporção do $1^{\circ}$ atendimento odontológico de gestantes realizado variam de $12 \%$ (2018) a 19\% (2020) no Brasil, 13\% (2018) a 22\% (2020) na Região Sul e 14\% (2018) a 29\% (2020) no Paraná. Mostram-se bem abaixo do esperado pois a meta é $60 \%$ ou mais de cobertura. No PR a cobertura é superior para todos os anos pesquisados, quando comparada a nível de Brasil e Região Sul, mas ainda muito abaixo do esperado para este indicador.

Discussão: De acordo com as diretrizes do SUS as gestantes são prioridades nos serviços de saúde. Por isso, necessitam de um olhar mais apurado. (SILVA et al., 2018). Os resultados de acesso aos serviços odontológicos para o Brasil chegou a (19\%) no ano de 2020. Segundo George et al, 2010, os serviços odontológicos utilizados por gestantes são significativamente baixos. As taxas na Austrália, EUA, Reino Unido e Grécia variam de $20 \%$ a $50 \%$. Os obstáculos para o acesso ao atendimento odontológico a gestante são diversos, desde a baixa procura, até as dificuldades de acesso aos serviços públicos (ALBUQUERQUE et al., 2004).Também, por falta de conhecimento ou receio, alguns profissionais adiam a operação ou não intervêm na solução de problemas bucais em gestantes (CODATO et al., 2008). Da mesma forma, o obstetra é responsável por desmistificar o atendimento pois é nele que ela deposita mais confiança. A proximidade do dentista com a equipe durante o prénatal, aliado ao conhecimento técnico, proporcionará segurança para o atendimento e resolução das necessidades de saúde bucal (CARDOSO, 2010; RODRIGUES et al., 2018). Os diferentes resultados encontrados para os indicadores de acesso da gestante ao pré-natal odontológico podem estar relacionados à cobertura da ESF, as distintas formas de organização das equipes, a assistência à saúde bucal nos municípios; sendo o monitoramento e a avaliação meios importantes para contribuir na melhora dos indicadores de saúde, incluindo o de acesso das gestantes ao pré-natal odontológico. (PIMENTEL, 2014). 
Conclusão: Conclui-se que com novas políticas públicas como o Previne Brasil e PMAQ-AB, houve melhora no indicador PGAO, porém ainda está abaixo do esperado, refletindo que a maioria das gestantes não têm acesso ao atendimento odontológico. Recomenda-se mais pesquisas e ações como a capacitação dos profissionais que alimentam o sistema de informação, monitoramento e avaliação dos dados e resultados, definição de metas junto às equipes de saúde, realização de atividades educativas, estimulando o autocuidado e orientando a importância da saúde bucal na gestação em busca da melhoria deste indicador.

\section{Referências}

ALBUQUERQUE, OLGA MARIA RAMALHO DE; ABEGG, CLAÍDES; RODRIGUES, CECILE SORIANO. Percepção de Gestantes do Programa Saúde da Família em Relação a Barreiras no Atendimento Odontológico em Pernambuco, Brasil. Cad Saúde Pública; 20(3):789-796, mar.2004.

BOTELHO, Diana Larissa Leitão et al. Odontologia e Gestação: A importância do pré-natal odontológico. SANARE (Sobral, Online), Jul-Dec;18(2):69-77, 2019. Disponível em: https://sanare.emnuvens.com.br/sanare/article/download/1376/701 Acesso em: 20 june.2020.

BRASIL. Ministério da Saúde. Portaria No 1.654, de 19 de Julho de 2011: Institui, no âmbito do Sistema Único de Saúde, o Programa Nacional de Melhoria do Acesso e da Qualidade da Atenção Básica (PMAQ-AB) e o Incentivo Financeiro do PMAQ$A B$, denominado Componente de Qualidade do Piso de Atenção Básica Variável PAB Variável. Diário Oficial da União, Brasília, v. p. 80, jul. 2011.

CODATO Lucimar Aparecida Britto; NAKAMA, Luiza; MELCHIOR, Regina. Percepções de Gestantes sobre Atenção Odontológica Durante a Gravidez. Ciência \& Saúde Coletiva, 2008; 13(3):1075-1080.

CARDOSO, Laís Santos de Magalhães.; MENDES, Larissa Loures; MELÉNDEZ, Gustavo Velásquez. Diferenças na Atenção Pré-natal nas Áreas Urbanas e Rurais do Brasil: Estudo Transversal de Base Populacional. REME - Rev Min Enferm. [Internet]. 2013; 17(1). Disponível em: http://www.dx.doi.org/10.5935/1415-2762.20130008. Acesso em:10 nov. 2016.

FAGUNDES, Daniely Quintão.; OLIVEIRA, Adauto Emmerich. Educação em Saúde no Pré-Natal a partir do Referencial Teórico de Paulo Freire. Tra. Educ. Saúde, Rio de Janeiro, vol.15, n.1, pp.223-243, 2017. Disponível em: DOI: http://dx.doi.org/10.1590/1981-7746-sol00047 Acesso em: 20 june.2020.

FIGUEIREDO, Camilla Silva de Araujo et al., Systemic alterations and their oral manifestations in pregnant women. The Journal of Obstetrics and Gynaecology Research, v.43, n. 1, p. 16-22, jan. 2017. Disponível em: DOI: 10.1111 / jog.13150 Acesso em: 20 june.2020. 


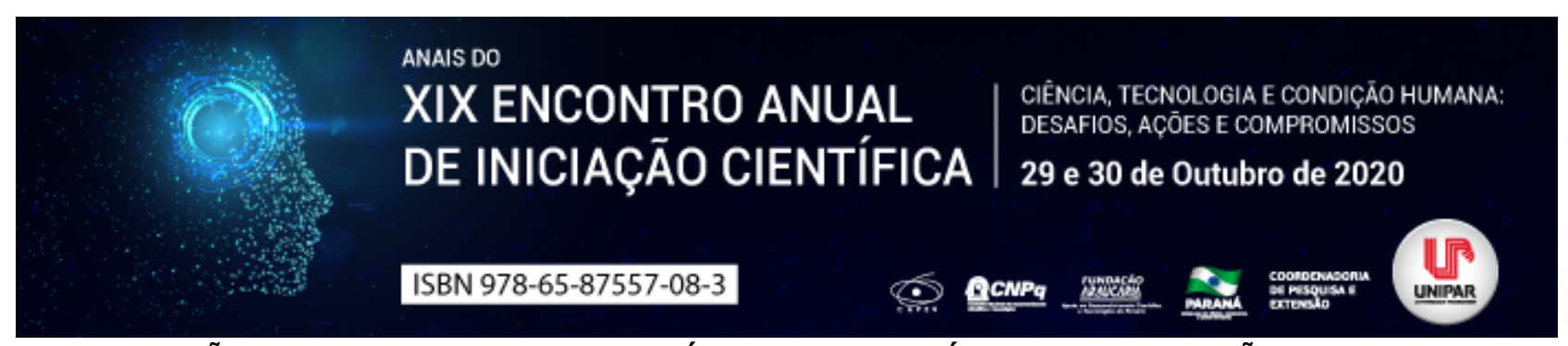

A UTILIZAÇÃO DA OZONIOTERAPIA NA PRÁTICA ODONTOLÓGICA: UMA REVISÃO DE LITERATURA

\author{
${ }^{1}$ MILENA GEMELLI, ${ }^{2}$ ANDRESSA VANDERLINDE NUENBERG DA SILVA, ${ }^{3}$ EVERTON JOSE FELIX, ${ }^{4}$ JENIFFER URBANO \\ DEGASPERI, ${ }^{5}$ EVELINE CLAUDIA MARTINI
}

\footnotetext{
${ }^{1}$ Acadêmico do Curso de Odontologia da UNIPAR

${ }^{1}$ Acadêmico do Curso de Odontologia da UNIPAR

${ }^{2}$ Acadêmico do Curso de Odontologia da UNIPAR

${ }^{3}$ Acadêmica do Curso de Odontologia da UNIPAR

${ }^{4}$ Docente da UNIPAR
}

Introdução: O ozônio é um composto existente na natureza que pode ser utilizado na terapia de diversas patologias devido seu potencial antimicrobiano, anti-inflamatório e cicatrizante. Na odontologia demonstra sucesso na regressão de determinadas lesões superficiais de cárie, na cicatrização de feridas, regeneração de lesões de líquen plano oral, gengivite e periodontite, halitose, entre outras alterações (SUH et al., 2019; DOMB, 2014). A ozonioterapia já demonstrou relevância devido à sua eficácia e mínima presença de efeitos colaterais, agregando para a prática odontológica principalmente devido à sua capacidade de combater bactérias, já que a maior parte das doenças orais são de origem infecciosa, agindo como meio auxiliar nos diversos tratamentos (SILVA; DRUMMOND, 2019).

Objetivo: Pautar as características do uso do ozônio nas terapias orais por meio de uma revisão de literatura, a fim de esclarecer seus benefícios para a prática odontológica.

Desenvolvimento: Como primário interesse dos dentistas, o tratamento das lesões cariosas é um dos principais possíveis benefícios do ozônio. Essa molécula possui grande poder redutor do número de microrganismos, entretanto, no tratamento de lesões, ainda exige mais pesquisas que afirmem sua eficácia, apesar de ser de grande auxílio no controle das bactérias no biofilme oral. Pesquisas microbiológicas mostraram que o ozônio é capaz de eliminar tanto bactérias Gram positivas quanto Gram negativas, sendo importante também no combate à doença periodontal. Tem-se uma maior indicação terapêutica para o tratamento da gengivite ulcerativa necrosante aguda o uso do óleo ozonizado, e para efeitos antissépticos possui grande indicação a água ozonizada, já que possui alta biocompatibilidade com os tecidos (NAIK et al., 2016). Quando a halitose está relacionada com a presença de microrganismos como fungos ou bactérias, o ozônio pode auxiliar no tratamento. Experimento realizado na Universidade de Basileia, na Suíça, mostrou que a água ozonizada acelera a cicatrização de feridas na mucosa oral, devido a maior produção do fator de crescimento transformante beta tipo 1 quando há presença de ozônio (SUH et al., 2019). Isso se dá ao fato de que a presença do ozônio aumenta a porcentagem de oxigênio nos tecidos, ativando o metabolismo celular e processos aeróbios. Além disso, possui importância no fortalecimento do sistema imune, pois aumenta a produção de moléculas específicas, o que mostra relevância no tratamento de pacientes com déficit imunológico aqui destaca-se novamente a relevância no tratamento da doença periodontal (NAIK et al., 2016). Na endodontia, o ozônio possui interessante indicação como agente irrigante e medicamento intracanal pela sua ação antibacteriana, sendo utilizado o óleo ozonizado na limpeza e lubrificação das limas e a água ozonizada para irrigação. Em um estudo clínico realizado por Marina Beloti (2011) a ozonioterapia demonstrou sucesso na sensibilidade pós tratamento endodôntico, apesar de não influenciar na regeneração óssea (SILVA; DRUMMOND, 2019). Também pode ser utilizado o ozônio na forma gasosa, mas com o uso de um sistema de sucção selado para que o excesso não seja inalado pelo paciente. Para pacientes com intoxicação por álcool, gestantes e lactantes, alérgicos ao ozônio, cardíacos, portadores de hipertireoidismo, anemia severa e outros deve-se evitar o uso do ozônio, minimizando assim possíveis efeitos colaterais como tosse, dor de cabeça ou até vômitos. Apesar de o ozônio ser tóxico em seu estado puro, quando é administrado em doses terapêuticas, os riscos de reações adversas são inviabilizados (SILVA, 2019; FERREIRA et al., 2014).

Conclusão: O ozônio pode ter sua utilização em forma de gás, óleo ou água ozonizada, e com ele é possível realizar aplicação em toda a arcada para controle do biofilme, irrigar o canal no tratamento endodôntico, limpeza e lubrificação das limas endodônticas, auxiliar no processo de cicatrização de feridas orais e estimular o sistema imunológico, importante para o tratamento da doença periodontal. Apresenta mínima presença de efeitos colaterais, entretanto, deve ser ampliado os conhecimentos sobre o assunto, já que as dosagens e protocolos para utilização do ozônio na odontologia ainda não estão bem estabelecidos. Destaca-se assim a importância do conhecimento dessa terapia alternativa pelos profissionais, a fim de agregar positivamente no tratamento das patologias.

\title{
Referências
}


DOMB, William C. Ozone therapy in dentistry: A brief review for physicians. Interventional Neuroradiology, v. 20, n. 5, p. 632 636, 2014.

FERREIRA, Rafael. et al. Ozonioterapia: uma visão crítica e atual sobre sua utilização em periodontia e implantodontia: revisão de literatura. Innovations Implant Journal: Biomaterials and Esthetics, São Paulo, v. 9, n. 2/3, p. 35-39, 2014.

NAIK, Saraswathi. et al. Ozone - A Biological Therapy in Dentistry - Reality or Myth? The Open Dentistry Journal, v. 10, n. 1, p. 196 206, 2016.

SILVA, Nuelen Larissa Silvestre da; DRUMMOND, Victor Paranaiba Almeida. Ozonioterapia na odontologia: Revisão de literatura. Orientador: Luís Henrique Borges. 2019. Trabalho de Conclusão de Curso (Graduação em Odontologia) - Universidade de Uberaba, Uberaba, 2019.

SILVA, Ludmylla Costa. Uso da Ozonioterapia na Odontologia: Revisão de literatura integrativa. Orientador: Barbara Velame Ferreira Teixeira. 2019. Monografia (Graduação em Odontologia) - Faculdade Maria Milza, Governador Mangabeira, 2019.

SUH, Yiji; PATEL, Shrey; KAITLYN, Re; et al. Clinical utility of ozone therapy in dental and oral medicine. Medical Gas Research, v. 9, n. 3, p. 163 167, 2019.

Coordenadoria de Pesquisa e Extensão - COPEX

Departamento de Editoraçāo e Divulgaçāo Científica - DEDIC 


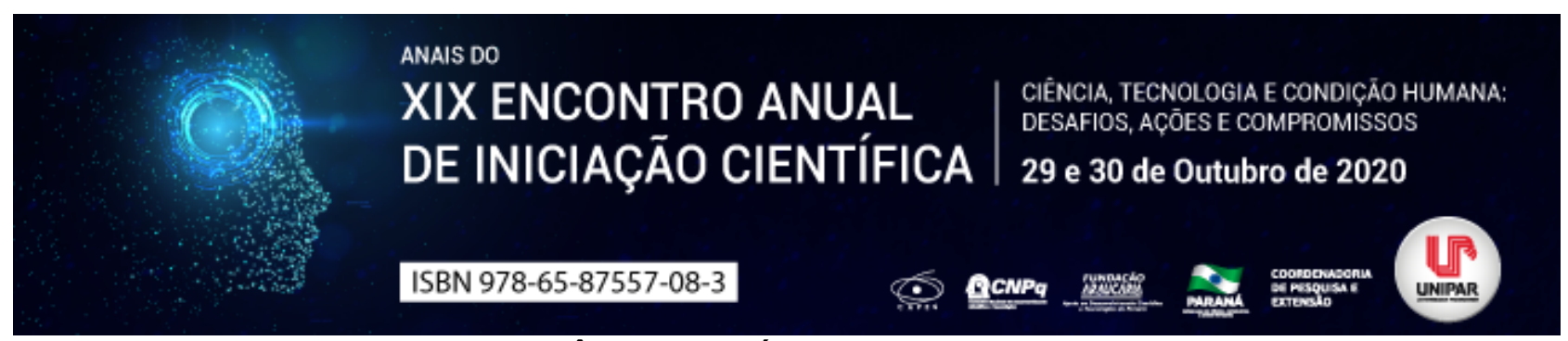

GRANULOMA PIOGÊNICO EM LÁBIO INFERIOR - RELATO DE CASO

\title{
${ }^{1}$ ALINE TESKER VALDAMERI, ${ }^{2}$ HELENA CAROLINE DA SILVA, ${ }^{3}$ JENIFFER URBANO DEGASPERI, ${ }^{4}$ LETICIA DE FREITAS CUBA GUERRA, ${ }^{5}$ ANA CLAUDIA POLETTO
}

\author{
${ }^{1}$ Acadêmica do Curso de Odontologia da UNIPAR \\ ${ }^{1}$ Acadêmica do Curso de Odontologia da UNIPAR \\ ${ }^{2}$ Acadêmica do Curso de Odontologia da UNIPAR \\ ${ }^{3}$ Docente da UNIPAR \\ ${ }^{4}$ Docente da UNIPAR
}

Introdução: O granuloma piogênico é uma lesão comum da cavidade bucal semelhante a um tumor, porém considerado de natureza não neoplásica caracterizando-se como um processo muco cutâneo proliferativo composto por tecido de granulação com extensa vascularização. É considerado uma hiperplasia reativa que se desenvolve em resposta a uma irritação local crônica de baixa intensidade ou trauma (TOMMASI, 2013). O tratamento consiste na excisão cirúrgica conservadora, que usualmente é curativa (YORADJIAN et al., 2013). O objetivo do trabalho é relatar um caso clínico de granuloma piogênico em um local de menor prevalência, o lábio inferior.

Relato de Caso: Paciente masculino, 45 anos, procurou atendimento na Clínica Odontológica da Unipar, Francisco Beltrão - PR, com a seguinte queixa: apareceu uma bola na gengiva após ter sido anestesiado pelo dentista e acabei me mordendo . O paciente relatou ter notado a presença da lesão há e 35 dias. Em relação a história médica, estava em tratamento medicamentoso para hipercolesterolemia. Ao exame físico extra oral o paciente não apresentou alterações dignas de nota, já no exame clínico intra oral, notou-se a presença de um nódulo localizado na mucosa labial inferior medindo cerca de $7 \mathrm{~mm}$ de diâmetro, de coloração avermelhada, com bordos nítidos, indolor a palpação. As hipóteses de diagnóstico inicial foram fibroma e granuloma piogênico. Diante disso, foi realizada biópsia excsional da lesão e confirmado o diagnóstico de granuluma piogênico mediante ao exame histopatológico. Tendo em vista que o granuloma piogênico é uma alteração benigna, não foi necessário outro tipos de tratamento além da intervenção cirúrgica. Após 1 ano e 10 meses de acompanhamento não houve recidiva da lesão.

Discussão: O granuloma piogênico é um aumento de volume com superfície lisa ou lobulada, que usualmente é pediculada, embora algumas lesões sejam sésseis. Histologicamente, o granuloma piogênico é uma lesão revestida por epitélio pavimentoso estratificado queratinizado com aspecto atrófico em algumas áreas(FERREIRA, et al., 2018). O tratamento consiste na excisão cirúrgica conservadora, que usualmente é curativa. Segundo Neville (2016), os granulomas piogênicos orais mostram uma marcante predileção pela gengiva, representando $75 \%$ dos casos, em contrapartida o caso relatado apresentou-se na região de lábio inferior. Evidenciando o presente caso que se apresentou em local pouco usual um dos principais fatores associados à etiopatogenia da lesão é a ocorrência de trauma anterior ao aparecimento da doença, assim, como o paciente relatou ter mordido a mucosa labial.

Conclusão: Apesar de o granuloma piogênico ter um aspecto clínico bem característico é importante ressaltar as diferenças que podem ocorrer quanto a esse aspecto e localização, pois uma interpretação errada das características das lesões em geral, pode levar a um diagnóstico e conduta terapêutica incorreta.

\section{Referências}

FERREIRA, Josfran da Silva Filho, et al. Exuberante granuloma piogênico em localização incomum: Relato de caso. Rev. Cir. Traumatol. Buco-Maxilo-Fac., Camaragibe. Jul./set. 2018. p. 22-25.

NEVILLE, Brad. Patologia Oral e Maxilofacial. 4. ed. Rio de Janeiro: Elsevier, 2016.

TOMMASI, Maria Helena. Diagnóstico em patologia bucal. 4. ed. Rio de Janeiro: Elsevier, 2013.

YORADJIAN, Alessandra, et al. Granuloma Piogênico: descrição de dois casos incomuns e revisão da literatura. RevistaSurgical\&CosmeticDermatol. p. 1-6, agosto. 2013. Disponível em: http://www.surgicalcosmetic.org.br/detalheartigo/286/Granuloma-Piogenico--descricao-de-dois-casos-incomuns-e-revisao-da-literatura. Acesso em: 20/08/2020. 


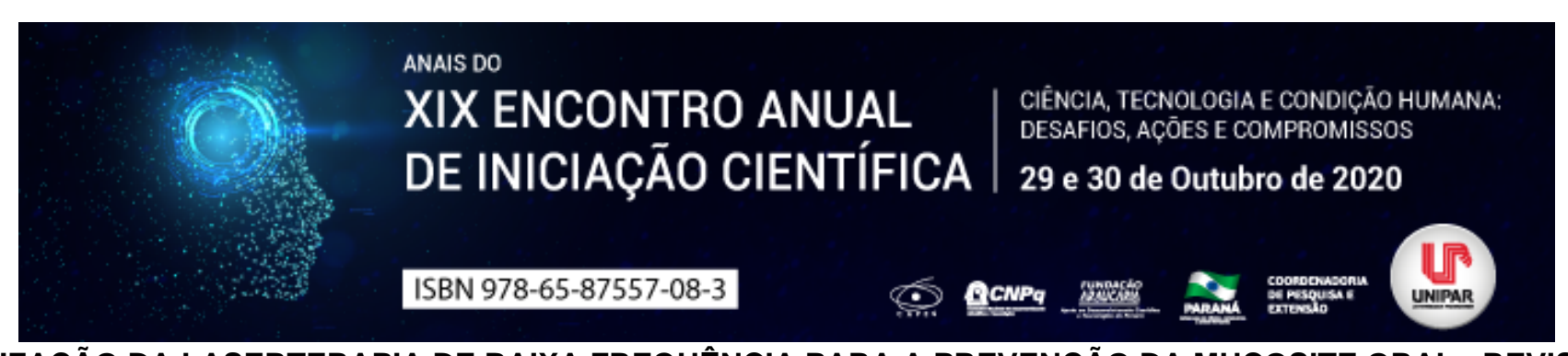

\title{
A UTILIZAÇÃO DA LASERTERAPIA DE BAIXA FREQUÊNCIA PARA A PREVENÇÃO DA MUCOSITE ORAL - REVISÃO DE LITERATURA
}

\begin{abstract}
${ }^{1}$ ANDRESSA VANDERLINDE NUENBERG DA SILVA, ${ }^{2}$ MILENA GEMELLI, ${ }^{3}$ FABIO LUIS FAEDO SCANDOLARA, ${ }^{4}$ JENIFFER URBANO DEGASPERI, ${ }^{5}$ LETICIA DE FREITAS CUBA GUERRA
\end{abstract}

\author{
${ }^{1}$ Acadêmica do Curso de Odontologia da UNIPAR/ Campus Francisco Beltrão - PR \\ ${ }^{1}$ Acadêmica do Curso de Odontologia da UNIPAR/ Campus Francisco Beltrão - PR \\ ${ }^{2}$ Acadêmico do Curso de Odontologia da UNIPAR/ Campus Francisco Beltrão - PR \\ ${ }^{3}$ Acadêmica do Curso de Odontologia da UNIPAR/ Campus Cascavel - PR \\ ${ }^{4}$ Docente do curso de Odontologia da Universidade Paranaense UNIPAR / Campus Francisco Beltrão e Cascavel PR.
}

Introdução: A mucosite oral (MO) é uma das complicações mais recorrente e dolorosa que se sucede em tratamentos antineoplásicos (RAMPINI et al., 2009). Sendo assim, cerca de $11 \%$ da descontinuidade terapêutica oncológica está relacionada ao desenvolvimento da $\mathrm{MO}$ em estágio avançado (BONAN et al., 2005). A princípio não há uma consonância sobre a melhor intervenção para essa enfermidade, portanto, os tratamentos para a mucosite oral são diversificados e tais intervenções procuram abrandar a sintomatologia dolorosa da lesão ou preveni-la (CURRA et al., 2018). Por conseguinte, compreender os sintomas e os protocolos de prevenção mais recentes, como o da laserterapia, para a mucosite oral é imprescindível para o cirurgião-dentista oferecer uma qualidade de vida superior para o paciente oncológico.

Objetivo: Essa revisão de literatura, procura analisar os estudos feitos sobre a aplicação da laserterapia de baixa frequência como recurso terapêutico eficaz para a mucosite oral.

Desenvolvimento: A mucosite oral é uma sequela induzida por radioterapia e/ou quimioterapia, principalmente em pacientes submetidos à radioterapia na região da cabeça e pescoço, e quimioterapia de altas doses quando se tem transplante de medula óssea (RUBENSTEIN et al., 2004). Os pacientes oncológicos, quando apresentam essas manifestações orais, possuem um grande desconforto, como dor intensa ao mastigar e odinofagia, sendo necessário a suspensão da terapia oncológica e a realização de uma nutrição via enteral/parenteral. Tais lesões da $\mathrm{MO}$ servem de entrada para microorganismos que constituem a flora da cavidade oral, podendo gerar bacteremia e septicemia, especialmente em pacientes com neutropenia, ocasionando um aumento de infecções sistêmicas (RAMPINI et al., 2009). Sendo assim, a abordagem odontológica é de suma importância previamente ao início do tratamento antineoplásico, com o intuito de diminuir essas complicações. Desse modo, clinicamente, a mucosite oral consiste na inflamação da mucosa com presença de eritema e edema, e avança para úlceras e formação de pseudomembrana. Os locais mais afetados são o assoalho da boca, borda lateral da língua, ventre lingual, mucosa jugal e palato mole (RAMPINI et al., 2009). O dentista deve realizar exame dos tecidos moles, dental e periodontal, realizar radiografias, remover aparelho ortodôntico e próteses dentárias mal-adaptadas, extrações dentárias se necessário, realização de restaurações, instrução de higiene oral e a adequação do meio bucal com clorexidina a $0,12 \%$ previamente ao tratamento oncológico. Essas ações são necessárias tendo em vista que a condição dental do paciente é um fator que interfere na progressão da MO, assim como o consumo de álcool e tabaco (RAMPINI et al., 2009). Após a instalação da mucosite oral, o tratamento depende do grau da enfermidade, que é avaliada pela Escala de Toxicidade Oral, em uma gradação estabelecida pela Organização Mundial da Saúde (OMS). Desse modo, a OMS, apresenta uma conduta que é seguida pela maioria das Instituições Brasileiras, Americanas e Europeias. Tal protocolo é o uso de analgésicos tópicos até opioides, de acordo com a dor e gravidade. Um exemplo de tratamento que tem se destacado para essa moléstia é a utilização do laser de baixa frequência, pois se trata de um tratamento não invasivo e de baixo custo. Além desses benefícios, esse modo terapêutico, apresenta bons resultados na redução da dor e também na aceleração da cicatrização, de acordo com diversos estudos. A redução da dor é efetiva, pois logo no início se tem a liberação da endorfina na lesão e também a redução de mediadores inflamatórios, além da indução do aumento dos queratinócitos e liberação de fatores de crescimento, através de macrófagos e linfócitos, aumentando a reabsorção de fibrina e síntese de colágeno (KELNER; CASTRO, 2007). Para o tratamento dessa doença é utilizado o protocolo preventivo, no qual, consiste em retardar o aparecimento de úlceras e diminuir a gravidade das possíveis lesões de mucosite bucal, e também se tem o protocolo curativo, que tem como função acelerar a cicatrização das lesões já existentes (LEITE et al., 2015). A laserterapia apresenta um comprimento de onda indicado, no caso da laser de baixa frequência, é utilizado a faixa de 640-940 nm, pois é onde o tecido absorve uma simples camada de energia (FIGUEIREDO et al., 2013) Dentre os lasers, o HélioNeônio (He/Ne) que se tem comprimento entre 630 e $690 \mathrm{~nm}$, e o de Diodo-Arseneto de gálio e alumínio (As-Ga-Al) com comprimento de 760 e $850 \mathrm{~nm}$ são os mais empregados para MO. Sendo o He/Ne utilizado em tecidos mais superficiais, cujo objetivo é a reparação local, através da emissão de luz vermelha e o As-Ga-Al com luz infravermelha com capacidade de alvejar 
tecidos mais profundos promovendo um efeito analgésico (WEISSHEIMER, 2016).

Conclusão: Por fim, o laser de baixa frequência tem sido usado com grande eficiência para o tratamento de mucosite oral. Contudo, ainda se faz indispensável novos estudos complementares. para que se consiga padronizar os protocolos direcionados à profilaxia e à terapêutica curativa, de modo a conseguir resultados cada vez melhores.

\section{Referências}

BONAN, Paulo Rogério Ferreti et al. Aspectos clínicos, biológicos, histopatológicos e tratamentos propostos para a mucosite bucal induzida por radioterapia: revisão da literatura. Revista Brasileira de Cancerologia, Rio de Janeiro, v. 3, n. 51, p. 235-242, 2005.

CURRA, Marina et al. Protocolos quimioterápicos e incidência de mucosite bucal: Revisão integrativa. Revista Einstein, São Paulo, v. 16, n. 1, p. 1-9, jan/ago 2018.

FIGUEIREDO, André Luiz Peixoto Laser terapia no controle da mucosite oral: um estudo de metanálise. Revista da Associação Médica Brasileira v. 59, n. 5, p. 467-474, Set/Out 2013.

KELNER, Natalie; CASTRO, Jurema Freire Lisboa de. Laser de baixa intensidade no trabalho da mucosite oral induzida pela radioterapia: relato de casos clínicos. Revista Brasileira de Cancerologia, Rio de Janeiro, v. 53, n. 1, p. 29-33, fev. 2007.

LEITE, Cristiane Almeida et al. Fototerapia com laser em baixa intensidade no tratamento da mucosite oral. UNOPAR Científica: Ciências Biológicas e da Saúde, v. 3, n.17, p. 203-205, mar. 2015.

WORLD HEALTH ORGANIZATION, Collaborating Centre for Oral Precancerous lesions. Definition of leukoplakia and related lesions: an aid to studies on oral precancer. Oral Surg Oral Med Oral Pathol, v. 46, p.518-539,1978.

RAMPINI, Mariana Pereira. Utilização da terapia de laser de baixa potência para a prevenção de mucosite oral - revisão de literatura. Revista Brasileira de Cancerologia, v. 55, n. 1, p. 59-68, 2009.

RUBENSTEIN Edward B. et al. Clinical practice guidelines for the prevention and treatment of cancer therapy-induced oral gastrointestinal mucositis. Cancer v. 100, n.9, p.1995-2046, Mai. 2004.

WEISSHEIMER, Camila. Fotobiomodulação na prevenção de mucosite oral em pacientes submetidos a transplante de células progenitoras hematopoiéticas: comparação de dois protocolos clínicos. 2016. 62 f. Dissertação (Mestrado) - Curso de Odontologia, Faculdade de Odontologia de Piracicaba da Universidade Estadual de Campinas, Piracicaba, 2016. 


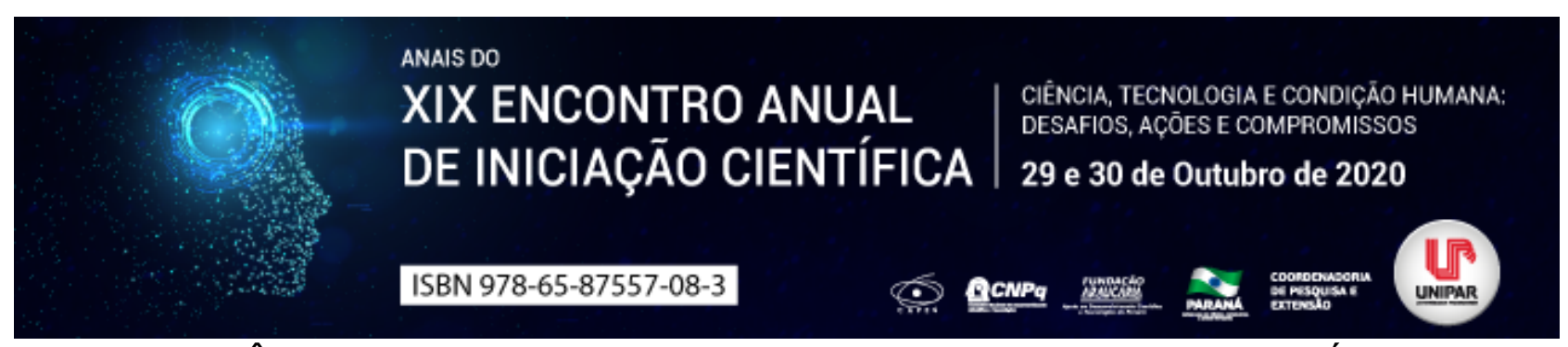

INFLUÊNCIA DO TREINAMENTO RESISTIDO NA HIPERTROFIA SARCOPLASMÁTICA

\title{
${ }^{1}$ WILLIAN BUENO GONCALVES, ${ }^{2}$ FERNANDO HENRIQUE PAVAO
}

\author{
${ }^{1}$ Acadêmico do curso de Educação Física da UNIPAR \\ ${ }^{1}$ Docente do curso de Educação Física da UNIPAR
}

Introdução: Hipertrofia muscular, segundo Santarém (1999), é o aumento no tamanho das fibras musculares devido ao acúmulo de substâncias (actina, miosina, glicogênio e água) no interior do músculo. A hipertrofia e aumento de força estão relacionados ao treino de alta intensidade e micro lesão no músculo. O treinamento resistido com pesos, que depende do tipo, intensidade e duração do estímulo, causando sobrecarga, é utilizado com o propósito de gerar micro lesão, mas o resultado pode ser limitado pelo nível hormonal e de condicionamento do indivíduo praticante (FETT; REZENDE FETT, 2003). Segundo Mathews e Fox (1986), a hipertrofia sarcoplasmática é o aumento do Retículo Sarcoplasmático (RS) obtida através de treinos metabólicos com alto número de repetições e uma carga reduzida de aproximadamente 30 a 50\% de uma repetição máxima, contando com um baixo tempo de descanso entre as séries. $O$ intuito do baixo intervalo entre as séries é promover o inchaço das células, prolongando o estresse metabólico. Além da já citada hipertrofia sarcoplasmática tem-se a hipertrofia miofibrilar que, segundo Santarém (1999), é a multiplicação das miofibrilas proteicas com capacidade contrátil, que ocorre como adaptação à sobrecarga tensional nos músculos em atividade. Pode-se dizer que o estímulo tensional é colocado em prática visando hipertrofia miofibrilar, pela alta carga utilizada, baixas repetições e intervalos de descanso longos a fim de proporcionar a recuperação dos músculos e do sistema energético. Com o intuito de oferecer um melhor resultado aos praticantes, o tema hipertrofia sarcoplasmática e miofibrilar é de grande valia para os profissionais da área, pois é essencial que eles tenham conhecimento de diferentes métodos de treino e aplicabilidade prática.

Objetivo: Verificar na literatura científica se métodos de treinamento tidos como metabólicos favorecem a hipertrofia muscular em praticantes de treinamento resistido.

Desenvolvimento: Trata-se de um estudo de revisão bibliográfica que foi realizado nas bases de dados Scielo, Periódicos Capes e Google Acadêmico, selecionando estudos que verificassem a hipertrofia sarcoplasmática e miofibrilar em praticantes de treinamento resistido. Foram utilizados os seguintes descritores: hipertrofia muscular, hipertrofia sarcoplasmática, hipertrofia miofibrilar, treinamento resistido e método de treinamento. Foram encontrados 10 artigos que vinham de encontro ao tema proposto e os principais achados se dão a seguir. No estudo de Benitez, Alves e Vitorassi (2019), que avaliou cinco indivíduos com experiência de no mínimo 1 ano e meio de treinamento contínuo em musculação, que participaram do treinamento Sarcoplasma Stimulating Training SST, foi possível constatar que houve melhora na composição corporal, porém não foi possível afirmar, após seis semanas de treinamento, superioridade do método e tipo de hipertrofia gerada. Já no estudo de Ceola e Tumelero (2008), com nove indivíduos de nível de condicionamento avançado, avaliou os métodos super série 1 (quatro exercícios em sequência para o mesmo grupo muscular), super série 2 (dois exercícios em sequência para agonista e antagonista) e método clássico de treinamento. Concluíram que se utilizado por um período máximo de um mês de treinamento, o método super série 1 é favorável para o ganho de hipertrofia muscular, força e resistência muscular localizada. Porém se utilizado por um longo período pode ocorrer catabolismo muscular, visto que se passa um longo tempo em alta intensidade de treinos. Por isso, se o treinamento for acima de um mês o melhor método para hipertrofia e força é o clássico, devido ao seu tipo de treinamento sua intensidade não é tão alta, favorecendo o indivíduo a ter um melhor rendimento no treino. Parta o ganho de força muscular para membros superiores acima de um mês, o método mais eficiente foi o super serie 2. Aparentemente, o estímulo tensional serviria de base para a o treinamento de força que visa a hipertrofia muscular, porém, treinos que favoreçam o estímulo metabólico, onde o tempo em tensão do músculo é maior, também possibilita a sinalização para a hipertrofia muscular (BEZERRA; RIBEIRO, 2019). Treinamentos que envolvam a realização de ações excêntricas, isoladas ou combinadas às ações concêntricas, se mostraram mais eficazes para o ganho de força e hipertrofia (COLLIANDER, 1990; DUDLEY, 1991).

Conclusão: Através deste trabalho é possível concluir que a hipertrofia muscular ocorre por meio de dois tipos de hipertrofias, sarcoplasmática (estímulo metabólico) e miofibrilar (estímulo tensional), e que os dois tipos de hipertrofias se complementam nos métodos de treino, sendo essenciais para os praticantes da modalidade.

\section{Referências}

BENITEZ, Matheus Felipe; ALVEZ, Thyago; VITORASSI, Jackson. As Adaptações Provocadas pela Aplicação da Filosofia de Treino Sarcoplasma Stimulating Training (SST). Revista Pleiade, v. 13, n. 27, p. 65-67, 2019.

BEZERRA, Ewertton. RIBEIRO, Alex Silva. Hipertrofia Muscular: evidências do treinamento resistido. Manaus: Editora Vitória, 2019. 
CEOLA, Mário Henrique Jordão; TUMELERO, Sérgio. Grau de hipertrofia muscular em resposta a três métodos de treinamento de força muscular. Revista Digital Efdeportes.com, v. 13, n. 21, 2008.

COLLIANDER, E. B.; TESCH, P. A. Effects of eccentric and concentric muscle actions in resistance training. Acta Physiologica Scandinavica, v. 140, p. 31-39, 1990.

DUDLEY, G., TESCH, P. A.; MILLER B.J., BUCHANAN, P. Importance of eccentric actions in performance adaptations to resistance training. Aviation, Space, and Environmental Medicine. v. 62, p.543-550, 1991.

FETT, Carlos Alexandre; REZENDE FETT, Waléria Christiane. Correlação de parâmetros antropométricos e hormonais ao desenvolvimento da hipertrofia e força muscular. Revista brasileira de ciência \& movimento, v. 11, n. 4, p. 27-32, 2003.

FOX, Edward. Donald, Mathews. Bases fisiológicas da educação física e dos desportos. 3. ed. Rio de Janeiro: Guanabara Koogan, 1986. 488 p. cap. 2.

SANTARÉM, José Maria. O exercício: preparação fisiológica, avaliação médica, aspectos especiais e preventivos. São Paulo: Atheneu, 1999. 496p. cap. 4. (35-50).

TOGASHI, Giovanna Benjamin. Dano muscular induzido pelo sistema de treinamento de cargas descendentes em exercício resistido. 2009. 112 f. Dissertação (Mestrado em Ciências) - Interunidades em Bioengenharia. Universidade de São Paulo, São Paulo, 2009.

UCHIDA, Marco Carlos. et al. Manual de musculação: uma abordagem teórico-prática do treinamento de força. 6 ed. São Paulo: Editora Phorte, 2010. 


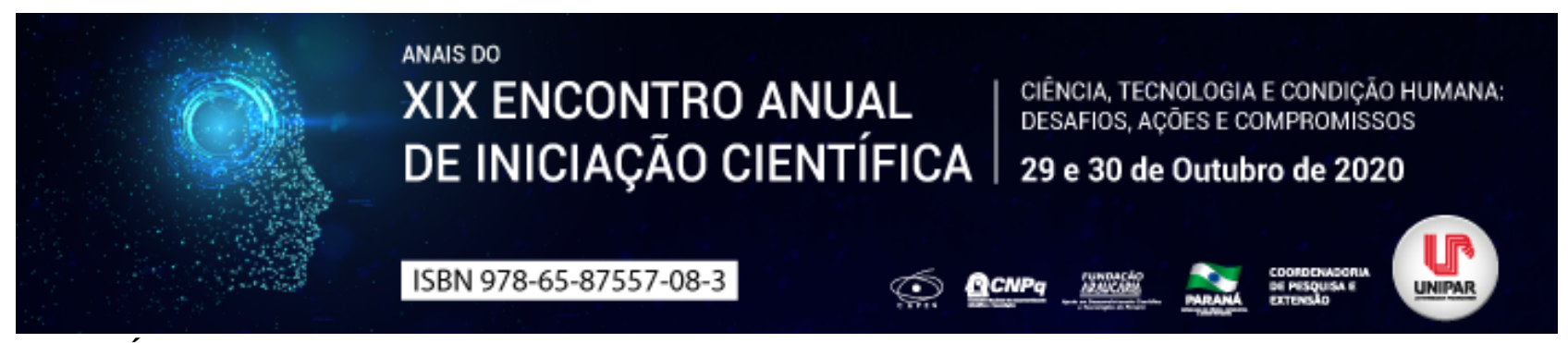

CARACTERÍSTICAS POPULACIONAIS E PRINCIPAIS MEDIDAS PREVENTIVAS ENVOLVENDO PROGRAMAS DE EXERCÍCIOS FÍSICO PARA PORTADORES DE DIABETES TIPO 2

\author{
${ }^{1}$ MARIELI KETLYN QUEIROZ DA SILVA, ${ }^{2}$ LUANA RODRIGUES MENDES DA SILVA, ${ }^{3}$ THAIS MUNIQUE GONCALVES \\ CARDOSO, ${ }^{4}$ IITOR HUGO RAMOS MACHADO
}

\author{
${ }^{1}$ Acadêmica do Curso de Ciências Contábeis da UNIPAR \\ ${ }^{1}$ Acadêmica do Curso de Educação Física da UNIPAR \\ ${ }^{2}$ Acadêmica do Curso de Educação Física da UNIPAR \\ ${ }^{3}$ Docente da UNIPAR
}

Introdução: De acordo com Petermann et al. (2015), no Brasil, no ano de 2007, cerca de $72 \%$ das mortes eram relacionadas às DCNT, e em 2003, 6\% dos óbitos eram provenientes de Diabetes Mellitus no País. O DM está entre as principais causas de morte, podendo chegar a sétima colocação dos óbitos em 2030. Na época de 1990-2000, na Cidade do Rio de Janeiro, foi constatado uma taxa de incidência de amputações em membros inferiores em diabéticos 4,6 vezes maior em pessoas com idade de 55 a 74 anos (92, 19/100.000 hab) por ano quando comparados com aqueles com 30 a 54 anos (20,1/100.000 hab). Ressaltase que 40,1\% das amputações foram localizadas na região supragenicular (TAVARES, et al, (2009). Flor e Campos, (2017), ressaltam que o Brasil esteve em $4^{\circ}$ lugar entre os países com maior número de pessoas diabéticas, sendo que 11,9 milhões desses casos são entre indivíduos adultos (20-79 anos). E entre 1996 e 2007, houve um aumento de cerca de 2,0\% na mortalidade por conta disso. Pesquisas apontam que no ano de 2010, cerca de 285 milhões de pessoas com mais de 20 anos vivem com diabetes no mundo e, em 2030, esse número pode chegar a 439 milhões (COSTA AF, et al, (2017).

Objetivo: Analisar as características populacionais e principais medidas preventivas envolvendo programas de exercícios físico para portadores de Diabetes tipo 2.

Desenvolvimento: Procedimentos simples como, o controle metabólico associado a medidas preventivas é capaz de prevenir ou retardar o aparecimento das complicações crônicas do diabetes mellitus (de PAIVA, BERSUSA e ESCUDER, 2006). Para Fernandes et al. (2008), o DM está entre as principais síndromes crônicas da atualidade, sendo que a do tipo 2 é a de maior incidência. Nos dias atuais é perceptível uma epidemia de DM, com valores preocupantes para este século, principalmente nos países em desenvolvimento. Estudos mostram que o cigarro aumenta a sensibilidade insulínica, aumenta a concentração da gordura abdominal e eleva excessivamente a concentração glicêmica após um teste oral de tolerância à glicose, mas para LYRA, OLIVEIRA, LINS e CAVALCANTI (2006), não há uma relação direta entre cigarro e o diabetes, pois para eles o risco pode estar relacionado com a quantidade de cigarros e a duração do tabagismo. De acordo com Cardoso et al. (2007), nos dias de hoje o DM do tipo 2 é um grande impasse para a saúde pública no seu diagnóstico, controle e tratamento. Percebe-se que a constância e a junção da atividade física, seja ela aeróbica ou exercício resistido ligada a uma boa alimentação contribuem na manutenção dos níveis glicêmicos. Reeducação alimentar, mudança dos hábitos de vida, atividades físicas frequentes, abandono do cigarro, caso o indivíduo fume e avaliar o nível glicêmico antes e após as sessões de exercícios são algumas medidas que os portadores de DM devem tomar (Consenso Brasileiro sobre Diabetes, 2003). A prática de exercícios constante contribui na diminuição de peso corporal, na redução a necessidade de medicamentos orais, na diminuição da resistência à insulina e ajudam na melhora do controle glicêmico, que faz com o risco de complicações reduza (FECHIO e MALERBI, 2004). De acordo com Fechio e Malerbi (2004), a atividade física possui suas vantagens, mais a maioria da população é sedentária ou não se exercita a ponto de alcançar resultados positivos para a saúde. Aproximadamente $50 \%$ dos indivíduos que começam um programa de exercício interrompem-no nos primeiros seis meses. Para Junior, Pires e Junior, (2009), exercícios físicos oferecem vantagens para os portadores de DM, pois diminuem os efeitos desagradáveis, além de prevenir proporcionando uma melhora na qualidade de vida. A Organização Mundial da Saúde (OMS), prediz que, em 2030, a população brasileira venha a ser de 11,3 milhões de diabéticos, onde quase 33\% terão entre 60 e 79 anos (SILVA, et al, (2016). Segundo Vitoi, et al. (2015), na atualidade, cerca de 346 milhões de pessoas são diabéticas; em 2030, pode ser que as mortes por Diabetes Mellitus dobrem levando em conta o ano de 2005 . Em pesquisas atuais de indivíduos que possuem Diabetes Mellitus com idade entre 20 e 79 anos no Brasil é de 11,9 milhões, que representa $6 \%$ da população brasileira. Diabetes Mellitus com idade entre 20 e 79 anos no Brasil é de 11,9 milhões, equivalente a quase $6 \%$ da população brasileira. Os fatos disponíveis nos mostram que 382 milhões de pessoas vivem com Diabetes Mellitus (8,3\%), e no ano de 2035 esse número poderá chegar a quase 592 milhões (Flor e Campos, (2017).

Conclusão: Pode se concluir que o índice de pessoa que convivem com DM vem crescendo cada vez mais nos últimos anos. Onde muitos acabam tendo um agravamento no quadro e acabam sofrendo procedimento como amputações de membros e algumas vezes podem vir a óbito, por não tomarem os devidos cuidados e não se dedicarem ao tratamento que lhes é proposto. 
Sugere-se que indivíduos que tenha DM não tratem apenas com medicamentos e sim que pratiquem atividade física com mais frequência e que optem por fazer uma reeducação alimentar.

\section{Referências}

CARDOSO, Leda Márcia; OVANDO, Ramon Gustavo de Moraes; SILVA, Sabrina Fernanda; OVANDO, Luiz Alberto. Aspectos importantes na prescrição do exercício para o diabetes mellitus tipo 2. Periódico do Instituto Brasileiro de Pesquisa e Ensino em Fisiologia do Exercício.

COSTA, Amine; FLOR, Luísa; CAMPOS, Mônica; OLIVEIRA, Andreia; COSTA, Maria; SILVA, Raulino; SCHRAMM, Joyce. Carga do diabetes mellitus tipo 2 no Brasil.

SILVA, Aline; ENGROFF, Paula; SGNAOLIN, Vanessa; GOMES, Irenio. Prevalência de diabetes mellitus e adesão medicamentosa em idosos da estratégia saúde da família de Porto Alegre/RS.

PAIVA, Daniela; BERSUSA, Ana; ESCUDER, Maria. Avaliação da assistência ao paciente com diabetes e/ou hipertensão pelo Programa Saúde da Família do Município de Francisco Morato, São Paulo, Brasil.

FECHIO, Juliane; MALERBI, Fani. Adesão a um programa de atividade física em adultos portadores de diabetes.

FERNANDES, Carlos; CAROLINO, Idalina; ELIAS, Rui; JUNIOR, Nelson. Efeito do exercício físico aeróbio sobre o perfil lipídico de pacientes idosas, portadoras de Diabetes Mellitus tipo 2, atendidas em Unidade Básica de Saúde, Maringá, Estado do Paraná.

FERREIRA, Sandra; ALMEIDA, Bianca; SIQUEIRA, Antonela; KHAWALI, Cristina. Intervenções na prevenção do diabetes mellitus tipo 2: é viável um programa populacional em nosso meio?.

LYRA, Ruy; OLIVEIRA, Mônica; LINS, Daniel; CAVALCANTI, Ney. Prevenção do diabetes mellitus tipo 2.

PETERMANN, Xavéle; MACHADO, Isadora; PIMENTEL, Bianca; MIOLO, Silvana; MARTINS, Luciane. Epidemiologia e cuidado à diabetes mellitus praticado na atenção primária à saúde: uma revisão narrativa.

TAVARES, Darlene; DIAS, Flávia; PEREIRA, Gilberto. Perfil de clientes submetidos a amputações relacionadas ao diabetes mellitus.

VITOI, Nayla; FOGAL, Aline; NASCIMENTO, Clarissa; FRANCESCHINI, Sylvia. Prevalência e fatores associados aos diabetes em idosos no município de Viçosa, Minas Gerais. 


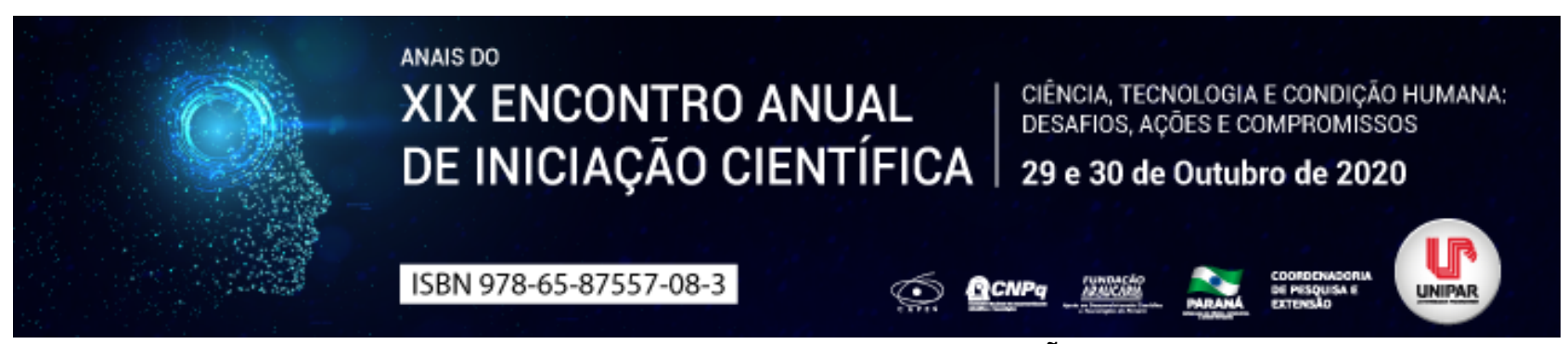

ADOECIMENTO DA EQUIPE DE ENFERMAGEM: REVISÃO DA LITERATURA

\begin{abstract}
${ }^{1}$ MARCOS ANTONIO DA SILVA LIMA, ${ }^{2}$ KELI TOMBINI, ${ }^{3}$ GRACY SCHROEDER, ${ }^{4}$ BRUNA KAUYNE PEREIRA PLACK, ${ }^{5}$ DANIELI DAMASCENO SOARES, ${ }^{6}$ DAISY CRISTINA RODRIGUES
\end{abstract}

\footnotetext{
${ }^{1}$ Acadêmico do Curso de Enfermagem da UNIPAR

${ }^{1}$ Acadêmica do Curso de Enfermagem da UNIPAR

${ }^{2}$ Acadêmica do Curso de Enfermagem da UNIPAR

${ }^{3}$ Acadêmica do Curso de Enfermagem da UNIPAR

${ }^{4}$ Acadêmica do Curso de Enfermagem da UNIPAR

${ }^{5}$ Mestre em Enfermagem Docente da UNIPAR
}

Introdução: O adoecimento dos profissionais de enfermagem que são os que cuidam de outros indivíduos podem estar ligado a diversos fatores como químicos, físicos, biológicos, ergonômicos, mecânicos, psicossociais, que podem causar doenças ocupacionais e também os acidentes de trabalho.(RIBEIRO;et al.2012).

Objetivo: Conhecer as produções científicas relacionadas ao adoecimento dos trabalhadores da área da enfermagem.

Metodologia: Revisão da literatura, realizada na base de dados eletrônica Scielo. Para a busca, foram utilizados descritores referentes à temática. Foram localizadas 14 produções,submetidas à leitura dos títulos e resumos. De acordo com a adequação aos critérios de inclusão, analisaram-se 03 produções científicas.

Desenvolvimento: Mediante a analise dos estudos percebe-se que a enfermagem adoece por longas jornadas de trabalho,dimensionamento inadequado dos profissionais diante da necessidade de atenção que os pacientes necessitam, associado também ao acúmulo de empregos relacionado a remuneração insuficiente.(MELO;et al .2019).O estresse que é gerado no ambiente de trabalho, e o risco de contaminação por acidentes com materiais biológicos são outros fatores identificados como umas das causas de adoecimento da enfermagem. Diante das situações supracitadas, somando aos longos anos de atuação resultam em um esgotamento profissional, e o que antes cuidava passa a necessitar de cuidados. (SOUZA; et al .2015).

Conclusão: As causas de adoecimento da equipe de enfermagem podem ser prevenidas, diante de condições melhores de trabalho com espaço físico, recursos materiais e humanos adequados, associado a remuneração condizente ao trabalho realizado. As educações permanentes também se mostram como uma opção a ser considerada no quesito de evitar o adoecimento da equipe de enfermagem.

\title{
Referências
}

MELO., Cynthia de Freitas; CAVALCANTE, Ana Karine Sousa; FAÇANHA, Klediane Queiroz.Invisibilização do adoecimento psíquico do trabalhador: limites da integralidadena rede de atenção á saúde. Trab. educ. saúde.Rio de Janeiro. 08 Apr 2019. vol.17 no.2. Disponível em: >https://www.scielo.br/scielo.php?script=sci_arttext\&pid=S1981$77462019000200508 \& l a n g=p t<$ Acesso em: 28 de julho de 2020.

RIBEIRO, Renata Perfeito;MARTINS, Julia Trevisan; MARZIALE, Maria Helena Palucci; ROBAZZI, Maria Lucia do Carmo Cruz . Adoecer pelo trabalho na enfermagem: uma revisão integrativa. RevEscEnferm USP. São Paulo.2012. 46(2):495-504. Disponível em: >https://www.scielo.br/pdf/reeusp/v46n2/a31v46n2.pdf < Acesso em: 28 de julho de 2020.

SOUSA, Viviane Ferro da Silva; ARAUJO, Tereza Cristina Cavalcanti Ferreira .Estresse ocupacional e resilliência entre os profissionais da saúde. Psicol. cienc. Prof. Brasília July/Sept. 2015.vol.35 no.3 . Disponível em:>https://www.scielo.br/scielo.php?script=sci_arttext\&pid=S1414-98932015000300900\&lang=pt< Acesso em: 28 de julho de 2020.

Coordenadoria de Pesquisa e Extensão - COPEX

Departamento de Editoraçāo e Divulgaçāo Científica - DEDIC 


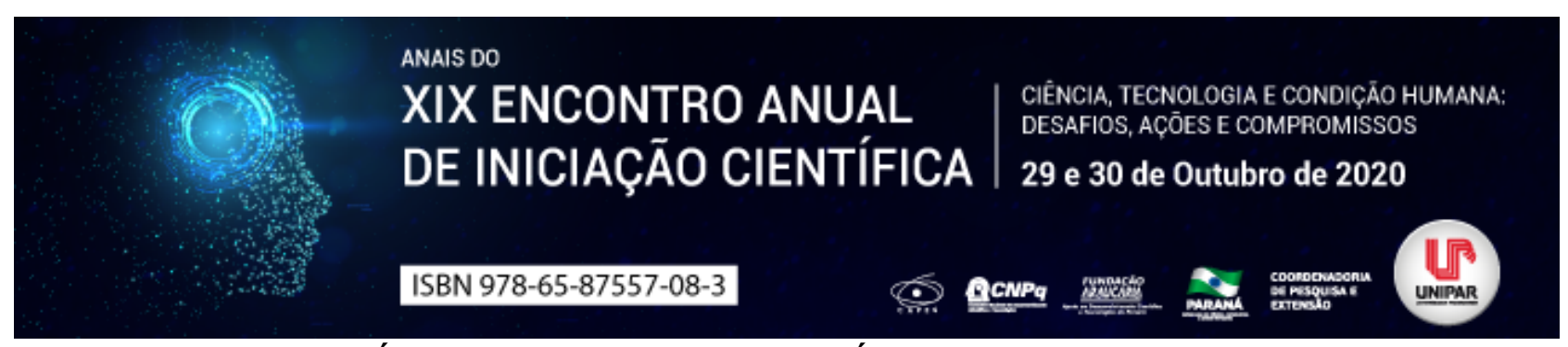

HISTÓRIA DA HOMEOPATIA: DE HIPÓCRATES A HAHNEMANN

\title{
${ }^{1}$ ALLAN CHENU ROMANO, ${ }^{2}$ MARCELO RIBEIRO ROMANO
}

\author{
${ }^{1}$ Acadêmico do curso de Medicina da UNIPAR \\ ${ }^{1}$ Pesquisador da Embrapa
}

Introdução: Hipócrates (460-350 a.C.), considerado o |"Pai da Medicinal", introduziu a avaliação metódica dos sinais e sintomas como a base para o diagnóstico. Sempre tratava o paciente de forma abrangente, e defendia que o tratamento era constituído de três princípios básicos: a Natura medicatrix, onde a natureza se encarrega de restabelecer a saúde do doente; a cura pelos contrários (Contraria Contrariis Curentur), consolidada por Galeno (129-199 d.C.) e Avicena (980-1037), que é a base da medicina alopática; e a cura pelos semelhantes (Similia Similibus Curentur), reavivada no século XVI por Paracelso (14931541) e consolidada pelo médico alemão Samuel Hahnemann, o Pai da Homeopatia

Objetivo: Sintetizar a história da homeopatia aos estudos de Hipócrates, Paracelso e Hahnemann.

Desenvolvimento: No século XVI um grande número de epidemias assolava a Europa. Neste contexto surgem as idéias de Paracelso, com uma visão totalmente oposta a medicina galênica, que prevaleceu por aproximadamente 1500 anos e era embasada na cura pelos contrários (Contraria Contrariis Curentur). Paracelso acreditava que uma enfermidade podia ser tratada pelo semelhante (Similia Similibus Curentur), e enxergava, como Hipócrates, o ser humano como um todo, constituído de mente e corpo (CORRÊA \& SIQUEIRA-BATISTA, 1996). Para ele os organismos possuem uma anima - princípio vital ignoto e arcano instância capaz de garantir a perpetuação da vida (PARACELSO, 1973). Este também chegou a ser considerado o médico maldito , por ter combatido os grandes mestres seguidos pelos médicos de sua época (CORRÊA \& SIQUEIRA-BATISTA, 1996) . O criador da homeopatia, Christian Frederich Samuel Hahnemann, nasceu em 1755 na cidade de Meissen, Alemanha. Em 1775, iniciou o curso de medicina em Liepzig e aos 24 anos obteve o título de médico pela Universidade de Erlangen. Hahnemann clinicou durante algum tempo, porém se tornou insatisfeito com os resultados obtidos com a medicina tradicional, a exemplo de Paracelso, optando por traduzir livros médicos. Em 1790, durante a tradução da Matéria Médica, de William Cullen, ficou intrigado com as explicações dadas para os efeitos terapêuticos da China officinallis (quina). Experimentou-a em si mesmo, observando manifestações semelhantes às apresentadas por pacientes com malária. Concluiu, então, que a quina era utilizada no tratamento da malária porque produzia sintomas semelhantes em pessoas saudáveis (CORRÊA, 1995). Apoiado em suas evidências experimentais e na filosofia hipocrática (Similia similibus curentur), Hahnemann idealizou uma nova forma de tratamento, com base na cura pelos semelhantes. $\mathrm{O}$ ano de 1796 ficou conhecido como o marco inicial da homeopatia, com a publicação de I"Ensaio Sobre um Novo Princípio para Averiguar os Poderes Curativos das Substâncias Medicinaisl", no qual Hahnemann fazia um apanhado sobre seus experimentos e relatava alguns fatos observados anteriormente por outros autores, e com o seu retorno à profissão médica, tratando seus pacientes pela aplicação de suas novas idéias (HAHNEMMAN, 1796). Hahnemman postulou a existência de uma energia vital, na qual o desequilíbrio corresponderia ao estado de doença do homem. Ele também criou o conceito de dinamização para o preparo dos medicamentos, que consiste na diluição em doses mínimas e na sucussão da solução medicamentosa (CAIRO, 1996). A partir desse momento, os resultados obtidos foram muito positivos, e a Medicina Homeopática começou a se difundir e a ganhar popularidade. Em 1810, publicou a primeira edição do Organon da Arte de Curar, que passou a ser considerado a Bíblia da homeopatia . Entretanto, em meados do século XIX, começaram a ser descobertos vários microorganismos causadores de doenças, passando-se a crer que toda enfermidade possuía uma causa material específica. A partir de então, um cunho mais científico foi introduzido à medicina decorrente das influências oriundas da Filosofia Cartesiana de René Descartes (1596-1650). Deste modo a medicina homeopática sofreu um grande impacto negativo, pois as comprovações do seu mecanismo não podiam (e em parte ainda não podem) ser obtidas. Atualmente, graças ao avanço tecnológico, está se conseguindo propor alguns mecanismos capazes de explicar a atuação dos medicamentos homeopáticos (CORRÊA et al., 2006).

Conclusão: Conclui-se que a medicina homeopática desenvolvida por Hahnemann tem como precursores Hipócrates (460-350 a.C.) e Paracelso (1493-1541). Ela consiste na cura pelos semelhantes, com uma visão integralizada do homem, tendo a energia vital como determinante do estado de saúde e doença. Entretanto, a homeopatia sofreu um grande impacto negativo em meados do século XIX, com a descoberta de microorganismos causadores de doenças. Com isso, conceitos como energia vital e integração entre físico, mente e emoção foram quase perdidos e muitas das idéias que não podiam ser comprovadas experimentalmente foram refutadas. No Brasil, os estudos homeopáticos chegaram com a fundação da Escola Homeopática do Rio de Janeiro em 1841, por Benoit-Jules Mure. E em 1980, o Conselho Federal de Medicina reconheceu oficialmente a homeopatia como especialidade médica. 


\section{Referências}

CAIRO, Nilo. Guia de Medicina homeopática. São Paulo: Livraria Teixeira. 1996

CORRÊA, Anderson Domingues. Samuel Hahnemann. Scientia Medica, v. 1, n. 1, p. 68-70, 1995.

CORREAA, Anderson Domingues; SIQUEIRA-BATISTA, Rodrigo. Paracelso o 'médico maldito'. Principais contribuições para o desenvolvimento da medicina e química. Rio de Janeiro: Arquivos Brasileiros de Medicina, v. 70, n. 12, p. 641-644, 1996.

CORRÊA, Anderson Domingues; SIQUEIRA-BATISTA, Rodrigo; QUINTAS, Luis Eduardo; SIQUEIRA-BATISTA, Romulo. Similia Similibus Curentur: revisitando aspectos históricos da homeopatia. nove anos depois. Rio de Janeiro: História, Ciências, Saúde - Manguinhos, v.13, n.1, jan/mar, 2006. Disponível em: https://www.scielo.br/pdf/hcsm/v13n1/02.pdf. Acesso em: 31 ago. 2020. HAHNEMANN, Samuel. Similia, similibus curentur. J Pract Arzneyk, v. 2, p. 391-561, 1796.

PARACELSO. A chave da alquimia. São Paulo: Ed. Três. 1973. 


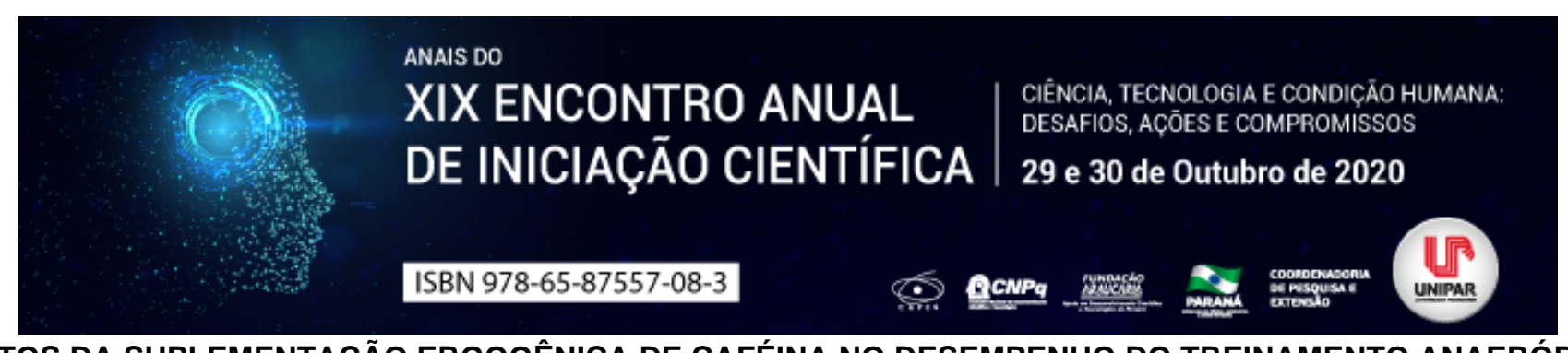

EFEITOS DA SUPLEMENTAÇÃO ERGOGÊNICA DE CAFÉINA NO DESEMPENHO DO TREINAMENTO ANAERÓBICO

\title{
${ }^{1}$ IGOR CORREA ZANOTTO, ${ }^{2}$ JAYME RODRIGUES DIAS JUNIOR
}

\author{
${ }^{1}$ Acadêmico do curso de Educação Física da UNIPAR \\ ${ }^{1}$ Docente da UNIPAR
}

Introdução: A busca pela melhora no rendimento em um treinamento resistido, no que diz respeito à uso de suplementações, têm sido cada vez mais frequente. Visto que, este assunto já não é considerado mais um tabu, como nos anos anteriores. Segundo Materko; Santos (2011), os recursos ergogênicos são alternativos farmacológicos de melhoria do desempenho desportivo, em especial o treino de força. Muitos praticantes têm utilizado com o propósito de retardar a fadiga muscular e melhorar o desempenho durante uma sessão. Dentre os mais variados suplementos, a cafeína tem se destacado no âmbito de maior uso para treinamento de força, hipertrofia muscular e até mesmo exercícios aeróbios. Embora o seu uso em academias, centros de treinamento tem sido algo comum, a mesma não dispõe de tanta eficácia para estes objetivos.

Objetivo: Investigar por meio da literatura os efeitos da suplementação ergogênica de cafeína no desempenho do treinamento anaeróbico.

Desenvolvimento: A cafeína (1,3,7-trimetilxantina), é uma das substâncias psicoativas mais consumidas no mundo devido à sua presença em diversos alimentos e bebidas, como café, chá e chocolate(RIVERS; WEBBER, 1907). Segundo Guerra et al, (2000), a administração de uma dose única, porém elevada de cafeína produz insônia, inquietação, ansiedade, confusão mental, palpitações, vertigem, cefaléia, transtornos visuais e auditivos. Esses efeitos são mais nítidos e se apresentam com doses menores em indivíduos não habituados ao consumo de café.

Segundo Fabrizio, et al. (2012), A administração de cafeína provoca benefícios no desempenho no protocolo de MAOD (máximo déficit acumulado de oxigênio) em indivíduos atletas ou não. Entretanto, uma vez que evidências mostraram que a ingestão de cafeína parece melhorar o desempenho quando o sujeito é avaliado em protocolo até a exaustão. No entanto, os efeitos dessa substância variam de indivíduo para indivíduo, sendo eles: treinados ou não treinados . Essa substância apresenta eficácia na melhora do desempenho desportivo de atletas em treinamento anaeróbico quando consumida em doses baixas e controladas, porém, se tratando de doses elevadas, além de não gerar melhora no desempenho, ainda pode causar efeitos colaterais graves (Goldstein et al, 2010). Dessa forma, aumentando as chances de desenvolver doenças como: arritimia ventricular, insônia, hipocalemia, hipertensão arterial, (MALINAUSKAS et al, 2007), dentre outros.

Uma variedade de estudos utilizou o protocolo anaeróbio de Wingate para analisar o efeito da ingestão de cafeína em exercícios anaeróbios, em sujeitos destreinados, no qual não foram encontrados benefícios da administração de cafeína na potência pico, potência média e índice de fadiga (CAPUTO et al, 2012).

Se tratando de exercícios específicos em meio ao treinamento resistido (musculação), a suplementação de cafeína não demonstrou tanta eficácia em performance de força muscular máxima e submáxima em exercícios como supino reto e puxada alta, utilizando carga relativa a 10RM, a 60\% de 1RM (ASTORINO; ROHMANN; FIRTH, 2008; GOLDSTEIN et al., 2010).

Entretanto, um estudo feito por Goldstein et al. (2010), em concordância dos resultados anteriores, a utilização da suplementação ergogênica desta substância mostrou melhora na força muscular a 100\% de 1RM no supino reto e $80 \%$ de 1 RM na cadeira extensora.

Conclusão: Visto que, muitos estudos na área da suplementação da substancia cafeína e seus efeitos no treinamento anaeróbio, demonstram resultados controversos e muitas vezes não compreendido, pois, sua eficácia varia de individuo para individuo e de situação de cada um dos mesmos, não sendo algo universal para todos que a utilizam. Concluímos que a suplementação deve ser levada a sério de forma em que haja controle e responsabilidade, pois, é evidente que haja melhora no desempenho de força e, consequentemente, hipertrofia muscular, porém é necessário sempre um acompanhamento médico e nutricional.

\section{Referências}

ASTORINO, T. A.; ROHMANN, R. L.; FIRTH, K. Effect of caffeine ingestion on one-repetition maximum muscular strength. European Journal of Applied Physiology. Berlin, v.102, n.2, p. 127-132, 2008.Disponível em: https://pubmed.ncbi.nlm.nih.gov/17851681/ Acesso em: 19 de jul. 2020.

CAPUTO, Fabrizio et al. Cafeína e desempenho anaeróbio. Revista Brasileira de Cineantropometria \& Desempenho humano. Universidade de Santa Catarina, v.14, n.5, 2012. Disponível em: https://www.scielo.br/scielo.php?script=sci_arttext\&pid=S1980$00372012000500012 \&$ lang=en Acesso em: 19 de jul. 2020.

GOLDSTEIN, E. et al. Caffeine enhances upper body strength in resistance-trained women. Journal of the International Society 
of Sports Nutrition. Woodland Park, v.14, n.7, p.18-23, $2010 . \quad$ Disponível em: https://www.ncbi.nlm.nih.gov/pmc/articles/PMC2876999/ Acesso em: 19 de jul. 2020.

GUERRA, Ricardo O. et al. Cafeína e esporte. Revista Brasileira de Medicina do Esporte. Universidade de Granada, v.6, n.2, mar/abr, 2000. Disponível em: https://www.scielo.br/scielo.php?script=sci_arttext\&pid=S1517$86922000000200006 \&$ Ing=pt\&nrm=iso Acesso em: 27 de jul. 2020.

MATERKO, W.; SANTOS, E.L. Efeito agudo da suplementação da cafeína no desempenho da força muscular e alterações cardiovasculares durante o treino de força. Motricidade. Universidade Federal do Rio de Janeiro,v.7, n.3, jul/2011. Disponível em:http://www.scielo.mec.pt/scielo.php?script=sci_arttext\&pid=S1646- 07X2011000300005\&lang=en Acesso em: 01 de mai. 2020.

Malinauskas, B. M. et al. A survey of energy drink consumption patterns among college students. Nutrition Journal, East Carolina University, Oct/2007. Disponível em: https://pubmed.ncbi.nlm.nih.gov/17974021/ Acesso em: 21 de jul. 2020.

MATTOS, Fabiana de O. et al. Eficácia ergogênica da suplementação de cafeína sobre o desempenho de força? uma análise crítica. Revista da Educação Física/UEM. Universidade de São Paulo USP, v.25, n.3, July-Sept/2014. Disponível em: https://www.scielo.br/scielo.php?script=sci_arttext\&pid=S1983-30832014000300501\&lang=enAcesso em: 01 de mai. 2020.

RIVERS, W. H, WEBBER, H. N. The action of caffeine on the capacity for muscular work.The Journal of Physiology, v.36, n.1, p.33-47, Aug/1907 Disponível em: https://www.ncbi.nlm.nih.gov/pmc/articles/PMC1533733/ Acesso em: 30 de aug. 2020. 


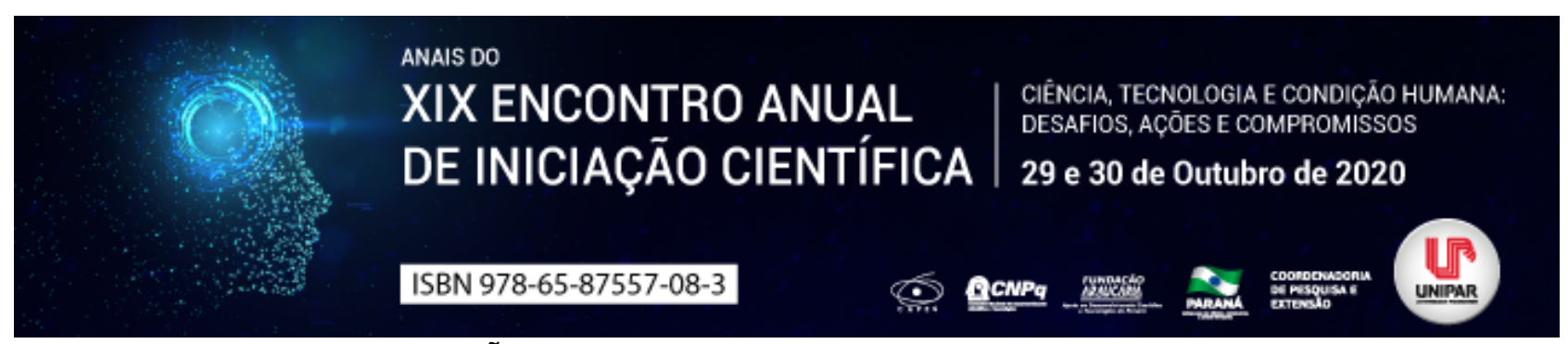

INTERAÇÕES MEDICAMENTOSAS EM PACIENTES IDOSAS

\title{
${ }^{1}$ CAMILA SIMONE RIBEIRO, ${ }^{2}$ ANA CAROLINE FERRARO VIVIAN, ${ }^{3}$ SUELLEN LAIS VICENTINO VIEIRA
}

\author{
${ }^{1}$ Discente do Curso de Farmácia, Ciências da Saúde, Universidade Paranaense - Umuarama-PR. \\ ${ }^{1}$ Discente do Curso de Farmácia, Ciências da Saúde, Universidade Paranaense - Umuarama-PR. \\ ${ }^{2}$ Docente do Curso de Farmácia, Ciências da Saúde, Universidade Paranaense - Umuarama-PR.
}

Introdução: A população idosa está aumentando por todo o mundo e com isso há uma elevação na prevalência de doenças crônicas, como hipertensão arterial, diabetes, insuficiência renal, entre outras, elevando consequentemente o consumo de medicamentos por essa população (BOTOSSO; MIRANDA; FONSECA, 2011). O uso de vários medicamentos como estratégia terapêutica e o crescente número de principios ativos e formas farmacêuticas no mercado, são fatores que podem contribuir para ampliar os efeitos benéficos de um tratamento, mas que também possibilita o aparecimento de efeitos indesejados, como interações medicamentosas (SECOLI, 2001). Desta forma, o farmacêutico apresenta um papel fundamental no acompanhamento do paciente idoso, tendo um olhar atencioso para evitar situações como as interações entre fármacos.

Objetivo: Realizar um levantamento da utilização de fármacos em um grupo de idosas e verificar a possibilidade de interação entre fármaco/fármaco.

Material e Método: Este trabalho obteve aprovação do Comitê de Ética Envolvendo Seres Humanos sob parecer $n^{\circ}$ 3.291.375. A pesquisa foi realizada com mulheres com idade igual ou superior a 60 anos, que participavam de um grupo de alongamento do núcleo de atendimento da saúde familiar na cidade de Umuarama-PR. Foram realizados dois encontros semanais no período matutino com duração de 30 minutos cada encontro, para conversar com as idosas e coletar as informações. Inicialmente as voluntárias foram informadas do objetivo da pesquisa de forma clara, e posteriormente solicitadas para que nos próximos encontros trouxessem suas prescrições e/ou medicamentos utilizados. As idosas participaram de uma entrevista que questionava quanto ao perfil do paciente, histórico social, quais os medicamentos utilizados, horários e forma da utilização dos mesmos.

Resultados: Obteve-se 20 anamneses. As voluntárias apresentaram idade média de 62 anos. Foram coletadas informações da utilização de 42 diferentes fármacos (sendo considerados fármacos de diferentes princípios ativos e associações). Foram encontradas 58 interações medicamentosas na literatura. Apenas $35 \%$ voluntárias faziam o uso de medicamentos com prescrição médica, enquanto que as demais faziam uso de fármacos com prescrição e alguns ainda por conta própria (automedicação).

Discussão: A combinação de fármacos pode reduzir a eficácia de um ou mais fármacos e/ou promover reações adversas (BANDEIRA, DE OLIVEIRA, 2014), sendo considerada como interação medicamentosa. Dos 42 diferentes fármacos verificados para uma possível interação medicamentosa, foram encontradas algumas interações quando o feito uso simultâneo das seguintes classes terapêuticas: A combinação de anti-hipertensivos e anti- inflamatórios não esteroidais pode levar a uma insuficiência renal, redução da atividade antihipertensiva, ocasionando aumento da pressão arterial; o uso simultâneo de analgésicos e/ou antitérmico com antidepressivos podem aumentar o risco de hemorragias digestivas e diminuir o efeito do analgésico e/ou antitérmicos; a associação de antiespasmódicos com anti-hipertensivos podem levar a uma insuficiência renal e cardíaca no paciente; redutores de colesterol ou inibidores da bomba de próton administrados juntos com a levotiroxina, podem acarretar na redução da eficácia do hormônio; a ingestão de antidiabéticos com analgésicos e/ou antitérmicos, quando em altas doses de ácido acetil salicícilo, diminui as concentrações de glicose no sangue; antidiabéticos associados pode aumentar o risco de hipoglicemia; o uso de hipocoleretolêmicos e anti-hipertensivo, como sinvastatina e anlodipino respectivamente, pode causar dor muscular e fraqueza; a associação de hipocolesterolêmicos com hipoglicemiantes, pode potencializar o efeitos de redução glicêmica (JACOMINI; DA SILVA, 2011).

Conclusão: As interações encontradas com maior frequência nesta pesquisa foram de fármacos das classes terapêuticas de anti-hipertensivos, analgésicos e antidepressivos. A falta de informação e orientação sobre os fármacos é muito comum entre a população idosa, fazendo com que estes sejam submetidos ao risco de uma interação entre fármacos. O acompanhamento com um farmacêutico é essencial, pois quando há a potencial presença de interações na utilização de medicamentos, o profissional tem o dever de observar-las e orientar o paciente adequadamente, a fim de propiciar a melhor farmacoterapia e melhoria da qualidade de vida do idoso.

\section{Referências}

BANDEIRA, Vanessa Adelina Casali; DE OLIVEIRA, Karla Renata. Potenciais interações entre medicamentos usados na síndrome metabólica. Scientia Medic. v. 24, n. 2, p. 156-64, 2014.

BOTOSSO, Rosa Maria; MIRANDA, Eglivani Felisberta; DA FONSECA, Marilda Aparecida Souza. Reação adversa 
medicamentosa em idosos. Revista Brasileira de Ciências do Envelhecimento Humano. v. 8, n. 2, p. 285-297, 2011.

JACOMI, Luiza Cristina Lacerda; DA SILVA, Tania Maria. Interação Medicamentosa. Rio de Janeiro: Guanabara Koogan, 2011. SECOLI, Silvia Regina. Interações medicamentosas: fundamentos para a prática clínica da enfermagem. Revista da Escola de Enfermagem da USP. v. 35, n. 1, p. 28-34, 2001.

Coordenadoria de Pesquisa e Extensāo - COPEX

Departamento de Editoraçāo e Divulgaçāo Científica - DEDIC 


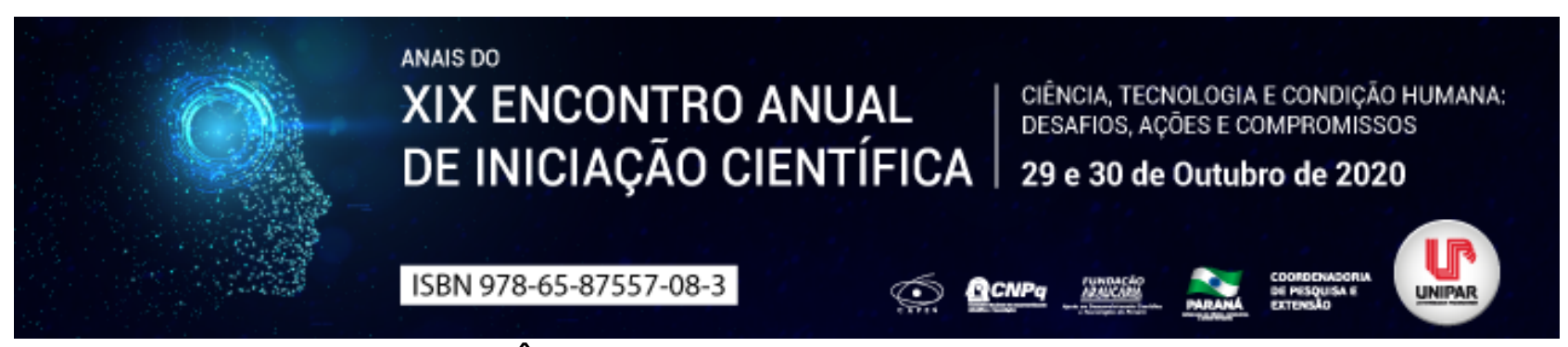

FATORES DE INFLUÊNCIA NO MANCHAMENTO DAS RESINAS COMPOSTAS

\author{
${ }^{1}$ KAROLINA FERNANDA ABEGG QUEIROZ, ${ }^{2}$ ALLAN FERREIRA DE LIMA ANTONELLI, ${ }^{3}$ GEOVANE CAPANA FIDELI, \\ ${ }^{4}$ JENIFFER URBANO DEGASPERI, ${ }^{5}$ RAYANE CRISTINA DE OLIVEIRA SOARES, ${ }^{6}$ WAGNER BASEGGIO
}

\author{
${ }^{1}$ Acadêmico do PIC Unipar \\ ${ }^{1}$ Acadêmico do Curso de Odontologia da UNIPAR \\ ${ }^{2}$ Acadêmico do Curso de Odontologia da UNIPAR \\ ${ }^{3}$ Acadêmica do Curso de Odontologia da UNIPAR \\ ${ }^{4}$ Acadêmica do Curso de Odontologia da UNIPAR \\ ${ }^{5}$ Docente da UNIPAR
}

Introdução: Em uma era com padrão estético elevado, a resinas compostas tem um papel fundamental na odontologia, visando reproduzir as propriedades óticas dos tecidos dentais e restabelecendo a estética (KANG, 2012; MATHIAS, 2015). Mesmo apresentando características extremamente favoráveis, como o fácil manuseio e uso, semelhanças com à estrutura dental e comportamento clínico aceitável para restauração, as resinas compostas, em boca, se deparam com adversidades térmicas, químicas, abrasões e exposição a agentes pigmentantes, fatores que interferem a longevidade das restaurações. Um dos aspectos, amplamente estudado, é o comprometimento da estabilidade cromática das resinas, relacionado a uma etiologia multifatorial: fatores extrínsecos relacionados a alimentos e bebidas com ricos teores de pigmentos, intrínsecos como a alteração da matriz resinosa, da interface carga/matriz, e condições da rugosidade superficial e porosidade.

Objetivo: O objetivo dessa revisão de literatura é apresentar os fatores que causam manchamento nas restaurações de resina composta.

Desenvolvimento: $\mathrm{Na}$ busca por melhores padrões de estética nas restaurações odontológicas, um grande inimigo é o manchamento das restaurações de resinas compostas. O manchamento tem etiologia multifatorial, e com frequência é a causa de substituições das restaurações, total ou parcial, carretando o desgaste de estrutura dentária sadia no processo de preparo ou remoção (REDDY, 2013). Basicamente a composição das resinas compostas se dá por cargas inorgânicas, com tamanhos variados de acordo com o tipo de resina, agentes de união, iniciadores de polimerização, radiopacificadores, pigmentos e estabilizadores. Assim a estabilidade da resina se dá desde uma correta fotopolimerização para que não haja monômeros não reagente que propiciam a sorção de água e solubilidade, e futuramente microtrincas que facilitam a entrada de pigmentos resultando em manchamento, até o aspecto amarelado das restaurações causado por resquícios de canforquinona não ativada completamente. Na matriz orgânica da resina composta, devido a sua afinidade com água, aumenta sua absorção, dificultando a estabilidade de cor. Já quando se refere a matriz inorgânica a quantidade e tamanho da partícula tem ligação com a maior estabilidade de cor e com melhores acabamentos e polimentos, agregando lisura superficial e dificultando o acumulo de matérias que causem manchamento (AL-SAMADANI, 2013). Ao referir as substâncias extrínsecas tem-se inúmeras substâncias citadas pela literatura, como café, vinho, chá, chimarrão, tabagismo entre outros, são associadas a manchamento superficial das restaurações e dentes. Essas substâncias têm seus potenciais de manchamento variados, levando em consideração a temperatura que são ingeridas, sua acidez e as partículas de pigmentos presentes (ARDU et al, 2013). Quando o manchamento é referido ao tabagismo se tem uma pigmentação amarronzada, nos refrigerantes sua acidez tem potencial corrosivo, acrescido de alterações de cor e aumento da susceptibilidade a manchamento (AL-SAMADANI, 2013; MATHIAS, 2010). Independente da substância, muitos estudos apontam que a estabilidade da cor, redução de manchamento e longevidade clínica das restaurações está ligada a regularidade superficial, dada pelo polimento.

Conclusão: O correto conhecimento e ação do profissional fazem toda a diferença no prevenção e minimização das pigmentações, por meio de técnicas restauradoras com polimerização efetiva, acabamento harmonioso e polimento adequado, o saber orientar o paciente referente ao cuidado na higiene e hábitos nocivos a preservação da restauração e a proservação da restauração com repolimento profissional periódico.

\title{
Referências
}

AL-SAMADANI Khalid $\mathrm{H}$. Color stability of restorative materials in response to Arabic coffee, Turkish coffee and Nescafe. J Contemp Dent Pract 2013;14(4):681-90.

ARDU Stefano, BRAUT Vedrana, GUTEMBERG Daniel, KREJCI Ivo , DIETSCHI Didier, FEILZER Albert J. A long-term laboratory test on staining susceptibility of esthetic composite resin materials. Quintessence Int 2010;41(8):695-702.

KANG Aromi, SON Sung-Ae, HUR Bock, KWON Young Hoon, RO Jung Hoon, PARK Jeong-Kil. The color stability of silorane- 
and methacrylate-based resin composites. Dent Mater J 2012;31(5):879-84.

MATHIAS P, SILVA Emily Vivianne Freitas da, VITÓRIA Lívia Andrade, AZEVEDO Juliana Fillipi de. Pigmantação de restaurações de resina composta: uma revisão de literatura. Revista Odontológica de Araçatuba, v.36, n.2, p. 29-35, Julho/Dezembro, 2015.

MATHIAS Paula, COSTA Leonardo, SARAIVA Letícia Oliveira, ROSSI Thais Aranha, CAVALCANTI Andrea Nóbrega, NOGUEIRA-FILHO Gentúlio da Rocha. Morphologic texture characterization allied to cigarette smoke increase pigmentation in composite resin restorations. J Esthet Restor Dent 2010;22(4):252-9.

PÉREZ María M, GHINEA Razvan, UGARTE-ALVÁN Laura I, PULGAR Rosa, PARAVINA Rade D. Color and translucency in siloranebased resin composite compared to universal and nanofilled composites. J Dent 2010;38 Suppl 2:e110-6.

REDDY P Sarveshwar, TEJASWI K L Sunil, SHETTY Suneeth, ANNAPOORNA B M, PUJARI Sudarshan C, THIPPESWAMY H $M$. Effects of commonly consumed beverages on surface roughness and color stability of the nano, microhybrid and hybrid composite resins: an in vitro study. J Contemp Dent Pract. 2013;14(4):718-723. Published 2013 Jul 1. doi:10.5005/jpjournals-10024-1390.

Coordenadoria de Pesquisa e Extensão - COPEX

Departamento de Editoraçāo e Divulgaçāo Científica - DEDIC 


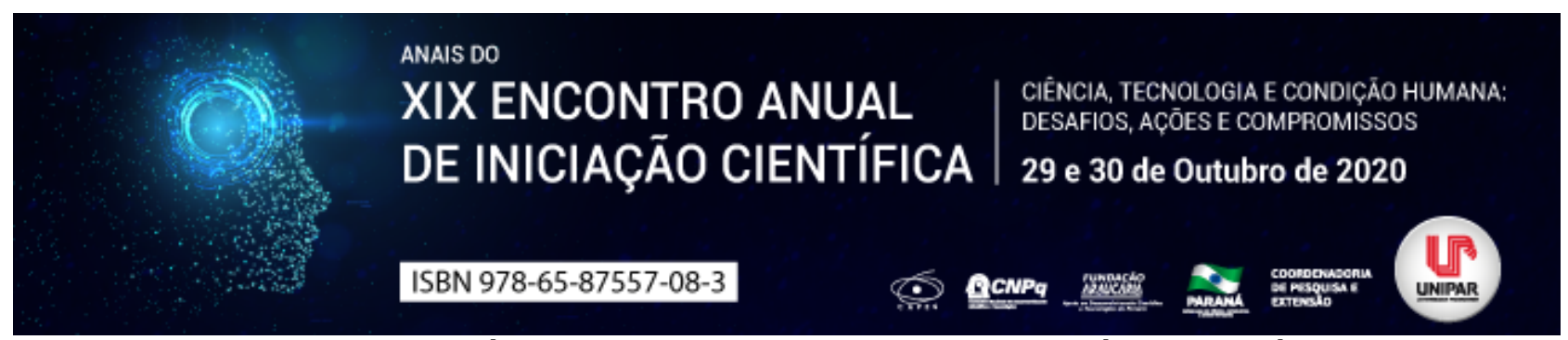

DISPLASIA ECTODÉRMICA: ETIOPATOGENIA E CARACTERÍSTICAS CLÍNICAS

\begin{abstract}
${ }^{1}$ Roger Sousa Lima, ${ }^{2}$ ELLEN DIONÉLIA ALENCAR RODRIGUES ROSA, ${ }^{3}$ CAROLINE MELO dOS SANTOS, ${ }^{4}$ IGNEZ AURORA DOS ANJOS HORA, ${ }^{5}$ GISELE PEDRO MOI, ${ }^{6}$ GABRIELA MANCIA DE GUTIERREZ
\end{abstract}

\begin{abstract}
${ }^{1}$ Discente do curso de graduação em Odontologia da Universidade Federal de Sergipe
${ }^{1}$ Discente do curso de graduação em Odontologia da Universidade Federal de Sergipe

${ }^{2}$ Discente do curso de graduação em Odontologia da Universidade Federal de Sergipe

${ }^{3}$ Professora associada ao Departamento de Odontologia da Universidade Federal de Sergipe

${ }^{4}$ Professora associada ao Departamento de Odontologia da Universidade Federal de Sergipe

${ }^{5}$ Professora associada ao Departamento de Odontologia da Universidade Federal de Sergipe
\end{abstract}

Introdução: A displasia ectodérmica (DE) é classificada como grupo heterogêneo de doenças hereditárias que atinge duas ou mais estruturas originárias do folheto embrionário ectoderma como cabelos, unhas, dentes, pele, glândulas sudoríparas e sebáceas, acarretando anomalias. Há inúmeras formas de expressão desse grupo doenças, no entanto, a DE hidrótica e a hipoidrótica ou anidrótica são as formas mais recorrentemente encontradas no âmbito clínico.

Objetivo: O presente estudo objetiva através de revisão da literatura avaliar causas e manifestações clínicas da displasia ectodérmica, além de ressaltar a importância de seu diagnóstico e tratamento precoce.

Desenvolvimento: Buscou-se na literatura os principais artigos científicos que foram publicados sobre a temática no período dos últimos 10 anos nas bases de dados Scielo, PUBMED e Scopus. A literatura apontou a DE hipoidrótica, caracterizada por meio da tríade de malformações congênitas hipotricose, hipoidrose e hipodontia como a forma mais recorrente. Essa forma, diferentemente dos outros padrões de herança genética, expressa alterações dentárias e faciais proeminentes como dentes conóides, nariz em sela, mento sulcado, labios protrusos, o que por vez, afeta o bem-estar e a autoestima do indivíduo. Quanto ao seu diagnóstico, além da análise da ausência de algumas unidades dentárias e de pelos finos e esparsos, são recorrentes episódios prolongados de hipertermia devido ausência total ou parcial das glândulas sudoríparas, podendo causar danos ao cérebro devido as convulsões desencadeadas pela febre persistente. Com base nisso, se mostra unânime o papel e a responsabilidade do cirurgião-dentista pela sua importância no diagnóstico precoce e na reabilitação oral, evitando também problemas de autoestima e dificuldade de interagir socialmente. Nesse sentido, é de extrema importância que o tratamento seja realizado com diversas especialidades da saúde.

Conclusão: Conclui-se que embora não haja tratamento específico, o diagnóstico precoce e o trabalho multidisciplinar são indispensáveis no restabelecimento das funções estética, mastigatória, fonética e psicológica do indivíduo, reintegrando-o ao convívio social, além de evitar danos cerebrais ou morte advindos da hipertermia secundária devido a hipoidrose.

\title{
Referências
}

FERREIRA, Christiane Santos et al. Displasia Ectodérmica: relato de caso. Arq. Odontol. [online], Belo Horizonte, v.48, n.1, p. 47-52, jan./mar. 2012. Disponível em: http://revodonto.bvsalud.org/scielo.php?script=sci_arttext\&pid=S151609392012000100007. Acesso em: 7 jul. 2020.

MACÊDO, Thiago Felippe Caldas et al. Características clínicas e diagnóstico da displasia ectodérmica: relato de caso. Revista Odontológica de Araçatuba, Salvador, v.66, n.1, p. 27-31, jan./jun. 2013. Disponível em: https://apcdaracatuba.com.br/revista/2014/03/04.pdf. Acesso em: 12. Jul. 2020

NEVES, Frederico Sampaio et al. Displasia Ectodérmica: Relato de dois casos clínicos. Revista de Odontologia da Universidade da Cidade de São Paulo, São Paulo, v. 23, n.2, p. 194-199, maio/ago. 2011. Disponível em: http://files.bvs.br/upload/S/1983-5183/2011/v23n2/a2268.pdf. Acesso em: 10 jul. 2020.

SILVEIRA, Juliana Matos et al. Reabilitação estético-funcional de paciente com displasia ectodérmica em idade precoce. Rev. Assoc. Paul. Cir. Dent., São Paulo, v.66, n.1, p. 42-47, jan./mar. 2012. Disponível em: http://revodonto.bvsalud.org/scielo.php? script=sci_arttext\&pid=S0004-52762012000100007. Acesso em: 10 jul. 2020. 


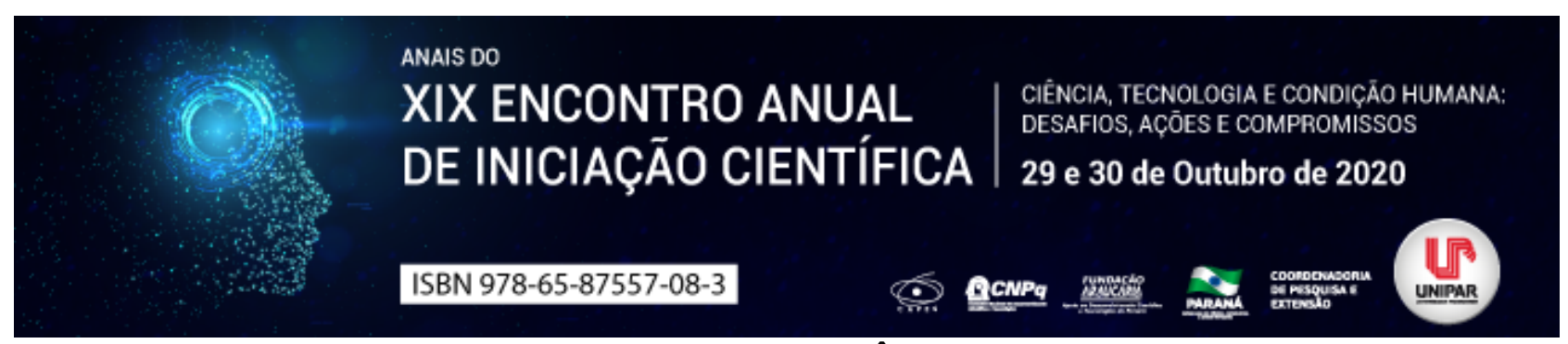

FLARE UP ENDODÔNTICO

\title{
${ }^{1}$ DHIEGO MANFRIM DE OLIVEIRA, ${ }^{2}$ VANESSA RODRIGUES DO NASCIMENTO, ${ }^{3}$ LUIZ FERNANDO TOMAZINHO
}

\author{
${ }^{1}$ Acadêmico do curso de Odontologia da UNIPAR \\ ${ }^{1}$ Docente da UNIPAR \\ ${ }^{2}$ Docente da UNIPAR
}

Introdução: O flare up é uma complicação que se desenvolve durante ou entre as sessões de tratamento endodôntico (TE), que é caracterizada por dor intensa, aguda ou tumefação. Na maioria dos casos está relacionada interações de bactérias e hospedeiros que pode requerer uma consulta de urgência.

Objetivo: Discorrer sobre a dor pós-operatória sentida após o tratamento endodôntico.

Desenvolvimento: $O$ tratamento endodôntico tem como objetivo intervir em qualquer circunstância com o intuito de minimizar ou cessar danos sentidos pelo paciente queixoso. É um procedimento corriqueiro, com a intenção de remover tecido orgânico, detritos infetados e bactérias patogênicas do sistema de canais radiculares, através da instrumentação mecânica associada a protocolos de irrigação com agentes desinfetantes (FIGINI et al., 2008). Existem algumas circunstâncias nas quais os microrganismos podem causar dor, entre consultas como resultado de um desequilíbrio das bactérias hospedeiras, induzida pelo TE. As espécies bacterianas podem estar associadas a lesões perirradiculares e existe a possibilidade de que as bactérias associadas ao flare up serem as mesmas que aquelas envolvidas nas infecções endodônticas primárias (JAYAKODI et al., 2012). Existem fatores de equilíbrio que são estabelecidos entre o sistema de defesa do hospedeiro e os irritantes contidos no interior do sistema dos canais radiculares que quando são lançados através do procedimento de instrumentação químicamecânica simulando a forma de um êmbolo que empurra a carga microbiana pelo forame apical chegando até o periodonto, contendo restos de detritos ou raspas de dentina contaminada, o equilíbrio pode ser rompido, provocando irritações apicais no decorrer do procedimento, ademais o hospedeiro desenvolve uma resposta inflamatória para que o equilíbrio seja reestabelecido. O flare up é uma degradação de tecidos pulpares que é ocasionada pela colonização de bactérias e considerada a causa mais comum e com predominância de microrganismos anaeróbios. As facultativas também podem estar presentes neste caso. Fatores como etiologia, idade, sexo, microbiota, cultura e estado de saúde do paciente vem a influenciar no desenvolvimento da resposta inflamatória do tecido periodontal, determinada de periodontite apical localizada, que sujeitam o paciente a dores classificadas de moderadas a intensas entre uma sessão e outra. No início da lesão o hospedeiro se encontra em boas condições (quadro crônico). Devido ao número de agressões causadas pelas toxinas das bactérias, as etapas vão avançando e o mecanismo de defesa fica comprometido desenvolvendo possivelmente para uma infecção mais aguda e até mesmo um abscesso.

Além disso, Sousa (2000), relata que um preparo bem conduzido o trauma gerado é menor, induzindo a uma resposta inflamatória de pequena intensidade, assim o edema resultante também será pequeno e seu conteúdo será drenado pelos mecanismos próprios para o interior do canal, vez que realizado a desobstrução, não resultando em dor, já que as terminações nervosas não serão comprimidas.

Conclusão: É sabido, que a complexibilidade anatômica e o terço apical são os que apresentam maior dificuldade de acesso para os instrumentos rotatórios realizarem a limpeza e descontaminação dos canais é de fundamental importância que o endodontista obedeça os princípios físicos, químicos e biológicos do tratamento endodôntico fatores estes com direta relação com a dor pós-operatório. Diante disto, como já citado, as manifestações dolorosas durante ou após o tratamento endodôntico tem como causa múltiplos fatores determinantes. O sucesso ou falha do procedimento endodôntico não será apenas do cirurgião dentista. Contudo, caso o paciente relate dor, entre consultas a imediata intervenção será feita com o auxílio de analgésicos e anti-inflamatórios para o controlar a dor e conter os sintomas pós-operatório.

\section{Referências}

FIGINI, Lara. et al. Single versus multiple visits for endodontic treatment of permanent teeth: a Cochrane systematic review. Journal of Endodontics, v. 34, n. 9, p. 1041-1047, 2008.

JAYAKODI, Harikaran. et al. Clinical and pharmacological management of endodontic flare-up. Journal of pharmacy \& bioallied sciences, v. 4, n. Suppl 2, p. S294, 2012.

SOUZA, Ronaldo Araújo. Limpeza de forame e sua relação com a dor pós-operatória. Jornal Brasileiro de Endo/Perio, v. 1, n. 3, p. 45-8, 2000. 
Coordenadoria de Pesquisa e Extensão - COPEX

Departamento de Editoraçāo e Divulgaçāo Científica - DEDIC 


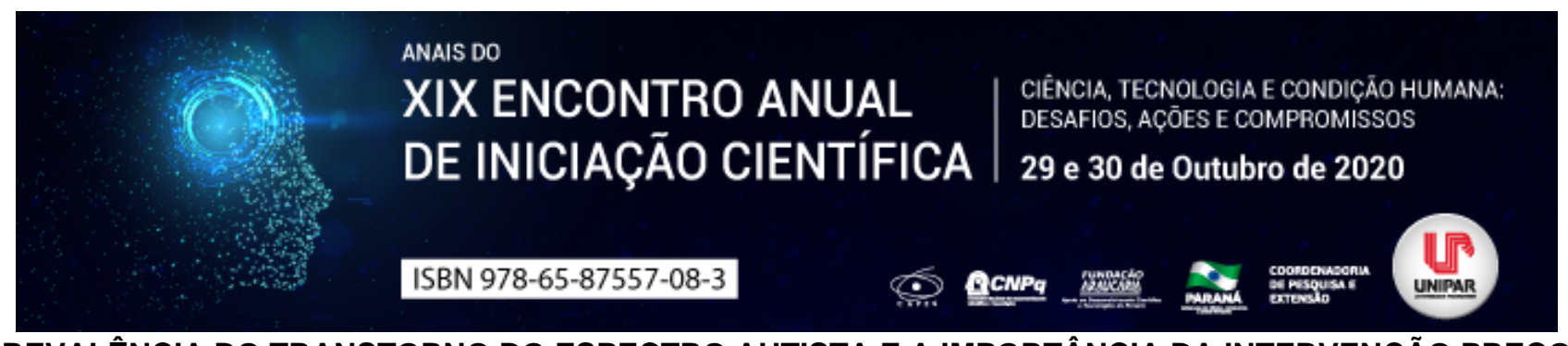

A PREVALÊNCIA DO TRANSTORNO DO ESPECTRO AUTISTA E A IMPORTÂNCIA DA INTERVENÇÃO PRECOCE

\author{
${ }^{1}$ Danielle Elias Mendes, ${ }^{2}$ LAURA CRISTINA DA SILVA CARVALHO , ${ }^{3}$ MARIA EUGÊNIA OLIVEIRA CAMPOS , ${ }^{4}$ VERÔNICA \\ CAMPOS RESENDE, ${ }^{5}$ GABRIELA OLIVEIRA DE MOURA RIGONATO, ${ }^{6}$ CRISTIANE ANGELICA DE PAIVA PAULA
}

\author{
${ }^{1}$ Estudante de Medicina no Centro Universitário Master de Ensino Presidente Antônio Carlos \\ ${ }^{1}$ Estudante de Medicina na Faculdades das Americas \\ ${ }^{2}$ Estudante de Medicina na Universidade Nove de Julho \\ ${ }^{3}$ Estudante de Medicina na Universidade Nove de Julho \\ ${ }^{4}$ Estudante de Medicina no Centro Universitário Master de Ensino Presidente Antônio Carlos \\ ${ }^{5}$ Docente da Universidade Presidente Antonio Carlos
}

Introdução: O Transtorno do Espectro Autista (TEA), é um conjunto de transtornos que afetam diretamente o neurodesenvolvimento das crianças, podendo ser decorrente de fatores genéticos, fisiológicos e ambientais. Sua gravidade é variável e baseia-se nos sintomas da doença (APA, 2013; OPAS, 2017). Atualmente, acredita-se que haja uma grande incidência do transtorno. Estima-se que cerca de $1 \%$ dos indivíduos de cada país possua algum grau de TEA, sendo mais frequente no sexo masculino. (APA, 2013). Em relação ao prognóstico do TEA, este é variável e a intervenção precoce tem demonstrado ser o melhor procedimento a ser realizado, já que permite minimizar os impactos do transtorno, indicando um prognóstico positivo (VASCONCELOS, 2009). Assim, é justamente devido a essa considerável incidência do TEA na população e a necessidade de uma intervenção precoce que se dá a importância da realização de estudos que envolvam o tema. Essa revisão literária conta com dados retirados do SciELO, PudMED, entre outras fontes, com os seguintes indexadores: diagnóstico precoce do TEA, TEA e prevalência. Foram elegíveis dissertações e artigos publicados a partir de 2007, com contribuição teórica e prática sobre a prevalência do TEA e a importância da intervenção precoce.

Objetivos: Realizar uma revisão literária acerca da prevalência do TEA e a importância da intervenção precoce para o desenvolvimento dos indivíduos.

Desenvolvimento: O TEA é uma condição na qual ocorrem comprometimentos, em diferentes graus, na comunicação, na linguagem e no comportamento social. É comum a ocorrência de padrões de comportamento restritos e repetitivos, além de dificuldades na interação social que podem incluir déficits na reciprocidade sociemocional e nos comportamentos comunicativos não verbais (APA, 2013; OPAS, 2017). Nos últimos anos estudos sugerem uma alta incidência do TEA, cerca de 1\% dos indivíduos de cada país possuem algum grau do transtorno, sendo mais frequente no sexo masculino (APA, 2013). Outros estudos ainda afirmam que uma a cada 160 crianças no mundo possuem TEA (OPAS, 2017). Nos Estado Unidos a estimativa de 2014, mediada pela Rede de Monitoramento de Deficiência de Desenvolvimento e Autismo (ADDM), era de 16,8 por 1.000 crianças com 8 anos. (MAENER et. al., 2016). Em 2016 a estimativa mostrou que a incidência do transtorno é de 18,5 por 1000 crianças de 8 anos, o que significa um aumento de $10 \%$ no número de casos (MAENER et. al., 2016). Acredita-se que isso se deve as expansões dos critérios diagnósticos e a visibilidade que o transtorno vem conquistando na sociedade (APA, 2013).

No Brasil, ainda não há estudos, especificamente, referentes a prevalência do TEA. Mas, uma pesquisa realizada na cidade de Atibaia, no interior de São Paulo, mostrou uma incidência dos Transtornos Invasivos do Desenvolvimento (TID) de 0.88\%, com uma razão 3:1 meninos a cada meninas. (RIBEIRO, 2007) .Esses dados podem ser relevantes, pois a TEA pode ser classificada como um dos tipos de TID (BATISTA; ARAUJO, 2019). Sendo o prognóstico do TEA variável e o diagnóstico complexo, atualmente, há critérios que auxiliam no diagnóstico e na definição de sua gravidade, visando um rastreamento precoce e a possibilidade de uma Intervenção Precoce (IP) (APA, 2013). A IP busca, através de uma prática multidisciplinar, acolher as demandas e necessidades das crianças com o transtorno, fornecendo ferramentas de estimulação precoce que visam minimizar os fatores que viriam a prejudicar o desenvolvimento da criança e as interferências significativas que poderiam provocar na vida desta e de sua família. (FRANCO, MELO; APOLONIO, 2012; COSTA, 2014). A IP pode ocorrer tanto, logo após o nascimento ou imediatamente depois do diagnóstico, se este for realizado até a primeira infância (VASCONCELOS, 2009). A importância da IP nessa idade é que, além de proporcionar benéficos para o funcionamento familiar, apresenta ser capaz de intervir atenuando as limitações de origem, como por exemplo, a possibilidade de atenuar ao nível das transformações sinápticas neurais, que ainda estão flexíveis, graças a plasticidade neural presente nas primeiras idades (COSTA, 2014). Com isso, crianças e adolescentes têm apresentado uma propensão maior na redução da preponderância dos sintomas e, até mesmo, um neurodesenvolvimento 
normal (VASCONCELOS, 2009). Há relatos de que a atenção compartilhada e o contato visual estão entre as funções básica que, com IP adequadas, podem ser desenvolvidas pelos portadores do TEA (DUARTE et. al., 2016).

Conclusões: Com as revisões literárias realizadas, foi possível perceber que há uma grande prevalência do TEA, este pode atingir até $1 \%$ dos habitantes de cada país, um número relativamente alto. No Brasil, não foram encontrados dados direcionados, especificamente, a prevalência do TEA, dessa forma, fica evidente a necessidade de mais estudos e produções cientificas acerca do tema. Por fim, foi possível verificar que há uma enorme necessidade da IP, já que esta possibilita ao portador do TEA, maiores chances de desenvolver um prognóstico favorável, graças a capacidade de neuroplasticidade presente na primeira infância.

\section{Referências}

AMERICAN PSYCHIATRIC (APA). Diagnostic and statistical manual of mental disorders. $5^{\circ}$ ed. Washington: American Psychiatric Association; 2013.

BATISTA, Carolina; ARAUJO, Jessica. Benefícios da hipoterapia em crianças com Transtorno do Espectro Autista (TEA). 2019. Orientadora Jadiane Dionísio. Trabalho de Conclusão de Curso (Graduação em Fisioterapia) Universidade Federal de Uberlândia, Uberlândia, 2019.

COSTA, Daniela. Intervenção Precoce no Transtorno do Espectro do Autismo. Orientador: SARAIVA, Horácio Pires Gonçalves Ferreira. 2014. Dissertação (Mestrado em Ciências da Educação) Escola Superior de Educação João de Deus, Lisboa, 2 out. 2014.

DUARTE, Cíntia et. al. Diagnóstico e Intervenção Precoce no Transtorno do Espectro do Autismo. In: CAMINHA, Vera Lúcia; HUGUENIN, Julliane; ASSIS, Lúcia ; ALVES, Priscila Pires. Autismo: vivências e caminhos. Blucher São Paulo. 2016. p. 45-56. FRANCO, Vitor. et al. Problemas do desenvolvimento infantil e intervenção precoce. Educar em Revista. 2012, n.43, p.49-64. Disponível em:scielo.br/scielo.php?pid=S0104-40602012000100005\&script=sci_abstract\&tlng=pt. Acesso em: 20 ago. 2020.

MAENNER, Matthew. et al. Prevalência de Transtorno do Espectro do Autismo entre Crianças de 8 anos - Rede de Monitoramento de Deficiências de Desenvolvimento e Autismo, 11 Sites, Estados Unidos, 2016. MMWR Surveill Summ $202^{\circ}$. Vol 69. Disponível em: https://www.cdc.gov/mmwr/volumes/69/ss/ss6904a1.htm?s_cid=ss6904a1_w\#suggestedcitation.Acesso em: 18 ago. 2020.

OPAS. Organização Pan-Americana de Saúde. Folha informativa: Transtorno de Espectro Autista. Abr. 2017. Disponível em: https://www.paho.org/bra/index.php?ltemid=1098. Acesso em: 20 ago. 2020.

RIBEIRO, Sabrina. Prevalência dos transtornos invasivos do desenvolvimento no município de Atibaia: um estudo piloto. Orientador: Marcos Tomanik. 2007. Dissertação (Mestrado em Psicologia) - Universidade Presbiteriana Mackenzie, São Paulo, 2007. 


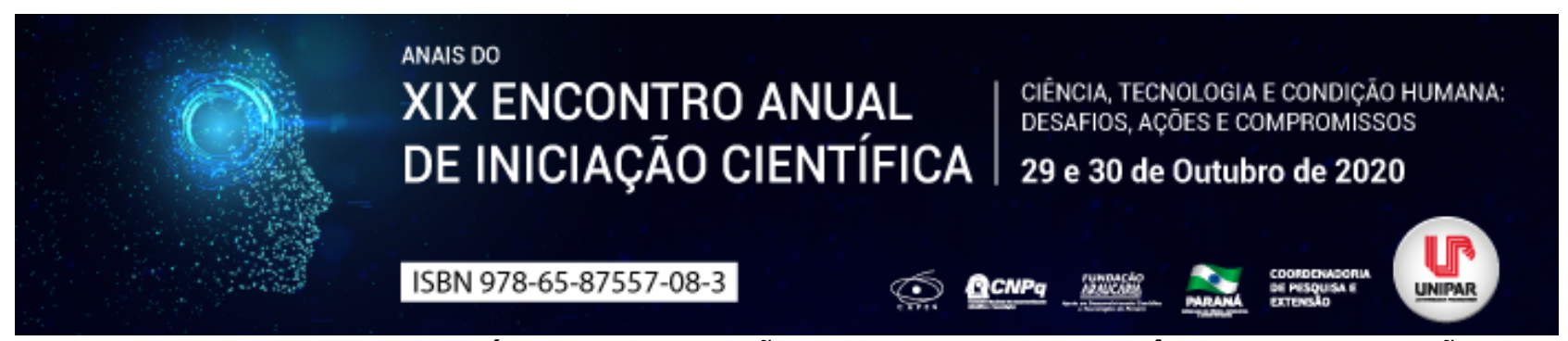

TEORIA NEUROIMUNOENDÓCRINA: A LIGAÇÃO ENTRE ESTRESSE CRÔNICO E DEPRESSÃO

\begin{abstract}
${ }^{1}$ FERNANDA DE ABREU BRAGA, ${ }^{2}$ GABRIEL TRENTINI PAGNUSSAT, ${ }^{3}$ TAIS DA SILVA SCHMIDT, ${ }^{4}$ LEANDRO MARTINS LIMA SOUZA, ${ }^{5}$ FRANCISLAINE APARECIDA DOS REIS LIVERO
\end{abstract}

\author{
${ }^{1}$ Acadêmica do Curso de Medicina e bolsista do PEBIC/CNPq \\ ${ }^{1}$ Acadêmico do Curso de Direito da UNIPAR \\ ${ }^{2}$ Acadêmica do Curso de Medicina da UNIPAR \\ ${ }^{3}$ Acadêmico do Curso de Medicina da UNIPAR \\ ${ }^{4}$ Docente da UNIPAR
}

Introdução: A depressão tem etiologia parcialmente desconhecida. Há diversas teorias aceitas pela literatura científica sobre sua fisiopatologia, uma delas é a teoria neuroimunoendócrina, que analisa o eixo hipotálamo-pituitária-adrenal (HPA), principal sistema responsável pela resposta ao estresse. O estresse é um estado de homeostasia ameaçada, na qual o organismo para preservar seu equilíbrio interno, reage com uma série de respostas adaptativas específicas ao estressor ou não específicas e generalizadas (SOUSA; SILVA; COELHO, 2015), sendo que a reiterada exposição a eventos estressores no decorrer da vida podem desembocar em estresse crônico (DONATO, 2013), do qual a ativação prolongada leva a imunossupressão e alterações do humor, o que é evidenciado como um ponto crucial na gênese da depressão maior (GOMES; GASPAR, 2018).

Objetivo: Demonstrar a relação do estresse crônico com o desenvolvimento do transtorno depressivo.

Desenvolvimento: $O$ transtorno depressivo maior é uma desordem psiquiátrica, associado a um significativo impacto negativo na qualidade de vida, morbimortalidade e função cognitiva (BASTOS, 2011). É uma das principais causas mundiais de incapacidade, e um quinto da população irá desenvolver a doença em algum momento ao longo da vida (APA, 2013). Apesar de amplamente estudada, sua etiologia é parcialmente desconhecida (MENARD et al., 2017). Acredita-se que os mecanismos da doença sejam múltiplos, dessa forma, desvendar a patofisiologia da depressão é um desafio, bem como devido a sua heterogeneidade e pela impossibilidade de reproduzir sentimentos de culpa e suicídio em modelos animais (JESULOLA; MICALOS; BAGULEY, 2018). Uma das teorias para a gênese da depressão é a neuroimunoendócrina, a qual explora a complexidade do eixo hipotálamo-pituitária-adrenal (HPA), principal sistema responsável pela resposta ao estresse, em virtude de ser um importante fator de secreção de corticotrofina (CRF), do cortisol, do hormônio adrenocorticotrófico (ACTH), da adrenalina e noradrenalina (PEREIRA, 2018), pois, na depressão maior é observado um significativo percentual de pacientes que apresentam: concentrações aumentadas de cortisol no plasma, urina, líquido cefalorraquidiano; uma resposta exagerada do cortisol ao hormônio adrenocorticotrófico (ACTH); e um aumento das glândulas pituitária e adrenal (MELLO et al., 2007). A relação entre o sistema imune e sistema nervoso é mediada por citocinas, que ativam o eixo HPA, através do hormônio liberador de CRF, que é compartilhado com mediadores da inflamação. As citocinas e outros mediadores imunológicos agem como moléculas sensoras, para transformar estímulos não cognitivos (processo inflamatório) em cognitivos, com o objetivo de elaborar uma resposta integrada ao evento periférico. Desse modo, as moléculas liberadas durante eventos inflamatórios periféricos podem influenciar os fatores centrais que controlam a homeostase e o comportamento (TAFET; BERNARDINI, 2003). Há evidências consideráveis de que o estresse psicológico pode desencadear um aumento significativo na atividade inflamatória, mesmo com ausência de injúria física. Esse aumento pode, por sua vez, provocar mudanças profundas no comportamento, que incluem o início de sintomas depressivos (KIECOLT-GLASER; DERRY; FAGUNDES, 2015). Nesse viés, o cortisol age como um regulador de feedback negativo diminuindo a secreção de CRF e ACTH. Esse também exerce uma função de feedback negativo no eixo HPA através do hipocampo. Sua regulação ocorre através de um sistema duplo de receptores de mineralocorticóides e de glicocorticóides. Na depressão, o eixo está desregulado e os mecanismos de feedback negativos são enfraquecidos. Desse modo, favorecendo uma maior atividade da via glutamatérgica, que promove o estresse oxidativo que ao reagir com os neurônios que causam apoptose (GOMES; GASPAR, 2018). Portanto, a alteração do hipocampo produzida por níveis prolongados e excessivos de cortisol, com consequente comprometimento do ciclo de feedback negativo nesta fase, explicaria a incapacidade do glicocorticóide de regular sua própria secreção durante o estresse crônico (NESTLER et al., 2002). Essas observações deram origem à hipótese da ligação entre o estresse e a origem da depressão com uma alteração do sistema límbico-hipotálamopituitária-adrenal (L-HPA), especialmente com foco na regulação negativa de glicocorticóides em níveis hipocampais e hipotalâmicos, com resultante hipercortisolismo (STEIN, 2018).

Conclusão: Resta claro a relação do estresse crônico com a depressão, o qual através dos mecanismos desencadeados pela desregulação do eixo hipotálamo-pituitária-adrenal torna o estresse um importante gatilho no desencadeamento da depressão. 


\section{Referências}

American Psychiatric Association. Diagnostic and statistical manual of mental disorders: DSM-5, 5th ed. American Psychiatric Association, Washington, D. C. 2013.

BASTOS, Teresa da Conceição de Neiva Moura. A Neurobiologia da Depressão. Dissertação (Mestrado em Medicina) Faculdade de Medicina da Universidade do Porto (FMUP), Porto, Portugal, 2011.

DONATO, Franciele. Envolvimento dos sistemas dopaminérgico e serotoninérgico no efeito tipo antidepressivo causado pelo fenilselenometil-1,2,3-triazol em camundongos. Dissertação (Mestrado em Bioquímica) - Universidade Federal do Pampa (UNIPAMPA), 2013.

GOMES, Joyce de Pontes; GASPAR, Danielle Macêdo. A origem da depressão: Teorias sobre o desconhecido. In: IV simpósio de pesquisa em ciências médicas, 2018.

JESULOLA, Emmanuel; MICALOS, Peter; BAGULEY, lan J. Understanding the pathophysiology of depression: From monoamines to the neurogenesis hypothesis model - are we there yet? Behav. Brain Res, v. 341, p. 79 90, 2018.

KIECOLT-GLASER, Janice K.; DERRY, Heather M.; FAGUNDES, Christopher P. Inflammation: depression fans the flames and feasts on the heat. Am J Psychiatry, v. 172, n. 11, p. 1051, Nov, 2015.

MELLO, Andrea Feijo et al. Depressão e estresse: existe um endofenótipo? Rev Bras Psiquiatr, v. 29(Supl I), p. 13-8, 2007.

MENARD, Caroline et al. Social stress induces neurovascular pathology promoting depression. Nature Neuroscience, v. $20, n$. 1752 1760, 2017. https://doi.org/10.1038/s41593-017-0010-3

NESTLER, Eric J. et al. Neurobiology of Depression. Neuron, v. 34, p. 13 25, March, 2002.

SOUSA, Maria Bernadete Cordeiro; SILVA, Hélderes Peregrino; COELHO, Nicole Leite Galvão. Resposta ao estresse: I. homeostase e teoria da alostase. Estud. psicol, v. 20, n. 1, Natal, jan./mar., 2015.

STEIN, Dirson João. Estresse social, resiliência e inflamação: relação com comportamento tipo-depressivo. Tese (Doutorado em Psiquiatria e Ciências do Comportamento) - Universidade Federal do Rio Grande do Sul, Porto Alegre, 2018.

TAFET, Gustavo E.; BERNADINI, Renato. Psychoneuroendocrinological links between chronic stress and depression. Progress in Neuro-Psychopharmacology \& Biological Psychiatry, v. 27, p. 893-903, 2003. 


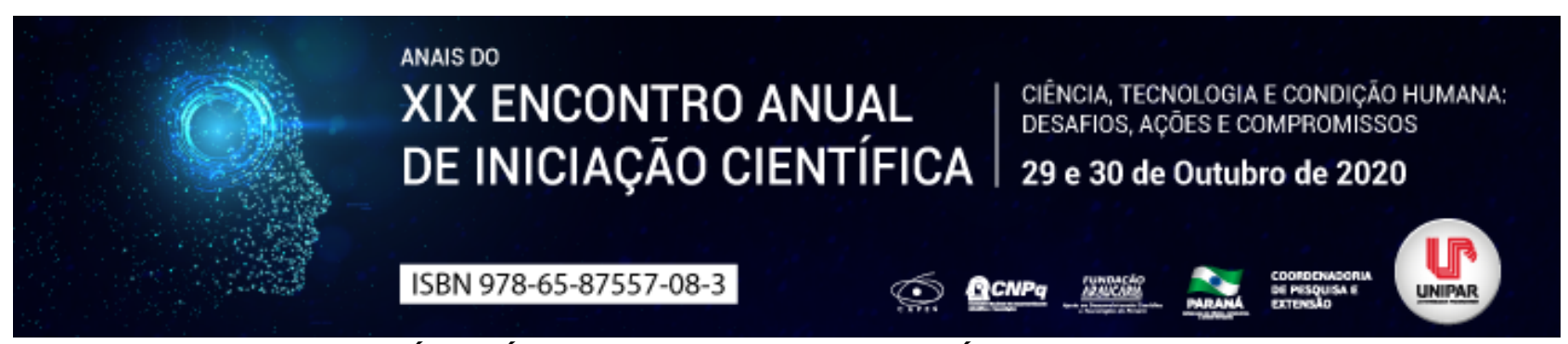

EXERCÍCIO FÍSICO PARA PESSOAS COM SÍNDROME DE DOWN

\title{
1JOAO VICTOR AVANCCO LIMA, ${ }^{2}$ MARIA GABRIELLA GIROTO
}

\author{
${ }^{1}$ Discente do curso de Educação Física, Ciências da Saúde, Universidade Paranaense UNIPAR \\ ${ }^{1}$ Docente do curso de Educação Física, Ciências da Saúde, Universidade Paranaense UNIPAR
}

Introdução: A Síndrome de Down é uma desordem genética, que causa alteração no cromossomo 21 ou seja na divisão celular se estabelecem três pares do cromossomo 21, assim ficam 47 cromossomos em suas células em vez de 46, como a maioria da população. Esta desordem traz características peculiares para quem desenvolve a Síndrome, entre elas as características fenotípicas como fronto-occipital muito pequeno, fissuras palpebrais com inclinação superior, hipoplasia da região mediana da face, displasia; a língua é protrusa e hipotônica. Em geral, as crianças com SD apresentam hipotonia muscular ocorrendo um atraso no desenvolvimento de alguns reflexos (SILVA; DESSEM, 2002). Estas características aumentam o risco de desenvolvimento de doenças secundárias como problemas no coração, síndromes respiratórias, obesidade, entre outros. E neste sentido a prática de exercício físico pode ser um instrumento aliado para a manutenção e melhoria de níveis de saúde destes indivíduos. Nesta perspectiva, a investigação de tipos de prática de exercícios adequadas e seus benefícios são fundamentais para o profissional que irá trabalhar com este público.

Objetivo: Investigar através da literatura quais são os efeitos do exercício físico em pessoas com Síndrome de Down.

Desenvolvimento: A síndrome de Down constitui a anormalidade cromossômica mais comum do homem. No Brasil sua incidência é cerca de 13:1.000 nascidos vivos. Em 1959, com o advento da cariotipagem, foi descrita a principal causa da síndrome, a trissomia do cromossomo 21 (SILVA; DESSEM, 2002). Essa anomalia acontece pela presença de três cromossomos 21, fazendo possuírem 47 cromossomos em vez de 46 . Estes indivíduos nascem com algumas características, de acordo com Gundim (2007, p. 32) a face achatada, baixa estatura, a existência de uma prega típica no canto dos olhos, cabelos lisos, dentição irregular, obesidade. . Independentemente das suas características são capazes de alcançar um bom desenvolvimento das capacidades motoras e cognitivas. Dessa forma, para Queiros et al. (2016) em sua pesquisa afirmam que pessoas com SD tem tendência de uma menor taxa metabólica basal, hipotireoidismo, obesidade, e doenças causadas pelo sedentarismo e pela má alimentação. Além de hipotonia que é a diminuição do tônus muscular e da força, levando o indivíduo possuir moleza e flacidez, podendo deste modo acarretar doenças neuromusculares e atraso no desenvolvimento motor. Entretanto Schuster et al (2012) relatam que doenças respiratórias são as principais causas de morte em pessoas com Síndrome Down, sendo fundamental que esses indivíduos possuam uma dieta saudável juntamente com a prática de exercícios físicos. Para Ferreira et al. (2015) a atividade física é capaz de melhorar a circulação sanguínea, diminuir o índice de obesidade e de doenças do coração e reduzindo o nível de estresse. Desta forma Junior et al (2007) relatam em sua pesquisa que o treinamento da resistência muscular localizada foi priorizado por ser importante para o condicionamento físico do indivíduo e também para a melhora do seu tônus muscular, uma vez que a pessoa com Síndrome de Down apresenta como característica a hipotonia generalizada e destaca que os exercícios físicos precisam ser adequados de acordo com cada características e necessidades. De acordo com Stein (1999) para a prática de exercícios físicos é recomendável uma avaliação medica, para pessoas com problemas cardíacos recomenda-se um cardiologista para uma avaliação mais detalhada, a partir da decisão clinica que será possível saber se esse indivíduo está apto para a prática ou não, e quais exercícios poderão ser realizados. é importante uma boa avaliação, sempre estar em contado com os pais, perguntar ao aluno sobre suas limitações e indispensável o atestado médico. Desta maneira Albuquerque (2010) descreve que a prática de atividade física é essencial para pessoas com Síndrome de Down em todas as fases da vida, as atividades mais indicadas são atletismo, natação, futebol e tênis. Para algumas pessoas que apresentam problema respiratório e obesidade, as atividades mais indicadas são caminhas e passeios de bicicleta.Essas atividades promovem agilidade,velocidade e propriocepção, melhora os fortalecimento de músculo.

Conclusão: Conclui-se que a prática de atividades físicas diminuem os riscos de doenças causadas pela SD, diminuindo então o nível de sedentarismo, obesidade, melhorando suas capacidades físicas como coordenação motora, força e potencial respiratório, além de ajudar na formação social do indivíduo.

\section{Referências}

ALBUQUERQUE, R. P. Benefícios dos exercícios físicos para pessoas com Síndrome de Down.2018. Disponível em: https://www.gndi.com.br/saude/blog-da-saude/beneficios-dos-exercicios-fisicos-para-pessoas-com-sindrome-de-down. Acesso em: 21 jul. 2020.

FERREIA, J. S.; CORREIA, S. H.; PEDRO, D. A. Influência da prática e atividade física sobre a qualidade de vida de usuários de SUS. SAUDE DEBATE. V. 39, n.106, p.792-801, jul/set.2015.Disponível em: https://www.scielo.br/pdf/sdeb/v39n106/0103-1104- 
sdeb-39-106-00792.pdf. Acesso em: 20 jul. 2020.

GUNDIM,S.M. A inclusão de alunos com Síndrome de Down em escolas de Goiânia. 2017.145f. Dissertação (Programa de Pós-graduação em Educação). Faculdade de Educação, Universidade Federal de Goiás, Goiania, 2017. Disponível em: https://repositorio.bc.ufg.br/tede/bitstream/tde/1984/1/dissertacao\%20shirley.pdf. Acesso em: 18 jul. 2020.

JUNIOR, C. A. da S.et al. Musculação para um aluno com síndrome de Down e o aumento da resistência muscular localizada. Revistal Digital n.104, jan.2007. Disponível em: https://www.efdeportes.com/efd104/sindrome-de-down.htm. Acesso em: 20 jul.2020.

QUEIROS, F. de. et.al. Perfil nutricional de portadores de síndrome de Down no agreste de Pernambuco. Nutri. clin. Hosp. v. 36, n.3, p.122-129, abril/junio.2016. Disponível em: https://revista.nutricion.org/PDF/fariasqueiroz.pdf. Acesso em: 18jul. 2020.

SCHUSTER, R. C.; ROSA, L. R. da.;FERREIRA, D. G. Efeitos do treinamento muscular respiratório em pacientes de síndrome de down: estudo de casos. Rev Fisioter S Fun. v.1, n.1, p.52-57, Jan/Jun. 2012. Disponível em: file:///C:/Users/Usuario/Downloads/20536-Texto\%20do\%20artigo-50067-1-10-20171030.pdf. Acesso em: 18 jul. 2020.

SILVA, N. L. P.; DESSEN, M. A. Síndrome Down: Etiologia, caracterização e impacto na família. Interação em Psicologia. v.2, n.6, p. 167-176. jul/dez. 2002.

STEIN, R. Atividade Física e saúde pública. Rev Bras Med Esporte. v.5, n.4,1999. Disponível em: https://www.scielo.br/scielo.php?script=sci_arttext\&pid=S1517-86921999000400006. Acesso em: 23ago.2020 


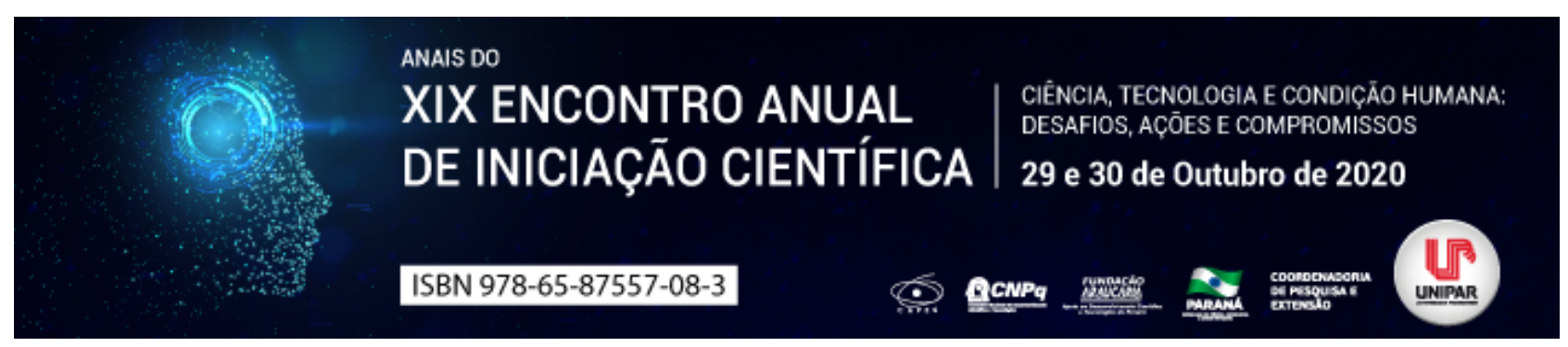

DESENVOLVIMENTO DA TOXOPLASMOSE NO HOMEM

\title{
${ }^{1}$ KARINE DELGADO SOUZA, ${ }^{2}$ ISABELA CARVALHO DOS SANTOS, ${ }^{3}$ EMERSON LUIZ BOTELHO LOURENÇO
}

\author{
${ }^{1}$ Acadêmica do Curso de Doutorado Em Ciencia Animal Com Enfase Em Produtos Bioativos \\ ${ }^{1}$ Acadêmica do Curso de Doutorado Em Ciencia Animal Com Enfase Em Produtos Bioativos \\ ${ }^{2}$ Docente no programa de Pós-graduação em Ciência Animal com ênfase em produtos bioativos
}

Introdução: O Toxoplasma gondii (T. gondii) é um parasita intracelular obrigatório pertencente ao filo Apicomplexa e de ordem Coccidea (RORMAN, 2006) que causa a doença conhecida mundialmente como toxoplasmose. Essa doença não é transmitida de pessoa para pessoa, tendo então três principais rotas de transmissão para o homem: ingestão de água ou alimentos mal cozidos que estejam infectados, de animal para pessoa, e de mãe para filho (congênita) (CDC, 2017). A prevalência de anticorpos IgG no Brasil varia de 54\% no Centro-Oeste a $75 \%$ no Norte (FRENCKEL, 2002). A infecção aguda pela toxoplasmose em indivíduos adultos imunocompetentes normalmente é assintomática. Quando há manifestação de sintomas, o indivíduo sente dores de cabeça e mal estar, além de febre baixa e linfoadenopatia cervical. Em indivíduos imunocomprometidos, como portadores de HIV ou câncer, a toxoplasmose pode levar até a morte. Isso acontece pois nesses pacientes a doença se manifesta de forma severa, causando manifestações graves, como: encefalites, miocardites e pneumonia (IDDAWELA, 2017). Quanto às formas de transmissão da doença, a congênita é a de maior risco e mais devastadora, pois pode causar lesões patológicas e má formações no feto ou neonatos. Mulheres grávidas com toxoplasmose aguda ou reativada podem transmitir a doença via transplacentária para o feto, pois o parasito quebra a barreira placentária, e se propaga nos órgãos do feto, comprometendo o processo de desenvolvimento embrionário (OZ, 2017). O T. gondii possui ciclo de vida heteroxênico, sendo os felídeos os hospedeiros definitivos e os humanos e outros animais homeotérmicos os hospedeiros intermediários. Os hospedeiros intermediários são infectados principalmente por via oral através da ingestão de carne mal cozida contendo cistos ou água e alimentos contaminados com oocistos do T. gondii (DUBEY, 2008).

Objetivo: Descrever o curso da toxoplasmose no organismo humano, assim como suas manifestações.

Desenvolvimento: $\mathbf{O}$ toxoplasma no organismo humano: Quando ingeridos, os oocistos que contém esporozoítos penetram nas células intestinais, multiplicam-se e transformam-se em taquizoítos, sendo essa a forma de multiplicação rápida do parasito (DAVIDSON, 2000). Os taquizoítos, então, disseminam-se pelo sistema vascular e atingem vários órgãos, como o sistema nervoso central (SNC), músculo esquelético, vísceras e olhos. Nestes tecidos, os taquizoítos se multiplicam intracelularmente e, caso a multiplicação seja intensa, causam lise celular e desencadeiam reação inflamatória local. O desenvolvimento de resposta imune protetora leva ao encistamento do organismo, formando os cistos teciduais que contêm bradizoítos (forma de multiplicação lenta), os quais permanecem latentes sem causar doença (DUBEY et al., 1998). Infecção sintomática: Uma minoria de pessoas saudáveis infectadas com $T$. gondii após o nascimento desenvolvem sintomas, e quando acontece, estes costumam ser leves e incluem: febre, mal-estar e linfoadenopatia (MONTOYA, 2004). Porém, em casos de reinfecção, o indivíduo pode desenvolver a doença de forma grave e até fatal com manifestações pulmonares, multiviscerais e oculares. Imunocomprometidos e gestantes: Esses são os casos que requerem mais preocupação e atenção. Em indivíduos que já possuem o sistema imunológico comprometido, a apresentação clínica geralmente inclui focos de encefalite com dor de cabeça, confusão, fraqueza motora, febre e, se não for tratada, pode progredir para convulsões, estupor, coma e até anormalidades na fala e hemiparesia (LUFT, 1993). A transmissão congênita geralmente ocorre quando a mulher é infectada pelo parasita pela primeira vez, e durante o primeiro trimestre de gestação. Essa forma de infecção pode levar a uma variedade de manifestações clínicas de grande importância, como aborto espontâneo, bebês natimortos ou com hidrocefalia ou microcefalia, calcificações cerebrais ou retinocoriodite, ou sintomas neurológicos mais tardios (REMINGTON, 2006).

Conclusão: A toxoplasmose é uma doença que atinge grande parte da população mundial, e por isso se tornou um problema de saúde pública. Apesar de a maioria dos indivíduos não apresentarem manifestações sintomáticas, temos casos específicos, principalmente em imunocomprometidos e gestantes, que requerem muita atenção e cuidados.

\section{Referências}

Centers for Disease Control and Prevention. Parasites - Toxoplasmosis (Toxoplasmainfection). March 1, 2017; https://www.cdc.gov/parasites/toxoplasmosis/. Acesso em 9 de janeiro de 2018.

DAVIDSON, M. G. Toxoplasmosis. Veterinary Clinics of North America small Animal Practice, v. 30, p. 1051-1062, 2000.

DUBEY, J. P.; JONES, J. L. Toxoplasma gondii infection in humans and animals in the United States. International Journal for Parasitology, v. 38, n. 11, p. 1257- 1278, 2008.

DUBEY, J. P.; LINDSAY, D. S.; SPEER, C. A. Structures of Toxoplasma gondii tachyzoites, bradyzoites, and sporozoites and 
biology and development of tissue cysts. Clinical Microbiology Review. v. 11, p. 267-299, 1998.

FRENCKEL JK. Toxoplasmose. In: Veronesi R, editor. Tratado de infectologia. 2a ed. São Paulo: Atheneu, p. 1310-25, 2002.

IDDAWELA, D.; VITHANA, S. M. P.; RATNAYAKE, C. Seroprevalence of toxoplasmosis and risk factors of Toxoplasma gondii infection among pregnant women in Sri Lanka: a cross sectional study. BMC public health, v. 17, n. 1, p. $930,2017$.

LUFT, B.J., HAFNER, R., KORZUN, A.H., LEPORT, C., ANTONISKIS, D., BOSLER, E.M., BOURLAND 3RD, D.D., UTTAMCHANDANI, R., FUHRER, J., JACOBSON, J., MORLAT, P., VILDE, J., REMINGTON, J.S. Toxoplasmic encephalitis in patients with the acquired immunodeficiency syndrome. Members of the ACTG 077p/ANRS 009 study team. N. Engl. J. Med. 329, 995 1000. 1993.

MONTOYA, J.G., LIESENFELD, O. Toxoplasmosis. The Lancet 363, 1965 1976, 2004.

OZ, H. S. Fetomaternal and Pediatric Toxoplasmosis. Journal of Pediatric Infectious Diseases, v. 12, n. 4, p. $202-208,2017$.

REMINGTON, J.S., MCLEOD, R., THULLIEZ, P., DESMONTS, G. Toxoplasmosis. In: Remington, J.S., Klein, J.O., Wilson, C.B., Baker, C.J. (Eds.), Infectious Diseases of the Fetus and Newborn Infant. Elsevier Saunders, Philadelphia, pp. $9471091,2006$.

RORMAN E, ZAMIR CS, RILKIS I, BEN-DAVID H, Congenital toxoplasmosisprenatal aspects of Toxoplasma gondii infection. Reproductive Toxicology, v. 21, n. 4, p. 458 472, 2006. 


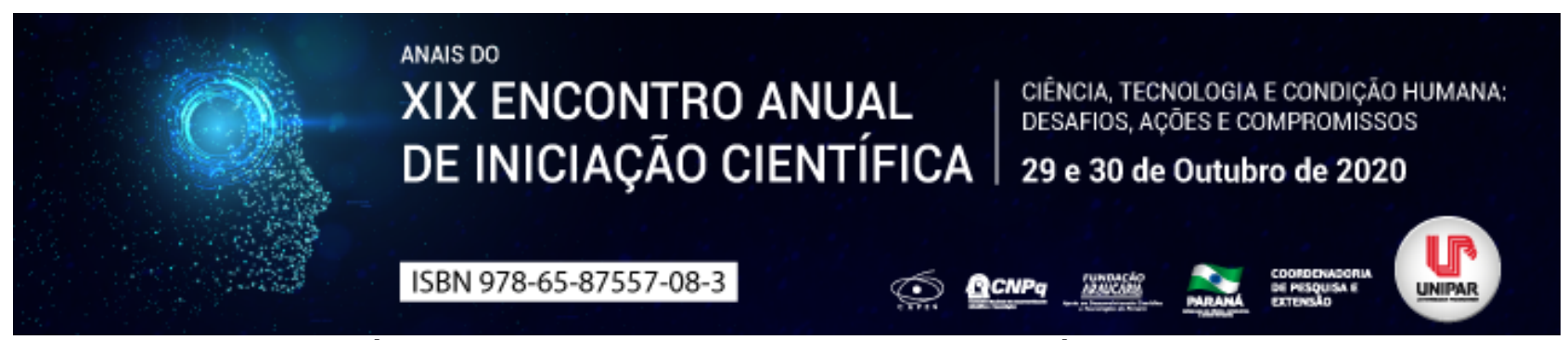

ÓLEOS ESSENCIAIS E SEUS EFEITOS TERAPÊUTICOS

\title{
${ }^{1}$ ANDREIA DIAS DOS SANTOS, ${ }^{2}$ DIELY MELONARI DALLA COSTA
}

\author{
${ }^{1}$ Acadêmica do Curso de Biomedicina, UNIPAR-Cascavel \\ ${ }^{1}$ Docente da UNIPAR
}

Introdução: O conhecimento das propriedades e composição das plantas é explorado desde a época antes de Cristo (NETO e LOPES, 2007) e a busca por insumos fitoterápicos que apresentem efeitos benéficos, mas composição de menor teor tóxico para uso terapêutico se faz até hoje (LIMA et al., 2017). Os fitoterápicos são muito utilizados na prática da medicina popular, e compreende o uso de plantas no atendimento primário à saúde (FRANZ, 2010). A fitoterapia e o uso de plantas medicinais apresenta certa eficácia,, podendo complementar ao tratamento usualmente empregado para a população de menor poder aquisitivo (LIMA et al., 2017). Os óleos essenciais são substâncias orgânicas aromáticas lipossolúveis, fitoterápicas, voláteis, de diversas propriedades terapêuticas (ANDREI e DEL COMUNE, 2005).

Objetivo: A partir da literatura existente, demonstrar o potencial terapêutico dos óleos essenciais utilizados como fitoterápicos.

Desenvolvimento: Os óleos essenciais são subprodutos do metabolismo secundário da planta, geralmente produzidos como componentes de defesa do vegetal (NETO e LOPES, 2007). Entre os constituintes químicos dos óleos estão principalmente monoterpenos, sesquiterpenos e fenilpropenos, entre outros grupos funcionais (FRANZ, 2010). Há uma grande gama de óleos essenciais, cerca de três mil gêneros de plantas, e em torno de 300 deles são de maior potencial industrial e comercial, sendo o Brasil um dos maiores produtores a nível mundial, juntamente com a Índia, China e Indonésia (BIZZO, HOVELL e REZENDE 2009). Existem variados métodos de obtenção dos óleos essenciais, como: arraste e destilação a vapor, hidrodestilação, enfleurage, prensagem a frio, extração por solvente ou maceração, fluido supercrítico, entre outros (BUSATO, 2014). As formas mais comuns de administração dos óleos são inalação e uso tópico, não sendo recomendada a ingestão. Entre os efeitos terapêuticos dos óleos essenciais já documentados estão o antibacteriano (FREIRE et al., 2014), cicatrizante, antiséptico, antifúngico, antioxidante, antiinflamatorio (ANDREI e PERES, 2005), bem como na restauração das energias no aspecto emocional (MALUF, 2008). Os mecanismos de ação dos óleos essenciais não estão completamente entendidos, porém sugerese que, a inalação das moléculas voláteis são capazes de estimular a liberação de neurotransmissores, os quais promovem efeito analgésico, de bem-estar e relaxamento (CORAZZA, 2002). No que diz respeito às ações antimicrobianas, os óleos essenciais causam efeitos tóxicos à membrana celular do microrganismo, causando lise e comprometendo a permeabilidade da mesma, com perda de componentes essenciais, como íons, e a inibição da respiração (SIKKEMA et al., 1995; CARSON et al., 2006).

Conclusão: Os óleos essenciais são capazes de promover diversos efeitos terapêuticos já comprovados cientificamente e, devido sua origem natural, estimula o crescente interesse pela população, que faz uso de modo alternativo na busca da melhoria de disfunções.

\section{Referências}

ANDREI, Patrícia; DEL COMUNE, Aparecida Peres. Aromaterapia e suas aplicações. Cadernos do Centro Universitário São Camilo. São Paulo, v. 11, n. 4, p. 57-68, out./dez. 2005.

BIZZO, R. Humberto; HOVELL C. Maria Ana; REZENDE M. Cláudia. Óleos essenciais no Brasil:Aspectos gerais, desenvolvimento e perspectivas. Química Nova, São Paulo, v..32, n. 3, 2009.

BUSATO, Viégas Nathália; SILVEIRA Cristina, Jeniffer; Costa Souza Oliveira Andréa; JUNIOR Costa Ferreira Esly. Estratégias de modelagem da extração de óleos essenciais por hidrodestilação e destilação a vapor. Ciência Rural, Santa Maria, Espírito Santo, v. 44, n. 9, p. 1574-1582, set, 2014.

CARSON, C. F.; HAMMER, K. A.; RILEY, T. V. Melaleuca alternifolia (Tea Tree) oil: a Review of antimicrobial and on the medicinal properties. Clinical Microbiology Reviews, v. 19, n. 1, p. 50-62, 2006.

Corazza, Sonia Regina. Aromacologia: uma ciência de muitos cheiros. São Paulo: SENAC; 2002.

FRANZ, Chlodwig. Essential oil research: past, present and future. Wiley InterScience. Receiv. Flavour Fragr. p. 112-113, February, 2010.

FREIRE, I. C. M.; PÉREZ, A. L. A. L.; CARDOSO, A. M. R.; MARIZ, B. A. L. A.; ALMEIDA, L. F. D.; CAVALCANTI, Y. W.; PADILHA, W. W. N. Atividade antibacteriana de Óleos Essenciais sobre Streptococcus mutans e Staphylococcus aureus. Rev. Bras, PI. Med. Campinas, v. 16, n. 2, p. 372-377, 2014.

LIMA, Araújo Torres Alane; MELO, Fraga Mol Lívia; MORAES, Esteves Júlia; FERREIRA, Paiva Ríudo; SALES, C. Diana Maria. Atividade antimicrobiana da espécie Schinus terebinthifolius Raddi (aroeira- vermelha): III Seminário Científico da Facig. Minas 
Gerais, novembro, 2017.

NETO, Gobbo Leonardo; LOPES, P. Norberto. Plantas medicinais: fatores de influência no conteúdo de metabólitos secundários.Quim. Nova. São Paulo, v. 30, n. 2, p. 374-381, 2007.

MALUF, Sâmia. Aromaterapia: uma abordagem sistêmica. São Paulo: Ed. do Autor, 2008.

SIKKEMA, Jan; BONT, Jan.A.M.; POOLMAN, Bert. Interactions of cyclic hydrocarbons with biological membranes. Journal of Biological Chemistry. v. 269, p. 8022-8, 1994.

Coordenadoria de Pesquisa e Extensão - COPEX

Departamento de Editoração e Divulgaçāo Científica - DEDIC 


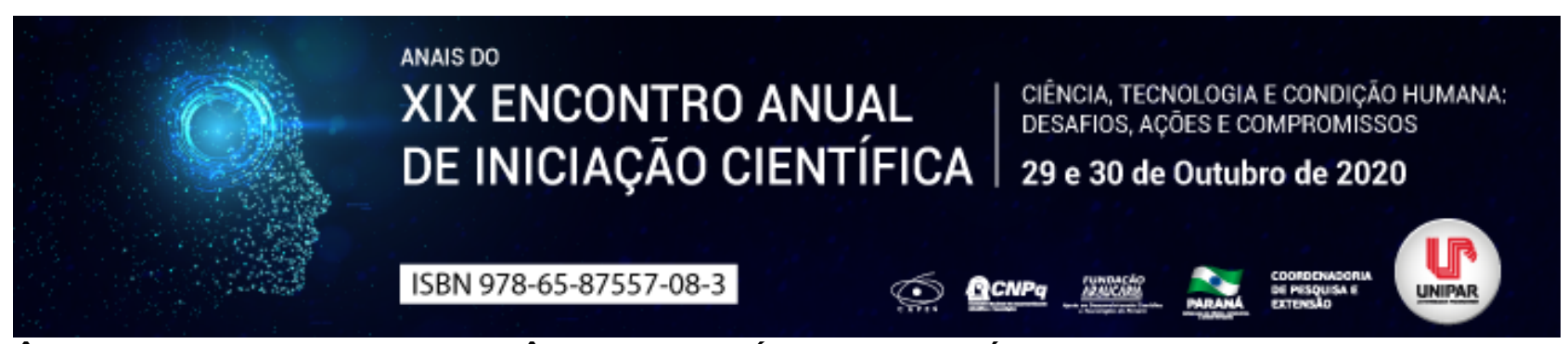

RELEVÂNCIA DA RADIOGRAFIA PANORÂMICA NO AUXÍLIO DO DIAGNÓSTICO PRECOCE DA OSTEOPOROSE: UMA REVISÃO

\author{
${ }^{1}$ GUSTAVO BARBOSA CORREA DE MORAIS, ${ }^{2}$ CAROLINE DOMINGUES, ${ }^{3}$ AMANDA CHIULO GIROTTO, ${ }^{4}$ QUEREN ALVES \\ DE PAULA, ${ }^{5}$ ANA CAROLINE DOS SANTOS GRUNOW, ${ }^{6}$ DANIELA DE CASSIA FAGLIONI B CERANTO
}

\begin{abstract}
${ }^{1}$ Discente do Curso de Odontologia PIC/UNIPAR
${ }^{1}$ Discente do Curso de Odontologia PIC/UNIPAR

${ }^{2}$ Discente do Curso de Odontologia PIC/UNIPAR

${ }^{3}$ Discente do Curso de Odontologia PIC/UNIPAR

${ }^{4}$ Discente do Curso de Odontologia PIBIC/UNIPAR

${ }^{5}$ Docente da UNIPAR
\end{abstract}

Introdução: A osteoporose (OSP) é caracterizada pela baixa densidade mineral óssea e pela degeneração da sua microarquitetura, que aumentam a fragilidade do osso e o risco de fraturas. Trata-se de uma doença assintomática e com alta prevalência entre os idosos pelo maior risco de fraturas nessa população e apresenta alto custo relacionado ao tratamento clínico-cirúrgico (VARGAS; SCHMITT, 2016). Diante dos elevados gastos em saúde pública com pacientes vítimas de fraturas e outras complicações da osteoporose, fica evidente a necessidade de um programa de prevenção da doença com métodos mais rentáveis do que os atuais (RODRIGUES et al, 2014). Segundo Pistelli et al. (2014), aumenta progressivamente a utilização de radiografias panorâmicas para auxílio de diagnóstico de patologias orais, de tal forma que vêm sendo produzidos muitos estudos com uso das radiografias para diagnóstico de OSP, na qual alguns associam a alterações no trabeculado mandibular. Desse modo, esse procedimento possibilita o direcionamento precoce para o tratamento mais adequado, demonstrando a relevância da utilização desse exame radiográfico como contribuição no diagnóstico da doença, sendo um método mais rentável e acessível para os cofres públicos e parte da população.

Objetivo: Realização de um levantamento bibliográfico sobre o uso da radiografia panorâmica como ferramenta para uma detecção precoce de sinais sugestivos de osteoporose.

Desenvolvimento: De acordo com Godeiro (2017), a imagem radiográfica panorâmica refere-se a um exame extra oral rotineiramente usada por cirurgiões dentistas em seus ambientes de trabalho, tendo grandemente aplicação por obter abundância de vantagens, como a dose baixa de exposição à radiação X, a oportunidade de contemplar de uma só vez todos os dentes e suas estruturas de suporte, como também os terços inferior e médio da face. Segundo Meneses, Paula e Pereira (2020), em relação análise dessa radiografia é satisfatório a utilização do índice cortical mandibular (ICM), considerando qualitativamente a margem da cortical mandibular, com intuito de estabelecer uma relação da sua morfologia com a presença de osteoporose. Desse modo, pode-se classificar de 3 modalidades: C1) considerada normal por apresentar uma margem lisa e aguda, C2) evidencia um quadro de osteopenia, onde a margem apresenta defeitos semilunares (reabsorções lacunares), C3) aponta um quadro de osteoporose, quando a margem apresenta espessura cortical reduzida e está claramente porosa. Os índices mandibular cortical e visual modificado são índices qualitativos simples, que dependem apenas da análise visual da radiografia panorâmica, e foram os que apresentaram maior capacidade para predizer o diagnóstico de baixa densidade mineral óssea e de osteoporose (LEITE et al, 2008). Conforme Souza (2010), o diagnóstico precoce de OSP evitaria muitas fraturas antes que ocorresse a primeira ruptura, de tal modo que preveniria pessoas de incapacidades temporárias e definitivas, assim resguardando vidas. A osteoporose também pode apresentar manifestações na cavidade oral, caracterizadas por: reabsorção do processo alveolar, perda dentária, doença periodontal crônica destrutiva, dores relacionadas ao seio maxilar ou fraturas (PISTELLI et al, 2014). De acordo com Watanabe (2009), existem evidências satisfatórias que a radiografia panorâmica usada frequentemente pelos cirurgiões dentistas demonstram sinais importantes referentes a propriedades ósseas, mostrando a relevância de conhecer e compreender esses detalhes para auxiliar no diagnóstico antes que ocorra em outros sítios ósseos, pois a detecção precoce conduz um tratamento mais adequado aliviando decorrências inconvenientes.

Conclusão: Em virtude dos fatos mencionados é notório que radiografias panorâmicas possuem informações suficientes para identificar sinais de indivíduos com baixa densidade óssea mineral, sendo um exame mais acessível à população, demonstrando a importância da contribuição do profissional de saúde capacitado, que se torna capaz de colaborar de maneira efetiva no tratamento e qualidade de vida dos pacientes.

\title{
Referências
}

GODEIRO, João Paula da Costa. Investigação das alterações da osteoporose em radiografias panorâmicas em idosos. 
Orientador: Patrícia Teixeira de Oliveira. 2017. 19 f. Monografia (Graduação em Odontologia) Universidade Federal do Rio Grande do Norte. Centro de Ciências da Saúde, Natal, 2017.

LEITE, André Ferreira, et al. Radiografia panorâmica instrumento auxiliar no diagnóstico da osteoporose. Revista Brasileira de Reumatologia. Campinas, v. 48, n.4, p. 226-233, jul/ago. 2008.

MENEZES, Rodrigo Coelho Bezerra, et al. Medição da cortical óssea através de radiografia panorâmica para diagnóstico de osteopenia e osteoporose em mulheres. Medicina (Ribeirão Preto Online), v. 53, n. 1, p. 9-13, 27 abr. 2020. Disponível em: https://www.revistas.usp.br/rmrp/article/view/157738.

PISTELLI, Gustavo Chab, et al. Contribuição da radiografia panorâmica no diagnóstico da osteoporose. Revista de Odontologia da Universidade Cidade de São Paulo. São Paulo, v. 26, n. 1, p. 71-80, jan/abr. 2014.

RODRIGUES, Janderson Teixeira, et al. Avaliação de pacientes odontológicos para auxílio no diagnóstico precoce da osteoporose. Revista Brasileira de Odontologia. Rio de Janeiro, v. 71, n. 2, p. 211-215, jul./dez. 2014.

SOUZA, Márcio Passini Gonçalves de. Diagnóstico e tratamento da osteoporose. Revista Brasileira de Ortopedia. Rio de Janeiro, v. 45, n. 3, p. 220-229, 2010.

VARGAS, Renato Magalhães ;SCHMITT, Eduardo Augusto. Os efeitos da osteoporose na cavidade bucal e a contribuição do cirurgião dentista: revisão de literatura. Orientador: Jorge Abel Flores. Trabalho de conclusão de curso (Graduação em Odontologia) - Universidade Federal de Santa Maria, Centro de Ciências da Saúde, RS, 2016.

WATANABE, Plauto Christopher Aranha. Osteoporose e a radiografia panorâmica: o que o cirurgião dentista pode analisar. Revista da ABRO. Brasília, v. 11, n. 3, p. 5-21, 2009. 


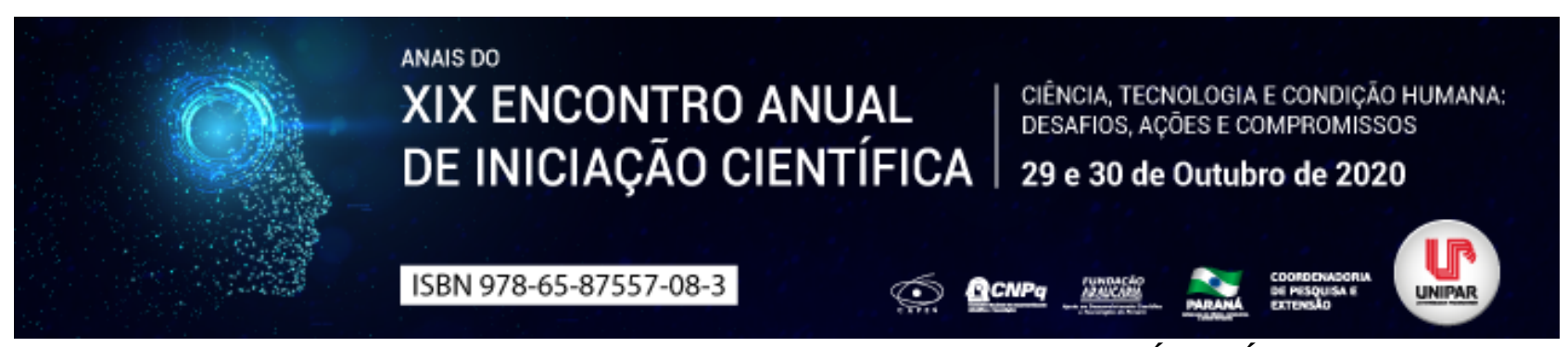

QUALIDADE DE VIDA EM IDOSOS QUE PRATICAM O EXERCíCIO FÍSICO

\title{
${ }^{1}$ LICI BEATRIZ DE SOUZA, ${ }^{2}$ PEDRO LUCAS PINHEIRO
}

\author{
${ }^{1}$ Acadêmica do Curso de Educação Física da UNIPAR \\ ${ }^{1}$ Docente da UNIPAR
}

Introdução: O envelhecimento é um processo natural que acontece ao longo da vida, não sendo uma condição isolada do ser humano, pois devemos considerar diversos fatores biológicos, ambientais e sociais, onde não está condicionado à pré-existência de uma doença (PALÁCIOS, 2004). Nesta fase da vida ocorre uma deterioração geneticamente programada, promovendo um envelhecimento celular e uma infinidade de alterações, levando a perca de funções fisiológicas e físicas. O presente estudo se desenvolve abrangendo os impactos do exercício físico, se este tem relevância na promoção da qualidade de vida dos idosos, averiguando se o mesmo pode oferecer benefícios a esta população que cresce exponencialmente no mundo todo.

Objetivos: Analisar os efeitos da prática regular de exercícios físicos na qualidade de vida dos idosos.

Desenvolvimento: Podemos afirmar, que o processo de envelhecimento esta relacionado com inúmeras transformações com implicações na funcionalidade, na mobilidade, na autonomia, na saúde e, claro, na qualidade de vida da população idosa, (CARVALHO, 1999, p. 95) . Para Smith 1984, citado por Willis Campbell, 1992, refere que, apesar do envelhecimento ser um fato inevitável, grande parte do declínio fisiológico que lhe esta associado deve-se a atrofia muscular . A inatividade física, o estilo de vida o sedentarismo e a má alimentação são fatores, que desenvolve o agravamento de doenças cardíacas ou outras complicações, principalmente na velhice, consequentemente acarreta a incompetência que permite com que o idoso realize suas tarefas diárias. Efetivamente, a frequência de participação do idoso em programas de atividade física regular pode modificar este panorama de sedentarismo, de diminuição das capacidades funcionais e de precipitação da mobilidade (SARDINHA \& BAPTISTA, 1999, p. 54). A falta de equilíbrio, a fadiga e a dependência de demais pessoas faz com que o idoso chegue à conclusão que ele já não é mais útil para o convívio em sociedade e familiar, afetando não só as funcionalidades motoras, mas também a capacidade psicológica. Os benefícios psicossociais decorrentes da prática de atividade física são: o enaltecimento do valor destes indivíduos, ajudando-os a ter um papel mais ativo na sociedade; o aumento da integração social e cultural; a formação de novas amizades; e o alargamento das relações sociais. Então, importa saber qual é o papel do exercício físico na melhoria da qualidade de vida do idoso, sem ignorar, a necessidade específica de todos os indivíduos, respeitando suas diferenças físicas, sociais e ambientais, desenvolvendo oportunidades de igualdade, garantindo o conforto e bem estar do idoso.

Conclusão: Desta forma, constatou-se que os exercícios físicos para os idosos trazem inúmeras vantagens, entretanto, o histórico de vida e as potencialidades genéticas que estes indivíduos carregam ao longo da vida, irão influenciar diretamente nas condições de saúde durante à velhice. Sem mencionar, o tipo de atividade física especifica, devemos observar e respeitar as limitações de cada um para a aplicação do exercício. Com isso, nota-se que a participação em programas de exercícios físicos é um dos fatores positivos para qualidade de vida dos idosos.

\section{Referências \\ CARNEIRO, Rachel Shimba. A relação entre habilidades sociais e qualidade de vida na terceira idade. Rev. bras.ter. cogn., Rio de Janeiro , v. 2, n. 1, p. 45-54, jun. 2006. Disponível em: http://pepsic.bvsalud.org/scielo.php?script=sci_arttext\&pid=S1808- 56872006000100005. Acessado em: 19 jul. 2020. \\ CARVALHO J. Aspectos metodológicos no trabalho com idosos. In J Mota, J Carvalho: Actas do seminário qualidade de vida no idoso: o papel da actividade física; Porto, Faculdade de Ciências do Desposto e de Educação Física da Universidade do Porto, 1999. \\ SANTOS, Flávia Heloísa dos; ANDRADE, Vivian Maria; BUENO, Orlando Francisco Amodeo. Envelhecimento: um processo multifatorial. Psicol. estud., Maringá , v. 14, n. 1, p. 3-10, Mar. 2009. Disponível em: https://doi.org/10.1590/S1413- 73722009000100002. Acessado em 19 jul. 2020.}




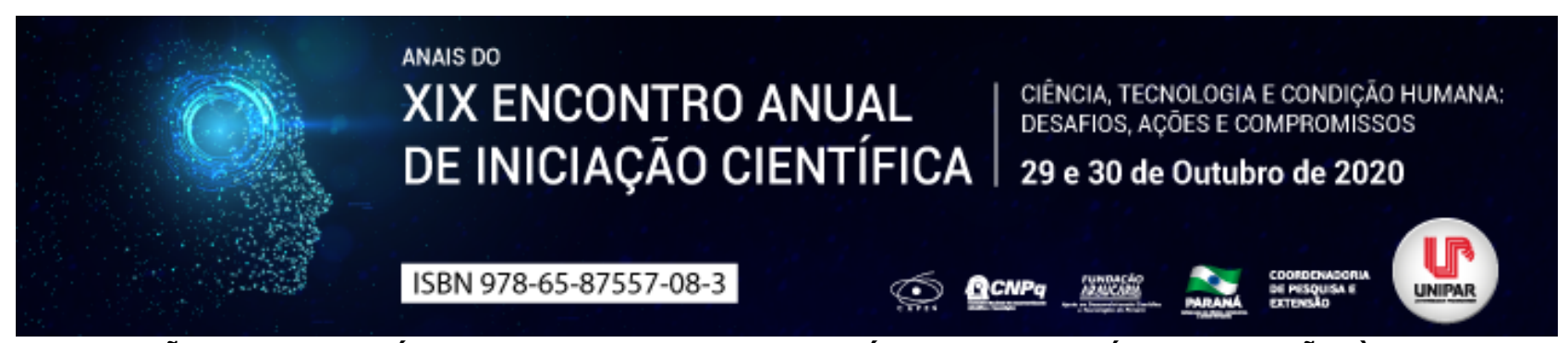

SITUAÇÃO EPIDEMIOLÓGICA DA $8^{\text {a }}$ REGIONAL DE SAÚDE DO PARANÁ EM RELAÇÃO À COVID-19

\title{
${ }^{1}$ VANESSA GABRIELE TONELLI, ${ }^{2}$ PATRICIA AMARAL GURGEL VELASQUEZ
}

\author{
${ }^{1}$ Acadêmica do Curso de Farmácia da Universidade Paranaense UNIPAR Unidade Francisco Beltrão \\ ${ }^{1}$ Docente do Curso de Farmácia da Universidade Paranaense UNIPAR - Unidade Francisco Beltrão
}

Introdução: A atual pandemia global de COVID-19 tem gerado grande preocupação das entidades de saúde por se tratar de um vírus ainda pouco conhecido, altamente contagioso e de rápida evolução (ARAUJO-FILHO et al., 2020). O agente etiológico da COVID-19, conhecido como SARS-CoV-2 (Severe Acute Respiratory Syndrome Coronavirus 2), é transmitido de pessoa a pessoa através de aerossóis respiratórios, contato com gotículas de tosse, espirro, catarro, ou qualquer outro tipo de secreção oriunda de um paciente infectado (GANDHI et al.,2020; MATHESON; LEHNER, 2020). Atualmente a COVID-19 já vem sendo considerada como a síndrome viral mais severa em toda a história, superando até mesmo a gripe H1N1 de 1918 (FERGUSON et al.,2020).

Objetivo: Realizar um levantamento das principais características epidemiológicas dos casos de COVID-19 na $8^{\mathrm{a}}$ Regional de Saúde (RS) do Paraná (PR).

Material e Métodos: Os dados foram obtidos através dos Boletins Epidemiológicos (BE) da Secretaria Estadual de Saúde do Paraná (SESA-PR). Os dados, coletados do BE do dia 26 de agosto de 2020, foram: número de casos até a presente data no Paraná e na $8^{a}$ RS do PR, qual município apresentava maior número de casos e número de óbitos até a presente data. Para comparação foram utilizados dados obtidos a partir de BEs de outras datas do Paraná e Brasil.

Resultados: Até a data pesquisada o Paraná apresentava 120.920 casos (coeficiente de incidência de 1.054/100 mil habitantes) e 3.064 óbitos (coeficiente de mortalidade de 26,7 óbitos/100 mil habitantes). Já na $8^{a}$ RS do PR o total de casos nos 27 municípios que compõem a regional era de 3.450 (960 casos/100 mil hab), com 55 óbitos (15,3 óbitos/100 mil hab). Todos os municípios que compõem a $8^{\mathrm{a}} \mathrm{RS}$ do PR já haviam notificados casos até o momento pesquisado, e 18 haviam notificado óbitos. O município que apresentava a maior taxa de prevalência no momento da coleta de dados foi Capanema, com 0,0204 casos/habitante, seguida de Enéas Marques $(0,0181)$, Dois Vizinhos $(0,0179)$ e Cruzeiro do Iguaçu $(0,0171)$. Já a menor taxa de prevalência observada foi em Flor da Serra do Sul, com uma taxa de 0,0008 casos/habitante, seguida por Pinhal de São Bento e Pranchita, ambas com 0,0011. Em relação aos óbitos, o município de Enéas Marques foi o que apresentou a maior mortalidade $(50,08$ óbitos/100 mil hab), seguido por Pérola D’Oeste $(46,82)$ e Verê $(40,86)$. O município de Francisco Beltrão, maior município que integra a $8^{a}$ RS do PR apresentou 17,78 óbitos/100 mil hab.

Discussão: A primeira notificação de COVID-19 no Brasil ocorreu no dia 29 de fevereiro de 2020. Já na $8^{\text {a }}$ RS do PR, os dois primeiros casos foram divulgados no Boletim Epidemiológico da SESA do dia 31 de março de 2020, um caso da cidade de Francisco Beltrão e outro da cidade de Verê. Nesta data, havia 179 notificações no estado do Paraná. Analisando o Boletim Epidemiológico de 26 de agosto de 2020 do Estado do Rio Grande do Sul (CEVSRS, 2020), o mesmo apresentava 109.943 (967/100 mil hab) casos confirmados com 3.071 óbitos (27,1/100 mil), situação muito próxima à observada no estado do Paraná. No Paraná, a $5^{\text {a }}$ RS (Guarapuava) possuía a menor incidência na data pesquisada, 325 casos confirmados/100 mil habitantes, valor muito abaixo do observado na $8^{\mathrm{a}} \mathrm{RS}$. Já a $1^{\mathrm{a}} \mathrm{RS}$ (Paranaguá) apresentava uma incidência de 1.628 na ocasião, número próximo ao observado no Brasil (1.789,9) (BRASIL, 2020). Já em relação aos óbitos, a $5^{a}$ RS foi a que apresentou o menor coeficiente de mortalidade $(4,4)$ contra 42,6 da $2^{\mathrm{a}}$ RS (Metropolitana), mostrando que a $8^{\mathrm{a}} \mathrm{RS}$ apresentou um valor baixo se comparado com a $1^{a}$ posição no estado, e até mesmo com valores abaixo do coeficiente estadual. No Brasil, a Região Sul é a região com a menor mortalidade $(28,7)$, enquanto que a Região Norte apresenta a maior $(72,2)$, sendo que no estado de Roraima esse valor chega a 96,7 (BRASIL, 2020). No entanto, dentro da $8^{a}$ RS observou-se que alguns municípios estão com dados de mortalidade acima do observado na Região Sul e no estado do Paraná, tornando necessário observar mais de perto esses locais. Baqui e cols (2020) observaram um aumento da mortalidade na Região Norte do país o qual pode ser justificado pela associação de comorbidades relacionadas à um nível socioeconômico reduzido nessas regiões e também em locais onde há maior população parda e negra, com menor acesso aos serviços de saúde. Além destes fatos, quando se compara regiões tão distintas, num país com dimensões continentais como o Brasil, deve-se levar em consideração questões como disponibilidade de exames diagnósticos, número de UTIs, acesso e compreensão das informações sobre a doença e as tomadas de decisões para controle da pandemia (MARSON, ORTEGA, 2020).

Conclusão: Diante dos dados observados, pode-se concluir que até a presente data a disseminação do vírus já tinha alcançado os 27 municípios que compõe a $8^{\mathrm{a}}$ RS do Paraná chegando à marca de 3.450 e um total de 55 óbitos. O município de Capanema foi o que apresentou a maior prevalência de casos da COVID-19 e o município de Flor da Serra do Sul o menos atingido. Em relação aos óbitos, Enéas Marques liderou com a maior mortalidade, seguido de Pérola D'Oeste e Verê. 


\section{Referências}

ARAUJO-FILHO, Jose de Arimateia Batista et al. Pneumonia por COVID-19: qual o papel da imagem no diagnóstico? J Bras Pneumol, São Paulo, v.46, n.2, e20200114, 2020.

BAQUI, Pedro et al. Ethnic and regional variations in hospital mortality from COVID-19 in Brazil: a cross-sectional observational study. Lancet Glob Health. V.8, n.8, e1018 e1026, 2020.

BRASIL, Ministério da Saúde. Painel de casos de doença pelo coronavírus 2019 (COVID-19) no Brasil pelo Ministério da Saúde. Disponível em . Acesso em: 27 de agosto de 2020.

CEVSRS. Centro Estadual de Vigilância em Saúde do Rio Grande do Sul. Boletim Epidemiológico CoVID-2019. Centro de Operações de Emergência do Rio Grande do Sul/COERS Semana Epidemiológica 34 de 2020. Disponível em . Acesso em: 27 de agosto de 2020.

FERGUSON, Neil, et al. Report 9: impact of non-pharmaceutical interventions (NPIs) to reduce COVID19 mortality and healthcare demand. Imperial College COVID-19 Response Team 16 March 2020. Disponível em Acesso em: 27 de agosto de 2020.

GANDHI, Rajesh et al. Mild or Moderate Covid-19. N Engl J Med. April 24, 2020. Disponível em . Acesso em: 22 de agosto de 2020.

MARSON, Fernando Lima, ORTEGA, Marcos. CoVID-19 in Brazil. Pulmonology. V.26, n.4, p 241 244, Published online 2020 Apr 27. Disponível em Acesso em 27 de agosto de 2020.

MATHESON, Nicholas J.; LEHNER, Paul J. How does SARS-CoV-2 cause COVID-19? Science 31 Jul 2020:Vol. 369, Issue 6503, pp. 510-511 


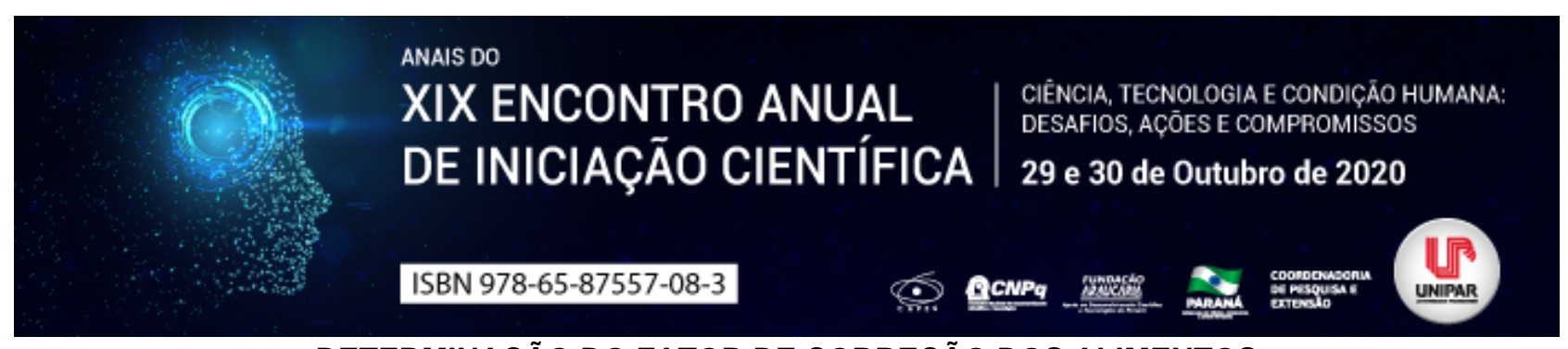

DETERMINAÇÃO DO FATOR DE CORREÇÃO DOS ALIMENTOS

\title{
${ }^{1}$ EDUARDA GOULARTE SARTORETTO, ${ }^{2}$ INDIOMARA BARATTO
}

\author{
${ }^{1}$ Acadêmico do PIC/UNIPAR \\ ${ }^{1}$ Docente da UNIPAR
}

Introdução: A nutrição é definida como um processo de transformação e utilização dos alimentos pelo homem, que se inicia com a ingestão dos alimentos, sua digestão em substâncias alimentares, os nutrientes, seguida pela absorção, pelo transporte, metabolismo e pela eliminação de subprodutos, a alimentação é uma necessidade básica do ser humano. São os alimentos que fornecem todos as substâncias necessárias para a manutenção da saúde (MAHAN, 2010). Apesar dos alimentos serem tão fundamentais e necessários, o Brasil tem índices elevados de desperdício de alimentos, fato que afeta a economia e acentua os problemas sociais. O planejamento inadequado do processamento de alimentos, desde a pós-colheita até o consumo, é uma das causas (LEMOS, et al., 2011). A perda de alimentos é uma questão importantíssima para a gestão de uma cozinha industrial, definida como subsistema que desempenha atividades fins ou meios, as quais contemplam o planejamento e a elaboração de refeições equilibradas, nutritivas, salubres e seguras da perspectiva de higiene, visando auxiliar o desenvolvimento de hábitos alimentares saudáveis. Existe um indicador para o desperdício de alimentos, chamado Fator de Correção (FC), sendo definido como a relação entre o peso do alimento bruto, ou seja, na forma como foi adquirido, com cascas, talos, sementes, e o peso do alimento líquido, após passar por processo de limpeza. É um indicador que determina a quantidade exata de alimento que será descartada e que deve ser empregado no planejamento quantitativo de um cardápio e consequentemente, no seu valor nutricional. Deve-se considerar que o FC depende do manipulador, dos utensílios e dos equipamentos utilizados no processamento, do tipo de produto, da qualidade, do grau de amadurecimento e da safra (PERONE, 2004). O FC é um instrumento de suma importância, pois permite diagnosticar e controlar as perdas do processo produtivo de um alimento.

Objetivo: Determinar o FC em grupos alimentares (raízes e tubérculos, legumes e hortaliças e frutas) e elaborar material para ser utilizado/consultado no laboratório de dietética por alunos e docentes.

Métodos: O presente estudo está sendo desenvolvido no laboratório de dietética da UNIPAR, Unidade de Francisco Beltrão. Será realizado estudo descritivo com coleta de dados. Os gêneros alimentícios estão sendo previamente selecionados de acordo com a disponibilidade local e sazonalidade. Para determinar o FC estamos utilizando a fórmula desenvolvida por Araújo et al. (2007), que calcula a relação entre o peso do alimento como adquirido (Peso Bruto (PB)) e o peso do alimento após a limpeza (Peso Líquido $(\mathrm{PL})$ ) ( $\mathrm{FC}=\mathrm{PB} / \mathrm{PL})$. o FC refere-se por tanto a uma constante (valores médios) para cada alimento, sempre $>1$. Ele representa a previsão de perdas dos alimentos durante o pré-preparo. Para aferir o peso dos alimentos será utilizada balança digital com precisão de $0,1 \mathrm{~g}$, da marca ÚTIL e utensílios do laboratório de dietética. Utilizaremos para determinar as medidas caseiras, balança de precisão da marca ÚTIL. Após a tabulação dos dados será elaborada uma tabela, na qual os alimentos serão classificados de acordo com os gêneros já citados.

Resultados: Os resultados ainda não foram concluídos. Contudo alguns dados já foram coletados, referente ao fator de correção dos grupos das hortaliças e legumes sendo eles: Acelga 1,4; Alface americana 1,5; Alface crespa 1,63; Couve manteiga 1,3; Repolho branco 1,35; Rúcula 1,7; Vagem 1,33; Pepino 1,4; Cenoura 1,24; Tomate 1,03.

Discussão: Através deste estudo e de revisão bibliográfica, verificou-se que existem poucas pesquisas realizadas especificamente com FC, é necessário abranger mais este assunto para evitar a carência de informações, pois estas são muito utilizadas por profissionais da área de Nutrição. Fica possível visualizar que todos os alimentos acima pesquisados, mostraram uma perca importante que aconteceu antes de seu preparo, ficando nítido a necessidade de o FC ser aplicado de forma correta na hora da aquisição dos alimentos. Esse cálculo é fundamental no dia a dia de uma cozinha industrial, uma vez que a quantidade de alimentos comprada normalmente é bem diferente da quantidade final que se obtém após a limpeza de cada insumo. O FC dos alimentos é uma constante única para cada alimento, que é obtida do cálculo entre seu peso bruto e seu peso líquido, o FC também é conhecido como indicador de parte comestível, uma vez que permite prever a quantidade que de fato haverá de cada alimento ao final do processo de manipulação. Tudo o que é eliminado com a limpeza dos alimentos, como ossos, gordura, pele, talos, sementes e cascas dos alimentos, está dentro do fator de correção dos alimentos, nesse sentido, o FC nada mais é do que a relação entre o produto na sua forma in natura e em sua forma limpa (PERONE, 2020).

Conclusão: Este trabalho ainda não foi concluído, mas entende-se que o FC é uma medida útil e necessária para a previsão de compras principalmente, pois facilitam a compreensão exata das quantidades corretas. Sugere-se que este trabalho mesmo após sua finalização tenha continuidade, tendo em vista o aprimoramento, cada vez maior, de uma tabela com informações.

\section{Referências}


ARAÚJO, W.M.C.; MONTEBELLO, N.P.; BOTELHO, R.B.A. Alquimia dos alimentos. Brasília: Senac, 2007.

LEMOS, A.G.; BOTELHO, R.B.A.; AKUTSU, R.C.C.A. Determinação do fator de correção das hortaliças folhosas comercializadas em Brasília. Horticultura Brasileira. 29: 231-236, 2011.

MAHAN, L.K. Alimento, nutrição e dietoterapia. 9.ed. São Paulo: Roca, 1998.

PERONE, M. País do desperdício. Disponível em: http://redeglobo.globo.com/ cgibin/jornaldaglobo. Acesso em: 20 de junho de 2020.

Coordenadoria de Pesquisa e Extensão - COPEX

Departamento de Editoraçāo e Divulgaçāo Científica - DEDIC 


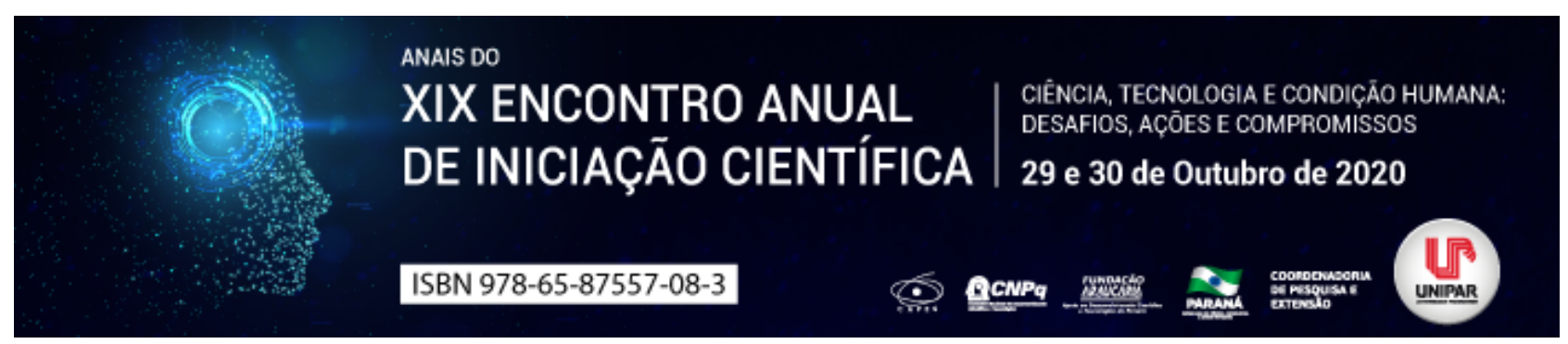

ESTOMATOLOGIA APLICADA A ODONTONTOPEDIATRIA: DENTE NATAL E NEONATAL

\author{
${ }^{1}$ Ana Paula Fonseca Campos de Andrade, ${ }^{2}$ KATIELI FAGUNDES GONÇALVES
}

\author{
${ }^{1}$ Acadêmica do Curso de Odontologia UNIFASIPE \\ ${ }^{1}$ Docente da UNIFASIPE
}

Introdução: O cirurgião-dentista deve ter conhecimento acerca do complexo maxilo-mandibular e saber reconhecer as mudanças que neste podem ocorrer, para assim, diagnosticar e aplicar o tratamento necessário de acordo com cada caso. Ao se pensar na erupção dos dentes decíduos se tem por base que os primeiros dentes erupcionam por volta dos seis meses de idade, porém, há casos em que o bebê nasce com um ou mais elementos dentários, de série normal ou supranumerário, chamados dentes natais ou ainda esses elementos podem aparecer durante o primeiro mês de vida, chamados de dentes neonatais.

Objetivo: O objetivo da presente pesquisa foi averiguar a respeito da ocorrência de dentes natais e neonatais e a importância de o cirurgião-dentista ser capacitado para realizar um diagnóstico preciso e que auxilie na escolha do tratamento. Para tal fora realizada uma revisão de literatura fundamentada em trabalhos publicados no período de 2008 até 2018.

Desenvolvimento: De acordo com Diniz (2008), os dentes natais e neonatais são anomalias de erupção, sendo caracterizados por seu irrompimento na cavidade oral durante o período intra-uterino ou no primeiro mês de vida respectivamente, podendo fazer parte da dentição decídua normal ou supranumerária. Paranna (2017), refere que a etiologia ainda é desconhecida, mas tem sido relacionada a vários fatores, como posição superficial do germe dentário, infecção ou desnutrição, estados febris, erupção acelerada por incidentes febris ou estimulação hormonal, transmissão hereditária de um gene autossômico dominante, atividade osteoblástica dentro do germe ou pode estar relacionada à o fenômeno de remodelação e hipovitaminose. Lemos (2009), aborda que a ocorrência de dentes natais é consideravelmente rara, com uma frequência de um caso para cada 2.000 nascimentos; dentes natais são encontrados com mais frequência do que os neonatais numa proporção de três para um. Gonçalves (1998) apud Bertotti (2018), constata que os dentes natais e neonatais manifestam-se de diversos formatos e tamanhos, variando de pequenos e cônicos à estruturas semelhantes aos dentes normais. Por isso, segundo Lopes (2008), é importante o correto diagnóstico para o tratamento adequado, pois, muitas vezes, os dentes natais e neonatais são confundidos com cistos de lâmina dentária, nódulos de Bohn e pérolas de Epstein, pois, podem apresentar características semelhantes. Oliveira (2017), relata que se o recém-nascido não for tratado adequadamente, pode desencadear: desinteresse pela amamentação, resultando em deficiência no desenvolvimento craniofacial; perturbação do sistema imunológico e do crescimento devido à falta de anticorpos e nutrientes presentes no leite materno. De acordo com Lopes (2008) e Oliveira (2017), o ideal é que os dentes natais/neonatais maduros sejam mantidos na cavidade bucal, uma vez que a extração destes pode ocasionar perda de espaço, dificultando ou impedindo a erupção do dente sucessor permanente. Paranna (2017), relata que quando este é mantido, esses dentes precisam ter as bordas incisais polidas para não machucar o mamilo materno e evitar a Úlcera Riga-Fede no recém-nascido, a qual se trata de uma ulceração na superfície ventral da língua do bebê, devido ao trauma incisal. Além de necessitar de uma boa conduta de preservação, higiene oral e instruções claras aos responsáveis. No caso de dentes natais/neonatais supranumerários e/ou que podem colocar a saúde do recém-nascido em risco, o ideal é a extração, pois há casos que devido à grande mobilidade por falta de inserção óssea extensa, há perigo de deslocamento e aspiração ou deglutição do elemento. E nesse caso, a exodontia do elemento é recomendada, após o décimo dia de vida, para evitar uma possível hemorragia demasiada pela deficiência de vitamina K do bebê como aponta LOPES (2008).

Conclusão: Conclui-se que o diagnóstico dessa alteração deve ser feito minuciosamente, devido a existência de patologias semelhantes e a decisão de manter ou não o dente natal/neonatal deve ter como subterfúgio o conhecimento científico do cirurgião-dentista, grau de mobilidade do elemento, suporte radiográfico, verificar se o dente é normal ou supranumerário, conferir a etapa de rizogênese e avaliar a amamentação, para abster a mãe e o bebê de malefícios.

\title{
Referências
}

BERTOTTI, Maitê. QUEVEDO, Alexandre Silva; PONZONI, Deise. Levantamento de dentes natais e neonatais em pacientes atendidos na Unidade de Cirurgia Buco-maxilofacial do Hospital de Clínicas de Porto Alegre estudo retrospectivo. 2018. Programa de Pós-Graduação em Odontologia. Faculdade de Odontologia, Universidade Federal do Rio Grande do Sul, Porto Alegre, 2018. Disponível em:https://www.lume.ufrgs.br/handle/10183/186039. Acesso em: 25 ago. 2020.

DINIZ, Micheli Baffi et al. A importância da interação entre odontopediatras e pediatras no manejo de dentes natais e neonatais. Revista Paulista de Pediatria, v. 26, n.1, São Paulo, Mar/2008.

LEMOS, Letícia Vargas Freire Martins et al. Dente natal e neonatal, Trabalho realizado na Faculdade de Odontologia de São José dos Campos da Universidade Estadual Paulista Júlio de Mesquita Filho UNESP, São José dos Campos (SP). Einstein, 
7(1 Pt 1):112-3. Brasil, 2009.

LOPES, L. D.; ULSON, R. C. B.; CORRÊA, M.S. N. P. Dente neonatal: relato de caso clínico. Revista do Instituto Ciência da Saúde, São Paulo, v. 26, n. 1, p. 130-138, 2008.

OLIVEIRA, Leila Maria Chevitarese et al. DENTE NATAL E NEONATAL: DIAGNÓSTICO E CONDUTA TERAPÊUTICA. Revista Odontológica da Universidade Cidade de São Paulo, São Paulo, v. 29, n. 2, p. 53-149, mai/ago2017.

PARANNA, Sujatha; KAMATH, Punitha. Riga Fede disease in association with natal teeth. Journal of Dental Research and Review, v. 4, n. 3, p.69-71, 2017.

Coordenadoria de Pesquisa e Extensão - COPEX

Departamento de Editoraçāo e Divulgaçāo Científica - DEDIC 


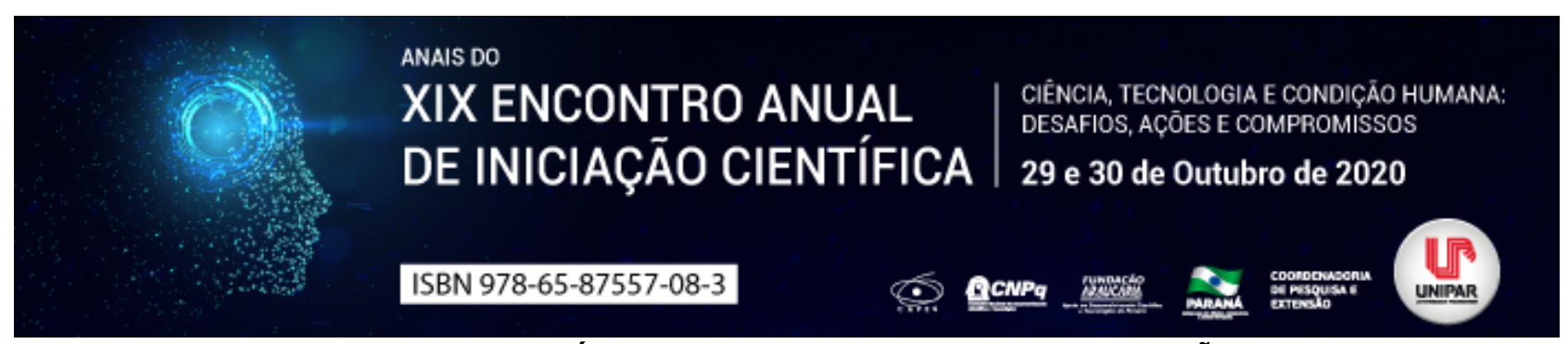

ATIVIDADE BIOLÓGICA DA Baccharis trimera: UMA REVISÃO

\section{${ }^{1}$ ISABELA PAOLA DALLA LONGA SALLES, ${ }^{2}$ LEONARDO LUAN PERICO, ${ }^{3}$ LEONARDO GARCIA VELASQUEZ}

${ }^{1} 1$ Discente do curso de Farmácia, PIC - UNIPAR Unidade de Francisco Beltrão

${ }^{1}$ Discente do curso de Farmácia, PIBIC - UNIPAR Unidade de Francisco Beltrão

${ }^{2}$ Docente do Programa de Mestrado Profissional em Plantas Medicinais e Fitoterápicos na Atenção Básica/UNIPAR

Introdução: A Baccharis trimera (Less.) (B. trimera) pertence à família Asteraceae, popularmente conhecida como carqueja, uma planta medicinal, que auxilia no tratamento e na prevenção de doenças. É um arbusto ramificado, que atinge 0,5 a $1,0 \mathrm{~m}$ de altura, com 3 alas descontínuas e mais largas, medindo cerca de 0,5 a 1,3 cm de largura, folhas muito reduzidas e ovais. Pertencente a Mata Atlântica, no Brasil, apresenta ampla dispersão nos estados de Minas Gerais, Rio de Janeiro, São Paulo, Paraná, Santa Catarina e Rio Grande do Sul (KARAM et al., 2013). Através de bioensaios pode-se comprovar atividade biológica da carqueja, destacando-se ação inibitória na diferenciação de células neuronais in vitro quando tratadas cronicamente; ação fungicida, ação inseticida e repelente (MOSSI, 2015); ação anti-hipertensiva e diurético; atividade alelopática (GONÇALVES, 2014); atividade antimicrobiana (ALEIXO, 2013); ação antioxidante e gastroprotetor (RABELO, 2017); atividade mutagênico (PINHO, 2020).

Objetivo: Realizar uma revisão bibliográfica sobre a ação biológica de diferentes extratos da Baccharis trimera.

Desenvolvimento: A carqueja é uma erva medicinal com amplo uso popular e que vem sendo muito estudada ultimamente. Um dos potenciais usos dela é sobre a proliferação celular. O óleo essencial da Baccharis trimera apresenta ação inibitória sobre as células de retina em cultura in vitro, inibição da arborização axodendrítica e redução na proliferação e diferenciação de células gliais. Seu óleo essencial também foi avaliado como potencial ação fungicida, inseticida e repelente (MOSSI et al., 2015). Além dos óleos essenciais, inúmeros estudos têm sido realizados com o extrato da planta, dentre eles têm destaque aqueles realizados para avaliar sua atividade anti-hipertensiva, antioxidante, antimicrobiana, hipolipemiante e hepatoprotetor. Nos estudos feitos com o extrato aquoso da carqueja obteve ação anti-hipertensivo e diurético em ratos hipertensos, e também atividade alelopática (GONÇALVES, 2014). Gonçalves (2014), analisou ação antimicrobiana frente a Helicobacter pylori em extrato acetato de etila (CIM iguais a $250 \mathrm{mg} / \mathrm{mL}$ ), extrato etanólico e etanol 70\% (CIM de $500 \mathrm{mg} / \mathrm{mL}$ ). Em outro estudo, já utilizando o extrato hidroalcoólico foi avaliada a atividade antimicrobiana frente a bactérias gram-positivas do gênero Staphylococcus e Enterococcus com inibição de 100\%. Entre as bactérias o S. epidermidis apresentou maior sensibilidade em $250 \mu \mathrm{g} / \mathrm{ml}$, E. faecalis e S. aureus em $500 \mu \mathrm{g} / \mathrm{ml}$ e S. saprophyticus apresentou maior resistência em $1250 \mu \mathrm{g} / \mathrm{ml}$ (ALEIXO et al., 2013). O extrato hidroalcoólico também apresentou ação antioxidante, o qual foi capaz de inibir a formação de radicais livres formados durante a metabolização do APAP e de regular a expressão de importantes enzimas da reação redox. Além disso, os extratos hidroetanólico e extrato aquoso apresentaram ação gastroprotetora e antioxidante. No estudo foi possível avaliar a melhora na hepatotoxicidade induzida pelo etanol tanto no modelo in vitro quanto in vivo (RABELO, 2017). Outra atividade da carqueja também relatada pela medicina tradicional é a gastroprotetora. Com o extrato metanólico, Souza (2012) observou ação hipolipemiante com a inibição da lipase pancreática. O extrato etanólico de B. trimera $(30,100$ e $300 \mathrm{mg} / \mathrm{kg})$ exerceu ação hepatoprotetora, refletindo por uma melhora na esteatose e a normalização dos valores de aminotranferase. Em um estudo recente observou-se ainda que a fração solúvel de B. trimera em etanol apresenta atividade imunomoduladora (GUMY, 2020). Cabe ressaltar que, plantas medicinais também podem apresentar efeitos tóxicos quando utilizadas de maneira errada (doses elevadas e/ou forma de administração). Em pesquisa de Pinho et al. (2020), através da infusão, observaram efeito mutagênico em células vegetais de Allium cepa (cebola) em $200 \mathrm{gL}$, já em células humanas cultivadas apresentou anomalias cromossômicas e numéricas e estruturais com aumento dose-dependente.

Conclusão: Conclui-se que a B. trimera possui importantes atividades de interesse farmacológico as quais podem ser alvo de estudos futuros que visem comprovar sua eficácia e segurança para uso humano e animal. Ressalta-se ainda a importância da conscientização da população quanto ao uso correto e racional, uma vez que plantas medicinais também podem apresentar efeitos tóxicos ao organismo.

\section{Referências}

ALEIXO, Álan Alex. et al . Antibacterial activity of Baccharis trimera (Less.) DC. (carqueja) against bacteria of medical interest. Revista Ceres, Viçosa, v. 60, n. 5, p. 731-734, Out. 2013

GONÇALVES, Carlos Eduardo Prates. Alelopatia de carqueja (Baccharis trimara less) e ação de fungos em capim-anonni (Eragrostis plana ness). 2014. 88 f. Dissertação (Mestrado em Ciências Biológicas) - Universidade Federal de Santa Maria, Santa Maria, Rio Grande do Sul, 2014. 
GUMY, Mariane Pavani. Atividade imunomoduladora da Baccharis trimera frente a doença cardiovascular e diabetes. 2020. 58 f. Dissertação (Mestrado em plantas medicinais e fitoterápicos na atenção básica) - Universidade Paranaense, Umuarama, Paraná, 2020.

KARAM, T.K. et al . Carqueja (Baccharis trimera): utilização terapêutica e biossíntese. Revista brasileira de plantas medicinais, Botucatu, v. 15, n. 2, p. 280-286, 2013.

MOSSI, Altemir. José; et. al.; Efeito repelente e inseticida de Baccharis trimera (less) dc no controle de insetos (Acanthoscelides obtectus) em grãos de feijão armazenados, p. 7831-7836 . Em: Anais do XX Congresso Brasileiro de Engenharia Química COBEQ 2014 [= Blucher Chemical Engineering Proceedings, v.1, n.2]. São Paulo: Blucher, 2015.

PINHO, Daiane S. de et al . Avaliação da atividade mutagênica da infusão de Baccharis trimera (Less.) DC. em teste de Allium cepa e teste de aberrações cromossômicas em linfócitos humanos. Revista brasileira farmacognosia, Curitiba , v. 20, n. 2, p. 165-170, Maio 2010.

RABELO, Ana Carolina Silveira. Baccharis trimera protege contra a hepatotoxicidade induzida pelo etanol em células HepG2 e em ratos. 2017. 130 f. Dissertação (Mestrado em Ciências Biológicas) - Núcleo de Pesquisas em Ciências Biológicas, Universidade Federal de Ouro Preto, Ouro Preto, Minas Gerais, 2017. 


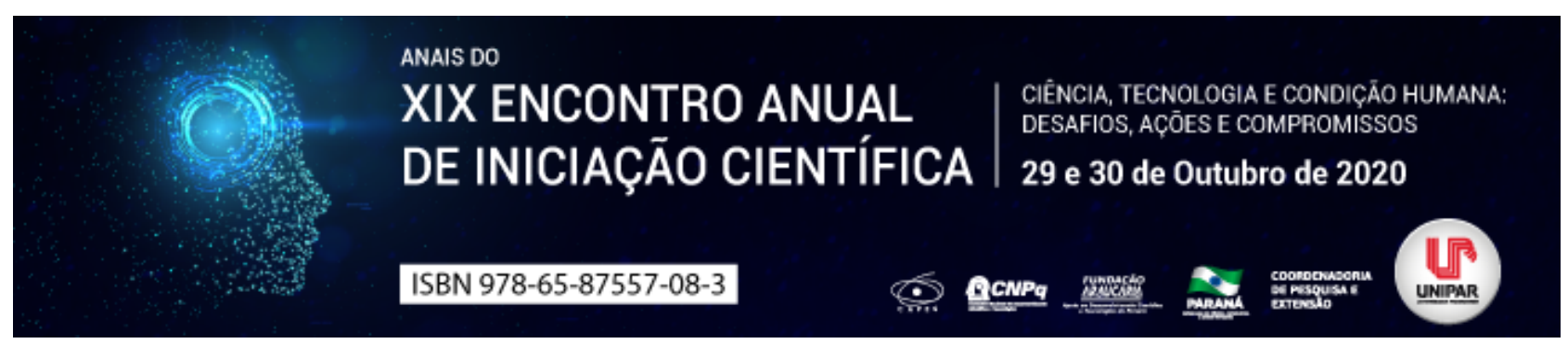

ESTADO NUTRICIONAL DE CRIANÇAS ENTRE 3 E 4 ANOS COM ENFOQUE NA OBESIDADE INFANTIL

\author{
${ }^{1}$ ALANA MARINA GORALSKI DE MEDEIROS, ${ }^{2}$ JANAINA STRAPAZZON RAFAGNIN
}

${ }^{1}$ Discente do curso de Nutrição/ UNIPAR

${ }^{1}$ Docente da UNIPAR

Introdução: A obesidade é uma síndrome multifatorial que consiste em alterações fisiológicas, bioquímicas, metabólicas, anatômicas, além de alterações psicológicas e sociais, sendo caracterizada pelo aumento de adiposidade e de peso corporal , envolvendo fatores genéticos e ambientais. Há evidências de que fatores genéticos são capazes de modular a resposta do organismo às variações dos fatores ambientais, como dieta e atividade física. A ingestão de dieta com valor calórico elevado e o gasto energético diminuído têm sido apontados como os principais fatores causais da obesidade. (SIMON, V. G. N. et al., 2009). Nas últimas décadas ocorreram mudanças no padrão alimentar da população brasileira, caracterizado pela diminuição do consumo de alimentos in natura e minimamente processados, em detrimento do aumento da ingestão de produtos processados e ultra processados. Tais mudanças repercutem numa dieta com maior densidade energética, associado a um aumento na ingestão de aditivos químicos, açúcar, sódio, gordura saturada e trans. e à diminuição do consumo de fibras(SILVA; MILAGRES; CASTRO; FILGUEIRAS et al., 2019). Segundo os dados da Organização Mundial da Saúde (OMS; 2019) as estimativas sugerem que quase 2,3 bilhões de crianças e adultos estão acima do peso e mais de 150 milhões de crianças com baixa estatura para a idade. No entanto, em países de baixa e média renda, essas questões emergentes se sobrepõem em indivíduos, famílias, comunidades e países. O avanço da tecnologia, com desenvolvimento de jogos eletrônicos, prendem as crianças a aparelhos tecnológicos, esses também diminuem drasticamente o gasto energético diário, colaborando para o sobrepeso e obesidade infantil. (FRANCISCO, C. C.; SOUZA, J. F. et al., 2015).

Objetivo: Classificar o estado nutricional de crianças entre 3 e 4 ano atendidas em um Centro Municipal de Educação Infantil em um município do sudoeste do Paraná.

Material e métodos: A coleta dos dados foi realizada antes do período de pandemia, por meio da aferição do peso registrada em quilos $(\mathrm{kg})$ e altura registrada em centímetro $(\mathrm{cm})$. Os participantes foram pesados descalços e com roupas leves, e para a mensuração da altura adotou-se o seguinte posicionamento: em pé, na posição ortostática, realizar uma inspiração máxima, sendo neste momento aferido a medida da altura no vértex da cabeça. Os instrumentos utilizados foram fita métrica e balança. Para o levantamento dos dados foi feito o Índice de Massa Corporal (IMC) para idade, utilizando a fórmula: P/A² e posteriormente analisado no gráfico IMC para idade correspondente, de acordo com o sexo (WHO; 2006). Esta pesquisa obedece aos aspectos éticos, sob o parecer número 096935/2020.

Resultados: Foram avaliadas 29 crianças, sendo 11 meninas e 18 meninos. Observou-se, no total da amostra, que $37.93 \%$ ( $\mathrm{n}=$ 11) dos avaliados apresentaram diagnóstico nutricional de obesidade, 34,48\% ( $n=10$ ) de sobrepeso e 27,58\% ( $n=8$ ) encontravam-se em eutrofia. Quando separados por sexo, nas meninas o diagnóstico nutricional mais prevalente foi o de obesidade, encontrada em $36,36 \%(n=4)$ das avaliadas e o sobrepeso diagnosticado em $36,36 \%$ ( $n=4)$ das avaliadas. A eutrofia foi observada em 27,27\% $(n=3)$ da amostra. Dos meninos, observou-se um maior número de diagnóstico de sobrepeso, em $38,88 \%(n=7)$ dos avaliados, seguido de obesidade com 33,33\% ( $n=6)$. Encontravam-se eutróficos 27,77\% ( $n=5)$ dos avaliados.

Discussão: Dentre os diversos estudos encontrados na literatura a obesidade infantil apresenta um crescimento entre as crianças de todo mundo, com a modernização do estilo de alimentação, com refeições industrializadas e os famosos fast food, nada saudáveis as pessoas se acomodaram sem ter o trabalho e o prazer de preparar suas refeições (OMS; 2019; SILVA; COSTA; GIUGLIANI;2019).

Sobre o estado nutricional de crianças podemos afirmar que: O sobrepeso e a obesidade foram mais prevalentes em crianças do sexo masculino (10,1\% e 7,0\%), pertencentes às famílias com níveis de renda intermediários, de $1 / 2$ a 1 salário mínimo per capita $(10,9 \%$ e $6,2 \%)$ e de 1 a 5 salários mínimos per capita (11,1\% e 7,4\%), residentes na zona urbana (10,3\% e 6,6\%) e nas regiões Sul, Centro-Oeste e Sudeste $(12,7 \%, 11,0 \%$ e $10,6 \%$ para o sobrepeso e $5,7 \%, 6,2 \%$ e $7,3 \%$ para a obesidade, respectivamente) ( PEREIRA,2016).

Os resultados revelaram que o excesso de peso, aqui representados pelo somatório das duas condições - sobrepeso/obesidade , apresentou maior prevalência que o deficit estatural (desnutrição), deixando clara a necessidade da atenção a esse problema para viablizar intervenções que contribuam com a melhoria do estado Nutricional de escolares (RAMIRES, Elyssia Karine Nunes Mendonça et al v. 32, n. 3, p. 200-207, Sept. 2014).

Conclusão: Este estudo observou uma prevalência de sobrepeso e obesidade no público avaliado. Estes resultados corroboram com os achados da literatura, com a presença de obesidade infantil sendo um grande problema de saúde pública. 


\section{Referências}

SILVA, Giselia Alves Pontes da; BALABAN, Geni; MOTTA, Maria Eugênia F. de A.. Prevalência de sobrepeso e obesidade em crianças e adolescentes de diferentes condições socioeconômicas. Rev. Bras. Saude Mater. Infant., Recife , v. 5, n. 1, p. 5359, Mar. 2005. disponível em: . access on 04 Sept. 2020.

ILVA, Mariane Alves et al. O consumo de produtos ultraprocessados está associado ao melhor nível socioeconômico das famílias das crianças. Ciênc. saúde coletiva, Rio de Janeiro, v. 24, n. 11, pág. 4053-4060, novembro de 2019. Disponível em . acesso em 04 de setembro de 2020.

ORGANIZAÇÃO MUNDIAL DA SAÚDE. et al. mais de um em cada três países de baixa e média renda enfrentam extremos da má nutrição, 17 de Dezembro de 2019.

PEREIRA, Ingrid Freitas da Silva et al. Estado nutricional de menores de 5 anos de idade no Brasil: evidências da polarização epidemiológica nutricional. Ciênc. saúde coletiva, Rio de Janeiro, v. 22, n. 10, p. 3341-3352, Oct. 2017 . Disponível em . access on 04 Sept. 2020.

SILVA, Marina Vieira da et al . Acesso à creche e estado nutricional das crianças brasileiras: diferenças regionais, por faixa etária e classe de renda. Rev. Nutr., Campinas, v. 13, n. 3, p. 193-199, Dec. 2000 . Disponível em . access on 04 Sept. 2020. SILVA, Giselia A.P.; COSTA, Karla A.O.; GIUGLIANI, Elsa R.J.. Alimentação infantil: além dos aspectos nutricionais. J. Pediatr. (Rio J.), Porto Alegre, v. 92, n. 3, supl. 1, p. 2-7, jun. 2016 . Disponível em . acessos em 04 set. 2020. 


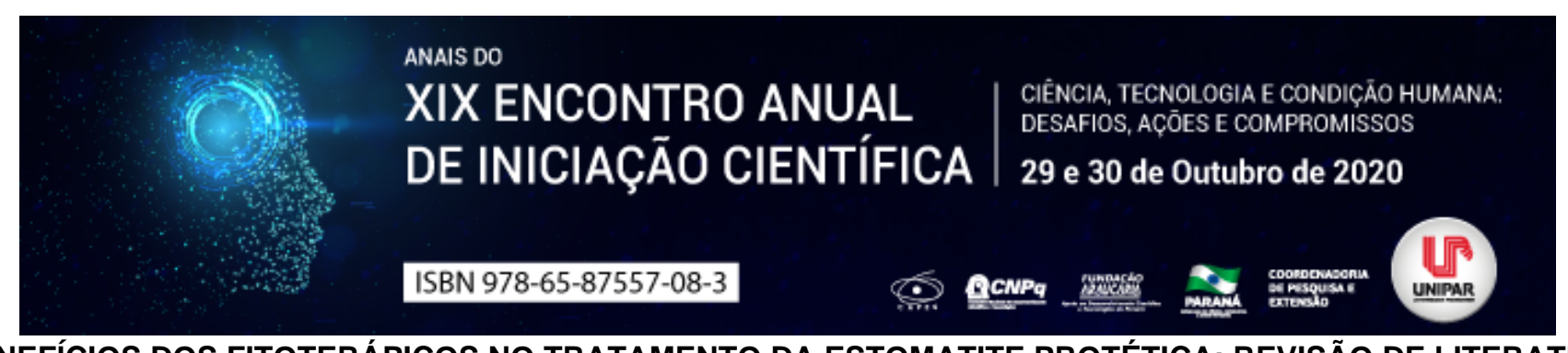

BENEFÍCIOS DOS FITOTERÁPICOS NO TRATAMENTO DA ESTOMATITE PROTÉTICA: REVISÃO DE LITERATURA

\author{
${ }^{1}$ ELOISA PEREIRA DE SOUZA, ${ }^{2}$ GIOVANA SOLER DOS SANTOS, ${ }^{3}$ HELOISA GARCIA FRANCOZO, ${ }^{4}$ ARGEMIRO RIBEIRO \\ DE ALMEIDA NETO, ${ }^{5}$ SUELEN STEFANONI BRANDAO, ${ }^{6}$ DANIELA DE CASSIA FAGLIONI B CERANTO
}

\author{
${ }^{1}$ Acadêmica do PIC/UNIPAR \\ ${ }^{1}$ Acadêmica do PIC/UNIPAR \\ ${ }^{2}$ Acadêmica do PIC/UNIPAR \\ ${ }^{3}$ Acadêmico do PIC/UNIPAR \\ ${ }^{4}$ Acadêmica bolsista do PIBIC/UNIPAR \\ ${ }^{5}$ Docente da UNIPAR
}

Introdução: Pacientes usuários de próteses dentárias desgastadas pelo uso ou em condições inadequadas, como má higiene, trauma, associado ou não à doenças sistêmicas, como alergias, patologias auto-imunes, têm maior predisposição ao desenvolvimento de doenças fúngicas, principalmente as causadas por Candida albicans, apesar de estudos relacionarem também outras espécies ao desenvolvimento de Estomatite Protética (EP). A EP corresponde a uma infecção na mucosa oral subjacente à prótese dentária. O diagnóstico pode ser feito através do exame clínico e o tratamento baseia-se na orientação da correta higiene, bem como no uso de antifúngicos, tópicos e/ou sistêmicos, dependendo da gravidade da doença. Como todo medicamento, os antifúngicos também podem causar efeitos colaterais, desta forma a busca por métodos mais naturais é uma constante, como é o caso do uso de fitoterápicos que tenham atividade antifúngica.

Objetivo: Revisar a literatura sobre o uso de fitoterápicos no tratamento de Estomatite Protética.

Desenvolvimento: A perda total ou parcial de dentes pode ser compensada com o uso de próteses. As próteses dentárias permitem que estética, mastigação e fonética sejam readquiridas, proporcionando conforto ao paciente, preservação, restauração e manutenção da saúde dos dentes remanescentes e tecidos orais. A utilização das próteses removíveis pode ocasionar lesões na cavidade bucal, devido à traumas constantes em virtude da má adaptação da peça protética e dificuldade de higienização, favorecendo o ambiente para que surjam infecções fúngicas que causam a Estomatite Protética (OLIVEIRA et al, 2019), tradicionalmente tradas com antifúngicos. Como tratamento alternativo podemos utilizar os fitoterápicos. O uso de plantas com propriedades medicinais através de raízes, folhas, flores e sementes que são industrializados para que os compostos bioativos sejam separados e aproveitados para tratamento e/ou para prevenção de várias doenças, é cada vez mais procurado. $\mathrm{O}$ tratamento por meio de plantas, até algum tempo atrás, era apenas considerado como prática milenar, transmitido de geração em geração sem base científica, mas isso tem mudado bastante com o investimento em pesquisas que comprovem cientificamente $o$ seu uso. Segundo a Agência Nacional de Vigilância Sanitária (2014) a medicação fitoterápica é aquela obtida através de matérias primas vegetais ativas, de misturas complexas existentes na planta uma ou mais substâncias. Na área odontológica, trabalhos mostram que as plantas medicinais podem ser utilizadas com várias funções. Dentre elas com ação anti-inflamatória, como cicatrizantes, com efeito antimicrobiana e ansiolítica, de custo acessível, manuseio fácil e com efeitos colaterais menores quando comparados aos medicamentos alopáticos (DE FARIAS, 2019). Os fitoterápicos são comercializados como cápsulas, pomadas, soluções aquosas hidro alcoólicas e infusões como chás, comprimidos e gel. Alguns destes fitoterápicos são utilizados como controladores de biofilme dental e infecções bucais tais como própolis, romã, aroeira, dentre outras. Destaca-se a aroeira (S. terenithiofolius) que possui ação antimicrobiana, anti-inflamatória e antiulcerogênica, sendo utilizada como antisséptico e no tratamento de estomatites. Além disso, apresenta atividade bactericida e bacteriostática contra Streptococcus mutans, Streptococcus mitis, Streptococcus sobrinus, Streptococcus sanguis, Lactobacillus casei e ação antifúngica sobre Candida albicans, Candida tropicalis e Candida krusei (FREIRES et al, 2010).

Conclusão: $\mathrm{O}$ uso de fitoterápicos, seja para tratamento de Estomatite Protética como para outras patologias bucais, está em ascensão, apesar de não ser por todos aceito ou explorado. Esta é uma área que ainda requer muita pesquisa para comprovar indicações, contra-indicações e possíveis efeitos colaterais dos derivados de plantas medicinais, mas ao que tudo indica o futuro dos fitoterápicos na Odontologia é promissor.

\title{
Referências
}

BRASIL. ANVISA. Diretoria Colegiada da Agência Nacional de Vigilância Sanitária. Instrução normativa $n^{\circ} 4$, de 18 de junho de 2014. Determina a publicação do Guia de orientação para registro de Medicamento Fitoterápico e registro e notificação de Produto Tradicional Fitoterápico. Disponível em:https://bitlybr.com/fre4DXZ. Acesso em: 26 ago. 2020.

DE FARIAS, Ana Clara Lima et al. O uso de fitoterápicos para o controle do medo e ansiedade no tratamento odontológico. 
Anais da Jornada Odontológica de Anápolis-JOA, 2019. Disponível em: https://bitlybr.com/r08Zqry. Acesso em: 26 ago. 2020. FREIRES, Irlan de Almeida et al. Atividades antibacteriana e antiaderente in vitro de tinturas de Schinus terebinthinfolius (Aroeira) e Solidago microglossa (Arnica) frente a bactérias formadoras do biofilme dentário. Odontologia Clínico-Científica (Online), v. 9, n. 2, p. 139-143, 2010. Disponível em: https://bitlybr.com/x6ff. Acesso em: 26 ago. 2020.

OLIVEIRA , Iracildo Carvalho et al. Patologias associadas ao uso de próteses totais removíveis: Revisão de literatura/Pathologies Associated with the use of total removable prosthesis: Literature Review. ID on line Revista de Psicologia v. 13, n. 47, p. 875888, 2019. Disponível em: file:///D:/Downloads/2091-8287-1-PB.pdf. Acesso em: 26 ago. 2020.

Coordenadoria de Pesquisa e Extensão - COPEX

Departamento de Editoraçāo e Divulgaçāo Científica - DEDIC 


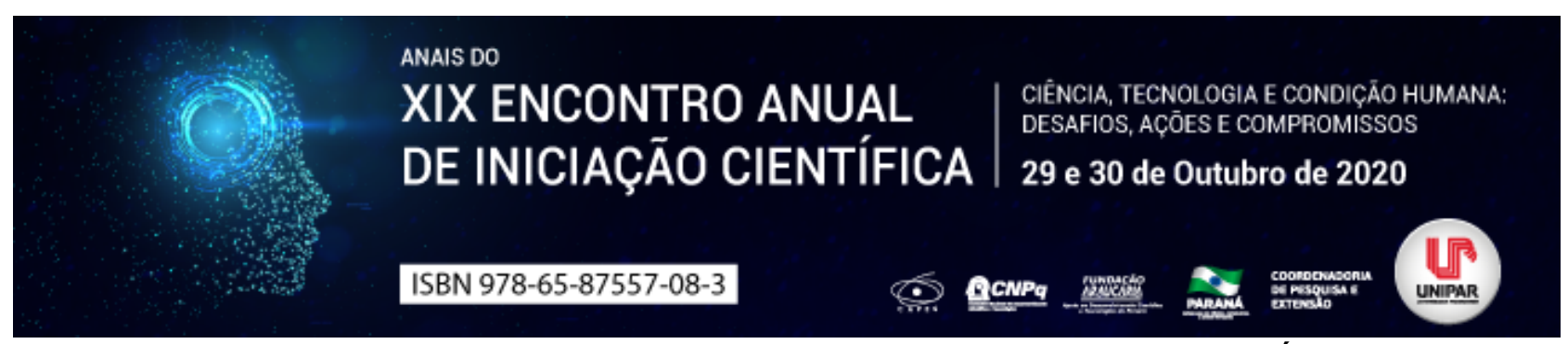

O USO DA ACUPUNTURA COMO TRATAMENTO PARA LOMBALGIA EM GESTANTES QUE JÁ REALIZARAM CIRURGIA BARIÁTRICA

\author{
${ }^{1}$ MARIA VICTORIA VECCHIETTI, ${ }^{2}$ LETICIA FLOIS FERREIRA, ${ }^{3}$ DJEICE DIANE HECK, ${ }^{4}$ POLYANA ALCANTARA DOS \\ SANTOS, ${ }^{5}$ DORA DE CASTRO AGULHON SEGURA
}

\author{
${ }^{1}$ Acadêmico do PIC/UNIPAR \\ ${ }^{1}$ Acadêmica do Curso de Fisioterapia da UNIPAR \\ ${ }^{2}$ Acadêmica do Curso de Fisioterapia da UNIPAR \\ ${ }^{3}$ Acadêmica do Curso de Fisioterapia da UNIPAR \\ ${ }^{4}$ Docente da UNIPAR
}

Introdução: A cirurgia bariátrica, também nominada de gastroplastia, surgiu nas últimas décadas como opção de tratamento para a obesidade mórbida, sendo que a maioria das pessoas que procuram pelo procedimento são mulheres em idade reprodutiva. Estas se mostraram mais férteis e aptas a engravidar após a cirurgia (LIMA et al., 2006). Entretanto, para Falcone et al. (2018), toda a parte nutricional, hormonal e física sofre alterações após o procedimento, e para tanto é necessário um cuidado maior por parte das mulheres durante o planejamento e própria gravidez. No período gestacional é notório que um percentual considerável de mulheres sofre com lombalgia, sendo considerada muitas vezes incapacitante. Todavia, a dor lombar pode ser solucionada utilizando medicamentos convencionais, porem sabe-se que os efeitos colaterais podem trazer danos ao feto e a mãe. É neste momento que surgem as terapias alternativas como a acupuntura, buscando de uma forma natural o tratamento da dor lombar (MARTINS et al., 2018).

Objetivo: Discorrer sobre o uso da acupuntura para tratamento da lombalgia em mulheres grávidas que já realizaram cirurgia bariátrica.

Desenvolvimento: A cirurgia bariátrica tem sido uma alternativa eficaz quando o assunto é redução de peso em indivíduos obesos. O objetivo do procedimento é minimizar riscos de doenças como hipertensão, câncer e diabetes mellitus tipo 2. O método cirúrgico atualmente mais utilizado devido a sua eficiência é o modelo Bypass com Y de Roux (FALCONE et al., 2018). Segundo Lima et al. (2006), o procedimento traz além dos benefícios já conhecidos com a perda de peso, melhora na sexualidade, fertilidade e na regulação hormonal, permitindo que as pacientes após um certo período de pós operatório engravidassem de forma mais facilitada e tivessem uma gestação saudável. Todavia, para Johansson et al. (2015), a gravidez após a cirurgia bariátrica deve ser estudada e planejada com cautela, visto que devido as alterações hormonais, nutricionais e físicas sofridas podem trazer sérias consequências para o feto e/ou para a mãe. O uso de polivitamínicos após a cirurgia deve ser indicado devido a limitação de absorção nutricional no tracto digestório (LIMA et al., 2006). Para Costa et al. (2016), a maioria dos brasileiros não ingere a quantidade adequada de cálcio e vitamina $\mathrm{D}$, e quando se trata de pacientes pós cirúrgicos bariátricos a porcentagem de ingestão é ainda mais baixa. A falta destes dois componentes no organismo leva a prevalência de baixa massa óssea na coluna lombar. Unido a isso, o aumento abdominal na gravidez, promovendo o deslocamento do centro de gravidade associado a mudança hormonal, promove a lombalgia em gestantes (ALVARENGA; GAMBA; MOSER, 2008). Como uma maneira eficaz, segura, e benéfica, a acupuntura entra como um meio natural de tratamento da dor, mostrando-se eficiente e com efeitos positivos na saúde das gestantes, tanto no tratamento da dor, quanto em aspectos diversos como redução dos níveis de estresse e ansiedade e melhora da qualidade do sono (MARTINS et al., 2018).

Conclusão: Devido a grande incidência de mulheres que eram obesas, passaram por cirurgia bariátrica, e que relatam dor na região lombar durante o período gestacional, a busca de um meio alternativo e eficaz para tratamento da dor sem interferir na proteção e saúde materno fetal fez com que a acupuntura se demonstrasse uma terapêutica segura e eficiente, concluindo que a técnica deve ser indicada e utilizada, sem risco de promover prejuízos.

\title{
Referências
}

ALVARENGA, G. M.; GAMBA, H. R.; MOSER, A. D. L. Análise cinemática pré e pós-operatória em pacientes submetidos à cirurgia bariátrica: Um estudo preliminar. Anais do XXI Congresso Brasileiro de Engenharia Biomédica, Salvador-BA, 2008.

COSTA, T. M. R. L.; PAGANOTO, M.; RADOMINSKI, R. B.; BORBA, V. Z. C. Impacto da deficiência nutricional na massa óssea após cirurgia bariátrica. Arquivos Brasileiros de Cirurgia Digestiva, v. 29, n. 1, p. 38-42, 2016.

FALCONE, V.; STOPP, T.; FEICHTINGER, M.; KISS, H.; EPPEL, W.; HUSSLEIN, P. W.; PRAGER, G.; GÖBL, C. S. Pregnancy after bariatric surgery: A narrative literature review and discussion of impact on pregnancy management and outcome. BMC Pregnancy and Childbirth, v. 18, n. 1, p. 01-13, 2018. 
JOHANSSON, K.; CNATTINGIUS, S.; NASLUND, I.; ROOS, N.; LAGERROS, Y. T.; GRANATH, F.; STEPHANSSON, O.; NEOVIUS, M. Outcomes of pregnancy after bariatric surgery. The New England Journal of Medicine, v. 372, n. 9, p. 814-824, 2015.

LIMA, J. G. D.; NÓBREGA, L. H. C.; MESQUITA, J. B.; NÓBREGA, M. L. C.; MEDEIROS, A. D. C.; MARANHÃO, T. M. D. O.; AZEVEDO, G. D. Gestação após gastroplastia para tratamento de obesidade mórbida: Série de casos e revisão da literatura. Revista Brasileira de Ginecologia e Obstetrícia, v. 8, n. 2, p. 107-111, 2006.

MARTINS, E. S.; TAVARES, T. M. C. L.; LESSA, P. R. A.; AQUINO, P. S.; CASTRO, R. C. M. B.; PINHEIRO, A. K. B. Tratamento com acupuntura: Avaliação multidimensional da dor lombar em gestantes. Revista de Escola de Enfermagem da USP, v. 52, p. 01-09, 2018. 


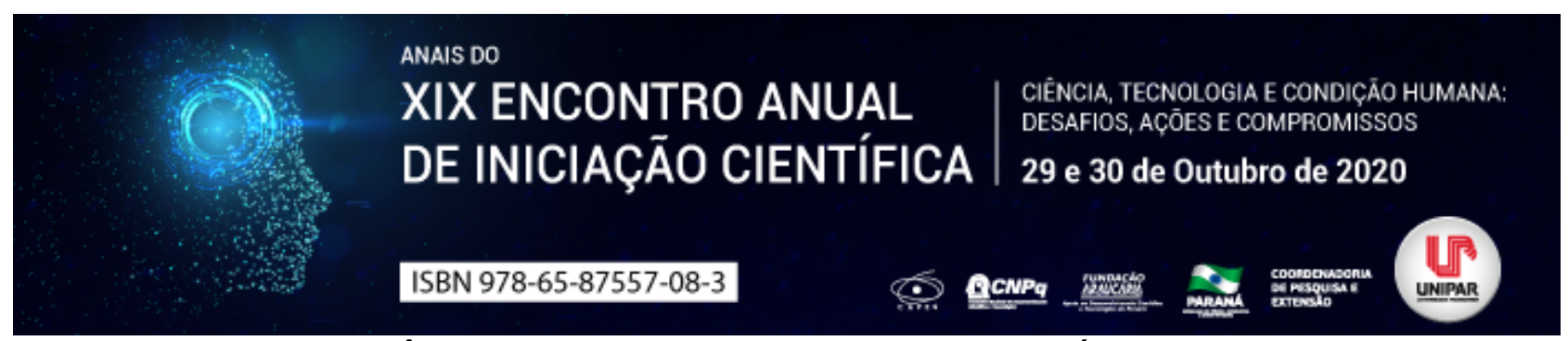

A IMPORTÂNCIA DO ACONSELHAMENTO NO TESTE RÁPIDO PARA HIV

\author{
${ }^{1}$ ELCIO DE SOUZA JUNIOR, ${ }^{2}$ AMANDA NASCIMENTO VASQUES DE SOUZA
}

\author{
${ }^{1}$ Acadêmico Unipar \\ ${ }^{1}$ Docente da UNIPAR
}

Introdução: O acolhimento do paciente é compreendido como forma de se aproximar, de estar perto, de incluir, de consideração e respeito no atendimento, representando a humanização nas relações do profissional de saúde e usuário, onde acontece a escuta ao paciente com responsabilidade, favorecendo intervenções (BRASIL, 2019a). No Brasil após 30 anos do primeiro caso de AIDS, teve uma estabilização da doença, no boletim epidemiológico do ano de 2010, foram notificados 608.230 casos de aids acumulados de 1980 a junho de 2011, em 2008 foram notificados 36.523 casos contra 34.212 casos em 2010 (BRASIL, 2019b). Mas para que houvesse essa estabilização foram desenvolvidos centro de apoio para assistência e prevenção, como, os Centros de Orientação e Aconselhamento Sorológico em IST (COAS), que posteriormente se tornou os Centros de Testagem e Aconselhamento (CTA), a testagem rápida reforça a prevenção, frente a resultados positivos oferecer tratamento adequado para uma qualidade de vida e orientações para diminuir a transmissão do vírus do HIV (BRASIL, 2020).

Objetivo: Com base na literatura científica, o trabalho tem como objetivo esclarecer a importância do aconselhamento na realização do teste rápido.

Desenvolvimento: É recomendado pelo Ministério da Saúde o aconselhamento pré e pós-teste para realização do teste rápido é realizado uma conversa sigilosa com o paciente e centralizada, tem como prioridade criar um vínculo com o mesmo com o objetivo que haja uma reflexão e auto avaliação do risco exposto assim originando uma melhor aceitação ao tratamento (TAQUETTE, 2017). Esse momento é importante para que seja estabelecida uma confiança paciente e profissional, onde haja uma boa comunicação, e que todas as informações sejam passadas de forma clara, e assim também reduzir o estresse e ansiedade (PEREIRA et al 2014). A coleta do teste rápido é de fácil de coletar necessitando fazer um pequeno furo na ponta do dedo para coletar uma amostra de sangue e o resultado sai dentro de 20 minutos, simplificando e agilizando o diagnóstico por HIV ( LIMA, 2020). Torna-se importante ressaltar que independentemente do resultado (reagente e não reagente), o usuário recebe aconselhamento, sendo não reagente orientações de prevenção e se reagente orientações tratamento, exames e encaminhamentos (BRASIL, 2018).

Conclusão: Sendo assim, pode se concluir que para um ótimo aconselhamento é necessário que o profissional tenha uma boa escuta, e que o mesmo também seja claro em suas orientações de prevenção e promoção de saúde, que seja empático no seu atendimento. A relação de confiança relação de confiança entre paciente e profissional é essencial na redução da ansiedade e estresse do usuário na realização da testagem rápida.

\title{
Referências
}

Brasil. Ministério da Saúde (MS). Secretaria de Vigilância em Saúde. Programa Nacional de DST e Aids. Boletim Epidemiológico AIDS e DST. Brasília: MS; 2019.

BRASIL. Ministério da Saúde. Secretaria de Vigilância em Saúde Departamento de Vigilância, Prevenção e Controle das DST, Aids e Hepatites Virais. Acolhimento, Aconselhamento e Orientações Pré e Pós-Teste. São Paulo: Revista Recien, 2020.

PEREIRA, Bianca de Souza et al. Fatores associados à infecção pelo HIVIAIDS entre adolescentes e adultos jovens matriculados em Centro de Testagem e Aconselhamento no Estado da Bahia, Brasil. Ciênc. saúde coletiva, Rio de Janeiro, v. 19, n. 3, p. 747-758, Mar. 2014.

TAQUETTE, S R; RODRIGUES, A O; BORTOLOTTI,L R. Percepção de pacientes com AIDS diagnosticada na adolescência sobre o aconselhamento pré e pós-teste HIV realizado. Ciênc. saúde coletiva, Rio de Janeiro, v. 22, n. 1, p. 23-30, Jan. 2017.

LIMA, PAULA BARRETO SILVA XENOFONTE COSTA et al . Percepção dos profissionais de saúde e dos usuários sobre o aconselhamento no teste rápido para HIV. Esc. Anna Nery, Rio de Janeiro , v. 24, n. 2, 2020. 


\title{
ANAIS DO XIX ENCONTRO ANUAL | CIÊNCIA, TECNOLOGIA E CONDIÇĀO HUMANA: DE INICIAÇÃO CIENTÍFICA DESAFIOS, AÇŌES E COMPROMISSOS DE INICIAÇĀO CIENTÍFICA 29 e 30 de Outubro de 2020 \\ ISBN 978-65-87557-08-3

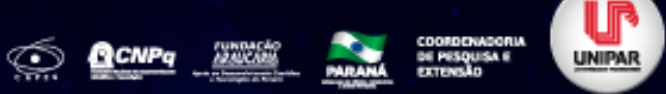 \\ EXCESSO DE PESO CORPORAL EM CRIANÇAS E ADOLESCENTES EM MUNICÍPIOS BRASILEIROS: UMA ANÁLISE A PARTIR DO SISTEMA INTEGRADO DE GESTÃO DE SERVIÇOS DE SAÚDE
}

\section{${ }^{1}$ ANDRE FERNANDO PASSOS DE OLIVEIRA , ${ }^{2}$ JESIEL DE SOUZA SOARES, ${ }^{3}$ DURCELINA SCHIAVONI BORTOLOTI}

\author{
${ }^{1}$ Discente do Curso de Nutrição PIC/UNIPAR Cascavel \\ ${ }^{1}$ Discente do Curso de Enfermagem PIC/UNIPAR Francisco Beltrão \\ ${ }^{2}$ Docente do Curso de Educação Física Bacharelado PIC/UNIPAR Francisco Beltrão
}

Introdução: A obesidade é considerada, atualmente, um problema mundial de saúde pública, visto que predispõe ao surgimento ou agravo de doenças crônicas não transmissíveis. A Organização Mundial da Saúde estima que o número de crianças e adolescentes com excesso de peso é alto, com estimativas superiores a 340 milhões (WHO, 2019). O excesso de peso em idades cada vez mais precoces tem despertado a preocupação de pesquisadores e profissionais da área da saúde, em razão dos danos e agravos à saúde, tais como hipertensão, cardiopatias, diabetes, dentre outras (CONDE et al., 2018; MOREIRA et al., 2020).

Objetivo: O propósito da presente investigação foi de analisar a prevalência de obesidade em crianças e adolescentes por meio do Índice de Massa Corporal, de acordo com sexo nos municípios brasileiros a partir de dados extraídos no Sistema Integrado de Gestão de Serviços de Saúde SIGSS.

Materiais e Métodos: Conduziu-se a coleta de dados de avaliações de Índice de Massa Corporal (IMC) de crianças e adolescentes (idades entre 2 e 19 anos) inseridos em um sistema terceirizado utilizado pela gestão municipal na atenção primária (Sistema Integrado de Gestão de Serviços de Saúde SIGSS). Para tanto, foram coletados os dados abastecidos pelos municípios no SIGSS no período de janeiro de 2019 a julho de 2020. Tais registros foram inseridos pelos profissionais Nutricionistas e Agentes Comunitários de Saúde (ACS), seguindo os procedimentos descritos nas regulamentações do Sistema Único e Saúde (SUS) (DATASUS, 2019). Os dados extraídos foram transportados para uma planilha do Microsoft ${ }^{\circ}$ Office Excel, onde foram excluídos os valores duplicados e discrepantes, e categorizados os valores adequados e inadequados (acima para idade e sexo) de IMC de acordo com tabelas normativas. Posteriormente os dados foram analisados por meio de estatística descritiva e teste de qui-quadrado para associação entre classificação do IMC e fase da vida (criança e adolescente) e municípios avaliados. Para tanto utilizou-se o programa SPSS 25,0 e o nível de significância adotado foi de $p<0,05$.

Resultados: Foram encaminhadas 40 declarações de permissão para utilização de dados, aos gestores municipais de saúde, porém, foram recebidas apenas quatro autorizações até a conclusão deste estudo, contudo devido ao atual cenário de pandemia pelo Covid-19, não houveram muitos registros no ano de 2020. Assim, foram avaliados um total de 2617 registros de IMC de crianças e adolescentes de quatro municípios brasileiros (Capanema PR; Guaíra - PR; Gaspar - SC; Chapadão do Céu - GO). Os valores médios do IMC foram de $17,12 \pm 2,86 \mathrm{~kg} / \mathrm{m}^{2}$ e $21,05 \pm 4,58 \mathrm{~kg} / \mathrm{m}^{2}$ para crianças e adolescentes respectivamente. Em relação a classificação do nível de adequação, observou-se que para as crianças houve 1204 registros $(73,1 \%)$ com IMC adequado de acordo com sexo e idade e 443 registros $(26,9 \%)$ com valores de IMC inadequados. Para os adolescentes verificouse 726 registros $(74,8 \%)$ de IMC adequado e 244 registros $(25,2 \%)$ de IMC inadequado de acordo com sexo e idade. Não foi evidenciada associação significante entre os valores de IMC e fases da vida ou municípios $(p>0,05)$. Ao analisar os valores de inadequação do IMC por municípios verificou-se maiores prevalências em Capanema (29,5\%), seguidas de Guaíra (26,8\%) e Chapadão do Céu (19,8\%). O município de Gaspar fez apenas quatro registros dos quais todos estavam com IMC adequados.

Discussão: Este estudo apresentou uma identificação importante no estado nutricional das crianças e adolescentes de ambos os sexos dos municípios investigados, com valores de sobrepeso ou obesidade variando de $19,8 \%$ a $29,5 \%$. Vale destacar que, todos os municípios apresentam Índice de Desenvolvimento Humano Municipal (IDHM) classificados como alto (Capanema 0,706; Guaíra 0,724; Chapadão do Céu 0,742; Gaspar 0,765) (IBGE, 2010), fator relevante, principalmente porque infere-se um nível socioeconômico que pode indicar uma ausência de estados de desnutrição, contudo, preocupante quando observados dados que inferem excesso de peso. Com isso, no espectro do estado de nutrição, principalmente nos indivíduos na faixa de idade de dois à dezoito anos, se observa uma tendência de incremento na prevalência do excesso de peso ou obesidade em ritmo semelhante àquele observado entre a população adulta (LIMA et al., 2017; CONDE et al., 2018), fato que pode predispor ao surgimento de doenças crônicas e degenerativas em idades precoces.

Conclusão: Foram observados que, apesar da falta de registros nas bases de alguns municípios, em decorrência do atual cenário enfrentado pela pandemia (Covid-19), os registros dos municípios avaliados apresentaram quadro preocupante de sobrepeso ou obesidade $(19,8$ a $29,5 \%)$ em crianças e adolescentes avaliados por meio do IMC. 


\section{Referências}

CONDE, Wolney Lisbôa, et. al. Estado nutricional de escolares adolescentes no Brasil: a Pesquisa Nacional de Saúde dos Escolares 2015. Revista Brasileira de Epidemiologia, v. 21, Supl. 1, p. e180008, 2018.

INSTITUTO BRASILEIRO DE GEOGRAFIA E ESTATÍSTICA. Cidades. Brasília, 2010. Disponível em: http://cidades.ibge.gov.br. Acesso em: 15 agosto. 2020.

LIMA, Niedja Maria da Silva, et. al. Excesso de peso em adolescentes e estado nutricional dos pais: uma revisão sistemática. Ciência \& Saúde Coletiva, v. 22, n.2, p. 627-636, 2017.

MOREIRA, Natália Boia Soares. et al. Prevalência de sobrepeso e obesidade em crianças de uma escola da rede privada na cidade de Teresópolis, Rio de janeiro. Revista da Jopic. v. 3, n. 6, p. 49-54, 2020

WHO. World Health Organization. Obesity and overweight 2019. Disponível em: https://www.who.int/news-room/factsheets/detail/obesity-and-overweight Acesso em: 18 agosto. 2020.

Coordenadoria de Pesquisa e Extensão - COPEX

Departamento de Editoração e Divulgaçāo Científica - DEDIC 


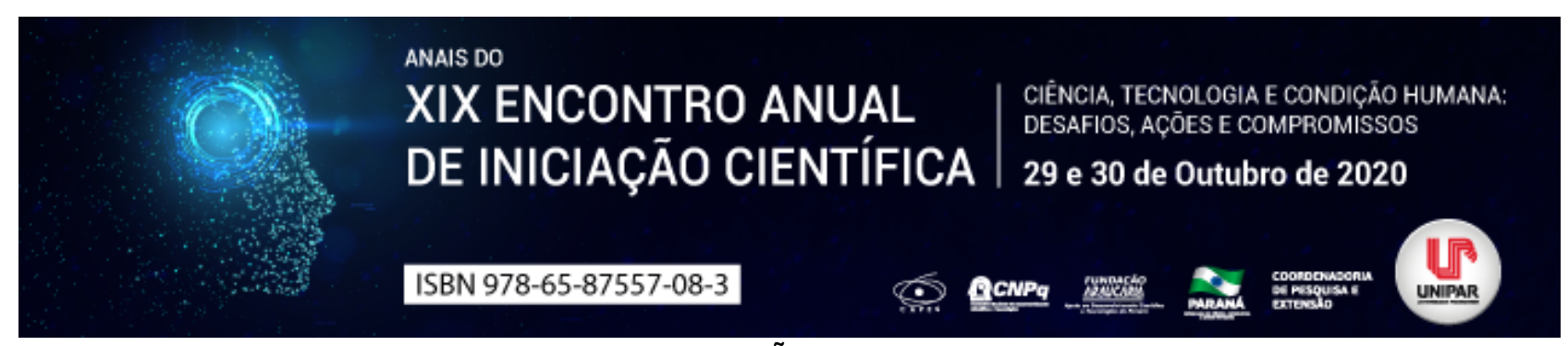

\title{
O USO DA VALERIANA (Valeriana officinalis) NA REDUÇÃO DA ANSIEDADE DE PROFISSIONAIS DE ENFERMAGEM QUE ATUAM NA LINHA DE FRENTE DA DOENÇA COVID-19
}

${ }^{1}$ WESLEY FERNANDO AGUIAR NEVES, ${ }^{2}$ IRINEIA PAULINA BARETTA

\author{
${ }^{1}$ Acadêmico de Enfermagem UNIPAR \\ ${ }^{1}$ Docente da UNIPAR
}

Introdução: Os transtornos de ansiedade estão entre os distúrbios mentais mais comuns em todo o mundo, despertando para uma preocupação com tratamentos eficazes para a qualidade de saúde do sujeito, este, inserido em uma sociedade contemporânea que valoriza a liquidez. Segundo Santana e Silva (2015), descreve a ansiedade como um estado emocional que afeta tanto aspectos psicológicos e fisiológicos, podendo se dar de forma benéfica, quando é estável para o desenvolvimento do sujeito e patológica quando acarreta em prejuízo para saúde e qualidade de vida do mesmo. No momento encontramos vivenciando o contexto com a pandemia do Coronavírus Disease (COVID 19), sendo declarando pela OMS (Organização Mundial de saúde) como situação de emergência em saúde pública de preocupação internação, um alerta vermelho, afetando e alastrando por todos os países colocando a saúde e integridade física da população em risco, conforme informação no site da OMS, 2020. A vivência com a chegada e as infectações de uma grande parcela da população associada com a falta de uma vacina e medida de prevenção e proteção contra o Covid-19, gerou em uma parcela da população um desequilíbrio emocional, contribuindo para níveis de ansiedade preocupante, sendo assim esse trabalho tem a intenção de refletir o uso do fitoterápico como um recurso para o alívio e tratamento para ansiedade.

Objetivo:Promover o uso de valeriana como um tratamento alternativa para controle do distúrbio de ansiedade.

Desenvolvimento: A utilização de plantas medicinais no Brasil tem crescido e desde 2006, duas importantes políticas foram publicadas para a área de plantas medicinais e fitoterápicos, a Política Nacional de Práticas Integrativas (PNPIC) no Sistema Único de Saúde (SUS) e a Política Nacional de Plantas Medicinais e Fitoterápicos (PNPMF). Essas políticas visam ter mais opções terapêuticas com acesso às plantas medicinais e fitoterápicos, com garantia, segurança e eficácia aos usuários do SUS (SAÚDE, 2006). Algumas plantas medicinais podem ser utilizadas no tratamento da ansiedade, como a Cava- Cava (Piper methysticum G. Forst), Maracujá (Passiflora incarnata) e a Valeriana (Valeriana officinalis). Essas plantas têm ação ansiolítica e atuam no SNC (FAUSTINO ET AL, 2010). Segundo Faustino et al (2010) nos dias de hoje no mercado farmacêutico tem uma base de $25 \%$ dos fármacos produzindo a utilização de plantas medicinais direta e indireta, como pôr exemplo morfina. A valeriana é uma planta perene nativa da Europa e Ásia, mais foi naturalizada na américa do norte. O gênero valeriana pertence a família valerianaceae, ordem dipsacales, inclui mais de 250 espécie. A espécie de valeriana mais comumente utilizado na terapêutica é a Valeriana officinalis, apesar de V.edulis. (Valeriana mexicana) e V. wallichii (valeriana indiana), também serem utilizadas. A composição química varia de acordo com a subespécie, variedade, idade de planta, condições de crescimento, idade e tipo de extrato (VIDAL; TOLEDO, 2014-2015). A valeriana é eficaz contra ansiedade, angústia, desequilíbrios do sistema nervoso e não tem contra indicação. Por não ter contra indicação é uma das primeiras plantas em que se deve pensar para ansiedade, ainda não determinaram exatamente quais constituintes são responsáveis pela ação sedativa. Pode ser que a valeriana atue sobre neurotransmissor ácido gama- aminobutírico (GABA), já que o aumento da concentração desse neurotransmissor está associado a diminuição da atividade do SNC e essa ação pode estar implicada na atividade sedativa (GARCIA; SOLíS,2007). Somente a raiz da valeriana europeia é consumida e utilizada como uma droga oficial. Mais quando é utilizado a planta seca ela e feita e servida em forma de chás. Segundo os autores Vidal e Toledo (2015), o gaba é um neurotransmissor fundamental quando se fala em controle de ansiedade.

Conclusão: Durante anos a valeriana vem sem usada como um ansiolítico natural e leve, devido a sua ação na diminuição da ansiedade, e não ser contra indicada, seria uma alternativa para os profissionais de saúde na luta contra covid-19, vivência essa, que podem desencadear sofrimento prejudicando a qualidade desse profissionais em espaço que atuam indireta e diretamente na linha de frente contra o COVID- 19, agindo como aliado para o descanso e alívio da ansiedade, cooperando com seu desempenho profissional.

\section{Referências}

FAUSTINO T.T, ALMEIDA R.B, ANDREATINI R. Plantas medicinais no tratamento do transtorno de ansiedade generalizada: uma revisão dos estudos clínicos controlados. Revista Brasileira de Psiquiatria. Vol 32. №4. Maio. 2010.

Organização Mundial de Saúde (OMS). (2020). Mental health and psychosocial considerations during the COVID-19 outbreak. Geneva: Author. Retrieved from https://www.who.int/docs/default-source/coronaviruse/mental-health-considerations

SANTANA, G.S.; SILVA, A. M. (2015). III Simpósio de Assistência Farmacêutica. O uso de plantas medicinais no tratamento 


\section{da ansiedade}

Local: centro universitário são camilo.

VIDAL Ranulfo J.L e TOLEDO Cleyton, E. M.; VALERIANA OFFICINALIS,. No Tratamento da insônia e ansiedade. Brazilian jornal of surgery and clinical research BJSCR; V.9, Nº1, PP.78-83. Dez 2014/Fev 2015.

Coordenadoria de Pesquisa e Extensão - COPEX

Departamento de Editoraçāo e Divulgaçāo Científica - DEDIC 


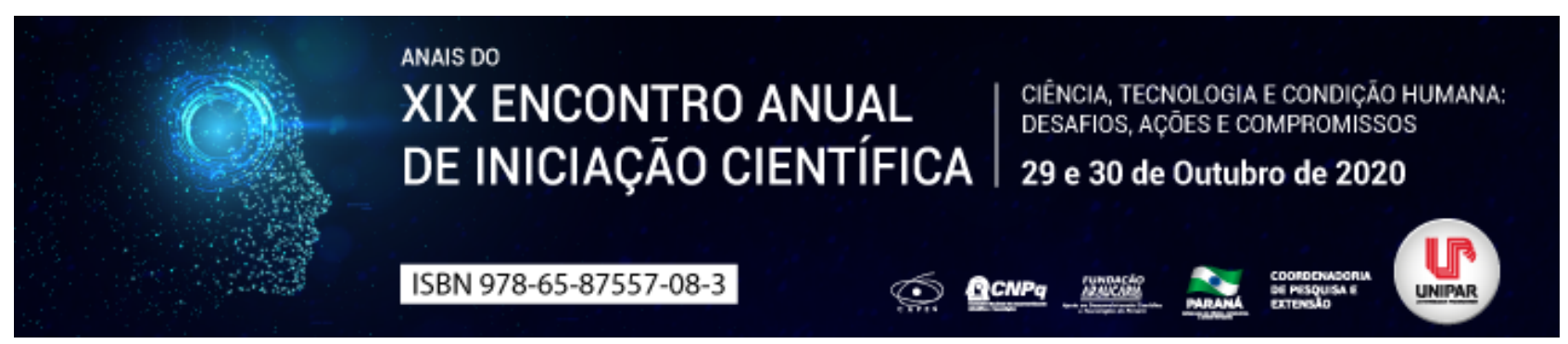

ESTUDOS RECENTES COM Curcuma longa L. NA UNIVERSIDADE PARANAENSE

\title{
${ }^{1}$ DAIANE CRISTINA PREILIPPER, ${ }^{2}$ JULIANA PELISSARI MARCHI, ${ }^{3}$ FERNANDA ELOIZE KUBA, ${ }^{4}$ LUCIANA PELLIZZARO
}

\author{
${ }^{1}$ Acadêmica do Curso de Estética e Cosmética da UNIPAR \\ ${ }^{1}$ Docente da UNIPAR \\ ${ }^{2}$ Acadêmica do Curso de Estética e Cosmética da UNIPAR \\ ${ }^{3}$ Docente da UNIPAR
}

Introdução: Curcuma longa L. é uma planta conhecida popularmente como açafrão, pertencente à família Zingiberaceae, originária da Índia e Ásia. Seus rizomas são usados na culinária devido à sua cor e sabor. Algumas pesquisas testam suas propriedades terapêuticas, identificam e mensuram seus componentes e outras objetivam melhorar sua produção e até mesmo verificar sua interação com outros seres vivos (MARCHI, 2016). Neste contexto, a cúrcuma vem sendo objeto de estudos de várias pesquisas universitárias, as quais servem de embasamento para estudos acadêmicos e novas pesquisas.

Objetivo: Descrever e divulgar as pesquisas recentes com Curcuma longa desenvolvidas na Universidade Paranaense e apresentadas no seu Encontro Anual de Iniciação Científica.

Desenvolvimento: Estudo da composição química de rizomas de $C$. longa provenientes de três diferentes locais apontou diferença no número de compostos entre eles, porém, os três compartilharam mesmos compostos majoritários: ar-tumerona e curlona (SANCHES et al., 2018). Melo et al. (2018) concluíram que diferentes processos de extração e preparação dos rizomas podem alterar a expressão dos componentes químicos, o que foi comprovado no estudo de SOARES et al. (2019) no qual o extrato seco por spray drying não apresentou curcuminoides em relação ao extrato obtido por esgotamento. Houve redução no rendimento do óleo essencial e aumento na produção de seus compostos quando $C$. longa foi exposta a estresse salino (BONACINA et al., 2019). França e Porciuncula (2018) testaram a temperatura de secagem dos rizomas e concluíram que fatias secas a 50 e a $60^{\circ} \mathrm{C}$ não apresentaram mudanças significativas nos teores de curcumina e cor. Com relação à atividade antimicrobiana, estudo mostrou que a suspensão do pó se mostrou com maiores efeitos comparada com a oleoresina contra Escherichia coli (BANDEIRA et al., 2018). Extrato bruto seco e oleoresina inibiram o crescimento de S. aureus em várias concentrações testadas (SANTOS et al., 2018), porém contra Klebsiella pneumoniae (ARALDI et al., 2018) e Pseudomonas aeruginosa (TIEPO et al., 2018) não houve efeito algum, possivelmente devido à baixa concentração de curcuminoides, os quais em maior quantidade interferem na multiplicação desses micro-organismos. SANTOS et al. (2019) comprovaram haver ação nematicida eficiente do óleo essencial de $C$. longa contra os fitonematóides Meloidogyne incognita e Pratylenchus brachyurus, sendo os monoterpenos e sesquiterpenos os componentes responsáveis. Um ensaio de aclimatação de $C$. longa mostrou que a adição de Fungos micorrízicos arbusculares (FMAs) a vermiculita, substrato comercial e vermicomposto mostrou-se eficiente para o crescimento e sustentabilidade da planta (QUEIROZ et al., 2019); os FMAs Rhizophagus clarus e Claroideoglomus etunicatum, quando associados à vermiculita provocaram aumento na produção de compostos fenólicos em $C$. longa aclimatada (FERRARI et al., 2019) e o fungo Glomus etunicatum mostrou-se eficiente para o aumento da sua atividade antioxidante (FERRARI et al., 2018). ROCHA et al. (2019) apontaram em sua revisão que a inclusão de C. longa na ração de frangos de corte, no lugar de antibióticos promotores de crescimento resulta em maior ganho de peso, inibição da colonização intestinal por Salmonella typhimurium além de diminuir os custos de produção, mas sugere outros estudos para dosar a quantidade. Rosa et al. (2019) administraram óleo de $C$. longa a 0,5\% em suínos em crescimento e não observaram efeito antiestressante, medindo sua taxa de cortisol.

Conclusão: Vários são os estudos realizados com C. longa na Unipar, que incluem avaliação de métodos de preparo dos rizomas, técnicas de extração dos seus produtos (óleo, oleoresina, extratos), ação antibacteriana que se mostrou mais eficiente nas gram positivas, possivelmente pela ação dos seus componentes interação com a produção animal (suínos e aves) e com fungos micorrízicos. Todos esses estudos certamente contribuem para o embasamento de trabalhos acadêmicos e para novas pesquisas a serem desenvolvidas.

\section{Referências}

ARALDI, Debora Cristina et al. Atividade antimicrobiana do extrato bruto seco e da oleoresina de Curcuma longa L. sobre a bactéria Klebsiella pneumoniae. 2018. Disponível em: https://sisweb02.unipar.br/eventos/anais/4021/html/17096.html BANDEIRA, Debora Marina et al. Atividade antimicrobiana da Curcuma longa L. sobre Escherichia coli. 2018. Disponível em: https://sisweb02.unipar.br/eventos/anais/4021/html/17069.html

BONACINA, Cristine et al. Efeito do estresse salino na composição química do óleo essencial da Curcuma longa L. 2019. 
Disponível em: https://sisweb02.unipar.br/eventos/anais/4354/html/19406.htm

FERRARI, Meire Pereira de Souza et al. Atividade antioxidante em Curcuma longa aclimatadas com fungos micorrízicos arbusculares. 2018. Disponível em: https://sisweb02.unipar.br/eventos/anais/4021/html/15425.html

FERRARI, Meire Pereira de Souza et al. Compostos fenólicos em Curcuma longa aclimatizada com fungos micorrizos arbusculares. 2019. Disponível em: https://sisweb02.unipar.br/eventos/anais/4354/html/18621.html .

França, Ana Teresa Rodrigues; PORCIUNCULA, Bárbara Daniele de Almeida. Análise dos parâmetros de qualidade de cúrcuma desidratada. 2018. Disponível em: https://sisweb02.unipar.br/eventos/anais/4021/html/15391.html

MATHEUS SOUZA ROCHA, Matheus Souza et al. Emprego de Curcuma longa em dietas para frangos de corte. 2019. Disponível em: https://sisweb02.unipar.br/eventos/anais/4354/html/19755.html

MARCHI, Juliana Pelissari et al. Curcuma longa L.: o açafrão-da-terra e seus benefícios medicinais. Arq Cienc Saúde UNIPAR. v. 20, p. 189-194, 2016

MELO, Ailton da Cruz et al. Influência do método de extração na composição química dos rizomas de Curcuma longa L. 2018. Disponível em: https://sisweb02.unipar.br/eventos/anais/4021/html/15217.html

QUEIROZ, Mayara dos Santos et al. Aclimatização de Curcuma longa cultivada in vitro. 2019. Disponível em: https://sisweb02.unipar.br/eventos/anais/4354/html/19381.html_

ROSA, Gilneia da et al. Efeito da suplementação com óleo essencial de Curcuma longa no nível de cortisol de suínos em crescimento. 2019. Disponível em: https://sisweb02.unipar.br/eventos/anais/4354/html/20123.html

SANCHES, Lincon et al. Composição química do óleo essencial de rizomas de Curcuma longa L. 2018. Disponível em: _https://sisweb02.unipar.br/eventos/anais/4021/html/16680.html

SANTOS Cleyton Emanoel et al. Óleo essencial de Curcuma longa no controle de Meloidogyne incognita e Pratylenchus brachyurus. 2019. Disponível em: https://sisweb02.unipar.br/eventos/anais/4354/html/19275.html).

SANTOS, Natiely Souza dos et al. Avaliação da atividade antimicrobiana da Curcuma longa $L$ sobre Staphylococcus aureus. 2018. Disponível em: https://sisweb02.unipar.br/eventos/anais/4021/html/17047.html

SOARES, Ana Karina Vargas et al. Caracterização fitoquímica e atividade antioxidante do extrato de rizomas de Curcuma longa L. 2019. Disponível em:

https://sisweb02.unipar.br/eventos/anais/4354/html/18967.html

TIEPO, Maiara Luziana et al. Composição fitoquímica da Curcuma longa e sua ação sobre a bactéria Pseudomonas aeruginosa. 2018. Disponível em: https://sisweb02.unipar.br/eventos/anais/4021/html/17020.html 


\title{
(

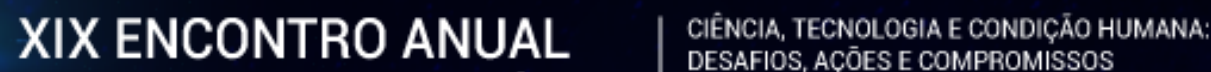 DE INICIACÃO CIENTÍFICA DESAFIOS, AQÖESE EOMPROMISSOS DE INICIAÇĀO CIENTIFFICA 29 e 30 de Outubro de 2020 \\ ISBN 978-65-87557-08-3

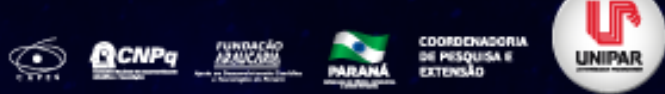 \\ INCIDÊNCIA DE NEURALGIA TRIGEMINAL EM PACIENTES DA FACULDADE DE ODONTOLOGIA DA UNIVERSIDADE FEDERAL DE UBERLÂNDIA
}

\begin{abstract}
${ }^{1}$ Caio Fossalussa da Silva, ${ }^{2}$ ANNA GIULIA MELLO PAIVA, ${ }^{3}$ ANNY ISABELLY DOS SANTOS SOUZA, ${ }^{4}$ JOÃO CÉSAR GUIMARÃES HENRIQUES, ${ }^{5}$ FÁBIO FRANCESCHINI MITRI
\end{abstract}

\author{
${ }^{1}$ Faculdade de Odontologia da Universidade Federal de Uberlândia/Graduando \\ ${ }^{1}$ Faculdade de Odontologia da Universidade Federal de Uberlândia/Cirurgiã-Dentista \\ ${ }^{2}$ Faculdade de Odontologia da Universidade Federal de Uberlândia/Graduanda \\ ${ }^{3}$ Professor Doutor em Biopatologia Bucal, Universidade Federal de Uberlândia \\ ${ }^{4}$ Professor Doutor da Disciplina de Anatomia Humana na Universidade Federal de Uberlândia
}

Introdução: A natureza e a prevalência da dor são mecanismos essenciais para o diagnóstico da dor orofacial. A neuralgia do trigêmeo (NT) tem incidência de 4,3 por 100.000 na população, com maior prevalência de mulheres (3: 2), após a quarta década de vida (ALVES; AZEVEDO; CARVALHO, 2004; MANZONI; TORELLI, 2005). A NT é um distúrbio incomum caracterizado por uma dor paroxística e penetrante, semelhante a um choque elétrico ou queimação, com duração de alguns segundos a minutos (SINGH; DAVIS; SHARMA, 2016), geralmente unilateral, com recidiva de meses ou anos (BORSOOK et al., 2007). Episódios de dor geralmente são desencadeados por um leve toque na face ou na mucosa oral ou outros hábitos, como escovar os dentes, beber, mastigar, fazer a barba, aplicar maquiagem (LOVE; GRADDGE; COAKHAM, 2001; FRIZZO; HASSE; VERONESE, 2004). A terapia medicamentosa é considerada o tratamento de primeira linha para NT idiopática, sendo o anticonvulsivante carbamazepina o fármaco mais utilizado em cerca de $60 \%$ a $80 \%$ dos casos, seguido pela gabapentina (ALVES; AZEVEDO; CARVALHO, 2004). A aplicação da toxina botulínica A pode ser considerada uma opção para bloquear os impulsos nervosos e dessensibilizar a região afetada (TALARICO, 2014; KOWACS et al., 2015).

Objetivo: Estabelecer a incidência de NT em pacientes atendidos no Programa de Cuidados Específicos para Doenças Estomatológicas (PROCEDE) da Faculdade de Odontologia da Universidade Federal de Uberlândia (FOUFU), considerando o sexo e a idade dos pacientes, ramos afetados do nervo trigêmeo e os tratamentos mais comumente usados para essa neuropatia. Informações sobre a identificação da população afetada e as características da incidência da NT podem se tornar uma importante ferramenta para ampliar o conhecimento do profissional e facilitar o estabelecimento da abordagem, tratamento e preservação do paciente.

Material e métodos: Este trabalho foi realizado por meio de um estudo observacional retrospectivo, no qual 200 prontuários de pacientes com 18 anos ou mais, atendidos no PROCEDE, localizado na cidade de Uberlândia em Minas Gerais, localizada no Brasil de 2014 a 2018. A pesquisa foi realizada de acordo com o protocolo aprovado pelo Comitê de Ética e Pesquisa da Universidade Federal de Uberlândia, sob o registro $n^{\circ}$ 2.844.148. Assim, registrou-se a incidência de NT nesses pacientes, incluindo os ramos do trigêmeo mais acometidos, faixa etária, sexo e formas de tratamento. A frequência de cada variável foi avaliada por meio de análise estatística. Os dados coletados foram submetidos ao teste Qui-Quadrado (SigmaPlot versão 12.0, SPSS Inc., Califórnia, EUA).

Resultados: Com base na observação dos 200 prontuários de pacientes atendidos no PROCEDE, de 2014 a 2018,20 pacientes foram diagnosticados com neuralgia do trigêmeo, dos quais 14 eram mulheres e 6 eram homens. Dos 20 pacientes com diagnóstico de NT, 7 apresentavam envolvimento do ramo mandibular (V3), 12 do ramo maxilar (V2) e 1 do ramo oftálmico (V1). O lado direito foi acometido em 14 (70\%) pacientes e o esquerdo em $6(30 \%)$ deles. Além disso, apenas 1 paciente com diagnóstico de NT tinha menos de 40 anos.

Discussão: A incidência de NT em uma população é baixa, mas não incomum. Assim, dos 200 prontuários observados de pacientes adultos, atendidos no PROCEDE de 2014 a 2018, 10\% foram diagnosticados com a doença. Esses dados estão de acordo com relatos da literatura, confirmando a baixa ocorrência da doença na população mundial (GUSMÃO; MAGALDI; ARANTES, 2003). A incidência anual de NT na população mundial é de cerca de 4,3 por 100.000 habitantes (MANZONI; TORELLI, 2005). A ocorrência mais comum em relação ao par de nervos cranianos afetado é a forma unilateral. O quadro bilateral desta doença é raro (COSTA; CAPOTE; GASPAR, 2006). Em relação aos ramos do nervo trigêmeo, nossos resultados revelaram a maior prevalência de NT no V2, de $60 \%$, seguida de $35 \%$ no V3 e $5 \%$ no V1, o que está de acordo com os estudos de Di Stefano et al (2018), que relataram a mesma sequência de ramos afetados pela neuralgia em estudo com 140 pacientes.No que se refere ao gênero, nossos resultados também revelaram que a prevalência de NT é maior nas mulheres do que nos homens, com $70 \%$ e 30\%, respectivamente, apresentando uma relação mulher / homem de 2,3: 1. Além disso, a idade também se torna um fator relevante fator, visto que a maior parte dos pacientes tinham mais de 40 anos. Esses dados 
concordam com outros relatos da literatura e confirmam a alta incidência de NT em mulheres a partir de 40 anos (ALVES; AZEVEDO; CARVALHO, 2004). Em nossos estudos, todos os casos foram unilaterais.

Conclusão: A incidência da NT é significativa, representando 10\% da população estudada, na proporção 2,3:1 de mulheres para homens. A condição unilateral foi mais comum, sendo o lado direito mais prevalente e os ramos $\mathrm{V} 2$ e $\mathrm{V} 3$ estão entre os mais afetados. A carbamazepina é o medicamento de escolha para o tratamento da NT.

\section{Referências}

ALVES TCA, AZEVEDO GS, CARVALHO ES. Tratamento Famacológico da Neuralgia do Trigêmeo: Revisão Sistemática e Metanálise. Rev Bras Anestesiol, v. 54, n. 6, p. 836 849, 2004.

BORSOOK D, MOULTON EA, PENDSE G, MORRIS S, COLE SH, AIELLO-LAMMENS M, SCRIVANI S, BECERRA LR. Comparison of evoked vs. spontaneous tics in a patient with trigeminal neuralgia (tic doloureux). Molecular Pain, v. 3, n. 34, p. 1 16, 2007.

COSTA CC, CAPOTE TSO, GASPAR AMM. Neuralgia trigeminal uma revisão bibliográfica sobre etiologia, sintomas e tratamento. Rev. Fac. Odontol., v. 8, n. 2, p. 50 52, 2006.

DI STEFANO G, MAARBJEG S, NURMIKKO T, TRUINI A, CRUCCU G. Triggering trigeminal neuralgia. Cephalalgia, v. 38, n. 6, p. 1049 1056, 2018.

FRIZZO HM, HASSE PN, VERONESSE RM. Neuralgia do trigêmeo: revisão bibliográfica analítica. Rev Cir e Traumatol BucoMaxilo-Facial, v. 4, n. 4, p. 204 57, 2004.

GUSMÃO S, MAGALDI M, ARANTES A. Rizotomia trigeminal por radiofrequência para tratamento da neuralgia do trigêmeo: resultados e modificação técnica. , 61(2): , 2003. Arquivos de Neuropsiquiatria, v. 61, n. 2, p. 434 440, 2003.

KOWACS PA, UTIUMI MA, NASCIMENTO FA, PIOVESAN EJ, TEIVE HAG. OnabotulinumtoxinA for trigeminal neuralgia: a review of the available data. Arquivos de neuro-psiquiatria, v. 73, n. 10, p. 877-884, 2015.

KRAFFT RM. Trigeminal neuralgia. Am Fam Physician, v. 77, p. 1291-1296, 2008.

LOVE S, GRADIDGE T, COAKHAM HB. Trigeminal neuralgia due to multiple sclerosis: ultrastructural findings in trigeminal rhizotomy specimens. Neuropathol Appl Neurobiol, v. 27, p. 238 244, 2001.

MANZONI GC, TORELLI P. Epidemiology of typical and atypical craniofacial neuralgias. Neurol Sci, v. 26, n. 2, p. 65 67, 2005. SINGH R, DAVIS J, SHARMA S. Radiosurgery for Trigeminal Neuralgia: A Retrospective Multi-Institutional Examination of Treatment Outcomes. Cureus, v. 8, n. 4, p. 554 567, 2016.

TALARICO S. Toxina botulínica: uma nova opção para o tratamento da neuralgia pós-herpética? Revista HUPE, v. 13, n. 1, p. 21-27, 2014. 


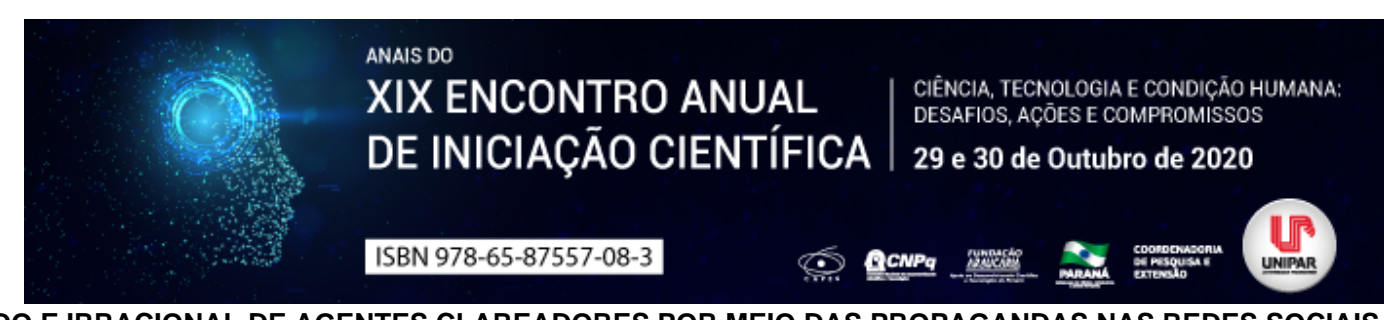

USO INDEVIDO E IRRACIONAL DE AGENTES CLAREADORES POR MEIO DAS PROPAGANDAS NAS REDES SOCIAIS E FAKE NEWS

${ }^{1}$ BRENDA FERRARI SEABRA, ${ }^{2}$ CAMILA SESTITO FRANCISCATO, ${ }^{3} \mathrm{KLISSIA} \mathrm{ROMERO} \mathrm{FELIZARDO}$

${ }^{1}$ Acadêmica do Curso de Odontologia/UNIPAR

${ }^{1}$ Acadêmica do Curso de Odontologia/UNIPAR

2Docente da UNIPAR

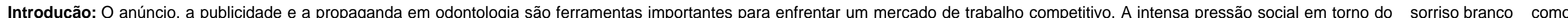

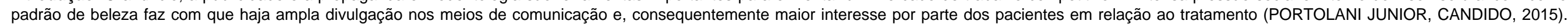

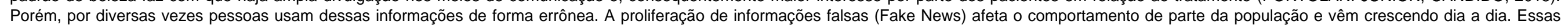

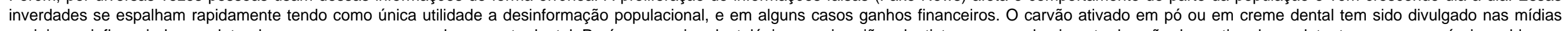

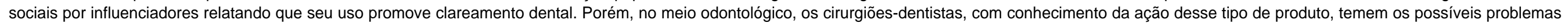

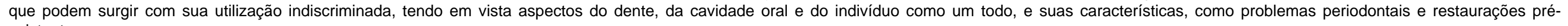
existentes.

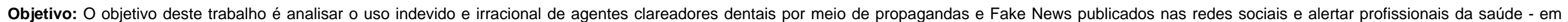

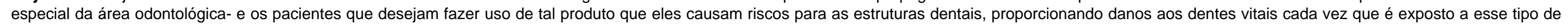
tratamento.

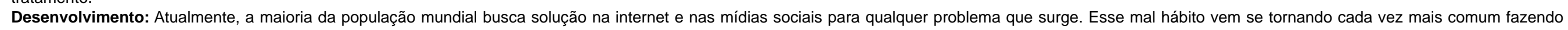

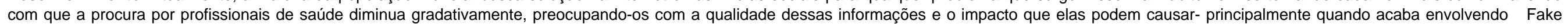

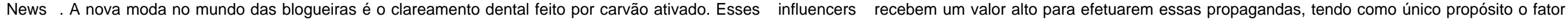

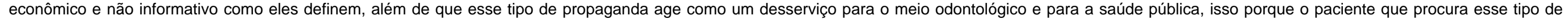

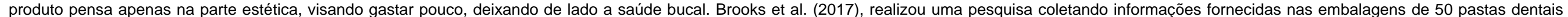

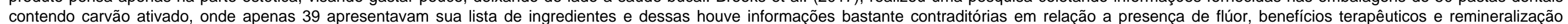

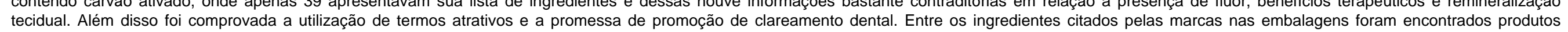

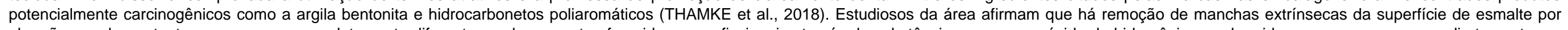

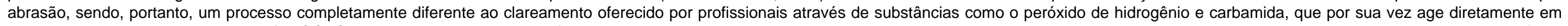

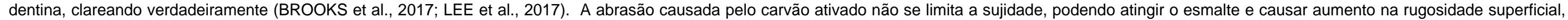

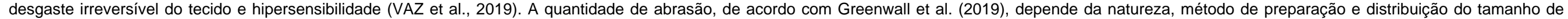

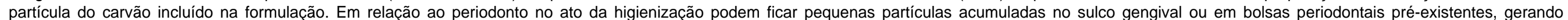

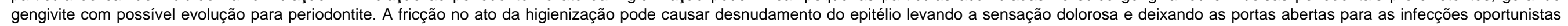
(BROOKS et al., 2017).

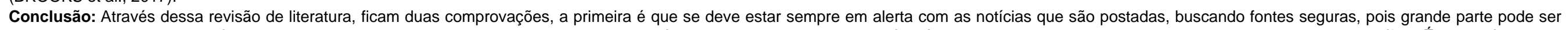

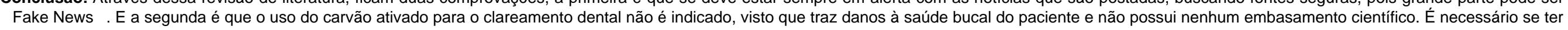
em mente que sempre que necessitar de qualquer tipo de tratamento, deve-se buscar profissionais que entendam de tal área, visando tratamento adequado e não soluções imediatas.

\section{Referências}

PORTOLANI JUNIOR, MV; CANDIDO, MSM. Efeito dos agentes clareadores sobre as estruturas dentais. Revista de Odontologia da UNESP, 2015.

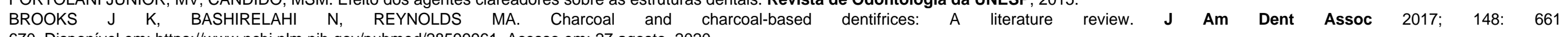
670. Disponível em: https://www.ncbi.nlm.nih.gov/pubmed/28599961. Acesso em: 27 agosto. 2020.

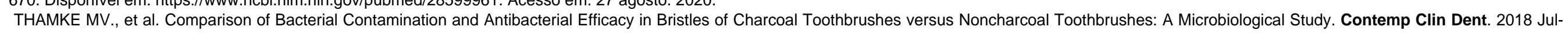
Sep;9(3):463-467. Disponível em: http://www.contempclindent.org/article. asp?issn=0976-237X;year=2018;volume=9;issue=3;spage=463;epage=4 67;aulast=Thamke. Acesso em: 27 agosto. 2020.

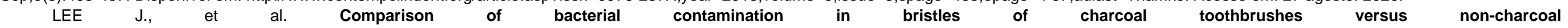

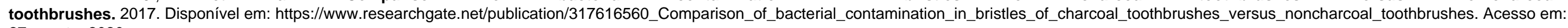
27 agosto, 2020.

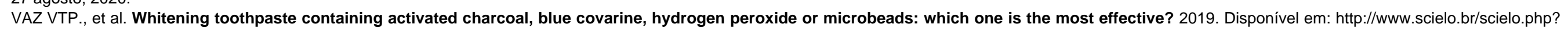


script=sci_arttext\&pid=S1678-77572019000100429. Acesso em: 27 agosto, 2020.

GREENWALL LH, GREENWALL-COHEN J, WILSON NHF. Charcoal-containing Dentifrices. 2019; 226 (9): 697 27 agosto, 2020.

Coordenadoria de Pesquisa e Extensão - COPEX

Departamento de Editoraçāo e Divulgaçāo Científica - DEDIC 


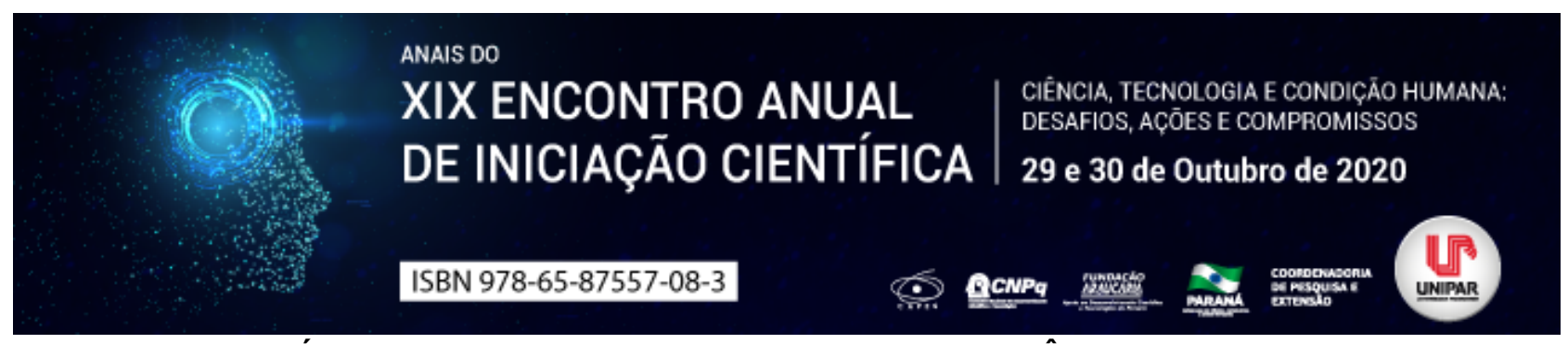

O PAPEL DA BACTÉRIA PORPHYROMONAS GINGIVALIS NA PATOGÊNESE DA ARTRITE REUMATOIDE

\begin{abstract}
${ }^{1}$ Caroline Rodrigues Thomes, ${ }^{2}$ ROBERTA DEL PIERO TEIXEIRA, ${ }^{3}$ CÁTIA SUFIA ALVES FREIRE DE ANDRADE, ${ }^{4}$ TAINÃ SANTOS FIGUEIREDO, ${ }^{5}$ ALFREDO CARLOS RODRIGUES FEITOSA
\end{abstract}

\footnotetext{
${ }^{1}$ Acadêmica da Universidade Federal do Espírito Santo

${ }^{1}$ Acadêmica da Universidade Federal do Espírito Santo

${ }^{2}$ Acadêmica da Universidade Federal do Espírito Santo

${ }^{3}$ Acadêmica da Universidade Federal do Espírito Santo

${ }^{4}$ Docente da Universidade Federal do Espírito Santo
}

Introdução: A artrite reumatoide (AR) é uma doença autoimune de etiologia ampla e não totalmente esclarecida que se baseia principalmente em fatores relacionados à genética, obesidade, hormônios, poluentes ambientais, hábitos nocivos, além da existência de inter-relações com outras doenças como, por exemplo, a doença periodontal (DP) (KRIAUCIUNAS et al., 2019). Ela é caracterizada por danos imunomediados nas articulações sinoviais e por anticorpos para antígenos citrulinados (BAÑUELOS et al., 2019). Embora os eventos estocásticos possam explicar a discordância que existe no desenvolvimento da doença entre indivíduos em risco, o modelo atual de AR depende da contribuição de um fator ambiental, muito provavelmente um agente microbiano, que pode ser responsável pelo desencadeamento da doença em indivíduos suscetíveis (BAÑUELOS et al., 2019). A gengivite caracteriza-se pela vermelhidão da margem gengival, edema, sangramento mediado após estimulação mecânica, sendo um quadro clínico completamente reversível, se tratada adequadamente. A periodontite é um grupo de patologias que têm em comum a perda de inserção e osso, formação de bolsa e recessão gengival. São sempre precedidas de gengivite e, portanto, se esta for evitada, é possível prevenir uma periodontite bem mais grave. O sinal característico da periodontite é a formação da bolsa periodontal associada à mobilidade dentária (FIORILLO, 2019). Estudos relataram a existência de um risco aumentado de periodontite crônica em indivíduos portadores de artrite reumatoide em comparação com indivíduos sem a doença (BAÑUELOS et al., 2019; ERIKSSON et al., 2019; KRIAUCIUNAS et al., 2019). As principais bactérias presentes na progressão da periodontite crônica são: Porphyromonas gingivalis, Prevotela intermedia, Tannerella forsythia e Aggregatibacter actinomycetemcomitans. Estas bactérias também podem ser encontradas no plasma e no líquido sinovial das articulações de pacientes que sofrem de AR (KRIAUCIUNAS et al., 2019).

Objetivo: Analisar o papel da bactéria Porphyromonas gingivalis na patogênese da artrite reumatoide por meio de revisão de literatura narrativa.

Desenvolvimento: A identificação dos estudos foi realizada por meio de uma busca bibliográfica no portal eletrônico PubMed utilizando os MeSH terms Porphyromonas gingivalis e Rheumatoid Arthritis. Após a aplicação dos critérios de elegibilidade, de um total inicial de 148 estudos, foram selecionados 13, publicados no período de 2015 a 2020 . Os critérios de inclusão foram revisões sistemáticas e não sistemáticas e estudos clínicos randomizados e não randomizados. Os critérios de exclusão foram relatos de casos, estudos in vitro, estudos com animais, capítulos de livro, editoriais e àqueles fora do período e da temática investigada. As evidências científicas analisadas demonstraram que Porphyromonas gingivalis indiretamente causa reações inflamatórias exacerbadas no corpo em indivíduos com AR (BAÑUELOS et al., 2019; FIORILLO et al., 2019; KRIAUCIUNAS et al., 2019). Este patógeno persistente produz uma enzima chamada peptidilarginina-deiminase (PAD) que transforma o aminoácido L-arginina em citrulina. A transformação ocorre quando a enzima destrói o grupo amino em L-arginina e ocorre a citrulinação do autoantígeno RA (por exemplo, fibrinogênio), provocando uma resposta imunológica e a partir disso, são produzidos anticorpos que atuam contra os antígenos da proteína citrulinada. Esses anticorpos são chamados de anticorpos antiproteína citrulinada (ACPA). Estes reagem com antígenos contendo citrulina (que é um aminoácido não padrão produzido após a modificação pós-tradução da arginina) (KRIAUCIUNAS et al., 2019). A inflamação crônica associada tanto à AR quanto à DP é semelhante ao fenótipo imunológico adaptativo predominante, ao desequilíbrio entre as citocinas pró e anti-inflamatórias e ao papel do tabagismo e da base genética como fatores de risco. O dano estrutural que ocorre em consequência da inflamação crônica é a causa final da perda de função e incapacidade observada com a progressão da AR e DP (DE MOLON et al., 2019). Portanto, não é conclusivo ainda a relação entre AR e $P$. gingivalis. Um fator complicador é que cada ensaio tem implicações diferentes no que diz respeito ao estado de P.gingivalis no paciente (por exemplo, portador, infecção ativa ou exposição passada e presente), e sua importância é provavelmente influenciada pela fonte do antígeno (no caso de anticorpos), coleta de amostra periodontal e grupo controle usado para comparação (por exemplo, OA, não AR, controles saudáveis com ou sem DP) (BAÑUELOS et al., 2019).

Conclusão: A persistência da bactéria Porphyromonas gingivalis na cavidade oral pode afetar de forma negativa a etiologia da 
artrite reumatoide, de modo que os indivíduos portadores de AR tiveram melhoras quando os focos patogênicos disbióticos presentes na DP foram tratados.

\section{Referências}

BAÑUELOS, Eduardo Gómez et al. Rheumatoid Arthritis-Associated Mechanisms of Porphyromonas gingivalis and Aggregatibacter actinomycetemcomitans. Journal of Clinical Medicine, Baltimore, v. 8, n. 9, 2019. Disponível em: https://www.ncbi.nlm.nih.gov/pmc/articles/PMC6780899/pdf/jcm-08-01309.pdf Acesso em: 14 ago.2020.

DE MOLON, Rafael Scaf et al. Linkage of Periodontitis and Rheumatoid Arthritis: Current Evidence and Potential Biological Interactions. International Journal of Molecular Sciences, Araraquara, v. 20, n. 18, 2019. Disponível em: https://www.ncbi.nlm.nih.gov/pmc/articles/PMC6769683/. Acesso em: 10 ago. 2020.

ERIKSSON, Kaja et al. Periodontal Health and Oral Microbiota in Patients with Rheumatoid Arthritis. Journal of Clinical Medicine, Sweden, v. 8, n. 5, 2019. Disponível em: https://www.ncbi.nlm.nih.gov/pmc/articles/PMC6572048/pdf/jcm-0800630.pdf. Acesso em: 25 ago. 2020.

FIORILLO, Luca et al. Porphyromonas gingivalis, Periodontal and Systemic Implications: A Systematic Review. Dentistry Journal, , v. 7, n. 4, 2019. Disponível em: https://www.ncbi.nlm.nih.gov/pmc/articles/PMC6960968/pdf/dentistry-07-00114.pdf. Acesso em: 12 ago. 2020.

KRIAUCIUNAS, Albertas et al. The Influence of Porphyromonas Gingivalis Bacterium Causing Periodontal Disease on the Pathogenesis of Rheumatoid Arthritis: Systematic Review of Literature. Cureus, Kaunas, v. 11, n. 5, 2019. Disponível em: https://pubmed.ncbi.nlm.nih.gov/31363455/. Acesso em: 14 ago.2020. 


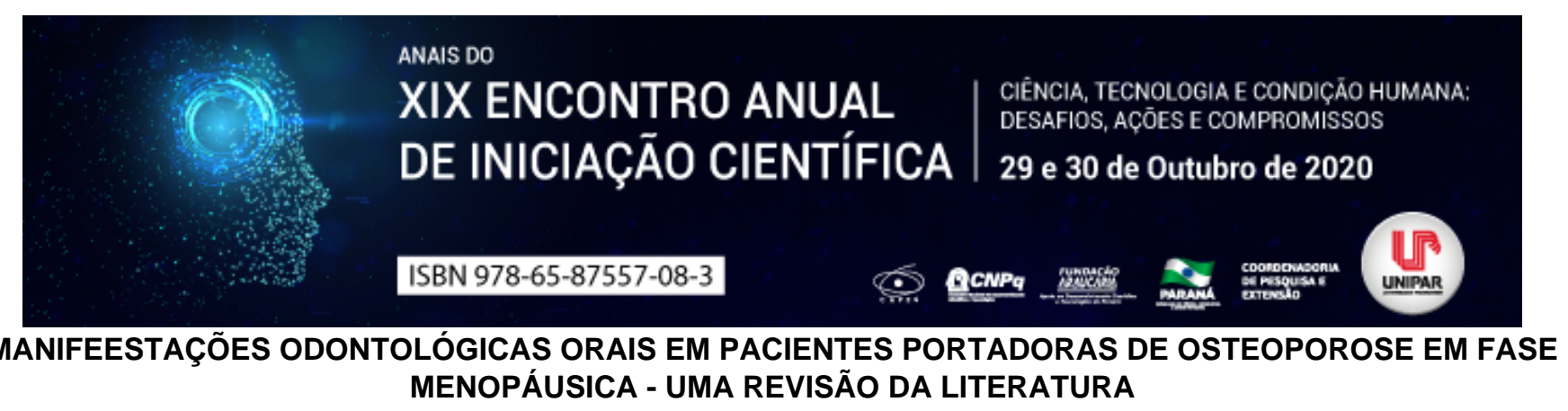

\title{
${ }^{1}$ AMANDA CHIULO GIROTTO, ${ }^{2}$ GABRIEL MACIEL DA SILVA, ${ }^{3}$ ANA CAROLINE DOS SANTOS GRUNOW, ${ }^{4}$ CAROLINE DOMINGUES, ${ }^{5}$ GUSTAVO BARBOSA CORREA DE MORAIS, ${ }^{6}$ DANIELA DE CASSIA FAGLIONI B CERANTO
}

\author{
${ }^{1}$ Acadêmico do PIC/Unipar. \\ ${ }^{1}$ Acadêmico do Curso de Cirurgia Periodontal e Introducao A Implantodontia - Turma Viii da UNIPAR \\ ${ }^{2}$ Acadêmica do Curso de Odontologia da UNIPAR \\ ${ }^{3}$ Acadêmica do Curso de Odontologia da UNIPAR \\ ${ }^{4}$ Acadêmico do Curso de Odontologia da UNIPAR \\ ${ }^{5}$ Docente da UNIPAR
}

Introdução: Definida pela Organização Mundial de Saúde a osteoporose é uma doença metabólica óssea sistêmica, que causa a deterioração da microarquitetura óssea diminuindo o volume de massa ósseae e leva a um a maior suscetibilidade à fraturas (SANTOS; SANTOS; F. NETO, 2015). A perda da densidade mineral óssea possui vários fatores que podem ter sua evolução para osteoporose, as mulheres na fase menopáusica podem ser um dos principais fatores, e em associação outros como ingestão de bebidas alcoólicas, tabagismo, sedentarismo, baixa ingestão de cálcio e vitamina D (PASSOS; COUTO; FREITAS, 2015). Com o avançar da idade, a densidade mineral óssea tende a diminuir, perdendo a qualidade, fazendo com que a arquitetura esquelética fique mais propensa a doenças como a Osteoporose (OP), um problema de saúde comum na população mais velha que, geralmente, resulta em uma série de adversidades (International Osteoporosis Foundation, 2017). Atualmente no Brasil existem cerca de 30 milhões de mulheres entre 45 a 65 anos, ou seja, 32\% da população feminina esta passando pelo período do climatério e a menopausa, com a expansão da expectativa de vida, acredita-se que estas passam um terço da vida na menopausa. Etapa compreendida como transição do período reprodutivo para não reprodutivo; onde a menopausa é dita como marco na vida da mulher, representando o último fluxo menstrual, através da ausência da menstruação por um período de 12 meses consecutivos (SANTOS, et al., 2016; REZENDE, et al., 2019).

Objetivo: Realizar um levantamento bibliográfico sobre as manifestações odontológicas orais em pacientes portadores de osteoporose em fase menopáusica.

Material e método: Foi realizada uma revisão da literatura com base nas seguintes plataformas: PubMed (PubMed® ), MedLine (Medical Literature Analysis and Retrieval System Online) e Lilacs entre os anos de 2015 a 2020.

Desenvolvimento: Várias doenças sistêmicas podem acometer o sistema estomatognático, acarretando o seu desequilíbrio ou mau funcionamento, dentre as quais, a osteoporose. Existe comprometimento da osteoporose a nível sistêmico e também em outras localidades, podendo a mesma afligir a região da face e suas adjacências. Nos ossos maxilares pode ocorrer também osteopenia e osteoporose (SPEZZIA, 2014; 2016; 2017). Nesse contexto, e inerente a possível presença da osteoporose no sistema estomatognático, sabe-se que no geral, têm-se envelhecimento com o passar dos anos em todas estruturas do organismo, incluindo as localizadas na cavidade bucal, onde ocorrem muitas alterações, que levam possivelmente a instalação de alterações funcionais e facilitam o acometimento por doenças. Cemento e osso alveolar com o avançar da idade, apresentam alterações, como: diminuição da capacidade metabólica de cicatrização; menor vascularização e possível presença de osteoporose (SPEZZIA, 2017).

A osteoporose está relacionada ao metabolismo ósseo, alterando a microarquitetura dos ossos, inclusive os da face. Várias áreas da medicina e da odontologia têm grande interesse no tecido ósseo e no seu conteúdo mineral, sob diferentes pontos de vista, levando ao estudo de medicamentos que possam auxiliar o processo de remodelação ereparação ósseas. As manifestações ósseas bucais da osteoporose envolvem possivelmente, acometimento por disfunção temporomandibular; redução do rebordo alveolar; redução da massa e densidade óssea maxilar; edentulismo; diminuição da espessura óssea cortical e o acometimento por problemas periodontais, entre outras ocorrências (SPEZZIA, 2017).

Conclusão: Portanto, visto que os mecanismos fisiopatológicos citados e a patogênese ainda não estão completamente estabelecidos, bem como o fato de o complexo maxilo-mandibular ser direta e indiretamente afetado pela osteoporose, novas pesquisas relacionadas ao entendimento destas alterações ainda são necessárias.

\section{Referências}

SANTOS, Eleni Conceição dos; SANTOS, Elizângela Valverde dos; F. NETO, Joel de Souza. Osteoporose e os riscos de fraturas. Anais do Simpósio ICESP Promove, Brasília-DF, p. 1706-1713, jun. 2015. 
PASSOS, Anderson Gonçalves; COUTO, Débora Fernandes; FREITAS, Gisele de Aguiar. O uso da densitometria óssea em mulheres pós menopausa e homens acima de 60 anos para o auxílio no diagnóstico da osteoporose. Anais do Simpósio ICESP Promove, Brasília-DF, p. 1810-1817, dez. 2015.

AVEIRO, Mariana Chaves, et al. Water-versus land-based treatment for postural control in postmenopausal osteoporotic women: a randomized, controlled trial. Climacteric, v. 20, n. 5, p. 427-435, 2017.

COSMAN, Felicia, et al. Clinician's guide to prevention and treatment of osteoporosis. Osteoporosis international, v. 25, n. 10, p. 2359-2381, 2015

SPEZZIA, Sérgio. Inter-relação entre osteoporose e doenças periodontais. Revista Implant News Perio. v. 1, n.6, p.1207-13, 2016.

SPEZZIA, Sérgio. Manifestações ósseas bucais da osteoporose. , Revista de Ciências Médicas. v. 26, n. 2, p. 67-76, 2017.

SPEZZIA, Sérgio. O papel da osteoporose na odontologia. Revista da Associação Paulista de Cirurgiões Dentistas. v. $68, n$. 4, p.366-7, 2017.

Coordenadoria de Pesquisa e Extensão - COPEX

Departamento de Editoraçāo e Divulgaçāo Científica - DEDIC 


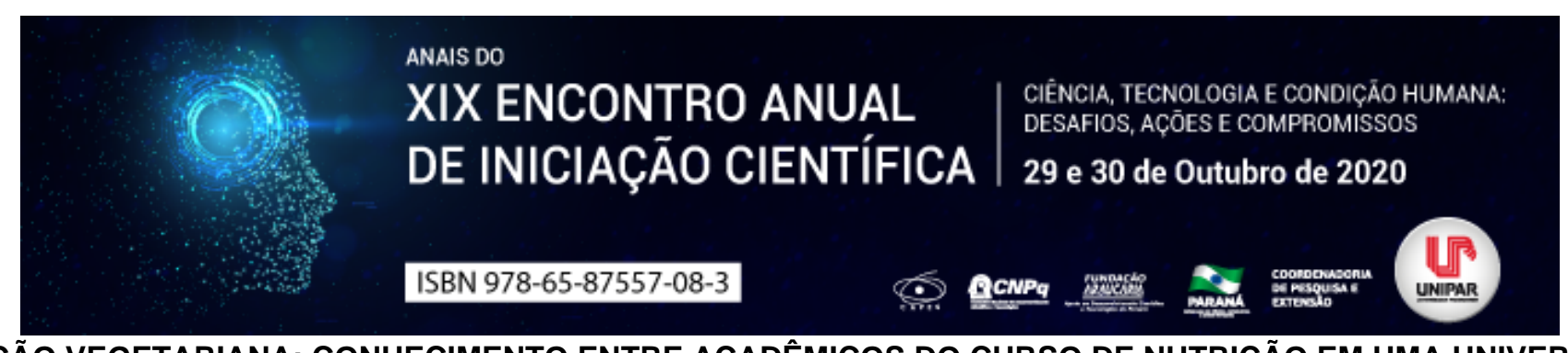

\title{
NUTRIÇÃO VEGETARIANA: CONHECIMENTO ENTRE ACADÊMICOS DO CURSO DE NUTRIÇÃO EM UMA UNIVERSIDADE PRIVADA NO INTERIOR DO PARANÁ
}

\author{
${ }^{1}$ ALLANA GABRIELY LUZA MONTEIRO, ${ }^{2}$ INDIOMARA BARATTO
}

\author{
${ }^{1}$ Discente do curso de nutrição/UNIPAR \\ ${ }^{1}$ Docente da UNIPAR
}

Introdução: O vegetarianismo possui padrões que o diferenciam, principalmente quando são incluídos ou excluídos produtos de origem animal da alimentação (CONCEIÇÃO, 2016, Forestell, 2012). Pode ser classificado de acordo com o grau de restrição de alimentos advindos de animais, como, vegetarianismo estrito, ovolactovegetarianismo, vegetarianismo semiestrito (lactovegetariano/ovovegetariano) e veganismo (LIMA, 2017, SILVA, 2014). Uma das preocupações das pessoas ao se tornarem vegetarianas é sobre a obtenção de micronutrientes essenciais e como irão atingir os níveis de recomendações de proteínas sem exacerbar o consumo de carboidratos. Nos últimos anos houve crescimento de $75 \%$ da aderência ao estilo de vida vegetariano nas regiões metropolitanas e quase $55 \%$ dos brasileiros optam por alimentos vegetarianos se estiverem descritos nas embalagens. Esses dados mostram como as pessoas estão preocupadas em mudar seus hábitos de vida para um estilo saudável e sustentável levando em consideração o ativismo vegetariano e quebrando o dilema do especismo que é imposto pela indústria alimentar (VALLE, 2018).

Objetivos: Análise de dados obtidos sobre o conhecimento a respeito de dietas vegetarianas entre os acadêmicos do curso de nutrição em uma universidade privada no interior do Paraná.

Métodos: Esse estudo está sendo realizado em uma universidade privada no interior do Paraná, onde o público alvo são acadêmicos que estão regularmente matriculados no curso de graduação em nutrição. Será aplicado um questionário sociodemográfico e um específico sobre vegetarianismo para medir o conhecimento dos acadêmicos de nutrição em relação ao tema. Esse estudo foi aprovado pelo comitê de ética sob o parecer 4.110.773/2020.

Resultados: Os resultados ainda não foram concluídos. Até o momento percebeu-se que $89,5 \%$ dos acadêmicos sabem o que é vegetarianismo, enquanto apenas 10,5\% não conseguem identificar esse tipo de alimentação. Já 31,6\% não sabem o que é o vegetarianismo estrito e ovolactovegetarianismo. Ao contrário de quando perguntados sobre o estilo ovovegetariano e lactovegetariano, onde, respectivamente, $49,1 \%$ e 50,9\% conseguem discernir sobre essa alimentação. Ao serem questionados sobre veganismo, cerca de $87 \%$ compreendem a diferença dessa alimentação perante as outras já mencionadas. Para manter uma dieta saudável, é importante que todos os nutrientes estejam balanceados. Em torno de $26,3 \%$ dos acadêmicos não tem certeza de que nutrientes priorizar na hora de prescrever uma dieta de padrão vegetariano. $66,7 \%$ acredita que uma alimentação nesse padrão não consegue garantir o aporte proteico necessário e que os adeptos a essa dieta exageram na quantidade de lipídeos e carboidratos ingeridos. Devido a isso, 35,1\% acham que não estão preparados para atender pacientes vegetarianos, $43,9 \%$ não tem certeza, e apenas $21 \%$ se sentem capacitados para atendimento.

Discussão: Dados levantados pelo IBOPE em 2018 mostram que a taxa de pessoas adeptas ao vegetarianismo aumentou 6\% comparando com os dados de 2012 , sendo que $14 \%$ da população brasileira se declarou vegetariana, representando quase 30 milhões de adeptos a esse estilo de vida. Esses dados mostram como as pessoas estão preocupadas em mudar seus hábitos de vida para um estilo saudável e sustentável levando em consideração o ativismo vegetariano e quebrando o dilema do especismo que é imposto pela indústria alimentar (VALLE, 2018). ). A alimentação baseada em vegetais promove mais qualidade de vida e longevidade ao corpo, esses alimentos fornecem carboidratos, proteínas, gorduras, vitaminas e minerais em quantidade suficiente para suprir as necessidades básicas do corpo humano (SLIWICHI, 2019). Segundo Sliwichi (2019), as recomendações de proteína nas dietas vegetarianas são um pouco a baixo das recomendações para onívoros, atingindo cerca de $12 \%$ a $13,8 \%$ do VCT, apesar dessa ingesta ser menor, os vegetarianos costumam consumir níveis acima do necessário sem correr o risco de desnutrição proteica. Seguindo nessa linha, é de suma importância que o profissional nutricionista siga as recomendações nutricionais descritas pela OMS ao prescrever uma dieta vegetariana. Nesse ponto, com o primeiro levantamento de dados do questionário especifico para os acadêmicos de nutrição, observou-se que os mesmos não estão se sentindo preparados para atender pacientes vegetarianos e também não tem certeza da quantidade de micro e macronutrientes recomendar para 0 paciente.

Conclusão: A tabulação de dados ainda não foi finalizada, porem os dados levantados até agora mostram que os acadêmicos entrevistados sabem o que é vegetarianismo, em contraponto, boa parte não consegue identificar esse tipo de alimentação. A preparação do profissional nutricionista começa durante a graduação. Os acadêmicos não têm certeza de quais nutrientes priorizar ao prescrever uma dieta vegetariana, ao mesmo tempo, ainda não se sentem preparados para atender esse público. Tendo isso exposto, se faz necessário o aprofundamento sobre a adequação da dieta vegetariana para os 


\section{Referências}

BAENA, Renato Corrêa. Dieta vegetariana: Riscos e Benefícios. Diagnóstico e tratamento, v. 20, n. 2, p-56-64, 2015.

IBOPE, Inteligência, Pesquisa de opnião publica sobre vegetarianismo, Brasil, 12 a 16 de abril, 2018. Disponível em: https://www.svb.org.br/images/Documentos/JOB_VEGETARIANISMO.pdf. Acesso em: 08 maio. 2020.

SLYWITCH, Eric, Sociedade Vegetariana Brasileira. Guia Alimentar de Dietas Vegetarianas para Adultos, v. 2, p. 7-56, 2012. SLYWITCH, Eric, Sociedade Vegetariana Brasileria. Tudo o o que você precisa saber sobre nutrição vegetariana. v. 2, p. 337, 2019.

VALLE, Christian. Sociedade Vegetariana Brasileira. Pesquisa IBOPE aponta crescimento histórico ao número de vegetarianos no Brasil. São Paulo, Maio, 2018. Disponível em: https://www.svb.org/2469-pesquisa-do-ibope-apontacrescimento-historico-ao-numero-de-vegetarianos-no-brasil. Acesso em: 08 maio, 2020.

Sociedade Vegetariana Brasileira, vegetarianismo, São Paulo, 2017. Disponivel em: https://www.svb.org.br/vegetarianismo1/oque-e. Acesso em: 07 abril, 2020. 


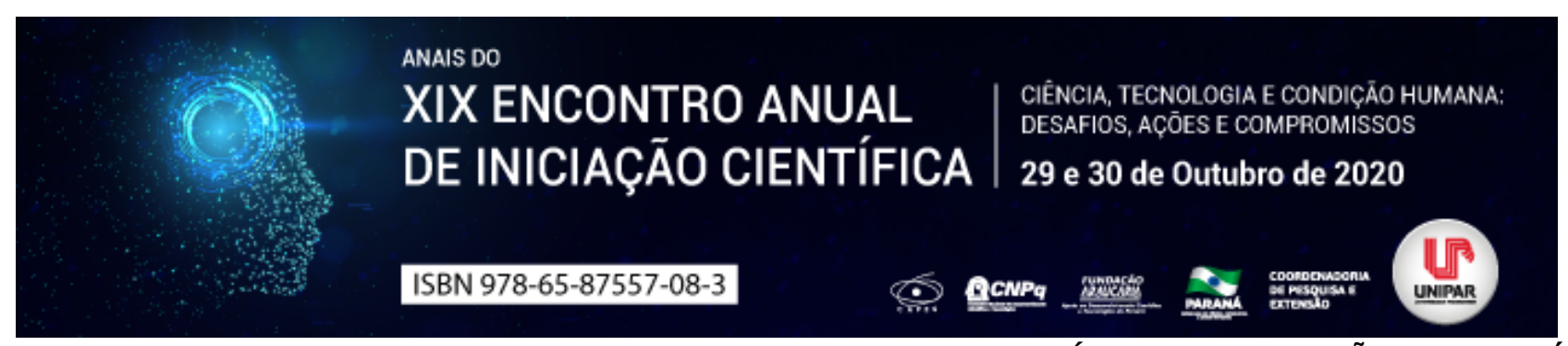

FISIOPATOLOGIA DA COVID-19 SOBRE A HIPERCOAGULABILIDADE SANGUÍNEA E A EVOLUÇÃO CARDIOLÓGICA: UMA REVISÃO DE LITERATURA

\author{
${ }^{1}$ MARIO MARQUES PEREIRA FILHO, ${ }^{2}$ VANESSA MARCONDES BRASILEIRO FREDERICO, ${ }^{3}$ FABIANE ANGELICA DE PAIVA \\ PAULA, ${ }^{4}$ JESSICA ZANQUIS FERREIRA, ${ }^{5}$ SUELEN STEFANONI BRANDAO, ${ }^{6}$ RICARDO MARCELO ABRAO
}

\author{
${ }^{1}$ Acadêmico do PIBIC do curso de Medicina da UNIPAR \\ ${ }^{1}$ Acadêmica do Curso de Medicina da UNIPAR \\ ${ }^{2}$ Acadêmica do Curso de Medicina da UNIPAR \\ ${ }^{3}$ Acadêmica do Curso de Medicina da UNIPAR \\ ${ }^{4}$ Acadêmica do Curso de Medicina da UNIPAR \\ ${ }^{5}$ Professor Titular do curso de Medicina da UNIPAR
}

Introdução: A Síndrome Respiratória Aguda Grave (SARS-CoV-2) pode ser caracterizada e conceituada pela pneumonia viral primariamente encontrada na cidade de Wuhan, China, no final de 2019, e posteriormente espalhada para 184 países, dando origem na história humana de um período único relacionado à situação de pandemia. Nesse sentido, é inegável que essa doença apresenta graus variados de manifestações clínicas distintas e respectiva severidade, entre as quais podem ocorrer infecções assintomáticas de indivíduos e, eventualmente, levar à disfunção de múltiplos órgãos e à morte. Ressalta-se que, em termos de terminologia, que a Organização Mundial da Saúde (OMS) a classifica como uma doença causada pelo Coronavírus 2019 (COVID-19). A expressiva notificação de casos e a correlação da COVID-19 com a piora do quadro de pacientes cardíacos eleva a necessidade de entendimento deste imbróglio (PRADO et al., 2020).

Objetivo: Analisar a relação estabelecida entre acometimento por COVID-19 com o tromboembolismo e evolução cardiológica.

Desenvolvimento: É inegável que o vírus causador da COVID-19 pode afetar o sistema cardiovascular em múltiplas manifestações, como dano miocárdico, insuficiência cardíaca, síndrome de Takotsubo (ST), arritmia, miocardite e choque. O dano ao sistema cardiovascular pode ser multifatorial. Pode ser causado pelo desequilíbrio entre a alta demanda metabólica e a baixa reserva cardíaca, ou inflamação sistêmica e trombose. Também pode ser devido aos efeitos diretos do vírus no coração. O mecanismo fisiopatológico que atrela o COVID-19 ao sistema cardiovascular ocorre principalmente em pacientes com fatores de risco cardiovascular (idade avançada, hipertensão e diabetes) ou que já sofreram de doenças cardiovasculares (DCV) (COSTA et al., 2020). É importante notar que os pacientes com COVID-19 podem estar em um estado hipercoagulável, o que indica que os níveis séricos de fator VIII, fator de von Willebrand e fibrinogênio estão elevados. Acredita-se que a origem da hipercoagulabilidade se deva ao aumento dos fatores pró-coagulantes e à diminuição dos fatores anticoagulantes presentes no plasma de pacientes infectados (ROBERTO et al., 2020). Dessa maneira, a resposta inflamatória produzida pela infecção viral pode causar danos ao sistema cardiovascular, juntamente com aumento de dímero D, procalcitonina, proteína C reativa, ferritina, troponina e NT-proBNP, o que acaba levando a complicações cardiovasculares ou culminando na morte do indivíduo. Pacientes que morreram também apresentavam níveis mais elevados de dímero $\mathrm{D}$, IL-6, ferritina e DHL, ou seja, tais marcadores inflamatórios podem interferir diretamente no prognóstico. Outro ponto a ser considerado é que pode ocorrer dano ao sistema cardiovascular secundário ao vírus, relacionado à enzima conversora de angiotensina 2 (ECA2). Isso ocorre porque ECA2 está relacionado ao sistema imunológico e existe em altas concentrações nos pulmões e no coração. A ECA 2 regula negativamente 0 sistema renina-angiotensina ao inativar a Angiotensina II (RODRIGUES et al., 2020). A fisiopatologia do acometimento cardíaco em função da infecção viral ocorre porque o SARS-CoV-2 contém quatro proteínas estruturais principais: proteína spike (S), proteína do nucleocapsídeo $(\mathrm{N})$, proteína da membrana $(\mathrm{M})$ e envelope proteico $(\mathrm{E})$. Assim sendo, por meio da proteína spike, o vírus se liga ao receptor ECA2 e entra na célula hospedeira por meio deste link, onde ocorre a inativação de ECA2. Devido à alta concentração de ECA2 no coração, podem ser originadas graves lesões ao sistema cardiovascular. Ademais, indivíduos com hipertensão terão maior expressão de ACE2 após o uso de inibidor da enzima de conversão da angiotensina (IECA) ou bloqueador do receptor da angiotensina II (BRA), o que pode aumentar o risco de SARS-CoV-2 e a sensibilidade à infecção. Apesar disso, é indicado que tais pacientes sejam constantemente avaliados, preferencialmente mantendo-se a medicação e conseguinte controle dos seus níveis pressóricos (DE SOUZA et al., 2020).

Conclusão: Pacientes com comorbidades cardíacas têm maior probabilidade de ser gravemente afetados pela infecção por SARS-Cov-2, têm pior prognóstico e maior índice de mortalidade. Portanto, além da manutenção da medicação para o controle adequado dos níveis pressóricos dos pacientes acometidos pela COVID-19, faz-se imprescindível uma maior assistência a esse segmento. 


\section{Referências}

COSTA, Isabela Bispo Santos da Silva et al. O Coração e a COVID-19: O que o Cardiologista Precisa Saber. Arquivos Brasileiros de Cardiologia, v. 114, n. 5, p. 805-816, 2020.

RODRIGUES, Carolina Magalhães Britto et al. COVID-19: sistema renal e cardíaco. Revista Ulakes, v. 1, 2020.

DE SOUZA, Suzana Bastos Jácome et al. Compreensão das características clínicas do COVID-19: uma revisão narrativa. Revista Eletrônica Acervo Saúde, n. 46, p. e3762-e3762, 2020.

ROBERTO, Gabriel Antônio et al. COVID-19 e eventos tromboembólicos. Revista Ulakes, v. 1, 2020.

PRADO, Marcelo Freitas do et al. Análise da subnotificação de COVID-19 no Brasil. Revista Brasileira de Terapia Intensiva, $n$. ahead, 2020.

Coordenadoria de Pesquisa e Extensão - COPEX

Departamento de Editoraçāo e Divulgaçāo Científica - DEDIC 


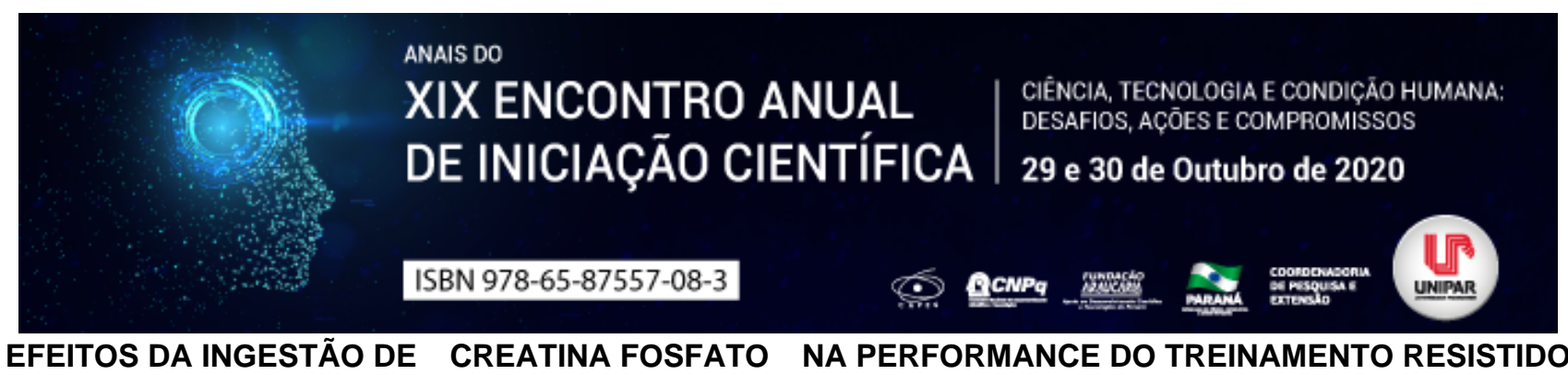

\title{
${ }^{1}$ VITOR HUGO BRITO, ${ }^{2}$ OTAVIO DUTRA CALDERON, ${ }^{3}$ VITOR HUGO RAMOS MACHADO
}

\author{
${ }^{1}$ Acadêmico do Curso de Educação Física da UNIPAR \\ ${ }^{1}$ Acadêmico do Curso de Educação Física da UNIPAR \\ ${ }^{2}$ Docente da UNIPAR
}

Introdução: Você já ouviu falar, ou fez o uso de Creatina? Se não fez o uso, provavelmente já ouviu falar a respeito. Está é uma substância que tem ocorrência natural no corpo humano sendo a principal fonte de energia do músculo (BOTTURA 2018). A Creatina é produzida nos rins, fígado e pâncreas, e secretada na corrente sanguínea até o tecido muscular. Essa substância é formada a partir de uma cadeia de aminoácidos, sendo eles a Arginina, Glicina e Metionina, sendo uma molécula produzida pelo corpo que é encontrada em boa quantidade em comidas como carnes, ovos e peixes (GUIMARÃES, 2019). A creatina fosforilada é uma reserva de energia nas células musculares. Durante um exercício intenso, a sua quebra libera energia é usada para regenerar o trifosfato de adenosina aproximadamente $95 \%$ do pool de creatina encontra-se na musculatura esquelética e sua regeneração após o exercício é um processo dependente de oxigênio (GUIMARÃES, 2019). Na célula muscular, a creatina em sua forma fosforilada, creatina-fosfato (CP), constitui uma reserva de energia para a rápida regeneração do trifosfato de adenosina (ATP), em exercícios de alta intensidade e curta duração, como por exemplo, durante um sprint de 100m rasos ou em uma sequência de levantamento de peso em um treino de halterofilismo como mostra as novas pesquisas atuais de 2020 (BOTTURA, 2018).

Objetivo: Analisar e ilustrar o potencial que a creatina no organismo humano, mostrando as características fisiológicas que o corpo produz para que ocorra potenciais de energia e faça com que os seres vivos geram movimentos.

Desenvolvimento: A creatina é considerada o suplemento com maior potencial ergogênico e vem sendo estudada intensamente desde os anos 90, quando se tornou popular depois que alguns atletas relataram seu uso nas olimpíadas em 1992. (HALUCH, 2019). Diferente da maioria dos suplementos, a creatina é um suplemento para aumentar a performance que tem suporte de um bom conjunto de evidências científicas. A creatina é uma substância produzida pelo organismo sintetizada principalmente no fígado e nos rins a partir dos aminoácidos arginina, glicina e metionina. A síntese endógena da creatina é de aproximadamente $1 \mathrm{~g}$ e por estar presente nas carnes, uma dieta mista pode oferecer cerca de $1 \mathrm{~g}$ de creatina do nosso corpo é armazenada no músculo esquelético (95\%) na forma de creatina livre e fosfocreatina. (HALUCH , 2019). No treinamento resistido (musculação) a creatina mostra grande potencial para aumento da força e da massa magra. Esse ganho de massa magra é atribuído a capacidade osmótica da creatina, que promove aumento da retenção hídrica intracelular. No entanto, existem evidências que esse ganho de massa magra, que varia de 1 a $2 \mathrm{~kg}$ em média, não é apenas retenção de água intramuscular, mas também ocorre por aumento das proteínas musculares. Mesmo não mostrando aumento na síntese e degradação proteica, a suplementação de creatina parece aumentar níveis de IGF-1 no músculo e reduz as concentrações de miostatina (proteína que inibe a síntese proteica e o crescimento muscular), o treinamento de força por si só já aumenta as concentrações de IGF-1 e reduz a miostatina (HALUCH, 2019). Os estudos mostram que a suplementação de creatina é segura, sem prejuízos as funções renal e hepática. Os protocolos de uso geralmente recomendam uma fase de saturação que pode durar de 4 a 7 dias, usando dosagens de aproximadamente $20 \mathrm{~g} / \mathrm{dia}$ (ou $0,3 \mathrm{~g} / \mathrm{kg} / \mathrm{dia}$ ), seguida da dose de manutenção, onde se usa 3 a $5 \mathrm{~g}$ por dia. A creatina não causa aumento de gordura corporal ou de retenção subcutânea como relatados por muitos, o que ocorre na verdade é um aumento de água dentro do músculo, que é algo totalmente positivo. Apesar de existirem várias formas de creatina no mercado, sem dúvida alguma, a creatina monohidratada ainda é considerada a melhor de todas, os outros tipos de creatina existentes só terão efeito no seu bolso, fazendo você gastar dinheiro á toa. (GUIMARÃES, 2019)

Conclusão: Os estudos aqui apresentados citaram os benefícios envolvendo a creatina como suplemento e recurso complementar na recuperação da musculatura esquelética em inatividade ou em atividade, associada a um treinamento de reabilitação encontrado na literatura, onde sugerem que o suplemento oral de creatina pode ser uma estratégia terapêutica e eficaz para incrementar a reabilitação do músculo esquelético, nas diversas situações de atrofia por desuso, objetivando dessa forma de impedir, entreter ou minimizar as adaptações que ocorrem na região envolvida. E além de realçar a capacidade funcional do músculo nos pacientes portadores de doenças neuro muscular, a creatina aumenta a aptidão para atividade, promovendo um notável aumento da capacidade de regeneração muscular.

\section{Referências}

BOTTURA, Caio. Dieta Flexível e nutrição alimentar e suplementação. São Paulo, SP. Schoba, 2018.

GUALANO E COLABORADORES. Livro creatina e testes relacionado a processo recuperativo, 2010. 
GUIMARÃES NETO, Waldemar Marques. Anabolismo total: Treinamento de força levado a sério. 9a ed. São Paulo, Phorte, 2019.

HALUCH, Treinamento associado a suplementação, 2019.

PERALTA, Jose. AMANCIO, Olga Maria Silverio. A creatina como suplemento ergogênico para atletas. Rev. Nutr., Campinas, 15(1):83-93, jan./abr., 2002.

Coordenadoria de Pesquisa e Extensão - COPEX

Departamento de Editoraçāo e Divulgaçāo Científica - DEDIC 


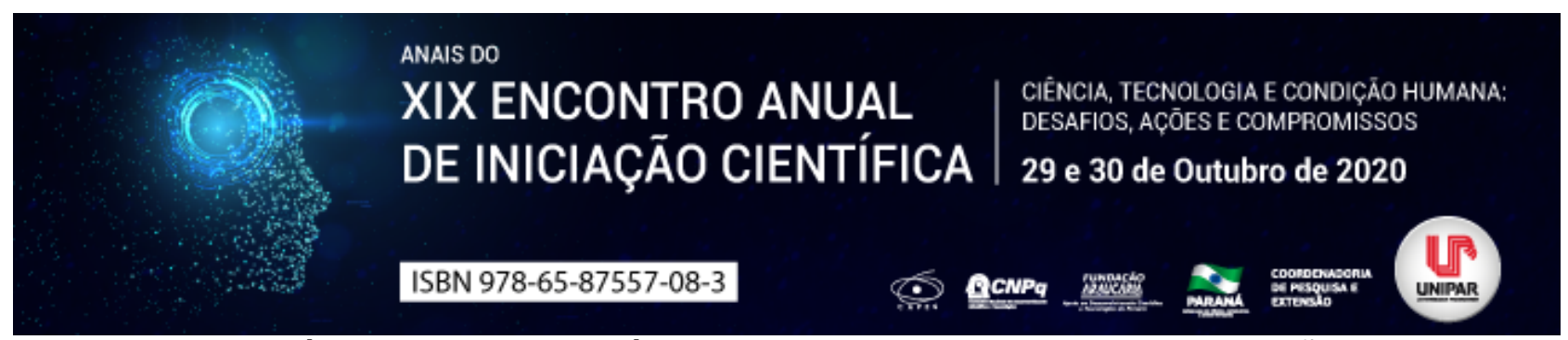

DIAGNÓSTICO TARDIO DA SÍFILIS EM GESTANTES E SUAS COMPLICAÇÕES

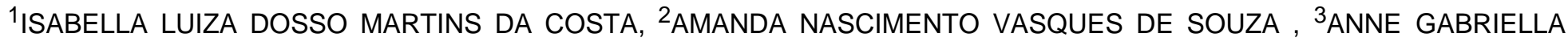 PACITO MONTEIRO, ${ }^{4}$ ADALBERTO RAMON V. GERBASI, ${ }^{5}$ NANCI VERGINIA KUSTER DE PAULA
}

\author{
${ }^{1}$ Acadêmica do Curso de Enfermagem PIC/UNIPAR \\ ${ }^{1}$ Mestranda no Programa em Plantas Medicinais e Fitoterápicas na Atenção Básica, PIC/UNIPAR \\ ${ }^{2}$ Acadêmica do Curso de Enfermagem PIC/UNIPAR \\ ${ }^{3}$ Docente da UNIPAR \\ ${ }^{4}$ Docente da UNIPAR
}

Introdução: A sífilis é uma infecção causada pelo Treponema pallidum, classificada em sífilis recente e tardia, transmitida por via sexual, vertical ou sanguínea. Apesar da via sexual ser prevalente, a vertical pode ocorrer em toda a gestação, por via transplacentária ou pelo contato com as lesões sifilíticas no momento do parto (AVELLEIRA; BOTTINO G,2006). Rocha (2019) destaca que em 2018 a taxa de sífilis adquirida aumentos 44.1 por 100 mil habitantes e os grupos mais afetados são jovens, mulheres, que somam $14,1 \%$ dos casos da sífilis adquirida e em gestantes, ressaltando ainda que as mulheres em maior número, sendo 10 mulheres para cada sete casos em homens. Toldo, Menagozzo, Solto (2018), acrescentam que segundo boletim epidemiológico a taxa de sífilis na região Sul dobrou, sugerindo que possa estar ocorrendo subnotificação de Sífilis Congênita (2018).

Objetivo: O objetivo do presente estudo é destacar as complicações do diagnóstico tardio da sífilis pela gestante.

Desenvolvimento: Quando a gestante não recebeu tratamento ou foi incompleto durante o pré-natal ocorre a sífilis congênita, a qual recebe essa classificação independente dos resultados clínicos e laboratoriais, sendo que nesse caso o Treponema pallidum passa diretamente para corrente sanguínea fetal (BRASIL, 2019 a). A doença pode ser adquirida em qualquer período da gestação ou estágio da doença na mãe e as complicações resultantes do diagnóstico tardio da doença estão relacionadas a aborto, prejuízos causados ao recém-nascido, bebê natimorto, parto pré-termo (BRASIL,2019b). Rafalle et al (2016), também destacaram que vários estudos abordam que a sífilis congênita ocasiona complicações tanto na forma precoce quanto na tardia quando não tratada adequadamente como morte intraútero, aborto, natimorto e óbito neonatal. Nos recém-natos a infecção pode ser assintomática ou sintomática, destacando como sintomas precoces sintomas hematológicos; neurológicos; musculoesqueléticas, mucocutânea e sistêmicas. Quanto as manifestações clínicas congênitas tardias destacam-se, nariz em sela, hipodesenvolvimento maxilar, glaucoma secundário, cicatriz córnea,perda aditiva sensorial, dentes de Hutchinson, , comprometimento intelectual, hidrocefalia, crises convulsivas, atrofia do nervo óptico, paresia juvenil, tíbia em sabre, entre outros (BRASIL, 2019 a).

Conclusão: É de grande importância que a sífilis seja investigada na gestação, pois as complicações acarretam inúmeras consequências para o desenvolvimento de uma gestação saudável e para o desenvolvimento do recém nato.

\section{Referências}

AVELLEIRA, João Carlos Regazzi; BOTTINO, Giuliana. Sífilis: diagnóstico, tratamento e controle. An. Bras. Dermatol., Rio de Janeiro , v. 81, n. 2, p. 111-126, Mar. 2006 . Disponível em: . Acesso em 01/09/2020.

BRASIL. Ministério da Saúde. Secretaria de Vigilância em Saúde. Departamento de Doenças de Condições Crônicas e Infecções Sexualmente Transmissíveis Protocolo Clínico e Diretrizes Terapêuticas para Prevenção da Transmissão Vertical do HIV, Sífilis e Hepatites Virais / Ministério da Saúde, Secretaria de Vigilância em Saúde, Departamento de Doenças de Condições Crônicas e Infecções Sexualmente Transmissíveis. Brasília : Ministério da Saúde, 2019 a.

BRASIL. Ministério da Saúde, Boletim Epidemiológico. Secretaria de Vigilância em Saúde. Outubro, 2019 b.

RAFFALE , Amanda Medeiros ; SILVA, Celso Guilherme; SILVA ,Dáfine Kelly Maria Lopes; DORNELA, Dayanna Ribeiro Gaia ; SILVA, Ellyda Layanny Aguiar ; SILVA, Geovany Antônio Alves. As principais complicações da sífilis congênita: revisão integrativa da literatura. Ver Saúde. v10. N1. 2016. Disponível em: http://revistas.ung.br/index.php/saude/article/view/2618/1986 Acesso em: 01/08/2020.

ROCHA, Julia. Epidemia de Sífilis. Revista Radis. 2019. Disponível em: https://portal.fiocruz.br/noticia/revista-radis-abordaepidemia-de-sifilis Acesso em 01/08/2020.

TOLDO, Mariane Kloppel Silva ; MENEGAZZO, Luiza Silva ; SOUTO Anaelise Steglich. A recrudescência da sífilis congênita. $\begin{array}{llll}\text { Arq. } & \text { Catarin } & \text { 47(1):02-10. } & 2018 .\end{array}$ em: http://www.acm.org.br/acm/seer/index.php/arquivos/article/view/165 Acesso em: 25/08/2020. 
Coordenadoria de Pesquisa e Extensão - COPEX

Departamento de Editoraçāo e Divulgaçāo Científica - DEDIC 


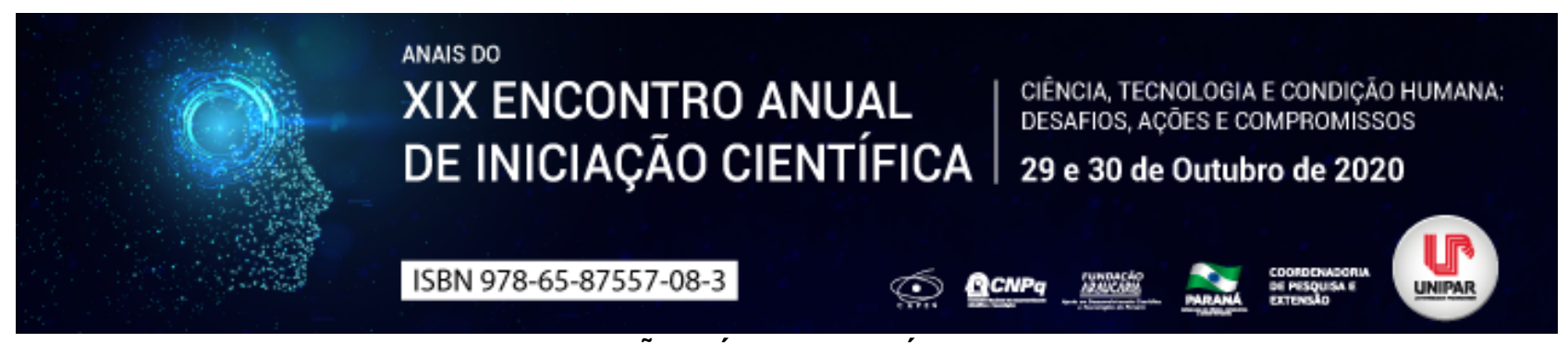

TREINAMENTO FUNCIONAL NA RECUPERAÇÃO PÓS-OPERATÓRIA DO LIGAMENTO CRUZADO ANTERIOR EM ATLETAS DE FUTEBOL

\author{
${ }^{1}$ VITOR AUGUSTO GUIZZO FERRAZ, ${ }^{2}$ JEAN CARLOS CANDIDO DE OLIVEIRA, ${ }^{3}$ JESSICA FERNANDA SILVA TORRES, \\ ${ }^{4}$ DORA DE CASTRO AGULHON SEGURA
}

\author{
${ }^{1}$ Acadêmico do Curso de Educação Física da UNIPAR \\ ${ }^{1}$ Acadêmico do Curso de Educação Física da UNIPAR \\ ${ }^{2}$ Acadêmica do Curso de Educação Física da UNIPAR \\ ${ }^{3}$ Docente da UNIPAR
}

Introdução: Segundo Roi et al. (2004) e Hägglund et al. (2005), as lesões mais graves e comuns entre os futebolistas envolvem a articulação do joelho, sendo uma das estruturas mais afetadas o ligamento cruzado anterior, tornando a recuperação e o retorno para o desporto um desafio a ser cumprido de forma precoce. Para Almeida (2005), a reconstrução cirúrgica do ligamento cruzado anterior objetiva criar uma réplica do ligamento original e a recuperação no pós-operatório tem por finalidade restaurar as capacidades funcionais comparativamente ao membro não operado, ou seja, integrá-lo no mais curto espaço de tempo útil, não só nas suas atividades de vida diária, mas sobretudo, na vida desportiva. Para Sá (2013), o protocolo de reabilitação mais eficaz para o atleta designa-se protocolo de reabilitação acelerado, tendo duração aproximada de 6 meses, enquanto outros protocolos tradicionais podem durar até 12 meses, e é completamente focado no treinamento funcional.

Objetivo: Dissertar os efeitos do treinamento funcional no pós-operatório do ligamento cruzado anterior em atletas de futebol.

Desenvolvimento: As características anatômica do joelho tornam essa articulação predisposta à diversos tipos de lesões, tanto por mecanismos sem contato quanto por contato direto. A lesão por contato pode ocorrer quando o joelho está na posição de hiperextensão por uma força externa, podendo o ligamento cruzado anterior ser tracionado e tensionado, sofrendo um cisalhamento. A lesão sem contato é observada quando um corredor desacelera bruscamente, ou quando o fêmur roda lateralmente sobre a tíbia, enquanto o pé está fixo no chão, movimentos comuns no futebol. O entorse de joelho agredindo o ligamento cruzado anterior é a lesão mais comum referida entre os atletas (KONIN, 2006). Ekstrand, Hägglund, Waldén (2011) descrevem que a ruptura do ligamento cruzado anterior é a lesão recorrente e funcionalmente mais limitante entre os atletas de futebol. Acredita-se que em atletas de alto rendimento, a cada 2.000 horas de prática desportiva, 14\% das entorses de joelho promovem a ruptura parcial ou total do ligamento cruzado anterior, deixando o time desfalcado. Assim, existe a necessidade de técnicas que recuperem a articulação e a função o mais breve possível. Segundo Risberg, Lewek e SnyderMackler (2004), os principais objetivos da reabilitação funcional do joelho em um pós-operatório de ligamento cruzado anterior envolvem promover a normal funcionalidade da articulação, restaurar a amplitude de movimento, a força muscular e a coordenação neuromuscular, devolver o equilíbrio estático e dinâmico e a propriocepção. Colado, Chulvi e Heredia (2007) descrevem o exercício funcional como uma nova modalidade de treinamento baseada na funcionalidade, que, primordialmente, inclui a seleção de atividades, exercícios e movimentos considerados funcionais. Esta proposta deve ser compreendida sob a ótica do princípio da funcionalidade, o qual preconiza a realização de movimentos integrados e multiplanares. Esses movimentos implicam aceleração, estabilização (incrementando em alguns movimentos, elementos desestabilizadores) e desaceleração, com o objetivo de aprimorar a habilidade de movimento, força da região do tronco (CORE) e eficiência neuromuscular (FERNANDEZ; CORRALES, 2011).

Conclusão: Sendo assim, analisando a gravidade da lesão do ligamento cruzado anterior em atletas de futebol concluiu-se que após a reconstrução da estrutura as disfunções causadas podem ser sanadas pelo treinamento funcional devidamente orientado por um profissional, promovendo retorno precoce com todas as habilidades normais.

\title{
Referências
}

ALMEIDA, I. B. Protocolo de recuperação após ligamentoplastia do LCA. Fisio online, v.1, n.2, p. 26-39. 2005.

COLADO, J. C.; CHULVI, I.; HEREDIA, J. R. Criterios para el diseño de los programas de acondicionamiento muscular desde una perspectiva funcional. Editora Medica Panamericana, 2007.

EKSTRAND, J.; HÄGGLUND, M.; WALDÉN, M. Epidemiology of muscle injuries in professional football (soccer). Am J Sports Med, v. 39, n. 6, p. 1226-1232, 2011.

FERNANDEZ, J. G.; CORRALES, B.S. Nuevas orientaciones para una actividad física saludable en centros de fitness. Editorial Wanceulen, 2011.

HÄGGLUND, M.; WALDÉN, M.; BAHR, R.; EKSTRAND, J. Methods of epdemiological study of injuries to professional football 
players, developing the UEFA model. British Jornal of Sports Medicine, n. 39, p. 340-346, 2005.

KONIN, J. G. Cinesiologia prática para fisioterapeutas. Rio de Janeiro: Editora Guanabara Koogan. 2006.

RISBERG, M. A.; LEWEK, M.; SNYDER-MACKLER, L. A. systematic review of evidence for anterior cruciate ligament rehabilitation: How much and what type? Physical Therapy in Sport, n. 5, p. 125-145, 2004.

ROI, G. S.; NANNI, G.; TAVANA, R.; TENCONE, F. Epidemiologia of anterior cruciate ligament ruptures in first league soccer players. Jornal of Sports Sciences, v. 6, n. 22, p.591-595, 2004.

SÁ, N. M. Comparação de dois protocolos de reabilitação pós reconstrução cirúrgica do ligamento cruzado anterior. Dissertação (Mestrado em Fisioterapia), Escola Superior de Tecnologiada e Saúde de Lisboa, Lisboa, 2013.

Coordenadoria de Pesquisa e Extensão - COPEX

Departamento de Editoraçāo e Divulgaçāo Científica - DEDIC 


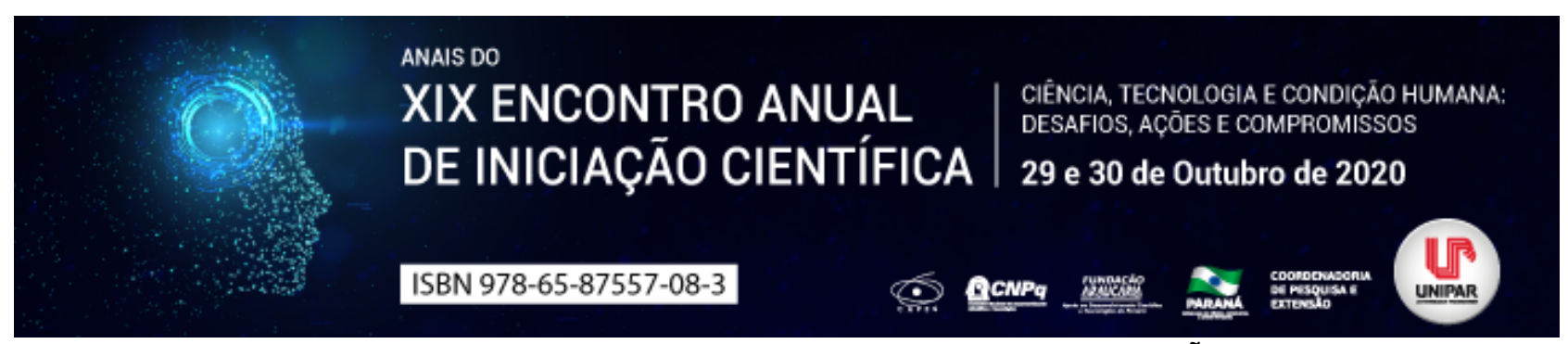

ESPONDILITE ANQUILOSANTE - UM ESTUDO DE REVISÃO

\author{
${ }^{1}$ LUCAS REZENDE, ${ }^{2}$ HIGOR DIAS DO PRADO, ${ }^{3}$ ISABELA FARIAS MARQUES, ${ }^{4}$ LUDMILA SIMONETTO DA SILVA ALVES, \\ ${ }^{5}$ ELENIZA DE VICTOR ADAMOWSKI CHIQUETTI
}

\author{
${ }^{1}$ Acadêmica do Curso de Medicina da UNIPAR \\ ${ }^{1}$ Acadêmico do Curso de Medicina da UNIPAR \\ ${ }^{2}$ Acadêmica do Curso de Medicina da UNIPAR \\ ${ }^{3}$ Acadêmica do Curso de Medicina da UNIPAR \\ ${ }^{4}$ Docente da UNIPAR
}

Introdução: A espondilite anquilosante (EA) é caracterizada como uma espondiloartropatia que acomete, geralmente, adultos jovens entre 20 a 40 anos de cor branca e do sexo masculino. Cerca de $80 \%$ dos portadores apresentam os antígenos HLA-B27 positivos, os quais são raros nas populações negras africanas, sendo pouco frequente nessa etnia (SAMPAIO - BARROS, et al; 2007). No entanto, como o Brasil é um país de intensa miscigenação étnica, a espondilite anquilosante, bem como outras espondiloartropatias, costuma ser encontrada em mulatos devido à influência da ascendência genética europeia. Todavia, tratase de uma condição bastante rara em negros não miscigenados (SAMPAIO - BARROS, et al; 2007).

Objetivo: $O$ presente trabalho visa realizar uma revisão geral sobre espondilite anquilosante, uma espondiloartropatia, frequentemente encontrada em indivíduos brancos do sexo masculino que possuem o antígeno chamado HLA b27.

Desenvolvimento: A espondiloartropatia conhecida como Espondilite anquilosante caracteriza-se por ser uma doença inflamatória crônica que acomete preferencialmente a coluna vertebral provocando, eventualmente, rigidez e limitações funcionais no esqueleto axial. Seus sintomas iniciais geralmente se manifestam depois dos 16 anos com a incidência de lombalgia de ritmo inflamatório, rigidez matinal prolongada e o predomínio dos sintomas axiais. Dentre esses sintomas também podem haver o acometimento articular periférico, o que pode ocasionar oligoartrite nas articulações dos membros inferiores (tornozelo, joelho e coxofemorais) e entesopatias que se tratam de inflamações nas inserções tendinosas ou ligamento dos ossos (SAMPAIO - BARROS, et al; 2007). Além disso, também pode provocar fadiga, perda de apetite e de peso, e anemia (DATASUS; 2012). Dessa maneira, a EA prejudica diretamente a qualidade de vida do portador afetando os seus aspectos sociais, econômicos e psicológicos. Sendo assim, pode-se dizer que a EA é uma doença extremamente difícil de ser quantificada e mensurada devido ao seu grande leque de manifestações; portanto, exames clínicos e laboratoriais aliados à parâmetros desenvolvidos a partir dos anos 90 são usados para avaliar a doença, o bem-estar dos paciente e sua capacidade funcional (SHINJO, et al; 2006). O seu diagnóstico pode ser feito através de ressonância magnética verificando componentes como edemas erosão, infiltração gordurosa e anquilose. Por outro lado, o tratamento para a condição consiste na reabilitação postural e da musculatura flexora e extensora, além do uso de medicamentos, podendo ser ministrados ao paciente corticoesteróides, AINH, drogas ANTI-TNF, entre outros (SAMPAIO-BARROS, et al; 2013). Estudos têm demonstrado que o uso contínuo de antiinflamatórios não hormonais pode reduzir a progressão radiológica da espondilite anquilosante, portanto, esses medicamentos também são considerados modificadores da doença. Após sua fase aguda,grande parte dos pacientes não necessita mais de remédios, desde que participem de um programa regular de exercícios (DATASUS; 2012).

Conclusão: A Espondilite anquilosante é uma doença inflamatória soronegativa crônica, que ataca as articulações do esqueleto axial, podendo levar a entesite e anquilose. Essa patologia acomete principalmente a população masculina de cor branca, na faixa etária dos 20 a 40 anos. E sua epidemiologia se baseia na presença do antígeno HLA - B27 na população.

\title{
Referências
}

COIT, Patrick et al. Genome-wide DNA methylation analysis in ankylosing spondylitis identifies HLA-B27 dependent and independent DNA methylation changes in whole blood. Journal of Autoimmunity, v.120, p. 126 - 132, 2019.

FRONTERA, Walter R. Essentials of Physical Medicine and Rehabilitation. 4.ed. Montreal: Elsevier, 2020.

Kuo, F.-C., Chiang, K.-L., \& Kao, Y.-S. (2019). Structural damage and motion rhythm of the spine and hip during trunk lateral bending in ankylosing spondylitis patients with mild to moderate radiographic signs. Clinical Biomechanics, v.63, p. 112 118, 2019.

SAMPAIO-BARROS, Percival Degrava et al. Recomendações sobre diagnóstico e tratamento da espondilite anquilosante. Revista Brasileira de Reumatologia, v. 53, n. 3, p. 242-257, 2013.

SAMPAIO-BARROS,Percival Degrava et al. Consenso Brasileiro de Espondiloartropatias: Espondilite Anquilosante e Artrite Psoriásica Diagnóstico e Tratamento

Primeira Revisão. Revista Brasileira de Reumatologia, v.47, n.4 , p.233 - 242, 
2007.

SHINJO, Samuel Katsuyuki; GONÇALVES, Roberta; GONÇALVES, Célio Roberto. Medidas de avaliação clínica em pacientes com espondilite anquilosante: revisão da literatura. Revista Brasileira de Reumatologia, v. 46, n. 5, p. 340-346, 2006.

SOCIEDADE BRASILEIRA DE REUMATOLOGIA. Espondilite anquilosante. Datasus, 2012. Disponível em: < http://formsus.datasus.gov.br/novoimgarq/46461/9617187_345331.pdf>. Acesso em: 2 de jun. 2020.

Coordenadoria de Pesquisa e Extensão - COPEX

Departamento de Editoraçāo e Divulgaçāo Científica - DEDIC 


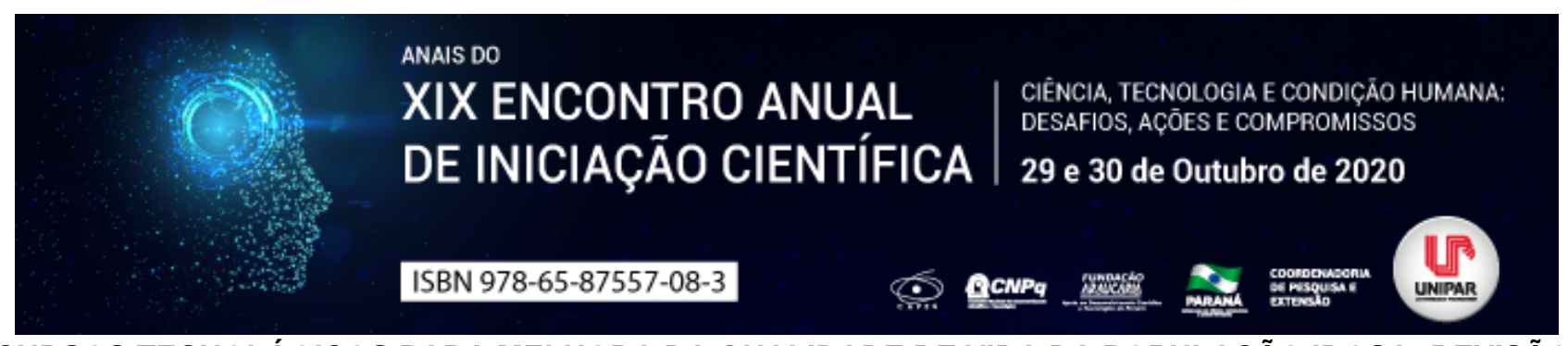

RECURSOS TECNOLÓGICOS PARA MELHORA DA QUALIDADE DE VIDA DA POPULAÇÃO IDOSA: REVISÃO DE LITERATURA

\section{${ }^{1}$ VANESSA ROSALINE COSTA OLIVEIRA}

\section{${ }^{1}$ DOCENTE DA UNIVERSIDADE PARANAENSE}

Introdução: Com um mundo mais virtual a população idosa esta cada vez mais conectados, aumentado pelo leque de oportunidades por meio do mundo das tecnologias (GOLDSTEIN, 2013).

A Qualidade de Vida (QV) esta relacionado com vários aspectos da vida sendo eles: aspectos físicos, psicológicos, sociais e ambientais do ser humano. Atualmente aumentou-se a expectativa de vida em todo o mundo, surgindo a necessidade de se desenvolver estratégias para manutenção da qualidade de vida durante o envelhecimento. Os exergames têm sido considerados a possibilidade de intervenção lúdica para manutenção e melhora da qualidade de vida em todas as idades (BRANDÃO et. al., 2017).

Objetivo: Com isto o objetivo desta pesquisa bibliográfica é conhecer alguns artigos que já utilizam recursos tecnológicos (exergames) que melhoram a qualidade de vida da população idosa.

Desenvolvimento: Em grande parte, o aumento atual do número de pessoas idosas em países menos desenvolvidos é decorrente do alto número de nascimentos durante as primeiras décadas deste século, associado a um progressivo decréscimo nas taxas de mortalidades. Da mesma forma, o envelhecimento da população de países europeus das últimas décadas se deve a taxas de natalidade relativamente altas no primeiro quarto do século associadas a taxas decrescentes de mortalidades em todos os grupos etários. Em seguida as taxas de natalidade decaíram, fazendo com que a proporção de adultos progressivamente aumentasse. O processo é portanto dinâmico; para que uma população envelheça é necessário que primeiro nasçam muitas crianças, segundo que as mesmas sobrevivam até idades avançadas e que, simultaneamente, o número de nascimentos diminua. Com isso a entrada de jovens na população decresce, e a proporção daqueles que sobreviveram até idades mais avançadas passa a crescer (KALACHE, 1987). Desde a década de 80 já são observados o aumento da população idosa, onde nos faz pensar que os estudos antigos estavam certos e que isto vem acontecendo atualmente. Com o aumento da população idosa o mesmo procura um desejo de realizar suas atividades, estilo de vida e necessidades básicas com mais liberdade e isto requer do mesmo a procura de automotivação para ser realizadas (GOLDSTEIN, 2013). Segundo Goldstein (2013), a população idosa utiliza a tecnologia para pertencer ao mundo cada vez mais digital, os mesmos faz o uso de sites de redes sociais para ter o contato mais próximo com seus familiares bem como o conhecimento sobre assuntos relativos ao seu grupo de convivência e com o mundo. A evolução tecnológica e seu impacto na área de reabilitação humana tem gerado um grande número de pesquisas multidisciplinares, resultando no desenvolvimento de vários mecanismos e técnicas para melhorar a qualidade de vida das pessoas, tornando-as menos dependentes e colaborando para a integração destes indivíduos de forma mais produtiva à sociedade (BORTOLE, 2011). Umas destas tecnologias são chamadas de exergames, são jogos eletrônicos capazes de captar e visualizar movimentos dos usuários que utilizam este tipo de tecnologia (BARRACHO, 2012). No Brasil estudos sobre os exergames são escassos com esta população necessitando um olhar multiprofissional e mais estudos sobre a técnica tecnológica (GOLDSTEIN, 2013). Segundo RIVERO (2012), As pesquisas avaliadas teve como resultado que o videogame exerce uma influência sobre os usuários que vai além dos aspectos comportamentais, atuando diretamente no desenvolvimento de diversas funções cognitivas. Mais especificamente, os dados sugerem possíveis relações causais no treino de habilidades cognitivas como a atenção seletiva visual, atenção visuoespacial, atenção auditiva, processamento perceptivo visual e espacial, rotação mental, sensibilidade ao contraste, flexibilidade cognitiva, memória operacional e diminuição do tempo de processamento de informações. Segundo Goldsteim (2013), literaturas atuais mostram resultados satisfatórios quanto ao uso do videogame para os exergames e o uso de jogos interativos, pois melhoram a atenção e cognição do idoso. É uma ferramenta acessível, adaptável ao usuário, mas como qualquer outra atividade deve ser acompanhada por profissional da área da saúde. Segundo Pelisser et. al. (2017), o exergame é uma boa ferramenta tecnológica que pode ser utilizado como avaliação do desenvolvimento motos nos idosos com relação a sua flexibilidade e força nos membros inferiores, pois os resultados correlacionaram-se significativamente em relação a testes tradicionais para mensuração destas variáveis. É possível observar o benefício que o videogame exerce nas pessoas, sendo uma proposta válida para a melhora na qualidade de vida.

Conclusão: Com isto podemos concluir que o vídeogame pode ser uma proposta válida para a melhoria da qualidade de vida na população idosa em relação a avaliação motora e também com relação a atenção e cognição, com a utilização do exergames que são jogos interativos com a realização de movimentos. Para a realização destas atividades é fundamental que um profissional da saúde faça esse acompanhamento, pois o mesmo poderá escolher o melhor programa para os objetivos particulares e individuais de um tratamento sejam alcançados. Como há uma escassez de literatura nessa área é necessário 


\section{Referências}

BRANDÃO, P. S., Ft., NETO, I. V. de S., RAUBER, S. B., PIMENTE, R. P. F. de A. P., ZUKOWSKI, M. S., FAGUNDES, F., CAMPBELL, C. S. G. Impacto de exergames na qualidade de vida de idosos. Fisioterapia Brasil. V. 18, n. 3, p. 320-328, 2017.

BARACHO, A. F. de O., GRIPP, F. J., LIMA, M. R. de. Os exergames e a educação física escolar na cultura digital. Revista. Brasileira. Ciência. Esporte, Florianópolis, v. 34, n. 1, p. 111-126, jan./mar. 2012

BORTOLE, MAGDO; BASTOS FILHO, TEODIANO FREIRE. Desenvolvimento de um sensor hibrido para aplicacoes em robotica e fisioterapia. In: X Simposio Brasileiro de Automacao Inteligente. 2011.

GODSTEIN, G. C. A. Exergames como recurso de promoção de saúde e envelhecimento ativo. Revista Portal. v. 37, p. 21-28, 2013.

KALACHE, Alexandre; VERAS, Renato P.; RAMOS, Luiz Roberto. O envelhecimento da população mundial: um desafio novo. Revista de saúde pública, v. 21, p. 200-210, 1987.

PELISSER, M. GARLIPP, D. C. SANT' ANNA, M. M. Correlação entre os resultados obtidos em testes motores e o desempenho em exergames em idosos. Revista do Deparatmento de Educação Física e Saúde e do Mestrado em Promoção da Saúde da Universidade de Santa Cruz do Sul / Unisc. v. 18, n. 3, p. 179-184, 2017

RIVERO, T. S. GUERINO, E. H. G. ALVES, I. S. Videogame: seu impacto na atenção, percepção e funções executivas. Revista Neuropsicologia Latinoamericana v. 4, p. 38-52, 2012.

Coordenadoria de Pesquisa e Extensão - COPEX

Departamento de Editoraçāo e Divulgaçāo Científica - DEDIC 


\section{GRUPO 3: HUMANAS E SOCIAIS APLICADAS}




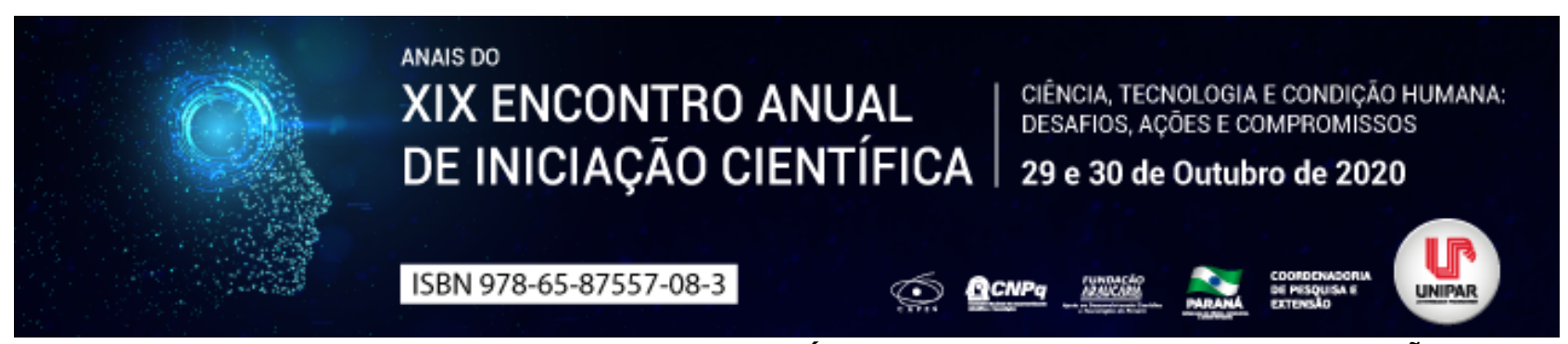

OS IMPACTOS DO SONO EM CRIANÇAS NO INÍCIO DO PROCESSO DE ESCOLARIZAÇÃO

${ }^{1}$ Gabriel Henrique da Silva Honorio, ${ }^{2}$ MARIA ADELAIDE PESSINI

${ }^{1}$ Bacharel de Psicologia da Universidade Paranaense Unipar

${ }^{1}$ Docente da UNIPAR

Introdução: O sono é um estado comportamental, reversível e cíclico e exerce diversas funções tanto fisiológicas, quanto psicológicas. É essencial às crianças em idade pré-escolar, para modular inúmeras funções cognitivas tais como: a memória e a aprendizagem. Valle, Valle \& Reimão (2009), realizaram pesquisas com 258 alunos escolares na faixa etária de 6 a 9 anos, de cinco escolas de ensino fundamental de Poços de Caldas, Minas Gerais. A pesquisa revelou que crianças necessitam de uma qualidade de vigília para ser um fator ao sucesso do aprender, e ainda, que apenas $5 \%$ dos pais admitiam a influência do sono na aprendizagem.

Objetivo: Revisar a literatura especializada da Neuroaprendizagem sobre as características do sono, em crianças no início do processo de escolarização, e suas implicações sobre o comportamento, a rotina diária e a qualidade de vida dessas crianças, direcionando pais e professores a intervenções mais assertivas.

Desenvolvimento: $O$ sono é considerado fundamental para os processos fisiológicos da vida, pois quando acontece com qualidade, permite a plasticidade neural, a consolidação da memória, a regulação hormonal, efeitos estes primordiais para o desempenho da saúde do sujeito (LENT, 2004). Nos períodos de início da vida, a vigília pode ser identificada em estágios como o sono calmo, sono agitado, estado de vigília calmo, estado de vigília agitado que podem vir com ou sem choros. Na criança, esta estrutura e duração tende a evoluir para tornar-se ao sono próximo do adulto no início da puberdade (MENDES, 2008, p. 10). Nos processos de aprendizagem escolar, principalmente em crianças, se torna como fator relevante para a qualidade da aquisição do aprender, pois quando não acontece de forma satisfatória, é comumente na escola a atenção e humor oscilante, tibieza física falta de impulsos e interesses, dentre outros, e que podem influenciar no rendimento escolar, repercutindo na aprendizagem. Assim, são necessários aos agentes educacionais investigar junto a família, se é existente alguma desordem na vigília e no sono e que podem dificultar o processo do aprender, como a insônia, pesadelos, sonambulismo, ronco, bruxismo, enurese, etc. Além disso, hábitos do sono nos sistemas sociais devem promover medidas educativas as condutas do dormir, como o estabelecimento dos horários, evitar estimulações sejam físicas ou mentais e alimentação próximo ao horário de sono, e ainda, diminuir a fonte luminosa (VALLE, VALLE \& REIMÃO, 2009).

Conclusão: É grande a importância do sono na vida diária, especialmente pensando no desenvolvimento físico e psicológico da criança, e suas influências sobre o comportamento infantil e o aprendizado. Ao se referir ao sono, é preciso levar em conta questões endógenas, sociais e ambientais das crianças em idade pré-escolar, para que ocorra a consolidação da aprendizagem. Embora escassos de diálogos que abordam sono e aprendizagem em crianças, agentes educacionais devem orientar pais e professores, que a rotina de sono possibilita condutas satisfatórias em crianças no início do processo de escolarização, repercutindo significativamente na aprendizagem, seja no ambiente intra ou extraescolar, possibilitando maior reconhecimento da relação entre problemas no sono e os transtornos de aprendizagem.

\section{Referências}

LENT, Roberto. Cem bilhões de neurônios: conceitos fundamentais de neurociência. São Paulo: Editora Atheneu, 2004.

MENDES, Rosa Maria das Neves. A criança, o sono e a Escola. In: Referência Revista de Enfermagem. Vol II, N. 7, p. 07-19, 2008. Disponível em http://www.index-f.com/referencia/2008pdf/7-0719.pdf. Acesso em 18 de jun. 2020.

VALLE, Luiza Elena Leite Ribeiro do.; VALLE, Eduardo Leite Ribeiro do.; REIMÃO, Rubens. Sono e aprendizagem. In: Revista Psicopedagogia. Vol. 26, N. 80, p. 286-90, 2009. Disponível em http://pepsic.bvsalud.org/scielo.php?script=sci_arttext\&pid=S0103-84862009000200013\&lng=pt\&tlng=pt. Acesso em: 09 de jun. 2020. 


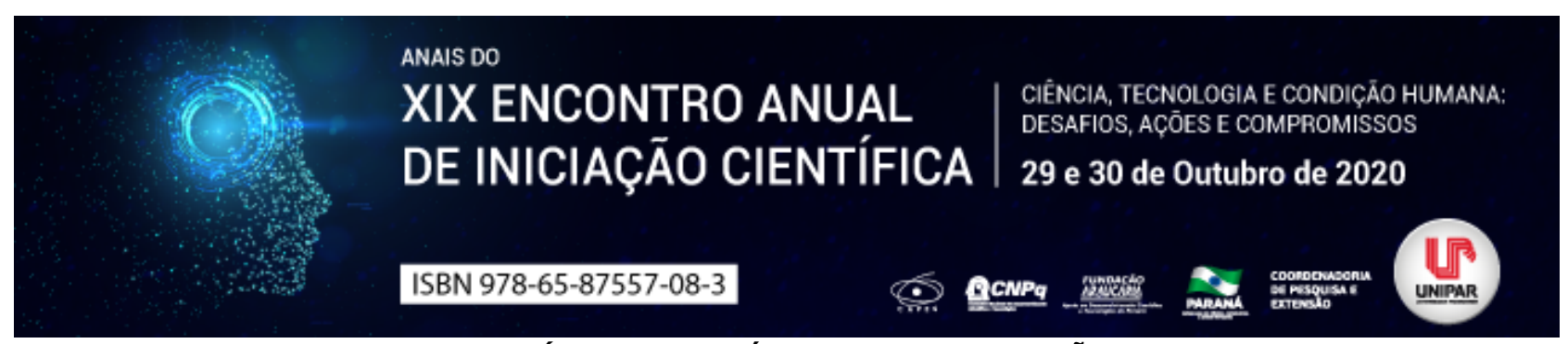

NARCISO COMO CARACTERÍSTICA SAUDÁVEL NA CONSTRUÇÃO DA PERSONALIDADE

\begin{abstract}
${ }^{1}$ Gabriel Henrique da Silva Honorio, ${ }^{2}$ MAURO SERGIO DA ROCHA
\end{abstract}
${ }^{1}$ Bacharel de Psicologia da Universidade Paranaense Unipar.

${ }^{1}$ Docente da UNIPAR

Introdução: Quando abordamos o desenvolvimento da personalidade do sujeito a partir dos estudos psicanalíticos, voltamos aos processos de satisfação de si mesmo precursores às relações objetais o outro , denominada de processos narcísicos. Porém, quando referenciada através da palavra narcisista logo constrói-se imagens com aspectos repugnantes ou perversos, como em ditos na mitologia. Contudo, é importante desconstruir este referencial de egoísmo e desprezo, considerando pontos em que esta característica se torna algo positivo para o desenvolvimento do sujeito. Assim, faz-se necessário compreender de modo a considerar tais características narcísicas necessárias a psique durante a infância e em períodos posteriores do desenvolvimento.

Objetivo: Explanar a característica narcísica, percebendo sua importância para o desenvolvimento saudável do sujeito.

Desenvolvimento: O mito de Narciso, segundo Brandão (2000), nasce na Grécia e conta a história de um jovem que viveria como o mais belo mortal. Conta ainda que, na fala do adivinho Tirésias, o mesmo desfrutaria sua vida desde que não visse a própria imagem. Porém no verão, Narciso aproxima-se do rio e ao ver seu reflexo na água, não consegue sair, pois se apaixona pela imagem refletida no lago, permanecendo naquele local até sua morte. Segundo Holmes (2005) um dos primeiros a correlacionar os estudos psicanalíticos ao mito grego foi Heverlock, abordando-o como inclinações sexuais e aspectos da visão patologizante da homessexualidade. Com Freud (2006), diz-se que a atitude narcisista é uma resistência a transferência intensa, ou seja, o indivíduo possui um objeto que projeta energia libidinal, porém, é retirado dele e resistindo a outro, auto-erotiza-se. Com ditos de Lacan a partir de Greco (2011), apresenta-se o aspecto narcisista como sendo um processo de identificação, é fundamental a presença de outro a quem recorrer para formulação de seu eu que funcionaria como escudo narcísico para separar o sujeito ser de imagens e símbolos do real. Com o enfoque psicanalítico escrito por Kohut (1988), apresenta-se o aspecto narcísico como um conteúdo que cabe ao indivíduo para aceitar-se de forma que internalize valores, garantindo autoconfiança. Segundo Freud (2006), o desenvolvimento saudável nas relações de pais e filhos, não se vê mais do que o narciso dos pais renascido nos filhos que projetam o objeto. Nestes aspectos, entende-se que por meio da presença do outro, a pessoa pode conhecer-se e aceitar-se. Uma criança desperta em seus pais o desejo de proteção e amor, importante para a mesma, pois é a partir desta relação paterna e materna que se tem o cuidado e a ponte para relações individuais e introjeção de objetos externos, para construção do seu mundo. Com isso, a característica narcísica colabora para o desenvolvimento do sujeito através do investimento libidinal em si mesmo. Assim, é fundamental proporcionar aos filhos ambientes que favorecem o narciso saudável de forma a colaborar em seu processo de desenvolvimento, possibilitando ao sujeito a relação com seus conteúdos positivos e negativos, pois estará com investimento libidinal suficiente para elaborar as situações e conteúdos do dia a dia. À medida que a criança vai amadurecendo, projeta apego a objetos externos, processo que depende em parte dos responsáveis pelo início de seu desenvolvimento e, em sua estruturação narcísica saudável, encontrará meios e condições para realizar as transformações em seu processo de crescimento.

Conclusão: A partir dos referenciais psicanalíticos, conclui-se a necessidade de ampliar a perspectiva ao se pensar as características da personalidade. Entende-se a importância de abordar o desenvolvimento de narciso quanto a segurança e às escolhas no decorrer do processo de desenvolvimento do sujeito. Em seu desenvolvimento, aspectos saudáveis narcísicos se vincularão com a autoconfiança e autoestima, assim como na elaboração de conteúdos projetados sobre os objetos. Estas relações fornecerão a base para a construção do seu mundo. Abordar esta temática possibilita ir além da unilateralidade, abrangendo a pluridimensionalidade que problematiza conceitos e estigmas ainda presentes.

\title{
Referências
}

BRANDÃO, Junito de Souza. Mitologia grega. Rio de Janeiro: Vozes, 2000.

FREUD, Sigmund. A história do movimento psicanalítico artigos sobre metapsicologia e outros trabalhos. Trad. Themira de Oliveira Brito. Rio de Janeiro: Imago, 2006.

GRECO, Lacan Musso. Os espelhos de Lacan. Opção Lacaniana. São Paulo, vol. 2, n.6, nov. 2011. Disponível em: http://www.opcaolacaniana.com.br/pdf/numero_6/Os_espelhos_de_Lacan.pdf. Acesso em 08 de jul. 2020.

HOLMES, Jeremy. Narcisismo. Trad Carlos Mendes Rosa. São Paulo: Duetto, 2005.

KOHUT, Heinz. Análise do Self. Trad. Maria T. B. Marcondes. Rio de Janeiro: Imago, 1988. 
Coordenadoria de Pesquisa e Extensão - COPEX

Departamento de Editoraçāo e Divulgaçāo Científica - DEDIC 


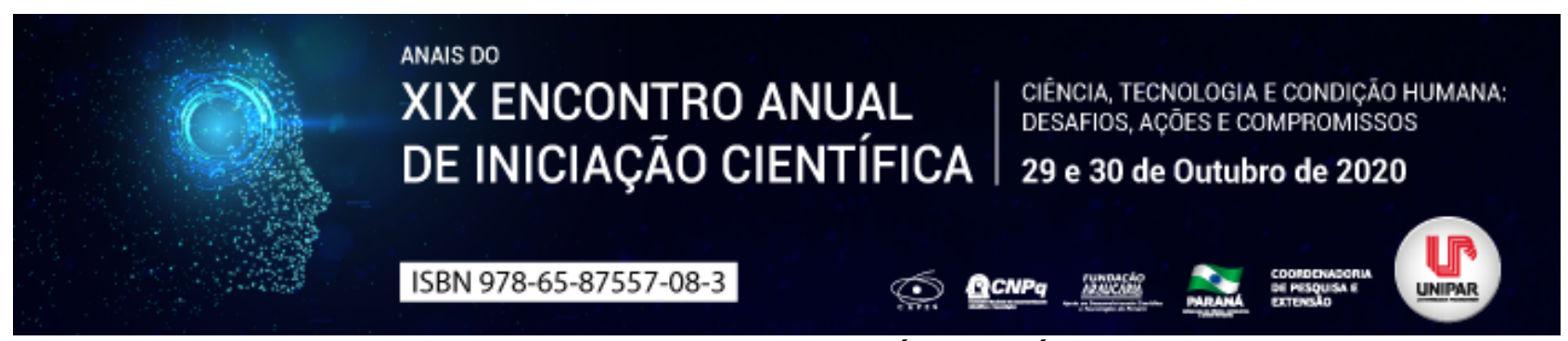

O ATIVISMO JUDICIAL E AS POLÍTICAS PÚBLICAS

\author{
${ }^{1}$ JIHAD MAHMOUD RAMOS NAGE, ${ }^{2}$ JONATAS LUIZ MOREIRA DE PAULA, ${ }^{3}$ ALEXANDRE MAGNO AUGUSTO MOREIRA
}

${ }^{1}$ Acadêmico bolsista do PIBIC/UNIPAR

${ }^{1}$ Docente da UNIPAR

${ }^{2}$ Docente da UNIPAR

Introdução: No presente trabalho se pretende debater os essenciais conceitos sobre o ativismo judicial realizado no Brasil, como também demonstrar de que maneira esta ferramenta pode reivindicar políticas públicas por parte dos outros poderes, além de explicitar qual é a função do magistrado em relação à discricionariedade administrativa e às necessidades sociais. A presente pesquisa realizar-se-á sobre o método dedutivo, com revisão de análise bibliográfica.

Objetivo: Apresentar a importância do ativismo judicial para auferir os objetivos fundamentais previsto na Constituição Federal, almejando a efetivação das políticas públicas.

Desenvolvimento: As transformações sociais desejadas, pelo preceito contido no artigo $3^{\circ}$ da Constituição Federal, são uma obrigatoriedade institucional do Estado e do Direito e decorrem do desenvolvimento socioeconômico nacional (PAULA, 1999, $p$. 39). Esse compromisso do Estado com a sociedade, em certas ocasiões, é omitido. E é justamente isso que bem legitima o ativismo judicial: o aperfeiçoamento da atividade pública para fins de efetividade dos direitos fundamentais a partir das premissas jurídicas (PAULA, 2018, p. 412). Diante disso, é preciso redefinir o espaço político na jurisdição, a fim de alcançar a sua legitimidade. Logo, a legitimidade da atividade jurisdicional decorre de suas funções na sociedade atual: a racionalidade e a proteção dos direitos fundamentais (PAULA, 2002, p. 54). Por fim, a atividade jurisdicional não se resume a uma operação técnica de declaração da lei ao caso concreto, como tradicionalmente proclamavam um segmento doutrinário Montesquiano (PAULA, 2014, p. 40). Portanto, deve-se refletir sobre a finalidade e o limite de atuação do Poder Judiciário, diante de tamanha demanda por direitos sociais e fundamentais, porquanto não serem apenas mandamentos programáticos, mas sim, garantias subjetivas do povo.

Conclusão: $O$ ativismo judicial é importante para o desenvolvimento da atividade jurisdicional, visto que propicia um contínuo processo de cidanização. Portanto, inspira, como consequência, alcançar a realidade social dos demandantes e os fins da jurisdição.

\title{
Referências
}

PAULA, Jônatas Luiz Moreira de. A Jurisdição como elemento de inclusão social: revitalizando as regras do jogo democrático. $1^{\circ}$ ed. Barueri SP: Editora Manole LTDA, 2002.

PAULA, Jônatas Luiz Moreira de. Democracia e Jurisdição. 1 ed. Curitiba: JM Editora e Livraria Jurídica, 2014.

PAULA, Jônatas Luiz Moreira de. O Estado Jurisdicional no Brasil. 1 ed. Belo Horizonte: Editora D’Plácio, 2018.

PAULA, Jônatas Luiz Moreira de. Uma visão crítica da jurisdição civil. $1^{\circ}$ ed. Leme SP: LED Editora de Direito LTDA, 1999. 


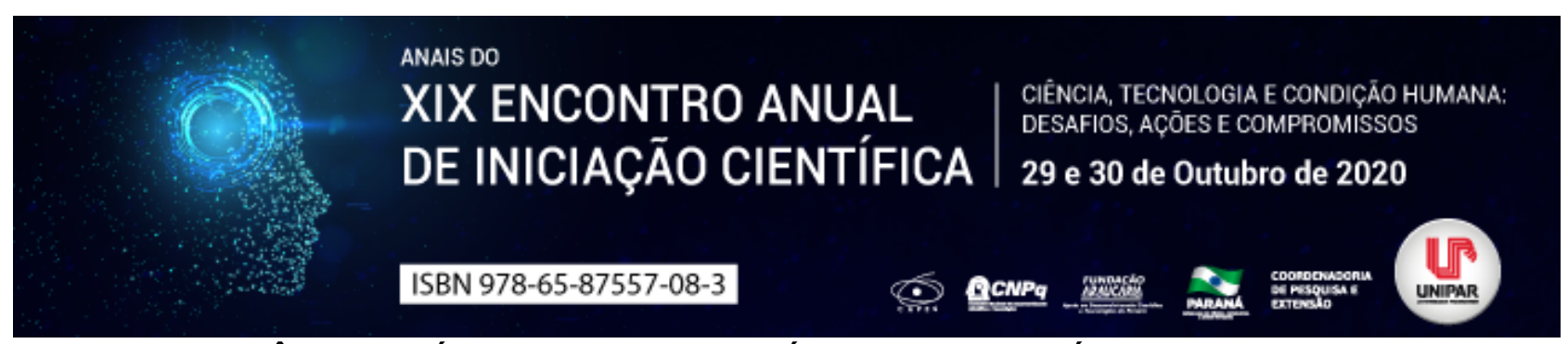

A INFLUÊNCIA DA ÉTICA GREGA E ARISTÓTELES SOBRE A ÉTICA DO ADVOGADO

\title{
${ }^{1}$ GABRIEL TRENTINI PAGNUSSAT, ${ }^{2}$ LUIZ ROBERTO PRANDI
}

\author{
${ }^{1}$ Acadêmico do curso de Direito e bolsista do PEBIC/CNPq/UNIPAR \\ ${ }^{1}$ Doutor em Ciências da Educação, Docente e Pesquisador da UNIPAR
}

Introdução: O advogado brasileiro é direcionado por um conjunto de princípios e regras de conduta ético-profissional. O Código de Ética e Disciplina (CED) da OAB consiste nesse conjunto de deveres éticos, os quais, ao lado do Estatuto da Advocacia (Lei n. ${ }^{\circ}$ 8.906/94) são responsáveis pelo norteamento da atuação profissional. Nesse diapasão, este estudo analisa o pensamento ético grego e aristotélico, no sentido em que se fundamenta e liga-se aos valores do Código de Ética e Disciplina da Ordem dos Advogados do Brasil OAB, bem como ao conjunto de deveres deontológicos do advogado.

Objetivo: Analisar a ligação da ética grega e aristotélica com o novo Código de Ética e Disciplina da Ordem dos Advogados do Brasil OAB.

Desenvolvimento: $O$ artigo $1^{\circ}$ do Código de Ética e Disciplina da OAB (CED) que outorga que: O exercício da advocacia exige conduta compatível com os preceitos deste Código, do Estatuto, do Regulamento Geral, dos Provimentos e com os demais princípios da moral individual, social e profissional (OAB, 2015, [10] p.), portanto, o advogado tem sua conduta vinculada a esses preceitos. O preâmbulo do CED dispõe os imperativos de conduta da classe, jungindo conceitos tais como: os de lutar sem receio pelo primado da justiça; pugnar pelo cumprimento da constituição e pelo respeito à lei; observar os fins sociais e visar ao bem comum ao interpretar as leis e a constituição e; defender com o mesmo denodo os humildes e poderosos. Somam-se a esses também: ter lealdade e boa-fé; jamais deixar que o anseio de ganho sobreleve a finalidade social do trabalho, aprimoramento no culto dos princípios éticos e no domínio da ciência jurídica e; contribuir para o aprimoramento da nação e das instituições; sendo esses os princípios deontológicos que norteiam a conduta do advogado. Ademais, no Código de Ética encontra-se regulamentado o comportamento do advogado em questões tais como: relações com os clientes, sigilo profissional, publicidade, honorários e o dever de urbanidade. No que tange à imagem do advogado, essa é constantemente ligada ao valor da justiça, como se infere logo no preâmbulo do Código de ética, e em suas demais disposições normativas. Até mesmo a Constituição 1988, em seu artigo 133, dispõe que [o] advogado é indispensável à administração da justiça (BRASIL, 1988, [120] p.). Acontece que é na ética grega que se encontra a base de toda a ética ocidental. Para os gregos, a filosofia como um todo é marcada pelo meio-termo, pela justa medida entre os extremos (REALE; ANTISIERI, 2003). Para Platão, o ético é ligado à ideia do bem, se constituindo em: ordem, medida e proporção, uma combinação ou mistura desses formando harmonia. Sendo a justa medida o bem próprio de cada essência, e a justa medida para o homem consiste em realizar em todas as suas ações o bem que lhe corresponde por sua essência (SANTOS, p. 5, 2001). Aristóteles mantém a mesma linha característica dos gregos, o meio-termo. Sendo que para esse filósofo, o bem não se liga à uma ideia, mas sim às virtudes empíricas e humanas, uma vez que: O bem do homem vem a ser uma atividade da alma de conformidade com a virtude [...] (ARISTÓTELES, 2017, p. 27), sendo a virtude em resumo a posição intermediária (ARISTÓTELES, 2017, p. 47) que é a excelência no caráter. Aristóteles é finalista, ou seja, vê como objetivo das ações a felicidade e o bem; felicidade ou bem agir, que se dá por meio da prática de ações virtuosas (ações moderadas) em busca da excelência. Nessa senda, essas virtudes podem ser obtidas por meio de um processo de ensino, formação, desenvolvimento, resultando em uma disposição permanente de caráter (hábito) (ARISTÓTELES, 2017). Sendo a virtude suprema a justiça, porque quem a possuir tem o poder de a usar não apenas para si, mas também com outrem (ARISTÓTELES, 2017). É notório que a ética grega e aristotélica estão ligadas à ética da advocacia, pois no preâmbulo do CED exprime-se como imperativo ao advogado a ligação de seu agir com a justiça, bem como pelo que se dispõe no artigo $2^{\circ}$ do CED em suas alíneas IX e X, bem como da classe é exigido aprimoramento ético, intelectual, pessoal e profissional (preâmbulo CED; art. $2^{\circ} \S$ único, inc. IV CED), ou seja, virtudes em busca de excelência. Ademais, a moderação é reiteradamente requerida $\left(2^{\circ}, \S\right.$ único, inc. VIII, alínea f, CED; art. $48 \S 6^{\circ}, \mathrm{CED}$; art. $\left.49 \mathrm{CED}\right)$, já que é vedado cobrar valores aviltantes, e por outro lado deve observar o valor mínimo da Tabela de Honorários, ou seja, o meio termo. A exigência por moderação também é destacada em relação à publicidade (art. 39, CED) e ao trato social (art. 27 e 28, CED).

Considerações finais: A ética grega, precipuamente a aristotélica está intimamente ligada à ética da advocacia, uma vez que o advogado tem sua imagem ligada à justiça, justamente nos moldes desse pensador. Soma-se a isso, reiteradamente exige-se desse profissional, por meio de seu Código de Ética, o aprimoramento ético, intelectual, pessoal e profissional, ou seja, suas virtudes em busca de excelência. Ademais, a ética advocatícia está claramente marcada pela moderação (meio termo), tão característica da ética grega, em todas as searas de seu agir.

\section{Referências}


ARISTÓTELES. Ética a Nicômaco. 2. ed. São Paulo: Forense, 2017.

BRASIL. Constituição da República Federativa do Brasil de 1988 . Disponível em: http://www.planalto.gov.br/ccivil_03/constituicao/ConstituicaoCompilado.htm. Acesso em: 24 jun. 2020.

OAB. Resolução n. 02/2015. Código de Ética e Disciplina da OAB. Disponível em: https://www.oab.org.br/arquivos/pdf/LegislacaoOab/codigodeetica.pdf. Acesso em: 24 jun. 2020.

REALE, Giovanni; ANTISIERI, Dario. História da Filosofia: Filosofia pagã antiga. v. 1. São Paulo: Paulus, 2003.

SANTOS, Jorge Augusto da Silva. Ética e Felicidade em Platão e Aristóteles: semelhanças, tensões e convergências.

Cadernos de Atas da ANPOF. n. 1, 2001.

Coordenadoria de Pesquisa e Extensão - COPEX

Departamento de Editoraçāo e Divulgaçāo Científica - DEDIC 


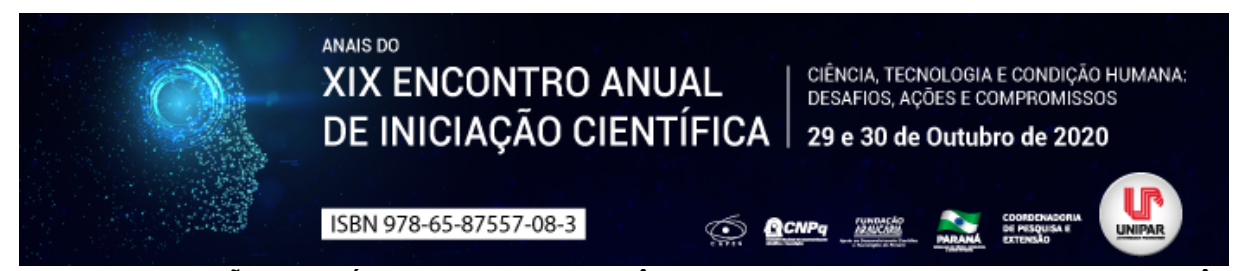

PRINCIPAIS ALTERAÇÕES NO CÓDIGO CIVIL COM A VIGÊNCIA DO ESTATUTO DA PESSOA COM DEFICIÊNCIA

${ }^{1}$ ALANA CAROLINE MOSSOI, ${ }^{2}$ LETICIA BIANCA PINHEIRO, ${ }^{3}$ GILMARA GONCALVES BOLONHEIZ , ${ }^{4}$ ELON KALEB RIBAS VOLPI, ${ }^{5}$ MIRIAM FECCHIO CHUEIRI

${ }^{1}$ Acadêmica do PICPG/UNIPAR

${ }^{1}$ Acadêmica do PICPG/UNIPAR

${ }^{2}$ Acadêmica do Curso de Mestrado Em Direito Processual e Cidadania - Turma XX da UNIPAR

${ }^{3}$ Acadêmico do Curso de Mestrado Em Direito Processual e Cidadania - Turma XX da UNIPAR

${ }^{4}$ Docente da UNIPAR

Introdução: O Estatuto da Pessoa com Deficiência realizou algumas inovações no Código Civil, principalmente no âmbito da capacidade civil, alterando significativamente os arts. $3^{\circ}$ e $4^{\circ}$ do referido código. Promoveu ainda, alterações/criações relativas ao casamento, prescrição e decadência, nulidade de atos praticados por relativamente incapazes, ato de ser testemunha, doação, responsabilidade subsidiária, curatela compartilhada e tomada de decisão apoiada, todos com fundamento na dignidade da pessoa humana ou da igualdade. Mas para alguns autores, determinadas mudanças foram prejudiciais para as partes que dela se beneficiavam.

Objetivo: Demonstrar as principais mudanças no Código Civil frente à vigência o Estatuto da Pessoa com Deficiência e os direitos/princípios protegidos.

Desenvolvimento: $O$ Estatuto da Pessoa com Deficiência (Lei $n^{\circ}$ 13.146/2015) realizou algumas inovações/alterações no Código Civil de 2002, em especial na capacidade civil das pessoas acometidas de alguma deficiência. Referido código previa uma visão muito simplista da incapacidade, na medida em que excluía a plena capacidade para os atos civis pelo simples fato da pessoa ser acometida de um transtorno ou debilidade mental (BERLINI; AMARAL, 2017). Isso porque, o Código Civil era precipuamente patrimonialista e discriminatório e hoje busca promover a dignidade da pessoa humana e as liberdades fundamentais das pessoas com deficiência (BUFULIN; SANTOS; REINHOLZ, 2018). A principal alteração promovida pelo Estatuto foi através do seu art. 114, que modificou os art. $3^{\circ} \mathrm{e} 4^{\circ}$ do Código Civil, restringindo a capacidade absoluta ao critério etário (menores de 16 anos) e deixou de considerar como relativamente incapaz os que tenham deficiência mental com discernimento reduzido ou excepcional sem desenvolvimento mental completo. Portanto, esta incapacidade deixou de ser considerada presumida, como ocorria antes. Outro ponto que merece destaque é a alteração da prescrição e decadência. Com a vigência do Estatuto foi afastada a suspensão da prescrição e da decadência para o deficiente mental e intelectual, prevista no art. 198 do Código Civil, permitindo que os prazos corram naturalmente. Essa mudança sofre algumas críticas, especialmente pela isonomia no seu sentido material. Para Daneluzzi e Mathias (2016), permite-se, a partir de agora, por exemplo, que os bens da pessoa com deficiência possam ser usucapidos, o que não ocorria até então, ocasionando, possivelmente, prejúzos patrimoniais. A responsabilidade da pessoa com deficiência também soa prejudicial na medida em que a responsabilidade, antes subsidiária, não mais existe, sendo estas pessoas obrigadas a responder com o patrimônio próprio, nos termos do art. 927 do Código Civil. Diversamente das críticas, o instituto da curatela compartilhada se coaduna com a proposta do direito civil constitucional que preza pela manutenção e aplicação da clausula geral da tutela e promoção da pessoa humana, na medida em que há mudança de paradigma ao considerar pessoas com deficiência como plenamente capazes e fornecer meios para essa capacidade (BASTOS, 2017). Na esteira da dignidade da pessoa humana e da isonomia, veio a tomada de decisão apoiada, instituto diverso da tutela e curatela, que fornece uma espécie de assistência qualifica, onde faz-se necessária a participação de duas pessoas, além do próprio assistido (COSTA; BRANDÃO, 2016). Portanto, a tomada de decisão apoiada é um modelo utilizado por pessoas plenamente capazes, porém em situação de vulnerabilidade em decorrência da sua deficiência, em consonância com os objetivos do Estatuto da Pessoa com Deficiência.

Conclusão: Pode-se dizer que o Estatuto da Pessoa com Deficiência foi criado para resolver muitas questões relacionadas, especialmente, com a dignidade da pessoa humana e igualdade, como de fato o fez, excluindo os deficientes do rol dos incapazes. Não obstante, algumas modificações, como na prescrição, decadência e da própria responsabilidade, fez nascer outras discussões, como no caso da efetiva aplicação da proteção das pessoas com deficiência, pois passam a estar expostas a situações que podem perder seu patrimônio, o que inviabilizará, de certa forma, a dignidade e a própria igualdade visada pelo Estatuto.

\section{Referências}

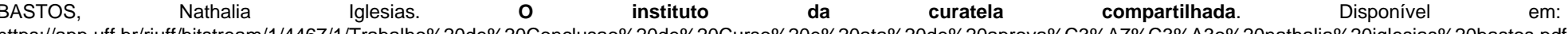
https://app.uff.br/riuff/bitstream/1/4467/1/Trabalho\%20de\%20Conclusao\%20de\%20Curso\%20e\%20ata\%20de\%20aprova\%C3\%A7\%C3\%A30\%20nathalia\%20iglesias\%20bastos.pdf. Acesso em: 8 jul. 2020.

BERLINI, Luciana; AMARAL Paloma Francielly do. Os impactos do estatuto da pessoa com deficiência no direito protetivo pátrio e sua antinomia com o novo código de processo civil. Themis, Revista da ESMEC, vol.15, no 2, 2017.

BUFULIN, Augusto Passamani; SANTOS, Katharine Maia dos; REINHOLZ, Rayanne Otília. As repercussões do estatuto da pessoa com deficiência na teoria das incapacidades. Revista dos Tribunais Online, vol. 86, fev. 2018.

COSTA, Aline Maria Gomes Massoni da; BRANDÃO, Erci Scapim Cunha. As alterações promovidas pela Lei $\boldsymbol{n}^{\circ}$ 13.146/2015 (Estatuto da pessoa com deficiência) na teoria das incapacidades e seus consectários. Disponível em: http://www.tjij.jus.br/documents/10136/3543964/artigo-interdicao.pdf. Acesso em: 30 jun. 2020. DANELUZZI, Maria Helena Marques Braceiro; MATHIAS, Maria Ligia Coelho. Repercussão do Estatuto da Pessoa com Deficiência (lei 13.146/2015), nas legislações civil e processual civil. Revista de Direito Privado, vol. 66, abr-jul. 2016.

Coordenadoria de Pesquisa e Extensão - COPEX

Departamento de Editoraçāo e Divulgaçāo Científica - DEDIC 


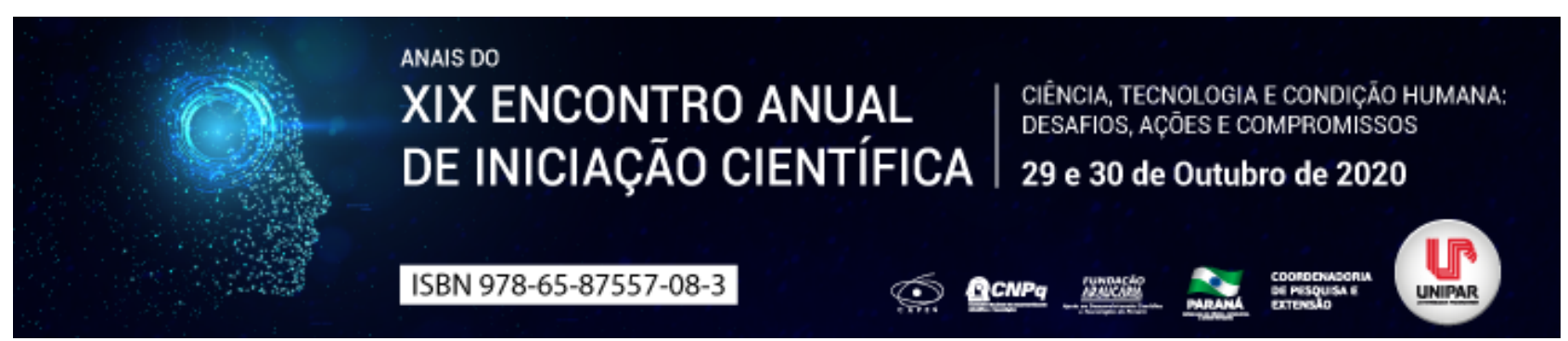

USUCAPIÃO FAMILIAR: ANÁLISE CRÍTICA DO ARTIGO 1.240-A DO CÓDIGO CIVIL BRASILEIRO

\section{${ }^{1}$ KIVIA DOS SANTOS FIGUEIREDO, ${ }^{2}$ PAULO CESAR DE SOUSA}

${ }^{1}$ Acadêmica do curso de Direito da UNIPAR

${ }^{1}$ Docente da UNIPAR

Introdução: O estudo em questão direciona a análise crítica da modalidade de usucapião instituído pela Lei 12.424/2011, por meio da inclusão do artigo 1.240-A do Código Civil, considerando em discutir sua aplicabilidade.

Objetivo: Examinar, mediante uma análise crítica, a inclusão do art. 1.240-A, examinando a adequação de alguns requisitos previstos para se requerer a usucapião familiar.

Desenvolvimento: A usucapião familiar origina-se da Lei no 12.424/2011, junto com o Programa Minha Casa - Minha Vida . Esse preceito teve o objetivo garantir o direito da moradia ao cônjuge abandonado, porém essa proteção, nos moldes que foi criada, enseja questionamentos. Dentre esses questionamentos, um refere-se ao prazo prescricional de dois anos, o mais breve do ordenamento, sem que haja uma justificativa razoável para tanto. Com efeito, o prazo do exercício da posse é substancialmente menor que qualquer prazo de prescrição aquisitiva mencionado no Código Civil de 2002 (WESENDONCK, 2012, p. 5). A crítica pertinente é que o prazo fixado é muito exíguo, pois o período em que casais se habituam com a separação ou um possível restabelecimento ao vínculo conjugal se dá nesse período de tempo. A segunda indagação diz respeito à metragem do imóvel, que não pode ser superior a $250 \mathrm{~m}^{2}$. Ora o fato de o imóvel possuir tal área não importa que o proprietário seja pessoa de baixa renda. Em grandes cidades, um imóvel com essa área tem um alto valor de mercado. A crítica cabível: se o intento da lei é o de tutelar pessoas de baixa renda, o tamanho do imóvel não é um critério que assegura seu alcance. Outra crítica quanto ao mesmo fator: a usucapião em causa não ampara quem residir em imóvel rural. Mais um ponto que externa falha na configuração do instituto reside no fato de que a subsunção do fato à norma exige que a posse do imóvel seja exercida em composse com [...] ex-cônjuge ou ex-companheiro que abandonou o lar [...] (BRASIL, 2012). A crítica que se tece relaciona-se ao fato de que, em determinadas situações, casais se submetem a permanecer no imóvel, suportando-se mutuamente. Porém, como afirmado Pena (2013): Uma norma não pode e nem deve ter esse condão de pressionar as pessoas, que não mais possuam condições de convivência mútua, a viver sob o mesmo teto apenas para preservar um direito seu, patrimonial . Logo, o instituto intensifica conflitos com essa configuração.

Conclusão: O legislador, ao tentar resguardar o direito de moradia daquele que permanecer habitando imóvel havido em comum, não atua de modo apropriado à medida que limita injustificadamente os requisitos para aquisição da propriedade do imóvel ao agente que foi abandonado.

\section{Referências}

BRASIL. Código Civil. Lei n. 10.406, de 10 de janeiro de 2002. In: Vade Mecum, 14.ed. São Paulo: Saraiva: 2012.

BRASIL. Lei $\mathbf{n}^{\circ} \mathbf{1 2 . 4 2 4}$, de 16 de junho de 2011. Altera a lei 11.977/2009 que dispõe sobre o Programa Minha Casa, Minha vida... Disponível em: http://www.planalto.gov.br/ccivil_03/_ato2011-2014/2011/Lei/L12424.htm. Acesso em: 09 set. 2020.

PENA, Stephanie Lais Santos. Aspectos inconstitucionais da usucapião familiar. Jus navigandi. Teresina, n. 3571, ano 18, 11 abr., 2013. Disponível em: https://jus.com.br/artigos/24163/aspectos-inconstitucionais-da-usucapiao-familiar/2. Acesso em: 08 jun. 2020.

WESENDONCK, Tula. Usucapião familiar: uma forma de solução de conflitos no direito de família ou (re) criação de outros?. 2012. Disponível em: http://www.publicadireito.com.br/artigos/?cod=0f3c5d0c3666eec8. Acesso em: 08 jul. 2020. 


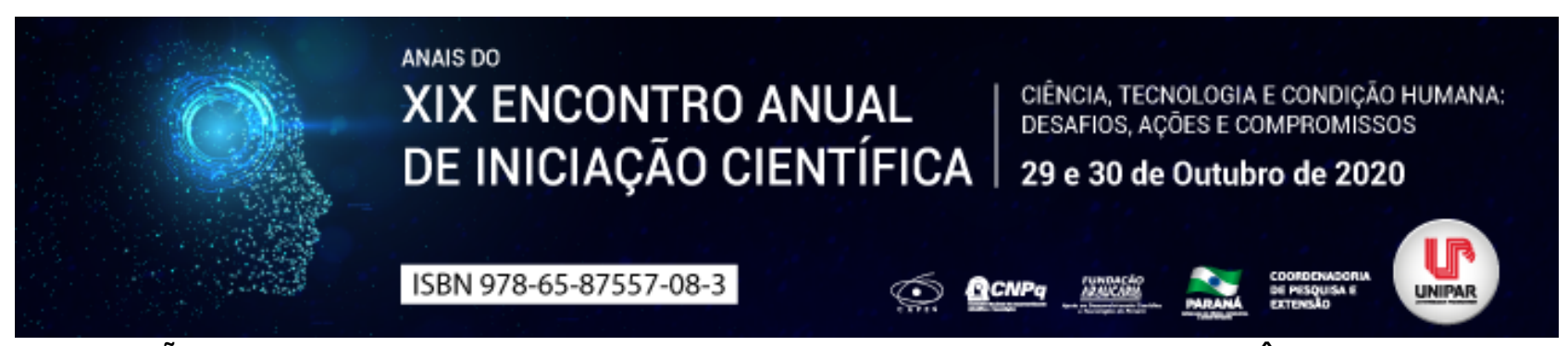

A ESTABILIZAÇÃO DA TUTELA (ART. 304 DO CPC) PELO PROJETO DE LEI № 4902 DA CÂMARA DOS DEPUTADOS

\title{
${ }^{1}$ JULIA IZABELLE TONETO ROMANO MAZIERO, ${ }^{2}$ CELSO HIROSHI IOCOHAMA
}

\author{
${ }^{1}$ Acadêmica do Mestrado em Direito Processual e Cidadania e do PIC/UNIPAR \\ ${ }^{1}$ Docente da UNIPAR
}

Introdução: O Projeto de Lei (PL) nº 4902 que tramita atualmente na Câmara dos Deputados, traz como uma de suas propostas, alterações ao art. 304 do CPC, que dispõe sobre a estabilização da tutela, para prever que ela não ocorra nos casos previstos no art. 72 do CPC (quando houver necessidade de nomeação de curador), além de complementar o seu $\$ 1^{\circ}$, e incluir os $\$ \S 2^{\circ}$-A e $7^{\circ}$. Todavia, apesar de parte da alteração ser conveniente, há também algumas incoerências na proposta, que, caso aprovada, poderá surtir o efeito contrário e ferir direitos.

Objetivo: Demonstrar a pertinência, bem como tecer críticas a respeito da proposta de alteração da redação do art. 304 do CPC. Desenvolvimento: O Código de Processo Civil de 2015 trouxe o procedimento da tutela de urgência antecipada concedida em caráter antecedente, em seu art. 303, para os casos em que a urgência da medida for contemporânea à propositura da ação. Logo na sequência, o art. 304 dispõe que, caso não interposto o recurso cabível, a tutela concedida nos termos do art. 303, tornar-se-á estável, caso em que o processo será extinto $\left(\S 1^{\circ}\right)$, mas poderá ser revista, reformada ou invalidada por qualquer das partes $\left(\S 2^{\circ}\right)$, no prazo de dois anos $\left(\S 5^{\circ}\right)$, e conservará seus efeitos enquanto isto não ocorrer $\left(\S 3^{\circ}\right)$. Porém, conforme $\S 6^{\circ}$, a decisão que concede a tutela não fará coisa julgada. O PL pretende incluir no caput a ressalva de que a tutela deferida nos termos do art. 303 não estabilizará nos casos previstos no art. 72 do CPC, ou seja, quando tratar-se de réu incapaz, sem representante legal, réu preso, ou réu citado por edital ou hora certa, hipóteses em que será necessário designar curador especial, que deverá adotar as medidas cabíveis em defesa do réu, inclusive impugnar a medida urgente (TALAMINI, 2012, p. 25). A proposta também acrescenta a redação do $\S 1^{\circ}$, para constar que nos casos do caput do artigo, o processo será extinto sem resolução do mérito, e que a tutela antecipada se estabilizará mesmo que o autor não tenha promovido o aditamento a que se refere o inciso I do $\S 1^{\circ}$ do art. 303. A justificativa para tanto é que há aparente contradição do código quando autor e réu, ao mesmo tempo, se omitem: o primeiro, em aditar a petição inicial; o segundo, em impugnar. Todavia, a consequência da não impugnação pelo réu é a estabilização da tutela (art. 304, caput), assim como a consequência ao autor por não aditar a inicial (art. $303, \S 2^{\circ}$ ), é a extinção do processo sem resolução do mérito. Além disso, caso o réu não interponha o recurso, a tutela estabiliza-se, de maneira que seria desnecessária a apresentação do pedido principal (MEDINA, 2017, p. 362). A proposta inclui ainda o $\S 2^{\circ}$-A, segundo o qual, além da interposição do recurso de que trata o caput deste artigo, o réu poderá impedir a estabilização da tutela mediante simples petição apresentada perante o juízo que proferiu a decisão, ressalvando seu direito de impugnar a pretensão do autor na contestação. Tal alteração parece ser viável, na medida em que há discussões quanto a abrangência do termo recurso , de forma que permitir a extensão do significado para abarcar também simples petição, contestação, ou ainda manifestação quanto a audiência de conciliação e mediação, contribui para a celeridade do processo, economizando o agravo de instrumento, pois mostra inequívoca intenção do réu em exaurir o debate com o prosseguimento do feito (MARINONI, 2017, p. 400). A última proposta, inclui o $\S 7^{\circ}$ ao art. 304, que dispõe que o juiz, ao conceder a tutela provisória nos termos do art. 303, deve fixar os honorários de sucumbência em favor do advogado do autor, determinando que se esclareça ao réu que, se não recorrer nem apresentar a petição a que alude o § $2^{\circ}$-A deste artigo, será aplicado o disposto no art. 701, caput e $\S 1^{\circ}$, para restringi-los a cinco por cento do valor atribuído à causa e para dispensá-lo do pagamento de custas processuais. Todavia, tal proposta é equivocada, uma vez que o art. 701, assentado no capítulo referente à ação monitória, dispõe que, sendo evidente o direito do autor, o juiz deferirá a medida competente, e concederá ao réu o prazo de quinze dias para o cumprimento e pagamento de honorários advocatícios de cinco por cento do valor atribuído à causa, e se cumprido no prazo, será isento do pagamento das custas processuais. Entende-se que a intenção do legislador é estimular o réu a não impugnar a tutela concedida, todavia, o pedido do autor é fundado em urgência, não havendo evidência do seu direito, mas sim mera probabilidade, sendo fundamental o direito de impugnação do réu para evitar a estabilização de um direito que pode não ser certo.

Conclusão: A proposta de alteração do art. 304 é conveniente no tocante ao caput do artigo, para ressalvar os casos previstos no art. 72 do CPC, bem como não há maiores problemas quanto à complementação do $\S 1^{\circ} \mathrm{e}$ do $\S 2^{\circ}$-A. Porém, a inserção do $\S$ $7^{\circ}$ deve ser vista com cautela, sob pena de coagir o réu a não impugnar a estabilização da tutela, apenas por receio de pagar honorários e custas processuais, o que pode mitigar seu direito de defesa, além de se deixar estabilizar a tutela de um direito que poderá se mostrar, na verdade, descabido.

\section{Referências}


TALAMINI, Eduardo. Tutela de urgência no Projeto de novo Código de Processo Civil: a estabilização da medida urgente e a monitorização" do processo brasileiro. Revista de Processo, São Paulo, n. 209, p. 14-34, 2012.

MEDINA, José Miguel Garcia. Curso de Direito Processual Civil Moderno. 3. ed. São Paulo: Revista dos Tribunais, 2017.

MARINONI, Luiz Guilherme; ARENHART, Sergio Cruz; MITIDIERO, Daniel. Novo Código de Processo Civil Comentado. 3. ed. São Paulo: Revista dos Tribunais, 2017.

Coordenadoria de Pesquisa e Extensão - COPEX

Departamento de Editoraçāo e Divulgaçāo Científica - DEDIC 


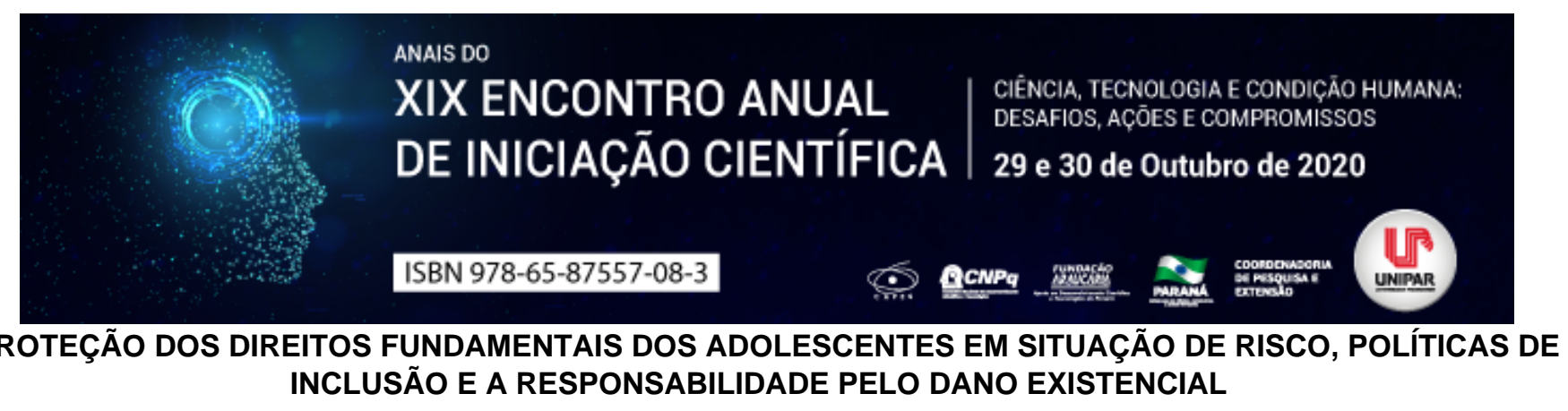

${ }^{1}$ ALEXANDRE CESAR RODRIGUES DA SILVA, ${ }^{2}$ TEREZA RODRIGUES VIEIRA

${ }^{1}$ Acadêmico do PIC/UNIPAR
${ }^{1}$ Docente da UNIPAR

Introdução: A família é considerada a base fundamental da sociedade, assim, toda criança ou adolescente têm o direito de crescer em um ambiente harmonioso. No seio familiar a criança e o adolescente devem receber proteção e assistência necessárias para o desenvolvimento pleno da sua personalidade e potencialidades. Documentos importantes como a Constituição da Federal (BRASIL, 1988) e a lei n. 8069 (BRASIL, 1990), que dispõe sobre o Estatuto da Criança e do Adolescente (ECA), estabelecem os seus fundamentais direitos. Atenção especial devem receber os adolescentes em situação de risco, em decorrência da sua vulnerabilidade.

Objetivo: Analisar os direitos fundamentais dos adolescentes em situação de risco e verificar a responsabilidade pelo dano existencial em relação a estes jovens vulneráveis.

Desenvolvimento: Até o ano de 1990, a lei que regulamentava a questão da criança e do adolescente, no âmbito jurídico brasileiro era a Lei $n .{ }^{\circ} 6.697 / 1979$ que instituía o Código dos Menores, hoje já revogado pelo ECA. O antigo código era nada mais do que I"[...] um Código Penal do Menor travestido em sistema tutelar, cujas medidas eram verdadeiras penas disfarçadas de medidas de proteçãol" (MAZZUOLI. 2018, p. 329). Assim, Crianças e adolescentes considerados em risco, seja em função de pobreza, abandono ou maus-tratos, eram recolhidos e levados a instituições que também recebiam quem tinha menos de 18 anos e cometia furto, roubo ou mesmo atentava contra a vida de outra pessoa. Nesse período, a preocupação da lei era manter a ordem social, corrigindo quem se encontrava em situação irregular e incomodava, segregando-os da sociedade. (PARANÁ, 2020) De acordo com Amin (2018), o ECA retirou o Estado de uma simples posição assistencialista, passando a categoria, de titulares de direitos subjetivos. Conforme estabelece o ECA no caput do seu artigo $2^{\circ}$, criança é a pessoa até 12 anos de idade e adolescente, entre 12 a 18 anos completos. A Constituição Federal de 1988, por sua vez, nos artigos 227 e 228 trata especificamente a respeito dos direitos fundamentais da criança e do adolescente. $O$ texto constitucional destes dois artigos trouxe o Brasil para o seleto rol das nações mais avançadas na defesa dos interesses infantojuvenis (AMIN, 2018, p. 41). Os direitos fundamentais que tanto a CF/88 e o ECA resguardam para as crianças I"São direitos inatos ao ser humano, mas variáveis ao longo da história. Estão atualmente previstos na Declaração Universal dos Direitos do Homem e do Cidadão e presentes no Estadol" (AMIN, 2018, p. 60). Não é despiciendo lembrar que o Estado é o principal responsável em estabelecer políticas, planos, programas e serviços para a primeira infância que atendam às especificidades dessa faixa etária, visando a garantir seu desenvolvimento integral (LENZA. 2019, p. 986). Cumpre lembrar que, com a pandemia do novo Coronavírus, COVID-19, o Governo Federal, por meio da Portaria no 59 (BRASIL, 2020), em 22 de abril de 2020, aprovou orientações e recomendações gerais aos gestores e trabalhadores do Sistema Único de Assistência Social dos estados, municípios e Distrito Federal para o atendimento nos serviços de acolhimento de crianças e adolescentes no contexto de emergência em saúde pública. Se o Estado for efetivo na sua atribuição referente às crianças, desde o seu nascimento, conseguirá minimizar os riscos aos adolescentes.

Conclusão: Conclui-se que em todos os rincões do país existem adolescentes vivendo em condições de risco, portanto, incumbe ao Estado conceder prioridade absoluta a meninos e meninas de diferentes etnias e condições sociais, contemplando-os com proteção integral. Não há necessidade da implantação de novas leis, bastando apenas cumprir o Estatuto da Criança e do Adolescente em sua integralidade, fortalecendo ações que assegurem os direitos dos nossos jovens em desenvolvimento. Sem políticas públicas que previnam ou diminuam as desigualdades sociais não se conseguirá reduzir os casos de envolvimento com a prática de infrações.

\section{Referências}

AMIN, Andréa Rodrigues. Curso de direito da criança e do adolescente: aspectos teóricos e práticos. 11 ed. São Paulo: Saraiva Educação, 2018.

BRASIL. Constituição da Republica Federativa do Brasil, 8 de outubro de 1988. Presidência da República. Disponível em: www.planalto.gov.br. Acesso em: 17 ago. 2020.

Lei $\mathrm{n}^{\circ} \mathbf{8 . 0 6 9}$, de 13 de julho de 1990. Dispõe sobre o Estatuto da Criança e do Adolescente e dá outras providências. Publicado no DOU 16.7.1990 e retificado em 27.9.1990.

Portaria $n^{\circ}$ 59, de 22 de abril de 2020. Ministério da Cidadania/Secretaria Especial do Desenvolvimento 
Social/Secretaria Nacional de Assistência Social. Diário Oficial da União. Publicado em: 24 abr. 2020, edição 78, seção 1, p. 145. LENZA, Pedro. Direito constitucional esquematizado. 23 ed. São Paulo: Saraiva Educação 2019.

MAZZUOLI, Valerio de Oliveira. Curso de direitos humanos. 5. ed. São Paulo: Método, 2018.

PARANÁ. Ministério Público do Paraná. Especial 30 anos ECA. 30 anos de Estatuto da Criança e do Adolescente: avanços e desafios. Edição de 24 jan. 2020.

Coordenadoria de Pesquisa e Extensão - COPEX

Departamento de Editoraçāo e Divulgaçāo Científica - DEDIC 


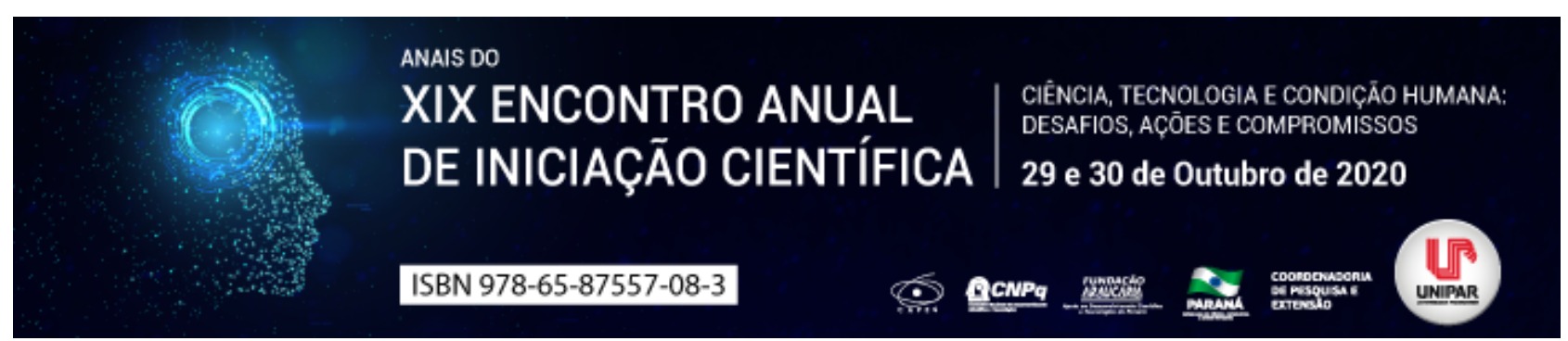

APOLO E DIONÍSIO COMO ENERGIAS INFLUENCIADORAS NA RELAÇÃO COM O CORPO

\begin{abstract}
${ }^{1}$ RAFAELA GOMES LUIZ, ${ }^{2}$ ANA CLARA FRANCOLIN TRENTO, ${ }^{3}$ LAIANY MAIARA QUIRINO DE PAULA, ${ }^{4}$ MAURO SERGIO DA ROCHA
\end{abstract}

${ }^{1}$ Acadêmica do curso de Psicologia da UNIPAR

${ }^{1}$ Acadêmica do Curso de Psicologia da UNIPAR

${ }^{2}$ Acadêmica do Curso de Psicologia da UNIPAR

${ }^{3}$ Docente da UNIPAR

Introdução: As histórias mitológicas narram eventos como a criação do mundo, a origem do homem, animais, plantas e tantos outros fenômenos que contribuem para a transformação humana dos tempos primórdios à atualidade (ELIADE, 2013). A Psicologia Junguiana, referencial adotado para este resumo, compreende os mitos como exemplos das situações vividas, considerando que os arquétipos se materializam através deles e oferecem um entendimento dos comportamentos e relações humanas (SAVARIS, 2007). Por isso, podemos compreender como atualmente se apresenta a relação com o corpo através de conteúdos que apresentam a influência das energias de Apolo e Dionísio, representando pólos opostos da vivência psíquica. Esta explanação torna-se relevante tendo em vista que a forma de uma cultura lidar com o corpo e a sexualidade é, também, argumentada em vários mitos (CECCARELLI, 2007).

Objetivo: Busca-se com esse resumo compreender a relação com o corpo através de conteúdos arquetípicos.

Desenvolvimento: É fato que, com o passar do tempo, as narrativas mitológicas foram desvalorizadas em comparação às explicações objetivas e racionais. No entanto, é inegável seu valor atual para a compreensão da psique humana dentro da psicologia analítica, considerando que os mitos representam encontros arquetípicos e, por consequência, possibilitam a compreensão e relação entre o sujeito e sua coletividade (JUNG, 2016; SAMUELS, 2003). Neste sentido, a visão de alguns conteúdos mitológicos pode contribuir para o entendimento de como o corpo é visto atualmente. De Dionísio vem o caráter das explosões dos instintos e dos excessos. Este é considerado o deus dos vinhos, das festas, das mulheres e da tragédia e, assim sendo, a natureza dionisíaca representa os estados alterados da consciência (BRANDÃO, 1987). Psicologicamente falando, não entrando em contato com essas energias, elas permanecem na psique como emoções selvagens, incapazes de se vincular à realidade do corpo. Segundo a índole dionisíaca, a experiência com o corpo proporciona relações íntimas com os próprios sentimentos. Corpo este, que fala, pulsa, afeta, transborda e sente, proporcionando ao sujeito vivências libertadoras ou aprisionadoras. Contrapõe-se a essas energias o deus Apolo, portador da luz, harmonia e equilíbrio (BRANDÃO, 1987). Digno de perfeição, a natureza apolínea representa a conquista da consciência solar, em que o ego é considerado centro (Ribeiro, 2012). Apolo e Dionísio são representações de conceitos opostos e complementares e, da sua integração dessas energias, tem-se o processo de individuação. A experiência de vivenciar a loucura dionisíaca atrelada à harmonia de Apolo funde o princípio da reciprocidade, compreendido como meio de desvincular a unilateralidade e permitir o conhecimento da polaridade inconsciente, seja ela de caráter apolíneo ou dionisíaco, inserindo-os dentro das relações conscientes (RIBEIRO, 2012). Apesar da constante transformação social, a relação com o corpo e com os desejos ainda continua sendo por vezes um tabu, visto que, a relação com a energia mitológica de Dionísio por vezes não é reconhecida. Dessa forma, nota-se uma vivência unilateral, na qual forças apolíneas são priorizadas em detrimento dos impulsos dionisíacos. Gerando uma vivência em que o desejo, em sua forma natural, seja reprimida.

Conclusão: Entendemos que a relação com o corpo, pela perspectiva da psicologia analítica, movimentam conteúdos que podem influenciar o sujeito, de modo a produzir fantasias eróticas que podem ser vivenciadas por ele de maneira negativa ou positiva. A vivência negativa acontece de forma unilateral, com a polarização apenas de Dionísio ou Apolo, na qual o sujeito se fecha em seus próprios desejos, fantasias e questões inconscientes. Não as vivenciam de forma consciente, permitindo que o inconsciente as manifeste de formas desconhecida e por vezes irracionais. É importante que o sujeito aprenda a reconhecer e se relacionar com os próprios conteúdos, integrar partes conscientes e inconscientes, a fim de considerar sua individualidade, desejos e vontades (JACOBY, 2011). Consequentemente, as energias dionisíacas e apolíneas, enquanto forças criativas precisam ser integradas a fim de proporcionar o equilíbrio psíquico e contribuir com o processo de individuação, no qual, além de uma relação mais consciente com seu corpo - visto que lidamos com conteúdos não encenados do cotidiano -, compreendemos também partes irreconhecidas da dualidade, em que se estabelece uma forma diferenciada de lidar com essas energias, de forma individual e coletiva. Sendo assim, conclui-se que aspectos da relação com o corpo se vinculam com a dinâmica de forças mitológica e opostas na psique, que podem estar unilaterais ou integradas, e estas influenciam na forma do sujeito se relacionar com estes conteúdos. 


\section{Referências}

BRANDÃO, Junito de Souza. Mitologia Grega. Vol II. Petrópolis-RJ: Vozes, 1987.

CECCARELLI, Paulo Roberto. Mitologia e processos identificatórios. Tempo psicanalítico, Rio de Janeiro, v.39, p.179-193, 2007.

ELIADE, Mircea. Mito e realidade. São Paulo: Perspectiva, 2013.

JACOBY, Mario. O encontro analítico: transferência e relacionamento humano. Petrópolis, Rio de Janeiro: Vozes, 2011.

JUNG, Carl Gustav. O homem e seus símbolos. 3. ed. Rio de Janeiro: HarperCollins Brasil, 2016.

RIBEIRO, Marcelo. Drogas: uma leitura junguiana da história e da clínica das dependências. Orientador: Victor Palomo. Monografia (título de membro-analista) Sociedade Brasileira de Psicologia Analítica de São Paulo, 2012.

SAMUELS, Andrew; SHORTER, Bani; PLAUT, Alfred. Dicionário crítico de análise junguiana. 1. ed. Rio de Janeiro: Imago, 2003.

SAVARIS, Luciana Elisabete. Mitos e arquétipos. Symbolon, 2007. Disponível em: http://www.symbolon.com.br/artigos/mitosearquetip.htm. Acesso em: 13 jul. 2020.

Coordenadoria de Pesquisa e Extensão - COPEX

Departamento de Editoraçāo e Divulgaçāo Científica - DEDIC 


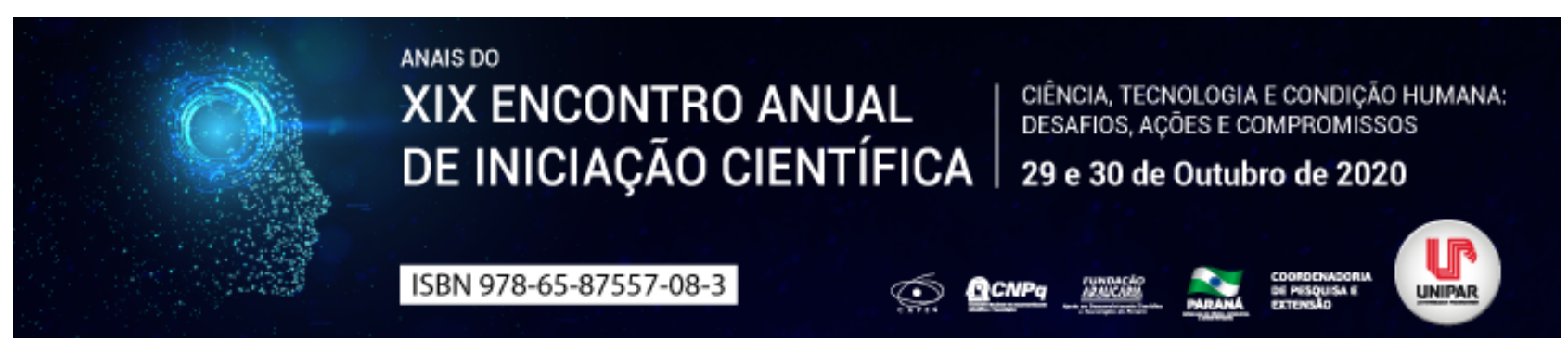

A BASE DO DIREITO À DIGNIDADE HUMANA

\title{
${ }^{1}$ NORAYA SABRINA ROMERO, ${ }^{2}$ ROSEMARI APARECIDA PEDROSO SZEZERBATZ
}

\author{
${ }^{1}$ Acadêmica do Curso de Pedagogia da UNIPAR \\ ${ }^{1}$ Docente da UNIPAR
}

Introdução: A Dignidade humana é o valor supremo que atrai o conteúdo de todos os direitos fundamentais do homem desde o direito à vida. E se faz necessária a partir de um princípio em que respeitando a igualdade entre os homens evita que o ser humano seja desrespeitado ou tenha seus direitos e princípios negados. Por isso falar sobre a dignidade é garantir o direito de decidir de forma autônoma considerando a condição do indivíduo.

Objetivo: Mostrar a importância da dignidade humana e quais limitações que ela nos determina.

Desenvolvimento: Moraes (2002. p. 128) aponta, com conviç̧ão que: "A dignidade é um valor espiritual e moral inerente à pessoa, que se manifesta singularmente na autodeterminação consciente e responsável da própria vida e que traz consigo a pretensão ao respeito [...]". Acredito que a dignidade humana é algo próprio da pessoa, determinada por si. Ademais, a dignidade carrega consigo a pretensão ao respeito do ser humano, seus direitos, valores e escolhas. No entanto, ela possui limitações e restrições em sua igualdade às pessoas, como pode notar no seguinte trecho: "Todos os homens, ao nascerem, são iguais em dignidade; o que os diferencia num momento posterior, é o contexto sociocultural e econômico no qual estão inseridos." (AWAD, 2012, v. 21, n. 1). Com isso, percebemos que a dignidade humana não possui valor igualitário a todos; ela depende de sua posição e seu valor na sociedade. Desse modo, alguns são "mais dignos" que outros, perante a sociedade. Como Awad disse "[...] a dignidade humana serve de limitação à autonomia da vontade." Com isso, podemos tirar a conclusão que a dignidade humana nos dá liberdade mas, em contraponto, limita o nosso poder de decisão. Quando a possuímos, nós tomamos o entendimento de que certas decisões e situações não cabe à nós, devido à nossa dignidade e nosso caráter. Desse modo, por respeito de nossa dignidade e da alheia, somos limitados à não fazermos certas coisas, principalmente pelas regras e normas regentes da sociedade em que vivemos, como diz Awad, "Os limites dos significados diferem de uma sociedade para outra, de um espaço para outro, uma vez que são formados por influências religiosas, filosóficas e morais, embora todos procurem relatar uma mesma realidade.". A dignidade não possui um único conceito ou um valor invariável. Ela varia conforme as regras que regem a sociedade e os grupos e instituições sociais nas quais estamos inseridos. Com isso, ela não é única. Nós determinamos a nossa própria dignidade, mas cabe aos outros ou não respeitá-la, alterando nosso valor perante os mesmos.

Conclusão: Pode-se concluir que a dignidade humana é a essência de toda a existência humana, assegurando-lhe o direito básico de sua liberdade e independência. A dignidade está presente no âmago de seu ser, quanto nos aspectos físicos, como sociais e morais. O direito à dignidade humana torna a pessoa humana como sendo o centro de tudo, assegurando-na o básico da vida, o direito ao respeito mínimo.

\section{Referências}

MORAES, Alexandre de. Constituição do Brasil interpretada e legislação constitucional. São Paulo: Atlas, 2002.

AWAD, Fahd. O princípio constitucional da dignidade da pessoa humana. Revista Justiça do Direito, v. 21, n. 1, 2012. 


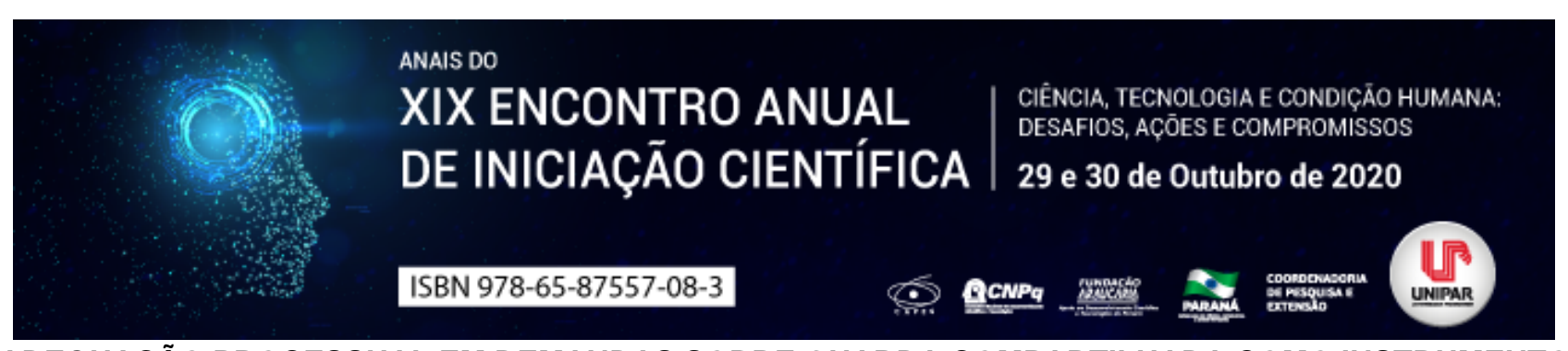

\title{
DA ADEQUAÇÃO PROCESSUAL EM DEMANDAS SOBRE GUARDA COMPARTILHADA COMO INSTRUMENTO DE PREVENÇÃO DE ALIENAÇÃO PARENTAL
}

\author{
${ }^{1}$ RENATA AMORIM LOPES, ${ }^{2}$ PAULO CESAR DE SOUSA
}

${ }^{1}$ Acadêmica do curso de Direito da UNIPAR

${ }^{1}$ Docente da UNIPAR

Introdução: Observando como os tribunais têm julgado os pedidos de guarda compartilhada, é possível afirmar que o devido processo legal não tem sido adequadamente aplicado. Isso porque há observância das regras no plano formal sem efetiva solução que examine a fundo a questão e realize a ordem jurídica justa. Tal fato ocorre porque, na maioria das vezes, apenas são estipuladas regras quanto ao dia, hora e local da guarda sem preocupação maior com o bem- -estar do menor.

Objetivo: Apontar que uma releitura do art. 694 do CPC à luz do devido processo legal pode atender melhor ao postulado da ordem jurídica justa à medida em que, nas ações que versem sobre guarda compartilhada.

Desenvolvimento: Nas ações que versam sobre guarda compartilhada de crianças e adolescentes, é recorrente que a atuação jurisdicional fique adstrita a disciplinar o dia, hora e lugar em que o menor será pego e entregue. Pouco ou nada é feito no tocante ao acompanhamento da implantação desse novo regime de convívio familiar. O resultado disso pode ser a alienação parental do menor, realizada ou induzida por um dos pais (NOGUEIRA, NORONHA, 2016) ou seus avós, ou outro adulto que tenha autoridade sobre ela. Tal maneira de proceder não se coaduna com o art. 694 do CPC, que prevê que todos os esforços sejam utilizados, com o auxílio de profissionais de outras áreas. Nas ações de família, dissolve-se o vínculo conjugal e define-se onde o infante residirá. Embora não totalmente, preciso: Segundo o IBGE, em 2010, em 87,3\% dos casos, as mães ficam com a guarda dos filhos. Com isso, cerca de $1 / 3$ dos filhos não têm contato com os pais, ficando alheios do convívio e afeto respectivos (PALERMO, 2012, p. 12). A interrupção do contato entre o menor e seu genitor infringe o contido no art. 19 do ECA. Por conseguinte, a mudança na prática dos atos processuais, com a realização de acompanhamentos do processo de rompimento do convívio dos pais é uma proposta que, se implantada, pode propiciar a prevenção da alienação parental. Ao invés de o Estado atuar em um único dia, em uma audiência, ele acompanharia a transformação da realidade familiar.

Conclusão: Para não ocorrer a alienação parental por meio das ações que versem sobre guarda compartilhada, devem ser praticados atos processuais que acompanhem a dissolução conjugal e a transformação do núcleo familiar, o que permitirá efetivar o devido processo legal.

\section{Referências}

BRASIL. Lei n. 13.105, de 16 de março de 2015. Código do Processo Civil. Disponível em: encurtador.com.br/anBEH. Acesso em: 28 jul. 2020.

NOGUEIRA, Brenno Antônio Macedo; NORONHA, Elizangela do Socorro de Lima. Alienação parental: aspectos psicológicos e a nova lei da Guarda Compartilhada. Revista Jus Navigandi, Teresina, ano 20, n. 4341, 21 maio 2015. Disponível em: https://jus.com.br/artigos/39297. Acesso em: 15 jun. 2020.

PALERMO, Roberta. Ex-marido, Pai Presente: Dicas Para Não Cair na Armadilha da Alienação Parental. São Paulo: Mescla Editorial, 2012. 


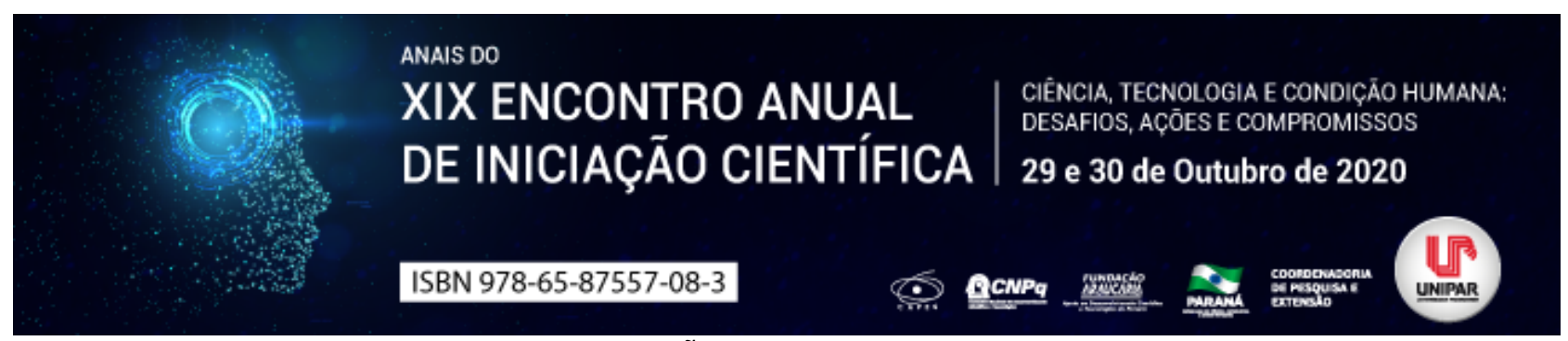

DA CRIMINALIZAÇÃO DO ABANDONO DE IDOSOS

\title{
${ }^{1}$ KAMILA REZENDE, ${ }^{2}$ LUIZ ROBERTO PRANDI
}

\author{
${ }^{1}$ Mestranda em Direito Processual e Cidadania/UNIPAR \\ ${ }^{1}$ Doutor em Ciências da Educação, Docente e Pesquisador da UNIPAR
}

Introdução: Os crescentes números de abandonos e a violências contra idosos é um problema grave de saúde pública, visto que a dependência ocasionada pelo envelhecimento, muitas vezes, ocasiona a violência contra o idoso, e até em alguns casos o abandono da pessoa pela família.

Objetivo: Expor de forma clara e concisa como a criminalização do abandono e da violência contra a pessoa idosa trouxe punição aos agressores.

Desenvolvimento: A Lei $n$. 10.741, de $1^{\circ}$ de outubro de 2003, também conhecida como Estatuto do Idoso, veio para legislar e garantir direitos a pessoa idosa, bem como para punir crimes cometidos contra essa população. Em seu artigo $1^{\circ}$ assegura que $o$ idoso deve ser protegido e respeitado, tendo a família o dever de respaldá-lo em suas necessidades básicas, sem prejuízo de sua proteção integral (BRASIL, 2003). Para tanto, essa lei, ancora-se nos preceitos fundamentais da Carta Magna, que garante a dignidade da pessoa humana em seu artigo $1^{\circ}$, considerando um dos principais objetivos da República a promoção do bem de todos, sem preconceitos de origem, raça, sexo, cor, idade e quaisquer outras formas de discriminação (BRASIL, 1988). O Estatuto do Idoso traz o rol de crimes cometidos contra a pessoa idosa, especificamente, em Título IV, no qual se elencam várias formas de violências cometidas contra o idoso. Dentre essas, a mais cruel, descrita no artigo 98: Abandonar o idoso em hospitais, casas de saúde, entidades de longa permanência, ou congêneres, ou não prover suas necessidades básicas, quando obrigado por lei ou mandado (BRASIL, 2003, p. 03), prevendo ainda uma pena de detenção para quem o faz de 6 (seis) meses a 3 (três) anos e multa. Dessa forma, ao criminalizar esses atos o legislador agrega uma importância a pessoa idosa, podendo ser comparado de mesma forma a qual ele faz no Estatuto da Criança e do Adolescente, pois ao cometer tal ato criminoso, o indivíduo comete um crime em proporções e com comoção de grande dimensão, em razão da vulnerabilidade conferida ao idoso pela lei. Para Oliveira, et al. (2012, p. 07), a violência prejudica todo o conjunto familiar, podendo provocar adoecimento: Diante desse quadro é fundamental que a sociedade, como um todo, preste mais atenção à pessoa idosa, elaborando alternativas com o fim de erradicar as causas das diversas violências que este contingente populacional sofre e evitar as consequências da agressão . Por conseguinte, com o advento do Estatuto do idoso, o abandono de idoso em hospitais e lugares congêneres a este o indivíduo, passou a ser punido de forma pecuniária e pena de detenção além de haver um julgamento pela sociedade.

Conclusão: A lei n. 10.741/2003 conferiu importância aos atos cometidos contra a dignidade do idoso, dedicando-se, especificamente, uma seção para elencar os atos que se enquadram nessa conduta. A partir dessa especificação, o Estado poderá exercer seu dever de segurança a estes indivíduos que são tão frágeis.

\section{Referências}

BRASIL. Constituição (1988). Constituição da República Federativa do Brasil. Brasília, DF: Senado Federal. Disponível em: encurtador.com.br/eiop8. Acesso em: 20 jun. 2020.

BRASIL. Lei $\mathbf{n}^{\circ} \mathbf{1 0 . 7 4 1}$, de $1^{\circ}$ de outubro de 2003. Estatuto do Idoso. Brasília, DF. Disponível em: http://www.planalto.gov.br/ccivil_03/leis/2003/10.741.htm. Acesso em: 20 jun. 2020.

OLIVEIRA, S, C. LEITE, A, C. MONTEIRO, L, C, A. PAVARINI, S, C, I. Violência em idosos após a aprovação do Estatuto do Idoso: revisão integrativa. Revista Eletrônica de Enfermagem, v. 14, n. 4, p. 974-982, out./dez., 2012. Disponível em: encurtador.com.br/kvT46. Acesso em: 15 jun. 2020. 


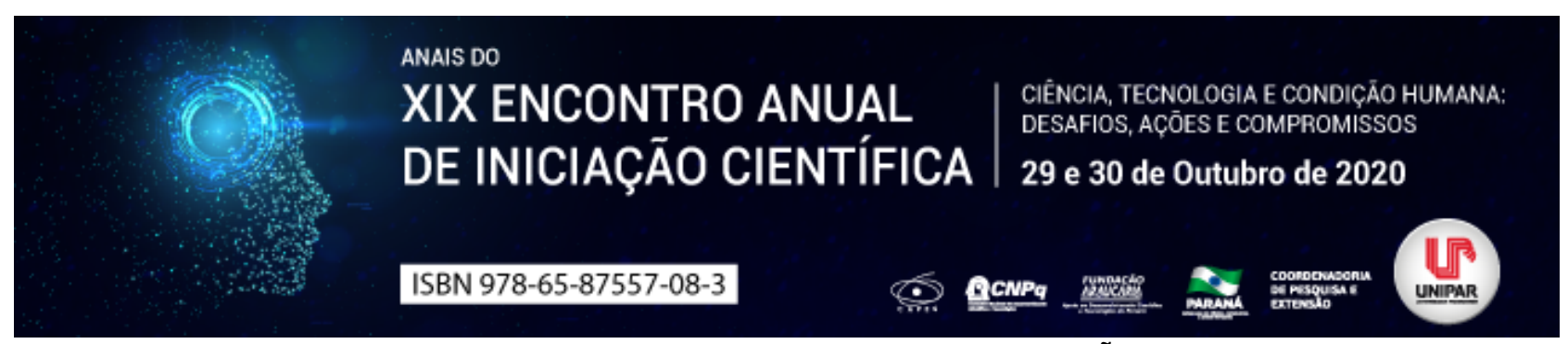

AS NOVAS POSSIBILIDADES DA BNCC PARA EDUCAÇÃO INFANTIL

\title{
${ }^{1}$ AUDREY BALAROTI , ${ }^{2}$ THAYNA SOLANGE CERRIALI, ${ }^{3}$ CAMILA BARROS CHAVES, ${ }^{4}$ ANALIDES FLAVIA CARUSO COSTA
}

\author{
${ }^{1}$ Acadêmica do Curso de Pedagogia Presencial da Unipar \\ ${ }^{1}$ Acadêmica do Curso de Pedagogia da UNIPAR \\ ${ }^{2}$ Acadêmica do Curso de Pedagogia da UNIPAR \\ ${ }^{3}$ Docente da UNIPAR
}

Introdução: No ano de 1998, o Referencial Curricular Nacional para a Educação Infantil (RCNEI) retratou um grande passo para a educação da época, porém, foi apenas uma orientação dos conteúdos e objetivos de aprendizagem para direcionar os professores como ensinar, deixando a identidade e o modo de pensar da criança de lado, ou seja, a mesma não era o foco principal. Já as Diretrizes Curriculares Nacionais para a Educação Infantil (DCNEI), de 2009, na contramão do RCNEI as diretrizes trouxeram um avanço na educação infantil dividindo em eixos estruturantes do currículo tendo foco nas interações e brincadeiras introduzindo a criança na centralidade dos seus conhecimentos, respeitando as diferenças e realidades locais. E a partir do educar e cuidar, com base nas DCNEI em dezembro de 2017 foi homologado o documento Base Nacional Comum Curricular (BNCC) onde traz a igualdade educacional colocando o aluno como protagonista de sua aprendizagem. Na educação infantil a base destaca a importância do processo educacional inicial, tendo em vista os eixos estruturantes e os seis direitos de aprendizagem que irá assegurar que a criança desde a primeira fase possa desempenhar um papel ativo.

Objetivo: Identificar as novas possibilidades de aprendizagem na educação infantil apontadas no novo documento federal, denominado Base Nacional Comum Curricular.

Desenvolvimento: A Base Nacional Comum Curricular busca deixar a educação mais igualitária e que todos os alunos possam estar no mesmo nível básico de ensino. A interação durante o brincar caracteriza o cotidiano da infância, trazendo consigo muitas aprendizagens e potenciais para o desenvolvimento integral das crianças. Nas competências gerais, encontramos como direitos de aprendizagem e desenvolvimento seis ações que possibilitam colocar os campos de experiências em ação, sendo eles: Conviver, Brincar, Participar, Explorar, Expressar e Conhecer-se, constituindo um arranjo curricular que acolhe as situações e as experiências concretas da vida cotidiana das crianças e seus saberes, entrelaçando-os aos conhecimentos que fazem parte do patrimônio cultural. No entanto, o Referencial Curricular Nacional para a Educação Infantil (RCNEI), de 1998, representou um avanço para a época, porém, era mais como uma orientação dos conteúdos e objetivos de aprendizagem e não fazia a criança e sua identidade o foco principal. Ele reunia objetivos, conteúdos e orientações didáticas. A formação estava no desenvolvimento integral da criança, no qual era vista como alguém que responde aos estímulos dados pelos adultos (no caso da escola, os professores). Sua organização se apresentava em formato de eixos: movimento, identidade e autonomia, conhecimento de mundo, artes visuais, música, linguagem oral e escrita, natureza e sociedade e matemática. Em contrapartida a BNCC reconhece a Educação Infantil como uma etapa essencial e avança na ideia de que a criança deve estar no centro do processo de aprendizagem. O documento ainda orienta os educadores a olharem para as formas particulares que as crianças se apropriam do seu conhecimento e de novas experiências, e assim podendo aprender e se desenvolver dentro dos campos de experiência: EU, O OUTRO E O NÓS, desenvolve a identidade, a subjetividade, a autonomia, empatia, valoriza a própria imagem e respeita as diferenças dos outros. CORPO, GESTOS E MOVIMENTOS, desenvolvem a expressão corporal e como se situar no mundo por meio de atividades do uso do espaço e movimento, o faz de conta, a música e a dança. TRAÇOS, SONS, CORES E FORMAS, desenvolvem as preferências artísticas, identificam os tipos de sons, a improvisação e o repertório musical. ESCUTA, FALA PENSAMENTOS E IMAGINAÇÃO, desenvolve a linguagem oral, a imaginação e o gosto pela leitura por meio das cantigas, jogos cantados, brincadeiras de roda e a conversa. ESPAÇO, TEMPO, QUANTIDADES, RELAÇÕES E TRANSFORMAÇÕES, desenvolve a noção de espaço (rua, bairro, cidade, país); Desenvolve a noção de tempo (dia e noite/hoje, ontem e amanhã); Desenvolve a ordem temporal (depois da aula, antes de dormir); Histórica (na época da Páscoa, fizemos uma viagem).

Conclusão: A BNCC estabelece cinco Campos de Experiência que passam a substituir as disciplinas no RCNEI como norte para o conteúdo ensinado, além de instituir seis Direitos do Aprendizado. Pela BNCC, a criança é definida como centro do processo de aprendizado e exige que mesmo nas atividades dirigidas por professores todas devem ter tempo e espaço para serem participantes ativas. Os profissionais encontrarão uma série de desafios e deverão aprender a desenvolver as competências do aluno, além de colocar a pedagogia diferenciada em prática e garantir todos os direitos de aprendizagem.

\section{Referências}


BRASIL. Ministério da Educação. Base Nacional Comum Curricular: Educação é a base. Disponível em: http://basenacionalcomum.mec.gov.br/images/BNCC_publicacao.pdf. Acesso em: 31 jul. 2019.

BRASIL. Ministério da Educação. Conselho Nacional de Educação; Câmara de Educação Básica. Resolução nº 7, de 14 de dezembro de 2010. Fixa Diretrizes Curriculares Nacionais para o Ensino Fundamental de 9 (nove) anos. Diário Oficial da União, Brasília, 15 de dezembro de 2010, Seção 1, p. 34. Disponível em: http://portal.mec.gov.br/dmdocuments/rceb007_10.pdf. Acessos em: 31 jul. 2019.

BRASIL. Ministério de Educação e do Desporto. Referencial curricular nacional para educação infantil. Brasília, DF: MEC.

BRASIL, L. D. B. Lei 9394/96 Lei de Diretrizes e Bases da Educação Nacional. Disponível http://www. Planalto. gov. br/ccivil_03/leis/l9394. htm. Acessado em: 30 mar. 2015.

Coordenadoria de Pesquisa e Extensão - COPEX

Departamento de Editoraçāo e Divulgaçāo Científica - DEDIC 


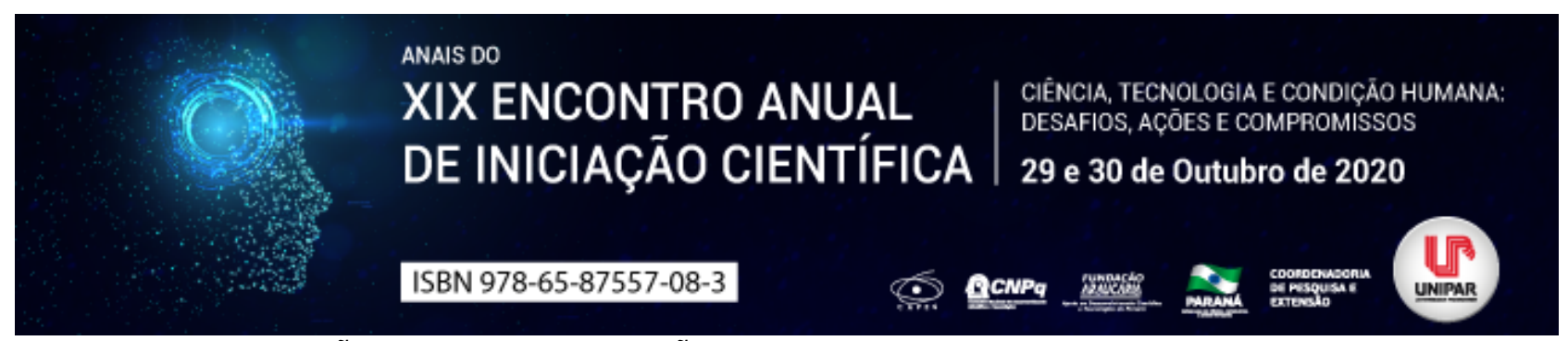

O PAPEL DA GESTÃO NA IMPLEMENTAÇÃO DA BASE NACIONAL COMUM CURRICULAR (BNCC)

\title{
${ }^{1}$ CAMILA BARROS CHAVES, ${ }^{2}$ AUDREY BALAROTI , ${ }^{3}$ THAYNA SOLANGE CERRIALI, ${ }^{4}$ ANALIDES FLAVIA CARUSO COSTA
}

\author{
${ }^{1}$ Acadêmica do Curso de Pedagogia da UNIPAR \\ ${ }^{1}$ Acadêmica do Curso de Pedagogia da UNIPAR \\ ${ }^{2}$ Acadêmica do Curso de Pedagogia da UNIPAR \\ ${ }^{3}$ Docente da UNIPAR
}

Introdução: As competências gerais da Base Nacional Comum Curricular (BNCC) são um conjunto de valores, conhecimentos e habilidades que visam desenvolver os alunos em todos os aspectos: intelectual, físico, social, cultural e emocional. Mas para que isso ocorra de forma efetiva, somente as práticas pedagógicas em sala de aula não são suficientes. É necessária uma mudança nos vários âmbitos da escola, como formação de professores, avaliação, Projeto Político Pedagógico (PPP) e na gestão escolar. O documento propõe um modelo de Educação a qual o aluno é o protagonista e o ambiente escolar tem uma importância fundamental. Portanto, são necessários espaços de diálogos e debates de ideias, para construir um ambiente propício para o estabelecimento de mediações de conflitos. A pesquisa é de cunho bibliográfica e viabiliza o entendimento da trajetória da BNCC e o contexto histórico da gestão escolar.

Objetivo: Analisar o papel da gestão escolar na implementação da Base Nacional Comum Curricular (BNCC), visando o papel do Gestor na adequação de novas regras propostas pelo documento.

Desenvolvimento: Pensar na Base Nacional Comum Curricular (BNCC) como um documento normativo, permite refletir sobre a adequação da mesma, nas distintas realidades da sociedade brasileira. Afinal, a BNCC está normatizando um modelo educacional que abrange tanto o ensino público como o privado, o que necessariamente não representa a mesma condição social ou realidade do indivíduo. Segundo Batista (2002), pensar sobre o final da década de 1980 e 1990, é fundamental para entender as grandes mudanças realizadas no papel da Gestão escolar, dentro de um movimento de luta pela democratização da educação. Segundo Libâneo et al.(2007), a Gestão escolar é responsável pela organização e a gestão de pessoas de forma democrática e interativa, visando o diálogo e o debates de todos nas decisões que serão tomadas. Em 2014 o Plano Nacional da Educação é constituído e já abordava a necessidade de um currículo comum para garantir uma Educação de qualidade. Essas foram as raízes formadores do que viria a ser promulgado como a primeira versão da BNCC em 2016. Pensar a igualdade de ensino é refletir sobre os limites da condição de acesso, permanência no ensino e a realidade da comunidade escolar que a instituição está inserida. Pensar em uma educação homogênea em um país como o Brasil, vasto e cheio de diversidades é complexo. Portanto, pensar no papel do gestor nessa realidade é fundamental. Com a normativa de ajuste do PPP escolar, proposta pela BNCC, a reflexão acerca das atribuições da Gestão Escolar no que se refere ao preparo e organização deste documento, se tornam imprescindíveis. Segundo Peroni (2012), a gestão escolar é peça fundamental para a construção de uma sociedade democrática. Neste sentido, a construção do PPP, a participação em conselhos, a autonomia financeira, a eleição da diretoria, são peças fundamentais para uma Educação democrática. Peroni (2012) ainda defende que, para lutarmos contra o engessamento da educação, é preciso superar a ideia de Gestão fragmentada. A BNCC pode, sem o devido cuidado, normatizar de forma dura o currículo escolar, e perder a identidade escolar. Nas análises realizadas por Peroni (2012) é perceptível que há duas sugestões para o caminho da Educação.

Conclusão: Concluímos nesse resumo que, a partir das leituras realizadas sobre a BNCC e a Gestão Escolar, há um debate sendo realizado desde a promulgação em 2016. Será que é possível padronizar e normatizar um currículo escolar em uma sociedade tão vasta e heterogênea como o Brasil? Segundo os autores, isso depende de um conjunto de fatores, mas o importante é o trabalho que a Gestão Escolar deve ter ao unificar todo o corpo escolar em consonância com a comunidade social de cada escola. A preparação e elaboração de um Projeto Político Pedagógico (PPP) que acompanhe a normatização da BNCC e ainda priorizar a democratização do ensino, é fundamental. Não se pode perder o trabalho educacional de inclusão e democratização que vem ocorrendo desde o final da década de 1980 e 1990. Portanto, é imprescindível a liderança ativa da Gestão Escolar na implementação da BNCC, para que não ocorra um retrocesso educacional.

\section{Referências}

BATISTA, Neusa Chaves. Democracia e patrimonialismo: dois princípios em confronto na gestão da escola pública municipal de Porto Alegre. Dissertação de Mestrado - POA/UFRGS/ PPGS, 2002.

BRASIL. MINISTÉRIO DA EDUCAÇÃO. SECRETARIA DE EDUCAÇÃO BÁSICA. Texto Preliminar do documento BNCC, 2016. Disponível em: http://basenacionalcomum.mec.gov.br/ Acesso em: 10/05/2020. 
LIBÂNEO, José Carlos; OLIVEIRA, João Ferreira de; TOSCHI, MirzaSeabra. Educação escolar: políticas, estrutura e organização. São Paulo: Cortez, 2007.

PERONI, V. M. A democratização da escola em tempos de parceria entre o público e o privado. In: Rev. Pró-posições, Campinas, v. 23, n.2 (68), p. 19-31, mai/ago, 2012.

Coordenadoria de Pesquisa e Extensão - COPEX

Departamento de Editoraçāo e Divulgaçāo Científica - DEDIC 


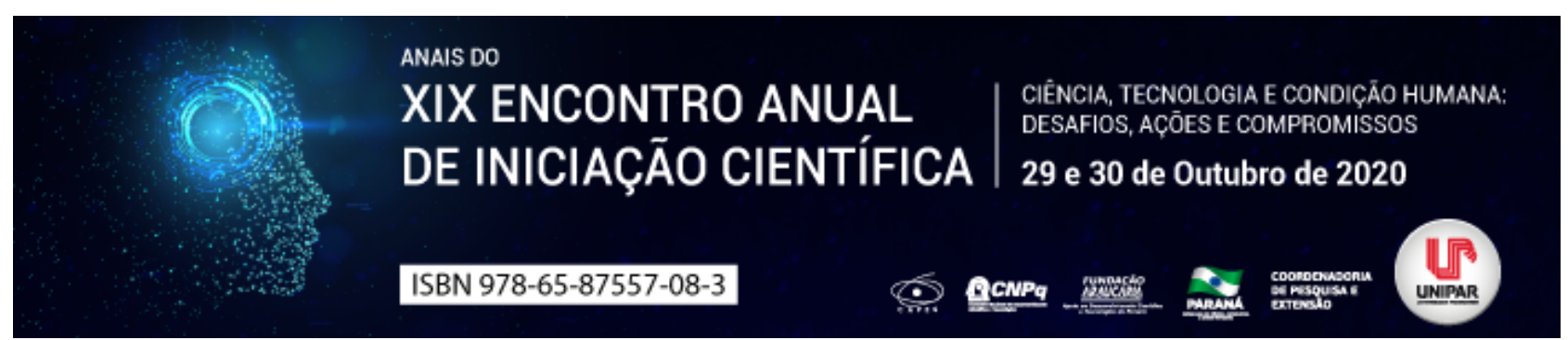

BREVE ANALISE SOBRE A LEI DE LIBERDADE ECONÔMICA

\title{
${ }^{1}$ KAMILA REZENDE, ${ }^{2}$ HELOISA CRISTINA LUIZ CAPPELLARI, ${ }^{3}$ HORACIO MONTESCHIO
}

\author{
${ }^{1}$ Acadêmica do Programa de Mestrado da UNIPAR \\ ${ }^{1}$ Acadêmica do Programa de Mestrado da UNIPAR \\ ${ }^{2}$ Docente da UNIPAR
}

Introdução: As inovações introduzidas pela Lei 13.874/2019 vieram como uma iniciativa do Poder Executivo Federal de destravamento da economia através desburocratização da atividade econômica em âmbito nacional, diminuição da intervenção estatal e aumento da liberdade dos particulares, como uma forma de contribuir para o desenvolvimento nacional da economia pautado no texto constitucional. O trabalho tem como problema a questão envolvendo a liberdade econômica. Utiliza do método dedutivo, com a revisão bibliográfica e apresenta como conclusão a diminuição da intervenção do Estado das atividades empresariais.

Objetivo: Analisar brevemente as mudanças trazidas pela lei de liberdade econômica e os benefícios de cunho econômico por ela trazidos.

Desenvolvimento: A Medida Provisória n. 881 de 2019, posteriormente convertida em Lei 13.874 de 2019, mais conhecida como Lei da Liberdade Econômica, foi uma iniciativa do chefe do Poder Executivo Federal, com o objetivo de facilitar o exercício de atividades econômicas no Brasil através da diminuição do poder estatal sobre as relações comerciais e prevalência da autonomia de vontade, considerando que o Brasil é um dos países mais burocráticos e de maior intervenção estatal do mundo, e estudos econômicos realizados no século XX revelaram que os países com menor atuação do Estado e menor burocratização da economia geraram melhores resultados econômicos. Desta forma, a Lei traz em seu corpo novas regras para o desenvolvimento econômico, além de declaração de direitos de atividades econômicas e diversas modificações legislativas incluindo no Código Civil, sendo pautada em princípios constitucionais, conforme versa seu art. 2, incisos I, II e III, especificamente nos princípios Ia presunção de liberdade no exercício de atividades econômicas; II - a presunção de boa-fé do particular; e III - a intervenção subsidiária, mínima e excepcional do Estado sobre o exercício de atividades econômicas, presunção de Boa Fé do particular , que garantem a interferência mínima do Estado na economia particular e ainda salientam uma nova perspectiva sobre o princípio da autonomia da vontade, menos intervencionista, mais próxima aos ditames liberais, motivo pelo qual se fala em novo parâmetro regulatório de livre mercado, fazendo referência ao art. 170 da Constituição Federal que estabelece: A ordem econômica, fundada na valorização do trabalho humano e na livre iniciativa, tem por fim assegurar a todos existência digna, conforme os ditames da justiça social [...] . Apesar das inúmeras mudanças trazidas pela Lei, sua fundamentação é clara no sentido de que suas mudanças nos textos legais e na questão da liberdade e boa-fé do particular trazem mudanças positivas

sem implicar em retrocesso ao equilíbrio dos pactos, e, consequentemente, atender aos propósitos internos e externos mantidos em relação à retomada do crescimento econômico em conjunto com a adoção de políticas econômicas e de governança eficientes , (OLIVEIRA e FERREIRA, 2019).

Conclusão: Com base nos fatos acima elencados podemos concluir que a Lei de Liberdade Econômica surgiu como uma proposta do governo federal de melhorar a economia do país através da desburocratização da atividade econômica e da diminuição da intervenção estatal no ramo, contendo em seu texto legal diversas alterações tanto no Código Civil, como na lei trabalhista, tributária e orçamentária, baseada em princípios constitucionais, possibilitando que o particular tenha maior liberdade para desenvolver sua atividade econômica e desta forma, contribuindo para o melhoramento da economia nacional.

\section{Referências}

BRASIL. Constituição (1988). Constituição da República Federativa do Brasil. Brasília, DF: Senado Federal. Disponível em: encurtador.com.br/jIMOV Acesso em: 16 jul. 2020.

BRASIL. Lei № 13.874, de 20 de Setembro de 2019. Lei de Liberdade Econômica. Brasília, DF: Senado Federal. Disponível em: encurtador.com.br/iwSYZ. Acesso em: 18 jul. 2020.

BRASIL. Lei 10.406, de 10 de janeiro de 2002. Código Civil. Diário Oficial da República do Brasil, Brasília, DF: Senado Federal. Disponível em: encurtador.com.br/kAHJY. Acesso em: 18 jul. 2020.

OLIVEIRA. M, G, M, D. FERREIRA. J, S, A, B, N. A Medida Provisória 881/2019: Novo Parâmetro Regulatório da Economia e os Reflexos no Desenvolvimento. Florianópolis: CONPEDI, 2019. Disponível em:

encurtador.com.br/evT27 Acesso em: 16 jul. 2020. 
Coordenadoria de Pesquisa e Extensão - COPEX

Departamento de Editoraçāo e Divulgaçāo Científica - DEDIC 


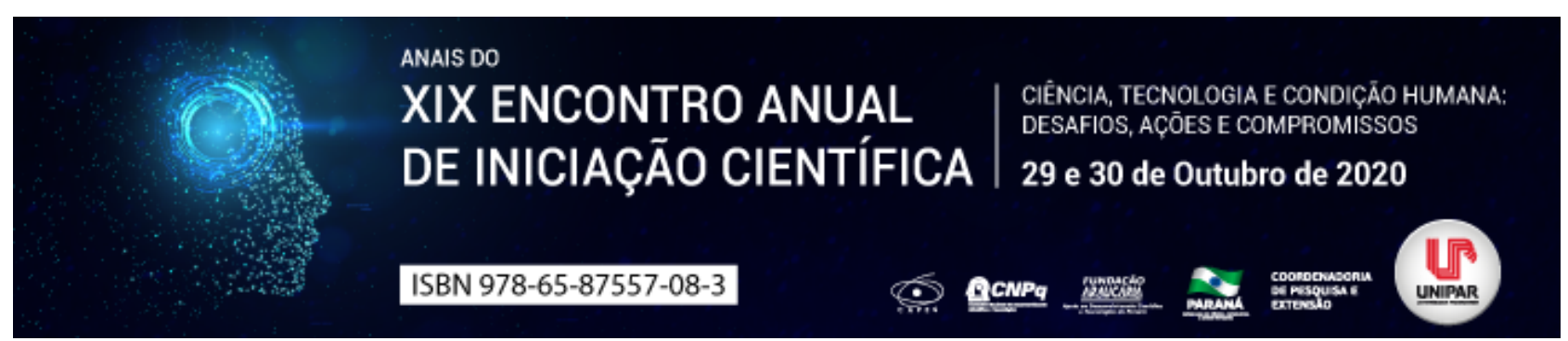

PSICOLOGIA COMO AGENTE DE TRANSFORMAÇÃO SOCIAL: UM ESTUDO BIBLIOGRÁFICO

\title{
${ }^{1}$ ALANA GIRARDI, ${ }^{2}$ JULIANA MULLER RIOS, ${ }^{3}$ CLAUDIA MAIO ANTONELLI
}

\author{
${ }^{1}$ Acadêmica do Curso de Psicologia da UNIPAR \\ ${ }^{1}$ Acadêmica do Curso de Psicologia da UNIPAR \\ ${ }^{2}$ Docente da UNIPAR
}

Introdução: Este resumo partiu do interesse das acadêmicas na atuação do Psicólogo na Psicologia social. O texto busca, através de estudo bibliográfico discutir a atuação do psicólogo no Centro de Referência da Assistência Social (CRAS), dispositivo de proteção social básica que faz parte da Política do Sistema Único de Assistência Social (SUAS) direcionado à prevenir a ocorrência de situações de vulnerabilidades e riscos sociais as famílias. Com a crescente presença do psicólogo nas políticas públicas sociais, sua identidade passa a ser ser orientada, menos pelas estratégias clínicas individuais e mais pelo compromisso social e ético com a realidade atual e suas contradições, como: a desigualdade, a pobreza e a falta de acesso a direitos básicos. Lane (1989), assinala que o objetivo da psicologia social deve ser conhecer o sujeito nas suas relações sociais, em como se manifesta socialmente e no grupo, compreendendo como esse indivíduo, além de produto, pode ser produtor de sua própria história, da sua vida e da sociedade. Considerando então, que a subjetividade dos sujeitos advém de tais condições de vida, a atuação do profissional deverá ser no sentido de apropriar-se do contexto social ao qual se insere e buscar a promoção do bem estar, da autonomia e da cidadania desse coletivo.

Objetivo: Reconhecer e compreender as demandas e possibilidades da atuação do psicólogo social no espaço do CRAS.

Desenvolvimento: A Partir de uma revisão bibliográfica que de acordo com Gil (2010, p.29) é elaborada com base em material já publicado. Tradicionalmente, esta modalidade de pesquisa inclui material impresso como livros, revistas, jornais, teses, dissertações e anais de eventos científicos . Foram elencados importantes materiais que discutem o papel do psicólogo na Assistência Social abordando formas de atuar. A política pública da Assistência Social se constitui num importante espaço de atuação do psicólogo no Brasil, que é um país de extrema desigualdade social. De acordo com o CREPOP (2007), o psicólogo inserido no CRAS tem objetivo de desenvolver o local com foco na prevenção e promoção da vida, o trabalho do psicólogo deve priorizar as potencialidades e assim o fortalecimento de vínculos familiares e comunidade, buscando desenvolver o desejo de superação da situação que se encontram, fortalecendo as Políticas Públicas compreendendo o usuário como sujeitos que possui direitos. Na intenção de atuar efetivamente o psicólogo segundo Silveira (2014) alerta que: O importante é desvelar todas as variáveis ou o maior número possível delas. Identificar o início de tudo torna-se crucial para traçar a história e nos permite também compreendê-la um pouco mais antes de estabelecer melhor nosso papel (SILVEIRA, 2014, p.18). Dessa forma deverá desenvolver o que OLIVEIRA (2016, p. 35) descreve como: [...] uma competência potencial para solucionar questões referentes à subjetividade, à coletividade e ao universo particular dos sujeitos em situação de vulnerabilidade social ou cujos direitos foram violados. Ao adentrar no serviço do CRAS é fundamental que o profissional psicólogo conheça as particularidades daquela comunidade, seus desafios e potencialidades a fim de poder contribuir junto com a equipe multiprofissional e os próprios usuários do serviço para ações voltadas a suas reais necessidades e anseios. A psicologia social vê o sujeito valorizando a dimensão subjetiva desde, tendo como um produto da história e da cultura a qual está inserido, sendo assim a transformação vai partir do comum em conjunto com os desejos e da ética, fazendo com que se desenvolva uma força prática, um agir em comum, ou seja buscar a transformação social é agir nas afecções do corpo e da mente como fenômenos sociais e como lugar de transformação para o conjunto da sociedade. Enfim, é entender que o social e o individual constituem uma única substância (SAWAIA, 2014). Assim, não é possível manter uma visão de dicotomia entre indivíduo e sociedade uma vez que ambos se constituem social e historicamente. Dessa perspectiva a psicologia amplia seu papel fortalecendo a identidade coletiva na luta por uma sociedade mais igualitária e de menor sofrimento.

Conclusão: O estudo evidenciou a necessidade da atuação do psicólogo no espaço do CRAS, no sentido do comprometimento social e ético com as demandas atuais de uma sociedade excludente, onde prevalecem contradições sociais que afetam a vida e a subjetividade dos sujeitos. O sujeito só consegue romper com a exclusão se conseguir se ver em um lugar de poder, atribuindo novo significado a todo o contexto de vulnerabilidade, o psicólogo ao pôr em prática seus saberes deve levar em conta a subjetividade do usuário dando voz aquela pessoa, promovendo sua emancipação e intervindo em processos psicossociais.

\section{Referências}

GIL, A. C. Como elaborar projetos de pesquisa. 5a Ed. São Paulo: Atlas, 2010.

LANE, Silvia T. Meurer. CODO, Wanderley. Psicologia Social: o homem em movimento. 8. ed. Brasília: Brasiliense, 1989. 112p.

OLIVEIRA, Nívia Lúcia de Andrade et al . Relato de experiência: a atuação do psicólogo no CRAS e sua contribuição para o 
fortalecimento dos direitos sociais. Psicol. rev. (Belo Horizonte), Belo Horizonte, v. 22, n. 1, p. 31-45, maio 2016 . Disponível em . acessos em 06 jul. 2020. http://dx.doi.org/DOI-10.5752/P.1678-9523.2016V22N1P31.

Referência técnica para atuação do(a) psicólogo(a) no CRAS/SUAS / Conselho Federal de Psicologia (CFP). -- Brasília, CFP, 2007

SAWAIA, Bader Burihan. Transformação social: um objeto pertinente à psicologia social?. Psicol. Soc., Belo Horizonte , v. 26, n. spe2, p. 4-17, 2014. Available from . access on 07 July 2020. https://doi.org/10.1590/S0102-71822014000600002.

SILVEIRA, Andrea. Socialmente Engajados: refletindo sobre as intervenções psicossociais. 1a. ed. São Paulo, 2014,84 p.

Coordenadoria de Pesquisa e Extensão - COPEX

Departamento de Editoraçāo e Divulgaçāo Científica - DEDIC 


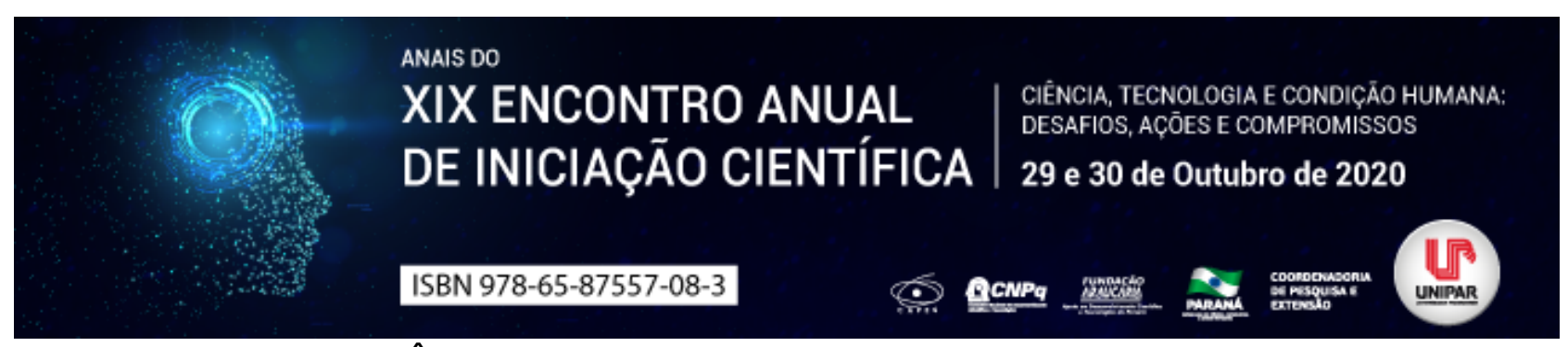

A IMPORTÂNCIA DO BRINCAR PARA O DESENVOLVIMENTO HUMANO

\begin{abstract}
${ }^{1}$ LAISA LIMA PERES, ${ }^{2}$ CíNTHIA FERREIRA DOS SANTOS COSTA, ${ }^{3}$ DÉBORA DE ALMEIDA DOS SANTOS, ${ }^{4}$ MARIANA GOMES DE AZEVEDO, ${ }^{5}$ VIVIANNE AUGUSTA PIRES SIMÕES
\end{abstract}

\begin{abstract}
${ }^{1}$ Acadêmica do curso de Pedagogia da UNIPAR
${ }^{1}$ Acadêmica do curso de Pedagogia da UNIPAR

${ }^{2}$ Acadêmica do curso de Pedagogia da UNIPAR

${ }^{3}$ Acadêmica do curso de Pedagogia da UNIPAR

${ }^{4}$ Docente da UNIPAR
\end{abstract}

Introdução: O brincar para o desenvolvimento humano é muito importante, porém, nunca houve a plena valorização, as pessoas não compreendem a necessidade das brincadeiras, e o quanto a falta de tempo para brincar, prejudica o desenvolvimento infantil. A educação escolar prioriza a teoria e a formação intelectual, negando as habilidades motoras.

Objetivo: Enfatizar a importância do brincar para o sujeito e os prejuízos causados pela falta do brincar.

Desenvolvimento: Brinquedos e brincadeiras não é algo novo, isso já está presente em nosso meio desde a antiguidade, isso nos mostra o quanto a brincadeira é viva e presente na vida das pessoas, pois todos passam pela infância e é neste período em que descobrimos as brincadeiras. $O$ ato de brincar não proporciona simplesmente diversão e entretenimento, mas também muito aprendizado. Brincar é aprender; na brincadeira, reside a base daquilo que, mais tarde, permitirá à criança aprendizagens mais elaboradas. O lúdico torna-se, assim, uma proposta educacional para o enfrentamento das dificuldades no processo ensinoaprendizagem . (ROLIM, et al.,2008, p.177). Os brinquedos e brincadeiras podem desenvolver na criança aspectos cognitivos, afetivos, emocionais e sociais, desenvolvem também o raciocínio, atenção, criatividade, imaginação. Para Costa et al (2012, p. 38) O brincar é a forma de a criança traduzir informações, adquirir conhecimentos, resolver situações difíceis e dar vazão a sentimentos de raiva, dor e alegria . Com isso podemos observar que a brincadeira também pode ser uma maneira de perceber as emoções da criança, ou até mesmo diagnosticar alguma situação pelo qual aquela criança esteja passando, $O$ brinquedo traz à tona muito mais que uma situação imaginária, traz uma situação que pode estar sendo vivenciada pela criança no momento que ela tem acesso a esse brinquedo, é nesse momento que tudo para ela faz sentido, pois vivencia situações reais através de um determinado objeto que para ela naquele momento se torna um brinquedo e que através do ato de brincar ela se realiza . (NIEIRO, 2018). O brincar também possibilita às crianças desenvolverem suas próprias habilidades de pensamento. Elas superam a sua própria condição infantil, agindo como se fossem maiores, desafiando seus limites (CARVALHO, 2016). Por isso a importância da valorização do brinquedo e brincadeiras na vida da criança. Os pais precisam ter consciência desta importância, e participar desta fase lúdica na vida da criança. Os educadores também são extremamente importantes neste processo, pois devem utilizar os brinquedos e as brincadeiras em suas práticas pedagógicas. Os professores devem estar atentos para essa prática lúdica e aprimorar uma contextualização para as brincadeiras. Por meio da observação do brincar, os educadores são capazes de compreender as necessidades de cada criança, os seus níveis de desenvolvimento, a sua organização e, a partir daí, de planejar ações pedagógicas . (ROLIM et al, 2008, p.177). Crianças que não brincam, passam muito tempo ligados á tecnologia, com muitos afazeres escolares, ficando sem tempo para brincar, ou até mesmo aquelas crianças que são submetidas ao trabalho infantil, mesmo sendo uma prática irregular, estabelecido no art. 60 do Estatuto da Criança e do Adolescente (ECA) dispõe que: É proibido qualquer trabalho a menores de quatorze anos de idade, salvo na condição de aprendiz. Estas crianças sofrem prejuízos em seu desenvolvimento, sendo eles: timidez, dificuldade em se relacionar com outras pessoas, pouca criatividade e autonomia, Quando uma delas tem esse direito básico tirado, há grandes chances da criança não entender as diferenças de papéis nas relações pessoais. Assim, poderá terá o desenvolvimento pessoal e intelectual comprometidos e, ao pular essa etapa na vida, ela pode encontrar dificuldades com regras de convívio social diz psicóloga em entrevista para o site JUSBRASIL (2016).

Conclusão: É possível perceber que a prática do não brincar na infância, obstrui o desenvolvimento integral da criança. Através do brincar o sujeito vai exteriorizar suas emoções e expor situações que tenha vivenciado, facilitando na observação de terapeuas ou professores/pedagogos afim de verificar se há algo de errado em sua vida, como por exemplo o abuso, violência, entre outros. Vai também explorar novas texturas, aprimorar habilidades motoras, ampliar relações sociais, compreender o mundo real de forma lúdica. É na brincadeira que a criança desenvolve e descobre o mundo, o interesse pelo o que gosta de fazer, em qual área deseja trabalhar, aprende a lidar com diversos sentimentos, entre outros aspectos que podem ser desenvolvidos brincando. O brincar é de suma importância para a aprendizagem, pois as aulas se tornam mais dinâmicas, facilitando o processo de ensino-aprendizagem. Facilita na fixação dos conteúdos, por ser interesse da criança, assim ela 


\section{Referências}

BRASIL. ESTATUTO DA CRIANÇA E DO ADOLESCENTE. Capítulo 5, artigo 60. Acesso em: 23 março de 2020.

CARVALHO, Marianne Cruz. A IMPORTÂNCIA DO BRINCAR NA CONSTRUÇÃO DE CONHECIMENTOS DE CRIANÇAS NA PRÉ-ESCOLA. Porto. 2016. Disponível em: https://bdigital.ufp.pt/bitstream/10284/6928/1/DM_Marianne\%20de\%20Carvalho.pdf. Acesso em: 23 março de 2020.

COSTA, Gisele Nair Melo; SOUZA, Janaina Neide; BONFANTI, Claudete. BRINCAR E APRENDER: a experiência de docência na prática de ensino em Educação Infantil. Florianópolis, Entre Ver, 2012. Disponível em: file:///C:/Users/Madson/Downloads/34237-113919-1-PB.pdf. Acesso em: 23 março de 2020.

MARTORELLI, Flávia. O trabalho infantil à luz do Estatuto da Criança e do Adolescente. Jusbrasil, 2016. Disponível em: . Acesso em: 23 março de 2020.

NIEIRO, Elania Ribeiro. O BRINCAR NA EDUCAÇÃO INFANTIL: O LÚDICO COMO ESTRATÉGIA DE APRENDIZADO. Disponível em: https://multivix.edu.br/wp-content/uploads/2018/12/o-brincar-na-educacao-infantil-o-ludico-como-estrategia-deaprendizado.pdf. Acesso em: 23 março de 2020.

ROLIM, Amanda Alencar Machado; GUERRA, Siena Sales Freitas; TASSIGNY, Mônica Mota. Uma leitura de Vygotsky sobre o brincar na aprendizagem e no desenvolvimento infantil. Fortaleza, Rev. Humanidade, 2008. Disponível em: http://brincarbrincando.pbworks.com/f/brincar\%20_vygotsky.pdf. Acesso em: 23 março de 2020.

Coordenadoria de Pesquisa e Extensão - COPEX

Departamento de Editoraçāo e Divulgaçāo Científica - DEDIC 


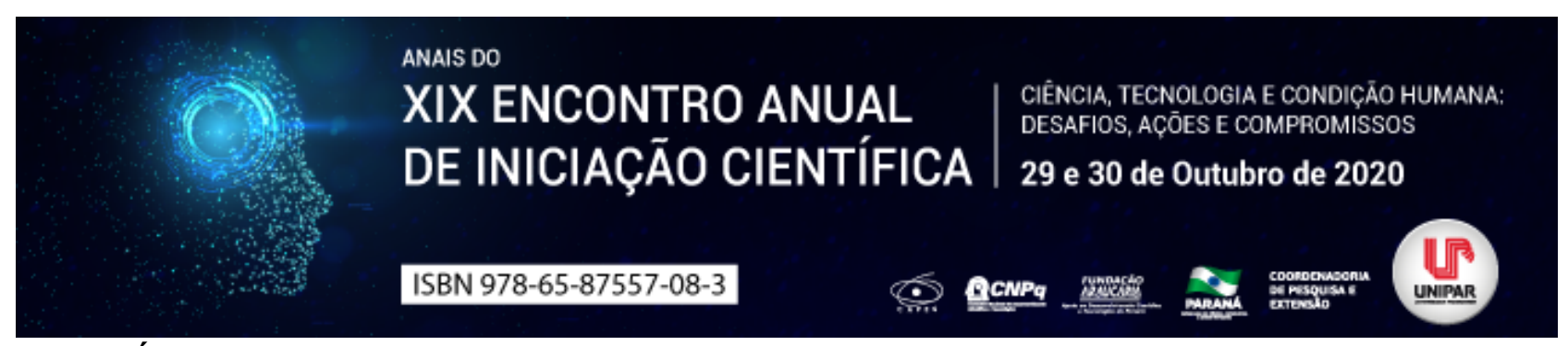

A CULTURA LÚDICA INFANTIL TRADUZIDA A PARTIR DA LEITURA DO VIDEOCLIPE EVERYTHING HAS CHANGED

\author{
${ }^{1}$ JULIA GRASSI KELER, ${ }^{2}$ RODRIGO OLIVA
}

${ }^{1}$ Acadêmica bolsista do PIBIC/UNIPAR

${ }^{1}$ Docente da UNIPAR

Introdução: Este resumo apresenta uma discussão sobre o processo da cultura lúdica infantil. Segundo Souza e Salgado (2008), a cultura lúdica infantil é definida como um espaço social no qual as crianças, por meio de brincadeiras e jogos constroem valores, conhecimentos e identidades. Este estudo se baseia numa análise do videoclipe Everything has changed (2013), performatizado pela cantora americana Taylor Swift em parceria com o cantor Ed Sheeran. A abordagem será baseada nos estudos da Psicologia Social e do desenvolvimento da criança.

Objetivo: Discutir e analisar o videoclipe Everything has changed, a partir dos conceitos de Psicologia Social e do desenvolvimento da criança.

Desenvolvimento: Segundo Sant'ana (2005) o jogo e a brincadeira, por serem mecanismos da aprendizagem próprios ao mundo da infância, favorecem a formação do self por incorporar e organizar os novos conteúdos de experiência. A Psicologia Social estuda a sociedade em si, como as pessoas se comportam no dia a dia, seus pensamentos e atitudes. O videoclipe Everything has changed, apresenta em sua composição narrativa o mundo da infância, revelando o processo de desenvolvimento da criança a partir da aprendizagem. É interessante revelar como a linguagem do videoclipe, mesmo sendo um produto do entretenimento, promove uma situação de representação que faz com que possamos pensar sobre temáticas sociais. Segundo Soares (2013, p. 147), os videoclipes I"situam-se num contexto cultural em que um determinado fenômeno é atravessado, traz inscritos e se situa em consonância com as ordens histórico-sociais. Percebe-se que o videoclipe analisado utiliza-se como campo de investigação formal e expressiva, assumindo um forte caráter reflexivo, o que o conceito de interação entre planos e rompe com a pretensa unicidade de uma narrativa audiovisual, como é característico da linguagem do videoclipe. Neste caso, percebe-se também, que não há uma debate crítico e sim, representações sobre o ambiente da escolha e o favorecimento de interações que promovem nas crianças uma representação do desenvolvimento cognitivo a partir das interações escolha. Vemos uma garotinha que espera no ponto de ônibus para ir na escola. Ao entrar dentro do ônibus, ela procura um lugar e acaba sentando no lado de um garotinho: ele todo concentrado lendo seu jornal e tomando seu café. Eles chegam na escola e começam o dia sendo confeiteiros, fazendo decoração com criatividade e interação. A segunda aula é assistir um filme que conta uma história sobre Paris na França. Outro momento, a garota se veste de rainha com sua espada, ela coroa o garoto como guarda para proteger o reino e, assim, termina um teatro feito pelas crianças. Logo após o intervalo das crianças começa a aula de música, eles fazem a festa, cada um com um tipo de instrumento, que deixa até a professora sem reação, e o garoto toca violão para a garota, um olhando diretamente ao outro, como se estivesse só os dois ali, que nada mais importasse para eles. Quando estão separados eles conversam um com outro com celulares de brinquedo, quando chegam na quadra da escola eles dançam juntos, como se estivessem em um baile escolar e se imaginam no baile, com roupas formais e tudo. Chega a hora de ir embora a irmã da garota chega para buscar ela, e o irmão do garoto também, que trocam olhares que indica que a mesma coisa aconteceu quando ambos irmãos eram pequenos. É importante destacar que o videoclipe busca discutir a cultura lúdica infantil, sendo algo que faz com que as crianças mostram seu indivíduo, na sociedade em que vive, por meio de alguns jogos que os protagonistas do vídeo fez, como é importante a figura cultural que cada um em seu meio social em que vive.

Considerações finais: Portanto, vemos no videoclipe Everything has changed representações que formam o imaginário infantil e de como a cultura lúdica infantil, com os trabalhos voltados para educação e lazer, formam a subjetividade dos sujeitos. Em nenhum momento temos uma performance da cantora que, somente aparece no final do videoclipe como se fosse uma personagem do enredo da trama. Toda a narrativa se desenvolve a partir das personagens crianças, por meio de experiências que mostram como a cultura lúdica infantil opera uma série de princípios e de ideais no tratamento das atividades com e para a infância.

\title{
Referências
}

SANT‘ANA, R. B. Psicologia Social na escola. Disponível em: https://www.scielo.br/pdf/psoc/v17n1/a10v17n1.pdf. Acesso em: 23 jul. 2020.

SOARES, T. A estética do videoclipe. João Pessoa: Editora da UFPB, 2013.

SOUZA, S. J; SALGADO, R. G. A criança na idade mídia: reflexões sobre cultura lúdica, capitalismo e educação. In: SARMENTO, M.; GOUVEA, M. C. (orgs); Estudos da Infância: educação e práticas sociais. Petrópolis, Vozes: 2008.

SWIFT, T. Everything has changed (2013). Disponível em: https://www.youtube.com/watch?v=w1oM3kQpXRo. Acesso em: 10 
ago. 2020.

Coordenadoria de Pesquisa e Extensão - COPEX

Departamento de Editoraçāo e Divulgaçāo Científica - DEDIC 


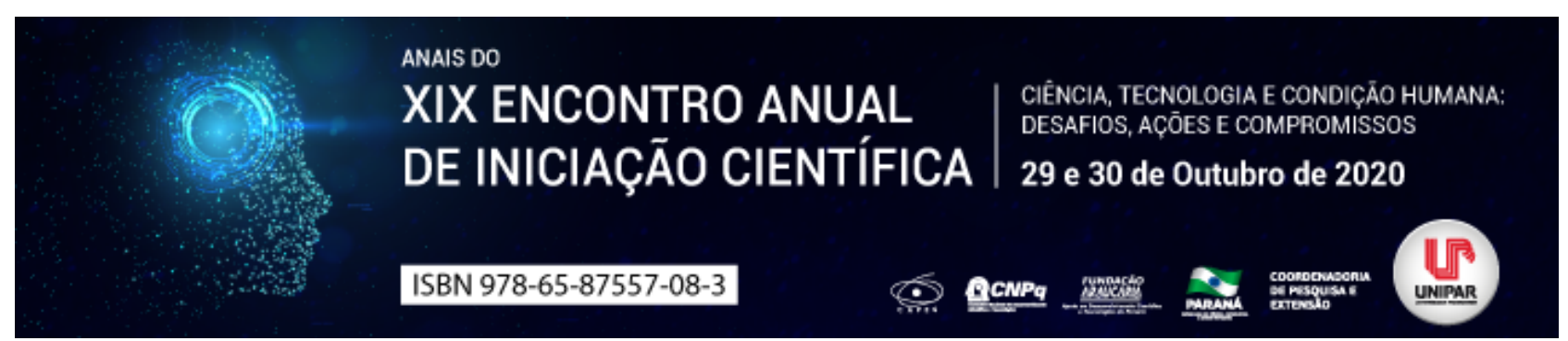

INTELIGÊNCIA EMOCIONAL COMO RECURSO NA RESOLUÇÃO DE CONFLITOS NA GESTÃO ESCOLAR

\title{
${ }^{1}$ KAMILLA RODRIGUES DE SOUZA, ${ }^{2}$ GUILHERME VIEIRA ALFARO, ${ }^{3}$ ANALIDES FLAVIA CARUSO COSTA
}

\author{
${ }^{1}$ Acadêmica do Curso de Pedagogia EAD da Unipar \\ ${ }^{1}$ Acadêmico do Curso de Educação Física da UNIPAR \\ ${ }^{2}$ Docente da UNIPAR
}

Introdução: O papel do gestor escolar não envolve somente o direcionamento de professores, alunos, funcionários, pais e responsáveis, ele também ocupa-se da elaboração de estratégias didáticas para o melhor resultado no ensino aprendizagem dos alunos, gerindo as práticas pedagógicas utilizadas durante o ano, além do cumprimento de regras no ambiente escolar. Seu papel está ligado diretamente a resolução de conflitos e sua mediação se faz necessária utilizando-se de uma ferramenta muito importante: a inteligência emocional. Conforme Ruivo e Rebelo (2014), a inteligência emocional nos coloca como ser portador de emoções, de afetos, onde devemos ter um olhar para o indivíduo não apenas de maneira racional, mas um olhar ligado as suas emoções, em como elas impactarão nas suas atitudes, e neste contexto, como elas poderão influenciar na gestão e ambiente escolar. Nota-se uma preocupação relacionada mais a métodos burocráticos, técnicas e conteúdo, e segundo Luck (2000) é necessário que hoje, os gestores tenham um preparo para lidar com as emoções dos alunos e com as questões socioemocionais, recorrentes no ambiente de trabalho e que atingem diretamente o processo de ensino-aprendizagem.

Objetivo: Refletir acerca do papel do gestor escolar na mediação de conflitos e a oferta de capacitação continuada, para as equipes pedagógicas no âmbito da inteligência emocional.

Desenvolvimento: Segundo Silva (2009), é papel do gestor escolar de maneira positiva e organizacional, liderar uma gestão participativa e cooperativa entre toda sua equipe pedagógica e funcionários, gerando um clima harmonioso e agradável dentro de sua instituição. Para que isso ocorra, de acordo com Silva (2009), é necessária uma boa dose de inteligência emocional, pois ela está diretamente ligada ao sucesso escolar, que é algo constantemente buscado e que inquieta todas as pessoas que participam do deste ambiente, tanto os alunos, pais, funcionários e todo o corpo docente. Levando em consideração a importância que a inteligência emocional traz consigo para a educação, o documento federal normatizado em 2018 denominado Base Nacional Comum Curricular (BNCC), elaborou dez competências para a reflexão sobre a atuação da gestão escolar e gestão pedagógica, no qual a competência de número nove diz que o gestor deve: Exercitar a empatia, o diálogo, a resolução de conflitos e a cooperação, fazendo-se respeitar e promovendo o respeito ao outro e aos direitos humanos, com acolhimento e valorização da diversidade de indivíduos e de grupos sociais [...] (BRASIL, 2017, p. 24). A gestão escolar bem preparada e capacitada, vai de encontro ao estudo da inteligência emocional, proposta por Goleman (1995), como a capacidade de compreender e gerar os próprios sentimentos e das outras pessoas. Um comportamento onde a inteligência emocional deve ser aplicada é na indisciplina, pois não é um acontecimento esporádico no ambiente escolar, pelo contrário, acontece diariamente e é um dos maiores obstáculos enfrentados por professores e gestores. E o que leva a criança a ter um comportamento indisciplinar? Vários são os questionamentos que deveriam ser entendidos antes de qualquer atitude, pois problemas de socialização, bullying, violência, medo, insegurança, preconceito entre outros fatores podem influenciar neste tipo de conduta. A inteligência emocional é uma ferramenta que pode ser usada como aliada a todos os conflitos enfrentados no dia a dia escolar pelos gestores, sendo usada para a compreender e saber llidar com os sentimentos negativos. A ideia é trabalhar o mais cedo possível a educação para as emoções, pois a escola é muitas vezes o ambiente onde as crianças passam a maior parte do seu tempo, apesar dos exemplos que trazem do convívio familiar, na escola ela lida com criações, costumes e comportamentos diferentes de seu ambiente familiar, colocando em prova suas habilidades tanto intelectuais como emocionais (GOLEMAN, 1995). Alnda o autor aponta alguns comportamentos que auxiliariam neste processo, tais como: empatia, virtude, esta última responsável em compreender os sentimentos e preocupações dos outros; autoconsciência, conhecer a si mesmo e suas limitações, assim como aprender a lidar com os seus sentimentos, compreendendo o que está por trás de cada um deles (a mágoa, ira, tristeza entre outros). Ao se preparar para as habilidades socioemocionais o gestor se fortalece em argumentos, sendo capaz de interferir na resolução de conflitos sem se envolver emocionalmente.

Conclusão: A sociedade está mudando e junto a ela o ambiente escolar, hoje as crianças tem outros tipos de conflitos emocionais, sendo assim o tema inteligência emocional faz-se necessário estar presente em formações continuadas, uma vez que este é um tema abordada na BNCC, para que a equipe pedagógica escolar esteja preparada para mediar os conflitos emocionais apresentados durante o processo de ensino aprendizagem. Com todo esse preparo o gestor poderia ajudar a desenvolver crianças mais seguras, ousadas, empáticas, sonhadoras e com a capacidade de se reinventar diante das frustrações encontradas ao decorrer da vida. 


\section{Referências}

BRASIL, Mistério da Educação. Base nacional comum curricular. Brasília-DF: MEC, Secretaria de Educação Básica, 2017.

DA SILVA, Eliene Pereira. A importância do gestor educacional na instituição escolar. Revista Conteúdo, Capivara, v. 1, n. 2, 2009.

GOLEMAN, Daniel. Inteligência emocional: a teoria revolucionária que redefine o que é ser inteligente. Rio de Janeiro: Editora Objetiva, 1995.

LUCK, Heloisa. Ação integrada: administração, supervisão e orientação educacional. Vozes, 1990.

RUIVO, João; REBELO, Sandra. A inteligência emocional na gestão das instituições educativas em Portugal. Campo Abierto: Revista de Educación, v. 33, n. 1, p. 137-150, 2014.

Coordenadoria de Pesquisa e Extensão - COPEX

Departamento de Editoraçāo e Divulgaçāo Científica - DEDIC 


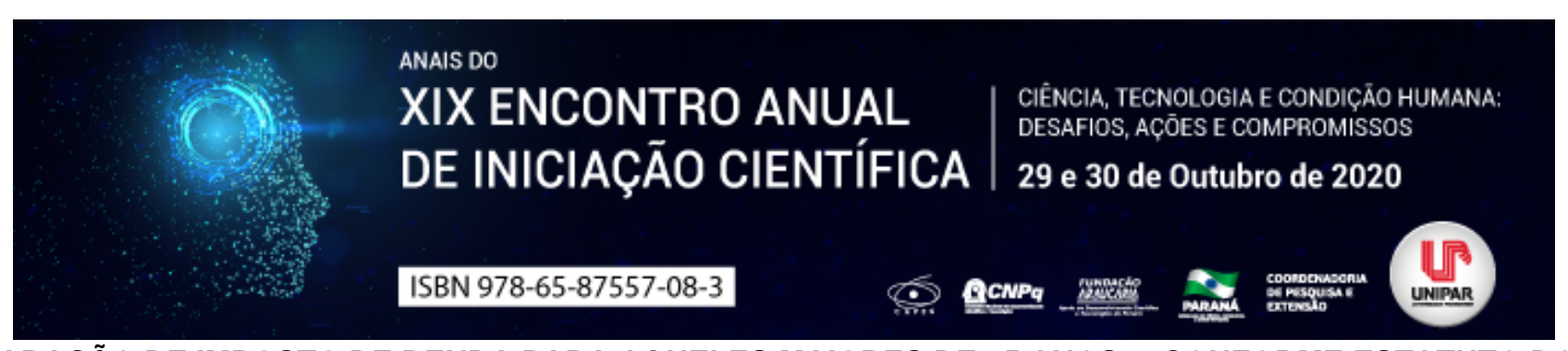

\title{
A DECLARAÇÃO DE IMPOSTO DE RENDA PARA AQUELES MAIORES DE 65 ANOS CONFORME ESTATUTO DO IDOSO E LEGISLAÇÕES PERTINENTES
}

\author{
${ }^{1}$ THIAGO DOS SANTOS OLIVEIRA, ${ }^{2}$ LUIZ ROBERTO PRANDI
}

${ }^{1}$ Acadêmico do Curso de Direito e participante do PIC/UNIPAR

${ }^{1}$ Doutor em Ciências da Educação/UFPE, escritor, professor titular e pesquisador da UNIPAR

Introdução: A declaração de Imposto de Renda da Pessoa Física (DIRPF) é um tipo de informativo anual, que deve ser apresentado à Receita Federal do Brasil (RFB), todos os anos, por aqueles obrigados pela legislação.

Objetivo: Abordar a isenção concedida aos maiores de sessenta e cinco anos, nos rendimentos oriundos de vossos trabalhos e aposentadorias, na declaração do imposto de renda, e outros benefícios concedidos pelo Estatuto do Idoso e legislações pertinentes.

Desenvolvimento: A DIRPF sempre é apresentada nos meses de março e abril, para a apresentação das movimentações do ano anterior.Há vários fatores que obrigam o contribuinte a elaborar tal declaração e conforme Instrução Normativa n.1924/2020 da RFB, em 2020 a principal obrigatoriedade para a entrega se dá aquele que: recebeu rendimentos tributáveis, sujeitos ao ajuste na declaração, cuja soma foi superior a R\$28.559,70 (BRASIL, 2020). Ainda, aos contribuintes maiores de 65 anos que gozam de isenção nas parcelas de seu rendimento: A parcela isenta na declaração está limitada a até $R \$ 1.903,98$, por mês, no ano-calendário de 2019, a partir do mês em que o contribuinte completar 65 anos (BRASIL, 2020). Além disso, aqueles que recebem aposentadoria gozam de certa isenção, destacada no Art. 6, XIV, da Lei 7.713/1988, quando o mesmo possua alguma das molestias destacadas no Artigo, adquiria antes ou após a aposentadoria, sendo algumas delas, por exemplo, tuberculose ativa, alienação mental, esclerose múltipla, neoplasia maligna, cegueira, hanseníase, paralisia irreversível e incapacitante [...] (BRASIL, 1988). Esse benefício deve ser requerido a RFB, com atestado da doença e sua gravidade, devendo ser realizado o preenchimento da declaração, e informando tal situação. Outro benefício trazido pela legislação é o do Art. 3, IX, Lei 10.741/2003, prevê ao idoso a prioridade no recebimento da restituição do imposto de renda (BRASIL, 2003), ou seja, na tabela de restituição deverá ter o depósito como prioridade, não importando a data de transmissão de sua declaração. As situações de enquadramento na tributação, daqueles que estão obrigados a apresentar tal declaração a RFB, devem ser sempre observadas, já que ao tributar valores que são considerados isentos, ou isentar valores que deveriam ser tributados, poderá gerar transtornos tributários ao titular da declaração, caindo na chamada malha fina da Receita Federal, resultando em multas.

Conclusão: No preenchimento da declaração de Imposto de Renda da Pessoa Física, deve ser sempre observado todas as legislações pertinentes, particularmente o Estatuto do Idoso e Manual da DIRPF, para não se perder isenções concedidas, e acabar em uma tributação maior, ou até mesmo isentar valores tributados.

\section{Referências}

BRASIL. Lei n. 7.713, de 22 de dezembro de 1988. Altera a legislação do imposto de renda e dá outras providências. Disponível em: http://www.planalto.gov.br/ccivil_03/leis//7713.htm. Acesso em: 10 jun. 2020.

BRASIL. Lei n. 10.741, de 01 de outubro de 2003. Dispõe sobre o Estatuto do Idoso e dá outras providências. Disponível em: http://www.planalto.gov.br/ccivil_03/leis/2003//10.741.htm. Acesso em: 10 jun. 2020.

BRASIL, Receita Federal. Instrução Normativa n.1924 de 19 de fevereiro de 2020. Dispõe sobre a apresentação da Declaração de Ajuste Anual do Imposto de Renda da Pessoa Física referente ao exercício de 2020, ano calendário 2019, pela pessoa física residente no Brasil. Disponível em: http://normas.receita.fazenda.gov.br/sijut2consulta/link.action?idAto=107054. Acesso em: 10 jun. 2020

Coordenadoria de Pesquisa e Extensão - COPEX

Departamento de Editoraçāo e Divulgaçāo Científica - DEDIC 


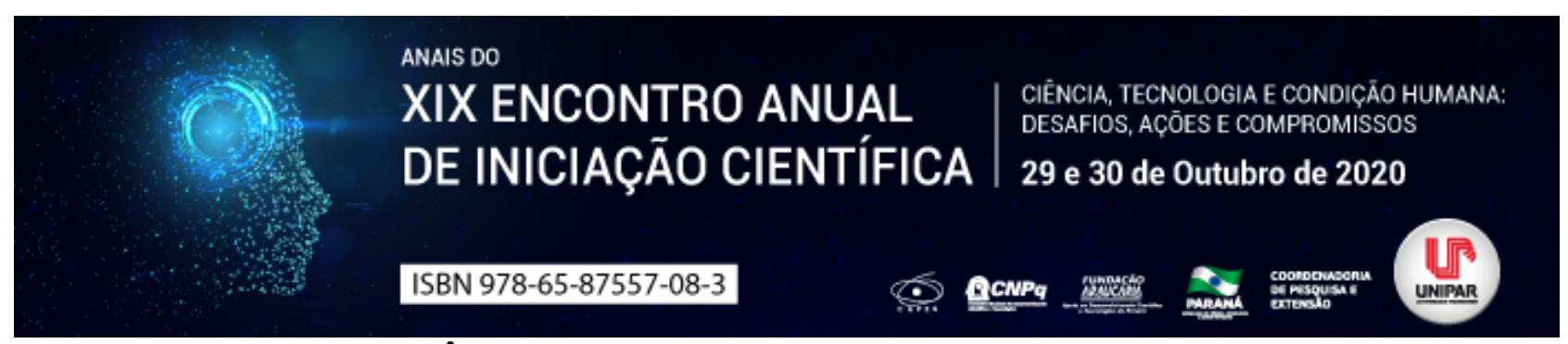

VIOLÊNCIA CONJUGAL EM CONTEXTO DE PANDEMIA

\title{
${ }^{1}$ HELENA CINQUE, ${ }^{2}$ TEREZA RODRIGUES VIEIRA
}

\author{
${ }^{1}$ Discente do Curso de Direito e Integrante PIBIC UNIPAR \\ ${ }^{1}$ Docente do Mestrado em Direito Processual e Cidadania na UNIPAR
}

Introdução: O recorrente número de denúncias de transgressão dos direitos fundamentais das mulheres que vivem em situação de violência conjugal aumentou assustadoramente após a imposição do isolamento domiciliar em época de pandemia, criada pelo novo Coronavírus (COVID-19). O alarmante aumento dos casos traz a necessidade de intervenção do judiciário, além da busca de novas alternativas à denúncia e formas seguras de realizá-la.

Objetivo: Analisar o aumento da violência conjugal no contexto de pandemia e apontar possíveis soluções para a sua diminuição ou extinção.

Desenvolvimento: Todos os direitos e garantias fundamentais aplicáveis aos brasileiros e aos estrangeiros residentes no Brasil estão tutelados constitucionalmente, todavia, é importante salientar que no âmbito da violência doméstica tal proteção é relativizada, uma vez que o machismo coloca a mulher em uma posição de desvantagem e violação dos direitos constitucionais. A Lei 11.340/06 (BRASIL, 2006), mais conhecida como Lei Maria da Penha , que possui como objetivo criar mecanismos que possam coibir a agressão doméstica e familiar contra a mulher traz medidas de assistência e proteção às mulheres que não estão seguras dentro de suas próprias casas, sendo que, além das medidas protetivas de urgência presentes na Lei, o magistrado também poderá acolher alternativas expressas na legislação brasileira, como forma de salvaguardar a vítima. Na perspectiva da Pandemia, entre as medidas recomendadas pela Organização Mundial da Saúde para conter o número de casos, o isolamento domiciliar é, por enquanto, considerado uma das mais efetivas. Todavia, a problemática social que resulta do distanciamento social atinge diretamente as vítimas de violência doméstica conjugal, uma vez que estas se encontram em convivência forçada com o agressor, tendo, como consequência, o aumento alarmante dos casos de agressão. (AUN, 2020) Como salienta a Carta Capital (MARTINS, 2020), no Ligue 180 houve um crescimento de 17\% das denúncias no período de apenas um mês, fato que demonstra o aumento dos conflitos internos nos relacionamentos conjugais. Apesar do acesso à ajuda ter sido reduzido em época de isolamento, de forma emergencial novas medidas foram tomadas pelo Estado e pela sociedade para atender as mulheres em situação de risco, como a possibilidade do registro das denúncias por meio da delegacia eletrônica (PAGNAN, 2020). Ademais, divulgação por meio de cartazes é o foco da campanha Quarentena sem Violência (CNJ, 2020), assim como pode-se citar a urgência do judiciário em analisar os pedidos de medidas protetivas (CONJUR, 2020) e a proposta da Ordem dos Advogados do Brasil, que sugeriu a criação de delegacias móveis e a prorrogação automática de medidas protetivas de urgência por prazo indeterminados (VIESSERI, 2020). O Ministério da Mulher, da Família e dos Direitos Humanos atendeu à necessidade social, ampliando os canais para denúncia, sendo que, [...] o aplicativo 'Direitos Humanos Brasil' foi lançado pela pasta, para que as vítimas possam fazer contato com as autoridades de forma virtual (VIESSERI, 2020), garantindo a discrição e a segurança da ofendida, e ainda, houve a união de cerca de 700 voluntárias na chamada Rede de Justiceiras , que oferece diversas assistências, como jurídica, médica e psicológica às vítimas via WhatsApp (MARTINS, 2020). O secretário-geral da Organização das Nações Unidas realizou um apelo global para que os governos protegessem as mulheres em época de Pandemia (MARTINS, 2020), uma vez que o aumento dos casos de violência doméstica durante o isolamento domiciliar mostra a vulnerabilidade das vítimas e, nada pode ser feito sem que o Estado intervenha e que a sociedade abra espaço para a resolução da problemática.

Conclusão: Dado o exposto, identifica-se que a imposição do isolamento domiciliar, causado pelo COVID-19, contribuiu para o aumento de casos de violência conjugal, uma vez que as vítimas se encontram em convivência forçada com os agressores. Apesar da aplicação da Lei № 11.340/06 para minimizar os efeitos da agressão doméstica, a sociedade e o judiciário passam por um momento de adaptação ao novo contexto social, principalmente por meio de novas alternativas à denúncia, com o foco em maneiras inovadoras e seguras de realizá-la.

\section{Referências}

AUN, Heloisa. Projeto acolhe vítimas de violência doméstica na quarentena. Catraca Livre, São Paulo, 09 abr. 2020. Disponível em: https://catracalivre.com.br/cidadania/projeto-acolhe-vitimas-de-violencia-domestica-na-quarentenal. Acesso em: 10 jun. 2020.

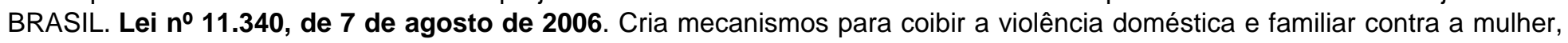
nos termos do $\S 8^{\circ}$ do art. 226 da Constituição Federal, da Convenção sobre a Eliminação de Todas as Formas de Discriminação contra as Mulheres e da Convenção Interamericana para Prevenir, Punir e Erradicar a Violência contra a Mulher e dá outras providências. Publicado no DOU de 8 ago. 2006. 
JUSTIÇA reforça divulgação de canais para denunciar violência doméstica. ConJur, São Paulo, 11 abr. 2020. Disponível em: https://www.conjur.com.br/2020-abr-11/justica-reforca-canais-denunciar-violencia-domestica/. Acesso em: 10 jun. 2020.

MARTINS, Rodrigo. Na quarentena, a violência doméstica e a fome caminham de mãos dadas. Carta Capital, São Paulo, 14 abr. 2020. Disponível em: https://www.cartacapital.com.br/sociedade/na-quarentena-a-violencia-domestica-e-a-fome-caminham-demaos-dadas/. Acesso em: 10 jun. 2020.

PAGNAN, Rogério. Ocorrências de violência doméstica saltam 20\% em SP na quarentena. Folha de São Paulo, São Paulo, 20 abr. 2020. Disponível em: https://www1.folha.uol.com.br/cotidiano/2020/04/ocorrencias-de-violencia-domestica-saltam-20-em-spna-quarentena/. Acesso em: 10 jun. 2020.

RS ganha reforço na campanha Quarentena sem Violência. CNJ, Brasília, 09 abr. 2020. Disponível em: https://www.cnj.jus.br/rsganha-reforco-na-campanha-quarentena-sem-violencia-domestical. Acesso em: 10 jun. 2020.

VIESSERI, Bruna. Governo federal lança aplicativo para que vítimas denunciem violência contra mulher de forma online. Gauchazh, Rio Grande do Sul, 02 abr. 2020. Disponível em: https://gauchazh.clicrbs.com.br/coronavirusservico/noticia/2020/04/governo-federal-lanca-aplicativo-para-que-vitimas-denunciem-violencia-contra-a-mulher-de-formaonline/. Acesso em: 10 jun. 2020. 


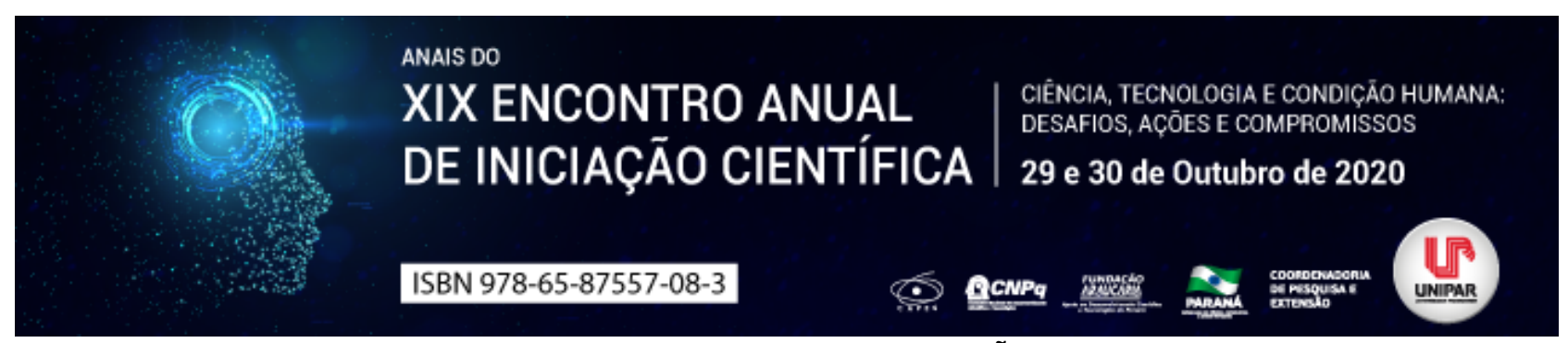

A INDISPENSABILIDADE DO ADVOGADO PARA A ADMINISTRAÇÃO DA JUSTIÇA E O PROCEDIMENTO ADMINISTRATIVO QUANDO REALIZADAS INFRAÇÕES ÉTICAS

\title{
${ }^{1}$ IGOR OLIVEIRA CABRAL, ${ }^{2}$ GABRIEL TRENTINI PAGNUSSAT, ${ }^{3}$ LUIZ ROBERTO PRANDI
}

\author{
${ }^{1}$ Acadêmico do curso de Direito/UNIPAR e bolsista do PEBIC/Fundação Araucária \\ ${ }^{1}$ Acadêmico do Curso de Direito/UNIPAR e bolsista PEBIC/CNPq \\ ${ }^{2}$ Doutor em Ciências da Educação UFPE, Professor Titular e Pesquisador da UNIPAR
}

Introdução: Conforme o artigo 133 da Constituição Federal de 1988, em conjunto com Código de Ética e Disciplina da OAB (CED), o advogado tem função indispensável à administração da justiça. Assim, o CED, como toda lei, trata-se de um ideal, uma norma dirigente, que deve ser alcançada. Tal mister o confere elevadas obrigações morais e sociais, as quais estão dispostas no CED e no Estatuto da Advocacia e da OAB. Descumprindo essas, estará sujeito à sanções disciplinares. O método para apurar a responsabilidade do profissional é previsto, cumulativamente, no Código e no Estatuto, através de um processo administrativo.

Objetivo: Analisar a relação entre a indispensabilidade do advogado para a administração da justiça, a vinculação do exercício da atividade advocatícia com o Código de Ética e Disciplina da Ordem dos Advogados Brasileiros e o procedimento administrativo diante da incompatibilidade da conduta com o preceito de caráter vinculatório.

Desenvolvimento: A Constituição Federal dispõe em seu artigo 133 que o advogado é indispensável à administração da justiça, mas isso não poderia deixar de ser, tendo em vista à função social da classe profissional. Em primeiro ponto na qualidade de defensor técnico, na qual defende os interesses de seu cliente, visando a tutela estatal do que entendem por devido. Em segundo ponto como o promotor da justiça, que além promover essa defesa de mérito de seu cliente, zelará pelo cumprimento do devido processo legal e, consequentemente, dos princípios democráticos e da dignidade humana (KHALIL, 2014). Para a Teoria Tridimensional do Direito (REALE, 2002), esse é fato, valor e norma. Como um dever ser, busca a concretização de valores no plano fático e, é nesse sentido que o advogado pode ter sua indispensabilidade. De acordo com legislação infraconstitucional, no artigo $3^{\circ}$ do CED dispõe que: $\mathrm{O}$ advogado deve ter consciência de que o Direito é um meio de mitigar as desigualdades para o encontro de soluções justas e que a lei é um instrumento para garantir a igualdade de todos (OAB, 2015, p. 2). O que constituiria a afamada equidade: tratar igualmente os iguais e desigualmente os desiguais, na exata medida de suas desigualdades (NERY JÚNIOR, 1999, p. 42), ou seja, o Direito deve ser método de suavizar as desigualdades sociais em busca do ideal da justiça; o qual encontra-se ligado a alguns princípios do Estado Democrático brasileiro, tais como o de Princípio do Acesso à Justiça, Princípio da Ampla Defesa e o Princípio do Contraditório. Os dois últimos princípios são derivados do Princípio do Devido Processo Legal (Art. $5^{\circ} \mathrm{CF}$, inciso LV). Ambos se complementam, no sentido de que a Ampla Defesa consiste em usar todos os meios e recursos inerentes, tanto aos litigantes quanto aos acusados, visto que, ao contrariar de maneira objetiva aquilo que está sendo dito, caracteriza-se então o Contraditório. É notório que pelo conhecimento do douto da lei, a população poderá ter melhor garantido a apreciação de seus direitos pelo Estado. Ademais, também é cabível ao advogado atuar como árbitro ou conciliador para resolução extrajudicial das lides. Nesse sentido, o advogado deve atentar-se a concretizar, em cada caso, os legítimos interesses dos seus constituintes, que, por conta de sua capacidade postulatória e pela outorga de poderes que Ihe foi concedida, atua em nome da parte perante juízo, concretizando nesse sentido, função indispensável à justiça. Por outro lado, há um outro ideal de justiça cabível a essa classe profissional, o estabelecido pelo CED e Estatuto.

Conclusão: Nota-se a correlação entre a função do advogado e o exercício da justiça. Em primeiro ponto em sobre a sua função de defensor técnico, a qual serve para garantir o acesso ao sistema judiciário, utilizando-se do saber para a melhor efetividade; seja por meio de contrato entre esse e o cliente, por advocacia dativa, ou advocacia pública. Posteriormente, o Código de Ética e Disciplina da $O A B$ e o Estatuto da Advocacia e a OAB apresentam normas programáticas, isto é, normas que contemplam um dever-ser, imperativos de conduta que vinculam a atuação do profissional, garantindo, teoricamente, melhor atuação e concretização dos objetivos que são inerentes à sua atuação. No que tange às infrações disciplinares e ao processo administrativo, pretende-se apurar a responsabilidade do profissional, tendo em vista o descumprimento de determinado preceito de caráter vinculatório, respeitando os Princípios do Contraditório e Ampla Defesa, pautados no Princípio do Devido Processo Legal.

\section{Referências}

AFONSO SILVA, José da. Curso de Direito Constitucional. ed. 42. São paulo: Malheiros, 2019.

BRASIL. Constituição da República Federativa do Brasil de 1988.

http://www.planalto.gov.br/ccivil_03/constituicao/ConstituicaoCompilado.htm. Acesso em: 19 fev. 2020. 
BRASIL. Lei $\mathbf{n}^{\circ}$ 8.906, de 4 de julho de 1994. Estatuto da Advocacia e a Ordem dos Advogados do Brasil. Disponível em: https://www.oab.org.br/arquivos/pdf/LegislacaoOab/estatuto.pdf. Acesso em: 19 fev. 2020.

OAB. Código de Ética e Disciplina da OAB. Disponível em: https://www.oab.org.br/visualizador/19/codigo-de-etica-e-disciplina. Acesso em: 19 fev. 2020.

KHALIL. Antoin Abou. A questão ética na advocacia: uma abordagem crítica. Tese de doutorado (Filosofia e Teoria Geral do Direito). USP. São Paulo, 2014.

REALE, Miguel. Filosofia do Direito. ed. 20. São Paulo: Saraiva, 2002.

NERY JUNIOR, Nelson. Princípios do processo civil na constituição federal. 5. ed. rev. e ampl. São Paulo: Revista dos Tribunais, 1999.

BITTAR, Eduardo Carlos Bianca. Curso de ética jurídica: Ética geral e Profissional. São Paulo: Saraiva, 2012.

Coordenadoria de Pesquisa e Extensão - COPEX

Departamento de Editoraçāo e Divulgaçāo Científica - DEDIC 


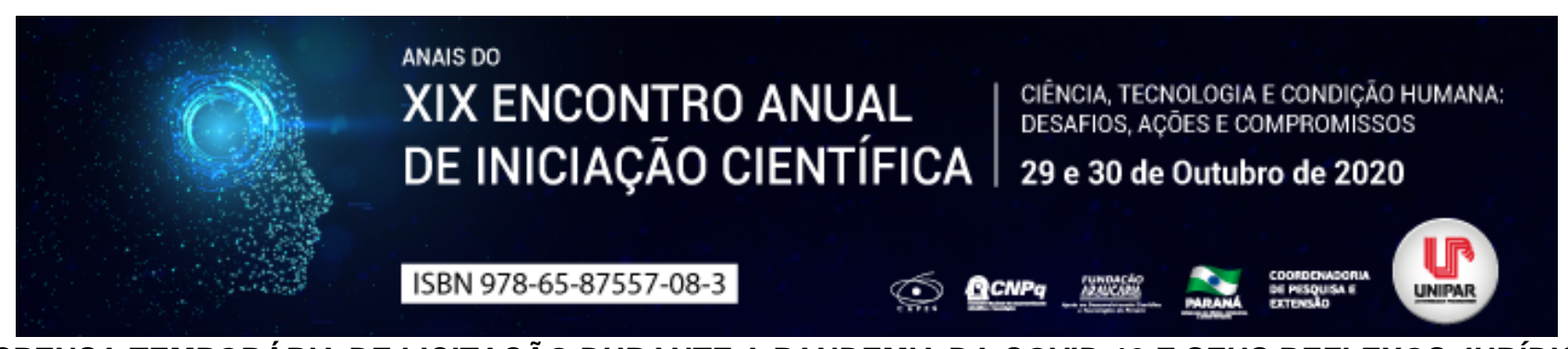

A DISPENSA TEMPORÁRIA DE LICITAÇÃO DURANTE A PANDEMIA DA COVID-19 E SEUS REFLEXOS JURÍDICOS

\author{
${ }^{1}$ RHAMON PAGANOTI DA SILVA, ${ }^{2}$ RICARDO SOARES MESTRE JANEIRO
}

${ }^{1}$ Acadêmico do PIC/UNIPAR

${ }^{1}$ Docente da UNIPAR

Introdução: Em virtude da pandemia do coronavírus que assola o país, foi sancionada a Lei no $13.979 / 2020$, que dispõe sobre medidas emergenciais para o enfrentamento do vírus, uma delas, é a dispensa temporária de licitação. Porém, tal medida é excepcional, devendo ser utilizada com observância dos princípios da legalidade, moralidade e da primazia do interesse público.

Objetivo: Analisar a dispensa temporária de licitação prevista na Lei 13.979/2020 frente aos princípios que regem a administração pública e a Lei no 8.666/93.

Desenvolvimento: A Constituição Federal, em seu artigo 37, inciso XXI, dispõe que salvo os casos especificados em lei, as obras, serviços, compras e alienações serão contratadas mediante processo de licitação (BRASIL, 2020, p. 57). Nesse sentido, a Lei $n^{\circ} 8.666 / 93$, em seu art. 24, IV, previu a dispensa em casos de calamidade pública, definida como o reconhecimento, pelo Poder Público, de situação anormal provocada por desastres, causando sérios danos à comunidade afetada, inclusive à incolumidade ou à vida de seus integrantes (FERNANDES, 2016, p. 263). Assim, com o fim de dar celeridade às contratações na situação de calamidade gerada pela Covid-19, foi autorizada a dispensa temporária de licitação pela Lei $n^{\circ}$ 13.979/2020. Por isso, a medida é constitucional, pois, autorizada por lei, bem como necessária e urgente, visto que não é razoável que se aguarde um processo licitatório para a aquisição de bens e serviços que precisam chegar imediatamente ao Poder Público, tais como aquisição de equipamentos de proteção aos agentes de saúde. Mas, em que pese a dispensa, o administrador deve agir com moralidade e visando ao interesse público, sob pena de ser responsabilizado, pois ao deixar de licitar sob alegação dessa situação de dispensa [...] se for comprovado superfaturamento, responderão solidariamente pelo dano causado à fazenda pública o fornecedor ou o prestador de serviços e o agente público responsável, sem prejuízo de outras sanções legais cabíveis (art. 25, § 2. ${ }^{\circ}$ ) (ALEXANDRINO; PAULO, 2017, p. 753). Dessa maneira, não pode o administrador, por exemplo, contratar uma empresa para realizar o recapeamento asfálticos, sob o fundamento no art. $4^{\circ}$ da Lei $n^{\circ} 13.979 / 2020$, pois, estaria agindo contra a lei, podendo responder pelo crime previsto no art. 89 da Lei $n^{\circ} 8.666 / 93$, que possui uma pena de 03 a 05 anos de detenção e multa. Assim, mesmo na aquisição de bens e serviços destinados ao combate da pandemia, o administrador é obrigado a obedecer às regras estampadas na Lei no 8.666/93 e aos princípios norteadores do direito administrativo.

Conclusão: Desse modo, vislumbra-se que a dispensa temporária de licitação é constitucional e necessária, porém, seu uso deve observar os ditames legais do ordenamento jurídico, sob pena do administrador ser responsabilizado civil e penalmente.

\title{
Referências
}

BRASIL. Constituição da República Federativa do Brasil. In: Vademecum. JusPodivm. 7. ed. Salvador: JusPodivm, 2020. ALEXANDRINO, Marcelo; PAULO, Vicente. Direito administrativo descomplicado. 25. ed. rev. e atual. São Paulo: MÉTODO, 2017.

FERNANDES, Jorge Ulisses Jacoby. Contratação direta sem licitação. 10. ed. rev. atual. e ampl. Belo Horizonte: Fórum, 2016. 


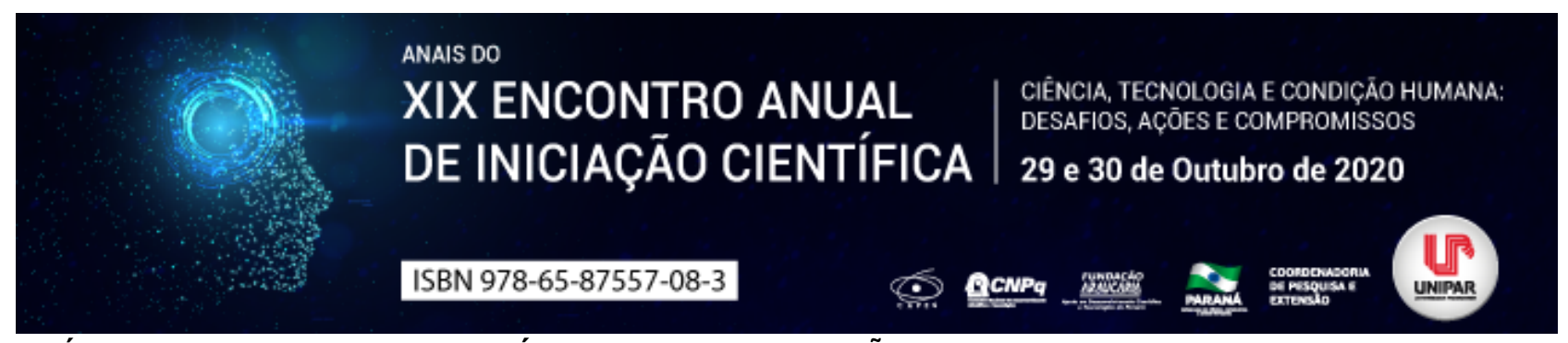

\title{
OS HONORÁRIOS PARA A ADVOCACIA PÚBLICA DIANTE DA AÇÃO DIRETA DE INCONSTITUCIONALIDADE N 6.053/DF E O PROJETO DE LEI No $6.381 / 19$
}

\author{
${ }^{1}$ RHAMON PAGANOTI DA SILVA, ${ }^{2}$ LORENA GABRIELLY ANDRADE BATISTA, ${ }^{3}$ CELSO HIROSHI IOCOHAMA
}

\author{
${ }^{1}$ Acadêmico do PIC/UNIPAR \\ ${ }^{1}$ Acadêmica do PIC/UNIPAR \\ ${ }^{2}$ Docente da UNIPAR
}

Introdução: O Supremo Tribunal Federal (STF), no julgamento da ação direta de inconstitucionalidade (ADI) $n^{\circ}$ 6.053/DF (BRASIL, 2020a), declarou constitucional o pagamento dos honorários sucumbenciais aos advogados públicos. No entanto, o Projeto de Lei $n^{\circ} 6.381 / 19$, visa revogar o $\S 19$ do art. 85 do Código de Processo Civil (CPC), extinguindo o pagamento da verba honorária sucumbencial aos advogados públicos, justificando a proposta legislativa sob o argumento de incompatibilidade da norma com a Constituição Federal.

Objetivo: Analisar o controle de constitucionalidade frente à edição de leis, cuja matéria foi objeto de apreciação do STF, bem como demonstrar a possibilidade da aprovação do Projeto de Lei $n^{\circ}$ 6.381/19 diante da ADI n 6053/DF.

Desenvolvimento: Em um Estado de Direito onde há uma supremacia da Constituição sobre às demais leis como é o nosso, se faz necessário a existência de um órgão capaz de analisar e decidir os eventuais conflitos entre a legislação infraconstitucional e a Lei Maior (ALEXANDRINO; PAULO, 2017, p. 724). No Brasil, o controle de constitucionalidade jurídico, possui uma natureza repressiva, de maneira a ser realizado após a edição das leis, com o fim de filtrar a legislação aos olhos da Carta Magna (MORAES, 2017, p. 1360). O STF exerce, principalmente, o controle concentrado, em especial, nas ações diretas de inconstitucionalidade (ADIs) e ações declaratórias de constitucionalidade (ADCs), que possuem, em regra, eficácia erga omnes e vinculam o Poder Judiciário e a Administração Pública, nos termos do art. 28, parágrafo único, da Lei Federal n $9.868 / 99$ (BRASIL, 2020b, p. 1770). Apesar disso, o Poder Legislativo não está subordinado aos efeitos de tais decisões, visto que foi excluído do rol descrito no artigo supracitado, ao passo que o legislador poderá editar nova lei sobre o mesmo assunto que foi objeto da $A D I$ ou $A D C$, em especial quanto à esta última, sendo a hipótese mais lógica. Logo, caso uma nova lei, cuja matéria já foi objeto de apreciação do controle de constitucionalidade concentrado no STF venha a ser editada, não haverá reclamação perante o Supremo - podendo haver nova ação direta ou declaratória - uma vez que o legislador não está vinculado aos fundamentos da decisão judicial acerca da constitucionalidade ou não daquela lei (BARROSO, 2016, p. 146). Visto isso, constata-se com a ADI no 6.053/DF que o pagamento dos honorários sucumbenciais ao advogado público está de acordo com a Constituição Federal, não afrontando os princípios que regem nosso ordenamento jurídico. Em contrapartida, o Projeto de Lei ${ }^{\circ}$ $6.381 / 19$, visa revogar o art. 85 , § 19 do CPC, com o intuito de extinguir os honorários advocatícios do advogado público, justificando-se na incompatibilidade da norma processual fronte a Lei Maior. Apesar da evidente perda de fundamento do projeto, considerando a questão da inconstitucionalidade superada pela ADI mencionada, o projeto ainda poderia prosperar? A resposta, parece-nos que seria positiva, considerando a inexistência de obstáculos para a atividade legislativa neste sentido. Um exemplo claro dessa possibilidade, é o art. 100, inciso I, do CPC de 1973, que previa o foro da residência da mulher para a ação de divórcio, o qual foi revogado pelo Novo CPC de 2015, mesmo após o julgamento do STF no Recurso Extraordinário n 227.114, em que se decidiu que a norma processual havia sido recepcionada pela Constituição Cidadã, sendo, pois, constitucional.

Conclusão: À luz do exposto, percebe-se que o controle de constitucionalidade repressivo não tem o condão de vincular o Poder Legislativo, de maneira que o legislador é livre para editar novas leis com textos similares, idênticos ou revogar as leis objetos de apreciação pelo STF. Assim, o Projeto de Lei n 6.381/19, que visa a extinção dos honorários para a advocacia pública poderá vir a ser aprovado pelo Congresso Nacional.

\section{Referências}

ALEXANDRINO, Marcelo; PAULO, Vicente. Direito administrativo descomplicado. 25. ed. rev. e atual. São Paulo: MÉTODO, 2017.

BARROSO, Luís Roberto. O controle de constitucionalidade no direito brasileiro: exposição sistemática da doutrina e análise crítica da jurisprudência. 7. ed. rev. e atual. São Paulo: Saraiva, 2016.

BRASIL. Supremo Tribunal Federal. ADI n 6.053/DF. Plenário. Relator: Ministro Marco Aurélio. Sessão Virtual de 12/06/2020 a 19/06/2020. Disponível em: https://bit.ly/3gP2mOE. Acesso em: 08 ago 2020a.

Lei $n^{\circ}$ 9.868, de 10 de novembro de 1999. Dispõe sobre o processo e julgamento da ação direta de inconstitucionalidade e da ação declaratória de constitucionalidade perante o Supremo Tribunal Federal. In: Vademecum. JusPodivm. 7. ed. Salvador: JusPodivm, 2020b. 
MORAES, Alexandre de. Direito constitucional. 34. ed. São Paulo: Atlas, 2018.

Coordenadoria de Pesquisa e Extensāo - COPEX

Departamento de Editoraçāo e Divulgaçāo Científica - DEDIC 


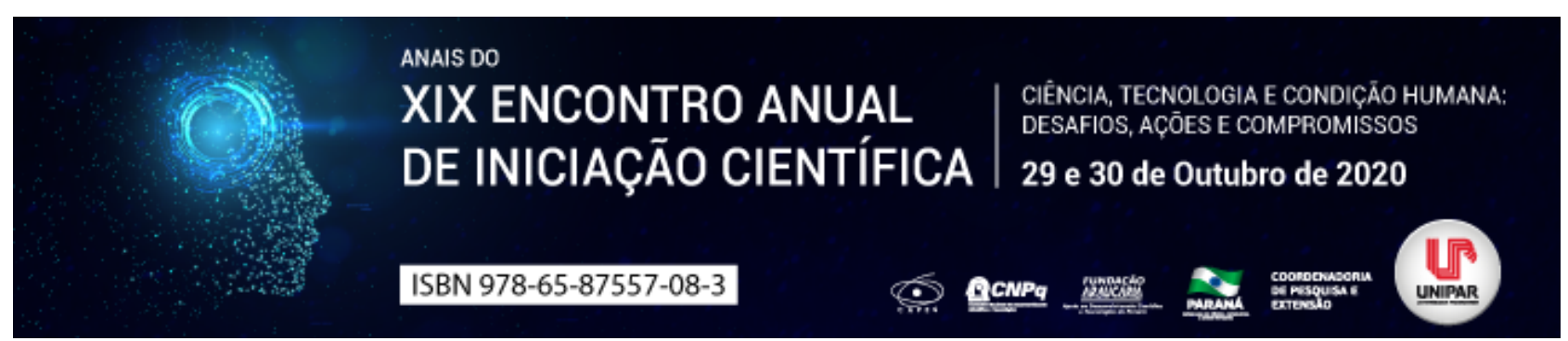

AMBIVALÊNCIA DA MÍDIA: INFORMA OU DESINFORMA A POPULAÇÃO

\title{
${ }^{1}$ DEBORA DE ALMEIDA DOS SANTOS , ${ }^{2}$ VIVIANNE AUGUSTA PIRES
}

\author{
${ }^{1}$ Acadêmica do curso de pedagogia-UNIPAR \\ ${ }^{1}$ Docente da UNIPAR
}

Introdução: A tecnologia está incorporada no dia-a-dia das pessoas, muitas delas passam horas no celular, ou em frente à TV, perceber quanto se passou. A tecnologia e as mídias desempenham um papel de grande importância e influência na vida do sujeito. Através dos meios de comunicação recebe-se informações, assim também se faz o repasse das mesmas, isso tem seus prós e contras, por isso deve-se filtrar e saber quais informações devem ser absorvidas e quais descartadas, e compreender que nem tudo que é exposto pela mídia é verídico. É preciso concordar que essa pode não ser uma tarefa muito fácil, pois a todo instante todo tipo de informação chega até o ouvinte, seja ela por mensagem de voz, imagem, vídeos, reportagens, e-mails e outros diversos tipos, e na maioria das vezes a informação é tomada por verdadeira, algo que pode não ser.

Objetivo: Evidenciar o poder e a grande influência que a mídia exerce na sociedade, despejando sobre o indivíduo todo tipo de informação, seja ela importante ou irrelevante, verídica ou obscura.

Desenvolvimento: Segundo Gonnet (2004, p.16) não existe definição única das mídias. Do mesmo modo que a informação e a comunicação, trata-se de um vocábulo que foi constantemente enriquecido ao longo das últimas décadas, a ponto de, às vezes, designar conceitos muito afastados uns dos outros... Passamos a uma redescoberta do termo pelos anglo-saxões, que introduziram a noção de mass media, meios de comunicação de massa . A todo instante recebe-se mensagens, seja quando se está em casa, no trabalho, na faculdade ou até mesmo dirigindo, o grande responsável por esse repasse de informações de maneira rápida são as mídias. A mídia alcançou um lugar dominante no dia-a-dia da nossa vida. Ela cria as demandas, orienta os costumes e hábitos da civilização, de maneira até então nunca vista (BARROSO, 2006, p.92). E tais informações são capazes de influenciar na opinião, nos valores, nos saberes, e até na subjetividade do indivíduo. Segundo Guareschi (2004, p.34, apud ALMEIDA, SANT'ANA, 2017, p.2) poderíamos argumentar que temos a possibilidade de discordar do que é dito e mesmo criticar o que chega até nós. Mas uma coisa não podemos fazer: é saber o que foi propositadamente ocultado, o não-dito, o silenciado. Essas informações muitas vezes chegam até o receptor de maneira distorcidas, não condizentes com a realidade, e muitas vezes com informações importantes, mas que não foram exibidas na notícia, o que pode modificar todo o contexto da informação, o que muitas vezes pode-se levar a tomar decisões equivocadas. As mídia fornecem informações para que cidadãos possam tomar decisões consistentes e racionais, incluindo a decisão do voto. De acordo com este ponto de vista, os meios de comunicação afetam o processo político ao transmitirem informações de forma objetiva e imparcial ou manipulando e deturpando os fatos (PORTO, 1998, p.17). A Partir do trecho do autor Porto, pode-se perceber o quanto a mídia pode influenciar na tomada das decisões de acordo com os interesses dela, e o quanto isso trará consequências em um futuro próximo. Isso não só no campo político, mas nos mais diversos meios. A realidade de hoje exige cada vez mais que os sujeitos saibam lidar com uma imensa gama de informações que invadem diariamente sua vida cotidiana, de forma desconhecida para nossas gerações precedentes. Lidar com o impacto desse fluxo acelerado de informações e, principalmente, dar-lhes um significado, ou seja, interpretá-las, integrando-as em sua visão de mundo, é uma tarefa inevitável dos sujeitos modernos (GUARESCHI, 2006, p.30).

Conclusão: Com todas estas informações pode-se concluir que a mídia está presente em nossas vidas e tem se tornado cada dia mais indispensável sua participação em nosso cotidiano, é preciso atentarmos quando uma notícia, é recebida como informação ou uma forma de influenciar as opiniões distorcidas, omitindo informações, ou até mesmo simplesmente roubando o tempo do ouvinte. Com isso, para não que sejamos levados a tomar decisões errôneas, ou até mesmo repassar informações incoerentes e enganosas, deve-se questionar, duvidar e se for preciso procurar mais informações e fontes a respeito da notícia, deve-se também tomar os devidos cuidados ao repassar qualquer tipo de informação. Por isso é necessário atentar-se para tudo aquilo que se recebe e se repassa, não tomando de imediato como verdadeiro e seguro, até mesmo quando a fonte parece ser segura. Deve-se adotar pensamento crítico e questionador, para que assim se tenha uma sociedade pensante, detentora do poder, onde as influências midiáticas não exerçam poder sobre as decisões e opiniões do público.

\section{Referências}

ALMEIDA, Cristóvão Domingos. SANT'ANA, Vitória Ayala. Violência Contra Haitianos e a Repercussão na Mídia Brasileira. Intercom Sociedade Brasileira de Estudos Interdisciplinares da Comunicação XVIII Congresso de Ciências da Comunicação na Região Sul Caxias do Sul - RS 15/07 a 17/06/2017. Disponível em: https://portalintercom.org.br/anais/sul2017/resumos/R550128-1.pdf Acesso em: 14 jul. 2020. 
BARROSO, Suzana Faleiro. O uso da imagem pela mídia e sua repercussão na subjetividade contemporânea. Belo Horizonte, psicologia em revista, v.12 n.19 jun.2006 Disponível em: http://pepsic.bvsalud.org/scielo.php? script=sci_arttext\&pid=S1677-11682006000100011 Acesso em: 13 jul. 2020.

GONNET, Jacques. Educação e mídias. São Paulo, Loyola, 2004. Disponível em: https://books.google.com.br/books? id=balkvBfsnK4C\&pg=PA16\&lpg=PA16\&dq Acesso em: 14 jul. 2020.

GUARESCHI, Pedrinho. Mídia e Cidadania. Conexão Comunicação e Cultura, UCS, Caxias do Sul, v. 5, n. 9, p. 30, jan./jun. 2006 Disponível em: http://www.ucs.br/etc/revistas/index.php/conexao/article/view/202/193 Acesso em: 14 jul. 2020.

PORTO, Mauro. Muito além da informação: mídia, cidadania e o dilema democrático. São Paulo, COMUNICAÇÃO \& INFORMAÇÃO v.12, n. 4, Out/Dez 1998. Disponível em: http://produtos.seade.gov.br/produtos/spp/v12n04/v12n04_03.pdf Acesso em: 13 jul. 2020. 


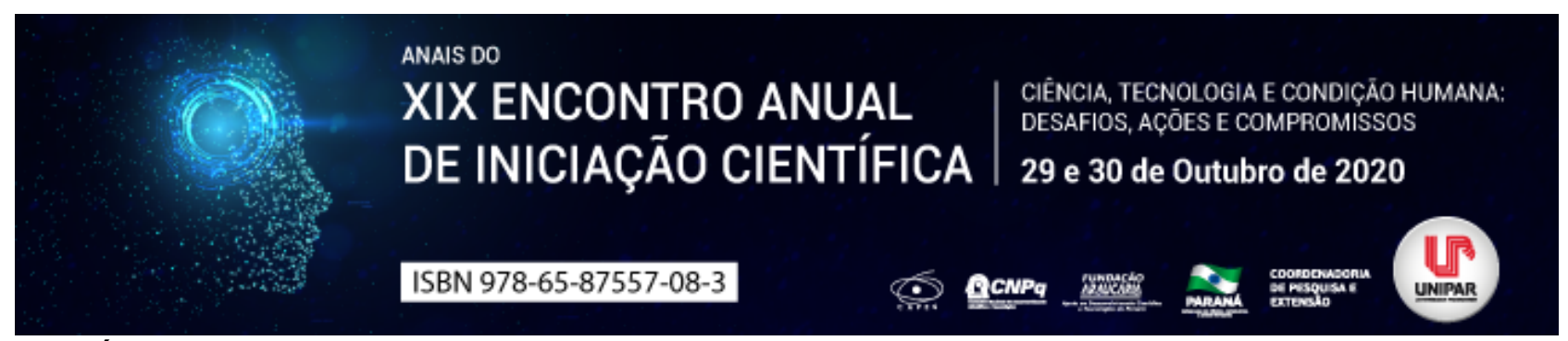

UMA ANÁLISE DA EFETIVIDADE DO ESTATUTO DO IDOSO FRENTE AO PROCESSSO DE ENVELHECIMENTO POPULACONAL

${ }^{1}$ BRUNO HENRIQUE PUCHETTI DE CENE, ${ }^{2}$ MATHEUS HENRIQUE RAPHAEL DE PAULA, ${ }^{3}$ ELYON GONCALVES GALDINO DA SILVA, ${ }^{4}$ MATHEUS HENRIQUE DE FREITAS URGNIANI, ${ }^{5}$ GABRIEL TRENTINI PAGNUSSAT, ${ }^{6}$ LUIZ ROBERTO PRANDI

\author{
${ }^{1}$ Acadêmico do Curso de Direito e do PIC/UNIPAR \\ ${ }^{1}$ Acadêmico do Curso de Direito e bolsista do PIBIC/UNIPAR \\ ${ }^{2}$ Acadêmico do Curso de Direito e do PIC/UNIPAR \\ ${ }^{3}$ Acadêmico do Curso de Direito e do PIBIC/UNIPAR \\ ${ }^{4}$ Acadêmico do Curso de Direito da UNIPAR \\ ${ }^{5}$ Doutor em Ciências da Educação, Docente e Pesquisador da UNIPAR
}

Introdução: A lei no 10.741/03 reforçou e enfatizou diversos direitos e garantias às pessoas com idade igual ou superior a 60 (sessenta) anos. Contudo, o expressivo aumento da população idosa nos últimos anos, trouxe consigo uma série de problemas que desafiam nosso sistema, sendo necessário dessa forma, averiguar a efetividade do Estatuto do Idoso no que tange às necessidades geradas pelo envelhecimento populacional.

Objetivo: Analisar a efetividade do Estatuto do Idoso frente ao processo de envelhecimento populacional, de modo, a constatar se o Brasil está preparado para o enfretamento da problemática social, jurídica e humanitária, ocasionada pelo aumento da expectativa de vida da população.

Desenvolvimento: Atualmente, há cerca de 30 milhões de pessoas idosas no Brasil, número que representa 14\% da população do país conforme projeção da população, divulgada em 2018 pelo Instituto Brasileiro de Geografia e Estatística (IBGE, 2018). Isso somente foi possível graças aos diversos avanços da saúde e da tecnologia que permitiram à população brasileira uma melhor qualidade de vida e, consequentemente, contribuiu para o aumento na expectativa de vida. Entretanto, desencadeou o processo de envelhecimento populacional, que representa um dos maiores triunfos da humanidade e também um dos grandes desafios a serem enfrentados pela sociedade. A fim de que os idosos de hoje e do futuro tenham qualidade de vida, é necessário garantir direitos fundamentais como saúde, trabalho, assistência social, educação, cultura esporte, habitação, previdência, entre outros. Nesse sentido, no Brasil, esses direitos são regulamentados pela Constituição Federal, pela Política Nacional do idoso e pelo Estatuto do idoso. De acordo com o art. $8^{\circ}$ da Lei n. 10.741/03, o envelhecimento é um direito personalíssimo e sua proteção um direito social, nos termos desta lei e da legislação vigente (BRASIL, 2003, p. 1045), portanto a população idosa encontra-se amparada por direitos inalienáveis, que se encontram fora do comércio e que merecem a devida proteção legal, conforme bem enfatiza Gonçalves (2013, p. 184). Não obstante a existência de diversos direitos e garantias destinados à população idosa, sua eficácia no cotidiano ainda é questionável, porquanto, sua concretização depende de políticas de atendimento ao idoso, por meio de conjunto articulado de ações governamentais e não-governamentais da União, dos Estados, do Distrito Federal e dos Municípios, conforme dispõe o art. 46 da Lei n. 10.741/03 (BRASIL, 2003, p. 1048). Contudo, por meio de uma rápida leitura da Política Nacional do Idoso (PNI) e do Estatuto do Idoso é possível constatar uma grande dívida do Estado com esse expressivo segmento populacional - que em meados de 2060 constituirá aproximadamente 73 milhões de pessoas (IBGE, 2018) - sendo que a reponsabilidade e o ônus de cuidar não pode apenas ser sobrecarregada à família.

Conclusão: Em face de todo exposto, é possível constatar que o Estado Brasileiro não se encontra preparado para atender às necessidades da população idosa. Embora o Estatuto do Idoso tenha criado um sistema de garantias, sua efetividade no plano prático ainda é uma utopia, sendo necessário o desenvolvimento de políticas efetivas que atendam e concretizem os direitos fundamentais inerentes aos idosos.

\title{
Referências
}

BRASIL. Legislação complementar 10.741/03. In: Vademecum. JusPodivm. 5. ed. Salvador: JusPodivm, 2019. GONÇALVES, Carlos Roberto. Direito civil brasileiro: Parte geral. 11. ed. São Paulo: Saraiva. 2013.

IBGE. Instituto Brasileiro de Geografia e Estatística. Projeção da população do Brasil e Unidades da Federação por sexo e idade para o período 2010-2060. Rio de Janeiro, 2018. Disponível em: encurtador.com.br/lJKR2. Acesso em: 01 jun. 2020. 


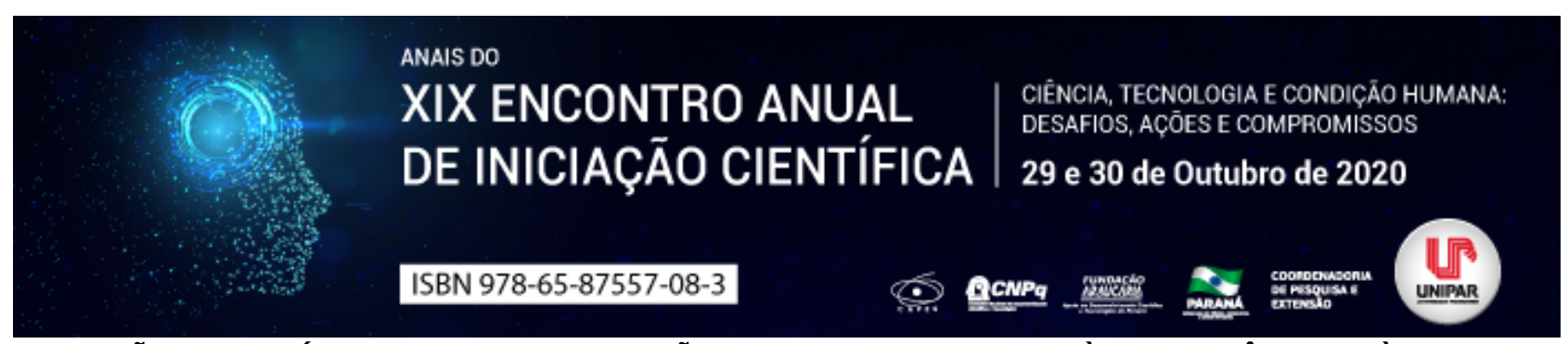

IMPLEMENTAÇÃO DE POLÍTICAS DE REINTEGRAÇÃO SOCIAL NO COMBATE À REINCIDÊNCIA E À CRIMINALIDADE

\author{
${ }^{1}$ CARLA BEATRIZ CIESLAK DE BARROS, ${ }^{2}$ LUDMILA KOLB DE VARGAS CAVALLI
}

\author{
${ }^{1}$ Acadêmica de Direito/UNIPAR \\ ${ }^{1}$ Docente da UNIPAR
}

Introdução: O presente trabalho objetiva a análise do Sistema Prisional Brasileiro frente aos direitos do preso e as condições carcerárias no Brasil. Para tal, analisaremos o surgimento da instituição corretiva, bem como o papel do Estado em punir os indivíduos infratores. Neste contexto, será feita uma breve explicação do surgimento do nosso Código Penal, e ainda, passamos à análise dos direitos previstos ao preso e as condições penitenciárias nas quais estes indivíduos cumprem suas penas. Trazendo à discussão, deste modo, o distanciamento da previsão legal e da realidade prisional, partindo para a verificação da necessidade de se implementar políticas públicas voltadas a melhorar as condições do cumprimento da pena e a observância dos direitos do apenado.

Objetivo: Analisar o Sistema Penitenciário Brasileiro e políticas públicas que podem ser adotadas para incentivar a reintegração social e minimizar a reincidência.

Desenvolvimento: Ao aderirem à formação dos Estados, os sujeitos de direito sacrificaram parte de sua liberdade com o intuito de viver em maior segurança. Desta forma, o conjunto das porções de liberdade é o fundamento do direito de punir (BECCARIA, 1764). Assim, leis foram criadas para fixar as penas de cada delito, sendo o delinquente um elemento negativo e disfuncional que não se encaixa, onde a punição torna-se uma justa retribuição (RODRIGUES, 2001). O tratamento punitivo virou uma grande problemática, pois, a prática de retribuição como forma de controle não ameniza a criminalidade, pelo contrário, intensifica o cometimento de delitos. O primeiro Código Penal Brasileiro surgiu em 1830, sendo sancionado por D. Pedro I, e tinha como base os princípios da responsabilidade moral e do livre-arbítrio. No século XIX, o positivismo criminológico passou a influenciar a forma como o delito era analisado, tirando aquela visão de castigo do antigo regime, buscando analisar melhor as causas de sua existência (TEIXEIRA, 2008). A Constituição Federal de 1988 deixou sua nítida preferência pelo sistema acusatório (BRASIL, 1988), e através do modo de privação de liberdade busca conter a propagação de violência desenfreada. Entretanto, tal modelo não tem obtido resultados eficazes, visto que os indivíduos mesmo após serem punidos, voltam a adentrar no mundo do crime. Muito se deve observar o cenário no qual se encontram as penitenciárias no Brasil, pois, é para lá que são enviados os indivíduos que ameaçam a paz social. Para o Conselho Nacional do Ministério Público [...] as prisões no Brasil são sujas, apresentam falta de luz, ventilação, alimentação inadequadas, noites mal dormidas por falta de espaço e maus tratos (CNMP, 2009). Esses fatores em nada contribuem com a reabilitação do apenado, pois para que a pena se torne útil, é importante lutar contra os efeitos nocivos da prisionalização. Diante disto, deve haver uma garantia jurídica de que os direitos do preso serão observados. Conforme a Lei de Execução Penal (LEP), em seu art. $3^{\circ}$, serão assegurados ao condenado todos os direitos não atingidos pela sentença ou pela lei (BRASIL, 1984). É garantida, também, [...] a assistência material, à saúde, jurídica, educacional, social e religiosa, pois, tão somente assim serão reduzidos os altos índices de reincidência pós-cárcere (JUNQUEIRA, 2005). A incapacidade de controle pelo poder público sobre a população carcerária, a falta de apoio ao egresso, além do descaso do Estado aos direitos dos presos evidenciam a realidade alarmante e preocupante das prisões brasileiras. Diante disto, no Brasil, o Ministério da Justiça e Segurança Pública tem elaborado um plano Nacional de Política Criminal e Penitenciária onde um dos focos tem sido fortalecer a política de reintegração social, tendo como objetivo, [...] racionalizar e humanizar o sistema penitenciário e outros ambientes de encarceramento (BRASIL, 2018). Para isto, é preciso ampliar os instrumentos que permitam a implementação de projetos e ações que possam representar alternativas à gestão prisional tradicional, onde seja possível conciliar com equilíbrio direitos e deveres fundamentais à nossa sociedade (BRASIL, 2019). O desenvolvimento desse sistema é uma questão de segurança pública, o que os presos precisam no ambiente prisional, são medidas que favoreçam a recuperação de sua bússola moral, isto é, noções estruturadas de família, escola, trabalho e religião que funcionem como variáveis dissuasórias da criminalidade (SCHLEMPER, 2018).

Conclusão: Diante do exposto, conclui-se que o sistema penitenciário brasileiro tem se afastado do seu objetivo primordial, a ressocialização, uma vez que, consequentemente tem se tornado um sistema falido. Contudo, frente a tantas dificuldades encontradas pelo sistema prisional no país, o Estado tem se dedicado a pensar formas de buscar por meio da pena a regeneração do apenado. Um exemplo disto, é o Plano Nacional de Política Criminal, criado pelo Conselho Nacional de Política Criminal e Penitenciária, que tem por objetivo apresentar medidas e propostas a serem adotadas pelos estados, com o intuito de minimizar os efeitos nefastos da pena e reestabelecer a ordem, com estabelecimentos prisionais em melhores condições e medidas socioeducativas focadas em reabilitar os apenados. 


\section{Referências}

BECCARIA, Cesare. Dos Delitos e das Penas. 2 ed. São Paulo: Martin Claret, 2001.

BRASIL. Constituição (1988). Constituição da República Federativa Brasileira. promulgada em 5 de outubro de 1988. 8. ed. São Paulo: Revista dos Tribunais, 2003. Disponível em: http://www.revistadostribunais//constituição.htm. Acesso em: 11 jun. 2020.

Lei de Execução Penal. Lei no 7.210 de 11 de julho 1984. Vade Mecum. São Paulo: Saraiva, 2017.

CONSELHO NACIONAL DO MINISTÉRIO PÚBLICO. CPI do sistema carcerário. 2009. Disponível em: http://bd.camara.gov.br/bd/handle/bdcamara/2701 Acesso em: 02 jun. 2020.

JUNQUEIRA, Ivan de Carvalho. Dos Direitos Humanos do Preso. São Paulo: Lemos \& Cruz, 2005.

MINISTÉRIO DA JUSTIÇA E SEGURANÇA PÚBLICA. Plano Nacional de Política Criminal e Penitenciária, Brasília, Distrito Federal, 2015. Disponível em: https://www.conjur.com.br/dl/plano-nacional-politica-criminal.pdf. Acesso em: 03 mar. 2020.

16 abr. 2020.

Sistema Eletrônico de Informações. Disponível em: http://www.sei. mj.gov.br/sei/mj/documento8674099. Acesso em:

RODRIGUES, Anabela Miranda. Novo olhar sobre a questão penitenciária: estatuto do recluso e socialização, jurisdicionalização, consensualismo e prisão. São Paulo: Editora Revista dos Tribunais, 2001.

SCHLEMPER, Alexandre Luiz. Economia do crime: uma análise para jovens criminosos no Paraná e Rio Grande do Sul. 2018. 164 f. Tese (Doutorado em Desenvolvimento Regional e Agronegócio) Universidade Estadual do Oeste do Paraná, Toledo/PR. 2018.

TEIXEIRA, Sergio William. Estudo Sobre a Evolução da Pena. 2008. 216 f. Dissertação de Mestrado Escola de Direito Fundação Getúlio Vargas, Rio de Janeiro, 2008. 


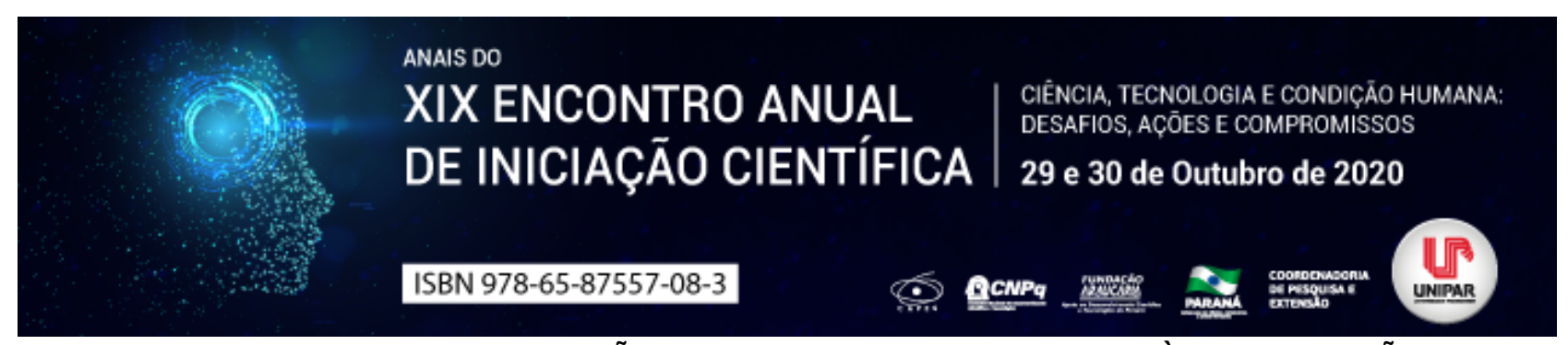

NEOCONSTITUCIONALISMO: DA EFETIVAÇÃO DOS DIREITOS FUNDAMENTAIS À FRAGILIZAÇÃO DO ESTADO DEMOCRÁTICO DE DIREITO EM TEMPOS DE COVID-19

\title{
${ }^{1}$ SIMONE FRITZEN DO PRADO,${ }^{2}$ DIOGO LOPES CAVALCANTE
}

\author{
${ }^{1}$ Acadêmica de Direito - Unipar \\ ${ }^{1}$ Docente da UNIPAR
}

Introdução: $O$ presente trabalho tem por intento realizar uma análise acerca do Neoconstitucionalismo, especificamente quanto à efetivação dos direitos fundamentais no contexto do Estado Democrático de Direito em tempos de COVID-19. Ora, é notória a força que esta teoria atingiu neste momento histórico, entretanto é imprescindível analisar os aspectos que levaram a essa evolução e os desdobramentos atuais. Constitucionalismo, nesse sentido, constitui o movimento que dá origem a Constituição em um complexo de vários momentos históricos e culturais; que nasce como limitação ao poder estatal e se desenvolve frente à garantia da dignidade humana. Partindo deste ponto de análise, este trabalho busca enfatizar a importância dos Poderes consistente no ativismo judicial, na politização da justiça, entre outras temáticas que podem abalar o Estado Democrático de Direito em meio à pandemia do coronavírus.

Objetivo: Identificar, no contexto do Neoconstitucionalismo, os desdobramentos dos direitos sociais por ocasião da pandemia do novo coronavírus.

Desenvolvimento: Ao longo da história desenvolveu-se um pensamento crítico e então revolucionário de limitação do poder estatal e proteção da dignidade humana. Canotilho (2003) cita a existência de diversos movimentos constitucionalistas e define estes em dois grupos, o movimento constitucionalista antigo e o moderno. Dutra (2017) expõe que o movimento antigo denota o desejo do homem pela liberdade, e que o movimento constitucionalista moderno, no final do século XVIII, surge com os desígnios de limitar o poder estatal absoluto. O marco histórico do movimento moderno está na criação das Constituições norteamericana (1787) e francesa (1791), com ideais que buscaram romper o despotismo absolutista e despertar para um novo modelo de Estado, com a presença de direitos e garantias fundamentais mínimas e a descentralização do Poder Político. Contudo, por ocasião de um pretenso constitucionalismo contemporâneo, emerge uma preocupação com a adoção de medidas de efetiva concretização dos direitos fundamentais. Azevedo (2014) narra que a teoria do neoconstitucionalismo, nesse contexto, após a Segunda Guerra Mundial, não deve apenas determinar a limitação do poder político e positivação direitos fundamentais, mas a sua efetivação. Ávila (2009) cita alguns elementos desse novo modelo de constitucionalismo como uma maior utilização de princípios ao invés de regras, maior ponderação do que subsunção, uma análise mais individualizada do que geral ou abstrata, uma sublimação do Poder Judiciário em face aos demais poderes estatais e a expansão da Constituição ao invés da lei. Diante desse cenário, deve-se questionar a atuação do Estado. Caetano (2020) o mundo tem passado por inúmeras transformações decorrentes de uma nova visão de sociedade globalizada, que impõe mudanças e reflexões no posicionamento dos institutos do Direito, em especial da Constituição Federal. Nesse contexto, o mesmo autor relata ainda a necessidade de discussão de algumas decisões tomadas por representantes do executivo e a reação respectiva do legislativo e do judiciário. Sarlet e Pedra (2020) chamam atenção para o grande o número de providências em caráter de urgência expedidas pelo STF na atualidade em face ao executivo, envolvendo questões tão diversas, como a limitações aos direitos fundamentais tais como a liberdade religiosa e de locomoção, a saúde, o trabalho, dentre outros. Especificamente no contexto do Covid-19, Sarlet e Pedra (2020) alertam para a produção de leis que possibilitam a adoção de medidas de isolamento, quarentena, restrição de entrada e saída do país, de locomoção interestadual e intermunicipal, e inclusive a requisição de bens e serviços, o que corroboram ainda mais para a geração na instabilidade constitucional que se instalou no país. Ou seja, diante de um cenário excessivo de regulamentação e de ativismo judicial, o que se observa é uma aparente fragilização da harmonia existente entre os poderes face uma tentativa destes em harmonizar a proteção à saúde e o desempenho da economia.

Conclusão: Diante do que foi discutido compreende-se que, embora o movimento constitucionalista e neoconstitucionalista tenha atingido o seu objetivo a entrega do controle estatal aos cidadãos evidente que o ano de 2020 e a pandemia do coronavírus apresentou problemas em matéria de concretização de direitos e garantias fundamentais. De um lado o direito à saúde, e de outro a liberdade de locomoção e atividade econômica. O mais central de outros inúmeros conflitos de direitos ocorridos na atualidade. Outro aspecto notório, ainda, são as mudanças influenciadas pela politização do judiciário que fragilizam a harmonia que deve existir entre os três poderes, e consequentemente colocam em aflição o Estado Democrático de Direito.

\section{Referências}

ÁVILA, Humberto. NEOCONSTITUCIONALISMO : ENTRE A CIÊNCIA DO DIREITO E O DIREITO DA CIÊNCIA Revista Eletrônica de Direito do Estado (REDE), Salvador, Instituto Brasileiro de Direito Público, $\mathrm{n}^{\circ}$. 17, 
janeiro/fevereiro/março, 2009. Disponível em: http://www.direitodoestado.com.br/rede.asp. Acesso em: 06 ago. 2020

AZEVEDO, Douglas Matheus. O Neoconstitucionalismo e a fragilização do direito. Orientadora: Prof. Me. Mateus Bassani de Matos. 2014. 73 f. Monografia (título de Bacharel em Direito) Centro Universitário Univates, Lageado, 2014. Disponível em: https://www.univates.br/bdu/bitstream/10737/659/1/2014DouglasMateusDeAzevedo.pdf. Acesso em: 27 jul. 2020.

CAETANO, José Eduardo Silverino. Covid-19 frente ao Estado democrático de direito e os direitos fundamentais. Jus.com, abril, 2020. Disponível em: https://jus.com.br/artigos/81101/covid-19-frente-ao-estado-democratico-de-direito-e-os-direitosfundamentais. Acesso em: 06 ago. 2020.

CANOTILHO, José Joaquim Gomes. Direito Constitucional. 7. ed. Coimbra: Livraria Almedina, 2003.

DUTRA, Luciano. Do constitucionalismo antigo ao contemporâneo. Genjurídico: Direito Constitucional, jan., 2017. Disponível em: http://genjuridico.com.br/2017/01/27/do-constitucionalismo-antigo-ao-contemporaneo/. Acesso em: 04 ago. 2020.

SARLET, Ingo Wolfgang; PEDRA, Adriano Sant'Ana. Democracia e I"emendismol" constitucional em tempos de pandemia. Consultor Jurídico, abril, 2020. Disponível em: https://www.conjur.com.br/2020-abr-26/democracia-emendismo-constitucionaltempos-pandemia. Acesso em: 31 jul. 2020. 


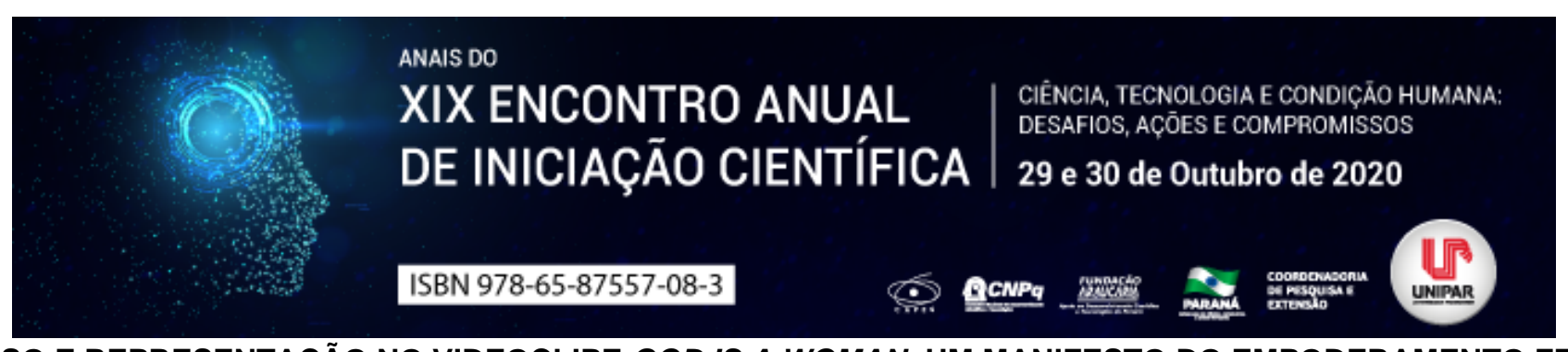

DISCURSO E REPRESENTAÇÃO NO VIDEOCLIPE GOD IS A WOMAN: UM MANIFESTO DO EMPODERAMENTO FEMININO

1'LETICIA TIEMI USHIJIMA OHASHI, ${ }^{2}$ RODRIGO OLIVA

${ }^{1}$ Acadêmica do PIC/UNIPAR
${ }^{1}$ Docente da UNIPAR

Introdução: Este resumo apresenta uma análise do discurso estético no videoclipe God is a woman, da cantora americana Ariana Grande. A abordagem busca revelar o discurso social presente no videoclipe, que pauta-se em temas e subtemas que percorrem o conceito do empoderamento feminino. É por meio das cenas e as representações simbólicas que serão destacados os conteúdos que promovem as discussões sociais.

Objetivo: Debater o conceito do empoderamento feminino, a partir das audiovisualidades do videoclipe God is a woman, da cantora Ariana Grande.

Desenvolvimento: Lançado em 2018, o videoclipe God is a woman, da cantora Ariana Grande, apresenta um discurso artístico que trata sobre questões sociais, políticas e culturais. Verifica-se que muitas produções de videoclipes tem tratado de temas sociais atualmente, vistos a partir de performances embaladas pela cultura pop. Segundo Soares (2013, p. 144), I"os videoclipes performatizam as canções que os originam, propondo uma forma de fazer ver a canção a partir de códigos inscritos nas próprias canções populares massivas.l" Em God is a woman, o empoderamento feminino é revelado primordialmente: entendendo empoderamento como ato de empoderar-se a si mesmo. Destaca-se algumas cenas que simbolicamente representam aspectos relevantes para entender como se traduz o conceito de empoderamento por meio da performance da cantora no videoclipe. Primeiramente, há uma referência a Madonna, que representa uma voz divina, a associação a Madonna é importante, pois a cantora é referência simbólica nas questões que envolvem os temas da mulher. Aqui temos uma intertextualidade com o filme Pulp Fiction, do cineasta Quentin Tarantino - o texto narrado está no filme e representa uma passagem bíblica. A parte em que ela arremessa o martelo que estilhaça o teto de vidro, se refere à expressão famosa em inglês Glass Ceiling, que significa, a barreira invisível que impede que mulheres atinjam altos cargos nas empresas ou que sejam promovidas. O videoclipe God is a woman é considerado uma linguagem híbrida, principalmente, no campo artístico, se utiliza da performance artística, para representar sua contextualidade, do começo ao fim. Como apontado, o videoclipe se organiza esteticamente a partir de uma série de cenas que são mostradas como se fossem quadros que representam as ideias tratadas e manifestada pela cantora. A performance é uma forma de expressão artística híbrida, isto é, que pode mesclar diversas linguagens como teatro, música, poesia e artes visuais. Por exemplo, na última cena, Ariana estaria representando a figura de Deus, da obra de Michelangelo,

Criação de Adão . Em entrevista ao programa Zach Sang Show, a cantora aponta que God is a Woman, na verdade, não é uma música sobre Deus. É sobre mulheres e energia feminina e como a energia feminina, foi responsável por toda a criação do universo. Segundo Pinto; Oliveira (2016), a construção social da mulher sempre foi pautada em dissociação com o homem, mas o contexto social e histórico da mulher vem se modificando com o decorrer dos anos. Este debate é correlacionado a cena em que Ariana Grande inverte totalmente os papéis da hierarquia social, pois ela surge de forma superior aos homens, sentada em cima de um livro, reproduzindo a pose que faz referência a escultura de O pensador , de Rodin. Outra cena imprescindível em que surgiram várias mulheres viradas de costas e a única que está de frente é a cantora, destacando-se por ser completamente diferente das demais. Essa cena gera impacto social, moral e ético, pois ela não vai seguir o que é imposto pela sociedade e fazer o que as pessoas esperam. Portanto, o videoclipe apresenta uma série de discussões por meio de uma linguagem figurativa, são variadas cenas que por meio de representações nos faz pensar sobre o papel e desafios das mulheres frente a realidade e o mundo que as cerca.

Conclusão: God is a Woman é sobre o que há de mais íntimo e mais feminino. Com sutileza e sensibilidade, o videoclipe representa aquilo que muitas vezes não pode ser dito: a vida interna e secreta das mulheres e o que as mulheres enfrentam diariamente, mas que não possuem a coragem suficiente de expor suas ideias. Apoia-se ao embate político e provoca discussões sobre os enfrentamentos e papel social das mulheres. Neste sentido, pontua-se que a linguagem do videoclipe manifesta uma temática e implementa uma provocação por meio de uma discurso cheio de figuras, performances e representações.

\section{Referências}

GRANDE, Ariana. God is a woman. Disponível em: https://www.youtube.com/watch?v=kHLHSIExFis. Acesso em: 20 jul. 2020.

PINTO, Damires; OLIVEIRA, Waidd. F. Estereótipos e violência contra mulher: a necessidade de empoderamento para alcançar a igualdade de gênero. Revista Athenas, FDC, dezembro, 2016.2 Disponivel em: http://www.fdcl.com.br/revista/site/download/fdcl_athenas_ano5_vol1_2016_artigo5.pdf. Acesso em: 23 jul. 2020. 
SOARES, Thiago. A Estética do Videoclipe. João Pessoa: Editora da UFPB, 2013.

ZACH SANG SHOW. Ariana Grande Talks God Is A Woman. Disponível em: https://youtu.be/qOTPgR9zYUl. Acesso em: 20 jul. 2020.

Coordenadoria de Pesquisa e Extensão - COPEX

Departamento de Editoraçāo e Divulgaçāo Científica - DEDIC 


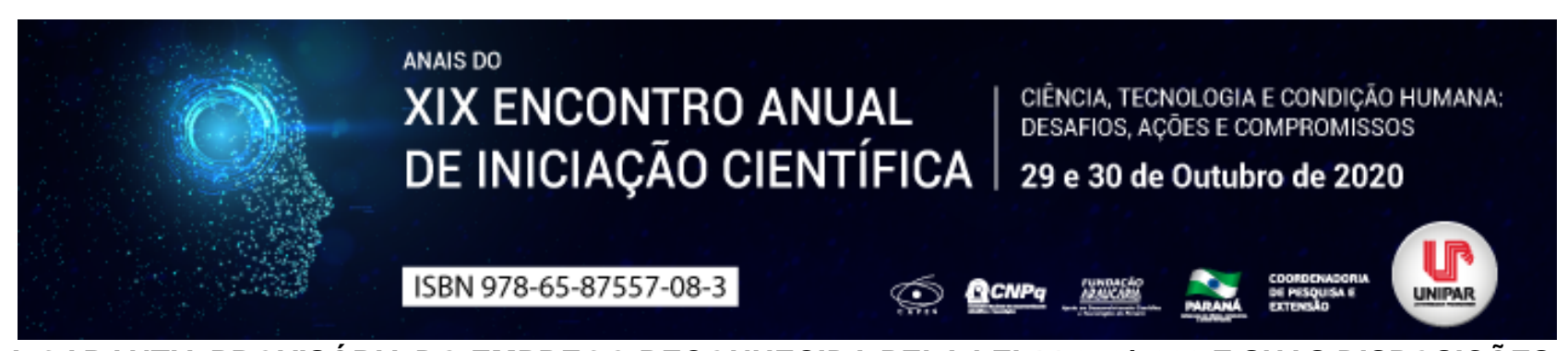

A GARANTIA PROVISÓRIA DO EMPREGO RECONHECIDA PELA LEI 14.022/2020 E SUAS DISPOSIÇÕES

\title{
${ }^{1}$ THIAGO DOS SANTOS OLIVEIRA, ${ }^{2}$ LUIZ ROBERTO PRANDI
}

\author{
${ }^{1}$ Acadêmico do Curso de Direito e participante do PIC/UNIPAR \\ ${ }^{1}$ Doutor em Ciências da Educação/UFPE, escritor, professor titular e pesquisador da UNIPAR
}

Introdução: Com o intuito de amenizar as demissões em massa que poderiam ocorrer por causa da pandemia que se vivencia, a Lei $n^{\circ} 14.022 / 2020$, objetivoucolaborar no pagamento das remunerações parciais ou totais dos empregados privados, em contrapartidaesses teriam reconhecidasuaestabilidade do emprego.

Objetivo: Analisar a garantia provisória do emprego do trabalhador, após o cumprimento de afastamento ou redução da jornada de trabalhodefinido na Lei $n^{\circ} 14.022 / 2020$, em empresas privadas que optaram por esse enquadramento.

Desenvolvimento: Ao adentrar na calamidade do COVID-19 no Brasil, o Governo Federal, por meio da Medida provisória $\mathrm{n}^{\circ}$. 936/2020, convertida na Lei no. 14.022/2020 referente ao Programa Emergencial de Manutenção do Emprego e da Renda. Esse programa tem como finalidade o auxílio direto aos empresários, pagando parte das remunerações de seus colaboradores que deveriam ter seus horários de trabalhos reduzidos, ou até mesmo, a remuneração em seu total, quando o colaborador for suspenso do trabalho, sendo em prazos diferentes e distintos cada modalidade. A lei em seu Art. 1 define como objetivo: I preservar o emprego e a renda; II - garantir a continuidade das atividades laborais e empresariais; e III - reduzir o impacto social decorrente da calamidade pública e de emergência de saúde pública [...] (BRASIL, 2020, p. 01). Em contrapartida, e para fazer jus ao benefício do governo, a empresa que resolver optar pelas modalidades descritas, no Art. 5, tem o dever de: I - redução proporcional de jornada de trabalho e de salário; e/ou II - suspensão temporária do contrato de trabalho [...] (BRASIL, 2020), bem como preservar o emprego daquele colaborador, por igual período que foi concedido o benefício, conforme o Art. 10, Nunes (2020) em análise ao artigo, indaga: A medida prevê a garantia provisória no emprego durante o período de suspensão e pelo mesmo período após o restabelecimento do contrato de trabalho[...] (NUNES, 2020, p. 03). A estabilidade abordada na legislação é [...] o direito do trabalhador de permanecer no emprego, mesmo contra a vontade do empregador, enquanto existir uma causa relevante e expressa em lei que permita sua dispensa (NASCIMENTO, 2005, p.203). Por conseguinte, um benefício para o trabalhador, que tem uma garantia de não perder sua fonte de renda. Para que o empregador não precisar cumprir tal benefício empregatício, segundo Nader (2020) este deverá [...]além das verbas rescisórias devidas, uma indenização prevista no art. $10, \S 1^{\circ}$ da Medida Provisória $n^{\circ} 396$, de $1^{\circ}$ de abril de 2020 , que é o pagamento do salário integral durante o período de estabilidade [...] (NADER, 2020, p. 01), assim, a estabilidade do colaborador no quadro das empresas que esteja vinculado, poderá não ser aplicada.

Conclusão: A conservação do emprego é o resultado esperado, quando da edição da Lei no 14.022/2020, foi uma assertiva, já que exige do empresário a estabilidade do emprego de seu colaborar, quando da adesão à modalidade de redução da carga horária, ou ate mesmo a suspensão do seu contrato de trabalho. Contudo, essa estabilidade pode ser excluída, se o empresário optar em pagar as verbas rescisórias, juntamente com a multa imposta pela Lei.

\section{Referências}

BRASIL. Lei n.14.020, de 06 de julho de 2020. Instituo o Programa Emergencial de Manutenção do Emprego. Disponivel em: http://www.planalto.gov.br/ccivil_03/_ato2019-2022/2020/Lei/L14020.htm Acesso em: 07 jul. 2020.

BRASIL. Medida Provisória n. 936, de 01 de abril de 2020. Institui o Programa Emergencial de Manutenção do Emprego. Disponível em: http://www.planalto.gov.br/ccivil_03/_ato2019-2022/2020/mpv/mpv936.htm. Acesso em: 15 jun. 2020.

NADER, Danielle. MP 936: Entenda a estabilidade e multas para quem rescindir contrato de trabalho. Disponível em: encurtador.com.br/myBQU. Acesso em: 15 jun. 2020.

NASCIMENTO, Amauri Mascaro. Curso de direito do trabalho. 20. ed. São Paulo: Saraiva, 2005

NUNES, Lethicia Domingues. Análise da MP 936/2020: Alternativas trabalhistas para enfrentamento da crise gerada pelo covid19. Disponível em: encurtador.com.br/yMQZ8. Acesso em: 15 jun. 2020. 


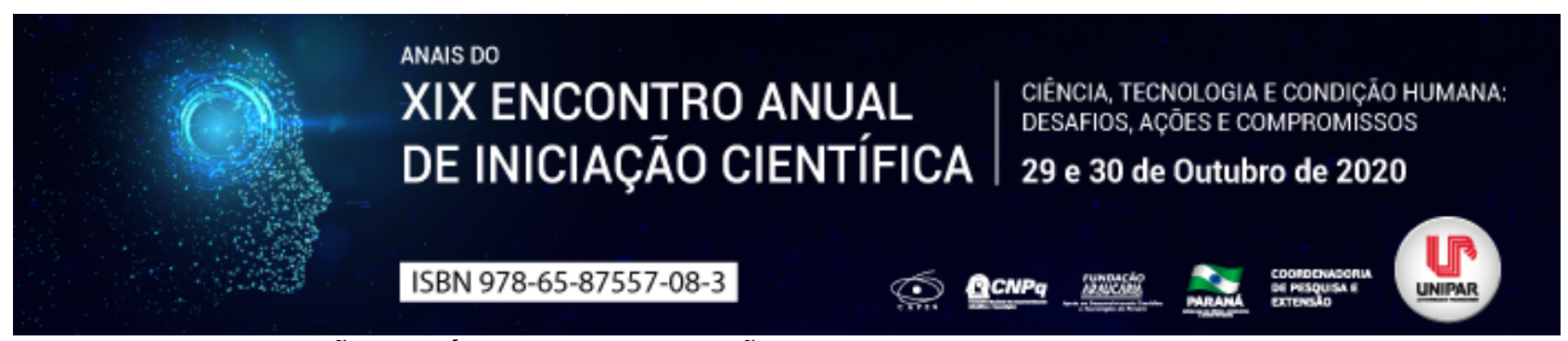

CONFIGURAÇÃO JURÍDICA DA USUCAPIÃO EXTRAJUDICIAL NO DIREITO BRASILEIRO

\author{
${ }^{1}$ RAFAEL DELAZARI AMERICO, ${ }^{2}$ PAULO CESAR DE SOUSA
}

${ }^{1}$ Acadêmico do curso de Direito da UNIPAR

${ }^{1}$ Docente da UNIPAR

Introdução: O presente estudo aborda a configuração jurídica da usucapião extrajudicial no direito brasileiro. Isso porque, com o advento do CPC/2015, foi extrajudicializado o reconhecimento da usucapião, motivo pelo qual, no cotidiano dos serviços notariais e registrais, surgem questionamentos acerca de como levar a efeito o procedimento administrativo para consolidação da propriedade imobiliária.

Objetivos: Entender a configuraçao jurídica da usucapião extrajudicial, com base na legislação e doutrina pátrias.

Desenvolvimento: A usucapião extrajudicial foi instiú́da pelo artigo 216-A da Lei $n^{\circ}$ 6.015/1973. Da leitura do Provimento $n^{\circ}$ $65 / 2017$ do CNJ, se extraei, para fins de sistematização, diferentes conjuntos de requisitos, tais como: subjetivos (pessoa física, pessoa jurídica, capacidade, quantidade de propriedades, estado civil, etnia); objetivos (imóvel urbano ou rural, quantidade de imóveis, tamanho do imóvel); temporal (quantidade de tempo na posse do bem); formais (justo título), possessórios (qualidade da posse, exercício da posse, finalidade da posse, animus domini, boa-fé) e especiais quanto à espécie de usucapião. Aponta Fábio Caldas de Araújo (2015), que o interessado deve formular pedido, por meio de advogado, com ata notarial, documentos e certidões que corroborem à declaração do tempo de posse e a inexistência de ação possessória ou reivindicatória sobre o imóvel usucapiendo. Conforme o artigo $4^{\circ}$, inciso I, do Provimento $n^{\circ}$ 65/2017 CNJ, deve constar da ata: qualificação do requerente, descrição do imóvel, tempo e as características da posse, a forma de aquisição da posse, a modalidade de usucapião pretendida, o número de imóveis, localização, valor do imóvel. Com a apresentação do pedido perante o ofício imobiliário, será publicado edital em jornal de grande circulação, para ciência de terceiros e, caso queiram, se manifestar no prazo de quinze dias, na medida em que o silêncio é interpretado como aceitação/anuência. É preciso notificar as fazendas públicas para manifestarem eventual interesse no imóvel usucapiendo. Havendo impugnação ao pedido, será este encaminhado à esfera judicial (ARAUJO, p.434). Atendidos os requisitos, haverá registro em matrícula imobiliária da aquisição por usucapião. Se a documentação não estiver em ordem, o pedido será rejeitado, o que não impede o ajuizamento da ação declaratória respectiva. É oportuno observar não ser necessário ajuizar a ação de usucapião, caso seja suscitada dúvida junto ao Juízo corregedor para exame da pertinência da recusa feita pelo registrador. Por fim, é importante sublinhar que uma ação de usucapião pode ser convertida em usucapião extrajudicial, desde que atendidos os requisitos legais.

Conclusão: A usucapião extrajudicial, para sua efetivação, deve observar os requisitos subjetivos, objetivos, temporal, formais e possessórios, contemplados por lei e atos regulamentares.

\title{
Referências
}

ARAÚJO. F. C. Usucapião. 3. ed., São Paulo: Malheiros Editores, 2015.

BRASIL. Lei n. 6.015, de 31 de dezembro de 1973. Dispões sobre registros públicos... Brasília, DF. Disponível em: http://www.planalto.gov.br/CCivil_03/leis/L6015compilada.htm. Acesso em: 25 de jul. 2020.

Provimento 65/2017. Conselho Nacional de Justiça. Disponível em: https:/l atos.cnj.jus.br/files/ provimento/provimento_65_14122017_19032018152531.pdf. Acesso em: 25 jul. 2020. 


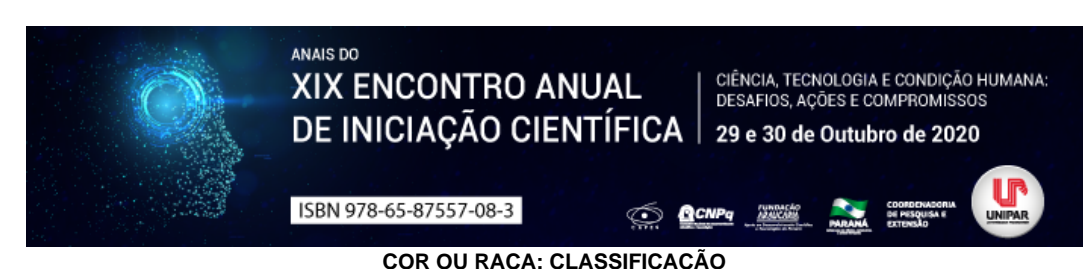

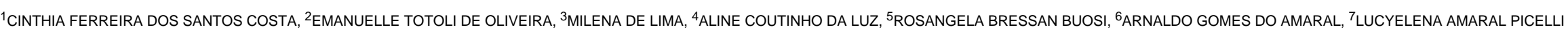

${ }^{1}$ Acadêmico do PIC/UNIPAR

${ }^{1}$ Acadêmica do Curso de Pedagogia da UNIPAR

${ }^{2}$ Acadêmica do Curso de Engenharia Civil da UNIPAR

${ }^{3}$ Acadêmica do Curso de Engenharia Civil da UNIPAR

${ }^{4}$ Docente da UNIPAR

${ }^{5}$ Docente da UNIPAR

${ }^{6}$ Docente da UNIPAR

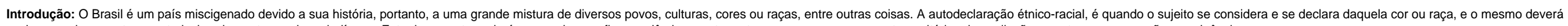
assinar um documento se autodeclarado, preto, pardo ou indígena. Este documento poderá ser usado para fins acadêmicos, entre outros, que passaram por outros critérios de avaliações e outras comprovações e exigências.

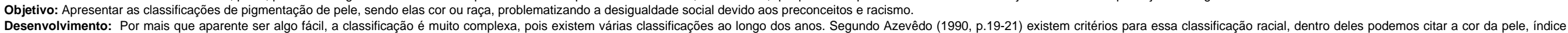

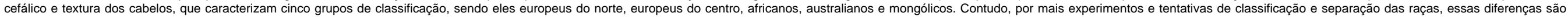

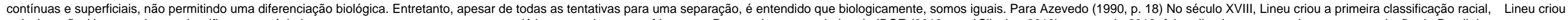

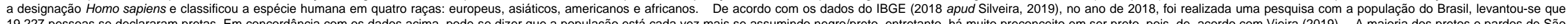

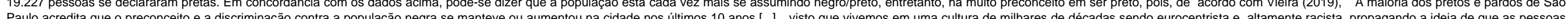

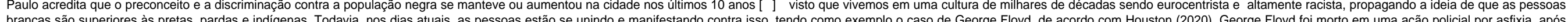

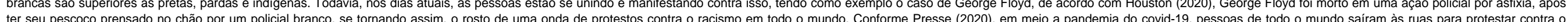

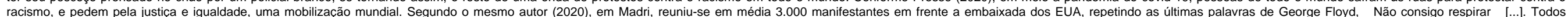

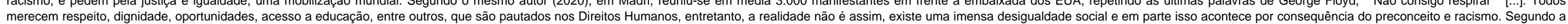

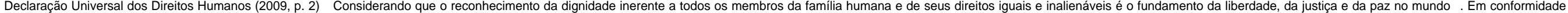

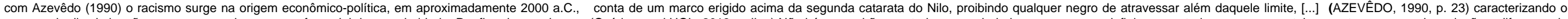

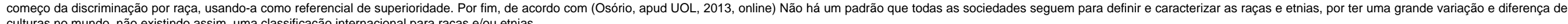
culturas no mundo, não existindo assim, uma classificação internacional para raças e/ou etnias.

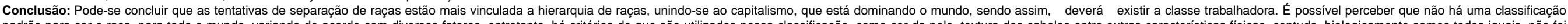

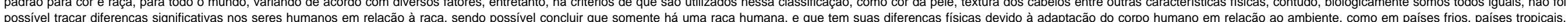
desertos, oceanos, entre outros, que o organismo humano evolui e se melhora para melhor sobrevivência.

\section{Referências}

AZEVÊDO, Eliane. RAÇA Conceito e preconceito. $2^{\mathrm{a}}$ edição. São Paulo. Editora ática, 1990.

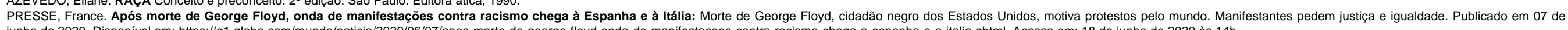
junho de 2020, Disponível em: https://g1.globo.com/mundo/noticia/2020/06/07/apos-morte-de-george-floyd-onda-de-manifestacoes-contra-racismo-chega-a-espanha-e-a-italia.ghtml. Acesso em: 18 de junho de 2020 às 14h
Secretaria de comunicação da UFRGS. o que é a Autodeclaração Étnico-Racial? Ingresso na graduacão. Como entrar na. UFRGS DS

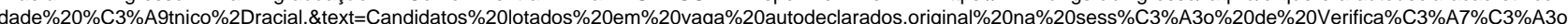
Acesso em 16 jun

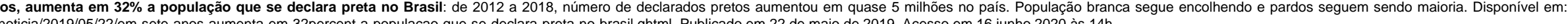
hitps://g1.globo.com/economia/noticia/2019/05/22/em-sete-anos-aumenta-em-32percent-a-populacao-que-se-declara-preta-no-brasil.ghtml. Publicado em 22 de maio de 2019 . Acesso em 16 junho 2020 às $14 \mathrm{~h}$

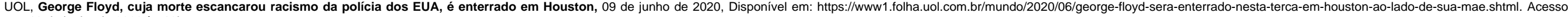

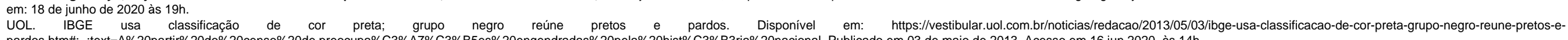
pardos.htm\#: : text=A\%20parti\%\%20do\%20cens0\%20de,preocupa\%C3\%A7\%C3\%B5es\%20engendradas\%20pela\%20histoC3\%B3ria\%20nacional. Publicado em 03 de maio de 2013. Acesso em 16 jun 2020. às 14h paulo/noticia/2019/11/13/73percent-dos-pretos-e-pardos-acreditam-que-preconceito-contra-populacao-negra-se-manteve-ou-aumentou-em-sp-diz-pesquisa.ghtml. Acesso em: 18 de junho de 2020 às $19 \mathrm{~h} 30 \mathrm{~min}$. 


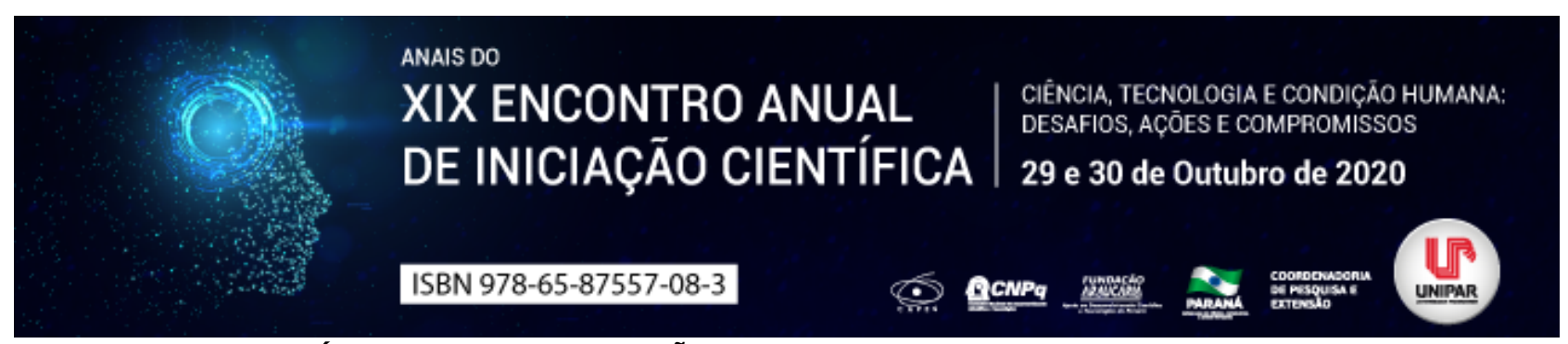

PRINCÍPIO DA CONCENTRAÇÃO NO DIREITO MATERIAL E PROCESSUAL

\author{
${ }^{1}$ BRUNA FERNANDA BARBADO MIGLIOZZI, ${ }^{2}$ FABIO CALDAS DE ARAUJO
}

${ }^{1}$ Acadêmica do PIC/UNIPAR

${ }^{1}$ Docente da UNIPAR

Introdução: A Lei no 13.097/2015, que surgiu pouco antes do advento do Novo Código de Processo Civil (Lei $n^{\circ}$ 13.105/2015), abordou nos artigos 54 a 62 o tema do Registro na Matrícula dos Imóveis, incluindo a aplicação efetiva do princípio da concentração, providenciando maior segurança jurídica ao terceiro de boa-fé na aquisição de bens imóveis.

Objetivo: Avaliar a aplicação do princípio da concentração na matrícula e proteção das partes na aquisição de bens imóveis, compará-la com os diferentes sistemas jurídicos, notadamente o português e alemão, a fim de analisar sua eficiência e possibilidade de futuras alterações.

Desenvolvimento: $O$ sistema registral brasileiro é bastante similar ao sistema português, ambos possuindo presunção juris tantum (PALÁCIO, 2016), diferentes do sistema germânico que, atualmente, é considerado um dos mais eficazes e possui presunção juris et de jure (CALDAS, 2020). No direito registral brasileiro se aplica o princípio da concentração, o que significa que os atos e situações jurídicas que podem influenciar um imóvel devem, necessariamente, constar na matrícula (REMÉDIO; AGUIAR, 2017, p. 4), como por exemplo a situação jurídica de credor. O principal objetivo do princípio da concentração é garantir a integridade da transmissão dos bens, de forma a proteger o adquirente de boa-fé. O terceiro de boa-fé pode ser prejudicado pela eviç̧ão que ofende princípio basilar do direito de propriedade: nemo plus iuris ad alium transferre potest quam ipse habet , ou seja, ninguém pode transferir mais direitos do que ele próprio tem (MIRANDA, 2001, § 1.573). Com o surgimento da Lei 13.097/2015 e do CPC/2015 foram instituídas novas normas acerca da transmissão e proteção do terceiro de boa-fé adquirente. Houve a relativização da proteção conferida ao proprietário com o surgimento do parágrafo único do artigo 54 da Lei $n^{\circ}$ 13.097/2015, que garante a transmissão a non domino. Com isso, coloca-se à prova a sobrevivência do art. 1.247, parágrafo único do Código Civil em face da redação do art. 54, parágrafo único da lei 13.097/2015. A jurisprudência do STJ deverá interpretar o dispositivo e delimitar a tensão entre o proprietário e o terceiro de boa-fé.

Conclusão: Com este estudo conclui-se que o princípio da concentração no direito registral brasileiro tem eficácia prática no tocante ao seu objetivo (proteção do terceiro de boa-fé), mas ainda atribui presunção relativa à veracidade do contido na matrícula, passível de ser elidida com prova em sentido contrário. Em contrapartida, no sistema alemão o registro possui presunção absoluta de veracidade, o que garante maior segurança jurídica tanto ao proprietário do bem como ao terceiro adquirente de boa-fé, sendo o sistema ideal a ser seguido pelo Brasil em futuras alterações legislativas.

\title{
Referências
}

ARAÚJO, Fabio Caldas de. O Terceiro de Boa-Fé na aquisição da propriedade móvel e imóvel. São Paulo: RT, 2020. LAGO, Ivan Jacopetti do. A Lei 13.097 de 2015 e sua Contribuição Para a Governança Fundiária. Revista do Direito Imobiliário. São Paulo (SP) Editora Revista dos Tribunais, vol. 81, jul./dez. 2016. Disponível em: https://bityli.com/XyuHd. Acesso em: 26 jul. 2020.

MIRANDA, Pontes de. Tratado de Direito Privado: Parte Especial Pretensões e ações imobiliárias dominicais. Perda da propriedade imobiliária Tomo 14. São Paulo (SP): Bookseller, 2001.

PALÁCIO, Ticiany Gedeon Maciel. Proteção ao terceiro de boa fé nas aquisições a non domino: estudo comparado Brasil Portugal. Dissertação (Mestrado em Direito) Universidade Autónoma de Lisboa. Lisboa, 2016.

REMÉDIO, Antonio; AGUIAR, Marcus Vinícius Pacheco. A Lei 13.097/2015 e a Efetivação do Princípio da Concentração no Registro de Imóveis. Revista Jurídica: Direito \& Paz. São Paulo (SP) Lorena, Ano IX, n. 37, p. 4-25, 2º Sem. de 2017. 


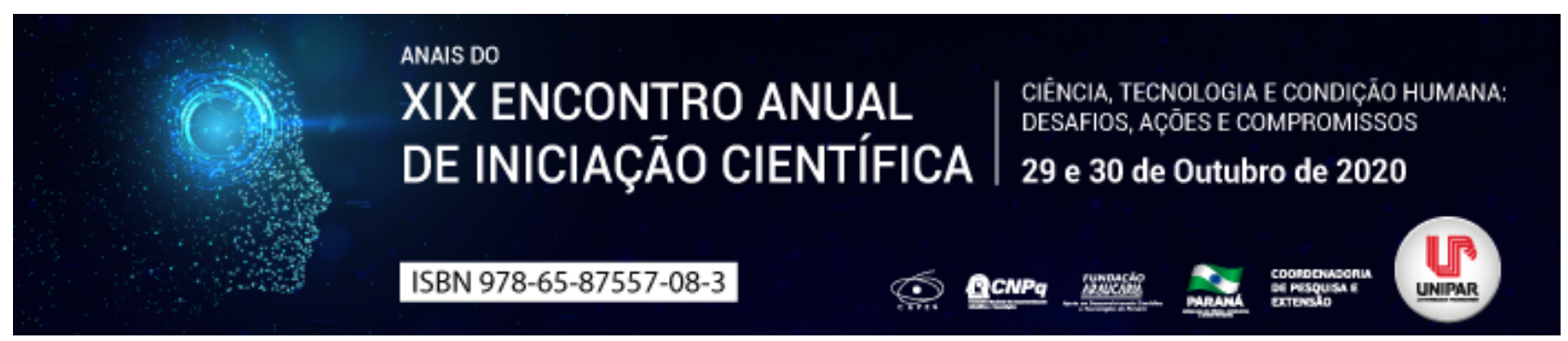

A VULNERABILIDADE DOS REFUGIADOS NO CONTEXTO DA COVID-19

\section{${ }^{1}$ JESSICA DE OLIVEIRA SILVA, ${ }^{2}$ HELENA CINQUE, ${ }^{3}$ TEREZA VIEIRA}

${ }^{1}$ Acadêmica do Curso de Psicologia da Unipar e integrante do PIC.

${ }^{1}$ Acadêmica do Curso de Direito da UNIPAR e participante do PIBIC.

${ }^{2}$ Docente do Mestrado em Direito Processual e Cidadania na UNIPAR

Introdução: No decorrer dos últimos anos, centenas de milhares de pessoas foram obrigadas a abandonarem suas casas, fugindo de áreas de conflito e violência. Hoje, os refugiados vivem em acampamentos superlotados, com mínimos níveis de higiene e escassos serviços de saúde, fato que os tornam vulneráveis aos surtos de doenças, epidemias e pandemias. Sucede que, regras de confinamento social impostas em razão da COVID 19 têm dificultado o acesso aos suprimentos necessários, agravando a situação de vulnerabilidade, justificando o presente estudo.

Objetivo: Analisar, por meio de pesquisa bibliográfica, a situação de vulnerabilidade e os direitos das pessoas nos campos de refugiados em meio à pandemia da COVID-19.

Desenvolvimento: O ACNUR Brasil (2020), ou seja, Alto Comissariado das Nações Unidas para os Refugiados, classifica-os como indivíduos que estão fora do seu país de origem devido a justificados temores de perseguição, e, além de lidarem com o iminente risco de morte, lidam com a extraterritorialidade e a existência de aglomerações nos campos de refugiados. O Brasil, sendo um país comprometido com tal causa internacional, possui como pilares básicos no ordenamento jurídico a Constituição Federal e a Lei 9.474/97, que abrange a proteção da dignidade da pessoa humana e todos os direitos dos refugiados no país. Após o Comitê Nacional para os Refugiados (CONARE) conceder o refúgio, eles [...] terão os direitos de um cidadão normal e os deveres de um estrangeiro em território nacional [...] (MAZZUOLI, 2016, p. 832), sendo de responsabilidade do Estado oferecer aos refugiados, por intermédio dos órgãos responsáveis e do Poder Público, políticas de acolhimento. No contexto da pandemia criada pela COVID-19, entre as medidas mais recomendadas pela Organização Mundial da Saúde, estão o isolamento dos casos suspeitos e confirmados e, o distanciamento social. Todavia, é importante mencionar que, além da insegurança sanitária, econômica e política causada no território brasileiro por conta da COVID-19, a problemática social que resulta do isolamento domiciliar atinge diretamente os diversos grupos de refugiados, que se tornam vulneráveis aos efeitos da crise. Sendo indivíduos que convivem em uma situação precária, de superlotação e sem possibilidades de distanciamento social, a ACNUR (2020) está adotando ações de prevenção e enfrentamento à pandemia do novo COVID-19, possibilitando acesso à esclarecimentos através de sessões informativas com a população refugiada, com conteúdo em vários idiomas, além de propagar por meio de grupos de WhatsApp e outras redes de apoio. O Oxford Committee for Famine Reliefe/Comitê de Oxford para o Alívio da Fome (OXFAM, 2020) tem o intuito de aumentar o número de torneiras, encanamento e banheiros nos campos de refugiados, além de oferecer suprimentos e produtos de higiene básica. Vale mencionar que a pandemia da COVID-19 não está atacando apenas nossa saúde física, mas também vem aumentando o sofrimento psicológico de todos. É uníssono o conhecimento sobre a negligência em investimentos nos serviços de saúde mental, atingindo famílias e comunidades com um estresse mental adicional. Os que estão em maior risco são os profissionais de saúde, idosos, adolescentes, jovens, aqueles com condições de saúde mental preexistentes e os que vivem em situações de conflito e crise, como os refugiados. Estes possuem um aumento substancial de risco, relativamente à população normal, de sofrerem perturbações psiquiátricas relacionadas com a exposição à guerra, violência, tortura, migração forçada, exílio e incerteza quanto ao seu estatuto nos países onde buscam asilo (KIRMAYER et al, 2011 apud ANTUNES, 2017, p. 119). Às experiências traumáticas como a tortura, prisão, cenários de guerra, permanência em campos de refugiados, perda de entes queridos, testemunho de assassinados ou abusos, perda de pertences e risco de vida, juntam-se o trauma de perderem o seu próprio país, os seus familiares e amigos, viagem em busca de refúgio, incerteza da permanência e o stress de adaptação a uma nova cultura, muitas vezes feita na solidão e enfrentando à intolerância e o racismo (BUHMANN, 2014 apud ANTUNES, 2017, p. 116). Para aqueles que têm a sorte de viver confortavelmente e com segurança, o impacto psicológico de ser expulso de casa fugindo de guerras ou desastres é difícil de imaginar e avaliar.

Conclusão: À luz do exposto, é nítido como a pandemia da COVID-19 agravou a situação de vulnerabilidade já existente em face dos indivíduos que buscam o refúgio, especialmente no que tange aos superlotados campos de refugiados. Além disso, a vida dos refugiados já vem sendo assolada por traumas e experiências anteriores, que geraram um impacto muito maior nesse momento de grande crise mundial, dificultando assim a sua convivência, higiene, isolamento e afetando de forma negativa a saúde mental de todos que vivenciam este momento de desespero. Seus direitos humanos e essenciais em terras estrangeiras devem ser considerados, reconhecidos e concretamente efetivados. 


\section{Referências}

ACNUR Brasil. Alto Comissariado das Nações Unidas para os Refugiados. Refugiados. Brasília, 10 abr. 2016. Disponível em: https://www.acnur.org/portugues/quem-ajudamos/refugiados/. Acesso em: 10 jul. 2020.

CORONAVÍRUS e refugiados, o que o ACNUR está fazendo no Brasil e no mundo. ACNUR Brasil, Brasília, 20 mar. 2020. Disponível em: https://www.acnur.org/portugues/2020/03/27/coronavirus-e-refugiados-o-que-o-acnur-esta-fazendo-nobrasil-e-no-mundo/. Acesso em: 10 jul. 2020.

ANTUNES, José António Pereira de Jesus. Refugiados e saúde mental: acolher, compreender e tratar. Psic., Saúde \& Doenças, Lisboa, v. 18, n. 1, abr. 2017. Disponível em: http://www.scielo.mec.pt/scielo.php?script=sci_arttext\&pid=S164500862017000100010/. Acesso em: 10 jul. 2020.

MAZZUOLI, Valerio de Oliveira. Curso de direito internacional público. 10. ed. São Paulo: Revista dos Tribunais, 2016.

OXFAM Brasil. Oxford Committee for Famine Reliefe. Como estão os campos de refugiados em meio à pandemia do corona vírus. São Paulo, 20 mar. 2020. Disponível em: https://www.oxfam.org.br/blog/como-estao-os-campos-de-refugiados-em-meio-apandemia-do-coronavirus/. Acesso em: 10 jul. 2020. 


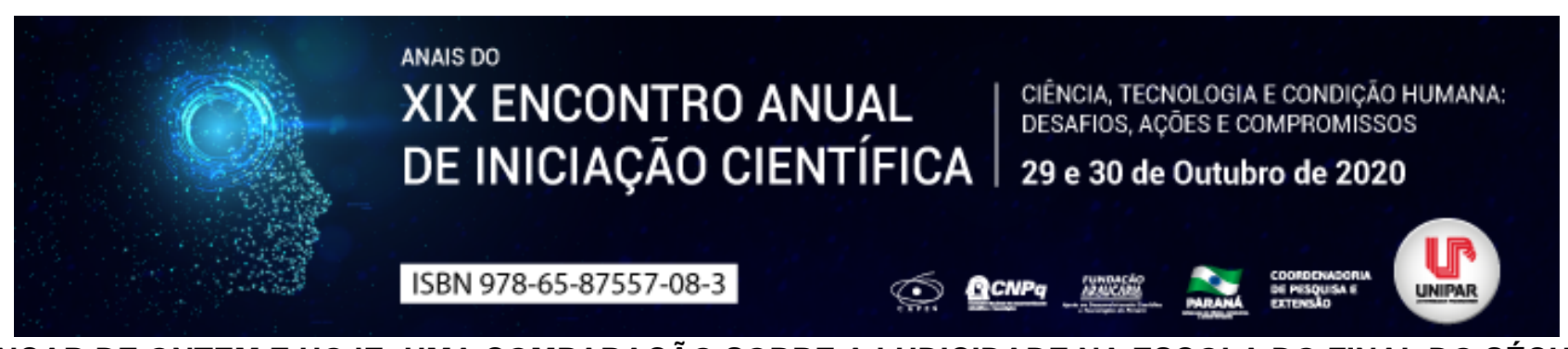

\title{
O BRINCAR DE ONTEM E HOJE: UMA COMPARAÇÃO SOBRE A LUDICIDADE NA ESCOLA DO FINAL DO SÉCULO XX COM OS DIAS ATUAIS
}

\author{
${ }^{1}$ CINTHIA FERREIRA DOS SANTOS COSTA, ${ }^{2}$ LUCYELENA AMARAL PICELLI
}

\author{
${ }^{1}$ Acadêmica do Curso de Pedagogia da UNIPAR- PIC \\ ${ }^{1}$ Docente da UNIPAR
}

Introdução: O brincar é muito importante para a aprendizagem e desenvolvimento humano. De acordo com Lopes (2020), o brincar é o momento e oportunidade para que a criança se desenvolva, aprendendo e experimentando o mundo, conhecendo as pessoas a sua volta, e a si mesma, desenvolvendo sua autonomia, e também aprendendo a lidar com emoções e sentimentos, entretanto, ainda encontramos pessoas no cotidiano que desconhecem a importância do brincar. Será que o brincar de hoje, nas instituições escolares, mantém as mesmas características do brincar de outros tempos?

Objetivo: Comparar os movimentos lúdicos ocorridos em ambiente escolar no final do século XX com a atualidade, bem como analisar algumas mudanças significativas nesse processo.

Desenvolvimento: Ao realizar a revisão bibliográfica de textos publicados no final do século XX, deparamo-nos com autores que retratam o brincar como uma necessidade básica da criança, podendo até ser confundida com a própria vida na infância, visto que, se uma criança para de brincar pode ser um sinal de que ela está doente. Constatamos que a maioria dos autores dessa época afirma que o brincar ajuda no desenvolvimento integral do sujeito, tanto nos seus aspectos físicos e cognitivos, quanto na socialização, principalmente quando se brinca com outras crianças. Complementam ainda, que a criança aprende a lidar e conviver com o outro, a melhorar sua vida afetiva, pela satisfação nas atividades lúdicas, proporcionando alívio de tensões, estimulando o desenvolvimento intelectual, por meio de brincadeiras que exigem atenção, imaginação, criatividade, melhorando também, suas habilidades de comunicação tanto verbal, quanto a não-verbal (MEDEIROS, 1979). Em relação ao âmbito escolar, Pinto (1998) afirma que os profissionais da educação infantil não relacionavam ou associavam o brincar como algo livre, mas sim, como algo prazeroso. A autora acredita que isto é uma distorção com consequências infelizes, percebendo então, o prazer, e não a sua causa, a liberdade. O autoritarismo de muitos professores e adultos, acaba impondo atividades e brincadeiras para as crianças, por considerar que as mesmas são prazerosas e esses convites acabam sendo convocações que não podem ser recusadas. Entretanto, para alguns teóricos, o brincar em ambiente escolar era visto de forma negativa, levando o autor Amonachvili (1991), descrever sobre os efeitos negativos do ensino pelos jogos. O autor acreditava que quanto mais a criança for restringida de ocupações sérias, pior será no futuro para que se adapte a elas, pois considera ainda ser papel da escola tornar interessantes as ocupações sérias, porque a atividade lúdica por si só não assegura o total desenvolvimento da criança, afirmando que tais proporcionam-Ihe a liberdade, mas isso não significa que ela precise apenas de divertimentos e que devemos satisfazer-Ihe os mínimos caprichos (AMONACHVILI, 1991, p. 17). Para ele, deve-se conservar o sentido da liberdade, respeitando a integridade de sua vida, assim não será preciso reduzi-la com brincadeiras, divertimentos ou bajulações, pois o tratamento sério e respeitoso de sua personalidade é que ajudará o colegial a resolver os complexos de problemas com os quais irá se deparar em matéria de conhecimentos, moral e conduta (AMONACHVILI, 1991, p. 17). Referendando autores da atualidade, temos Carneiro (2012), que confronta as brincadeiras em grupo, que eram muito comuns antigamente e que estão cada vez mais se tornando individualizadas, em virtude ao pouco espaço físico. Há pais que optam por ter somente um filho, dificultando a interação em grupos familiares e consequentemente existindo o aumento do uso de equipamento eletrônicos, prejudicando assim, o desenvolvimento dos movimentos corporais e até mesmo o uso da linguagem falada. As brincadeiras do final do século XX, de acordo com Garcia (2017), em geral, se definiam como brincadeiras em grupo e em lugares abertos. No entanto, as brincadeiras da atualidade, são caracterizadas pela tecnologia. Com o passar dos anos e o avanço dos estudos na área pedagógica, percebemos o brincar como um comportamento a ser ensinado nas escolas, pois o mesmo se trata de uma linguagem que aproxima a criança do aprendizado e para o professor um recurso para atingir o objeto a ser estudado, portanto sendo o lúdico uma ferramenta para o ensino, verificamos um consenso, em relação aos teóricos do final do século, de acordo com Silva (2019): a ludicidade na infância, contribui com o desenvolvimento de competências interativas, a criança se torna mais espontânea, aprende regras, limites e entre outros.

Conclusão: Há muitos profissionais da educação que não associam o brincar como algo livre, mas sim como algo prazeroso, distorcendo o contexto, pois ela acredita que a liberdade de brincar faz a criança sentir prazer. Contradizendo com ações de muitos professores e adultos, sendo autoritários e privando a liberdade da brincadeira. Porém ao passar dos anos podemos perceber que a ludicidade como metodologia em sala de aula está ganhando cada vez mais proporção e reconhecimento, pois o professor escolherá brincadeiras que desenvolva integralmente seus alunos, se encaixando no objetivo da aula, assim, a criança aprende e se desenvolve brincando. 


\section{Referências}

AMONACHVILI, Chalva. Um impulso vital. O correio da Unesco. ed. n07, Brasil, 1991.

CARNEIRO, Maria Ângela Barbato. O brincar hoje: da colaboração ao individualismo, Campo Grande/ Simpósio Internacional da OMEP, Jul/2012. Disponível em: Acesso em 23 de julho de 2020 às $21 \mathrm{~h}$ e $12 \mathrm{~min}$.

GARCIA, Roosevelt. Dez diversões da época em que criança ainda brincava na rua: Carrinho de rolimã, pião, Corre Cotia: uma lista para relembrar as brincadeiras. 2017. Disponível em: Acesso em 02 agosto de 2020 às $17 \mathrm{~h}$ e 16 min.

LOPES, Patrícia. A importância do brincar. Disponível em: Acesso em 10 de julho de 2020 às 14h.

MEDEIROS, Ethel Bauzer. Brincar: uma das ocupações mais sérias da infância. Revista Brasileira de estudos Pedagógicos, v. 62, no 143. 1979.

PINTO, Heloysa Dantas de Souza. O brincar e suas teorias. São Paulo, Editora Pioneira, 1998.

SILVA, Gabriele. Benefícios da ludicidade para as crianças: Saiba como as atividades lúdicas contribuem com o desenvolvimento infantil. 2019. Disponível em: Acesso em 02 agosto de 2020 às 17h.

Coordenadoria de Pesquisa e Extensão - COPEX

Departamento de Editoraçāo e Divulgaçāo Científica - DEDIC 


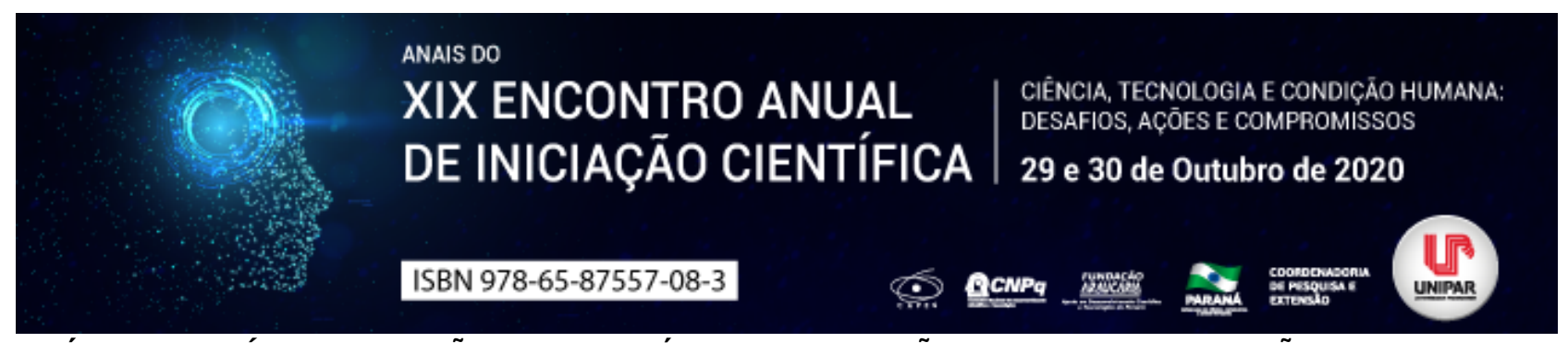

O PSICÓLOGO JURÍDICO: REVISÃO BIBLIOGRÁFICA E REFLEXÃO ACERCA DA ATUAÇÃO PROFISSIONAL EM INTERFACE COM O DIREITO

\author{
1ISADORA GAGLIOTTO GALVAN, ${ }^{2}$ ALINE PERIN PADILHA, ${ }^{3}$ ANA CLAUDIA PANSERA, ${ }^{4}$ MATEUS JOAO CORDEIRO \\ SCHMOELLER DE LIMA, ${ }^{5}$ NAYSSARA CAROLINA SILVA TASCHIN, ${ }^{6}$ EVERLINE BEDIN CAMARGO
}

\begin{abstract}
${ }^{1}$ Acadêmica do Curso de Psicologia da UNIPAR
${ }^{1}$ Acadêmica do Curso de Psicologia da UNIPAR

${ }^{2}$ Acadêmica do Curso de Psicologia da UNIPAR

${ }^{3}$ Acadêmico do Curso de Psicologia da UNIPAR

${ }^{4}$ Acadêmica do Curso de Psicologia da UNIPAR

${ }^{5}$ Docente da UNIPAR
\end{abstract}

Introdução: Ao considerar a trajetória da Psicologia como profissão e os rumos que seguiram em diferentes áreas, a Psicologia Jurídica tece discussões sobre as distintas demandas que lhe cabem, e seus estreitos laços com o Direito (BRITO, 2012). Apesar dos encontros e desencontros epistemológicos que permeiam sua atuação na interface com o Direito, Teixeira (2012) denota que as ciências estão interligadas pelo estudo da conduta humana; onde a Psicologia se compromete com o estudo e investigação do comportamento e o Direito em prescrever formas de regulá-lo, estabelecendo um acordo que intermedia conflitos e garante um contrato social que sustenta a vida em sociedade.

Objetivos: Por meio de uma revisão bibliográfica sobre os principais temas desta área, o trabalho propõe uma reflexão sobre a atuação do psicólogo jurídico.

Desenvolvimento: Para Gomide (2016) a Psicologia Jurídica corresponde ao conhecimento psicológico e sua aplicação ao sistema de justiça, civil ou criminal; em suma é caracterizada como uma ciência autônoma, complementar ao Direito. A designação como interface, engloba profissionais lotados nos Tribunais de Justiça, Defensorias Públicas e no Sistema Penitenciário, mas também, peritos e assistentes técnicos que executam trabalhos sem possuir vínculo empregatício.

Embora conhecida como uma área de atuação recente, a literatura internacional carrega entendimentos de que as demandas do Poder Judiciário foram primordiais para o reconhecimento como profissão e consolidação como ciência (Brito, 2012) e conforme as diretrizes da Resolução no 013/2007 do Conselho Federal de Psicologia, que discorre sobre o exercício da profissão do psicólogo, o âmbito jurídico contempla uma ampla variedade de atuações. Em se tratando de história brasileira, inicialmente a inserção profissional foi atrelada à Psiquiatria Forense e a indicação de peritos por magistrados da Vara Criminal, com o intuito de fornecer diagnósticos psicológicos; e somente na década de 80 , tem-se o conhecimento da primeira implementação concursos junto ao Poder Judiciário no estado de São Paulo (BRITO, 2012).

Lago et al. (2009) elenca que a participação do psicólogo é demandada nas áreas do Direito de Família, da Criança e do Adolescente, Direito Civil, Penal e do Trabalho. Atrelado à atividades nos Tribunais de Justiça, o psicólogo se insere nas Vara da Infância e Juventude, Vara da Família e Vara Criminal, sendo responsável por auxiliar o juizado em avaliações psicossociais e prestar assistência psicológica de menores e familiares com envolvimento à justiça. Suas atribuições consistem na elaboração de pareceres, relatórios psicológicos e perícias, e na contribuição em estudos multidisciplinares com o Serviço Social, recomendar e assessorar o encaminhamento de intervenções quando necessário.

Em condições diferenciadas de atendimentos de crianças e adolescentes, o psicólogo jurídico tem sua escuta empregada na realização de Depoimentos Especiais e Perícias com menores vítimas ou testemunhas de violência. Atendendo uma demanda solicitada pela Vara Criminal, ambas as metodologias possuem caráter investigativo, com o intuito de apurar possíveis situações de violências sofridas e produzir provas; sendo que a primeira consiste na oitiva do menor perante a autoridade judiciária e a segunda, é respaldada em uma Avaliação Psicológica que busca responder quesitos propostos pelas partes (BRASIL, 2017).

Somada as atuações supracitadas, com a promulgação da Lei de Execução Penal ( $n^{\circ}$ 7.210/84), o psicólogo passou a ser requisitado em instituições penitenciárias. Sua atuação é voltada à produção de laudos e pareceres para subsidiar decisões de progressão de pena ou de liberdade condicional, encaminhamento de presos (as) em situação de sofrimento mental para unidades de tratamento psiquiátrico, atestar sobre a sanidade mental em casos de retorno à sociedade ou sobre a dependência toxicológica e entre outros (CFP, 2009). Apesar da prestação de serviço à uma instituição e de cumprir os objetivos das demandas processuais, é mister considerar o Código de Ética do Psicólogo (CFP, 2005) e corroborar com os intuitos da profissão, com atuação pautada na promoção à saúde e qualidade de vida das pessoas e contribuindo para a eliminação de quaisquer formas de negligência, discriminação, violência, crueldade e opressão. Em se tratando da ética, também prevista no Código de Ética, a manutenção do sigilo deve ser assegurada em toda a atuação, salvo exceções em que deverá se embasar na 
busca do menor prejuízo e expondo apenas o estritamente necessário (GOMIDE, 2016).

Conclusão: Desta forma, com algumas críticas ao que tange à judicialização da vida e suas repercussões relacionadas a subjetividade de cada um, o Psicólogo Jurídico é inserido para produzir uma escuta diferenciada, capaz de promover a questões conflituosas conclusões mais adequadas e justas. Esse aparato técnico e teórico constrói a Psicologia com um saber que possibilita contribuir de forma assertiva e eficiente na decisão final de um processo. Ademais, colabora de maneira humanizada, proporcionando melhor apoio emocional e afetivo às partes no decorrer do processo, que geralmente, é desgastante.

\section{Referências}

BRASIL. Lei no 13.431, de 4 de abril de 2017. Estabelece o sistema de garantia de direitos da criança e do adolescente vítima ou testemunha de violência e altera a Lei $n^{\circ}$ 8.069, de 13 de julho de 1990 (Estatuto da Criança e do Adolescente). Diário Oficial [da] República Federativa do Brasil, Brasília, DF, 2017.

BRITO, Leila M. T. Anotações Sobre a Psicologia Jurídica. Revista Psicologia Ciência e Profissão, n. 32, p. 194-205, 2012. Disponível em: https://www.scielo.br/scielo.php?pid=S1414-98932012000500014\&script=sci_arttext\&tlng=pt.

CONSELHO FEDERAL DE PSICOLOGIA. Resolução $n^{\circ}$ 010/2005, de 27 de agosto de 2005. Código de Ética do Profissional Psicólogo. Disponível em: https://site.cfp.org.br/wp-content/uploads/2012/07/codigo-de-etica-psicologia.pdf .

CONSELHO FEDERAL DE PSICOLOGIA. Resolução CFP nº 013/2007, de 14 de setembro de 2007. Institui a Consolidação das Resoluções relativas ao título Profissional de Especialista e dispõe sobre normas e procedimentos para seu registro. Disponível em: https://site.cfp.org.br/wp-content/uploads/2008/08/Resolucao_CFP_nx_013-2007.pdf.

CONSELHO FEDERAL DE PSICOLOGIA. A prática profissional dos(as) psicólogos no Sistema Prisional. CFP: Brasília, 2009. Disponível em: http://crpsp.org.br/interjustica/pdfs/outros/a-pratica-profissional-dos-as-psicologos-as-no-sistemaprisional.pdf.

GOMIDE, Paula I. C. (org.). Introdução à Psicologia Forense. Editora Juruá: Curitiba, 2016.

LAGO, Vivian de Medeiros et al. Um breve histórico da psicologia jurídica no Brasil e seus campos de atuação. Revista Estudos de Psicologia, Campinas, v. 26, n. 4, p. 483-491, 2009. Disponível em: https://www.scielo.br/pdf/estpsi/v26n4/09.pdf.

TEIXEIRA, Jorge. Manual de Psicologia Jurídica para operadores do Direito, 6 a ed. Livraria do Advogado Editora: Porto Alegre, 2012. 


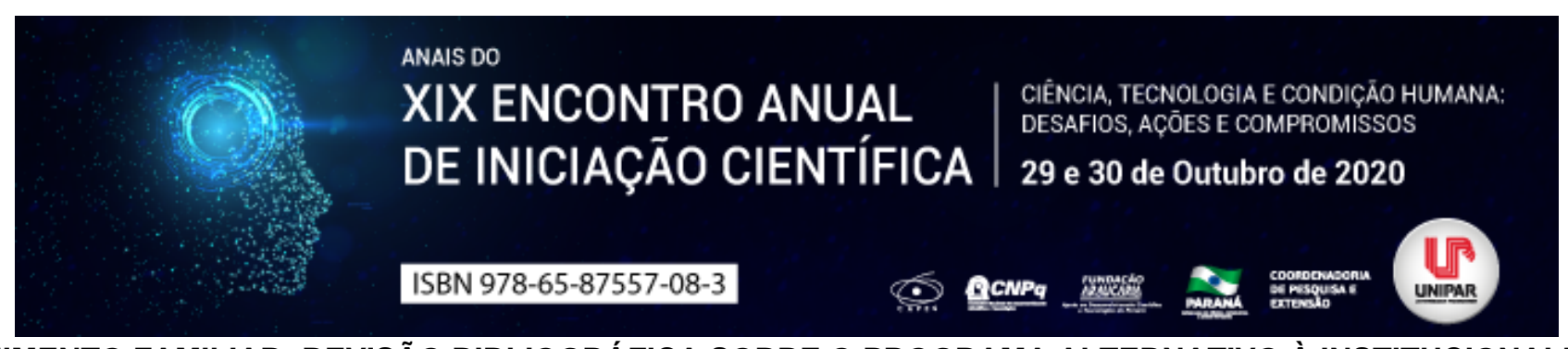

ACOLHIMENTO FAMILIAR: REVISÃO BIBLIOGRÁFICA SOBRE O PROGRAMA ALTERNATIVO À INSTITUCIONALIZAÇÃO

\author{
${ }^{1}$ NAYSSARA CAROLINA SILVA TASCHIN, ${ }^{2}$ ANA CLAUDIA PANSERA, ${ }^{3}$ ALINE PERIN PADILHA, ${ }^{4}$ ISADORA GAGLIOTTO \\ GALVAN, ${ }^{5}$ MATEUS JOAO CORDEIRO SCHMOELLER DE LIMA, ${ }^{6}$ EVERLINE BEDIN CAMARGO
}

${ }^{1}$ Acadêmica do Curso de Psicologia da UNIPAR
${ }^{1}$ Acadêmica do Curso de Psicologia da UNIPAR
${ }^{2}$ Acadêmica do Curso de Psicologia da UNIPAR
${ }^{3}$ Acadêmica do Curso de Psicologia da UNIPAR
${ }^{4}$ Acadêmico do Curso de Psicologia da UNIPAR
${ }^{5}$ Docente da UNIPAR

Introdução: A institucionalização tem como prioridade proteger a criança de vulnerabilidades e situações de risco, de ordens sociais e psíquicas, que são apresentadas na conjuntura de sua família biológica (BRASIL,1990). Conforme a Constituição Federal Brasileira (BRASIL,1988) e o Estatuto da Criança e do Adolescente (ECA), é dever da família, da sociedade em geral e do Estado garantir a efetivação dos direitos referentes à vida, saúde, alimentação, educação, liberdade e à convivência familiar e comunitária; além de proteger de todas as formas de negligência, discriminação, exploração, violência, crueldade e opressão. Visando atender os princípios de convivência familiar, no Brasil, os projetos de Acolhimento Familiar estão sendo incorporados pelas redes municipais, na tentativa de atender tais demandas, e intensificando a realização de seminários, encontros, capacitações, grupos de discussão e grupos de estudos sobre esta temática.

Objetivos: O resumo tem por intuito propor uma contextualização sobre o cenário alternativo à institucionalização, por meio de uma revisão bibliográfica.

Desenvolvimentos: Diante de uma institucionalização que ultrapassa os preceitos de brevidade e perdura por anos, acaba-se violando o direito de crescimento no meio familiar e comunitário, acarretando em diversos danos no desenvolvimento físico e cognitivo do infante ou adolescente (COSTA; ROSSETTI-FERREIRA, 2008). Tanto o acolhimento institucional quanto o familiar, são previstos até que seja possível o retorno dos mesmos à família de origem ou o encaminhamento para adoção; nesse sentido, intermediando o abandono dos ciclos de fragilidade, maus tratos e negligência no âmbito da família biológica (PERNAMBUCO, 2019). Fomentado pela realização de diversas pesquisas nacionais sobre as condições de institucionalização, e seguindo o exemplo de outros países, um importante movimento levou à construção e aprovação do Plano Nacional de Promoção, Proteção e Defesa do Direito de Crianças e Adolescentes à Convivência Familiar e Comunitária (PNCFC/2006); que reflete o compromisso nacional de priorizar a convivência familiar e comunitária, com vistas na implementação de políticas públicas que assegurem direitos das crianças e adolescentes, de forma integrada com os demais programas de governo.

Os objetivos e diretrizes do PNCFC/2006 estão respaldados na prevenção do rompimento dos vínculos familiares, na qualificação do atendimento dos serviços de acolhimento e no investimento para o retorno da criança e do adolescente ao convívio com a sua família de origem. O Plano estabelece que somente se forem esgotadas todas as possibilidades de cumprimento desses fundamentos, é que justifica o encaminhamento para a destituição do poder familiar e a colocação em família substituta. Para Costa (2009 apud VALENTE, 2013) os programas de Família Acolhedora são caracterizados pela alternativa de proteção que se distingue do acolhimento institucional (abrigo), especialmente pela atenção individualizada à criança; pela possibilidade de construção de novos vínculos afetivos; pelo favorecimento de uma convivência familiar que traz experiência à criança de uma rotina de família e um sentimento de pertencimento; pela inserção comunitária que a família proporciona. A legislação que fundamenta o acolhimento familiar como prática formal preconiza a importância da intervenção do estado quando a família não pode cuidar da criança ou adolescente; o interventor deve priorizar o convívio familiar, mesmo que provisório e o abrigamento deve ser utilizado apenas quando não há uma família disponível para o acolhimento. É elencado no ECA, Artigo 34 § 1, que os programas de Acolhimento Familiar são prioridade em detrimento ao acolhimento institucional. Tais programas, difundidos como políticas públicas, possibilitam a vivência e pertencimento a um núcleo familiar e desenvolver-se socialmente nesse período de excepcionalidade (PARANÁ, 2017/2018). Todavia, os laços constituídos em família acolhedora diferem dos construídos por meio da adoção. No acolhimento familiar, a transferência dos deveres e direitos da família de origem para outra família é temporária por meio da guarda de responsabilidade, sem a finalidade de substituir a família e o rompimento com sua história. Ao considerar a tentativa de reintegração ao ambiente biológico, se faz necessário uma ação multidisciplinar objetivando estruturar políticas de atendimento à família, redes de serviços que serão ofertados e propostas de potencializar suas competências para o cuidado com os filhos.

Conclusão: Ao discutir sobre a possibilidade de construção de uma nova cultura de acolhimento, é necessária uma 
reorganização das políticas de proteção social e dos significados de infância e juventude, sobre o papel da família e suas diferentes composições, e dos conceitos de vínculo e parentalidade. Considerando que o desenvolvimento humano, depende de atendidas as necessidades básicas e da qualidade das relações humanas que são construídas, o Acolhimento Familiar constituise como um projeto privilegiado a ser efetivado em prol do desenvolvimento de crianças e adolescentes expostos à risco em seu contexto de origem.

\section{Referências}

BRASIL. Constituição da República Federativa do Brasil [recurso eletrônico]. Brasília: Supremo Tribunal Federal, 579 p., 1988. Disponível em: < https://www.stf.jus.br/arquivo/cms/legislacaoConstituicao/anexo/CF.pdf > .

BRASIL. Lei no 8.069, de 13 de julho de 1990. Dispõe sobre o Estatuto da Criança e do Adolescente e dá outras providências. Diário Oficial [da] República Federativa do Brasil, Brasília, DF, 16 jul. 1990.

BRASIL. Plano Nacional de Promoção, Proteção e Defesa do Direito de Crianças e Adolescentes à Convivência Familiar e Comunitária. Brasília, 2006. Disponível em: .

COSTA, Nina R. do A.; ROSSETTI-FERREIRA, Maria C. Acolhimento Familiar: Uma Alternativa de Proteção para Crianças e Adolescentes. Revista Psicologia: Reflexão e Crítica, 22(1), p. 111-118, 2008. Disponível em: .

PARANÁ. Corregedoria-Geral da Justiça. Manual de Acolhimento Familiar- Orientações Iniciais. Poder Judiciário do Estado do Paraná, v.3, biênio 2017/2018. Disponível em: .

PERNAMBUCO. Ministério Público do Estado. A casa é sua: implementando programas de Acolhimento Familiar. CAOP Infância e Juventude. Recife: Corregedoria-Geral da Justiça, 2019. Disponível em:

VALENTE, Jane. Família acolhedora: as relações de cuidado e de proteção no Serviço de Acolhimento. São Paulo: Editora Paulus, 2013. Disponível em: . 


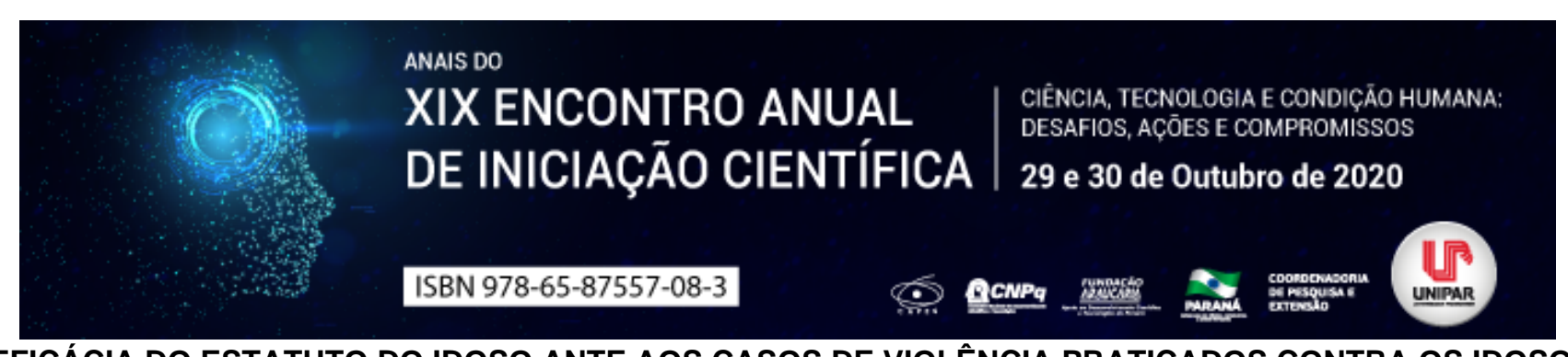

A INEFICÁCIA DO ESTATUTO DO IDOSO ANTE AOS CASOS DE VIOLÊNCIA PRATICADOS CONTRA OS IDOSOS NO BRASIL

\author{
${ }^{1}$ MATHEUS HENRIQUE RAPHAEL DE PAULA, ${ }^{2}$ MATHEUS HENRIQUE DE FREITAS URGNIANI, ${ }^{3}$ BRUNO HENRIQUE \\ PUCHETTI DE CENE, ${ }^{4}$ GABRIEL TRENTINI PAGNUSSAT, ${ }^{5}$ LUIZ ROBERTO PRANDI
}

\author{
${ }^{1}$ Acadêmico Bolsista PIBIC/UNIPAR \\ ${ }^{1}$ Acadêmico do Curso de Direito da UNIPAR \\ ${ }^{2}$ Acadêmico do Curso de Direito da UNIPAR \\ ${ }^{3}$ Acadêmico do Curso de Direito da UNIPAR \\ ${ }^{4}$ Professor Titular e Pesquisador da UNIPAR
}

Introdução: Viver e envelhecer com saúde e dignidade é um direito personalíssimo, sendo garantia constitucional atinente a toda pessoa, inclusive aos idosos, que possuem um estatuto que tem por escopo garantir os seus direitos. Entretanto, alguns casos de violência sofridos por essas pessoas mostra a ineficácia desse dispositivo normativo, no que tange a garantia e cumprimento destas prerrogativas.

Objetivo: Analisar as garantias expressas no estatuto do idoso e apontar estatísticas de violência sofridas por essas pessoas que evidenciam a ineficiência desse dispositivo normativo.

Desenvolvimento: Dispõe o $\S 2^{\circ}$ do artigo 10 do Estatuto do Idoso que é obrigação do Estado e da sociedade, assegurar à pessoa idosa a liberdade, o respeito e a dignidade, como pessoa humana e sujeito de direitos civis, políticos, individuais e sociais, garantidos na Constituição e nas leis. O Estatuto ainda prevê que o direito ao respeito consiste na inviolabilidade da integridade física, psíquica e moral, abrangendo a preservação da imagem, da identidade, da autonomia, de valores, ideias e crenças, dos espaços e dos objetos pessoais (BRASIL, 2003). Não obstante os idosos vêm sofrendo diversos tipos de agressão no Brasil. De acordo com um levantamento feito em 2018 pelo Ministério da mulher, da família e dos direitos humanos apontou que o disque 100, serviço disponibilizado pelo governo federal registrou 37.454 denúncias de abusos e agressões contra idosos dentre essas denúncias 38 \% estão relacionadas a negligência (espécie de violência psicológica ou física), 26,5 \% envolvem outros tipos de violência psicológica, 19,9 \% são de abuso financeiro e econômico e 12,6 \% foram denúncias envolvendo violência física (NÚMERO, 2019). É evidente que esses números alarmantes causam preocupação pelo simples fato de que após uma vida inteira de trabalho, é mais do que merecido que o idoso tenha uma boa vida, e sem abusos ou violências após a aposentadoria. Outro fato preocupante é que grande parte dessas violências são praticadas por pessoas da mesma família, já que um estudo divulgado recentemente apontou que 65\% dos casos de violência contra o idoso no Distrito Federal são praticados pelos próprios filhos (DISTRITO FEDERAL, 2019). Esses dados enfatizam a necessidade dos governos municipais, estaduais e do governo federal, realizar programas de conscientização na sociedade e impor sansões mais duras, com intuito de mitigar a violências sofridas pelos idosos em todo o território nacional.

Conclusão: Observa-se que apesar de o Estatuto do Idoso ter completado 17 anos de vigor no Brasil, esse dispositivo se mostra ineficaz no que tange a inibir ou mitigar os casos de violência e violação de direitos sofridos por essa população no Brasil.

\title{
Referências
}

BRASIL. Lei $n^{\circ} 10.741$ de $1^{\circ}$ de outubro de 2003. Estatuto do idoso. Disponível em: encurtador.com.br/egvDV. Acesso em: 13 jul. 2020.

DISTRITO FEDERAL. Tribunal de Justiça do Distrito Federal e Territórios. Violência contra idosos: mulheres são as maiores vítimas e filhos os principais agressores.

Disponível em: encurtador.com.br/CIMOV. Acesso em: 14 jul. 2020.

NÚMERO de denúncias de violência contra idosos aumentou 13\% em 2018. Agência Brasil, 12 jun. 2019. Disponível em: encurtador.com.br/CPX36. Acesso em: 13 jul. 2020. 


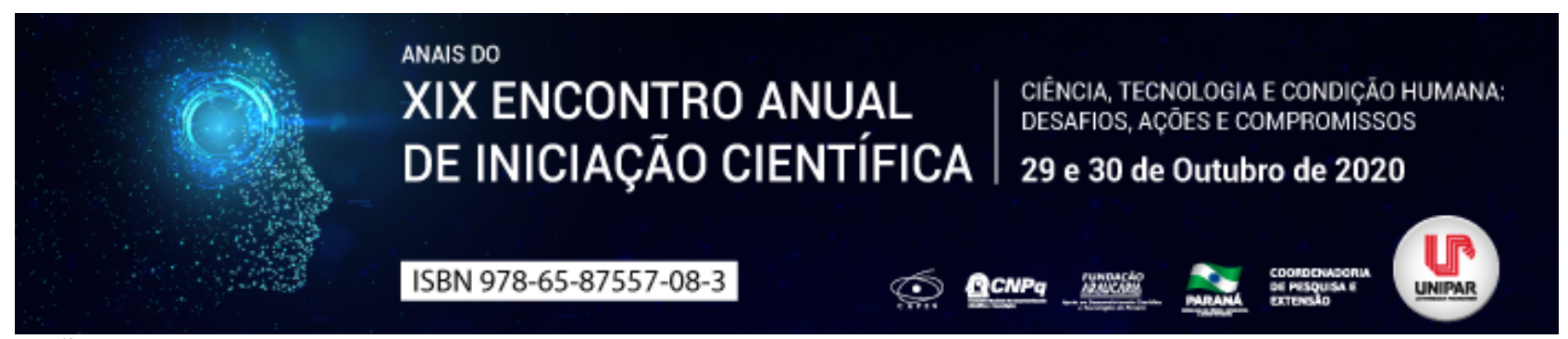

\title{
AVALIAÇÃO DOS PROJETOS ARQUITETONICOS ELABORADOS POR ARQUITETOS E ENGENHEIROS SOB A OTICA QUANTITATIVA
}

\author{
${ }^{1}$ HELOISA MAGNABOSCO, ${ }^{2}$ MARIANE ADRIANA SEHN, ${ }^{3}$ VINICIUS DE LIMA DA SILVA, ${ }^{4}$ FLAVIO HENRIQUE DA ROSA \\ UREN
}

${ }^{1}$ Acadêmica do PIC/Unipar

${ }^{1}$ Acadêmica do PIC/Unipar

${ }^{2}$ Acadêmica do PIC/Unipar

${ }^{3}$ Docente da UNIPAR

Introdução: Este projeto de pesquisa tem o intuído de identificar quem são os profissionais, seja da engenharia civil ou da arquitetura, do tão disputado mercado da construção civil no município de Cascavel - Pr que atualmente dispõe de 1000 registros no CREA(Conselho Regional de Engenharia e Agronomia) e 588 no CAU( Conselho de Arquitetura e Urbanismo). O fato é que são duas profissões distintas, mas por regulamentação profissional e conforme o código de ética CAU/BR ambas têm as mesmas atribuições no que diz respeito ao ato de projetar. Nesse sentido, através da busca de informações nos arquivos disponíveis da Prefeitura Municipal de Cascavel (processos e tabelas), referente ao ano de 2019, a pesquisa busca conhecer por meio de percentuais relativos, quantos arquitetos e engenheiros aprovam projetos e quais tipos de aprovações. Dessa forma, poderemos claramente identificar a realidade da atuação desses profissionais no mercado profissional do Município.

Objetivo Geral: Identificar através de dados numéricos a realidade da produção da construção civil em Cascavel, produzida por arquitetos e por engenheiros.

Desenvolvimento: É perceptível que o público leigo, pouco sabe sobre as reais atribuições profissionais de um arquiteto e de um engenheiro civil. E por esse motivo, quando questionados, em geral, tendem a crer que arquitetos são profissionais para apenas desenhar plantas ou cuidar da decoração e elaboração de fachadas . No entanto, a diferença fica nítida na própria formação, enquanto a graduação em Arquitetura e Urbanismo tem características multidisciplinares, com foco em projetos e o olhar no espaço, a faculdade de Engenharia Civil apresenta um currículo focado em cálculos estruturais e o comportamento dos materiais na obra. Ressaltando que ambas buscam o mesmo fim, mas por caminhos completamente diferentes. Para isso, com base na lista de alvarás expedidos pela Prefeitura, investigou-se o real quadro estatístico das atividades de aprovação de projeto de arquitetura em Cascavel, no ano de 2019, tanto realizada por arquitetos, como por engenheiros. Foi verificado os percentuais, e quais os tipos de projetos que são aprovados: edificações residenciais, comerciais, residenciais e comerciais, regularizações e edificações verticais, bem como bairros com maior incidência de projetos. Por se tratar de um número pouco expressivo, não foi incluído neste estudo, a análise edificações de caráter industrial, educacional, esportivas e institucionais, que poderá ser fruto de futura investigação.

Discussão dos dados: Considerou-se $70 \%$ dos 1976 processos que deram entrada, no ano de 2019, na prefeitura municipal de Cascavel. Sendo que a investigação e estatística focou nos seguintes dados: No primeiro quesito, Profissão x Finalidade, apontou que para do total da amostra, 617 engenheiro projetaram na área residencial, comparado a 459 arquitetos. 0 segundo quesito, Tipo de construção x Profissão, revelou que 584 engenheiros atuaram em edificação em alvenaria, comparado a 424 arquitetos. No terceiro quesito, Área x profissão, arquitetos projetaram 147497 mil metros quadrados, e $117098 \mathrm{~m} 2$ foram projetados por engenheiros. Esse dado demonstra uma aparente contradição com os anteriores. Detectou-se que arquitetos projetam menor quantidade de edificações, porém com maior número de $\mathrm{m} 2$. O quarto quesito buscou conhecer qual o Tipo de Construção que mais frequente em Cascavel e a pesquisa apontou para edificação residencial em alvenaria com $81,49 \%$ do total analisado; em segundo lugar com 14,87\%, regularização de edificação; em terceiro lugar com 2,91\%, ampliação e reforma, e em quarto lugar com 0,73, edifício em alvenaria. No quinto quesito Tipo de construção x Área, surge uma grande diferença: em primeiro lugar a edificação em alvenaria com $154498,25 \mathrm{~m} 2$, em segundo e com surpresa, o edifício em alvenaria com $50542,42 \mathrm{~m} 2$; e em terceiro lugar surge regularização de edificação com 36972,52m2, confirmando a mesma posição no quarto item; e na quarta posição com 50542,42m2, a ampliação e reforma.

Conclusão: Acreditava-se que os arquitetos apresentariam uma diferença bem sensível e vantajosa frente às demandas de projeto de arquitetura, em relação aos engenheiros, cujo foco são atividades voltadas à construção, projeto estrutural e demais complementares. As grades curriculares são distintas, mas há um sombreamento entre ambas, no que se refere às atribuições profissionais nos órgãos de classe, principalmente quanto a elaboração do projeto arquitetônico, pois as duas profissões possuem essa atribuição. Esse estudo apontou a realidade do município de Cascavel - PR, no ano de 2019, nos remetendo a mais reflexões sobre a cultura local, bem como sobre o conhecimento que a população tem sobre as atribuições de cada 
profissional, buscando assim, analisar hipóteses sobre quais os motivos que tem levado a sociedade cascavelense a buscar engenheiros para realização de projetos de Arquitetura ao invés de arquitetos, apontando possibilidades para novas investigações.

\section{Referências}

CREA(Conselho Regional de Engenharia e Agronomia) 2020

CAU( Conselho de Arquitetura e Urbanismo)2020

Prefeitura Municipal de Cascavel 2020

Código de Ética e Disciplina para arquitetos e urbanistas. CAU/BR.2020

Coordenadoria de Pesquisa e Extensão - COPEX

Departamento de Editoraçāo e Divulgaçāo Científica - DEDIC 


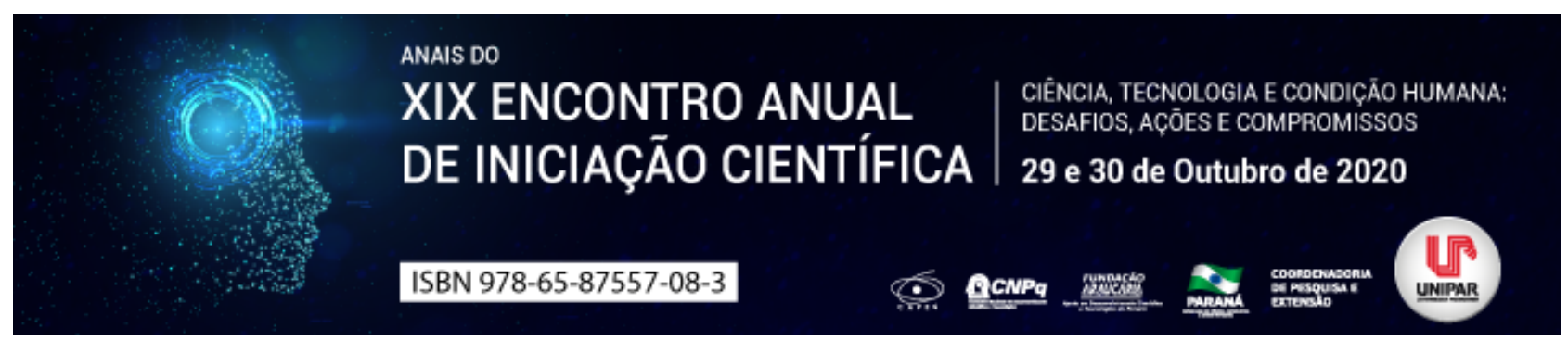

LEITURA PROCESSUAL DO INSTITUTO DA MULTIPROPRIEDADE

\author{
${ }^{1}$ BRUNA EDUARDA DE OLIVEIRA CESAR, ${ }^{2}$ PAULO CESAR DE SOUSA
}

${ }^{1}$ Acadêmica do curso de Direito da UNIPAR

${ }^{1}$ Docente da UNIPAR

Introdução: A multipropriedade foi instituída pela Lei 13.777/2018, transformando-se em dogma no campo dos direitos reais. Sua regulamentação consta de 20 artigos, cuja leitura exige que se faça uma conciliação entre tais dispositivos com normas processuais civis a serem aplicadas em lides que versem sobre a multipropriedade ou o direito a ela conexo.

Objetivo: Investigar como se dá a aplicação de normas processuais no que tange aos conflitos que envolvam a multipropriedade ou incidam sobre direitos a ela concernentes.

Desenvolvimento: A multipropriedade é uma espécie de condomínio consistente no fato de que um determinado imóvel pertence a vários proprietários, com aproveitamento econômico de um bem repartido em unidades fixas de tempo, de modo que cada titular possa se utilizar do bem com exclusividade, dentro do limite temporal que the couber (TEPEDINO, 1993). O instituto foi reconhecido no direito brasileiro em dezembro de 2018, por meio da Lei 13.777. Dado ser uma inovação jurídica, natural que haja discussões a respeito do tema e, dentre elas como aplicar institutos processuais quando controvérsias envolverem a multipropriedade direta ou indiretamente. Como exemplo, há peculiaridades sobre a penhora do bem objeto de multipropriedade. Mesmo considerada um direito real que dá ao proprietário direito de uso, gozo e disposição com eficácia erga omnes (GOMES, 2008), a penhora não pode atingir a totalidade do bem, como tradicionalmente ocorre, pois poderia atingir direitos dos outros coproprietários, tendo em vista que no condomínio e nas outras categorias de compropriedade, coexistem os direitos pessoais da comunhão e o direito real de cada comuneiro (MIRANDA, 2016, p. 230), que podem se defender por meio de embargos de terceiros, quer como possuidores, quer como proprietários. Outro aspecto observado refere-se ao foro competente, conforme o art. 47 do CPC, o foro para ações fundadas em direito real sobre imóveis é o lugar onde se situa a coisa. Como a multipropriedade surgiu com finalidade preponderantemente turística, destinada a pessoas de classe média que buscam um local para passar férias, sem poder manter vários imóveis (VENOSA, 2004), tem-se que, na maioria dos casos, os proprietários terão domicílio em local diverso da situação do imóvel, fato que implicará a morosidade na resolução do litígio. Trata-se de hipótese de competência absoluta, razão pela qual o foro não pode ser mudado. Tais constatações não possuem caráter exaustivo, visto que o assunto ainda permite incursões quanto a outros institutos processuais (ação de usucapião, por exemplo), os quais dizem respeito à efetividade da multipropriedade.

Conclusão: Verifica-se a necessidade de conciliar a aplicação de institutos processuais com a figura da multipropriedade, tendo em vista que a eficácia da norma material é assegurada por normas processuais.

\title{
Referências
}

GOMES, Orlando. Direitos reais. 19. ed. Rio de Janeiro: Forense, 2008. p.11.

MIRANDA, Francisco Cavalcanti Pontes de. Tratado das ações. São Paulo: Revista dos Tribunais, 2016. p. 230.

TEPEDINO, Gustavo. Multipropriedade Imobiliária. 1. ed. São Paulo: Saraiva, 1993. p. 01.

VENOSA, Silvio de Salvo. Direito civil: Direitos reais. 4. ed. São Paulo: Atlas, 2004. p. 357. 


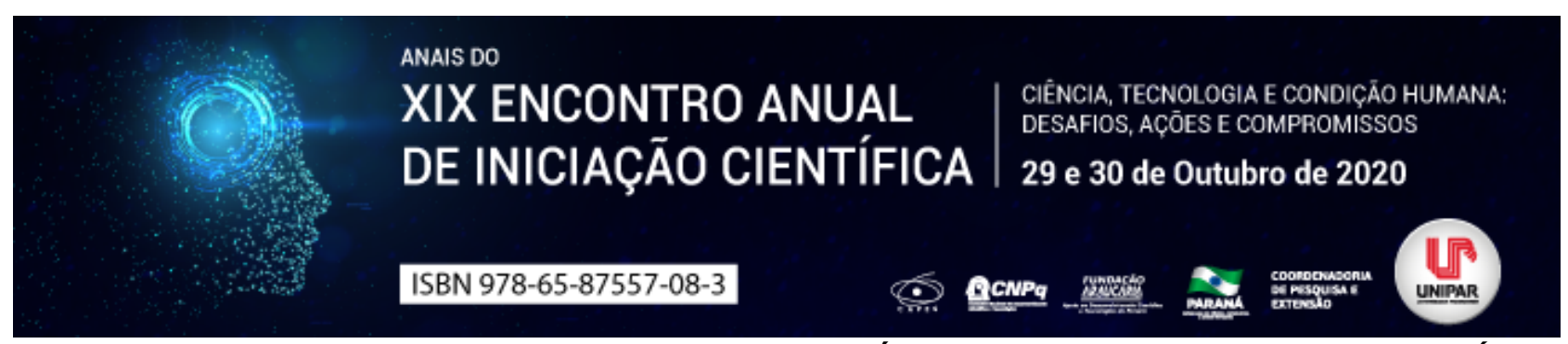

DIREITO DOS EMPREGADOS AO ACOMPANHAMENTO MÉDICO DE MENORES A LUZ DOS PRINCÍPIOS CONSTITUCIONAIS E INFRACONSTITUCIONAIS

\title{
${ }^{1}$ MARCELLE LUISA CALEGARI, ${ }^{2}$ CLARICE MENDES DALBOSCO
}

\author{
${ }^{1}$ Acadêmica do Curso de Direito da UNIPAR \\ ${ }^{1}$ Docente da UNIPAR
}

Introdução: Considerando a importância e responsabilidade do poder familiar no provento das necessidades básicas dos filhos, com o presente trabalho objetiva-se discutir a limitação da CLT e possibilidade de ampliação legislativa com relação ao afastamento dos genitores para o acompanhamento médico de menores, a fim de garantir os princípios constitucionais da manutenção do trabalho ao empregado, e a proteção integral da criança e do adolescente pela família, amparado pelo ECA. A pesquisa é de cunho dedutivo, sob análise de natureza bibliográfica.

Objetivo: Discutir a limitação da CLT e possibilidade de ampliação legislativa com relação ao afastamento de genitores para o acompanhamento médico de crianças e adolescentes.

Desenvolvimento: No Brasil, com a Constituição Federal de 1988 e o surgimento do Estatuto da Criança e do Adolescente (ECA), houve a consolidação do direito dos filhos de serem amparados e cuidados pelos pais, onde do Art. $1^{\circ}$ ao $5^{\circ} \mathrm{o}$ ECA estabelece a base de todo o seu regulamento. Conforme o art. $2^{\circ}$ do ECA, considera-se criança a pessoa até doze anos de idade incompletos, e adolescente àquela que está entre 12 e 18 anos, a quem se atribui aos cuidados da família, garantia constitucional prevista no Art. 227 da CF/88; O ECA dispõe no Art. 22 o mesmo dever da família em relação aos filhos, sendo este irrenunciável, conforme Art. 27. Em relação a necessidade do acompanhamento do menor pelos genitores para tratamento médico, a CLT prevê nos incisos do Art. 473 as hipóteses em que o empregado pode deixar de comparecer ao trabalho sem prejuízo de seu salário. No entanto, mostra-se rasa quanto ao acompanhamento familiar para tratamento de saúde de dependentes, estando inserida nesse rol apenas a seguinte possibilidade, no inciso XI: 1 (um) dia por ano para acompanhar filho de até 6 (seis) anos em consulta médica. Tal amparo está longe de ser suficiente para atender as necessidades dos genitores que, por exemplo, precisam acompanhar seus filhos em tratamento médico contínuo, e mais, deixa de contemplar os filhos com idade até os 18 anos, que também estão sob o poder familiar e gozam dos direitos fundamentais inerentes à pessoa humana. Em decorrência disso, surge um conflito entre a legislação vigente e os princípios constitucionais que garantem a manutenção do trabalho, ao empregado, e a proteção integral da criança e do adolescente pela família, amparado pelo ECA. Se de um lado a legislação impõe o dever de garantir a saúde da criança e do adolescente, ao mesmo tempo em que prevê deveres em relação ao trabalho, deixa de estabelecer direitos que amparem o exercício mútuo desses direitos fundamentais, sem que haja prejuízo em uma ou outra esfera. Nos casos de internação da criança ou adolescente, por sua vez, o art. 12 do ECA garante o direito a permanência em tempo integral de um dos pais ou responsáveis. Apesar disso, não há nenhum amparo legislativo aos trabalhadores, e o que se observa na vigência dos contratos de trabalho são sucessivos descontos no salário pelas faltas, acordos entre o empregado e empregador e nas hipóteses mais graves, dispensa do trabalho. Assim, a ausência de legislação que regule essas situações acaba impedindo o direito de saúde do menor sob guarda. Contudo, existe em caráter jurisprudencial a possibilidade de concessão de auxílio doença parental, que deve ser visto como uma alternativa viável para estes casos. O auxílio doença é um beneficio já existente em lei, e pode ser concedido ao próprio segurado em casos de incapacidade por mais de 15 dias, mediante o cumprimento de certos requisitos. Para o INSS, no entanto, não existe auxilio doença para o cuidador. Apesar disso, há entendimentos jurisprudenciais favoráveis a concessão do beneficio, pautados nos princípios da dignidade humana e da proteção integral a criança e ao adolescente, [...] A obtenção do beneficio só se dar pela via judicial, implica na morosidade, sem falar que é inconcebível pensar no acesso a via judicial na vigência do contrato de trabalho, gerando uma decisão ineficaz e sem qualquer efetividade (STRAZZI, 2019). De fato, o que se traz aqui não se trata de inovação jurídica, posto que já tramita a PL do Senado n²86, de 2014, que cria o auxilio doença parental ao segurado do RGPS, acrescentando o art. 63-A a Lei no 8213/91. Embora uma interpretação sistemática do ordenamento jurídico possa facilmente resolver o problema, sabe-se que na prática a ausência de dispositivo legal obriga o empregado a recorrer ao Poder Judiciário para ter seu direito reconhecido, sobrecarregando todo o sistema. Além disso, o acionamento do Judiciário dificilmente ocorreria na vigência do contrato de trabalho, podendo gerar uma decisão ineficaz e sem qualquer efetividade.

Conclusão: Ante o exposto, observa-se que embora uma interpretação jurisprudencial possa resolver os casos concretos, conclui-se que a ampliação legislativa que insere a possibilidade do auxilio doença parental no Regime Geral da Previdência ou a ampliação das hipóteses de afastamento de trabalho, mesmo que em períodos mais curtos, é a medida mais assertiva a ser adotada, sendo mais eficaz e efetiva. 


\section{Referências}

BRASIL. Constituição da República Federativa do Brasil.Brasília, DF: Senado Federal, 1988.

Lei $n^{\circ}$ 8.069, de 13 de julho de 1990.Dispõe sobre o Estatuto da Criança e do Adolescente e dá outras providências. Disponível em: . Acesso em: 15 jun. 2020.

Decreto-Lei $\mathbf{n}^{\circ} \mathbf{5 . 4 5 2}$, de $\mathbf{1}^{\circ}$ de maio de 1943. Aprova a Consolidação das Leis do Trabalho. Disponivel em: . Acesso em: 17 jun. 2020.

CASTRO, Carlos, A. Pereira de; LAZZARI, João B. Manual de Direito Previdenciário.20 ed. Rio de Janeiro: Forense, 2017. COSTA, Marli Marlene M. da; NUNES, Josiane B. A. Auxílio doença parental: viabilidade e necessidade de sua criação com o fito de garantir a dignidade da pessoa humana, o bem estar e justiça social. In: XIII Seminário Internacional Demandas Sociais e Políticas Públicas na Sociedade Contemporânea \& IX Mostra Internacional de Trabalhos Científicos, 2016, Santa Cruz do Sul. Anais eletrônicos.Disponível em: . Acesso em: 20 abr. 2020.

DELGADO, Mauricio G. Curso de Direito do Trabalho. 18 ed. São Paulo: LTR, 2019.

DIAS, Maria Berenice. Manual de Direito das Famílias. 10 ed. Revista dos Tribunais: 2015. Disponível em: . Acesso em 10 jun. 2019.

OLIVEIRA, Caroline Gazzola S. de. et al. O direito fundamental à saúde e o principio da proteção integral da criança e do adolescente. Revista de Direito Público, Londrina, v. 6, n. 2, p. 184-201, ago/set. 2011. Disponível em: . Acesso em: 12 mar. 2020.

STRAZZI, Alessandra. Auxílio-doença parental: é possível afastamento para cuidar de familiar doente? 2019. Disponível em: . Acesso em: 17 jun. 2020. 


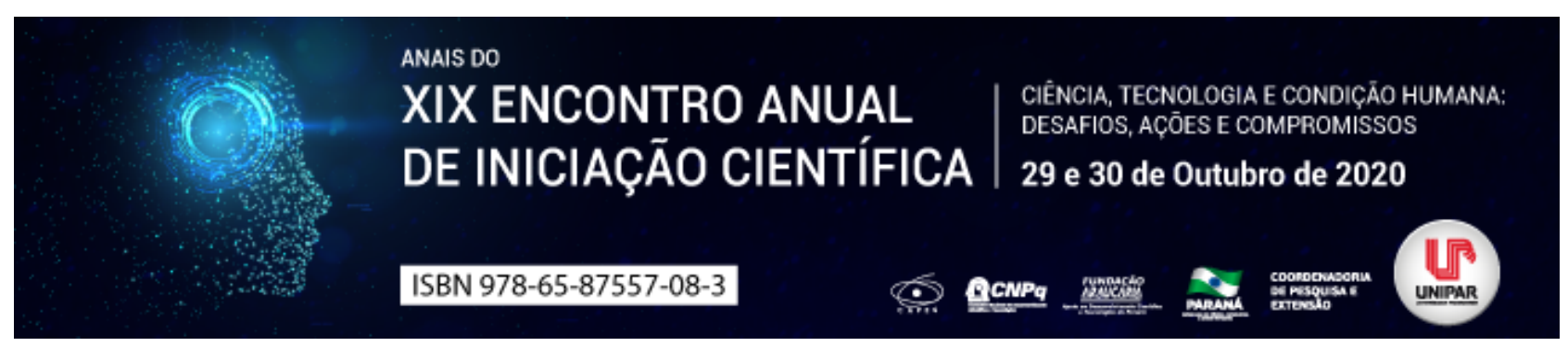

O DEVER DE ALIMENTOS AO IDOSO

\begin{abstract}
${ }^{1}$ GABRIEL TRENTINI PAGNUSSAT, ${ }^{2}$ BRUNO HENRIQUE PUCHETTI DE CENE, ${ }^{3}$ MATHEUS HENRIQUE DE FREITAS URGNIANI, ${ }^{4}$ MATHEUS HENRIQUE RAPHAEL DE PAULA, ${ }^{5}$ LUIZ ROBERTO PRANDI
\end{abstract}

\begin{abstract}
${ }^{1}$ Acadêmico do Curso de Direito e bolsista PEBIC/CNPq/UNIPAR
${ }^{1}$ Participante do Programa de Iniciação Científica (PIC) e Acadêmico do Curso de Direito da UNIPAR

${ }^{2}$ Participante do Programa de Iniciação Científica (PIC) e Acadêmico do Curso de Direito da UNIPAR

${ }^{3}$ Participante do PIBIC e Acadêmico do Curso de Direito da UNIPAR

${ }^{4}$ Doutor em Ciências da Educação, Docente e Pesquisador da UNIPAR
\end{abstract}

Introdução: A pirâmide etária está em processo de inversão no Brasil, bem como a expectativa de vida tem aumentado, entretanto, muitos idosos não conseguem manter a própria subsistência, dada as características específicas da senilidade. Nesse sentido, por meio do Estatuto do Idoso, a obrigação alimentar tornou-se direito desses.

Objetivo: Delinear os aspectos relativos ao direito alimentar do idoso.

Desenvolvimento: A dignidade da pessoa humana (CF, art. $1^{\circ}$, III) é fundamento do Estado Democrático de Direito brasileiro, nesse sentido, buscam-se mecanismos para defesa dos direitos inerentes ao homem, tal como sua vida, saúde, educação, etc. Nos artigos 203 e 204 e 260 e seguintes, estão elencados dispositivos sobre seguridade social e direito do idoso, entretanto, ensina Lima (2016), que apesar desses dispositivos estarem presentes na Constituição, a sociedade brasileira e a própria família do idoso não obedeciam o disposto na lei. Diante dessa omissão criou-se uma legislação que trata especificamente da pessoa idosa, o Estatuto do Idoso, que serve de instrumento de proteção e garantia dos direitos das pessoas idosas. O Estatuto é destinado a regular os direitos assegurados às pessoas com idade igual ou superior a 60 (sessenta) anos (Art. $1^{\circ}$ ), reafirmando os princípios em sede constitucional, asseverando mais algumas garantias ao idoso devido a sua faixa etária e a consequente fragilidade. Um desses direitos específicos é ao alimento, o qual é obrigação da família, comunidade, sociedade e do Poder Público (Art. $3^{\circ}$ ), portanto, obrigação solidária, cabendo ao idoso optar entre os prestadores (Art. 12); sendo que se a família não tiver condições econômicas de prover o sustento do idoso, será do Poder Público essa obrigação, por meio da assistência social (Art. 14). Ainda o artigo 45 da Lei $8.213 / 91$ prevê o acréscimo de $25 \%$ na aposentadoria por invalidez para o segurado que necessitar da assistência permanente de outra pessoa , para que a aposentadoria desse não seja aviltada no caso de não autossuficiência e assim, possa arcar com seu sustento. Ademais, para dar efetividade às normas e evitar o que ocorria enquanto o dever alimentar era apenas constitucional, o Estatuto tornou típico o ato de Expor a perigo a integridade e a saúde, física ou psíquica, do idoso, submetendo-o a condições desumanas ou degradantes ou privando-o de alimentos e cuidados indispensáveis, quando obrigado a fazê-lo, ou sujeitando-o a trabalho excessivo ou inadequado (BRASIL, 2003, [18] p.), com pena de detenção de 02 (dois) meses a 01 (um) ano e multa, e majorante se resultar em lesão corporal grave ou morte. Na mesma senda, o Estatuto alterou o artigo 244 do Código Penal, que passou a afirmar que: Deixar, sem justa causa, de prover a subsistência [...] de ascendente inválido ou maior de 60 (sessenta) anos, não lhes proporcionando os recursos necessários ou faltando ao pagamento de pensão alimentícia judicialmente acordada, fixada ou majorada (BRASIL, 1940, [75] p.), com a penalidade de detenção de 1 (um) a 4 (quatro) anos e multa de uma a dez vezes o salário mínimo. Por fim, destaca-se que o dever de prestar alimentos está sujeito às disposições do Código Civil, portanto, cabível as mesmas ações, direitos e deveres para ver-se satisfeito os alimentos da pessoa idosa.

Conclusão: O Estatuto do Idoso trouxe novos dispositivos para assegurar os direitos sociais da pessoa idosa, dentre esses, está o dever de alimento, ligado à vida, à saúde e à dignidade da pessoa humana. Esse será adimplido nos moldes da legislação civil pelos familiares e no caso de hipossuficiência do idoso, pelo Estado por meio da seguridade social. Ademais, a Lei foi certeira ao tipificar a negligência quanto ao idoso, forçando assim, por meio coercitivo penal a satisfação da obrigação alimentar, garantindo o bem-estar dessa população etária.

\title{
Referências
}

BRASIL. Lei $\mathbf{n}^{\circ}$ 10.741, de outubro de 2003. Dispõe sobre o Estatuto do Idoso e dá outras providências. Dispinível em: http://www.planalto.gov.br/ccivil_03/leis/2003/L10.741compilado.htm. Acesso em: 12 jun. 2020.

BRASIL. Lei $n^{\circ}$ 8.213, de 24 de julho de 1991. Dispõe sobre os Planos de Benefícios da Previdência Social e dá outras providências. Disponível em: http://www.planalto.gov.br/ccivil_03/leis/L8213compilado.htm. Acesso em: 12 jun. 2020.

BRASIL. Constituição da República Federativa do Brasil de 1988: promulgada em 05 de outubro de 1988. Disponível em: http://www.planalto.gov.br/ccivil_03/constituicao/ConstituicaoCompilado.htm. Acesso em: 12 jun. 2020. 
BRASIL. Decreto-Lei $\mathbf{n}^{\circ}$ 2.848, de $\mathbf{7}$ de dezembro de 1940 . Código Penal. Disponível em: http://www.planalto.gov.br/ccivil_03/Decreto-Lei/Del2848compilado.htm. Acesso em 12 jun. 2020.

LIMA, Ianna Pessoa. O dever obrigacional de alimentar o idoso. Âmbito Jurídico, n. 144, 2016. Disponível em: https://ambitojuridico.com.br/edicoes/revista-144/o-dever-obrigacional-de-alimentar-o-idoso/. Acesso em: 16 jun. 2020.

Coordenadoria de Pesquisa e Extensão - COPEX

Departamento de Editoraçāo e Divulgaçāo Científica - DEDIC 


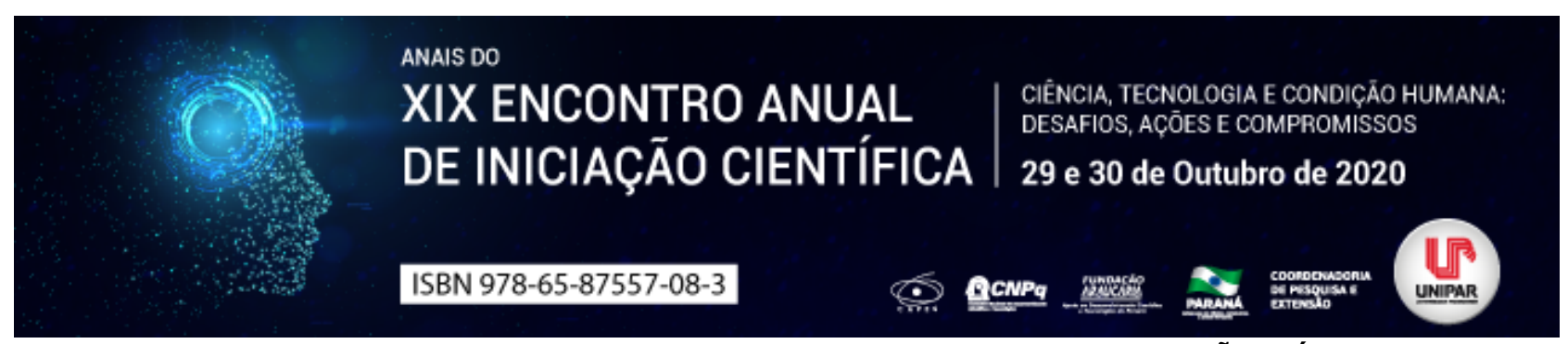

O USO DA APRENDIZAGEM BASEADA EM PROBLEMAS NA EDUCAÇÃO BÁSICA

\begin{abstract}
${ }^{1}$ Mariana Rodrigues, ${ }^{2}$ TAIANE APARECIDA RIBEIRO NEPOMOCENO
\end{abstract}

\author{
${ }^{1}$ Acadêmica de Letras na UNIOESTE. \\ ${ }^{1}$ Mestre em Ciências Ambientais pela Universidade Estadual do Oeste do Paraná.
}

Introdução: A educação básica tem por finalidade a promoção de conhecimentos, saberes e competências necessárias ao exercício da cidadania. No entanto, por muito tempo e até hoje, a formação escolar tem sido baseada em metodologias tradicionais de ensino. Dessa forma, o processo de ensino e aprendizagem se fundamentada especialmente em técnicas conteudistas, fragmentadas e disciplinares, onde o professor tem um papel central, de transmissor de informações e, o aluno, por sua vez, uma posição passiva. Contudo, no Brasil, nos últimos anos, se ampliaram as discussões sobre a utilização de metodologias ativas no processo de ensino e aprendizagem, em diversos níveis e modalidades da educação. Elas são consideradas poderosas estratégias pedagógicas e possuem como principal característica a participação direta e ativa do aluno na construção do conhecimento. As metodologias ativas motivam o aluno a analisar, refletir e decidir sobre determinada situação, ou seja, o aluno é o eixo central do seu aprendizado (ARAUJO, 2015). Por sua vez, a metodologia ativa de Aprendizagem Baseada em Problemas (ABP), surge como uma estratégia importante de integração às ações pedagógicas na educação básica. Isso, porque ela engloba a solução de uma problemática, que instiga o aluno a se colocar na condição de protagonista do seu aprendizado.

Objetivo: Discutir o uso da Aprendizagem Baseada em Problemas e sua importância como metodologia ativa de ensino no contexto da educação básica.

Desenvolvimento: A ABP é um método totalmente aplicável e inovador na educação, se aplica a diversos contextos e conteúdos curriculares. De acordo com Lopes et al., (2019) ela constitui-se uma estratégia que se estabelece em torno da investigação de problemas do mundo real. Não apenas os alunos, mas os professores se empenham na análise, pesquisa, entendimento e proposição de soluções para circunstâncias específicas, de forma a assegurar o alcance de competências e habilidades previstas no currículo escolar. As situações representam cenários relacionados ao cotidiano do aluno, seja da escola, contexto familiar ou de sua cidade. Isso significa, portanto, que o uso dessa metodologia cria um ambiente crítico, estimula nos envolvidos o desenvolvimento do raciocínio, para soluções fundamentadas. Ao usar a ABP na educação básica, o professor precisa ser além de orientador, possuir um bom planejamento. A aprendizagem na ABP requer o desenvolvimento de etapas específicas. Na primeira etapa, ocorre a formulação e análise do problema, na segunda busca-se informações e se definem estratégias para a resolução do problema, já na terceira etapa ocorre a discussão e avaliação até que se chegue a uma ou mais conclusões. Caso o problema seja resolvido de forma satisfatória sucede-se à produção do relatório final com a solução, caso contrário esse ciclo se reinicia (HMELO-SILVER, 2004). Essa metodologia ativa tem papel fundamental no preenchimento de lacunas do ensino tradicional, e apesar de pouco implementada, ela pode proporcionar uma aprendizagem interdisciplinar, significativa e o desenvolvimento das habilidades comunicativas, de interação e cooperação. Não se pode negar que possui muitas vantagens, como: motivação para a aprendizagem, integração do conhecimento e desenvolvimento do pensamento crítico. No entanto, não se pode deixar de citar algumas dificuldades que ainda surgem durante a utilização do método, dentre as principais, citam-se: insegurança inicial, inadequação do currículo, formação de professores e tempo (SOUZA; DOURADO, 2015). Mesmo com variações, ela reforça o papel ativo do aluno no processo de ensino e aprendizagem, a partir de um currículo flexível, temático e interdisciplinar, promovendo um novo rearranjo entre aluno e conhecimento.

Conclusão: $A$ ABP apresenta-se como uma metodologia que promove a aprendizagem integrada e contextualizada, de exploração de novas áreas. Ela valoriza a interação, o conteúdo a ser apreendido e principalmente a forma como o aprendizado acontece. Se apresenta como uma forte aliada à prática docente, ao desenvolvimento de habilidades sociais, cognitivas, técnicas e motoras.

\title{
Referências
}

ARAUJO, José Carlos Souza. Fundamentos da metodologia de ensino ativa (1890-1931). Florianópolis: UFSC, 2015. HMELO-SILVER, Cindy. Problem-Based Learning: What and How Do Students Learn? Educational Psychology Review, v. 16, n. 3, p. 235-266, 2004.

LOPES, Renato Matos et al. Características gerais da aprendizagem baseada em problemas. In: LOPES, Renato Matos et al. Aprendizagem baseada em problemas: fundamentos para a aplicação no ensino médio e na formação de professores. Rio de Janeiro: Publiki, 2019. p.47-74.

SOUZA, Samir Cristiano; DOURADO, Luis. Aprendizagem Baseada em Problemas (ABP): um método de aprendizagem inovador 
para o ensino educativo. Holos, v. 5, n. 31, p. 182-200, 2015.

Coordenadoria de Pesquisa e Extensão - COPEX

Departamento de Editoraçāo e Divulgaçāo Científica - DEDIC 


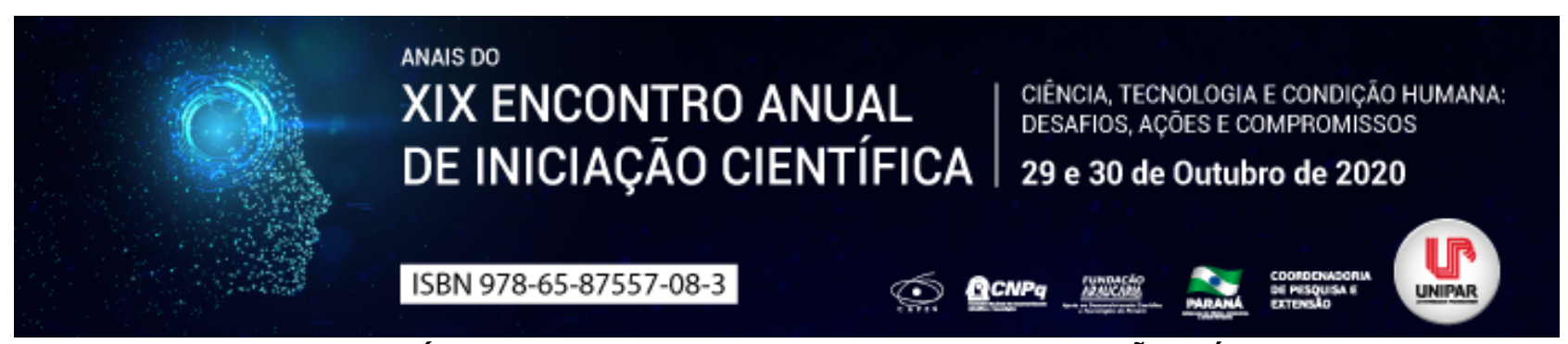

ENSINO HÍBRIDO: POTENCIAL E DESAFIOS NA EDUCAÇÃO BÁSICA

\begin{abstract}
${ }^{1}$ Mariana Rodrigues, ${ }^{2}$ TAIANE APARECIDA RIBEIRO NEPOMOCENO
\end{abstract}

\author{
${ }^{1}$ Acadêmica de Letras na UNIOESTE. \\ ${ }^{1}$ Mestre em Ciências Ambientais pela Universidade Estadual do Oeste do Paraná.
}

Introdução: As constantes inovações tecnológicas refletem sobre a sociedade e em diversos contextos, inclusive o educacional. Os modelos tradicionais de educação já não correspondem às expectativas dos alunos e pouco colaboram com a formação do aluno crítico, inovador e protagonista. Sabe-se que a sala de aula funciona como um espaço de construção, onde se recorre constantemente à novas possibilidades de aprimorar o processo de ensino e aprendizagem. Assim, o ensino híbrido, apesar de ser pouco empregado, é uma das mais discutidas tendências atualmente, pode ser caracterizado como uma mescla de conectividade e aprendizagem ativa. Isso, porque, ele promove uma mistura entre o ensino presencial e virtual. O ensino híbrido, pode ser implementado em todas as escolas, naquelas que possuem ou não uma insfraestrutura tecnológica moderna e, não se reduz a essa definição. Pelo contrário, considera a integração de processos formais e informais de educação, de uma educação aberta e em rede, onde todos ensinam ou aprendem ininterruptamente (MORAN, 2015). No entanto, sabe-se que infelizmente todos os avanços e tendências educacionais não tem chegado às salas de aulas com a mesma intensidade e qualidade esperada.

Objetivo: Propor uma reflexão em relação ao ensino híbrido, destacando potencialidades e obstáculos de sua aplicação na educação básica.

Desenvolvimento: $O$ ensino híbrido alia a sala de aula às tecnologias digitais, requer, portanto, a ressignificação do papel do professor e do aluno. Nesta modalidade, o professor assume o papel de mediador, utilizando-se de metodologias que direcionem o aluno a construção e apropriação do conhecimento. O processo de ensino e aprendizagem não está centrado apenas nas aulas presenciais, mas no ensino virtual, mediado pelas tecnologias e orientação docente. Dentre tantas potencialidades, o ensino híbrido, pode proporcionar uma aprendizagem contínua e emancipatória. $E$, diferentemente, do método tradicional, o tempo das aulas não é mais delimitado. Isso significa que os alunos podem acessar os conteúdos, atividades, fóruns, grupos de discussão ou praticar habilidades necessárias ao seu desenvolvimento de qualquer lugar e a qualquer horário, tendo como base uma experiência de aprendizado significativo e autônomo (NETO, 2017), contribuindo para o alcance de resultados e o desenvolvimento de competências e habilidades previstas no currículo escolar. Concorda-se que o ensino híbrido representa um ótimo e dinâmico aliado a prática pedagógica. Mesmo encontrando um sistema educacional ao avesso para as inovações, a luta pelo rompimento da educação tradicional e por uma sociedade com pessoas proativas, com poder de decisão e criticidade deve continuar (MACHADO et al., 2017). No entanto, não se pode negar que o quadro da educação no país aponta para a necessidade de repensar a educação como um todo, desde a formação inicial de professores, a exclusão digital e a própria realidade escolar. Além do mais, a inserção do ensino híbrido gera muitas transformações metodológicas, de gestão, prática docente, função do professor e papel do aluno. Portanto, no momento, a proposta do ensino híbrido na educação básica orienta para a reestruturação do sistema educacional, de modo que considere a qualidade daquilo que se propõe e a superação da passividade no processo de ensino e aprendizagem (SILVA, 2017). Ou seja, o ensino híbrido, requer propostas de ensino criadoras, dialógicas e abertas.

Conclusão: O ensino híbrido na educação básica apresenta possibilidades de protagonismo no processo de construção do aprendizado, integração, inclusão digital, inovação e desenvolvimento de novas habilidades dos alunos. Contudo, exige mais do que a simples integração harmônica entre ensino presencial e virtual, mas novos estilos de ensino e aprendizagem, capazes de transformar informações em conhecimentos significativos para a vida em sociedade.

\title{
Referências
}

MACHADO, Nathália Savione; LUPEPSO, Marina; JUNGBLUTH, Anna. Educação híbrida. Curitiba: UFPR, 2017.

MORAN, José. Educação híbrida: um conceito-chave para a educação, hoje. In: BACICH, Lilian; NETO, Adolfo Tanzi; TREVISANI, Fernando de Mello. (Orgs.). Ensino híbrido: personalização e tecnologia na educação. Porto Alegre: Penso, 2015. p. $27-45$.

NETO, Emílio Bertholdo. O ensino híbrido: processo de ensino mediado por ferramentas tecnológicas. Ponto e vírgula, v. $1, \mathrm{n}$. 22, p. 59-72, 2017.

SILVA, Edsom Rogério. O ensino híbrido no contexto das escolas públicas brasileiras: contribuições e desafios. Porto das letras, v. 3, n. 01, p. 151-164, 2017. 
Coordenadoria de Pesquisa e Extensão - COPEX

Departamento de Editoraçāo e Divulgaçāo Científica - DEDIC 


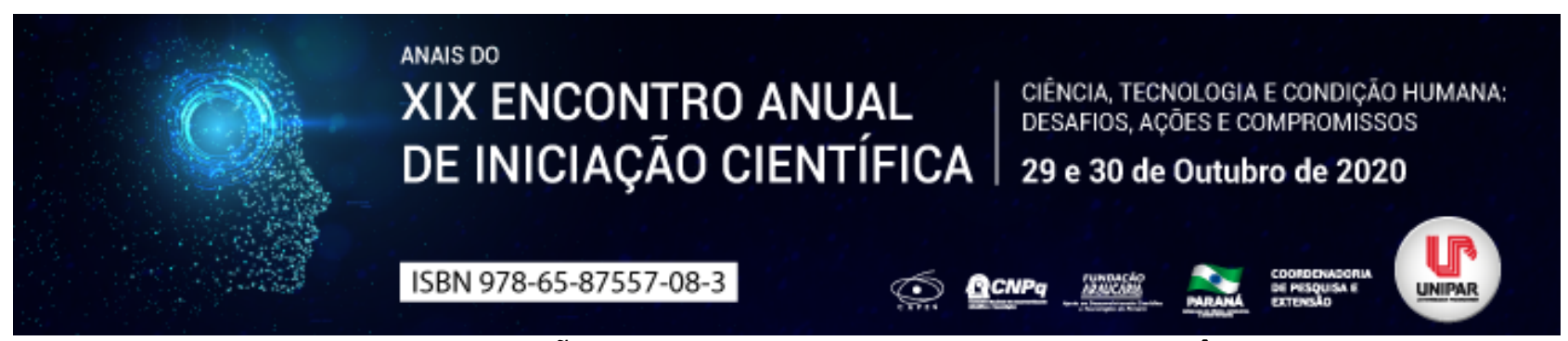

APLICABILIDADE E CONTRIBUIÇÕES DA ENTOMOLOGIA NO ENSINO DE CIÊNCIAS E BIOLOGIA

\author{
${ }^{1}$ Alex Junior Pietrobon, ${ }^{2}$ TAIANE APARECIDA RIBEIRO NEPOMOCENO
}

\author{
${ }^{1}$ Mestrando em Agronomia pela UNIOESTE \\ ${ }^{1}$ Mestre em Ciências Ambientais pela Universidade Estadual do Oeste do Paraná.
}

Introdução: A escola, atualmente, está comprometida com um ensino de qualidade para o exercício da cidadania. O ensino de Ciências e Biologia passaram por muitas reformulações, influenciados por tendências educacionais e demandas sociais e políticas. Os conteúdos curriculares dessas disciplinas são parte de um instrumental necessário para que os alunos se tornem capazes de compreender a realidade à sua volta, discutir, explicar e intervir de forma consciente na natureza. Segundo a nova Base Nacional Comum Curricular (2015) o estudo da vida, sua diversidade e níveis de organização leva ao entendimento da natureza, sua importância e recursos. Também possibilita a compreensão das ações antrópicas no planeta e o desenvolvimento de habilidades e competências relacionadas ao desenvolvimento da cidadania e do senso crítico ante questões de cunho socioambiental. Nesse contexto, além de ser conteúdo de diversas disciplinas da matriz curricular do ensino básico, o estudo da entomologia se faz urgente e necessário, porque ele é capaz de possibilitar reflexões a respeito das condições da biodiversidade e interdependência na terra.

Objetivo: Descrever o estudo da entomologia no ensino de Ciências e Biologia, e suas contribuições para a educação escolar.

Desenvolvimento: Os insetos desempenham função importante na manutenção dos ecossistemas, possuem grande importância econômica e social, portanto se apresentam como ricos componentes da ação educacional. Como a entomologia é uma área muito ampla, diversas são as suas formas de uso e contribuições para o ensino de ciências e Biologia. A abordagem com insetos na educação possibilita aprender valores e atitudes de respeito à vida e, segundo Lopes e Silva (2020), se torna uma ferramenta muito significativa de educação ambiental, sendo essas competências necessárias à formação de cidadãos mais críticos e compromissados com a saúde do meio em que vivem. De modo geral, além de tornar as aulas mais atrativas, representam um ótimo recurso didático para a superação de conceitos prévios equivocados sobre esta classe e, sobretudo para a articulação de conteúdos de ordem conceitual, procedimental e atitudinal. Sua aplicação no ensino de ciências e biologia vem sendo desenvolvida sobre diferentes estratégias, como: utilização e elaboração de caixas entomológicas, modelos didáticos tridimensionais, oficinas, jogos, observação de insetos, exibição de vídeos e atividades investigativas. O estudo da entomologia na educação básica, não se baseia apenas em conceitos específicos de morfologia, reprodução e comportamento, pelo contrário, nota-se que atualmente, ela vem sendo aplicada em diferentes áreas da ciência e biologia, fazendo parte de temáticas relacionadas aos aspectos de poluição, evolução, biomonitoramento e interações ecológicas (DIAS; VINHOLI JUNIOR, 2020). Este conteúdo, se encaixa nas práticas do ensino de ciências da educação infantil e séries iniciais, no desenvolvimento da cognição e em favor da aprendizagem significativa e criativa (AZEVEDO FILHO; TOLOTTI, 2015). Ou seja, a entomologia no ensino de ciências e biologia emerge como um instrumento facilitador do aprendizado, importante para a superação da fragmentação do conhecimento.

Conclusão: A entomologia, como área de estudo no ensino de ciências e biologia possibilita ao aluno estabelecer uma relação mais ampla entre o conteúdo abordado com a vida, cotidiano e realidade. Permite, ainda o rompimento de conceitos equivocados, a compreensão da funcionalidade dos insetos na terra e suas características ecológicas. $\mathrm{O}$ estudo dos insetos em diferentes níveis da educação formal amplia seu conhecimento acerca da diversidade entomológica e contribui para a formação científica e crítica do aluno.

\title{
Referências
}

AZEVEDO FILHO, Wilson Sampaio de; TOLOTTI, Adriana. Os insetos e a ciência na escola. Caxias do Sul: EDUCS, 2015. BRASIL. Base Nacional Comum Curricular. Brasília: MEC, 2015.

DIAS, Daniel Pereira do Padro; VINHOLI JUNIOR, Airton José. Estratégias, finalidades e contribuições da entomologia no ensino de ciências e biologia. Didasc@lia: Didáctica y Educación, v. 11, n. 1, p. 126-139, 2020. Disponível em: https://dialnet.unirioja.es/servlet/articulo?codigo=7361558. Acesso em: 05 Junho 2020.

LOPES, Bruno de Souza; SILVA, Nayane da. Entomologia na escola: o que os estudantes pensam sobre os insetos e como utilizá-los como recurso didático?. Reveduc, v. 14, n. $1, \quad$ p. 1-20, 2020. Disponível em: http://www.reveduc.ufscar.br/index.php/reveduc/article/view/3300. Acesso em: 07 Junho 2020. 



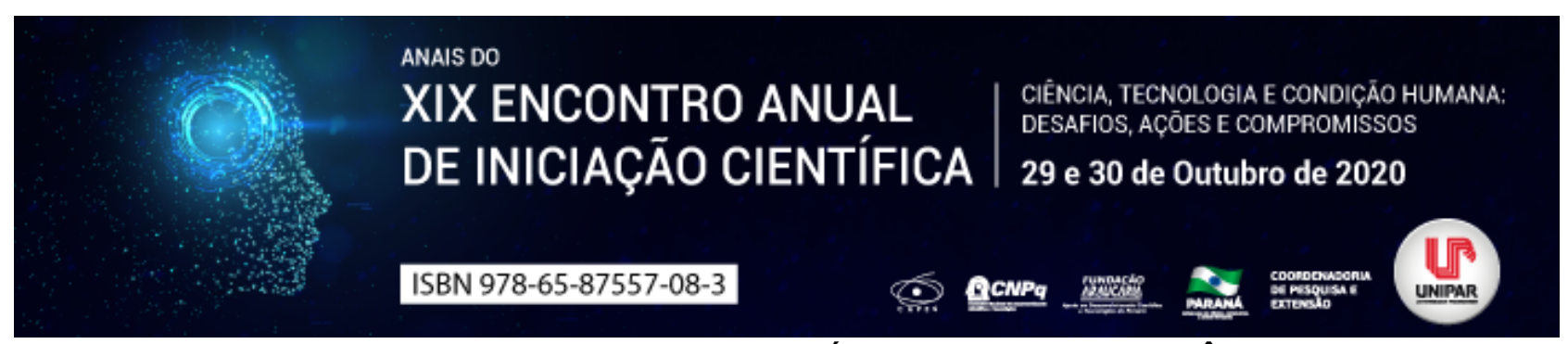

A HIDROPONIA COMO ELEMENTO DIDÁTICO NO ENSINO DE CIÊNCIAS

\author{
${ }^{1}$ Alex Junior Pietrobon, ${ }^{2}$ TAIANE APARECIDA RIBEIRO NEPOMOCENO
}

\author{
${ }^{1}$ Mestrando em Agronomia pela UNIOESTE \\ ${ }^{1}$ Mestre em Ciências Ambientais pela Universidade Estadual do Oeste do Paraná.
}

Introdução: O ensino de ciências deve ter por base, práticas interdisciplinares contextualizadas, com conteúdos relevantes, que repercutam de forma significativa no desenvolvimento cognitivo do aluno. Na era da informação, faz-se necessário ao ensino de ciências partir primeiramente da ação dos alunos sobre os objetos de estudo, despertando o raciocínio científico e o rompimento do caráter informativo (OLIVEIRA et al., 2010). Mas, para que o raciocínio científico seja assimilado pelo aluno como uma prática cotidiana é fundamental que a ciência esteja ao alcance de sua realidade e as ações tenham sentido para o praticante. As atividades práticas permanentes que fornecem propriedades sobre conteúdos estudados são importantes elementos didáticos no ensino de ciências. Nesse caso, a hidroponia, que é uma técnica de cultivo de plantas sem o uso do solo, representa uma possibilidade de integração curricular dinâmica e interdisciplinar.

Objetivo: Apresentar a técnica hidropônica como elemento didático para o ensino de ciências.

Desenvolvimento: Os elementos didáticos são ferramentas que auxiliam o processo de ensino e aprendizagem. No ensino de ciências, a hidroponia se constitui um importante aliado à prática docente, pois, a partir dela é possível abordar muitos conteúdos curriculares (NEVES, 2020), que permeiam desde questões de solo, controle biológico de pragas, fisiologia vegetal, alimentação saudável, fotossíntese até mesmo a sua integração com a educação ambiental e práticas sustentáveis. Utilizada na perspectiva interdisciplinar, ela abre caminhos para abordar conceitos de todas as disciplinas escolares, de forma atraente, mediando a aprendizagem diferenciada. Ainda oportuniza o trabalho em grupo, o compartilhamento de ideias, a valorização do trabalho do outro e o entendimento de sua ação. A hidroponia como elemento didático estimula a união de saberes, o desenvolvimento de competências de investigação, observação e registro científico (NASCIMENTO; SALOMÃO, 2014). E, para além disso, essa prática ainda possibilita a produção de alimentos de alto valor nutritivo e livre de agrotóxicos, que pode auxiliar na composição da merenda escolar. A hidroponia, pode ser caracterizada como um instrumento facilitador do conhecimento, de conscientização pelo meio ambiente, de educação alimentar e, especialmente para a transmissão de preceitos éticos e humanos. Ela colabora com mudanças dos modos de ação e atitudes, capacitando o aluno para o desenvolvimento sustentável, consciente e responsável (LIMA, 2017). Não obstante, se faz necessário a capacitação docente para a adequada utilização da hidroponia como elemento didático funcional para o ensino de ciências. A ação docente coerente com o currículo e o uso da hidroponia podem levar o aluno a melhoria de suas habilidades de participação, cooperação (LIMA, 2017), união e coletividade.

Conclusão: Como um elemento didático no ensino de ciências, a hidroponia possibilita o trabalho de conteúdos específicos da disciplina e a integração de outras temáticas como ambiente, tecnologia e sociedade. Favorece a abordagem interdisciplinar e a construção do conhecimento de modo unificado a partir de interações individuais e coletivas, assim como a aquisição de novas habilidades e atitudes essenciais para a vida e para a cidadania.

\title{
Referências
}

LIMA, Maria Rosilene Ceciano. A horta hidropônica como possibilidade do ensino das ciências: um estudo de caso numa escola de ensino fundamental do município de Horizonte Ceará. 2017. 103f. Dissertação (Mestrado em ensino de ciências a matemática) Universidade Federal do Ceará, Fortaleza, 2017.

NASCIMENTO, Carmem do Socorro Paiva; SALOMÃO, Izolene Teixeira. A hidroponia como recurso interdisciplinar no ensino fundamental. 2014. 52f. Trabalho de conclusão de curso (Graduação em Ciências Naturais) Universidade Federal Rural da Amazônia, Igarapé-açu 2014.

NEVES, João Paulo Santos. Contextualização e interdisciplinaridade: ensinando ciências através da hidroponia. Semana Acadêmica, v. 1, n. 195, p. 1-16, 2020.

OLIVEIRA, Irlane Maia de; FERREIRA, Rosilene Gomes da Silva; SANTOS, Elizabeth da Conceição. Ensino de ciências: uma proposta para utilizar a experimentação no ensino fundamental. Revista Arete, v. 3, n. 5, p. 110-123, 2010. 


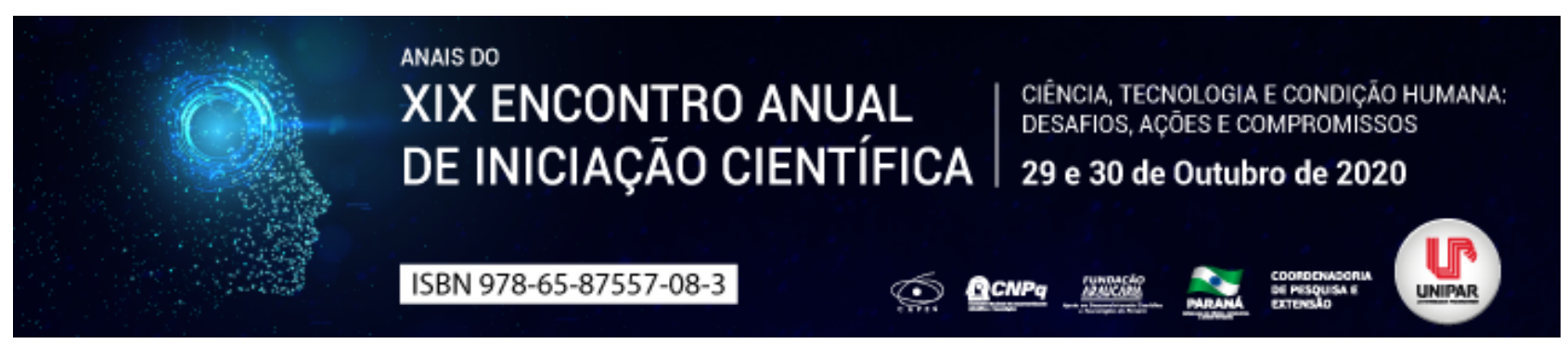

\title{
COVID-19 E O DIREITO AO LAZER: O IMPACTO DO ISOLAMENTO SOCIAL HUMANO NOS ANIMAIS QUE VIVEM EM CATIVEIRO
}

\author{
${ }^{1}$ CAROLINA RIBEIRO MORAIS, ${ }^{2}$ TEREZA RODRIGUES VIEIRA
}

${ }^{1}$ Discente do Curso de Direito da Universidade Paranaense (UNIPAR), campus Guaíra/PR

${ }^{1}$ Docente do Mestrado em Direito Processual e Cidadania da UNIPAR

Introdução: A nova pandemia da Covid-19 veio para mudar drasticamente a rotina do homem. Devido ao isolamento social, passeios de lazer são evitados, ou até proibidos em algumas localidades. Graças ao vazio ocasionado em parques e zoológicos, por exemplo, alguns animais vieram a apresentar comportamentos que denunciam danos à sua saúde, graças ao estilo de vida em cativeiro.

Objetivo: Despertar o debate acerca do impacto do isolamento social humano no comportamento animal e o direito do homem ao lazer, tutelado constitucionalmente.

Desenvolvimento: Em abril de 2020, alguns meios de comunicação noticiaram que um casal de pandas de um zoológico em Hong Kong, após dez anos tentando acasalar, finalmente teve êxito. (BARDEN, 2020). Os cuidadores associam o acontecimento ao isolamento gerado pela crise da pandemia da Covid-19, já que o local não está recebendo visitantes. Segundo Francione, a dificuldade de procriação entre animais que vivem em cativeiro não é incomum: O estresse do confinamento impede que os animais tenham comportamentos normais como praticar sexo e ter filhos [...] . (2013, p. 76). Ainda, há várias categorias de causas de estresse em animais selvagens em cativeiro, uma delas são os estressores somáticos, que consistem em: sons, imagens e odores estranhos, entre outros. (ORSINI; BONDAN, 2006). Assim, tal fato levantou o debate acerca das más condições de saúde que apresentam os bichos enjaulados para o entretenimento humano, o que se faz pensar ainda, se não deveria o Estado implantar medidas que protejam o bem-estar animal. A Constituição Federal de 1988, em seu artigo $6^{\circ}$, tutela o direito do homem ao lazer, que é também classificado como um direito social. Ainda, um pouco mais adiante, em seu artigo 225, $\S 1^{\circ}$, inciso VII, inovou ao expressamente proibir tratamento cruel para com a fauna. Assim, há uma forte discrepância, já que a legislação brasileira, ao mesmo tempo em que proíbe tratamento cruel para com os animais, continua a permitir a manutenção de eventos e locais como zoológicos, em que obviamente, se nota o desgaste físico e emocional dos espécimes.

Conclusão: O Estado deve tomar para si a responsabilidade de efetivamente zelar pela vida saudável da fauna, que é tão importante para a manutenção e equilíbrio do ecossistema. Ademais, o acasalamento é essencial para a conservação dessa espécie vulnerável. É papel do Estado atuar para que esse impacto seja limitado. De nada adianta legislar princípios altruístas se estes não ultrapassam as margens do papel.

\section{Referências}

BARDEN, Benita. Coronavírus: graças a isolamento, pandas em zoológico acasalam após dez anos de tentativa. BBC News Brasil, 7 abr. 2020. Disponível em: https://www.bbc.com/portuguese/geral-52100140. Acesso em: 16 maio 2020.

BRASIL. Constituição da República Federativa do Brasil de 1988, de 05 de outubro de 1988, Brasília, Presidência da República. Disponível em: http://www.planalto.gov.br/ccivil_03/constituicao/constituicao.htm. Acesso em: 1 jun 2020.

FRANCIONE, Gary L. Introdução aos direitos dos animais. Campinas: Unicamp, 2013.

ORSINI, Heloísa; BONDAN, Eduardo F. Fisiopatologia do estresse em animais selvagens em cativeiro e suas implicações no comportamento e bem-estar animal revisão de literatura. Revista do Instituto de Ciências da Saúde, v. 1, n. 24, jan./mar. 2006. Disponível em: https://www3.unip.br/presencial/comunicacao/publicacoes/ics/edicoes/2006/01_jan_mar/V25_N1_2006_p714.pdf. Acesso em: 10 maio 2020.

\footnotetext{
Coordenadoria de Pesquisa e Extensão - COPEX

Departamento de Editoraçāo e Divulgaçāo Científica - DEDIC
} 


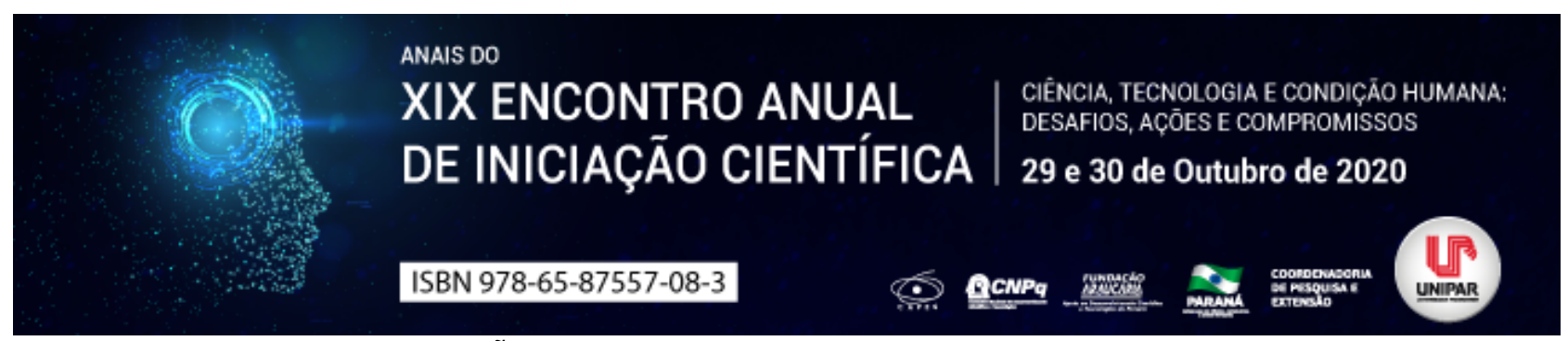

ENSINO, RELIGIÃO E SUAS VERTENTES EM FACE DO ESTADO LAICO

\title{
${ }^{1}$ CATUIANE GONSALVES DA SILVA, ${ }^{2}$ TANIA ARNECKE PEREIRA, ${ }^{3}$ TEREZA RODRIGUES VIEIRA
}

\author{
${ }^{1}$ Acadêmica do curso de Direito da Universidade Paranaense (UNIPAR), campus Guaíra/PR. \\ ${ }^{1}$ Mestranda em Direito Processual e Cidadania e integrante do PIC na UNIPAR. \\ ${ }^{2}$ Docente do Mestrado em Direito Processual e Cidadania na UNIPAR
}

Introdução: Durante muito tempo o catolicismo foi à religião oficial do Brasil, excluindo qualquer tipo de manifestação de crença que não fosse católica, porém com o Decreto 119-A de 1891, Igreja e Estado foram separados, onde a sociedade pode escolher sua religião e professá-la com liberdade, sem qualquer discriminação. Além de muitos professores não se encontrarem aptos a ministrarem aulas, com isenção, sobre todas as religiões, essa atribuição pode ser conferida à família, se esta o desejar. À escola cabe a erradicação do preconceito e do respeito à diversidade religiosa.

Objetivo: Demonstrar que o ensino religioso não deve ser imposto como matéria nas escolas públicas, visto que o Brasil é um Estado laico e garante a todos a livre manifestação de crença, e que o conteúdo ministrado nas salas de aula prejudica a liberdade religiosa.

Desenvolvimento: O Estado e a Igreja católica tiveram ligação desde a colonização portuguesa até 1889 (BUCHOLZ; DERISSO, 2020), período em que havia uma grande influência no ensino voltado ao catolicismo. Ocorre que após a constituição de 1891, Igreja e Estado foram separados, deixando o Brasil de ter uma religião oficial, e o ensino ficou sob os cuidados do Estado. A laicidade do Brasil passou a ser oficial com o Decreto 119-a de 1891, dando aos brasileiros garantia àqueles que professam alguma religião ou àqueles que optaram por não seguir caminhos religiosos (STRÜCKER; HAHN, 2019). Tal medida impede que o poder político interfira na liberdade de pensamento e de religião dos cidadãos. Atualmente, a Constituição Federal de 1988, em seu artigo $5^{\circ}$, estabelece e garante aos brasileiros a inviolabilidade da liberdade de consciência e crença, e assegura o livre exercício de cultos religiosos, no entanto, ainda ocorrem debates acerca da instituição de matéria religiosa nas escolas públicas, como a decisão do Supremo Tribunal Federal acerca da Ação Direta de Inconstitucionalidade n. ${ }^{\circ} 4.439$, que foi julgada improcedente autorizando o ensino religioso confessional em matérias que não fossem obrigatórias, com caráter facultativo, o que hoje é estabelecido pela Lei de Diretrizes e Bases na Educação Nacional, e também fundamentada no artigo 210 , $\S 1^{\circ}$ da Constituição Federal, que estabelece a faculdade do ensino religioso nas escolas públicas no grau fundamental, onde ainda se questiona se o Estado laico deve viabilizar o Ensino religioso confessional, mesmo que de forma facultativa (PINHEIRO; SILVA, 2020).

Conclusão: O ensino religioso não deve ser imposto nas escolas públicas, visto que após a constituição do Estado laico os brasileiros se sentem confortáveis em optarem de forma livre por suas crenças, sem qualquer imposição estatal. Sua instituição põe em questão a laicidade do Estado, levando-se em consideração que a maior parte da população é católica, o que poderia gerar privilégios nas salas de aula e desconforto aos praticantes das demais religiões, bem como aos ateus e aos agnósticos.

\section{Referências}

BRASIL. Constituição da República Federativa do Brasil: promulgada em 5 de outubro de 1988. Presidência da República. Disponível em: www.planalto.gov.br. Acesso em: 17 ago. 2020.

BUCHOLZ, Luize Gomes; DERISSO, José Luis. O ensino religioso nas leis de diretrizes e bases da educação nacional e os embates entre religiosos e laicos no Brasil. Revista IberoAmericana de Estudos em Educação, Araraquara, v. 15, n. 2, p. 667681, abr./jun. 2020.

STRÜCKER, Bianca; HAHN, Noli Bernardo. O princípio da laicidade e a utilização da linguagem religiosa na esfera pública. In: congresso latino-americano de gênero e religião, VI., 2019, São Leopoldo. Anais... São Leopoldo: EST, v. 6, 2019.

SALES PINHEIRO, Victor; ARAÚJO PIÇANCO DA SILVA, Victor Cláudio. A legitimidade constitucional do ensino religioso confessional em escolas públicas no Brasil: análise da ação direta de inconstitucionalidade 4.439 a partir da laicidade positiva em Bento XVI. Revista Latinoamericana de Derecho y Religión, [S.I.], v. 6, n. 1, p. 1-45, jun. 2020. ISSN 0719-7160. Disponível em : http://redae.uc.cl/index.php/RLDR/article/view/16413. Acesso em: 04 ago. 2020 


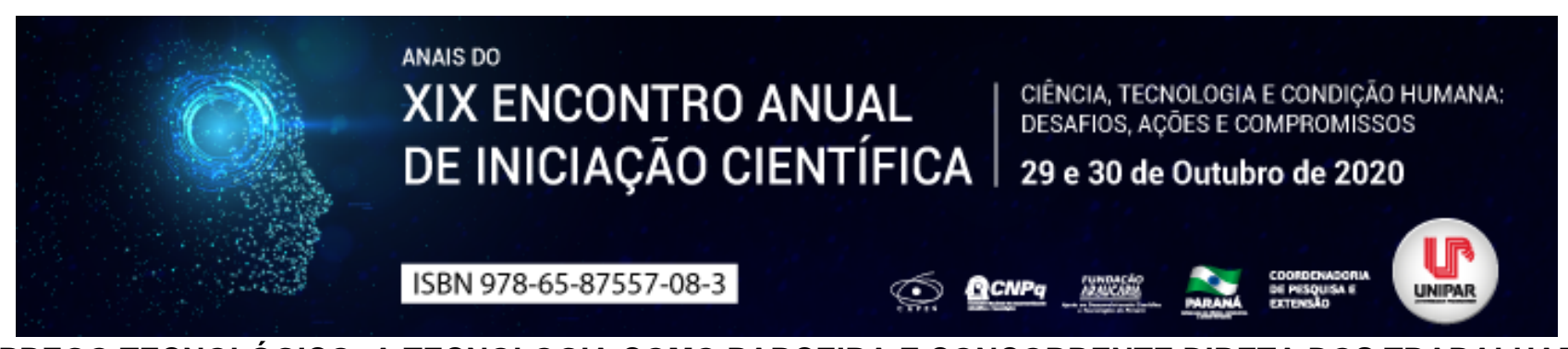

DESEMPREGO TECNOLÓGICO: A TECNOLOGIA COMO PARCEIRA E CONCORRENTE DIRETA DOS TRABALHADORES

\author{
${ }^{1}$ MAYRA MARIA ZOTTI, ${ }^{2}$ CLEVERSON IVAN MERLO
}

${ }^{1}$ Acadêmica pesquisadora do Curso de Direito da Universidade Paranaense

${ }^{1}$ Docente da Universidade Paranaense

Introdução: Os humanos sempre buscaram aperfeiçoar suas técnicas, a fim de satisfazerem suas necessidades. O estudo de aprimoramento dessas técnicas se denomina tecnologia (CAVALCANTE, 2020, p. 36). Assim, com a $4^{\mathrm{a}}$ Revolução Industrial, a tecnologia e a automação foram incorporadas à vida dos indivíduos, inclusive, no mundo do trabalho e, ocasionando o chamado desemprego tecnológico.

Objetivo: Analisar o impacto da tecnologia nas relações trabalhistas e ofertar soluções para minimizar o desemprego tecnológico.

Desenvolvimento: O desemprego tecnológico ou technological unemployment caracteriza-se pela substituição da mão de obra humana pela das máquinas, ou seja, a ocupação de postos de trabalho por meios tecnológicos, deixando trabalhadores desempregados e extinguindo profissões. Para entender esse fenômeno, é preciso compreender a distinção entre emprego e desemprego. Portanto, destaca-se que a relação de emprego é espécie do gênero relação de trabalho, configurando-se através de um vínculo entre empregado e empregador, no qual estão presentes: a pessoalidade, a não eventualidade; a onerosidade e a subordinação (DELGADO, 2019, p. 333 a 334). Já o desemprego possui algumas espécies, do ponto de vista econômico, sendo o conjuntural e o estrutural, os principais causadores do desemprego tecnológico, segundo Cunha e Guerra (2010), pois estão relacionados com a conjuntura socioeconômica dos países e a reestruturação das empresas, que optam por aderirem à tecnologia ao invés da mão de obra humana, por aquela ser mais vantajosa que esta. No Brasil, conforme dados do IBGE, a taxa de desemprego no primeiro trimestre de 2020 atingiu a marca de 12,2\% da população, sendo a região Nordeste a mais afetada e a Sul a menos impactada. Com a fabricação de carros autônomos, drones, impressoras 3D, entre outros equipamentos, setores como o de entregas, jornalismo, logística, agricultura, monitoramento, construção civil, indústria e assim por diante, correm o risco de serem afetados, extinguindo-se postos de trabalho. A profissão de cobrador também corre o risco de extinção, já que, atualmente, a grande maioria dos ônibus do transporte público conta com máquinas de leitura de cartões de passagem, por exemplo. No âmbito jurídico a tecnologia também já faz parte do dia a dia, ora com o surgimento dos processos eletrônicos, ora com o uso da inteligência artificial nos tribunais, como é o caso do sistema Victor, adotado pelo Supremo Tribunal Federal, e o Projeto Sócrates, incorporado pelo Superior Tribunal de Justiça (SALADINI, 2020, p. 24). Assim, como os efeitos da tecnologia são inevitáveis, Morais da Rosa (2019) acredita que os profissionais do Direito e os da tecnologia e automação devem trabalhar em conjunto, compartilhando conhecimentos, para que os postos de trabalho sejam preservados. Aproveitando-se desse gancho, como o uso da tecnologia é mais vantajoso aos empregadores, por aumentar a produtividade, diminuir gastos e evitar encargos trabalhistas, fazendo com que o uso da mesma seja inevitável, resta apenas a sugestão de possíveis soluções para o problema do desemprego tecnológico, como a educação e a profissionalização dos trabalhadores e a reciclagem e realocação daqueles que perderam seus postos de trabalho, além do uso da legislação para garantir os empregos, sem prejudicar os empregadores. Salienta-se, que nos dias de hoje obter conhecimentos é muito prático, bastando um clique ou toque. Porém, nota-se que todos os trabalhadores têm acesso a essa forma de educação, aumentando a concorrência entre eles. Por outro lado, mesmo que a tecnologia facilite o aprendizado, estudos indicam que países com melhores índices educacionais, tendem a sofrer mais com o desemprego tecnológico, pelo fato de a mão de obra especializada ser mais custosa. Quanto à legislação, uma solução para essa problemática seria o incentivo aos empregadores para manterem seus empregados humanos, mesmo com a tecnologia, realocando-os, para obterem benefícios, além da intensificação da proteção legal dos trabalhadores em face da automação, garantida no inciso XXVII, do art. $7^{\circ}$, da Constituição Federal de 1988. Por fim, traz-se à baila os protestos realizados pelos entregadores de aplicativos, ocorridos em julho de 2020, solicitando melhores condições de trabalho e a valorização de seus serviços. Neste caso, visualiza-se as duas faces da tecnologia, a facilitação de receber entregas com um simples pedido em um aplicativo e o prejuízo dos entregadores, que põem suas vidas em risco, por remunerações irrisórias. Ademais, é válido dizer que a tecnologia não é a única vilã nesta situação, mas sim, a busca incessante de vantagens pelos humanos, sem se preocuparem com seus semelhantes. Para resolver esse problema, o simples diálogo entre aplicativos e entregadores seria suficiente, já que estes últimos não buscam a vinculação com a Consolidação das Leis do Trabalho.

Conclusão: A tecnologia pode ser o lobo do homem, mas se utilizada de forma criativa e inteligente, promovendo o diálogo entre empregadores e empregados, além de garantir os postos de trabalho através de benefícios ao empresariado, pode ser uma parceira e não uma concorrente direta. 


\section{Referências}

CAVALCANTE, Jouberto de Quadros Pessoa. A sociedade, a tecnologia e seus impactos nos meios de produção: uma discussão sobre o desemprego tecnológico. Revista Eletrônica do Tribunal Regional do Trabalho da 9a Região. Paraná. v. 9, n. 86, p. 35-63, mar. 2020;

CUNHA, Piaza Merigue da, e GUERRA, Roberta Freitas. Desemprego, flexibilização e o Direito do Trabalho. Revista de Direito do Trabalho. v. 137/2010, p. 289-308, jan/mar. 2010;

DELGADO, Maurício Godinho. Curso de Direito do Trabalho. 18. ed. São Paulo: LTR Editora, 2019;

MORAIS DA ROSA, Alexandre. A questão digital: o impacto da inteligência artificial no Direito. Revista de Direito da Faculdade Guanambi, Guanambi, v. 6, n. 02, jul/dez. 2019;

SALADINI, Ana Paula Sefrin. Os debates sobre a Revolução 4.0 na Semana Institucional da Magistratura do Trabalho do Paraná de 2019. Revista Eletrônica do Tribunal Regional do Trabalho da 9a Região. Paraná. v. 9, n. 86, p. 20-34, mar. 2020.

Coordenadoria de Pesquisa e Extensão - COPEX

Departamento de Editoração e Divulgaçāo Científica - DEDIC 


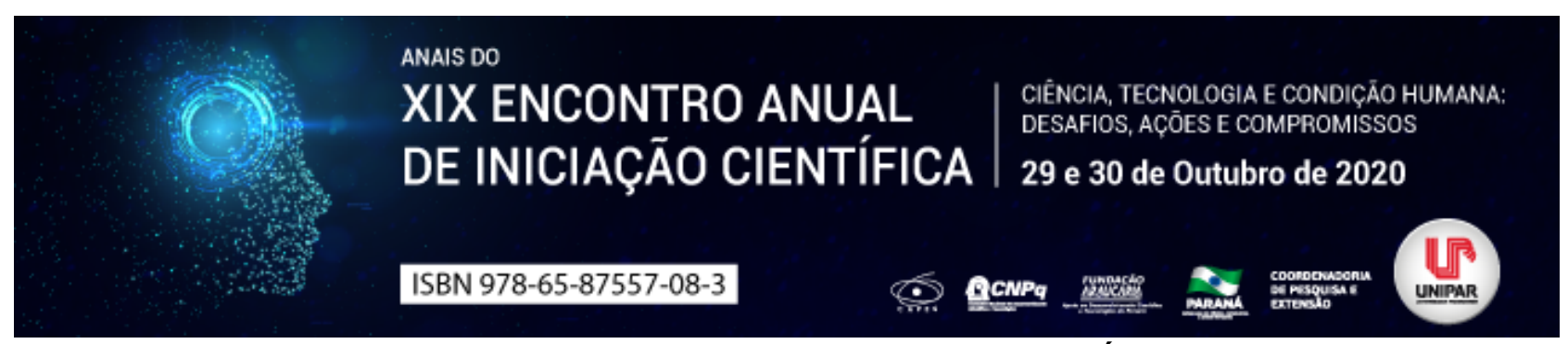

O TRABALHO ESCRAVO NA CONTEMPORANEIDADE SOB O VIÉS CONSTITUCIONAL

\title{
${ }^{1}$ ARILSON DE LARA FELIPE, ${ }^{2}$ MAIARA DOS SANTOS NORONHA
}

\author{
${ }^{1}$ Maiara dos Santos Noronha \\ ${ }^{1}$ Docente da UNIPAR
}

Introdução: O Estado Democrático de Direito brasileiro é caracterizado por constantes mudanças que refletem, em parte, a existência de uma sociedade em transformação. No entanto, em que pese a evolução seja o lema dos tempos modernos, verifica-se ainda a existência de práticas no âmbito da relação de emprego que remetem aos primórdios da civilização, como é o caso da escravidão. Essa, que com o passar dos tempos assumiu novas características, mas sem abandonar seus traços fundamentais de opressão, ainda está presente nas relações humanas, como menciona Matos: a escravidão está presente na humanidade desde os tempos mais remotos. A rigor, sempre caracterizada pela espoliação do homem pelo homem em nome do poder em transmutadas formas no tempo e no espaço (MATOS, 2005, p. 26-27).

Objetivo: Apresentar, através da pesquisa, de bibliográfia e de documentos jurídicos a ocorrência de trabalho análogo a de escravo na contemporaneidade, e uma possível solução do trabalho escravo.

Desenvolvimento: Na escravidão, que esta presente desde os tempos mais remotos, surgiu atrelada às relações de trabalho. A própria expressão trabalho, que conforme Leite, $(2018$, p.41) vem do termo latino tripalium, um instrumento romano de tortura, formado por três estacas cravadas no chão em formato de pirâmide, no qual eram supliciados os escravos, ou seja, torturava-se alguém no tripalium. Assume a condição de trabalho ilegal aquele que se assemelha à escravidão, uma vez que foge dos preceitos, princípios e valores que regem a relação laboral. O Estado Democrático de Direito, dentre as suas premissas basilares, prevê a dignidade da pessoa humana como um dos pilares para uma sociedade justa, fraterna e igualitária, qual seja, art. $1^{\circ}$, III da Constituição Federal (BRASIL, 1988). Contudo, nota-se que essa sociedade resta comprometida quando da existêcia de um trabalho escravo que acompanha a evolução da humanidade, e que com o passar dos anos moldou-se conforme os acontecimentos (BAUMER, 2018, p.41). Com relação aos seus efeitos, o que se verifica é que as pessoas submetidas a esse regime são levadas a situações desprezíveis, como é o caso de jornada de trabalhos desumano, condições de saúde e higiene precárias etc. Conforme Filho (l"apudl" MACHADO, 2013, p. 28-29), quando o homem trabalha em condições análogas a de escravos, ou seja, em condições degradantes sua honra está sendo ferida assim como o principio da dignidade da pessoa humana . O Código Penal brasileiro apresenta algumas circunstâncias nas quais se reduz o homem à condição análogo de escravo no seu artigo 149: Art. 149. Reduzir alguém a condição análoga à de escravo, quer submetendo-o a trabalhos forçados ou a jornada exaustiva, quer sujeitando-o a condições degradantes de trabalho, quer restringindo, por qualquer meio, sua locomoção em razão de dívida contraída com o empregador ou preposto (BRASIL, 1940). Quanto ao empregador, no que diz respeito à responsabilização, além da responsabilidade penal do empregador, pode ele ser condenado a indenizar por danos morais coletivos causados tanto ao grupo de empregados lesados, quanto aos potenciais trabalhadores, que seriam contratados em condições degradantes idênticas (LEITE, 2018, p 72).

Conclusão: A escravidão na relação de emprego é uma prática ilegal existente até hoje e que contraria regras e princípios considerados como a base do ordenamento jurídico brasileiro. Trata-se de um assunto relevante e que deve ser analisado com cautela, pois a abolição do trabalho escravo é de grande importância para a construção de uma sociedade digna, justa e solidária no Brasil.

\section{Referências}

SOARES, Fagno; MASSONI, Túlio; SILVA, Wallace; Fagno da Silva, Túlio de Oliveira, Wallace Dias. Trabalho análogo ao de escravo no Brasil contemporâneo: à guisa dos estudos históricos e jurídicos e suas disputas conceituais, Macapá, v. 3, n. 1, jan./jun. 2016, p. 69-98.

LEITE, Carlos Henrique Bezerra. Curso de direito do trabalho. 9. ed. São Paulo: Saraiva Educação, 2018.

MATOS, Hebe; RIOS, Ana Lugão. Memórias do cativeiro: família, trabalho e cidadania no pós-abolição. Rio de Janeiro: Civilização Brasileira, 2005.

BAUMER, Adriano Luiz. Trabalho em condições análogas a de escravo: mutações e os desafios ao seu combate. 2018. Páginas 64. Universidade federal de santa Catarina centro de ciências jurídicas, curso de graduação em Direito. Florianópolis/SC, 2018.

MACHADO, Ana Cristina Mourão da Matta, Conbate ao tráfico de pessoas e ao trabalho escravo contemporaneo. 2013 , p. 28/29.

BRASIL. Decreto-Lei 2.848, de 07 de dezembro de 1940. Código Penal. Diário Oficial da União. Rio de Janeiro, 31 dez. 1940. 
Coordenadoria de Pesquisa e Extensão - COPEX

Departamento de Editoraçāo e Divulgaçāo Científica - DEDIC 


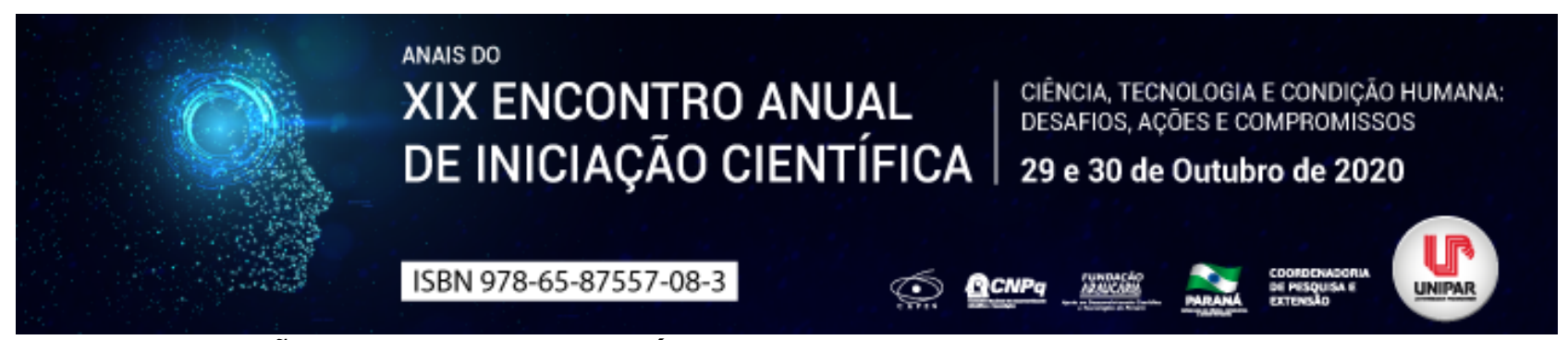

FAZERES E REFLEXÕES DX PSICOLOGXS CLÍNICOS NO CONTEXTO DA PANDEMIA DE COVID-19: ALGUMAS DISCUSSÕES

\title{
${ }^{1}$ JULIANA MULLER RIOS, ${ }^{2}$ GRACIANE BARBOZA DA SILVA
}

\author{
${ }^{1}$ Acadêmica do curso de psicologia da UNIPAR \\ ${ }^{1}$ Docente da UNIPAR
}

Introdução: A pandemia do COVID-19 é considerada a maior emergência de saúde pública das últimas décadas (SCHMIDT, 2020) pertencendo ao grupo de doenças que são provocadas pelo coronavírus, descoberta a Covid-19 pela primeira vez em dezembro de 2019 em uma cidade da China, Wuhan (MAIA, 2020). Os sintomas do covid-19 são tosse, febre e falta de ar que podem levar a óbito, a falta de medicamentos eficazes e vacinas geram preocupação. Para diminuir o impacto alguns países têm adotado medidas de distanciamento social, isolamento de casos suspeitos e a quarentena da população inclusive a de risco, buscando com isso diminuir a quantidade de pessoas infectadas no mesmo período comprometendo a pouca estrutura de atendimento em cuidados intensivos (SCHMIDT, 2020). Este cenário causa agravos na saúde mental por conta de incertezas e mudanças no estilo de vida. A Psicologia Frente a esse contexto por meio do Conselho Federal de Psicologia (CFP) e o sistema de conselhos regionais vem comunicando-se com a categoria sobre a conduta profissional no cenário da pandemia. Percebe-se a necessidade de reflexão, bem como de modelos de atuação do psicólogo/a clínico frente ao contexto de pandemia e seus impactos severos.

Objetivo: $O$ presente trabalho tem por objetivo discutir algumas necessidades de reflexão e possibilidades de atuação do psicólogo/a o clínico frente ao contexto da pandemia mundial de Covid-19.

Desenvolvimento: Moreira, Romagnoli, e Neves 2007 apresentam uma concepção de ética como escuta com técnicas, em que seu fazer ocupa outros espaços. Figueiredo (2008) corrobora com essa perspectiva argumentando que a ética é uma reflexão dos modos de subjetividade que estão sendo produzidos e, que este fazer se torna possível ao compreendermos o sujeito como ser social que possui uma história. A clínica psicológica se manifesta através da escuta do excluído sustentando tensões e conflitos, o profissional tem o papel de ser a escuta que o seu tempo necessita. Todo indivíduo possui uma história, é necessário o entendimento do lugar de fala do sujeito, saindo do setting tradicional para compreender os lugares nos quais pertencem a vida do indivíduo. O psicólogo clínico vai trabalhar com ética, pela escuta qualificada, compreendendo a subjetividade do período histórico em que atua. O que se vivência agora impõe ações para barrar a contaminação, como por exemplo os atendimentos realizados presencialmente, como é o caso dos atendimentos das emergências, necessitam dos cuidados recomendados por autoridades sanitárias, além disso, um novo formato de atendimento pode ocorrer através das tecnologias da comunicação e informação. O psicólogo deve analisar cada contexto e ver se o atendimento à distância é uma modalidade que possível diante das demandas em que se pretende aruar (CRP-PR 001, 2020). Com situações de calamidade, encontramos novos modelos de fazer psicológico, no atual contexto, os atendimentos online, novos cuidados na condução dos atendimentos e atuação clínica (no sentido de acolhimento e escuta) passam a ser necessários em diversos contextos, destacando aqui o escolar, hospitalar, políticas públicas de saúde, dentre outros espaços que passam a ter preocupação com o sofrimento psíquico de seus trabalhadores e usuários. Com a Covid-19, surgem incertezas que modificam o cenário de vida, podendo ocorrer crises gerando desesperança, pânico e tristeza ameaçando a saúde mental. Tais aspectos são agravados pelas informações imediatas, notícias falsas, medo do desconhecido, preocupação com a saúde própria e de terceiros, falta de um tratamento eficiente para a doença, isolamento social e a instabilidade econômica (OLIVEIRA, 2020). Com a pandemia muitas pessoas perderam seus trabalhos, a valorização da produtividade característico de nosso período histórico exemplificado por Ewald, Moura e Goulart (2017) traz sentimentos de fracasso. As equipes de saúde vivenciam sentimentos de incompetência pelo número elevado de mortes, o cansaço e a tensão também se fazem presentes. A concepção moderna de que conquistas e vitórias são responsabilidade do individuo (EWALD; MOURA; GOULART, 2017) leva por exemplo os jovens que estão sem aula a desenvolver sensações de ansiedade e de fracasso. Estar longe das pessoas que gostam, mudar a rotina e ter que se adaptar a um cenário novo em que um vírus leva a morte de muitas pessoas por dia no país, podem levar a sensações de ansiedade e medo, além de outros fatores como a rotina exaustiva que trazem sofrimento psíquico.

Conclusão: Compreender o momento atual faz entender esse sujeito que sofre, a economia, a educação, violência e vulnerabilidade são questões macro que tem impacto direto na vida produzindo sofrimento a nível micro. A atuação do psicólogo vai se pautar pelo tensionamento dos conflitos como os que se potencializam com o contexto atual, fazendo isso por meio da escuta e o acolhimento do sofrimento apresentado pelas da população em geral que se encontra vivênciando so impactos da covid-19. Oferecer espaço para a produção de subjetividades, com novos modos de ser no mundo, considerando sua história de vida, principalmente das pessoas vulneráveis que tem sua existência negligênciada, são parte importante da atuação do 


\section{Referências}

CFP. Resolução ${ }^{\circ} 26$ de Março. 4 ed. 2020.

CRP/PR. 001/2020: NOTA TÉCNICA CRP-PR. 1 ed. Paraná: Conselho Regional, 2020.

EWALD, Ariane Patricia; THIEME DE CARVALHO MOURA, Michelle; MELETTI DA SILVA GOULART, Samira. Contemporaneidade e sofrimento psíquico: Relações entre modos de vida e demandas psicoterapêuticas. Psicologia Argumento, [S.I.], v. 30, n. 68, nov. 2017. ISSN 1980-5942. Disponível em: . Acesso em: 20 ago. 2020. doi:http://dx.doi.org/10.7213/psicol.argum.5890.

FIGUEIREDO, Luís Cláudio M. Revisitando as psicologias: da epistemologia à ética das práticas e discursos psicológicos. Petrópolis: Vozes. 2008.

MAIA, Berta Rodrigues; DIAS, Paulo César. Ansiedade, depressão e estresse em estudantes universitários: o impacto da COVID19. Estud. psicol. (Campinas), Campinas , v. 37, e200067, 2020 . Disponível em . acessos em 23 jun. 2020. Epub 18-Maio-2020. https://doi.org/10.1590/1982-0275202037e200067.

MOREIRA, Jacqueline de Oliveira; ROMAGNOLI, Roberta Carvalho; NEVES, Edwiges de Oliveira. O surgimento da clínica psicológica: da prática curativa aos dispositivos de promoção da saúde. Psicol. cienc. prof., Brasília , v. 27, n. 4, p. 608-621, Dec.2007.Available from . access on 22 June 2020. https://doi.org/10.1590/S1414-98932007000400004.

OLIVEIRA, Ricardo Furtado de. INTERVENÇÃO PSICOLÓGICA EM SITUAÇÃO DE CRISE. Palmas: Ricardo Furtado, 2020.

SCHMIDT, Beatriz et al. Saúde mental e intervenções psicológicas diante da pandemia do novo coronavírus (COVID-19). Estud.psicol. (Campinas), Campinas , v. 37, e200063, 2020 . Disponível em . acessos em 23 jun. 2020. Epub 18-Maio-2020. http://dx.doi.org/10.1590/1982-0275202037e200063. 


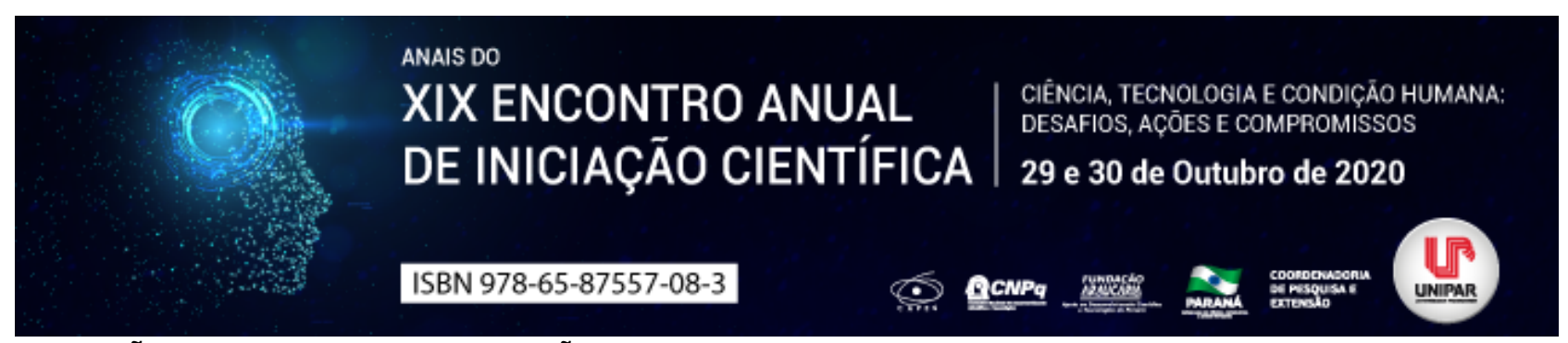

INSTITUIÇÕES TOTAIS E A DOCILIZAÇÃO DOS CORPOS NO FILME SOCIEDADE DOS POETAS MORTOS

\title{
1BEATRIZ PASCUTTI MARTINS, ²BARBARA COSSETTIN COSTA BEBER BRUNINI
}

\author{
${ }^{1}$ Acadêmica do curso de Psicologia da UNIPAR \\ ${ }^{1}$ Docente da UNIPAR
}

Introdução: O filme Sociedade dos Poetas Mortos (1989) envolve percucientes reflexões acerca das Instituições Totais, proporcionando discussões a respeito da influência desta sobre as subjetividades dos sujeitos. Soma-se à isso, a averiguação do uso de dispositivos disciplinares pela mesma, incluindo a análise das relações de poder/saber sobre a submissão e docilização dos corpos.

Objetivo: Refletir sobre questões relativas à instituição total representada no filme por estabelecimentos de educação, no que tange à utilização de dispositivos disciplinares e relações de poder/saber na docilização dos corpos.

Desenvolvimento: A película retrata as experiências vividas pelos alunos de um colégio interno ultraconservador e tradicional, que influencia diretamente diversos aspectos da vida dos mesmos. A trama desenvolve-se à medida que estes, inspirados por seu novo professor de literatura, começam a desafiar as normas e valores impostos. Tal insatisfação se deve ao rigoroso controle que o colégio exerce sobre uma totalidade da vida dos sujeitos. Isto porque, as instituições totais concentram a maioria das atividades dos indivíduos, quase todas as ações da vida do sujeito são efetuadas no mesmo local e sob uma única autoridade, sendo controladas por horários rígidos e vitais. (SANTOS, 2009, p. 236). Além disso, estas instituições possuem como finalidade [...] fixar os indivíduos em um aparelho de normalização dos homens. A fábrica, a escola, a prisão ou os hospitais tem por objetivo ligar o indivíduo a um processo de produção (FOUCAULT, 2002, p.114). E para isso, ela utiliza-se de dispositivos que contribuem para a disciplinarização dos internos, neste caso, estudantes da organização educacional. À priori, vale mencionar que referem-se ao espaço e tempo, visto que a estrutura arquitetônica do local integra uma das tecnologias disciplinares que visam promover a distribuição dos corpos em um espaço que seja passível de vigilância e controle, contribuindo então, para a produtividade. Em seguida, a administração minuciosa do tempo, almeja adaptar o corpo aos comandos temporais, para que dessa forma, possa extrair-se o máximo dos mesmos (BENELLI, 2004). Tudo isso só é possível, em razão do estabelecimento das relações de poder instituídas. Segundo Moraes e Nascimento (2002), entende-se que a disciplina é uma técnica de poder, organizada a partir de uma relação hierárquica, que visa o corpo como potência a formatação de um modelo útil e obediente, em outras palavras, dócil. O corpo docilizado é aquele submisso, acrítico e, consequentemente, dominável. No entanto, quando os alunos passam a resistir à essa relação, cria-se então, uma nova forma de subjetividade que desestabiliza e subverte os modos identitários de viver e possibilita inventividades múltiplas nos nossos corpos (BARRETO, 2016, p. 02), o que é conceituado como contra-poder, atitude de resistência à docilização dos corpos e seus processos de subjetivação. Uma vez que, de acordo com Foucault (2002), o contra-poder é aquele poder que vem de baixo e que permite aos grupos ou indivíduos exercerem um controle sobre si mesmos, assegurando, dessa maneira, sua própria ordem.

Conclusão: Verifica-se que as instituições totais, por meio da elaboração e aplicação de dispositivos disciplinares, estabelece uma relação hierárquica de poder/saber, que permite a esta produzir corpos passivos e obedientes, ou seja, docilizados. No entanto, a resistência a esses mecanismos ocasiona o desenvolvimento de subjetividades múltiplas, que subvertem as normatizações impostas e resistem aos processos de docilização/disciplinação de vidas.

\section{Referências}

BARRETO, Danielle Jardim. A (IN)VISIBILIDADE DOS PRAZERES, DAS SEXUALIDADES E DOS GÊNEROS E A PARRESIA NA FORMAÇÃO QUEERIZADA EM PSICOLOGIA: Narrativas de outras perspectivas e experiências docentes. 2016. 213 f. Tese (Doutorado em Psicologia) Faculdade de Ciências e Letras, Universidade Estadual Paulista, Assis, 2016.

BENELLI, Silvio José. A Instituição Total como agência de produção de subjetividade na sociedade disciplinar. Estudos de Psicologia, Campinas, v. 21, n. 3, p.237-252, set/dez. 2004.

FOUCAULT, Michael. A verdade e as formas jurídicas. 3. ed. Rio de Janeiro: NAU, 2002, 160 p.

MORAES, Thiago Drumond.; NASCIMENTO, Maria Lívia. Da norma ao risco: transformações na produção de subjetividades contemporâneas. Psicologia em Estudo, v. 7, n. 1, p. 91-102, jan./jun. 2002.

SANTOS, Robson dos. Interações, poder e instituições totais: a narrativa de primo Levi e a microssociologia de Erving Goffman. Rev. Sociol. Polít., Curitiba, v. 17, n. 34, p. 231-240, out. 2009. 



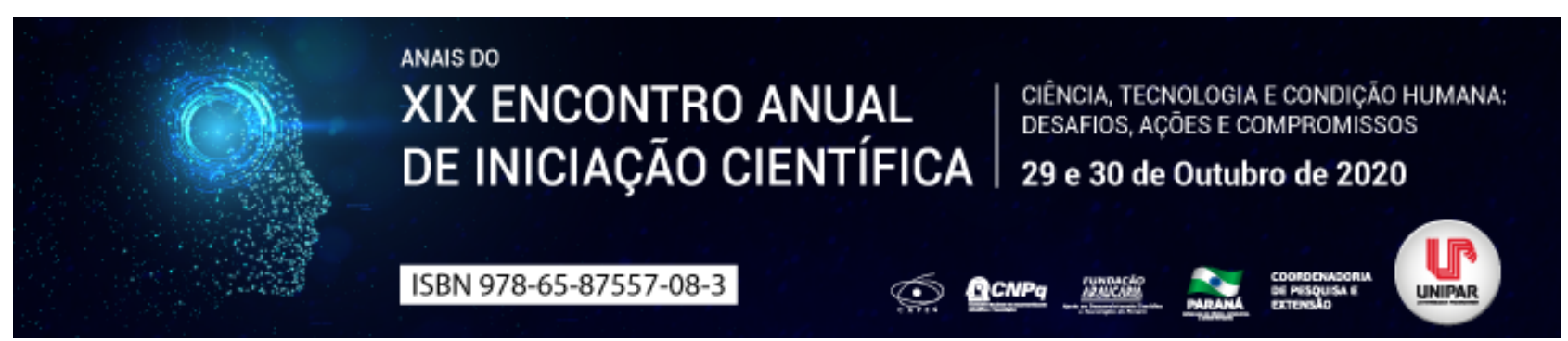

PAISAGISMO EM AMBIENTES ESCOLARES: UM ESTUDO DE CASO EM UM CENTRO MUNICIPAL DE EDUCAÇÃO INFANTIL (CMEI) DA CIDADE DE NOVA ESPERANÇA DO SUDOESTE PR

\author{
${ }^{1}$ GREICE QUELI VITORETI, ${ }^{2}$ ALANA CALEGARI, ${ }^{3}$ LARISSA CRISTINE GALLAS WERLE, ${ }^{4}$ MICHELLE STRUB, ${ }^{5}$ MONICA \\ APARECIDA GONCALVES SCATOLA
}

\footnotetext{
${ }^{1}$ Acadêmica do Curso de Arquitetura e Urbanismo da UNIPAR

${ }^{1}$ Acadêmica do Curso de Arquitetura e Urbanismo da UNIPAR

${ }^{2}$ Acadêmica do Curso de Arquitetura e Urbanismo da UNIPAR

${ }^{3}$ Acadêmica do Curso de Arquitetura e Urbanismo da UNIPAR

${ }^{4}$ Docente da UNIPAR
}

Introdução: A educação ambiental tem papel fundamental na formação do ser humano e da sociedade em geral, considerando a presente situação do meio ambiente, e também pensando no que será deixado para gerações futuras (LOUV, 2016). A fim de exemplificar a aproximação da educação ambiental e conscientização sobre a preservação do meio com o ambiente escolar, pode-se observar a aproximação de alunos de um CMEI (Centro Municipal de Educação Infantil) com o tema, para que desde seu primeiro contato com a escola, os alunos saibam lidar com a natureza da melhor forma. Com base nessas diretrizes, apresenta-se um estudo de caso de uma instituição de ensino infantil, localizada em Nova Esperança do Sudoeste PR.

Relato de Caso: A arquitetura utilizada no CMEI Sementes da Esperança conta com cores vibrantes, adequando-se ao ensino infantil, mas em questões paisagísticas, nada foi implantado, deixando o ambiente sem vida e desfavorecendo a ludicidade das crianças e sua convivência, desenvolvendo carência a educação ambiental. A partir dessa percepção, a coordenação e professoras do CMEI tomaram iniciativa para criar aos poucos um jardim com aproveitamento de pneus, plantando flores de estação e uma pequena horta com a ajuda dos alunos, de forma recreativa. Mesmo após modificações, identificou-se espaços vazios com forte potencial de aproveitamento, onde hoje, são inutilizados pela insolação direta e inexistência de materiais, reduzindo as brincadeiras ao ambiente do refeitório com brinquedos móveis e um balanço externo. Desta forma, este estudo colabora com o planejamento paisagísticos para demais espaços remanescentes no local, bem como a capacidade do paisagismo atuar como ferramenta da educação ambiental, visando o melhor uso dos espaços, para fins de aproveitar a infância das crianças no CMEl de maneira educacional, exercitando a criatividade, coordenação motora e convivência social, através da apropriação paisagística.

Discussão: Segundo Alexander (1977), na infância, crianças precisam se envolver com outras crianças em seus primeiros cinco anos de idade, para que as chances de problemas psicológicos em seu futuro sejam reduzidas. Brincadeiras com intuito criativo, beneficiam a saúde mental, exercitando a memória e imaginação. Quando mais de uma criança brincam juntas, aceleram esse ritmo com suas mentalidades, tornando-se ainda mais saudáveis. Por esse motivo, instituições de ensino infantil são essenciais ao crescimento humano, além de permitirem a convivência e interação social. A sustentabilidade no campo educacional tem adotado uma forma a prever necessidades ambientais das gerações futuras. O Cultivo de hortas com crianças, vem desenvolvendo métodos de formação para seu caráter e fortalecendo relações interpessoais, melhorando a autoestima e habilidades motoras. O jardim sensorial é um jardim que lida com as mais diferentes sensações, libertando os sentidos do ser humano. Ao fazer o uso desse espaço nos estabelecimentos de ensino infantil, obtém-se um formato de educação informal e autoconhecimento aos alunos. Tratando de educação infantil, brinquedos lúdicos podem ser incrementados ajudando no desenvolvimento escolar da criança, devido a capacidade de imaginação, independência para brincar, abstração e desempenho de emoções (MIRANDA, 2013). Aplicar a lucidez em CMEIS despertará uma série de crianças criativas e capazes de enfrentar seus próprios sentidos lidando com sua capacidade criativa. Para o CMEI de Nova Esperança do Sudoeste PR, foi desenvolvido um projeto paisagístico aplicando todas essas diretrizes através deste estudo de caso. Assim como o próprio nome do CMEI já diz, crianças são sementes da esperança, para um futuro e uma vida melhor. Por isso é tão importante aplicar educação ambiental nesse local. O primeiro conceito deste projeto, é a respeito das cores no paisagismo, para que as crianças sintam sua atenção voltada ao local e a curiosidade seja despertada para permanecer espontaneamente. Para envolver os sentidos das crianças, aplica-se um jardim sensorial no centro do projeto, trabalhando a consciência dos diferentes tipos de texturas, aromas e sons existentes na natureza. Como evidenciada a importância do lúdico na infância, um espaço próprio para isso foi criado, com bambolês, objetos geométricos e sucatas como caixas e garrafas pet. A reelaboração de uma horta foi implantada ao projeto para que as crianças conheçam as variedades das plantas e também cultivem esse hábito de cuidar da natureza desde pequenas.

Conclusão: Ao aplicar ações de paisagismo em instituições de educação infantil permite-se que o conhecimento ambiental seja 
inserido junto às séries iniciais, gerando maior consciência sobre a preservação do meio. Também há o despertar da criatividade, sensibilidade e aumento da coordenação motora das crianças através das atividades executadas junto à arquitetura da paisagem. Com a proposta paisagística inserida, o CMEI Sementes da Esperança conta com o planejamento e aproveitamento dos espaços, possibilitando a prática de diversas atividades com as crianças.

\section{Referências}

ALEXANDER, Chistopher. Uma linguagem de padrões. São Paulo: Bookman. 1977.

LOUV; RICHARD. A última criança na natureza: resgatando nossas crianças do transtorno do déficit de natureza. 2016.

MIRANDA, Alex Barbosa Sobreira de. O Lúdico na Educação Infantil. 2013. Disponível em: Acesso em: 15 nov. 2019.

Coordenadoria de Pesquisa e Extensão - COPEX

Departamento de Editoraçāo e Divulgaçāo Científica - DEDIC 


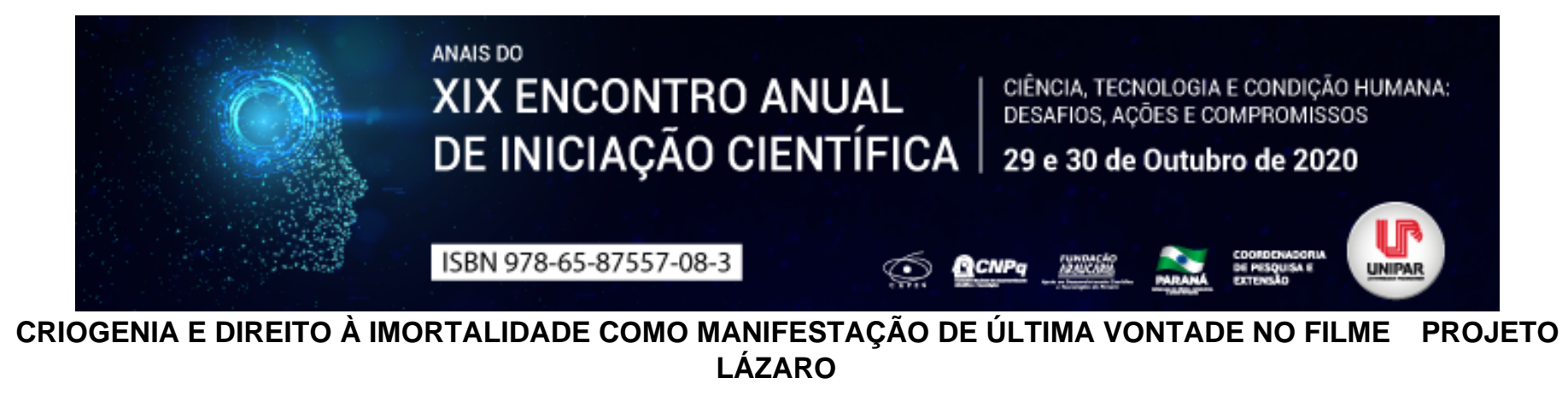

${ }^{1}$ Eloisy de Freitas Rodrigues, ${ }^{2}$ TEREZA RODRIGUES VIEIRA

\author{
${ }^{1}$ Egressa do PIC/UNIPAR \\ ${ }^{1}$ Pós-doutorada pelo Universidade de Montreal
}

Introdução: As manifestações de última vontade, em geral, relacionam-se com os bens móveis e imóveis, não sendo levado em consideração o método utilizado para o sepultamento do indivíduo, pois na grande parte das vezes não é mencionado no testamento/inventário. A imortalidade e a ressurreição são assuntos que deslumbram os seres humanos, assim, é possível que o indivíduo queira ser congelado após a morte para aguardar a cura futura de uma doença gravíssima.

Objetivos: Entender a criogenia e a sua relação com o direito e Identificar os limites e as formas de se respeitar a manifestação de última vontade do ser humano.

Desenvolvimento: A criopreservação de gametas e embriões já é empregada com sucesso há décadas, contudo, a criopreservação de corpos inteiros com vias à reanimação anos depois da morte, ainda, é uma incógnita, porém, é muito desejada por aqueles que anseiam pela imortalidade ou portadores de doenças ainda incuráveis. Só nos Estados Unidos, mais de trezentas pessoas já se submeteram ao congelamento em tanques de nitrogênio líquido, procedimento com alto custo monetário (BIERNATH, 2019). O filme Projeto Lázaro (em referência à ressuscitação de Lázaro na Bíblia), lançado em 2017, é usado como pano de fundo para essa discussão. A película, inicialmente, passa-se no ano de 2015, quando Marc Jarvis, um jovem e renomado engenheiro descobre ser detentor de um tumor na garganta. O protagonista decide por não mais realizar as quimioterapias e contratar o serviço de criogenia, acreditando que um dia poderiam ressuscitá-lo. (GIL, 2016) Em 2084, 69 anos depois, Marc foi ressuscitado, mas muita coisa mudou, inclusive o seu corpo, sendo que para sobreviver ele precisa estar sempre conectado à uma máquina. (GIL, 2016) Sobre o assunto, explica a clínica Alcor (2019, p.3): Acreditamos que a tecnologia médica avançará mais nas próximas décadas do que nos últimos séculos, permitindo-lhe curar os danos nos níveis celular e molecular e restaurar a saúde física e mental total . No Brasil, mesmo havendo disposição de próprio punho do falecido proferida em vida, na prática é a família quem decide sobre a inumação ou cremação. Na realidade, é possível encontrar todas as manifestações de última vontade nos testamentos e codicilos, o que facilita o andamento jurídico. De igual forma deve-se proceder quando se pretende utilizar a criogenia e/ou todo e qualquer método diferente do tradicional, não só deixando a manifestação de vontade, como também os fundos necessários para sua realização, tendo em vista o alto valor da técnica, não podendo recair sobre o Estado e nem, ainda, para os seus herdeiros e sucessores, a não ser que voluntariamente queiram patrociná-la. A Alta Corte de Londres autorizou a criogenização de uma adolescente de 14 anos, onze dias antes da sua morte, vitimada por um câncer raro. Segundo Bernand, por meio de uma carta endereçada ao Juiz, a garota solicitou uma chance de viver mais tempo I"Acho que no futuro poderemos encontrar uma cura para o meu câncer e me despertarl". No Brasil, recentemente, foi proferida decisão favorável para o método da criogenia. Dispôs a Desembargadora: [...] a imprecisão da época em que o falecido declinara a vontade contida nas declarações adunadas pelas Apeladas, não permite aferir se esta era consentânea com a época do óbito, uma vez que a mudança de opinião é inerente ao ser humano, especialmente no que concerne às manifestações de última vontade. Destaque-se que, além da impossibilidade de sepultamento convencional do cadáver, nenhum prejuízo maior se vislumbra na pretensão de congelamento do corpo, porquanto, o custeio de tal procedimento, por certo, deveras dispendioso, será suportado pela Apelante, não havendo que se falar em eventual diminuição do monte a ser partilhado e, por conseguinte, em prejuízo para os herdeiros. Desta forma, não poderia a vontade das Apeladas de sepultar o corpo de seu pai em solo nacional, se sobrepor à vontade por ele externada em vida, por isso que, ainda que a manifestação volitiva do falecido não tenha se dado de forma escrita e solene, o teor dos testemunhos, corroborado pela Ré, ora Apelante, que privara da intimidade e cuidara do falecido no ocaso de sua existência, indicam inequivocamente seu desejo . (RIO DE JANEIRO, 2019) Esse caso iniciou-se em 2012, mas só obteve decisão transitada em julgado em 2019, sendo favorável à criogenia.

Conclusão: A manifestação de vontade pode ser assegurada e cumprida com garantias, no entanto, a técnica da criogenia, ainda, é uma incógnita, uma vez que, para que ela seja possível é necessária tecnologia que, ainda, não existe e se/quando existir faz-se necessário investidores para disponibilizá-las a todos, ficando a critério do indivíduo se realmente vale a pena a espera do incerto. Para que seja de fato realizado qualquer método diferente do tradicional, entende-se necessária a manifestação de última vontade em testamento e, quando não possível, que seja registrado algum outro documento em cartório que comprove a veracidade da vontade, juntamente com a disponibilidade dos valores necessários para que o realizem. Excepcionalmente, em juízo, poderia ser admitida outra forma inequívoca da vontade. 


\section{Referências}

ALCOR. Disponível em: https://www.alcor.org/. Acesso em: 22 ago. 2019.

BERNARD, Philippe. La justice britannique donne le droit à une adolescente d'être cryogénisée. Le Monde. 18 nov. 2016.

BIERNATH, André. Existem 350 corpos congelados para serem ressuscitados no futuro. Disponível em:https://saude.abril.com.br/blog/tunel-do-tempo/existem-350-corpos-congelados-para-serem-ressuscitados-no-futuro/ Acesso em: 14 out. 2019.

GIL, Mateo. Projeto Lázaro / art. Hughes Tom ; dir. Gil Mateo. Arcadia Motion Pictures; Noodles Production; Scope Pictures; Television Española, 2016.

RIO DE JANEIRO. Tribunal de Justiça do Estado do Rio de Janeiro. Vigésima Câmara Cível AP 0057606-61.2012.8.19.0001 CSS 20. Decisão. Disponível em: http://www1.tjrj.jus.br/gedcacheweb/default.aspx? UZIP=1\&GEDID=000312018C79F1FFB9A6CE26EOFFCF5465E51CC4032B1658. Acesso em: 08 nov. 2019.

Coordenadoria de Pesquisa e Extensão - COPEX

Departamento de Editoraçāo e Divulgaçāo Científica - DEDIC 


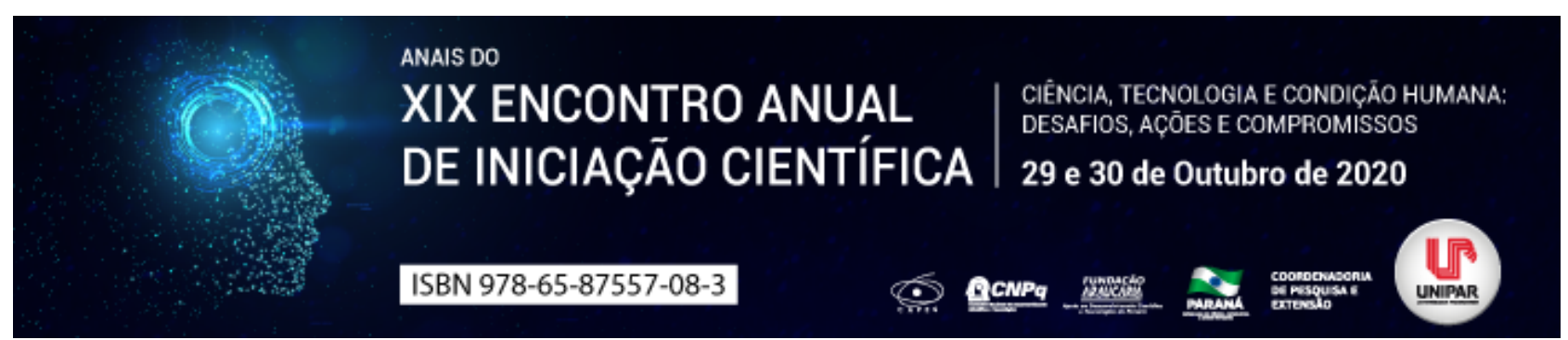

IMUNIDADE E RECONHECIMENTO DA ISENÇÃO TRIBUTÁRIA EM ENTIDADES FILANTROPICAS

\title{
${ }^{1}$ GLEISON DO PRADO DE OLIVEIRA, ${ }^{2}$ LUIZ ROBERTO PRANDI
}

\author{
${ }^{1}$ Acadêmico do Curso de Direito e participante do PIC/UNIPAR \\ ${ }^{1}$ Professor Titular e Pesquisador da UNIPAR
}

Introdução: A legislação que disciplina a essência da imunidade e o reconhecimento da isenção tributária passou por uma série de julgamentos que causaram mudanças na certificação das entidades e restituição de espécies tributárias.

Objetivo: Explicar a imunidade e o reconhecimento da isenção tributária em entidades filantrópicas.

Desenvolvimento: O Estado Democrático de Direito, por meio da realização de políticas públicas, visa a assegurar o bem-estar social. A problematização dos fatos, a formulação de alternativas e a tomada de decisão eficaz, eficiente e efetiva caracteriza uma política pública quanto a sua finalidade essencial, ou seja, mediar a relação entre Estado e sociedade quanto a sua finalidade de colocar à disposição da sociedade, os direitos fundamentais garantidos pela Constituição Federal de 1988. Decerto, por meio dos recursos financeiros arrecadados por meio dos tributos, são executadas as políticas públicas em função do bemestar social. Aristóteles, discípulo de Platão, na antiga Grécia, afirmou que o homem é um animal político que se relaciona, e que a natureza humana é regida pela vida em sociedade (ARISTÓTELES, 2017). Partindo dessa premissa, torna-se necessário que o homem promova a criação de estruturas políticas capazes de satisfazer as necessidades da sociedade e, consequentemente o seu bem-estar. O terceiro setor é constituído por organizações sem fins lucrativos, que tem por objetivo, atender às carências da sociedade, oferecendo serviços de caráter público. Logo, as entidades filantrópicas fazem parte do terceiro setor. No cenário atual, os aspectos legais do terceiro setor sujeitos à imunidade tributária, estão amparados pela Constituição Federal de 1988, na Lei n. 8.742/1993 (Lei Orgânica da Assistência Social LOAS), na Lei n. 12.101/2009, que dispõe sobre a certificação das entidades beneficentes de assistência social. Torna-se válido salientar, que a Carta Magna incentiva as entidades sem fins lucrativos garantindo-lhe a imunidade tributária e isenções, para que auxiliem o Estado no cumprimento dos direitos sociais e na efetivação da ordem social (BRASIL, 1988). As imunidades consideradas para as entidades filantrópicas alcançam o Imposto sobre Serviços de Qualquer Natureza (ISSQN), o Programa de Integração Social (PIS), Contribuição para o Financiamento da Seguridade Social (COFINS), e o Instituto Nacional da Seguridade Social (INSS) patronal e de terceiros, como o Risco Ambiental do Trabalho (RAT) e o Fundo de Previdência e Assistência Social (FPAS). A Constituição Federal de 1988, em seu artigo 156, inciso VI, alínea C, declara que a imunidade tributária atinge entidades de fins sociais e de caráter não lucrativo. Por outro lado, em seu artigo 195, parágrafo sétimo, define como isentas de contribuição para a seguridade social, as entidades beneficentes de assistência social. Conquanto, no curso do tempo, para a concreta obtenção da imunidade tributária das contribuições para as entidades filantrópicas, tornou-se necessário o cumprimento das exigências da Lei n. 12.101/2009, que dispõe sobre a certificação das entidades beneficentes de assistência social. Em março de 2020, o STF afastou a totalidade da gratuidade das assistências sociais para obtenção do CEBAS, e por consequência, garantiu a imunidade tributária das contribuições. Imprescindível mencionar que as entidades que tiveram seu pedido de certificação indeferido por não atenderem aos comandos da Lei 12.101/2009, terá direito de ter o CEBAS, inclusive poderá requerer a restituição dos pagamentos de contribuições sociais recolhidas para o fisco nos últimos 05 (cinco) anos, conforme determina o art. 168 do Código Tributário Nacional, haja vista o mais novo entendimento do STF no julgamento da ADI 4.480 .

Conclusão: Torna-se necessário considerar outros julgados sobre o assunto, inclusive de instâncias inferiores, especialmente a inexigibilidade das exigências contidas na Lei 12.101/2009, para fins de obtenção do CEBAS e consequentemente, imunidade tributária pelas entidades filantrópicas. Nota-se, que posição arguta do STF, acarretará na finalidade constitucional de ampliar a atuação das entidades filantrópicas do terceiro setor, a proporcionarem benefícios no âmbito da saúde para a sociedade no contexto atual.

\section{Referências}

ARISTÓTELES. A política. Trad. Nestor Silveira Chaves. São Paulo: Escala, 2017.
BRASIL.
Constituição
da República
Federativa
do Brasil
de 1988.
Disponível
em:

BRASIL. Supremo Tribunal Federal. Ação direta de inconstitucionalidade Certificação das entidades beneficentes de assistência social. Recorrente: Confederação Nacional dos Estabelecimentos de Ensino (CONFENEN). Recorrido: Presidente da República. Relator: Min. Gilmar Mendes, 23 de março de 2020. Disponível em: https://jurisprudencia.stf.jus.br/pages/search/sjur422079/false. Acesso em: 04 de ago. de 2020. 
Coordenadoria de Pesquisa e Extensão - COPEX

Departamento de Editoraçāo e Divulgaçāo Científica - DEDIC 


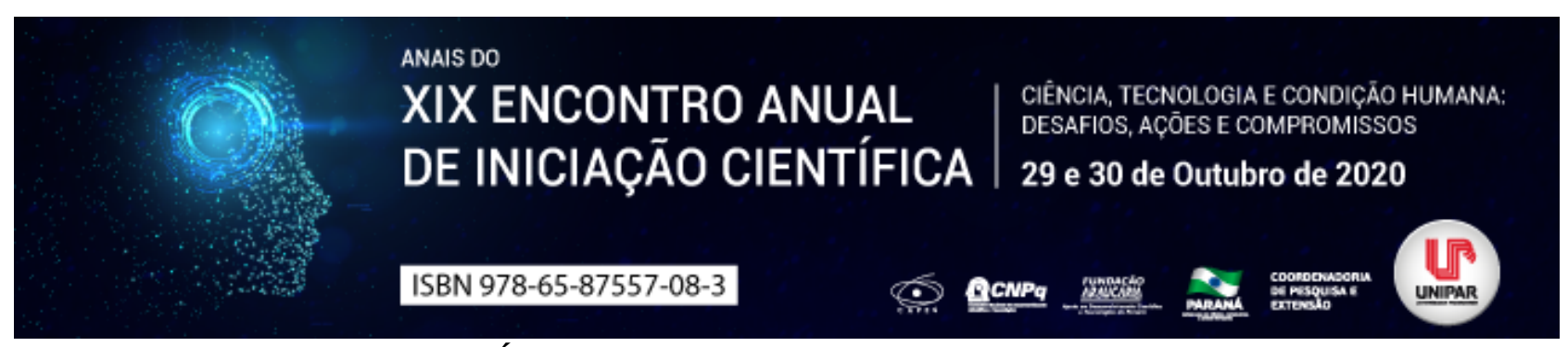

SUICÍDIO DE PESSOAS IDOSAS EM NIETZSCHE

\title{
${ }^{1}$ GLEISON DO PRADO DE OLIVEIRA, ${ }^{2}$ LUIZ ROBERTO PRANDI
}

\author{
${ }^{1}$ Acadêmico do Curso de Direito e participante do PIC/UNIPAR \\ ${ }^{1}$ Professor Titular e Pesquisador da UNIPAR
}

Introdução: No universo coletivo, muitas são as tentativas de prorrogar os anos de vida de si mesmo e de outrem. Mas uma representação intelectiva ecoa nas profundezas do homem: a reflexão de viver ou deixar de viver. Frente a tantos direitos resguardados para a pessoa idosa, a dor existencial e as limitações físicas causadas pelo curso do tempo têm causado pânico em pessoas com idade igual ou superior a 60 (sessenta) anos, aumentando o índice de suicídio no Brasil.

Objetivo: Apresentar reflexões filosóficas sobre os prazeres e desprazeres da vida, no tocante ao suicídio, evidenciando o aumento no índice de morte deliberada.

Desenvolvimento: O Estatuto do Idoso (Lei 10.741/2003) tem como premissa garantir os direitos da pessoa idosa, com idade igual ou superior a 60 (sessenta) anos. Todos os direitos são assegurados para a pessoa idosa e a lei lhes garante o acesso à saúde, bem como a preservação da integridade intelectual, física e moral. Não restam dúvidas quanto ao dever da sociedade de zelar e preservar a dignidade da pessoa idosa. A violação e descumprimento dos direitos previstos no Estatuto do Idoso, pressupõe punição por meio de lei. São direitos das pessoas idosas: envelhecer; liberdade, respeito e dignidade; alimentos; saúde; educação, cultura, esporte e lazer; exercício da atividade profissional; moradia; atendimento preferencial e acesso à justiça. Não obstante, embora o Estatuto garanta os direitos fundamentais aos idosos, um levantamento feito pelo sociólogo Julio Jacobo Waiselfisz, aponta que o suicídio entre as pessoas com idade igual ou superior a 60 (sessenta) anos de idade aumentaram em 215,7\%. Oliveto (2012), publicou uma edição especial da revista Ciência \& Saúde Coletiva com dados quantitativos e qualitativos, coordenado pela Escola Nacional de Saúde Pública da Fundação Oswaldo Cruz (Enasp/Fiocruz). Um dos trabalhos utilizou o Sistema de Informação sobre Mortalidade (SIM), do Ministério da Saúde, para calcular os registros de suicídio de pessoas idosas entre 1996 e 2007. Nesse período, os pesquisadores identificaram 91.009 mortes autoprovocadas, sendo que $14,2 \%$ ocorreram entre as pessoas com mais de sessenta anos. Uma indagação conduz a sociedade a uma reflexão: o que tem levado os idosos a anteciparem o final da própria existência? Destacam-se os fatores associados ao suicídio: alterações de humor e expressões de estados depressivos, conflitos familiares permeados por dificuldades financeiras, e uso abusivo de álcool e ideação suicida por anunciação do desejo de antecipar seu fim (SOUZA, et al., 2014). A filosofia alemã do século XIX, ao introduzir fragmentos da atual psicologia, elucidou argumentos para tal reflexão, conduzindo-nos a refletir sobre a morte deliberada. Nietzsche (2012), salientou que a ideia do suicídio nos ajuda a suportar muitas noites más. O gigante alemão, por meio de seus aforismos, também levou os leitores a se questionarem sobre a atitude deliberada das pessoas idosas, [...] por que seria mais louvável para um homem envelhecido, que sente a diminuição de suas forças, esperar seu lento esgotamento e dissolução, em vez de, em clara consciência, fixar um termo para si? (NIETZSCHE, 2012, p. 62), nestes termos, ainda mencionou que o suicídio é uma ação perfeitamente natural e racional. Afinal, há um direito segundo o qual, o homem pode tirar a vida de outro homem, todavia, tamanha seria a crueldade em tirar-lhe a própria morte.

Conclusão: Embora o Estatuto do Idoso garanta uma série de direitos para as pessoas com idade igual ou superior a 60 (sessenta) anos, o índice de suicídio entre essas pessoas tem aumentado significativamente. Ainda que as considerações filosóficas supracitadas sejam de certa maneira -, contrárias à vontade coletiva do prolongamento da vida da pessoa idosa, as mesmas asseguram o direito moral as escolhas feitas em prol da existência individual. Tal abordagem constitui oportunidades de pesquisa sobre a atitude das pessoas idosas frente as experiências sensoriais, direitos resguardados, possibilidades e oportunidades que se manifestam no contexto psicossocial, visando à benéfica decisão para o indivíduo no contexto da autonomia singular de deliberação.

\section{Referências}

SOUSA, Girliani Silva de et al. Circunstâncias que envolvem o suicídio de pessoas idosas. Interface-Comunicação, Saúde, Educação, v. 18, p. 389-402, 2014. Disponível em: encurtador.com.br/tuER. Acesso em: 16 jun. 2020.

NIETZSCHE, Friedrich Wilhelm. Humano, demasiado humano. Trad. Paulo César de Souza. São Paulo: Editora Companhia das Letras, 2012.OLIVETO, Paloma. Crescem os casos de suicídio no país. Correio Brasiliense, 2020. Disponível em: http://especiais.correiobraziliense.com.br/crescem-os-casos-de-suicidio. Acesso em: 09 jun. 2020. 



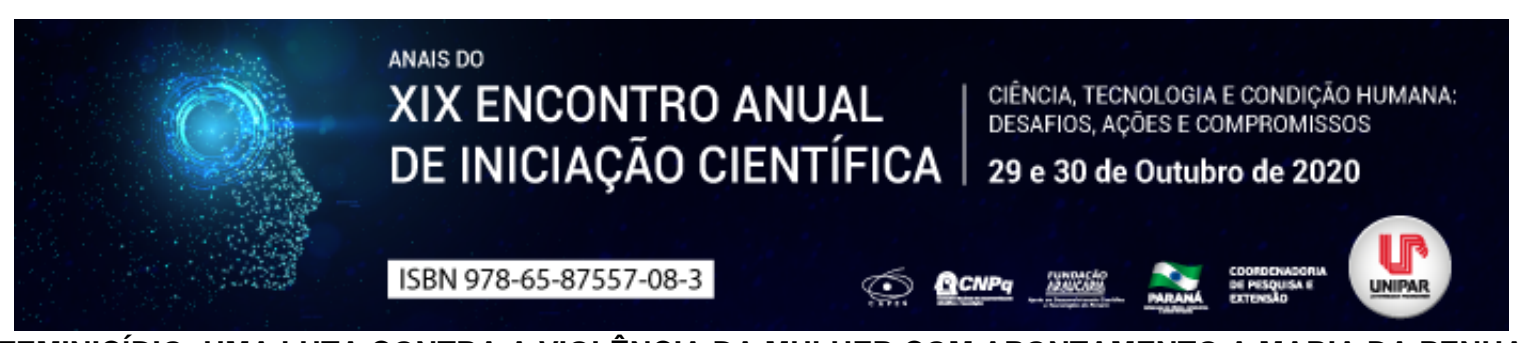

FEMINICÍDIO: UMA LUTA CONTRA A VIOLÊNCIA DA MULHER COM APONTAMENTO A MARIA DA PENHA

${ }^{1}$ THAISA CLAUDIA BEAL MACARI, ${ }^{2}$ BRUNO SMOLAREK DIAS

${ }^{1}$ Acadêmico do Curso de Direito da UNIPAR

${ }^{1}$ Docente da UNIPAR

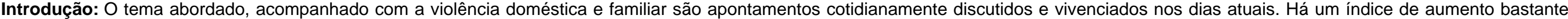

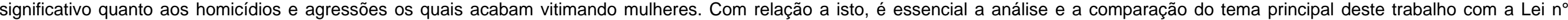
11.304/2006, a fim de que se chegue a uma proximidade de compreensão quanto ao que leva os criminosos a cometer esse tipo de delito.

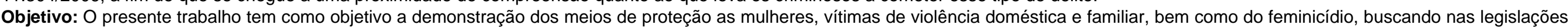
já existentes embasamento a fim de expandir a forma de prevenção e além disso a punição quanto a discriminação, preconceito e sofrimentos causados ás vítimas.

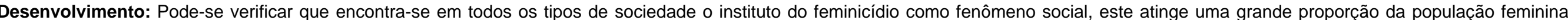

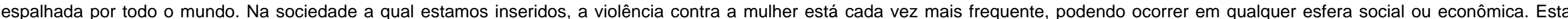

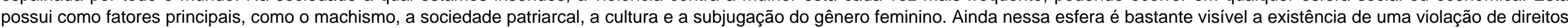

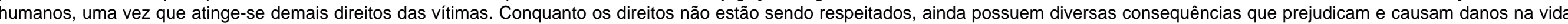

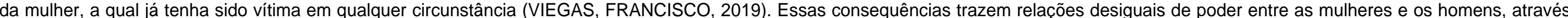

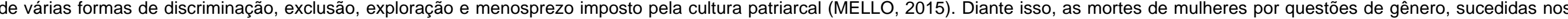

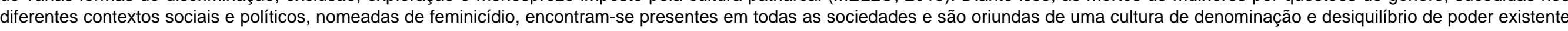

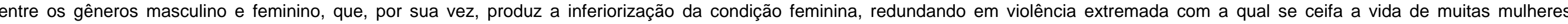

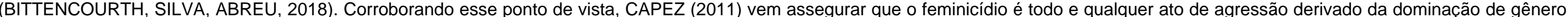

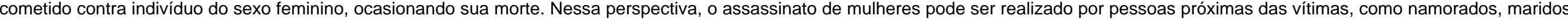

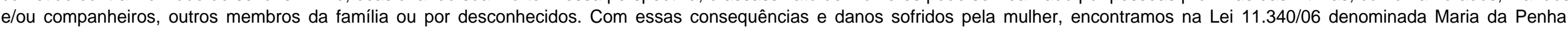

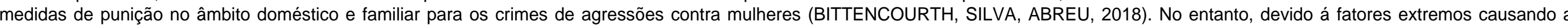

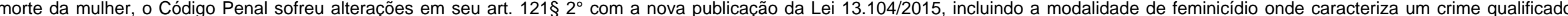

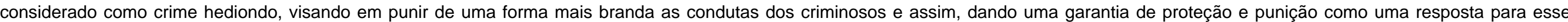
problema na sociedade (GOMES, BATISTA)

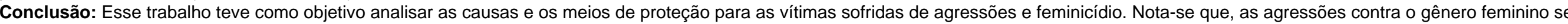

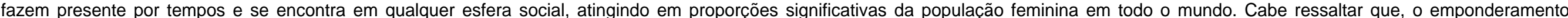

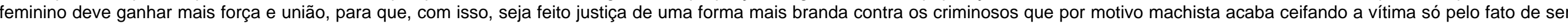

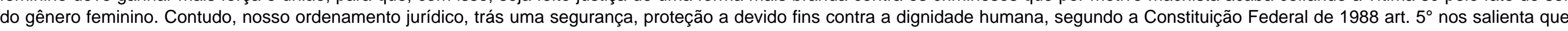

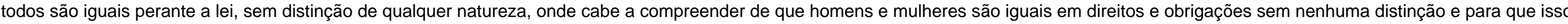

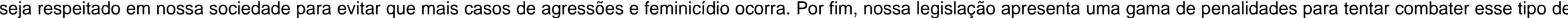
criminalidade, para que, de alguma forma, os homens respeitem mais a vida das mulheres.

Referências

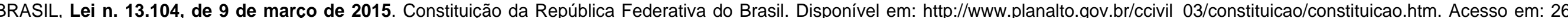
abr.2020.

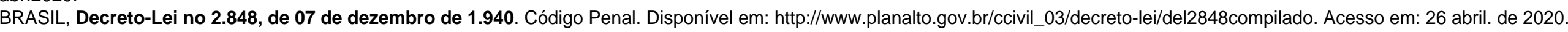

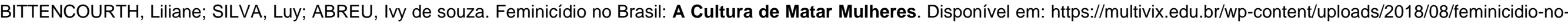
brasil-a-cultura-de-matar-mulheres.pdf. Acesso em: 26 abr de 2020. 
CAPEZ, Fernando. Curso de Direito Penal: Parte Geral. 15² Ed. São Paulo: Saraiva, v . 1 , 2011.

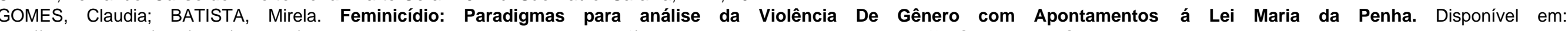
http://www.unsul.br/wps/wcm/connect/57571c15-0bd8-498c-baca-599dde5e74cf/artigo_gtdir_claudia-mirela_vii-spi.pdf?MOD=AJPERES. Acesso em: 26 abr de 2020.

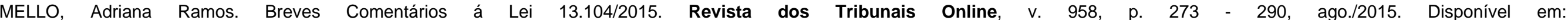
https://www.revistadostribunais.com.br/maf/app/resultList/dment?

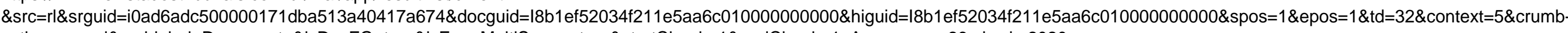
action=apend\&crublabel=Documento\&isDocFG=true\&isFromMultiSumm=true\&startChunk=1\&endChunk=1. Acesso em: 26 abr de 2020 .

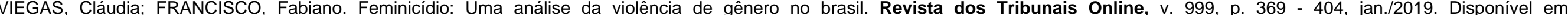
https://www.revistadostribunais.com.br/maf/app/resultList/docu-ment

guid=1046dd410ff6011e89c3100000000000\&higuid=I046dd410ff6011e89c101000000000000\&spos=2\&td=5\&crumb-action=append\&crumb-label=Document-

to\&DocFG=true\&isFromMultiSumm=true\&startChunk=1\&endChunk=1. Acesso em: 26 abr de 2020.

Coordenadoria de Pesquisa e Extensão - COPEX

Departamento de Editoração e Divulgação Científica - DEDIC 


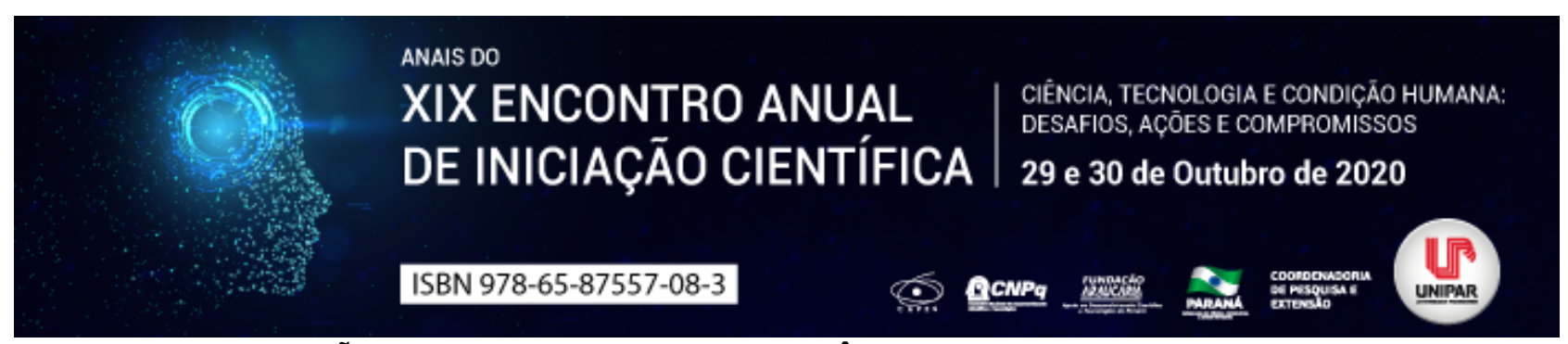

EDUCAÇÃO INCLUSIVA NO ENSINO DE CIÊNCIAS: REALIDADE OU UTOPIA?

${ }^{1}$ Taiane Aparecida Ribeiro Nepomoceno

${ }^{1}$ Mestre em Ciências Ambientais pela Universidade Estadual do Oeste do Paraná.

Introdução: Incluir é um processo social que se aplica no trabalho, no lazer, na educação e, especialmente na forma de perceber o outro. Falar em educação inclusiva significa partir do pressuposto do direito a uma educação de qualidade com e para todos. É mais que pensar apenas em como incluir no sistema escolar, alunos com deficiência, transtornos globais do desenvolvimento e altas habilidades ou superdotação, mas sobretudo refletir sobre o próprio ensino e a forma como ele vem sendo desenvolvido nos diversos níveis educacionais. A educação inclusiva tem possibilitado a participação efetiva de todos em sala de aula ou seria então, um atenuante às mazelas da realidade da educação brasileira? Estando, baseada em princípios de justiça e equidade, a educação defende uma formação para a cidadania democrática. Nesse contexto, torna-se clara a importância do ensino de ciências. E isto porque deve-se ensinar Ciências para possibilitar ao aluno ser protagonista de suas ações no mundo e agente de transformação social.

Objetivo: Relacionar a educação inclusiva e o ensino de ciências com base na perspectiva dos sistemas escolares atuais.

Desenvolvimento: A inclusão escolar é uma realidade, desenvolvida, em grande parte, de modo incoerente com o que sê prevê na legislação, especialmente em questões de qualidade. Não se trata de afirmar que ela é péssima, mas sim que ainda precisa ser aprimorada! A proposta da educação inclusiva visa a construção de aprendizagens e o desenvolvimento de potencialidades de todos os alunos na escola regular. Esse modelo pretende alcançar a todos no processo educativo, repercutindo na prática pedagógica do ensino de ciências, que tem como proposta curricular a disseminação do conhecimento tecnológico e científico inacabado, social e construído pela sociedade. Portanto, o professor de ciências tem papel crucial em sua ação docente, pois precisa tornar os conteúdos possíveis de serem incorporados por todos os alunos (NUNES; DUTRA, 2020). Na perspectiva do ensino de ciências, especialmente para aqueles alunos com deficiência ela se torna um desafio, são muitos aspectos microscópicos e uma complexidade de fenômenos para serem apreendidos, e como se sabe, as escolas públicas dispõe de poucos recursos (BASTOS et al., 2016). Embora haja muito que se pensar, há mais ainda para se fazer sobre a temática da inclusão no ensino de ciências. Primeiramente, porque se faz necessária a mobilização de saberes para a fragmentação de barreiras impostas pela inclusão e, segundo, pelo fato de os professores se desdobrarem para encontrar soluções e estratégias que possam corresponder aos anseios de aprendizado dos alunos com necessidades educacionais especiais no ensino regular. O ensino de ciências na perspectiva da inclusão requer, mais que uma sala inclusiva, precisa, portanto de práticas pedagógicas inclusivas, dedicação, afeto e compromisso. Além disso, precisa conceber como natural a diversidade e realizar adaptações curriculares, pedagógicas, estruturais e didáticas, materializando um ensino de ciências inclusivo (SANTANA; SOFIATO, 2019). Nesse sentido, muitos professores tem recorrido a diversas possibilidades, para serem empregadas no ensino de ciências. No entanto, cada estratégia deve ser adequada e em consonância com o currículo, fazendo com que o processo de ensino e aprendizagem seja alcançado por todos com satisfação e indicadores de qualidade (GRUDKA, 2019). A própria instituição escolar deve reforçar seu comprometimento, buscando soluções para que comportamentos atitudinais de exclusão sejam superados, causando uma mudança estrutural e educacional, de respeito e valorização das singularidades.

Conclusão: A aprendizagem das ciências da natureza é essencial na formação básica das pessoas e para sua atuação social. A educação inclusiva no ensino de ciências traz inúmeros desafios e anseios, mas também representa a possibilidade de intervenção didática para a formação ética concatenada ao reconhecimento da diversidade e equidade de oportunidades. E, mais do que isso, exige uma nova postura, uma adaptação da ação docente e de ferramentas didáticas, para que o conteúdo se torne mais acessível aos alunos. Ela implica na mudança do atual paradigma que a educação vive e a reformulação das políticas públicas, do sistema de ensino e, principalmente, do compromisso do Estado com a educação inclusiva.

\section{Referências}

BASTOS, Amélia Rota Borges de; LINDEMANN, Renata; REYES, Vitória. Educação inclusiva e o ensino de ciências: um estudo sobre as proposições da área. Journal of Research in Special Educational Needs, v. 16, n. 1, p. 426-429, 2016.

GRUDKA, Janice Helena. O ensino de ciências/biologia e a inclusão de alunos com deficiência. 30f. 2019. Trabalho de conclusão de curso (Graduação em Ciências Biológicas) Universidade Federal da Fronteira Sul, Cerro Largo, 2019.

NUNES, Rose Cristina; DUTRA, Carlos Maximiliano. Desafios da inclusão no ensino de ciências: Uruguaiana/RS. Brazilian Journal of Development, v. 6, n. 6, p. 38768-38785, 2020.

SANTANA, Ronaldo Santos; SOFIATO, Cássia Geciauskas. Ensino de Ciências para todos: uma experiência com um estudante com deficiência intelectual. Educação, v. 44, n. 1, p. 1-27, 2019. 
Coordenadoria de Pesquisa e Extensão - COPEX

Departamento de Editoraçāo e Divulgaçāo Científica - DEDIC 


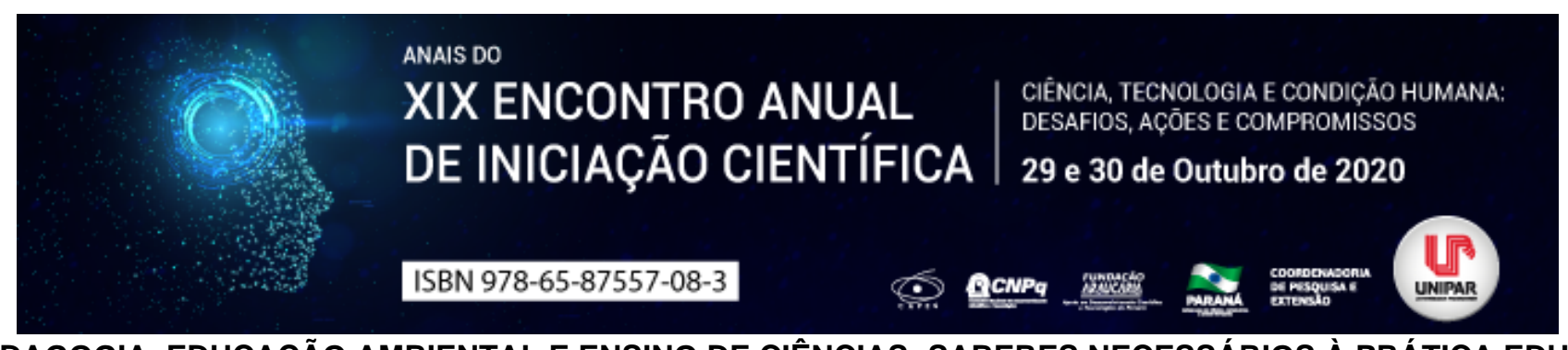

ECOPEDAGOGIA, EDUCAÇÃO AMBIENTAL E ENSINO DE CIÊNCIAS: SABERES NECESSÁRIOS À PRÁTICA EDUCATIVA

${ }^{1}$ Taiane Aparecida Ribeiro Nepomoceno

${ }^{1}$ Mestre em Ciências Ambientais pela Universidade Estadual do Oeste do Paraná.

Introdução: A educação como um todo vem demonstrando sinais de esgotamento especialmente pelas ações de ensino tradicional e por vezes, sem significado para o aluno. É, nesse contexto que se insere a ecopedagogia, ela se trata de uma aliada da educação ambiental, temática obrigatória na educação formal. A ecopedagogia tem o objetivo de trazer maior sentido para as ações ambientais e defende a cotidianidade nas práticas de educação ambiental, fornecendo subsídios para a superação dos obstáculos impostos pelo ensino tradicional. A educação ambiental deve ser desenvolvida de modo interdisciplinar e permanente, portanto se aplica ao ensino de ciências. A temática da educação ambiental no ensino de ciências pode contribuir com a construção do conhecimento científico de forma contextualizada, refletindo a realidade e suas ações diárias.

Objetivo: Discutir a relação entre ecopedagogia e a educação ambiental, enfatizando como elas podem ser incorporadas ao ensino de ciências na educação básica.

Desenvolvimento: A ecopedagogia ainda se encontra em desenvolvimento, mas já demonstra indícios de sua aplicabilidade e importância nos processos educacionais. Para entendê-la é preciso pensar o meio ambiente cotidianamente, de modo a reeducar o olhar das pessoas a partir de ações, interações e vivências. A realidade socioambiental comprova a ineficácia das práticas ambientais para a formação cidadã. E, a escola como espaço de aprendizagem e reflexão se mostra como propício para a ecopedagogia, isso porque ela pretende reorientar os currículos a partir de valores e princípios escolares e sociais. Ela é mais que uma simples teoria ao lado da educação ambiental, mas sim uma pedagogia do significado, que busca a promoção cotidiana da aprendizagem do sentido das coisas (GADOTTI, 2000). A ecopedagogia é uma forte aliada da educação ambiental e nos permite entender o que fazemos no dia a dia, a todo instante. Isto é, eu entendo a ação ambiental que faço em uma perspectiva global? Ou seja, me entendo como cidadão planetário? É um pensamento complexo, mas não impossível! A cidadania planetária tem a ver com todas as ações ambientais desenvolvidas na vida cotidiana num contexto local (onde realizado a ação), e o pensar das consequências dessa ação num contexto global (relativo ao planeta), já que ele é único. É se entender como ser singular e múltiplo simultaneamente. Por meio da ecopedagogia as ações ambientais se tornam mais significativas dentro e fora dos muros escolares. Numa abordagem dialógica e integradora, a ecopedagogia corresponde aos princípios da Educação Ambiental (MIRANDA, 2011) que também se amplia para os conteúdos de ciências. Nesse contexto, se apresenta como possibilidade de ser integrada aos currículos escolares, contribuindo para a formação de conhecimentos significativos sobre e para o planeta (GUTIÉRREZ; PRADO, 2013). Assim, educação ambiental e a ecopedagogia podem ser incorporadas no ensino de ciências de modo permanente, por meio de projetos ou programas ambientais. E, no decorrer desses, os conteúdos curriculares de ciências poderão ser abordados, em todas as perspectivas e possibilidades, estimulando a participação ativa e a integração do sentido para as práticas. Não há uma receita exata para isso, pelo contrário, a ecopedagogia é caminho ao andar (GUTIÉRREZ; PRADO, 2013), se redescobre a cada ação desenvolvida. A ecopedagogia considera as inter-relações entre ser humano e ambiente, e vice-versa. O seu papel é o de promover uma educação que possibilite ao ser humano a reconstrução da sua relação com a natureza, com o outro e consigo mesmo. Também pretende levar o ser humano se assumir parte de um ecossistema vivo, interligado. E não se esgota nisso. Ela é escola e comunidade, é o local e o global, tudo junto e, ao mesmo tempo.

Conclusão: A ecopedagogia pretende desenvolver uma nova forma de perceber os processos educativos, de modo global, apresentando meios para entender e transformar as ações fragmentadas e reducionistas de educação ambiental. As suas propostas curriculares têm o objetivo de reorientar práticas pedagógicas abrangentes, ou seja, trazendo sentido para aquilo que se realiza. Por meio dela é possível compreender o caráter multifacetado dos conteúdos curriculares das ações ambientais, e aqui pode-se englobar o ensino de ciências, como uma possibilidade para o entendimento da vida na terra e para a exploração das informações científicas presentes no cotidiano do aluno, oferecendo a eles a oportunidade de reconstrução, sobretudo, de uma postura significativa.

\section{Referências}

GADOTTI, Moacir. Pedagogia da Terra. São Paulo: Peirópolis, 2000.

GUTIÉRREZ, Francisco; PRADO, Cruz. Ecopedagogia e cidadania planetária. 3.ed. São Paulo: Cortez, 2013.

MIRANDA, Carlos Gomes Barreto. A inserção da ecopedagogia no ensino formal: uma vertente do desenvolvimento sustentável no ensino de ciências. 98f. 2011. Dissertação (Mestrado em ensino de ciências da saúde e do ambiente) Centro Universitário Plinio Leite, Niterói, 2011. 
Coordenadoria de Pesquisa e Extensão - COPEX

Departamento de Editoraçāo e Divulgaçāo Científica - DEDIC 


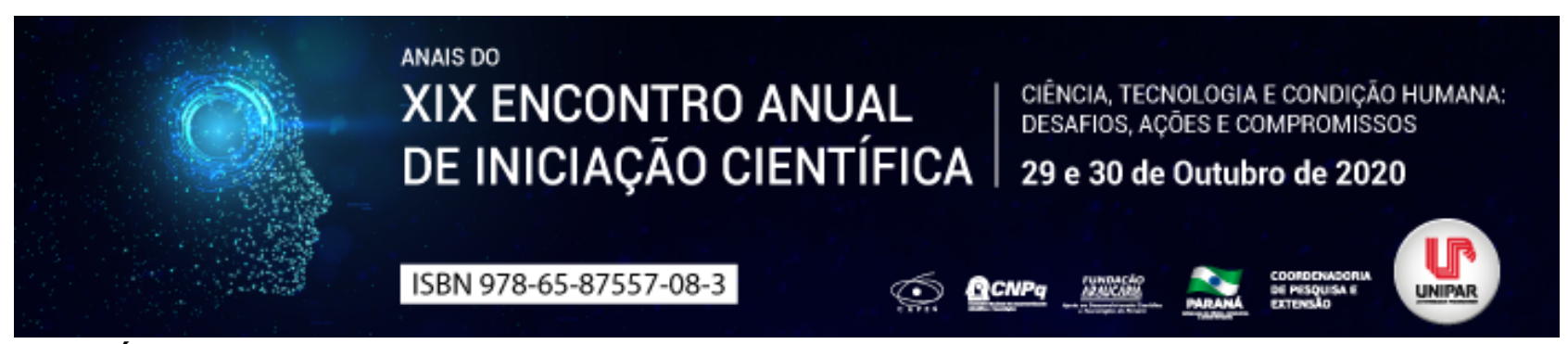

SAÚDE MENTAL NA ESCOLA: UMA PERSPECTIVA FOCADA EM ALUNOS E COLABORADORES

\title{
${ }^{1}$ JESSICA RODRIGUES DOS SANTOS, ${ }^{2}$ MARIA HELOIZA NEIS TURIN, ${ }^{3}$ THAIS CRISTINA GUTSTEIN NAZAR
}

\author{
${ }^{1}$ Acadêmica do Curso de Psicologia da UNIPAR \\ ${ }^{1}$ Acadêmica do Curso de Psicologia da UNIPAR \\ ${ }^{2}$ Docente da UNIPAR
}

Introdução: A questão de intervenção no âmbito escolar tem uma enorme relevância, as crianças estão em fase de desenvolvimento físico e psicológico, então uma maior fragilidade delas em diversas situações é presente. O psicólogo educacional trabalhará as influências que podem ser desenvolvidas na criança, de maneira biopsicossocial a partir da compreensão de seu estado emocional, buscando proporcionar meios para o indivíduo se desenvolver de forma mais saudável e autônoma (CFP, 2013). A intervenção do psicólogo educacional com os professores é bastante significativa, o educador adota uma função muito importante dentro da escola, como pilar da instituição e como repassador de conhecimento, porém, se o trabalho do professor for exaustivo e estressante, poderá implicar em sua saúde emocional e, consequentemente, nos alunos a partir do modo como ambos se relacionam. A escola é um modo de organizar a formação, de pensá-la e de fazê-la, é uma organização possível entre outras ainda não pensadas e não realizadas. (CFP, 2013, p.40), ou seja, é a escola que organiza o processo de ensino, pensa no que deve ser transmitido aos ali presentes, e, o psicólogo pode auxiliá-la com seus conhecimentos sobre aprendizagem, proporcionando uma interação mais ampla entre alunos e professores.

Objetivo: Pretendeu-se com esse trabalho, desenvolver técnicas de intervenções com a finalidade de atingir tanto os alunos quanto os profissionais na escola, enfatizando a importância dos mesmos no local e possibilitando novos caminhos para a compreensão desses papéis.

Material e métodos: Para a coleta de dados foram utilizados questionário de descrição do local, questionário feito pelos acadêmicos, instrumento WHOQOL-BREF, entrevistas formais e informais com os funcionários, observações dentro e fora das salas de aula e vivências no ambiente escolar. Para as intervenções foram utilizados vídeos informativos, filmes de animação, música, desenhos, livros ilustrados, encenações lúdicas. Com a equipe totalizou-se 4 encontros e foram propostos assuntos referentes a autoestima, autoconhecimento e melhores relações interpessoais, sendo realizadas a partir de rodas de conversa interativas e dinâmicas grupais. Com os alunos, totalizaram-se 12 intervenções, os encontros ocorriam uma vez por semana, o foco destas intervenções foi trabalhar a prevenção do bullying, a empatia, a autoestima e comportamento moral, o reconhecimento das emoções e a violência sexual infantil.

Resultados: No período de intervenção foram atendidos alunos e a equipe da escola. Nessas intervenções foram propostos assuntos referentes a autoestima, autoconhecimento e melhores relações interpessoais. Já com os alunos foram realizadas intervenções com todas as turmas do período vespertino e alguns alunos do reforço que eram do período matutino. Através das intervenções, tanto com os alunos quanto com a equipe, pode-se perceber que houveram mudanças significativas, tanto na forma de pensar como também de lidar com tais situações. Essas mudanças puderam ser compreendidas por meio de conversas informais, de relatos e exemplos que os mesmos acabavam compartilhando. $O$ engajamento de cada participante foi perceptível e isso facilitou a realização das atividades.

Discussão: O contexto escolar é um ambiente de grande relevância para o desenvolvimento social e subjetivo de todo indivíduo, assim, atribuiu-se a ela uma atenção especial. Pensando nisto, a área da psicologia escolar buscar intervir de uma forma integrada, com o intuito de promover resultados positivos em todas os setores da instituição, incluindo não apenas os alunos, mas sim toda a rede educacional (ESTANISLAU \& BRESSAN, 2014). A psicologia como ciência procura promover um ambiente saudável à todos os envolvidos, além de proporcionar uma maior autonomia, segurança e facilitar no processo de aprendizagem. As (os) psicólogas (os) poderam contribuir, portanto, como mediador fortalecendo o papel do professor como agente principal do processo de ensino e aprendizagem. (CFP, 2013, p.56, apud FACCl, 2004). Ao tratar de saúde mental nas escolas, devemos lembrar que ela é um ambiente importante para o desenvolvimento não só intelectual, mas, também emocional, onde se adquirem vivências, e por se tratar de um ambiente mais acessível à população do que muitas instituições de saúde, poderia ser melhor aproveitada por crianças, jovens e os adultos presentes para perceber sintomas. Buscou-se auxiliar os profissionais quanto às suas relações, podendo ressignificá-las, tornando o ambiente escolar menos exaustivo para que todos desempenhem melhor as suas funções, proporcionando uma maior qualidade de vida e, consequentemente, no sistema de ensino. Procurou-se possibilitar um desenvolvimento psicossocial e cognitivo infantil saudável para os alunos, com o enfoque na prevenção e na promoção da saúde mental, ajudando no reconhecimento de sentimentos e como lidar frente à situações inesperadas. E propiciar, de uma maneira acessível e lúdica, que as relações se apresentem com um caráter positivo, saudável e acolhedor, para que todos os envolvidos no processo de intervenção consigam uma melhora na saúde mental e por consequência, no 
ambiente escolar.

Conclusão: A proposta de trabalho foi realizada com adesão e participação de toda a escola, o que é de extrema relevância para o sucesso do trabalho. Devido a grande demanda que as escolas possuem, nota-se a necessidade de mais profissionais da área da psicologia inseridos nas instituições educacionais, para que estes possam realizar seu trabalho com mais eficácia, ressignificando experiências e tornando a escola como fator protetivo.

\section{Referências}

CFP - Conselho Federal de Psicologia. Referências técnicas para Atuação de Psicólogas(os) na Educação Básica. 1. ed. Brasília, 2013.

ESTANISLAU, Gustavo.; BRESSAN, Rodrigo Affonseca. Saúde mental na escola: o que os educadores devem saber. Porto Alegre. Artmed, 2014.

Coordenadoria de Pesquisa e Extensão - COPEX

Departamento de Editoraçāo e Divulgaçāo Científica - DEDIC 


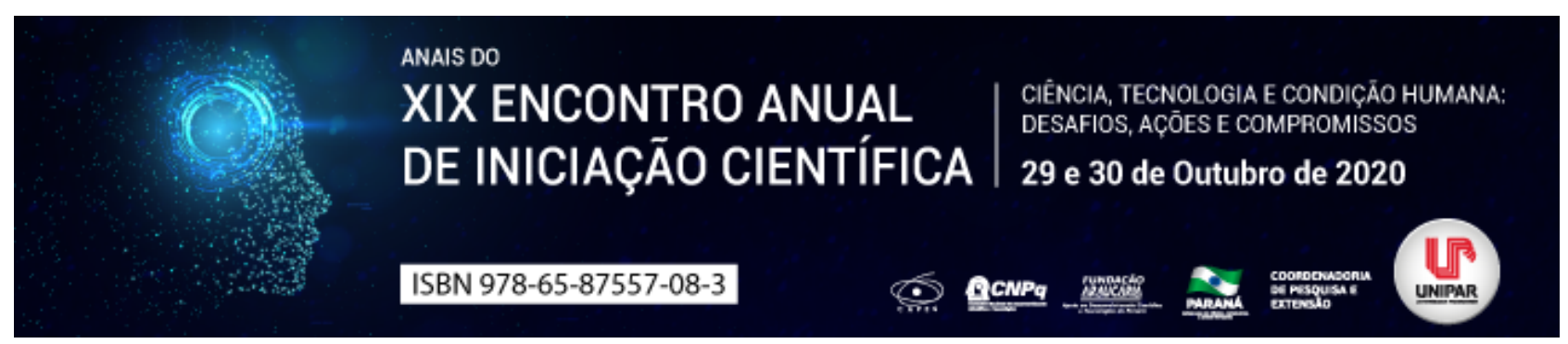

RESPONSABILIDADE CIVIL DECORRENTE DO ABANDONO AFETIVO

${ }^{1}$ MATHEUS HENRIQUE DE FREITAS URGNIANI, ${ }^{2}$ MATHEUS HENRIQUE RAPHAEL DE PAULA, ${ }^{3}$ BRUNO HENRIQUE PUCHETTI DE CENE, ${ }^{4}$ GABRIEL TRENTINI PAGNUSSAT, ${ }^{5}$ LUIZ ROBERTO PRANDI

\footnotetext{
${ }^{1}$ Acadêmico do curso de Direito e Bolsista do PIBIC/UNIPAR

${ }^{1}$ Acadêmico do curso de Direito e Bolsista do PIBIC/UNIPAR

${ }^{2}$ Acadêmico do Curso de Direito e participante do PIC/ UNIPAR

${ }^{3}$ Acadêmico do Curso de Direito da UNIPAR e bolsista PEBIC/CNPq

${ }^{4}$ Professor Titular e Pesquisador da UNIPAR
}

Introdução: É perceptível que o Estado tutela o direito de ressarcimento decorrente de ato ilícito praticado por terceiro, sendo esse material ou imaterial. Porém, não é sedimentado na atual jurisprudência e doutrina, responsabilidade ao sujeito quando do abandono afetivo do idoso, deixando-o desprotegido.

Objetivo: Analisar a possibilidade da aplicação do instituto da responsabilidade civil, decorrente do abandono afetivo do idoso.

Desenvolvimento: Pode-se definir a responsabilidade civil como a situação jurídica de quem descumpriu determinado dever jurídico, causando dano material ou moral a ser reparado (NADER, 2016. p. 34), ou seja, o sujeito responderá por sua conduta que vier a causar danos a outrem, podendo ser de natureza moral ou não. Figura-se que o art. 230 da Constituição Federal de 1988, prevê a todos o dever de amparar às pessoas idosas, a fim de que essas estejam ativas na sociedade, tenham uma vida digna e entre outros bens jurídicos tutelados. Seguindo essa sistemática, o Estatuto do Idoso, Lei 10. 741/2003, também pugna no decorrer dos seus artigos o dever de todos em zelar pela dignidade do idoso, com escopo de garantir a vida e outros direitos a serem asseguradas. Sendo assim, percebe-se que ambas as leis trazem o dever das pessoas em garantir o mínimo aos idosos. Em razão disso, é mister mencionar, que a afetividade se inclui nessas garantias, uma vez que não há que se falar em uma vida digna quando todos em sua volta o abandonam. Por isso, já que se configura como um dever jurídico, aquele que descumpre deve ser responsabilizado por tal atitude. Ainda, é notório que o STJ atribui a indenização por danos morais àqueles que tenham sofrido algum dano a um ou alguns dos seus direitos da personalidade, os quais, são afetados de maneira inevitável com o abandono afetivo, uma vez que atenta contra a vida, a honra e outros bem jurídicos incluídos na perspectiva de personalidade. Por isso, responsabilidade civil, em razão do abandono afetivo, é perfeitamente cabível, seja pelo não cumprimento de um dever ou por afetar direitos da personalidade.

Conclusão: Percebe-se pelo analisado, que o idoso faz jus à reparação civil por danos morais, em razão do abandono afetivo.

\section{Referências}

BRASIL. [CONSTITUIÇÃO(1988)]. Constituição da República Federativa do Brasil. Disponível em: http://www.planalto.gov.br/ccivil_03/constituicao/constituicao.htm. Acesso em: 28 mar. 2020.

BRASIL. Lei $\mathbf{n}^{\mathbf{0}}$ 10.741, de $1^{\circ}$ de outubro de 2003. Institui o Código Civil. $2002 . \quad$ Disponível em: http://www.planalto.gov.br/ccivil_03/leis/2003//10.741.htm. Acesso em: 25 de mar. de 2020.

BRASIL. Superior Tribunal De Justiça (3. Turma). Agravo em recurso especial - Danos materiais e morais. Venda e compra de imóvel entre particulares. Alegação de ocorrência de danos morais, em razão de protesto tirado em seu nome pela dívida de IPTU. Descabimento. Inexistência de ofensa aos direitos da personalidade por conduta dos requeridos em face das peculiaridades do caso concreto. Revisão deste entendimento. Impossibilidade. Aplicação da súmula $n^{\circ}$ 7/STJ. Adequação da decisão agravada. Agravo interno desprovido. Disponível em: https://scon.stj.jus.br/SCON/jurisprudencia/doc.jsp. Acesso em: 13 jul. 2020.

NADER, PAULO. Curso de direito civil: Responsabilidade Civil. 6. ed. Rio de Janeiro: Forense, 2016. 


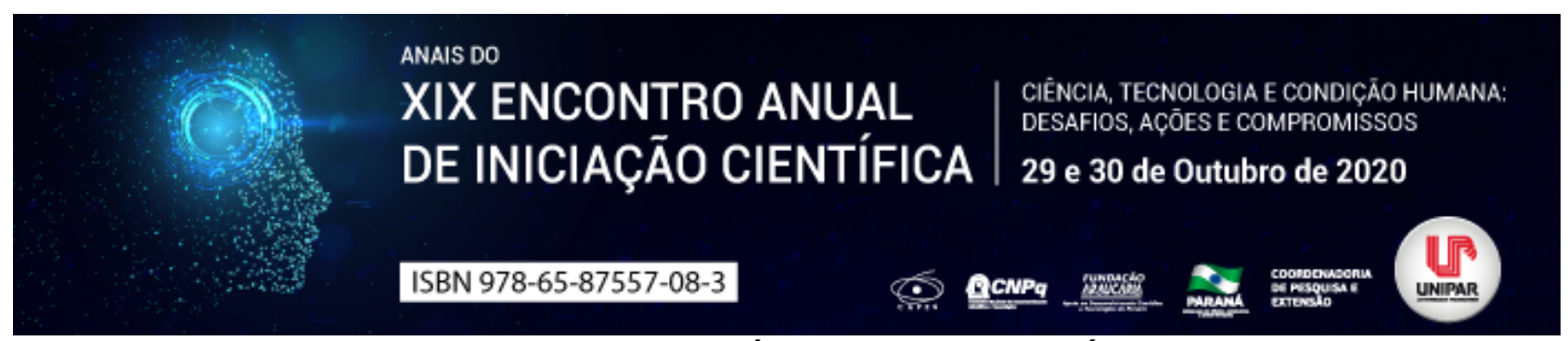

IMPENHORABILIDADE TRIBUTÁRIA DO BEM DE FAMÍLIA DO IDOSO

\section{${ }^{1}$ MATHEUS HENRIQUE DE FREITAS URGNIANI, ${ }^{2}$ LUIZ ROBERTO PRANDI}

${ }^{1}$ Acadêmico do curso de Direito e Bolsista do PIBIC/UNIPAR

${ }^{1}$ Professor Titular e Pesquisador da UNIPAR

Introdução: O Estado garante às pessoas o direito da impenhorabilidade do bem imóvel, porém traz algumas exceções legais, estando entre elas, a dívida advinda de tributos. Entretanto, também confere aos idosos garantia à moradia, a fim de concretizar a dignidade da pessoa humana.

Objetivo: Analisar a possibilidade da impenhorabilidade do bem imóvel do idoso, mesmo diante de dívida tributária.

Desenvolvimento: A doutrina pátria define bem de família o imóvel utilizado como residência da entidade familiar, decorrente de casamento, união estável, entidade monoparental, ou entidade de outra origem (TARTUCE, 2017. p. 270), ou seja, imóvel utilizado para fins de moradia da pessoa humana. Visando a proteger o bem de família, o Estado institui a Lei 8.009/1990 e o artigo 1.711 a 1722 do Código Civil de 2020 para efetivação desse bem jurídico. Embora o Estado tenha concedido tal direito, ao mesmo tempo o retira, conforme se contata no art. $3^{\circ}$ da Lei 8.009/1990 e artigo. 1.715 do Código Civil. Em que pese a concessão de penhorabilidade nesses artigos, a Lei 10.741/2003, Estatuto do Idoso, confere ao artigo 37 o direito do idoso de gozar de uma moradia digna. Soma-se a isso, também, no artigo 38 da mesma lei, assegura-lhes a prioridade nos programas habitacionais. Ou seja, há uma aparência de antinomia, o qual se resolve pela especialidade princípio jurídico que estabelece que a lei especial derroga a lei geral (SÃO PAUO, 2014, p. 2) e pela dignidade da pessoa humana, conforme preceitos definidos na Carta Magna. Por conseguinte, entende-se que no caso concreto, não poderá prevalecer a penhorabilidade, mas a impenhorabilidade, em razão de predominar o Estatuto do Idoso e a dignidade da pessoa humana, pelo qual, se o último não for observado, haverá consequentemente mitigação do referido princípio, além de atribuir caráter de menor valia ao direito de moradia dos idosos, em face ao patrimonial do Estado.

Conclusão: Percebe-se pelo analisado, que deve prevalecer a norma especial, portanto, conferir aos idosos a impenhorabilidade do bem imóvel, ante a dívida tributária, em razão da observância do princípio da especialidade da norma e da prevalência da dignidade da pessoa humana.

\section{Referências}

BRASIL. Lei $n^{\circ}$ 8.009, de 29 de março de 1990. Dispõe sobre a impenhorabilidade do bem de família. 1990. Disponível em: http://www.planalto.gov.br/ccivil_03/leis/L8009.htm. Acesso em: 26 mar. 2020.

BRASIL. Lei $\mathbf{n} 0$ 10.406, de 10 de janeiro de 2002. Institui o Código Civil. 2002. Disponível em: http://www.planalto.gov.br/ccivil_03/leis/L8009.htm. Acesso em: 25 mar. 2020.

BRASIL. Lei no $\mathbf{1 0 . 7 4 1}$, de $\mathbf{1}^{\circ}$ de outubro de 2003. Dispõe sobre o Estatuto do Idoso e dá outras providências. 2002. Disponível em: http://www.planalto.gov.br/ccivil_03/leis/2003/110.741.htm. Acesso em: 25 de mar. 2020.

SÃO PAULO. Supremo Tribunal Federal. $2^{\mathrm{a}}$ Turma. Reg. No recurso extraordinário com agravo 835.076/SP. Disponível em: http://redir.stf.jus.br/paginadorpub/paginador.jsp?docTP=TP\&docID=7133900. Acesso em: 26 jun. 2020.

TARTUCE, Flávio. Direito Civil: Lei de Introdução e Parte Geral. 13. ed. Rio de Janeiro: Editora Forense, 2017. 


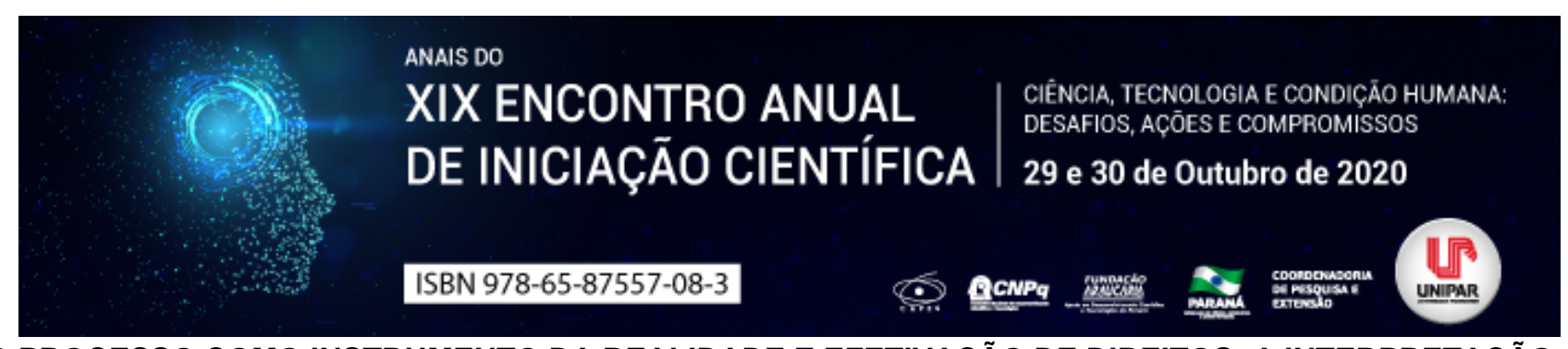

O PROCESSO COMO INSTRUMENTO DA REALIDADE E EFETIVAÇÃO DE DIREITOS: A INTERPRETAÇÃO, A VALORAÇÃO DAS PROVAS E A MOTIVAÇÃO DAS DECISÕES

\author{
${ }^{1}$ ANA CLAUDIA DO NASCIMENTO DE SOUZA, ${ }^{2}$ ALBINO GABRIEL TURBAY JUNIOR
}

\author{
${ }^{1}$ Acadêmica bolsista do PEBIC/ Fundação Araucária \\ ${ }^{1}$ Docente da UNIPAR
}

Introdução: O processo tem a missão de proporcionar que as partes apresentem a realidade dos fatos e, assim, concretizar direitos. Para isso, o juiz precisa compreender a leis, intrerpretá-las ao caso concreto, valorar as provas e, por fim, motivar suas decisões. Contudo, há que se observar o grau de liberdade que o magistrado possui ao longo do processo.

Objetivo: Analisar o processo como instrumento de conhecimento da realidade, com enfoque na interpretação, na valoração das provas e no dever de motivar as decisões judiciais.

Desenvolvimento: $\mathrm{O}$ Estado detêm a função jurisdicional, desse modo, ao ser provocado, pode resolver os conflitos entre litigantes, aplicando ao caso uma solução prevista pelo ordenamento jurídico. Para isso, o agente jurisdicional (juiz) deve buscar nos textos legislativos o sentido da lei, que depende dos valores sociais que reinam no caso concreto e, por fim, aplicar a lei (WAMBIER; TALAMINI, 2016, p. 108-109). Outrossim, para resolver o litígio e conhecer a verdade deve o magistrado interpretar a os fatos, valorar as provas que vierem a ser apresentadas e, em sua sentença, motivar as decisões que toma. Tendo a interpretação o papel de explicar, esclarecer, dar o verdadeiro significado do vocábulo, extrair da norma tudo o que nela se contém, revelando seu sentido apropriado para a vida real e conducente a uma decisão (DINIZ, 2013, p. 449). Ademais, Nader (2015, p. 173-176) fala do grau de liberdade dada para o judiciário ao interpretar, citando assim três correntes doutrinarias: a da livre estimação, onde o juiz teria uma ampla liberdade, a da Limitação à Subsunção, em que ele não cooperaria com sua experiência, e a da Complementação Coerente, que seria o equilíbrio entre as duas correntes. Outro ponto importante é a liberdade para interpretar as provas que são produzidas durante o processo, neste sentido, por força do art. 371 o juiz apreciará apenas as que constem nos autos, em respeito ao princípio do contraditório, e as valorará racionalmente, de forma que atenda às regras do raciocínio jurídico e de validade argumentativa. Destarte, não é admitido uma decisão baseada em fé ou achismos (DIDIER; BRAGA; OLIVEIRA, p. 106-107). Por fim, deve o juiz motivar suas decisões com base na norma jurídica, buscando refletir tudo o que foi realizado pelas partes. Fábio Caldas de Araújo ainda mostra que l"a motivação é necessária para que a própria decisão possa ser qualificada como justa e sobre sua leitura se realize o controle sobre o acerto da decisão judiciall" (ARAÚJO, p. 154). Além disso, é importante ressaltar que as decisões imotivadas são nulas, haja vista que a parte tem direito de saber o motivo da decisão.

Conclusão: $O$ juiz, agente jurisdicional, deve interpretar os fatos e as leis, valorar as provas e aplicar a norma adequada ao caso, motivando suas decisões. O comprometimento com a compreensão da realidade dos fatos apresentados para julgamento, assim, a interpretação dos fatos e da lei que será utilizada, constroem um processo justo, e o perfil democrático para concretização dos direitos fica garantido quando o juiz motiva, justifica e fundamenta suas conclusões e sua decisão.

\title{
Referências
}

ARAÚJO, Fábio Caldas de. Curso de processo civil. São Paulo: Malheiros, 2016.

DIDIER JR. Fredie; BRAGA, Paulo Sarno; OLIVEIRA, Rafael Alexandria de. Curso de direito processual civil. 11. ed. Salvador: Jus Podvim, 2016.

DINIZ, Maria Helena. Compêndio de introdução à ciência do direito. 24. ed. São Paulo: Saraiva, 2013.

NADER, Paulo. Introdução ao estudo do direito. 37. ed. Rio de Janeiro: Forense, 2015.

WAMBIER, Luiz Rodrigues; TALAMINI, Eduardo. Curso avançado de processo civil. 16. ed. São Paulo: Revista dos Tribunais, 2016. 


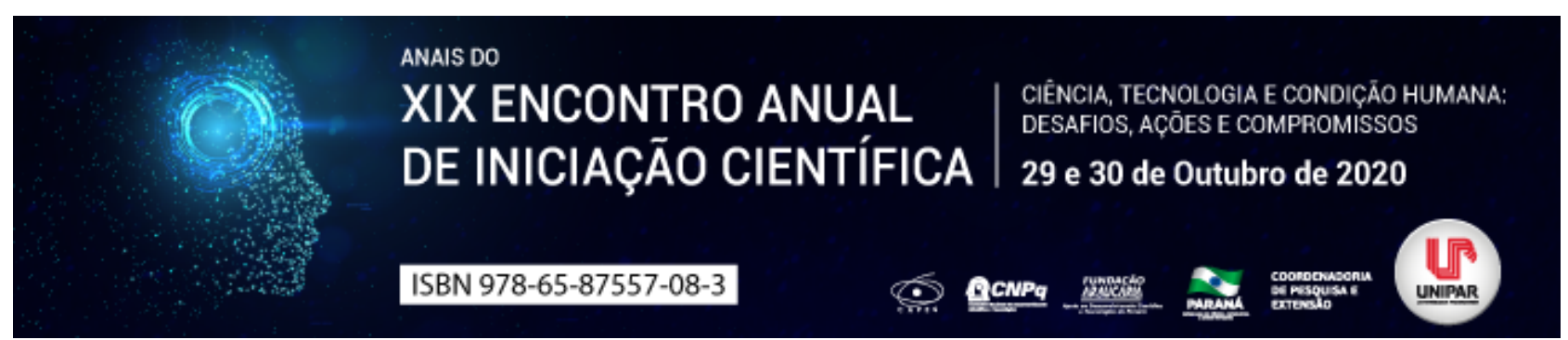

DIREITO AUTORAL E AS DIFICULDADES DO SÉCULO XXI

\author{
${ }^{1}$ ANA CLAUDIA DO NASCIMENTO DE SOUZA, ${ }^{2}$ PAULO CESAR DE SOUSA
}

${ }^{1}$ Acadêmica do Curso de Direito da UNIPAR

${ }^{1}$ Docente da UNIPAR

Introdução: Com objetivo de salvaguardar os direitos do autor, existem leis e tratados internacionais, que são extremamente importantes e necessários. Contudo, é questionável sua eficácia nos dias atuais, pois possuem um regramento que não se coaduna com os avanços tecnológicos na área de informação.

Objetivo: Discutir o descompasso existente entre a legislação do direito autoral vigente e a realidade social decorrente da evolução tecnológica (internet).

Desenvolvimento: $\mathrm{O}$ art. 29 da Lei de Direitos Autorais prevê que: I"depende de autorização prévia e expressa do autor a utilização da obra, por quaisquer modalidades [...]l" (BRASIL, 1998). O atual regime jurídico é construído a partir da premissa de que não se pode usar uma obra intelectual do autor sem o expresso consentimento deste. Isso implica o fato de que, em virtude desse postulado de cunho restritivo, muitos atos praticados corriqueiramente na WEB tornam-se ilegais. Não obstante, dada a evolução dos meios de comunicação, esperar que sejam cumpridas todas as normas autorais é incompatível com a realidade social, pois I"não existe nenhum governo, organismo internacional ou entidade que exerça controle ou domínio absoluto sobre a Internetl" (LEONARDI, 2019, p. 6). Em uma tentativa de atualizar sua legislação, o Parlamento Europeu aprovou um projeto de lei que responsabilizava as plataformas digitais, e não os usuários, pelos conteúdos postados sem a autorização do autor (UNIÃO EUROPEIA, 2019). Essa proposição normativa, naturalmente, preocupou as grandes plataformas digitais. Para a CEO do Youtube, tal proposta colocava em risco todo o sistema da plataforma, pois seria temerário manter conteúdos de criadores menores e tornaria viável trabalhar apenas com um pequeno grupo de grandes empresas (WOJCICKI, 2018, p.1). Há temor de que outros países, como o Brasil, inspirem-se nessa proposta legislativa e venham a adotar um regime normativo semelhante. Sem embargo, é clarividente a necessidade de que haja, tanto em nível de tratado internacional quanto em sede de lei no Brasil, uma readequação do regramento concernente aos direitos do autor, visto que o atual regime com raízes no século XIX não mais se harmoniza com o desenvolvimento tecnológico atual. Essa reforma precisa buscar fixar equilíbrio entre o direito de autor e o acesso ao conhecimento, compatibilizando com o Texto Constitucional (PARANAGUÁ; BRANCO, 2009, p. 71), dado que restringir e não incentivar o compartilhamento de conteúdos na WEB é também impedir o acesso facilitado a informação.

Conclusão: As normais de Direito Autoral não estão em harmonia com a evolução tecnológica, motivo por que precisam ser reformadas. No entanto, há que se cuidar para que isso não interfira no acesso ao conhecimento.

\title{
Referências
}

BRASIL, LEI No 9.610, DE 19 DE FEVEREIRO DE 1998. In: Vademecum: Rideel, 30. ed. São Paulo: Rideel, 2020.

LEONARDI, M. Fundamentos do Direito Digital. 1. ed. São Paulo: Revista Thomson Reuters Brasil, 2019.

PARANAGUÁ, P; BRANCO, S. Direitos Autorais. 1. ed. Rio de Janeiro: FGV, 2009.

UNIÃO EUROPEIA. Official Journal of the European Union, 2019. Disponivel em: . Acesso em: 12 de jun. 2020.

WOJCICKI, S. A Final Update on Our Priorities for 2018. Creator Blog, 2018. Disponível em: < encurtador.com.br/uvNU3>. Acesso em: 12 de jun. 2020. 


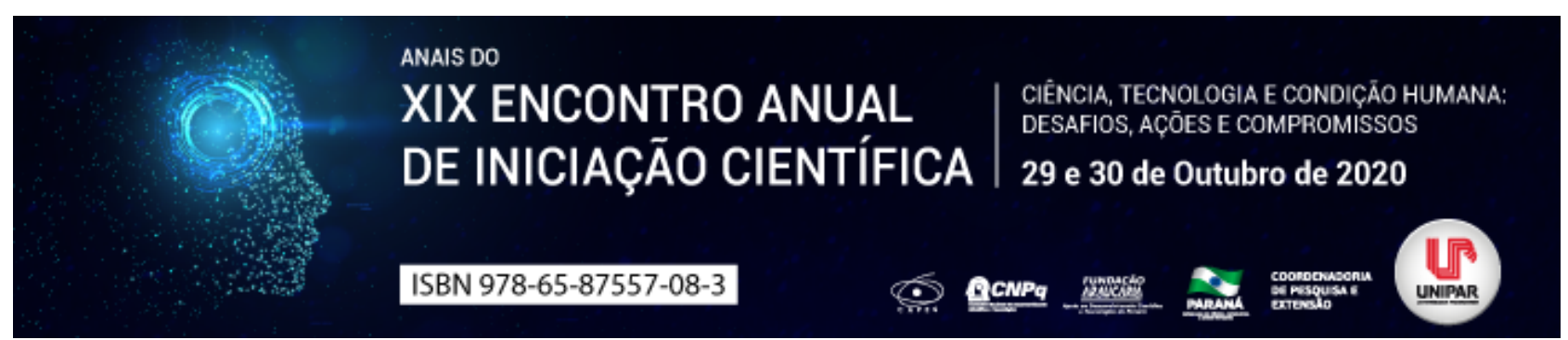

JUIZADO ESPECIAL CÍVEL COMO ACESSO À JUSTIÇA

\title{
${ }^{1}$ DAYSON RICARDO ALEXANDRE, ${ }^{2}$ DIEGO CANTON
}

\author{
${ }^{1}$ Acadêmico do curso de Direito da Unipar \\ ${ }^{1}$ Docente da UNIPAR
}

Introdução: A Constituição Federal de 1988 em seu art 98,I, trouxe a obrigatoriedade para que o estado criasse os Juizados Especiais Criminais e Juizados Especiais Cíveis, dando a possibilidade de acesso à justiça, julgado causas de menor complexibilidade, através do rito sumaríssimo e buscando preferencialmente a conciliação. Ainda o Juizado Especial estimulou o cidadão a exercer a cidadania, no sentido de buscar a justiça para exercer seu direito, e não fazer com as próprias mãos, muito menos de manter-se omisso diante uma violação de seus direito, sendo que a Lei 7.244/84, foi o fundamento para o Juizado das Pequenas Causas, sendo revogada pela Lei 9.099/95 que busca uma resposta quase imediata para pessoas com pouco poder aquisitivo, buscando como preceito primário a conciliação entre os litigantes. Destarte já conceituada é importante ressaltarmos a celeridade é um dos principais princípios da referida lei, bem com é norteado de princípios que visam o acesso e agilidade processual, contudo, se verifica no cotidiano algumas inconformidades em seu funcionamento prático.

Objetivo: $O$ presente estudo tem como objetivo compreender a analisar o procedimento judicial especial, bem como dos princípios que o norteiam, trazendo uma noção básica e geral sobre o JEC, esmiuçando e exemplificando algumas de suas falhas processuais e principiológicas.

Desenvolvimento: É notório que incumbe ao poder estatal observar e assegurar o funcionamento do ordenamento jurídico, visto que no estado moderno é este que monopoliza a força (WAMBIRT; ALMEIDA; TALAMINI. 1999, p.27). Baseado na ideia de trazer uma justiça mais satisfatória célere e acessível, já que segundo Marinoni (1996, p.100) a falta de acesso não permite que o cidadão liberte-se da insatisfação trazida pelo conflito, bem como fundado na Constituição Federal de 1988, foi criada a Lei 9.099/95, norteando os Juizados especiais com suas peculiaridades. Visando demonstrar as peculiaridades da a Lei 9.099/95, é importante verificar e entender os principais e inovadores princípios norteadores de tal instituto. Destacamos primeiramente o Princípio da oralidade, onde resumidamente os fatos narrados pela parte será reduzido a termo deixando de existir algumas formalidades existentes no procedimento comum, segundo Chiovenda (1945) o princípio da oralidade traz em seu bojo outros norteamentos complementares, podendo se dizer que esses princípios representam um todo incindível, no sentido de que atuação de cada princípio é necessária para que seja possível termos um processo verdadeiramente oral. Principio da Simplicidade de acordo com Tourinho Neto (2005, p.74) é que os pressupostos processuais estabelecidos devem se dar de maneira simples e informais com relação as partes durante o tramitar do processo, embora este princípio seja essencial para este instituto, muitas vezes acaba prejudicado em determinadas situações podendo até prejudicar a parte desacompanhada de advogado. O princípio da informalidade nada mais é de que atos processuais desacompanhados de tantas formalidades e não gerando nulidade do ato processual, um exemplo prático deste princípio é a parte fazendo requerimento a próprio punho presencialmente no respectivo cartório. Por sua vez o princípio da economia processual, dá acesso ao primeiro grau de jurisdição, e o demandante fica isento de pagar custas, gerando o barateamento de custos aos litigantes fundamentado na economia das despesas processuais (REINALDO FILHO, 1996, p.36), visando ainda a obtenção do máximo de rendimento da Lei como minimo de atos processuais (CHIMENTI, 2005). Princípio da celeridade segundo art. $5^{\circ}$, LXXVII da Constituição Federal de 1988, diz que o processo deve demorar o mínimo possível, mesmo sabendo que se exigem este mínimo para a tramitação natural do processo, a todos é assegurado a razoável duração do processo, e as ferramentas que proporcionam a celeridade, por muitas vezes mesmo que o JEC seja norteado por tal princípio devido ao acumulo de serventia ocorre a demora processual e muitas vezes ficando por determinado tempo paralisados os processos, e tramitando por anos, ferindo diretamente tal princípio. Princípio da equidade previsto no art $5^{\circ}$ e $6^{\circ}$ da Lei 9.099/95, visa buscar a harmonia das circunstâncias concretas sem distinção entre as partes litigantes, podendo possibilitar o ajuste da aplicabilidade da norma a depender da relação concreta, com intuito de proporcionar uma decisão ou sentença mais justa.

Conclusão: Nessa análise crítica é notória a importância e a indispensável participação do Juizado Especial Cível em relação ao acesso à justiça, abrindo portas para pessoas com poucas condições em buscarem o respaldo jurisdicional garantido constitucionalmente. Porém são visíveis algumas falhas e incompatibilidades entre a norma e a prática processual diária a qual fere os princípios conforme expostos, tornando muitas vezes o instituto não tão eficiente como deveria ser.

\section{Referências}

CHIMENTI, Ricardo Cunha.Teoria e prática dos juizados especiais cíveis estaduais e federais.São Paulo. Saraiva,2005. CHIOVENDA, Giuseppe. Instituições de Direito Processual Civil. 1 ed. São Paulo. Saraiva,1942-1945. 
MARINONI, Luiz Guilherme. Novas linhas do processo civil. São Paulo. Malheiros,1996.

REINALDO FILHO, Demócrito Ramos. Juizados Especiais cíveis. Comentários à Lei n.o 9.099/95, de 26.09.1995. $2^{\circ}$ ed. São Paulo. Saraiva. 1999.

TOURINHO NETO, Fernando da Costa e FIGUEIRA JR, Joel Dias. Juizados Especiais Estaduais Cíveis e Criminais. Comentários à Lei $\mathbf{n}^{\circ}$ 9.099/95. $5^{\circ}$ ed. São Paulo. Revista dos Tribunais, 2005.

WAMBIER, Luiz Rodrigues, ALMEIDA, Flávio Renato Correia e TALAMINI, Eduardo. Curso avançado de processo civilprocesso de execução. $2^{\circ}$ ed. São Paulo. Editora RT, 1999. Disponível em: http://www.rkladvocacia.com/juizado-especial-eaplicacao-do-novo-cpc-prolegomenos-do-novo-codigo-de-processo-civil-e-sua-aplicabilidade-nos-juizados-especiais-civeis-e-dafazenda-publica/

Coordenadoria de Pesquisa e Extensão - COPEX

Departamento de Editoraçāo e Divulgaçāo Científica - DEDIC 


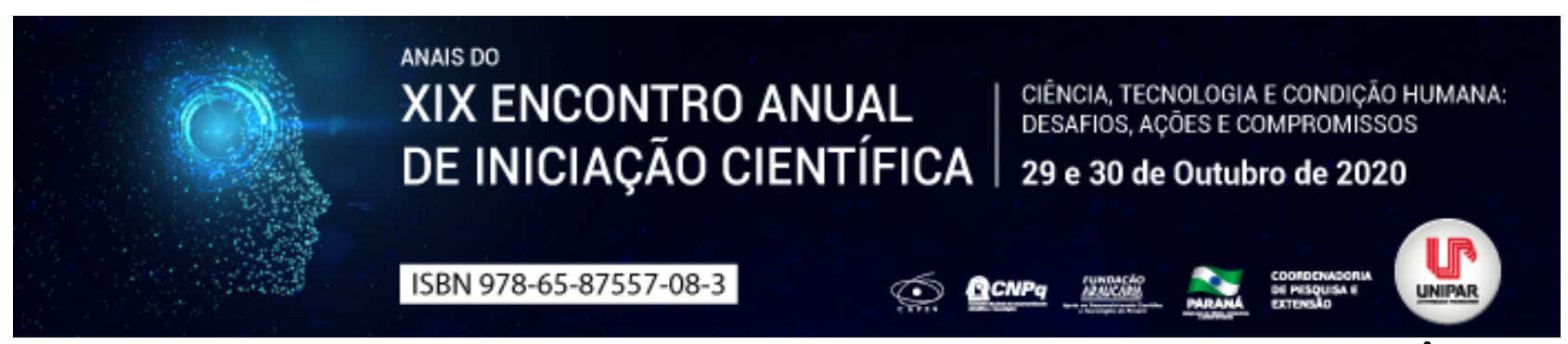

\title{
ANÁLISE SOBRE A (IM)PENHORABILIDADE DOS VALORES DEPOSITADOS EM PLANOS DE PREVIDÊNCIA PRIVADA COMPLEMENTAR
}

${ }^{1}$ MARIANA BORESKI NOVAIS, ${ }^{2}$ CELSO HIROSHI IOCOHAMA

\author{
${ }^{1}$ Acadêmica do PIC/UNIPAR \\ ${ }^{1}$ Docente da Graduação em Direito e do Programa de Mestrado em Direito Processual e Cidadania da UNIPAR
}

Introdução: Ao decorrer dos anos, a previdência privada se tornou uma garantia para o aposentado, visto que gera uma segurança econômico-financeira, bem como possui caráter alimentício, constituindo o sustento ao trabalhador aposentado.

Objetivo: Analisar o Projeto de Lei 1208/2015, que dispõe sobre a impenhorabilidade dos valores depositados em planos de previdência privada complementar, e que acrescenta o inciso XIII ao art. 833 da Lei 13.105, de 16 de março de 2015 (BRASIL, 2015).

Desenvolvimento: Nas circunstâncias atuais, os planos de previdência privada complementar tornaram-se de grande importância para o trabalhador aposentado, visto que é a garantia própria de um futuro amparado e certo. Sendo assim, é regido pelo Código de Processo Civil, Lei 13.105/2015 (BRASIL, 2015), em seu artigo 833, que a penhorabilidade não é absoluta, expondo em seu inciso IV que são impenhoráveis os vencimentos, os subsídios, os soldos, os salários, as remunerações, os proventos de aposentadoria, as pensões, os pecúlios e os montepios, bem como as quantias recebidas por liberalidade de terceiro e destinadas ao sustento do devedor e de sua família, os ganhos de trabalhador autônomo e os honorários de profissional liberal, ressalvado o $\S 2^{\circ}$ (BRASIL, 2015), sendo oponível em qualquer processo de execução civil, fiscal, previdenciária, trabalhista ou de outra natureza, salvo se movido. Visto isso, constata-se que o artigo em questão trouxe uma mudança substancial no que diz respeito ao estabelecimento da impenhorabilidade de verbas de natureza alimentar, o que consequentemente traz em destaque a questão da impenhorabilidade da previdência privada, posto que essa detém caráter alimentício, em razão dos valores lá depositados possuírem o destino de gerar um sustento ao trabalhador e sua família. Desta maneira, a Lei Complementar 109 de 29 de maio de 2001 (BRASIL, 2001) prevê a regulamentação do regime de previdência privada onde, em seu artigo 68, deixa evidente a autonomia do contribuinte que expressa que a concessão de benefício pela previdência complementar não depende da concessão de benefício pelo regime geral da previdência social, ou seja, um benefício independe do outro. (NOGUEIRA, 2013, p. 30). Dispõe, também, sobre o caráter facultativo da previdência privada, deixando a critério do contribuinte, tornar-se participante ou pedir seu desligamento, em razão de ser determinado pelo Estado somente padrões mínimos de segurança-econômico financeira e atuarial, ou seja, o Estado não pode interferir diretamente na vontade do contribuinte, apenas age estabelecendo critérios básicos caso o trabalhador opte por contribuir. Destarte, é de suma importância debater a proposta feita pelo projeto de Lei 1208/2015 (BRASIL, 2015), visto que procura garantir ao trabalhador aposentado seguridade e dignidade. Os princípios concernentes e de aplicação no âmbito da Previdência Social têm grande ligação com os da Previdência Privada e são eles: a dignidade da pessoa humana, a solidariedade, a igualdade, a liberdade, a irredutibilidade dos benefícios e da publicidade. (NOGUEIRA, 2013, p. 37). Entretanto, em um recente julgamento (BRASIL, 2014), o Superior Tribunal de Justiça, posicionou-se que é possível realizar a penhora dos créditos contidos na previdência privada, alegando que se trata apenas de um montante acumulado, que pode ser colocado e retirado a qualquer momento. Com isso, verifica-se a importância de haver a regulamentação acerca da impenhorabilidade da previdência privada, pois (...)se admitirmos a penhora dos valores contidos no plano de previdência complementar, estaríamos impondo ao cidadão devedor uma restrição inconcebível com a ordem constitucional e o princípio da isonomia(..) (NOGUEIRA, 2013, p. 42).

Conclusão: À vista disso, percebe-se que, uma vez que as pessoas depositam parte de seus fundos em uma aposentadoria privada, elas buscam estabilidade em um futuro incerto, e a penhora de toda a sua aplicação, equivaleria a uma indiferença em todo esforço que o trabalhador fez para que seu futuro fosse resguardado.

\section{Referências}

BRASIL. Lei Complementar 109, de 29 de maio de 2001. Dispõe sobre o regime de previdência complementar e dá outras providências. Diário Oficial da União, Brasília, p. 3, 29 de maio 2001.

BRASIL. Lei 13.105, de 16 de março de 2015. Código de Processo Civil. Diário Oficial da União, Brasília, p. 1, 17 mar. 2015. BRASIL. Projeto de Lei 1.208, de 22 de abril de 2015. Acrescenta o inciso XIII ao art. 833 da Lei $n^{\circ} 13.105$, de 16 de março de 2015. Câmara dos Deputados, Brasília, 22 de abril de 2015.

BRASIL. Superior Tribunal de Justiça. Embargos de Divergência em Recurso Especial n 1121719 . Parte Litigante Ricardo Ancede Gribel, Relatora Min. Nancy Andrighi, 12 fev. 2014. Diário da Justiça Eletrônico, Brasília, 04 abril 2014.

NOGUEIRA, Alexandre Guedes. Previdência Privada: Impenhorabilidade, $2013 . \quad$ Disponível em: 
http://intertemas.toledoprudente.edu.br/index.php/Direito/article/view/4375/4134 . Acesso em: 06 de jul. 2020.

Coordenadoria de Pesquisa e Extensão - COPEX

Departamento de Editoraçāo e Divulgaçāo Científica - DEDIC 


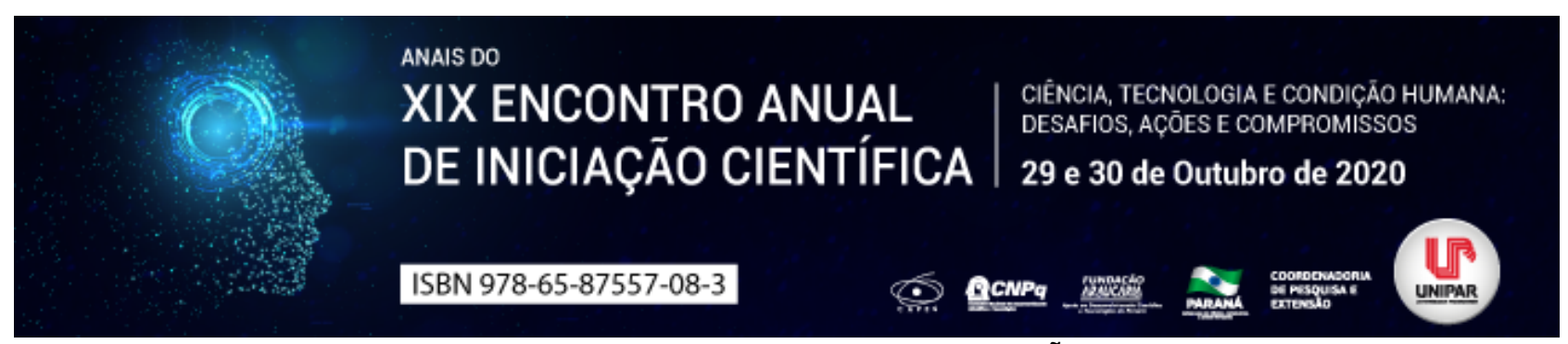

A PORNOGRAFIA E COLETIVIDADE NA PRODUÇÃO DO IDEAL

\author{
${ }^{1}$ LAIANY MAIARA QUIRINO DE PAULA, ${ }^{2}$ ANA CLARA FRANCOLIN TRENTO, ${ }^{3}$ RAFAELA GOMES LUIZ, ${ }^{4}$ MAURO SERGIO DA \\ ROCHA
}

${ }^{1}$ Acadêmica do curso de Psicologia da UNIPAR

${ }^{1}$ Acadêmica do Curso de Psicologia da UNIPAR

${ }^{2}$ Acadêmica do Curso de Psicologia da UNIPAR

${ }^{3}$ Docente da UNIPAR

Introdução: A coletividade e o conceito de inconsciente coletivo proposto pela Psicologia Analitica de Jung (2016) oferece base para uma reflexão sobre a pornografia permeando as relações sociais e culturais do indivíduo, e estabelecendo ideias e padrões adotados muitas vezes de forma inconsciente. Segundo Barros (2005), tais padrões agem como ferramentas para a construção e desconstrução do próprio ser em busca da imagem desejável, refletidos na relação com o outro, e gerando expectativas dificilmente supridas. Falamos aqui da vivência através das imagens concretas e fantasias idealizadas, e não do real apresentado.

Objetivo: Refletir como a pornografia permeia as relações sociais e culturais, produzindo ideias e padrões inconscientes.

Desenvolvimento: Considerando os estudos em psicologia, observou-se que, embora pouco debatida, a pornografia se apresenta como tema bastante presente - num universo velado, de relevância e influência no meio social. O conhecimento a respeito da pornografia pode ser erroneamente vinculado a uma visão reducionista, tornando-se comum pensá-la simplesmente como conteúdos que reproduzem relações sexuais de forma vulgar. No entanto, ao contrário do que o senso comum pode levar a pensar, não podemos limitá-la apenas a este pensamento. A pornografia aqui é compreendida como a encenação do obsceno (ob-sceno = fora de cena). Em suas mais variadas formas de percepção, normalmente vista apenas como objeto de desejo e como algo fora de cena, torna-se uma possível aliada referente ao acesso ao inconsciente individual e coletivo a fim de auxiliar na ressignificação de conteúdos. Dentro desse aspecto, o corpo e o desejo são colocados como produtos a serem consumidos. Nesta produção, a satisfação do prazer é buscada e impulsionada por uma indústria pornográfica regida pelo capitalismo, produzindo padrões sociais de conteúdos sexuais - corpo, potência, intensidade. Desta maneira, é inegável a influência dos meios de comunicação e da indústria do consumo sobre o incentivo de padrões idealizados, gerando inalcançáveis expectativas quando relacionadas ao real (RIBEIRO, M; ZORZETTO, R, 2004). Assim, nos encontramos como atores em um palco constituído por imagens pré estabelecidas, em que os sujeitos se colocam em situações nas quais não correspondem à personalidade de si mesmos. A pornografia aparece, como citado acima, nos movimentos en-cenados, naqueles em que o sujeito não se percebe. É neste processo que ele apenas satisfaz o desejo e não à totalidade de si. Em virtude disso, percebe-se que as relações são influenciadas por conteúdos inconscientes que afetam a forma do sujeito interagir consigo e com o outro. Assim, com relação à vida amorosa e à vida sexual, assistimos de um lado uma incitação constante à sexualidade e, ao mesmo tempo, a veiculação de modelos rígidos que ditam modos de ser e agir frente a esses conteúdos. Esses modelos, quando não reconhecidos e trazidos à consciência, podem ser prejudiciais ao sujeito e às suas relações, tendo em vista que serão regidos por projeções e imagens inconscientes, contrapondo-se ao autoconhecimento e autonomia do sujeito. Essa busca por desenvolvimento e autoconhecimento, Edinger (2004) afirma que o processo de individuação é uma condição em que o sujeito busca também a si através da relação com o desejo e toma consciência de suas projeções. Uma oportunidade de transcender através da integração das partes, consciente e inconscientes, a fim de reorientar e reorganizar a vida psíquica. Reconhecendo o seu modo de ser, não buscando modelos sexuais de forma compulsiva.

Conclusão: Entendemos que as representações da pornografia, pela perspectiva da psicologia analítica, movimentam conteúdos que influenciam o sujeito, de modo a produzir fantasias eróticas que podem ser vivenciadas por ele de maneira negativa ou positiva. Assim, considerando o processo de individuação e sua relação com a coletividade, cabe ao sujeito o reconhecimento de si, em meio às tantas imagens que entrelaçam o campo inter-relacional. É a partir disso que o sujeito pode, então, se diferenciar do coletivo e buscar sua própria existência, tomando consciência das projeções (BARROS, 2005). Neste contexto, a análise simbólica desses conteúdos pode colaborar com o sujeito, fazendo com que o mesmo se perceba nesse emaranhado de situações, ideais e reais, conscientes e inconscientes, objetivando uma conexão entre seu corpo e a relação com a própria sexualidade.

\title{
Referências
}

BARROS, Daniela Dias. Imagem corporal: a descoberta de si mesmo. História, Ciência, Saúde. Rio de Janeiro, v. 12, p. 547- 
54, 2005.

EDINGER, Edward F. Ciência da alma: uma perspectiva junguiana. São Paulo: Paulus, 2004.

JUNG, Carl Gustav. O homem e seus símbolos. 3. ed. Rio de Janeiro: HarperCollins Brasil, 2016.

RIBEIRO, Marili; \& ZORZETTO, Ricardo. O avesso de Narciso. São Paulo: Revista Pesquisa Fapesp, 2004.

Coordenadoria de Pesquisa e Extensão - COPEX

Departamento de Editoraçāo e Divulgaçāo Científica - DEDIC 


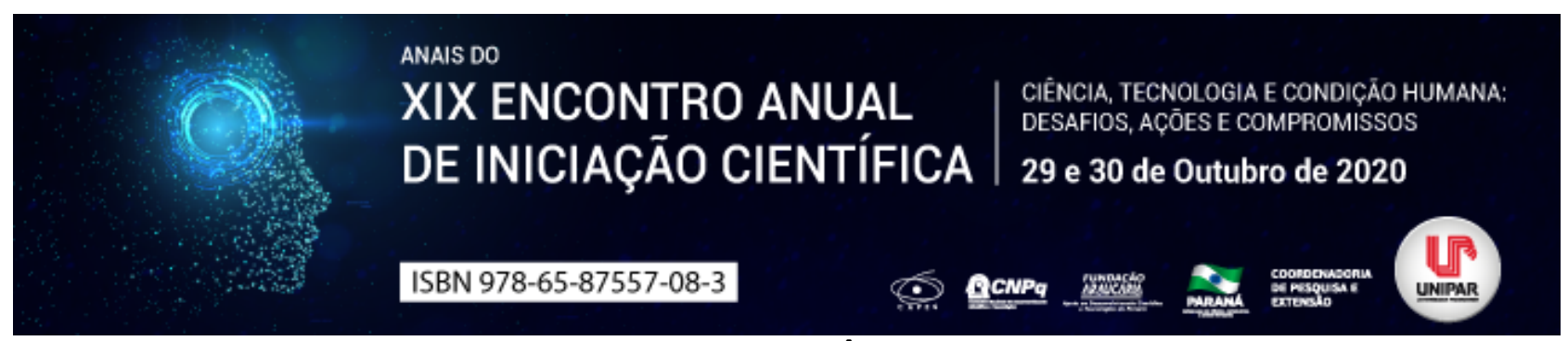

O TRABALHO ESCRAVO CONTEMPORÂNEO E A DIGNIDADE HUMANA

\title{
${ }^{1}$ EDUARDA BORGES SILVA, ${ }^{2}$ BRUNO SMOLAREK DIAS
}

\author{
${ }^{1}$ Acadêmico do PIC/UNIPAR \\ ${ }^{1}$ Docente da UNIPAR
}

Introdução: Os direitos fundamentais estão intimamente ligados a dignidade humana, e estão assegurados no art. $5^{\circ}$ da Constituição Federal (CF) vigente, dentre essas garantias, está o direito à liberdade, onde todos possuem o direito de ir e vir, bem como, o direito à opinião, informação e escusa de consciência, contudo, muitos trabalhadores ainda são submetidos a situações que os privam de sua liberdade.

Objetivos: Analisar o contexto de trabalho escravo na atualidade e observar as situações indignas que esses trabalhadores estão sujeitos a enfrentar.

Desenvolvimento: O Brasil foi um dos últimos países a abolir a escravidão, com a Lei № 3.353 de 13 de maio de 1888, conhecida como Lei Áurea, que declara a extinção da escravidão no Brasil (BRASIL, 1888) porém, mesmo após o seu fim, é possível observar muitos casos em que trabalhadores até hoje são submetidos a situações análogas à escravidão. Segundo relatos de trabalhadores que vivenciaram essas situações, os mesmos eram atraídos pelas falsas promessas de emprego e bom salário. E após aceitarem as propostas e irem para o local de trabalho, o trabalhador não tem mais a opção de desistir do emprego e passam a viver em condições precárias de moradia e alimentação, além de não receberem seu salário da maneira que deveriam. No ano de 2000, vários trabalhadores foram iludidos e levados para a Fazenda Brasil Verde, onde viveram em situações indignas e humilhantes de trabalho. Em 2016 a Corte Interamericana de Direitos Humanos condenou o Brasil pelas práticas de trabalho forçado e violação de direitos por estes fatos ocorridos na fazenda (CIDH, 2016, p. 122). No documento conhecido como Lista Suja, são divulgados pela administração pública nomes de pessoas que sofreram autuação administrativa em razão da exploração da mão-de-obra, ou seja, casos em que empregadores submetem os seus empregados a situações humilhantes, que se configuram como trabalho análogo à escravidão. Segundo dados do Radar da Subsecretaria de Inspeção do Trabalho, em 2019, foram encontrados mais de mil trabalhadores vivendo em condições análogas a de escravo (2019). Depois de resgatado, o Poder Público passa a analisar medidas que auxiliem esse trabalhador a se inserir de volta na sociedade e essas medidas também se configuram como uma forma de combate ao trabalho escravo contemporâneo, formas estas que serão amplamente abordadas no trabalho completo que futuramente será publicado.

Conclusão: Pelas colocações apresentadas, e pela própria natureza do Direito que estabelece um comportamento ideal dentro de uma determinada sociedade, existe uma infeliz separação entre o comportamento idealizado chamado de l"dever serl" e a triste realidade, na qual ainda nos defrontamos com situações de violação dos mais básicos direitos dos seres humanos, em especial o de ser tratado como um ser humano e não um objeto, uma ferramenta ou um instrumento de trabalho. São estas as concepções que precisam ser alteradas, que precisam ser socialmente corrigidas, e para as quais o direito auxilia, mas precisa ser complementado com um trabalho e conscientização social para que vejamos efetiva mudança.

\section{Referências}

BRASIL. LEI IMPERIAL No 3.353 DE 13 DE MAIO DE 1888. DECLARA EXTINTA A ESCRAVIDÃO NO BRASIL. Rio de janeiro: Paço do Senado, [1888]. Disponível em: http://www.planalto.gov.br/ccivil_03/leis/LIM/LIM3353.htm. Acesso em: 15 jul. 2020.

BRASIL. Portal da Inspeção do Trabalho. Mais de 1 mil trabalhadores foram resgatados de situação análoga à escravidão no país em 2019. Brasília, 2020. 5 p. Disponível em: https://sit.trabalho.gov.br/radar/. Acesso em: 06 jul. 2020

CORTE INTERAMERICANA DE DIREITOS HUMANOS. Sentença de 20 de outubro de 2016. Execuções preliminares, mérito, reparação

e custos.

Disponível

em:

http://www.itamaraty.gov.br/images/Banco_de_imagens/Sentenca_Fazenda_Brasil_Verde.pdf. Acesso em: 20 jul. 2020. 


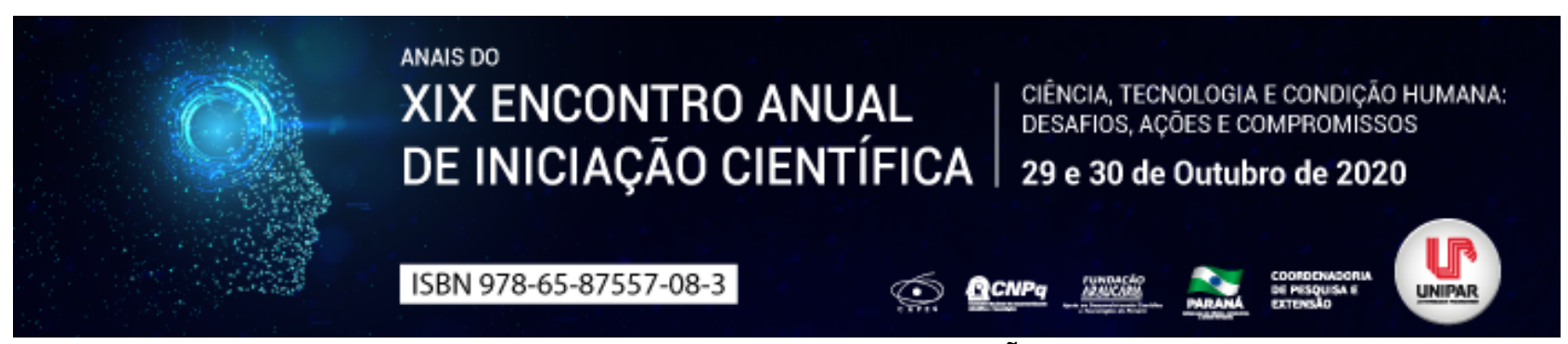

\title{
OS REFLEXOS DO DECRETO 2.673/2019 SOBRE OS CUSTOS DE AQUISIÇÃO E OS PREÇOS DE VENDA DE POLPAS DE FRUTAS E AÇAÍS
}

\section{${ }^{1}$ RENATA BISSI DE OLIVEIRA, ${ }^{2}$ FRANCIELE DO PRADO DACIÊ}

\author{
${ }^{1}$ Contadora na Metha Consultoria Empresarial \\ ${ }^{1}$ Professora na Universidade Estadual de Maringá
}

Introdução: O ambiente cada vez mais competitivo traz desafios às organizações, sobretudo nas decisões de gestão dos custos e prática de preços. Esse cenário, aliado a complexa regulação tributária, requer dos empresários empenho para manutenção do sucesso no mercado (ZUCCOLOTTO; COLODETI FILHO, 2007). Sabe-se que os impostos incidentes sobre as operações podem exercer efeito significativo no valor de aquisição e venda de mercadorias. Dentre as arrecadações de impostos, o ICMS tem a receita tributária mais expressiva, é um dos impostos que mais sofrem mudanças na legislação paranaense (IBPT, 2019; ROCHA, 2016) e é regulamentado pelo Decreto $n^{\circ}$ 7.871/2017 (RICMS PR, 2017). Quando na modalidade de ICMS substituição tributária (ICMS ST), por exemplo, o recolhimento único pode refletir no preço de repasse dos itens ao longo de toda sua cadeia de valor (Dornelles et al. 2015). Dessa forma, acredita-se que as alterações relativas a incidência desse imposto sobre a comercialização afeta as práticas empresariais.

Objetivo: Analisar o reflexo do Decreto 2.673/2019, no qual exclui o ICMS substituição tributária das polpas de frutas e açaís, sobre os custos das mercadorias e a formação do preço de venda.

Material e métodos: A pesquisa é realizada com dados de uma empresa que atua no comércio atacadista de polpas de frutas e açaís, localizada no Paraná e optante pelo regime de tributação lucro real. A comercialização de polpas de frutas e açaís ocorre somente no Paraná e representa 50\% do faturamento da empresa. A base de dados são as notas fiscais do período de 2019 transações de um mesmo fornecedor, também optante pelo lucro real. A base de cálculo empregou o comércio de pacotes com 1 $\mathrm{kg}$ de polpa de frutas e potes de 220 gramas de açaís. Foram analisados os tributos incidentes na operação (ICMS ST, ICMS normal, PIS, COFINS) para apurar o valor de aquisição e preço de venda. Assim, verificou-se os reflexos monetários nas operações em que haviam a incidência do ICMS ST (antes do Decreto 2.673/2019) e com o ICMS normal (após a vigência do Decreto 2.673/2019). O preço de venda foi calculado a partir do mark-up, pois é considerado o método mais tradicional entre os gestores (BRUNI; FAMÁ, 2003; SANTOS, 2005; MARTINS, 2010). O mark-up divisor incluiu os impostos incidentes na operação de venda; as despesas fixas; as comissões sobre vendas e lucro desejado.

Resultados: Os achados do estudo mostram que nas operações com ICMS ST o custo de aquisição das polpas de frutas foi de $\mathrm{R} \$ 40,32$, e dos açaís de $\mathrm{R} \$ 7,34$. O ICMS ST torna-se parte do custo de aquisição e é posteriormente distribuído ao comércio varejista. No entanto, as próximas operações tornam-se isentas do recolhimento de ICMS. No cálculo com incidência de ICMS normal, o custo de aquisição de polpas de frutas foi de $R \$ 29,85$, e dos açaís de $R \$ 5,44$. Nesse procedimento, o distribuidor compensa os créditos relativos ao ICMS normal e recolhe o valor devido na venda. Diante disso, os resultados mostram que a exclusão do regime de ICMS ST gera uma redução média de $25,98 \%$ no valor de aquisição. O mark-up aplicado como divisor do custo das mercadorias quando sujeitas ao regime de ICMS ST foi 0,5375; enquanto no regime de ICMS normal foi 0,4175. A incidência de ICMS ST nas operações fez com que os preços de venda das polpas de frutas fossem de $R \$ 75,03$ e dos açaís de $\mathrm{R} \$ 13,66$. Com a exclusão do ICMS ST, verificou-se que os preços de venda das polpas de frutas passaram a ser de $\mathrm{R} \$ 71,50$, e dos açaís de $\mathrm{R} \$ 13,02$. Isso mostra uma redução média de $4,70 \%$ sobre o preço de venda a partir da exclusão do ICMS ST nas operações.

Discussão: Os achados dessa pesquisa mostram empiricamente o exposto por Costa e Barroso (2020), que descrevem que o emprego do ICMS ST impede que os contribuintes se beneficiem do crédito nas operações posteriores ao recolhimento. Assim como evidenciado em estudos anteriores, o desembolso antecipado provocado pelo ICMS ST onera o primeiro contribuinte, aumentando o custo dos produtos e o preço de venda. Como consequência, ocorre a diminuição da margem de contribuição e seus efeitos no fluxo de caixa, capital de giro e lucratividade dos negócios (FERREIRA; LORANDI; IMBRÓSIO, 2011; DORNELLES et al. 2015; MATTOZO; KLOSOWSKI, 2015; CORREIA et al., 2016). Os resultados mostram também que a interferência do governo estadual na economia tributária tem impacto direto nos custos das mercadorias e nos preços de vendas. Conclusão: Sabe-se que a constituição de uma política de preços de venda é assunto complexo, pois depende de fatores exógenos, como potenciais consumidores, mercado de atuação, criação de interesse no produto e condições de atuação. No entanto, uma análise tributária que identifique como as mudanças na legislação alteram custos e preços de venda é necessária às empresas que sofreram alterações de enquadramento tributário nos seus produtos. Assim, considerando a necessidade da gestão das operações e da análise dos reflexos que as legislações exercem sobre os preços praticados, acredita-se na potencial contribuição dos resultados para aplicação e reflexão empírica, uma vez que estimula o emprego na análise tributária como 
ferramenta de competitividade e propensão ao sucesso no mercado de atuação.

\section{Referências}

BRUNI, A. L.; FAMÁ, R. Gestão de custos e formação de preços: com aplicação na calculadora HP 12C. 2 ed. São Paulo: Atlas, 2003.

CORREIA, J. J. A. et al. O Impacto do ICMS Substituição Tributária no Custo das Mercadorias Adquiridas pelo Comércio Varejista de Alimentos. Id on Line Revista Multidisciplinar e de Psicologia, n.10, v.32, 2016.

COSTA, K. G. M.; BARROSO, K. A. O efeito da substituição tributária do ICMS que incide sobre a Pessoa Jurídica. Revista Científica Multidisciplinar Núcleo do Conhecimento, v.1, n.2, 2020.

DORNELLES, M. T, et al. Efeitos da adoção do regime de substituição tributária do ICMS na cadeia vinícola do vale dos vinhedos. Revista Ambiente Contábil, v.7, n.2, p.135-152, 2015.

FERREIRA, L. F.; LORANDI, J. A.; IMBRÓSIO, M. A. ICMS por Substituição Tributária e a formação do preço de venda de artigos de Papelaria. In: CONGRESSO BRASILEIRO DE CUSTOS, 18; 2011. Anais... Rio de Janeiro, 2011.

INSTITUTO BRASILEIRO DE PLANEJAMENTO TRIBUTÁRIO, IBPT. Boletim do Impostômetro mostra que ICMS tem a maior fatia de impostos recolhidos no país. Mato Grosso Econômico, 30 ago. 2019.

MARTINS, E. Contabilidade de Custos. 10 ed. São Paulo: Atlas, 2010.

MATTOZO, M. A.; KLOSOWSKI, A. L. M. ICMS - ST e MVA: um estudo dos reflexos do imposto na formação do preço de venda no setor de revenda de peças. In: CONGRESSO EMPRESARIAL DOS PRESTADORES DE SERVIÇO; 2015. Anais... Ponta Grossa, 2015.

PARANÁ. Decreto no 2.673/2019, de 10 de setembro de 2019. Diário Oficial do Estado, 10 set. 2019.

PARANÁ. Decreto no 7.871/2017, de 29 de setembro de 2017. Diário Oficial do Estado, n.10041, 3 out. 2017.

ROCHA, A. I. ICMS é tributo que mais contribui para cofres públicos. Exame, 8 jul. 2016. Disponível em: https://exame.abril.com.br/economia/icms-e-tributo-que-mais-contribui-para-cofres-publicos/. Acesso em: 06 maio 2020.

SANTOS, J. J. Fundamentos de custos para a formação do preço e do lucro. 5 ed. São Paulo: Atlas, 2005.

ZUCCOLOTTO, R.; COLODETI FILHO, E. Gerenciamento de preços em empresas de pequeno porte por meio do custeio variável e do método de Monte Carlo. Enfoque Reflexão Contábil, v. 26, n. 3, p. 39-52, 2007. 


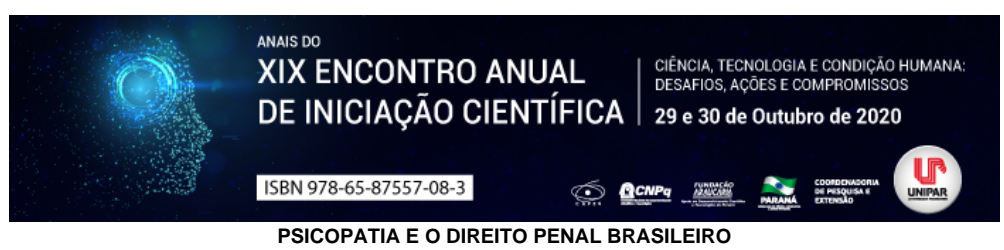

${ }^{1}$ DHEBORA CANDIL DA FONSECA, ${ }^{2}$ BARBARA COSSETTIN COSTA BEBER BRUNINI

${ }^{1}$ Acadêmica do Curso de Direito Unipar

${ }^{1}$ Docente da UNIPAR

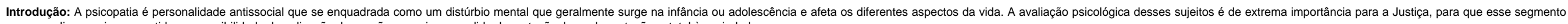
possa analisar o crime cometido e a possibilidade de aplicação de sanções penais ou medida de proteção, levando proteção estatal à sociedade.

Objetivo: Discorrer sobre psicopatia e as possíveis aplicações do Código Penal perante sujeitos acometidos por essa patobja.

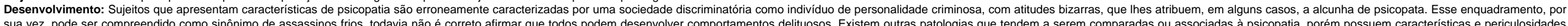

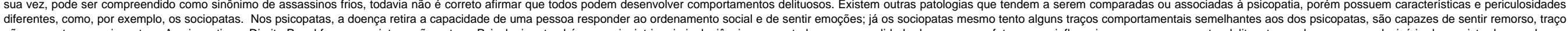

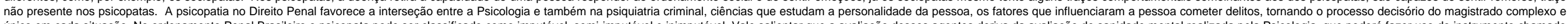

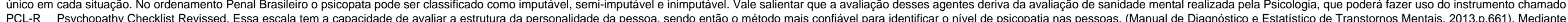

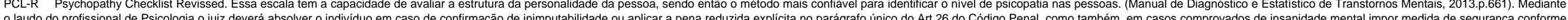

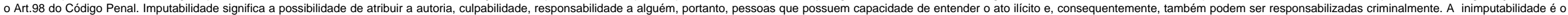

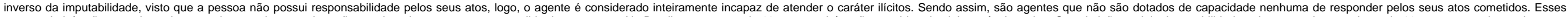

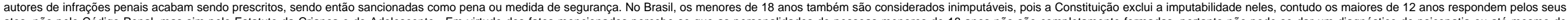

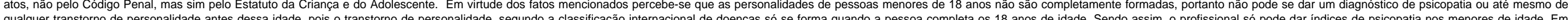

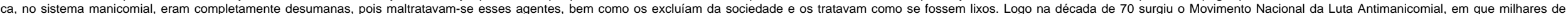

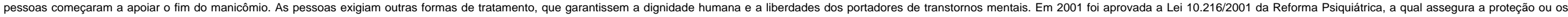
direitos da pessoa, seja civis, econômicos, proteção contra qualquer forma de discriminação e etc. em pessoas acometidas de transtornos mentais. Portanto, no Brasil é possivel sim aplicar uma medida para que esses agentes possam cumprir o seu ato iliciti.

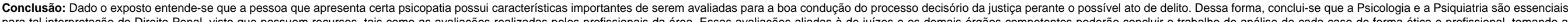

Referências
AMERICAN PSYCHIATRIC ASSOCIATION (2014). Manual Diagnóstico e Estatístico de Transtornos Mentais. DSM-V.2013. 5a. Ed. Porto Alegre: Artmed.

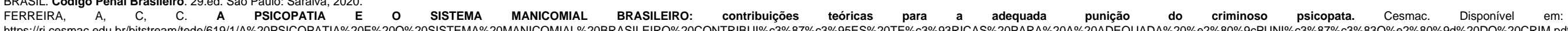

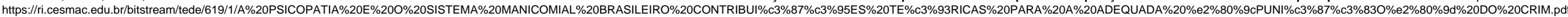

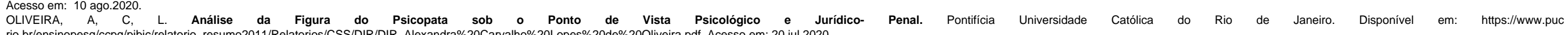
rio.br/ensinopesq/ccpg/pibic/relatorio_ resumo2011/Relatorios/CSS/DIR/DIR_Alexandra\%20Carvalho\%20Lopes\%20de\%200liveira.pdf. Acesso em: 20 jul.2020.
OLIVEIRA,F.A.A. Psicopatas e o Direito Penal Brasileiro. Repositório Unitau. Disponivel em: http://repositorio.unitau.br:808//spuilbitstream/20.500.11874/3596/1/TG-Fernando_Ap.pdfAcesso em: 15 jul.2020. 


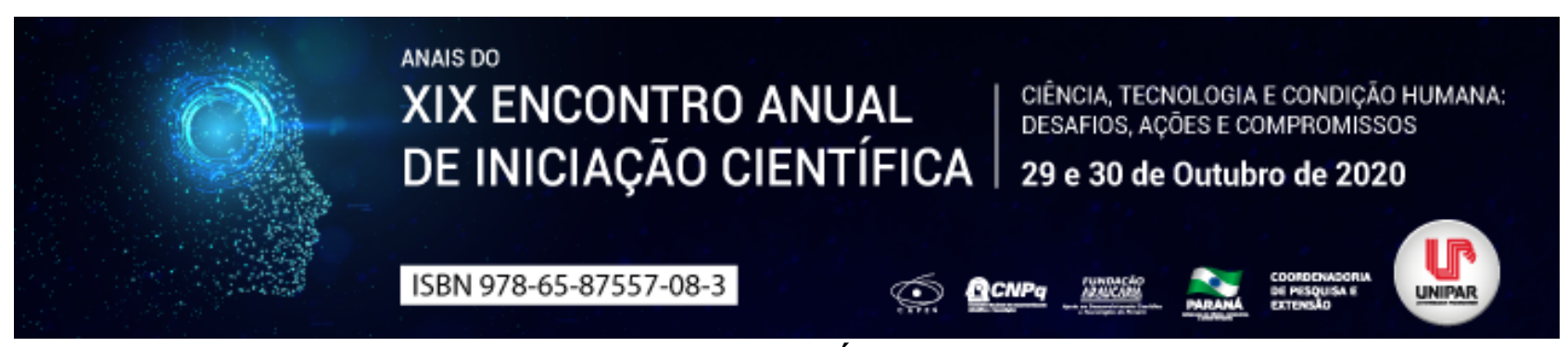

NEOCONSTITUCIONALISMO E O CÓDIGO DE PROCESSO CIVIL

\title{
1'LETICIA DO NASCIMENTO GOBETTI, ${ }^{2}$ EDUARDO AUGUSTO SALOMAO CAMBI
}

\author{
${ }^{1}$ Acadêmico bolsista do PIBIC/UNIPAR \\ ${ }^{1}$ Docente da UNIPAR
}

Introdução: Este artigo, como uma pesquisa bibliográfica, procura analisar o neoconstitucionalismo e código de processo de civil, tais como seus pontos positivos e mudanças trazidas, mostrando que esse vem para adequar o pós-positivismo junto à realidade social presente nos dias atuais, demonstrando também a influência do neoconstitucionalismo sobre o código processual, assim evitando que o direito fique atrasado frente ás mudanças e a evolução jurídica do Brasil. Tem-se que o neoconstitucionalismo, foi desenvolvido na Europa, depois da segunda guerra mundial, e assim, como consequência, surgiu o Estado democrático de direito, como explica Luís Roberto Barroso (2007, p. 2).

Objetivo: Fazer o detalhamento de como o processo civil, foi transformando após o Neoconstitucionalismo.

Desenvolvimento: Como já é visto, como abordam muitos doutrinadores, o movimento Neoconstitucionalismo, possui uma significação baseada em uma forma diferente de fazer a interpretação do direito, fazendo uma ampliação dos princípios redigidos pela Constituição Federal, e possuindo uma amplitude em relação a isso, tendo como objetivo explanar por todos os setores que o direito pertence, a basilar Constituição Federal, fazendo assim, com que esse movimento se torne essencial a toda a sociedade. O Neoconstitucionalismo, como dito, é um movimento que nasceu após o fim da Segunda Guerra Mundial, e possuía o dever de uma nova interpretação da Constituição, dando a ela, maior força, e valoração assim, aqui cita-se, que é frente ao Código de Processo Civil. O Neoconstitucionalismo, com seu embasamento na Constituição Federal, vem para fazer a demonstração de que no âmbito jurídico, é necessário que sempre hajam mudanças para que assim, venha a existir uma adequação frente a sociedade que a cada século vem a mudar, de modo a analisar que o Constitucionalismo, sozinho, não conseguiria obter um resultado objetivo e positivo diante das mudanças necessárias, e não seria capaz de deixar que se realize a ativismo judicial, quando o legislador possui um papel maior frente ao âmbito jurídico. Em relação ao direito processual civil, está associado com a ampliação de direitos presentes na Constituição, junto ao Código de processo civil. Analisando os artigos do código, é possível perceber que a Constituição se faz presente, de forma a constituir uma realização, pois segue que o Código de Processo Civil será ordenado, de forma a consolidar os contidos na Constituição Federal. Dessa forma, pode-se reconhecer que pontos positivos são muito perceptíveis, levando em consideração que para a sociedade é de grande valor, a modificação realizada, tornando os princípios, parte do processo civil. Como visto no artigo primeiro, do Código de Processo Civil, Lei $\mathrm{n}^{\circ}$ 13.105, de 16 de março de 2015: Art. $1^{\circ}$ O Processo civil será ordenado, disciplinado e interpretado conforme os valores e as normas fundamentais estabelecidos na Constituição da República Federativa do Brasil, observando-se as disposições deste Código. Assim, no novo código de processo civil, está presente com muita clareza os princípios da Constituição Federal, tornando desta forma, enorme importância ao legislador, observar sempre esses princípios que regem o âmbito jurídico, adequando as formas da Constituição Federal e agora do Código de processo civil, não podendo agir de forma a desvincular isso, sendo que essa exclusão pode gerar prejuízos a quem se destina, e com essa inclusão, pode-se gerar ao legislador e julgador, uma ampliação do seu papel.

Conclusão: Assim, caberá ao julgador, fazer o julgamento com base nos artigos do Código de Processo Civil, com a junção da Constituição, possuindo assim os efeitos que são almejados, buscados para satisfazer de forma solida a concordância da Constituição, que visa à conservação dos princípios, e esclarece os caminhos a serem adotados para que assim, dentro do processo, não haja o isolamento de alguns fatores importantes para a sociedade, favorecendo assim, ao chamado ativismo judicial, procurando e gerando ao legislador uma ampla participação ao processo. $O$ direito processual é aberto a grandes avanços, sendo um deles, o Neoconstitucionalismo, e esse, faz à revisão de categorias processuais, trazendo ao mundo jurídico, novas concepções. Assim, o magistrado, deve elaborar uma conjunção de meios para o processo se tornar o mais correto que puder, e ser fonte de direitos fundamentais que forem possíveis de aplicação, norteados pela Constituição Federal. Portanto, devem os legisladores sempre fazer o uso dos direitos fundamentais e da constituição. Assim, o poder judiciário passa a ser de extrema importância para a aplicação dos direitos fundamentais, trazendo-o para o Código de Processo civil.

\section{Referências}

BARROSO, Luís Roberto.Neoconstitucionalismo e constitucionalização do Direito: O triunfo tardio do Direito Constitucional no Brasil .2007. Disponível em: Disponível em: https://www.migalhas.com.br/arquivo_artigo/art04102005.htm. Acesso em 12 de Agosto de 2018.

BRABILLA, Leandro Vilela. O que se entende por neoconstitucionalismo? 2009. Disponível em: https://ffg.jusbrasil.com.br/noticias/1764534/o-que-seentende-por-neoconstitucionalismo-leandro-vilela-brabilla. Acesso em: 18 de Julho de 2018.
CAMBI,
Eduardo.
NEOCONSTITUCIONALISMO
E
NEOPROCESSUALISMO.
2008.
Disponível
em: 
https://files.cercomp.ufg.br/weby/up/662/o/Eduardo_Cambi_Neoconstitucionalismo_e_Neoprocessualismo.pdf. Acesso em 10 de Agosto de 2019. CARLUCCI, Stéfano Di Cônsolo. A influência do neoconstitucionalismo na Constituição Federal de 1988 e a constitucionalização do Direito Civil no Brasil. 2018. Disponível em: https://www.migalhas.com.br/depeso/271756/a-influencia-do-neoconstitucionalismo-na-constituicao-federal-de-1988-e-aconstitucionalizacao-do-direito-civil-no-brasil. Acesso em 10 de Agosto de 2019.

BRASIL. Novo Código de Processo Civil. Lei $\mathrm{n}^{\circ}$ 13.105, de 16 de Março de 2015. Brasília, DF: Senado, 2015, p. 89. Disponivel em: http://www2.senado.leg.br/bdsf/handle/id/507525. Acesso em: 20 de Agosto de 2018.

FIGUEIREDO, Filipe Borges de França et al. O Neoconstitucionalismo e o Estudo das Fontes do Direito: 0 novo cpc e a consolidação da jurisprudenia na concretização do direito. 2018. Disponível em: https://indexlaw.org/index.php/teoriasdireito/article/view/4433. Acesso em: setembro de 2018.

LOPES JUNIOR, Jaylton Jackson de Freitas. O novo codigo de processo civil: Construindo uma nova perspectiva metodológica para o processo a partir das influências do Neoconstitucionalismo. Junho de $2015.20 \mathrm{Disponível}$ https://www.lexml.gov.br/urn/urn:lex:br:rede.virtual.bibliotecas:artigo.revista:2015;1001044637. Acesso em: 20 de Julho de 2018.

Coordenadoria de Pesquisa e Extensão - COPEX

Departamento de Editoraçāo e Divulgaçāo Científica - DEDIC 


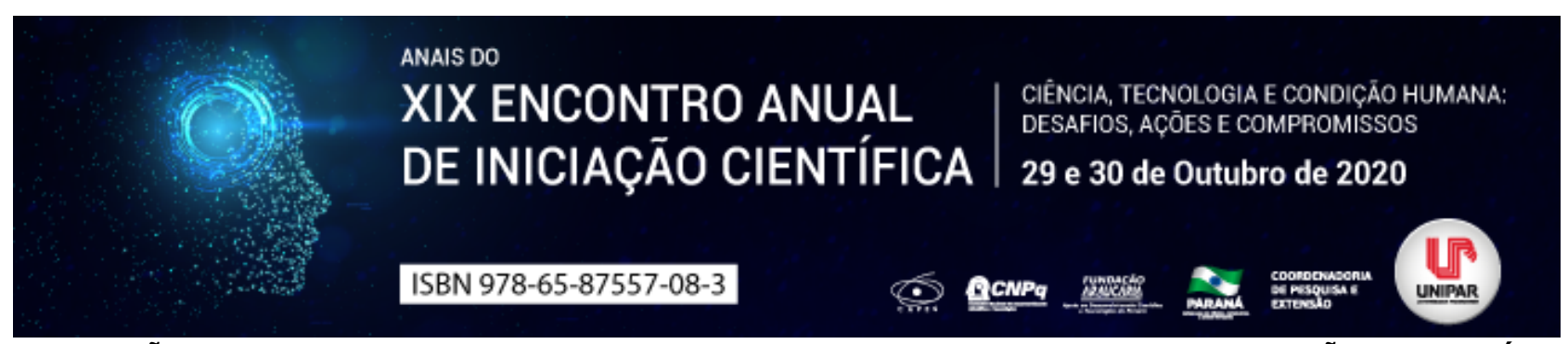

\title{
A ESTABILIZAÇÃO DA TUTELA ANTECIPADA ANTECEDENTE E POSSIBILIDADE DE DISCUSSÃO DA MATÉRIA APÓS TRÂNSITO EM JULGADO DA SENTENÇA ESTABILIZADORA
}

${ }^{1}$ AMANDA ROMANO GASPARETO, ${ }^{2}$ FABIO FERREIRA BUENO

\author{
${ }^{1}$ Acadêmica do PIC/UNIPAR \\ ${ }^{1}$ Docente da UNIPAR
}

Introdução: Dentre as inovações implementadas pelo Código de Processo Civil de 2015, cabe destacar o surgimento da tutela antecipada antecedente. A temática demanda, ainda, discussões acerca das possibilidades da estabilização, a doutrina em sua maioria defende que a estabilização se tornará imutável após o decurso do prazo decadencial para propositura da ação específica, com a exceção a propositura de uma ação rescisória.

Objetivo: Explanar estabilização da tutela antecipada antecedente e a discussão doutrinária que circunda o instituto, especialmente quanto à possibilidade de rescisão da decisão estabilizadora.

Desenvolvimento: Com o advento do novo Código de Processo Civil, respaldado nos princípios processuais e constitucionais já vigorantes como da celeridade e a segurança jurídica, o instituto da tutela antecipada também passou por incisiva modificação. De acordo com a irrefutabilidade processual e o risco ao perecimento do objeto ao qual o processo circunda, a tutela antecipada surge com nova roupagem para fornecer proteção e maior satisfação à parte. Como forma de exacerbar as novidades inseridas, a tutela antecipada antecedente é utilizada quando há a necessidade de antecipar-se os efeitos da futura sentença, de tal forma ratifica Neves (2016, p.439): a antecipação é dos efeitos práticos que seriam gerados com a concessão definitiva da tutela pretendida pelo autor e não da tutela jurisdicional em si. [...], mas sim os efeitos que essas tutelas geram no plano dos fatos. encontrando respaldo nos artigos 303 e 304 do CPC, exteriorizando caráter incidental, se limita a demonstração do gênero de urgência, prospectando, futuramente, pedir-se a tutela definitiva, adiantando, assim, seus efeitos sendo impreterível a demonstração da tutela final. O pedido de antecipação e a ação, contudo, devem se submeter aos pressupostos e condições processuais; nesse sentido, aduz, Araújo (2016, p. 996) o pedido deverá preencher os pressupostos processuais e as condições de ação que atuam como requisitos essenciais para permitir o início e a formação da relação processual. Essa verificação é essencial, pela possibilidade de estabilização da tutela de urgência (art. 304 CPC). O conflito doutrinário existente sobre tal instituto versa sobre a definitiva estabilização da tutela antecipada antecedente, após decorrido o prazo decadencial, pois, uma vez estabilizada a mesma continua exaurindo seus efeitos, com exceção a propositura de uma ação rescisória, segundo art. $304 \S 3^{\circ}$ o direito de ser revista, reformada ou invalidada por decisão de mérito proferida na ação de que trata o $\S$ $2^{\circ}$, de tal forma, segundo o entendimento de Talamini (2016, p.836) o direito de rever, reformar ou invalidar a decisão concessiva da tutela antecipada estabilizada submete-se ao prazo decadencial de dois anos (art. 404, $\$ 5^{\circ}$ do CPC/2015). Hegemonicamente, entende a doutrina majoritária, que mesmo após o decurso do prazo de dois anos previsto no artigo $304 \S 5^{\circ}$ do CPC, a estabilização não caracteriza coisa julgada, ratificando Didier (2016, p.625) a estabilização da tutela satisfativa antecedente não se confunde com a coisa julgada , evidenciado que trata-se de mera tutela provisória concedida, não podendo ser declarado que houve de fato um julgamento, afinal, fica a critério do magistrado estabelecer a extinção do processo sem que haja resolução de mérito, assentuando assim Araújo (2016, p.1002) o esgotamento do prazo de dois anos abre novo prazo, mas agora para propositura de ação rescisória , sendo possível justamente pela previsão que traz a própria estabilização da tutela, desde que presente o expresso no artigo 966 do CPC excepcionalmente no $\$ 2^{\circ}$, I do mesmo artigo, é reconhecido expressamente a contingência da rescisão que decai sobre decisão transitada em julgado.

Conclusão: É conclusivo, que com a necessidade de readequação da legislação processual, novos institutos foram inseridos no meio jurídico, a tutela antecipada antecedente, sendo uma dessas novidades, ainda traz consigo grande discussão acerca da estabilização e seus efeitos no âmbito jurídico, sendo certo que a doutrina dominante tem se posicionado favorável à rescisão da sentença estabilizadora mesmo quando decorrido o prazo decadencial de que trata o art. 304 , § $5^{\circ}$, do CPC.

\section{Referências}

ARAÚJO, Fábio Caldas. Curso de Processo Civil: Parte Geral. Tomo I. São Paulo: Malheiros, 2016.

BRASIL. Código de Processo Civil. Brasília 16 de março de 2015. Disponível em: http://www.planalto.gov.br/ccivil_03/_ato20152018/2015/lei/l13105.htm. Acesso em: 23 de jun de 2020.

DIDIER JUNIOR, Fredie; BRAGA, Paula Sarno; OLIVEIRA, Rafael Alexandria de. Curso de Direito Processual Civil: teoria da prova, direito probatório, decisão precedente, coisa julgada e tutela provisória. 11. ed. Salvador: Jus Podivm, 2016.

NEVES. Daniel Amorim Assumpção. Manual de Direito Civil volume único. 8. ed. Salvador: Jus podivm, 2016.

WAMBIER, Luiz Rodrigues; TALAMINE, Eduardo. Curso Avançado de processo Civil: Cognição Jurisdicional (processo 
comum de conhecimento e tutela provisória). 16. ed. 2.v. São Paulo: Revista dos Tribunais, 2016.

Coordenadoria de Pesquisa e Extensão - COPEX

Departamento de Editoraçāo e Divulgaçāo Científica - DEDIC 


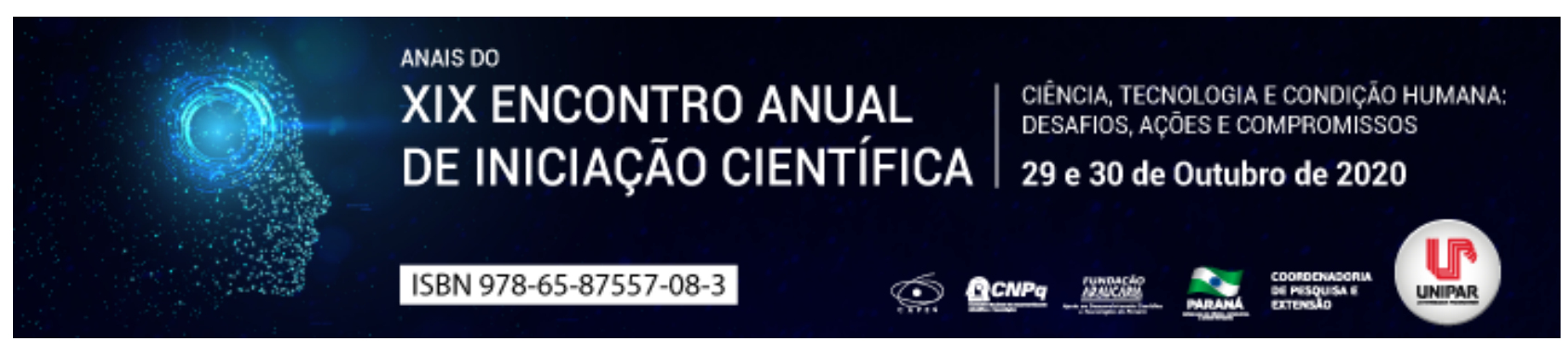

O DIREITO À DIFERENÇA E O ACESSO À IGUALDADE DE DIREITOS

\title{
${ }^{1}$ NATAN GALVES SANTANA, ${ }^{2}$ TEREZA RODRIGUES VIEIRA
}

\author{
${ }^{1}$ Mestrando em Direito Processual e Cidadania da UNIPAR \\ ${ }^{1}$ Docente do Mestrado em Direito Processual e Cidadania na UNIPAR
}

Introdução: A Constituição Federal de 1988 elenca no art. 5, que todos são iguais perante a lei, entretanto, é evidente a diferença da população brasileira, uma vez que estamos diante do multiculturalismo e do pluralismo, onde todas as pessoas buscam o respeito ao reconhecimento do direito à diferença. $\mathrm{O}$ direito de ser diferente pode ser definido como a possibilidade, a vontade ou a liberdade que todos têm de ter características ou atitudes distintas daquelas pessoas com as quais convive em sociedade.

Objetivo: Identificar e analisar o direito à diferença no ordenamento jurídico brasileiro como acesso e garantia à igualdade de direitos.

Desenvolvimento: Preliminarmente, convém elencar que o direito à diferença possui ligação com os direitos humanos, os quais surgiram após a $2^{\mathrm{a}}$ Guerra Mundial, marcada por acontecimentos bárbaros ocasionados pela intolerância à diferença e, nesse cenário, surge a importância da proteção da diversidade, também conhecida como grupos minoritários. Nesse aspecto, Martins e Mituzani (2011) elencam que a democracia não é apenas o governo da maioria, pois abrange as diversas visões existentes em uma comunidade, sendo que a Constituição Federal (1988) amplia as demandas sociais com o respeito às diferenças, preservando as minorias, uma vez que também fazem parte no processo democrático. Para Ramos (2020) a igualdade é o desejo de uma vida digna, pois busca um tratamento sem discriminação. A igualdade foi o marco das Declarações de Direitos do século XVIII, entretanto essa igualdade exigia tratamento idêntico para as pessoas, logo, tal igualdade não era suficiente, já que era necessária a igualdade efetiva, a igualdade que vinculava a uma vida digna, ou seja, deve-se proibir a discriminação negativa, a indevida, mas poderá discriminar para a igualdade efetiva, conhecida como discriminação positiva, já que tratar igualmente quem está em condições desiguais é manter desigualdade. Neste diapasão, surge a necessidade de se falar sobre as minorias, sendo que o direito à diferença se firma como um direito fundamental de cidadania. Deixar de reconhecer as diferenças e as especificidades fundantes dos diversos grupos sociais é não só lhes negar os direitos de cidadania, mas negarIhes a própria condição humana (ALVES, 2009). No cenário interno, pode-se notar a preocupação do legislador com a não discriminação, tendo em vista que no art. $3^{\circ}$, IV, dispõe que é objetivo fundamental da República promover o bem de todos, sendo vedado qualquer tipo de discriminação ou preconceito e no art. $4^{\circ}$ elenca que o Brasil rege-se pela prevalência dos direitos humanos (BRASIL, 1998). Compreende-se assim, que a proteção e o respeito à diferença são meios de garantir a dignidade da pessoa humana. Consoante esclarece Moraes (2014, p. 18) a dignidade é um valor espiritual e moral inerente à pessoa, que se manifesta singularmente na autodeterminação consciente e responsável da própria vida e que traz consigo a pretensão ao respeito por parte das demais pessoas , mas para tal, não poderá menosprezar a necessária estima que merecem todas as pessoas enquanto seres humanos e a busca ao Direito à Felicidade , reconhecendo-se, portanto, que o diferente tenha acesso ao direito à igualdade, já consagrado pela Lei Maior. De acordo com Santos e Lucas (2016) a Constituição avançou no sentido de valorizar a diversidade, já que a maioria não ficará acima da minoria, e que as diferenças não podem ser vistas como motivos de exclusões. O direito à diferença implica, portanto, o respeito, a aceitação da especificidade do outro. (DROIT, 2020).

Conclusão: $O$ direito à diferença é um direito que permite que a pessoa atue em sentido ou rumo distinto da maioria, porque ter encontrado sua realização em outro estilo de vida. As prerrogativas contidas neste direito permitem, portanto, a qualquer pessoa expressar a sua particularidade, a sua especificidade ou a sua singularidade, sem que os demais considerem esta diferença como uma inferioridade. Em assim sendo, não pode ser discriminada e nem odiada por não integrar a maioria, uma vez que o direito à igualdade de tratamento deve ser garantido e tolerado, conforme dispõem a Constituição Federal e os tratados internacionais de direitos humanos dos quais o Brasil é signatário.

\section{Referências}

ALVES, Fernando de Brito. Para uma fundamentação dos direitos de minorias em tempo de transição paradigmática. Orientador: Gilberto Giacoia. (Dissertação em Direito). Universidade Estadual do Norte do Paraná. Jacarezinho. 2009. Disponível em: http://www.dominiopublico.gov.br/download/teste/arqs/cp114395.pdf. Acesso em: 22 jul. 2020.

BRASIL. Constituição da República Federativa do Brasil, 5 de outubro de 1988. Diário Oficial da União. Brasília. 1988. Disponível em: http://www.planalto.gov.br/ccivil_03/constituicao/constituicao.htm. Acesso em: 10 jun. 2020.

DROIT à la différence. Disponível em : https://www.etudier.com/dissertations/Droit-\%C3\%A0-LaDiff\%C3\%A9rence/210502.html\#: :text=La\%20notion\%20de\%20droit\%20\%C3\%A0,qui\%20en\%20sont\%20la\%20base. Acesso 
em: 13 ago. 2020.

MARTINS, Argemiro Cardoso Moreira; MITUZANI, Larissa. Direito das Minorias Interpretado: o compromisso democrático do direito brasileiro. Revista Sequência. v. 32, n. 63. 2011. Disponível em: https://periodicos.ufsc.br/index.php/sequencia/article/view/18035. Acesso em: 07 ago. 2020.

MORAES, Alexandre de. Direito Constitucional. 30. ed. São Paulo: Atlas, 2014.

RAMOS, André de Carvalho. Curso de direitos humanos [livro eletrônico]. 7. ed. São Paulo: Saraiva Educação, 2020.

SANTOS, André Leonardo Copetti; LUCAS, Douglas Cesar. O direito à diferença e a proteção jurídica das minorias na América Latina. Revista do departamento de ciências jurídicas e sociais da Unijuí. n. 45, jan./jun, 2016. Disponível em: https://revistas.unijui.edu.br/index.php/revistadireitoemdebate/article/view/5555. Acesso em: 07 ago. 2020.

Coordenadoria de Pesquisa e Extensão - COPEX

Departamento de Editoraçāo e Divulgaçāo Científica - DEDIC 


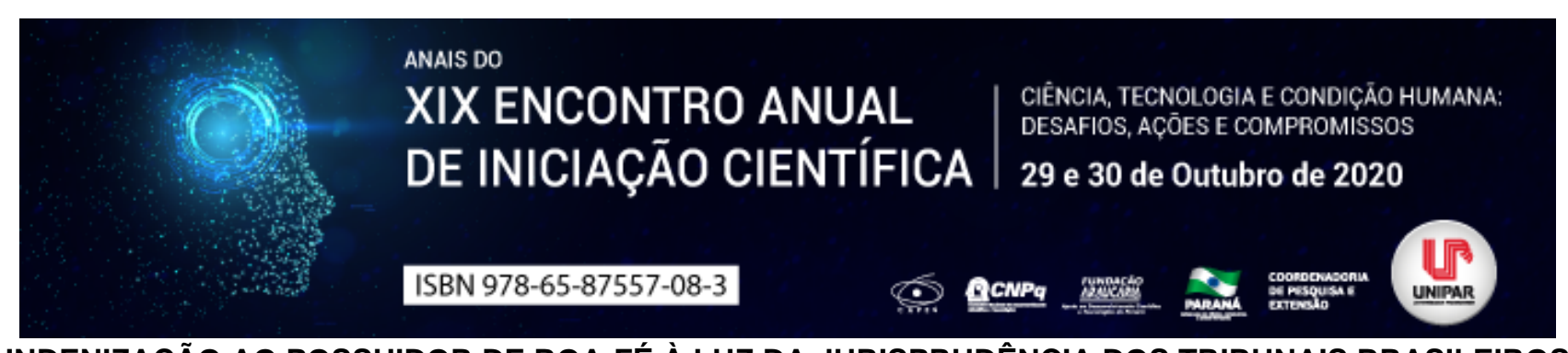

INDENIZAÇÃO AO POSSUIDOR DE BOA-FÉ À LUZ DA JURISPRUDÊNCIA DOS TRIBUNAIS BRASILEIROS

\title{
${ }^{1}$ ARIANE CAROLINE DOS SANTOS MELISINAS, ${ }^{2}$ PAULO CESAR DE SOUSA
}

\author{
${ }^{1}$ Acadêmica do curso de Direito da UNIPAR \\ ${ }^{1}$ Docente da UNIPAR
}

Introdução: Este estudo empreende uma pesquisa a respeito de como tribunais brasileiros têm aplicado o artigo 1.222 do Código Civil que disciplina a indenização devida ao possuidor de boa-fé em razão de benfeitorias por este efetuadas. A relevância da questão decorre do fato de o possuidor de boa-fé poder vir a ser prejudicado caso seja indenizado pelo valor atual da benfeitoria.

Objetivo: Analisar como a jurisprudência tem determinado o pagamento de indenização ao possuidor de boa-fé: se pelo valor atual, com as depreciações, ou pelo valor de seu custo.

Desenvolvimento: Para quantificar o valor da indenização de benfeitorias ao possuidor, o artigo 1.222 do Código Civil prevê dois critérios: um, para o caso de má-fé, que pode ser indenizado pelo valor do custo ou valor atual; e, outro, para o caso de boa-fé, segundo o qual cabe ao reivindicante pagar o valor das benfeitorias pelo valor atual. Extrai-se que a definição de um único critério pode prejudicar o possuidor de boa-fé, pois o valor atual da benfeitoria pode ser inferior ao de seu custo. Não se tem uma correspondência entre os valores, já que existe oscilação entre a inflação e o preço dos produtos (RIZZARDO, 2006). Com efeito:

A indenização far-se-á por critério único, qual seja, pelo seu valor atual, pouco importando se o possuidor gastou mais ou menos para fazer as benfeitorias (LOUREIRO, 2015, p. 1.121), o que gera controvérsia, dado que a indenização pode não se traduzir como justa e efetiva, o que esvazia o princípio da tutela da boa-fé, relegando-a ao plano meramente formal. A indenização apenas pelo valor atual l"só faria sentido, porém, se os níveis de custo fossem estáveis, dado que o valor atual e o do custo geralmente se equivaleriam, mas não em períodos de inflação elevada e crônica pelos quais passou o paísl" (GONÇALVES, 2017, p. 228). Busca-se analisar aqui, a aplicabilidade da sobredita regra aos casos concretos trazidos à apreciação do Judiciário. Pesquisou-se 50 julgados, em 10 Tribunais de Justiça, 1 Tribunal Regional Federal e Superior Tribunal de Justiça. Todos sob a égide do atual Código Civil, entre os anos de 2010 a 2020. Constatou-se que a minoria dos julgados favorecem o possuidor de boa-fé, pois, em 40 casos, foi determinada a indenização pelo valor atual, sem considerar possível prejuízo efetivo. Em contrapartida, 9 julgados determinaram que fosse pelo valor atual, mas consideraram a valorização do imóvel com o intuito de evitar o enriquecimento sem causa do retomante. Por fim, apenas 1 tribunal inovou e determinou aplicação de correção e juros desde a realização da benfeitoria.

Conclusão: Pela análise a indenização ao possuidor de boa-fé, é resultado de jurisprudência superveniente à vigência do atual Código Civil e, mostra-se eficiente ao assegurar a indenização pelas benfeitorias, porém, sem observar a efetividade de uma indenização que traduza o real prejuízo dele.

\section{Referências}

GONÇALVES, Carlos Roberto. Direito Civil Brasileiro. 12. ed. São Paulo: Saraiva, 2017.

LOUREIRO, Francisco Eduardo. A POSSE JUSTA E INJUSTA. In: PELUSO, Cezar (coord.). Código Civil Comentado: doutrina e jurisprudência. 9. ed. São Paulo: Manole, 2015.

RIZZARDO, Arnaldo. Direito das Coisas. 2. ed. Rio de Janeiro: Forense, 2006. 


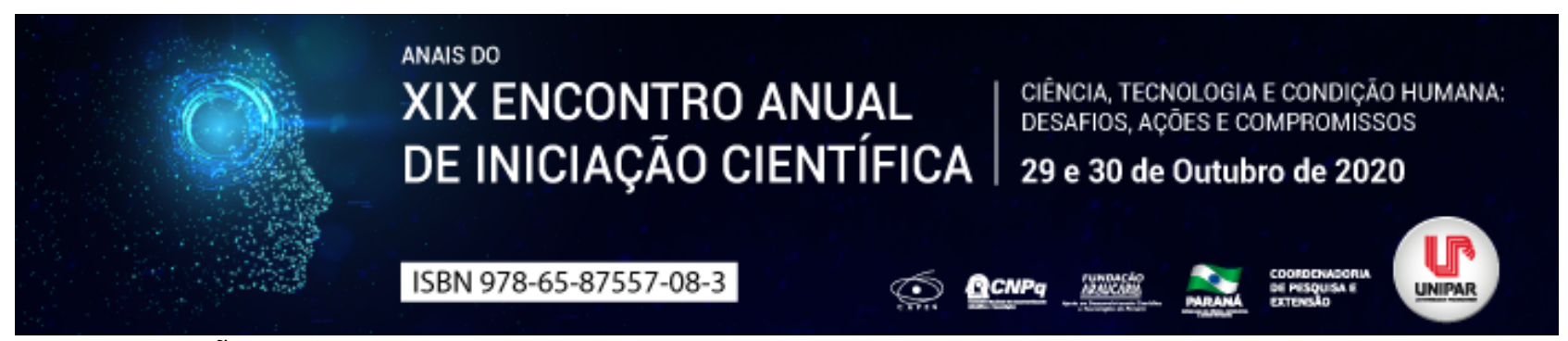

PROTEÇÃO E DIREITOS FUNDAMENTAIS DOS PORTADORES DE NECESSIDADES ESPECIAIS

\title{
${ }^{1}$ MAISA APARECIDA ALVES SILVA, ${ }^{2}$ NATAN GALVES SANTANA, ${ }^{3}$ TEREZA RODRIGUES VIEIRA
}

\author{
${ }^{1}$ Acadêmica do curso de Direito e integrante do PIC/UNIPAR \\ ${ }^{1}$ Mestrando em Direito Processual e Cidadania da UNIPAR e integrante do Programa de Iniciação Científica \\ ${ }^{2}$ Docente do Mestrado em Direito Processual e Cidadania na UNIPAR
}

Introdução: O mundo globalizado exige respeito à diversidade, neste aspecto, é fundamental que as pessoas que possuem alguma deficiência física ou mental tenham seus direitos garantidos e assegurados pelo Estado, seja por norma nacional ou internacional. Contudo, além da falta de políticas inclusivas, cotidianamente, as pessoas portadoras de deficiência se deparam com discriminação social e exclusão do mercado de trabalho, além das limitações de acessibilidade ao meio físico, à educação, ao transporte etc, configurando flagrante desrespeito ao direito ao exercício pleno da cidadania. Neste cenário, destacam-se os direitos fundamentais como via para assegurar a igualdade de oportunidades e o direito a uma vida digna.

Objetivo: O presente trabalho visa analisar os direitos fundamentais das pessoas portadoras de deficiência, bem como identificar as políticas públicas para a inclusão desse importante segmento.

Desenvolvimento: Primeiramente, frisa-se que deficiência é a perda de estrutura ou função, sendo uma anomalia, defeito ou perda de um membro, já incapacidade é uma restrição para desempenhar uma atividade ocasionada pela deficiência, por sua vez, desvantagem é o prejuízo a quem tem uma deficiência impedindo ou limitando que uma pessoa faça coisas que seriam comuns a outras pessoas da mesma idade ou sexo (AMIRALIAN et al, 2000). Logo, as pessoas com necessidade especial integram um grupo minoritário, ou seja, grupos ideologicamente menos poderosos CARVALHEIRO (2006, apud CARMO 2016, p. 203). Por sua vez, a Lei $n^{\circ} 13.146$, o Estatuto da Pessoa com Deficiência, em seu art. $2^{\circ}$ proclama: Considera-se pessoa com deficiência aquela que tem impedimento de longo prazo de natureza física, mental, intelectual ou sensorial, o qual, em interação com uma ou mais barreiras, pode obstruir sua participação plena e efetiva na sociedade em igualdade de condições com as demais pessoas. (BRASIL, 2015) Diante disso, o Estado deverá colocar a disposição de todos os cidadãos os direitos fundamentais para uma vida digna, pois do contrário haveria o dano existencial a essas pessoas. Segundo Frota (2014, apud STOCO, 2015) dano existencial constitui espécie de dano imaterial que acarreta à vítima, de modo parcial ou total, a impossibilidade de executar, dar prosseguimento ou reconstruir o seu projeto de vida [ ] e a dificuldade de retomar sua vida de relação de âmbito público ou privado . A Constituição Federal de 1988 garante a proteção, bem como a inclusão social, vez que proíbe a discriminação; determina percentual para as pessoas com deficiências em cargo ou emprego público; e em débitos vencidos terão preferência, no mesmo sentido leis infraconstitucionais possibilitam a inclusão, como passe livre para as pessoas com deficiência no transporte coletivo internacional nos termos da Lei $n^{\circ}$. 8.988/95. Outro exemplo de suma importância é a Lei $n^{\circ}$. 9.394/96 que estabelece as diretrizes e bases da educação nacional, norma essa que assegura igualdade às pessoas com deficiências e um tratamento especializado. Contudo, enquanto o mundo caminha para a inclusão dos vulneráveis, em 2019, a Presidência da República enviou à Câmara dos Deputados o Projeto de Lei 6.159/2019, que, entre outras medidas, desobriga as empresas de adotarem uma política de cotas para pessoas com deficiência ou reabilitadas. Evidentemente, referido Projeto de Lei foi amplamente criticado por diversos setores, I"inclusive do Ministério Público do Trabalho, mas também objeções assacadas por parlamentares, que, com toda razão, entendem que o PL contém medidas altamente questionáveis do ponto de vista constitucional, e mesmo em desacordo com o sistema de proteção internacional dos direitos humanos.l" (SARLET, 2020, p. 1) Nota-se que assegurar a inclusão é assegurar a dignidade humana. No dizer de Moraes (2014) a dignidade manifesta singularmente na autodeterminação consciente e responsável da própria vida e que traz consigo a pretensão ao respeito por parte das demais pessoas, constituindo-se um mínimo invulnerável que todo estatuto jurídico deve assegurar , assim, o Estado tem o dever de garantir que todas as pessoas terão respeitados os seus direitos mínimos, quais sejam, os direitos fundamentais. De acordo com Silva (2012, p. 223), esses direitos são indispensáveis ao ser humano, pois manterá a liberdade, e não poderá ser renunciado, bem como universais, eis que se aplicará a toda população, sem nenhuma distinção. As diferenças físicas ou psíquicas não podem dificultar os projetos de vida.

Conclusão: Conclui-se que, as políticas públicas para esse segmento devem ser desenvolvidas no intuito de assegurar o protagonismo das pessoas com deficiência, não com o escopo ultrapassado de caridade e assistencialismo. $\mathrm{O}$ atual Estatuto da Pessoa com Deficiência é uma lei progressista e não pode admitir retrocessos, conforme propõe o Projeto de Lei 6.159/2019. A pessoa deficiente deseja sentir-se útil à sociedade e não um estorvo para a família ou para o Estado. Assim, as empresas e todos os espaços sociais não podem ser excludentes e a acessibilidade deve ser garantida em todos os setores, pois somente assim as pessoas deficientes usufruirão de seu direito à igualdade de oportunidades. 


\section{Referências}

AMIRALIAN, Maria LT; et al. Conceituando deficiência.Revista de Saúde Pública. v. 34, p. 97-103, 2000. Disponível em: . Acesso em: 08 jun. 2020.

BRASIL. Lei no. 8.987, de 13 de fevereiro de 1995. Brasília, DF. 1995.

Lei $n^{\circ}$. 9.394, de 20 de dezembro de 1996. Brasília, DF. 1996.

.Lei no 13.146, de 6 de julho de 2015, institui a Lei Brasileira de Inclusão da Pessoa com Deficiência (Estatuto da Pessoa com Deficiência). Publicado no Diário Oficial da União em 7 jul. 2015.

CARVALHEIRO, José Ricardo. Da representação mediática à recepção política. Discursos de uma minoria. Sociologia, problemas e práticas, n. 51, p. 73-93, 2006. Disponível em: . Acesso em: 2 jul. 2020.

FROTA, Hidemberg Alves da; BIÃO, Fernanda Leite. O fundamento filosófico do dano existencial. Revista Jurídica UNIGRAN. Dourados, v. 12 24. Jul./Dez.2010. Disponível em: . Acesso em: 10 ago. 2020.

MORAES, Alexandre de. Direito Constitucional. 30. ed. São Paulo: Atlas, 2014.

SARLET, Ingo Wolfgang. Uma deficiente proteção das Pessoas com Deficiência? Disponível em: https://www.conjur.com.br/2020-jan-07/direitos-fundamentais-deficiente-protecao-pessoas-deficiencia Acesso em: 20 ago. 2020. SILVA, De Placido e. Vocabulário jurídico conciso. 3. ed. Rio de Janeiro: Forense, 2012. 


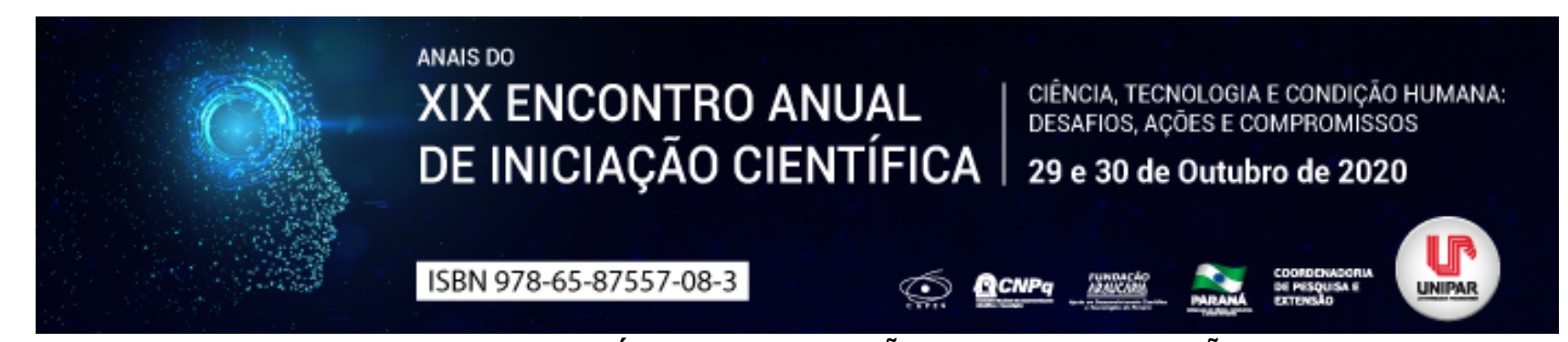

INCOSNTITUCIONALIDADE DO FORMULÁRIO DE APURAÇÃO DE TRANSGRESSÃO DISCIPLINAR (FATD)

\author{
${ }^{1}$ TATIANA CORREA ALVES DA COSTA, ${ }^{2}$ ALEXANDRE MAGNO AUGUSTO MOREIRA
}

\author{
${ }^{1}$ ACADÊMICO DO PIC/UNIPAR \\ ${ }^{1}$ Docente da UNIPAR
}

Introdução: As forças armadas se utilizam do Formulário de Apuração de Transgressão Disciplinar (FATD) quando da apuração de transgressões, a fim de manter a ordem e a disciplina. Contudo, como proposta de análise, percebe-se a afronta a princípios constitucionais no desenrolar de tal procedimentos. O presente trabalho pretende abordar como proposta, a inconstitucionalidade do FATD em razão dos procedimentos utilizados. O método de pesquisa utilizado é o dedutivo, com revisão bibliográfica.

Objetivo: Analisar a formalidade do Formulário de Apuração de Transgressão Disciplinar (FATD) aplicável aos Militares, estabelecendo como proposta, a ofensa a preceitos constitucionais na execução do procedimento administrativo.

Desenvolvimento: As organizações militares tem como fundamento, a disciplina e hierarquia, como pilares de sua própria estruturação, conforme artigo 142, caput, da Constituição (BRASIL, 1998). De acordo com o artigo 10 e 21 do Regulamento Disciplinar do Exército (RDE), a aplicação da medida disciplinar decorre do poder do seu superior de fiscalizar a conduta de seus subordinados, O direito punitivo funcional se enquadra dentro do direito administrativo, e emana da relação entre a Administração Pública e seus servidores, exatamente para preservar a disciplina que deve reinar na organização administrativa (CARVALHO FILHO, 2008, p. 61). O Problema reside no fato do caminho que é percorrido na apuração e na aplicação das penalidades impostas. O procedimento consiste no preenchimento de um formulário, onde o militar arrolado, tem 3 dias úteis para apresentar sua defesa pessoal escrita no verso do Formulário de Apuração de Transgressão Disciplinar. Se não o fizer, será julgado à revelia, conforme o anexo IV item 4, do RDE. Desta forma, a autoridade julgadora passa a acusar, influenciada por uma pré-concepção dos fatos, tornando-se parte interessada no feito, pois na formulação da acusação utiliza suas próprias convicções como está evidenciado nos anexos IV, V e VI do RDE. Neste norte, menciona Mirabete (1999, p. 40) No sistema inquisitivo encontra-se mais uma forma auto defensiva de administração da justiça do que um genuíno processo de apuração da verdade . Como complemento, sobre o ato discricionário (...) alguns elementos vêm definidos na lei, com precisão, e outros são deixados à decisão da Administração, com maior ou menor liberdade de apreciação da oportunidade e conveniência (DI PIETRO, 2014, p. 225). Desta forma, ainda que se tenha o propósito de defender a hierarquia e a disciplina militar, a autoridade não possui legitimidade para atuar em um processo disciplinar, pois, se reúnem na mesma autoridade, as funções, acusatória, investigativa, julgadora e executora, prejudicando absolutamente a imparcialidade e a impessoalidade, dando margem para a sua suspeição e o seu impedimento. Neste sentido, A punição disciplinar não deve ser um instrumento de coação, mas uma medida visando garantir a disciplina e a hierarquia nas diversas organizações militares e até mesmo fora dos aquartelamentos (LIMA, 2017, p. 75). Portanto, conclui-se como proposta, que o FATD fere o princípio constitucional do devido processo legal (nele compreendido o contraditório e ampla defesa), na garantia do acusado, vez que, cerceia os direitos à comunicação, à apresentação de alegações finais, à produção de provas e à interposição de recursos, nos processos que possam resultar sanções (MAZZA, 2015, p. 878).

Conclusão: Diante do exposto conclui-se que em relação ao procedimento do Formulário de Apuração de Transgressão Disciplinar (FATD), utilizado pelas forças militares verifica-se a existência de conflito com os princípios e garantias constitucionais.Assim sendo os direitos dos militares acabam sendo suprimidos e claramente prejudicados, haja vista ter pouco tempo para preparar sua defesa, como também o próprio que ordena a abertura do procedimento é o mesmo que julga.

\title{
Referências
}

BRASIL. Constituição da Republica Federativa do Brasil de

http://www.planalto.gov.br/ccivil_03/constituicao/constituicao.htm. Acesso em 12 de Junho de 2020.

BRASIL. Decreto n. 4.346, de 26-08-2002. Diário Oficial da União 27-08-2002. Regulamento Disciplinar do Exército. Disponível em: http://www.planalto.gov.br/ccivil_03/decreto/2002/D4346.htm, acesso em 12 de Junho de 2020.

CARVALHO FILHO, José dos Santos. Manual De Direito Administrativo. 19a ed. Rio de Janeiro: Lúmen luris, 2008.

MIRABETE, Julio Fabrini. Processo Penal. 10ª ed.São Paulo: Atlas,2000

DI PIETRO, Maria Sylvia Zanella. Direito Administrativo. 27a ed. São Paulo: Atlas, 2014;

LIMA, Eduardo Vieira de. O novo Regulamento Disciplinar do Exército: Suas adequações à Constituição Federal de 1988, o processo de apuração disciplinar, o Formulário de puração de Transgressão Disciplinar e principais falhas das autoridades julgadoras. In Revista do Exército Brasileiro, v. 153, n.1, 2017, p. 73-84.

MAZZA, Alexandre. Manual de Direito Administrativo. 5ª ed. São Paulo. Saraiva, 2015. 
Coordenadoria de Pesquisa e Extensão - COPEX

Departamento de Editoraçāo e Divulgaçāo Científica - DEDIC 


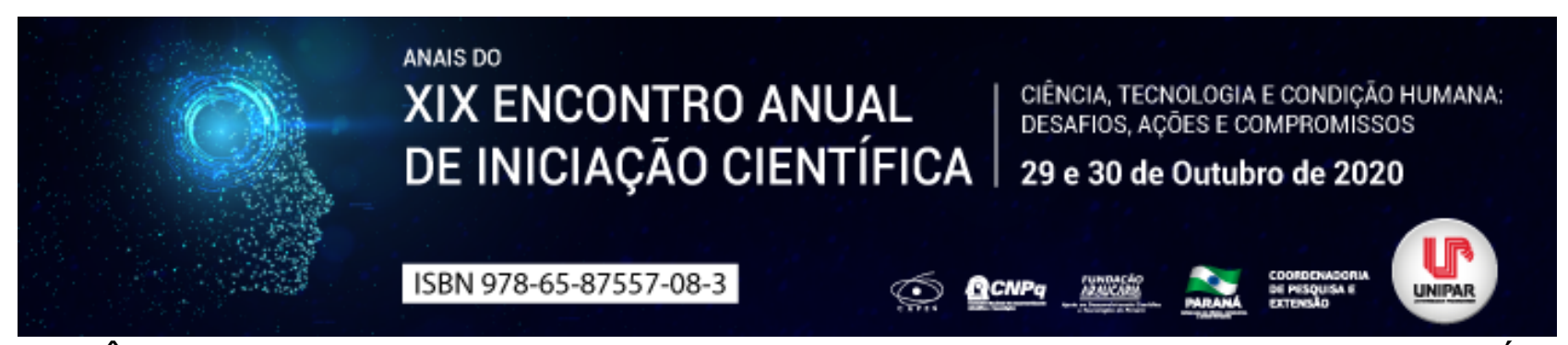

NEGLIGÊNCIA DO ESTADO NA GARANTIA DO ESTATUTO DA CRIANÇA E DO ADOLESCENTE NA PRÁTICA

\author{
${ }^{1}$ RAFAELA CAVALCANTE GARCIA, ${ }^{2}$ MICAELLY OKAMOTO MAZZETO, ${ }^{3}$ DORITA ZIEMANN HASSE
}

${ }^{1}$ Acadêmica do Curso de Direito da UNIPAR

${ }^{1}$ Acadêmica do Curso de Direito da UNIPAR

${ }^{2}$ Docente da UNIPAR

Introdução: O Estatuto da Criança e do Adolescente (ECA) é base para a garantia dos Direitos Humanos na infância e na juventude. Dessa forma, é dever estatal assegurar os princípios do ECA para que eles possam ser colocados na prática pela sociedade e pela família, para isso é necessário a análise da disponibilização de recursos públicos, que muitas vezes são negligenciados.

Objetivo: Analisar a negligência do Estado na garantia do Estatuto da Criança e do Adolescente na prática.

Desenvolvimento: Importantes conquistas foram trazidas à civilização a partir do século XVIII. Em todos os tempos a humanidade sempre enfrentou contradições, se por um lado avanços científicos demonstravam as conquistas da civilização de outro, o retrocesso era flagrante no trato humanitário. As transformações ocorridas na Europa com a Declaração dos Direitos do Homem e do Cidadão chegam entre nós mais, especificadamente, a partir da Constituição da República Federativa do Brasil de 1988, que estabelece em seu artigo 227 que É dever da família, da sociedade e do Estado assegurar à criança, ao adolescente e ao jovem, com absoluta prioridade, o direito à vida, [...] além de colocá-los a salvo de toda forma de negligência, discriminação, exploração, violência, crueldade e opressão (BRASIL, 1988, Art. 227). Nesse seguimento, em 1990, por meio da Lei n. 8.069/90, foi criado o Estatuto da Criança e do Adolescente ECA considerado modelo para a garantia de direitos na infância e juventude mundialmente. A partir disso, passou a ser responsabilidade do Estado fiscalizar, garantir e prover o cumprimento desses direitos, uma vez que a existência do direito subjetivo nem sempre depende da vontade de seu titular (KELSEN, 1962 apud NADER, 2010, p. 309). Portanto, a criança que outrora estava sujeita à violência da sociedade e omissão do Estado agora passa a ser sujeito de direitos e deveres para sua própria proteção. Contudo, esses direitos fundamentais não são realizados na prática, visto que o Estado falha ao não dar prioridade e ao não prover recursos públicos necessários para viabilizar a sua execução. Nesse sentido, ao se mostrar ineficaz na fiscalização e aplicação de investimentos nas áreas fundamentais, como da educação, saúde e segurança, o Estado é responsabilizado por negligência estatal. Assim, O Estado é responsável pela política de bem-estar do menor, porém a sociedade tem que se conscientizar da sua co-responsabilidade [...] (NOGUEIRA, 1998, p. 187). É função do Estado dar condições para o cumprimento do ECA, assim como é função da sociedade e da família fiscalizar para que essa política pública seja efetivada.

Conclusão: Os princípios extraídos do ECA têm como principal finalidade colocar as crianças e adolescentes a salvo de toda forma de negligência, discriminação, exploração, violência, crueldade e opressão. Porém, por falta de priorização do Poder Público na garantia desses direitos, o constitucional estabelecido ainda não foi consumado.

\title{
Referências
}

BRASIL. [Constituição (1988)]. Constituição da República Federativa do Brasil. Brasília: Senado Federal, 1988.

NADER, Paulo. Introdução ao estudo do direito. Rio de Janeiro: Forense, 2010. p. 309.

NOGUEIRA, Paulo Lúcio. Estatuto da criança e do adolescente. São Paulo: Saraiva, 1998.

SANDRÉ, Lu. ECA é referência mundial mas precisa ser posto em prática. Brasil de Fato, São Paulo,

20 jul. 2018. Disponível em: https://www.brasildefato.com.br/2018/07/20/eca-e-referencia-mundial-mas-precisa-ser-posto-emprática/. Acesso em: 04 jun. 2020. 


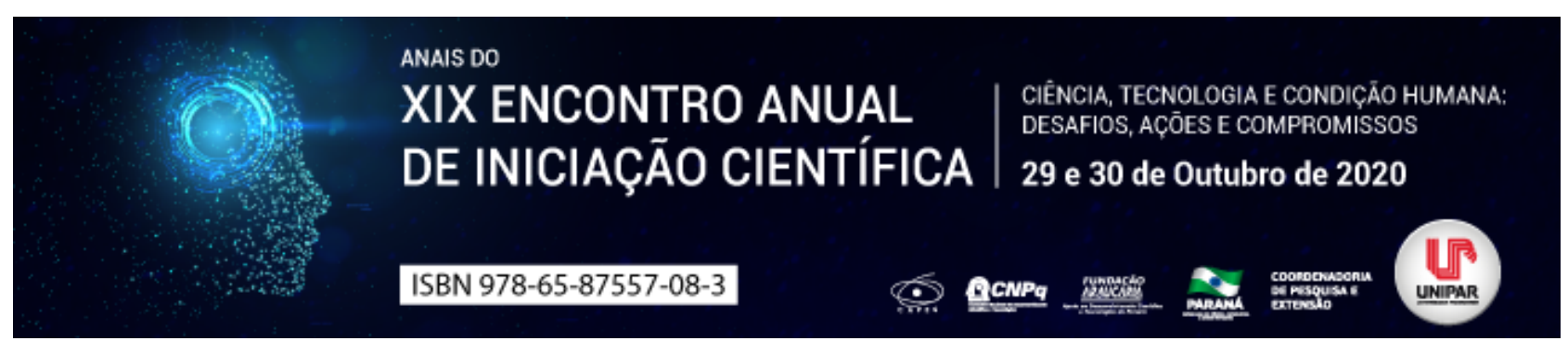

A PREVENÇÃO DO SUICÍDIO NO ÂMBITO DA PSICOLOGIA COMUNITÁRIA

\title{
${ }^{1}$ MARIA HELOIZA NEIS TURIN, ${ }^{2}$ JESSICA RODRIGUES DOS SANTOS, ${ }^{3}$ MAYARA NUNES ALMEIDA
}

\author{
${ }^{1}$ Acadêmica do Curso de Psicologia da UNIPAR \\ ${ }^{1}$ Acadêmica do Curso de Psicologia da UNIPAR \\ ${ }^{2}$ Docente da UNIPAR
}

Introdução: Diante das problemáticas sociais, é possível compreender a necessidade de uma área da psicologia mais ampla que possa acolher demandas coletivas, em especial daqueles que encontram-se em condições de vulnerabilidade social. Contribuir com estes em esferas de saúde mental, proporcionando dessa forma, ações efetivamente transformadoras. Considerando que, o foco principal da Psicologia Comunitária é facilitar e fortalecer a participação sociopolítica, promover crescimento individual e consequentemente coletivo, vê-se uma relevância em trabalhar questões relacionadas a saúde mental no âmbito comunitário, fundamentando que esta é essencial para que haja mudança. Dessa forma, unindo a equipe multidisciplinar, sugerindo trabalhos de promoção e prevenção de saúde, visa-se a problematização das implicações psicológicas nas estruturas sociais.

Objetivo: Buscou-se através deste, investigar as possibilidades de atuação dos psicólogos nas comunidades, trabalhando prioritariamente com questões referentes à prevenção ao suicídio.

Desenvolvimento: Falar sobre suicídio na contemporaneidade, é falar sobre responsabilidade social, pois este é um problema de saúde pública, sobretudo, em uma sociedade com o capitalismo tão estruturado e com consequências imensuráveis, como é possível observar na atualidade. Por isso, diante dos grandes números de suicídio, é necessário pensar na forma como a sociedade lida com tal fato (CFP, 2013). O suicídio vem crescendo nas últimas décadas, envolvendo diversas faixas etárias e diferentes cenários socioeconômicos. Sabendo que o comportamento suicida pode ser prevenido e, para isso, um bom planejamento e a criação de programas envolvendo diversos profissionais qualificados para tal fim são necessários (CFP, p.28, 2013). O fato de existirem crianças em idades consideravelmente baixas que praticam tal ato por exemplo, levanta muito mais problematizações. A OMS registra suicídios a partir dos cinco anos de idade e isso é altamente impactante, já que pensar que uma criança de cinco anos de idade, que está em processo de desenvolvimento cognitivo e emocional possa buscar intencionalmente uma alternativa para o seu sofrimento, tirando sua própria vida (CFP, 2013, p. 25). Ao relacionar o suicídio com a Psicologia Comunitária, somos levados a pensar no impacto que este causa a comunidade, seja aos familiares, amigos, instituições de ensino ou trabalho. Se faz necessário entender também que o sofrimento que o psicólogo comunitário pode ajudar a decifrar nunca é somente um sofrimento individual, é dor decorrente de processos de dominação de longa duração, envolvem situações inter-humanas na sua formação e, portanto, também na sua superação (SVARTMAN, GALEÃO-SILVA, p.345, 2016), assim, a atuação comunitária, abrange uma intervenção na dimensão coletiva-contextual e não centrada no indivíduo. O psicoterapeuta precisa desenvolver empatia no que se refere ao sofrimento humano, isto é, o profissional pode se disponibilizar para se aproximar do lugar onde o paciente está e, por meio de sua disponibilidade interpessoal, a esperança de que o cliente possa reconhecer suas potencialidades... (FUKUMITSU, p. 270, 2014). Portanto, para atuar na prevenção ao suicídio em comunidade, o profissional deve considerar e refletir sobre a complexidade dos modos de vidas que potencializam a busca pela morte e qual a interferência dos campos sociais e políticos neste cenário. Objetivando promover inicialmente melhores condições de vida aos sujeitos em risco suicida (SANTOS, KIND, 2020). A partir do diálogo, o psicólogo pode criar modos de existência que possam potencializar a vida do indivíduo e também da sua família, para que possam conseguir juntos, criar um ambiente de cuidado para com o outro, além disso, trazer formas de incentivo a autonomia, prestar um serviço acolhedor que demonstre real interesse pelo sofrimento do sujeito. Por isso, a importância da criação de equipe multiprofissional para trabalhar com prevenção a respeito do comportamento suicida é uma alternativa possível dentro das comunidades. Instituições como escolas e empresas, onde a preocupação é maior, podem promover programas específicos sobre saúde mental com o auxílio da psicologia comunitária constantemente, objetivando abranger mais pessoas, também, é interessante a identificação de indivíduos que se encaixam num grupo de risco maior, para assim receberem uma intervenção mais direcionada, diminuindo o risco de suicídio. Dentro da sociedade é de extrema utilidade programas de informação à comunidade, tendo em mente que é um trabalho a ser realizado por toda a comunidade, e não restringir apenas ao profissional da saúde, sendo assim, necessário a criação de projetos de valorização da vida nas escolas, que desenvolvam habilidades que possam ressignificar a vida nessa comunidade.

Conclusão: Por se tratar de um tema tão delicado, o psicólogo precisa desenvolver algumas habilidades para tratar destas situações, especialmente no que se trata de escuta qualificada, ajudando o indivíduo no reconhecimento de suas características positivas. Este trabalho reafirmou que o psicólogo deve usar a escuta e o diálogo como ferramentas. 


\section{Referências}

CFP. Conselho Federal de Psicologia. O suicídio e os desafio para a psicologia. $1^{\text {a }}$ Ed. Brasília, dezembro, 2013.

FUKUMITSU, Karina Okajima. O psicoterapeuta diante do comportamento suicida. Psicol. USP , São Paulo, v. 25, n. 3, p. 270275, dezembro de 2014. Disponível em .

SANTOS, Luciana Almeida; KIND, Luciana. Integralidade, intersetorialidade e cuidado em saúde: caminhos para se enfrentar o suicídio. Interface (Botucatu). 2020. Disponível em: .

SVARTMAN, Bernardo Parodi; GALEÃO-SILVA, Luís Guilherme. Comunidade e Resistência à Humilhação Social: Desafios para a Psicologia Social Comunitária. Rev. colomb. psicol., Bogotá, v. 25, n. 2, p. 331-349, Dez 2016 . Disponível em: .

Coordenadoria de Pesquisa e Extensão - COPEX

Departamento de Editoraçāo e Divulgaçāo Científica - DEDIC 


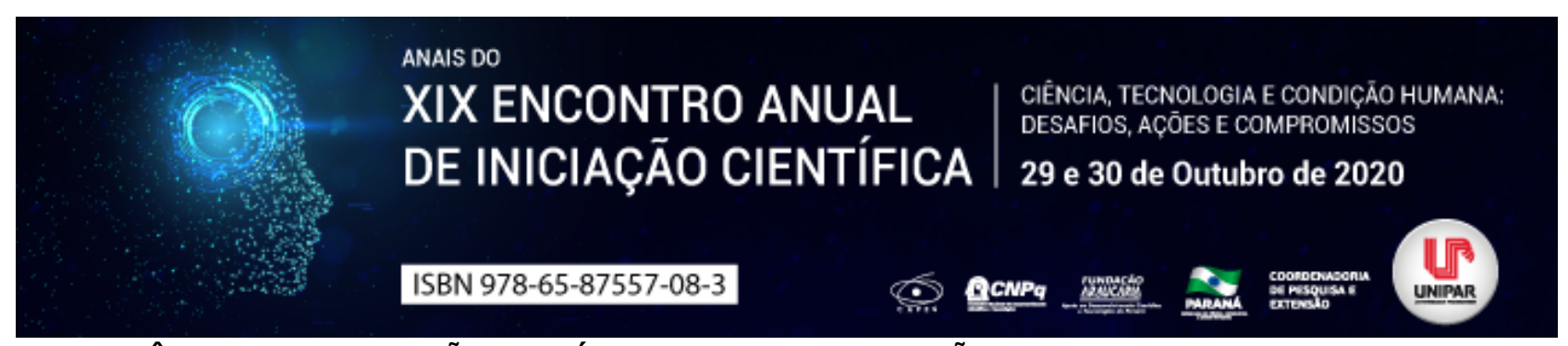

DIREITO SISTÊMICO: A UTILIZAÇÃO DA TÉCNICA DA CONSTELAÇÃO FAMILIAR COMO MEIO ALTERNATIVO DE CONFLITO

\title{
${ }^{1}$ GRAZIELI BATISTELLA VIEIRA, ${ }^{2}$ DIEGO CANTON
}

\author{
${ }^{1}$ Discente da UNIPAR \\ ${ }^{1}$ Docente da UNIPAR
}

Introdução: O presente trabalho aborda sobre o campo do Direito Sistêmico, mais precisamente a constelação familiar e a sua implantação no poder judiciário. Com o grande aumento do número de processos judicias, fez-se necessário uma busca de novos meios alternativos, eficazes e céleres para a pacificação de conflitos.

Objetivo: A compreensão da utilização da constelação familiar como uma técnica promissora na resolução de conflitos.

Desenvolvimento: A constelação sistêmica foi desenvolvida pelo filósofo alemão Bert Hellinger, que, através da descoberta de três leis sistêmicas, aprimorou métodos terapêuticos, os quais regem as relações humanas. Esse método foi estudado desde 2004 e aplicado no Brasil em 2012 pelo juiz de direito Sami Storch. Essa nova abordagem de resolução de conflitos traz à tona fatos que ocorreram nas gerações passadas, que, de algum modo, estão tumultuando e conflitando com o momento presente do indivíduo, tais como bloqueios, traumas, morte trágica na família, abandono, crimes, aborto, segredos e relacionamentos mal resolvidos. Tudo isso gera marcas no sistema familiar e, consequentemente, cria emaranhados que refletirão nas gerações futuras. Tais reflexos serão suportados em algum momento da vida do indivíduo (STORCH, 2018). Cumpre esclarecer que a constelação é realizada por um facilitador que não precisa ser formado em direito, mas apenas ter conhecimento sobre a área e agir em conjunto com um profissional jurídico. Pode ser aplicada tanto na esfera judicial quanto na extrajudicial (MASIERO, 2016). Assim, a constelação familiar é um modelo psicoterápico que estuda energias e emoções, sejam estas inconscientes ou conscientes, que diante da abordagem sistêmica auxilia a identificar ou direciona a compreensão dos fatores que deram origem ao conflito em si (BECKENKAMP; BRANDT, 2019). Com o aumento de demandas na justiça, os processos se tornam cada vez mais lentos, desgastando as partes até a decisão final, que nem sempre é satisfatória para ambas, ocasionando, tempos mais tarde, a reincidência do conflito e a procura novamente pelo judiciário. Com isso, veio à tona a necessidade de novos meios alternativos de solução de conflito mais eficazes e céleres. Em 2010, por meio da Resolução 125, do Conselho Nacional de Justiça, implementou-se a prática consensual e autocompositiva de litígio e a pacificação social por meio da conciliação e mediação, seguida da Lei de Mediação 13.140/2015. Posteriormente, com o novo Código de Processo Civil lei 13.105/2015, que ratifica essa tendência, com a criação de um capítulo para regular a mediação e a conciliação (arts. 165 a 175), estruturando o procedimento pela tentativa de autocomposição como ato anterior ao oferecimento da defesa pelo réu (arts. 334 e 695), permitindo a homologação judicial de acordo extrajudicial de qualquer natureza (art. 515, inciso III e art. 725, inciso VIII), permitindo que, no acordo judicial, seja incluída matéria estranha ao objeto litigioso do processo (art. 515 , $\S 2^{\circ}$ ) e permitindo acordos processuais atípicos (art. 190), ou seja, trouxe, ainda, mais meios para resolução de conflitos aos procedimentos litigiosos (DIDIER, 2017). Todavia, a constelação familiar se tornou uma nova alternativa para a resolução de conflito, em decorrência do número significativo de acordos entre as partes, nas palavras de Sami Storch (2015, p. 22), "após realizado o trabalho com a constelação, os participantes demonstram absorção dos assuntos tratados, um maior respeito e consideração em relação à outra parte envolvida, além da vontade de conciliar o que se comprova também com os resultados das audiências de conciliação realizadas semanas depois (os índices de acordos superam os 90\%) e com os relatos das partes e dos advogados. " Conclusão: Nessa perspectiva, conclui-se que a Resolução 125 do CNJ foi o marco inicial para a implantação de métodos autocompositivos de conflitos e, consequentemente, para a busca incessante por novos ainda mais eficazes. $\mathrm{O}$ juiz de direito Sami Storch incrementou a técnica da constelação familiar como um meio alternativo de conflito no judiciário, que, apesar de recente, vem ganhando espaço na área, de modo que a sua utilização não busca apenas dar uma resposta ao conflito e, sim, solucionar a questão conflituosa existente na vida do indivíduo. Nesse sentido, tem a finalidade de propiciar as partes uma melhor percepção do caso, além de diminuir o fluxo dos processos que se acumulam sem uma resolução totalmente satisfatória e definitiva entre as partes. Assim, é uma ferramenta que se mostra eficiente e comprovada, razão pela qual deve ser implantada a nível nacional com o aperfeiçoamento da técnica no judiciário.

\section{Referências}

BECKENKAMP, Cristine; BRANDT, Fernanda. O direito sistêmico: a aplicação das técnicas de constelações familiares para tratamento dos litígios nas varas de família. Seminário Internacional Demandas Sociais e Políticas Públicas na Sociedade Contemporânea, 2019.

DIDIER JUNIOR, Fredie. Curso de Direito Processual Civil. 19a edição. Salvador: Jus Podivm, 2017. 
MASIERO, Ana Carolina. Aplicabilidade da Constelação Sistêmica no âmbito do Direito. Minas Gerais: UFMG, 2016.

STORCH, Sami. Direito Sistêmico: primeiras experiências com constelações no judiciário. In Filosofia, Pensamento e Prática das Constelações Sistêmicas n n 4. São Paulo: Editora Conexão Sistêmica, 2015.

STORCH, Sami. Direito sistêmico é uma luz no campo dos meios adequados de solução de conflitos. Jun. 2018. Disponível em: . Acesso em 07 de junho de 2020.

Coordenadoria de Pesquisa e Extensão - COPEX

Departamento de Editoraçāo e Divulgaçāo Científica - DEDIC 


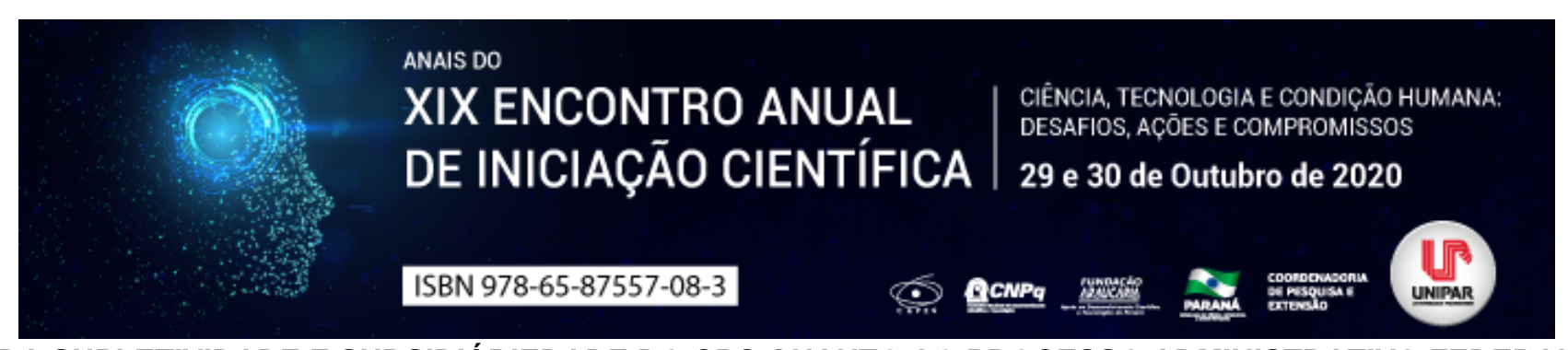

DA SUPLETIVIDADE E SUBSIDIÁRIEDADE DO CPC QUANTO AO PROCESSO ADMINISTRATIVO FEDERAL

\author{
${ }^{1}$ JHENYFFER PAULA GIROTTO E SILVA, ${ }^{2}$ PAULO CESAR DE SOUSA
}

${ }^{1}$ Acadêmica do curso de Direito da UNIPAR

${ }^{1}$ Docente da UNIPAR

Introdução: O processo administrativo, no âmbito da administração pública federal, é disciplinado pela Lei 9.784/1999. Entretanto, esta possui lacunas quanto ao modo de se praticar determinados atos procedimentais, razão por que elas devem ser preenchidas supletiva e subsidiariamente pelo CPC, conforme previsto pelo artigo 15 do Código de Processo Civil. Trata-se de um aprimoramento dogmático que precisa ser adequadamente compreendido quanto ao alcance.

Objetivo: Compreender como o direito processual civil deve ser aplicado supletiva e subsidiariamente ao processo administrativo federal, com a identificação das lacunas a serem supridas.

Desenvolvimento: O processo administrativo, entendido como um conjunto de atos, interligados, com objetivo de alcançar determinado fim específico por parte da Administração Pública, pode, ser instaurado tanto por iniciativa própria da administração, quanto a pedido de um particular interessado. No atual Código de Processo Civil está previsto, em seu artigo 15 que, na ausência de normas que regulem processos eleitorais, trabalhistas ou administrativos, as disposições deste Código lhes serão aplicadas supletiva e subsidiariamente (BRASIL, 2015). O CPC desempenha um papel de fonte quanto às lacunas de outros ramos do direito processual (THEODORO JÚNIOR, 2015). Entretanto, o fato de o artigo em questão referir que as normas do CPC são aplicáveis, subsidiariamente não significa que seu emprego ocorrerá apenas se existir lacuna. Nesse sentido, [...] tanto nos casos em que se constatar omissão legislativa como naqueles em que o dispositivo a ser aplicado possa ser intensificado, valorizado ou aprimorado no caso concreto por meio da incidência de norma positivada no novo Código de Processo Civil (MOREIRA, 2016, p. 316), haverá aplicação das normas processuais civis. Uma leitura que sugira o uso do Processo Civil apenas se houver lacunas não é a leitura mais adequada para definir o efetivo alcance da norma processual civil. Outro detalhe importante é que [...] a aplicação do CPC também só poderá ocorrer naquilo que não for incompatível com as regras específicas de cada procedimento (ALVIM, 2016, p. 74). A razão de o CPC servir como alicerce do processo administrativo reside no fato de este não ter a vocação de exaurir o conteúdo procedimental. O CPC de 1973 era omisso quanto a essa matéria, por isso, reportava-se, em seu artigo 271, a causas com limitação a regras do procedimento comum. Já o CPC de 2015 deve ser aplicado todas as espécies de processos, quer de modo supletivo (completando as lacunas), quer subsidiariamente (completando aquilo que já estiver na lei).

Conclusão: O artigo 15 do atual CPC aprimorou o regime do artigo 271 do CPC de 1973 a medida que contempla a aplicabilidade do direito processual civil de forma supletiva e subsidiária ao processo administrativo, o que influi diretamente no modo de a Administração Pública na prática de seus atos.

\title{
Referências
}

ALVIM, A. A. et al. Comentários ao Código de Processo Civil. São Paulo: Saraiva, 2016.

BRASIL. Lei n. 13.105, de 16 de março de 2015. Código de processo civil. 25. ed. São Paulo: Saraiva, 2018.

MOREIRA, E. B. O novo Código de Processo Civil e sua aplicação no processo administrativo.Revista de Direito Administrativo. v. 273. Rio de Janeiro, p. 316, 2016.

THEODORO JÚNIOR, H. Curso de direito processual civil. 15. ed. Rio de Janeiro: Forense, 2015 


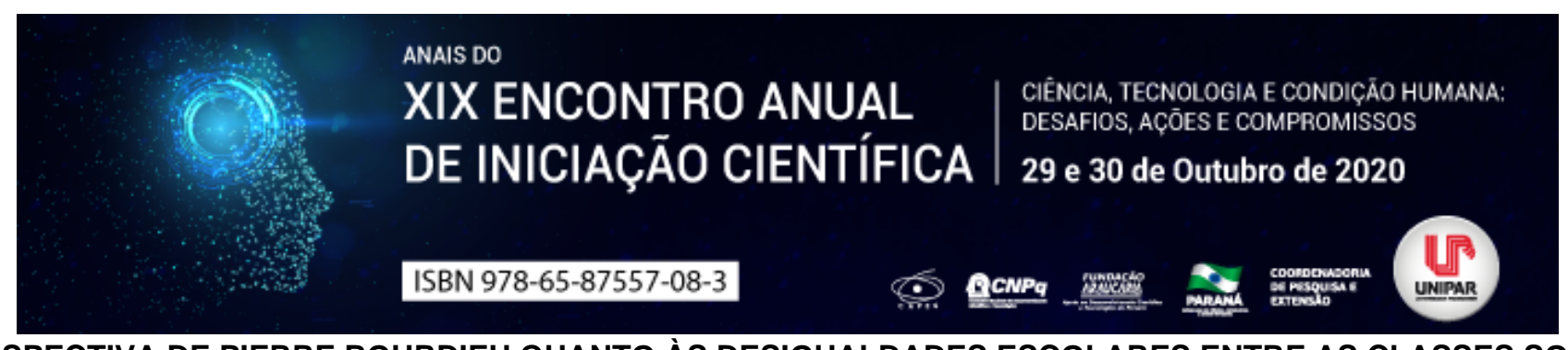

A PERSPECTIVA DE PIERRE BOURDIEU QUANTO ÀS DESIGUALDADES ESCOLARES ENTRE AS CLASSES SOCIAIS

\title{
${ }^{1}$ BEATRIZ MEDEIROS BAZANA, ${ }^{2}$ JORGE ANTONIO VIEIRA
}

\author{
${ }^{1}$ Acadêmica do curso de Pedagogia da UNIPAR \\ ${ }^{1}$ Docente da UNIPAR
}

Introdução: Nota-se uma grande desigualdade no âmbito escolar brasileiro quanto ao desempenho e expectativas referentes à escolarização prolongada, conforme as classes sociais, especialmente no ensino superior. Almeida (2017) analisa a forte influência do fator socioeconômico das famílias dos estudantes no desempenho escolar, assim como os apontamentos de Bourdieu (1998) que nos apresenta a influência do fator sociocultural para a análise do desempenho e expectativas na escolarização, e nos conduz na busca da relação entre origem social, capital cultural familiar e o histórico de escolarização dos estudantes.

Objetivo: Identificar a relação entre o baixo desenvolvimento escolar dos estudantes de camadas populares e a origem social e a herança familiar.

Desenvolvimento: A concepção de Pierre Bourdieu (1964) entende a estrutura social como um sistema hierarquizado de poder, a qual se determina tanto por relações materiais quanto econômicas(salário,renda), culturais (saberes e conhecimentos reconhecidos por diplomas e títulos) e simbólicas (prestígio ou honra) entre os indivíduos. Esses fatores econômicos, sociais, culturais e simbólicos se ligam na origem social dos indivíduos e participam na formação do habitus de classe. Setton (2002) expõe a concepção de Bourdieu quanto ao habitus como sendo uma mediação entre indivíduo e sociedade, em que o pessoal e o subjetivo são concomitantemente incorporados, formando uma subjetividade socializada, uma incorporação subjetiva individual de disposições para ações. Outro elemento incorporado na origem social do sujeito é o capital cultural. Segundo Sousa (2015) a posse e a transmissão do capital cultural relacionam-se com a fração de classe na qual a família pertence. O capital cultural é o conjunto variável de habilidades cognitivas (ligadas à linguagem, cultura erudita, arte) que permite ao indivíduo possuir bens simbólicos e materiais os quais influenciam em suas relações com a escolarização. A diversidade de posse do capital cultural segundo as classes sociais interfere nos históricos de escolarização dos indivíduos segundo suas origens sociais. Bourdieu (1992) apresenta o fato de que a escola não valoriza a baixa posse de capital cultural das camadas populares e que realiza um tipo de seleção mantendo a ordem social preexistente. A escola não cobra apenas habilidades cognitivas, mas também habilidades comportamentais, docilidade e boa vontade, características estas mais comum em indivíduos provenientes de camadas com alta posse de capital cultural. Santos, Ferreira e Ferreira (2017) apontam como e quais formas a escola exerce uma violência simbólica nos estudantes. Nogueira e Nogueira (2002) ressaltam que Bourdieu analisa a ideia de violência simbólica através da noção de arbitrário Cultural , de forma a apontar que nenhuma cultura pode ser objetivamente superior a outra. A cultura legitimada na escola seria imposta pela classe dominante, pois esta cultura corresponde à força da classe social que a sustenta na imposição e legitimação do arbitrário cultural presente na sociedade. Para Bourdieu (1992) a não neutralidade da escola se dá pelo fato da distância existente entre o arbitrário cultural apresentado pela cultura escolar como cultura legítima e a cultura familiar de origem dos alunos de camadas populares. Nesse sentido, a escola dissimula que a cultura imposta e exigida é a cultura das classes dominantes e encobre os efeitos que isso tem para o sucesso escolar das classes dominantes e também para o insucesso das classes populares. Assim, as diferenças nos resultados obtidos pelos alunos seriam entendidas como diferenças na capacidade (dons desiguais), enquanto que na realidade seria resultado da maior ou menor proximidade entre a cultura escolar e cultura familiar do aluno, vindo a gerar resultados como: fracasso escolar, evasão, e o não ingresso ao ensino superior para estudantes das camadas populares. Com isso a escola cumpriria sua função de reprodução e legitimação das desigualdades sociais. Nogueira e Nogueira (2002) discorre sobre a escola como fator de reprodução e legitimação das desigualdades sociais apresentando dados quanto à frustração de jovens das camadas populares diante de falsas promessas do sistema escolar.

Conclusão: As dificuldades no desempenho escolar dos estudantes de camadas populares (evasão, escolarização curta, dificuldades de aprendizagem) estão relacionadas à baixa posse de capital cultural desses sujeitos e ao sistema de ensino que age por meio da violência simbólica, impondo um arbitrário cultural dominante. A legitimação das desigualdades sociais ocorre pois a escola encobre os resultados de diferenças escolares entre as classes recorrendo à ideologia do dom e à meritocracia, dissimulando que a cultura escolar está mais próxima da cultura das camadas elitizadas e muito distante do capital cultural dos estudantes de camadas populares.

\section{Referências}

ALMEIDA, Luana Costa. As desigualdades e o trabalho das escolas: Problematizando a relação entre desempenho e localização 
socioespacial. Rio de Janeiro: Revista Brasil Educação, 2017. Disponível em: http://www.scielo.br/scielo.php? script=sci_arttext\&pid=S1413-24782017000200361. Acesso em: 23 abr. 2020.

BOURDIEU, Pierre; PASSERON, Jean Claud. A Reprodução. Rio de Janeiro: Francisco Alves, 1992.

BOURDIEU, Pierre; PASSERON, Jean Claude. Os Herdeiros. França: 1964.

NOGUEIRA, Cláudio Martins; NOGUEIRA, Maria Alice. A SOCIOLOGIA DA EDUCAÇÃO DE PIERRE BOURDIEU: Limites e contribuições. Campinas: Educação e Sociedade, 2002. Disponível em: https://www.scielo.br/scielo.php? script=sci_arttext\&pid=S0101-73302002000200003\#nota. Acesso em: 21 jun. 2020.

SANTOS, Natália; FERREIRA, Camila; FERREIRA, Thiago. A herança familiar e o rendimento acadêmico: A relação entre os capitais herdados e o rendimento acadêmico no ENADE 2015. Londrina: XXsemeAD, 2017. Disponível em: https://bit.ly/2BoO1sq. Acesso em: 20 jun. 2020. cesso em: 23 abr. 2020.

SETTON, Maria da Graça Jacintho. A teoria do habitus em Pierre Bourdieu: uma leitura contemporânea. Rio de Janeiro: Revista Brasil educação, 2002. Disponível em: https://www.scielo.br/scielo.php?script=sci_arttext\&pid=S1413-24782002000200005. Acesso em: 5 ago. 2020.

SOUSA, Larissa renó Gomide De. Trajetórias Escolaes no Ensino Fundamental: Estudo de uma Escola Pública. São Paulo: Unesp, 2015. Disponível em: https://repositorio.unesp.br/bitstream/handle/11449/132711/000856106.pdf?sequence=1. Acesso em: 28 mar. 2020.

Coordenadoria de Pesquisa e Extensão - COPEX

Departamento de Editoraçāo e Divulgaçāo Científica - DEDIC 


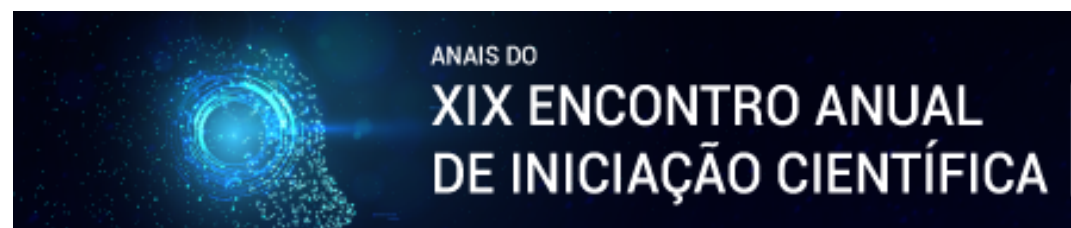

CIÊNCIA, TECNOLOGIA E CONDIÇĀO HUMANA: DESAFIOS, AC̄ŌES E COMPROMISSOS

29 e 30 de Outubro de 2020

ISBN 978-65-87557-08-3

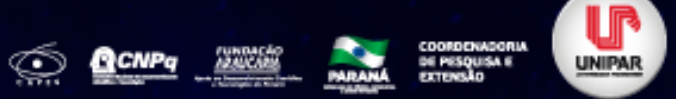

\title{
SOFRIMENTO PSÍQUICO E RELAÇÕES CONTEMPORÂNEAS: ANÁLISE DO FILME BRILHO ETERNO DE UMA MENTE SEM LEMBRANÇAS
}

\begin{abstract}
${ }^{1}$ ANA CLAUDIA PANSERA, ${ }^{2}$ ISADORA GAGLIOTTO GALVAN, ${ }^{3}$ LETICIA PEGORARO LIMA, ${ }^{4}$ NAYSSARA CAROLINA SILVA TASCHIN, ${ }^{5}$ GRACIANE BARBOZA DA SILVA
\end{abstract}

\footnotetext{
${ }^{1}$ Acadêmica do curso de Psicologia da UNIPAR

${ }^{1}$ Acadêmica do Curso de Psicologia da UNIPAR

${ }^{2}$ Acadêmica do Curso de Psicologia da UNIPAR

${ }^{3}$ Acadêmica do Curso de Psicologia da UNIPAR

${ }^{4}$ Docente do curso de Psicologia da UNIPAR
}

Introdução: As produções cinematográficas têm se apresentado como uma ferramenta excelente para trabalhar com aspectos subjetivos e demandas, tanto particulares quanto coletivas, conforme possibilita ao telespectador ampliar sua visão de mundo e refletir sobre outras formas de existência humana, com outras realidades e problemas. A partir disso, o presente trabalho se propõe a relacionar o enredo do longa metragem Brilho Eterno de Uma Mente sem Lembranças (2004) com a existência em uma sociedade pautada nos modelos difundidos pela hipermodernidade, abordando sofrimento psíquico, relacionamentos amorosos e as consequências de uma vida contemporânea baseada no rendimento exacerbado e na pressão por atingir a felicidade plena.

Objetivo: O intitulado trabalho objetiva, por meio de revisão bibliográfica, promover uma análise do filme Brilho Eterno de Uma Mente sem Lembranças, atrelados à contemporaneidade do sofrimento psíquico.

Desenvolvimento: Quão fácil seria apagar algo ou alguém da mente? O filme de ficção Brilho eterno de uma mente sem lembranças retrata a possibilidade de Joel esquecer seu complicado envolvimento amoroso com Clementine por meio de um procedimento invasivo que propõe apagar as memórias sobre outra pessoa. Em suma, grande parte do filme perpassa dentro da memória de Joel e no andamento do procedimento é nítido sentimentos de arrependimento sobre o ato, proporcionando reflexões sobre a importância do sofrimento e do lembrar-se para a constituição subjetiva do ser humano. Por meio disso, adentramos na hipermodernidade (EWALD, MOURA; GOULART, 2012) com uma constituição múltipla de laços sociais, amparadas na dificuldade de gerir e manter esta multiplicidade e o que é produzido destas relações intersubjetivas (BIRMAN, 2019). O filme enuncia a importância das vivências sociais para a construção da memória e da personalidade como um todo e dentro desse contexto, as relações da hipermodernidade são carregadas de inquietações e anseios. A sustentação é baseada na existência de relacionamentos sem apego profundo, independência afetiva e vazio interior; cada indivíduo vive a sua indiferença no conforto de seus interesses e paixões. Gonçalves (2011, p. 331) salienta que o indivíduo quer ser só, sempre e cada vez mais só, ao mesmo tempo em que não suporta a si mesmo estando só . Para além do enredo principal sobre relacionamento amoroso, o filme discorre também o sofrimento causado por uma sociedade imediatista, voltada para o controle extremo e o máximo desempenho dos indivíduos. Joel transparece angústia e frustração de forma passional, depressiva, discorrendo sobre uma vida monótona e desinteressante, ao mesmo tempo em que Clementine, com uma personalidade ansiosa e impulsiva, apresenta discursos voltados para a insatisfação crescente com a superficialidade das relações, portando-se resistente a esse modelo de vida. Dessa maneira, o comportamento e a personalidade das personagens sofre forte influência da condição social em que vivem, onde o mundo moderno capitalista vende uma existência modelo em que o sujeito é pressionado a atingir uma felicidade plena e constante (EWALD, MOURA; GOULART, 2012). Através dessa busca desenfreada pela felicidade utópica, encontra-se mecanismos geradores de sofrimento psíquico, produzindo um sujeito moderno que se impõe uma autodisciplina doentia, tentando controlar tudo de irregular e inesperado na sua experiência subjetiva (EWALD, MOURA; GOULART, 2012). Esse sujeito hipermoderno intensifica a liberdade individual, sendo possível perceber a intersubjetividade e sofrimento psíquico intenso, aludindo a atribuição exclusivamente individual da responsabilidade pelo fracasso ou sucesso de cada um (EWALD, MOURA; GOULART, 2012). Dentro de todos esses potencializadores de angústias e de uma contemporaneidade acelerada, os novos sofrimentos são produzidos e incorporados na subjetividade humana, fazendo-se necessário um novo olhar clínico, mais aprimorado e capaz de perceber traços de adoecimentos implícitos, que foram esquecidos pelo fazer clínico anterior (BIRMAN, 2019).

Conclusão: Durante o estudo apresentado, foi possível concluir que o conceito de hipermodernidade muito se relaciona com apequenar as interações sociais e reduzir a coletividade em sua expressão. O filme é uma bela amostra de que a afetividade é essencial para a constituição psíquica e é intrínseca à condição humana para a construção de laços sociais que atravessam as vivências. O sofrimento psíquico é constituinte do ser humano tanto quanto outros sentimentos, porém com a hipermodernidade há uma certa discriminação da tristeza como um sentimento legítimo.Em síntese, a trama do filme e a intenção dos personagens 
principais resume-se na tentativa falha de eximir-se do sofrimento psíquico, inerente a seu relacionamento e suas lembranças, caracterizando essa atitude além de análoga à hipermodernidade, uma regressão próxima do infantil, não reconhecendo esse sofrimento como uma das ferramentas fundamentais para desenvolver autoconhecimento, pensamento crítico, consciência de si, do outro e dos valores que perpassam a realidade de cada um.

\section{Referências}

BRILHO eterno de uma mente sem lembranças. Direção de Michel Gondry. Los Angeles: Universal, 2004, DVD (108 min). BIRMAN, Joel. O sujeito da contemporaneidade: espaço, dor e desalento. In: SOARES, Alexandre S. F. et al. Discurso, interlocuções e.....Caxias do Sul, RS: Educs, 2019, p. 111- 136. Disponível em: . Acesso em: 15 de junho de 2020.

EWALD, A. P.; MOURA, M. T. de C.; GOULART, S. M. da S. Contemporaneidade e sofrimento psíquico: Relações entre modos de vida e demandas psicoterapêuticas. Revista Psicologia Argumento- PUCPR, Curitiba, v. 30, n. 68, p. 119-129, 2012. Disponível em: https://periodicos.pucpr.br/index.php/psicologiaargumento/article/view/20271. Acesso em: 15 de junho de 2020.

GONÇALVES, Marco A. Indivíduo hipermoderno e consumo. Anais do VII Seminário de Pós-Graduação em Filosofia da UFSCar, São Carlos- SP, p. 327- 336, 2011. Disponível em: . Acesso em: 15 de junho de 2020. 


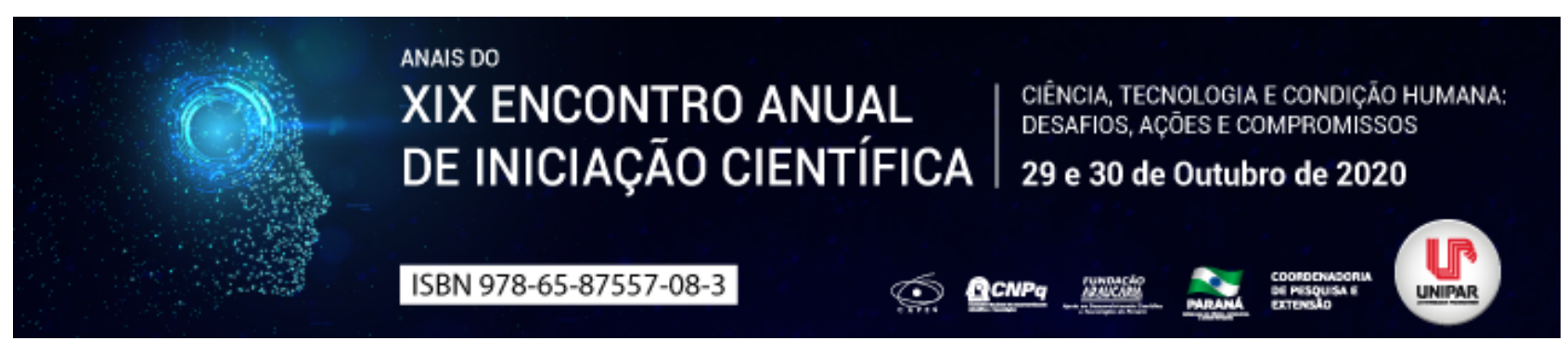

ALTERAÇÕES DO CPC NA INTERDIÇÃO E CURATELA E A GARANTIA DA DIGNIDADE HUMANA

\author{
${ }^{1}$ LETICIA BIANCA PINHEIRO, ${ }^{2}$ ALANA CAROLINE MOSSOI, ${ }^{3}$ MIRIAM FECCHIO CHUEIRI
}

\author{
${ }^{1}$ Acadêmica PIC/UNIPAR \\ ${ }^{1}$ Acadêmica PIC/UNIPAR \\ ${ }^{2}$ Docente da UNIPAR
}

Introdução: O Código de Processo Civil de 2015 incluiu diversas modificações quanto à interdição (processo que estabelece a curatela), regulada na Seção IX, do Capítulo XV que trata dos Procedimentos de Jurisdição Voluntária da Lei no 13.105/2015 (CPC). Alterações necessárias para garantir a autodeterminação da pessoa com deficiência e garantir a preservação da sua dignidade humana, não ficando mais refém da interdição como uma medida de retirada de direitos.

Objetivos: O presente trabalho tem como objetivo a visualização das alterações realizadas no processo de interdição e consequente curatela, de forma a analisar os benefícios das mudanças trazidas à vida dos curatelados, que passam a ter maior autonomia e garantia de seus direitos fundamentais.

Desenvolvimento: O artigo 1.072 do CPC/2015, revogou os artigos 1.768 a 1.773 do Código Civil que previa sobre os aspectos processuais da curatela dos interditos, passando a prever em seu bojo os artigos 747 a 763 acerca do processo de interdição. Apesar do CPC/2015 ter sido publicado antes da Lei no 13.146/2015 (EPCD), o primeiro ter entrado em vigor em 18/03/2016, e a segunda em 02/01/2016, incide o que prevê o artigo 121 da Lei no 13.146/2015, em especial o parágrafo único, aduz que prevalecerá a norma mais benéfica à pessoa com deficiência (MEDINA, 2016, p. 894). Ressalta-se quanto à legitimidade na ação de interdição, que o CPC/2015 não prevê possibilidade da Autointerdição. (DONIZETTI, 2017). José Miguel Garcia Medina (2016, p. 282) entende ser possível a autointerdição: [...] a finalidade do instituto liga-se à própria autodeterminação do ser humano, e isso restaria inegavelmente restringido caso não se admitisse que a iniciativa de requere-lo partisse da própria pessoa. [...] . Maior relevância se dá também ao artigo 758 do CPC/2015, ao estabelecer que o curador deverá buscar tratamento e apoio apropriados à conquista da autonomia pelo interdito . Assim, o curador tem papel indispensável na busca conjunta da autonomia e empoderamento do interditado, não atendo-se somente à suprir as necessidades da pessoa com deficiência, fazendo assim com que evoluindo nos tratamentos, possa ser dispensada a curatela total ou parcialmente (LAGO JÚNIOR; BARBOSA, 2016, p. 15).

Conclusão: Foram várias modificações incluídas pelo CPC/2015 na interdição e curatela, entre as mais relevantes estão a legitimidade para ação de interdição, a possibilidade de nomeação de curador provisório, a realização de entrevista (antes tida como oitiva), a possibilidade do interditando ser ouvido do local onde estiver, e o dever do curador de buscar tratamento e apoios apropriados buscando trazer maior autonomia e dignidade à pessoa com deficiência.

\title{
Referências
}

BRASIL. Código de Processo Civil Lei no 13.105 de 16 de Março de 2015. Disponível em: Acesso em: 18 ago. 2020.

BRASIL. Estatuto da Pessoa com Deficiência Lei no 13.146 de 6 de Julho de 2015. Disponível em: Acesso em: 18 ago. 2020. MEDINA, José Miguel Garcia Curso de Direito Processual Civil Moderno 2. Ed. São Paulo: Editora Revista dos Tribunais 2016.

DONIZETTI, Elpídio Novo Código de Processo Civil Comentado 2 ed. São Paulo Atlas - 2017.

LAGO JÚNIOR, Antonio; BARBOSA, Amanda Souza. Primeiras Análises sobre o Sistema de (In)Capacidades, interdição e curatela pós Estatuto da Pessoa com Deficiência e Código de Processo Civil de 2015. Revista de Direito Civil Contemporâneo vol. 8/2016 p. 49-89 Jul-Set-2016 DTR201623930. 


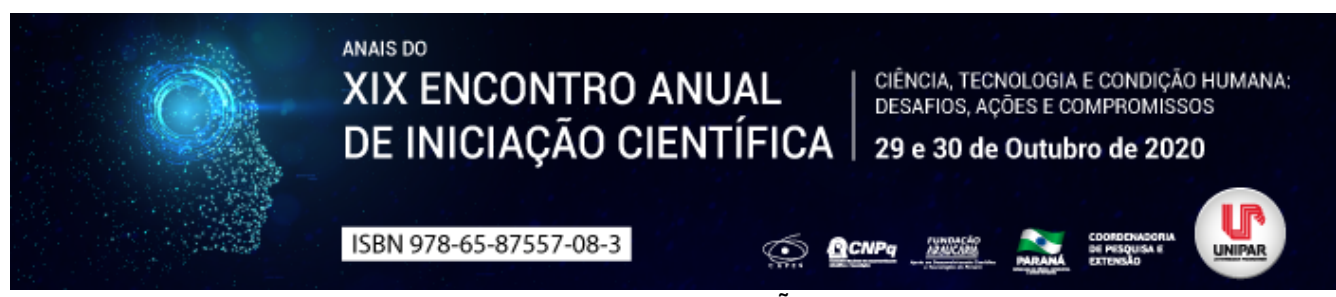

FRAUDE EM LICITAÇÕES

\author{
${ }^{1}$ RICARDO ANTONIO ORTINA, ${ }^{2}$ FABIO LUIZ SANTIN DE ALBUQUERQUE
}

\author{
${ }^{1}$ Acadêmico curso de Direito UNIPAR \\ ${ }^{1}$ Docente da UNIPAR
}

Introdução: Cada vez mais os princípios e as leis que regem as licitações são corriqueiramente desrespeitados, gerando um número exorbitante de investigações e denúncias. Por óbvio que os grandes escândalos de fraudes em licitações públicas e a desenfreada inobservância das regras referentes ao tema não é de hoje, durante muitos anos inúmeros tipos de fraudes ocorreram e ocorrem no País, porém, no atual cenário vivido, onde a informação e o acesso à internet se tornou mais abrangente, a globalização e a popularização dos meios de comunicação, ajudam na divulgação de tais fraudes, causando ainda mais indignação e comoção social. Desse modo, diante de tal cenário, a presente pesquisa se faz relevante a fim de discutir e levantar questões de suma importância, envolvendo o administrador público, a coisa pública, os princípios norteadores e a essência da licitação.

Objetivo: O presente estudo tem como objetivo a compreensão das licitações, bem como as fraudes que podem vir a existir em suas elaborações, abrangendo assim os princípios norteadores de tal instituto jurídico, as modalidades de licitação e os seus objetivos individuais, bem como as penalidades ante a fraude. Por essa razão, este trabalho tem como finalidade a explanação de pontos essenciais e indispensáveis referente as licitações e as possíveis fraudes advindas.

Desenvolvimento: Conforme José Carlos Oliveira A licitação é o meio pelo qual o Poder Público seleciona a proposta mais vantajosa para suas aquisições/contratações, através de um procedimento administrativo que propiciará a igualdade entre àqueles que desejam contratar com a Administração Pública, sob a égide da eficiência e moralidade, e, principalmente, que atenda ao interesse público $(2020$, p. 03). Ainda, importante saber que a licitação é regida por alguns princípios os quais permitem que o administrador solucione conflitos não previstos explicitamente no corpo legislativo (OLIVEIRA, 2020). Trata-se assim, de oito princípios relacionados as licitações, quais sejam, Princípio da Isonomia, Princípio da Legalidade, Princípio da Impessoalidade, Princípio da Moralidade, Princípio da Publicidade, Princípio da Probidade Administrativa, Princípio da Vinculação ao Instrumento Convocatório e Princípio do Julgamento Objetivo, os quais julga-se ser os mais corriqueiros e aplicados, uma vez que quanto ao tema de princípios há uma gama maior, sendo que todos possuem a sua importância destacada. Ainda, observa-se que há modalidades diferente de licitações para cada tipo de obtenção de objeto ou serviço por parte da Administração Pública, citando-se as modalidades de: Concorrência, Tomada de Preço, Convite, Concurso, Leilão e Pregão. Interessante pontuar que tais diretrizes, ou seja, os princípios e modalidades citados, são estipuladas para, além de facilitar o modo de aplicação da licitação, evitar as fraudes e prejudiciais em desfavor do ente público. Porém, como já descrito, a fraude em licitações está interligada não somente a ganância e a audácia de burlar um sistema para auferir vantagens próprias, muitas vezes está ligada com uma cultura de dar um jeito ou, de fato sempre obter vantagens primeiro e sob direitos alheios. Infelizmente, não é somente no sistema Brasileiro que vemos tal corrupção, uma vez que a ganância e a sede de poder está, muitas vezes, no amago do ser humano, porém, a divulgação dos atos fraudulentos, bem como a punição dos responsáveis por tais praticas revela-se um ponto de partida para a contenção ou desestimulo as fraudes, uma vez que causa repulsa na sociedade em saber que uma funcionário público ou licitante, o qual deveria presar pelas normas e seguridade do ente público, passa a fraudá-lo a fim de obter vantagens pessoais com produtos ou serviços que deveriam ser adquiridos para o bem e utilidade comum.

Conclusão: Nessa perspectiva e posterior a análise desse trabalho conclui-se que uma das formas de prevenir a fraude em licitações é confecção um edital bem elaborado, atendendo ao princípio da vinculação ao instrumento convocatório. Um edital incompleto é um caminho para que ocorra o ato ilícito e tenham-se interpretações dúbias. Para uma boa elaboração, é preciso que as pessoas responsáveis se empenhem, façam um trabalho bem feito, de acordo com os princípios da licitação, com uma boa definição do objeto a ser comprado e com as devidas condições necessárias para a habilitação das empresas (MENDONÇA, 2020).

\title{
Referências
}

DELEGADO, Rafael A. Fraudes em processos de licitação. Disponível em: https://facnopar.com.br/conteudo-arquivos/arquivo-2017-06-14-14974728446976.pdf. Acesso em: 03/05/2020.

LEMES, Priscila Alexandre. As fraudes nos processos licitatórios. Disponível em: https://www.faef.br/userfiles/files/14\%20\%20AS\%2OFRAUDES\%20NOS\%20PROCESSOS\%20LICITATORIOS.pdf. Acesso em: 03/05/2020.

Mazza, Alexandre. Manual de direito administrativo. 2. ed. São Paulo: Saraiva, 2012.

Mazza, Alexandre. Manual de direito administrativo. 3. ed. São Paulo: Saraiva, 2013

MEIRELLES, Hely Lopes. Direito administrativo brasileiro. 39. ed. São Paulo: Malheiros, 2013.

MELLO, Celso Antônio Bandeira de. Curso de Direito Administrativo. 27 ed. rev. atual. São Paulo: Malheiros Editores. 2010.

MENDONÇA, Bárbara Maria Serrano. Análise das principais fraudes ocorridas no processo licitatório na esfera federal e suas medidas preventivas. Disponível em: https://repositorio.ufpb.br/jspui/bitstream/123456789/1840/1/BMSM2882017.pdf. Acesso em 29/06/2020.

OLIVERA. José Carlos de. Princípios no processo licitatório. Disponível em: https://acervodigital.unesp.br/bitstream/123456789/47310/1/a1_m1_s04_107.pdf. Acesso em: 03/05/2020.

ROGÉRIO, Paula. Crime de corrupção na administração pública. https://aberto.univem.edu.br/bitstream/handle/11077/552/Crime\%20de\%20corrup\%c3\%a7\%c3\%a30\%20na\%20administra\%c3\%a7\%c3\%a30\%20p\%c3\%bablica.pdf? sequence=1\&isAllowed=y. Acesso em: 03/05/2020.

ROSA, Márcio Fernando Elias. Direito administrativo. 3. ed. São Paulo: Saraiva, 2011.

SANTOS, Leandro Evangelista. Crimes praticados por funcionários públicos contra a administração pública: uma análise do peculato. Disponível em: http://homolog.creasp.org.br/assets/uploads/artigos/TCC.pdf. Acesso em: 03/05/2020.

VRIELINK, Gabriela. Fraudes nas licitações: uma análise crítica dos crimes da Lei 8.666/93. Disponível em: https://repositorio.unisc.br/jspui/bitstream/11624/849/1/TC\%20II\%20-\%20Gabriela\%20Vrielink.pdf. Acesso em: 03/05/2020. 


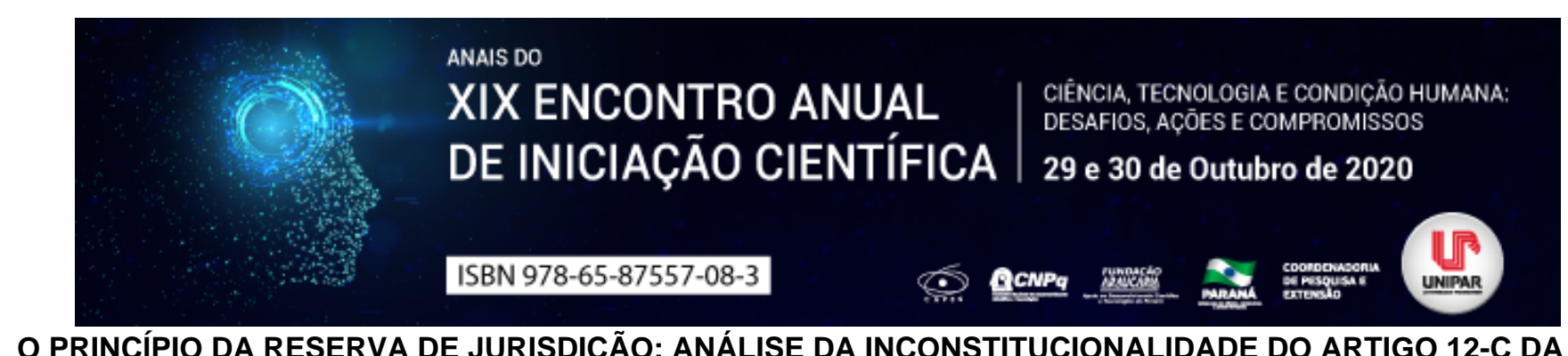

O PRINCÍPIO DA RESERVA DE JURISDIÇÃO: ANÁLISE DA INCONSTITUCIONALIDADE DO ARTIGO 12-C DA LEI $13.827 / 2019$

\title{
${ }^{1}$ LUANE TAISA DE MORAES, ${ }^{2}$ JANE MARA DA SILVA PILATTI
}

\author{
${ }^{1}$ Acadêmica do curso de Direito da UNIPAR \\ ${ }^{1}$ Docente da UNIPAR
}

Introdução: Considerando o atual debate sobre a Lei $n^{\circ} 13.827 / 2019$, que culminou na ADIN $n^{\circ} 6.138$ em trâmite no Supremo Tribunal Federal, objetiva-se examinar a inconstitucionalidade do artigo 12-C do normativo referendado, sob a égide do princípio da reserva de jurisdição. A lei traz em sua redação uma ampliação em relação à aplicação de medidas protetivas de urgência, na qual estabelece a possibilidade de o delegado de polícia e/ou o policial conceder medidas protetivas de urgência ao tomar conhecimento das agressões sofridas pela vítima.

Objetivo: Analisar a inconstitucionalidade do artigo 12-C da Lei 13.827/2019 como elemento de colisão ao princípio da reserva da jurisdição.

Desenvolvimento: Nota-se que o comportamento humano não é apenas regulamentado por leis que o Direito apresenta, vai muito além disso, trazendo para a convivência de um homem e uma mulher os costumes, crenças religiosas e os hábitos, condutas estas, que uma legislação não consegue alcançar (NORONHA, 2010, p. 22-23). A lei 11.340/06, a qual tem como título Maria da Penha criou mecanismos para coibir a violência no âmbito doméstico em que tem como principal vítima a mulher, entre eles, as chamadas medidas protetivas de urgência as quais buscam garantir a integridade física, moral, sexual e psicológica da mulher. Em sentido amplo, não se fala apenas em violência física, mas também atos que submetam a mulher a fazer algo contra sua vontade, obrigando-a viver em um ambiente de violência e privação de liberdade. (TELLES; MELO,2002, p.25). A lei 13.827/2019, alterou em parte a lei 11.340/06 e implementou o artigo 12-C incisos II e III, admitindo-se que o delegado de polícia ou o policial, na ausência de delegado no momento da notícia do fato, determinem a aplicação de medidas protetivas, em situação emergencial, às mulheres submetidas a atos de violência intrafamiliar (e seus dependentes), em cidades onde não há juiz, vale dizer, naquelas que não são sede de comarca. (BRASIL, 2019). A ideia de princípio da reserva de jurisdição está relacionada com determinadas matérias em que cabe apenas ao juiz manifestar a primeira e última palavra, não sendo possível delegar esta função a outro órgão (CANOTILHO, 2003, p.580). Da mesma forma, a Constituição Federal em seu art. $2^{\circ}$ consagra o princípio da separação dos poderes entre o executivo, legislativo e judiciário, de modo que qualquer decisão judicial deve ser emanada por uma autoridade judicial. Por sua vez, a alteração legislativa faz com que a atividade jurisdicional que pressupõe a capacidade técnica de interpretar a lei para julgar, esteja na outorga da autoridade policial. Logo, torna-se manifesto o conflito entre o artigo 12-C e o princípio da reserva de jurisdição, ao passo que restringir a liberdade de alguém (art. $5^{\circ}$ LIV, CF), e ingressar no domicílio (art. $5^{\circ}, \mathrm{XI}, \mathrm{CF}$ ) são atos de competência da jurisdição absoluta conferidas aos magistrados. (BRASIL, 1988).

Conclusão: A Lei Federal 13.827/2019 inseriu a possibilidde de concessão de medida protetiva em âmbito policial, atribuindo assim, um maior número de legitimados à aplicação do mecanismo de proteção. No entanto, ao outorgar função exclusiva dos magistrados (como preceitua a Carta Magna de 1988) às autoridades policiais, é decorrida clara ofensa ao princípio da reserva de jurisdição absoluta e ao ideário democrático.

\section{Referências}

BRASIL. Lei $\mathrm{n}^{\circ} \mathbf{1 1 . 3 4 0}$ de 07 de agosto de 2006. Instituiu os mecanismos para coibir a Violência Doméstica e Familiar contra a mulher. Disponível em: http://www.planalto.gov.br/ccivil_03/_ato2004-2006/2006/lei//11340.htm. Acesso em: 15 de ago. 2020.

BRASIL. Lei $\mathrm{n}^{\circ} \mathbf{1 3 . 8 2 7}$ de 13 de maio de 2019. Instituiu casos específicos que a Autoridade Policial poderá conceder medidas protetivas de urgência. Disponível em: http://www.planalto.gov.br/ccivil_03/_Ato2019-2022/2019/Lei/L13827.htm. Acesso em: 15 de ago. 2020.

BRASIL. Constituição (1988). Constituição da República Federativa do Brasil. Brasília, DF: Senado Federal: Centro Gráfico, 1988. Disponível em: http://www.planalto.gov.br/ccivil_03/constituicao/constituicao.htm. Acesso em: 16 de ago. 2020.

CANOTILHO, J.J. Gomes. Direito Constitucional e Teoria da Constituição. 7. ed. Coimbra: Almedina, 2003. p.580

NORONHA, Joanna Vieira. De Desdêmona a Alice: Gênero, Ação Política e Violência Doméstica. Dissertação (Mestrado em Direito) Pontifica Universidade Católica do Rio de Janeiro-RJ, 2010. p. 22-23 Disponível em: https://www.maxwell.vrac.pucrio.br/16511/16511_1.PDF Acesso em: 14 de agosto de 2020

TELES, Maria Amélia de Almeida; MELO, Mônica de. O que é violência contra a mulher. Coleção Primeiros Passos. São Paulo: Brasiliense, 2002. p. 15. 
Coordenadoria de Pesquisa e Extensão - COPEX

Departamento de Editoraçāo e Divulgaçāo Científica - DEDIC 


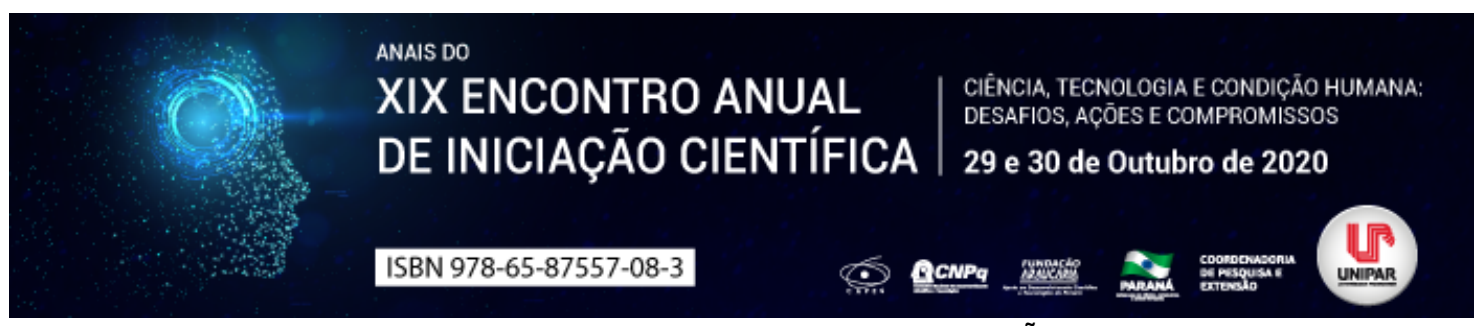

MULTICULTURALISMO, RELATIVISMO CULTURAL E A PROTEÇÃO DOS POVOS AMISH

\author{
${ }^{1}$ NATAN GALVES SANTANA, ${ }^{2}$ TEREZA RODRIGUES VIEIRA
}

\footnotetext{
${ }^{1}$ Mestrando em Direito Processual e Cidadania e integrante do PIC da UNIPAR

${ }^{1}$ Docente do Mestrado em Direito Processual e Cidadania da UNIPAR
}

Introdução: $\mathrm{Na}$ atualidade, é possível constatar que todos os países são ricos em diversidade cultural, aonde grupos lutam para manter a sua cultura e seus costumes, por outra via, a globalização coloca em cheque alguns tipos de culturas, uma vez que os grupos majoritários desejam estabelecer o seu padrão cultural. Desta feita, surge a necessidade da proteção das comunidades minoritárias, como é o caso dos povos Amish. Objetivo: Identificar e analisar os direitos fundamentais dos povos Amish em face do multiculturalismo.

Desenvolvimento: O multiculturalismo implica na convivência pacífica de várias culturas em um mesmo espaço. Trata-se de um elemento social ligado à globalização e às sociedades ocidentais, onde há vários imigrantes, que os tornam grupos de minorias (DAMÁZIO, 2011). Abellán (apud Lucas, 2008) elenca que o multiculturalismo possui dois grupos, o primeiro exige o reconhecimento igualitário, assim, as diferenças devem ser eliminadas, precisando de uma cultura política compartilhada, valorizando o pluralismo cultural e o direito individual para seguir a sua cultura. Já o segundo grupo tem ligação com o relativismo, logo, deverão ser reconhecidos e protegidos os diferentes grupos culturais, como sujeitos do direito coletivo, no qual se dá importância à identidade de seus integrantes. Nesse sentido, a Declaração Universal sobre a Diversidade Cultural (2002), em seu art. 3, dispõe que a diversidade amplia a possibilidade de escolhas, pois possui referência com o desenvolvimento, não apenas econômico, mas intelectual, moral e espiritual, corroborando com o art. 27 da Declaração Universal de Direito Humanos (1948), o qual assegura que toda pessoa tem o direito de tomar parte livremente na vida cultural da comunidade [...] . Posto isso, cumpre salientar que o Estado garantirá a todos o pleno exercício dos direitos políticos e acesso às fontes da cultura nacional, e apoiará e incentivará a valorização e a difusão das manifestações culturais, devendo proteger (MORAES, 2014, p. 862). Neste aspecto, entram em cena os povos Amish, comunidade que vive isolada, principalmente nos Estados Unidos e no Canadá. Esses povos não fazem uso da tecnologia, como celulares e automóveis, não tiram fotos, as crianças participam de escola exclusiva e nunca vão cursar faculdade, tudo isso fundamentado nos textos bíblicos, pois vivem literalmente a sagrada escritura. Os Amish exercem o direito à religião e aos costumes, por outro lado, é notória a ofensa aos direitos fundamentais como a proibição de acesso à internet, declarado como direito humano nos tempos atuais. Evidente que esta comunidade, ao exercer um direito fundamental, renunciou o outro direito, uma vez que, parte da doutrina entende que este direito é irrenunciável, considerando que a irrenunciabilidade tem como base a dignidade da pessoa humana. Assim, todo homem possui dignidade, direito irrenunciável (MENDES, 2009). Por outra banda, para que ocorra a restrição dos direitos fundamentais é necessário passar pelo crivo da proporcionalidade, com o objetivo de saber se a restrição/redução do direito fundamental é ou não o mais correto a se fazer.

Conclusão: Toda comunidade busca a liberdade e a proteção à dignidade humana, devendo haver proteção aos costumes e à cultura de origem, garantidos por tratados internacionais de direitos humanos. Os povos Amish sacrificam direitos fundamentais para exercerem o direito à religião, direito essencial para manter a dignidade, logo, enquanto manifesto de liberdade é a comunidade que deverá decidir qual direito deve preponderar desde que não ofenda os direitos de terceiros. Assim, a proteção do multiculturalismo possui papel fundamental para a proteção de grupos minoritários, portanto, a imposição de direitos seria um regresso e desrespeito aos direitos humanos.

\title{
Referências
}

DAMÁZIO, Eloise da Silveira Petter. Colonialidade e descolonialidade da (anthropos)logia jurídica: da uni-versalidade e pluri-versalidade epistêmica. Orientador: Thais Luzia colaço. 2011. Tese (Doutorado em Direito). Universidade Federal de Santa Catarina, Florianópolis, 2011. Disponível em: https://repositorio.ufsc.br/handle/123456789/95973. Acesso em: 12 jun. 2020.

LUCAS, Douglas Cesar. Direitos Humanos e interculturalidade: um diálogo entre a igualdade e a diferença. Orientador: Vicente de Paulo Barretto. 2008. Tese (Doutorado em Direito) Universidade do Vale do Rio dos Sinos, São Leopoldo, 2008. Disponível em: http://www.repositorio.jesuita.org.br/handle/UNISINOS/2481. Acesso em: 12 jun. 2020.

MENDES, Laura Schertel F. Um debate acerca da renúncia aos direitos fundamentais: para um discurso dos direitos fundamentais como um discurso de liberdade. Estudos, Conferências e Notas, n. 13, jul. Set. 2006.2 Disponível em: http://dspace.idp.edu.br:8080/xmlui/bitstream/handle/123456789/544/Direito\%20Publico\%20n132006_Laura\%20Schertel\%20F\%20Mendes.pdf? sequence=1. Acesso em: 12 jun. 2020.

MORAES, Alexandre de. Direito Constitucional. 30. ed. São Paulo: Atlas, 2014.

ONU. Declaração universal dos direitos humanos. 1948. Disponível em: https://nacoesunidas.org/wp-content/uploads/2018/10/DUDH.pdf. Acesso em: 05 maio 2020.

UNESCO. Declaração universal sobre a diversidade cultural. $2002 . \quad$ Disponível em: https://www.oas.org/dil/port/2001\%20Declara\%C3\%A7\%C3\%A30\%20Universal\%20sobre\%20a\%20Diversidade\%20Cultural\%20da\%20UNESCO.pdf. Acesso em: 13 jun. 2020. 


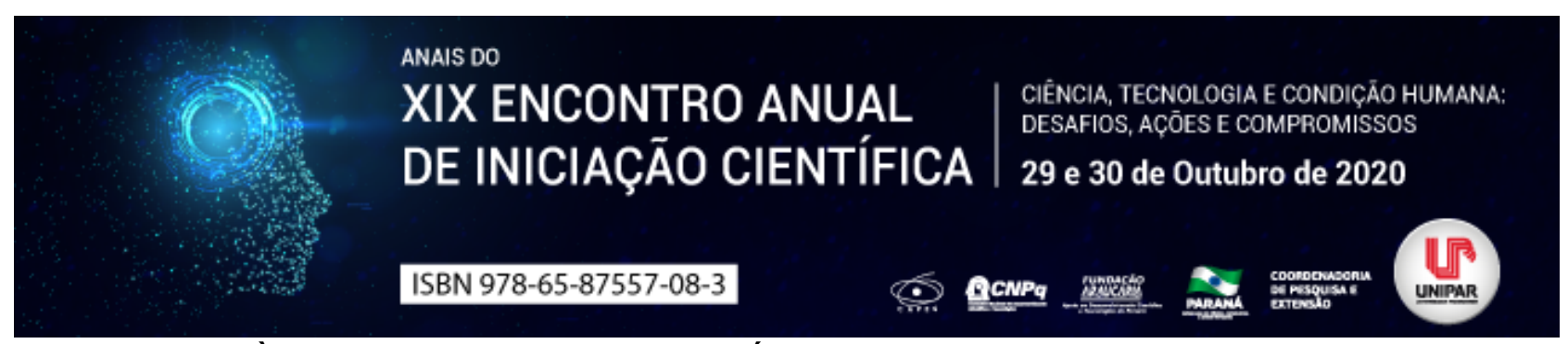

DIREITO À VIDA E O ABORTO LEGAL: ANÁLISE SOBRE O ENFOQUE DA MICROCEFALIA

\title{
${ }^{1}$ LETICIA VANDRESEN MELATI, ${ }^{2}$ LUDMILA KOLB DE VARGAS CAVALLI
}

\author{
${ }^{1}$ Acadêmica do curso de Direito da UNIPAR \\ ${ }^{1}$ Docente da UNIPAR
}

Introdução: O presente trabalho irá tratar do principal direito fundamental no ordenamento jurídico brasileiro, o direito à vida, junto ao aborto legal e posteriormente uma análise sobre o enfoque da microcefalia. Partindo da análise da liberdade de escolha da mulher, da dignidade, da saúde e de sua autodeterminação.

Objetivo: $\mathrm{O}$ presente estudo tem como objetivo apresentar uma nova visão referente ao direito à vida e ao aborto legal, frente ao direito de escolha da mulher, sua liberdade, dignidade, saúde e autodeterminação. Apresentando uma breve análise com os mesmos argumentos, acima mencionados para fundamentar a solução do caso da interrupção da gravidez do feto com microcefalia.

Desenvolvimento: Os direitos fundamentais são aqueles previstos no ordenamento constitucional de uma nação, isso é o que os diferencia dos direitos humanos, logo estes são aqueles que vão além das fronteiras de uma nação. Ou seja, os direitos fundamentais são os direitos básicos, individuais, coletivos e sociais do homem, sendo aqueles considerados inerentes à pessoa humana (SARLET, 2009, p.29-35). Os direitos fundamentais estão expressos no art. $5^{\circ}$ da Constituição Federal: Todos são iguais perante a lei, sem distinção de qualquer natureza, garantindo-se aos brasileiros e aos estrangeiros residentes no País a inviolabilidade do direito à vida, à liberdade, à igualdade, à segurança e à propriedade (BRASIL, 1988). Sendo assim, dentre todos os direitos fundamentais, consideramos o direito à vida como o direito fundamental mais importante dentro de nosso ordenamento jurídico, pois sem a vida não seria possível usufruir dos outros direitos inerentes à pessoa humana. Nota-se que podemos ligar o direito à vida à luz da dignidade da pessoa humana, uma vez que a vida é necessária para que os demais direitos existam e possuam sentido. Eis um dos motivos de este direito ser considerado o mais importante e fundamental, porém o respeito à dignidade da pessoa humana é imprescindível para que a vida perdure com as devidas garantias e condições sociais (MACHADO, 2015, p.74). Quando falamos sobre o direito fundamental à vida, estamos falando sobre viver com dignidade, com o mínimo de cidadania, viver com qualidade de vida, com liberdade, alegria, integridade moral, e física, entre muitos outros. No ordenamento jurídico brasileiro, a exceção ao direito à vida que se destaca é o aborto legal, previsto no artigo 128 do Código Penal para os casos de gravidez com risco de óbito da gestante e concepção resultante de violência sexual (BRASIL, 1940). Mediante construção jurisprudencial, admite-se também nos casos de anencefalia fetal, pela impossibilidade de sobrevida do nascituro ao parto (ADPF $n^{\circ} 54$ ). No aborto necessário há conflito entre dois valores fundamentais: a vida da gestante e a vida do feto. $\mathrm{E}$ o legislador dá preferência àquela, por se tratar de pessoa madura e completamente formada, sem a qual dificilmente 0 próprio feto poderia seguir adiante. Por sua vez, no aborto em caso de gravidez resultante de estupro, o Código Penal encontra seu fundamento de validade na dignidade da pessoa humana, nos termos do art. $1 .^{\circ}$, III) da Constituição (BRASIL, 1988). Entendeu o legislador que seria atentatório à mulher exigir a aceitação em manter uma gravidez e criar um filho decorrente de uma situação trágica e covarde, que somente lhe traria traumas e péssimas recordações (MASSON, 2015, p.100). Analisando assim, com base nos mesmos argumentos acima descritos, nos casos de microcefalia, podemos comparar com as razões de decidir da ADPF $n^{\circ} 54$, que garantiu o direito às mulheres grávidas interromperem a gestação de feto anencéfalo. O objetivo é justamente investigar a relação entre as razões de decidir da ADPF n ${ }^{\circ} 54$ e os casos de microcefalia, que se espalharam pelo Brasil, causando condição neurológica que se caracteriza por anormalidades no crescimento do cérebro, em geral, ela ocorre quando os ossos do crânio se fundem e não deixam espaço para que o cérebro cresça (BELTRAME, 2020). Porém neste caso mostra-se inaplicável o argumento da atipicidade da conduta de interrupção da gravidez de feto anencéfalo, tendo em vista que na microcefalia não há propriamente a inviabilidade da vida extrauterina, mas apenas um conjunto ainda incerto de sequelas que poderão restringir em maior ou menor grau as funções do bebê. No entanto, a outra razão de decidir na ADPF 54 trata da impossibilidade de se exigir da mulher o prolongamento da gestação, expondo-a a desnecessário sofrimento físico e/ou psíquico com grave dano à sua dignidade, liberdade, autodeterminação, saúde, privacidade e ao pleno reconhecimento dos direitos sexuais e reprodutivos. Estes argumentos utilizados, por sua vez, são sim aptos a fundamentar também a solução do caso da interrupção da gravidez do feto com microcefalia (DIAS DA SILVA; MELIM BRAGA. 2019, p.237).

Conclusão: Ante o exposto, concluímos que nos casos em que o aborto legal é permitido em nosso ordenamento jurídico brasileiro, os argumentos utilizados para tal construção (seja legislativa ou jurisprudencial), foram baseados no direito de escolha das mulheres, o direito de ter uma vida digna, com saúde e autodeterminação. Estes fundamentos também são capazes de amparar o aborto nos casos de microcefalia. 


\section{Referências}

BELTRAME https://www.tuasaude.com/microcefalial. Acesso em 20 de agosto de 2020.

BRASIL, Constituição da República Federativa do Brasil de 1988 . Disponível em < http://www.planalto.gov.br/ccivil_03/constituicao/constituicao.htm> Acesso em 03 de agosto de 2020.

BRASIL, Decreto lei $\mathbf{n}^{\circ}$ 2.848, de 7 de dezembro de 1940. Disponível em < http://www.planalto.gov.br/ccivil_03/decretolei/del2848compilado.htm> Acesso em 03 de agosto de 2020.

BRASIL. Arguição de Descumprimento de Preceito Fundamental 54 Distrito Federal. Acesso em 14 de agosto de 2020.

DIAS DA SILVA. Roberto Baptista; MELIM BRAGA. Thiago. As razões de decidir da ADPF 54 e suas implicações nos casos de microcefalia. Constituição, Economia e Desenvolvimento: Revista da Academia Brasileira de Direito Constitucional. Curitiba, 202, vol. 11, n. 21, p. 213-239, ago-dez, 2019. Acesso em 7 de agosto de 2020.

MACHADO. Janaína. A Proteção ao Direito à vida e a Dignidade da Pessoa Humana: Controvérsias Acerca do Aborto de Anencéfalos. Revista do Departamento de Ciências jurídicas e Sociais da Unijuí. pg. 66-92. 2015.

MASSON, Cleber. Direito Penal Esquematizado, Vol. 2, Parte Especial (arts. 121 a 212), $7^{\circ}$ ed. rev., atual. e ampl.- Rio de Janeiro: Forense; São Paulo: Método, 2015.

SARLET, Ingo Wolfgang. A eficácia dos direitos fundamentais. 10. ed. Porto Alegre: Livraria do Advogado, 2009. 


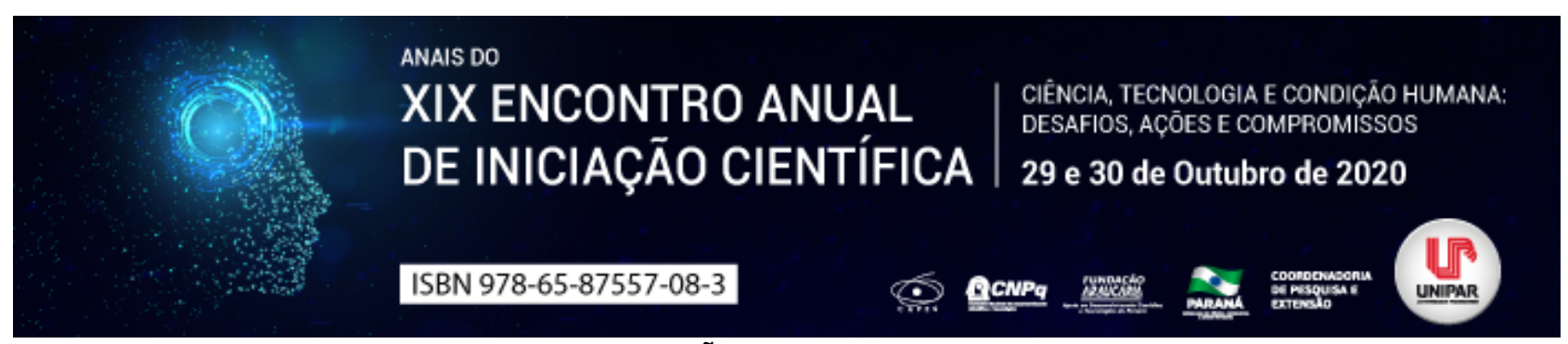

ATIVIDADE PERIGOSA NA VISÃO DO TRIBUNAL SUPERIOR DO TRABALHO

\author{
${ }^{1}$ KARINA DE MELO SANTANA, ${ }^{2}$ PAULO CESAR DE SOUSA
}

${ }^{1}$ Acadêmica do curso de Direito e PIC/UNIPAR

${ }^{1}$ Docente da UNIPAR

Introdução: O presente estudo investiga a interpretação jurisprudencial que tem sido levada a efeito pelo Tribunal Superior do Trabalho quanto à expressão atividade perigosa , constante do enunciado do parágrafo único do artigo 927 do Código Civil de 2002.

Objetivo: Compreender como o conceito jurídico vago atividade perigosa , constante da parte final do parágrafo único do artigo 927 do Código Civil, tem sido interpretado e aplicado pela jurisprudência do TST.

Desenvolvimento: Os riscos pelo empreendimento, a teor do que dispõe o caput do artigo $2 .^{\circ}$ da CLT, devem ser assumidos por quem desempenhar uma atividade econômica (BRASIL, 1943). É consequência do que se denomina princípio da alteridade. Nesse passo, há o reconhecimento da responsabilidade objetiva do empregador de compensar danos decorrentes da violação de direitos do empregado. Isso porque a obrigação de indenizar parte da ideia de violação do direito de segurança da vítima (CAVALIERI FILHO, 2012, p. 189). O parágrafo único do artigo 927 do Código Civil prevê que a responsabilidade civil pode ter como fundamentos a teoria do risco em duas hipóteses: a primeira, nos casos especificados em lei; a segunda, quando se tratar de uma atividade perigosa que, por sua natureza, implique riscos para o direito de outrem. Essa última hipótese é um conceito jurídico indeterminado cuja interpretação e aplicação dependem de um juízo de valor por parte da autoridade julgadora. Nas relações de trabalho, essa situação é recorrente. Com frequência, o TST precisa decidir sobre a aplicação desse conceito normativo, pois o perigo com relação a terceiros em geral, dentre os quais o empregado é fator que rende ensejo a que o juiz defina quanto a ocorrência ou não de atividade de risco no caso concreto (VENOSA; RODRIGUES, 2019). Esse conceito jurídico vago possibilita à jurisprudência e à doutrina fixar parâmetros para definir o alcance efetivo de seu conteúdo. Por conseguinte, ao examinar-se mais de 50 julgados do TST, proferidos entre os anos de 2005 a 2020, nota-se que têm sido qualificadas como perigosas atividades empresariais concernentes a: atividade com motocicleta; mecânica de automóveis; atividade portuária; telefonia; transporte de valores; transporte de cargas; operação de máquinas; construção civil; coleta de lixo e carpintaria. Por sua vez, não têm sido consideradas atividades perigosas aquelas decorrentes da interferência do trabalhador, cita-se as que envolvem culpa da vítima.

Conclusão: A pesquisa realizada permite afirmar que, entre os anos de 2005 a 2020, a matéria, que inicialmente não teve nenhuma aplicação, passou a ser examinada com mais intensidade nos anos de 2014/2015, com ampliação ainda maior nos anos de 2019/2020. Assim, embora seja ainda difícil prever a exata extensão que a jurisprudência dará à norma, é possível considerar que seu conceito vem sendo ampliado a fim de abranger as mais diversas situações possíveis, visando proteger o empregado.

\title{
Referências
}

BRASIL. Decreto-Lei $n^{\circ} 5.452$, de $1^{\circ}$ de maio de 1943. Aprova a Consolidação das Leis Trabalhistas. In: Vademecum: método. Rio de Janeiro: Forense, 2020.

CAVALIERI FILHO, Sérgio. Programa de responsabilidade civil.10. ed. São Paulo: Atlas, 2012.

VENOSA, Sílvio. S.; RODRIGUES, Cláudia. Código Civil interpretado. 4. ed. São Paulo: Atlas, 2019. 


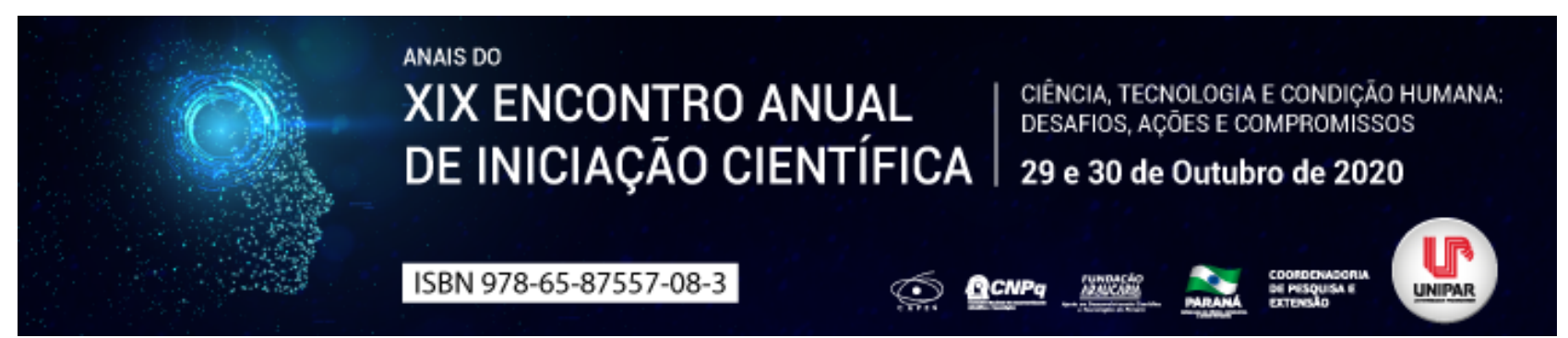

\title{
RELATO DE EXPERIÊNCIA DA ATIVIDADE DE EXTENSÃO UNIVERSITÁRIA NO CAMPO DA ORIENTAÇÃO PROFISSIONAL: CONTRIBUIÇÕES SIGNIFICATIVAS NA FORMAÇÃO DE PSICOLOGIA
}

\author{
${ }^{1}$ LUANI AKEMI FURYAMA, ${ }^{2}$ JENIFFER LEITE LIMA, ${ }^{3}$ MARIA ADELAIDE PESSINI
}

\author{
${ }^{1}$ Acadêmica do PIC/UNIPAR \\ ${ }^{1}$ Acadêmico do Curso de Psicologia da UNIPAR \\ ${ }^{2}$ Docente da UNIPAR
}

Introdução: As atividades de extensão universitária são oportunizadas aos acadêmicos nas Instituições de Ensino Superior, classificadas como Universidade ou Centros de Ensino Superior. O tripé pesquisa, ensino e extensão que baliza uma instituição de ensino superior como Universidade . A extensão universitária são projetos destinados à comunidade e ao aprimoramento acadêmico, buscando trazer contribuições ao público externo e experiências aos acadêmicos através da integração entre teoria e prática (MANCHUR; SURIANI; CUNHA; 2013). A orientação profissional, tem o intuito de beneficiar jovens do Ensino Médio em sua escolha profissional, da mesma maneira adultos que estejam no processo de re-orientação profissional, trazendo-lhes a ampliação sobre as profissões existentes, o autoconhecimento e a interação entre o grupo (NAZAR et al., 2018). Fundamental reforçar que a orientação profissional, se constitui em uma área de atuação do futuro profissional da Psicologia, que no atual cenário social, econômico e político se apresenta como promissora. Tal afirmativa se justifica, posto que, há um grande nicho da população em situação de vulnerabilidade profissional, em situações de desemprego, de mudança de profissão e de reinvenção da atual profissão.

Objetivos: Relatar as experiências acadêmicas na orientação profissional, considerando o compromisso ético e social das orientadoras, enquanto facilitadoras no momento da escolha da profissão, e as contribuições para sua formação acadêmica.

Desenvolvimento: $O$ projeto de extensão universitária denominado: Projeto de vida: orientação profissional e de carreira, oferecido pela Universidade Paranaense, Campus Sede, tem como enfoque o atendimento ao público egresso do ensino médio, bem como, jovens e adultos que buscam reorientar suas práticas profissionais. Os enfoques teóricos da atividade extensionista são da Análise do Comportamento, cujo princípio fundamental é que toda situação de escolha profissional envolve um conjunto de três variáveis: variáveis pessoais, profissionais e da tomada de decisão, e a Sócio-histórica, que considera o sujeito e a sociedade como âmbitos de um mesmo processo. O sujeito escolhe e, para compreender o seu processo de escolha, é preciso estudar seu movimento pessoal (seus sentidos) e o conjunto de significações e condições objetivas e sociais onde está inserido. Os encontros são realizados semanalmente com um número limitado de alunos, sendo de oito a doze, para que o processo grupal ocorra de maneira efetiva. São realizados cinco encontros semanais de duas horas cada, quatro em grupo, e um individual onde se dá a entrevista de devolutiva. As atividades desenvolvidas, referem-se ao autoconhecimento, as relações sociais implicadas no momento da escolha, o conhecimento das profissões e a escolha propriamente dita. Como estratégias, são utilizadas técnicas de dinâmicas de grupo, dramatizações, entrevistas, sites de profissões, jogos interativos, análise de filmes, etc ...Os resultados no final do processo de cada grupo foram satisfatórios e enriquecedores, sendo possível observar os relatos dos orientandos através de um questionário aplicado no último encontro que objetivou avaliar o desempenho do orientador, e as contribuições do projeto aos orientandos. Os projetos de extensão permitem o estreitamento das relações entre teoria e prática, da mesma maneira, Universidade e sociedade, e com a Orientação Profissional isso pode ser evidenciado. Através desta experiência, passamos a enxergar na prática o quanto nossas construções dependem das relações estabelecidas ao nosso redor, afinal de contas, sabemos que jamais iremos chegar com respostas prontas aos orientandos, mas estabelecemos conexões de afeto e acolhimento, o que permitiu compreendermos o que buscavam no processo, e como nós poderíamos ajudálos. Foi perceptível também, que os grupos poderiam iniciar-se de formas similares, no entanto, no decorrer dos encontros cada grupo adquiria suas próprias configurações e as estagiárias da Psicologia atuavam como mediadoras dessas diferentes culturas e estruturas sociais de forma a realizarem práticas contextualizadas a cada contexto grupal .

Conclusão: Através das leituras e práticas vivenciadas no projeto de extensão, foi possível experienciar o processo da Orientação Profissional, que contemplam a interação social, expressão verbal, escuta ativa, auto-reflexão, pesquisa teórica, planejamento e elaboração dos encontros. As relações estabelecidas entre acadêmico e orientando, bem como, acadêmico e professora orientadora, permitiram ampliação dos conhecimentos no campo da Orientação Profissional. Além disso, por ser um projeto externo ao ambiente acadêmico, este contato com a comunidade foi muito relevante, para uma qualificação da formação pessoal e profissional, possibilitando o estímulo ao desenvolvimento de interações práticas com o meio, resultando em atuações contextualizadas à realidade.

\section{Referências}


MANCHUR, J; SURIANI, A; CUNHA, M. A contribuição de projetos de extensão na formação profissional de graduando de licenciatura. Revista Conexão UEPG, Ponta Grossa, v. 9, n. 2, p. 334-341, jul./dez. 2013.

NAZAR, T. C. G. et al. Escolha certa: relato de experiência de um projeto de orientação profissional. EDUCERE - Revista da Educação, Umuarama, v. 18, n. 1, p. 183-204, jan./jun. 2018.

Coordenadoria de Pesquisa e Extensão - COPEX

Departamento de Editoraçāo e Divulgaçāo Científica - DEDIC 


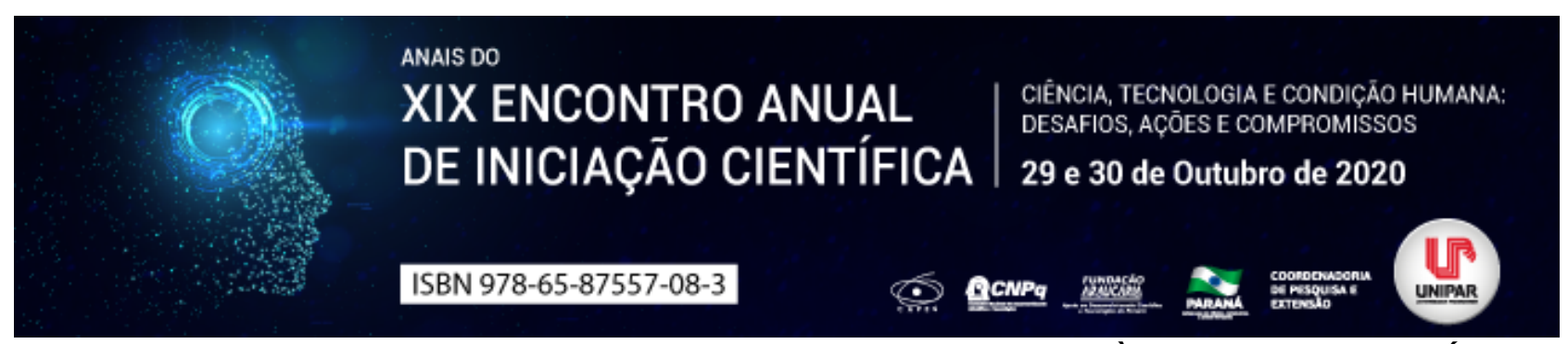

ATIVISMO JUDICIAL: DA EFETIVIDADE DOS DIREITOS FUNDAMENTAIS À INSEGURANÇA JURÍDICA

\title{
${ }^{1}$ BRUNA APARECIDA DALLO, ${ }^{2}$ DIOGO LOPES CAVALCANTE
}

\author{
${ }^{1}$ Acadêmica do curso de Direito da Unipar \\ ${ }^{1}$ Docente da UNIPAR
}

Introdução: O fenômeno do ativismo judicial, que emerge no cenário pós-constituição de 1988, decorre diretamente do neoconstitucionalismo e da nova hermenêutica constitucional comprometida com a máxima efetividade dos direitos fundamentais, que conferem ao magistrado um processo interpretativo cada vez mais amplo. Trata-se, segundo Barroso (2009) de uma participação mais ampla e intensa do Judiciário na concretização dos valores e fins constitucionais, com maior interferência no espaço de atuação dos outros dois poderes. Dessa forma, nos últimos anos, é notório a gradual tomada de espaço do Judiciário e sobretudo da Corte Suprema na cena política, que tem sido convocada a manifestar-se de forma crescente sobre questões antes tradicionalmente resolvidas no Legislativo e Executivo, traduzindo-se na judicialização da política. Essa centralidade vem gerando decisões sobre grandes questões nacionais que repercutem em toda a sociedade e suscita aplausos e críticas, pois convergem para uma crescente postura ativista. Por um lado, o fenômeno é justificado pela maior efetividade dos direitos e garantias fundamentais, ante a inércia dos demais poderes. Todavia, tal atuação vem sofrendo questionamentos a luz da insegurança no universo jurídico.

Objetivo: Analisar os desdobramentos do ativismo judicial no Brasil e a insegurança no âmbito jurídico.

Desenvolvimento: Hodiernamente, questões complexas em matéria de direitos fundamentais estão sendo levadas ao Supremo Tribunal Federal. A Corte, por sua vez, na maioria das situações, tem apresentado uma posição claramente ativista. Campos (2014), discerne que a atuação da Corte Máxima como ativista judicial supri lacunas legislativas e expande o alcance de normas vagamente definidas na Constituição. Destarte, o fenômeno tem sua face positiva: o Judiciário está atendendo a demandas da sociedade que não puderam ser satisfeitas pelo Executivo e Legislativo (BARROSO, 2009, p. 24). Em contrapartida, há uma sinalização claramente negativa no tocante à desfiguração da função típica do judiciário, em detrimento dos demais poderes, o que fragiliza a harmonia entre os poderes. Conforme bem menciona George Salomão Leite (2020, p. 152) atuar de forma harmônica significa agir em conformidade com o Texto Constitucional . Dessa forma, faz-se importante não tão somente agir em conformidade com o texto constitucional, mas, conjuntamente, nortear as decisões e interpretações pelo enunciado normativo, este, muitas vezes, eivado de princípios, cláusulas abertas e conceitos jurídicos indeterminados e, é nesse cenário que o STF tem sido provocado para se manifestar sobre a constitucionalidade de diversos temas avaliados como polêmicos, e a interpretação dos magistrados abre espaço ao chamado decisionismo . Nos dizeres de Sarmento (2007), muitos juízes, diante dos princípios e da possibilidade de através deles, buscarem a justiça ou que entendem por justiça -, passaram a negligenciar no seu dever de fundamentar racionalmente os seus julgamentos. Esta l"euforial" com os princípios abriu um espaço muito maior para o decisionismo judicial . Essa prática acaba por culminar insegurança no universo jurídico brasileiro. A amostra advém de recentes decisões, como o caso da prisão antes do trânsito em julgados dos processos, que se mostraram antagônicas ao próprio entendimento e jurisprudência da Corte, convergindo, assim, para a imprevisibilidade das decisões. Denota-se, nesse ponto, que a jurisprudência assume um papel importante em sede de segurança jurídica, vez que é uma das fontes do direito e possibilita a previsibilidade das decisões, gerando estabilidade nas relações jurídicas, assim, evitando surpresas que possam minar a confiança no Judiciário. Portanto, os recentes julgamentos antagônicos com interpretações divergentes entre si evidenciam o lado negativo da postura ativista, pois torna o direito muito menos previsível e repercute de forma danosa ao Estado Democrático de Direito. Lenio Streck (2013), ressalta a importância de se privilegiar não apenas a estabilidade e previsibilidade das decisões, mas também a sua coerência, no sentido de que a aplicabilidade isonômica dos princípios deve ocorrer quando se tratarem de casos semelhantes, sobretudo, idênticos entre si, e a integridade, resta assegurada pela força normativa da Constituição, por representar legítima proteção contra arbitrariedades interpretativas.

Conclusão: Diante do exposto, notória a expansão do ativismo no cenário brasileiro. Não resta dúvida que a postura ativa do judiciário, principalmente do STF, tem caminhado no sentido de garantir os direitos fundamentais àqueles que se valem da tutela jurisdicional, todavia, essa postura deverá nortear-se pelo enunciado normativo objeto de interpretação, aliada a decisões coerentes, que permite maior segurança jurídica das decisões, além, conferir ao Texto Constitucional a máxima efetividade possível, tarefa que, em última instância, Ihe foi atribuída pela própria Constituição.

\section{Referências}

BARROSO, Luís Roberto. Judicialização, ativismo judicial e legitimidade democrática. Anuario iberoamericano de justicia

n. $\quad 2009$. Disponível em: file:///C:/Users/user/Downloads/Dialnet- 
JudicializacaoAtivismoJudicialELegitimidadeDemocra-5124286.pdf. Acesso em: 02 ago. 2020.

CAMPOS, Carlos Alexandre de Azevedo. Dimensões do Ativismo Judicial do STF. Rio de Janeiro: Forense, 2014.

LEITE, George Salomão. Eficácia e aplicabilidade das normas constitucionais. Livraria do Senado, vol 275, 2020. Disponível em: https://www2.senado.leg.br/bdsf/bitstream/handle/id/570639/Eficacia_aplicabilidade_normas_constitucionais.pdf? sequence=3\&isAllowed=y. Acesso em: 05 de ago. 2020.

SARMENTO, Daniel. Ubiquidade constitucional: os dois lados da moeda. A Constitucionalização do Direito: fundamentos teóricos e aplicações específicas. 1ed. Rio de Janeiro: Lumen Juris, p. 113-148, 2007.

STRECK, Lenio Luiz. Por que agora dá para apostar no projeto do novo CPC! Revista Consultor Jurídico, 2013. Disponível em: https://www.conjur.com.br/2013-out-21/lenio-streck-agora-apostar-projeto-cpc. Acesso em: 05 de ago. 2020.

Coordenadoria de Pesquisa e Extensão - COPEX

Departamento de Editoraçāo e Divulgaçāo Científica - DEDIC 


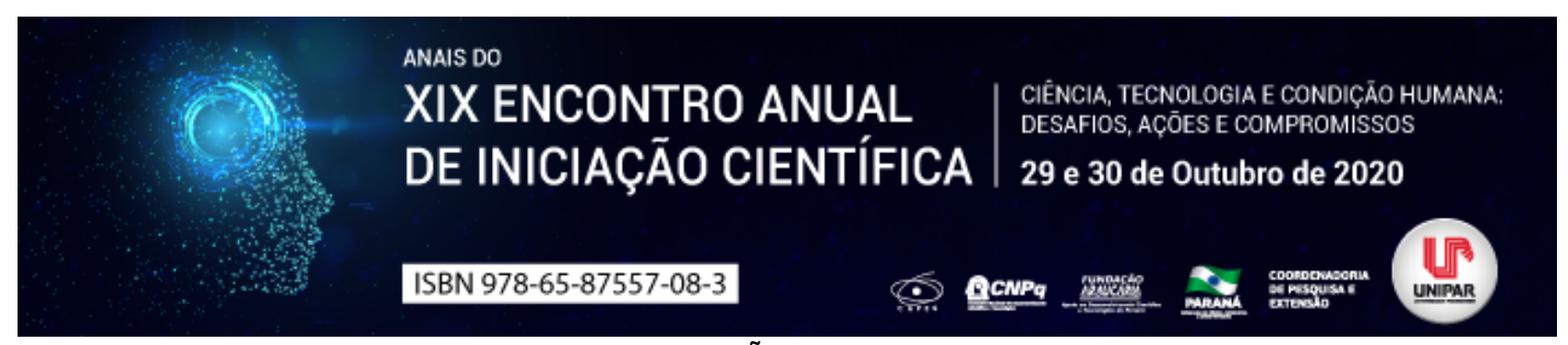

TECNOLOGIA COMO INSTRUMENTO DE OCULTAÇÃO DE IDENTIDADE NOS PROCESSOS INVESTIGATIVOS

\title{
1LUCIANE STRAPASSON CORREA DE PAULA, ${ }^{2}$ ANTONIO DA SILVA JUNIOR
}

\author{
${ }^{1}$ Acadêmica do Curso de Direito UNIPAR - Francisco Beltrão \\ ${ }^{1}$ Docente da UNIPAR
}

Introdução: Com a evolução dos parâmetros tecnológicos surge a necessidades de desenvolver estratégias para seu esclarecimento. Neste sentido a Inteligência Criminal é essencial para conter o crime organizado. Também, em um âmbito de avanço temos a criatividade, o dinamismo e a inovação que caracterizam o fenômeno criminoso, que deve ser analisado a fim de estabelecer uma adequada investigação para a solução de cada caso. O presente trabalho traz consigo uma nova fase de um perfil investigativo em questões técnicas e virtuais, nos parâmetros da criminalística brasileira tornando tal inovação praticável e ao mesmo tempo, eficaz.

Objetivo: Análise fática sob o Pacote Anticrime vigente desde janeiro de 2020, que trouxe alterações na lei 12.850/13 das Organizações Criminosas no âmbito de infiltração de agentes em ambiente virtual, com foco no procedimento das investigações, sua segurança e vantagens para elucidações de casos.

Desenvolvimento: Direito Criminal é visto como um instrumento de notória importância para estabelecer o regramento da vida em sociedade, impondo os limites da conduta pessoal. Segundo Gottlieb (1998, p.13), a Análise Investigativa é considerada um dos principais instrumentos para orientar o trabalho policial e ele a define como conjunto de processos sistemáticos direcionados para o provimento de informação oportuna e pertinente sobre os padrões do crime e suas correlações de tendências. Apesar de no Brasil ser conhecida como Inteligência Policial, podemos chama-la de Inteligência Criminal por abranger nesse âmbito outras instituições como as Guardas Municipais, Exército, Ministério Público, dentre outros. Contudo, a finalidade de ambas seria obter conhecimentos suficientes para inspirar um processo decisório, em benefício da sociedade e Estado. As diferenças nesse contexto estão relacionadas as suas metodologias aplicadas, enquanto uma analisa diversas áreas do conhecimento como: tecnológicas, políticas e militares, a criminal se atem apenas na área de Segurança Pública, onde qualquer ação que não envolva comportamento ilícito não é de sua responsabilidade. Valendo-se de um sistema hierarquizado de funções, qualificando demandas que operam em desfavor da criminalidade organizada, atuando de forma sofisticada e eficiente, temos a infiltração de agentes que desenvolvem técnicas úteis em correlação a inteligência e enfrentamento dessas Organizações Criminosas. A Criminalística brasileira não tem uma definição transparente do sistema de inteligência, cada Estado da Federação é dividido com um ou mais organismos de Entendimento Criminal, cada departamento operacional tem sua classificação, delegacia ou setor, sendo visto a contento como muitos órgãos e pouca inteligência. Em contrapartida as modificações à norma legal alteram suas formas de investigação e infiltração anexadas a um sistema tecnológico facilitadores de qualquer comunicação, deslocamento de dados e acesso a diversos conteúdos. Com a nova Lei no 13.964/2019 tópicos como:

Art. 10-C. Não comete crime o policial que oculta a sua identidade para, por meio da internet, colher indícios de autoria e materialidade dos crimes previstos no art. $1^{\circ}$ desta Lei vieram inseridos a esta plataforma, como métodos inovadores de esclarecimento de delitos a fim de auxiliar esse meio criminal. A previsão consiste em investigações totalmente virtuais de até 06 (seis) meses, ainda que prorrogadas, com o fim de evidenciar crimes previstos nesse âmbito e demais conexos. O legislador faz a ressalva de que a técnica investigativa em questão é permitida desde que demonstrada sua necessidade e indicados o alcance das tarefas, os nomes ou apelidos das pessoas investigadas e, quando possível, os dados de conexão ou cadastrais que permitam a identificação dessas pessoas (Figueiredo e Velloso, s/d). Por esses conteúdos cibernéticos estarem dispostos a facilitar o interior e o propósito, seja em conversas, fotos, vídeos ou até outros meios, a forma que cada um se expõe nessa plataforma é muito ampla, tendo sim um resumo seguro desses dados, com ressalva em questões investigativas onde o trabalho de Inteligência é mais opinativo do que o tradicionalmente feito pela polícia judiciária.

Conclusão: Em que pese sejam institutos essenciais da criminalística brasileira não há correspondência entre o trabalho da investigação criminal e do sistema penal, ocasionando duplicação de esforços, rivalidades e atritos entre seus operadores. Embora haja essas dificuldades, o sistema investigatório é fundamental e nesse sentido, a infiltração de agentes é uma inovação que colabora para a elucidação dos casos. Essas evoluções seguem um plano histórico de total representatividade, atuando de forma concreta, fundamentada e proporcional nos diferentes casos evidenciados atualmente.

\section{Referências}

GARAY, Humberto de Sá. Pacote Anticrime e seu Impacto na Inteligência de Segurança Pública. Disponível em: . Acesso em 03 de mai. 2020.

MINGARDI, Guaracy. O trabalho da Inteligência no Controle do Crime Organizado. Estudos Avançados. V. 21, São Paulo: Scielo, 
2007.

Relatório Lei $\mathrm{n}^{0}$ 13.964, de 24 de dezembro de 2019, Figueiredo e Velloso. Disponível em: https://www.migalhas.com.br/arquivos/2020/1/1533F750ECA4DC_estudo.pdf. Acesso em 02 junho de 2020

SOARES, Gustavo Torres. Investigação criminal e inovações técnicas e tecnológicas: perspectiva e limites. 307 p. Tese de Doutorado. Faculdade de Direito, Universidade de São Paulo, São Paulo, 2014.

Coordenadoria de Pesquisa e Extensão - COPEX

Departamento de Editoração e Divulgaçāo Científica - DEDIC 


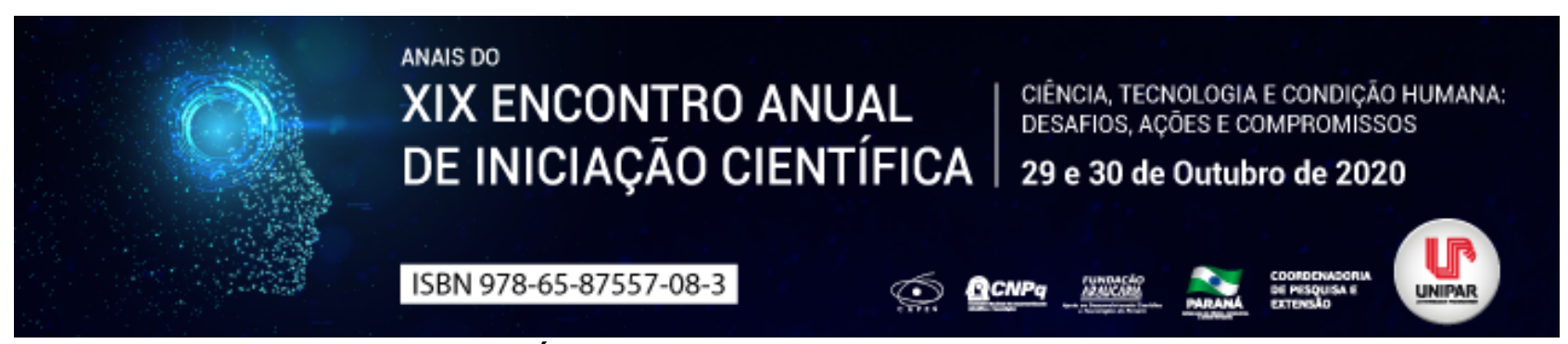

AS PROBLEMÁTICAS DO SISTEMA PRISIONAL BRASILEIRO

\title{
${ }^{1}$ ANDERSON NATALE PELISSARI, ${ }^{2}$ MAIARA DOS SANTOS NORONHA
}

\author{
${ }^{1}$ Acadêmico do Curso de Direito da UNIPAR \\ ${ }^{1}$ Docente da UNIPAR
}

Introdução: O sistema prisional brasileiro, compreendido como uma imagem de punição aos que infringem as normas legais, repercute, do modo como está estruturado, em prejuízos ao apenado e a própria sociedade, uma vez que torna incerto o futuro daqueles que estão sob à égide do Estado. A ressocialização, enquanto norte às detenções, na prática não cumpre seu propósito, ao revés, amplia o potencial delinquente dos apenados.

Objetivo: Analisar, de forma crítica, a situação do sistema prisional brasileiro, visando alternativas que contribuam no processo de ressocialização do detento.

Desenvolvimento: Nas antigas civilizações, as penas aplicadas tinham como finalidade a preservação da integridade moral da tribo, juntamente com as entidades divinas. Nesse sentido, destaca Mirabete que dada a ideia de castigo que então predominava nessas civilizações antigas, a pena mais utilizada era a de morte, sendo que a punição que atingia os espólios dos cometedores dos crimes, também acarretava em efeitos para os seus descendentes. A pena de morte foi usada durante séculos, culminada de várias outras penas cruéis e degradantes (MIRABETE, 2002). Com a evolução das sociedades, fez-se necessário uma reforma do modelo punitivista, especialmente no que diz respeito à aplicabilidade das penas e os locais de retenção dos infratores. A pena, portanto, seria resposta justa pelo ilícito cometido. As punições mais cruéis e violentas foram aos poucos sendo retiradas da maioria das sociedades, sendo substituídas por serviço comunitários e, em alguns casos, prisões domiciliares. O Estado assume o papel de resguardar a vida de seus apenados, o qual elencou alguns dos direitos no art. 41 da LEP, como por exemplo a alimentação e vestuário, trabalho e remuneração, previdência social, distribuição do tempo ao trabalho, descanso e recreação, assistência à saúde, jurídica, educacional, social e religiosa, e dentre outras. A reincidência acaba sendo o principal fator da deficiência do sistema jurídico social, pois é notório saber que os indivíduos que adentram nas instituições prisionais, são dotadas de carências, sendo a falta de moradia digna, sem grau de escolaridade, sem qualificações profissionais, e que, depois de cumprida sua pena, saem do sistema com as mesmas deficiências de quando adentraram. Além da ausência de projetos de ressocialização do apenado e a consciência da sociedade que o estigmatiza, ainda acabam existindo mais problemas devido a superpopulação penitenciária, tais como alimentação inadequada e a falta de higiene para as necessidades básicas. Com presídios superlotados, os direitos fundamentais dos detentos muitas vezes não são cumpridos, devido as péssimas condições carcerárias, acabam adoecendo por falta de assistência médica, somado a isso a falta de estrutura básica e violência praticada por agentes do Estado. Diversos projetos foram criados, os quais possuíam uma estrutura apta para o condicionamento de seus apenados, acompanhamento médico e psíquico desde a entrada até a saída do indivíduo do sistema prisional, possuindo ainda um espaço para sugestões ou reclamações do apenado, prestando até mesmo auxílio a sua família. Com uma população crescente a cada ano, o projeto se tornou inviável e caro demais para o Estado manter ou se quer aprová-lo.

Conclusão: A aplicação de pena tem como propósito promover a reflexão do apenado sobre a conduta praticada, não somente puni-lo, como forma de garantir seus direitos e sua dignidade como pessoa humana, visando com isso diminuir o índice de reincidência no sistema prisional brasileiro. No entanto, essa finalidade de ressocialização, que é a busca por reinserir o apenado na sociedade, dificilmente será alcançada em um ambiente totalmente precário, indigno e insalubre. A realidade das penitenciárias brasileiras, revelam o caos desse sistema, que mal consegue fornecer o mínimo de saúde, higiene e alimentação para os seus apenados.

\author{
Referências \\ ARAGÃO, Antonio Moniz Sodré. As três escolas penais. Rio de Janeiro. Freitas Bastos, 1938. \\ FALCONI, Romeu. Sistema presidial: reinserção social? São Paulo: ícone, 1998. \\ FRAGOSO, Heleno C. Lições de direito penal: A nova parte geral. $4^{\mathrm{a}}$ ed. Rio de Janeiro: Forense, 1994. \\ MIRABETE, Júlio Fabbrini. Execução Penal. 10 ed. São Paulo: Atlas, 2002. p. 244. \\ SHECAIRA, Sergio Salomão e CORRÊA JUNIOR, Alceu, Pena e Constituição. São Paulo: RT, 1995. \\ ZACARIAS, André Eduardo de Carvalho. Execução Penal Comentada. 2 ed. São Paulo: Tend Ler, 2006.
}




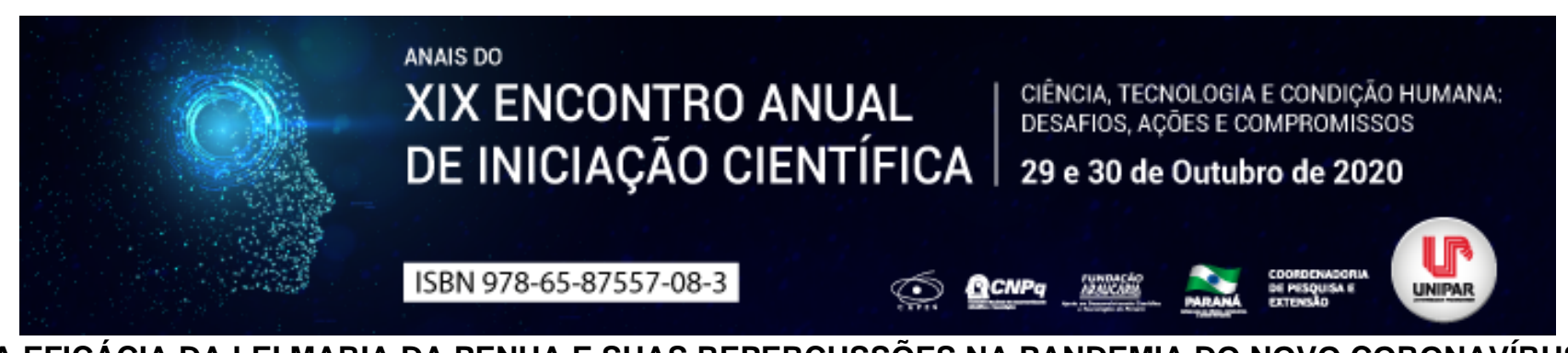

A EFICÁCIA DA LEI MARIA DA PENHA E SUAS REPERCUSSÕES NA PANDEMIA DO NOVO CORONAVÍRUS

\author{
${ }^{1}$ GABRIELA ZARNOTT, ${ }^{2}$ EDIANE CARDOSO, ${ }^{3}$ LAIANE TAINARA ALVES, ${ }^{4}$ RENATA BELIM SALVINI, ${ }^{5}$ ADRIANO \\ CONSENTINO CORDEIRO
}

${ }^{1}$ Acadêmica bolsista do PIBIC/UNIPAR

${ }^{1}$ Acadêmica do Curso de Direito da UNIPAR

${ }^{2}$ Acadêmica do Curso de Direito da UNIPAR

${ }^{3}$ Acadêmica do Curso de Direito da UNIPAR

${ }^{4}$ Docente da UNIPAR

Introdução: No ano de 2020, o mundo entrou em colapso com a pandemia ocasionada pelo novo coronavírus. Uma doença que rapidamente se espalhou pelo planeta e acometeu diversas pessoas, das mais variadas idades, gêneros e lugares. Sem distinção sócio-econômica ou cultural, com milhares de vítimas. Porém, as vítimas não se resumiram somente ao vírus. Com o isolamento social e muitas mulheres trancadas dentro de casa, o número de casos de violência doméstica aumentou consideravelmente, trazendo o assunto à tona para discussões novamente (MONTEIRO, Solange Aparecida de Souza, et. al., 2020).

Objetivo: O objetivo deste trabalho é investigar através de análises em literatura e dados atuais como a pandemia e o isolamento social têm impactado a vida de muitas mulheres que sofrem abusos diariamente dentro de suas casas, e como a Lei Maria da Penha tem auxiliado aquelas que não podem pedir ajuda.

Desenvolvimento: $O$ isolamento social veio com uma proposta de proteção individual e coletiva, bem como para dificultar e diminuir a transmissão do vírus. No entanto, observou-se um aumento significativo nos casos de violência doméstica e de feminicídio, o qual levantou diversos questionamentos sobre até que ponto a quarentena estaria salvando vidas. Além das preocupações físicas, é necessário olhar para os impactos psicológicos que muitas mulheres sofrem estando confinadas com seus agressores. O Estado possui algumas maneiras de auxiliar mulheres que se encontram em situações como essa, sendo uma delas e a mais conhecida, a Lei Maria da Penha, que diz: cria mecanismos para coibir a violência doméstica e familiar contra a mulher, nos termos do art. 226 da Constituição Federal, da Convenção sobre a Eliminação de Todas as Formas de Discriminação contra as Mulheres e da Convenção Interamericana para Prevenir, Punir e a Violência contra a Mulher; dispõe sobre a criação dos Juizados de Violência Doméstica e Familiar contra a Mulher; altera o Código de Processo Penal, o Código Penal e a Lei de Execução Penal; e dá outras providências . Infelizmente, os números continuam subindo e milhares de mulheres são vítimas dentro de seu próprio lar (LIMA, Thainá de., 2017). No Brasil, em 2020, durante o mês de março, reconhecido internacionalmente como mês da mulher, foi registrado um aumento de 18\% nas denúncias de violência doméstica, segundo a Ouvidoria Nacional dos Direitos Humanos (ONDH), o Ministério da Mulher, da Família e dos Direitos Humanos (MMFDH). Em 2019, cerca de 35\% dos homicídios de mulheres foram identificados como feminicídios, evidenciando que o único motivo pelo qual morreram foi seu gênero. Essa é uma triste realidade que assola o país e o mundo. Somente durante a quarentena, os índices de violência doméstica triplicaram na China, e em países europeus como França, Itália e Espanha também houve um aumento significativo nos registros policiais do mesmo crime (VIEIRA, Pâmela Rocha, et. al., 2020). A Lei Maria da Penha está em vigor, juntamente com a Lei do Feminicído, e são um grande suporte para mulheres em situações delicadas, leis pedagógicas dos direitos humanos, que têm sua eficácia comprovada mesmo com os números subindo, pois lutam constantemente pelo fortalecimento de vias disponíveis para registrar ocorrências, como é o caso do 180, por exemplo (CRUZ, Fundação Oswaldo, 2020). Além disso, atuam em parcerias com delegacias de atendimento à mulher, desenvolvendo mecanismos de medidas preventivas e protetivas para evitar que sofram agressões novamente, ou até mesmo a morte.

Conclusão: Apesar das leis e de toda luta contra a violência contra a mulher, isso ainda não é suficiente. É preciso conscientização de toda sociedade para o enfrentamento dessa doença impregnada dentro de muitas casas. Em uma tentativa de amenizar esses quadros, vale lembrar-se da importância de denunciar, registrar os casos e ligar para o 180. Com pequenas atitudes, é possível salvar vidas.

\title{
Referências
}

FUNDAÇÃO OSWALDO CRUZ. ESCOLA NACIONAL DE SAÚDE PÚBLICA SERGIO AROUCA. Entrevista: Aumentam casos de violência doméstica durante a pandemia da Covid-19. Informe ENSP, 28 maio 2020. 3 p.

LIMA, Thainá de. A qualificadora do feminicídio no sistema penal brasileiro: é uma forma eficaz de combate à violência contra a mulher?. 2017. 60 f. Monografia (Graduação) Faculdade de Ciências Jurídicas e Sociais, Centro Universitário de Brasília, 
Brasília, 2017.

MONTEIRO, Solange Aparecida de Souza; YOSHIMOTO, Eduardo; RIBEIRO, Paulo Rennes Marçal. A produção acadêmica sobre a questão da violência contra a mulher na emergência da pandemia da COVID-19 em decorrência do isolamento social. DOXA: Revista Brasileira de Psicologia e Educação, [S.I.], p. 152-170, june 2020.

VIEIRA, Pâmela Rocha; GARCIA, Leila Posenato; MACIEL, Ethel Leonor Noia. Isolamento social e o aumento da violência doméstica: o que isso nos revela?. Rev. bras. epidemiol., Rio de Janeiro, v. 23, e200033, 2020 .

LEI No 11.340, DE 7 DE AGOSTO DE 2006: Cria mecanismos para coibir a violência doméstica e familiar contra a mulher, nos termos do art. 226 da Constituição Federal, da Convenção sobre a Eliminação de Todas as Formas de Discriminação contra as Mulheres e da Convenção Interamericana para Prevenir, Punir e a Violência contra a Mulher; dispõe sobre a criação dos Juizados de Violência Doméstica e Familiar contra a Mulher; altera o Código de Processo Penal, o Código Penal e a Lei de Execução Penal; e dá outras providências.

Coordenadoria de Pesquisa e Extensão - COPEX

Departamento de Editoraçāo e Divulgaçāo Científica - DEDIC 


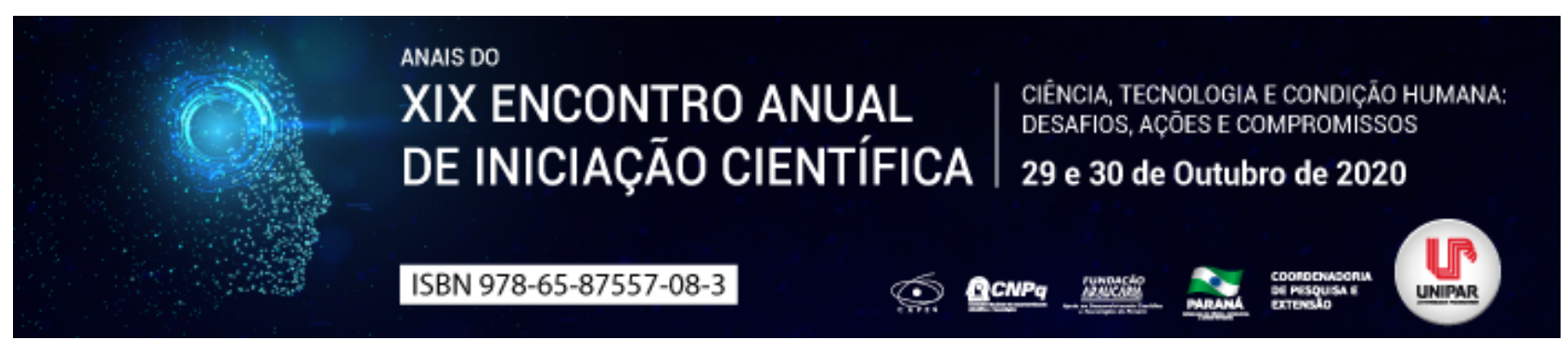

REFORMA DA PREVIDÊNCIA E O RETROCESSO SOCIAL

\author{
${ }^{1}$ CLAUDINEI SAVARIS TRUCOLLO, ${ }^{2}$ CLARICE MENDES DALBOSCO
}

\author{
${ }^{1}$ Acadêmico da UNIPAR \\ ${ }^{1}$ Docente da UNIPAR
}

Introdução: $O$ trabalho tem por finalidade analisar a reforma da previdência, sobre a hipótese de violação ao princípio da vedação do retrocesso social e violação a Constituição da República Federativa do Brasil. A pesquisa desenvolveu-se sobre o método dedutivo com análise de cunho bibliográfico.

Objetivo: Analisar a reforma da previdência, referente à hipótese de violação ao princípio da proibição do retrocesso social e juntamente com violação à Constituição da República Federativa do Brasil.

Desenvolvimento: Os princípios são muito importantes para qualquer ramo do direito ele é a base, o fundamento, a origem, a razão fundamental sobre a qual se discorre sobre qualquer matéria. Sendo assim, verificasse que o princípio da vedação de retrocesso social é a proteção de direitos fundamentais em face de medidas do poder público, e visam à proteção de direitos contra o legislador e o administrador que buscam diminuir ou restringir direitos fundamentais. Portanto deve ser tratado como um direito constitucional de resistência. Essa vedação é uma forma de garantir os direitos fundamentais positivados para que não subtraia a proteção que por eles já foi conferido. Assim sendo a previdência um direito fundamental social previsto pela constituição federal em seu Art. $6^{\circ}$ (BRASIL. constituição 1988), juntamente com o direito à dignidade da pessoa humana, mínimo existencial, integridade física, liberdade de ir e vir, igualdade, justiça social e outros direitos, percebe-se que com a violação da vedação do retrocesso social ocorre também a violação à Constituição Federal. O princípio da vedação do retrocesso social ainda que não esteja expresso na letra da lei, a sua previsão constitucional se encontra no Art. $5^{\circ}$, §2 da Constituição Federal, juntamente com o Art. $7^{\circ}$ (BRASIL. constituição 1988), caput, o qual prevê o direito à aposentadoria enquanto direito individual do trabalhador seja ele trabalhador rural, urbano ou trabalhador doméstico, sem prejuízo de outros que visem à melhoria de sua condição social. Diante desse princípio, percebe-se a inconstitucionalidade, em tese de normas infraconstitucionais, como exemplo as que limitam o pagamento de salário-família e auxílio-reclusão aos segurados de baixa renda. (CASTRO; LAZZARI, 2020, p. 162). Essas mudanças trazidas pela reforma da previdência que reduzem o valor dos benefícios previdenciários, além de retardar o início da aposentadoria e restringir o alcance da assistência social, dentre outras várias modificações que violaram o princípio da vedação do retrocesso social, o qual Seria a impossibilidade de redução das implementações de direitos fundamentais já realizadas (CASTRO; LAZZARI, 2020, p. 162), logo se percebe que os direitos não podem ser diminuídos seja na esfera das pessoas abrangidas ou valor de benefícios ou seu alcance, eventos que geram amparo social, preservando 0 mínimo existencial.

Conclusão: Ante o exposto, verifica-se que a reforma da previdência violou o princípio da vedação ao retrocesso social no que se refere aos direitos sociais e as garantias constitucionais, violando assim a própria Constituição Federal e gerando uma incerteza quando a dignidade do valor dos benefícios futuros. A referida reforma não dispõe de legitimidade democrática por representar um enorme retrocesso social.

\title{
Referências
}

BRASIL. Constituição da República Federativa do Brasil. Brasília, DF: Senado Federal, 1988.

CASTRO, C. A. P; LAZZARI, J. B. Manual de direito previdenciário. 23a. Ed. Rio de Janeiro. Forense, 2020. $2398 \mathrm{p}$.

KERTZMAN, Ivan. Entendendo a Reforma da Previdência. 1a. Ed. São Paulo. Juspodivm, 2019. 304p.

LAZZARI, João Batista. Comentários à Reforma da Previdência. 1ª. Ed. Rio de Janeiro. Forense, 2019. 296p.

NUNES J.A; MOURA A. S. Proibição de retrocesso e a proposta de reforma da previdência social, pec 6/2019: breves considerações sobre a constitucionalização do desmonte dos direitos sociais. XVI Seminário Internacional, Santa Cruz do Sul RS, unisc, 20 p. 2019. 


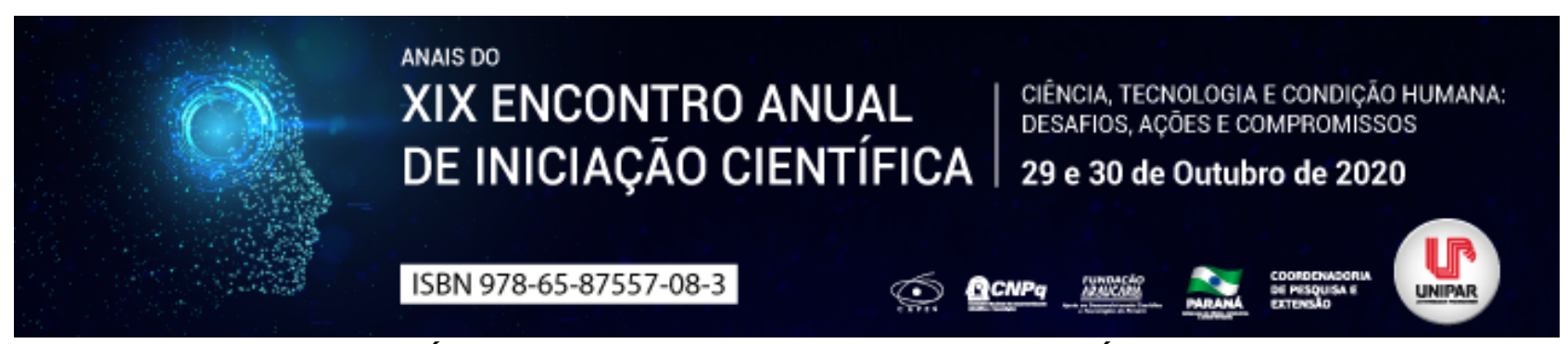

A MÍDIA E A JUSTIÇA CRIMINAL: UM OLHAR CRÍTICO

${ }^{1}$ ANA CAROLINE RODRIGUES PAZINATO, ${ }^{2}$ KARINNY LEAL AZEVEDO, ${ }^{3}$ KEYLA CAROLINA DA SILVA, ${ }^{4}$ NATALIA SANTOS GASPARETTO, ${ }^{5}$ FERNANDA GARCIA VELASQUEZ

${ }^{1}$ Acadêmica de Direito PIC/UNIPAR
${ }^{1}$ Acadêmica de Direito PIC/UNIPAR
${ }^{2}$ Acadêmica de Direito PIC/UNIPAR
${ }^{3}$ Acadêmica de Direito PIC/UNIPAR
${ }^{4}$ Mestre em Direito Processual e Cidadania

Introdução: A sociedade busca se comunicar desde os primórdios, e ao transmitir suas ideias, acabou dando origem à mídia, que tem hoje o papel de grande difusora de informações para os cidadãos através de suas inúmeras formas. Em meio a tantas notícias, destacam-se aquelas ligadas ao Direito Penal.

Objetivo: Compreender a influência da mídia no processo penal e suas consequências para um julgamento criminal justo.

Desenvolvimento: Entende-se por mídia o conjunto de meios de comunicação que tem o papel de informar a sociedade, e recebeu, segundo Netto (2013), o título de quarto poder , já que estaria incumbida de desempenhar o papel de fiscalizadora dos outros três poderes (legislativo, executivo e judiciário) os estabelecidos na lei maior. O direito de informação está contido no artigo $5^{\circ}$, incisos IV e XIV da Constituição Federal, os quais asseguram a todos o direito de se expressarem e transmitirem as informações que acharem pertinentes. Perante o entendimento de Machado (2013) a liberdade de imprensa é uma garantia plena e de grande relevância no ordenamento jurídico. Entretanto, não se pode esquecer de que, como todo direito, a liberdade de imprensa também não é absoluta . É cada vez mais comum ver os comunicadores utilizando erroneamente seus direitos, sem se atentar a tais limites; a seara criminal é uma das mais expostas ao bombardeamento de informações, principalmente quando são expostos processos, ferindo o direito à imagem e à privacidade dos indivíduos envolvidos nos casos, já que a intenção não é apenas a de informar imparcialmente, mas obter lucros, deturpando as notícias e selecionando o que poderá atrair mais audiência. Dessa feita, verifica-se o sensacionalismo midiático para causar maior apelo emocional ao público, o que traz consequências dramáticas, como um julgamento popular imediato e equivocado do caso, fenômeno conhecido como I"The Trial by Medial", conforme Mahecha (2016). Desta maneira, a mídia acaba abrindo espaço para diversas teorias, como a do Direito Penal do Inimigo, criada por Gunther Jakobs, que propõe uma distinção no direito penal entre cidadão e inimigo. Ao primeiro seria atribuído um processo penal justo e imparcial. Já ao segundo, um processo rigoroso e arbitrário, pois este não seria mais um cidadão e sim um inimigo, sendo-lhe, portanto, retirados os direitos e garantias (DINIZ, 2012, p. 107-108).

Conclusão: Portanto, através de um amplo sistema de informações, a mídia, aproveitando-se de sua liberdade de imprensa, noticia os fatos com discursos superficiais que acabam colocando em xeque a veracidade dos acontecimentos, influenciando a decisão popular, e por consequente, a decisão dos tribunais, e com isso gera consequências imensuráveis àqueles expostos por ela.

\section{Referências}

DINIZ, Eduardo Saad. Inimigo e pessoa no direito penal. São Paulo: LiberArts, 2012.

MACHADO, Machado Silveira. Análise sobre garantismo penal e a sua observância (ou não) pela mídia: um estudo de caso. Disponível em: https://www.webartigos.com/artigos/analise-sobre-garantismo-penal-e-a-sua-observancia-ou-nao-pela-midia-umestudo-de-caso/116122/\#ixzz3LVTTaOD3. Acesso em: 23 maio 2020.

MAHECHA, Mona. Media Trial: A Threat to Fair Trial. Amity Journal of Media \& Communication Studies (ISSN 22311033 ). 2016, v. 5. n. 3.

NETTO. Reynaldo Carilo Carvalho. Quarto Poder e censura democrática. 


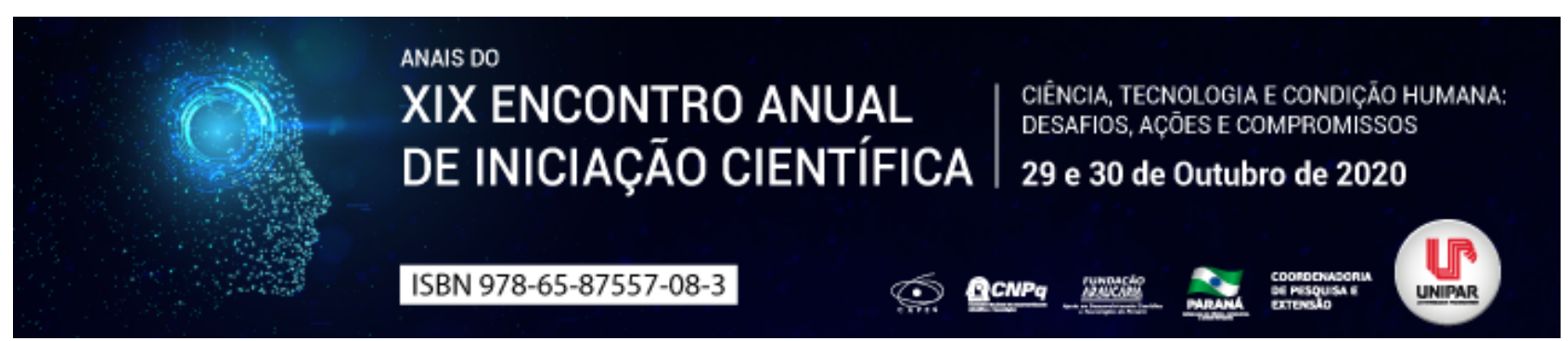

DIREITOS FUNDAMENTAIS SOCIAIS INERENTES À EDUCAÇÃO, EFICAZES OU INEFICAZES?

\title{
${ }^{1}$ OLIVIO CICHOVICZ NETO, ${ }^{2}$ CLARICE MENDES DALBOSCO
}

\author{
${ }^{1}$ Aluno do Curso de Direito da UNIPAR \\ ${ }^{1}$ Docente da UNIPAR
}

Introdução: Tendo em vista a importância dos Direitos Fundamentais Sociais inerentes à educação, e a questão concernente a sua eficácia ou ineficácia, o presente trabalho tem por objetivo demonstrar como esses direitos estão estabelecidos na Constituição Federal, nas políticas públicas e na sociedade, assim evidenciando os dados que cercam os objetivos desses direitos. A pesquisa teve desenvolvimento explanatório, com análises bibliográficas.

Objetivos: Demonstrar a ineficácia dos Direitos Fundamentais Sociais inerentes à educação, ainda que propensos ao grande apoio legislativo e governamental visando ao crescimento dessa área.

Desenvolvimento: A Constituição de 1988 ao inserir os Direitos Sociais junto aos Direitos Fundamentais, mostrou sua real importância, criando um marco na democratização e no reconhecimento desses direitos. Articulada com tal princípio, a Constituição alargou o projeto de democracia [...] reconhecendo a participação social como um dos elementos chave na organização das políticas públicas (JACCOUD; SILVA; BEGHIN, 2005, p. 2). Assim, o art. $6^{\circ}$ trouxe a educação como Direito Fundamental Social, educação esta constituída desde os primeiros contatos com a sociedade, como cita Rothbard: a necessidade de instrução formal apoia-se no fato de que as faculdades das crianças não estão desenvolvidas, existem apenas potencialidades, e que precisam de experiência para ordená-las (ROTHBARD, 2013, p. 16). Porém, a educação como Direito Fundamental de natureza social no Brasil está em um abismo social. Conforme dados do IBGE 2017, apenas 51\% dos estudantes conclúram o ensino fundamental, realidade que atrasa o crescimento e surgimento de um cidadão mais efetivo na sociedade. Embora abordada pela CF em seu art. 205: direito de todos e dever do Estado e da família, será promovida e incentivada com a colaboração da sociedade, visando ao pleno desenvolvimento da pessoa, seu preparo para o exercício da cidadania e sua qualificação para o trabalho ; sua aplicação ainda se faz de maneira desdenhosa e com pouca eficácia, o que faz com que o analfabetismo funcional de pessoas entre 15 e 64 anos fosse registrado em $28 \%$ no ano de 2009 (IBOPE); $34 \%$ dos alunos que chegam ao $5^{\circ}$ ano de escolarização ainda não conseguem ler (Todos pela Educação); $20 \%$ dos jovens que concluem o ensino fundamental, e que moram nas grandes cidades, não dominam o uso da leitura e da escrita (Todos pela Educação), dentre outros números que mostram a ineficácia dos Direitos Fundamentais Sociais no que se refere à educação.

Conclusão: Entende-se os Direitos Fundamentais Sociais inerentes à educação como de extrema importância, pois eles são responsáveis pelo presente e futuro da sociedade. Sendo assim, esses direitos não deveriam se destacar como ineficazes, assemelhando-se a uma norma programática.

\section{Referências}

JACCOUD, L.; SILVA, F.; BEGHIN, N. Políticas sociais no Brasil: participação social, conselhos e parcerias. In: Jaccoud, L. (Org.). Questão social e políticas sociais no Brasil contemporâneo. 1. vol. - Brasília: Ipea, 2005.

ROTHBARD. Murray N. Educação: livre e obrigatória. 1ª ed. São Paulo: Instituto Ludwig von Mises Brasil. 2013.

SOARES, Dilmanoel de Araújo. O direito fundamental à educação e a teoria do não retrocesso social. Revista de Informação Legislativa. Brasília v. 48. p. 186, abril/jun. 2010.

JUNIOR, Marco Aurélio Serau Junior. Análise crítica dos direitos fundamentais sociais: aspectos teóricos e conceituais. 2007. 14. Tese (Mestrado em Direitos Humanos) Faculdade de Direito da Universidade de São Paulo FADUSP. São Paulo. 2007. BRASIL. Constituição (1998). Constituição da República Federativa do Brasil. Brasília: Senado Federal, 1988.

BRUINI, Eliane da Costa. I"Educação no Brasill"; Brasil Escola. Disponível em: https://brasilescola.uol.com.br/educacao/educacao-no-brasil.htm. Acesso em 11 de setembro de 2020. 


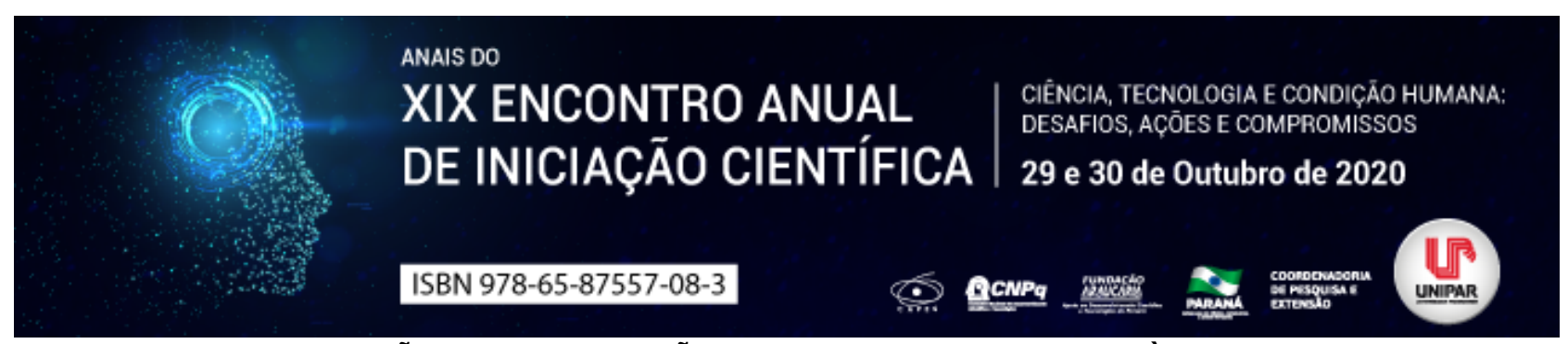

A MANIPULAÇÃO DA INFORMAÇÃO: Fake News, UMA AMEAÇA À DEMOCRACIA

\title{
${ }^{1}$ KEYLA CAROLINA DA SILVA, ${ }^{2}$ ANA CAROLINE RODRIGUES PAZINATO, ${ }^{3}$ KARINNY LEAL AZEVEDO, ${ }^{4}$ NATALIA SANTOS GASPARETTO, ${ }^{5}$ FERNANDA GARCIA VELASQUEZ
}

\author{
${ }^{1}$ Acadêmica do Curso de Direito PIC/UNIPAR \\ ${ }^{1}$ Acadêmica do Curso de Direito PIC/UNIPAR \\ ${ }^{2}$ Acadêmica do Curso de Direito PIC/UNIPAR \\ ${ }^{3}$ Acadêmica do Curso de Direito PIC/UNIPAR \\ ${ }^{4}$ Mestre em Direito Processual e Cidadania
}

Introdução: Vivemos em um Estado Democrático de Direito, o qual estabelece não apenas a igualdade entre os cidadãos, mas também diversos outros direitos, podendo-se destacar o de transmitir e obter informações, além da liberdade de expressão. Ressalta-se que esses direitos devem ser utilizados de forma correta, de modo a não violar os demais, basilares da Constituição, principalmente quando utilizados pela mídia.

Objetivo: Analisar o fenômeno da fake news e seus reflexos no processo (des) democratizador.

Desenvolvimento: A mídia juntamente com a sociedade vem evoluindo com o passar dos anos, ficando cada vez mais fácil para os cidadãos obterem e transmitirem informações. Contudo, as informações deveriam ser pautadas conforme preceitua a lei e a ética, apenas na verdade, nos fatos ocorridos, todavia, não é isso que vem acontecendo. Determinados indivíduos, agindo de má-fé, acabam transmitindo informações manipuladas, portanto falsas, e até maldosas sobre pessoas e eventos, gerando deste modo a fake news (notícias falsas). Essas, uma vez transmitidas, passam a adquirir um enorme poder sobre a sociedade, pois as pessoas acreditam em uma verdade manipulada e projetada para enganá-las, mudando assim os resultados de ações que podem acabar com a estabilidade do Estado Democrático de Direito (ABREU, 2020). É cada vez mais recorrente vermos nos mais diversos meios de comunicação, já que, quando bem formuladas acabam gerando à mídia ganho econômico, principalmente nos anos de eleições, ou quando tais notícias se baseiam em processos penais. Assim, é notória a influência exercida por essa prática no meio político-social brasileiro. Por isso, no presente ano, foi discutido o Projeto de Lei (PL) n. 2.630/2020, que institui a liberdade, responsabilidade e transparência na internet, aprovado por maioria no Plenário. Ressalta-se que o referido projeto, ainda não sancionado pelo presidente da república, não representará um retrocesso à liberdade de expressão, pois, como se verifica em seu parágrafo único do artigo $9^{\circ}$, as medidas estabelecidas no caput devem ser proporcionais, não discriminatórias e não implicarão em restrição ao livre desenvolvimento da personalidade [...] (BRASIL, 2020), problematizando somente o uso deste para causar males e sensacionalismo. Atualmente, porém, a fake news não constituem crime no Brasil, mas meios podem ser encontrados para punir os seus agentes; podem elas ser associadas ao artigo 139 do Código Penal, que institui pena ao crime de difamação, ato ofensivo à reputação (BRASIL, 1940). A criação de legislação específica para as notícias falsas representa um grande avanço, pois agiliza a conclusão de processos sobre tal, e, de certa forma, incentivará o repúdio a essa prática tão abusiva, tornando as decisões da população em geral mais democráticas, baseadas em fatos reais e na resolução que cada um absorve desses.

Conclusão: À luz do exposto, é visível que a fake news são um perverso instrumento de ideologização das massas, levando-as a tomar decisões baseadas em mentiras, aludindo a uma democracia utópica, não real. A partir disso, fica cada vez mais gritante a necessidade de atitudes governamentais a fim de resolver por completo ou ao menos amenizar esse problema, processo que felizmente já está em andamento.

\section{Referências}

ABREU, Pedro Vitor Serodio de. Democracia e Fake News: duas coisas que não andam juntas. 2020. Disponível em: https://jus.com.br/artigos/82729/democracia-e-fake-news-duas-coisas-que-nao-andam-juntas. Acesso em: 01 ago. 2020.

BRASIL. Lei n. 2.848, de 07 de dezembro de 1940. Código Penal. In: Vade Mecum Saraiva, São Paulo, v. 1, n. 29, p. 395, jan., 2020.

BRASIL. Projeto de Lei $\mathbf{n}^{\circ} \mathbf{2 . 6 3 0}$ de 2020. Institui a Lei Brasileira de Liberdade, Responsabilidade e Transparência na Internet. Brasília: Senado Federal, 2020. Disponível em: https://www25.senado.leg.br/web/atividade/materias/-/materia/141944. Acesso em: 04 ago. 2020. 



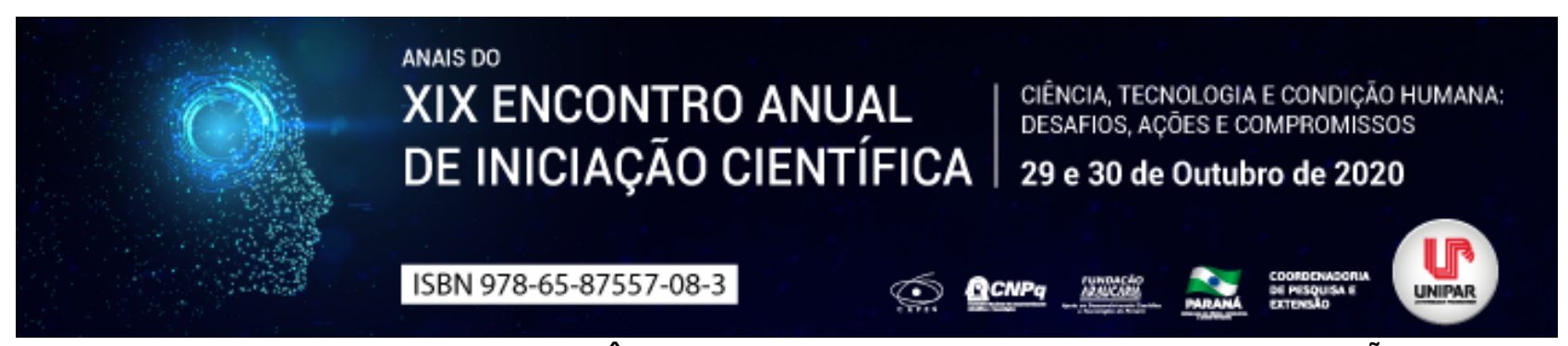

SUSTENTABILIDADE NA ESCOLA: IMPORTÂNCIA DO AMBIENTE ESCOLAR PARA A EDUCAÇÃO AMBIENTAL

\author{
${ }^{1}$ RAIANE OLIVEIRA DA SILVA, ${ }^{2}$ CAROLINA AMARAL TAVARES DA SILVA
}

${ }^{1}$ Dicente do curso de Letras EAD Unipar Campus Sede

${ }^{1}$ Docente do curso de Tecnologia em Gestão ambiental da UNIPAR

Introdução: A sustentabilidade de acordo com Boff (2017), compreende ações que a curto e longo prazos satisfazem as necessidades, e preservam elementos essenciais à sobrevivência e ao crescimento das potencialidades humanas. Neste contexto, as questões ambientais têm sido algumas das principais preocupações de órgãos públicos devido ao grande impacto que as ações de consumo e descarte têm sobre o meio ambiente (OLIVEIRA; BASSETTI, 2016). Por isso, é de extrema importância que o assunto seja tratado de forma abrangente nas escolas, contribuindo para o conhecimento, conscientização e responsabilidade das novas gerações (GONÇALVES et al., 2017).

Objetivo: Entender a importância do ambiente escolar na conscientização dos jovens para promoção de mudanças nas atitudes em relação a sustentabilidade e meio ambiente.

Desenvolvimento: O principal objetivo de se trabalhar Meio Ambiente na escola é contribuir para que as crianças e jovens se tornem cidadãos conscientes e aptos a tomar decisões favoráveis ao bem estar social e ambiental (BRASIL, 1997). Nas Diretrizes Curriculares Nacionais para a Educação (DCNE), é estabelecida a sustentabilidade ambiental como meta universal, salientando a necessidade dos educadores de ampliarem seus conhecimentos a respeito do tema para melhor abordá-lo no compromisso com o despertar de interesse da juventude (BRASIL, 2013). Desta forma, Vestena e Vestena (2017) explicam que o tema meio ambiente deve ser abordado em todas as áreas de ensino e não como uma disciplina específica, de forma a facilitar o entendimento do aluno a respeito da amplitude do assunto. Todavia, em pesquisas realizadas em escolas, foi possível verificar que os assuntos ambientais são associados, em sua maioria, apenas às disciplinas Ciências e Geografia, assim como a Língua Portuguesa que trabalha textos de formas e assuntos variados (GASQUES et al., 2016). Outros estudos apontam a tentativa das escolas de implementarem a Educação Ambiental sem um planejamento adequado, promovendo campanhas em datas pontuais que abordam o tema de forma generalizada e descontextualizada, ignorando os assuntos que fazem parte da realidade da escola e comunidade, como também, evidenciando o despreparo dos professores ao implementarem o tema em suas aulas (FERREIRA, 2011). Marvila e Guisso (2019), reforçam a ideia de que o planejamento pedagógico, quando visa a transversalidade, possibilita que os conhecimentos teóricos sejam trabalhados de forma integral, a fim de tornar significativo os conteúdos escolares. Desta forma, Ferreira (2011), sugere que é necessária uma participação ativa de professores e equipes pedagógicas no processo do planejamento da implantação da Educação Ambiental, além do acesso a cursos de capacitação. Para Pituco et al. (2016), o planejamento, execução e avaliação de projetos em educação ambiental é tão importante quanto o resultado. Isto porque, a conscientização de qualquer tema é um processo que exige a participação ativa e a reflexão constante do indivíduo sobre o assunto, principalmente se for trabalhado em consonância a realidade. A escola tem papel fundamental de sensibilização com enfoque humanista e sustentável na formação de indivíduos conscientes. É por meio da escola que o aluno aprende e desenvolve o pensamento crítico e complexo sobre vários assuntos que dizem respeito ao seu cotidiano (OLIVEIRA; BASSETTI, 2016). Além de fornecer informações e conceitos, é necessário uma metodologia voltada às práticas para desenvolvimento das habilidades e comportamentos pessoais nos diversos ambientes que possam se expor (BRASIL, 1997). Diante disto, família e comunidade têm papel importante nessas práticas, levando em consideração, fazerem parte do dia a dia das crianças e jovens (BRASIL, 1997).

Conclusão: Conclui-se com o estudo que o ambiente escolar exerce um papel fundamental quando se trata de Educação Ambiental, mas ainda se encontra em um processo de consolidação. O que se observa em estudos são metodologias, em sua maioria, ainda fragmentadas e rotineiras, sem grandes reflexões. Para que seja efetivo o ensino à sustentabilidade pautado no meio ambiente é preciso uma integralidade nas ações de ensino, com o intuito de que os conhecimentos sejam vinculados à realidade.

\title{
Referências
}

BRASIL. Parâmetros curriculares nacionais: meio ambiente. Brasília: MEC, 1997.

BRASIL. Diretrizes Curriculares Nacionais Gerais para a Educação Profissional de Nível Tecnológico. Brasília: MEC, 2013.

BOFF, L. Sustentabilidade: o que é-o que não é. Editora Vozes Limitada, 2017.

FERREIRA, C.E.A. O meio ambiente na prática de escolas públicas da rede estadual de São Paulo: intenções e possibilidades, 2011. Tese de Doutorado. Universidade de São Paulo. Disponível em: https://periodicos.furg.br. Acesso em: 17 jul. 2020.

GASQUES, A.C.F.; OKAWA, C.M.P.; SANTOS, J.D.; GASQUES, E.G.F.; DELABIO, F. Educação Ambiental: Estudo de caso em 
dois colégios estaduais da cidade de Sarandi (PR). Revista Brasileira de Educação Ambiental (RevBEA), v. 11, p. 123 138, 2016. Disponível em: http://revbea.emnuvens.com.br. Acesso em: 17 jul. 2020.

GONÇALVES, A.F.L.; SCHUCK, M.A.; SENNE, S.C.; TRINDADE, T.V. A educação ambiental em escolas municipais: um estudo de caso na escola municipal Cei Ritta Anna de Cássia. Memorial TCC Caderno da Graduação, v. 3, n. 1, p. 481-499, 2017. Disponível em: https://memorialtcccadernograduacao.fae.edu. Acesso em: 17 jul. 2020.

MARVILA, N.C.; GUISSO, L.F. Educação ambiental e sua aplicabilidade no ambiente escolar. Revista Eletrônica Acervo Saúde, n. 25, p. 632-632, 2019. Disponível em: https://acervomais.com.br. Acesso em: 17 jul. 2020.

OLIVEIRA, E. M. DE; BASSETTI, F. D. J. Atividades de sensibilização ambiental em um colégio de ensinos fundamental e médio. Revista Científica ANAP Brasil, v. 9, n. 16, p. 1 18, 31 dez. 2016. Disponível em: http://www.amigosdanatureza.org.br. Acesso em: 17 jul. 2020.

PITUCO, M.M.; SANTOS, T.O.; VINCENZI, S.L.; BIAZUS, M.A. Educação Ambiental voltada para disseminação de práticas sustentáveis. Fórum Internacional de Resíduos Sólidos (INSTITUTO VENTURINI), 2016. Disponível em: http://www.institutoventuri.org.br. Acesso em: 17 jul. 2020.

VESTENA, C.L.B.; VESTENA, L.R. Análise da percepção e das práticas de Educação Ambiental em escolas de Curitiba/PR: subsídio à sensibilização socioambiental. Ateliê Geográfico, v. 11, n. 1, p. 87-108, 2017. Disponível em: https://www.revistas.ufg.br. Acesso em: 17 jul. 2020.

Coordenadoria de Pesquisa e Extensão - COPEX

Departamento de Editoraçāo e Divulgaçāo Científica - DEDIC 


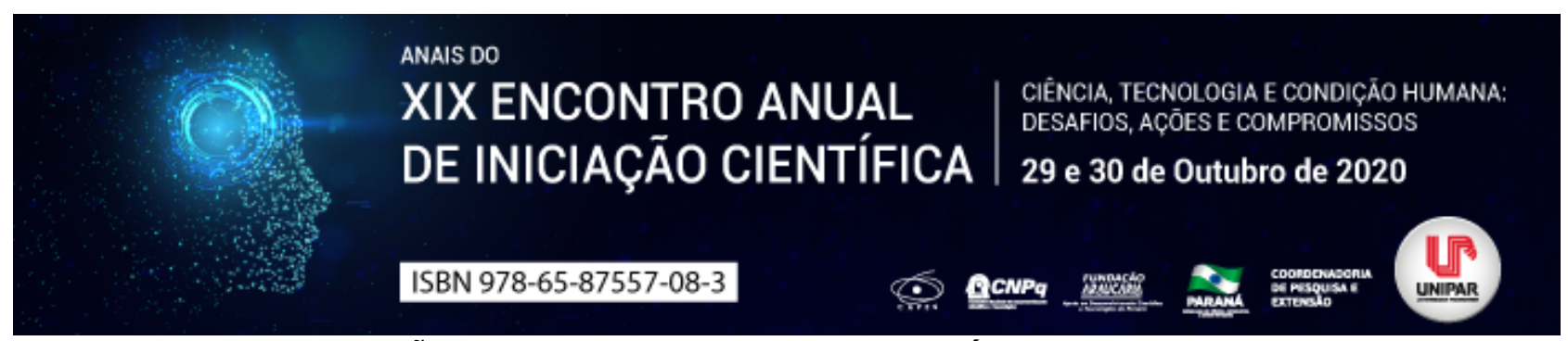

EDUCAÇÃO AMBIENTAL NA DISCIPLINA DE LÍNGUA PORTUGUESA

\author{
${ }^{1}$ RAIANE OLIVEIRA DA SILVA, ${ }^{2}$ CAROLINA AMARAL TAVARES DA SILVA
}

\author{
${ }^{1}$ Dicente do curso de Letras EAD Unipar Campus Sede \\ ${ }^{1}$ Docente da UNIPAR
}

Introdução: O tema meio ambiente tem sido cada vez mais relevante dentro das discussões contemporâneas, devido aos impactos causados pelas ações humanas, sempre com o intuito, muitas vezes controverso, de fornecer o desenvolvimento tecnológico e aumento da qualidade de vida da população (SAGGIN, 2014). É necessário, portanto, uma nova perspectiva e o desenvolvimento de uma consciência responsável e ecológica (ABRÃO, 2014). A escola tem papel fundamental neste processo, visto que, no ambiente escolar é possível que o indivíduo desenvolva suas habilidades e capacidades de sensibilização, conscientização e reflexão crítica (OLIVEIRA; BASSETTI, 2016). Neste sentido, a Educação Ambiental (EA) na disciplina de Língua Portuguesa pode contribuir de forma satisfatória a discussão do tema, considerando que a transversalidade do assunto possibilita o trabalho com gêneros textuais, interpretação e conteúdos gramaticais (SAGGIN, 2014).

Objetivo: Este trabalho teve como objetivo a realização de uma revisão de literatura sobre como trabalhar a Educação Ambiental nas aulas de Língua Portuguesa.

Discussão: O objetivo das aulas de Língua Portuguesa, em termos gerais é que o aluno seja capaz de compreender e realizar diferentes tipos de textos escritos ou orais, como também, adquirir a capacidade de compreender a sua língua gramaticalmente, e analisar os diferentes tipos de linguagem, desarmando-se de preconceitos linguísticos (BRASIL, 1997). Quando se trata de temas sociais, a Língua Portuguesa assume um papel importante, dado que através da linguagem é possível desenvolver discussões e reflexões, expressando aquilo que se pensa sobre o mundo (SAGGIN, 2014). A Educação Ambiental (EA) no ambiente escolar, de acordo com Ferreira (2013), deve ser discutida de forma transversal, ou seja, é relevante em diferentes tipos de abordagens de forma que não se enquadra em uma única disciplina. Segundo Abrão (2014), vários estudos sugerem a abordagem do tema ambiental na Língua Portuguesa, por meio de análise e produção de textos, como também o estímulo ao debate para melhor consolidação das ideias. Lima, Costa e Pinto (2015), propõem em seus estudos a Sequência Didática como instrumento de ensino, desta forma iniciando a abordagem com o reconhecimento do conhecimento prévio do aluno através da produção de texto, em seguida a abordagem do tema de forma aprofundada com leitura, discussão e uso de jogos didáticos, por fim uma nova produção de texto para análise da evolução. De forma crítica, Campanini (2016), defende que ao se planejar uma aula sobre o tema ambiental, com o intuito de obter respostas transformadoras, é necessário instigar a curiosidade do aluno e não subestimar sua capacidade de entender temas complexos. De fato, o que é observado em estudos a respeito da abordagem ambiental em sala de aula é a fragmentação de temas repetitivos focados em ações individuais, visto que apesar de sua importância, isto se torna insuficiente quando o objetivo é a transformação de pensamento e consciência crítica em relação ao ser humano como parte da natureza (BUCZENKO; ROSA, 2018).

Conclusão: Conclui-se com o estudo que a disciplina de Língua Portuguesa pode contribuir de forma significativa para o estudo de temas Ambientais em sala de aula, visto que fornece ferramentas que possibilitam o desenvolvimento de temas complexos, porém ainda é necessário de acordo com estudos o amadurecimento da didática e enriquecimento do debate com ideias inovadoras e transformadoras pois em muitos casos, ainda se encontra fragmentada e limitada.

\title{
Referências
}

RUHENA, Keber Abrão. Conexões entre a língua portuguesa e a educação ambiental: da legislação à aplicação. FABE em Revista, Faculdade Bertioga, v. 4, n. 5, p. 26 33, 2014. Disponível em: http://fabeemrevista.com.br. Acesso em: 17 jul. 2020.

BRASIL. Parâmetros curriculares nacionais : Língua Portuguesa. Brasília: MEC/SEF, v. 2, p. 87, 1997.

BUCZENKO, Gerson Luiz.; ROSA, Maria Arlete. Educação Ambiental na Escola e natureza: uma relação necessária para a produção do conhecimento. Revista Eletrônica do Mestrado em Educação Ambiental, Ed. Especi, n. 1, p. $308322,2018$. Disponível em: https://periodicos.furg.br. Acesso em: 17 jul. 2020.

CAMPANINI, Barbara Doukay. Análise da contribuição das histórias em quadrinhos na problematização de questões ambientais no ensino fundamental. Orientador: Marcelo Borges Rocha, 2016, Dissertação (Mestrado em Ciência, Tecnologia \& Educação) - Centro Federal de Educação Tecnológica Celso Suckow da Fonseca, CEFET/RJ, Rio de Janeiro, 2016.

FERREIRA, Helena Maria. A transversalidade nas aulas de língua portuguesa: a educação ambiental em questão. Anais do SILEL, v. 3, n. 1, p. 1 10, 2013. Disponível em: http://www.ileel.ufu.br. Acesso em: 17 jul. 2020.

LIMA, Thomaz Santos.; PINTO, Valberth Francisco Nunes.; COSTA, Taciana Kramer de Oliveira. Sequência didática, uma proposta interdisciplinar: linguagem e educação ambiental. 110 ENFOPE - 120 FOPIE, v. 53, n. 9, p. $16891699,2015$. 
Disponível em: https://eventos.set.edu.br. Acesso em: 17 jul. 2020)

SAGGIN, Marli Regiane Ogliari. Estratégias a serem utilizadas pelos professores de língua portuguesa para inserir o tema transversal meio ambiente nas suas aulas. [s.I.] Monografia (Especialização em Linguística Aplicada ao Ensino da Língua Portuguesa e Literatura Brasileira) - Instituto Superior de Educação do Vale Do Juruena (AJES), 2014.

OLIVEIRA, E. M. DE; BASSETTI, F. D. J. Atividades de sensibilização ambiental em um colégio de ensinos fundamental e médio. Revista Científica ANAP Brasil, v. 9, n. 16, p. 1 18, 31 dez. 2016. Disponível em: http://www.amigosdanatureza.org.br. Acesso em: 17 jul. 2020.

Coordenadoria de Pesquisa e Extensão - COPEX

Departamento de Editoraçāo e Divulgaçāo Científica - DEDIC 


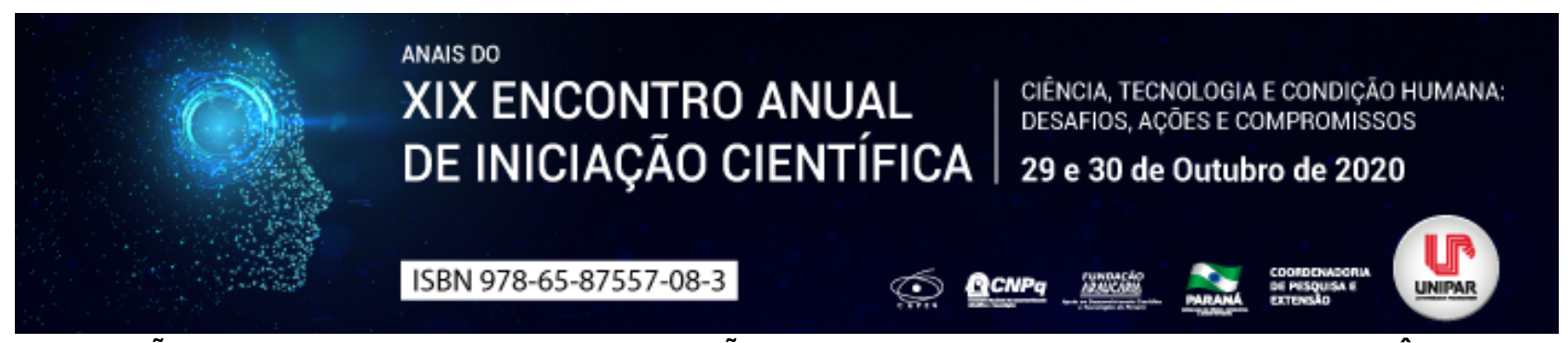

A RELAÇÃO ENTRE A PSICOLOGIA E A RELIGIÃO/RELIGIOSIDADE: COMPREENDENDO VIVÊNCIAS DE UNIVERSITÁRIOS E UNIVERSITÁRIAS DE PSICOLOGIA

\author{
${ }^{1}$ Bianca de Carvalho Archillia, ${ }^{2}$ SYLVIA MARA PIRES DE FREITAS
}

\author{
${ }^{1}$ Acadêmica do PIC/UEM \\ ${ }^{1}$ Docente da Universidade Estadual de Maringá
}

Introdução: Pesquisas apontam que a graduação em Psicologia influencia nas crenças e valores adotados pelos alunos, os quais podem entrar em conflito com os conceitos psicológicos aprendidos. Pereira e Holanda (2016) apresentam o contexto cientificista do nascimento da Psicologia, que teve como resultante a patologização da experiência religiosa (p. 388). Segundo os autores, as produções científicas sobre religião são silenciadas e confundidas com o discurso religioso propriamente dito. À vista disso, Sampaio (2004) coloca em questão a neutralidade científica por parte do psicólogo, já que este também atribui significado ao mundo, sendo impossível uma prática totalmente neutra. Tendo em vista que a neutralidade do psicólogo deve ser entendida como a ausência de julgamentos e imposições o que não significa que ele deva abandonar suas crenças religiosas ele deve ter consciência disto. Assim sendo, podemos inferir que, se a formação ética do estudante de Psicologia não abordar o fenômeno da experiência religiosa, esse futuro profissional poderá induzir seu cliente às suas convicções religiosas (do profissional), ou ainda, induzir seu cliente a abandonar suas práticas religiosas. Posicionar-se como neutro no sentido de não abordar esse tema não é garantia de uma prática ética, mas possivelmente de uma negação dos fenômenos que decorrem da relação entre o indivíduo e a religião. A partir disso, entendemos que compreender a experiência de acadêmicos de Psicologia diante da relação Psicologia-Religião/Religiosidade poderá adensar o auxílio à formação ética de psicólogos pela possibilidade dos resultados desta pesquisa elucidarem as formas pelas quais eles apreendem o fenômeno religioso, bem como oportunizar a indicação de meios para abordar, na graduação, a Religião e a Religiosidade como fenômenos.

Objetivo: Compreender como alunos e alunas do $5^{\circ}$ ano de Psicologia da Universidade Estadual de Maringá - UEM, Paraná, vivenciam a relação entre a ciência e a religião e religiosidade.

Material e métodos: O método utilizado para a realização das entrevistas foi inspirado no método fenomenológico de Husserl, o qual propõe a realização da redução fenomenológica, operação filosófica que [...] começa com a suspensão do circuito de validade dos demais egos existentes (que não o de quem está filosofando) e dos saberes compartilhados (BARREIRA, 2018, p. 3). Ou seja, devem ser suspensos os saberes, conceitos e valores adotados pelo pesquisador, a fim de priorizar a vivência de cada entrevistado, que é o real objeto de estudo. Foram realizadas sete entrevistas individuais com acadêmicos do quinto ano de Psicologia da UEM. Antes do início dessas, foi lido e entregue aos participantes o Termo de Consentimento Livre e Esclarecido (TCLE). A pesquisa foi aprovada pelo Comitê Permanente de Ética em Pesquisa com seres humanos (COPEP) da UEM com Parecer $n^{\circ}$ 3.227.325, de 27 de março de 2019. Todas as entrevistas ocorreram na Unidade de Psicologia Aplicada (UPA/UEM) e o instrumento utilizado foi a entrevista semidirigida, valendo-se de perguntas disparadoras do diálogo entre acadêmicapesquisadora e acadêmicos-entrevistados.

Resultados e discussão: A análise foi realizada com base no pensamento do filósofo existencialista Jean-Paul Sartre. Apesar das significações singulares atribuídas ao fenômeno religioso por cada estudante, observou-se que a Psicologia exerce influência na experiência de todos eles. O que se mostrou mais relevante em nossa análise foi o fato de a formação em Psicologia, baseada na respectiva ciência que diz buscar compreender o ser humano a partir de todas suas manifestações, negligenciar um tema tão relevante para a apreensão dos valores atribuídos pelo indivíduo. Essa análise é ilustrada pela vivência dos estudantes, pois seis dos sete entrevistados mencionaram ter vivenciado conflito em algum momento da graduação diante da Psicologia e suas crenças religiosas; alguns ainda afirmaram ter experienciado sofrimento psíquico pela falta de acolhimento, do sentimento de não pertencimento e das ações preconceituosas direcionadas a eles. Foi possível observar que a religião/religiosidade é vista por eles como fonte de amparo, já que a Psicologia não proporciona esse acolhimento almejado; ou seja, a negligência acadêmica em relação ao fenômeno religioso acaba por reforçar a necessidade da religião. Ademais, todos os entrevistados enfatizaram a falta de preparo por parte da academia, no que diz respeito a formação deles para lidarem com a temática religiosa. Segundo eles, discussões sobre esse tema agregariam para uma melhor compreensão do ser humano, diante disso, todos afirmam que gostariam de ter discutido mais sobre esse assunto na graduação.

Conclusão: Concluiu-se que os cursos de Psicologia precisariam abordar esse tema durante a formação, mesmo que seja em minicursos, como disciplinas optativas ou em grupo de estudos, a fim de propiciar um espaço adequado para discutirem um assunto que se mostra extremamente presente nas vivências de seus acadêmicos.

\title{
Referências
}


BARREIRA, Cristiano. Escuta suspensiva. Anais. Foz do Iguaçu. 2018. Disponível em: . Acesso em: 05 mar. 2020 PEREIRA, Karine; HOLANDA, Adriano. Espiritualidade e religiosidade para estudantes de Psicologia: Ambivalências e expressões do vivido. Revista Pistis Praxis. Curitiba, v.8, n.2, p.385-413, Maio/Ago. 2016. Disponível em: Acesso em: 11 out. 2018.

SAMPAIO, Mariana. Neutralidade na relação terapêutica. Reflexões a partir da abordagem gestáltica. Arquivos Brasileiros de Psicologia, v. 56, n. 1, p. 49-56, 2004. Disponível em: Acesso em: 27 out. 2018. 


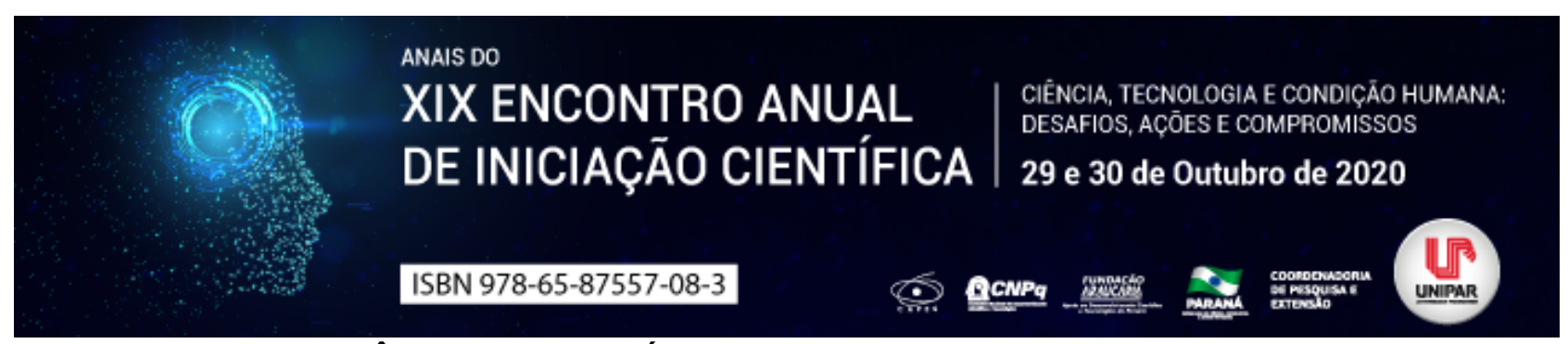

A VIVÊNCIA DE CONTEÚDOS INCONSCIENTES NA SEXUALIDADE

\begin{abstract}
${ }^{1}$ ANA CLARA FRANCOLIN TRENTO, ${ }^{2}$ LAIANY MAIARA QUIRINO DE PAULA, ${ }^{3}$ RAFAELA GOMES LUIZ, ${ }^{4}$ MAURO SERGIO DA ROCHA
\end{abstract}

${ }^{1}$ Acadêmica do Curso de Psicologia da UNIPAR

${ }^{1}$ Acadêmica do Curso de Psicologia da UNIPAR

${ }^{2}$ Acadêmica do Curso de Psicologia da UNIPAR

${ }^{3}$ Docente da UNIPAR

Introdução: Através de um olhar fundamentado na Psicologia analítica e em suas diversas possibilidades de representações, abordamos o tema principal deste resumo: projeções e sexualidade. Segundo Jacoby (2011) falamos de projeção quando conteúdos intrapsíquicos do sujeito são vivenciados no mundo externo, de forma inconsciente. Essa relação se faz possível considerando que compreendemos, aqui, que o sujeito pode se utilizar de fantasias sexuais para projetar sua relação com o corpo e com sua sexualidade.

Objetivo: Refletir acerca das projeções e desejos inconscientes e como estes se relacionam com fantasias sexuais.

Desenvolvimento: Ao reprimir suas próprias vontades e desejos, o sujeito não as vivencia de forma consciente, experimentando-as, por exemplo, através das projeções. Este mecanismo psíquico ocorre quando um aspecto desconhecido da nossa personalidade é ativado, fazendo com que o sujeito o veja em outro objeto, não tendo consciência de que este conteúdo pertence a si mesmo (SANFORD, 1987). Quando isso acontece, o outro pode ser reduzido ao papel inconsciente que o sujeito deu à ele, reduzindo-o a um objeto de posse (JACOBY, 2011). Essa relação inconsciente com o outro, com quem se relaciona, poderá acontecer caso o sujeito não esteja consciente dos seus próprios conteúdos e do que o leva a buscar a realização de sua sexualidade através de fantasias que não contribuem para o processo de individuação de si, nem da relação com o outro. Na busca desta realização, intensifica-se uma relação superficial com o outro, tornando-o um corpo a ser usado e descartado. Com isso, busca-se com que o outro supra a necessidade de prazer imediato, evidenciando a necessidade de uma estruturação psíquica, que esclareça e introjete essas projeções. Dessa forma, é necessário que haja um esclarecimento do que pertence ao sujeito e do que pertence ao outro, para que o outro não se torne apenas um objeto de necessidades e fantasias inconscientes. Quando há reconhecimento, o próprio sujeito pode ser capaz de compreender a representação de conteúdos envolvidos em sua própria sexualidade, integrando partes de sua psique até então desvalorizadas. Nessa reflexão sobre o tema, tem-se as implicações de conteúdos arquetípicos que estão relacionados aos conteúdos masculinos e femininos inconscientes. Falamos aqui da figuração anima/animus. Esses conteúdos podem ser representantes da sedução, sensibilidade e encantamento. Enquanto estabelecerem relações com o ego, de forma que o sujeito esteja consciente de como isso opera, servem como um guia para transformação e crescimento. Todavia, uma vez conectados através de seus aspectos inconscientes, estas estruturas psíquicas, quando não desenvolvidas, mantêm-se infantilizadas, levando o sujeito a relações fantasiosas e idealizadas (JUNG, 2016). Neste sentido, podem levar o sujeito a se relacionar com a sexualidade de forma compulsiva como meio de alimentar suas vontades eróticas, projetando suas fantasias e desejos (CECCARELLI, 2011). Ao não se relacionar com o par anima/animus, o sujeito pode ser tomado pelas características negativas desses arquétipos e obter resultados catastróficos em suas relações projetadas. Analisando esse tema, podemos perceber que essas fantasias vinculadas à sexualidade podem indicar ao sujeito duas rotas, uma na qual é vivenciada de forma consciente, e outra em que se concretiza através do vício ou da idealização de um par sexual que corresponda os desejos de seu inconsciente. Na primeira o sujeito integra partes de si, introjetando conteúdos antes desvalorizados - uma ampliação da consciência. Já no segundo caso, ao ter as fantasias sexuais sucumbidas à compulsão, a psicologia será essencial para a compreensão simbólica dos conteúdos, como possibilidade de, mesmo com dificuldade, elevar o conteúdo à consciência e contribuir para o processo de individuação do sujeito (SANFORD, 1987).

Conclusão: Mediante as explicações apresentadas percebe-se que, quando esse conteúdo é experienciado apenas na realidade externa, o sujeito pode se tornar vítima e dependente de suas próprias fantasias (JUNG, 2016). Aqui, em específico, das fantasias vinculadas à sexualidade. É importante que o sujeito aprenda a reconhecer e se relacionar com os próprios conteúdos, relacionar partes conscientes e inconscientes, a fim de considerar sua individualidade, desejos e vontades (JACOBY, 2011). Ter consciência das imagens projetadas e entrar em contato com os próprios conteúdos psíquicos é relevante para o autoconhecimento, transformando a relação com a sexualidade e com os outros - o que implicaria numa relação mais realista, em que não seja dependente ou escravo de tais conteúdos. O entendimento desse processo pode proporcionar uma elaboração, auxiliando na redescoberta da totalidade e estabelecendo uma forma diferenciada de lidar com essas energias psíquicas - de forma individual e coletiva (LÓPEZ-PEDRAZA, 2002). 


\section{Referências}

CECCARELLI, Paulo Roberto. A pornografia e o ocidente. Revista (In) visível. Portugal, 2011.

JACOBY, Mario. O encontro analítico: transferência e relacionamento humano. Petrópolis, Rio de Janeiro: Vozes, 2011. JUNG, Carl Gustav. O homem e seus símbolos. 3. ed. Rio de Janeiro: HarperCollins Brasil, 2016.

LÓPEZ-PEDRAZA, Rafael. Dionisio no exílio: sobre a repressão da emoção e do corpo. São Paulo: Paulus, 2002.

SANFORD, John. Os parceiros invisíveis: o masculino e o feminino dentro de cada um de nós. São Paulo: Paulus, 1987.

Coordenadoria de Pesquisa e Extensão - COPEX

Departamento de Editoraçāo e Divulgaçāo Científica - DEDIC 


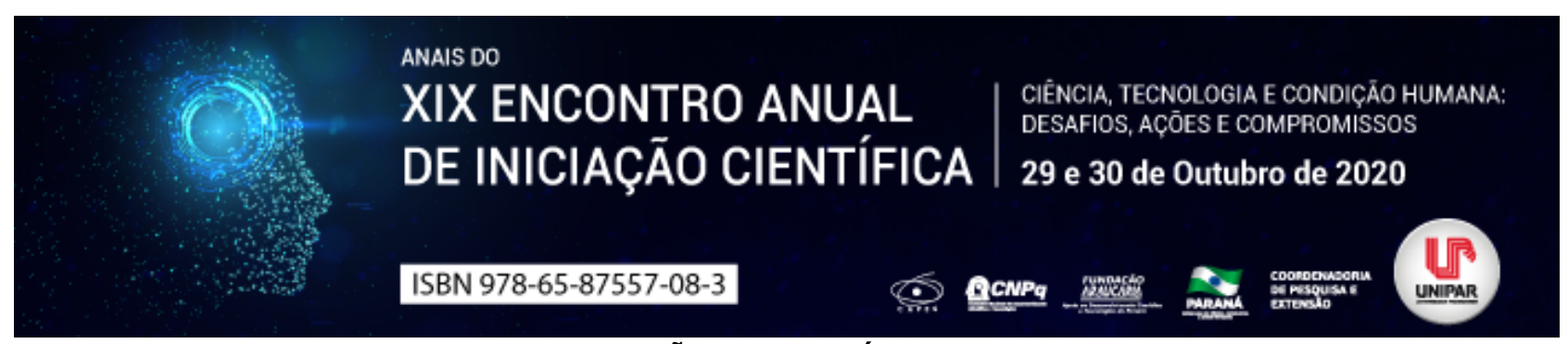

A VULNERABILIDADE DA POPULAÇÃO CARCERÁRIA COM A PANDEMIA DO COVID 19

\author{
${ }^{1}$ MARIANA DE OLIVEIRA CARVALHO, ${ }^{2}$ TEREZA RODRIGUES VIEIRA
}

${ }^{1}$ Acadêmica do curso de Direito e integrante do PIBIC.

${ }^{1}$ Docente do Mestrado em Direito Processual e Cidadania na UNIPAR

Introdução: A aglomeração carcerária é uma realidade constante nas prisões brasileiras com celas superlotadas em circunstâncias insalubres, ambiente ideal para a proliferação do coronavírus e outras moléstias respiratórias. Diante da imposição do isolamento social durante a pandemia da COVID 19, cabe refletir acerca do direito à saúde dos presos que vivem sem as condições mínimas de higiene em ambientes concentrados de pessoas.

Objetivo: Analisar os aspectos atinentes às condições carcerárias durante a pandemia COVID 19, e demonstrar o descaso estatal com a população correcional.

Desenvolvimento: $\mathrm{O}$ surgimento do Corona Vírus e sua rápida propagação colocou a população mundial em alerta. Os números de mortos e infectados aumentam dia após dia, e a criação de uma vacina segue sendo apenas uma esperança para 2021. Errôneo é dizer que estão todos na mesma situação de risco, tendo em vista o ambiente insalubre no qual vivem os presos brasileiros. Diante disso, o Conselho Nacional de Justiça (CNJ) elaborou a recomendação ${ }^{\circ} 62 / 2020$ (CNJ, 2020), suspendendo as visitas dos familiares, atendimentos jurídicos e a ida da Pastoral Carcerária. Referida decisão afetou a saúde psicológica dos presos, os quais se viram sem os objetos de higiene pessoal, levados pelos familiares, uma vez que esses não são proporcionados eficazmente pelo Estado. Em entrevista, Everaldo Patriota, Coordenador de Acompanhamento Carcerário da Ordem dos Advogados do Brasil, salientou: Quando você restringe o acesso do advogado ao preso, você fecha a porta dos presídios e de todos os seus problemas para o mundo exterior . (ALESSI, 2020, p.3). Sendo ainda motivo de intensificação da tensão entre os presos, aumentando o risco de rebeliões. Além disso, para decisões como essa serem capazes de conter a proliferação da doença, seria necessário o devido isolamento de todos que trabalham na delegacia, o que não vem ocorrendo. Após o contato do vírus com os presos, fica impossível o controle com a superlotação. Estima-se que, em uma cela de 150 pessoas, após o primeiro contágio, em apenas 21 dias ocorrerá a contaminação de todos. Tem-se notícia que, somente no Complexo Penitenciário da Papuda, no Distrito Federal, mais de 900 pessoas se infectaram em um período de 15 dias (...), enquanto no Rio Grande do Sul, em menos de uma semana, os casos saltaram de 21 para 135 (...). Com atualizações sistemáticas (...) mais de 223 presos no Paraná testaram positivo para covid-19 . (ENSP, 2020, p. 1) Também foi recomendado pelo $\mathrm{CNJ}$ o desencarceramento de réus pertencentes ao grupo de risco ou que não cometeram crimes graves, que fossem beneficiados com a prisão domiciliar. É impossível mensurar quantos pertencentes ao sistema já foram contaminados até o presente momento, pois os números crescem todos os dias. É preciso acentuar que o processo de criminalização é um reflexo da miséria do Estado, consoante frisa Loic Wacquant (2003), uma vez que boa parte dos apenados se encontra nessa situação por falta de oportunidades.

Conclusão: Conclui-se que as medidas para impedir que o coronavírus se alastre nas cadeias e penitenciárias são necessárias, em decorrência da alta vulnerabilidade dessa população que vive aglomerada. No cárcere, a propagação ocorre rapidamente, uma vez que as condições de higiene são precárias e o acesso aos serviços de saúde são parcos e falhos.

\title{
Referências
}

ALESSI, Gil. Sem visitas nem acesso a advogados, presos temem coronavírus. Primeira vítima morre em cadeia do Rio. El País. Disponível em: https://brasil.elpais.com/brasil/2020-04-17/sem-visitas-nem-acesso-a-advogados-presos-temem-coronavirusprimeira-vitima-morre-em-cadeia-do-rio.html. Acesso em: 4 ago. 2020.

CONSELHO NACIONAL DE JUSTIÇA. ATOS. Recomendação $n^{\circ}$ 62/2020. Disponível em: https://atos.cnj.jus.br/atos/detalhar/3246. Acesso em: 26 jul. 2020.

ENSP. Escola Nacional de Saúde Pública Sérgio Arouca. Novo coronavírus expõe fraquezas da assistência à saúde no cárcere. Edição de 10 ago. 2020. Disponível em: http://www.ensp.fiocruz.br/portal-ensp/informe/site/materia/detalhe/49699 Acesso em: 13 ago. 2020.

WACQUANT, Loïc. Punir os pobres: a nova gestão da miséria nos Estados Unidos [A onda punitiva]. trad. Sérgio Lamarão, v. 3. Rio de Janeiro: Revan, 2003. 


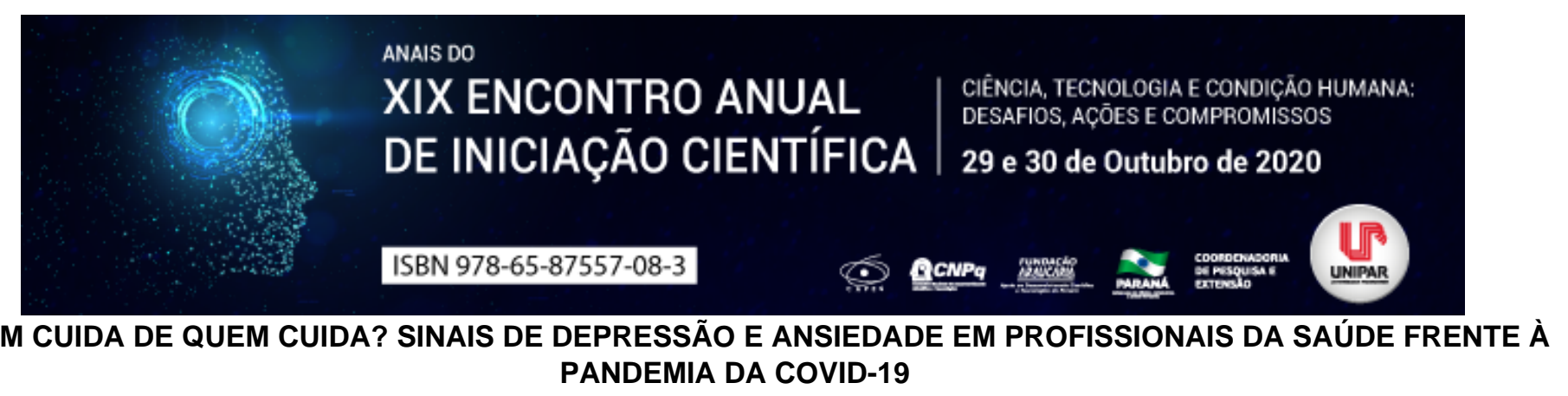

\begin{abstract}
${ }^{1}$ GEISIANE GASPARIN RAMOS, ${ }^{2}$ EDUARDA VOSS JACONDINO, ${ }^{3}$ AGATHA IZIS PIEROZAN DA SILVA, ${ }^{4}$ GRACIANE BARBOZA DA SILVA, ${ }^{5}$ THAIS CRISTINA GUTSTEIN NAZAR
\end{abstract}

\author{
${ }^{1}$ Acadêmica do PIC/UNIPAR \\ ${ }^{1}$ Acadêmica do Curso de Psicologia da UNIPAR \\ ${ }^{2}$ Acadêmica do Curso de Psicologia da UNIPAR \\ ${ }^{3}$ Docente da UNIPAR \\ ${ }^{4}$ Docente e orientadora PIC/PIBIC da UNIPAR
}

Introdução: A pandemia do Covid-19 veio modificando os cenários e as rotinas, não só no Brasil mas também do mundo, desencadeando em novos estilos de vida a serem adotados para prevenir a contaminação, já que se trata de uma doença de fácil contágio. Segundo SCHMIDT et al (2020) Pandemias como essa causam grandes preocupações na população em geral, diante dos poucos conhecimentos e dados que existem sobre a forma de contágio e possíveis maneiras de prevenção, sem uma data certa para terminar, sendo o isolamento social a maneira mais eficaz até o momento de prevenção. Algumas doenças podem ser desencadeadas pelo pânico causado, tanto na população geral, como nos profissionais da saúde, posto que, nesses momentos, mais do que nunca, eles são profissionais da linha de frente. A depressão, variável a qual será comentada no presente trabalho, trata-se de um transtorno de humor que segundo Cunha (2001) apresenta sintomas como a apatia, perda de interesse, tristeza, perda de apetite, falta de concentração e múltiplas queixas somáticas. Sendo cerca de 3,5 milhões de trabalhadores da saúde (somente no SUS) enfrentando incertezas nesse período de pandemia, que acabam por desencadear demais problemas como a depressão. Por sua vez, a ansiedade refere-se como uma reação psicológica, podendo ser uma reação de defesa do organismo e pode-se dividir em níveis. CASTILLO et al, 2000 discorre sobre a ansiedade como algo que pode aumentar a produtividade do indivíduo mas, quando em excesso, pode vir a ser patológico e atrapalhar no cotidiano, sendo um sentimento desagradável de medo, tensão, desespero sobre algo novo ou desconhecido.

Objetivo: Avaliar sinais de ansiedade e depressão em profissionais da saúde frente à pandemia de COVID-19.

Materiais e Métodos : A presente pesquisa foi aprovada pelo Comitê de Ética em Pesquisa parecer: 4.127 .990 e $n^{\circ}$ CAAE: 93703418.4.0000.0109, acontecendo de forma on-line dentro dos parâmetros éticos científicos. Para a coleta de dados utilizouse do Termo de Consentimento Livre e Esclarecido (TCLE), bem como a escala HAD (Avaliação do nível de estresse e depressão). A pesquisa foi realizada com 70 profissionais da saúde, sendo eles 85,7\% do gênero feminino e 14,3 \% do gênero masculino, com idade variável entre 20 e 55 anos, sendo a maior parte, 75,7\% da cidade de Francisco Beltrão - PR. Para a análise dos dados foi criado de um banco de dados no Statistical Package for the Social Sciences (SPSS) utilizando-se de estatísticas descritivas (frequência).

Resultados: Após a análise dos dados, obteve-se Depressão Provável 18,3\% (n=13), Depressão Improvável 20,0 (n=14), Depressão Possível 61,4\% ( $n=43)$. Ansiedade Improvável 21,4 \% ( $n=15)$, Ansiedade Possível 54,3\% ( $n=38)$, Ansiedade Provável $24,3 \%(n=17)$.

Discussões: Os dados de ansiedade permitem inferir que a maior parte da amostra apresenta sinais/sintomas de ansiedade embora de maneira moderada, chamando atenção o fato de que é maior o percentual de participantes que já apresentam sinais/sintomas de ansiedade em níveis elevados (ansiedade possível) se comparados a aqueles que apresentam sinais/sintomas leves (ansiedade improvável). Ao analisar os dados sobre depressão, os sinais/sintomas dos participantes estão em níveis elevados (depressão possível) comparando aos dados dos participantes que apresentam sintomas de forma mais amena (depressão impossível).Um estudo realizado por Gomes, Oliveira em 2013, obteve-se resultado semelhante aos aqui expostos, em que a maioria dos participantes eram do gênero feminino, com sinais/sintomas de ansiedade e depressão acentuados, às autoras afirmam ainda que, os profissionais da saúde são um público suscetível ao sofrimento psíquico no ambiente de trabalho.

Conclusão:Conclui-se dessa forma que a pesquisa atingiu seu objetivo principal que era analisar os sinais de depressão e ansiedade nos profissionais da saúde frente á pandemia do COVID-19.No momento atual e com os estilos de vida que vivenciamos, Schmidt et al., 2011 , diz que a ansiedade e depressão são recorrentes e causam grande impacto no cotidiano dos indivíduos, fato observado com a realização desta pesquisa, uma vez que, os sinais/sintomas de depressão possível e ansiedade possível são elevados, quando comparado com os sinais/sintomas dos participantes com depressão impossível e ansiedade impossível. Ressalta-se ainda a importância de mais pesquisas na área, uma vez que, se trata de um novo cenário. 


\section{Referências}

CASTILLO, Ana Regina GL et al . Transtornos de ansiedade. Rev. Bras. Psiquiatr., São Paulo, v. 22, supl. 2, p. 20-23, Dec. 2000. Disponivel em: . acesso 19 de Julho ui8gh de 2020. https://doi.org/10.1590/S1516-44462000000600006.

GOMES, Rosemeire Kuchiniski; OLIVEIRA, Vera Barros de. Depressão, ansiedade e suporte social em profissionais de enfermagem. Bol. psicol, São Paulo, v. 63, n. 138, p. 23-33, jun. 2013. Disponível em . acessos em 05 ago. 2020.

MACHADO M. H. Profissionais de Saúde em tempos de COVID-19. Jornal O Globo. 17 abr. de 2020. Disponível em: Acesso em: 05 ago. 2020.

SCHMIDT, Beatriz et al . Saúde mental e intervenções psicológicas diante da pandemia do novo coronavírus (COVID-19). Estud. psicol. (Campinas), Campinas, v. 37, e200063, 2020. Available from . access on 17 June 2020. Epub May 18, 2020. http://dx.doi.org/10.1590/1982-0275202037e200063 


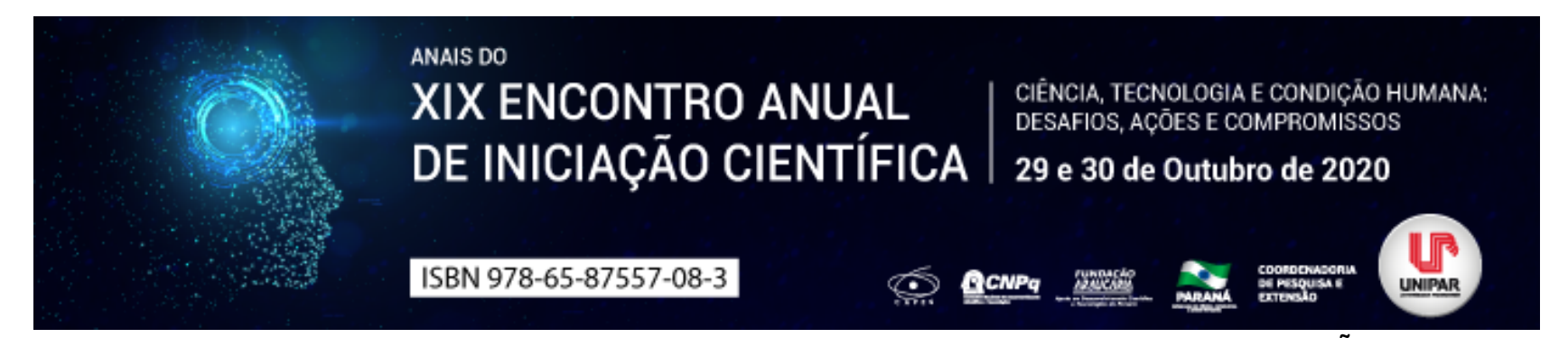

O CONTRATO DE TRABALHO DOS ATLETAS PROFISSIONAIS DE FUTEBOL E A LEGISLAÇÃO BRASILEIRA

\author{
${ }^{1}$ LINEIA VITORIA ARMANI, ${ }^{2}$ MAIARA DOS SANTOS NORONHA
}

\author{
${ }^{1}$ Acadêmica do Curso de Direito da UNIPAR \\ ${ }^{1}$ Docente da UNIPAR
}

Introdução: O direito desportivo, diante da legislação brasileira vigente, vem ganhando grande repercussão enquanto regulador de relações jurídicas, uma vez que envolve uma das práticas esportivas de maior destaque no país, qual seja, o futebol. Devido a isso, tornou-se necessário analisar, de forma crítica, os requisitos adotados para a formação do contrato de trabalho dos jogadores de futebol, principalmente diante das suas peculiaridades em relação ao contrato de trabalho ordinário.

Objetivo: Verificar de forma crítica os requisitos adotados para a confecção do contrato de trabalho dos jogadores profissionais de futebol, especialmente no que diferem das normas que regem o contrato de trabalho ordinário, tendo em vista a sua importância no Brasil.

Desenvolvimento: Atualmente, o direito desportivo exige a inclusão de requisitos específicos para a composição do contrato de trabalho dos jogadores de futebol firmados com os clubes. A Consolidação das Leis Trabalhistas permite que o contrato de trabalho ordinário seja expresso ou tácito, entretanto, a legislação desportiva exige que o contrato de trabalho dos atletas de futebol seja celebrado por escrito (MARTINS, 2016, p. 35). Segundo Alice Monteiro de Barros (2002, p. 93), a subordinação jurídica dos jogadores difere do contrato de trabalho ordinário, pois, para o desenvolvimento da atividade desportiva é necessário que o atleta siga as orientações do clube durante os treinos, períodos de concentrações, excursões para jogos, como também, é realizado o controle na alimentação, peso, horas de sono, comportamento sexual, vestuário, aparência externa e na forma de comunicação dos jogadores. Outra diferença relevante, está na remuneração do atleta, pois, engloba como natureza salarial as luvas e demais premiações pagas pelos clubes ou profissionais que integram a comissão técnica e a área médica (POSSÍDIO, 2019 , p. 50). Ademais, o contrato de trabalho dos jogadores de futebol deve conter prazo determinado para rescisão, sendo o mínimo três meses e máximo de cinco anos, juntamente com a exigência de cláusulas compensatórias, devidas pelos clubes para os atletas, e, cláusulas indenizatórias, devidas pelos atletas aos clubes nos casos de rompimento contratual antecipado (FILHO; SANTORO, 2019, p. 170). Para que a elaboração contratual dos jogadores seja realizada de acordo com os direitos e deveres destes atletas, é necessária a utilização de requisitos contratuais específicos que forneçam a este trabalhador maior segurança jurídica, sendo que as características indispensáveis para a formação do contrato de trabalho são fundamentais, pois, as entidades organizadoras do desporto vedam que os atletas desenvolvam suas atividades profissionais sem registros do renomado contrato, fazendo com que estes requisitos possuam especial importância (OLIVEIRA, 2016, p.60). Ocorre que, alguns destes requisitos podem ser questionados em relação aos direitos e garantias fundamentais do indivíduo, ainda que, em situação de trabalho característico. $\mathrm{O}$ art. $5^{\circ}$ da Constituição Federal, determina que todos são iguais perante a lei, sem distinção de qualquer natureza, de modo que, o inciso $X$ reflete sobre a inviolabilidade da intimidade, da vida privada, da honra e da imagem das pessoas (BRASIL, 1998, art. $5^{\circ}$ ), mesmo que esta igualdade esteja no sentido de equidade, de acordo com a característica de cada função, algumas restrições impostas pelos clubes representam ameaça à direitos e garantias dos atletas profissionais, pois, muitas vezes, restringe-se de forma exagerada o consumo de produtos alimentícios, como refrigerantes e comidas com gorduras saturadas, e até mesmo a prática de relações sexuais ou participação de festas de família (BARROS, 2002, p. 93). Mesmo que algumas situações sejam justificadas pela razoabilidade da função, os excessos confrontam diretamente direitos e garantias fundamentais do atleta.

Conclusão: Não há que se negar o avanço normativo no que diz respeito às contratações dos atletas profissionais de futebol com seus clubes, que prevê requisitos específicos para o estabelecimento desse vínculo de trabalho. Requisitos que são tidos como essenciais para proteção dos atletas, cita-se como exemplo a Lei Pelé no 9.615 de 24 de março de 1998, mas, que muitas vezes permitem o estabelecimento de restrições que podem ser vistas como contrárias aos direitos e garantias fundamentais desses trabalhadores, pois em períodos de concentração possuem sua liberdade restringida nas mais simples atividades do dia a dia, algumas destas restrições extrapolam a liberdade do atleta, ainda que, por vezes, justificadas como necessárias pelos clubes.

\title{
Referências
}

BARROS, Alice Monteiro de. Contratos e regulamentações especiais de trabalho. São Paulo: LTr, 2002.

BRASIL. Constituição da República Federativa do Brasil: promulgada em 5 de outubro de 1988.

BRASIL. Decreto-Lei 9.615, de 24 de março de 1998. Lei Pelé. Ministério Do Esporte e Turismo.

FILHO, Álvaro Melo; SANTORO, Luiz Felipe. Direito do Futebol: Marcos Jurídicos e Linhas Mestra. São Paulo: Editora 
Quartier Latindo Brasil, 2019.

MARTINS, Sergio Pinto. Direitos Trabalhistas do Atleta Profissional de Futebol. $2^{\mathrm{a}}$ Ed. São Paulo: Editora Saraiva, 2016.

OLIVEIRA, Jean Marcel Mariano de. O Contrato de Trabalho do Atleta Profissional de Futebol. $2^{\mathrm{a}}$ Ed. São Paulo: Editora LTr, 2016.

POSSÍDIO, Cristiano Augusto Rodrigues. Direito Desportivo Trabalhista - Contrato Especial de Trabalho Desportivo. Editora Jaruá, 2019.

Coordenadoria de Pesquisa e Extensão - COPEX

Departamento de Editoração e Divulgaçāo Científica - DEDIC 


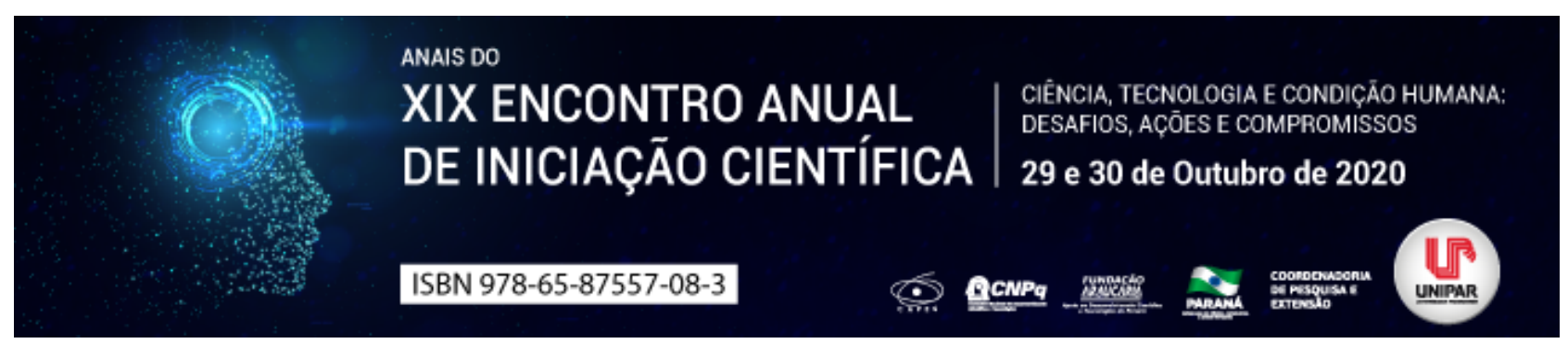

A (IM) PARCIALIDADE DO EXERCICIO E OS LIMITES JURISDICIONAIS

\author{
${ }^{1}$ MOACIR MOTTA DA SILVA, ${ }^{2}$ ALEXANDRE MAGNO AUGUSTO MOREIRA
}

\author{
${ }^{1}$ Acadêmico Unipar \\ ${ }^{1}$ Docente da UNIPAR
}

Introdução: $O$ presente trabalho tem por proposta retratar as ações cometidas pelo Poder Judiciário em relação ao Poder Executivo. Tais atitudes levam a (im)parcialidade do exercício pois bate frontalmente com o texto da Constituição brasileira no que diz respeito a separação dos poderes. A presente pesquisa desenvolveu-se sobre um método dedutivo com pesquisa e análise de cunho bibliográfico.

Objetivo: Demonstrar como proposta, a violação constitucional, quanto a interferência do Poder Judiciário de forma indistinta, nas políticas públicas implantadas pelo do Poder Executivo.

Desenvolvimento: Ao revisitar a obra de Montesquieu (1998, p.168), com a pretensão de buscar o entendimento da separação dos poderes, observou-se a essencial liberdade dos indivíduos, partindo da premissa que é necessário que os poderes mantenham-se livres e harmônicos em suas atuações, sem interferência recíproca na esfera de suas competências e prerrogativas, pois não haverá liberdade se o Poder de Julgar não estiver separado do Poder Legislativo e do Executivo. Porventura se materializasse a unificação de Judiciário e Legislativo enquanto poder legitimador, o poder sobre a vida e a liberdade dos cidadãos seria arbitrário, uma vez que ao Juiz, se atribuiria a atividade legiferante Por sua vez, o Judiciário como parte integrante do Executivo, por certo, o Juiz poderia ter a força de um opressor (MONTESQUIEU, 1998, p.168). Ainda, discorrendo do pensamento de Montesquieu (1998), haveria a necessidade de um limite de atuação entre os poderes, instituindo então, os freios e contrapesos de nosso ordenamento jurídico, o que impõem que cada poder delimite a sua jurisdição de atuação. Na mesma linha de raciocínio, demonstra que a democracia só existe quando não se abusa do poder, mesmo em se tratando de experiência eterna de que todo homem que possui poder é levado a dele abusar (MONTESQUIEU, 1998, p.166). Ademais, Canotilho (2000) propõe a observância divisão horizontal dos poderes, bem como a observância da divisão vertical, própria, a princípio, da divisão federalista ou seja na separação da União, Estados e Municípios. Nesta linha de pensamento, assevera que há uma funcionalidade dos entes de governo como complexos orgânicos com competências e regimes definidos e sendo interdependentes e separados (CANOTILHO, 2000, p. 513). Como complemento, nos dizeres de Moraes (2007, p. 388), os órgãos exercentes das funções estatais, para serem independentes, conseguindo frear uns aos outros, com verdadeiros controles recíprocos, necessitavam de certas garantias e prerrogativas constitucionais. E tais garantias são invioláveis e sob pena de ocorrer desequilíbrio entre eles e desestabilização do governo. Quando há atuação do Poder Judiciário nas atividades do Estado de forma exacerbada, provoca-se um conflito nas esferas de competências e prerrogativas exclusivas entre os poderes, culminando a instabilidade na autonomia e o poder legitimador peculiar, dentro de suas esferas de atuação.

Conclusão: A necessidade de respeitar o contido em nossa Carta Magna, onde o princípio da separação e respeito aos três poderes necessários para o peso e contrapeso para se manter um estado democrático de direito em razão da obediência as regras internacionais, bem como ao primado constitucional, é dever do Judiciário atuar de forma imparcial nas ações dos demais poderes sob pena de configuração da interferência jurisdicional dos poderes. É cediço que a atuação do Judiciário de forma ponderada é sempre necessária, mas se exercida de forma desproporcional, cria-se um vácuo constitucional quando da interferência ou do ativismo Jurisdicional de forma desmedida

\title{
Referências
}

BRASIL. Constituição (1988). Constituição da República Federativa do Brasil: promulgada em 5 de outubro de 1988. 4. ed. São Paulo: Saraiva, 1990

CANOTILHO, J. J. Gomes. Direito constitucional e teoria da constituição. 4a ed. Coimbra: Almedina, 2000.

MORAES, Alexandre de. Direito Constitucional. 21 a ed. São Paulo: Atlas, 2007. p. 385

MONTESQUIEU, Charles de Secondat, Baron de. O Espírito das Leis: as formas de governo, a federação, a divisão dos poderes, presidencialismo versus parlamentarismo. São Paulo: Saraiva, 1998. 


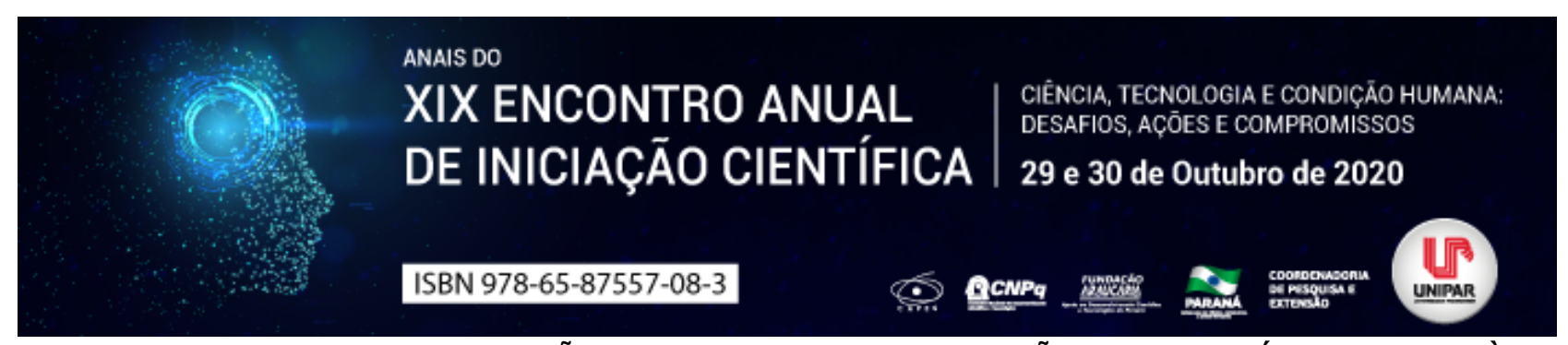

\title{
O NOVO NORMAL: ANSIEDADE E DEPRESSÃO PRESENTES NA POPULAÇÃO UNIVERSITÁRIA EM MEIO À PANDEMIA DA COVID-19
}

\author{
${ }^{1}$ ISABELLA VALANDRO, ${ }^{2}$ DAIANA SILVEIRA CONTE, ${ }^{3}$ GRACIANE BARBOZA DA SILVA, ${ }^{4}$ THAIS CRISTINA GUTSTEIN \\ NAZAR
}

\begin{abstract}
${ }^{1}$ Bolsista do Programa Institucional de Bolsas de Iniciação Científica (PIBIC) e Discente do curso de Psicologia, UNIPAR Campus de Francisco

${ }^{1}$ Bolsista do Programa Institucional de Bolsas de Iniciação Científica (PIBIC) e Discente do curso de Psicologia, UNIPAR Campus de Francisco

${ }^{2}$ Docente da UNIPAR

${ }^{3}$ Docente e Orientadora PIC/PIBIC- Psicologia/UNIPAR
\end{abstract}

Introdução: No contexto pandêmico anunciado pela OMS em março de 2020, o novo coronavírus (COVID-19) é considerado de alto contágio e altas taxas de mortalidade. Nessa conjuntura, o sistema educacional tem dirigido-se no sentido para suspender completamente os calendários acadêmicos pelo tempo necessário ou o uso de alternativas como o ensino remoto. Com isso, o presente estudo se dispõe investigar aspectos de saúde mental frente a circunstância em que os estudantes universitários vem sofrendo com o deslocamento do ensino presencial para o ensino remoto. Dessa maneira, um dos aspectos investigados nessa pesquisa é a ansiedade e a depressão, onde a ansiedade é observada como um transtorno prevalente em acadêmicos universitários, com maior frequência no sexo feminino pelo estudo de Chaves et al. (2015). Outrossim, Bolsoni-Silva e Loureiro (2017) em um estudo que discutiu o impacto da depressão nas habilidades sociais de estudantes universitários, ressaltam o fato da depressão ser um dos transtornos mais prevalentes na população em geral. Assim se faz necessário investigar questões associadas à saúde mental desses estudantes.

Objetivo: A presente pesquisa tem por objetivo o levantamento de dados via online para identificar sinais de depressão e ansiedade em estudantes universitários, buscando realizar a caracterização dessa situação.

Material e Métodos: A presente pesquisa foi aprovada pelo Comitê de Ética em Pesquisa, parecer: 4.127 .990 e n CAAE: 93703418.4.0000.0109 e todos os participantes assinaram o Termo de Consentimento Livre e Esclarecido (TCLE). Responderam o questionário 195 estudantes universitários, 82\% $(n=160)$ do gênero feminino e $18 \%(n=35)$ do masculino, entre a faixa etária $53 \%(n=102)$ estão entre 18 e 20 anos, 36\% ( $n=70)$ entre 21 e 25 anos e os demais universitários estão entre 26 anos e acima. Desses 195 participantes, 55\% ( $n=108)$ estudam em 5 instituições públicas e 45\% (n=87) em 5 instituições privadas do estado do Paraná, totalizando 30 cursos de diversas áreas. O instrumento utilizado foi a Escala HAD - Avaliação do Nível de Ansiedade e Depressão (BOTEGA, 1995), que possui 14 itens, dos quais sete são voltados para a avaliação da ansiedade (HADS-A) e sete para a depressão (HADS-D). Os instrumentos foram disponibilizados em um formulário online através da plataforma Google Forms e os estudantes universitários foram convidados a participar da pesquisa a partir de um link divulgado nos e-mails das secretarias de cada Curso/Universidade e nas redes sociais (Instagram, Facebook e WhatsApp). A análise dos dados deu-se por meio da criação de um banco de dados no Statistical Package for the Social Sciences (SPSS), utilizando-se de estatísticas descritivas (média e desvio padrão) e do teste de correlação de Pearson.

Resultados: No que corresponde a ansiedade, foi verificado que 17\% $(n=33)$ dos participantes apresentam Ansiedade Improvável, 41\% ( $n=80)$ apresentam Ansiedade Possível e 42\% ( $n=82)$ apresentam Ansiedade Provável. Da mesma forma, no que corresponde a depressão, 46\% ( $n=90)$ apresentavam Depressão Improvável, 35\% ( $n=68)$ com Depressão Possível e 19\% $(n=37)$ com Depressão Provável. Quando submetidos os dados ao teste de correlação de Pearson, identificaram-se correlações significativamente negativas no nível de $0,05(p=-0,130)$ entre as variáveis de gênero e ansiedade, além disso foram encontradas também correlações entre às variáveis de faixa etária e ansiedade em nível de 0,05 ( $p=-0,67)$.

Discussão: Os resultados apontam que os sinais/sintomas de ansiedade, encontram-se em níveis elevados para a maior parte dos participantes e, ainda que em menos frequência, os participantes apresentam também sinais/sintomas de depressão em níveis elevados. Conforme os resultados, há correlação nas variáveis preditoras (faixa etária e sexo), corroborando com resultados do estudo de Maltoni, Palma e Neufeld (2019) no qual nove sintomas de ansiedade e oito de depressão possuem associação com a variável sexo feminino, inclusive, foi verificado também que os sintomas de ansiedade foram mais prevalentes na amostra estudada do que os de depressão, assim como no presente estudo. O estudo de Chaves et al. (2015), também está de acordo, mostrando que os maiores níveis de ansiedade estão relacionados ao sexo feminino.

Conclusão: Conforme discutido, é visto que a comunidade acadêmica vive uma fase de transição e adaptação aos novos paradigmas que o ensino remoto traz, de forma que sintomas moderados e severos de ansiedade se apresentam nos resultados. 
No entanto, os estudos apresentados, que foram realizados antes da pandemia mostram frequência desses sintomas nessa população, sobressaindo a ideia de que ser um estudante universitário é um fator contribuinte para o desenvolvimento desses sintomas. Ademais, as universidades têm papel fundamental na assistência acadêmica.

\section{Referências}

BOLSONI-SILVA, Alessandra Turini; LOUREIRO, Sonia Regina. O Impacto das Habilidades Sociais para a Depressão em Estudantes Universitários. Psic.: Teor. e Pesq., Brasília, v. 32, n. 4, e324212, 2017. Disponível em: https://doi.org/10.1590/0102.3772e324212. Acesso em: 30/072020.

BOTEGA, Neury J. et al. Transtornos do humor em enfermaria de clínica médica e validação de escala de medida (HAD) de ansiedade e depressão. Rev. Saúde Pública, São Paulo, v. 29, n. 5, p. 359-363, 1995. Disponível em: http://dx.doi.org/10.1590/S0034-89101995000500004. Acesso em: 30/07/2020.

CHAVES, Erika de Cássia Lopes et al. Ansiedade e espiritualidade em estudantes universitários: um estudo transversal. Rev. Bras. Enferm., Brasília, v. 68, n. 3, p. 504-509, 2015. Disponível em: http://dx.doi.org/10.1590/0034-7167.2015680318i. Acesso em: 20/08/ 2020.

MALTONI, J.; PALMA, P. DE C.; NEUFELD, C. B. Sintomas ansiosos e depressivos em universitários brasileiros. Psico, v. 50, n. 1, p. e 29213, 8 maio 2019. Disponível em:https://doi.org/10.15448/1980-8623.2019.1.29213. Acesso em: 24/08/2020. 


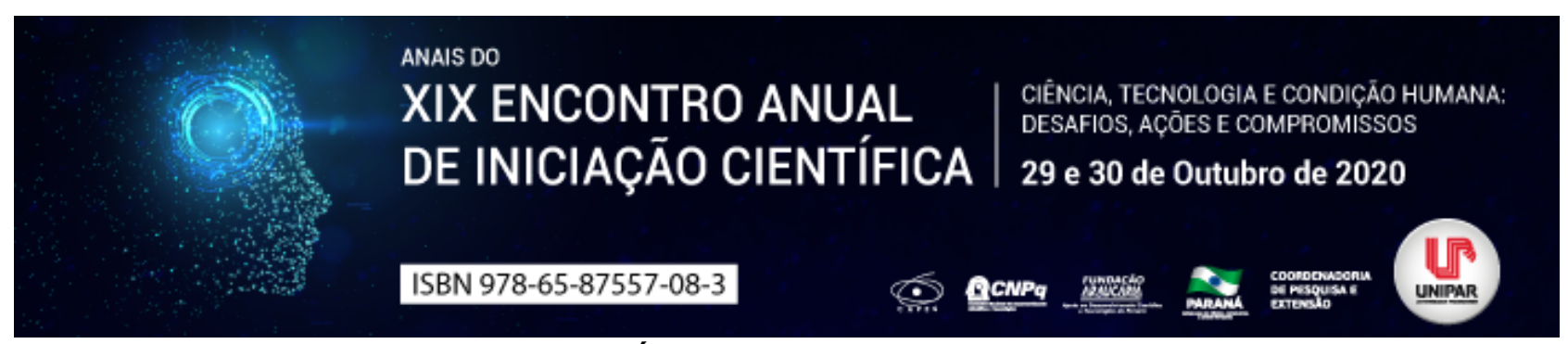

O EXCESSO DE MEDIDAS PROVISÓRIAS POR PARTE DO PODER EXECUTIVO FEDERAL

\author{
${ }^{1}$ EDUARDO VINICIUS HORBACH, ${ }^{2}$ MAIARA DOS SANTOS NORONHA
}

${ }^{1}$ Acadêmico da Unipar

${ }^{1}$ Docente da UNIPAR

Introdução: Com a promulgação da Constituição da República de 1988 a medida provisória, espécie normativa até então inédita na política brasileira, tornou-se uma ferramenta de uso frequente por parte do Poder Executivo brasileiro, em razão de sua eficácia imediata. No entanto, o grande número de medidas provisórias editadas traz à tona a indagação acerca da fiel observância dos critérios constitucionais à edição de matérias que serão apreciadas pelo Congresso Nacional, sucedendo assim, conflitos e debates acerca da sua pertinência perante a democracia brasileira.

Objetivo: Busca-se fazer uma análise crítica acerca da edição excessiva de medidas provisórias no Estado Democrático de Direito brasileiro por parte do Executivo Nacional, especialmente no que tange aos aspectos normativos indispensáveis à sua edição.

Desenvolvimento: A origem da medida provisória no ordenamento jurídico brasileiro ocorreu com o advento da Magna Carta de 1988, espelhando-se no modelo italiano, surgiu como um instrumento adverso ao já extirpado Decreto-lei. Para Leon Frejda Szklarowsky "o Poder Executivo necessita de um instrumento ágil para fazer frente às necessidades urgentes e inadiáveis, de relevância tal que sua não realização poderá afetar a ordem pública e social“ (SZKLAROWSKY, 2003, pag. 98). Ao longo dos anos, vários questionamentos foram feitos a respeito dessa espécie normativa, o autor Danilo Mansano Barioni preleciona que "originariamente, o art. 62 da Constituição Federal não previa qualquer limitação explícita à edição de medidas provisórias" (BARIONI, 2004, pag. 78), ficando a encargo do Presidente da República utilizar o referido dispositivo sem qualquer limitação material. Em resposta à instabilidade gerada pelos abusos constantes do Poder Executivo, a Emenda Constitucional n. ${ }^{\circ} 32$ foi promulgada no ano de 2001, trazendo inovações positivas, segundo Gilmar Ferreira Mendes, pois ela "acrescentou várias limitações materiais explícitas ao uso das medidas provisórias, consolidando a jurisprudência e acolhendo ponderações doutrinárias" (MENDES, 2017, p. 812). A aludida emenda adicionou o disposto no $\S 6^{\circ}$ do art. 62 da Constituição Federal, trazendo o chamado sobrestamento de pauta, inovando ao determinar que após 45 dias de tramitação da medida provisória, todas as pautas da casa legislativa ficariam paralisadas. Nesse sentido, Guilherme Ferreira da Costa entende que a Emenda Constitucional $n^{\circ} 32 / 01$ "limitou as matérias passíveis de disciplina por meio de Medida Provisória, bem como ensejou a perspectiva da análise pelas Casas Legislativas em lapso temporal razoável“" (COSTA, 2010, pág. 51). Embora tenha trazido avanços com suas limitações, a referida Emenda limitou-se ao não disciplinar o número de medidas a ser editada por ano ou por mandato. Conforme dados fornecidos pela Agência Senado, somente no ano de 2019 foram editadas 48 medidas provisórias (SENADO, 2020). Destarte, mesmo que a emenda necessite ser apreciada pelo Poder Legislativo, cabe ao Executivo Federal determinar qual a temática será apreciada pelo legislador, além de poder editar sucessivas medidas de temas diferentes, resultando em uma função quase absolutista desse mecanismo legal que corrompe a democracia brasileira quando não é empregado devidamente.

Conclusão: A medida provisória tende a ser um instrumento de grande valia na democracia brasileira, devendo ser utilizada em regime de exceção, como uma alternativa para casos de urgência. Porém, normativamente concedeu-se ao Executivo Federal um poder capaz de interferir bruscamente no processo legislativo, ainda que indiretamente, e que pode gerar várias problemas quando utilizado indevidamente. Apesar de o legislador adicionar determinados limites ao uso dessa prerrogativa do Chefe de Estado, respeitando a Teoria dos freios e contrapesos, ainda ocorrem diversos abusos em sua utilização excessiva, caracterizando-se, muitas vezes, um instrumento de governabilidade de forma ditatorial.

\title{
Referências
}

SZKLAROWSKY, Leon Frejda. Medidas Provisórias: Instrumento de Governabilidade. São Paulo: Ndj, 2003.

BARIONI, Danilo Mansano. Medidas Provisórias. São Paulo: Pillares, 2004.

MENDES, Gilmar Ferreira. Curso de Direito Constitucional. 12a ed. São Paulo: Saraiva, 2017.

COSTA, Guilherme Ferreira da. Conflito: a força do executivo, pelo excesso de medidas provisórias, incomoda o legislativo? 62 páginas. Monografia de Curso de Pós-Graduação Lato Sensu em Direito Constitucional. Instituto Brasiliense de Direito Público IDP. Brasília, 2010.

REDAÇÃO, Primeiro ano de governo teve 48 medidas provisórias editadas. Agência Senado, 2020. Disponível em https://www12.senado.leg.br/noticias/materias/2020/01/10/primeiro-ano-de-governo-teve-48-medidas-provisorias-editadas.

Acesso em 24 de agosto de 2020. 
Coordenadoria de Pesquisa e Extensão - COPEX

Departamento de Editoraçāo e Divulgaçāo Científica - DEDIC 


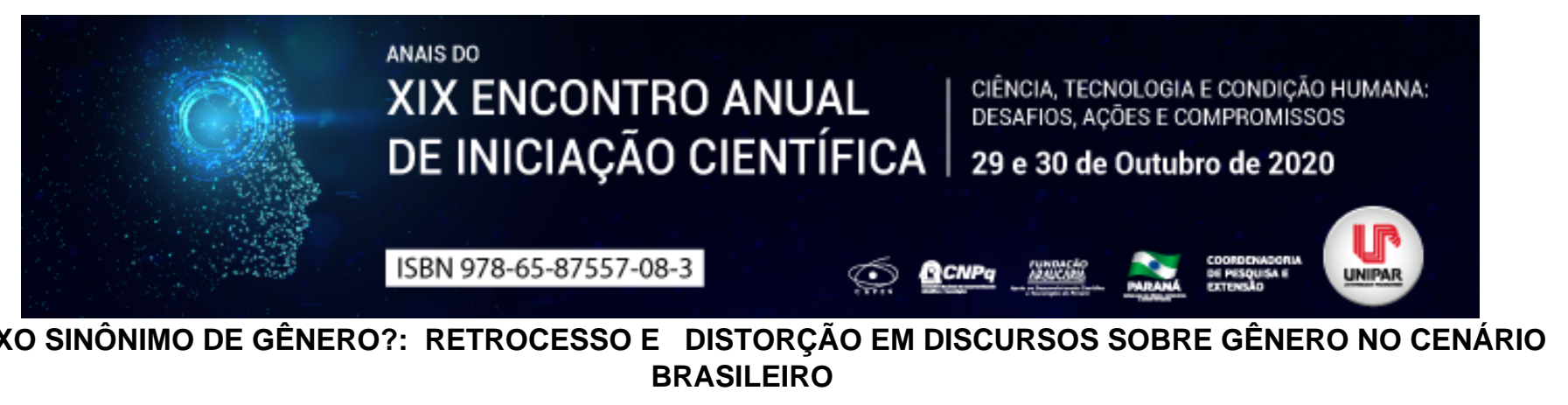
${ }^{1}$ EDUARDO MEZZAROBA WERLANG, ${ }^{2}$ ELOISA POMPERMAYER RAMOS, ${ }^{3}$ TATIANE PELISSARI, ${ }^{4}$ LUIZ AUGUSTO MUGNAI
VIEIRA JUNIOR

\footnotetext{
${ }^{1}$ Acadêmico de Psicologia - PIC/UNIPAR Cascavel

${ }^{1}$ Acadêmica de Psicologia - PIC/UNIPAR Cascavel

${ }^{2}$ Acadêmica de Psicologia - PIC/UNIPAR Cascavel

${ }^{3}$ Docente do PIC/UNIPAR
}

Introdução: Os discursos de gênero são pautas importantes e muito debatidas no cenário global, tendo como peça-chave para tais discussões a Organização das Nações Unidas (ONU), uma vez que esta busca sancionar Objetivos de Desenvolvimento Sustentáveis (ODS) a serem aplicados pelos países na posterioridade. Dentre os ODS da agenda de 2030, no seu quinto objetivo, objetiva-se alcançar a igualdade de gênero e empoderar todas as mulheres e meninas , pois é de suma importância aprofundar e dar continuidade na edificação de uma igualdade de gênero (OMS, 2017, s.p). Entretanto, como foi repercutido em muitos portais de notícias, como o Portal Globo (2019, s.p), tal documento sofreu críticas do atual chefe de Estado brasileiro, uma vez que para ele o ODS 5 apresenta uma nefasta ideologia de gênero e o aborto, sob o disfarce de direitos sexuais reprodutivos. Observa-se que tal declaração demonstra falta de conhecimento do Presidente da República frente ao assunto, assim como representa a compreensão distorcida sobre gênero na atual política governante.

Objetivo: O presente estudo visa descrever e denunciar o retrocesso frente às discussões de gênero no Brasil, assim como a frequente distorção encontrada nos discursos que dizem representar o país no cenário mundial.

Desenvolvimento: Para se aprofundar sobre a distorção de gênero, é necessário compreender o que se entende por gênero. A antropóloga Sandenberg (2002) afirma que não se pode reduzir gênero a uma coisa, simplificar o conceito e o despolitizar, devese buscar compreender que este é uma construção cultural e que está para além do biológico, são fenômenos envoltos por uma teorização. Não obstante, é preciso dizer que mesmo havendo diversos estudos sobre gênero e sexualidade, ainda se observa que na sociedade brasileira há dificuldade e muitas vezes falta de compreensão acerca dos termos. A não compreensão de gênero e sexualidade gera, com frequência, a banalização e a distorção de muitos dos avanços possibilitados pelo movimento feminista (LEITE, 2011). Mesmo que tais confusões e distorções se mostram ainda tão presentes no cenário brasileiro, observase que atualmente existe uma forte tentativa de criminalizar as discussões e as pesquisas referentes a gênero no Brasil. Os discursos que distorcem o conceito gênero criam no imaginário social um inimigo a ser combatido sob a alegação da defesa e promoção da família. Um movimento formado pela aliança composta, principalmente, por grupos evangélicos e católicos mais ortodoxos e organizações conservadoras, que unidas disseminam informações distorcidas impedindo medidas que promovam a equidade de gênero, o respeito à diversidade sexual e a diminuição das violências baseadas em gênero (REIS; EGGERT, 2017). Ainda, conforme Reis e Eggert (2017), tal movimento frequentemente acusa pesquisadores e pessoas que possibilitam o debate sobre o tema de fazerem parte de um grupo totalitarista que impõem uma ideologia de gênero que busca desconstruir os papéis de gênero tradicionais e consequentemente a família. No entanto, o que podemos perceber é que ironicamente quem busca impor uma identidade de gênero e sexualidade são justamente os adeptos do movimento, que buscam impor a heterossexualidade, a cisgeneridade e a manutenção da desigualdade de gênero (REIS; EGGERT, 2017).

É preciso chamar atenção para as distorções dos estudos de gênero, pois medidas que são para prover igualdade de gênero agora com o discurso distorcido acerca de gênero são vistas com pânico moral, um inimigo a ser combatido (MISKOLCI, 2007). Criou-se no país um movimento que visa apagar o assunto gênero do currículo escolar. Agora este apagamento volta com o governo de Jair Bolsonaro ao vetar o termo gênero nas resoluções da ONU afirmando ser ideologia de gênero e incentivo ao aborto. Representantes do Brasil na reunião em Genebra para discussão das resoluções da ONU pedem alterações que distorcem as pautas sobre gênero. Tal posicionamento gerou repercussão e mal-estar como relata o jornalista Chade (2019); uma vez que demonstram certo alinhamento do Brasil a países conservadores. Entre as sugestões que foram propostas na reunião estão: trocar o termo violência com base em gênero por violência sexual , o termo gênero por igualdade entre homens e mulheres, como também solicitaram que a frase vulnerabilidade à violência sexual e com base em gênero fosse retirada do texto, justificando que gênero é uma construção social, e o que deve prevalecer na visão dos representantes brasileiros é a realidade biológica (CHADE, 2019).

Considerações Finais: Observa-se na análise aqui realizada que existe uma distorção acerca da temática de gênero. Parte de representantes brasileiros pratica uma espécie de malabarismo para adequar os discursos científicos, em especial, o da 
medicina, às suas opiniões distorcidas sobre gênero. A tentativa de biologização do gênero, que foi superada pelas ciências naturais, é elaborada a partir de trechos científicos superados ou mesmo de fragmentos dos estudos atuais descontextualizados do original. Tudo no esforço de validar as distorções por meio de manipular a cientificidade que contradiz exatamente o saber no qual pretendem se fundamentar.

\section{Referências}

CHADE, J. UOL (2019). Brasil veta termo gênerol" em resoluções da ONU e cria mal-estar. Disponível em:. Acesso em: 19 jul. 2020.

GLOBO. In: Valor (2019). Agenda 2030 da ONU contém nefasta ideologia de gênero e o aborto, diz Bolsonaro. Disponível em: . Acesso em: 31 dez.2019.

LEITE, A. M. P. Educação, gênero e sexualidade: entreolhares e problematizações. Disponível em: . Acesso em: 23 jul. 2020. MISKOLCl, Richard. Pânicos morais e controle social reflexões sobre o casamento gay. Cadernos Pagu (28), janeiro-junho de 2007.

ONU. Organização das Nações Unidas. Igualdade de Gênero: alcançar a igualdade de gênero e empoderar todas as mulheres e meninas. Disponível em:. Acesso em: 20 jul. 2020.

REIS, T.; EGGERT, E. Ideologia de gênero: uma falácia construída sobre os planos de educação brasileiros. Revista Educação e Sociedade, Campinas, v. 38, n. 138, p. 9-26, Jan. 2017. Disponível em: https://doi.org/10.1590/es010173302017165522. Acesso em 22 Jul 2020.

SARDENBERG, Cecília. Estudos Feministas: um esboço crítico. I Simpósio Cea-rense de Estudos e Pesquisas sobre a Mulher e Relações de Gênero. NEGIF/UFC. Fortaleza (CE), 03/2002. 


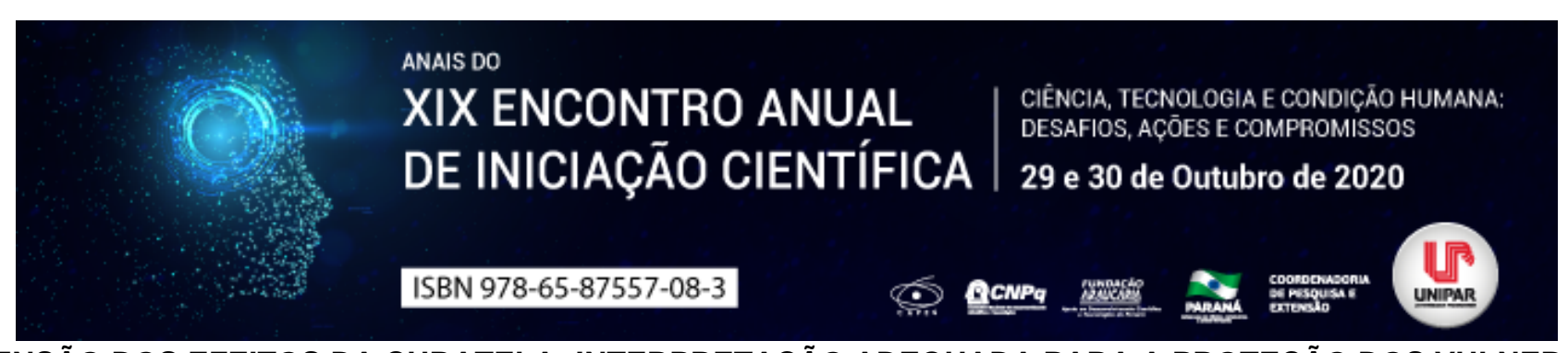

A EXTENSÃO DOS EFEITOS DA CURATELA: INTERPRETAÇÃO ADEQUADA PARA A PROTEÇÃO DOS VULNERÁVEIS

\author{
${ }^{1}$ KELLY CARDOSO, ${ }^{2}$ MARCIA YARA FECCHIO RENON, ${ }^{3}$ EDSON GUSTAVO FAXINA, ${ }^{4}$ MARICELES CRISTHINA FECCHIO, \\ ${ }^{5}$ MIRIAM FECCHIO CHUEIRI
}

\author{
${ }^{1}$ Bolsista Capes PNPD do Programa de Mestrado em Direito UNIPAR \\ ${ }^{1}$ Docente da UNIPAR \\ ${ }^{2}$ Docente da UNIPAR \\ ${ }^{3}$ Docente da UNIPAR \\ ${ }^{4}$ Docente da UNIPAR
}

Introdução: As alterações legislativas em decorrência da promulgação do Estatuto da Pessoa com Deficiência, Lei no 13.146/15, ainda reverberam a necessidade de críticas em razão da tratativa à teoria das incapacidades, abstrata e universalista, se manter. Requer-se a necessidade, especialmente em relação ao deficientes mentais ou intelectuais, de uma interpretação adequada em proteção aos vulneráveis, permitindo, assim, a extensão dos efeitos da curatela aos direitos existenciais.

Objetivo: Analisar e tecer críticas à vagueza legislativa, arguindo pela interpretação judicial adequada que concede a extensão dos efeitos da curatela como meio de proteção às pessoas com deficiência mental ou intelectual.

Desenvolvimento: A Lei $n^{0}$ 13.146/15 baseada na Convenção Internacional das Pessoas com Deficiência, propugna a autonomia absoluta da pessoa com deficiência no exercício dos direitos civis, sejam eles patrimoniais ou existenciais. Mesmo assim, ainda permitiu a possibilidade de processo de curatela/interdição (art.747 e seguintes, do CPC e arts. 84 e 85 do Estatuto) para administração de direitos patrimoniais e negociais, proibindo expressamente a intervenção de curador em direitos existenciais (art. $6^{\circ}$ do Estatuto). A despeito do intuito maior do Estatuto em promover a igualdade e a inclusão social do deficiente, a legislação manteve o universalismo e a abstratalidade ao inverso, ao não considerar casos concretos que demandam curador também para questões afetas a direitos existenciais no que tange à pessoa com deficiência mental ou intelectual. Nesse sentido, quando a pessoa não possui competência para consentir ou dissentir sobre questões médicas, a figura do curador não deve ser entendida como prejuízo, mas manutenção de proteção e, também, de promoção de uma existência digna à pessoa com deficiência mental ou intelectual. Assim, se propugna por uma interpretação adequada da legislação vigente em prol da proteção dos vulneráveis. Para tanto, a extensão dos efeitos da curatela, defendida por doutrinadores como Nelson Rosenvald (2016), ou seja, a possibilidade do curador administrar bens patrimoniais e negociais, bem como, decidir em relação à questões médicas, pelo curatelado, consubstancia a proteção daqueles que comprovadamente precisam de auxílio em todos os âmbitos de sua vida. Baseada nessa interpretação, é que alguns tribunais têm concedido a extensão dos efeitos, perante o reconhecimento em situações excepcionais da necessidade de que a curatela implique afastamento total da possibilidade de o curatelado exercer os atos da vida civil, justificando que: O princípio da igualdade substancial exige tratamento desigual na medida das desigualdades. Fere o preceito constitucional da dignidade da pessoa e toda a estrutura do ordenamento jurídico pretender dar o mesmo tratamento a pessoas que apresentam graus diferentes de deficiência (TJ-SP, Apelação Cível no 1006992-64.2017.8.26.0292, Rel. Desembargador Enéas Costa Garcia, dj: 20/03/2020).

Conclusão: A interpretação adequada às questões existenciais se demonstra de extrema importância ao possibilitar a extensão dos efeitos da curatela. Há, também, promoção da igualdade e de existência digna da pessoa com deficiência mental ou intelectual, que não possui competência para consentir ou dissentir sobre questões médicas, quando lhe nomeado curador para decidir por ela. $\mathrm{O}$ universalismo normativo não pode servir de respaldo para desproteger àqueles que ainda são vulneráveis perante os demais.

\title{
Referências
}

BRASIL. Lei no 13.105, de16 de março de 2015. Código de Processo Civil. Diário Oficial da União, Brasília, 17 mar. 2015. Disponível em: Acesso em: 09 nov. 2017.

BRASIL. Lei n. 13.146, de 6 de julho de 2015. Institui a Lei Brasileira de Inclusão da Pessoa com Deficiência. Diário Oficial da União, 7 jul. 2015b. Disponível em: http://www.planalto.gov.br/ccivil_03/_Ato2015-2018/2015/Lei/L13146.htm. Acesso em: 02 nov. 2017.

ROSENVALD, Nelson. O modelo social de direitos humanos [...]. In: MENEZES, Joyceane Bezerra de. (Org.). Direito das pessoas com deficiência psíquica e intelectual nas relações privadas: convenção sobre os direitos da pessoa com deficiência e lei brasileira de inclusão. Rio de Janeiro: Processo, 2016, p. 91-110. 
Coordenadoria de Pesquisa e Extensão - COPEX

Departamento de Editoraçāo e Divulgaçāo Científica - DEDIC 


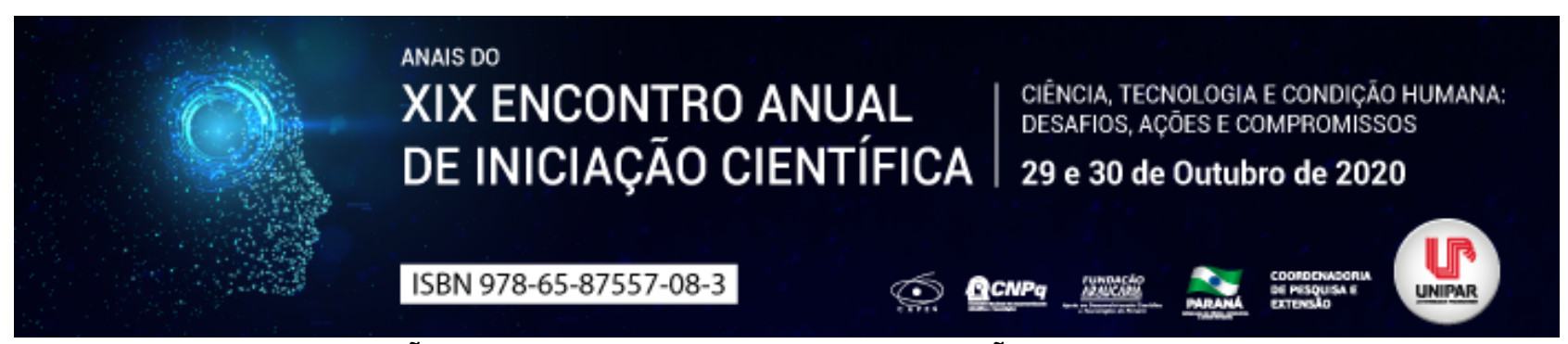

A DESAPROPRIAÇÃO POR DESCUMPRIMENTO DA FUNÇÃO SOCIAL DA PROPRIEDADE

\title{
${ }^{1}$ NATAN NICOLETTI LEMES DA ROZA, ${ }^{2}$ DIEGO CANTON
}

\author{
${ }^{1}$ Acadêmico do curso de Direito da UNIPAR \\ ${ }^{1}$ Docente da UNIPAR
}

Introdução: No trabalho, objetivou-se explorar o tema da desapropriação, o qual é um ato que o Poder Público, sendo o único meio de que o Estado dispõe mediante prévio procedimento e indenização justa, em razão de uma necessidade ou utilidade pública, ou ainda diante do interesse social, fazer com que se cumpra a função social da propriedade, desapossando alguém de sua propriedade e a tomando para o Estado, abrangendo ainda suas espécies e hipóteses em que é efetuada.

Objetivo: O presente estudo tem como objetivo a compreensão do instituto da desapropriação, vigente em nosso ordenamento jurídico, trazendo um breve relato sobre a história da desapropriação em nosso ordenamento jurídico, abordando e explicando suas espécies e hipóteses sobre os momentos em que ocorrem, buscando entender a conceituação da propriedade e sua relação com a desapropriação.

Desenvolvimento: A desapropriação surgiu em nosso ordenamento jurídico, com sua denominação de fato conhecida por todos hoje, na Constituição de 1891, que, com fulcro no artigo 72 , §17, previu a possibilidade de desapropriação em casos de necessidade ou utilidade pública, mediante prévia indenização, com base nesta Constituição, fora promulgado o antigo Código Civil (Lei 3071/1916) que tratou a desapropriação como uma perda da propriedade e passou a disciplinar os casos de necessidade e utilidade pública em que o Poder Público poderia fazer com que se cumpra sua função social. A propriedade é resultado direto da organização política. No decorrer da história, a utilização continuada do mesmo solo pelos mesmos habitantes, pela mesma tribo e pela mesma família passa a vincular o homem à terra na qual ele usa e habita, fazendo desta forma nascer à primeira concepção de propriedade coletiva e posteriormente a individual. Mostra-se que a propriedade coletiva primitiva, foi o marco inaugural da manifestação da função social da propriedade (SILVIO DE SALVO VENOSA, 2011). Destaca que, o exercício da propriedade é limitado, caso não seja observado a função social da propriedade poderá ocorrer a desapropriação por necessidade ou utilidade pública e por interesse social. A função social para ser cumprida deve atender alguns requisitos especificados na Carta Magna, como aproveitamento racional e adequado; utilização adequada dos recursos naturais disponíveis e preservação do meio ambiente; observância das disposições que regulam as relações de trabalho e exploração que favoreça o bem-estar dos proprietários e dos trabalhadores (FLÁVIO TARTUCE, 2011). Destaca a possibilidade de intervenção do Estado na propriedade privada, usando a supremacia que possui em relação aos indivíduos (JOSÉ DOS SANTOS CARVALHO FILHO, 2013). Em virtude do interesse público devidamente mencionado no ordenamento jurídico, o Estado pode transferir para outrem a propriedade, particular sendo uma forma de sanção por não cumprimento da função social da propriedade. Conceitua a desapropriação como meio de transmissão obrigatória da propriedade de um particular por ordem do Poder Público, em casos de necessidade pública, utilidade pública ou interesse social (MARCELO NOVELINO, 2013). Destaca que a lei deverá especificar o procedimento para desapropriação por necessidade ou utilidade pública, ou por interesse social (GILMAR FERREIRA MENDES, 2013). A desapropriação em questão, é chamada também de desapropriação sanção, visto que ocorre na hipótese de não atendimento da função social da propriedade, caracterizada por um ato ou omissão do expropriado, que faz com que a propriedade desatenda á função social. Dessa forma, quando a referida propriedade não cumprir sua função social, a indenização deixará de se submeter as regras da desapropriação estabelecidas no artigo $5^{\circ}$, inciso XXIV, da Constituição e em leis e decretos esparsos, como por exemplo, o Decreto lei 3.365/1941, que é chamado de lei geral das desapropriações, e passam a sujeitar-se as modalidades de desapropriação sancionatórias que se encontram nas disposições da nossa Constituição nos artigos 182, $\S 4^{\circ}$, III, que seria denominado de desapropriação urbanística, no artigo 184 que tem como nome desapropriação para fins de reforma agrária e por fim no artigo 243, chamada de desapropriação confisco, é denominada dessa forma por não prever qualquer tipo de indenização ao particular.

Conclusão: Buscou-se com tal estudo demonstrar a forma como o termo desapropriação surgiu em nosso ordenamento jurídico, além de conter a explicação do conceito de propriedade, fora explicitado também que caso a propriedade deixe de atender sua função social poderá ocorrer a citada desapropriação e o modo de intervenção do Estado nesta propriedade. Assim, ter propriedade acarreta a responsabilidade de torna-la útil à coletividade social, e com isso, o sistema legal criou mecanismos eficientes de coação a aqueles que não dão essa destinação, superando assim, o princípio constitucional de propriedade privada visando proteger à coletividade social. Por fim, fora comentado brevemente sobre as modalidades de desapropriação do referido trabalho, que seriam as desapropriações sancionatórias.

\section{Referências}


CARVALHO FILHO, José dos Santos. Manual de Direito Administrativo. 26. ed. São Paulo :Atlas, 2013, p.1266. MENDES. Gilmar Ferreira. Curso de Direito Constitucional. 8 ed. São Paulo: Saraiva. 2013. 1424p.

NOVELINO. Marcelo. Manual de Direito Constitucional. 8 ed. Rio de Janeiro: Forense; São Paulo: método. 2013. 1125p. TARTUCE, Flávio. Direito das coisas. 3. Ed. Rio de Janeiro: Forense, 2011.583 p.

VENOSA, Sílvio de Salvo. Direito Civil: direitos reais. 11 Ed. São Paulo: Atlas, 2011. 664 p.

Coordenadoria de Pesquisa e Extensão - COPEX

Departamento de Editoração e Divulgaçāo Científica - DEDIC 


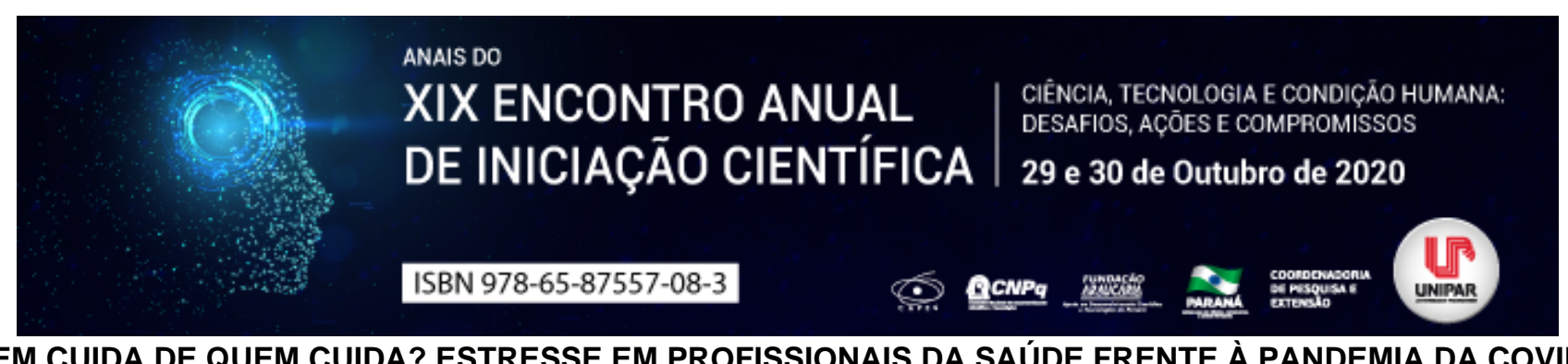

QUEM CUIDA DE QUEM CUIDA? ESTRESSE EM PROFISSIONAIS DA SAÚDE FRENTE À PANDEMIA DA COVID-19

\author{
${ }^{1}$ EDUARDA VOSS JACONDINO, ${ }^{2}$ GEISIANE GASPARIN RAMOS, ${ }^{3}$ AGATHA IZIS PIEROZAN DA SILVA, ${ }^{4}$ GRACIANE \\ BARBOZA DA SILVA, ${ }^{5}$ THAIS CRISTINA GUTSTEIN NAZAR
}

\begin{abstract}
${ }^{1}$ Discente do curso de Psicologia da Universidade Paranaense e integrante do Programa de Iniciação Científica (PIC)
${ }^{1}$ Discente do curso de Psicologia da Universidade Paranaense e integrante do Programa de Iniciação Científica (PIC)

${ }^{2}$ Discente do curso de Psicologia da Universidade Paranaense

${ }^{3}$ Colaboradora do Programa de Iniciação Científica (PIC) e do Programa Institucional de Bolsas de Iniciação Científica (PIBIC). Docente do cur

${ }^{4}$ Orientadora do Programa de Iniciação Científica (PIC) e do Programa Institucional de Bolsas de Iniciação Científica (PIBIC). Docente do cur
\end{abstract}

Introdução: O presente trabalho refere-se a uma pesquisa realizada pelo Projeto de Iniciação Científica (PIC) da Universidade Paranaense - Unipar campus de Francisco Beltrão, com o intuito de caracterizar aspectos de saúde mental dos profissionais da área da saúde, frente ao momento vivenciado de pandemia do Coronavírus (SARS-CoV-2), causador da doença COVID-19. Segundo Lipp e Malagris (2001), o estresse, variável em questão, é uma reação biológica que gera um desequilíbrio na saúde mental do sujeito. Além de que, pode vir a atrapalhar suas relações profissionais e pessoais, afetando diretamente sua qualidade de vida. Em sua pesquisa SCHMIDT et al (2020), afirma que, no Brasil, os profissionais de saúde não possuem muito preparo para atuar em emergências de grande porte, como a que está sendo vivenciada no momento, o que passa a ser então, mais um evento estressor para os mesmos. Estes profissionais, linha de frente, foram rapidamente treinados para atender da melhor maneira possível a população, entretanto, é necessário olhar para a sua saúde mental.

Objetivo: Avaliar os níveis de estresse em profissionais da área da saúde, levando em consideração o contexto de pandemia da COVID-19.

Metodologia: A presente pesquisa foi aprovada pelo Comitê de Ética em Pesquisa parecer: 4.127 .990 e $n^{\circ}$ CAAE: 93703418.4.0000.0109, acontecendo de forma on-line dentro dos parâmetros éticos científicos. Para a coleta de dados utilizou-se do Termo de Consentimento Livre e Esclarecido (TCLE), bem como a Escala de Percepção de Estresse 10 (EPS-10). A pesquisa contou com a participação de 70 profissionais da saúde, sendo eles $85,7 \%$ do gênero feminino e $14,3 \%$ do gênero masculino, com idade variável entre 20 e 55 anos, sendo a maior parte, 75,7\% residente da cidade de Francisco Beltrão. O questionário contou com 10 questões da Escala de Percepção de Estresse 10 ( EPS - 10), com 5 opções de respostas, sendo que o participante optava por uma delas. As opções eram Nunca , Quase nunca , Às vezes , Pouco frequente e Muito frequente

Resultados: Após a análise dos dados, foi possível perceber que obteve-se uma média de $26,6(d p=8,43)$. Quando comparados tais dados com os da amostra normativa da EPS-10 identifica-se que na pesquisa realizada por Cohen (1984) obteve-se média de 12,9\% ( $d p=6,2)$; e na pesquisa realizada por Reis e Petroski (2004) observou-se uma média de 17,3\% $(\mathrm{dp}=0,4)$.

Discussão: A partir da comparação dos dados frente às amostras normativas da EPS -10, é possível constatar que o índice de estresse em profissionais da saúde no atual contexto de pandemia da COVID-19, é substancialmente superior. Em estudo realizado por Zhang et al. (2020) com a participação de 1.563 médicos que trabalhavam em hospitais localizados na China, local onde se iniciou a pandemia, observou-se a existência de sintomas que caracterizam a ocorrência do estresse em $73,4 \%$ dos indivíduos. Dessa forma, é possível relacionar os fatores das situações de emergência com o aumento dos níveis de estresse presente em profissionais da saúde.

Conclusão: Conclui-se que a percepção de estresse na população de profissionais da saúde estudada, pode ser acentuada frente a situações de crise, como a atual pandemia do COVID-19. Tais achados chamam atenção para a necessidade de serem pensadas intervenções voltadas a saúde mental dos profissionais que estão na linha de frente de enfrentamento da pandemia.

\title{
Referências
}

Lipp, Marilda E. N., \& Malagris, Luia E. N. (2001). O stress emocional e seu tratamento. In B. Rangé (Ed.), Psicoterapias cognitivo-comportamentais: Um diálogo com a psiquiatria (pp. 475-490). Porto Alegre: Artmed. Disponível em:

Acesso em 24 de agosto de 2020.

SCHMIDT, Beatriz et al . Saúde mental e intervenções psicológicas diante da pandemia do novo coronavírus (COVID-19). Estud. psicol. (Campinas), Campinas, v. 37, e200063, 2020. Disponível em:

Acesso em 24 de agosto de 2020. 
Wang, Lisheng., Wang, Yuri., Ye, Dawei., \& Liu, Quingquan. (2020). A review of the 2019 Novel Coronavirus (COVID-19) based on current evidence. International Journal of Antimicrobial Agents. Disponível em:

Acesso em 24 de agosto de 2020.

Xiao, Han., Zhang, Yan., Kong, Desheng., Li, Shiyue., \& Yang, Ningi. (2020). The effects of social support on sleep quality of medical staff treating patients with coronavirus disease 2019 (COVID-19) in January and February 2020 in China. Medical Science Monitor, 26, e923549. Disponível em:

;

Acesso em 24 de agosto de 2020.

Coordenadoria de Pesquisa e Extensão - COPEX

Departamento de Editoraçāo e Divulgaçāo Científica - DEDIC 


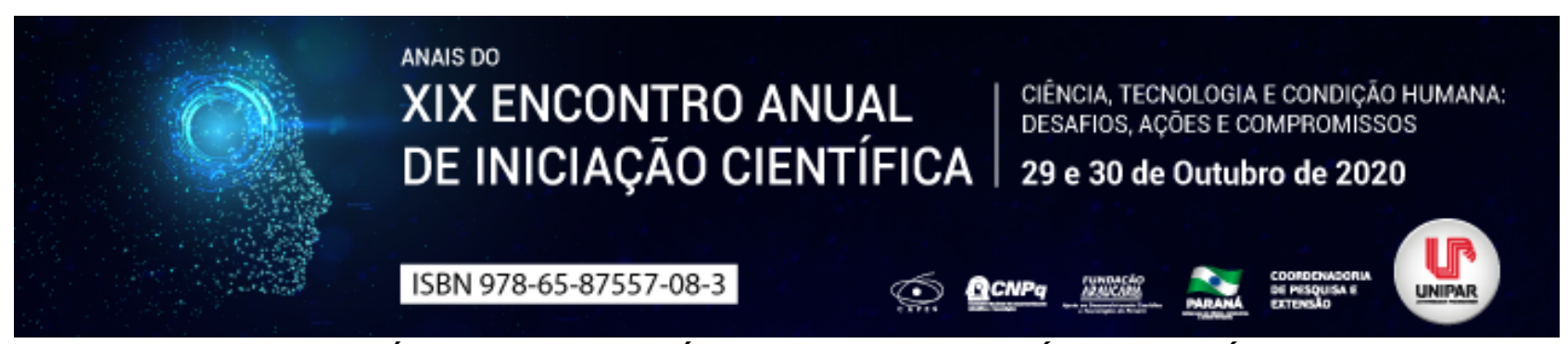

BREVE ANÁLISE SOBRE NEGÓCIOS PROCESSUAIS TíPICOS E ATÍPICOS

\title{
${ }^{1}$ HELOISA CRISTINA LUIZ CAPPELLARI, ${ }^{2}$ KAMILA REZENDE, ${ }^{3}$ CELSO HIROSHI IOCOHAMA
}

\author{
${ }^{1}$ Mestranda do Curso de Mestrado em Direito Processual e Cidadania da UNIPAR \\ ${ }^{1}$ Mestranda do Curso de Mestrado em Direito Processual e Cidadania da UNIPAR \\ ${ }^{2}$ Docente da Graduação em Direito e do Programa de Mestrado em Direito Processual e Cidadania da UNIPAR
}

Introdução: O novo Código de Processo Civil trouxe mudanças significativas no que tange aos negócios processuais típicos e principalmente atípicos, como forma de melhor regular estes fatos jurídicos, além de flexibilizar a solução de conflitos, possibilitando as partes uma maior liberdade ao pactuar negócios jurídicos a fim de atender suas necessidades.

Objetivo: Analisar brevemente as mudanças trazidas pelo Novo Código de Processo Civil no que tange aos negócios processuais típicos e atípicos, bem como seus benefícios para as partes de uma relação processual.

Desenvolvimento: O novo Código de Processo Civil trouxe inovações sobre negócios processuais típicos e atípicos. Segundo Cabral (2016, p. 98), negócios processuais são negócio jurídico plurilateral, pelo qual as partes, antes ou durante o processo e sem necessidade de intermediação de nenhum outro sujeito, determinam a criação, modificação e extinção de situações jurídicas processuais, ou alteram o procedimento . No que tange aos negócios típicos, como a própria nomenclatura pressupõe, já são previstos em lei, de forma que as partes não precisam lutar por sua admissão em nosso ordenamento jurídico, estes negócios já existiam no Código de Processo Civil de 1973, tendo sido mantidos pelo novo CPC, sendo exemplos o calendário processual, a suspensão do processo e a convenção e renúncia de prazos. Com relação aos negócios processuais atípicos, estes encontram sua primeira regulamentação formal junto ao CPC, que diz em seu artigo 190 (BRASIL, 2015), que Versando o processo sobre direitos que admitam autocomposição, é lícito às partes plenamente capazes estipular mudanças no procedimento para ajustá-lo às especificidades da causa e convencionar sobre os seus ônus, poderes, faculdades e deveres processuais, antes ou durante 0 processo, possibilitando que as partes possam pactuar sobre procedimento do feito, ônus, poderes, deveres, entre outras matérias de relevância, ressaltando-se que esta convenção dá-se dentro dos parâmetros legais de nosso ordenamento jurídico, e uma vez realizada vincula todas as partes envolvidas no feito, bem como auxiliares de justiça e o próprio julgador. Questão interessante sobre estes negócios diz respeito ao pacto de non petendo , que é quando as partes convencionam não debater sobre determinada questão em sede judicial, nas palavras de Araújo (2016, p. 761) o pacto de non petendo não elimina propriamente o direito de ação, mas apenas impede a judicialização de determinada pretensão , ainda para Araújo, mesmo que haja forte desavença doutrinaria sobre o assunto é possível que haja esta liberdade de convencionar entre as partes, desde que dentro dos limites do artigo 190 e de nosso ordenamento jurídico atual. De fato, os benefícios da aplicação do instituto são vastos, como o aumento da liberdade das partes para litigar, celeridade processual, efetividade na solução de conflitos, entre tantas outras.

Conclusão: Considerando os fatos acima exarados podemos concluir que os negócios processuais típicos e atípicos sofreram mudanças com a instauração do novo Código de Processo Civil, que em seu artigo 190 trás uma flexibilização do processo, especificamente no que tange a seu procedimento, possibilitando as partes convencionarem sobre a melhor forma de solucionar seu conflito, vinculando a si mesmas ao cumprimento do acordado e até mesmo a convencionar sobre a não judicialização de determinados conflitos.

\section{Referências}

ARAÚJO, Fabio Caldas de. Curso de processo civil: parte geral. São Paulo: Malheiros, 2016. BRASIL. Lei $\mathbf{N}^{\circ}$ 13.105, de 16 de março de 2015. Novo Código de Processo Civil. Disponível em: http://www.planalto.gov.br/ccivil_03/_ato2015-2018/2015/lei//13105.htm. Acesso em: 13 ago. 2020.

CABRAL, Antonio do Passo. Convenções processuais. Salvador: JusPodium, 2016. 


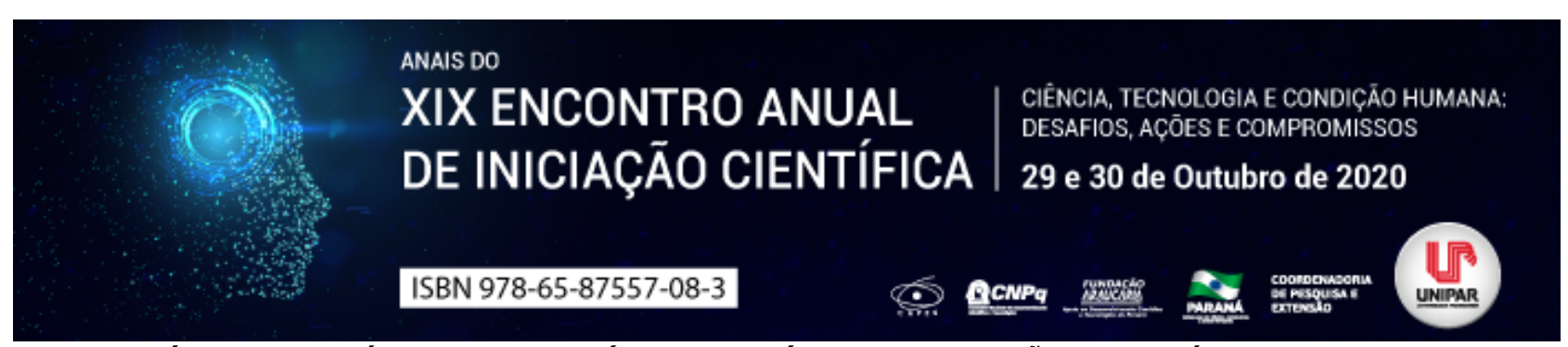

CÉDULA DE CRÉDITO BANCÁRIO CONSTITUÍDO ATRAVÉS DA ALIENAÇÃO FIDUCIÁRIA COM GARANTIA DE BEM IMÓVEL

${ }^{1}$ RICARDO FRIZZO, ${ }^{2}$ CLARICE MENDES DALBOSCO

${ }^{1}$ Acadêmico do curso de Direito da UNIPAR

${ }^{1}$ Docente da UNIPAR

Introdução: A cédula de Crédito Bancário é um título emitido em favor de uma instituição financeira, que representa promessa de pagamento em dinheiro decorrente da operação de crédito. Desta forma, serão abordadas neste trabalho as relações da lei de Cédula de Crédito Bancário com o instituto da alienação fiduciária de bem imóvel, contemplando as particularidades dos requisitos essenciais do negócio jurídico.

Objetivo: Abordar a possibilidade de uma Cédula de Crédito Bancário com inadimplência garantida por alienação fiduciária ser aditada.

Desenvolvimento: A Cédula de Crédito Bancário é um título emitido por pessoa física ou jurídica em favor da instituição financeira ou de entidade a esta equiparada, o qual representa promessa de pagamento em dinheiro, decorrente de operação de crédito de qualquer modalidade (NEWLANDS JR, 2014, p. 193). Conforme a Lei 10.931/04 que rege a Cédula de Crédito Bancário, as garantias prestadas podem ser: garantia fidejussória, prestada por pessoa e não por bens, ou garantia real, prestada através de um bem, móvel, imóvel ou anticrese, pertencente ao próprio devedor ou a terceiro garantidor (TARTUCE, 2018). Isto posto, a Cédula de Crédito Bancário garantido por alienação fiduciária e regida pela Lei 9.514/97 será acessório ao principal, a própria Cédula de Crédito Bancário, devendo respeitar os requisitos estabelecidos na mesma. A Alienação Fiduciária vem a dar maior garantia para o credor, pois sendo propriedade resolúvel, tem o credor à possibilidade de, quando houver inadimplência da parte fiduciante, realizar a constituição em mora através de notificação do Cartório de Registro de Imóveis, não sendo esse valor adimplido, o credor consolidará a propriedade, e posterior em trinta dias, levará a leilão público extrajudicial para satisfazer o débito com a venda do bem.

Conclusão: Em suma, a Cédula de Crédito Bancário através da garantia de Alienação Fiduciária é um instrumento jurídico eficiente, com agilidade no recebimento do crédito do credor, através da consolidação de propriedade e conseguinte leilão extrajudicial.

\section{Referências}

BRASIL. Lei No9.514, de 20 de novembro de 1997.

BRASIL. Lei No10.931, de 02 de agosto de 2004.

NEWLANDS JUNIOR, Carlos Arthur, Sistema financeiro e bancário. 4. ed. Rio de Janeiro: Elsevier, 2014.

TARTUCE, Flávio. Manual de direito civil: volume único. 8. ed. São Paulo: Método, 2018. 


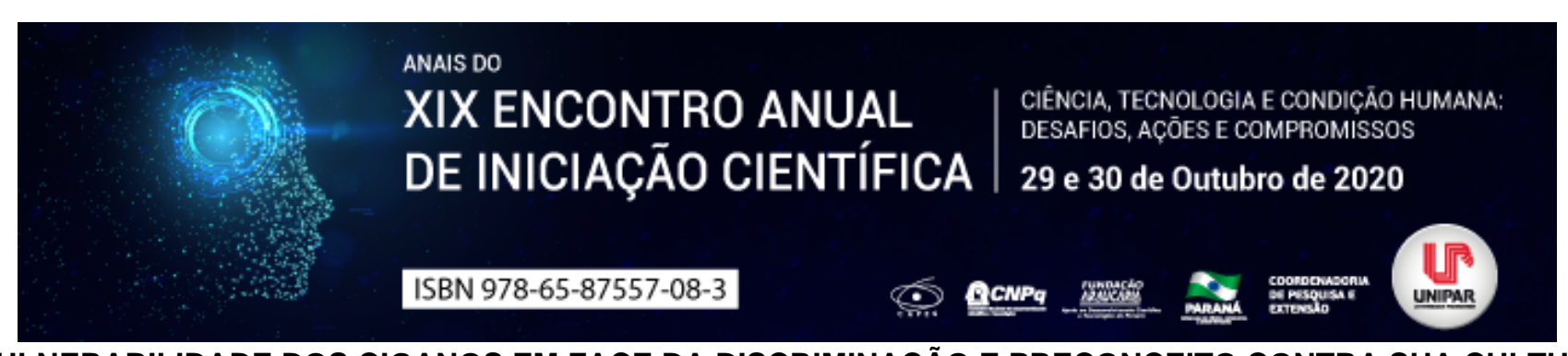

A VULNERABILIDADE DOS CIGANOS EM FACE DA DISCRIMINAÇÃO E PRECONCEITO CONTRA SUA CULTURA

\author{
${ }^{1}$ CLARA LUANA DE ANDRADE, ${ }^{2}$ TEREZA RODRIGUES VIEIRA
}

${ }^{1}$ Acadêmica do curso de Direito e integrante do PIC/UNIPAR

${ }^{1}$ Docente do Mestrado em Direito Processual e Cidadania na UNIPAR

Introdução: Comunidades ciganas são vistas com preconceito em todos os países, uma vez que não têm endereço fixo, possuem diferentes costumes, crenças, rituais, religiões e são incompreendidas por viverem suas vidas de maneira bastante diversa da população local. Em decorrência disso, essa população enfrenta diversos problemas relacionados aos seus direitos fundamentais.

Objetivos: Analisar a comunidade cigana sob um panorama cultural e jurídico, visando, identificar os direitos fundamentais que Ihes são ameaçados enquanto cidadãos.

Desenvolvimento: Ao longo da história o povo Rom sofreu inúmeras perseguições por conta de sua cultura, costumes, e em alguns locais até mesmo pelo tom de sua pele. Foram renegados pela Igreja Católica e perseguidos pela Inquisição (grupo jurídico dentro da instituição da Igreja Católica, o qual punia quem não seguia seus preceitos), apenas por terem práticas culturais de adivinhação (BRASIL, 2007, p.14). Isto ocasionou preconceito e dificuldade de interação social destes povos com os demais, resultando em exclusão social que os fizeram ser levados para as áreas marginalizadas da sociedade, impedindo-os de exercerem seus direitos fundamentais como cidadãos, elencados no art. $5^{\circ}$ da Constituição Federal (BRASIL, 1988). Devido a realidade imposta à comunidade cigana os níveis de pobreza se expandiram, e por consequência, suas chances de recorrerem às autoridades para buscar seus direitos diminuíram, pela falta de recursos financeiros e conhecimento de suas garantias legais (CSONTA, 2014, p. 10). Logo, a alternativa que encontraram para buscar oportunidades e melhores condições de vida foi o nomadismo, onde muitas vezes foram ainda rejeitados e expulsos pelas autoridades dos locais onde se alojavam. Porém, atualmente cada vez mais estão buscando melhores condições de vida na cidade, estabelecendo residências fixas e buscando seus direitos como cidadãos brasileiros. E, apesar de ainda não haver legislação especifica sancionada que ampare a comunidade cigana, contando apenas um projeto de lei que ainda está em votação no Senado (Projeto de Lei no 248 , de 2015), existem dispositivos legais da própria Constituição Federal que são aplicados à comunidade cigana por extensão, porém ainda é nítida a discriminação e falta de inclusão social que esta parcela da população enfrenta (BRASIL, 2007, p.31).

Conclusão: No Brasil não há nenhum dispositivo legal que ampare de maneira direta e explícita a comunidade cigana, porém como parcela da população inserida nesta sociedade os ciganos possuem os mesmos direitos e garantias de todos os demais cidadãos brasileiros, devendo, portanto, terem oportunidades e garantias iguais. Cabe ao Estado o dever de realizar políticas públicas de inserção para esta parcela marginalizada cuja pátria é onde seus pés estão.

\title{
Referências
}

BRASIL. Constituição (1988). Constituição da República Federativa do Brasil. Promulgada em 5 de outubro de 1988.

BRASIL. Secretaria Especial dos Direitos Humanos (SEDH). Povo Cigano o direito em suas mãos Brasília: SEDH, 2007. Disponível em: . Acesso em: 15 set. 2020.

CSONTA, Ágnes; NITA, Delia-Luiza; Defesa dos Direitos Humanos em nome das Comunidades Ciganas. Um guia para profissionais do Direito. Centre for Legal Resources (Romania) Tradução de Armandina Heleno. Pardedós: Net Kard Project Ano: 2014. 


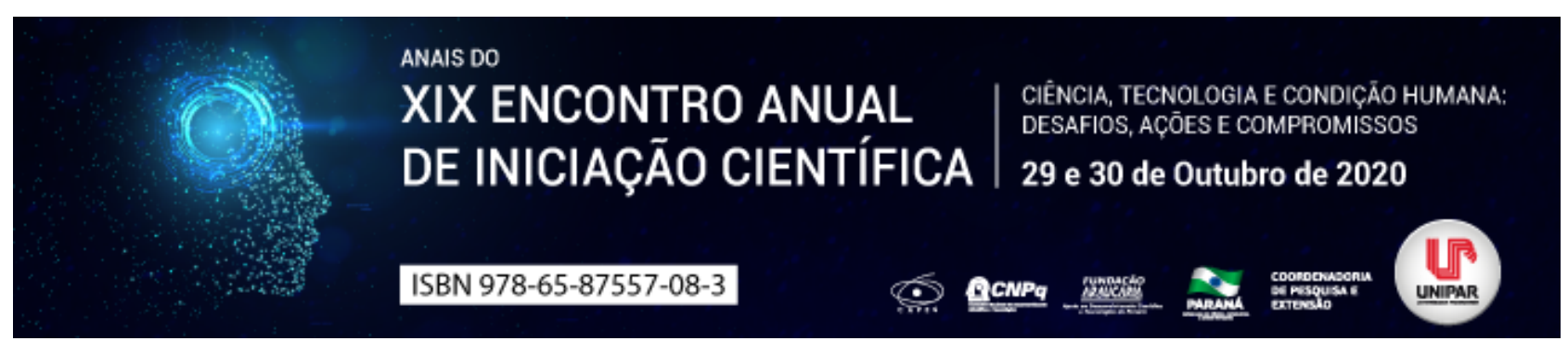

A OBRIGATORIEDADE DO DEVER DE FUNDAMENTAÇÃO NOS JUIZADOS ESPECIAIS CÍVEIS

\begin{abstract}
${ }^{1}$ ANNA FERNANDA SCALLA MENOTTI, ${ }^{2}$ JULIA IZABELLE TONETO ROMANO MAZIERO, ${ }^{3}$ LAIS SILVA ZIMIANI, ${ }^{4}$ CELSO HIROSHI IOCOHAMA
\end{abstract}

\author{
${ }^{1}$ Acadêmica do Curso de Mestrado em Direito Processual e Cidadania - Turma XXI da UNIPAR \\ ${ }^{1}$ Acadêmica do Curso de Mestrado em Direito Processual e Cidadania - Turma XXI da UNIPAR \\ ${ }^{2}$ Acadêmica do Curso de Mestrado em Direito Processual e Cidadania - Turma XXI da UNIPAR \\ ${ }^{3}$ Docente da Graduação em Direito e do Programa de Mestrado em Direito Processual e Cidadania da UNIPAR
}

Introdução: Após a entrada em vigor do Código de Processo Civil de 2015, o Fórum Nacional dos Juizados Especiais (FONAJE), com fundamento na aplicação do art. 38 da Lei dos Juizados Especiais, editou enunciado com a previsão de inaplicabilidade do artigo 489 da norma processual civil que exige a fundamentação das decisões judiciais, em evidente violação aos princípios constitucionais da legalidade, motivação das decisões e segurança jurídica.

Objetivo: Demonstrar a aplicabilidade do dever de fundamentação do artigo 489 do Código de Processo Civil de 2015 nas decisões judiciais proferidas no âmbito dos Juizados Especiais Cíveis e da Fazenda.

Desenvolvimento: A Constituição Federal Brasileira de 1988, em seu art. 98, inciso I, estabeleceu a criação de Juizados Especiais para o processamento de causas de menor complexidade, pautada no princípio de acesso à justiça (BRASIL, 1988). A Lei 9.099/95 prevê em seu art. $2^{\circ}$ (BRASIL, 1995), os princípios que devem nortear todo o procedimento, sendo eles a oralidade, simplicidade, informalidade, economia processual e celeridade. Para a garantia da celeridade e informalidade, o art. 38 da Lei 9.099/95 (BRASIL, 1995) estabelece que a sentença deve mencionar os elementos de convicção do Juiz, com um breve resumo dos fatos relevantes ocorridos em audiência, dispensado o relatório. O CPC/2015 estabeleceu objetivamente, no $\S 1^{\circ}$, do art. 489 (BRASIL, 2015), com base no art. 93, inciso IX da CFRB/88 (BRASIL, 1988), os critérios para a adequada fundamentação da decisão judicial que inclui: a necessidade da explicação da correlação entre a norma aplicada e o caso concreto, a vedação do uso de conceitos jurídicos indeterminados, a repressão à limitação de invocação de precedentes ou enunciado de súmulas sem o apontamento da relação com o caso em análise, a imprescindibilidade do enfrentamento de todos os argumentos deduzidos no processo, e a inevitabilidade de perscrutar enunciados de súmulas, jurisprudência ou precedente a não ser que demonstre na decisão a distinção do caso em julgamento ou até mesmo a superação do entendimento (BRASIL, 2015). Em princípio, deve o juiz analisar todos os pedidos e todas as causas de pedir arroladas pelo autor na petição inicial, bem como sobre todas as matérias de defesa suscitadas pelo réu na contestação, devendo-se ressaltar que a sentença com fundamentação sucinta não deve ser confundida com aquela de fundamentação deficiente (NERY, 2018, p. 1320 e 1322). Porém, em flagrante violação aos princípios da legalidade, da motivação e da segurança jurídica, o Fórum Nacional dos Juizados Especiais - FONAJE no Enunciado $n^{\circ} 162$ (BRASIL, 2020), consignou que não se aplica aos Juizados Especiais a regra do art. 489 do CPC/2015 (BRASIL, 2015), diante da previsão do art. 38 da Lei 9.099/95 (BRASIL, 1995). Interessante constar que a doutrina de Honório, Linhares e Baldan (2019, p. 2015) elucida que o FONAJE é composto por membros da magistratura dos Juizados Especiais e edita enunciados que se assemelham a Súmulas dos Tribunais, no que corresponde a interpretação da Lei 9.099/1995. Apesar da natureza de meras orientações doutrinárias e do fato dos enunciados não possuírem qualquer vinculatividade, os tribunais têm afastado o dever de fundamentação das decisões judiciais nos Juizados Especiais (cf. TJPR - $2^{\mathrm{a}}$ Turma Recursal - 000451385.2018.8.16.0025 - Rel.: Juíza Rita Borges de Area Leão Monteiro - J. 17.04.2020). Ora, a previsão da simplicidade, informalidade, celeridade e a dispensa de relatório, previstas nos arts. $2^{\circ}$ e 38 da Lei 9.099/95 (BRASIL, 1995), não afastam o dever de fundamentação adequada da decisão. Não pode o julgador, sob o pretexto da simplicidade e informalidade inerentes ao procedimento, se eximir de fundamentar objetiva, adequada e criteriosamente suas decisões, pois a compreensão dos elementos que formam a convicção do juiz e o efetivo exercício do contraditório substancial, são fatores essenciais para a observância da legalidade e efetivação do acesso à justiça.

Conclusão: Criados como forma de facilitação do acesso à justiça, os Juizados Especiais Cíveis são norteados por princípios como a informalidade, simplicidade e celeridade. Mesmo que a Lei 9.099/95 dispense o relatório como elemento da sentença, subsiste a necessidade de fundamentação adequada, o que torna obrigatória a aplicabilidade do art. 489 do CPC/2015, sob pena de violação dos princípios da legalidade, motivação e segurança jurídica e consequente nulidade da decisão por falta de fundamentação adequada.

\title{
Referências
}

BRASIL. Constituição da República Federativa do Brasil de 1988. Disponível em: . Acesso em: 02 set. 2020. 
BRASIL. Fórum Nacional dos Juizados Especiais (FONAJE). Enunciados Cíveis. Disponível em: . Acesso em: 04 ago. 2020.

BRASIL. Lei n. 9.099, de 26 de setembro de 1995. Dispõe sobre os Juizados Especiais Cíveis e Criminais e dá outras providências. Disponível em: . Acesso em: 04 ago. 2020.

BRASIL. Tribunal de Justiça do Estado do Paraná. Embargos de declaração 0004513-85.2018.8.16.0025. Relatora Rita Borges de Area Leão Monteiro. $2^{\mathrm{a}}$ Turma Recursal. Data do julgamento: 17/04/2020. DJe: 30/04/2020. Disponível em: . Acesso em: 04 ago. 2020.

BRASIL. Lei 13.105, de 16 de março de 2015. Código de Processo Civil. Disponível em: . Acesso em: 04 ago. 2020.

HONÓRIO, Maria do Carmo; LINHARES, Erick; BALDAN, Guilherme Ribeiro. Os enunciados cíveis do Fonaje e seus fundamentos [recurso eletrônico]. Porto Velho, RO: Emeron, 2019.

NERY JUNIOR, Nelson; NERY, Rosa Maria de Andrade. Código de Processo Civil comentado. 17 ed. São Paulo: Thomson Reuters Brasil, 2018. 


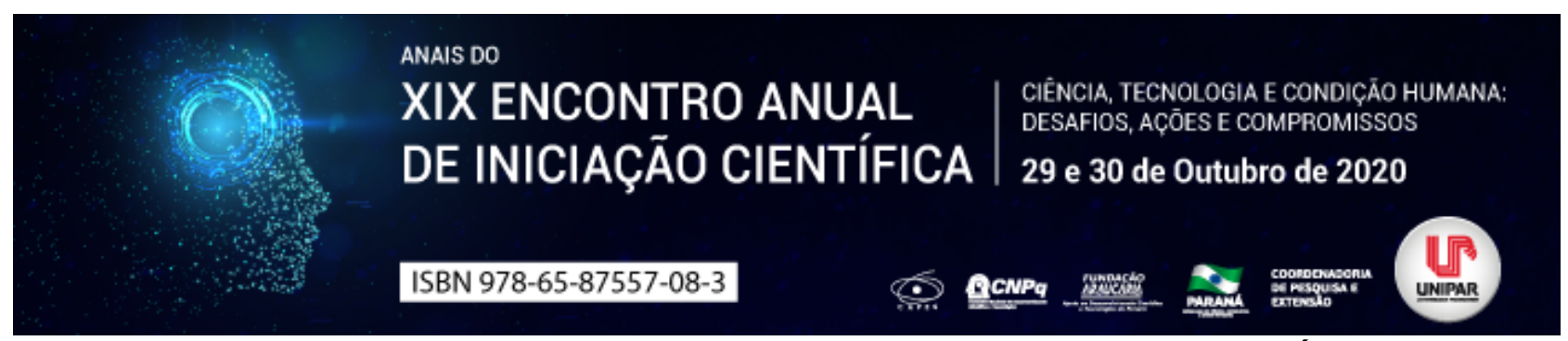

VULNERABILIDADE DO EGRESSO PRISIONAL: ASPECTOS SOCIAIS E JURÍDICOS

\title{
${ }^{1}$ ANNA FERNANDA SCALLA MENOTTI, ${ }^{2}$ ISABELA BRANDANI CRUZ, ${ }^{3}$ TEREZA RODRIGUES VIEIRA
}

\author{
${ }^{1}$ Mestranda em Direito Processual e Cidadania e Integrante do PIC, na UNIPAR. \\ ${ }^{1}$ Acadêmica do Curso de Psicologia e Integrante do PIC, na UNIPAR \\ ${ }^{2}$ Pós-Doutora em Direito pela Université de Montreal e Docente do Mestrado em Direito Processual e Cidadania na UNIPAR.
}

Introdução: O sistema prisional brasileiro anda na contramão da finalidade da pena, considerando as precárias condições a que a população carcerária é submetida, afetando profundamente a psique destes sujeitos. Após o fim da execução da pena, essas pessoas carregam estigmas pelo resto de suas vidas, uma descrição que não poderá ser afastada no contexto de sua existência. A população egressa prisional vive em constante dificuldade de inclusão social, uma vez que não lhe são ofertadas condições mínimas de reabilitação, e a inexistência de políticas de inclusão podem potencializar a reincidência prisional.

Objetivos: Analisar a legislação existente no Brasil em relação aos egressos prisionais; identificar as políticas de reinserção social e examinar projetos de lei voltados a essa população.

Desenvolvimento: O egresso prisional é o condenado que já cumpriu a pena e se encontra fora dos estabelecimentos prisionais. A Lei da Execução Penal, 7.210/84 (BRASIL, 1984), é cristalina ao mencionar que o objetivo da pena é a reinserção do preso na comunidade. Ainda, seus artigos 10 e 25 (BRASIL, 1984) introduzem no ordenamento jurídico a necessidade da assistência ao egresso prisional, que, de acordo com a Lei, consiste na orientação e apoio para reintegrá-lo à vida em liberdade e na concessão, caso seja necessário, de alojamento e alimentação, em estabelecimento adequado, pelo prazo de 2 (dois) meses. Deve ser observado o fato de que a pena é temporária e que o indivíduo retornará à sociedade, ressocializado ou não. Assim, o cumprimento da sentença imposta pela decisão judicial tem a finalidade de que o condenado, após cumprida sua pena, ou quando posto em liberdade, continue sua vida de forma digna. Quando se observa o texto normativo, é de fácil percepção que a Lei de Execução Penal trouxe mais ao ordenamento jurídico do que a simples normatização de procedimentos da execução penal, pois apresentou o conceito de responsabilização solidária, ou seja, toda a sociedade deve participar da reintegração do apenado ao contexto social. Em conjunto com a Lei de Execução Penal e com o intuito de promover a (re)integração social e evitar a reincidência penitenciária que políticas públicas e programas de inclusão social de egressos do sistema prisional foram criados e estimulados visando proporcionar condições melhores que as anteriores à pena, desfazendo o estigma criado, sobre os indivíduos, principalmente pela própria família, e garantindo meios para a elevação do nível de escolaridade, qualificação profissional e (re)inserção no mercado de trabalho (COMISSÃO, 2013, p. 31-35). É crucial evidenciar que o sistema penitenciário brasileiro está longe de cumprir seu papel de correção com eficácia mesmo com a legislação, políticas públicas e programas de apoio ao egresso, não oferecendo estrutura e assistências básicas para melhor vivência dentro destes ambientes, mas sim, espaços superlotados, alimentação, higiene básica e assistência médica precária, se tornando muito mais difícil realizar processos de ressocialização e atender toda essa população carcerária (SERON, 2017). O sistema penitenciário brasileiro é um dos principais fatores da reincidência criminal. Cumpre mencionar proposta de lege ferenda do Deputado Federal Alexandre Padilha, PT-SP, que recomenda para efeito de contratação pelo poder público com a finalidade de reinserção social do egresso, prorrogar contrato de trabalho celebrado por até três anos após o término do cumprimento da pena. Consoante Padilha, é comum a queixa de gestores públicos de que são obrigados a interromper abruptamente contratos de prestação de trabalho da pessoa presa ao término da pena aplicada. (2019, p.2) Não obstante a inequívoca precariedade, a Política Nacional de Atenção às Pessoas Egressas do Sistema Prisional, publicada no ano de 2020 pelo Governo Federal, menciona a existência de 11 iniciativas públicas estruturadas para o atendimento e assistência aos egressos prisionais, duas delas se encontram no Estado do Paraná, sendo uma na capital, Escritório Social de Curitiba, e outra em Londrina, Patronato Penitenciário de Londrina (MELO, 2020, p.13). Este último fornece atendimento à população egressa bem como às suas famílias, qualificando-as para a reinserção no mercado de trabalho, fornecendo atendimento multidisciplinar, como psicológico e jurídico, viabilizando a assistência e garantindo direitos fundamentais à população egressa.

Conclusão: Conforme o exposto, conclui-se que o sistema carcerário brasileiro é precário, o que torna quase impossível a ressocialização dos presos após o cumprimento da pena. É necessário, portanto, ampliar o tempo de transição para aquele que teve a chance de trabalhar para o poder público durante o cumprimento da pena de prisão. Outras iniciativas estão sendo apresentadas pelo Governo Federal, e já implementadas em nove dos vinte e sete estados da Federação. Se forem implantadas futuramente em todos os Estados e microrregiões, podem atingir o objetivo da efetivação de direitos mínimos e básicos desta população, como a dignidade da pessoa humana, positivada constitucionalmente como fundamento da República.

\section{Referências}


BRASIL. Lei 7210, de 11 de julho de 1984. Institui a Lei de Execução Penal. Presidência da República. Publicada no DOU de 13.7.1984.

COMISSÃO DE FORMAÇÃO TEÓRICA E PRÁTICA DO PRESO. O egresso do sistema prisional: do estigma à inclusão social. 1. ed. Belo Horizonte: Instituto Elo, 2013.

MELO, Felipe Athayde Lins de. Política Nacional de Atenção às Pessoas Egressas do Sistema Prisional. Ministério da Justiça e Segurança Pública, 2020. Disponível em:https://www.gov.br/depen/DEPEN/relatorio-de-acoes-dogoverno/1.RelatorioanualDepenverao20.04.2020. Acesso em: 03 ago. 2020.

PADILHA, Alexandre. Projeto de lei que altera a Lei no 7.210, de 11 de julho de 1984 que institui a Lei de Execução Penal. Sala de Sessões. Brasília, outubro de 2019. Disponível em: https://www.camara.leg.br/proposicoesWeb/prop_mostrarintegra? codteor=1826938. Acesso em: 30 ago 2020.

SERON, Paulo Cesar. Desafios e limites de (re)introduzir socialmente o egresso prisional no Brasil. Abril, 2017. Disponível em:https://jus.com.br/artigos/56938/desafios-e-limites-de-re-introduzir-socialmente-o-egresso-prisional-no-brasil. Acesso em: 05 ago. 2020.

Coordenadoria de Pesquisa e Extensão - COPEX

Departamento de Editoraçāo e Divulgaçāo Científica - DEDIC 


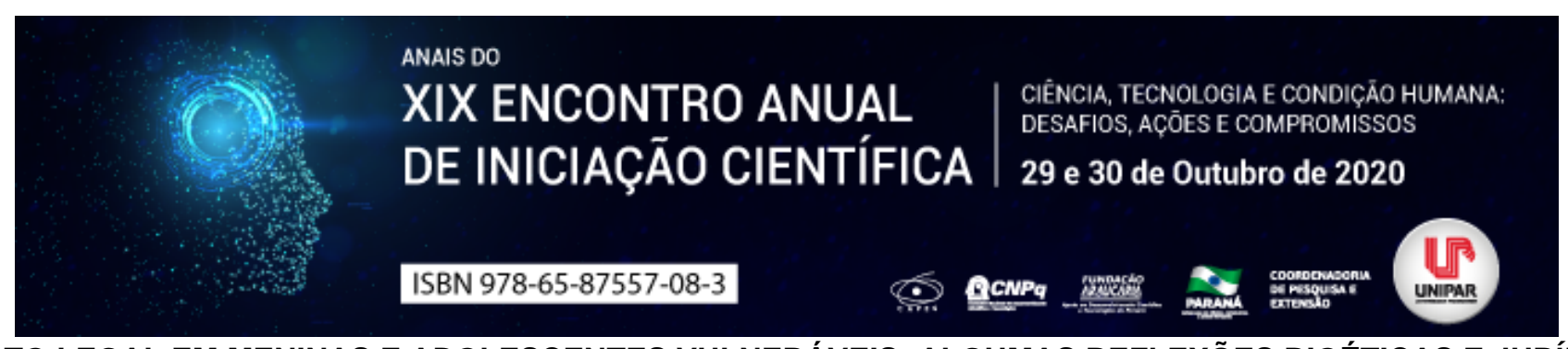

ABORTO LEGAL EM MENINAS E ADOLESCENTES VULNERÁVEIS: ALGUMAS REFLEXÕES BIOÉTICAS E JURÍDICAS

\author{
${ }^{1}$ TEREZA RODRIGUES VIEIRA, ${ }^{2}$ VALÉRIA SILVA GALDINO CARDIN
}

${ }^{1}$ Pós-Doutora em Direito pela Université de Montreal e Docente do Mestrado em Direito da UNIPAR

${ }^{1}$ Docente da Universidade Estadual de Maringá e Programa de Pós Graduação em Direito na UNICESUMAR

Introdução: O estupro é um crime execrável, uma vez que essa violência sexual causa danos físicos, morais, psicológicos e sociais à vítima, principalmente quando esta é criança ou adolescente do sexo feminino. Uma das piores consequências é a gravidez indesejada, surgindo a possibilidade da interrupção da gestação. Sucede que o sistema de saúde ainda não apresenta infraestrutura adequada em todo o país para o acolhimento integral dessas mulheres, o que acaba, muitas vezes, levando a questão para o âmbito judicial. O Poder Judiciário tem sido provocado nos casos de abortamento, embora a lei seja clara no tocante ao chamado aborto legal, ao declarar no artigo 128, inciso II, do Código Penal (BRASIL, 2020), que o aborto decorrente de violência sexual não é punível. Ocorre que a questão ainda não se encontra apaziguada em diversos meios sociais, acarretando manifestações diante dos poucos hospitais que realizam o procedimento legalmente no país.

Objetivo: Identificar e analisar, por meio de pesquisa bibliográfica, os principais questionamentos bioéticos e jurídicos que envolvem o aborto legal em casos de crianças e adolescentes no Brasil.

Desenvolvimento: O estupro continua sendo um dos crimes mais abomináveis praticados contra pessoas vulneráveis, principalmente crianças e adolescentes. As consequências indeléveis da violência sexual são físicas, psíquicas ou sociais, impossibilitando levar adiante uma gravidez indesejada. Como é sabido, o direito penal é quem estuda o exercício do poder punitivo do Estado, considerando ações delituosas e atribuindo a elas sanções. Penalistas não questionam o disposto no art. 18, II, do Código Penal (BRASIL, 1984), porém, fundamentalistas religiosos e alguns grupos de extrema direita ainda insistem em interferir no direito da gestante estuprada e do poder de decisão dos seus representantes legais. O teólogo Mário Sanches retoma uma conhecida questão bioética: diante de uma gravidez fruto de estupro temos um conflito ético e para ele não há ótima solução, as soluções são sempre precárias e dolorosas. Há os que alardeiam que interromper tal gravidez é o certo a fazer, ignorando o valor e a dignidade do feto; outros afirmam que o certo é manter a vida das duas pessoas envolvidas a qualquer preço, ignorando totalmente a angústia que ser abusada pode significar e quão insuportável pode ser vivenciar uma gravidez imposta . (2020, p.1) Em pesquisa publicada por Alberto Pereira Madeiro e Débora Diniz (2016, p. 563) são descritos os resultados de um estudo com métodos mistos nos serviços de aborto legal no Brasil. Foram avaliados 68 serviços, em duas etapas. [...] As mulheres que abortaram tinham predominantemente entre 15-29 anos, e eram solteiras e católicas. O aborto foi por estupro, até 14 semanas, com emprego da aspiração manual intrauterina. Para os profissionais, as principais dificuldades no funcionamento dos serviços são a pequena disponibilidade de médicos para o aborto e a capacitação escassa da equipe. Os dados mostram que ainda há distanciamento entre a previsão legal e a realidade dos serviços. Segundo dados do Ministério da Saúde, pelo menos seis abortos autorizados legalmente são realizados diariamente em meninas de 10 a 14 anos no Brasil. E, apenas nos últimos onze anos, foi registrada a média de 104 abortos deste tipo por ano no Paraná. A título de ilustração, em terras paranaenses, no período analisado, Curitiba apresenta 252 abortos entre meninas. Em seguida aparecem as cidades de Cascavel (63), Ponta Grossa (60), Foz do Iguaçu (55), Colombo (50), Guarapuava (38), Maringá (36), Paranaguá, São José dos Pinhais e Umuarama (31). (UMUARAMA, 2020). Sucede que, apesar da previsão da Lei n. 12.845 (BRASIL, 2013 ), que determina atendimento multidisciplinar às vítimas de violência sexual, inclusive, a chamada profilaxia da gravidez , muitos hospitais não oferecem assistência adequada às mulheres que procuram o abortamento legal no país.

Conclusão: Ao se atender ao pedido da gestante vulnerável e vítima de estupro, o Poder Judiciário, além de cumprir o disposto na lei penal, cumpre o princípio fundamental da dignidade da pessoa humana, protegido constitucionalmente, garantindo que esta não seja submetida a tratamento desumano e cruel, equivalente à tortura. Contudo, o direito ao aborto nos casos de estupro é garantido por lei, portanto não há necessidade de autorização judicial. É papel do Estado laico garantir que as necessidades sociais emergentes sejam acolhidas demonstrando que o pluralismo deve imperar em todas as nações democráticas.

\title{
Referências
}

BRASIL. Código Penal. Decreto-lei no 2.848, de 7 de dezembro de 1940. Publicado no DOU de 13.7.1984. Disponível em: http://www.planalto.gov.br/ccivil_03/decreto-lei/del2848compilado.htm. Acesso em: 25 ago. 2020.

BRASIL. Lei $\mathbf{n}^{\circ} \mathbf{1 2 . 8 4 5}$, de $1^{\circ}$ de agosto de 2013. Dispõe sobre o atendimento obrigatório e integral de pessoas em situação de violência sexual. Publicado no DOU de 2.8.2013. Disponível em : http://www.planalto.gov.br/ccivil_03/_Ato20112014/2013/Lei/L12845.htm. Acesso em: 25 ago 2020.

MADEIRO, Alberto Pereira; DINIZ, Débora. Serviços de aborto legal no Brasil um estudo nacional. Revista Ciências da Saúde 
Coletiva, v. 21, n. 2, Fev 2016. Disponível em: https://www.scielosp.org/article/csc/2016.v21n2/563-572. Acesso em: 22 ago. 2020.

SANCHES, Mário Antonio. Aborto e bioética: tire as sandálias. Whatsapp [Grupo Educação em Bioética]. 20 ago. 2020. 11h02. Recursos Virtuais.

UMUARAMA está entre as cidades do Paraná com maior número de abortos autorizados. Disponível em: https://cianorte.portaldacidade.com/ Acesso em: 23 ago. 2020.

Coordenadoria de Pesquisa e Extensão - COPEX

Departamento de Editoração e Divulgaçāo Científica - DEDIC 


\title{
ANAIS DO XIX ENCONTRO ANUAL | CIÊNCIA, TECNOLOGIA E CONDIÇĀO HUMANA: DE INICIAÇÃO CIENTÍFICA DESAFIOS, AÇŌES E COMPROMISSOS DE INICIAÇĀO CIENTÍFICA 29 e 30 de Outubro de 2020 \\ ISBN 978-65-87557-08-3

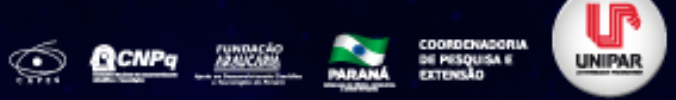 \\ REVISÃO BIBLIOGRÁFICA ACERCA DA INSERÇÃO DO PSICÓLOGO NA SAÚDE PÚBLICA NOS PARÂMETROS DO CONSELHO FEDERAL DE PSICOLOGIA
}

\author{
${ }^{1}$ MATEUS JOAO CORDEIRO SCHMOELLER DE LIMA, ${ }^{2}$ ALINE PERIN PADILHA, ${ }^{3}$ ANA CLAUDIA PANSERA, ${ }^{4}$ ISADORA \\ GAGLIOTTO GALVAN, ${ }^{5}$ NAYSSARA CAROLINA SILVA TASCHIN, ${ }^{6}$ TATIANE PECORARO
}

\author{
${ }^{1}$ Acadêmico do curso de Psicologia da UNIPAR \\ ${ }^{1}$ Acadêmica do Curso de Psicologia da UNIPAR \\ ${ }^{2}$ Acadêmica do Curso de Psicologia da UNIPAR \\ ${ }^{3}$ Acadêmica do Curso de Psicologia da UNIPAR \\ ${ }^{4}$ Acadêmica do Curso de Psicologia da UNIPAR \\ ${ }^{5}$ Docente da UNIPAR
}

Introdução: As perspectivas para a Psicologia da Saúde contemplam atuações profissionais que desenvolvam para além do arsenal terapêutico tradicional da prestação de serviços clínicos (CFP, 2010). A Psicologia, no contexto de Saúde Pública, é amparada pela perspectiva da integralidade biopsicossocial e a Política Nacional de Humanização, que norteia o Sistema Único de Saúde, e garante que este produza desempenhos resolutivos ao atender as necessidade da população. A atuação do profissional de psicologia é norteada por desafios e limitações, as possibilidades de intervenções a serem aplicadas são de acordo com os recursos disponíveis, as demandas e as realidades regionais (CFP, 2010).

Objetivo: O presente estudo objetiva, por meio de revisão bibliográfica, apresentar uma breve discussão sobre a inserção das e dos profissionais de psicologia no contexto da saúde brasileira, especialidade regulamentada pela Resolução n 003/2016.

Desenvolvimento: Psicologia da Saúde compete uma área de atuação voltada para a promoção e prevenção de saúde, através da integração de diversos domínios do saber. Tal prática leva em consideração conceituações como saúde e doença, buscando compreender seus significados e influências nos aspectos sociais, culturais e de bem-estar (TEIXEIRA, 2004). A partir desse novo espaço conquistado, profissionais de psicologia passaram a inserir-se no meio, responsabilizando-se por suporte e apoio às equipes multiprofissionais, protagonizando atividades grupais, facilitando relacionamentos e estabelecimento de vínculos, atuando nos três níveis de atenção à saúde, a saber: atenção primária, secundária e alta complexidade (PAULIN; LUZIO, 2009). Em contrapartida a essa conquista, o profissional depara-se com diversas dificuldades para desenvolver um trabalho qualificado, considerando que a realidade da saúde ainda é constituída por um sistema fortemente vinculado às práticas centradas no indivíduo, resistente às mudanças e ressignificações necessárias ao trabalho em equipe (PAULIN; LUZIO, 2009). Dimenstein (1998) correlaciona essa dificuldade ao pouco conhecimento produzido na área, a baixa investidura em teorias atreladas a saúde, ao pouco tempo de criação e implantação do SUS e o baixo número dos psicólogos na atenção básica, consequência do prevalecimento do modelo biomédico inserido na cultura brasileira. Concomitante a esse descaso com a produção de conhecimentos e a insistência na perspectiva clínica, tem-se enfrentado diversas incompatibilidades técnicas-teóricas ao tentar aplicar convicções provenientes de outros contextos socioculturais nesse campo. Angerami (2002), problematiza essa aplicação de teorias já consagradas mundialmente na sociedade brasileira e atenta para a necessidade de certa adaptação e criação de novas técnicas e práticas psicológicas que possam ter mais resultados e estejam mais adaptadas ao contexto em que será aplicada, considerando as especificidades de cada comunidade. Observou-se entretanto, que a partir de meados da década de 1990, iniciou-se movimentos de mudanças nas formações em Psicologia, abrindo possibilidades para outras formas de inserção das psicólogas e psicólogos, fazendo-se presente também uma reformulação das práticas clínicas, processos que ainda estão ocorrendo de forma gradativa (CAMURI; DIMENSTEIN, 2009). Neste sentido, a Psicologia fundamenta a sua atuação em saúde considerando o sujeito a partir de um modelo biopsicossocial, rompendo com a dicotomia presente no modelo biomédico tradicional. A partir disso, a condição de saúde do sujeito é vista integralmente, de acordo com o contexto em que está inserido, da cultura, dos fatores sociais e psicológicos que o acometem. Um dos obstáculos para a atuação do profissional da Psicologia no campo da saúde, mais especificamente relacionado ao SUS, é a falta de conhecimento e o uso limitados das técnicas, resultado de uma formação que não prepara os psicólogos para a atuação no serviço público de saúde já que muitas graduações se limitam à clínica tradicional (PAULIN; LUZIO, 2009).

Conclusão: O caminho traçado pela Psicologia na saúde ainda é recente e abundante em demandas e complicações, tornandose assim uma área de ricas possibilidades de investimento, tanto em pesquisa quanto em aplicação de técnicas e serviços que fujam da lógica clínica e segmentada, a qual pouco considera os contextos culturais, sociais e históricos. Origina-se, a partir disso, a necessidade de maior comprometimento das instituições de ensino em apresentar ênfases para além do consultório particular, engajando o futuro profissional teórico-metodologicamente para prestar serviços com resultados satisfatórios e 
condizentes com a política da saúde pública. Somado à isto a função de psicólogas e psicólogos inseridos nesse contexto, é acrescida de desmistificar questões atreladas a sua profissão e inserir na comunidade a importância desse serviço.

\section{Referências}

CONSELHO FEDERAL DE PSICOLOGIA. Resolução CFP N.o 003/2016. Brasília (DF), fevereiro de 2016. CONSELHO FEDERAL DE PSICOLOGIA. Práticas Profissionais de Psicólogos e Psicólogas na Atenção Básica à Saúde, $1^{\mathrm{a}}$ ed. Brasília, 2010.

CAMURI, Danilo; DIMENSTEIN, Magda Diniz Bezerra. Processos de Trabalho em Saúde: práticas de cuidado em saúde mental na estratégia saúde da família. Saúde soc., São Paulo , v. 19, n. 4, p. 803-813, dez. 2010.

DIMENSTEIN, Magda Diniz Bezerra. O psicólogo nas Unidades Básicas de Saúde: desafios para a formação e atuação profissionais. Estudos de Psicologia - 1998, 3(1), 53-81.

PAULIN, Tathiane; LUZIO, Cristina Amélia. A psicologia na saúde pública: desafios para a atuação e formação profissional. Rev. de Psico da UNESP, 8(2), 2009.

TEIXEIRA, José A. Carvalho. Psicologia da Saúde. Análise Psicológica - 2004, 3 (XXII): $441-448$. 


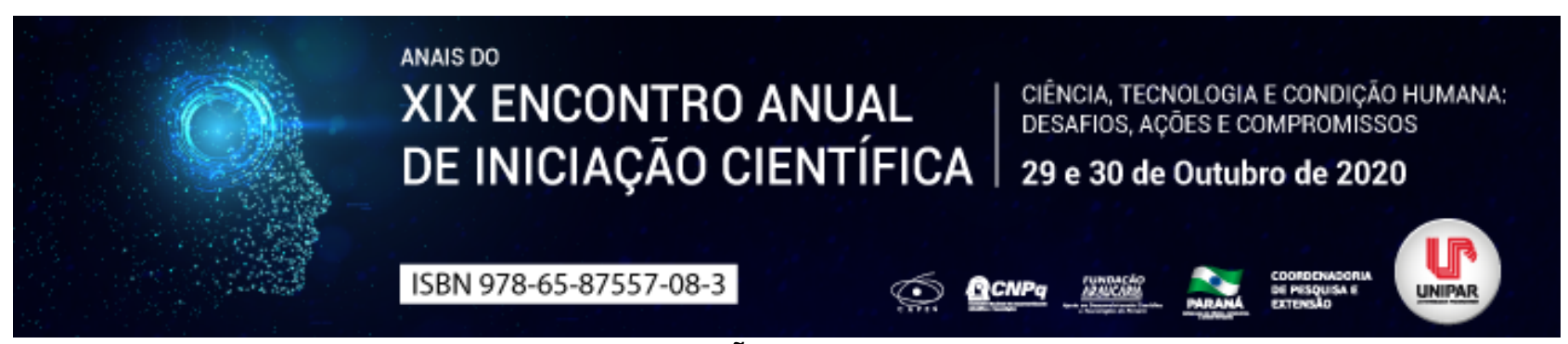

O PEDIDO NAS AÇÕES DE MEDICAMENTOS

\title{
${ }^{1}$ SIVONEI SIMAS, ${ }^{2}$ LEONARDO FRATINI XAVIER DE SOUZA
}

\author{
${ }^{1}$ Mestrando em Direito Processual e Cidadania (UNIPAR) \\ ${ }^{1}$ Mestrando em Direito Processual e Cidadania (UNIPAR)
}

Introdução: O acesso à justiça possibilitou a concretização de direitos fundamentais por meio do Poder Judiciário. Para muito, de forma ativista. O direito à saúde, direito fundamental que é (art. $6^{\circ}$ da CRFB/88), dever do Estado e direito de todos (art. 196 da CRFB/88), é diuturnamente buscado pela via judicial em razão da omissão dos Poderes Legislativo e Executivo no planejamento, formulação e execução de políticas públicas voltadas à saúde. Talvez por insuficiência de recursos financeiros. Como requisito da petição inicial, a parte autora deve especificar seu pedido (art. 319, IV, do CPC), e é aqui que reside a problemática proposta neste trabalho.

Objetivo: Verificar se o pedido mediato deve ser determinado, com a indicação do medicamento e sua quantidade, ou se é admitida sua postulação de forma genérica, para tratamento de saúde.

Material e método: Pesquisa qualitativa, com revisão bibliográfica e jurisprudencial, e método dedutivo.

Desenvolvimento: Conforme leciona FUX (2012, p. 26), A Jurisdição Constitucional, à luz da concepção tradicional da jurisdictio, significa a aplicação, pelo judiciário, das normas constitucionais . Portanto, é nesta jurisdição, com aplicação de hermenêutica própria, que deve se desenvolver o processo que visa assegurar o direito fundamental à saúde. Conforme MONNERAT (2018, p. 246), a provocação do autor contém não um, mas dois pedidos: a) um dirigido ao Estado-juiz para que este preste tutela jurisdicional; e b) outro dirigido contra o réu, consistente na entrega do bem jurídico em poder deste para si . 0 primeiro seria o pedido imediato e o segundo o pedido mediato. Em decorrência do disposto no art. 324 do Código de Processo Civil, o pedido formulado na ação deve ser determinado, não sendo admissível, salvo exceção legal, a formulação de pedido genérico. Conforme MEDINA (2020, p. 804), Determinado é o pedido mediato quando individuado o bem da vida; indeterminado (ou genérico) é o pedido mediato realizado de modo abrangente e impreciso quanto aos seus limites . O pedido mediato poderá ser genérico nas hipóteses previstas nos incisos do $\S 1^{\circ}$ do art. 324 do Código de Processo Civil. No caso do medicamento, o pedido mediato pode ser realizado de maneira determinada, com indicação do nome e quantidade do fármaco, ou de maneira genérica pleiteando o tratamento de saúde da pessoa pelo Estado, quando não for possível determinar, desde logo, as consequências do fato, da doença. Em qualquer hipótese, mesmo havendo determinação do pedido mediato e em atenção ao princípio da inércia de jurisdição (art. 492 do CPC), deve ser observado que em sede de jurisdição constitucional devem ser observadas as formas de interpretação que lhe é inerente. Assim, entre negar a modificação do pedido depois da citação, ou depois da decisão de saneamento (art. 329, I e II do CPC), e concretizar direito fundamental, deve ser dada primazia a esta decisão. Conforme CANOTILHO (1993, p. 227), esse é o objetivo do princípio da interpretação efetiva, no caso de dúvidas deve preferir-se a interpretação que reconheça maior eficácia aos direitos fundamentais . Em razão da força normativa da Constituição, deve-se dar realização ótima aos seus preceitos fundamentais (SARLET, 2018, p. 206). Por fim, conforme entendimento do Superior Tribunal de Justiça, se o ordenamento constitucional garante a todos o direito à saúde, a simples troca nos medicamentos postulados na inicial não configura modificação do pedido, o qual é o próprio tratamento médico (BRASIL, STJ, AgRg no REsp 1222387/RS).

Conclusão: Portanto, no caso de haver pedido determinado na petição inicial, eventual alteração após a citação ou a decisão de saneamento poderá ser realizada, pois tal postura se mostra mais compatível com a hermenêutica aplicável na jurisdição constitucional. Enfim, a impossibilidade de modificação do pedido violaria o devido processo legal, em sua acepção substantiva, por ser desarrazoada tal medida, eis que haverá nova ação com o pedido novo.

\section{Referências}

MEDINA, José Miguel Garcia. Curso de direito processual civil moderno [livro eletrônico]. 5. ed. São Paulo: Thomson Reuters Brasil, 2020.

MONNERAT, Fábio Victor da Fonte. Introdução ao estudo do direito processual civil. 3. ed. São Paulo: Saraiva Educação, 2018.

FUX, Luiz. Jurisdição constitucional: democracia e direitos fundamentais. Luiz Fux. Belo Horizonte: Fórum, 2012.

CANOTILHO, José Joaquim Gomes. Direito constitucional. 6. ed. Coimbra: Livraria Almedina, 1993.

SARLET, Ingo Wolfgang; MARINONI, Luiz Guilherme; MITIDIERO, Daniel. Curso de direito constitucional. 7. ed. São Paulo: Saraiva Educação, 2018.

BRASIL. [STJ]. AgRg no REsp 1222387/RS, Rel. Ministro Herman Benjamin, Segunda Turma, julgado em 15/03/2011. 
Disponível em: [https://ww2.stj.jus.br/processo/revista/documento/mediado/? componente=ATC\&sequencial=14050538\&num_registro=201002155832\&data=20110401\&tipo=51\&formato=PDF]. Acesso em 23 jul. 2020.

Coordenadoria de Pesquisa e Extensão - COPEX

Departamento de Editoraçāo e Divulgaçāo Científica - DEDIC 


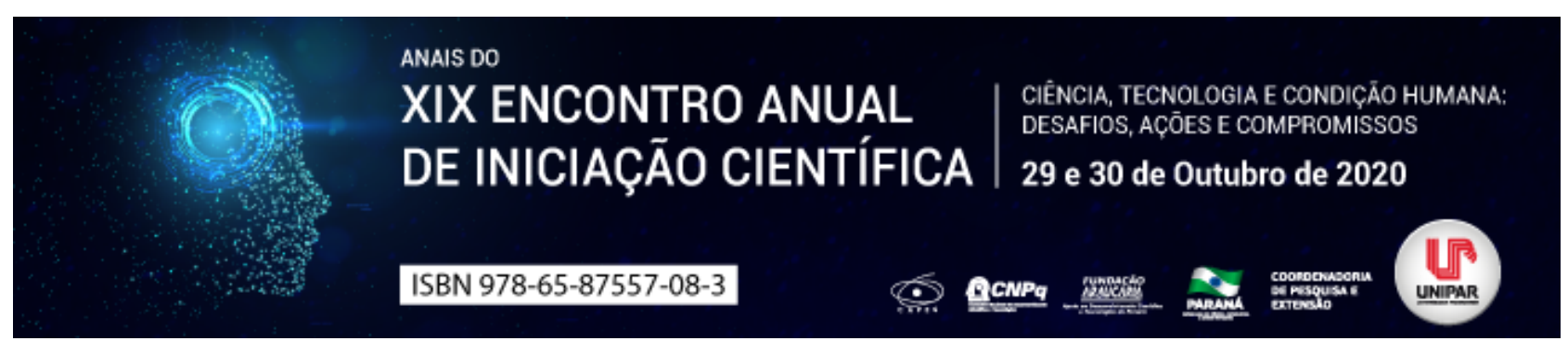

A IMPORTÂNCIA DAS ESTRATÉGIAS DE MARKETING NA GESTÃO

\title{
1.JESSICA CARVALHO ROZARIO, ${ }^{2}$ MATEUS DANIEL GONCALVES, ${ }^{3}$ ANA PAULA DE LIMA DA SILVA
}

\author{
${ }^{1}$ Acadêmica do Curso de Administração da UNIPAR \\ ${ }^{1}$ Acadêmico do Curso de Administração da UNIPAR \\ ${ }^{2}$ Docente da UNIPAR
}

Introdução: As estratégias de marketing na gestão são compreendidas como um conjunto de ações que são realizadas com o intuito de alavancar a marca ou a organização e fazer com que elas sejam aceitas pelos consumidores de uma maneira positiva. Os esforços realizados na construção das estratégias de marketing ocorrem para que os clientes tenham-nas como preferência e não apenas como opção. Isto é, para que assim a organização seja a primeira e melhor opção e o negócio tenha uma boa visibilidade.

Objetivo: Estudar a importância das estratégias de marketing na gestão.

Metodologia: O procedimento metodológico utilizado nessa pesquisa foi por meio de referências bibliográficas. Sendo assim, é um estudo exploratório de natureza qualitativa.

Desenvolvimento: Segundo Kotler e Keller (2006), para desenvolver a estratégia de marketing é necessário saber claramente como ele funciona e utilizar a combinação de disciplina e flexibilidade. Contudo as estratégias devem ser aprimoradas constantemente levando em consideração a evolução do mercado.

As estratégias de marketing têm como alicerce o planejamento estratégico, que conjuntamente irão influenciar nas decisões sobre a formulação de preço, estratégia de produto e também quanto sua distribuição e promoção, de acordo com público selecionado e o posicionamento pretendido. Com base nesses fatores haverá a elaboração de um planejamento estratégico em longo prazo que será responsável pelo resultado final da empresa envolvendo todos os setores.

As estratégias de marketing para Magalhães e Sampaio (2007) permitem que as organizações atentem-se as suas forças e fraquezas contidas em seu ambiente interno e as oportunidades e ameaças apresentada no ambiente externo, dessa maneira possibilita que a empresa leve o produto certo para o cliente certo, com preços definidos corretamente e contando com a comunicação exata. Hooley, Saunders e Piercy (2005) propõem três fases para a elaboração de uma estratégia de marketing. A primeira fase refere-se à estratégia central, onde, é definido o propósito da organização. Levando em consideração os clientes e o mercado competitivo. A segunda fase está relacionada em criar o posicionamento competitivo da empresa, este posicionamento ocorre por meio da escolha do público-alvo e estabelece uma vantagem competitiva, ou seja, define onde e como a organização irá competir. A terceira fase é a discussão da implementação. É por meio desta fase que se define como utilizar o mix de marketing para o posicionamento da marca. Ao entregar ao público-alvo o posicionamento anunciado por meio do composto mercadológico, a empresa consegue satisfazer as necessidades e desejos resolvendo problemas/ angústias e entregando benefícios aos seus consumidores.

Conclusão: Percebe-se portanto que, as estratégias de marketing auxiliam na gestão organizacional de uma maneira muito assertiva, pois, é por meio delas que são elaboradas formas de manter os clientes ativos e captar novos. Ela pode ser elaborada considerando tanto o curto quanto o longo prazo, e também sofrer alterações de acordo com a evolução do mercado. A empresa consegue selecionar público alvo e compreender suas exigências, proporcionando excelência no atendimento.

Dessa maneira, a empresa consegue gerir os produtos de maneira positiva e construir uma marca sólida.

\section{Referências}

Hooley, G. J.; Saunders, J. A.; Piercy, N. F. Estratégia de marketing e posicionamento competitivo. 3. ed. São Paulo: Pearson, 2005.

Kotler, P.; Keller, K. L. Administração de marketing. 12. ed. São Paulo: Pearson, 2006.

Magalhães, M. F.; Sampaio, R. Planejamento de marketing: conhecer, decidir e agir do estratégico ao operacional. São Paulo: Pearson, 2007. 


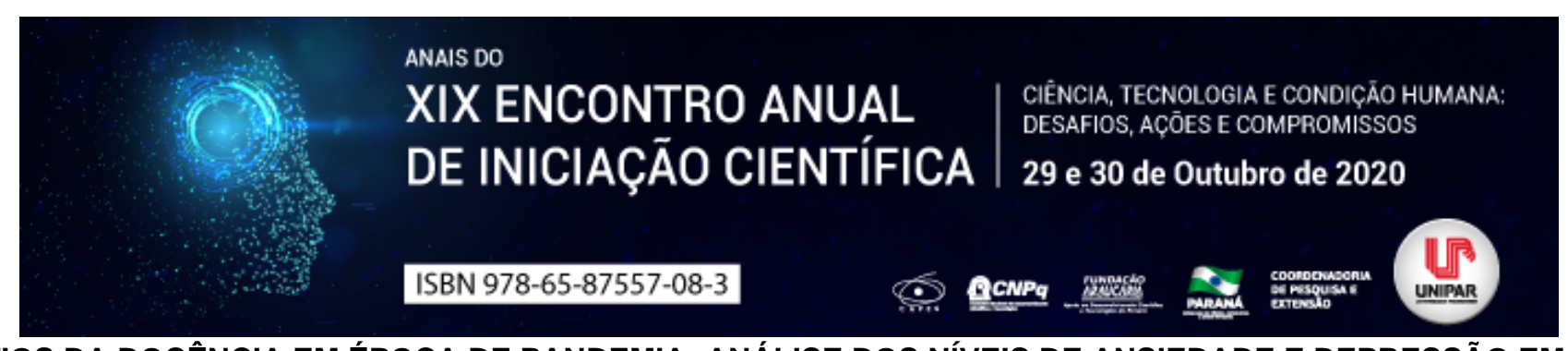

\title{
DESAFIOS DA DOCÊNCIA EM ÉPOCA DE PANDEMIA: ANÁLISE DOS NÍVEIS DE ANSIEDADE E DEPRESSÃO EM SAÚDE MENTAL DIANTE DO ISOLAMENTO SOCIAL
}

\author{
${ }^{1}$ JAINE LIMA DE ANDRADE, ${ }^{2}$ KAROLINE SQUINSANI DA ROSA, ${ }^{3}$ GRACIANE BARBOZA DA SILVA, ${ }^{4}$ THAIS CRISTINA \\ GUTSTEIN NAZAR
}

\author{
${ }^{1}$ Acadêmica do PIC/UNIPAR \\ ${ }^{1}$ Acadêmica do Curso de Psicologia da UNIPAR \\ ${ }^{2}$ Docente da UNIPAR \\ ${ }^{3}$ Docente e Orientadora PIC/PIBIC da UNIPAR
}

Introdução: $O$ ano de 2020 está sendo marcado por um momento histórico com a pandemia pela Organização Mundial da Saúde da COVID-19 (DANTAS, 2020). O isolamento social se fez uma medida necessária para combate e prevenção, surgindo novos obstáculos para a atuação dos docentes. Soares et al (2009) argumenta que o professor e a professora tem um papel fundamental no processo de ensino e aprendizagem, com a possibilidade de mediar o saber em seu papel de facilitador das possibilidades dos sujeitos, em que o exercício de lecionar vai muito além da apreensão de conteúdos. Valle (2011) evidencia que o trabalho do professor gera consequências na sua vida cotidiana, pois faz com que esse profissional se exponha a situações que influem no aspecto biopsicossocial de sua vida, sendo elas físicas, emocionais e psicológicas.

Objetivo: Objetivou-se avaliar os níveis de ansiedade e depressão de profissionais da educação do Ensino Fundamental, Básico e Superior, público e privado no contexto atual de pandemia.

Material e Métodos: A presente pesquisa foi aprovada pelo Comitê de Ética em Pesquisa parecer: 4.127 .990 e no CAAE: 93703418.4.0000.0109. O instrumento utilizado foi a Escala HAD (BOTEGA et al, 1995) que avalia as variáveis de ansiedade e depressão dos sujeitos em 14 frases, com respostas atributivas de 0 à 03 a partir da quantidade de vezes que as sensações descritas nas frases ocorrem. A pesquisa deu-se com professores, com mais de 18 anos, que atuam no Ensino Básico, Fundamental e Superior em instituições públicas e privadas do sudoeste do Paraná. Desta forma, estes foram convidados a partir de plataformas onlines, momento ao qual receberam as instruções e os materiais aos quais precisaram responder para tornar-se participante da pesquisa. Participaram desta pesquisa 77 docentes, sendo $84,4 \%(n=65)$, do gênero feminino, $14,3 \%$ ( $n: 11)$ do gênero masculino e 1,3\% ( $n=1)$ de gênero não especificado. A faixa etária das (os) participantes variou de 18 à 50 prevalecendo as participantes com idade entre 31 à 35 anos e 36 à 40 anos. A pesquisa contou com um maior número de profissionais atuantes na rede pública de ensino, com $70,1 \%(n=4)$ do total, como também com $28,6 \%(n=22)$ da rede privada e $1,3 \%(n:=1)$ atuante em ambas. Além disso, confirmou-se que dos participantes 29,9\% $(n=23)$ atuam no nível de ensino superior, 50,6\% $(n=$ 39) em fundamental séries iniciais (predominante), $7,8 \%(n=6)$ fundamental séries finais e $11,7 \%(n=9)$. A análise dos dados deu-se por meio da criação de um banco de dados no Statistical Package for the Social Sciences (SPSS) utilizando-se de estatísticas descritivas (frequência) e do teste de correlação de Pearson.

Resultados: À respeito da variável de ansiedade no total da amostra avaliada, obteve-se $40,3 \%$ ( $n=31)$ de ansiedade improvável, $41,6 \%(n=32)$ de ansiedade possível e 18,2\% $(n=14)$ de ansiedade provável. Com a variável de depressão, verificou-se que 53,2\% (n= 41) demonstra depressão improvável, 36,4\% (n=28) depressão possível e 10,4\% $(n=8)$ depressão provável. A pesquisa verificou correlações significativas de gênero em relação à depressão em nível de $0,05(p=-0,206)$ e à ansiedade em nível de $0,05(p=-0,207)$.

Discussão: Os dados permitem inferir que a maior parte das(os) docentes apresentam sinais de ansiedade, e uma menor parte apresentam possíveis sinais de depressão. Ferreira-Costa e Pedro-Silva (2019) apontam que ansiedade e depressão em um grau leve pode-se haver a perda da qualidade de vida, acarretando em sintomas de irritabilidade, impaciência, agitação, desatenção, dificuldade no sono, na aprendizagem, entre outras, sendo que em grau moderado já existe a presença de um adoecimento mental. Os mesmos autores em uma pesquisa contou com 105 professores, e concluiu que os níveis de ansiedade encontrados demonstram ser prejudiciais ao processo educacional, bem como a qualidade de vida desses profissionais, e a outras contextos sociais de suas vidas. Scandolara et al (2015) avaliou o nível de possíveis distúrbios relacionados ao estresse psicológico e possíveis indicadores de estado de depressão em 106 docentes concluiu que há alteração no desempenho e estresse desses profissionais, independente de suas idades, gêneros, período de trabalho e séries em que atuam, e o tempo de atuação na profissão de docente também está relacionado ao nível de estresse e depressão. Também foi observado ao decorrer da análise dos dados que a variável gênero foi identificada como fator que influencia na redução dos índices de ansiedade e depressão. Cabe ressaltar que nesta pesquisa a maior parte das(os) participantes foram do gênero feminino, ficando aberto o questionamento de que o gênero feminino poderia influenciar em menores sinais/sintomas de ansiedade e depressão, o que só 
poderá ser afirmado a partir de futuros estudos comparativos.

Conclusão: Observa-se que uma maior parte das(os) docentes apresentam sinais de ansiedade, e uma menor parte apresentam possíveis sinais de depressão. Isso faz com que torne-se necessário refletir sobre a saúde mental dessas e desses profissionais nessas instituições, se há uma atenção voltada a isso nesses espaços e como isso se dá.

\section{Referências}

BOTEGA, Neury Junior et al. Transtornos do humor em enfermaria de clínica médica e validação de escala de medida (HAD) de ansiedade e depressão. Revista de Saúde Pública, v. 29, n. 5, p. 355-63, October, 1995. Disponível em: https://doi.org/10.1590/S0034-89101995000500004. Acesso em: 21 abr. 2020.

DANTAS, Flávio. Resultados terapêuticos da homeopatia em pacientes suspeitos ou confirmados de CoVID-19 no Brasil: protocolo para estudo observacional prospectivo. São Paulo, 2020. Disponível em: http://homeopatia.bvs.br/2020/04/16/resultados-terapeuticos-da-homeopatia-em-pacientes-suspeitos-ou-confirmados-de-covid19-no-brasil-protocolo-para-estudo-observacional-prospectivo/. Acesso em: 21 abr. 2020.

FERREIRA-COSTA, Rodney Querino; PEDRO-SILVA, Nelson. Níveis de ansiedade e depressão entre professores do Ensino Infantil e Fundamental. Pro-Posições, v. 30, p. 1-29, September, 2019. Disponível em: https://www.scielo.br/scielo.php? pid=S0103-73072019000100503\&script=sci_arttext. Acesso em: 14 jun. 2020.

SCANDOLARA, Thalita Basso et al. Avaliação dos níveis de estresse e depressão em professores da rede pública do município de Francisco Beltrão - PR. Arq. Cienc. Saúde UNIPAR, Umuarama, v. 19, n. 1, p. 31-38, jan./abr./2015.

SOARES, Adriana Benevides et al. Estudo comparativo de habilidades sociais e variáveis sociodemográficas de professores. Psicol. teor. prat., v. 11, n. 1, June, 2009. Disponível em: http://pepsic.bvsalud.org/scielo.php? script=sci_arttext\&pid=S1516-36872009000100004. Acesso em: 21 abr. 2020.

VALLE, Luiza Elena L. Estresse e distúrbios do sono no desempenho de professores: saúde mental no trabalho. 2011. Tese (Doutorado em Psicologia Social) - Instituto de Psicologia da Universidade de São Paulo, São Paulo, 2011.

Coordenadoria de Pesquisa e Extensão - COPEX

Departamento de Editoraçāo e Divulgaçāo Científica - DEDIC 


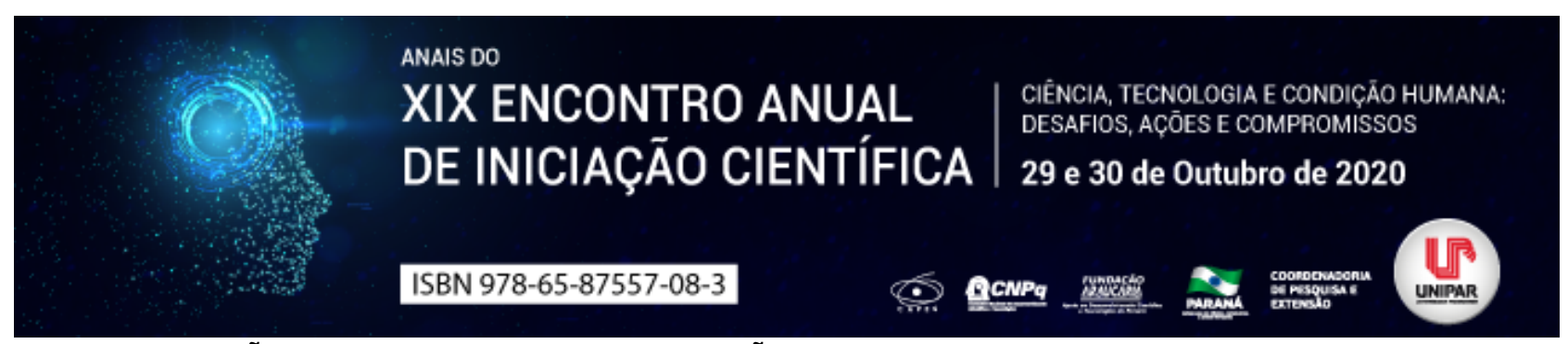

REVISÃO DOS CONTRATOS DE LOCAÇÃO EM TEMPO DE PANDEMIA DO COVID-19

\title{
${ }^{1}$ LUCAS JORGE SCHEID , ${ }^{2}$ MAIARA DOS SANTOS NORONHA
}

\author{
${ }^{1}$ Acadêmico do Curso de Direito UNIPAR \\ ${ }^{1}$ Docente da UNIPAR
}

Introdução: No fim do ano de 2019, uma pandemia teve surgimento na China e acabou atingindo o mundo inteiro. O novo coronavírus, também conhecido como COVID-19, tem afetado a economia mundial, nas mais diversas áreas, bem como os contratos de locação e demais negócios jurídicos existentes. A partir dos seus desdobramentos, pode-se caracterizar a pandemia como sendo um acontecimento inesperado que gera onerosidade excessiva à muitos contratantes, uma vez que ocasionou um grande desequilíbrio na situação patrimonial de muitos contratantes.

Objetivo: O presente trabalho tem como escopo analisar as possibilidades de revisão dos contratos de locação em decorrência da pandemia do COVID-19, devido a modificação das condições financeiras de muitos contratantes.

Desenvolvimento: O surgimento da pandemia e a acelerada propagação do vírus da COVID-19 afetou o mercado financeiro mundial, o qual sente impactos de uma crise já existente. A situação fática vivenciada trata-se de fato imprevisto, que causa um dano efetivo para os locatários, tornando excessivamente onerosa a obrigação originalmente pactuada. Sobre o tema Marçal Tucci aduz que os contratos firmados no âmbito do direito privado podem ser revisados quando eventos imprevisíveis, não conhecidos quando da celebração da avença, tornarem suas prestações excessivamente onerosas a um dos contratantes [...]

(TUCCI, 2020, p. 02). Com relação aos contratos de locação, faz-se necessário mencionar o art. 565 do Código Civil Brasileiro, que conceitua essa modalidade contratual como sendo o contrato pelo qual uma das partes se obriga a ceder à outra, por tempo determinado ou não, o uso e gozo de coisa não fungível, mediante certa retribuição (BRASIL, 2002). Ainda sobre a modalidade específica de contratos abordada no presente trabalho, destaca-se que estes tratam-se de contratos bilaterais, determinando em suas cláusulas prestações e contraprestações à ambas as partes. Sabe-se que crise existente não gera a resolução ou revisão automática dos contratos, porém, estas poderão se fundamentar através de instrumentos já existentes no sistema normativo, mais especificadamente previstos no Código Civil. Dispõe o art. 317 do referido dispositivo legal que

quando, por motivos imprevisíveis, sobrevier desproporção manifesta entre o valor da prestação devida e o do momento de sua execução, poderá o juiz corrigi-lo, a pedido da parte, de modo que assegure, quanto possível, o valor real da prestação (BRASIL, 2002). Tal artigo possibilita que se vislumbre a revisão contratual por fato superveniente, diante de uma imprevisibilidade somada à onerosidade excessiva, sendo dessa maneira conhecida, através da atuação jurisdicional, uma das formas de revisão contratual. Os efeitos da pandemia servirão de alavanca para a configuração de diversas situações, as quais serão mencionadas na sequência. Uma das possibilidades abrange a alegação de caso fortuito ou força maior, que segundo Flávio Tartuce por esse comando, o devedor não responde pelos prejuízos resultantes desses eventos se expressamente não se houver por eles responsabilizado, por força do contrato (TARTUCE, 2019, p. 85). Outra possibilidade trata-se da aplicação da teoria da onerosidade excessiva, a qual refere-se à constatação objetiva do desequilíbrio superveniente, estranho às partes, que não poderia ser esperado legitimamente, resultando em excessiva onerosidade e enorme sacrifício a uma das partes contratantes, sem que seja necessário esmiuçar a situação subjetiva dos envolvidos. Verifica-se como sendo mais uma possibilidade, a aplicação da teoria da imprevisão, prevista no art. 478 do Código Civil, a qual em síntese trata-se da constatação de alteração que fosse inesperada e imprevisível quando da celebração do contrato. Válido ainda se faz ressaltar, que o ordenamento jurídico pátrio impõe aos contratantes uma séria de princípios que representam direitos e deveres da relação contratual. Sendo por esse motivo importante mencionar a relevância desses princípios, em especial o princípio da boa-fé contratual, considerando que a pandemia vem impactando a sociedade como um todo. Segundo Danielle Freitas, nas relações contratuais privadas de qualquer natureza deve ser observado o princípio da boa-fé, do qual se extrai não apenas o dever de lealdade entre as partes, mas também a indispensável cooperação e o dever de proteção ao outro contratante, o que se traduz em seu auxílio em momento de grave anormalidade para a consecução do objeto contratual (FREITAS, 2020, p. 02).

Conclusão: A revisão contratual motivada pelas circunstâncias causadas pela COVID-19 pode de fato ocorrer. Nesse sentido, entende-se que é primordial a análise de cada caso concreto, para que se alcance de fato uma solução favorável a todos os interessados. Além do mais, a renegociação amigável do contrato também pode ser vislumbrada como uma solução benéfica, tendo em vista que através da exposição de suas necessidades, podem chegar de uma forma consensual a um denominador comum.

\section{Referências}

BRASIL. Lei n. 10.406, 10 de janeiro de 2002. Institui o Código Civil. Diário Oficial da União, Brasília, DF, 11 jan. 2002. 
Disponível em: http://www.planalto.gov.br/ccivil_03/leis/2002/L10406compilada.htm. Acesso em: 22 ago. 2020.

FREITAS, Danielle Silva Fontes Borges. Como a pandemia da Covid-19 está afetando os contratos de locação. Consultor Jurídico. São Paulo, 30 de maio de 2020. Disponível em: https://www.conjur.com.br/2020-mai-30/danielle-freitas-pandemiacontratos-locacao. Acesso em: 11 de ago de 2020.

ROSENVALD, Nelson. Código civil comentado. 7. ed. Barueri: Manole, 2013.

SANTOS, José Van Cleef de Almeida; CASCALDI, Luis de Carvalho. Manual de Direito Civil. 2. ed. São Paulo: Editora Revista dos Tribunais, 2014.

TARTUCE, Flávio. Direito Civil. Teoria Geral dos Contratos e Contratos em Espécie. v. 3. ed. 14. Rio de Janeiro: Forense, 2019. TUCCI, Rogério Lauria Marçal. Alterações imprevisíveis das circunstâncias: impactos contratuais. Consultor Jurídico. São Paulo, 01 de abril de 2020. Disponível em: https://www.conjur.com.br/2020-abr-01/rogerio-tucci-alteracoes-imprevisiveiscircunstancias. Acesso em: 24 de jun. de 2020.

Coordenadoria de Pesquisa e Extensão - COPEX

Departamento de Editoraçāo e Divulgaçāo Científica - DEDIC 


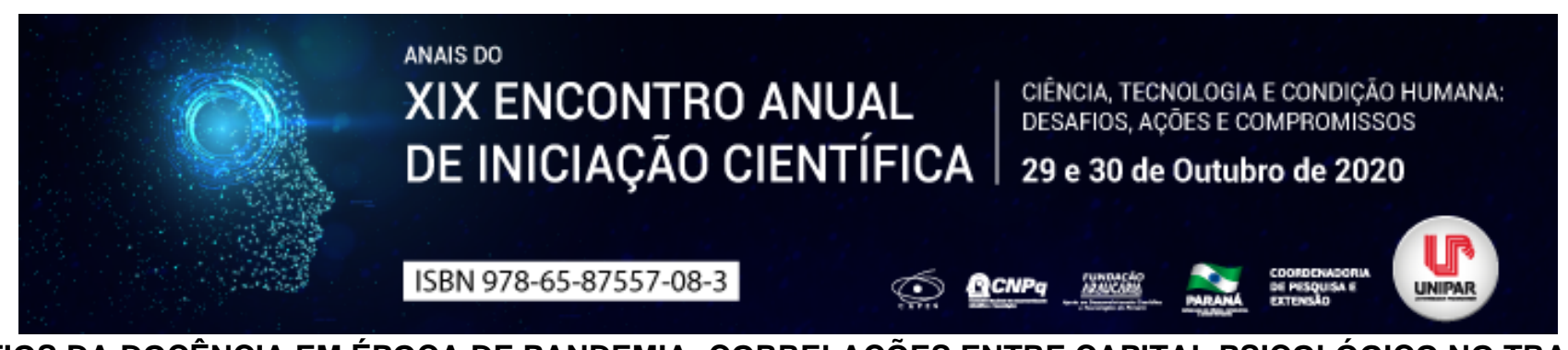

DESAFIOS DA DOCÊNCIA EM ÉPOCA DE PANDEMIA: CORRELAÇÕES ENTRE CAPITAL PSICOLÓGICO NO TRABALHO DOCENTE E ESTRESSE PERCEBIDO DIANTE DO ISOLAMENTO SOCIAL

\author{
${ }^{1}$ KAROLINE SQUINSANI DA ROSA, ${ }^{2}$ JAINE LIMA DE ANDRADE, ${ }^{3}$ GRACIANE BARBOZA DA SILVA, ${ }^{4}$ THAIS CRISTINA \\ GUTSTEIN NAZAR
}

\author{
${ }^{1}$ Acadêmico do PIC/UNIPAR \\ ${ }^{1}$ Acadêmica do Curso de Psicologia da UNIPAR \\ ${ }^{2}$ Docente da UNIPAR \\ ${ }^{3}$ Docente e orientadora PIC/PIBIC da UNIPAR
}

Introdução: Estamos inseridos em uma atual realidade de pandemia do vírus SARS-CoV-2 (COVID-19), o que implica em uma adaptação na forma como vivemos e nos relacionamos com as pessoas, o mundo e nós mesmos, em um necessário isolamento social. O professor e a professora tem um papel fundamental no processo de ensino e aprendizagem, com a possibilidade de mediar o saber em seu papel de facilitador das possibilidades dos sujeitos, em que o exercício de lecionar vai muito além da apreensão de conteúdos (SOARES et al, 2009). Há fatores que contribuem para uma saúde mental favorável, como a compreensão de variáveis desfavoráveis que interferem negativamente nas relações tanto entre os indivíduos, como do indivíduo para com os demais contextos de sua vida, podendo afetar e prejudicar a adaptação em ambientes, bem como produzir ou intensificar vulnerabilidades psicológicas nesses indivíduos em sua vida (VALLE, 2011). Com isso evidencia-se de grande importância a análise e investigação dos facilitadores e dificultadores que perpassam a prática docente, tanto na sua vida profissional e como para além dela.

Objetivo: Objetivou-se caracterizar o capital psicológico no trabalho e estresse, bem como suas correlações na atuação profissionais da educação do Ensino Fundamental, Básico e Superior, público e privado no contexto atual de pandemia.

Material e Métodos: A presente pesquisa foi aprovada pelo Comitê de Ética em Pesquisa parecer: 4.127.990 e $n^{\circ}$ CAAE: 93703418.4.0000.0109, e na sua realização foi utilizado o Inventário de Capital Psicológico no Trabalho ICPT-25 (SIQUEIRA; MARTINS; SOUZA, 2014) e Escala de Percepção de Estresse-10 (EPS-10) (REIS; HINO; RODRIGUEZ-AÑEZ, 2010). Os instrumentos foram disponibilizados aos participantes a partir de um formulário on-line. Para participar desta pesquisa os e as profissionais precisaram inicialmente aceitar responder e assinar o TCLE da pesquisa fundamentada na resolução 422/2012. Desta forma, estes foram convidados a partir de plataformas onlines, momento em que receberam as instruções e os materiais aos quais precisaram responder para tornar-se participante da pesquisa. Participaram desta pesquisa 77 docentes, sendo $84,4 \%$ $(n=65)$, do gênero feminino, 14,3\% $(n=11)$ do gênero masculino e 1,3\% $(n=1)$ de gênero não especificado. A faixa etária das (os) participantes variou de 18 à 50 prevalecendo as participantes com idade entre 31 à 35 anos e 36 à 40 anos. A pesquisa contou com um maior número de profissionais atuantes na rede pública de ensino, com $70,1 \%(n=4)$ do total, como também com $28,6 \%(n=22)$ da rede privada e 1,3\% (n:=1) atuante em ambas. Além disso, confirmou-se que dos participantes $29,9 \%(n=23)$ atuam no nível de ensino superior, 50,6\% $(n=39)$ em fundamental séries iniciais (predominante), 7,8\% ( $n=6)$ fundamental séries finais e $11,7 \%(n=9)$ no ensino médio. A análise dos dados deu-se por meio da criação de um banco de dados no Statistical Package for the Social Sciences (SPSS) utilizando-se de estatísticas descritivas (frequência) e do teste de correlação de Pearson.

Resultados: Em relação ao estresse os dados apontaram uma média de 19,96 (dp=7,69), quanto aos dados dos fatores do Capital Psicológico identificou-se Esperança no Trabalho média 4,1948 ( $d p=0,45435)$, Resiliência no Trabalho 3,1147 ( $d p=0,67009$ ), Otimismo no Trabalho média 4,0390 ( $d p=0,59563$ ), Eficácia no Trabalho média 4,1429 ( $d p=0,43807$ ). Quando analisadas as correlações entre às variáveis de estresse e os fatores de capital psicológico identificou-se correlações negativas significativas em nível de 0,01 entre os níveis de estresse e todos os fatores de capital psicológico a saber esperança no trabalho $(p=-0,315)$, resiliência no trabalho $(-0,466)$, otimismo no trabalho $(p=-0,442)$ e eficácia no trabalho $(p=-0,391) 0,01$.

Discussão: Quanto aos resultados de estresse quando comparados os dados com a amostra normativa (REIS; HINO; RODRIGUEZ-AÑNEZ, 2010), percebe-se níveis mais elevados permitindo hipotetizar que o momento atual de isolamento social pode ser fator de risco ao desenvolvimento de estresse. Quanto aos dados de Capital psicológico quando comparados aos da amostra normativa percebe-se a Esperança no Trabalho, o Otimismo no Trabalho e a Eficácia no Trabalho podem ser classificados como escores altos, já a resiliência no trabalho pode ser classificada como escore médio (SIQUEIRA; MARTINS; SOUZA, 2014). Os resultados indicam que os professores percebem que no contexto do trabalho são capazes de resolver problemas, que as coisas darão certo e que podem encontrar maneiras de realizar os sonhos no trabalho, além disso, há em certa medida a percepção de que ficam mais fortes após enfrentar problemas no trabalho. Quando analisados os dados de 
correlação percebe-se a influência negativa do estresse sobre as percepções em relação ao trabalho acima relatadas, ou seja, quanto mais elevados os níveis de estresse menos os níveis de capital psicológico.

Conclusão: Por meio desta pesquisa demonstrou-se que quanto menos estresse maior é o capital psicológico, apontando a necessidade de cuidado e minimização dos estressores em saúde mental. Entendo que tal olha proporcionará uma atuação docentes mais eficaz.

\section{Referências}

REIS, Rodrigo Siqueira.; HINO, Adriano Akira Ferreira; RODRIGUEZ-AÑEZ, Ciro Romélio. Perceived stress scale: reliability and validity study in Brazil. Journal of health psychology, v. 15, n. 1, p. 107 114, jan./2010. Disponível em: https://doi.org/10.1177/1359105309346343. Acesso em: 29 abr. 2020.

SIQUEIRA, Mirlene Maria Matias; MARTINS, Maria do Carmo Fernandes; SOUZA, Warton da Silva. Capital psicológico no trabalho. In: SIQUEIRA, Mirlene Maria Matias (Org). Novas medidas do comportamento organizacional: ferramentas de diagnóstico e de gestão. Porto Alegre: Artmed, 2014.

SOARES, Adriana Benevides et al. Estudo comparativo de habilidades sociais e variáveis sociodemográficas de professores. Psicol. teor. prat., v. 11, n. 1, June, 2009. Disponível em: http://pepsic.bvsalud.org/scielo.php?script=sci_arttext\&pid=S151636872009000100004. Acesso em: 21 abr. 2020.

VALLE, Luiza Elena L. Estresse e distúrbios do sono no desempenho de professores: saúde mental no trabalho. 2011. Tese (Doutorado em Psicologia Social) - Instituto de Psicologia da Universidade de São Paulo, São Paulo, 2011.

Coordenadoria de Pesquisa e Extensão - COPEX

Departamento de Editoraçāo e Divulgaçāo Científica - DEDIC 


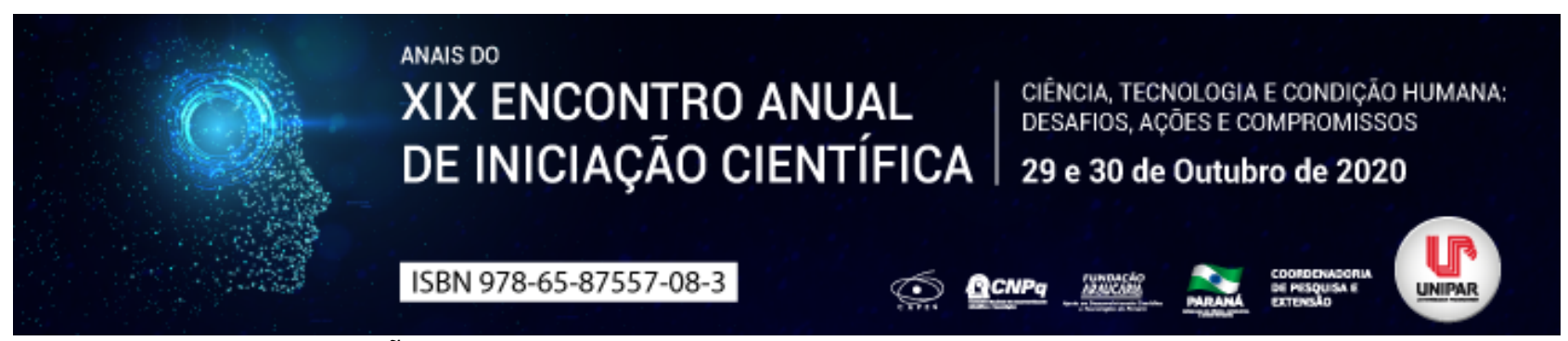

A DUPLA PENALIZAÇÃO DE TRAVESTIS E TRANSEXUAIS NO SISTEMA PRISIONAL BRASILEIRO

\author{
${ }^{1}$ FERNANDO SKREYPCZAK, ${ }^{2}$ FERNANDA GARCIA VELASQUEZ
}

\author{
${ }^{1}$ Acadêmico da UNIPAR \\ ${ }^{1}$ Docente da UNIPAR
}

Introdução: O Brasil, ao adotar um sistema prisional de caráter binário sexual, especialmente em se tratando de regime fechado, impossibilita que travestis ou transexuais cumpram sua pena com respeito aos princípios constitucionais que lhe são garantidos, havendo assim uma dupla penalização aos infratores.

Objetivo: Apresentar a dupla penalização de travestis e transexuais ocorrida no âmbito do sistema prisional brasileiro.

Desenvolvimento: Segundo dados da Transrespect Versus Transphobia, o Brasil ocupa o primeiro lugar na lista de países em que mais se matam travestis e transexuais, demonstrando as mazelas de um país preconceituoso e intolerante (TRANSRESPECT, 2014). O sistema prisional brasileiro não é diferente, especialmente no que tange ao regime fechado, visto que não há locais específicos para o cumprimento de pena dessa população, expondo os indivíduos aos mais diversos perigos e usurpações de direitos. Um relatório trazido pelo Ministério da Mulher, da Família e dos Direitos Humanos, demonstra que existem 618 (seiscentos e dezoito) travestis e transexuais encarceradas no Brasil, que somado à população LGBT (lésbicas, gays, bissexuais, transgêneros, transexuais e travestis) totalizam 4.751 (quatro mil setecentos e cinquenta e um) detentos. Além disso, apenas 17 (dezessete) Estados brasileiros possuem celas/alas destinadas à população LGBT, totalizando apenas 106 (cento e seis) espaços. (LGBT, 2020). A Constituição Federal garante ao indivíduo preso alguns direitos e garantias individuais, que não são observados no cumprimento da pena, tais como: a dignidade da pessoa humana (art. $1^{\circ}$, III); garantia da individualização da pena (art. 50, XLVI); o respeito à integridade física e moral do preso (art. 5०, XLIX); a proibição de discriminação (art. $\left.3^{\circ}, I V\right)$; intimidade, vida privada e honra (art. $5^{\circ}, X$ ); direito à saúde (arts. 196 e seguintes, especialmente 0 art. 199, § $4^{\circ}$ ) (LENZA, 2018). O único instrumento jurídico que instrui o impasse é uma Resolução Conjunta produzida pelo Conselho Nacional de Combate à Discriminação, Ministério da Justiça e Conselho Nacional de Política Criminal e Penitenciária CNPCP, de 15 de abril de 2014, que estabelece os parâmetros de acolhimento da população LGBT no sistema prisional do Brasil (RESOLUÇÃO CONJUNTA No 1, 2014). A não existência de leis específicas sobre o assunto traz controvérsias em sede jurisprudencial, como demonstra a decisão de uma magistrada da Vara de Execuções Penais do Distrito Federal, que julgou improcedente o pedido de 11 (onze) transexuais e travestis que buscavam a alocação em penitenciárias femininas. Segundo a magistrada, a Resolução acima citada não faz referência expressa a penitenciárias femininas, e sim determina que haja espaços específicos para os indivíduos, separados dos presos masculinos (BRASIL, 2018). Isso demonstra a falta de observância aos princípios constitucionais e tratados internacionais de direitos humanos. Nesse sentido, o Princípios de Yogyakarta, que trata da aplicação da legislação internacional de direitos humanos em relação à orientação sexual e identidade de gênero, ressalta que todos os seres humanos, independente de gênero ou qualquer outra característica, nascem livres e iguais em dignidade e direitos. Do mesmo modo, a orientação sexual e a identidade gênero são essenciais para a dignidade e humanidade de cada pessoa e não devem ser motivo de discriminação ou abuso (PRINCÍPIOS DE YOGYAKARTA, 2017). É público e notório que a grande maioria dos presídios brasileiros não possuem qualquer condição e estrutura para encarcerar um ser humano, possuindo celas imundas e superlotadas, sem qualquer salubridade. Esses locais, que estão em total desacordo com a lei, expõe os indivíduos apenados aos mais diversos perigos e violências ( $\mathrm{NUCCl}, 2014)$. As violações de direitos e garantias individuais contra travestis e transexuais são ainda maiores, expondo os indivíduos a perigos, humilhações, torturas, estupros, proibição de tratamento hormonal, entre outros, necessitando de uma urgente ação por parte dos poderes competentes (MITRE, 2019).

Conclusão: Ante o exposto, verifica-se que o sistema prisional brasileiro acaba por punir as travestis e transexuais por duas vezes, a primeira através da privação de liberdade e a segunda pela não observância aos direitos e garantias individuais e fundamentais do apenado.

\title{
Referências
}

BRASIL. Constituição da República federativa do Brasil de $1988 . \quad$ Disponível em: http://www.planalto.gov.br/ccivil_03/constituicao/constituicao.htm Acesso em: 20 jun. 2020.

BRASIL. Tribunal de Justiça do Distrito Federal e Territórios. Processo n. ${ }^{\circ}$ 0002253-17.2018.807.0015. Disponível em: https://www.tjdft.jus.br/institucional/imprensa/noticias/2018/maio/presas-transexuais-nao-devem-ser-alocadas-em-presidio-

feminino Acesso em: 20 jun. 2020.

CONSELHO NACIONAL DE COMBATE À DISCRIMINAÇÃO. Resolução Conjunta $\mathbf{n}^{\circ} \mathbf{1}$. Disponível em: http://depen.gov.br/DEPEN/depen/cnpcp/resolucoes/2014/ResoluoConjuntaCNCDeCNPCPLGBT.pdf Acesso em: 20 de jun. de 
LENZA, Pedro. Direito constitucional esquematizado. 22. ed. São Paulo: Saraiva Educação, 2018.

MITRE, Jaquelina Leite da Silva. Mulheres transexuais e a indiferença de gênero no sistema carcerário. Migalhas, 2019. Disponível em: https://www.migalhas.com.br/depeso/318114/mulheres-transexuais-e-a-indiferenca-de-genero-no-sistemacarcerario Acesso em: 20 jun. 2020.

$\mathrm{NUCCl}$, Guilherme de Souza. Manual de direito penal. 10. ed. Rio de Janeiro: Forense, 2014.

PRINCÍPIOS DE YOGYAKARTA. Princípios sobre a aplicação da legislação internacional de direitos humanos em relação à orientação sexual e identidade de gênero. Disponível em: http://www.clam.org.br/uploads/conteudo/principios_de_yogyakarta.pdf Acesso em: 20 jun. 2020.

TRANSRESPECT VERSUS TRANSPHOBIA. Trans Murder Monitoring results: TMM IDAHOT 2014 Update. Disponível em: https://transrespect.org/en/tvtproject/tmm-results/idahot-2014.htm Acesso em: 20 jun. 2020.

Coordenadoria de Pesquisa e Extensão - COPEX

Departamento de Editoraçāo e Divulgaçāo Científica - DEDIC 


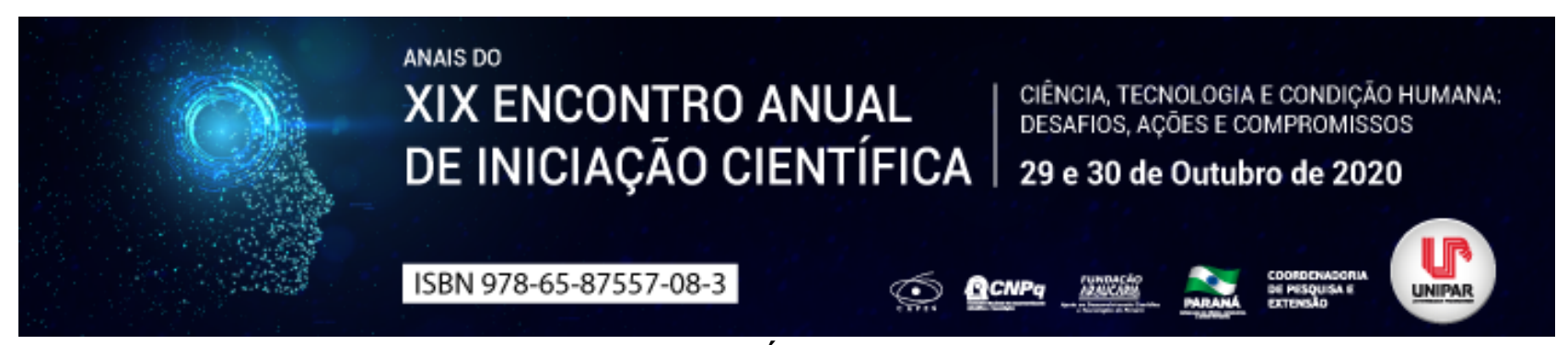

UM ESTUDO SOBRE O CONSUMO A PARTIR DA ANÁLISE DOS FIGURINOS DO VIDEOCLIPE VIDEOPHONE

\title{
${ }^{1}$ TAMARA RESENDE MERCADO, ${ }^{2}$ RODRIGO OLIVA
}

\author{
${ }^{1}$ Acadêmico bolsista do PIBIC/UNIPAR \\ ${ }^{1}$ Docente da UNIPAR
}

Introdução: Este estudo analisa os figurinos do videoclipe Video phone da cantora americana Beyoncé (com participação de Lady Gaga). Neste resumo, destaca-se, também, o comportamento do consumidor de moda, a partir das representações projetadas nas mídias, com foco na linguagem do videoclipe.

Objetivo: Discutir os figurinos do videoclipe Video phone da cantora Beyoncé, revelando a imagem e potência do consumo.

Desenvolvimento: Atualmente, os consumidores tornaram-se mais exigentes relativamente à qualidade de vida, à comunicação, à saúde, ao meio-ambiente e às questões sociais. Segundo Lipovetsky (2007, p. 36) l"queremos objetos para viver, mais do que objetos para exibir; compramos isto ou aquilo não tanto para ostentar, para evidenciar uma posição social, mas para ir ao encontro de satisfações emocionais e corporais, sensoriais e estéticas, relacionais e sanitárias, lúdicas e recreativas.l" Nota-se que o consumo vem se ampliando e tornando-se compulsivo em amplas as áreas, potencializado pelos meios de comunicação. A linguagem do videoclipe está inserida nos meios audiovisuais e os clipes são considerados produtos para atrair consumidores, ou seja, chamam a atenção de pessoas que gostam de seguir a moda, divulgada pelos seus artistas favoritos. Os criadores ou os artistas exibem suas riquezas e consumos, tanto na escolha dos figurinos, nas diversas trocas de looks, como no excesso de acessórios e adereços. O videoclipe pode ser considerado como estratégia de marketing, utilizado pelos cantores para a divulgação do seu trabalho. I"Sendo produto audiovisual contemporâneo, o videoclipe é parte de um processo histórico dinâmico, onde produtores e consumidores se encontram no meio e, também, de onde partem definições acerca dos usos do clipe. De forma que a existência do videoclipe pressupõe uma configuração estrutural e de uso, compreendendo uma lógica de produção, dentro de uma escala de circulação e de consumo.l" (SOARES, 2004, p. 59).'. Ao apreciar os figurinos pode-se observar que, tanto Beyoncé quanto Lady Gaga usam modelos de maiôs, que realça suas curvas, trazendo a ideia de feminilidade e sensualidade. Correlaciona-se perfeitamente na letra da música, onde ressalta-se questões ligadas ao desejo. As roupas de Beyoncé projetam segurança, personalidade forte, traduzidas em empoderamento. Em todas as cenas do videoclipe, ela parece ter certeza de que tem o total controle de tudo, fazendo até o uso de armas em algumas cenas: os figurinos complementam a narrativa do videoclipe e da canção que valoriza o empoderamento feminino. O videoclipe começa com Beyoncé e mais quatro homens, ela com um traje muito sexy, um maiô, um sobretudo, botas de salto fino e uma máscara, todas as peças na cor preta, os homens de terno, gravata e sapato pretos, e camisa branca. O fundo musical estilo faroeste, com uma mistura de pop. Ela parece conduzir os homens, parece ser chefe deles, e pelo seu andar, parece ter certeza de ter o total controle de tudo. Em seguida, ela aparece com um homem em uma tomada subjetiva, neste momento está vestida com um tipo de biquíni e uma máscara em sua mão, mas que, em alguns momentos ela usa em seu rosto, uma bota que vai acima do joelho, acompanhando o look, sempre com muitos acessórios. O que percebemos é que com o desenrolar da narrativa, a cantora estabelecerá em sua performance, uma série de tipos: egípcia, futurista com destaque para o uso de variados tipos de maiôs e biquinis. Quando vai chegando ao final do videoclipe as cenas vão variando, e aparece as duas cantoras em todos os looks usados no videoclipe, como se fosse uma reapresentação do guarda roupa que fora apresentado. No final, Beyoncé está sentada em uma moto, com a arma colorida na mão, um maiô laranja com um tecido super leve voando, e pra fechar o videoclipe, ela ainda na moto, mas com uma montagem com a cena dela no início. Vemos que a performance da cantora é acentuada pelo uso que se faz dos figurinos, estes acabam por auxiliar e potencializar o debate que está por trás: moda, consumo e empoderamento feminino.

Considerações finais: Atualmente, pessoas tendem a querer suprir necessidades psicológicas com coisas materiais, isso é o que acontece com pessoas compulsivas por compras. As mesmas sentem necessidade de adquirir um objeto, imaginando assim que aquela felicidade irá durar por muito tempo. Neste emaranhado em que vivemos, como parte da sociedade do espetáculo, o videoclipe potencializa o consumo, pois são apresentados por meio de imagens e sons, representações da moda dos mais variados estilos e os figurinos fazem parte desta produção. Como vimos no videoclipe Video Phone, os figurinos são usados para caracterizar as personagens por trás das divas do pop e seus valores introjetados a partir de estratégias de divulgação por meio de imagens e sons, que potencializam, debatem e promovem, ao mesmo tempo, o desejo do consumo.

\section{Referências}

BEYONCÉ - VIDEO phone (Extended Remix featuring Lady Gaga). Produção Beyoncé. Youtube, 2009. (5 min), son., color. Disponível em: https://www.youtube.com/watch?v=CGkvXp0vdng. Acesso em: 5 ago. 2020.

LIPOVETSKY, Gilles. A felicidade paradoxal. Ensaio sobre a sociedade de hiperconsumo. São Paulo: Companhia das Letras, 
2007.

SOARES

Thiago.

Videoclipe:

elogio

da

desarmonia.

Disponível

em: https://www.academia.edu/38557400/Videoclipe_O_elogio_da_desarmonia. Acesso em: 20 jul. 2020.

Coordenadoria de Pesquisa e Extensão - COPEX

Departamento de Editoraçāo e Divulgaçāo Científica - DEDIC 


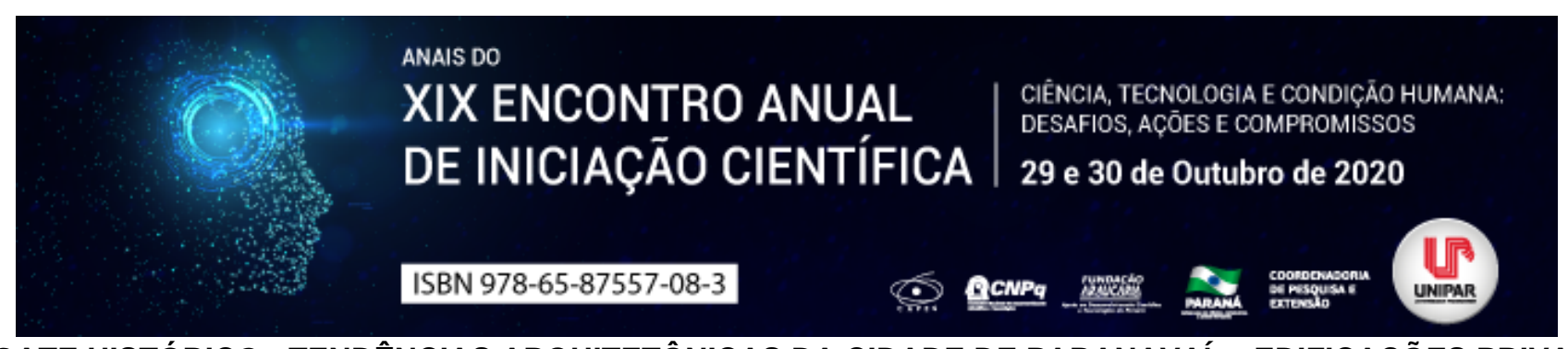

\title{
RESGATE HISTÓRICO - TENDÊNCIAS ARQUITETÔNICAS DA CIDADE DE PARANAVAÍ EDIFICAÇÕES PRIVADAS, PÚBLICAS E DE USO COMUM
}

\author{
${ }^{1}$ FABIO EDUARDO ALMEIDA SALDANHA MUNIZ, ${ }^{2}$ ELIANA RODRIGUES BARONE, ${ }^{3}$ HELOISA REGINA RODRIGUES \\ MENDES, ${ }^{4}$ IARA NACLE, ${ }^{5}$ MARIANA GIACOBBO, ${ }^{6}$ TATIANA QUEIROZ BARDI AUGUSTO
}

\begin{abstract}
${ }^{1}$ Acadêmico do PIC/UNIPAR
${ }^{1}$ Acadêmico do PIC/UNIPAR

${ }^{2}$ Acadêmico do PIC/UNIPAR

${ }^{3}$ Acadêmico do PIC/UNIPAR

${ }^{4}$ Acadêmico do PIC/UNIPAR

${ }^{5}$ Docente da UNIPAR
\end{abstract}

Introdução: Toda pesquisa denota esforço e um certo grau de aprofundamento no tema estudado. Em se tratar de um projeto em que engloba várias obras arquitetônicas existentes na cidade de Paranavaí, remete a um aprofundamento minucioso sobre as edificações como também ao embasamento que cada edificação oferta ao histórico da Cidade.

Objetivo: Levantamento e resgate de obras de uso privado, público ou de áreas de convívio comum que causam evocação à memória para os habitantes de Paranavaí, por meio de análise da repercussão e importância de cada edificação para o contexto urbano.

Material e Métodos: Analisar as correntes arquitetônicas de uma cidade se torna indispensável para a caracterização e valorização do patrimônio e suas correntes arquitetônicas. A princípio é necessário compreender os principais movimentos e estilos que surgiram como reações aos momentos em que a sociedade estava vivenciando (Daudén, 2020). No Brasil, até no século XIX durante o início da era industrial, a arquitetura possuía uma forte herança colonial portuguesa com técnicas construtivas rudimentares (REIS FILHO, 2014). Em 1922, houve a semana de arte moderna no Brasil, onde renegavam tudo que era do passado e assim o modernismo se afirmava no Brasil e com a construção de Brasília, se concretiza. Segawa diz que a repercussão internacional da arquitetura moderna brasileira representou uma legitimação e um reconhecimento social inédito começando apresentar progressão em seu modo de representação estético e ideológico, formando a escola de arquitetura carioca de Lucio Costa e Oscar Niemeyer e a paulista de Paulo Mendes da Rocha. BORGES et al. (2017, p. 04) explica as duas vertentes: A Escola Carioca possui características mais plásticas e maior uso de materiais, seguindo os cinco pontos corbusianos, enquanto a Paulista opta pela geometria pura e simplicidade, ideais de seus conceitos políticos . Paranavaí surge em meio da influência massiva do modernismo o que pode ser observado nas edificações, mas impactantes da Cidade.

Resultados: A definição das obras se deve a importância que são para os moradores local. Para a análise foram feias visitas ao local, uma investigação nos arquivos da Prefeitura Municipal e com os responsáveis pelas obras. As obras analisadas foram: Paço Municipal Antônio José Messias, Edifício Mônaco, Igreja São Sebastião, Residência Jardim Heriane, Escola Municipal Ayrton Senna da Silva- CAIC. A primeira estudada foi o Paço Municipal Antônio José Messias de Paranavaí, inaugurada em 1968. A técnica construtiva da obra é o concreto armado, a fachada principal evidencia as linhas horizontais e formas retangulares com pilares aparentes junto com as janelas rítmicas de vidro e outros elementos decorativos verticais em pedra. Estes elementos arquitetônicos caracterizam como estilo modernista, embora seja uma manifestação mais tardia dessa corrente. O Edifício Mônaco construído em 1987, uso misto, tendo comercio e kit nets. A platibanda possui detalhes que ajudam na harmonização e quebra da verticalidade. Janelas com linhas horizontais e um grande vidro fixo circular no volume superior central. Enquadra-se na corrente modernista principalmente pela sua forma retilínea, extenso uso de concreto armado, presença de brises verticais lineares na fachada. A Igreja São Sebastião foi inaugurada em 1965. Seu método construtivo foi de alvenaria e concreto armado com revestimento do piso em mármore brasileiro. Possui cobogós e vitrais responsáveis pelo toque religioso, a volumetria possui linhas retas e arcos definidos como beirais, elementos coerentes com o modernismo. A casa modernista de 1980, está localizada no Jardim Heriane possuindo planta livre, linhas retas, forma bem definida, grandes aberturas, sistema construtivo em concreto aparente e elementos em concreto inclinado contornando todo o terreno. Possui uma volumetria única com traços fortes da arquitetura moderna. Por fim, o Centro de Atenção Integral a Criança, de 1994. A utilização dos elementos pré-fabricados, modulação dos espaços, brises, concreto aparente e o uso de iluminação zenital por 'Sheds' evidenciam a forte influência do modernismo.

Discussão: Tendo em conta as emoções que a obra de arquitetura é capaz de provocar aos indivíduos, a arquitetura é concebida para comover, isto aparece quando a construção causa a expansão de um universo cujas leis padecemos, constatamos e contemplamos (CORBUSIER, 1994). O ambiente deve ser permanentemente inteligente, gerando lugares, 
elementos espaciais dos quais as proporções e limites sejam capazes de transformá-las, preparadas de comportar o modelo de relações das pessoas que vão utilizá-las.

Conclusão: Os aspectos relativos à cultura e à identidade de uma sociedade estão diretamente relacionados com a memória coletiva e a transmissão do conhecimento para as gerações futuras. Esta pesquisa ressalta a importância de uma edificação a sociedade em que está inserida. Assim, gerou-se uma produção teórica com intuito de servir de apoio científico para entusiastas do tema, a sociedade como um todo preservando a história e a cultura da Cidade.

\section{Referências}

BORGES, Bruna Carolina et al. Escola Carioca X Escola Paulista: Comparação Morfológica entre o Palácio Gustavo Capanema e o MASP Museu de Arte de São Paulo. Centro Universitário FAG, [S. I.], p. 1-5, 21 jun. 2017.

DAUDÉN, Julia. Características e diferenças de 12 estilos arquitetônicos. ArchDaily: Artigo, 14 de junho, 2020. Disponível em: https://www.archdaily.com.br/br/898742/caracteristicas-e-diferencas-de-12-estilos-arquitetonicos. Acesso em: 06 de julho, 2020.

REIS FILHO, Nestor Goulart. Quadro da Arquitetura no Brasil. São Paulo: Perspectiva, 2014.

Coordenadoria de Pesquisa e Extensão - COPEX

Departamento de Editoraçāo e Divulgaçāo Científica - DEDIC 


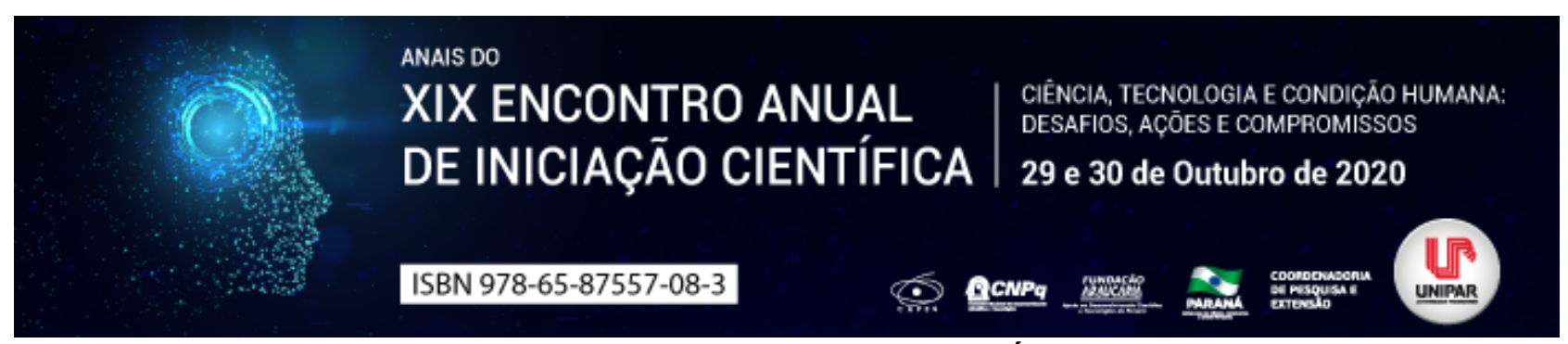

IMPROBIDADE ADMINISTRATIVA NO PROCESSO LICITATÓRIO E O DANO IN RE IPSA

\author{
${ }^{1}$ MAICON DE LARA LOPES, ${ }^{2}$ FABIO LUIZ SANTIN DE ALBUQUERQUE
}

$1_{\text {acadêmico Unipar }}$

${ }^{1}$ Docente da UNIPAR

Introdução: Os cenários econômico e político atuais têm tornado o tema corrupção um assunto de destaque, seja pela veiculação massiva nas diferentes mídias, seja na própria pauta de estudos, plataformas e nos debates políticos e campanhas eletorais nas diferentes esferas políticas. Aliado a tudo isso, fatores ambientais vivenciados em nosso país nos fazem perceber a importância de processos licitatórios legais e que atendam aos interesses da sociedade. Nesse sentido, a da Lei $n^{\circ} 8.666$, de 21 de junho de 1993 estabelece os crimes praticados por aqueles que tentam burlar os certames licitatórios. O estudo, porém, se propõe a analisar o que está fora desse rol, temática de grande divergência doutrinária e jurisprudencial. Essa análise ganha força com as frequentes dispensas de licitação realizadas para suprir as demandas envolvendo a Pandemia do Novo Coronavirus (Covid-19). Os estudos relacionados à improbidade se referem ao que pode ser comprovado com dano ao Erário, enquanto o presente estudo foca no dano presumido.

Objetivo: Verificar as condenações por improbidade administrativas nos processos de licitação nos casos em que há presunção de dano, sob a luz da legislação, doutrina e jurisprudência.

Desenvolvimento: Para adentrar no tema é necessário primeiro compreender o o que vem a ser a improbidade . A expressão vem do latim improbitate e quer dizer desonestidade. Ao cometer crime de improbidade o sujeito também viola o princípio da normalidade (FIGUEIREDO, 2009 apud ZANDONADI, 2017). Embora atual, a tipificação da improbidade é antiga. Há relatos desde o Direito Romano, por volta de 149 a.c. Nessa época os agentes públicos já respondiam pelas lesões causadas aos cofres públicos por desvio de tributos (OSORIO, 1998, apud FARIA, 2919). No entanto, segundo Fazzio (2007, apud Zandonadi, 2017), foi apenas em 1957 que o tema foi incluído no direito brasileiro. Para Faria (2019), porém, já na Constituição de 1934 havia a presença da improbidade no artigo 113, já que legitimava todo cidadão a pleitear a nulidade dos atos lesivos contra o patrimônio público. Ainda segundo o autor, o conceito que surgiu em 1934, foi foi ampliado em 1946 e culminou com a promulgação da Lei $\mathrm{n}^{\circ}$ 1.079, de 10 de abril de 1950, que trata dos crimes de responsabilidade. Décadas depois o então Presidente Fernando Collor de Melo encaminhou o Projeto de Lei $n^{\circ} 1.446 / 91$, que no ano seguinte deu origem à Lei no 8.492 , de 2 de junho de 1992 , a Lei de Improbidade Administrativa. Duarte Junior (2017, apud Pinheiro, 2019) argumenta que a lei se preocupa com a tipificação dos crimes de improbidade e suas sanções, mas não define o que vem a ser o ato improbo. Embora muitas sejam as definições, Silva (2015, apud Faria, 2019) o define como todo prejuízo que alguém sofre em seu patrimônio, sua pessoa ou seus direitos. Ao se aplicar esse conceito à Administração Pública, sobretudo nos processos licitatórios tem-se que, ao dispensar uma licitação indevidamente. O prejuízo decorrente da dispensa indevida de licitação é presumido (dano in re ipsa), consubstanciado na impossibilidade da contratação pela Administração da melhor proposta (STJ, AgRg no REsp 1.499.706/SP, Rel. Gurgel de Faria, $1^{\mathrm{a}}$ Turma, Dje de 14/03/2017).

Conclusão: Após realizar a revisão bibliográfica e jurisprudencial é possível compreender a importância da tipificação dos atos de improbidade administrativa, causados especificamente nos processos licitatórios, como no caso de indevida dispensa de licitação e na realização de licitações irregulares, cujo dano é presumido (in re ipsa), consoante entendimento consolidado do Superior Tribunal de Justiça.

\title{
Referências
}

FARIA, Gabriela de Lacerda. Improbidade administrativa por dispensa indevida de licitação a questão do dano in re ipsa e a possibilidade de comprovação de ausência de dano. 2019. 73 p. Trabalho de conclusão de curso universidade Federal de Santa Catarina, Florianópolis SC, 2019. Disponível em: Acesso em: 04 de maio de 2020.

PINHEIRO, Leonardo Ferreira. A (im)prescindibilidade do prejuízo efetivo ao erário para configuração de ato de improbidade administrativa por fraude ou dispensa indevida de licitação. 2019. 58f. Monografia (Graduação em Direito) Universidade Federal do Rio Grande do Norte, Centro de Ciências Sociais Aplicadas, Departamento de Direito, Natal, 2019. Disponível em: ttp://monografias.ufrn.br/handle/123456789/9998. Acesso em 04 de maio de 2020.

STJ, AgRg no REsp 1499706 / SP, AGRAVO REGIMENTAL NO RECURSO ESPECIAL 2014/0309323-3, Relator(a) Ministro GURGEL DE FARIA (1160), Órgão Julgador T1 - PRIMEIRA TURMA, Data do Julgamento 02/02/2017, Data da Publicação/Fonte DJe 14/03/2017. Disponível em: https://scon.stj.jus.br/SCON/jurisprudencia/toc.jsp? processo=1499706\&tipo_visualizacao=RESUMO\&b=ACOR\&thesaurus=JURIDICO\&p=true> Acesso em: 26 de agosto de 2020. RODRIGUES, Marcelle Gonçalves; FREITAS, Renato Alexandre da Silva. Improbidade administrativa dos agentes políticos 
em face da corrupção. 2019. 79 p. Trabalho de conclusão de curso - Centro universitário Toledo. Araçatuba SP, 2019. Disponível em:

ttp://www.unitoledo.br/repositorio/handle/7574/2347> Acesso em: 04 de maio de 2020.

ZANDONADI, Celita. Breves considerações em relação ao conceito de gestão pública, agente público, princípios administrativos, probidade e improbidade administrativa e análise doutrinária acerca da aplicação das penas. 2017.55 . Monografia - Universidade de Caxias do Sul, Caxias do Sul - RS, 2017. Disponível em: https://repositorio.ucs.br/11338/4048. Acesso em: 04 de maio de 2020.

Coordenadoria de Pesquisa e Extensão - COPEX

Departamento de Editoraçāo e Divulgaçāo Científica - DEDIC 


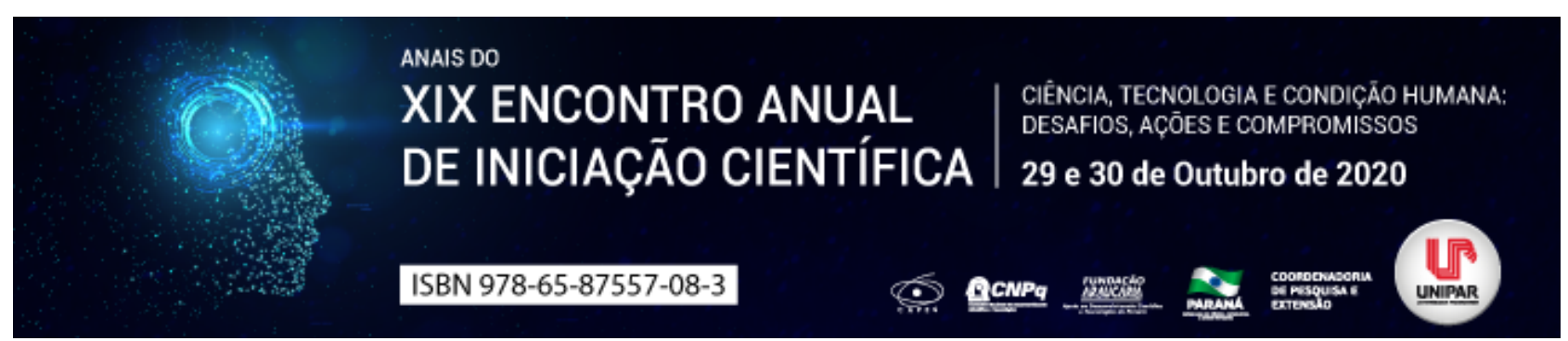

\title{
APONTAMENTOS SOBRE O TRÁFICO DE PESSOAS PARA REMOÇÃO DE ÓRGÃOS E A DIFICULDADE DE CONTROLE ESTATAL PARA FINS DE PREVENÇÃO
}

\author{
${ }^{1}$ MARCELO EDUARDO ALBERTON, ${ }^{2}$ ALEXANDRE MAGNO AUGUSTO MOREIRA
}

\author{
${ }^{1}$ Acadêmico do Curso de Direito da UNIPAR \\ ${ }^{1}$ Docente da UNIPAR
}

Introdução: O tráfico de pessoas vem evoluindo constantemente. Devido a essa constante evolução, surgiram várias modalidades desse delito, sendo que o tráfico para fins de remoção de órgãos e tecidos é uma das quais possuem mais destaque. Por se tratar de um crime que muitas vezes é invisível perante a sociedade, o caminho fica livre para que os aliciadores, pratiquem o comércio ilegal de órgãos. A presente pesquisa tem a finalidade de abordar as formas de prevenção adotadas pelo Brasil no combate ao referido crime, bem como buscar formas eficazes de combate. A presente pesquisa será realizada sob um método dedutivo, com pesquisa de cunho bibliográfico.

Objetivo: Analisar o crime de tráfico de pessoas para fins de remoção de órgãos e demonstrar as dificuldades enfrentadas pelo Estado para fins de prevenção ao crime.

Desenvolvimento: $O$ tráfico de órgãos pode ser compreendido como a prática ilegal de comercializar órgãos do corpo humano (SILVA, 2015, p. 06). Diversos fatores sociais influenciam para a prática do crime objeto dessa pesquisa, como a alta demanda pelos órgãos em comparação com a oferta, a condição social e financeira das vítimas, e a falta de informação (SILVA, 2015, p. 7,11). Contudo, os receptores geralmente são pessoas de classe alta, as quais tem condições financeiras e acabam recorrendo ao comércio ilegal para obtenção de um órgão necessitado por algum familiar, para não precisar submetê-lo ao procedimento de transplantação (ALENCAR, 2007, p. 42). Salienta-se ainda, que o crime de tráfico de órgãos, muitas vezes é cometido dentro de hospitais pelos próprios profissionais da saúde responsáveis, como foi o caso do menino Paulo Pavesi, o qual teve rins e córnea retirados enquanto ainda estava vivo, sendo que os médicos responsáveis realizaram a venda desses órgãos para lucrar (SILVA, 2015, p. 13). Desse modo, segundo Silva (2015, p. 04) essas pessoas se dispõem a matar para ver a vida de quem pode pagar. Ademais, é importante destacar que o tráfico de órgãos ofende o princípio da dignidade da pessoa humana, assegurado pela Constituição Federal, sendo que as vítimas têm lesionado seu direito a indisponibilidade do próprio corpo, e a prática oferece eminente risco à vida dos doadores, bem como dos receptores, pois muitas vezes esse procedimento é feito longe de um estabelecimento de saúde e sem profissionais da área. Logo, em razão do aumento do número de vítimas, tornou-se necessária a implantação de medidas de prevenção para o tráfico de órgãos. O Brasil, no ano de 2004 aderiu ao Protocolo de Palermo, o qual é o principal instrumento de prevenção e combate ao tráfico de pessoas na atualidade (BRASIL, 2004). Salienta-se que, em 2008 foi criada a Declaração de Istambul, que conceituou o crime de tráfico de órgãos com o intuito de proteger os grupos mais vulneráveis do comércio ilegal de órgãos e do turismo de transplante. Atualmente, o Brasil dispõem de alguns mecanismos de prevenção ao crime de tráfico de pessoas em todas as suas modalidades, dos quais destaca-se a Campanha Coração Azul, realizada em todo o país durante a $6^{a}$ Semana Nacional de Mobilização de Enfrentamento ao Tráfico de Pessoas, iniciada em 30 de julho - Dia Mundial e Nacional de Enfrentamento ao Tráfico de Pessoas, a qual visa coibir e combater os grupos criminosos (BRASIL, 2019). Ainda, em 2018 adveio o terceiro Plano Nacional de Enfrentamento ao Tráfico de Pessoas (PNETP), que reforça as ações de combate ao tráfico de pessoas, buscando a capacitação de profissionais e instituições, além de trazer diretrizes para a redução das ocorrências e dos impactos gerados pelo crime no país, e minimizar as situações de vulnerabilidade da população (BRASIL, 2019).

Conclusão: Ante o exposto, é possível concluir que atualmente a maneira mais eficaz de prevenir e combater o tráfico de órgãos é por meio de políticas públicas, programas de prevenção, campanhas sociais para informar a sociedade, bem como, é de suma importância o acompanhamento às vítimas, para que as mesmas possam se recuperar psicologicamente e retomar suas vidas. Conclui-se também que programas para combater a pobreza e o desemprego ocasionado pela desigualdade entre classes, seria de grande valia na prevenção a esse delito, sendo que várias pessoas decidem por vender um órgão próprio por insuficiência financeira.

\section{Referências}

ALENCAR, Emanuela Cardoso Onofre de. Tráfico de seres humanos no Brasil: aspectos sociojurídicos - caso do Ceará. 2007. Dissertação (Mestrado em Direito) Universidade de Fortaleza UNIFOR. Fortaleza, 2007. Disponível em: http://dominiopublico.mec.gov.br/download/texto/cp037035.PDF. Acesso em: 28 jun. 2020.

BRASIL. Constituição da República Federativa do Brasil: promulgada em 5 de outubro de 1988. Brasília, DF: Presidência da República. Disponível em: http://www.planalto.gov.br/ccivil_03/constituicao/constituicao.htm. Acesso em: 01 maio 2020. 
BRASIL. Decreto 5.017, de 12 de março de 2004. Promulga o Protocolo Adicional à Convenção das Nações Unidas contra o Crime Organizado Transnacional Relativo à Prevenção, Repressão e Punição do Tráfico de Pessoas, em Especial Mulheres e Crianças. Brasília, DF: Presidência da República. Disponível em: http://www.planalto.gov.br/ccivil_03/_Ato20042006/2004/Decreto/D5017.htm. Acesso em: 02 maio 2020.

BRASIL. Ministério da Justiça e Segurança Pública. 30 de julho: Dia Mundial e Nacional de Enfrentamento ao Tráfico de Pessoas. Ministério da Justiça, 2019. Disponível em: https://www.justica.gov.br/news/collective-nitf-content1564500407.99 Acesso em: 29 jun. 2020.

SILVA, Louise Menezes. Tráfico de órgãos: sob a ótica dos direitos humanos. 2015. Trabalho de conclusão de curso (Bacharelado em Direito) Universidade Tiradentes UNIT. Aracaju, $2015 . \quad$ Disponível em: https://openrit.grupotiradentes.com/xmlui/bitstream/handle/set/1501/FINAL.pdf?sequence=1 Acesso em: 01 maio 2020.

TURQUIA. Declaração de Istambul: sobre o tráfico de órgãos e turismo de transplantação. Istambul. Disponível em: http://www.declarationofistanbul.org/images/stories/translations/doi_portuguese.pdf. Acesso em: 02 maio 2020.

Coordenadoria de Pesquisa e Extensão - COPEX

Departamento de Editoraçāo e Divulgaçāo Científica - DEDIC 


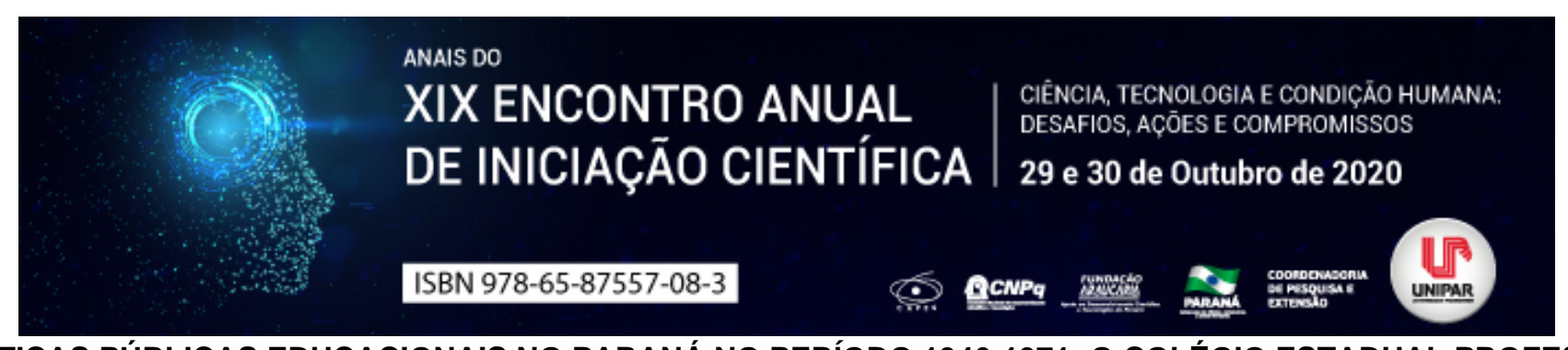

POLÍTICAS PÚBLICAS EDUCACIONAIS NO PARANÁ NO PERÍODO 1946-1971: O COLÉGIO ESTADUAL PROFESSOR CLETO

${ }^{1}$ Letícia Rodrigues de Oliveira, ${ }^{2}$ ALBONI MARISA DUDEQUE PIANOVSKI VIEIRA

${ }^{1}$ Acadêmico bolsista de iniciação científica voluntária da PUCPR.
${ }^{1}$ Orientadora e professora do curso de Pedagogia na Pontifícia Universidade Católica do Paraná, campus Curitiba. Doutora em
Educação

Introdução: O projeto de pesquisa Políticas públicas educacionais no Paraná no período 1946-1971: o Colégio Estadual Professor Cleto está vinculado ao projeto de pesquisa Políticas educacionais, formação de professores e educação escolar da linha de pesquisa História e Políticas da Educação do Programa de Pós-Graduação em Educação - Mestrado e Doutorado, da Pontifícia Universidade Católica do Paraná. O estudo deu sequência às análises realizadas no âmbito da formação de professores no Paraná, buscando compreendê-lo junto ao espaço de realização das políticas públicas de educação, bem como sua relação com a instrução primária que se realizava nos grupos escolares de Curitiba, no período de 1946 a 1971.

Objetivos: Essa pesquisa tem por objetivo geral identificar a relação das políticas públicas de educação com a formação dos professores e a instrução pública primária que se realizava nos grupos escolares de Curitiba, no período de 1946 a 1971 e, por objetivos específicos, identificar as influências das políticas nacionais sobre as políticas estaduais de educação no período estudado; identificar a relação das políticas nacionais e estaduais com a formação de professores no Paraná.

Material e Métodos: Para que a pesquisa fosse desenvolvida, no primeiro momento foi realizado um resgate histórico das políticas públicas educacionais no período 1946-1971. No segundo momento, foi realizada uma reflexão sobre a importância da formação continuada do professor como profissional no âmbito escolar. Além dessa compreensão, também requer trazer como se deu a implantação dos programas de formação de professores. Adotamos uma perspectiva metodológica bibliográfica, na qual destacamos os dados coletados de alguns autores como Vieira (2010, 2017), Saviani (2011), Tanuri (2000) e Nóvoa (1995), trazendo conceitos envolvidos no assunto. Para desenvolver a análise foram tomados como referência alguns estudos que tematizam as políticas públicas educacionais no Brasil e a formação continuada dos professores.

Resultados: Para melhor compreensão e discussão da educação como uma política pública, é necessário localizá-la dentro da esfera em que está posicionada, ou seja, do campo social, onde ocorrem as políticas sociais que com ela coexistem. Segundo Vieira (2017, p.190), é necessário inserir a educação no espaço próprio das políticas públicas, nas quais estão traduzidos os modos de articulação entre o Estado e a sociedade, neles considerados a divisão social do trabalho e as relações de produção Tendo em vista uma educação de qualidade para todos, as políticas públicas educacionais têm proporcionado muitas mudanças em relação à formação dos alunos, a terem como direito uma educação de qualidade e dos professores, tendo como direito de enriquecer sua profissão, buscando formar cidadãos capacitados e reflexivos, capazes de agirem diante de diferentes situações em que a sociedade apresenta. $O$ bom êxito da educação, ou das políticas educacionais, sempre esteve ligado ao trabalho do professor, tanto no período provincial como no período republicano. Assim sendo, durante a prática docente o professor também está em processo de aperfeiçoamento, podendo fazer uma articulação entre a teoria e a prática, refletindo sobre o que é ser professor.

Discussão: Entre os resultados encontrados, está a compreensão do que são as políticas públicas de educação e como elas se desenvolveram durante os anos de 1946 e 1971. Verificou-se como elas estavam posicionadas junto às políticas sociais, pois, ao que apontaram as pesquisas bibliográficas, elas partem das articulações que ocorrem entre o Estado e a sociedade, sendo formadas devido às condições de trabalho e às relações de produção das indústrias com seus funcionários. Ainda, as políticas educacionais podem ser I"um instrumento político-econômico que visa disciplinar, ideologizar, instrumentar e profissionalizar a futura força de trabalhol" (FREITAG apud HORA, 2003, p. 12). Portanto, pode-se perceber a importância de continuar a implementação de políticas públicas na formação continuada dos professores, podendo trazer uma contribuição para sua vida profissional e experiências pessoais, podendo torná-los mais reflexivos e autônomos para que tenham uma formação de qualidade.

Conclusão: Concluímos o artigo ressaltando que, ao longo do tempo, houve um processo de complexificação dos direcionamentos da política educacional no Brasil. Movimento entrelaçado ao aparecimento de novas dinâmicas, tais como a necessidade de continuar com implementações das políticas públicas, visto ser seu papel relevante na sociedade, na qual, a partir de suas regras, se está buscando melhorias para a educação.

\section{Referências}

HORA, D. L. Educação e gestão educacional na sociedade brasileira contemporânea: algumas reflexões. Revista Linhas, 2003. 
Disponível em: http://www.periodicos.udesc.br/index.php/linhas/article/view/1212/1026. Acesso em: 23 out. 2019.

NÓVOA, A. Formação de professores e profissão docente. In: NÓVOA, A. (Org.). Os professores e a sua formação. Lisboa: Dom Quixote, 1995, p. 15-33.

TANURI, L. M. História da formação de professores. Revista Brasileira de Educação, n. 14, 2000. Disponível em: http://www.scielo.br/pdf/rbedu/n14/n14a05. Acesso em: 15/06/2020.

VIEIRA, A. M. D. P. Educação em Curitiba: trinta anos de políticas públicas. 1. Ed. Curitiba: Appris, 2017.

VIEIRA, A. M. D. P. Caminhos e descaminhos na formação continuada de professores: as políticas públicas da Rede Municipal de Ensino de Curitiba (1963 a 1996), Tese (Doutorado em Educação), Programa de Pós-Graduação em Educação da Pontifícia Universidade Católica do Paraná, Curitiba, 2010.

SAVIANI, D. Educação e colonização: as ideias pedagógicas no Brasil. In: STEPHANOU, M. e BASTOS, M. H. (Org.) Histórias e memórias da educação no Brasil, vol. I: séculos XVI-XVIII. Petrópolis, RJ: Vozes, 2011. p. 121-130.

Coordenadoria de Pesquisa e Extensão - COPEX

Departamento de Editoraçāo e Divulgaçāo Científica - DEDIC 


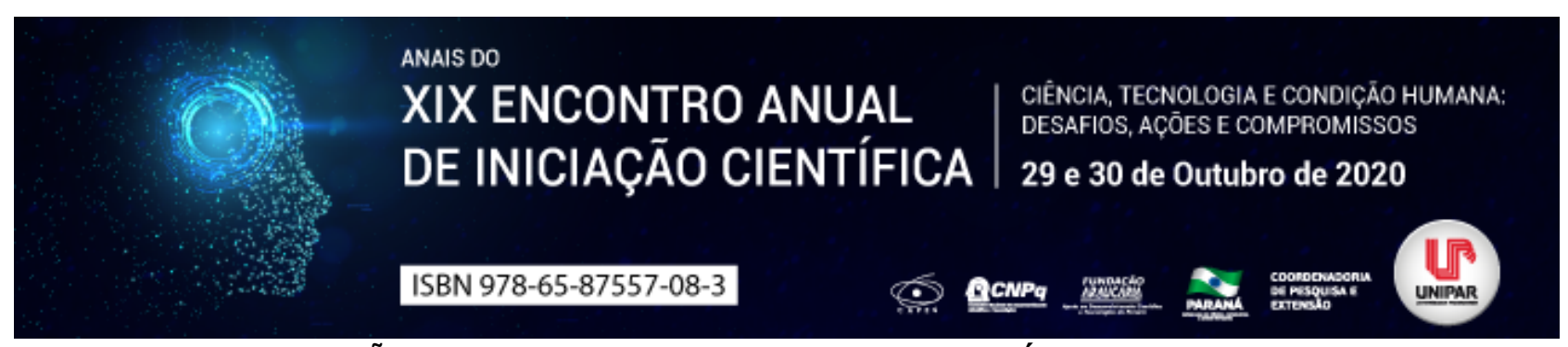

EVASÃO E ABANDONO ESCOLAR DO ENSINO MÉDIO NO BRASIL

\author{
1JESSICA PEREIRA BERTOLLI, ${ }^{2}$ NAYELLEN DAIANA PALIOTO GONCALVES, ${ }^{3}$ JANAINA DOS SANTOS DA SILVA, \\ ${ }^{4}$ VIVIANNE AUGUSTA PIRES
}

\author{
${ }^{1}$ Acadêmica do Curso de Pedagogia da UNIPAR \\ ${ }^{1}$ Acadêmica do Curso de Pedagogia da UNIPAR \\ ${ }^{2}$ Acadêmica do Curso de Pedagogia da UNIPAR \\ ${ }^{3}$ Docente da UNIPAR
}

Introdução: Um dos grandes desafios da educação escolar na atualidade no Brasil vem sendo a Evasão Escolar. Por mais que, atualmente, as oportunidades de ensino sejam maiores, uma grande parcela de estudantes abandonam o ensino médio por diversos fatores, como dificuldades no aprendizado, falta de significação do conteúdo com a realidade do discente e de flexibilidade no currículo, educação enfraquecida, preconceitos, assim como necessidade de trabalhar em período integral, entre outros.

Objetivo: Identificar os fatores que contribuem para a evasão e abandono escolar do Ensino Médio no Brasil e o que é possível fazer para tentar solucionar tal problema.

Desenvolvimento: A evasão e o abandono escolar acontecem por diversos fatores, que inclusive, ultrapassam os muros da escola, como: gravidez, o envolvimento com drogas em um período frágil como a juventude, necessidade de trabalhar em período integral, dificuldades no aprendizado, falta de significação do conteúdo com a realidade do discente, o bullying e a violência que afeta diretamente a dinâmica escolar e a vida emocional e social dos envolvidos, entre outros. Além disso ainda, existe a desmotivação da escola, não atrativa, autoritária, exigente, que tenta colocar o indivíduo em seus moldes, vedando sua liberdade de expressão, o que se torna um local pouco convidativo para esses jovens. Assim, subentendem que não há necessidade de se estudar, pois os conhecimentos aprendidos nela não terão validade ou função. (INSPER, 2018, p.39) A escola tem a função de educar os alunos para que sejam autônomos e capazes de analisar e criticar de forma reflexiva tudo que está a sua volta, conhecendo seus direitos e irem em busca de melhorias. A instituição escolar tem o papel de formar cidadãos aptos para convívio em sociedade, sendo assim, deve orientar seus discentes a pensarem o que é melhor para seu futuro e de seu país, fazendo assim, escolhas justas. Os jovens ainda estão em processo de desenvolvimento da autonomia e responsabilidade, é a fase do impulso , tão pouco pensam em consequências de seus atos de forma consciente, no entanto, a educação é fundamental nesse processo, pois, por meio de debates pode fornecer subsídios para a consciência desses jovens enquanto indivíduos atuantes em sociedade, para que tenham atitudes pontuais. Educação não é a modelagem de pessoas, porque não temos o direito de modelar a partir do seu exterior, também não é a mera transmissão de conhecimentos, mas a produção de uma consciência verdadeira, isto seria inclusive da maior importância política, formando pessoas emancipadas, conscientes e racionais (ADORNO, 1995, p. 141-142). A escola não deve culpabilizar somente o jovem por sua saída, ao contrário deve antes analisar seu papel em sociedade. Garantir um espaço acolhedor, enquanto segunda casa do jovem. Precisa observar cada aluno individualmente, não padronizando seus métodos e conteúdos, e também indo além de meros conteúdos. Pois, tem um papel fundamental em auxiliar suas atitudes e práticas, formar pessoas capazes de desempenhar um papel ressignificador em sociedade, mudando suas vidas e suas atitudes dentro e fora da escola. Formar jovens que questionem, se engajem, participem, debatam, tenham voz e sejam capazes de melhorar sua realidade social. A educação deve ser acolhedora e incentivar o protagonismo juvenil, fazendo com que este se sinta pertencente do espaço escolar, além de permitir uma formação rica e integral dos jovens que compõem e formam a sociedade. Pautado nesse pensamento, Freire (2004, p. 98), afirma que: A função da educação é auxiliar os homens na produção de sua própria realidade material e de sua consciência sobre ela. A formação para o trabalho, a qualificação para o mercado, embora seja uma função importante, não pode se constituir em única, nem mesmo em principal, função da educação: como experiência especificamente humana, a educação é uma forma de intervenção no mundo.

Conclusão: Desta forma o estabelecimento educacional precisa contar com profissionais preparados para lidarem com as diferenças e a diversidade de sua clientela de alunos. Deve ter consciência de sua função e do seu papel social para melhorar a vida dos estudantes. Trabalhando não apenas conteúdos meramente ciurriculares, mas levar a refletir sobre as atitudes e praticas dos jovens para que tomem consciência e tenham subsideos para agir em sociedade de forma justa.

\title{
Referências
}

ADORNO, Theodor Wiesengrund. Educação e emancipação. 3 ed. Rio de Janeiro: Paz e Terra,2003. 
FREIRE, Paulo. Pedagogia da autonomia: saberes necessários à prática educativa. 29 ed. São Paulo: Paz e Terra, 2004. (Coleção Leitura)

Relatório Políticas públicas para redução do abandono e evasão escolar de jovens. In: Instituto Ayrton Senna, Instituto Unibanco e Fundação BRAVA, 2018. Disponível em: https://www.insper.edu.br/wp-content/uploads/2018/09/Políticas-públicas-para-aredução-do-abandono-e-evasão-escolar-de-jovens.pdf. Acesso em: 12 ago. 2020.

Coordenadoria de Pesquisa e Extensão - COPEX

Departamento de Editoraçāo e Divulgaçāo Científica - DEDIC 


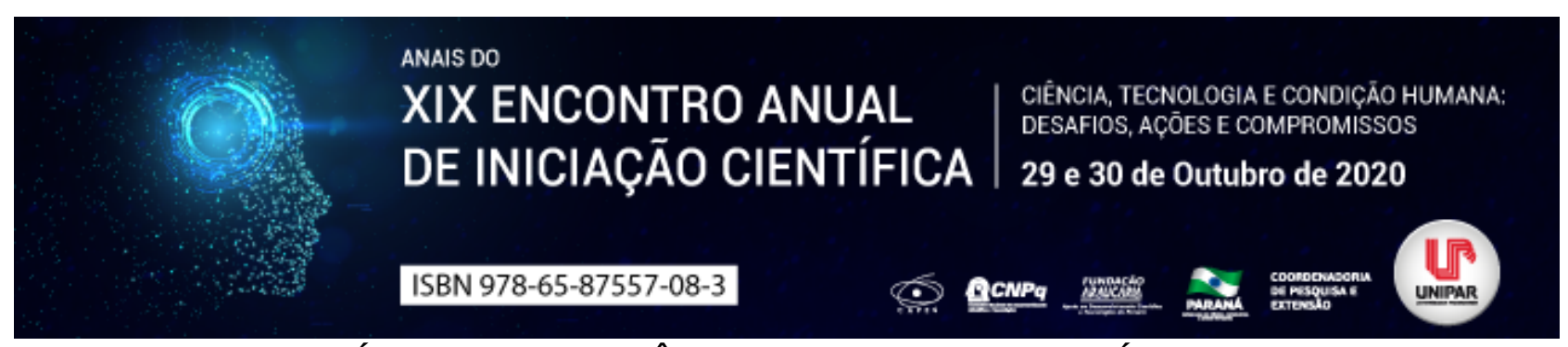

O PRINCÍPIO DA INSIGNIFICÂNCIA E SEUS IMPACTOS JURÍDICO-SOCIAIS

\title{
${ }^{1}$ DIEGO GODINHO BEBER, ${ }^{2}$ MAIARA DOS SANTOS NORONHA
}

\author{
${ }^{1}$ Acadêmico de Direito da Unipar \\ ${ }^{1}$ Docente da UNIPAR
}

Introdução: O princípio da insignificância é alvo de constantes debates no Brasil devido à recorrência com que são praticados crimes de baixa ofensividade no país. A reduzida lesividade desses crimes, levando-se em consideração o bem jurídico protegido, representa um fator que deve ser analisado com cautela quando diante da persecução criminal, inicialmente por parte da autoridade policial. Sua aplicação na fase pré-processual, pela autoridade policial, merece ser analisada, uma vez que repercute no contexto social e jurisdicional pátrio, especialmente no que diz respeito à redução de demandas judiciais e o desafogamento nos numerosos processos que envolvem crimes de menor teor ofensivo.

Objetivo: Abordar, de forma crítica, a possibilidade de aplicação do princípio da insignificância pela autoridade policial, enquanto ferramenta que contribui com o Judiciário brasileiro.

Desenvolvimento: $O$ princípio da insignificância compreende a ideia de que para uma conduta ser considerada criminosa, inicialmente são necessárias análises minuciosas acerca da adequação do fato ao tipo penal descrito em lei, bem como uma análise no tocante à lesão significativa a bens jurídicos relevantes da sociedade. A análise do princípio da insignificância requer se atentar à tipicidade material, que se trata da lesão ou perigo de lesão ao bem jurídico tutelado. Nesse sentido, Rogério Greco preleciona que o princípio da insignificância serve como instrumento de interpretação, a fim de que o exegeta leve a efeito uma correta ilação do tipo penal, dele retirando, de acordo com a visão minimalista, bens que, analisados no plano concreto, são considerados de importância inferior àquela exigida pelo tipo penal quando da sua proteção em abstrato (GRECO, 2010, p. 88). O Supremo Tribunal Federal tem adotado em suas decisões o princípio da insignificância desde que o caso concreto preencha alguns requisitos, quais sejam, a mínima ofensividade da conduta do agente, nenhuma periculosidade social da ação, o reduzido grau de reprovabilidade do comportamento e a inexpressividade da lesão jurídica provocada. E por essa razão, as Cortes Superiores vêm trancando Inquéritos Policiais, que foram instaurados sem justa causa, para apurar fato formal ou materialmente atípico, como exemplo, o Habeas Corpus 218.234, onde ocorreu um furto simples, de um cone de trânsito, em que foi considerado ínfimo o valor do bem, não sendo necessária assim mais movimentação do poder judiciário. Conforme entende Masson: o princípio da insignificância afasta a tipicidade do fato. Logo, se o fato é atípico para a autoridade judiciária, também apresenta igual natureza para a autoridade policial (MASSON, 2015, p.44). O art. $2^{\circ}$ da Lei 12.830 de 2013 deduz que a autoridade policial faz uma análise técnico-jurídica da infração penal, ou seja, expõe que o delegado não analisa apenas a tipicidade formal do caso (BRASIL, 2013). Ademais, conforme entendimento de Andreucci: embora o delegado de Polícia não possa arquivar autos de inquérito policial, poderá arquivar a notitia criminis se não houver justa causa para a instauração do inquérito (ANDREUCCI, 2011, p. 50). Assim, não havendo tipicidade o fato é atípico, não existindo fundadas razões para instauração do inquérito policial quem dirá de uma ação penal, como bem menciona Aury Lopes Júnior a função de evitar acusações infundadas é o principal fundamento da investigação preliminar (LOPES JÚNIOR, 2012, p. 297). A aplicação do Princípio da Insignificância pelo delegado de polícia traria inúmeros benefícios, já que haveria a garantia de direitos fundamentais, como exemplo, suprimiria o individuo de passar por diversas etapas de um processo, que mais tarde poderia considerar atípica a conduta. Ademais, de um ponto de vista de economia, eficiência e celeridade, teria uma redução de investigação de casos onde não houve violação de um bem jurídico relevante, e assim por consequência, as instituições policiais poderiam se focar em casos de maior grau de lesividade, respondendo o interesse público de maior segurança e resolução de crimes mais expressivos. Uma analise econômica também é possível, já que como entendimento do Ministro do Supremo Gilmar Mendes em Habeas Corpus 140201 MG, que não é razoável mover toda a máquina do Estado para se ocupar de casos de bagatela, levando em consideração não só os recursos das instituições policiais, mas também de todo o judiciário, que no final das contas seriam um desperdício já que o resultado seria a configuração da atipicidade da conduta.

Conclusão: Ante o exposto, verifica-se a importância da aplicação do princípio da insignificância pela autoridade policial, de modo desafogar o judiciário de ações penais cujo objeto é um fato materialmente atípico, que poderia ser resolvido fora do âmbito judicial, evitando gastos e tornando mais célere o meio judicial para situações onde o há uma lesão expressiva ao bem jurídico.

\section{Referências}

ANDREUCCl, Ricardo Antonio. Código de Processo Penal Anotado. São Paulo: Saraiva, 2011.

GRECO, Rogério. Direito Penal do Equilíbrio: uma visão minimalista do Direito Penal. 5. ed. Rio de Janeiro: Impetus, 2010. 
LOPES JÚNIOR, Aury. Direito Processual Penal. 9. ed. rev. e atual. São Paulo: Saraiva, 2012.

MASSON, Cleber. Direito penal esquematizado. 9. ed. rev., atual. e ampl. Rio de Janeiro: Forense, 2015.

NUCCl, Guilherme de Souza. Direito Penal Parte Geral. vol. 1. São Paulo: Editora Revista dos Tribunais, 2012.

STJ, HC: 218.234 SP 2011/0216878-6, Relator: Ministro Gilson Dipp, Data de Julgamento 13/03/2012 QUINTA TURMA, Data de Publicação: Dje 20/03/2012.

Coordenadoria de Pesquisa e Extensão - COPEX

Departamento de Editoração e Divulgaçāo Científica - DEDIC 


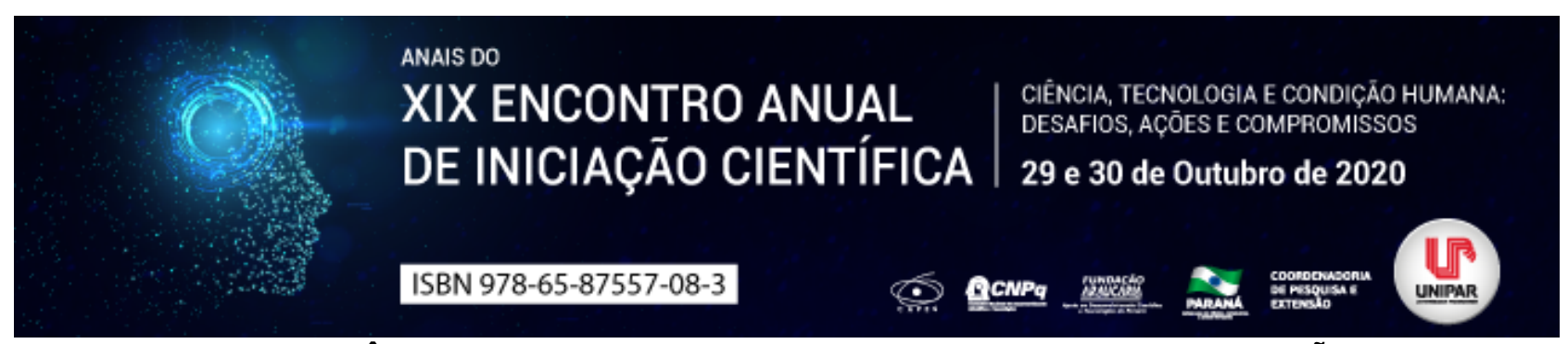

TRABALHO E DEFICIÊNCIA: UM OLHAR A PARTIR DA TEORIA DAS REPRESENTAÇÕES SOCIAIS

\author{
${ }^{1}$ Ana Luíza de Ávila Ribeiro Simões, ${ }^{2}$ REGIANE CRISTINA DE SOUZA FUKUI
}

\author{
${ }^{1}$ Graduanda em Psicologia e acadêmico do PIC n.6963/2019 / Universidade Estadual de Maringá (UEM) \\ ${ }^{1}$ Dra. em Psicologia (UEM) e Professora Adjunta do Departamento de Psicologia da UEM, Orientadora do PIC n.6963/2019
}

Introdução: O intuito desta revisão bibliográfica é fornecer dados para aprofundar nos temas de como a partir da teoria das Representações Sociais é possível entender às relações existentes entre a inclusão/exclusão de pessoas com deficiência (PCDs) no mundo do trabalho, entendendo que, no presente contexto, este exerce um papel central na vida, na identidade e personalidade das pessoas.

Objetivo: $O$ objetivo foi investigar a centralidade do trabalho atualmente e a relação que se estabelece com às pessoas com deficiência, na díade entre inclusão/exclusão, a partir da teoria das representações sociais. Em um primeiro momento apresentar o que é a Teoria RS, estabelecer a conexão entre às RS e o Trabalho, para então questionar a relação entre as pessoas com deficiência e sua respectiva inserção no mundo do trabalho.

Desenvolvimento: A teoria das representações sociais é apresentada pela primeira vez em 1961 por Moscovici, e segundo Jovchelovitch (2000), explicita a relação entre sociedade e indivíduo dialeticamente. O ser humano, como indivíduo, se faz e se constrói a partir dessa relação dialética com o que está externo a si, ou seja, com a vida pública, marcada pela alteridade. Essa relação dialética entre indivíduo-público, onde uma pessoa age sobre o espaço público, é que possibilita a existência das representações sociais, que na verdade são saberes sobre a própria comunidade desenvolvidos a partir da mesma, em um espaço público. Representações sociais estabelecem a mediação, na tentativa de transpassar a construção simbólica de uma sociedade a um nível quase material, concretizando às representações sociais na vida social. Esse processo pode ocorrer pela objetivação ou pela ancoragem, sendo o primeiro termo referente a passar um conceito do abstrato ao concreto, e o segundo referente ao processo de conectá-lo a um significado conhecido e familiar. Ao entender saberes produzidos sobre a sociedade como formas de representações sociais (RS), que são formas de conhecimento produzidas pela própria, é possível correlacionar como a construção do sentido do trabalho, a partir da Revolução Industrial, dos movimentos Fordista-Taylorista, e posteriormente o Toyotismo, refletem e repercutem na centralidade do trabalho na atualidade. Ou seja, permitem compreender o estudo do significado do trabalho, em dado contexto histórico-cultural, como o estudo das representações sociais do trabalho no mesmo período-local. Com essa consideração, entendemos a partir de Enriquez (1999) que o trabalho alcança um papel central da construção de nossas identidades, retomando a dialética entre indivíduo-social, e ainda, trazendo que a própria perda do trabalho seria responsável por uma desagregação da identidade/personalidade dos sujeitos, é possível questionar como se encontra a relação entre aqueles que são excluídos do mundo do trabalho, principalmente quando se fala de trabalhadores com deficiência. Em seu Art. $2^{\circ}$, a Lei 13.146/2015 afirma que a pessoa com deficiência é considerada aquela que possui impedimento de longo prazo de natureza física, mental, intelectual ou sensorial, o qual, em interação com um ou mais obstáculos, pode vir a obstruir sua plena e efetiva participação na sociedade em igualdade de condições com os demais. Historicamente, a deficiência vem sendo conceituada a partir dos modos de produção vigentes. Assim, observamos que a exclusão de pessoas com deficiências demonstra uma característica presente em todos os momentos da história, mesmo quando a proposta de inclusão permeia os discursos, não desprovidos de interesses, do mundo capitalista. Com a centralidade do trabalho, Enriquez (1999) entende que há uma mobilização nas pessoas, na qual os que não se encaixam nas relações de trabalho são excluídos socialmente. No Brasil (2020), existem leis que exigem a contratação e inclusão de -PCD nas empresas, contudo nota-se que essas leis afirmativas ainda são cumpridas apenas por obrigação, sendo raras as empresas que contratam -aqueles profissionais além do que é obrigado na lei.

Conclusão: Conclui-se, a partir do exposto, que compreender como se dão as tentativas de inclusão de um grupo de sujeitos historicamente excluídos, em um cenário específico como o do trabalho, é significativo para que possamos pensar nas construções de representações que vêm sendo estruturadas e vivenciadas por esses indivíduos. Assim, pensar naqueles que foram excluídos desse direito de trabalhar, muitas vezes pela inospitalidade do ambiente, por relações permeadas de preconceitos, por culpabilização do indivíduo por sua condição, ora pela não aceitação em um processo de recrutamento e seleção ou até dentre outros possíveis aspectos, é pensar nas representações de afetos vivenciados por essas pessoas e que temos a hipótese de que são os grandes construtores e transformadores das ações humanas em seus diversos contextos sociais, inclusive e principalmente o trabalho.

\title{
Referências
}

JOVCHELOVITCH, Sandra. Vivendo a vida com os outros:intersubjetividade, espaço público e Representações Sociais. In: 
GUARESCHI, Pedrinho; JOVCHELOVITCH, Sandra (Org.). Textos em representações sociais. Petrópolis: Editora Vozes, 2000. p. 63-88.

ENRIQUEZ, Eugène. Perda do trabalho, perda da identidade. Cadernos da Escola do legislativo, Belo Horizonte: Assembleia Legislativa do Estado de Minas Gerais, v. 5, n. 9, p. 53-73, jul./dez. 1999.

BRASIL. Lei $n^{\circ}$ 13.146, de 6 de julho de 2015. Institui a Lei Brasileira de Inclusão da Pessoa com Deficiência (Estatuto da Pessoa com Deficiência). Brasília, DF: Presidência da República.

Coordenadoria de Pesquisa e Extensão - COPEX

Departamento de Editoração e Divulgaçāo Científica - DEDIC 


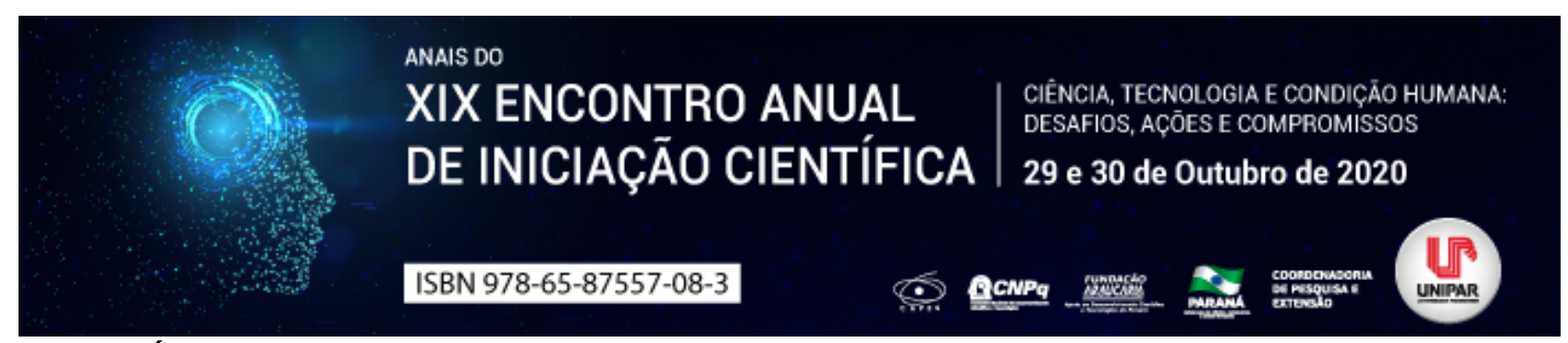

CARACTERÍSTICAS COMPORTAMENTAIS EMPREENDEDORAS DE MICROS E PEQUENAS EMPRESAS: UMA ESTRATIFICAÇÃO DE EMPRESAS LOCALIZADAS EM FRANCISCO BELTRÃO (PR)

\title{
${ }^{1}$ LARISSA ENDERLE, ${ }^{2}$ ANDRE LUIZ COMUNELO
}

\author{
${ }^{1}$ Acadêmico do PIC/UNIPAR \\ ${ }^{1}$ Docente da UNIPAR
}

Introdução: O presente estudo tem como objetivo analisar as características empreendedoras de micros e pequenas empresas situadas em Francisco Beltrão, Paraná. No atual cenário econômico, vivenciamos uma mortalidade de empresas, sendo que outras permeiam por anos de forma sólida. Nesse sentido, dúvidas emanam na sociedade para descobrir quais são esses fatores e/ou características que os empreendedores devem ter para dar continuidade aos seus negócios, tornando-se empreendedores bem-sucedidos. Assim, surgem as características comportamentais empreendedoras, estudadas por vários pesquisados, como McClelland (1972), Dornelas (2001), Hisrich e Peters (2009) entre outros. A partir da compilação entre os autores podemos identificar algumas características que serão objeto desse estudo, como a persistência, iniciativa e busca de oportunidades, rede de contatos e persuasão, planejamento e monitoramento sistemático e estabelecimento de metas e objetivos.

Relato de Caso: Em relação a pesquisa, até a 31 de julho de 2020, retornaram 20 questionários, sendo que o mesmo ficará disponível até 31 de outubro de 2020, nesse sentido, o presente estudo trata-se de uma estratificação da pesquisa, com as respostas que retornaram. Os respondentes são todos micros e pequenas empresas situados na cidade de Francisco Beltrão (PR) das mais variadas atividades econômicas. Em relação as devolutivas destacamos que $80 \%$ afirmam dedicar tempo para encontrar a solução do problema e continuam em sua tarefa mesmo diante de adversidades. Em relação a gostar de desafios, buscar novas oportunidades para seu negócio e ficar atualizado no seu ramo, $75 \%$ afirmaram que desenvolvem. Outro ponto importante destacado é que $60 \%$ dos respondentes gostam de pensar no longo prazo. Podemos citar ainda que $65 \%$ dos respondentes mantém contato com empresários do município e de outras cidades e tem um bom relacionamento com empresas do mesmo ramo. Por fim destacamos que apenas $20 \%$ dos respondentes, ao planejar um projeto grande, divide-o em tarefas mais simples.

Discussão: As características comportamentais empreendedoras estudadas foram a de persistência onde tem-se como objetivo identificar a maneira com que o empresário enfrenta os desafios das mais variadas formas e a mesma mostrou-se aderente os respondentes, pois, 16 empreendedores dedicam tempo para encontrar solução para os problemas e persistem em sua tarefa mesmo diante de obstáculos. A segunda característica estudada é a de iniciativa onde identifica-se a busca de novas oportunidades para seu negócio e ainda quando o empresário faz as coisas antes de ter sido solicitado expandindo os negócios para novas áreas de atuação, nesse sentido, 15 respondentes, afirmaram que aventuram-se a fazer coisas novas e diferentes das que já fizeram, sendo essa uma característica aderente. A terceira característica é a rede de contatos e persuasão e está associada a utilização do conhecimento de pessoas e/ou referências para atingir os próprios objetivos, nesse sentido 13 respondentes mantém contato com empresários de outros centros, sendo outra característica aderente. A quarta característica estudada é o estabelecimento de metas, a qual está associada a objetivos que são definidos no longo prazo, nesse sentido 12 respondentes sempre gostam de pensar no futuro, sendo essa outra característica aderente. A quinta e última característica estudada é o planejamento e monitoramento sistemático, sendo compreendido como a divisão de tarefas de grande porte em subtarefas com prazos definidos, sendo que apenas 04 empreendedores realizam o fracionamento de atividades em tarefas mais simples, sendo essa a única característica não aderente entre os respondentes.

Conclusão: O presente estudo demonstrou que das cinco características comportamentais empreendedora analisadas, quatro estão presentes entre os respondentes (persistência, iniciativa, rede de contatos e persuasão e estabelecimento de metas) e uma não está aderente na grande maioria (planejamento e monitoramento sistemático). A presente pesquisa demonstra que, a característica menos aderente entre os respondentes está relacionada com o planejamento e a resolução de problemas, condicionada ao conhecimento de ferramentas e técnicas de gestão, sendo assim isso nos remete a formação acadêmica dos empreendedores, onde apenas 5 dos 20 respondentes tem curso superior na área de gestão. Ainda, cabe ressaltar que, caso, uma características comportamental empreendedora não esteja presente no empresário ele poderá construir dentro do seu perfil, pois, não existe uma característica que seja mais importante dentro do crescimento e da longevidade das empresas, mas sim, o conjunto delas que fará com que as empresas tenham um crescimento sustentável. Por fim, a presente pesquisa trata-se de uma estratificação da amostra, contendo 20 questionários, o qual estará em aberto para receber as respostas até 31 de outubro de 2020.

\section{Referências}


Dornelas, J. C. A. Empreendedorismo: transformando idéias em negócios. Rio de Janeiro: Elsevier. 2001 Hisrich, R. D., Peters, M. P., \& Shepherd D. A. Empreendedorismo. Porto Alegre: Bookman. 2009

McClelland, D. C. A sociedade competitiva: realização e progresso social. Rio de Janeiro: Expressão e Cultura. 1972

Coordenadoria de Pesquisa e Extensão - COPEX

Departamento de Editoraçāo e Divulgaçāo Científica - DEDIC 


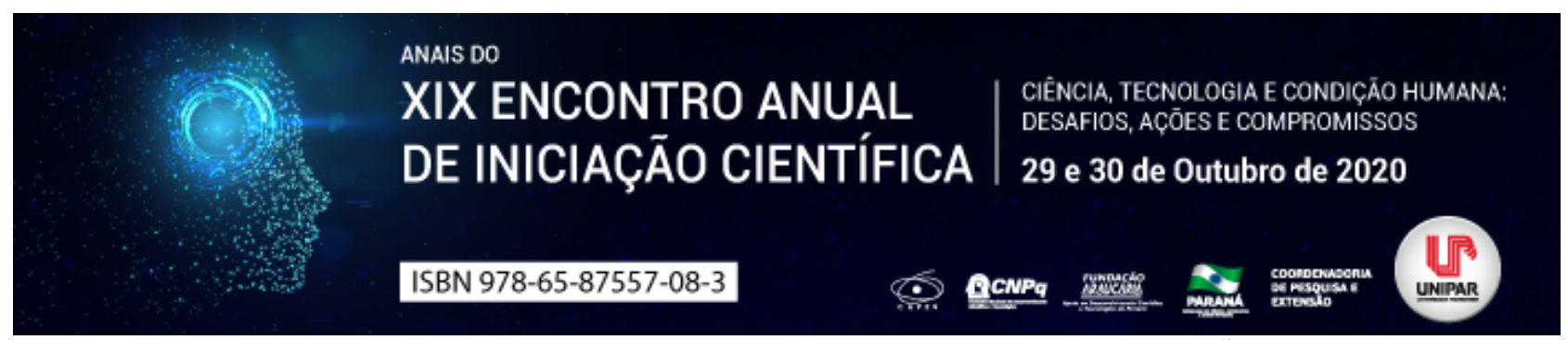

O PROCESSO E SEUS ESCOPOS COMO INSTRUMENTO DE CONCRETIZAÇÃO DOS DIREITOS

\author{
${ }^{1}$ JULIA CAROLINA FERREIRA, ${ }^{2}$ ALBINO GABRIEL TURBAY JUNIOR
}

\author{
${ }^{1}$ Acadêmico do PIC/UNIPAR \\ ${ }^{1}$ Docente da UNIPAR
}

Introdução: Na evolução da teoria, caminhando nas novas vias do processo moderno, o processo deixou de ser visto como um fim em si mesmo e passou a ser encarado como um instrumento de obtenção dos direitos, que se dá através da concretização dos escopos do processo.

Objetivo: Analisar a instrumentalidade do processo e seus escopos para o alcance da efetivação dos direitos.

Desenvolvimento: Conforme Dinamarco (2009, p. 177): é vaga, e pouco acrescenta ao conhecimento do processo a usual afirmação de que ele é um instrumento, enquanto não acompanhada da indicação dos objetivos a serem alcançados mediante seu emprego . Dessa forma, é necessário consolidar os escopos do processo, visto que isso equivale, ainda, a revelar o grau de sua utilidade (DINAMARCO, 2009, p. 177.). Percebe-se então, que existem três tipos de escopos, sendo eles: escopo social, escopo político e escopo jurídico. O primeiro, em um viés simples, tem como função pacificar com justiça e eliminar conflitos através de critérios justos. De acordo com Dinamarco (2009, p.189) viver em sociedade gera insatisfações, e é a partir do escopo social que o Estado atua, resolvendo esse descontentamento. O processo, age de forma com que ao final da lide, a parte vencedora tenha garantido seus direitos e que a parte vencida se sinta conformada, e não renitente. Sobre o escopo político, Câmara discorre que (2011, p. 89): podem ser considerados os mais relevantes, na medida em que a jurisdição é uma manifestação do poder do Estado, e tal poder tem, indubitavelmente, natureza política . Dessa forma, como finalidade deste, existem três: afirmar a característica imperativa do Estado de decidir, exercer culto ao valor da liberdade , em que o Estado delimita a liberdade dos cidadãos sem ferir a democracia, e por último, garantir que os cidadãos participem dos destinos da sociedade política. Por este escopo político, o intuito é que ao Estado cabe decidir e impor sua decisão, criando efeitos imediatos sobre a situação, e que, cada uma das partes aja de acordo com sentença. Por fim, o escopo jurídico, definido por Theodoro Junior (2000, p. 169): é o mais tradicionalmente reconhecido: é o de fazer atuar a vontade concreta da lei, mantendo íntegro e efetivo o ordenamento jurídico . Desse modo, é possível dizer que o escopo jurídico é a aplicação do direito ao caso concreto e se dedica ao desenvolvimento da técnica. É dessa forma que o conflito entre as partes se resolve, e é criada uma norma jurídica especial para a lide. É possível perceber a ideia de instrumentalidade do processo em dispositivos do Código de Processo Cilvil de 2015 (BRASIL, 2015), por exemplo, no $\S 3^{\circ}$ do artigo $3^{\circ}$ que trata do estímulo aos meios adequados de resolução de conflitos, sendo vinculado ao escopo social, em que as partes, como ocorre na mediação, participam diretamente da solução do conflito na busca da pacificação. Ainda, a instrumentalidade das formas está presente nos artigos 188 e 277 do Código de 2015 (BRASIL, 2015) demonstrando a finalidade da concretização do direito material.

Conclusão: Diante de todas as informações, fica claro que os escopos do processo influenciam durante todo o trâmite processual e quando atendidos de forma correta e eficaz, auxiliam, facilitam e fazem com que o processo ocorra de forma justa, cumprindo a finalidade de concretizar direitos, assim, dando a quem tenha um direito tudo aquilo que lhe pertence, atingindo-se a máxima efetividade do processo.

\title{
Referências
}

BRASIL. Lei.13.105 de 16 março de 2015. Código de Processo Civil. Diário Oficial da União, Seção 1, 17 mar. 2015 , p.1.

DINAMARCO, Cândido Rangel. A instrumentalidade do processo. 14. ed. São Paulo: Malheiros, 2009.

THEODORO JÚNIOR, Humberto. Jurisdição e competência. Revista Da Faculdade de Direito da UFMG, n. 38, p. 145-182, 2000.

CÂMARA, Alexandre Freitas. Lições de direito processual civil. 21. ed. Rio de Janeiro: Lumen Juris, 2011. 537 p. v. 1. 


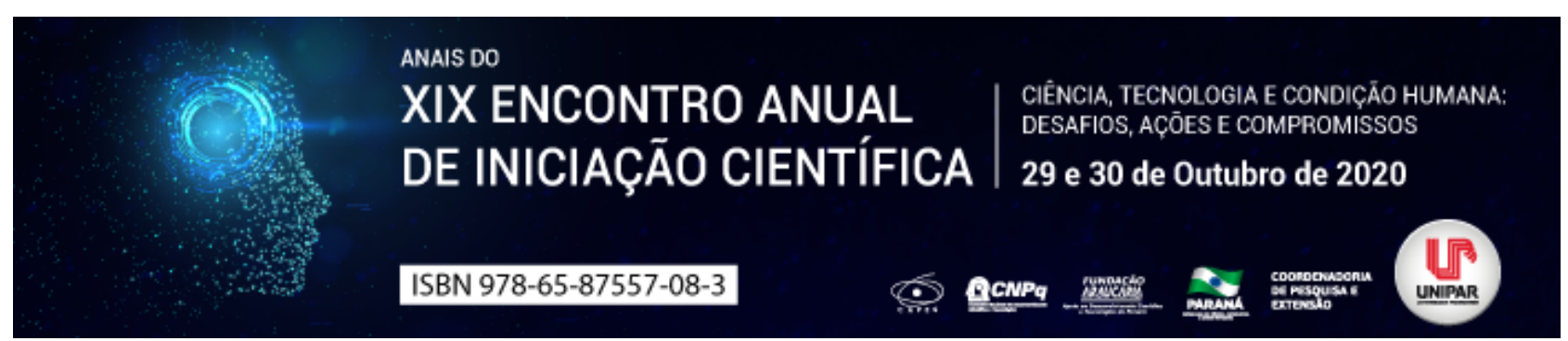

ABANDONO AFETIVO DO IDOSO E SEUS CONTORNOS JURÍDICOS

\section{${ }^{1}$ PEDRO HENRIQUE MARANGONI, ${ }^{2}$ LUIZ ROBERTO PRANDI}

${ }^{1}$ Mestrando em Direito Processual e Cidadania e Bolsista CAPES/UNIPAR

${ }^{1}$ Professor Titular e Pesquisador da UNIPAR

Introdução: O abandono afetivo do idoso é marcada por embates jurídicos, eis que o próprio Estatuto do Idoso não faz previsão expressa sobre a questão. Entretanto, a previsão jurídica quanto ao dever de relação afetiva entre o idoso e seus descendentes pode ser, ainda que de forma ampla, encontrada na Constituição Federal de 1988. Utiliza-se do método dedutivo mediante a análise de legislação e revisão bibliográfica.

Objetivos: Explorar os entornos acerca da responsabilidade civil, bem como, da obrigação de fazer dos descendentes frente à falta de cuidados para com os ascendentes idosos.

Desenvolvimento: $O$ Estatuto do Idoso, consagrado na Lei $n^{\circ} 10.741 / 2003$, segundo Cambi e Cossi $(2015$, p. 2) [...] surgiu para preencher lacuna no ordenamento jurídico brasileiro, pretendendo regular de forma clara, precisa e minuciosa os direitos dos idosos , os quais encontram amparo nos artigos 229 e 230 ambos da Constituição Federal de 1988. O artigo 229 dispõe que

[...] os filhos maiores têm o dever de ajudar e amparar os pais na velhice, carência ou enfermidade (BRASIL, 1988); por sua vez, o artigo 230 dispõe que a família tem o dever de amparar as pessoas idosas [...] defendendo sua dignidade e bem-estar e garantindo-Ihes o direito à vida (BRASIL, 1988). Apesar do Estatuto do Idoso não fazer menção expressa quanto ao direito à afetividade, observa-se que o texto do art. 229 da CF determina aos filhos o dever de amparar aos pais na velhice quanto à carência. De outro modo, direitos como a dignidade e bem-estar, dispostos pelo art. 230 da CF, também compreendem o direito à afetividade em suas adjacências. Logo, observa-se que atos dos familiares que transgridam o dever do texto constitucional configuram-se ato ilícito, conforme os arts. 186 e 187, ambos do Código Civil, sendo passíveis de reparação pelo art. 997 do mesmo Código, mas também de serem exigidos, na forma dos arts. 247 a 249, ambos do Código Civil, e 815 e 816, ambos do Código de Processo Civil. Quanto à responsabilidade civil, trata-se de dano moral presumido, não havendo necessidade probatória, mas tão somente comprovar a omissão do dever de cuidado. Para Cambi e Cossi (2015, p. 04): O dano relacionado ao abandono afetivo do idoso tem natureza moral (extrapatrimonial) e recai sobre a pessoa, atingindo o que ela é em sua profundidade. É um dano pessoal, insuscetível de reposição por ser financeiramente imensurável, pois a pecúnia não retira a dor [...] , razão pela qual a tutela referente à obrigação de fazer mostra-se mais plausível, eis que o idoso necessita de afetividade e não da ineficiente reparação cível do ato ilícito por meio de pecúnia.

Conclusão: $O$ dever da responsabilidade afetiva dos filhos para com os pais idosos encontra-se positivado pela Constituição Federal nos artigos 229 e 230, sendo passíveis de reparação judicial e de exigência para que se cumpra na forma de obrigação de fazer.

\section{Referências}

BRASIL. Constituição da República Federativa do Brasil de 1988 Disponível em: http://www.planalto.gov.br/ccivil_03/constituicao/constituicao.htm. Acesso em: 20 jul. 2020.

BRASIL. Lei $\mathrm{n}^{\circ}$ 10.406, de 10 de janeiro de 2002. Institui o Código Civil. Disponível em: http://www.planalto.gov.br/ccivil_03/leis/2002/l10406compilada.htm. Acesso em: 20 jul. 2020.

BRASIL. Lei $\mathbf{n}^{\circ} \mathbf{1 0 . 7 4 1}$, de $\mathbf{1}^{\circ}$ de outubro de 2003. Dispõe sobre o Estatuto do Idoso e dá outras providências. Disponível em: http://www.planalto.gov.br/ccivil_03/leis/2003/l10.741.htm. Acesso em: 20 jul. 2020.

CAMBI, Eduardo; COSSI, Nathália Pessini. Tutela do abandono afetivo do idoso. Revista dos Tribunais Online. Revista de Direito Privado, v. 56, p. 345-358, out./dez., 2013. 


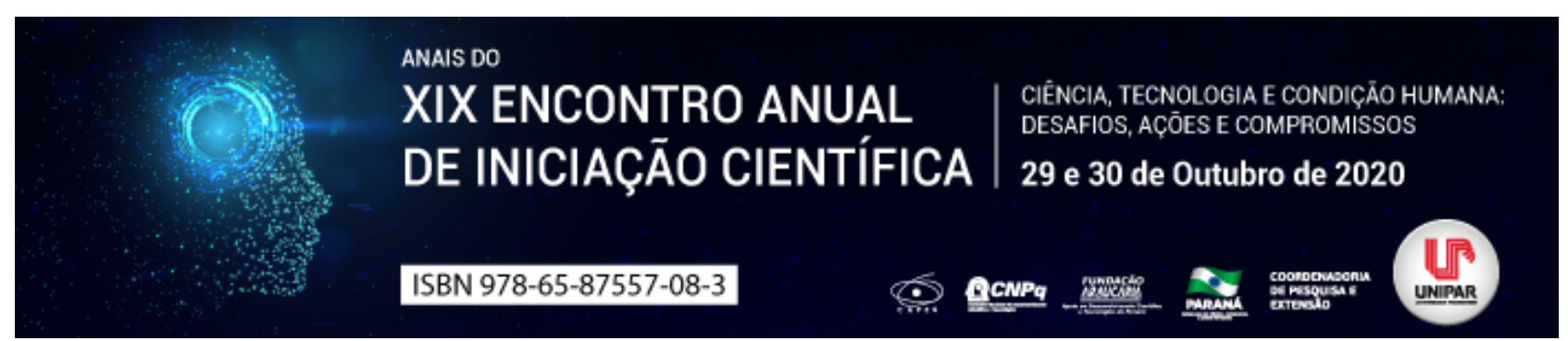

\title{
A LEGITIMIDADE AD CAUSAM DO MINISTÉRIO PÚBLICO PARA PROPOR AÇÃO DE TUTELA POR ABANDONO AFETIVO AO IDOSO
}

\author{
${ }^{1}$ PEDRO HENRIQUE MARANGONI, ${ }^{2}$ LUIZ ROBERTO PRANDI \\ ${ }^{1}$ Mestrando em Direito Processual e Cidadania e Bolsista CAPES/UNIPAR \\ ${ }^{1}$ Professor Titular e Pesquisador da UNIPAR
}

Introdução: Ainda que o idoso possua maturidade ou que sua idade não tenha afetado o exercício de seus direitos, tampouco a capacidade de exprimir sua vontade, quando seu direito fundamental relativo à afetividade for ameaçado ou violado, passará o idoso a situação de hipervulnerabilidade, momento em que o Ministério Público poderá atuar como seu substituto processual para requerer a tutela adequada quanto ao abandono afetivo.

Objetivos: Analisar a legitimidade do Ministério Público para requerer tutelas individuais relacionadas ao abandono afetivo do idoso.

Desenvolvimento: A legitimidade para propor a ação de danos morais por abandono afetivo, quanto para exigir a obrigação de fazer em relação aos direitos elencados nos arts. 229 e 230 da Constituição Federal, em regra, é do idoso titular do direito. Para tanto, caberia ao idoso, mesmo com a idade avançada, possuir maturidade, desde que não tenha afetado o exercício pessoal de seus direitos em razões de incapacidades previstas pelo art. $4^{\circ}$ do Código Civil, ingressar com a ação judicial. Nesse sentido, Cambi e Cossi (2015, p. 04) ressaltam que: Por vezes, a velhice aparece marcada pela senilidade, fraqueza mental que impede o discernimento, a autonomia da vontade, causando ao idoso, confusão mental, comprometendo o seu poder decisório. Nestes casos, caberá ao representante legal, curador ou ao Ministério Público , para, assim, agir em seu nome, defendendo seus interesses judicial e extrajudicialmente. Ocorre que, o art. 74, inciso III, em consonância com o art. 43, inciso II do Estatuto do Idoso, dispõem que compete ao Ministério Público atuar como substituto processual do idoso em situação de risco que decorre por falta, omissão ou abuso da família. Assim, observa-se que a idade avançada do idoso o torna vulnerável, mas não incapaz de requerer seus direitos perante a máquina judiciária. Ocorre que, quando há violação dos direitos do idoso previstos nos arts. 229 e 230 da Constituição Federal, este, passa a situação de hipervulnerabilidade, momento em que necessita de medidas de proteção, como a substituição processual pelo Ministério Público. Isso ocorre devido a sua família, aquela que deveria ajudar e amparar, possuir conflito de interesse da demanda, eis que serão os réus na ação judicial. Por conseguinte, considerar o idoso como capaz e não realizar qualquer intervenção ministerial, será uma clara violação ao acesso à justiça.

Conclusão: Portanto, em regra, para tutelar os atos da vida civil, somente as incapacidades previstas no art. $4^{\circ}$ do Código Civil exigirão a representação do idoso. Entretanto, quando envolver violação ao seu direito de afetividade, o Ministério Público poderá atuar como substituto processual.

\section{Referências}

BRASIL. Constituição da República Federativa do Brasil de 1988 Disponível em: http://www.planalto.gov.br/ccivil_03/constituicao/constituicao.htm. Acesso em: 20 jul. 2020.

BRASIL. Lei $\mathrm{n}^{\circ}$ 10.406, de 10 de janeiro de 2002. Institui o Código Civil. Disponível em: http://www.planalto.gov.br/ccivil_03/leis/2002/10406compilada.htm. Acesso em: 20 jul. 2020.

BRASIL. Lei $\mathbf{n}^{\circ} \mathbf{1 0 . 7 4 1}$, de $1^{\circ}$ de outubro de 2003. Dispõe sobre o Estatuto do Idoso e dá outras providências. Disponível em: http://www.planalto.gov.br/ccivil_03/leis/2003/l10.741.htm. Acesso em Acesso em: 20 jul. 2020.

CAMBI, Eduardo; COSSI, Nathália Pessini. Tutela do abandono afetivo do idoso. Revista dos Tribunais Online. Revista de Direito Privado, v. 56, p. 345-358, out./dez., 2013. 


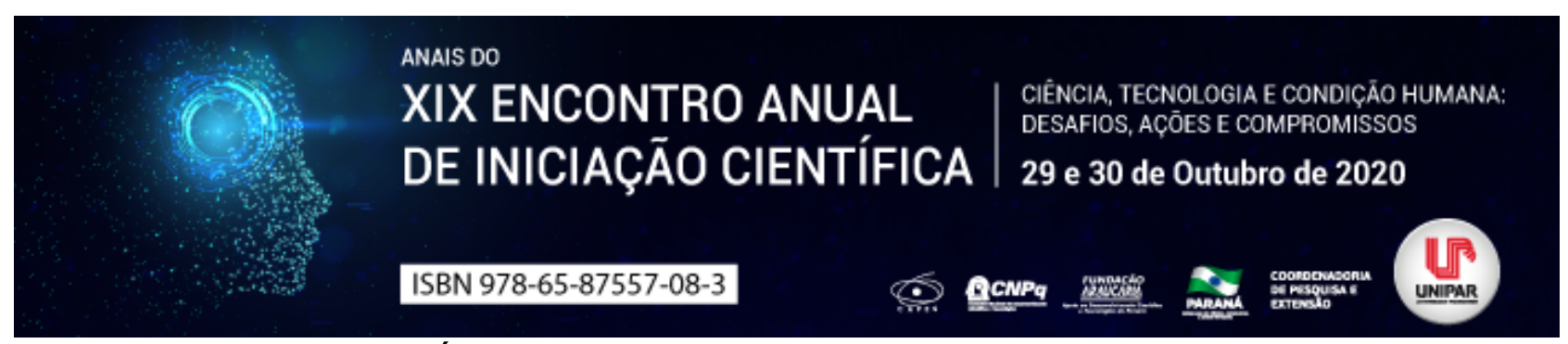

O TRÁFICO NACIONAL E INTERNACIONAL DE PESSOAS

\title{
${ }^{1}$ DARLANA LOPES BERNASKI, ${ }^{2}$ BRUNO SMOLAREK DIAS
}

\author{
${ }^{1}$ Acadêmica do Curso de Direito da UNIPAR \\ ${ }^{1}$ Docente da UNIPAR
}

Introdução: O Tráfico de pessoas é um dos crimes mais arcaicos, pois o ser humano possui um histórico de exploração de pessoas desde os primórdios da civilização. Esses indivíduos eram expostos a situações de risco a saúde contra vontade para fins de trabalho forçado, como exploração sexual, escravidão, entre outros.

Objetivo: Este trabalho tem como objetivo mostrar de que forma é o tráfico humano, como se deu início a exploração de pessoas, como acontece, quais os tipos de exploração existentes, como são as leis que visam combater o crime e qual a sua eficiência em relação ao crime.

Desenvolvimento: O Tráfico de pessoas não é um tema recente, melhor dizendo, é um tema muito falado desde o século XIX, em que o Tráfico Internacional de Pessoas era associado ao tráfico de escravas brancas (White Slave Trade), termo este que apareceu pela primeira vez em um texto no ano de 1839 (DOEZEMA ,2000). Desta forma, trazendo um entendimento do Tráfico como uma forma de escravidão. A expressão do tráfico de escravas brancas referia-se a histórias de mulheres europeias que seriam trazidas por redes internacionais de traficantes para os Estados Unidos da América e para as colônias para trabalhar como prostitutas. (DERKS, 2000). O Tráfico de pessoas é um crime sem fronteiras, correspondendo a um modelo de violação aos direitos humanos, que abrange países com uma economia mais baixa, fazendo com que as pessoas busquem melhores condições em outros lugares. Segundo a UNODC, a exploração de uma pessoa traficada pode gerar até 30 mil dólares por ano, isto é, só perde em questão de rentabilidade para o Tráfico de armas e drogas. (BRASIL, 2007, p.57). A Globalização é causa e cenário do Tráfico de pessoas. Segundo pesquisa feita pela OIT, a globalização contribui com o tráfico humano pelo fato de provocar uma desregulamentação no mercado de trabalho, por conta da competição global entre países, fazendo com que assim as pessoas se sujeitem a formas oriundas de trabalho em condições de escravidão. (OIT, 2005, p.75). A emigração irregular, ou seja, aquela que ocorre à margem dos procedimentos legais, propicia a ocorrência de crimes como o tráfico de migrantes e tráfico de pessoas, pois agrava a situação de vulnerabilidade dos emigrados com relação aos exploradores. (OIT, 2006). No que atine às rotas mundiais do tráfico de pessoas destaca-se o território da União Europeia, uma vez que sua criação é um dos fatores apontados para o crescimento da prática do comércio ilegal de pessoas, haja vista a abertura de suas fronteiras, permitindo a livre circulação dos traficantes em seu âmbito (NEVES, 2003, p. 37). De modo similar à situação brasileira, a definição de rotas é tarefa árdua ante a dinamicidade de sua estipulação. A Convenção da ONU contra o Crime Organizado Transnacional ou Convenção de Palermo nasceu de uma preocupação voltada ao combate do crime organizado, desse modo percebe-se que não contempla aspectos específicos da modalidade criminosa do tráfico de seres humanos, o que foi trabalhado em Protocolos adicionais (JESUS, 2003, p.38). Assim, a partir de um intenso debate acerca de uma das práticas mais desumanas da criminalidade organizada, criou-se o Protocolo para Prevenir, Suprimir e Punir o Tráfico de Pessoas, Especialmente Mulheres e Crianças, também conhecido como Protocolo de Palermo ou Protocolo Adicional à Convenção das Nações Unidas contra o Crime Organizado Transnacional (SAKAMOTO; PLASSAT, 2008, p.10). Segundo a redação da Convenção seu objetivo é a promoção da cooperação para uma maior eficácia na prevenção e combate do crime organizado. De maneira similar, os fins do Protocolo são a prevenção e combate do tráfico de pessoas, proteção das vítimas e a promoção da cooperação entre os Estados a fim de tornar efetivos esses objetivos (BRASIL, 2004). Na legislação brasileira percebe-se a preocupação com o tráfico de seres humanos desde o Código Penal Republicano de 1890, por meio do tipo do tráfico de mulheres (JESUS, 2003, p.76). Considerada um novo marco legal para o enfrentamento ao tráfico de pessoas, a Lei 13.344/2016 é resultado do projeto de lei 479/2012 apresentado pela CPI do tráfico de pessoas. A fim de adequar a legislação pátria ao Protocolo de Palermo, a nova lei, já em seu primeiro artigo, define que o enfrentamento ao tráfico de pessoas se dá em três eixos: prevenção, repressão e assistência às vítimas. Abandonando o viés moralista da norma penal referente ao tema que vigorou até a edição da nova lei. (MPF, 2017).

Conclusão: Diante do exposto, conclui-se que o Tráfico de pessoas atualmente ainda é um dos crimes mais blasfemos que existe, e que se dá por conta da desigualdade entre países, fazendo com que assim ao buscar condições melhores de vida, as pessoas acabam sendo enganadas quanto a seus trabalhos, e se tornando prisioneiras dos mesmos. A legislação em algumas situações se torna eficaz, mas ainda há muito o que ser trabalhado para evitar por completo este tipo de exploração

\section{Referências}

BRASIL. Decreto $n^{\circ}$ 5.017, de 12 de março de 2004. Promulga o Protocolo Adicional à Convenção das Nações Unidas contra o 
Crime Organizado Transnacional Relativo à Prevenção, Repressão e Punição do Tráfico de Pessoas, em Especial Mulheres e Crianças. Disponível em: http://www.planalto.gov.br/ccivil_03/_ato2004-2006/2004/decreto/d5017.htm. Acesso em: 09 set. 2020. BRASIL. Ministério da Justiça. Política Nacional de Enfrentamento ao Tráfico de Pessoas. Brasília: Ministério da Justiça, 2007. Disponível em: http://www.planalto.gov.br/ccivil_03/consulta_publica/trafico-pessoa.htm. Acesso em: 09 set. 2020.

DERKS, Annuska (2000), From White Slaves to Trafficking Survivors - Notes on the Trafficking Debate. Princeton University, Center for Migration and Development, Working Paper Series. Disponível em: https://childhub.org/en/system/tdf/library/attachments/derks_2000_from_white_slav.pdf?file=1\&type=node\&id=16245. Acesso em 11 Jun. 2020.

DOEZEMA, Jo. Loose Women or Lost Women?. International Studies Convention Washington, DC, February 16 - 20, 1999 Gender Issues, Vol. 18, no. 1, Winter 2000, pp. 23-50. Disponível em:https://walnet.org/csis/papers/doezema-loose.html. Acesso em: 11 jun. 2020.

JESUS, Damásio Evangelista de. Tráfico internacional de mulheres e crianças - Brasil: aspectos regionais e nacionais. São Paulo: Saraiva, 2003.

MPF. Tráfico de Pessoas. Coletânea de artigos, vol. 2, 2017. Disponível em: http://www.mpf.mp.br/atuacaotematica/ccr2/publicacoes/coletaneas-de artigos/003_17_coletanea_de_artigos_trafico_de_pessoas.pdf. Acesso em: 20 jun. 2020.

NEVES, João Ataíde das. Avançar no combate ao tráfico de seres humanos. Sub Judice. Justiça e sociedade, Coimbra, Fascículo 16, out/dez, 2003.

OIT. Aliança Global contra o trabalho forçado: Relatório Global do Seguimento da Declaração da OIT sobre Princípios e Direitos Fundamentais no Trabalho. Brasília: OIT, 2005.

OIT. Tráfico de pessoas para fins de exploração sexual, Brasília: OIT, 2006.

SAKAMOTO, Leonardo; PLASSAT, Xavier. Desafios para uma política de enfrentamento ao tráfico de seres humanos para o trabalho forçado. In: BRASIL. Secretaria Nacional de Justiça. Política nacional de enfrentamento ao tráfico de pessoas. Brasília: SNJ, 2 ed., 2008. 


\title{
a CIÊNCIA, TECNOLOGIA E CONDIÇĀO HUMANA: DESAFIOS, AÇŌES E COMPROMISSOS \\ 29 e 30 de Outubro de 2020 \\ ISBN 978-65-87557-08-3 \\ 6 을 (1). \\ QUANDO A VIDA MUDA: CARACTERIZAÇÃO DO ESTRESSE DE ESTUDANTES UNIVERSITÁRIOS DO ESTADO DO PARANÁ NO PERÍODO DE PANDEMIA DA COVID-19
}

\author{
${ }^{1}$ DAIANA SILVEIRA CONTE, ${ }^{2}$ GRACIANE BARBOZA DA SILVA, ${ }^{3}$ ISABELLA VALANDRO, ${ }^{4}$ THAIS CRISTINA GUTSTEIN \\ NAZAR
}

${ }^{1}$ Integrante do (PIC) e Bolsista do (PIBIC). Discente do curso de Psicologia, UNIPAR - Campus de Francisco Beltrão

${ }^{1}$ Docente da UNIPAR

${ }^{2}$ Acadêmico do Curso de Psicologia da UNIPAR

${ }^{3}$ Docente e orientadora PIC/PIBC da UNIPAR

Introdução: Atualmente, estamos vivendo em um contexto de pandemia, por conta da Covid-19. A partir disso, os universitários que estão buscando uma profissionalização, além de se deparar com a cobrança e a responsabilidade de definir sua futura profissão, em que envolve mudança de papéis, sonhos, idealizações, aliados as perdas que podem representar desde o contato com a família, amigos, relacionamentos afetivos, entre outros (PINHO, 2016, p.115), também estão tentando conciliar os estudos e as novas formas de conviver devido a pandemia, trazendo impactos na saúde mental. Assim, um desses impactos são as manifestações psicológicas e fisiológicas de estresse, resultando na diminuição do rendimento escolar, tensão, medo, cansaço, preocupações, dificuldades em relacionamentos interpessoais, entre outros (MOTA et al., 2016). Contudo, estudar o estresse em estudantes universitários é uma forma de prevenção de outras doenças e também colabora para uma melhor qualidade de vida pessoal e acadêmica, uma vez que as universidades poderão criar estratégias para melhorar os fatores de risco que ocasionam o estresse.

Objetivo: Esse trabalho visa fazer um levantamento de dados (via online) e a caracterização do nível de estresse dos universitários de instituições públicas e privadas do estado do Paraná no período de pandemia da Covid-19.

Material e Métodos: A presente pesquisa foi aprovada pelo Comitê de Ética em Pesquisa, parecer: 4.127.990 e n CAAE: 93703418.4.0000.0109 e todos os participantes assinaram o Termo de Consentimento Livre e Esclarecido (TCLE). Responderam o questionário 195 estudantes universitários, $82 \%(n=160)$ do gênero feminino e $18 \%(n=35)$ do masculino, entre a faixa etária $53 \%(n=102)$ estão entre 18 e 20 anos, 36\% $(n=70)$ entre 21 e 25 anos e os demais universitários estão acima de 25 anos. Desses 195 participantes, 55\% ( $n=108)$ estudam em 5 instituições públicas e 45\% (n=87) em 5 instituições privadas do estado do Paraná, totalizando 30 cursos de diversas áreas. Os instrumentos foram disponibilizados mediante formulário online através da plataforma Google Forms, contendo a identificação de dados Sociodemográficos e a Escala De Percepção De Estresse - EPS10, uma medida global de estresse que se propõe avaliar o grau em que um indivíduo aprecia as suas situações de vida como estressantes (REIS; HINO; RODRIGUES, 2010) e os estudantes universitários foram convidados a participar da pesquisa a partir de um link divulgado nos e-mails das secretarias de cada Curso/Universidade e nas redes sociais (Instagram, Facebook e WhatsApp). A análise dos dados deu-se por meio da criação de um banco de dados no Statistical Package for the Social Sciences (SPSS), utilizando-se de estatísticas descritivas (média e desvio padrão) e do teste de correlação de Pearson.

Resultados: Quando analisadas as estatísticas descritivas, identificou-se que a média do estresse nos estudantes universitários foi de 25,95 ( $\mathrm{dp}=6,81$ ), dados que quando comparados com a amostra normativa brasileira (média 16, 3, dp.= 0,6; e média 18, 3, $\mathrm{dp}=0,3$, podem ser considerados valores elevados, ou seja, indicativos de alta presença de sinais e sintomas de estresse. Foram também identificadas correlações negativas significativas entre as variáveis de estresse e faixa etária em nível de 0,01 ( $p=$ $-0,236)$ e correlações negativas significativas entre as variáveis de estresse e gênero em nível 0,05 ( $p=-0,147)$.

Discussão: Diante dos resultados, o estresse correlacionou com as variáveis preditoras (faixa etária e gênero). Quanto ao resultado de outras amostras, os estudos de Nazar e Silva (2020), com estudantes universitários, apontou que o gênero feminino é mais suscetível ao desenvolvimento de estresse com $58,4 \%$ da amostra total. Outro estudo em que o resultado está em conformidade é o de Lameu; Salazar e Souza (2016), em que a ocorrência de estresse foi significativamente maior no sexo feminino que no masculino (respectivamente $56,20 \%$ vs $38,80 \%$ ). Também, na revisão sistemática de Graner e Cerqueira, foi identificado que ser do sexo feminino e idade a partir de 18 anos são características associadas ao sofrimento psíquico em universitários, enfatizando que possivelmente as mulheres tenham maior facilidade de identificar e relatar sintomas, buscando ajuda ou apoio social (2019, p.1340).

Conclusão: A partir do levantamento de dados, foi possível identificar a presença de níveis elevados de sintomas de estresse nos universitários, podendo ser consequência do atual momento de pandemia, contudo, os resultados de estudos anteriores também foram compatíveis, salientando então, que o ambiente acadêmico é permeado de estressores. Desse modo, é considerável a importância das instituições de ensino na organização de estratégias e medidas de prevenção e promoção da 


\section{Referências}

GRANER, K. M.; CERQUEIRA, A. T. A. R de. Revisão integrativa: sofrimento psíquico em estudantes universitários e fatores associados. Ciênc. saúde coletiva, RJ, v. 24, n. 4, 2019, p. 1327-1346. Disponível em: http://www.scielo.br/scielo.php? script=sci_arttext\&pid=S1413-81232019000401327\&lng=en\&nrm=iso>. Acesso em: 18 Ago. 2020.

LAMEU, J. N. do.; SALAZAR, T. L.; SOUZA, W. F. de. Prevalência de sintomas de stress entre graduandos de uma universidade pública. Psicol. educ. 2016, n.42, p. 13-22. Disponível em: http://dx.doi.org/10.5935/2175-3520.20150021. Acesso em: 18 ago. 2020.

MOTA, N. I. F.; ALVES, E. R. P.; LEITE, G. O.; SOUSA, B. S. M. A.; FERREIRA-FILHA, M. O.; DIAS, M. D. Estresse entre graduandos de enfermagem de uma universidade pública. Rev. Eletrônica Saúde Mental Álcool Drog, 2016, 163-170. Disponível em: http://pepsic.bvsalud.org/pdf/smad/v12n3/pt_05.pdf. Acesso em: 29 jul. 2020.

NAZAR, T. C. G.; SILVA, G. B. da. Estresse em acadêmicos da área da saúde: um estudo de caracterização. In: GUILHERME, W. D. A educação como diálogo intercultural e sua relação com as políticas públicas 2. Ponta Grossa: Atena, 2020. p. 1-12. Disponível em: https://www.atenaeditora.com.br/post-artigo/31042. Acesso em: 18 ago. 2020.

PINHO, R.. Caracterização da clientela de um programa de atendimento psicológico a estudantes universitários. Psicología, Conocimiento y Sociedad. Vol. $6, \quad^{\circ}$. 1, 2016. Disponível em: https://revista.psico.edu.uy/index.php/revpsicologia/article/view/282. Acesso em: 27 jul. 2020.

REIS, R. R., HINO, A. A. F., \& RODRIGUES, C. R. (2010). Perceived Stress Scale: Reliability and validity study in Brazil. Journal of Health Psychology, 107-114. Disponível em: https://journals.sagepub.com/doi/abs/10.1177/1359105309346343. Acesso em: 28 jul. 2020. 


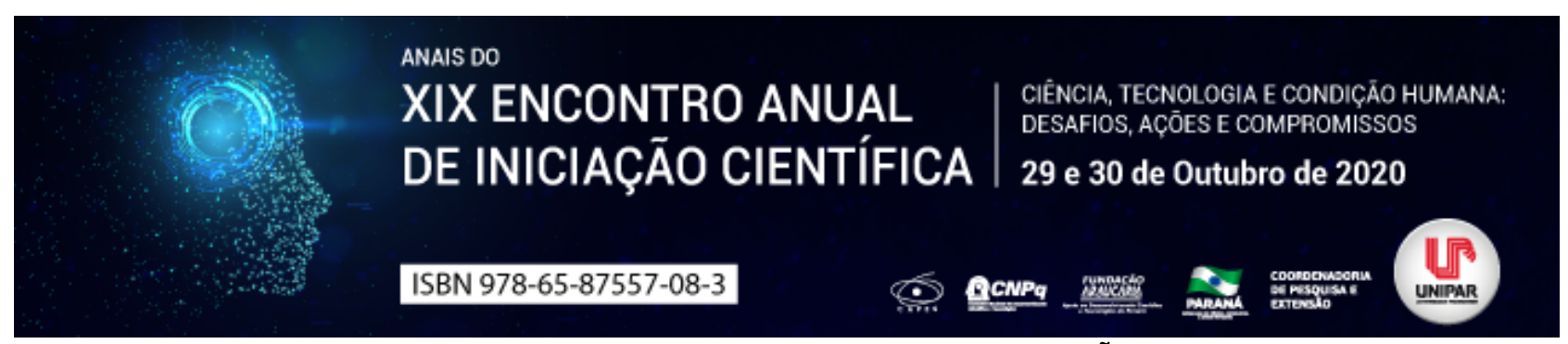

A (IN)VISIBILIDADE NO ENVELHECIMENTO DA POPULAÇÃO LGBTTQIA+

\title{
${ }^{1}$ LETICIA PEREIRA ALMEIDA DE JESUS, ${ }^{2}$ SOPHIA DIAS ARIEIRA, ${ }^{3}$ DANIELLE JARDIM BARRETO
}

\author{
${ }^{1}$ Acadêmica do Curso de Psicologia - PIBIC/UNIPAR \\ ${ }^{1}$ Acadêmica do Curso de Psicologia - PIC/UNIPAR \\ ${ }^{2}$ Docente da UNIPAR
}

Introdução: O presente trabalho tem como intuito problematizar as relações LGBTfóbicas na universidade, por meio da análise do curtas-metragem. Na presente pesquisa, abordaremos especificamente o curta metragem I"Cinco Minutosl" que conta a história de Alice e Adélia, um casal lésbico, que vive junto em um apartamento na cidade do Rio de Janeiro, onde criaram Stella, a filha do primeiro casamento de Adélia. Com a morte de Adélia, Stella e Alice têm que lidar com a dor e as lembranças da longa relação amorosa. Neste estudo, nos debruçamos na teoria sobre gênero e sexualidade de Butler (2018), para agenciarmos problematizações sobre as vivências de envelhecimento e relações afetivas entre mulheres que amam e desejam outras mulheres.

Objetivo: Problematizar através da análise teórica do curta-metragem I"Cinco Minutosl" (2008) sobre as concepções de envelhecimento e solidão nas relações afetivas de mulheres lésbicas.

Discussão: As construções históricas sobre gênero e sexualidade, tornam-se essenciais nesse primeiro momento para discutirmos logo adiante sobre a lesbianidade e envelhecimento. Como trás Butler (2018) o gênero não é ser, mas estar em movimento, sempre se (re)fazendo em suas possibilidades de performatividade, não sendo esta livre, pois é afirmada em um mundo que já está posto desde que nascemos dentro de uma matriz heterossexual. Dentro desse universo heteronormativo padronizado, ocupar o lugar da lesbianidade, em muitas situações, é estar a margem até nas lutas sociais onde a homossexualidade tem mais visibilidade, pois: I"Se for mesmo preciso dar lugar às sexualidades ilegítimas, que vão incomodar noutro lugar: que incomodem lá onde possam ser reescritas, senão nos circuitos da produção, pelo menos nos lucros.l" (FOUCAULT, 1988). Ou seja, a vivência lésbica só é aceita, quando ela segue estas normas e não se afasta do viriarcado. Só há a validação social da lesbianidade, quando os homens heterossexuais podem ter algum proveito dela, e o que distancia desse lugar machista é invisibilizado. Evidenciando que, a lésbica é colocada como indigna desde o seu surgimento pela visão heterossexista, torna-se ainda mais difícil para elas, sair dessa zona colocada pela referência machista, a qual prega que uma mulher se relacionar com alguém do mesmo gênero é considerado um erro, uma inexperiência sexual, ou até a falta dela, com um homem (TOLEDO \& TEIXEIRA, 2010). Pensando nesse viés, a população LGBTTQIA+, especificamente, as mulheres lésbicas em seu processo de envelhecimento, carregam o dupla estigma: a sua identificação de gênero + a velhice. Em função disso, existem alguns aspectos que contribuem para a (in)visibilidade da velhice dessa população, os quais influenciam diretamente no isolamento social, levando em conta fatores como a homofobia internalizada e também a violência estrutural (CRENITTE; MIGUEL e JACOB, 2018). Uma outra reflexão que é trazida pelos autores supracitados anteriormente, são quanto aos estigmas da velhice, onde precisamos considerar que na nossa realidade, a faixa etária da infância até a juventude são super valorizadas e categorizadas como o ápice da idade, com ideais de beleza, estereótipos de corpo e noção de produtividade em massa, havendo então uma desvalorização dessa fase da vida. Por consequência de todas essas afirmações em um lugar de invisibilidade da mulher lésbica que está envelhecendo, o sentimento de solidão é muito presente, tornando-se mais intenso, em função das práticas LGBTfóbicas (CRENITTE; MIGUEL E JACOB, 2018).

Conclusão: Por meio da pesquisa desempenhada, conclui-se que o processo de envelhecimento da população LGBTTQIA+, especificamente as lésbicas, precisa ser visibilizado. Buscando, então, (re)pensar em tais processos, rompendo com a lógica estereotípica, e dando lugar, vez e voz, aos corpos desejantes e pulsantes, como sujeitos de vivências válidas e de direitos.

\section{Referências}

BUTLER, J, P. Problemas de gênero: feminismo e subversão da identidade.. 1 ed. Rio de Janeiro: Civilização Brasileira, 2018;

CRENITTE, M. R. F.; MIGUEL, D. F. ; JACOB FILHO, W. Abordagem das particularidades da velhice de lésbicas, gays, bissexuais e transgêneros. GERIATRICS, GERONTOLOGY AND AGING, v. 13, p. 50-56, 2019.

FOUCAULT, M. História da Sexualidade I: A vontade de saber. Rio de Janeiro. 13 ed. Rio de Janeiro: Edição Graal, 1988;

TOLEDO, L. G.; TEIXEIRA FILHO, F. S. Na sexualidade, o homem é referência: lésbicas tiveram uma relação frustrada com homens e aguardam um homem que as satisfaçam?. In: COSTA, H. et al. (Org.). Retratos do Brasil Homossexual: fronteiras, subjetividades e desejos. São Paulo: Imprensa Oficial, 2010, v. 1, p. 921-930.

CINCO minutos. Direção: Ricky Mastro. Brasil, 2008 
Coordenadoria de Pesquisa e Extensão - COPEX

Departamento de Editoraçāo e Divulgaçāo Científica - DEDIC 


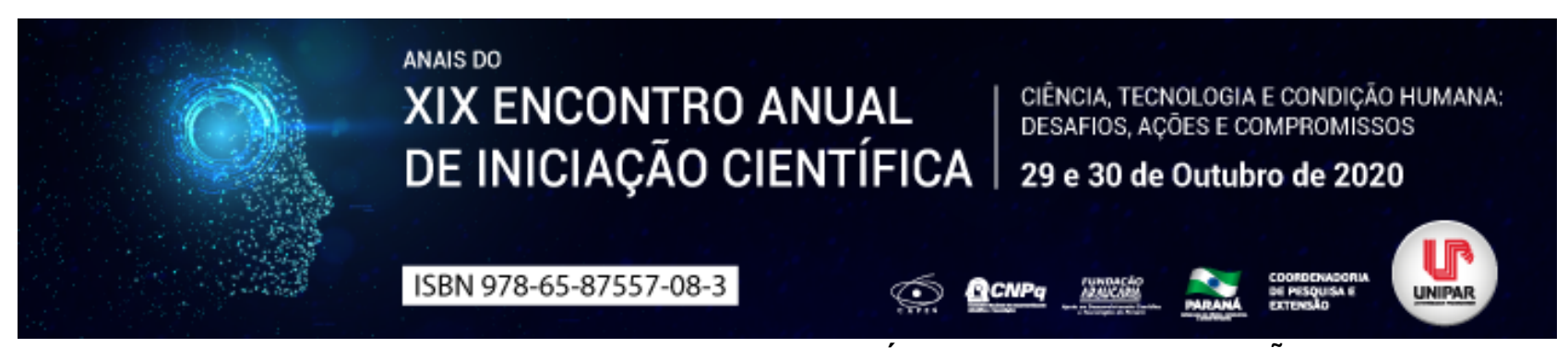

HIPERVULNERABILIDADE: IDOSO DUPLAMENTE VULNERÁVEL FRENTE AS RELAÇÕES DE CONSUMO

\title{
${ }^{1}$ FELIPE ESPOLADOR SCARPETA, ${ }^{2}$ LUIZ ROBERTO PRANDI
}

\author{
${ }^{1}$ Acadêmico do curso de Direito e bolsista do PIBIC/UNIPAR \\ ${ }^{1}$ Professor Titular e Pesquisador da UNIPAR
}

Introdução: A Constituição Federal de 1988 dentre os institutos jurídicos defende ferozmente os direitos das minorias, dentre elas o direito dos idosos e dos consumidores. Quando unido ambas as partes em uma única relação jurídica, configura-se a denominação de consumidor hipervulnerável, o qual faz jus a proteção do Poder Público.

Objetivo: Analisar a Lei $n^{\circ} 10.741 / 03$, Estatuto do Idoso, em conjunto com a Lei $n^{\circ}$ 8.078/90, norma consumerista, para determinar a exatidão da ocorrência da hipervulnerabilidade do idoso frente a relação de consumo.

Desenvolvimento: É notório que a Constituição Federal de 1988, em seu art. 230, caput defende que o Estado tem o dever de cuidar das pessoas idosas, defendendo sua dignidade e bem-estar (BRASIL, 2015, p. 65). Tornando explícito os ditames constitucionais por meio da Lei $n^{\circ}$ 10.741/03, o qual estabelece em seu art. 20 O idoso tem direito a educação, cultura, esporte, lazer, diversão, espetáculos, produtos e serviços que respeitem sua peculiaridade condição e idade (BRASIL, 2003), determinando que todo tratamento que envolva idosos, deverá conter maiores especificidades, visto que, a sua condição mais debilitada, exigindo uma conduta mais explicativa. Por isso, o Código de Defesa do Consumidor, no seu art. 39, inc. IV, prevê que é proibido ao fornecedor se aproveitar da ignorância ou fraqueza do consumidor, devido a sua idade avançada. Seguindo a vertente normativa, entende a doutrina majoritária que [...] o idoso é um consumidor duplamente vulnerável, necessitando de uma tutela diferenciada e reforçada (SCHMITT, 2011, p. 483). Dessa forma, é explícito o direito claro e certo dos idosos frente as relações de consumo, conferindo necessidade de os fornecedores agirem de forma diversa com essa parcela da população, protegida por forte amparo legal. Por fim, fundamenta o Superior Tribunal de Justiça no REsp n ${ }^{0} 586.316$ [...] vale dizer, não desconhece que há consumidores e consumidores, que existem aqueles que, no vocabulário da disciplina, são denominados hipervulneráveis, como as crianças, os idosos [...] (BRASIL, 2007), assim, qualquer conduta de fornecedores ou prestadores de serviços, ou seja, relações de consumo cumulada com o consumidor idoso, deve se atentar duplamente ao ditame normativo, dado o amparo conferido ao idoso pelo Poder Judiciário.

Conclusão: É possível afirmar que a CF/88 protege o consumidor, bem como o idoso. Ainda, quando o idoso, cometido de uma conduta jurídica que possui respaldo nas duas normas, esse poderá ser hipervulnerável frente ao fornecedor, pois também deverá ser analisado individualmente a relação jurídica e não presumível somente pela relação de consumo e idade.

\section{Referências}

BRASIL. Constituição (1988). Constituição da República Federativa do Brasil: promulgada em 8 de outubro de 1988. 48. ed. Brasília, DF: Senado, DF, 1988, 2015. p 65.

BRASIL. Lei $\mathbf{n}^{\circ}$ 8.078, de 11 de setembro de 1990. Dispõe sobre código de defesa do consumidor. Disponível em: http://www.planalto.gov.br/ccivil_03/leis//8078compilado.htm. Acesso em: 15 jun. 2020.

BRASIL. Lei $\mathbf{n}^{\circ}$ 10.741, de 01 de outubro de 2003. Dispõe sobre estatuto do idoso. Disponível em: http://www.planalto.gov.br/ccivil_03/leis/2003/l10.741.htm. Acesso em 15 de jun. 2020.

BRASIL. Superior Tribunal de Justiça. Recurso Especial no 586.316. Parte Litigante Ministério Público do Estado de Minas Gerais, Relator Herman Benjamin. DJ:10/04/2007. Disponível em: Ww2.stj.jus.br. Acesso em: 15 jun. 2020.

SCHIMITT, C. H. A hipervulnerabilidade do consumidor idoso. Doutrinas Essenciais Direito do Consumidor. 1. ed. vol. II. São Paulo: Revista dos Tribunais, 2011. p. 483. 


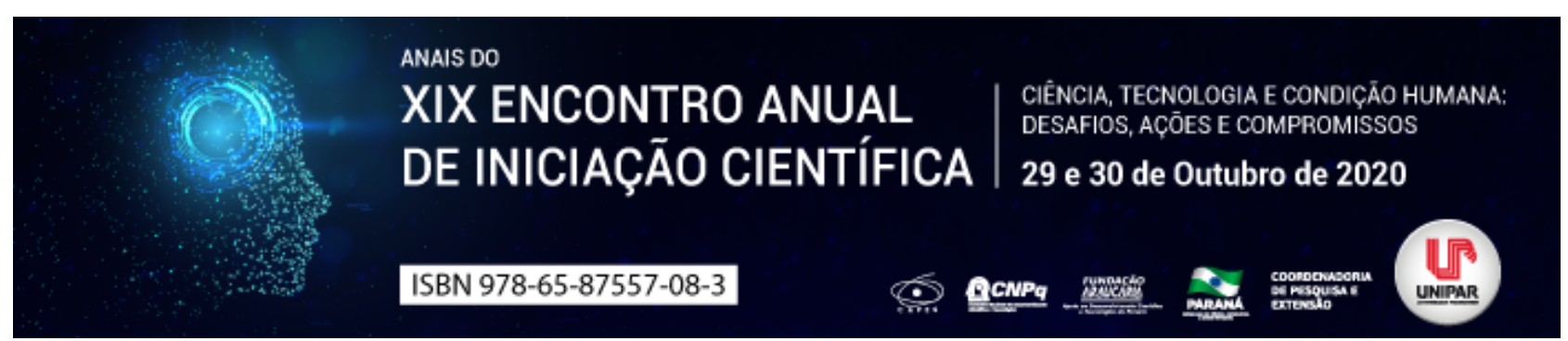

A NATUREZA JURÍDICA DA ESTABILIZAÇÃO DA TUTELA ANTECIPADA ANTECENDENTE

\title{
${ }^{1}$ AMANDA GONCALVES MESSIAS, ${ }^{2}$ FABIO FERREIRA BUENO
}

\author{
${ }^{1}$ Acadêmica do PIC/UNIPAR \\ ${ }^{1}$ Docente da UNIPAR
}

Introdução: Evidenciando a importância dos princípios processuais fundamentais, o novo Código de Processo Civil de 2015 trouxe a modificação de diversos institutos. A estabilização da tutela antecipada antecedente, prevista nos artigos 303 e 304 do NCPC/2015 foi alvo de revisão, apresentando, em seu novo formato, mais celeridade e efetividade diante dos desafios da tutela material.

Objetivo: Analisar a natureza jurídica do instituto processual da estabilização da tutela antecipada antecedente, observando, especialmente, os princípios da celeridade e da eficácia processual.

Desenvolvimento: A vertente temporal do Direito é agente motivador de diversas discussões, de nada vale alcançar um resultado justo no processo, se a justiça já não for mais capaz de atingir os efeitos materiais pretendidos, em razão do decurso do tempo. Frente a isso, baseado na verossimilhança da alegação e no fundado receio de dano ou risco ao resultado útil do processo por efeito do perigo da demora, o instituto da tutela antecipada requerida em caráter antecedente, previsto no artigo 303 do NCPC, se apresenta justamente com a finalidade de conferir maior efetividade ao processo e celeridade ao sistema. Esclarece Fredie Didier (2015, p. 567) A principal finalidade da tutela provisória é abrandar os males do tempo e garantir a efetividade da jurisdição (os efeitos da tutela). Serve, então, para redistribuir, em homenagem ao princípio da igualdade, o ônus do tempo do processo . À luz da disposição expressa no artigo 304 do novo Código de Processo Civil, a decisão que conferiu a tutela nos termos do 303, tornar-se-á estável se dela não houver interposição de recurso, e diante disso o processo será extinto. Sobre isso, o jurista Guilherme Marinoni diz que, por um lado, a regra que prevê a estabilização tem por objetivo afastar a necessidade de discussão, de uma questão que já não gera mais controvérsia, diante da falta de vontade do réu em dar prosseguimento ao feito e, por outro, outorga capacidade de gerar efeitos a uma decisão interna de uma demanda que resulta extinta sem resolução de mérito. Aqui, faz-se importante esclarecer que a tutela provisória é fundamentada em cognição sumária, ou seja, o juiz profere uma decisão pautada em um juízo de probabilidade, com um grau mínimo de certeza, pois não há oportunidade de exaurimento de todos os meios probatórios do feito. Elucida Didier (2015, p. 595) A probabilidade do direito a ser provisoriamente satisfeito/realizado ou acautelado é a plausibilidade de existência desse mesmo direito. [...] é preciso que se visualize, nessa narrativa, uma verdade provável sobre os fatos, independentemente da produção de prova . Ainda, esgotado o prazo decadencial de dois anos sem interposição de recurso sobre a decisão que conferiu a tutela, ocorre a formação da coisa julgada material. Apresentam-se na doutrina diversas discussões acerca da natureza jurídica do instituto da estabilidade da tutela antecipada antecedente, essencialmente quando refletida no precedente judicial da coisa julgada, da perempção ou até mesmo da preclusão. Nesta perspectiva, os processualistas Roberto Campos Gouveia Filho, Ravi Peixoto e Eduardo José da Fonseca Costa caracterizam o critério da imutabilidade das eficácias antecipadas, que traz como preceito uma estabilidade situada entre a coisa julgada material, e a preliminar estabilização da tutela, atuando no sentido de impedir a alteração da eficácia da tutela antecipada, sem, no entanto, impedir a rediscussão do direito material em ação própria. À vista de tais características, nota-se que os efeitos da estabilidade da tutela antecipada antecedente devem ser vistos a partir de um instituto singular, a ser compreendido e estudado mediante princípios e regras de natureza própria.

Conclusão: Diante do exposto, observa-se que o instituto da tutela antecipada antecedente traz nada mais que a permanência dos efeitos da decisão antecipada, enquanto não apresentado o pedido de reforma pelas partes, conforme estabelece os termos dos artigos 303 e 304 do NCPC/2015. Quanto a natureza da estabilidade, esta, ainda que suscitando de discussões doutrinárias, deve ter seus efeitos e recursos vistos a partir de um instituto sem precedentes no sistema jurídico brasileiro. Desta forma, conclui-se que o legislador se empenhou em, por meio da estabilização, conferir maior celeridade às demandas que carecem de urgência, sem deixar de contemplar a eficácia processual e a segurança jurídica medida em relação ao tempo.

\section{Referências}

DIDIER JR., Fredie, BRAGA, Paula Sarno, OLIVEIRA, Rafael Alexandre de. Curso de Direito Processual Civil. 10ª ed. São Paulo: JusPodivm, 2015.

MARINONI, Luiz Guilherme. Tutela provisória: tutela de urgência e tutela da evidência. $3^{a}$ ed. São Paulo: Editora Revista dos Tribunais, 2017.

THEODORO JÚNIOR, Humberto. Novo código de processo civil anotado. 20a ed. Rio de Janeiro: Forense, 2016.

BRASIL. Decreto-Lei n. 3.105, de 16 de março de 2015. Código de Processo Civil. Disponível em: 
http://www.planalto.gov.br/ccivil_03/_ato2015-2018/2015/lei/l13105.htm. Acesso em: 24 ago. 2020.

GOUVEIA FILHO, Roberto P. Campos; PEIXOTO, Ravi.; COSTA, Eduardo José da Fonseca. Estabilização, imutabilidade das eficácias antecipadas e eficácia da coisa julgada: uma versão aperfeiçoada. Revista Eletrônica de Direito Processual REDP, Rio de Janeiro, v. 17, n. 2. Julho a Dezembro de 2016. Disponível em: https://doi.org/10.12957/redp.2016.26611. Acesso em: 24 ago. 2020.

Coordenadoria de Pesquisa e Extensão - COPEX

Departamento de Editoraçāo e Divulgaçāo Científica - DEDIC 


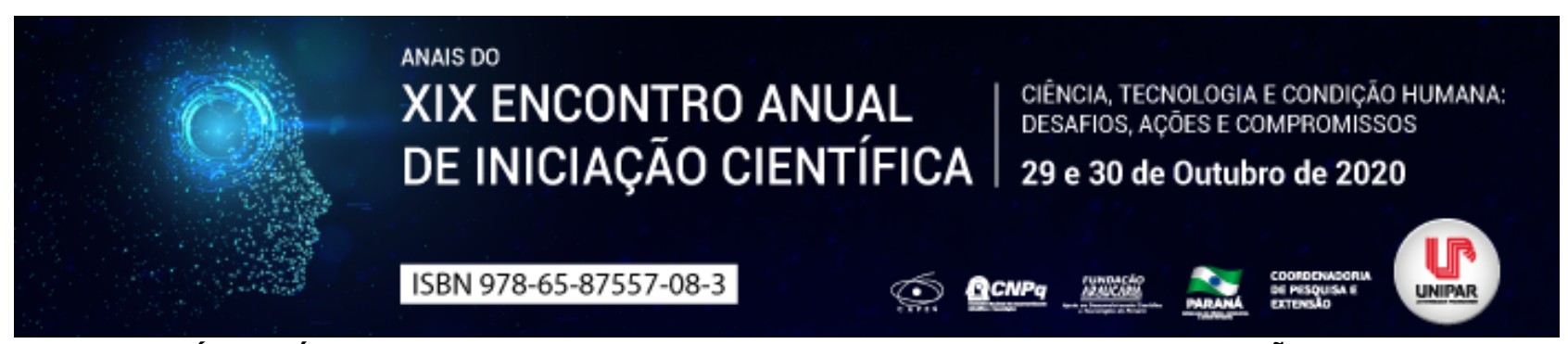

GENOCÍDIO CÁTARO: GUERRA SANTA OU CRUZADA CONTRA A EMANCIPAÇÃO FEMININA?

\author{
${ }^{1}$ Cesar Augusto, ${ }^{2}$ ALANA NOGUEIRA AUgUSTO, ${ }^{3}$ CÉSAR AUguSto
}

\begin{abstract}
${ }^{1}$ SESAP Prefeitura Municipal de Praia Grande - SP
${ }^{1}$ Estudante Colégio Novomundo - Praia Grande - SP

${ }^{2}$ SESAP Prefeitura Municipal de Praia Grande - SP
\end{abstract}

Introdução: A Cruzada Cátara ou Albigense foi um conflito armado ocorrido em 1209 a 1244, por iniciativa do Papa Inocêncio III com o apoio da Dinastia Capetíngia (reis da França na época) com o fim de eliminar pela força o Catarismo, um movimento religioso cristão qualificado como herege pela Igreja Católica assentado principalmente em Languedoc (região sul da França) que resultou no extermínio de milhares de pessoas. O movimento Cátaro proliferava em meio a uma situação de evidente corrupção e descaso eclesiástico que acabou resultando num movimento que se tornou contrário a vários dogmas da Igreja Católica (como a não aceitação do dízimo, da santíssima Trindade, da indissolubilidade do matrimônio, etc.) e num modo de vida dissidente dos costumes da época.

Objetivo: Pretende-se nesse trabalho investigar quais foram os antecedentes históricos e culturais que propiciaram este movimento, e o papel do Estado e da Igreja como instituições legitimadoras do genocídio e suas alegadas motivações.

Metodologia: A metodologia consta da análise histórica de uma ampla revisão da literatura pertinente, sob um prisma multidisciplinar para se compreender os fenômenos que levaram ao genocídio.

Resultados: A análise crítica, imparcial e isenta deve ser a postura que deve nortear nossas conclusões sempre que nos depararmos com assuntos polêmicos e deve fazer parte do espírito investigativo de qualquer pesquisador desta forma algumas afirmações tidas como históricas como a de que: Se os Cátaros houvessem prevalecido e se espalhado pelo mundo resultaria na queda da civilização acabou sendo contrafeita pelos fatos, já que em seu tempo duas das cidades que se declararam Cátaras: Beziers e Carcassonne, gozavam de fama de lugares de efervescente progresso material e cultural, em Béziers houve a tradução da Bíblia para o idioma Occitano e Carcassonne era considerada a mais exuberante cidade de seu tempo. E, ainda, a qual: Os Cátaros matavam mulheres grávidas pelo fato de conceber matéria impura não parece fundamentada pois o país Cátaro era conhecido com a terra dos bons homens, isso devido à sua extremada preocupação com os que sofriam, os enfermos e oprimidos. Amparavam, também, mulheres rejeitadas e vítimas de maus tratos. Diante dessas evidências é inverossímil que pessoas com essa reputação fossem capazes de assassinar gestantes. Ao contrário, percebe-se que esse tipo de relato resultou de detratores dos Cátaros, provavelmente para denegrir sua reputação ou para encobrir mortes cruéis e ensandecidas de seus algozes que, entre outros crimes hediondos, foram capazes do extermínio de uma cidade inteira (Béziers). O genocídio Cátaro foi um fato marcante para a história determinando um novo espaço geopolítico na Europa e o extermínio da antiga cultura do Languedoc. Os trabalhos analisados orbitam, principalmente, entre a tese de uma guerra de conquista francesa contra a Occitânia (motivada pela ambição dos reis franceses pois a região era fértil e próspera) ou de uma empreitada da igreja para salvaguardar a fé católica (pois vários de seus dogmas, além de sua estrutura, eram contestados). Porém, pôde-se perceber, entre os relatos e trabalhos consultados, que a mulher Cátara tinha uma condição excepcional em se tratando dos costumes da época, pois homens e mulheres eram considerados almas iguais sendo o corpo apenas uma roupagem, assim as mulheres tinham direito a educação, opinião e respeito. Era permitido que presidissem cultos e reuniões além de opinar em assuntos capitais. Além disso, podiam se divorciar e geralmente o faziam frente aos maus tratos. Diante disso começaram a aparecer na sociedade Cátara mulheres cultas, refinadas, enérgicas e carismáticas, como a Duquesa Leonor de Aquitânia, a Dama Branca (Esclarmonde de Foix), Cecile de Trencavel, etc. Que colocavam em xeque a cultura patriarcal predominante de modo absoluto na época. O choque foi extremo e toda mulher que se afirmava livre era considerada uma ameaça ao sistema estabelecido a à autoridade religiosa. Não obstante a isso as mulheres eram as principais divulgadoras da nova fé, que passou a abrigar um número crescente de mulheres vítimas de opressão e maus tratos. Despertando, um ódio crescente da sociedade patriarcal da época.

Conclusão: O fenômeno sucedido nessa região, demonstrou uma vez mais que poder (do Estado e o Religioso) utilizaram toda sua autoridade e agentes operacionais para organizar um ato brutal que visava o extermínio total de uma sociedade por motivos culturais, religiosos e políticos. A despeito dos motivos principalmente alegados não se pode deixar de perceber que essa cruzada também visava extirpar o mau exemplo, para a época, das mulheres Cátaras, bem como a utopia de uma sociedade igualitária. Neste triste episódio da história humana mais uma vez a ambição e a intolerância, juntamente com a opressão contra a mulher prevaleceram. Traçando um paralelo com o mundo moderno onde, devido a crises recorrentes, vários movimentos fundamentalistas, reacionários e intolerantes tendem a recrudescer com o risco de aniquilar várias conquistas feministas, fica a pergunta: Até quando iremos permitir cruzadas de opressão as mulheres e de embargo aos seus direitos fundamentais? 


\section{Referências}

ALVES, Branca Moreira; Pitanguy, Jacqueline. O que é feminismo? Coleção Primeiros Passos. Ed. Brasiliense, São Paulo, 1981. Disponível em: .

BARROS, Maria Nazareth Alvim. Deus Reconhecerá os Seus: A história secreta dos Cátaros. Ed. Rocco, 2007. Disponível em http://lelivros.love/book/baixar-livro-deus-reconhecera-os-seus-maria-nazareth-alvim-de-barros-em-pdf-epub-mobi-ou-ler-online/.

BRÁULIO, Thaynná Atheniense. Catarismo: Fé e Guerra no Pays d'Oc. 2013. Monografia apresentada à Universidade Federal de Juiz de Fora para obtenção do título de Bacharel em História. Juiz de Fora (MG) 2013. Disponível em: .

COSTA, Ives Leocelso Silva Costa. A cruzada Albigense: Uma análise historiográfica. Revista Horizontes Históricos, v.1, n.1, 2018. Disponível em: .

Declaração dos Direitos Humanos das Mulheres. Organização das Nações Unidas, 2018. Disponível em: .

FRANCO JR, Hilário. Catarismo uma manifestação utópica medieval. Topoi (Rio J.), Rio de Janeiro, v. 19, n. 38, p. 6-34, mai./ago. 2018 | www.revistatopoi.org. Disponível em: .

GARCIA, Carla Cristina. Breve história do feminismo. Ed. Claridade. São Paulo, 2018. Disponível em: https://pt.scribd.com/book/405772461/Breve-Historia-do-feminismo.

GOMES, Calil de Siqueira. A educação feminina como forma de emancipação na história das mulheres. Revista Intersaberes, vol.9, n. 18, pág. 374-394, jul.-dez. 2014. Disponível em: .

Todas referências revisadas com acesso em: 16/08/2020. 


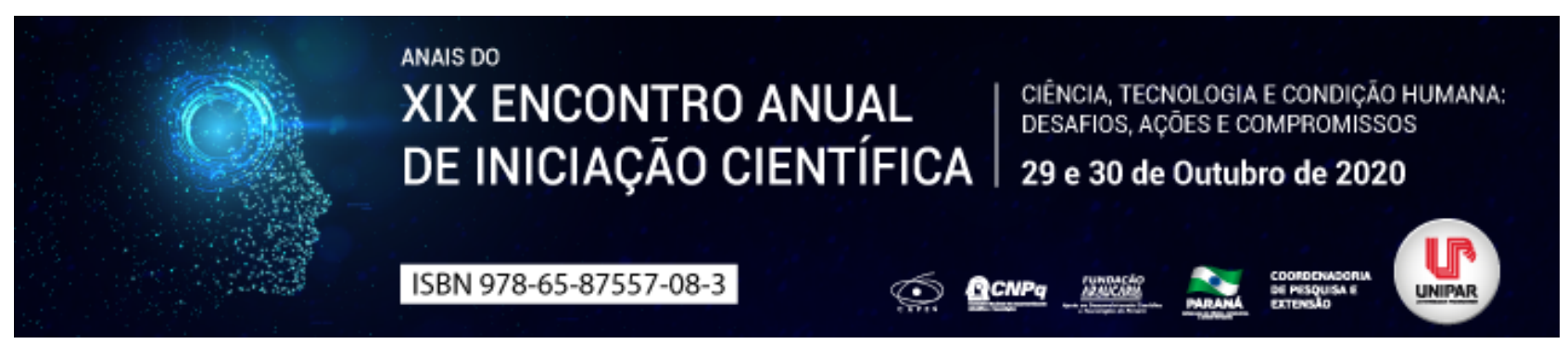

RESPONSABILIDADE CIVIL EXTRACONTRATUAL DO ESTADO POR CONDUTA OMISSIVA

\section{JOAO PEDRO LYRA PIOVESAN, ${ }^{2}$ FABIO LUIZ SANTIN DE ALBUQUERQUE}

${ }^{1}$ Orientado do Prof. Fabio L. S. Albuquerque (11596)

${ }^{1}$ Docente da UNIPAR

Introdução: O presente trabalho tem por finalidade abordar a responsabilidade civil extracontratual do Estado mediante condutas omissivas que causem danos a outrem e demonstrar os principais argumentos para a adoção da teoria objetiva ou subjetiva em vista da omissão legislativa de disciplinar o tema.

Objetivo: Apontar os principais argumentos de ambas as correntes com o propósito de sanar a falta de dispositivo legal.

Desenvolvimento: Na seara do direito público, em se tratando de responsabilidade do Estado por omissão, há controvérsias doutrinárias e jurisprudenciais quanto à aplicabilidade do art. $37, \S 6^{\circ}$ da Constituição Federal de 1988, dispositivo este que estabelece como regra a teoria objetiva da responsabilidade do Estado mediante atos positivos, mas não faz referência sobre sua aplicação em relação aos atos omissivos. Aliás, é o texto legal que traz o principal argumento para a corrente que defende a responsabilidade objetiva do Estado. A norma é mesma para a ação ou a omissão do Poder Público. Assim, para caracterizar a responsabilidade do Estado bastaria a comprovação da ação ou omissão do dano e do nexo de causalidade. Não se cogita culpa ou dolo (DI PIETRO, 2017), todavia, a corrente que defende a responsabilidade subjetiva majoritária na doutrina brasileira, entende que seria necessário, além do dano e do nexo causal, a comprovação de que o Poder Público tenha concorrido de forma culposa ou dolosa para o comportamento omissivo. No entanto, tal omissão só ensejaria responsabilidade do Estado no momento em que aquele deveria agir mas não o fez. Quando o Poder Público deixa de realizar uma conduta que deveria fazer, acaba praticando ato ilícito e, assim, atrai a teoria da responsabilidade subjetiva. Portanto, não há conduta ilícita do Estado que não advenha de culpa ou dolo (LAGOS, 2016). Diante da dificuldade em comprovar que o Estado agiu com culpa ou dolo ao omitir-se de seu dever legal de agir a corrente subjetivista alude que haverá uma presunção de culpa do Estado, ocorrendo a inversão do ônus da prova no âmbito do Poder Judiciário, cabendo ao Estado comprovar que agiu dentro dos seus padrões esperados. Com efeito, nos casos de omissão ( falta de serviço ) admitir-se presunção de culpa do Poder Público porque o administrando é considerado hipossuficiente frente ao Poder Público. Razoável, portanto, que nesta hipótese ocorra a inversão do ônus da prova (BANDEIRA DE MELLO, 2010). Destarte, a própria corrente subjetivista prevê temperamento , admitindo a aplicação da teoria objetiva em algumas hipóteses. Por vezes o próprio Estado cria situações de risco, possibilitando ambiente suscetível a gerar dano e, consequentemente, causar prejuízos a outrem. O dano não será causado diretamente pelo Estado, mas por ter criado esta situação (LAGOS, 2016). Ademais, tal temperamento recai também acerca da omissão do Estado em relação de custódia, como em casos de agressões em escolas ou presídios. Nesses casos, a responsabilidade será objetiva dada a assunção do Estado no dever de velar pela integridade física das pessoas.

Conclusão: Apesar de os argumentos da teoria objetiva serem sedutores, a teoria subjetiva de responsabilização do Estado por atos omissivos tem prevalecido na doutrina e jurisprudência, mas ela própria admite exceções. São justamente essas exceções que fazem com que a matéria ainda desperte certas discussões.

\section{Referências}

BANDEIRA DE MELLO, Celso Antônio. Curso de Direito Administrativo. 27. ed. São Paulo: Malheiros, 2010.

DI PIETRO, Maria Sylvia Zanella. Direito Administrativo. 26. ed. São Paulo: Atlas, 2017.

HACHEM, Daniel Wunder: Responsabilidade Civil do Estado por Omissão: uma proposta de releitura da teoria da faute du service. São Paulo: Atlas, 2013.

LAGOS, Leonardo Bas Galupe: A responsabilidade civil do Estado por Omissão: Objetiva ou Subjetiva?. Revista AGU Brasília, 2016. Disponível em: Acesso em: 01/05/2020.

TARTUCE, Flávio: Manual de Direito Civil. Vol. Único / 10. ed - Rio de Janeiro: Forense, 2020. 


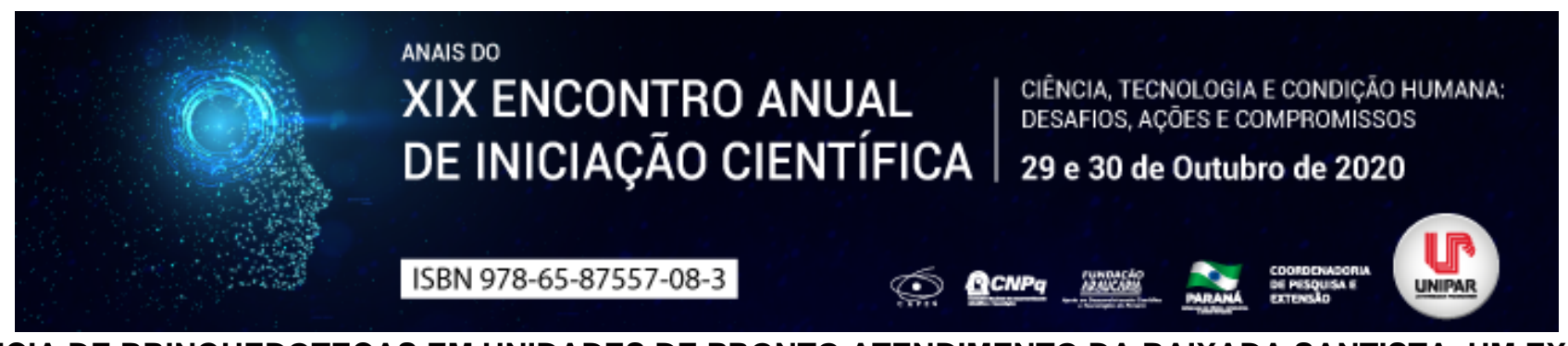

\title{
AUSÊNCIA DE BRINQUEDOTECAS EM UNIDADES DE PRONTO ATENDIMENTO DA BAIXADA SANTISTA, UM EXEMPLO DE INTERVENÇÃO MULTIDISCIPLINAR PARA SANAR ESSA DEMANDA
}

\author{
${ }^{1}$ Cesar Augusto, ${ }^{2}$ ALANA NOGUEIRA AUGUSTO
}

${ }^{1}$ SESAP Prefeitura Municipal de Praia Grande - SP

${ }^{1}$ Estudante Colégio Novomundo - Praia Grande - SP

Introdução: A importância de atividades lúdicas como coadjuvantes no processo de tratamento e recuperação da saúde em crianças é um fato amplamente demonstrado pela literatura pertinente face ao fato de ser promotora de redução de estresse. As situações estressantes que decorrem da ida de uma criança a uma unidade de Pronto Atendimento caracteriza-se como uma situação angustiante (concretamente ou fantasiosa) de modo que estímulos chegam ao sistema nervoso, mais especificamente na área do cérebro conhecida como hipotálamo, que recebe os estímulos emocionais, e os processa influenciando o funcionamento de outros órgãos (coração, intestino, bexiga, brônquios, etc.) resultando, então, de sintomas corporais: diarreia, cólicas abdominais, vômitos, taquicardia, broncoespasmos, etc.) ou então, esse estresse pode se manifestar como depressão, negatividade e falta de colaboração. Estes aspectos acabam agravando o quadro clínico primário que motivou a procura de atendimento ou se torna um agravo quando a criança é acompanhante. Sendo assim, a importância e relevância do lúdico para a criança em situação de vulnerabilidade tem tido amplo reconhecimento e a brinquedoteca como espaço para essa atividade tende a ser cada vez mais implementada no mundo contemporâneo. No Brasil, as autoridades governamentais criaram a lei $\mathrm{n}^{\circ}$ 11.104, de 21 de março de 2005 que dispõe sobre a obrigatoriedade de instalação de brinquedotecas nas unidades de saúde que ofereçam atendimento pediátrico em regime de internação, porém as unidades de Pronto Atendimento que vem sendo construídas, aparentemente não dispõem desse espaço.

Objetivo: Avaliar 15 unidades de Pronto Atendimento da Baixada Santista (SP) e verificar a existência de brinquedoteca, na eventualidade de existir essa deficiência propor uma intervenção no sentido de se criar esse espaço.

Metodologia: Visitação das unidades e estudo de seu espaço. Na ausência de brinquedotecas, fazer avaliação do fluxo de atendimento para justificar essa implantação e, também, para fornecer dados que ajudem a determinar o local mais adequado para o projeto.

Resultados: Foram visitadas 15 unidades de Pronto Atendimento na Baixada Santista (1 em Peruíbe, 1 em Itanhaém, 2 em Mongaguá, 3 em Praia Grande, 2 em São Vicente, 3 em Santos, 1 em Cubatão e 2 em Guarujá) e foi constatado que unidade alguma possuía brinquedoteca. Apesar do fato da presença desse espaço vir a ser de vital importância para o bom andamento do atendimento, já que a proporção do público infantil nessas unidades tende a ser muito expressiva, seja pelo fato das mães não terem onde deixar as crianças quando de suas consultas, seja pela necessidade de uma consulta das próprias crianças. Logo acabam passando algum tempo na unidade, seja pela espera da consulta para si ou para familiar, seja por espera de resultados de exames, por necessidade de reavaliação, ou de procedimentos, etc. Situações geradoras de estresse tanto para os acompanhantes como para a criança. A brinquedoteca, nesse caso, reduziria esse estresse promovendo uma melhor receptividade dos procedimentos, auxiliaria no tratamento e proporcionaria melhoria da consulta médica, seja por gerar uma maior disposição para colaboração ou por redução de sintomas correlatos resultantes do estresse. Desta forma foi escolhido o Pronto Socorro Quietude da cidade de Praia Grande para se propor uma intervenção no sentido de se adaptar este local para receber uma brinquedoteca. Após estudo da planta física e do fluxo de atendimento foi escolhido um local considerado adequado para receber esse espaço, ou seja, arejado, amplo, iluminado e à vista dos acompanhantes, isso sem atrapalhar o fluxo do atendimento. O resultado final com uma proposta de projeto dentro de uma perspectiva multidisciplinar será apresentado.

Conclusão: A falta de brinquedoteca em unidades de Pronto Atendimento tem sido uma tendência, seja por falta de uma explicitação da lei, ou pelo fato de não se prever longos períodos de tempo (que na realidade ocorrem) durante os atendimentos ou, talvez mesmo, por uma questão de abstenção de projeto acaba sendo uma realidade em nosso meio. Esse espaço é muito importante para o bom andamento dos atendimentos e procedimentos relativos ao público infantil sendo assim, uma proposta de intervenção arquitetônica para sanar essa deficiência foi realizada. Entendendo-se que a instalação deste espaço implica numa perspectiva multidisciplinar onde é preciso uma visão Sanitarista para se estabelecer um protocolo de desinfecção dos objetos da brinquedoteca para evitar que se tornem contaminantes e também um escopo de Terapia Ocupacional no sentido de se treinar e preparar o pessoal destinado ao local.

\section{Referências}

Brasil - Presidência da República. Lei n 11.104, de 21 de março de 2005. Brasília: Casa Civil; 2005. Em: .

Como montar uma brinquedoteca. Cursos Escola Educação. Em: . 
COSTA, D. T. L et al. O brincar na assistência de enfermagem à criança: revisão integrativa. Ver. Soc. Bras. Enferm. Ped. V. 16, n.1, p. 36-43, jun. 2016. Em: < https://sobep.org.br/revista/component/zine/article/222-o-brincar-na-assistencia-deenfermagem-crianca-revisao-integrativa.html>.

GESSNER, R. et al. Protocolo de desinfecção de brinquedos em unidade de internação pediátrica: vivência acadêmica de enfermagem. Cienc. Cuid. Saúde, 2013. JAN/MAR, 12(1): 184-188. Em: .

JURDI, A. P. S.; AMIRALIAN, M. L. T. M. Ética do cuidado: a brinquedoteca como espaço de atenção a crianças em situação de vulnerabilidade. Interface (Botucatu-SP), 2013, vol.17, n.45, pp.275-286. Em: .

MAGALHÃES, C. M. C.; PONTES, F. A. R. Criação e manutenção de brinquedotecas: Reflexões acerca do desenvolvimento de parceria. Psicol. Reflexa. Críticos. 2002, vol.15, n.1, pp.235-242. Em: < https://www.scielo.br/scielo.php?pid=S0102$79722002000100024 \&$ script=sci_abstract\&tIng=pt>.

PUGLIEIRO, A. P. S.; SOUZA, M. A.; MELO, L. L. Da doação à autorreflexão: vivências de voluntários de uma brinquedoteca para crianças com câncer. Esc. Anna Nery 2018;22(1): e20170258. Em: .

ROMANIUC, R. C.; RUBIO, J. A. S. Stress infantil: Causas e efeitos do stress na criança. Revista Eletrônica Saberes da Educação Volume $3 \quad \mathrm{n}^{0} 1$ 2012. Em: .

Referências revisadas com acesso em: 16/08/2020. 


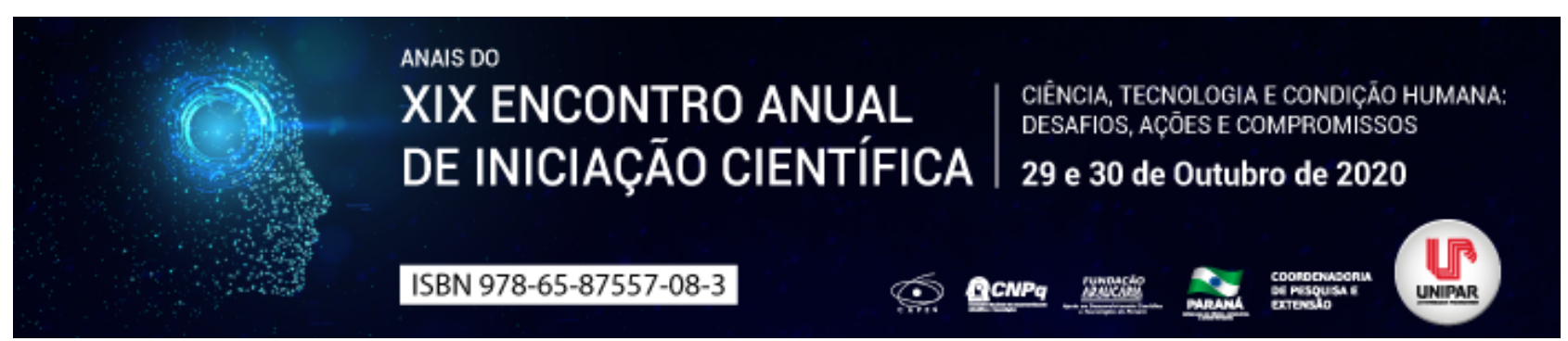

MUDANÇA DE NOME E GÊNERO NO REGISTRO CIVIL DO MENOR TRANSGÊNERO BRASILEIRO

\author{
${ }^{1}$ NATALIA CILIAO DE ALMEIDA, ${ }^{2}$ TEREZA RODRIGUES VIEIRA
}

\author{
${ }^{1}$ Acadêmico do PIC/UNIPAR \\ ${ }^{1}$ Docente da UNIPAR
}

Introdução: Os indivíduos transgêneros aos poucos vêm conquistando espaço na sociedade brasileira. A grande conquista recente foi o Provimento 73 do Conselho Nacional de Justiça (ANOREG, 2018), que permitiu aos indivíduos trans a possibilidade administrativa de modificação do nome e gênero, superando a necessidade de processo judicial. No entanto, essa normativa só beneficia transgêneros maiores e capazes, os quais podem requerer essas alterações diretamente no Cartório do Registro Civil das Pessoas Naturais. Assim, os menores transgêneros continuam submissos a longos processos e ao arbítrio do magistrado.

Objetivo: Demonstrar as possibilidades que ensejam a mudança de nome e gênero do menor trans e identificar as suas dificuldades e caminhos.

Desenvolvimento: $O$ indivíduo transgênero é tido como aquele que não possui compatibilidade entre sua anatomia sexual e sua verdadeira identidade de gênero. O binarismo é quem tem conduzido as opiniões acerca do tema. As pessoas trans, por não corresponderem às expectativas sociais de gênero e sexualidade, são ainda tidas como ilegítimas e fora do padrão, desmerecedoras de consideração e de direitos iguais. Sucede que, a identidade de gênero alude à experiência de uma pessoa com o seu próprio gênero, ou seja, o modo como a pessoa se vê. Hoje, a transexualidade é considerada uma condição humana, não uma patologia, uma vez que a identidade é constituída pelo eu e não por agentes terceiros, devendo a criança transgênero e toda a sociedade encontrar amparo e reconhecimento na pluralidade do Direito . (VAZ, 2020, p. 20) A exclusão do menor trans pode ser extremamente prejudicial, uma vez que esta minoria sofre preconceitos e bullying, conforme entende Vieira e Gomes (2018, p. 343): A não aceitação por parte da pessoa cisgênero, pode impedir o crescimento pessoal, o bem-estar, o conforto, a segurança da pessoa trans. O bullying, em casos mais graves, por não controlar o estresse, pode levar à depressão ou ao suicídio. A discussão acerca da mudança do nome e gênero do menor trans chegou até as escolas e com a promulgação do decreto 8.727 de 2016, o menor trans pode utilizar o nome social no âmbito da administração pública, porém este decreto não suprime os problemas reais, conforme explica Costa $(2019$, p. 58): Da mesma forma, o uso do nome social pela criança transexual no âmbito escolar representa mais uma alternativa transversa que macula o preconceito e confere a tais indivíduos o que se denomina como cidadania a conta gota . Portanto, é notório que a legislação é submissa no que tange ao menor transgênero acarretando diversos problemas sociais e psicológicos, problema que somente será sanado com o preenchimento destas lacunas legislativas garantindo aos menores transgêneros seus direitos e garantias constitucionais.

Conclusão: Conclui-se que a questão da mudança do nome e gênero da criança e do adolescente transgênero ainda é cercada por tabus e preconceitos. Verifica-se que as conquistas em relação ao indivíduo transgênero foram somente parciais, uma vez que o provimento 73 do Conselho Nacional de Justiça privilegiou apenas os indivíduos trans maiores de 18 anos, marginalizando o menor transgênero. Esta exclusão expõe os menores trans a conflitos e agressões morais e físicas, sobretudo na escola, causando depressão, ansiedade, mutilações e tendências suicidas. Além da luta pelo reconhecimento do nome e do gênero no Registro Público, pugna-se também por políticas públicas voltadas ao fortalecimento dos direitos fundamentais das crianças e adolescentes transgêneros.

\title{
Referências
}

ANOREG/BR. Provimento $n^{\circ} 73$ do $\mathrm{CNJ}$ regulamenta a alteração de nome e sexo no Registro Civil. Disponível em: . Acesso em: 11 abr. 2020.

Decreto $\mathrm{n}^{\circ}$ 8.727, de 28 de abril de 2016. Disponível em: . Acesso em: 13 ago . 2020.

COSTA, Fabrício Veiga. A problemática juridica da transexualidade infantil para além do binarismo. In: VIEIRA, Tereza Rodrigues (org.). Transgêneros. Brasília: Zakarewicz, 2019.

VIEIRA, Tereza Rodrigues; GOMES, Luiz Geraldo do Carmo. A família trans e o direito. In: Tereza Rodrigues Vieira; Valéria Silva Galdino Cardin; Bárbara Cossettin C. B. Brunini (organizadoras). Famílias, Psicologia e Direito. 2. Ed. Brasília: Zakarewicz, 2018.

VAZ, Flávio Marcos de Oliveira. Transexualidade infantil para além do binarismo. Divinópolis, Motres, 2020. 


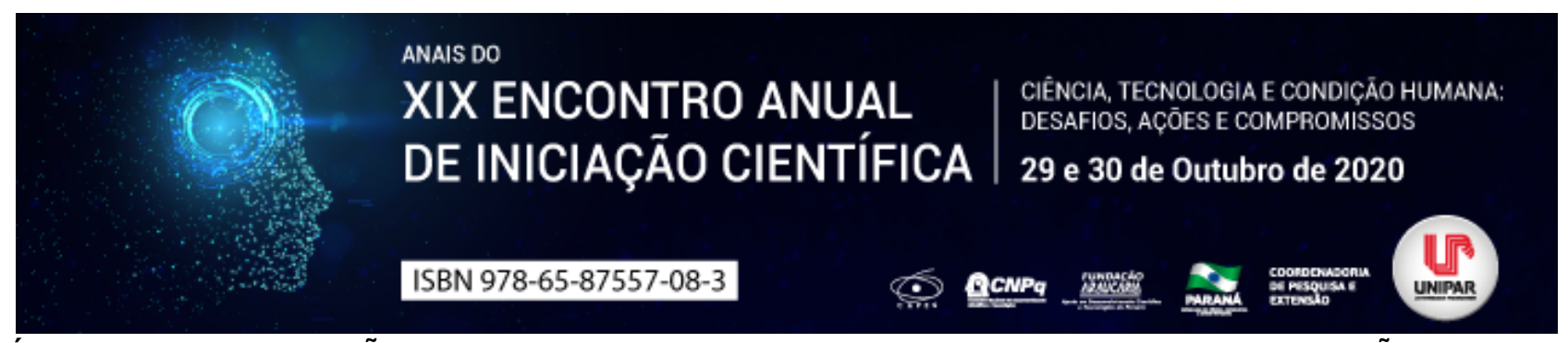

ANÁLISE DAS MODIFICAÇÕES FEITAS PELA LEI 13.964/2019 AO INSTITUTO DA COLABORAÇÃO PREMIADA

\author{
${ }^{1}$ RAFAELA MARTINS DA SILVA, ${ }^{2}$ KARINA DE MELO SANTANA, ${ }^{3}$ RICARDO MUCIATO MARTINS
}

${ }^{1}$ Acadêmica do PIC/UNIPAR

${ }^{1}$ Acadêmica do PIC/UNIPAR

${ }^{2}$ Docente da UNIPAR

Introdução: A Lei 12.850/2013 dispõe sobre a colaboração premiada, contudo possuía lacunas e contradições. Assim, visando aperfeiçoar tal legislação, a Lei 13.964/2019 promoveu modificações no referido diploma legal.

Objetivo: Analisar as principais modificações trazidas pela Lei 13.964/2019 quanto ao instituto da colaboração premiada e compará-las com a antiga redação da Lei 12.850/2013.

Desenvolvimento: A colaboração premiada pode ser conceituada, de acordo com Renato Brasileiro de Lima (2020), como uma técnica especial de investigação através da qual o coautor/partícipe do delito cometido confessa o seu envolvimento no fato delituoso e também fornece ao Ministério Público informações pertinentes em troca de um prêmio legal. Dessa forma, inicialmente a novel legislação, visando positivar o entendimento já sedimentado da doutrina e jurisprudência, optou por incluir o art. $3^{\circ}$-A à Lei 12.850/2013 que dispõe expressamente quanto a natureza jurídica do acordo de colaboração premiada, qual seja a de negócio jurídico. Sucessivamente, o legislador entendeu por necessária a delimitação do início do dever de confidencialidade pelas partes, dessa forma, incluiu o art. $3^{\circ}$-B o qual dispõe que o recebimento da proposta de acordo é o que constitui o marco de confidencialidade, se essa não for sumariamente indeferida, conforme dispõe o $\S 1^{\circ}$ do mesmo artigo. Desse modo, o dever de guardar sigilo decorre tão somente do recebimento da proposta e não especificamente da lavratura do termo de confidencialidade, como antes se imaginava (LIMA, 2020). Nesse contexto, a 2a e $5^{\mathrm{a}}$ Câmara de Coordenação do Ministério Público Federal já haviam editado o item 4 da Orientação Conjunta n. 1/2018, que possui o mesmo sentido da modificação. Outra alteração bastante notória feita pela Lei 13.964/2019 foi a vedação da negociação de regime de pena e tempo de progressão. Tal modificação é um dos requisitos a serem analisados pelo juízo quando da homologação, nos termos do art. $4^{\circ}$, $\S 7^{\circ}$, II, que limita a discricionariedade regrada que possui o Parquet ao propor o acordo, pois agora são consideradas nulas as cláusulas que violem o critério de definição do regime inicial de cumprimento de pena, bem como as regras de cada um dos regimes previstos no Código Penal, e também os requisitos de progressão de regime (PACELLI, 2020, p. 839), de forma que fica vedado a adoção de sanções premiais não previstas em lei. Por fim, a modificação mais importante trazida pela Lei Anticrime é aquela prevista no art. $4^{\circ}, \S 10-A$ da Lei 12.850/2013, que dispõe sobre a ordem de manifestação dos acusados quando há réu delator em uma ação com múltiplos acusados. Essa foi inspirada no precedente formado pela $2^{\circ}$ Turma do Pretório Excelso, que antes da entrada em vigor da lei modificadora, entendeu que nas ações penais que envolvam vários acusados e dentre eles haja algum ou alguns colaboradores que tenham delatados os outros, esses devem apresentar alegações finais somente após àqueles, sob pena de violação dos princípios do contraditório e ampla defesa (LIMA, 2020). No entanto, a Lei 13.964/2019 foi além ao incluir no art. $4^{\circ}$ da Lei 12.850, o §10-A que prevê que o acusado delatado deve ter a oportunidade de se manifestar, em todas as fases do processo, após o delator, assim, por exemplo, o delatado deverá ser interrogado somente depois da oitiva do delator.

Conclusão: Perfaz que, embora a Lei 13.964/2019 tenha trazido melhorias e avanços ao instituto da colaboração premiada, o legislador não aproveitou a oportunidade para trazer grandes inovações ao referido instituto, de forma que apenas positivou entendimentos jurisprudenciais ou mesmo aquilo que já era aplicado na prática.

\title{
Referências
}

BRASIL. Lei $n^{\circ}$ 12.850, de 02 de agosto de 2013. Define organização criminosa e dispõe sobre a investigação criminal, os meios de obtenção da prova, infrações penais correlatas e o procedimento criminal. Disponível em: http://www.planalto.gov.br/ccivil_03/_ato2011-2014/2013/lei/l12850.htm. Acesso em: 06 jul. 2020.

Lei $n^{\circ}$ 13.964/2013, de 24 de dezembro de 2019. Aperfeiçoa a legislação penal e processual penal. Disponível em: http://www.planalto.gov.br/ccivil_03/_ato2019-2022/2019/lei/L13964.htm. Acesso em: 06 jul. 2020.

. Supremo Tribunal Federal. Habeas Corpus n 157.627, Rel. Edson Fachin, Segunda Turma, julgado em 27 ago. 2019.

Acórdão. Disponível em: http://portal.stf.jus.br/processos/detalhe.asp?incidente=5472232. Acesso em: 06 jul. 2020.

LIMA, Renato Brasileiro de. Manual de Processo Penal. 8. ed. Salvador: JusPodivm, 2020.

PACELLI, Eugênio. Curso de Processo Penal. 24. ed. São Paulo: Atlas, 2020. 
Coordenadoria de Pesquisa e Extensão - COPEX

Departamento de Editoraçāo e Divulgaçāo Científica - DEDIC 


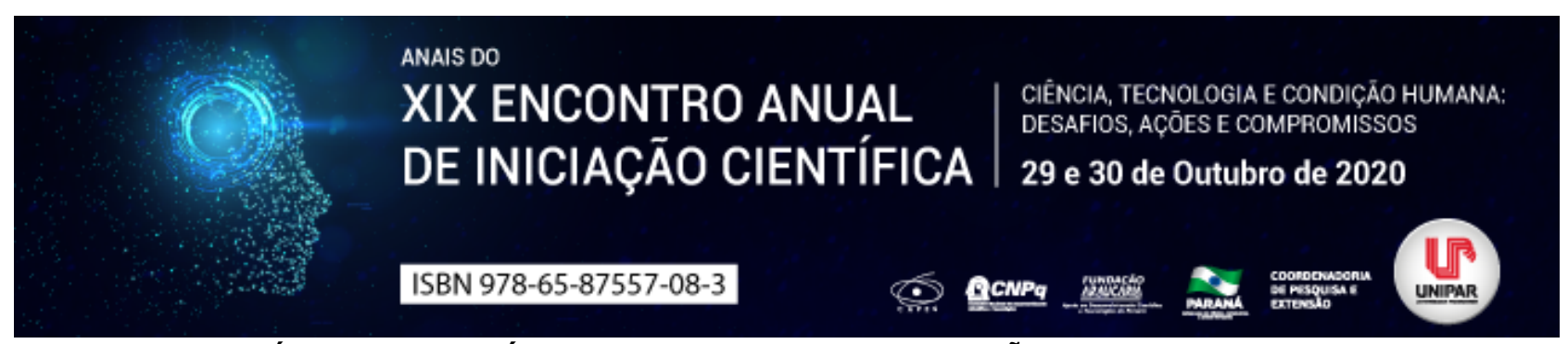

UMA ANÁLISE BIBLIOMÉTRICA SOBRE A DEMONSTRAÇÃO DE VALOR ADICIONADO

\title{
${ }^{1}$ VITORIA GABRIELI SIQUEIRA SANGA, ${ }^{2}$ JEFFERSON CARLOS RIBEIRO, ${ }^{3}$ JOSE LUIZ BORSATTO JUNIOR, ${ }^{4}$ ISABEL CRISTINA GOZER
}

\author{
${ }^{1}$ Discente. Universidade Paranaense (UNIPAR); Graduação de Ciências Contábeis; Bolsista PIBIC \\ ${ }^{1}$ Discente. Universidade Paranaense (UNIPAR); Graduação de Ciências Contábeis; Programa PIC \\ ${ }^{2}$ Docente da UNIPAR; Curso de Ciências Contábeis \\ ${ }^{3}$ Docente da UNIPAR; Curso de Ciências Contábeis
}

Introdução: A Demonstração do Valor Adicionado (DVA) segundo De Luca (1998, p. 28), é [...] um relatório contábil que visa demonstrar o valor da riqueza gerada pela empresa e a distribuição para os elementos que contribuíram para sua geração. É de acordo com essa ferramenta contábil importante e obrigatória desde 2008, que o trabalho se sustenta. A análise bibliométrica tem a finalidade de avaliar e entender o desempenho das atividades de produção científica acadêmica sobre determinada área, utilizando para tanto uma quantidade de dados, referentes ao período pesquisado, para a extração das informações necessárias Wolfram (2017).

Objetivos: Analisar os periódicos constantes na base de dados dos congressos USP e ANPCONT sobre a demonstração do valor adicionado dentre o período de 2012 a 2019, e por meio de uma análise bibliométrica descrever as características das publicações.

Material e Métodos: O método da pesquisa é considerado como descritivo e utiliza-se do apoio da análise bibliométrica sem o tratamento matemático estatístico para a análise dos artigos, estando publicados na base de dados dos Congressos USP e ANPCONT. Sendo delimitado o tema e período proposto, filtraram-se 25 artigos em ambos os congressos.

Análise Dos Resultados e Discussão: No Congresso ANPCONT, observa-se que a maioria dos artigos foram publicados no decurso de 2017, resultando em 6 artigos, cerca de (33,33\%) e nenhuma publicação em 2015. Já no Congresso USP, o período majoritário de publicações de artigos foram entre 2013 e 2019, cerca de 3 artigos (30\%) e nenhuma publicação entre 2014 e 2016. Na confluência entre ambos, o período mais próspero de publicações foi o ano de 2017, com 6 artigos (24\%), seguido pelos anos de 2013 e 2019, cerca de 4 artigos (16\%) e o período em minoria foi 2015, 1 artigo (4\%). Quanto à quantidade de autores por artigos, na ANPCONT, analisou-se que em um período de sete anos não houve a publicação de nenhum artigo elaborado somente por um autor, entretanto, o trabalho em dupla se destacou nos períodos; cerca de 10 trabalhos $(66,66 \%)$, seguido de 6 trabalhos redigidos por quatro autores (24\%), com exceção do ano de 2015 em que não foi identificado nenhum elaborado por um autor. Na USP, verifica-se que a maioria são escritos por 3 autores (40\%) e 5 autores (40\%). Por outro lado, nenhum artigo com apenas um autor foi identificado. Nos dois congressos, a maioria dos artigos são escritos por 2 autores, cerca de (48\%). Segundo as IES vinculadas dos autores, na ANPCONT, observa-se que a maioria dos autores vieram de universidades públicas, como é o caso da USP com 11 autores. Na USP, observa-se, no entanto, que a maioria dos autores também vieram da própria USP, cerca de 12 autores. Em convergência aos congressos, observa-se que a maioria dos autores que publicaram sobre a demonstração do valor adicionado no período determinado veio da USP, sendo 12 autores. Em relação ao grau de titulação dos autores da ANPCONT, a maioria apresenta grau de doutor, cerca de 17 pesquisadores. Na USP, a maioria também são doutores, cerca de 14. Nos dois congressos, percebe-se a prevalência de doutores entre os autores, quantificando no total cerca de 31 autores, podendo ser explicado pela provável presença dos mesmos em cursos de pós-graduação e às exigências impostas pela CAPES quanto à publicação para avaliação destes programas. Em relação às metodologias de pesquisas dos artigos, na ANPCONT, observa-se que a maioria das pesquisas dos artigos possuem uma pesquisa descritiva (11), com métodos documentais (6), técnicas quantitativas (9), possuindo 1 amostragem probabilística e 1 não probabilística. Na USP, a maioria das pesquisas também abordou uma pesquisa do tipo descritiva (7), com métodos documentais (4) e técnicas quantitativas (7). Em ambos os congressos, a pesquisa descritiva foi predominante nos artigos investigados. Nos métodos de pesquisas, o documental é o que vigora em maior quantidade. Sendo a técnica quantitativa a mais utilizada.

Conclusão: Os resultados demonstraram que a quantidade de artigos publicados durante os anos analisados é reduzida, sendo que a maioria dos artigos é escrita por dois autores, seguido por quatro autores, em que estes são oriundos de universidades públicas e federais e a maioria tem titulação de doutor. Apreende-se também, que a maioria dos trabalhos se referem a estudos de análises, registros e interpretação dos fatos do mundo físico sem a interferência do pesquisador, abrangendo uma pesquisa descritiva, tendo a maioria técnicas de análises quantitativas.

\section{Referências}


DE LUCA, M. M. M. et al. Demonstração do Valor Adicionado: do cálculo da riqueza criada pela empresa ao valor do PIB. 2. ed. São Paulo: Editora Atlas, 2009.

SANDRO, Soares. PICOLLI, Icaro. CASAGRANDE, Jacir. PESQUISA BIBLIOGRÁFICA, PESQUISA BIBLIOMÉTRICA, ARTIGO DE REVISÃO E ENSAIO TEÓRICO EM ADMINISTRAÇÃO E CONTABILIDADE. DOI 10.13058/raep.2018.v19n2.970. Disponível em>Pesquisa Bibliográfica, Pesquisa Bibliométrica, Artigo de

Congresso USP -https://congressousp.fipecafi.org/Congresso/Anais

Congresso Anpcont -http://anpcont.org.br/

Coordenadoria de Pesquisa e Extensão - COPEX

Departamento de Editoraçāo e Divulgaçāo Científica - DEDIC 


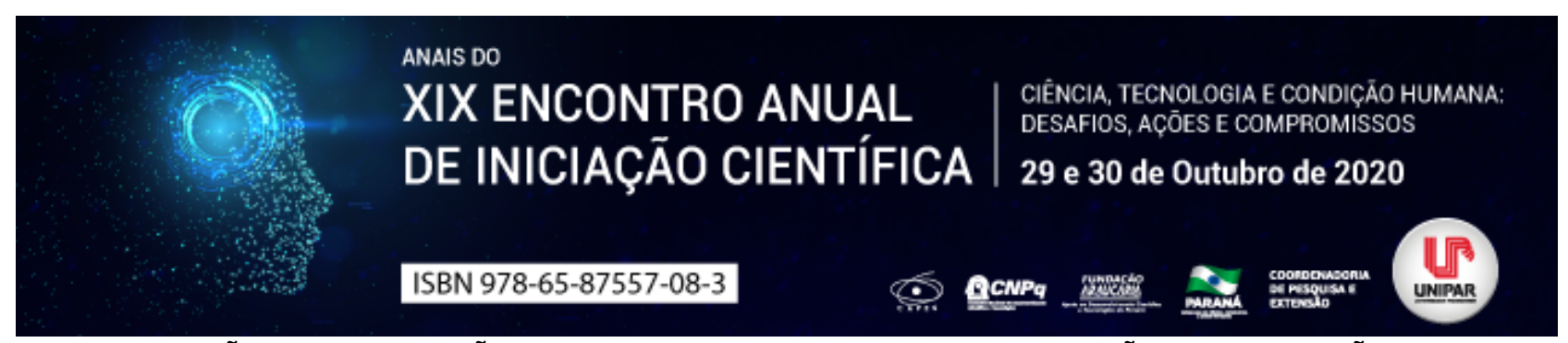

A UTILIZAÇÃO DA CONFISSÃO CIRCUNSTANCIADA NO ACORDO DE NÃO PERSECUÇÃO PENAL

\author{
${ }^{1}$ RAFAELA MARTINS DA SILVA, ${ }^{2}$ ALESSANDRO DORIGON
}

${ }^{1}$ Acadêmica do curso de Direito/UNIPAR

${ }^{1}$ Docente da UNIPAR

Introdução: O acordo de não persecução penal (ANPP) é um instituto da justiça consensual que surgiu no Brasil através da Resolução $n^{\circ}$ 181/17 do Conselho Nacional do Ministério Público, o qual foi implantado no Código de Processo Penal (CPP) pela Lei no 13.964/2019 (Lei Anticrime), sendo um de seus requisitos a confissão circunstanciada do crime pelo infrator.

Objetivo: Avaliar a legalidade da exigência da confissão circunstanciada, bem como a sua utilização na instrução processual quando do descumprimento do ANPP pelo infrator.

Desenvolvimento: Trata-se o ANPP de um pacto entre o Ministério Público e o autor do fato delituoso, no qual esse deve confessar formal e circunstanciadamente a prática do delito, submetendo-se ao cumprimento de condições pactuadas entre ele e o parquet, em troca do não oferecimento de denúncia (LIMA, 2020, p. 274). A celebração do ANPP pressupõe a existência de requisitos previstos no caput e no $\S 2^{\circ}$ do art. 28-A do CPP, dentre eles, a análise de arquivamento do inquérito, o delito deve ser cometido sem violência ou grave ameaça e sua pena mínima ser inferior a quatro anos, bem como o infrator deve confessar circunstanciadamente o crime, isto é, admitir a prática do delito, apresentando detalhe dos fatos, de modo que as informações possuam coerência lógica e sejam compatíveis com as demais provas existentes (SOUZA, 2020). Assim, a aludida confissão é necessária para a celebração do ANPP, pois ela evita que acordos sejam pactuados nos casos desprovidos de provas. Todavia, a inserção de um mecanismo novo no ordenamento jurídico sempre levanta debates a seu respeito, não seria diferente com o instituto do ANPP. Uma das principais controvérsias acerca desse mecanismo é a utilização da confissão circunstanciada em sede de ANPP como prova na instrução processual quando do descumprimento do acordo. Nesse sentido, Castro e Netto (2020) entendem que não é possível estender os efeitos da confissão para outros fins que não o da celebração do acordo, pois com isso haveria um rompimento do sistema acusatório e dos princípios do contraditório, ampla defesa e nemo tenetur se detegere. Contudo, Cabral (2020, p. 183) preleciona que uma das consequências do descumprimento do ANPP é a possibilidade do Ministério Público utilizar a confissão circunstanciada, feita pelo investigado quando da celebração do ANPP, devendo tal utilização ser feita como fonte de informação, tanto para corroborar outras provas, como também para contrapor a depoimentos e até mesmo ao interrogatório do réu. Assim, observa-se que o valor probatório dado à confissão será verificado através dos mesmos critérios adotados para outros elementos de prova, sendo que a utilização da confissão para fins probatórios está de acordo com a legislação processual penal brasileira.

Conclusão: Constata-se que a utilização da confissão circunstanciada na instrução processual não viola a legislação penal vigente, vez que não implica em prejuízo ao réu, pois a confissão não pode ser tratada de forma isolada, devendo o juiz analisála em conjunto com outros elementos probatórios para a formação de sua convicção.

\title{
Referências
}

CABRAL, Rodrigo Leite Ferreira. Manual do acordo de não persecução penal: À luz da Lei 13.964/2019 (Pacote Anticrime). Salvador: JusPodivm, 2020.

CASTRO, Carolina Soares Castelliano Lucena de; NETTO, Fábio Prudente. Comentários sobre a exigência da confissão no acordo de não persecução penal. Consultor Jurídico, Rio de Janeiro, 15 fev. 2020. Disponível em: https://bit.ly/3gTmrlZ. Acesso em: 02 set. 2020.

LIMA, Renato Brasileiro de. Manual de processo penal. 8. ed. Salvador: JusPodivm, 2020.

SOUZA, Renee do Ó. Acordo de não persecução penal: o papel da confissão e a inexistência de plea bargain. Consultor Jurídico, Rio de Janeiro, 07 jan. 2019. Disponível em: https://bit.ly/2WYkayz. Acesso em: 27 jul. 2020. 


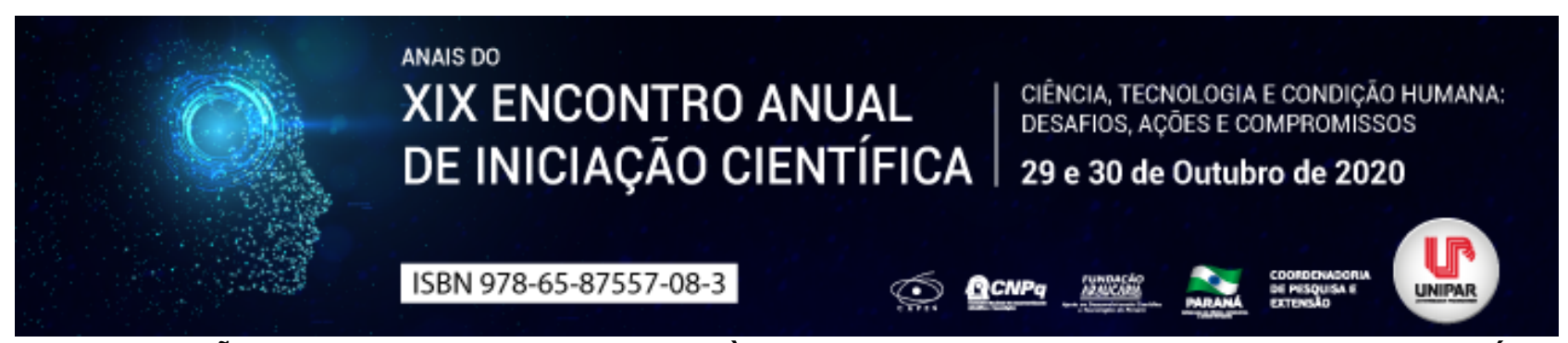

REDE DE ATENÇÃO PSICOSSOCIAL NO CUIDADO À CRIANÇA E AO ADOLESCENTE DA GRANDE VITÓRIA - ES

\author{
${ }^{1}$ Samile Kumaira Fernandes, ${ }^{2}$ LETICIA DOS SANTOS DIAS, ${ }^{3}$ TERESINHA CID CONSTANTINIDIS
}

\author{
${ }^{1}$ Acadêmica de Terapia Ocupacional/ UFES \\ ${ }^{1}$ Acadêmica de Terapia Ocupacional/ UFES \\ ${ }^{2}$ Docente do Departamento de Terapia Ocupacional UFES
}

Introdução: A atenção psicossocial infantojuvenil foi constituída em um vazio histórico, até os anos de 1980, contava apenas com instituições que remetiam à ideia de acolhimento e o modelo de atendimento era mais voltado a medicalização de problemas de ordem comportamental ou educacional, esquivando a criança da possibilidade de subjetivar suas questões (DIAS, 2009). A implementação de políticas de saúde mental do Sistema Único de Saúde (SUS) voltadas para infância e adolescência, ocorreu apenas em 2002 por meio da Portaria 336/2002 (BRASIL, 2002). A elaboração da RAPS possibilitou a descentralização da saúde no Brasil, sancionada pela portaria 3.088 de 2011, com um intuito primeiramente de sistematizar o fluxo de pessoas no serviço, reforçando processos de regionalização e do modelo piramidal de assistência (QUINDERÉ, JORGE e FRANCO, 2014). A ESF e o NASF são equipamentos da rede ofertados pela Atenção Básica que devem, junto a outros dispositivos, garantir a integralidade do cuidado em saúde mental, mas apesar das mudanças propostas pela Portaria $\mathrm{n}^{\circ} 3.088$, ainda são incipientes as suas influências na rede de saúde mental infanto-juvenil (BELOTTI, MAIA, AVELLAR E SILVA (2019).

Objetivo: Esse estudo teve como objetivo conhecer o trabalho em rede na produção de atenção e cuidado ao infantojuvenil em sofrimento psíquico na região metropolitana de Vitória, ES - a partir da perspectiva dos profissionais da saúde mental da RAPS.

Metódo: O projeto foi aprovado pelo Comitê de Ética e Pesquisa da UFES, CEP-CCS/UFES, por meio do Parecer Consubstanciado do CEP no 1.566.200, de 25/05/2016, respeitando-se assim os princípios éticos fundamentais adotados na abordagem aos colaboradores, na coleta e tratamento dos dados, com base na Resolução no 466 de 12/12/2012. A pesquisa proposta é exploratória de natureza qualitativa e para a coleta de dados foi realizado grupo focal que foi realizado com mediação de dois professores especialistas na técnica e um aluno de Iniciação Científica, no dia 5 de maio de 2017, com a participação dos trabalhadores de saúde mental que compõem a RAPS dos municípios da Grande Vitória, sendo dois do CAPSi de Vitória, um de UBS de Cariacica, um de UBS da Serra e um de UBS de Vila Velha. O Grupo Focal foi transcrito pelo aluno de Iniciação Científica e o tratamento do material, a sua codificação, se deu por intermédio da análise de conteúdo.

Resultados: A partir da análise de conteúdo, as falas do grupo focal delinearam dois núcleos de sentido: 1. Desafios para implantação de serviços de atenção e cuidado em Saúde mental infantojuvenil; 2. Cuidado atrelado a intersetorialidade.

Discussão: O município de Vitória e, mais recentemente, de Vila Velha, Serra e Cariacica, apresentam ações de saúde mental para infância e adolescência com um plano específico, integrado à política geral de saúde mental do SUS. Os profissionais referem parcerias intersetoriais com CRAS e CREAS. Ainda com esses avanços, os participantes da pesquisa, ressaltam que a criança tende a ser esquecida e as ações voltadas à produção de cuidado na atenção à saúde mental infantojuvenil não são vistas como prioridade nos serviços. Esse cenário é o reflexo da dificuldade articular a intersetorialidade nessa produção de cuidado. Couto et al (2008) apontam que os dispositivos mais acessados no país por crianças e adolescentes são primeiramente as escolas e em seguida as ESFs, sendo essas portas de entrada para a construção de uma rede em saúde mental. Para os autores, apenas uma rede de intersetorialidade é capaz de produzir o cuidado, sem estigmatizar, partilhando e aperfeiçoando o serviço. Os profissionais relatam que os atendimentos a esta população na atenção básica, restringe-se a atendimentos ambulatoriais realizados por psicólogos, que atendem demandas escolares. Este resultado aponta à herança histórica das ações relacionadas à saúde mental da infância e adolescência serem delegadas aos setores educacional e de assistência social, com quase ausência de proposições pela área da saúde mental, conforme afirmam Couto et al (2008) e Muylaert (2015). De acordo com Silva e Pinho (2015), cada território possui suas características e por isso se torna necessário um suporte intersetorial para interpretar a importância do local na produção de cuidado, o cuidado também deve ser pensado para além dos setores institucionalizados.

Conclusão: Diante disso, a produção de cuidado em saúde mental, relatada na pesquisa é marcada por desafios que concernem à falta de prioridade da saúde mental infantojuvenil nas políticas públicas, na dificuldade da realização do trabalho intersetorial, no tensionamento na relação com a escola, na falta da participação da atenção básica na produção do cuidado em rede. Apesar dos desafios, os profissionais buscam construir um campo de atenção e cuidado à criança e adolescentes, cientes da importância do trabalho em rede e da intersetorialidade, da contextualização do trabalho no território. Necessário destacar a importância da valorização das conquistas e resultados obtidos nesse processo.

\title{
Referências
}


DIAS, Fábio Walace de Souza. A criança e o adolescente no campo da saúde mental: Que lugar? Revista ClinicAPS Impasses da clínica. v. 23, n7, p.1-7, 2009.

BRASIL. Ministério da Saúde. Portaria $\mathrm{n}^{\circ}$ 336, de 19 de fevereiro de 2002. Define e estabelece diretrizes para o funcionamento dos Centros de Atenção Psicossocial. Diário Oficial da União, 2002.

QUINDERÉ, Paulo Henrique Dias; JORGE, Maria Salete Bessa; FRANCO, Túlio Batista. Rede Atenção Psicossocial: qual o lugar da saúde mental? Revista de Saúde Coletiva. v. 24. n.1, p.253-271, 2014. Disponível em: https://www.scielosp.org/pdf/physis/2014.v24n1/253-271/pt. Acesso: 21 mai. 2019.

BELOTTI, Meyrielle; MAIA, Camila Carlos; AVELLAR, Luziane Zacché; SILVA, Priscilla de Oliveira Martins da. Concepções de Profissionais de Saúde sobre as Atribuições em um Centro de Atenção Psicossocial Infanto-Juvenil (CAPSi). Psicologia: Teoria e Pesquisa. V, 34, 2018. Disponível em: https://www.scielo.br/pdf/ptp/v34/1806-3446-ptp-34-e34430.pdf. Acesso em: 21 de mai. de 2019.

COUTO, Maria Cristina Ventura; DUARTE, Cristiane S.; DELGADO, Pedro Gabriel Godinho. A saúde mental infantil na Saúde Pública brasileira: situação atual e desafios. Revista Brasileira de Psiquiatria. V. 30, n. 4, p. 390-398, 2008. Disponível em: https://www.scielo.br/pdf/rbp/v30n4/a15v30n4. Acesso em: 01 jun. 2019.

MUYLAERT, Camila Junqueira; DELFINI, Patrícia dos Santos de Sousa; REIS, Alberto Olavo Advincula. Relações de Gênero entre familiares, cuidadores de crianças e adolescentes de serviços de saúde mental. Physis. Rio de Janeiro, v.25, n.1, p. 41-58, junho-setembro, 2015.

SILVA, Aline Basso da; PINHO, Leandro Barbosa. Território e saúde mental: contribuições conceituais da geografia para o campo psicossocial. Revista Enfermagem Uerj. Rio de Janeiro, v.23, n. 3, p. 420-424, maio/jun, 2015. Disponível em: https://www.lume.ufrgs.br/bitstream/handle/10183/129915/000976078.pdf?sequence=1\&isAllowed=y. Acesso em: 5 de maio de 2019 . 


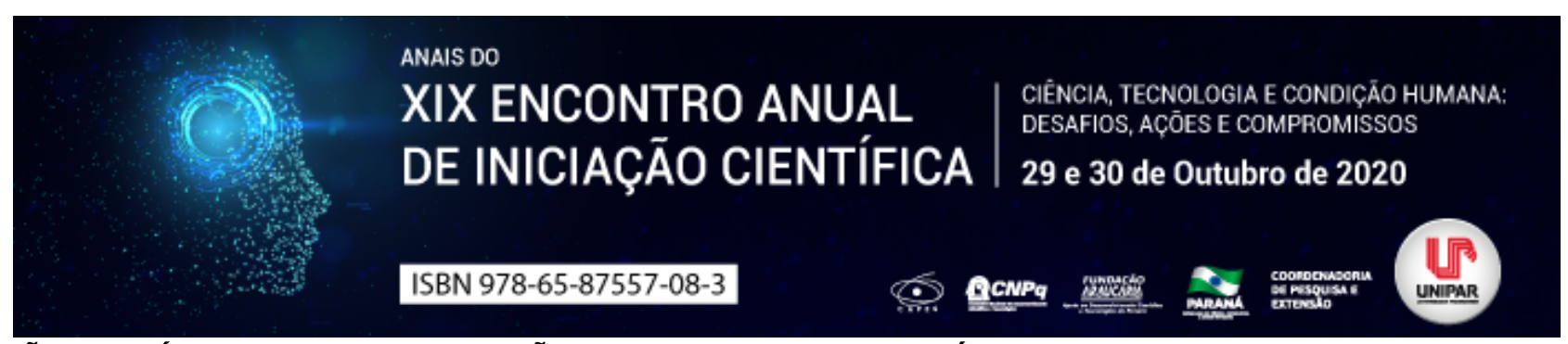

\title{
SUCESSÕES LEGÍTIMAS E SUAS LIMITAÇÕES: DA HERANÇA ATRAVÉS DO TESTAMENTO, INVENTARIO-PARTILHA E ARROLAMENTO
}

\author{
${ }^{1}$ MARCIO ANTONIO DA VEIGA GAYARDO, ${ }^{2}$ FABIO LUIZ SANTIN DE ALBUQUERQUE
}

\author{
${ }^{1}$ Acadêmico Unipar \\ ${ }^{1}$ Docente da UNIPAR
}

Introdução: O Direito Sucessória fundamenta-se no direito de propriedade e na sua função social presente no art. $5^{\circ}$, XXII e XXIII, da CF/1988, mas vai além, tem base na valorização ininterrupta da dignidade da pessoa humana, de viés individual ou coletivo, conforme leciona o art. $1^{\circ}$, III, e o art. $3^{\circ}, \mathrm{I}$, ambos da Constituição Federal de 1988. Para tanto, o direito das sucessões regulamenta a maneira que ocorre a sucessão em caso de morte, seja pela sucessão legítima, seja pela testamentária, pois seu objeto é a transmissão de bens mortis causa. A legítima é uma proteção dada aos herdeiros necessários pela legislação civil do nosso ordenamento brasileiro (art. 1845), em cada modalidade de sucessão mortis causas possibilitada na legislação brasileira, a sucessão legítima e a sucessão testamentária. É uma limitação à faculdade de testar bastante severa, a grande monta de metade do patrimônio deve ser resguardada para proteção da legitima, pode ser o fator determinante para que os brasileiros não utilizem o testamento com opção de modalidade de sucessão. Destarte já conceituada é imprescindível reporta-se ao quão tal figura é importante dentro da vida em sociedade. Por este motivo o presente trabalho apresentará de forma breve alguns pontos referentes a já mencionada figura.

Objetivo: O presente estudo tem como objetivo a é o de pesquisar, compreender e distinguir as duas possibilidades de sucessão patrimonial: a sucessão legítima e a sucessão testamentária.

Desenvolvimento: Sucessão traduz-se no ato de suceder, ou seja, substituição de pessoas ou coisas, transmissão de bens ou direitos, em uma relação jurídica contínua, o que ocorre nas situações de falecimento de pessoas, onde e transmitida a herança ao herdeiro, que sucede ao de cujus nas questões relativas aos direitos e obrigações relacionadas ao seu patrimônio (OLIVEIRA; AMORIM, 2013). A herança compreende os bens que são transferidos ao sucessor em virtude da morte de alguém, ou seja, o patrimônio herdado ou espólio, é a universalidade dos bens deixado pelo falecido que se transferem em bloco para os herdeiros, ficando comuns a todos até a divisão por meio da partilha (OLIVEIRA; AMORIM, 2013). A sucessão causa mortis pode ser transmitida em sucessão legítima ou sucessão testamentária, admitindo, ainda, algumas possíveis formas irregulares ou anômalas de transmissão; em relação a abrangência, pode ser a título universal ou singular (OLIVEIRA; AMORIM, 2013). A sucessão legítima é aquela que decorre da lei, mais especificamente do art. 1829, do Código Civil, que prevê a existência legal e a ordem na qual ocorre. Cumpre ressaltar que ao se ler cônjuge, deve-se levar em consideração o companheiro igualmente (TARTUCE, 2020). Não havendo testamento do de cujus, a sucessão será a legítima, na qual o patrimônio é passado aos herdeiros conforme indicado pela lei, obedecendo-se a ordem hereditária (DINIZ, 2009). Quanto a sucessão testamentária, esta ocorre com a expressão da última vontade do de cujus, quando revestido por ato solene exigido pela lei, entretanto, prevalece a lei no que o testamento for omisso (DINIZ, 2009). A legítima é uma proteção dada aos herdeiros necessários pela legislação civil do nosso ordenamento brasileiro (art. 1845), em cada modalidade de sucessão mortis causa possibilitada na legislação brasileira, a sucessão legítima e a sucessão testamentária (OLIVEIRA FILHO, 2018). Os fundamentos que embasam a legitima devem ser repensados, pois todos são facilmente rebatidos pois entram em choque com outros direitos igualmente importantes (OLIVEIRA FILHO, 2018), portanto, deve-se procurar algum instrumento normativo que possa prover uma maior proteção aos herdeiros ou demais parentes que verdadeiramente necessitem de um aporte financeiro.

Conclusão: $O$ instituto da legítima entra em choque com a liberdade da pessoa, ainda mais em se tratando de um direito disponível como é a propriedade. Os fundamentos sobre os quais foi criado este instituto, atualmente, não são mais suficientes para confirmar sua necessidade quando entra em choque com outros princípios do ordenamento jurídico.

\section{Referências}

BRASIL. Constituição da República Federativa do Brasil. Brasília, DF: Senado Federal, 1988.

Código Civil. Brasília, DF: Senado Federal, 2002.

$\overline{D I N I Z}$, Maria Helena. Curso de direito civil brasileiro. 26 ed. São Paulo: Saraiva, 2009.

OLIVEIRA, Euclides de; AMORIM, Sebastião. Inventários e Partilhas: direito das sucessões teoria e prática. 23 ed. São Paulo: Livraria e Editora Universitária de Direito, 2013.

OLIVEIRA FILHO, Francisco Furtado de. Da necessidade de repensar a legítima. Disponível em: https://jus.com.br/artigos/66911/da-necessidade-de-repensar-a-legitima.Acessado em 19 de Agosto de 2020.

TARTUCE, Flávio. Manual de Direito Civil. 10 ed. Rio de Janeiro: Forense. São Paulo: Método, 2020. 
Coordenadoria de Pesquisa e Extensão - COPEX

Departamento de Editoraçāo e Divulgaçāo Científica - DEDIC 


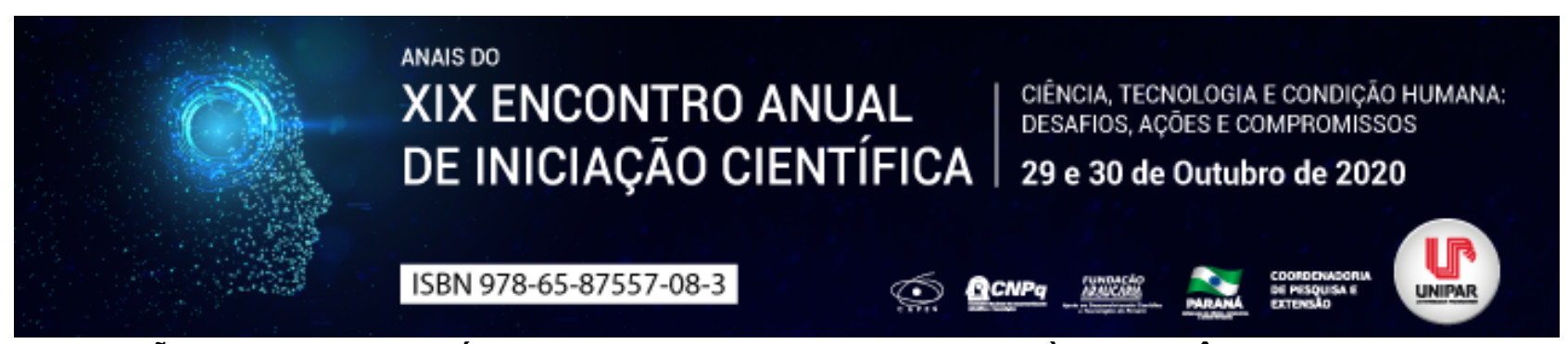

MÃES E FILHOS NO CÁRCERE E O DIREITO FUNDAMENTAL À CONVIVÊNCIA FAMILIAR

\title{
${ }^{1}$ PATRICIA FISCHER SILVERIO, ${ }^{2}$ SNAYDER ROBERTO RODRIGUES ZAHA, ${ }^{3}$ RAPHAEL PRIETO DOS SANTOS
}

\author{
${ }^{1}$ Acadêmica do curso de Direito da UEMS - Naviraí \\ ${ }^{1}$ Acadêmico do curso de Direito da UEMS - Naviraí \\ ${ }^{2}$ Docente da UEMS - Naviraí
}

Introdução: O direito à convivência familiar está elencado no caput do artigo 227, da Constituição Federal (BRASIL,1988). Contudo, existem barreiras a serem rompidas para a consolidação deste Direito Social no âmbito das penitenciárias femininas de todo o país. Assim, a presente pesquisa utiliza-se do método dedutivo mediante a análise de legislação vigente e revisão bibliográfica, cuja finalidade é vislumbrar a relação entre mães presidiárias e seus filhos e a importância do direito à convivência familiar no cárcere.

Objetivo: Estudar a realidade vivenciada por mães e filhos nas penitenciárias femininas, bem como, apontar alguns mecanismos disponíveis de efetivação do direito à convivência familiar no cárcere e de reintegração da mulher na sociedade.

Desenvolvimento: A convivência familiar é um direito fundamental inerente ao ser humano, de conviver com a sua família consanguínea ou adotiva, sobretudo, nas fases iniciais da vida, as quais ocorrem o desenvolvimento físico e emocional da criança e do adolescente (MACIEL, 2018). Todavia, no contexto das penitenciárias femininas, este direito social está longe de ser uma realidade, visto que as normas jurídicas de proteção à família não têm sido efetivamente aplicadas no cárcere, em outras palavras, mães encarceradas e seus filhos são esquecidos pela sociedade e por décadas têm seus direitos negligenciados pelo Poder Público. Segundo o estudo intitulado I"Dar à luz na sombral" (2015, p. 21) esse é um retrato da superveniência da lógica punitiva sobre outros aspectos da vida social . Não obstante, faz-se necessário um olhar crítico sobre a atuação do Estado no que tange a efetivação do direito fundamental à convivência familiar, conforme dispõe o caput do art. 227 da Constituição Federal (BRASIL,1988), pois é notório o abandono por parte das autoridades em face do modelo prisional aderido pelo Estado Brasileiro, ademais, o Poder Público é o principal agente responsável pela construção e manutenção das penitenciárias. A Lei de Execução Penal prevê que a penitenciária feminina deve possuir um ambiente para gestantes e parturientes, bem como, creche para abrigar crianças maiores de 6 (seis) meses e menores de 7 (sete) anos. Recentemente, o Código de Processo Penal passou a prever em seus artigos 318-A e 318-B hipóteses de prisão domiciliar da mulher gestante ou mãe de filhos com até 12 anos incompletos. É importante ressaltar que os dispositivos mencionados estão em consonância com as denominadas I"Regras de Bangkokl", que são um acordo internacional das Nações Unidas que promove um olhar a população feminina encarcerada, como também, a necessidade da aplicação de medidas não privativas de liberdade, com o intuito de desencarcerar uma parcela de mulheres infratoras, especialmente, nas hipóteses em que não houve o trânsito em julgado da sentença condenatória. Segundo dados do Departamento Penitenciário Nacional (Depen), que lançou o Levantamento Nacional de Informações Penitenciárias (Infopen) de dezembro de 2019, o número de mulheres encarceradas aumentou para 37,2 mil. Em março de 2020, o meso órgão realizou um mapeamento de mulheres presas grávidas, parturientes, mães de crianças até 12 anos, idosas ou doentes no sistema prisional brasileiro, e, do total de presas, 12.821 são mães de crianças até 12 anos. Por fim, não resta dúvida de que são necessárias a implementação de políticas públicas consistentes, no sentido de promover a integração entre mãe e filho em um ambiente saudável e com oportunidades de ressocialização. Não obstante, de acordo com Andrade e Cambi (2019), é imprescindível que os membros do Poder Judiciário reconheçam o paradoxo da efetivação dos Direitos HumanosFundamentais no sistema carcerário brasileiro e para sanar a questão invoquem normas internacionais de proteção, a fim de impedir a aplicação de penas degradantes as mulheres, bem como, a transcendência da sanção ao nascituro, promovendo, desse modo, a efetivação da dignidade humana nos presídios femininos.

Conclusão: Depreende-se que o direito fundamental à convivência familiar entre mães detentas e seus filhos é um dever de todos, destarte, devem ser desenvolvidas políticas públicas no sentido de tornar o ambiente carcerário adequado e acolhedor para receber as crianças e adolescentes que ali permanecerão, enquanto perdurar o cumprimento da pena das mães.

\section{Referências}

BRASIL. Constituição da República Federativa do Brasil: promulgada em 5 de outubro de 1988. Vade Mecum Saraiva. Ed. 27 - São Paulo: Saraiva Educação,2019.

Lei $n^{\circ} 11.942$, de 27 de maio de 2009. Lei de Execução Penal, para assegurar às mães presas e aos recém-

nascidos condições mínimas de assistência. Vade Mecum Saraiva. Ed. 27 - São Paulo: Saraiva Educação,2019

Ministério da Justiça. Dar a luz na sombra: condições atuais e possibilidades futuras para o exercício da

maternidade por mulheres em situação de prisão. Secretaria de Assuntos Legislativos. Brasília: Ministério da Justiça, IPEA, 
CONSELHO NACIONAL DE JUSTIÇA. Regras de Bangkok: Regras das Nações Unidas para o Tratamento de Mulheres Presas e Medidas Não Privativas de Liberdade para Mulheres Infratoras. Conselho Nacional de Justiça. Brasília: Conselho Nacional de Justiça, 2016.

INFOPEN - Levantamento Nacional de Informações Penitenciárias/ Período de julho a dezembro de 2019. Disponível em: http://antigo.depen.gov.br/DEPEN/depen/sisdepen/infopen/infopen. Acesso em: 28 jul. 2020.

MACIEL, K. R. F. L. A. Curso de Direito da Criança e do Adolescente: Aspectos teóricos e práticos .11. ed. São Paulo: Saraiva, 2018.

ANDRADE, A. P.; CAMBI, E. Encarceramento da Maternidade no Estado de Coisas Inconstitucional. Revista Brasileira de Ciências Criminais, v. 160, p. 295 317, Out . 2019

Coordenadoria de Pesquisa e Extensāo - COPEX

Departamento de Editoraçāo e Divulgaçāo Científica - DEDIC 


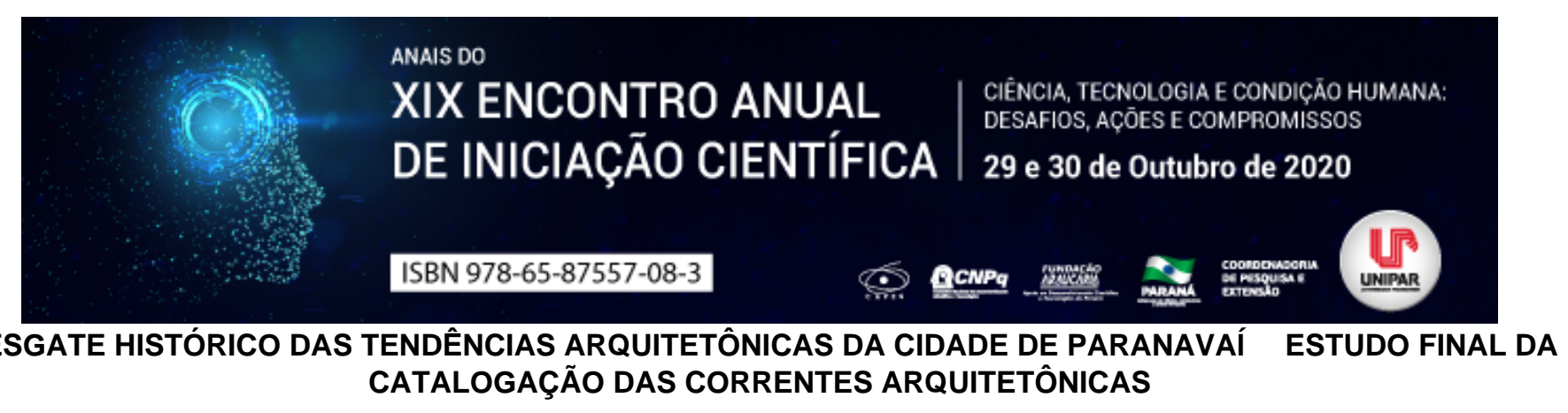

\begin{abstract}
${ }^{1}$ MARIANA GIACOBBO, ${ }^{2}$ IARA CAMARGO NACLE MERLINI, ${ }^{3}$ HELOISA REGINA RODRIGUES MENDES, ${ }^{4}$ ELIANA RODRIGUES BARONE, ${ }^{5}$ FABIO EDUARDO ALMEIDA SALDANHA MUNIZ, ${ }^{6}$ TATIANA QUEIROZ BARDI AUGUSTO
\end{abstract}

\begin{abstract}
${ }^{1}$ Acadêmico do Curso de Arquitetura e Urbanismo da UNIPAR
${ }^{1}$ Acadêmica do Curso de Arquitetura e Urbanismo da UNIPAR

${ }^{2}$ Acadêmica do Curso de Arquitetura e Urbanismo da UNIPAR

${ }^{3}$ Acadêmica do Curso de Arquitetura e Urbanismo da UNIPAR

${ }^{4}$ Acadêmico do Curso de Arquitetura e Urbanismo da UNIPAR

${ }^{5}$ Docente da UNIPAR
\end{abstract}

Introdução: O resgate arquitetônico, além de ferramenta de aprendizagem, mostra a importância de um edifício ou local, bem como sua identidade e história, transmitindo para os usuários o dever de sua preservação. A arquitetura, desde os primórdios, representa a história de seu tempo e a necessidade de seu povo, assim como afirma o arquiteto Mies Van der Rohe ao dizer a arquitetura é a vontade de uma época traduzida em espaço (SCHMIDT, 2014). Este estudo une os artigos desenvolvidos desde 2018, que resgatam obras da cidade de Paranavaí, sendo o caráter de escolha dos edifícios, a relevância que ela apresenta, sendo de forma estética, estrutural, histórica ou impacto social. A cidade, com início da colonização desde a década de 20 , ganhou independência em 1952, assim, endo em vista que a área mais antiga da cidade se localiza no atual centro comercial, as edificações passaram a ser escolhidas a partir desde local, onde estão localizadas as edificações e espaços mais antigos da cidade.

Objetivo: Finalizar o estudo efetuado das correntes e tendências arquitetônicas dos edifícios e espaços da cidade de Paranavaí, relembrando as discussões e resultados encontrados nos estudos, trazendo a importância de tal analise para os habitantes, estudantes e pesquisadores, criando um acervo de imagens e conteúdo teórico para mostrar a linha temporal da arquitetura na cidade, seu contexto, história e métodos, bem como a necessidade de sua preservação, tendo em vista sua importância tanto em sua característica física como para a história da cidade e população, objetivando sua preservação ou criação de sua memória.

Material e Métodos: Primeiramente analisou-se os estudos anteriores, trazendo à tona as teorias levantadas e pesquisada, elencando-se as discussões pertinentes para o estudo final, tendo em vista o objetivo e tema principal. Posteriormente reuniu-se as obras analisadas, dividindo-as conforme estilo arquitetônico, bem como levantando suas análises e, por fim, criação de acervo fotográfico e teórico sobre o tema.

Resultados: Nos estudos de Neto et al (2018), Nacle et al (2019) e Muniz et al (2020), foram resgatadas 13 obras, sendo elas 5 residências, 6 edifícios de serviços (fórum, secretaria de esportes, secretaria do meio ambiente, paço municipal, escola e igreja) 1 de uso misto e 1 uma praça pública. Das residências, 3 possuem estilo colonial, caracterizadas pelo extenso uso de madeiras em piso, paredes e teto e também pelo tijolo de barro aparente (NETO et al, 2018). As outras 2 residências, bem como o fórum, paço municipal, escola, igreja e o edifício de uso misto, encontram-se na vertente modernista, pelo extenso uso do aço, concreto armado, janelas padronizadas e lineares, brises, formas retilíneas, pilotis, pré-moldados, sheds e ritmidade (MUNIZ et al, 2020). Já a secretaria de esportes e do meio ambiente foram classificadas como vernaculares, pelo uso de tijolos aparentes, telha cerâmica e toras de madeira com função estrutural, diferenciando-se da arquitetura colonial por não utilizar madeira de forma extensa e por sua volumetria mais contemporânea, sendo que a secretaria de esportes também possui traços modernistas (NACLE et al, 2019).

Discussão: Segundo Corbusier (1994), o espaço é uma forma genérica de comunicação, repleta de significados, e completa que a arquitetura é concebida para comover. Gehl (2015), traz ainda, que o local de encontro contribui para melhoria da sustentabilidade social e criação de uma sociedade aberta e democrática, gerando uma cidade viva. Neste sentido, está o termo patrimônio, que representa a herança, onde as obras escolhidas possuem grande carga emocional e histórica para a população, sendo que a noção de cultura e identidade, bem como noção de cidadania, são diretamente ligadas à memória coletiva e à preservação destes bens. Tais obras são diversas vezes apontadas como ponto de localização e encontro, também definidos como Pontos Nodais: locais estratégicos da cidade onde o observador pode entrar (LYNCH, 2011). Dentre as correntes constatadas, o estilo colonial é a arquitetura realizada desde 1500, importando estilos da capital europeia e adaptando ao clima e materiais disponíveis, sofrendo modificações e traçados. Já a arquitetura moderna iniciou-se na década de 20 , quando o país ganhou grande desenvolvimento industrial e exigiu-se uma arquitetura nova, que acompanhasse o crescimento do país. Por fim, a arquitetura vernacular esteve presente em todas as civilizações, utilizando os materiais locais e solucionando as necessidades 
do usuário sob o devido clima.

Conclusão: Este estudo concluiu que as arquiteturas estudadas possuem grande importância para a cidade, tanto por muitas delas serem da época da colonização quanto por seu caráter estético, sendo imprescindível a catalogação e criação de acervo e material teórico para transmitir a todos a função social e necessidade da preservação de tais bens, uma vez que faltam documentos referentes aos edifícios e sua importância, além de diversos destes locais sofrerem com pressão imobiliária ou afins, correndo o risco de passarem por demolições ou reformas que as desconfigurem.

\section{Referências}

GEHL, Jan. Cidade Para Pessoas. 3. ed. São Paulo: Perspectiva, 2015.

LE CORBUSIER. Por uma arquitetura. São Paulo: Perspectiva, 1994.

LYNCH, Kevin. A imagem da cidade, trad. Jefferson Luiz Camargo. $3^{\text {a }}$ ed. Sao Paulo: WMF Martins Fontes, 2011.

MUNIZ, Fábio Eduardo Almeida Saldanha; BARONE, Eliana Rodrigues; MENDES, Heloisa Regina Rodrigues; NACLE, Iara; GIACOBBO, Mariana; AUGUSTO, Tatiana Queiroz Bardi. Resgate histórico - Tendências arquitetônicas da cidade de Paranavaí Edificações privadas, públicas e de uso comum. Paranavaí, XIX Encontro Anual de Iniciação Científica. Unipar, 2020.

NACLE, Iara; COSTA, Isabela Cristina; RODRIGUES, Jonatan; GIACOBBO, Mariana; SANTANA, Renato Carrazoni; AUGUSTO, Tatiana Queiroz Bardi. Resgate Histórico das Tendências Arquitetônicas da cidade de Paranavaí Catalogação das correntes arquitetônicas das edificações públicas e áreas de convívio comum. Paranavaí, IV Congresso Internacional de Ciencia, Tecnologia e Inovação. Unipar, 2019.

NETO, Roberto Ortega Moura. Resgate Histórico das Tendências Arquitetônicas da Cidade de Paranavaí. Paranavaí, III Congresso Internacional de Ciencia, Tecnologia e Inovação. Unipar, 2018.

SCHMIDT, Laila Rotter. LESS IS MORE: Interseções entre o surgimento do design gráfico moderno e o minimalismo de Mies van der Rohe. Congresso de pesquisa e desenvolvimento em design, [S. I.], p. 1-11, 30 set. 2014.

Coordenadoria de Pesquisa e Extensão - COPEX

Departamento de Editoraçāo e Divulgaçāo Científica - DEDIC 


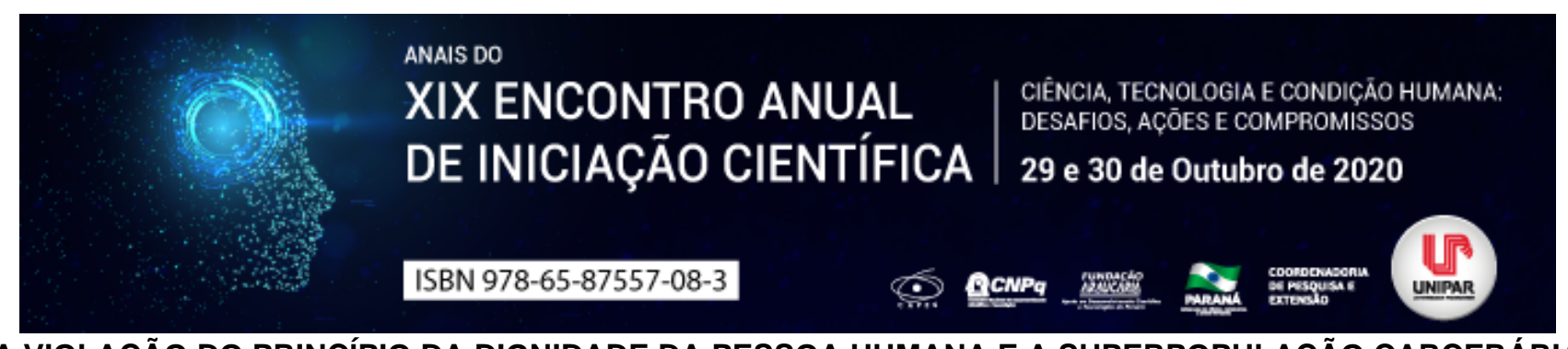

A VIOLAÇÃO DO PRINCÍPIO DA DIGNIDADE DA PESSOA HUMANA E A SUPERPOPULAÇÃO CARCERÁRIA

\author{
${ }^{1}$ MAYCON PELENTIR DUMMEL, ${ }^{2}$ LUDMILA KOLB DE VARGAS CAVALLI
}

\author{
${ }^{1}$ Acadêmico de Direito da Unipar \\ ${ }^{1}$ Docente da UNIPAR
}

Introdução: Todos os indivíduos possuem garantia constitucional de respeito a seus direitos humanos e fundamentais. Porém, em razão da superlotação carcerária, há notória e constante violação dos direitos mais básicos dos reclusos, em nítido desrespeito à dignidade da pessoa humana.

Objetivo: Analisar a aplicabilidade dos direitos humanos e fundamentais no sistema prisional brasileiro sob a ótica da superpopulação carcerária. A pesquisa se faz pelo método dedutivo, examinada através da análise bibliográfica.

Desenvolvimento: Ao longo dos anos é possível observar um elevado aumento carcerário em nosso país. Dada a inexistência de ampliação significativa das vagas em unidades prisionais, há também um aumento da superpopulação carcerária. A prática leva, inevitavelmente, ao desrespeito aos direitos humanos mais básicos. De acordo com o art. 50, inciso III, da Constituição Federal (BRASIL, 1988), nota-se que ninguém será submetido à tortura nem a tratamento desumano ou degradante , este sendo ou não criminoso. Por sua vez, ao observarmos o art. 10 da Lei de Execuções Penais - LEP, é visto que a assistência ao preso e ao internado é dever do Estado, objetivando prevenir o crime e orientar o retorno à convivência em sociedadel" (BRASIL, 1984). O mesmo diploma, em seu art. 40 , também impõe às autoridades o respeito à integridade física e moral dos condenados e dos presos provisórios. No entanto, mesmo com estas ferramentas, observa-se que, conforme se tornam as condições mais pertinentes a expansão do problema, mais se torna difícil a realização das funções do encarceramento, a buscar reintegrar o indivíduo socialmente. Todavia, é comum por grande parte da sociedade tratar da temática proposta de maneira rasa e sem aprofundamento, muitas vezes ligando quem busca solucionar ou atenuar o problema com a ideia de defensor de bandido Percebe-se que é exatamente o oposto, pois aplicando de maneira legítima e correta as previsões dispostas as garantias positivadas na Constituição com e na legislação infraconstitucional, o problema da criminalidade tende a diminuir, melhorando até mesmo a função da ressocialização do indivíduo perante a sociedade. Nesta ideia, é notório que são diversas as irregularidades na organização jurídica carcerária, como intitula a Revista em Discussão (EM DISCUSSÃO, 2016, p.19): Os presos podem ser extorquidos, ameaçados ou sofrer qualquer outro tipo de violência. Contudo, é bastante possível que nada seja devidamente comprovado, investigado ou averiguado, diz o relatório do Mecanismo Nacional de Prevenção e Combate à Tortura (MNPCT), sobre o Presídio Central de Porto Alegre. Assim é possível compreender o tamanho descaso referente à aplicabilidade do princípio do princípio da dignidade da pessoa humana. O mesmo periódico expõe como exemplo a situação do Complexo Penitenciário de Pedrinhas, em São Luís - MA em que os presos vivem em condições insalubres de saúde, compartilhando seu ambiente com ratos e baratas e consumindo alimentos estragados (EM DISCUSSÃO, 2016, p.19). Essa realidade presenciada no presídio de Pedrinhas é o reflexo de outras realidades prisionais instituídas na sociedade brasileira. Nessa percepção, ressalta-se mais uma vez a falta da constância do Estado a enfrentar a má situação carcerária, com base nos mecanismos constitucionais, pois sendo também o direito à vida assegurado pelo estado, este deve ser garantido em sua dupla acepção, sendo a primeira com relação ao direito de continuar vivo e a segunda de se ter uma vida digna quanto a sua subsistência (MORAES, 2017, p. 35). Assim, o princípio fundamental, deve ser garantido a qualquer cidadão, haja vista que, em regra, todos (até mesmo o maior de todos os criminosos) detém o atributo intrínseco da pessoa humana, mesmo não se comportando dignamente com os demais integrantes da sociedade (GOMES, 2016, p. 15).

Conclusão: Apesar da garantia constitucional de respeito aos direitos fundamentais dos presos, o que se observa na prática é que a superpopulação carcerária leva inevitavelmente à violação da dignidade da pessoa humana. Neste sentido, a melhoria das condições do ambiente prisional e a redução da superpopulação são passos necessários na busca pela ressocialização do encarcerado e por políticas de segurança pública realmente efetivas. Apenas o respeito à dignidade da pessoa humana no sistema prisional tornará possível que a pena atenda à finalidade de recuperação do delinquente, justificando a sua imposição.

\title{
Referências
}

FERNANDES, Bruno Lacerda Bezerra, Direitos Fundamentais Como Limites ao Dever-Poder de Punir do Estado: Um Novo Paradigma a Execução Penal Brasileira. Orientador: Walter Nunes da Silva Júnior. 2016. 131 f. Dissertação (Mestrado em Ciências Jurídicas) - Universidade Federal do Rio Grande do Norte, Natal, 2016. Disponível em: https://repositorio.ufrn.br/jspui/bitstream/123456789/21314/1/DireitosFundamentaisLimites_Fernandes_2016.pdf Acesso em: 24/08/2020.

MORAES, Alexandre de. Direito Constitucional. 34ª ED. São Paulo. Atlas. 2017. 
EM DISCUSSÃO. A visão social do Preso. Brasília, n. 29 - setembro de 2016 . Disponível em: https://www12.senado.leg.br/emdiscussao/edicoes/privatizacao-de-presidios/privatizacao-de-presidios/a-visao-social-do-preso Acesso em: 16/08/2020.

BRASIL. 05 de Outubro de 1988. Constituição da República Federativa do Brasil. CONSTITUIÇÃO DA REPÚBLICA FEDERATIVA DO BRASIL - 1988. Diário Oficial da União, Brasília, D.O.U de 05/10/1988, pág. no 1.

BRASIL. Lei no 7.210, de 11 de julho de 1984. Lei de Execuções Penais - LEP. INSTITUI A LEI DE EXECUÇÃO PENAL. Diário Oficial da União de 13/07/1984 (p. 10227, col. 2).

Coordenadoria de Pesquisa e Extensão - COPEX

Departamento de Editoraçāo e Divulgaçāo Científica - DEDIC 


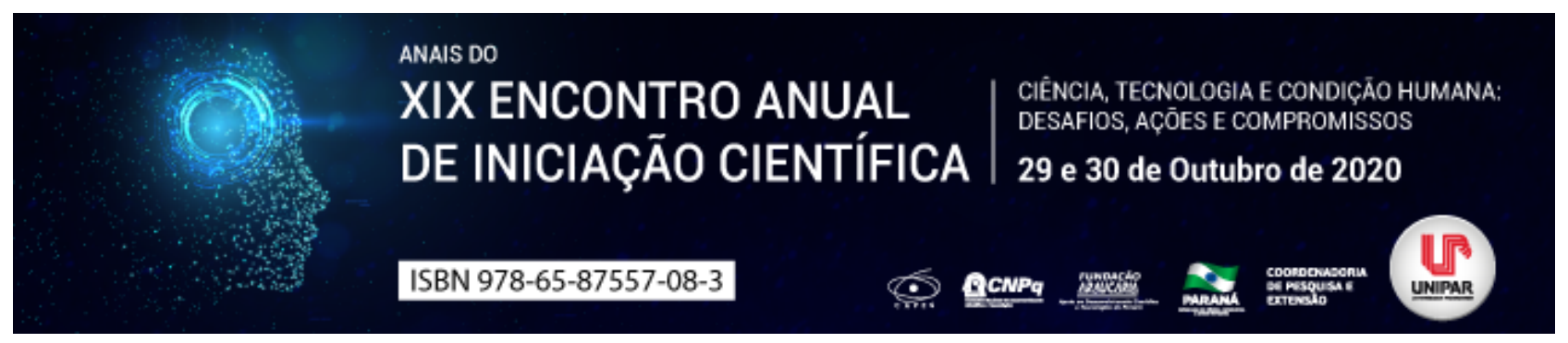

TREINAMENTO E DESENVOLVIMENTO: UMA FERRAMENTA PARA O SUCESSO EFICAZ DE UMA EMPRESA

\author{
${ }^{1}$ GABRIEL MAGALHAES DOS SANTOS, ${ }^{2}$ ELIZANGELA MARIA MENEGASSI DE LIMA
}

\author{
${ }^{1}$ Acadêmico do PIC/ Unipar \\ ${ }^{1}$ Docente da UNIPAR
}

Introdução: Em um mercado tão concorrido, abrangente e tecnológico, ter uma equipe de qualidade se torna imprescindível aos planos de uma empresa. Para se oferecer produtos e serviços que satisfaçam a demanda do cliente e supere a concorrência, é preciso de colaboradores prontos e capazes de proporcionar o que a organização planejou e serem eficientes e eficazes nos processos. Assim, a ferramenta de Treinamento e Desenvolvimento de Pessoas (T\&D) entra em ação, capacitando os colaboradores, onde o treinamento prepara a curto prazo, tornando-os aptos para a execução das tarefas operacionais do cargo, corrigindo erros pontuais, e o desenvolvimento, numa especialização a longo prazo, criando valor para a equipe, aperfeiçoando suas características e aprendizado, tornando-os parte da estrutura da organização.

Objetivo: O objetivo deste estudo é descrever o processo do Treinamento e Desenvolvimento de Pessoas no âmbito empresarial.

Desenvolvimento: Segundo Romero, Silva, Kops (2013), o processo de T\&D é algo contínuo e cíclico, que capacita os profissionais, levando-os a se desenvolverem sistematicamente, e para isso, este processo precisa ser estruturado com etapas essenciais, começando pelo levantamento das necessidades, que diz o que precisa ser desenvolvido e mudado, seguido pelo programa de preparação, onde se elabora o projeto de treinamento, depois é a execução do projeto e por fim a avaliação, que traz os resultados do processo. Assim, esse ciclo se reinicia a cada necessidade levantada, para garantir o sucesso da empresa a cada empecilho que surgir. Treinamento é o processo educacional de curto prazo aplicado de maneira sistemática e organizada, pelo qual as pessoas aprendem conhecimentos, atitudes e competências em função de objetivos previamente definidos. (CHIAVENATO, 2010, p. 495). Desse modo, é necessário entender o treinamento como um investimento, no qual, se prepara o empregado para exercer seu cargo com eficiência, de acordo as funções estabelecidas, trazendo retorno inevitável para a empresa. Com isso, os níveis do colaborador e da empresa se elevam, incentivando estes a se desenvolverem cada vez mais, onde a organização deve manter esses incentivos, pois sem a motivação, não há resultados eficazes. Em conjunto com o treinamento, está o desenvolvimento de pessoas, que de acordo com Paiva (2019), diz respeito ao conhecimento adquirido pelo colaborador, preparando-o para exercer atividades em um futuro próximo, num período de médio e longo prazo, formando sua carreira profissional. Portanto, o desenvolvimento se enquadra como o aperfeiçoamento do treinamento, onde, o que foi absorvido pela pessoa se torna algo único, gerando valor a esta, no qual, irá usar desta experiência para ajudar a empresa em todos os quesitos, tanto no presente, como também nas ações futuras.

Conclusão: Diante disso, o processo de treinamento e desenvolvimento leva a empresa a ter uma equipe de colaboradores qualificados e aptos para desempenharem seus cargos e funções. Essa ferramenta vai gerar funcionários muito mais preparados, tanto para lidar e corrigir os erros de suas ações, quanto para promoverem mudanças nos processos da empresa, com todo o aprendizado que Ihes foram impostos, para alterar o quadro da organização, gerando mais eficiência e eficácia nos métodos. Assim, a equipe se tornará mais que um capital humano, serão participantes e também responsáveis pelo sucesso de toda a empresa.

\title{
Referências
}

ROMERO, Sonia Mara Thater; SILVA, Selma França da Costa e; KOPS, Lucia Maria. Gestão de pessoas: conceitos e estratégias. Curitiba: InterSaberes, 2013.

CHIAVENATO, Idalberto. Gestão de Pessoas: o novo papel dos recursos humanos nas organizações. 3ed. Rio de Janeiro: Elsevier, 2010.

PAIVA, Kely César Martins de. Gestão de Recursos humanos: teorias e reflexões. Curitiba: InterSaberes, 2019. 


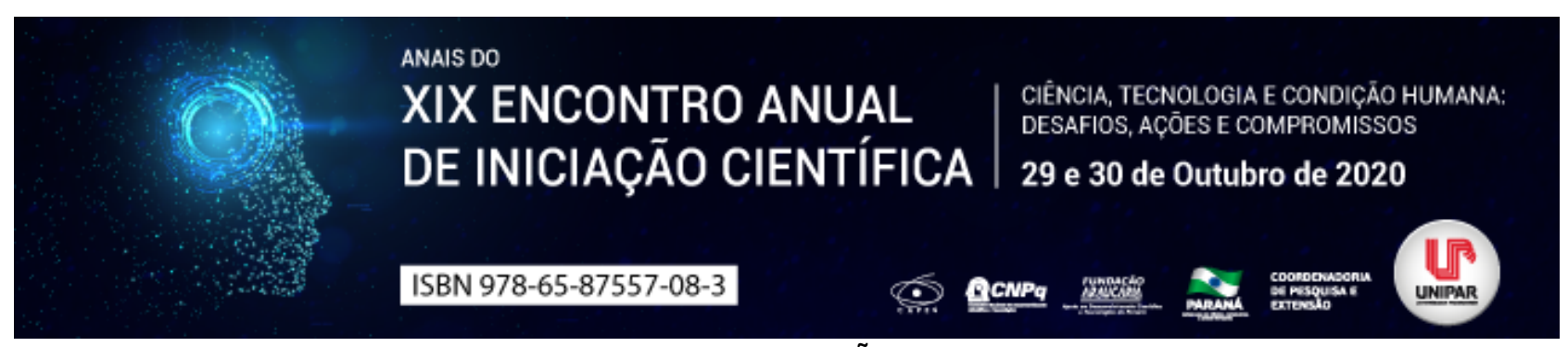

O INSTITUTO DA DELAÇÃO PREMIADA

\author{
${ }^{1}$ RODRIGO DE SOUZA SCHMITZ, ${ }^{2}$ ANTONIO DA SILVA JUNIOR
}

\author{
${ }^{1}$ ACADÊMICO DO CURSO DE DIREITO DA UNIPAR \\ ${ }^{1}$ Docente da UNIPAR
}

Introdução: O instituto da delação premiada é um acordo entre delator e o Estado, com a confissão ou com informações relevantes do delator que negocia com o Estado, benefícios que reduzam sua pena ou the propiciem a obtenção do perdão judicial. Vem sendo utilizado cada vez mais no Brasil diante do quadro crítico e das mais variadas organizações criminosas que estão sendo descobertas e investigadas pelo poder público, seguindo uma tendência mundial no combate ao crime organizado. Em outro ponto, a adoção da delação premiada expõe a incapacidade do Estado no combate as inúmeras ações criminosas, percebe-se que é um ato necessário no combate à criminalidade atual. Muito ouvimos falar na doutrina sobre controvérsias da delação premiada, mais especificamente como procedimento antiético. Neste ponto, fere os princípios constitucionais? A delação premiada é eficaz? Quais critérios para sua utilização? Para isso apresento-lhes: O Instituto da Delação Premiada

Objetivo: Tem por objetivo demonstrar se existe efetividade e eficácia no combate a conduta criminosa com ênfase nos crimes de maior repercussão social e lavagem de dinheiro.

Desenvolvimento: A delação premiada possui origem etimológica do Latim a l"delationel", que significa delatar algo, sendo esta adotada pelo ordenamento jurídico brasileiro através da Lei 8.072/90, lei esta que trata dos crimes hediondos, como também prevista nos crimes de extorsão mediante sequestro, art. 159, $\S 4^{\circ}$ do Código Penal, ademais, fora inserida também em crimes semelhantes aos hediondos praticados por concurso de pessoas. Ou seja, o instituto abordado, conceitua-se como sendo a adoção da conduta voluntária do indivíduo de colaborar com a autoridade, seja nomeando um terceiro como autor, coautor ou partícipe, seja fornecendo informações acerca do delito em questão, devendo estas informações serem concretas e relevantes a solução do caso, como por exemplo a recuperação de produto do crime ou apreensão dos demais membros do concurso criminoso. Não é suficiente apenas a repassagem de informações, estas deverão ser convenientes e úteis em grau máximo para aplicação do prêmio. São chamados de I"pentitil" aqueles sujeitos que confessam seus próprios crimes e proporcionam à autoridade informações necessárias para reconstituir o fato delituoso e nomeação dos participantes do delito. Em suma, pode-se dizer que a delação premiada é um instituto que garante ao indivíduo colaborador, devendo este ser investigado, acusado, indiciado ou condenado, um prêmio pela colaboração para elucidação do crime cometido, sendo este prêmio a redução de sua pena, porém, pode-se chegar até a isenção da pena do sujeito. Os defensores da delação premiada asseveram que este é um meio legal e eficiente de descobrir e destruir quadrilhas e organizações criminosas, aumentando a possibilidade de punição dos seus integrantes, sendo instrumento útil para o interesse público e social. Assim o estudo da delação premiada contribui na compreensão de sua eficácia dentro do direito penal.

Conclusão: Se pode compreender pelo estudo apresentado que através do instituto da delação premiada tornou-se uma ação de grande importância para as ações de combate à criminalidade organizada, tornando então legal os atos da delação. Não obstante esses apontamentos são necessários destacar também os argumentos contrários de delação premiada. O principal ponto negativo é impunidade, afinal, aquele que entrega seus comparsas possuirá benefícios; além disso, não é visto com bons olhos que se premie aquele que cometeu um crime e que denunciou os seus outrora companheiros, em um ato individualista. Ademais, é possível que a delação seja retrato de uma incriminação puramente vingativa.

\title{
Referências
}

BADARÓ, Gustavo Henrique; BOTTINI, Pierpaolo Cruz . Lavagem de Dinheiro: Aspectos Penais e Processuais: Comentários à Lei 9.613/98 com alterações da Lei 12.683/12. 2 ed. São Paulo: Editora Revista dos Tribunais, 2013.

BITTAR, Walter Barbosa. Delação Premiada (Direito estrangeiro, Doutrina e Jurisprudência). 2 ed. Rio de Janeiro: editora Lumen Juris, 2011.

CARVALHO, Natália Oliveira de. A delação premiada no Brasil, Editora Juris. O valor da confissão como meio de prova no processo penal. São Paulo: RT, 1997.

FILHO, Vicente Greco. Manual de Processo Penal, 9 Edição. São Paulo: Editora Saraiva, 2012.

GUIDI, José Alexandre Marson. Delação premiada no combate ao crime organizado. São Paulo: Lemos e Cruz, 2006.

GUIMARÃES, Deocleciano Torrieri. Dicionário Técnico Jurídico. 9. Ed. São Paulo: Rideel, 2007.

JESUS, Damásio Evangelista de. Direito Penal: Parte Geral. 28. Ed. São Paulo: Saraiva, 2006. Vol. 1.

LIMA, Renato Brasileiro de. Legislação criminal especial comentada. 2. ed. Salvador: Juspodium, 2014. 
LIMA, Renato Brasileiro. Manual de Processo Penal. $3^{\mathrm{a}}$ ed. Rev. E atual. Salvador: Editora Juspodium, 2015. LOPES JR., Aury. Direito Processual Penal. 9. Ed. São Paulo: Saraiva, 2012.

MACHADO, Antonio Alberto. Curso de processo penal. 3. ed. São Paulo: Atlas, 2010.

MACHADO, Antonio Alberto. Teoria geral do processo penal. Sao Paulo: Atlas, 2009.

MIRABETE, Julio Fabbrini. Processo penal. 17 ed. rev. Atual São Paulo: Atlas, 2005.

NUCCI, Guilherme de Souza. Provas no processo penal. 2. ed. São Paulo: Revista dos Tribunais, 2011.

OLIVEIRA, Eugenio Pacelli de. Curso de processo penal. 12 ed. Rio de Janeiro: Lumen Juris, 2009.

TÁVORA, Nestor. ALENCAR, Rosmar Rodrigues. Curso de Direito Processual Penal. 3. Ed. Salvador: Jus Podium, 2009.

YAROCHEWSKY, Leonardo Isaac. Delação Premiada no Projeto de Reforma do Código Penal: Nova Roupagem, Antigos

Problemas. R. EMERJ, Rio de Janeiro, v. 15, n. 60, p. 126-142, out.-dez. 2012.

Coordenadoria de Pesquisa e Extensão - COPEX

Departamento de Editoraçāo e Divulgaçāo Científica - DEDIC 


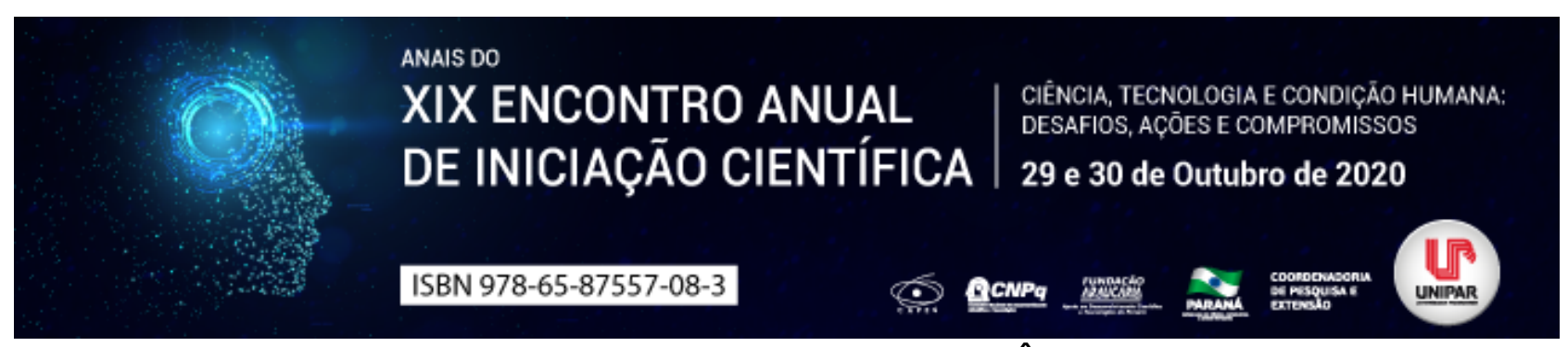

BIBLIOTERAPIA INFANTIL: UMA PROPOSTA TERAPÊUTICA HOSPITALAR

\begin{abstract}
${ }^{1}$ GRAZIELE BRAGA, ${ }^{2}$ LETICIA ZANFRILLI, ${ }^{3}$ ANNI CAROLINI FARIA, ${ }^{4}$ CLARICE REGINA CATELAN FERREIRA, ${ }^{5}$ MARIANNA COSTA OLIVEIRA, ${ }^{6}$ GILBERTO ALVES
\end{abstract}

\author{
${ }^{1}$ Acadêmica PIC/Unipar \\ ${ }^{1}$ Acadêmica do Curso de Psicologia da UNIPAR \\ ${ }^{2}$ Acadêmica do Curso de Psicologia da UNIPAR \\ ${ }^{3}$ Docente da UNIPAR \\ ${ }^{4}$ Docente da UNIPAR \\ ${ }^{5}$ Docente da UNIPAR
}

Introdução: A literatura, em todas suas formas, possui valor terapêutico seja de descontração, informação, percepção do social, reflexão de si, além de estimular a imaginação. Contudo, ao obter valor científico, distinguir-se na análise psicoterapêutica, a Biblioterapia é uma técnica que oferece subsídios em processos de prevenção e cura, utilizada em diversos contextos, situações, sobretudo na compreensão de crianças mediante procedimentos hospitalares (CALDIN, 2001).

Objetivo: Apresentar a Biblioterapia como recurso terapêutico em tratamentos hospitalares de crianças.

Desenvolvimento: Há tempos perceberam a função terapêutica da leitura, onde no contato com a arte escrita se faz interlocução entre a realidade e a fantasia, pensamento e sentimento, comunicam com fatores subjetivos que propiciam transformações. Ao constatar a eficácia em tratamentos de doenças mentais no início do século XX, a Terapia por meio de Livros tem se estruturado e adquirido espaço como forma de intervenção (ARAúJO, 2018). Sendo assim, a Biblioterapia se insere em espaços de tratamento, prevenção e processos de cura na interação do sujeito com a narração, imaginação, interpretação, trocas de vivências entre a história, os demais participantes e o facilitador, integrando elementos que promovem transformações. Para isto, Caldin (2001) pontua alguns componentes biblioterapêuticos tais como catarse, humor, identificação, introjeção, projeção e introspecção. De acordo com Silva, Lima \& Colheiros(2019), todas as estruturas hospitalares foram feitas para facilitar o trabalho dos profissionais e para atender o maior número de pessoas possíveis de forma eficiente, porém o bem estar emocional do paciente foi deixado de lado, principalmente quando se referem às crianças, pelo fato delas estranharem o local com mais facilidade ou por não entender a doença que estão enfrentando no momento. Com isso, a ideia de apresentar a Biblioterapia como recurso terapêutico em procedimentos hospitalares de crianças surge com o propósito de minimizar a angústia, isolamento e a fragilidade física e emocional decorrente da internação. Visto o enriquecimento que a Biblioterapia proporciona, as ampliações nas legislações de saúde tem aberto espaço para repensar práticas e estratégias que tornem o hospital num ambiente humanizado e acolhedor (BRASIL, 2010). Ao pensar na criança hospitalizada, a ruptura no processo habitual de desenvolvimento ocorrem mudanças na rotina, readaptação, acometendo também toda a rede de a qual pertence, família, escola, sociedade. Por meio da literatura as tensões podem ser aliviadas, as dores se canalizam, as emoções tomam forma, as possíveis consequências deste procedimento doloroso pode ser minorado, além de viabilizar a compreensão de determinadas técnicas, contribuindo assim com a evolução do processo, seja no aspecto biológico e/ou emocional (HAYGERTT, et al 2019). Há relatos de intervenções realizadas nestes espaços que validam os aportes teóricos. Costa (2020) apresenta a prática, primeiramente da Literacura, onde crianças em processos de hospitalização em conexão com livros percebem seus sentimentos, as semelhanças e diferenças com as histórias narradas, interagem com os que estão ao seu redor e expandem o elo da dor em confiança e força para superarem os desafios. A renovação de um sujeito, contagia todos ao seu redor. O contato a Biblioterapia em todos seus componentes, especialmente com o imaginário, sobrepõe a tocante realidade das situações dolorosas e invasivas e vivifica não apenas as crianças, mas seus familiares, a equipe que as atende, até mesmo os mediadores desta modalidade terapêutica (CALDIN, 2002). Uma dessas intervenções de grande sucesso surgiu na cidade de Umuarama com a escritora Ângela Russi. A autora combateu o câncer em 2006 e durante o tratamento foi encaminhada para a ala infantil, devido a superlotação, e dali surgiu o desejo de criar histórias que fizessem com que o processo de luta contra a doença fosse feito de forma mais leve. A coleção Vire a Página , conta com livros ilustrados, que de forma lúdica, explicam para a criança o que está acontecendo dentro de seus pequenos corpos. Utiliza metáforas como a de uma árvore perdendo as folhas para explicar a perda dos cabelos, de figuras como um bravo caçador chamado químio ao descrever o processo de quimioterapia, entre outras histórias que empregam figuras literárias para explicar e fazer com que as crianças entendam o que se passa e amenizem o medo do processo (PORTAL DE UMUARAMA, 2019).

Conclusão: A bibliografia levantada apresenta tamanha contribuição da Biblioterapia em tratamentos hospitalares de crianças e sua influência àqueles que estão ao seu redor. Assim, através deste método, o desconforto causado pelo processo de internação 
é minimizado por meio de atividades que tranquilizem o ambiente hospitalar e melhore a qualidade de vida do paciente, e assim, automaticamente também trás benefícios no tratamento do indivíduo. Com isso, ainda que tal prática esteja um tanto distanciada de nossa realidade, o contato com esta literatura acadêmica, científica, impele o desejo de viabilizar este projeto de Biblioterapia se insira em nosso contexto.

\section{Referências}

ARAÚJO, Maria C. S. A BIBLIOTERAPIA COMO INSTRUMENTO DE SOCIOEDUCAÇÃO. 2018 Brasília -FOLHAf.- Trabalho de Conclusão de Curso (Monografia)- Faculdade de Ciência da Informação da Universidade de Brasíl, Brasília, 2018.

BRASIL. Ministério da Saúde. Secretaria de Atenção à Saúde. Núcleo Técnico da Política Nacional de Humanização. Ministério da Saúde, Secretaria de Atenção à Saúde, Núcleo Técnico da Política Nacional de Humanização. 2. ed. Brasília: Editora do Ministério da Saúde, 2010

CALDIN, Clarice F.. A Leitura como Função Terapêutica: Biblioterapia. Enc. Bibli: R. Eletr. Bibliotecon. Ci. Inf., ISSN 1518-2924, Florianópolis- SC, n.12, p. 32-44, 2001.

CALDIN, Clarice F. BIBLIOTERAPIA PARA CRIANÇAS INTERNADAS NO HOSPITAL UNIVERSITÁRIO DA UFSC: Uma experiência. Enc. Bibli: R. Eletr. Bibliotecon. Ci. Inf., ISSN 1518-2924, Florianópolis- SC, n.14, p.38-54, 2002.

HAYGERTT, Rafaela O. et al. BIBLIOTERAPIA- Humanização do Espaço Hospitalar na Internação Pediátrica. Universidade Estadual do Rio Grande do Sul. Porto Alegre- RS, 2019

PORTAL DA CIDADE DE UMUARAMA, Coleção Vira a Página , da escritora Ângela Russi, completa dez anos. Postado em 29/05/2019. Acessado em 20/08/20

SILVA, Ana C. P.; LIMA, Fabiana S.; COLHEIROS, Maria I. F. Percepção de Acadêmicos de Psicologia sobre a importância do acolhimento da Contação de História em um Hospital Universitário: Relatos de sua Prática.- GEPNEWS, Maceió, a.3, v.2, n.2, p.461-468, abr./jun. 2019

SONAY, Deyse B. C. A BIBLIOTERAPIA COMO FONTE MEDICINAL: Um Estudo sobre a prática da Leitura no Hospital Varela Santiago Natal. 44f. Trabalho de Conclusão de Curso (Monografia)- Universidade Federal do Rio Grande do Norte, Natal-RN, 2020 


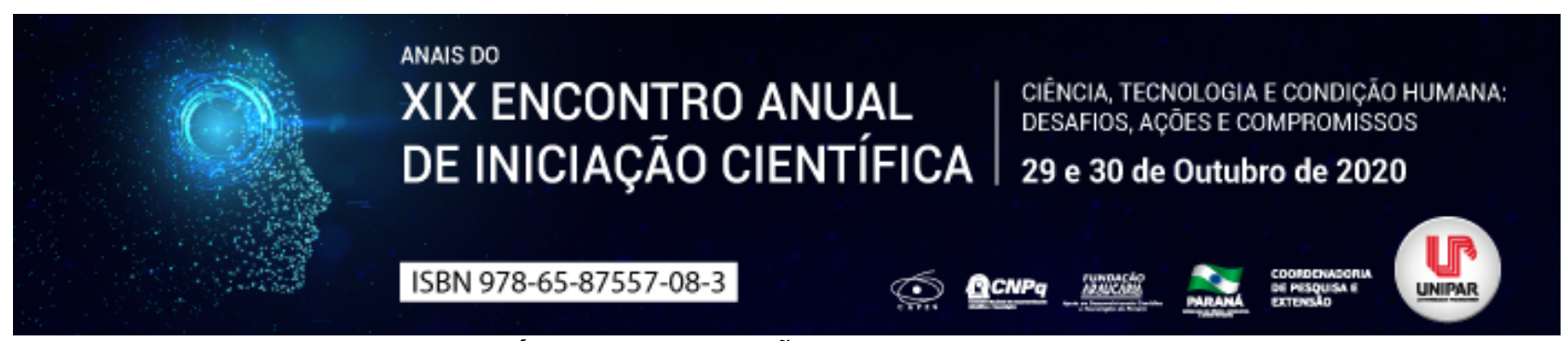

NATUREZA JURÍDICA DA RELAÇÃO ENTRE ADVOGADO E CLIENTE

\author{
${ }^{1}$ EMANNUEL AUGUSTO GOUVEIA SANTOS, ${ }^{2}$ PAULO CESAR DE SOUSA
}

${ }^{1}$ Acadêmico do Curso de Direito da UNIPAR

${ }^{1}$ Docente da UNIPAR

Introdução: Existe controvérsia a respeito da natureza jurídica da relação existente entre um advogado e seu cliente. Alguns doutrinadores e tribunais entendem que se trata de relação de consumo, outros não. Daí a importância em se compreender qual a norma de regência dessa relação: se o Estatuto da Ordem dos Advogados Brasileira (EOAB), só, ou conjuntamente com o Código de Defesa do Consumidor (CDC).

Objetivo: Investigar os fundamentos da controvérsia entre a aplicabilidade da Lei 8.906/94 e a Lei 8.078/90 na relação entre advogado e cliente a fim de encontrar o melhor entendimento a ser aplicado.

Desenvolvimento: Após o advento da Lei 8.906/94, conhecida como o Estatuto da Advocacia e Ordem dos Advogados do Brasil, surgiram controvérsias doutrinárias e jurisprudenciais sobre qual texto normativo teria aplicabilidade na relação entre advogado e cliente: se o CDC, conjuntamente com o Estatuto da Advocacia ou se apenas este último. De um lado, para alguns doutrinadores é, de fato, relação de consumo. Segundo Tartuce (2018, p. 1243) a relação entre advogado e cliente é, sim, uma relação de consumo, pela presença de uma prestação de serviços realizada a um destinatário final fático e econômico, que é o cliente . Seu argumento é construído a partir da aplicação da teoria do diálogo das fontes, em que o sistema jurídico é considerado integrado, mesmo se determinado assunto dispuser de lei específica. Perfilando esse raciocínio, encontram-se julgados nos tribunais de justiça de Minas Gerais, São Paulo e no Supremo Tribunal Federal. Do outro lado, há o entendimento de que a relação entre advogado e cliente não é de consumerista e deve ser regida preponderantemente pela Lei 8.906/94. Esse posicionamento parte da premissa de que, entre o advogado e seu cliente, há uma relação de natureza contratual sujeita a lei específica. A esse propósito, está se consolidando o entendimento do STJ, sendo possível encontrar 13 de seus julgados proclamando não haver relação de consumo na hipótese. O fundamento para essa posição é de que a legislação própria contém princípios éticos, direitos e obrigações específicas do exercício da advocacia, tornando-se a mais apta para tratar do assunto. Nota-se que a pacificação da controvérsia tende adotar a posição dominante segundo a qual o CDC não alcança a relação advogado e cliente.

Conclusão: A natureza jurídica entre advogado e cliente já foi considerada consumerista pela jurisprudência, atualmente não mais o é, pois prevalece o pensamento de que o EOAB é a norma de regência dessa relação.

\title{
Referências
}

LINS, Thiago Drummond de Paula Lins. Responsabilidade civil de profissionais liberais. 1. ed. São Paulo: Forense. 2016.

TARTUCE, Flávio. Manual de responsabilidade civil. 1. ed. São Paulo: Método. 2018.

BRASIL. Superior Tribuna de Justica. REsp 1632766 / SP 2013/0248358-4. Relatora: Ministra Nancy Andrighi. DJ: 06/06/2017. STJ, 2017. Disponível em: encurtador.com.br/gJOZ4. Acesso em: 25 jul. 2020.

MINAS GERAIS. Tribunal de Justiça. Acórdão n. 10024112873419001 MG. Relator: Amorim Siqueira, DJ:01/03/2016. Disponível em: encurtador.com.br/ouFQU. Acesso em: 28 jul. 2020.

SÃO PAULO. Tribunal de Justiça. Apelação n. 00009438220118260664 SP 0000943-82.2011.8.26.0664. Relator: Hamid Bdine, DJ: 10/09/2014. Disponível em: encurtador.com.br/eFH78. Acesso em: 28 jul. 2020 


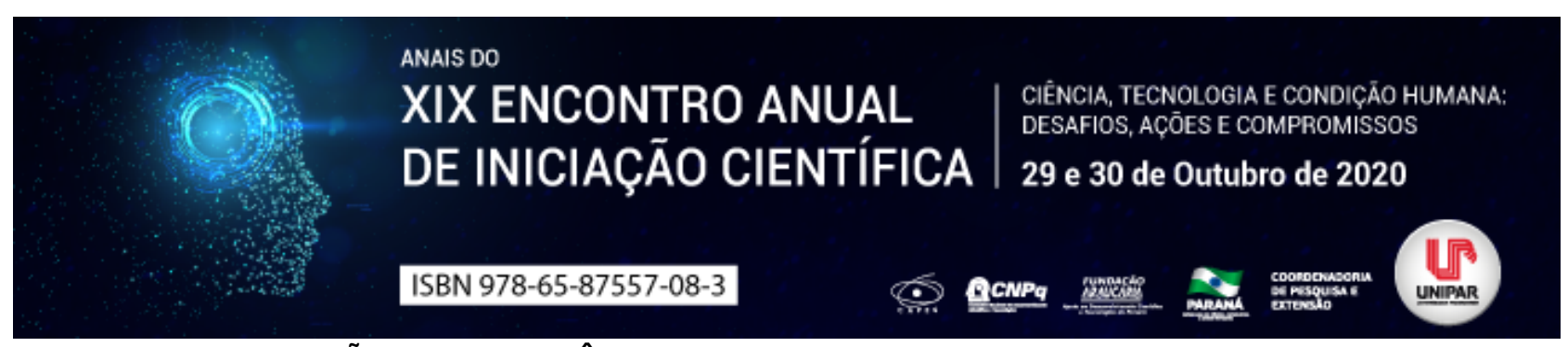

SISTEMA VICTOR: A APLICAÇÃO DA INTELIGÊNCIA ARTIFICIAL EM PROCESSOS DO SUPREMO TRIBUNAL FEDERAL

\author{
${ }^{1}$ GUILHERME KRAVUTSCHKE GOMES DE ANGELO, ${ }^{2}$ ANGELICA GIOSA CANDIDO
}

\author{
${ }^{1}$ Acadêmico do PIC/Unipar \\ ${ }^{1}$ Docente da UNIPAR
}

Introdução: Diante de um cenário de avanço tecnológico exponencial, o uso de ferramentas de Inteligência Artificial deixou o universo da ficção científica para tornar-se realidade cotidiana. No Poder Judiciário o uso de tecnologias também tem crescido consideravelmente, sendo atualmente utilizada inclusive para agilizar a admissibilidade (ou inadmissibilidade) de processos no STF, por meio do sistema Victor, proporcionando avanços significativos em termos de eficiência processual. Por outro lado, levantam-se preocupações relacionadas à confiabilidade e segurança jurídica de tais atos.

Objetivo: Analisar o uso de ferramentas de Inteligência Artificial no Direito, com foco no estudo do sistema Victor, adotado pelo STF.

Desenvolvimento: A Inteligência Artificial diz respeito à programação de computadores que visa à imitação do processo cognitivo do ser humano, para três principais finalidades: aprendizagem, percepção e planejamento. Esse modelo computacional permite que, a partir da análise de um banco de dados, a tecnologia passe a elaborar os próprios resultados, imprevisíveis aos próprios programadores, por meio de um mecanismo conhecido como machine learning (BRAGANÇA et al, 2019, p. 68). O uso de ferramentas deste tipo é crescente no Direito: nos Estados Unidos, os sistemas Ross e Watson são utilizados por escritórios advocatícios para realizar pesquisas jurídicas, analisar documentos, redigir contratos e prever resultados; em Londres, cerca de 48\% dos escritórios advocatícios já utilizam sistemas de inteligência artificial (NUNES et al, 2018, p. 421). No Brasil, atualmente destacam-se os softwares utilizados pelo Tribunal de Contas da União, pelo Superior Tribunal de Justiça (Sócrates), pela Procuradoria do Distrito Federal (Dra. Luzia), e pelo Supremo Tribunal Federal, o Victor. O último possui como principais funções: a) substituição de imagens em textos; b) separação de documentos; c) classificação de peças processuais mais utilizadas pelo STF, e; d) reconhecimento de temas de repercussão geral com maior incidência na Corte (PEREIRA JÚNIOR et al, 2020, p. 107). Trata-se de iniciativa do STF em parceria com a Universidade Nacional de Brasília, , implementada no segundo semestre de 2018, que propõe o uso da inteligência artificial para aumentar a eficiência e a velocidade de avaliação judicial nos processos que chegam à Corte, por meio da substituição de tarefas historicamente feitas manual e individualmente, como é o caso da classificação das peças processuais e identificação dos principais temas de repercussão geral, para devolução do recurso à origem ou sua rejeição. Isso é realizado por meio de redes neurais que se alimentam de decisões anteriores do próprio SFT sobre a aplicação de temas de repercussão geral (MARQUES, 2019, p. 8-9). A principal finalidade do Victor é tornar menos morosa a tramitação de processos, inclusive com a pretensão de ampliação da ferramenta para todos os demais tribunais no médio prazo, de modo a tornar mais eficiente o sistema brasileiro de precedentes, o que poderia impactar na redução de 2 anos ou mais de tramitação apenas na fase de reconhecimento da Repercussão Geral. Ressalva-se que, por enquanto, não foi possível definir se o projeto Victor é efetivamente capaz de contribuir para o Princípio da Razoável Duração do Processo, pois trata-se de inovação recente, e ainda não há dados suficientes para comparação com base nos anos anteriores (ANDRADE et al, 2020, p. 329-332). Esta capacidade de automação é ainda a primeira entre três níveis, enquanto limita-se a apoiar e auxiliar o ser humano na atividade decisória. Neste sentido, a possibilidade de substituição do julgador por meio de decisões automatizadas sem interferência ou revisão humana ainda é matéria sob estudo e de grande polêmica, especialmente devido a existência de barreiras ainda não solucionadas como a existência de vieses algorítmicos que levam a comportamentos preconceituosos das máquinas, bem como a obscuridade dos processos de decisão produzidos por redes neurais empregadas em sistemas de machine learning, que tornam difícil se não impossível a auditabilidade do sistema a fim de verificar a razão pela qual a máquina chegou a determinados resultados (MEDINA et al, 2020, p. 8).

Conclusão: A aplicação de sistemas de Inteligência Artificial no âmbito do Poder Judiciário, a exemplo do projeto Victor, possui capacidade de conferir maior eficiência e qualidade à prestação jurisdicional. Essas tecnologias ainda estão limitadas ao auxílio a decisões humanas em sua maior parte, e por isso as atividades desenvolvidas pelo Victor não representam grandes riscos. De toda sorte, é necessário o aprofundamento de estudos relacionados a auditabilidade de sistemas de Inteligência Artificial e de superação dos vieses algorítmicos, para que essas tecnologias possam avançar no direito revestidas da necessária segurança jurídica.

\title{
Referências
}

ANDRADE, Mariana Dionísio de. PINTO, Eduardo Régis Girão de Castro. LIMA, Isabela Braga de. GALVÃO, Alex Renan de Sousa. Inteligência Artificial para o rastreamento de ações com repercussão geral: O projeto Victor e a realização do Princípio da 
Razoável Duração do Processo. Revista Eletrônica de Direito Processual, v. 21, p. 312-335, Jan-Abr/2020. ISSN 1982-7636. Disponível em: https://bityli.com/jzKXf. Acesso em: 18 ago. 2020.

BRAGANÇA, Fernanda; BRAGANÇA, Laurinda Fátima da F. P. G.. REVOLUÇÃO 4.0 NO PODER JUDICIÁRIO: LEVANTAMENTO DO USO DE INTELIGÊNCIA ARTIFICIAL NOS TRIBUNAIS BRASILEIROS. Revista da Seção Judiciária do Rio de Janeiro, [S.I.], v. 23, n. 46, p. 65-76, nov. 2019. ISSN 2177-8337. Disponível em: . Acesso em: 30 jul. 2020.

MARQUES. Ricardo Dalmaso. Inteligência Artificial e direito: O uso da tecnologia na gestão do processo no sistema brasileiro de precedentes. Revista dos Tribunais Online, v. 3/2019, abr-jun/2019, DTR201935395. Disponível em: https://bityli.com/IJ27p. Acesso em: 18 ago. 2020.

MEDINA. José Miguel Garcia. MARTINS. João Paulo Nery dos Passos. A era da Inteligência Artificial: As máquinas poderão tomar decisões judiciais? Revista dos Tribunais Online, v. 1020/2020, out/2020, DTR202011420. Disponível em: Acesso em: 18 ago. 2020.

NUNES, Dierle; MARQUES, Ana Luiza Pinto Coelho. Inteligência Artificial e Direito Processual: Vieses algorítmicos e os riscos de atribuição de função decisória às máquinas. Revista dos Tribunais Online, v. 285/2018, p. 421-447, nov. 2018, DTR201820746. Disponível em: https://bityli.com/hlcsh. Acesso em: 30 jul. 2020.

PEREIRA JUNIOR, Antonio Jorge; MELO, Vinicius Holanda. OS LIMITES DA INTELIGÊNCIA ARTIFICIAL NO EXERCíCIO DA PRUDÊNCIA: AS ATIVIDADES JURÍDICAS CORREM RISCO? Revista dos Tribunais Online, v. 1015/2020, p. 107-127, mai. 2020, DTR20206970. Disponível em: https://bityli.com/eFS9I. Acesso em: 30 jul. 2020.

Coordenadoria de Pesquisa e Extensão - COPEX

Departamento de Editoraçāo e Divulgaçāo Científica - DEDIC 


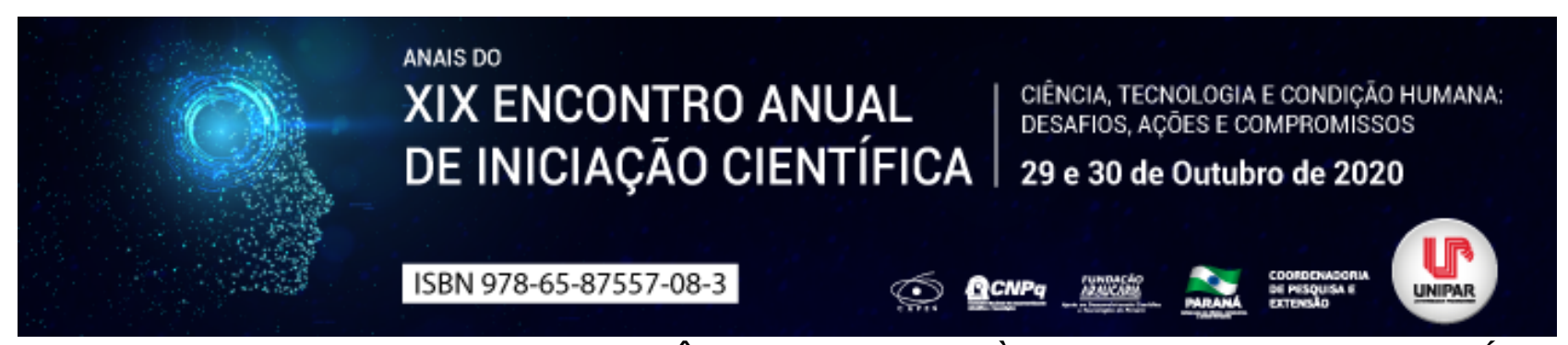

A VULNERABILIDADE DA MULHER TRANSGÊNERO E O DIREITO À ISONOMIA NA LEI DO FEMINICÍDIO

\title{
${ }^{1}$ NICOLE FERNANDA MANDUCA DE CARVALHO, ${ }^{2}$ TEREZA RODRIGUES VIEIRA
}

\author{
${ }^{1}$ Acadêmica de Direito e Integrante do PIC/UNIPAR \\ ${ }^{1}$ Pós-Doutora em Direito pela Université de Montreal Canadá; Docente do Mestrado em Direito Processual e Cidadania.
}

Introdução: O princípio da igualdade, apesar de previsto constitucionalmente desde 1988, não garante a aplicabilidade isonômica do direito, uma vez que a igualdade material não abrange a todos e, por consequência, esse nobre princípio se mostra ineficaz para as minorias. Dentre essas minorias encontram-se as mulheres trans, que lutam pelo reconhecimento da paridade com as mulheres cisgêneros.

Objetivo: Identificar e examinar as dificuldades e os obstáculos na luta pelo reconhecimento do tratamento isonômico da mulher trans na inclusão na Lei do Feminicídio e na Lei Maria da Penha.

Desenvolvimento: Apesar de a Lei Maria da Penha ter o intuito de criar mecanismos para coibir e prevenir a violência doméstica e familiar contra a mulher [...] conforme dita o artigo $1^{\circ}$ da Lei 11.340 (BRASIL, 2006), esta só tutelava mulheres cisgêneros, deixando então, mulheres transexuais sem o devido amparo legal. Somente em 2017 surgiu um Projeto de Lei do Senado, n⿳ 191/2017, objetivando viabilizar a inclusão da mulher trans, modificando a redação do art. $2^{\circ}$ da Lei Maria da Penha, promovendo assim uma proteção legal para todas as mulheres, independente da identidade de gênero. Como uma tentativa de diminuir a violência contra a mulher e complementar a Lei 11.340, em 2015 foi aprovada a Lei do Feminicídio, passando a considerar a violência doméstica e familiar contra a mulher como crime hediondo. Por vez, fez-se necessário o debate pela inclusão das transexuais nesta lei também, pois segundo o novo dossiê da Associação Nacional de Travestis e Transexuais, ANTRA (BENEVIDES; NOGUEIRA, 2019, p. 24): No ano de 2019, foram confirmadas informações de 124 assassinatos de pessoas trans, sendo 121 Travestis e Mulheres Transexuais [...] . Vale acrescentar ainda que o Brasil foi considerado o país que mais matou pessoas transexuais em 2018, conforme os dados da ONG Transgender Europe (SEGUNDO, 2018). Mesmo neste cenário, a pauta pela inclusão das mulheres transexuais na Lei 13.104/2015 gerou muitas controvérsias, principalmente por parte de correntes mais conservadoras, como aponta o promotor de justiça e mestre em direito, Francisco Dirceu Barros (2016): identifica-se a mulher em sua concepção genética ou cromossômica. Neste caso, como a neocolpovulvoplastia [cirurgia de transgenitalização] altera a estética, mas não a concepção genética, não será possível a aplicação da qualificadora do feminicídio. Todavia, conforme assevera Rogério Sanches Cunha (2019) no caso de pessoa trans, que formalmente adquire o direito de ser identificada civilmente como mulher, não há como negar a incidência da lei penal, uma vez que, para todos os demais fins, essa pessoa será considerada mulher. Ademais, cumpre notar que a jurisprudência está posicionando-se a favor da inclusão da mulher trans, como foi o caso da $3^{a}$ Turma Criminal do Tribunal de Justiça do Distrito Federal e Territórios que, em 2019, admitiu como sujeito passivo do feminicídio uma mulher transgênero. Além disso, os desembargadores também destacaram a dupla vulnerabilidade dos transgêneros femininos, os quais estão sujeitos tanto à discriminação relativa à condição de mulher quanto ao preconceito enfrentado para se obter o reconhecimento da identidade de gênero assumida (BRASIL, 2019, p. 01).

Conclusão: Crimes motivados por ódio à condição de pessoa transgênero caracterizam menosprezo, discriminação e preconceito ao gênero feminino adotado, uma vez que o conceito de gênero abarca mais que o sexo biológico, envolvendo também os caracteres comportamentais e psicológicos. Ainda que a mulher trans tenha conquistado seu espaço nas leis do feminicídio e Maria da Penha, este é só o começo de uma longa jornada de lutas por uma vida digna e com isonomia de direitos.

\footnotetext{
Referências

BARROS, Francisco Dirceu. Feminicídio e Neocolpuvulvoplastia: As Implicações Legais do Conceito de Mulher para Fins Penais. Disponível em: http://franciscodirceubarros.jusbrasil.com .br /artigos/1 73139 537/feminicidio -e neocolpovulvoplastia-asimplicacoes-legais- do-conceito-de-mulher-para-os-fins-penais. Acesso em: 10 ago. 2020.

BENEVIDES, Bruna G.; NOGUEIRA, Sayonara Naider Bonfim. Dossiê dos assassinatos e da violência contra travestis e transexuais brasileiras em 2019. Disponível em: https://antrabrasil.files.wordpress.com/2020/01/dossic3aa-dos-assassinatos-eda-violc3aancia-contra-pessoas-trans-em-2019.pdf. Acesso em: 11 ago. 2020

BRASIL. Lei $\mathbf{n}^{\circ} \mathbf{1 1 . 3 4 0}$, de 7 de agosto de 2006. Cria mecanismos para coibir a violência doméstica e familiar contra a mulher, nos termos do $\S 8^{\circ}$ do art. 226 da Constituição Federal. Disponível em: http://www.planalto.gov.br/ccivil_03/_ato20042006/2006/lei/l11340.htm. Acesso em: 19 ago. 2020.
}

BRASIL. Lei $\mathbf{n}^{\circ}$ 13.104, de 9 de março de 2015. Altera o art. 121 do Decreto-Lei nº 2.848, de 7 de dezembro de 1940 - Código 
Penal, para prever o feminicídio como circunstância qualificadora do crime de homicídio. Disponível em: http://www.planalto.gov.br/ccivil_03/_ato2015-2018/2015/lei//13104.htm. Acesso em: 19 ago. 2020.

BRASIL. Tribunal de Justiça do Distrito Federal e Territórios. Acórdão 1184804, 20180710019530RSE, Relator Des. Waldir Leôncio Lopes Júnior, $3^{\mathrm{a}}$ T.Cr., 4 jul. 2019, publicado no DJe: 12 jul. 2019 Disponível em: https://www.tjdft.jus.br/consultas/jurisprudencia/informativos/2019/. Acesso em: 10 ago. 2020.

CUNHA, Rogério Sanches. Manual de Direito Penal. Parte Especial (arts. 121 a 361). 8. ed. rev. ampl. atual. Salvador: Juspodivum, 2019.

SEGUNDO relatório da TGEU, Brasil segue no $1^{\circ}$ lugar do ranking de assassinatos de transexuais. Paradasp, 27 nov. 2018. Disponível em: http://paradasp.org.br/segundo-relatorio-tgeu-brasil-segue-no-1o-lugar-do-ranking-de-assassinatos-detransexuais. Acesso em: 11 ago. 2020.

Coordenadoria de Pesquisa e Extensão - COPEX

Departamento de Editoraçāo e Divulgaçāo Científica - DEDIC 


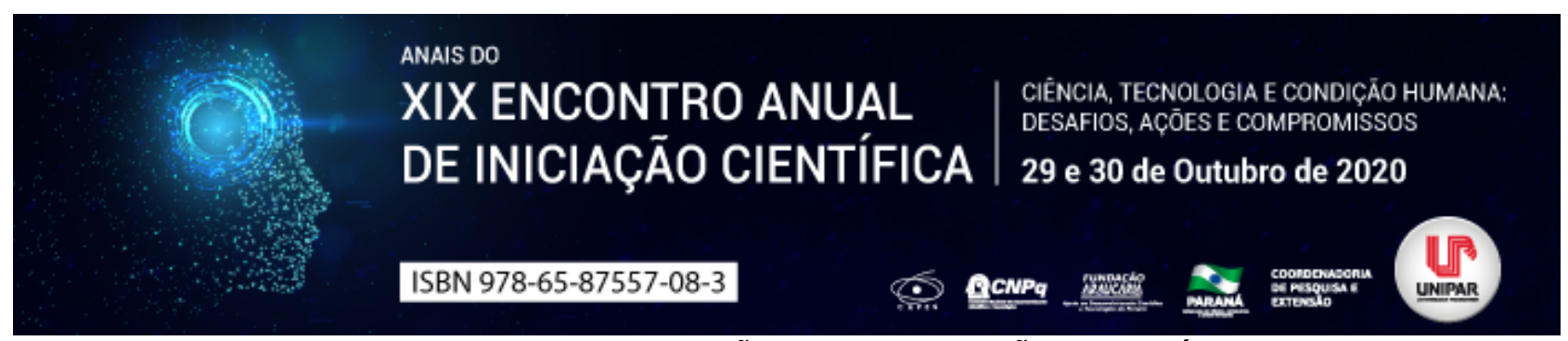

\title{
BALANÇO PERGUNTADO: POSSIBILIDADE DE OBTENÇÃO DE INFORMAÇÕES CONTÁBEIS PARA O GERENCIAMENTO DE MICRO E PEQUENAS EMPRESAS
}

\author{
${ }^{1}$ GABRIEL DENKE MACHADO, ${ }^{2}$ JOSE LUIZ BORSATTO JUNIOR
}

\author{
${ }^{1}$ Acadêmico do curso de Ciências Contábeis - Unipar \\ ${ }^{1}$ Docente da UNIPAR
}

Introdução: A realidade das pequenas empresas é caracterizada muitas vezes pela informalidade, deficiência informacional na elaboração de medidas e tomadas de decisão. Tais características dificultam a permanência dessas empresas no mercado. Uma causa provável a este conjunto de problemas se destina à ausência de ferramentas e um sistema de informação contábil que proporcione informações úteis aos usuários da informação. Dentro deste contexto a inserção da ferramenta denominada Balanço Perguntado pode ser relevante no tocante a construção de um sistema de informação contábil, o que produziria informações para a tomada de decisão e para o gerenciamento do negócio. Tendo em vista as circunstâncias supracitadas, define-se pergunta norteadora desta pesquisa: como o Balanço Perguntado pode contribuir na obtenção de informação gerencial em micro e pequenas empresas?

Objetivo: Explicar o papel do Balanço Perguntado para a formalização da contabilidade e obtenção de informações gerenciais e úteis para a tomada de decisão em micro e pequenas empresas.

Desenvolvimento: Com o advento da inserção tecnológica, o ambiente mercadológico das micro e pequenas empresas se projeta em consecutivos loops de volatilidade. A qualidade informacional é um fator crucial para que os gestores definam estratégias e tomem decisões consistentes, embasadas, acertadas e em consonância ao princípio contábil de continuidade. Entretanto, segundo Riedi et al. (2020, p.36), muitas médias e pequenas empresas não usam ou não conhecem nenhum tipo de informação para tomadas de decisões acabando às vezes errando em suas atividades contábeis ou até mesmo na administração . Em decorrência dessa circunstância, observa-se nas pequenas empresas dificuldades no que tange ao controle de custos e despesas, no controle dos tributos, na escrituração dos eventos patrimoniais, na aplicação de controle e avaliação de resultados, ineficiência nas tomadas decisões, ou seja, uma conjuntura de fatores que propiciam a incidência primária da insolvência empresarial, e secundariamente, falência empresarial. Logo, o Balanço Perguntado pode contribuir na elaboração de um sistema informacional primário e respectivamente, respaldar os gestores na atribuição da contabilidade gerencial. Ademais, tais contribuições possibilitariam a redução da ocorrência de falências. Isso seria possível, pois o Balanço Perguntado é um método utilizado no levantamento de informações para se elaborar relatórios contábeis de empresas que não possuem estes relatórios formalizados. A coleta de dados ocorre por meio de questionário e análise documental no sentido de se obter dados para a elaboração dos relatórios contábeis (KASSAl; KASSAl; NOSSA, 2000). O questionário em si é destinado ao gestor ou responsável da empresa, e contudo, são estipuladas criteriosamente diversas perguntas para se extrair dados sobre: impostos, resultados operacionais, capital imobilizado, estoques, disponibilidades financeiras, relacionamento com fornecedores e outras obrigações, quadro de funcionários, saldos de empréstimos e financiamentos, dentre outras informações cujo se observem relevantes para serem enaltecidas e apregoadas nos relatórios oriundos do Balanço Perguntado (KASSAI; KASSAI; NOSSA, 2000). Assim, entende-se que a ferramenta permite a organização ou mesmo os primeiros registros que formariam a contabilidade de pequenos negócios. Por meio desses registros contábeis, é possível se elaborar o Balanço Patrimonial, a Demonstração de Resultado e Demonstração de Fluxo de Caixa, sendo estes relatórios primordiais para formar a contabilidade gerencial, ao qual, se define como uma ferramenta que fornece grande valia informacional ao gestor e a empresa no tocante a tomadas de decisão, otimização processos operacionais e desenvolver meios de controle e estratégias empresariais. Logo, o Balanço Perguntado contribui com a possibilidade de se extrair informações gerenciais, e segundo Kassai e Kassai (2001) permite diagnosticar a situação econômica e financeira de uma determinada empresa, servindo também como instrumento de planejamento empresarial e gerenciamento.

Conclusão: Conclui-se que o Balanço Perguntado demonstra ser uma ferramenta relevante as micro e pequenas empresas, uma vez que possibilita o levantamento de informações gerenciais imprescindíveis para se elaborar o início de um sistema de informações e registros contábeis. Deste modo, é útil na elaboração de relatórios gerenciais que são úteis para elaboração de diretrizes para decisão, organização e controle gerencial, as quais são contributivas para a progressão e continuidade destas empresas.

\section{Referências}

KASSAI, S; KASSAI, J.R; NOSSA,V; Pequenas Empresas - Como é Difícil I"Levantar Dinheirol"! - VII Congresso Brasileiro de Custos Recife, PE, Brasil, 2 a 4 de agosto de 2000 
RIEDI, R; MARTINI, R; BUGALHO, D.K; BUGALHO, F.M; Contabilidade gerencial: percepção dos gestores de micro e pequenas empresas- Cadernos de Gestão e Empreendedorismo - Rio de Janeiro, v. 8 n. 1 | jan. abr. 2020.

KASSAI, J.R.; KASSAI, S.; Balanço perguntado: solução para as pequenas empresas. In Anais do Congresso Brasileiro de Custos-ABC - 2001.

Coordenadoria de Pesquisa e Extensão - COPEX

Departamento de Editoraçāo e Divulgaçāo Científica - DEDIC 


\title{
ANAIS DO XIX ENCONTRO ANUAL | CIÊNCIA, TECNOLOGIA E CONDIÇĀO HUMANA: DE INICIAÇÃO CIENTÍ́FICA DESAFIOS, AÇŌES E COMPROMISSOS DE INICIAÇAO CIENTIFICA 29 e 30 de Outubro de 2020 \\ ISBN 978-65-87557-08-3

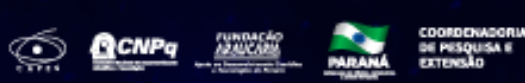 (1) \\ A ATUAÇÃO DOS PROFISSIONAIS DA PSICOLOGIA NO CONTEXTO DO TRABALHO: UMA ANÁLISE A PARTIR DA TEORIA DAS REPRESENTAÇÕES SOCIAIS
}

${ }^{1}$ Luana Jaime Alves, ${ }^{2}$ REGIANE CRISTINA DE SOUZA

\author{
${ }^{1}$ Acadêmica PIC/UEM ( Processo 6962/2019); Graduanda no 4o ANO de Psicologia UEM. \\ ${ }^{1}$ Professora Adjunta/UEM; Orientadora do PIC( Processo 6962/2019); Doutora em Psicologia - UEM.
}

Introdução: Para Moscovici (2007) todas as interações humanas, surjam elas entre duas pessoas ou entre dois grupos, pressupõem representações (p.40). Por esse motivo, optamos pela Teoria das Representações Sociais (TRS) a fim de compreender como essas representações funcionam, enquanto direcionadoras dos pensamentos, afetos e, consequentemente, das ações das pessoas. Nossa pesquisa se aprofunda ao estudo da Psicologia Organizacional e do Trabalho (POT) definida como uma área da psicologia com enfoque dedicado ao conhecimento das interações humanas, dos grupos e também das organizações, portanto, buscamos a partir dessa pesquisa situar e compreender a atuação do profissional de psicologia no âmbito das organizações, entendendo que essa atuação se dá a partir de possíveis e diversas representações sociais.

Objetivo: Compreender, a partir da Teoria das Representações Sociais (TRS), como são construídas as atuações dos profissionais que atuam na área da psicologia do trabalho.

\section{Desenvolvimento:}

Serge Moscovici inaugura a Teoria das Representações Sociais em 1961, partindo da ideia de que as pessoas e grupos não são tidos como meros receptores, mas enquanto seres pensantes que produzem e comunicam suas próprias representações e soluções às diversas questões do mundo, ou seja, os indivíduos constroem e transformam as representações sociais produzidas e reproduzidas dentro de diferentes grupos sociais. Ainda, o autor aponta para o fato de que a característica específica dessas representações é precisamente a de que elas corporificam ideias em experiências coletivas e interações em comportamento

(MOSCOVICl, 2003, p.48).

Complementar a essas questões, criamos representações porque não nos sentimos confortáveis ao que não nos é familiar. A dinâmica das relações é uma dinâmica de familiarização (MOSCOVICl, 2003, p.55). A fim de transformar palavras nãofamiliares em palavras familiares existem dois processos que geram representações sociais, eles são descritos como ancoragem e objetivação. O primeiro deles vai apreender algo que nos é estranho e compará-lo a uma ideia, para que este se encaixe em uma categoria de referência. É quase como ancorar um bote perdido, afirma Moscovici (2003).

Já o conceito de objetivação, se define pela transformação de algo abstrato em algo concreto, unindo aquilo que é não-familiar com a realidade, e que, segundo Sá (2000), tem como objetivo dar forma ao conhecimento que se adquire de determinado objeto. Por essas razões, as representações sociais seriam capazes de formar os pensamentos e as atitudes dos seres humanos frente determinados objetos e situações cotidianas, pois através da ancoragem e objetivação é possível compreender de que maneira uma representação foi construída. Em relação à psicologia no contexto do trabalho, esta surgiu, por volta dos anos 1900, no contexto Norte-Americano, objetivando atender as demandas do sistema capitalista que naquele contexto estava em ascensão com a perspectiva do trabalho na indústria. Entretanto, a psicologia se desenvolveu em três momentos distintos e igualmente complementares, isto é, em três fases no sentido histórico, e que são também chamadas de faces, no sentido epistêmico, como descrito por Tomanik (2003). Cada uma delas apresentou modelos para interpretar a relação homem-trabalho, modelos estes capazes de suprir as demandas de cada época. Sampaio (1998) é um dos autores que descreve a história da psicologia no contexto do trabalho, e para ele, a primeira face é denominada Psicologia Industrial, que se desenvolveu buscando critérios para avaliar e selecionar pessoas para as indústrias em ascensão. A segunda face chamada de Psicologia Organizacional (1940 aproximadamente), ancora sua prática na noção de lucratividade e por esse motivo debruçou-se aos modelos estruturais de organização. Por fim, a terceira face (por volta de 1980), denomina-se Psicologia do Trabalho e compreende aspectos da Sociologia do Trabalho e, neste sentido, passa a questionar as relações de poder dentro das organizações. Passou a entender o trabalho não como mero produtor de bens materiais, mas como importante constituinte da subjetividade dos sujeitos. Pautando-se nessas questões entendemos que uma profissão consiste em uma comunidade de pessoas que, em torno de uma base mais ou menos comum de práticas, deve compartilhar valores e regras de conduta que assegurem tanto o padrão de qualidade de suas intervenções quanto às relações com seus pares e com a sociedade (BASTOS, 2013, p.25).

Conclusão: Considerando a TRS e os materiais bibliográficos pesquisados acerca da atuação do profissional da Psicologia no contexto do trabalho, concluímos como resultados parciais da pesquisa que as Representações Sociais (RS) são construídas e transformadas nas relações dialéticas. Assim, as práticas profissionais são construídas desde o momento da graduação (disciplinas, projetos, etc.) perpassando pela atuação profissional e pelas relações estabelecidas em equipes multi e 
interdisciplinares. Assim, as práticas do profissional em POT serão a ancoragem e a objetivação daquilo que é subjetivamente construído e intersubjetivamente compartilhado.

\section{Referências}

BASTOS, A. V. B. et al. Compromisso Social e Ético: Desafios para a atuação em psicologia organizacional e do trabalho. In: BORGES, L.O.; MOURÃO, L. (Org.). O Trabalho e as Organizações. Porto Alegre: Artmed, 2013. p. 25-52.

JOVCHELOVITCH, S. Vivendo a vida com os outros: Intersubjetividade, espaço público e representações sociais. In: GUARESCHI, P. A.; JOVCHELOVITCH, S. (Org.) Textos em Representações Sociais. Petrópolis: Vozes, 1995. p 63-85.

MOSCOVICI, S. O Fenômeno das Representações Sociais. In: Representações Sociais: Investigações em psicologia social. Tradução de Pedrinho A. Guareschi. Petrópolis: Vozes, 2003. p. 29-109.

MOSCOVICI, S. Representações Sociais: investigações em psicologia social. 5 ed. Petrópolis, Rio de Janeiro: Vozes, 2007. SÁ, C.P. Representações Sociais: o conceito e o estado atual da teoria. In: MOREIRA, A. S. P.; OLIVEIRA, D. C. (Org.). Estudos interdisciplinares de representação social. Goiânia: AB, 2000. 328p.

SAMPAIO, J. R. (1998). Psicologia do trabalho em três faces. In: GOULART, I. B.; SAMPAIO, J. R. (Orgs.), Psicologia do Trabalho e Gestão dos Recursos Humanos: estudos contemporâneos. São Paulo: Casa do Psicólogo, 1998. p. 19-40. TOMANIK, E. A. Para onde andará o Lobo Mau da Psicologia. Maringá: Psicologia em Estudo, 2003. p. 157-159. 


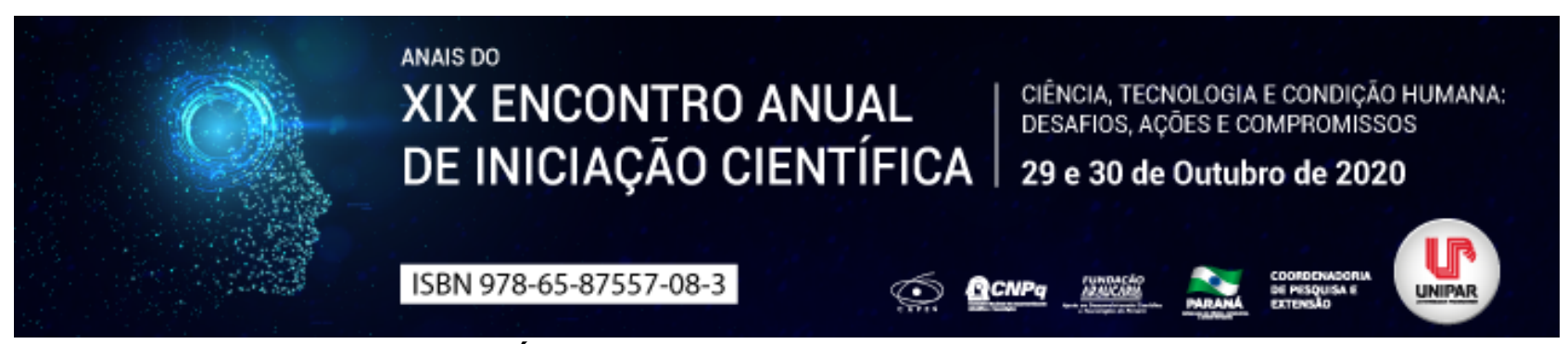

A SAÚDE MENTAL DOS POLICIAIS MILITARES

\begin{abstract}
${ }^{1}$ Snayder Roberto Rodrigues Zaha, ${ }^{2}$ NAYARA KARINE SILVA, ${ }^{3}$ PATRÍCIA FISCHER SILVÉRIO, ${ }^{4}$ RAPHAEL PRIETO DOS SANTOS
\end{abstract}

\author{
${ }^{1}$ Acadêmico do Curso de Direito da UEMS \\ ${ }^{1}$ Acadêmica do Curso de Direito da UEMS \\ ${ }^{2}$ Acadêmica do Curso de Direito da UEMS \\ ${ }^{3}$ Docente da UEMS
}

Introdução: O Policial Militar cujo juramento realizado ao ingressar na corporação, tem o compromisso de defender a sociedade com o risco da própria vida. Contudo, durante seu trabalho enfrenta várias situações de estresse e risco, onde de um lado está a população no qual jurou proteger e, do outro, o perigo iminente contra sua vida. Se mostrando uma profissão que por sua própria natureza já compromete a integridade psicológica do profissional que a exerce, surgindo a preocupação quanto à saúde mental deste, pois o indivíduo é inseparável do trabalho que realiza.

Objetivo: Mostrar a importância de se investir em políticas internas visando a proteção da saúde mental dos policiais militares.

Desenvolvimento: A polícia militar é um órgão da segurança pública, estabelecido em nossa Carta Magna em seu art. 144, inciso V. Ficando incumbida de realizar o policiamento ostensivo e preservar a ordem pública, sendo força auxiliar e reserva do Exército, subordinando-se aos Governadores dos Estados (BRASIL, 1988). O policial durante o desempenho de sua atividade está exposto a várias situações de estresse e risco, estando em constante estado de alerta, o que com o tempo pode desencadear vários desequilíbrios psíquicos e transtornos mentais, como por exemplo a depressão, a síndrome do pânico, ansiedade, e nos casos mais graves vindo a tirar a própria vida, devido principalmente à falta de cuidado por parte de seus superiores hierárquicos, a tratamentos especializados e individualizados (MINAYO, SOUZA, CONSTANTINO, 2007). Importante ressaltar que para o ingresso nas fileiras da instituição possuem etapas no concurso onde o candidato é submetido a testes físicos e psicológicos, para avaliar se possuem pré-requisitos para a profissão, entretanto após o seu ingresso não há um trabalho de rotina, preventivo que visa acompanhar sua saúde mental e identificar mudanças de comportamento. Conforme reportagem de 2019 do Fantástico da rede Globo, após um levantamento em relação à saúde mental dos policiais militares de todo o Brasil, concluiu-se que pelo menos 43 policiais são afastados por dia em decorrência de transtornos psiquiátricos (G1/FANTÁSTICO, 2019). Em outra matéria do jornal O GLOBO de 2019, apurou que os policiais teriam morrido mais em decorrência de suicídio do que em função da atividade policial, em atendimento de ocorrências. Segundo os dados do $13^{\circ}$ Anuário Brasileiro de Segurança Pública foram 104 suicídios de policiais, sendo no mesmo período, 87 profissionais de segurança vítimas de crimes, em geral, durante confrontos com bandidos. Ainda a publicação destaca a alta taxa de suicídio, que é de 23,9 por 100 mil policiais militares, quando comparado com a população em geral que é de 5,8 por 100 mil habitantes (O GLOBO, 2019). Diante desse cenário podemos citar muitos fatores que contribuem para esses números assustadores, entre eles a precariedade da infraestrutura policial, salário baixo, promoções atrasadas e o baixo efetivo sobrecarregando os policiais no dia a dia. Por se tratar de um serviço de risco, o profissional de segurança pública está sempre em alerta, com medo de sofrer algum atentado contra a sua vida ou de algum familiar. A metodologia usada nos cursos de formação para o ingresso, em que muitas vezes ocorrem abusos físicos e psicológicos, onde se buscam criar uma mentalidade de que o policial é superior aos problemas, as dificuldades e as falhas não são admitidas. Além dos problemas gerados devido aos abusos provenientes da hierarquia militar, onde o subordinado está fadado a apenas cumprir as ordens, não podendo questioná-las (MUNIZ J, 1999). Porém, uma importante mudança ocorreu com a Lei n. 13.967 de 26 de dezembro de 2019, que extinguiu a pena de prisão disciplinar para as polícias militares e os corpos de bombeiros militares dos Estados, Territórios e do Distrito Federal. A norma determina que essas corporações sejam regidas por um Código de Ética e Disciplina, aprovado por lei estadual específica, no prazo de 12 meses (BRASIL, 2019).

Conclusão: Ante ao exposto, verifica-se a importância de buscar medidas visando enfrentar um dos problemas que aflige as polícias militares do país, sobretudo repensando a maneira como são tratados, necessitando de políticas internas que garantam os princípios constitucionais, visando o cuidado e a promoção contínuos e efetivos, da saúde mental para os seus profissionais. Buscando e investindo em um atendimento individualizado, como exemplo, a obrigatoriedade periódica de avaliação psicológica, como já ocorre em muitos estados com a avaliação física. 
BRASIL. Lei $n^{\circ}$ 13.967, de 26 de dezembro de 2019. Disponível em: < http://www.planalto.gov.br/ccivil_03/_ato20192022/2019/lei/L13967.htm>. Acesso em 18 de jun. 2020.

G1/FANTÁSTICO. No Brasil, pelo menos 43 PMs são afastados por dia por transtornos psiquiátricos. Disponível em: < https://g1.globo.com/fantastico/noticia/2019/09/15/no-brasil-pelo-menos-43-pms-sao-afastados-por-dia-por-transtornos-

psiquiatricos.ghtml>. Acesso em 18 jun. 2020.

MINAYO M.C.S.; SOUZA E.R.; CONSTANTINO P. Riscos percebidos e vitimização de policiais civis e militares na (in)segurança pública. Cad Saúde Pública; 2007.

MUNIZ J. Ser policial é sobretudo uma razão de ser: cultura e cotidiano da Polícia Militar do Rio de Janeiro [tese]. Rio de Janeiro: UCAM; 1999.

O GLOBO. Suicídio de policiais supera mortes em operações no país, aponta relatório. Disponível em: < https://oglobo.globo.com/brasil/suicidio-de-policiais-supera-mortes-em-operacoes-no-pais-aponta-relatorio-23950319>. Acesso em 18 jun. 2020.

Coordenadoria de Pesquisa e Extensão - COPEX

Departamento de Editoraçāo e Divulgaçāo Científica - DEDIC 


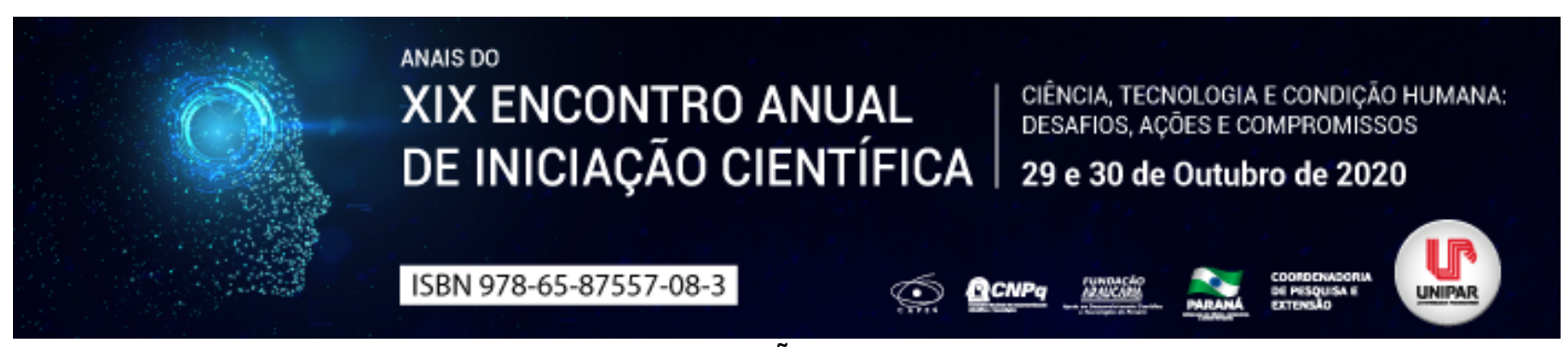

A TUTELA PROCESSUAL DO NASCITURO: A EFETIVAÇÃO DA BILATERALIDADE NO CONFLITO DE INTERESSES

\author{
${ }^{1}$ LUCIANA FERREIRA DA SILVA, ${ }^{2}$ CELSO HIROSHI IOCOHAMA
}

\author{
${ }^{1}$ Acadêmica do PIC/UNIPAR \\ ${ }^{1}$ Docente da Graduação em Direito e do Programa de Mestrado em Direito Processual e Cidadania da UNIPAR
}

Introdução: Tendo em vista que o ordenamento jurídico apresenta lacunas, quando há conflito de interesses entre o nascituro e seus genitores é salutar, à luz da isonomia, a nomeação de um curador especial com base no art. 72 do Código de Processo Civil, para resguardar os interesses da pessoa humana já concebida e ainda não nascida, bem como efetivar o seu direito fundamental à vida.

Objetivo: Analisar a importância do curador especial para a garantia da igualdade processual com foco na proteção do nascituro diante da possibilidade de interrupção da gravidez.

Desenvolvimento: Considerando que o nosso ordenamento jurídico resguarda os direitos daquele que há de nascer, observa-se que é [...] inegável a existência da vida humana no nascituro concebido, uma vez que ele, desde a concepção, emerge como um ser dotado de uma estrutura e de uma dinâmica humanas autônomas, embora, funcionalmente dependente da mãe (CAPELO DE SOUSA, 1995, p. 157). Destarte, há de se considerar que o nascituro possui identidade própria, mesmo que transitoriamente dependa de sua genitora. Não obstante, negar ao nascituro a tutela da vida, ou de outros direitos seria não apenas contrariar valores éticos e morais, como também contrariar a ordem jurídica [...] , aponta Silma Mendes (2016, p. 76). Neste caso, o inciso I do art. 72 do Código de Processo Civil aborda a nomeação de um curador especial ao incapaz, se não tiver representante legal ou se os interesses deste colidirem com os daquele, enquanto durar a incapacidade (BRASIL, 2015, Art. 72, inciso I), isto é, posto que o princípio da igualdade deve transpassar o formalismo dentro do ordenamento jurídico invocar o dispositivo acima em defesa do nascituro é reequilibrar as partes dentro do processo, permitindo que litiguem em paridade de armas (CINTRA; GRINOVER; DINAMARCO; 2009, p. 60). Sendo assim, negar tal tutela àquele que há de nascer é permitir que, aquele, fique à mostra de uma vida nua, pois qualquer um pode matar o homo sacer sem cometer homicídio, logo, os seus direitos estariam em um contínuo estado de exceção, como bem descreve Giorgio Agamben (2007, p. 189). Portanto, o art. 72 do Código de Processo Civil tende a ser produto de gestão para a eficácia material, sendo factível a nomeação de um curador especial, garantindo o exercício da atributividade dentro do processo.

Conclusão: Deveras, conclui-se que o princípio da igualdade revela a importância do curador especial que ao se deparar com a divergência entre o nascituro e os seus genitores é legitimo para suprir tal lacuna no ordenamento. Trata-se de garantir que as partes possam exercer de modo efetivo os seus direitos com igualdade e convicção.

\title{
Referências
}

AGAMBEN, Giorgio. Homo Sacer: o poder soberano e a vida nua I. Tradução de Henrique Burigo. Belo Horizonte: UFMG, 2007.

BERTI, Silma Mendes. Os direitos do nascituro. In: TAITSON, Paulo Franco, et al. Bioética: vida e morte. 2. ed. Belo Horizonte: PUC Minas, 2016.

BRASIL. Lei no 13.105, de 16 de março de 2015. Código de Processo Civil. Senado Federal, 2015. Disponível em: http://www.planalto.gov.br/ccivil_03/_ato2015-2018/2015/lei//13105.htm. Acesso em: 25 de jul. 2020.

CAPELO DE SOUSA, Rabindranath Valentino Aleixo. O direito geral de personalidade. Coimbra: Coimbra, 1995.

CINTRA, Antonio Carlos de Araújo; GRINOVER, Ada Pellegrini; DINAMARCO, Cândido Rangel. Teoria geral do processo. 25. ed. São Paulo: Malheiros, 2009. 


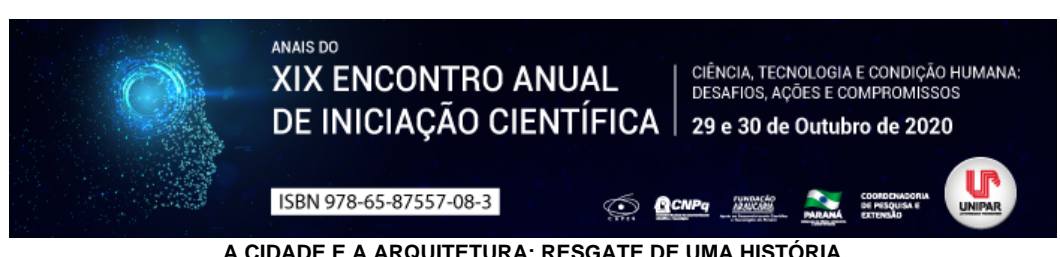

${ }^{1}$ ANA CAROLINA FAGUNDES FERREIRA, ${ }^{2}$ ROBSON GUEDES FERREIRA, ${ }^{3}$ ANA CAROLINE POLICARPO DA SILVA, ${ }^{4}$ WANDA TEREZINHA BONONI, ${ }^{5}$ PAULA ANDREIA GOMES DA CRUZ

${ }^{1}$ Acadêmico do Curso de Arquitetura e Urbanismo da UNIPAR ${ }^{1}$ Acadêmico do Curso de Arquitetura e Urbanismo da UNIPAR ${ }^{2}$ Acadêmica do Curso de Arquitetura e Urbanismo da UNIPAR ${ }^{3}$ Docente da UNIPAR

4 Docente da UNIPAR

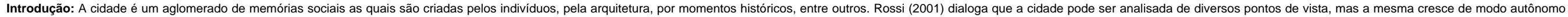

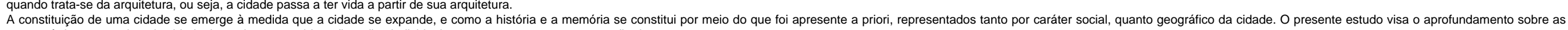
característica e conceitos da cidade, levando em consideração ações individuais que acrescentam na construção da mesma.

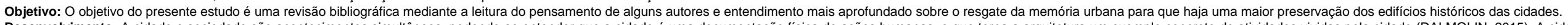

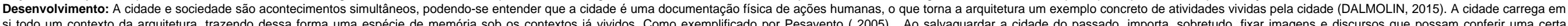

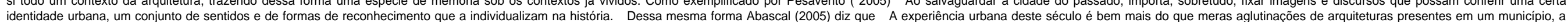

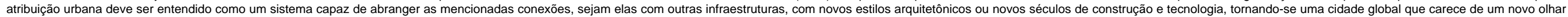
dos arquitetos. Mesmo utilizando como prerrogativa o municíio, a ideia do autor abrange o quesito cidade, como demonstrado, a cidade traz em si atribuiçôes que faz com que seja um registro dessas informações, para que assim construa sua história

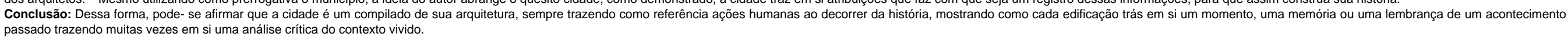

Referências

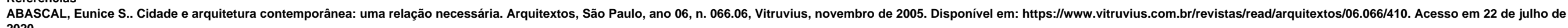

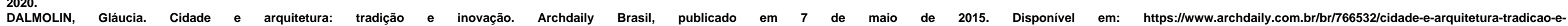

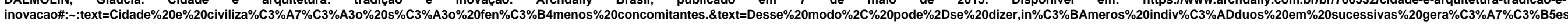
Acesso em 22 de julho de 2020 .

PINHEIROS, Eloisa P.; GOMES, Marco Aurélio A. de Filgueiras. A cidade como história: os arquitetos e a historiografia da cidade e do urbanismo. EDUFBA: Salvador - Bahia, 2005.

ROSSI, Aldo. Arquitetura da cidade. São Paulo: Martins Fontes, 2001. 320

Coordenadoria de Pesquisa e Extensāo - COPEX
Departamento de Editoraçăo e Divulgặăo Científica - DEDIC 


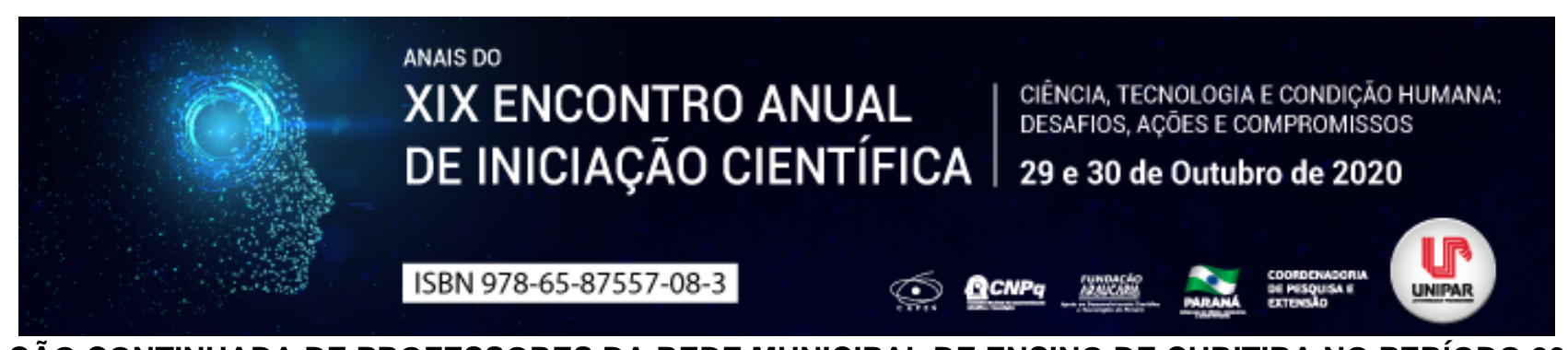

FORMAÇÃO CONTINUADA DE PROFESSORES DA REDE MUNICIPAL DE ENSINO DE CURITIBA NO PERÍODO $2005-2012$

\author{
${ }^{1}$ Merilin do Amarante Lima, ${ }^{2}$ ALBONI MARISA DUDEQUE PIANOVSKI VIEIRA
}

\begin{abstract}
${ }^{1}$ Graduanda do curso de Pedagogia na Pontifícia Universidade Católica do Paraná, campus Curitiba, e Bolsista PIBIC da Fundação Araucária.

${ }^{1}$ Orientadora e professora do curso de Pedagogia na Pontifícia Universidade Católica do Paraná, campus Curitiba. Doutora em Educação.
\end{abstract}

Introdução: Esta pesquisa busca contribuir aos estudos de formação continuada de professores por meio da análise de políticas públicas. Sendo assim, explora se houve a intenção de implantar políticas voltadas para a formação docente e discute sua efetivação.

A análise dos passos percorridos pela Prefeitura Municipal de Curitiba, no que diz respeito à formação continuada, revela estratégias utilizadas atualmente pelos docentes, o que impacta diretamente em como os alunos aprendem. As informações levantadas possibilitam uma reflexão acerca das atuais práticas pedagógicas.

Objetivos: Analisar as relações entre as políticas públicas de educação adotadas pela Rede Municipal de Ensino de Curitiba no período compreendido entre 2005 e 2012 e a formação continuada de professores, e investigar como a formação continuada de professores da RME repercutiu na prática pedagógica docente.

Material e Métodos: Após a finalização do referencial teórico, com apoio em Almeida e Pimenta (2014), Ball (2001), Boneti (2018), Dourado (2007), Morais (2009) e Vieira (2017), o qual foi sendo enriquecido durante a pesquisa, optou-se por analisar apenas os documentos com registros relacionados à formação de professores inclusos no período delimitado. A documentação analisada incluiu relatórios, projetos de cursos, ofícios e outros documentos localizados no acervo do Arquivo Público Municipal. Resultados: Em tempos atuais, muitas são as discussões acerca do tema políticas públicas. Mas, assim como tudo na vida tem um ponto inicial, é importante destacar o surgimento das políticas públicas. Do surgimento das políticas públicas, pode-se perceber seu início com a seguinte situação apresentada por Vieira: Não se pode negar, porém, que no século XX, com o surgimento dos direitos humanos e sociais, ocorreu uma mudança de paradigma na área de atuação do Estado, que passou a pensar em políticas públicas que neutralizassem a força desagregadora e excludente da economia capitalista, promovendo o desenvolvimento da pessoa humana (VIEIRA, 2017, p. 188). Contudo, não se pode pensar que, dentro das delimitações territoriais, as políticas públicas apresentam-se da mesma forma. Sobre essa participação alheia, pressupõe-se então que falar em políticas públicas implica falar em hegemonia. Dentro das estudadas políticas públicas, há também as políticas voltadas exclusivamente ao campo educativo. A esfera educativa, formativa e tão importante para uma sociedade, conta com muitos pesquisadores motivados a levantar e avaliar essas políticas.

No desenrolar dos anos, mas mais recentemente, esse assunto tem ganhado popularidade no país. Vale ressaltar que, mesmo que se tenha a formação contínua como uma das possíveis soluções para os problemas educacionais, os resultados de qualidade das escolas ainda denunciam sua precariedade. Na Rede Municipal de Ensino de Curitiba, em 2005, foram ofertados 112 cursos, enquanto em 2006 foram realizados 153 cursos e, em 2007 o número de cursos subiu para 264 . No ano de 2008 , foi encontrado apenas um projeto que visava substituir a sala de capacitação de professores por uma sala de arte, não sendo assim um documento como os demais analisados. Correspondentes ao ano de 2009, foram encontrados 32 cursos de formação de professores. Já no ano de 2010, foram encontrados 17 cursos de formação de professores, e, quanto ao ano de 2011 , havia 29 registros de cursos para os docentes. No que se refere ao último ano analisado, o de 2012 , 42 cursos para formação de professores foram encontrados.

Discussão: Voltando-se para a formação continuada de professores na cidade de Curitiba, entre 2005 e 2012 , pode-se perceber um crescimento no número de cursos e vagas durante o período de 2005 e 2007. Apesar de o ano de 2008 não contar com documentos relacionados à formação de professores exclusivamente, em 2009 pode-se perceber a preocupação dos organizadores com o brincar, com a deficiência visual e com a amamentação. No caso da formação para a amamentação, essa não se tornou tão discutida posteriormente como as demais. Inclusive, a mesma situação aconteceu no ano de 2010 , quando os cursos de jogos dramáticos e confecção de bonecos também não ganharam destaque posteriormente, havendo sucesso apenas em um segmento de três analisados, o qual se detinha de um curso voltado para a importância da animação. Porém, no ano seguinte, de 2011, nenhum dos temas apresentou muita discussão, assim como a maioria dos de 2012, exceto pela repercussão do uso de tecnologias.

Conclusão: Tendo em vista que os temas mencionados, todos relevantes para a prática docente, foram abordados nas formações, pode-se entender que, mesmo que não tenham gerado grande repercussão, seguida de um resultado positivo, contribuíram para o processo de aprimoramento dentro das escolas. Percebeu-se que os assuntos abordados nos 
cursos foram pertinentes à melhoria da qualidade da educação, mas sua repercussão pode não ter acontecido devido à forma, possivelmente, como estes foram trabalhados com os professores.

\section{Referências}

ALMEIDA, Maria Isabel de; PIMENTA, Selma Garrido. Estágios supervisionados na formação docente. São Paulo: Cortez, 2014. 25-74 p.

BALL, Stephen. Diretrizes políticas globais e relações políticas locais em educação. Currículo sem fronteiras, dez. 2001. v. 1 n.2, p. 99-116.

BONETI, Lindomar Wessler. Políticas públicas por dentro. 4. ed. ljuí: Unijuí, 2018. 15-23 p.

DOURADO, Luiz Fernandes. Políticas e gestão da educação básica no Brasil: limites e perspectivas. Educ. Soc. [online]. 2007, vol.28, n.100, p.921-946.

MORAIS, Marta Christina Ferreira Zimermann Bueno de. Os caminhos da formação continuadas na Rede Municipal de Ensino de Curitiba. 2009. 241 f. Dissertação. Programa de Pós Graduação em Educação do Setor de Educação da Universidade Federal do Paraná, Curitiba, 2009.

VIEIRA, Alboni Marisa Dudeque Pianovski. Educação em Curitiba: trinta anos de políticas públicas. 1. ed. Curitiba: Appris, 2017. $193 \mathrm{p}$.

Coordenadoria de Pesquisa e Extensão - COPEX

Departamento de Editoraçāo e Divulgaçāo Científica - DEDIC 


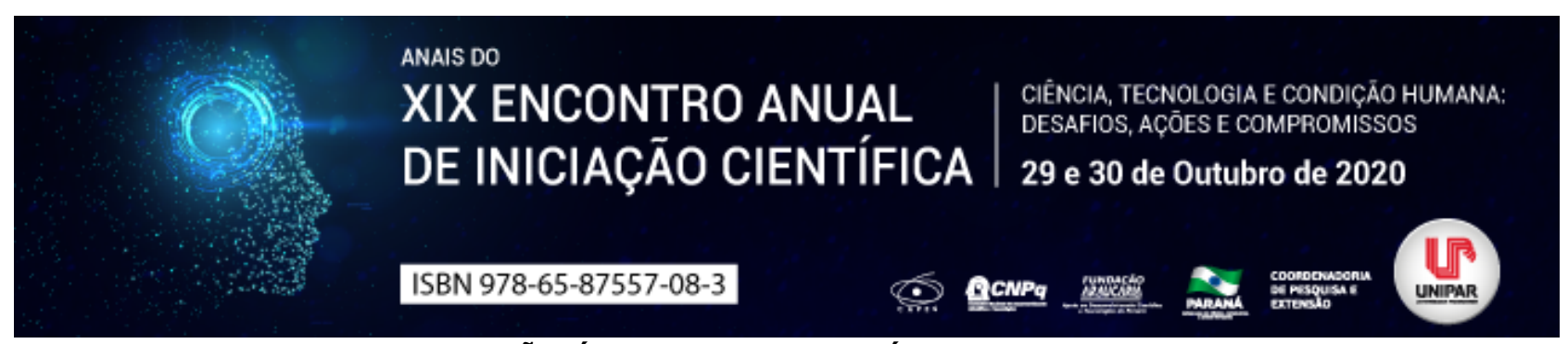

AUTODECLARAÇÃO ÉTNICO RACIAL NO ÚLTIMO CENSO NO BRASIL

\author{
${ }^{1}$ ARNALDO GOMES DO AMARAL, ${ }^{2}$ ALINE COUTINHO DA LUZ, ${ }^{3}$ EMANUELLE TOTOLI DE OLIVEIRA, ${ }^{4}$ MILENA DE LIMA, \\ ${ }^{5}$ CINTHIA FERREIRA DOS SANTOS COSTA, ${ }^{6}$ ROSANGELA BRESSAN BUOSI
}

\author{
${ }^{1}$ Docente da UNIPAR - PIC \\ ${ }^{1}$ Acadêmica do Curso de Engenharia Civil da UNIPAR \\ ${ }^{2}$ Acadêmica do Curso de Pedagogia da UNIPAR \\ ${ }^{3}$ Acadêmica do Curso de Engenharia Civil da UNIPAR \\ ${ }^{4}$ Acadêmica do Curso de Pedagogia da UNIPAR \\ ${ }^{5}$ Docente da UNIPAR
}

Introdução: $\mathrm{Na}$ diversidade dos contatos humanos e nas experiências vividas por suas andanças pelo mundo iniciou-se a diferenciação de cada povo. Na sabedoria do homem, cada grupo tenta expor suas qualidades e supremacia gerando um etnocentrismo diferenciando os povos de cada época. Esta seleção provocou vários conflitos e possivelmente confrontos armados na intenção de se apoderar das terras e fazer uso de trabalho escravo dos derrotados. A etnia dentro da sociedade permitiu essa agressão, pois os povos que não respeitavam ou aceitavam os costumes daqueles em que encontravam em suas andanças subjulgavam-os pela sua linguagem, cultos e costumes.

Objetivo: Apresentar como a população brasileira se declara em razão de sua etnia racial.

Desenvolvimento: Segundo historiadores a ciência das raças apresenta cada povo com suas características, Aristóteles elevava a I"raça helênical". O povo europeu devido ao clima frio apresenta espírito e carência em outras características. O povo asiático era inteligente, carente de espírito. Os antigos egípcios se denominavam homens enquanto seus vizinhos não passavam de rústicos e leigos. (MAGNOLIO, 2009). No dicionário italiano Pianigiani traz a denominação de razza, em outras línguas apresenta relação de significado como raiz, gênero, origem, plantar, marca. O termo designa todos aqueles que pertencem a uma mesma família, provenientes do mesmo tronco (PETRUCCELLI, 2013, s/p). Para Olivares (2006, p 16) o parágrafo $3^{\circ}$ do Art. 17 da Lei $n^{\circ} 586$ de 1850 que, dispondo sobre o orçamento do Império, autorizava o governo a realizar os gastos para elaborar, província por província, do Censo Geral do Império e estabelece o 'registros regulares de nascimentos e óbitos anuais'. Em 18 de junho de 1851, eram expedidos dois decretos - $\mathrm{n}^{\circ} 797$ e 798 - que mandavam executar ambas as medidas . Para o mesmo autor (2006, p 30) Registro e a Lei do Censo dirigiam-se explícitamente a contar e descobrir o número dos livres e pobres, informando nome, endereço e situação familiar . Segundo Schwartzman (1999, p. 01) até o século XIX, a informação relevante era a classificação da população em termos de sua condição civil, entre |"livresl" e escravos, e os recenseamentos de 1872 e 1890 já introduziam as questões de raça ou cor . Segundo do mesmo autor nos anos de 1940,1950 e 1970 o Brasil não aplicou esta categoria no censo. Para Souza $(2019, \mathrm{~s} / \mathrm{p})$ no Censo de 1980 a questão é reintroduzida com o mesmo conjunto de categorias: preta, branca, amarela e parda . No Censo de 1991, acrescenta-se a estas categorias o termo indígena como forma de pensar a questão étnica indígena. A partir de 1990 estas categorias mantêm-se até hoje. Para Magnolio (2009) o poder do estado que rejeita o princípio de igualdade dos cidadãos apresentam políticas usando o nome de multiculturalismo para dividir cidadãos em brancos, negros e outras categorias. Para Osório (2003, p. 6-7) a classificação das raças é três métodos: $\mathrm{O} 1^{\circ}$ - a auto-atribuição de pertença, no qual o próprio sujeito da classificação escolhendo o grupo que se considera membro. $\mathrm{O} 2^{\circ}$ é a heteroatribuição de pertença, no qual outra pessoa define o grupo do sujeito. $\mathrm{O} 3^{\circ}$ método é a identificação de grandes grupos populacionais verificando os ascendentes próximos por meio de técnicas biológicas, através do DNA . A classificação deve idealmente ser composta pelas categorias mais difundidas e frequentes nas classificações espontâneas, e ser condizente com o tipo de informação que se visa levantar mediante a pergunta sobre cor ou raça. A classificação racial atualmente empregada pelo IBGE distingue as variedades pela característica cor da pele , sendo branca, preta, amarela, e parda e indígena. Esta classificação usada no $1^{\circ}$ Recenseamento do Brasil, realizado em 1872, quando a forma mais comum para classificar pessoas segundo as raças era pela cor da pele. As categorias preta e parda eram as únicas aplicáveis à parcela escrava da população, embora pudessem também enquadrar pessoas livres, assim nascidas ou alforriadas (PETRUCCELLI, 2013). Segundo o IBGE (2010) a população brasileira contava com 190.755 .799 pessoas, que se autodeclararam como: Branca - 91.051.646; Preta - 14.517.961; Amarela - 2.084.288; Parda - 82.277.333; Indígena - 817.963 e sem declaração - 6.608 pessoas. Os dados da Pesquisa Nacional por Amostra de Domicílios (2019), 42,7\% dos brasileiros se declararam como brancos, 46,8\% pardos, 9,4\% pretos e 1,1\% amarelos ou indígenas. IBGE (2020).

Conclusão: A classificação utilizada pelos povos no decorrer dos tempos, leva-se em conta várias características que na realidade apontam como uma forma de separação como sendo membros pertencentes a mesma família. Estas classificações são 
pautadas por Lei e apresenta diversas formas de categorias dependendo do poder político vigente. No censo de 2010 apresentou que 47,7\% declaram-se Branco, 7,61 preta, 1,09\% Amarela, 43,1\% Parda, 0,43\% Indígena e 0,003\% sem declaração. Com este dados percebe-se que não houve diferença significativa nos valores apresentados variando em $-5 \%$ para branco, um acréscimo de $3,7 \%$ para pardos, acréscimo de 1,8\% para preta. Isto demonstra que a população brasileira, concorda e se enquadra na forma de classificação utilizada pelos órgãos oficial do governo.

\section{Referências}

IBGE. Sistema IBGE de Recuperação Automática SIDRA. Censo Demográfico. Tabela 3175 - População residente, por cor ou raça, segundo a situação do domicílio, o sexo e a idade. 2010. Disponível em: https://sidra.ibge.gov.br/Tabela/3175\#notas-tabela. Acesso 27 ago 2020.

IBGE. Conheça o Brasil - População - Cor ou Raça. 2020. Disponível em: https://educa.ibge.gov.br/jovens/conheca-obrasil/populacao/18319-cor-ou-raca.html. Acesso em 15 jul 2020.

MAGNOLIO, Demétrio. Uma Gota de Sangue: história do pensamento racial. São Paulo: Contexto, 2009.

OLIVARES, Guillermo de Jesus Palacios y. Revoltas camponesas no Brasil escravista: a 'Guerra dos Maribondos' (Pernambuco, 1851-1852). almanack braziliense $n^{\circ} 03$ maio $2006 . \quad$ Disponível em: http://www.revistas.usp.br/alb/article/view/11631/13400. Acesso 20 jul 2020.

OSORIO, Rafael Guerreiro. O sistema classificatório de cor ou raça do IBGE. Instituto de Pesquisa Econômica Aplicada (IPEA). Brasília, novembro de 2003.

PETRUCCELLI, José Luis. Raça, identidade, identificação: abordagem histórica conceitual. In: Características Étnicoraciais da População: Classificações e identidades. PETRUCCELLI, José Luis; SABOIA, Ana Lucia (Org.). Ministério do Planejamento, Orçamento e Gestão. Instituto Brasileiro de Geografia e Estatística IBGE. Rio de Janeiro, 2013. Disponível em: https://biblioteca.ibge.gov.br/visualizacao/livros/liv63405.pdf. Acesso em 15 jul 2020.

SCHWARTZMAN, Simon. Fora de foco: diversidade e identidades étnicas no Brasil. Novos Estudos CEBRAP, 55, Novembro 1999, pp. 83-96. Disponível em: http://www.schwartzman.org.br/simon/pdf/origem.pdf .Acesso 20 jul 2020.

SOUZA, Guilherme Nogueira de. Análise do sistema de classificação por corl raça no Brasil. Rio de Janeiro : State University. 2019. 


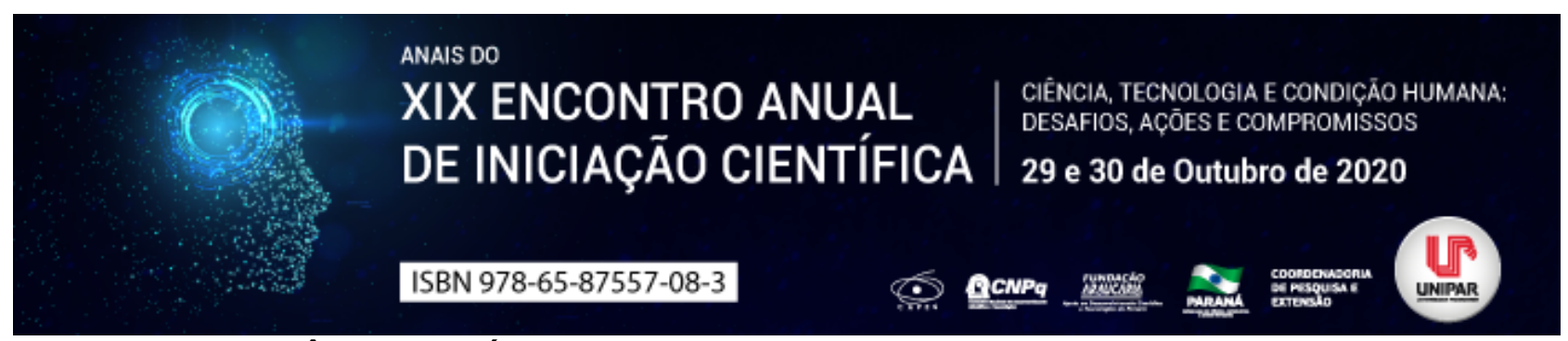

A VIOLÊNCIA DOMÉSTICA NO BRASIL DURANTE A PANDEMIA DO COVID-19

\author{
${ }^{1}$ Snayder Roberto Rodrigues Zaha, ${ }^{2}$ NAYARA KARINE SILVA, ${ }^{3}$ PATRÍCIA FISCHER SILVÉRIO, ${ }^{4}$ RAPHAEL PRIETO DOS \\ SANTOS
}

${ }^{1}$ acadêmico do curso de direito da UEMS

${ }^{1}$ acadêmica do curso de direito da UEMS

2acadêmica do curso de direito da UEMS

${ }^{3}$ Docente da UEMS

Introdução: Sancionada em 07 de agosto de 2006 a Lei no 11.340/2006, resultado da luta da cearense Maria da Penha Maia Fernandes, vítima de violência doméstica durante 23 anos de casamento, tornando mais rigorosa a punição para agressões contra a mulher quando ocorridas no âmbito familiar e doméstico. Neste contexto, surge a preocupação quanto a efetividade e aplicação de tal dispositivo durante a pandemia do Covid-19 no Brasil, onde o regime de isolamento tem imposto uma série de consequências não apenas para os sistemas de saúde, mas também para a vida de muitas mulheres que já viviam em situação de violência doméstica.

Objetivo: Mostrar a importância de se criar e intensificar mecanismos de proteção e fiscalização relativo à violência doméstica durante a pandemia do Covid-19.

Desenvolvimento: Em 2006 entrou em vigor a Lei Maria da Penha que tornou mais rigorosa a punição para agressões contra a mulher quando ocorridas no âmbito familiar e doméstico. Pois, alterou o Código Penal possibilitando que os agressores dessas mulheres sejam presos em flagrante ou tenham prisão preventiva decretada. Essa mudança permitiu que os agressores não poderiam mais ser punidos apenas com penas alternativas, como por exemplo, pagamento de cestas básicas. Outra mudança positiva foi o aumento do tempo máximo de detenção que antes era de um ano, passando agora para três anos, determinando ainda medidas como a saída do agressor do domicílio e a proibição de sua proximidade com a mulher agredida e os filhos (BRASIL, 2006). Nesse sentido, surge a preocupação quanto ao aumento dos números referentes a violência doméstica durante o período de quarentena, em que famílias passam o dia todo no mesmo círculo social, em uma convivência forçada que pode catalisar as discussões e tensões familiares. Um ponto importante a se destacar é que o desemprego decorrente da crise afeta principalmente as mulheres, que se concentram no setor de serviços mais atingido pela crise, como por exemplo as domésticas. Criando um ambiente onde as mulheres ficam mais dependentes financeiramente de seus cônjuges, muitas vezes, sem um lugar para ir, ou alguém próximo para procurar ajuda. Alguns fatores dificultam ainda mais a fiscalização e a denúncia, como o fato da grande maioria da população estar em quarentena, ou em alguns casos pela diminuição de renda, pela própria convivência forçada e ininterrupta com o autor das agressões e também contribui nesse momento a restrição de alguns serviços públicos de proteção as mulheres que limitaram o atendimento ao público presencial (VIEIRA, GARCIA, MACIEL, 2020). A Ouvidoria Nacional de Direitos Humanos informou que as denúncias cresceram em média 14\% até abril deste ano em relação ao mesmo período do ano passado (BRASIL, 2020). Uma iniciativa importante foi realizada pelo Conselho Nacional de Justiça (CNJ) e a Associação dos Magistrados Brasileiros (AMB) com a campanha Sinal Vermelho, onde o objetivo é oferecer um canal silencioso, permitindo que essas mulheres se identifiquem nos locais fazendo um X nas mãos e, a partir daí, sejam ajudadas e tomadas as devidas soluções, ligando para o 190. Vale destacar também a iniciativa do Tribunal de Justiça de Mato Grosso do Sul (TJMS), com um projeto-piloto Protetivas On-line, que garante que às mulheres vítimas de violência doméstica domiciliadas em Campo Grande possam pedir uma medida protetiva pela internet. O atendimento é feito pelo site do TJMS, onde procura atender as mulheres, que por alguma razão, não podem se dirigir até a Casa da Mulher Brasileira (BRASIL, 2020). Para enfrentar à violência contra a mulher no contexto da pandemia é preciso mais que o simples acolhimento das denúncias. Devem direcionar os esforços para o aumento das equipes nas linhas diretas de prevenção e resposta à violência, assim como investir na divulgação dos serviços de ajuda disponíveis, a capacitação dos profissionais da saúde para identificar situações de risco, e o fortalecimento e a expansão das redes de apoio, sobretudo a garantia do funcionamento e ampliação das vagas nos abrigos para mulheres em situação de risco (VIEIRA, GARCIA, MACIEL, 2020).

Conclusão: Ante ao exposto, verifica-se a importância de buscar medidas visando enfrentar um dos fenômenos crescentes com a quarentena nas cidades, onde os agressores e vítimas estão sob o mesmo teto 24 horas por dia. Onde a busca por canais de denúncia via telefone ou presencial tendem a diminuir sua eficiência, uma vez que a pessoa agredida em muitos casos não consegue pedir ajuda reservadamente, assim fica evidente a necessidade de se investir em meios eletrônicos, através de plataformas digitais, seja pelo computador ou celular. 


\section{Referências}

BRASIL. CÂMARA DOS DEPUTADOS Crescem denúncias de violência doméstica durante pandemia. Disponível em: https://www.camara.leg.br/noticias/661087-crescem-denuncias-de-violencia-domestica-durante-pandemial. Acesso em: 08 jun. 2020.

BRASIL. LEI MARIA DA PENHA. Disponível em: https://www12.senado.leg.br/noticias/entenda-o-assunto/lei-maria-da-penha/. Acesso em: 01 jun. 2020.

BRASIL. CNJ NOTÍCIAS - MS: Em um mês, serviço Protetivas On-line recebe pedido até de vítima indígena. Disponível em: https://www.cnj.jus.br/ms-em-um-mes-servico-protetivas-on-line-recebe-pedido-ate-de-vitima-indigenall. Acesso em: 18 ago. 2020.

VIEIRA, P. R.; GARCIA, L. P.; MACIEL, E. L. N. Isolamento social e o aumento da violência doméstica: o que isso nos revela?. Revista Brasileira de Epidemiologia., Rio de Janeiro , v. 23, e200033, abr. 2020.

Coordenadoria de Pesquisa e Extensão - COPEX

Departamento de Editoração e Divulgaçāo Científica - DEDIC 


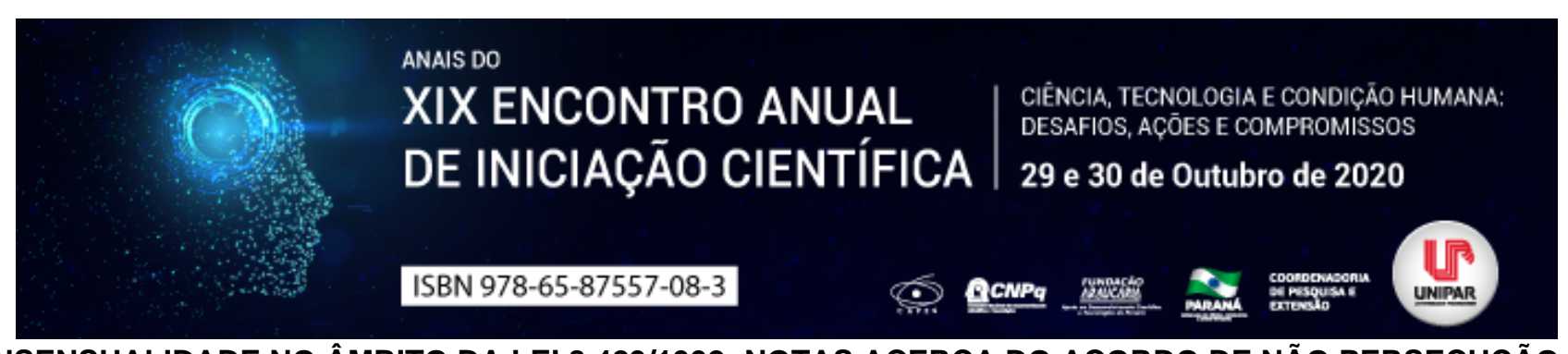

A CONSENSUALIDADE NO ÂMBITO DA LEI 8.429/1992: NOTAS ACERCA DO ACORDO DE NÃO PERSECUÇÃO CÍVEL

\begin{abstract}
${ }^{1}$ DIOGO DE ARAUJO LIMA, ${ }^{2}$ CASSIO DE PAULA XAVIER, ${ }^{3}$ MARIANA SARTORI NOVAK, ${ }^{4}$ TANIA ARNEKE PEREIRA, ${ }^{5}$ EDUARDO AUGUSTO SALOMÃO CAMBI
\end{abstract}

\begin{abstract}
${ }^{1}$ Discente do Mestrado em Direito Processual e Cidadania UNIPAR
${ }^{1}$ Discente do Mestrado em Direito Processual e Cidadania UNIPAR

${ }^{2}$ Discente do Mestrado em Direito Processual e Cidadania UNIPAR

${ }^{3}$ Discente do Mestrado em Direito Processual e Cidadania UNIPAR

${ }^{4}$ Docente da UNIPAR
\end{abstract}

Introdução: A partir do dia 23.01.2020, entrou em vigor o Pacote Anticrime (Lei 13.964/2019), que, suprimindo a vedação do art. 17, $\S 1^{\circ}$, da Lei 8.429 (BRASIL, 1992), passou a admitir expressamente a consensualidade no âmbito da improbidade administrativa por meio do Acordo de Não Persecução Cível (ANPC). Apesar do mérito que a inovação significou, o avanço poderia ter sido maior, não fosse o veto presidencial ao dispositivo que disciplinava os parâmetros procedimentais e materiais do acordo. Se ao menos não inviabilizou a implementação dos ANPC's, a medida trouxe um cenário de insegurança jurídica, ante lacuna normativa sobre a matéria. É preciso, pois, construir balizas que auxiliem o intérprete na delimitação dos contornos do acordo.

Objetivo: Elaborar, mediante pesquisa descritiva de análise doutrinária e de precedentes judiciais, um substrato jurídico capaz de balizar a implementação do ANPC's no campo da improbidade administrativa.

Desenvolvimento: Diferentemente do art. 28-A do CPP, que trata do Acordo de Não Persecução Penal (ANPP), o Pacote Anticrime deixou de disciplinar aspectos procedimentais e materiais do ANPC. O art. $4^{\circ}$ do D.L. 4.657 (BRASIL, 1942) estabelece que, quando a lei for omissa, o juiz decidirá o caso de acordo com a analogia, os costumes e os princípios gerais de direito . É preciso recorrer ao microssistema anticorrupção e, por meio da Teoria do Diálogo das Fontes (MARQUES, 2009), buscar uma solução coordenada entre as fontes normativas que permita uma aplicação que potencialize ao máximo a efetividade da proteção do bem jurídico tutelado pela Lei 8.429/92. Não se pode olvidar que o termo de ajustamento de conduta (TAC), a teor do art. $1^{\circ}$ da Res. 179 do Conselho Nacional do Ministério Público (BRASIL, 2017), é o instrumento adequado a veicular obrigações de fazer, não fazer, de dar (nesta contemplada a de pagar quantia certa). Inapropriado, assim, para impor sanções não pecuniárias como as previstas no art. 12 da Lei 8.429/92. Por isso, compreende-se que o regramento jurídico do TAC fica adstrito aos casos de improbidade de baixa gravidade, ou seja, aqueles cujas consequências não desbordem do plano da improbidade, ou, se assim não for, que se circunscrevam às infrações penais leves, compreendidas como as que admitem composição civil, transação penal ou suspensão condicional do processo (arts. 74, 76 e 89, da Lei 9.099) (BRASIL, 1995). Basicamente, seriam as hipóteses do art. 11, caput, da Lei 8.429/92. Passando para o nível seguinte de uma escala progressiva de gravidade, a valoração negativa dos fatos exige uma contrapartida maior por parte do agente para fazer jus ao benefício. Para este modelo, mostram-se adequadas as regras do ANPP, que trabalham com a matriz do guilty plea (assunção de culpa) do sistema de consenso processual norte americano (BRANDALISE, 2016). Além da terminologia comum, o diálogo entre os microssistemas penal e administrativo sancionador evitaria uma contradição axiológica - um defeito de lógica legislativa, no plano deontológico (GARCIA, 2017) -, pois não abonaria o raciocínio lógico sustentar que um agente público que fraude uma licitação possa celebrar ANPC, pela prática de ato lesivo ao erário, independentemente de confissão, mas, na esfera criminal, esse mesmo agente somente poder celebrar um ANPP, pela prática do mesmo fato, se confessar sua participação no ilícito (ANDRADE, 2020). Destarte, aos atos ímprobos de média gravidade, considerados como aqueles dos quais possam advir sanções da Lei 8.429/92 e também penais (neste caso, restrito às hipóteses que admitem ANPP), adequada a interpretação analógica para fins de ANPC. Quanto aos atos ímprobos graves e delitos correlatos extrapolem os limites do ANPP, não está descartada a hipótese de consensualidade. É que as hipóteses de acordos substitutivos não se restringem às do art. 28-A do CPP. Porém, nessas situações, não basta a confissão, exige-se uma efetiva colaboração na obtenção de informações, especialmente sobre outros partícipes e/ou coautores, e apresentação de provas de autoria. Nessa vertente, é possível trabalhar com normas de direito premial, como a Lei 12.846 (BRASIL, 2013), cujo art. 16 estabelece parâmetros e condições para a celebração do acordo de leniência, complementadas pelas Leis 12.529 (BRASIL, 2011) e 12.850, que versa a respeito da colaboração premiada (BRASIL, 2013), e por convenções internacionais adotadas pelo Brasil.

Conclusão: A nova redação do art. $17, \S 1^{\circ}$ da Lei 8.429/92 representou significativo avanço no combate à corrupção, mas se perdeu uma grande oportunidade de encerrar definitivamente discussões sobre a consensualidade nos casos de improbidade. A lacuna normativa, no entanto, não impede a efetiva implementação do ANPC, cuja consecução pode ser dar por meio de uma 
construção hermenêutica e de interpretação sistemática com outros institutos semelhantes. Mediante um paralelismo entre Direito Penal e Direito Administrativo Sancionador, propõe-se a regulamentação da matéria a partir de uma escala gradual de gravidade de fatos, iniciando pelas regras que disciplinam o TAC, passando pelas do ANPP e até chegar nas do acordo de leniência e da colaboração premiada.

\section{Referências}

ANDRADE, Landolfo. Acordo de não persecução cível: primeiras reflexões. Gen Jurídico, 05 março 2020. Disponível em: http://genjuridico.com.br/2020/03/05/acordo-de-nao-persecucao-civel/. Acesso em: 17 ago. 2020.

BRANDALISE, Rodrigo da Silva. Justiça penal negociada. Negociação de sentença criminal e princípios processuais penais relevantes. Curitiba: Juruá, 2016.

BRASIL. Lei $\mathrm{n}^{\circ}$ 13.964, de 24 de dezembro de 2019. Disponível em: http://www.planalto.gov.br/ccivil_03/_Ato20192022/2019/Lei/L13964.htm. Acesso em: 25 ago. 2020. ago. 2020.

.Lei $\mathrm{n}^{\circ}$ 8.429, de 2 de junho de 1992. Disponível em: http://www.planalto.gov.br/ccivil_03/leis//8429.htm. Acesso em: 25

. Código de Processo Penal. Decreto-Lei $n^{\circ} 3.689 / 1941$, de 3 de outubro de 1941 . Disponível em: http://www.planalto.gov.br/ccivil_03/decreto-lei/del3689compilado.htm. Acesso em: 25 ago. 2020.

. Decreto-Lei $n^{\circ} 4.657 / 1942$, de 4 de setembro de 1942. Disponível em: http://www.planalto.gov.br/ccivil_03/DecretoLei/Del4657.htm. Acesso em: 25 ago. 2020.

.Conselho Nacional do Ministério Público. Resolução $n^{\circ}$ 179, de 26 de julho de 2017. Regulamenta o $\S 6^{\circ}$ do art. $5^{\circ}$ da Lei $n^{\circ} 7.347 / 1985$, disciplinando, no âmbito do Ministério Público, a tomada do compromisso de ajustamento de conduta. Disponível em: https://www.cnmp.mp.br/portal/images/Resolucoes/Resolu\%C3\%A7\%C3\%A3o-179.pdf. Acesso em: 25 ago. 2020.

.Lei $\mathrm{n}^{\circ}$ 12.846, de $1^{\circ}$ de agosto de 2013. Disponível em: . Acesso em: 25 ago. 2020.

GARCIA, Emerson. A consensualidade no direito sancionador brasileiro: potencial de incidência no âmbito da Lei no 8.429/1992. Revista Síntese: Direito Administrativo, São Paulo, v. 12, n. 141, Edição Especial, pp. 542-595, set. 2017.

MARQUES, Cláudia Lima; BENJAMIN, Antonio Herman V.; BESSA, Leonardo Roscoe. Manual de direito do consumidor. $2^{\mathrm{a}}$ ed. São Paulo: Editora Revista dos Tribunais, 2009. p. 90. 


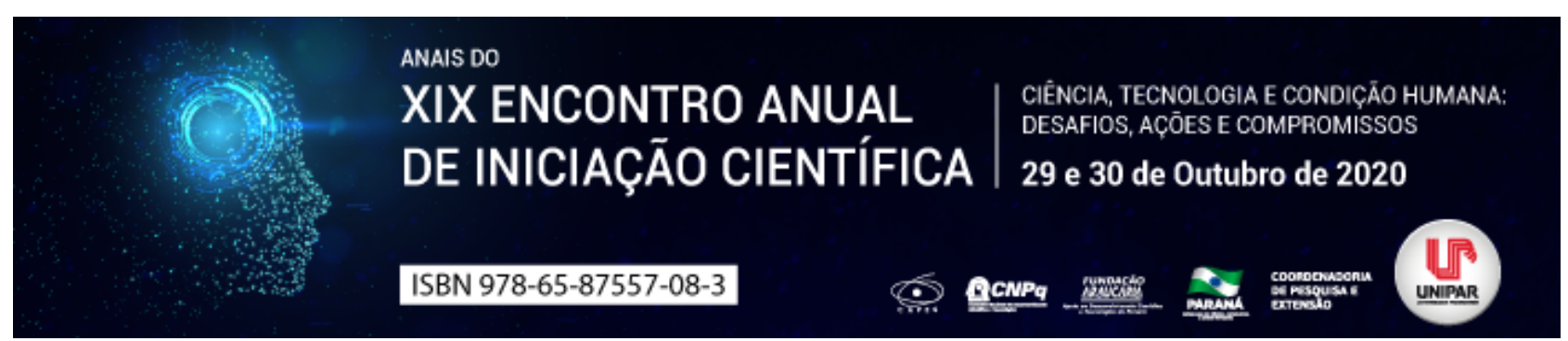

O HOMO SACER CONTEMPORÂNEO: A VIDA NUA E O DEVIDO PROCESSO LEGAL

\author{
1'LUCIANA FERREIRA DA SILVA, ${ }^{2}$ DORITA ZIEMANN HASSE
}

\author{
${ }^{1}$ Acadêmica do PIC/UNIPAR \\ ${ }^{1}$ Docente da UNIPAR
}

Introdução: Tendo em vista a principiológica complexidade do devido processo legal, art. $5^{\circ}$, inciso LIV da Constituição da República Federativa do Brasil, é possível traçar um paralelo entre a realidade processual e a necessidade de se recorrer aos direitos do homem marcados pela vida nua , apolítica e carente de proteção.

Objetivo: Contemplar a figura do homo sacer e sua relação com um sujeito exposto à precarização da vida a partir da negação do aparato normativo jurídico.

Desenvolvimento: Considerando que a intersecção presente entre biopolítica e soberania na perspectiva de Agamben nos leva à figura metafísica do homo sacer, sujeito exposto à precarização da vida, que pode ser mutável através do meio jurídico. Esse conceito - resgatado do contexto romano- representa a vida indigna de ser vivida ao se perguntar se [...] existem vidas humanas que perdem a tal ponto a qualidade de bem jurídico, que a sua continuidade, tanto para o portador da vida como para a sociedade, perdeu permanentemente todo o valor (AGAMBEN, 2010. p. 133). Aqui se encontra presente a aplicação da semiótica, teoria dos signos, estabelecendo relações entre código e mensagem ou signo e discurso. Como bem descreve o semiólogo italiano Umberto Eco (1997, p. 19), não se faz a semiótica do signo se não se fizer a semiótica do discurso. Sem embargo, o professor Winfried Brugger (2007, p. 118) descreve que o discurso de ódio expressa muito mais uma conduta do que uma narrativa. Logo, a despersonalização do sujeito não docilizado revela a negação do dispositivo normativo jurídico assegurado na Constituição Federal em seu art. $5^{\circ}$, inciso LIV, que dispõe: ninguém será privado da liberdade ou de seus bens sem o devido processo legal , (BRASIL, 1988, Art. $5^{\circ}$, inciso LIV). Por conseguinte, o devido processo legal traz garantias que não servem apenas aos interesses das partes, como direitos públicos subjetivos (ou poderes e faculdades processuais) destas, mas que configuram, antes de tudo, a salvaguarda do próprio processo, objetivamente considerado, como fato legitimamente do exercício da jurisdição (CINTRA, et al, 2007, p. 88). Observa-se, portanto, que a aplicação do devido processo legal reside no asseguramento a todas as etapas previstas em lei e não como mero dispositivo formal incapaz de minimizar o ambiente ameaçador que atinge o homo sacer e que, por isso, está em constante relação com o poder que o excluiu. A violência é uma realidade humana e dela não se pode fugir, porém, é necessário que haja desenvolvimento social para possibilitar que mudanças aconteçam.

Conclusão: Deveras, conclui-se que nenhum sujeito tem o dever de suprir as expectativas morais do outro, já que, por lei, todos possuem acesso às etapas processuais, que compreendem a ampla defesa e o contraditório. Trata-se de desmistificar o sujeito marginalizado como destruidor dos laços sociais ao compreender que este possui os mesmos direitos e deveres frente ao ordenamento jurídico.

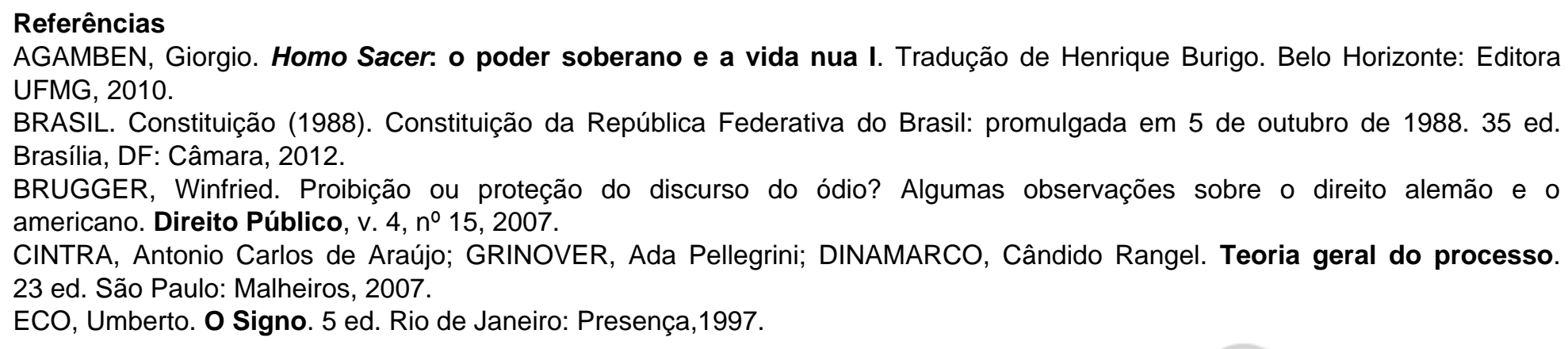

AGAMBEN, Giorgio. Homo Sacer: o poder soberano e a vida nua I. Tradução de Henrique Burigo. Belo Horizonte: Editora UFMG, 2010.

BRASIL. Constituição (1988). Constituição da República Federativa do Brasil: promulgada em 5 de outubro de 1988.35 ed. Brasília, DF: Câmara, 2012.

BRUGGER, Winfried. Proibição ou proteção do discurso do ódio? Algumas observações sobre o direito alemão e o americano. Direito Público, v. 4, no 15, 2007.

CINTRA, Antonio Carlos de Araújo; GRINOVER, Ada Pellegrini; DINAMARCO, Cândido Rangel. Teoria geral do processo. 23 ed. São Paulo: Malheiros, 2007.

ECO, Umberto. O Signo. 5 ed. Rio de Janeiro: Presença,1997. 


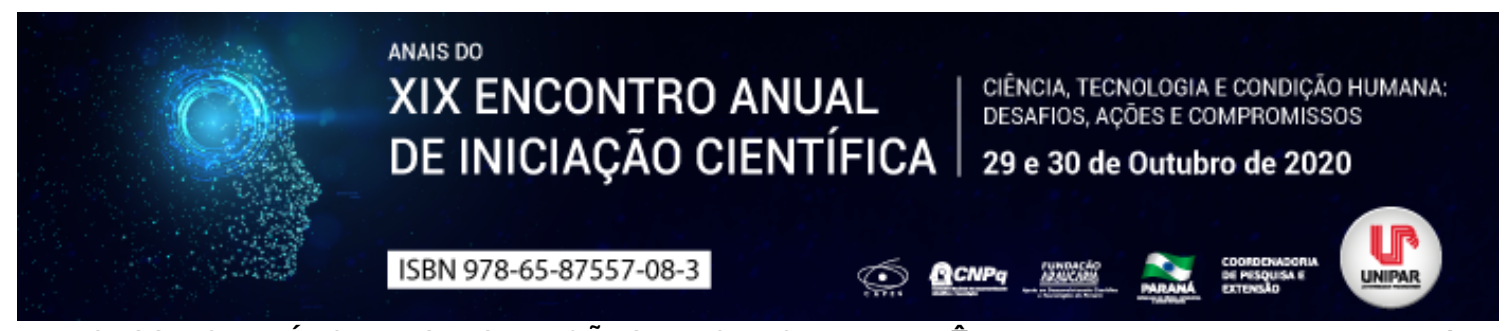

RETROCESSO CIENTÍFICO? AS DISTORÇÕES DO CONCEITO DE GÊNERO NO PROJETO DE LEI 2578/2020

\author{
${ }^{1}$ SARAH CAROLINA KLEIN, ${ }^{2}$ KETTLYN CARLA DE SOUZA, ${ }^{3}$ CARLA SABRINA GOMES LEAL DE OLIVEIRA, ${ }^{4}$ LUIZ AUGUSTO MUGNAI \\ VIEIRA JUNIOR
}

\author{
${ }^{1}$ Acadêmica de Psicologia - PIC/UNIPAR Cascavel \\ ${ }^{1}$ Acadêmica de Psicologia - PIC/UNIPAR Cascavel \\ ${ }^{2}$ Acadêmica de Psicologia - PIC/UNIPAR Cascavel \\ ${ }^{3}$ Docente e Orientador do PIC/UNIPAR - Cascavel
}

Introdução: O projeto de Lei 2578/2020, redigido pelo deputado Filipe Barros do PSL/PR, dispõe que tanto o sexo biológico como as características sexuais primárias e cromossômicas definem o gênero do indivíduo (BARROS, 2020). Tal visão contradiz os estudos de gênero, já que identidade de gênero deve ser pensada deslocada da biologia de acordo com Berenice Bento (2017, p. 107) que ainda destaca: ao produzir as identidades de homem e mulher com base na biologia, estamos produzindo identidades de gênero a partir de um processo extremamente violento. Quer dizer que, além de não ser científico, negar que gênero é uma construção social consiste em manipular e proporcionar uma política de exclusão. É preciso destacar que gênero refere-se à construção histórica, social e subjetiva do que é lido como masculino e feminino (GIDDENS, 2010), bem como consiste em aspectos políticos, visto que as relações de gênero se fundamentam nas relações de poder (SCOTT, 1990). A pesquisadora Bento (2017, p.157) alerta que gênero é, hoje, um assunto de Estado ; todavia, na maioria das vezes, tratado com distorção, sendo observada nos trâmites recorrentes de projetos de lei tocantes aos estudos de gênero que são chamados, equivocadamente, de ideologia de gênero.

Objetivo: Problematizar a distorção dos conceitos de gênero, sexo e sexualidade trazidos pelo projeto de Lei 2578/2020 movimentada por seu autor Filipe Barros - PSL pautando-se em estudos científicos de gênero.

Desenvolvimento: Segundo a historiadora Joana Pedro (2005, p.79) em 1968, Robert Stoller, no livro I"Sex and Genderl", empregou a palavra ।"gênerol" com o sentido de separação em relação ao l"sexol". Para a autora, a palavra l"gênerol" foi e tem sido usada nos debates feministas, criando assim uma categoria de análise para pensar a subordinação das mulheres que são, fundamentalmente, constituídas no interior das relações de poder (SCOTT, 1990). Os movimentos feministas foram ganhando força ao longo do tempo em decorrência da desigualdade de poder entre o masculino e o feminino. Ao contrário da percepção científica, a justificação do projeto de Barros (2020) vê gênero como uma ameaça, pois é nocivo e hostil à instituição da família e foi estrategicamente inventado pelas tendências mais extremistas do feminismo mundial. O projeto de Lei 2578/2020 também coloca que gênero seria um sinônimo para o sexo biológico (BARROS, 2020, p.1). Em oposição à afirmação do deputado, gênero é uma construção social daquilo que é visto como masculino e feminino; porém, Barros (2020), além de expressar uma confusão recorrente pelo senso comum que sexo e gênero são sinônimos, ainda biologiza as identidades de gênero. Ademais, o autor do projeto nega a cientificidade dos estudos de gênero bem como desqualifica e não reconhece a importância da pesquisadora e filósofa Judith Butler, classificando-a como uma feminista radical. É importante destacar que o projeto de lei 2578/2020 não é uma divergência científica ou filosófica, pois se pauta numa concepção de que gênero e sexo são sinônimos, já superada pela ciência. Ainda, o deputado confunde a homossexualidade, que consiste num tipo de orientação sexual, com gênero. O projeto parece ter a intenção de excluir a diversidade e a pluralidade de vivenciar as identidades de gênero, uma tentativa de deslegitimar, por exemplo, a transexualidade, o que o torna provido de um discurso muito próximo da inconstitucionalidade.

Conclusão: Observa-se que o projeto de lei é desprovido de embasamento científico, bem como lotado de distorções, manipulações e negacionismos dos estudos de gênero. Negar que nas relações de gênero estão as de poder, como as que subalternizam as mulheres ou que a transfobia é uma violência, é uma possível forma de escapar de um desconfortável conhecimento que pode colocar em desmonte a manutenção de poder de gênero que o autor, provavelmente, se beneficia. Vale destacar que as distorções de gênero não são exclusividade deste projeto de lei, tampouco do deputado Filipe Barros; logo, a discrepância de entendimento, somado aos interesses e compreensões individuais (e não científicas) refletem largamente nos projetos de lei. Inclusive, o Supremo Tribunal Federal tem anunciado que os projetos de lei que proíbem o ensino ou que tentam proibir que se fale sobre as questões de gênero nas escolas são inconstitucionais.

\title{
Referências
}

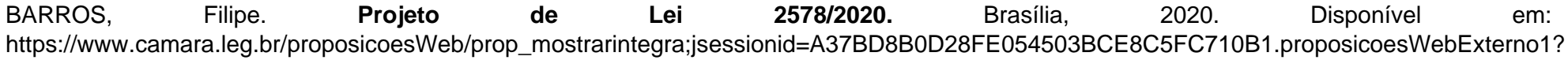
codteor=1892753\&filename=Tramitacao-PL+2578/2020. Acesso em: 24 jul. 2020.

BENTO, Berenice. Transviad@s: gênero, sexualidade e direitos humanos. Salvador: EDUFBA, 2017.

GIDDENS, Anthony. Gênero e Sexualidade. In: Sociologia. Lisboa: Fundação Calouste Gulbenkan, 2010.

PEDRO, Joana. Traduzindo o debate: o uso da categoria gênero na pesquisa histórica. HISTÓRIA, SÃO PAULO, v.24, N.1, P.77-98, 2005.

SCOTT, Joan Wallach. Gênero: uma categoria útil para análise histórica. Recife: SOS Corpo, 1991. 


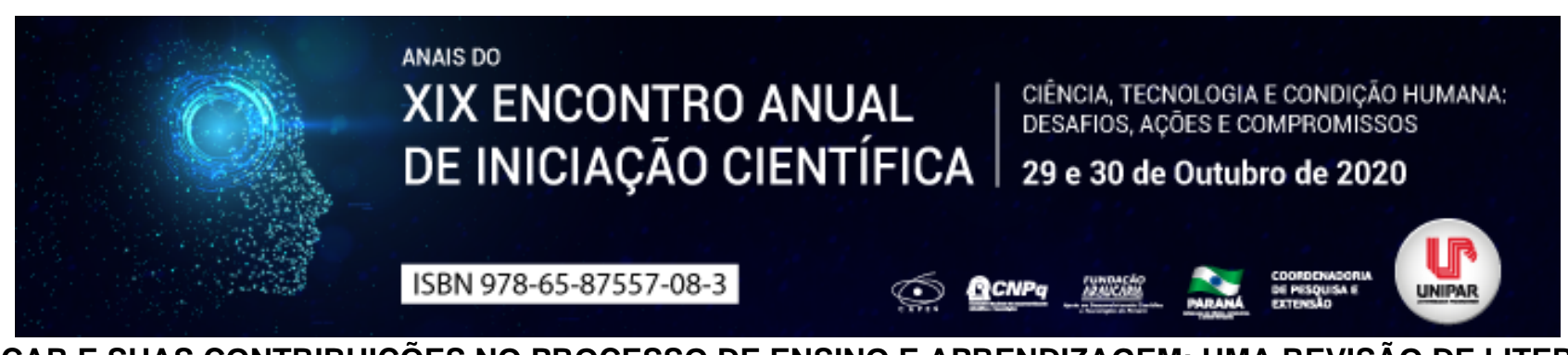

O BRINCAR E SUAS CONTRIBUIÇÕES NO PROCESSO DE ENSINO E APRENDIZAGEM: UMA REVISÃO DE LITERATURA

\author{
${ }^{1}$ Gabriel Antonio Parra Valhejo, ${ }^{2}$ LUCYELENA AMARAL PICELLI
}

${ }^{1}$ Pós-graduando em Psicomotricidade pela Pontifícia Universidade Católica do Paraná PUC/Curitiba

${ }^{1}$ Docente da UNIPAR

Introdução: O brincar é inerente a vida humana, fazendo parte dela desde o tempo em que os seres humanos viviam nas cavernas até hoje, e, demonstra e possibilita aos sujeitos inúmeros benefícios para sua formação, enquanto sujeitos de uma sociedade, repleta de valores, regras e conceitos. Zatz, Zatz e Halaban (2006, p. 14), relatam que brincando, a criança aprende a se relacionar, a compartilhar as coisas, a se comunicar e a expressar suas ideias e sentimentos. Descobre o prazer de cantar, dançar, desenhar, representar. Desenvolve seu raciocínio, sua linguagem, sua criatividade (...) e por fim, conta o mundo a si mesma e exercita sua imaginação

Objetivo: Averiguar se o brincar contribui no processo de ensino e aprendizagem enquanto ação metodológica.

Desenvolvimento: De acordo com Catunda (2005, p. 40) o brincar configurado como uma forma, uma maneira, um modo-deser, apresenta-se como possibilidade concreta para o desenvolvimento dos processos de educação que envolva a responsabilidade com os corpos. Isso porque, ao brincar, o ser humano passa a interagir com sua vivência e com a vivência do outro, logo interferindo nas relações interpessoais, o que pode facilitar a intervenção no desenvolvimento da cultura lúdica . O processo de ensino e aprendizagem precisa ser atualizado e repensado, pois constatamos que criança aprende conceitos abstratos brincando e muitos professores continuam fazendo uso de metodologias ultrapassadas, o que por sua vez não atende a demanda que temos hoje. Cunha (2005, p. 11), a fundadora da Brinquedoteca no Brasil, responde ao um grande paradigma que permeia na sociedade: por que brincar? Segundo esta renomada autora brincando, a criança experimenta, descobre, inventa, exercita e confere suas habilidades. (...) é indispensável à saúde física, emocional e intelectual da criança. É uma arte, um dom natural que, quando bem cultivado, irá contribuir, no futuro, para eficiência e o equilíbrio do adulto . Já a autora Santos (2011) coloca que o brincar com finalidade educativa, proporciona aos alunos um interesse pelo processo de aprendizagem e assim a escola cumpre com seu papel de educar, bem como abre ao educador um leque de possibilidades, pois através do brincar não ensina apenas conteúdos conceituais, como também está formando sujeitos integralmente, por meio do desenvolvimento físico, intelectual, afetivo, social e moral que lhes é propiciado. Para sua aprendizagem e seu pleno desenvolvimento, a criança, necessita de estímulos e de planejamento por parte do professor, a fim de atender as suas demandas subjetivas e as especialidades de cada aluno. Vygotsky (1988) apud Kishimoto (1994) nos elucida que a ação principal dos indivíduos nos primeiros anos de vida é a brincadeira, em que estabelece proveniência de desenvolvimento ao gerar zonas de desenvolvimento proximal. Ao providenciar situações que a imaginação é base solidificadora através do brincar, a criança desenvolve a iniciativa, expõe seus desejos e abstrai para si as regras presentes na sociedade em que está inserida. Neste sentido, o professor visto como mediador da aprendizagem, tem como dever em sua práxis pedagógica, apresentar uma metodologia ou uma ação inovadora, que desperte nos alunos a motivação para a aprendizagem, deixando-os com I"sedel" de conhecimento e informação. Como responsáveis ativos do mecanismo, tem objetivo de formar sujeitos críticos, responsáveis, cidadãos constituídos de ética, capazes de transformar a sociedade em que está inserido. Para Winnicott (1982, p. 163) a criança adquire experiência brincando. (...) A brincadeira fornece uma organização para a iniciação de relações emocionais e assim propicia o desenvolvimento de contatos sociais . Deste modo, o brincar vem como uma via de possibilidades, pois a partir do momento que o educador embasa seu planejamento por meio deste ato, muitas oportunidades são abertas, para que a motivação do aluno seja revelada e aprendizagem aconteça da melhor maneira possível. Também, visto como um ato desafiador, que proporciona às crianças possibilidades de desenvolvimento, superação de desafios tanto físico quanto cognitivo, apreciação pelo prazer lúdico e interação com os demais indivíduos, deste modo, constituído de objetivos (co)ligados ao processo de aprendizagem.

Conclusão: Portanto, o brincar por meio da exploração e da imitação, revela-se e torna-se uma grande chave, um auxílio, para os professores, já que através desta ação, considerada por muitos como insignificante, é que as crianças internalizam em si conhecimentos, experiências, regras e valores sociais. O uso apenas da metodologia tradicional não levará a um processo de aprendizagem de qualidade, pois as crianças do presente século necessitam de algo a mais do que meras aulas expositivas, na qual o professor é o detentor do conhecimento e, basicamente, o repassa aos seus alunos. Deste modo, o brincar pode aparecer como uma metodologia inovadora para o contexto escolar, pois proporciona um ensino e aprendizagem rico e de qualidade, que estimula o interesse e que forme integralmente os educandos.

\title{
Referências
}


CATUNDA, Ricardo. Brincar, criar, vivenciar na escola. Rio de Janeiro: Sprint, 2005.

CUNHA, Nylse Helena Silva. Brinquedos: desafios e descobertas. Petrópolis: Vozes, 2005.

KISHIMOTO, Tizuko Morchida. O jogo e a educação infantil. São Paulo: Pioneira, 1994.

SANTOS, Santa Marli Pires dos. O brincar na escola: metodologia lúdico-vivencial, coletânea de jogos, brinquedos e dinâmicas. $2^{\mathrm{a}}$ ed. Petrópolis: Vozes, 2011.

WINNICOTT, Donald Woods. A criança e o seu mundo. 6a ed. Rio de Janeiro: LTC, 1982.

ZATZ, Sílvia; ZATZ, André; HALABAN, Sergio. Brinca comigo!: tudo sobre brincar e os brinquedos. São Paulo: Marco Zero, 2006.

Coordenadoria de Pesquisa e Extensão - COPEX

Departamento de Editoraçāo e Divulgaçāo Científica - DEDIC 


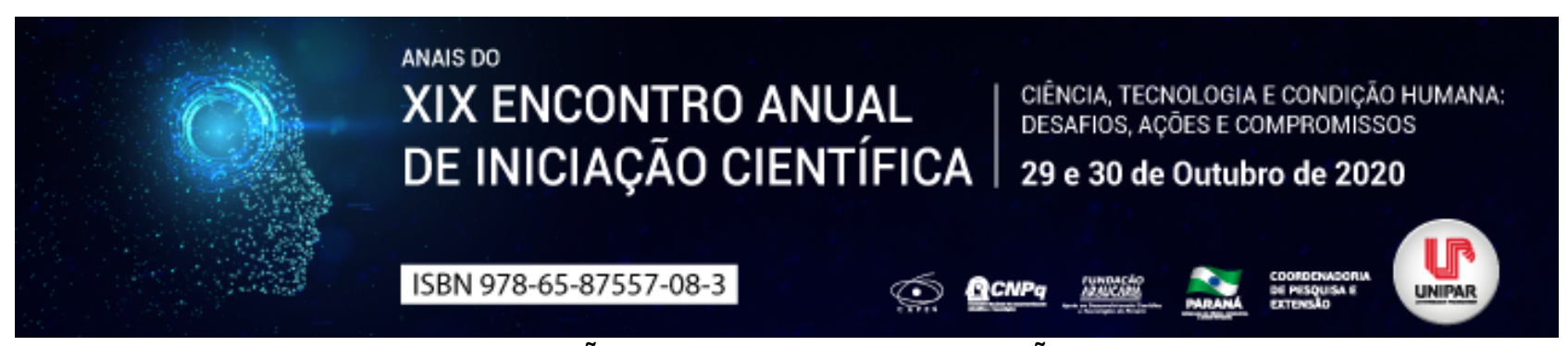

DESCABIMENTO DE RECLAMAÇÃO PARA DISCUTIR APLICAÇÃO DE RECURSO REPETITIVO

\title{
${ }^{1}$ GILMARA GONCALVES BOLONHEIZ, ${ }^{2}$ ALANA CAROLINE MOSSOI
}

\author{
${ }^{1}$ Mestranda em Direito Processual Civil e Cidadania \\ ${ }^{1}$ Mestranda em Direito Processual Civil e Cidadania
}

Introdução: A Corte Especial do Superior Tribunal de Justiça decidiu, recentemente, que não é cabível a ação de reclamação contra decisões dos tribunais locais para discutir aplicação de recurso repetitivo, com base no art. 988, do Código de Processo Civil e sim de ação rescisória. Referido julgamento vai de encontro ao posicionamento da doutrina, visto a interpretação do dispositivo legal na prática do exercício da advocacia em segundo grau.

Objetivo: Demonstrar que o acórdão proferido pela Ministra Relatora Nancy Andrighi (Reclamação no. 36.476 SP), gera controvérsia no mundo jurídico diante do entendimento de alguns doutrinadores acerca da possibilidade de reclamação dentro dos precedentes do Código de Processo Civil.

Desenvolvimento: Embora a Ministra Relatora Nancy Andrighi tenha feito um estudo histórico da evolução da reclamação em seu voto, no sentido de que este é um instituto voltado para preservar a competência e a garantia da autoridade dos julgados, decidiu pelo não cabimento dessa ação sob a alegação de que as hipóteses admissíveis estão elencadas nos incisos do caput do art. 988, do Código de Processo Civil, sendo que o parágrafo $5^{\circ}$ do mesmo dispositivo legal trata de situações em que não é cabível a reclamação. Da análise do caput do artigo em discussão, é sabido que não há possibilidade de propor reclamação em julgamento de recurso repetitivo. Entretanto o acórdão vai de encontro com o $\S 5^{\circ}$, do art. 988 , do CPC, segundo o qual é cabível a reclamação quando esgotadas as possibilidades recursais ordinárias, e por conseguinte, não tenha havido o trânsito em julgado, consoante súmula 734 do STF. Segundo Medina (2016, p. 1459) o disposto no caput I"além de padecer de grave incoerência logica (...), não está em harmonia com o que dispõe o art. 988, do $\S 5^{\circ}$, Il do CPC/15 (...), que se refere a garantia observância de (...) ou de acórdão proferido em julgamento de recursos extraordinário ou especial repetitivos . De acordo com outro entendimento doutrinário, a disposição desse parágrafo possui três efeitos, quais sejam, expande literalmente o cabimento da reclamação, já que elenca também os recursos extraordinários nos quais houve o reconhecimento de repercussão geral; torna admissível a reclamação com base em recursos repetitivos, que não seriam cabíveis a partir da leitura isolada do caput e terceiro, cria um requisito de admissibilidade específico para as reclamações que tenham por paradigma precedente formado em julgamento de recurso extraordinário com repercussão geral ou de recursos especial ou extraordinário repetitivos, qual seja, o esgotamento das instancias ordinárias, o que significa que apenas caberá reclamação após a decisão do tribunal local, da qual cabe recurso especial e ou recurso extraordinário, conforme o caso (MACEDO, 2019). Outrossim, no sentido de provocar mais discussões doutrinárias, há de se observar a literalidade do $\S 4^{\circ}$, do art. 988, do CPC vigente, que colide frontalmente com o acórdão em questão, tendo em vista que esse parágrafo dispõe ser cabível a reclamação exatamente em face de aplicação indevida da tese jurídica fixada em recurso especial repetitivo. Não obstante, um entrave processual não deve servir de impedimento a efetivação do direito buscado, temos que nessa hipótese cabível a proposição de Reclamação Constitucional diretamente ao STF ou STJ, na forma do art. 988, § $4^{\circ}$, do CPC (PAIXÃO CORTES, 2016, p. 256). Porquanto é bastante plausível o entendimento doutrinário no sentido de que é possível o cabimento da reclamação para além das hipóteses contidas no caput do art. 988 do Código de Processo Civil, visto tratar de um instrumento relevante por que não raras são as hipóteses que o tribunal a quo repete em inúmeros julgados uma interpretação equivocada do precedente (...).।" (ZANETI JR, 2019, p. 385). Porém, a partir do julgamento em comento, temos que a solução adequada e sim, em consequência de não ser feito o distinguishing em recurso especial e extraordinário repetitivo via agravo interno do Presidente do Tribunal Regional Local, é o ajuizamento da ação rescisória, segundo o art. 966, inciso V, § 5º do CPC/15.

Conclusão: Conclui-se que a Corte Especial do Superior Tribunal de Justiça decidiu que é aplicável tão somente a ação rescisória para garantir que os recursos repetitivos sejam aplicados, cuja decisão traz uma declaração de inconstitucionalidade implícita dos parágrafos do art. 988, do CPC, visto que a doutrina defende o direito da parte de acesso mediante recursos especial ou extraordinário repetitivos, via reclamação constitucional.

\section{Referências}

BRASIL. Superior Tribunal de Justiça (Corte Especial). Reclamação 36.476/SP. RECLAMAÇÃO. RECURSO ESPECIAL AO QUAL O TRIBUNAL DE ORIGEM NEGOU SEGUIMENTO, COM FUNDAMENTO NA CONFORMIDADE ENTRE O ACÓRDÃO RECORRIDO E A ORIENTAÇÃO FIRMADA PELO STJ EM RECURSO ESPECIAL REPETITIVO (RESP 1.301.989/RS - TEMA 658). INTERPOSIÇÃO DE AGRAVO INTERNO NO TRIBUNAL LOCAL. DESPROVIMENTO. RECLAMAÇÃO QUE SUSTENTA A INDEVIDA APLICAÇÃO DA TESE, POR SE TRATAR DE HIPÓTESE FÁTICA DISTINTA. DESCABIMENTO. PETIÇÃO INICIAL. 
INDEFERIMENTO. EXTINÇÃO DO PROCESSO SEM RESOLUÇÃO DO MÉRITO. Reclamantes: Adilson Riva e outros. Reclamado: Tribunal de Justiça do Estado de São Paulo. Relatora: Min. Nancy Andrighi, 05 de fevereiro de 2020. Disponível em: https://ww2.stj.jus.br/processo/pesquisa/?

termo=Rcl+36476\&aplicacao=processos.ea\&tipoPesquisa=tipoPesquisaGenerica\&chkordem=DESC\&chkMorto=MORTO. Acesso em: 26 ago. 2020.

MACEDO, Lucas Buril de. Precedentes Judiciais e o direito processual civil. 3ed. Salvador: Juspodivm, 2019.

MEDINA, José Miguel Garcia. Direito Processual Civil Moderno. 2ed. São Paulo: Revista dos Tribunais, 2016.

PAIXAO CORTES, Osmar Mendes. A reclamação para os tribunais superiores no CPC/2015, com alterações da Lei 13.256/2016. Revista de Processo. São Paulo, v.41, n.257, p.255-266, jul.2016.

ZANETI JR, Hermes. O valor vinculante dos precedentes: teoria dos precedentes normativos formalmente vinculantes. 4ed. Salvador: Juspodivm, 2019.

Coordenadoria de Pesquisa e Extensão - COPEX

Departamento de Editoraçāo e Divulgaçāo Científica - DEDIC 


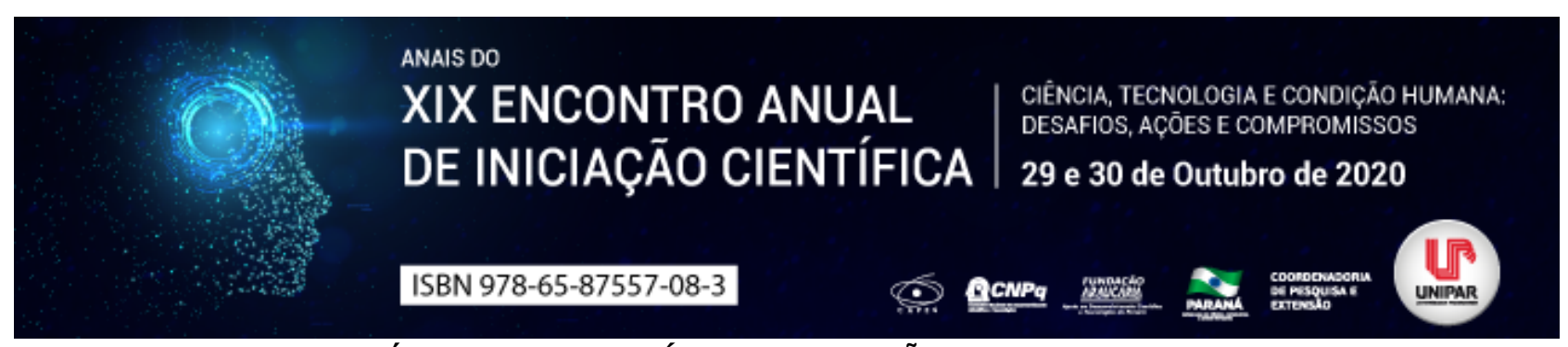

ASPECTOS PRÁTICOS DO PRINCÍPIO DA VEDAÇÃO DO JULGAMENTO SURPRESA

\title{
${ }^{1}$ JUSCELINO PIRES DA FONSECA, ${ }^{2}$ JONATAS LUIZ MOREIRA DE PAULA
}

\author{
${ }^{1}$ Acadêmico do Mestrado de Direito Processual Civil e Cidadania - UNIPAR \\ ${ }^{1}$ Docente da UNIPAR
}

Introdução: O princípio do Contraditório é amplamente abordado no Código de Processo Civil, com intuito de garantir a possibilidade de participação das partes no debate processual, sendo que ao assegurar o direito de influência nas convicções do juiz, foi erigido outro princípio que dele deriva denominado vedação do julgamento surpresa, tendo como sustentáculos a cooperação e legitimidade democrática.

Objetivo: Apresentar aspectos práticos do princípio da proibição da decisão surpresa, que em suma, busca extirpar do sistema processual a visão restritiva de que as partes tem o direito apenas de serem ouvidas, sendo suas razões desconsideradas, o que resultaria em um processo meramente formal, com uma decisão sem interação e portanto nula, já que surpresa e inapta a gerar efeitos.

Desenvolvimento: O princípio da vedação do julgamento surpresa é baseado em uma perspectiva democrática do processo, no qual há uma participação efetiva influenciando o desenvolvimento e colaborando para o fim pretendido quando da decisão final (THEODORO JR, 2020, p. 85). É assegurado as partes participar da construção do provimento jurisdicional que vai impactar diretamente suas vidas (PINHO, 2020, p. 94). A participação se diferencia conforme se tratar de direitos disponíveis (sem reaçãorevelia) e indisponíveis (é exigido o enfrentamento do pedido, ainda que não diretamente pela parte) (NEVES, 2020, p. 41). O contraditório efetivo, abarca além das partes litigantes envolvidas o próprio juiz que deve zelar pelo seu cumprimento e submeterse ao mesmo (MARINONI et. al, 2020, p. 537). Não haverá julgamento surpresa se houve concessão da informação para oportunidade de manifestação de forma prévia, pelo que a reação não é obrigatória (RIBEIRO, 2014, p. 19). Para apreciação do julgamento surpresa a decisão precisa ser controlável (não será aferível de forma subjetiva), a partir da comparação com um standard objetivo, que permitirá concluir se as partes seriam capazes de antever aquela decisão dadas as peculiaridades e discussões erigidas dentro daquele processo (COSTA et al, 2018, p. 167). O art. 10 do CPC/15, não proíbe que matérias de

ordem pública sejam apreciadas de oficio, o que se discute é a forma de operacionalização da prolação destas decisões (THAMAY, 2016, p. 256). O termo partes , deve ser interpretado ampliativamente, abrangendo terceiros como Ministério Público (fiscal da lei), Defensoria Pública (custos vulnerabilis), e amicus curiae (BUENO, 2020, p. 415). As partes tem o direito de pronunciarem-se sobre os fundamentos fáticos e jurídicos de forma prévia a tomada de decisão, garantindo que não serão diversas daquela já sustentadas, de forma que o brocardo iura novit cúria, só permite que seja dado fundamento diverso se houver prévia possibilidade de indagação antes da decisão. (MARINONI et al, 2020, pg. 538).

Conclusão: O princípio da vedação do julgamento surpresa, garante as partes o direito de antever as conclusões do juiz, pois suas razões devem constar da fundamentação que se aterá ao que foi discutido pelas partes em contraditório, gerando decisões mais adequadas e justas, e efetivando direitos fundamentais do jurisdicionado, como: duração razoável do processo, celeridade, devido processo legal, ampla defesa, cooperação, igualdade, e principalmente segurança jurídica a sociedade.

\section{Referências}

BUENO, Cassio Scarpinella. Curso Sistematizado de Direito Processo Civil, Vol. 1: Teoria Geral do Direito Processual Civil: Parte Geral do Código de Processo Civil. 10 ed. São Paulo: Saraiva Educação, 2020. COSTA, José Augusto Fontoura. GARCIA, Marco Aurélio Fernandes. Contraditório e Aplicação de Ofício do Direito Estrangeiro no NCPC. Revista de Processo, vol. 286, dez. 2018.

MARINONI, Luiz Guilherme. ARENHART, Sérgio Cruz. MITIDIERO, Daniel. Curso de Processo Civil. Teoria do Processo Civil. Volume 1. 5 ed. rev. atual. e ampl. São Paulo: Thomson Reuters Brasil, 2020

NEVES, Daniel Amorim Assumpção. Código de Processo Civil Comentado. 5 ed. rev. e atual. Salvador: Jus Podivm, 2020 PINHO, Humberto Dalla Bernardina de. Manual de Direito Processual Civil Contemporâneo. 2 ed. São Paulo: Saraiva Educação, 2020.

RIBEIRO, Darci Guimarães. A Dimensão Constitucional do Contraditório e seus Reflexos no projeto do novo CPC.

Revista de Processo, v. 232, jun. 2014.

THAMAY, Rennan Faria Krüger. O Efeito Translativo na Barca de Caronte. Revista de Processo, vol. 255, mai. 2016.

THEODORO JUNIOR, Humberto. Curso De Direito Processual Civil. Teoria Geral do Direito Processual Civil, Processo de Conhecimento e Procedimento Comum. Vol I. 61․ed.Rio de Janeiro: Forense, 2020. 
Coordenadoria de Pesquisa e Extensão - COPEX

Departamento de Editoraçāo e Divulgaçāo Científica - DEDIC 


\title{
ANAIS DO \\ XIX ENCONTRO ANUAL | CIÊNCIA, TECNOLOGIA E CONDIÇÃO HUMANA: DE INICIAÇÃO CIENTÍFICA DESAFIOS, AÇŌES E COMPROMISSOS \\ DE INICIAÇĀO CIENTÍFICA 29 e 30 de Outubro de 2020 \\ ISBN 978-65-87557-08-3 \\ 0 ing \\ REFLEXÕES SOBRE VIOLAÇÕES DOS DIREITOS FUNDAMENTAIS DAS MINORIAS NO BRASIL: UM CENÁRIO DE DISCRIMINAÇÃO
}

\author{
${ }^{1}$ CLARA MARTINS CERCI, ${ }^{2}$ TEREZA RODRIGUES VIEIRA
}

\author{
${ }^{1}$ Graduanda do Curso de Direito e Bolsista do PIBIC/UNIPAR, campus Umuarama. \\ ${ }^{1}$ Pós-Doutora em Direito pela Université de Montreal Canadá; Docente do Mestrado em Direito Processual e Cidadania.
}

Introdução: A Constituição Federal de 1988 consagrou a nossa República como um Estado Democrático de Direito e impôs a implementação de uma série de políticas públicas. Fundada na dignidade da pessoa humana e no pluralismo político, prevê como objetivos republicanos a promoção do bem de todos e a redução das desigualdades sociais. Contudo, o Estado tem sido omisso em dar plena efetividade a essas disposições, tendo em vista que a discriminação contra as minorias é algo presente em nossa sociedade, como se percebe, por exemplo, no baixo índice de negros e de mulheres ocupando determinados cargos, e na ocorrência de episódios preconceituosos por motivo de classe social.

Objetivo: Apresentar uma breve reflexão sobre o atual grau de efetivação dos direitos fundamentais das minorias, no que tange às violações decorrentes de atos discriminatórios, e a responsabilidade estatal.

Desenvolvimento: Por muito tempo, as minorias têm sido eliminadas, discriminadas e massacradas por grande parte da sociedade, cenário que fere os seus direitos fundamentais, em especial o direito à igualdade. O conceito de minoria não está atrelado à quantidade numérica, sendo definido pela doutrina como um grupo de pessoas que de alguma maneira são objeto de preconceito social e/ou não tem respeitado os seus direitos de cidadania, necessitando de proteção e reconhecimento de direitos na sociedadel" (KOSOVSKI, 2001 apud VIALLI; SANTOS, 2016, p. 2). Nesse sentido, temos como exemplos as minorias sociais, étnico-raciais, de gênero, sexuais, indígenas e religiosas. Recentemente, a comunidade testemunhou por meio da mídia nacional, o grave insulto de um morador de um condomínio em Valinhos SP a um entregador, que foi ofendido em razão de sua cor e de sua baixa condição econômica. Sob a ótica de acesso a determinados cargos, pode-se citar que: dos 11 ministros no Supremo Tribunal Federal, temos apenas duas mulheres, e nenhum negro (BRASIL, 2020). Todas essas situações evidenciam violações aos direitos fundamentais das minorias. Ora, em uma sociedade democrática, deve-se buscar o equilíbrio e a satisfação dos interesses de todos, sendo dever do Estado garantir a proteção, a inclusão e a igualdade de direitos fundamentais das minorias, como determina o artigo $3^{\circ}$ da Constituição Federal, quando proclama que é objetivo fundamental da República Federativa do Brasil [...] I - construir uma sociedade livre, justa e solidária; [...] III - erradicar a pobreza e a marginalização e reduzir as desigualdades sociais e regionais; IV - promover o bem de todos, sem preconceitos de origem, raça, sexo, cor, idade e quaisquer outras formas de discriminação. (BRASIL, 1988). Porém, as políticas púbicas de inclusão têm se mostrado frágeis e ineficientes, tendo em vista que mesmo existindo normativas legais de proteção e reconhecimento das minorias em nosso Estado, como a Declaração Universal dos Direitos Humanos, Pacto Internacional dos Direitos Civis e Políticos e a Constituição Federal de 1988, as minorias ainda possuem seus direitos fundamentais violados. Desse modo, explica Martins e Mituzani (2011, p. 335), ao afirmar que a marginalização desses grupos deu-se por meio de discriminação social, representação política deficiente ou inexistente, subvalorização cultural, omissão ou mesmo violência das instituições estatais [...]. Como consequência de um Estado que não garante a representatividade e a inclusão social das minorias, estamos diante de um dano existencial, que ocorre sempre que opere uma modificação negativa no modo de ser do indivíduo ou nas atividades que ele exerce com relação ao projeto de vida pessoal, independentemente de prejuízo econômico [...] (BEÇAK; SILVEIRA; FERREIRA, 2019, p. 216). Como afirma Lopes (2008, p.26-27) é tarefa do Estado reconhecer em primeiro lugar, essas diferenças para assim protegê-las, proibindo qualquer tipo de discriminação e promovendo o bem de todos [...] . Logo, se os direitos fundamentais das minorias não forem assegurados, os demais direitos perdem o sentido de ser. A justiça social deve imperar. Liberdade em um ambiente desigual gera opressão, estimula exploração e o Estado é responsável pela adoção de medidas para a reversão do contexto atual.

Conclusão: A não implementação dos direitos fundamentais das minorias no Brasil agrava a desigualdade, a qual é construída com a exclusão moral, social e econômica dos mais vulneráveis. Diante disso, cabe ao Estado adotar políticas públicas abrangentes e efetivas para a inclusão social das minorias e a eliminação de atos discriminatórios, em respeito aos compromissos assumidos num Estado Democrático de Direito, em especial quanto aos objetivos descritos no art. $3^{\circ}$ da Constituição Federal brasileira.

\section{Referências}

BEÇAK, Rubens; SILVEIRA, Vladmir Oliveira da; FERREIRA, Fernanda Busanello. Direitos humanos e efetividade: fundamentação e processos participativos. In: XXVIII Congresso Nacional do CONPEDI Conselho Nacional de Pesquisa e Pós- 
Graduação em Direito. 2019.

BRASIL. Constituição da República Federativa do Brasil de 1988 Disponível em: http://www.planalto.gov.br/ccivil_03/constituicao/constituicao.ht. Acesso em: 2 jun. 2020.

Entregador sofre ofensas racistas em condomínio de Valinhos. EPTV. Disponível em: https://g1.globo.com/sp/campinasregiao/noticia/2020/08/07/entregador-registra-boletim-de-ocorrencia-apos-sofrer-ofensas-racistas-em-condominio-de-valinhosvideo.ghtml. Acesso em: 31 ago. 2020.

LOPES, Ana Maria D'Ávila. Proteção constitucional dos direitos fundamentais culturais das minorias sob a perspectiva do multiculturalismo. Revista de Informação Legislativa, v. 45, n. 177, p. 19-29, jan./mar. 2008. Disponível em: http://www2.senado.leg.br/bdsf/handle/id/160330. Acesso em: 2 jun. 2020.

VIALLI, Flávia Catarina Alves; SANTOS, Lana Alpulinário Pimenta. Direito das minorias e os múltiplos olhares jurídicos e sociais. Revista Científica Semana Acadêmica, v. 1, n. 149, p. 1-13, 2018. Disponível em: https://semanaacademica.org.br/artigo/direito-das-minorias-e-os-multiplos-olhares-juridicos-e-sociais. Acesso em: 2 jun. 2020. MARTINS, Argemiro Cardoso Moreira; MITUZANI, Larissa. Direito das Minorias Interpretado: o compromisso democrático do direito brasileiro. Revista Sequência Estudos Jurídicos e Políticos, v.32, n. 63, p. 319 352, 2011. Disponível em: https://periodicos.ufsc.br/index.php/sequencia/article/view/2177-7055.2011v32n63p319. Acesso em: 29 ago. 2020. Supremo Tribunal Federal. Composição. Disponível em: http://portal.stf.jus.br/ostf/. Acesso em: 31 ago. 2020. 


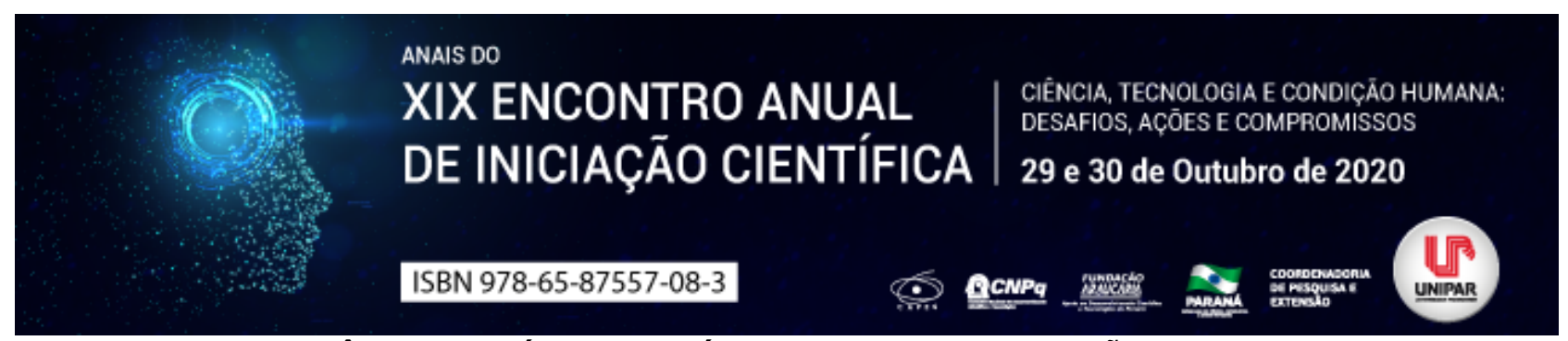

O AUMENTO DA VIOLÊNCIA DOMÉSTICA EM ÉPOCA DE PANDEMIA: AÇÕES DE ENFRENTAMENTO E A RESPONSABILIDADE CIVIL DO AGRESSOR

\author{
${ }^{1}$ RODRIGO FELIPE MARTINS CLARO, ${ }^{2}$ EDIANE CARDOSO, ${ }^{3}$ LAIANE TAINARA ALVES, ${ }^{4}$ RENATA BELIM SALVINI, \\ ${ }^{5}$ ADRIANO CONSENTINO CORDEIRO
}

\author{
${ }^{1}$ Acadêmico Bolsista do PIBIC/UNIPAR \\ ${ }^{1}$ Acadêmica do Curso de Direito da UNIPAR \\ ${ }^{2}$ Acadêmica do Curso de Direito da UNIPAR \\ ${ }^{3}$ Acadêmica do Curso de Direito da UNIPAR \\ ${ }^{4}$ Docente da UNIPAR
}

Introdução: Desde o início do ano de 2020, o mundo foi surpreendido por uma crise pandêmica global sem precedentes, e que colocou em alerta máximo os governos e as autoridades de todo o mundo. No entanto, as medidas de enfrentamento adotadas para a contenção do vírus, embora necessárias, favoreceram, também, o surgimento de efeitos negativos na vida de muitas mulheres, além de um aumento expressivo da violência doméstica. Frente a esse problema, o poder público junto a sociedade civil, vem adotando novas medidas a fim de combater essa crise considerada não só de segurança, mas também de saúde pública. Aborda-se ainda neste trabalho, a respeito da responsabilização civil do agressor, e a possibilidade do mesmo reparar civilmente a sua vítima pelo dano existencial causado. Conforme afirma Soares (2007) o dano existencial é um conceito relativamente novo que vem sendo estudado no Brasil, e inspirado, sobretudo, na doutrina jurídica italiana. Ademais, a produção deste trabalho contribue à reflexão sobre a violência doméstica e os impactos dos danos existenciais causados à vítima, muitas vezes não levados em conta. Possibilita, também, repensar novas possibilidades de ações de enfrentamento da violência doméstica, e quais as respostas jurídicas mais adequadas.

Objetivos: Verificar e descrever as variáveis que influem no fenômeno da violência doméstica no Brasil, sobretudo a despeito do seu aumento em época de pandemia. E refletir a respeito da responsabilidade civil do agressor em casos de violência doméstica, contribuindo-se assim ao debate sobre esse fenômeno.

Desenvolvimento: A partir do aumento da violência doméstica contra a mulher no ano de 2020, reflete-se ultimamente sobre os impactos do isolamento social, decorrentes da pandemia do Covid-19, e quais as ações mais urgentes para o seu enfrentamento. Segundo o Fórum Brasileiro de Segurança Pública (2020) houve no Brasil durante a pandemia, um aumento abrupto da violência doméstica contra as mulheres. Porém, ao mesmo tempo houve também uma redução no número de medidas protetiva concedidas, sugerindo, não que a violência decresceu, mas pelo contrário, que ela foi subnotificada. Devido, também, a necessidade do isolamento em ambiente domiciliar por conta da pandemia, o convívio intensivo de mulheres com seus agressores as impediram em muitos casos, de acessarem a justiça e os meios de denúncia. Assim, o aumento da violência, pode ainda ser maior por conta das subnotificações. Segundo aponta Oliveira (2020), no Brasil, a crise provocada pelo coronavírus atinge especialmente as mulheres negras e de baixa renda, pois, são as mais afetadas pelo desemprego. Por outro lado, é importante observar que hoje ocorre uma maior mobilização do poder público e da sociedade civil no enfrentamento à violência contra a mulher, e que vêm produzindo medidas inovadoras e pertinentes aos problemas atuais. Nesse contexto, surge também a importância de se refletir a respeito das repercussões jurídicas do crime praticado contra a mulher no âmbito doméstico, e sobre a resposta do sistema jurídico em relação a esses casos. Portanto, como alternativa à via penal, debate-se a respeito da responsabilização civil do agressor frente a vítima lesada. A Lei Maria da Penha recentemente recebe uma importante edição no seu art. $9^{\circ}$, sendo alterada pela Lei 13.871, de 17 de setembro de 2019, tratando agora especificamente sobre a obrigação do agressor em reparar os danos causados à vítima. Assim, tornam passíveis de indenização, quaisquer danos, sejam morais ou materiais, causados pelo agressor. Nesse sentido, discute-se, também, sobre a abordagem de uma modalidade de dano que é relativamente nova. Trata-se do conceito de dano existencial. Segundo Frota: O dano existencial constitui toda espécie de dano, que acarreta à vítima, de modo parcial ou total, a impossibilidade de executar, dar prosseguimento ou reconstruir o seu projeto de vida (na dimensão familiar, afetivo-sexual, intelectual, artística, científica, desportiva, educacional ou profissional, dentre outras) e a dificuldade de retomar sua vida de relação (de âmbito público ou privado, sobretudo na seara da convivência familiar, profissional ou social). (2010, p.204). Numa perspectiva ampliada, a violência doméstica transcende o dano físico ou uma lesão essencialmente subjetiva, como apontada pelo dano moral, pois, para além disso, atinge, em muitos casos o projeto de vida da vítima e sua capacidade de retomar ou assumir novas atividades.

Conclusão: A violência contra a mulher, antes de tudo, tem profunda relação com as categorias de gênero, e as relações de poder existentes. E podem produzir danos existenciais profundos na vida da vítima. Por isso, há uma necessidade vigente em 
promover ações educativas e culturais, e a sensibilização de agentes públicos para uma atuação não apenas pontual, mas, amplificada sobre o fenômeno.

\section{Referências}

BRASIL. Lei 13.871 de 17 de Setembro de 2019. Altera a Lei $n^{\circ}$ 11.340, de 7 de agosto de 2006 (Lei Maria da Penha), para dispor sobre a responsabilidade do agressor pelo ressarcimento dos custos relacionados aos serviços de saúde prestados pelo Sistema Único de Saúde (SUS) às vítimas de violência doméstica e familiar e aos dispositivos de segurança por elas utilizados. Diário Oficial da União, Brasília, Edição: 181, Seção: 1, p. 2, 18 set. 2019.

FÓRUM BRASILEIRO DE SEGURANÇA PÚBLICA. Nota técnica Violência Doméstica Durante Pandemia de Covid-19- ed.2. Forum Brasileiro de Segurança Pública. 29 mai.2020. Disponível em: https://forumseguranca.org.br/publicacoes_posts/violenciadomestica-durante-pandemia-de-covid-19-edicao-02/. Acesso em: 31 jul. 2020.

FROTA, Hidemberg Alves da. Noções fundamentais sobre o dano existencial. Revista do Tribunal Regional do Trabalho da 13a Região, João Pessoa, v. 17, n. 1, p. 203-214, 2010. Disponível em: http://bdjur.stj.jus.br/dspace/handle/2011/37603. Acesso em: 18 ago. 2020.

OLIVEIRA, Anita Loureiro de. A espacialidade aberta e relacionalL do lar: a arte de conciliar maternidade, trabalho remoto e domésticona pandemia da Covid-19. Revista Tamoios, [S.I.], v. 16, n. 1, maio 2020. ISSN 1980-4490. Disponível em: https://www.e-publicacoes.uerj.br/index.php/tamoios/article/view/50448. Acesso em: 22 jul. 2020.

SOARES, Flaviana Rampazzo. Dano existencial : uma leitura da responsabilidade civil por danos extrapatrimoniais sob ótica da proteção. 2007. 36 f. Dissertação (Mestrado em Direito) - Pontifícia Universidade Católica do Rio Grande do Sul, Porto Alegre, 2007. 


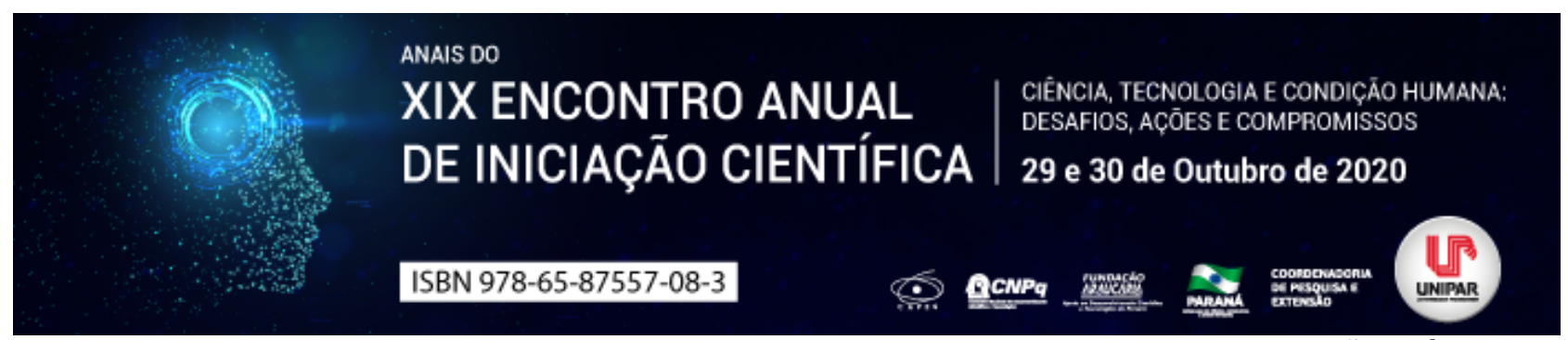

OS IMPACTOS DA PANDEMIA NO PROCESSO ENSINO-APRENDIZAGEM NA EDUCAÇÃO BÁSICA

\title{
${ }^{1}$ LUANA LOPES STUGAL, ${ }^{2}$ CLAUDIA LOPES PERPETUO
}

\author{
${ }^{1}$ Acadêmica do curso de Pedagogia da UNIPAR \\ ${ }^{1}$ Docente da UNIPAR
}

Introdução: Desde o final de 2019, em declarações das autoridades chinesas à Organização Mundial da Saúde (OMS), o mundo percebeu o surgimento de um novo vírus corona (COVID-19), e a organização imediatamente o classificou como perigoso para a população. No dia 11 de março, a OMS declarou a transmissão do COVID-19 como sendo uma pandemia. O termo é usado para descrever situações em que uma doença infecciosa ameaça muitas pessoas de forma simultânea no mundo inteiro. Dessa forma, a educação enfrentou um novo desafio com o ensino remoto nos mais variados níveis de ensino.

Objetivo: Demonstrar alguns impactos causados na educação em decorrência da pandemia do Coronavírus (COVID-19).

Desenvolvimento: A princípio na pandemia do COVID-19 quando foi anunciada a paralisação das aulas no Brasil no dia 19 de março de 2020, foi programado e imaginado uma parada de 2 a 3 semanas sem aula, ninguém havia antecipado tamanha proporção, com o tempo constatou-se que seria necessário mais alguns meses com as crianças e jovens longe das salas de aula. É importante dar uma resposta a isso, pois o Brasil já tem desigualdades educacionais enormes, visto que escolas particulares enviaram aulas online desde poucos dias após a pandemia, as redes públicas tiveram que agir de uma maneira emergencial. As escolas particulares se estruturaram mais rapidamente por ter um problema logístico muito menos complexo que redes públicas que lidam com milhões de alunos, se falarmos, por exemplo, a partir dos dados levantados no Censo Escolar realizado em 2019, o qual traz uma média, entre esnino fundamental e médio, de 21.413,391 alunos matriculados (VILELA, 2019), ou seja, uma imensa demanda de trabalho organizacional ainda que fosse fora de uma situação emergencial. É necessário entender que o grupo social que encontramos dentro de uma escola pública e dentro de uma escola particular são distintos de forma que a aprendizagem já fica comprometida de certa forma devido à limitação do acesso a tecnologia. Podemos perceber conforme traz Senhoras (2020) que àquelas famílias que apresentam maior escolarização e maior poder aquisitivo, apresentam condições de darem continuidade aos estudos de forma remota, em contraposição àquelas de menor escolaridade e menores condições, que tem seu acesso ao ensino remoto limitado, vindo assim a comprometer os estudos a curto e em médio prazo. Até aqui estamos falando dos estudantes, sem mencionar o impacto da pandemia para os professores, que uma maioria não tem formação para dar aulas virtuais. É cada vez mais inegável que a pandemia teve grande impacto, de forma que as pessoas não conseguem dimensionar em suas vidas diárias e as evidências e fraquezas que afetam a educação de um país. Além disso, esses resultados devem ser considerados cuidadosamente para assim poder, se é que é possível, minimizar os impactos no processo de desigualdade social.

Conclusão: Destaca-se que os alunos em formação, os profissionais da educação envolvidos no processo e seus familiares devem envidar todos os esforços para que tenham conhecimento científico de qualidade, além da manutenção da saúde mental e segurança. Por fim, cabe ressaltar que todos os que compõem uma escola têm seus papéis e responsabilidades, sejam eles poder público, professores, pais ou alunos. É muito cedo para avaliar todo o histórico educacional no contexto da pandemia, mas já podemos perceber impactos pedagógicos e tecnológicos que dificultam, prejudicam e impedem o ensino remoto, porém se a estratégia for mantida pelas vantagens ou mínimas exequibilidades que se tem mostrado na realidade escolar até o momento, é necessário promover a tendência de combinar esse estilo de ensino com o ensino presencial no período pós-pandêmico para poder mitigar seus efeitos e proporcionar mudança e uma educação que possa gerar autonomia.

\section{Referências}

VILELA, Pedro Rafael. Censo Escolar: cresce número de matrículas na creche e na pré-escola. Agência Brasil/EBC. Brasília, 2019. Disponível em: https://agenciabrasil.ebc.com.br/educacao/noticia/2019-12/censo-escolar-cresce-numero-de-matriculas-nacreche-e-na-pre-escola Acesso em: 28 ago. 2020.

SENHORAS, Eloi Martins. CORONAVÍRUS E EDUCAÇÃO: ANÁLISE DOS IMPACTOS ASSIMÉTRICOS. Boletim de Conjuntura (BOCA), Boa Vista, ano 2020, v. 2, ed. N5, p. 128-136, 2020. Disponível em: https://bityli.com/r7HIZ. Acesso em: 23 ago. 2020. 


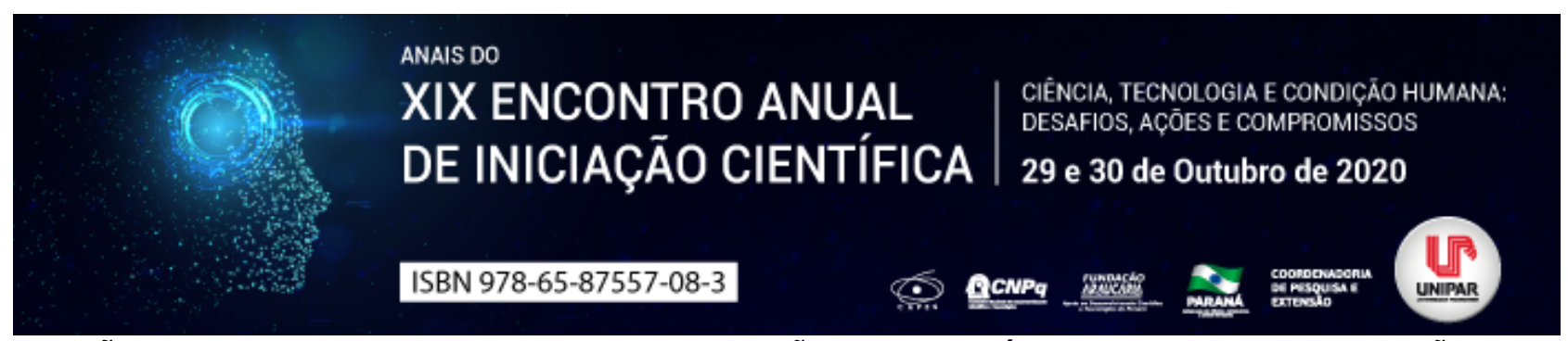

\title{
CONSIDERAÇÕES SOBRE O FEMINISMO MARXISTA: REVISÃO BIBLIOGRÁFICA SOBRE A EXPLORAÇÃO FEMININA NA PERSPECTIVA DA OBRA CALIBÃ E A BRUXA
}

\author{
${ }^{1}$ ANA CLAUDIA PANSERA, ${ }^{2}$ ALINE PERIN PADILHA, ${ }^{3}$ ISADORA GAGLIOTTO GALVAN, ${ }^{4}$ MATEUS JOAO CORDEIRO \\ SCHMOELLER DE LIMA, ${ }^{5}$ NAYSSARA CAROLINA SILVA TASCHIN, ${ }^{6}$ TATIANE PECORARO
}

${ }^{1}$ Acadêmica do Curso de Psicologia da UNIPAR
${ }^{1}$ Acadêmica do Curso de Psicologia da UNIPAR
${ }^{2}$ Acadêmica do Curso de Psicologia da UNIPAR
${ }^{3}$ Acadêmico do Curso de Psicologia da UNIPAR
${ }^{4}$ Acadêmica do Curso de Psicologia da UNIPAR
${ }^{5}$ Docente do Curso de Psicologia da UNIPAR

Introdução: Os movimentos feministas tem como característica a ação de mulheres em defesa dos interesses do gênero feminino, a horizontalidade das decisões e a promoção de críticas sobre as construções sociais e atribuições sobre os gêneros. Para Ribeiro (2006), a expansão é concomitante com as transformações sociais produzidas pelo capitalismo. Nessa lógica, Silvia Federici (2017) se propõe a estudar sobre as políticas de Estado que culminaram na exploração e subversão feminina. A partir disso, o presente trabalho utiliza-se da obra l"Calibã e a Bruxa (2017)।" para investigar a opressão feminina no decorrer da história.

Objetivo: O estudo objetiva, por meio de revisão bibliográfica, apresentar uma breve discussão sobre os movimentos feministas e o papel do Estado na opressão da mulher segundo o livro Calibã e a Bruxa de Silvia Federici (2017).

Desenvolvimento: $O$ movimento feminista visa desconstruir a concepção histórica feminina dedicada a maternidade, o cuidado da família e o serviço doméstico. A luta contra essa inclinação dos papéis sociais viabiliza um local de fala, acolhimento, escuta, empatia e representação (TIBURI, 2018). As chamadas ondas feministas , subdivididas por interesses distintos em cada momento histórico, contemplavam necessidades de um grupo social, geralmente da mulher branca, e por estes interesses foram assim conceituados (ALVES; ALVES, 2013). A primeira onda, propagada nos séculos XIX e XX era permeada por questões da imposição de papéis e da submissão voltada às mulheres. Com isto, almejam a emancipação feminina, a liberdade, igualdade das revoluções burguesas e o direito ao voto. Por volta da década de 60, a segunda onda traz novos ideais: a luta pela liberdade e autonomia feminina principalmente sobre as decisões do próprio corpo. As feministas passam a criar teorias e saberes, contestando a história e ciência contada pelos homens e conceitos como sexualidade e gênero passam a ser debatidos e remodelados. Com a terceira onda feminista, visões hierarquizadas e fragmentadas de classe, raça e etnia dentro do próprio movimento são pleiteadas. Concomitante a esse rompimento com a supremacia branca, argumentos como sexualidade, subjetividade e diversidade de identidades relacionadas ao sujeito feminino são lançados (ALVES; ALVES, 2013). As ondas feministas ramificam-se em diversas conceituações teóricas. Neste texto, buscamos por meio de análise marxista investigar quais são os meios de opressão das mulheres; será abordado resumo do livro O Calibã e a Bruxa , de Silvia Federici, autora feminista marxista que analisa o período medieval, relacionando com o desenvolvimento do capitalismo, da exploração feminina e da divisão sexual do trabalho. No decorrer do livro, é reconhecido que os cercamentos, iniciados no final do século XV na Inglaterra, fundaram-se na privatização de terrenos até então de acesso comum, visando expandir propriedades e abolir os campos abertos. Tal operação afetou o modo de vida dos camponeses, que utilizavam as terras para subsistência e socialização. Conscientes do impacto negativo que essas ações iriam causar, os camponeses reuniram-se em diversas rebeliões na tentativa de reprimir os avanços dos cercos. As mulheres, cientes da importância desses espaços para a sobrevivência, envolveram-se intensamente nos movimentos, assumindo papel de liderança em muitos deles (FEDERICl, 2017).

Nessa realidade de intensos conflitos sociais, o Estado britânico instaurou medidas para controlar e deter as manifestações, implantando leis voltadas para coibir qualquer forma de socialização e sexualidade coletiva ligadas a criação de laços afetivos, limitando a convivência para o privado e família. O corpo feminino passa a ser visto como propriedade do Estado, reduzido a reprodução. As mulheres, antes com autonomia sob seus corpos, são privadas de qualquer ação de cunho independente emancipatório. Nesse contexto, é incentivado na comunidade a espionagem, visando evitar qualquer atividade sexual não reprodutiva, tentativa de infanticídio e controle de natalidade. Como consequência, o corpo feminino transforma-se em instrumento de expansão da força de trabalho (FEDERICI, 2017). Federici (2017) conclui que essa política de controle e incentivo a uma maternidade compulsória serviu como estopim para a criação da imagem da mulher dona de casa , com tarefas domésticas reduzidas a obrigações, sem qualquer reconhecimento. Tal proposta viabilizou no casamento e na construção da família a única forma de sobrevivência para o sexo feminino. 
Conclusão: Os movimentos feministas marxista apontam para uma luta pelo reconhecimento do movimento e pela visibilidade e identificação da misoginia. Procuram combater o patriarcado e os valores impostos que não garantam a integridade. Especificamente, tal a corrente marxista centra a discussão na relação com o trabalho e como as políticas governamentais foram fundamentais para limitar os direitos das mulheres, boicotando as tentativas de empoderamento e autonomia através da censura, medo e ameaças. Instauraram uma imagem da mulher ideal, tornando-se visível a tentativa de controle, alienando-as a fim de materializar um papel social de máquina reprodutora e de mão de obra, comprometida em atender as demandas do sistema capitalista e machista.

\section{Referências}

ALVES, Ana C. F.; ALVES, Ana K. S. As trajetórias e lutas do movimento feminista no Brasil e o protagonismo social das mulheres. IV Seminário CETROS: Neodesenvolvimento, Trabalho e Questão Social. Fortaleza: Universidade Estadual do Ceará, 2013. Disponível em: . Acesso em: 26 de junho de 2020.

FEDERICI, Silvia. Calibã e a bruxa: mulheres, corpo e acumulação primitiva. São Paulo:Editora Elefante, 2017.

RIBEIRO, Matilde. O Feminismo em novas rotas e visões. Rev. Estudos Feministas, 14(3), 272, Florianópolis, 2006. Disponível em: < https://www.scielo.br/pdf/ref/v14n3/a12v14n3.pdf>. Acesso em: 26 de junho de 2020.

TIBURI, Marcia. Feminismo em comum: Para todas, todes e todos, $7^{\mathrm{a}}$ ed. Rio de Janeiro: Rosa dos Tempos, 2018.

Coordenadoria de Pesquisa e Extensão - COPEX

Departamento de Editoraçāo e Divulgaçāo Científica - DEDIC 


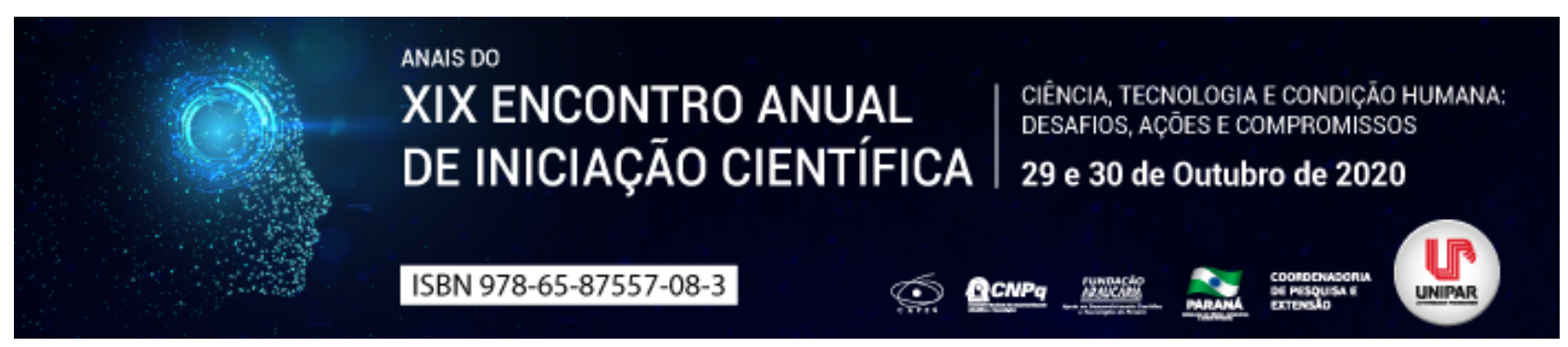

RESPONSABILIDADE SOCIAL E CONSUMO DURANTE A PANDEMIA DO COVID-19

\title{
${ }^{1}$ OLAIR DOMINGOS DACHERY JUNIOR, ${ }^{2}$ ALEXANDRE MAGNO AUGUSTO MOREIRA
}

\author{
${ }^{1}$ Acadêmico do Curso de Direito da UNIPAR \\ ${ }^{1}$ Docente do Curso de Direito da UNIPAR
}

Introdução: O presente trabalho tem por objetivo demonstrar o contraponto entre consumo individual e responsabilidade social das empresas. Neste sentido, em meio a situação pandêmica global, observa-se relevante crescimento do individualismo entre as pessoas. Tais atitudes são perceptíveis, quando nas situações do cotidiano, tem-se a ausência do consumo consciente, o consumo que pensa no próximo como um cidadão de direito. Isso evidencia a necessidade de um olhar especial da responsabilidade social, em especial das empresas. A presente pesquisa far-se-á sobre o método dedutivo, com revisão bibliográfica.

Objetivo: Demonstrar a importância do papel da responsabilidade social da empresa em tempos de crise, utilizando-se como contraponto, a questão do consumo.

Desenvolvimento: A responsabilidade social empresarial resume-se no direcionamento das ações empresariais pautadas em valores éticos, com o objetivo de desenvolver uma sociedade mais inclusiva e igualitária para os clientes das empresas, para os colaboradores, fornecedores e para a sociedade em si (RICO, 2004). Segundo Reis (2020, online): À medida em que avança a pandemia do COVID-19, empresas de todos os ramos cumprem seu papel de responsabilidade social e fazem grandes doações para combater o novo coronavírus e evitar que a crise gere efeitos socioeconômicos irreparáveis . Essas doações são as responsáveis por trazer ao alcance da sociedade os instrumentos necessários de proteção, que são principalmente direcionados às pessoas mais carentes, as quais não conseguem ter acesso ao tão procurado álcool em gel, as máscaras ou a qualquer produto de limpeza, que é indispensável ao momento. Sendo assim, a solidariedade está vinculada tanto às relações em âmbito individuais, entre sujeitos, pertencentes a um grupo social, quanto é aplicada em meio ao coletivo (WESTPHAL, 2008). Dessa forma, nota-se que diante do aumento do número de contaminados, principalmente nas periferias das grandes cidades, há uma resposta solidária de alguns setores sociais e empresariais, mobilizando o aumento da responsabilidade social diante do presente contexto. Nesse sentido, para haver uma quantificação da responsabilidade social, deve ser analisada a conduta da empresa quanto às políticas que garantam um lucro consciente, diminua os riscos e busque alcançar o equilíbrio entre as necessidades humanas e a geração de lucro para a empresa, pautada na preservação dos recursos naturais e no desenvolvimento mais ético e sustentável. Em outras palavras, a empresa tem o lucro como objetivo principal, porém, embasada nas normas vigentes, deve garantir o pleno emprego através da valorização do trabalho humano, bem como a atuação para redução das desigualdades regionais e sociais. (SANTOS, 2016). Em relação à responsabilidade empresarial e o consumo durante esse período histórico crítico, há a necessidade de ressaltar a mudança nos hábitos consumistas das pessoas, instaurando uma massa de consumidores individualistas e voltados para a satisfação material (GERBASI, 2014). Esse fenômeno está intimamente relacionado a uma crença social de que a acumulação de bens do mercado é sinal de êxito pessoal e promessa efetiva de felicidade eleva a capacidade de consumir como categoria de essência do homem (GONÇALVES, CESCON, p. 157) . Com base nisso, foi possível presenciar por parte dos consumidores, a aquisição exacerbada e desenfreada de produtos que auxiliam na rotina, como produtos de limpeza e alimentos, e que possibilitem a realização de atividades mesmo durante a pandemia, a exemplo de álcool em gel e máscaras, demonstrando a falta de solidariedade e o individualismo durante $o$ momento de crise.

Conclusão: Dentro desse contexto inusitado que encontra-se o mundo, nota-se o aumento da procura por produtos de limpeza e alimentos, com a finalidade de estoque, expondo, a partir disso, o crescimento do lado individualista da comunidade, onde a compra sem controle de quantidade desencadeia o acesso somente para uma pequena parcela da população, deixando muitas pessoas desamparadas e sem as condições necessárias para a proteção e alimentação segura, além de disseminar o pânico e o medo. Com base nisso, é papel da empresas, através de sua responsabilidade social, regulamentar o acesso aos produtos, garantir seu lucro mas sem inserir valores abusivos nos itens com procura aumentada, garantindo assim que grande parte da sociedade acesse e utilize as mercadorias indispensáveis para a sobrevivência e cuidado no dia a dia e, principalmente, durante o período da pandemia do COVID-19.

\section{Referências}

GERBASI, Vinícius Aleixo. O Consumo no Capitalismo: notas para pensar o mercado, a internet e o individualismo. Revista Habitus: Revista da Graduação em Ciências Sociais do IFCS/UFRJ, Rio de Janeiro, v. 12, n. 2, p. 62-69, dezembro. 2014. Disponível em: https://revistas.ufrj.br/index.php/habitus/article/view/11437/8387. Acesso em: 11 Jun. 2020. 
GONÇALVES, Marco Antonio; CESCON, Everaldo. Ética e Consumo: o consumo como estratégia ético-política. Conjectura: Filos. Educ., Caxias do Sul, v. 18, n. 3, p. 155-165, set./dez. 2013.

REIS, Giovanna. Doações de itens de higiene e limpeza por empresas se espalham pela América Latina. Folha de São Paulo, São Paulo, 14 maio de 2020. Disponível em: https://www1.folha.uol.com.br/empreendedorsocial/2020/05/doacoes-de-itens-dehigiene-e-limpeza-por-empresas-se-espalham-pela-america-latina.shtml. Acesso em: 15 jun. 2020.

RICO, Elizabeth de Melo. A responsabilidade social empresarial e o Estado: uma aliança para o desenvolvimento sustentável. São Paulo Perspec., São Paulo , v. 18, n. 4, p. 73-82, Dec. 2004 . Dispobível em: https://www.scielo.br/scielo.php? script=sci_arttext\&pid=S0102-88392004000400009\&lng=en\&nrm=iso. Acesso em: 14 Jul. 2020.

SANTOS, Maria Angélica Chichera dos. A responsabilidade corporativa da empresa: sob a ótica do desenvolvimento sustentável. 2016. 118 f. Dissertação (Mestrado em Direito) - Universidade Nove de Julho, São Paulo.

WESTPHAL, Vera Herweg. Diferentes matizes da idéia de solidariedade. Rev. katálysis, Florianópolis, v. 11, n. 1, p. 43-52, June 2008. Disponivel em: https://www.scielo.br/scielo.php?script=sci_arttext\&pid=S141449802008000100004\&lng=en\&nrm=iso. Acesso em: 13 Jul. 2020.

Coordenadoria de Pesquisa e Extensão - COPEX

Departamento de Editoraçāo e Divulgaçāo Científica - DEDIC 


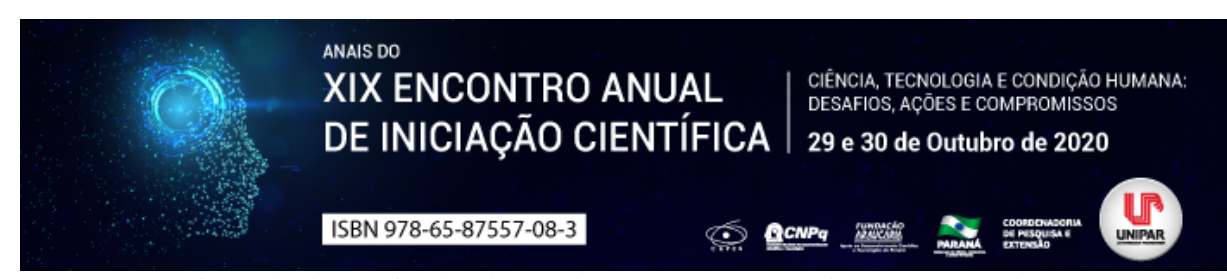

A INSERÇÃO DE DIRETRIZES EDUCACIONAIS ACERCA DA CULTURA AFRO-BRASILEIRA E AFRICANA NA EDUCAÇ̃̃o BÁSICA

${ }^{1}$ MARIANA GOMES DE AZEVEDO, ${ }^{2}$ ROSEMARI APARECIDA PEDROSO SZEZERBATZ

${ }^{1}$ Discente do curso de Pedagogia da UNIPAR

${ }^{1}$ Docente da UNIPAR

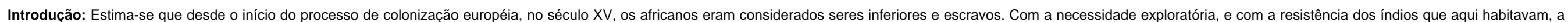

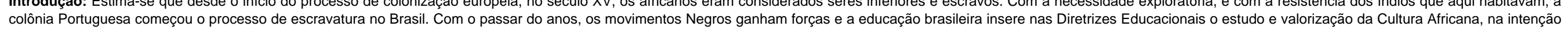
colônia Portuguesa começou op
de restituir danos históricos.

de restituir danos históricos.

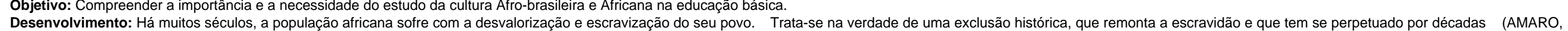

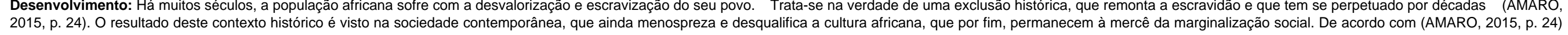

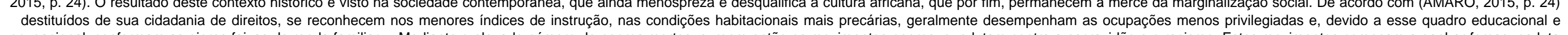

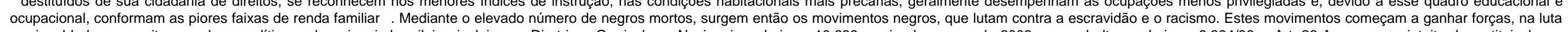

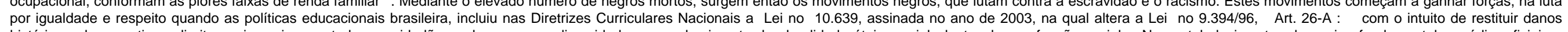

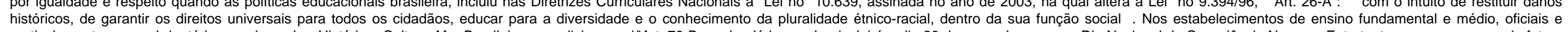

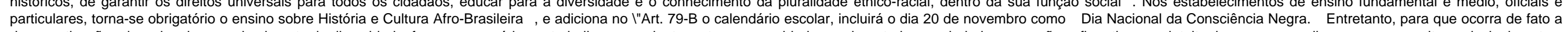

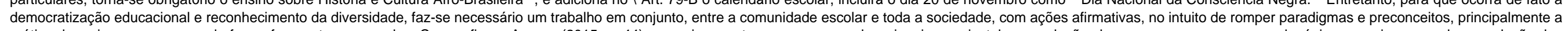

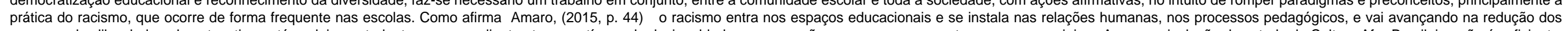

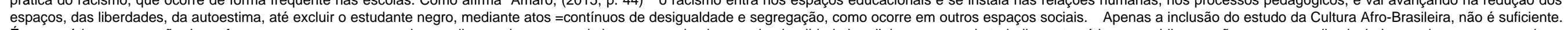

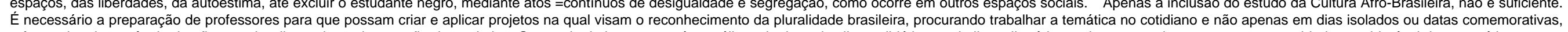

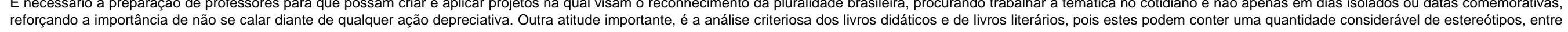

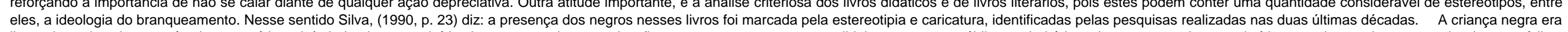

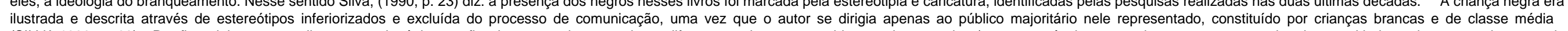

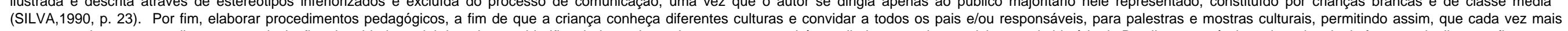

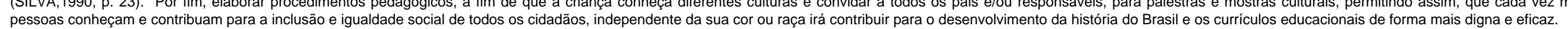

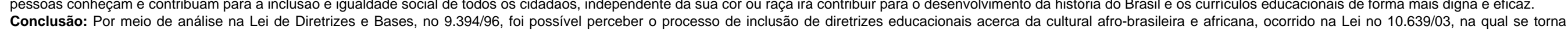

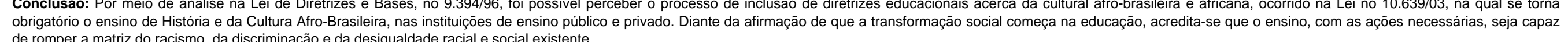
de romper a matriz do racismo, da discriminação e da desigualdade racial e social existente.

\section{Referências}

AMARO, Sarita. Racismo: Igualdade Racial e Políticas de Ações Afirmativas no Brasil, Porto alegre/RS. Editora Edipucrs. 2015

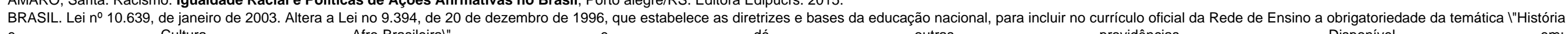

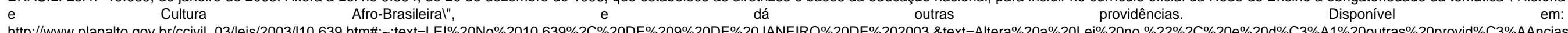

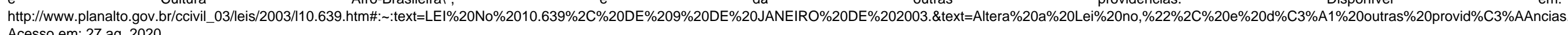
Acesso em: 27 ag. 2020.

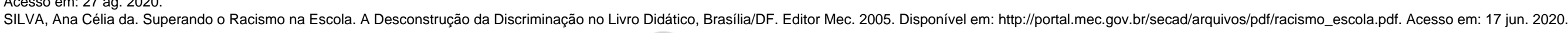

Coordenadoria de Pesquisa e Extensāo - COPEX

Departamento de Editoraçāo e Divulgaçāo Científica - DEDIC 


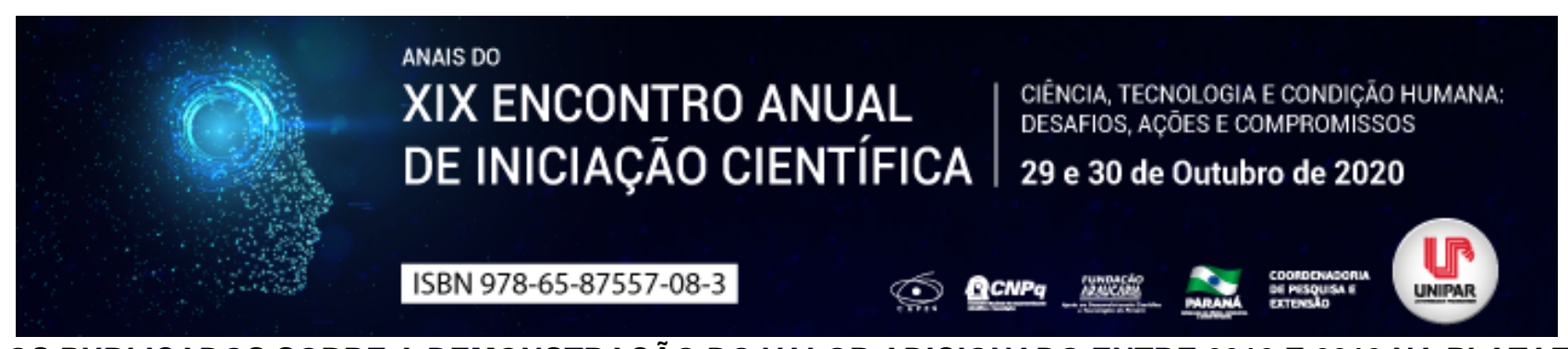

\title{
ARTIGOS PUBLICADOS SOBRE A DEMONSTRAÇÃO DO VALOR ADICIONADO ENTRE 2012 E 2019 NA PLATAFORMA GOOGLE ACADÊMICO: UM ESTUDO BIBLIOMÉTRICO
}

\author{
${ }^{1}$ BEATRIZ GONCALVES BERTA, ${ }^{2}$ GABRIELLE DA SILVA BOZZANO, ${ }^{3}$ JOSE LUIZ BORSATTO JUNIOR, ${ }^{4}$ ISABEL CRISTINA \\ GOZER
}

\author{
${ }^{1}$ Acadêmica do PIC/UNIPAR \\ ${ }^{1}$ Acadêmica do PIC/UNIPAR \\ ${ }^{2}$ Docente da UNIPAR \\ ${ }^{3}$ Docente da UNIPAR
}

Introdução: Segundo o Pronunciamento Técnico CPC 09 (CPC, 2008), a demonstração do valor adicionado (DVA) é um demonstrativo que evidencia a quantidade de riqueza gerada pelas organizações e como esta se distribui em determinado espaço de tempo entre os agentes econômicos. No Brasil, ela é obrigatória para empresas de capital aberto através da Lei 11.638. Desta forma, realizou-se uma pesquisa bibliométrica a fim de se analisar a disseminação deste instrumento no campo de estudo acadêmico, haja vista que através dele é possível identificar a contribuição das entidades nos aspectos econômicos e sociais em que operam.

Objetivo: Realizar um estudo bibliométrico acerca dos artigos publicados sobre a demonstração do valor adicionado no período de 2012 a 2019 na plataforma do Google Acadêmico.

Material e Métodos: Foi utilizado o método descritivo (Gil, 2009), pois o estudo busca descrever as características das divulgações sobre a DVA, com abordagem quantitativa que, segundo Raupp e Beuren (2009), se qualifica pelo uso estatístico na coleta e análise de dados. Através da pesquisa bibliográfica e bibliométrica, realizou-se a identificação dos artigos disponíveis no Google Acadêmico entre 2012 e 2019, bem como a investigação de seus aspectos quantitativos. O processo de seleção das obras ocorreu da seguinte forma: a) aplicação das palavras chaves (demonstração do valor adicionado; valor adicionado; e DVA) e delimitação do ano de 2012 até 2019 no filtro de busca da plataforma; b) coleta dos dados no Google Acadêmico; c) definição dos artigos, por meio da leitura dos títulos e/ou resumos. Nesta definição foram descartados 2 resultados falsos, atingindo uma amostra de 70 artigos que foram analisados através da relação entre o ano e a quantificação dos seguintes critérios: artigos; referências; autores e instituição de afiliação.

Resultados: De acordo com a análise dos 70 artigos, o número de obras coletadas de 2012 a 2019 foram de 10, 9, 6, 8, 10, 6, 8 e 13 respectivamente, representando uma média de 8 por ano. No trato das referências, identificou-se que os artigos reuniram um total de 2.213 fontes de pesquisas, sendo 193 o número mínimo abordado e 457 o máximo. Já em relação a nacionalidade da literatura, verificou-se que $82,42 \%$ são nacionais e $17,58 \%$ internacionais, o que evidencia a prevalência de citações brasileiras no período.

No que diz respeito aos autores, observou-se que 7 artigos possuem um autor; 18, dois autores; 26, três autores; 15, quatro autores e 4, com cinco ou mais autores. Isto demonstra que a maior parte das publicações concentram três autores (37,14\%), em seguida dois $(25,71 \%)$ e quatro (21,43\%). Cabe destacar que 203 pessoas estiveram envolvidas com publicações, sendo $55,67 \%$ do sexo masculino e $44,33 \%$ do feminino. Pesquisou-se também a afiliação destes indivíduos e foi constatado que suas obras estão vinculadas a 55 instituições. O maior número de pesquisas é 27 e encontra-se na USP, seguida pela UFSC com 26 e FURB e UFC com 8. As demais apresentaram um resultado igual ou inferior a 7 pesquisas.

Discussão: A análise acusa que, apesar de constatado dois períodos de declínio, houve tendência de crescimento no número de artigos publicados sobre DVA, corroborando com as pesquisas de Alexandre (2010) e Oliveira, Santos e Botinha (2014) e Teodoro et al (2012). Em segundo plano, no que se refere a utilização das referências, os números demonstram uma grande concentração de artigos que utilizam bibliografia nacional, semelhante aos estudos de Alexandre (2010) e Oliveira, Santos e Botinha (2014). Isto pode ser relacionado a obrigatoriedade deste relatório apenas no Brasil, o que provoca um volume de pesquisas maior do que em locais que não possuem tal exigência.

Verifica-se também que o maior gerador de produções científicas é a USP, em concordância com os estudos de Alexandre (2010), Teodoro et al (2012) e Oliveira, Santos e Botinha (2014), seguido de outras instituições no Sul e Sudeste do país, principalmente a UFSC. Apesar disso, as publicações encontram-se bem distribuídas e espera-se o seu crescimento nos próximos anos.

Por fim, ao comparamos a frequência de autores por artigo, observa-se algumas semelhanças e diferenças na literatura. $O$ estudo de Oliveira, Santos e Botinha (2014) estimou a predominância de 3 autores, seguido de 4. Já Alexandre (2010), apresentou a incidência de 4 autores, seguido de 3. A participação de vários autores se faz relevante para o compartilhamento de 
saberes sobre este relatório contábil, além de nos auxiliar para a coleta de um número maior de dados.

Conclusão: Este trabalho teve como objetivo identificar o perfil dos artigos disponíveis sobre DVA no Google Acadêmico entre 2012 e 2019 através da bibliometria. A partir dos critérios escolhidos, foi possível selecionar 70 artigos que contribuíram para descrever as características das divulgações. Nota-se tendência de crescimento das publicações sobre DVA, porém seus níveis ainda são baixos, o que demonstra a pouca exploração feita acerca do tema. Dado isto, este estudo também visa contribuir para produção de novas pesquisas, considerando que essas informações tornam-se úteis para outras abordagens bibliométricas.

\section{Referências}

ALEXANDRE, Ciaclei. L. Demonstração do valor adicionado: um estudo bibliométrico em revistas nacionais constantes no portal da capes. Florianópolis, 3 dez. 2010. Disponível em: https://repositorio.ufsc.br/bitstream/handle/123456789/127032/Contabeis294055.pdf?sequence=1\&isAllowed=y. Acesso em: 31 jul. 2020.

COMITE DE PRONUNCIAMENTOS CONTÁBEIS. Pronunciamento técnico CPC 09: Demonstração Valor Adicionado. Disponível em: http://static.cpc.aatb.com.br/Documentos/175_CPC_09_rev\%2014.pdf. Brasília, 11 nov. 2008. Acesso em: 31 jul. 2020.

GIL, Antonio. C. Métodos e técnicas de pesquisa social. 6. ed. São Paulo: Atlas, 2009.

OLIVEIRA, Tatiane. P. D; SANTOS, Cassius. K. S; BOTINHA, Reiner. A. Demonstração do valor adicionado: um estudo bibliométrico de artigos listados nos periódicos a2 e b1 do qualis 2014 da capes. Minas Gerais, 21 out. 2016. Disponível em: http://www.ifetec.com.br/evento/index.php/enpe/3enpe/paper/viewFile/117/76. Acesso em: 14 ago. 2020.

RAUPP, Fabiano. M.; BEUREN, Ilse. M. Metodologia da pesquisa aplicável às ciências sociais. 3. ed. São Paulo: Atlas, 2009. TEODORO, Jocelino. D. et al. Valor adicionado: tendências metodológicas e temáticas adotadas no período 1970-2010. Revista Ambiente Contábil, v. 4, n. 2, Outubro, 2012. Disponível em: https://periodicos.ufrn.br/ambiente/article/view/2143/1577. Acesso em: 31 jul. 2020. 


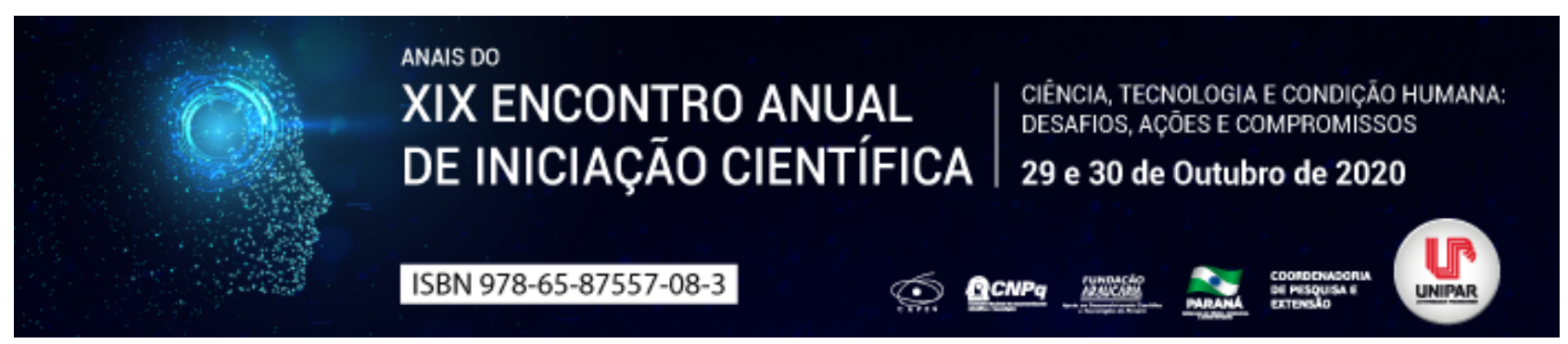

O PROGRAMA DE COMPLIANCE E SEUS REFLEXOS NA ESFERA PRIVADA E SOCIAL

\title{
${ }^{1}$ TATIANE BORTOLINI DE AZEREDO, ${ }^{2}$ ALEXANDRE MAGNO AUGUSTO MOREIRA
}

\author{
${ }^{1}$ Acadêmica do PIC/UNIPAR \\ ${ }^{1}$ Docente da UNIPAR
}

Introdução: O presente estudo pretende como proposta, apresentar o programa de compliance, como padrão ético organizacional capaz de influenciar colaboradores envolvidos nos programas de governança, e os reflexos positivos que pode trazer a sociedade. A presente pesquisa realizou-se pelo método dedutivo, com revisão de cunho bibliográfico. A partir do problema de pesquisa: O programa de compliance como ferramenta estratégica da empresa aplicada aos colaboradores, e os reflexos positivos que pode trazer a sociedade?

Objetivo: Apresentar o programa de compliance, como instrumento ético de padrão de conduta em prol dos colaboradores da empresa, com reflexos positivos a sociedade.

Desenvolvimento: Segundo a associação brasileira de bancos internacionais (ABBI) compliance é o dever de cumprir, de estar em conformidade e fazer cumprir regulamentos internos e externos impostos às atividades da instituição . Porém, o objetivo não se esgota em apenas estar em conformidade com as obrigações legais da empresa e seus padrões éticos. A prática exige alto comprometimento com a missão e com os valores organizacionais de todos os envolvidos dentro da organização. Neste sentido,

compliance é um conjunto de regras, padrões, procedimentos éticos e legais, que, uma vez definido e implantado, será a linha mestra que orientará o comportamento da instituição no mercado em que atua, bem como a atitude dos seus funcionários (CANDELORO; RIZZO; PINHO, 2012, p. 30). Pode-se afirmar, portanto, que seu significado vai além de um roteiro de regras a ser seguido, e seu alcance pode ultrapassar os portões da empresa, resultando em desenvolvimento econômico, posicionamento de mercado, consolidação da marca e lucratividade. Com a implantação da política de compliance e os objetivos definidos, todas as ações da empresa tendem a ser mais eficazes e econômicas, já que os seus recursos serão voltados aos objetivos já definidos anteriormente. Em consequência, a empresa ganha em competitividade no mercado, gerando custos menores, e, consequentemente lucros mais elevados. Os valores são as crenças e as atitudes básicas que ajudam a determinar o comportamento individual, sendo construtores da integridade e responsabilidade que definem o que as pessoas e organizações são, devendo ser abertos e publicamente expressados, repetidos e reafirmados (CHIAVENATO, 2005, p. 135). Desta forma, uma empresa ética transmite confiança tanto para seu colaborador como para com seu fornecedor, sendo capaz de construir relacionamento sólido, de longo prazo. Funcionário que se sente seguro, feliz e satisfeito em seu local de trabalho, dificilmente quer deixar de fazer parte da empresa. A organização ganha, diminuindo a rotatividade e aumentando a produtividade. Além disso, o empregas age como porta voz da empresa, e ao falar bem da sua organização, esta criando uma imagem positiva dela perante a sociedade, com reflexo positivo a sua própria reputação como colaborador. O sucesso da organização é diretamente ligado a confiança pública, refletida no valor de sua marca, na capacidade de atrair e fidelizar cliente, investidor, parceiro e até empregado. Estudos recentes têm demonstrado como estão à frente as organizações que apresentam uma estrutura sólida de preceitos éticos e atuam de forma responsável, em detrimento das demais que atuam de forma diversa (COIMBRA; MANZI, 2010, p. 5). Portanto, que o programa de compliance, pode auxiliar além do desenvolvimento da empresa, exteriorizando fortes reflexos na sociedade, partindo da premissa que, a cultura e os padrões éticos de conduta da empresa podem tornar-se hábitos influenciáveis nos comportamentos e decisões dos funcionários fora do ambiente organizacional.

Conclusão: Conclui-se, que após implantada a política de compliance dentro da organização, materializa-se na empresa maior vantagem competitiva, levando em consideração que tende a se obter maior confiança dos investidores e credibilidade no mercado. Com isto, alcançar-se-á níveis mais altos de cooperação tanto interna quanto externa, provocando, como consequência indireta o aumento de lucro, de maneira sustentável, trazendo benefícios não apenas à organização, mas aos seus empregados e à sociedade.

\section{Referências}

FEBRABAN

Associação

brasileira

de

bancos

Funções

Compliance.

Disponívelem:https://www.febraban.org.br/7rof7swg6qmyvwjcfwf7iOasdf9jyv/sitefebraban/funcoescompliance.pdf Acesso em 20 de agosto de 2020.

CHIAVENATO, I., Gestão de Pessoas, Segunda Edição, totalmente revista e atualizada. 9.ed. Rio de Janeiro:Editora Elsevier, 2005. 528p

CULTRIX, 2000.CANDELORO, Ana Paula P.; RIZZO, Maria Balbina Martins de; PINHO, Vinícius. Compliance 360 : riscos, estratégias, conflitos e vaidades no mundo corporativo. São Paulo: Trevisan Editora Universitária, 2012. 
COIMBRA, Marcelo de Aguiar; MANZI, Vanessa Alessi (Coord.). Manual de Compliance: preservando a boa governança e a integridade das organizações. São Paulo: Atlas, 2010

GONÇALVES, José Antônio Pereira. Alinhando processos, estrutura e compliance à gestão estratégica. São Paulo: Atlas, 2012 .

Coordenadoria de Pesquisa e Extensão - COPEX

Departamento de Editoraçāo e Divulgaçāo Científica - DEDIC 


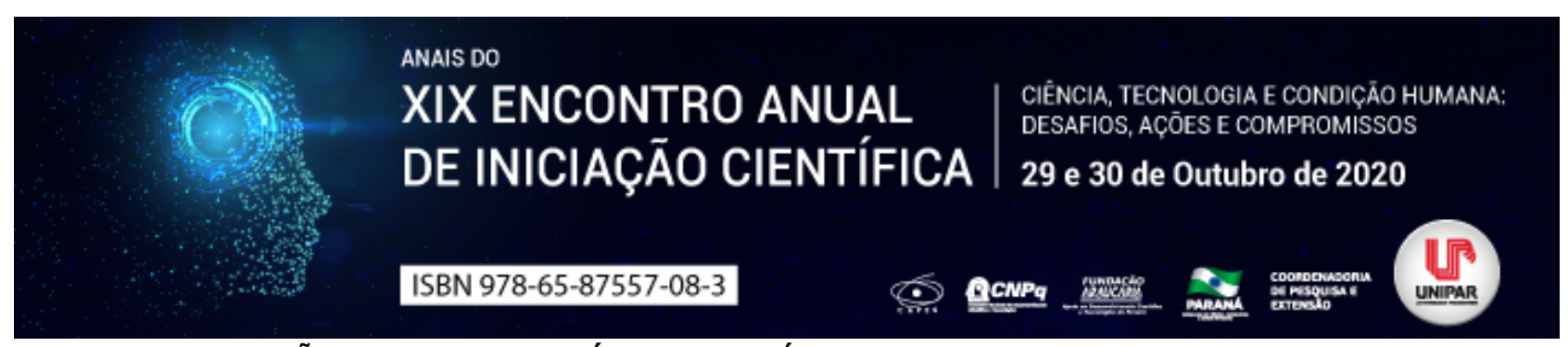

ARBORIZAÇÃO E CONFORTO TÉRMICO: ANÁLISE EM VIAS URBANAS DE CIANORTE - PR

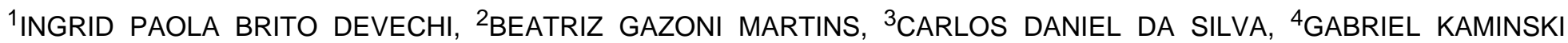
MOIOL, ${ }^{5}$ NATALIA MAIRA CUNHA, ${ }^{6}$ ANA PAULA TORQUETI GAVIOLI
\end{abstract}

\begin{abstract}
${ }^{1}$ Acadêmico do Curso de Arquitetura e Urbanismo da Unipar
${ }^{1}$ Acadêmica do Curso de Arquitetura e Urbanismo da UNIPAR

${ }^{2}$ Acadêmico do Curso de Arquitetura e Urbanismo da UNIPAR

${ }^{3}$ Acadêmico do Curso de Arquitetura e Urbanismo da UNIPAR

${ }^{4}$ Acadêmico do Curso de Arquitetura e Urbanismo da Unicampo

${ }^{5}$ Docente da UNIPAR
\end{abstract}

Introdução: A urbanização das cidades vem gerando situações adversas, por um lado contribui para o melhor funcionamento do meio urbano, mas como consequência altera significamente o microclima, causando desconforto térmico. A fim de amenizar este problema, deve-se pensar não somente na construção de edificações mas sim na implantação de áreas verdes, proporcionando uma melhoria significativa na sensação térmica, reduzindo altas temperaturas e equilibrando a umidade relativa do ar. Com um bom planejamento, além de favorecer o microclima, as áreas verdes podem incentivar a interação social, a prática de esportes além melhorar significamente a qualidade de vida dos residentes locais. A cobertura vegetal tem o poder de captar e filtrar uma grande parcela de materiais particulados e elementos tóxicos, que se retém no trono das árvores. Sendo assim quanto mais densa for a vegetação, mais protegida estará a nossa saúde (HIROTA E VORMITTAG, 2015).

Metodologia: Para obter os dados utilizados neste estudo, foram retiradas informações climáticas in loco nas Avenidas América, São Paulo e Espírito Santo por meio do aparelho eletrônico de medição com bulbo úmido. Para a pesquisa, foram utilizados intervalos de tempo por volta de $10 \mathrm{em} 10$ minutos para coleta manual dos dados apontados eletronicamente. Esta medida foi tomada para que qualquer mudança significativa durante o tempo de medição fosse levada em conta durante as conclusões baseadas na coleta de tais informações. Com o aparelho utilizado, pôde-se medir fatores que interferem diretamente na sensação de conforto sentida pelo ser humano. Insolação (direta e difusa), ventilação e umidade foram medidos por meio do equipamento posicionado em seu tripé na altura aproximada de uma pessoa com estatura mediana, por volta de 1,60 metros, considerando assim, dentro das possibilidades do estudo, a influência mais próxima que estes fatores podem ter no conforto térmico sentido pelo ser humano.

Resultado e discussão: A fim de comparar o índice de conforto térmico para os usuários, os trechos das três vias selecionadas contam com diferentes coberturas vegetais. O ponto selecionado da Avenida América possui pouquíssimas árvores com porte capaz de sombrear, sendo protegida apenas pelas construções do entorno. Já o ponto selecionado da Avenida Espírito Santo, tem em seus canteiros vários exemplares de Palmeira Imperial (Roystonea oleracea) ao longo de toda sua extensão. Segundo Malentachi (2013), a coleta de dados sobre o conforto térmico proporcionado pela Palmeira Imperial é dificultado pelo formato de sua copa e o caule que a eleva em grandes altitudes. Por último, o ponto selecionado da Avenida São Paulo é dotada de vários Flamboyant (Delonix Regia) que formam uma cobertura vegetal expeça. Entretanto, o espaço estudado apresenta fileiras de Flamboyant com áreas de sombra densa. A partir das informações supracitadas, levando ainda em consideração que as medições foram feitas em dias de sol pleno, nos horários das 10 e 16 horas, no primeiro (04/11) e segundo (05/11) dia de coleta as diferenças entre as avenidas com pouca cobertura vegetal (Espírito Santo e América) para a com grande área sombreada (Av. São Paulo) ficaram, em média, com $5,5^{\circ} \mathrm{C}$ e $6,2^{\circ} \mathrm{C}$, respectivamente. Já no terceiro dia (06/11), essa discrepância chegou à $7,7^{\circ} \mathrm{C}$ e a $7,3^{\circ} \mathrm{C}$ na última medição (07/11). Dessa forma, evidencia-se a necessidade de vegetação de grande porte e, ainda mais importante, com copa densa, uma vez que pouquíssima diferença é percebida entre as temperaturas coletadas em áreas de palmeiras (Av. Espírito Santo) para a com a Avenida América, onde não há qualquer vegetação capaz de produzir sombra relevante. No período da tarde, as temperaturas estão ainda mais elevadas, como no dia 04/11 em que atingiu-se a média de $42,2^{\circ} \mathrm{C}$ sob a sombra das palmeiras da Avenida Espírito Santo e $42,1^{\circ} \mathrm{C}$ à sol pleno na Avenida América, ressaltando, mais uma vez, a ineficácia das Palmeiras Imperiais no auxílio ao conforto térmico. Entretanto, é imperativo notar que, mesmo a temperatura mais amena obtida $25,7^{\circ} \mathrm{C}$ no dia $07 / 11$ às $10 \mathrm{hrs}$ é classificada como leve desconforto, segundo o nível de desconforto térmico Terjung (1966), segundo Farias e Brandão (1996) onde ele define como leve desconforto temperatura de $24^{\circ} \mathrm{C}$ a $27^{\circ} \mathrm{C}$.

Conclusão: A urbanização da cidade traz como consequência o desconforto térmico causado pela alteração do microclima. Com base na pesquisa feita, foi possível constatar uma diferença de $6,6^{\circ} \mathrm{C}$ e $6,5^{\circ} \mathrm{C}$ entre avenidas com densidades de arborização diferentes, mas ainda assim, seria possível ter uma amenização maior do desconforto térmico com a utilização das espécies recomendadas pela Secretaria do Meio Ambiente para a cidade de Cianorte. Logo, é de extrema necessidade o planejamento e 
manejo de árvores urbanas a fim de gerenciar o micro e meso clima da cidade, proporcionando maior conforto térmico aos cidadãos. Tal atitude acarreta em melhor qualidade de vida, uma vez que motiva as pessoas a interagirem, saírem de casa para aproveitar a sombra e a brisa ao ar livre, bem como a beleza da natureza que as cerca.

\section{Referências}

HIROTA, Márcia; VORMITTAG, Evangelina. Como as Áreas Verdes nas Cidades Geram Benefícios Para a Saúde: Há evidências de que a proximidade às áreas verdes traz inúmeros benefícios físicos, psicológicos e mentais à saúde. GLOBO.com, Revista Época; 03/11/2015. Blog do Planeta. Disponivél em:

FROTA, Anésia Barros. Manual de Conforto Térmico : arquitetura, urbanismo / Anésia Barros Frota, Sueli Ramos Schiffer.

5. ed. São Paulo : Studio Nobel, 2001.

FARIAS, H. S.; BRANDÃO A. M. P. M. O Campo Térmico como Indicador de Qualidade Ambiental para Políticas Públicas: Estudo de Caso no Bairro Maracanã/RJ. In: Encontro da ANPPAS, III., 2006. Brasília, 2006

MALENTACHI, I. F. Levantamento da Vegetação Arbórea e Avaliação do Conforto Térmico das Cinco Espécies de Maior Incidência de Uruaçu, GO. Dissertação (Mestrado Em Ecologia e Produção Sustentável), PUC-Goiás, Goiânia, 2013. Disponivél em: < http://tede2.pucgoias.edu.br:8080/handle/tede/2539> 


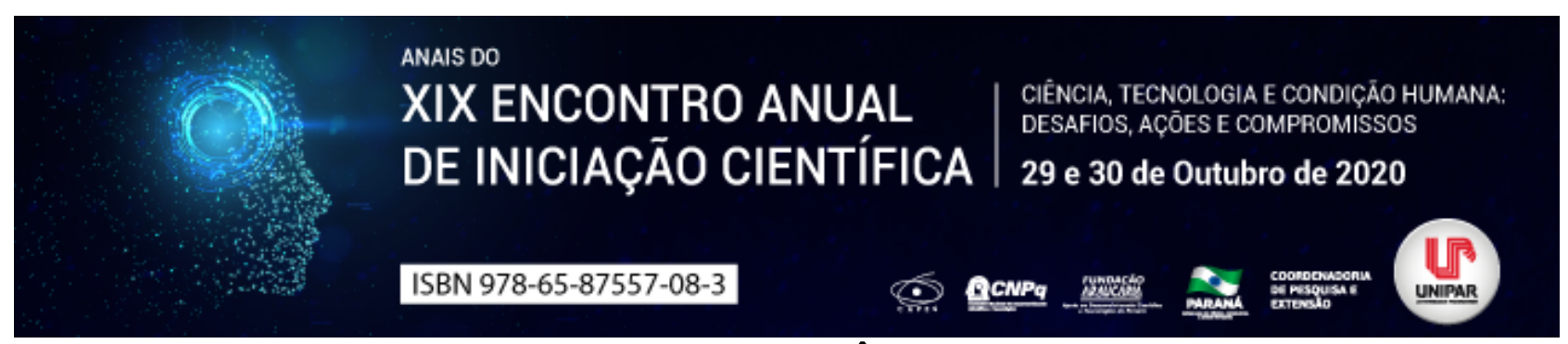

NEUROARQUITETURA: A NEUROCIÊNCIA NA ARQUITETURA

\title{
${ }^{1}$ INGRID PAOLA BRITO DEVECHI, ${ }^{2}$ CESAR AUGUSTO HOFFMANN
}

\author{
${ }^{1}$ Acadêmico do Curso de Arquitetura e Urbanismo da Universidade Paranaense - UNIPAR \\ ${ }^{1}$ Docente do Curso de Arquitetura e Urbanismo da Universidade Paranaense - UNIPAR
}

Introdução: Um dos efeitos da urbanização é a aglomeração das pessoas em pequenos espaços mal projetados, sem nenhuma preocupação em como essas ações afetam a condição física e mental da sociedade. Assim, para entender melhor como a arquitetura e o meio urbano pode influenciar diretamente no comportamento humano, há um estudo interdisciplinar popularmente chamado de neuroarquitetura, que segundo Paiva e Jedon (2019) busca I"[...]ampliar o conhecimento sobre a relação entre o ambiente e seus usuários, com foco em como o espaço físico pode influenciar o cérebro e o comportamento.l" Também mencionado por Crizel (2020) esses efeitos nem sempre são percebidos de maneira consciente, e sim pelo inconsciente do cérebro humano, tornando necessário que os arquitetos compreendam como os usuários irão vivenciar o espaço. Por tanto a presente pesquisa é sobre quais fatores e como podem melhorar a vivência do indivíduo nos espaços.

Relato de caso: Os espaços físicos podem transmitir diversos tipos de sensações e sentimentos, alguns desses efeitos podem ser percebidos apenas observando o comportamento do indivíduo. Pode-se citar como exemplo a atual situação de quarentena e isolamento social para evidenciar que nem todos esses efeitos são positivos ao bem-estar físico e mental, já que a experiência do enclausuramento das pessoas em suas próprias casas gerou uma procura por melhorar os espaços. Tal ocorrência concede a arquitetura maior responsabilidade ao projetar espaços eficientes e saudáveis para as pessoas. A neuroarquitetura apresenta diversas formas de impactar positivamente os usuários dos espaços físicos levando em consideração alguns elementos como: 0 uso específico de iluminação e ventilação (preferencialmente natural, que traz sensação de conforto e aconchego), a aplicação das cores e texturas (remetendo aos 5 sentidos sensoriais) e principalmente na divisão dos ambientes (tornando-os mais eficientes). Ela também possibilita uma apropriação do ambiente pelos indivíduos considerando suas diversidades culturais e experiências de vida. Para que isso aconteça, segundo Paiva (2018) a retina capta informações do ambiente e os envia para o cérebro, mesmo quando os indivíduos não estão olhando diretamente para lugar nenhum. Quer dizer, mesmo quando as pessoas não são conscientemente prestando atenção aos sons, texturas ou cheiros, os sentidos estão captando informações e enviando-os para o cérebro. Com isso observa-se que si o ambiente for mal projetado pode prejudicar a saúde física ou mental das pessoas sem à mesma perceber a causa.

Desenvolvimento: $O$ ambiente pode gerar dois principais tipos de efeito no nosso organismo: efeitos de curto prazo, que são aqueles mais imediatos e efêmeros, e efeitos de longo prazo, que são mudanças mais estruturais que demoram mais para acontecer e também persistem por mais tempo. No curto prazo, o nosso organismo se adapta rapidamente às condições do meio onde se encontra e, como consequência, nós podemos sofrer alterações no humor ou nas emoções, mudanças de comportamentos e até mesmo na forma como percebemos o próprio espaço onde estamos (PAIVA; JEDON, 2019). Deve-se considerar que os espaços não afetará a todos da mesma forma, pois segundo Paiva (2018) se em um edifício houver muito mármore e este estiver inserido em uma cultura onde o material seja símbolo de riqueza, o impacto nas pessoas será de forma diferente ao de uma outra cultura onde o mesmo material seja símbolo de pobreza. Isso ocorre, porque cada ser humano carrega consigo uma cultura e uma vivência diferente, por tanto, segundo a neuroarquitetura o arquiteto deve também considerar o perfil de seus usuários. I"[...] a arquitetura que melhora a vida tem que abordar todos os sentidos simultaneamente e fundir nossa imagem de nós mesmos com nossos experiência do mundo.l" (PALLASMAA, 2005, p. 11). Levando em consideração as informações anteriormente citadas, a arquitetura pode determinar se os espaços, por exemplo, irão estimular ou prejudicar o aprendizado e contribuir na recuperação da saúde. Logo a aplicação dos conceitos da neuroarquitetura pode oferecer ambientes escolares, por exemplo, que estimulem o aprendizado e ambientes hospitalares que diminuam os níveis de estresse ajudando no bem-estar físico e mental. Utilizando a neurociência para entender como os ambientes impactam no cérebro de forma inconsciente também pode-se melhorar os ambientes residenciais, tornando-os mais produtivos para a atual situação de isolamento e quarentena.

Conclusão: Em tempos de isolamento e quarentena, a neuroarquitetura demonstra a importância dos espaços serem construídos para pessoas. Pois pode-se perceber que diversos fatores do meio em que o indivíduo se insere pode influenciar, até inconscientemente, o humor ou bem-estar. Conclui-se que em seus estudos a neuroarquitetura tem como foco criar ambientes que possam estimular e agregar positivamente o usuário do espaço, criando assim uma mudança na forma em que arquitetos projetam. Para isso alguns elementos como luz, ventilação, cores, texturas e a humanização dos espaços são primordiais.

\section{Referências}


CRIZEL, Lori. - Entendendo melhor sobre Neuroarquitetura - 13, Março 2020 - Disponivel em: Acesso em: 25/08/2020 PAIVA, Andrea De., JEDON, R. - Short- and long-term effects of architecture on the brain: Toward theoretical formalization. Frontiers of Architectural Research - Volume 8, Issue 4, December 2019.

PAIVA, Andrea De - Neuroscience for Architecture: How Building Design Can Influence Behaviors and Performance Jornal de Engenharia Civil e Arquitetura 12 (2018) 132-138 - Fundação Getulio Vargas, FGV, Instituto de Desenvolvimento Educacional, São Paulo 01310-100, Brasil

PAIVA, Andrea De - Como a Neuroarquitetura transforma a forma de projetar - Disponivel em: Acesso em: 25/08/2020

PALLASMAA, Juhani. Os Ihos da pele: A arquitetura e os sentidos. Porto Alegre, Bookman, 2011. 76 p.

Coordenadoria de Pesquisa e Extensão - COPEX

Departamento de Editoraçāo e Divulgaçāo Científica - DEDIC 


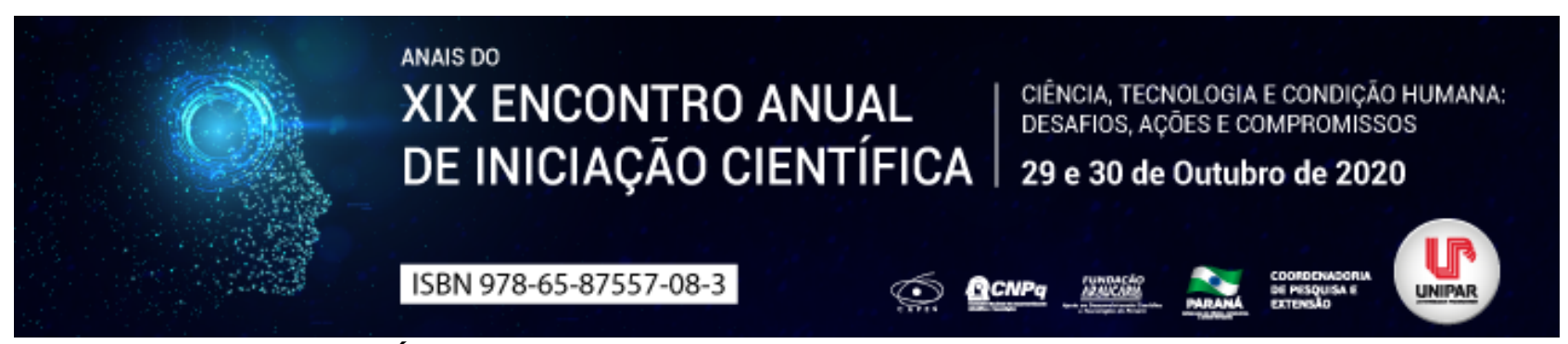

SOFRIMENTO PSÍQUICO E HIPERMODERNIDADE NO FILME DOLOR Y GLORIA (2019)

\title{
${ }^{1}$ JESSICA BEGNINI FRANZ, ${ }^{2}$ LARISSA FIORESE, ${ }^{3}$ MATEUS JOAO CORDEIRO SCHMOELLER DE LIMA, ${ }^{4}$ ANA CLAUDIA PANSERA, ${ }^{5}$ GRACIANE BARBOZA DA SILVA, ${ }^{6}$ TAISE SIGNORINI
}

\author{
${ }^{1}$ Acadêmica do Curso de Psicologia da UNIPAR \\ ${ }^{1}$ Acadêmica do Curso de Psicologia da UNIPAR \\ ${ }^{2}$ Acadêmico do Curso de Psicologia da UNIPAR \\ ${ }^{3}$ Acadêmica do Curso de Psicologia da UNIPAR \\ ${ }^{4}$ Docente da UNIPAR \\ ${ }^{5}$ Docente da UNIPAR
}

Introdução: Em um tempo hipermoderno, com mudança dos valores que permearam a humanidade desde o século XVIII, com a revolução francesa, percebe-se uma metamorfose no capitalismo, priorizando-se o consumo desenfreado e a individualidade narcisista. Assim se faz pertinente entender como a patologia psíquica entra em desacordo com os valores hipermodernos: euforia, consumo, velocidade e superficialidade (LAKOSKI et al., 2013). Com base nisso, o referido trabalho busca investigar a presença de ações, contextos e acontecimentos ligados a hipermodernidade no longa metragem Dolor y Gloria (2019)

Objetivo: $O$ presente trabalho tem por finalidade, através de revisão bibliográfica, analisar a obra cinematográfica Dolor $Y$ Gloria (2019) com base nos conceitos de hipermodernidade e sofrimento psíquico, abordando a influência do envelhecimento e adoecimento na qualidade de vida dos indivíduos.

Desenvolvimento: O filme Dolor y Gloria (2019) retrata a crise criativa do diretor de cinema Salvador Mallio, sendo este um personagem que se confunde com o próprio diretor do longa, fazendo da obra um curioso caso metalinguístico do cinema. $O$ enredo parte de um homem de 60 anos diagnosticado com vários problemas de saúde, ao mesmo tempo que enfrenta um bloqueio criativo. Por ser um filme contemporâneo que retrata o período da vida de Salvador Mallio, é possível relacionar o seu sofrimento com a forma em que vivemos, um mundo onde se dá valor à um indivíduo baseando-se em quanto ele produz para o sistema vigente, e onde também alinhado à esses valores de produção, individualidade e passividade sócio-política se dará o valor ao homem. Nessa hipermodernidade que o ser humano vive, sua vida só tem sentido quando ligada ao trabalho, justo por isso pode-se inferir que ao dedicar décadas para a direção de seus filmes, Salvador negligenciou outras partes de sua vida. Além dessa pouca vida do personagem também é possível atribuir à hipermodernidade o fato de Salvador sofrer com patologias de cunho psíquico como a síndrome do pânico, a ansiedade e depressão (EWALD, MOURA, GOULART, 2012). Durante todo o filme, a obra dispõe do uso proposital de cores para fomentar ainda mais os sentimentos e impasses vivenciados por Salvador, a exemplo da cor vermelha quando aborda a tensão sexual no episódio em o protagonista vê Eduardo tomando banho e das cores vivas e vibrantes para retratar a solidão, lembranças do passado e ligação com a mãe. Essa exposição, assim como outras presentes no decorrer do filme, são permeadas pelo sofrimento do desejo, transpassando e influenciando todas as cenas de Salvador (NASIO, 2007). Ainda no que tange o enredo, Salvador transmite melancolia, dores físicas intensas, depressão e amargura, visto que seu corpo já não é mais o mesmo, ainda mais em uma sociedade hipermoderna que valoriza a estética do corpo jovem e belo, condenando o processo de envelhecer (MOREIRA, 2012) e atribuindo culpa ao seu corpo por não se enquadrar nesses padrões pré estabelecidos. Além do mais, no início da produção, são enumerados os problemas de saúde de Salvador, tendo seu princípio no começo da meia idade e abrangendo tanto dores físicas quanto da alma , forma como é referido a depressão e ansiedade, e que impulsionam ele a usar heroína para a fuga das dores. Segundo Zimerman (1997, p. 61): O fenômeno da somatização implica no fato de que se forma algum tipo de lesão orgânica, sendo que isso pode ocorrer em praticamente todos os órgãos. (...) é muito difícil reconhecer nas somatizações, alguma especificidade de significação simbólica do conflito . Como bem coloca Lacan (1966), em sua teoria psicanalítica, existe um valor fundamental nas experiências precoces para a estruturação das pulsões, defesas e formação do inconsciente, visto que no filme, retrata a experiência de Salvador com ainda 8 anos á sua vida sexual, como na cena com Eduardo já citada, e levando em conta o fato de o protagonista ser homossexual, e em como, para a classe dominante e pela cultura cristã da Espanha, podemos inferir, que o recalque desse desejo de Salvador, provocado pela mãe, também contribuiu para o seu sofrimento psíquico e sua dependência da mãe provocou submissão no seu processo de envelhecimento e o fato dele demorar anos para aprender conviver com o processo de velhice e doença, bem como entender que na vida existe Dor e Glória.

Conclusão: $O$ indivíduo hipermoderno sofre pressão do tempo, tanto da vida privada como no trabalho, estando propenso ao suicídio, depressão, uso excessivo de medicamentos e embriaguez de liberdade. Como é o caso de Salvador, que em seu processo de envelhecimento vive conflitos internos e dores físicas devido uma pressão sofrida pelo capitalismo que tem como 
favoritismo a produção. Com o tempo, ele passa a lidar com essas questões, recuperado o sentido da vida, constata-se a retomada do Ego e da criação de seus projetos através da Produção de trabalho, assim se encaixando como sujeito na geração hipermoderna. Ao passar pela trajetória de Salvador o longa-metragem expõe um homem com vários sofrimentos, físicos e psíquicos, que enfrenta a dor no seu corpo e de suas escolhas contrastando com a glória atingida na sua carreira.

\section{Referências}

DOLOR y Gloria. Direção de Pedro Almodòvar. Espanha. El Deseo/Universal, 2019 (113 min).

EWALD, Ariane Patrícia; MOURA, Michelle Theme de Carvalho; GOULART, Samira Meletti da Silva. Contemporaneidade e sofrimento psíquico: Relações entre modos de vida e demandas psicoterapêuticas. Psicologia Argumento, [S.I.], v. 30, n. 68, nov. 2017. Disponível em: https://periodicos.pucpr.br/index.php/psicologiaargumento/article/view/20271. Acesso em: 05 jun. 2020. LACAN, Jacques. (1966). O lugar da psicanálise na medicina. Opção Lacaniana, 32:8-14. 2001.

LAKOSKI, Pricilla Braga, et al. A hipermodernidade e a clínica psicanalítica. Revista brasileira de psicoterapia. Porto Alegre. Vol. 15, n. 2 (2013), p. 14-24. Disponível em: https://www.lume.ufrgs.br/handle/10183/117281. Acesso em: 03 ago. 2020.

MOREIRA, Jacqueline de Oliveira. Mudanças na Percepção Sobre o Processo de Envelhecimento: Reflexões Preliminares. Psic.: Teor. e Pesq. vol.28 no.4 Brasília out./dez. 2012. Disponível em: . Acesso em 15 jun. 2020.

NASIO, Juan David. Édipo: o complexo do qual nenhuma criança escapa. Tradução André Telles. Rio de Janeiro: Jorge Zahar, 2007. 154 p. ISBN 978-85-7110-972-8.

ZIMERMAN, David E. Como Trabalhamos com Grupos. Editora Artes médicas, POA, 1997. 


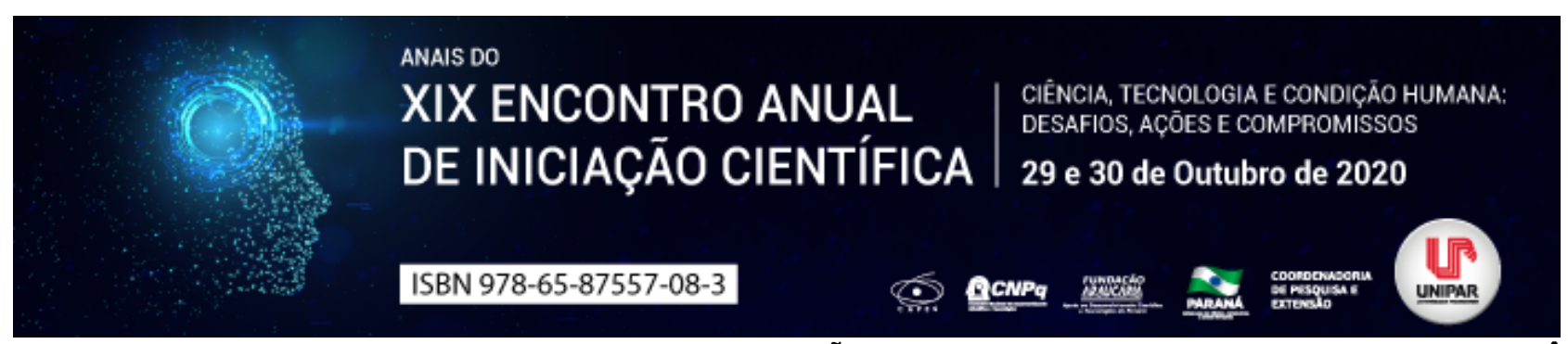

\section{REQUERIMENTO DE TUTELA ANTECIPADA NA SUSTENTAÇÃO ORAL: PROJETO DE LEI Nº 8.688/2017 DA CÂMARA DOS DEPUTADOS}

${ }^{1}$ LORENA GABRIELLY ANDRADE BATISTA, ${ }^{2}$ RHAMON PAGANOTI DA SILVA, ${ }^{3}$ CELSO HIROSHI IOCOHAMA

${ }^{1}$ Acadêmica do PIC/UNIPAR

${ }^{1}$ Acadêmico do PIC/UNIPAR

${ }^{2}$ Docente da Graduação em Direito e do Programa de Mestrado em Direito Processual e Cidadania da UNIPAR

Introdução: O Código de Processo Civil (CPC), é responsável por respaldar as possibilidades de requerimento e deferimento de tutela, dentro do teor do processo civil. Neste diapasão, fica à disposição do juiz antecipar ou não os efeitos práticos requeridos pela parte, por meio de seu pedido de antecipação de tutela anterior à decisão judicial final.

Objetivo: Verificar a importância do requerimento de tutela e a antecipação dos seus efeitos em sede de sustentação oral.

Desenvolvimento: O Projeto de Lei $n^{\circ} 8688 / 2017$, pretende acrescentar o parágrafo $\S 2^{\circ}$ ao art. 294 da Lei 13.105 (CPC), com a seguinte redação A tutela poderá ser requerida na sustentação oral (BRASIL, 2017a). Dessa forma, deve-se garantir a proteção da parte de forma imediata, sem esperar a tramitação normal do processo e é importante essa tutela antecipada para evitar os efeitos maléficos do tempo, viabilizando a satisfação do direito requerido pela parte em juízo (ARAÚJO, 2016). Sabe-se que a tutela antecipada poderá ser concedida desde que seja feito o requerimento que demonstrará a verossimilhança e a prova inequívoca pela parte, os quais proporcionarão a antecipação dos efeitos da tutela por convencimento do magistrado (NICOLEIT, 2012). No CPC, não há nenhum artigo que possibilite a antecipação de tutela em sustentação oral, mas isso é um fato que já se verificou na prática levando em consideração a jurisprudência, como já decidiu o STJ no Recurso Especial no 1332766/SP, o qual salientou que se o pedido poderia ser formulado ao juiz, o Colegiado também seria responsável por apreciar tal recurso, considerando que novas circunstâncias poderiam fazer com que a tutela antecipada fosse autorizada, de maneira que o requerimento também venha ser deduzido em sessão de julgamento, em feito que comporta sustentação oral (BRASIL, 2017b). A antecipação de tutela na sustentação oral torna-se viável por possibilitar que a pessoa possa usufruir do seu direito, que já foi expressamente definido, no entanto é plausível que as decisões judiciais sejam tomadas de acordo com a lei vigente e não apenas com base na jurisprudência, para então proporcionar segurança jurídica no processo.

Conclusão: A regulamentação do direito de pleitear a antecipação de tutela na sustentação oral é um importante mecanismo para se acelerar a proteção dos direitos das partes e a regulamentação por via do projeto garantirá maior segurança jurídica, respaldando-as na lei e não apenas na jurisprudência.

\section{Referências}

ARAÚJO, Fábio Caldas de. Curso de Processo Civil: parte geral. Atualizado com a Lei 13.256/2016. São Paulo: Malheiros, 2016.

BRASIL. Congresso. Câmara dos Deputados. Atividade Legislativa. Projeto de Lei e Outras proposições. PL n 8.688/2017. Brasília: Augusto Carvalho - SD/DF. Disponível em: https://bit.ly/3j5QsAF. Acesso em: 16 ago 2020a.

Superior Tribunal de Justiça. RE no 1332766/SP. Quarta turma. Relator: Ministro Luis Felipe Salomão. Data do Julgamento: 01/06/2017. Disponível em: https://bit.ly/3gfWJYG. Acesso em: 16 ago 2020b.

NICOLEIT, Rudolfo Radaelli. A valoração da prova e a verossimilhança nas medidas de urgência. Páginas de Direito. Disponível em: https://bit.ly/3giKpXv. Acesso em: 16 ago 2020. 


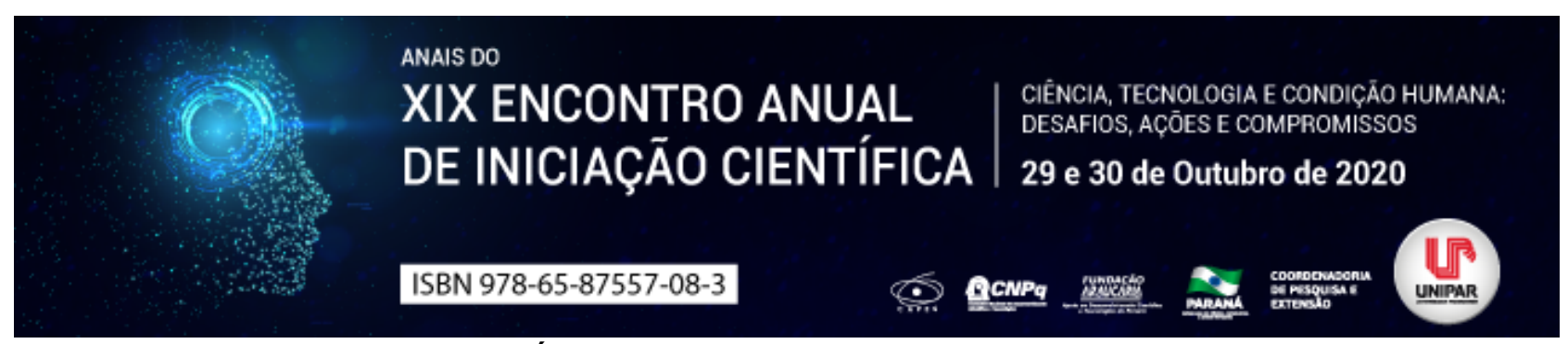

SANEAMENTO BÁSICO : EXPECTATIVA DE UMA NOVA REALIDADE

\title{
${ }^{1}$ JENNIFER CANDIDO DE REZENDE, ${ }^{2}$ BRUNO SMOLAREK DIAS
}

\author{
${ }^{1}$ Acadêmico do PIC/UNIPAR \\ ${ }^{1}$ Docente da UNIPAR
}

Introdução: O Saneamento Básico conecta-se com um dos mais básicos direitos existentes: o direito à vida. Para que possamos vivenciá-la com qualidade é necessário um conjunto de fatores, dentre os quais se encontra a existência de um mínimo sanitário em que o saneamento básico se integra, direcionando assim uma reversão para o ponto inicial da sustentabilidade.

Objetivo: Analisar os novos pilares da lei 14.026 do saneamento básico.

Desenvolvimento: A sustentabilidade, entendida como o equilíbrio entre os fatores bióticos e abióticos de um sistema proporciona qualidade de vida (DIAS, MARDEGAN, 2011). Mas para que haja isso é necessário que todas as necessidades básicas do seres humanos sejam atendidas primeiro(no caso o mínimo sanitário),como a manutenção dos valores de padrões de consumo, dentro dos limites das possibilidades econômicas, não podendo por em risco os sistemas naturais que sustentam a vida na terra (solo, atmosfera, água e os seres vivos) e os recursos não renováveis (minerais e combustível fósseis). Nesse diapasão, a Lei $n^{\circ} 14.026$ de Saneamento Básico (BRASIL, 2020), chamada de novo marco regulatório do saneamento básico com uma nova redação do art. 29 , $\S 3^{\circ}$, traz disposição muito importante para a racionalização do consumo de água, ao prever que as novas edificações condominiais adotarão padrões de sustentabilidade ambiental que incluam, entre outros procedimentos, a medição individualizada do consumo hídrico por unidade imobiliária ( ) . À Agência Nacional de Águas [ANA] foi atribuída a competência para regular a prestação do serviço de saneamento básico por meio da edição de normas de referência (arts. $1^{\circ}$ e $3^{\circ}$ da Lei $n^{\circ} 9.984 / 2000$ e art. 25-A da Lei $n^{\circ} 11.445 / 2007$ ), como, por exemplo, sobre padrões de qualidade e eficiência na prestação, na manutenção e na operação dos sistemas de saneamento básico, metas de universalização dos serviços. ANTUNES,2020).Ademais, em contrapartida, Giullo discorre que a forma resulta em aproximar o setor de saneamento a gestão de água e acompanhar relação entre as agências reguladoras e as empresas de saneamento. Porém, ocorre que os riscos estão na própria inovação podendo corromper a gestão de água no Brasil. Para mais, sendo suplementar aos interesses do setor de saneamento, a indistinção dos recursos financeiros para a regulação de saneamento, possibilitando reduzir os recursos do sistema de água para cobrir os custos da regulação de saneamento e, assim, a ausência de participação social. Contudo será definido entre as instâncias de cada Estado. Sendo assim, a água pode começar a ser tratada como mercadoria. Além disso, por falta de estruturação, podendo gerar outro risco a qual devendo ser observado principalmente nas áreas afetadas pelas populações de minoritárias.

Conclusão: Nota- se que para ter um equilíbrio na sustentabilidade o ser humano precisa que suas necessidades básicas sejam atendidas, a nova regulamentação da legislação brasileira veio para advertir esse excesso de água pra uns e a escassez para outros que tem se mostrado , mas diante disso ocorre riscos na maneira de inovação relacionados a estruturação do saneamento básico e o consumo hídrico com instrumento de mercadoria. Mesmo com riscos, o legislador preza pela eficiência futura e um aguardo para uma nova realidade.

\section{Referências}

BRASIL. Lei $n^{\circ} 14026$, de 15 de julho de 2020. Atualiza o marco legal do saneamento básico. Disponível em: http://www.planalto.gov.br/ccivil_03/_Ato2019-2022/2020/Lei/L14026.htm. Acesso $\quad$ em: 28 ago. 2020.

ANTUNES,Paulo de Bessa. Breves considerações sobre o novo marco regulatório do saneamento básico Lei $n^{\circ} 14.026$, de 15 de julho de 2020. Genjuridico,23 jul.2020. Disponível em: http://genjuridico.com.br/2020/07/23/marco-regulatorio-saneamentobasico. Acesso em: 28 ago. 2020.

DIAS, Bruno Smolarek; MARDEGAN, Herick. Sustentabilidade como fundamento da cidadania transnacional. Revista Eletrônica Direito e Política, Programa de Pós-Graduação Stricto Sensu em Ciência Jurídica da UNIVALI, Itajaí, v. 6, n.2, $2^{\circ}$ quadrimestre de 2011. Disponível em: www.univali.br/direitoepolitica. Acesso em: 28 ago. 2020.

GIULLO,Vicente Andreu.Especialistas debatem o novo marco do saneamento e os impactos na gestão dos recursos hídricos. Engeplus,14 ago. 2020. Disponível em: http://www.engeplus.com.br/noticia/geral/2020/especialistas-debatem-o-novomarco-do-saneamento-e-os-impactos-na-gestao-dos-recursos-hidricos. Acesso em: 23 set. 2020. 



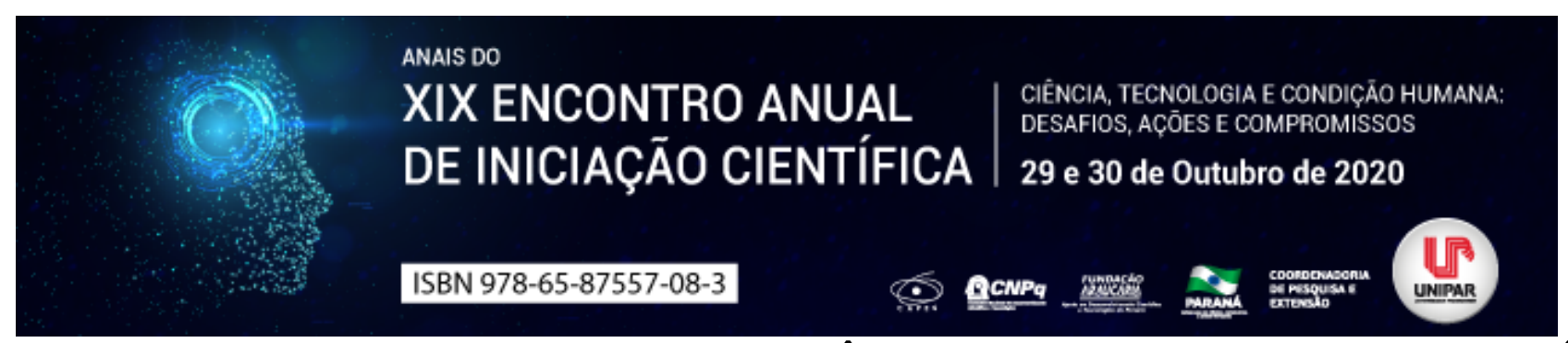

TRANSEXUALIDADE NA ALDEIA? NARRATIVAS SOBRE A VIVÊNCIA LGBTTQI+ DE UMA MULHER TRANS, INDÍGENA, NO INTERIOR DO BRASIL

\author{
${ }^{1}$ DANIELLE ARAUJO DE SOUZA, ${ }^{2}$ CAROLINE FELIX SATURNINO, ${ }^{3}$ BARBARA COSSETTIN COSTA BEBER BRUNINI, \\ ${ }^{4}$ DANIELLE JARDIM BARRETO
}

\author{
${ }^{1}$ Acadêmica Bolsista do PIBIC/UNIPAR \\ ${ }^{1}$ Acadêmica do Curso de Psicologia da UNIPAR \\ 2Docente da UNIPAR \\ ${ }^{3}$ Docente da UNIPAR
}

Introdução: É comum ouvirmos que a arte imita a vida. Mas fica a pergunta: de que arte e de que vida estamos falando, afinal? Segundo Melo (2016), por meio das artes, a complexidade do humano ultrapassa o território científico e ganha voz e visibilidade nas mais diversas formas de existir. A partir deste aspecto, este resumo justifica-se para que por meio da análise de um curtametragem que retrata a vida de uma mulher trans, indígena, possamos propor uma discussão, sobre a existência de uma realidade e vivência LGBTTQI+ ( Lésbicas, Gays, Bissexuais, Transsexuais, Travestis, Queers, Intersex) que atravessa e transcende a lógica do capturado, instituído e colonizado, irrompendo com a cultura de massa que produz, exatamente, indivíduos: indivíduos normalizados, articulados uns aos outros segundo sistemas hierárquicos, sistemas de valores, sistemas de submissão (GUATTARI \& ROLNIK, 2005, p.22). Esta vivência, questiona os padrões impostos pelo colonizador, que já estão absorvidos pela comunidade dita civilizada. A partir do projeto de iniciação científica da Universidade Paranaense: (Re) conhecendo LGBTTfobia nas relações universitárias, realizou-se uma curadoria de curtas-metragens com a temática LGBTTQI+; sendo escolhido para a produção deste trabalho, o curta intitulado Majur . Majur, uma mulher trans, indígena, é chefe de comunicação em sua aldeia, no sul do Mato Grosso, terra indígena Tadarimana. Sua vivência e atuação são de extrema importância para a comunidade e agenciam os diálogos para além da aldeia, em assuntos relacionados à educação das crianças, promoção da cultura indígena e à própria vivência dissidente da transsexualidade.

Objetivo: Problematizar outras perspectivas sobre a vivência indígena como pessoa LGBTTQI+, a partir da análise do curta metragem Majur, com o intuito de desconstrução da naturalização colonizada da experiencia da transsexualidade.

Discussão: Em nossa sociedade considera-se que a sexualidade é algo natural, porém, de acordo com Louro (2000) a sexualidade é construída ao longo de nossa vida e essa ideia de natureza se encontra dentro de cada contexto cultural, pois cada cultura julga o que é natural e, consequentemente, aceitável para si. Na cultura capitalista ocidental em que estamos inseridos, os dispositivos atuam para que o corpo aceitável seja o que se encontra no padrão europeu, qual seja, - homem branco, cristão, de classe média ou alta e heterossexual -, sendo os que não se enquadram nesses padrões são considerados anormais. Para Preciado (2008) esses corpos que fogem dos padrões, que não se encontram nas normas, biologicamente, do feminino e do masculino são patologizados. Dentre eles, abordamos aqui, os que são atravessados pela transexualidade, que está relacionada com a identidade pessoal e a necessidade de reconhecimento legal e social dessa identidade, seja ela, como homem ou como mulher, sem olvidarmos que a transexualidade não está, necessariamente, ligada à orientação sexual (JESUS, 2012). De acordo com Foucault (1988) são os discursos que agenciam o poder, fazendo com que ele atue em toda a estrutura social e opere a todo momento. São essas relações de poder que produzem as desigualdades e os discursos hegemônicos, sendo responsáveis pela desqualificação da população LGBTTQI+. No curta-metragem, através das falas de Majur a questão cultural se evidencia quando ela se refere que os preconceitos sobre a sexualidade, chegaram com o homem branco, e ainda, que sofreu transfobia (violência física, verbal ou emocional contra pessoas transexuais) nas redes sociais. O Brasil é um território que foi colonizado por europeus e marcado pelo genocídio dos povos primitivos e as mazelas da escravidão, embora o período colonial tenha se encerrado há séculos, ainda podemos perceber os vestígios do colonialismo na produção dos padrões universais de comportamentos e, consequentemente, os padrões sobre o ser mulher. Esse modelo colonial produz os preconceitos e desigualdades das mulheres indígenas e negras no contexto brasileiro, marginalizando-as (PETRONE, 2019). Sendo assim, precisamos reconhecer os marcadores sociais de Majur, que além de mulher trans, também é indígena, e a partir disto compreender que emanamos de lugares diferentes, praticando tal reflexão para que não continuemos reproduzindo as exclusões e opressões para os múltiplos modos de vida (LORDE, 2019).

Conclusão: Mesmo sendo o país que mais mata transexuais no mundo (PETRONE, 2019) - talvez até por isso -, produções audiovisuais como Majur são desconhecidos e até negligenciados, no Brasil, fazendo com que o padrão hegemônico colonizador seja reforçado. No entanto a vivência de Majur no interior da sua aldeia e nos outros territórios em que transita, infiltra-se nas fissuras da molaridade, criando linhas de fuga com seu próprio corpo (DELEUZE \& GUATTARI, 1996); corpo que 
não se cala, não se resigna, ao contrário, se lança, atende ao desejo e quebra o estereótipo instituído.

\section{Referências}

DELEUZE, Gilles. \& GUATTARI, Felix. Mil Platôs Capitalismo e Esquizofrenia: vol.3. Rio de Janeiro: $34,1996$.

FOUCAULT, Michel. História da sexualidade I: A vontade de saber. 13 ed. Rio de Janeiro: Edições Graal, 1988.

GUATTARI, Felix.; ROLNIK, Suely. Micropolítica: Cartografias do Desejo. 4 ed. Petrópolis: Vozes, 1996.

JESUS, Jaqueline Gomes de. Orientações sobre identidade de gênero: conceitos e termos. 2 Ed, Brasília, 2012. Disponível em: https://www.researchgate.net/publication/234079919_Orientacoes_sobre_Identidade_de_Genero_Conceitos_e_Termos Acesso em: 05 Ago. 2020.

LORDE, Audre. Irmã outsider: ensaios e conferências. 1. ed. Belo Horizonte: Autêntica, 2019.

LOURO, Guacira Lopes. O corpo educado: pedagogias da sexualidade. 2. ed. Belo Horizonte: Autêntica, 2000.

MAJUR. Direção: Rafael Irineu. Produção: Patricia Ribeiro. Mato Grosso: Ayrton Senna Amaral, 2018. (20 min), son., color. Disponível em: https://www.mixbrasil.org.br/play/curtas/majur-2018/. Acesso em: 12 jun. 2020.

MELO, Rogério Amador de. Imagens, sensações e afetos: as personagens gays nos curtas-metragens brasileiros exibidos no Festival Mix Brasil de Cultura da Diversidade. 2016. 152 f. Dissertação (Mestrado em Psicologia) Universidade Estadual Paulista Júlio de Mesquita Filho , Assis/SP: UNESP - 2016.

PRECIADO, Beatriz. Testo yonqui. Madrid: Espasa, 2008.

PETRONE, Talíria. Prefácio à edição brasileira. In: ARRUZZA, Cinzia.; BHATTACHARYA, Thiti.; FRASER, Nanci. Feminismo para os 99\%: um manifesto. 1. ed. São Paulo: Boitempo, 2019. 


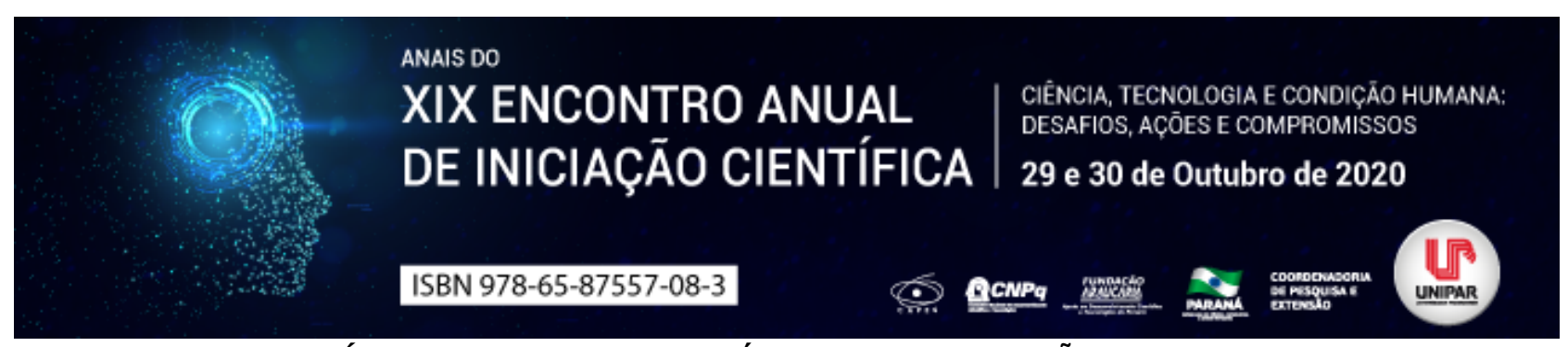

\title{
CEGO AOS OLHOS, MAS VISÍVEL AO BOLSO: UMA ANÁLISE DA DIVULGAÇÃO DOS RISCOS AMBIENTAIS SOBRE O ACIDENTE NAS BARRAGENS DE MARIANA E BRUMADINHO
}

\section{${ }^{1}$ Letícia Silva Costa, ${ }^{2}$ MARA CRISTINA PIOVESAN CORTEZIA, ${ }^{3}$ FRANCIELE DO PRADO DACIÊ}

\author{
${ }^{1}$ Acadêmica do curso de Ciências Contábeis da UEM \\ ${ }^{1}$ Professora na Universidade Estadual de Maringá \\ ${ }^{2}$ Professora na Universidade Estadual de Maringá
}

Introdução: Nos últimos cinco anos, o Brasil foi cenário de dois rompimentos de barragens que geraram impactos ambientais, sociais e econômicos. Em 2015, o rompimento da barragem do Fundão, pertencente à Samarco S/A, liberou aproximadamente 45 milhões de $\mathrm{m}^{3}$ de rejeitos, devastou o subdistrito de Bento Gonçalves, provocou a morte de 19 pessoas e poluiu $663,20 \mathrm{~km}$ de água (IBAMA, 2016). Em 2019, fato semelhante ocorreu na barragem I da Mina do Córrego do Feijão, de propriedade da Vale S/A. Uma enxurrada de lama provocou 252 vítimas fatais, destruiu 125 hectares de floresta e afetou o abastecimento de água de 21 municípios (WWF BRASIL, 2019). O desastre ambiental gerou um impacto financeiro de cerca de R\$350 milhões em multas, e o bloqueio judicial de bilhões de reais destinados a indenizar empregados e ressarcir prejuízos as famílias evacuadas dos locais de risco (VALE, 2019). Embora esses fatos ocorram, a divulgação dos riscos ambientais no Brasil ainda é voluntária, dando autonomia para que as empresas apresentem fatos que entenderem como relevantes. Sob a perspectiva da Teoria da Legitimidade, as divulgações se tornam um mecanismo pelo qual as empresas passam a influenciar a percepção externa sobre suas atitudes (PENEDO et al., 2004). No entanto, embora as evidenciações tornem as atividades da empresa conhecidas e legítimas (EUGÉNIO, 2010), a falta de padronização dos relatórios dificulta o entendimento, refletindo negativamente na credibilidade do conteúdo divulgado (MARTINI JUNIOR; SILVA; MATTOS, 2014). Esse contexto, portanto, possibilita manobras comunicacionais para com os usuários. Diante do estímulo à divulgação de informações ambientais como forma de aproximar a relação empresa-sociedade (SILVA et al., 2009), o Global Reporting Initiative (GRI) se insere como um modelo para elaboração desses relatórios, a fim de promover a capacidade de padronização e comparabilidade das informações (GRI, 2019). Em 2010, o Pacto Global da ONU adotou as diretrizes do GRI como estrutura recomendada para as empresas apresentarem seus progressos sustentáveis (GRI, 2019), possibilitando identificar e mensurar eventos ambientais, e gerar informações para suporte da tomada de decisões.

Objetivo: Verificar qual o comportamento dos níveis de aderência aos indicadores do Global Reporting Initiative (GRI), em relação à divulgação dos riscos ambientais nos relatórios das empresas Samarco e Vale no período de 2014 a 2018.

Material e métodos: Os dados foram extraídos dos Relatórios de Sustentabilidade divulgados nos sites das empresas, pois estudos mostram ele apresenta maior volume de evidenciações ambientais (MUSSOI et al., 2010). A identificação dos indicadores do GRI foi realizada a partir da análise de conteúdo dos documentos. Para medir os níveis de aderência, foram atribuídos pesos conforme o tipo e abrangência da informação apresentada (conforme as expectativas do GRI). Os pesos foram: (1) aderência plena (100\%), (2) aderência parcial (66,67\%), (3) informação não disponível (33,33\%), e (4) não aplicável (0\%) ou (5) omitido com justificativa (0\%) ou (6) omitido (0\%). A técnica foi adaptada de Silva, Maia e Leal (2017).

Resultados: Nos relatórios divulgados pela Samarco S/A foi observado que alguns aspectos contemplados pelo GRI, antes imateriais, passaram a ter maior evidenciação quantitativa após o desastre na barragem. Os principais tópicos que apresentaram diferença significativa no nível de aderência aos critérios do GRI durante o período de análise foram: 302_energia (+6,67\% de divulgação), 304_biodiversidade (+41,67\% de divulgação), 305_emissões (+14,28\% de divulgação), 306_efluentes sólidos (-13,33\% de divulgação) e 307_conformidade ambiental (+100,00\% de divulgação). Nos relatórios divulgados pela Vale S/A, as diferenças nos níveis de aderência dos tópicos do GRI foram identificados nos tópicos: 302_energia (-40,00\% de divulgação), 303_água (+22,22\% de divulgação), 305_emissões (+29,67\% de divulgação), 306_efluentes sólidos (+66,67\% de divulgação), 307_conformidade ambiental (-100,00\% de divulgação, deixa de divulgar) e 413_comunidades locais (+33,33\% de divulgação).

Discussão: Identificou-se uma mudança quantitativa no nível de divulgação dos tópicos vinculados ao GRI, ou seja, as informações tornaram-se mais expressas em valores monetários. Acredita-se que tal mudança se relacione aos rompimentos das barragens de rejeitos, uma vez que as evidenciações de ambas organizações se apresentaram mais objetivas no ano imediatamente posterior aos acontecimentos. Embora os resultados quantitativos não apresentem as informações subjetivas diagnosticadas, a análise de conteúdo permitiu identificar que, após os desastres ambientais, as empresas passaram a evidenciar melhor as informações tanto nos aspectos quantitativos quanto qualitativos, em especial as que dizem respeito a riscos ambientais, sociais e econômicos relacionados a barragens. Os resultados desse estudo convergem com a Teoria da Legitimidade, que preconiza que as empresas tendem a utilizar seus relatórios como forma de manter sua legitimidade (MACHADO; OTT, 2015), influenciando a forma como os usuários externos veem as atividades da organização. 
Conclusão: A análise das evidenciações ambientais que compõem os relatórios de sustentabilidade das empresas Samarco e Vale, trouxe resultados significativos para a presente pesquisa. Verificou-se que as evidenciações não são realizadas de forma clara e completa, apresentando falhas e não atendendo de forma plena os indicadores do GRI, assim como apontado por Martini Junior, Silva e Mattos (2014).

\section{Referências}

EUGÊNIO, T. Avanços na divulgação de informação social e ambiental pelas empresas e a Teoria da Legitimidade. Revista Universo Contábil, v.6, n.1, 2010.

GRI- Global Reporting Initiative. Padrões para Relato de Sustentabilidade. Disponível em: https://www.globalreporting.org/standards/gri-standards-download-center/. Acesso em: 12 ago. 2019.

IBAMA. Rompimento da Barragem de Fundão: Documentos relacionados ao desastre da Samarco em Mariana/MG. Disponível em: https://bit.ly/38DUjPD. Acesso em 05 jun. 2019.

MACHADO, D. P.; OTT, E. Estratégias de Legitimidade social empregadas na evidenciação ambiental: um estudo à luz da Teoria da Legitimidade. Revista Universo Contábil, v. 11, n. 1, 2015.

MARTINI JUNIOR, L. C.; SILVA, E. R.; MATTOS, U. A. O. Análise da transparência corporativa por meio dos relatórios de Sustentabilidade com base na global reporting initiative de empresas do Setor brasileiro de energia elétrica. Revista Eletrônica Sistemas \& Gestão, v. 9, n. 1, 2014.

PENEDO, J. et al. Contabilidade ambiental: divulgação de informação. In: Congresso de Contabilidade de Portugal, 10. 2004, Lisboa. Anais... Estoril: Iscal, 2004. CDROM.

SILVA, J. O.; ROCHA, I.; WIENHAGE, P.; RAUSCH, R. B. Gestão ambiental: uma análise da evidenciação das empresas que compõem o índice de sustentabilidade empresarial (ISE). RGSA Revista de Gestão Social e Ambiental, v. 3, n. 3, 2009.

SILVA, T. L. G. B.; MAIA, L. C. C.; LEAL, E. A. Grau de Aderência aos Indicadores de Desempenho Ambiental do GRI em um Mercado Emergente: Uma Análise em Empresas com Potencial Poluidor em Dois Segmentos. Revista Ambiente Contábil, v. 9. n. 1, 2017.

VALE, S/A. Relatório de Sustentabilidade. 2019. Disponível em: https://bit.ly/2TzcSjD. Acesso em: 21 ago. 2019.

WWF BRASIL. Ruptura de barragem em Brumadinho causou perda de 125 hectares de florestas. Disponível em: https://bit.ly/39CUaNB. Acesso em: 17 jun. 2019. 


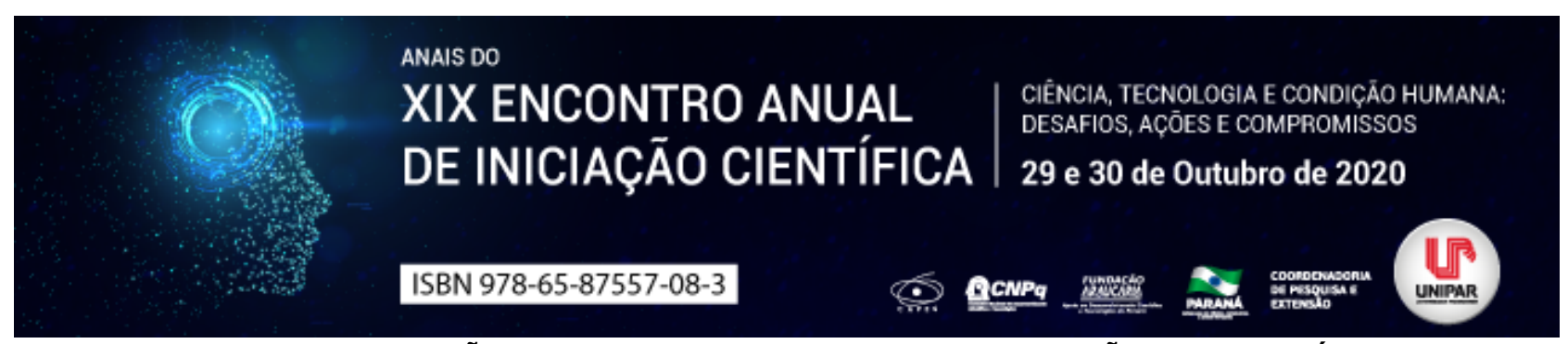

FOUCAULT E A VISÃO PUNITIVISTA DO ESTADO: UMA REVISÃO BIBLIOGRÁFICA

\title{
${ }^{1}$ OLAIR DOMINGOS DACHERY JUNIOR, ${ }^{2}$ ANA CLAUDIA PANSERA, ${ }^{3}$ JANE MARA DA SILVA PILATTI
}

\author{
${ }^{1}$ Acadêmico do Curso de Direito da UNIPAR \\ ${ }^{1}$ Acadêmica do Curso de Psicologia da UNIPAR \\ ${ }^{2}$ Docente do Curso de Direito da UNIPAR
}

Introdução: Ao longo da história, o Estado modificou gradativamente seu modo de lidar com crimes e aplicações de penas, seja pela alteração das formas de governo, pela pressão da sociedade ou pela ineficácia das medidas adotadas. Com base nisso, a obra Vigiar e Punir de Michel Foucault compromete-se em explicitar a evolução punitivista do Estado, pautando-se em alterações nas regras e costumes sociais, nas formas de existência e na ciência do Direito, mais especificamente na Criminologia e no Direito Penal, explicitando os mecanismos de controle do Estado e as relações de poder dentro da sociedade.

Objetivo: Analisar o pensamento foucaultiano sobre a evolução das penas aplicadas e as formas utilizadas pelo Estado para combater delitos e garantir a manutenção da ordem social.

Desenvolvimento: A utilização das penas em períodos mais remotos visava manter a paz e o bem estar social, bem como transformar o cidadão infrator em uma figura de exemplo a não ser seguida perante toda sociedade. É com essa finalidade que as punições eram aplicadas em praça pública, seguidas de torturas direcionadas ao corpo do infrator, demonstrando o poder do Estado em face do particular (FOUCAULT, 2013). Ademais, o medo era fundamental para manter o controle e a disciplina A aplicação das penas, [...] era uma forma de 'treinamento' para corrigir o indivíduo delinquente e o transformar com valores fundamentais da sociedade moderna (PASTANA, 2012, p. 29). Conseguinte, no século XIX, houve diversas alterações nas legislações penais de vários países, onde segundo Foucault (2013, p. 17): I"Desapareceu o corpo supliciado esquartejado, amputado, simbolicamente marcado no rosto ou nos ombros, exposto vivo ou morto, apresentado como espetáculo. Desapareceu o corpo como alvo principal da repressão penal . Em consequência disso, o Estado assume punições dadas como mais efetivas, tais como prisão, reclusão e trabalho forçado, voltadas para a restrição da liberdade e correção do comportamento desviante do infrator. A punição assume uma face mais oculta do processo penal e as cenas de tortura outrora comuns em ambientes públicos, ganham uma nova casa, as penitenciárias, onde é vigente a reformulação de comportamentos para, em teoria, o marginalizado ser reinserido à sociedade (FOUCAULT, 2013). Outrossim, o discurso vigente na obra Vigiar e Punir incide sobre os mecanismos de controle do Estado e os comportamentos dos infratores. Esses conceitos são permeados por relações de poder que submetem os corpos a um discurso normativo específico e é com base nisso que Galvão (2016, p. 12) afirma que: Tanto o discurso normativo quanto às práticas entre indivíduos se traduzem em relações de poder, e essas relações proporcionaram a emergência de uma modalidade específica: o poder disciplinar.l" Esse poder disciplinar é responsável pela produção dos corpos dóceis e pelo adestramento dos infratores. Os corpos dóceis, representados por indivíduos eficientes e úteis para a sociedade, são produtos da adestração do Estado, voltado para a construção de seres comprometidos com as condutas esperadas e correção de posturas desviantes (GALVÃO, 2016). Seguindo esse princípio, Pastana (2012, p. 30) sustenta que I"[...] a evolução das punições demonstra a sua real finalidade, que é servir como exercício continuado e ininterrupto do treinamento correcional.l" Em síntese, os corpos que contrapõe as normativas do sistema são punidos pelo poder disciplinar para assim adequarem-se aos corpos dóceis, elemento de domesticação presente em todas as relações sociais. Essa visão reforça que as pessoas devem adaptar -se às normas vigentes para tornaram-se úteis ao meio.

Conclusão: O discurso de Foucault ilustra como o passar da história alterou as formas punitivas, permeado de modificações e adaptações segundo as mudanças e necessidades da sociedade em cada período histórico. Ao contextualizar com a realidade brasileira, por exemplo, percebe-se as demandas pelo combate à criminalidade interligados a um sentimento público de intranquilidade e insegurança, levadas a um anseio popular por respostas e ações punitivas para aqueles com comportamentos desviantes. Entretanto, o ideário de reclusão para correção pensado em uma ótica de reinserção social é fortemente sucateado e negligenciado. Nesse sentido, acaba em cárcere compulsório os cidadãos marginalizados, aqueles que não contam com acesso adequado à educação, cultura, lazer e condições de vida dignas. Com essa perspectiva, é explícito como o Estado negligencia os problemas sociais que incidem na vida dos civis, utilizando do poder normativo e da punição como ferramenta para retirar do convívio social aquele que apresenta comportamentos julgados como inadequados, acabando por negligenciar as demandas sociais envoltas na vida dos infratores em questão.

\section{Referências}

FOUCAULT, Michel. Vigiar e Punir: nascimento da prisão. Edições 70, novembro de 2013.

GALVÃO, Bruno Abilio. A arqueologia do dispositivo de poder disciplinar a partir de uma genealogia do poder na obra Vigiar e 
Punir de Michel Foucault. Dissertação (Mestrado em Filosofia) Universidade Federal do Espírito Santo, Centro de Ciências Humanas e Naturais. Espírito Santo, 2016.

PASTANA, Debora Regina. Estado punitivo e pós-modernidade: Um estudo metateórico da contemporaneidade. Rev. Crít. Ciênc. Soc., 98. Setembro, 2012. p. 25-44. 


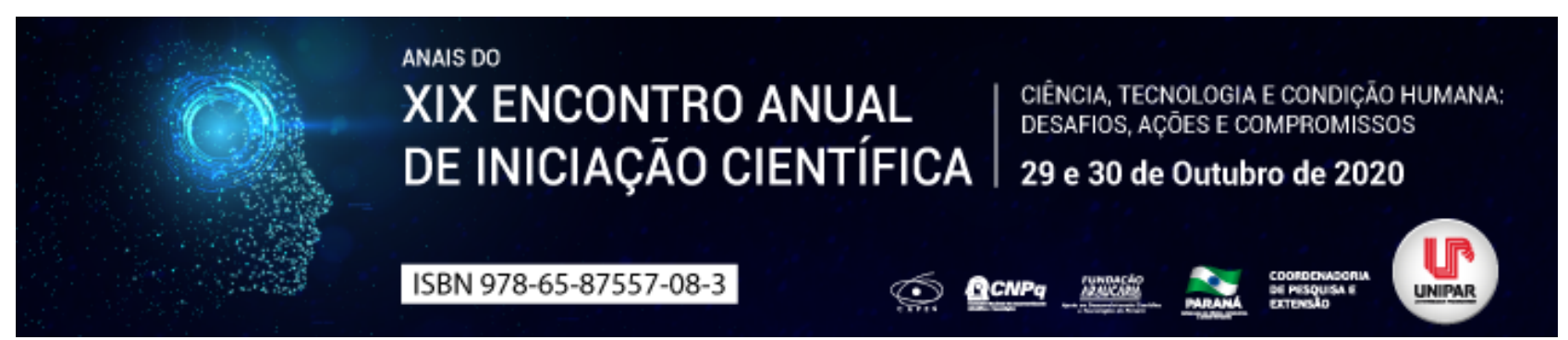

A BELEZA NEGRA COMO INSTRUMENTO DE RESGATE E VALORIZAÇÃO DA IDENTIDADE NEGRA

\begin{abstract}
${ }^{1}$ NIKITA DE FREITAS, ${ }^{2}$ CAMILA BATISTA DALLA VECCHIA, ${ }^{3}$ EMANUEL JOSE LAHOS BORGES, ${ }^{4}$ GIOVANA LABIAK PEREIRA, ${ }^{5}$ KAROLYNE RIBEIRO DA CUNHA, ${ }^{6}$ CLAUDIA LOPES PERPETUO
\end{abstract}

\begin{abstract}
${ }^{1}$ Participante do PIC/UNIPAR - Acadêmica do Curso de Psicologia da UNIPAR
${ }_{1}^{1}$ Participante do PIC/UNIPAR - Acadêmica do Curso de Psicologia da UNIPAR

${ }^{2}$ Participante do PIC/UNIPAR - Acadêmico do Curso de Psicologia da UNIPAR

${ }^{3}$ Participante do PIC/UNIPAR - Acadêmica do Curso de Psicologia da UNIPAR

${ }^{4}$ Participante do PIC/UNIPAR - Acadêmica do Curso de Psicologia da UNIPAR

${ }^{5}$ Orientadora do PIC/UNIPAR - Docente da UNIPAR
\end{abstract}

Introdução: As concepções de beleza adotadas socialmente estão permeadas de valores contaminados pelo racismo estrutural. A instituição do padrão branco eurocêntrico como sendo o belo e correto, em detrimento do fenótipo negro, é uma grave expressão da falsa ideologia da superioridade racial. Questionar a estrutura e a representatividade racial na mídia veiculada em todos os meios de comunicação, principalmente no que está relacionado aos estereótipos reforçados, é essencial para reestruturação social e instituição de um pensamento verdadeiramente antirracista.

Objetivo: Demonstrar a influência que as concepções de belo exercem no nível de representatividade, integração e valorização social do negro.

Desenvolvimento: É importante lembrar a concepção eurocêntrica sobre a qual foi fundada a visão de homem adotada em nossa sociedade e as ideologias que permearam a humanidade apontando os negros como biologicamente inferiores aos brancos e até mesmo teorias que alegavam a inexistência da alma da pessoa negra como forma de justificar e autorizar a escravidão. Ainda que todos estes ideais tenham sido desacreditados, as consequências sociais do período escravocrata e da propagação dessa linha de pensamento se apresentam até os dias atuais. Dentro desse contexto histórico, no qual a negritude foi relacionada a noções de ruim e marginalização, nasce o ideal branco de conduta e beleza. É este padrão que é desejado, buscado e exibido nos mais diversos meios de comunicação e representado majoritariamente em novelas, filmes e publicidades, mesmo que a população negra corresponda a $55,8 \%$ do total da população brasileira (IBGE, 2019). É a autoridade da estética branca quem define o belo e sua contraparte, o feio, nesta sociedade classista, onde os lugares de poder e tomada de decisões são ocupados hegemonicamente por brancos. É ela quem afirma 'o negro é o outro do belo'. É esta mesma autoridade quem conquista, de negros e brancos, o consenso legitimador dos padrões ideológicos que discriminam uns em detrimento de outros. (SOUZA, 2008). A representação do negro em publicidades entre os anos de 1987 e 2017 é de apenas 12\%, sendo 8\% de homens e 4\% de mulheres (CAMPOS; FELIX, [2019?]). Pode-se observar que além da sub-representação racial há também a questão gênero, que é um grande reflexo social que mostra o ser mulher e negra como um dos marcadores sociais de maior opressão. Destaca-se ainda que incluídos neste baixíssimo índice representativo estão papéis desfavoráveis à construção de imagem positiva do negro, pois muitas vezes o negro está presente, mas apenas para reforçar estereótipos de hiperssexualização e subalternidade. Essa não-humanização do corpo negro e a ausência de reconhecimento do negro como belo gera graves danos à formação identitária do sujeito negro (bem como do não-negro) e gera o auto-ódio. Estas máculas causadas ao imagético do negro levam-no a conceber um ideal de ego branco e negar a si mesmo ao adotar tentativas de embranquecimento de sua representação social, seja por meio da estética ou dos comportamentos espelhados. São comuns os relatos de pessoas que durante a infância utilizaram alvejante em sua pele como tentativa de clareá-la e também o uso de pregadores no nariz diariamente com o objetivo de afiná-lo, além dos tradicionais alisamentos capilares e da aplicação de maquiagem em tons mais claros. A negritude é uma construção social e cultural. Por isso, ainda que uma pessoa nasça com a pele retinta, cabelo crespo ou cacheado e traços marcados, pode demorar anos para se reconhecer enquanto pessoa negra.

Assim, ser negro não é uma condição dada, a priori. É um vir a ser. Ser negro é tornar-se negro. (SOUZA, 2008). Embora o movimento em defesa da estética negra seja questionado e muitas vezes considerado superficial, é importante compreender que a beleza é um representativo de poder social e, portanto, um instrumento fundamental de mobilização social. A ausência de representatividade negra é uma constante afirmação de que a beleza branca é superior à negra e, consequentemente, induz a sociedade a perpetuar pensamentos e valores de subalternização e inferiorização da população negra. Reconhecer e promover a beleza negra é imprescindível para confrontação do sistema de dominação e opressão e para gerar questionamentos a respeito do racismo internalizado, pois tornar consciente a razão de existência destes pré-julgamentos é o caminho para que eles sejam transformados. A construção de uma sociedade antirracista perpassa necessariamente pela ressignificação da negritude e em especial da imagem do corpo negro, com todos os seus traços característicos, e em especial do cabelo, pois ultrapassa o campo 
estético e se estabelece como símbolo de revolução social e política.

Conclusão: A promoção de representatividade racial contribui de forma efetiva com a luta antirracista, posto que os conceitos de beleza exercem grande impacto político e questionar a interpretação de nossos olhos quanto ao que é belo é ato necessário para o processo de transformação social.

\section{Referências}

CAMPOS, Luiz Augusto; FELIX, Marcelle. Diversidade racial e de gênero na publicidade brasileira das últimas três décadas (1987-2017). [2019?]. Disponível em: http://gemaa.iesp.uerj.br/infografico/diversidade-racial-e-de-genero-na-publicidadebrasileira-das-ultimas-tres-decadas-1987-2017/. Acesso em: 20 agosto. 2020.

IBGE Instituto Brasileiro de Geografia e Estatística. Pretos ou pardos estão mais escolarizados, mas desigualdade em relação aos brancos permanece. 13.11.2019. Disponível em: https://agenciadenoticias.ibge.gov.br/agencia-sala-deimprensa/2013-agencia-de-noticias/releases/25989-pretos-ou-pardos-estao-mais-escolarizados-mas-desigualdade-em-relacaoaos-brancos-permanece. Acesso em: 20 agosto. 2020.

SOUZA, Neusa Santos. Tornar-se negro: as vicissitudes da identidade do negro brasileiro em ascensão social. 2. ed. Rio de Janeiro: Edições Graal, 1983. p. 29 e 77. 


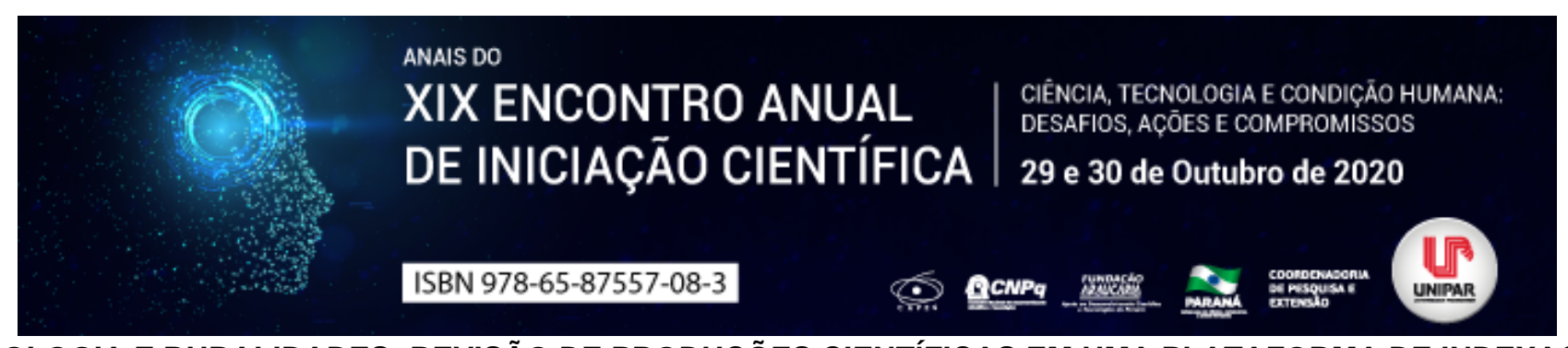

PSICOLOGIA E RURALIDADES: REVISÃO DE PRODUÇÕES CIENTÍFICAS EM UMA PLATAFORMA DE INDEXAÇÃO

\author{
${ }^{1}$ LUANI AKEMI FURYAMA, ${ }^{2}$ ISABELA SANTOS MENDONCA, ${ }^{3}$ MARIANA DUARTE MILANI DE HOLANDA, ${ }^{4}$ CLARICE REGINA \\ CATELAN FERREIRA
}

${ }^{1}$ Acadêmica do PIC/UNIPAR
${ }^{1}$ Acadêmica do PIC/UNIPAR
${ }^{2}$ Acadêmica do PIC/UNIPAR
${ }^{3}$ Docente da UNIPAR

Introdução: As definições de rural ainda são permeadas de estereótipos equivocados que acarretam em estigmas relacionados às populações do campo, caracterizando-as como pobres e atrasados e desconsiderando a amplitude de contextos e vivências experienciadas por esses indivíduos (LOPES; FERREIRA; FRIEDRICH, 2018). Segundo dados do IBGE (2015), 15,28 $\%$ de toda população nacional são moradores de zonas rurais, logo, considerando o indivíduo como biopsicossocial e que tem como um dos componentes de constituição da sua subjetividade o meio em que se relaciona, se vislumbra a necessidade de um olhar diferenciado entre as comunidades rurais e urbanas dos profissionais que atuam no campo, inclusive no que tange à Psicologia. A Psicologia como ciência e profissão deve considerar essas singularidades para que possa atuar abarcando a integralidade e complexidade do campo, no entanto, Leite, Macedo, Dimenstein et al (2013) evidenciam que há uma carência na discussão desta temática nas graduações em Psicologia, o que acarreta em um despreparo de profissionais inseridos nesses locais. Considerando essa relação entre o rural e a Psicologia, essa pesquisa refere-se a uma investigação das produções científicas no campo da Psicologia e das ruralidades, com a finalidade de realizar um levantamento dessas produções e da importância dos estudos a respeito dessa temática.

Objetivos: Investigar as produções científicas realizadas no campo da Psicologia sobre a temática ruralidades.

Desenvolvimento: Essa pesquisa, em andamento, está sendo realizada com finalidades investigativas das produções científicas relacionadas à Psicologia nos contextos rurais. A plataforma escolhida foi a Scielo, tendo em vista que a mesma está vinculada à FAPESP, BIREME e CNPq, o que demonstra qualidade e processos rigorosos de seleção de periódicos, além disso, ela indexa 88 periódicos na área de ciências humanas e é uma plataforma gratuita. Após a escolha da plataforma, os descritores utilizados para a pesquisa foram Psicologia e Rural , e não foram especificados os anos das produções como filtro. Como resultado desta etapa de busca, obtivemos 88 artigos, publicados entre os anos 1999 e 2020. O próximo passo da pesquisa foi realizar a seleção de artigos que continham no título ou nas palavras-chave o termo Psicologia e Rural, restando 45 artigos. Os motivos que levaram ao descarte dos outros 43 artigos foram: não possuir relação com a proposta da pesquisa, não ter pelo menos um autor Psicólogo, ou ser de uma língua estrangeira. Logo após foi realizada mais uma filtragem através da leitura dos resumos para definir quais artigos contribuem e que estão de fato relacionados ao campo da Psicologia e das ruralidades, sendo assim, restaram 34 artigos. Os 11 artigos descartados estavam mais relacionados aos campos de história, sociologia, serviço social e saúde. Após o procedimento de seleção dos 34 artigos, avançou-se para a etapa de distribuição dos artigos em categorias com o objetivo de obter dados de quais áreas a Psicologia está mais inserida nas questões do campo. Totalizou-se 8 categorias, sendo: crianças e adolescentes no campo (8 artigos); tradições, culturas e significações (7 artigos); políticas públicas no campo (7 artigos); reflexões sobre a atuação do Psicólogo no campo (3 artigos); mulheres no campo (3 artigos); movimentos sociais (3 artigos); educação no campo (2 artigos); saúde dos moradores do campo (1 artigo).

Conclusões: Conclui-se até o momento da pesquisa, que o número de publicações no campo da Psicologia e das ruralidades é pequeno considerando a quantidade de pessoas que habitam localidades rurais. Sendo assim, percebe-se a necessidade de mais estudos e publicações relacionadas à essa temática e que possam embasar as práticas do profissional Psicólogo. As universidades devem promover esse contato com outras realidades nas graduações e os profissionais devem estar adeptos e preparados à adequarem suas práticas a cada contexto e suas vivências.

\title{
Referências
}

LEITE, J. F.; et al. A formação em Psicologia para a atuação em contextos rurais. In: LEITE, J. F.; DIMENSTEIN, M. (Orgs). Psicologia e Contextos Rurais. RN: EDUFRN, 2013. p. 27 - 56.

LOPES, E. M.; FERREIRA, C. R. C.; FRIEDRICH, D. R. Psicologia e Ruralidades: caminhos para um fazer psicológico transformador. Rev. Psicologia, Conocimiento y Sociedad, v. 8, n. 1. maio./out. 2018.

IBGE. Pesquisa nacional de amostra por domicílio: síntese de indicadores. Rio de Janeiro: IBGE, 2015. Disponível em: https://biblioteca.ibge.gov.br/index.php/biblioteca-catalogo?view=detalhes\&id=298887. Acesso em: 20 jul. 2020. 
Coordenadoria de Pesquisa e Extensão - COPEX

Departamento de Editoraçāo e Divulgaçāo Científica - DEDIC 


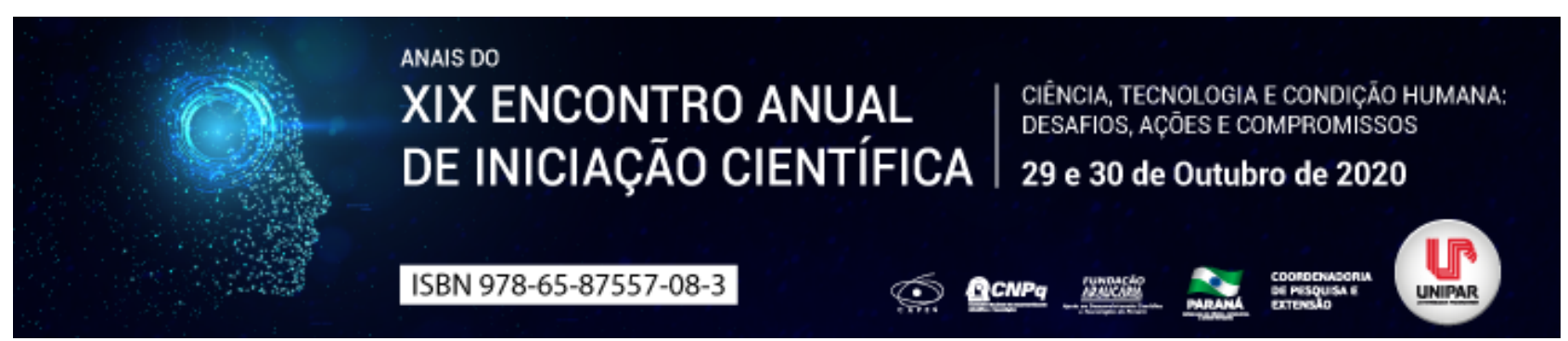

AS HOMOFOBIAS NA UNIVERSIDADE E SEUS IMPACTOS NO SOFRIMENTO PSICOSSOCIAL

\section{${ }^{1}$ CAROLINE FELIX SATURNINO, ${ }^{2}$ GILBERTO ALVES, ${ }^{3}$ DANIELLE JARDIM BARRETO}

${ }^{1}$ Discente do curso de Psicologia da UNIPAR. Bolsista PEBIC/Fundação Araucária

${ }^{1}$ Docente da UNIPAR

${ }^{2}$ Docente da UNIPAR

Introdução: Este trabalho busca problematizar as relações universitárias, com ênfase as que implicam em relações homofóbicas, reconhecidas em uma pesquisa científica já finalizada em 2018. De acordo com Louro (2000), os discursos ditam as possibilidades de se construir identidades na dicotomia homem-mulher, sendo as expectativas de pluralidade diante da sexualidade aniquiladas, os prazeres e desejos são limitados e estabelecidos socialmente. Esses discursos geram violências homofóbicas e causam impactos que degradam a saúde mental dos indivíduos que fogem da norma. Este trabalho é relevante tanto do ponto de vista da formação de acadêmicos na área de conhecimento da Psicologia Social, quanto para a gestão de políticas educacionais singulares dentro do nosso ambiente universitário.

Objetivo: Problematizar as práticas de homofobia acometidas no interior da universidade e, diante disso, as possíveis consequências na saúde mental para acadêmicos.

Material e Métodos: Este trabalho tem como fonte de dados, questionários aplicados na pesquisa intitulada LGBTFOBIA E RE(VE)LAÇÕES UNIVERSITÁRIAS: construindo um instrumento de pesquisa (ALMEIDA JUNIOR; ZONTA; BARRETO; 2018), aprovada pelo comitê de ética sob o protocolo 74185517.4.0000.0109. A amostra foi composta de 671 participantes, onde 20 se auto declaram homens gays e os questionários destes foram separados para realizar a atual pesquisa, na qual analisamos os dados de práticas homofóbicas ocorridas no interior da universidade através das respostas obtidas em seis itens dos questionários aplicados, a saber: item 26: Quais as práticas LGBTfóbicas percebidas com este público LGBT? ; item 30:

Caso você se identifique como um LGBT, você já foi vítima de discriminações e preconceitos no ambiente acadêmico? ; item 31: Quais foram às práticas de discriminação e preconceitos feitas com você? ; item 34: Como você se sentiu após o ocorrido? e item 35: Você já relatou alguma dessas discriminações para alguém ou para algum órgão competente com o intuito de pedir ajuda? . Além das análises quantitativas realizadas através dos cálculos das porcentagens das respostas, utilizamos também análises qualitativas dos resultados das homofobias sofridas pelos acadêmicos e efeitos delas.

Resultados: Diante das respostas dos questionários analisados, podemos afirmar que para $90 \%$ dos respondentes homens gays, a LGBTfobia no interior da universidade, teve efeitos extremamentes prejudiciais a saúde mental, visto que os acadêmicos relataram que após os ataques homofóbicos se sentirem ofendidos, tristes, irritados, desanimados com o ambiente universitário, depressivos e ansiosos.

Discussão: A homofobia se caracteriza pela repulsa dos indivíduos que fogem à norma, tornando-os sujeitos desviantes, abomináveis e anormais. Ela contribui para a manutenção da supervalorização da heterossexualidade e se apresenta desde as formas mais violentas até as mais sutis (BORRILLO, 2001). De acordo com Louro (2000), grande parte das instituições atuam para padronizar os corpos esperando-se que os sujeitos possuam uma conduta de acordo com as normas e os que não seguem esses padrões são marginalizados. Esses corpos marginalizados são tratados como desviantes e patologizados, onde por muito tempo a ciência foi grande contribuinte disso (FOUCAULT, 1988). Segundo Amarante (2013), podemos pensar saúde mental como um conceito amplo, devendo levar em conta as homofobias sofridas pelos homens gays no contexto universitário. Podemos refletir também sobre a sutileza nas práticas LGBTfóbicas sofridas ou presenciadas pelos homens gays respondentes, que se mostraram em maior parte através de piadas, que para Borrillo (2001), são práticas de violência veladas. As desqualificações, ofensas e difamações também apresentam alto índice entre as violências sofridas apresentadas nos questionários, para Nardi (2013), essas violências podem possivelmente acompanhar as vítimas desde seu ingresso na universidade pois desde os trotes universitários as práticas humilhantes através de chacotas com o público homossexual acontecem, podem acontecer também através dos discursos de alunos e inclusive de professores no ambiente universitário.

Conclusão: Considerando o conceito ampliado de saúde mental no qual, de acordo com Amarante (2013), precisamos analisar além do bem-estar físico mas também o bem-estar do contexto social, onde ambos se encontram interligados para contribuir com a saúde dos sujeitos, devemos repensar sobre as possibilidades de aceitação de diversos modos de vida no ambiente universitário, para que este seja um local de respeito e contribuições efetivas à saúde mental da comunidade universitária. É necessário também, buscar um novo modelo de educação na universidade, onde esses modos de vida sejam aceitos e os profissionais sejam formados para atuar com ética e respeito para com a comunidade LGBTTI+ (NARDI et al., 2013).

\section{Referências}


ALMEIDA JUNIOR, Claudio Leão de.; ZONTA, Fernanda Gracielle Aguiar.; BARRETO, Danielle Jardim. LGTBfobia e re(ve)lações universitárias: construindo um instrumento de pesquisa. In: III Colóquio Nacional de Estudos de Gênero e História: epistemologias, interdições e justiça social, 2018, Marechal Cândido Rondon. Anais do III Colóquio Nacional de Estudos de Gênero e História: epistemologias, interdições e justiça social, 2018. p. 987-999.

AMARANTE, Paulo. Saúde mental e atenção psicossocial. 4. Ed. Rio de Janeiro: Editora Fiocruz, 2013.

BORRILLO, Daniel. Homofobia. 1. ed. Barcelona: Bellaterra, 2001.

FOUCAULT, Michel. História da sexualidade I: a vontade de saber. 13. ed. Rio de Janeiro: Edições Graal, 1988.

LOURO, Guacira Lopes. O corpo educado: pedagogias da sexualidade. 2. ed. Belo Horizonte: Autêntica, 2000.

NARDI, H. et al. O armário da universidade: O silêncio institucional e a violência, entre a espetacularização e a vivência cotidiana dos preconceitos sexuais e de gênero. Teoria e Sociedade, v. 21, n. 2, p. 179-200, jul/dez. 2013.

Coordenadoria de Pesquisa e Extensão - COPEX

Departamento de Editoraçāo e Divulgaçāo Científica - DEDIC 


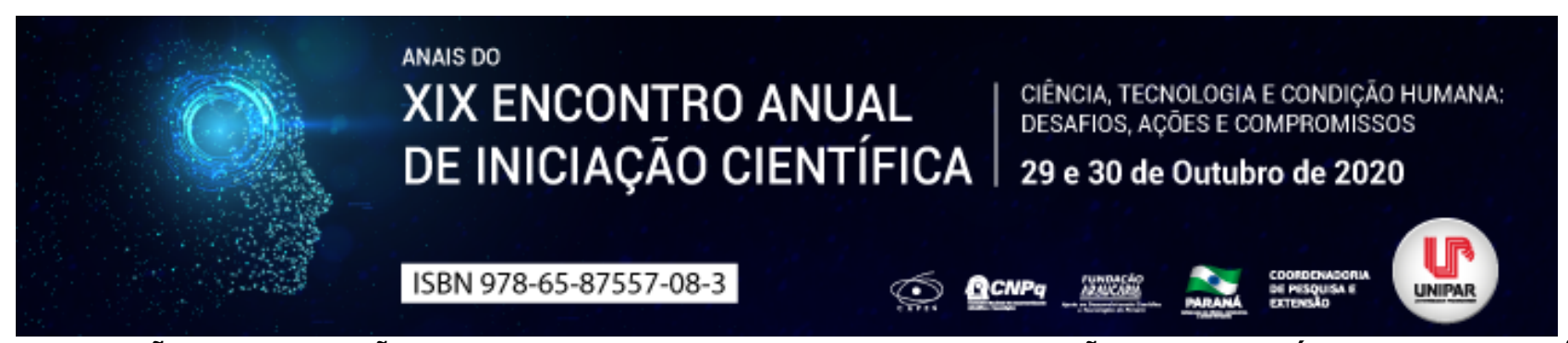

REPERCUSSÕES DA SOLIDÃO NA QUALIDADE DE VIDA DO IDOSO: REVISÃO BIBLIOGRÁFICA SOBRE SAÚDE MENTAL NA TERCEIRA IDADE

\author{
${ }^{1}$ ALINE PERIN PADILHA, ${ }^{2}$ NAYSSARA CAROLINA SILVA TASCHIN, ${ }^{3}$ ANA CLAUDIA PANSERA, ${ }^{4}$ ISADORA GAGLIOTTO \\ GALVAN, ${ }^{5}$ MATEUS JOAO CORDEIRO SCHMOELLER DE LIMA, ${ }^{6}$ CLAUDIA MAIO ANTONELLI
}

\begin{abstract}
${ }^{1}$ Acadêmica do curso de Psicologia da UNIPAR
${ }^{1}$ Acadêmica do Curso de Psicologia da UNIPAR

${ }^{2}$ Acadêmica do Curso de Psicologia da UNIPAR

${ }^{3}$ Acadêmica do Curso de Psicologia da UNIPAR

${ }^{4}$ Acadêmico do Curso de Psicologia da UNIPAR

${ }^{5}$ Docente da UNIPAR
\end{abstract}

Introdução: O quadro demográfico do século 21 no Brasil indica que o avanço da medicina, das políticas de saúde e sociais, acarretaram no aumento considerável da população idosa nos últimos anos (PARANÁ, 2018). Nesse período ocorrem mudanças físicas, psíquicas e sociais, que interferem na forma como se envelhece. Os objetivos das redes de saúde são manter a qualidade de vida e a independência do idoso, no entanto é necessário maior atenção a políticas voltadas à saúde mental e ressocialização do idoso. Lopes, Lopes e Câmara (2009) apontam a solidão como um fator prejudicial para a qualidade de vida, que se torna mais evidente na terceira idade. Aprofundar o conhecimento sobre o sentimento de solidão e seu impacto na qualidade de vida da população idosa, implica em rever práticas profissionais e preparar os serviços de saúde, com contribuições dos profissionais da psicologia, para atendimento das novas demandas de saúde (BRASIL, 2006).

Objetivos: Por meio de uma revisão bibliográfica, apresentar uma breve discussão sobre as consequências da solidão para a população idosa.

Desenvolvimento: Para Papalia e Feldman (2013), a velhice é caracterizada como Vida Adulta Tardia, compreendendo as idades acima de 65 anos, induzindo ao declínio físico do organismo e carregando elementos que atribuem novos papéis na sociedade e novas etapas no desenvolvimento psicossocial. Com a mudança da pirâmide demográfica e acesso a possibilidades de melhores condições de vida, a população de pessoas que chegam a velhice aumentou significamente. A qualidade de vida na velhice está intrinsecamente ligada a alegria na vida, amor e amizade, além da importância de um envelhecimento com saúde que dependerá de características econômicas e, primordialmente, às políticas públicas que possibilitem autonomia, exercícios físicos, bons relacionamentos e bem estar psicológico. (IRIGARAY; TRENTINI, 2009). Entretanto, nota-se que a realidade da maioria dos idosos é uma sucessão de doenças, diminuição da capacidade funcional, ao abandono e a perdas significativas em todas as esferas da vida (COSTA, 2013). É comum o idoso enfrentar mudanças emocionais decorrentes de separações, isolamento e dores corporais. Em muitos casos eles estão desamparados para lidar com esses problemas, o que pode incitar o sentimento de solidão (SANTOS; SILVA, 2009). Segundo Gomes, Loureiro e Alves (2012) ao longo de toda a vida as pessoas criam laços afetivos que se tornam a base de sua felicidade, e com a velhice muitos desses laços são perdidos, muitas vezes pela própria morte de cônjuges, familiares, amigos. A própria antecipação do seu fim, geralmente intensificada com essas perdas remetem, comumente a sentimentos intensos de solidão e angústia. A solidão é uma experiência subjetiva que, de uma perspectiva sociológica, é produto de uma sociedade que celebra o individualismo (COSTA, 2013). A experiência da solidão está relacionada com a qualidade das interações sociais e dos laços afetivos que os sujeitos possuem. As queixas desse sentimento são alusivas à vínculos poucos satisfatórios que não suprimem a necessidade de contato e de apoio (FONSECA, 2015). A disponibilidade de apoio emocional e a construção de laços positivos é imprescindível para a manutenção da saúde, além de auxiliar na satisfação de vida em face dos traumas e estresses dessa etapa. Pesquisas de Hawkley e Cacioppo (2007 apud PAPALIA; FELDMAN, 2013) apontam que a solidão e o isolamento social podem acelerar o declínio físico e cognitivo, além de constituir um fator de risco para a mortalidade, doenças crônicas, transtornos de ansiedade e depressão.

Azeredo e Afonso (2016) definem a solidão como um afeto penoso e angustiante, e que a não compreensão e validação dessas vivências pode propiciar o surgimento de uma depressão com manifestações atípicas, que passa despercebida. A solidão está associada a doenças físicas e psíquicas e pode ser um fator de risco alto para suicídio. Leandro-França e Murta (2014) ratificaram que estudos sobre prevenção e promoção da saúde mental para idosos são escassos e reiteram a importância desses programas voltadas a qualidade de vida na velhice. Ademais, demonstram que já existe algum caminho trilhado nessa direção, com a invenção de práticas benéficas como a Universidade Aberta da Terceira Idade (UnATI) que possibilita uma maior inclusão do idoso.

Conclusão: Ao considerar o fenômeno do envelhecimento e sua relação com a solidão, fica evidente a necessidade de esforços 
da família, das equipes e da própria sociedade para ofertar condições dignas e humanizadas. Reduzir preconceitos, acolher, ressocializar e manter vínculos afetivos e sociais propiciam a valorização do sujeito idoso e a diminuição do seu isolamento. É fundamental o cuidado integral através da articulação de políticas de atenção em rede; saúde, assistência social, previdência social e direitos humanos. Destaca-se aqui, a emergência de um olhar acerca da subjetividade do idoso, no sentido de desenvolver políticas voltadas a saúde mental, visando minimizar o sofrimento psíquico e transtornos mentais como a depressão, possibilitando uma qualidade de vida que reconquiste de sua cidadania.

\section{Referências}

AZEREDO, Zaida de Aguiar Sá; AFONSO, Maria Alcina Neto. Solidão na perspectiva do idoso. Revista brasileira de Geriatria e Gerontologia, Rio de Janeiro, v. 19, n. 2, p. 313-324, 2016. Disponível em: < https://www.scielo.br/scielo.php?pid=S180998232016000200313\&script=sci_abstract\&tlng=pt $>$.

BRASIL. Ministério da Saúde. Envelhecimento e saúde da pessoa idosa. Departamento de Atenção Básica Brasília : Ministério da Saúde, 2006.

COSTA, Filipa Cardoso. A solidão como fator de risco para depressão, na terceira idade. Dissertação (Mestrado em Psicologia Clínica e da Saúde)- Universidade Católica Portuguesa, Braga, 2013. Disponível em: .

FONSECA, Doralice M. Abandono e Solidão na Terceira Idade: 0 Caso de São Vicente. Monografia (Grau de Licenciatura em Sociologia)- Universidade do Mindelo, Mindelo, 2015. Disponível em: .

GOMES, Lucy; LOUREIRO, Altair Macedo Lahud; ALVES, Vicente Paulo. O velho e a morte. Rev. Kairós, p. 117-132, 2012.

IRIGARAY, Tatiana Quarti; TRENTINI, Clarissa Marceli. Qualidade de vida em idosas: a importância da dimensão subjetiva. Estud. psicol. (Campinas) vol.26 no.3 Campinas July/Sept. 2009. Disponível em: .

LEANDRO-FRANÇA, Cristineide; MURTA, Sheila G. Prevenção e promoção da saúde mental no envelhecimento: conceitos e intervenções. Revista Psicologia: Ciência e profissão, v. 34, n. 2, p. 318-329, 2014.

LOPES, Renata Francioni; LOPES, Maria Teresinha Francioni; CÂMARA, Vilma Duarte. Entendendo a solidão do idoso. Revista Brasileira De Ciências Do Envelhecimento Humano, v. 6, n. 3, p. 373-381, Passo Fundo-RS, 2009. Disponível em: .

PAPALIA, Diane. E.; FELDMAN, Ruth Duskin. Desenvolvimento humano, 12a ed. Porto Alegre: AMGH Editora, 2013.

PARANÁ. Secretaria de Estado da Saúde do Paraná. Linha guia da saúde do idoso. Curitiba : SESA, 2018.

SANTOS, Luís Fernando S; SILVA, Daniel Tomaz. Viva bem a terceira idade, 1.ed. Rio de Janeiro: Livre expressão, 2009.n 


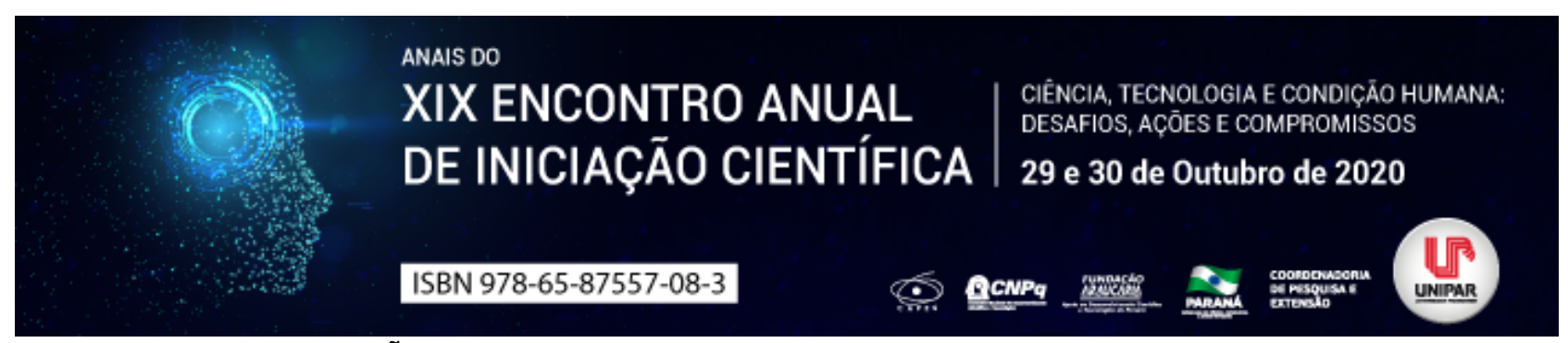

\title{
A EFETIVIDADE DA CONSTITUIÇÃO FEDERAL DE 1988: UMA ANALISE SOBRE SEU SIMBOLISMO PARA POPULAÇÕES POBRES
}

\author{
${ }^{1}$ RODOLFO EVANDRO TITON, ${ }^{2}$ BRUNO SMOLAREK DIAS
}

\author{
${ }^{1}$ Acadêmico do Curso de Direito da UNIPAR \\ ${ }^{1}$ Docente da UNIPAR
}

Introdução: O presente trabalho pretende tratar sobre a efetividade da constituição federal em determinados bolsões de pobreza pelo Brasil. Nota-se que a Magna Carta foi criada com preceitos sociais, direitos fundamentais e garantias constitucionais, provenientes de correntes progressista dos últimos anos que aludiam a constituição alemã e italiana. Estes e outros fatores, como o fim da ditadura em 1985, fizeram-na com que fosse chamada de Constituição cidadã. Trinta e dois anos após sua promulgação ela ainda encontra barreiras legislativas, políticas e judiciárias para surtir efeito. Para determinados grupos, como o presente caso vai apresentar sobre Paraná e Rio de Janeiro, ela é simbólica. A presente pesquisa se perfaz sob método dedutivo com analise de cunho bibliográfico e o método dialético, empregado em pesquisa qualitativa, considera que os fatos não podem ser considerados fora de um contexto social; as contradições se transcendem dando origem a novas contradições que requerem soluções.

Objetivos: Demonstrar a importância de uma Carta Constituinte e como a sua baixa efetividade, marginaliza e cria bolsões de pobreza pelo Brasil, fazendo com que ao mesmo tempo estes sejam os que mais precisam eficácia constitucional. Por fim incentivar o debate jurídico sobre este âmbito.

Desenvolvimento: Sendo criada após o fim de uma ditadura militar que durou vinte e um anos, a Constituição Federal de 1988 trouxe à tona um Estado democrático de Direito qual dedicar-se-ia a promulgar e efetivar direitos e garantidas fundamentais, sejam elas individuais ou sociais (BRASIL,1988.) Isto se daria através de um esforço coletivo de todas as esferas de seus poderes, judiciário, legislativo e executivo da maneira que existiram métodos de pesos e contrapesos para isso ocorrer. (MORAES, 2007). Os mais amplos direitos em que a Carta Magna se comprometeu em prover foram direitos da $1^{\mathrm{a}}$, $2^{\mathrm{a}}$ e $3^{\mathrm{a}}$ dimensão dos direitos fundamentais. Entretanto, em uma análise estatística nota-se a deficiência em entregar estes serviços à população. A síntese fica para áreas da saúde, educação, transporte e segurança esmiuçadas durante o trabalho. Com os bolsões de pobreza, isto é favelas, englobando $6 \%$ de população brasileira, cerca de 12 milhões de pessoas (IBGE, 2018) a falta de acesso a esses sistemas cria estas regiões e faz com que seus moradores entrem num ciclo vicioso de demanda por um Estado mais presente, que na pratica não ocorre. Nota-se que as razões são pautadas, como o fato de que o legislador preocupa-se apenas na produção das normas e não em criar ou analisar determinado ambiente (KINDERMANN, 1988, p. 227 apud NEVES, 2011, p. 31). A esfera legislativa não fica só, no sistema Judiciário ocorre o déficit de juízes e a sobrecarga daqueles que lá estão (CNJ, 2018), coexistindo ainda fatores econômicos e sociais que dificultam o acesso desses moradores à justiça; soma-se isso a um poder Executivo que vem anualmente, governo após governo, sendo investigado por corrupção - o Brasil é $106^{\circ}$ menos corrupto (IPC, 2019) traduzindo-se numa má gestão das políticas públicas. Perfaz-se o estudo sobre o caso do Rio de Janeiro onde a primeira favela brasileira se encontra e escancara a negligencia do estado com esta parcela populacional através de programas mal administrados. Não distante da realidade carioca está o Paraná, sendo o sexto estado com mais favelas do Brasil (IBGE, 2018) e com um número expressivo de assentamentos irregulares. Portanto a questão tornase social e estrutural, com a baixa efetividade da constituição federal nessas regiões temos milhões e milhões de brasileiros a deriva, encarando a mais alta lei desse país de maneira simbólica, como descrito por Marcelo Neves as leis constituem meios insuperáveis para se alcançar determinados fins 'desejados' pelo legislador, especialmente a mudança social, implica um modelo funcional simplista e ilusório (NEVES, 2011, p. 29).

Conclusão: Aqui cabe ressaltar que a Constituição sendo o ápice da norma em um ordenamento jurídico, e também reflexo para as outras normas hierarquicamente inferiores, compreende-se que a função simbólica que nela recai é o princípio primeiro da ordem jurídica. Faz-se necessário que a constituição deixe de ser simbólica no seu mais profundo espectro pois tal problema não se direciona unicamente a favela e seus habitantes, afeta a todos e em todas as esferas. A longo prazo a inobservância de direitos fundamentais resulta em danos cada vez mais irreversíveis.

\section{Referências}

BRASIL. Constituição (1988). Constituição da República Federativa do Brasil. Brasília, DF: Senado Federal: Centro Gráfico, 1988

IBGE, 2018. Disponível em: https://www.ibge.gov.br/estatisticas/downloads-estatisticas.html._Acesso em: 26 de junho de 2020. INTERNATIONAL, Transparency $\quad$ Corruption $\quad$ Perceptions Index 2019 Disponível 
https://www.transparency.org/en/countries/brazil. Acesso em: 24 de junho e 2020.

JUSTIÇA, Conselho Nacional. Justiça em Números. CNJ. Brasília, 2019. Disponível em: https://www.cnj.jus.br/wpcontent/uploads/conteudo/arquivo/2019/08/justica_em_numeros20190919.pdf. Acesso em: 24 de junho de 2020.

MORAES, A de. Direitos Humanos Fundamentais: Teoria geral. $8^{a}$ ed. São Paulo: Atlas, 2007

NEVES, Marcelo. A constitucionalização simbólica. 3. Ed. São Paulo: WMF Martins Fontes, 2011.

NEVES, Marcelo. Constituição e direito na modernidade periférica. 1. Ed. São Paulo: WMF Martins Fontes, 2018.

Coordenadoria de Pesquisa e Extensāo - COPEX

Departamento de Editoração e Divulgaçāo Científica - DEDIC 


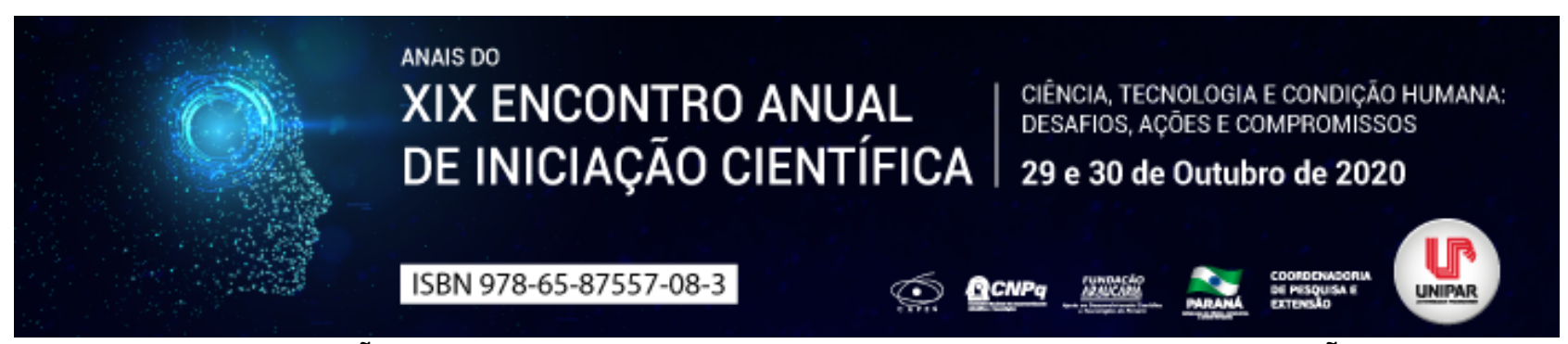

A EDUCAÇÃO SOCIOEMOCIONAL NO CONTEXTO ESCOLAR: CONTRIBUIÇÕES

\author{
${ }^{1}$ Gabriel Antonio Parra Valhejo, ${ }^{2}$ MARIA DO CARMO DE O NOGUEIRA
}

${ }^{1}$ Pós-graduando em Psicomotricidade pela Pontifícia Universidade Católica do Paraná PUC/Curitiba PR. Graduado em PEDAGOGIA - UNIPAR

${ }^{1}$ Docente PEDAGOGIA-Presencial / UNIPAR

Introdução: Na visão da escola tradicional, ensinar e disseminar conhecimentos e competências socioemocionais e desenvolver a criticidade nos e dos alunos são consideradas irrelevantes, haja vista, seu foco ser a mera e inevitável transmissão do conhecimento de modo verticalizado, ou seja, tendo o professor como agente ativo e detentor de todo conhecimento e, o aluno como sujeito passivo, que apenas recebe as informações e tem de decorá-las, desconsiderando toda sua cultura e especificidade.Muito se tem dito sobre revitalizar o processo de ensino e aprendizagem, que a metodologia tradicional já não consegue mais alcançar o estudante de modo que internalize em si os conceitos e os conhecimentos trabalhados em sala de aula. Desde modo, a busca incessante por formar os sujeitos por completo é inevitável. Como é o caso da relevância de se trabalhar a educação socioemocional na escola.

Objetivo: Compreender a importância da educação socioemocional no contexto escolar, bem como o favorecimento de competências e habilidades quando veiculada neste meio.

Desenvolvimento: Um dos problemas presente na educação do século XXI é conseguir proporcionar um processo de ensino e aprendizagem que consolide os interesses dos estudantes que adentram os muros escolares e todo conhecimento histórico, cultural e científico acumulado pela humanidade, ao invés de uma educação verticalizada. De acordo com Abed (2016, p. 14) a função da escola vai muito além da transmissão do conhecimento, pois é urgente e necessário fortalecer muitas e variadas competências nas nossas crianças e jovens, que Ihe possibilitem construir uma vida produtiva e feliz em uma sociedade marcada pela velocidade das mudanças. Em consonância a esta ótica o processo escolar deve constituir e formar os sujeitos de modo integral, ou seja, não apenas em competência cognitiva, isto quando consegue alcançar este objetivo, mas em caráter criativo, ético, crítico e socioemocional. Este último, segundo IAS (2014, p. 09 apud CARVALHO E SILVA, 2017, p. 184) é um aspecto que abre caminhos para se relacionar com os outros e consigo mesmo, compreender e gerir emoções, estabelecer e atingir objetivos, tomar decisões autônomas e responsáveis e enfrentar situações adversas de maneira criativa e construtiva. As competências socioemocionais priorizadas nesse contexto são aquelas que desempenham um papel crucial na obtenção do sucesso escolar e na vida futura das crianças e jovens. Tal prerrogativa enfatiza a importância de trabalhar a competência socioemocional no processo de ensino e aprendizagem, não somente ele, mas em conjunto às demais competências e habilidades necessárias na formação dos sujeitos. Deste modo, torna-se relevante e de fundamental notoriedade trabalhar as habilidades socioemocionais, na qual dentre elas são imprescindíveis, conforme diz Abed (2016), a motivação, autonomia, trabalho em equipe e resiliência, além de responsabilidade, empatia, relações saudáveis consigo mesmo, com o próximo e com o meio, entre outras. Motta e Romani (2019, p. 50) coloca que ao longo do desenvolvimento, a criança passa por diversas etapas em que necessita de suporte emocional do meio , sendo por sua vez, a escola um local em que ela passa grande parte do seu tempo, é mais do que viável trabalhar suas emoções e sentimentos, com intuito de formar sujeitos que ocasionarão transformações na sociedade com seu jeito e forma de interagir com o próximo, na busca por mais respeito e empatia. A educação socioemocional (ESE) é o processo de adquirir habilidades necessárias para reconhecer e gerenciar emoções, desenvolver cuidado e preocupação com outros, estabelecer relações positivas, tomar decisões responsáveis e manejar situações desafiadoras de forma eficaz (WEISSBERG et al, 2013, apud MOTTA E ROMANI, 2019, p. 50). Assim, definem-se, também, as competências socioemocionais como capacidades individuais que podem ser manifestadas com um padrão consistente de pensamentos, sentimentos e comportamentos, desenvolvidas por meio de experiências de aprendizagens formais e informais (OCDE, 2015, p. 35 apud LIMA, 2018, p. 21). O que se constata é que propondo uma formação que englobe esses princípios seria possível atender as angústias e anseios que os educandos têm consigo mesmo e com os outros, trazendo assim, interesse para os estudos, além de favorecer o seu desenvolvimento inter e intrapessoal, bem como melhores atitudes e habilidades.

Conclusão: Portanto, propõe-se ensinar os conteúdos curriculares a partir de uma matriz de competências para o século XXI, flexível e customizável a diferentes modelos de escola que combina competências cognitivas como a resolução de problemas e o pensamento crítico com competências socioemocionais como a colaboração e a responsabilidade (IAS, 2014, p. 13, apud CARVALHO E SILVA, 2017, p. 185). Neste sentido, é possível observar o quão importante e perspicaz é a educação englobar em sua formação um ensino socioemocional, que leve a constituir sujeitos críticos e cidadãos autênticos que levem à sociedade as mudanças necessárias para se viver em congruência uns com os outros. 


\section{Referências}

ABED, Anita Lilian Zuppo. 0 desenvolvimento das habilidades socioemocionais como caminho para a aprendizagem e o sucesso escolar de alunos da educação básica. São Paulo: Construção Psicopedagógica, vol. 24, nº 25, 2016. Disponível em: encurtador.com.br/mopwZ. Acesso em: 24 Ago. 2020.

CARVALHO, Rodrigo Saballa de, SILVA, Roberto Rafael Dias da. Currículos socioemocionais, habilidades do século XXI e o investimento econômico na educação: as novas políticas curriculares em exame. Curitiba: Educar em Revista, $n^{\circ} 63$, jan./mar. 2017. Disponível em: encurtador.com.br/hlG13. Acesso em: 16 Jul. 2020.

LIMA, Lígia Cristina Poffo. Competências socioemocionais na educação: um estudo sobre a sociabilidade requerida pelo capital no século XXI. Florianópolis: UFSC, 2018. Disponível em: encurtador.com.br/ILPTZ. Acesso em: 23 Jun. 2020.

MOTTA, Pierre Cerveira, ROMANI, Patrícia Fasolo. A educação socioemocional e suas implicações no contexto escolar: uma revisão de literatura. São Paulo, 49, $2^{\circ}$ sem. de 2019. Disponível em: encurtador.com.br/goszA. Acesso em: 25 Ago. 2020.

Coordenadoria de Pesquisa e Extensão - COPEX

Departamento de Editoraçāo e Divulgaçāo Científica - DEDIC 


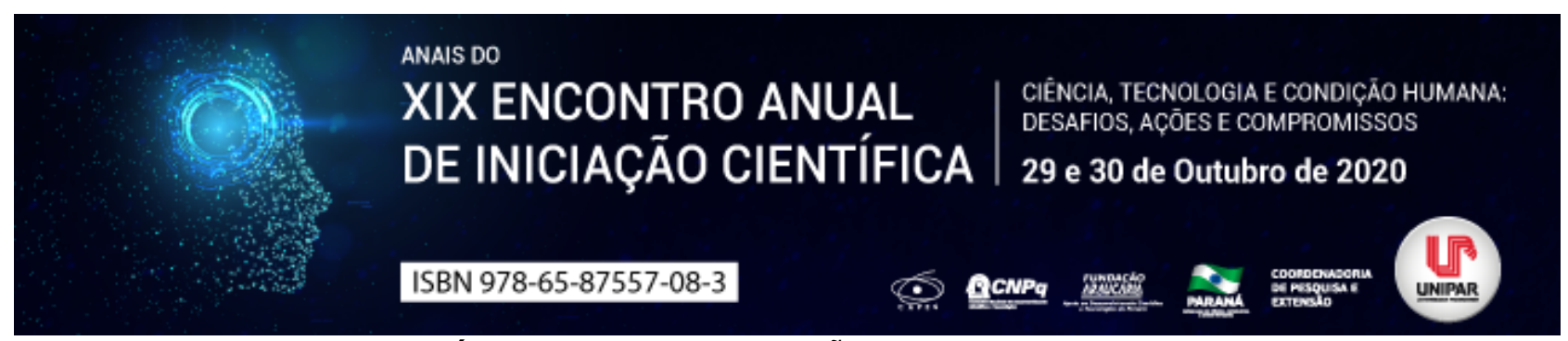

HISTÓRICO DA CLASSIFICAÇÃO RACIAL NO BRASIL

\title{
${ }^{1}$ MILENA DE LIMA, ${ }^{2}$ CINTHIA FERREIRA DOS SANTOS COSTA, ${ }^{3}$ ALINE COUTINHO DA LUZ, ${ }^{4}$ EMANUELLE TOTOLI DE OLIVEIRA, ${ }^{5}$ ROSANGELA BRESSAN BUOSI, ${ }^{6}$ ARNALDO GOMES DO AMARAL
}

\author{
${ }^{1}$ Discente do Curso de Engenharia Civil da UNIPAR \\ ${ }^{1}$ Acadêmica do Curso de Pedagogia da UNIPAR \\ ${ }^{2}$ Acadêmica do Curso de Engenharia Civil da UNIPAR \\ ${ }^{3}$ Acadêmica do Curso de Pedagogia da UNIPAR \\ ${ }^{4}$ Docente da UNIPAR \\ ${ }^{5}$ Docente da UNIPAR
}

Introdução: No Brasil encontra-se uma diversidade étnica de cor e raça que são classificados através de traços físicos, trajetória de vida do indivíduo e condições financeiras. É apresentado um histórico da classificação étnico-racial onde é composta por descendentes de três grandes grupos os indígenas, os africanos e os europeus.

Objetivo: Apresentar o histórico racial no Brasil.

Desenvolvimento: Tem-se registro que a escravidão no Brasil se instalou no início dos séculos XVI em 1535 a 1888. Nessa época era comum casos de fuga, no qual os donos de escravos publicavam anúncios de busca com a descrição física mais acurada possível, incluindo os detalhes de nuanças de cor da pele, dos cabelos e outros traços ou marcas, como cicatrizes ou falta de algum membro, para permitir e facilitar a identificação e a recuperação de quem tivesse fugido. Desenvolveu-se, dessa maneira, desde aquela época, uma terminologia de descrição da aparência ou traços físicos das características raciais dos indivíduos. (PETRUCCELLI, 2013, p.22). Oficialmente, nas estatísticas públicas, foi por ocasião do primeiro Recenseamento do Brasil, realizado em 1872, que se cristalizou um sistema de classificação da cor no País, com a utilização das seguintes categorias: branco, preto, pardo e caboclo. Ressalva-se que tal escolha foi muito apropriada, pois em um levantamento dessa natureza é importante que os termos empregados tenham uso corrente e o mais disseminado possível para proporcionar maior uniformidade e confiabilidade aos dados obtidos (OSORIO, 2003, p. 8). No início da história do Brasil a miscigenação se formou através da mistura das diversas etnias, dando origem a nova população. Antes da invasão dos europeus eram habitados por indígenas, já os povos negros africanos foram trazidos a força para ser escravizados para contribuir com a economia do país, por meio de mão de obra barato. Percebe-se uma mudança radical de perspectiva, pois o que se valoriza não são mais os tipos raciais originários, mas a 'cor', isto é, as tonalidades de pele (CAMARGO, 2010). De acordo com o IBGE na sua pesquisa no Censo Demográfico atualmente as cores predominantes são branca, preto, amarela, parda e indígena.

Conclusão: Conclui-se que o histórico da classificação racial no Brasil é caracterizada pela miscigenação no qual as cores e raças se mantém predominantes atualmente. A miscigenação historicamente e a mistura de povos que dão origem uma nova população, mantendo os traços físicos e culturais. Que vem como cultura passada a ser usada para identificação e forma de separação racial.

\section{Referências}

CAMARGO, A. de P. R. Classificações raciais e formação do campo estatístico no Brasil (1872-1940). In: SENRA, N. de Castro; CAMARGO, A. de P. R. (Org.). Estatísticas nas Américas: por uma agenda de estudos históricos comparados. Rio de Janeiro: IBGE, 2010. p. 229-263. (Estudos e análises. Documentação e disseminação de informações, n. 2). Disponível em: https://biblioteca.ibge.gov.br/visualizacao/livros/liv63405.pdf. Acesso em: 19.Jul.2020.

IBGE Educa - Conheça o Brasil - População cor ou raça. Disponível em: https://educa.ibge.gov.br/jovens/conheca-obrasil/populacao/18319-cor-ou-raca.html. Acesso em: 22.Agos.2020.

OSORIO, R. G. A mobilidade social dos negros brasileiros. Brasília, DF: Instituto de Pesquisa Econômica Aplicada - IPEA, 2004. 24 p. (Texto para discussão, n. 1033). Disponível em: https://biblioteca.ibge.gov.br/visualizacao/livros/liv63405.pdf. Acesso em: 19.Jul.2020.

PETRUCCELLI, José Luis; SABOIA, Ana Lúcia (orgs). Características étnico-raciais da população: classificações e identidades. Estudos e Análises Informação Demográfica e Socioeconômica, número 2. Rio de Janeiro: IBGE,2013.. Disponível em: https://biblioteca.ibge.gov.br/visualizacao/livros/liv63405.pdf. Acesso em 19.Jul.2020. 
Coordenadoria de Pesquisa e Extensão - COPEX

Departamento de Editoraçāo e Divulgaçāo Científica - DEDIC 


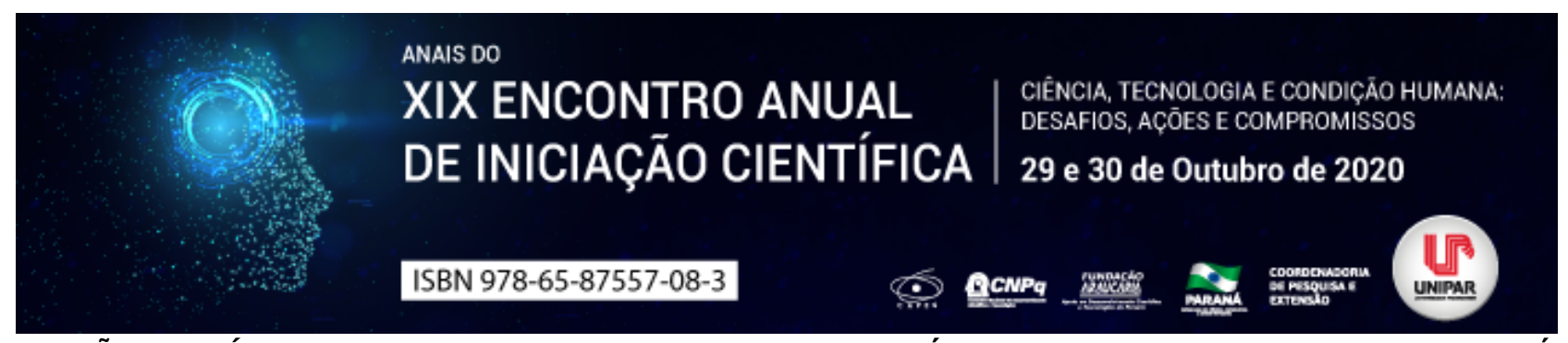

PROTEÇÃO DO MÍNIMO EXISTENCIAL AO CONSUMIDOR DE CRÉDITO SUPERENDIVIDADO E O NECESSÁRIO RECONHECIMENTO DO DANO EXISTENCIAL

\author{
${ }^{1}$ FILIPE DE LIMA CRUZ, ${ }^{2}$ BRUNO ROGER CAUMO, ${ }^{3}$ IVANILDA VAZ BATISTA DE OLIVEIRA, ${ }^{4}$ LIDIA RICCI ROQUE, ${ }^{5}$ MARIA \\ CAROLINA SILVA DA FONSECA, ${ }^{6}$ VALERIA BONONI GONCALVES DE SOUZA
}

\author{
${ }^{1}$ Acadêmico PIC/Universidade Paranaense - UNIPAR \\ ${ }^{1}$ Acadêmico do Curso de Direito da UNIPAR \\ ${ }^{2}$ Acadêmica do Curso de Direito da UNIPAR \\ ${ }^{3}$ Acadêmica do Curso de Direito da UNIPAR \\ ${ }^{4}$ Acadêmica do Curso de Direito da UNIPAR \\ ${ }^{5}$ Docente da UNIPAR
}

Introdução: A massificação do consumo de crédito no Brasil e a ausência de regulamentação normativa sobre o tema geram, não raras vezes, o superendividamento do consumidor (pessoa física) que atinge seu mínimo existencial, necessitando de uma efetiva tutela jurídica para a reparação dos eventuais danos decorrentes da violação.

Objetivo: Analisar a necessária proteção do mínimo existencial da pessoa física consumidora nos contratos de crédito, inclusive, a solução proposta pelo Projeto de Lei no 3.515/15 e demonstrar a necessidade e fundamentos para o reconhecimento do dano existencial decorrente do superendividamento como dano autônomo, para além da concepção naturalística de dano moral.

Desenvolvimento: A garantia do mínimo existencial é, essencialmente, direito fundamental de todos os indivíduos ainda que expressamente não positivado constitucionalmente ou na legislação infraconstitucional, sobretudo por ser corolário lógico do princípio da dignidade da pessoa humana, um dos fundamentos da República Federativa do Brasil. Neste sentido, Sarlet (2008, p. 9), entende que mínimo existencial é compreendido como todo o conjunto de prestações materiais indispensáveis para assegurar a cada pessoa uma vida condigna, portanto, saudável , o qual independe de expressa previsão constitucional para ser reconhecido. Isto porque trata-se da própria proteção da dignidade da pessoa humana, constituindo núcleo de direitos fundamentais que devem ser protegidos contra qualquer violação, seja de terceiros ou do próprio Estado. Não obstante, o Projeto de Lei n. 3.515/15 - que atualiza o Código de Defesa do Consumidor - em trâmite no Congresso Nacional e com parecer de constitucionalidade pela Comissão Especial da Câmara dos Deputados (BRASIL, 2015), inova positivamente, uma vez que traz possibilidade expressa de proteção e garantia do mínimo existencial aos consumidores. Ainda, passa a regulamentar a prevenção e tratamento do consumidor pessoa física superendividada, modificando o rol exemplificativo de direitos básicos dos consumidores para acrescer a preservação do mínimo existencial na forma preventiva (art. $\left.6^{\circ}, \mathrm{XI}\right)$, na renegociação (art. $\left.6^{\circ}, \mathrm{XII}\right)$ e no tratamento (art. 104-A). Lado outro, segundo Marques (2010, n. p.) o superendividamento pode ser conceituado como a

impossibilidade global do devedor-pessoa física, consumidor, leigo e de boa-fé, de pagar todas as suas dívidas atuais e futuras de consumo em um tempo razoável com sua capacidade atual de rendas e patrimônio , atingindo a dimensão social da existência humana, por comprometer a subsistência mínima, o adequado convívio social, familiar e projeto de vida, configurando a hipótese de dano existencial. Faz-se imperativo destacar que nos casos em que há o superendividamento do consumidor pessoa física, o mínimo existencial é gravemente violado. Portanto, imprescindível não só a prevenção e proteção do mínimo existencial, mas também a tutela jurídica em face ao dano sofrido. Neste contexto, segundo Lopes (2015, p. 3) o dano existencial configura verdadeira lesão que compromete as várias atividades através das quais a pessoa atua para plena realização na esfera individual. Seus efeitos comprometem as realizações do interesse da pessoa quotidianamente nas várias áreas de sua atuação, comprometendo sua qualidade de vida . Insta destacar que o dano existencial, protrai-se no tempo, manifestando-se na alteração substancial da qualidade de vida da pessoa, forçando tanto o devedor quanto a sua família à supressão dos gastos com necessidades básicas, à exclusão social e do consumo para existir . (VERBICARO; ATAÍDE; LEAL, 2018, p. 17). Todavia, há resistência de parte da doutrina e do Poder Judiciário para o reconhecimento do dano existencial decorrente da conduta do fornecedor de crédito como categoria autônoma, fundando-se no conceito naturalístico de dano moral, o que se revela, indubitavelmente, insuficiente para reparar adequadamente as dimensões da existência humana, especialmente a tutela do consumidor pós-moderno. Deveras, é necessário o reconhecimento do dano existencial como categoria autônoma de dano extrapatrimonial quando se tratar de violação do mínimo existencial do consumidor superendividado, uma vez que o dano existencial é dano-consequência que repercute na atividade externa do consumidor e de constatação objetiva, enquanto o dano moral (concepção ampla) repercute na esfera interna e subjetiva, distinção que repercute na própria compreensão do dano subjacente à violação do mínimo existencial.

Conclusão: De fato, o mínimo existencial possui extrema relevância no grupo dos direitos fundamentais, constituindo-se um 
dos cernes da dignidade da pessoa humana. Desse modo, as propostas do PL $\mathrm{n}^{\circ} 3.515 / 15$ efetivamente preveem normas específicas de proteção e garantia do mínimo existencial. Todavia, há a necessidade de seu reconhecimento como modalidade autônoma de dano, qual seja o dano existencial, pois a violação do mínimo existencial gera um tipo de dano-consequência que reflete de forma externa e objetiva, devendo ser observada para a reparação correta e integral do dano causado ao consumidor pessoa física superendividada.

\section{Referências}

BRASIL. Projeto de Lei n. 3.515/15. Altera a Lei $n^{\circ}$ 8.078, de 11 de setembro de 1990, e o art. 96 da Lei $n^{\circ} 10.741$, de $1^{\circ}$ de outubro de 2003, para aperfeiçoar a disciplina do crédito ao consumidor e dispor sobre a prevenção e o tratamento do superendividamento. Brasília. DF. 2015.

LOPEZ, Teresa Ancona. Dano Existencial. Revista de Direito Privado: Doutrinas Essenciais de Dano Moral, Vol. 1/2015 p. 1037-2053, Jul/2015.

MARQUES, Cláudia Lima, Comentários ao Código de Defesa do Consumidor [livro eletrônico] / Cláudia Lima Marques, Antônio Herman V. Benjamin, Bruno Miragem. -- 3. ed. -- São Paulo: Thomson Reuters Brasil, 2019. 6 Mb; e-PUB 3. ed. em ebook baseada na 6 . ed. Impressa. Páginas não númeradas.

SARLET, Ingo Wolfgang. Direitos fundamentais sociais, mínimo existencial e direito privado. Revista de Direito do Consumidor. vol. 61/2007. p. 90 125.Jan - Mar / 2007.

VERBICARO, Dennis; ATAIDE, Camille da S. A.; LEAL, Pastora do S. T. Fundamentos ao reconhecimento do dano existencial nos casos de superendividamento: considerações sobre o mínimo existencial, o valor do tempo e a concepção normativa do dano. Revista de Direito do Consumidor. Vol. 120/2018. p. 365-396. Nov.-Dez 2018. Revista dos Tribunais. 


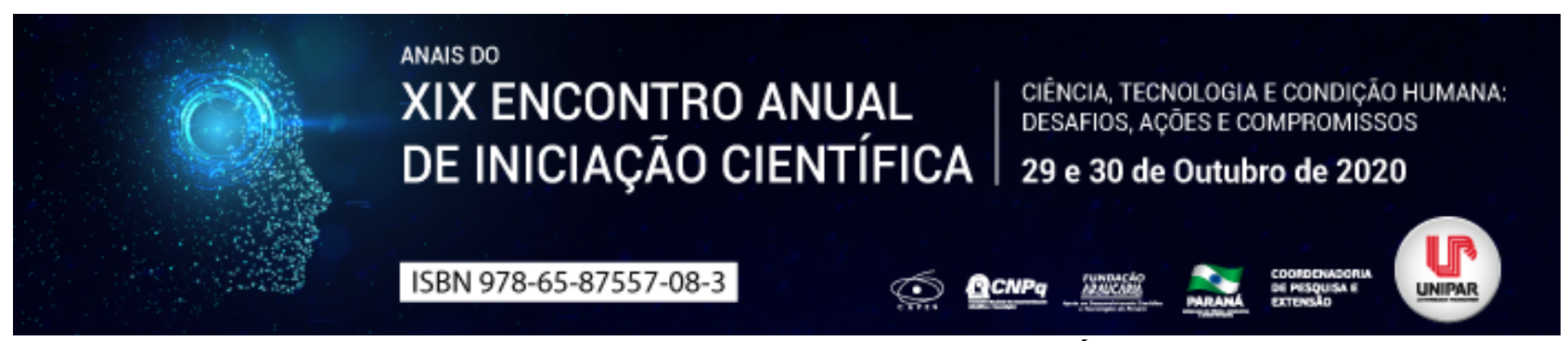

LOTEAMENTOS CLANDESTINOS E IRREGULARES DO MUNICÍPIO DE CIANORTE- PR

\title{
${ }^{1}$ CAROLINE FAVORETTO, ${ }^{2}$ CESAR AUGUSTO HOFFMANN
}

\author{
${ }^{1}$ Discente de Arquitetura e Urbanismo Universidade Paranaense UNIPAR \\ ${ }^{1}$ Docente de Arquitetura e Urbanismo da Universidade Paranaense - UNIPAR
}

Introdução: O déficit habitacional é considerado como um dos aspectos sociais mais discutidos do século XX, pois a estes, estão associados os altos índices de pobreza, desigualdade social e violência gerada pela disputa do uso e ocupação do solo urbano. Segundo Negreiros et all (2008) apontam que, no Século XX ocorreram os primeiros conflitos e consequentemente as primeiras invasões no Brasil, devido à falta de moradia por parte da população de baixa renda, estes eventos concentram-se principalmente nos grandes centros. O crescimento desordenado das cidades, assim como a especulação imobiliária e a falta de políticas públicas são indutores do déficit habitacional, de acordo com IPARDES (2000), este efeito corresponde ao atendimento da demanda não solúvel nas condições atuais do mercado habitacional, e a reposição total de unidades precárias. Desta maneira, a Organização das Nações Unidas - ONU, elaborou a agenda 2030 contendo 17 objetivos para o desenvolvimento sustentável. O seu objetivo número onze do documento que visa tornar as cidades e os assentamentos humanos inclusivos, seguros, resilientes e sustentáveis. Tal medida foi primordial para garantir o acesso à moradia digna por parte desta população, assim como os serviços básicos, visando o ordenamento do solo urbano. Segundo Pasternak (2010), é dever da prefeitura do município estabelecer uma política de regularização de loteamentos irregulares, e convertê-los em Zonas Especiais de Interesse Social (Zeis). Além disso, como mencionado na Lei $n^{\circ}$ 13.465, de 2017, da republica federal do Brasil, a REURB corresponde a um conjunto de medidas jurídicas, ambientais, urbanísticas e sociais designadas a incorporação dos núcleos urbanos informais ao ordenamento territorial urbano e à titulação dos seus ocupantes.

Objetivo: Este trabalho tem por objetivo apresentar o déficit habitacional existente no município de Cianorte, assim como realizar a identificação dos loteamentos clandestinos e irregulares existentes no município.

Desenvolvimento: De acordo com o IBGE (2009), o Brasil possui um déficit habitacional de 9,3\%, totalizando 5,8 milhões de famílias que não possuem local para morar ou que vivem em situações inadequadas. Segundo o IPARDES (2000), o déficit habitacional do estado do paraná é de 169.224 domicílios que representa um total de 6\%, já o município de Cianorte possui um déficit absoluto 855 (famílias aguardando por sua casa própria) e relativo de 5,17\%. Tendo como base o déficit habitacional no município de Cianorte comparou se a sua relação com os loteamentos clandestinos e irregulares presentes no município. A população do município de Cianorte, de acordo com o instituto Brasileiro de Geografia e Estatística IBGE (2019), está em um contínuo crescimento, e por consequência é acompanhado pelo déficit habitacional. Negreiros, et all (2008), ressalta que frequentemente, as ocupações irregulares acontecem de maneira inadequada ao meio ambiente: em áreas consideradas impróprias à implantação de habitações, como por exemplo, fundos de vale, locais insalubres, sujeitos a alagamento. Menarim (2019), aponta que segundo pesquisas realizadas no acervo da Prefeitura de Cianorte, não se encontra registros de habitações em áreas de riscos, e, áreas de preservação permanentes ou com alto grau de depreciação. Negreiros, et all (2008) ressalta que o Loteamento irregular á aquele que possui algum tipo de registro, onde o responsável possa ter realizado algum tipo de consulta ou ter dado entrada na documentação, porém não chegou aprovar o projeto, resultando em uma área com infraestrutura incompleta e sem as mínimas condições de ser habitada. Loteamento clandestino é aquele executado sem qualquer tipo de consulta à prefeitura e onde o loteador não respeita nenhuma norma urbanística. Não há garantia, sequer, de que o loteador é o proprietário da área. De acordo com a Cohapar (2019), os loteamentos clandestinos presentes na cidade de Cianorte, que localizam se no espraiamento da cidade são, o loteamento da saúde que não possui rede de esgoto e galerias pluviais, o loteamento ao lado da Docian, que está localizado dentro da faixa de domínio de da PR 323, o loteamento Nogueira que está situado em um manancial de abastecimento do município, e pôr fim a estrada pão de açúcar caracterizada por moradias de pessoas de baixa renda. Cianorte possui um loteamento irregular, o loteamento Cassidori que não possui rede de esgoto e aguas pluviais, que se localiza no espraiamento da cidade. A cartilha REURB ressalta que a prefeitura do município é o principal agente da regularização fundiária, visto que também pertence a este o planejamento e a gestão da ocupação urbana.

Conclusão: O estudo realizado possui uma grande importância, visto que possibilita uma melhor compreensão dos loteamentos clandestinos e irregulares no município de Cianorte, estes, localizados nos espraiamentos da cidade. Ao se tratar dos loteamentos irregulares, é relevante citar a REURB, como possível solução de organização do solo, desta maneira, possibilita que o espaço, cumpra com o papel social da propriedade. Já os loteamentos clandestinos, os quais estão diretamente ligados ao déficit habitacional demandam de políticas públicas a modo de atender o exposto no objetivo 11 das ODS. Desta maneira novos estudos se fazem necessários os quais apresentem soluções às necessidades desta parcela menos favorecida da população. 


\section{Referências}

COHAPAR. Plano Estadual de Habitação de Interesse Social do Paraná PEHIS PR

sobre Necessidades Habitacionais do Paraná. Disponível em: . Acesso em: 25 ago. 2020.

Instituto Paranaense de desenvolvimento social. Atlas de necessidades habitacionais no Paraná. Curitiba. IPARDES, 2004. $76 p$

PASTERNAK, Suzana; Loteamentos irregulares no município de São Paulo: uma avaliação espacial urbanística;

Planejamento e políticas públicas / Instituto de Pesquisa Econômica Aplicada. n. 34 (jun. 2010) -. Brasília: Ipea, 2010.

Prefeitura de Cianorte, Downloads. Disponível em: https://www.cianorte.pr.gov.br/downloads acesso 30/07/2020

ORGANIZAÇÃO DAS NAÇÕES UNIDAS BRASIL - ONU BRASIL. A Agenda 2030: Objetivos de Desenvolvimento Sustentável (ODS). Traduzido pelo Centro de Informações das Nações Unidas para o Brasil (UNIC Rio) Rio de Janeiro, RJ. Disponível em: . Acesso em: 25 ago. 2020.

REURB, Ministério das cidades, Regularização Fundiária e a Lei n¹3.465, de 2017. Disponível em: https://www.mdr.gov.br/images/stories/ArquivosSNH/ArquivosPDF/Publicacoes/cartilha_reurb.pdf acesso em: 20/08/2020

XII CONGRESSO NACIONAL DE TECNOLOGIA DO AMBIENTE CONSTRUÍDO, 2008 Fortaleza, CE. NEGREIROS, Iara; AULICINIO, Patrícia; ABIKO, Alex. Sustentabilidade Ambiental na regularização de loteamentos: o caso do programa lote legal em São Paulo. 2008

III CONGRESSO INTERNACIONAL DE POLÍTICA SOCIAL E SERVIÇO SOCIAL: DESAFIOS CONTEMPORÂNEOS, IV SEMINÁRIO NACIONAL DE TERRITÓRIO E GESTÃO DE POLÍTICAS SOCIAIS, III CONGRESSO DE DIREITO À CIDADE E JUSTIÇA AMBIENTAL. 2019, Londrina, PR. Déficit habitacional em Cianorte-PR caminhos para solução, Londrina, nov. 2019. 


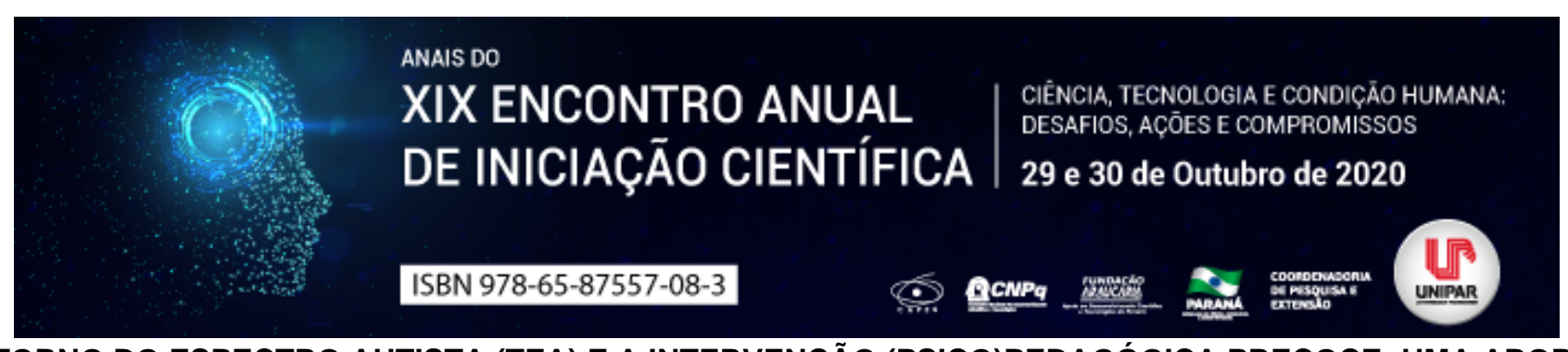

TRANSTORNO DO ESPECTRO AUTISTA (TEA) E A INTERVENÇÃO (PSICO)PEDAGÓGICA PRECOCE: UMA ABORDAGEM NECESSÁRIA

\title{
${ }^{1}$ THAIS RIBEIRO MARTINS, ${ }^{2}$ GEORGEANA RODRIGUES DINIZ, ${ }^{3}$ ANA PAULA APARECIDA DO AMARAL, ${ }^{4}$ LAURIENY PESOTI REI DE SOUZA, ${ }^{5}$ ROSANA VASCONCELOS VITO
}

\author{
${ }^{1}$ Acadêmica do Curso de Pedagogia da UNIPAR \\ ${ }^{1}$ Acadêmica do Curso de Pedagogia da UNIPAR \\ ${ }^{2}$ Acadêmica do Curso de Pedagogia da UNIPAR \\ ${ }^{3}$ Acadêmica do Curso de Pedagogia da UNIPAR \\ ${ }^{4}$ Docente da UNIPAR
}

Introdução: Atualmente, no âmbito escolar, os profissionais da educação têm-se deparado frequentemente com situações de alunos considerados de inclusão, que são diagnosticados como autistas . Muitos professores, apresentam conhecimento básico sobre a educação especial, com isso, realizam ações que contemplam parcialmente as necessidades do aluno em questão. Por outro lado, existe profissionais que mesmo com o conhecimento básico, apresenta dificuldades em estabelecer ações diferenciadas ao aluno autista, pois existem diferenças fundamentais dentro dessa categoria patológica. A patologia

[...] se refere ao continuum do quadro que vai do grau severo ao grau de alto funcionamento. Conhecer esse continuum é fundamental para que se estabeleça tratamento adequado o mais precocemente possível (LIMA, 2019, p. 9). É com essa preocupação, que esse estudo propõe a reflexão sobre algumas características do (TEA), pois, tais fatores limitam o desenvolvimento da criança, em vários aspectos do cotidiano, prejudicando algumas habilidades cognitivas necessárias a aprendizagem escolar (comportamento, psicomotricidade, socialização e outros.

Objetivo: Apresentar as características basilares do (TEA), propiciando reflexões aos professores(as) e pedagogos(as) sobre a importância da intervenção (psico)pedagógica precoce.

Desenvolvimento: O (TEA) é um distúrbio neurológico que interfere na comunicação social (verbal e não verbal); socialização; audição; psicomotricidade; condutas repetitivas, ou restritivas (DSM-5). O termo autismo surgiu no início do século XX, e posteriormente foi reforçado como Autismo infantil pelo doutor Kanner, que observou e relatou casos de crianças que se diferenciavam das demais apresentando comportamentos peculiares (repetitivos) e dificuldades extremas em estabelecer relações interpessoais, levando-as ao isolamento (BAPTISTA, 1995). Em 2013, o Manual de Diagnóstico e Estatística de Transtornos Mentais, conhecido como DSM-5, caracteriza o autismo como (TEA), considerando outras categorias de transtornos mentais dentro dessa patologia.). Na avaliação psicopedagógico do aluno especificamente, a observação do comportamento deve englobar: formas de explorar o meio, maneiras de relacionar-se com as pessoas, maneira de relacionar-se com os objetos, nível de interação em situação não estruturada, desenvolvimento da comunicação, alterações motoras (estereotipias, autoagressão), rituais e jogos. A avaliação deve ser global, cuidadosa e detalhada, porque uma das características dos autistas é a falta de uniformidade no seu rendimento (Analúcia S. Leppos Seyfarth, 1995). A relação professor-aluno constitui-se no cerne de todo o atendimento, pois dependerá da qualidade dessa relação a chance de retirar esse aluno do isolamento que o caracteriza. Qualquer que seja a programação estabelecida está só ganhará dimensão educativa dentro dessa interação. Quanto mais significativo para a criança for o seu professor, maiores serão as chances de este promover novas aprendizagens. As possibilidades de vinculação dessas pessoas com profunda dificuldade de interação espontânea viabilizamse, em grande parte, pela tolerância a frustração e persistência do profissional que se propõe a trabalhar com elas. Além destes traços de personalidade, o educador deverá basear o relacionamento com seu aluno em um conhecimento o mais abrangente possível da Síndrome de Autismo Infantil, das características especificas da criança que educa e de técnicas de ensino atualizadas (Lúcia Helena de V. Freire, 1995). Para uma boa intervenção psicopedagógico dentro da escola é necessário que a criança já tenha um diagnóstico fechado por uma equipe multidisciplinar, composta por psicólogo, fonoaudiólogo, neurologista e um psicopedagogo.

Conclusão: Diante da pesquisa bibliográfica, concluímos que os profissionais da educação (professores e equipe (psico)pedagógica, devem buscar conhecimento relativos a essa categoria de atendimento especializado (alunos com TEA), por meio de formação inicial e/ou continuada, em cursos na área da Educação Especial, para que possam assegurar a atendimento (psico)pedagógico, influindo qualitativamente na vida do estudante. O professor juntamente com a equipe pedagógica deverá compreender a especificidade do transtorno e fazer as adaptações curriculares necessárias, oportunizando um ensino qualitativo, para que o aluno com (TEA), possa desenvolver suas potencialidades. É importante destacar que, apesar de apresentar avanços, ainda é um caminho longo a ser percorrido, por isso, solicita formação e comprometimento dos profissionais da 
educação, devido a necessidade de intervenções diferenciadas e específicas na prática educativa. Desse modo, para assegurar um trabalho qualitativo, se faz necessário iniciar a abordagem desde a Educação Infantil, pois é nesta etapa que se principia o estímulo ao desenvolvimento das áreas cognitivas e psicomotoras da criança. Por esse motivo, ressalta-se a importância da intervenção precoce na obtenção de resultados significativos.

\section{Referências}

BEREOHFF, Ana Maria, P. / SEYFARTH, Analúcia, S. Leppos / FREIRE, Lúcia Helena, de V. / RUTTER. Abordagem psicopedagógica para o atendimento ao portador de conduta típica (autismo e psicose infantil). In: SCHWARTZMAN, José, Salomão. Autismo Infantil. São Paulo: Editora Memnon, 1995, p. 211216.

CAPONI. Sandra. O DSM-V como dispositivo de segurança. Disponível em: https://www.scielo.br/pdf/physis/v24n3/0103-7331physis-24-03-00741.pdf. Acesso em 09 de agosto de 2020.

JUNIOR, Francisco, Baptista, A. Conceitos e classificação das síndromes artísticas. In: SCHWARTZMAN, José, Salomão. Autismo Infantil. São Paulo: Editora Memnon, 1995, p. 3.

KANNER, Introdução. In: SCHWARTZMAN, José, Salomão. Autismo Infantil. São Paulo: Editora Memnon, 1995, p. 1.

SILVA DA, Pereira, Ezequiel. O AUTISMO E A INTERVENÇÃO PSICOPEDAGÓGICA NA ESCOLA , São Paulo, 13 jun 2019. Disponível em https://monografias.brasilescola.uol.com.br/educacao/o-autismo-intervencao-psicopedagogica-naescola.htm\#indice_1, acesso em 15 ago. 2020.

Coordenadoria de Pesquisa e Extensão - COPEX

Departamento de Editoraçāo e Divulgaçāo Científica - DEDIC 


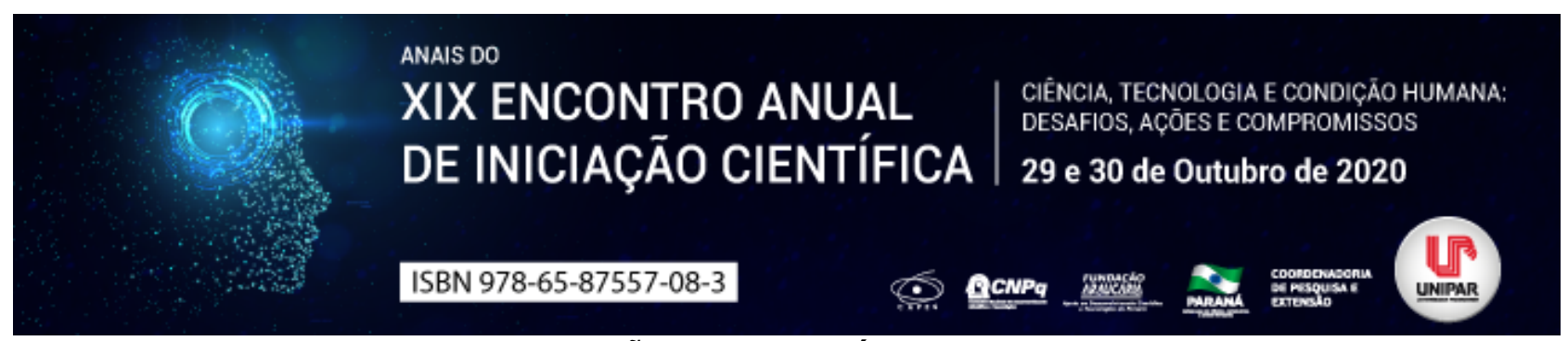

FUNÇÕES DA BOA-FÉ OBJETIVA

\begin{abstract}
${ }^{1}$ MARISTELA APARECIDA SIQUEIRA DAVIZ, ${ }^{2}$ CASSIO DE PAULA XAVIER, ${ }^{3}$ LAIS SILVA ZIMIANI, ${ }^{4} \mathrm{HORACIO}$ MONTESCHIO, ${ }^{5}$ JUSSARA SUZI ASSIS BORGES N. FERREIRA
\end{abstract}

\author{
${ }^{1}$ Discente do Mestrado em Direito Processual e Cidadania UNIPAR \\ ${ }^{1}$ Discente do Mestrado em Direito Processual e Cidadania UNIPAR \\ ${ }^{2}$ Discente do Mestrado em Direito Processual e Cidadania UNIPAR \\ ${ }^{3}$ Docente da UNIPAR \\ ${ }^{4}$ Docente da UNIPAR
}

Introdução: A boa-fé objetiva cuida-se de regra abstrata de conduta a todos imposta, que deve ser operada por padrões médios. Cuida-se de preceito de ordem pública, dando diretriz ao campo negocial, logo importante delimitar sua utilização e a revisão bibliográfica foi utilizada para sistematizar as funções.

Objetivo: Demonstrar a relevância da boa-fé objetiva como instrumento de criação, interpretação e controle.

Desenvolvimento: $O$ instituto não está estagnado em modelo prévio legislativo, sendo atemporal e mutável. Traz em si padrão de comportamento ligado à lealdade, honestidade, solidariedade e cooperação. A verificação da ilicitude objetiva se dá no exercício do direito subjetivo pela contrariedade a tais. A relação obrigacional é pautada na cooperação, em que credor e devedor assumem deveres e interesses. Em relação à função nomogenética (MARTINS-COSTA, 2018, p. 239), os deveres que dizem respeito ao cumprimento da própria prestação, núcleo fundamental da obrigação, consistem no dar, fazer ou não fazer, assim desamotinando o conteúdo obrigacional, os deveres de prestação podem ser primários/principais e secundários/acidentais, quando concirnam ao núcleo da relação ou garantam o direito de crédito. Noutra via, os deveres anexos/instrumentais garantem a maneira como o direito de crédito, núcleo da relação, será satisfeito. Portanto, têm vínculo com a prestação principal e interessam ao seu cumprimento, buscando otimizar o adimplemento. Decorrem de lei ou previsão contratual, os deveres de proteção/laterais são destinados não apenas aos que participam da relação obrigacional, vez que caminham em paralelo com ela. O seu descumprimento culmina na chamada violação positiva do contrato. A função hermenêutica e integrativa está situada no art. 113, do Código Civil, e, nessa perspectiva, a cláusula geral exerce influência sobre todos os negócios jurídicos, não apenas no âmbito do direito contratual ou obrigacional; indo além, irradia sua eficácia no direito de família, sucessório, empresarial ou direitos reais. Proporciona que todos os negócios sejam filtrados pela boa-fé objetiva, integrando-os conforme os seus preceitos, vindo a preencher lacunas (perspectiva integrativa) ou propiciando o direcionamento e consequências da relação obrigacional (perspectiva interpretativa). Noutro giro, a atuação humana relevante para o Direito diz respeito ao exercício de atos jurídicos lícitos e ilícitos. O princípio da boa-fé está previsto no art. 187, do Código Civil, como baliza ao exercício jurídico lícito e pode impactar no plano da eficácia, como fator de conformação. Conseguinte, ora determina a ineficácia, ora eficácia parcial, ou a indenizatória, ou ainda a paralisatória. A ilicitude objetiva não se limita a constatação do abuso do direito e deve ser compreendida como a atuação humana conforme as normas aplicáveis e se apresenta ilícita por contrariedade ao sistema na globalidade, ao atingir vetores fundamentais como a lealdade, confiança, finalidade e utilidade. É aferida in concreto, pois são os elementos fáticos que permitem descobrir se há na atuação formalmente adequada, um exercício de direitos, poderes ou faculdades, contrário aos vetores axiológicos fundamentais do sistema jurídico. A boa-fé objetiva serve de fundamento para verificação do exercício desleal que pode ser contraditório, disfuncional ou desmedido (MARTINS-COSTA, 2018, p. 669). Conjugando-se o princípio da boa-fé com os da coerência e da utilidade, evita-se alcançar o benefício ilícito da situação construída, nascendo as nominadas figuras parcelares, cujo fim é repelir a contradição. A contraditoriedade deve ser aferida como inescusável para ser ilícita. São elas: venire contra factum proprium non potest; tu quoque; nemo auditur propriam turpitudinem allegans; supressio e surrectio; e exceptio doli (MARTINS-COSTA, 2014, p. 7).

Conclusão: Confirma-se o papel salutar que o instituto tem no âmbito das relações obrigacionais não apenas como fonte de direitos e deveres (função nomogenética ou criadora), mas como vetor interpretativo (função interpretativa e de integridade) e de controle do modo exercício de posições jurídicas, direitos e faculdades.

\title{
Referências
}

BRASIL. Código de Processo Civil. 2015.

MARTINS-COSTA, Judith. A boa fé no direito privado: critérios para sua aplicação. 2 ed., São Paulo: Saraiva, 2018. Os avatares do abuso do direito e o rumo indicado pela boa-fé. Disponível em: . Acesso em 15 jul. 2020. 
Coordenadoria de Pesquisa e Extensão - COPEX

Departamento de Editoraçāo e Divulgaçāo Científica - DEDIC 


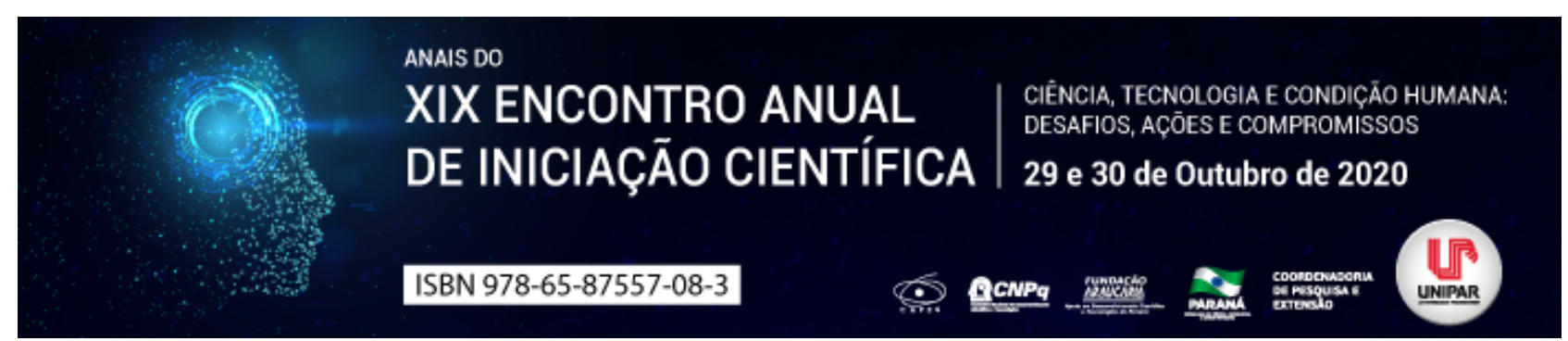

ESTUDO BIBLIOMÉTRICO SOBRE DEMONSTRAÇÃO DO VALOR ADICIONADO NOS CONGRESSOS UFSC E UNB DE CONTABILIDADE ENTRE OS ANOS DE 2012 E 2019

\title{
${ }^{1}$ LUCAS GABRIEL MACEDO, ${ }^{2}$ JEFERSON MEIRA JUNIOR, ${ }^{3}$ JOSE LUIZ BORSATTO JUNIOR, ${ }^{4}$ ISABEL CRISTINA GOZER
}

\author{
${ }^{1}$ Acadêmico bolsista do PIBIC/UNIPAR \\ ${ }^{1}$ Acadêmico do Curso de Ciências Contábeis da UNIPAR \\ ${ }^{2}$ Docente da UNIPAR \\ ${ }^{3}$ Docente da UNIPAR
}

Introdução: Com as incertezas no setor econômico em que se encontra o Brasil atualmente, é fundamental que existam meios para que os órgãos e empresas que participam do mercado financeiro possam se orientar e ter conhecimento sobre formas de agir que beneficiem não apenas as instituições como também a economia do país como um todo. A Demonstração do Valor Adicionado (DVA) torna-se essencial nesse contexto para dar suporte e apresentar de uma forma clara as operações financeiras ocorridas em determinado período. Essa pesquisa tem o intuito de explorar as obras que analisam este assunto, assim como sua frequência de publicações, fontes utilizadas nas referências e quantidade de autores por artigo.

Objetivo: Analisar por meio da bibliometria a produção científica sobre a Demonstração do Valor Adicionado no período de 2012 a 2019.

Desenvolvimento: Essa pesquisa de abordagem quantitativa, foi realizada com base nos anais dos Congressos da Universidade Federal de Santa Catarina (UFSC) e Universidade de Brasília (UnB), ambos congressos tradicionais na pesquisa da área de contabilidade societária, disponíveis nos sites das respectivas instituições, buscando artigos que continham no título ou nas palavras-chave os termos DVA ou valor adicionado. Conforme o pronunciamento CPC 09 (2008), emitido pelo Comitê de Pronunciamentos Contábeis (CPC), a DVA tem como objetivo apresentar a forma como determinada empresa agrega valor ao PIB (Produto Interno Bruto), o capital que é obtido de terceiros e o que é consumido ou vendido durante o período em que foi realizado a demonstração. Ressalta-se que a DVA se tornou obrigatória a partir de 2008 para empresas de capital aberto listadas na B3. Foram encontrados 14 artigos que condiziam com o tema proposto. Destes, 8 (oito) artigos da UFSC e 6 (seis) da UnB, destaca-se que só foram encontrados artigos que se encaixavam nessa pesquisa a partir de 2015 . Também foi realizado um estudo sobre a quantidade de autores por artigo, sendo um total de 5 (cinco) textos com dois autores, 7 (sete) com três e apenas 2 (dois) com quatro autores. Nenhum artigo contido nessa pesquisa conta com apenas um autor, sendo este fato explicado por se tratar de congressos realizados em universidades, onde os trabalhos normalmente contam com auxílio de professores. Nas abordagens mais usuais, a quantitativa se destaca por estar presente em 8 (oito) textos, um fato que é esperado, pois nessa área é fundamental a interação com números e informações para melhor reprodução dos dados inclusos. Por último, foi realizado um estudo em relação as fontes das referências inclusas nos artigos analisados, tanto em relação ao tipo de referência, como também a nacionalidade. Foi identificado um grande número de referências nacionais com 294 de 322 referências totais $(91,30 \%)$, demonstrando que há uma grande biblioteca sobre contabilidade e DVA no país, sendo poucas vezes necessários utilizar de referências internacionais para desenvolver textos na área. Já em relação ao tipo de fonte utilizada, Revistas e Livros são responsáveis por mais da metade das referências com 183 (58,7\%). Dissertações por outro lado são deixadas de lado com apenas 11 citações (3,42\%), fato que pode ser explicado pela boa reputação que outros tipos de fontes possuem.

Conclusão: Apesar de representarem apenas 1,12\% do total da pesquisa realizada, os artigos sobre DVA demonstram que o conhecimento sobre o tema está mais acessível na última década, com diferentes fontes de informação e variados tipos de autores. Nos 14 artigos analisados nesta pesquisa, é notável a coautoria na hora de realizar os textos, também vale ressaltar a grande quantidade de referências nacionais, um bom sinal para o futuro, pois com a maior quantidade de textos sobre contabilidade e DVA nas bibliotecas brasileiras, será mais fácil instigar estudantes e pesquisadores a não apenas se interessarem pelo tema, como também escreverem a respeito.

\section{Referências}

COMITÉ DE PRONUNCIAMENTOS CONTÁBEIS (CPC). Pronunciamento Técnico CPC 09 de 12 de novembro de 2008 : Demonstração do Valor Adicionado. Brasília, nov, 2008.

COSENZA, José. A Eficácia Informativa da Demonstração do Valor Adicionado. Revista Contabilidade \& Finanças - USP, São Paulo, Edição comemorativa, p. $7 \quad$ 29, out. 2002.

CUNHA, Jaqueline; RIBEIRO, Maisa; SANTOS, Ariovaldo. A Demonstração do Valor Adicionado Como Instrumento Mensuração da Distribuição da Riqueza. Revista Contabilidade \& Finanças - USP, São Paulo, n. 37, p. 7 23, jan./abr. 2005. 
JUNIOR, Valdério; VASCONCELOS, Adriana; MONTE, Paulo. Perfil dos Trabalhos Publicados de 2004 e 2010 na Área Educação e Pesquisa do Congresso USP de Controladoria e Contabilidade. Revista Ambiente Contábil UFRN, Natal-RN v. 6 , n. 2, p. 36 54, jul./dez. 2014.

Coordenadoria de Pesquisa e Extensão - COPEX

Departamento de Editoraçāo e Divulgaçāo Científica - DEDIC 


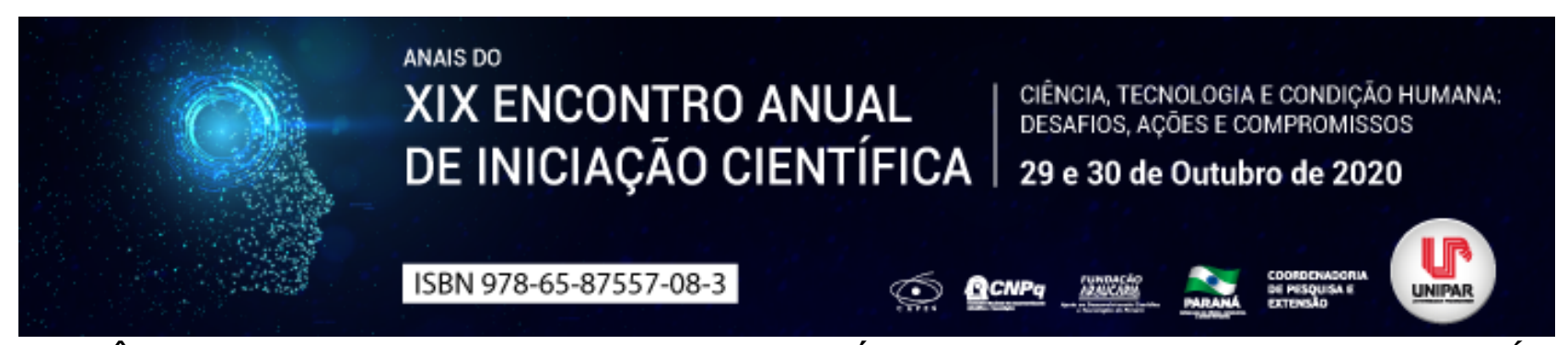

INTELIGÊNCIA ARTIFICIAL VERSUS MENTE HUMANA: ATÉ QUE PONTO O JUIZ PODE SER SUBSTITUÍDO?

\title{
${ }^{1}$ ANGELICA GIOSA CANDIDO, ${ }^{2}$ DANIELA BACHI MARTINEZ
}

\author{
${ }^{1}$ Professor Orientador PIC \\ ${ }^{1}$ Acadêmica do Curso de Direito da UNIPAR - PIC
}

Introdução: Tema extremamente presente na atualidade, a Inteligência Artificial vem ganhando espaço em diversas searas da vida humana, inclusive na Judiciária. Há diversos questionamentos e visões a respeito da implantação deste tipo de tecnologia no Poder Judiciário, principalmente no que diz respeito à produção e valoração das provas.

Objetivo: Analisar o impacto da inteligência artificial na fase probatória do processo, bem como refletir sobre a possibilidade desta substituir o magistrado no que tange à valoração das provas.

Desenvolvimento: É fato que a maré da tecnologia já atingiu o ramo Judiciário mundial. Foi desenvolvida nos EUA uma ferramenta que auxilia o juiz a realizar a dosimetria penal, calculando uma suposta possibilidade de reincidência do réu. Uma pesquisa realizada pela ProPublica constatou que os acusados negros tinham $77 \%$ mais chances de serem reincidentes em relação aos acusados brancos, sob as mesmas circunstâncias (PROPUBLICA, 2016). Apesar de muitos acreditarem que a inteligência artificial seja um método objetivo e imparcial, seus mecanismos tem origem em dados abstratos incluídos por programadores, fazendo com que hajam pontos cegos nos algoritmos, refletindo as opiniões de seu criador (NUNES E MARQUES, 2018). Um estudo realizado pelos pesquisadores da Universidade de Oxford constatou que, se no banco de dados houver algum padrão discriminatório enraigado, este será refletido e aprimorado pela máquina, apresentando assim uma falsa ideia de algoritmo objetivo. Em Wisconsin (EUA), os juízes fazem uso de um algoritmo que utiliza um sistema de pontos sigilosos, calculando e definindo a possibilidade de concessão de liberdade provisória, por meio de um questionário de avaliação de periculosidade do réu (CARVALHO, 2018). Assim, movida pela tecnologia, é imprescindível que se estabeleça limites da aplicação desta, de forma que não afete negativamente o aspecto processual das decisões, bem como a aplicação do direito material, visto que a reprodução dos vieses discriminatórios fere não só um dos objetivos fundamentais da República Federativa do Brasil, mas também princípios constitucionais, como o da presunção da inocência, da individualização da pena e da humanidade na execução penal. Ressalte-se que a etapa de produção de provas em um processo é de extrema complexidade e importância, haja vista ser o cerne da orientação processual, razão pela qual é fundamental que sua valoração seja feita corretamente (BUSTAMANTE, 2013). Conceituando a valoração das provas, diz-se ser a consideração do juiz sobre os materiais que tentam demonstrar os fatos deduzidos no processo (FENOLL, 2010, p. 19). No mesmo sentido, Dinamarco e Lopes (2017, p. 183) definem como sendo o juízo da capacidade de demonstração dos fatos realizado pelo juiz com referência a todos os meios de prova concretamente efetivados no processo e a cada uma das fontes de prova trazidas a este Considerando o teor de importância da correta valoração das provas, poderia esta função ser confiada aos sistemas de inteligência artificial? Para Herkenhoff (2005, p. 148), é essencial que o juiz tenha: coragem, bom senso e lógica. Se além dessas três qualidades o juiz souber um pouco de direito, ajuda bastante

Conclusão: Portanto, a resposta a pergunta anterior é negativa. O magistrado, ao analisar e valorar uma prova transcende ao campo lógico, sendo deveras importante que também analise o contexto social e psicológico do processo, ou seja, o aspecto humanístico, ponderando sensitivamente sobre o valor das provas, e não resolvendo uma simples equação matemática, como a máquina o faria.

\section{Referências}

ANGWIN, J. et al. Machine Bias: There's software used across the country to predict future criminals And it's biased against blacks. ProPublica. 23 maio 2016. Disponível em: https://www.propublica.org/article/machine-bias-risk-assessments-in-criminalsentencing. Acesso em: 10 ago. 2020.

BUSTAMANTE, E. N. G. A valoração racional das provas no processo judicial: uma aproximação ao tema. In: XXII Encontro Nacional do CONPEDI/UNINOVE, São Paulo: CONPEDI, 2013. p. 407-428. Disponível em: http://www. publicadireito.com.br/artigos/?cod=531d29a813ef9471. Acesso em: 05 ago. 2020.

CARVALHO, C. C. B. A inteligência Artificial na justiça dos EUA e o Direito Penal brasileiro. Consultor Jurídico. 10 jun. 2018. Disponível em: https://www.conjur.com.br/2018-jun-10/claudia-bonard-inteligencia-artificial-direito-penal-brasileiro. Acesso em: 05 ago. 2020.

DINAMARCO, C. G.; LOPES, B. V. C. Teoria Geral do Novo Processo Civil. 2. Ed. São Paulo: Malheiros, 2017, PDF.

FENOLL. J. N. La valoración de la prueba. Madri: Marcial Pons, 2010, PDF.

HERKENHOFF, João Batista. Como aplicar o Direito: à luz de uma perspectiva axiológica, fenomenológica e sociológico 
política. Rio de Janeiro: Forense, 2005.

NUNES, D.; MARQUES, A. L. P. C. Inteligência artificial e direito processual: vieses algorítmicos e os riscos de atribuição de função decisória às máquinas, Revista de Processo, São Paulo, v. 285, pp. 421-447, nov./2018.

Coordenadoria de Pesquisa e Extensão - COPEX

Departamento de Editoraçāo e Divulgaçāo Científica - DEDIC 


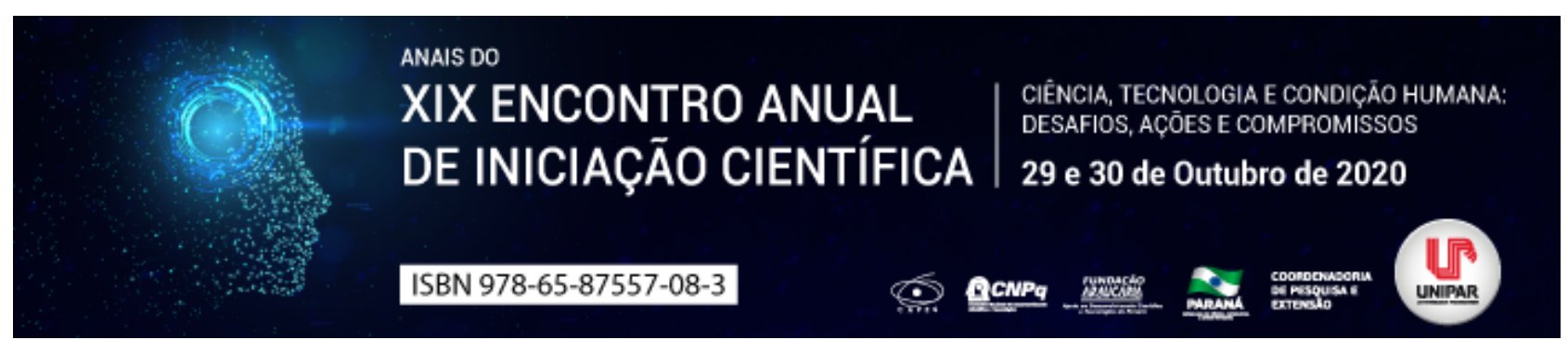

O DIREITO AO MEIO AMBIENTE: UM DIREITO HUMANO?

\title{
${ }^{1}$ HEVELLYN GABRIELA ANDRADE CRUZ, ${ }^{2}$ ANDRE ALVES DE OLIVEIRA, ${ }^{3}$ DORITA ZIEMANN HASSE
}

\author{
${ }^{1}$ Acadêmica do PIC/UNIPAR \\ ${ }^{1}$ Acadêmico do PIC/UNIPAR \\ ${ }^{2}$ Docente da UNIPAR
}

Introdução: A preocupação com o desenvolvimento sustentável não pode ser objeto de análise sem que seja considerada a sua relação direta com os direitos fundamentais do homem e a dignidade da pessoa humana. Por sua vez a degradação ambiental é consequência das atividades humanas sobre o meio ambiente o que requer que sejam tomadas medidas para limitar e reverter a destruição ambiental que compromete a qualidade de vida e a dignidade humana de todos.

Objetivo: Analisar a importância da questão do meio ambiente e sua relação direta com os direitos humanos.

Desenvolvimento: Os princípios que regem e orientam a proteção ambiental no âmbito internacional colocam em destaque a responsabilidade do Estado no que se refere à proteção ambiental considerando que é impossível que se considere apenas o seu espaço territorial ou a sua jurisdição. A doutrina internacional destaca que, a dignidade humana é o centro das preocupações das normas ambientais, que visam promover a construção de um meio ambiente equilibrado em prol do bem-estar das presentes e futuras gerações , (PORTELA, 2019, p. 518). Assim o humanismo renascentista como movimento intelectual moderno coloca em destaque a importância de se valorizar o ser humano e principalmente a condição humana no ambiente em que vive. A premissa da preservação ambiental paralela com o desenvolvimento tecnológico e o progresso econômico perpassam por um desenvolvimento sustentável que não tenha como consequência a degradação ambiental ameaçando a qualidade da vida do homem. Assim, a preocupação com o meio ambiente e a formação de um corpus júris de proteção ambiental são fenômenos bastante recentes da história da humanidade , (MAZZUOLI, 2012, p. 989). Ao se reconhecer que é do Estado soberano a responsabilidade também se reconhece que a internalização das normas internacionais se aplicam a todos aqueles que usufruem dos seus benefícios independentemente de fronteiras ou divisões territoriais, ou seja, os rios transfronteiriços não mudam de cor quando atravessam mais de um Estado e as aves que os sobrevoam não levam consigo qualquer documento de viagem! , (MAZZUOLI, 2012, p. 991). A discussão sobre a proteção ambiental e a sua estreita relação com os direitos humanos tem sido objeto declarações internacionais como a Declaração de Estocolmo, em 1972, momento em que deixou de estar distanciado da humanidade para se reconhecer que é direito fundamental do homem, entre outros, usufruírem de uma vida digna também através do meio ambiente. É o que infere o artigo 225 da Constituição da República Federativa do Brasil, I"Todos têm direito ao meio ambiente ecologicamente equilibrado, bem de uso comum do povo e essencial à sadia qualidade de vida, impondo-se ao poder público e à coletividade o dever de defendê-lo e preservá-lo para as presentes e futuras geraçõesl" (BRASIL, 1988, Art. 225), ao reconhecer que a vida em condições de dignidade depende da proteção do meio ambiente.

Conclusão: Diante do exposto, é possível compreender a importância da preservação ambiental para que se cumpram os preceitos do respeito à dignidade humana. Portanto, deve ser objeto das declarações internacionais a discussão e o reconhecimento dos direitos ambientais para humanidade restando ao Estado a responsabilidade de garantir a proteção ambiental independentemente da sua jurisdição e soberania.

\section{Referências}

BRASIL.

Constituição

(1988).

Constituição

da República

Federativa

do

Brasil.

Brasília,DF,out.1988.Disponívelem:http://www.planalto.gov.br/ccivil_03/constituicao/constituicaocompilado.htm Acesso em: 14 jul.2020.

MAZZUOLI, Valério de Oliveira. Curso de direito internacional público. 6 ed. rev.,atual. e ampl. São Paulo: Editora Revista dos Tribunais, 2012.

PORTELA, Paulo Henrique Gonçalves. Direito internacional público e privado: incluindo noções de direitos humanos e de direito comunitário. 11 ed. Salvador, JusPODIVM, 2019. 


\title{
ANAIS DO \\ XIX ENCONTRO ANUAL | CIÊNCIA, TECNOLOGIA E CONDIC̄ĀO HUMANA: DE INICIAÇÃO CIENTÍFICA DESAFIOS, AC̄ōES E COMPROMISSOS DE INICIAÇĀO CIENTÍFICA 29 e 30 de Outubro de 2020 \\ ISBN 978-65-87557-08-3

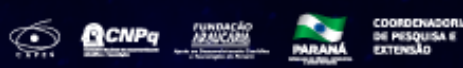 \\ A IMPORTÂNCIA DOS PARQUES URBANOS E ÁREAS VERDES NAS CIDADES ESTUDO PARA A IMPLANTAÇÃO DE UM PARQUE URBANO NO MUNICÍPIO DE CASCAVEL - PR
}

\author{
${ }^{1}$ SADRAQUE CAETANO DA SILVA, ${ }^{2}$ AMANDA MARCIANO, ${ }^{3}$ DANIELA DE CARVALHO BENNEMANN, ${ }^{4}$ MARIA LUIZA RUBEL DO PRADO, \\ ${ }^{5}$ DEBORAH DE CAMARGO PACIORNIK
}

\footnotetext{
${ }^{1}$ Acadêmico de Arquitetura e Urbanismo PIC/UNIPAR

${ }^{1}$ Acadêmica de Arquitetura e Urbanismo PIC/UNIPAR

${ }^{2}$ Acadêmica de Arquitetura e Urbanismo PIC/UNIPAR

${ }^{3}$ Acadêmica de Arquitetura e Urbanismo PIC/UNIPAR

${ }^{4}$ Docente da UNIPAR
}

\begin{abstract}
Introdução: A discussão da problemática ambiental tem se tornado uma pauta de grande destaque, a crescente urbanização constitui uma preocupação de todos os profissionais e segmentos ligados à essa questão. As cidades avançam e apresentam um crescimento rápido, e muitas vezes sem planejamento adequado, a paisagem vem sendo modificada pela ação do homem, que intervém na natureza, em busca do atendimento de seus interesses sendo eles urbanos, industriais e agrícolas. Neste panorama de crise ambiental, é fundamental o surgimento de uma nova percepção da realidade, de modo que os princípios ambientais se manifestem como princípios de educação, de administração e de política (CAPRA, 1994).
\end{abstract}

Objetivo: A presente pesquisa tem como objetivo o estudo sobre a importanciância das áreas verdes e a implantação de um parque urbano na região Norte do município de Cascavel-PR.

Desenvolvimento: A qualidade de vida urbana está diretamente atrelada a vários fatores que vão desde a infraestrutura, desenvolvimento econômico-social e degradação ambiental (FERNANDES, 2004 p. 101). As áreas verdes, fortemente presente nos parques urbanos, são fatores importantes para a qualidade ambiental das cidades, pois constituem-se de elementos imprescindíveis para o bem-estar da população. No que se refere aos parques urbanos, são grandes as mudanças atribuídas ao uso desse espaço, que vai desde um ambiente elitizado, voltado ao passeio da classe dominante a espaços democráticos, que possibilitam a integração de todos os usuários, onde os recursos naturais são preservados, possibilitando inúmeros benefícios para as cidades (SILVA, 2003).

Recorrendo a SZEREMETA, BANI; ZANNIN, PAULO; apud NUCCI, 2001; MASCARÓ, 2002, temos que os parques são caracterizados como um tipo de área verde urbana, pois apresentam predomínio de vegetação (independente do porte), que integram o ambiente construído, além de possuírem outras características naturais. Esses ambientes com predominância da natureza devem fazer parte do dia a dia da população urbana, por possuir diversas funções que são atribuídas ao bem-estar dos habitantes de uma cidade. Eles podem apresentar a função recreativa, ser favorável ao melhoramento da saúde mental das pessoas, tendo em vista as sensações que uma área verde pode trazer e também a função social, de aproximação da comunidade, trazendo o sentimento de pertencer àquele espaço (SERPA, 2007).

O Município de Cascavel, é banhado por uma extensa rede de drenagem. No local da área de estudo se encontra o Rio Sanga Funda, afluente que faz parte da Bacia Hidrográfica do Rio Piquiri, essa que se encontra localizada inteiramente no estado do Paraná (TOSIN, 2005). A bacia ocupa uma área de drenagem de $24,156 \mathrm{~km}^{2}$ aproximadamente e é a terceira maior bacia hidrográfica do estado (IAP - Instituto Ambiental do Paraná, 2004). O bairro Floresta (área da pesquisa) conta com aproximadamente 13.173 habitantes segundo a Secretaria de Planejamento e Desenvolvimento Urbano de Cascavel (SEPLAN, 2016). O terreno se encontra em uma área periférica da cidade, porém bastante utilizada pelos moradores por estar numa das principais ruas do bairro, a rua Leonardo da Vinci. Sua topografia apresenta um significante desnível e o terreno se caracteriza como Zona de Fragilidade Ambiental Urbana - Subzona de Proteção (Área de Proteção), segundo dados da Consulta Prévia gerada pelo GEOPORTAL de Cascavel. Um parque urbano tem como principal objetivo otimizar a vida de seus usuários, por meio da ampliação de áreas verdes dotadas de infraestrutura e acessibilidade adequada. Os parques urbanos têm sido valorizados como um espaço que tem um significado especial para a comunidade. Diversos benefícios têm sido associados à presença de parques, como a diminuição da criminalidade, a redução dos custos de saúde, o aumento da produtividade, o controle da poluição entre outros (REIS, 1997). A implantação também possibilitará a recuperação ambiental da área em questão, pelo fato de estar um tanto degradada e abandonada, o que leva a certos habitantes usá-la como descarte de resíduos e vandalismo.

Conclusão: O planejamento adequado de um parque urbano no Bairro Floresta, oferecerá diversas opções de lazer para a comunidade, incentivando sua aproximação com a natureza ao mesmo tempo em que a preservará. A geração de diretrizes e políticas subsidiadas pelo manejo correto da área, servirão de base para a implantação desse projeto, possibilitando assim a construção de um ambiente ecologicamente equilibrado. É preciso mudar as relações humanas, sociais e ambientais, possibilitando transformações dos nossos valores, instituições e modos de vida. Devemos entender que, quando as necessidades básicas forem atingidas, o desenvolvimento humano será primariamente voltado a ser mais, não a ter mais (CARTA DA TERRA, 2000), possibilitando assim avançar na construção de uma sociedade cada vez mais sustentável.

\section{Referências}

CAPRA, F. A teia da vida. São Paulo: Cultrix, 1994.

FERNANDES, E. Impacto socioambiental em áreas urbanas sob a perspectiva jurídica. In: MENDONÇA, Francisco (Org.). Impactos Socioambientais Urbanos. Curitiba: Ed. UFPR, 2004, p. 99- 128.

IAP - Instituto Ambiental do Paraná. Disponível em http://www.iap.pr.gov.br/ I. Acesso em: 09 jul. 2020.

REIS, R, S. Determinantes ambientais para a realização de atividades físicas nos parques urbanos de curitiba: uma abordagem sócioecológica da percepção dos usuários Dissertação (Mestrado em Educação Física Área de Concentração de Atividade Física Relacionada à Saúde) Centro de Desportos da Universidade Federal de Santa Catarina. Santa Catarina SC, 2001. 
TOSIN, G, A, S. Caracterização física do uso e ocupação da bacia hidrográfica do rio Cascavel Dissertação (Mestrado em Engenharia Agrícola, área de concentração em Engenharia de Recursos Hídricos e Meio Ambiente) Centro de Ciências Exatas e Tecnológicas, Universidade Estadual do Oeste do Paraná. Cascavel PR, 2005.

SEPLAN - SECRETARIA DE PLANEJAMENTO E URBANISMO DE CASCAVEL. Diagnóstico do Plano Diretor. Cascavel, 12 jul. 2020. Disponível

https://portaldosmunicipios.pr.gov.br/download/public/arquivos/documentos/58/2019/02/28/X73ID6W4UkajKLhXZFZoOMuf2UcX17eQksXaDnRt.pdf. Acesso em: 09 jul. 2020.

SILVA F, D. F. Silvicultura urbana: o desenho florestal da cidade. IPEF, 2003. Site do Instituto de Pesquisas Florestais, Piracicaba, São Paulo. MINISTÉRIO DO MEIO AMBIENTE. Carta da Terra, 2000 Disponível em: https://www.mma.gov.br/responsabilidade-socioambiental/agenda21/carta-da-terra.html. Acesso em: 15 jul. 2020.

SERPA. Ângelo. O espaço público na cidade contemporânea. São Paulo: Contexto, 2007.

SZEREMETA, BANI; ZANNIN, PAULO; $\mathbf{A}$ importância dos parques urbanos e áreas verdes na promoção da qualidade de vida em cidades. Universidade Federal do Paraná (UFPR). Curitiba PR., 2013.

Coordenadoria de Pesquisa e Extensāo - COPEX

Departamento de Editoraçāo e Divulgaçāo Científica - DEDIC 


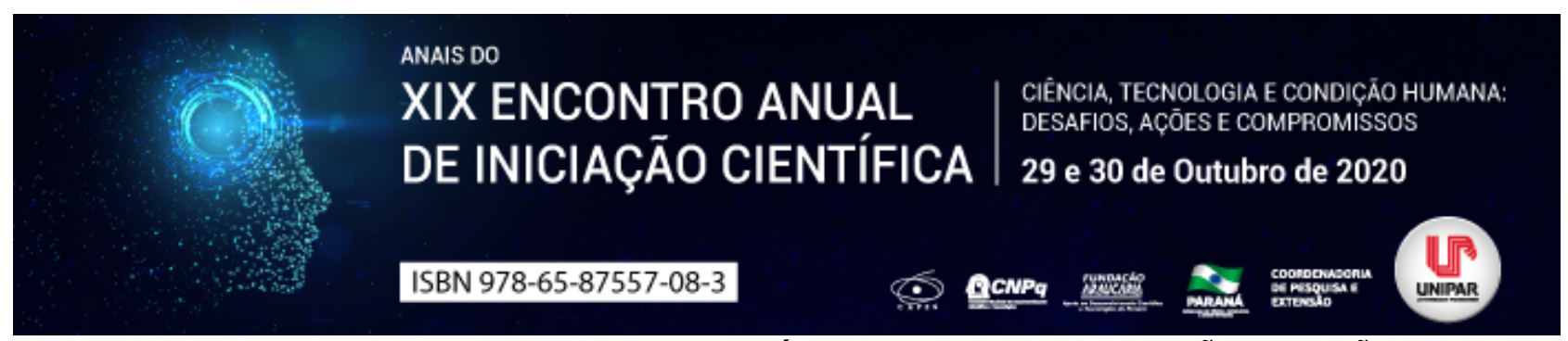

A PEDAGOGIA DE PROJETO E O CURRÍCULO ESCOLAR: FORMAÇÃO CIDADÃ

\title{
1JOICE FERNANDA SANTANA DOS SANTOS, ${ }^{2}$ MARIA DO CARMO DE O NOGUEIRA
}

\author{
${ }^{1}$ Acadêmica do curso de Pedagogia- Presencial / UNIPAR Monitora PIBIM. \\ ${ }^{1}$ Docente da UNIPAR
}

Introdução: O currículo escolar atua de forma importante para a construção da cidadania, por meio dele que a escola determina sua função social, e incluindo a pedagogia de projetos neste documento, faz com que o processo de ensino- aprendizagem esteja integrado as práticas vividas.

Objetivo: Realizar análise bibliográfica a cerca da importância de acrescentar a metodologia da pedagogia de projetos no currículo escolar, para a formação de alunos críticos, criativos e reflexivos.

Desenvolvimento: Segundo Veiga (1997) o currículo é uma construção social do conhecimento, pressupondo a sistematização dos meios para que esta construção se efetive, a transmissão dos conhecimentos historicamente produzidos e as formas de assimilá-los, portanto, produção, transmissão e assimilação são processos que compõem uma metodologia de construção coletiva do conhecimento escolar e é o instrumento utilizado pela escola, para marcar suas intencionalidades, reunindo conteúdos históricos, científicos, valores, cultura e conhecimento prático. Além destes elementos, é fundamental que as escolas incluíam neste documento a metodologia da pedagogia de projetos, para que através do conhecimento teórico e prático, haja a transcendência do indivíduo durante a formação acadêmica. De acordo com Nogueira (2006) podemos pensar nos projetos como estratégias facilitadoras do trabalho voltado à globalização, ou seja, aquele que leve o aluno a enxergar relações além das disciplinas de tal forma a interpretar o mundo, a realidade e a sociedade na qual estão inseridos. Um olhar mais voltado à complexidade da vida e do mundo, um olhar mais holístico e transdisciplinar com relação ao conhecimento, além dos conteúdos e das disciplinas acadêmicas. O projeto é uma proposta pedagógica que proporciona a atividade de aprender um sentido novo, percorrendo várias fases: escolha do objetivo central e formulação dos problemas, planejamento, execução, avaliação, divulgação dos trabalhos, onde as necessidades de aprendizagem aparecem nas tentativas de resolver as situações problemáticas. Por meio deste, a escola contribui para a construção da cidadania, com alunos participativos, ativos e atuantes. Hernández (1988) enfatiza que o trabalho por projeto não deve ser visto como uma opção puramente metodológica, mas como uma maneira de repensar a função da escola. Visto que, cabe a escola utilizar a pedagogia de projeto, para a formação de sujeitos culturais, pois para que o projeto seja executado, é necessário autonomia e responsabilidades dos alunos, sendo os corresponsáveis, e os professores mediadores do conhecimento por meio das situações de aprendizagens reais e diversificadas. Ao escolherem o tema do projeto é preciso analisar os assuntos presentes na sociedade, realizando alguns questionamentos entre si, como: qual o problema que está acontecendo e precisa ser solucionado? Como exemplo, de objeto de estudo do projeto, temos os temas transversais que envolvem as questões sociais, que são fatores importantes para a transformação educacional, oriundos da urgência e emergência destas discussões e transformação para a cidadania. Através da análise destas situações se permite ao aluno fazer uma reflexão, dentro de um contexto e em sua totalidade, fazendo o uso dos saberes adquiridos das disciplinas e sua experiência sociocultural para a resolução, desenvolvendo assim uma nova forma de ver e sentir o mundo. Diante deste momento que estamos vivendo de pandemia, a metodologia da pedagogia de projeto está sendo de suma importância, pois com o ensino remoto, houve a necessidade de os professores se reinventarem. Por meio da tecnologia estão utilizando recursos didáticos que desperte o interesse e atenção dos alunos, como: jogos, vídeos em desenhos animados, aulas com cenários diferenciados, atividade pedagógicas com interações, dentre outros, sendo que desta forma estão buscando diminuir o distanciamento, mantendo os alunos ativos no ambiente escolar/doméstico. E os conteúdos estão cada vez mais voltados à realidade, visando o desenvolvimento da consciência crítica e reflexiva. Ressaltamos esses aspectos, com a afirmação de Barbosa e Horn (2008), que a aprendizagem somente será significativa se houver a elaboração de sentido e se essa atividade acontecer em um contexto histórico e cultural, pois é na vida social que os sujeitos adquirem marcos de referência para interpretar as experiências e aprender a negociar os significados de modo congruente com as demandas da cultura. A presença do outro, adultos ou pares, e a coerência de interações com conflitos, debates, construções coletivas são fonte privilegiada de aprendizagem.

Conclusão: Em virtudes dos fatos mencionados, nota-se a importância de as escolas incluírem em seus currículos a metodologia da pedagogia de projetos, para que forme sujeitos participativos, críticos-reflexivos, que cumpram seu papel de cidadão na sociedade, sabendo discutir e resolver problemas de questões sociais.

\section{Referências}

VEIGA, Ilma Passos Alencastro. Projeto Político-Pedagógico da Escola: uma construção possível. Campinas: Papirus, 1997. 
$247 \mathrm{p}$.

BARBOSA, Maria Carmen Silveira; HORN, Maria da Graça Souza. Projetos Pedagógicos na educação Infantil. Porto Alegre: ArtMed- Grupo A, 2008. 128 p.

NOGUEIRA, Nilbo Ribeiro. Pedagogia dos projetos: etapas, papeis e atores. São Paulo: Érica, 2006.54 p.

HERNÁNDEZ, Fernando. Transgressão e Mudança na Educação: Os Projetos de Trabalho. Porto Alegre: ArtMed- Grupo A, 1998. 144 p. Disponível em: http://eadconsultoria.com.br/matapoio/biblioteca/textos_pdf/texto18.pdf. Acesso em: 23 mar. 2020.

Coordenadoria de Pesquisa e Extensão - COPEX

Departamento de Editoraçāo e Divulgaçāo Científica - DEDIC 


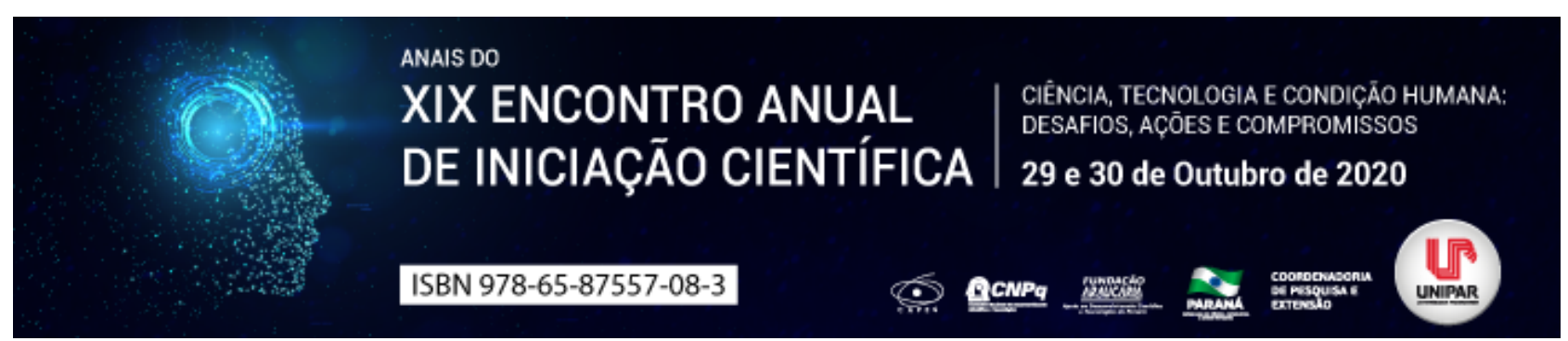

AUTISMO - A INCLUSÃO NA ESCOLA

\begin{abstract}
${ }^{1}$ LAURA VASCONCELOS, ${ }^{2}$ ANA MARIA DE ANGELO, ${ }^{3}$ VITORIA LOPES DOS PRAZERES, ${ }^{4}$ TAINARA RIGATTI, ${ }^{5}$ VIVIANNE AUGUSTA PIRES SIMÕES
\end{abstract}

\author{
${ }^{1}$ Acadêmica do Curso de Pedagogia da UNIPAR \\ ${ }^{1}$ Acadêmica do Curso de Pedagogia da UNIPAR \\ ${ }^{2}$ Acadêmica do Curso de Pedagogia da UNIPAR \\ ${ }^{3}$ Acadêmica do Curso de Pedagogia da UNIPAR \\ ${ }^{4}$ Docente da UNIPAR
}

Introdução: A inclusão de alunos com autismo no ensino comum tem mostrado um grande desafio para os professores, estudantes e suas famílias. A inclusão não é tão simples quanto na teoria, pois existem muitas escolas que não aceitam crianças com o autismo ou até mesmo que não tem recursos para tal ato. Mas como se dá esse processo? O que pais, professores e outros profissionais podem fazer para impulsionar a entrada desses alunos nos ambientes educacionais? É sempre importante lembrar que a inclusão é algo muito significativo na vida de quem recebe a ação. Esta etapa é imprescindível na vida dos estudantes de maneira geral, pois ele passa a lidar com situações bem diferentes dentro da sala de aula.

Objetivo: Explicar de forma sucinta sobre os tratamentos para esse transtorno, além de discutir sobre a educação de crianças dentro do TEA (Transtorno do Espectro Autista) e sua inclusão na escola.

Desenvolvimento: O Autismo, como é comumente conhecido, é definido como um déficit de comunicação social, seja ela verbal ou não verbal. A descoberta da síndrome é datada na década de 40. Segundo ROTTA, (2007, p. 423). I"Hoje, sabe-se que o autismo não é uma doença única, mas sim um distúrbio de desenvolvimento complexo, que é definido de um ponto de vista comportamental, que apresenta etiologias múltiplas e que se caracteriza por graus variados de gravidade . Em 2013, o autismo passou a ser chamado de Transtorno do Espectro Autista (TEA) justamente devido à comprovação de que existem vários tipos de autismo. Nesse viés, atualmente, vive-se uma época em que todos os ambientes devem trabalhar com a inclusão, principalmente no âmbito escolar, pois é no mesmo, que o indivíduo é preparado para viver em sociedade. A inclusão é muito mais que o inserir, é mais do que o simples fato de matricular na escola. A inclusão para realmente fazer jus à palavra, precisa acompanhar uma preparação tanto do professor quanto da escola, que é de grande importância para o desenvolvimento da criança, pois não é o indivíduo autista, como aqui estudado, que deve adaptar-se ao ambiente, mas sim o ambiente que deve ser adaptado e receber a educação inclusiva, pois já, há leis que determinam esta afirmação. Dentre as diversas barreiras que o espectro autista está envolto, a que levanta mais murmúrios e indagações é a educação inclusiva, pois é visível que dentro da sociedade contemporânea ainda existem muitos tabus e preconceitos para com os portadores de necessidades especiais, principalmente dentro do âmbito escolar. Porém com as Declarações de Salamanca e Jomtien que marcaram a educação como um direito a todos que assegura e direciona a inclusão de alunos com necessidades especiais no ensino regular, os professores e educadores perceberam que havia a necessidade de aprimoramento das técnicas pedagógicas, resultando nas práticas atuais, como atividades práticas que auxiliam a aprendizagem, por exemplo circuito motor, que pode ser expandido para diferentes áreas dentro da alfabetização. Ao analisar a realidade escolar no processo inclusivo no contexto do autismo na escola da rede pública, onde estudou-se como ocorre a inclusão dos alunos autistas na sala regular, identificando-se as principais dificuldades apresentadas para a inclusão dos autistas na escola pública de ensino regular, onde considerou-se a importância da relação família e escola como fator necessário para a inclusão dos alunos autistas.

Conclusão: A inclusão nas escolas de ensino regular pode ser útil tanto para os alunos com necessidades educacionais especiais quanto, para os ditos normais, desde os alunos até o corpo docente e administrativo da escola, pois a mesma traz consigo o resgate dos valores e o respeito pela diferença. Como Carvalho (1999) afirma que, a inclusão traz benefício a todos, pois podem desenvolver solidariedade, respeito às diferenças e cooperação uns para com os outros. Incluir não é só integrar não é estar dentro de uma sala onde há a inexistência de consciencialização de valores e a aceitação não existe. É aceitar integralmente e incondicionalmente as diferenças de todos, em uma valorização do ser, enquanto semelhante a nós, com igualdade de direitos e oportunidades. É mais do que desenvolver comportamentos, é uma questão de consciencialização e de atitudes (CAVACO, 2014, p. 31), dessa forma permitindo que todos os alunos, presentes e futuros, encontrem equidade no âmbito escolar.

\title{
Referências
}

CAVACO, 2014. Autismo na escola: pontos e contrapontos na escola inclusiva. Disponível em: https://bit.ly/2FUqSR4 
Acesso em: 23 abr 2020.

PAPIM, Ângelo A P.; SANCHES, Kelly Gil. Autismo e Inclusão: Levantamento das dificuldades encontradas pelo professor do atendimento educacional especializado em sua prática com crianças com autismo. Lins: UNISALESIANO, 2013

Revista Autismo. O que é autismo? Versão online. Disponível em: https://bit.ly/33RnoXC Acesso em: 28 abr. 2020.

VINOCUR, Evelyn Autismo: o que é, sintomas e tipos. Disponivel em : https://bit.ly/3cpJaFD Acesso em: 23 abr. 2020.

Coordenadoria de Pesquisa e Extensão - COPEX

Departamento de Editoraçāo e Divulgaçāo Científica - DEDIC 


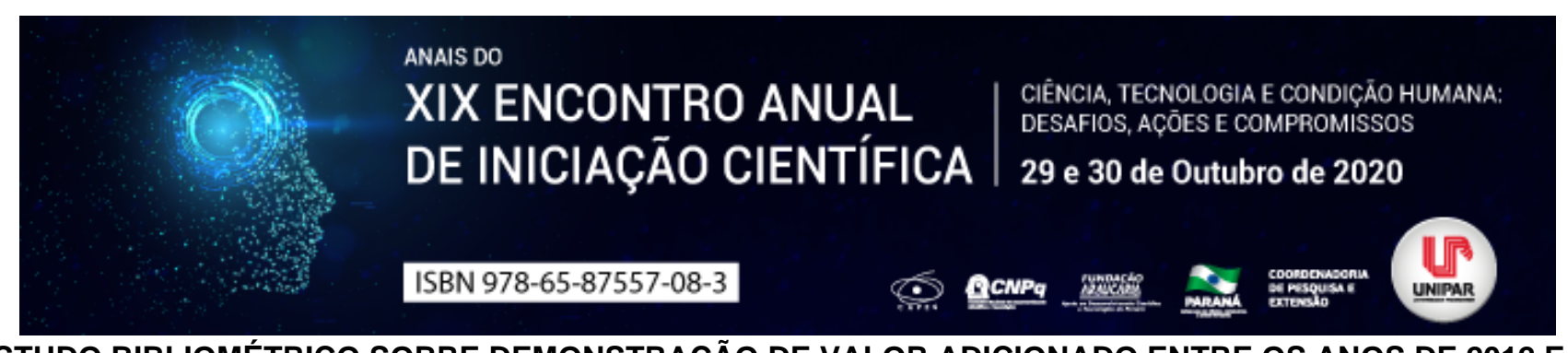

UM ESTUDO BIBLIOMÉTRICO SOBRE DEMONSTRAÇÃO DE VALOR ADICIONADO ENTRE OS ANOS DE 2012 E 2019

\author{
${ }^{1}$ FABRICIO BALESTRIN, ${ }^{2}$ ADRIAN KEVEN COSTA, ${ }^{3}$ JOSE LUIZ BORSATTO JUNIOR, ${ }^{4}$ ISABEL CRISTINA GOZER
}

\author{
${ }^{1}$ Acadêmico do PIC/UNIPAR \\ ${ }^{1}$ Acadêmico do PIC/UNIPAR \\ ${ }^{2}$ Docente da UNIPAR \\ ${ }^{3}$ Docente da UNIPAR
}

Introdução: A contabilidade é provedora de informações aos usuários, auxiliando no processo de decisão e gestão das organizações (Klöppel, Schnorrenberger e Lunkes, 2013). A partir de 2008, passou a ser obrigatório a elaboração e divulgação da Demonstração do Valor Adicionado (DVA) por empresas de capital aberto através da Lei 11.638, trazendo informações úteis sobre a capacidade de geração de riqueza e a destinação entre seus agentes (governo, financiadores externos e os proprietários) (Souza et al, 2008).

Objetivo: Analisar por meio da bibliometria a produção científica acerca da demonstração do valor adicionado (DVA) entre os anos de 2012 e 2019 nas plataformas Spell, Scopus e Scielo.

Material e Métodos: Para obtenção das produções científicas utilizou-se o método ProKnow-C (Knowledge Development Process Constructivist), proposto por Ensslin et al. (2010) através de uma busca eletrônica nas bases de dados (Spell, Scopus e Scielo) com o tema valor adicionado ou dva. Após a utilização de filtros buscou-se artigos que possuíssem essas palavras no título, resumo ou palavras-chaves entre os anos de 2012 e 2019 e chegou-se a um total de 103 artigos. Com a utilização do EndNote Web para gerenciar as referências bibliográficas, eliminou-se duplicidades de artigos e após a leitura dos resumos excluíram-se as produções que não eram relacionados ao tema, sobrando 56 artigos. Estes foram organizados e tabulados no Planilhas Google de acordo com as seguintes variáveis: ano de publicação, autores por artigo, periódicos, citações recebidas e palavras-chave.

Resultados: Ao associar artigos com o ano de publicação o resultado foi para 2012, 4 trabalhos (7,14\%), para 2013, 7 artigos (12,50\%), em 2014, 8 artigos (14,29\%), 2015 com 7 artigos (12,50\%), 2016 teve 10 trabalhos (17,86\%), 2017 com 4 artigos (7,14\%) e 2018 e 2019 com 8 artigos cada e 14,29\% para cada ano. Encontrou-se 4 trabalhos (7,14\%) com 2 autores, 29 trabalhos (51,79\%) com 3 autores, 17 artigos (30,36\%) com 4 autores, 5 trabalhos (8,93\%) com 5 autores e somente 1 artigo $(1,79 \%)$ com 6 autores. No total tivemos 150 autores nos 56 artigos, 136 destes (90,67\%) publicaram um único artigo sobre o tema, 11 autores (7,33\%) estiveram presentes em 2 artigos e 3 autores (2,00\%) contribuíram em 3 trabalhos. As publicações estavam em 31 periódicos e os três que mais tiveram artigos relacionados com o tema foram Enfoque Reflexão Contábil e Revista Catarinense da Ciência Contábil com 5 trabalhos (8,93\% do total) cada e a Revista Mineira de Contabilidade que teve 4 trabalhos $(7,14 \%)$. Os artigos analisados estavam em periódicos A2, A3, B1, B2, B3, B4 e B5, com $3(5,36 \%), 3(5,36 \%), 17$ (30,36\%), $17(30,36 \%), 12(21,43 \%), 3(5,36 \%)$ e $1(1,79 \%)$ publicações, respectivamente. Em relação as palavras-chaves, valor adicionado, distribuição de riqueza e qualidade da informação, estavam presente em 28,8 e 6 trabalhos, respectivamente.

Discussão: Há evolução da produção relacionada ao valor adicionado, como corroboram Teodoro et al. (2012) ao analisar os períodos de 1970 a 2010. Oliveira, Santos e Botinha (2016) identificaram uma linha de tendência de crescimento entre os anos 1992 a 2015, destacando ainda um aumento no ano de 2007 devido ao processo de convergência às IFRS e a obrigação da publicação do DVA pelas empresas de capital aberto, esse aumento também é verificado em Ponte, Gonçalves e Krisley Mendes (2018) que pesquisaram o tema entre os anos de 1966 e 2017. Cabe ressaltar que não houve uma uniformidade das publicações no período, também citado por Libarino (2019), ao estudar o tema entre os anos de 2009 e 2018. Autores com somente uma contribuição totalizam 90,67\%, próximo dos 95\% encontrado por Mendes (2018), o que caracteriza uma dispersão entre autores. Dos 56 artigos, 51,79\% tiveram 3 autores, Oliveira, Santos e Botinha (2016) tiveram a maioria dos artigos com 3 autores (32\%) também, porém em Lorandi e Alexandre (2011) a maioria possuía 4 autores $(35,71 \%)$, demonstrando uma cooperação entre autores e troca de experiência acerca do tema. Os periódicos B1 (30,36\%) e B2 (30,36\%), possuem a maioria do artigos, já para Libarino (2019) a maioria se concentra em B3 (38,89\%) e B2 (22,22\%), para Lorandi e Alexandre (2011) em B3 (30\%) e B1 (21\%) e Oliveira, Santos e Botinha (2016) somente analisando A2 e B1, com a seguinte distribuição $28 \%$ e $72 \%$, respectivamente. De acordo com Libarino (2019) as palavras-chaves mais citadas são demonstração de valor adicionado, balanço social e distribuição de riqueza , o que se assemelha com o presente trabalho.

Conclusão: Devido ao aumento das pesquisas, flagrou-se uma emergência em estudar o tema, embora ainda haja variações expressivas na quantidade de publicações por ano. Mais autores por artigo ajudam a difundir e ocasionam uma troca de 
experiências importante, mesmo que a grande maioria tenha participado de apenas um trabalho. Publicações em periódicos bem avaliados ajudam na comunicação e divulgação do conhecimento científico. Ressalta-se, porém, a necessidade de expandir pesquisas nessa área devido à escassez de trabalhos, ainda que esse trabalho fosse limitado às bases Spell, Scopus e Scielo.

\section{Referências}

ENSSLIN, L.; ENSSLIN, S. R.; LACERDA, R. T. O.; TASCA, J. E. (2010). Processo de análise sistêmica. Processo técnico com patente de registro pendente junto ao INPI. Brasil

KLÖPPEL, F.; SCHNORRENBERGER, D.; LUNKES, R. J. Análise da Geração e Distribuição da Riqueza Originada pelas Empresas que Compõem o Ibovespa por Meio da DVA. Revista Catarinense da Ciência Contábil, v. 12, n. 34, p. $2339,2013$.

LIBARINO, R. DA S. Perfil dos artigos científicos sobre DVA publicados no repositório da CAPES entre os anos de 2009 a 2018Vitória da Consquisata, BA, 2019. Disponível em: . Acesso em: 2 ago. 2020

LORANDI, J. A.; ALEXANDRE, C. L. Demonstração do valor adicionado: um estudo bibliográfico nas revistas nacionais constantes no portal da CAPESAnais do Congresso ANPCONT 2011Vitória, ES, 2011. Disponível em:

OLIVEIRA, T. P. DE; SANTOS, C. K. S.; BOTINHA, R. A. Demonstração do valor adicionado: Um estudo bibliométrico de artigos listados nos periódicos A2 e B1 do Qualis 2014 da CapesAnais do $3^{\circ}$ Encontro de Pesquisa e ExtensãoPatrocínio, MG, 2016. Disponível em: . Acesso em: 2 ago. 2020

PONTE, D. DE M.; GONÇALVES, M. M.; KRISLEY MENDES. Análise da relação entre DVA e Comércio Exterior: avaliação bibliométrica à luz da Lei de LotkaAnais do $8^{\circ}$ Congresso UFSC de Iniciação Científica em ContabilidadeFlorianópolis, SC, 2018. Disponível em: . Acesso em: 2 ago. 2020

SOUZA, Marcos Antonio de, et al. Evidenciação voluntária de informações contábeis por companhias abertas do sul brasileiro. Revista Universo Contábil, Blumenau, v. 4, n. 4, p. 39-56, out./dez. 2008.

TEODORO, J. D. et al. Valor adicionado: Tendências metodológicas e temáticas adotadas no período 1970-2010. REVISTA AMBIENTE CONTÁBIL - UFRN, v. 4, p. 132 148, 2012.

Coordenadoria de Pesquisa e Extensão - COPEX

Departamento de Editoraçāo e Divulgaçāo Científica - DEDIC 


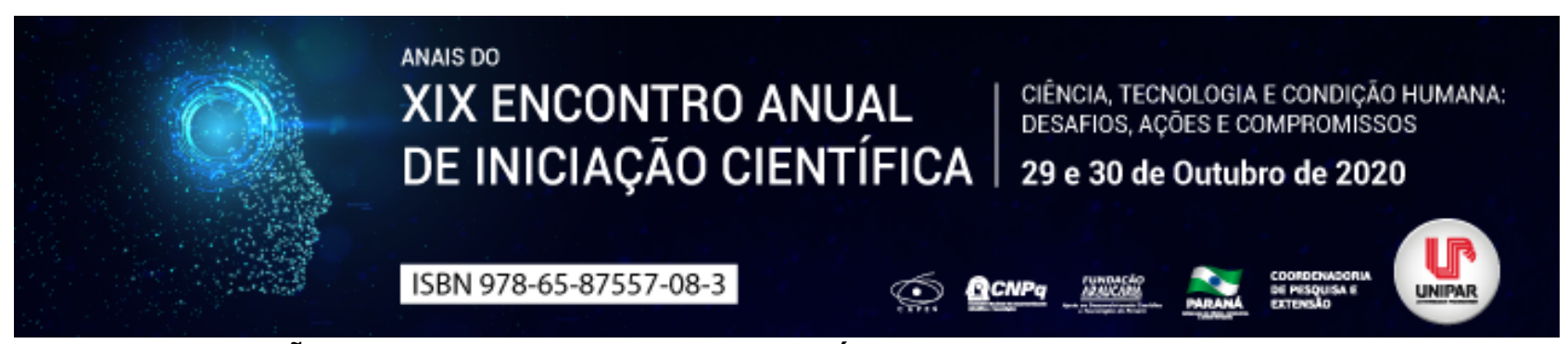

CONSIDERAÇÕES SOBRE PSICOLOGIA COMUNITÁRIA FRENTE AO CONTEXTO BRASILEIRO

\author{
${ }^{1}$ LUIZ AUGUSTO BAESSO TURCI, ${ }^{2}$ STEPHANEI COELHO PAULINI, ${ }^{3}$ EMANUEL JOSE LAHOS BORGES, ${ }^{4}$ MATHEUS LIMA \\ DOS SANTOS, ${ }^{5}$ CLAUDIA LOPES PERPETUO
}

\footnotetext{
${ }^{1}$ Acadêmico de Psicologia da Unipar

${ }^{1}$ Acadêmica do Curso de Psicologia da UNIPAR

${ }^{2}$ Acadêmico do Curso de Psicologia da UNIPAR

${ }^{3}$ Acadêmico do Curso de Psicologia da UNIPAR

${ }^{4}$ Docente da UNIPAR
}

Introdução: No contexto latino americano, a injustiça estrutural é cotidiana e hegemônica (MARTíN-BARÓ 1996), quando se aproxima isso do contexto brasileiro, fica mais evidente, dentro deste recorte se faz útil trabalhos sociais em meio aos contextos comunitários, onde se encontram os grupos que mais sofrem de injustiça estrutural, e neste trabalho, profissionais da psicologia encontram uma área atuante, pois como diz Martín-Baró (1996) a conscientização social é uma ferramenta para a emancipação desses locais, logo, a atuação do psicólogo assume caráter comprometedor com a emancipação de sujeitos, e na realização disso é de suma importância discutir quais os métodos serão necessários.

Objetivo: Discutir alguns tópicos importantes para a psicologia em contexto de comunidade e suas ideações para produção de emancipação social nesses locais.

Desenvolvimento: O meio social é o que forma a condição humana (REBOUÇAS JÚNIOR \& XIMENES 2010), isso decorre em pensar que estudar a sociedade é uma forma muito relevante de chegar no entendimento do sujeito, sendo assim, a psicologia encontra seu papel de atuação social, pois compreender o humano é compreender a sociedade (REBOUÇAS JÚNIOR \& XIMENES 2010). Em diversos campos de atuação, o psicólogo pode gerar contextos que exaltam e valorizam os sujeitos, ou mantê-los desvalorizados e em precariedade emocional, e isso não é diferente em situações comunitárias, sendo assim, a atuação do profissional de psicologia deve se realizar respeitando e entendendo o limite dos espaços sociais e agindo de forma a mediar o processo sem impor sua realidade perante os outros (MARTINS, 2007), deve haver responsabilidade na atuação social, e respeito aos limites que a comunidade dos envolvidos impõe, a fim de não prejudicar o processo a ser realizado. Ainda, segundo Rebouças Júnior \& Ximenes (2010), mesmo que seja uma forma importante de contato com a comunidade, a psicologia não deve se apresentar como forma hegemônica e determinadora de processo terapêutico, a própria comunidade enquanto grupo de indivíduos deve ser tida como uma das formas de se realizar esse processo, afinal, coisas como o vínculo social que a comunidade constrói na relação entre os sujeitos ou o diagnóstico apresentado pela comunidade devem ser norteadores, e a inserção do psicólogo é apenas um mediador do processo (REBOUÇAS JÚNIOR \& XIMENES 2010). Ainda neste viés, cabe dizer que o psicólogo acaba por ser visto em contextos de injustiça estrutural como um detentor do conhecimento, e essa visão acaba por reproduzir lógicas de dominação, que podem atrapalhar o enfoque da psicologia na comunidade em produzir um bem comum para os envolvidos (MARTINS 2007), pois, o poder do processo deve encontrar nas relações dentro da comunidade.

Conclusão: Sendo assim, a psicologia se faz como ferramenta importante na sociedade e sua atuação no contexto comunitário respalda em atender necessidades da comunidade como ferramenta auxiliadora e não hegemônica de emancipação social, que causa impacto nas relações dentro da sociedade e deve ser usada com cautela dentro dos limites que o contexto social da atuação irá definir.

\title{
Referências
}

MARTINS, S. T. F. Psicologia Social e processo grupal: a coerência entre fazer, pensar e sentir em Sílvia Lane. Psicologia \& Sociedade, São Paulo, v. 19, 2. ed. p. 76-80, jul./set. 2007.

MARTíN-BARÓ, I. O papel do psicólogo. Estudos de Psicologia, [S. I], v. 2, n. 1, p. 7-27. 1996.

REBOUÇAS JÚNIOR, F. G.; XIMENES, V. M. Psicologia comunitária e psicologia histórico-cultural: análise e vivência da atividade comunitária pelo método dialógico-vivencial. Pesquisas e Práticas Psicossociais, São João del-Rei, v. 5, n. 2, p. 151162, ago./dez. 2010. 


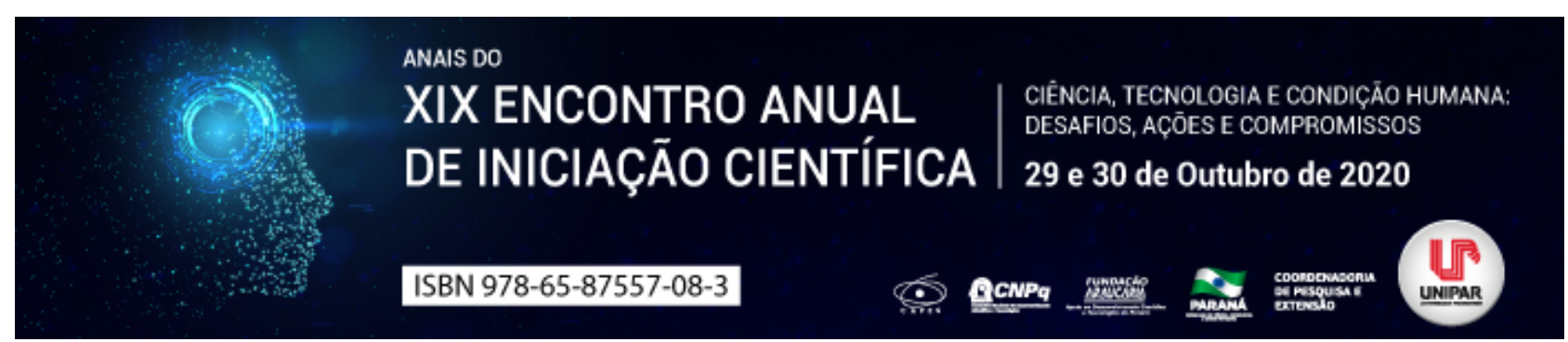

OS ANIMAIS DOMÉSTICOS COMO SUJEITOS DE DIREITO NO ORDENAMENTO JURÍDICO BRASILEIRO

\title{
${ }^{1}$ ELOISA HUNGARO MOLONHA, ${ }^{2}$ PAULO CESAR DE SOUSA
}

\author{
${ }^{1}$ Acadêmica do curso de Direito da Unipar \\ ${ }^{1}$ Docente da UNIPAR
}

Introdução: Tramita perante a Câmera dos Deputados o Projeto de Lei no 6799, de 2013, o qual classifica os animais domésticos como sujeitos de direito no ordenamento jurídico brasileiro, e não mais como coisas. Com isso, muda-se a natureza jurídica quanto ao instituto dos semoventes, deixando esses de ser considerados objeto de relação jurídica, passando ao status de titulares de direitos.

Objetivo: Analisar os contornos do regime jurídico especial para os animais de estimação, bem como a mudança de paradigma de seu tratamento pelo ordenamento jurídico.

Desenvolvimento: O Código Civil Brasileiro atual, ao definir a natureza jurídica dos animais, os tipificou como: bens móveis, suscetíveis de movimento próprio, ou de remoção por força alheia, sem alteração da substância ou da destinação econômicosocial (BRASIL, 2002). Nesse sentido, os animais ainda são considerados como objetos de relação jurídica e podem ser negociados, adquiridos de diversas maneiras, o que reforça a concepção do pensamento segundo o qual o ser humano possui uma posição centralizada em relação a todo o universo, conhecida como antropocentrismo . Todavia, no Projeto de Lei $n^{\circ}$ 6799/13, observa-se que a justificativa do texto respectivo traz a argumentação relacionada à preocupação de que os animais não humanos possuem natureza biológica e emocional por serem seres sencientes. Cabe ressaltar que a senciência dos animais não humanos foi reconhecida em 2012, na Conferência de Cambridge e pode ser definida como a capacidade que um ser possui de sentir algo conscientemente, ou seja, de ter percepções conscientes do que the acontece e do que o rodeia (LOW et al., 2012). Consequentemente, importa a modificação do plano jurídico civil em que os animais ainda são submetidos ao mesmo tratamento das coisas. Em verdade, é cada vez maior o consenso em relação à necessidade de, pelo menos, dotar os animais não humanos de um estatuto jurídico que reconheça as suas diferenças e natureza, quer face aos humanos, quer face às coisas inanimadas (GOMES, 2015, p. 29). Essa alteração também objetiva contribuir para a construção de uma sociedade mais solidária e consciente, ao prever aos animais não humanos uma tutela jurídica, uma proteção aos seus direitos essenciais. Vale destacar que essa proposição legislativa se encontra consonante à tendência mundial, visto já ser observada, por exemplo, em países como Alemanha, Suíça, Áustria, França e Portugal.

Conclusão: O Projeto de Lei 6799/13 ancora-se na premissa de atribuir uma natureza jurídica sui generis aos animais não humanos, a fim de contribuir para a proteção desses seres e inseri-los na sociedade, não mais como meros objetos de direito, mas como sujeitos de relação jurídica, por serem capazes de sentimentos. Com isso, muda-se o modelo de juízo de valor adotado aos animais no ordenamento jurídico, devido à mudança observada na sociedade.

\section{Referências}

BRASIL. Lei $\mathbf{n}^{\circ}$ 10.406, de 10 de janeiro de 2002. Código Civil. Disponível em: www.planalto.gov.br. Acesso em: 02 ago. 2020. GOMES, C. A. Animais: Deveres e Direitos. In: Conferência promovida pelo ICPJ. Instituto de Ciências Jurídico-Políticas, 2015. Disponível em: https://www.icjp.pt/publicacoes/pub/1/5105/view. Acesso em: 03 ago. 2020.

LOW, P., et al. Declaração de Cambridge. In: Conferência Francis Crick Memorial sobre a Consciência em animais humanos e não humanos. Universidade de Cambridge, Reino Unido, 2012. 


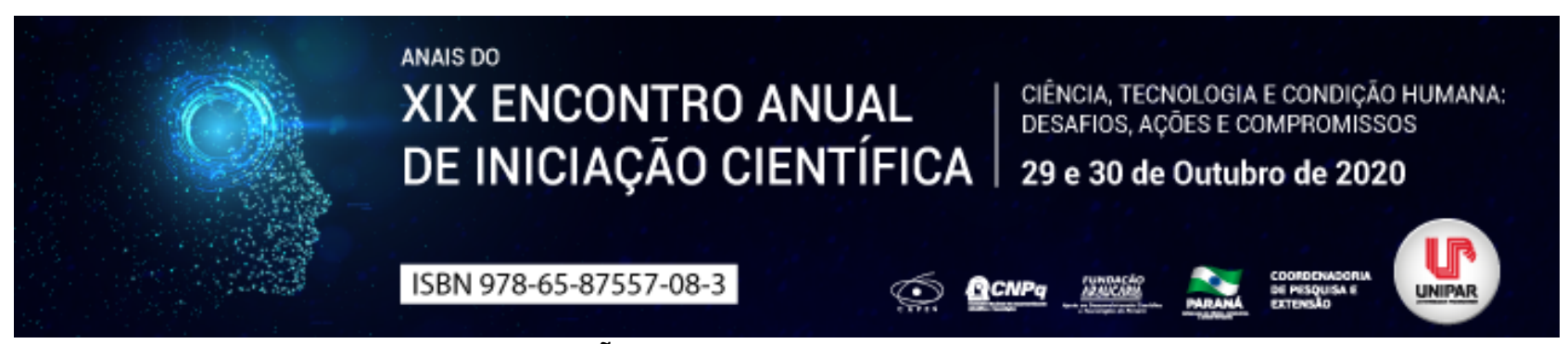

AUTOCOMPOSIÇÃO, TECNOLOGIA E TEORIA DOS JOGOS

\title{
${ }^{1}$ EDISON FRANCA LANGE JUNIOR, ${ }^{2}$ ALBINO GABRIEL TURBAY JUNIOR
}

\author{
${ }^{1}$ Acadêmico do PIC/UNIPAR \\ ${ }^{1}$ Docente da UNIPAR
}

Introdução: O Código de Processo Civil acolhe técnicas de negociação como meios propícios destinados a favorecer a autocomposição dos conflitos. Destaca-se, nesta toada, o método relativo ao Projeto de Negociação da Universidade de Harvard, que contém técnicas avançadas tendentes a favorecer a celebração de acordos. Do mesmo modo, a teoria dos jogos, que utilizase da lógica matemática para resolver problemas relacionados a conflitos de interesses, mostra-se apta a propiciar a autocomposição. A pesquisa procurou tratar sobre esses mecanismos de negociação de litígios, aliando à tecnologia como meio capaz de cooperar para a solução pacífica dos conflitos.

Objetivo: O objetivo da pesquisa consiste em analisar como a tecnologia pode colaborar para a solução de conflitos patrimoniais, partindo-se da aplicação dos princípios extraídos do Projeto de Negociação da Universidade Harvard e da utilização da teoria dos jogos para a composição de interesses divergentes.

Desenvolvimento: Segundo o $\S 3^{\circ}$ do art. 166 do Código de Processo Civil, admite-se a aplicação de técnicas negociais, com o objetivo de proporcionar ambiente favorável à autocomposição . Nessa esteira, a pesquisa parte inicialmente da análise das soluções consensuais de conflitos utilizando-se como referência o método extraído do Projeto de Negociação da Universidade de Harvard. O método propõe que a negociação esteja focada não nas posições dos negociantes, mas nos interesses envolvidos na disputa. Segundo Fisher, Ury e Patton (2018, p. 64), o problema básico de uma negociação não está em posições conflitantes, mas no conflito entre necessidades, desejos, preocupações e medos de cada lado. Uma vez estabelecidos os interesses das partes torna-se possível a busca pelas melhores opções que atendam às necessidades e desejos envolvidos. Utilizamos, então, a teoria do jogos, que pode ser aplicada como um modelo racional de resolução de divergências, através da análise matemáticoformal, que tem por finalidade encontrar as melhores opções para as partes dentro da dinâmica do conflito. Por meio do equilíbrio de Nash, que está fundamentado em estratégias dos jogadores em que cada uma é a melhor resposta à outra (SPENGLER; SPENGLER NETO, 2009, p. 79), permite-se chegar, na maioria dos litígios, em um termo que leva em conta a melhor decisão, considerando as estratégias e os interesses, mutuamente, de uma e da outra parte. Mas para o estabelecimento das estratégias, um fator é fundamental: informação. Para a teoria dos jogos, havendo assimetria de informação (onde um dos participantes conta com informação que os outros não possuem), um dos jogadores pode agregar valor à esta informação (SPENGLER; SPENGLER NETO, 2009), em vantagem sobre os outros jogadores. Algumas informações são imprescindíveis para a escolha entre o acordo e a judicialização, como o percentual de chance de êxito (caso o conflito seja ajuizado), o tempo de tramitação do processo, e ainda, os custos envolvidos na discussão judicial. E neste ponto, a tecnologia tem muito a contribuir. A alimentação de um banco de dados judiciais, ao lado da utilização da tecnologia de inteligência artificial, pode colaborar no sentido de proporcionar melhores decisões voltadas para a solução consensual. Já existem softwares, com funcionalidades denominadas como Business Intelligence, capazes de acompanhar processos com decisões já proferidas e calcular os riscos de sucesso no contencioso processual (COSTA; HOCHMANN, 2019). Destaca-se, ainda, o desenvolvimento da online dispute resolution (ODR), como uma forma de solução de conflitos em ambiente virtual, que tem se demonstrado financeiramente vantajosa e com evidente economia de tempo (LIMA; FEITOSA, 2016), tendo como exemplo de sucesso, no Brasil, a eficiente plataforma Consumidor.gov.br (FIGUEIREDO, 2020).

Conclusão: O método do Projeto de Negociação de Harvard tem muito a contribuir em favor da autocomposição, por meio da perspectiva concentração da busca pela solução dos conflitos nos interesses das partes e não em suas posições. Através da análise dos interesses, chega-se a uma variável gama de opções. As melhores, capazes de resolver de forma mais satisfatória a demanda, podem ser evidenciadas pela aplicação da lógica da teoria dos jogos. Entretanto, para a aplicação da teoria do jogos é fundamental avaliar o nível de informação dos envolvidos no litígio. A tecnologia da informação pode colaborar com o fornecimento de dados que ajudam na tomada de decisões na negociação, favorecendo, assim, o acordo. A resolução de conflitos em ambiente virtual já é uma realidade e tem se mostrado eficaz enquanto método de resolução consensual de conflito.

\section{Referências}

COSTA, Fernanda Granja Cavalcante da; HOCHMANN, Eleandro Granja Costa Vanin e. O gerenciamento dos riscos judiciais das empresas por meio de softwares. Revista de Direito, Inovação, Propriedade Intelectual e Concorrência. Belém, v. 5, n. 2, p. 60 79, Jul/Dez. 2019.

FIGUEIREDO, Bianca Fernandes. Consumidor.gov.br: a exigência de utilização da plataforma digital de solução adequada de 
conflitos antes do ajuizamento de ação de consumo como fator de eficiência do Poder Judiciário, à luz da análise econômica do direito. Revista CNJ, Brasília, v 4, n. 1, jan/jun 2020.

FISHER, Roger; URY, William; PATTON, Bruce. Como chegar ao sim. Tradução de Rachel Agavino. 1. ed., rev. e atual. Rio de Janeiro: Sextante, 2018.

LIMA, Gabriela Vasconcelos; FEITOSA, Gustavo Raposo Pereira. Online dispute resolution (ODR): a solução de conflitos e as novas tecnologias. Revista do Direito. Santa Cruz do Sul, v. 3, n. 50, p. 53-70, set./dez. 2016.

SPENGLER, Fabiana Marion; SPENGLER NETO, Theobaldo. A possibilidade do tratamento de conflitos no âmbito do judiciário por meio da teoria dos jogos. Revista Desenvolvimento em Questão. Editora Unijuí, ano 7, n. 13, jan./jun. 2009.

Coordenadoria de Pesquisa e Extensão - COPEX

Departamento de Editoraçāo e Divulgaçāo Científica - DEDIC 


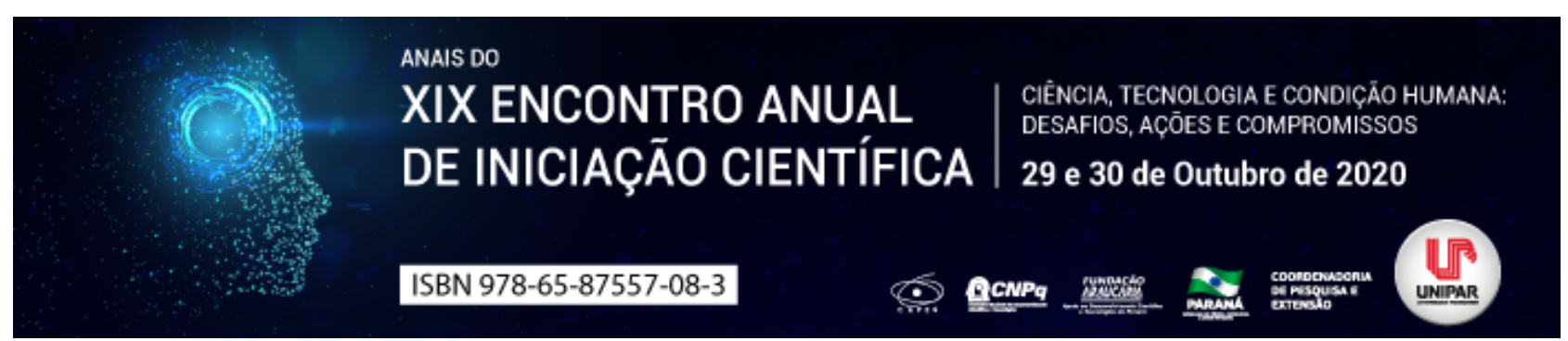

PRÁTICAS EDUCATIVAS AMBIENTAIS NA EDUCAÇÃO INFANTIL

\section{${ }^{1}$ ROZILDA JOSE PEREIRA BERTOLLI, ${ }^{2}$ CAROLINA AMARAL TAVARES}

${ }^{1}$ Acadêmica do curso de Licenciatura em Pedagogia da UNIPAR

${ }^{1}$ Docente do curso de Tecnologia em Gestão Ambiental da UNIPAR

Introdução: A Constituição Federal Brasileira 1988, foi sancionada para a regulamentação da Educação Ambiental em todos os níveis de ensino, publicada, no ano de 1994, por intermédio da Política Nacional de Educação Infantil (MEC). Em atendimento à lei (LEI 9.795, 1999, art. $1^{\circ}$ ), a Educação Ambiental (EA), passou a fazer parte dos currículos escolares, como metodologia integrada e obrigatória, para a formação do sujeito ecológico, e a construção de uma cidadania responsável e comprometida com a preservação do meio ambiente (BRASIL, 2005).

Objetivo: Identificar a importância da Educação Ambiental na educação infantil.

Desenvolvimento: De acordo com Jacobi (1997), a educação precisa ir em busca de elementos sólidos, mediando a igualdade e o respeito à diferença, por meio práxis democráticas, interativas e dialógicas, com o objetivo de gerar novas condutas e atitudes em relação ao convívio social, conscientizado sobre comportamentos individuais e coletivos e desse modo, entende-se a importância da inserção da EA na educação infantil despertando o desenvolvimento ecológico ainda nos primeiros anos de escolaridade (CARVALHO, 2008, p.156). Ressalta-se ainda a necessidade das ações educativas dos professores da educação infantil, para que seja contextualizada, integrada, de modo a possibilitar às crianças pequenas a formação de valores a respeito da preservação do meio ambiente (VASCONCELOS, 2010). Dessa forma, busca-se a incorporação de novos hábitos nas crianças, através da educação de forma lúdica e ativa, resultando em melhor aprendizagem sobre a utilização de recursos naturais de maneira sustentável (ALMEIDA, 1995). No contexto escolar, diante da reflexão à partir de Torres $(1999$, p.90) a problemática da Educação Ambiental associadas às propostas das políticas-pedagógicas efetiva, leva a ação reflexiva sobre os problemas ambientais do mundo . Por seguinte, ao refletir sobre a obra Os sete saberes necessário à educação do futuro (MORIN, 2001), é possível entender que para possibilitar o desenvolvimento deste espírito crítico e consciente, é fundamental que o estímulo escolar aconteça de forma concreta, com um conhecimento palpável, buscando sempre, aproximar a prática pedagógica da realidade na qual está inserido o aluno.

Conclusão: Concluímos, que o desafio da sustentabilidade ambiental, é aproximar o processo educacional da formação do sujeito ecológico, vinculando sociedade e natureza. Construindo valores e conceitos, visando o desenvolvimento das habilidades e das atitudes em relação ao meio ambiente.

\section{Referências}

DIAS, G. Educação Ambiental: princípios e práticas, 6.ed. São Paulo: Gaia, 2010.

JACOBI, P. et al. (orgs.). Educação, meio ambiente e cidadania: reflexões e experiências. São Paulo: SMA, 1998.

MORIN, E. Os sete saberes necessários à Educação do futuro. São Paulo: Cortez, 2000.

SANTOS, R.C. et al. Contribuições de um jogo didático para a construção identitária de alunos sobre educação ambiental. Revista Educação Ambiental em Ação, n. 49, ano XIII, set.-nov.2014. 


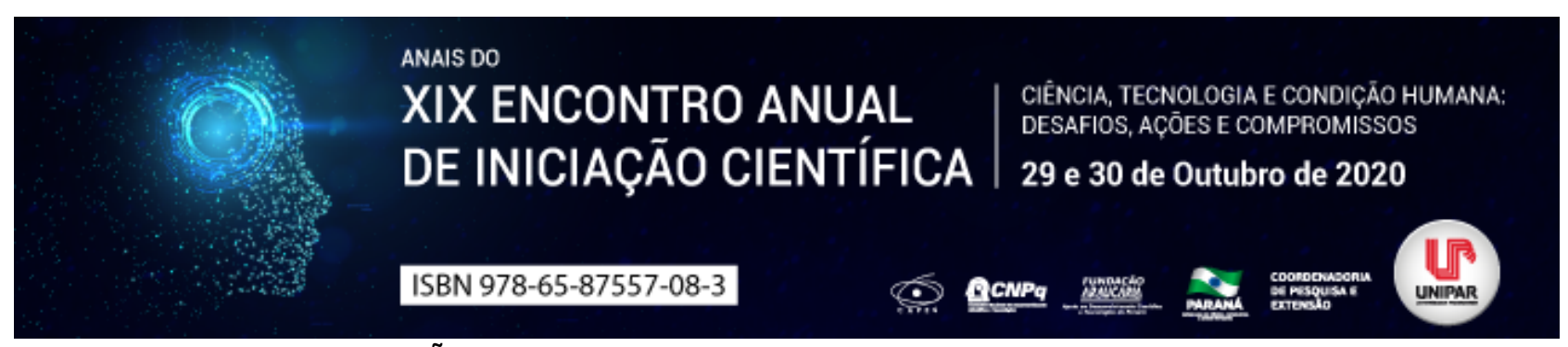

EDUCAÇÃO AMBIENTAL NO ENSINO INFANTIL E FUNDAMENTAL

\author{
${ }^{1}$ MIKAEL OTTO, ${ }^{2}$ CAROLINA AMARAL TAVARES DA SILVA
}

${ }^{1}$ Acadêmico do curso de Pedagogia $2^{\circ}$ licenciatura e discente PIC/UNIPAR

${ }^{1}$ Docente do curso de Tecnologia em Gestão Ambiental EAD-UNIPAR

Introdução: A problematização da educação ambiental deve ser abordada em todos os níveis de ensino, a conscientização e a construção do conhecimento iniciam-se na fase pré-escolar onde o educando começa a ter uma visão de cuidado ao meio ambiente. Barcelos (2008) ressalta que a escola seria o espaço ideal para o começo da conscientização ambiental, lembrando-se que o estímulo à criatividade é essencial para um bom trabalho. Neste sentido, é preciso difundir estratégias de ensino da Educação ambiental na comunidade escolar com o intuito de ampliar a visão crítica dos educandos, fomentar discussões e rever as metodologias de ensino inseridas nos documentos que regem os currículos oficiais escolares.

Objetivo: Estudar a abordagem da Educação Ambiental nos anos iniciais da Educação Básica.

Desenvolvimento: A educação ambiental é um campo pedagógico muito diverso, pois, não está relacionada somente com a ciência ambiental, mas, com as práticas sociais, políticas e ideológicas e com isto, os docentes podem encontrar certas dificuldades no planejamento de suas aulas e na mediação dos conceitos ambientais. Desse modo, metodologias lúdicas apresentam-se como estratégias didáticas promissoras para os processos de ensino-aprendizagem nos anos iniciais na Educação Ambiental (DANTAS; SANTANA; ZAKAYAMA, 2012). Nessa perspectiva, deve-se considerar a importância de práticas metodológicas que tragam algo novo à Educação Ambiental devendo considerar a importância do envolvimento dos sentimentos e a ludicidade dos participantes na prática docente (BARCELOS, 2008). Dessa forma, os jogos didáticos podem propiciar momentos de descontração e estimulo cognitivo dos discentes contribuindo para construção do conhecimento científico (SIQUEIRA; ANTUNES, 2013). Tal ponto de vista corrobora com o Dohme (2008, p.113) as atividades lúdicas, podem colocar o aluno em diversas situações, onde ele pesquisa e experimenta, fazendo com que ele conheça suas habilidades e limitações, que exercite o diálogo... . Nesse contexto, o desenvolvimento de paródias musicais e vídeos didáticos é um caminho interdisciplinar dinâmico para aprendizagem significativa contribuindo para assimilação dos conceitos ambientais (BERGO, 2018). Assim, por meio do uso de documentários de divulgação científica que abordam as problemáticas ambientais em sala de aula permite sensibilizar e modificar concepções prévias errôneas dos alunos acerca das questões socioambientais (MATTA; ROCHA, 2017). Desse modo, os Textos de Divulgação Científica (TDC's), apresentam-se como importantes ferramentas para os processos de ensino aprendizagem com objetivo de contextualizar as questões ambientais atuais na prática docente (SULAIMAN, 2011). Nesta perspectiva, o ensino dos conceitos socioambientais nos anos iniciais desenvolve-se de maneira bastante prática, atrativa, divertida. Contudo, as questões ambientais devem ser abordadas desde os anos iniciais com objetivo de formar cidadãos críticos na sociedade, pois, as problematizações voltadas ao meio ambiente estão presentes no cotidiano dos alunos (GRZEBIELUKA; KUBIAK; SCHILLER, 2014).

Conclusão: Portanto, é necessário introduzir metodologias de ensino que articulem e facilitem a assimilação dos conceitos de natureza e meio ambiente com a realidade do aluno sob uma perspectiva epistemo-metodológica da Educação Ambiental. Nesta ótica, as produções acadêmicas apresentam estratégias didáticas contextualizadoras no ensino dos conceitos socioambientais por meio do uso de jogos didáticos, (TDC's), recursos didáticos artísticos e digitais que se mostram como importantes ferramentas didáticas para a Alfabetização Científica.

\title{
Referências
}

BARCELOS, V. Educação Ambiental: sobre princípios, metodologias e atitudes. Editora Vozes. Petrópolis. 2008.

BERGO, G. S. M. Ciência, Música e Ambiente: Experiências e estratégias transdisciplinares no ensino básico integral modelo GEO (Ginásio Experimental Olímpico). Dissertação de mestrado. Programa de Pós-Graduação em Ensino em Biociências e Saúde Instituto Oswaldo Cruz. Rio de Janeiro, 161 p. 2018. Disponível em: https://www.arca.fiocruz.br/bitstream/icict/30222/2/giovanna_bergo_ioc_mest_2018.pdf. Acesso em 26 de agosto de 2020.

DANTAS, O. M. S; SANTANA, A. R; NAKAYAMA, L. Teatro de fantoches na formação continuada docente em educação ambiental. Educ. Pesqui., São Paulo, v. 38, n. 3, p. 711-726, Sept. 2012 . Disponível em: http://www.scielo.br/scielo.php? script=sci_arttext\&pid=S1517-97022012000300012\&lng=en\&nrm=iso . Acesso em 26 de agosto de 2020.

DOHME, V. Atividades Lúdicas na educação: o caminho de tijolos amarelos do aprendizado. $4^{\mathrm{a}}$ ed. Editora Vozes. Petrópolis. 2008.

GRZEBIELUKA, D; KUBIAK, I; SCHILLER A. M. Educação Ambiental: A importância deste debate na Educação Infantil. Revista Monografias Ambientais - REMOA v.13, n.5, dez. 2014, p.3881-3906. Disponível em: 
https://periodicos.ufsm.br/remoa/article/viewFile/14958/pdf. Acesso em: 13 de agosto de 2020.

MATTA, R. R; ROCHA, M. B. Divulgação Cientifica e Educação Ambiental: trabalhando as Unidades de Conservação na Educação Básica através de um documentário. Revista Práxis, v. 9, n. 17, jun., 2017, 17p. Disponível em: http://revistas.unifoa.edu.br/index.php/praxis/issue/view/39. Acesso em: 25 de agosto de 2020.

SIQUEIRA, I. J; ANTUNES, A.M. Jogo de trilha Lixo Urbano : educação ambiental para sensibilização da comunidade escolar. Ensino, Saude e $\quad$ Ambiente $2013.185-201, \quad$ Disponível em: http://www.ensinosaudeambiente.uff.br/index.php/ensinosaudeambiente/article/view/154. Acesso em 26 de agosto de 2020.

SULAIMAN, S. N. Educação ambiental, sustentabilidade e ciência: o papel da mídia na difusão de conhecimentos científicos. Ciênc. educ. (Bauru), Bauru , v. 17, n. 3, p. 645-662, 2011 . Disponível em: http://www.scielo.br/scielo.php? script=sci_arttext\&pid=S1516-73132011000300008\&lng=en\&nrm=iso. Acesso em 26 Agosto de 2020.

Coordenadoria de Pesquisa e Extensão - COPEX

Departamento de Editoraçāo e Divulgaçāo Científica - DEDIC 


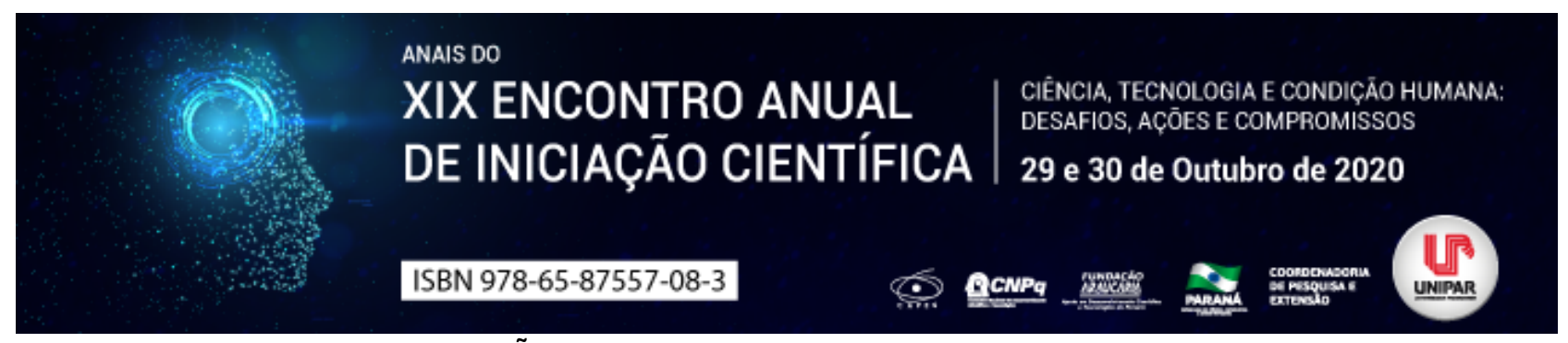

O PAPEL DA ESCOLA PARA AFIRMAÇÃO DA AUTOIDENTIDADE E ENCORAJAMENTO PARA AUTODECLARAÇÃO

\begin{abstract}
${ }^{1}$ ROSANGELA BRESSAN BUOSI, ${ }^{2}$ ALINE COUTINHO DA LUZ, ${ }^{3}$ CINTHIA FERREIRA DOS SANTOS COSTA, ${ }^{4}$ EMANUELLE TOTOLI DE OLIVEIRA, ${ }^{5}$ MILENA DE LIMA, ${ }^{6}$ ARNALDO GOMES DO AMARAL
\end{abstract}

\author{
${ }^{1}$ Professora do Curso de Pedagogia - UNIPAR - Umuarama Sede. \\ ${ }^{1}$ Acadêmica do Curso de Engenharia Civil da UNIPAR \\ ${ }^{2}$ Acadêmica do Curso de Pedagogia da UNIPAR \\ ${ }^{3}$ Acadêmica do Curso de Pedagogia da UNIPAR \\ ${ }^{4}$ Acadêmica do Curso de Engenharia Civil da UNIPAR \\ ${ }^{5}$ Docente da UNIPAR
}

Introdução: Com a promulgação da Lei 10.639/2003, foi implantado nas escolas uma nova prática e todos os profissionais da educação precisaram repensar alternativas para atender às determinações legais, em que foram introduzidas as temáticas da História da Cultura Afro-Brasileira e Africana no currículo escolar. A Lei 11.645/2008, alterou a Lei 10.639/2003 estabelecendo diretrizes para a educação nacional incluindo no currículo oficial do ensino público e privado a obrigatoriedade da temática

História e cultura afro-brasileira e indígena . Somente a partir daí que o tema da Cultura Afro-brasileira e indígena foi veiculada nos espaços escolares, como um tema do currículo e não como uma data a ser comemorada, nem uma maneira estereotipada de apresentar os temas. Mas mesmo após 12 anos dessa obrigatoriedade, muitos estudantes ainda não se sentem a vontade em se autoidentificar ou autodeclarar como pessoa negra ou indígena. Através da revisão de literatura, pretende-se com esse trabalho, mostrar como a escola pode trabalhar a valorização da identidade de cada estudante como prática pedagógica cotidiana.

Objetivo: Verificar como a prática pedagógica cotidiana fortalece a afirmação da autoidentidade e encorajamento para autodeclaração.

Desenvolvimento: Acreditamos que cada educador, no seu trabalho pedagógico, pode ressignificar e implementar sua prática, enriquecendo e ampliando capacidade de ações pedagógicas críticas e criativas para contribuir o processo de transformação das escolas ao incorporar fisicamente e não apenas conceitualmente, as diversas culturas, especialmente a negra e a indígena, na sua ação didático-pedagógica. E com isso promover construção de uma educação brasileira multicultural. Carvalho, (2012) afirma que a pluralidade cultural presente no cotidiano escolar ratifica a diversidade como traço fundamental na construção das identidades, que se reconstroem a todo momento em que se manifestam outras formas concretas e diversas de inter-relação social CARVALHO, 2012, p. 223). Trabalhar pedagogicamente a consciência e o incentivo a autodeclaração é uma forma de promover a afirmação da identidade negra e indígena na escola e em todos os espaços sociais. Quando pensamos a autodeclaração, especificamente no ambiente escolar, estamos pensando não só em um trabalho de valorização do ser diferente, mas também de repensar valores já enraizados pela cultura. Segundo Sodré (2007), diversidade remete também à existência de valores atribuídos a determinadas aparências, gerando estigma, estereótipo, preconceito e discriminação, ou seja, pressupõe julgamento de valor. O diverso, o diferente, é definido a partir da comparação com o que é considerado a referência , o universal , que, por ser modelo , é considerado e se considera superior. Dessa maneira, a autodeclaração é desencorajada pela permanência de desigualdades, ideologias preconceituosas e estereótipos racistas que levam os estudantes a negarem seu pertencimento. O texto, Diálogos e reflexões para práticas pedagógicas efetivas na educação das relações étnico-raciaisl" da SEED/SEDD/PR (2015, p.4), relata que não podemos negar que a educação das relações étnico-raciais, vem construindo novos paradigmas ao longo desses anos de trabalho no interior da escola, no entanto, percebe-se pouca mudança na postura dos sujeitos, em especial, dos negros em relação à afirmação da sua identidade e a autodeclaração. Os índices de sujeitos que se autodeclaram estão relacionados à eficácia das políticas educacionais de reconhecimento e das estratégias pedagógicas de valorização da diversidade . SEED/SEDD/PR (2015, p.7). Nesse contexto Buosi, (2014) relata que a temática racial deve ser trabalhada de modo que permeie todo o cotidiano escolar e não somente projetos isolados, ou de maneira estigmatizada e descontextualizada. É fundamental o engajamento da escola na construção de ações pedagógicas que viabilizem espaços que favoreçam o reconhecimento da diversidade e uma convivência respeitosa baseada no diálogo entre os diferentes atores sociopolíticos, oportunizando igualmente o acesso e a socialização dos múltiplos saberes . (Silva, 2010, p.46, apud. SEED/SEDD/PR).

Conclusão: Diante do exposto, é imprescindível que cada profissional da educação, assuma seu protagonismo realizando a reflexão e problematização acerca da temática Afro-brasileira e indígena. Abordando a temática durante todo o ano letivo, em suas disciplinas ou quando o assunto surgir em sala de aulla. Contextualizando o assunto em pauta, com a realidade dos 
estudantes. A temática da igualdade racial na escola deve ser abordada por meio de explicações sobre as diferenças da valorização e da admiração das características físicas dos estudantes, tais como o cabelo, a cor da pele, propiciando desse modo vivências em que os alunos, principalmente negros e indígenas, possam experienciar a autoestima e sentir-se valorizados. Resultando com essa prática, uma audoidentificação e autodeclaração de forma legítima.

\section{Referências}

BRASIL. Lei 10.639 de 09 de Janeiro de 2003. Estabelece as diretrizes e bases da educação nacional, para incluir no currículo oficial da Rede de Ensino a obrigatoriedade da temática I"História e Cultura Afro-Brasileiral". Disponível em http://www.planalto.gov.br/ccivil_03/leis/2003//10.639.htm. Acesso em 29 de Agosto de 2020.

Lei 11.645, de 10 de Março de 2008. Estabelece as diretrizes e bases da educação nacional, para incluir no currículo oficial da rede de ensino a obrigatoriedade da temática História e Cultura Afro-Brasileira e Indígena . Disponível em http://www.planalto.gov.br/ccivil_03/_Ato2007-2010/2008/Lei/L11645.htm . Acesso em 29 de Agosto de 2020.

CARVALHO, Mauro. A construção das identidades no espaço escolar. Revista Reflexão e Ação, Santa Cruz do Sul, v.20, n1, p.209-227, jan./jun.2012. Disponível em http:// file:///C:/Users/Usuario/Downloads/2161-14344-1-PB.pdf. Acesso em 22 de Agosto de 2020.

PARANÁ. SEED/SEDD. Diálogos e reflexões para práticas pedagógicas efetivas na educação das relações étnico-raciais. Secretaria de Estado da Educação. Superintendência da Educação Departamento da Diversidade, 2015. Disponível em http: http://www.educadores.diaadia.pr.gov.br/arquivos/File/equipesmultidisciplinares/quarto_encontro2015_impressao.pdf. Acesso em 28 de Agosto de 2020.

SODRÉ, Muniz. Claros e escuros: identidade do povo e mídia no Brasil. Petrópolis, RJ. Vozes, 2007

UNIPAR. Universidade Paranaense. Guia didático: Educação Especial e Inclusão Social. EAD. Org. Rosângela Bressan Buosi. UNIPAR, 2014. 


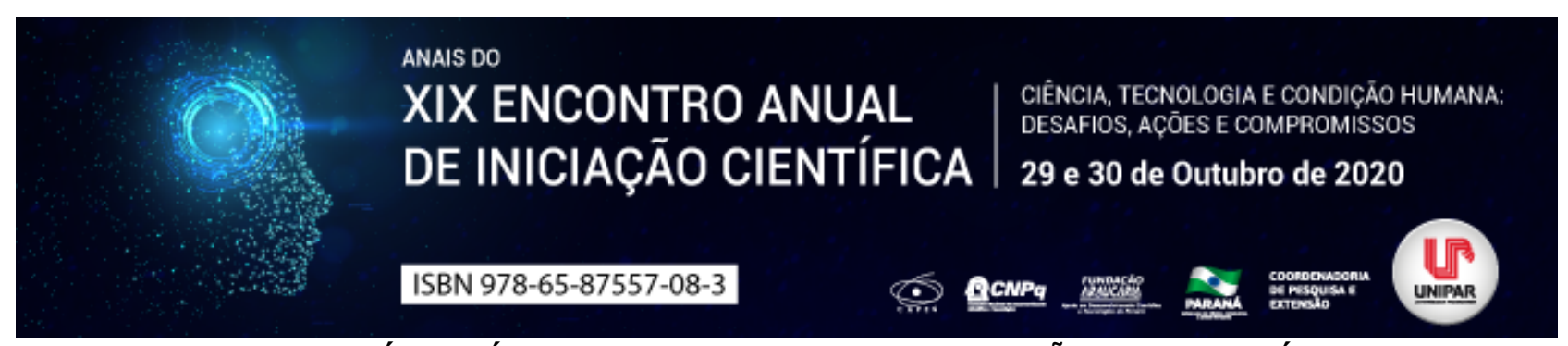

(I)LEGITIMIDADE DO MINISTÉRIO PÚBLICO PARA PROPOSITURA DE AÇÃO DECLARATÓRIA DE INDIGNIDADE

\author{
${ }^{1}$ MARIANA SARTORI NOVAK, ${ }^{2}$ CASSIO DE PAULA XAVIER, ${ }^{3}$ DIOGO DE ARAUJO LIMA, ${ }^{4}$ TANIA ARNECKE PEREIRA, \\ 5 JOSE MIGUEL GARCIA MEDINA
}

\begin{abstract}
${ }^{1}$ Discente do Mestrado em Direito Processual e Cidadania UNIPAR
${ }^{1}$ Discente do Mestrado em Direito Processual e Cidadania UNIPAR

${ }^{2}$ Discente do Mestrado em Direito Processual e Cidadania UNIPAR

${ }^{3}$ Discente do Mestrado em Direito Processual e Cidadania UNIPAR

${ }^{4}$ Docente do Mestrado em Direito Processual e Cidadania - UNIPAR
\end{abstract}

Introdução: A Lei $n^{\circ} 13.532$ (BRASIL, 2017) alterou o Código Civil e inseriu novo parágrafo $\S 2^{\circ}$ no art. 1.815, passando a atribuir legitimidade ao Ministério Público para propositura de Ação Declaratória de Indignidade nos casos de homicídio doloso, consumado ou tentado, contra o autor da herança, seu cônjuge, companheiro, ascendente ou descendente (art. 1.814, I, do Código Civil), a fim de excluir da sucessão o autor do ato atentatório. Em sendo a herança caracterizada por se tratar de direito eminentemente patrimonial e, portanto, disponível, tanto que admite renúncia (art. 1.806 do Código Civil), oportuna a análise do novel dispositivo à luz do art. 127 da Constituição Federal (BRASIL, 1988), que delimita a atuação ministerial.

Objetivo: Examinar a constitucionalidade do parágrafo segundo do art. 1.815 do Código Civil (BRASIL, 1988).

Desenvolvimento: Inaugurando o capítulo atinente às funções essenciais à justiça, o art. 127 da Constituição Federal dispõe que ao Ministério Público compete a defesa da ordem jurídica, do regime democrático e dos interesses sociais e individuais indisponíveis (BRASIL, 1988). A defesa da ordem jurídica consiste em assegurar o cumprimento da Constituição e da legislação infraconstitucional, bem como os princípios gerais de direito que a informam. O regime democrático, como valor fundante da República (art. $1^{\circ}$, caput, Constituição Federal), é protegido quando da garantia da igualdade e liberdade individual, bem como do equilíbrio no sistema de separação dos poderes (MAZZILLI, 1997, p. 9). No que tange aos interesses passíveis de tutela pelo Ministério Público, fala-se, de modo geral, em interesse público primário (MAZZILLI, 2007, p. 108), assim compreendido como interesse da coletividade em geral, em contraponto com o interesse próprio da Administração (ALESSI apud MAZZILLI, p. 108), destinado aos interesses patrimoniais do Estado. Caberia ao Ministério Público a defesa dos direitos difusos, coletivos e individuais homogêneos quando constatada razão de interesse social (BRASIL, 2014). Por interesse individual indisponível, compreende-se a impossibilidade de renúncia, e que pode ser exemplificado, sob a vertente da legitimidade do Parquet, pela propositura de ação civil pública visando o fornecimento de medicamentos (BRASIL, 2018). Do artigo129 da CF decorrem as funções institucionais. O $\S 2^{\circ}$ do art. 1.815 do Código Civil, segundo parcela da doutrina (MORAES, 2017, p. 598), teria como fundamento a norma de encerramento prevista no inc. IX do art. 129 da Constituição Federal. Porém, não há como negar o caráter eminentemente patrimonialista e, portanto, disponível, da hipótese de indignidade em questão, afinal o recebimento do patrimônio do de cujus por meio da sucessão. Rodolfo Pamplona Filho e Pablo Stolze Gagliano argumentam que, embora se trate de direito disponível, tal não deveria se sobrepor ao senso ético que se espera nas atitudes humanas, mormente no seio familiar (2018, p. 1510). O interesse público, segundo o Projeto de Lei que originou a alteração legislativa, é presumível ante a gravidade do delito de homicídio (BRASIL, 2007). Maria Helena Diniz que a hipótese envolve violação da ordem jurídica, frente à prática de crime contra a vida, onde, mesmo assim, seu agente poderá receber a herança ou legado (2016, p. 199). Silvio Venosa argumenta pela legitimidade ministerial na situação, contanto que não hajam outros herdeiros que possam pleitear nesse sentido, pois trata-se de situação que atenta contra a Moral e a Lógica do Direito (2015, p. 63). Observa-se, contudo, que a concretude do interesse público mencionado pelos doutos é confundida com a questão da repulsa, natural, ao homicídio que embasa a ação. No que tange à ordem jurídica, a violação a ser neutralizada pelo Estado se dá por meio do jus puniendi, cujos efeitos, porém, devem ficar adstritos à esfera penal, ao menos sob essa ótica processual sobre a legitimação ativa. O clamor público não tem o condão de alterar a natureza (individual e disponível) do direito patrimonial. Falase, portanto, em interpretação conforme a Constituição do referido dispositivo, pendendo pela legitimidade em se tratando de herdeiro incapaz (MEDINA, 2020, p. 230).

Conclusão: A procedência da ação declaratória de indignidade não beneficia a comunidade em geral ou grupo de pessoas com interesse social relevante, mas somente os coerdeiros ou a Fazenda Pública, em caso de herança jacente. O $\S 2^{\circ}$ do art. 1.815 do Código Civil, portanto, deve ser interpretado conforme o art. 127, caput, da CF, em ordem a autorizar a legitimidade ativa do Parquet na hipótese em referência quando subsistir interesse de incapaz. 
ALESSI, Renato. Sistema istituzionale del diritto amministrativo italiano. Milano: Giuffrè, 1953

BRASIL, Câmara dos Deputados. Projeto de Lei 1.159/2007. Disponível em:
https://www.camara.leg.br/proposicoesWeb/prop_mostrarintegra?codteor=1491324\&filename=Tramitacao-PL+1159/2007> Acesso em: 25 ago. 2020.

Código Civil. Lei no 10.406, de 10 de janeiro de 2002. Disponível em: . Acesso em: 25 ago. 2020 Constituição da República Federativa do Brasil. Disponível em: . . Acesso em: 25 ago. 2020.

, Supremo Tribunal Federal. RE 605.533, Relator Min. Marco Aurélio, pleno. Julgado em: 15.08.2018

, Supremo Tribunal Federal. RE 631.111, Relator Min. Teori Zavascki, julgado em: 07.08.2014..

DINIZ, Maria Helena. Curso de Direito Civil Brasileiro: Direito das Sucessões. Vol. 6. São Paulo: Saraiva, 2017.

GAGLIANO, Pablo Stolze; PAMPLONA FILHO, Rodolfo. Manual de Direito Civil. 2. ed. São Paulo: Saraiva, 2018.

MAZZILLI, Hugo Nigro. Ministério Público e a Defesa do Regime Democrático. Revista Justitia, do Ministério Público de São Paulo, vol. 179-180, p. 139 e s., jul-dez. 1997. p. 9. Disponível em: Acesso em: 29 jun. 2020 , Hugo Nigro. Regime Jurídico do Ministério Público. 6. ed. São Paulo: SaraivaJur, 2007.

MEDINA, José Miguel Garcia. Constituição Federal comentada. 5. ed. rev. atual. ampl. São Paulo: Thomson Reuters Brasil, 2020.

MORAES, Alexandre. Direito Constitucional. 33 ed. São Paulo: Atlas, 2017.

VENOSA. Sílvio de Salvo. Direito das sucessões. 15 ed. v. 7. São Paulo: Atlas, 2015.

Coordenadoria de Pesquisa e Extensão - COPEX

Departamento de Editoraçāo e Divulgaçāo Científica - DEDIC 


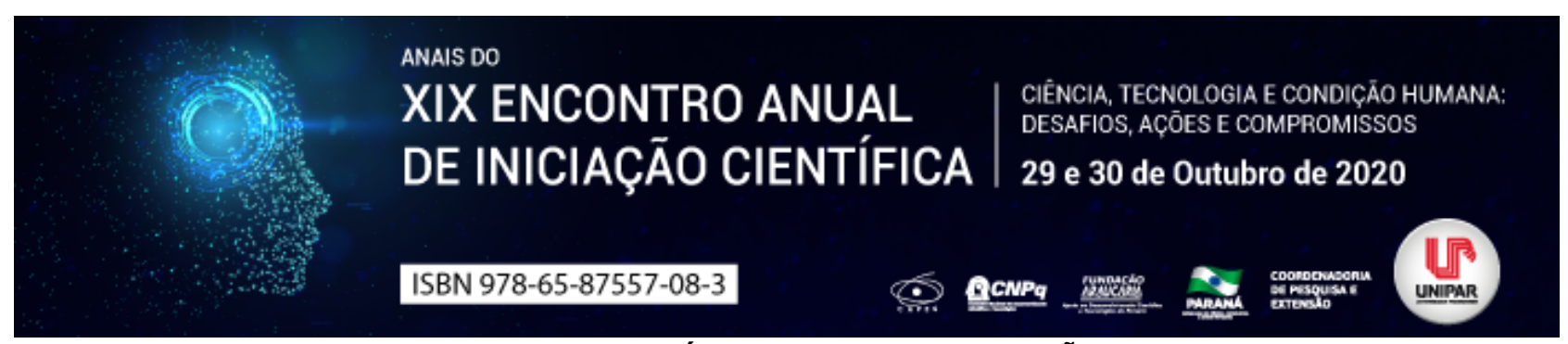

O PAPEL DA MÚSICA NA ALFABETIZAÇÃO

\title{
${ }^{1}$ GABRYELLI DAYANNE DA SILVA, ${ }^{2}$ ROSANGELA BRESSAN BUOSI
}

\author{
${ }^{1}$ Acadêmica do curso de Pedagogia - UNIPAR \\ ${ }^{1}$ Docente da UNIPAR
}

Introdução: A música é um elemento inerente ao ser humano. Nos primórdios somente era utilizada como divertimento e meio de socialização, por exemplo, nos rituais de nativos, em festas como na Europa e depois como forma de expressão. Ao longo da história, a música foi tomando espaço e repercussão, foi se desenvolvendo, organizando-se em ritmos, melodias e letras, permitindo a qualquer pessoa aprendê-la. Consequentemente foi buscando histórias a serem contadas e sentimentos a serem expressados e dessa forma passou a fazer parte da sociedade o que incide também no trabalho escolar. A música tem um papel fundamental no processo de ensino e aprendizagem. E nesse espaço, a música afeta também o processo de alfabetização (FEIER; GEDOZ, 2015).

Objetivo: Mostrar a importância de trabalhar com músicas, durante o processo de alfabetização.

Desenvolvimento: A música auxilia no desenvolvimento cognitivo, corporal, linguístico do alfabetizando. Ela exerce grande influência na vida das pessoas, pois, é algo que toca o ser humano profundamente e é através dela, que as pessoas se comunicam emocionalmente, seja por meio dos ritmos, movimentos, sons ou simplesmente pelas melodias harmoniosas. Sendo assim, a música se resume num processo de construção envolvendo o perceber, o sentir, o emitir, o experimentar, o criar, o recriar e o refletir (BRAGATTO, 2012). O papel da música na educação, não é apenas no foco da experiência lúdica, mas é um direcionamento de sua potência afetiva para se tornar uma grande ferramenta facilitadora do processo de aprendizagem, tornando a escola, a aula, as atividades mais alegres e receptivas. A música pode contribuir com a aprendizagem, favorecendo $o$ desenvolvimento cognitivo/ linguístico, psicomotor e socioafetivo da criança, pois, já que estão todos correlacionados, áreas indissociáveis formam um único ser provido de necessidades, sociais ou afetivas (SOARES; RUBIO, 2012). Segundo Almeida \& Costa (2015), desde a educação infantil é visível a importância de se trabalhar com a musicalização, pois ela contribui em muitos aspectos no processo de ensino aprendizagem no âmbito escolar. De acordo com Bragatto (2012), é possível visualizar uma sala de aula com alunos em processo de alfabetização, se sentido plenos de alegria e prazer em aprender e compreender como se formam as palavras para posteriormente constituir uma escrita própria e uma leitura de maneira convencional da mesma. Tudo isso graças ao trabalho com a música. Arte que fornece espaço para a criação e recriação, ou seja, construção do conhecimento, através do trabalho rotineiro e ao mesmo tempo diversificado com música. Quando a criança entra em contato com as melodias pode desenvolver muitas habilidades e competências, principalmente na leitura, início da alfabetização e durante o processo de aprendizagem, em sua capacidade de memória, portanto torna-se relevante o trabalho com música dentro e fora da sala de aula (ALMEIDA; COSTA, 2015).

Conclusão: Em virtude dos fatos mencionados, podemos concluir que, a música é mais do que entretenimento e arte, ela é metodologia de ensino. Ela ativa vários sentidos cognitivos dos alunos, auxilia no desenvolvimento sócio-afetivo, linguístico, na memorização, criação e recriação. E além de tudo, é uma ferramenta que transforma as aulas e a escola em um ambiente mais divertido.

\section{Referências}

ALMEIDA, Camila de Carvalho; COSTA, Ligia de Oliveira. A CONTRIBUIÇÃO DA MÚSICA NA ALFABETIZAÇÃO. Revista Científica Eletrônica De Ciências Aplicadas Da FAIT , Itapeva/SP, ano 2015, ed. 6º , Novembro 2015. Disponível em: http://fait.revista.inf.br/imagens_arquivos/arquivos_destaque/gvSTH8xiVwP9D1i_2017-1-21-10-54-40.pdf. Acesso em: 22 mar. 2020.

BRAGATTO, Rosangela Aparecida Marques de Morais. A importância da música no processo de alfabetização. Orientador: Flóida Moura Carlesso Batista. 2012. 43 f. Monografia (Especialização) - Universidade Tecnológica Federal do Paraná, Medianeira, 2012. Disponível em: http://repositorio.roca.utfpr.edu.br/jspui/bitstream/1/4740/1/MD_EDUMTE_II_2012_37.pdf. Acesso em: 22 jul. 2020.

FEIER, Elisnara Samanta; GEDOZ, Sueli. RELAÇÃO ENTRE MÚSICA, ALFABETIZAÇÃO E LETRAMENTO. XIII JORNADA CIENTÍFICA DA UNIVEL, Cascavel/PR, 2015. Disponível em: https://www.univel.br/sites/default/files/conteudorelacionado/relacao_entre_musica_alfabetizacao_e_letramento.pdf. Acesso em: 17 mar. 2020.

SOARES, Maura Aparecida; RUBIO, Juliana de Alcântara Silveira. A Utilização da Música no Processo de Alfabetização. Revista Eletrônica Saberes da Educação, [s. l.], $\quad$ v. $3, \quad$ n. 1 , p. $1-14, \quad 2012 . \quad$ Disponível em: https://www.passeidireto.com/arquivo/57349141/artigo-3. Acesso em: 11 jun. 2020. 
Coordenadoria de Pesquisa e Extensão - COPEX

Departamento de Editoraçāo e Divulgaçāo Científica - DEDIC 


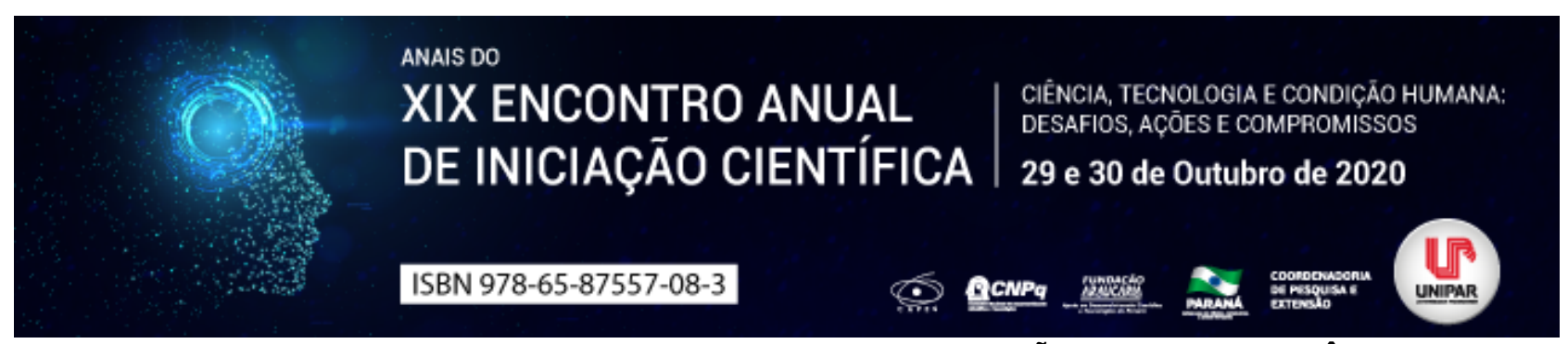

PRECEDENTES JUDICIAIS COMO MEIO DE UNIFORMIZAÇÃO DA JURISPRUDÊNCIA

\author{
${ }^{1}$ MARIANA SARTORI NOVAK, ${ }^{2}$ ALBINO GABRIEL TURBAY JUNIOR
}

${ }^{1}$ Discente do Mestrado em Direito Processual e Cidadania UNIPAR

${ }^{1}$ Docente do Mestrado em Direito Processual e Cidadania - UNIPAR

Introdução: Conforme disposição do art. 926 do Código de Processo Civil, aos Tribunais atribui-se o dever de manter a jurisprudência estável, íntegra e coerente. Para garantia de tal desiderato, o legislador apresentou a ideia de precedentes, sejam eles detentores de caráter vinculante ou persuasivos, orientando a atuação do magistrado que se vê, perante o julgamento do caso concreto, diante de possibilidades interpretativas do texto legal atinente à questão. $A$ uniformização da jurisprudência, que pode realizar-se por precedentes, é medida salutar para que sejam garantidos os princípios da isonomia (art. 50, caput, Constituição Federal) e, principalmente, da segurança jurídica (art. $5^{\circ}, \mathrm{XXVI}$, Constituição Federal), ínsitos à manutenção de um Estado Democrático de Direito.

Objetivo: Análise do instituto dos precedentes judiciais como forma de uniformização da jurisprudência, por meio da estabilidade, integridade e coerência das decisões.

Desenvolvimento: A decisão judicial, segundo Daniel Mitidiero (2012, p. 85-99), possibilita uma análise resultante em dois discursos: aquele concernente à resolução do caso concreto, relacionado com o direito da parte ao processo justo (art. $5^{\circ}$, inciso LIV, e 93, inciso IX, CF) e outro relativo à ordem jurídica estruturado para promover a unidade do direito e visa à realização da segurança jurídica, da igualdade e da coerência normativa. Os precedentes judiciais, dentro das diversas possibilidades de eficácia (BARROSO; CAMPOS, 2016, p. 22) exsurgem como uma das formas de garantia da estabilidade, integralidade e coerência do ordenamento jurídico por meio da introdução da noção de uma ratio a ser extraída da decisão que poderá ser replicada em outros julgamentos (MEDINA, 2017, p. 894). Sobre os conceitos de integridade, estabilidade e coerência, fala-se que a integridade diz respeito à decisão proferida levando-se em consideração a evolução histórica das decisões sobre o mesmo tema; a estabilidade significa que a decisão não pode aplicar entendimento em detrimento de linha formada por decisões constantes e uniformes sobre a matéria; a coerência no sentido que, em casos semelhantes, seja aplicado o mesmo arcabouço principiológico e legal (CÂMARA, 2016, p. 368-373). Com o manejo de precedentes judiciais, independentemente das diversas críticas tecidas à nomenclatura e utilização do instituto no direito brasileiro, a resolução do caso concreto não resta aberta à interpretação totalmente discricionária do julgador, que ater-se-á ao caso semelhante já julgado e a ratio construída, evitando-se, assim, que a prolação de decisões se constitua em verdadeira loteria do judiciário, violando princípios constitucionais da segurança jurídica e da igualdade. A igualdade, nesse sentido, é a chamada igualdade pelo processo - diversa daquela dentro do processo - que é a igualdade diante dos resultados produzidos pelo processo (ARENHART; MARINONI; MITIDIERO, 2017, p. 168). Não há que se falar em engessamento do direito ao se utilizar de entendimento já aplicado em caso semelhante, muito menos em entendimento prolatado em detrimento das peculiaridades do novo caso, pois a própria técnica admite a superação do precedente quando aquele restar obsoleto para julgamento de demandas naquele sentido (overruling), bem como a distinção do caso paradigma com o posto a julgamento (distinguishing). A uniformização decorre, assim, da unidade do direito trazida pelos precedentes, que guiarão a interpretação futura do direito pelos demais juízes (ARENHART; MARINONI; MITIDIERO, 2017, p. 1004).

Conclusão: Com o respeito aos casos paradigmáticos semelhantes e a construção jurídica, produzir-se-ão decisões uniformes dentro do sistema, no contexto de suas excepcionalidades, o que, muito além de assegurar a integridade, estabilidade e coerência, tão valoradas pelo NCPC, proporciona segurança jurídica e a própria credibilidade do jurisdicionado no direito e nos órgãos responsáveis pela sua aplicação.

\title{
Referências
}

ARENHART, Sergio Cruz; MARINONI, Luiz Guilherme; MITIDIERO, Daniel. Código de processo civil comentado. 3. ed. rev. atual. ampl. São Paulo: Editora Revista dos Tribunais, 2017.

BRASIL. Constituição da República Federativa do Brasil. Disponível em: Acesso em: 07 ago. 2020

Código de Processo Civil. Lei 13.105 de 16 de março de 2018. Disponível em:

< http://www.planalto.gov.br/ccivil_03/_ato2015-2018/2015/lei/l13105.htm>. Acesso em: 07. Ago. 2020

CÂMARA, Alexandre. O novo processo civil brasileiro. 3. ed. rev. atual. ampl. São Paulo: Atlas, 2017.

CAMPOS MELLO, Patricia Perrone; BARROSO, Luis Roberto. Trabalhando com uma nova lógica: a ascensão dos precedentes no Direito brasileiro. Revista da AGU, Brasília-DF, v. 15, n. 03, p. 09-52, jul./set. 2016.

MEDINA, José Miguel Garcia. Curso de direito processual civil moderno. 3. ed. São Paulo: Editora Revista dos Tribunais, 
2017.

MITIDIERO, Daniel. Fundamentação e precedente: dois discursos a partir da decisão judicial. In: AMARAL, Guilherme Rizzo (Coord.). Processo civil: estudos em homenagem ao professor doutor Carlos Alberto Alvaro de Oliveira. São Paulo: Atlas, 2012, p. 85-99.

Coordenadoria de Pesquisa e Extensão - COPEX

Departamento de Editoraçāo e Divulgaçāo Científica - DEDIC 


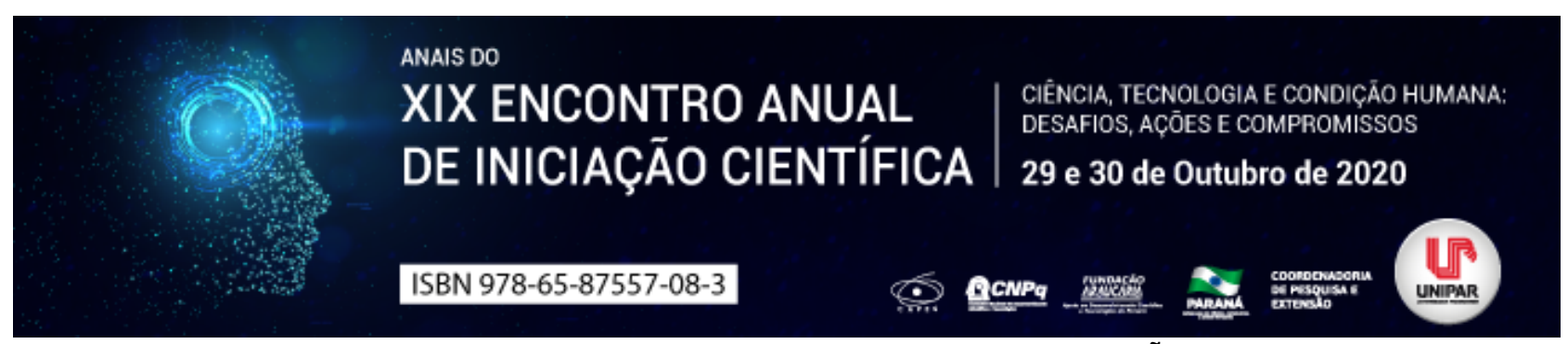

IMPACTO DA LEI 13.964/2019 NO INSTITUTO DA COLABORAÇÃO PREMIADA

\title{
${ }^{1}$ MAISA CASTANHEIRA FEITOSA, ${ }^{2}$ RICARDO MUCIATO MARTINS
}

\author{
${ }^{1}$ Acadêmico do curso de Direito da UNIPAR \\ ${ }^{1}$ Docente da UNIPAR
}

Introdução: A origem da delação premiada não é tão recente quanto se imagina, podendo ser encontrada, por exemplo, no sistema anglo-saxão, dando origem a expressão testemunha da coroa. A Lei 13.964/20 ou como é mais conhecida, o Pacote anticrimel" instituiu modificações significativas no âmbito penal e processual penal, dentre elas, a colaboração premiada e sua normatização.

Objetivo: Analisar algumas das diversas mudanças realizadas pela Lei 13.694/2019, dando ênfase no que diz respeito à colaboração premiada e sua natureza.

Desenvolvimento: Sancionada em 24 de dezembro de 2019, a Lei 13.964/2019 trouxe uma grande reforma na legislação penal, alterando o padrão substancial, tanto no âmbito processual, quanto material. Entretanto, na tentativa de abordar diversas temáticas, o legislador acabou pecando em sua complexidade. Em vez de promover uma reforma individualizada sobre cada matéria, o que se teve, foi um emaranhado de correções esparsas, deixando dessa forma, de tratar de assuntos necessários. O instituto da colaboração premiada não escapou dessa regulamentação e apesar de promover o ajuste de alguns aspectos cruciais, em outros, foi omissa. Lima (2020, p. 866) define a colaboração premiada como tipo de direito premial pautado numa técnica especial de investigação na qual [...] o coautor e/ou partícipe da infração penal, além de confessar seu envolvimento no fato delituoso, fornece aos órgãos responsáveis pela persecução penal informações [...] eficazes para a consecução de um dos objetivos previstos em lei, recebendo, em contrapartida, determinado prêmio legal . É importante lembrar que, não se pode confundir a colaboração premiada com a simples confissão. Na colaboração, o agente terá garantias previstas nos dispositivos legais que tratam sobre esse segmento, apenas quando admitir sua participação no delito cometido e fornecer informações de forma objetiva e eficaz para a descoberta dos fatos previamente conhecidos. Dito isso, a colaboração premiada, é um meio extraordinário, cujo objetivo é a identificação da fonte da prova, além de ser também, considerada como um negócio jurídico processual. Antes da Lei 13.964/2019, mesmo com a redação proibindo sentenças condenatórias somente tendo como base as declarações prestadas pelo delator, não era o que ocorria na prática. Diversas delações foram causa exclusiva para determinação de prisão temporária ou preventiva dos delatados, expondo uma contradição indevida, visto que não poderia fundamenta-la, apenas com base na delação, não restando dúvidas de que medidas drásticas como a prisão cautelar, também não seriam adequadas. É o que diz o informativo 796 do STF, que prevê que nenhuma sentença condenatória poderia ser proferida com fundamento apenas nas declarações do colaborador. Visando solucionar possíveis arbitrariedades advindas da insuficiência da fundamentação judicial, o famoso Pacote Anticrime acrescentou que nenhuma medida cautelar poderá ser decretada com base somente nas declarações do delator. Além disso, as medidas ficam restritas aos fatos investigados. Segundo Nucci (2020), com a nova lei, o delator deve narrar todos os fatos ilícitos nos quais concorreu e que tenham relação de maneira direta com os fatos investigados. Assim, não se pode mais usar do acordo para revelar crimes que não estejam relacionados diretamente à investigação em curso. Ademais, outro assunto abordado na nova lei, diz respeito à impossibilidade de que a denúncia seja recebida, exclusivamente, com base nas declarações do colaborador. O mesmo dar-se-á no que tange ao recebimento da denúncia ou queixa-crime, devendo ser observado, da mesma forma, que a sentença de cunho condenatório, não podendo ser proferida somente com fundamento na colaboração premiada. No cenário atual, para que o juiz se convença, se faz crucial somar o acordo de colaboração premiada aos demais elementos probatórios, na intenção de propiciar uma fonte de prova sólida e concreta, sob pena de esvaziar o núcleo do seu próprio objetivo..

Conclusão: A lei objetiva modernizar os institutos penais, mas não deve ser erroneamente compreendida como mecanismo exclusivo para redução da criminalidade. Ainda existe muito a ser discutido, já que estamos falando de um ordenamento novo. Com a nova disciplina é possível perceber os avanços em nossa legislação, sendo uma positivação das várias considerações prestadas pela doutrina brasileira.

\section{Referências}

BRASIL. Supremo Tribunal Federal. Informativo 796, de 24 a 28 de agosto de 2015 . Disponível em: http://www.stf.jus.br/arquivo/informativo/documento/informativo796.htm. Acesso em: 05 ago. 2020. LIMA, Renato Brasileiro de. Manual de processo penal. 8. ed, Salvador: JusPodivm, 2020.

NUCCl, Guilherme de Souza. Lei anticrime e delação. GenJurídico, em: http://genjuridico.com.br/2020/01/28/lei-anticrime-e-delacao/. Acesso em: 03 ago. 2020. 
Coordenadoria de Pesquisa e Extensão - COPEX

Departamento de Editoraçāo e Divulgaçāo Científica - DEDIC 


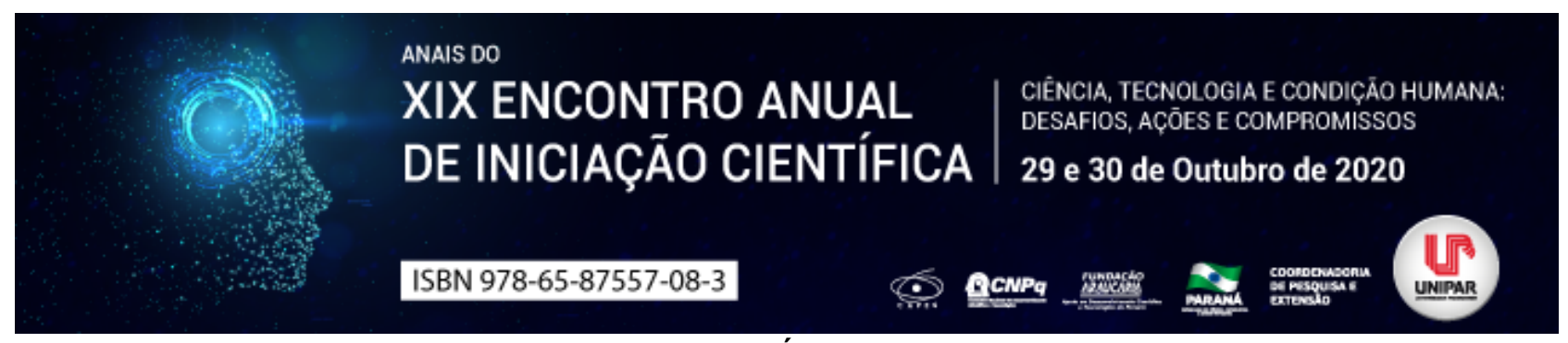

OS ENFRENTAMENTOS DO LADO DILLAH: POR TRÁS DOS HOLOFOTES E DO GLAMOUR DOS PALCOS

\author{
${ }^{1}$ MARIANA FIGUEIREDO BARROS, ${ }^{2}$ GABRIELA MARQUEZI BORGES, ${ }^{3}$ BARBARA COSSETTIN COSTA BEBER BRUNINI, \\ ${ }^{4}$ DANIELLE JARDIM BARRETO
}

\author{
${ }^{1}$ Acadêmica bolsista do PIBIC/UNIPAR \\ ${ }^{1}$ Acadêmica do Curso de Psicologia da UNIPAR \\ ${ }^{2}$ Docente da UNIPAR \\ ${ }^{3}$ Docente da UNIPAR
}

Introdução: O presente trabalho busca problematizar a LGBTfobia nas universidades mediante discussão através de exposição de curtas-metragens em encontros virtuais. Neste trabalho trataremos do documentário intitulado Do Lado Dillah (2018), que explicita a narrativa e as vivências de uma artista drag em conseguir trabalho formal ou fora do circuito artístico informal. No curta-metragem, Edivaldo compartilha as situações que se deparou enquanto travestido para dar vida à Dillah: discriminação, preconceito, humilhação, brigas, desvalorização e claro, a carência financeira advinda da dificuldade em conseguir trabalho fora dos palcos, haja vista que o envelhecimento do corpo atinge diretamente aquele que vive do show drag.

Objetivo: Analisar o curta-metragem Do Lado Dillah (2018) problematizando os dispositivos de discriminação que agenciam a LGBTfobia.

Discussão: A sexualidade é um dispositivo de subjetivação, que se agencia historicamente, baseados em diversos discursos regulatórios, que instituem saberes, que geram l"verdadesl" (Louro, 2000). A história de Dillah/Edivaldo mostra como o capitalismo é capaz de capturar as oportunidades e para quem elas serão distribuídas, visto que o corpo glamourizado do palco é aplaudido, desejado, cultuado, porém nas ruas, este mesmo corpo quando performa a pobreza e o adoecimento é desprezado, marginalizado, excluído. Esta contradição é efeito das interseccionalidades encarnadas nesta vida e no corpo de Dillah; as interseccionalidades abordam o modo como ações e políticas específicas forjam opressões, estabelecendo aspectos dinâmicos ou ativos do desempoderamento (CRENSHAW, 2002, p. 117). Os enfrentamentos da população LGBTTQIA+ com foco nas vivências transsexuais e travestis, explicita rótulos e discriminações, já teorizados através de estudos sobre o racismo estrutural, os efeitos do corpo colonizado capturado pelo capitalismo, além da questão da interseccionalidade e do preconceito dentro da própria comunidade não cisheteronormativa. Dillah Dilluz nos palcos, Edivaldo nas ruas, a interseccionalidade da vivência de uma drag que, há 25 anos, enfrenta a LGBTfobia e o racismo na pele, literalmente. Para esclarecer tal conceito, Jesus (2012) explica que drag queens/king são transformistas, que invertem o gênero como diversão, usando essa ferramenta para o entretenimento e espetáculo, não como identificação. Perpassando sobre o curta a fim de problematizar as relações universitárias, Edivaldo mostra que muito além de feridas emocionais, estas violências causam feridas sociais, impedindo ou limitando oportunidades, produzindo regras e padrões, agenciando saberes excludentes. A LGBTfobia é, ainda, atrelada à questão da decolonialidade, que de acordo com Reis e Andrade (2018) o objetivo do pensamento decolonial é problematizar a perpetuação das características coloniais da epistemologia, alcançando a autonomia absoluta de todas as formas de opressão e dominação, ao correlacionar interdisciplinarmente cultura, política e economia de modo a conceber um pensamento transformador que evidencie os subsídios locais em contrapartida aos legados impostos pela situação colonial.

Conclusão: O intérprete de Dillah relata suas lutas diárias na tentativa de superar limites socialmente impostos, ao mesmo tempo em que reafirma também o reflexo da colonialidade no momento em que valoriza o aprimoramento da língua inglesa. Essa dualidade expõe a captura de corpos e saberes, que perduram e reafirmam modelos a serem seguidos, principalmente no que tange vidas marginalizadas.

\title{
Referências
}

CRENSHAW, Kimberlé. Documento para o encontro de especialistas em aspectos da discriminação racial relativos ao gênero. Tradução: Liane Schneider. Rev. Estud. Fem. [online]. 2002, v. 10, n. 1. Disponível em: https://www.scielo.br/scielo.php? pid=S0104-026X2002000100011\&script=sci_abstract\&tlng=pt. Acesso em: 03 ago. 2020.

JESUS, Jaqueline Gomes de. Orientações sobre identidade de gênero: conceitos e termos. Guia técnico sobre pessoas transexuais, travestis e demais transgêneros, para formadores de opinião. 2. ed. Brasília: 2012.

LOURO, Guacira Lopes. O corpo educado: pedagogias da sexualidade. 2. ed. Belo Horizonte: Autêntica, 2000.

REIS, Maurício de Novais; ANDRADE, Marcilea Freitas Ferraz de. O pensamento decolonial: análise, desafios e perspectivas. Revista Espaço Acadêmico, n. 202. Março/2018. 
Coordenadoria de Pesquisa e Extensão - COPEX

Departamento de Editoraçāo e Divulgaçāo Científica - DEDIC 


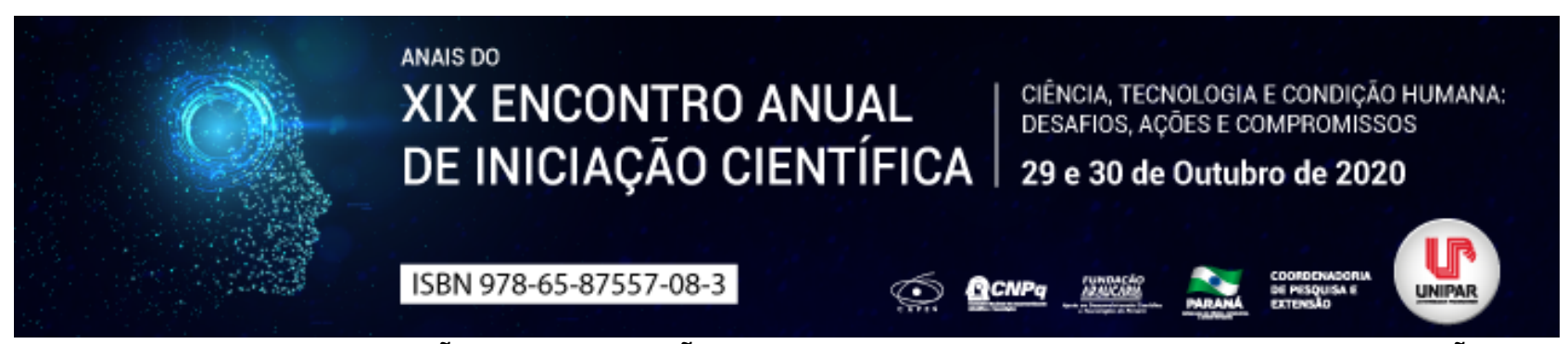

LIBERDADE E EDUCAÇÃO: CONTIBUIÇÕES DA FILOSOFIA SARTREANA PARA A EDUCAÇÃO

\title{
${ }^{1}$ GABRYELLI DAYANNE DA SILVA, ${ }^{2}$ JORGE ANTONIO VIEIRA
}

\author{
${ }^{1}$ Acadêmica do PIC - UNIPAR \\ ${ }^{1}$ Docente da UNIPAR
}

Introdução: Neste trabalho apresentamos uma pesquisa sobre a filosofia de Sartre voltada para o campo educacional escolar. Embora Sartre não tenha escrito especificamente sobre educação, alguns autores (LIMA, 2014; BURSTOW, 2000) mencionam que a filosofia existencial sartreana pode indicar uma tendência progressista educacional. Entretanto, Benhamida (apud. BURSTOW, 2000) faz uma oposição quanto ao pensamento sartreano poder contribuir para uma teoria pedagógica, ao destacar que, no pensamento de Sartre, a única possibilidade de relação entre as pessoas é o conflito. Todavia, veremos algumas interpretações da filosofia sartreana que vêem como possível outra relação existencial para além do conflito (BURSTOW, 2000; LIMA, 2014).

Objetivo: Identificar algumas contribuições da filosofia existencial sartreana para compreensão das relações educacionais escolares.

Desenvolvimento: As relações escolares são marcadas historicamente pela pedagogia tradicional dentro de um sistema de controle e autoritário, o qual desconsidera a liberdade dos jovens e adolescentes. Essa imposição de valores e modos de viver por parte da escola tradicional, nos dias atuais, pode vir a gerar uma revolta (LIMA, 2009) do aluno para com a escola. Essas relações negativas se dariam pelo fato de se tornar difícil que educadores conservadores se relacionem com jovens autônomos e não são mais passivos nas relações com os adultos. Diante desse possível conflito, devido à natureza conflituosa das relações humanas, podemos identificar nos autores Lima (2014) e Burstow (2000) sugestões e contribuições da filosofia sartreana para pensar uma relação escolar na qual houvesse uma compreensão maior da liberdade existencial dos sujeitos. É preciso examinar inicialmente as noções sartreanas de existência e liberdade. A existência humana é caracterizada pelas dimensões do ser-para-si e do ser-para-outro, envolvidas pela liberdade. Ao analisar a existência em termos de liberdade, Sartre trata do tema da resistência o que remete à questão do outro Sartre (1997, p 376) afirma que o outro é um limite a minha liberdade e que pelo olhar do outro eu me torno objeto, pois o outro atribui a mim qualidades como se atribui a um celular, por exemplo. Contudo, apesar do outro limitar a liberdade, é preciso lembrar que somos seres-para-outros, pois o outro é um situação fundamental da existência humana. O que significa, que o ser humano é um ser-para-muitos-outros e que, querendo ou não, os outros podem limitar essa minha liberdade (BURSTOW, 2000). Assim, sendo seres-para-outros, nós nos relacionamos com esse outro, e essas relações podem ser de cooperação, auxílio e de motivação. Nesse sentido, Sartre indica a possibilidade de uma ética da libertação e da salvação (1997, p. 511). Segundo Burstow I"na necessidade de nosso ser-para-outro já se pode encontrar as premissas de uma proposta educacionall" (2000, p. 111). Nessa perspectiva, o papel dos educadores seria despertar seus educandos quanto às situações de sua liberdade. Nas palavras de Burstow (2000, p.124) uma boa base na filosofia sartreana poderia possibilitar que o educador dê às crianças a assistência de que precisam para tratar de maneira positiva as situações, dilemas existenciais com os quais necessariamente se defrontarão . Essas situações a que o autor se refere são as escolhas que farão, os projetos que adotarão para sua vida e sendo assim, as responsabilidades que irão assumir perante essas situações. De acordo com Silva (2005, p.191), o importante é que o educador se relacione com o educando como um sujeito e não como um objeto ou como um ser ignorante, mas sim reconhecer os sujeitos como liberdade existencial, e colaborar com o aluno para que ele não venha a escolher irrefletidamente um projeto fundamental (BURSTOW, 2000, p.124). Para Sartre (1997) quando se escolhe um projeto fundamental, o sujeito se fixa em uma qualidade e decide ser essa qualidade, negando a facticidade. E é aí, que as relações conflituosas podem prevalecer. Frente a essa situação em que o sujeito se encontra limitado, um bom ato professoral (BURSTOW, 2000, p.115) é auxiliar os educandos a olharem a si mesmos, as suas situações e as suas ligações com os outros, levando-os para a conversão radical. A conversão radical consiste na consciência reflexiva da liberdade e responsabilidade existenciais diante dos projetos de vida visualizados em escolhas e decisões. E para alcançar a conversão, o sujeito deve olhar para sua escolha e ver sua inautenticidade. A conversão radical não é um processo fácil e é marcada pela análise e aceitação de sua liberdade em situações, tendo no educador, alguém que vá respeitar, apoiar e estimular essa liberdade (BURSTOW, 2000, p.116-117). Nesse sentido Sartre não defende uma educação autoritária, mas uma educação libertária, dialógica, ligada às necessidades individuais.

Conclusão: É possível a partir da filosofia existencial sartreana, além das contribuições para a compreensão do existir humano, identificar também, elementos que contribuem para uma compreensão das relações escolares menos autoritárias, onde as relações entre educador e aluno, são voltadas paras as necessidades e liberdades de cada um, não sendo exercida nenhuma forma de imposição, e sim estabelecendo relações e formas de cooperação, auxílio, motivação, estímulo. 


\section{Referências}

BURSTOW, Bonnie. A filosofia sartreana como fundamento da educação. Educação \& Sociedade, ano XXI, v. 21, n. 70 , p. 103 126, Abril 2000. Disponível em: https://www.scielo.br/pdf/es/v21n70/a07v2170.pdf. Acesso em: 11 jun. 2020.

LIMA, Walter Matias. Algumas considerações sobre educação em Jean-Paul Sartre. Revista Tempos e Espaços em Educação, UFS, v. 3, p. 9 - 22, 2014. Disponível em: https://seer.ufs.br/index.php/revtee/article/viewFile/2209/1880. Acesso em: 4 ago. 2020. LIMA, Walter Matias. Revolta e Liberdade: Sartre e a Educação. Revista SulAmericana de Filosofia e Educação, v. 3, p. 14-19, 2004.

SARTRE, Jean-Paul. O ser e o nada: Ensaio de ontologia fenomenológica. Petrópolis: Vozes, 1997.

SILVA, Luciano Donizetti da. Existencialismo e educação: A filosofia sartriana da liberdade como fundamento pedagógico?. APRENDER - Cad. de Filosofia e Psic. da Educação, [s. I.], ano III, n. 4, p. 175 - 200, 2005. 


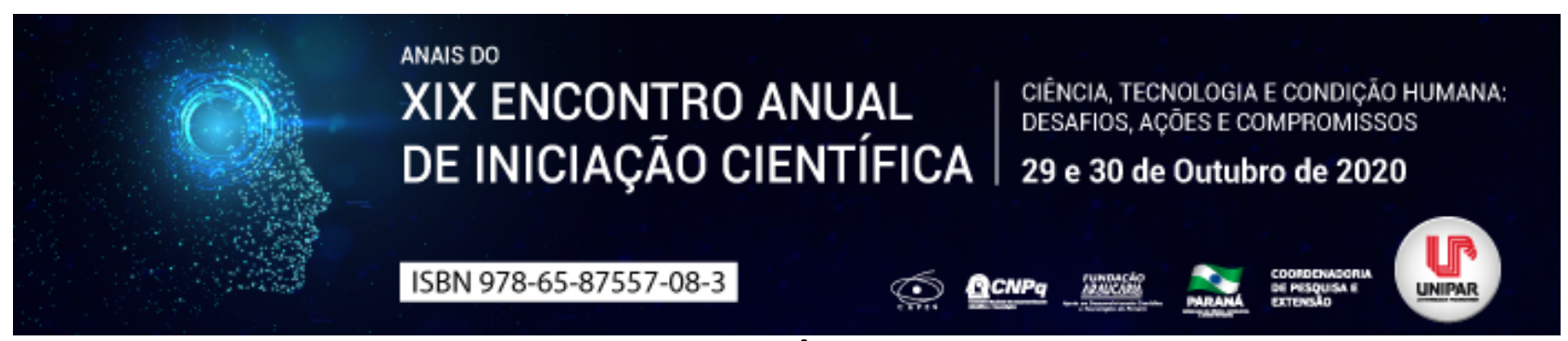

ESTUPRO MARITAL E A OCORRÊNCIA DE UM CRIME VELADO

\author{
${ }^{1}$ CLAUDIA APARECIDA CAOBIANCO DOS SANTOS, ${ }^{2}$ FERNANDA GARCIA VELASQUEZ
}

${ }^{1}$ Acadêmica do curso de Direito da Unipar

${ }^{1}$ Mestre em Direito Processual e Cidadania

Introdução: O Brasil é enquadrado como um dos países que sempre protegeu as ações violentas do esposo, concernente às características físicas e ideológicas de superioridade. Essa proteção leva em consideração o fato de na sociedade patriarcal a mulher sempre foi vista como fonte de prazer e procriação.

Objetivo: Demonstrar que independentemente de previsão legal, o estupro de mulheres casadas e conviventes acontecem, embora velado pelos preceitos do matrimônio.

Desenvolvimento: Vislumbra-se que por muito tempo a conjunção carnal violenta dentro do matrimônio foi descriminalizada, pautando no exercício regular do esposo. Com isso, a história e cultura deixaram marcas, tornando difícil a análise do crime. $\mathrm{O}$ estupro está disposto no artigo 213 do Código Penal, possibilitando aumento de pena no artigo 226, inciso II, quando o agente é companheiro da vítima. A Lei Maria da Penha, no artigo $7^{\circ}$, inciso III, trouxe a violência sexual nas relações de convívio doméstico e familiar. A mulher sempre foi hierarquicamente inferior, sendo na maioria das vezes o sujeito passivo do crime. Existem duas correntes doutrinárias entorno do crime de estupro marital, a primeira é aquela em que há um débito conjugal e um dever de coabitação que a esposa consentiu com o casamento (SANTOS, 2019). A segunda corrente expõe o justo consentimento da esposa na relação sexual, respaldando que a primeira corrente está desatualizada, visto que os direitos conjugais são de ambos (NUCCl, 2020). A violência contra a mulher nas relações de afeto é cometida para forçar a conjunção carnal e/ou atos libidinosos, confrontando fortemente a liberdade e, assim violando os direitos essenciais do ser humano (DIAS, 2007). Não se deve confundir os deveres do matrimônio com o desrespeito à liberdade sexual da mulher, a presunção do exercício regular do direito é algo inaceitável. Por conseguinte, o que torna ineficaz a aplicação do direito da vítima é a inconsciência de ser sujeito passivo do crime, além da dependência afetiva e financeira e por fim, quando existe compreensão do ato ilícito, a materialização de provas é difícil com a decorrência do lapso temporal.

Conclusão: $O$ tipo penal existe, porém não é algo de fácil aplicação, visto que as questões ideológicas influenciam até hoje na inconsciência da vítima. Por isso, mostra-se necessário o combate à problemática social, para que assim o sujeito ativo seja investigado e, posteriormente sofra as sanções do crime de estupro no âmbito da relação matrimonial.

\title{
Referências
}

BRASIL. Decreto-Lei 2.848, de 07 de dezembro de 1940. Código Penal. Disponível em: https://tinyurl.com/kchzuvw. Acesso em: 09 jul. 2020.

\section{jul. 2020 .}

. Lei no 11.340, de 7 de agosto de 2006. Lei Maria da Penha. Disponível em: https://tinyurl.com/4e76bfr . Acesso em 09

DIAS, M. B. A Lei Maria da Penha na justiça: a efetividade da Lei 11.340/2006 de combate à violência doméstica e familiar contra a mulher. São Paulo: Editora Revista dos Tribunais, 2007.

NUCCI, G. S. Manual de direito penal. 16. ed. Rio de Janeiro: Forense, 2020.

SANTOS, J. L. M. F. S. Estupro marital sob a ótica do ordenamento jurídico. Âmbito Jurídico, 27 jul. 2019. Disponível em: https://tinyurl.com/y77rs2k5. Acesso em 09. jul. 2020. 


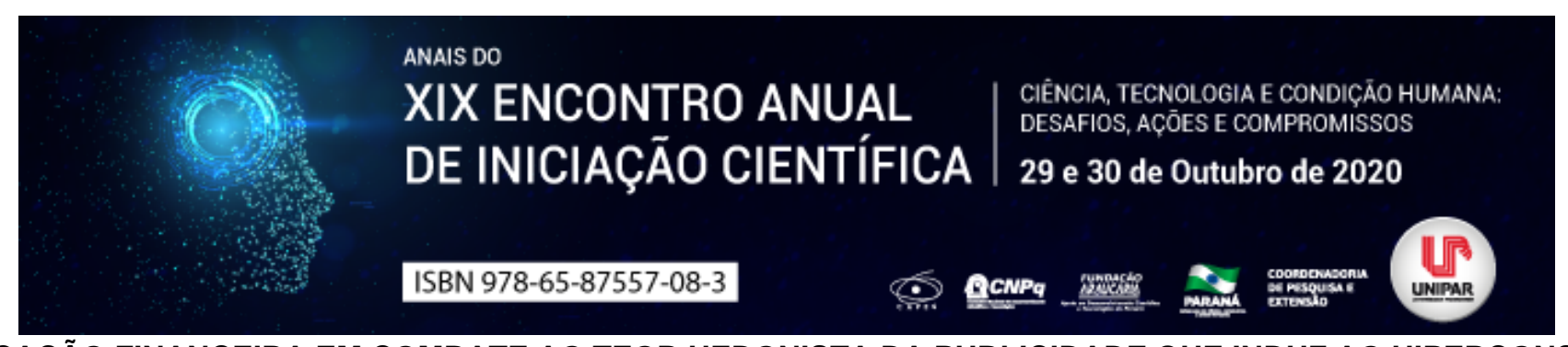

\title{
A EDUCAÇÃO FINANCEIRA EM COMBATE AO TEOR HEDONISTA DA PUBLICIDADE QUE INDUZ AO HIPERCONSUMO E AO SUPERENDIVIDAMENTO DO CONSUMIDOR
}

\author{
${ }^{1}$ BRUNO ROGER CAUMO, ${ }^{2}$ FILIPE DE LIMA CRUZ, ${ }^{3}$ IVANILDA VAZ BATISTA DE OLIVEIRA, ${ }^{4}$ LIDIA RICCI ROQUE, ${ }^{5}$ MARIA \\ CAROLINA SILVA DA FONSECA, ${ }^{6}$ VALERIA BONONI GONCALVES DE SOUZA
}

\author{
${ }^{1}$ Acadêmico do PIC/UNIPAR \\ ${ }^{1}$ Acadêmico do Curso de Direito da UNIPAR \\ ${ }^{2}$ Acadêmica do Curso de Direito da UNIPAR \\ ${ }^{3}$ Acadêmica do Curso de Direito da UNIPAR \\ ${ }^{4}$ Acadêmica do Curso de Direito da UNIPAR \\ ${ }^{5}$ Docente da UNIPAR
}

Introdução: As forças valorativas e culturais da publicidade que ligam o consumo à satisfação e realização pessoal, atraem o consumo exagerado e tornam os consumidores com menor conhecimento financeiro, mais aptos ao superendividamento.

Objetivo: Apontar e analisar a importância da educação financeira, com o intuito de regular a prática publicitária moderna atrelada a filosofia da felicidade através do consumo, evitando a figura do consumidor superendividado.

Desenvolvimento: A ordem econômica e publicitária moderna que foi criada entre os séculos XIX e XX, fortaleceu as grandes economias mundiais através do mercado de consumo. Victor Lebow expôs $(1955$, p.3) ao Journal of Retailing, o ideário do mercado e da publicidade moderna, disse que nossa economia extremamente produtiva exige que façamos do consumo nosso modo de vida, (...) que busquemos nossas satisfações espirituais, nossas satisfações de ego, no consumo , desta forma nasceu a sociedade de hiperconsumo. Villas Bôas e Santos (2014, p.3), conceituam o hiperconsumo como o consumo excessivo daquilo que não é essencial para atender às necessidades básicas , na tentativa de suprir o vazio da existência, criando um imperativo social que induz o homem, pois, na sociedade de consumo a publicidade, o marketing e as práticas comerciais criam desejos, tentações mesmo, exigências sociais novas, até necessidades visando o lucro, e ninguém está liberto dessas pressões, seja de qual classe social for (MARQUES, 2010, p.3). O consumo exacerbado e desnecessário, adjacente à ignorância financeira e o crédito fácil, fomentaram o superendividamento que, nas palavras de Marques (2010, p.4) pode ser definido como a impossibilidade global do devedor-pessoa física, consumidor, leigo e de boa-fé, de pagar todas as suas dívidas atuais e futuras de consumo (excluídas as dívidas com o Fisco, oriundas de delitos e de alimentos) em um tempo razoável com sua capacidade atual de rendas e patrimônio . Com isso, o Projeto de Lei 3515 de 2015 - originário do SenadoFederal e atualmente em tramitação na Câmara dos Deputados - no intuito de melhorar a regulamentação dos créditos aos consumidores e fornecer meios de prevenção e tratamento ao superendividamento, alterando a Lei $n^{\circ} 8.078$ de 11 de setembro de 1990, intitulada como Código de Defesa do Consumidor, pretende inovar, implantando por exemplo, através do inciso IX, que será acrescentado ao artigo $4^{\circ}$, a educação financeira caracterizada como um princípio da Política Nacional das Relações de Consumo, além disso, determinará sua qualidade como direito básico do consumidor através do inciso $\mathrm{XI}$, que será inserido ao artigo $6^{\circ}$. O projeto também prevê a inserção ao CDC do artigo 54-C, como um regulador importante para a oferta de crédito, não necessariamente publicitária e, outro regulador valioso deste tipo de oferta será o artigo 54-D, que assim dispõe: Na oferta de crédito, previamente à contratação, o fornecedor ou intermediário deve, entre outras condutas: I - informar e esclarecer adequadamente o consumidor, considerando sua idade, saúde, conhecimento e condição social, sobre a natureza e a modalidade do crédito oferecido, sobre todos os custos incidentes, observado o disposto nos arts. 52 e 54-B, e sobre as consequências genéricas e específicas do inadimplemento; II - avaliar a capacidade e as condições do consumidor de pagar a dívida contratada, mediante solicitação da documentação necessária e das informações disponíveis em bancos de dados de proteção ao crédito, observado o disposto neste Código e na legislação sobre proteção de dados; III - informar a identidade do agente financiador e entregar ao consumidor, ao garante e a outros coobrigados cópia do contrato de crédito . Tais meios de regulação da oferta do crédito são novidades importantes trazidas pelo PL-3515/15, cabendo destacar a importância do inciso I do artigo 54-D, que fornece as informações necessárias para que o consumidor tenha plena consciência de seus riscos, garantindo sua liberdade, enquanto o inciso II do mesmo artigo, impõe ao fornecedor a necessária constatação de uma provável capacidade de adimplir ao que for pactuado, visando de forma conjunta, garantir a segurança financeira do consumidor, permitindo que este exerça de forma responsável e plena, seu direito de contratar e utilizar o crédito, mecanismo influente e essencial para o mercado de consumo.

Conclusão: A educação financeira é uma forma de prevenção ao superendividamento, qualificada como um ponto essencial do Projeto de Lei 3515/15, capaz de prevenir, como também tratar as cicatrizes do mercado de consumo e tornar os consumidores aptos para gerir suas relações, retornando ao mercado conscientes de suas necessidades e limites. 


\section{Referências}

BRASIL. Projeto de Lei n. 3.515/15. Altera a Lei $n^{\circ}$ 8.078, de 11 de setembro de 1990, e o art. 96 da Lei $n^{\circ} 10.741$, de $1^{\circ}$ de outubro de 2003, para aperfeiçoar a disciplina do crédito ao consumidor e dispor sobre a prevenção e o tratamento do superendividamento. Brasília. DF. 2015.

LEBOW, Victor. Price Competition in 1955, Journal of Retailing, Spring, 1955, seção The Real Meaning of Consumer Demand. Disponível em: https://pt.scribd.com/doc/965920/LebowArticle. Acesso em: 28 de Agosto de 2020.

MARQUES, Claudia Lima. Algumas Perguntas e Respostas sobre Prevenção e Tratamento do Superendividamento dos Consumidores Pessoas Físicas. Revista Direito do Consumidor. Vol 75/2010, p. 9-42, Jun-Set 2010. Doutrinas Essenciais de Direito do Consumidor. Vol. 2, p. 563-593, Abr 2011.

VILLAS BÔAS, Regina Vera e SANTOS, Leyde Aparecida Rodrigues dos. A FELICIDADE EM CONSUMIR, O HIPERCONSUMO E OS DIREITOS HUMANOS E FUNDAMENTAIS, III Seminário Internacional de Direito-UNISAL, 2014. Disponível em: http://www.lo.unisal.br/direito/semidi2014/publicacoes.aspx?livro=DHSC. Acesso em: 28 de Agosto de 2020. 


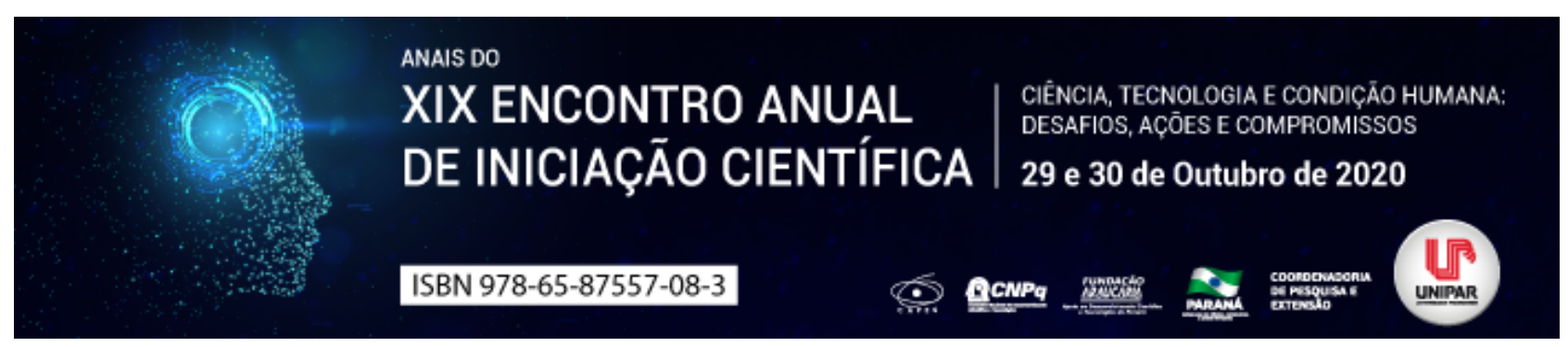

AUTONOMIA DAS PARTES PARA DEFINIR A GUARDA COMPARTILHADA

\title{
${ }^{1}$ AMANDA MARQUES CRUZ, ${ }^{2}$ CELSO HIROSHI IOCOHAMA
}

\author{
${ }^{1}$ Acadêmica do curso de Direito da Unipar e Integrante do PIC/Unipar \\ ${ }^{1}$ Docente da Graduação em Direito e do Programa de Mestrado em Direito Processual e Cidadania da UNIPAR
}

Introdução: A guarda compartilhada prevista na Lei 13.058/14 dispõe sobre a responsabilidade conjunta dos genitores no exercício dos direitos e deveres sobre os filhos, visando a concretização do princípio do melhor interesse para a criança. No entanto, o Projeto de Lei n. 2491/2019 tem a pretensão de criar um critério objetivo para que em casos de violência doméstica e/ou familiar isso seja causa impeditiva para o exercício da guarda compartilhada.

Objetivo: Analisar a compatibilidade da regulamentação do Projeto de Lei n. 2491/2019 com os critérios de definição da guarda compartilhada e a autonomia dos genitores.

Desenvolvimento: No ordenamento jurídico brasileiro, a guarda compartilhada surgiu com o objetivo de que os filhos de pais separados continuassem assistidos por ambos mesmo após a separação, para que assim o foco maior fosse no cuidado destes e não somente no divórcio, como afirma Azevedo (2001). No Brasil, a decisão da guarda ou é por acordo das partes, sendo assim requerida (art.1584, I, Código Civil), ou por decisão judicial (art.1584, II, Código Civil), sendo nessa última analisadas as causas impeditivas ao exercício da guarda, quando o genitor alega que não deseja a guarda ou incapacidade para exercer, podendo assim a guarda ser unilateral, compartilhada ou alternada (BRASIL, 2002). O Estatuto da Criança e do Adolescente, criado em 1990, dispõe em seu art. 22 sobre o dever equitativo de ambos os genitores e sua autonomia para decidir o melhor para seu filho (BRASIL, 1990). É nesse ponto que há uma colisão entre a autonomia dos pais e o critério objetivo discutido. O projeto de autoria do Senador Rodrigo Cunha (PSDB/AL) n. 2491/2019, voltado para um tema social, tramitando no Senado Federal, tem o objetivo de alterar a redação do § 20 do art. 1.584 da Lei n. 10.406, de 10 de janeiro de 2002 (Código Civil) e acrescenta o art. 699-A à Lei n. 13.105, de 16 de março de 2015 (Código de Processo Civil), para estabelecer o risco de violência doméstica ou familiar como causa impeditiva ao exercício da guarda compartilhada, bem como para impor ao juiz o dever de indagar previamente o Ministério Público e as partes sobre situações de violência doméstica ou familiar, envolvendo o casal ou os filhos (BRASIL, 2019). À luz desse cenário para que o juiz homologue a guarda compartilhada, é necessário, primeiramente, a análise de fatores importantes e não somente um único ponto como prevê o projeto, sendo necessária uma reformulação do projeto para que o foco seja o risco ao filho e não a relação dos genitores como causa impeditiva à convivência familiar, e também a incoerência de suspender o processo para que se faça provas no momento do acordo. Assim, o principal foco da guarda deve ser sempre o melhor para o filho, a liberdade das partes de decidirem sobre o desenvolvimento e a convivência familiar de que ele necessita.

Conclusão: Diante disso, a pretensão do projeto busca analisar, de forma objetiva, um único critério para estabelecer o impedimento da guarda, o que destoa com o melhor entendimento sobre o tema, uma vez que é necessário analisar inúmeros fatores e principalmente respeitar a liberdade das partes no que diz em relação ao menor.

\footnotetext{
Referências

AZEVEDO, Maria Raimunda Teixeira. A guarda compartilhada. Rio de Janeiro, 25 abr. 2001. Disponível em: https://www.pailegal.net/guarda-compartilhada/mais-a-fundo/analises/208-a-guarda-compartilhada. Acesso em: 04 ago. 2020. BRASIL, Código Civil Brasileiro. Lei n 10.406, de 10 de janeiro de 2002. Institui o Código Civil. Diário Oficial da União, Brasília, 10 jan. 2002.

BRASIL, Estatuto da Criança e do Adolescente. Lei no 8.069, de 13 de julho de 1990. Dispõe sobre o Estatuto da Criança e do Adolescente e dá outras providências. Diário Oficial da União, Brasília, 13 jul. 1990.

BRASIL. Lei no 13.058, de 22 de dezembro de 2014. Altera os arts. 1.583, 1.584, 1.585 e 1.634 da Lei no 10.406, de 10 de janeiro de 2002 (Código Civil), para estabelecer o significado da expressão guarda compartilhada e dispor sobre sua aplicação. Diário Oficial da União, Brasília, 22 dez. 2014.

BRASIL, Projeto de Lei n. 2491/2019. Altera a redação do § 20 do art. 1.584 da Lei no 10.406, de 10 de janeiro de 2002 (Código Civil) e acrescenta o art. 699-A à Lei no 13.105, de 16 de março de 2015 (Código de Processo Civil), para estabelecer o risco de violência doméstica ou familiar como causa impeditiva ao exercício da guarda compartilhada, bem como para impor ao juiz o dever de indagar previamente o Ministério Público e as partes sobre situações de violência doméstica ou familiar, envolvendo o casal ou os filhos. Brasília: Senado Federal. Disponível em: https://www25.senado.leg.br/web/atividade/materias/Imateria/136476. Acesso em: 27 jul. 2020.
} 
Coordenadoria de Pesquisa e Extensão - COPEX

Departamento de Editoraçāo e Divulgaçāo Científica - DEDIC 


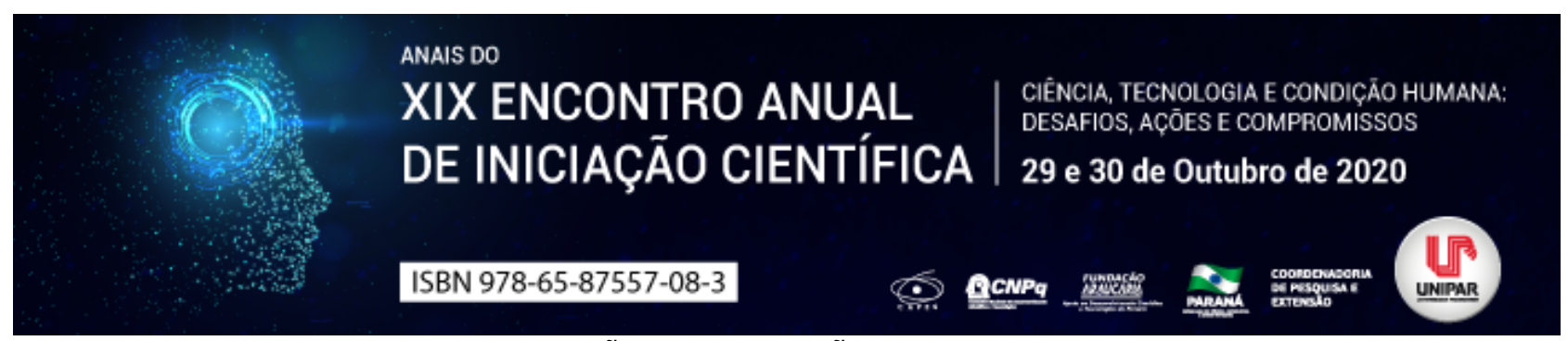

O DEVER DE FUNDAMENTAÇÃO DAS DECISÕES JUDICIAIS E O PROCESSO JUSTO

\author{
${ }^{1}$ CAMILA DA SILVA FURLAN DE MORAES, ${ }^{2}$ ALBINO GABRIEL TURBAY JUNIOR
}

${ }^{1}$ Acadêmico do PIC/UNIPAR

${ }^{1}$ Docente da UNIPAR

Introdução: O atual Código de Processo Civil apresentou alterações influenciadas pela Constituição Federal, colaborando para um processo que respeite os princípios processuais constitucionais, com viés democrático. Entre os princípios, está a fundamentação judicial que recebeu um maior protagonismo perante o sistema processual, garantindo um processo justo e democrático.

Objetivo: Analisar o dever de fundamentação das decisões judiciais e sua importância para a justiça do processo e a concretização dos direitos.

Desenvolvimento: A necessidade de fundamentação está estabelecida na Constituição Federal no artigo 93, IX, sendo tratado como um elemento indispensável para garantir a segurança jurídica. O dever de fundamentação das decisões judiciais está entre os princípios essenciais de um Estado Democrático, sendo considerado uma garantia fundamental, pois, reflete na justiça que é alcançada quando o processo possui um pronunciamento justo, sendo este necessariamente fundamentado. Segundo Medina (2016, p.747): Fundamentar é apresentar, racionalmente, as bases fáticas e jurídicas da decisão . Com as mudanças ocorridas no Código de Processo Civil em 2015 houve alterações acerca do dever de fundamentação que estabeleceram um maior empenho por parte dos magistrados em argumentarem suas justificações das decisões judiciais (MARANHÃO; VASCONCELOS, 2015). O artigo $489 \S 1^{\circ}$ do Código de Processo Civil vigente instaurou alguns requisitos que delimitam o que é fundamentação, com o objetivo de evitar decisões arbitrárias ou fracas de argumentos. Conforme o Código de Processo Civil vigente em seu artigo 11 a quebra do dever de fundamentação leva a nulidade do processo, causa uma instabilidade jurídica, além de ser inconstitucional. A fundamentação deve atender a certas funções: ser clara, apresentar às partes do processo as razões de ter levado tal julgamento, além de permitir que os advogados, Ministério Público e juízes superiores tenham os elementos necessários para fiscalizar a atuação, podendo inclusive reformá-la (COELHO, 2016, p.151). É importante ressalvar que, com os avanços da modernidade, as atividades passaram a ser otimizadas, o mesmo ocorreu com os processos judiciais que tentam ser mais rápidos, gerando consequência no ato de fundamentar e acabam não atendendo aos requisitos. $O$ magistrado tem o dever de expor os argumentos que o levaram a tomar a decisão proferida, para que a ação judicial alcance seu objetivo, garantindo concretização dos direitos dentro de uma ordem justa.

Conclusão: Conclui-se que a validade do processo depende da fundamentação da decisão judicial, assim, torna-se imprescindível, sendo dever do magistrado ao proferir sua decisão respeitar os requisitos necessários estabelecidos pela legislação processual. Cabendo ressaltar que ao fundamentar a decisão de forma correta, o processo estará atendendo a uma das exigências constitucionais, garantindo às partes do processo segurança jurídica, justiça e efetividade na concretização dos direitos que lhes pertencem.

\title{
Referências
}

BRASIL. Lei.13.105 de 16 março de 2015. Código de Processo Civil. Diário Oficial da União, Seção 1, 17 mar. 2015 , p.1. COELHO, Marcus Vinicius Furtado. Garantias constitucionais e segurança jurídica. 1ed. Belo Horizonte: Fórum, 2016. p.159 MARANHÃO, Clayton de Alburquerque; VASCONCELLOS, Fernando Andreoni. Criação de enunciados interpretativos sobre novo CPC é iniciativa louvável. In: Conjur- Consultor Jurídico. Brasil, 9 out. 2015. Disponível em :< encurtador.com.br/eBIQT>. Acesso em 18 jul. 2020.

MEDINA, José Miguel Garcia. Direito processual civil moderno. 2ed. São Paulo: Revista dos Tribunais, 2016. p.1740. 


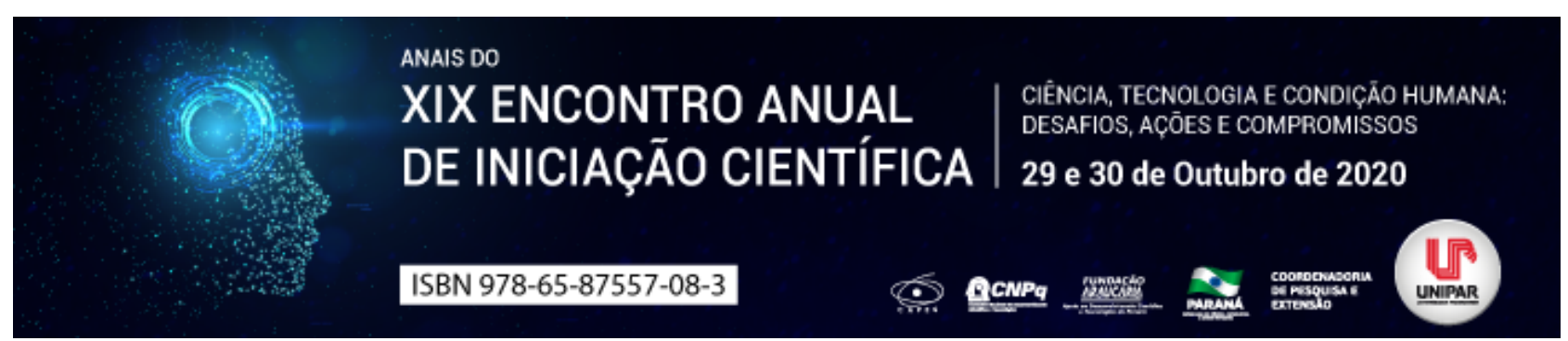

A PRESENÇA DO RÉU COLABORADOR E A GARANTIA DO DEVIDO PROCESSO LEGAL

\title{
${ }^{1}$ AMANDA PEREIRA PERRUT, ${ }^{2}$ RICARDO MUCIATO MARTINS
}

\author{
${ }^{1}$ Acadêmica do PIC/UNIPAR \\ ${ }^{1}$ Docente da UNIPAR
}

Introdução: A pluralidade de réus é um assunto acordado recentemente no Direito brasileiro, oriundo da introdução da figura do réu colaborador, tendo por pano de fundo a discussão sobre a plena garantia do devido processo legal e os princípios constitucionais da ampla defesa e contraditório. A legislação não possui regra quanto a ordem de interrogatório e apresentação de alegações finais nas ações com réu colaborador, o que ocasiona prejuízos para a defesa.

Objetivo: Analisar por meio de revisão bibliográfica, a ordem de manifestação dos réus em ação criminal com multiplicidade de acusados e réu colaborador e eventuais prejuízos aos princípios constitucionais da ampla defesa e contraditório.

Desenvolvimento: A Constituição Federal de 1988, em seu art. $5^{\circ}$, confere a todos o direito a ampla defesa e ao contraditório (BRASIL, 2020). Porém, tais princípios traduziam-se em mera letra morta na matéria processualística, especificamente no que concerne às ações com multiplicidade de réus. O Código de Processo Penal de 1941, antes da alteração de seu art. 395, coibia o réu de manifestar-se novamente depois de sua defesa, proporcionando desvantagem entre os acusados, pois aquele que apresentasse por último seu argumento o faria considerando o que já havia sido exposto pelos demais. A tentativa de impor prazos comuns às partes tornou-se impossível, visto que os litigantes deveriam fazer carga dos processos, e estes eram físicos, ocorrendo, segundo Renato Vieira (2014) uma violação à paridade de armas. Ademais, o início das então alegações preliminares se dava após o término do último interrogatório, seguindo para a inquirição das testemunhas, que começava na mesma data para todos os réus. A ordem dos interrogatórios seguia a constante na denúncia ou queixa-crime. Logo, a preocupação com a agilidade dos processos, fez com que garantias constitucionais fossem infringidas, conforme Gajardoni (2018, p. 57): [...] a celeridade processual não pode ser perseguida com atropelos às garantias processuais . Com o processo digital, a contagem de prazo comum tornou-se possível, mas a introdução da figura do réu colaborador, na lei n8.072/90(Lei dos Crimes Hediondos) e, posteriormente, na Lei $n^{\circ}$ 12.850/2013 ( Lei das Organizações Criminosas), acentou o prejuízo. Isto levou o Supremo Tribunal Federal - STF a decidir no Habeas Corpus n¹66.373, impetrado no âmbito da Operação Lava Jato, que os réus não colaboradores têm direito a serem interrogados e apresentarem alegações finais depois dos colaboradores.

Conclusão: Constata-se que as modificações no regulamento processual penal, a implantação do processo digital e o acórdão do STF, foram de suma importância, para determinar uma ordem para a manifestação dos acusados nas ações com multiplicidade de réus e a figura do colaborador, evitando prejuízos pela falta de prazo razoável e garantindo que a defesa somente se manifeste após todas as provas acusatórias serem produzidas.

\section{Referências}

BRASIL. Constituição da República Federativa do Brasil: promulgada em 8 de outubro de 1988. 53 ed. Brasília, DF: Senado, 2020.

BRASIL. Supremo Tribunal Federal. Habeas Corpus n. 166.373. Relator Ministro Edson Fachin. Data de Julgamento: 26 set. 2019, Data de Publicação: 15 out. 2020. Disponível em: . Acesso em 15 jul 2020.

GAJARDONI, Fernando da Fonseca; DELLORE, André; OLIVEIRA JUNIOR, Zulmar Duarte. Teoria Geral do Processo: comentários ao CPC 2015. Parte Geral. 2.ed. São Paulo: Método, 2018.

VIEIRA, Renato Stanziola. Paridade de Armas no Processo Penal. Coleção Ada Pellegrini Grinover. Goiânia: Gazeta Jurídica, 2014.

Coordenadoria de Pesquisa e Extensão - COPEX

Departamento de Editoraçāo e Divulgaçāo Científica - DEDIC 


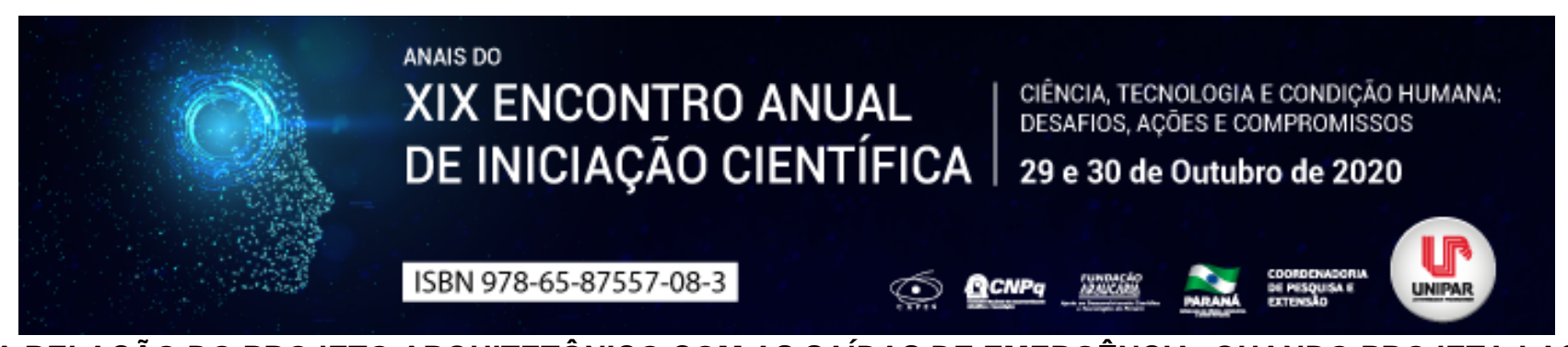

A RELAÇÃO DO PROJETO ARQUITETÔNICO COM AS SAÍDAS DE EMERGÊNCIA: QUANDO PROJETA-LAS

\author{
${ }^{1}$ NICOLE DO NASCIMENTO VIANA, ${ }^{2}$ BEATRIZ OLIVEIRA BORELLA, ${ }^{3}$ MATHEUS HENRIQUE ROSSATTO CASOLA, \\ ${ }^{4}$ WELLINGTON GABRIEL AGUIAR XAVIER, ${ }^{5}$ THAINA COUTINHO DA LUZ, ${ }^{6}$ IGO HENRIQUE SILVA NUNES
}

\author{
${ }^{1}$ Acadêmico do PIC- UNIPAR \\ ${ }^{1}$ Acadêmica do Curso de Arquitetura e Urbanismo da UNIPAR \\ ${ }^{2}$ Acadêmico do Curso de Engenharia Civil da UNIPAR \\ ${ }^{3}$ Acadêmico do Curso de Engenharia Civil da UNIPAR \\ ${ }^{4}$ Acadêmica do Curso de Engenharia Civil da UNIPAR \\ ${ }^{5}$ Docente da UNIPAR
}

Introdução: A segurança contra incêndio no Brasil, é um tema que muitas vezes só é lembrado quando estamos enfrentando uma nova catástrofe, momentos em que as pessoas pensam em como poderia ser diferente caso esses ambientes fossem projetados de forma diferente. Atualmente os projetos de segurança de incêndio têm recebido mais atenção, porém ainda é um assunto que muitas vezes é pouco aprofundado e levado em consideração somente no final, após a concepção do projeto arquitetônico. Se tratando de medidas de incêndio, as saídas de emergência são de suma importância, quando bem projetadas podem diminuir ou até mesmo zerar o número de vítimas em eventos como esses, quando mal executados ou projetados os números de vítimas podem aumentar substancialmente, um exemplo é o acontecido em 2013 na Boate Kiss em Santa Maria, no Rio Grande do Sul, onde muitas pessoas não conseguiram deixar o local com vida. (MONTENEGRO, 2016)

Objetivo: Com base na revisão bibliográfica, apresentar os benefícios de projetar o arquitetônico em conjunto com uma das principais medida de segurança, as saídas de emergência.

O Projeto: Segundo Venezia e Ono (2014), as soluções adotadas durante a concepção de um projeto, influenciam diretamente no resultado final e na qualidade do produto entregue, ou seja: pode-se assim definir arquitetura como construção concebida com a intenção de ordenar plasticamente o espaço, em função de uma determinada época, de um determinado meio, de um determinado material, de uma determinada técnica e de um determinado programa. (Costa, 1954, pg.38). Deve-se levar em consideração todas as condicionantes presentes no projeto de acordo com as necessidades do cliente e algumas que muitas vezes não serão requisitadas pelo mesmo, mas são tão importantes quanto as demais, como por exemplo as normas de segurança contra incêndio, porém, dependendo da ocupação, área, risco e altura há medidas de segurança mínimas específicas a serem atendidas. De acordo com Wagner (2008), na maioria das vezes durante o projeto e execução de uma obra, as diferentes equipes envolvidas, sejam elas estrutural, arquitetônico, segurança de incêndio e entre outros, desenvolvem separadamente o projeto, chamado de processo tradicional de projeto, gerando maior gama de problemas de compatibilização entre os projetos trabalhados. Isso tudo além de atrasar o desenvolvimento do projeto, pode também gerar custos desnecessários, caso o problema seja identificado tardio durante a fase de construção. Hoje, por exemplo, fala-se somente em

aprovar o projeto no Corpo de Bombeiros , que é simplesmente uma aprovação no final do processo, depois de ele já estar todo desenvolvido. Nessa fase, grande parte da concepção já está pronta e, às vezes, é tardio querer atender a algumas questões (REVISTA TÉCHNE, 2013, p. 26). Para maior eficiência e compatibilização de todas as fases do projeto, é necessário que todas as diferentes equipes trabalhem juntos, dessa forma além de diminuir exponencialmente os problemas que podem aparecer durante a fase de projeto e obra, economizam tempo, dinheiro, e muitas vezes podem adotar medidas nos projetos que podem ser mais eficazes e funcionais, gerando assim uma melhor união entre os projetos estruturais, arquitetônicos, de segurança de incêndio e entre outros. Dentro da segurança de incêndio existem várias medidas a serem adotadas, sejam elas passivas ou ativas, as saídas de emergência são consideras medidas de proteção passivas, e fazem parte dos projetos de segurança contra incêndios, uma ferramenta muito importante frente aos incêndios, para maior efetividade deve ser pensada juntamente ao projeto arquitetônico. (WAGNER, 2008).

Conclusão: Conclui-se com o presente trabalho, que é extremamente indispensável que todos os projetos necessários para a execução de uma obra, sejam pensados em equipe paralelamente, para um melhor resultado, economizando tempo e dinheiro. O projeto de segurança de incêndio, as saídas de emergência dentre eles, precisa ser pensado juntamente com o projeto arquitetônico, ou seja, o projeto arquitetônico deve ser o primeiro a iniciar e o último a concluir.

\title{
Referências
}

COSTA, L. (1954). Considerações sobre o ensino da arquitetura: Artigos e Estudos de Lúcio Costa; org. Centro de Estudos de Teoria de Arquitetura, Faculdade de Arquitetura - UFRGS. 
MONTENEGRO, M. L. O. (2016). Análise de desempenho das saídas de emergência por meio de simulações computacionais - $O$ caso de projetos de edifícios universitários. Dissertação da pós graduação em Arquitetura e Urbanismo. Natal, Universidade Federal do Rio Grande do Norte Centro de Tecnologia - UFRN.

ONO, Rosaria. Arquitetura preventiva: depoimento. [21 de Setembro, 2013]. São Paulo: Revista Téchne, Editora PINI, edição 198, p.26. Entrevista a Renato Faria e Ana Sachs.

VENEZIA, A. P. P.G. e ONO, R. (2014). Parâmetros para qualidade do projeto sob o aspecto da segurança contra incêndio. XV Encontro Nacional de Tecnologia do Ambiente Construído. Maceió - ENTAC.

WAGNER, R. (2008). Projeto para saídas de emergência: O conceito de desempenho em Santa Catarina. Dissertação da pós graduação em Arquitetura e Urbanismo. Florianópolis, Universidade Federal de Santa Catarina - UFSC.

Coordenadoria de Pesquisa e Extensão - COPEX

Departamento de Editoraçāo e Divulgaçāo Científica - DEDIC 


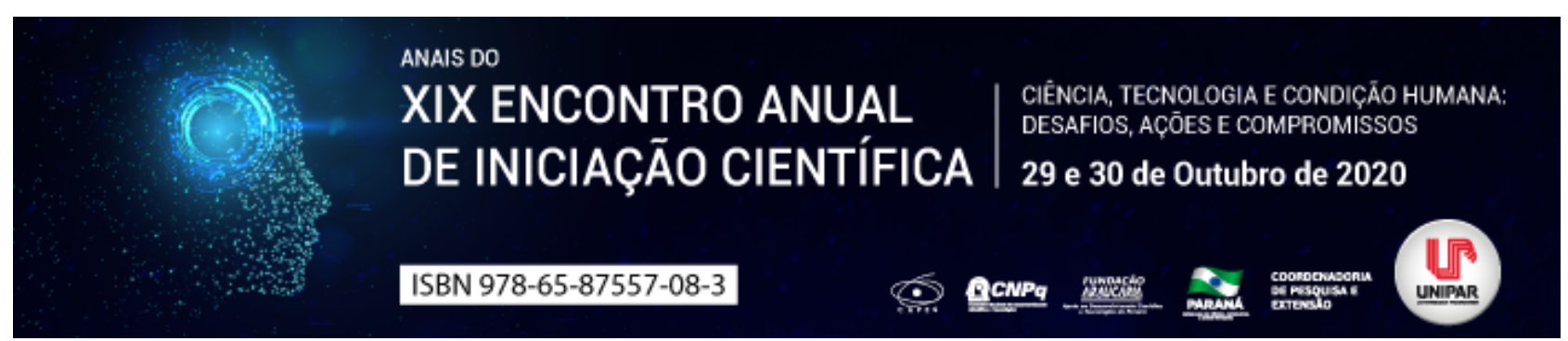

MÚSICA E DIREITO: UMA ANÁLISE DOS LIMITES DO INTÉRPRETE

\author{
${ }^{1}$ GABRIEL RICARDO TOFANIN BATISTA, ${ }^{2}$ FERNANDA GARCIA VELASQUEZ
}

\author{
${ }^{1}$ Acadêmico do PIC/UNIPAR \\ ${ }^{1}$ Docente da UNIPAR
}

Introdução: Considerando a Teoria Tridimensional do Direito, o intérprete deve valorar o Fato para a experiência completa do Direito, por isso o trabalho deste se torna árduo, uma vez que, assim como um musicista tem que se ater ao que está escrito na partitura , o intérprete do Direito não pode ultrapassar o texto legal, podendo cair no Direito Penal de Autor.

Objetivo: Analisar os limites dos intérpretes da música e da lei, especialmente no que tange ao Direito Penal.

Desenvolvimento: Como se vê em A música e o Direito do ex-ministro do STF Eros Grau (2014, p.1): Ambos são alográficos, isto é, reclamam um intérprete: o intérprete da partitura musical, de um lado; o intérprete do texto constitucional ou da lei, de outro , logo é possível afirmar que os dois necessitam do papel do intérprete para sua completude, precisam de um indivíduo dotado de valor, como definido na teoria de Miguel Reale, para que possa interpretar o princípio norteador. Prova da necessidade da valoração se demonstra em Nilo Batista (2007, p. 99), que disserta sobre o Princípio da Humanidade no Direito Penal, afirmando que: a pena nem visa fazer sofrer o condenado [...], nem pode desconhecer o réu enquanto pessoa humana[...] . Logo , o Direito foge da simples aplicação da lei, necessitando de uma valoração, neste caso, a atribuição de condição humana ao réu, assim como se dá na execução musical, na qual o simples tocar de notas, não representa a aplicação correta a música. Por conseguinte, na interpretação, de ambos os casos, dá-se a tônica máxima do processo de fazer a música e fazer o Direito , conferindo ares incertos ao que se denota na pauta musical e na pauta legal : Esta dinâmica incerta e criativa do intérprete é a tônica que alcança e justifica a metáfora (LOPES, 2018, p.8). Entretanto, para a correta execução da partitura musical, observar-se-á o intérprete ao que está escrito, caso contrário, estaria esse ultrapassando os limites impostos pela partitura, atentando contra a liberdade de interpretar como assevera Lopes (2018, p. 96) só o temperamento proporcionou à música 'liberdade plena'. O temperamento se define como organização musical criada por Bach. Similar processo se dá no Direito Penal, onde se vê a 'Reserva Legal', que concede ao legislador instrumentos sistematizados, assim como o temperamento de Bach para [...] garantir os interesses da liberdade individual (BATISTA, 2007, p.73). Porém, o ponto fundamental dessa análise está no fato de assim como errado está o musicista que extrapola a partitura, atribui-se o mesmo valor ao juiz que valora o fato esquecendo-se do seu limite, e incorre em julgar o autor do fato, e não o fato propriamente dito.

Conclusão: Direito e música, apesar de parecerem áreas sem associação, possuem alguns pontos de análise em comum, especialmente no campo valorativo da interpretação, musicistas e juízes têm similar limite. O primeiro não pode ultrapassar a partitura e o segundo a lei, podendo incorrer no caso do magistrado, um julgamento seletivo, ultrapassando o fato e incorrendo no Direito Penal de Autor.

\title{
Referências
}

LOPES, Monica Sette. Música e Direito: uma metáfora. Belo Horizonte, Initia Via, 2018. $2^{\mathrm{a}}$ edição. 224p.

GRAU, Eros Roberto. A música e o Direito. O Globo, v. 13, 2014.

BATISTA, Nilo. Introdução crítica ao direito penal brasileiro. Rio de Janeiro: Revan, 2007.11 a edição. 136p. 


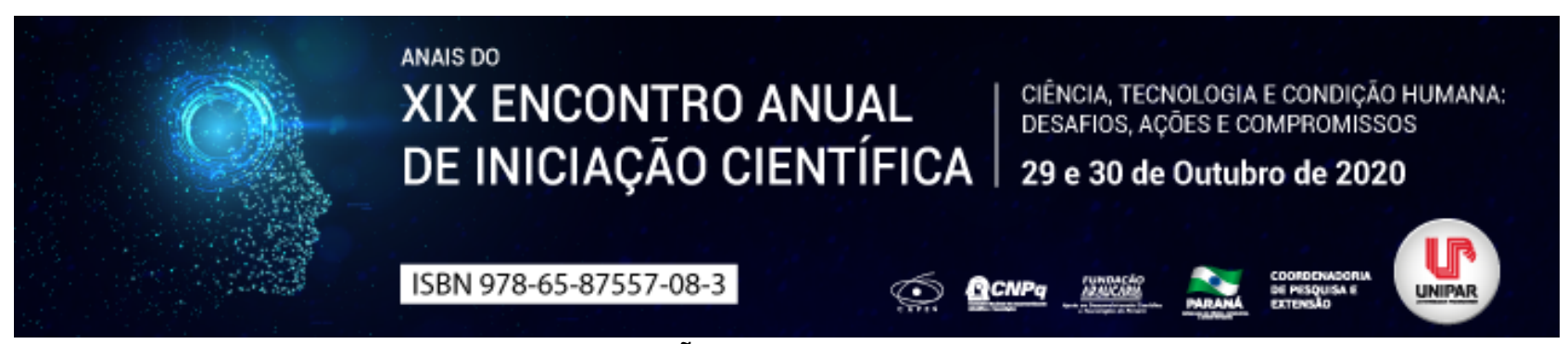

PROCESSOS DE SUBJETIVAÇÃO NO CONTEXTO LGBT: Ou melhor, GGG?

\title{
${ }^{1}$ STEPHANEI COELHO PAULINI, ${ }^{2}$ EMANUEL JOSE LAHOS BORGES, ${ }^{3}$ LUIZ AUGUSTO BAESSO TURCI, ${ }^{4}$ MATHEUS LIMA DOS SANTOS, ${ }^{5}$ TAYNA CECCON MARTINS
}

\author{
${ }^{1}$ Acadêmica do curso de Psicologia da UNIPAR \\ ${ }^{1}$ Acadêmico do Curso de Psicologia da UNIPAR \\ ${ }^{2}$ Acadêmico do Curso de Psicologia da UNIPAR \\ ${ }^{3}$ Acadêmico do Curso de Psicologia da UNIPAR \\ ${ }^{4}$ Docente da UNIPAR
}

Introdução: A partir de Guattari \& Rolnik (1996), compreende-se que tudo aquilo que chega a nós e que nos circunda, é algo a ser consumido; nesse sentido, há uma sujeição subjetiva a partir da cultura de massa, a qual cria indivíduos submissos a partir de sistemas hierárquicos, de valores, de submissão indivíduos da norma os quais são receptores e reprodutores de certos valores e práticas; assim, nos deparamos com uma subjetividade de natureza social que se faz vivenciar alternando entre dois espectros: o singular e de expressão ou o alienante e de opressão. Considerando as críticas comentadas por Colling (2015) em relação às rígidas categorias identitárias no campo LGBT que acabam por tornarem-se normalizadas e naturalizadas por certos discursos, faz-se necessário abordar a subjetivação desses moldes de ser-estar, relacionando-as à esse campo.

Objetivo: Estabelecer a relação entre a subjetivação capitalística de imagens identitárias e as representatividades predominantes dentro do movimento LGBT.

Desenvolvimento: Considerando que [...] a identidade é aquilo que faz passar a singularidade de diferentes maneiras de existir por um só e mesmo quadro de referência identificável (GUATTARI \& ROLNIK, 1996, p. 68-69, grifo dos autores) e está igualmente associada ao reconhecimento, podemos entender a identidade como uma maneira de nos referenciar, identificar, fixar

nos cristalizar, em determinados lugares. Segundo Colling (2015), uma estratégia utilizada por movimentos LGBT, recheados de discursos de igualdade, é a utilização de um essencialismo estratégico, que produz uma identidade essencial como método para a obtenção de direitos; coisa que se reflete, por exemplo, na crença e adesão a uma suposta necessidade de criar uma imagem considerada respeitável , e que é, portanto, heteronormativa a própria recusa a tratar de temas como relações poliamorosas ou práticas sexuais divergentes daqueles advindos da família nuclear burguesa demonstra tal conceito. Podemos conceber, então, uma subjetivação identitária, que atrai o consumo e molda o comportamento das pessoas; são imagens/espelho, criadas e modificadas pela própria massa de modo a se tornarem figuras de imitação e referência (MORAES \& NASCIMENTO, 2002). É a despersonalização capitalista, que ao mesmo tempo em que tenta afogar os processos de singularização de uma subjetividade singular em relação às configurações de vivências divergentes, propõe modelos de serestar a partir de uma concepção de igualdade liberal individualista, de modo que o sujeito possa, então, se afirmar como si mesmo (GUATTARI \& ROLNIK, 1996). Dentro dos movimentos LGBT, ou como aponta Colling (2015), movimentos muitas vezes considerados LG ou GGG devido a hiper representatividade lésbica-gay ou, na pior das hipóteses, somente gay temos um ativismo voltado a uma determinada identidade ou até mesmo um pequeno grupo de identidades com características consideradas intrínsecas, as quais as demais devem se acoplar e/ou se identificar, criando assim, exclusões em prol desse movimento, que ao mesmo tempo em que elabora discursos sobre quem representa como método inicial de luta, torna externo aqueles que não se encaixam em tais moldes. A própria insistência em acoplar todas as configurações de ser-estar em uma única sigla demonstra essa problemática. A apropriação pela mídia da bandeira LGBT sob os dizeres de um suposta inclusão possui papel essencial na subjetivação do sujeito; produz verdades através de mecanismos de curiosidade, sedução e anseio de aquisição, que resultam em imagens estigmatizantes e individualizantes (MORAES \& NASCIMENTO, 2002). Desta maneira, pode-se falar de uma hierarquia identitária, que não somente garante visibilidade à determinadas vivências, como também delimita como tais vivências devem ser. Em razão de um inimigo em comum, as pluralidades tornam-se inexistentes para tornarem-se signos hegemônicos gay , lésbica , os detentores da verdade daqueles que são tidos como outros (COLLING, 2015); assim, embora haja uma busca pela auto-afirmação de identidades que não correspondam ao padrão normativo como válidas, temos uma via de mão-dupla, que reforça a normatização e naturalização binarista e que, por fim, cria uma nova camada de exclusão a dos sujeitos que se tornarão os outros dos outros

Conclusão: Embora entenda-se a importância da representatividade como método de inclusão e resistência, deve-se estar-se atento aos efeitos da subjetivação de experiências específicas, que acabam por tornar-se estereótipos a serem consumidos. Dentro do próprio movimento LGBT, narrativas hegemônicas daquilo que é ser gay, lésbica, bi, trans, travesti com uma ênfase na visibilidade dos dois primeiros , tornam-se as marcas e as vozes de seres-estares muito mais plurais, desqualificando-os em 
suas próprias formas de apresentação; assim, a urgência de se compreender e de abraçar as possibilidades de existências em suas próprias maneiras singulares ainda tem um longo caminho a ser trilhado, mas que é essencial para alternativas de inclusão mais autênticas.

\section{Referências}

COLLING, L. Que os outros sejam o normal: tensões entre movimento LGBT e ativismo queer. Salvador: Edufba, 2015.

GUATTARI, F.; ROLNIK, S. Micropolítica: Cartografias do Desejo. 4 ed. Petrópolis: Vozes, 1996.

MORAES, T. D. NASCIMENTO, M; L. Da norma ao risco: transformações na produção de subjetividades contemporâneas.

Psicologia em estudo, Maringá, v. 7, n. 1, p. 91-102, jan./jun. 2002.

Coordenadoria de Pesquisa e Extensão - COPEX

Departamento de Editoraçāo e Divulgaçāo Científica - DEDIC 


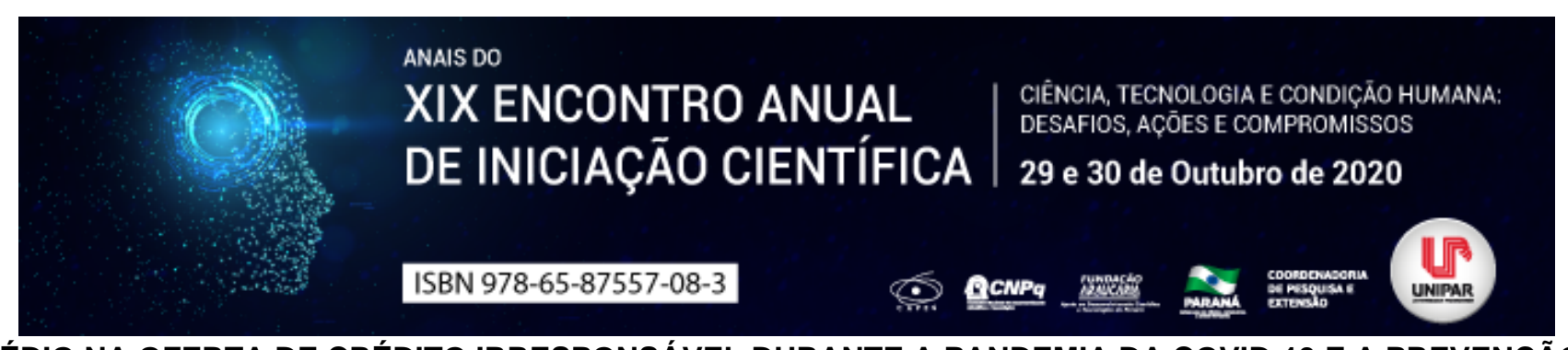

\title{
ASSÉDIO NA OFERTA DE CRÉDITO IRRESPONSÁVEL DURANTE A PANDEMIA DA COVID-19 E A PREVENÇÃO AO SUPERENDIVIDAMENTO DO CONSUMIDOR
}

\author{
${ }^{1}$ LIDIA RICCI ROQUE, ${ }^{2}$ BRUNO ROGER CAUMO, ${ }^{3}$ FILIPE DE LIMA CRUZ, ${ }^{4}$ IVANILDA VAZ BATISTA DE OLIVEIRA, ${ }^{5}$ MARIA \\ CAROLINA SILVA DA FONSECA, ${ }^{6}$ VALERIA BONONI GONCALVES DE SOUZA
}

\author{
${ }^{1}$ Acadêmica do PIC/UNIPAR \\ ${ }^{1}$ Acadêmico do Curso de Direito da UNIPAR \\ ${ }^{2}$ Acadêmico do Curso de Direito da UNIPAR \\ ${ }^{3}$ Acadêmica do Curso de Direito da UNIPAR \\ ${ }^{4}$ Acadêmica do Curso de Direito da UNIPAR \\ ${ }^{5}$ Docente da UNIPAR
}

Introdução: A pandemia da Covid-19 aumentou consideravelmente o superendividamento do consumidor brasileiro, visto que, diante do atual contexto de crise econômica, muitos consumidores afetados pela pandemia se veem obrigados a recorrer a ofertas aparentemente milagrosas de concessão de crédito e acabam entrando em um problema maior, quiçá, sem saída.

Objetivo: Demonstrar como ocorrem e quais as consequências das publicidades enganosas de concessão de crédito, em especial em tempos de pandemia, assim como apresentar soluções de combate a esta prática e formas de auxílio ao consumidor atingido.

Desenvolvimento: Inicialmente, faz-se necessário ressaltar que superendividamento se refere à impossibilidade global de o devedor pessoa física, consumidor leigo e, frisa-se, de boa-fé, adimplir todas as suas dívidas atuais e de consumo (MARQUES, 2011). O superendividamento divide-se em passivo e ativo, de modo que o passivo ocorre involuntariamente, por motivos alheios à vontade do consumidor, ou seja, por imprevistos da vida, como morte de familiares, doenças, acidentes, entre outros. Já o ativo se dá de forma voluntária, visto que o consumidor contrai a dívida voluntariamente, podendo este ato ser pautado na má-fé ou boa-fé do consumidor, esta última, quando ele crê que poderá adimplir suas obrigações, entretanto, por má-fé dos fornecedores, cai no superendividamento. Segundo a Pesquisa de Endividamento e Inadimplência do Consumidor (Peic), elaborada pela Confederação do Comércio, no início da pandemia da Covid-19, em março do corrente ano, o índice de famílias brasileiras endividadas estava em $66,2 \%$, níveis estes que só tendem a aumentar, resultando em uma maior vulnerabilidade dos consumidores perante os fornecedores de crédito. Diante desta fragilidade, muitos fornecedores de crédito, utilizando de má-fé e violando os direitos básicos do consumidor, previstos no artigo $6^{\circ}$ do Código de Defesa do Consumidor, oferecem créditos aparentemente milagrosos e acessíveis que, na realidade, estão mascarados por uma publicidade enganosa, e, assim, levam o consumidor ao superendividamento, comprometendo até mesmo o seu mínimo existencial. Insta salientar que são consumidores que não souberam calcular o impacto da dívida no seu orçamento, porque não foram previamente informados dos encargos da contratação ou que tiveram acesso ao crédito concedido de forma irresponsável pelo fornecedor de crédito; enfim consumidores de boa-fé que acreditavam que conseguiriam honrar suas obrigações (LIMA, BENJAMIN, e MARQUES, 2014). Portanto, verifica-se tratar de consumidores pessoas físicas que, de boa-fé, ao tentarem transpassar uma crise financeira mundial, caem em armadilhas e fraudes de fornecedores que, ao agirem de má-fé, ocultam informações ou as passam de forma incorreta, causando, por consequência, o superendividamento daqueles. Insta salientar que, na maioria das vezes os consumidores são pessoas simples, sem instrução especial, ou até mesmo idosos, analfabetos e deficientes, de modo que são ludibriados por fornecedores que, no intuito de oferecerem crédito facilitado , optam por práticas abusivas e excessivamente vantajosas a si, em detrimento dos consumidores. Tendo em vista que o consumidor pessoa física não possui uma proteção específica como o consumidor pessoa jurídica, o qual é abrangido pela lei falimentar, e visando solucionar situações como as supramencionadas, foi proposto o Projeto de Lei 3.515/15, atualmente em tramitação na Câmara dos Deputados, o qual sugere a criação de novas regras para a concessão de crédito ao consumidor, prevenindo, assim, o superendividamento, mediante várias estratégias, dentre as quais está a vedação à publicidade enganosa, prevista no art. 54-C do referido projeto, ao passo que visa proibir a veiculação de publicidade de crédito com anúncios que contenham termos como sem juros , gratuito , taxa zero , ou outros verbetes neste sentido.

Conclusão: Diante do crescente nível de superendividamento decorrente de fraudes de fornecedores, e, tendo em vista que este fenômeno tende a ter um aumento ainda mais significativo no contexto pós pandemia, é imprescindível a aprovação de mecanismos de proteção contra o assédio na oferta de crédito, estes presentes no Projeto de Lei n. 3.515/1, o qual também possui um papel propedêutico e pedagógico. 


\section{Referências}

BRASIL, Presidência da República, LEI n.8.078 de 11 de setembro de 1990. Código de Defesa do Consumidor. Dispõe sobre a proteção do consumidor e dá outras providências.

LIMA, Clarissa Costa De; BENJAMIN, Antonio Herman; MARQUES, Claudia Lima. O tratamento do superendividamento e o direito de recomeçar dos consumidores. Revista dos tribunais. vol.1. São Paulo. 2014.

BRASIL. Projeto de Lei n.3.515/15. Altera a Lei $n^{\circ} 8.078$, de 11 de setembro de 1990, e o art. 96 da Lei $n^{\circ} 10.741$, de $1^{\circ}$ de outubro de 2003, para aperfeiçoar a disciplina do crédito ao consumidor e dispor sobre a prevenção e o tratamento do superendividamento. Brasília. DF.2015.

MARQUES, Claudia Lima. Algumas perguntas e respostas sobre prevenção e tratamento do superendividamento dos consumidores pessoas físicas. Revista Direito do Consumidor. Vol 75/2010, p.9-42, jun-set 2010. Doutrinas essenciais de Direito do Consumidor. V. 2, p. 563-593, abr 2011.

CLAUDIA, Maria. Covid-19: endividamento das famílias chega a 66,6\% em abril, diz CNC. Agência Brasil. Disponível em: https://agenciabrasil.ebc.com.br/economia/noticia/2020-04/covid-19-endividamento-das-familias-atinge-recorde-em-abril-diz-cnc. 


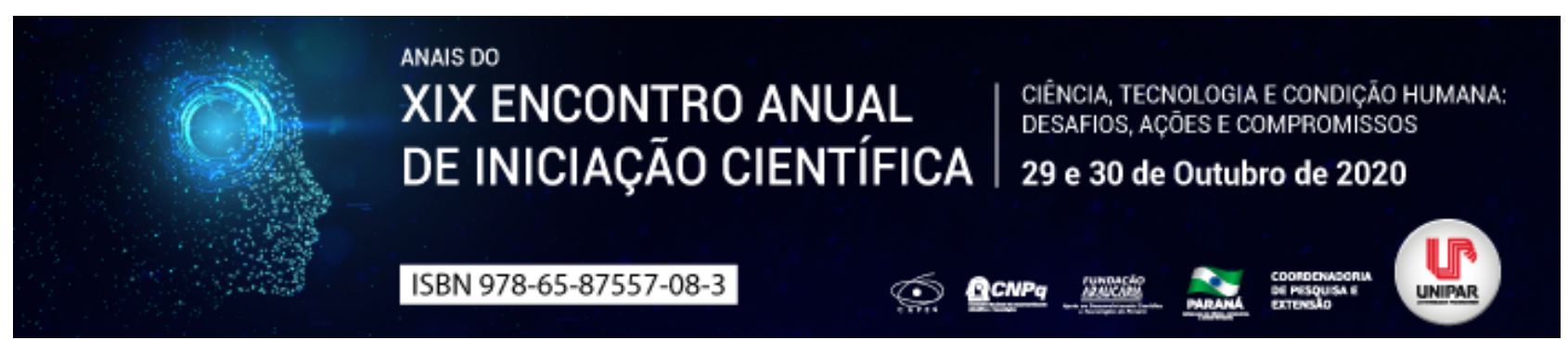

O HOMEM VITRUVIANO E SUA LIGAÇÃO COM O DIREITO

\title{
${ }^{1}$ IGOR SILVA GOBBO, ${ }^{2}$ DORITA ZIEMANN HASSE
}

\author{
${ }^{1}$ Acadêmico do curso de Direito da UNIPAR \\ ${ }^{1}$ Docente da UNIPAR
}

Introdução: Entende-se por arte, muitas vezes, grandes obras, como o Homem Vitruviano, de Leonardo da Vinci durante o Renascimento. Já em relação ao Direito, infere-se lei e justiça. Contudo, ambos podem ter pontos em comum.

Objetivo: Demonstrar a ligação entre o Homem Vitruviano e o Direito.

Desenvolvimento: O Homem Vitruviano e o Direito surgem na Idade Moderna, período de criação dos Estados modernos e a estruturação da sociedade capitalista, resultando no Direito moderno. Também do antropocentrismo renascentista, que prezava pelo homem no centro do mundo. As ligações com o Direito surgem devido ao movimento renascentista, a partir do qual foram possíveis mudanças sociais e um pensamento racional. A balança, símbolo do Direito, representa o equilíbrio, igualdade e a justiça do homem que passou a ser o centro do mundo com o Renascimento. Já em relação ao Homem Vitruviano,esse tem, entre as principais características, o equilíbrio, a proporção e uma visão humanista. Por conseguinte, o Direito e a obra não se alteram, já que a mudança é no pensar, assim como o juiz ao julgar um caso de diferentes maneiras sem alterar a lei. Logo: 0 mau operador do direito advogado ou juiz transforma uma lei boa em má, ao passo que o bom operador é capaz de dar boa aplicação até a uma lei ruim (PRADO, 2002). O mesmo raciocínio se aplica ao Homem Vitruviano, que ao longo do tempo continua ganhando significado, uma vez que [...] contém, na realidade, traços de dois homens, em idades diferentes. Talvez até de três [...] (STEFANELLI, 2019). Ou seja, se ligam pela hermenêutica, tem como foco o Homem e a vida e mudanças de pensamentos e a justiça que é a essência do Direito, mantenedora da paz e harmonia social. Direito e Justiça estão interligados pela particularidade do justo e correto, e podem ser associados como uma única coisa pela sociedade, mas nem tudo que é justo pode se chamar de direito; e nem tudo que é direito necessariamente é justo. Sobre isso destaca Calamandrei (2000, p. 175): A fundamentação das sentenças é certamente uma grande garantia de justiça, quando consegue reproduzir exatamente, como um esboço fotográfico o itinerário lógico que o juiz percorreu para chegar à sentença . Isso acontece porque os valores da justiça estão ligados ao ser humano e suas ações, como sua honestidade e liberdade.

Conclusão: Direito e o Homem Vitruviano partem do tempo e analisando pode-se considerar que ambos contam histórias e estão sujeitos a descobertas. Soma-se a isso, prezam o Homem como o centro e são tratados de formas abstratas. O Direito, por sua vez, apresenta aspectos que o liga à justiça de maneira que trabalhem juntos, em vista o ser humano com seus valores e cultura.

\section{Referências}

CALAMANDREI, Piero. Eles, os juízes, vistos por um advogado. São Paulo: Matins Fontes, 2000.

CAVALIERI FILHO, Sérgio. Direito, Justiça e Sociedade.Revista da EMERJ. v.5, n.18. Disponível em: https://www.emerj.tjr.jus.br/revistaemerj_online/edicoes/revista18/revista18.pdf. Acesso em: 9 jun. 2020.

PRADO, David. No país do BBB, Judiciário é instrumento de paz social. Revista Consultor Jurídico. 2002. Disponível em: encurtador.com.br/AKL18. Acesso em: 9 jun. 2020.

STEFANELLI, Elisabetta. Pesquisador faz novas descobertas sobre O Homem Vitruviano . Istoé. N.263112/06.Disponível em: encurtador.com.br/iHSTX. Acesso em: 5 jun. 2020. 


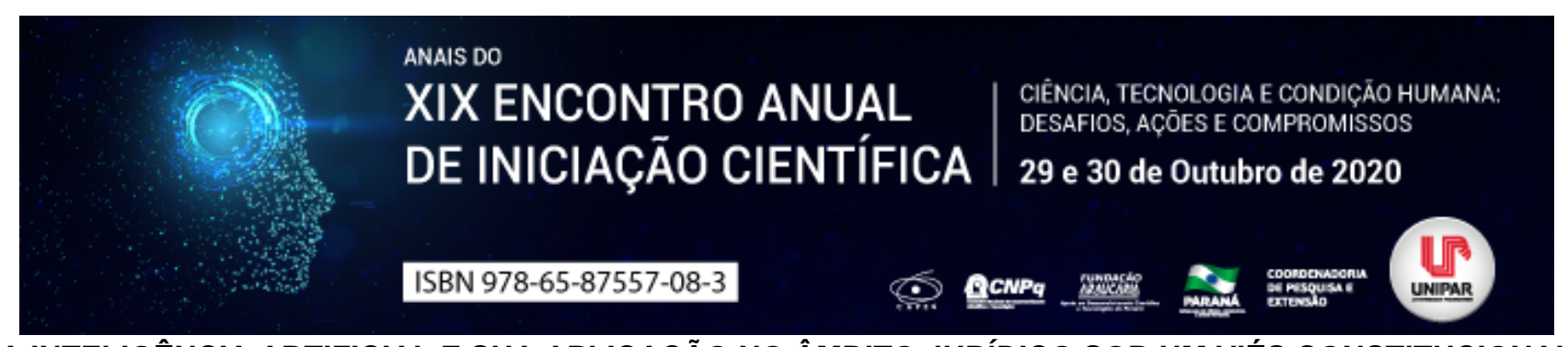

A INTELIGÊNCIA ARTIFICIAL E SUA APLICAÇÃO NO ÂMBITO JURÍDICO SOB UM VIÉS CONSTITUCIONAL

\author{
${ }^{1}$ LAYANI RAFAELA DA SILVA, ${ }^{2}$ ANGELICA GIOSA CANDIDO
}

\author{
${ }^{1}$ Acadêmica UNIPAR PIC \\ ${ }^{1}$ Docente da UNIPAR
}

Introdução: A inteligência artificial é a representação da relação cognitiva entre homem e máquina. Sua aplicação vem se intensificado tanto no setor privado como no setor público, especialmente no judiciário. Diante da potencialização e fascínios deste sistema, quais riscos podem advir da delegação da função decisória a algoritmos, máxime nas relações jurídicas? A partir deste questionamento funda-se a presente pesquisa, com o escopo de explanar perigos não evidentes resultantes da utilização da inteligência artificial.

Objetivo: Analisar a intensificação do uso da inteligência artificial no cenário jurídico brasileiro, investigando as consequências da atribuição do caráter decisório a uma máquina face a segurança nas relações jurídicas.

Desenvolvimento: Inteligência artificial (IA) corresponde a um sistema de máquinas criado para realizar atividades que normalmente seriam desempenhadas por seres humanos, portanto, uma tentativa de fazer com que sistemas computacionais imitem as capacidades cognitivas do homem (OLIVEIRA; COSTA, 2018, p. 24). Este tipo de tecnologia vem crescendo em um ritmo avassalador e, por vezes, não é observado pela sociedade com a necessária cautela. Nota-se a grande influência da inteligência artificial em todos os setores ocupacionais, não sendo diferente com o setor jurídico, que, inclusive, já possui mecanismos de inteligência artificial sendo desenvolvidos como, por exemplo, o sistema Victor, criado a partir de uma parceira entre o Supremo Tribunal Federal (STF) e a Universidade de Brasília (UnB), para analisar todos os recursos extraordinários ao identificar aqueles que trazem em seu bojo temas de repercussão geral (MAIA FILHO; JUNQUILHO, 2018, p. 222). De outro lado, a utilização destas ferramentas computacionais encantam a maioria de seus usuários pelos inúmeros benefícios que aparentam oferecer. Em uma análise sucinta, dos benefícios encontrados na área jurídica, mencione-se a diminuição das demandas judiciais a partir da utilização de mecanismos tecnológicos capazes de realizar atividades humanas repetitivas, possibilitando a prestação de serviços com maior eficiência e agilidade (NUNES; MARQUES, 2018, p. 4). Entretanto, diante deste cenário, surge a ideia da substituição da tomada de decisões judiciais pelas máquinas, visto que alguns contemplam uma falsa sensação de maior assertividade e imparcialidade nas decisões que possam ser proferidas por sistemas computacionais. Todavia, pode-se considerar esta situação hipotética como utópica, pois, em que pese os diversos benefícios aparentemente propiciados pela máquina, há vícios obscuros não vislumbrados por aqueles que enaltecem-na. A par disso, impende-se a necessidade de esclarecer brevemente como a inteligência artificial (IA) se desenvolve e como isso pode afetar na tomada de decisões. Ela é obtida a partir de algoritmos, que ditam regras que devem ser seguidas pelo sistema operacional. Os referidos algoritmos são obtidos através de modelos seguidos por uma sociedade, analogicamente vistos como precedentes, que instruem o sistema operacional de inteligência artificial a desempenhar comandos dados por seu programador (FERRARI; BECKER; WOLKART, 2018, p. 3-5). Assim, se uma sociedade for permeada pela desigualdade, discriminação e preconceito, estes irão refletir no sistema computacional, que produzirá decisões com os mesmos preceitos, entretanto, permeadas pela ideia ilusória da imparcialidade das máquinas. Além disso, é imperioso destacar que estes modelos serão incorporados ao sistema por meio do programador, que por si só já possui concepções próprias, que poderão transpassar à inteligência artificial, fazendo com que esta julgue de acordo com as subjetividades de seu criador (NUNES; MARQUES, 2018, p. 5-6). Nesse contexto, imagine-se que a máquina, programada para realizar a tomada de decisões judiciais, condene o sujeito réu da demanda. Ao ser cientificado acerca da sentença, o réu revela a seu patrono o desejo de recorrer daquele pronunciamento. Consigne-se que para impugnar algo é preciso conhecê-lo e compreendê-lo, contudo, surgem os seguintes questionamentos: como impugnar algo do qual todos são leigos? Como rechaçar os fundamentos que levaram aquela decisão se estes não forem expostos? Há possibilidade de impugnar decisões judiciais proferidas por magistrados pelo rigor da fundamentação, mas como realizar o mesmo com máquinas que são camufladas pela objetividade e imparcialidade da matemática? (NEVES, 2019, p. 185-186). Ademais, outras situações podem ser mencionadas conforme os exemplos fornecidos pelas autoras Dierle Nunes e Ana Luiza Pinto Coelho Marques (2018, p. 7) tais como, [...] um sistema de reconhecimento facial criado pela Google identificou pessoas negras como gorilas; [...]; Tay, mecanismo de IA lançado pela Microsoft para interagir com usuários do Twitter, passou a reproduzir mensagens xenofóbicas, racistas e antissemitas [...] . Diante das pontuações realizadas, notam-se como as incertezas no uso da inteligência artificial podem acarretar em sérios riscos a sociedade, especialmente quanto à manutenção de direitos e garantias fundamentais, como o devido processo constitucional, contraditório e ampla defesa.

Conclusão: Desse modo, a inteligência artificial traz consigo inúmeros benefícios que podem e devem ser utilizados a favor da humanidade, entretanto, há também malefícios não evidentes que deixam de ser observados com a devida atenção e que podem 
afetar de forma significativa direitos fundamentais conquistados a partir de muito sacrifício. Portanto, deve-se aplicar este sistema como ferramenta de apoio aos magistrados e não em sua substituição, pois a capacidade de decidir demandas concretas com problematizações reais necessita de um ser humano, capaz de entender os anseios e desejos de uma sociedade.

\section{Referências}

FERRARI, Isabela; BECKER, Daniel; WOLKART, Erik Navarro. Arbitrium ex machina: panorama, riscos e a necessidade de regulação das decisões informadas por algoritmos. Revista dos Tribunais, v. 995, set. 2018.

MAIA FILHO; Mamede Said; JUNQUILHO, Tainá Aguiar. Projeto Victor: perspectivas de aplicação da inteligência artificial ao direito. Revista de Direitos e Garantias Fundamentais, Vitória, vol. 19, n. 3, p. 219-238, set./dez. 2018. DOI: >. Disponível em: . Acesso em: 08 ago. 2020

NEVES, Daniel Amorim Assumpção. Manual de direito processual civil. 11. ed. Salvador: Juspodivm, 2019.

NUNES, Dierle; MARQUES, Ana Luiza Pinto Coelho. Inteligência artificial e direito processual: vieses algorítmicos e os riscos de atribuição de função decisória às máquinas. Revista dos Tribunais, vol. 285/2018, p. 421-447, nov. 2018.

OLIVEIRA, Samuel Rodrigues de; COSTA, Ramon Silva. Pode a máquina julgar? Considerações sobre o uso de inteligência artificial no processo de decisão judicial. Revista de Argumentação e Hermenêutica Jurídica, Porto Alegre, v. 4, n. 2, p. 21-39, jul./dez. 2018. DOI: >. Disponível em: >. Acesso em: 08 ago. 2020. 


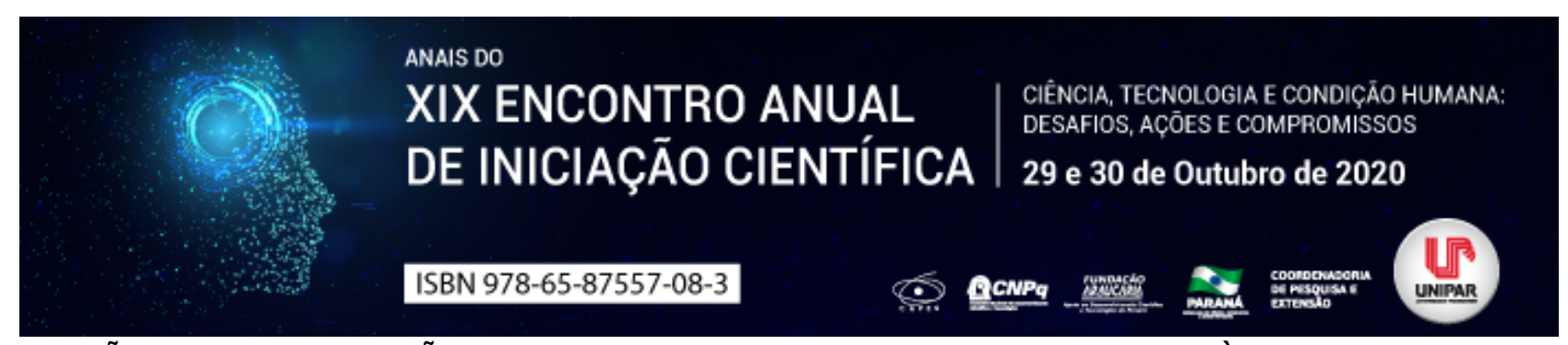

EXCEÇÃO DE CONTRATO NÃO CUMPRIDO: IMPACTOS CONTRATUAIS EM MEIO À PANDEMIA COVID-19

\author{
${ }^{1}$ LAURA CORBARI MEGGIOLARO, ${ }^{2}$ LUDMILA KOLB DE VARGAS CAVALLI
}

\author{
${ }^{1}$ Acadêmica da UNIPAR \\ ${ }^{1}$ Docente da UNIPAR
}

Introdução: O presente trabalho versa sobre a possibilidade de aplicação da exceção de contrato não cumprido aos negócios firmados ou vigentes em meio à pandemia de COVID-19. Pretende-se analisar quais seriam os possíveis impactos contratuais decorrentes das dificuldades e restrições causadas pelo vírus que assolou o mundo, as quais trouxeram onerosidade excessiva ou até mesmo inviabilizaram o adimplemento de obrigações.

Objetivo: Abordar a aplicabilidade do princípio da exceção de contrato não cumprido em contratos celebrados em meio à pandemia de COVID-19.

Desenvolvimento: Infere-se do art. 476 do Código Civil (BRASIL, 2002) que qualquer dos contratantes pode, ao ser demandado pelo outro, utilizar-se de uma defesa denominada exceptio non adimpleti contractus, ou exceção do contrato não cumprido. Desta forma, uma das partes pode recusar a sua prestação sob o fundamento de que o demandante não cumpriu a que lhe competia. Aquele que não satisfez a própria obrigação não poderia, portanto, exigir o implemento da do outro (GONÇALVES, 2017). Em face das repercussões sociais e financeiras ocasionadas pelo vírus COVID-19, tornou-se necessário lançar um novo olhar em relação à aplicabilidade do princípio da exceção de contrato não cumprido aos contratos celebrados em meio à referida pandemia, tendo em vista a onerosidade excessiva que pode recair sobre uma das partes. Neste sentido, deve-se analisar as hipóteses em que esse princípio é válido, sendo elas a impossibilidade e a incerteza de cumprimento. A impossibilidade de cumprimento pode ser definitiva ou temporária. No primeiro caso, há obstáculo à realização da prestação que não deve desaparecer ou se atenuar com a fluência do tempo. No segundo caso, a impossibilidade se circunscreve a certo período, indicando que poderá ainda ser realizada, mas não no prazo originalmente previsto (MIRAGEM, 2020). Quanto à incerteza, ocorre pelo fato de que não é possível até o momento se determinar o final das medidas de segurança impostas pelo poder público. Dentro deste panorama, o art. 477 do Código Civil (BRASIL, 2002) remete à exceção por inseguridade, dispondo que se, depois de concluído o contrato, sobrevier a uma das partes a diminuição de seu patrimônio capaz de comprometer ou tornar duvidosa a prestação cuja qual se obrigou a cumprir, a outra parte poderá recusar-se da prestação que lhe incumbe, até que aquela satisfaça a que lhe compete ou dê garantia o bastante de satisfazê-la. Sendo assim, o artigo supracitado restringe-se a situações onde há uma diminuição do patrimônio de uma das partes, mas tendo em vista a situação vivida atualmente, o conceito aludido pode se estender para que haja a admissibilidade de outras circunstâncias. Como exemplo prático, não poderá o comprador exigir do vendedor a entrega da mercadoria, enquanto não cumprir a sua obrigação de efetuar o pagamento do preço ou oferecer garantia bastante de satisfazê-la. Se promover ação judicial para esse fim, poderá aquele opor a exceção de contrato não cumprido (GONÇALVES, 2017). No entanto, importante ressaltar que aqui não estamos tratando de contratos aleatórios, que dizem respeito a coisas ou fatos futuros, os quais possuem inerentemente um risco já conhecido e assumido pelos contratantes. Nestes, caso não se efetive a prestação de um dos contratantes, terá outro direito de receber integralmente o que lhe foi prometido, desde que de sua parte não tenha havido dolo ou culpa, ainda que nada do avençado venha a existir (RIBEIRO, 2020). Portanto, ao analisar tal princípio, entende-se que este poderá ter sua aplicabilidade estendida para algumas situações diante do cenário atual.

Conclusão: Perante o exposto, verifica-se haver a possibilidade de aplicação da exceção do contrato não cumprido para as partes que tiverem sua realidade abruptamente alterada devido à pandemia de COVID-19, podendo então a parte lesada invocar tal princípio para que assim possa resolver o contrato, seja de forma total ou parcial de acordo com sua capacidade.

\title{
Referências
}

BRASIL. Lei no 10.406, de 10 de janeiro de 2002. Institui o Código Civil. Diário Oficial da União: seção 1, Brasília, DF, ano 139, n. 8, p. 1-74, 11 jan. 2002.

GONÇALVES, Carlos Roberto: Direito civil brasileiro, volume 3; contratos e atos unilaterais - 14. ed. São Paulo: Saraiva, 2017.

RIBEIRO, Tulio Santana; Exceção do contrato não cumprido: possibilidade de revisão contratual e os reflexos da pandemia Covid-19 nas relações jurídicas; Disponível em: http://oabms.org.br/wpcontent/uploads/2020/04/Exce\%C3\%A7\%C3\%A3o-de-contrato-n\%C3\%A3o-cumprido- possibilidade-de-revis\%C3\%A30contratual-e-os-reflexos-da-pandemia-coronav\%C3\%ADrus-Covid-19-nas-rel $\quad$ a\%C3\%A7\%C3\%B5es-jur\%C3\%ADdicas..pdf

Acesso em: 26 de abr. 2020. 
SILVA, Rodrigo da Guia: Novas perspectivas da Exceção do contrato não cumprido: repercussões da boa-fé objetiva sobre o sinalagma contratual; Revista de Direito Privado, vol. 78, p. 43-83. 2017.

RODRIGUES BARLETTA, Fabiana; A revisão contratual no Código Civil, no Código de Defesa do Consumidor e a pandemia do coronavírus (covid-19); Revista de Direito do Consumidor, vol. 129/2020, p. 111-129. 2020.

MIRAGEM, Bruno; Nota relativa à pandemia de coronavírus e suas repercussões sobre os contratos e a responsabilidade civil; Revista dos Tribunais, vol. 1015/2020, p. 353 363. 2020.

Coordenadoria de Pesquisa e Extensão - COPEX

Departamento de Editoraçāo e Divulgaçāo Científica - DEDIC 


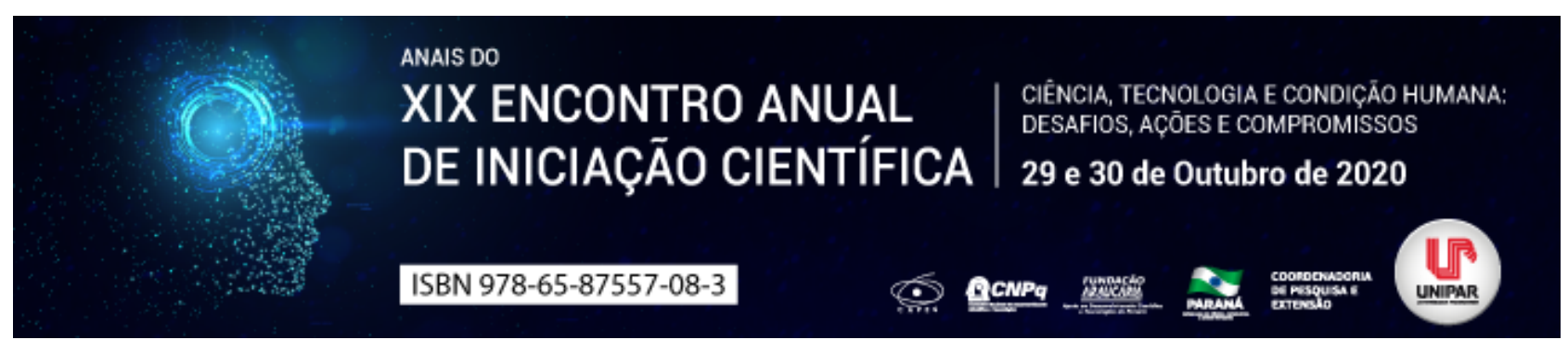

ESTRESSE RELACIONADO ÁS DOENÇAS OCUPACIONAIS

\author{
${ }^{1}$ LARISSA DELAZARI ANTONHOLI, ${ }^{2}$ BEATRIZ EDUARDA DE LIMA, ${ }^{3}$ CAROLINE FAVARO PANHAN, ${ }^{4}$ ORLETE MARIA \\ POMPEU DE LIMA
}

\author{
${ }^{1}$ Acadêmico do PIC/UNIPAR \\ ${ }^{1}$ Acadêmica do Curso de Psicologia da UNIPAR \\ ${ }^{2}$ Acadêmico do Curso de Psicologia da UNIPAR \\ ${ }^{3}$ Docente da UNIPAR
}

Introdução: Esse é um resumo que visa cumprir os objetivos voltados para o Projeto de Iniciação Científica (PIC) Encefalite Herpética relacionado ao estresse: estudo de caso. O presente estudo aborda as variáveis de comportamentos que ocorrem mediante ao alto nível de estresse ocupacional, gerado em cargos de alta complexidade, mas o sintoma mais presente em meio às ocorrências é o estresse. Havendo escassez de estudos sobre o presente assunto, podemos ver a importância desse estudo de caso, e comprovação de doenças que são causadas por altos níveis.

Objetivo: Mediante a uma revisão bibliográfica, serão abordados os conceitos, causas e consequências do estresse relacionado ao trabalho.

Desenvolvimento: De acordo com Dias (2015) o estresse ocupacional ocorre quando o indivíduo não consegue atender as demandas solicitadas por seu trabalho, causando sofrimento psíquico, mal estar, mudanças de comportamento, distúrbios do sono e sentimentos negativos. Visando os cargos que pessoas acarretadas por essa doença estão exercendo, o nível de tensão, na qualidade de vida é muito presente em grande maioria dos estudos, sem confirmação de incidência por estresse. No entanto iremos pautar o caso em si, não apenas a sua ocorrência, mas um todo, pois como podemos ver é uma gama de fatores em meio social e biológico que se interligam. De acordo com Bezerra (2012)os desgastes profissionais vem se intensificando cada vez mais, podendo levar a surgimento de doenças e agentes estressantes de diversas naturezas. Levando essa pessoa a ser afastada de seu cargo por não poder estar mais em atuação, Segundo Bezerra (2012) o estresse é algo sério, podendo causar pequenos danos aos empregados como dores de cabeça e azia, até mesmo doenças graves, como depressão e doenças orgânicas, comprometendo a posição do indivíduo dentro da organização.

Conclusão: Assim sendo abordando vários estudos, mas não se comprovando a causa de doenças auto imunes, sendo comprovado que o nível de estresse diário e o desprovimento de uma qualidade de vida, estes colaboradores encontram-se expostos, a falta de estudos direcionado para doenças ocupacionais em meio a grandes empresas ou uma alta demanda de mão de obra desse funcionário podendo o levar a algum tipo de adoecimento, deste modo podendo se concluir que se é um campo não tão amplo. Na presença da atual situação de pandemia, o vigente trabalho foi parcialmente afetado, sendo assim não podendo ocorrer abordagem com esse pacinte.

\title{
Referências
}

DIAS, F. M. O estresse ocupacional e a síndrome do esgotamento profissional (burnout) em trabalhadores da indústria do petróleo: uma revisão sistemática. Rio de Janeiro, 26 de Nov. de 2016. Disponível em: https://www.scielo.br/scielo.php? script=sci arttext\&pid=S0303-76572016000100401\&1ng=pt\&tlng=pt. Acesso em: 15 de Jul. de 2020.

BEZERRA, R. S. Estresse ocupacional: Análise dos colaboradores do recursos humanos da CNI. Brasília, 18 de Mai. de 2012. Disponível em: https://repositorio.uniceub.br/bistream/123456789/1008/2/20850378.pdf. 


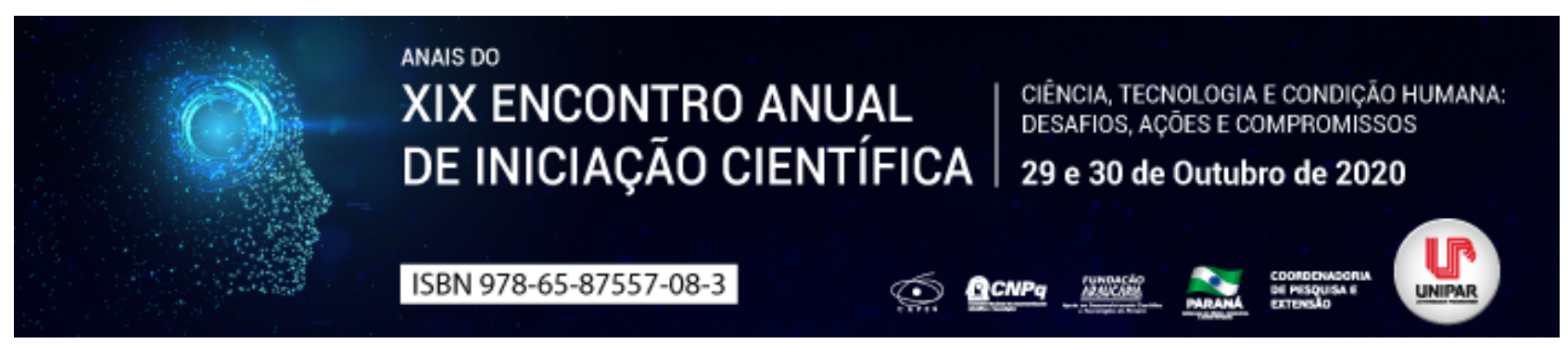

INTERSECCIONALIDADE: O HOMEM NO FEMINISMO

\begin{abstract}
${ }^{1}$ EMANUEL JOSE LAHOS BORGES, ${ }^{2}$ GIOVANA LABIAK PEREIRA, ${ }^{3}$ KAROLYNE RIBEIRO DA CUNHA, ${ }^{4}$ MARIANA GUILHERME GONCALVES, ${ }^{5}$ NIKITA DE FREITAS, ${ }^{6}$ CLAUDIA LOPES PERPETUO
\end{abstract}

\begin{abstract}
${ }^{1}$ Acadêmico do PIC/UNIPAR
${ }^{1}$ Acadêmica do PIC/UNIPAR

${ }^{2}$ Acadêmica do PIC/UNIPAR

${ }^{3}$ Acadêmica do PIC/UNIPAR

${ }^{4}$ Acadêmica do PIC/UNIPAR

${ }^{5}$ Docente da UNIPAR
\end{abstract}

Introdução: O machismo constrói-se estruturalmente. A partir de Foucault (1988) podemos compreender que a reunião de discursos, fundações científicas, visões do humano, são tidas como dispositivos. Portanto, pode-se conceituar o machismo como dispositivo, tendo como primária função a manutenção de um padrão relacional. Este padrão também afeta a qualidade de vida de garotos e homens, forçando-os a submeterem-se a padrões agressivos para serem considerados, de fato, homens; o risco de não ser considerado homem, é ser considerado mulher, e com essa situação, sofrer como uma (WELZER-LANG, 2001). Quando tomamos homens feministas como uma possibilidade, falamos de homens e garotos conscientes de que o machismo e 0 patriarcado forçam-os a adotar papéis que nem sempre irão corresponder com o que imaginam para si. O que estes homens e garotos feministas têm a oferecer?

Objetivo: Investigar o conceito de interseccionalidade e a partir deste situar a possibilidade do papel do homem na sociedade atual como importante ponto para a luta feminista conceituando o machismo como aspecto que afeta as performatividades masculinas.

Desenvolvimento: Homens são construídos a partir de repetições, mimetismos (WELZER-LANG, 2001), e estes formatam-os à violência como método primário e mais válido de se relacionar com o mundo aqueles que tendem a desviar disso em nossa sociedade são recebidos com sofrimento em seus corpos. Existem, entretanto, diversas linhas teóricas feministas que se situam como intolerantes à presença de homens falantes de sexismo, ou até mesmo homens feministas (HOOKS, 2018). A própria expressão homem feminista parece nos alcançar com estranhamento, mas esse sentimento ocorre pois não foram oferecidas visões críticas da masculinidade no início do feminismo, e se houvessem, teria sido impossível para qualquer pessoa dispensar o movimento com a justificativa de ser anti-homem (HOOKS, 2018). O conceito de interseccionalidade pode ser evocado para falarmos mais apropriadamente de homens no feminismo, onde fortemente se assemelha de outsider within , forasteiras de dentro em tradução livre Collins o conceitua afirmando que cada indivíduo a partir do local que ocupa tem e terá uma visão específica daquilo que vive (ASSIS, 2019). Outsider Within e interseccionalidade são ambos conceitos que permitem uma análise de como categorias diferentes de ser nos colocam em espaços diferentes, mas como não abdicamos de certos privilégios baseados em uma ou outra secção de nossos corpos muitas escritas críticas são feitas a partir de uma lógica onde somente analisa-se corpos em contextos específicos, porém, esquece-se marcadores. Questionamentos do feminismo negro ao feminismo branco sempre trouxeram desconforto, como se a perguntar se aquele movimento era mesmo para todas as mulheres, onde muitos corpos (mulheres negras, indígenas) não estavam inclusos. Similarmente, feministas começaram a se questionar se o patriarcado também não tirava direitos de homens, impondo aos mesmos padrões violentos (WELZER-LANG, 2001; HOOKS, 2018). A interseccionalidade é um forte e importante conceito que jamais deve ser descartado, ainda mais quando inserimos-o com o local de fala; é importante denotar que todos têm local de fala, não só grupos marginalizados historicamente (ASSIS, 2019). Qual poderia ser o local de fala do homem, inserido nos cernes de socialização machista, violenta, quando o consideramos no feminismo? O machismo é um problema estrutural, e quando falamos de homens no feminismo, é com relação à alienação dos corpos masculinos pelo sistema patriarcal, e como são motivados à dominação feminina (WELZER-LANG, 2001). Portanto, com a secção específica de ser homem , assim como a compreensão de que este espaço causa mal pois obriga-os à violência como forma legítima de ser (WELZER-LANG, 2001), o olhar perante a opressão seria diferente do olhar de uma mulher pois cada corpo sofre a opressão de uma forma, e a construção de pontes, diálogos, pontos em comum, tendo em vista que não há hierarquia de opressão (ASSIS, 2019).

Conclusão: A partir da bibliografia utilizada, é possível analisar que ainda é rara a inserção de homens no movimento feminista sem que isso seja tomado como um perigo ou desconforto em geral; homens são construídos a partir do pressuposto da dominação, então em espaços feministas, poderiam cercear os locais de fala no entanto, esta concepção é possivelmente falsa, pois ao considerar que homens também sofrem com o machismo, e que este não é um dado localizado e sim uma 
estrutura discursiva e um dispositivo social, o local de fala e os sofrimentos também são válidos. A validade, no entanto, deste sofrimento, deve ser vista não como maior, ou sequer menor, do que outras, assim compreende-se a importância da interseccionalidade em quaisquer análise de gênero; porquanto contextos localizados trazem sofrimentos específicos e quaisquer luta social deve ser preenchida com posicionamentos que trarão pontos comuns.

\section{Referências}

ASSIS, D. N. C. Interseccionalidades. Salvador: UFBA, Instituto de Humanidades, Artes e Ciências, 2019.

FOUCAULT, M. História da sexualidade I: A vontade de saber. 13 ed. Rio de Janeiro: Edições Graal, 1988.

HOOKS, B. O feminismo é para todo mundo: políticas arrebatadoras. 1 ed. Rio de Janeiro: Rosa dos tempos, 2018.

WELZER-LANG, D. A construção do masculino: dominação das mulheres e homofobia. Revista Estudos Feministas, Florianópolis, v. 9, n. 2, p.460-482, jul-dez. 2001. 


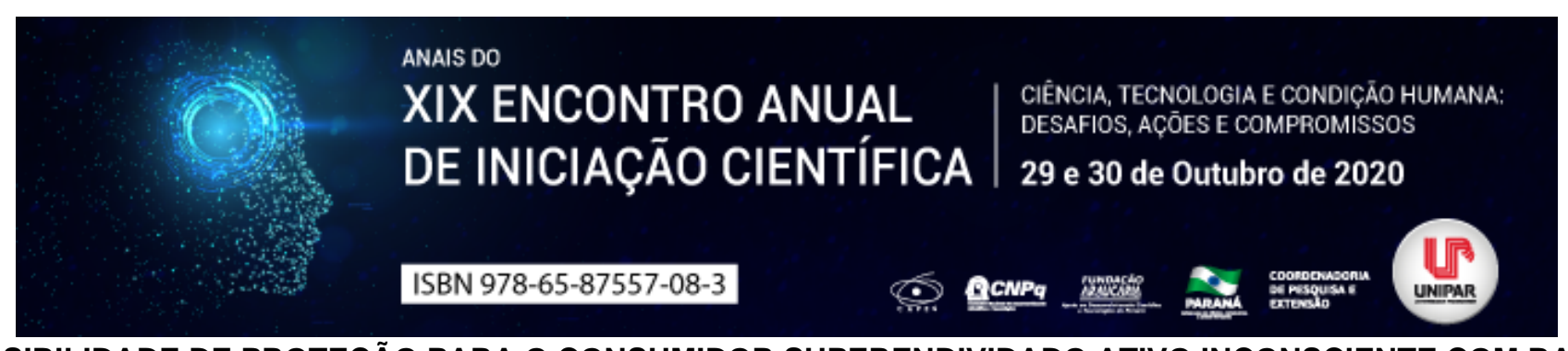

\title{
A POSSIBILIDADE DE PROTEÇÃO PARA O CONSUMIDOR SUPERENDIVIDADO ATIVO INCONSCIENTE COM BASE NA BOA-FÉ OBJETIVA
}

\author{
${ }^{1}$ MARIA CAROLINA SILVA DA FONSECA, ${ }^{2}$ BRUNO ROGER CAUMO, ${ }^{3}$ FILIPE DE LIMA CRUZ, ${ }^{4}$ IVANILDA VAZ BATISTA DE \\ OLIVEIRA, ${ }^{5}$ LIDIA RICCI ROQUE, ${ }^{6}$ VALERIA BONONI GONCALVES DE SOUZA
}

\author{
${ }^{1}$ Acadêmica PIC/Universidade Paranaense - UNIPAR \\ ${ }^{1}$ Acadêmico do Curso de Direito da UNIPAR \\ ${ }^{2}$ Acadêmico do Curso de Direito da UNIPAR \\ ${ }^{3}$ Acadêmica do Curso de Direito da UNIPAR \\ ${ }^{4}$ Acadêmica do Curso de Direito da UNIPAR \\ ${ }^{5}$ Docente da UNIPAR
}

Introdução: Muito se busca, atualmente, destacar a relevância e importância da proteção do consumidor, pessoa física e de boafé, perante o fenômeno do superendividamento, que se dá pela forma facilitada com que todos contraem créditos constantemente, perante a ausência de uma norma regulamentadora que proteja esse consumidor.

Objetivo: Demonstrar as diferenças entre as classificações de superendividado ativo e passivo, bem como de analisar a possibilidade destes serem protegidos pelo ordenamento jurídico, seguindo o critério principiológico.

Desenvolvimento: O superendividamento pode ser conceituado como a impossibilidade do devedor, pessoa física, consumidor de boa-fé, de honrar suas dívidas atuais e ainda as que vão vencer, em um razoável período de tempo e com suas condições econômicas naquele momento, (MARQUES, 2010). Havendo duas principais classificações, quais sejam, o superendividamento passivo e o ativo. Segundo Marques (2010) o superendividado passivo é aquele consumidor que se endivida por consequência de fatores alheios a sua vontade, como o desemprego, divórcio, redução de salários, altas taxas de juros, etc, ou seja, são fatores que acabam tornando seus recursos econômicos desfavoráveis para quitar suas dívidas, enquanto que, o ativo caracteriza-se pelo abuso de créditos, acabando por consumir muito acima do que seu orçamento permite. Contudo, segundo Schmidt Neto (2009) a classificação de superendividamento ativo se divide entre: superendividamento ativo consciente, que é aquele que de má-fé já contrai as dívidas sabendo que não vai poder quitá-las, onde ele visa enganar o credor, ou seja, sua intenção aqui nunca foi honrar a dívida; e o superendividamento ativo inconsciente que é aquele que mesmo agindo impulsivamente e não tendo acontecido nenhum fato alheio à sua vontade, acabou por endividar-se por inconsequência mas não com dolo. No Projeto de Lei no 3515 de 2015 - originário do Senado Federal e atualmente em tramitação na Câmara dos Deputados - trata-se expressamente, na inclusão no Código de Defesa do Consumidor, do art. 54-A, que dispõe acerca da proteção do consumidor de boa-fé que está superendividado, principalmente daquele que não contraiu as dívidas de maneira dolosa, tendo sua redação, o seguinte teor: Art. 54-A. Este Capítulo tem a finalidade de prevenir o superendividamento da pessoa natural e de dispor sobre o crédito responsável e sobre a educação financeira do consumidor (BRASIL, 2015). Dessa forma, de acordo com a proposta legislativa, para que se possa proteger o consumidor do superendividamento, um dos requisitos necessários, é que esse consumidor tenha contraído o crédito de boa-fé, ou seja, com a intenção de saldar a dívida. No entanto, podemos perceber que a forma como a concessão do crédito hoje se dá, de forma extremamente atrativa e fácil, colabora para que o consumidor acabe se superendividando, por não ter controle adequado sobre suas finanças. Conforme expõe Sant'anna (2018, p. 09) não há como negar que a expansão na oferta de crédito assim como o aumento de práticas mercadológicas facilitadoras à sua obtenção podem representar, sim, instrumentos de desenvolvimento e inclusão social fazendo com que isso gere efeitos prejudiciais aos consumidores, visto que por muitas vezes esses estímulos ao consumo derivam de condutas abusivas dos fornecedores. Sant'anna (2018) explica que a concessão de crédito indiscriminada e irresponsável é uma afronta à dignidade do consumidor e como exemplo disso cita o envio de cartão de crédito e o aumento no limite do cheque especial sem a autorização do consumidor e também os anúncios, direcionados a quem está negativado, da concessão de empréstimos. Buscando coibir essas práticas é que, doutrina e jurisprudência, passaram a estabelecer os deveres anexos que aumentavam os efeitos do princípio da boa-fé objetiva. Segundo Morais (2019) o descumprimento do dever de conduta que é oriundo da boa-fé objetiva podem ter como consequências: danos, desequilíbrio e injustiças contratuais. Dessa forma, como evidenciado por Sant'anna (2018) com o superendividamento ativo inconsciente há também uma considerável participação dos fornecedores, visto que estes exploram a fragilidade do consumidor, usando técnicas publicitárias agressivas, não tendo o mínimo de zelo com o consumidor tomador do crédito, pois o fornecedor tem como objetivo somente o retorno financeiro, deixando de lado a observação da boa-fé objetiva que deveria nortear as relações de consumo.

Conclusão: Deste modo percebeu-se que muitas vezes o consumidor, diante da facilidade de contrair créditos, acaba por se 
endividar além do seu orçamento econômico e com isso se mostra a importância de, além de proteger o superendividado passivo, se tutelar a proteção do superendividado ativo inconsciente diante da presunção de boa-fé. Além disso, é notório a importância que tem o PL n⿳ 3.515/15, que alterará o Código de Defesa do Consumidor, visto que mostra a relevância da educação financeira aos consumidores, bem como direciona a forma com que as instituições devem conceder créditos de maneira mais responsável.

\section{Referências}

BRASIL. Projeto de Lei n. 3.515/15. Altera a Lei $n^{\circ} 8.078$, de 11 de setembro de 1990, e o art. 96 da Lei $n^{\circ} 10.741$, de $1^{\circ}$ de outubro de 2003, para aperfeiçoar a disciplina do crédito ao consumidor e dispor sobre a prevenção e o tratamento do superendividamento. Brasília. DF. 2015.

MARQUES, Claudia Lima. Algumas perguntas e respostas sobre a prevenção e tratamento do superendividamento dos consumidores pessoas físicas. Revista de Direito do Consumidor. v. 75/2010, p. 09 - 42, jul - set, 2010. Doutrinas Essenciais De Direito do Consumidor. Vol. 2, p. 563-593, Abr 2011. Revista dos Tribunais Online.

MORAIS, Ezequiel. A boa-fé objetiva pré-contratual: deveres anexos de condutas [livro eletrônico]. São Paulo: Thomson Reuters Brasil, 2019.

SANT'ANNA, Adriana. Boa-fé objetiva e superendividamento do consumidor: uma abordagem crítico-reflexiva do estado da arte das relações consumerista e das práticas mercadológicas. Revista de Direito do Consumidor. v. 119/2018, p. 227-266, set out, 2018.

SCHMIDT NETO, André Perin. Superendividamento do consumidor: conceito, pressupostos e classificação. Revista de Direito do Consumidor. v. 71/2009, p. 9 - 33. Revista dos Tribunais Online. 


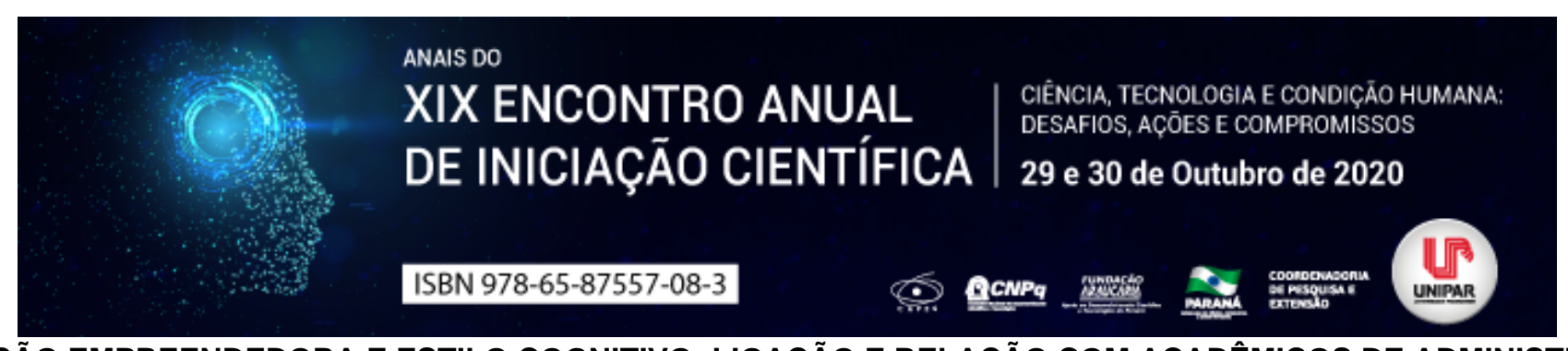

\title{
INTENÇÃO EMPREENDEDORA E ESTILO COGNITIVO: LIGAÇÃO E RELAÇÃO COM ACADÊMICOS DE ADMINISTRAÇÃO E CIÊNCIAS CONTÁBEIS
}

\author{
${ }^{1}$ EDUARDA WELTER GARBOZZA, ${ }^{2}$ EDILENE DE OLIVEIRA NOGUEIRA, ${ }^{3}$ JHEINEFER IESS DA SILVA, ${ }^{4}$ LARISSA DE \\ MORAIS, ${ }^{5}$ MARIA EDUARDA SOUZA JORGE, ${ }^{6}$ SERGIO BUENO FERNANDES
}

\author{
${ }^{1}$ Acadêmico do PIC/UNIPAR \\ ${ }^{1}$ Acadêmica do Curso de AnÃ jlise e Desenvolvimento de Sistemas da UNIPAR \\ ${ }^{2}$ Acadêmica do Curso de AdministraÃß̃̃£o da UNIPAR \\ ${ }^{3}$ Acadêmica do Curso de AdministraÃß̃̃£o da UNIPAR \\ ${ }^{4}$ Acadêmica do Curso de CiÃanncias Cont $\tilde{A}_{i}$ beis da UNIPAR \\ ${ }^{5}$ Docente da UNIPAR
}

Introdução: $O$ ato de empreender é uma mudança pessoal, profissional e social. Instituições Superiores privadas instigam seus acadêmicos ao desejo de empreender e inovar em suas ideias (ALLINSON; HAYES, 2012). Estudar o estilo cognitivo nesse contexto tem a finalidade de conhecer o desenvolvimento profissional do indivíduo, saber suas habilidades e fraquezas e desenvolver um autoconhecimento que possa identificar diferentes competências individuais. Assim, Kirton (1976) apresenta dois modelos de indivíduos com intenção empreendedora, o chamado de inovador com novas formas de desenvolver o projeto e o

adaptador que aprimora a ideia já existente. Estudar o modelo cognitivo e a intenção empreendedora na educação superior estimula a criação de novos perfis inovadores e aptos a empreender.

Objetivo: Identificar possíveis conexões entre o estilo cognitivo e intenção empreendedora dos estudantes de administração numa IES privada.

Material e Métodos: O presente trabalho teve por objetivo identificar possíveis conexões entre o estilo cognitivo e a intenção empreendedora dos estudantes de administração e ciências contábeis. Para desenvolvimento deste estudo utilizamos o seguinte delineamento de pesquisa: quanto à abordagem optou-se pela pesquisa quantitativa; quanto aos objetivos utilizou-se a pesquisa descritiva e quanto aos procedimentos é um estudo de caso, levantamento ou survey e bibliográfica. Foi utilizado um questionário estruturado fechado contendo 33 perguntas na escala Likert e aplicado por meio do formulário online do Google. A coleta de dados foi feita com os estudantes dos cursos de Administração e Ciências Contábeis de uma IES privada localizada no Sudoeste do Paraná.

Resultados: De acordo com o questionário elaborado com trinta e três perguntas aplicadas aos alunos dos cursos de Administração e Ciências Contábeis de uma unidade universitária da cidade de Francisco Beltrão - PR, pôde-se observar que os respondentes demonstraram com maior prevalência comportamento proativo e buscam inovar a partir de velhos problemas, tem atitudes criativas e de polivalência, estão atentos aos detalhes o que demonstra atenção à qualidade e eficiência, principalmente quando se deparam com situações difíceis. Possuem espírito de liderança na medida em que respeitam opiniões de seus subordinados e são autoconfiantes quando necessitam discordar de seus superiores. Não gostam de chefes e padrões de trabalho rígidos. Possuem capacidade de adaptação organizacional e demonstram cautela para expressar suas ideias antes de necessário.

Discussão: Os resultados preliminares apontam que os respondentes possuem caráter proativo, criativo e versátil, tem predisposição para adaptar-se em qualquer tipo de estrutura organizacional e demonstram cautela para expressar suas ideias antes do necessário. Esses atributos condizem com as informações de Kirton (1976) defendendo que estilo cognitivo é a forma que o indivíduo utiliza a informação e faz suas escolhas para chegar a uma tomada de decisão, levando em consideração as condições aplicadas para resolver problemas (pode-se observar essa característica na pergunta referente a possuírem espírito de liderança na medida que respeitam seus subordinados e discordam de seus superiores), a adoção de comportamentos e a posição diante de políticas e objetivos organizacionais, onde decisões são características pessoais baseadas a partir de relações cognitivas. Já a intenção empreendedora segundo Ajzen (1991) são sinais do quanto a pessoa é capaz de se esforçar, para mostrar um comportamento promissor características essas que se destacaram nos respondente nas questões que se referiam a inovação, seja ela para resolver novos ou velhos problemas. O intuito de realizar um ato é formado por três ações: atitude, normas subjetivas e comportamento controlado. Nos estudos de Kirton (1976) e Ajzen, as decisões são baseadas nas representações cognitivas e seus comportamentos, assim, previamente julga-se que a intenção empreendedora se sobressai em relação a decisão de criar um próprio e novo negócio, isso evidencia nos votos frequentes da questão sobre não gostar de chefes e padrões rígidos, e no quesito possuem espírito de liderança na medida em que respeitam opiniões de seus subordinados e são autoconfiantes quando necessita, discordar de seus superiores. 
Conclusão: Conclui-se que os acadêmicos de Administração e Ciências Contábeis possuem estilo cognitivo adaptador, pois neste estilo os empreendedores são vistos como confiáveis, conformados, previsíveis e inflexíveis e também por adaptar-se com facilidade à uma estrutura organizacional já existente. Com base nos resultados foi perceptível a associação entre o estilo cognitivo e a intenção empreendedora a partir dos comportamentos dos respondentes diante as situações, considerando suas atitudes, as pressões sociais e autocontrole.

\section{Referências}

ALLINSON, C.; HAYES, J. The cognitive style index: technical manual and user guide. United Kingdom: Pearson, 2012.

AJZEN, I. The theory of planned behavior. Organizational Behavior and Human Decision Processes,

v. 50, n.2, p..179-211, 1991.

CAMOZZATO, Elen Sauer. SERAFIM, Fernanda Kruger. Cavalheiro, Cledinei Clóvis de Melo LIZOTE, Suzete Antonieta. VERDINELLI, Miguel Angel. Estilo Cognitivo E Intenção Empreendedora Dos Estudantes De Administração. Revista GUAL, Florianópolis, v. 11, n. 3, p. 105-121, setembro 2018. Disponivel em: https://periodicos.ufsc.br/index.php/gual/article/view/19834535.2018v11n3p105/37268.

KIRTON, M. J. Adaptors and innovators: a description and measure. Journal of Applied Psychology, v. 61, n. 5, p. 622-629, 1976. 


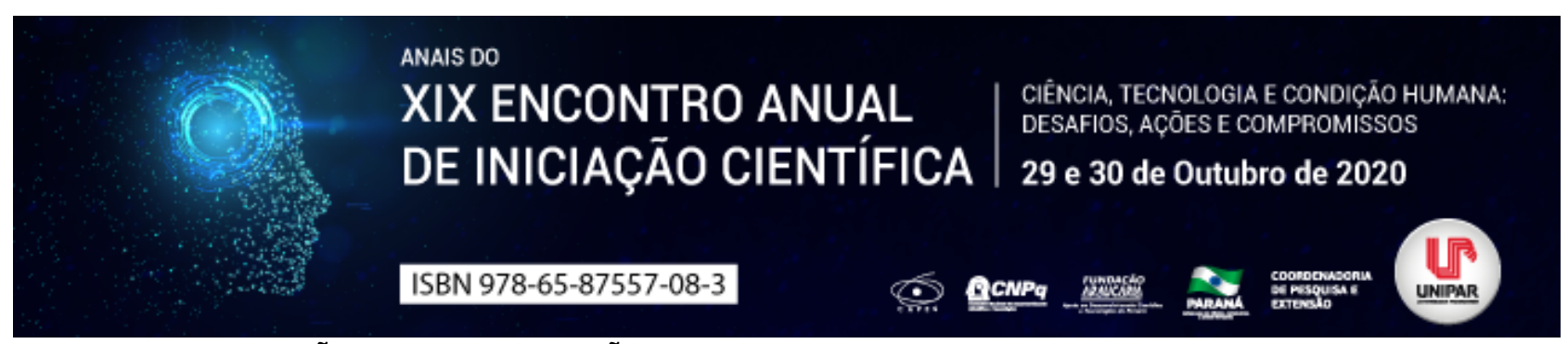

O DIREITO DE NEGOCIAÇÃO E A CONCILIAÇÃO COMO FORMA DE TRATAMENTO AO SUPERENDIVIDAMENTO DO CONSUMIDOR PESSOA FÍSICA

\author{
${ }^{1}$ IVANILDA VAZ BATISTA DE OLIVEIRA, ${ }^{2}$ BRUNO ROGER CAUMO, ${ }^{3}$ FILIPE DE LIMA CRUZ, ${ }^{4}$ LIDIA RICCI ROQUE, ${ }^{5}$ MARIA \\ CAROLINA SILVA DA FONSECA, ${ }^{6}$ VALERIA BONONI GONCALVES DE SOUZA
}

\author{
${ }^{1}$ Acadêmico do PIC/UNIPAR \\ ${ }^{1}$ Acadêmico do Curso de Direito da UNIPAR \\ ${ }^{2}$ Acadêmico do Curso de Direito da UNIPAR \\ ${ }^{3}$ Acadêmica do Curso de Direito da UNIPAR \\ ${ }^{4}$ Acadêmica do Curso de Direito da UNIPAR \\ ${ }^{5}$ Docente da UNIPAR
}

Introdução: A ausência da conciliação como tentativa de resolução de conflitos e recuperação patrimonial da pessoa física nos casos de superendividamento leva a seu distanciamento do mercado de consumo, além de causar demora na resolução da problemática, o que contribui para o aumento de processos judiciais e a instabilidade da estrutura econômica e social do consumidor.

Objetivos: Demonstrar como a conciliação em conjunto com o direito de negociação serve de instrumento eficaz na redução e tratamento do superendividamento do consumidor pessoa física, além do impacto positivo nas demandas judiciais.

Desenvolvimento: Diante do cenário em que os consumidores superendividados vivem, a conciliação antes do processo de judicialização busca uma aproximação com vistas a solucionar as relações entre credor e o superendividado. Oportuno esclarecer que o superendividamento do consumidor se refere às pessoas físicas que se encontram em estado descontrolado , muitas vezes por fatores alheios a sua vontade, bem como inesperados, os chamados acidentes da vida , ou, ainda, pela própria falta de preparo quanto a educação financeira. Ocorre que, como normalmente o consumidor possui mais de um credor, a renegociação de dívidas para tratamento do superendividamento acaba encontrando maior a dificuldade para a recomposição patrimonial. O Código de Defesa do Consumidor dispõe em seu art. $6^{\circ}$ que são direitos básicos do consumidor.

V - a modificação das cláusulas contratuais que estabeleçam prestações desproporcionais ou sua revisão em razão de fatos supervenientes que as tornem excessivamente onerosas (BRASIL, 1990). Para que isso ocorra de modo rápido e efetivo deve haver acordo das partes, sobre essa perspectiva: I"A conciliação é, possivelmente, a forma mais célere e menos custosa de resolução de conflitos I"(BERGSTEIN, 2019). Entre outros fundamentos, pautados também na negociação, pode-se abordar o Projeto de Lei n. 3.515/2015, originário do Senado Federal, mas atualmente tramitando na Câmara dos Deputados (BRASIL, 2015), que vislumbra dar maior regulamentação aos direitos dos consumidores superendividados, assim como sua efetiva tutela e prevenção, dispondo em seu capítulo $\mathrm{V}$ os critérios a serem seguidos e forma de condução deste instituto face o superendividamento do consumidor. Nesse sentido, o art. $4^{\circ}$ trata da educação financeira do consumidor como forma de prevenir o superendividamento, porém deve ser também, meio de tratamento. Além do caráter preventivo, é relevante ainda destacar que o objetivo do Projeto de Lei é promover maior eficiência no tratamento do superendividamento, ao dispor em seu art. 104-A que:

a requerimento do consumidor superendividado pessoa. natural, o juiz poderá instaurar processo de repactuação de dívidas, visando à realização de audiência conciliatória, presidida por ele ou por conciliador credenciado no juízo, com a presença de todos os credores, em que o consumidor apresentará proposta de plano de pagamento com prazo máximo de 5 (cinco) anos, preservados o mínimo existencial, nos termos da regulamentação, e, as garantias e as formas de pagamento originalmente pactuadas (BRASIL, 2015), o que o torna instrumento de extrema importância para a recuperação do consumidor por inteiro, assim como a regeneração da economia. De acordo com Marques (2019), para as partes, o direito de cobrança e, simultaneamente o de negociar, deve sobressair a cooperação de boa-fé, garantindo o equilíbrio de tais relações. O procedimento através da conciliação para a negociação de dívidas oriundas de relação de consumo, exige que seja o devedor de boa-fé e, no que tange a formalização do acordo, deve ser homologado para ser válido, tornando-se assim um título executivo. Além disso a conciliação pode ser realizada não apenas pelo Poder Judiciário, mas em competência concorrente, nos termos do o art. 104-C. Por intermédio de Projeto Piloto, conforme demonstra MARQUES et al. (2015), no período de 5 anos aconteceram 3.225 audiências de conciliação em bloco de superendividados e seus credores realizadas por magistrados e conciliadores do TJRS, em que o nível de êxito foi maior do que o dobro da média nacional, foi possível estabelecer um plano de pagamento por acordo, conciliando $64,3 \%$ dos casos, com isso evitando a propositura de processos judiciais. Além do mais, ao atingir todos os credores do consumidor superendividado, se torna mais fácil seu efetivo pagamento, com isso o consumidor pode retomar ao meio econômico e o credor recebe mais rápido os valores que poderiam perdurar muito tempo até serem pagos. 
Conclusão: A proposta de alteração do Código de Defesa do Consumidor que se encontra em andamento por meio do Projeto de Lei n. 3515/15, tem por uma de suas finalidades incentivar o instituto da conciliação por entender que a não judicialização de ações de cobrança não beneficiará somente o consumidor superendividado que poderá adimplir suas dívidas da forma mais adequada às suas condições financeiras, como também trará benesses aos credores, pois restarão satisfeitos com 0 recebimento de seus créditos. Desta feita, o direito de negociação se torna efetivo também por intermédio da conciliação.

\section{Referências}

BRASIL. Lei no 8.78, DE 11 de Setembro de 1990. Código de Defesa do Consumidor. Disponível em: https://cutt.ly/foLH5CP, acesso em 25 jul. 2020.

BERGSTEIN, Laís. O tempo do consumidor e o menosprezo planejado [livro eletrônico]: o tratamento jurídico do tempo perdido e a superação das suas causas. São Paulo : Thomson Reuters Brasil, 2019.

BRASIL, Projeto de Lei n. 3.515/15. Altera a Lei $n^{\circ} 8.078$, de 11 de setembro de 1990, e o art. 96 da Lei $n^{\circ} 10.741$, de $1^{\circ}$ de outubro de 2003, para aperfeiçoar a disciplina do crédito ao consumidor e dispor sobre a prevenção e o tratamento do superendividamento. Brasília. DF. 2015. Disponível em https:/lcutt.ly/FoL5FIU, acesso em 04 jul. 2020.

MARQUES, Claudia Lima.; BENJAMIN, Antônio Herman V.; MIRAGEM, Bruno . Comentários ao Código de Defesa do Consumidor [livro eletrônico]. 3. ed. São Paulo : Thomson Reuters Brasil, 2019.

MARQUES, Claudia Lima.; LIMA, Clarissa Costa de.; BERTONCELLO, Karen Rick Danilevicz. Dados preliminares da pesquisa empírica sobre o perfil dos consumidores superendividados da comarca de porto alegre (2007 a 2012) e o l"observatório do crédito e superendividamento ufrgs-mj. Revista de Direito do Consumidor. Vol. 99/2015. p. 411 - 436, Maio Jun, 2015. Revista dos Tribunais Online. 


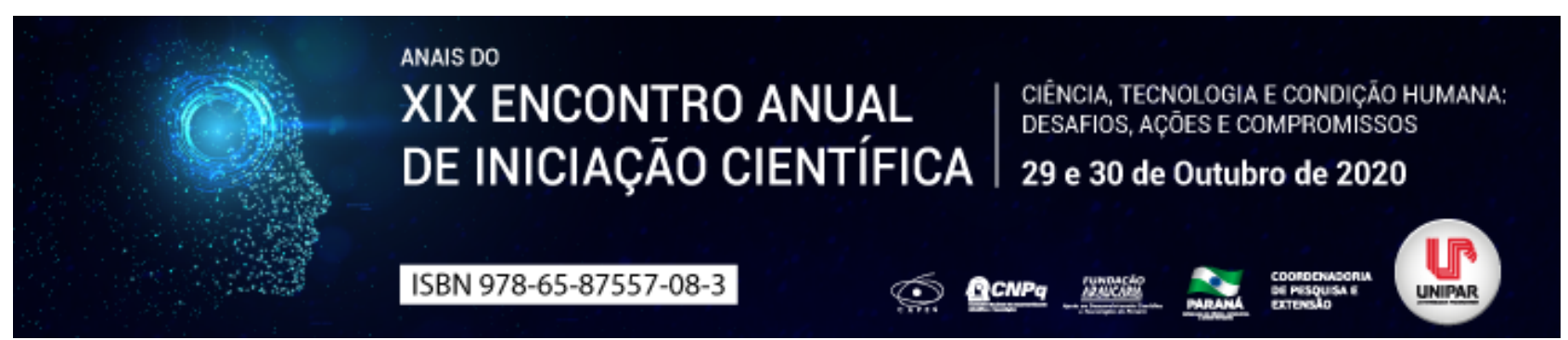

TEORIA DA INVALIDADE DO NEGÓCIO JURÍDICO E A APLICAÇÃO DO Utile per inutile non vitiatur

\author{
${ }^{1}$ NATALIA ZEFERINO CASTANHEIRA, ${ }^{2}$ GERALDO SCRAMIN NETO, ${ }^{3}$ LUIZ MANOEL GOMES JUNIOR, ${ }^{4}$ JUSSARA SUZI \\ ASSIS BORGES N. FERREIRA
}

${ }^{1}$ Acadêmica do PIC/UNIPAR
${ }^{1}$ Docente da UNIPAR
${ }^{2}$ Docente da UNIPAR
${ }^{3}$ Docente da UNIPAR

Introdução: A codificação civil vigente incorporou múltiplas normas legais concernentes ao princípio da conservação dos atos e negócios jurídicos, além de reproduzir cláusula geral acerca de tal assunto, norma esta sucedânea do diploma anterior. A regra atinente à nulidade parcial, por meio da qual o útil não será viciado pelo inútil, é concretização do princípio da conservação negocial, sendo que sua observância é impreterível para a efetiva manutenção da autonomia privada inerente a todos.

Objetivos: Analisar o conceito de negócio jurídico dedicando-se às possibilidades de invalidade deste, evidenciar a distinção entre situações de nulidade total e nulidade parcial, além de traçar uma relação entre o princípio da conservação dos atos e negócios jurídicos e a parêmia utile per inutile non vitiatur.

Desenvolvimento: O negócio jurídico consiste em declaração de vontade que tem por desígnio a constituição, modificação ou extinção de uma relação jurídica. Como bem asseveram Nery e Nery Júnior (2019, p. RB-10.4), em relação às possibilidades de invalidade do negócio jurídico, compreendidas através do plano de validade, há de se demonstrar a diferença entre nulidade total e nulidade parcial acerca do negócio jurídico. Uma vez que o vício compreendido através do acordo de vontades abrange-o completamente, estendendo-se desde a essência de seu conteúdo negocial, não podendo este ser objeto de redução ou confirmação a critério das partes, tratar-se-á de nulidade total. Sob outra perspectiva, em razão de o vício cometido através da declaração de vontade se limitar a uma ou mais cláusulas, atingindo apenas parte do conteúdo preceptivo, sem que lhe afete o cerne negocial, cuidar-se-á de nulidade parcial. Com vistas ao princípio da conservação dos atos e negócios jurídicos, havendo possibilidade, preservar-se-á o elemento volitivo consistente no negócio jurídico, suprimindo deste, sua parcela inválida, objetivando a manutenção da intenção das partes no momento em que pactuaram a avença. Certo é que A nulidade de uma cláusula, por sua vez, apesar de o negócio ser um todo, pode não levar à nulidade do negócio; a regra da nulidade parcial (utile per inutile non vitiatur) admite que o negócio persista, sem a cláusula defeituosa, 'se esta for separável' (art. 153 do CC) (AZEVEDO, 2008, p. 68 e 69). Esta regra de nulidade parcial existe desde a codificação de 1916, em seu artigo 153, reproduzindo-se através do Código Civil de 2002, artigo 184, que alude: Respeitada a intenção das partes, a invalidade parcial de um negócio jurídico não o prejudicará na parte válida, se esta for separável; a invalidade da obrigação principal implica a das obrigações acessórias, mas a destas não induz a da obrigação principal . Dessa forma, o negócio jurídico perdurará, não obstante à nulidade parcial, visto que o útil não será viciado pelo inútil. Quando, porém, o negócio principal é válido e uma estipulação acessória ou desnecessária deixa de revestir a forma prescrita em lei, seu defeito não contamina o primeiro, porque 'utile per inutile non vitiatur' (art. 184 do Código Civil) (PEREIRA, 2017, p. 399). Segundo decisão proferida pelo Tribunal de Justiça de São Paulo, exarada no Recurso de Apelação no 1024365-59.2004.8.26.0100, compreende-se que, em situações onde há nulidade parcial do negócio jurídico, haverá redução deste nos limites de sua parte válida, suprimindo-lhe as disposições inválidas, a fim de que se conserve a substância negocial. Nesta hipótese, v.g., constatou-se a inserção posterior de folha extra no instrumento de contratação, não obstante a impossibilidade de admitir validade ao título executivo de folha exógena, haverá a preservação da contratação ante às demais disposições contratuais, uma vez que a nulidade parcial do negócio jurídico não o contaminará completamente nas situações em que houver possibilidade de separação, havendo consequente redução do negócio jurídico aos seus limites válidos.

Conclusão: Em virtude das questões suscitadas, a análise da nulidade parcial acerca do negócio jurídico carecerá de aferição, investigando se a exclusão de disposição inválida não compromete o núcleo negocial. $\mathrm{O}$ aproveitamento do negócio jurídico ocorrerá nas situações em que não houver interferência na essência do acordo de vontades, posto que, nestas hipóteses utile per inutile non vitiatur, ou seja, o útil não é viciado pelo inútil.

\title{
Referências
}

AZEVEDO, A. J. Negócio Jurídico: Existência, Validade e Eficácia. 4. ed. São Paulo: Saraiva, 2008.

BRASIL. Lei n. 10.406, 10 de janeiro de 2002. Institui o Código Civil. Diário Oficial da União, Brasília, DF, 11 jan. 2002. Disponível em: https://cutt.ly/as6vwy1. Acesso em: 30 jul. 2020. 
NERY, R. M. DE A.; NERY JUNIOR, N. Instituições de Direito Civil: parte geral do código civil e direitos da personalidade. Volume I, 2. ed. São Paulo: Thomson Reuters Brasil, 2019.

PEREIRA, C. M. da S. Instituições de Direito Civil: Introdução ao Direito Civil: Teoria geral de direito civil. Volume 1, 30. ed. Rio de Janeiro: Forense, 2017.

SÃO PAULO. Tribunal de Justiça de São Paulo. Apelação Cível 1024365-59.2004.8.26.0100. Relator: Caio Marcelo Mendes de Oliveira, 22 de fevereiro de 2018. Disponível em: https://cutt.ly/Jd3slcD. Acesso em: 30 jul. 2020.

Coordenadoria de Pesquisa e Extensão - COPEX

Departamento de Editoraçāo e Divulgaçāo Científica - DEDIC 


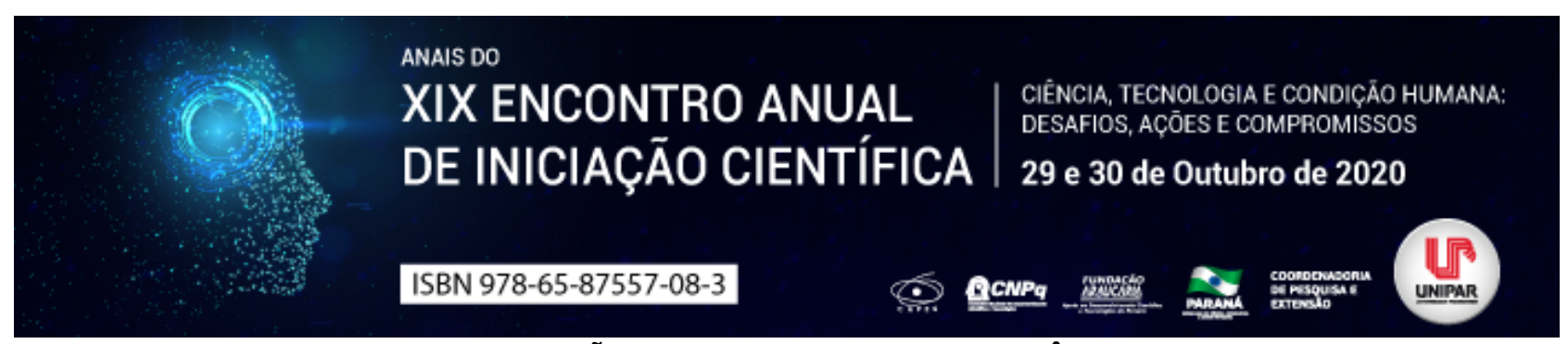

PROCESSOS DE SUBJETIVAÇÃO DO HOMEM: SERIA A VIOLÊNCIA UM DISPOSITIVO?

\title{
${ }^{1}$ EMANUEL JOSE LAHOS BORGES, ${ }^{2}$ STEPHANEI COELHO PAULINI, ${ }^{3}$ LUIZ AUGUSTO BAESSO TURCI, ${ }^{4}$ MATHEUS LIMA DOS SANTOS, ${ }^{5}$ TAYNA CECCON MARTINS
}

\author{
${ }^{1}$ Acadêmico do Curso de Psicologia da UNIPAR \\ ${ }^{1}$ Acadêmica do Curso de Psicologia da UNIPAR \\ ${ }^{2}$ Acadêmico do Curso de Psicologia da UNIPAR \\ ${ }^{3}$ Acadêmico do Curso de Psicologia da UNIPAR \\ ${ }^{4}$ Docente da UNIPAR
}

Introdução: Não se nasce homem, torna-se. O resumo se propõe a refletir criticamente sobre os processos de subjetivação da masculinidade e que a compreensão da violência enquanto dispositivo muito mais que um termo que se fecha em si mesmo, vem de uma possibilidade de discussão para ampliação do debate. Welzer-Lang em seus estudos (2001) fala sobre a construção da masculinidade tendo como primazia os processos de mimetismos violentos; ocupando espaços monossexuados, os garotos aprendem que ser homem é em primeiro momento, não ser mulher ocupando assim, um espaço em branco, o que os grandes homens disserem é válido, pois assim se tornará homem como estes (WELZER-LANG, 2001). A violência é protagonizada não só pelas mãos dos homens mas por seus corpos nestes espaços monossexuados; utilizando a noção de dispositivo de Foucault (1998), a possibilidade de analisarmos o dispositivo de violência se faz pois tomando discursos, espaços, noções, práticas, um discurso de dispositivo se forma. Não poderia ser, então, a violência um dispositivo, pois forma homens, e os ensina a agir?

Objetivo: Analisar o processo de socialização de homens, demonstrando a violência como aspecto primário e a partir disso investigar a generificação dos corpos tendo a violência como dispositivo masculinizante.

Desenvolvimento: $O$ processo de subjetivação de garotos é preenchido de violência. Num processo sadomasoquista e, os meninos aprendem que devem primeiro se fechar à dor, pelo medo de não poder ser (WELZER-LANG, 2001). Essa generificação explora os corpos dos garotos, antes mesmos de se tornarem garotos, e subsequentemente, tornam-se homens a partir desta (WELZER-LANG, 2001); homem, assim, é sofrer. No entanto, denotar os processos de subjetivação é importante, porquanto são os veículos, modelos e moldes sociais que nos formatam a agir de dita maneira, ou não, pois cria-se imagens, valores, costumes, onde estas por sua vez tornam-se obrigatórias para que digamos quem somos, de onde viemos, e o que queremos porém, estas semióticas nos individualizam no mesmo ritmo que as buscamos em processos não [...] centrados em agentes individuais, nem em agentes grupais. Implicam o funcionamento de máquinas de expressão que podem ser de natureza extrapessoal, extra-individual, quanto de natureza infra-humana (GUATTARI; ROLNIK, 1996, p. 31). Portanto, a construção do garoto para homem não só depende dos referenciais que os permitirão identificar-se pois há o risco de ser comparável à mulher (WELZER-LANG, 2001) mas também de sua relação com estes. Atos violentos são parte essencial da compreensão do que é ser homem, pois os garotos enrijecem-se para tornarem homens insensíveis, inconsequentes, e sadistas, já que assim fora com eles (WELZER-LANG, 2001); esta construção sadomasoquista é cíclica, onde já ocorrera anteriormente, e continuará mantendo-se. A violência assim sendo, não poderia ser um dispositivo? De acordo com os estudos de Foucault (1988), conceituar dispositivo significa reconhecer como certos discursos, visões, morais se formatam; um dispositivo é formado a partir não só de noções científicas, como religiosas, populares, culturais a violência nos corpos ditos homens é o próprio método pelo qual torna-se tal, como o meio pelo qual outros poderão vir-a-ser. Um dispositivo então é utilizado mas a importância também está no ato de ser utilizado; os homens que foram violentados irão se justificar no ato, pois cada homem se torna ao mesmo tempo iniciado e iniciador (WELZER-LANG, 2001). A concretização da masculinidade torna-se o próprio fim enquanto também é o meio, pois através do dispositivo de violência estes homens performam seu gênero, sua subjetividade, aquilo que lhes concedeu status de válido aos homens não-válidos , resta a violência, agora não como forma de enrijecimento, mas como distanciamento (WELZER-LANG, 2001). O dispositivo de violência permanece como auge da masculinidade, onde fortalece barreiras de gênero, de legitimidade, e cria uma hegemonia do que poderia vir a ser homem.

Conclusão: Entender a violência como aspecto primário das relações machistas é um importante ponto para possibilitarmos visões mais equalitárias de gênero. Nenhuma performance é inerente à existência logo, ao demonstrar a volatilidade do que é violência e como tal é estruturante do processo de construção de homens, é possível tomar uma posição mais crítica em relação ao patriarcado. A violência cria homens, e os torna violentos para que possam, novamente, serem os porteiros da masculinidade. Ser homem é, em primeiro momento, ocupar um espaço de dor. Relações machistas são feitas a partir da noção de como homens se relacionam com o mundo e entre si, e observar tal questão como a atuação de um dispositivo possibilitaria entendê-lo como meio e fim em si só, com o intuito da captura do corpo. Quebrar com esta noção seria quebrar com alguma parte do 
patriarcado, mesmo que ínfima.

\section{Referências}

FOUCAULT, M. História da sexualidade I: A vontade de saber. 13. ed. Rio de Janeiro: Edições Graal, 1988.

GUATTARI, F.; ROLNIK, S. Micropolítica: Cartografias do Desejo. 4 ed. Petrópolis: Vozes, 1996.

WELZER-LANG, D. A construção do masculino: dominação das mulheres e homofobia. Revista Estudos Feministas, Florianópolis, v. 9, n. 2, p.460-482, jul-dez. 2001.

Coordenadoria de Pesquisa e Extensão - COPEX

Departamento de Editoraçāo e Divulgaçāo Científica - DEDIC 


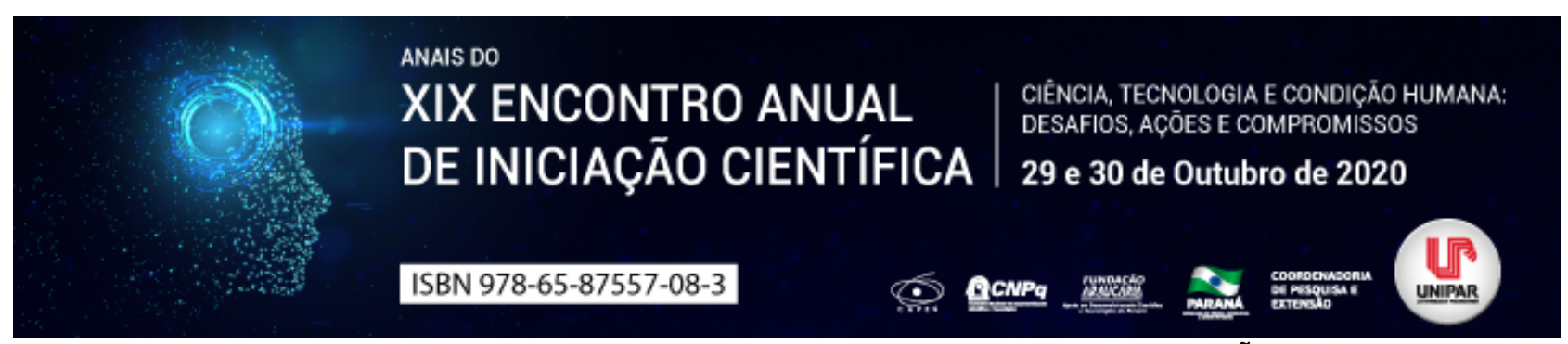

O SISTEMA BLOCKCHAIN COMO TECNOLOGIA ANTICORRUPÇÃO

\author{
${ }^{1}$ RENAN WILLIAM DE DEUS LIMA, ${ }^{2}$ LUIZ ROBERTO PRANDI
}

\author{
${ }^{1}$ Mestrando em Direito pela PUC/PR - bolsista CAPES \\ ${ }^{1}$ Professor Titular e pesquisador da Universidade Paranaense - UNIPAR
}

Introdução: No mundo inteiro nos últimos anos, intensificou-se a preocupação com o tema corrupção. Embora tal prática não seja algo novo, sem dúvida alguma ela foi potencializada e se tornou sistêmica no Brasil. Atualmente, existem diversas leis no país que tentam inibir essa prática: como a Lei 12.846/2013 (Anticorrupção); a Lei 8.429/1992 (Improbidade administrativa); o Código Penal; a Lei 1.079/1950 e o Decreto-Lei 201/1967 (Crimes de responsabilidade); a Lei Complementar 135/2010 (Ficha Limpa). Porém, conforme o Índice de Percepção da Corrupção (IPC/2019) dos últimos anos, observa-se que esta vasta legislação não tem atingido os resultados esperados. De acordo com BECKER (1974), a decisão de se tornar um criminoso seria algo racional, uma decisão baseada exclusivamente na comparação dos custos e benefícios de determinada ação. Para ele, o agente sabendo dos benefícios e dos custos que determinada conduta pode apresentar, opta sempre por aquela ação que lhe cause maiores benefícios. É por esta razão que se tornou necessária a utilização de formas alternativas de fiscalização e combate à corrupção, de modo que tal prática seja desincentivada.

Objetivo: Verificar um quadro conceitual das principais características e benefícios da tecnologia Blockchain, e verificar como a sua utilização no setor público poderia contribuir para a diminuição dos casos de corrupção no Brasil.

Desenvolvimento: Uma das principais formas que podem ser utilizadas no combate à corrupção no Brasil é a utilização de tecnologias. A mais promissora delas foi criado em 31 de outubro de 2008, por um pseudônimo chamado Satoshi Nakamoto, com o trabalho A Peer-to-Peer Electronic Cash System (2009, p. 1-9). O artigo sugere a criação de um dinheiro virtual, uma criptomoeda chamada bitcoin. Porém, a grande revolução deste estudo foi a criação da tecnologia que sustentaria esse sistema, qual seja, a tecnologia Blockchain. O sistema é composto por um conjunto de softwares que passariam a constituir um protocolo disruptivo de transferência e armazenamento de informações. O sistema tentaria resolver os problemas da centralização e da validação dos dados, operando na internet e registrando todas as interações que ocorrem entre os usuários como: transferências de ativos, pagamentos, remessa de informações e arquivos, etc. A cada 10 minutos todas essas operações seriam reunidas em um único bloco de informações, gerando um código hash. Para que o hash desse bloco de informações fosse validado pelo sistema, garantindo assim a autenticidade de todas as operações contidas no bloco, seria preciso que ocorresse um consenso entre os outros nós da rede (também chamados de mineradores). Caberia aos mineradores, a validação dos blocos por meio da prova de trabalho (proof of work), que nada mais é do que a resolução de um desafio matemático que exige um grande poder computacional. Cada novo bloco dependeria de validação do bloco anterior, e assim sucessivamente, desde o primeiro realizado em 2009. Por esta razão, para Eyal (2013, p. 436-454) a tentativa de se comprometer a integridade da tecnologia Blockchain é algo que, ao menos computacionalmente, é impossível de acontecer, uma vez que os custos para realizar tal ato seriam indescritivelmente superiores aos lucros eventualmente obtidos. Hoje, uma das principais aplicações deste sistema é por meio dos Smart Contracts (contratos inteligentes), que funcionam sobre plataformas do sistema Blockchain. As cláusulas ou meramente, scripts, destes contratos são pré-determinadas e os termos são convertidos em linguagem de programação computacional, e havendo o cumprimento da cláusula $\mathrm{X}$, o resultado será a execução da cláusula $\mathrm{Y}$. Além da celeridade e a auto execução dos contratos, o sistema preserva a transparência e elimina a possibilidade de erro humano, que é a grande responsável pela fraude e corrupção nos procedimentos estatais. O registro das operações realizadas pelo poder púbico neste sistema, como licitações e repasse de recursos, permitiria que as informações ficassem acessíveis a todos os computadores da rede, fazendo com que qualquer pessoa pudesse se tornar um auditor das contas públicas.

Conclusão: Veja-se, que a utilização de mecanismos alternativos de fiscalização e combate à corrupção no Brasil, como por exemplo, a implantação do sistema Blockchain, permitiria que as contas públicas fossem registradas, autenticadas, fiscalizadas e auditadas por todos os cidadãos; possibilitando também a adoção de uma auditoria automática das rotinas burocráticas por meio da incorporação de smart contracts, forçando os agentes públicos a se manterem na legalidade, uma vez que os investimentos necessários para quebrar as diretrizes do sistema seriam eminentemente superiores aos valores eventualmente desviados.

\title{
Referências
}

BECKER, Gary Stanley. Crime and Punishment: an economic approach. National of Economic Research, 1974. p. 74. EYAL, Ittay; SIRER, Emin Gun. Majority Is Not Enough: Bitcoin Mining Is Vulnerable. Department of Computer Science, Cornell University, vol. 5. p. 436-454. 2013.

NAKAMOTO, Satoshi. Bitcoin: A Peer-to-Peer Electronic Cash System. 2009. Disponível em: http://bitcoin.org/bitcoin.pdf. Acesso 
em: 27 ago. 2020.

TRANSPARÊNCIA Internacional. Índice de Percepção da Corrupção - IPC $2019 . \quad$ Disponível em: https://www.transparency.org/en/cpi. Acesso em: 27 ago. 2020.

Coordenadoria de Pesquisa e Extensão - COPEX

Departamento de Editoraçāo e Divulgaçāo Científica - DEDIC 


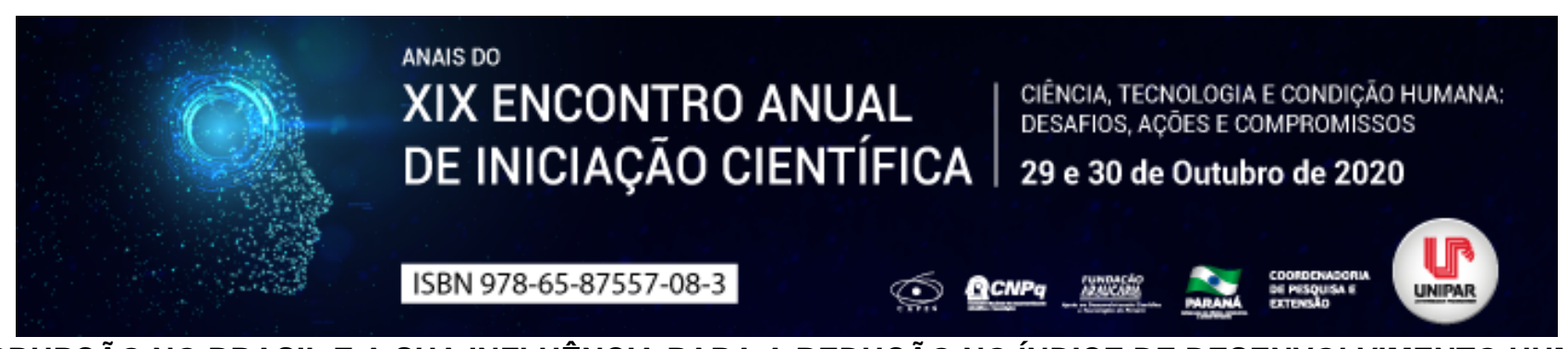

A CORRUPÇÃO NO BRASIL E A SUA INFLUÊNCIA PARA A REDUÇÃO NO ÍNDICE DE DESENVOLVIMENTO HUMANO

\author{
${ }^{1}$ RENAN WILLIAM DE DEUS LIMA, ${ }^{2}$ LUIZ ROBERTO PRANDI
}

\author{
${ }^{1}$ Mestrando em Direito pela PUC/PR - bolsista CAPES \\ ${ }^{1}$ Professor Titular e pesquisador da Universidade Paranaense - UNIPAR
}

Introdução: A corrupção está presente na história brasileira, porém, atualmente ela também é considerada um problema global que representa uma séria ameaça ao desenvolvimento de todas as nações. Entre as variáveis que podem ajudar a compreender o caso brasileiro, encontram-se aspectos históricos, sociais, comportamentais e institucionais.

Objetivo: Analisar o fenômeno da corrupção no Brasil e as suas influências para o índice de desenvolvimento humano no país. Desenvolvimento: Não há dúvidas, de que a corrupção gera uma série de ineficiências no Brasil, contribuindo para baixos níveis de PIB per capta, contribuindo também para a diminuição dos índices sociais de desenvolvimento, como a saúde e a educação. Por esta razão, há fortes indícios de que há uma ligação entre subdesenvolvimento humano e corrupção. Para Treisman (2007, p. 211) [...] ainda não está claro se o desenvolvimento humano reduz a corrupção, se uma alta corrupção atrasa o desenvolvimento humano, ou se ambos são causados por um terceiro fator . Todavia, não é exagerado afirmar que elas caminham juntas e pertencem ao mesmo ciclo nefasto e vicioso, em que o baixo desenvolvimento humano de um país é uma clara decorrência dos gastos excessivos do Estado para arcar com o dinheiro que escapa pela corrupção. Selcuk Akçai (2006, p. 29-48) explorou a fundo esta relação, afim de testar o impacto de uma sobre a outra. Os resultados dos seus testes revelaram que existe uma relação estatística entre o desenvolvimento humano e a corrupção. Para verificar se esta relação de fato existe no Brasil, analisou-se o nível de corrupção no país em contraponto à sua taxa de desenvolvimento humano. No caso da corrupção, embora não existam formas matemáticas diretas para medi-la, existem várias maneiras indiretas de obter informações sobre sua prevalência em um país ou em uma instituição, sendo a principal delas o Índice de Percepção da Corrupção (IPC). Visando fazer a comparação entre os países, a ONG Transparency Internacional, passou a utilizar o IPC a partir de 1995 para avaliar por meio de representantes do setor privado, os níveis de corrupção em nível global. Ao final do levantamento dos dados uma nota que varia de zero (mais corrupto) à 10 (menos corrupto) é atribuída a cada um. Deste modo, embora seja uma medida apenas de percepção da corrupção, as métricas permitem verificar como tais índices afetam os investimentos estrangeiros nos países. No caso do Brasil, desde 2014 o IPC vem decrescendo. A nota do país caiu oito pontos nesse período e sua posição saiu de $69^{\circ}$ para $105^{a}$ na última avaliação, a sua pior colocação desde 2011. Em 2018 (IPC, 2019) o país ficou com a nota 3,5 e permaneceu na mesma posição de nações como Zâmbia, Costa do Marfim, Egito e Timor-Leste, ficando atrás de países como Filipinas $\left(9^{\circ}\right)$ e Mongólia $\left(93^{\circ}\right)$. Já no caso do IDH (Índice de Desenvolvimento Humano), ele foi aplicado pela primeira vez em 1990 pelo Programa das Nações Unidas para o desenvolvimento (Pnud), com a finalidade de medir a qualidade de vida nos países com base em três elementos: renda (PIB per capta); saúde (expectativa de vida) e educação (taxa de escolarização). Semelhante ao IPC, as taxas do IDH variam de 0 (país com baixíssimo desenvolvimento humano) a 1 (país com elevado desenvolvimento humano). O Brasil saiu de 0,611 (médio IDH) em 1990, para 0,759 (elevado IDH) em 2017, quando o índice foi realizado pela última vez. A análise do IPC e do IDH brasileiro confirmam que a corrupção está significativamente associada a baixos índices de desenvolvimento, consistente com os achados anteriores, como Gupta et al (2002, p. 23-45). Essa evidência apoia a hipótese de que o nível de desenvolvimento de uma determinada localidade, afeta a percepção das pessoas sobre a extensão da corrupção.

Conclusão: Pela análise pode-se contatar que, diversos autores afiram a existência de uma relação intrínseca entre o desenvolvimento e a corrupção, ao passo que o nível de desenvolvimento de uma determinada localidade, afeta a percepção das pessoas sobre a extensão da corrupção. Apesar da limitação do estudo, os dados apresentados foram suficientes para confirmar que no caso do Brasil, quanto maior o índice de desenvolvimento humano, maior tende a ser o IPC, ou seja, menores serão os índices de corrupção. Por outro lado, quanto menor o desenvolvimento econômico do país, maiores serão os seus índices de corrupção.

\title{
Referências
}

AKÇAI, Selcuk, Corruption and Human Development. Cato Journal, v. 26, n.1, p. 29-48. 2006.

GUPTA, Sanjeev; HAMID R Davoodi; and ALONSO-TERME, Rosa. Does Corruption Affect Income Inequality and Poverty? Economics of Governance, vol. 3, p. 23-45. 2002.

PNUD. Relatório de desenvolvimento humano 2016: objetivos de desenvolvimento do milênio. Lisboa: Tricontinental. Disponível em: http://www.br.undp.org/content/dam/brazil/docs/RelatoriosDesenvolvimento/undp-br-2016-human-developmentreport-2017.pdf. Acesso em: 27 ago. 2020. 
TRANSPARÊNCIA INTERNACIONAL. Índice de Percepção da Corrupção, 2019 . Disponível em: http://ipc2018.transparenciainternacional.org.brL. Acesso em: 27 ago. 2020.

TREISMAN, Daniel. What have we learned about the causes of corruption from ten years of cross-national empirical research? Annual Review of Political Science, v. 10. p. 211. 2007.

Coordenadoria de Pesquisa e Extensão - COPEX

Departamento de Editoraçāo e Divulgaçāo Científica - DEDIC 


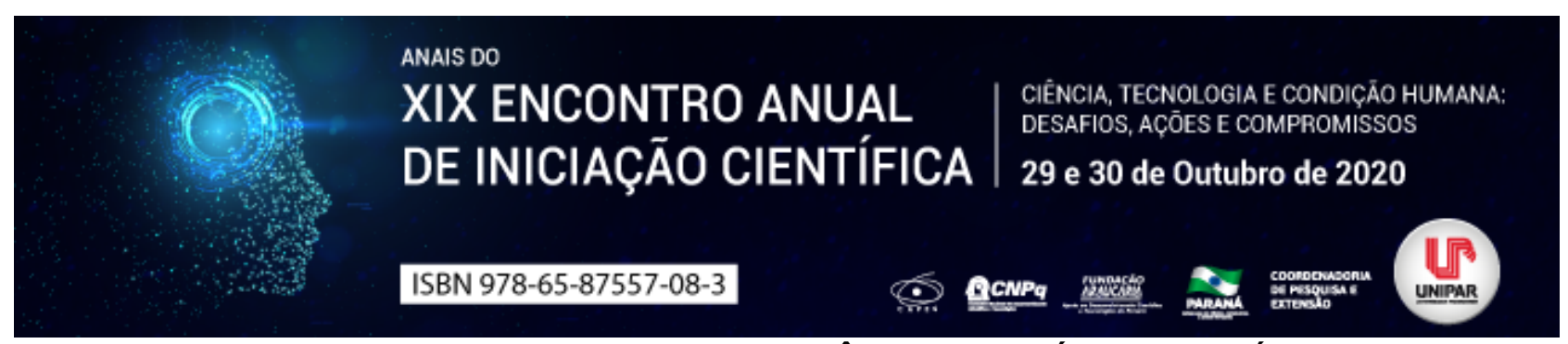

BIBLIOTERAPIA: O (RE)VIVER DA EXISTÊNCIA ATRAVÉS DAS HISTÓRIAS

\author{
${ }^{1}$ DANIELLE AGUIAR RAMALHO, ${ }^{2}$ GEANE KELLY RODRIGUES BARBOZA, ${ }^{3}$ HENRIQUE FERNANDO DOMINHASQUIS \\ RODRIGUES, ${ }^{4}$ CLARICE REGINA CATELAN FERREIRA, ${ }^{5}$ MARIANNA COSTA OLIVEIRA, ${ }^{6}$ GILBERTO ALVES
}

\author{
${ }^{1}$ Acadêmica bolsista do PIBIC/UNIPAR \\ ${ }^{1}$ Acadêmica do Curso de Psicologia da UNIPAR \\ ${ }^{2}$ Acadêmico do Curso de Psicologia da UNIPAR \\ ${ }^{3}$ Docente da UNIPAR \\ ${ }^{4}$ Docente da UNIPAR \\ ${ }^{5}$ Docente da UNIPAR
}

Introdução: Ao chegar à velhice muitos idosos enfrentam um período de adaptação à nova realidade. São comuns os sentimentos de inutilidade e incapacidade, bem como o sentimento de não pertencimento social. A biblioterapia pode ser uma importante ferramenta de acolhimento e resgate do equilíbrio emocional e senso de propósito. O referido resumo foi construído a partir de discussões realizadas no Programa de Iniciação científica intitulado: Biblioterapia: uma proposta de apoio aos universitários Unipar, na qual investiga-se teoricamente o conceito de biblioterapia como instrumento atenuante a laboração de tomada de consciência, dada no processo psicoterapêutico, onde é possível criar um espaço de acolhimento e escuta, por meio de contos, poemas, histórias. Isto posto, indaga-se sobre a biblioterapia com a população da terceira idade em instituições de longa permanência e a contribuição desta ferramenta.

Objetivo: Apresentar uma revisão teórica e discutir a importancia da biblioteria para o desenvolvimento e vivência terapêutica com a popução idosa e seus processos de subjetivação em instituições de longa permanencia.

Desenvolvimento: Atendendo ao desempenho terapêutico, a literatura apresenta subsídios transgressivos para a identificação do leitor com os personagens. De acordo com Von Franz (1990), os contos em um processo psicoterápico dão ao leitor a possibilidade de compreender melhor alguns de seus conteúdos. Portanto, a biblioterapia é um método terapêutico com base na leitura de textos literários que visa com um aspecto mais focado no sujeito, com o objetivo de auxiliar o paciente a entender melhor suas reações psicológicas e físicas de frustração e conflito, pela identificação, catarse e insight (FERREIRA, 2003). A metodologia biblioterapeutica se dá através da comunicação catalisadora, visto que, é pelo diálogo que é possível visualizar o todo, ou seja, a pluralidade de perspectivas sobre o mesmo conto. Assim, as diversas interpretações permitem a existência da alteridade e a criação de novo sentidos" (CALDIN, 2001, p. 37). Considerando as modificações sociais e todos os melhoramentos perante as tecnologias, verifica-se o quanto a interação social direta foi se perdendo. Assim sendo, os idosos diante de tantas transformações, sofrem demasiadas dificuldades ao se relacionarem nesse meio, especialmente com o público jovem (JERÔNIMO et al, 2012). Isto posto, a velhice acaba por se tornar solitária, em especial os que residem em instituições de longa permanência, pela escassa relação com sua rede de apoio (família). Diante de tais condições, é necessário que o devido apoio e compreensão emocional sejam dados às pessoas que se encontram nessa fase da vida, partindo do princípio de que a velhice não deve ser encarada como um empecilho ou fator delimitante. A biblioterapia surge, portanto, como um importante meio condutor para garantir a essas pessoas o acesso à cultura, identificação social, relaxamento, novos conhecimentos, valores e perspectivas de diferentes épocas, levando - e acompanhando - os idosos a uma jornada de autodescobertas e superação. Busca-se de tal forma um reajustamento ocupacional da velhice, atualização educacional, socialização e motivação (SEITZ, 2006, p. 29).

Nesse sentido, o idoso que se submeter a Biblioterapia deve estar ciente e disposto a participar de discussões em grupo, tendo como norte uma leitura dirigida, na qual todos os participantes poderão expressar livremente seus sentimentos, sensações e interpretações, de forma que, as visões de cada um serão igualmente compartilhadas e respeitadas. Esta pessoa não estará - e mais importante, não se sentirá - sozinha para resolver seus conflitos internos, o que resultará em uma experimentação mutuamente benéfica da compreensão de seus conteúdos (FERREIRA, 2003).

Conclusão: Considerando a realidade vivida pelos idosos, os quais muitas vezes são desprezados pela sociedade e abandonados em asilos por suas próprias famílias, conclui-se que a biblioterapia é uma abordagem benéfica para garantir o bemestar emocional de tais idosos. Por fim, verificou-se que, durante a realização deste resumo, pouco material referente ao assunto foi encontrado, o que ressalta a importância e urgência de haver mais discussões e estudos pertinentes sobre o tema. Desta forma, é necessário que a biblioterapia seja direcionada como forma de acolhimento à velhice, no intuito de proporcionar a melhorias na qualidade de vida desta parcela da população a médio e longo prazos, tornando-a merecedora do título de l"melhor idadel". 


\section{Referências}

CALDIN, Clarice F. A leitura como função terapêutica: biblioterapia. Enc. Bibli: R. Eletr. Bibliotecon. Ci. Inf., ISSN 1518-2924, Florianópolis, Brasil, n.12, p. 32-44, 2001.

FRANZ, Marie L.V. A individuação nos contos de fada. São Paulo: Paulus, 1990

FERREIRA, Danielle T. Biblioterapia: uma prática para o desenvolvimento pessoal. ETD

Campinas, SP, v.4, n.2, p 35-47, jun. 2003 [ISSN: 1517-2539].

JERÔNIMO, V; ROSSETTO, P, A; SILVA, F, R, P; GONÇALVES, E; TREIN, J. Biblioterapia na melhor idade. Revista ACB:

Biblioteconomia em Santa Catarina, Florianópolis, v.17, n.2, p.460-471, jul./dez., 2012 SEITZ, Eva M. Biblioterapia: uma experiência com pacientes internados em clínica médica. Revista ACB: Habitus em Santa Catarina, Florianópolis, 2006.

Educação Temática Digital, 


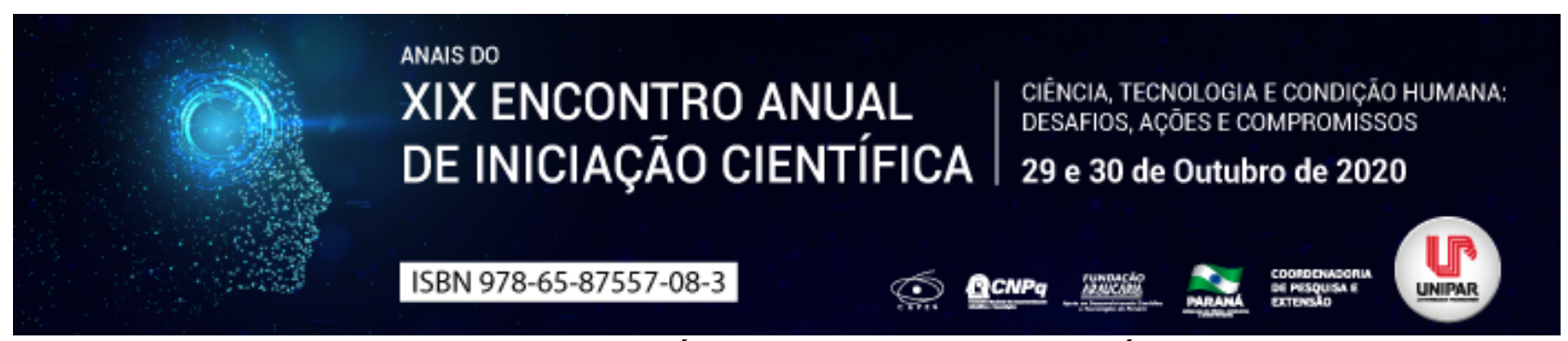

APLICABILIDADE DA ORTOTANÁSIA EM PACIENTES EM ESTÁGIO TERMINAL

\title{
${ }^{1}$ VICTOR KENNEDY DAL POZZO, ${ }^{2}$ PAULO CESAR DE SOUSA
}

\author{
${ }^{1}$ Acadêmico do Curso de Direito da UNIPAR \\ ${ }^{1}$ Professor Titular e Pesquisador da UNIPAR
}

Introdução: A eutanásia, a distanásia e a ortotanásia são processos de abreviação da morte humana que sustentam inúmeras divergências. Tal discussão é de grande relevância social, por não haver previsão legal específica.

Objetivo: O estudo propõe-se discorrer sobre os processos de abreviação da morte humana, com ênfase maior, à licitude da ortotanásia em pacientes que se encontram em estágio terminal. Além de discutir sobre os requisitos que configuram a ortotanásia no direito brasileiro.

Desenvolvimento: A eutanásia, ilegal no Brasil, é o ato de cessar a vida do paciente sem dor. Sua preocupação central é a qualidade da vida em seu estágio final, com o objetivo de eliminar o sofrimento do indivíduo. Já a distanásia, não se configura como crime, e consiste em um procedimento para prolongar a vida ao máximo, sem preocupação com a qualidade de vida e dignidade do paciente. Ainda, tem-se a ortotanásia que etimologicamente significa morte correta (JUNGLES, 2010). Esse procedimento direciona-se para uma morte sem sofrimento. Diversamente da eutanásia, ela não provoca a morte, apenas, escusa o emprego de métodos invasivos que prolongam a vida. No ordenamento jurídico brasileiro, sua prática não é considerada crime, se observados os requisitos de sua configuração. Embora não haja expressa previsão legal que enumere seus pressupostos, há a Resolução 1.805/2006 do Conselho Federal de Medicina CFM, que prevê a possibilidade de se liminar ou suspender demasiados tratamentos que prolonguem a vida do paciente em estágio terminal (CFM, 2006). Contudo, o Ministério Público Federal ingressou com uma ação civil pública em que pleiteou a declaração de ilegalidade da resolução, sob o argumento de ela não ser norma formalmente adequada para disciplinar uma conduta tipificada como crime. Esse pedido foi julgado improcedente. Na fundamentação da sentença, foi averbado que a resolução que regulamenta a possibilidade de o médico limitar ou suspender procedimentos e tratamentos que prolonguem a vida do doente na fase terminal de enfermidades graves e incuráveis, realmente não ofende o ordenamento jurídico posto (BRASílIA, 2010). Os pressupostos para a prática lícita desse procedimento são: paciente em quadro terminal; existência de doença grave e incurável; e, autorização expressa do paciente ou de seu representante. Acrescenta-se ainda que a prática de ortotanásia pode configurar homicídio privilegiado, se não forem observadas essas exigências (VILLAS-BÔAS, 2008). A restrição de recursos que visam ao prolongamento artificial da vida não é ilícita desde que realizada em consonância com os requisitos elencados acima.

Conclusão: No direito brasileiro, são requisitos para se praticar a ortotanásia, licitamente: ser paciente em estado terminal; acometido por doença grave e sem cura; e a autorização expressa do próprio enfermo ou de seu responsável.

\section{Referências}

BRASÍLIA. Justiça Federal. 14a Vara Federal do Distrito Federal. Sentença da Ação Civil Pública n. 2007.34.00.014809-3. Juiz Roberto Luis Luchi Demo. DJ: 9/12/2010. Disponível em: encurtador.com.br/elswz. Acesso em: 31 jul. 2020.

CONSELHO FEDERAL DE MEDICINA. Resolução $n^{\circ}$ 1.805, publicada em 28 de novembro de 2006. Disponível em: encurtador.com.br/suAQV. Acesso em: 31 jul. 2020.

JUNGES. J.R. Reflexões legais e éticas sobre o final da vida: uma discussão sobre a ortotanásia. Revista Bioética: 2010, p. 277.

VILLAS-BÔAS, M. E. A ortotanásia e o Direito Penal brasileiro. Revista Bioética, v. 16. Conselho Federal de Medicina. Brasília: 2008.

Coordenadoria de Pesquisa e Extensão - COPEX

Departamento de Editoraçāo e Divulgaçāo Científica - DEDIC 


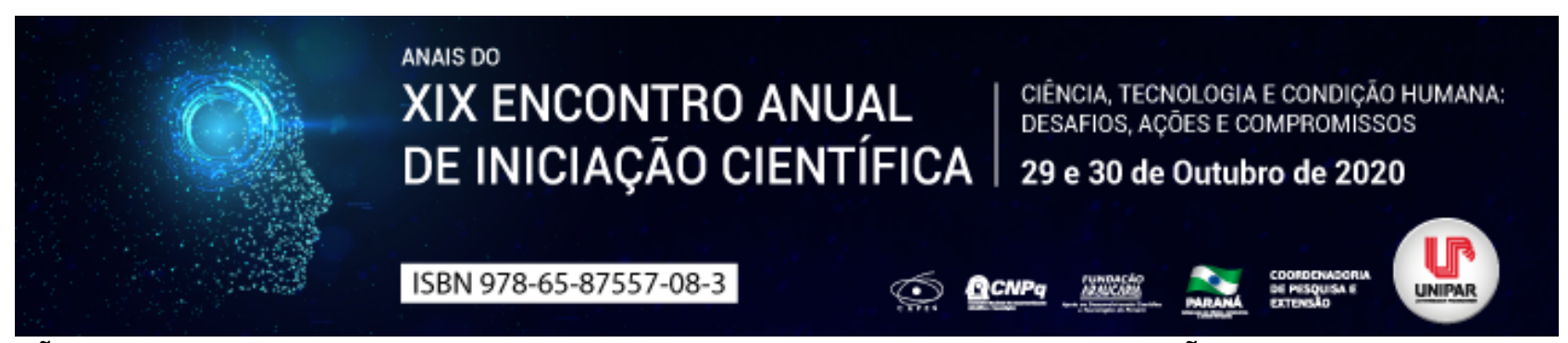

VIOLAÇÃO DOS DIREITOS FUNDAMENTAIS DO PRESO: A SUPREMACIA DAS FACÇÕES CRIMINOSAS NO SISTEMA CARCERÁRIO BRASILEIRO

\title{
${ }^{1}$ CARINA RITA DE LIMA, ${ }^{2}$ BRUNO SMOLAREK DIAS
}

\author{
${ }^{1}$ Acadêmica do PIC/UNIPAR - Campus Cascavel \\ ${ }^{1}$ Docente da UNIPAR
}

Introdução: A realidade carcerária é completamente contraditória ao ordenamento jurídico, visto que a ausência de condições básicas de sobrevivência, consequentes principalmente da superpopulação, é motivo suficiente para adoção de comportamentos revoltosos e indisciplinados, visando reconhecimento do Estado para manutenção dos meios assistenciais, até então inexistentes.

Objetivo: Analisar a atuação das organizações criminosas na realidade carcerária e propor a aplicação de métodos de aplicabilidade de pena alternativos associados aos direitos humanos que, se executados de acordo com a Lei de Execução Penal, diminuiriam a superlotação e tornaria possível a ressocialização do preso.

Desenvolvimento: Émile Durkheim em As Regras do Método Sociológico (DURKHEIM, 2004, pg. 104) discorre que: O dever do homem de Estado não é empurrar violentamente as sociedades para um ideal que se lhe afigura sedutor, antes o seu papel é o do médico: prevenir a eclosão das doenças com uma boa higiene e, quando se declaram, procurar curá-las . A este fragmento introduz-se a realidade do sistema carcerário brasileiro. O sistema prisional em sua forma de cárcere surge como alternativa de isolamento do agente condenado e, segundo definição da Lei de Execução Penal, possui finalidade de "prevenir o crime e orientar o retorno à convivência em sociedade, onde tal isolamento visa a romper o vínculo do infrator com o crime, dando a ele a possibilidade de refletir sobre seu ato (MALAGUETA, 2007, p. 67). Ocorre que, como consequência da má aplicação/manutenção da execução de pena somada a precariedade institucional, nasce o estado de superlotação do sistema carcerário, que a cada ano insere mais pessoas (LIMA; PFLUG, 2019, p. 2), violando tanto os direitos constitucionais estabelecidos ao preso, como também os assegurados na Lei de Execução Penal. Malagueta (2007, pg. 75) parte da premissa de que algumas circunstâncias, como superlotações carcerárias, inoperantes administradores, enfraquecimento das medidas técnicas relacionadas com o desenvolvimento psíquico, condições sanitárias rudimentares, bem como precária assistência médica, social, educacional, jurídica, violência entre os presos, entre outros, são o ponto de partida para que haja confronto entre grupos que visam a tomar o poder institucional e exercê-lo sobre os demais. Para Juck e Panucci (2016), a junção desses fatores constituiu motivo essencial para maior solidariedade e aproximação dos aprisionados, concedendo-lhes motivação suficiente para criação de grupos reivindicatórios de melhorias. Consegue-se denotar que a prejudicialidade da estrutura prisional pode ser considerada como o fator desencadeante para formação da multidão carcerária, organizada e com os mesmos objetivos (JUCK; PANUCCI, 2016, p. 11).

Conclusão: Ante a breve análise descrita, conclui-se que a lei carrega em si um paradoxo: como esperar que indivíduos se adequem mais às regras sociais segregando-os completamente da sociedade e inserindo-os em um microcosmo prisional com suas próprias regras e cultura? (ANDRADE et al., 2015, p. 42). Logo, não resta dúvida de que essa invisibilidade (demonstrada pela exclusão) é propícia para o surgimento do crime organizado, colocando em perigo a sociedade que permanece insegura, bem como o sistema prisional, onde presos comuns são submetidos às regras das organizações criminosas que decretam leis próprias, com ou sem o beneplácito do Estado. (MALAGUETA, 2007, p. 100). Neste sentido, com a finalidade de propor medidas alternativas para aplicação dos direitos fundamentais do preso, até então inexistentes, o Supremo Tribunal Federal julgou a ADPF 347, ajuizada pelo partido PSOL, o qual pediu reconhecimento do Estado de Coisa Inconstitucional, bem como a violação dos direitos humanos no cárcere brasileiro. Pode se definir que o estado de coisas inconstitucionais é um conjunto de atos, ações e omissões provenientes dos poderes públicos que dão espaço a uma violação massiva de Direitos Fundamentais (LIMA; PFLUG, 2019, p. 4).

\section{Referências}

ANDRADE, Carla Coelho. Et al. O desafio da reintegração social do preso: uma pesquisa em estabelecimentos prisionais. Brasília: IPEA, 2015.

MALAGUETA, Soliane. O Sistema Prisional e o Crime Organizado. Monografia (Graduação em Direito). 2007. Faculdades Integradas Antônio Eufrásio de Toledo: Presidente Prudente, SP, 2007. Disponível em. Acesso em 13 de junho de 2020.

Lima, R., \& Meyer Pflug, S. (2019). O estado de coisas inconstitucionais e a superlotação do sistema carcerário brasileiro. Revista De Direito Internacional E Direitos Humanos Da UFRJ. Rio de Janeiro, v. 2, n. 1, 2019.

JUCK, F, \& PANUCCI, J. (2016). A criminalidade de massa como fator de origem e perpetuação das facções criminosas. 
Violência e criminologia/Luiz Fernando Kazmiercza \& Alberto Pintado Alcázar, organizadores, Paraná,1 ed, p. 4-25, 2016. DURKHEIM, Émile. Lés Régies de la Méthode Sociologique. $9^{a}$ Ed. Lisboa: Editorial Presença, 2004.

Coordenadoria de Pesquisa e Extensão - COPEX

Departamento de Editoraçāo e Divulgaçāo Científica - DEDIC 


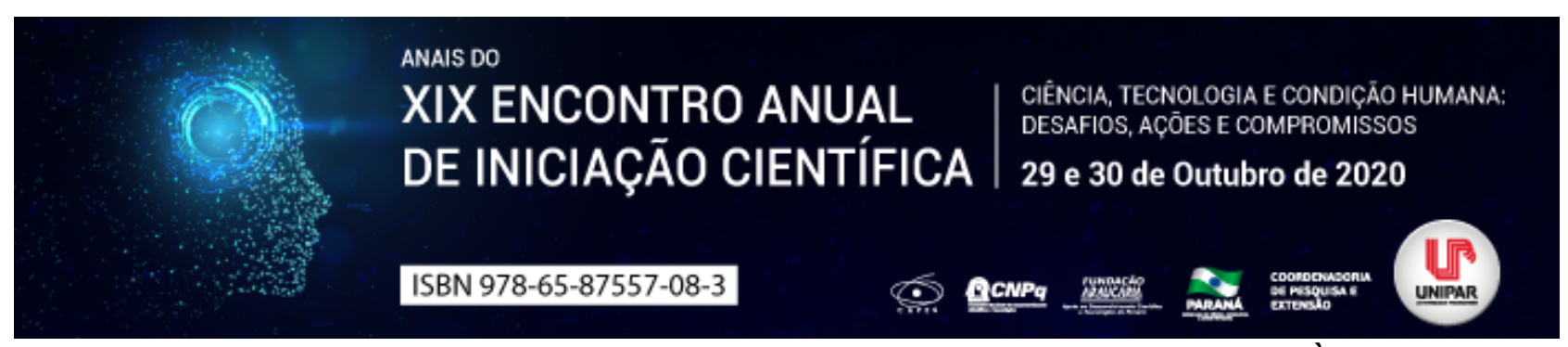

CORPOS NEGADOS: DA INTERSEXUALIDADE E DO RECONHECIMENTO DO TERCEIRO SEXO À LUZ DOS DIREITOS DA PESONALIDADE

${ }^{1}$ Jamille Bernardes da Silveira Oliveira dos Santos, ${ }^{2}$ VALERIA SILVA GALDINO CARDIN

${ }^{1}$ Mestranda bolsista CAPES/PROSUP em Ciências Jurídicas, UNICESUMAR.

${ }^{1}$ Docente da UNICESUMAR

Introdução: A intersexualidade é marcada por corpos ambíguos, os quais apresentam características físicas relacionadas tanto ao sexo feminino quanto ao masculino. Inexiste no Brasil qualquer norma que trate do reconhecimento das pessoas intersexos e, em virtude disso, estas ocupam uma posição de invisibilidade social e têm seus direitos básicos, em especial os da personalidade, negados. Diante deste cenário, vê-se a relevância de pesquisas que possuam por intento promover o reconhecimento da intersexualidade.

Objetivos: Demonstrar o tratamento médico legal dispensado às pessoas intersexos e a necessidade de reconhecimento jurídico do terceiro sexo à luz dos direitos da personalidade.

Desenvolvimento: No meio médico, a intersexualidade é conceituada como Anomalia de Diferenciação do Sexo (ADS) pela Resolução 1.664/2003 do Conselho Federal de Medicina (CFM). De acordo com este documento, a ADS possui alguns espectros, contudo, a pesquisa em tela, concentra-se nos casos conhecidos como 'genitália ambígua', pois, à princípio, esta é a situação que causa maior embate no meio jurídico. Para o CFM, verificado que o recém-nascido possui o genital 'indefinido', este deverá passar por diversos exames médicos, acompanhado de equipe multidisciplinar, a fim de designar qual o seu sexo predominante e, a partir deste resultado, submetê-lo à uma cirurgia de 'correção' do órgão sexual. (BRASIL, 2003). Esta abordagem médica é reforçada juridicamente pela impossibilidade de a Certidão de Nascimento ser lavrada com a designação 'intersexo' como indicativo do sexo da criança. Segundo a Lei de Registros Públicos (Lei n. ${ }^{\circ}$ 6.015/1973), no ato do assentamento civil, os genitores deverão indicar o nome e o sexo da criança (BRASIL, 1973). A norma em comento não define quais sexos podem ser indicados, contudo, na prática social, entende-se como válidos apenas os corpos que possam ser definidos como feminino ou masculino e, portanto, não há a possibilidade de o documento civil ser lavrado com o termo intersexo no espaço destinado à informação sexo. Recorda-se que, a importância da Certidão de Nascimento reside no motivo de que, sem este documento, as pessoas existem apenas no mundo dos fatos, entretanto, não é reconhecida juridicamente (SOUZA, 2008). Alguns países, como a Alemanha, Canadá e Malta, preveem alternativas para o registro da pessoa intersexo, sendo que, Malta possui a legislação mais avançada no que tange à proteção das pessoas intersexos, porquanto, neste país é proibido qualquer procedimento médico cirúrgico de 'correção' da genitália antes da criança ter condições de manifestar, livremente, sua identidade de gênero (ARPEN BRASIL, 2017). Sabe-se que os direitos da personalidade são l"aqueles caracterizados por serem essenciais ao desenvolvimento humano e, por isso, são salvaguardados, pelo Código Civil brasileiro, como direitos absolutos e, portanto, possuem estreita relação com o princípio da dignidade da pessoa humana.l" (GOMES, 1974, p. 168). Sob a ótica destes direitos, tem-se que os Estados precisam garantir a integridade do corpo, a autonomia e a autodeterminação da criança intersexo e ainda garantir que ninguém será sujeito de tratamento médico ou cirúrgico desnecessário durante a infância ou adolescência. (GORISCH; VICTÓRIO, 2018, p. 286).

Conclusão: Por todo o exposto, conclui-se que, o reconhecimento judicial da intersexualidade como um terceiro sexo, representará uma proteção aos direitos das pessoas intersexos e Ihes garantirá a devida visibilidade e dignidade, bem como lhes assegurará os seus direitos da personalidade, em especial no que concerne ao direito à identidade e à integridade física.

\section{Referências}

ASSOCIAÇÃO NACIONAL DOS REGISTRADORES DE PESSOAS NATURAIS. Clipping Jornal. Deutsche Welle (Alemanha) Onde o terceiro gênero é reconhecido no mundo. ARPEN BRASIL, 2017. Disponível em: http://arpenbrasil.org.br/noticia/6024. Acesso em: 25 nov. 2019.

BRASIL. Conselho Federal de Medicina. Resolução n. 1.664 de 13 de maio de 2003. CFM, 2003. Define as normas técnicas necessárias para o tratamento de pacientes portadores de anomalias de diferenciação sexual. 2003. Disponível em: http://www.portalmedico.org.br/resolucoes/cfm/2003/1664_2003.htm. Acesso em: 24 nov. 2019.

BRASIL. Lei n. 6.015, de 31 de dezembro de 1973. Dispõe sobre os registros públicos, e dá outras providências. Disponível em: http://www.planalto.gov.br/ccivil_03/leis/L6015compilada.htm. Acesso em: 15 ago. 2019.

GOMES, Orlando. Introdução ao direito civil. Rio de Janeiro: Forense, 1974.

GORISCH, Patrícia.; VICTÓRIO, Paula Carpes. A patologização do intersexo pela OMS no CID

UNISANTA Law and Social Science, v. 7, n. 3, p. 275-293,

11: Violações dos IRights?. 2018. Disponível em: 
https://periodicos.unisanta.br/index.php/lss/article/view/1714/1411. Acesso em; 20 jul. 2020.

SOUZA, Rogerio de Oliveira. Certidão de Nascimento e segurança jurídica. Revista da EMERJ, Rio de Janeiro, v. 11; n. 43, p. 132-136, jul./ago./set. 2008. Disponível em: http://www.emerj.tjrj.jus.br/revistaemerj_online/edicoes/revista43/Revista43_132.pdf. Acesso em: 24 jul. 2019.

Coordenadoria de Pesquisa e Extensão - COPEX

Departamento de Editoraçāo e Divulgaçāo Científica - DEDIC 


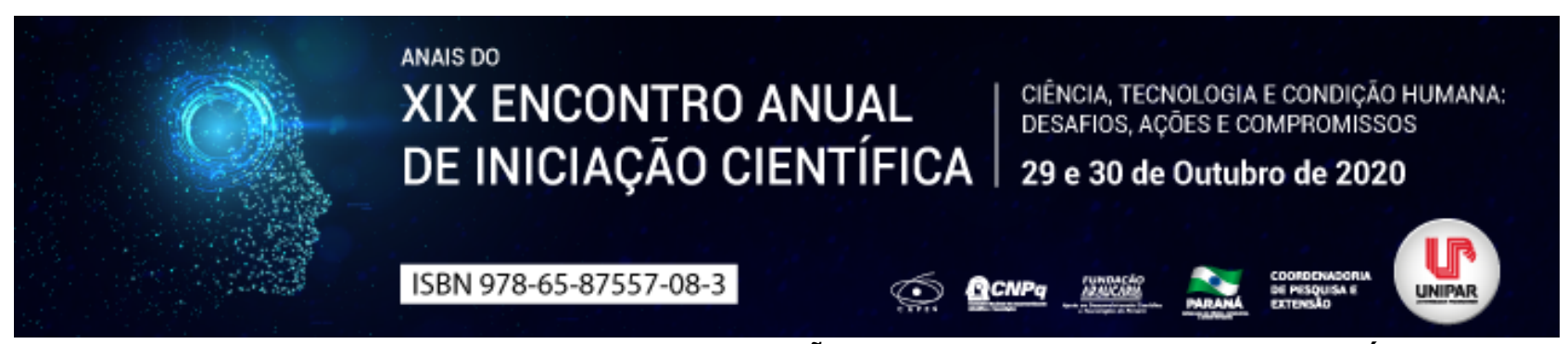

ATIVISMO JUDICIAL: OS RISCOS DA ATUAÇÃO EXTRALEGAL DO PODER JUDICIÁRIO

\author{
${ }^{1}$ MURILO FERNANDES LUCIETTO, ${ }^{2}$ JANE MARA DA SILVA PILATTI
}

\author{
${ }^{1}$ Discente UNIPAR \\ ${ }^{1}$ Docente da UNIPAR
}

Introdução: O debate acerca da atuação extralegal do Poder Judiciário, também conhecido como ativismo judicial, e a extrapolação de uma função contramajoritária em oposição ao papel representativo do Poder Legislativo na conquista de direitos e garantias fundamentais, acaba por sinalizar um risco tanto para o ordenamento jurídico, como para a separação dos poderes. A postura efetivamente discricionária do magistrado acarreta uma insegurança jurídica, a qual é rebatida no contra-argumento de que a adoção de uma conduta mais ativa nas decisões é justificável diante da inércia tanto do Legislativo quando do Executivo, em prol da efetividade dos direitos e garantias fundamentais.

Objetivo: Através dos métodos de abordagem hipotético-dedutivos de caráter descritivo e analítico com base em seleção bibliográfica, buscar-se-á fazer uma análise dos efeitos gerados na atuação extralegal e contramajoritária do controle judicial para o ordenamento jurídico e ao ideário democrático.

Desenvolvimento: As funções do Poder Judiciário são, entre elas, a resolução de conflitos e o dever de defender e resguardar os direitos fundamentais, sendo assim, tudo o que o poder judiciário fizer além de sua competência, ou seja, suas funções típicas é julgado como ativismo judicial. Acredita-se que a necessidade da interferência do judiciário nos outros poderes seja tanto pelas I"regras mal redigidas, conflituosas, com pouca durabilidade. Eis aí, outro desafio ao poder judiciário: mover-se, com razoabilidade, dentro desse cipoal legislativo, que lembra o emaranhado dantesco constituindo selva selvagem, densa e forte I"(DOMBROWOLSKI, 1995, p. 95), ou ainda talvez seja pela pela má qualidade técnica dos demais poderes, entre eles o legislativo, que cria normas muitas vezes incapazes de suprir com a necessidade do povo diante das demandas processuais, deixando assim uma lacuna que deve ser preenchida para a lei ser efetivada, dando espaço para o Ativismo Judicial . Para Luis Felipe Salomão (2018) I"O ativismo relaciona-se ao comportamento dos juízes. Significa conduta que desborda da atuação puramente técnica e judicial. A interpretação ocorre de maneira expansiva.l" Os conceitos e definições variam, Granja (2013) adota um conceito mais simplista ao enfatizar que: Entende-se como ativismo judicial, quando o judiciário age além dos poderes que the são conferidos pelo ordenamento jurídico. Diante de tais definições é que nos questionamos se esta atuação extralegal não representaria um risco para o ordenamento jurídico. Em resposta Ralho (2016, p. 89), traz o apontamento: I"Essa intervenção do Judiciário nas questões de competência tanto do executivo como do legislativo fere gravemente o princípio da separação de poderes, princípio este já objeto de considerações por grandes autores em clássicas obras no decorrer da história.I" Percebe-se, assim, que tal ativismo demasiado fere gravemente a Constituição Federal em sua separação dos poderes, criando uma insegurança jurídica, trazendo a incerteza, já que muitas vezes os juízes têm julgado de forma parcial diante de um apelo social, moral, econômico entre outros. O crescimento de hermenêuticas é imprescindível diante de tantos I"espaços livresl" e do grande crescimento de leis e entendimentos, que são jogados no ordenamento jurídico todos os dias de uma forma crescente como uma I"bola de nevel" (COELHO, 2015). Em contrapartida deve-se observar que, em certas ocasiões, a adoção de uma postura mais ativa do controle judicial é indispensável para que se cumpra a justiça, onde somente aplicando a lei, não conseguimos alcançar a mesma. Neste âmbito, o ativismo é necessário para que se cumpra os direitos fundamentais garantidos pela Constituição Federal e assumidos pelo público (GRANJA, 2013). Diante de tais fatos, os julgadores precisam ter ।"jogo de cintural" para atuar com neutralidade diante do grande poder que lhes são conferidos, para que não manipulem o direito de forma discricionária, e sim, com imparcialidade e respeito às instituições democraticamente instituídas.

Conclusão: Impulsionado pela ascensão institucional do Poder Judiciário, o ativismo judicial apresenta o perfil dicotômico de instrumento na efetivação de diretos fundamentais e mecanismo de exacerbação do controle judicial, acarretando riscos para a sociedade, para a harmonia entre os poderes e sobretudo para com o ordenamento jurídico. Deve-se, assim, sempre analisar com cuidado quando é necessário e quando apresenta algum risco em sua atuação demasiada, preservando-se a neutralidade do poder judiciário, a harmonia com os demais poderes e, compromissado com o avanço social e aprofundamento democrático.

\title{
Referências
}

COELHO, Inocêncio Mártires. Apontamento para um debate sobre o ativismo judicial. Revista brasileira de políticas públicas, volume 5, 2015.

DOBROWOLSKI, Sílvio. A necessidade do ativismo judicial no estado contemporâneo. Sequência: Estudos Juridicos e Politicos. janeiro 
em: https://www.researchgate.net/publication/49618180_A_necessidade_de_ativismo_judicial_no_estado Acesso em: 07 jul. de 2020.

GRANJA, Cícero Alexandre. O ativismo judicial no Brasil como mecanismo para concretizar direitos fundamentais sociais, 01 de dezembro de 2013. Disponível em:

https://ambitojuridico.com.br/cadernos/direito-constitucional/o-ativismo-judicial-no-brasil-como-mecanismo-para-concretizardireitos-fundamentais-sociais/

Acesso em: 10 jul. de 2020.

RALHO, Luiz Renato Adler. Efeitos do ativismo judicial sobre o estado democrâtico de direito. Revista de Direito da Faculdade Guanambi. Ano 2, vol. 2, n. 1. Jan-Jun 2016.

SALOMÃO, Luis Felipe. Ativismo judicial: Para quem e porquê ?. 19 de outubro 2018. Disponível em: em: https://www.migalhas.com.br/depeso/289426/ativismo-judicial-para-quem-e-por-que.

Acesso em: 15/04/2020.

Coordenadoria de Pesquisa e Extensāo - COPEX

Departamento de Editoraçāo e Divulgaçāo Científica - DEDIC 


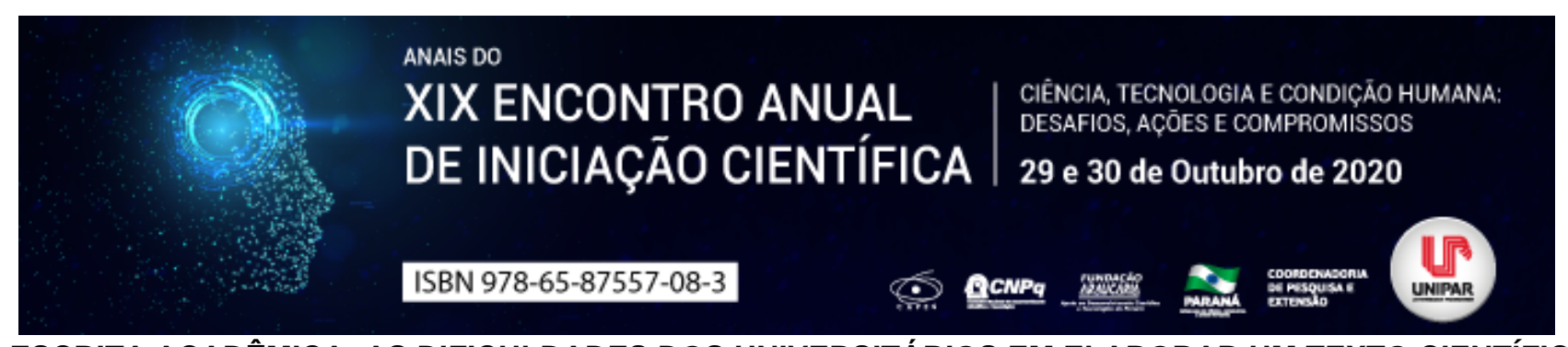

A ESCRITA ACADÊMICA: AS DIFICULDADES DOS UNIVERSITÁRIOS EM ELABORAR UM TEXTO CIENTÍFICO

\author{
${ }^{1}$ SHEILA GONCALVES GOMES, ${ }^{2}$ VIVIANNE AUGUSTA PIRES
}

\author{
${ }^{1}$ Acadêmico do PIC/UNIPAR \\ ${ }^{1}$ Docente da UNIPAR
}

Introdução: A escrita acadêmica é um manifesto de ideias, valores, sendo importante para a formação individual, cultural e social de um indivíduo, seja fora ou dentro de um contexto educacional. É a forma como o sujeito manifesta seus pensamentos desde os primeiros anos de sua vida escolar, que se estende ao longo de sua trajetória, até a formação universitária. Atualmente, as exigências das Instituições de Ensino Superior (IES), se remetem as bases do conhecimento científico, como saber ler, interpretar e escrever, de acordo com os padrões mínimos e normas para os trabalhos acadêmicos, preestabelecidos pela Associação Brasileira de Normas Técnicas (ABNT), que visa organizar a elaboração de trabalhos e facilitar a busca de informações dentro do processo de comunicação e conhecimento científico.

Objetivo Analisar as dificuldades dos acadêmicos do ensino superior na elaboração de textos científicos, evidenciando os mesmos na escrita acadêmica.

Desenvolvimento: Escrever não é um ato natural, é uma atividade que gera muita angústia e frustração entre os universitários, pois na cabeça de quem escreve, as palavras parecem ser claras e objetivas, porém, quando posta em prática simplesmente desaparecem. Não é fácil e nem espontâneo para aqueles que fazem da escrita um afazer cotidiano (jornalistas, escritores) nem para os que têm na escrita uma de suas principais atividades, como os profissionais das ciências sociais e das humanidades. (MARTíN, p. 1, 2018). Ainda segundo (MARTíN, 2018), as dificuldades dos acadêmicos não está e nem deve estar na escrita, mas na construção de ideias, pois o conhecimento científico se constrói por adição e, em alguns casos por contradição com conhecimentos anteriores. A escrita acadêmica, em algumas universidades brasileiras não é uma disciplina obrigatória na grade curricular. No entanto, se torna cada vez mais recorrente a exigência da escrita científica, como a publicações de periódicos e artigos no ensino superior. A pressão pela publicação se torna ainda mais dramática quando consideramos que cada vez mais cedo se exige dos estudantes publicações, sem necessariamente oferecer os recursos para que elas sejam factíveis e de uma qualidade aceitável. (MARTíN, p.4, 2018). Uma das maiores dificuldades encontradas pelos universitários, na elaboração de um texto científico, está na falta de tempo para escrever, devido aos afazeres profissionais, pessoais, e também na falta de organização de tempo para o mesmo. Além de dificuldades que alguns acadêmicos desenvolveram desde o ensino médio, em alguns casos por falta de uma boa metodologia de ensino e aprofundamento no aprendizado, relacionados a leitura e interpretação e na escrita de redações. O medo da rejeição de um texto científico, também se torna um empecilho no mundo acadêmico para desenvolver a escrita, pelo fato da cobrança por parte de professores e orientadores ser rigorosa em todos os requisitos de acordo com as normas ABNT para a apresentação de trabalhos, sendo o pesadelo de alguns universitários. No entanto, cada vez mais a escrita digital faz parte das práticas cotidianas das Universidades, onde a troca de mensagens é uma ação recorrente e incorporada à rotina acadêmica. A tecnologia dos computadores pessoais vem desenvolvendo novas linguagens, estratégias e possibilidades, transformando os contextos em que se escreve. (DAUSTER, et al, p.5, 2007). Com base nesta mesma ideia de tecnologia Fonseca (2019), considera que a geração do conhecimento no ensino superior deve se comprometer com a formação de estudantes capazes de compreender os discursos e os dizeres veiculados pelos textos científicos, de forma que consigam afinar a sua visão sobre ciência para escrever, ou seja, as Universidades devem oferecer recursos para que seus graduandos melhorem e estudem suas escritas acadêmicas, desenvolvendo assim bons textos científicos.

Conclusão: Conclui-se que, a elaboração de um texto científico não é uma simples ação cotidiana de um universitário, requer tempo para pesquisa e a escrita, pois refere-se ao resultado de uma investigação em diálogo com a bibliografia prévia sobre determinado assunto. No entanto, se define a uma realidade onde acadêmicos do ensino superior encontram dificuldades em sua elaboração, por falta de conhecimento básico, medo da rejeição, entre outros. Por fim, foi constatada a importância de recursos como cursos, palestras, aulas, disciplinas, projetos, que devem ser ofertados pelas Universidades para complementar e desenvolver estímulo ao conhecimento e a escrita científica.

\title{
Referências
}

DAUSTER, Tânia et al. Mundo acadêmico - professores universitários, práticas de leitura e escrita e diversidade social. Avá. n.10, p.119-131. 2007.

FONSECA, Janaína. Z. B. Universidade e produção de conhecimento na formação inicial: Uma estratégia didática para o ensino da escrita acadêmica. Trab. Ling.Aplic. n.58.3, p.1264-1281. 2019. 
MARTÍN, Eloísa. Ler, escrever e publicar no mundo das ciências sociais. Revista Sociedade e Estado. v. 33 n. 3 , p. $941-961$. 2018.

Coordenadoria de Pesquisa e Extensão - COPEX

Departamento de Editoraçāo e Divulgaçāo Científica - DEDIC 


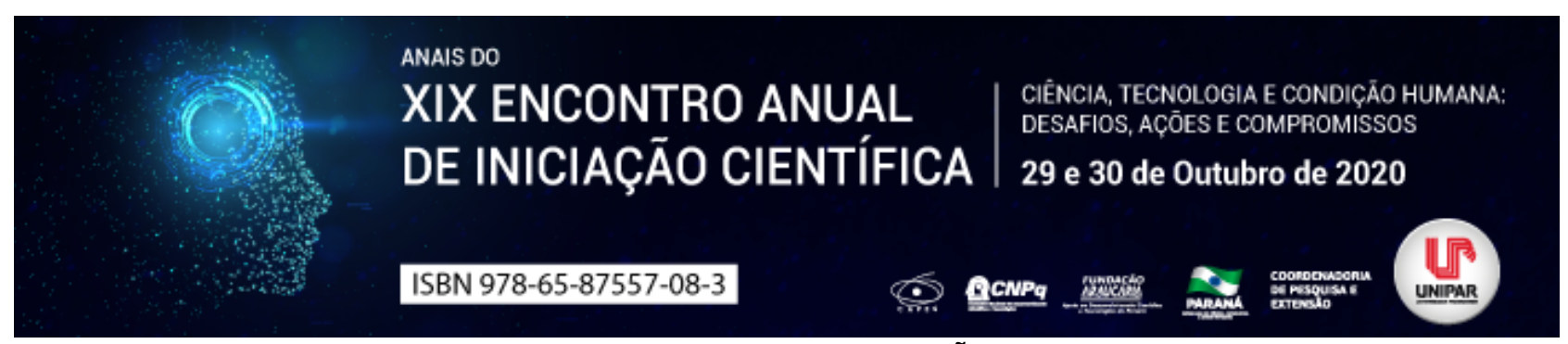

A LINGUAGEM COMO FERRAMENTA DE DISSEMINAÇÃO DO RACISMO DE TODO DIA

\author{
${ }^{1}$ KAROLYNE RIBEIRO DA CUNHA, ${ }^{2}$ NIKITA DE FREITAS,${ }^{3}$ EMANUEL JOSE LAHOS BORGES, ${ }^{4}$ CAMILA BATISTA DALLA \\ VECCHIA, ${ }^{5}$ MARIANA GUILHERME GONCALVES, ${ }^{6}$ CLAUDIA LOPES PERPETUO
}

\footnotetext{
${ }^{1}$ Acadêmica do Curso de Psicologia da UNIPAR

${ }^{1}$ Acadêmica do Curso de Psicologia da UNIPAR

${ }^{2}$ Acadêmico do Curso de Psicologia da UNIPAR

${ }^{3}$ Acadêmica do Curso de Psicologia da UNIPAR

${ }^{4}$ Acadêmica do Curso de Psicologia da UNIPAR

${ }^{5}$ Docente da UNIPAR
}

Introdução: Este resumo foi construído a partir de discussões realizadas no Programa de Iniciação Científica no projeto intitulado: Psicologia e Interseccionalidades: os marcadores sociais de raça/etnias e gênero, a partir do qual investiga-se e discute-se teoricamente o conceito de interseccionalidade, visando compreender as articulações dos diferentes marcadores sociais (raça/etnia, gênero, entre outros) e como estes se relacionam e atravessam a vida dos sujeitos. A partir dessas discussões buscou-se nesse trabalho refletir sobre como o vocabulário da sociedade se constrói com o passar do tempo, provocando atitudes agressivas e que desqualificam o negro, isso como consequência do racismo estrutural tão presente nas formas de conviver atualmente, podemos perceber o racismo e a discriminação da população negra velado a partir das brincadeiras , piadas e no uso de expressões linguísticas no cotidiano das relações.

Objetivo: Discutir o racismo linguístico expresso em atitudes e falas discriminatórias no cotidiano e qual contribui para perpetuação do racismo estrutural.

Desenvolvimento: Em primeiro plano, é de suma importância considerar o contexto da formação dos povos e suas formas de se relacionar com o outro. A escravidão, teve seu fim há muitos anos, mas deixou marcas que geram discriminação e preconceito linguístico contra a população negra, com termos que ao longo do tempo foram naturalizados e são usados de geração em geração e no nosso cotidiano. Não podemos negar que as palavras tem o poder de nos atingir, visto que modelam sentimentos e emoções, como podemos ver em Vieira (2019), o preconceito racial disseminado sob a forma linguística, o seu uso intenso faz com que os falantes incorporem valores preconceituosos que permeiam a linguagem e passem a considerá-los como seus. (VIEIRA, 2019, p.3). O uso de termos como: criado-mudo, denegrir, pé na cozinha, mulata e dia de branco, fazem parte de um vocabulário extenso que se faz presente no discurso discriminatório da população. Termos que trazem significados fortes que ao investigar encontramos histórias de escravos que perderam a língua por não terem o direito de se mexer e falar como a história do criado mudo por volta de 1820, época da escravidão, palavras usadas em contextos de ofensa que remetem ao negro, definir a cozinha como único espaço da mulher e sexulizar seus corpos ao mesmo tempo, e colocar apenas o trabalho do homem branco como o único digno escondendo o peso do trabalho escravo e sem reconhecimento. Estas, são algumas das expressões tão presentes no vocabulário, palavras que levam significados que podem ofender o indivíduo de pele retinta, e esconder o racismo que está por trás das mesmas. Diante desse contexto, não é possível compreender o racismo somente como derivação automática dos sistemas econômico e político, como é possível ver em Almeida (2019), pois a estrutura do racismo está ligada às peculiaridades da formação social. (SILVA, 2019, p.55). Assim, fica visível a necessidade de mudança no momento de formar o vocabulário pois é desde a infância que fazemos a construção de pensamentos e crenças. Sendo importante refletir a mudança que precisamos provocar em nós mesmos para que seja possível disseminar a reflexão e o movimento de luta anti racista.

Conclusão: Considerando os fatos expostos, mesmo sendo um assunto não tão explorado o quanto deveria, este já se faz de grande importância para que possamos buscar melhores condições no tratamento direcionado aos negros e repensar sobre o vocabulário usado diariamente, para que possamos desvelar o preconceito racial que está presente nas piadas, palavras e expressões que são naturalizadas nos nossos discursos cotidianos.

\title{
Referências
}

ALMEIDA, S. Racismo estrutural. 3 ed. São Paulo: Sueli Carneiro, Pólen, 2019.

FERREIRA, H, B, A. Mini dicionário: o dicionário da língua portuguesa. 8 ed. Curitiba: Positivo, 2010. 


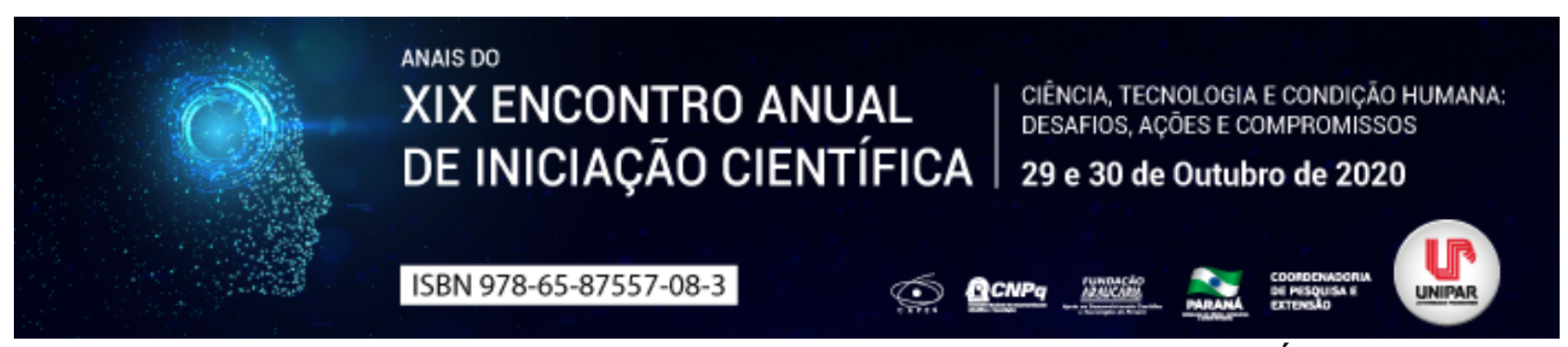

O PROCESSO CIVIL BRASILEIRO E SEU PAPEL NO SISTEMA DEMOCRÁTICO

\title{
${ }^{1}$ LUIZA CRISTINA RODRIGUES MENDES, ${ }^{2}$ ALBINO GABRIEL TURBAY JUNIOR
}

\author{
${ }^{1}$ Acadêmico do PIC/UNIPAR \\ ${ }^{1}$ Docente da UNIPAR
}

Introdução: Na perspectiva de ciência jurídica e de ser produto da cultura social, o direito processual civil está sujeito a constante transformação e adaptação de suas regras e princípios processuais à realidade social, isto é, a norma processual civil exterioriza a evolução da sociedade, marcada pelo contexto cultural contemporâneo. Nessa conjuntura, o Código de Processo Civil de 2015, estabeleceu-se como legítima plataforma democrática, de modo a ampliar a efetividade da cidadania no Estado Democrático de Direito.

Objetivo: Analisar os principais pontos do processo civil contemporâneo que representam sua função no Estado Democrático.

Desenvolvimento: Inicialmente, impende explanar que no século XIX existiam dois grandes modelos processuais, o chamado liberalismo processual em que o juiz, representante do estado, detinha uma função passiva de manter a ordem processual, enquanto era concedida maior autonomia as partes; e o movimento denominado de socialização processual que, em oposição, enfraqueceu o poder das partes, reforçando os poderes dos magistrados (MOTTA; HOMMERDING, 2013, p. 186). Todavia, ambos os modelos foram insuficientes para garantir a efetividade da tutela jurisdicional em um Estado Democrático de Direito, sendo que o atual modelo processual neoliberal preza pela necessidade de construir um ambiente processual que guarde a autonomia do Direito, bem como, que zele pelo tecido vivo constitucional, que tenha por base uma jurisdição democráticoconstitucionalizada (HOFFMAM; MARAIS, 2016, p. 268). Desse modo, o Código de Processo Civil de 2015 incluiu no ordenamento jurídico, dispositivos legais e princípios que evidenciam a aproximação desta ciência jurídica com o texto constitucional, refletindo o compromisso democrático do direito processual civil. Sendo que, este viés de democracia deliberativa, funda-se em uma participação ativa das partes, de modo a estabelecer a cooperação e o diálogo durante todo o processo, destacando-se, neste contexto, o direito fundamental ao contraditório, o qual garante a efetiva participação processual, consistente na possibilidade de a parte conhecer e, querendo, contradizer tudo o que for alegado e produzido nos autos, direito de influenciar a formação da convicção do julgador, bem como, veda-se decisões-surpresa (MARINONI; ARENHART; MITIDIERO, 2016, p. 178-179). Igualmente, os princípios processuais da isonomia e da cooperação, previstos respectivamente nos artigos $6^{\circ}$ e $7^{\circ}$ do Código de Processo Civil (2015), exteriorizam importante fundamento do Estado Democrático. Outrossim, diante do sistema da democracia representativa presente no sistema brasileiro, o processo civil apresenta uma função essencial de aproximar o diálogo entre o Estado (julgador) e a sociedade (partes), possibilitando o efetivo exercício da democracia. Para tanto, segundo Didier Jr. (2017, p. 49) se faz necessário reconhecer a hermenêutica jurídica atual, a qual possibilita a criação de um papel normativo a partir da função jurisdicional, razão pela qual deve o julgador, diante do caso concreto, após efetiva participação das partes, realizar a interpretação da norma, garantindo a construção de um processo civil democrático em consonância com a constituição, na medida em que a análise e interpretações das leis não se faz de modo autoritário ou inquisitório pelo Estado-juiz, mas sim como consequência do diálogo processual. Ademais, é possível pensar no processo civil como forma democrática de fiscalização daqueles que são eleitos pelo povo, considerando que os membros dos poderes legislativos e executivos são considerados representantes do povo, eleitos periodicamente pelo voto, e o processo civil pode ser utilizado como instrumento para impugnação dos atos praticados por esses poderes.

Conclusão: Portanto, o direito processual civil, indubitavelmente, é considerado importante instrumento no sistema democrático, uma vez que através do direito fundamental ao contraditório, princípios como da isonomia e cooperação, alinhados a possibilidade de questionamento de leis e atos do Poder Público pela via judicial, proporcionam a efetiva participação das partes e, em consequência, o exercício da democracia.

\section{Referências}

BRASIL. Lei 13.105 de 16 de março de 2015. Código de Processo Civil. Diário Oficial da União, Seção 1, 17 de março de 2015, p. 1.

DIDIER JR, Fredie. Curso de direito processual civil: introdução ao direito processual civil, parte geral e processo de conhecimento. 19ª Ed. Salvador. Editora Jus Podivm. 2017. 880 p.

MOTTA, Francisco José Borges; HOMMERDING, Adalberto Narciso. O que é um modelo democrático de processo? Revista do Ministério Público do RS. Porto Alegre, n. 73, p. 183-206, 2013.

HOFFMAM, Fernando; DE MORAIS, Jose Luis Bolzan. Fundamentos hermenêuticos para um processo civil constitucionalmente adequado. Revista da Faculdade de Direito-RFD-UERJ. Rio de Janeiro, n. 30, p. 266-296, dez. 2016. 
MARINONI, Luiz Guilherme; ARENHART, Sérgio Cruz; MITIDIERO, Daniel. O novo processo civil. $2^{\text {a }}$ Ed. Revista, atualizada e ampliada. São Paulo. Editora Revista dos Tribunais, 2016, 606 p.

Coordenadoria de Pesquisa e Extensão - COPEX

Departamento de Editoraçāo e Divulgaçāo Científica - DEDIC 


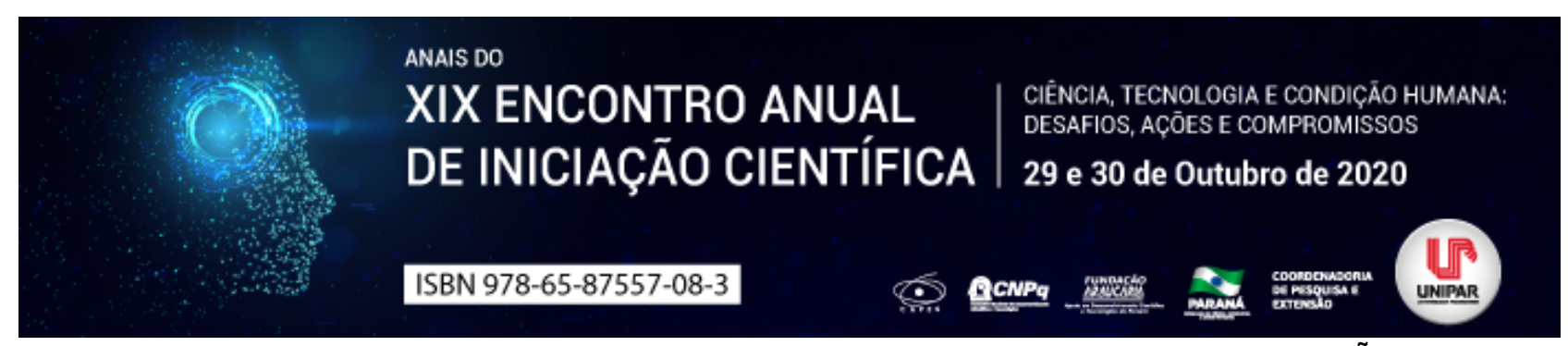

CONTROLE DE CONSTITUCIONALIDADE DIFUSO: ASPECTOS RELEVANTES DE SUA APLICAÇÃO NOS TRIBUNAIS CONFORME DISPOSIÇÕES DO CÓDIGO DE PROCESSO CIVIL DE 2015

\author{
${ }^{1}$ ANA PAULA QUEIROZ, ${ }^{2}$ ADRIELLI PINHO DA SILVA, ${ }^{3}$ MARIA ALICE ORTIZ, ${ }^{4}$ ADRIANE HAAS
}

${ }^{1}$ Acadêmica do PIC/UNIPAR

${ }^{1}$ Acadêmica do PIC/UNIPAR

${ }^{2}$ Acadêmica do PIC/UNIPAR

${ }^{3}$ Docente Orientadora do PIC/UNIPAR

Introdução: O controle de constitucionalidade difuso foi consagrado no ordenamento brasileiro desde a Constituição de 1891, sua aplicação compete a qualquer órgão do Poder Judiciário, desde os juízes de primeiro grau, os tribunais, e até mesmo o guardião da Constituição, o Supremo Tribunal Federal - STF. Caracteriza-se por ser exercido de forma incidental nos casos onde o principal objetivo é a resolução da lide em um caso concreto. Existem, porém, certas peculiaridades que devem ser observadas quando for arguida a inconstitucionalidade no âmbito dos Tribunais, que é objeto do presente.

Objetivo: Abordar as peculiaridades da arguição de inconstitucionalidade no âmbito dos tribunais, a cláusula de reserva de plenário, as suas exceções e demais aspectos a serem observados nos termos do Código de Processo Civil de 2015.

Desenvolvimento: Em conformidade com o princípio da Supremacia da Constituição, as normas hierarquicamente inferiores devem estar em consonância com as disposições da norma parâmetro. Para assegurar tais disposições, são utilizados os mecanismos do controle de constitucionalidade, e dentre as suas formas, destaca-se o controle de constitucionalidade difusoconcreto. Marcelo Novelino (2019), enaltece que o controle difuso vem sendo consagrado no Brasil desde a primeira Constituição Republicana brasileira, podendo ser exercido por qualquer órgão, de acordo com a sua competência. A notoriedade do controle de constitucionalidade difuso foi adquirida principalmente como aponta Lenza (2018), com o voto do Juiz Marshall, no célebre caso norte-americano Marbury x Madison de 1803, onde declarou-se que, em caso de conflito entre lei infraconstitucional e a Constituição, deve ser aplicada a última, pelo critério hierárquico para se resolver antinomias da norma. Portanto, ao contrário do controle de constitucionalidade concentrado, que é exercido unicamente pelo STF, de forma abstrata, o controle difuso de constitucionalidade possui como finalidade, a proteção de direitos subjetivos, devendo ocorrer sua análise de forma incidenter tantum, na fundamentação da decisão (Novelino, 2019). No âmbito dos Tribunais, a aplicação do controle difuso de constitucionalidade é previsto pelo incidente de arguição de inconstitucionalidade em tribunal, que possui certas peculiaridades a serem verificadas, como é o caso da cláusula de reserva de plenário ou full bench, a qual determina a regra de competência funcional, onde a declaração de inconstitucionalidade somente poderá ser declarada pelo pleno ou órgão especial do Tribunal, em sua maioria absoluta, conforme disposto no art. 97 da CF, ficando vedado o tribunal afastar a norma inconstitucional de acordo com a Súmula Vinculante $n^{\circ} 10$, ainda que este não declare expressamente a inconstitucionalidade. Quanto à natureza

esse incidente não é recurso nem ação autônoma nem outro meio de impugnação atípico de decisão judicial. Ele é, ao contrário, uma etapa no processo da criação da decisão, e não da sua impugnação (DIDIER, 2020, p. 836). O CPC de 2015, prevê este incidente em seu artigo 948, e apresenta no parágrafo único do artigo 949 a exceção da cláusula de reserva de plenário, sendo esta cabível nas questões em que já existam pronunciamentos pelo pleno ou órgão especial dos Tribunais, ou pelo STF.

Conclusão: Existem mecanismos e instrumentos de controle de constitucionalidade, que asseguram a supremacia da CF. A inconstitucionalidade pode ser arguida nos casos concretos, de forma incidental, perante a qualquer órgão jurisdicional, a fim de garantir os direitos subjetivos das partes através do controle de constitucionalidade difuso. Quando o incidente de inconstitucionalidade é alegado nos Tribunais, devem ser observadas a particularidades determinadas pela CF e pelo CPC, como a regra da full bench, que por sua é mitigada face ao parágrafo único do art. 949, do CPC/2015.

\title{
Referências
}

BRASIL. Constituição da República Federativa do Brasil de 1988. Disponível em: . Acesso 28 de junho de 2020.

BRASIL. Lei $\mathrm{n}^{\circ}$ 13.105, de 18 de Março de 2015. Disponível em: http://www.planalto.gov.br/ccivil_03/_ato20152018/2015/lei/l13105.htm. Acesso em 28 de junho de 2020.

BRASIL. Supremo Tribunal Federal. Súmula Vinculante $n^{\circ} 10 . \quad$ Disponível em: http://www.stf.jus.br/portal/jurisprudencia/menuSumario.asp?sumula=1216. Acesso em: 28 de agosto de 2020.

DIDIER JR, Fredie. CUNHA, Leonardo Carneiro da. Curso de Direito Processual Civil. Volume 3. Meios de impugnação às decisões judiciais nos tribunais. 17 ed. Salvador. Juspodvim, 2020, p.836. 
LENZA, Pedro. Direito Constitucional Esquematizado. 22 ed. São Paulo. Editora: Saraiva Educação, 2018. p. 281. NOVELINO, Marcelo, Curso de Direito Constitucional. 14 ed. Salvador. Juspodvim, 2019. p. 206.

Coordenadoria de Pesquisa e Extensão - COPEX

Departamento de Editoraçāo e Divulgaçāo Científica - DEDIC 


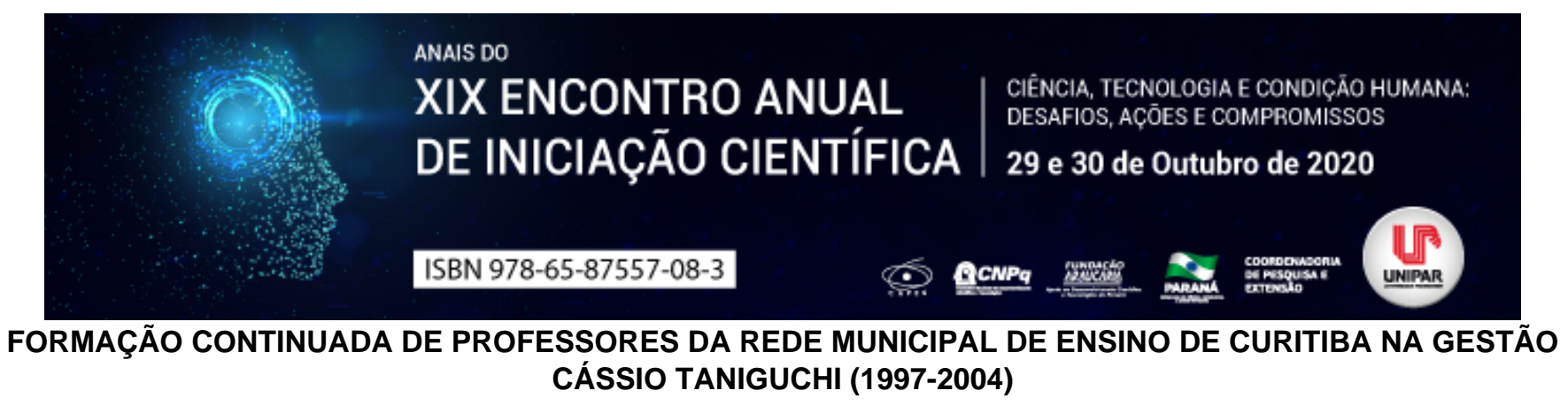

${ }^{1}$ Eduarda Venturini Câmara, ${ }^{2}$ ALBONI MARISA DUDEQUE PIANOVSKI VIEIRA

${ }^{1}$ Graduanda do curso de Pedagogia na Pontifícia Universidade Católica do Paraná, campus Curitiba.
${ }^{1}$ Orientadora e professora do curso de Pedagogia na Pontifícia Universidade Católica do Paraná, campus Curitiba. Doutora em
Educação.

Introdução: Trata-se de pesquisa sobre as relações entre as políticas públicas adotadas pela Rede Municipal de Ensino de Curitiba (RME) no período compreendido entre 1997 e 2004 e a formação continuada de professores. As políticas educacionais adotadas pela Prefeitura Municipal de Curitiba, em relação à formação continuada de professores, tiveram efeito direto no fazer pedagógico do professor e na aprendizagem. O olhar afastado de quem se dedica ao estudo dessas intercorrências possibilita analisar as iniciativas correspondentes aos programas de capacitação existentes, à luz da época em que ocorreram, discutindo suas implicações na prática pedagógica.

Objetivos: Essa pesquisa tem por objetivo geral analisar as relações entre as políticas públicas de educação adotadas pela Rede Municipal de Ensino de Curitiba, no período compreendido entre 1997 e 2004 e a formação continuada de professores e, por objetivos específicos, verificar como foi realizada a formação continuada de professores no período 1997 a 2004 , na Rede Municipal de Ensino de Curitiba; investigar como a formação continuada de professores da RME repercutiu na prática pedagógica docente; e catalogar os documentos relativos à formação continuada de professores na RME de Curitiba, no período pesquisado.

Materiais e Métodos: Para que a pesquisa fosse desenvolvida, num primeiro momento foi utilizado da pesquisa bibliográfica, fundamentando cada um dos objetivos da pesquisa. Em um segundo momento, iniciou-se a coleta de dados, em fontes documentais, que serviram como base do estudo acerca do tema. Com a análise de fontes secundárias (livros e artigos científicos), foram encontradas diversas maneiras de abordar o tema proposto, o que permitiu à pesquisadora entrar em contato com uma gama de ideias diversificadas de acordo com o tema produzido, e, por fim, sua análise, para então alcançar os objetivos da pesquisa. Assim, autores como Barbosa \& Fernandes (2017), Barros (2019), Boneti (2011), Oliveira (2010), Vieira (2010), entre outros, foram utilizados durante o processo de pesquisa.

Resultados: Em 1997, com o projeto Digitando o Futuro, os cursos de formação continuada passaram a ser voltados para a educação ambiental e as novas tecnologias, em fase inicial, propiciaram um processo de informatização nas escolas. Morais (2009) destaca que foram propostos cursos como: educação ambiental no zoológico; autoconscientização em educação ambiental - visão naturista; enfoque curricular centrado na integração professor-ensino; a construção do conhecimento linguístico na interação social; ciências na era da contestação; da consciência corporal à consciência ecológica; os mass media difusores da cultura primeira e, além desses, também cursos sobre geografia em canção; ação do professor: compromisso e limite; práticas de educação ambiental urbana; projeto terra viva: melhoria da qualidade de vida; do senso comum ao conhecimento científico e capacitação para professores regentes em educação física . (MORAIS, 2009, p. 64). Pode-se notar que, nesse período, os cursos voltados às tecnologias superavam os de outras áreas, porém, da mesma forma, ainda havia os cursos específicos por área. Taniguchi, em seu segundo mandato, deixa evidente a quase nulidade da oferta de cursos em outras áreas e a predominância do trabalho com as tecnologias.

Discussão: Posteriormente à análise e compreensão dos dados sobre as políticas públicas e as políticas públicas educacionais adotadas para a formação dos professores, foi possível perceber a importância da formação continuada para a educação básica e o quanto uma educação efetiva e de qualidade depende do investimento do Estado. Segundo Vieira (2010), o conceito de formação de professores traduz múltiplas possibilidades voltadas à superação de si mesmo, tanto do ponto de vista pessoal como profissional do desenvolvimento humano. No caso da formação docente, requer um encontro entre pessoas adultas que aspiram modificar-se favoravelmente o contexto escolar em que atuam (VIEIRA, 2010, p. 253). Dessa forma, o professor que entrava no processo de formação continuada ia buscar novos pensamentos para sua melhoria e para a melhoria do contexto em que estava inserido. O estar em formação era algo livre e que deveria ser criativo, de uma forma que implicasse em um investimento pessoal para que, assim, o professor construísse sua identidade.

Conclusão: Na gestão do prefeito Cássio Taniguchi foi aceita a diversidade e, a partir dela, inseridos novos projetos, com base no princípio de que somos todos diferentes. Sendo assim, os conteúdos escolares foram direcionados para que todas as diferenças fossem transformadas em um convívio pacífico. Em sua administração, a cidade, mais do que nunca, passou a ser ensinada sobre o meio ambiente, poluição e afins. 


\section{Referências}

BARBOSA, Marinalva Vieira; FERNANDES, Natália Aparecida Morato (org.). Políticas públicas para formação de professores.
Em
Aberto, Brasília,
v. 30 ,
98,
p. 1-231,
jan./abr.
2017.
Disponível

em: http://portal.inep.gov.br/documents/186968/485895/Pol\%C3\%ADticas+p\%C3\%BAbli

Coordenadoria de Pesquisa e Extensão - COPEX

Departamento de Editoraçāo e Divulgaçāo Científica - DEDIC 


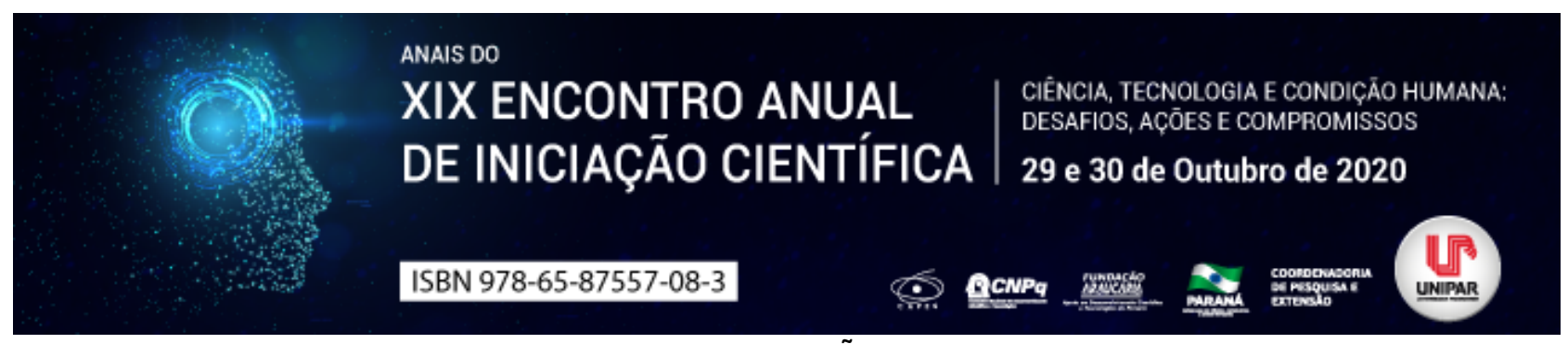

A ARBITRAGEM COMO FORMA ALTERNATIVA DE RESOLUÇÃO DE CONFLITOS NOS CONTRATOS EMPRESARIAIS

\author{
${ }^{1}$ ADRIANO SILVEIRA, ${ }^{2}$ ALEXANDRE MAGNO AUGUSTO MOREIRA
}

${ }^{1}$ Acadêmico do PIC - UNIPAR

${ }^{1}$ Docente da UNIPAR

Introdução: Este trabalho tem por objetivo elucidar o uso do instituto da arbitragem como método alternativo na resolução de litígios em contratos empresariais. Nesta senda, pretende-se abordar as principais características deste instituto, assim como, suas vantagens em face do judiciário brasileiro. O presente trabalho será desenvolvido sobre o método de pesquisa dedutivo, com revisão bibliográfica.

Objetivo: Abordar o instituto da Arbitragem como alternativa viável para solução dos litígios empresariais.

Desenvolvimento: O monopólio jurisdicional do Estado foi introduzido pela Democracia como um meio de afastar a autotutela, e assim evitar os descalabros da lei do mais forte. Neste sentido, a ideia a partir da teoria dos poderes democráticos expressada por Bonavides (2000, p. 177) descreve que, (..) A liberdade política exprimirá sempre o sentimento de segurança, de garantia e de certeza que o ordenamento jurídico proporcione às relações de indivíduo para indivíduo, sob a égide da autoridade governativa. Contudo, com o passar do tempo o judiciário começou a dar sinais de sobrecarga, tendo em vista que com a morosidade se acumulou as demandas, tornando o processo tardio. Para resolver tal problemática foram introduzidos microssistemas dentro e fora do judiciário para amenizar a crise, sendo inseridas a Conciliação, a Mediação e a Arbitragem para pacificação da situação (BACELLAR. 2012, p. 142). Aqui cabe destacar a Arbitragem, um método de resolução de conflitos extrajudicial na forma Heterocompositiva, regrado pela Lei 9.307/1996, que somente ocorrerá nos casos convencionados previamente pelas das partes, pois enquanto o juiz sustenta seu poder na lei, o árbitro sustentará na submissão das partes (BACELLAR. 2012, p. 122). O legislador, no artigo $4^{\circ}$ menciona expressamente como serão resolvidos os litígios com cláusula compromissória, e no artigo $9^{\circ}$ dispõe sobre a resolução com compromisso arbitral. Assim sendo, este instituto compreende tanto a cláusula compromissória, (convenção prévia, antes do surgimento do conflito entre as partes da relação contratual) quanto o compromisso arbitral (o animus de submeter o litígio existente a apreciação do juízo arbitral, afastando a tutela jurisdicional estatal contrato de renúncia a atividade estatal) conforme DIDIER JR. (2015, p. 170). A Arbitragem é um método de resolução de conflitos que nos contratos empresariais tem se mostrado mais rápido e eficaz do que a prestação jurisdicional estatal. Dado que este instituto permite que as partes escolham o árbitro especialista para cada demanda, dirimindo os gastos com a prova pericial, pois no judiciário além de arcar com os honorários periciais, também terão que indicar seus assistentes técnicos para amparar a conclusão da prova pericial (BACELLAR. 2012, p. 134). Outro atrativo para utilização da Arbitragem nos contratos empresariais é a confidencialidade que usualmente é utilizado nos compromissos e cláusulas arbitrais como imposição, diante da importância nas relações empresariais, visto que traz para as partes uma reserva de publicidade, inviabilizando qualquer tipo de exposição que denigra a imagem da empresa. Em última análise, a instância única tem-se mostrado mais um atrativo aos empresários, pois tendo sentença arbitral, ocorre a solução do litígio (DE BARROS, 2019, p. 3).

Conclusão: A Arbitragem como método de solução de conflitos se desenvolve muito bem nos contratos empresariais, visto que é muito mais célere do que o modo tradicional de prestação

jurisdicional estatal, traz muitos benefícios aos empresários, os quais tem pressa de solucionar seus litígios para retomar suas atividades empresariais o mais breve possível.

\title{
Referências
}

BRASIL. Lei $\mathbf{9 . 3 0 7}$ de 23 de Setembro de 1996 . Dispõe sobre a arbitragem. Disponível em: http://www.planalto.gov.br/ccivil_03/leis/l9307. Acesso em: 23 jul. 2020.

BONAVIDES, Paulo. Ciência Política. 10. ed. São Paulo: Malheiros Editores, 2000.

DIDIER JR, Fredie. Curso de direito processual civil: introdução ao direito processual civil, parte geral e processo de conhecimento - 17. ed. - Salvador: Ed. Jus Podivm, 2015.

BACELLAR, Roberto Portugal. Mediação e arbitragem. São Paulo: Saraiva, 2012.

DE BARROS, Maria Gabriella Dignani. A cláusula compromissória como negócio jurídico. Revista de Direito Privado. v. 99, p. 265-281, 2019. 


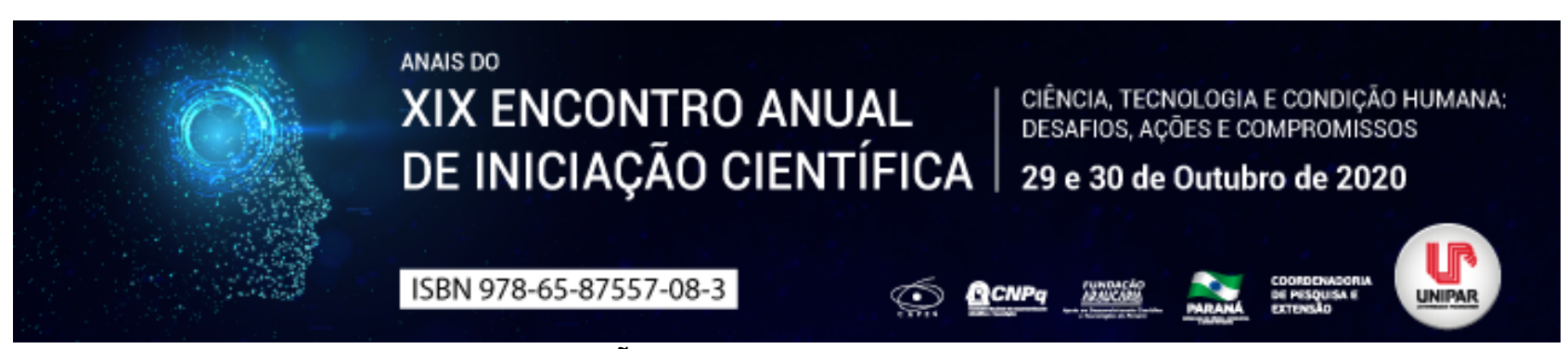

\title{
A CONSTITUCIONALIDADE DA INTERPRETAÇÃO EXTENSIVA QUE EQUIPARA A HOMOTRANSFOBIA AO CRIME DE RACISMO
}

\author{
${ }^{1}$ DIEGO MUNEMORI, ${ }^{2}$ RAFAEL MASSAU KIMURA, ${ }^{3}$ EDUARDO AUGUSTO SALOMAO CAMBI
}

\author{
${ }^{1}$ Acadêmico do PIC/UNIPAR \\ ${ }^{1}$ Acadêmico do PIC/UNIPAR \\ ${ }^{2}$ Docente da UNIPAR
}

Introdução: O constitucionalismo moderno ou pós-positivista é marcado por objetivar a concretização dos direitos fundamentais, deixando a Constituição Federal de ser um mero texto político, para ter força normativa vinculatória. O Supremo Tribunal Federal, como guardião da Constituição e de sua eficácia no plano material, na Ação Direta de Inconstitucionalidade por Omissão n 26 , classificou a homotransfobia como forma discriminatória abrangida pela Lei $n^{\circ} 7.716 / 89$.

Objetivo: Demonstrar que o acórdão proferido na ADO n 26 não feriu o princípio penal da Legalidade, mas protegeu os direitos fundamentais da comunidade LGBTIQ+.

Desenvolvimento: Não obstante a apreensão da comunidade jurídica em verificar, no acórdão proferido na $A D O n^{\circ} 26$, uma suposta usurpação de competência legislativa pelo STF, percebe-se que não houve lesão ao princípio penal da Legalidade. Isso porque a Corte Constitucional não estabeleceu um novo tipo penal, bem como não cominou pena em abstrato, mas se manteve no papel de intérprete da Constituição. Outrossim, não aplicou analogia in malam partem ao considerar a homotransfobia como forma de discriminação e preconceito de raça (racismo), pois o termo raça , encontrado nos tipos penais da Lei $n^{\circ} 7.716 / 89$, é impreciso, não científico, quando utilizado para diferenciar indivíduos ou grupos da espécie humana a partir de características físicas. Conforme afirma Santos et al. (2010) as diferenças mais aparentes (cor da pele, textura dos cabelos, formato do nariz) são determinadas por um grupo insignificante de genes . Dessa forma, como intérprete, coube ao STF precisar o conceito atual de raça , sendo que, para a antropologia moderna, raça é uma construção histórica e social, isto é, as pessoas se dividem segundo o grupo histórico-social que pertencem. Nesse sentido, a interpretação extensiva da Lei $n^{\circ} 7.716 / 89$ não violou o princípio constitucional da Legalidade, uma vez que a norma não foi transportada para outro âmbito jurídico, apenas alastrada de forma intrínseca para atingir sua maior amplitude (ESTEFAM, GONÇALVES, 2018). Portanto, o STF tão somente conferiu interpretação mais ampliada dos termos linguísticos da Lei no 7.716/89, sem extrapolar a mens legis (espírito da lei).

Conclusão: $O$ acórdão do STF proferido na ADO $n^{\circ} 26$, ao tempo que não feriu o princípio penal da Legalidade, elevou a proteção dos direitos fundamentais da população LGBTIQ+, um dos grupos mais vulneráveis da sociedade brasileira, que sofre preconceitos em razão da intolerância quanto ao direito fundamental à orientação sexual, o que confere maior efetividade à dignidade da pessoa humana.

\section{Referências}

BARROSO, L. R. Neoconstitucionalismo e constitucionalização do Direito (O triunfo tardio do direito constitucional no Brasil). Revista de Direito Administrativo, Rio de Janeiro, v. 240, p. 1-42, abr., 2005.

CAMBI, E. Neoconstitucionalismo e neoprocessualismo: direitos fundamentais, políticas públicas e protagonismo judiciário. 1. ed. São Paulo: Almedina, 2016.

ESTEFAM, A.; GONÇALVES, V. Direito Penal Esquematizado: Parte Geral. 7. ed. São Paulo: Saraiva Educação, 2018.

SANTOS, D. J. S. et al. Raça versus etnia: diferenciar para melhor aplicar. Dental Press Journal of Orthodontics, v. 15, n. 3, p. 121-124, 2010.

SCHWARCZ, L. M. Racismo no Brasil. Publifolha, 2001. 


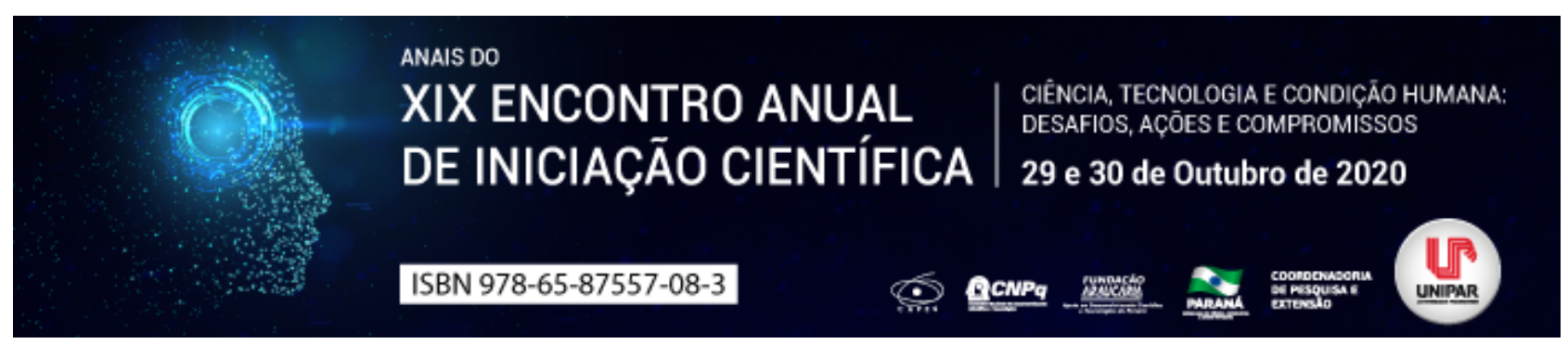

O PAPEL DO BRANCO NA LUTA ANTIRRACISTA

\begin{abstract}
${ }^{1}$ CAMILA BATISTA DALLA VECCHIA, ${ }^{2}$ EMANUEL JOSE LAHOS BORGES, ${ }^{3}$ KAROLYNE RIBEIRO DA CUNHA, ${ }^{4}$ MARIANA GUILHERME GONCALVES, ${ }^{5}$ GIOVANA LABIAK PEREIRA, ${ }^{6}$ CLAUDIA LOPES PERPETUO
\end{abstract}

\author{
${ }^{1}$ Acadêmico do PIC/UNIPAR \\ ${ }^{1}$ Acadêmico do Curso de Psicologia da UNIPAR \\ ${ }^{2}$ Acadêmica do Curso de Psicologia da UNIPAR \\ ${ }^{3}$ Acadêmica do Curso de Psicologia da UNIPAR \\ ${ }^{4}$ Acadêmica do Curso de Psicologia da UNIPAR \\ ${ }^{5}$ Docente e orientadora do PIC/UNIPAR
}

Introdução: Este resumo foi construído a partir de discussões do Programa de Iniciação Científica por meio do projeto intitulado: Psicologia e Interseccionalidades: os marcadores sociais de raça/etnias e gênero, visando compreender as articulações dos diferentes marcadores sociais e como estes se relacionam e atravessam a vida dos sujeitos. Buscou-se, neste trabalho, trazer o marcador social de raça, enfocando as discussões referentes ao papel do branco/a em uma luta antirracista, visto que o racismo se caracteriza é como uma forma de hierarquizar as raças e etnias pelo colonialismo, sendo necessário descolonizar os conhecimentos para evidenciar como as identidades têm sido historicamente silenciadas ou fortalecidas. É importante expor que enquanto acadêmica pertencente à raça branca e à classe média, tenho a percepção da extrema necessidade de um mundo racialmente mais justo onde o conceito de branquitude crítica e acrítica (CARDOSO, 2010) deve ser dissolvido.

Objetivo: Discutir o papel do branco na luta antirracista.

Desenvolvimento: 13 maio de 1888, abolição da escravatura no Brasil pela Lei Áurea ${ }^{1}$. Desde então, mesmo após a libertação da narrativa desumana enfrentada, quase um século e meio depois, isso se repete em tons diferentes (mas não positivos). $O$ racismo vivenciado na sociedade em geral, é um fenômeno que se ancora em crenças e valores que sistematizam e se renovam, marcando a estrutura da distribuição desigual de acesso a oportunidades, trabalho, atenção e poder no cotidiano, na sociedade e nas políticas de Estado (CARREIRA, 2018). Ao discutir as motivações para essa desigualdade, percebe-se que ser branco é considerado como padrão normativo único, o que originou a hierarquização de saberes como produto da classificação racial da população, que segundo Ribeiro (2017), tornou necessário que negros reivindicassem seus direitos de terem voz e vida. É nítido que existe uma cobrança maior em relação a esses individuos como se fossem mais obrigados a falar sobre opressão que os grupos localizados no poder, aqui sendo necessário perceber o papel do branco nessa luta, retomando o fato de que o racismo é um problema que não se restringe a uma luta única e exclusiva dos negros, mas sim da sociedade de maneira geral. Mas o que significa ser branco em uma luta antirracista que tem como base o questionamento dos privilégios brancos? Segundo Carreira (2018), significa retirar as almofadas protetoras que não desenvolvem habilidades de tolerância para com o estresse racial que envolve dialogar sobre o racismo e enfrentar o questionamento sobre os próprios privilégios, pois essa proteção proporciona a desconstrução da importância da abordagem do assunto, tornando-o mais um tema como outro qualquer. Dessa forma, a branquitude acrítica atua pela manutenção dos privilégios simbólicos que a população branca possui, e a branquitude crítica ainda possui essa concepção, mesmo que em discursos velados. Para se tornar um sujeito antirracista, é necessário enfrentar o desconforto dessas discussões, estar aberto a refletir sobre como ser branco se constrói em nossa história de vida, nas nossas relações e nas nossas práticas sociais. É preciso reconhecer que fomos educados/as para nos reconhecermos representantes da universalidade humana, a norma e o mérito ao lugar de poder. A conscientização sobre a magnitude e a complexidade do sofrimento gerado à população negra de nosso país é de extrema importância nesse processo, pois não são somente as violências explícitas, mas também sutis, como os silêncios, os olhares, as omissões e a negação da situação de preconceito vivida por esses sujeitos. Ainda com base nas problematizações de Carreira (2018), como seria possível reeducar o olhar, a escuta e os sentidos? Não basta apenas estudar, conhecer as teorias, é necessário abraçar a literatura, o cinema, a música, buscar por esses sujeitos nas redes sociais, e não apenas desfrutar dessas produções culturais, mas apoiar, compartilhar e valorizar o trabalho desses indivíduos. Também é indispensável que o avanço para políticas que desconstruam a segregação racial fortalecendo a dimensão pública como espaço de todos como condição para o desenvolvimento de uma cultura democrática e promoção de branquitudes antirracistas que compreendam o seu lugar na manutenção de privilégios e na transformação dessa realidade.

Considerações Finais: Uma vez que a branquitude antirracista se apoia na visualização da realidade injusta, percebe-se a necessidade da discussão sobre o lugar do branco nessa luta, não como proprietário, mas como partícipe disposto a encarar essa situação como coautor da reconstrução das relações, do desconforto, medo e desconhecimento, buscando a reeducação 
dos olhares e escutas. É preciso reconhecer a necessidade de dar devida abertura para assumir tudo aquilo que perdemos como seres humanos ao negar a dignidade, os conhecimentos, a história, as culturas e os valores do povo negro. Como Carreira (2018) propõe em sua posição, não se pode cair na armadilha da passividade e acomodação de que somente os sujeitos negros e indígenas têm o que dizer sobre como enfrentar o racismo.

\section{Referências}

13 de maio de 1888 - Dia da Abolição da Escravatura. Biblioteca Nacional, 2015. Disponível em: https://www.bn.gov.br/acontece/noticias/2015/05/13-maio-1888-dia-abolicao-escravatura. Acesso em 26/08/2020.

CARREIRA, Denise. O lugar dos sujeitos brancos na luta antirracista. Revista Internacional de Direitos Humanos, São Paulo, V. 15, N. 28, 127-137, Novembro 2018.

RIBEIRO, Djamila. O que é lugar de fala? Belo Horizonte: Letramento, 2017.

CARDOSO, Lourenço. Retrato do branco racista e anti-racista. Reflexão e Ação: 2010.

Coordenadoria de Pesquisa e Extensão - COPEX

Departamento de Editoraçāo e Divulgaçāo Científica - DEDIC 


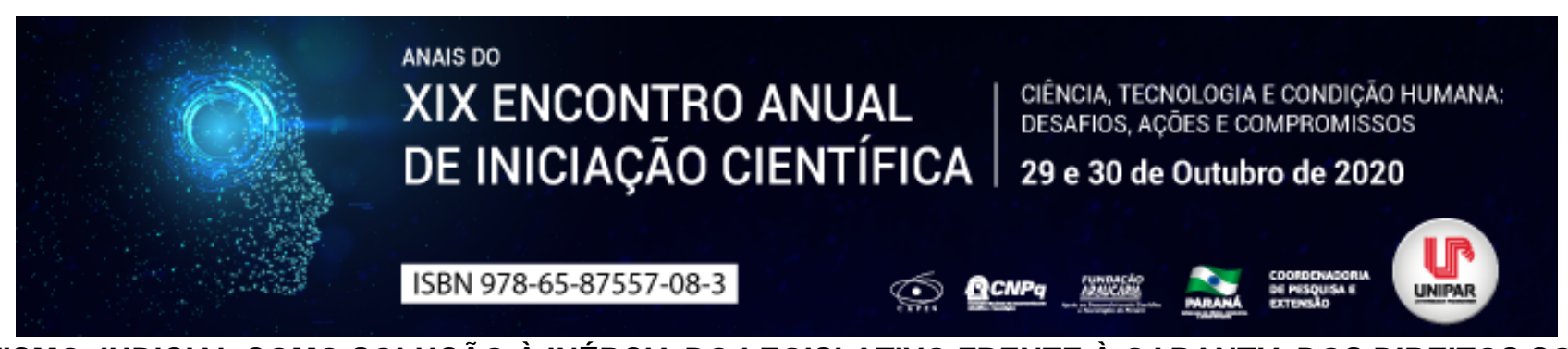

O ATIVISMO JUDICIAL COMO SOLUÇÃO À INÉRCIA DO LEGISLATIVO FRENTE À GARANTIA DOS DIREITOS SOCIAIS

\title{
${ }^{1}$ GABRIELA CRISTINA GUZZO, ${ }^{2}$ JONATAS LUIZ MOREIRA DE PAULA, ${ }^{3}$ ALEXANDRE MAGNO AUGUSTO MOREIRA
}

\author{
${ }^{1}$ Acadêmico do PIC/UNIPAR \\ ${ }^{1}$ Docente da UNIPAR \\ ${ }^{2}$ Docente da UNIPAR
}

Introdução: O Ativismo Judicial é encarado, majoritária e historicamente, como agente violador do princípio da harmonia e interdependência dos poderes. Historicamente porque, desde Aristóteles, em A Política e Montesquieu, em O Espírito Das Leis , o sistema de freios e contrapesos é defendido como um meio de garantia à perpetuação do Estado Democrático de Direito. Conquanto, ainda envolva grande divergência entre os doutrinadores, o Ativismo Judicial, hodiernamente, pode ser encarado como algo positivo no que diz respeito às lacunas provindas de um Legislativo inerte, principalmente, quando no âmbito da garantia de direitos sociais, como o direito à saúde. A pesquisa desenvolveu-se sobre o método dedutivo com análise de cunho bibliográfico.

Objetivo: Analisar a atuação e interferência do Judiciário como solução à inércia do Poder Legislativo e questionar a legitimidade ante a violação do princípio da separação dos poderes.

Desenvolvimento: À época na qual o conhecimento político era formado, preponderantemente, por especulações, senso comum e explicações baseadas em metafísica, Montesquieu (2005) mostrava estar à frente de seu tempo com teorias, escritos e estudos os quais ainda persistem em discussões do mundo hodierno. Dentre suas obras, encontra-se O Espírito das Leis , obra esta, que trata dos três poderes, os quais Montesquieu nomeia: O Poder Legislativo, o Poder Executivo das coisas que dependem do direito das gentes e o Poder Executivo das coisas que dependem do Direito Civil (MONTESQUIEU, 2005, p. 167). Em suma, Montesquieu externalizava o significado e relação entre os três poderes, que hoje, estão incorporados na Constituição Federal do Brasil de 1988 em seu artigo segundo, que trata da relação entre os poderes e a garantia de uma autocontenção e harmonia entre os citados (BRASIL, 1988). É importante ressaltar que, a teoria da separação dos poderes não serve única e exclusivamente para uma organização estatal, mas, também, para uma proteção de direitos e da democracia, uma vez que, de acordo com Montesquieu (2005, p. 149) quando na mesma pessoa o poder legislativo está reunido ao poder executivo, não há liberdade, assim como não haverá liberdade se o poder de julgar não estiver separado dos poderes Legislativo e Executivo. $O$ Ativismo Judicial é o fenômeno que tem ascendência a partir do momento no qual o Legislativo, aquele poder responsável pela criação das leis, não age com rapidez e eficácia as quais as evoluções sociais exigem (SILVESTRE, 2019). Com base nisso, o Ativismo Judicial pode ser ferramenta fundamental na proteção da garantia dos direitos sociais, como por exemplo, o direito à saúde. Ao término do ano de 2019, uma crise sanitária que acabou por culminar em uma crise econômica e social, assolou o mundo. A COVID-19, causada pelo novo coronavírus (SARS-CoV-2), facilmente transmitida, acabou por transformar toda e qualquer espécie de relação humana. Dessa forma, com base no contexto brasileiro atual, cabe ao judiciário, em face da deficiência do Estado, realizar políticas públicas em prol de um objetivo constitucional e democrático, em um chão de direitos humanos e fundamentais (OBARA, 2020), isto é, a atuação do judiciário é pertinente no que diz respeito à garantia daquilo que está previsto na Constituição, principalmente em momentos excepcionais, como a crise da COVID-19. Em abril de 2020, uma decisão do Supremo Tribunal Federal (STF) confirmou a autonomia de prefeitos e governadores na adoção de medidas de combate à disseminação do coronavírus (LAURIS). Além da decisão supracitada, Obara (2020) cita, como exemplo, ação de obrigação de fazer na Comarca de Porto Alegre, sob autos $n^{0}$. 501994270.2020.8.21.0001, que faz referência à tutela provisória de urgência, para o fornecimento de materiais para a prevenção do contágio pelo novo coronavírus aos agentes policiais, como máscaras, luvas e álcool em gel. Com base nas decisões apresentadas é perfeitamente possível inferir que, o poder judiciário tomou posse de uma função que não lhe é típica (LENZA, 2012) e atuou como legislador, uma competência que não lhe caberia quando observadas suas funções essenciais, isto é aquilo que se espera do poder Judiciário (LENZA, 2012).

Conclusão: Conclui-se, portanto, que o cenário atual de grandes transformações sociais, propicia uma atuação eficaz do Poder Judiciário, não como Poder interventor em face dos demais poderes, mas como poder de controle das atividades omissas do Executivo na figura do ativismo judicial como instrumento de efetivação dos direitos sociais e fundamentais, o que, por certo, não provoca a quebra do princípio da harmonia e separação dos poderes. Isto é, o objetivo não é refutar os clássicos de Montesquieu e Aristóteles, mas sim esclarecer que, novos tempos exigem adaptações e atitudes imediatas, desde que, claro, perdure o equilíbrio e a constitucionalidade.

\section{Referências}


BRASIL. Constituição (1988). Constituição da República Federativa do Brasil: promulgada em 5 de outubro de 1988. 4. ed. São Paulo: Saraiva, 1990.

SILVESTRE, Átila. Ativismo Judicial Como Forma De Suprir As Omissões Inconstitucionais. Disponível em: https://sisweb02.unipar.br/eventos/anais/4354/html/20147.html. Acesso: 10 de jul de 2020.

OBARA, Hilbert Maximiliano Akihito. A Excepcionalidade Constitucional E Democrática Da Concretização De Políticas Públicas Pelo Judiciário No Brasil: Análise Da Decisão Que Determinou O Fornecimento De Materiais De Prevenção Para Servidores Públicos Em Face Da Pandemia Do Coronavírus. Disponível em: http://www.escoladaajuris.org.br/observatorio/images/artigo_decis\%C3\%A3o_policiais_2.pdf > Acesso: 10 de junho de 2020.

LAURIS, Élida. Judiciário E Pandemia: O STF Pode Escolher Qual A Defesa Que Fará Da Constituição Federal Em Meio À Crise? Disponível em: https://terradedireitos.org.br/acervo/artigos/judiciario-e-pandemia-o-stf-pode-escolher-qual-a-defesa-quefara-da-constituicao-federal-em-meio-a-crise/23345. Aceso em: 01 de agosto de 2020.

LENZA, Pedro. Direito Constitucional Esquematizado. 16. Ed. São Paulo: Saraiva, 2012.

Coordenadoria de Pesquisa e Extensão - COPEX

Departamento de Editoraçāo e Divulgaçāo Científica - DEDIC 


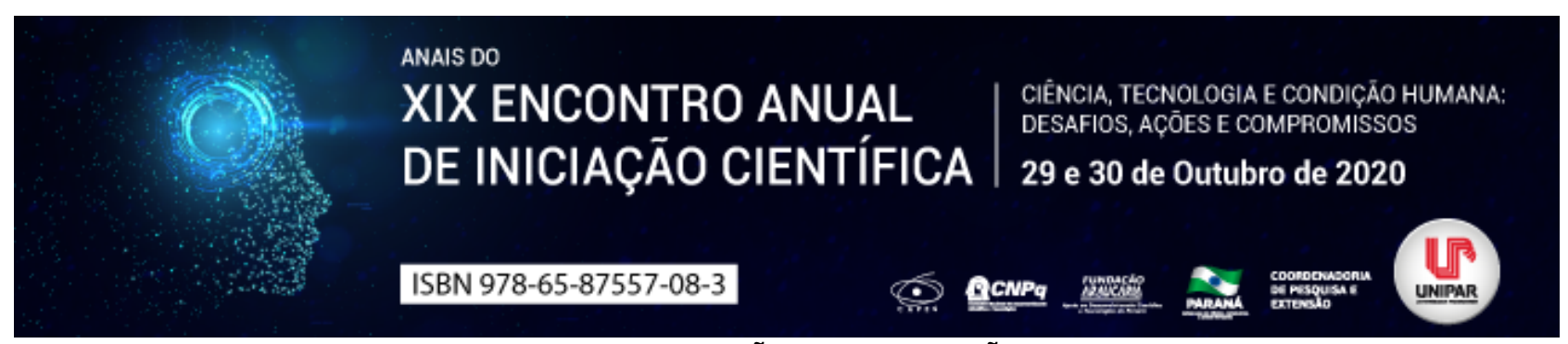

A PRIVATIZAÇÃO DA MEDIAÇÃO

\title{
${ }^{1}$ GABRIEL HERMES, ${ }^{2}$ DIEGO CANTON
}

\author{
${ }^{1}$ Acadêmico do curso de Direito da UNIPAR \\ ${ }^{1}$ Docente da UNIPAR
}

Introdução: O presente trabalho tem a finalidade de abordar a mediação no Brasil, com a finalidade de expô-la de forma minuciosa com enfoque nas futuras problemáticas em que as mudanças do Código de Processo Civil de 2015 poderá trazer ao sistema judiciário, nesta mesma toada, trazer uma abordagem de como esses métodos estão sendo utilizados em outros países por meio de um direito comparado.

Objetivo: Demonstrar os benefícios trazidos pela privatização da mediação, assim como as problemáticas trazidas pelo novo Código de Processo Civil, como o auto sufocamento em que este sistema se encontrará em um futuro não longínquo.

Desenvolvimento: A adoção de métodos alternativos para resolução de conflitos no Brasil está sendo uma tentativa de uma resposta rápida e eficaz do judiciário as lides do privado. Apesar de ter sido incluída no código civil há pouco tempo, por meio da Lei $n^{\circ} 13.140$ e do Código de Processo Civil, ambos de 2015, estes métodos já vêm sendo utilizado há muito, em vários países e com resultados positivos. Desta forma podemos enaltecer de imediato os Estados Unidos da América e Argentina, que se beneficiam cada vez mais de seus resultados, em modelos um pouco diferentes dos aplicados aqui. Nos Estados Unidos os primeiros passos para a utilização destes métodos alternativos se reportam ao ano de 1925, onde ocorreu a instituição da Federal Abritration Rules e ao ano seguinte, 1926, quando foi criada a American Arbitration Association em Nova York (FARIA, 2012). Em suma, a título de exemplo, está metodologia foi responsável por uma redução de cerca $70 \%$ (setenta por cento) de questões judiciais no Estado da Florida (GARCEZ, 2013), assim como na Califórnia, que se trata de 90\% da demanda (CHAGAS, 2013). Em 1991 na Argentina o Ministério da Justiça começou a capitanear a elaboração do Plano Nacional de Mediação para implementar programas consensuais em diversos setores da sociedade. A partir de tal ano diversas iniciativas foram engendradas para ampliar a mediação no país, até que em 1995 foi promulgada a Lei no 24.573 para instituir a mediação prévia judicial em caráter obrigatório (TARTUCE, 2016). Dessa maneira, o dispositivo em lei define que todas as ações a serem propostas no judiciário dependem de um procedimento de mediação anterior, pois, caso contrário, o autor não terá sua pretensão acolhida pelo Estado. Assim, este procedimento promoverá a comunicação direta entre as partes para a solução extrajudicial do conflito. As partes ficarão isentas do cumprimento deste trâmite se provarem que antes do início da ação existiu a mediação perante mediadores registrados pelo Ministério da Justiça (ARGENTINA, 1995). Consequentemente, através de estudos realizados, conclua-se que somente $35 \%$ dos casos submetidos a mediação é que se tornam causas judiciais e que a título de exemplo, um processo envolvendo mediação familiar é solucionado com o método em 29 dias e que se fosse enfrentar um processo judicial, uma ação de alimentos, demoraria entre 8 meses a 01 ano (MERA, 2004). Com o novo código de processo civil a mediação passou a ser requisito obrigatório ou essencial para o processo, pois preenchido os requisitos essenciais da inicial e não for caso de improcedência liminar do pedido, o juiz designará audiência de conciliação ou de mediação (BRASIL, 2015). De fato, este método já vem trazendo resultados positivos, o que já era esperado, no entanto, como a mediação será realizada pelo próprio judiciário, isso acaba apenas mudando de endereço o problema, passando para os CEJUSCs e NUPEMECs, abarrotando estes sistemas com audiências e travando o andamento do processo, tendo em vista que a demanda de audiências extrapola os limites do judiciário brasileiro.

Conclusão: Logo, percebe-se que manter este método heterocompositivo em que necessita da disposição judiciária não irá dar a devida celeridade ao processo e sim atrasa-lo ainda mais, desestimulando as partes a passarem por esta etapa. Desta forma, podemos notar que métodos, como os utilizados da argentina, são mais benéficos, tendo em vista a autonomia dada ao poder judiciário de se conveniar com instituições de mediação privada para que seja realizada extrajudicialmente a mediação, otimizando o tempo dos magistrados e servidores para que deem andamento nos demais procedimentos em que não houveram acordo.

\section{Referências}

ARGENTINA. Ley $\mathbf{2 4 . 5 7 3}$ de 1995 . Disponível em http://servicios.infoleg.gob.ar/infoleglnternet/anexos/2500029999/29037/norma.htm. Acesso em 29/06/2020.

Ley 26.589 de 2010. Disponível em http://servicios.infoleg.gob.ar/infoleglnternet/anexos/165000169999/166999/norma.htm. Acesso em: 29 jun. 2020.

BRASIL. Código de Processo Civil: Lei n.13.105, de março de 2015. Brasília: Senado Federal, 2015. Disponível em: http://www.planalto.gov.br/ccivil_03/_ato2015-2018/2015/lei//13105.htm. Acesso em: 06 jul. 2019 
CHAGAS, Bruno Anunciação. Jurisdição e $(m)$ crise: um retrato da américa latina, Brasil e Europa. Constituição, Economia e Desenvolvimento: Revista da Academia Brasileira de Direito Constitucional. Curitiba, 2013, vol. 5, n. 8, Jan-Jun. p. $205-232$. FALECK, Diego. TARTUCE, Fernanda. Introdução histórica e modelos de mediação. Disponível em www.fernandatartuce.com.br/artigosdaprofessora. Acesso em: 29 jun. 2020.

FARIA, Marcela Kohlbach. Os Meios Alternativos de Solução de Controvérsias em uma perspectiva comparada. Revista Eletrônica de Direito Processual REDP. Volume IX. Periódico da Pós-Graduação Stricto Sensu em Direito Processual da UERJ. p. 472.

GARCEZ, José Maria Rossani. ADRS: Métodos Alternativos de solução de conflitos. Rio de Janeiro: Editora Lumen Juris, 2013. p.68.

MERA, Alejandra. Mercanismos Alternativos de Solucion de Conflictos em América Latina. Diagnóstico y debate em um contexto de reformas. p. 396/397.

Coordenadoria de Pesquisa e Extensāo - COPEX

Departamento de Editoraçāo e Divulgaçāo Científica - DEDIC 


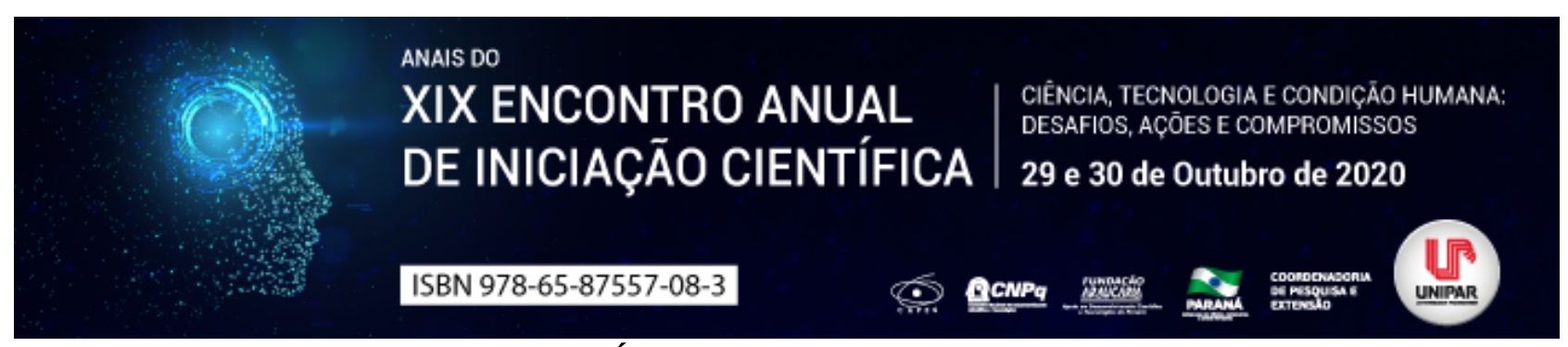

A VIABILIDADE JURÍDICA DOS CONTRATOS EM BLOCKCHAIN

\title{
${ }^{1}$ DOUGLAS SCHNEID VAZ LUIZ, ${ }^{2}$ JANE MARA DA SILVA PILATTI
}

\author{
${ }^{1}$ Acadêmico do Curso de Direito da UNIPAR \\ ${ }^{1}$ Docente da UNIPAR
}

Introdução: Os avanços nas formas como são realizadas as negociações jurídicas exigem ferramentas atualizadas, que atendam às novas demandas mundiais e cumpram os requisitos jurídicos, de maneira a firmar sua validade. Diante disso, este estudo busca apreciar as formas disponíveis de contratos que utilizam meios eletrônicos para sua elaboração, até a chegada do Blockchain, uma cadeia criptografada de registros eletrônicos permanentes (LACERDA, 2017), assim como a sua factibilidade jurídica. A pesquisa será desenvolvida pelo método dedutivo, com análise de cunho bibliográfico.

Objetivo: Avaliar a viabilidade jurídica de contratos digitais em Blockchain, verificando sua segurança e autenticidade.

Desenvolvimento: As formas contratuais mantêm constante evolução, de maneira a acompanhar a demanda da ascensão humana. Em uma breve retomada histórica, podemos observar a Lei Modelo da Uncitral, de 1996, que serviu como um fundamental marco na evolução contratual, já que foi o nascedouro da aceitação jurídica dos contratos eletrônicos. (PINHEIRO, 2016). Já nos dias atuais, com a internet das coisas e o aumento da relações contratuais inter sistêmicas, ocorre então o surgimento do conceito contratos digitais. (PINHEIRO, 2016). Os quais se caracterizam por possuir a importante funcionalidade de manifestar a vontade humana por meio de máquinas pré programadas, conforme Pinheiro (2016). No entanto, para que possam produzir efeitos jurídicos, e da mesma forma que os contratos tradicionais, os eletrônicos e digitais também possuem requisitos para sua validade, assim, as premissas básicas estão dispostas no art. 104 do Código Civil, sendo elas: agente capaz (I), objeto lícito, possível, determinado ou determinável (II) e forma prescrita ou não defesa em lei (III) (PINHEIRO; WEBER e NETO, 2019, p. 78). Dentre tais premissas, pode-se destacar a manifestação de vontade do agente capaz, o qual, segundo Gonçalves (2015, p. 72), é mais importante requisito dos negócios jurídicos, pois é o momento que a vontade se torna conhecida e apta a produção de efeitos jurídicos, e sem ela não existe o contrato. Outro requisito existente, e este é exigido para que o contrato possua força executiva, é a assinatura de duas testemunhas, conforme a previsão do art. 784, III, do Código de Processo Civil. Desta forma, o judiciário tende a desqualificar a força executiva do contrato digital que falte este requisito. Ocorre que, em contratos digitais, essa exigência é quase incoerente, já que estes são realizados de forma totalmente digital, com as partes muitas vezes em qualquer lugar do planeta (PINHEIRO; WEBER; NETO, 2019, p. 22). Esse cenário vem mudando, como visto na interpretação do Superior Tribunal de Justiça no REsp 1.495.920/STJ, do relator Ministro Paulo de Tarso Sanseverino, que corrobora com o fortalecimento tecnológico das negociações, e reconhece a executabilidade dos contratos, mesmo que sem as assinaturas das testemunhas, desde que o contrato possua a assinatura digital certificada pela Infraestrutura de Chaves Públicas Brasileira, responsável por garantir a autenticidade, a integridade e a validade jurídica de documentos em forma eletrônica. Neste atual contexto de constante evolução dos meios disponíveis na internet, e com a possibilidade de recrudescer ainda mais a segurança jurídica, surge uma tecnologia que promete mudanças substanciais na forma como são firmados os negócios digitais, o Blockchain, que consiste em um sistema astuto de armazenamento baseado na comunicação e autenticação de registros distribuídos ponto a ponto, assim chamada de Distributed Ledger Technology (DLT). Sua segurança se dá pela forma que é construído, através de ligações criptográficas em blocos, de maneira a garantir a inviolabilidade da informação (LACERDA, 2017). Quanto à aceitação jurídica da tecnologia, tem-se como exemplo o caso de Hangzhou, cidade chinesa, que realizou importante avanço na sua corte especializada em litígios relacionados à internet, ao reconhecer que o Blockchain é capaz de suprir os requisitos da legislação aplicável para garantir a confiabilidade dos dados digitais. (PINHEIRO; WEBER; NETO, 2019, p. 116). Fato semelhante ocorreu no Brasil com a decisão da desembargadora Fernanda Gomes Camacho, no Agravo de Instrumento $\mathrm{n}^{\circ}$ 2237253-77.2018.8.26.0000, em que admitiu o Blockchain, junto à plataforma OriginalMY, como hábil a comprovar a veracidade e existência dos conteúdos.

Conclusão: Torna-se indispensável o aprofundamento da pesquisa, pois com o nível de inovação e a irrestrita possibilidade de abrangência, é impossível delimitar à um estudo introdutório a definição total do tema. Admitindo a ideia de que os contratos digitais possuem a segurança jurídica necessária, e em que pese não haver uma legislação reguladora, o Blockchain, com um avançado sistema de criptografia, que gera a possibilidade registros seguros e com muitos recursos tecnológicos, perfazem uma possibilidade disruptiva exequível de forma contratual, ainda com soluções a serem atingidas, mas com ganho ilimitado de utilidades. 
BRASIL. Código de Processo Civil. Editora Saraiva. 27. ed. São Paulo: Saraiva, 2019.

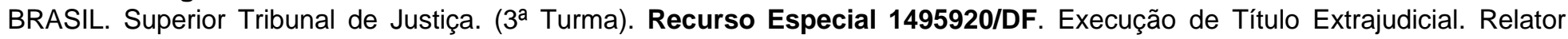
Ministro Paulo de Tarso Sanseverino. Acórdão. 15 maio 2018. Disponível em: https://ww2.stj.jus.br/processo/revista/documento/mediado/?

componente=ITA\&sequencial=1698344\&num_registro=201402953009\&data=20180607\&formato=PDF . Acesso em: 20 jun 2020. BRASIL. Tribunal de Justiça de São Paulo. (5a Câmara de Direito Privado). Agravo de Instrumento $\mathbf{n}^{\circ}$ 2237253- $^{2}$ 77.2018.8.26.0000. Relatora Desembargadora Fernanda Gomes Camacho. Acórdão. 18 dezembro 2018. Disponível em: https://www.migalhas.com.br/arquivos/2019/3/art20190325-11.pdf .Acesso em: 20 jun 2020.

GONÇALVES, Carlos Roberto. Direito Civil Brasileiro: Contratos e Atos Unilaterais. $12^{\mathrm{a}}$ ed. São Paulo: Saraiva, 2015.729 p. LACERDA, Eduardo. A segunda era da Internet, as infraestruturas de assinaturas digitais e os entes confiáveis KSI, PKI e Blockchain Permissionado. Instituto Nacional de Tecnologia da Informação, Brasília, 2017. Disponível em: . Acesso em: 18 jun. 2020.

PINHEIRO, Patrícia Peck; WEBER, Sandra Tomazi; NETO, Antonio Alves de Oliveira. Fundamentos dos Negócios e Contratos Digitais. $1^{\text {a }}$ ed. ampliada. Thomson Reuters Revista dos Tribunais. $169 \mathrm{p}$.

PINHEIRO, Patrícia Peck Garrido. Contratos digitais ou eletrônicos: apenas um meio ou uma nova modalidade contratual? Revista dos Tribunais, vol. 966/2016, p. 21 - 40. Ano 2016. Disponível em: http://www.tjpa.jus.br/CMSPortal/VisualizarArquivo? idArquivo=340926. Acesso em: 06 jun 2020. 


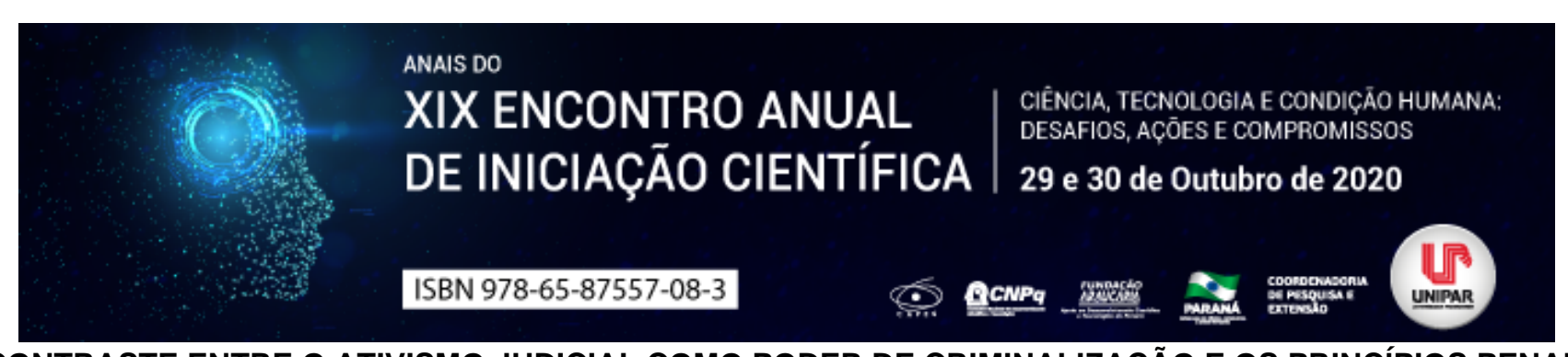

O CONTRASTE ENTRE O ATIVISMO JUDICIAL COMO PODER DE CRIMINALIZAÇÃO E OS PRINCÍPIOS PENAIS E CONSTITUCIONAIS

\author{
${ }^{1}$ LIVIA TONINATO VIGNOTO, ${ }^{2}$ RUAN VICTOR SOUZA LOPES, ${ }^{3}$ ALBINO GABRIEL TURBAY JUNIOR
}

\author{
${ }^{1}$ Acadêmica do Curso de Direito da UNIPAR \\ ${ }^{1}$ Acadêmico do Curso de Direito da UNIPAR \\ ${ }^{2}$ Docente da UNIPAR
}

Introdução: O ativismo judicial é relevante para discutir os limites de atuação do Judiciário, pois, contribui para que demandas sociais sejam abrangidas, especialmente, em relação à interpretação das leis a partir dos valores constitucionais. Porém, há situações em que os limites são excedidos, como na criminalização da homotransfobia. Assim, os magistrados, de certa forma, assumem o papel dos outros Poderes, contrariando princípios constitucionais.

Objetivo: Analisar a criminalização da homotransfobia sob o prisma do ativismo judicial e dos princípios constitucionais e penais.

Desenvolvimento: A Constituição Federal de 1988 tem aspectos principiológicos, com normas abertas que precisam de interpretação e densificação no caso concreto, criando um cenário propício para a difusão do ativismo judicial. Tal situação pode beneficiar a efetivação dos direitos fundamentais, mas, ao mesmo tempo, permite que os magistrados, sobretudo no Supremo Tribunal Federal, possam ir além das funções a eles atribuídas, sendo plausível questionar se o que há, hoje, no âmbito jurídico, é uma supremacia constitucional ou judicial (TASSINARI, 2012, p. 43). Em 2019, houve no STF o julgamento da Ação Direta de Inconstitucionalidade por Omissão (ADO) 26 e do Mandado de Injunção (MI) 4733, que resultou na criminalização da homofobia e transfobia. Esta decisão contrasta com os princípios penais e constitucionais, uma vez que, segundo o artigo $5^{\circ}$, inciso XXXIX, da Constituição Federal, não há crime sem lei anterior que o defina, nem pena sem prévia cominação legal (BRASIL, 1988). Assim, o STF, ao definir tal conduta como crime, feriu os princípios da legalidade penal e da taxatividade (visto que o tipo não estava, especificamente, previsto em lei), da proibição da analogia in malam partem (pois a criminalização ocorreu por interpretações da Lei $n^{\circ}$ 7.716/89) e da separação dos Poderes (porque a competência para legislar sobre matéria penal é exclusiva do Congresso Nacional). Apesar de, no caso citado, observar-se clara omissão inconstitucional, é aparente que

criminalizando uma conduta até que sobrevenha a lei específica, pode ser caracterizado como usurpação de uma função do Poder Legislativo. (GONÇALVES; CALDAS; PORTILHO, 2020). Então, STF deveria apenas ter notificado e estabelecido prazo para que os congressistas votassem uma lei acerca do assunto.

Conclusão: Pela análise, denota-se a importância do judiciário na sociedade. Assim, o STF deve agir de acordo com os preceitos constitucionais, não ultrapassando os limites de sua competência, para não desarmonizar o sistema e os Poderes.

\title{
Referências
}

BRASIL. Constituição da República Federativa do Brasil. Diário Oficial da União n. 191-A de 5-10-1988. Vade Mecum Saraiva 27. ed. São Paulo, 2019.

GONÇALVES, Jonas Rodrigo; CALDAS, Paulo Gustavo Barbosa; PORTILHO, Grazielle Jordão Portilho. O ativismo judicial do Supremo Tribunal Federal na criminalização da homofobia e transfobia (ADO 26/DF). Revista Processus de Estudos de Gestão, Jurídicos e Financeiros. Brasília, jan./jun., 2020.

TASSINARI, Clarissa. A atuação do judiciário em tempos de constitucionalismo contemporâneo: uma crítica ao ativismo judicial. Rev. Fac. Dir. Sul de Minas, Pouso Alegre, v. 28, n. 2: 31-46, jul./dez. 2012. 


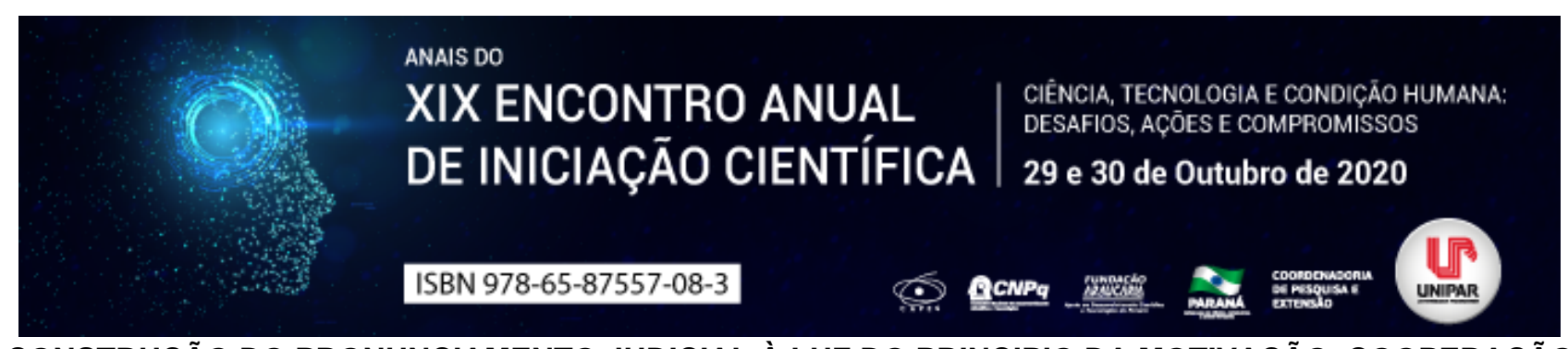

\title{
A CONSTRUÇÃO DO PRONUNCIAMENTO JUDICIAL À LUZ DO PRINCIPIO DA MOTIVAÇÃO, COOPERAÇÃO E CONTRADITÓRIO
}

\author{
${ }^{1}$ JUSCELINO PIRES DA FONSECA, ${ }^{2}$ ALESSANDRO OTAVIO YOKOHAMA
}

\author{
${ }^{1}$ Acadêmico do Mestrado em Direito Processual e Cidadania / UNIPAR \\ ${ }^{1}$ Docente da UNIPAR
}

Introdução: A concepção de que o pronunciamento judicial decorre de atividade solitária do magistrado, aplicando a interpretação do texto ao fato juridicamente valorado, através de silogismo ou subsunção, é recusada pelo processo civil contemporâneo. As decisões judiciais devem ser construídas, a partir de uma filtragem constitucional, através da qual restam impostos os deveres de fundamentação e a garantia de efetiva participação e influência de todos os sujeitos processuais.

Objetivo: Demonstrar que na atual perspectiva democrática de processo, não há mais lugar para o protagonismo de apenas um dos sujeitos processuais, restando afastadas as antigas concepções que davam margem à arbitrariedades e solipsismos, uma vez que estão solidificadas as bases legais e critérios para formação da norma jurídica concreta, na forma de decisão que assegure tanto a efetividade da tutela como o contraditório efetivo no processo, numa espécie de legitimação pelo procedimento. Desenvolvimento: $O$ juiz decide exercendo a jurisdição, aplicando a lei ao caso concreto sob sua análise, com a intenção final de pacificar o conflito entre as partes. (THEODORO JUNIOR, 2016, p. 125). O juiz não deve ser um mero aplicador das leis de forma impulsiva e automática, que desdenhe da necessidade de interpretação. Como tal, ele não deve ser um mero aplicar mecânico da lei, seguindo a ultrapassada ideia de juiz boca da lei de Monstesquieu, desdenhando da necessária interpretação dos textos para formação da norma adequado no caso concreto. Um magistrado cioso de sua condição jamais daria ouvidos ao alerta de Voltaire no Dicionário filosófico , no sentido de que interpretar a lei quase sempre é corrompe-la É claro que existe uma submissão ou ainda um limite da atuação estatal do juiz a lei, mas a este é livre a interpretação sendo que mesmo que pareça inicialmente a decisão contrária a algum preceito legal, o importante é esta se mostrar em compatibilidade com o sistema jurídico (ALVIM, et al, 2016, p. 316). Por intermédio da fundamentação a decisão pode ser vista sobre três prismas: um ato de inteligência (revelação do raciocínio jurídico), uma declaração (demonstrar como foi construída a norma individual) e como resposta (cabe ao juiz encerrar a discussão do diálogo processual com uma conclusão final atento ao que foi debatido no processo), efetivando o princípio do contraditório (MEDINA, 2016, p. 748). O diálogo entre todos os sujeitos processuais, inclusive o juiz, é denominado como cooperação, e demonstra uma preocupação de todas as partes com o proferimento de uma decisão mais adequada, que acredita-se, será possível com a ampliação da discussão processual do objeto do processo pelos interessados, no qual defenderão seu próprio direito (BUENO, 2020, p. 136).

Conclusão: O julgador não possui liberdade absoluta para decidir conforme suas convicções pessoais, tampouco esta atividade se restringe a mera reprodução da lei, que só tem importância jurídica pelo significado que o aplicador do direito constrói, criando a norma jurídica. Neste ponto, exige-se fundamentação, que se desenvolve pela observância de outros princípios (contraditório, devido processo legal e cooperação), concretizando direitos fundamentais como segurança jurídica e duração razoável do processo.

\section{Referências}

ALVIM, Angélica Arruda. ASSIS, Araken de Assis. ALVIM, Eduardo Arruda. LEITE, George Salomão Leite. Comentários ao Código de Processo Civil. São Paulo: Saraiva, 2016.

BUENO, Cassio Scarpinella. Curso Sistematizado de Direito Processo Civil, Vol. 1: Teoria Geral do Direito Processual Civil: Parte Geral do Código de Processo Civil. 10 ed. São Paulo: Saraiva Educação, 2020.

MEDINA, José Miguel Garcia. Direito Processual Civil Moderno. $2^{\circ}$ ed. São Paulo: Revista dos Tribunais, 2016.

THEODORO JUNIOR, Humberto. Curso de Direito Processual Civil: Teoria Geral do Direito Processual Civil, Processo de Conhecimento e Procedimento Comum. v.1 Rio de Janeiro: Forense, 2016. 


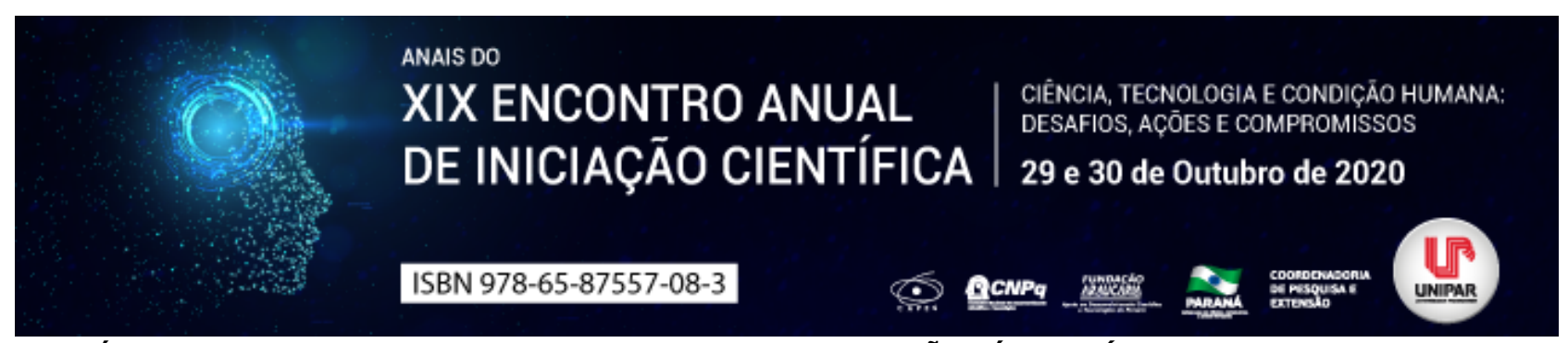

PETROBRÁS E O ENVOLVIMENTO EM ESQUEMAS DE CORRUPÇÃO: É POSSÍVEL CONFIAR NOVAMENTE? UMA ANÁLISE SOB A PERSPECTIVA DA TEORIA DA LEGITIMIDADE SOCIAL

\author{
${ }^{1}$ CARLA ALVES FURIO, ${ }^{2}$ NAYARA LOPES GIOMO, ${ }^{3}$ JOSE LUIZ BORSATTO JUNIOR
}

\author{
${ }^{1}$ Acadêmica do PIC/UNIPAR \\ ${ }^{1}$ Acadêmica do PIC/UNIPAR \\ ${ }^{2}$ Docente da UNIPAR
}

Introdução: Para obter uma posição favorável no mercado e garantir sua sobrevivência as empresas precisam legitimar suas ações diante da sociedade, para então conseguir aceitação no meio social. A Teoria da Legitimidade é a teoria que fornece melhores argumentos para explicar esse fenômeno. Segundo Fank e Beuren (2010), evidenciações são comumente utilizadas pelas empresas na busca por legitimidade por serem um instrumento de comunicação com grande relevância com os seus usuários, através das divulgações as empresas podem transparecer os objetivos de suas ações. Recentemente, a Petrobrás foi alvo de uma investigação da Operação Lava-Jato, por estar envolvida em escândalos de corrupção e lavagem de dinheiro, consequentemente esse acontecimento trouxe prejuízos quanto a imagem da empresa, pois sua legitimidade foi afetada, o que levou a empresa a tomar atitudes para reverter esse cenário.

Objetivo: Compreender como a Petrobrás busca recuperar sua legitimidade social após os escândalos de corrupção, por meio de divulgações obrigatórias e voluntárias.

Metodologia: Estudo de natureza qualitativa, com coleta de dados por meio de pesquisa documental nas divulgações da empresa Petrobrás entre 2014 e 2019 e análise de dados por meio de análise de conteúdo temática à luz da Teoria da Legitimidade Social.

Resultados: A Petrobrás foi alvo de uma investigação da Operação Lava-Jato por estar envolvida em escândalos de corrupção e lavagem de dinheiro entre funcionários, fornecedores e empreiteiras. Após esse episódio, a empresa buscou recuperar sua legitimidade explicando o ocorrido em suas Notas Explicativas. Também foram criados comitês e programas anticorrupção, além do tema corrupção ser bastante abordado nos últimos anos nos relatórios da empresa, afim de demonstrar transparência aos seus usuários.

Discussões: A Teoria da Legitimidade é baseada na premissa de que a empresa opera por meio de um contrato social e que suas ações precisam estar em conformidade com os valores, normas e crenças impostas pela sociedade (SUCHMAN, 1995). O mesmo autor propõe três desafios na busca por legitimidade: ganhar, manter ou recuperar legitimidade social. No desafio de recuperar legitimidade, foram apontadas práticas que são utilizadas pelas empresas, dentre elas há, de forma pragmática, a ação

rejeitar . São práticas que estão presentes nos relatórios da Petrobrás, onde a empresa como organização repudia os crimes de corrupção. É possível identificar tal negativa presente nas Notas Explicativas de 2015, em que a empresa descreve os acontecimentos e cita a Petrobras não tolera corrupção ou quaisquer práticas de negócio ilegais por parte de seus fornecedores ou o envolvimento de seus empregados [...]. Em seu site de comunicação com investidores, é notável o aumento de informações sobre programas de prevenção à corrupção, boa conduta e ética, o que, segundo a Teoria da Legitimidade, seria uma forma moral de justificar-se e rever práticas relacionadas ao acontecimentos. A criação do Programa Petrobrás de Prevenção à Corrupção se deu após o envolvimento da empresa com o esquemas de corrupção entre funcionário, fornecedores e empreiteiras; esse programa elenca uma série de práticas de boas condutas, leis que serão aplicadas, a criação de uma gestão para tais práticas, criação de um canal de denúncia, hábitos que foram banidos da rotina da empresa, entre outros. Na Teoria da Legitimidade a criação desse programa está ligado a estratégia de desassociar pois a empresa demonstra que está fazendo a mudança acontecer. Criar monitores é uma estratégia de recuperação da legitimidade conforme a teoria, essa estratégia também foi utilizada pela Petrobrás como a criação do Código de Ética e Código de Boas Práticas, onde são abordadas normas que deverão ser seguidas pela empresa, para ser acompanhado de perto, a Petrobrás criou o Monitoramento PPPC, para monitorar se todas as novas práticas e condutas criadas estão em conformidade e sendo seguidas por todos. Dessa forma, essas estratégias contribuem para a recuperação da legitimidade tornando a empresa mais transparente, devido a necessidade da mesma em explicar-se diante dos fatos, além de restaurar a confiança dos usuários, pois a mudança no comportamento da empresa é notável.

Conclusão: A partir desse estudo é possível concluir que a Petrobrás utilizou várias estratégias propostas por Suchman na Teoria da Legitimidade, para recuperar a confiança de seus usuários, a mesma utiliza seu próprio site de forma espontânea para publicar tais informações, disponível para qualquer pessoa de interesse. Dentre as estratégias utilizadas estão rejeitar ,

justificar-se, rever práticas e criar monitores. Tais estratégias podem ser encontradas nos relatórios publicados pela empresa de forma obrigatória, como a nota explicativa, ou em publicações em seu próprio site, de forma voluntária, o que mostra 
a preocupação da empresa em ser transparente com seus usuários, assim como denota ações voltadas para a recuperação da legitimidade perdida em função dos episódios de corrupção ocorridos na empresa.

\section{Referências}

FANK, Odir Luiz; BEUREN, Ilse Maria. Evidenciação das estratégias de legitimidade da tipologia de Suchman (1995) nos relatórios da administração da Petrobras. Revista de Contabilidade e Organizações, v. 4, n. 10, p. 25-47, 2010.

SUCHMAN, Mark C. Managing legitimacy: Strategic and institutional approaches. Academy of management review, v. 20, n. 3 , p. 571-610, 1995.

Coordenadoria de Pesquisa e Extensão - COPEX

Departamento de Editoraçāo e Divulgaçāo Científica - DEDIC 


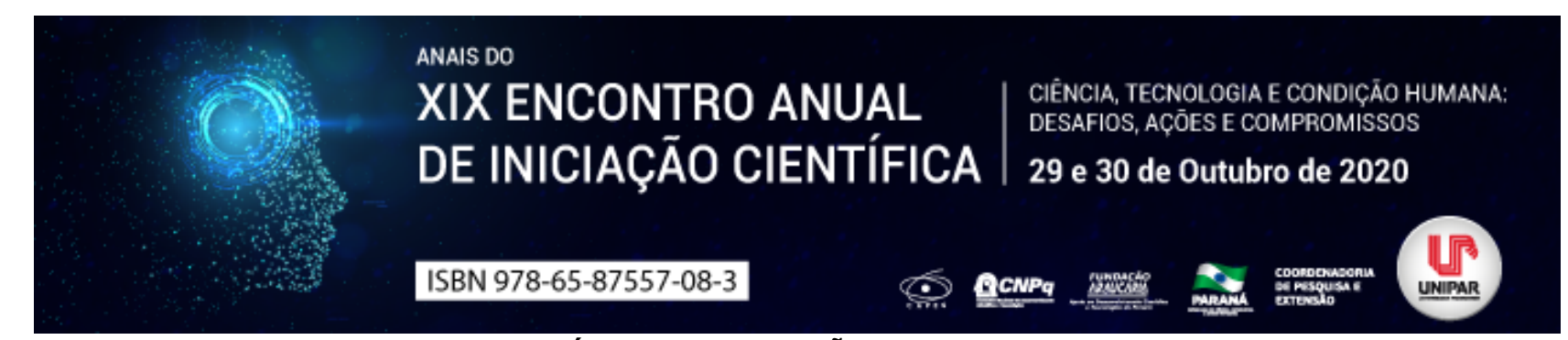

LEVANTAMENTO DAS PRINCIPAIS PRÁTICAS DE GESTÃO DE PESSOAS EM EMPRESAS DO MUNICIPIO DE PARANAVAÍ

${ }^{1}$ SILVIA MARA OLIVEIRA GUIMARAES

${ }^{1}$ Docente do Curso de Administração EaD

Introdução: A área de gestão de pessoas tem grandes responsabilidades e relevância no contexto organizacional, pois, as pessoas são de extrema importância para o sucesso de uma empresa, sendo elas que gerenciam, comandam, executam, controlam suas atividades e processos. Neste sentido, gerir as pessoas significa governar suas ações, atividades e desenvolvimento como participantes da organização, sendo que é justamente por meio das ações que é possível formular e atingir objetivos organizacionais.

Objetivo: O presente trabalho tem por finalidade, o levantamento das principais práticas de gestão de pessoas em empresas do município de Paranavaí-Pr.

Desenvolvimento: A moderna gestão de recursos humanos teve origem, como objeto de estudo e ensino, entre as década de 1970 e 1980, nos Estados Unidos (BREWSTER; MORLEY; BUCIUNIENE, 2010). É correto afirmar que a gestão de recursos humanos sempre existiu no contexto empresarial, mas sua importância e valor neste meio se intensificou com o desenvolvimento das ciências comportamentais, principalmente devido ao reflexo de suas práticas no desempenho organizacional (SCROGGINS; BENSON, 2010). A Gestão de Recursos Humanos é composta por um conjunto de atividades, práticas e políticas, para a adequada gestão dos funcionários (BOSELIE; DIETZ; BOON, 2005). Para Fischer (2002) a gestão de pessoas é a maneira pela qual uma empresa organiza, gerencia e orienta o comportamento das pessoas. Nesse contexto, Milkovich e Boudreau (2006, p. 19) a conceituam como uma série de decisões integradas que formam as relações de trabalho e influenciam diretamente a capacidade da organização e de seus agentes de atingir seus objetivos . Embora todas as empresas tenham obrigatoriamente que gerenciar as pessoas, é preciso considerar que não conseguem fazê-lo igualmente em todos os contextos (BREWSTER; MORLEY; BUCIUNIENE, 2010; GUEST, 2011), pois, variações contextuais podem promover melhorias ou restrições sobre as práticas de Gestão de Recursos Humanos de determinada organização ou de setores industriais específicos (JACKSON; SCHULER, 1995). Uma pesquisa recente afirma que, as práticas de gestão de pessoas e os resultados organizacionais positivos são influenciados por fatores culturais, econômicos, políticos e sociais dos países em que as organizações atuam, assim, apenas a intenção e consciência no uso de práticas de gestão de RH, não garante sua contribuição para a eficácia organizacional. A gestão de pessoas é responsável por agregar valor, cuidar, supervisionar e motivar os colaboradores de uma organização. De acordo com Chiavenato (2004), as principais práticas de gestão de pessoas e recursos humanos mais conhecidas são relacionadas à: 1) politicas de provisão suprimentos e agregação de pessoas, exemplo recrutamento e seleção de pessoas; 2) políticas de aplicação de pessoas, fazem parte o planejamento, alocação, movimentação interna, plano de carreira, etc.; 3) políticas de remuneração de pessoas, onde as principais práticas são a definição dos critérios de remuneração direta, remuneração indireta como plano de benefícios e critérios de incentivos e participação nos lucros e resultados; 4) políticas de desenvolvimento de pessoas, responsável por definir critérios de preparação, atualização e aperfeiçoamento, e práticas que garantam as condições éticas e a excelência organizacional; 5) política de manutenção de pessoas, voltada ao desenvolvimento de critérios e práticas relativos à motivação e condições ambientais de trabalho; e, 6) políticas de monitoramento de pessoas, relativos à aplicação e adequação do sistema de gestão de pessoas. As práticas decorrentes destas políticas, estão diretamente ligadas ao crescimento da empresa, pois refletem no comportamento e percepções dos funcionários, o que refletirá nos resultados finais da organização

Conclusão: Para Chiavenato (2004), os objetivos organizacionais são o fim desejado que a organização pretende atingir e que orientam o seu comportamento em relação ao futuro e aos ambientes interno e externo . Neste contexto, é importante ressaltar, que o alcance dos objetivos organizacionais, está diretamente ligado à forma como a organização conduz as pessoas que nelas trabalham. Neste sentido, as ações, as interações, as políticas, as técnicas, os métodos e as práticas adequadas à realidade de cada empresa, podem impactar significativamente seu desempenho. Portanto, pode-se dizer, que as atividades do RH, ou melhor, em uma versão mais moderna, da gestão de pessoas, vão além de entrevistar, selecionar, contratar e demitir funcionários, pois esta, não trata apenas da relação com os funcionários dentro da empresa, mas também de entender sua posição no mercado e entender do segmento de negócio que estão exercendo. A qualidade da empresa é resultante da qualidade do seu capital intelectual, e os líderes de uma organização podem fazer muito por ela mesma, desenvolvendo as pessoas que nela estão.

\section{Referências}


BOSELIE, P., DIETZ, G.; BOON, C. Commonalities and contradictions in HRM and performance research. Human Resource Management Journal, v. 15, n. 3, p. 67-94, 2005. http://dx.doi.org/10.1111/j.1748-8583.2005. tb00154.x

BREWSTER, C.; MORLEY, M.; BUCIUNIENE, I. The reality of human resource management in Central and Eastern Europe. Baltic Journal of Management, v. 5, n. 2, p. 145-155, 2010. http:// dx.doi.org/10.1108/17465261011045098

CHIAVENATO, I. Gestão de Pessoas: o novo papel dos recursos humanos nas organizações. 2ed. Rio de Janeiro. Campus, 2004.

FISCHER, A. L. Um resgate conceitual e histórico dos modelos de gestão de pessoas. In: FLEURY, M. T. L. (Org.). As pessoas na rganização. 9. ed. São Paulo: Gente, 2002. p. 11-33.

JACKSON, S. E.; SCHULER, R. S. Understanding human resource management in the context of organizations and their environments. Annual Review of Psychology, v. 46, p. 237-264, 1995. PMid:19245335. http://dx.doi. org/10.1146/annurev.ps.46.020195.001321 


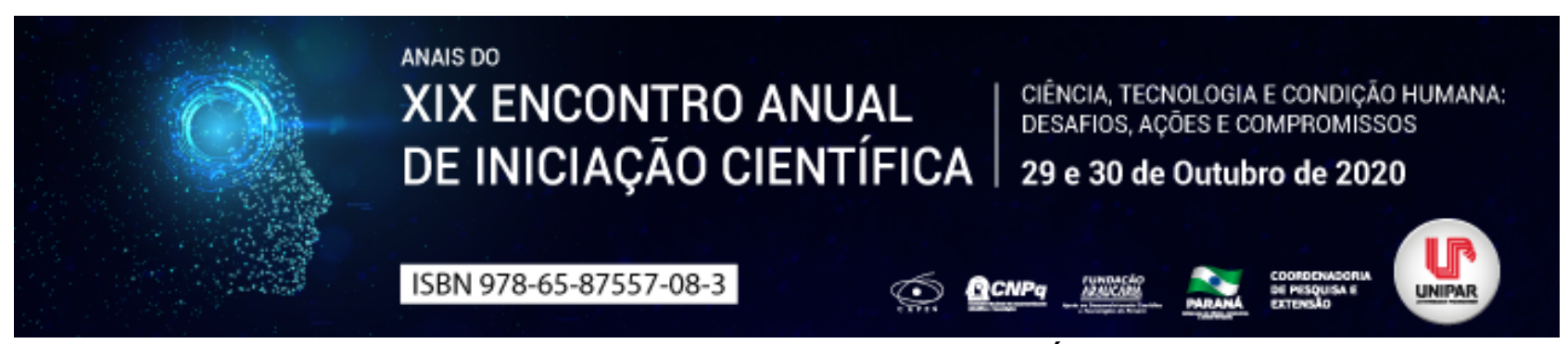

A CIDADANIA E A SOCIEDADE DEMOCRÁTICA

\title{
${ }^{1}$ IGOR FABIANO DA SILVA, ${ }^{2}$ ALBINO GABRIEL TURBAY JUNIOR
}

\author{
${ }^{1}$ Acadêmico bolsista do PEBIC/CNPQ \\ ${ }^{1}$ Docente da UNIPAR
}

Introdução: Exercer a cidadania é forma de alcançar os direitos previstos para o povo, em especial os direitos fundamentais. Ainda, é importante pensar na cidadania como forma de participação democrática, o que requer uma reflexão sobre cidadania, sociedade democrática e instrumentos de participação. Para este trabalho a pesquisa foi realizada por revisão bibliográfica em doutrinas utilizando o método dedutivo.

Objetivo: Compreender cidadania e sua relação com uma sociedade democrática.

Desenvolvimento: $O$ conceito de democracia surge na Grécia antiga, em Atenas, como uma nova forma de governo. Sua proposta inicial pôde ser descrita em anos póstumos pelo presidente republicano Abraham Lincoln: é o governo do povo, pelo povo, para o povo (MATTOS, 2017, online). Entretanto, ainda há, dentro da mesma, subdivisões: a democracia indireta e direta. A democracia é indireta quando os cidadãos elegem um representante para legislar suas leis (democracia representativa), e, direta, quando o próprio povo legisla suas leis, podendo votar e criar propostas legislativas. O sistema político Brasileiro vigente é a democracia representativa, embora a Constituição cidadã forneça mecanismos suficientes de participação popular, que, se efetivados, tornariam o país uma democracia participativa, na qual há uma ampla participação popular. Porém, com o desconhecimento e não efetivação dos mesmos mecanismos, faz-se inexequível a prática de uma democracia participativa. Junto com a democracia, o conceito de cidadania emerge na sociedade. Vale salientar que a cidadania só pode ser efetivada dentro de uma sociedade democrática. O conceito de cidadão, juridicamente, é aquele que vota e pode ser votado. Etimologicamente, cidadania vem do latim ciuitas, que deriva de ciuis. Ciuis é o ser humano livre e, por isso, ciuitas carrega a noção de liberdade em seu centro (FUNARI, 2003, p. 49). Para Hannah Arendt, filósofa contemporânea: A cidadania é o direito a ter direitos. Entende-se, portanto, que cidadania é o direito supremo dentro de uma democracia, que busca, por finalidade, a exequibilidade da democracia por parte dos cidadãos (SIQUEIRA JR; OLIVEIRA, p. 241). No Brasil, como relatado anteriormente, nos encontramos em uma democracia que, se efetivada, pode ser participativa, logo, faz-se mister o ato de difundir suas formas de exercício. Comecemos pelas esferas: atuação jurídica e atuação política; no âmbito da atuação jurídica, são os meios de fiscalização dos negócios do estado, por intermédio do Poder Judiciário, dentre esses temos a ação civil pública e a ação popular (SIQUEIRA JR; OLIVEIRA, p. 249). No âmbito da atuação política, se dá a própria democracia participativa, salientando que, quanto mais amplo a participação popular, mais legítimo e democrático é o governo. Dentro da atuação política há alguns instrumentos que garantem a efetivação da cidadania: as audiências públicas e a cidadania no processo legislativo (SIQUEIRA JR; OLIVEIRA, p. 251). As audiências públicas são instrumentos de participação do povo nos negócios do Estado, sendo assim, o meio pelo qual se observa, presencialmente, transparência nas ações governamentais (SIQUEIRA JR; OLIVEIRA, p. 254). Por fim, a cidadania no processo legislativo engloba processos que, por intermédio, levam a autonomia política; o mesmo é efetuado através do plebiscito, referendo e iniciativa popular, sendo plebiscito feito a priori, com a votação de leis, e, referendo a posteriori com a ratificação das mesmas leis; e, por último, a iniciativa popular, conforme o artigo $61 \S 2^{\circ}$ da Constituição Federal (BRASIL, 1988), como meio pelo qual qualquer cidadão pode dar início ao processo legislativo, caso obtenha, $1 \%$ de votos federalmente em 5 estados distintos, com pelo menos $0,3 \%$ votos de cada estado (SIQUEIRA JR; OLIVEIRA, p. 256-257). Para o francês Bernard de Chantebout, citado por Benevides (CHANTEBOUT apud BENEVIDES, 1994): I"a democracia do governo do povo pelo povo deve continuar a admitir formas de democracia direta, mesmo à custa de imenso esforço de educação política dos cidadãos

Conclusão: A cidadania precisa de um ambiente democrático para ser efetivada. Mesmo em uma democracia representativa é possível a ampliação da participação popular nas decisões políticas, assim, o exercício da cidadania, com a utilização de instrumentos que permitam uma participação direta nas decisões, como, por exemplo, o plebiscito e o referendo. Desta forma, constrói-se o caminho para uma cidadania em uma sociedade democrática participativa.

\section{Referências}

BENEVIDES, Maria Victoria de Mesquita. Cidadania e democracia. Lua Nova: revista de cultura e política. n. 33, ag. 1994. Disponível em: https://www.scielo.br/scielo.php?script=sci_arttext\&pid=S0102-64451994000200002\&lng=pt\&tlng=pt. Acesso em 20 jul. 2020.

BRASIL. [Constituição (1988)]. Constituição da República Federativa do Brasil de 1988. Brasília, DF: Presidência da República. Disponível em: http://www.planalto.gov.br/ccivil_03/Constituicao/Constituiçao.htm. Acesso em: 10 set. 2020 
FUNARI, Pedro Paulo. A cidadania entre os romanos. In: PINSKY, Jaime; PINSKY, Carla Bassanezi (ORG.). História da cidadania. 2. ed. São Paulo: Contexto, 2003.

MATTOS, Alessandro Nicoli de. O que é democracia? Politize, 2017. Disponível em: https://www.politize.com.br/democracia-oque-el. Acesso em: 20 jul. 2020.

SIQUEIRA JÚNIOR, Paulo Hamilton; OLIVEIRA, Miguel Augusto Machado de. Direitos humanos e cidadania. 2. ed. São Paulo: Editora Revista dos Tribunais, 2009.

Coordenadoria de Pesquisa e Extensão - COPEX

Departamento de Editoraçāo e Divulgaçāo Científica - DEDIC 


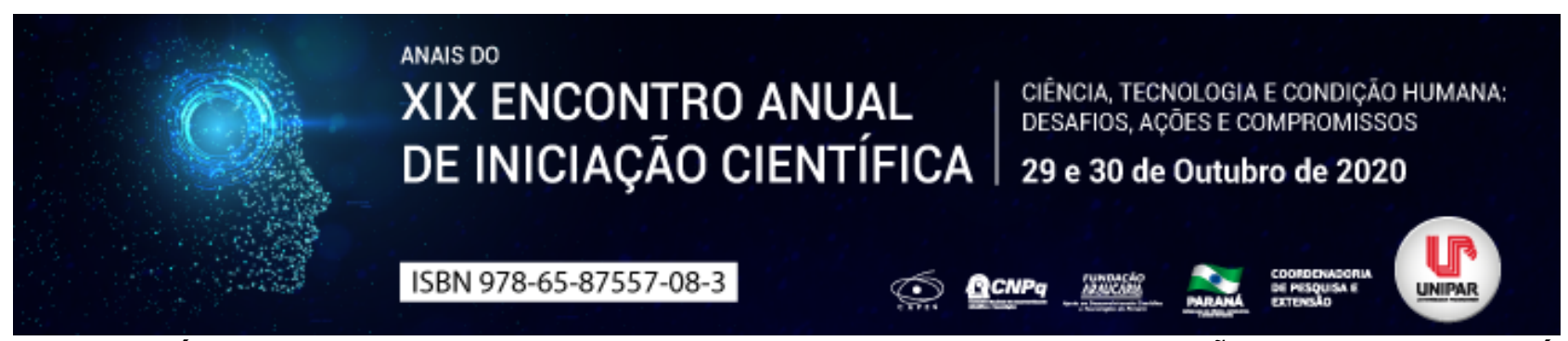

\title{
A PRESENÇA DE RÉU DELATOR E A GARANTIA DO DEVIDO PROCESSO LEGAL NA AÇÃO CRIMINAL COM MÚLTIPLOS RÉUS
}

\author{
${ }^{1}$ KAUANE GABRIELA PERBELINI NASCIMENTO, ${ }^{2}$ RICARDO MUCIATO MARTINS
}

\author{
${ }^{1}$ Acadêmico do PIC/UNIPAR \\ ${ }^{1}$ Docente da UNIPAR
}

Introdução: Num contexto de maior evidência da criminalidade organizada no Brasil, surgiu, no início dos anos 90, o instituto da delação premiada. A delação, forma original da colaboração premiada, fundamentava-se na disposição unilateral do réu em contribuir com a polícia ou com o juízo, nos casos em que os crimes eram praticados em concurso de agentes. Desde então, por razão dos intensos debates acerca de sua aplicabilidade e legalidade, houve a necessidade de avanços normativos pertinentes ao tema no ordenamento jurídico pátrio.

Objetivo: Analisar o surgimento e a evolução do instituto da delação premiada no sistema normativo jurídico brasileiro.

Desenvolvimento: Notoriamente, o direito penal e processual penal foram originados visando coibir, em sua essência, a criminalidade individual, praticada, majoritariamente, de maneira primária e por classes sociais mais baixas. Entretanto, a criminalidade organizada atua ao inverso da individual, pois é regida por uma estrutura complexa, portando a presença de vários membros, em diferentes níveis hierárquicos, que praticam condutas criminosas elaboradas, calcadas na intimidação e poderio econômico, usando-se de meios para supressão de provas e de um código do silêncio (TEIXEIRA, 2006). Mediante tal conjuntura, os métodos investigativos tradicionais acabaram por se revelar ineficazes, tornando imprescindível a criação do fenômeno da delação premiada para buscar maior eficácia na investigação e combate às organizações criminosas. A Lei 8.072/90, conhecida como Lei dos Crimes Hediondos, foi a primeira a ter abarcado expressamente o referido instituto, dispondo em seu artigo $8^{\circ}$, parágrafo único, que o participante e o associado que denunciar à autoridade o bando ou quadrilha, possibilitando seu desmantelamento, terá a pena reduzida de um a dois terços (BRASIL, 1990), havendo, contudo, a condição de ser uma associação permanente e não mero concurso eventual de agentes. Semelhantemente, várias leis posteriores trataram do assunto, diferenciando-se quanto ao objetivo da delação e quanto aos benefícios para o delator, sendo elas a Lei dos Crimes contra o Sistema Financeiro Nacional, no seu art. 25, § $2^{\circ}$; art. 16, parágrafo único da Lei dos Crimes contra a Ordem Econômica e Financeira; art. $6^{\circ}$ da Lei 9.034/95; art. $1^{\circ}$, $\S 5^{\circ}$ da Lei 9.613/98; arts. 13 e 14 da Lei de Proteção a Vítimas e a Testemunhas Ameaçadas; arts. 86 e 87 da Lei 12.529/11 que trata da delação via acordo de leniência e art. 41 da Lei de Drogas. Dentre as supracitadas, cabe a ressalva para a Lei do Crime Organizado, de 3 de maio de 1995, que embora tenha iniciado um caminho investigativo no cenário brasileiro, pecou gravemente ao descrever de modo precário pontos considerados cruciais acerca da delação premiada, não oferecendo a segurança jurídica necessária para a atuação eficiente das autoridades públicas. Além disso, com a única previsão de prêmio sendo a diminuição da pena, de um a dois terços, não havia encorajamento para qualquer tipo de colaboração premiada por parte do coautor ou partícipe do delito, pois este reconhecia de antemão a inegável probabilidade de continuar cumprindo pena, se duvidar, no mesmo estabelecimento prisional dos seus antigos comparsas, ficando sujeito a punição da traição com verdadeira pena de morte como consta no Código de Ética dos criminosos (LIMA, 2020). Por conseguinte, a Lei $n^{\circ} 12.850 / 13$, conjuntamente à inclusão da redação dada pela Lei $n^{\circ} 13.964 / 19$, alterou essa realidade, tendo sido recepcionada no ordenamento jurídico como a mais significativa norma a discorrer com detalhes sobre a forma que as colaborações deveriam ser trazidas e utilizadas nos autos, acrescentando ainda, em seu art. $4^{\circ}$, um rol de benefícios legais para incentivo ao réu delator, desde que esse atinja os resultados ali elencados. Destarte, as lacunas conceituais e procedimentais, que eram alvos de debates tanto na doutrina, quanto na jurisprudência, finalmente viram-se preenchidas com os novos parâmetros trazidos pelos avanços legislativos listados.

Conclusão: Constata-se que a progressão legislativa concernente a colaboração premiada logrou êxito no combate à criminalidade organizada, porquanto possibilitou que as autoridades estatais, com efetividade, chegassem ao núcleo dos grupos criminosos, alcançando os seus líderes.

\section{Referências}

BRASIL. Lei $\mathbf{n}^{\circ}$. 8.072, de 25 de julho de 1990. Dispõe sobre os crimes hediondos, nos termos do art. $5^{\circ}$, inciso XLIII, da Constituição Federal, e determina outras providências. Disponível em: http://www.planalto.gov.br/ccivil_03/leis//8072.htm. Acesso em: 03 ago. 2020.

LIMA, Renato Brasileiro de. Manual de Processo Penal. 8. ed. São Paulo: JusPodivm, 2020.

TEIXEIRA, Geraldo Nunes Laprovitera. A Colaboração Premiada Como Instrumento do Ministério Público no Combate às Organizações Criminosas. Cadernos do Ministério Público do Estado do Ceará. Disponível em: encurtador.com.br/dkqAP. 
Acesso em: 30 jun. 2020.

Coordenadoria de Pesquisa e Extensão - COPEX

Departamento de Editoraçāo e Divulgaçāo Científica - DEDIC 


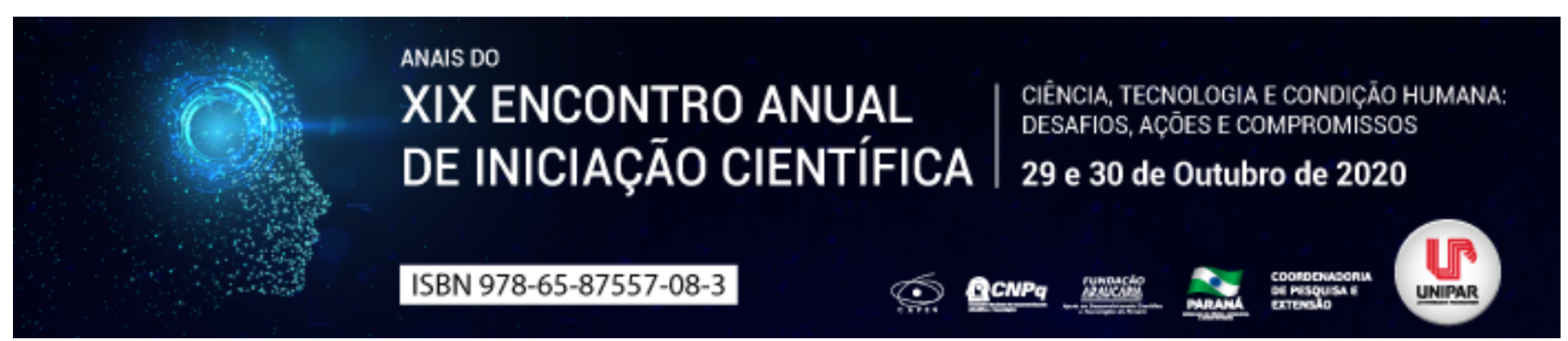

A NECESSIDADE DE ADEQUAÇÃO DAS SÚMULAS DO TST APÓS A REFORMA TRABALHISTA (LEI 13.467/2017)

\author{
${ }^{1}$ DANIEL FERNANDO GOTTEMS, ${ }^{2}$ CLEVERSON IVAN MERLO
}

${ }^{1}$ Acadêmico PIC/UNIPAR

${ }^{1}$ Docente da UNIPAR

Introdução: O presente trabalho tem por intento desvendar a necessidade de adequação das Súmulas do Tribunal Superior do Trabalho após a Reforma Trabalhista Lei 13.467/2017. É fato notório que a Consolidação das Leis Trabalhistas está submetida a uma legislação ultrapassada, assim, passível de desregulamentação. A fim de solucionar algumas destas controvérsias, para o enfretamento das múltiplas questões que permeiam diante da reforma trabalhista, os julgadores optam pela criação de jurisprudências, súmulas e orientações jurisprudenciais, onde a partir destes entendimentos, é possível, na ausência de norma regulamentadora a aplicação supletiva e subsidiaria destes entendimentos.

Objetivo: A presente pesquisa tem como objetivo demonstrar os casos em que ocorre a necessidade de adequação Súmulas do Tribunal Superior do Trabalho, a fim de solucionar algumas destas controvérsias, para o enfretamento das múltiplas questões que permeiam diante da Reforma Trabalhista.

Desenvolvimento: Em 10 de novembro de 1943 entrava em vigor o decreto lei n. 5.452 que aprovava a Consolidação das Leis do Trabalho, reunindo, sistematicamente, a legislação trabalhista da época, bem como procedendo alterações em diversos institutos. Sendo assim, desde a década de 40, a legislação trabalhista não sofreu mudanças significativas, ou seja, segundo Saad (2015, pg.17) suas disposições envelheceram, de tal forma que não acompanharam o crescimento e desenvolvimento da sociedade brasileira. Assim com o passar dos anos e diante da constante evolução da sociedade, houve a criação de variadas controvérsias no direito, e a fim de solucionar algumas destas controvérsias, para o enfretamento das múltiplas questões que permeiam diante da constante evolução da sociedade os julgadores optam pela criação de jurisprudências, súmulas e orientações jurisprudenciais. Já em 2017 entrou em vigor a Lei 13.467/2017, mais conhecida como Reforma Trabalhista, havendo significativas mudanças no âmbito do Direito do Trabalho, que tem causado enorme discussão no mundo jurídico, e a que abordaremos no artigo, é a necessidade de adequação das Súmulas do Tribunal Superior do Trabalho após a Reforma Trabalhista. DELGADO (2017, pg.382).

Conclusão: No estudo sobre o tema, concluímos que o conteúdo da Lei 13.467/2017, trouxe significativas mudanças, capazes de estabelecer novos tipos de contrato de trabalho, ou novos permissivos para o desenvolvimento da economia, a abertura de novos postos de emprego. Acredita-se que a maior afetação da Reforma Trabalhista sob a ótica dos operadores do direito, foi a desconstrução da carga valorativa do Direito do Trabalho, já que a Lei $n^{\circ} 13.467 / 2017$ se contrapõe em seus princípios, suprimindo regras benéficas ao trabalhador, priorizando a norma menos favorável ao empregado, prevalecendo a livre autonomia da vontade, entre outros. Ante ao exposto, restou evidenciado que as Súmulas do Tribunal Superior do Trabalho, necessitam de adequações, pois devem ser utilizadas de forma conjunta pelos operadores do Direito. É fato que o Direito do Trabalho possui matérias extremamente lacunosas, o que prejudica a sua aplicação e a eficácia da tutela jurisdicional prestada, exigindo-se que os Julgadores utilizam de Súmulas, orientações jurisprudenciais e jurisprudência para que não haja inconstância na aplicação das normas.

\title{
Referências
}

SAAD, D. E. J; SAAD, G. E; BRANCO, C. S. M. A; Consolidação das leis do trabalho: comentada. São Paulo: LTr, 2015. DELGADO, Maurício Godinho; DELGADO, Gabriela Neves. A reforma trabalhista no Brasil: com os comentários à Lei $\mathbf{n}$. 13.467/2017. São Paulo: LTr, 2017. 382 p. 


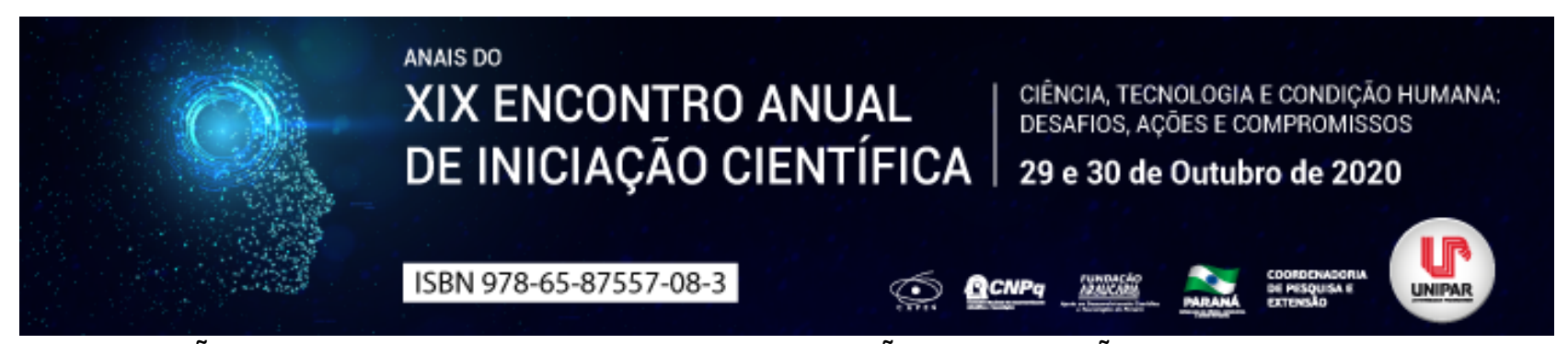

ORGANIZAÇÕES E COMPLIANCE: MEDIDAS DE PREVENÇÃO E MITIGAÇÃO PERANTE A LEI N. 12.846/13

\author{
${ }^{1}$ THAIS NAKAOKA BALAN, ${ }^{2}$ PAULO CESAR DE SOUSA
}

\author{
${ }^{1}$ Acadêmica do Curso de Direito da UNIPAR \\ ${ }^{1}$ Docente da UNIPAR
}

Introdução: A cada dia nossa sociedade vem exigindo uma atuação mais transparente e ética dos agentes econômicos, medida que se faz necessária à adoção de um programa de Compliance, a fim de prevenir e mitigar atos de corrupção previstos na Lei 12.846/13, primordiais para a credibilidade das organizações perante seus stakeholders.

Objetivo: Analisar a relação entre a Lei 12.846/13 e as práticas de Compliance que a compõem e expor como essas práticas podem ser adotadas.

Desenvolvimento: Não é de hoje que se observam casos de escândalos corporativos envolvendo atos de corrupção. Devido à crescente mutualidade econômica em âmbito nacional e internacional, a corrupção se expande com as operações de grande valor, realizadas pelas organizações privadas ou públicas. A corrupção é um fenômeno difuso relacionado em geral ao crime organizado, com contornos bem delineados, embora dinâmicos, que, atuando na clandestinidade, ameaçam a estrutura do Estado (LIVIANU, 2014). Neste contexto, a exigência de uma conduta revestida de transparência e ética dos agentes econômicos é cada vez maior por parte tanto da sociedade, quanto de seus colaboradores. Conforme Marília Cecília Coutinho de Arruda (2001, pág. 149): [...] quando a ciência econômica não se subordina à ética, não contribui para o verdadeiro bem estar e desenvolvimento da sociedade. Esses comportamentos desviados acabaram por vezes desestabilizando o sistema financeiro brasileiro, resultando na busca de políticas de combate à corrupção, como a desenvolvida pela $L$ ei $n .^{\circ} 12.846 / 13$, a qual dispõe sobre a responsabilização, no âmbito civil e administrativo, das pessoas jurídicas que venham a praticar atos contra a administração pública, seja esta nacional ou estrangeira. Xavier (pág. 38, 2015) comenta acerca da crítica sobre essa lei, a qual não abrangeu a responsabilidade penal da pessoa jurídica: independente daqueles que defendam ou não [...] é fato que as aspirações sociais da grande maioria dos países impuseram a necessidade de se estabelecer punições aos entes jurídicos coletivos (pessoas jurídicas) e não apenas aos indivíduos (pessoas naturais) que os componham . A Lei de Anticorrupção é regulamentada pelo Decreto $n$. 8.420/15, o qual prevê, em seu conteúdo, algumas ações que servem como instrumento de prevenção no cometimento de atos lesivos à administração pública, tais como as práticas de compliance adotadas pela organização, as quais, em caso de eventual condenação, serão levadas em conta no momento da aplicação das penalidades. Segundo entendimento de Célia Regina P. Lima Negrão (2017, pág. 109), o compliance: Atua proativamente e apoia as outras áreas da organização na execução dos seus objetivos de forma correta, em conformidade com a legislação e normativos vigentes, e com base no código de ética da organização . Por sua vez, o compliance anticorrupção, que é o que interessa para este estudo, vem a ser o conjunto de mecanismos e medidas que visam à prevenção, à detecção e ao combate de crimes de corrupção e outros atos contra a administração pública, bem como assegurar que valores e normas de conduta sejam observados pelos empregados. (XAVIER, pág. 48, 2015). De acordo com Sanches Cunha (págs. 112-113, 2020) os parâmetros para a implantação do programa de integridade, previstos no Decreto n. 8.420/15, estão divididos em 05 grupos: a) comprometimento da alta administração da corporação (dos administradores, sócios, dirigentes e liderança da empresa com o programa); b) análise de riscos (risk assesment mapeamento dos riscos internos e externos); c) criação de políticas e procedimento (elaboração de código de conduta, de ética e implantação de um canal de denúncias); d) comunicação e treinamento para proporcionar a eficácia da fase anterior, bem como e) monitoramento, auditoria e remediação (fase em que todo o programa é colocado em prática, a fim de assegurar sua função preventiva e a repressiva).

Conclusão: A implementação das práticas de Compliance se mostra essencial às empresas no combate a fraudes e lavagem de dinheiro. Este mecanismo não visa apenas trazer conformidade com as normas vigentes, mas também, desenvolver uma cultura organizacional ética e consciente. Advindo do Decreto 8.420/2015, o Programa de Integridade versa, em especial, a respeito de hábitos que coíbem atos lesivos à Administração Pública, cujo aparato é utilizado pelas empresas privadas como meio de prevenção e mitigação perante eventuais sanções administrativas.

\title{
Referências
}

ARRUDA, M. C. C.; WHITAKER, M. DO CARMO; RAMOS, J. M. R. Fundamentos de ética empresarial e econômica. São Paulo: Atlas, 2001.

CUNHA. R. S. Lei Anticorrupção Empresarial. 3. ed. Salvador: JusPodivm, 2020.

LIVIANU, R. Corrupção Incluindo a Lei Anticorrupção. 2. ed. São Paulo: Quartier Latin, 2014.

NEGRÃO, C. R. P. L. Compliance, controles internos e riscos: a importância da área de gestão de pessoas. 2. ed. Brasília: 
Senac, 2017.

XAVIER, C. P. G. Programas de compliance anticorrupção no contexto da lei 12.846/13: elementos e estudo de caso.

Orientador: Wanderley Fernandes. 2015. 100 f. Dissertação (Mestre em Direito) - Fundação Getúlio Vargas, São Paulo, 2015.

Coordenadoria de Pesquisa e Extensão - COPEX

Departamento de Editoraçāo e Divulgaçāo Científica - DEDIC 


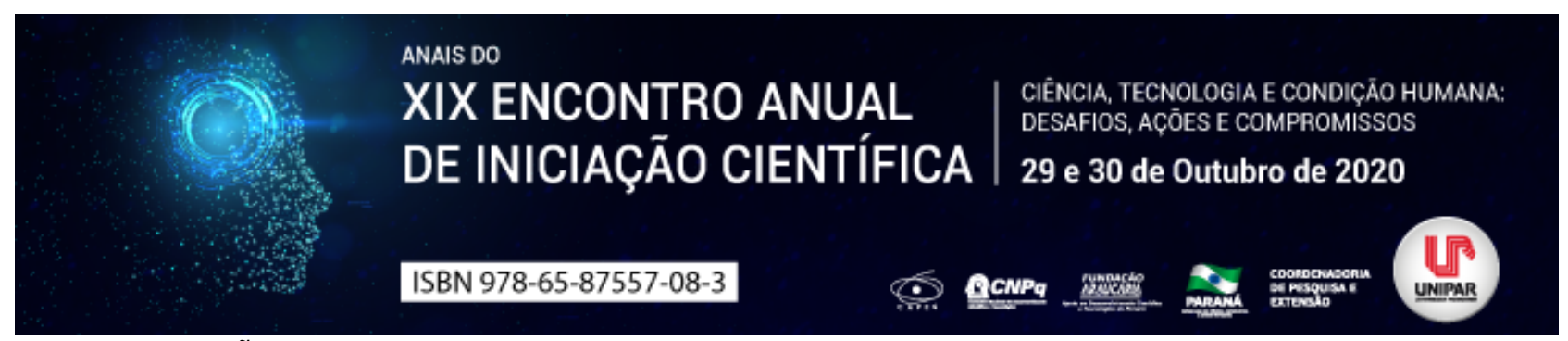

AUTOAVALIAÇÃO DAS HABILIDADES PROFISSIONAIS DEMANDADAS PELO MERCADO DE TRABALHO

\author{
${ }^{1}$ Eva Isidoro da Silva, ${ }^{2}$ ALBERTH MARTINS BATISTA, ${ }^{3}$ DANIELI PINTO
}

\author{
${ }^{1}$ Acadêmica do curso de Administração/ FACEC \\ ${ }^{1}$ Docente/ FACEC \\ ${ }^{2}$ Docente/ FACEC
}

Introdução: O mercado de trabalho brasileiro vem se caracterizando ao longo dos anos por uma trajetória complexa e repleta de mudanças contínuas de seus padrões de empregabilidade, o que o caracteriza como dinâmico. Atrelado a isso, está o fato da carga de responsabilidade sobre o sucesso profissional não depender exclusivamente do trabalhador (HELAL; ROCHA, 2011). A ênfase nas competências reforça, sobretudo, uma mobilização subjetiva de cada um nas relações de trabalho e emprego, suas modalidades e constrangimentos e o empenho natural das qualidades pessoais que configuram os atuais perfis profissionais (MARQUES, 2013).

Objetivo: Avaliar a autopercepção dos indivíduos acerca das habilidades profissionais necessárias para a colocação e recolocação deles no mercado de trabalho.

Material e método: Esta pesquisa compreende um estudo exploratório quantitativo. A coleta de dados aconteceu por meio de um questionário. Foi pedido aos participantes que eles fizessem uma autoavaliação das habilidades relacionadas com a comunicação, relacionamento interpessoal, proatividade, poder de negociação, trabalho em equipe, criatividade, disciplina e liderança. Para cada habilidade foi apresentada uma escala de cinco pontos (Likert, 1932), sendo (5) muito evidente e (1) muito pouco evidente. A escolha da amostra foi aleatória e consistiu em 47 indivíduos que estão fora do mercado de trabalho e à procura de emprego. Os dados brutos oriundos da pesquisa foram organizados em planilhas do MS-Excel e tabulados no software STATA.

Resultados: As habilidades mais pontuadas com a nota (5) foram trabalho em equipe (53\%), disciplina (49\%), relacionamento interpessoal (47\%) e proatividade (46\%). As notas (3) , (2) e (1) foram mais expressivas em relação ao poder de negociação (55\%), a liderança (49\%), a comunicação (45\%) e a criatividade (40\%).

Discussão: Para Fragoso, Valadas e Paulos (2019), a lista de competências mais importantes para os empregadores é, de fato, grande, sendo elas, a proatividade, motivação para desempenhar a função, flexibilidade para realizar várias tarefas distintas, dedicação, capacidade de inovar, dentre outras. Marques (2007) afirma que o novo modelo de empregabilidade prevalece sobre a proatividade, adequação e capacidade de resolver problemas dentro do ambiente de trabalho. Mezzavila e Cardoso (2016) apontam que apesar do notável dinamismo do mercado de trabalho que exige mais preparação, muitos indivíduos não dão a devida importância de se prepararem, mesmo quando possuem essa oportunidade dentro das organizações onde já trabalham e que o esforço e a dedicação são parte fundamental para alcançar o sucesso profissional.

Conclusão: A autoavaliação evidencia que os indivíduos da amostra se veem mais preparados para exercerem atividades de cunho operacional, uma vez que as habilidades voltadas para atividades de gerenciamento que envolvem tomada de decisão (poder de negociação, liderança, criatividade e negociação) foram menos pontuadas como muito evidentes e evidentes Como trabalhos futuros pretende-se investigar como os indivíduos se preparam para o mercado de trabalho e se há uma percepção por parte deles da importância do desenvolvimento dessas habilidades.

\title{
Referências
}

FRAGOSO, A.; VALADAS, S. T.; PAULOS, L. Ensino superior e empregabilidade: percepções de estudantes e graduados. CEDES, v. 40, 2019.

HELAL, D. H.; ROCHA, M. O discurso da empregabilidade: o que pensam a academia e o mundo empresarial. Cadernos EBAPE.BR, Rio de Janeiro, v. 9, n. 1, p. 139-154, 2011.

LIKERT, R. A technique for the measurement of attitudes. New York: Columbia University Press, 1932.

MARQUES, A. P. Empregabilidade e (novos) riscos profissionais. Comunicação e Sociedade, 2013.

Mercados e Estratégias de Inserção Profissional Licenciados versus Empresas da Região Norte. Melntegra, 2007.

MEZZAVILA, I. C. V.; CARDOSO, J. M. M. Qualificação profissional e empregabilidade: reflexões pertinentes. Revista de Pós Graduação Faculdade Cidade Verde, v. 2, 2016. 


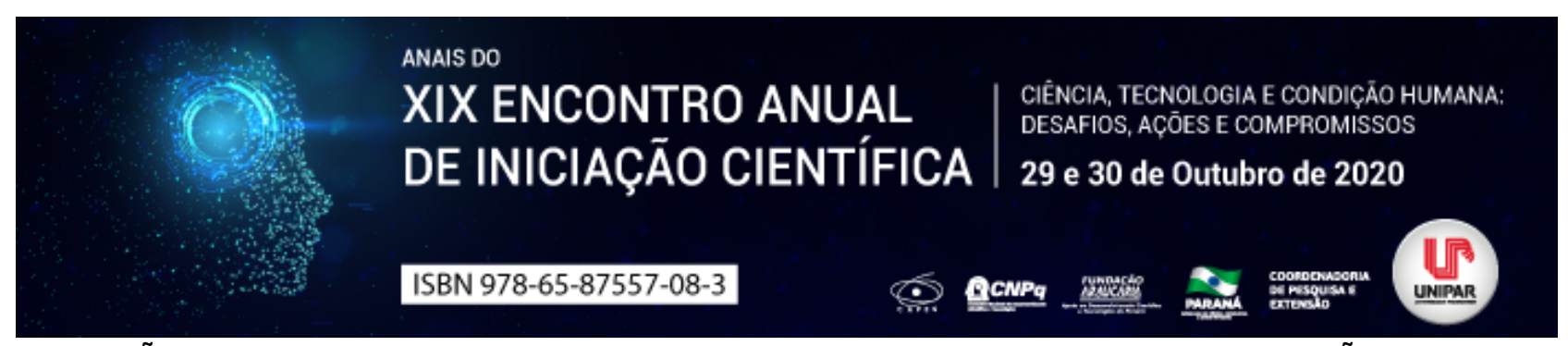

A LIBERAÇÃO DO PORTE DE ARMAS DE FOGO E SUA (IN)EFETIVIDADE PARA A DIMINUIÇÃO DOS CRIMES

\author{
${ }^{1}$ EVERSON ELEANDRO MARQUES DA SILVA, ${ }^{2}$ ALESSANDRO DORIGON
}

${ }^{1}$ Acadêmico do curso de Direito na Universidade Paranaense UNIPAR, Umuarama

${ }^{1}$ Docente da UNIPAR

Introdução: É cediço que todos os cidadãos têm o direito inerente a sua autodefesa, liberdade e propriedade, bem como, tem por direito fundamental, erigido na Carta Magna, à vida, ao patrimônio, à liberdade e à segurança. Neste sentido, o porte de armas de fogo se mostra crucial na manutenção desses frente à criminalidade.

Objetivo: Analisar o porte de arma de fogo como direito inerente aos cidadãos, bem como, demonstrar a inefetividade da restrição do porte de arma de fogo para a diminuição dos crimes.

Desenvolvimento: Conforme ensina Nascimento (2017) para John Locke a propriedade é um direito natural, pois é inerente ao homem em estado de natureza, sendo que esta é definida como a soma dos direitos à vida, à liberdade e aos bens materiais. No mesmo sentido, a Constituição Brasileira define por meio de seu artigo $5^{\circ}$ a vida, o patrimônio, a liberdade e a segurança como direitos fundamentais do cidadão brasileiro e dos estrangeiros residentes no país. Assim, o direito ao porte de arma de fogo mostra-se fundamental para assegurar os demais, dado que com frequência, a segurança falha em ser garantida pelo Estado e o indivíduo precisa realizar a autodefesa para a manutenção de si, sua liberdade e propriedade. Isto posto, dado que é insofismável, cabe apenas investigar a efetividade ou não do porte de armas de fogo para a redução dos crimes. Conforme estudos do IPEA (Instituto de Pesquisa Econômica Aplicada) realizados por Cerqueira e Mello (2012), os quais reuniram dados do Estado de São Paulo, concluíram que após o vigor do Estatuto do Desarmamento, entre 2001 e 2007, o número de homicídios no estado diminuiu $60,01 \%$. Entretanto, não houve uma queda generalizada da criminalidade e os crimes contra a pessoa e contra o patrimônio aumentaram $20 \%$. Ainda destacam que houve apenas redução dos crimes praticados com arma de fogo; ademais, as lesões corporais dolosas aumentaram e os resultados indicaram que em relação aos crimes contra o patrimônio a difusão de armas não interfere de maneira estatisticamente significativa. Outros estudos sugerem que o criminoso deixa de cometer crimes quando a população se arma para autodefesa. Nesta senda, Mustard e Lott (1996) afirmam que os dados coletados a nível nacional nos Estados Unidos demonstram um aumento nos crimes contra a propriedade quando a legislação exige que o porte de arma seja feito de maneira oculta.

Conclusão: $O$ direito ao porte de armas se classifica como fundamental na defesa da liberdade, propriedade e segurança. Ademais, demonstrou-se que a taxa de crimes, em geral, não se reduz com a restrição de armas, bem como, após a vigência do Estatuto do Desarmamento, esses aumentaram no Estado de São Paulo. Também nos Estados Unidos o porte oculto de arma também levou ao aumento desse gênero de crimes.

\title{
Referências
}

CERQUEIRA, Daniel Ricardo de Castro; MELLO, João Manoel Pinheiro de. Menos armas, menos crimes. Ipea. 2012. Disponível em: encurtador.com.br/cejJ5. Acesso em: 02 jun. 2020.

MUSTARD, David B.; LOTT, Lohn. Crime, Deterrence, and Right-to-Carry Concealed Handguns. Coase-Sandor Institute for Law \& Economics Working Paper. n .41, 1996.

NASCIMENTO, Christian Lindberg Lopes do. O direito em John Locke. Supere aude, Belo Horizonte, v. 8, n. 16, p. 429-442, ago./dez., 2017. 


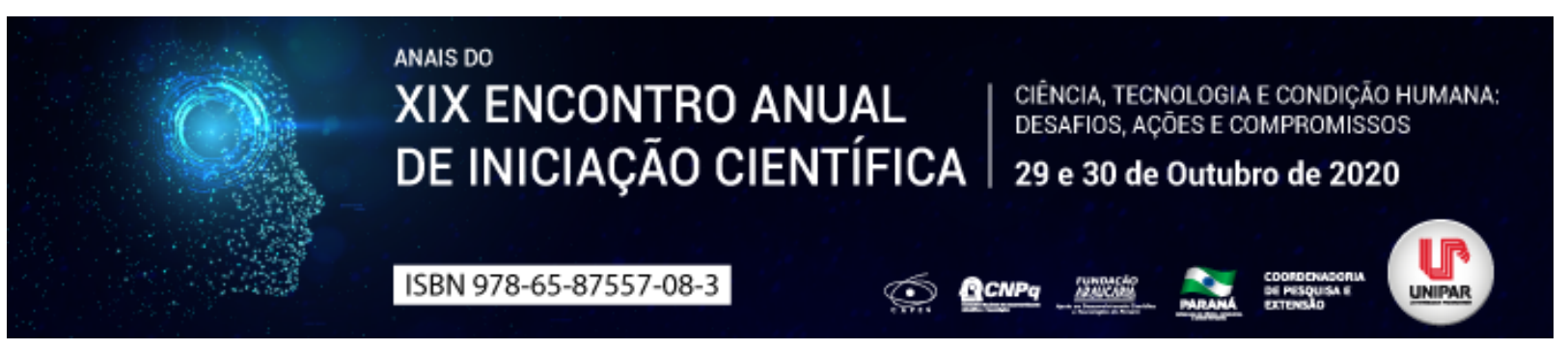

A PANDEMIA POR COVID-19 E DIREITOS FUNDAMENTAIS

\title{
${ }^{1}$ RAQUEL LAURIANO RODRIGUES FINK, ${ }^{2}$ LILIAN CRISTINA PINHEIRO GOTO, ${ }^{3}$ EDUARDO MAFFEI, ${ }^{4}$ LAURIANO PEREIRA DA LUZ, ${ }^{5}$ CELSO HIROSHI IOCOHAMA
}

\author{
${ }^{1}$ Discente do Mestrado em Direito Processual e Cidadania UNIPAR \\ ${ }^{1}$ Discente do Mestrado em Direito Processual e Cidadania UNIPAR \\ ${ }^{2}$ Discente do Mestrado em Direito Processual e Cidadania UNIPAR \\ ${ }^{3}$ Discente do Mestrado em Direito Processual e Cidadania UNIPAR \\ ${ }^{4}$ Docente da Graduação em Direito e do Programa de Mestrado em Direito Processual e Cidadania da UNIPAR
}

Introdução: A pandemia causada pela COVID-19 provocou inúmeras mudanças na sociedade e no cotidiano das pessoas não só em nível nacional, como em todo o mundo, em razão da globalização. Os efeitos da pandemia são trágicos e atingiram todas as esferas da sociedade, sejam elas de interesse público ou privado. O direito não ficou isento desses impactos e sofreu mudanças em decorrência da situação epidemiológica que sobreveio em escala mundial, com vistas à autorizar medidas restritivas potencialmente capazes de reduzir os efeitos da pandemia. Como consequência, verificou-se a adoção, em todo o globo terrestre, de medidas no intuito de controlar ou refrear o alastramento da doença que, em regra, implicam em restrições de liberdades fundamentais. Para a pesquisa utilizou-se o método descritivo, bem como a pesquisa bibliográfica.

Objetivo: Analisar os impactos da pandemia no que tange às restrições a direitos fundamentais individuais impostas pelo Estado.

Desenvolvimento: É inegável que a pandemia provocada pelo novo coronavírus COVID-19 trouxe inúmeras repercussões ao cotidiano da vida pessoal e coletiva. As pandemias demandam o enfrentamento necessário e eficaz com vistas a reduzir seus efeitos em todas as esferas da sociedade, sejam elas de caráter econômico, social, de saúde pública. No âmbito do direito, uma pandemia pode significar restrição de liberdades fundamentais. Isto porque a gramática da vigilância epidemiológica compreende a quarentena, a limitação ou interdição de viagens, o recrudescimento do controle fronteiriço ou mesmo o fechamento de fronteiras, a imposição de terapias, a restrição ou supressão de reuniões públicas, a vacinação obrigatória, ou até ingerências no modo como se realizam os funerais (VENTURA, 2010, p. 42). As medidas de restrição adotadas por entes públicos, embora visem a segurança e a proteção das pessoas, restringem direitos constitucionais e/ou garantidos em normas internacionais (FREITAS, CÂNDIDO, RODRIGUES, 2020, p. 175). O Pacto de São José da Costa Rica, em seu artigo 22, assim como outras normas internacionais de direito humanos, prevê a liberdade de locomoção. No Brasil, embora o direito à liberdade e de ir e vir estejam garantidos na Constituição estes, e vários outros direitos individuais, acabaram por serem cerceados durante a pandemia em prol do bem comum, o que está autorizado no capítulo $\mathrm{V}$, artigo 32 do Pacto de São José da Costa Rica (OEA, 1969). Durante o período, os diferentes entes federados, concorrentemente, editaram normas que impuseram restrições ao direito à livre circulação não só de pessoas, mas também de mercadorias. A questão envolvendo a competência dos entes públicos, aliás, foi tratada pelo Supremo Tribunal Federal na Ação Direta de Inconstitucionalidade (ADI) 6341, que decidiu que os entes federados podem atuar de forma concorrente para legislar e adotar providências de enfrentamento à pandemia (BRASIL, 2020). Para Sotero e Soares (2020, p. 101) o sistema constitucional de crises, entendido pelo

conjunto de requisitos constitucionais que tem como objetivo identificar as situações de crise, bem como assegurar o Estado de Direito em tempos emergenciais está previsto nos artigos 136 a 141 da Constituição da República e contempla o estado de defesa e o estado de sítio, como regimes jurídicos excepcionais. Visando estimular a organização de países no combate à pandemia, a Comissão Interamericana de Direitos Humanos editou a Resolução no 01/2020 (CIDH, 2020) elencando medidas de restrição de direitos fundamentais para manter o isolamento da população (SOTERO, SOARES, 2020, p.104). As medidas de enfrentamento e contenção do alastramento da pandemia adotadas, tais como o isolamento social, inegavelmente, restringiram direitos fundamentais da população. Todavia, esse cerceamento temporário de direitos adotado pelos entes públicos está respaldado em regramentos específicos que autorizam a mitigação, ou mesmo a restrição, de direitos individuais em benefício da saúde da coletividade. Assim, imposições como o isolamento social durante a pandemia estão autorizados, ainda que temporariamente, como forma de proteção de um bem maior, em atenção à supremacia do interesse público em detrimento do particular.

Conclusão: As restrições impostas pelos entes públicos em tempos de pandemia, embora possam implicar em restrição de direitos individuais, estão autorizadas por lei e normas internacionais e visam o resguardo da saúde pública e, em última instância, da vida.

\section{Referências}

BRASIL. Supremo Tribunal Federal. Ação Direta de Inconstitucionalidade 6341, Relator: Ministro Marco Aurélio, Brasília, DF, 15 de abril de 2020, DJ 07.05.2020. Disponível em: http://portal.stf.jus.br/processos/detalhe.asp?incidente=5880765. Acesso em: 28 ago. 2020.

BRASIL, Lei $\mathbf{n}^{\text {o }} \mathbf{1 3 . 9 7 9 / 2 0 2 0}$ editada em 06.02.2020. Disponível em: http://www.planalto.gov.br/ccivil_03/_ato2019- 
Washington, 22 de outubro de 2002.

FREITAS, Jucycler Ferreira., CÂNDIDO, Estelita Lima; RODRIGUES, Sandra Maria Bezerra. Repercussões sobre a legislação e o exercício dos Direitos Fundamentais Individuais na pandemia por COVID-19. Diálogos Interdisciplinares, 2020, p. 174-181. Disponível em: https://revistas.brazcubas.br/index.php/dialogos/article/view/891. Acesso em 28 ago.2020.

ORGANIZAÇÃO DOS ESTADOS AMERICANOS OEA. Convenção Americana sobre Direitos Humanos. Washington, Estados Unidos: OEA, 1969.

SOTERO, Ana Paula Da Silva; SOARES, Ricardo Maurício Freire. Constituição e Restrição a Direitos Fundamentais em Tempos de Pandemia de COVID-19: um Breve Estudo do lockdown no Estado do Maranhão. In: BAHIA, Saulo José Casali; MARTINS, Carlos Eduardo Behrmann Rátis (Org.). Direitos e deveres fundamentais em tempos de coronavírus. São Paulo: Editora lasp, 2020. Volume 2. 510p.

Disponível

em: http://www.escoladaajuris.org.br/observatorio/images/DIREITOS_E_DEVERES_FUNDAMENTAIS_EM_TEMPOS_DE_CORONAVIRUS2.pdf\#page=92. Acesso em: 28 ago. 2020.

VENTURA, D. F. L. Pandemias e estado de exceção. In: Anais do VII Congresso Internacional de Direito da USJT. 2010. p. 41-56. Disponível em: https://www.academia.edu/2263089/PANDEMIAS_E_ESTADO_DE_EXCE\%C3\%87\%C3\%830. Acesso em 28 ago.2020. 


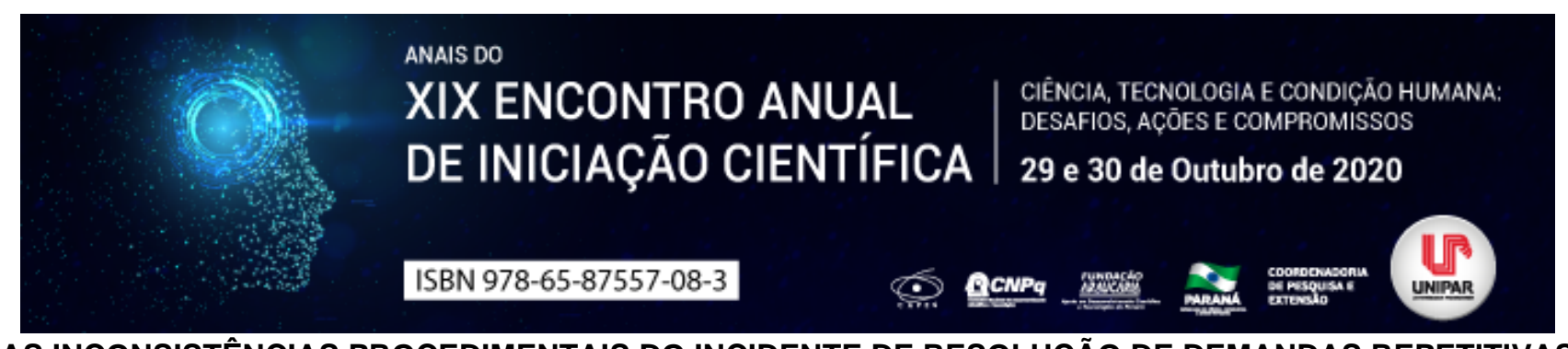

AS INCONSISTÊNCIAS PROCEDIMENTAIS DO INCIDENTE DE RESOLUÇÃO DE DEMANDAS REPETITIVAS

\author{
${ }^{1}$ JULIA IZABELLE TONETO ROMANO MAZIERO, ${ }^{2}$ ANNA FERNANDA SCALLA MENOTTI, ${ }^{3}$ LAIS SILVA ZIMIANI , ${ }^{4}$ JUSSARA \\ SUZI ASSIS BORGES N. FERREIRA
}

\footnotetext{
${ }^{1}$ Acadêmica do Mestrado em Direito Processual e Cidadania - UNIPAR

${ }^{1}$ Acadêmica do Mestrado em Direito Processual e Cidadania - UNIPAR

${ }^{2}$ Acadêmica do Mestrado em Direito Processual e Cidadania - UNIPAR

${ }^{3}$ Docente da UNIPAR
}

Introdução: O Código de Processo Civil de 2015 inovou o ordenamento jurídico brasileiro com a previsão do Incidente de Resolução de Demandas Repetitivas (IRDR), que visa conceder soluções iguais a processos idênticos em matéria de direito, buscando um modo de diminuir a quantidade de demandas submetidas ao Judiciário. Contudo, as decisões proferidas no incidente deveriam ser submetidas a um criterioso processo de conformidade, para evitar a violação de direitos e garantias processuais como a do contraditório, da influência e da segurança jurídica.

Objetivos: Analisar a legislação processual civil referente ao IRDR e as relevantes inconsistências procedimentais em relação aos direitos e garantias processuais.

Desenvolvimento: As novas normas processuais civis vieram permeadas de procedimentos, cuja pretensão é a de uniformizar a jurisprudência, para garantia de sua estabilidade, coerência e integridade. Nessa linha, o IRDR foi introduzido ao ordenamento jurídico (arts. 976 a 987, CPC) para consumar a ideia de uniformização, tendo como principais fundamentações a busca pela garantia de eficiência, isonomia e segurança jurídica, pautadas na necessidade de previsibilidade. Segundo Marinoni (2016, p. 51), o incidente propõe julgar uma questão e não propriamente as demandas repetitivas. Isso tem extrema importância, pois as demandas repetitivas, embora dependam do julgamento de uma mesma questão, certamente exigirão a consideração de outras circunstâncias que podem variar conforme cada uma das ações individuais. A proposição de repartição estanque entre quaestiones facti e a quaestiones iuris é um dos problemas irrefutáveis do IRDR, pois muitas questões comuns são fáticas, como as causas consumeristas, em que a questão comum é definir se um produto ou serviço é defeituoso, disponibilizado ao consumidor com erros na sua produção, ou se uma construção foi vendida com vícios estruturais decorrentes de falhas no projeto, prejudicando dezenas, centenas de pessoas; ou se uma atividade laboral é insalubre; ou se as condições de trabalho de uma fábrica importam em riscos aos trabalhadores e por aí em diante (CABRAL; CRAMER, 2016, p. 1.440). Ademais, a decisão proferida no incidente constitui nítida proibição de litigar a questão já decidida, nos casos de decisão negativa àqueles que não puderam participar e discutir, assemelhando-se a um ilegítimo collateral estoppel (ou impedimento colateral), em verdadeira transgressão ao princípio do contraditório e ao direito de influência. Por esse raciocínio, outro problema do IRDR está na equivocada suposição de que a sua decisão é precedente e que, assim, poderia se aplicar a todos os litigantes sem qualquer violação de direitos fundamentais processuais. A questão é que a decisão proferida em apenas uma demanda pode beneficiar terceiros, mas nunca prejudicá-los (art. 506, CPC/2015). Em outras palavras, a decisão proferida no incidente de resolução não pode retirar o direito de discutir a questão daquele que não participou efetivamente do processo (arts. $7^{\circ}, 9^{\circ}, 10$ e $489, \S^{\circ}$, inciso IV, CPC/2015). Verifica-se que o texto legal contém termos que, além de complexos, são absolutamente abstratos e dão ampla margem para subjetivismos do julgador. A repetição da questão de direito exigida pela norma processual abre margem para a discricionariedade judicial, diante da evidente ausência de parâmetros ou critérios objetivos a serem considerados pelo julgador para a indicação de quais seriam as causas com matérias idênticas de direito.

Conclusão: A instauração do IRDR pode gerar potenciais prejuízos aos jurisdicionados e culminar na violação direta das garantias constitucionais do contraditório, da influência e segurança jurídica, vez que o procedimento tende a atingir metas exclusivamente quantitativas do Judiciário em detrimento da necessidade de qualidade das decisões e da necessidade da decisão judicial adequada.

\title{
Referências
}

BRASIL. Código de Processo Civil. 2015.

CABRAL, Antonio do Passo; CRAMER, Ronaldo. Comentários ao novo código de processo civil. 2 ed. Rio de Janeiro: Forense, 2016.

MARINONI, Luiz Guilherme. Incidente de Resolução de Demandas Repetitivas: decisão de questão idêntica x precedente. São Paulo: Revista dos Tribunais, 2016. 
Coordenadoria de Pesquisa e Extensão - COPEX

Departamento de Editoraçāo e Divulgaçāo Científica - DEDIC 


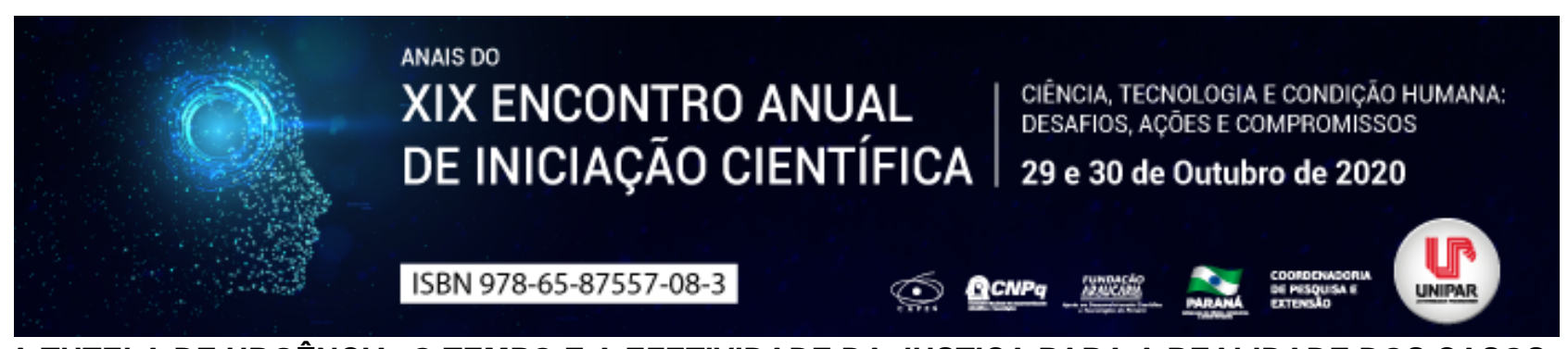

A TUTELA DE URGÊNCIA, O TEMPO E A EFETIVIDADE DA JUSTIÇA PARA A REALIDADE DOS CASOS

\author{
${ }^{1}$ ELI MATHEUS ROCHA MUNIZ SILVA, ${ }^{2}$ ALBINO GABRIEL TURBAY JUNIOR
}

\author{
${ }^{1}$ Acadêmico do PIC/UNIPAR \\ ${ }^{1}$ Docente da UNIPAR
}

Introdução: O processo civil tem natureza instrumental, assim, é compreendido como instrumento para a concretização do direito material, o que requer modelos processuais e técnicas adequadas conforme o direito material que se apresenta no caso concreto. Dessa forma, deve possuir institutos capazes de garantir a tutela jurisdicional efetiva, inclusive quando há risco iminente e necessidade de rápido provimento jurisdicional, o que pode ser alcançado pela tutela de urgência.

Objetivo: Analisar o instituto da tutela de urgência como um meio para garantir a tutela efetiva de direitos.

Desenvolvimento: O tempo é um fator natural extremamente relevante para a vida social, gerando importantes reflexos para o direito. Se no passado o tempo foi desprezado na construção do processo, conforme assinala Luiz Guilherme Marinoni (2016, p. 205): Houve um momento em que o tempo não era visto como algo importante na vida do processo, em um frio e indiferente purismo metodológico [...] , na atualidade marcada pela percepção de um processo instrumental que visa atingir resultados no mundo dos fatos, reconhece-se o tempo como um fator de corrosão de direitos ou inabilitação do processo de cumprir sua missão de dar efetividade a estes (DINAMARCO; BADARÓ; LOPES, 2020, p. 519). À luz da Constituição Federal, o princípio da inafastabilidade da jurisdição, previsto no art. $5^{\circ}$, XXXV da Carta Magna é o fundamento constitucional que autoriza a adoção de medidas para combater os malefícios do tempo e tutelar situações urgentes, uma vez que tal dispositivo não consiste simplesmente no acesso formal ao Judiciário, mas no acesso efetivo à ordem jurídica justa, a garantia de uma prestação jurisdicional tempestiva [...] (PIZZOL; MIRANDA, 2020). Assim, a legislação infraconstitucional deve possuir mecanismos aptos a garantir a tutela de direitos em todas as situações, segundo Cândido Rangel Dinamarco (2020, p.519): Oferecer medidas jurisdicionais urgentes significa, pois, dar integral cumprimento a essa disposição constitucional . É nesse contexto que se insere a tutela de urgência, prevista entre os arts. 300 e 310 do Código de Processo Civil, sendo uma espécie de tutela provisória. A concessão da tutela de urgência se dá mediante um juízo de cognição sumária que vislumbra a presença concomitante de dois elementos: a probabilidade de direito (fumus boni iuris) e o perigo de dano ou risco ao resultado útil do processo (periculum in mora). Há probabilidade de direito quando ocorrem idôneos elementos conducentes ao reconhecimento de que o autor pode ter o direito alegado (DINAMARCO; BADARÓ; LOPES, 2020, p.523); já o perigo de demora diz respeito ao fundado temor da parte sofrer algum dano decorrente da demora do processo, se a tutela tardar, pode o ilícito ocorrer, continuar ocorrendo, ocorrer novamente ou pode o dano ser irreparável, de difícil reparação ou não encontrar adequado ressarcimento (MARINONI; ARENHART; MITIDIERO, 2016, p.209). Os elementos autorizadores não devem ser interpretados separadamente, conforme observação de José Miguel Garcia Medina (2016, p. 514): A proeminência do fumus pode justificar a concessão de liminar, ainda que menos ostensivo o periculum, e vice-versa. A tutela de urgência se divide em duas modalidades: tutela antecipada e tutela cautelar. A primeira é uma tutela satisfativa, que permite a fruição imediata dos efeitos do possível acolhimento do pedido [...] (MEDINA, 2016, p.507), ao passo que a cautelar é provimento jurisdicional que visa assegurar o resultado útil e eficaz do processo (PIZZOL; MIRANDA, 2020). A dicotomia existente entre as modalidades de tutela de urgência é relativizada ante a existência da regra de fungibilidade prevista pelo parágrafo único do art. 305 do CPC, as medidas cautelares e as antecipatórias são estruturalmente iguais, podendo ser tratadas conjuntamente, embora funcionalmente diferentes e tendo objetivos diversos (DINAMARCO; BADARÓ; LOPES, 2020, p. 522). A tutela de urgência é ainda provimento precário, instável, que pode ser revogado ou modificado ao longo do processo (MARINONI; ARENHART; MITIDIERO, 2016, p.219). Em um mundo globalizado marcado por relações instantâneas e demandas imediatas, o descompasso entre o tempo da sociedade e o tempo do direito não é saudável, por isso, a tutela de urgência revela sua importância ao permitir a proteção de direitos em situações de iminente necessidade. Um exemplo concreto de sua relevância está nas demandas relacionadas à saúde, uma vez que nestes casos a demora pode submeter o paciente a risco de vida, sendo a tutela de urgência capaz de dar uma solução provisória a questão sem prejuízo de um contraditório futuro.

Conclusão: A tutela de urgência é um instrumento que tem por finalidade evitar que o decurso do tempo cause o perecimento de direitos, bem como prive o processo de sua utilidade. Assim, revela-se como um instituto indispensável ao processo civil, permitindo o pleno cumprimento das garantias constitucionais da inafastabilidade da jurisdição e da duração razoável do processo, garantindo efetividade à justiça.

\title{
Referências
}

BRASIL. Lei n 13.105, de 16 de março de 2015. Código de Processo Civil. Diário Oficial da União, Brasília, Seção 1, p. 1, 17 
mar. 2015.

DINAMARCO, Cândido Rangel; BADARÓ, Gustavo Henrique Righi Ivanhy; LOPES, Bruno Vasconcellos Carrilho. Teoria geral do processo. 32. ed. São Paulo: Editora Jus Podivm, 2020.

MARINONI, Luiz Guilherme; ARENHART, Sérgio Cruz; MITIDIERO Daniel. Novo curso de processo civil: tutela dos direitos mediante procedimento comum. São Paulo: Editora Revista dos Tribunais, 2016.

MEDINA, José Miguel Garcia. Direito processual civil moderno. 2. ed. São Paulo: Editora Revista dos Tribunais, 2016.

PIZZOL, Patrícia Miranda; MIRANDA, Gilson Delgado. A tutela de urgência como instrumento de acesso à justiça. Revista do processo. São Paulo. v. 302/2020, p. 175-216. Abr/2020.

Coordenadoria de Pesquisa e Extensão - COPEX

Departamento de Editoraçāo e Divulgaçāo Científica - DEDIC 


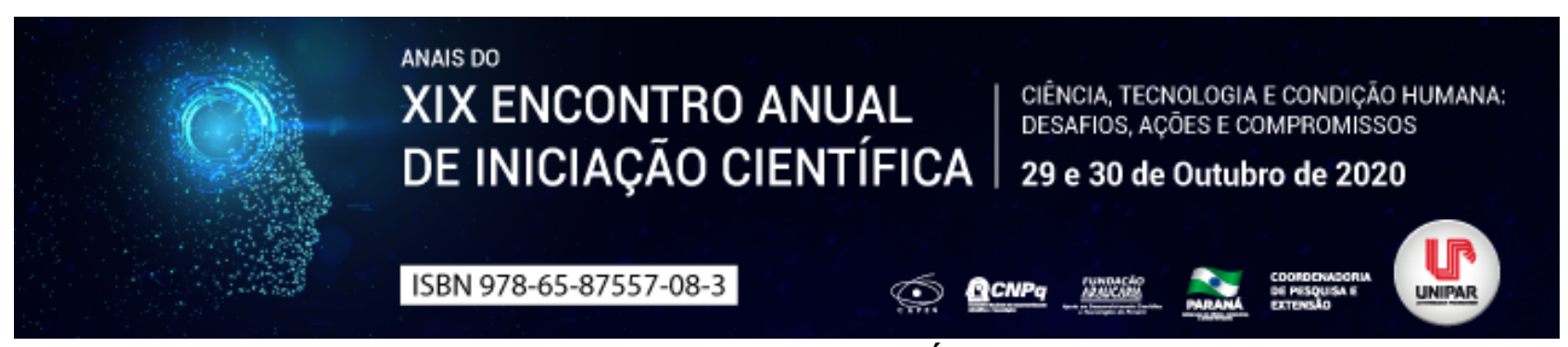

A PSICOTERAPIA E UMA PERSPECTIVA SIMBÓLICA SOBRE ANSIEDADE

\author{
${ }^{1}$ GRAZIELE BRAGA, ${ }^{2}$ VANESSA MARIA BONIOLO, ${ }^{3}$ DANIELLE AGUIAR RAMALHO, ${ }^{4}$ RAFAELA GOMES LUIZ, ${ }^{5}$ MAURO \\ SERGIO DA ROCHA
}

\author{
${ }^{1}$ Acadêmica do Curso de Psicologia da UNIPAR \\ ${ }^{1}$ Acadêmica do Curso de Psicologia da UNIPAR \\ ${ }^{2}$ Acadêmica do Curso de Psicologia da UNIPAR \\ ${ }^{3}$ Acadêmica do Curso de Psicologia da UNIPAR \\ ${ }^{4}$ Docente da UNIPAR
}

Introdução: $O$ processo psicoterapêutico através da perspectiva junguiana visa conscientizar o sujeito de seu processo de individuação. A partir de uma visão simbólica, compreende a ansiedade dentro de uma perspectiva que analisa as interações do indivíduo com a coletividade, intencionando o reconhecimento dos conteúdos envolvidos na patologia.

Objetivo: Descrever o processo psicoterapêutico de forma sucinta, oferecendo uma visão teórica da proposta prática da psicologia analítica sobre a ansiedade.

Desenvolvimento: A teoria analítica considera que o ser humano é constituído e influenciado por aspectos individuais integrados ao inconsciente coletivo. Ao aprofundar o conhecimento sobre suas experiências, o sujeito torna- se consciente do que permeia suas vivências, a realidade é ampliada e o funcionamento do inconsciente passa a ser percebido como atuante (JUNG, 1985 ; EDINGER, 2004). O objetivo da psicoterapia é propiciar um espaço no qual o sujeito possa compreender a si mesmo e seus conteúdos, por meio da reflexão das situações de crise possibilitando ampliar sua consciência e adquirir recursos internos para lidar com seus conflitos. Por meio da verbalização frequente de determinada temática, evidencia-se a cronicidade do complexo de tonalidade afetiva, conteúdo manifesto e trabalhado em psicoterapia (JUNG, 2013). Ainda que este não apareça de imediato à consciência, as energias psíquicas se intensificam e movimentam complexos que podem afetar o ego e alertar mecanismos de defesas. No processo psicoterapêutico a dinâmica dessas energias podem ser vistas através de sintomas manifestos por sensações corporais e psíquicas. A ansiedade, por exemplo, é trabalhada através de uma ótica simbólica e, seria a ausência da relação com esse conteúdo que colocaria o sujeito em situações conflitivas na vida, enfraquecendo a personalidade consciente e sua relação com a totalidade (JUNG, 2013; PENNA, 2013 ; VALLADÃO, 2017). Verifica-se então a importância do psicoterapeuta expandir a visão sobre o sintoma apresentado (VALLADÃO, 2017). Dentro do processo psicoterapêutico, observa-se também a influência das relações parentais no desencadeamento de um estado patológico. Essa interação fará com que o ego se fortaleça e se estabeleça enquanto sujeito que assume seu lugar, diferenciado do outro (STEIN, 2000). Conflitos nessa relação podem contribuir com o despertar de conteúdos inconscientes, rompendo as defesas do ego e fazendo com que a personalidade se desestruture (FIERZ, 1997). Na procura por um laço substituto, o papel pode ser transferido para o médico, assim como o cuidado materno encontrado na instituição clínica, ou até mesmo nos processos terapêuticos, sejam eles psicológicos ou medicamentosos (FIERZ, 1997). Contudo, Fierz (1997), aponta a necessidade do sujeito volte o olhar para si e encontre a organização, e descubra sua vivência no princípio relacional, consigo e com o outro. Neste percurso, a insegurança, o medo e a ansiedade de ser insuficiente, em ser incapaz de corresponder às exigências sociais podem contribuir nos processos de resistência do sujeito ao tratamento (Lopez-Pedraza,1997). Hillman (2015), ao falar desse processo, continua a mencionar que a ansiedade é um embate entre ação e emoção, inibidas pelo medo, angústia do novo, da morte, da transformação, de entrar em contato com o numinoso. Os sintomas, vistos nesta perspectiva, podem ser entendidos como mecanismo de preservação da estrutura psíquica e, ao mesmo tempo, como uma reação, um caminho para entrar em contato com a natureza do complexo ativado. Corroborando com a prática clínica, através da fala, tais conteúdos podem ser acessados, favorecendo o processo de individuação do sujeito. Quando escreve o que não deseja verbalizar, desenha, associa a alguma música, série, livro, a fim de sair da unilateralidade, o sujeito em processo inova seu mundo e equilibra vivências. Segundo Valladão (2017), esta atuação psicoterapêutica diferenciada oferece melhores condições de vida, valorizando processos psíquicos que ampliam a consciência, para que o sujeito não se perca frente às demandas sociais patologizantes.

Conclusão: A compreensão da realidade através de uma perspectiva simbólica oferece à prática psicoterapêutica uma forma diferenciada de trabalho. Esta visão faz com que a ansiedade seja trabalhada dinamicamente com conteúdos individuais e coletivos, se valendo de amplas formas de expressão. É considerado ainda o papel da relação parental no desenvolvimento do sujeito e da sintomatologia, influenciando nos conteúdos que auxiliarão o sujeito em seu processo de individuação.

\title{
Referências
}


EDINGER, Edward F. Ciência da alma: uma perspectiva junguiana. São Paulo: Paulus, 2004.

FIERZ, Heinrich K. Psiquiatria Junguiana. São Paulo- SP: Paulus, 1997.

JUNG, Carl. G. Psicogênese das doenças mentais. Petrópolis- RJ: Vozes, 2013.

LÓPEZ- PEDRAZA, Rafael. Ansiedade cultural. São Paulo-SP: Paulus, 1997

PENNA, Eloisa M.D. Epistemologia e método na obra de C. G. Jung. São Paulo: EDUC, 2013.

STEIN, Murray. O mapa da Alma. São Paulo-SP: Editora Cultrix, 2000.

VALLADÃO, Lucas S. Ansiedade e Contemporaneidade: Uma leitura Junguiana. 2017. 91 f. Dissertação apresentada à Banca Examinadora da Pontifícia Universidade Católica de São Paulo, como exigência parcial para a obtenção do título de Mestre em Psicologia Clínica. São Paulo- SP, 2017

Coordenadoria de Pesquisa e Extensão - COPEX

Departamento de Editoraçāo e Divulgaçāo Científica - DEDIC 


\section{ANAIS DO \\ \begin{tabular}{l|l} 
XIX ENCONTRO ANUAL & CIËNCIA, TECNOLOGIAE CONDICĀOA HUMANA: \\
DESAFIOS, AÇŌES E COMPROMISSOS
\end{tabular} \\ DE INICIAÇÃO CIENTÍFICA \\ 29 e 30 de Outubro de 2020 \\ ISBN 978-65-87557-08-3

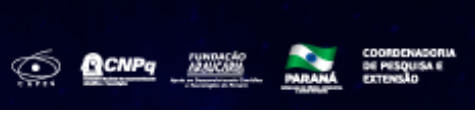

${ }^{1}$ CAROLINE RINALDI VIEIRA, ${ }^{2}$ YURI MENDES DEL QUIQUI, ${ }^{3}$ BARBARA COSSETTIN COSTA BEBER BRUNINI, ${ }^{4}$ LUIS WANDERLEY GAZOTO

${ }^{1}$ Acadêmica do curso de Direito da UNIPAR

${ }^{1}$ Acadêmico do Curso de Direito da UNIPAR

${ }^{2}$ Docente da UNIPAR

${ }^{3}$ Docente da UNIPAR

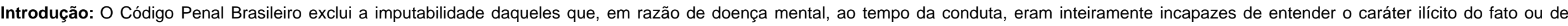
determinarem-se de acordo com esse entendimento (CP, art. 26). Entretanto, o Código Penal não especifica quais são tais doenças.

Objetivo: Analisar a forma de punibilidade do Código Penal Brasileiro em relação ao indivíduo com quadros de psicopatia.

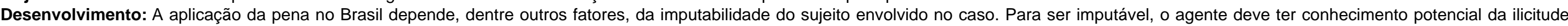

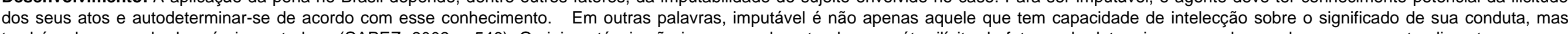

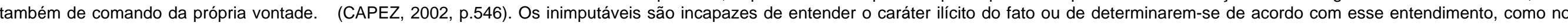

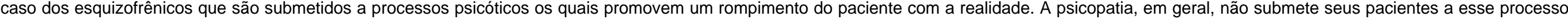

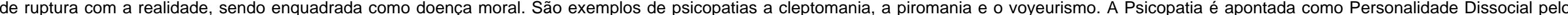

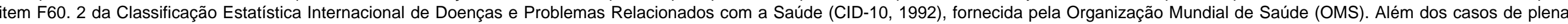

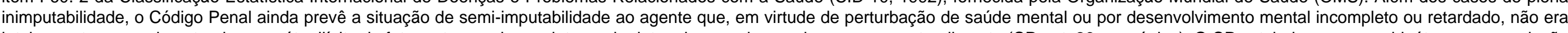

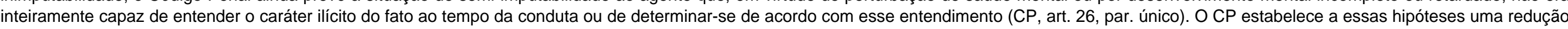

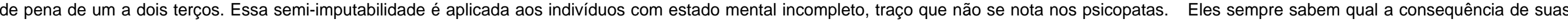

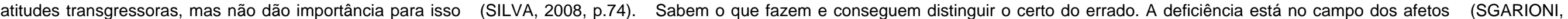
2009, p.6).

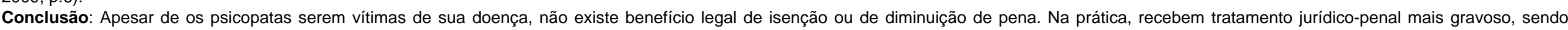

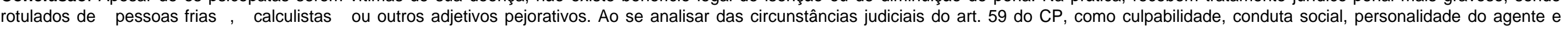
motivos do crime, isso tudo corrobora para os magistrados imporem penas mais severas.

\section{Referências}

BRASIL. Decreto-Lei 2.848, de 07 de dezembro de 1940. Código Penal. Diário Oficial da União, Rio de Janeiro, 31 dez.1940.

CAPEZ, Fernando. Curso de direito penal. 4ed. São Paulo, Saraiva, 2018.

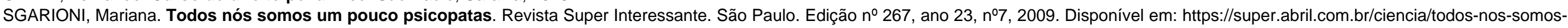
um-pouco-psicopatas/. Acesso em: 03 set. 2020.

SILVA, Ana Beatriz Barbosa. Mentes Perigosas: o psicopata mora ao lado. Rio de Janeiro, Objetiva, 2008.

ORGANIZAÇÃO MUNDIAL

$\mathrm{DA}$

SAÚDE.

CID-10.

Disponível

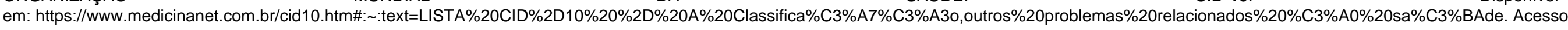
em: 03 set. 2020

Coordenadoria de Pesquisa e Extensão - COPEX

Departamento de Editoraçāo e Divulgaçāo Científica - DEDIC 


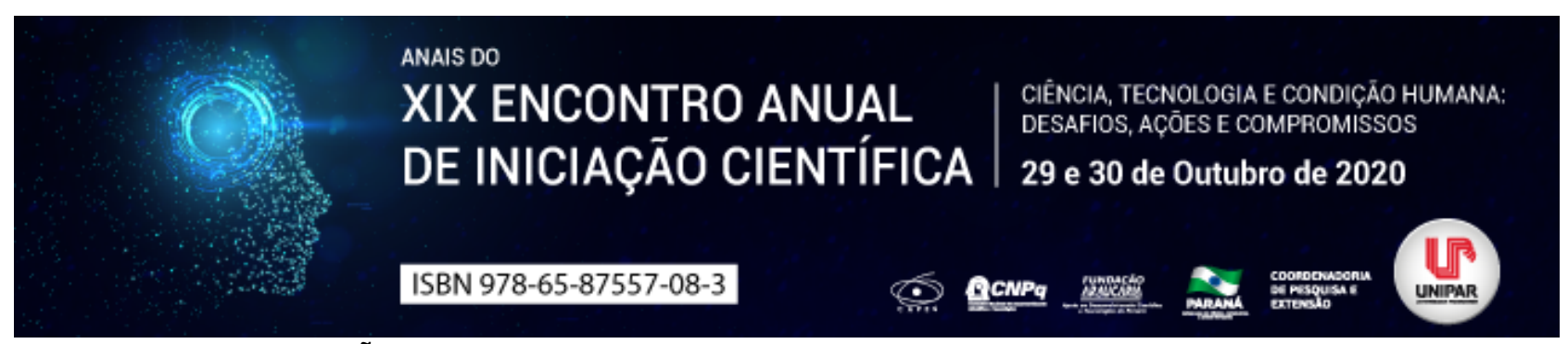

CORRUPÇÃO E LAVAGEM DE DINHEIRO: O CASO DA EMPRESA PETROBRAS

\author{
${ }^{1}$ NAYARA LOPES GIOMO, ${ }^{2}$ CARLA ALVES FURIO, ${ }^{3}$ JOSE LUIZ BORSATTO JUNIOR
}

\author{
${ }^{1}$ Acadêmica do PIC/UNIPAR \\ ${ }^{1}$ Acadêmica do PIC/UNIPAR \\ ${ }^{2}$ Docente da UNIPAR
}

Introdução: Em 2014 a empresa Petrobras se tornou alvo de uma das maiores investigação Brasileiras, denominada de Operação Lava Jato , que tinha como objetivo combater a corrupção e a lavagem de dinheiro no país. Segundo o Ministério Público Federal (2017), essa operação começou dentro de um posto de gasolina, local onde ocorria uma grande quantia de lavagem de dinheiro, onde se desdobrou em vários outros esquemas de corrupção envolvendo contratação de empreiteiras, operadores financeiros, funcionários da Petrobras e agentes políticos. Corrupção é conceituada como práticas ilícitas realizada com interesses próprios ou de um coletivo, que são motivadas pela ambição do indivíduo em acumular riquezas e possui raízes na cultura brasileira, amplamente ligada a questões morais, éticas, sociais, históricas e culturais (ARAÚJO; SOEIRO; MATOS; BAUTISTA; 2020). Segundo Borini e Grisi (2009), a corrupção no ambiente de negócios pode ser encontrada de acordo com os seguintes fatores: suborno; roubo; sonegação; tráfico de informações; pirataria; concorrência desleal; propina; fraude.

Objetivo: Descrever e classificar quais foram as práticas de corrupção que ocorreram na empresa Petrobras por meio da análise das divulgações feitas pelo Ministério Público Federal.

Material e Métodos: Estudo de natureza qualitativa, com coleta de dados por meio de pesquisa documental nas divulgações do Ministério Público Federal e análise de dados por meio de análise de conteúdo temática.

Resultado: O esquema de corrupção ocorrido na Petrobras baseou-se, segundo a explicação fornecida pelo Ministério Público Federal (2017), em uma organização de um cartel envolvendo grandes empreiteiras onde as mesmas participavam de licitações para contratação de serviços da Petrobras e que pagavam propina para diretores e outros cargos importantes da empresa e agentes públicos, por meio do envolvimento de operadores financeiros que realizavam a lavagem de dinheiro.

Discussão: Borini e Grisi (2009) classificam em seu estudo algumas das principais práticas de corrupção realizadas no âmbito empresarial. No caso da Petrobrás, inicialmente é possível identificar que nesse esquema ocorreu grandes práticas de

Suborno , uma vez que foram oferecidas parte do dinheiro roubado como pagamento por troca de informações, vantagens na obtenção de serviços, entre outros benefícios que contribuíram com toda essa operação. Diante disso, para que essa pratica acontecesse as licitações eram realizadas de maneira ilegal, se encaixando nos fatores de Concorrência Desleal , todos os fornecedores se reuniam entre si para tomar decisões para seu benefício próprio, em que os preços oferecidos à Petrobras eram calculados e ajustados em reuniões secretas nas quais se definia quem ganharia o contrato (Ministério Público Federal, 2017). Nesse esquema também acontecia o Tráfico de Informações e Fraudes por parte de funcionários internos da Petrobras que repassavam informações sigilosas de dentro da empresa e escondiam a formação do cartel. O Fator Propina foi detectado em práticas de pagamento para agentes públicos que eram responsáveis por indicar e manter os diretores da Petrobras (Ministério Público Federal, 2017). Contudo, o dinheiro sujo no qual era repassado para todos envolvidos no caso, tinha a necessidade de passar primeiro por operadores financeiros que disfarçavam essa propina em dinheiro limpo, com o intuito de não se tornarem alvos da fiscalização. Essa prática de lavagem de dinheiro é considerada por Borini e Grisi (2009) como

Roubo sendo um dos fatores mais predominante nesse esquema. Por meio das Notas Explicativas, em 2015, a Petrobras divulgou alguns dos impactos da corrupção mensurados pela contabilidade, dentre eles é possível destacar a necessidade imediata da empresa em reduzir o ritmo de seus investimentos, pois suas receitas operacionais já se encontravam em declínio, e os outros meios de financiamentos foram limitados, sendo insuficientes para suprir suas necessidades, além disso, a empresa entrou em uma carência de fornecedores qualificados disponíveis para seus serviços como consequência das restrições criadas logo após todas as investigações da Operação Lava Jato

Conclusão: Com esse estudo conclui-se que a empresa Petrobras teve o seu nome negativamente afetado como consequência de todos os escândalos de corrupção na qual foi envolvida. Dentre todas os fatores de práticas ilegais descobertas por meio da

Operação Lava Jato , realizada em 2014, é possível as classificar em suborno , concorrência desleal , tráfico de informações, fraudes, propina e roubo

\title{
Referências
}

BORINI, Felipe Mendes; GRISI, Fernando Correa. A corrupção no ambiente de negócios: survey com as micro e pequenas empresas da cidade de São Paulo. Revista de Administração-RAUSP, v. 44, n. 2, p. 102-117, 2009.

COSENZA, José Paulo. Os efeitos colaterais da Contabilidade Criativa. Revista de contabilidade do mestrado em ciências 
contábeis da UERJ, v. 7, n. 2, p. 63-78, 2013.

MINISTÉRIO PÚBLICO FEDERAL. (2017). Caso Lava Jato. Disponível em: . Acesso em 15 de agosto de 2020.

NASCIMENTO DE ARAÚJO, João Gabriel et al. JEITINHO BRASILEIRO, CORRUPÇÃO E CONTABILIDADE. Revista

Evidenciação Contábil \& Finanças, v. 8, n. 2, 2020.

Coordenadoria de Pesquisa e Extensão - COPEX

Departamento de Editoraçāo e Divulgaçāo Científica - DEDIC 


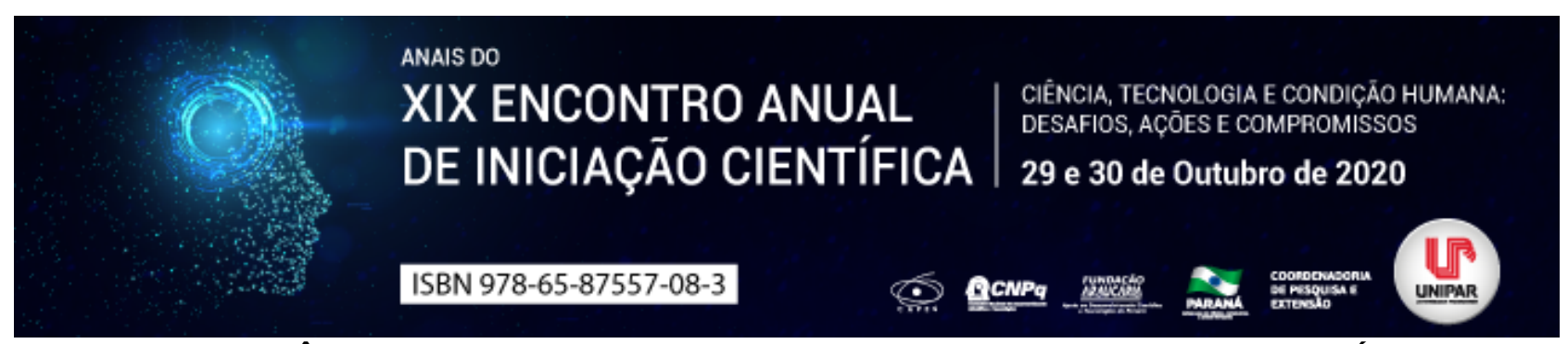

A RELEVÂNCIA DO ARQUITETO E URBANISTA OSCAR NIEMEYER PARA BRASÍLIA

\title{
${ }^{1}$ IARA CAMARGO NACLE MERLINI, ${ }^{2}$ ANA PAULA TORQUETI GAVIOLI
}

\author{
${ }^{1}$ Acadêmica do Curso de Arquitetura e Urbanismo da UNIPAR \\ ${ }^{1}$ Docente da UNIPAR
}

Introdução: Oscar Niemeyer se tornou um dos mais significativos arquitetos do século XX, com obras assinadas em várias partes do mundo, se tornou um dos precursores da arquitetura moderna brasileira, realizou aproximadamente 600 projetos (nem todos executados), se tornou famoso internacionalmente, por seu talento nas propostas formais e estéticas. Foi designado pelo então presidente Juscelino Kubitscheck de Oliveira, para ser o arquiteto dos principais edifícios que iriam compor o novo desenho urbano e os espaços simbólicos de Brasília, capital do país, da inauguração aos dias atuais, o arquiteto acrescentou ainda diversas outras edificações na capital hoje conta com mais de 60 obras assinadas por ele.

Objetivo: O objetivo do presente artigo é ressaltar a importância do arquiteto e urbanista Oscar Niemeyer para construção e formação urbanística da atual capital brasileira, dando ênfase na importância e na estética das edificações assinadas e executadas por ele.

Desenvolvimento: Brasília se destacou como uma extraordinária criação a partir do zero, uma cidade inteira, a capital de um país, uma das grandes experiências que o homem já empreendeu para ter o seu ambiente construído. A participação de Oscar Niemeyer na construção de Brasília deu-se, principalmente no Eixo Monumental, marcando de forma decisiva, o formato da nova capital, que se tornaria uma das grandes referências da arquitetura moderna. $O$ Eixo monumental , nesse caso, é composto pela Praça dos Três Poderes, centro do poder republicano, formado pelo Supremo Tribunal Federal e pelo Palácio do Planalto, com volumetria, soluções arquitetônicas e estruturais que se assemelham, mas não são iguais, e o Congresso Nacional, constituído pela Câmara Federal, pelo Senado e pelos edifícios de escritórios dos parlamentares. Lucio Costa e Oscar Niemeyer ousaram como poucas vezes no mundo se conseguiu. Enfatizaram algumas questões como volumetria, simbologias, estruturas, transparências, aberturas, relação exterior-interior, simplicidade dos materiais e áreas livres nos projetos urbanísticos e arquitetônicos (OHTAKE, 2007). Com o passar dos anos, Niemeyer projeta vários monumentos em Brasília, e passa a ser chamado com frequência para projetos de grande valor monumental e pouco conteúdo programático específico. À medida que seu renome cresce internacionalmente, o valor simbólico de sua intervenção projetual se torna maior, desde 1950, seu caminho se torna cada vez mais escultural, abandonando progressivamente aspectos funcionais em prol da expressão do novo, da surpresa e da emoção visual. Niemeyer procura adotar princípios de simplicidade e pureza. Evita soluções recortadas, com formas e elementos construtivos, mas adota um partido compacto e simples, onde a beleza da obra decorresse apenas da proporção e da própria estrutura (BASTOS E ZEIN, 2010). A leveza do Palácio da Alvorada é observada em sua fachada que surge sem peso, onde o volume principal do edifício junto a uma caixa de vidro posicionada entre duas lajes ressaltadas parecem flutuar sobre o espelho da água encontrado na fachada principal do palácio. A ilusão é aumentada devido ao reflexo exercido pelo espelho da água na fachada, havendo uma manipulação das formas, podendo-se notar a postura surrealista de Niemeyer na obra, em um jogo entre o clássico e o convencional (UNDERWOOD, 2002). Na sequência dos palácios projetados em Brasília, Niemeyer usou a ideia de modelo, onde uma forma foi sendo trabalhada com pequenas variações, seguindo um modelo moderno de palácio. Para Niemeyer, a forma não segue a função, o desejo da forma é mais forte, e impõe-se ao programa. Sendo assim a forma nasce antes, a forma é o problema essencial. Essa característica passa a partir de então, marcar com força as obras de Niemeyer principalmente após 1980, e já não pode mais ser entendida como um defeito, e sim como uma condição. Brasília foi o encerramento de um ciclo, a partir do qual as experiências mais inovadoras da arquitetura brasileira teriam superado a de São Paulo.

Conclusão: $O$ arquiteto foi essencial, sem os projetos e a presença de Oscar Niemeyer, a capital Brasília, não teria um vasto conteúdo arquitetônico, sendo hoje um dos principais centros de referência arquitetônica, e onde se destinam maior parte de seus projetos assinados, todas a suas obras foram muito bem penadas não só esteticamente mas também, funcionalmente e de forma que se encaixassem no espaço urbano.

\section{Referências}

BASTOS, M. A. J; ZEIN, R.V. Brasil: Arquiteturas após 1950. Editora Perspectiva S.A. São Paulo, 2010.

CAPELLO, M. A revista brasília na construção da Nova Capital: Brasília (1957-1962). Risco Revista De Pesquisa Em Arquitetura E Urbanismo (Online), (11), 43-57. São Paulo, 2010.

MINDLIN, H. Arquitetura Moderna no Brasil. $2^{a}$ edição. Rio de Janeiro, Aeroplano, Iphan, Ministério da Cultura, 2000.

NIEMEYER, Oscar. Forma e função na arquitetura. Módulo, v. 4, n. 21, p. 2-7, 1960. 
OHTAKE, R. Oscar Niemeyer. Publifolha. São Paulo, 2007.

PAPADAKI, Stamo. The work of Oscar Niemeyer. New York: Reinhold, 1951.

PEDROSA, M. Dos Murais de Portinari aos Espaços de Brasília. AMARAL, Aracy (org). São Paulo: Editora Perspectiva, 1981. SILVA, L.S.D. A Construção de Brasília: modernidade e periferia. Goiânia: Ed. da UFG, 1997.

UNDERWOOD, D. K. Oscar Niemeyer e o modernismo de formas livres no Brasil. São Paulo, 2002.

Coordenadoria de Pesquisa e Extensão - COPEX

Departamento de Editoração e Divulgaçāo Científica - DEDIC 


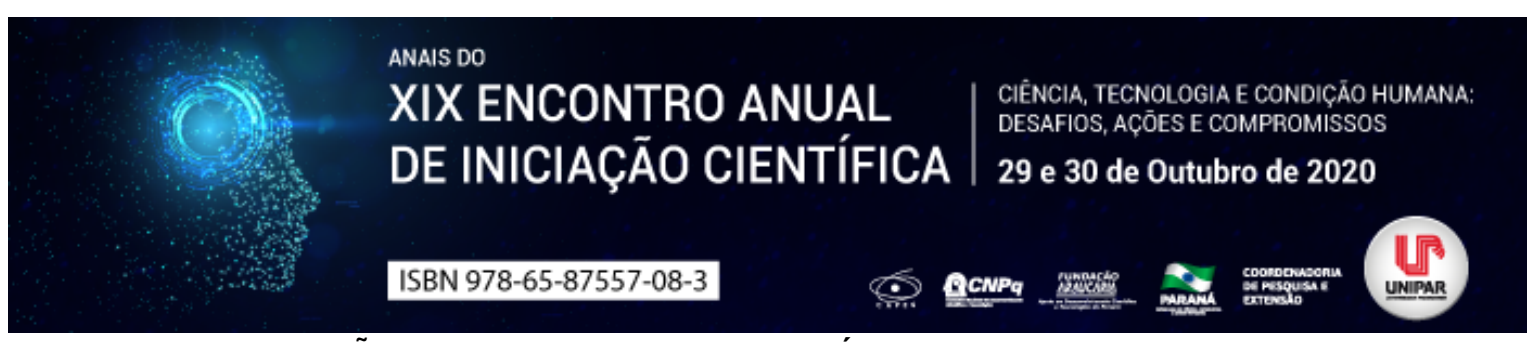

AS DISTINÇÕES ENTRE PSICOLOGIA DA SAÚDE E PSICOLOGIA HOSPITALAR

\author{
${ }^{1}$ GABRIELA AMARAL SILVA, ${ }^{2}$ LUANI AKEMI FURYAMA, ${ }^{3}$ BARBARA COSSETTIN COSTA BEBER BRUNINI
}

\author{
${ }^{1}$ Acadêmica do Curso de Psicologia da UNIPAR \\ ${ }^{1}$ Acadêmica do Curso de Psicologia da UNIPAR \\ ${ }^{2}$ Docente da UNIPAR
}

Introdução: O presente estudo abordará questões que discorrem sobre o contexto da Psicologia da Saúde e da Psicologia Hospitalar. Abordando as formas de atuação de cada uma, evidenciará as suas características e particularidades de atuação. Deste modo, serão apresentados alguns eixos que compõe as práticas que atendem o âmbito da saúde e da instituição hospitalar.

Objetivo: Elucidar as distinções das práticas no âmbito da Psicologia da Saúde e da Psicologia Hospitalar.

Desenvolvimento: A especialidade da Psicologia intitulada no Brasil como hospitalar é conhecida por ser uma área recente, e com particularidades em relação às práticas e definições de países do exterior, que as compreendem e denominam somente como Psicologia da Saúde. Primeiramente, ambas apresentam denominações e significados distintos, como saúde e hospital, além disso, suas funções não são equivalentes uma vez que saúde visa as funções orgânicas, físicas e mentais e em contrapartida o hospital é uma instituição concreta com finalidade de atendimento à pacientes. A Psicologia da Saúde é um campo que respalda o seu trabalho especialmente na promoção e na educação para a saúde, na qual visa ações que auxiliem a população em seu dia a dia para que consigam evitar problemas no contexto sanitário e riscos para a própria saúde (CASTRO, BORNHOLDT, 2004). Essa área da Psicologia tem por objetivo aspectos biopsicossociais, que trabalham para diagnosticar, tratar ou prevenir doenças físicas, mentais ou qualquer outra que desestabilize a saúde, desenvolvendo práticas que vão além das exercidas dentro do hospital. Ela pode estar inserida na atenção Primária (ações coletivas e preventivas), Secundária (especialidades médicas e ambulatorial) ou Terciária (alta complexidade), já a Psicologia Hospitalar, frequentemente se aplica a serviços de atenção secundária e terciária (CONSELHO FEDERAL DE PSICOLOGIA, 2019). O acolhimento deverá ser um dos primeiros procedimentos realizado no atendimento em Psicologia Hospitalar, como também acontece em diversas intervenções psi, já que o mesmo proporciona o estabelecimento de vínculos e pode ser realizado tanto com paciente ou com a família, a depender da situação. O acompanhamento da profissional nestes espaços hospitalares é geralmente oferecido para os familiares de pacientes que estão a espera de uma cirurgia, internamentos, situações de urgência e emergência e internamentos em UTI, como ao próprio paciente quando se faz possível a intervenção. A avaliação Psicológica também é um procedimento que pode ou não ser realizado dependendo da necessidade e da situação, casos como cirurgia bariátrica, de redesignação sexual, de amputamento ou retirada de membros entre outros que necessitam do processo de avaliação psicológica. O processo de comunicação é imprescindível nesse contexto e deve englobar a tríade paciente, família e instituição, pois todos devem estar informados diante das situações envolvidas. Dentro do hospital há diversas outras rotinas que muitas vezes acabam fazendo parte da atuação da(o) psicóloga(o) e esta deve adaptar suas práticas do melhor modo possível para atuar de forma eficaz e ética respeitando também protocolos de atendimento do estabelecimento. Sendo assim, no hospital será uma atuação bem adaptada dos moldes convencionais, visto que o setting de atendimento pode conter muitos estímulos ao mesmo tempo, como barulhos de TV, pacientes compartilhando o mesmo quarto, em muitos casos tem a possibilidade de ocorrer outros procedimentos ao mesmo tempo, como exames de rotina ou curativo, pensando nessa adaptação é preciso ter cautela ao realizar o atendimento por conta do sigilo das informações (CONSELHO FEDERAL DE PSICOLOGIA, 2019). Portanto, a Psicologia da Saúde está mais relacionada ao âmbito biopsicossocial e suas intervenções em políticas e prevenção da saúde, enquanto a Psicologia nos hospitais se configura a partir da tríade: paciente, família e instituição, sendo a comunicação fundamental para a relação que ocorre no processo de adoecimento, internação e restabelecimento da saúde do paciente, exigindo da psicóloga(o) intervenções em espaços restritos pelas estruturas e procedimentos hospitalares.

Conclusão: Por meio da revisão bibliográfica é possível observar que tanto a Psicologia da Saúde quanto a Psicologia Hospitalar possuem características particulares, na qual definem os seus moldes de atuação. Sendo visível que a Psicologia da Saúde trabalha com o intuito de prevenção e aspectos da saúde coletiva, atendendo em comunidades, organizações não-governamentais, centros de saúde e fazendo visitas domiciliares, enquanto a Psicologia Hospitalar realiza procedimentos em instituições hospitalares e atua com a finalidade de auxiliar o processo de adaptação e restabelecimento da saúde do paciente. Portanto, ambas, no Brasil, possuem significados distintos tendo em vista que o hospital é uma instituição e que o Psicólogo introduzido nesses espaços deve primar pelo atendimento de pacientes que ali estão inseridos, enquanto a Psicologia da saúde pode ser sim uma área de atuação dentro do hospital, mas ela pode estar inserida em diversas outras ambiências, não sendo restritas aos hospitais.

\title{
Referências
}

CASTRO, E. K.; BORNHOLDT, E. Psicologia da Saúde x Psicologia Hospitalar: Definições e Possibilidades de Inserção Profissional. Rev. Psicologia Ciência e Profissão, v.24, n. 3, p. 48-57. 2004. Disponível em: https://www.scielo.br/scielo.php?script=sci_arttext\&pid=S141498932004000300007\#: : :text=Apesar\%20das\%20imprecis\%C3\%B5es\%20entre\%20essas,doen\%C3\%A7a\%20(Kerbauy\%2C\%202002). Acesso em: 19 ago. 2020.

CONSELHO FEDERAL DE PSICOLOGIA. Referências Técnicas para Atuação de Psicólogas(os) nos serviços hospitalares do SUS. 1.ed. Brasília: CFP, 2019. 



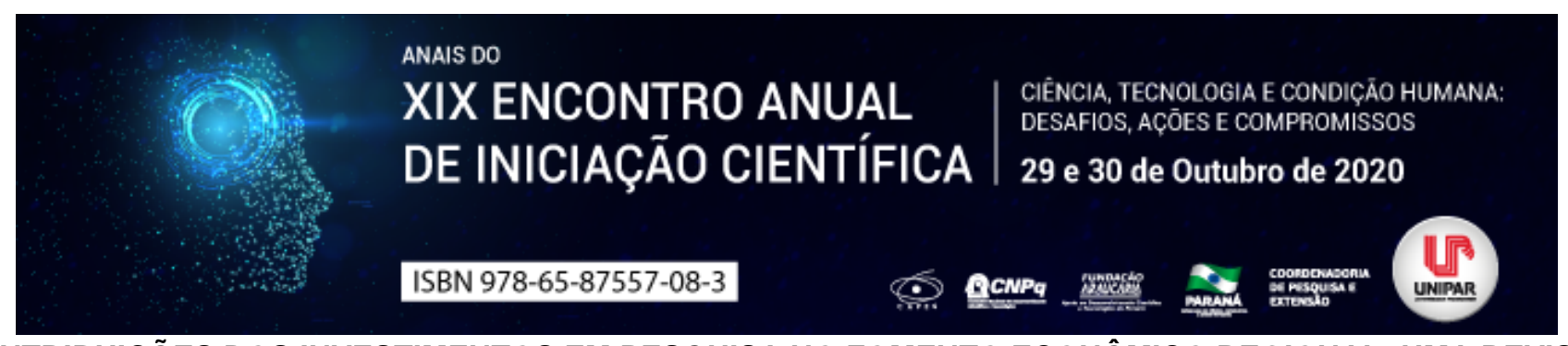

AS CONTRIBUIÇÕES DOS INVESTIMENTOS EM PESQUISA NO FOMENTO ECONÔMICO REGIONAL: UMA REVISÃO DE LITERATURA

\title{
${ }^{1}$ Larissa Lima Ferreira, ${ }^{2}$ FRANCIELE DO PRADO DACIÊ
}

\author{
${ }^{1}$ Acadêmica do curso de Ciências Contábeis da UEM \\ ${ }^{1}$ Professora na Universidade Estadual de Maringá
}

Introdução: A universidade se encarrega de atuar em uma série de ambientes, assumindo um papel que vai além de transferir conhecimento às pessoas (RAIHER, 2017). Através dos pilares de ensino, pesquisa e extensão, elas atuam desenvolvendo e integrando competências, e colaborando potencialmente para o desenvolvimento regional. A criação de capital humano, mão de obra capacitada, desenvolvimento de produtos, tecnologia e inovação, criação de patentes e materiais publicados em veículos científicos são os produtos finais das diversas atividades desenvolvidas por essas instituições. No entanto, nos últimos anos, os desinvestimentos estatais nas universidades aceleraram drasticamente, sobretudo no apoio a pesquisa (OWEN-SMITH, 2018). O fato gera preocupação, considerando que os pilares da universidade devem ocorrer de forma sistematizada para 0 alcance dos seus objetivos. Uma vez que o processo é desequilibrado, todo o sistema é afetado. No Brasil, por exemplo, após a década de 1980, houve um estímulo intenso a um novo formato de relação universidade-sociedade, condicionando o financiamento das atividades de pesquisa dessas instituições diretamente a sua contribuição para economia (RAPINI, 2007). Dessa forma, esse trabalho é motivado a investigar quais as contribuições que o desenvolvimento de pesquisas pode oferecer.

Objetivo: Apresentar, através de uma revisão de literatura, os benefícios econômicos que o processo de pesquisa nas universidade pode provocar no local em que as pesquisas são realizadas.

Desenvolvimento: Estudos segregam três principais atribuições às universidades, a capacitação de pessoas, a geração de novos conhecimentos e a interação com entidades que a cercam (CANTU-ORTIZ et al., 2009). A capacitação de pessoas está intimamente relacionada ao desenvolvimento de capital humano, no qual o conhecimento obtido na academia é aprimorado e divulgado em meio científico (FROMHOLD-EISEBITH; WERKER, 2013). Como resultado, as universidades desenvolvem novos acadêmicos, profissionais qualificados e cidadãos atuantes na sociedade (YASSI et al., 2010; OWEN-SMITH, 2018). Essas pessoas, por sua vez, se inserem no mercado e aumentam a competitividade das empresas através do estoque de conhecimento (YIN, 2017). A geração de novos conhecimentos, envolve esforços de vários agentes da sociedade, como pesquisadores, técnicos e alunos, com diferentes competências, que buscam desenvolver boas ideias (SÃVESCU et al, 2011). Diferente do esperado, os retornos do processo de pesquisa não se limitam a publicação de artigos científicos, como também ao desenvolvimento de novos produtos, como medicamentos, alimentos, vacinas, patentes e softwares (CANTU-ORTIZ et al., 2009; RIBEIRO; NAGANO, 2018). A terceira atribuição das universidades ocorre na interação entre universidade-indústria-governo. $O$ elo entre essas três entidades tem sido fortemente incentivado, pois sabe-se que os retornos tendem a ser maximizados quando os recursos pertencentes a cada entidade são compartilhados (RIBEIRO; NAGANO, 2018). O elo que existe entre universidade/pesquisa-indústria, por exemplo, é capaz de fornecer soluções e oportunidades ao complexo ambiente mercadológico. Os problemas abordados pela ciência a partir dos casos empíricos se tornam, também, propícios e ideais para o desenvolvimento de pesquisas universitárias úteis (YIN,2017). Dessa forma, as indústrias se apropriam do conhecimento fornecido pelas pesquisas desenvolvidas nas universidades e, empregando seus recursos, as transformam em objeto de inovações, beneficiando-se internamente e ao seu público alvo (a sociedade) (RIBEIRO; NAGANO, 2018). Outra maneira de visualizar os benefícios dessas parcerias se traduz nos chamados Spin Off. Eles são empreendedores acadêmicos, que empregam os conhecimentos acadêmicos no mercado, gerando emprego e renda para região (LAl; VORNOTAS, 2019). No processo de pesquisa nas universidades, é importante destacar outras situações imperceptíveis a sociedade, como o investimento nos comércios locais através da compra de materiais, contratação de pessoas e serviços para operacionalização da pesquisa fato que provoca aquecimento econômico e receitas tributáveis ao Estado. Além disso, as pessoas contratadas para as atividades gastam seu dinheiro com alimentação, moradia, saúde e lazer no local em que moram, contribuindo ao mercado ( URANOVÁ, 2009).

Conclusão: Os apontamentos realizados mostram que os investimentos realizados nas universidades, sobretudo direcionados ao processo de pesquisa, são capazes de oferecer potenciais contribuições ao local no qual ela é realizada ora direta, ora indiretamente. Dessa forma, a atuação da universidade assume um papel relevante na região, contribuindo de diversas maneiras. Acredita-se que para a conscientização desses reflexos, é necessário que os resultados mensurados através de páginas de artigos ultrapassem os muros da academia, alçando e dialogando com a sociedade. Para isso é essencial que os interesses da universidade estejam alinhados aos interesses locais, provendo assim retornos satisfatórios, como dinamismo econômico e regional. 


\section{Referências}

CANTU-ORTIZ, F J. et al. A knowledge-based development model: the research chair strategy. Journal of Knowledge Management, v. 13, n. 1, 2009.

FROMHOLD-EISEBITH, M.; WERKER, C. Universities' functions in knowledge transfer: a geographical perspective. : a geographical perspective. The Annals of Regional Science, v. 51, n. 3, 2013.

LAI, Y.; VONORTAS, N. S. Regional entrepreneurial ecosystems in China. Industrial and Corporate Change, v. 28, n. 4, 2019.

OWEN-SMITH, J. Research Universities and the Public Good: discovery for an uncertain future. California: Stanford Business Books, 2018. 243 p.

RAIHER, A. P. As Universidades Estaduais e o Desenvolvimento Regional do Paraná. Ponta Grossa: UEPG, 2017. 248 p.

RIBEIRO, S. X; NAGANO, M. S. Main dimensions that impact knowledge management and university-business-government collaboration in the Brazilian scenario. Revista de Gestão, v. 25, n. 3, 2018.

SĂVESCU, D.; SIMA, M.; BÂRSAN, S.-C. The Importance of Knowledge in Regional Development. In: EUROPEAN CONFERENCE ON KNOWLEDGE MANAGEMENT, 12., 2011, Transylvania. Proceedings Transylvania. 2011.

SURANOVÁ, J. Universities in the Context of Regional Dimension. In: CENTRAL EUROPEAN CONFERENCE IN REGIONAL SCIENCE CERS, 3., 2009, Bratislava. Proceedings Bratislava: Department Of Public Administration And Regional Development, 2009.

YASSI, A. et al. The Good, the Bad, and the Ugly of Partnered Research: revisiting the sequestration thesis and the role of universities in promoting social justice. International Journal Of Health Services, v. 40, n. 3, 2010.

YIN, Y. Research on the Influencing Factors and Promotion Measures of Knowledge Transfer in Industry-University-Research Alliance. Advances in Computer Science Research, v. 61, 2017. 


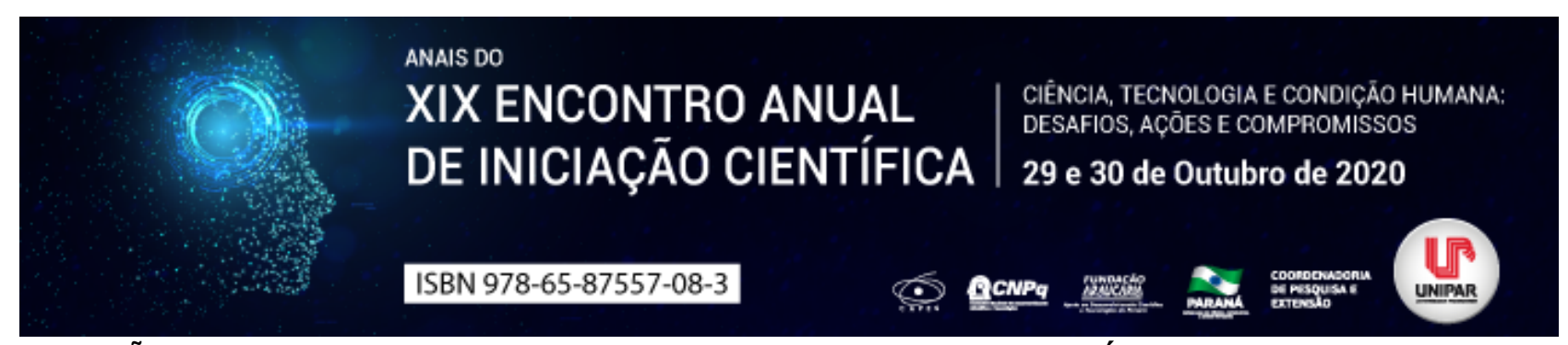

A VEDAÇÃO DO ABUSO DE DIREITOS E A LIBERDADE CONTRATUAL EM ÉPOCA DE PANDEMIA DO NOVO CORONAVÍRUS

\title{
${ }^{1}$ LAIS SILVA ZIMIANI, ${ }^{2}$ CASSIO DE PAULA XAVIER, ${ }^{3}$ MARISTELA APARECIDA SIQUEIRA D'AVIZ, ${ }^{4}$ HORACIO MONTESCHIO, ${ }^{5}$ JUSSARA SUZI ASSIS BORGES N. FERREIRA
}

\author{
${ }^{1}$ Acadêmica do Mestrado em Direito Processual e Cidadania - UNIPAR \\ ${ }^{1}$ Acadêmico do Mestrado em Direito Processual e Cidadania - UNIPAR \\ ${ }^{2}$ Acadêmica do Mestrado em Direito Processual e Cidadania - UNIPAR \\ ${ }^{3}$ Docente da UNIPAR \\ ${ }^{4}$ Docente da UNIPAR
}

Introdução: A pandemia do novo coronavírus ocasionou uma série de dificuldades sociais e econômicas no cenário nacional, impactando no cumprimento de obrigações contratuais e culminando no questionamento sobre a obrigatoriedade do cumprimento de cláusulas contratuais previamente pactuadas.

Objetivo: Analisar o impacto da pandemia do novo coronavírus nas relações contratuais em relação a vedação ao abuso de direitos em contraponto com a intervenção mínima nos contratos e a liberdade contratual.

Desenvolvimento: O Código Civil Brasileiro estabelece em seus artigos 112, 113 e 422, que nas declarações de vontade vale mais a intenção nelas consubstanciadas do que o sentido literal da linguagem, assim como os negócios jurídicos devem ser interpretados conforme a boa-fé. Por outro ângulo, o princípio alterum non laedere impõe que atos próprios não devem provocar prejuízos a terceiros, servindo como limite à autonomia das partes (ARAúJO; MEDINA, 2014, p. 394). Ocorre o abuso de direito (art. 187, CCB) quando o exercício de determinada posição jurídica, apesar de aparentemente legítima, afasta-se da realização dos interesses pessoais do agente que foram o objetivo da norma que o confere, ocasionando prejuízo à outrem (DUARTE, 2011, p. 915). A boa-fé objetiva impõe, portanto, deveres negativos aos contratantes e veda abusos de direito, pois da boa-fé nascem, mesmo na ausência de regra legal ou previsão contratual específica, os deveres anexos, laterais ou instrumentais de consideração com o alter, de proteção, cuidado, previdência e segurança com a pessoa e os bens da contraparte. Entre as figuras parcelares da contraditoriedade desleal o ponto em comum é a vedação do exercício de um direito subjetivo, faculdade, ou posição jurídica em contradição com a sua anterior conduta interpretada objetivamente segundo a lei, segundo os bons costumes e a boa-fé, ou quando o exercício posterior se choque com a norma de conduta pautada pela boa-fé (MARTINSCOSTA, 2018, § 73). Com a pandemia e a consequente instabilidade das relações negociais, houve a judicialização de demandas referentes a contratos (como pedidos de redução de mensalidades escolares, de redução do valor de locação residencial e comercial, de resolução de contratos por impossibilidade de cumprimento na data acordada, entre outros), com argumentos voltados para a adoção dos institutos da teoria da imprevisão, caso fortuito e força maior e/ou da onerosidade excessiva. Contudo, se o contrato prevê expressamente os modos de solução em caso de ocorrência de situações imprevisíveis, a cláusula deve ser devidamente considerada, não podendo ser contra legem ou desvirtuar as cláusulas gerais de ordem pública. Nessa linha, não é toda situação em tempo de crise que gera a revisão contratual ou mesmo a resolução contratual com aplicação de multa, pois as relações devem ser verificadas sob o aspecto do comportamento habitual das partes (factum proprium), não podendo colidir com a boa-fé objetiva e o comportamento de confiança esperado entre os contratantes. Destacase, neste ponto, que a Lei da Liberdade Econômica no 13.874/2019 prevê o princípio da intervenção mínima nos contratos e a excepcionalidade da revisão contratual (art. 421, parágrafo único, CC), sendo que deve ser limitada e excepcional, por presumirem-se os contratos paritários e simétricos, até que se constatem elementos concretos que justifiquem o afastamento dessa presunção (art. 421-A, III, CC). Imperativa, portanto, a análise judicial de cada instrumento contratual e do caso concreto, que conterão os elementos para verificação se a pandemia do novo coronavírus tornou inviável, efetivamente, o cumprimento das obrigações contratuais.

Conclusão: Em época de crise econômica mundial, repercussões complexas surgem em todas as esferas negociais, cabendo ao Judiciário o dever de análise criteriosa de cada caso concreto, visando a valorização dos deveres anexos do contrato, evitando-se a banalização de abuso de direitos e garantindo-se a aplicação normativa da boa-fé objetiva e da liberdade contratual nos limites da função social do contrato.

\section{Referências}

ARAÚJO, Fabio Caldas de; MEDINA, José Miguel Garcia. Código Civil Comentado. São Paulo: Revista dos Tribunais, 2014. DUARTE, Ronnie Preuss. Boa-fé, abuso de direito e o novo código de civil brasileiro. In: TEPEDINO, Gustavo; FACHIN, Luiz 
Edson. Obrigações e contratos: contratos, princípios e limites. Coleção doutrinas essenciais. v. III. São Paulo: Revista dos Tribunais, 2011. p. 889-947.

MARTINS-COSTA, Judith. A boa-fé no direito privado: critérios para a sua aplicação. 2 ed. São Paulo: Saraiva Educação, 2018.

Coordenadoria de Pesquisa e Extensão - COPEX

Departamento de Editoraçāo e Divulgaçāo Científica - DEDIC 


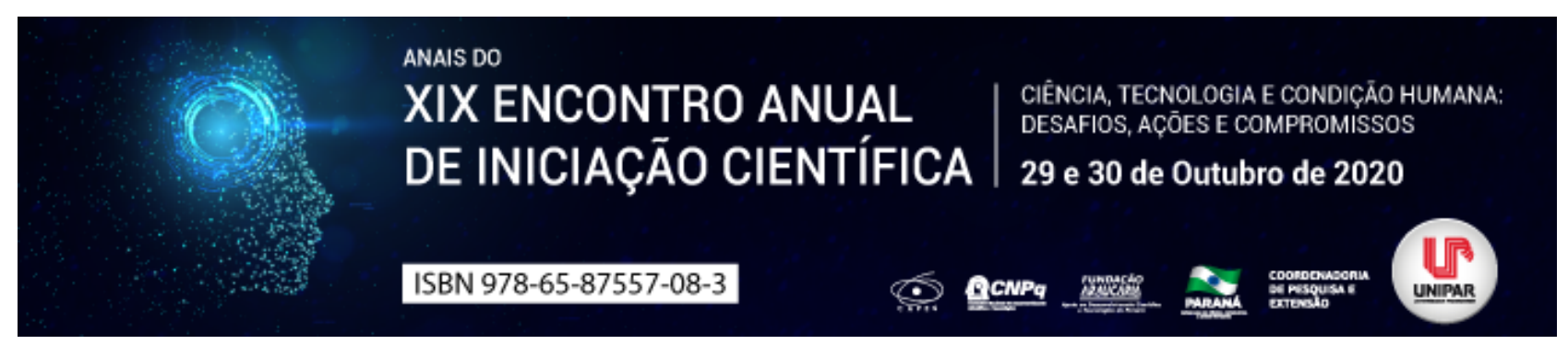

\title{
A PUBLICIDADE DOS ATOS PROCESSUAIS E ADMINISTRATIVOS COMO UM DOS PRESSUPOSTOS PARA A EFETIVAÇÃO DO ESTADO DEMOCRÁTICO DE DIREITO
}

\author{
${ }^{1}$ ALESSANDRA FREI SILVA, ${ }^{2}$ BRUNO SMOLAREK DIAS
}

\author{
${ }^{1}$ Mestranda integrante do PIC - UNIPAR \\ ${ }^{1}$ Docente da UNIPAR
}

Introdução: O presente trabalho é relevante tendo em vista que a Publicidade dos atos processuais é uma garantia fundamental estampada na CF em seu art. $5^{\circ}$, LX e art. 93, IX, bem como foi reproduzida pelo art. 11, CPC. Estando ainda presente em outros ramos do direito, a exemplo do que acontece com o Direito Administrativo, o qual abarca em seu bojo a Publicidade dos atos administrativos como um dos princípios explícitos da Administração Pública estampado na Constituição Federal em seu art. 37, de modo que o estudo em análise torna-se essencial.

Objetivo: A pesquisa em comento objetiva demonstrar a necessidade primordial de que os processos administrativos e processuais tramitem consoante um devido processo legal, tendo em vista ser este um dos pressupostos para o exercício efetivo da democracia dentro de um Estado Democrático de Direito como o Brasil, de modo a compreender como a garantia fundamental da publicidade dos atos contribui de fato para a efetivação da democracia.

Desenvolvimento: A publicidade dos atos processuais e administrativos consiste em garantia fundamental com o objetivo maior de se conferir transparência absoluta a todos os atos do Poder Público, de modo que qualquer pessoa possa então estar investigando se tudo está acontecendo de acordo com o trâmite legal previsto em nosso ordenamento jurídico ou se há algum vício, para então poder resolver a questão pelas vias adequadas para que não haja prejuízo de seu direito. Nas palavras de SILVEIRA (2010), o princípio da publicidade dos atos é uma forma de se assegurar a transparência das investigações, julgamentos e instruções, na medida em que contribui para que não haja ofensa de outras garantias fundamentais. Nessa linha de intelecção, deve ser esclarecido, portanto, que a regra geral em nosso ordenamento jurídico é a publicidade dos atos processuais e administrativos, sendo certo que apenas em hipóteses pontuais e específicas é que há a possibilidade de restringir essa publicidade. São as hipóteses previstas pelo constituinte originário no que diz respeito ao segredo de justiça, posto que o art. $5^{\circ}, X$, determina que são invioláveis a intimidade, a honra, a vida privada e a imagem das pessoas, garantindo a indenização por danos morais ou materiais àqueles que forem lesados. Interessante ressaltar que, além das restrições existentes no texto constitucional existem tentativas de restrição por meio de legislação infraconstitucional, como foi o caso do artigo $6^{\circ}$-B da Lei 13.979/2020, o qual restringiu o acesso às informações prestadas por órgãos públicos durante a pandemia do Covid-19. Essa tentativa de restrição teve a sua teve a sua eficácia suspensa em razão de recente decisão do Supremo Tribunal Federal (2020, on-line) que veio a conceder medida cautelar nesse sentido na ADI 6351 e fazendo prevalecer, portanto, a regra da publicidade dos atos. Conforme ensina DI PIETRO (2014, p. 73-74), pode haver conflito por exemplo entre o direito individual ao sigilo para se resguardar a intimidade de determinada pessoa, e outro direito individual como a liberdade de opinião e de imprensa, o julgador deve se valer de um juízo de proporcionalidade para verificar se a restrição a determinado direito se justifica em razão da aplicação do direito contraposto, sendo que conforme a autora a publicidade dos atos na esfera administrativa pode ser relativizada também nas situações em que seja imprescindível a aplicação do sigilo tendo em vista a segurança da sociedade e do Estado, nos termos do art. $5^{\circ}$, XXXIII, CF, além das hipóteses trazidas pelo art. $5^{\circ}$, LX da Carta Magna. Ademais, BULOS (2012, p. 1.010) assevera que a possibilidade de impetração de habeas data por aquele que tiver violado seu direito à publicidade e informação também consiste numa projeção do princípio da publicidade, justificado pelo poder que emana do povo, ou seja, pela Democracia.

Conclusão: Pelo trabalho foi possível verificar que o segredo de justiça é aplicável a apenas determinadas hipóteses em que a publicidade do ato processual ou administrativo possa gerar um dano maior do que o próprio sigilo, a respeito do que acontece nas hipóteses previstas pelo art. $5^{\circ} \mathrm{LX}, \mathrm{CF}$ e no caso dos atos administrativos, também o inciso XXXIII. Assim, a publicidade dos atos administrativos e processuais é meio para a concretização de uma efetiva democracia, tendo em vista que através da publicidade dos atos processuais é que qualquer pessoa vai poder tomar conhecimento acerca de informações e dados que possam vir a atingi-lo direta ou indiretamente e então possa produzir a defesa de seus bens e direitos que possam estar sob ameaça de lesão e também resguardando direitos e interesses de toda a coletividade.

\section{Referências}

BRASIL. Código de Processo Civil. Lei 13.105 de 16 de março de 2015 . Disponível em http://www.planalto.gov.br/ccivil_03/_ato2015-2018/2015/lei//13105.htm. Acesso em 27 de julho de 2020.

BRASIL. Constituição da República Federativa do Brasil de 1988.

Disponível

em: 
http://www.planalto.gov.br/ccivil_03/constituicao/constituicaocompilado.htm. Acesso em: 27 de julho de 2020.

DI PIETRO, Maria Sylvia Zanella. Direito administrativo. 27 ed. São Paulo: Atlas, 2014. p. 73-74.

BULOS, Uadi Lammêgo. Curso de direito constitucional. 7. ed. rev. e atual. de acordo com a Emenda Constitucional $\mathrm{n}$. 70/2012. p. 1.010.

SILVEIRA, Rodrigo Mansour Magalhães Da. A publicidade e suas limitações a tutela da intimidade e do interesse social na persecução penal. Orientador: Antonio Magalhães Gomes Filho. 2010. p.12. Dissertação (Mestrado em Direito Processual Penal)

Universidade de São Paulo, São Paulo, 2010. Disponível em https://www.teses.usp.br/teses/disponiveis/2/2137/tde-02022011092647/publico/Dissertacao Rodrigo 15032010 Final.pdf. Acesso em: 27 de julho de 2020.

STF. AÇÃO DIRETA DE INCONSTITUCIONALIDADE. ADI: 6351 DF. Relator: Ministro Alexandre de Moraes. DJ: 30/03/2020. Jusbrasil, 2020. Disponível em: https://www.jusbrasil.com.br/processos/132684860/processo-n-6351-do-supremo-tribunalfederal. Acesso em: 10 de agosto de 2020.

Coordenadoria de Pesquisa e Extensão - COPEX

Departamento de Editoraçāo e Divulgaçāo Científica - DEDIC 


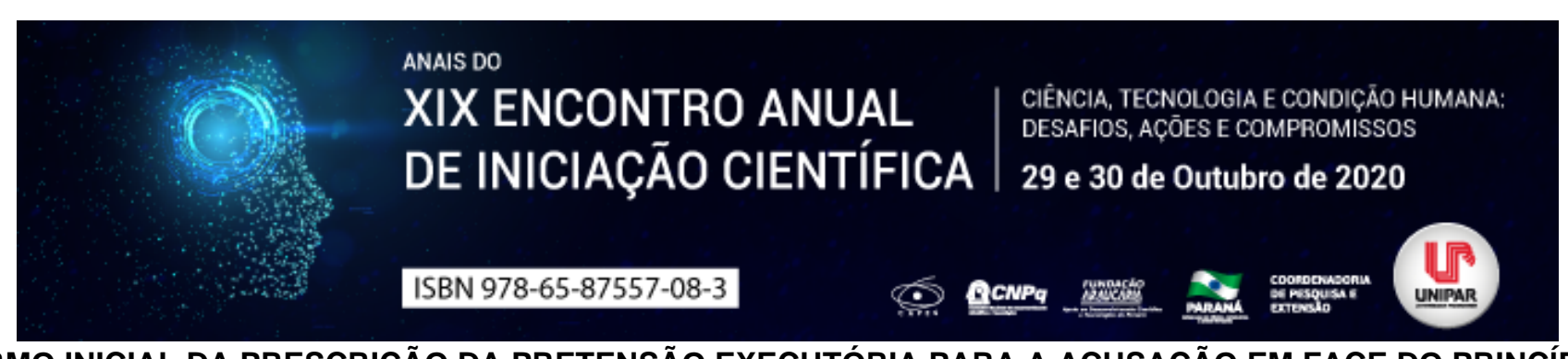

\title{
O TERMO INICIAL DA PRESCRIÇÃO DA PRETENSÃO EXECUTÓRIA PARA A ACUSAÇÃO EM FACE DO PRINCÍPIO DA LEGALIDADE
}

\author{
${ }^{1}$ YARA SANTOS QUIRINO DA SILVA, ${ }^{2}$ EDMAR JOSE CHAGAS
}

\author{
${ }^{1}$ Acadêmica Unipar PIC \\ ${ }^{1}$ Docente da UNIPAR
}

Introdução: A prescrição da pretensão executória é consiste na perda do jus puniend do Estado, devido a sua omissão durante um prazo determinado. Considerando que tal prescrição se move em função ao acusado, a não aceitação pelos tribunais pelo termo inicial dessa prescrição trazida pelo Código Penal mostra verdadeiro retrocesso e descaso com o acusado.

Objetivo: Analisar a importância de se considerar o trânsito em julgado para a acusação como termo inicial da prescrição da pretensão executória em função da aplicação do princípio da legalidade em benefício ao réu.

Desenvolvimento: O Art. 112, inciso I do Código Penal traz o termo inicial da prescrição da pretensão executória: o trânsito em julgado da sentença para a acusação. Em face do princípio constitucional da presunção da inocência, tribunais tem considerado como termo inicial o trânsito em julgado para ambas as partes, A questão atualmente aguarda julgamento pelo STF no ARE 848107 RG/DF. Contudo, a tese da necessidade de trânsito em julgado para ambas as partes para o início do termo incial não merece prosperar. O princípio constitucional da legalidade objetiva submeter o Estado às leis impostas e a literalidade do Art. 112 traz a desnecessidade de trânsito em julgado para a defesa. Sendo assim, a necessidade de trânsito em julgado para a defesa apenas conceberia uma interrupção à prescrição que não está mencionada em lei anterior, indo contra o tal princípio, o que torna decisão contrária inconstitucional. Diante disso, o Estado deve-se submeter a tal entendimento, como bem aponta Rogério Sanches Cunha (2016, p. 335) Enquanto o dispositivo não for modificado (...), o termo inicial deve respeitar o direito posto, decorrência lógica do princípio da legalidade . A prescrição da pretensão executória surge como um instituto que garante que o acusado não fique por tanto tempo ameaçado pelo poder estatal, como bem sustenta Cézar Roberto Bitencourt (2010) é inaceitável a situação de alguém que, tendo cometido um crime, fique sujeito, ad infinitum, ao império da vontade estatal punitiva . Outrossim, deve se mover em função e proveito ao indiciado. Ademais, é indubitável a desigualdade do jus puniend do Estado frente jus libertatis do acusado, que gera a necessidade de manter uma situação que seja mais benéfica ao réu. $O$ termo já trazido pelo Código penal apresenta-se mais favorável ao acusado, tal como exposto por Cleber Masson (p.512, 2014)

(...) é extremamente favorável ao réu. De fato, a prescrição da pretensão executória depende do trânsito em julgado para ambas as partes, mas, a partir do momento em que isso ocorre, seu termo inicial retroage ao trânsito em julgado para a acusação."

Conclusão: O termo inicial da prescrição da pretensão executória, já apresentado pelo Código Penal, por iniciar antes do trânsito em julgado para ambas as partes, é o mais benéfico para o réu, devendo esse ser mantido. Para mais, entendimentos dos tribunais devem-se ater ao antes exposto em respeito ao princípio constitucional da legalidade.

\section{Referências}

BRASIL. Decreto-Lei 2.848, de 07 de dezembro de 1940. Código Penal. Diário Oficial da União, Rio de Janeiro, 31 dez. 1940. BRASIL. Supremo Tribunal Federal. Repercussão Geral No Recurso Extraordinário Com Agravo 848.107. Parte Litigante Edson Rodrigues de Oliveira, Relator Min. Dias Toffoli, 11 dez. 2014. Diário da Justiça Eletrônico, Brasília, 11 fev. 2015.

BITENCOURT, Cézar Roberto. Supressão de parcela da prescrição retroativa: inconstitucionalidade manifesta. $N^{\circ} 87$, ano Revista Brasileira de Ciências Criminais. LOCAL, 2010

CUNHA, Rogério Sanches. Manual de Direito Penal: Parte geral (arts. $1^{\circ}$ ao 120). 4 ed. Salvador. Editora Jus Podivm. 2016. MASSON, Cleber. Código Penal comentado. 2 ed. São Paulo. Método. 2014 


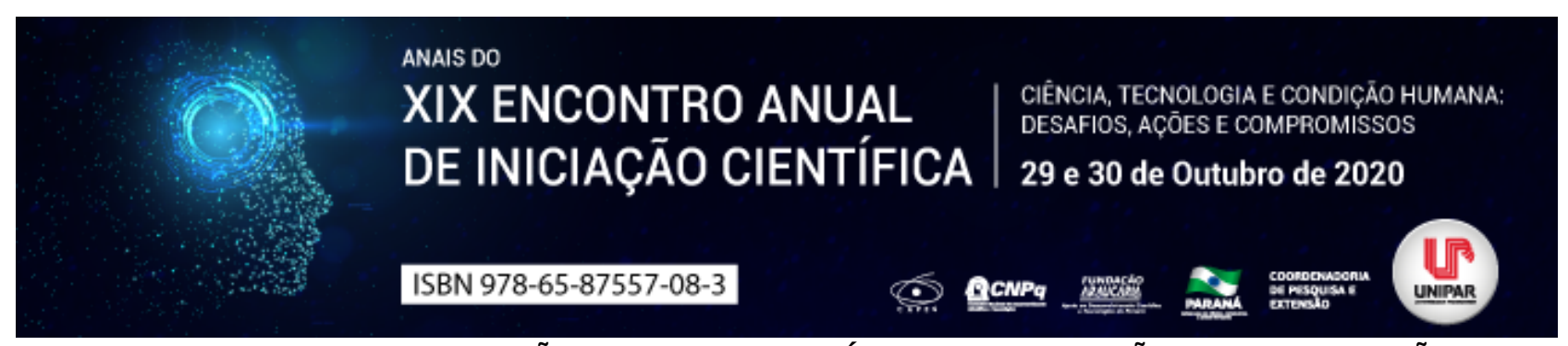

A OBRIGATORIEDADE DA FUNDAMENTAÇÃO JUDICIAL ESPECÍFICA E A PROIBIÇÃO DA DESATENÇÃO NA ATIVIDADE JUDICIAL

\title{
${ }^{1}$ LAIS SILVA ZIMIANI, ${ }^{2}$ ALBINO GABRIEL TURBAY JUNIOR
}

\author{
${ }^{1}$ Acadêmica do Mestrado em Direito Processual e Cidadania - UNIPAR \\ ${ }^{1}$ Docente do Programa de Mestrado em Direito Processual e Cidadania UNIPAR
}

Introdução: O Código de Processo Civil de 2015 instituiu mecanismos específicos com o fim de combater os riscos advindos de decisões discricionárias, por meio do reforço da obrigatoriedade da fundamentação da decisão judicial e a previsão de critérios objetivos a serem observados pelos magistrados, com comando implícito da proibição da desatenção na atividade judicial.

Objetivo: Analisar a obrigatoriedade da fundamentação judicial pela norma processual civil infraconstitucional e a proibição da desatenção na atividade judicial.

Desenvolvimento: O princípio da fundamentação das decisões judiciais foi consagrado no art. 11 do Código de Processo Civil de 2015, sendo que os artigos 371, 489, 926 e 927, especialmente, estabelecem critérios objetivos para a prolatação das decisões judiciais. Ninguém vai ao Judiciário em busca de uma solução a ser inventada pelo juiz, o que se busca é o reconhecimento de um direito que já se tem (e daí a natureza declaratória da jurisdição). Cabe ao juiz dar à causa uma solução conforme o direito, ou seja, o papel do juiz, como intérprete não é inventar uma norma jurídica para solucionar a causa, mas aplicar a norma jurídica adequada ao caso concreto, devendo fazê-lo sem exercer qualquer tipo de poder discricionário (CÂMARA, 2020, pp. 33-34). Nesse contexto, é primordial que se mencione a importância do artigo 371 do CPC, que excluiu de seu bojo o livre convencimento do magistrado. Foi retirada da norma processual civil a expressão que antes era utilizada como justificativa para decisões que não estavam amparadas no ordenamento jurídico, nas provas e nos elementos do processo. Ressalta-se que a decisão judicial per relationem ou referencial, não se coaduna com o § $1^{\circ}$ do art. 489 do CPC/2015, uma vez que não basta mera citação de dispositivo legal sem a análise detalhada e criteriosa do caso concreto pelo magistrado, para que seja considerada legalmente fundamentada. Inclusive, não é possível justificar uma decisão judicial pelo livre convencimento motivado ou pela livre apreciação da prova . No caso, por exemplo, em que uma prova, parcela de uma prova ou mesmo um fato provado não são tomados em consideração pela narrativa judicial, há incompletude, afetando a relação de congruência que deve existir entre a narrativa judicial e os fatos provados. Não é incomum que sentenças deixem de referir determinados depoimentos testemunhais, partes deles, ou ainda a fatos provados (MARINONI; ARENHART, 2019, p. 329). O juiz deve analisar, a princípio, todos os pedidos e todas as causas de pedir arroladas pelo autor na petição inicial, bem como todas as matérias de defesa suscitadas pelo réu na contestação. Não é mais possível serem rejeitados, por exemplo, embargos de declaração, ao argumento de que o juiz não está obrigado a pronunciar-se sobre todos os pontos da causa (NERY, 2018, pp. 1320 e 1322). Nessa linha, a atenção e o interesse do juiz em ouvir as partes serão fundamentais para que sua presença não seja simbólica. A desatenção durante a produção da prova oral, além de violar o direito de defesa, torna a decisão arbitrária, uma vez que será tomada sem a imediação (CALDAS, 2016, p. 138). Não se deve admitir, num Estado Democrático de Direito, que os julgadores decidam conforme sua consciência, utilizando-se de discricionariedade em suas decisões. O artigo 489 do CPC/2015 estabelece os elementos indispensáveis de uma sentença e funciona como parâmetro constitucional das decisões judiciais, reforçando o conteúdo do artigo 93, IX da Constituição Federal Brasileira de 1988 e sugerindo, claramente, que não deve existir margem para o protagonismo judicial que advém do uso discricionário do procedimento. Assim, é imperativo que o Judiciário não imponha às partes, decisões que não condizem com o ordenamento jurídico e muito menos que não oportunize um processo cooperativo e o direito de influência para todos os interessados.

Conclusão: A imposição legal infraconstitucional da fundamentação específica da decisão judicial pretende evitar a desatenção e os voluntarismos judiciais, buscando a efetividade da garantia da resposta judicial adequada, bem como pretende consolidar a necessidade de respeito às regras e princípios constitucionais como condição de legitimação das instituições democráticas, necessárias para manutenção das funções estatais e para resguardar força normativa da Constituição Federal Brasileira.

\section{Referências}

ARAÚJO, Fabio Caldas de. Curso de processo civil: parte geral. São Paulo: Malheiros, 2016.

CÂMARA, Alexandre Freitas. O novo processo civil brasileiro. 6 ed. São Paulo: Atlas, 2020.

MARINONI, Luiz Guilherme e ARENHART, Sérgio Cruz. Prova e convicção. 5 ed. São Paulo: Editora Revista dos Tribunais, 2019.

NERY JUNIOR, Nelson; NERY, Rosa Maria de Andrade. Código de processo civil comentado. 17 ed. São Paulo: Thomson Reuters Brasil, 2018. 
Coordenadoria de Pesquisa e Extensão - COPEX

Departamento de Editoraçāo e Divulgaçāo Científica - DEDIC 


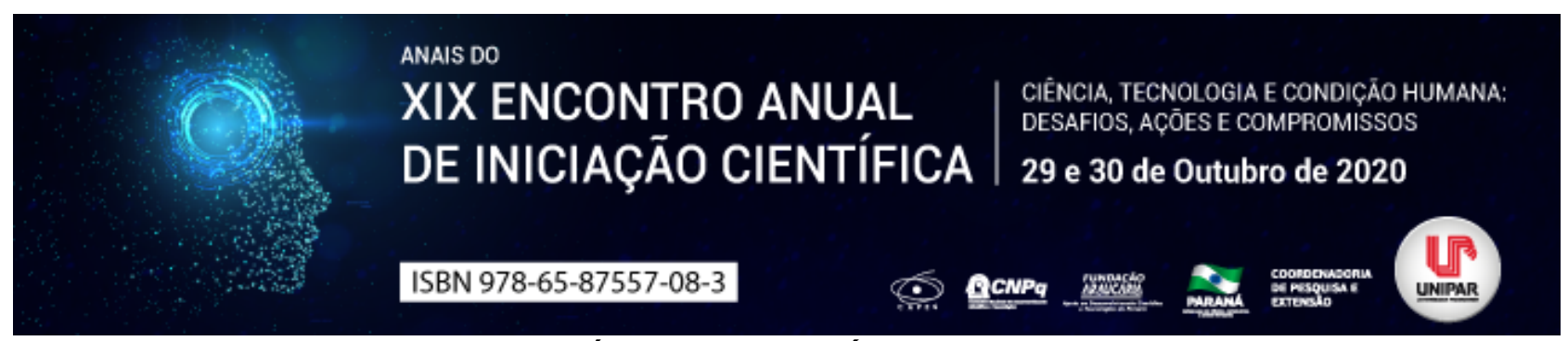

O AVILTAMENTO DOS HONORÁRIOS ADVOCATÍCIOS E O ARTIGO 85 DO CPC DE 2015

\author{
${ }^{1}$ MATEUS BONETTI RUBINI, ${ }^{2}$ CLEVERSON IVAN MERLO
}

\author{
${ }^{1}$ Acadêmico do PIC/UNIPAR \\ ${ }^{1}$ Docente da UNIPAR
}

Introdução: A honrável profissão do advogado é essencial e indispensável para a administração da justiça. Tais profissionais recebem como retribuição de seu trabalho, a verba chamada de honorários advocatícios. No entanto, a importância da atuação destes profissionais muitas vezes é menosprezada no momento da fixação de suas verbas honorárias.

Objetivos: Esclarecer o abuso que existia na égide do CPC/1973, no que se refere a fixação dos honorários advocatícios por parte dos julgadores, bem como realizar um comparativo com a realidade atual, na vigência do CPC/2015.

Desenvolvimento: Na égide do CPC/1973 corriqueiramente notava-se decisões injustas por parte de alguns magistrados de primeiro grau e por parte de alguns tribunais superiores, que no momento da fixação da verba honorária, não observaram o mínimo estabelecido e minoravam drasticamente os honorários devidos ao advogado, sob o fundamento de aplicação do princípio de equidade, princípio da proporcionalidade e até mesmo princípio da vedação do enriquecimento sem causa. Com o advento do $\mathrm{CPC} / 2015$ práticas como estas já não estão logrando êxito no dia a dia jurídico. $\mathrm{O} \S 2^{\circ}$ do artigo 85 , prevê expressamente que os honorários advocatícios serão fixados entre o mínimo de dez e o máximo de vinte por cento sobre o valor da condenação, do proveito econômico obtido ou, não sendo possível mensurá-lo, sobre o valor atualizado da causa, atendidos os critérios qualitativos de seus incisos. Ademais, uma outra mudança trazida pelo legislador é ao que se refere nas condenações contra a Fazenda Pública, sendo que, nestas situações, o juiz observará os critérios estabelecidos no $\$ 3^{\circ}$ do mesmo artigo. Quanto ao critério equitativo do juiz, este ficou reservado somente para as hipóteses de causas em que for inestimável ou irrisório o proveito econômico ou, ainda, quando o valor da causa for muito baixo, previstas no $\$ 8^{\circ}$ do artigo 85 . Constata-se que os tribunais já vêm se posicionando de forma favorável e correta quanto a aplicação dos honorários advocatícios, observando os critérios estabelecidos no art. 85 do CPC/2015. Inclusive, o STJ já se posicionou quanto a necessidade de observância dos limites estabelecidos no $\S 2^{\circ}$ do art. 85 do CPC, deixando claro que a aplicação do $\S 8^{\circ}$ tem caráter excepcional para as situações ali previstas.

Conclusão: Conclui-se que após a vigência do CPC/2015, a prática costumeira de fixar os honorários advocatícios ao advogado, abaixo dos patamares devidos, já não vem logrando êxito nos tribunais superiores. Claro, ainda percebemos certa resistência por parte de alguns juízes de $1^{\circ}$ grau e tribunais superiores. No entanto, o legislador tratou de ser muito claro ao prever expressamente no art. 85 do CPC os limites quantitativos a serem observados no momento de tal fixação e a hipótese de aplicação do princípio da equidade. Desta forma, não cabe aos magistrados de $1^{\circ}$ grau aplicarem um entendimento diverso, mas sim o estabelecido por lei.

\title{
Referências
}

BASTOS, Athena. Honorários advocatícios: tudo que o advogado precisa saber para cobrar. 2018. Disponível em: https://blog.sajadv.com.br/guia-honorarios-advocaticios/. Acesso em: 6 mai. 2020.

PORFIRIO, Fernando. TJ-SP reduz honorário milionário para R\$ 20 mil. 2011. Disponível em: . Acesso em: 26 mai. 2020.

STJ, Superior Tribunal de Justiça. Agravo interno no agravo em recurso especial: Aglnt no AREsp 1491650 PR 2019/0114867-2. 2019. Disponível em: https://stj.jusbrasil.com.br/jurisprudencia/859841402/agravo-interno-no-agravo-emrecurso-especial-agint-no-aresp-1491650-pr-2019-0114867-2?ref=serp. Acesso em: 8 jul. 2020. 


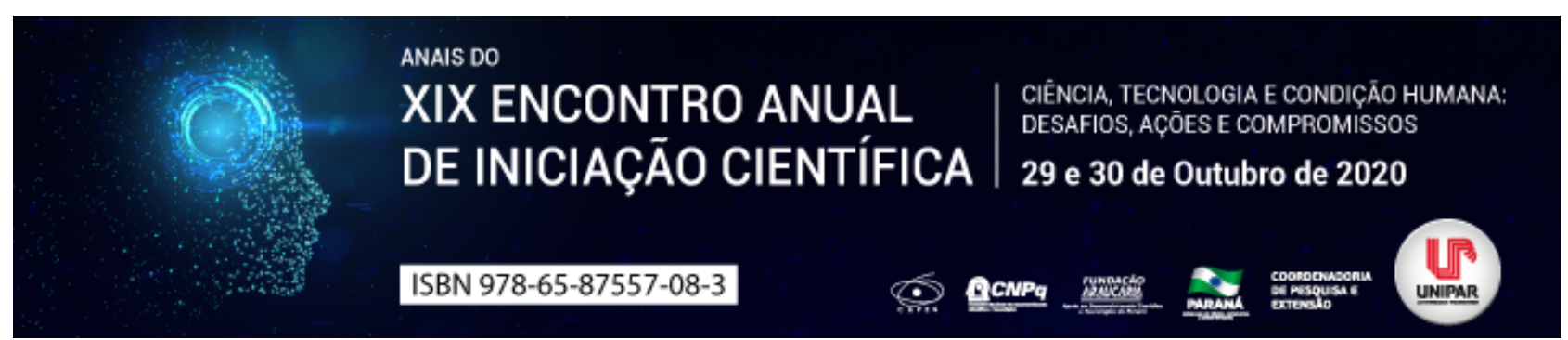

NORMAS GERAIS DO DIREITO INTERNACIONAL DO MEIO AMBIENTE: GÊNESE DO DIREITO INTERNACIONAL DOS DIREITOS HUMANOS

\author{
${ }^{1}$ LUIZ HENRIQUE SABION DA SILVA, ${ }^{2}$ DORITA ZIEMANN HASSE
}

\author{
${ }^{1}$ Acadêmico do PIC/UNIPAR \\ ${ }^{1}$ Docente da UNIPAR
}

Introdução: O Direito Internacional dos direitos humanos é a fonte moderna sistemática de proteção dos direitos do homem, quais sejam, os direitos fundamentais, que indiretamente, abrange a proteção ao meio ambiente como garantia à efetivação, a exemplo, do direito à vida.

Objetivo: Discutir a proteção do meio ambiente a fim de garantir à efetivação da tutela dos direitos humanos, como uma via transindividual e transgeracional, com o auxílio de documentos internacionais que regem as normas gerais de proteção à biosfera.

Desenvolvimento: A proteção da biosfera é um meio para se efetivar o cumprimento dos direitos humanos, pois na medida em que ocorre dano ao ambiente, consequentemente, haverá infração a outros direitos fundamentais do homem, como a vida, a saúde, bem-estar e entre outros. Para que isso ocorra, faz-se necessário, principalmente aos países signatários dos documentos internacionais, como a Declaração Estocolmo de 1992, Declaração do Rio de 1992, Agenda 21, e demais tratados voltados para proteção ambiental, como A Convenção para o Tratado da Flora, da Fauna e das Belezas Cênicas Naturais dos Países da América em 1949 (Dec. 58.054/66) usarem seus conteúdos como status de soft law, como ponte para assegurar a proteção do meio ambiente, e logo, a proteção dos direitos fundamentais do homem. Visto que, conforme leciona Rocha e Carvalho o meio ambiente é como um Direito fundamental de terceira geração, uma vez que se trata de um corolário do próprio Direito à vida (2006, p. 132). E se tratando de direito à vida, fala-se em direito transindividual ou coletivo, ou seja, um direito de todo cidadão. Isto porque, conforme ensina oportunamente Sarlet não há dúvidas de que os direitos fundamentais, de certa forma, são também sempre direitos humanos, no sentido de que seu titular sempre será o ser humano, ainda que representado por entes coletivos (2009, p. 29). Desta forma, vislumbra-se que a proteção ao meio ambiente é um direito que transcende os limites da esfera de cada Estado, tratando-se, assim, de um interesse internacional, e neste espeque, Trindade aduz que A conservação do meio-ambiente e o controle da poluição tornam-se igualmente uma questão de interesse internacional (1993, p. 39). Ainda de acordo com Trindade o meio ambiente é essencial à continuidade da espécie humana e à dignidade do ser humano enquanto animal cultural [...] tornando a vida plena em todos os aspectos (1993, p. 76). Assim, para que haja um ambiente sadio, qualidade de vida, saúde e bem-estar, a um alto nível de eminência, se faz necessário à integração e interação dos Estados, signatários ou não, nos interesses de preservação da biosfera.

Conclusão: Destarte, torna-se inevitável a fruição de um meio ambiente ecologicamente equilibrado, como um direito internacional indissociável à qualidade de vida, usando como pilar de apoio as Declarações e Tratados já existentes, afastando, assim, o temor de que a humanidade possa estar destinada ao suicídio coletivo pela ausência de interesses e ações a garantir a proteção do meio ambiente, e logo, a proteção dos direitos humanos.

\title{
Referências
}

ROCHA, Leonel; CARVALHO, Delton Winter de. Policontextualidade Jurídica e Estado Ambiental. In: Constituição, Sistemas Sociais e Hermenêutica. Programa de Pós-Graduação em Direito da UNISINOS. Mestrado e Doutorado. Anuário 2006, n. 3, pp. 129-47. Porto Alegre: Livraria do Advogado, 2006.

SARLET, Ingo Wolfgang. A Eficácia dos direitos fundamentais: uma teoria geral dos direitos fundamentais na perspectiva constitucional. Porto Alegre: Livraria do Advogado Editora, 2009.

TRINDADE, Antônio Augusto Cançado. Direitos humanos e meio ambiente: paralelo dos sistemas de proteção internacional. Porto Alegre: Sergio Antonio Fabris, 1993. 


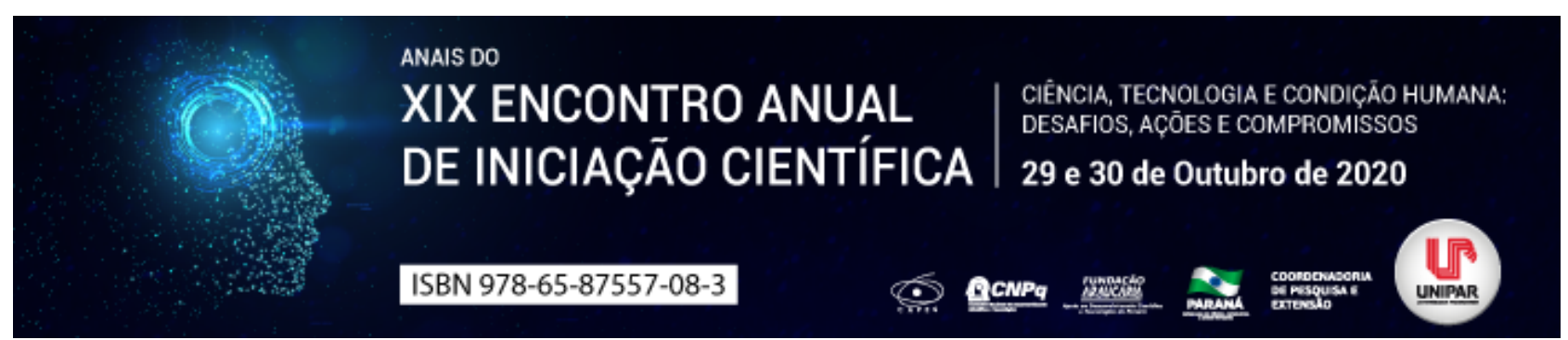

A USUCAPIÃO ESPECIAL DE BEM IMÓVEL URBANO PELO CÔNJUGE ABANDONADO

\section{${ }^{1}$ MATHEUS HENRIQUE DE SOUZA FONSECA, ${ }^{2}$ ANDRESSA SALES DO CARMO, ${ }^{3}$ MICHEL ELIAS DE AZEVEDO OLIVEIRA}

${ }^{1}$ Acadêmico do curso de Direito da UNIPAR

${ }^{1}$ Acadêmica do Curso de Direito da UNIPAR

${ }^{2}$ Docente da UNIPAR

Introdução: A usucapião especial na aquisição de bem imóvel urbano é um direito previsto no artigo 1.240-A do Código Civil brasileiro, que dispõe sobre a possibilidade do cônjuge abandonado, na aquisição da propriedade do bem imóvel urbano.

Objetivo: Analisar os requisitos necessários da posse ad usucapionem de imóvel urbano pelo lar conjugal e suas especificidades, amparado pelo Código Civil e a Constituição Federal de 1988 presentes no ordenamento jurídico brasileiro.

Desenvolvimento: O Código Civil, em seu artigo 1.240-A, classifica como sendo necessária, para a usucapião especial urbana por abandono do lar, a posse ininterrupta e sem oposição pelo período de dois anos; metragem do imóvel urbano de até $250 \mathrm{~m}^{2}$; a utilização deve limitar-se à moradia própria ou familiar e; o cônjuge abandonado não pode ser proprietário de outro imóvel urbano ou rural (BRASIL, 2002). Esse dispositivo visa a proteger aquele que rompeu com a união estável ou sociedade conjugal, mas que ainda reside no imóvel, não dividindo-o mais com o ex-cônjuge ou ex-companheiro que abandonou o lar. Diferentemente das outras modalidades de usucapião, a usucapião especial urbana por abandono do lar possui um prazo menor do que as demais, sendo este de 2 anos (TARTUCE, 2012). O artigo 1.240-A foi introduzido pela Lei 12.424/11, que reduziu o prazo mínimo de 5 anos para 2 anos, procurando atender às políticas públicas dos direitos sociais, amparados na Constituição Federal (OLIVEIRA; PEREIRA, 2014). Dentro dos requisitos necessários, a posse é indispensável para que se configure a usucapião especial, devendo esta ser contínua, mansa e pacífica com animus domini. Logo, aquele que pretende adquirir o domínio precisa mostrar que possui a coisa como sua, sem qualquer oposição, todavia, havendo qualquer disputa, judicial ou extrajudicial, relativa ao imóvel, entre os cônjuges, não ficará caracterizada a posse ad usucapionem. Ainda, deve ser constatado o lapso temporal entre a separação fática e o ajuizamento da usucapião sem qualquer oposição (SARMENTO, 2013). A usucapião especial pode atingir cônjuges ou companheiros, inclusive homoafetivos, dado o caráter atribuído a essas de entidade familiar, equiparada à união estável. Fica claro, conforme destaca Tartuce (2012) que o instituto tem incidência restrita entre os componentes da entidade familiar, sendo esse o seu âmbito inicial de aplicação.

Conclusão: A possibilidade da usucapião especial na aquisição de bem imóvel urbano se dará, tão somente, se forem respeitados os requisitos necessários da posse ad usucapionem, previstos no artigo 1.240-A do Código Civil brasileiro, responsável, pela proteção do direito à moradia, do qual foi rompido pelo abandono de um dos cônjuges.

\section{Referências}

BRASIL. Lei no 10.406, de 10 de janeiro de 2002. Institui o Código Civil. Diário Oficial da União: seção 1, Brasília, DF, ano 139, n. 8, p. 1-74, 11 jan. 2002.

TARTUCE, F. A usucapião especial urbana por abandono do lar conjugal. Revista Síntese Direito de Família, v. 14, n. 71, p. 16-18, 2012.

DE OLIVEIRA, D. K. L.; PEREIRA, D. M. Usucapião familiar: uma garantia ao direito à moradia. Âmbito Jurídico, São Paulo, 2014. Acesso em: 15 jun. 2020.

SARMENTO, D. M. B. Usucapião e suas Modalidades. Curso de Direitos Reais. Rio de Janeiro: EMERJ, 2013. 


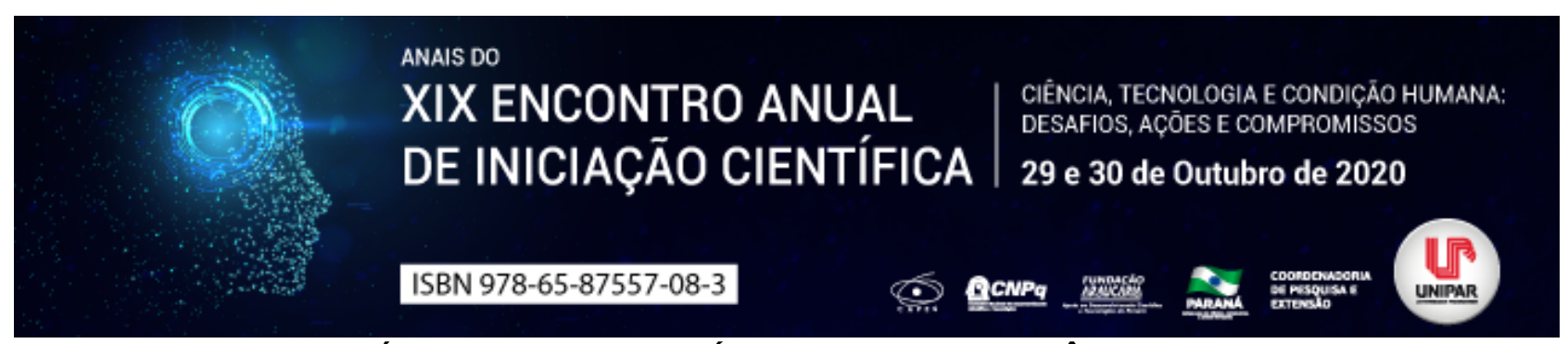

ÓLEOS ESSENCIAIS CÍTRICOS COMO TERAPÊUTICOS

\author{
${ }^{1}$ VALDINEY MARQUES DE OLIVEIRA, ${ }^{2}$ IRINEIA PAULINA BARETTA
}

\author{
${ }^{1}$ Acadêmico/PIC UNIPAR \\ ${ }^{1}$ Docente da UNIPAR
}

Introdução: Os óleos essenciais significam uma importante fonte de renda para diversos setores, têm sua produção aumentada ano a ano, devido ao crescente consumo nas indústrias de alimentos e de cosméticos, além de as novas aplicações organolépticas (cor, sabor, odor e o que pode ser percebido pelos sentidos) e biológicas. Este trabalho de revisão baseia-se no processo de extração e utilidade dos óleos essenciais cítricos, obtidos a partir da laranja doce, laranja amarga e bergamota.

Objetivo: Apresentar os óleos essenciais cítricos, oriundos da laranja doce, laranja amarga, bergamota e o uso destes na aromaterapia para saúde humana, bem-estar e o auxílio destes como coadjuvante no tratamento de transtornos de ansiedades em pessoas usuárias do SUS na UBS/CSE.

Desenvolvimento: Os óleos essenciais (OE) são definidos como materiais voláteis presentes em plantas, geralmente com odor e fragrância características, apresentam importância na economia de ramos industriais em escala mundial. Eles são utilizados como aromatizantes para fabricar alimentos e bebidas, com destaque crescente na utilização por parte da indústria farmacêutica, também na área de cosmetologia, devido as propriedades medicinais apontadas pelas pesquisas científicas recentes e difundidas pela medicina popular desde tempos remotos (STEFFENS, 2010).

A extração dos óleos essenciais se dá principalmente por enfloração a frio, hidrodestilação (destilação por arraste a vapor), prensagem a frio, extração por fluídos, por raspagem, com uso de solventes orgânicos e outros meios. Podem ser extraídos óleos essenciais de folhas, flores, raízes, caule, cascas, sementes e frutos. Aqui vamos nos deter aos cítricos específicos que são: laranja doce, laranja amarga e bergamota. A extração do óleo essencial de bergamota, na literatura consultada ocorreu por raspagem da casca, seu principal uso é aromatizante de balas, chás, sorvetes, tabacos, deixando nestes um aroma suave e adocicado. Pode ainda ser usado como base em perfumarias, em loções, colônias cítricas, sabonetes, cremes, loções bronzeadoras e maquiagem, deixando nestes produtos um aroma suave e refrescante, assim como outros cítricos com limoneno (ARAÚJO\&FARIAS, 2003). O óleo essencial de laranja doce segundo o autor consultado é extraído por prensagem do pericarpo do fruto e usado em larga escala na indústria de sucos. Derivados de óleo essencial de laranjas, são usados em perfumaria, cosméticos, sabonetes e na área farmacêutica em geral, além de materiais de limpeza, em balas e bebidas. O rendimento máximo de extração de óleos cítricos é de $0,4 \%$, ou seja, para cada tonelada de fruta processada são obtidos $4 \mathrm{~kg}$ de óleo. As frutas cítricas são as mais cultivadas no mundo, sendo a laranja a principal delas. O Brasil é líder de produção de cítricos, a perfumaria utiliza laranja doce, laranja amarga e bergamota como os principais cítricos mais vendidos no mundo (BIZZO et al, 2009). Os óleos essenciais são misturas complexas de compostos naturais, hidrofóbico, com odores fortes e possuindo ações terapêuticas. Os aromas provêm de uma variedade de compostos químicos. As principais aplicações dos óleos essenciais na área farmacêutica passam por ação terapêutica em medicamentos de uso interno e externo e as suas características odoríferas permitem a sua utilização em produtos farmacêuticos como excipientes de correção de óleos essenciais, como agentes terapêuticos, o sabor e odor em medicamentos destinados à via oral e como aromatizantes em medicamentos de aplicação tópica. Os OE são empregues essencialmente nos cuidados de saúde primários e em aromaterapia (FERREIRA, 2014). As atividades biológicas dos OE: bergamota - redução de ansiedade, depressão, pode atuar em dores musculares, como antiespasmódico e estimulante do sistema imunitário; laranja amarga - exerce ação anti-inflamatória e antimicrobiana, antiespasmódicas, digestivas, antissépticas, antifúngica, antimicrobiana, estimulante das secreções brônquicas, ação sedativa. Laranja doce antioxidantes como o ácido ascórbico, fenólicos, carotenóides, flavonóides, antocianinas, carboidratos para nutrição humana, terpenóides, hidrocarboneto monoterpenos que servem como tratamento de doenças degenerativas, tais como as cardiovasculares e alguns tipos de câncer. São antioxidantes naturais, evita o ranço e a oxidação de lipídeos, elimina radicais livres, contém propriedades anti-inflamatórias (flavonóides), funciona como inseticida, regula enzimas (LEÃO, 2015). A aromaterapia é um ramo da fitoterapia que faz uso de técnicas de inalação, administração oral e tópica de óleos essenciais (massagens, banhos, compressas impregnadas), e se utiliza de diversos óleos dependendo da ação pretendida. O uso de óleos essenciais como agentes terapêuticos na promoção e manutenção do bem-estar da pessoa humana, passa pelo tratamento e prevenção de doenças, bem como no tratamento de estados emocionais alterados (COELHO, 2009). Aromaterapia é uma terapia da medicina complementar ou alternativa, utilizada nos cuidados de saúde primários, sendo compatível com a terapêutica clássica. A aromaterapia é uma prática natural e não invasiva, desenhada para não atuar apenas no sintoma ou na doença, mas também para manter o equilíbrio natural do organismo como um todo, pelo correto uso dos óleos essenciais. Tal definição dá o sentido de visão holística a esta terapêutica, isto é, aborda o organismo na sua totalidade incluindo a parte física e mental do 
indivíduo (FERREIRA, 2014).

Conclusão: Diante disto, se percebe a importância dos óleos essenciais extraídos a partir dos cítricos: laranja doce, laranja amarga e bergamota, além de utilizado nas indústrias alimentícias, de bebidas, de cosméticos, perfumarias, produtos farmacêuticos, os OE são importantes para auxiliar a saúde da mente e do corpo, são antidepressivos, anti-ansiolíticos naturais, sem efeitos colaterais, auxiliam em processos físicos, anti-inflamatórios, metabolizador, regulador, prevenindo e amenizando dores musculares, atuando como benfeitor do coração e das células de todo o organismo.

\section{Referências}

ARAÚJO, Julio Maria de Andrade. FARIAS, Ana Paula Santa Fé. Redução do teor de limoneno e bergapteno do óleo essencial de bergamota adsorvido em sílica gel pelo $\mathrm{CO}_{2}$ supercrítico. Ciência tecnol. Aliment. Campinas, vol. 23, número 02, 2003.Disponível em:< https://www.scielo.br/scielo.php?script=sci_arttext\&pid=S0101-20612003000200002.>Acesso em 22/08/2020.

BIZZO, Humberto R. et al, 2009. Óleos essenciais no Brasil: aspectos gerais, desenvolvimento e perspectivas. Química Nova, São Paulo, vol. 32, número 03, 2009. Disponível em:< https://www.scielo.br/scielo.php?script=sci_arttext\&pid=S010040422009000300005.>Acesso em: 22/08/2020.

COELHO, Meirilane Gonçalves, 2009. Óleos essenciais para aromaterapia. Tese (Mestrado em Biotecnologia e Bioempreendedorismo em Plantas Aromáticas e Medicinais) - Universidade do Minho, Braga, 2009. Disponível em:http://repositorium.sdum.uminho.pt/bitstream/1822/10751/1/tese.pdfAcesso em: 22/08/2020.

FERREIRA, Ana Rita Alves. Uso de óleos essenciais como agentes terapêuticos. Dissertação ( Mestrado em ciências farmacêuticas) - Universidade Fernando Pessoa, Porto-PT, 2014.

LEAO, Marina. Análise do óleo essencial da laranja doce citrus sinensis: obtido das cascas secas e frescas através do método de extração por hidrodestilação. 2015. Monografia (graduação em Farmácia) - Universidade de Santa Cruz do Sul, Santa Cruz do Sul-RS, 2015.

STEFFENS, Andréia Hoeltz. Estudo da composição química dos óleos essenciais obtidos por destilação por arraste a vapor em escala laboratorial e industrial. Dissertação (Mestre em engenharia e tecnologia de materiais) - pontifícia Universidade Católica do Rio Grande do Sul, Porto Alegre-RS, 2010. Disponível em:< http://tede2.pucrs.br/tede2/bitstream/tede/3155/1/423851.pdf.>Acesso em: 22/08/2020. 


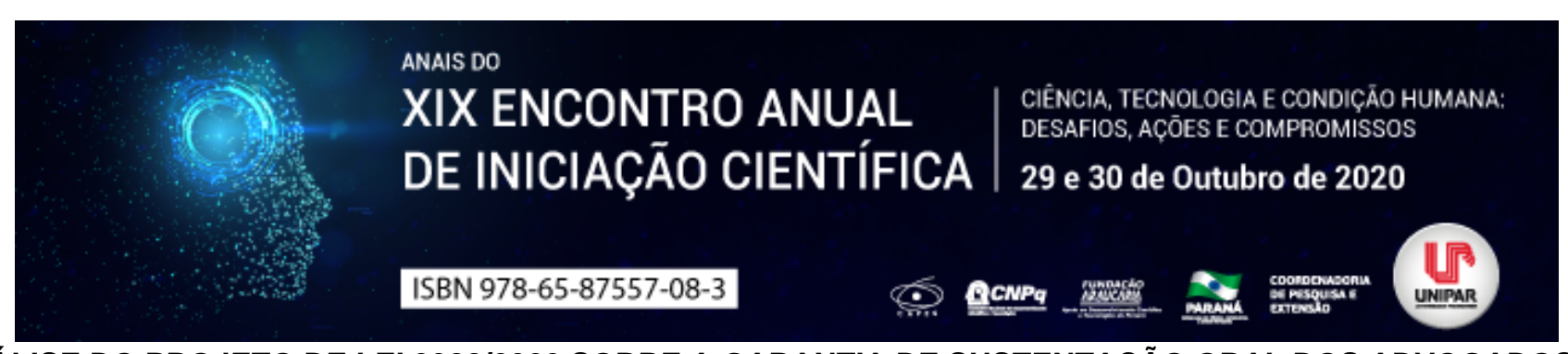

\title{
ANÁLISE DO PROJETO DE LEI 3388/2020 SOBRE A GARANTIA DE SUSTENTAÇÃO ORAL DOS ADVOGADOS EM SESSÃO PRESENCIAL OU VIDEOCONFERÊNCIA AO VIVO
}

\author{
${ }^{1}$ FRANCISCO ROMERO JUNIOR, ${ }^{2}$ CELSO HIROSHI IOCOHAMA
}

\author{
${ }^{1}$ Aluno do Mestrado em Direito Processual e Cidadania UNIPAR \\ ${ }^{1}$ Docente da Graduação em Direito e do Programa de Mestrado em Direito Processual e Cidadania da UNIPAR
}

Introdução: O presente Projeto de Lei 3388/2020, apresentando em 17 de junho de 2020, em trâmite na Câmara dos Deputados, tem por ementa alterar o Código de Processo Civil (CPC/2015) para garantir que a sustentação oral dos advogados, nos casos em que couber, deve ser feita preferencialmente em sessão presencial, ou, excepcionalmente, por videoconferência, ao vivo, de modo que a comunicação entre partes e julgadores possa ser imediata e direta.

Objetivo: Analisar a alteração proposta pelo legislador no artigo 937 do Código de Processo Civil (Lei n. 13.105 de 16 de março de 2015) que propõe que nas ações e recursos em que couber sustentação oral, deverá esta sessão ser presencial, sendo vedada a realização virtual de julgamento que não permita a participação, em tempo real do advogado.

Desenvolvimento: A Constituição Federal Brasileira de 1988 em seu artigo 133, diz ser indispensável o advogado para a Administração da Justiça, conforme ensina Medina (2019, p. 713) a ausência de representação por advogado tornaria evidentemente mais débil a defesa dos interesses da parte, o que prejudicaria a concretização da aspiração constitucional. Prescreve também a Constituição em seu art. $5^{\circ}$, LV, o direito ao contraditório e da ampla defesa, que, conforme explica Araújo consiste no direito à informação a possibilidade de reação $(2019$, p. 108) e o no direito de defesa da pretensão e da exceção em juízo $(2019$, p. 117). A sustentação oral em diversas ações e recursos, é uma forma de garantir o pleno exercício dos princípios do contraditório e da ampla defesa, devendo ser garantido ao advogado que participe efetivamente deste e possa reagir aos acontecimentos. Não se pode admitir que sejam aceitos julgamento fechados, sem participação dos advogados, devendo ser garantido a sustentação em tempo real, perante os julgadores, pois a própria Constituição estabelece no artigo $93, \mathrm{X}$, que todos os julgamentos do Poder Judiciário devem ter publicidade.

Conclusão: Tem-se vivido tempos de isolamento social em um período de calamidade pública, estando diversos Tribunais pelo País fechados, sem atendimento ao jurisdicionados. A PL 3388/2020 visa garantir a sustentação oral dos advogados nos casos em que couber ser feita, em sessão presencial, ou, excepcionalmente, por videoconferência on-line e ao vivo, em que a participação do advogado será garantida de forma direta e imediata do causídico e os julgadores, isso trará uma enorme segurança jurídica e garantirá um processos justo, respeitados os preceitos constitucionais.

\section{Referências}

ARAÚJO, Fabio Caldas de. Curso de processo civil: parte geral. Atualizado com a Lei 13.256/2016. São Paulo: Malheiros, 2016.

BRASIL. Constituição da República Federativa do Brasil, de 05.10.1988. Brasília, 1988. Disponível em: http://www.planalto.gov.br/ccivil_03/constituicao/constituicao.htm. Acesso em: 29.08.2020.

BRASIL. Lei 13.105, de 16.03.2015. Código de Processo Civil (LGL20151656). Diário Oficial da União, Brasília, DF, 16.03.2015. Disponível em: www.planalto.gov.br/ccivil_03/_ato2015-2018/2015/lei/l13105.htm. Acesso em: 29.08.2020

MEDINA, José Miguel Garcia. Constituição Federal comentada: com jurisprudência selecionada do STF e de outros Tribunais. 4. ed. rev., atual. e ampl. São Paulo: Thomson Reuters Brasil, 2019. 


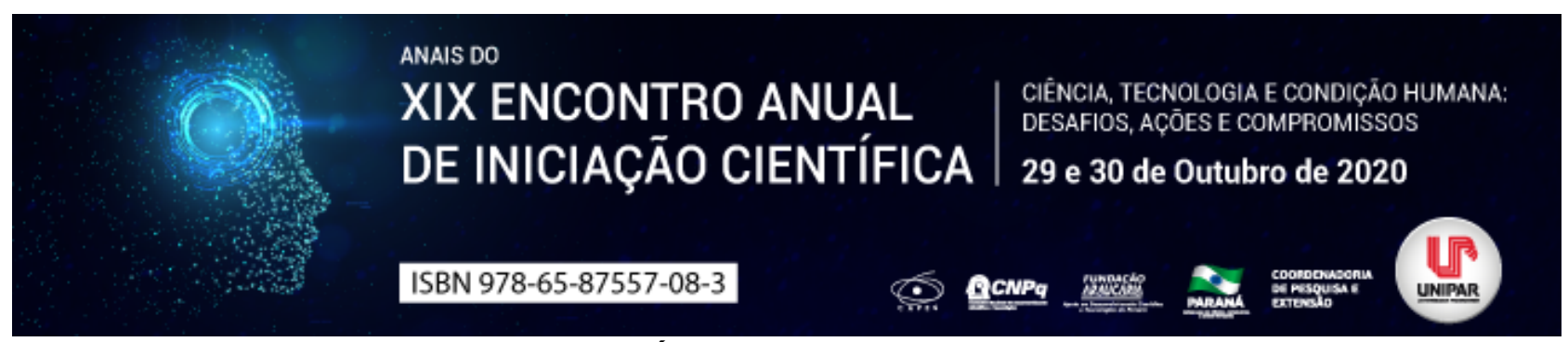

VULNERABILIDADE DA COMUNIDADE INDÍGENA BRASILEIRA EM FACE DA PANDEMIA DA COVID-19

\section{${ }^{1}$ LUCAS CALLOI DE SOUZA, ${ }^{2}$ CLARA MARTINS CERCI, ${ }^{3}$ TEREZA RODRIGUES VIEIRA}

${ }^{1}$ Acadêmico do Curso de Direito e integrante do PIC na UNIPAR

${ }^{1}$ Graduanda do Curso de Direito e Bolsista do PIBIC/UNIPAR

${ }^{2}$ Pós-Doutora em Direito pela Université de Montreal e Docente do Mestrado em Direito Processual e Cidadania na UNIPAR.

Introdução: Os povos indígenas já existiam muito antes da frota de Pedro Álvares Cabral avistar a terra que hoje é denominada Brasil. Assim que os primeiros portugueses desembarcaram no Novo Mundo , logo tomaram posse das terras, bem como realizaram os primeiros contatos com os indígenas. O período da colonização quase dizimou esta população nativa, tendo em vista que os portugueses trouxeram várias doenças como a gripe, a tuberculose, a sífilis e a varíola para um contexto desprovido de imunização. Tal cenário pode ser comparado com a atual disseminação da COVID-19 nas comunidades indígenas, vulneráveis à pandemia e negligenciadas pelo Poder Público.

Objetivos: Demonstrar os desafios atuais das comunidades indígenas no tocante à saúde; identificar a quem é atribuída a responsabilidade pela proteção da saúde indígena e verificar as consequências que uma contaminação em massa pela COVID19 pode trazer para estas comunidades.

Desenvolvimento: No Brasil, as políticas públicas de saúde destinadas aos povos indígenas tiveram seu marco com a chegada da Constituição Federal de 1988, uma vez que por meio desta foram reconhecidos os direitos dessas comunidades. Nesse sentido, além do reconhecimento constitucional dos povos indígenas, o Estatuto do Índio (Lei no 6.001/1973) também proclama o direito à saúde do indígena quando dispõe, em seu artigo 54, que os índios têm direito aos meios de proteção à saúde facultados à comunhão nacional . (BRASIL, 1973). Como primeira forma de proteção da saúde indígena, em 1999, foi criado o Subsistema de Atenção à Saúde Indígena (SASI), que hodiernamente é subordinado à Secretaria Especial de Saúde Indígena (SESI), que tem como objetivo prestar assistência médica para toda essa comunidade. Contudo, na prática, esse subsistema evidencia que as autoridades [...] instituíram uma operacionalização que se mostrou perversa, desperdiçadora de recursos e pouco capaz de atender, de maneira ética e tecnicamente eficaz, às responsabilidades que lhes foram atribuídas [...] (GARNELO, 2014, p. 134), principalmente nos tempos atuais, com a disseminação da COVID-19. Sem o amparo efetivo do Subsistema de Saúde Indígena, esse grupo corre o risco de ter sua população dizimada, assim como já ocorreu em outras épocas. Todos os povos, indígenas ou não, estão suscetíveis a adquirir a COVID-19, contudo, é evidente que as comunidades indígenas estão muito mais vulneráveis à pandemia, considerando suas precárias condições sociais, econômicas e de saúde, como por exemplo, o fato de que muitas tribos moram em grupo e a presença de garimpeiros ilegais em suas terras, o que facilita a disseminação do novo vírus. Além disso, Queiroz (2020) acrescenta que quarenta por cento da população indígena do país vive em aldeias de regiões que tiveram a natureza devastada. Com isso, atividades de caça, pesca e coleta de alimentos tornaram-se impraticáveis, contexto que obriga os índios a buscar alimentos nas cidades. Observa-se que apesar de ser ideal no plano jurídico, o SASI ainda é intangível para algumas comunidades indígenas, isso devido à falta de assistência efetiva e a sua má organização, levando em consideração toda a sua estrutura e integração nas comunidades. Conforme Cardoso (2014, p. 861) o modelo médico assistencial para as populações indígenas no Brasil ainda é precário, mesmo para a execução das ações básicas em saúde para estas populações, predominando um cenário de doenças carenciais e de controle infectoparasitário . Dessa forma, é indiscutível a vulnerabilidade dos povos indígenas em face da pandemia da COVID-19, tanto em razão de suas condições socioeconômicas e ambientais quanto pelo sistema de saúde público que ainda se mostra ineficiente para atender às suas necessidades básicas de saúde.

Conclusão: Diante do exposto, verifica-se que a saúde indígena é negligenciada pelo Poder Público, uma vez que não há investimentos adequados e muito menos fiscalização, o que torna muito mais difícil o acesso à saúde e o combate ao vírus nas comunidades indígenas. Logo, com a finalidade de assegurar o acesso efetivo à saúde aos povos indígenas, o Poder Público deve assegurar o cumprimento da funcionalidade do SASI, bem como garantir a assistência adequada às necessidades das comunidades autóctones.

\section{Referências}

BRASIL. Lei no 6.001, de 19 de dezembro de 1973. Dispões sobre o Estatuto do Índio. Diário Oficial da União, v. 21, n. 12, p. 1, 19 dez. 1973. Disponível em: http://www.planalto.gov.br/ccivil_03/Leis/L6001.htm. Acesso em: 10 jun. 2020.

CARDOSO, Marina Denise. Saúde e povos indígenas no Brasil: notas sobre alguns temas equívocos na política atual. Cadernos de Saúde Pública, v. 30, n. 4, p. 860-866, abr. 2014. Disponível em: https://www.scielo.br/pdf/csp/v30n4/0102-311X-csp-30-40860.pdf. Acesso em: 10 jun. 2020. 
GARNELO, Luiza. O SUS e a saúde indígena: matrizes políticas e institucionais do Subsistema de Saúde Indígena. In: TEIXEIRA, Carla Costa; GARNELO, Luiza (orgs.). Saúde indígena em perspectiva: explorando suas matrizes históricas e ideológicas. Rio de Janeiro: Fiocruz, 2014. p. 107-142.

QUEIROZ, Christina. Covid-19 e indígenas: os desafios no combate ao novo coronavírus. Viva Bem, São Paulo, 2 maio 2020. Disponível em: https://www.uol.com.br/vivabem/noticias/redacao/2020/05/02/covid-19-e-indigenas-os-desafios-no-combate-aonovo-coronavirus.htm?app=uol-noticias. Acesso em: 8 jun. 2020.

Coordenadoria de Pesquisa e Extensão - COPEX

Departamento de Editoraçāo e Divulgaçāo Científica - DEDIC 


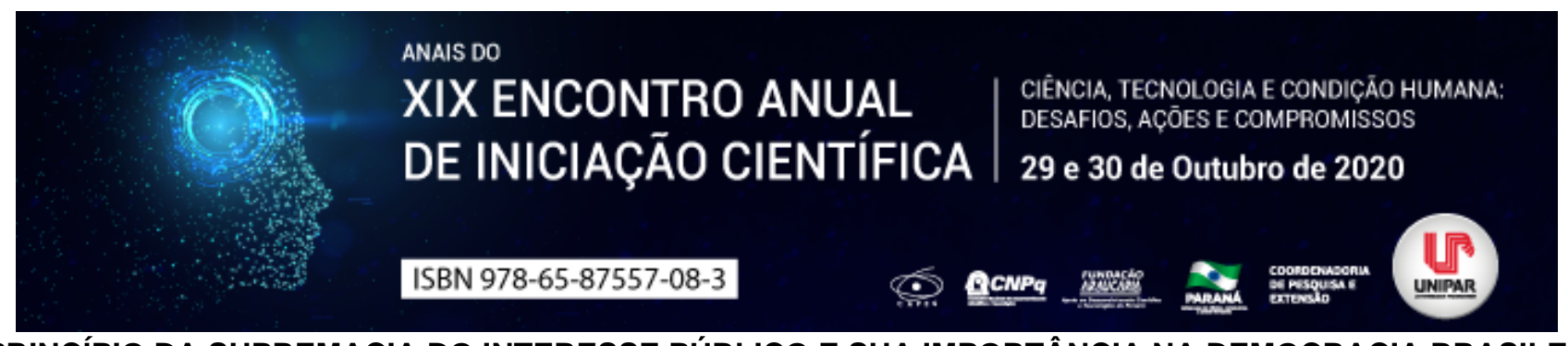

O PRINCÍPIO DA SUPREMACIA DO INTERESSE PÚBLICO E SUA IMPORTÂNCIA NA DEMOCRACIA BRASILEIRA

\author{
${ }^{1}$ MATEUS ELIAS BORGES, ${ }^{2}$ ALBINO GABRIEL TURBAY JUNIOR
}

${ }^{1}$ Acadêmico do $4^{\circ}$ ano do Curso de direito da UNIPAR

${ }^{1}$ Docente da UNIPAR

Introdução: A liberdade e os interesses individuais sempre foram motivo de defesa contra a força dos Estados, especialmente quando a discussão se concentra em Estados absolutistas. Mas é preciso refletir sobre o tema quando se trata de democracia, pois os interesses privados devem ser protegidos, mas, é preciso um equilíbrio em relação ao interesse público, neste sentido, esta pesquisa tem seu foco na relação Estado e administrado, pelo prisma do princípio da supremacia do interesse público.

Objetivos: Analisar o princípio do interesse público na sociedade democrática brasileira com foco na área administrativa.

Desenvolvimento: Há dificuldade de compreender a eficácia do princípio da supremacia do interesse público para o sucesso de uma instituição democrática, jurídica e que visa a liberdade do cidadão. Para Celso Spitzcovsky (2018): este princípio é responsável pela possibilidade do Poder Público, em nome dos interesses que representa, impor aos administrados, de maneira unilateral, o cumprimento de determinados comportamentos, ainda que nenhuma irregularidade tenham praticado [...] . Para Emerson Gabardo (2017): A maioria absoluta das doutrinas e jurisprudências administrativas reconhece o princípio da supremacia do interesse público sobre o privado como categoria fundamental do Direito administrativo brasileiro [...] . Neste sentido, pode-se chegar a uma concepção social de interesse público, pois será interesse público aquele interesse individual de cada participante na sociedade que está inserido, visando atender o bem comum e o bem-estar social, ou seja, garantir a dignidade da pessoa humana (WEINMANN, 2010, p. 53). O maior valor que advém ao Estado em relação aos súditos, consiste em que a ordem jurídica confere aos indivíduos qualificados como órgãos do Estado, ou, pelo menos, a alguns deles os chamados órgãos da autoridade pública a faculdade de obrigar os súditos através de uma manifestação unilateral de vontade (comando) (HANS KELSEN, 2006, p. 311). A análise dessa questão à luz da doutrina brasileira é delicada, pois, nessa discussão o principal conflito está na questão de duas visões, sendo a primeira a posição do princípio da supremacia do interesse público como inibidor de direitos individuais, o que fere os direitos fundamentos, sendo este o posicionamento adotado por boa parte da doutrina que não concorda com a majoritária (FERNANDES; MENDONÇA, 2016). A segunda visão, que é o posicionamento majoritário, acredita que para uma sociedade ser considerada sólida, necessita que o bem comum e a busca pela igualdade trazida pela junção das vontades de todas seja protegida, e esta é função primordial do Estado (FERNANDES; MENDONÇA, 2016). A partir da pesquisa, pode-se chegar a uma concepção social de interesse público, pois será interesse público aquele interesse individual de cada participante na sociedade que está inserido, visando atender o bem comum e o bem-estar social, ou seja, garantir a dignidade da pessoa humana (WEINMANN, 2010, p. 53). Entre discussões contrárias e favoráveis a existência do princípio da supremacia do interesse público, deveria se optar pela prevalência da análise do caso concreto, e desta forma, chegar a solução de tais conflitos entre público e privado através da interferência de servidores público, cidadãos e todos que participam da atual sociedade democrática de direito (FERNANDES; MENDONÇA, 2016).

Conclusão: Conclui-se que devemos saber equilibrar a atividade do princípio da supremacia do interesse público, ele deve ter limites sim, como a lei o dispõe, mas sempre deve permanecer superior ao interesse do particular, inclusive para defender a liberdade individual de cada um. Dessa forma tanto a doutrina quanto a jurisprudência tentam harmonizar o princípio da supremacia do interesse público com os direitos e garantias individuais previstos na Constituição federal.

\title{
Referências
}

FERNANDES, M. J.; MENDONÇA, M. L. O Pricípio da Supremacia do Interesse Público á Luz da Doutrina. EEDIC - XII ENCONTRO DE EXTENSÃO, DOCÊNCIA E INICIAÇÃO, v. 3, n.1, $2016 . \quad$ Disponível em: http://publicacoesacademicas.unicatolicaquixada.edu.br/index.php/eedic/article/view/954. Acesso em: 25 ago. 2020.

GABARDO, E. O Princípio da Supremacia do Interesse Público sobre o Interesse Privado como fundamento do Direito Administrativo Social. Revista de Investigações Constitucionais, Curitiba, v. 4., n. 2., mai./ago. 2017. Disponível em: https://revistas.ufpr.br/rinc/article/view/53437/33212. Acesso em: 25 ago. 2020.

KELSEN, H. Teoria Pura do Direito. São Paulo: Martins Fontes, 2006.

SPITZCOVSKY, C. Direito Administrativo. São Paulo: Saraiva Jur, 2018.

WEINMANN, G. S. Interesse Público e sua Supremacia sobre o Interesse Privado. Orientador: Romeu Felipe Bacellar Filho. 2010. 57 f. Trabalho de Curso (Graduação Direito) - Universidade Federal do Paraná. 2010. Disponível em: https://acervodigital.ufpr.br/bitstream/handle/1884/31407/M1417JU.pdf?sequence=1\&isAllowed=y. Acesso em: 25 de ago. 2020. 
Coordenadoria de Pesquisa e Extensão - COPEX

Departamento de Editoraçāo e Divulgaçāo Científica - DEDIC 


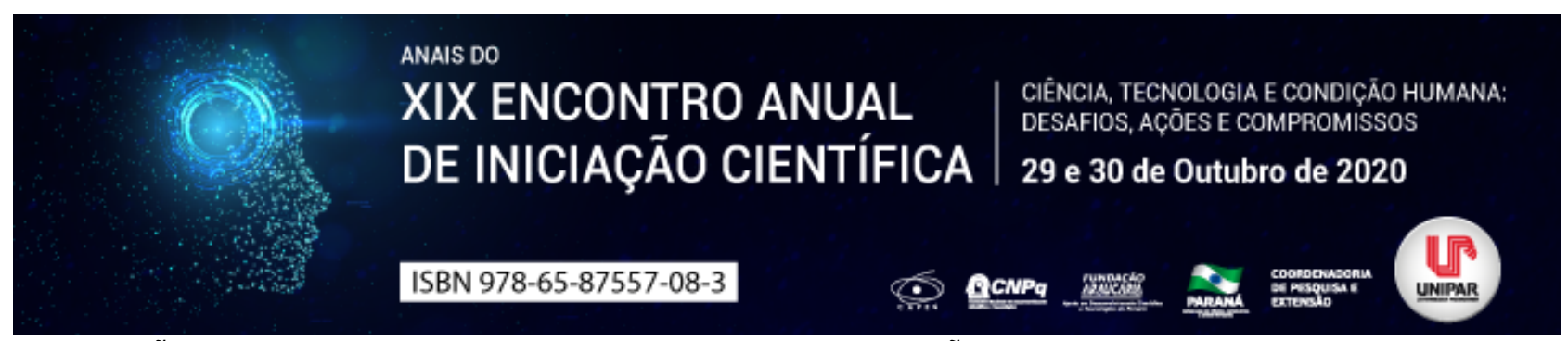

PETIÇÃO INICIAL E A CAUSA DE PEDIR COMO DELIMITAÇÃO DOS FATOS A SEREM JULGADOS

\author{
${ }^{1}$ THAMIRES LAIS DE MORAES GONCALVES, ${ }^{2}$ ALBINO GABRIEL TURBAY JUNIOR
}

\author{
${ }^{1}$ Acadêmico do PIC/UNIPAR \\ ${ }^{1}$ Docente da UNIPAR
}

Introdução: A petição inicial é tida como aquela que dá abertura aos processos e tem por essa razão sua importância assim como previsto no artigo $2^{\circ}$ do CPC nenhum juiz prestará a tutela jurisdicional senão quando parte ou interessado a requerer nas formas legais , além disso, é nela em que o autor descreve os fatos que ele tem a intenção de que sejam julgados ao longo do processo, explicitando assim a causa de pedir.

Objetivo: Compreender a petição inicial e sua finalidade de apresentar os fatos e dar início a um processo, analisar seus requisitos, principalmente, a causa de pedir.

Desenvolvimento: A delimitação da realidade dos fatos ocorre na narração realizada na petição inicial, descrita por Tiago Fachini (2020) como: [...] o documento mais importante de toda a disputa judicial, pois é nela que os fatos são apresentados para o julgador. , que propõe a abertura de um processo em que a parte interessada, utilizando o direito de agir, apresenta uma situação demonstrando algum direito lesado. O direito de ação se encaixa no direito público subjetivo e é posto em prática através do pedido de proteção dos direitos do autor, pedido este realizado ao Estado por meio do Poder Judiciário, visando a solução. A petição inicial concretiza o direito de ação, momento em que o autor apresenta seu caso para ser analisado em juízo, possuindo os requisitos presentes no artigo 319 do Código de Processo Civil (2015) que devem ser respeitados, sendo eles: o juízo a que é dirigida; os nomes, os prenomes, o estado civil, a existência de união estável, a profissão, o número de inscrição no Cadastro de Pessoas Físicas ou no Cadastro Nacional da Pessoa Jurídica, o endereço eletrônico, o domicílio e a residência do autor e do réu; o fato e os fundamentos jurídicos do pedido; o pedido com as suas especificações; o valor da causa; as provas com que o autor pretende demonstrar a verdade dos fatos alegados; a opção do autor pela realização ou não de audiência de mediação ou conciliação . A ausência dos requisitos pode levar ao indeferimento da petição inicial, nos termos do artigo 330 do Código de Processo Civil (2015). Importante destacar que o pedido deve ser certo e determinado, conforme artigo 322 e 324 , deixando claro a prestação jurisdicional pretendida e o bem objeto do caso. específico e detalhado quanto a intenção de conciliação ou não e quanto ao objetivo. Para que o juiz entenda a realidade dos fatos, destaca-se o que dispõe o inciso III do artigo 319 do Código e Processo Civil (2015) quanto a causa de pedir que, como aponta Fernanda Braga (2008) é: [...] o conjunto dos fatos necessários para deduzir, com base em norma jurídica, que o autor é titular de um direito violado pelo réu. , sendo dividida em causa de pedir próxima e remota, que é a parte da petição que se descreve fatos e ocorridos servindo como justificativa para o julgamento de mérito do conflito existente. Ainda como causa de pedir próxima e remota entende-se que a causa de pedir próxima trata da fundamentação jurídica do pedido e a remota é a que trata explicitamente do fato ocorrido podendo ser dividida em causa de pedir remota ativa, tratando essa do fato que gera o direito (como um acidente) e a causa remota passiva, sendo esse o acontecimento que faz com que a pessoa precise procurar meios legais para resolução de conflito (como o não pagamento de indenização). Ressalta-se na petição inicial a necessidade de fundamentação clara e objetiva, incluindo o exercício do direito lesado por alguém, essa exposição deve ser feita sem defesa de partes ou julgamento de mérito visando apenas o esboço da ação a seguir. Desta forma, torna-se claro que a petição inicial é, como descreveu Humberto Theodoro Júnior (2015, p.1121): O veículo de manifestação formal da demanda [...] que revela ao juiz a lide e contem o pedido da providencia jurisdicional, frente ao réu, que o autor julga necessária para compor litigio.

Conclusão: Desta forma, a causa de pedir é o motivo pelo qual a petição pede a abertura de um processo e delimita os fatos e intenções. A petição em sua totalidade é o documento de maior importância de todos os processos justamente por ter contida nela toda a causa de pedir e informações relevantes para que o processo possa ter continuidade.

\title{
Referências
}

BRAGA, Fernanda. O que é causa de pedir remota ativa e passiva? Jusbrasil. Disponível em: https://cutt.ly/ffGH4cP. Acesso em: 10 jul. 2020.

BRASIL. Lei 13.105 de 16 de março de 2015. Código de Processo Civil. Diário Oficial da União. Brasília, seção 1, 17 mar. 2015 , p. 1.

FACHINI, Tiago. Tudo o que você precisa saber sobre Petição Inicial. Projuris. Disponível em: https://www.projuris.com.br/peticao-inicial. Acesso em: 02 jun. 2020.

THEODORO JÚNIOR, Humberto. Curso de direito processual civil. 56. ed. Rio de Janeiro: Forense, 2015. v. 1. 
Coordenadoria de Pesquisa e Extensão - COPEX

Departamento de Editoraçāo e Divulgaçāo Científica - DEDIC 


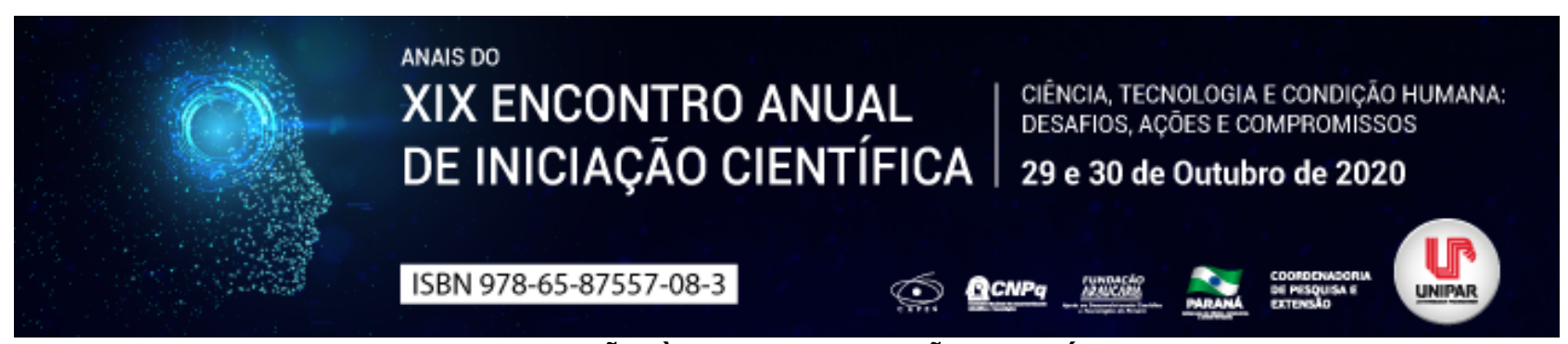

DA DESPATRIMONIALIZAÇÃO À PERSONIFICAÇÃO DO CóDIGO CIVIL DE 2002

\begin{abstract}
${ }^{1}$ PATRICIA CARNEIRO PERAL MORO, ${ }^{2}$ GERALDO SCRAMIN NETO, ${ }^{3}$ LUIZ MANOEL GOMES JUNIOR, ${ }^{4}$ JUSSARA SUZI ASSIS BORGES N. FERREIRA
\end{abstract}

${ }^{1}$ Acadêmico do PIC/UNIPAR
${ }^{1}$ Docente da UNIPAR
${ }^{2}$ Docente da UNIPAR
${ }^{3}$ Docente da UNIPAR

Introdução: O percurso do Código Civil de 2002 seguiu com intuito de descodificação, e levou anos entre o desenvolvimento do projeto e seu efetivo advento, construído sob a égide menos formalista e metódica, principalmente no que se refere às relações negociais e o advento de uma nova principiologia.

Objetivo: Demonstrar como a revolução humanista foi trazida para a vigente codificação, bem como, perpassar os princípios basilares que regeram a estruturação do CC/02.

Desenvolvimento: O Código Civil foi concretizado dentre outros elementos com a distinção normativa específica de portar em seu corpo legislativo, princípios da magnitude da sociabilidade, da eticidade e da operabilidade, verdadeiros delimitadores de uma nova roupagem dada, primordialmente, ao direito negocial. A sociabilidade, enquanto um dos pontos marcantes, aborda essa visão moderna, pela qual o coletivo ganha espaço naqueles ambientes de cunho eminentemente individual, vale dizer, $v . g$., a função social dos contratos, restando ainda mais evidente, inclusive, o princípio da boa-fé e a relação dos contratantes no ambiente privado. Já no que tange ao princípio da eticidade, dentre suas contribuições, estão a mitigação da formalidade e o autoritarismo intrínsecos do codéx anterior. Segundo Reale (1999, p. 7), o cuidado fundamental do princípio da eticidade seria o valor da pessoa humana como fonte de todos os direitos, e assim também é o que preconiza o texto constitucional, alicerçado no princípio da dignidade da pessoa humana, fundamento do Estado Democrático de Direito, bem como, em um dos objetivos fundamentais de República Federativa do Brasil, qual seja, uma sociedade livre, justa e solidária, que aliás, costura laços com a solidariedade tratada alhures. Por fim, mas não menos importante e nem haveria de ser o princípio da operabilidade, conforme lição de Gagliano e Pamplona Filho (2020, p. 83), importa na concessão de maiores poderes hermenêuticos ao magistrado, verificando, no caso concreto, as efetivas necessidades a exigir a tutela jurisdicional. Discorrem ainda os citados autores como exemplo de se ter privilegiado a normatização através de cláusulas gerais, o art. $927 \mathrm{CC}$ em que se admite a obrigação de reparar o dano independentemente de culpa. Deste modo, deve ser analisada a realidade fática, não devendo o magistrado se ater apenas e tão somente ao que o ordenamento expressamente dispõe, podendo ocorrer a flexibilização para o fim de ver concretizado o anseio principiológico querido pelo código Reale. Nesse sentindo e a respeito da operabilidade, reforça Gonçalves (2017, p. 39), que leva em consideração que o direito é feito para ser efetivado, para ser executado. Por essa razão, o novo Código evitou o bizantino, o complicado, afastando as perplexidades e complexidades. Exemplo desse posicionamento, dentre muitos outros, encontra-se na adoção de critério seguro para distinguir prescrição de decadência, solucionando, assim, interminável dúvida. As mudanças de esfera humanista se tornaram cada vez mais evidentes com o efetivo advento do novo código, atenuando a envergadura mecânica de outrora, calcada porque não dizer na patrimonilização, passando a servir como um instituto multiportas, assim deixando de perquirir outras condições metódicas, leva em consideração que a liberdade de contratar deve ser respeitada entre as partes, prestigiando em partes o brocado pacta sunt servanda, donde se extrai que o contrato faz lei entre os contratantes e deve ser mantido. Ocorre que, [...] Tal princípio, todavia, vem perdendo substância nas últimas décadas em decorrência de restrições criadas em leis (NADER, 2016, p. 50). Os reflexos da nova codificação, foram extremamente relevantes, impactando, por exemplo, como marco no direito de família e a forte expressão sobre aspectos de igualdade do pátrio poder hodiernamente, poder familiar , além de questões específicas no direito de sucessões, empresarial, das coisas ou reais, dentre outras searas e suas influências decorrentes dessa personalização/personificação.

Conclusão: Portanto, é possível identificar que os princípios em comento, contribuíram decisivamente com o patamar galgado pelo código vigente e a eterna luta para fazer valer a influência da dignidade da pessoa humana no texto civil. Daí dizer de sua (des)patrimonialização para a colocação da pessoa como figura central do sistema privado, aliás, de um direito civil constitucional.

\title{
Referências
}

GAGLIANO, Pablo Stolze; PAMPLONA FILHO, Rodolfo. Novo Curso de Direito Civil, parte geral. ed. 22. São Paulo: Saraiva, 2020. p. 82-83. 
GONÇALVES, Carlos Roberto. Direito civil brasileiro, parte geral. 15. ed. São Paulo: Saraiva, 2017. p. 38-39.

NADER, Paulo. Curso de Direto Civil, parte geral. 10. ed. Rio de Janeiro: Forense, 2016. p. 50-51.

REALE, Miguel. Visão geral do projeto de código civil. Revista dos Tribunais.v. 752, Junho 1999. Disponível em: http://gg.gg/lsbo7. Acesso em 01 ago. 2020.

Coordenadoria de Pesquisa e Extensão - COPEX

Departamento de Editoraçāo e Divulgaçāo Científica - DEDIC 


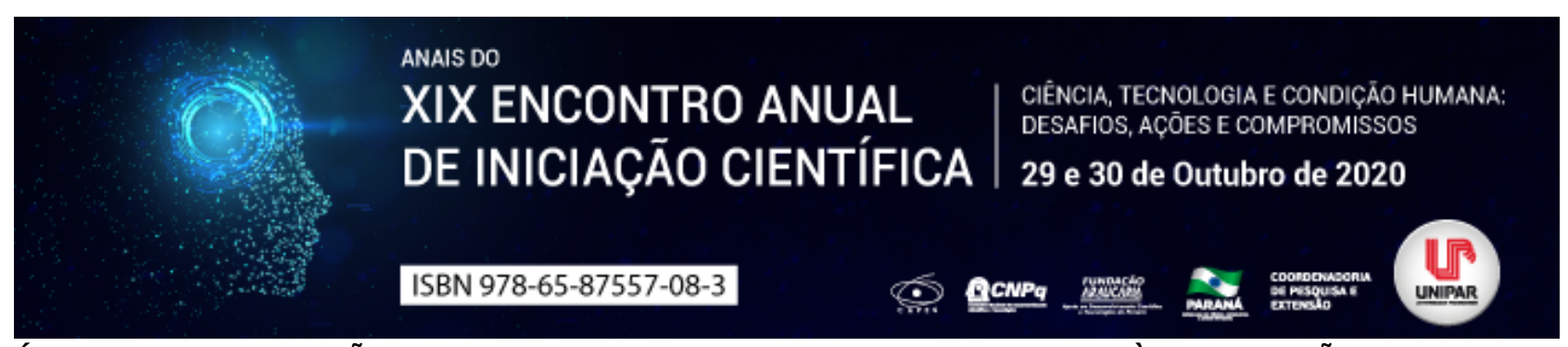

PRINCÍPIO DA CONSERVAÇÃO NEGOCIAL: DA TEORIA DO APROVEITAMENTO À CONVERSÃO SUBSTANCIAL DO NEGÓCIO JURÍDICO

\author{
${ }^{1}$ NATALIA ZEFERINO CASTANHEIRA, ${ }^{2}$ GERALDO SCRAMIN NETO, ${ }^{3}$ LUIZ MANOEL GOMES JUNIOR, ${ }^{4}$ JUSSARA SUZI \\ ASSIS BORGES N. FERREIRA
}

${ }^{1}$ Acadêmica do PIC/UNIPAR
${ }^{1}$ Docente da UNIPAR
${ }^{2}$ Docente da UNIPAR
${ }^{3}$ Docente da UNIPAR

Introdução: O Código Civil de 2002 dedicou vasta atenção aos negócios jurídicos, além de utilizá-los como instrumento de autorregramento, estatuído através da autonomia privada. A conversão substancial dos negócios jurídicos é materialização do princípio da conservação dos atos e negócios jurídicos, sendo que sua observância é imprescindível para efetiva preservação da autonomia da vontade inerente a todos.

Objetivo: Analisar o princípio da conservação negocial, contextualizando a teoria do aproveitamento e a conversão substancial do negócio jurídico, além de evidenciar os requisitos da conversibilidade.

Desenvolvimento: $\mathrm{A}$ análise dos negócios jurídicos será sempre realizada com vistas à tricotomia da existência-validadeeficácia, que forma a Escada Ponteana, desenvolvida por Pontes de Miranda (BUSSATTA, 2006, pp. 3 e 4). A fim de alcançar o objetivo pelo qual foi concebido o acordo de vontades, torna-se possível a produção dos efeitos jurídicos pretendidos pelas partes e não obstados pela ordem jurídica. A inobservância de determinado pressuposto implicará em invalidade do negócio jurídico, logo, não produzirá efeitos no campo externo. Todavia, se tal ato jurídico detém, em sua essência, vontade apta a repercutir efeitos, dever-se-á preservá-la. O princípio da conservação dos atos e negócios jurídicos é o respaldo utilizado a fim de que, havendo possibilidade, preserve-se a intenção das partes no momento em que pactuaram a avença, objetivando a preservação da liberdade de agir, inerente a toda relação jurídica privada. Tanto o legislador, quanto o intérprete, deverão preservar em todos os planos da escada, o negócio jurídico acordado pelos agentes emissores de vontade. Portanto, o princípio da conservação

[...] é a consequência necessária do fato de o ordenamento jurídico, ao admitir a categoria negócio jurídico, estar implicitamente reconhecendo a utilidade de cada negócio jurídico concreto (AZEVEDO, 2002, p. 67). Derivada do princípio da conservação negocial e situando-se no plano de validade, a conversão substancial do negócio jurídico é um instituto trazido pelo CC/02 em seu artigo 170, e que busca incessantemente a conservação da finalidade almejada pelas partes, no momento em que pactuaram o negócio jurídico. O juiz, ao utilizar-se deste instrumento, observa a vontade emitida na declaração nula, e a adequa em outra espécie negocial, respeitando os requisitos objetivos e subjetivos, além dos fins colimados pelas partes, através de um novo negócio jurídico. Os requisitos objetivos da conversibilidade traduzem-se na existência e invalidade absoluta do negócio jurídico a ser convertido, e que este reúna os requisitos de conteúdo e forma exigidos para efetiva conversão em um novo negócio jurídico. Os requisitos subjetivos compreendem-se na vontade das partes mantenedoras do negócio, e, caso aquelas tivessem conhecimento a respeito da nulidade, optariam por outra espécie negocial, além disso, há necessidade de ignorância das partes acerca da nulidade que atingiu o negócio originariamente configurado (NERY JUNIOR; NERY, 2019, p. 506). Não obstante, O aspecto da conversão requer a existência de um suporte fático no negócio jurídico a converter-se (BRASIL, 2012, p. 19). Segundo o Superior Tribunal de Justiça (BRASIL, 2014), em situações onde há nulidade de elemento essencial do negócio jurídico, haverá a conversão deste em outra espécie negocial, a fim de conservar a vontade exaurida pelas partes, v.g., o contrato de doação é nulo por haver inobservância à solenidade que a lei considera essencial para sua validade, e o mais coerente à espécie é que se lhe converta em um contrato de mútuo gratuito, de fins não econômicos, buscando interpretação restritiva aos contratos benéficos e manutenção do elemento volitivo negocial apurado através do negócio jurídico originalmente concebido.

Conclusão: A conversão substancial adequa-se ao princípio da conservação dos atos e negócios jurídicos por ser mecanismo pelo qual o negócio jurídico inválido respeitados os pressupostos estabelecidos, transforma-se em outro negócio, plenamente válido, tendo em vista a conservação negocial e a preservação das vontades consubstanciadas, fundamentadas através da autonomia privada.

\title{
Referências
}

AZEVEDO, A. J. Negócio Jurídico: Existência, Validade e Eficácia. 4. ed. São Paulo: Saraiva, 2002.

BRASIL, Superior Tribunal de Justiça. Recurso Especial 1.225.861. Relatora: Min. Nancy Andrighi, 22 de abril de 2014. 
Disponível em: https://cutt.ly/Os6xmfq. Acesso em: 30 jul. 2020.

. Jornada de direito civil I. Enunciado $n^{\circ} 13$. Coordenador científico Ministro Ruy Rosado de Aguiar Júnior. Brasília: Conselho da Justiça Federal, Centro de Estudos Judiciários, 2012. Disponível em: http://gg.gg/la323. Acesso em: 30 jul. 2020.

BUSSATTA, E. L. Conversão substancial do negócio jurídico. Revista de Direito Privado. v. 26, abr - jun. 2006. RTOnline. NERY JUNIOR, N; NERY, R. M. de A. Código Civil Comentado. 13. ed. São Paulo: Revista dos Tribunais, 2019.

Coordenadoria de Pesquisa e Extensão - COPEX

Departamento de Editoraçāo e Divulgaçāo Científica - DEDIC 


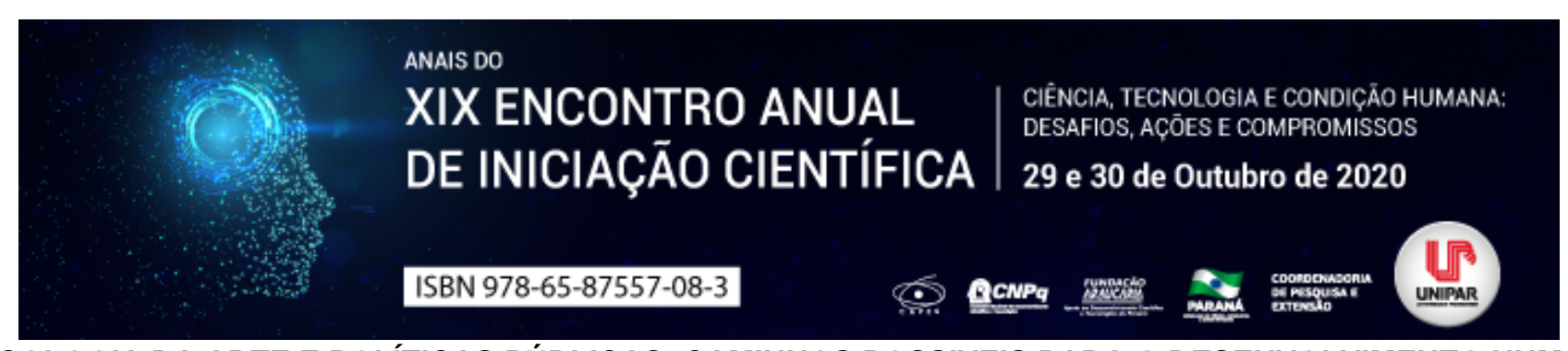

PSICOLOGIA DA ARTE E POLÍTICAS PÚBLICAS: CAMINHOS POSSIVEIS PARA O DESENVOLVIMENTO HUMANO

\author{
${ }^{1}$ DOUGLAS WILLIAM ALVES, ${ }^{2}$ TATIANE SUPERTI
}

\author{
${ }^{1}$ Acadêmico do curso de Psicologia da Unipar \\ ${ }^{1}$ Docente da UNIPAR
}

Introdução: A arte para Vygotsky surge no movimento dialético dos sentimentos internalizados e a necessidade destes de serem superados, retirando elementos do cotidiano. Assim, é provocado impactos no psiquismo ao ocorrer a superação e à partir dessa superação, a materialização da obra. Diante disso, ocorre a catarse no indivíduo, a qual segundo Vigotski, é um espécie de curto-circuito entre os conteúdos interno do indivíduo e conteúdos já objetivados; ocorrendo a aquele que cria a obra ou por aquele que sofre mediações do significado da obra. Compreende-se a arte como produto social humano de maior complexidade, o que a torna importante instrumento para que ocorra a produção de autonomia e humanização nos indivíduos.

Desenvolvimento: $O$ seguinte trabalho foi desenvolvido com o objetivo de emergir o conceito de arte segundo o autor russo Lev Seminovich Vygotski. Nessa concepção, Vygotsky contradiz Tolstoi ao afirmar que a arte vai além de um contágio momentâneo, esta impacta o psiquismo do indivíduo, transformando-o (movimento catártico), assim, entende-se a arte como produtora de humanização, a qual não reproduz a alienação do sistema capitalista, diferentemente da arte comercial. E, mais especificamente, este trabalho aborda como o processo artístico e seu produto final pode ser utilizado nas políticas públicas de acordo com seu viés de superação (VIGOTSKI, 1999). Desta forma, foi analisado através de artigos o diferencial da arte nos Serviços de Convivência e Fortalecimento de Vínculos (este situado dentro da política pública de Assistência Social) e na Educação. Os Serviços de Convivência e Fortalecimento de Vínculos (SCFV), fornecem serviços voltados a crianças em situação de vulnerabilidade social. Neste contexto, utiliza-se a arte como forma de superar a realidade imediata em que se encontram e compreender as contradições históricas produtoras de pauperização (CAMBAÚVA; SILVA, 2009). Com seu potencial transformador, a arte carrega em sua essência conteúdos objetivados historicamente, tanto pelo sentimento individual quanto pelo o que foi apreendido pelo coletivo. Isso possibilita a utilização da arte como instrumento de educação estético, a qual vai além do prazer e do gozo, como também se desvincula da moral burguesa, classista pautada no capitalismo. A educação estética exige esforço psíquico para que ocorra ampliação da compreensão do indivíduo singular(VIGOTSKI, 2003). Diante disso, defende-se a verdadeira arte e sua utilização em todos os períodos de desenvolvimento humano, estes quais são guiados por atividades principais (não se deve entender como etapistas)( $\mathrm{FACCl}, 2004)$. As atividades principais, devem ser utilizadas como meio para, intencionalmente, o mediador coloque a arte para exercer sua função humanizadora nos indivíduos. Dessa forma, cabe ao educador criar estratégias para que ocorra essa transformação no psiquismo do indivíduo o qual entra em contato com a arte(LEAL, 2010).

Conclusão: Ao abordar a arte proposta por Vygotski (1999), tem-se um objeto cultural carregado de conteúdos históricos e sociais. A arte, então é oriunda da sensibilidade humana em busca da sobrevivência da realidade material, essencial na transformação humana. Considerando a arte como o objeto mais complexo da espécie humana, e defendendo que todos os indivíduos devem ter contato com o que há de mais complexo em sua realidade material, urge a necessidade de utilizar a arte nas políticas públicas, proporcionando o desenvolvimento psíquico e complexificando o sujeito em seus processos criativos.

\title{
Referências
}

CAMBAÚVA, Lenita Gama; SILVA, Lúcia Cecilia da. A História da Psicologia e a Psicologia na História. In: Marilda Gonçalves Facci, Silvana Calvo Tuleski, Sônia Mari Shima Barroco. (Org.). Escola de Vigotski: contribuições para a Psicologia e a Educação. $1^{\text {aed. }}$ Maringá: EDUEM, 2009, v. 1, p. 23-35.

FACCI, Marilda Gonçalves Dias. A periodização do desenvolvimento psicológico individual na perspectiva de Leontiev, Elkonin e Vigotski. Cad. CEDES, Campinas, v.24, no, 62, p.64-81, Abril 2004. Disponível em: . Acesso em 15 Nov. 2019

LEAL, Záira Fátima de Rezende Gonzalez. Educação escolar e constituição da consciência: um estudo com adolescentes a partir da Psicologia Histórico-Cultural. Tese (Doutorado). Instituto de psicologia, Universidade de São Paulo -- São Paulo, 2010.

VIGOTSKI, Lev Semyonovich. Psicologia pedagógica. Porto Alegre: Artmed, 2003. (Trabalho original publicado em 1926).

VIGOTSKI, Lev Semyonovich. Psicologia da Arte. São Paulo: Martins Fontes, 1999. 


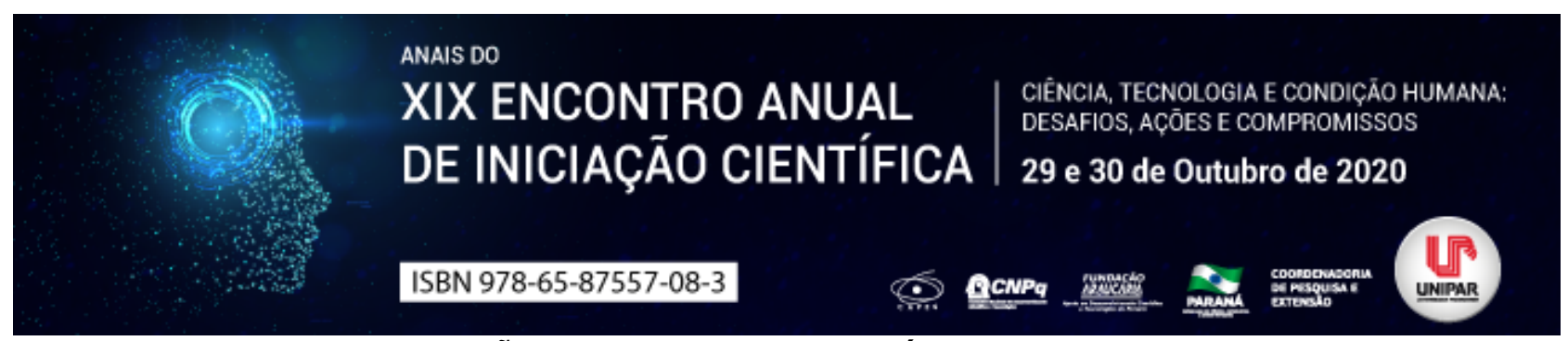

\title{
ANÁLISE DA LEI 14.039/2020 QUE DISPÕE SOBRE A NATUREZA TÉCNICA E SINGULAR DOS SERVIÇOS PRESTADOS POR ADVOGADOS
}

${ }^{1}$ FRANCISCO ROMERO JUNIOR, ${ }^{2}$ CELSO HIROSHI IOCOHAMA

\author{
${ }^{1}$ Aluno do Mestrado em Direito Processual e Cidadania UNIPAR \\ ${ }^{1}$ Docente da Graduação em Direito e do Programa de Mestrado em Direito Processual e Cidadania da UNIPAR
}

Introdução: No dia 18 de agosto de 2020 entrou em vigor a Lei no 14.039/2020, que insere na legislação a previsão expressa de que os serviços prestados por advogados e contadores possuem natureza técnica e singular. Deve-se entender o contexto que envolve essa alteração legislativa tanto na interpretação da Lei de Licitação (Lei n. 8666/93) e também no Estatuto da Ordem dos Advogados do Brasil (Lei n 8.906/94) com a inserção do artigo 3०-A.

Objetivo: O presente resumo tem por objetivo a análise da alteração trazida pela Lei $n^{\circ}$ 14.039/2020, que inseriu dispositivos no Estatuto da OAB (Lei no 8.906/94) afirmando, expressamente, que os serviços prestados pelos advogados são, por sua natureza, técnicos e singulares, quando comprovada sua notória especialização, nos termos da lei.

Desenvolvimento: A CF/88 impõe como regra que a Administração Pública somente pode contratar obras, serviços, compras e alienações se realizar uma licitação prévia para escolher o contratante (art. 37, XXI). O inciso XXI do art. 37 da CF/88 afirma que a lei poderá especificar casos em que os contratos administrativos poderão ser celebrados sem está prévia licitação. A isso, a doutrina denomina contratação direta. Assim, a regra na Administração Pública é a contratação precedida de licitação. Contudo, a legislação poderá prever casos excepcionais em que será possível a contratação direta, sem licitação. A Lei $n^{\circ}$ 14.039/2020 apenas repetiu aquilo que já era amplamente reconhecido pela Lei no 8.666/93 e pela jurisprudência recentemente julgada do STF e pela doutrina especializada, trazendo a nova lei de forma sutil, abolir, na prática, um dos requisitos exigidos pela Lei $n^{\circ} 8.666 / 93$ e pela jurisprudência: a natureza singular do serviço. Segundo Cavalcante (2020) a redação da Lei $n^{\circ}$ 14.039/2020, propositalmente, embaralha os conceitos ao afirmar que os serviços prestados por advogados e por profissionais de contabilidade são, por sua natureza, técnicos e singulares, quando comprovada sua notória especialização . Em outras palavras, em uma interpretação literal, o que dispositivo afirma é que o serviço desempenhado pelo profissional deve ser considerado técnico e singular quando for comprovada a sua notória especialização. Ocorre que não existe essa proposta relação de consequencialidade.

Conclusão: A interpretação literal da Lei $n^{0}$ 14.039/2020 levaria à conclusão de que se os serviços advocatícios e de contabilidade fossem realizados por profissional ou sociedade com notória especialização, automaticamente estaria dispensada a licitação. Essa interpretação, contudo, é inconstitucional e afronta a própria definição de inexigibilidade. A inexigibilidade de licitação ocorre quando a competição não é possível. Se o serviço de advocacia ou contabilidade é comum (não singular), existe a possibilidade de competição e, portanto, não há razões jurídicas ou morais para se evitar a licitação, instituto que existe não apenas para atender a um comando constitucional expresso, como também para garantir a moralidade e a impessoalidade na Administração Pública.

\section{Referências}

BRASIL. Constituição da República Federativa do Brasil, de 05.10.1988. Brasília, 1988. Disponível em: http://www.planalto.gov.br/ccivil_03/constituicao/constituicao.htm. Acesso em: 29.08.2020.

BRASIL. Supremo Tribunal Federal. Inq n 3074 SC. Relator: Min. Roberto Barroso. Brasília, DF, 26 de agosto de 2014. Diário de Justiça Eletrônico. Brasília.

BRASIL. Lei no 14.039, de 18 de agosto de 2020. Altera a Lei no 8.906, de 4 de julho de 1994 (Estatuto da OAB), e o Decreto-Lei n 9.295 , de 27 de maio de 1946, para dispor sobre a natureza técnica e singular dos serviços prestados por advogados e profissionais de contabilidade ... Diário Oficial da União. Brasília, DF, Disponível em: https://www.in.gov.br/en/web/dou/-/lei-n14.039-de-17-de-agosto-de-2020-272747881. Acesso em: 29.08.2020.

CAVALCANTE, Márcio André Lopes. Comentários à Lei 14.039/2020, que dispõe sobre a natureza técnica e singular dos serviços prestados por advogados e por profissionais de contabilidade. 2020. Márcio André Lopes Cavalcante. Disponível em: https://www.dizerodireito.com.br/2020/08/comentarios-lei-140392020-que-dispoe.html. Acesso em: 18 ago. 2020. 


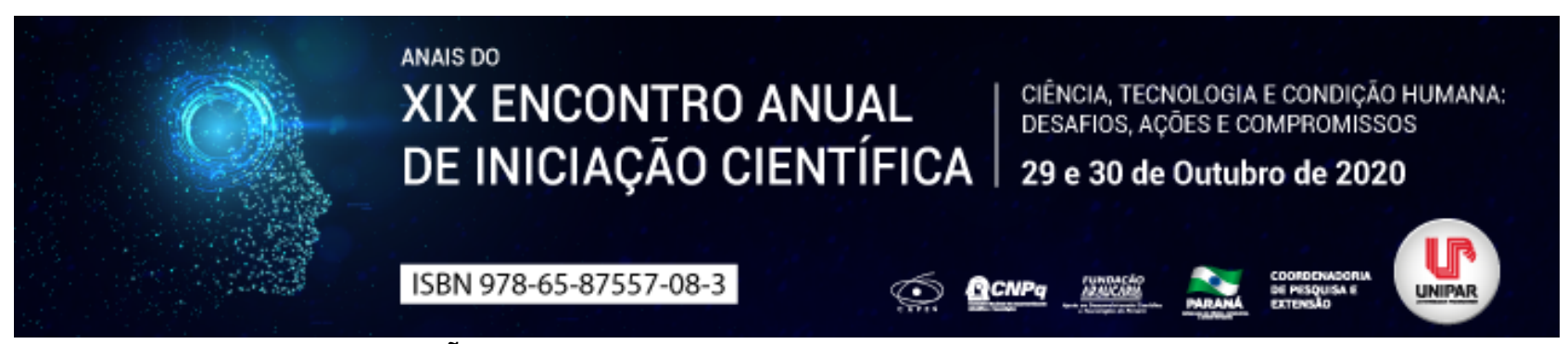

A ALIENAÇÃO PARENTAL EM TEMPOS DE PANDEMIA DO COVID-19

\author{
${ }^{1}$ BARBARA RAFAELA PASSADORE DE SOUZA, ${ }^{2}$ MARIA CAROLINA GOMES SANSINI
}

${ }^{1}$ Acadêmica do curso de Direito da Unipar de Cianorte/PR

${ }^{1}$ Ex-discente da Unipar

Introdução: A prática de alienação parental, como se sabe, não é novidade, mas, com a chegada do novo coronavírus, os casos aumentaram, dificultando e prejudicando ainda mais a convivência entre pais e filhos.

Objetivo: Demonstrar como ocorre a alienação parental, os prejuízos causados em decorrência da prática, bem como, algumas soluções para que, em tempos de pandemia, a relação entre pais e filhos não seja perdida.

Desenvolvimento: A alienação parental, diz respeito aos atos que interferem na formação psicológica da criança ou adolescente, promovido pelo genitor guardião ou por terceiros que possuam sua guarda, fazendo com que os infantes repudiem, se afastem e criem um sentimento de desamor em face do outro genitor (MADALENO, R.; MADALENO, A., C., C., 2018). Ao alienar, o guardião causa prejuízo no vínculo entre pais e filhos, bem como, prejuízos na formação psicológica da criança e ainda por cima, fere direitos fundamentais e personalíssimos, como a dignidade, o respeito, a convivência familiar e o afeto da criança com o genitor. De acordo com Venosa (2013, p.165) Incumbe a ambos os pais o sustento material e moral dos filhos. A orientação educacional e fundamental não só no lar, como também na escola, sendo ambas, em ultima análise, obrigações legais dos pais . Sendo assim, os filhos são de responsabilidade dos dois genitores, que têm o dever e o direito de educar e preparar seus filhos para uma vida digna e sem traumas. Atualmente, o país vivencia uma crise sanitária causada pelo novo coronavírus (COVID-19), que tem afetado diversas áreas da nossa sociedade, incluindo a convivência familiar. Pais separados, que, antes da pandemia discutiam no Judiciário sobre guarda, visita e pensão, hoje, utilizam seus filhos como meros objetos e não como sujeitos de direitos, beneficiando-se do atual cenário pandêmico como pretexto para impedir que o menor mantenha qualquer contato com o genitor. No cenário atual, é importante analisar se o genitor não-guardião está ou não infectado, se ele se expos ou se expõe a graves riscos e se possui condições de cumprir as medidas de isolamento e garantir a segurança da criança/adolescente, se nenhum desses casos estiverem presentes, não há motivos para o impedimento do convívio familiar, caso contrário, uma das possibilidades para substituir o contato semanal ou diário seria o regime utilizado em época de férias escolares, cita-se, como exemplo, 15 (quinze) dias com cada um dos pais. Como última solução, pode-se substituir o contato físico pelo contato eletrônico, por meio de mensagens, vídeo-chamadas, caso um dos genitores ofereça maiores riscos ao infante, tudo visando o não rompimento dos vínculos existentes entre estes, contribuindo, assim, para a prevenção à prática da alienação parental, pois, I"A convivência familiar, [...], corresponde ao direito que tem a criança e o adolescente de viverem e formarem laços de afetividade com seus pais e demais parentesl" (MENEZES e AMORIM, 2020, p.8).

Conclusão: Portanto, podemos concluir que a alienação parental é o ato de interferir nas relações entre pais e filhos, causando prejuízos na formação psicológica da criança/adolescente, e com a chegada do novo coronavírus, alguns pais utilizam de seus filhos para atingir um ao outro, sem pensar no bem-estar da criança, ignorando a existência de possíveis meios para que a relação não seja perdida por conta de sentimentos inacabados entre os genitores.

\title{
Referências
}

MADALENO, Rolf; MADALENO, Ana Carolina Carpes. Síndrome da Alienação Parental: importância da deteç̧ão - aspectos legais e processuais. 5. ed. Rio de Janeiro: Forense, 2018.

MENEZES, Joyceane Bezerre; AMORIM, Ana Monica Anselmo. Os impactos do COVID-10 no direito de família e a fratura do dialogo e da empatia. civilistica.com. v. 9, n. 1. Disponível em: https://civilistica.emnuvens.com.br/redc/article/view/517. Acesso em 27 de julho de 2020.

VENOSA, Silvio de Salvo. Direito Civil: Direito de Família. 13. ed. São Paulo: Atlas, 2013. 


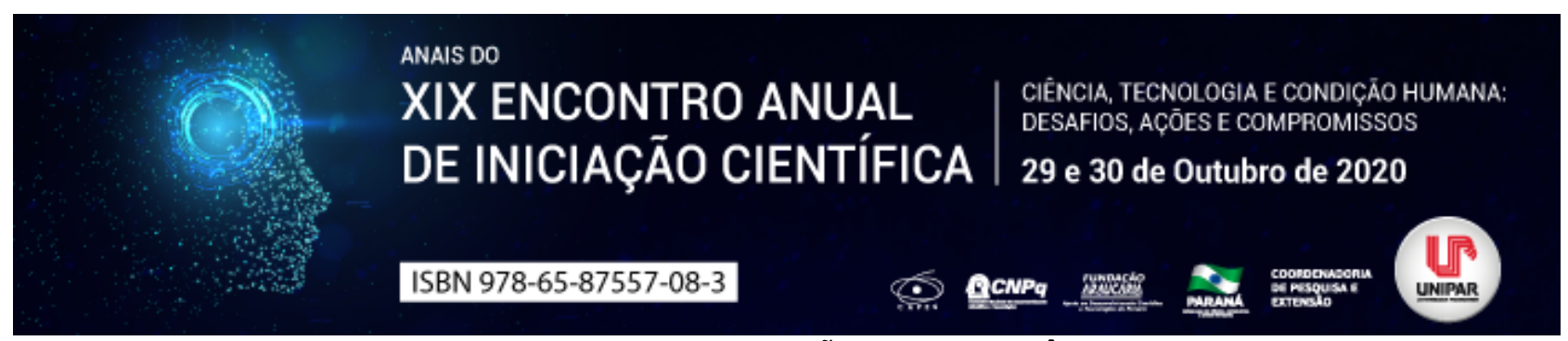

INSTRUMENTALIDADE DO PROCESSO: A FUNDAMENTAÇÃO COMO ESSÊNCIA DA ESTRUTURA DAS DECISÕES JUDICIAIS

\author{
${ }^{1}$ BRUNA APARECIDA DOS SANTOS DA SILVA, ${ }^{2}$ ALBINO GABRIEL TURBAY JUNIOR
}

\author{
${ }^{1}$ Acadêmico do PIC/UNIPAR \\ ${ }^{1}$ Docente da UNIPAR
}

Introdução: Com a evolução da sociedade os Estados passaram a ter um papel importante na organização e na manutenção da ordem. O Brasil sendo um Estado Republicano Democrático de Direito adota o sistema materialmente e formalmente constitucionalista, do qual o cerne é a proteção dos direitos, em especial os chamados direitos fundamentais, e para isso ele é detentor do poder de dizer o direito, a jurisdição, e o processo com sua instrumentalidade é um dos meios de exteriorização deste poder. Mas com o poder vem os deveres para que o poder seja democratizado, um destes deveres é o da fundamentação das decisões.

Objetivo: Analisar a fundamentação da decisão dentro da instrumentalidade do processo, para chegar-se a tão almejada ordem social, buscada pelo Estado Democrático.

Desenvolvimento: A característica do Brasil como um Estado Republicano Democrático de Direito, é de um governo que visa o interesse da maioria, a ordem, paz social e justiça, e para isso o Estado se utiliza da concentração de poder para a solução de conflitos, por meio de duas atividades jurídicas: a legislação e a jurisdição estatal (CINTRA; GRINOVER; DINAMARCO, 2015, p. 60-61). Ele é o detentor do poder de dizer o direito através do processo, este por sua vez, segundo Carnelutti (2015, p. 66):

Serve para fazer com que entrem em juízo aqueles que não têm juízo. Visto que é próprio do homem, o processo serve para substituir o juízo de um pelo juízo de outro ou outros, de modo que o juízo de um se torne a regra de conduta dos outros . Para que essa concentração de poder funcione é preciso que, exista uma ponte de complementariedade entre o direito processual e o direito material, essa ponte é chamada de instrumentalidade do processo (DIDIER JUNIOR, 2017, p. 45). Observa-se que essa instrumentalidade não deve ser vista apenas como um mero meio técnico do Estado de resolver conflitos, mas, como um meio de obter a justiça, paz e ordem social (CINTRA; GRINOVER; DINAMARCO, 2015, p. 64-65). Com a passagem pelos instrumentos necessários do processo de conhecimento para chegar-se à tutela jurisdicional, o processo chega em uma fase denominada decisória, em que o juiz proferirá uma sentença e essa por sua vez, deverá ser fundamentada, sendo assim, um critério de processo justo e democrático. Todavia, para que ela seja considerada válida, eficaz e justa é preciso a somatória de condições intrínsecas (essenciais) e formais conforme o art. 489 do CPC/2015 que traz nos incisos I, II e III tais condições, a saber: 1) o relatório, que é o histórico do debate processual, ele delimita o campo do pedido, controvérsias e questões carecedoras de resolução, por ser requisito de validade, inexistindo o, torna a sentença nula; 2) os fundamentos de fato e de direito, isto é, a motivação do decisório, que é a base lógica construída pelo magistrado, através do exame das questões de fato e de direito, exprimindo as razões jurídicas que o levou a decidir as questões processuais e as questões materiais do caso concreto - tal motivação deve existir, ser completa e coerente, pois, é inadmissível pelo Código de Processo Civil de 2015 que ela seja incompleta; 3) e o outro elemento essencial é o dispositivo, ou seja, a conclusão do julgado, o fecho da sentença, podendo ser direto quando especifica a prestação a ser imposta ao vencido, ou indireto, onde o magistrado se reporta ao pedido do autor julgando procedente ou improcedente. Cabe destacar que, também deve ser observado as condições formais da sentença, prescritas pelo código, ou seja, aquelas condições essenciais anteriores a sentença, como por exemplo, a existência de uma relação processual válida, e a concorrência das condições da ação (THEODORO JÚNIOR, 2015, p. 1338-1345). Vale frisar que, os três elementos supracitados e as condições formais, unidos, formam a idônea fundamentação da decisão, que de acordo com Marinoni (2015, p. 415): I"a fundamentação constitui um autêntico elemento de uma administração democrática da Justiça Civil Conclusão: Em virtude de todos os argumentos mencionados, é possível concluir que, para existir justiça, ordem e paz social em um Estado Democrático de Direito, é necessária uma organização da concentração do poder. Observa-se que, a instrumentalidade do processo é um reflexo dessa organização, é um instrumento a serviço da paz social e a sentença como sendo uma técnica do processo deve possuir em sua estrutura uma fundamentação válida e eficaz para a concretização da ordem social.

\title{
Referências
}

CARNELUTTI, Francesco. Como se faz um processo. São Paulo: Editora Pillares, 2015.

CINTRA, Antonio Carlos de Araújo; GRINOVER, Ada Pellegrini; DINAMARCO, Cândido Rangel. Teoria geral do processo. São Paulo: Editora Malheiros, 2015.

DIDIER JR, Fredie. Curso de direito processual civil: introdução ao direito processual civil, parte geral e processo de 
conhecimento. Salvador: Editora Jus Podivm, 2017.

MARINONI, Luiz Guilherme; ARENHART, Sérgio Cruz; MITIDIERO, Daniel. Novo curso de processo civil: tutela dos direitos mediante procedimento comum. São Paulo: Editora Revista dos Tribunais, 2015.

THEODORO JÚNIOR, Humberto. Curso de direito processual civil: teoria geral do direito processual civil, processo de conhecimento e procedimento comum. Rio de Janeiro: Editora Forense, 2015.

Coordenadoria de Pesquisa e Extensão - COPEX

Departamento de Editoraçāo e Divulgaçāo Científica - DEDIC 


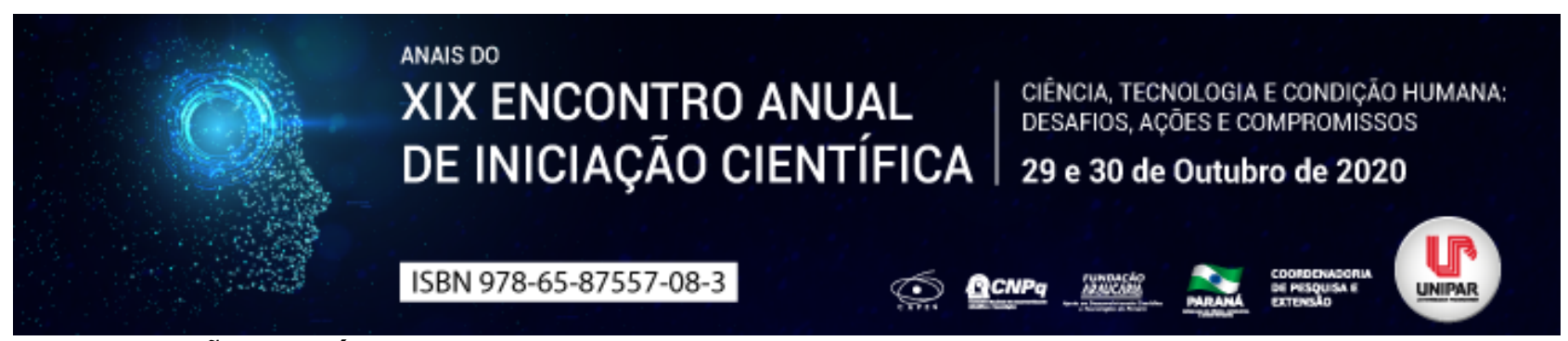

EVOLUÇÃO HISTÓRICO-NORMATIVA DO GEORREFERENCIAMENTO NO DIREITO BRASILEIRO

\title{
1JOAO PEDRO CAMILO, ${ }^{2}$ PAULO CESAR DE SOUSA
}

\author{
${ }^{1}$ Acadêmico do curso de Direito da UNIPAR \\ ${ }^{1}$ Docente da UNIPAR
}

Introdução: O georreferenciamento, meio pelo qual se busca confirmar dados ou corrigir erros nos limites e confrontações dos imóveis, foi instituído por meio da Lei 10.267/2001. Todavia, tem sofrido mudanças em sua regulamentação, pois muitos são os problemas e discussões que envolvem medições e os dispositivos que as regulamentam. Por conseguinte, uma visão da história do instituto pode propiciar sua melhor aplicação.

Objetivo: Examinar a evolução histórico-normativa do georreferenciamento no ordenamento jurídico brasileiro e os efeitos que causa na prática.

Desenvolvimento: O georreferenciamento surgiu com a Lei $n^{0} 10.267 / 2001$, entretanto, tem passado por alterações em sua regulamentação. Os prazos para sua exigência foram estipulados pelo Decreto $n^{\circ} 4.449 / 2002$, porém, não se mostraram suficientes devido à complexidade de seu processo, o que levou o Poder Executivo a efetuar a prorrogação. Com efeito: $\mathrm{A}$ principal razão para a nova redação do Decreto no 4.449/2002 eram os prazos exíguos (SOUZA, 2014, p. 26). Há, na lei que instituiu a obrigatoriedade do georreferenciamento, autorização para prorrogação de prazos por meio de ato do poder executivo. No art. $3^{\circ}$, é averbado que a identificação de que trata o §3o tornar-se-á obrigatória para efetivação de registro, em qualquer situação de transferência de imóvel rural, nos prazos fixados por ato do Poder Executivo . Soma-se a isso, também, confere-se autorização ao INCRA para determinações técnicas do procedimento. Mesmo com a ausência de fixação de parâmetros legais claros e específicos, o INCRA tem elaborado inúmeras exigências e regulamentado todo o procedimento. Posteriormente à implantação da necessidade de georreferenciamento nos casos legalmente estipulados, a Corregedoria de Justiça, mediante Ofícios Circulares 121/2014, 97/2017 e 31/2018, regulamentou a matéria concernente à necessidade de georreferenciamento e de procedimentos adotados nos casos de confrontações com rios e córregos, matérias que, a rigor, devem ser tratadas por outras vias legislativas. Ainda, a Presidência da República editou medida provisória para tratar de anuências de confrontantes das áreas a serem georreferenciadas. O problema é que essa multiplicidade legislativa possui significativa importância no transcorrer do processo de regularização, bem como sem as exigências da Corregedoria e do INCRA, não há como concluir o procedimento. Assim: Os dados dos imóveis georreferenciados e certificados serão levados a registro por requisição do proprietário. Um imóvel imediatamente certificado não significa que o registro está atualizado (BOSCATTO, 2018, p. 02). Portanto, nota-se a existência de uma complexa normatização sobre um tema tão relevante para a economia. O que se ocasiona em razão da constante alteração da regulamentação, no efeito prático, é a insegurança jurídica da parte, bem como a complicação aos orgãos responsaveis pela homologação do procedimento, dividindo sua historia com alterações em aspectos importantes.

Conclusão: A exigência do georreferenciamento cuida de ser uma medida significativa para a regularização cadastral de áreas rurais. Sua implantação tem ensejado o surgimento de questões complexas não contempladas suficientemente pela legislação, motivo por que se mostram necessárias adequações que compatibilizem o instituto com a realidade.

\section{Referências}

BOSCATTO, F. Georrefenciamento territorial e georreferenciamento de imóveis. Florianópolis: Publicação do IFSC, 2018.

BRASIL. Decreto n. 4.449, de 30 de outubro de 2002. Regulamenta a Lei № 10.267, de 28 de agosto de 2001. Disponível em: http://www.planalto.gov.br/Ccivil_03/decreto/2002/D4449.htm. Acesso em: 30 jul. 2020

BRASIL. Lei n. 10.267, de 28 de agosto de 2001. Altera dispositivos das Leis no 4.947, de 6 de abril de 1966. Disponível em: http://www.planalto.gov.br/ccivil_03/leis/LEIS_2001/L10267.htm. Acesso em: 30 jul. 2020.

SOUZA, E. P. R. Os imóveis rurais na prática notarial e registral: noções elementares. 2. ed. São Paulo: IRIB, 2014. 


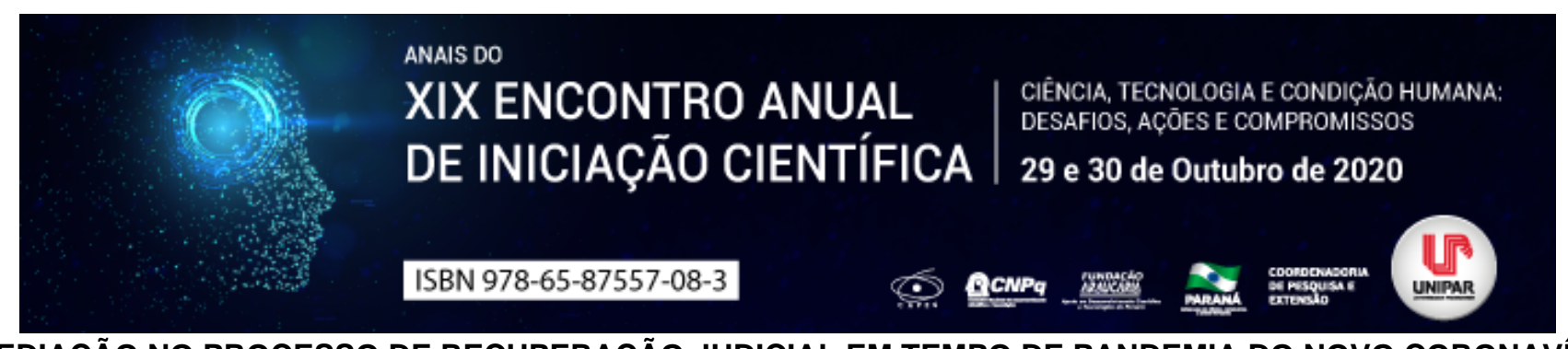

A MEDIAÇÃO NO PROCESSO DE RECUPERAÇÃO JUDICIAL EM TEMPO DE PANDEMIA DO NOVO CORONAVÍRUS

\author{
${ }^{1}$ MAIARA LANGUER BA, ${ }^{2}$ ALEXANDRE MAGNO AUGUSTO MOREIRA
}

\author{
${ }^{1}$ Acadêmico do Curso de Direito UNIPAR \\ ${ }^{1}$ Docente da UNIPAR
}

Introdução: O presente pretende tratar sobre o instituto da mediação no processo de recuperação judicial, buscando-se abordar os reais benefícios do uso desta técnica em tempos de pandemia. Quando em situações excepcionais, como a que ora se vive, é indispensável a utilização de mecanismos adequados à solução de conflitos, com o fim de se minimizar os nefastos problemas provocados pela crise financeira atual, em especial no que concerne à situação das empresas em processo de recuperação judicial. A pesquisa foi desenvolvida pelo método dedutivo e revisão bibliográfica.

Objetivo: Analisar a aplicação do instituto da mediação em tempos de pandemia, no processo de recuperação judicial.

Desenvolvimento: Nos últimos anos, a mediação tem sido destacada como importante instrumento para solução rápida e pacífica dos conflitos,tanto na área judicial, quanto na esfera extrajudicial (DIDIER, 2017, p. 305). Nos termos da legislação processual civil vigente (art. 165, $\S 3^{\circ}$ ), o mediador fará com que as partes entrem em comum acordo, por si próprios, encontrando a solução satisfatória da lide (BRASIL, 2015).Em tempos de isolamento social, algumas empresas tiveram que suspender suas atividades. Por outro lado, as remanescentes lutam incansavelmente para cumprir com acordos realizados anterior a pandemia. A consequência direta de tal dinâmica é o aumento da inadimplência das empresas e famílias, causando uma crise financeira e o colapso do sistema de crédito (FERREIRA JUNIOR, p. 467). Nos processos de recuperação judicial, onde empresas buscam superar as crises econômicas enfrentadas, é profícuo optar pela utilização da mediação, realizando um acordo com os credores, efetivando o plano de recuperação judicial de maneira que seja proveitosa a ambas as partes (credor e devedor) (ROCHA, 2017, p. 246). A recuperação representa a possibilidade de todos os credores virem a receber seus créditos, em razão do sacrifício que eles (ou parte deles) concordarem suportar. Não se justifica o comprometimento dessa possibilidade por força da negativa de uma parcela minoritária dos credores em aderir ao plano de recuperação (COELHO, 2011, p. 432). As partes envolvidas deverão estar com a visão aberta a negociação, de forma pacífica,deixando, em último caso, para análise do Poder Judiciário, quando não se obtém a solução do conflito (BRASIL, 2019).I"No TJ-PR, as negociações irão acontecer em um Centro Judiciário de Solução de Conflitos e Cidadania (Cejusc), criado especificamente para atender empresas em risco. $O$ Cejusc funciona como uma espécie de passo pré-processual.( ANGELO,2020). Segundo o Enunciado $\mathrm{n}^{\circ} 45$ da I Jornada de Prevenção e Solução Extrajudicial de Litígio: a mediação e conciliação são compatíveis com a recuperação judicial, a extrajudicial e a falência do empresário e da sociedade empresária, bem como em casos de superendividamento, observadas as restrições legais

Conclusão: Em tempos de pandemia a alternativa mais célere é a mediação, pois, sabemos que o judiciário já está lotado de ações, e com a efetivação de acordo muitas etapas processuais serão suprimidas. Os Tribunais de Justiça estão realizando videoconferências e outros recursos tecnológicos de transmissão de sons e imagens em tempo real, com o objetivo de estimular a realização de acordos e amenizar a atual crise financeira no país. Por meio dos acordos pactuados durante a mediação, os contratos podem ser cumpridos com êxito, mesmo que de forma mais lenta, podendo se tornar a solução mais viável para ambas as partes, conferindo maior efetividade e celeridade à solução dos conflitos, além de evitar a judicialização das causas.

\title{
Referências
}

ANGELO, TIAGO. Tribunais podem não dar conta de demandas de recuperação judicial. Revista Consultor Jurídico. Disponível em: https://www.conjur.com.br/2020-abr-22/tribunais-podem-nao-dar-conta-demandas-recuperacaojudicial\#author Acesso em: 10 ago. 2020.

BRASIL, Lei 13.105, de 16 de março de 2015. Dispõe sobre o Código de processo civil brasileiro. Disponível em http://www.planalto.gov.br/ccivil_03/_ato2015-2018/2015/lei/l13105.htm Acesso em 27 jul. 2020.

BRASIL. Conselho Nacional de Justiça. Recomendação no 58 de 22/10/2019 DJe/CNJ no 229/2019, de 30/10/2019, p. 4-6. Disponível em: https:/latos.cnj.jus.br/atos/detalhar/3070. Acesso em 29 jul. 2020.

COELHO, Fábio Ulhoa. Manual de direito comercial: direito de empresa. 23. ed. São Paulo: Saraiva, 2011.

FERREIRA JUNIOR, Reynaldo Rubem; SANTA RITA, Luciana Peixoto. Impactos da Covid-19 na Economia: limites, desafios e políticas. Revista Teste, v. 1, n. 7, p. 35-47, dez. 2016. Disponível em: https://portalseer.ufba.br/index.php/Teste/article/view/37324/21222. Acesso em: 12 ago. 2020.

ROCHA, MARCELO HUGO DA.Direito empresarial sintetizado.São Paulo; MÉTODO, 2016.

DIDIER JR., Fredie. Curso de Direito Processual Civil (19 ed.) Salvador: Editora JusPodivm, 2017. 
Coordenadoria de Pesquisa e Extensão - COPEX

Departamento de Editoraçāo e Divulgaçāo Científica - DEDIC 


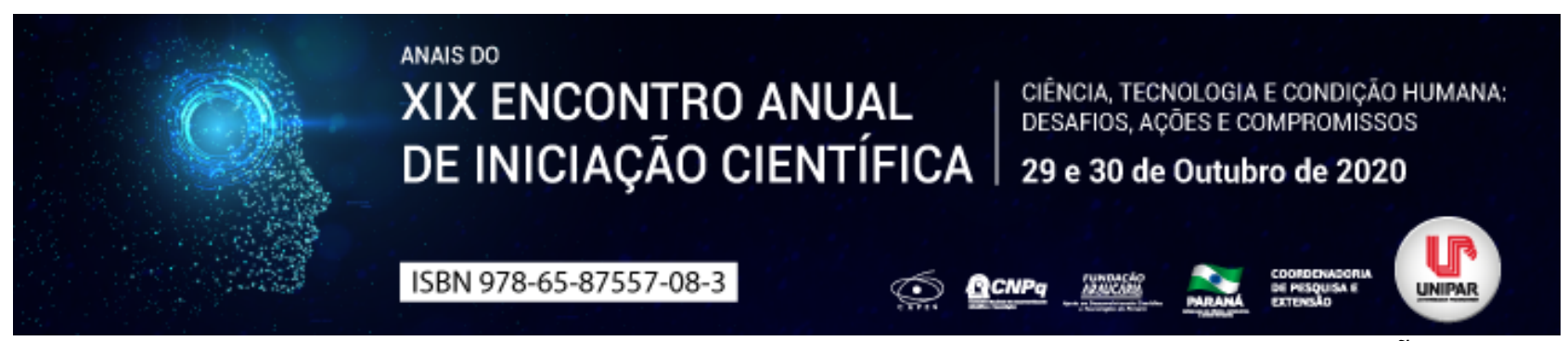

CLIMA ORGANIZACIONAL: UM INSTRUMENTO DE PESQUISA PARA AS ORGANIZAÇÕES

\author{
${ }^{1}$ GABRIEL VINICIUS DO AMARAL ALVES, ${ }^{2}$ ELIZANGELA MARIA MENEGASSI DE LIMA
}

\author{
${ }^{1}$ Elizangela MARIA MENEGASSI DE LIMA \\ ${ }^{1}$ Docente da UNIPAR
}

Introdução: A organização tem uma carência e necessidade que precisam ser atendidas, o clima organizacional pode ser compreendido como a tendência ou inclinação ao atendimento da necessidade pessoal, manifestando-se como um indicativo da eficiência organizacional. O clima organizacional é composto por elementos relacionado ao trabalho, tais como: salário, benefícios, reconhecimento, chefia, colegas e outras condições que precisam ser atendidas, caracterizando-se como um indicador do nível de satisfação dos empregados.

Objetivo: Descrever a importância do clima organizacional para as organizações.

Desenvolvimento: A necessidade de verificar a satisfação, por meio de pesquisa do clima organizacional, é um conceito que envolve diversas variáveis, sendo divididas em três níveis: macro, micro e individual. Macro: consiste em fatores externos a empresa e que agem sobre ela e sobre cada um seu membro; Micro: sistemas próprios da empresa; Individual: experiências de cada funcionário (BARÇANTE; CASTRO, 1995). Esses três níveis formam os pilares organizacional de uma empresa que se determina a ser seguida. Desta forma, Barçante e Castro (1995) define o clima organizacional como I" uma atmosfera resultante das percepções que os funcionários tem dos diferentes aspectos que influenciam seu bem-estar e sua satisfação no dia a dia de trabalhol". É compreensível as influências de clima organizacional, no aspecto motivacional dos colaboradores de uma organização não estudada? Com a moderna administração, os idealistas clássicos demarcaram que, o trabalhador tem a aparência poupada, ou seja, buscaram relações com as organizações de satisfação relacionadas às compensações econômicas. Para Graça (1999), quando o administrador compreende o conceito de clima organizacional, pode manejar a motivação de seus colaboradores, aumentando a eficiência de sua equipe. De acordo com Gareth (2010), a cultura organizacional é um o conjunto de valores e normas compartilhados que controlam as interações entre os membros da organização, seus fornecedores, clientes e outras pessoas fora dela. São padrões que as pessoas obedecem, sem levar em conta o seu significado, podendo ser explicitas, ou seja, definidas em manuais, estatutos, regulamentos, ou implícitas quando as pessoas obedecem, mas não possuem consciência das mesmas.

Conclusão: Fundamentalmente é necessário, identificar pessoas, que tenha visão sistêmica nas organizações, ativo e provocador de decisões estratégicas, não mais como um recurso empresarial. Quando a empresa estabelece e clarifica o conjunto de hábitos e crenças, por meio de normas, valores e atitudes compartilhadas por todos os membros da organização, esses fatores influenciam as características comportamentais de executivos, proprietários e liderança algo mais particular.

\title{
Referências
}

BARÇANTE, L. C., CASTRO, G. C. Ouvindo a voz do cliente interno. Rio de Janeiro: Qualitymark, 1995

CODA, R.; BERGAMINI, C. W. (Org.). Psicodinâmica da vida organizacional: motivação e liderança. 2. ed. São Paulo: Atlas, 1997.

CHIAVENATO, Idalberto. Desempenho Humano nas empresas: como desenhar cargos e avaliar o desempenho para alcançar resultados. 7. ed. Barueri: Manole, 2016.

GARETH, R. Jones. Teoria das Organizações. 6. ed. São Paulo: Person, 2010.

GRAÇA, Hélio. Clima organizacional: uma abordagem vivencial. Brasília: FUNADESP, 1999

Coordenadoria de Pesquisa e Extensão - COPEX

Departamento de Editoraçāo e Divulgaçāo Científica - DEDIC 


\title{
ANAIS DO XIX ENCONTRO ANUAL | CIÊNCIA, TECNOLOGIA E CONDIÇĀO HUMANA: DE INICIAÇ̃̃ CIENTÍFICA DESAFIOS, AÇŌES E COMPROMISSOS DE INICIAÇAO CIENTIFICA 29 e 30 de Outubro de 2020 \\ ISBN 978-65-87557-08-3

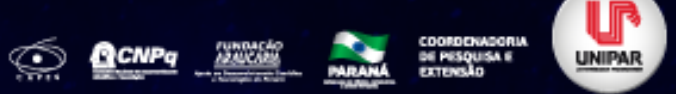 \\ TECNOLOGIAS VESTÍVEIS: IMPLICAÇÕES JURÍDICAS DO MONITORAMENTO DE PACIENTES COM SINTOMAS DA COVID-19 À PROTEÇÃO DE DADOS PESSOAIS
}

\author{
${ }^{1}$ RAISSA ARANTES TOBBIN, ${ }^{2}$ VALÉRIA SILVA GALDINO CARDIN
}

\author{
${ }^{1}$ Mestranda em Ciências Jurídicas pela Universidade CESUMAR; Graduada em Direito pela UNIPAR \\ ${ }^{1}$ Pós-Doutora em Direito pela Universidade de Lisboa; Doutora pela PUC/SP; Docente da UEM e do Mestrado em Ciências \\ Jurídicas do CESUMAR
}

Introdução: As tecnologias vestíveis, do inglês wearables, unem elementos de tecnologia, moda e design para facilitar diversas atividades do cotidiano de seus usuários por meio de relógios, joias, pulseiras, tecidos inteligentes e outros dispositivos acoplados ao corpo humano. Na área da saúde, o grande potencial dos vestíveis é o monitoramento remoto de pacientes e suas funções fisiológicas, especialmente em sede de pandemias, como a da COVID-19. Contudo, é fundamental verificar as implicações éticas e jurídicas do armazenamento, da transparência e da privacidade de dados dos usuários, com o fim de preservar sua dignidade humana e os direitos da personalidade.

Objetivo: Analisar as implicações éticas e jurídicas da utilização do monitoramento remoto de pacientes com sintomas da COVID-19 à proteção dos dados pessoais do usuário.

Desenvolvimento: Por meio de aprendizagem de máquina, a inteligência artificial pode ser utilizada para reconhecimento prévio de pessoas com sintomas da COVID-19, bem como para o monitoramento de pacientes. Conforme Barbosa (2020), os dispositivos vestíveis são tecnologias acopladas ao corpo humano e que podem ser utilizadas para monitorar a circulação sanguínea, batimentos cardíacos, a oxigenação, a pressão arterial, a frequência respiratória, a variação do pulso e substratos específicos. Dallagassa (2020) ressalta que estes dispositivos podem reconhecer até mesmo hábitos e analisar situações de prevenção. Contudo, de acordo com Barbosa (2020), são desafios à implementação das tecnologias vestíveis no setor da saúde a falta de estudos científicos que comprovem seu uso em situações reais, o que implica na desconfiança quanto à aplicabilidade e ao desempenho destes aparelhos, especialmente em países menos desenvolvidos, com menos recursos para adquirir e/ou custear o uso destes dispositivos em massa. Além disso, há o questionamento em relação ao armazenamento, a transparência e a privacidade de dados pessoais dos pacientes coletados pelas tecnologias vestíveis, principalmente em termos de compartilhamento e domínio de informações ligadas à saúde populacional no meio digital. Como observa Palhares et al. (2020, p. 184), a utilização de dados fornecidos por aparelhos móveis de telecomunicação mostra-se tão atraente para o combate da pandemia . (PALHARES et al., 2020, p. 184). No Brasil, a Lei Geral de Proteção de Dados Pessoais (Lei $n^{\circ}$ 13.709/2018) prescreve, em seu art. $6^{\circ}$, que as atividades de tratamento de dados pessoais deverão observar a boa-fé e princípios como: I finalidade; II - adequação; III - necessidade: limitação do tratamento ao mínimo necessário para a realização de suas finalidades, com abrangência dos dados pertinentes, proporcionais e não excessivos em relação às finalidades do tratamento de dados ;

IV - livre acesso: garantia, aos titulares, de consulta facilitada e gratuita sobre a forma e a duração do tratamento, bem como sobre a integralidade de seus dados pessoais ; V - qualidade dos dados: garantia, aos titulares, de exatidão, clareza, relevância e atualização dos dados, de acordo com a necessidade e para o cumprimento da finalidade de seu tratamento ; VI

transparência; VII segurança; VIII - prevenção: adoção de medidas para prevenir a ocorrência de danos em virtude do tratamento de dados pessoais; IX - não discriminação e X - responsabilização e prestação de contas: demonstração, pelo agente, da adoção de medidas eficazes e capazes de comprovar a observância e o cumprimento das normas de proteção de dados pessoais e, inclusive, da eficácia dessas medidas . (BRASIL, 2018). Para Finkelstein, Federighi e Chow (2020, p. 27) no atual estágio do desenvolvimento tecnológico, não há que se questionar se usar ou não os dados pessoais no combate à COVID19, mas sim como utilizá-los. Segundo os autores, a pandemia está sendo um grande teste para as Democracias Liberais e esse momento não pode implicar em retrocessos nas liberdades individuais. Para isso, é fundamental um debate público acerca da forma como os dados pessoais estão sendo tratados pelas autoridades sanitárias, com vistas a evitar a vigilância intrusiva que vem ocorrendo em diversos países do mundo , entre eles, a Coréia do Sul, a Nova Zelândia e Singapura, que

vêm recorrendo a medidas de isolamento social e ao monitoramento da locomoção das pessoas por intermédio dos aparelhos de telefonia celular (PALHARES et al., 2020, p. 175), perspectivas com potencialidade de ofender a dignidade e os direitos da personalidade dos cidadãos.

Conclusão: As tecnologias vestíveis possuem grande potencial para o monitoramento remoto de pacientes em tempos de pandemia da COVID-19, contudo, é fundamental que o direito garanta que os dados pessoais coletados por estes aplicativos não sejam utilizados de forma indevida por autoridades ou empresas privadas com o fim de discriminação, publicidade direcionada, formação de perfis comportamentais e controle populacional, situações que ofendem a dignidade humana e os direitos da personalidade dos usuários. 


\section{Referências}

BARBOSA, Carlos Roberto Hall. Monitoramento fisiológico contínuo usando tecnologia vestível para informar manejo individual de doenças infecciosas, saúde pública e respostas de surto. Observatório de Evidências Científicas Covid-19, 13 ago. 2020. Disponível em: http://evidenciascovid19.ibict.br/index.php/2020/08/13/como-as-tecnologias-vestiveis-podem-auxiliar-noacompanhamento-dos-pacientes/. Acesso em: 20 ago. 2020.

BRASIL. Lei $\mathbf{n}^{\circ}$ 13.709, de 14 de agosto de 2018. Lei Geral de Proteção de Dados Pessoais (LGPD). Brasília, DF: Presidência da República, [2018]. Disponível em: http://www.planalto.gov.br/ccivil_03/_ato2015-2018/2018/lei/L13709.htm. Acesso em: 15 ago. 2020.

DALLAGASSA, Marcelo. Como a Inteligência Artificial auxilia a saúde em tempos de coronavírus. Saúde Debate, 30 mar. 2020. Disponível em: https://saudedebate.com.br/noticias/como-a-inteligencia-artificial-auxilia-a-saude-em-tempos-de-coronavirus. Acesso em: 20 ago. 2020.

FINKELSTEIN, Carlos; FEDERIGHI, André Catta; CHOW, Beatriz Graziano. O uso de dados pessoais no combate à Covid-19: lições a partir da experiência internacional. Revista Brasileira de Inteligência Artificial e Direito RBIAD, v. 1, n. 1, 2020. Disponível em: https://rbiad.com.br/index.php/rbiad/article/view/7/5. Acesso em: 20 ago. 2020.

PALHARES, Gabriela Capobianco. A privacidade em tempos de pandemia e a escada de monitoramento e rastreio. Estudos Avançados, São Paulo, v. 34, n. 99, p. 175-190, maio/ago. 2020. Disponível em: https://www.scielo.br/pdf/ea/v34n99/1806-9592ea-34-99-175.pdf. Acesso em: 20 ago. 2020. 


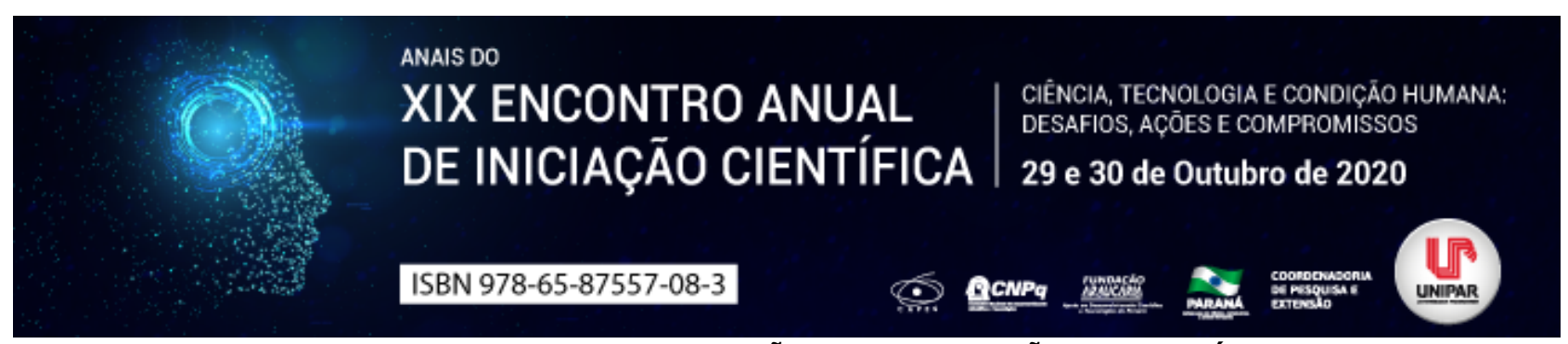

O TERMO INICIAL DA PRESCRIÇÃO DA PRETENSÃO EXECUTÓRIA

\section{${ }^{1}$ AUANE SAMIRA BARBOSA DA SILVA, ${ }^{2}$ EDMAR JOSE CHAGAS}

${ }^{1}$ Discente da UNIPAR - Integrante do Programa de Iniciação Científica - PIC

${ }^{1}$ Docente da UNIPAR

Introdução: $O$ instituto da prescrição corresponde à um benefício do réu ou sentenciado, uma vez que o Estado não poderia manter a pretensão punitiva e/ou executória ad aeternum, entretanto, a concessão dessa benesse pressupõe a inércia estatal. No que tange ao termo inicial da prescrição executória, tem surgido entre os profissionais da seara criminal inúmeros posicionamentos conflitantes, e inclusive, o tema foi reconhecido pelo STF como matéria de repercussão geral.

Objetivo: Relacionar as distintas colocações e argumentos quanto ao início do lapso temporal da prescrição executória, abordando a relevância social do tema, bem realizar breve análise da jurisprudência atual.

Desenvolvimento: A prescrição, enquanto causa de extinção da punibilidade do agente, diz respeito à limitação temporal do direito estatal, uma vez que ele não pode se prolongar ao longo dos anos; tal instituto se divide em duas espécies: a prescrição da pretensão punitiva, que estipula um prazo máximo para o Estado aplicar a sanção penal e a prescrição da pretensão executória, que delimita o período para a execução da pena já imposta (MASSON, 2020, p. 797 e 798). A prescrição da pretensão executória é a perda do poder de punir do Estado, que só ocorre após a certeza da culpa, isto é, quando a sentença condenatória se torna irrecorrível para ambas as partes (JUNQUEIRA e VANZOLINI, 2017, p. 755). Em relação ao termo inicial da prescrição executória, há tempos vem ocorrendo no Direito Penal Brasileiro divergências doutrinarias e jurisprudenciais; tamanha a relevância do tema, tramita no STF o ARE 848.107, sob a Relatoria do Min. Dias Toffoli. Tal recurso discute a recepção, ou não, pela Carta Magna de 1988 do art. 112, I do Código Penal , onde, em suma, o recorrente e a PGR sustentam que a interpretação literal do art. 112, I do CP se mostra inadequada por não considerar preceitos constitucionais, visto que, à luz do Princípio da Presunção da Inocência, o Estado não poderá executar a pena enquanto da sentença couber recursos; desse modo, alegam que iniciar o prazo da prescrição executória com o trânsito para a acusação feriria a essência do instituto da prescrição, uma vez que a impossibilidade de execução provisória da pena não diz respeito ao desinteresse estatal, pelo contrário, o Estado apenas resguarda o entendimento da Suprema Corte; por fim, abordam a tese de que após a edição da sentença, o prazo prescricional em andamento é o da pretensão punitiva, desse modo, argumentam que não se pode admitir que, dentro do mesmo lapso temporal, corram a prescrição da pretensão punitiva e a da pretensão executória. Diante deste ponto de vista, cabe frisar que o Princípio da Presunção da Inocência positivado no art. 5, LVII da CF/88, bem como no art. 283 do CPP pode ser conceituado como o direito da parte de não ser declarada culpado senão com o término do devido processo legal, durante o qual a mesma tenha utilizado seus direitos à ampla defesa e ao contraditório (BRASILEIRO DE LIMA, 2020, p. 47). Seguindo o entendimento de que o termo inicial da prescrição executória é o trânsito em julgado para ambas as partes, o Supremo Tribunal Federal tem julgados dizendo que se o titular do direito de punir estiver impossibilitado de executar provisoriamente a pena, não há que se falar em inércia do titular da pretensão executória (RE 696533 Rel. Min. Luiz Fux). Neste sentido, por meio das ADCs 43, 44 e 54, o STF tem assentado a constitucionalidade do art. 283 do CPP, condicionando o início da execução da pena ao trânsito em julgado da sentença condenatória, salvo hipóteses categoricamente estabelecidas e devidamente fundamentadas pelo julgador. A outra perspectiva, entende que o termo inicial da prescrição executória deverá ocorrer mediante o trânsito em julgado para ambas as partes, conforme prevê a legislação vigente em seu art. 112, I, primeira parte, do CP. Cezar Bitencourt (2016, p. 920) leciona que o lapso prescricional da pretensão executória deverá ter início com o trânsito em julgado da sentença condenatória para a acusação, contudo, para a averiguação dessa espécie de prescrição, faz-se necessário o trânsito para a acusação e defesa; desse modo, aduz o ilustre doutrinador que, nestes termos, faz-se possível correr paralelamente o prazo prescricional intercorrente e o prescricional executório. E é neste sentido que o STJ tem firmado seu entendimento, alegando que é preciso atentar-se ao disposto na legislação, bem como que deve prevalecer a interpretação legal que mais beneficia o condenado (AgRg nos EAREsp 908.359 Rel. Min. Nefi Cordeiro).

Conclusão: À vista do exposto, conclui-se que os argumentos de ambas as perspectivas são compreensíveis e pertinentes, pois como já salientado, ao mesmo tempo em que a prescrição, enquanto causa de extinção da punibilidade, tem como cerne ser um benefício para o acusado ou sentenciado, ela também necessita de uma inércia por parte do Estado; assim, entende-se que é preciso aguardar a apreciação do ARE 848.107 pela Suprema Corte para fins de consolidação da orientação jurisprudencial.

\section{Referências}

BITENCOURT, Cezar Roberto. Tratado de Direito Penal, vol. 1, parte geral. 22 ed. rev, ampl. e atual São Paulo: Saraiva, 2016. 
BRASIL. Superior Tribunal de Justiça. $3^{a}$ Seção. Agravo Regimental nos Embargos de Divergência em Agravo em Recurso Especial no. 908.359/MG. Parte Litigante Ministério Público Federal, Rel. Ministro Nefi Cordeiro. j. 26/9/2018, DJe 2/10/2018.

BRASIL. Supremo Tribunal Federal. Primeira Turma. Recurso Extraordinário 696533/SC. Rel. Ministro Luiz Fux, Rel. para Acórdão Min. Roberto Barroso, j. 6/2/2018

BRASIL. Supremo Tribunal Federal. Recurso Extraordinário com Agravo 848107. Min. Dias Toffoli.

JUNQUEIRA, Gustavo. VANZOLINI, Patrícia. Manual de Direito Penal: Parte Geral 3a . ed. São Paulo: Saraiva, 2017.

LIMA, Renato Brasileiro de. Manual de processo penal: volume único $\quad$ 8. ed. rev., ampl. e atual. Salvador: Editora JusPodivm, 2020.

MASSON, Cleber. Direito Penal: Parte Geral (arts. $1^{\circ}$ a 120) vol. $1 \quad$ 14 a ed. São Paulo: MÉTODO, 2020.

Coordenadoria de Pesquisa e Extensão - COPEX

Departamento de Editoraçāo e Divulgaçāo Científica - DEDIC 


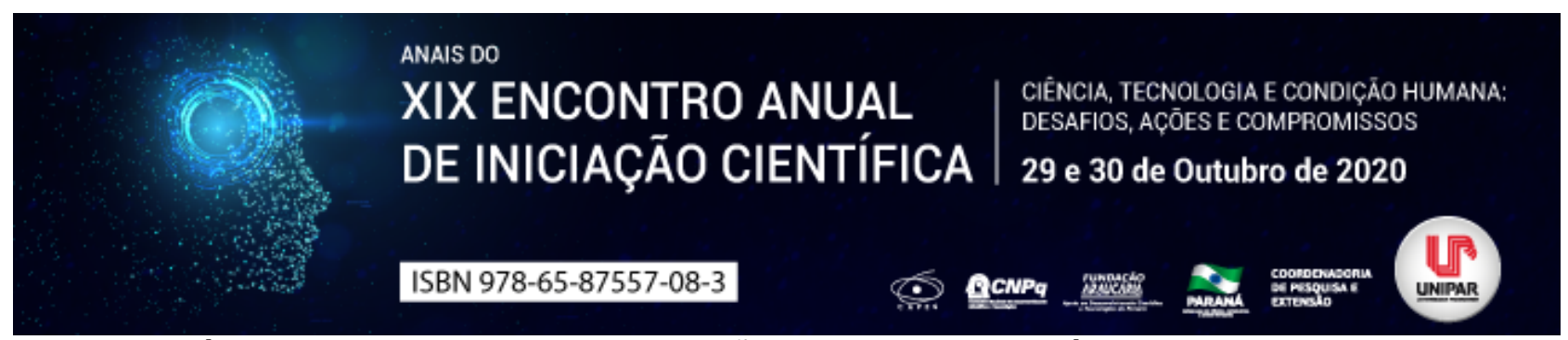

O MÉTODO DE CUSTEIO POR ABSORÇÃO: SUAS CARACTERÍSTICAS E UTILIDADES

\section{${ }^{1}$ LORENA MANZOLI LAVEIA, ${ }^{2}$ CAMILA DA SILVA, ${ }^{3}$ MIGUEL SILVA TARIFA NAVARRO, ${ }^{4}$ GERVALDO RODRIGUES CAMPOS}

${ }^{1}$ Acadêmica do PIC/UNIPAR

${ }^{1}$ Acadêmica do Curso de CiÃancias Cont $\tilde{A}_{i}$ beis da UNIPAR

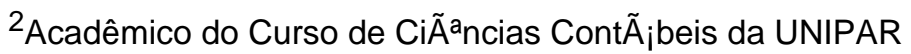

${ }^{3}$ Docente da UNIPAR

Introdução: Há diversos métodos de custeio, entretanto o custeio por absorção ou custeio integral, é o único que atende plenamente o fisco e a contabilidade financeira, sendo o principal método utilizado na área contábil, pois analisa todos os custos de produção, sejam fixos, variáveis, diretos ou indiretos, visando à distribuição de todos os gastos de fabricação para os itens produzidos ou serviços prestados, gerando a absorção de todos os custos no produto final.

Objetivo: Identificar e compreender as características e utilidades do método de custeio por absorção, suas vantagens e limitações no contexto da sua aplicabilidade.

Desenvolvimento: Para compreender as características do método de custeio por absorção, antes é necessário entender o conceito de custos e despesas. Para ludícibus, (1997), os custos são todos os gastos de recursos consumidos para a fabricação do produto, já as despesas são gastos incorridos pelos setores administrativos e não estão diretamente ligados com a produção. Desse modo, o custeio por absorção é conceituado como o método que verifica e realiza a distribuição de todos os gastos de produção para cada item fabricado ou serviço prestado, considerando, os custos fixos, variáveis, diretos e indiretos, fazendo com que ao final todos os produtos tenham absorvido não apenas os diretos, mas também os indiretos. Assim, este custeio é caracterizado por algumas vantagens, ele considera como já citado todos os gastos de fabricação agregando mais facilidade em sua implementação nas empresas, bem como é utilizado pelas empresas por obter legalidade para a realização das demonstrações de resultados, ademais é possível identificar o custo total de cada item ou serviço prestado, visto que é importante, pois fornece informações para as tomadas de decisões para efeito de longo prazo. Por outro lado ele possui algumas desvantagens, como as citadas pelos autores (Schultz, Silva e Borgert, (2008), em razão da maneira em que são distribuídos os custos indiretos, que geralmente é arbitrária, sendo um dos pontos mais criticados deste método no seu uso gerencial, pois ele pode ocultar potenciais desperdícios ou ineficiências, havendo dificuldade para a análise dos conceitos como o cálculo da margem de contribuição, fazendo com que os dados apresentados por ele não sejam adequados para tomadas de decisões no curto prazo. A Auditoria Externa tem-no como básico. Apesar de não ser totalmente lógico e de muitas vezes falhar como instrumento gerencial, é obrigatório para fins de avaliação de estoques (para apuração do resultado e para o próprio balanço), também o Imposto de Renda costumeiramente o usa: no Brasil é utilizado obrigatoriamente, com pequenas exceções (MARTINS, 2003, p. 38).

Conclusão: Pode-se concluir que o método de custeio por absorção possui vantagens e desvantagens na sua aplicação e que há outros métodos de custeio mais eficientes quanto às decisões no curto prazo. Dentre as vantagens destaca-se o atendimento às legislações fiscal e societária, já quanto às desvantagens ele possui pouca utilidade para tomadas de decisões a curto prazo como administração do preço de venda.

\section{Referências}

IUDíCIBUS, S. de. Teoria da contabilidade. 5. ed. São Paulo: Atlas, 1997.

MARTINS, E. Contabilidade de Custos. 9. ed. São Paulo: Atlas, 2003.

SCHULTZ, Charles; SILVA, Marcia Zanievicz; BORGERT, Altair. É o Custeio por Absorção o único método aceito pela Contabilidade?, XV Congresso Brasileiro de Custos, Curitiba, nov, $2008 . \quad$ Disponível em: https://anaiscbc.emnuvens.com.br/anais/article/viewFile/1370/1370. Acesso em: 11/08/2020. 


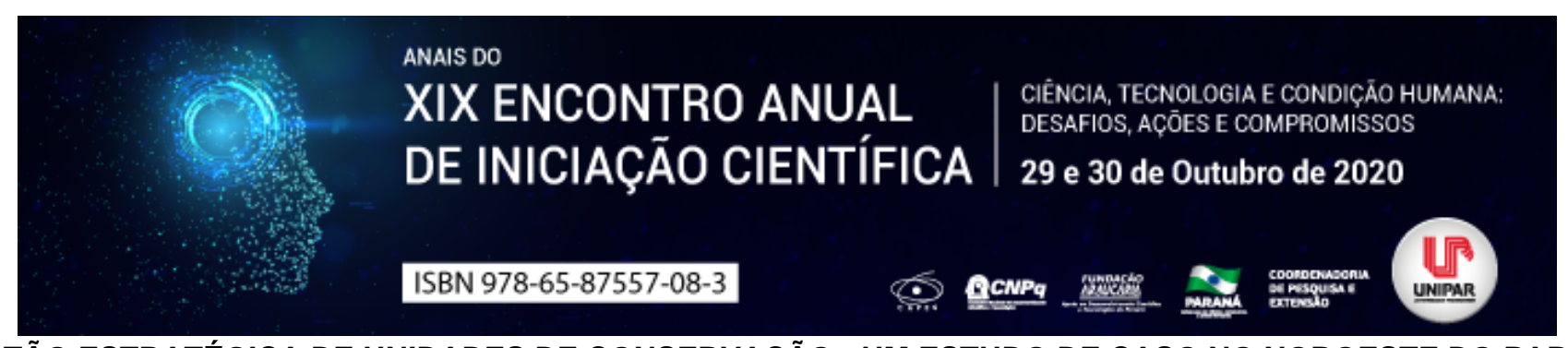

GESTÃO ESTRATÉGICA DE UNIDADES DE CONSERVAÇÃO - UM ESTUDO DE CASO NO NOROESTE DO PARANÁ

\author{
${ }^{1}$ André Luiz Wolf Jorge, ${ }^{2}$ DANIELI PINTO, ${ }^{3}$ MARCELO APARECIDO MARQUES, ${ }^{4}$ ALBERTH MARTINS BATISTA
}

${ }^{1}$ Acadêmico do curso de Administração/ FACEC

${ }^{1}$ Docente/ FACEC

${ }^{2}$ Docente/ FACEC

${ }^{3}$ Docente/ FACEC

Introdução: A Reserva Biológica das Perobas - Rebio Perobas é uma Unidade de Conservação (UC) criada em 20 de março de 2006 pelo Governo Federal com a finalidade de proteger seus ecossistemas e ações de manejo que visam recuperar/preservar o equilíbrio natural, a diversidade biológica e os processos ecológicos naturais (MINISTÉRIO DO MEIO AMBIENTE, 2020). Nesse sentido é relevante que a reserva tenha uma boa gestão estratégica. Assim, uma ferramenta de grande valia para o ajuste/acompanhamento da gestão é o diagnóstico estratégico organizacional (SANTOS; NEIVA; ANDRADE-MELO, 2013). De acordo com Cavalcanti \& Mello (1981), o diagnóstico visa levantar as necessidades passadas, presentes e futuras por intermédio de pesquisas internas com os colaboradores da instituição, a fim de descrever os problemas, dificuldades e prescrever uma intervenção propondo uma solução.

Objetivo: Diagnosticar práticas de gerenciamento adotadas pela Rebio Perobas, evidenciando as necessidades, oportunidades de melhoria e pontos fortes da unidade de conservação.

Material e método: Os dados foram coletados entre os meses de outubro de 2019 e fevereiro de 2020. A pesquisa foi realizada de acordo com as etapas propostas por Silva (2000). Foram realizadas entrevistas semiestruturadas com todos os colaboradores da Rebio Perobas, totalizando 10 pessoas, alocadas em cargo de chefia, assessoria, administrativo, serviços gerais e brigadistas. Isso oportunizou conhecer os processos de cada setor e analisar os pontos fortes e oportunidades de melhoria necessárias. As entrevistas foram gravadas mediante autorização dos participantes e transcritas na íntegra, sendo utilizada a análise de conteúdo (BARDIN, 1977) como metodologia de análise.

Resultados: Observou-se os seguintes pontos fortes em relação à gestão estratégica da Rebio Perobas: aumento dos números de colaboradores desde sua criação em 2006; relatório do plano de trabalho na unidade; plano de manejo; atendimento ao público (visitantes e pesquisadores); profissionais treinados para receber o público; controle de visitantes; foco em educação ambiental; reuniões semanais para discutir o andamento das atividades; importante polo de contribuição à ciência. Em relação às oportunidades de melhoria da gestão foram levantados os seguintes pontos: falta de infraestrutura; desatualização do plano de manejo; atualização de metas/objetivos; criação de indicadores; situação fundiária da reserva biológica não regularizada.

Discussão: As UC precisam de gestores e funcionários capacitados para atender as necessidades administrativas (FARIA, PIRES, 2012), o que pode ser comprovado por esta pesquisa. No entanto, algumas questões fogem da administração local, uma vez que dependem do parecer e financiamento de outros órgãos ou institutos, como por exemplo, o financiamento para sanar os problemas relacionados com a infraestrutura física para a realização das atividades administrativas e a definição do plano de manejo (CASES, 2012).

Conclusão: A gestão da UC em estudo atende as expectativas local. No entanto, há a necessidade de melhorias que dependem, dentre outras coisas, de verbas vindas da federação e dos municípios que abrangem a reserva, principalmente no que tange as questões relacionadas com a infraestrutura física e a atualização do plano de manejo, o que deixa a UC de mãos atadas

\title{
Referências
}

BARDIN, L. Análise de conteúdo. Tradução Luís Antero Reto e Augusto Pinheiro. São Paulo: Edições 70, 2011.

CASES, M. O. Gestão de Unidades de Conservação: compartilhando uma experiência de capacitação. Realização: WWFBrasil/IPE Instituto de Pesquisas Ecológicas. WWF-Brasil, Brasília, 2012.

CAVALCANTI, M.; MELLO, A.A. Diagnóstico organizacional: uma metodologia para pequenas e médias empresas. São Paulo: Loyola, 1981.

FARIA, H. H.; PIRES, A. S. Administração, manejo ou gestão de unidades de conservação? Fórum Ambiental, v. 8, n. 3, 2012.

MINISTÉRIO DO MEIO AMBIENTE. Rebio das Perobas. 2020. Disponível em:. Acesso em 14 de mai. 2020.

SANTOS, J. N.; NEIVA, E. R.; ANDRADE-MELO, E. A. Relação entre clima organizacional, percepção de mudança organizacional e satisfação do cliente. Psicologia: Teoria e Pesquisa, v. 29, n. 1, p. 31 39, 2013.

SILVA, A. Utilizando o planejamento como ferramenta de aprendizagem. São Paulo: Global, 2000. 
Coordenadoria de Pesquisa e Extensão - COPEX

Departamento de Editoraçāo e Divulgaçāo Científica - DEDIC 


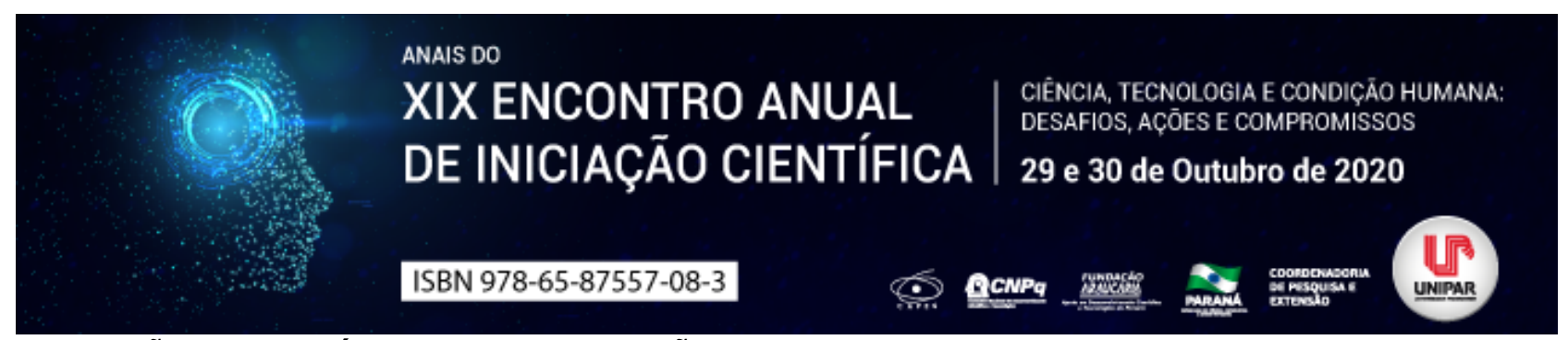

A VALORAÇÃO PROBATÓRIA DAS DECLARAÇÕES COLHIDAS POR MEIO DO INSTITUTO DA COLABORAÇÃO PREMIADA

\author{
${ }^{1}$ KARINA DE MELO SANTANA, ${ }^{2}$ RAFAELA MARTINS DA SILVA, ${ }^{3}$ RICARDO MUCIATO MARTINS
}

\author{
${ }^{1}$ Acadêmica do curso de Direito e PIC/UNIPAR \\ ${ }^{1}$ Acadêmica do Curso de Direito da UNIPAR \\ ${ }^{2}$ Docente da UNIPAR
}

Introdução: O presente estudo faz uma análise do instituto da delação ou colaboração premiada, prevista inicialmente para crimes hediondos, depois, visando o crime organizado, que tem sido levada a efeito pela justiça brasileira, e considerada essencial para o combate ao crime organizado.

Objetivo: Analisar como se dá a valoração probatória das declarações do colaborador diante do instituto da colaboração premiada, mormente no sentido de sua utilização como fundamento idôneo para o oferecimento da denúncia contra o delatado, capaz de ensejar condenação.

Desenvolvimento: $O$ instituto da colaboração premiada foi implementado pela Lei $n^{\circ}$ 8.072/90, que dispõe sobre crimes hediondos, com previsão no art. $8^{\circ}$, parágrafo único, que assevera que O participante e o associado que denunciar à autoridade o bando ou quadrilha, possibilitando seu desmantelamento, terá a pena reduzida de um a dois terços (BRASIL, 1990). Também, houve a implementação da colaboração na Lei $n^{\circ}$ 9.613/98, que dispõe sobre crimes e lavagem ou ocultação e bens, e na Lei $n^{\circ} 11.343 / 2006$, denominada lei de drogas . Embora o instituto tenha previsão legal em disposições esparsas, relevante tratar sobre a Lei no 9.807/1999, que dispõe dentre os artigos 13 a 15, sobre proteção às vítimas, testemunhas e ao réu colaborador. Nela, são elencados benefícios ao colaborador, que, em detrimento de sua fundamental participação, possibilitou a identificação de outros coautores ou partícipes do crime, a localização da vítima com a integridade preservada ou recuperação total ou parcial da coisa produto do crime (BRASIL, 1999). A Lei no 12.850/2013 também dispõe sobre essas cinco formas que, por meio das quais, o investigado/réu pode colaborar com a investigação e com o processo (CAVALCANTE, 2015). A

delação , como popularmente conhecida, ou colaboração premiada, se estabelece como meio de obtenção de prova para o processo penal, e, também, como causa de diminuição ou afastamento de pena para o delator na esfera penal. Com efeito, essa política criminal representa estratégia ao combate ao crime. Ademais, o depoimento do colaborador revela-se como meio de obtenção de prova hábil à formação do convencimento judicial, se corroborado com outros elementos de prova (ANSELMO, 2016). Isso porque o art. $4^{\circ}$, $\S 16$ da Lei $n^{\circ} 12.850 / 2013$ trata que nenhuma sentença condenatória será proferida como fundamento exclusivo das declarações do colaborador (BRASIL, 2013). A delação, por si só, sem um elemento de confirmação é inidônea, ou seja, não é capaz de ensejar condenação do delatado. Além disso, a condenação fundada isoladamente em delação premiada viola lei federal, cuja constatação independe de revolvimento do material probatório e poderá ser controlado mediante recurso especial (BADARÓ, 2015). Quanto ao momento, a colaboração premiada e a concessão de benefícios podem ocorrer na fase de investigação criminal, durante o curso do processo penal, ou após o trânsito em julgado da sentença penal condenatória (CAVALCANTE, 2015). Posto o direito, o colaborador poderá fazer jus aos seguintes benefícios: 1. Não oferecimento da denúncia; 2. Perdão judicial; 3. Redução da pena; 4. Substituição da pena privativa de liberdade por restritiva de direitos; 5. Progressão de regime. Dentre os critérios para escolha de quais benefícios serão aplicados estão a personalidade do colaborador, natureza, circunstâncias, gravidade e repercussão social do fato criminoso, além da eficácia da colaboração (BRASIL, 2013). Nesse sentido decidiu o STJ, em 2010 que, preenchidos os requisitos legais, o colaborador fará jus ao benefício, como se segue: ao contrário do que afirma o acórdão ora objurgado, preenchidos os requisitos da delação premiada, previstos no art. 14 da Lei no 9.807/1999, sua incidência é obrigatória (...) . Contudo, a lei atribui ao sigilo das informações grande importância para o êxito das investigações, nesse sentido, a preservação do sigilo a qualquer custo está na relação direta do sucesso da colaboração e do valor e importância das informaç̃̃es (DIPP, 2015). Com efeito, a colaboração premiada pode ser utilizada tanto na prevenção e repressão de infrações penais, havendo a necessidade de acordo escrito homologado pelo juiz. Ou seja, pode ser definida como uma atividade eficaz do investigado, imputado ou condenado de contribuição com a persecução penal em troca de benefícios penais, conforme acordo escrito homologado pelo juiz (MENDONÇA, 2013). E, para a valoração dessa prova, imprescindível a análise de todo o conteúdo probatório pelo eminente julgador.

Conclusão: A pesquisa realizada permite afirmar que a simples delação do corréu não é suficiente para ensejar a condenação, pois, as declarações do colaborador deverão estar em consonância com os outros elementos de prova, cabendo ao juiz a análise e valoração de todo o conteúdo probatório.

\title{
Referências
}


ANSELMO. Márcio Adriano. Colaboração premiada não pode prescindir da devida investigação criminal. Revista Consultor Jurídico. Disponível em: . Acesso em: 25 ago. 2020.

BADARÓ. Gustavo. O valor probatório da delação premiada: sobre o $\S 16$ do art. $4^{\circ}$ da Lei no 12.850/13. Consulex. n. 443, fev. 2015, p. 26-29.

BRASIL. Lei $\mathbf{n}$. 12.850, de 2 ago. 2013. Define organização criminosa e dispõe sobre a investigação criminal, os meios de obtenção da prova, infrações penais e o procedimento criminal. Disponível em: . Acesso em: 25 ago. 2020.

Lei n. 8.072, de 25 jul. 1990. Dispõe sobre os crimes hediondos. Disponível em: . Acesso em: 25 ago. 2020.

BRASIL. Lei n. 9.807, de 13 jul. 1999. Estabelece normas para a organização e a manutenção de programas especiais de proteção a vítimas e a testemunhas ameaçadas, institui o Programa Federal de Assistência a Vítimas e a Testemunhas Ameaçadas e dispõe sobre a proteção de acusados ou condenados que tenham voluntariamente prestado efetiva colaboração à investigação policial e ao processo criminal. Disponível em: . Acesso em: 25 ago. 2020.

Superior Tribunal de Justiça. HC n. 84.609/SP. Rel. Min. Laurita Vaz, 5a Turma, julgado em 04 fev. 2010, DJe de 01 mar. 2010. Disponível em: . Acesso em: 25 ago. 2020.

CAVALCANTE. Márcio André Lopes. Colaboração premiada. Disponível em: . Acesso em: 25 ago. 2020.

DIPP, Gilson. A delação ou colaboração premiada: uma análise do instituto pela interpretação da lei. Brasília: IDP, 2015. Disponível em: . Acesso em: 25 ago. 2020.

MENDONÇA. Andrey Borges de Mendonça. A Colaboração premiada e a nova Lei do Crime Organizado (Lei 12.850/2013).

Custos Legis: Revista eletrônica do Ministério Público Federal. Disponível em: . Acesso em: 25 ago. 2020. 


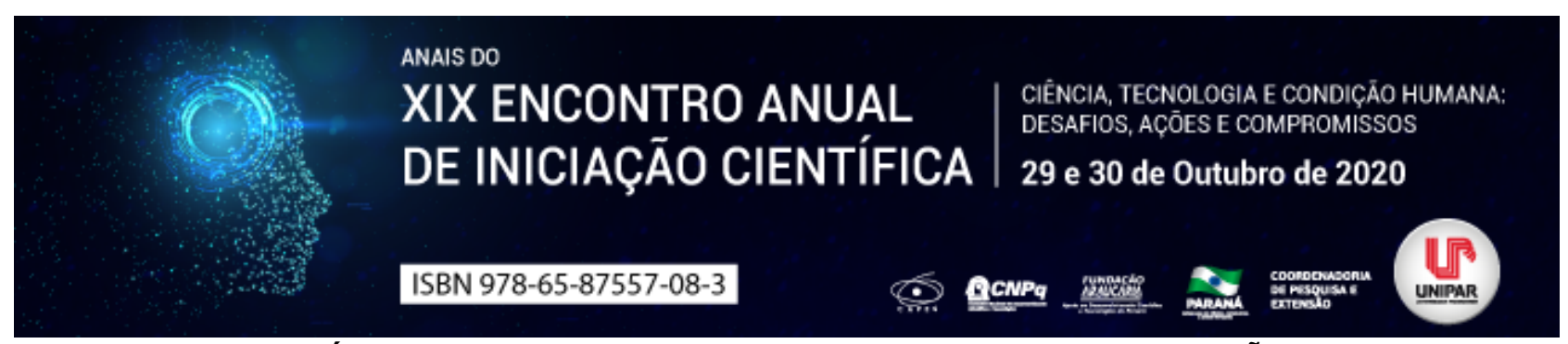

O MÉTODO DE CUSTEIO DIRETO: SUAS VANTAGENS E LIMITAÇÕES

\title{
${ }^{1}$ MIGUEL SILVA TARIFA NAVARRO, ${ }^{2}$ LORENA MANZOLI LAVEIA, ${ }^{3}$ CAMILA DA SILVA, ${ }^{4}$ GERVALDO RODRIGUES CAMPOS
}

\author{
${ }^{1}$ Acadêmico do PIC/UNIPAR \\ ${ }^{1}$ Acadêmica do Curso de Ciências Contábeis da UNIPAR \\ ${ }^{2}$ Acadêmica do Curso de Ciências Contábeis da UNIPAR \\ ${ }^{3}$ Docente da UNIPAR
}

Introdução: No atual ambiente em que as empresas estão inseridas, caracterizado por alta competitividade e diversidade de produtos, tornou-se imprescindível a eficiência no controle dos custos de produção, sob pena de não encontrarem espaço no mercado em que atuam. Para tanto as organizações empresarias precisam contar com adequados métodos de custeio. O custeio direto possibilita maior confiabilidade na determinação dos preços de venda, margem de contribuição e o consequente lucro da empresa.

Objetivo: Caracterizar o custeio direto e demonstrar as suas vantagens e limitações em relação a outros métodos de custeio.

Desenvolvimento: De acordo com Stark (2007, p. 39) o sistema de custeio tem a responsabilidade de mensurar monetariamente as ocorrências que afetam o patrimônio da empresa, ou seja, ele compõe a base de dados que a empresa utiliza para levantar suas informações sobre custos . É possível perceber, após a definição do autor, que o custo é um conceito utilizado dentro de uma organização, para que se consiga distinguir se o produto oferece ou não, margem de lucro para a empresa. O método do custeio direto consiste numa metodologia de custos alternativa ao custeio por absorção, o qual considera como custos dos produtos apenas os custos variáveis, enquanto que aquele reconhece além dos custos variáveis também os custos fixos como custos de produção. Esta metodologia direta possibilita a produção de uma quantidade de informações relevantes para auxiliar na gestão da empresa, como por exemplo, possibilita a identificação da margem de contribuição de cada produto, que consiste na sobra de cada produto para cobrir os custos fixos e gerar o lucro do negócio, onde dependendo da área da atuação da empresa, há gastos que ocorrem mesmo que a organização não esteja fabricando, esses gastos são considerados como fixos dentro de determinada capacidade instalada. Para identificar a margem de contribuição unitária de cada produto é utilizada uma equação que consiste no preço de venda deduzido os custos e despesas variáveis por unidade. Observando esse fato, constata-se que um desafio para os gestores é a elaboração do preço de venda, onde necessita apresentar uma solução mediadora entre o custo do produto ou serviço, a concorrência no mercado e a capacidade de pagamento por parte dos clientes. Por outro lado, uma vez conhecida a margem de contribuição dos produtos, isto é, a capacidade dos produtos de contribuir para a cobertura dos custos fixos e depois formar o lucro, torna-se possível também conhecer outra importante técnica de indispensável papel no auxílio ao processo de gestão das empresas que é o ponto de equilíbrio do negócio. Para Martins (2000), o ponto de equilíbrio é constatado quando ocorre a conjunção dos custos totais com as receitas totais. Há três tipos de pontos de equilíbrio que são mais utilizados no mercado, sendo eles: ponto de equilíbrio contábil: o qual estabelece uma igualdade entre os custos totais e as receitas totais, evidenciando o resultado nulo, o ponto de equilíbrio financeiro: nesse se faz necessário realizar ajustes nos custos, onde o desembolso não foi realizado, bem como a depreciação, e por fim o ponto de equilíbrio econômico: Nesse caso, precisa ser considerado, para fins de cálculo, o custo do capital investido na base de cálculo dos custos. Por outro lado trata-se de um método que não atende às legislações societária e fiscal, por não atender ao princípio de contabilidade da competência, por tratar os custos fixos como se fossem despesas do período.

Conclusão: Conclui-se que o método de custeio direto consiste em importante alternativa de gestão de custos com destaque para a contribuição no auxílio à tomada de decisão dos gestores, o qual possibilita ainda a aplicação de dois importantes conceitos de fundamental papel no contexto da gestão empresarial, quais sejam: a margem de contribuição dos produtos e o ponto de equilíbrio.

\section{Referências}

MARTINS, E. Contabilidade de Custos. São Paulo, Ed. Atlas, 2000.

STARK, José Antônio. Contabilidade de Custos. São Paulo: Pearson Education do Brasil, 2007. 


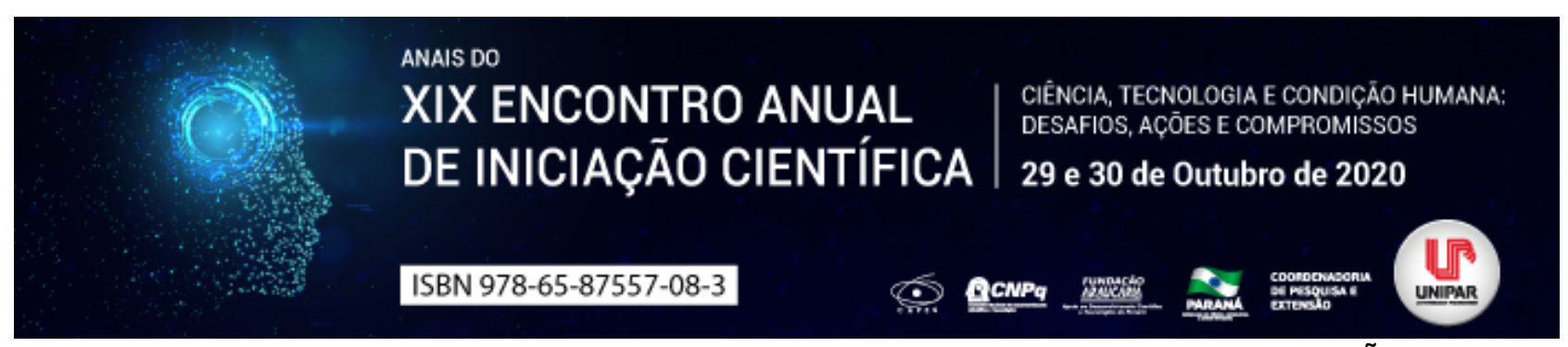

COMO NOSSOS PAIS - UM OLHAR SOBRE O CONSUMO DE DIFERENTES GERAÇÕES

\title{
${ }^{1}$ MARCOS JOSE ALVES DE LIMA, ${ }^{2}$ AMANDA MACHADO DALPASQUAL, ${ }^{3}$ JAQUELINE MARISANE BERTAO
}

\author{
${ }^{1}$ Docente do Núcleo de Design, Pesquisador - Universidade Paranaense - UNIPAR \\ ${ }^{1}$ Acadêmica do Curso de Design de Moda da UNIPAR \\ ${ }^{2}$ Acadêmica do Curso de Design de Moda da UNIPAR
}

Introdução: Como pesquisador de Moda, me dedico a uma espécie de 'voyeurismo', que na linguagem científica é chamado de observação não participativa. É bastante revelador e curioso observar como as pessoas se comportam ao escolher seus produtos, em especial os de moda. O projeto 'Precisar, não precisa', investiga de maneira mais objetiva, o comportamento de consumo (feminino), uma vez que se observa em escala global o aumento do consumo, que o promove ao status de consumismo, bem como, provocar a percepção sobre a própria maneira de consumir e refletir sobre como outras gerações o faziam, e, fazer um exercício imaginativo sobre como as próximas gerações consumirão, considerando que a cada novo comportamento, cada mudança na estrutura da sociedade, esta 'evolução' é rapidamente percebida e convertida em produtos e serviços que serão alvo de necessidade e de desejo dos consumidores, fortalecendo o conceito de sociedade de consumo, considerando que cada geração que sucede outra, consome mais e de maneira mais estruturada e sofisticada que a anterior. Na moda, a evolução partiu da nudez humana primitiva, à cobertura de peles animais, togas que figuraram 2000 anos, para roupas que mudavam de 10 em 10 anos no século XX (LAVER 2011), e, nos últimos 20 anos passou a um ritmo frenético e um futuro inimaginável que sempre fomentam mais e mais consumo, mais necessidade de visibilidade.

Objetivo: Discutir práticas de consumo de moda e suas relações com do Design no contexto da sociedade de consumo.

Material e Métodos: Pesquisa quantitativa e qualitativa, de natureza exploratória. A coleta de dados ocorreu por meio de Formulário Digital, que apresentou os objetivos da Pesquisa, o Termo de Consentimento Livre e Esclarecido e Consentimento Pós-informado, sete questões sobre as entrevistadas, e treze sobre hábitos de consumo. O formulário foi respondido por 125 voluntárias, caracterizadas como amostra por conveniência.

Resultados: As 13 questões sobre hábitos de consumo foram tratadas separadamente pelos participantes do grupo de pesquisa, e neste resumo se apresentará o resultado da primeira questão que inqueria sobre a crença ou percepção sobre hábitos de consumo dos pais e avós: Você acredita que a geração dos seus pais e avós consumiam menos produtos de moda e vestuário? Ao que se encontraram os seguintes resultados: 36 ENTREVISTADAS (28,8\%) Acreditam que consumiam MENOS pelo fato da moda ser menos acessível, as roupas eram mais caras. Duas $(1,6 \%)$ acreditam que meus pais e avós consumiam MAIS produtos de moda do que nós consumimos hoje; quatro $(3,2 \%)$ acreditam que meus pais e avós consumiam moda tanto quanto hoje (na mesma quantidade); $83(66,4 \%)$ acreditam que meus pais e avós consumiam muito MENOS do que consumimos hoje, eram outros tempos, tudo era diferente. Em especial, a exposição social.

Discussão: Buscou-se entender a percepção das entrevistadas sobre a progressão do consumo em relação a outras gerações. Em suas percepções $66,4 \%$ atribuem que outras gerações consumiam menos. Vários fatores podem ser elencados nesse item, desde o desenvolvimento da própria sociedade, maior ou menor oferta de produtos, mudanças de governo e economia, entre outras, todavia, Hill(2005) indica um caminho quando trata da tendência 'compre agora e não pague nunca', esclarecendo que a geração de pais e avós, temiam o endividamento, e este temor direcionava o comportamento de consumo só para as coisas essenciais, para certos sacrifícios econômicos. Outro grupo representativo, 36 entrevistadas (28,8\%) acreditam também que seus pais e avós consumiam menos, porém, justificam que a moda era menos acessível, pois as roupas eram mais caras. O que é uma percepção verdadeira, no primeiro sentido da acessibilidade, considerando que até os meios de aquisição de informação de moda para o consumidor eram menos acessíveis, como as revistas e os figurinos das novelas, todavia, como mencionado antes, o acesso a INTERNET derrubou definitivamente os limites físicos e temporais da informação. Quanto ao preço dos produtos a percepção também é adequada, pois antes da globalização do mercado e a massiva entrada de produtos feitos em países como Indonésia, Índia e a China, contava-se apenas com a produção interna e havia uma visão diferente sobre a qualidade e durabilidade do produto, já que comprar era mais difícil, os produtos eram mais caros, se procuraria estender o ciclo de vida daquele produto. Noutra geração a necessidade de ostentação era manter os filhos limpíssimos, mas sem a preocupação de estar repetindo sempre a mesma roupa de domingo (roupa de sair), desde que muito bem cuidada, e, mesmo que com um só par de sapatos o mesmo deveria estar muito limpo, engraxado, conservado. Sudjic (2010, p.21) explica a importância dos objetos tanto na sociedade caracterizada pelo consumo como na marcada pela modéstia: os objetos são nossa maneira de medir a passagem de nossas vidas. São o que usamos para nos definir, para sinalizar quem somos e o que não somos . A principal diferença é a mensagem que cada forma de consumo e uso transmitia, o que é complementado por Cobra (1997) que afirma que o vestuário é uma forma das pessoas demonstrarem a sua ascensão social. 
Conclusão: A ideia defendida não só perceber que outras gerações consumiam menos, mas, que mesmo consumindo menos ainda havia um sistema de status, de diferenciação social, poder e etc, estruturas do jogo social que ainda permanecerão por mais tempo. O que se sugere e se espera é que ao passo que o indivíduo evoluí, que ele precise menos de subterfúgios para alçar visibilidade e não se renda aos ritmos impostos pelos objetos como explicou Baudrillard $(2015$, p. 169) Se antes era o homem que impunha seu ritmo aos objetos, hoje são os objetos que impõem seus ritmos descontínuos aos homens [...] .

\section{Referências}

BAUDRILLARD, Jean. O sistema dos Objetos. São Paulo: Perspectiva, 2015.

COBRA, Marcos. Algumas reflexões acerca do marketing de moda. RAE Light, vol. 4, n.4, p. 2-5, 1997.

HILL, Sam. Sessenta tendências em sessenta minutos. Como desenvolver produtos aliando tendências e estratégia de marketing. São Paulo: Futura, 2003.

LAVER, James. A roupa e a moda: uma historia concisa. São Paulo: Companhia das Letras, 2011.

Coordenadoria de Pesquisa e Extensão - COPEX

Departamento de Editoraçāo e Divulgaçāo Científica - DEDIC 


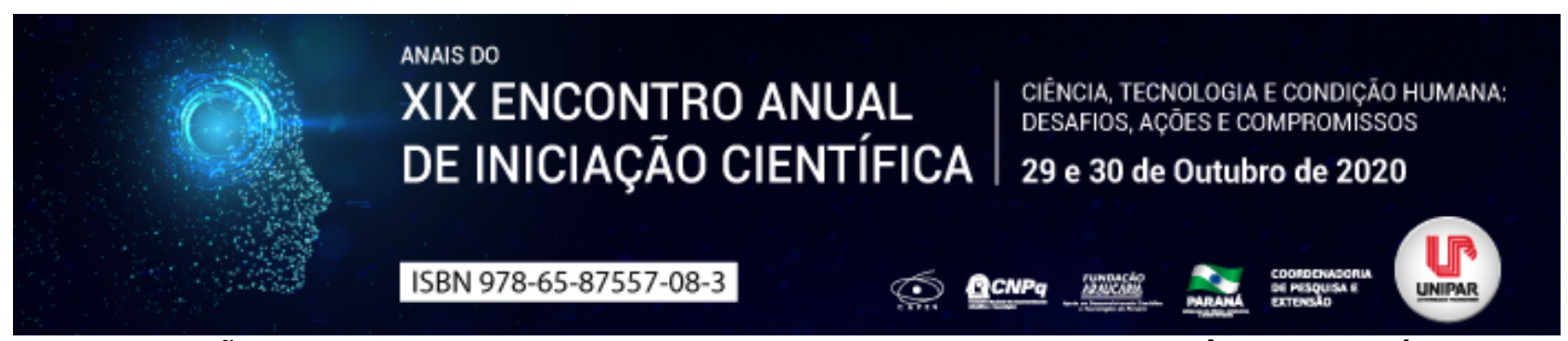

ALTERAÇÕES COMPORTAMENTAIS PROVENIENTE DE TRAUMATISMO CRÂNIO ENCEFÁLICO

\author{
${ }^{1}$ BEATRIZ EDUARDA DE LIMA, ${ }^{2}$ LARISSA DELAZARI ANTONHOLI, ${ }^{3}$ CAROLINE FAVARO PANHAN, ${ }^{4}$ ORLETE MARIA \\ POMPEU DE LIMA
}

\author{
${ }^{1}$ Acadêmico do PIC/UNIPAR \\ ${ }^{1}$ Acadêmica do Curso de Psicologia da UNIPAR \\ ${ }^{2}$ Acadêmico do Curso de Psicologia da UNIPAR \\ ${ }^{3}$ Docente da UNIPAR
}

Introdução: Este estudo apresenta uma parte da pesquisa sobre Encefalite Herpética decorrente do estresse: um estudo de caso, realizado no Projeto de Iniciação Cientifica Unipar. Alterações cognitivas e comportamentais relacionadas à encefalite herpética são conhecidas e descritas na literatura como semelhantes aos traumatismos cranianos.

Objetivo: Revisão bibliográfica sobre alterações comportamentais provenientes de Traumatismo Crânio Encefálico - TCE, como base para estudos sobre as consequências da Encefalite Herpética.

Desenvolvimento: De acordo com as diretrizes do Centro para Controle e Prevenção de Doenças (CCD) o TCE é definido como lesão do tecido encefálico causado por forças mecânicas externas, evidenciado por: perda de consciência devido ao trauma craniano, amnésia, outras neurológicas ou neuropsicológicas anormalidades, fratura de crânio e lesões intracranianas diagnosticadas ou morte. O TCE é classificado como penetrante ou fechado sendo a prevalência deste mais elevada. Nos traumas fechados há a ação de forças mecânicas que levam o cérebro contra os ossos do crânio (mecanismo de golpe e contragolpe). Respostas fisiológicas a esse dano primário, tais como edema cerebral, aumento da pressão intracraniana, isquemia cerebral, hipotensão e infecção podem também causar lesão neuronal, neste caso, são chamadas de lesões secundárias. O TCE penetrante, em geral, é mais grave e associado a maiores complicações. Este histórico traz tipos de alterações de personalidade; sendo o instável quando o aspecto predominante é uma instabilidade afetiva. Desinibido quando o aspecto predominante é um fraco controle dos impulsos, evidenciado por indiscrições sexuais. O agressivo acontece quando o aspecto predominante é um comportamento agressivo. O apático quando o aspecto predominante é uma acentuada apatia e indiferença. O paranóide tendo o aspecto predominante é a desconfiança ou ideação paranoide. Também existem evidências, a partir do histórico, do exame físico ou de achados laboratoriais, de que a perturbação é a consequência direta de uma condição médica geral. E ainda a perturbação não é mais bem explicada por outro transtorno mental (inclusive outros transtornos mentais causados por uma condição médica geral); a perturbação não ocorre exclusivamente durante o curso de delirium, a mesma causa sofrimento ou prejuízo clinicamente significativo no funcionamento social, ocupacional ou em outras áreas importantes (BRASIL, 2001). O aumento do estresse relacionado ao trabalho vem sendo destacado em alguns estudos como uma das importantes causas de Transtornos Mentais, acarretando também no aumento do absenteísmo. Estudos evidenciam o aumento no número de pessoas que adoecem e se afastam do trabalho pelos mais variados motivos de saúde, contudo os Transtornos Mentais e de Comportamento (TMC) têm sido os mais prevalentes e são uma das maiores causas de afastamento do trabalho de longo prazo (CUNHA; BLANK; BOING, 2009). E ainda de acordo com o a Organização Mundial da Saúde (OMS, 2001) as TMC são condições clinicamente significativas com características de alterações de humor, do modo de pensar ou de comportamentos associados com angústia pessoal e/ou deterioração do funcionamento.

Conclusão: Visto a gravidade e as consequências geradas nesses pacientes deve-se ressaltar a importância da avaliação de transtornos psiquiátricos pós TCE com relação ao avanço da identificação e tratamento desses transtornos mentais, os quais são muitas vezes identificados como reações normais, sendo que a evolução no atendimento e intervenção precoce no TCE, desfechos como transtornos psiquiátricos, desempenho cognitivo e qualidade de vida vão se tornando evidentemente importantes. Estudos com maior controle são necessários para investigar fatores prognósticos relacionados a transtornos psiquiátricos e cognição após TCE.

\title{
Referências
}

BRASIL. Ministério da Saúde. Doenças Relacionadas Ao Trabalho: Manual De Procedimentos Para Os Serviços De Saúde. Brasília, 2001. 290 p. Disponível em: http://bvsms.saude.gov.br bvs. Acesso em: 23/08/2020.

CUNHA, J. B.; BLANK, V. L. G.; BOING, A. F. Tendência Temporal De Afastamento Do Trabalho Em Servidores Públicos (19952005). Rev. bras. epidemiol., São Paulo, v. 12, n. 2, p. 226-236, jun. 2009. Disponível em: http://docs.uft.edu.br. Acesso em: 15 ago. 2020.

NAKANSIKI, C. T.; GONÇALVES, M. Correlação Entre Traumatismo Cranioencefálico E Transtornos Psiquiátricos (2016). 
vol. 21. Disponível em: http://www.polbr.med.br. Acesso em: 26 ago.2020.

Coordenadoria de Pesquisa e Extensão - COPEX

Departamento de Editoraçāo e Divulgaçāo Científica - DEDIC 


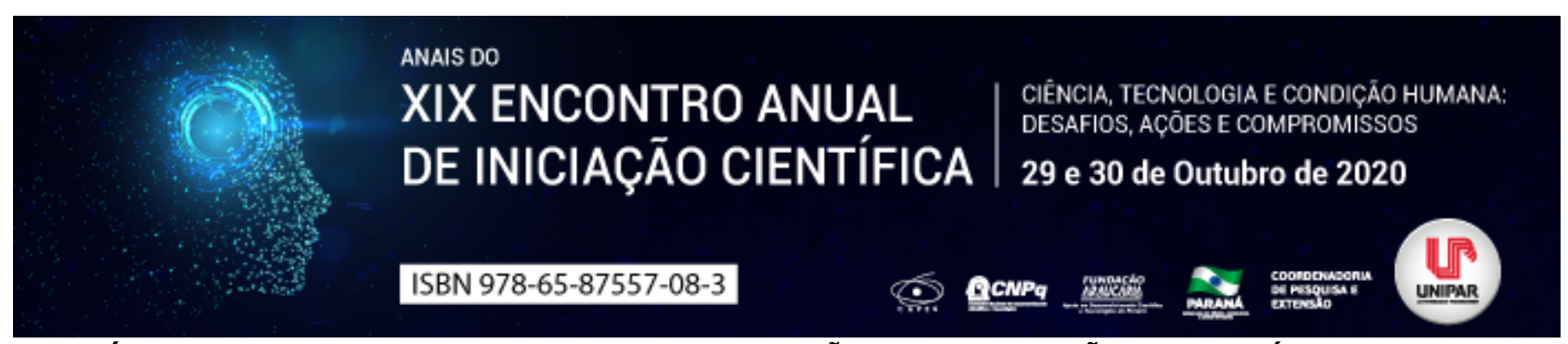

\title{
DA CONTROVÉRSIA SOBRE O TERMO INICIAL DA PRESCRIÇÃO DA PRETENSÃO EXECUTÓRIA FACE AO DIREITO DE PUNIR DO ESTADO
}

\author{
${ }^{1}$ CAIKE ASLEN NUNES DE ALMEIDA, ${ }^{2}$ EDMAR JOSE CHAGAS, ${ }^{3}$ EDMAR JOSE CHAGAS
}

\author{
${ }^{1}$ Acadêmico PIC/UNIPAR \\ ${ }^{1}$ Docente da UNIPAR \\ ${ }^{2}$ Docente da UNIPAR
}

Introdução: O Direito de punir do Estado é fracionado em duas pretensões. A primeira busca o êxito condenatório e a segunda em dar efetividade na sanção condenatória, denominada de pretensão executória. Analisar os prazos e termos prescricionais de tais pretensões é de suma importância na esfera penal.

Objetivo: Verificar o momento exato e mais coerente do termo inicial da prescrição da pretensão executória da pena.

Desenvolvimento: $\mathrm{Em}$ caso de sentença condenatória, surge para o Estado além da pretensão punitiva já alcançada na sentença a pretensão executória, também conhecida como jus punitionis ou jus executionis. Em tese, a partir desse momento o Estado já estaria apto a dar efetividade na sentença, isto é, impor a sanção do preceito secundário da norma penal que pode ser uma pena privativa de liberdade, restritiva de direito ou multa. O fundamento legal da pretensão executória permeia o artigo 110, $\S 1^{\circ}$ e 112, inciso I do Código Penal. Como as demais pretensões, a pretensão executória da pena também prescreve com base na quantidade da pena fixada na sentença, amoldada aos prazos do artigo 109 em atenção a súmula 604 do Supremo Tribunal Federal que diz: A prescrição pela pena em concreto é somente da pretensão executória da pena privativa de liberdade . Em uma interpretação gramatical e tradicional do artigo 112, I o termo inicial desta prescrição seria o trânsito em julgado para a acusação após sentença condenatória de piso. Destaca-se que na pendência de recurso da defesa corre de forma paralela duas modalidades de prescrição, sendo a prescrição intercorrente imbuída na pretensão punitiva e a prescrição executória. A par desta fruição de prazos prescricionais paralelos após a sentença de piso, Mirabetti lecionada Assim, se não se operar a prescrição da pretensão intercorrente, em face do trânsito em julgado para a defesa que o faz findar, continua a correr o prazo da prescrição da pretensão executória, iniciando na data do trânsito em julgado para a acusação (2003, p. 420). Entretanto, o embate crucial sobre matéria de prescrição penal é o exato momento do termo inicial da prescrição da pretensão executória. É correto afirmar que o trânsito em julgado apenas para acusação daria ensejo à fruição deste prazo? Ou seria o trânsito em julgado para ambas as partes? Em consonância com o primeiro entendimento Stoco afirma a prescrição da pretensão executória começa a correr do dia em que transita em julgado a sentença condenatória para a acusação (2007, p. 591). De forma não diversa é o posicionamento de Nucci O início da prescrição da pretensão executória contra o Estado a partir do momento em que há o trânsito em julgado da decisão somente para a acusação (2014, p. 493). De outro giro, é possível verificar julgados em sentido contrário, como o julgamento do Superior Tribunal de Justiça no HC 137.924/SP O termo inicial da contagem do prazo prescricional da pretensão executória é o trânsito em julgado para ambas as partes, porquanto somente neste momento é que surge o título penal passível de ser executado pelo Estado . A corte Superior mudou seu posicionamento quanto ao termo inicial ao julgar o HC 341.048 de relatoria do Ministro Joel Ilan Paciornik O acórdão impugnado encontra-se em desacordo com o entendimento desta Corte de que o prazo da prescrição da pretensão executória conta-se a partir do trânsito em julgado para a acusação, nos termos do art. 112, I, do Código Penal . Em relação a essa mudança de posicionamento, Greco faz sua crítica

Infelizmente, mudando, equivocadamente sua posição, passou o STJ a entender de forma diversa (2017, p. 899). Defendendo fielmente o trânsito em julgado para ambas as partes como termo a quo da prescrição da pretensão executória, a Magistrada Federal Denise Dias de Castro Bins elucida se não pode a acusação, antes da formação da coisa julgada sobre a condenação com o trânsito para ambas as partes , agir para buscar a execução da pena imposta, não está inerte; e se, só com esse trânsito em julgado amplo, nasce a pretensão executória (BINS, 2013, s/p.). Em seu turno, o Supremo Tribunal Federal também possui divergência em seus julgados no tocante a matéria. Atualmente, o Supremo reconheceu a repercussão geral da matéria que ainda está pendente de julgamento no (ARE 848107), onde dará sua posição e findará a discussão relativa ao termo inicial da prescrição da pretensão executória.

Conclusão: O presente exposto teve por objetivo uma breve explanação sobre o tema prescrição no âmbito penal, passando por uma análise doutrinária e jurisprudencial. Concluise que o termo inicial da prescrição da pretensão executória com o trânsito em julgado somente para a acusação não condiz com a lógica da marcha processual. A inexistência de recurso da sentença condenatória de primeiro grau manejado pela acusação não implica no fim do processo para ela, pois em caso de tese defensiva acatada em segunda instância pode o órgão acusador voltar ao polo ativo da persecução penal e interpor embargos ou até mesmo recurso especial e extraordinário ainda vivo na ação penal. O mais coerente é o termo inicial da pretensão de execução da pena ser o trânsito em julgado para ambas as partes. 


\section{Referências}

BINS, Denise Dias de Castro. Termo inicial da prescrição da pretensão executória: uma releitura da primeira parte do inciso I do artigo 112 do Código Penal à luz do sistema constitucional e processual penal contemporâneo. In. Revista de Doutrina TRF4. 2013. Disponível em: . Acesso em: 16 de jul. 2020.

GRECO, Rogério. Curso de Direito Penal: parte geral. v I. 19. ed. Niterói: Impetus, 2017.

MIRABETTI. Júlio Fabrini. Código de Processo Penal Interpretado. 2. ed. São Paulo: Atlas, 1994.

$\mathrm{NUCCl}$, Guilherme de Souza. Manual de direito penal. 10. ed., atual. ampliado. Rio de Janeiro: Forense, 2014.

STOCO, Rui. Código Penal e sua Interpretação. 8. ed. Revista dos Tribunais, 2007.

Coordenadoria de Pesquisa e Extensão - COPEX

Departamento de Editoraçāo e Divulgaçāo Científica - DEDIC 


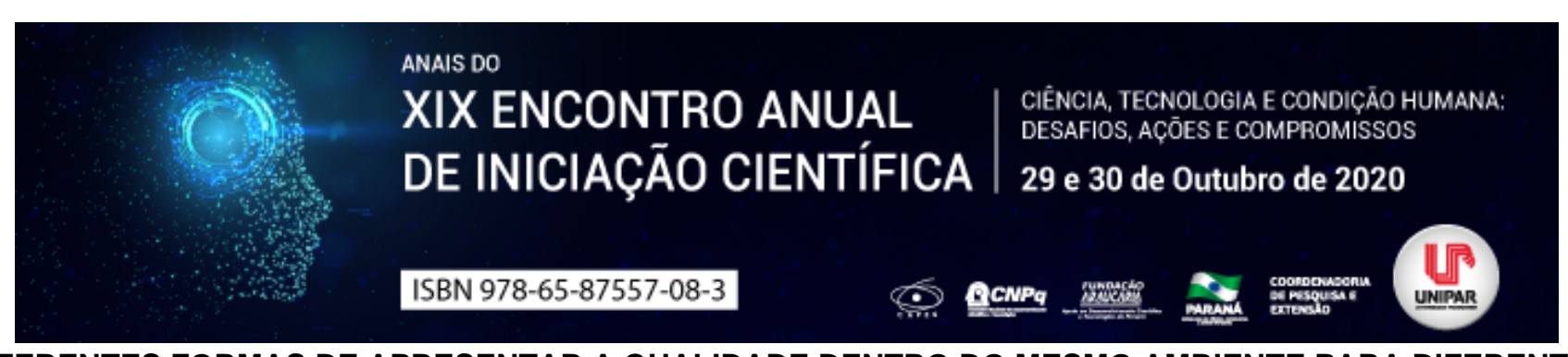

DIFERENTES FORMAS DE APRESENTAR A QUALIDADE DENTRO DO MESMO AMBIENTE PARA DIFERENTES CLIENTES

\author{
${ }^{1}$ NATALIA SOUZA COSTA, ${ }^{2}$ BEATRIZ DA MATTA MONTEIRO, ${ }^{3}$ ELIZANGELA MARIA MENEGASSI DE LIMA
}

\author{
${ }^{1}$ Acadêmicas do Curso de Administração da Unipar \\ ${ }^{1}$ Acadêmica do Curso de Administração da UNIPAR \\ ${ }^{2}$ Docente da UNIPAR
}

Introdução: No mundo contemporâneo, observa-se mercados mais competitivos, pois o consumidor não precisará mais entrar em uma loja para escolher um produto, já que possui uma enorme vitrine virtual, em diversos websites. Segundo pesquisa realizada pelo CETIC (Centro Regional de Estudos para o desenvolvimento da Sociedade), cerca de 70\% da população brasileira está conectada à internet. A intensificação dessa tecnologia resultou em uma drástica mudança no perfil do consumidor, levando as empresas a se reinventarem, buscando uma nova forma de atender seus clientes, não apenas oferecendo seus produtos, mas desenvolvendo um processo de experiência mais completa e com maior valor agregado.

Objetivo: Descrever as diferentes formas de apresentar a qualidade no contexto empresarial, tendo como principal objetivo atender perfeitamente às necessidades do cliente, buscando obter uma maior taxa de fidelização de seus consumidores. Além disso, essa gestão procura aprimorar o fluxo de trabalho, contribuindo para a melhoria na produtividade dos colaboradores, gerando maior motivação e um ambiente de trabalho mais saudável.

Desenvolvimento: A qualidade sempre foi algo discutido pela humanidade, porém, sua aplicação gerencial é recente. A partir do século XX, os mercados ficaram cada vez mais competitivos, como consequência do processo de globalização, levando as empresas a buscarem conhecimento sobre possíveis vantagens que contribua para o desenvolvimento do seu produto. Com isso, o estudo sobre a gestão da qualidade foi ganhando força. Após 1950, William E. Deming, considerado guru da qualidade, recebeu o convite para realizar palestras e conferências aos empresários japoneses. Com isso o Japão foi o primeiro país a aplicar os estudos da gestão de qualidade nos seus produtos e serviços. No Brasil a partir de 1990, começou a ser implantado alguns procedimentos, para que sempre fosse feito a interação interna e externa para fabricação de um produto, e buscando sempre a qualidade do mesmo. O governo também auxiliou criando programas de qualidade, trazendo o início da utilização das normas ISO 9000. A gestão da qualidade traz um modelo gerencial onde não existe margem para erros, implementando ferramentas para desenvolver e aprimorar os processos utilizados pelos meios de produção, até não existir possibilidades de falhas, tanto de pessoal, quanto de máquinas. Para a aplicação de estratégias de gerenciamento de qualidade, a empresa necessita passar por mudanças, principalmente, em sua cultura organizacional. Segundo Custodio (s.d p. 3), a qualidade está enraizada em nosso cotidiano, pois comparamos instintivamente os atributos de um produto, um serviço, um processo ou um comportamento. Dentro do ambiente existe uma relação entre a expectativa e a realidade que o cliente deseja para que satisfaça a sua necessidade, para isso é preciso conhecer o cliente e o que deseja. O termo qualidade possui inúmeros momentos, alguns clientes em certo momento vão optar por qualidade, por exemplo como a entrega rápido do seu serviço, visto que hoje com a correria do dia a dia o cliente poderá optar pelo conforto, como item importante dentro qualidade.

Conclusão: A qualidade das empresas estará sempre em constante mudança, pois o consumidor está cada vez mais exigente e isso se torna uma ferramenta importantíssima dentro das empresas, buscando solucionar os problemas e alcançar a perfeição. A qualidade dentro de uma empresa é um dos pontos mais fortes sobre um produto, pois isso agrega valor ao mesmo entre outras vantagens que a qualidade tem.

\title{
Referências
}

ARAUJO, Luis C. G. de. Organização, sistemas e métodos e as tecnologias de gestão organizacional. 3. ed. São Paulo: Editora Atlas, 2010.

MARSHALL JUNIOR, I. et al. Gestão da qualidade. 9. ed. Rio de Janeiro: Editora FGV, 2008.

FEIGENBAUM, Armand V. Controle da qualidade total. São Paulo: Makron Books, 1994.

CUSTODIO, M. F. Gestão da qualidade e produtividade. São Paulo: Pearson Education do Brasil, 2015.

LAKATOS, Eva Maria; MARCONI, Marina de Andrade. Fundamentos de metodologia científica. 5. ed. São Paulo: Atlas, 2003. 


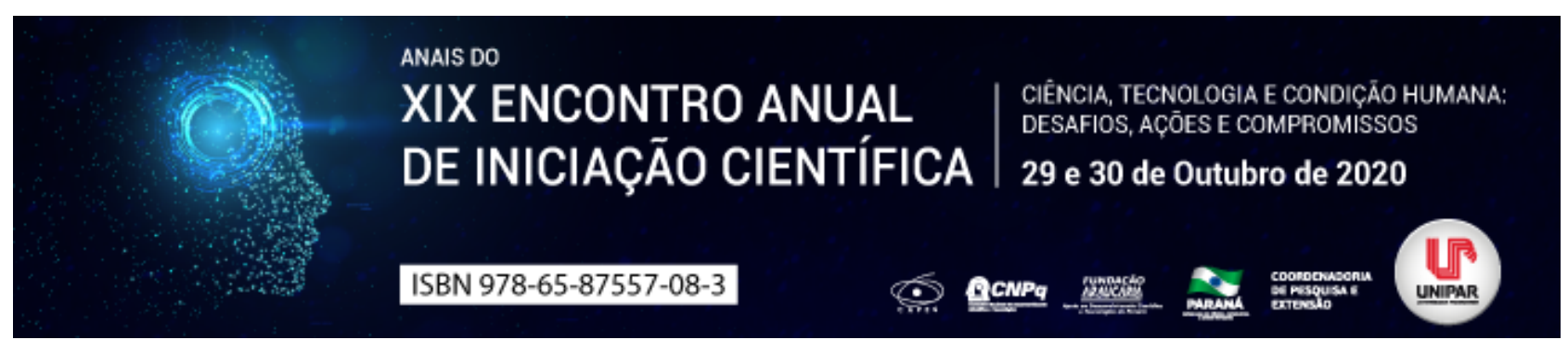

AS PLATAFORMAS ELETRÔNICAS COMO ALIADAS DAS RELAÇÕES CONSUMERISTAS

\author{
${ }^{1}$ MARIA ALICE ORTIZ, ${ }^{2}$ ADRIELLI PINHO DA SILVA, ${ }^{3}$ ANA PAULA QUEIROZ, ${ }^{4}$ ADRIANE HAAS
}

\author{
${ }^{1}$ Acadêmica do PIC/UNIPAR \\ ${ }^{1}$ Acadêmica do PIC/UNIPAR \\ ${ }^{2}$ Acadêmica do PIC/UNIPAR \\ ${ }^{3}$ Docente e Orientadora do PIC/Unipar
}

Introdução: O presente estudo busca identificar as lacunas da Lei de Proteção de Dados e o objetivo real das empresas ao aderirem novos meios de solução de conflitos com os consumidores. Evitando envolver o Poder Judiciário, as empresas ofertam possibilidades de acordos eletrônicos benéficos ao consumidor. Seriam essas, vias de boicote ou soluções equilibradas de conflitos entre as empresas e o consumidor?

Objetivo: Destacar como o Poder Judiciário pode apoiar relações consumeristas firmadas por acordos independentes entre o consumidor e o prestador de serviço ou fornecedor de produtos.

Desenvolvimento: Os direitos do consumidor são assegurados pelos Arts. $5^{\circ}$, inciso XXXII e 170, inciso V, ambos da CF, tendo sua especificidade no Código de Defesa do Consumidor. Nestes dispositivos, é visível a desvantagem das empresas quando o assunto é a amplitude de meios para sua defesa, isso porque o consumidor é tido como figura mais vulnerável da relação. Com isso, o meio empresarial atribui novas modalidades de negociação com os clientes insatisfeitos, utilizando-se dos meios eletrônicos como aliados na busca de resoluções mais céleres e justas (NUNES; et al., 2020). Em tempos de pandemia, quando os cidadãos ficam restritos ou ainda, impedidos de comparecerem a estabelecimentos, inclusive jurídicos, as plataformas online têm obtido uma grande importância, vez que permitem solucionar problemas sem onerar os litigantes e sem abarrotar o Poder Judiciário com ainda mais processos. Com a paralisia das atividades em geral causada pela pandemia do Covid-19, o mundo se voltou aos meios eletrônicos e, por consequência, foi necessário reformar as fontes de sua utilização, de forma que ficassem acessíveis para todos, inclusive pessoas leigas no uso de internet (MARTINS; et al., 2019). Desta forma, é válido salientar que o Poder Judiciário não busca inibir as ações de empresas que oferecem esses meios de solução, pelo contrário, busca incentivar que se adequem às modernidades, principalmente por pactuar com os princípios constitucionais, por considerar que essa modalidade de acordo online é uma fonte repleta de informações, quando em colaboração com o âmbito jurídico e que potencializa a celeridade e satisfação na resolução de conflitos (NUNES; et al., 2020). Neste seguimento, surge o interesse da comunidade jurídica e do meio consumerista em criar dispositivos voltados a tentativas de acordos online, de forma que seja garantido também a proteção do consumidor neste viés.

Conclusão: É crível conceber que o Poder Judiciário apoia os acordos firmados fora do seu âmbito; no entanto, esses acordos devem ser pautados nas leis que regem os direitos do consumidor e a proteção de dados pessoais dos utilizadores de plataformas eletrônicas, a fim de que o consumidor não seja ainda mais onerado. Para que isso aconteça, normas poderiam ser criadas para melhor regulamentar o assunto, em face da lacuna existente.

\title{
Referências
}

BRASIL, Código de Defesa do Consumidor. Lei n 8.078 de 11 de setembro de 1990. Dispõe sobre a proteção do consumidor e dá outras providências. Disponível em: . Acesso em 28 de junho de 2020.

BRASIL, Constituição Federal de 05 de outubro de 1998. Disponível em: . Acesso em 28 de junho de 2020.

FURTADO R. Gabriel; ALMEIDA JUNIOR A. Vitor. Direito Digital. $2^{\circ}$ ed. Indaiatuba: Editora Foco, 2019, p. 544-573.

WERNECK, Isadora. Inteligência Artificial e Direito Processual: Os impactos da virada tecnológica no direito processual. Salvador: editora JusPODIVM, 2020, p. 126-129. 


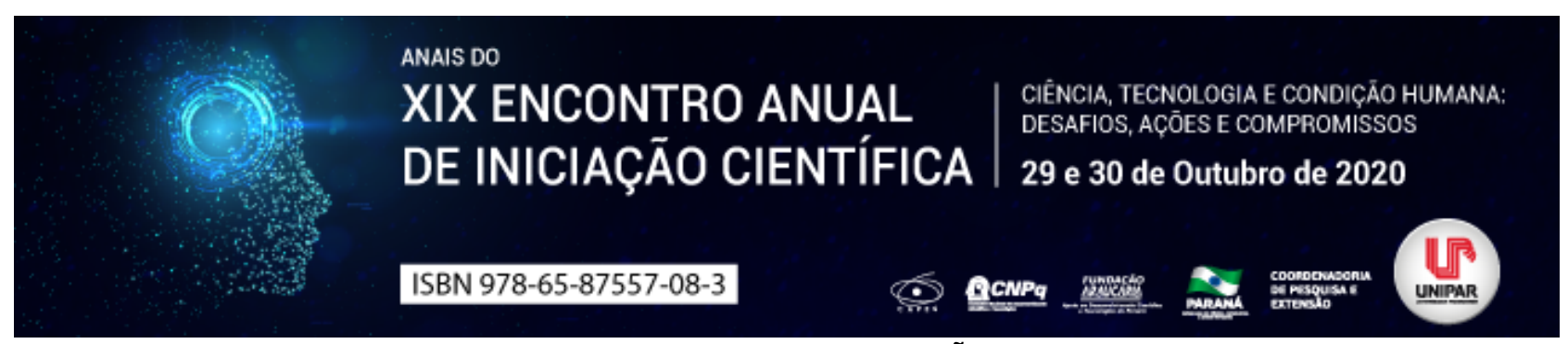

O DESENVOLVIMIENTO HUMANO NA VISÃO DE MONTAIGNE

\title{
${ }^{1}$ JOAO PEDRO ZULIANELLI BARDELA, ${ }^{2}$ VIVIANNE AUGUSTA PIRES
}

\author{
${ }^{1}$ Acadêmico do Curso de Pedagogia da UNIPAR \\ ${ }^{1}$ Docente da UNIPAR
}

Introdução: Este trabalho abordará Michel de Montaigne, com sua visão do ser humano, e sua vida dentro da sociedade da época. Mostrar sua visão acerca de assuntos que por muitos, ainda hoje, se fazem tabus sociais, os pensamentos humanos podem ser modernos, independente a época em que se vive. Juntamente com suas críticas para com a educação da época, mas também, ela como um todo, pontuando como poderia ser melhorada e como deveria agir socialmente.

Objetivo: Apresentar a visão de Montaigne no humanismo, relatando seu pensamento sobre as ideias da concepção humana.

Desenvolvimento: Michel de Montaigne (1533 1592), conhecido na filosofia por seus pensamentos humanistas, e na área da linguagem, por sua inauguração do gênero de escrito ensaio (SILVA, 2015). Montaigne é da época que se começa a surgir à classe social da burguesia, quando os senhores feudais começam sua decadência e os mercadores e comerciantes começam ascender socialmente. Montaigne vive no intervalo entre o começo do final do Renascimento e começo da Idade Moderna. Por muitos, considerado com o pensamento e ideias, muito a frente para o Renascimento, e para outros, muito ultrapassado para a modernidade. (BRUNO, 2020). Tendo uma notória vida política, mas de modo a não se identificar com os assuntos, se põe a escrever sua mais notória obra, tendo três volumes, e intituladas como Ensaio. Obras que transmitem com clareza seus pensamentos, e ideias voltadas para si mesmo, sendo explicitado por ele logo no inicio do Livro 1 do Ensaio 1, na nota Do Autor ao Leitor, Adverte-o ele de inicio que só escrevi para mim mesmo, e alguns íntimos, sem me preocupar com interesses que poderia ter para ti, nem pensar na posterioridade. , e seus desenvolvimento como ser humano (MONTAIGNE, 1980, p.7). Para ele, o pensamento humano vai mudar conforme a época em que se vive. Para se concluir isso, Montaigne, dividiu seu pensamento em três etapas de evolução, sendo a primeira, a do estoicismo, que pretendia estoicamente conseguir a verdade absoluta. A segunda etapa, que consequência da divisão da França entre os conflitos dos católicos e protestantes, é atraído pelos filósofos do ceticismo, que pensavam, como o homem que nem conhece a si próprio, conheceria ao mundo, a Deus e suas vontades. Fazendo Montaigne acreditar, que para que não haja o fanatismo religioso, a duvida é primordial. E como terceira etapa, e também consequente de sua atuação na escrita das obras Ensaios, ele acredita que o maior conhecimento é aquele provem de você mesmo (CABRAL, 2020). Para Montaigne, a educação é algo que se possa aplicar na vida, e que promova uma mudança, ou seja, a educação deve ser mais prática, do que teórica, faz críticas a educação conteudista, e nos deixa o seguinte dizer, mais vale uma cabeça bem feita, do que uma cabeça cheia (BRUNO, 2020). Vivendo na época das navegações, presenciou a morte e extinção de muitos povos nativos das colonizações européias, via as mortes como injustas, já que muitas eram justificadas com o fato de acharem que os povos eram bárbaros, para que ele dizia, chamamos bárbaro aquilo que não faz parte de nosso costumes (BRUNO, 2020), defendia também a tolerância religiosa, uma vez que, vivia em uma época de grandes conflitos religiosos, entre os católicos e os protestantes, mais conhecidos na época como huguenotes, em especial os calvinistas, assim denominados por seus rivais católicos. O humanismo de Montaigne vem quando há a volta aos modelos e às fontes da Antiguidade, onde era valorizada a natureza sensível do ser humano, e isso faz com que surgisse o humanismo renascentista, onde Montaigne encontra alimento espiritual.

Montaigne concorda com Cícero quando esse diz que, filosofar não é outra coisa senão preparar-se para a morte (MONTAIGNE, 1980, p.44). Em sua obra, Ensaio - Livro 1, capítulo XX, intitulado de, De como filosofar é aprender a morrer, ele diz e reflete muito profundamente sobre como as pessoas lidam com a morte, de maneira muito desesperada e perturbadora, e sempre buscam retardar a sua chegada, mas que sempre se esquecem de que ela está em todo lugar, deixando isso claro neste dizer do mesmo capitulo, Não sabemos onde a morte os aguarda, esperemo-la em toda parte. Meditar sobre a morte é meditar sobre a liberdade; quem aprendeu a morrer, desaprendeu de servir (MONTAIGNE, 1980, p.47), que vem dizer que quando deixamos a preocupação da morte de lado e aprendemos a lidar com ela, e sua inevitável chegada, conseguimos viver livremente, sem receio de absolutamente nada. E durante toda a leitura deste capítulo citado, se faz perceber que Montaigne está mais do que preparado para quando a morte o viesse buscar, encerrando assim sua vida, seus estudos e sua busca por volúpia.

Conclusão: Montaigne tinha uma visão muito à frente de seu tempo, em relação ao homem, e seus desenvolvimentos, possuía uma visão muito evoluída nos assuntos, que na época, eram considerados que iam de encontro à moral da sociedade existente. Lhe é atribuído dizeres de extrema sabedoria e relevância, até nos dias atuais, mostrando que sua obra e seu pensamento sempre foram, e sempre serão, de extrema importância para o desenvolvimento de uma sociedade melhor. 


\section{Referências}

CABRAL, João Francisco Pereira. I"As ideias de Michel de Montaignel": Brasil Escola. Disponível em: https://brasilescola.uol.com.br/filosofia/as-ideias-michel-montaigne.htm. Acesso em: 04 jun. 2020.

FILOSOFANDO, Michel de Montaigne e o Sec. XVI TV Mundo Maior, 2015. Disponível em: https://www.youtube.com/watch? $v=x t M U 32 X I n K 4 \& t=54 s$. Acesso em: 04 jun. 2020.

MONTAIGNE, Michel de. Ensaios. 2a edição, Abril S.A. Cultural e Industrial, São Paulo. 1980.

RENASCIMENTO: Humanismo Michel de Montaigne, Filosofia ENEM 2020. Explicaê, 2020 Disponível em: https://www.youtube.com/watch?v=cilCBxrD90g\&t=7s. Acesso em: 04 jun. 2020.

Coordenadoria de Pesquisa e Extensão - COPEX

Departamento de Editoraçāo e Divulgaçāo Científica - DEDIC 


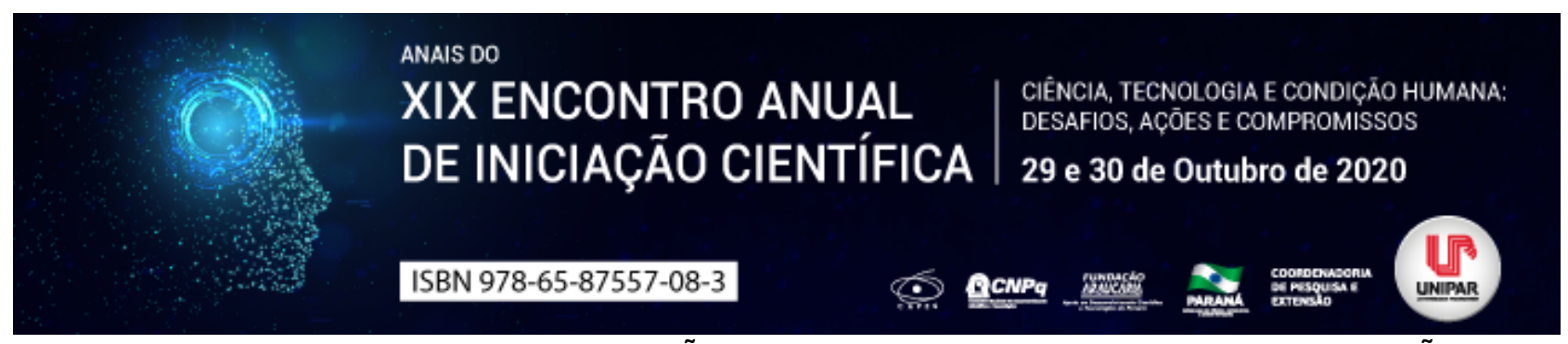

\title{
A INEXIGIBILIDADE DE PARTES IGUAIS NA ADMISSÃO DA PROVA EMPRESTADA E SUAS IMPLICAÇÕES ACERCA DO CONTRADITÓRIO
}

\author{
${ }^{1}$ LIVIA TONINATO VIGNOTO, ${ }^{2}$ CELSO HIROSHI IOCOHAMA
}

\author{
${ }^{1}$ Acadêmica do PIC/UNIPAR \\ ${ }^{1}$ Docente da Graduação em Direito e do Programa de Mestrado em Direito Processual e Cidadania da UNIPAR
}

Introdução: A esfera processual cível brasileira encontra-se abarrotada de processos que estão, há muitos anos, em andamento. Assim, a implementação de mecanismos que gerem uma concretização mais eficaz dos princípios da celeridade e do tempo razoável do processo é essencial, sendo este um dos motivos pelo qual a figura da prova emprestada está, cada vez mais, presente no cenário jurídico.

Objetivo: Analisar se a proposta do Projeto de Lei n $673 / 2019$, em relação à participação das partes, prejudica a efetivação do princípio do contraditório.

Desenvolvimento: A prova emprestada consiste na prova trasladada para um processo diverso do qual foi produzida, sob via documental, buscando evitar a repetição desnecessária de produção probatória. Desse modo, esse mecanismo passou a ser considerado prova típica com o advento do Código de Processo Civil (CPC) de 2015, visto que este almeja simplificar as complexidades processuais e promover a harmonia constitucional (PEREIRA, 2017, p. 44). Entretanto, o texto legal não regulamenta todas as controvérsias doutrinárias existentes sobre o assunto, principalmente, quanto à obrigatoriedade (ou não) da presença de partes iguais em ambos os processos. Assim, sobre essa questão, anteriormente à vigência do atual CPC, a compreensão predominante era de que, em relação à legitimidade da prova emprestada, esta está atrelada ao contraditório, de modo que as partes deverão ter participado do mesmo, no processo originário (SOUSA, 2015, p. 73). Porém, atualmente, o Superior Tribunal de Justiça entende não ser necessária a presença de litigantes idênticos, desde que seja assegurado às partes o direito ao contraditório e à ampla defesa. Nesse sentido, com o fim de corroborar o atual entendimento jurisprudencial e regulamentar, detalhadamente, essa temática, foi apresentado o PL nº 673/2019, que, entre outras alterações, adiciona o $\S 1^{\circ}$ ao artigo 372 do CPC, dispondo que: Em regra, a prova emprestada poderá ser utilizada ainda que nenhuma das partes no novo processo tenha sido parte no processo ao qual foi produzida a prova (BRASIL, 2019). Dessa forma, o proposto é que a prova seja admitida sempre que possível, podendo o juiz, através do livre convencimento motivado, atribuir, a esse instrumento probatório, valor igual ou diverso ao do processo originário. Sendo assim, o PL discorre, na nova redação proposta ao artigo 372 do CPC, que é vital [...] assegurar sempre o contraditório em prestígio aos princípios da duração razoável do processo e da economia processual (BRASIL, 2019), para que, dessa maneira, o magistrado tenha subsídios para realizar uma valoração adequada da prova emprestada.

Conclusão: Nota-se que a empregabilidade da prova emprestada em processos com partes diferentes, nas condições da proposta do PL supracitado, respeita e assegura o cumprimento do direito ao contraditório, além de, também, promover a celeridade processual.

\section{Referências}

BRASIL. Senado Federal. Projeto de Lei n 673/2019. Altera a Lei n 13.102, de 2015 (Código de Processo Civil). Autoria: Senador Weverton (PDT/MA). Disponível em: https://www25.senado.leg.br/web/atividade/materias/-/materia/135190. Acesso em: 20 ago. 2020.

PEREIRA, Lais Zumach Lemos. Uma proposta de redefinição científica do conceito de prova emprestada . 2017. Dissertação (Mestrado em Direito Processual Civil) - Universidade Federal do Espírito Santo. Vitória, 2017. Disponível em: http://repositorio.ufes.br/handle/10/8822. Acesso em: 20 ago. 2020.

SOUSA, Ana Paula Nascimento dos Reis. Da prova emprestada no processo civil. 2015. Dissertação (Mestrado em Direito) Programa de Estudos Pós-Graduados em Direito - Pontifícia Universidade Católica de São Paulo. São Paulo, 2015. Disponível em: https://tede2.pucsp.br/handle/handle/6790. Acesso em: 20 ago. 2020. 


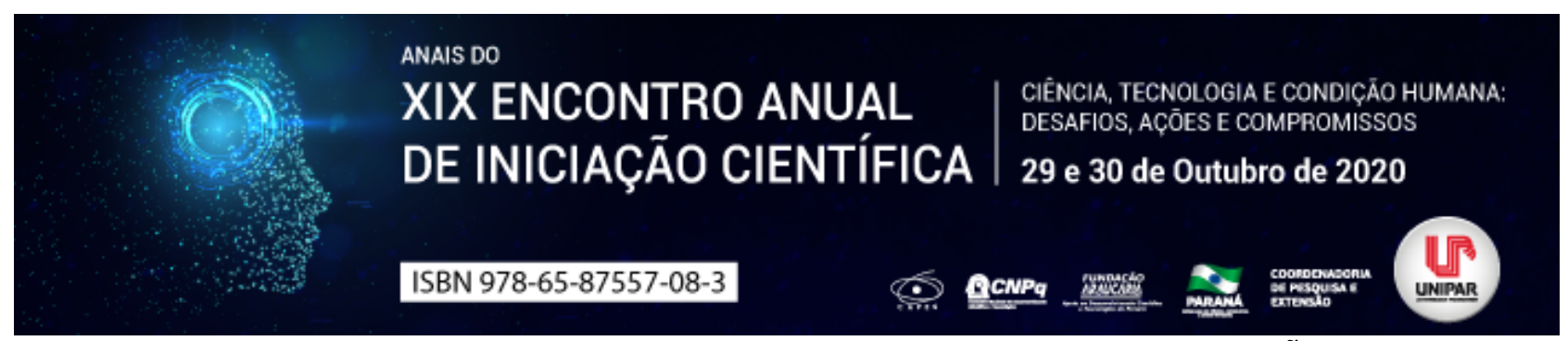

O PROCESSO DA CULTURA ORGANIZACIONAL PARA AS ORGANIZAÇÕES

\title{
${ }^{1}$ BEATRIZ BAZANELA SOUZA, ${ }^{2}$ GABRIEL MAGALHAES DOS SANTOS, ${ }^{3}$ ELIZANGELA MARIA MENEGASSI DE LIMA
}

\author{
${ }^{1}$ Acadêmica do Curso de Administração da Unipar \\ ${ }^{1}$ Acadêmico do PIC/Unipar \\ ${ }^{2}$ Docente da UNIPAR
}

Introdução: Uma empresa é composta essencialmente por pessoas, tornando-se necessário que essas estejam alinhadas com os valores de uma organização. Deste modo, conhecer a cultura organizacional como uma chave para o alcance dos objetivos organizacionais é imprescindível. A partir do momento que a cultura é estimulada, é possível criar características importantes para a estrutura empresarial, gerando uma essência, definindo assim, normas e princípios que vão tornar os colaboradores cada vez mais participantes da empresa.

Objetivo: O objetivo desse estudo é descrever o processo e a importância da cultura organizacional para as organizações.

Desenvolvimento: No cenário atual, a cultura organizacional vem tomando uma importância a mais no mercado, pois, para uma empresa ter sucesso ela precisa investir em seu público interno, pois esse é o responsável principal para o crescimento da organização. Podemos compreender a cultura como a argamassa da coesão social. Assim, imagine vários tijolos separados, representativos das pessoas, dos departamentos e dos setores. A cultura é a argamassa que irá manter esses tijolos unidos em prol de objetivos comuns (SOUZA, 2014, p.20). Cultura organizacional representa a maneira como as pessoas veem o mundo em que vivem. A partir dessa visão do mundo, dividida dentro de um grupo, que os povos irão garantir a manutenção e ajustamento de seus grupos. Muitos aspectos da cultura organizacional são percebidos com facilidade e são denominados aspectos informais e abertos, enquanto outros são de difícil percepção e são denominados de aspectos informais e ocultos (CHIAVENATO, 2004, p.373). Segundo Chiavenato (2004), esses aspectos são como um iceberg, no topo fica os aspectos formais, aqueles visíveis, onde estão às tarefas operacionais, já os aspectos informais ficam na parte inferior, e é de difícil percepção, lá se encontram os aspectos emocionais, que estão ligados aos aspectos psicológicos e sociais. As modificações e as mudanças que ocorrem na cultura organizacional são, de um modo geral, lentas. Isso é consequência de certa estabilidade que a cultura da à organização. No entanto, a cultura organizacional varia constantemente de forma gradativa e imperceptível para seus integrantes (DIAS, 2008, p. 204). Mudar apenas a estrutura não é necessário para garantir o sucesso, mas a mudança na cultura é essencial. É necessário que ocorra gradativamente sem perder sua integridade e personalidade.

Conclusão: Portanto, uma cultura organizacional bem desenvolvida é fundamental para levar a empresa a ter um caminho de sucesso, pois através deste processo, as equipes se tornarão parte dos valores da organização. Assim, é preciso que tanto aspectos estruturais quanto emocionais estejam atrelados e tenham a mesma visão de importância, entendendo que, em meio a um mercado tão concorrido e inovador, ter uma cultura que leva os colaboradores a criarem um significado para os produtos e para o ambiente interno, transforma a empresa em um referencial de destaque.

\section{Referências}

SOUZA, Carla Patricia da Silva. Cultura e clima organizacional: compreendendo a essência das organizações [livro eletrônico]. Curitiba: InterSaberes, 2014.

CHIAVENATO, Idalberto. Introdução à teoria geral da administração: uma visão abrangente da moderna administração das organizações. 7. ed. Rio de Janeiro: Elsevier, 2003.

DIAS, Reinaldo. Sociologia das organizações. São Paulo: Atlas S.A, 2008. 


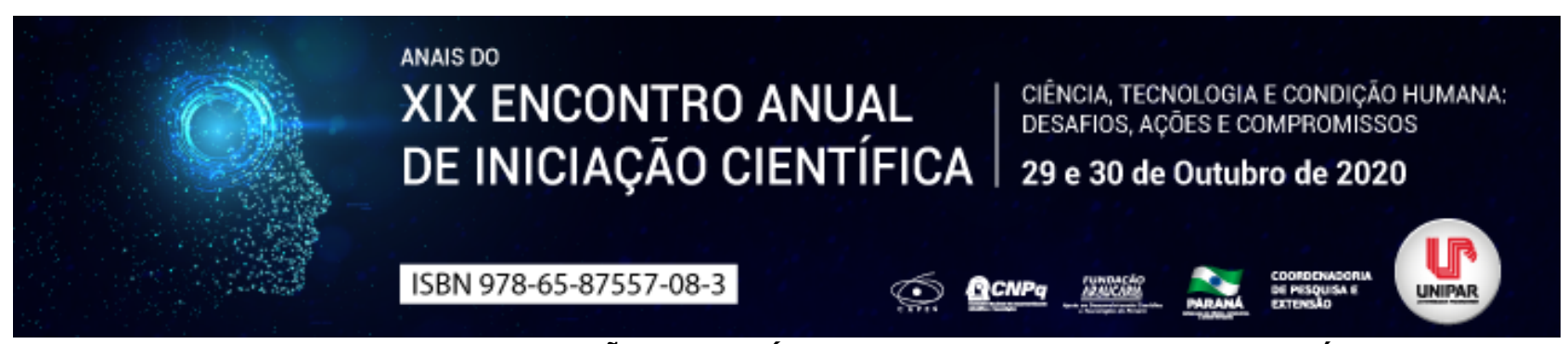

RECUSA DE TRANSFUSÃO SANGUÍNEA POR TESTEMUNHAS DE JEOVÁ

\author{
${ }^{1}$ DHEBORA CANDIL DA FONSECA, ${ }^{2}$ JOAO VITOR DA SILVA OLIVEIRA, ${ }^{3}$ ANA CAROLINA CAETANO PEREIRA, ${ }^{4}$ STELLA \\ DRUCIAK VIENSCOSKI, ${ }^{5}$ LUIS IRAJA NOGUEIRA DE SA JUNIOR
}

\footnotetext{
${ }^{1}$ Acadêmica do Curso de Direito da UNIPAR

${ }^{1}$ Acadêmico do Curso de Direito da UNIPAR

${ }^{2}$ Acadêmica do Curso de Direito da UNIPAR

${ }^{3}$ Acadêmica do Curso de Direito da UNIPAR

${ }^{4}$ Docente da UNIPAR
}

Introdução: A religião denominada de Testemunha de Jeová, surgida nos EUA, no final do século XIX, não aceita que seus integrantes realizam nenhum tipo de transfusão e nem façam a utilização dos componentes do sangue, pois de acordo com a religião uma vez que o sangue é removido do corpo, deve ser obrigatoriamente descartado.

Objetivos: Analisar as consequências negativas, da recusa de transfusão sanguínea, para a saúde dos adeptos de Testemunha de Jeová.

Desenvolvimento: Para as testemunhas de Jeová se acontecer a realização da transfusão de sangue não haverá mais razão para viver, pois, para eles isto será contra a vontade de Deus, ou seja, pecado. Por conta disso, a pessoa poderá ser excluída de vínculos familiares e até mesmo social. Contudo, a supremacia da liberdade de manifestação do pensamento, a liberdade de consentir, a liberdade de consciência e de crença estão previstas no artigo 5º, inciso II, da Constituição Federal (BRASIL,1988). Também, o Conselho Federal de Medicina editou a Resolução CFM 1.021/80, orientando o médico a como proceder no caso de pacientes que, por motivos diversos, inclusive de ordem religiosa, recusam a transfusão de sangue. As diretrizes são estas: Em caso de haver recusa em permitir a transfusão de sangue, o médico, obedecendo a seu Código de Ética Médica, deverá observar a seguinte conduta: $1^{\circ}$ Se não houver iminente perigo de vida, o médico respeitará a vontade do paciente ou de seus responsáveis. $2^{\circ}$ Se houver iminente perigo de vida, o médico irá praticar a transfusão de sangue, independentemente de consentimento do paciente ou de seus responsáveis. A jurisprudência tem decidido que o direito à vida se sobrepõe à liberdade de crenças, baseada no entendimento de que as convicções religiosas não podem prevalecer perante o bem maior que é a vida, previsto no caput do artigo $5^{\circ}$ da CF. Por conseguinte, nesta situação anulando o inciso VI do mesmo artigo. Para as Testemunhas de Jeová, ainda que a morte seja certa, mais vale aceitá-la, do que infringir as leis de sua crença, já que para eles não teriam sentido nenhum viver depois de infringir as leis da sua crença.

Conclusão: Nota-se que embora devam ser respeitadas as práticas religiosas, a vida antecede e se sobrepõe ao direito à liberdade, aqui incluída a liberdade de religião. Todavia, se o paciente Testemunha de Jeová não corre risco de vida e, a transfusão de sangue for prescrita pelo médico, a sua recusa deverá ser aceita sem qualquer tipo de objeção.

\title{
Referências
}

BRASIL. Constituição da República Federativa do Brasil. 29.ed. São Paulo: Saraiva, 2020.

BRASIL. Conselho Federal de Medicina. Resolução no 1021/80. Disponível em: . Acesso em: 1 mai. 2020.

POLICASTRO, Décio. As Testemunhas de Jeová e a transfusão de sangue. Conjur,n. 18 jan. 2018. Disponível em: https://www.conjur.com.br/2011-jan-18. Acesso em: 06 mai. 2020.

RODRIGUES, André Luiz. Et al. Direito a vida X Liberdade de Crença Religiosa. Âmbito Jurídico, n. 1 Set. 2015. Disponível em: encurtador.com.br/nIRW7. Acesso em: 6 mai. 2020.

Coordenadoria de Pesquisa e Extensão - COPEX

Departamento de Editoraçāo e Divulgaçāo Científica - DEDIC 


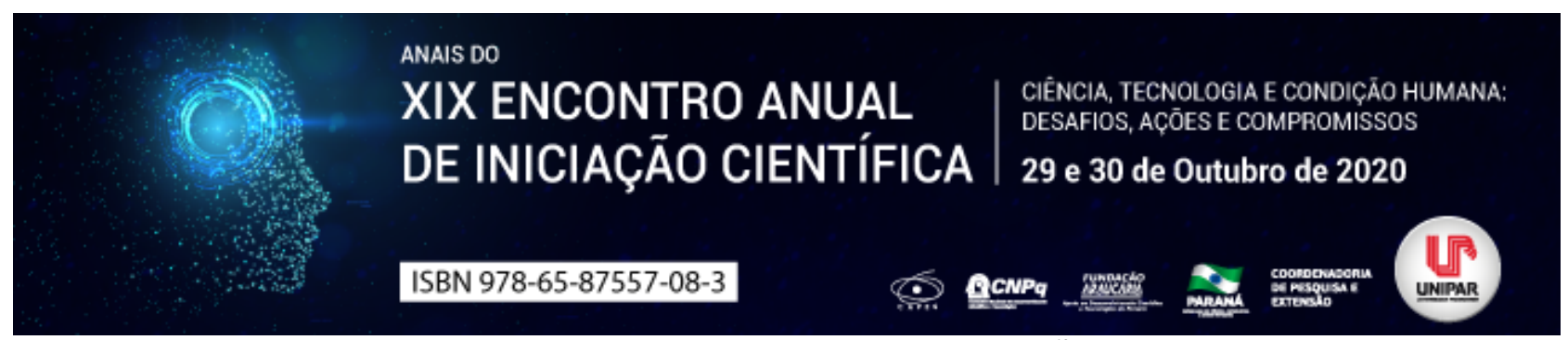

O SUPREMO TRIBUNAL FEDERAL DIANTE DAS OMISSÕES LEGISLATIVAS

\section{${ }^{1}$ MATHEUS ARAUJO BAIA LANUTI, ${ }^{2}$ SOHAILA HAISSA MATHEUS KADRI, ${ }^{3}$ THIAGO MORETO FIORI}

${ }^{1} 1$ Discente do Programa de iniciação científica PIC/UNIPAR, campus Guaíra/PR

${ }_{1}^{1}$ Discente do Programa de iniciação científica PIC/UNIPAR, campus Guaíra/PR

${ }^{2}$ Docente do Programa de iniciação científica PIC/UNIPAR, campus Guaíra/PR

Introdução: A sociedade, gradativamente, vem se tornando mais complexa e multiforme, devido aos altos índices sociais e econômicos. O que torna-se negativo, quando cotejado em face da morosidade legislativa, a qual não a acompanha com a mesma evolução. À vista disso, o próprio ordenamento jurídico, procurando atenuar tal dissonância, organizou o Estado com estrutura apta a mitigar os impactos causados pela progressão social.

Objetivo: Examinar a legitimidade e contribuição do Supremo Tribunal Federal junto à sociedade, ao julgar os litígios não abrangidos pelo ordenamento normativo e, também, aqueles que estão acobertado de forma fictícia, já que estão em contramão com a Lei Maior, inclusive acerca dos impactos sociais decorrentes de sua percepção progressista.

Desenvolvimento: A judicialização é um dos fenômenos decorridos da atual estruturação estatal, onde o Poder Judiciário decide, em caráter final, questões relevantes no ponto de vista político, social ou moral, que até então não constavam na legislação pátria (BARROSO, 2018). O Supremo Tribunal Federal, a mais alta corte dessa república, é o protagonista deste fenômeno, devido sua missão institucional, que consiste na proteção dos valores constitucionais, na concretização dos direitos fundamentais e na proteção da democracia. A atuação do STF diante das questões irresolutas, que necessitam de uma ligeira solução, é imprescindível, uma vez que é incabível aguardar o ânimo do Legislativo, pois a norma social que é, o direito não surge à toa na sociedade, mas para satisfazer as imprescindíveis urgências da vida. Ele é fruto das necessidades sociais e existe para satisfazê-las, evitando, assim a desorganização. (NETO, 1984, p. 212). Por conseguinte, é importante apontar algumas decisões paradigmas deste fenômeno: a equiparação das uniões homoafetivas às uniões estáveis heteroafetivas na ADI $n^{\circ} 4.277$ (BRASIL, 2011); pesquisas com células-tronco embrionárias na ADI n 3.510/DF (BRASIL,2008); interrupção da gestação de fetos anencefálicos na ADPF no 54/DF (BRASIL, 2007). Insta salientar, que algumas dessas decisões não afetaram a sociedade em um todo, mas foram de extrema importância para determinados indivíduos, o que não ocorreria em virtude da omissão, muitas vezes de propósito, dos órgãos eletivos sem a atuação do Judiciário.

Conclusão: Conclui-se, portanto, que o fenômeno da judicialização não é uma opção política do Judiciário, mas uma situação resultante da organização estrutural do Estado, a qual é de extrema importância para a democracia, resguardando e propiciando direitos àqueles com menor representação em órgãos eletivos. Entretanto, a atuação do Judiciário deve sempre caminhar pelos princípios e conceitos jurídicos pertinentes, a fim de evitar o rompimento da tênue fronteira com o ativismo judicial.

\section{Referências}

BARROSO, Luís Roberto. A judicialização da vida e o papel do supremo tribunal federal. $1^{\mathrm{a}}$ reimpressão, Belo Horizonte: Fórum, 2018, p. 44.

BRASIL. Supremo Tribunal Federal. ADI no 4.277. Parte Litigante Procurador-Geral da República. Relator Min. Ayres Britto Plenário, Brasília, 13. out. 2011, Diário de Justiça Eletrônico $\mathrm{n}^{\circ}$ 198, 14. out. 2011. Disponível em: http://redir.stf.jus.br/paginadorpub/paginador.jsp?docTP=AC\&docID=628635. Acesso em 27. ago. 2020.

Supremo Tribunal Federal. ADI $\mathbf{n}^{\circ}$ 3.510. Parte Litigante Procurador-Geral da República. Relator Min. Ayres Britto Pleno, Brasília, 29. maio 2008, Diário de Justiça Eletrônico no 96, 28. maio. 2008. Disponível em: http://redir.stf.jus.br/paginadorpub/paginador.jsp?docTP=AC\&doclD=611723. Acesso em 27. ago. 2020.

Supremo Tribunal Federal. ADPF $\mathbf{n}^{\circ}$ 54. Parte Litigante Confederação Nacional dos Trabalhadores da Saúde -CNTS.

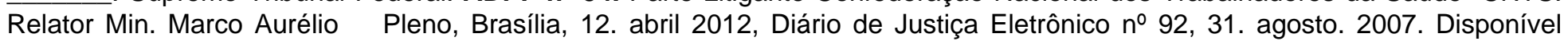
em:http://redir.stf.jus.br/paginadorpub/paginador.jsp?docTP=TP\&docID=3707334. Acesso em 27. ago. 2020.

NETO, Antônio Luiz Machado. Sociologia Jurídica. São Paulo: Saraiva, 1984, p. 412. 


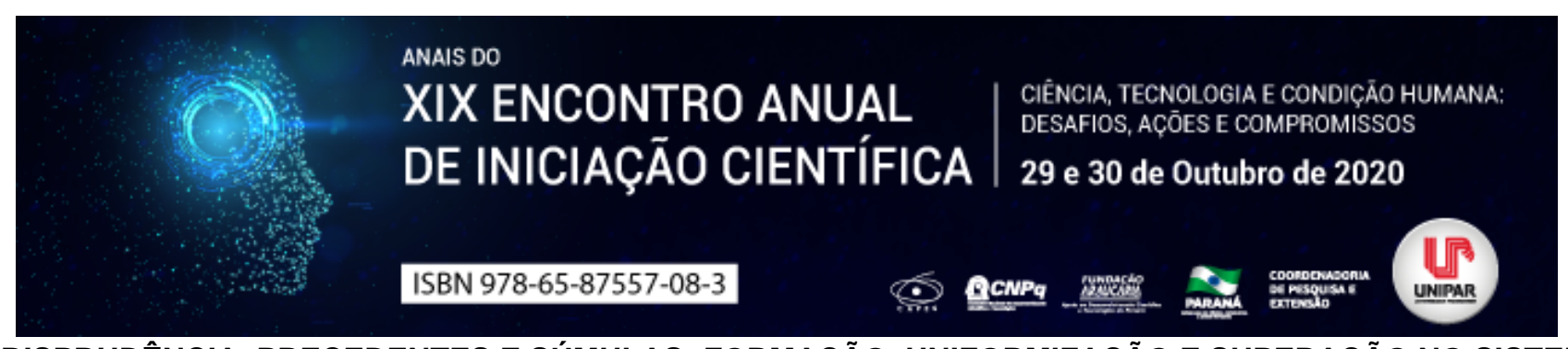

JURISPRUDÊNCIA, PRECEDENTES E SÚMULAS: FORMAÇÃO, UNIFORMIZAÇÃO E SUPERAÇÃO NO SISTEMA PROCESSUAL BRASILEIRO

\author{
${ }^{1}$ MARIA ANGELICA DE SOUZA MENEZES, ${ }^{2}$ ALBINO GABRIEL TURBAY JUNIOR
}

\author{
${ }^{1}$ Acadêmico bolsista do PEBIC / Fundação Araucária \\ ${ }^{1}$ Docente da UNIPAR
}

Introdução: O sistema jurídico brasileiro é baseado no sistema civil law, cuja sua principal característica é a utilização pelo ordenamento jurídico de normas escritas, publicadas e documentadas. A jurisprudência, o precedente e a súmula também integram esse ordenamento, auxiliando em muitos casos na resolução de conflitos, apesar de não serem fontes legislativas de direito, acabam tendo uma grande importância no ordenamento pátrio.

Objetivo: Compreender o processo de formação, uniformização e métodos de superação, da jurisprudência, precedente e súmula no Sistema Jurídico Brasileiro.

Desenvolvimento: Dentro do ordenamento jurídico brasileiro verifica-se a existência de jurisprudências, precedentes e súmulas, que auxiliam os magistrados nas resoluções de conflitos. Primeiro, é preciso estabelecer os conceitos de jurisprudência, precedente e súmula, pois, apesar de vinculados tem conceitos próprios. A jurisprudência é formada por um conjunto de decisões dos tribunais a respeito de uma dada matéria, que apresente similaridades, podendo ser formada também por precedentes, vinculantes e persuasivos, uma vez que eles venham sendo utilizados como razões para decidir das demais lides que versem sobre o mesmo tema. Medina (2016, p. 1204) ressalta que a jurisprudência: [...] além de integra, deve ser uniforme, estável e coerente (artigo 926 do CPC) , para poder ser utilizada pelo magistrado no caso concreto. Os precedentes podem se formar a partir de um caso paradigma ou de reiteradas decisões dos magistrados a respeito de um tema em questão, essas decisões tendem a versar sobre um mesmo resultado diante do problema exposto no processo, para Medina (2016, p. 1203): [...] os precedentes se ligam mais as circunstâncias do caso [...] . Entende-se que o ponto inicial para a formação de um precedente seria decisões bem fundamentadas, com boas bases normativas e que gere segurança jurídica para o ordenamento pátrio. A formação das súmulas se dá a partir do momento que temos uma jurisprudência constante, motivando assim a criação e edição do enunciado sumular. Muitas vezes as chamadas súmulas vinculantes acabam sendo consideradas mais forte que o texto constitucional, por conta de seu caráter vinculativo e por seu processo de formação mais rígido (MEDINA, 2016, p. 1209). A maneira de criação de uma súmula vinculante está listada no artigo 103-A da Carta Magna. O Brasil é um país constituído de uma pluralidade de órgãos julgadores, que em algum momento pode enfrentar iguais questões de direito, podendo assim ocorrer pronunciamentos judiciais contendo teses jurídicas diferentes, algo que não seria nada seguro e viável para a justiça, por isso nasce a necessidade de uniformização da jurisprudência pátria. O objetivo da uniformização não é tornar imutável as teses jurídicas, mas sim evitar que em um mesmo contexto, seja proferida pelos magistrados decisões diversas, a respeito de um mesmo tema (GONÇALVES, 2008, p. 170). O sistema de uniformização tem sua base nos artigos 926 e 927 do CPC, os tribunais com base nesses artigos devem manter sua jurisprudência estável, integra e coerente. A uniformização busca garantir ainda maior celeridade e segurança jurídica aos litígios, esse sistema veio corroborar com o anseio da sociedade por maior igualdade de tratamento, no mundo jurídico, para seus dilemas e questões. Tem-se a expectativa que a orientação adotada nos institutos citados seja o mais estável possível, no entanto pode ocorrer situações em que é necessário à sua modificação, a isso dá-se o nome de superação de um entendimento firmado. Para Medina (2016, p. 1227): As alterações nos valores sociais ou no modo de compreensão (doutrinária ou jurisprudencial) de princípios jurídicos que serviram de base a criação de dado precedente pode levar à sua superação. Apesar da necessidade de uniformização das jurisprudências, precedentes e súmulas, estes institutos podem ser alterados conforme consta no artigo $927, \S 2^{\circ}, 3^{\circ}$ e $4^{\circ}$ do CPC. O overruling é uma destas técnicas de superação, segundo Fredie Didier Jr. (2015, p. 494): [...] é a técnica através da qual um precedente perde sua força vinculante e é substituído (overruled) por outro precedente , é um método que deve ser executado pelo mesmo tribunal, pois, somente aquele que fixou o precedente pode substitui-lo. Distinguishing ou distinção é outra técnica utilizada que nada mais é que o meio ou método através do qual é feito o confronto entre o caso concreto e o paradigma a fim de verificar a possibilidade da aplicação deste último ao caso concreto. Ocorrendo a existência de semelhanças, este paradigma pode ser aplicado ou superado pelo magistrado, uma vez não verificadas as semelhanças, ocorre a distinção dos elementos confrontados.

Conclusão: A jurisprudência, precedente e súmula são de grande importância para o ordenamento pátrio, auxiliando os magistrados no momento da resolução de uma lide, esses institutos impedem que ocorra discrepância jurídica entre as decisões dos magistrados que versem sobre um mesmo tema, dando, assim, uma maior segurança jurídica bem como celeridade ao processo. 


\section{Referências}

DIDIER JR., Fredie; BRAGA, Paula Sarno; OLIVEIRA, Rafael Alexandria. Curso de direito processual civil: teoria da prova, direito probatório, ações probatórias, decisão, precedente, coisa julgada e antecipação dos efeitos da tutela. 10 ed. Salvador: Editora Juspodivm, 2015, v.2.

GONÇALVES, Marcus Vinicius Rios. Novo curso de direito processual civil. 4 ed. São Paulo: Editora Saraiva, 2008 , v. 2.

MEDINA, José Miguel Garcia. Curso de direito processual civil moderno. 2 ed. São Paulo: Editora Revista dos Tribunais, 2016.

Coordenadoria de Pesquisa e Extensão - COPEX

Departamento de Editoraçāo e Divulgaçāo Científica - DEDIC 


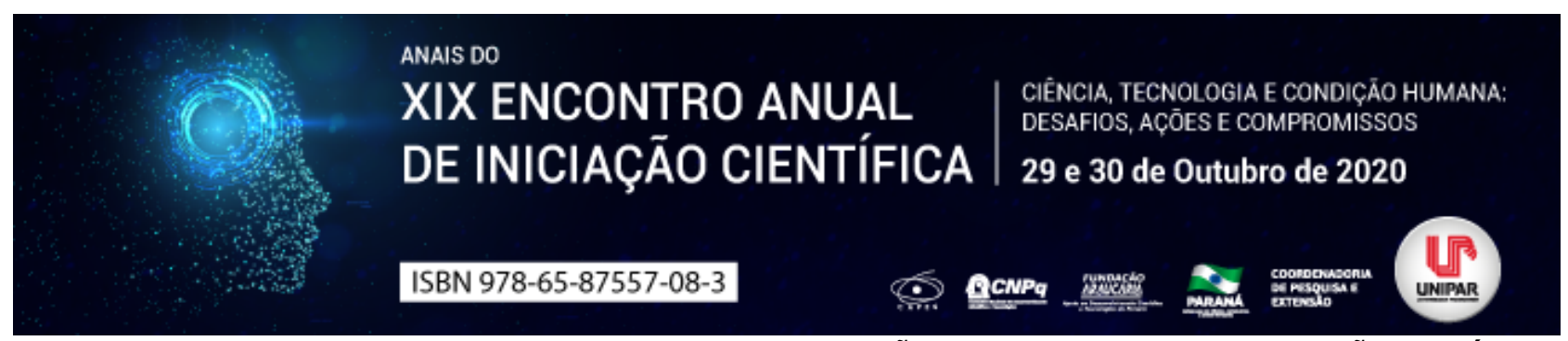

\title{
O SUPREMO TRIBUNAL FEDERAL E O RECONHECIMENTO DA UNIÃO HOMOAFETIVA COMO UNIÃO ESTÁVEL, FRENTE A INATUAÇÃO LEGISLATIVA
}

\author{
${ }^{1}$ SOHAILA HAISSA MATHEUS KADRI, ${ }^{2}$ MATHEUS ARAUJO BAIA LANUTI, ${ }^{3}$ THIAGO MORETO FIORI
}

\author{
${ }^{1}$ Discente do Programa de Iniciação Científica PIC/UNIPAR, campus Guaíra/PR \\ ${ }^{1}$ Discente do Programa de Iniciação Científica PIC/UNIPAR, campus Guaíra/PR \\ ${ }^{2}$ Docente Programa de Iniciação Científica PIC/UNIPAR, campus Guaíra/PR
}

Introdução: A atuação do Supremo Tribunal Federal frente as questões de largas repercussões políticas e sociais, possui grande destaque na jurisdição constitucional brasileira e vem ganhando ênfase na aplicação do direito contemporâneo. Tal atuação revela-se imprescindível ante a ligeira evolução da sociedade, tendo em vista que, os outros poderes que também sustentam os pilares do Estado Democrático de Direito, muitas vezes atuam, de forma morosa, diante do constante progresso percorrido pela humanidade.

Objetivo: Analisar uma das grandes decisões históricas proferidas pelo Supremo Tribunal Federal, onde a corte atribuiu nova interpretação ao artigo 1.723 do Código Civil (BRASIL, 2002) e ao artigo 226, §3º, da Constituição Federal (BRASIL, 1988), em conjunto com a omissão legislativa da norma. No julgamento da Ação Direta de Inconstitucionalidade (ADI) 4.277 e da Arguição de Descumprimento de Preceito Fundamental (ADPF) 132, a união estável para casais do mesmo sexo foi reconhecida, por unanimidade, pelos ministros da Corte Suprema. A decisão pautou-se, sobretudo, na proteção dos valores constitucionais; no princípio da dignidade da pessoa humana; nos princípios da igualdade e liberdade, os quais são afetos a autonomia da vontade e no direito à busca da felicidade (HAIDAR, 2011).

Desenvolvimento: Em virtude dos novos valores que inspiram a sociedade contemporânea, incumbe ao Poder Judiciário, valendo-se dos princípios hermenêuticos, preencher as lacunas existentes na lei, de forma a adequá-las às necessidades sociais. Essa atuação dá-se, pois, a inexistência de normatização não pode ser posta como fator impeditivo para o reconhecimento de efeitos jurídicos que emergem de fatos notórios, sob a ótica da sociedade (SILVA, 2009, p.12). Com base nisso, é inconteste que o Poder Judiciário detém um excesso de atribuições e afirmações de direitos que estão sob sua guarda, configurando como um pilar central dos poderes republicanos. Dessa forma, ainda que os outros dois poderes cumpram suas funções constitucionais ordinárias, existem situações especiais em que o Supremo Tribunal Federal poderá ser provocado para decidir questões que não estão afetas a sua capacidade institucional, entretanto, conforme bem assevera o ministro Luiz Fux: [...] Essas questões todas deveriam, realmente, ser resolvidas pelo Parlamento. [...] O Parlamento não quer pagar o preço social de decidir sobre o aborto, sobre a união homoafetiva e sobre outras questões que nos faltam capacidade institucional [...] (FUX, 2016). À vista disso, em maio de 2011, no julgamento da Ação Direta de Inconstitucionalidade n. 4.277 e da Arguição de Descumprimento de Preceito Fundamental n. 132, o Supremo reconheceu, por unanimidade, a união homoafetiva como entidade familiar e, aplicou, analogicamente, o regime concernente à união estável, previsto no artigo 1.723 do Código Civil (BRASIL, 2002). Em seu voto final, como relator, o ministro Ayres Britto expôs que o artigo $3^{\circ}$, inciso IV da Constituição Federal, veda qualquer discriminação decorrente de sexo, raça e cor. Tal argumento foi seguido pelos seus pares, resultando no efeito vinculante do julgamento proferido e, reconhecendo um quarto modelo de família brasileira (HAIDAR, 2011).

Conclusão: Referida decisão proferida pelo Supremo Tribunal Federal, teve por objetivo solucionar uma grande problemática enfrentada pela sociedade, efetivando direitos fundamentais existentes, os quais foram suprimidos por longos anos, e ainda não são regulamentados de forma adequada na norma, frente a inércia do Poder Legislativo.

\section{Referências}

BRASIL. Constituição da República Federativa do Brasil de 1988, promulgada em 05 de outubro de 1988 . Diário Oficial da República Federativa do Brasil, Brasília, DF, ano CXXVI, no 191-A, seção I.

ESTADÃO, conteúdo. 'Judiciário decide porque há omissão do Parlamento, diz Luiz Fux. Estadão Conteúdo. 05 dez. 2016. Disponível em: https://exame.com/brasil/judiciario-decide-porque-ha-omissao-do-parlamento-diz-luiz-fux/.. Acesso em: 26 ago. 2020.

HAIDAR, Rodrigo. Supremo Tribunal Federal reconhece união estável homoafetiva. 05 mai. 2011. Disponível em: https://www.conjur.com.br/2011-mai-05/supremo-tribunal-federal-reconhece-uniao-estavel-homoafetiva. Acesso em: 25 ago. 2020.

Lei $n^{\circ}$ 10.406, de 10 de janeiro de 2002, promulgada em 11 de janeiro de 2002. Institui o Código Civil. Diário Oficial da União, Brasília, DF, ano CXXXIX, nº 8, p. 1-74, seção I.

SILVA, Maria de Fátima Peres da. A união homoafetiva como entidade familiar. 2009. Monografia (Pós-graduação) Escola 
da Magistratura do Estado do Rio de Janeiro, Rio de Janeiro, 2009.

. Supremo Tribunal Federal. ADI n 4.277. Parte Litigante Procurador-Geral da República. Relator Min. Ayres Britto Pleno, Brasília, 05 maio 2011, Diário de Justiça Eletrônico no 198, 14. nov. $2011 . \quad$ Disponível em: http://redir.stf.jus.br/paginadorpub/paginador.jsp?docTP=AC\&docID=628635. Acesso em 27. ago. 2020.

Supremo Tribunal Federal. ADPF $\mathbf{n}^{\circ}$ 132. Parte Litigante Governador do Estado do Rio de Janeiro. Relator Min. Ayres Britto Pleno, Brasília, 05 maio 2011, Diário de Justiça Eletrônico, $14 . \quad$ nov. $2011 . \quad$ Disponível em: http://redir.stf.jus.br/paginadorpub/paginador.jsp?docTP=AC\&docID=628633. Acesso em 27. ago. 2020.

Coordenadoria de Pesquisa e Extensão - COPEX

Departamento de Editoraçāo e Divulgaçāo Científica - DEDIC 


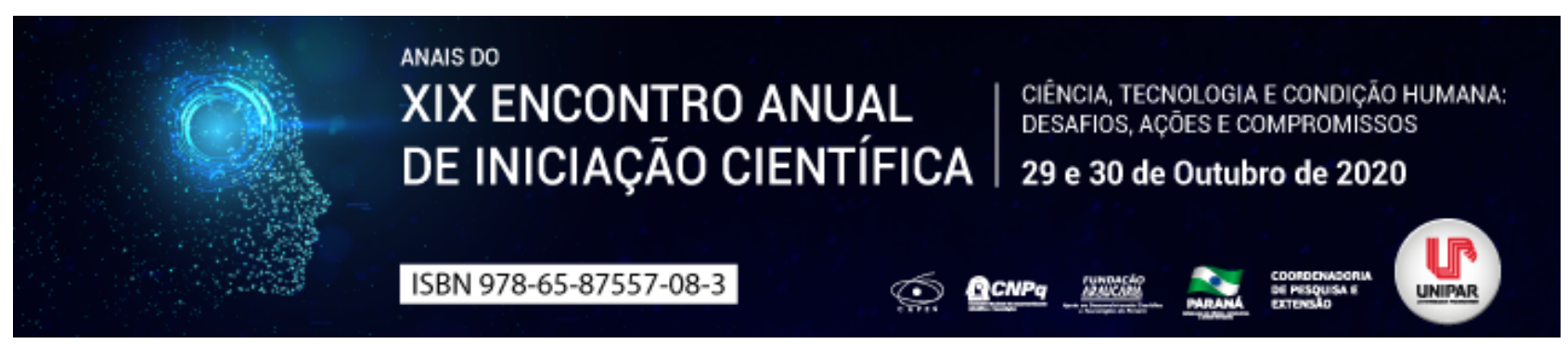

A ABSOLUTA IMPENHORABILIDADE DOS SOLDOS SALARIAIS PROPOSTA PELO PROJETO DE LEI $5320 / 2019$

\title{
${ }^{1}$ VITORIA LOPES ALMEIDA, ${ }^{2}$ CELSO HIROSHI IOCOHAMA
}

\author{
${ }^{1}$ Acadêmico do PIC/UNIPAR \\ ${ }^{1}$ Docente da Graduação em Direito e do Programa de Mestrado em Direito Processual e Cidadania da UNIPAR
}

Introdução: A mudança do CPC/1973 para 2015 estabeleceu uma relativização da impenhorabilidade das verbas contempladas no art 833, inciso IV, aumentando a insegurança jurídica daqueles que estão submetidos ao processo de execução.

Objetivo: Analisar a aplicação da impenhorabilidade de salários e seus correlatos dispostos no art. 833 do CPC/2015 com suas exceções legais e a forma em que o projeto de Lei 5320/2019 da Câmara dos Deputados busca incidir neste artigo.

Desenvolvimento: $O$ art. 833 do Novo Código de Processo Civil Brasileiro (DIDIER JR, 2019) estabelece um rol de bens impenhoráveis do devedor, entre eles os salários, exceto em casos de pensões alimentícias e salários que ultrapassem 50 salários mínimos. O salário atende, regra geral, a um universo de necessidades pessoais e essenciais do indivíduo e de sua família (DELGADO, 2013, p. 740). Essa teoria parte da premissa que a proteção salarial é fundamental para a garantia da dignidade humana, onde só se admite a penhora caso não impossibilite o acesso do devedor aos bens necessários assegurando a manutenção da própria subsistência. No antigo CPC/1973 também era permitido penhoras para pensões alimentícias, conforme cita Hertel $(2018$, p. 1) a penhora do salário é admitida, porque a constrição se justifica pela finalidade de alimentos, preservando a subsistência do alimentando. Ou seja, apenas por extrema necessidade é que se podia obter penhoras salariais, o que não condiz com o CPC/2015 que aumentou as exceções legais de penhorabilidade, deixando margem para maiores interpretações dos tribunais. Visando manter a proteção da impenhorabilidade salarial como no antigo CPC/1973 é que se propôs o Projeto de Lei 5320/2019, buscando a inserção do § $4^{\circ}$ ao art. 833 para tornar absolutamente impenhoráveis os vencimentos, os subsídios, os soldos, os salários, as remunerações, os proventos de aposentadoria, as pensões, os pecúlios e os montepios, o seguro de vida, a pequena propriedade rural e outros, ainda que mantenha a ressalva dos $\S \S 10$ e 20 , do art. 833 , ou seja, para pagamento de dívida relativa ao próprio imóvel, pensão alimentícia e no excedente a cinquenta salários mínimos.

Conclusão: Buscando evitar prejuízos ao patrimônio salarial adquirido pelo devedor, foi proposto o projeto de lei citado, incidindo diretamente nos interesses do executando, para que se proteja os salários e seus correlatos, resgatando-se a previsão do CPC de 1973 sobre a impenhorabilidade absoluta sobre os bens apontados.

\section{Referências}

DIDIER JR, Fredie; PEIXOTO, Ravi. Novo Código de Processo Civil. 6. ed. São Paulo: Editora JusPODIVM, 2019.

DELGADO, Maurício Godinho. Curso de Direito do Trabalho. 12. ed. São Paulo: LTR, 2013.

HERTEL, Daniel. Impenhorabilidade do salário, principais precedentes do Superior Tribunal de Justiça e o novo Código de Processo Civil. Revista Jus Navigandi, ISSN 1518-4862, Teresina, ano 22, n. 5249, 14 nov. 2017. 


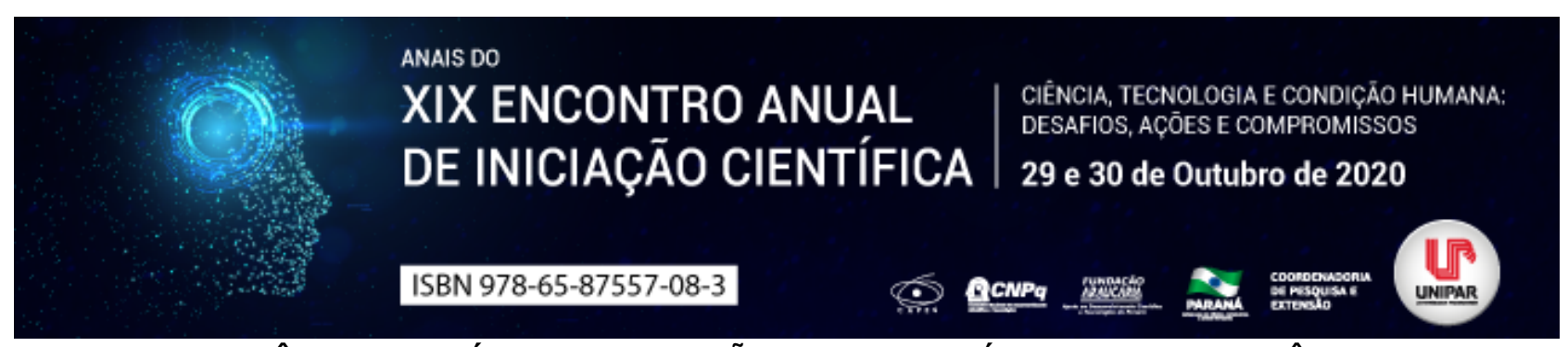

VIOLÊNCIA OBSTÉTRICA: REFLEXÕES DE UMA PRÁTICA CONTEMPORÂNEA

\begin{abstract}
${ }^{1}$ ANA PAULA TEODORO DOS SANTOS, ${ }^{2}$ ANY LOUIZE AIRES, ${ }^{3}$ CAMILA BEATRIZ KLEIN, ${ }^{4}$ ELAINE CRISTINA MUSSI DE LIMA, ${ }^{5}$ PATRICIA CRISTINA NOVAKI AOYAMA
\end{abstract}

\author{
${ }^{1}$ Acadêmica do Curso de Psicologia da UNIPAR / PIC \\ ${ }^{1}$ Acadêmica do Curso de Psicologia da UNIPAR / PIC \\ ${ }^{2}$ Acadêmica do Curso de Psicologia da UNIPAR / PIC \\ ${ }^{3}$ Acadêmica do Curso de Psicologia da UNIPAR / PIC \\ ${ }^{4}$ Docente da UNIPAR
}

Introdução: O processo de parturição sofreu grandes mudanças nos últimos anos, atualmente, o cenário é marcado pela ênfase nas práticas médicas intervencionistas, a qual possui como consequência a patologização dos processos naturais do parto. $O$ que por sua vez, corroborou para o aumento de práticas abusivas, materializada em diferentes tipos de condutas, contidas no rol da violência obstétrica institucional, tais como: ausência de informações sobre procedimentos, violência de ordem física e/ou verbal, negligência no cuidado com a parturiente, procedimentos desnecessários, dentre outros. É de extrema importância o compartilhamento de informações acerca das práticas que caracterizam a violência obstétrica, visando a identificação, o enfrentamento e a redução das intervenções que são desnecessárias e que violem os direitos das parturientes (ZANARDO et al., 2017; NASCIMENTO et al., 2019).

Objetivo: Compreender o conceito da violência obstétrica e sua relação com a prática profissional no campo da saúde, bem como refletir sobre práticas intervencionista mais humanitárias como forma de combate a essa violação.

Desenvolvimento: Dentre as inúmeras formas de violência contra a mulher temos a violência obstétrica, a qual é pouco abordada e consequentemente pouco conhecida. A violência obstétrica ainda não possui um conceito concreto descrito em documentos legais que a definem, criminalizem e assegurem os direitos das parturientes. Os escritores Oliveira e Albuquerque (2018 apud ESTRELA et al., 2020) apresentam um conceito norteador, sobre o que seria a violência obstétrica, a qual consiste na apropriação por parte dos profissionais de saúde do corpo e dos processos reprodutivos da parturiente, essa apropriação é externalizada através do abuso da medicalização, patologização dos processos naturais e pelos tratamentos violentos. As consequências dessas apropriações fomentam no descaminho da autonomia da parturiente e na incapacidade da mesma poder decidir sobre o seu corpo e a sua sexualidade livremente. Os procedimentos realizados de maneira desnecessárias e sem autorização da parturiente, como por exemplo, os toques vaginais excessivos, episiotomia, manobra de Kristeller, uso protocolar de ocitocina, tricotomia, realização de cessaria sem real indicação, lavagem intestinal, somando-se a isso ao impedimento do acompanhante durante o trabalho de parto, a negligência na assistência pelos profissionais de saúde, os maus tratos físicos e/ou verbais são exemplos que caracterizam a violência obstétrica. Muitos desses procedimentos são conhecidos pelas parturientes como práticas normais, isso se dá pela falta de informação, desconhecimento este que acarreta no aumento de abusos sofridos. A paciente está em um ambiente hospitalar que dispõe de tecnologia para o cuidado da sua saúde, isso faz com que a supervalorização das práticas intervencionistas por meio das tecnologias se sobressaia ao corpo da mulher, seus direitos e desejos. Bem como existe uma hierarquia entre as mulheres e os profissionais de saúde, em onde a capacidade de escolha fica exclusivamente nas mãos dos profissionais a despeito das vontades das usuárias, que perdem nesse contexto sua privacidade e autonomia, essas situações trazem para as mulheres a sensação de submissão, insegurança e descontrole, pois se sentem à margem da boa vontade e do cuidado de outras pessoas. As escolhas da mulher devem ser respeitadas pelos profissionais, sendo admitida a superação desta em casos de risco concreto a saúde da mãe e/ou do bebê, o qual deve ser fundamentado pelo médico responsável em conversa com a parturiente. De acordo com Barboza e Mota (2016 apud ESTRELA et al, 2020) a recusa em informar a parturiente sobre os procedimentos a serem realizados, bem como, negar informações sobre seu próprio corpo, materializa a violência obstétrica. Pela falta de informação, desconhecimento dos seus direitos e perda da sua autonomia, muitas vezes as práticas de violência obstétrica são banalizadas pelas parturientes, a ocorrência desses contextos favorece as hierarquias de reprodução e deixam as mulheres a margem da humanização no cuidado a sua saúde física e psicológica. Para Oliveira e Penna (2017) a violência obstétrica está presente na rotina da sala de parto, tanto com os profissionais de saúde que não conseguem identificar as violências obstétricas nas suas práticas assistenciais protocolares cotidianas, como nas mulheres que consentem de maneira silenciosa e por muitas vezes tendem a justificar as agressividades sofridas como parte inerente do processo de parto. É essencial que haja a reeducação da visão pública sobre o parto, sobrepondo as práticas de hospitalização, medicalização e patologização do processo reprodutivo para as práticas de assistência obstétrica humanitária, o nascimento é um processo natural ligado ao direito à vida, a reprodução, a sexualidade, a autonomia e dignidade da parturiente e do bebê. 
Conclusão: $O$ termo violência obstétrica ainda não possui um conceito concreto e por ser uma forma de violência pouco falada as mulheres não possuem muito conhecimento, nem informações acerca dessa temática previamente. Dessa maneira, se faz extremamente necessário o compartilhamento de informações, por meio dos órgãos oficiais, para minimizar as violações sobre os direitos das parturientes, as práticas desnecessárias e melhorar as experiências do processo de dar à luz. Bem como é fundamental que as instituições formadoras e as de saúde abordem esse tema com os profissionais da área da saúde, buscando alterações nas práticas realizadas no processo do parto visando que estas sejam de assistência obstétrica humanitária.

\section{Referências}

ESTRELA, Marcela Regina; DE AMORIM, Cloves Antônio Amissis; MOSER, Ana Maria. A Representação Social da Violência Obstétrica para Mulheres no Século XXI. Disponível em:< https://core.ac.uk/download/pdf/304371531.pdf>. Acessado em: 03 agosto 2020.

GUIMARAES, Liana Barcelar Evangelista; JONAS, Eline; AMARAL, Leila Rute Oliveira Gurgel do. Violência obstétrica em maternidades públicas do estado do Tocantins. Rev. Estud. Fem., Florianópolis, v. 26, n. 1, e43278, 2018. Disponível em . Acessos em 04 ago. 2020.

NASCIMENTO, Samilla Leal. et al. Conhecimentos e experiências de violência obstétrica em mulheres que vivenciaram a experiência do parto. Enfermería Actual de Costa Rica. [On-line]. 2019, version ISSN 1409-4568. Disponível em: Acessado em: 4 agosto 2020.

OLIVEIRA, Virgínia Junqueira; PENNA, Cláudia Maria de Mattos. Discutindo a violência obstétrica através das vozes da mulher e dos profissionais de saúde. Texto contexto - enferm., Florianópolis, v. 26, n. 2, e06500015, 2017. Disponível em . acesso em 04 ago. 2020. Epub 03 de julho de 2017.

PEDROSO, Clarissa Niederauer Leote da Silva; LOPEZ, Laura Cecilia. À margem da humanização? Experiências de parto de usuárias de uma maternidade pública de Porto Alegre-RS. Physis [online]. 2017, vol.27, n.4, pp.1163-1184. ISSN 1809-4481. Disponível em: . Acessado em: 4 agosto 2020.

ZANARDO, Gabriela Lemos de Pinho et al. Violência obstétrica no Brasil: Uma visão Narrativa. Psicol. Soc., Belo Horizonte, v. 29, e155043, 2017. Disponível em. Acessos em 04 ago. 2020. 


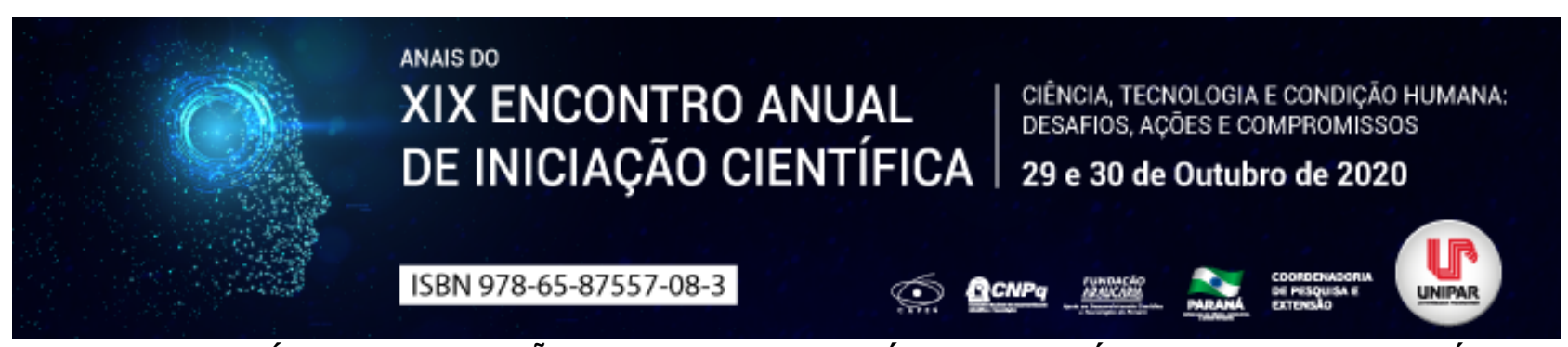

NATUREZA JURÍDICA DA RELAÇÃO ENTRE O SISTEMA ÚNICO DE SAÚDE (SUS) E SEUS USUÁRIOS

\author{
${ }^{1}$ NATHALIA ZUMAS DE ABREU SILVA, ${ }^{2}$ PAULO CESAR DE SOUSA
}

${ }^{1}$ Acadêmica do curso de Direito da UNIPAR

${ }^{1}$ Docente da UNIPAR

Introdução: Há divergência jurisprudencial a respeito da natureza jurídica da relação entre o SUS e os usuários de seus serviços: uns que a consideram consumerista; outros, meramente administrativa.

Objetivo: Explanar sobre a controvérsia a respeito da natureza jurídica da relação entre o SUS e seus usuários.

Desenvolvimento: A saúde, como um serviço público, é prestada pelo Estado por meio do SUS, um sistema de saúde pública que oferece acesso universal e gratuito a toda a população do país. Essa gratuidade para o usuário não significa gratuidade para o Estado, que custeia a prestação de serviços com tributos arrecadados pela administração. Diante dessa situação, surge um questionamento sobre a natureza jurídica de tal relação: se ela será regida pelo Código de Defesa do Consumidor (CDC) ou se trata de relação puramente administrativa. Mediante pesquisa jurisprudencial, constata-se uma contraposição entre os julgados. Uma corrente entende ser a relação entre o SUS e seus usuários consumerista, seguindo o norte de que o pagamento das despesas efetuado pelo Estado por meio de tributos configura remuneração indireta, o que faz com que ela fique sujeita ao CDC. Como exemplo, tem-se que, na fundamentação de uma recente decisão interlocutória em trâmite perante a Comarca de Icaraíma, Estado do Paraná, foi averbado que o art. $3^{\circ}$ do CDC define o serviço como qualquer atividade de consumo mediante remuneração, a qual não precisa vir, necessariamente, do bolso do usuário. [...] exatamente o que ocorre com o serviço prestado pelos hospitais através SUS, que de forma alguma prestam um serviço gratuito, mas remunerado por um órgão que repassa a eles recursos públicos (BRASIL, 2020b). Assim, o usuário poderia se valer do arcabouço de prerrogativas decorrentes do CDC. Entretanto, há outro posicionamento jurisprudencial que defende que essa relação é meramente administrativa. A $3^{a}$ Câmara Cível do Tribunal de Justiça do Estado do Paraná entende que: Em caso de serviço público custeado por meio de receitas tributárias, não se caracteriza uma relação de consumo e não se aplicam as regras do Código de Defesa do Consumidor (BRASIL, 2016). Não obstante, entendimento mais recente do STJ adota o posicionamento de que o CDC não incide nos casos de serviço fornecido pelo SUS. Quando ocorre falta de serviço em decorrência do atendimento prestado pelo SUS, não há que se falar em aplicação de regras da legislação de consumo (BRASIL, 2020a). É, sob esse prisma, de cunho meramente administrativo a relação entre o SUS e seus usuários.

Conclusão: Mesmo que os tribunais pátrios divirjam sobre a natureza da relação entre o SUS e seus usuários, o posicionamento majoritário a define como puramente administrativa. Consonante com o argumento de que essa relação não preenche os requisitos configuradores de uma relação consumerista, posto que o serviço em questão é custeado por meio de tributos e não de forma direta pelo usuário. À vista disso, conforme análise jurisprudencial realizada, restou demonstrado que o entendimento predominante é de que inexiste relação de consumo entre o SUS e seus usuários. Sendo incabível, assim, a aplicação do CDC.

\title{
Referências
}

BRASIL. Superior Tribunal de Justiça. REsp: 1406982 MG 2013/0328992-9. Relator: Ministro Antonio Carlos Ferreira. DJ 21/05/2020. Disponível em: encurtador.com.br/oAl09. Acesso em: 24 jul. 2020.

BRASIL. Tribunal de Justiça do Paraná. 3a Câmara Cível. Al - 1437572-7. Relatora: Denise Hammerschmidt. DJ: 01/03/2016. Disponível em: encurtador.com.br/svH89. Acesso em: 10 jun. 2020.

BRASIL. Vara Cível de Icaraíma. Processo: 0001334-42.2018.8.16.0091. Relatora: Lívia Simonin Scantamburlo. DJ: 07/06/2020. Disponível em: encurtador.com.br/xGPQS. Acesso em: 10 jun. 2020. 


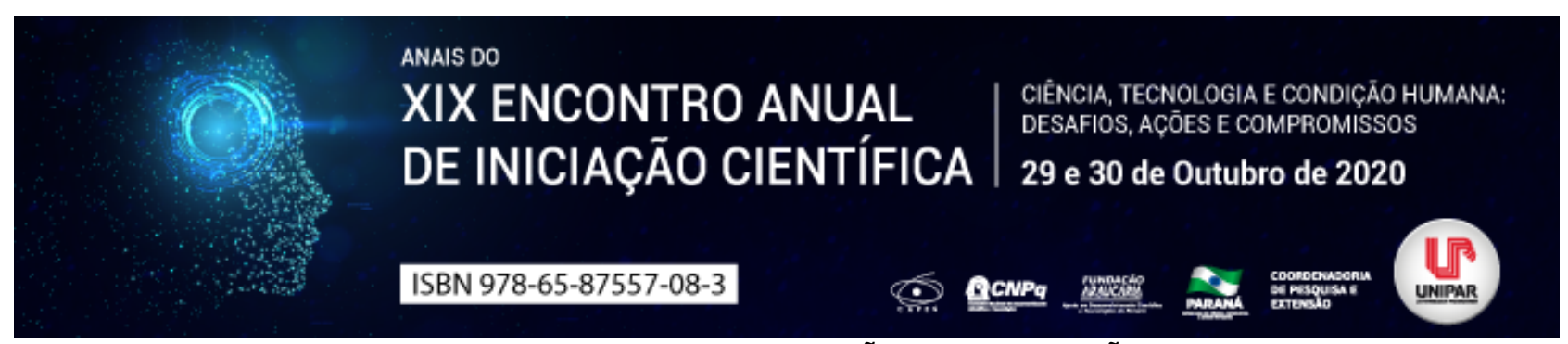

OS AVANÇOS DA GAMIFICAÇÃO NA EDUCAÇÃO

\begin{abstract}
${ }^{1}$ ANDRESSA CAROLINE SANTOS DE SOUZA, ${ }^{2}$ BEATRIZ MEDEIROS BAZANA, ${ }^{3}$ MARIA DO CARMO DE O NOGUEIRA, ${ }^{4}$ VIVIANNE AUGUSTA PIRES, ${ }^{5}$ ANA CAROLINA MOLINA PETINATI, ${ }^{6}$ LUCYELENA AMARAL PICELLI
\end{abstract}

\author{
${ }^{1}$ Acadêmica do Curso de Pedagogia da UNIPAR- PIC \\ ${ }^{1}$ Acadêmica do Curso de Pedagogia da UNIPAR - PIC \\ ${ }^{2}$ Docente da UNIPAR \\ ${ }^{3}$ Docente da UNIPAR \\ ${ }^{4}$ Acadêmica do Curso de Pedagogia da UNIPAR - PIC \\ ${ }^{5}$ Docente da UNIPAR
}

Introdução: A gamificação vem se expandindo e ganhando espaço na sociedade, seu potencial na educação se torna imenso de forma a despertar o interesse e a participação. Os avanços por meio desta tecnologia surgem e se instalam a cada dia mais na educação, possibilitando grande progresso no processo de ensino aprendizagem em meio a era digital do século XXI. Nos últimos anos, a quantidade de pesquisas sobre gamificação em ambientes de aprendizagem tem merecido destaque, o que consolida a gamificação como um fenômeno emergente (SILVA et al., 2019, p. 1).

Objetivo: Mostrar os avanços significativos obtidos com a gamificação no âmbito escolar.

Desenvolvimento: Buscando o significado de gamificação encontramos Fadel et al. (2014) que explica que o termo compreende a aplicação de jogos em atividades de não jogos . A palavra gamificação passou a ser utilizada em 2010, porém já é aplicada há um bom tempo, como por exemplo, na educação quando o trabalho da criança é recompensado com uma estrelinha . Para compreender os avanços da gamificação é preciso enxergar a tendência da sociedade contemporânea, está cada vez mais interessada por jogos. Vasconcellos (2016) complementa que tal prática tem conquistado a área educacional e vem sendo introduzida até em aplicativos e livros, o autor ressalta que a Gamification é uma constatação sobre como os seres humanos sentem-se atraídos por jogos. Sejam eles eletrônicos ou analógicos, a verdade é que a humanidade sempre teve grande engajamento para apreciar e participar de jogos (VASCONCELLOS, 2016, p.2). Desta forma a gamificação potencializa o envolvimento do indivíduo baseando-se em sistema de recompensa. Segundo Molinari (2019) a gamificação está dentro do conjunto para superar o desinteresse dos alunos pela escola que assim como a BNCC (Base Nacional Comum Curricular), busca formas de superar os métodos tradicionais de ensino, engajando e motivando os alunos nas atividades educacionais. A gamificação tende a mostrar para a escola que ela vai além de um entretenimento, no qual o uso de atividades gamificadas, favorece e envolve os jovens em atividades escolares vistas como monótonas. Os avanços da gamificação vêm para promover uma aprendizagem proativa e significativa ajudando a definir metas que possam ajudar o aluno no autoconhecimento e autonomia. Em concordância com Prensky (2001) apud Souza e Paulo (2018 p. 11), no começo do século XXI, encontra-se uma grande maioria dos adultos, incluindo os professores, sendo batizados de Imigrantes Digitais, pois apresentam algumas características em comuns, pensando e concebendo a educação e o processo educativo como forma analógica, tais profissionais ainda não compreenderam as novas demandas que emergem para aqueles que ensinam na contemporaneidade Por sua vez Carolei apud Garofalo (2019) afirma que o professor deve criar bons desafios, coerentes com as competências que se espera desenvolver no aluno, quanto mais ações e reflexões os desafios demandarem, mais significativo será o aprendizado , aplicando assim, jogos que tornem o aprendizado mais dinâmico e divertido, direcionado para atingir o objetivo da aula. Outro progresso que podemos citar e de acordo com Garofalo (2019), é a reestruturação das metodologias utilizadas pelos professores. Ela exemplifica um planejamento de um jogo para sala de aula, utilizado constantemente pelos profissionais da área, onde define-se o objetivo da aula, com divisão de grupos, para trabalhar de forma colaborativa e assim desenvolvendo habilidades e competência crítica, cognitiva, integrando as áreas do conhecimento. Designa-se personagem para cada aluno com missões a cumprir, cria-se um roteiro atrelado ao objetivo. E por fim é encerrado com a dinâmica denominada de tempestade cerebral. De acordo com Doyle (2019), muitos exemplos de gamificação na educação, foram inspirados em empresas renomadas que a utilizam para motivar a equipe gerando um maior engajamento entre eles.

Conclusão: Pode-se concluir que houve avanços da gamificação na educação, pois é possível perceber que, por volta do começo do século XXI, a gamificação era uma novidade, e ao longo do tempo os professores tiveram que se adaptar às novas tecnologias e novas metodologias, pois com a evolução veio a inovação da tecnologia e as metodologias tiveram que mudar para melhor atender e atingir os objetivos propostos. Assim a gamificação foi ganhando espaço na sala de aula, e hoje é uma metodologia muito utilizada, pois traz muitos resultados satisfatórios. Trazendo jogos e brincadeiras para sala de aula, o professor consegue prender a atenção do aluno, que muitas vezes acaba não aprendendo o conteúdo por achar chato ou 
desinteressante em aulas normais . Quando esse conteúdo é adaptado para gamificação, esse aluno se envolve e sua atenção é presa pelo jogo, assim, ele aprende e se diverte, promovendo uma aprendizagem proativa e significativa, ajudando a definir metas que possam ajudar o aluno no autoconhecimento e autonomia.

\section{Referências}

DOYLE, Daniella. Exemplos de gamificação nas empresas: confira 7 para se inspirar. Disponível em: https://www.siteware.com.br/gestao-de-equipe/exemplos-gamificacao-empresas/. Acesso em: 19 ago. 2020.

FADEL, Luciane Maria; ULBRICHT, Vania Ribas; BATISTA, Claudia Regina; VANZIN, Tarcisio. Gamificação na educação. São Paulo: Pimenta Cultural, 2014. Disponível em: Acesso em 7 ago. 2020.

GAROFALO, Débora. Dicas e exemplos para levar a gamificação para a sala de aula. 2019. Disponível em: https://novaescola.org.br/conteudo/15426/dicas-e-exemplos-para-levar-a-gamificacao-para-a-sala-de-aula. Acesso em 12 ago. 2020.

MOLINARI, Davi. Gamificação na sala de aula: jogar para aprender. São Paulo: Revista Educação, 2019. Disponível em: https://revistaeducacao.com.br/2019/07/01/gamificacao-na-sala-de-aula/. Acesso em 8 ago. 2020.

SILVA, João Batista da; SALES, Gilvandenys Leite; CASTRO, Juscileide Braga de. Gamificação como estratégia de aprendizagem ativa no ensino de física. Ceará: Revista Brasileira de ensino de Física, 2019. Disponível em: http://dx.doi.org/10.1590/1806-9126-RBEF-2018-0309. Acesso em 8 jul. 2020.

SOUZA, Flávio Marcelo Gabriel de; PAULO, Jacks Richard de. Gamificação na educação: Aproximações, estratégias e potencialidades. Vol. 39 ( No 40), Revista Espacios Ano 2018. Pág. $11 . \quad$ Disponível em: http://www.revistaespacios.com/a18v39n40/a18v39n40p11.pdf. Acesso em 13 ago. 2020.

VASCONCELLOS, Paulo. O que é gamificação? Conheça a ciência que traz os jogos para o cotidiano. São Paulo: TechTudo, 2016. Disponível em: https://www.techtudo.com.br/noticias/noticia/2016/07/o-que-e-gamificacao-conheca-ciencia-que-traz-osjogos-para-o-cotidiano.html. Acesso em 8 jul. 2020.

Coordenadoria de Pesquisa e Extensão - COPEX

Departamento de Editoraçāo e Divulgaçāo Científica - DEDIC 


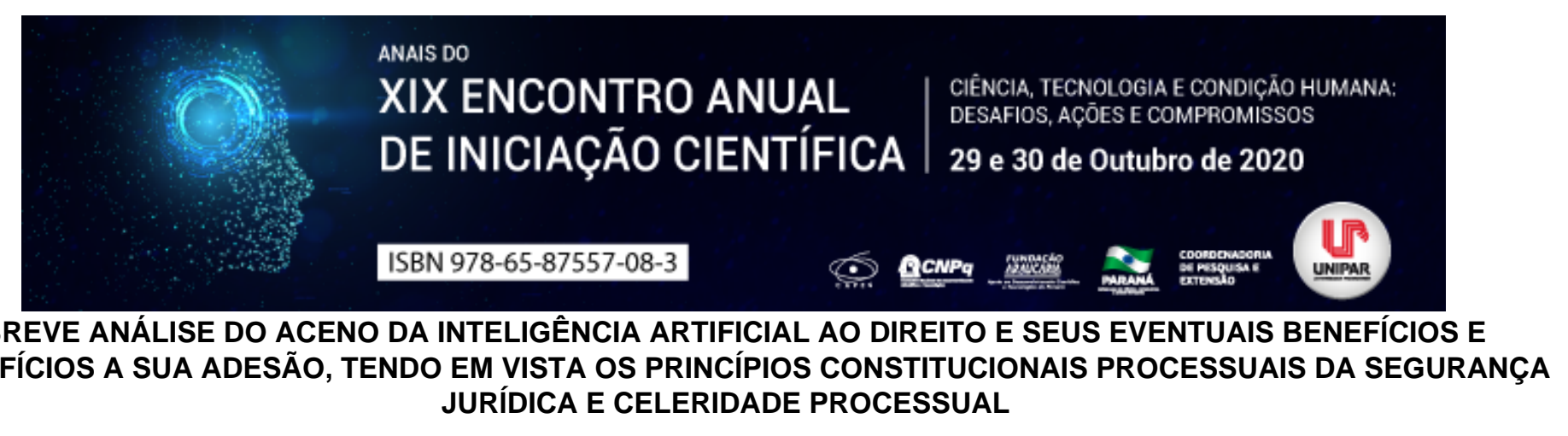

${ }^{1}$ SANATIEL HIPOLITO DOS SANTOS JUNIOR, ${ }^{2}$ ANGELICA GIOSA CANDIDO

${ }^{1}$ Acadêmico PIC/UNIPAR
${ }^{1}$ Docente da UNIPAR

Introdução: O avanço tecnológico já se tornou algo típico da sociedade contemporânea. A inteligência artificial ainda é uma tecnologia em desenvolvimento, mas seus avanços são notáveis. Contudo, tal tecnologia suscita uma série de discussões econômicas, sociais e éticas, que se desenrolam também em um ponto embrionário, e vem ganhando destaque quanto sua aplicação na área jurídica, até certo ponto de grande valia, mas ao mesmo tempo, suscitando um debate profundo acerca de garantias fundamentais e praticidades administrativas, bem como, econômicas.

Objetivo: Analisar a incidência da inteligência artificial no ambiente jurídico sob o enfoque dos princípios constitucionais processuais da segurança jurídica e celeridade processual.

Desenvolvimento: A inteligência artificial, assim como as demais tecnologias, procuram tornar a vida dos seres humanos cada vez mais cômoda, de forma a executar certas atividade cotidianas de forma mais célere e eficiente. Por mais que exista seu lado positivo é válido ressaltar que tais aparatos, em especial a Inteligência Artificial, suscita um forte debate sobre os seus inevitáveis efeitos, nos mais diversos ramos sociais. Ressalte-se, assim como sua evolução deu um salto em curto período, a mesma continua em expansão cada vez mais acelerada. Portanto como a mesma vem ocasionando uma série de mudanças em diversas camadas socias, no direito não seria exceção, tendo em vista o aumento dos litigios nos ultimos anos que acabam sobrecarregando o poder judicário, sendo assim tais ferramentas poderão ser inseridas cada vez mais fundo no cotidiano prático jurídico em função da sua capacidade operacional e de processamento e com isso os ganhos seriam gigantes com a adesão de tal assistente, atendendo inclusive o princípio da celeridade processual que assim como leciona Theodoro Junior (2019, p. 56) como um requisito fundamental para o acesso a justiça preocupar-se com a perseguição da solução de mérito é indispensável que ela seja quanto antes alcançada, evitando-se procrastinações incompatíveis com a garantia de pleno acesso à Justiça prometida pela Constituição. , já que assim como demonstram os relatórios do Conselho Nacional de Justiça (2019, p. 79) no ano de 2018 se encontravam em tramitação cerca de 78,7 milhões de processos, números sobre os quais não se pode esperar um atendimento célere para todos os casos, em virtude da limitação operacional que sofre o judiciário. No entanto, com a inteligência artificial operando a favor, ter-se-ia um ganho a médio prazo gigantesco em capacidade, pois a capacidade de análise de padrões e semelhanças de IA supera a humana, propiciando uma celeridade maior para fundamentação de julgados e, até mesmo, garantindo maior estabilidade nas decisões judiciais, que, em virtude do seu vasto campo decisório, limita a análise dos operadores do direito. Desse modo, tais benefícios acarretaria em uma maior celeridade processual e, de quebra, maior segurança jurídica, assim como como ensina Tavares (2009, p. 728) a segurança Jurídica repousa em três bases , a) a necessidade de certeza, de conhecimento do Direito vigente e de acesso ao conteúdo desse Direito; b) a possibilidade de conhecer, de antemão, as consequências pelas atividades e pelos atos adotados; e c) a estabilidade da ordem jurídica. A estabilidade mínima da ordem jurídica consiste em cláusulas pétreas, decorrente da dificuldade de alteração das normas constitucionais; e em limitações materiais impostas ao legislador e às demais fontes do Direito , conforme fica claro no projeto Victor, desenvolvido pelo Supremo Tribunal Federal, em parceria com uma equipe multidisciplinar da Universidade Nacional de Brasília, que visa filtrar causas de repercussão geral para julgamento. Logo de início já se mostrou muito eficiente como demonstra e alinhado aos seus objetivos, conforme assinala Mamede Said e Tainá Aguiar em seu estudo de caso Como assinalado, o projeto tem por objeto a aplicação de métodos de aprendizado computacional de máquina com o objetivo de usar seus potenciais no reconhecimento de padrões nos processos jurídicos relativos a julgamentos de repercussão geral do STF (2018, p. 225). Porém, apesar de tais benefícios, há de se observar os riscos de tal aplicação, que por mais eficiente que seja, dependerá de dados adicionados por humanos para que desenvolva-se, e isso trás um risco que seriam os vieses cognitivos padronizados em sua análise; Já existem alguns experimentos dos quais se pode retirar lições sobre o uso de tal ferramenta, principalmente quanto aos seus vieses. A título de exemplo se destaca uma matéria da revista Veja (2016, Exposto à internet, robô da Microsoft vira racista em $1 \mathrm{dia}$ ), a qual demonstra um projeto elaborado pela empresa Microsoft, que lançou uma IA para interação social por meio do Twitter, com o objetivo de que com essa interação, a mesma fosse desenvolvendo-se e ficando mais perspicaz na interação com seres humanos. Contudo, o resultado em menos de um dia foi um robô que desenvolveu características racistas, este é apenas um exemplo raso de como vieses absorvidos por essas tecnologias podem ser perigosos. Dessa forma, a inteligência artificial tem um potencial gigantesco para beneficiar procedimentalmente o judiciário, mas é 
importante a cautela, porque muitos fatores devem ser levados em consideração, principalmente para atividades de alta complexidade, que se mal observados podem acarretar em um atentado à segurança jurídica.

Conclusão: Portanto percebe-se uma grande mudança na estrutura judiciária com a integração da inteligência artificial. Como toda mudança, também são grandes os seus desafios, que devem ser debatidos de forma que não venham a atropelar princípios constitucionais que dão norte ao ordenamento jurídico na tutela dos direitos fundamentais, em destaque, a segurança jurídica e a celeridade processual.

\section{Referências}

Exposto à internet, robô da Microsoft vira racista em 1 dia. Veja. 2016. Disponivél em: https://veja.abril.com.br/tecnologia/exposto-a-internet-robo-da-microsoft-vira-racista-em-1-dia/. Acesso em 01 de julho de 2020.

Filho, M. S. M.; Junquilho, T. A. Projeto Victor: perspectiva de aplicação da inteligência artificial ao direito. Revista de Direitos e Garantias Fundamentais, Vitória, v. 19, n. 3, p. 219-238, set./dez. 2018. Disponivél em: Acesso em: 01 de julho de 2020.

CONSELHO NACIONAL DE JUSTIÇA. Relatório Justiça em Números 2019: ano-base 2018/Conselho Nacional de Justiça Brasília: CNJ, 2019. Disponível em: . Acesso em: 01 julho. 2020.

TAVARES, André Ramos. Curso de Direito Constitucional. 7. ed. São Paulo: Saraiva, 2009. p. $728-733$.

THEODORO JÚNIOR, Humberto. Curso de Direito Processual Civil. Vol. I. 60. ed. Rio de Janeiro: Forense, 2019. 


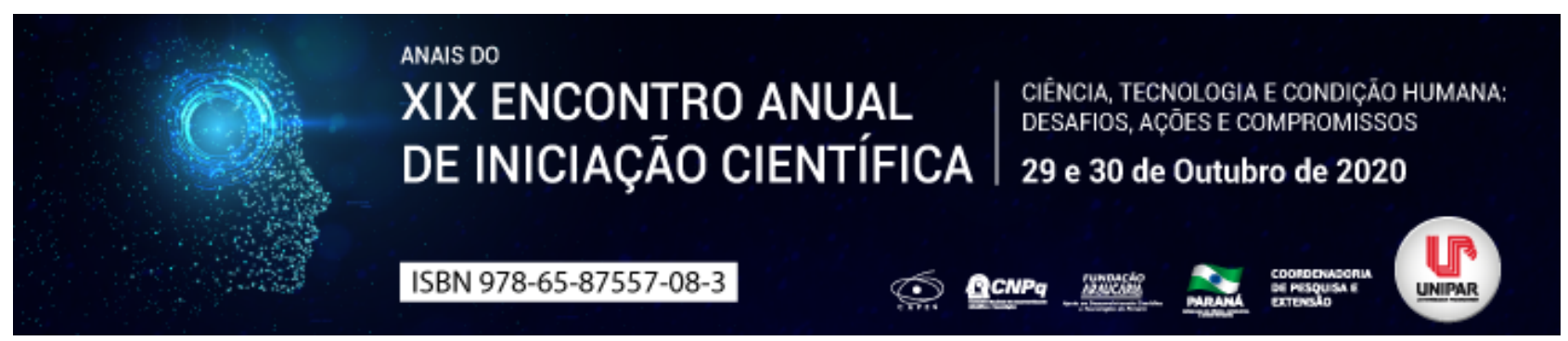

AS GRANDES FORTUNAS EM FACE DO PROJETO DE LEI COMPLEMENTAR 183/19

\author{
${ }^{1}$ MATEUS PADOVANI RAFAEL, ${ }^{2}$ JULIANA MOIRINHO DA SILVA, ${ }^{3}$ MARIA EDUARDA MARGATTO, ${ }^{4}$ MARTHA DE OLIVEIRA \\ SATO
}

${ }^{1}$ Acadêmico do Curso de Direito da UNIPAR

${ }^{1}$ Acadêmica do Curso de Direito da UNIPAR

${ }^{2}$ Acadêmica do Curso de Direito da UNIPAR

${ }^{3}$ Docente da UNIPAR

Introdução: A tributação sobre grandes fortunas está presente no artigo 153, inciso VII da Constituição Federal do Brasil. No entanto, ainda continua inconcluso a instituição de uma regulamentação especifica para esse tributo. Neste contexto surge a proposta de Lei Complementar 183/19, que visa inicialmente a tributação sobre grandes fortunas no Brasil.

Objetivo: Analisar o projeto de Lei Complementar 183/19 e sua incidência na economia brasileira.

Desenvolvimento: A tributação de grandes fortunas é um imposto federal, de competência exclusiva da União para sua instituição e aplicação. O projeto de lei complementar 183/19 traz a regulamentação sobre grandes fortunas no Brasil, tendo como objetivo utilizar os tributos na [...] tentativa de amenizar a grave desigualdade econômico-social que assola o país. [...] (BRASIL, 2019, p.1). Sugere-se no projeto de lei a tributação para fortunas acima de 12.000 (doze mil) vezes o limite mensal de isenção para pessoa física. Visto isso, operadores do direito apontam que poderia, a médio e longo prazo, funcionar como aparato para arrostar a onda de discussões diante do quadro de déficit de arrecadação do Estado e crescimento da desigualdade econômica e social no Brasil (MACEDO, p. 8). Em contrapartida, o projeto de lei 183/19 não teria o alcance desejado para a distribuição em politicas sociais, pois [...] a parcela da população atingida pelo imposto é muito pequena, de forma que a distribuição da carga tributária entre ricos e pobres, após sua instituição, permaneceria praticamente inalterada. (TAMS, 2018, p. 47). Outro questionamento certamente seria o fato de O Brasil já possui uma carga tributária extremamente elevada para um país que oferece muitas vezes pouco à população. O IGF, neste caso, poderia funcionar como mais um repelente de recursos, e por consequência investimentos, e maior desaquecimento econômico no país. (MACEDO, 2019, p. 62), bem como a evasão fiscal, por meio da não declaração de bens ou da declaração de valores inferiores aos reais passará a ser constante.

Conclusão: Pela análise do projeto citado, percebe-se a necessidade de rigorosa análise, tendo em vista que no Brasil a carga tributária já é extremamente alta. Assim sendo, é necessário cautela e estudos mais aprofundados acerca do assunto, pois poderia ser um obstáculo às empresas que visam empreender em nosso país.

\title{
Referências
}

BRASIL. Projeto de Lei Complementar n 183, de 2019. Diário Oficial [da] República Federativa do Brasil, Poder Executivo, Brasília 2019; 198o da Independência e 131ํㅡ da República. Brasília DF: Imprensa Nacional, 2020.

MACEDO, João Victor Pires. IGF A Tributação sobre Grandes Fortunas, sua Função Social e os Problemas de sua Implantação. Rio de. Janeiro, 2019; Trabalho de Conclusão de Curso; (Graduação em Direito) Pontifícia Universidade Católica do Rio de Janeiro, 2019.

TAMS, Rafael Argenta. Desigualdade e tributação sobre a riqueza: a (não) instituição do Imposto sobre Grandes Fortunas no Brasil; 2018; Dissertação (Mestrado em Economia) - Universidade Federal do Rio Grande do Sul, 2018. 


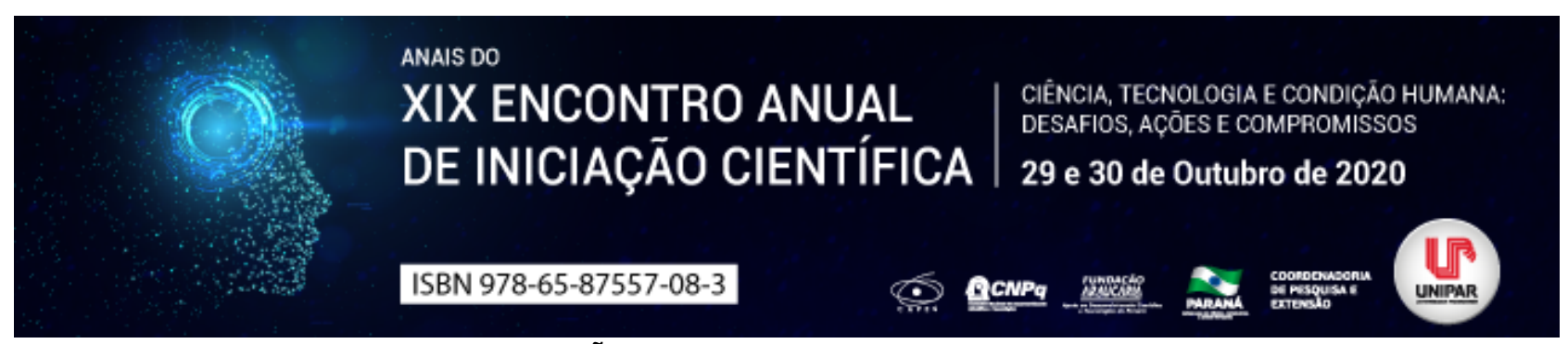

A NOÇÃO DE EMPATIA PARA SARTRE

\author{
${ }^{1}$ Beatriz Dutra Rosa, ${ }^{2}$ SYLVIA MARA PIRES DE FREITAS
}

\author{
${ }^{1}$ Acadêmica do curso de Psicologia, Projeto de Iniciação Científica, Universidade Estadual de Maringá \\ ${ }^{1}$ Docente do curso de Psicologia, Universidade Estadual de Maringá
}

Introdução: Este trabalho apresenta um recorte da Pesquisa de Iniciação Científica (PIC/UEM), realizada no período de maio de 2019 a abril de 2020, intitulada Reflexões acerca do outrar : o conceito de empatia para Husserl, Sartre e Rogers. Será abordado, então, a noção de empatia para Sartre. Para tanto, o percurso percorrido foi compreender as noções de Eu, Outro e Intersubjetividade para Sartre, necessárias para o entendimento do conceito chave da pesquisa: a empatia.

Objetivo: Compreender a noção da empatia para o filósofo existencialista Jean-Paul Sartre.

Material e Métodos: A referida pesquisa, de cunho teórico-conceitual, compreendeu leituras e fichamentos de produções do filósofo Jean-Paul Sartre, de seus antecessores e interlocutores, procedida da análise que estrutura a concepção de empatia aqui elucidada.

Resultados e discussão: É necessário partir da noção de consciência intencional desenvolvida por Edmund Husserl, para esclarecer o ponto de partida epistemológico de Sartre na fenomenologia. Revisita-se também a influência hegeliana no pensamento de Sartre, considerando que a noção de dialética foi fundamental para que desenvolvesse sua filosofia da existência. No livro A Transcendência do Ego, publicado em 1937, identifica-se os pontos que Sartre se contrapõe à fenomenologia husserliana para criar sua própria teoria. Um desses pontos discrepantes entre Husserl e Sartre é a concepção do Eu, ou então, do Ego, bem como a estrutura da consciência intencional. Apesar de manter o caráter relacional da consciência husserliana, (sendo sempre uma consciência de algo), para Sartre (2010), a consciência é pura liberdade, considerando que é o nada que permite o Ser se constituir enquanto uma totalização em curso. Nesta obra, Sartre (2010) também elucida que os estados e as qualidades do Eu (o $\mathrm{mim} / \mathrm{moi}$ ) são acessíveis ao outro; contudo, não há identificação entre mim e o outro no sentido dado ao meu Eu. Em O Ser e o Nada, Sartre (2004) retoma a relação ontológica entre Eu/Outro, considerando essa relação intersubjetiva como violenta, pois, para ele, o olhar do Outro seria sempre um olhar objetificante, tornando o Eu-sujeito em um Eu-objeto. Por conseguinte, é por esse olhar de Medusa que ocorre a vergonha e a angústia em quem se sente visto. Ainda que, para Sartre (2004), o outro é o mediador indispensável entre mim e mim mesmo (p. 290), ou seja, o outro é imperativo para a minha constituição como sujeito e meu autoconhecimento, seu olhar é reificante do meu ser. Contudo, Sartre, ao pontuar a diferença entre consciência (a que visa) e conhecimento (o visado), ele radica o conhecimento na vivência, e isso quer dizer que para conhecer o outro será necessário ter consciência de sua vivência conforme ele a comunica por suas ações. O outro é o que não sou, portanto, ele só pode ser compreendido como referência dele mesmo. Desta maneira, pode-se conhecer sua experiência vivida sem que incorra no erro de encaixa-lo em moldes que não o pertence, isto é, de reificá-lo. Portanto, é imperativo que se conheça como o outro aprende o mundo, como o visa e o significa, e para isso, a empatia será a atitude elementar. Na Crítica da Razão Dialética, publicada em 1960, Sartre (2002) ampliará sua compreensão de intersubjetividade, situando a subjetividade na história, logo na relação com o campo sociomaterial. Conforme Burstow (2000, p. 188), os escritos mais marxistas de Sartre abrem-se para muitas possibilidades. Propósitos comuns, projetos comuns e responsabilidade mútua ingressam no sistema . Essa possível fraternidade, conforme Sartre, ocorre devido a escassez, melhor dizendo, como não há no mundo recursos materiais suficientes para satisfazer as necessidades de todas as pessoas, e há mais impedimentos para supri-las individualmente, as pessoas necessitam agregar esforços para que, juntas, superem a escassez. Diante disto, modelos societais e relacionais são estruturados, considerando que o acesso aos recursos implica na relação com outros indivíduos. No entanto, Perdigão (1995) pontua que independentemente dessas relações virem a ser violentas (escravidão, exploração do trabalho etc.), elas se iniciam necessariamente com o reconhecimento da humanidade do outro.

Conclusão: Conforme Burstow (2000), Sartre discorre que a atitude empática é imprescindível para a compreensão do projeto de ser do outro. Compreensão que é possível realizar por meio do método fenomenológico e do progressivo-regressivo, tendo em conta ser uma maneira de compreender a singularidade na relação com o universal, tomando a própria pessoa como referência e acompanhamento seus movimentos dialéticos também pela lógica dialética. Desta forma, percebemos que os escritos posteriores de Sartre nos indicam que a atitude empática é indispensável não só para a compreensão da vivência do indivíduo, mas também para pautar a compreensão das relações dos indivíduos em grupos e coletivos.

\title{
Referências
}

BURSTOW, B. A filosofia Sartreana como fundamento da educação. Educação \& Sociedade. v. XXI, n. 70, 2000.

PERDIGÃO, P. Existência e Liberdade: Uma introdução à filosofia de Sartre. Porto Alegre: L\&PM, 1995. 
SARTRE, J. P. Crítica da razão dialética. Tradução de Guilherme João de Freitas Teixeira. Rio de Janeiro: DP\&A, 2002.

SARTRE, J. P. O ser e o nada. 15 ed. Tradução de Paulo Perdigão. Rio de Janeiro: Vozes, 2004.

SARTRE, J. P. A Transcendência do Ego. Cadernos Espinosianos XXII. Tradução de Alexandre de Oliveira Torres Carrasco, $p$. 183-228, 2010.

Coordenadoria de Pesquisa e Extensão - COPEX

Departamento de Editoraçāo e Divulgaçāo Científica - DEDIC 


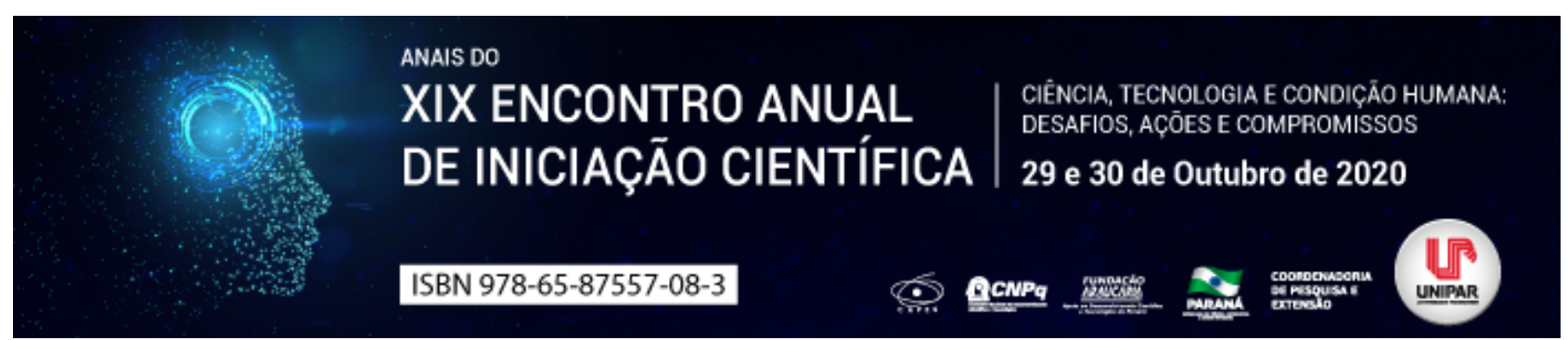

A APLICAÇÃO DA INTELIGÊNCIA ARTIFICIAL E A IMPARCIALIDADE NAS DECISÕES JUDICIAIS

\author{
${ }^{1}$ MARIA EDUARDA PEREIRA BORGES, ${ }^{2}$ ANGELICA GIOSA CANDIDO
}

\author{
${ }^{1}$ Acadêmica PIC/UNIPAR \\ ${ }^{1}$ Docente da UNIPAR
}

Introdução: A inteligência artificial é capaz de otimizar a interpretação e análise de textos em tempo real, potencializando o trabalho humano, reduzindo custos, bem como, cruzando informações com bases legadas e em diversos bancos de dados. Mas, seria esta capaz de julgar , decidir sobre a vida das pessoas em juízo?

Objetivo: Analisar a aplicação da inteligência artificial e seus impactos nas decisões proferidas pelo poder judiciário.

Desenvolvimento: Com o advento da Revolução Industrial, marco histórico no desenvolvimento tecnológico, o mundo modernizou-se, e a partir de então, vem possibilitando avanços nas mais diversas áreas. A ciência e a tecnologia estão presentes ao nosso redor, seja nos projetos de pesquisa de renome (como as pesquisas para a cura da COVID-19), seja nas mais singelas atividades do dia a dia, como o chat bout; automação inteligente; a função piloto automático ou até mesmo, plataformas de interação como o Siri. Na seara jurídica não é diferente. A tecnologia vem tomando seu espaço. Os processos passaram de físicos para eletrônicos, acessíveis em qualquer lugar mediante um sistema nuvem. A inteligência artificial cada vez mais presente, podendo auxiliar nas mais diversas tarefas, muitas vezes de forma benéfica. Mas qual o limite para delegar tarefas a uma máquina? A inteligência artificial é a possibilidade das máquinas executarem tarefas que são características da inteligência humana. Assim, os computadores, por intermédio de um software específico, exercem uma atividade cognitiva, ou seja, de contínuo aprendizado no sentido de coletar, processar, pesquisar, analisar semanticamente o conteúdo, compreendendo-o, e realizando tarefas a partir das informações obtidas nesse processo, como classificar e apresentar perspectivas de resultados práticos, ou sugestões de ação, e, mesmo, tomada de decisões. O Supremo Tribunal Federal (STF), por meio da Resolução n. ${ }^{\circ}$ 287, de 14 de abril de 2004, instituiu o processo eletrônico (e-STF) no Tribunal. No mesmo sentido, a Resolução n. ${ }^{\circ} 344$, de 25 de meio de 2007, regulamentou o meio eletrônico de tramitação de processos judiciais, comunicação de atos e transmissão de peças processuais. O mesmo se seguiu na justiça estadual, sendo que em março de 2010, o Conselho Nacional de Justiça assinou convênios de cooperação técnica para o desenvolvimento do novo sistema de Processo Judicial Eletrônico (PJe) com o CSJT, TST, TRTs de todo o país, CJF, TRF da $5^{a}$ Região e 16 Tribunais de Justiça, de modo a contemplar, além das necessidades da Justiça Federal, as peculiaridades da Justiça do Trabalho e da Justiça Comum Estadual. Ressalte-se, ainda, a utilização pelo Supremo Tribunal Federal, desde dezembro de 2017, em parceria com a UnB, do sistema Victor, ferramenta capaz de identificar temas de repercussão geral de maior incidência na Corte. Interpretar o Direito é uma tarefa que exige muito além que combinações e programações de sistemas, há um condão humanitário e assim a hermenêutica jurídica. O processo sociológico de interpretação das normas jurídica visaa aplicabilidade da lei ás relações sociais, de forma a ampliar seu sentido, objetivando alcançar as novas demandas não prognosticadas em sua criação e atender as necessidades atuais da sociedade (SOARES, 2019). Juízes que pertencem ao povo devem permanecer ao lado destes, (...). A atividade dos pretórios não se limita a ação racional, mas detém um viés pratico e humanizado, revelando a essência de sentimentos e a experiência da dura realidade da vida (MAXIMILIANO, 2017). Portanto, é fundamental ressaltar que a tecnologia e a ciência são áreas que podem sim atuar em prol da justiça, bem como auxiliar a tomada de decisões, bem como, proporcionar aos Magistrados e servidores atenderem ao grande número de demandas ao qual são submetidos diariamente para apreciação, assim como prega o princípio da duração razoável do processo, possibilitando as partes uma decisão segura, justa e em tempo hábil para atender as suas necessidades e seus direitos fundamentais. Ainda que a ciência da computação tenha evoluído de forma exponencial, a máquina não possui a capacidade de julgar. Há uma diferença entre escolher qual dispositivo legal aplicar e decidir qual a melhor solução para o litígio sob um aspecto subjetivo, mesmo que os processos judiciais sejam números , os pedidos e causas de pedir são diversificados, cada caso há uma história a ser apreciada, e a busca por um direito fundamental.

Conclusão: Desse modo, a inteligência artificial deve ser um apoio às tomadas de decisões, para sua agilidade e precisão, mas sem qualquer atuação autônoma. Falar em inteligência artificial não significa falar em substituição da inteligência humana pela

inteligência da máquina , até porque, principalmente no ramo do direito, não existe apenas a análise objetiva das questões postas em litígio, valendo-se em muitos casos, o operador do direito, da análise da equidade do que apenas a observação da subsunção do fato à norma legal, podendo até ser afastada a aplicação de determinada lei em um determinado caso concreto.

\title{
Referências
}

BRASIL. STF. >. Acessado em 10 de agosto de 2020.

Processo Judicial Eletrônico e sua Implantação no Poder Judiciário Brasileiro. Acessado em 10 de agosto de 
CONJUR. >. Algorítimos e inteligência artificial exigem atenção do Direito. Acessado em 10 de agosto de 2020. MAXIMILIANO, Carlos. Hermenêutica e Aplicação do Direito. 21. ed. Editora Forense, 2017. >. Revolução Industrial. Acessado em 10 de agosto de 2020.

SOARES, Ricardo Maurício Freire. Hermenêutica e Interpretação Jurídica. 4. ed. Editora Saraiva. 2019.

Coordenadoria de Pesquisa e Extensão - COPEX

Departamento de Editoraçāo e Divulgaçāo Científica - DEDIC 


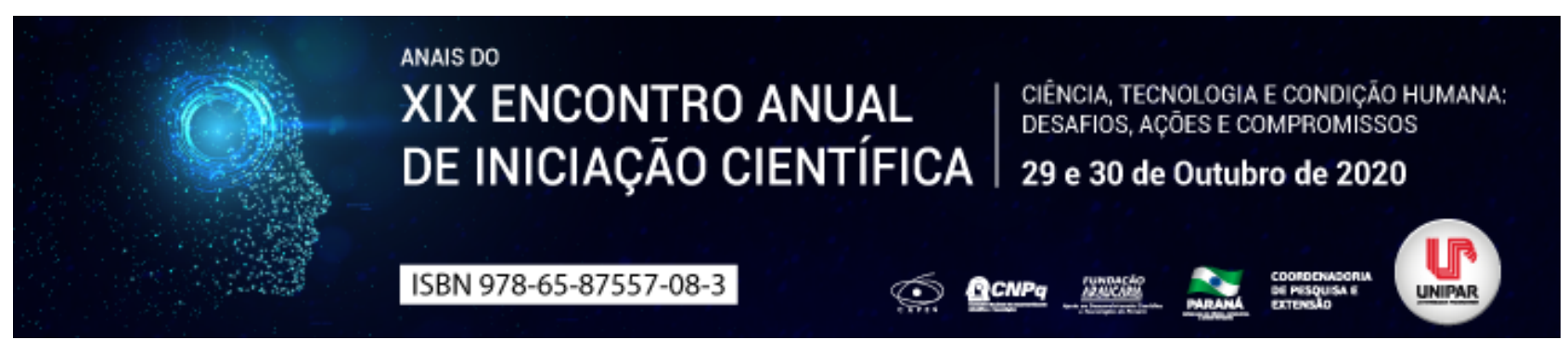

PRECISAR NÃO PRECISA - PERCEPÇÃO DO CONSUMIDOR SOBRE REUSO DE ROUPAS USADAS

\title{
${ }^{1}$ AMANDA MACHADO DALPASQUAL, ${ }^{2}$ JAQUELINE MARISANE BERTAO, ${ }^{3}$ MARCOS JOSE ALVES DE LIMA
}

\author{
${ }^{1}$ Acadêmica do Curso de Design de Moda, PIC/UNIPAR - Universidade Paranaense. \\ ${ }^{1}$ Acadêmica do Curso de Design de Moda, PIC/UNIPAR - Universidade Paranaense. \\ ${ }^{2}$ Docente do Núcleo de Design, Pesquisador - UNIPAR - Universidade Paranaense.
}

Introdução: A moda é um conceito que se materializa no vestuário e se reinventa com o passar do tempo como um reflexo do que acontece nesta ou naquela geração, para Miranda (2008), moda é o fenômeno que melhor demonstra a capacidade e necessidade de mudanças da sociedade, no comportamento de determinado grupo social e é refletida no processo de consumo de objetos de moda. Este processo de moda envolve historicamente continuidade de mudanças nos estilos de consumo, como diz Baudrillard (2005), todos se inserem no processo do consumo, produzindo relações que determinam novos perfis sociais e jeitos de pensar e de ser que visam, acima de tudo, a satisfação das necessidades. Uma perspectiva real e interessante considerando todos os novos e síncronos aspectos de uma geração plenamente conectada, cuja virtualização ressignificou muitas estruturas. Neste ambiente de constante mudança, até o consumo de moda foi impactado, contudo, paralelo a esta afoita dinâmica de consumo, um movimento de ideias mais consciente é introduzido por um público crescente. Com mais informações acessíveis aos consumidores, desperta-se uma consciência dos impactos de um produto, das práticas de um fornecedor, bem como, se permite redefinir a maneira de usar e de descartar o que não serve mais, como um comportamento fundamental.

Objetivo: Discutir práticas de consumo de moda e suas relações com do Design no contexto da sociedade de consumo.

Material e Métodos: Pesquisa quantitativa e qualitativa, de natureza exploratória. A coleta de dados ocorreu por meio de Formulário Digital, que apresentou os objetivos da Pesquisa, o Termo de Consentimento Livre e Esclarecido e Consentimento Pós-informado, sete questões sobre as entrevistadas, e treze sobre hábitos de consumo. O formulário foi respondido por 125 voluntárias, caracterizadas como amostra por conveniência.

Resultados: As treze questões sobre hábitos de consumo foram tratadas e apresentadas separadamente pelos participantes do grupo de pesquisa. A questão número dois trata sobre as roupas de segunda mão e roupas usadas, com três opções em respostas de sim ou não, 58 das entrevistadas (46,4\%) responderam que não usam, 67 (53,6\%) comprariam e usariam coisas de brechós, ou de serviços como o enjoei, um tipo de brechó virtual; 101 das entrevistadas $(80,8 \%)$ responderam que não e 24 $(19,2 \%)$ responderam que jamais comprariam ou usariam roupas usadas de desconhecidos; Quanto ao uso de peças de segunda mão, oriundas de familiares ou amigos próximos, 12 entrevistadas (9,6\%) responderam que não usariam e 113 (90,4\%) que sim. A questão número onze indaga sobre ter consciência dos impactos na hora de escolher o que comprar, de quem comprar e definir a maneira de usar e como descartar o que não serve mais, com opções de múltipla escolha a questão principal é como será feito o descarte ou destino das roupas que não usam mais, 1 única entrevistada $(0,8 \%)$ respondeu que joga no lixo comum e outra $(0,8 \%)$ que guarda, pois um dia poderia precisar; $53(42,4 \%)$ preferem separar e encaminhar para igrejas ou instituições de caridade e 70 das entrevistadas (56\%) separam e doam para familiares ou amigos próximos.

Discussão: A evolução na maneira de consumir discutida em outras questões dessa pesquisa aponta para um tempo onde, na percepção das entrevistadas, a aquisição de roupas eram mais difíceis, para toda uma geração a forma de comprar interferia diretamente na forma de descartar, contudo, o atual excesso de facilidades de consumo, variedade de estilo e preço, e crédito disponível (BARBOSA:2004, TOLOTTI:2007, HILL: 2003) condenou as roupas ao status de descartável. A principal iniciativa no sentido de reverter esse quadro é repensar o projeto do produto, e sobretudo, repensar o ciclo de vida da roupa, uma vez que é na posse do consumidor final que a vida pode ser prolongada e o descarte planejado e assistido, o que para esse grupo entrevistado já é uma realidade. Comprar peças que já foram usadas tem como premissa, o consumo consciente, gerando um desdobramentos no modelo de negócios de roupa usada, ressignificando o papel dos brechós, cujo atrativo principal é o preço acessível, resgate de peças com apelo estético diferenciado ou mesmo retrôs, por isso, esse tipo de loja - física ou virtual, ganham espaço e contribuem com a mensagem de sustentabilidade, além de retornar parte do dinheiro investido na roupa para quem está vendendo, ou, como em alguns brechós suas roupas usadas valem créditos para troca de produtos na própria loja. É válido mensurar que indiferente da forma que a roupa usada insere-se no processo de reuso - seja por meio de doação ou da aquisição da peça no brechó ou no bazar das igrejas - que a mesma deve passar por um processo criterioso de higienização, que é provavelmente o principal impedimento à adoção desta prática.

Conclusão: A evolução do consumo para consumismo nos obriga a repensar o papel de cada indivíduo, na construção da consciência e pensamento coletivo para a busca de alternativas de conservação do planeta. Parte das soluções como comprar menos, usar mais, reformar, doar e trocar estão ao alcance de todos. 


\section{Referências}

BARBOSA, Lívia. Sociedade de Consumo. Rio de Janeiro: Zahar, 2004.

BAUDRILLARD, Jean. A sociedade de consumo. Lisboa: Edições 70, 2005;

HILL, Sam. Sessenta tendências em sessenta minutos. Como desenvolver produtos aliando tendências e estratégia de marketing. São Paulo: Futura, 2003.

MIRANDA, Ana Paula de. Consumo de Moda: A Relação pessoa-objeto. São Paulo: Estação das Letras e Cores, 2008;

TOLOTTI, Márcia. As armadilhas do Consumo: Acabe com o endividamento. Rio de Janeiro: Elsevier, 2007.

Coordenadoria de Pesquisa e Extensão - COPEX

Departamento de Editoraçāo e Divulgaçāo Científica - DEDIC 


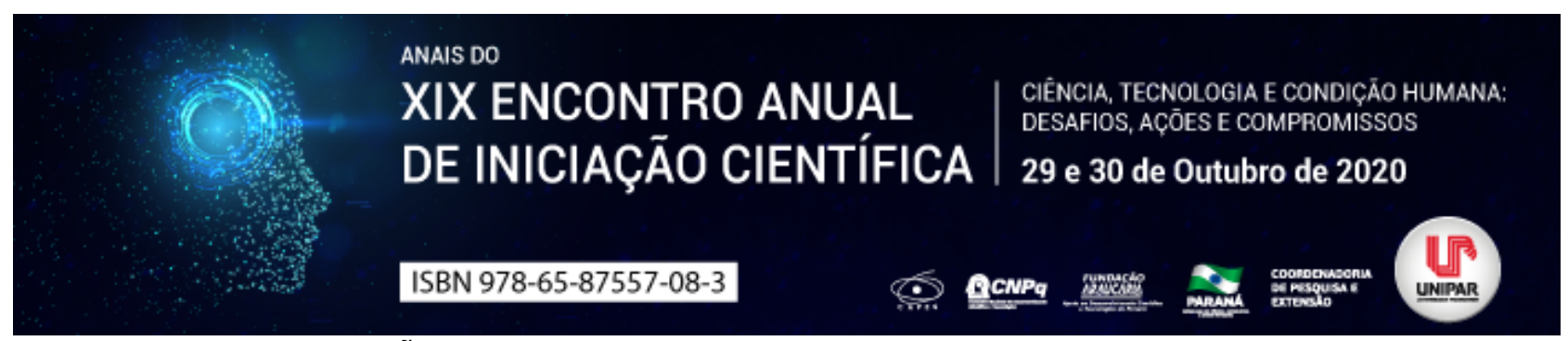

PRECISAR... NÃO PRECISA FATORES CONSIDERADOS NO ATO DA COMPRA

\section{JAQUELINE MARISANE BERTAO, ${ }^{2}$ AMANDA MACHADO DALPASQUAL, ${ }^{3}$ MARCOS JOSE ALVES DE LIMA}

${ }^{1} 1$ Acadêmica do Curso de Design de Moda, PIC/UNIPAR - Universidade Paranaense.

${ }^{1}$ Acadêmica do Curso de Design de Moda, PIC/UNIPAR - Universidade Paranaense

${ }^{2}$ Docente do Núcleo de Design, Pesquisador - UNIPAR - Universidade Paranaense.

Introdução: Consumir é uma prática essencial a qualquer ser vivo. Contudo, mesmo que o consumo é algo inseparável a existência, algumas sociedades sofisticaram muito esse ato. Com raríssimas exceções como a das formigas que estocam sua comida para o inverno, a maior parte dos seres vivos encontram-se no grupo que buscam diariamente o recurso para sobrevivência.A sociedade humana ao contrário, criou estruturas de compra, venda, sistema monetário, crédito, débito, poupança, hierarquias de poder baseadas nas posses, estratificação social, ou seja, elevou a um nível muito sofisticado o sistema de consumo. A área de interesse desse estudo: as relações ou hábitos de consumo de moda também se enquadram neste contexto onde a engenhosidade humana projetou um complexo e requintado sistema de diferenciação e identificação, entre outras coisas. Aquela necessidade primária de proteger o corpo das intempéries evoluiu para o vital desejo de existir socialmente e ter visibilidade.Conscientes do consumismo instalado na sociedade atual, que outros valores ou fatores são importantes ou influenciam o consumidor na hora na compra?

Objetivo: Discutir práticas de consumo de moda e suas relações com do Design no contexto da sociedade de consumo.

Material e Métodos: Pesquisa quantitativa e qualitativa, de natureza exploratória. A coleta de dados ocorreu por meio de Formulário Digital, que apresentou os objetivos da Pesquisa, o Termo de Consentimento Livre e Esclarecido e Consentimento Pós-informado, sete questões sobre as entrevistadas, e treze sobre hábitos de consumo. O formulário foi respondido por 125 voluntárias, caracterizadas como amostra por conveniência.

Resultados: As treze questões sobre hábitos de consumo foram tratadas e apresentadas separadamente pelos participantes do grupo de pesquisa, e neste resumo se apresentará o resultado da $12^{a}$ pergunta que inqueria, na percepção das entrevistadas Qual o fator mais importante que influencia na hora da sua compra de moda, com opções que melhor reflete seus hábitos ou preferências. Ao que se obteve o seguinte: 40 entrevistadas (32\%) responderam que o bom atendimento, quando os responsáveis/vendedores tem boa vontade e compreendem a necessidade ou desejo do cliente. 38 (30,4\%) indicaram que a qualidade dos produtos, produtos atrativos, matéria-prima de qualidade, certas especificações e taxa mínima de defeito são o principal diferencial na hora da compra. $28(22,4 \%)$ responderam que o fator preço, promoções e diferentes formas de pagamento é mais importante na hora da compra, porque muitas vezes o produto desejado é de um valor superior ao que teria no momento e gosto de pagar mais barato. $14(11,2 \%)$ a diversidade de produtos, cores e tamanhos que a loja apresenta, principalmente roupas para toda a família. Por fim, 5 delas (4\%) disseram ser influenciadas pelas redes sociais e por pessoas que podem ser consideradas formadoras e influenciadoras de opinião no âmbito da moda.

Discussão: Hábitos de consumo que muitas vezes tendem a progressão para o consumismo, em tempos de pandemia, isolamento social, comércio fechado, a preocupação com a manutenção da economia, em especial o varejo, figurou muitas discussões. Nesse período muitas ideias e iniciativas para manter as vendas foram tomadas o que remediou um pouco da situação. A pesquisa sobre os hábitos de consumo indicou que o atendimento personalizado ainda é um fator importante para o grupo entrevistado. Para Marques (1997) alguns requisitos básicos para um bom atendimento ao cliente são: conhecer bem suas funções; sua empresa e as normas e procedimentos; ouvir o cliente; falar, utilizando a linguagem adequada; perceber o cliente na sua totalidade. A personalização do atendimento baseada nesta observação apurada do cliente permite que o lojista diversifique sua forma de atender, dando atenção ao cliente que requer atenção, deixando o cliente independente servir-se no autoatendimento, porém, com toda equipe da loja disponível para promover o relacionamento do cliente com produto, o processo de venda propriamente dito. Segundo Deming (1990, p.26):Qualidade é um atributo de produtos, de serviços, mas pode se referir a tudo que é feito pelas pessoas. Quando se fala que alguma coisa foi feita com qualidade; entretanto não é fácil definir com presteza o que seja essa qualidade. Na qual indicada diretamente nas alternativas mais cotadas é também o anseio indireto, nas menos cotadas, relacionada com a política de preços, com a diversidade dos produtos e a influência de redes sociais no que tange ou parece um certificado de qualidade conferido por uma pessoa de confiança. E conforme explica Baudrillard (1995, pág. 47), a felicidade constitui a referência absoluta da sociedade de consumo, revelando-se como o equivalente autêntico da salvação , no ato de consumir os consumidores buscam realização, prazer, reconhecimento, ressignificando dentro um sistema pessoal a felicidade.

Conclusão: A pesquisa como um todo corrobora com a compreensão de como o grupo entrevistado consome e indica que apesar da modernidade desses tempos, do consumo, do consumismo, algumas receitas antigas como o bom atendimento e 
produtos de qualidade são ainda uma excelente garantia para manter os clientes comprando, mesmo que ele não esteja necessariamente precisando.

\section{Referências}

BAUDRILLARD, Jean. O sistema dos Objetos. São Paulo: Perspectiva, 1995.

DEMING, W. Edwards. Qualidade: A Revolução da Administração. Rio de Janeiro: Marques Saraiva, 1990.

MARQUES, Fábio. Guia prático da qualidade total em serviços. São Paulo: APMS, 1997.

Coordenadoria de Pesquisa e Extensão - COPEX

Departamento de Editoraçāo e Divulgaçāo Científica - DEDIC 


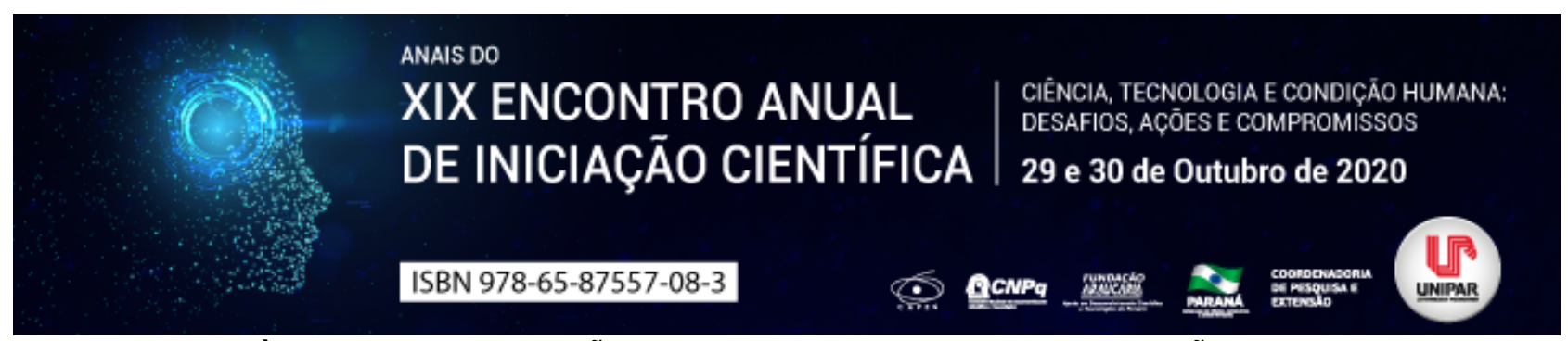

MP 954 E O DIREITO À AUTODETERMINAÇÃO INFORMACIONAL: STF E A PROTEÇÃO DE DADOS PESSOAIS EM TEMPOS DE CRISE

\author{
${ }^{1}$ RAISSA ARANTES TOBBIN, ${ }^{2}$ VALÉRIA SILVA GALDINO CARDIN
}

\author{
${ }^{1}$ Mestranda em Ciências Jurídicas pela Universidade CESUMAR; Graduada em Direito pela UNIPAR \\ ${ }^{1}$ Pós-Doutora em Direito pela Universidade de Lisboa; Doutora pela PUC/SP; Docente da UEM e do Mestrado em Ciências \\ Jurídicas do CESUMAR
}

Introdução: A hiperconectividade é uma das premissas da sociedade pós-moderna, que a cada dia mais baseia sua existência na vida virtual. Assim, surge a necessidade de proteção de dados pessoais do usuário, que teria o direito à autodeterminação informacional quanto ao compartilhamento de seus dados com autoridades e empresas privadas em tempos de crise, pauta objeto de recente decisão proferida pelo Supremo Tribunal Federal (STF), que declarou inconstitucional a Medida Provisória $\mathrm{n}^{\circ}$ 954, que previa o compartilhamento de dados de empresas de telefonia com o Instituto Brasileiro de Geografia e Estatística (IBGE), em 2020.

Objetivo: Analisar o direito à autodeterminação informacional diante da necessidade proteção dos dados pessoais em tempos de crise por meio do exame da declaração de inconstitucionalidade da MP 954 pelo Supremo Tribunal Federal.

Desenvolvimento: Tendo em vista o contexto hodierno de vida conectada, especialmente em tempos de necessidade de isolamento social em razão da COVID-19, a cidadania passa a ser constantemente exercida nos termos dos ditames digitais, de forma que diariamente o cidadão necessita estar conectado, identificar-se, preencher formulários e concordar com termos de uso de dispositivos e aplicativos on-line. No Brasil, em 2020, devido à alegada crise de saúde pública, a Medida Provisória (MP) 954 previa o compartilhamento de dados por empresas de telecomunicação prestadoras de serviço telefônico fixo comutado (STFC) e serviço móvel pessoal (SMP) com o Instituto Brasileiro de Geografia e Estatística (IBGE). A disponibilização deveria se dar por meio eletrônico e abranger a relação de nomes, números de telefone e endereço das pessoas físicas e jurídicas. Os dados seriam utilizados exclusivamente pelo IBGE, para fins de produção estatística oficial, com o objetivo de realizar entrevistas de caráter não presencial no âmbito de pesquisas domiciliares. (BRASIL, 2020). Apesar de a MP prever o descarte em no máximo 30 dias após o fim do estado de emergência, e proibir o IBGE de compartilhar esses dados com outros órgãos públicos ou empresas, foram apresentadas cinco ações diretas de inconstitucionalidade ao STF, questionando-a . (FINKELSTEIN; FEDERIGHI; CHOW, 2020, p. 21). A Ministra Rosa Weber, em decisão cautelar, em sede das ADIs 6.387, 6.390, 6.390 e 6.393, suspendeu os efeitos da MP 954, que posteriormente foi declarada inconstitucional pelo plenário do Supremo Tribunal Federal (STF). Em decisão histórica, dez dos onze ministros entenderam que havia na MP uma falta de explicação sobre finalidade de compartilhamento de dados de clientes entre empresas de telecomunicações e o IBGE durante o período da pandemia da COVID-19: segundo ela, a MP não definiu de forma clara como e para que seriam utilizados os dados em questão , de forma que a decisão observou justamente os efeitos causados por acontecimentos recentes no Brasil e no mundo, preocupando-se com a possibilidade de surgimento de um verdadeiro Estado de vigilância . (FINKELSTEIN; FEDERIGHI; CHOW, 2020, p. 22). Atualmente, cerca de 5,1 bilhão de pessoas (67\% da população mundial) usam algum tipo de aparelho de telefone celular (no Brasil 97\% utilizam) , de forma que o monitoramento e o controle de deslocamento de populações têm sido amplamente utilizados pelos países em tempos de COVID-19, tanto para a contenção do vírus quanto para os processos de retorno às atividades . (BAHIA; SUARDI, 2019 apud PALHARES et al., 2020, p. 184). É por isso que a utilização de dados fornecidos por aparelhos móveis de telecomunicação mostra-se tão atraente para o combate da pandemia . Todavia, são fundamentais métodos precisos de captação de dados, uma legislação adequada e transparência quanto ao controle destas informações para uma política pública adequada de gerenciamento de crises. (PALHARES et al., 2020). Conforme Palhares et al. (2020, p. 181) o direito à privacidade, demasiadamente valioso em contextos democráticos, precisa ser resguardado contra ingerências indevidas de pessoas físicas, jurídicas, de direito público e privado . (PALHARES et al., 2020, p. 181). Ainda, aos poucos se delineia o direito à autodeterminação informacional, que é um direito constitucional de personalidade que tem por objeto o poder do indivíduo sobre três aspectos : de decidir sobre a divulgação e o uso dos seus dados pessoais ; quando e dentro de quais limites esses dados podem ser revelados; e, por fim, de ter conhecimento sobre quem sabe e o que sabe sobre ele, além de quando e em que ocasião (FINKELSTEIN; FEDERIGHI; CHOW, 2020, p. 24), questionamentos essenciais diante da possibilidade de armazenamento e compartilhamento de informações no contexto virtual que podem ofender a dignidade e os direitos de personalidade do cidadão.

Conclusão: O controle de dados pessoais e o monitoramento remoto populacional pode ser uma arma para o controle de pandemias e outros momentos de crise, contudo, é necessário transparência quanto ao tratamento de dados, de forma que o indivíduo tenha seu direito à autodeterminação informativa respeitado contra ingerências estatais e de empresas privadas ligadas 


\section{Referências}

BRASIL. Medida Provisória no 954, de 17 de abril de 2020. Dispõe sobre o compartilhamento de dados por empresas de telecomunicações prestadoras de Serviço Telefônico Fixo Comutado e de Serviço Móvel Pessoal com a Fundação Instituto Brasileiro de Geografia e Estatística, para fins de suporte à produção estatística oficial durante a situação de emergência de saúde pública de importância internacional decorrente do coronavírus (covid-19), de que trata a Lei n 13.979 , de 6 de fevereiro de 2020. (Revogada). Diário Oficial da União, p. 1, 17 abr. 2020.

FINKELSTEIN, Carlos; FEDERIGHI, André Catta; CHOW, Beatriz Graziano. O uso de dados pessoais no combate à Covid-19: lições a partir da experiência internacional. Revista Brasileira de Inteligência Artificial e Direito RBIAD, v. 1, n. 1, 2020. Disponível em: https://rbiad.com.br/index.php/rbiad/article/view/7/5. Acesso em: 20 ago. 2020.

PALHARES, Gabriela Capobianco. A privacidade em tempos de pandemia e a escada de monitoramento e rastreio. Estudos Avançados, São Paulo, v. 34, n. 99, p. 175-190, maio/ago. 2020. Disponível em: https://www.scielo.br/pdf/ea/v34n99/1806-9592ea-34-99-175.pdf. Acesso em: 20 ago. 2020. 


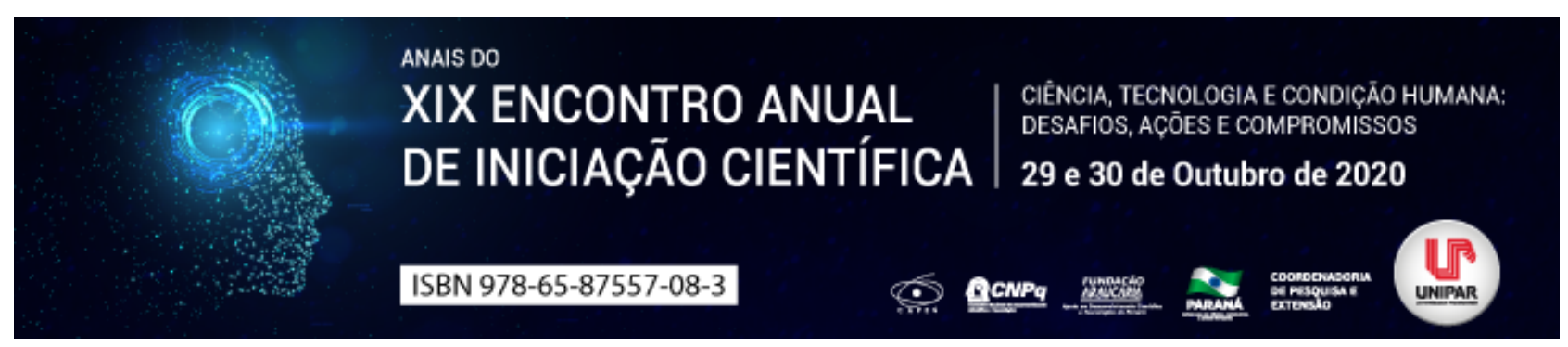

MASCULINIDADE NA CONTEMPORANEIDADE

\begin{abstract}
${ }^{1}$ MARIANA GUILHERME GONCALVES, ${ }^{2}$ CAMILA BATISTA DALLA VECCHIA, ${ }^{3}$ EMANUEL JOSE LAHOS BORGES, ${ }^{4}$ GIOVANA LABIAK PEREIRA, ${ }^{5}$ NIKITA DE FREITAS,${ }^{6}$ CLAUDIA LOPES PERPETUO
\end{abstract}

\author{
${ }^{1}$ Acadêmica do PIC/UNIPAR \\ ${ }^{1}$ Acadêmica do Curso de Psicologia da UNIPAR \\ ${ }^{2}$ Acadêmico do Curso de Psicologia da UNIPAR \\ ${ }^{3}$ Acadêmica do Curso de Psicologia da UNIPAR \\ ${ }^{4}$ Acadêmica do Curso de Psicologia da UNIPAR \\ ${ }^{5}$ Docente da UNIPAR
}

Introdução: Esse resumo foi construído a partir de discussões realizadas no Programa de Iniciação Científica no projeto intitulado: Psicologia e Interseccionalidades: os marcadores sociais de raça/etnias e gênero, a partir do qual investiga-se e discute-se teoricamente o conceito de interseccionalidade, visando compreender as articulações dos diferentes marcadores sociais (raça/etnia, gênero, entre outros) e como estes se relacionam e atravessam a vida dos sujeitos. A partir dessas discussões buscou-se neste trabalho pensar sobre a construção social do ser homem na atualidade.

Objetivo: Demonstrar como a construção do ser homem na atualidade pode afetar a saúde mental.

Desenvolvimento: Antes de iniciarmos a discussão sobre masculinidade, vale ressaltar o que é gênero. De acordo com Scott (1994 apud SANTOS, 2008), o papel de gênero foi criado pela sociedade para dividir tarefas entre homens e mulheres, estabelecendo assim, as relações de poder. Segundo Butler (2003), o conceito de gênero criado culturalmente pode ser mais determinante sobre o que é ser homem do que a própria biologia. Percebe-se que a construção social do ser masculino se dá a partir das relações de poder que vem se construindo historicamente gerando um ideal hegemônico, o homem, e este precisa provar-se constantemente. Moore (2000 apud SANTOS, 2008), trazem que os discursos sociais apresentam modelos definidos de como os sujeitos devem comportar-se, é através dos diálogos nos discursos, que os grupos são formados e os indivíduos têm que encaixar-se neles. Se por alguma razão, alguém tenha dificuldades em posicionar-se em determinado grupo, este alguém, poderá desenvolver problemas psicológicos, como crises e frustações, por sentir-se inadequado e fora do que é comum. Além dessas ocorrências geradas pela sensação de inadequação de gênero, existem muitos outros fatores externos que podem afetar a saúde mental do sujeito, caso ele não haja de acordo com o papel de homem que é estipulado a ele, como por exemplo: trabalho, vida sexual ativa, términos de relacionamentos, desempregos, percas pessoais, financeiras, entre outros (FREITAS, 2019). De acordo com Nolasco (1993 apud SANTOS, 2008), o primeiro fator que determina a masculinidade é o trabalho, trazendo ao homem um status social adequado e até elevado dependendo do serviço em que ele estiver atuando, e quando o homem não está inserido em algum tipo de trabalho, pode gerar nele sensação de derrota, pode perder ainda mais a sua autonomia, tendo sentimento de fracasso. Além desses fatores, é criado socialmente o estereótipo de que o homem não pode demonstrar sentimentos, sensibilidades e muito menos chorar, precisa manter a postura de homem forte o tempo inteiro, sem deixar transparecer suas emoções, caso contrário, poderá sofrer discriminações e julgamentos. Com isso, muitos homens optam por esconder esses sentimentos, sendo esta, uma opção praticamente necessária para não serem mal interpretados pela sociedade, sentem medo em expressarem-se e buscarem ajuda psicológica, para não perderem o status de homem forte e não serem vistos como quem não consegue lidar com os próprios problemas. Assim, vemos que os homens também sofrem machismo, enfrentam diversas pressões sociais para viverem de acordo com o que esperam deles e, muitas vezes, podem não conseguir cumprir toda a carga que o padrão social determina. Através desses enfrentamentos, muitos homens podem ficar ao seu limite de controle mental, tornando-se mais vulneráveis a cometerem o ato de suicídio. O Ministério da Saúde, comprova que os homens têm o maior número de percentual para suicídio, $79 \%$ em homens e $21 \%$ em mulheres. Um outro fator preocupante é que, apenas 50\% dos homens que cometeram suicídio buscaram algum tipo de ajuda psicológica (FREITAS, 2019). Santos, Detoni, Novais (2019), apresentam que existem grupos formados por homens em diferentes contextos, como: sociais, religiosos, terapêuticos, que reúnem-se frequentemente para discutirem e refletirem sobre como e quando cometem desvios comportamentais de masculinidade hegemônica, para que um possa ajudar o outro a não desviarem-se desses comportamentos e seguirem o determinismo. Quando há grupos formados por homens, são criados na maioria das vezes, para enfrentarem situações que vivenciam semelhantemente, como por exemplo: preconceitos raciais e gênero, violências, reabilitações, nos quais, unem os homens que enfrentam essas situações e divide-os dos restantes, sendo raramente, encontrados grupos de homens que se unem na busca por equidade.

Conclusão: Os estudos sobre o homem na contemporaneidade, possibilita uma reflexão de como a sociedade é modulada 
através dos discursos resultantes de interesses sociais e políticos, muitas vezes, os sujeitos sofrem por acharem que não são pertencentes aos padrões estabelecidos. A desconstrução das falas determinantes de como ser homem, é uma forma importante na busca por mudanças sociais, melhorar o convívio dos homens com a sociedade e com ele mesmo, tendo autonomia e liberdade, nos quais se perdem em meio a tantas falas, evitando assim, o surgimento e/ou agravamento dos transtornos psíquicos.

\section{Referências}

ALVES, Isabella Nara Costa. Saúde Mental do Homem e Construção das Masculinidades na Sociedade e na Escola. Tese (Programa de Pós-graduação em Neuropsicopedagogia)- Faculdade Metropolitana da Grande Recife.

BUTLER, Judith. Problemas de gênero: Feminismo e subversão da identidade. Rio de Janeiro: Civilização Brasileira, 2003.

FREITAS, Pedro Vinicius Paliares. Por que a taxa de suicídio é maior entre os homens? 23 set. 2019. Disponível em: https://medium.com/revista-subjetiva/por-que-a-taxa-de-suic\%C3\%ADdio-\%C3\%A9-maior-entre-os-homens-1e558ca2a061.

Acesso em: 28 ago. 2020.

SANTOS, Anna Maria Corbi Caldas. Gênero e Saúde Mental: a vivência de identidades femininas e masculinas e o sofrimento psíquico na sociedade brasileira contemporânea. Algumas reflexões a partir de relatos dos pacientes diagnosticados como portadores de transtornos mentais severos do CAPS- Araraquara SP. Orientadora: Eva Alterman Blay. 2008. Tese (Programa de Pós-Graduação em Sociologia)- Universidade de São Paulo, São Paulo, 2008.

SANTOS, Helen Barbosa; DETONI, Pricila Pavan; NOVAIS, Flávia Luciana Magalhães. Movimento de Homems; Homens em Movimento: Dissonância no debate sobre as masculinidades. Revista Diversidade e Educação, v. 7, n.2, p.254-277, Jul/Dez 2019. 


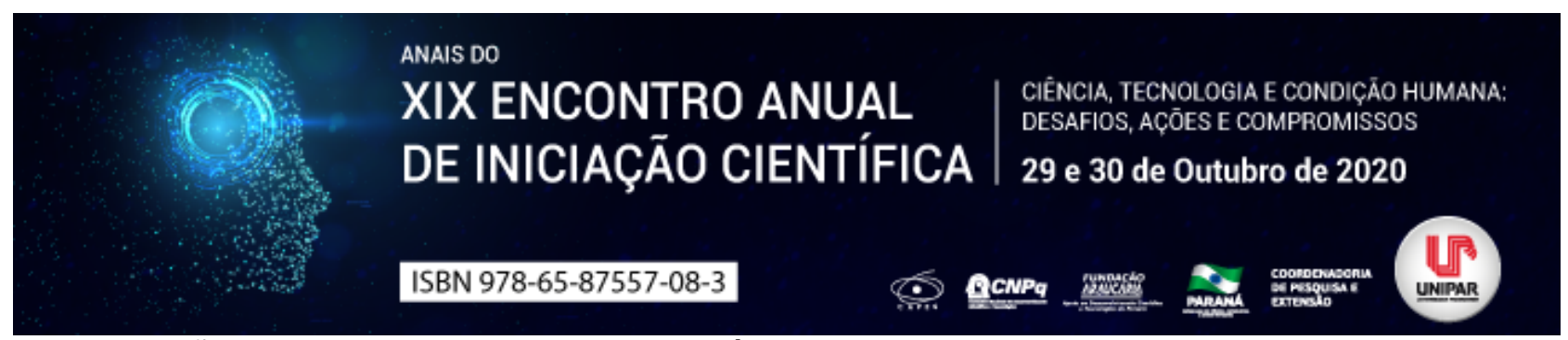

EVOLUÇÃO DO MARKETING E SUA IMPORTÂNCIA PARA AS EMPRESAS E PARA A SOCIEDADE

\title{
${ }^{1}$ VINICIUS ZANZARINO BENEDITO, ${ }^{2}$ ALADICASSIA SOARES SANTOS, ${ }^{3}$ VITOR HUGO RAMOS MACHADO
}

\author{
${ }^{1}$ Acadêmico do Curso de Ciências Contábeis da UNIPAR \\ ${ }^{1}$ Acadêmica do Curso de Administração da UNIPAR \\ ${ }^{2}$ Docente da UNIPAR
}

Introdução: A prática do marketing é uma das atividades mais antigas do mundo, tendo sua origem nas relações de trocas. Na época da Revolução Industrial a demanda era maior que a oferta, logo, as empresas conseguiam vender seus produtos sem nenhum esforço excessivo de vendas (DA SILVA, 2017). A partir dos anos 50, as empresas começaram a perceber que as vendas não eram constantes e não funcionavam mais a qualquer custo. Decorrente a isso, nessa época se deu início a uma maior valorização ao consumidor (DA SILVA, 2017). Segundo Kotler (2007) marketing é a ciência e a arte de explorar, criar e entregar valor para satisfazer às necessidades de um mercado-alvo com lucro. Desde então, as novas mudanças vieram ocorrendo no mercado, o que gerou novas percepções e um novo conceito para o marketing, onde o olhar deve se tornar pleno ao ser humano, eliminando o olhar como simples consumidores, mas sim como seres dotados de mente, coração e espírito (DA SILVA, 2017).

Objetivo: Demonstrar a origem e a evolução do marketing e sua importância para as empresas e para a sociedade.

Desenvolvimento: Na fase da Era Industrial tinha-se como objetivo à uniformização em larga escala, para atender o mercado em massa. Nessa época o consumidor não tinha voz perante as empresas, o seu papel era apenas consumir o que era ofertado pelas instituições. Durante todo esse período também conhecido como Era Ford , o objetivo era ganhar o mercado e manter o foco exclusivamente no produto (DOS SANTOS, 2014). Na fase do Marketing 1.0 não existia quaisquer subdivisão, os consumidores eram forçados a se adaptarem aos produtos que as entidades na época disponibilizavam. Como as empresas possuíam sua linha de produção em larga escala, os custos vindos da produção tornavam-se menores, sendo assim, os produtos chegavam aos consumidores por um preço mais baixo, o que permitia serem adquiridos por um número maior de clientes. A fase do Marketing 2.0 surge em meados dos anos 70, em virtude da tecnologia da informação e surgimento da internet, o seu foco estava em satisfazer e reter consumidores. Nesse período, os hábitos do marketing já não se aplicam mais com facilidade, os consumidores estão mais conscientes e rígidos. Com as empresas mudando suas estratégias e substituindo a produção em massa, a fim de atender as necessidades de seus clientes, a área do marketing precisou se elevar de um nível tático para um nível estratégico. Mudanças foram ocorrendo no mundo e o marketing foi se reinventando, chegando num período em que o foco não se limitava apenas ao consumidor em si, como também, para com as suas razões e emoções. O Marketing 3.0 nasceu e ganhou forma no Oriente. Pautado em valores, tinha como foco não considerar mais seus clientes como meros consumidores, mas sim como seres que possuem desejos e necessidades a serem realizadas. Quando pensamos em um mercado competitivo, fidelizar o cliente por meio da satisfação de seus desejos e necessidades, é essencial para as organizações. Em resumo, o Marketing 3.0 é aquele em que as práticas de marketing são influenciadas, sobretudo, pelas mudanças no comportamento e atitudes dos consumidores. Enxerga o mercado como um composto de seres humanos completos, com razão e emoção, fazendo com que as empresas se diferenciem por seus valores, tendo a busca pela diferenciação uma constante. No Marketing 4.0 é necessário dar uma importância cada vez maior à centralidade humana para conseguir atrair o consumidor na era digital. Uma vez que o lado humano dos consumidores foi transparecido, é hora das marcas também transparecer o seu lado humano e expressar peculiaridades humanas capazes de conquistá-los. KOTLER, KARTAJAYA e SETIAWAN (2017) destacam que as comunidades de consumidores tornaram-se poderosas e utilizam sua voz para partilhar histórias, boas e más sobre as empresas, podendo ser diferente da imagem que a mesma pretende passar. Logo, as decisões de compra se tornam sociais e somente após pesquisar sobre o produto, os consumidores realizam a compra. KOTLER, KARTAJAYA e SETIAWAN (2017), afirmam que em um universo Marketing 4.0, admiráveis produtos e admiráveis serviços são apenas artefatos, o fator UAU é o que distingue uma marca de suas oponentes. Segundo os autores a expressão UAU é pronunciada pelo cliente quando o mesmo fica sem palavras, em uma situação de grande satisfação. Por fim, empresas e marcas triunfantes são aquelas que não perdem o momento UAU para o acaso. Elas despertam o UAU intencionalmente. Guiam os clientes da consciência à defesa da marca. De forma inovadora, estabelecem comunicação com o cliente, dá satisfação à experiência e até ao engajamento.

Conclusão: Diante desta pesquisa podemos observar que estamos vivendo em uma Era de super valorização humana e de mudança. A comunicação e o marketing vem cada vez mais conduzindo as necessidades do ser humano, e, de tal forma se aperfeiçoando aos desejos extrínsecos e intrínsecos de nossa sociedade. Em uma realidade não tão longe da que nós vivemos, as instituições que se permitirem ousar e se envolver, a favor da ideia de ser, o que o ser humano requer, provocando o fator UAU intencionalmente em seus clientes, decerto irá conquistá-lo. 


\section{Referências}

CAVALLINI, Ricardo. O Marketing depois de amanhã. São Paulo: Ed. do Autor, 2008.

DA SILVA, Jéssica Nunes. Relacionamento Online nas Empresas Digitais: as dimensões da comunicação no Facebook do Banco Original. 2017. Monografia (Bacharel em Relações Públicas) Universidade Federal do Rio Grande do Sul, Porto Alegre, 2017.

DOS SANTOS, Felipe André. Marketing na Era Digital: análise da marca Chico Rei. 2014. Monografia (Bacharel em Comunicação Social/Jornalismo) Universidade Federal de Juiz de Fora, Juiz de Fora, 2014.

GABRIEL, Martha. Marketing na Era Digital: conceitos, plataformas e estratégias. São Paulo: Novatec, 2010.

KOTLER, Philip. Administração de Marketing: a edição do novo milênio. São Paulo: Pearson Prentice Hall, 2000.

KOTLER, Philip. Marketing de A a Z: 80 conceitos que todo o profissional precisa saber. 3. ed. Rio de Janeiro: Campus, 2003.

KOTLER, Philip; KARTAJAYA, Hermawan; SETIAWAN, Iwan. Marketing 3.0: as forças que estão definindo o novo marketing centrado no ser humano. Rio de Janeiro: Elsevier, 2010.

KOTLER, Philip; KARTAJAYA, Hermawan; SETIAWAN, Iwan. Marketing 4.0: mudança do tradicional para o digital. Rio de Janeiro: Sextante, 2017.

KOTLER, Philip; KELLER, Kevin Lane. Administração de Marketing. 12a ed. São Paulo: Pearson Prentice Hall, 2006.

LAS CASAS, Alexandre Luzzi. Marketing: conceitos, exercícios, casos. 4. ed. São Paulo: Atlas, 1997.

OGDEN, James R.; CRESCITELLI, Edson. Comunicação integrada de marketing: conceitos, técnicas e práticas. 2. ed. São Paulo: Pearson Prentice Hall, 2007.

TORRES, Cláudio. A Bíblia do Marketing Digital. São Paulo: Novatec, 2009. 


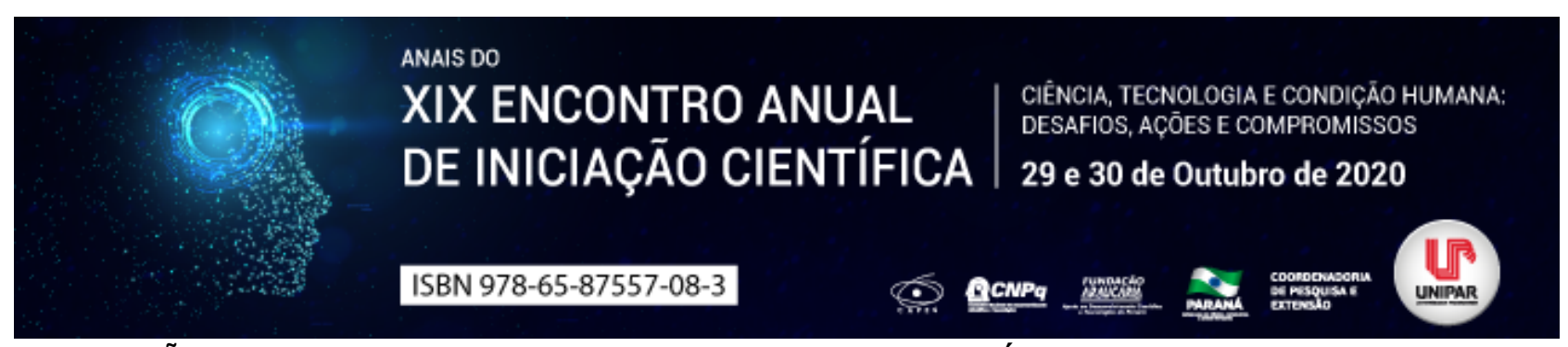

A ESTABILIZAÇÃO DA TUTELA ANTECIPADA ANTECEDENTE: UMA ANÁLISE SOBRE OS MEIOS DE IMPUGNAÇÃO

\author{
${ }^{1}$ ISABELA BUOSI RIBEIRO, ${ }^{2}$ FABIO FERREIRA BUENO
}

${ }^{1}$ Acadêmico do PIC/UNIPAR

${ }^{1}$ Docente da UNIPAR

Introdução: O novo Código de Processo Civil trouxe a possibilidade de estabilização da tutela antecipada antecedente, prevista nos artigos 303 e 304 do CPC. A decisão que concede a tutela não gera coisa julgada material, apenas garante a sua estabilização caso não for interposto o respectivo recurso, sendo esse o agravo de instrumento. Acontece que, a parte final do art. 304, referente ao modo de impugnação, gera uma série de discussões e questionamentos.

Objetivo: Discutir e questionar as diferentes teorias referente aos meios de impugnação da estabilização da tutela antecipada antecedente.

Desenvolvimento: Para realizar o requerimento da tutela antecipada antecedente, o autor deve cumprir todos os requisitos existentes no art. 303. No caso de concessão da tutela, o réu será intimado para apresentar sua defesa. De regra, o recurso cabível contra a decisão que concede a tutela antecipada é o Agravo de Instrumento, por força do art. 1.015, I do Código de Processo Civil. Caso o réu não agrave, o processo será extinto sem resolução do mérito, estabilizando os efeitos da tutela. Acontece que, há diferentes pensamentos sobre qual meio de impugnação manejado pelo réu tem eficácia suficiente para sustentar a estabilização, podendo ser: uma manifestação, o próprio agravo de instrumento ou até mesmo um pedido de reapreciação/reconsideração ajuizado na primeira instância. De acordo com Cássio Scarpinella Bueno (2015, p. 226), a decisão concessiva da tutela antecipada nos termos do art. 303, torna-se estável se não houver interposição do respectivo recurso (art. 304 , caput), que é o agravo de instrumento (art. 1.015, I) adotando uma postura mais objetiva. O TJ/MG (2016) entendeu pela interpretação restritiva e literal da exigência do art. 304 do Código de Processo Civil, não cabendo ao intérprete sua ampliação, no sentido de admitir qualquer impugnação para obstaculizar a estabilização concedida. Entretanto, deve ser analisado que a interpretação restritiva da norma seria improdutiva, ainda mais pelo prometido NCPC o esforço empregado para reduzir a recorribilidade direta das decisões interlocutórias (art. 1.015), uma vez que o Agravo de Instrumento acaba aumentando a demanda dos tribunais sem qualquer justificativa, quando há solução em uma simples manifestação de vontade. Analisando Código de 1973 o réu podia optar em não recorrer da decisão liminar antecipatória de tutela e limitar-se a apresentar defesa acompanhada de novos fatos e provas, cabendo ao juiz a tomada de decisão. A Exposição de Motivos do anteprojeto de novo CPC apresentada ao Senado Federal em 2009 detectou expressamente que o volume imoderado de recursos era um dos problemas a ser enfrentado por meio da diminuição do número de recursos que devem ser apreciados pelos Tribunais, justamente no campo do agravo de instrumento que se manifestou mais grave.

Conclusão: Conforme o exposto acima, há um impasse no meio de impugnação, sendo que uma mera manifestação é favorável ao descongestionamento de demandas nos tribunais, como também proporciona ao réu um meio mais eficaz para expressar o interesse no prosseguimento do processo.

\title{
Referências
}

BRASIL. Senado Federal. Código de processo civil: anteprojeto/comissão de juristas responsável pela elaboração de anteprojeto de Código de Processo Civil. Brasília: Senado Federal, Presidência, 2010.

BRASIL. Decreto Lei n. 3.105, de 16 de março de 2015. Código de Processo Civil. Disponível em: http://www.planalto.gov.br/ccivil_03/_ato2015-2018/2015/lei/l13105.htm. Acesso em: 20 jul. 2020.

BUENO, Cassio Scarpinella. Novo código de processo civil anotado. São Paulo: Saraiva, 2015, p.226.

MINAS GERAIS. Tribunal de Justiça do Estado de Minas Gerais. Acórdão n. $\mathbf{1 0 3 4 8 1 6 0 0 0 4 8 9 4 0 0 1}$ MG, Relator: Heloisa Combat, DJ: 03/11/2016, Câmaras Cíveis / 4ª CÂMARA CíVEL, DJ: 08/11/2016. 


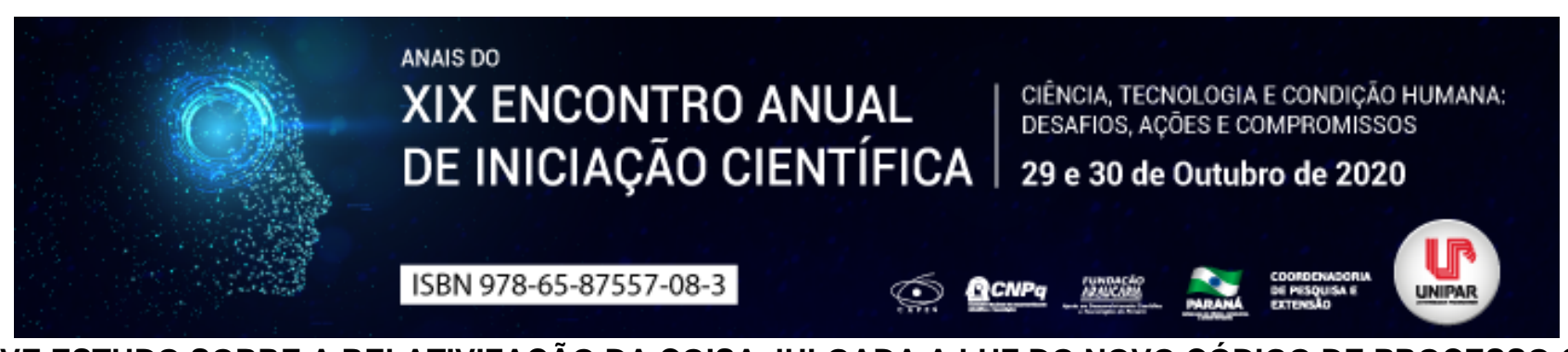

BREVE ESTUDO SOBRE A RELATIVIZAÇÃO DA COISA JULGADA A LUZ DO NOVO CÓDIGO DE PROCESSO CIVIL

\author{
${ }^{1}$ HELOISA CRISTINA LUIZ CAPPELLARI, ${ }^{2}$ FABIO CALDAS DE ARAUJO
}

\author{
${ }^{1}$ Mestranda em Direito Processual e Cidadania/UNIPAR \\ ${ }^{1}$ Docente da UNIPAR
}

Introdução: A coisa julgada é instituto de extrema importância em nosso ordenamento jurídico, entretanto, em determinados casos é necessária a reabertura e reanálise do feito, em razão de existir circunstância que fira direito constitucional ou eventual erro de julgamento, garantindo que o indivíduo que clama o poder judiciário tenha seu direito atendido, sendo este o principal objetivo do estado democrático de direito.

Objetivo: Analisar brevemente o instituto da relativização da coisa julgada a luz do novo código de processo civil, bem como os casos que permitem sua aplicação.

Desenvolvimento: A coisa julgada é um dos institutos mais importantes do ordenamento jurídico atual, considerando os princípios constitucionais por ela abrangidos, tais como o da segurança jurídica, o da supremacia da constituição como norteadora do Estado Democrático de Direito, o da estabilidade, entre tantos outros, conforme é o entendimento de Theorodo Jr (2016, p.838), como uma forma de, após transitado em julgado um determinado assunto, seja este considerado encerrado e imutável. Para Medina e Wambier (2003, p.197), a coisa julgada é a manifestação do princípio geral da segurança jurídica, capaz de proporcionar estabilidade e previsibilidade aos atos do Estado e aos atos jurisdicionais. Entretanto, o cumprimento estrito da coisa julgada pode gerar casos atípicos em que a permanência do julgado contraria além do direito em si, princípios constitucionais basilares, de forma que a doutrina, a jurisprudência e principalmente o Código de Processo Civil de 1973 já adotavam a possibilidade de relativização da coisa julgada, sendo a medida regulamentada com a vinda do novo código de processo civil - NCPC, aduzindo que a decisão transitada em julgado necessita, em determinados casos, ser revista, a fim de melhor se adequar ao caso concreto, ou corrigir eventual erro material proferido durante o julgamento, garantindo que o direito tenha atingido seu objetivo na demanda, que é a defesa dos direitos que originaram o clamor ao poder judiciário. Assim, visando garantir que o indivíduo não tenha seu direito lesionado por decisão erroneamente proferida, ou que não mais se adeque ao caso em análise, ou ainda que a aplicação procedimental religiosa não passe por cima do verdadeiro direito que se está a discutir, o NCPC prevê no rol taxativo do artigo 966 a possibilidade de ingresso de ação rescisória a fim de reabrir o caso e reajustar a decisão proferida conforme necessário. Nas palavras de Didier Jr (2016, p.421), a ação rescisória é a ação autônoma de impugnação, que tem por objetivos a desconstituição de decisão judicial transitada em julgado e, eventualmente, o rejulgamento da causa . O principal fundamento desta ação é a necessidade de reparar injustiças contidas em decisões transitadas em julgado e promover a reestabilização das relações jurídicas, a fim de que o direito não seja relativizado em uma busca de cumprimento fiel ao processualismo. Por enquanto, não há regulação definitiva para o assunto, a doutrina e jurisprudência divergem, restando ao julgador a discricionariedade sobre a aplicação do instituto.

Conclusão: Considerando os fatos acima exarados pode-se concluir que a coisa julgada é instituto de extrema importância em nosso ordenamento jurídico, entretanto, existem casos em que o cumprimento estrito do processualismo pode causar lesões ao direito inicialmente invocado, de forma que deve existir a relativização da coisa julgada, como forma de garantir a reabertura de casos que firam direitos ou que carreguem erros de julgamento, primando pela defesa dos direitos fundamentais que originaram o clamor ao poder judiciário, sendo este o principal objetivo do estado democrático de direito.

\title{
Referências
}

DIDIER Jr., Fredie. Curso de Direito Processual Civil: meios de impugnação às decisões judiciais e processo nos tribunais. Salvador: JusPodivm, 2016, 13. ed.

THEODORO JÚNIOR, Humberto. Curso de direito processual civil - vol III. 49a ed. Rio de Janeiro: Forense, 2016.

WAMBIER, Teresa Arruda Alvim; MEDINA, José Miguel Garcia. O dogma da coisa julgada: hipóteses de relativização. São Paulo: Revista dos Tribunais, 2003. 


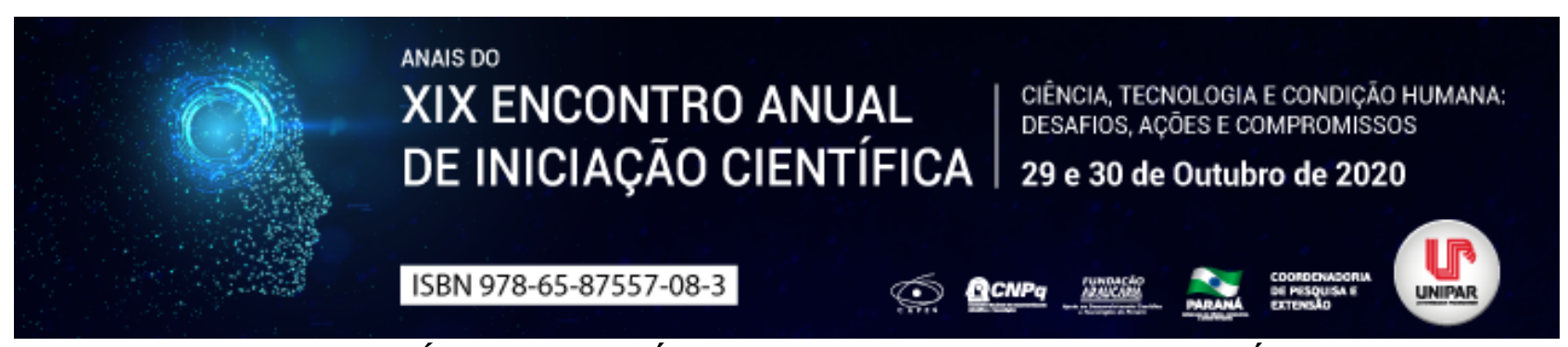

DIREITO, FAMÍLIA MULTIESPÉCIE E O ABANDONO DO ANIMAL DOMÉSTICO

\title{
${ }^{1}$ Valeria Silva Galdino Cardin, ${ }^{2}$ TEREZA RODRIGUES VIEIRA
}

\author{
${ }^{1}$ Docente da Universidade Cesumar e Docente da Universidade Estadual de Maringá \\ ${ }^{1}$ Docente do Mestrado em Direito Proc. e Cidadania e da Graduação de Medicina e Direito na UNIPAR
}

Introdução: A domesticação do animal foi um processo que transformou os lares e as famílias. Em decorrência desse afeto recíproco, a causa animal vem ganhando fôlego, encontrando adeptos e militantes em toda a sociedade e conquistando direitos, muitos deles graças aos tribunais, apesar da ausência de explícita formulação legal. A luta em prol de melhor qualidade de vida para os vulneráveis sociais lança também um olhar sobre os animais de companhia abandonados, uma vez que ficam mais suscetíveis à desnutrição, intempéries, ferimentos, ofensas e ataques, incidindo sobre a sociedade o dever de suprir suas básicas necessidades.

Objetivos: Identificar e analisar, por meio de pesquisa bibliográfica, as causas do abandono animal, bem como apresentar as consequências jurídicas do desamparo e desabrigo.

Desenvolvimento: Encontrar gatos e cães perambulando sem rumo pelas ruas em busca de comida e abrigo é uma constante em muitas cidades de quase todos os países, diferenciando apenas na quantidade de animais. Animal abandonado, segundo a Lei chilena n. 21.020, é: qualquer animal de estimação ou animal de companhia encontrado sem a supervisão da pessoa responsável por ele ou que vagueia pelas vias públicas. O animal abandonado também será considerado como qualquer animal deixado em situação de abandono em propriedade privada, sem cumprir as obrigações relacionadas à posse responsável adequada. (CHILE, 2017). De conformidade com levantamento realizado em 2019, Brasil possui 3,9 milhões de animais em situação de vulnerabilidade, sendo a maioria cães e gatos. A população pet no Brasil é de cerca de 140 milhões de animais, entre cães, gatos, peixes, aves e répteis e pequenos mamíferos. A maioria é de cachorros ( 54,2 milhões) e felinos (23,9 milhões), num total de 78,1 milhões de animais. Desses, $5 \%$ são Animais em Condição de Vulnerabilidade (ACV), o que representa 3,9 milhões de pets. (IPB, 2019). Cumpre frisar que diversas são as causas alegadas por aqueles que abandonam os animais. Cendón Panadés e Holm (2012, p. 5) elencam as mais comuns: Falta tempo para cuidar dele; Dá muito trabalho e pode causar danos; Problemas de agressividade ou adaptação devido à educação inadequada; Períodos de férias; Cães de guarda temporários nas obras; Irrita a vizinhança; O filhote ficou grande demais; Animais velhos e doentes; Compra não responsável e compulsiva; O animal foi um presente; Cria irresponsável, que força a adoções não refletidas; Problemas familiares; Mudança de casa; Desconhecimento de suas necessidades. Assim, o abandono animal é uma realidade ignorada politicamente, haja vista as poucas campanhas realizadas pelas prefeituras em canais de televisão com o objetivo de fomentar a adoção responsável dos milhares de cães e gatos. Exemplos bem sucedidos deveriam ser compartilhados, demonstrando que os animais de companhia não são objetos que saem de moda quando deixam de ser atrativos. Boa parte dos animais que vagam pelos espaços públicos não são castrados, nem identificados com chip e não acabam acolhidos pelos já superlotados abrigos. Sobram-lhes os perigos das ruas, as doenças, a morte. Aqueles que possuem apenas uma visão utilitarista do animal doméstico, seja para seu uso como proteção, pastoreio, assistência, salvamento, resgate, alimento, companhia, olvidam que a ele devemos a comida, o abrigo e o bem estar. Como bem observam Albuquerque e Ciari (2016, p. 18): É responsabilidade nossa, como seres humanos e como coespecíficos, respeitar esses animais e garantir seu bem-estar. Entender o comportamento e investigar as habilidades cognitivas dos cães, além de estudar que mecanismos estão envolvidos nas interações entre nós e eles são ferramentas essenciais para tornar essa relação interespecífica cada dia mais positiva. A legislação brasileira, por meio da Lei 9.605/98, dispõe: Art. 32. Praticar ato de abuso, maus-tratos, ferir ou mutilar animais silvestres, domésticos ou domesticados, nativos ou exóticos: Pena detenção, de 3 (três) meses a 1 (um) ano, e multa. § $2^{\circ}$. A pena é aumentada de 1/6 (um sexto) a1/3 (um terço), se ocorre morte do animal. Em decorrência do abandono, o magistrado poderá, inclusive, proibir o guardião de manter temporária ou permanentemente um animal de estimação. A atualidade do tema e a justificativa para o seu estudo estão demonstradas pela grande quantidade de animais abandonados nas ruas, pela superlotação nos abrigos a espera de um lar e pela constante ameaça da eutanásia imotivada.

Conclusão: Conclui-se que o abandono animal é uma realidade ignorada politicamente, haja vista as poucas campanhas realizadas pelas prefeituras com o objetivo de fomentar a adoção responsável dos cães e gatos. Exemplos bem sucedidos deveriam ser compartilhados, demonstrando que os animais de companhia não são objetos que saem de moda quando deixam de ser atrativos. Por meio do conhecimento das consequências do abandono do animal, deve-se combater suas causas e investir na responsabilização e educação dos novos tutores.

\section{Referências}


ALBUQUERQUE, N. de S.; CIARI, M. B. Cães e seres humanos: uma relação forte, complexa, duradoura e vantajosa. In: Chelini, M. O. M.; Otta, E. (Coord.). Terapia assistida por animais. Barueri, SP: Manole, 2016.

CENDÓN PANADÉS, M.; HOLM, A. Abandono de animales de compañía. Deontología y Veterinaria legal. Tutorado por Jaume Balague Estrems. Universidad Autònoma de Barcelona, 2012. CHILE. Ley núm. 21.020. Sobre tenencia responsable de mascotas y animales de compañía, de 02 ago. 2017. IPB, Instituto Pet Brasil. JCNET. Brasil possui 3,9 milhões de animais em condição de vulnerabilidade. Disponível em: https://www.jcnet.com.br/noticias/nacional/2019/08/562209-brasil-tem-3-9-milhoesde-animais-em-condicao-de-vulnerabilidade.html. Edição de 20 Ago. 2019. Acesso em: 01 dez. 2019.

VIEIRA, T.R. A vulnerabilidade do animal abandonado, família e direito. Família multiespécie: animais de estimação e direito. Brasília: Zakarewicz, 2020

Coordenadoria de Pesquisa e Extensão - COPEX

Departamento de Editoraçāo e Divulgaçāo Científica - DEDIC 


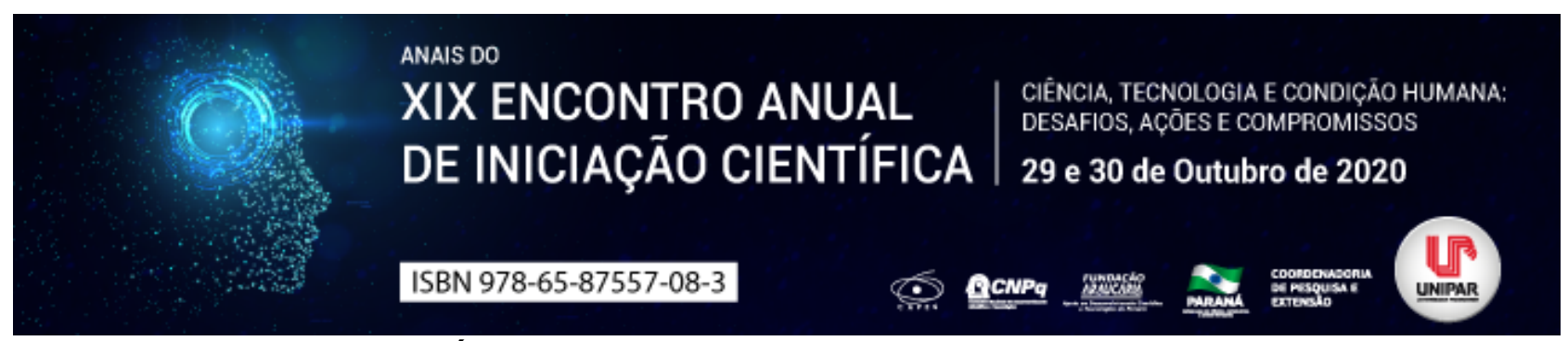

FATORES QUE COMPARAM ESTRATÉGIAS DE MARKETING UTILIZADAS POR EMPRESAS PARA AGREGAR VALORES DE REFERÊNCIA EM SEUS PRODUTOS

\title{
${ }^{1}$ JOAO VITOR MAESTA, ${ }^{2}$ MARCOS HENRIQUE DA SILVA, ${ }^{3}$ VINICIUS MARIANO, ${ }^{4}$ VITOR HUGO RAMOS MACHADO
}

\author{
${ }^{1}$ Acadêmico do Curso de Administração da UNIPAR \\ ${ }^{1}$ Acadêmico do Curso de Administração da UNIPAR \\ ${ }^{2}$ Acadêmico do Curso de Administração da UNIPAR \\ ${ }^{3}$ Docente da UNIPAR
}

Introdução: O conceito de marca sempre existiu, desde os tempos dos egípcios que faziam seus trabalhos manuais com os tijolos, sempre marcaram seus nomes ou símbolos em suas obras para poderem ter seus trabalhos reconhecidos e seus serviços diferenciados dos demais, assim progressivamente construindo suas marcas (MORI, 2012). O aumento da competitividade nos últimos anos vem crescendo muito entre todas as pessoas e negócios que tem como objetivo a venda de produtos, prestação de serviços e produção, por conta do grande aumento de produtividade depois da revolução industrial, e por isso, durante esses anos, com mais relevância a partir do século XX, houve um maior investimento em torno do conceito da marca (LOURENÇO, 2014). Como explica Lourenço (2014), as marcas apresentam-se no século XXI como sendo uma ferramenta de alavancagem e criação de sinergias positivas entre as empresas e os seus clientes. Segundo Mori (2012), a marca vale mais do que o produto e até mais do que a própria empresa. O marketing vive definitivamente a era das marcas, ter uma marca caracterizada e ser capaz de fixá-la na mente do consumidor é o grande desafio estratégico e tático almejado pelas organizações. Muitas empresas conseguem oferecer produtos com muitos benefícios, a apresentação que ela faz do seu produto para o consumidor e o atendimento exclusivo que ela pode oferecer aos clientes gera um valor maior a sua marca, uma conexão maior com o comprador e, consequentemente, o aumento das vendas (MATOS, 2013).

Objetivo: Analisar fatores que comparam estratégias de marketing que são utilizadas por diversas empresas para agregar valores de referência em seus produtos.

Desenvolvimento: Para realizar um bom desenvolvimento na marca da empresa, é necessário que se faça um planejamento estratégico para ter uma boa visão de onde vai atuar. Com base na análise de SWOT, vai conhecer seus pontos fortes e fracos, seus clientes e fornecedores, depois disso a empresa precisa reconhecer sua situação no mercado, descobrir qual será seu público-alvo e então apresentar seus diferenciais para conseguir atrair mais consumidores. Por fim se coloca todas as ações descritas no planejamento em prática, podendo sempre ir se adaptando e organizando da melhor forma (MATOS apud HOOLEY et al., 2005). Com a busca pela diferenciação pequenas e grandes empresas tiveram que passar a analisar mais fatores que buscam satisfazer a necessidade dos consumidores. Diante disso as empresas passam a se preocupar com qual forma é vista diante o mercado, pois a identidade da marca passa a ser percebida pelo seu diferencial diante outras marcas (SANTOS, 2015). A atração que a empresa e seus produtos geram em seus consumidores por causa de sua marca tem relação a fatores como: relacionamento criado com os clientes, qualidade que seus produtos e serviços entregam para eles e a lealdade com sua marca que vai aumentando progressivamente com as compras (MATOS, 2013). Como foi visto que o marketing é uma ferramenta que serve para que a empresa saiba como efetuar as suas trocas com os consumidores e como saber como ela é vista no mercado como um todo, é necessário entender que além dessas trocas, existe um fator importante para ser estudado, esse fator é a percepção dos clientes com a empresa. São causas propostas por Lourenço (apud AAKER, 1998) sobre Brand Equity, explicando que o valor da marca quem faz é o consumidor. Esses valores são dependentes das experiências que o cliente tem com os produtos, fazendo que ele possa identificar e ter preferência por sua marca. Outro fator que pode atrair o cliente a sua empresa, é o nome, segundo Lourenço (apud KELLER, 2003), o nome da marca é algo muito importante e decisivo desde que tenha relação com os produtos e apresente o papel central. Como explica Lourenço (apud DUNCAN, 2005), um bom nome deve apresentar as características: Benefícios da marca e produtos; Associações; Diferencial; Simplicidade. Segundo Santos (apud AAKER, 1998), se seus consumidores só compram seus produtos só com base nas características e nao se importam muito com o nome da marca, há pouco brand equity. Mas mesmo existindo concorrentes com preços e qualidades melhores, se o consumidor continua a comprar com você isso mostra que você tem um ótimo valor a sua marca, boa imagem e slogan. Ao analisar a logo de uma empresa, o cliente pode ter várias ideias como a de qualidade, valor, entre outras, pois são a percepção e as estratégias de marketing que buscam criar valor agregado. Isso se deve ao fato de que a marca pode proporcionar toda essa experiência para o cliente. Onde o cliente pode comprar um produto qualquer simplesmente pela sua percepção da marca, imagem e qualidade, além das funcionalidades em si (MATOS, 2013).

Conclusão: De forma geral, todo produto ou serviço é associado a uma marca, porém poucas empresas têm noção do que sua 
marca realmente representa para os consumidores e algumas não atendem adequadamente aos mesmos de forma única, a fim de ficar mais próximo deles e de poder medir sua satisfação e insatisfação. Conclui-se que a lealdade dos clientes a marcas é algo de extremo valor, e isso é um diferencial que impacta muito nas vendas em geral.

\section{Referências}

AAKER, D. A. (1991), Managing Brand Equity: Capitalizing on the Value of a Brand Name, Nova lorque: The Free Press. DUNCAN, T. (2005), Principles of advertising and IMC, Boston: McGraw Hill.

HOOLEY, Graham J. et al. Estratégia de Marketing e Posicionamento Competitivo. 3. Ed., São Paulo: Prentice Hall, 2005.

KELLER, K.L. (2003). Strategic Brand Management: Building, Measuring and Managing Brand Equity (2. Ed.), Upper Saddle River, NJ: Prentice Hall.

LOURENÇO, J.R.B. O VALOR DA MARCA: CASO SAMSUNG. Tese de Mestrado em Economia e Administração De Empresas. Orientado por Hortênsia Barandas. FACULDADE DE ECONOMIA UNIVERSIDADE DO PORTO, 2014.

MATOS, R.G. MARKETING E IDENTIDADE CORPORATIVA: ANÁLISE DAS ESTRATÉGIAS DA APPLE. Monografia em Pósgraduação de Marketing e Cadeia de Valor. Orientado por Mauro Castro M. Sc. CENTRO UNIVERSITARIO DE BRASILIA INSTITUTO CEUB DE PESQUISA E DESENVOLVIMENTO ICPD, BRASÍLIA, 2013.

MORI, M.M. GESTÃO DE MARCAS E RELAÇÕES PÚBLICAS: O PAPEL DA PROPAGANDA DE RELAÇÕES PÚBLICAS NA CONSTRUÇÃO E MANUTENÇÃO DA IMAGEM INSTITUCIONAL. Monografia em Graduação em Arquitetura, Artes e Comunicação. Universidade Estadual Paulista, Bauru, 2012.

SANTOS, Valério Givizies Vilete. LEALDADE A MARCA: OS FATORES RESPONSÁVEIS QUE LEVA UMA EMPRESA A SER

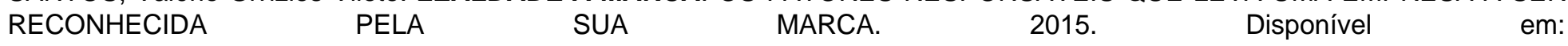
https://www.facefaculdade.com.br/arquivos/revistas/Lealdade_a_Marca_-

_Os_Fatores_Responsveis_que_leva_uma_Empresa_a_ser_Reconhecida_pela_sua_Marca.pdf. Acesso em: 28 ago. 2020. 


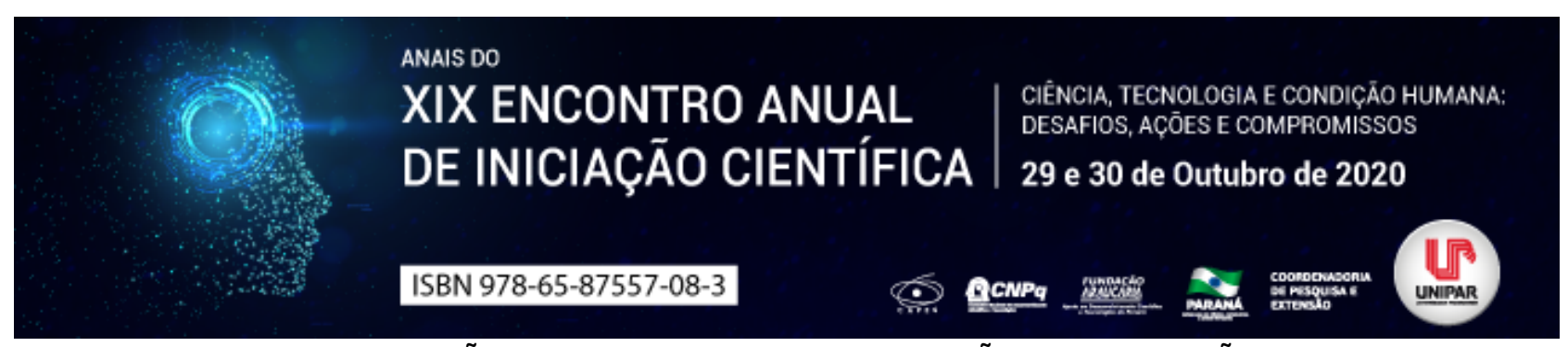

\title{
MEIOS CONSENSUAIS DE RESOLUÇÃO DE CONFLITOS: A CONCILIAÇÃO E A MEDIAÇÃO E OS DESDOBRAMENTOS DO EXERCÍCIO DA JURISDIÇÃO
}

\author{
${ }^{1}$ LILIAN CRISTINA PINHEIRO GOTO, ${ }^{2}$ BRUNO SMOLAREK DIAS
}

\author{
${ }^{1}$ Acadêmico do Pic/Unipar \\ ${ }^{1}$ Docente da UNIPAR
}

Introdução: Os desdobramentos da pós-modernidade amplificaram a litigiosidade, multiplicando demandas judiciais e exigindo uma reestruturação processual garantidora do acesso à justiça (CAPPELLETI E GARTH, 1988). Acentua Rui Portanova (2008) que o Princípio do acesso à justiça é um movimento para efetividade e igualdade material almejada por todos e consagrada pelo Estado Social. Para o professor Luciano Floridi (2019), a sociedade é híbrida, como o habitat dos manguezais, evidenciando a necessidade de aplicação de mecanismos processuais aptos a produzirem resultados efetivos na realização da justiça. Neste sentido a jurisdição passa a comportar tais meios e a busca do equilíbrio de sentimentos conflitantes em consonância com a autodeterminação das escolhas torna-se um propósito.

Objetivo: Este estudo pretende demonstrar que a finalidade do processo civil é a solução de controvérsias e que os meios consensuais de resolução de conflitos, em especial a mediação, surgem como uma resposta efetiva de pacificação social na concretização de direitos sociais fundamentais, proclamando-se e realizando-se a ordem jurídica, alargando os limites da jurisdição, por meio da mediação, de forma a buscar soluções mais adequadas no tratamento dos conflitos atendo-se à realidade social, pois será por meio da consciência coletiva de dever individual que será possível propagar uma cultura de paz e de mudança social.

Desenvolvimento: O Novo Código de Processo Civil aposta em meios adequados de resolução de controvérsias, por considerálos mais céleres, economicamente viáveis e eficientes, além do fato de que tais meios evitariam a imposição de uma sentença condenatória, favorecendo o bom-senso das partes e contribuindo para uma pacificação social. A mediação pressupõe a participação direta das partes na construção da solução do conflito, ou pela participação interativa de um terceiro desinteressado, denominado mediador, em processo no qual haverá grande liberdade de comunicação entre as partes, podendo levá-las a um consenso. Há na mediação a tentativa de restabelecer o diálogo entre os envolvidos, que estarão focados em seus verdadeiros interesses. Esta modalidade consensual de resolução de conflitos acabou sendo inserida como mecanismo intraprocessual no artigo 166 do Novo Código de Processo Civil e como mecanismo extrajudicial, conforme preleciona o artigo 175 do mesmo Código (ARAÚJO, 2016, p. 62). O processo, enquanto instrumento da jurisdição, sofreu alterações significativas com o advento do atual Código de Processo Civil que, atendendo à excessiva judicialização de demandas e ante a morosidade da prestação jurisdicional, estimulou a mediação e demais métodos de solução consensual de conflitos em seu artigo $3^{\circ}$, $\S 3^{\circ}$, além de estabelecer no artigo 334 a possibilidade de realização desta modalidade de audiência antes da resposta do réu (CAMBI, 2018, p. 659). Por outro lado, em que pese a necessidade de utilização deste meio específico de solução de litígios e sua recepção na nova processualística, há ainda, no Brasil, uma cultura de litígio, uma resistência à mudanças tanto por parte da sociedade civil, quanto por parte dos próprios operadores do Direito, o que se mostra um desafio a ser superado. A professora Ada Pelegrini Grinover, ao trabalhar a temática da mediação, afirma que ela integra um processo cooperativo, que leva em conta as emoções, as dificuldades de comunicação e a necessidade de equilíbrio e respeito dos conflitantes e que pode resultar num acordo viável, fruto do comprometimento dos envolvidos com a solução encontrada. No mesmo sentido é o entendimento de Francisco José Cahali (2014) quando afirma que a mudança desta cultura, provocada pela política pública proposta, aliada aos inúmeros estudos a respeito e sua prática cada vez mais difundida, nos âmbitos público e, principalmente, privado, exerce influência direta na própria sociedade. Acrescenta ainda que ao longo dos tempos, por inúmeros fatores, implementou-se a chamada 'cultura do litígio', pela qual recorrer ao Judiciário foi considerada a principal maneira de acomodação dos conflitos de interesses. E assim, as pessoas, de um modo geral, perderam a capacidade de, por si sós, ou com o auxílio de terceiros, superar suas adversidades para resolver seus problemas de forma amigável ou negociada. Passou a existir a terceirização do conflito, entregando-se ao Judiciário o poder da solução, que poderia ser alcançada por meios alternativos e diretos.

Conclusão: Da análise do tema exposto deduz-se que os meios consensuais de resolução de conflitos citados consistem em alternativa adequada, prospectiva, dialogal, justa, menos onerosa e viável para resolução de conflitos, pautados na ideia de autodeterminação da vontade, sendo perfeitamente possível falar-se em proteção jurisdicional adequada quando da sua aplicabilidade, carecendo de maior atenção nas grades curriculares dos cursos de Direito, por tornar-se obviamente necessária, uma tendência que já se vê construir com a implementação de vários Centros de Resolução de Conflitos e Cidadania (CEJUSC) e que o Estado não perde seu Poder de Jurisdição quando aceita como válidos tais meios consensuais de resolução de conflitos como válidos. 


\section{Referências}

ARAÚJO, Fábio Caldas de. Curso de Processo Civil. São Paulo; Malheiros, 2016.

BAUMAN, Zygmunt. Modernidade Líquida. Rio de janeiro: Jorge Zahar, 2001.

BRASIL. Lei $\mathbf{n}^{\circ}$ 13.105, março de 2015. Brasília, DF: Presidência da República, [1985. Disponível em: http://www. http://www.planalto.gov.br/ccivil_03/_Ato2015-2018/2015/Lei/L13105.htm. Acesso em: 21 de março de 2020.

CAHALI, Francisco José. Curso de Arbitragem: mediação: conciliação: Resolução CNJ 125/2010. $4^{a}$ Ed. São Paulo: Editora Revista dos Tribunais, 2014.

CAMBI, Eduardo. Neoconstitucionalismo e Neoprocessualismo. São Paulo: Almedina, 2018.

CAPPELLETTI, Mauro; GARTH, Bryant. Acesso à justiça. Porto Alegre: Sergio Antonio Fabris, 1988.

GRINOVER, Ada Pellegrini. O minissistema brasileiro de justiça consensual: compatibilidade e incompatibilidades. Publicações da Escola AGU, Brasília, v. 8, n. ja/mar. 2016, p. 15-36, 2016.

FLORIDI, Luciano. Entevista de Jaime D'Alessandro, publicada por La Repubblica em 29-09-2019, tradução de Luisa Rabolini.

A Era do Onlife . http://www.ihu.unisinos.br/78-noticias/593095-luciano-floridi-vou-explicar-a-era-do-onlife-onde-real-e-virtualse-com-fundem. Acesso em: 21 de julho de 2020.

MEDINA, José Miguel Garcia. Curso de Direito Processual Civil Moderno. São Paulo/SP: Revista dos Tribunais, 2018.

PORTANOVA, Rui. Princípios do Processo Civil. $7^{\text {a }}$ ed. Porto Alegre: Porto Alegre. 2008. p. 62. 


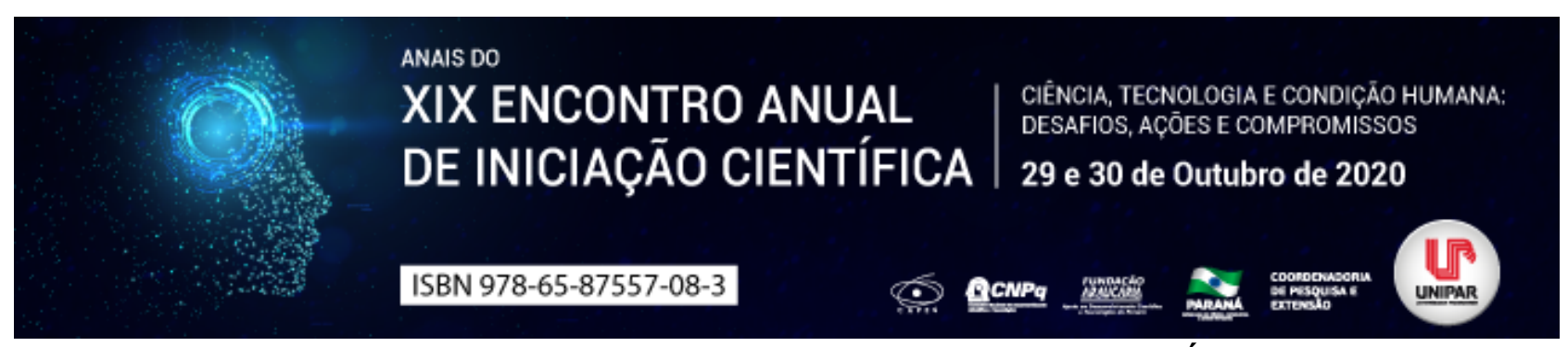

O FUTURO DO CONTADOR EM MEIO OS AVANÇOS TECNOLÓGICOS

\author{
${ }^{1}$ EDUARDO ZUPIROLI PINTO, ${ }^{2}$ CHRIGOR TRENTO MARTINELLI, ${ }^{3}$ GUSTAVO CONDOLUCCI, ${ }^{4}$ VITOR HUGO RAMOS \\ MACHADO
}

${ }^{1}$ Acadêmico do Curso de Ciências Contábeis da UNIPAR

${ }^{1}$ Acadêmico do Curso de Ciências Contábeis da UNIPAR

${ }^{2}$ Acadêmico do Curso de Ciências Contábeis da UNIPAR

${ }^{3}$ Docente da UNIPAR

Introdução: A Contabilidade é umas das ciências mais antigas e complexas de nossa sociedade. Segundo ludícibus (2000), a contabilidade é tão antiga quanto à origem do homem pensante. De acordo com alguns historiadores, os primeiros sinais das existências de contas foram registrados há aproximadamente 4000 a.C. Há uma possibilidade de antes mesmo de esta época os homens primitivos ter usado algum tipo de números em seus instrumentos de pesca e caça, ou até para contar e controlar os seus rebanhos. Assim como para Sá (1996) por volta de 3550 a.C. Os egípcios já possuíam os controles contábeis com uma apuração até mesmo rígida dos tributos coletados pelo estado e já havia registro numa espécie de livro por meio de escrita hieroglífica, com valores baseados na moeda egípcia. Segundo ludícibus (2000) antigamente na Babilônia as cobranças de impostos já eram feitas com escritas, embora elas fossem rudimentares, as trocas de bens e serviços eram feitas com simples registros ou relatórios sobre o fato. Sá (1995) explica que antes da era científica já se sabiam que haviam comprado isto ou aquilo, se eram gasto isso ou aquilo, porém não se tinha uma preocupação em esclarecer racionais medidas de relações entre as suas necessidades e seus meios materiais ou patrimoniais. Já Haberkamp (2005) diz que a contabilidade foi umas das pioneiras a usar a tecnologia da informação em função de seu processo rotineiro e dos cálculos regulares, a contabilidade vem tendo grandes mudanças por causa dos avanços tecnológicos, não somente a contabilidade, mas sim todas as áreas que abrangem a economia, esse avanços permite um maior rendimento de serviço e de idéias.

Objetivo: É analisar e buscar novas formas para que o profissional contábil se mantenha no mercado e mantenha a sua profissão viva.

Desenvolvimento: Os avanços tecnológicos trazidos pelas novas tecnologias de informações influenciaram para que aquelas técnicas utilizadas anteriormente pelos profissionais contábeis ficassem ultrapassadas. Segundo Padovezze (2000), diversas tarefas que anteriormente eram realizadas por processos manuais já são desenvolvidas dentro de softwares específicos, diminuindo o fluxo de papéis e documentos na empresa. Segundo Borges e Miranda (2011), a tecnologia da informação vem modificando os serviços contábeis há décadas, trazendo melhorias no processo operacional e nos atendimentos aos clientes, porém também com esses avanços os contadores vêm sendo afetado pelas quantidades de informação, as mudanças de comunicação e também os processos tomados. Em meio a tantos avanços tecnológicos Lunelli (2016), diz que a informação contábil precisa de uma resposta mais ágil diante das exigências do mercado atual, e essa evolução sugerem uma mudança no perfil do profissional contábil e por sua vez dos escritórios de contabilidade. Para que os profissionais da área contábil não se percam em um futuro próximo, ele há de aceitar alguns desafios para sua profissão, Pereira e Xavier (2000) citam alguns desses desafios da profissão contábil: O primeiro é mudar a imagem, o segundo é abandonar a idéia da contabilidade tradicional e o terceiro é deter a informação de tudo que ocorre na empresa, tratando esses dados de forma que sejam úteis aos gestores do negócio. Para Alsharayri (2011) e Choe (2004), ao enxergarem alguns impactos das tecnologias no sistema de informação, foram vistos somente impactos positivos entre o nível de tecnologia e a quantidade de informação que está sendo produzida pela gestão dos sistemas de informações. De acordo com Handel (2003), o aspecto que se chama mais atenção da tecnologia da informação na contabilidade foi à velocidade que se podem realizar as rotinas sob a responsabilidade dos contadores. Em decorrer dessas grandes quantidades de informações, que precisam ser disponibilizada em tempo real, Souza (2010) apud Gomes et al. (2015), diz que a evolução da contabilidade como ferramenta trouxe a necessidade de elaborar,coletar e proporcionar informações com rapidez e qualidade. Então para não ficar para trás o profissional contábil tem que estipular todas essas mudanças tecnológicas em suas rotinas, usando ela a seu favor, Ferreira (2013) e Souza (2010), fala que o profissional contábil tem que ter um perfil que se comprometa a buscar aperfeiçoamentos pessoais, para que possa ter suas capacitações profissionais, técnicas e acadêmicas melhores que os demais.

Conclusão: Diante dessas transformações que a profissão contábil vem sofrendo ao decorrer dos anos, o mais correto a se fazer será preparar os contadores, para que eles tenham em mente que os processos que a tecnologia da informação vem influenciando na contabilidade são processos dinâmicos e contínuos, e que para entender isso, os contadores tem que estudar profundamente a sua empresa, criando assim métodos e análises para possíveis problemas. 


\section{Referências}

ALLAHYARI, A .; RAMAZANI, M. Mudança tecnológica da empresa e sua efeitos na mudança da contabilidade gerencial: estudo de caso do iraniano empresas de manufatura. Jornal Global de Gestão e Negócios Pesquisa, v. 11, n. 9, pág. 56-62, 2011.

ASCENÇÃO Hugo da Silva, SOUZA Edson Alberto Farias de, SOUZA Ivan Barbosa de Souza. Adequação do profissional de contabilidade junto às novas tecnologias.

BORGES, V. A. A. de S.; MIRANDA, C. C. F. A contabilidade na era digital. XIII Inic EPG(Encontro Latino Americano de Iniciação Científica) e IX Encontro Latino Americano de Pós-Graduação UNIVAP, São José dos Campos, out/2011.

CHOE, J. Impacto das informações de contabilidade gerencial e AMT sobre desempenho organizacional. Journal of Information Technology, v.19, p. 203-214, 2004.

FERREIRA, V. P. O perfil do profissional contábil exigido pelo mercado de trabalho. Monografia (Bacharel em Ciências Contábeis). Curso de Ciências Contábeis. Universidade de Passo Fundo, Passo Fundo, RS, 2013.

HABERKAMP, A. M. Impacto dos investimentos em tecnologia da informação (TI) nas variáveis estratégicas das empresas prestadoras de serviços contábeis. Dissertação (Mestrado) UFRS Universidade Federal do Rio Grande do Sul, 2005.

HANDEL, M. J. Imagem complexa de tecnologia da informação e o emprego surge.Projeto Internacional Número P10168 da RI,Arlington, Virginia, 2003.

IUDíCIBUS, S. D. Teoria da Contabilidade. 6. ed. São Paulo: Atlas, 2000.

LUNELLI, R. L. A contabilidade e o avanço da tecnologia. Disponível em .Recuperado em 01 novembro, 2016.

MOURA, I.J.L. de. História da Contabilidade. 2013.

PADOVEZE, C. L. Sistemas de informações contábeis. 2. ed. São Paulo: Atlas, 2000.

PEREIRA, A. C., XAVIER, M. Q. Riscos profissionais de auditoria contábil e os avanços tecnológicos. Revista Álvares Penteado - FECAP, São Paulo, no 5, dez. 2000.

SÁ, A. L.; SÁ, A. M. L. Dicionário de Contabilidade. São Paulo: Atlas, 1995.

SÁ, A.L. Introdução à teoria da contabilidade. - Rio de Janeiro: Tecnoprint,1996.

SÁ, A.L.. PACIOLI, L: Um Mestre do Renascimento. 2a . Edição. Brasília: Fundação Brasileira de Contabilidade, 2004. SÁ, Antônio Lopes de. A Evolução da Contabilidade. 2a . Edição. - São Paulo: IOB, 2009. 


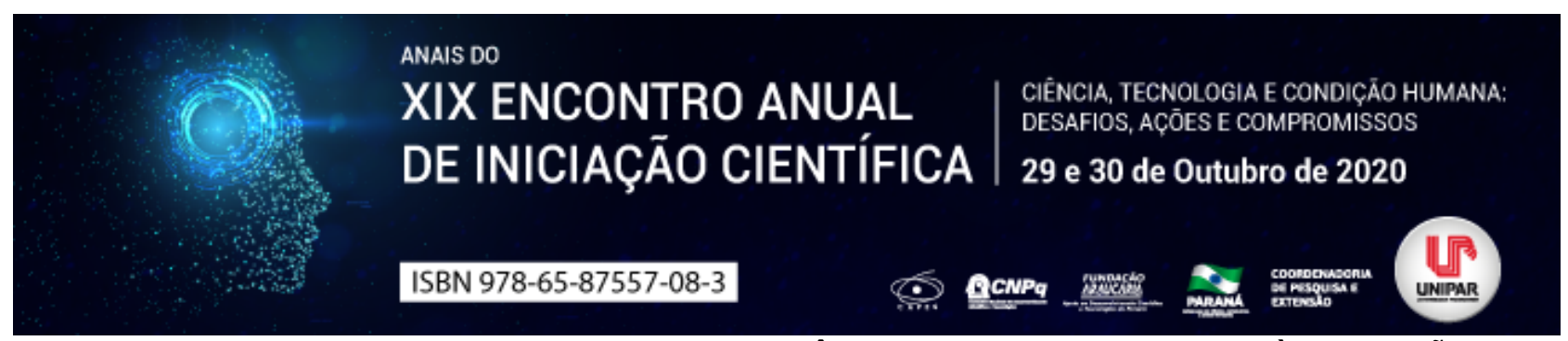

A ERA DA HIPERCONECTIVIDADE E A INTELIGÊNCIA ARTIFICIAL APLICADA À MEDIAÇÃO

\title{
${ }^{1}$ LILIAN CRISTINA PINHEIRO GOTO, ${ }^{2}$ RAQUEL LAURIANO RODRIGUES FINK, ${ }^{3}$ BRUNO SMOLAREK DIAS
}

\author{
${ }^{1}$ Acadêmico do Pic/Unipar \\ ${ }^{1}$ Acadêmica do Mestrado em Direito/Unipar \\ ${ }^{2}$ Docente da UNIPAR
}

Introdução: A Era da hiperconectividade deu novo tom acerca do futuro da mediação no Brasil. Na sociedade líquida ((BAUMAN, 2001), potenciais disputas encontraram novos métodos de resolução, que antes se atrelavam à um único canal: o Judiciário. Aliado à este cenário é que se apresentam as perspectivas de avanço efetivo, decorrentes em grande medida das novas tecnologias aplicadas à mediação por meio dos canais virtuais, os quais tem possibilitado um maior diálogo entre as partes, sendo responsáveis pela diminuição do tempo e consequentemente dos custos de um processo. Para Luciano Floridi a humanidade vive a era do Onlife , cada vez mais num universo que é digital. Assim, tal como a vida, o direito acompanha esta mesma perspectiva.

Objetivo: Objetiva-se com este ensaio demonstrar que há uma necessidade de verificação das novas tecnologias a exemplo das plataformas digitais, com intuito de rever de que forma as técnicas de mediação aplicadas nas audiências presenciais podem ser de igual forma empregadas nas salas virtuais.É necessário transportar-se à esfera virtual e considerar se esta será uma via segura e apta a conceder a devida prestação jurisdicional e acesso à justiça, que deve ser a todos plenamente garantida (CAPPELLETT e GARTH, 1988).

Desenvolvimento: O novo conjunto múltiplo de interações e de conexões entre os fluxos informativos redesenharam este século e consequentemente a atuação do Poder Judiciário, que vem se reformulando e se utilizando cada vez mais da inteligência artificial na realização da justiça. Esta readequação tem sido responsável pela otimização de resultados, conforme demonstrados no relatório analítico do CNJ, Justiça em Números, de 2020. O Novo Código de Processo Civil valorizou os meios consensuais de resolução de controvérsias, por questão de adequação e economicidade processual. Por meio da mediação as partes têm participação direta e dialogam entre si para encontrarem juntas uma resolução de seus conflitos. Esta previsão encontra-se expressa no Novo Código de Processo Civil nos artigos $3^{\circ}, \S^{\circ}, 166$ e 175 (CPC, 2015). A mediação pressupõe a participação direta das partes na construção da solução do conflito, ou pela participação interativa de um terceiro desinteressado, denominado mediador, em processo no qual haverá grande liberdade de comunicação entre as partes, podendo levá-las a um consenso (ARAÚJO, 2016). Neste ambiente de infindáveis avanços no que tange as relações sociais, decorrentes da disseminação cultural e da proeminente educação consumerista, considerada responsável pela era da judicialização de conflitos, vê-se emergir com grande robustez novas maneiras de focalizar o conflito. A comunicação assertiva e a utilização adequada das técnicas de mediação fomentam uma prestação jurisdicional qualificada. A fala, a escuta ativa, a postura afirmativa, a mescla de diferentes modos de humor, a utilização da intuição e dos questionamentos do terceiro facilitador promoverão um diálogo entre as partes, criando a ambientação ideal para identificação dos interesses envolvidos na relação interpessoal. As técnicas associadas à mediação e aplicadas nas salas presenciais podem e devem ser repensadas em ambientes virtuais, no intuito de possibilitar de igual forma a devida efetivação da justiça. A Inteligência Artificial recriou as salas de negociação utilizando-se de uma multiplicidade cada vez maior de canais, como via sistemas WhatsApp, SMS, e-mail e demais aplicativos. É possível a qualquer momento convidar as partes em um processo a comporem uma negociação automatizada, o que integra um conjunto de políticas públicas que tem por finalidade transformar a cultura de litígio em uma cultura de paz.

Conclusão: Pela presente abordagem, deduz-se que ante o claro avanço da utilização das novas plataformas digitais em ambiente judicial, em especial para realização das formas consensuais de resolução de conflitos, será necessário repensar as técnicas utilizadas nas audiências de conciliação e mediação presenciais, readequando-as e aplicando-as aos ambientes digitais. Os múltiplos canais de negociação disponíveis tendem à rápida expansão e é necessário preparar-se para um futuro que parece já ter chegado. A automatização dos sistemas com o uso da Inteligência Artificial tem remodelado a forma de se fazer justiça.

\section{Referências}

ARAÚJO, Fábio Caldas de. Curso de Processo Civil. São Paulo; Malheiros, 2016.

BAUMAN, Zygmunt. Modernidade Líquida. Rio de janeiro: Jorge Zahar, 2001.

BRASIL. Lei $n^{\circ}$ 13.105, março de 2015. Brasília, DF: Presidência da República, [1985. Disponível em: http://www. http://www.planalto.gov.br/ccivil_03/_Ato2015- 2018/2015/Lei/L13105.htm. Acesso em: 21 de março de 2020.

Conselho Nacional de Justiça CNJ. Justiça em Números. Disponível em: . Acesso em: 19 de agosto. 2020.

CAPPELLETTI, Mauro; GARTH, Bryant. Acesso à justiça. Porto Alegre: Sergio Antonio Fabris, 1988. 
FLORIDI, Luciano. Entevista de Jaime D'Alessandro, publicada por La Repubblica em 29-09-2019, tradução de Luisa Rabolini. A Era do Onlife . http://www.ihu.unisinos.br/78-noticias/593095-luciano-floridi-vou-explicar-a-era-do-onlife-onde-real-e-virtualse-com-fundem. Acesso em: 21 de julho de 2020.

Coordenadoria de Pesquisa e Extensão - COPEX

Departamento de Editoraçāo e Divulgaçāo Científica - DEDIC 


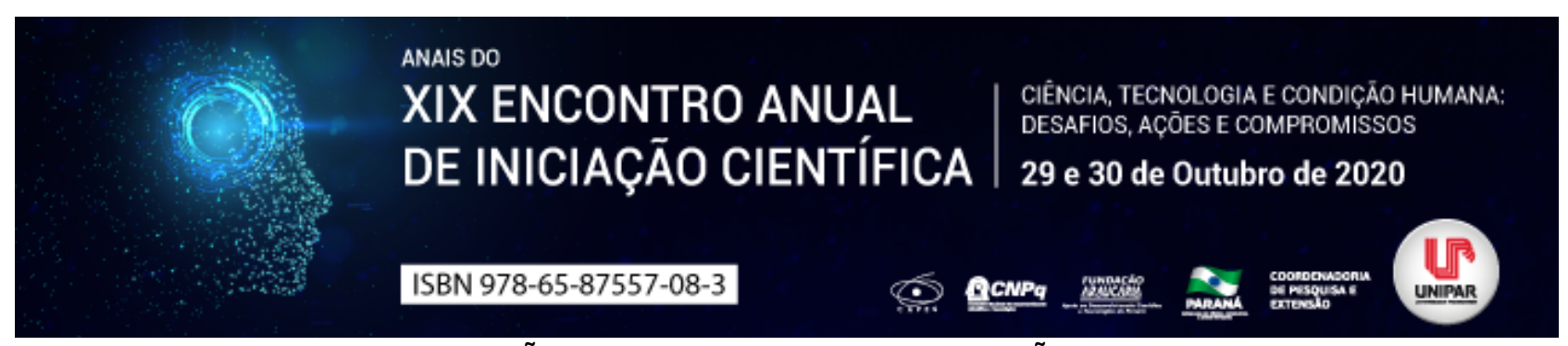

\title{
A DESIGUALDADE RACIAL E A ATUACÃO DA PSICOLOGIA NA PROMOÇÃO DOS DIREITOS FUNDAMENTAIS DAS MINORIAS
}

${ }^{1}$ MARIA AUGUSTA ZAGO MEXIA, ${ }^{2}$ TEREZA RODRIGUES VIEIRA

\author{
${ }^{1}$ Acadêmica do Curso de Psicologia e integrante do PIC/UNIPAR \\ ${ }^{1}$ Pós-Doutora em Direito pela Université de Montreal e Docente do Mestrado em Direito da UNIPAR
}

Introdução: A desigualdade racial no Brasil é uma característica recorrente devido a sua histórica construção. É indubitável que, por meio das análises relacionadas à cor e raça, o cidadão não branco brasileiro encontra-se em desvantagem. O racismo estrutural abrange toda a organização econômica e política da sociedade que se molda através de subsídios que reproduzem a desigualdade e a violência. Em decorrência dos atuais hábitos de segregação racial, observa-se que as garantias constitucionais brasileiras não são autossuficientes para promover a igualdade. Estando em uma batalha comum, a interdisciplinaridade entre o Direito e a Psicologia pretende promover uma luta antirracista cada vez mais constante e com resultados mais satisfatórios.

Objetivos: Apresentar a construção histórica do racismo no Brasil, assim como expor a atuação do Psicólogo no combate à desigualdade entre raças juntamente com a defesa dos direitos fundamentais destas minorias.

Desenvolvimento: A estratificação social é uma característica presente na formação de quase todos os países do mundo. No caso do Brasil, mesmo sendo um país construído dentre uma demarcada diversidade racial e étnico-cultural, não é diferente. Essa estratificação social promove, muitas vezes, a desigualdade e, nesse caso em especial, a desigualdade social por questão de raça ou cor. De acordo com um dos últimos informativos publicados em relação às pesquisas de indicadores sociais, o Brasil tem em sua composição populacional $55,8 \%$ dos indivíduos representados como pretos ou pardos, ou seja, a sociedade brasileira é majoritariamente formada por cidadãos desta raça ou cor (IBGE, 2019). Apesar de estarem em maior número, os

não-brancos são considerados minoria perante o contexto social brasileiro, visto que, esse grupo racial está condicionado, na maioria das vezes, a várias situações de marginalidade. É oportuno dizer, do ponto de vista teórico exposto por Almeida (2019, p. 34), que: [...] o racismo, como processo histórico e político, cria as condições sociais para que, direta ou indiretamente, grupos racialmente identificados sejam discriminados de forma sistemática. De fato, o fator cor ou raça tem sido há muito tempo um determinante expressivo para o desenvolvimento dos sujeitos e, torna o racismo um elemento de razão estrutural envolto essencialmente sob a ótica econômica e política (ALMEIDA, 2019). É possível validar tal afirmação pela assimetria entre as raças que são observadas nos índices de pessoas localizadas abaixo da linha de pobreza, sendo os indivíduos analisados com renda inferior a U\$ 5,50/dia, foram apresentados $15,4 \%$ deles de cor ou raça branca e 32,9\% de cor ou raça preta ou parda (IBGE, 2019). Ademais, convém ressaltar que, a meritocracia não funciona quando adentra cenários como os da sociedade brasileira. Isso importa dizer que, o valioso poder do psicólogo na ação de enfrentamento ao racismo é estabelecido pelo Centro de Referências Técnicas em Psicologia e Políticas Públicas (CFP, 2017), criado por iniciativa do Sistema de Conselhos de Psicologia (CFP, 2013), amparado pelas normas dispostas na Constituição Federal de 1988 (BRASIL, 1988) e no Estatuto da Igualdade Racial (BRASIL, 2010). Considerando que o racismo é derivado da constituição da sociedade e não de atos individuais, as medidas precisarão ir além da coibição institucional, atentando para as mudanças incisivas nas relações de ordem política, social e econômica (ALMEIDA, 2019). A constante e, também atual, luta antirracista, vista por meio dos recorrentes movimentos negros, mostra o quão urgente é a luta de ação social e constitucional para proporcionar paridade entre as raças.

Conclusão: Conclui-se que o racismo estrutural está presente na sociedade não como patologia, mas como profunda manifestação desenvolvida no contexto político e econômico social tornando, portanto, a busca pela igualdade complexa. Dessa forma, a Psicologia como ciência e profissão, juntamente com as garantias constitucionais, deve adentrar a subjetividade de cada sujeito, de maneira pessoal ou social, com o anseio de desconstruir a concepção de raça como fator de estratificação social que proporciona desvantagens aos sujeitos de raça ou cor preta e parda.

\section{Referências}

Referências: ALMEIDA, S. L. de A.; RIBEIRO, D. (Coord.). Feminismos plurais: Racismo estrutural. SP: Pólen, 2019.

BRASIL. Constituição Federal de 1988. Presidência da República Federativa do Brasil. Disponível em: www.planalto.com.br. Acesso em: 19 ago. 2020.

BRASIL. Lei N. 12.288, de 20 de julho de 2010. Institui o Estatuto da Igualdade Racial. Disponível em: www.planalto.com.br. Acesso em: 19 ago. 2020.

CONSELHO FEDERAL DE PSICOLOGIA. Relações raciais: referências técnicas para atuação de psicólogas/os. Brasília, CFP, set. 2017. $1^{\text {a }}$ Edição. Disponível em: file:///D:/Documents/PSICOLOGIA/PIC/RELA\%C3\%87\%C3\%95ES\%20RACIAIS\%20\%20CREPOP.pdf 
CONSELHO FEDERAL DE PSICOLOGIA. Referências Técnicas para a Prática de Psicólogas (os) no Centro de Referência Especializado da Assistência Social CREAS. Brasília, CFP, fev. 2013. 1 Ed. Disponível em: https://site.cfp.org.br/wpcontent/uploads/2013/08/CREPOP_CREAS_.pdf

IBGE, Estudos e Pesquisas; Informação Demográfica e Socioeconômica, n.41: Desigualdades Sociais por Cor ou Raça no Brasil. Disponível em: https://biblioteca.ibge.gov.br/visualizacao/livros/liv101681_informativo.pdf Edição de 2019. Acesso em: 18 ago. 2020.

Coordenadoria de Pesquisa e Extensão - COPEX

Departamento de Editoraçāo e Divulgaçāo Científica - DEDIC 


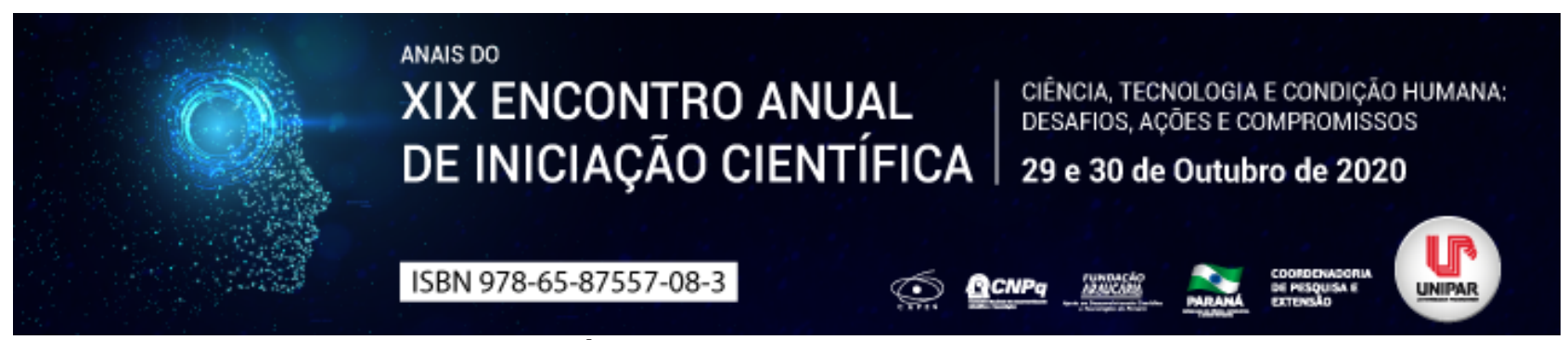

ENCEFALITE HERPÉTICA SIMPLES RELACIONADA AO ESTRESSE

\author{
${ }^{1}$ CAROLINE FAVARO PANHAN, ${ }^{2}$ LARISSA DELAZARI ANTONHOLI, ${ }^{3}$ BEATRIZ EDUARDA DE LIMA, ${ }^{4}$ ORLETE MARIA \\ POMPEU DE LIMA
}

\author{
${ }^{1}$ Acadêmico do PIC/UNIPAR \\ ${ }^{1}$ Acadêmica do Curso de Psicologia da UNIPAR \\ ${ }^{2}$ Acadêmica do Curso de Psicologia da UNIPAR \\ ${ }^{3}$ Docente da UNIPAR
}

Introdução: Este estudo faz parte do Projeto de Iniciação Científica (PIC), denominado Encefalite Herpética relacionado ao estresse: estudo de caso, que apresenta a evolução clínica e o tratamento proposto de um paciente, desde o surgimento dos primeiros sintomas da patologia, com dados coletados através de informações fornecidas pela família e pela equipe médica e as descrições contidas em prontuários médicos e psicológicos. Pacientes com doenças orgânicas que cursam com manifestações psiquiátricas e psicológicas, são um constante desafio para a Medicina e Psicologia.

Objetivo: Mediante revisão bibliográfica foram abordados a compreensão da patologia Encefalite Herpética Simples - EHS, suas sequelas e acometimentos.

Desenvolvimento: A patologia denominada Encefalite Herpética Simples - EHS é uma patologia grave, de alta mortalidade, caracterizada por extenso comprometimento encefálico e expressa-se clinicamente por início agudo de febre e sintomas neurológicos focais, principalmente, secundários ao acometimento do lobo temporal e especificamente associada à mudança de personalidade, convulsões focais ou generalizadas, afasia e, às vezes, coma (TAKAYANAGUI, 2007). A encefalite significa um processo inflamatório do parênquima cerebral e pode ser causada diretamente por uma variedade de vírus, sendo importantes os Herpes vírus e alguns arbovírus. (TAKAYANAGUI, 2007). O vírus Herpes Simples (HSV) é o causador da EHS, sendo esta a principal encefalite esporádica (não sazonal) no mundo ocidental. Alterações cognitivas e comportamentais relacionadas à encefalite herpética são conhecidas e descritas na literatura como amnésias, afasias, mudanças de personalidade, alucinações e desinibição e há poucos estudos sobre o tema, especificamente, nenhum a respeito do manejo dos sintomas psiquiátricos resultantes. Acredita-se que o paciente se torna mais susceptível a esta patologia quando exposto a fatores como trauma, imunossupressão e estresse (TAKAYANAGUI, 2007). Deve-se suspeitar de encefalite herpética quando se apresentar quadro agudo de febre, cefaleia e alterações comportamentais. Outros sinais e sintomas como afasia, convulsões, náuseas e coma podem surgir. É uma patologia grave, com índice de letalidade de $70 \%$ quando não tratada (LOPES et al, 2008). Quando não é tratada adequadamente ou não responde ao tratamento, a encefalite pode causar sequelas graves. A maioria das pessoas com diagnóstico de encefalite grave terá complicações. As complicações resultantes da encefalite podem incluir como paralisia muscular, problemas de memória e aprendizagem, dificuldades na fala e audição, alterações visuais e sensoriais, epilepsia e movimentos musculares involuntários. As complicações são mais prováveis de se desenvolverem em certos grupos, como adultos mais velhos, pessoas que tiveram sintomas semelhantes aos do coma e pessoas que não receberam tratamento imediatamente. (JOHNSON, 2018).

Conclusão: Os estudos realizados, permitiram a compreensão da EHS, as sequelas e os acometimentos por esta doença, haja vista se tratar doença pouco conhecida. No entanto, apesar da gravidade da patologia, no enfoque biológico, observou-se uma escassez de maiores estudos quanto ao nexo causal do estresse relacionado ao trabalho para o acometimento da patologia. Salienta-se que, em virtude da situação de pandemia, o presente trabalho acabou parcialmente prejudicado, devido a impossibilidade de realização de abordagem interpessoal com eventuais pacientes portadores da patologia.

\title{
Referências
}

LOPES, Antônio Carlos, et al. Encefalite herpética em paciente do sexo feminino de 48 anos previamente hígida, Rev Soc Bra Clin Med 6(2): 79-82, 2008.

JOHNSON, Shannon. Encefalite. 29 set. 2018. Disponivel em: https://www.healthline.com/health/encephalitis. Acesso em: 01 ago. 2020.

TAKAYANAGUI, Osvaldo M. NeuroAtual: boletim de resumos e atualidades em neurologia. Academia Brasileira de Neurologia, Volume 3, número 5, 09/2007. 


\title{
-

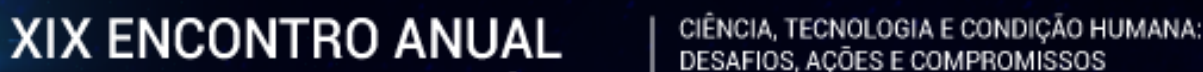 DE INICIACÃO CIENTÍFICA DESAFIOS, AQOEES E COMPROMISSOS DE INICIAÇAOO CIENTIFICA 29 e 30 de Outubro de 2020 \\ ISBN 978-65-87557-08-3

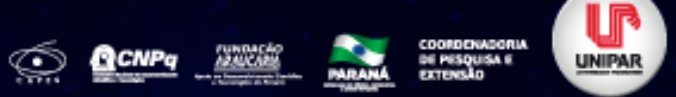 \\ DIVERSIDADE, DIREITOS HUMANOS E GESTÃO: INCLUSÃO I EXCLUSÃO DE DIREITOS DA APRENDIZAGEM EM TEMPOS DE PANDEMIA E A AÇÃO DA GESTÃO ESCOLAR
}

\author{
${ }^{1}$ AMANDA DANTAS VIVI, ${ }^{2}$ MARIA DO CARMO DE O NOGUEIRA
}

\author{
${ }^{1}$ Discente PEDAGOGIA-Presencial / PIBIM-UNIPAR MONITORIA (Gestão Educacional [Escolar e Não Escolar]) \\ ${ }^{1}$ Docente / PIBIM-UNIPAR MONITORIA (Orientadora - Gestão Educacional [Escolar e Não Escolar])
}

Introdução: A educação é o principal meio para instrução, construção e aprendizagem do homem como cidadão, nesse aspecto a CF1988, indica em seus Art. 205 e 206: A educação, direito de todos [...], ensino ministrado nos princípios: igualdade de condições para o acesso e permanência na escola; gratuidade do ensino público [...]; gestão democrática [...]; garantia de padrão de qualidade; garantia do direito à educação e à aprendizagem ao longo da vida [Emenda Constitucional $n^{\circ} 108$, de 2020] (BRASIL, 1988). Destaca que a educação básica é obrigatória e para todos, porém algumas vezes a mesma pode ser imparcial, excludente, competitiva, e individualista, sendo que, para que seja verdadeiramente democrática há que se repensar e reconstruir uma boa escola/educação que substitua a competição pela cooperação, o preconceito pela solidariedade, a alienação pela responsabilidade, o autoritarismo pela competência profissional, o trabalho isolado pelo coletivo (ALBUQUERQUE, 2011, p. 8). Tais ideais podem ser inquestionáveis nesse momento de pandemia, pois as práticas pedagógicas, ação gestora e as aprendizagens precisam de um olhar diferenciado no sentido da equidade/igualdade para todos, mas a realidade está banhada de desigualdade, a exemplo: no contexto tecnológico aos quais alunos estão enfrentando exclusão digital, e como visto também na LDB n. ${ }^{\circ}$ 9394/96, reforça o direito de acesso, igualdade e educação de qualidade (BRASIL, 1996). Sendo assim, é preciso conhecer, saber, reconhecer e demonstrar, quais são os caminhos traçados nessa educação que deve ser desconstruída para ser reconstruída neste momento de pandemia.

Objetivo: Promover uma análise acerca das ações pedagógicas da gestão educacional em período de pandemia e suas principais influências no cotidiano de estudo de inclusão/exclusão dos alunos, visando à compreensão dos fundamentos dos direitos humanos.

Desenvolvimento: A educação tem vivenciado um cenário diversificado e em evolução, por conta do momento de pandemia que demonstra drasticamente e mais visivelmente um cenário de desigualdade. Esse momento evidenciou a necessidade de repensar as políticas educacionais tendo em vista a equidade como um dos parâmetros centrais (JEDUCA, 2020), bem como traçar novos caminhos, tomar novas atitudes e ressignificar todo o processo de ensino-aprendizagem. Gestores, professores e equipe escolar demandaram de se adaptar ao contexto vivenciado em suas regiões e cenários educativo-escolares cotidianos, já que existem diferenciadas realidades socioeducacionais dos alunos demonstrando muitas dificuldades, divergências e complicações. É indispensável repensar as iniciativas tomadas e a forma como estão sendo elaboradas tais ações dentro das políticas educacionais, com visão de que determinadas adaptações na educação básica acabaram acontecendo de forma precipitada e sem debates das condições objetivas para garantir a democratização do acesso e o cumprimento das diretrizes legais, uma vez que as escolas e a sociedade não se prepararam para a urgência da inovação tecnológica, e como estão propostas tais medidas servirão apenas como processos de mercantilização da educação (SINPRO-DF, 2020). Nesse ínterim,

professores adaptaram seu modelo de ensino, onde grande parte das redes de ensino optou por meios tecnológicos, ou seja, o ensino a distância, ou ensino remoto síncrono e assíncrono, alguns lugares por iniciativa de seus gestores escolares e professores optaram pela entrega de materiais, bem como, em outros lugares optaram pelo adiantamento das férias ou suspensão das aulas. Toda a organização escolar ou familiar foi reestruturada criando novas estratégias, e ainda, na educação principalmente, houve a necessidade urgente de gestores e professores junto aos alunos, acompanharem as novas tendências para garantir a educação e o acesso destes às escolas (SPILLERE, 2020). Todas estas ações visam dar continuidade nas aprendizagens, de tal forma que as mudanças foram preciosas no ambiente de estudo, na colaboração dos pais, na forma de ensinar do professor, em virtude de reestruturar a educação no país, buscando medidas cabíveis para cada aluno, para que não houvesse perdas totais, mesmo que futuramente as equipes escolares devam resgatar e retomar processos de ensinoaprendizagens que não aconteceram.

Conclusão: Se a educação deve ser acessível para todos, nesse momento tem sido seletiva, se esquecendo de abranger e desenvolver o aluno, levando em conta sua realidade e contexto social, com raras exceções de educadores comprometidos que tem feito de tudo para que alunos não fracassem totalmente em seus estudos. Portanto, necessita-se impor meios, alternativas que busquem amenizar a desigualdade, o desinteresse, dificuldades e a evasão, seja capacitando os profissionais para lidarem com essa realidade, seja trazendo alternativas cabíveis ao processo e buscando adaptar o momento escolar de ensinoaprendizagem de maneira inclusiva, reflexiva, com envolvimento tecnológico de todos, trabalhando e usando a equidade como sinônimo do progresso, bem como avançar no caminho das iniciativas para o progresso do aluno em meio a tantas dificuldades e 


\section{Referências}

ALBUQUERQUE, Helena Machado de Paula. Gestão Escolar e o Plano Nacional de Educação em Direitos Humanos. Cadernos ANPAE, $\quad$ v. $1, \quad$ p. $\quad$ n.11, $2011 . \quad$ - $\quad$ (versão on-line). $\quad$ Disponível em: https://anpae.org.br/simposio2011/cdrom2011/PDFs/trabalhosCompletos/comunicacoesRelatos/0219.pdf. Acesso em: 10 jul. 2020.

BRASIL. CONSTITUIÇÃO DA REPÚBLICA FEDERATIVA DO BRASIL DE 1988. Brasília: Planalto, [1988]. Disponível em: http://www.planalto.gov.br/ccivil_03/constituicao/constituicao.htm. Acesso em: 28 Ago. 2020.

BRASIL. LEI No 9.394, DE 20 DE DEZEMBRO DE 1996. Brasília: Planalto, [1988]. Disponível em: http://www.planalto.gov.br/ccivil_03/Leis/L9394.htm. Acesso em: 28 Ago. 2020.

JEDUCA. Pandemia tornou desigualdades educacionais mais visíveis. 1 Vídeo (1:20:32) (e versão on-line) Notícias 2. Webnário. Canal da Associação de Jornalistas de Educação. [S.I] 07 de maio de 2020. Disponível em: https://jeduca.org.br/texto/pandemia-tornou-desigualdades-educacionais-mais-visiveis. Acesso em: 16 jun. 2020.

SINPRO-DF. Ead e exclusão escolar em tempos de pandemia. [S.I]. 30 de Março de 2020. Disponível em:

https://www.sinprodf.org.br/ead-e-exclusao-escolar-em-tempos-de-pandemia-2/. Acesso em: 10 Ago. 2020.

SPILLERE, Caio. Educação pós-pandemia: como se adaptar às mudanças no ensino. Fundacred Educação - Assessoria Martha Becker. 01 de Julho de 2020. Disponível em: https://www.fundacred.org.br/site/2020/07/01/educacao-pos-pandemiacomo-se-adaptar-as-mudancas-no-ensino/. Acesso em: 10 Ago. 2020. 


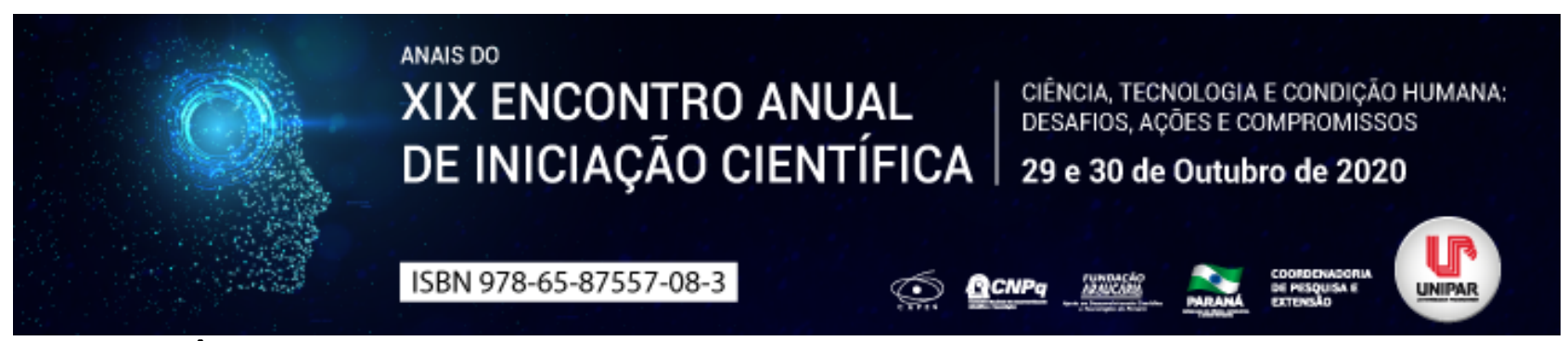

A IMPORTÂNCIA DOS PARQUES URBANOS NA MELHORIA DA QUALIDADE DE VIDA DAS CIDADES

\title{
${ }^{1}$ YASMIN LUANA BOLA, ${ }^{2}$ YASNAI LUELI BOLA, ${ }^{3}$ RODRIGO MASCHIO DE FREITAS
}

\author{
${ }^{1}$ Acadêmica do Curso de Arquitetura e Urbanismo da UNIPAR \\ ${ }^{1}$ Acadêmica do Curso de Engenharia Civil da UNIPAR \\ ${ }^{2}$ Docente da UNIPAR
}

Introdução: Os parques urbanos são áreas verdes com grande importância para a dinâmica urbana, inseridos nas cidades como fonte de lazer e cultura, proporcionando contato com a natureza e suas estruturas, quando adequadas são determinantes para a realização de atividades físicas podendo trazer diferentes benefícios psicológicos, sociais e físicos a saúde dos indivíduos, além de serem um lugar de contato com a natureza nas grandes cidades.

Objetivo: O estudo teve como objetivo geral destacar a importância dos parques urbanos para o indivíduo, bem como, para as cidades, acerca dos fatores ambientais e sociais.

Desenvolvimento: Os parques nasceram a partir do século XIX, da necessidade de dotar as cidades de espaços adequados para atender a uma nova demanda social como o lazer, e para opor-se a o ambiente urbano (MACEDO, 2003). Com as mudanças urbanísticas das cidades, os parques passam a evoluir, sendo assim marcado pelos valores sociais e culturais das populações urbanas. Os parques urbanos representam na dinâmica das cidades, um "espaço verde" fundamental no contexto de crescimento e desenvolvimento econômico e urbano, pois através deles, proporcionam para a comunidade dos bairros que os circundam como também para toda a cidade, um espaço destinado ao lazer, ao contato com a natureza, onde o homem se encontra totalmente inserido (MELAZO e COLESANTI, 2003, p.06). Desta forma surge o conceito de espaço verde urbano, na era industrial, com a vinda da população para as cidades, como o objetivo de recriar a presença da natureza no meio urbano. Deste modo os espaços verdes passam a ser locais de encontro, de estadia, de passeio público, promovendo a diversidade cultural de uma sociedade; e criando valor simbólico, identidade e a sensação de se pertencer a um lugar. Segundo o site archdaily, pelas suas qualidades intrínsecas, os espaços verdes possuem funções estratégicas nas cidades, enriquecendo a paisagem urbana e assumindo um papel central de arejamento sendo responsável pela diminuição das temperaturas, oferecem um ecossistema urbano apropriado para a conservação da biodiversidade, contribuem para a regulagem hídrica e para a redução do impacto da cidade construída sobre o meio ambiente. A estrutura verde formaliza-se numa paisagem de caráter urbano, garantindo sempre que possível uma relação de continuidade com áreas mais naturalizadas e onde deve persistir o caráter predominantemente verde destes espaços. A qualidade do ambiente urbano está relacionada a inúmeros aspectos entre eles pode-se ressaltar a influência do verde urbano na cidade. Loboda (2003) relaciona a ausência de áreas verdes às questões relacionadas a aspectos sociais, estéticos, de lazer, políticos e culturais, entre outros. É possível verificar que as áreas verdes assumem um papel muito importante no espaço urbano tanto na qualidade ambiental como também na qualidade de vida da população que necessita desse espaço público para lazer ou entretenimento. Deste modo, pode-se notar que as áreas que seriam capazes de estar assumindo essa finalidade estão abandonadas sem uso algum. Um espaço urbano de qualidade é um fator decisivo para a melhor qualidade de vida e saúde de uma população. $O$ ato de praticar atividades de lazer concede grandes benefícios à saúde, o ritmo de vida acelerado da população vem gerando enorme estresse, tanto físico como mental. Desta maneira, nota-se o quão importante são os parques públicos, fazendo desta uma alternativa imprescindível, pois a qualidade de vida está intimamente ligada ao lazer. Desta maneira, pode-se perceber que parques se tornaram essenciais para a vida nas cidades, quando o homem passa a procurar um lugar que possa fugir do barulho e exaustão constante da vida urbana.

Conclusão: Observou-se a importância dos parques na qualidade de vida das cidades e dos indivíduos, devido ao fato de as pessoas estarem sempre em grande movimento e rodeadas por grandes cidades, o que faz dos parques um ponto de fuga, para a pratica de atividades físicas, descanso e lazer, bem como, os parques urbanos se tornaram pulmões verdes dentro das cidades devido ao desenvolvimento tecnológico.

\section{Referências}

ARCHDAILY. Os espaços verdes públicos Entre demanda e possibilidades efetivas. 2012. Disponível em: www.archdaily.com.br/br/01-89370/os-espacos-verdes-publicos-nil-entre-demanda-e-possibilidades-efetivas. Acesso em: 01 de Ago. 2020.

BEZERRA, Maria do Carmo de Lima Bezerra; DA ROCHA, Mariana Arrabal; BOGNIOTTI, Gláucia Maria Côrtes. QUALIDADE DOS ESPAÇOS VERDES URBANOS: O PAPEL DOS PARQUES DE LAZER E DE PRESERVAÇÃO, estudos, Goiânia, n. 15, p. 128- 142, 2016.

LOBODA, Carlos Roberto. Estudo das áreas verdes urbanas de Guarapuava-PR. 2003. Dissertação (Mestrado em Geografia). 
Universidade Estadual de Maringá, Maringá/PR.

MELAZO, G. C.; COLESANTI, M. T. M. Parques Urbanos: importantes espaços verdes na dinâmica ambiental das cidades. In: II Simpósio Regional de Geografia Perspectivas para o cerrado no século XXI , 2003, Uberlândia. Anais. Universidade Federal de Uberlândia, 2003.

MACEDO, S.S; SAKATA, F.G. Parques Urbanos no Brasil. São Paulo: EDUSP: Imprensa Oficial do Estado de São Paulo, 2003. SILVA, Janaína Barbossa; PASQUALETTO, Antônio. O CAMINHO DOS PARQUES URBANOS BRASILEIROS: DA ORIGEM AO SÉCULO XXI*, estudos, Goiânia, v. 40, n. 3, p. 287-298, 13 jul. 2013.

Coordenadoria de Pesquisa e Extensão - COPEX

Departamento de Editoraçāo e Divulgaçāo Científica - DEDIC 


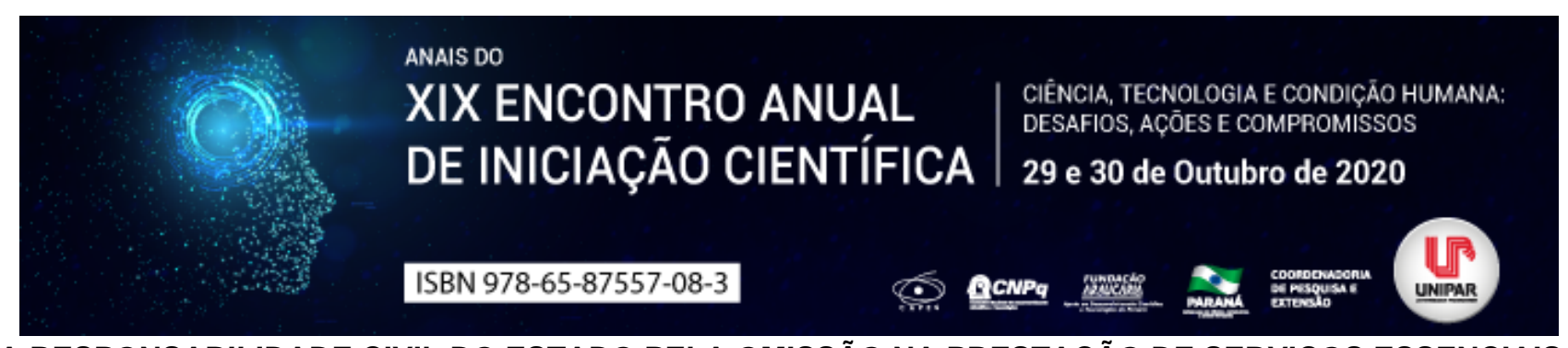

A RESPONSABILIDADE CIVIL DO ESTADO PELA OMISSÃO NA PRESTAÇÃO DE SERVIÇOS ESSENCIAIS

\author{
${ }^{1}$ JULIA KREWER KOLLENBERG, ${ }^{2}$ JANE MARA DA SILVA PILATTI
}

${ }^{1}$ Acadêmica do curso de Direito da UNIPAR

${ }^{1}$ Docente da UNIPAR

Introdução: A responsabilização civil do Estado é utilizada como forma de controlar a atuação dos órgãos e agentes públicos, tendo em vista que devem sempre buscar atender os interesses da coletividade, sob pena de violarem sua obrigação jurídica. No presente trabalho, buscar-se-á tratar como é feita a responsabilização do Estado nos casos em que for omisso, deixando assim de prestar serviços considerados essenciais e obrigatórios. A presente pesquisa pauta-se em um método dedutivo, de análise bibliográfica.

Objetivo: Demonstrar como é feita a responsabilização do Estado nos casos em que este for omisso, deixando assim de prestar os serviços considerados essenciais obrigatórios e como a doutrina e a jurisprudência tratam o tema.

Desenvolvimento: A responsabilidade civil nada mais é do que a obrigação civil de indenizar daquele que viola algum dever jurídico, e desta forma, acaba causando danos a terceiros. Marco Aurélio Bezerra de Melo (2015, p. 2) dispõe que: podemos definir a responsabilidade civil como a obrigação patrimonial de reparar e compensar o dano moral causado ao ofendido pela inobservância por parte do ofensor de um dever jurídico legal ou convencional . Ainda, conforme Pablo Stolze Gagliano e Rodolfo Pamplona Filho (2016, p. 55), a responsabilidade civil deriva da agressão a um interesse eminentemente particular, sujeitando, assim, o infrator ao pagamento de uma compensação pecuniária à vítima, caso não possa repor in natura o estado anterior das coisas. No caso da responsabilidade ser de natureza contratual, ocorre quando alguma das partes não cumpre o que foi estipulado em contrato. Já na extracontratual, ocorre quando há dano causado por uma ação ou omissão voluntária, negligência, imprudência ou imperícia - nesta última classificação, se enquadram principalmente os serviços essenciais que deveriam ser prestados pelo Estado. Tais serviços se encontram elencados no artigo 10 da Lei n 7.783 , (Lei da Greve), sendo os principais a assistência médica e hospitalar, e a distribuição e comercialização de medicamentos e alimentos. No Código Civil de 1916 já era prevista a responsabilidade civil subjetiva, onde era preciso comprovar a culpa do Estado. Após isso, a própria Constituição Federal de 1988 adotou a responsabilidade civil objetiva, em seu art. 37, §6 no que tange a responsabilização do Estado. Fernanda Marinela (2012, p. 962) preceitua que as funções estatais rendem ensejo à produção de danos mais intensos que os suscetíveis de serem gerador pelos particulares. Isso porque a função estatal é bastante ampla e engloba serviços e ações essenciais à coexistência pacífica dos seres em sociedade e à sua própria manutenção, portanto, quanto maior o risco, mais cuidado deve ser despendido e menor o nível de aceitação nas falhar, implicando em consequente responsabilização . Entretanto, isso não significa que a responsabilidade civil subjetiva esteja abolida quando se trata da Administração Pública, enquanto existem algumas situações que ensejam a verificação da culpa para que se configure de fato a responsabilidade civil. Conclusão: O trabalho resultou na percepção de que a responsabilidade civil sempre existiu, entretanto ocorreu uma evolução gradual na forma de reparação deste dano. No que diz respeito à responsabilidade civil do Estado, já houve grande divergência, mas atualmente é pacífico o entendimento de que é sim possível responsabilizar o Estado por omissão.

\title{
Referências
}

BRASIL. Constituição (1988). Constituição da República Federativa do Brasil. Brasília: Senado Federal, 1988.

BRASIL. Código Civil. Lei ${ }^{\circ} 3.071$ de $1^{\circ}$ de janeiro de 1916.

BRASIL. Código Civil. Lei $n^{\circ}$ 10406, de 10 de janeiro de 2002.

BRASIL, Lei $\mathbf{n}^{\mathbf{0}} \mathbf{7 . 7 8 3}$, de 28 de junho de 1989. Dispõe sobre o exercício do direito de greve, define as atividades essenciais, regula o atendimento das necessidades inadiáveis da comunidade, e dá outras providências.

GAGLIANO, Pablo Stolze; PAMPLONA FILHO, Rodolfo. Novo curso de Direito Civil. 14. ed. São Paulo: Saraiva, 2016. v.III, p. 55.

MARINELA, Fernanda. Direito Administrativo. 6. ed. Niterói: Impetus, 2012. p. 962.

MELO, Marco Aurélio Bezerra. Curso de Direito Civil. Responsabilidade civil. São Paulo: Atlas, 2015.v.4,p.2. 


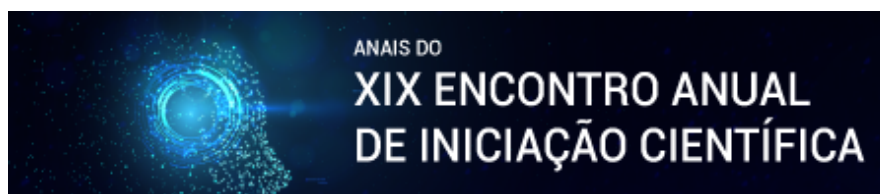
CIÊNCIA, TECNOLOGIA E CONDIÇĀO HUMANA: DESAFIOS, AÇŌES E COMPROMISSOS

XIX ENCONTRO ANUAL

29 e 30 de Outubro de 2020

ISBN 978-65-87557-08-3

6 을

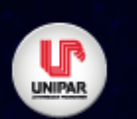

MEDIAÇÃO DE CONFLITOS: UMA ANÁLISE COMPARATIVA ACERCA DAS ESCOLAS DE MEDIAÇÃO E O MODELO BRASILEIRO ADOTADO PARA RESOLUÇÃO CONSENSUAL DOS LITÍGIOS

${ }^{1}$ ADRIELLI PINHO DA SILVA, ${ }^{2}$ ANA PAULA QUEIROZ, ${ }^{3}$ MARIA ALICE ORTIZ, ${ }^{4}$ ADRIANE HAAS

${ }^{1}$ Acadêmico do PIC/UNIPAR
${ }^{1}$ Acadêmico do PIC/UNIPAR
${ }^{2}$ Acadêmico do PIC/UNIPAR
${ }^{3}$ Docente e Orientadora PIC/UNIPAR

Introdução: O presente trabalho tem por finalidade expor sobre as escolas de mediação, demonstrando como funcionam os benefícios e embasamentos de cada uma, para auxílio na resolução de conflitos em consonância com os princípios do Novo Código de Processo Civil.

Objetivo: Analisar as categorias diferenciadas de mediação que cada escola apresenta e tentar buscar uma afinidade entre elas com o intuito de classificalas como um conjunto produtivo e inovador para o meio de resoluções de conflitos consensuais.

Desenvolvimento: A palavra conflito é um substantivo masculino, originada do latim como Conflictus e seus significados possuem variados sentidos. No meio jurídico, o conflito é praticamente o pontapé inicial para gerar o processo e proceder com as devidas medidas cabíveis. Nesta cena, encontram-se os métodos alternativos de resolução de conflitos, tais como a conciliação e a mediação. O Código de Processo Civil (Lei n. 13.105/2015) reafirmou a diferenciação entre tais métodos, no artigo 165, consignando na conciliação, que o terceiro facilitador da conversa interfere de forma mais direta na solução do litígio e pode chegar a sugerir opções para resolvê-lo (art. $165, \S 2^{\circ}$ ). Já na mediação, o mediador facilita o diálogo entre as pessoas para que elas mesmas proponham soluções (art. 165, § $3^{\circ}$ ). A mediação iniciou sua atuação historicamente em vários países com o papel de intervir de maneira pacífica e imparcial nos conflitos que surgiam na sociedade. Consigo, vários princípios a acompanharam, sendo alguns deles: imparcialidade do mediador, isonomia entre as partes, oralidade, informalidade, autonomia da vontade das partes, busca do consenso, confidencialidade e a boa-fé. Em 2010 no Brasil, teve-se a inserção dos métodos autocompositivos de resolução de conflitos por meio da Resolução 125 do CNJ que originou para estimular, apoiar e difundir a sistematização e o aprimoramento de práticas adotadas pelos tribunais para o tratamento adequado dos conflitos de interesses por meios autocompositivos e heterocompositivos. Por esta razão, reconheceu-se que a mediação é instrumento efetivo de pacificação social e de solução e prevenção de litígio, cuja implementação tem reduzido a excessiva judicialização dos conflitos e a quantidade de recursos e processos em execução. A Resolução foi objeto de atualização em 31 de janeiro de 2013 e tem por objetivos básicos disseminar a cultura da pacificação social e estimular a prestação de serviços autocompositivos de qualidade além de incentivar os tribunais a organizarem e planejarem programas amplos de autocomposição. Algumas escolas se aprofundam na questão de orientar os mediadores em como atuar diante das discrepâncias entre as partes, sendo as principais que se apresentaram inicialmente: o Modelo Tradicional Linear de Harvard, baseado no projeto de negociação de Harvard, que tem como objetivo gerar acordos sensatos, eficientes e pautados em padrões justos, com atuação do mediador através de técnicas que são chamadas de ferramentas para auxílio na negociação, foi adotada inicialmente pela Resolução 125/2010 para treinamento dos mediadores e conciliadores; o Modelo Transformativo de Bush e Folger, onde a questão central não é o acordo e sim a transformação das relações entre as partes e o modo como enxergam o conflito, com as premissas do empoderamento e reconhecimento; o Modelo Circular-Narrativo, da professora Sara Cobb, o qual se utiliza da narrativa das partes, para construir a história de uma melhor forma, onde elas serão transformadas e entrelaçadas com uma visão e conotação mais positiva, legitimando as partes nos conflitos sobre seus sentimentos e emoções (FALECK; TARTUCE, 2020). Outras escolas também surgiram, como a Mediação do Tipo Avaliativa que junto a ela implementou a mediação facilitativa como alternativa mais aplicada no Brasil onde se evidencia uma participação mais ativa do mediador em incentivar as partes a alcançar um acordo. Entretanto, nos Estados Unidos ainda é um método muito complexo e polêmico já que é difícil identificar a imparcialidade do terceiro, e caso não comprovada, há chances de causar danos à mediação. Dessa maneira, é uma boa opção apenas quando o único objetivo é fazer um acordo e encerrar o assunto rapidamente, emulando uma decisão de Tribunal. Vale ressaltar que esse tipo de mediação se aproxima bastante da conciliação, pois o mediador pode opinar, sugerir ou valorar no conflito que está acontecendo, contudo isso não tirará dele o seu caráter teoricamente neutro e nem o poder das partes em decidirem Por fim, tem-se a Mediação do Tipo Warattiana, proposta pelo professor e advogado argentino Luis Alberto Warat, que tem por objetivo trabalhar o amor e a sensibilidade como método de resolução do conflito e assim como o Modelo de Bush e Folger, esse tipo de mediação não tem como objetivo chegar a um acordo a todo custo. (MISORELLI, 2020).

Conclusão: Os métodos alternativos de resolução dos conflitos se tornaram uma prática curricular obrigatória nas faculdades de Direito, responsáveis por oferecer aos acadêmicos um núcleo de prática jurídica adequado ao cenário jurídico brasileiro. É fundamental que a utilização de tais métodos seja largamente disseminada entre os operadores do direito, juntamente com o auxílio do conhecimento de todas as fontes dispostas, inclusive as escolas que tratam do assunto, para que assim, a cultura do litígio ceda lugar a uma cultura de paz.

\section{Referências}

BRASIL. Conselho Nacional de Justiça. Qual a diferença entre conciliação e mediação? Disponível em: https://www.cnj.jus.br/qual-a-diferenca-entreconciliacao-e-mediacao/\#: : :text=Na\%20concilia\%C3\%A7\%C3\%A30\%2C\%200\%20terceiro\%20facilitador,165\%2C\%20\%C2\%A7\%203\%C2\%BA. Acesso em: 05/08/2020.

BRASIL. Conselho Nacional de Justiça. Resolução No 125 de 29/11/2010. Disponível em: https://atos.cnj.jus.br/atos/detalhar/atos-normativos? documento=156. Acesso em: 06/08/2020.

FALECK, Diego. TARTUCE, Fernanda. Introdução histórica e modelos de mediação. Disponível em: www.fernandatartuce.com.br/artigosdaprofessora. Acesso em 31/05/2020.

MISORELLI, Heloisa. Escolas clássicas de mediação. Disponível em: https://heloisamisorelli.jusbrasil.com.br/artigos/461154508/escolas-classicas-demediacao\#: :text=Regida\%20pelos\%20princ\%C3\%ADpios\%20da\%20independ\%C3\%AAncia,Folger\%2C\%200\%20M\%C3\%A9todo\%20Narrativo\%2DCircular. Acesso em 02/09/2020. 


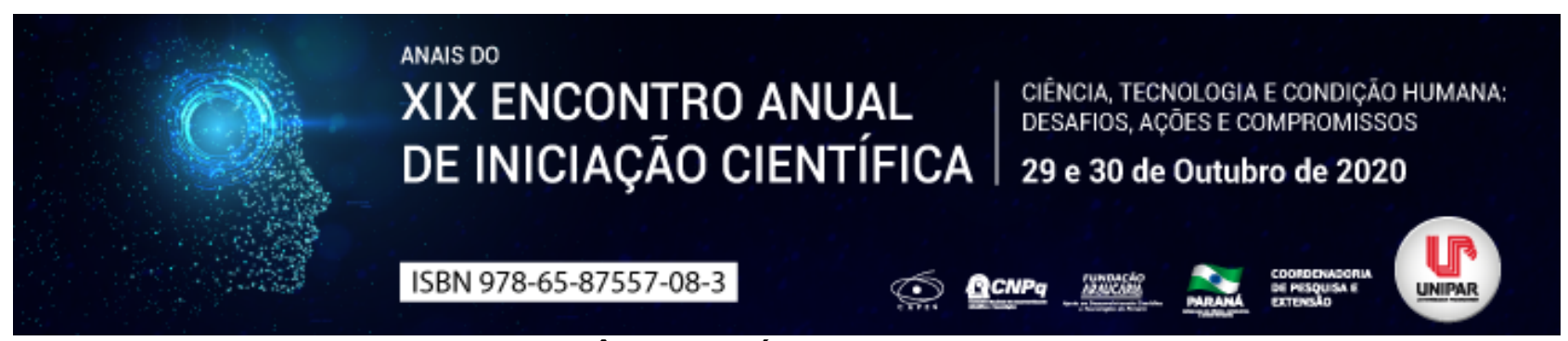

PATRIMÔNIO HISTÓRICO E O RESTAURO

\author{
${ }^{1}$ Acadêmica do Curso de Arquitetura e Urbanismo da UNIPAR \\ ${ }^{1}$ Acadêmica do Curso de Engenharia Civil da UNIPAR \\ ${ }^{2}$ Docente da UNIPAR
}

${ }^{1}$ YASMIN LUANA BOLA, ${ }^{2}$ YASNAI LUELI BOLA, ${ }^{3}$ LUANA VANESSA SPIAZZI

Introdução: Com a modernidade, o conceito de patrimônio vem sido discutido entre os órgãos de preservação, devido a salvaguarda em determinar estes elementos patrimoniais que de fato são uma representação simbólica de uma identidade, em uma sociedade que cresce e se transforma, mas que também preserva sua memória.

Objetivo: Tem-se por objetivo destacar a importância do restauro de monumentos históricos, bem como, a teoria do restauro e o papel do arquiteto nas restaurações de edifícios histórico.

Desenvolvimento: $O$ patrimônio histórico compõe parte de uma cultura, tem por objetivo a função de representar simbolicamente a identidade e a memória de uma sociedade. Este patrimônio deve contribuir para revelar a identidade de cada um, graças ao espelho que ele fornece de si mesmo e ao contato que ele permite com o outro. (Dominique Poulot, 2009, p. 14). Assim, a memória desempenha um grande papel, pois se faz recordar através do patrimônio o já vivido. Porém, a noção de patrimônio acarreta na atualização nas noções de conservação e restauro, se torna existente um dinamismo das formas de intervenção destes patrimônios, a relação da obra e de seu tempo histórico se faz retomar a ideia de Cesare Brandi que estabelece os momentos que caracterizam a inserção da obra de arte no tempo histórico para poder definir em qual desses momentos podem ser produzidas as condições necessárias a essa particular intervenção a que se chama restauro, e em qual desses momentos é lícita tal intervenção (BRANDI, 2017, p. 59). A preservação do patrimônio, dispõe de várias perspectivas daquilo que é considerado monumento histórico. $\mathrm{Na}$ arquitetura está, relaciona-se a características intrínsecas. A arquitetura é a única, entre as artes maiores, cujo uso faz parte de sua essência e mantém uma relação complexa com suas finalidades estética e simbólica (CHOAY, 2001, p. 230). Todo restauro necessita de um conhecimento de seu histórico, de suas estratificações, desta forma, Brandi traz a ideia de presentes históricos, que interligam um período intermediário entre a obra. Aquela que coincide com o ato de sua formulação, o ato da criação, e se refere, portanto, a um artista, a um tempo e a um lugar; e uma segunda historicidade que provém do fato de insistir no presente de uma consciência, e portanto, uma historicidade que se refere ao tempo e ao lugar que está naquele momento (BRANDI, 2017, p. 32). Como uma trajetória da obra, a imagem que chega a atualidade desde o tempo de criação da obra, se tornaram um passado, o que traz a ideia de restauração com traços de seu transito, e de fato é esta contemporização entre o antigo e o novo, que representa o restauro. Com tudo, critica-se o arquiteto modernista, por se dizer, este negar o passado e o interromper, para dar-se início o novo; esta noção do moderno para cada época, vem por causar uma divisão de algo que passa a ser considerado antigo. Desta forma, surge a noção de que o moderno de cada tempo parte do antigo de cada tempo, seja por vez, complementando-o, como ocorre com a história do patrimônio.

A teoria e a pratica do restauro vem carregadas de um passado, assim, cada um dos teóricos e críticos possuem sua própria atualidade, o que leva entender-se que o restaurador atual deve levar em consideração o seu próprio olhar para a obra, porem esta restauração deve ter o objetivo de reestabelecer o potencial da obra até onde seja possível, sem produzir uma eventual falsificação histórica ou artística, bem como, não apagar todo traço da passagem do tempo, bem como compor os traços artístico do restaurador.

Conclusão: Se faz entender que o patrimônio representa simbolicamente a identidade e a memória de um povo, este, não é apenas um mero vestígio, mas um símbolo de um tempo. Faz-se necessário o reconhecimento da importância real deste patrimônio como a identidade deste povo, e que este patrimônio precisa de fato ser preservado não apenas como demonstração de um momento da história, mas como um período significativo que nos perpetuam como somos hoje, assim, a modernidade deve estar em conciliação para a continuação da sociedade que venha a possuir uma história.

\title{
Referências
}

BRANDI, Cesare. Teoria da restauração. Tradução: Beatriz Mugayar Kühl. 4. ed. [S. I.]: Ateliê Editorial, 2017. 264 p. CHOAY, Françoise. A ALEGORIA DO PATRIMONIO. Tradução: Luciano Vieira Machado. 4. ed. [S. I.]: Estação Liberdade, 2001. $288 \mathrm{p}$.

CUNHA, Claudia dos Reis e. A atualidade do pensamento de Cesare Brandi. Vitruvius, 2004. Disponível em: https://www.vitruvius.com.br/revistas/read/resenhasonline/03.032/3181. Acesso em: 31 jul. 2020.

POULOT, Dominique. Uma história do patrimônio no Ocidente. Tradução: Guilherme J. F. Teixeira. 1. ed. [S. I.]: Estação Liberdade, 2009. $240 \mathrm{p}$. 
Coordenadoria de Pesquisa e Extensão - COPEX

Departamento de Editoraçāo e Divulgaçāo Científica - DEDIC 


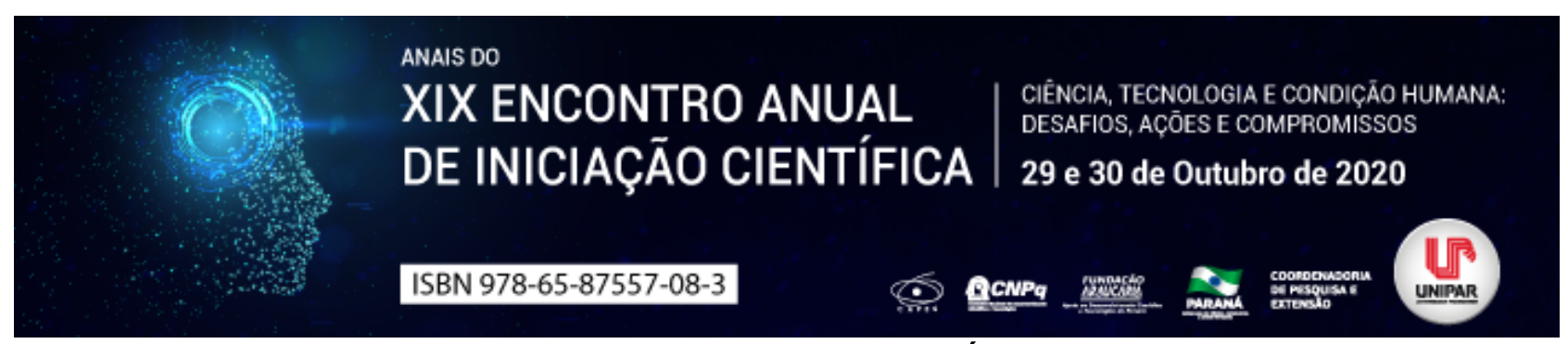

TERAPIA ASSISTIDA POR ANIMAIS AUXILIANDO A SAÚDE MENTAL DOS SUJEITOS

\begin{abstract}
${ }^{1}$ VANESSA MARIA BONIOLO, ${ }^{2}$ JOAO PEDRO TERRA PRADO BORGES, ${ }^{3}$ LETICIA DAIANI PERIN, ${ }^{4}$ DANIELLE AGUIAR RAMALHO, ${ }^{5}$ GRAZIELE BRAGA, ${ }^{6}$ MAURO SERGIO DA ROCHA
\end{abstract}

\author{
${ }^{1}$ Acadêmica do Curso de Psicologia da UNIPAR \\ ${ }^{1}$ Acadêmico do Curso de Medicina Veterinária da UNIPAR \\ ${ }^{2}$ Acadêmica do Curso de Psicologia da UNIPAR \\ ${ }^{3}$ Acadêmica do Curso de Psicologia da UNIPAR \\ ${ }^{4}$ Acadêmica do Curso de Psicologia da UNIPAR \\ ${ }^{5}$ Docente da UNIPAR
}

Introdução: O presente resumo foi construído através de revisão bibliográfica e discussões acerca da terapia assistida por animais (TAA), utilizada como ferramenta facilitadora no processo psicoterápico. A temática causou indagações em acadêmicos do curso de psicologia e medicina veterinária, no que tange o desempenho da atividade sob o olhar interdisciplinar.

Objetivo: Mostrar a eficácia da Terapia Assistida com animais para fins terapêuticos.

Desenvolvimento: Comumente as pessoas associam o conceito de terapia a sua forma tradicional, onde trata-se de um espaço com poltronas e duas pessoas, sendo uma delas o terapeuta - profissional capacitado e faz o uso de conhecimentos e técnicas psicológicas - e a outra, pessoa atendida que traz para a sessão a demanda a ser trabalhada. O que nem todos sabem é que ela pode ser ampliada, não sendo feita somente em setting terapêutico, mas em vários locais. Sendo possível a utilizacão de outras formas, instrumentos e espaços, a fim de promover um cuidado integral e humanizado ao paciente. A TAA é um recurso metodológico que dispõe de animais para a intervenção terapêutica, com o objetivo de promover a qualidade de vida e saúde mental, apresentando subsídios para o usuário ter um maior contato com seus conteúdos. No Brasil, a médica psiquiatra Nise da Silveira foi a pioneira na utilização de animais como co-terapeutas , sendo ela uma personagem de grande importância para as reformulações sob os métodos terapêuticos com usuários de hospitais psiquiátricos. É uma técnica que de acordo com Nise da Silveira auxilia na afetividade, autoestima, expressão, interação social e autoconfiança das pessoas em sofrimento psíquico, pois, esses animais agem como mediadores entre o imaginário e o real, potencializando o processo terapêutico (FERREIRA; PEREIRA; PEREIRA, 2007). Pensando nisso, em sua atuação com pacientes esquizofrênicos em um hospital psiquiátrico, Nise chamou a relação dos pacientes com animais como Afeto Catalisador, que condiz com a relação terapêutica produzida na relação entre o animal e o sujeito. Nessa relação, o paciente se conecta com algo da realidade externa através de uma relação na qual o animal é utilizado como ponte entre os envolvidos no processo (FÜLBER, 2011). A TAA pode ser praticada terapeuticamente em um processo grupal e individual, colocando o usuário em contato direto com o animal. Com isso, se trabalha todos os sentidos e sensações que o animal pode gerar no sujeito, tais como: a motricidade, na realização de passeios, no tatear o bicho, ao escová-lo, a sonoridade dos sons emitidos pelo animal, ou seja cria-se uma nova linguagem (NOBRE, 2017). Colocando em análise a historicidade, podemos pensar na relação do sujeito e os animais iniciada a milhões de anos como forma predatória e, mais tardar, o animal passou a ser colocado dentro das casas e domesticado (NOBRE, 2017). Posteriormente, a interação entre os bichos e a sociedade foram ficando cada vez mais familiares e despertando um intenso elo entre ambos, como por exemplo o cão e a associação feita sobre a fidelidade do animal ao seu dono. A TAA, como técnica terapêutica, visa a inclusão de animais contribuindo para efeitos benéficos em processos terapêuticos (VIEIRA, 2013). Ainda, considera-se nesse processo o acompanhamento de um médico veterinário, sua participação começa desde a seleção do animal, escolha da raça, porte físico e outras características específicas. Diante disso o veterinário tem a capacidade de perceber o perfil do animal para cada sujeito dentro de um aspecto cooperativo, possibilitando maior interação e relação terapêutica entre eles. Considerando a necessidade da terapêutica e o comportamento dos animais. Muitos animais são escolhidos ainda filhotes e o veterinário é responsável pelos exames e avaliação do comportamento destes animais (SILVA et al, 2017). Vale ressaltar também sobre a castração, como uma medida importante para redução de stress e diminuição de comportamentos instintivos. Assim, o veterinário participa/acompanha, desde a seleção do animal até sua aposentadoria como co-terapêuta.

Conclusão: Dessa forma, percebemos que a TAA intervém através de um trabalho interdisciplinar, sob a diligência metodológica alternativa, de encontro com o cuidado em saúde mental. Assim, promove uma maior qualidade de vida, socialização e autonomia ao sujeito em sofrimento psíquico. Apresenta resultados positivos, visto que, pode ser aplicada em diferentes públicos e faixas etárias colaborando significativamente com a melhora de aspectos mentais, sociais, físicos e emocionais.

\title{
Referências
}


FÜLBER, S. Atividade e terapia assistida por animais. 2011. 27 f. Monografia (Graduação em Medicina Veterinária) Faculdade de Veterinária, Universidade Federal do Rio Grande do Sul, Porto Alegre, 2011. Disponível em: . Acesso em: 28 agosto 2020.

PEREIRA, M. J. F.; PEREIRA, L.; FERREIRA, M.. L. Os benefícios da Terapia Assistida por Animais: uma revisão bibliográfica Saúde Coletiva, vol. 4, núm. 14, abril-maio, 2007, pp. 62-66 Editorial Bolina São Paulo, Brasil.

SILVA, N. C.; MADRID; SANTOS, M. C.C.; LUCAS, F. A.; OLIVA, V. N. L. S. O papel profissional do médico-veterinário na atividade de Terapia Assistida por Animais (TAA) / The veterinarian's professional role in Animal Assisted Therapy / Revista de Educação Continuada em Medicina Veterinária e Zootecnia do CRMV-SP / Journal of Continuing Education in Animal Science of CRMV-SP. São Paulo: Conselho Regional de Medicina Veterinária, v. 15, n. 2, p. 24-30, 2017.

SILVEIRA, N. O mundo das imagens. Editora Ática, 1992.

SQUILASSE, A. F.; SQUILASSE JUNIOR, F. T.; Intervenções assistidas por animais: considerações gerais I Animalassisted interventions: general considerations /Revista de Educação Continuada em Medicina Veterinária e Zootecnia do CRMV-SP/Journal of Continuing Education in Animal Science of CRMV-SP. São Paulo: Conselho Regional de Medicina Veterinária, v. 16, n. 2,p. 30-35, 2018.

VIEIRA, F. R. A terapia assistida por animais (TAA) como recurso terapêutico na clínica da terapia ocupacional. 2013. 56f. Monografia (Graduação em Terapia Ocupacional) Faculdade de Ceilândia, Universidade de Brasília, Brasília, 2013. Disponível em: . Acesso em: 20 de Agosto 2020. 


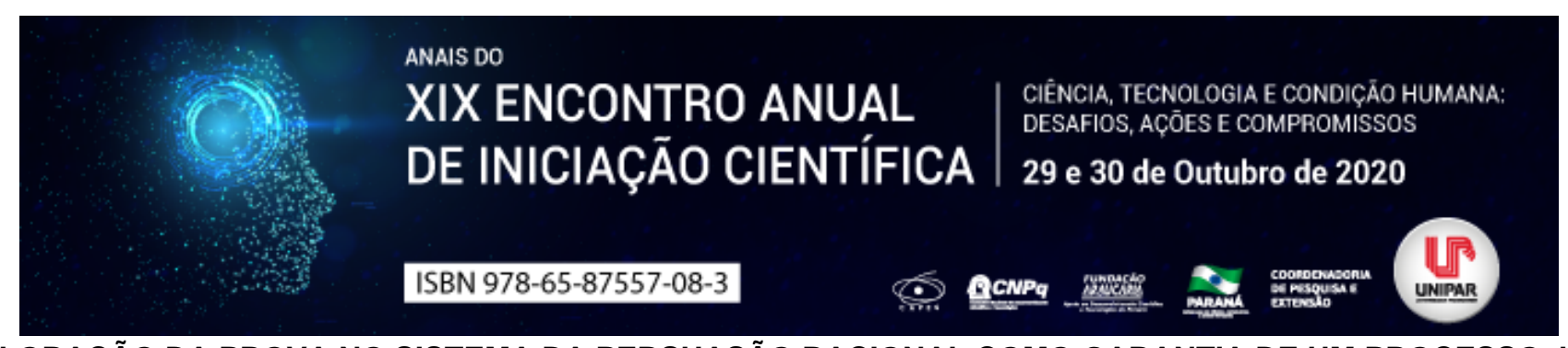

A VALORAÇÃO DA PROVA NO SISTEMA DA PERSUASÃO RACIONAL COMO GARANTIA DE UM PROCESSO JUSTO

\author{
${ }^{1}$ MILENA TONINATO VIGNOTO, ${ }^{2}$ ALBINO GABRIEL TURBAY JUNIOR
}

\author{
${ }^{1}$ Acadêmica do PIC/UNIPAR \\ ${ }^{1}$ Docente da UNIPAR
}

Introdução: A motivação da decisão judicial, em relação aos fatos, fundamenta-se por meio da prova e é um elemento essencial para o processo visto sob um aspecto instrumental, visando à concretização dos direitos em um processo justo. Por conseguinte, verifica-se a importância de um sistema de valoração das provas, que realize uma análise probatória imparcial e fundamentada, como o da persuasão racional, o que será analisado neste trabalho.

Objetivo: Analisar o sistema da persuasão racional como uma garantia processual para a efetivação da justiça.

Desenvolvimento: O Poder Judiciário, dentre as suas funções, possui o dever de exercer a jurisdição por meio da figura do Estado-juiz, responsável pela adequação e aplicação da lei ao caso particular e concreto. Para tanto, o magistrado dispõe da prova como uma ferramenta processual, que apresenta afirmações de fato, ou seja, alegações que podem, ou não, corresponder à realidade da situação fática ocorrida (ARENHART; MARINONI; MITIDIERO, 2015, p. 251). Dessa forma, ao apreciar a prova, o juiz deve seguir uma sistemática, que permita a determinação do valor probatório e o estabelecimento da veracidade dos fatos, com base em uma lógica. Para atingir essa finalidade, ao longo da história, foram adotados diferentes sistemas, sendo os principais: o da prova legal ou tarifada; o da íntima convicção ou do livre convencimento; e o da persuasão racional ou do livre convencimento motivado. Nesse âmbito, o primeiro sistema consistia na mecanização da ação jurisdicional, uma vez que as provas possuíam um valor pré-determinado, em lei, o que limitava a função do juiz a mero expectador da lide, para evitar a arbitrariedade nas decisões. Todavia, nota-se que havia uma confusão entre imparcialidade e omissão (GARCIA, 2018, p. 15), resultando na substituição desse sistema, pelo da íntima convicção, que, ao contrário da valoração pré-fixada, atribuía total liberdade ao magistrado, que poderia formar seu parecer baseado em suas experiências particulares e sem a necessidade de uma justificação. Consequentemente, tais aspectos pouco democráticos fizeram com que esse sistema enfraquecesse [...] por excessos, que chegam mesmo a conflitar com o princípio básico do contraditório, que nenhum direito processual moderno pode desprezar (THEODORO JÚNIOR, 2014, p. 1422). Diante de tais precariedades, o sistema da persuasão racional surge como melhor opção valorativa na atualidade, para as provas processuais civis, permitindo ao magistrado formular seu entendimento a partir de [...] quaisquer elementos que forem reproduzidos no processo, havendo, entretanto, o dever de fundamentação, isto é, da exposição por parte do julgador das razões que orientaram o seu convencimento (ALMEIDA, 2020, p. 14). Desse modo, o juiz é livre para avaliar os meios probatórios, contanto que utilize da racionalidade e respeite o direito posto, para exprimir os motivos, que culminaram no ato decisório. Ademais, além de ter sido adotada pelo Código de Processo Civil de 2015 (BRASIL, 2015), em seu artigo 371, essa sistemática foi integrada pela Constituição Federal do Brasil (BRASIL, 2019), por uma percepção principiológica, interligada aos demais princípios constitucionais e processuais, como o do contraditório e o do devido processo legal, cruciais para a efetividade das tutelas jurisdicionais. Logo, evidencia-se a importância da persuasão racional, para a formulação de um diálogo entre os litigantes e o juiz, a fim de proporcionar um ambiente comunicativo e democrático, que almeja a obtenção da justiça.

Conclusão: Apesar de alguns resquícios das formas antigas de valoração, na hodiernidade, a figura judicial utiliza para formar sua convicção a persuasão racional, que foi elevada ao status de princípio, garantido pelo próprio sistema do qual derivou. Por conseguinte, nota-se a relevância da prática desse método valorativo, que é capaz de gerar uma atuação processual justa e representa um dever, antes de um poder, para o julgador.

\title{
Referências
}

ALMEIDA, Felipe Souza Calmon de. Reflexões acerca da Teoria Geral da Prova à luz do Novo Código de Processo Civil.

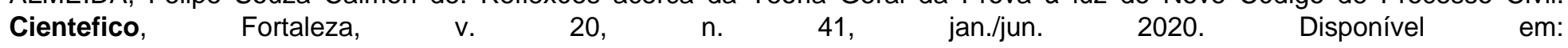
https://revistacientefico.adtalembrasil.com.br/cientefico/article/view/631. Acesso em: 20 ago. 2020.

ARENHART, Sérgio Cruz; MARINONI, Luiz Guilherme; MITIDIERO, Daniel. Novo curso de processo civil: Tutela dos direitos mediante procedimento comum. São Paulo: Editora Revista dos Tribunais, 2015.

BRASIL. Constituição da República Federativa do Brasil. Promulgada em 5 de outubro de 1988. In: Vade Mecum Saraiva. 27. ed. São Paulo: Saraiva, 2019.

BRASIL. Lei 13.105 de 16 de março de 2015. Código de Processo Civil. Diário Oficial da União, Seção 1, 17 mar. 2015 , p. 1.

GARCIA, Larissa Santana. A valoração da prova no âmbito do livre convencimento motivado à luz do Código de Processo Civil de 2015. 2018. Monografia (Bacharelado em Direito) - Universidade Federal da Paraíba, João Pessoa, 2018. Disponível 
em: https://repositorio.ufpb.br/jspui/handle/123456789/12864?locale=pt_BR. Acesso em: 20 ago. 2020.

THEODORO JÚNIOR, Humberto. Curso de direito processual civil: Teoria geral do processo civil e processo de conhecimento. 55.ed. Rio de Janeiro: Grupo Editorial Nacional, 2014.

Coordenadoria de Pesquisa e Extensão - COPEX

Departamento de Editoraçāo e Divulgaçāo Científica - DEDIC 


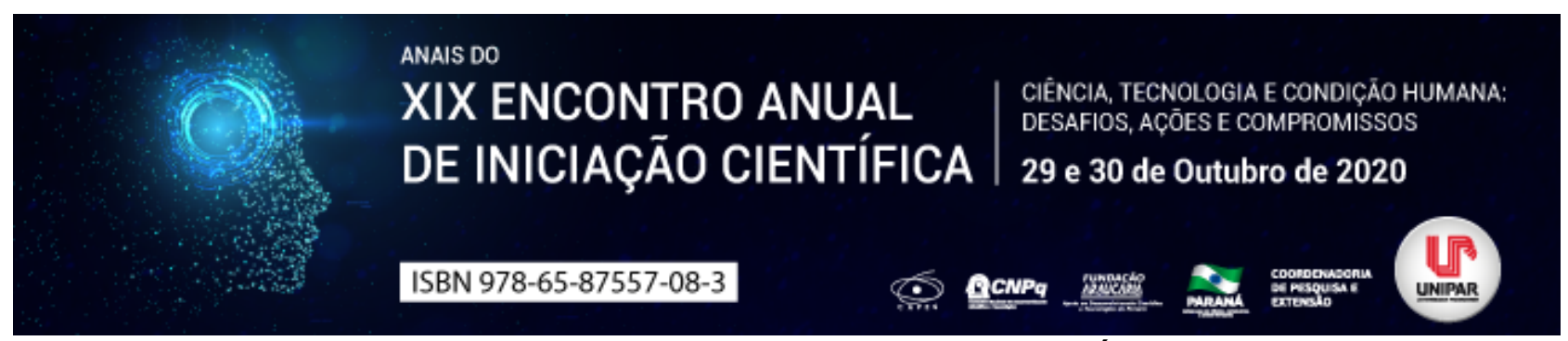

PARQUES URBANOS NA CIDADE DE CASCAVEL ESTUDO SOBRE ÁREAS VERDES DA CIDADE

\begin{abstract}
${ }^{1}$ MARIA LUIZA RUBEL DO PRADO, ${ }^{2}$ DANIELA DE CARVALHO BENNEMANN, ${ }^{3}$ AMANDA MARCIANO, ${ }^{4}$ SADRAQUE CAETANO DA SILVA, ${ }^{5}$ DEBORAH DE CAMARGO PACIORNIK
\end{abstract}

\author{
${ }^{1}$ Acadêmica do Curso de Arquitetura e Urbanismo da UNIPAR \\ ${ }^{1}$ Acadêmica do Curso de Arquitetura e Urbanismo da UNIPAR \\ ${ }^{2}$ Acadêmica do Curso de Arquitetura e Urbanismo da UNIPAR \\ ${ }^{3}$ Acadêmico do Curso de Arquitetura e Urbanismo da UNIPAR \\ ${ }^{4}$ Docente da UNIPAR
}

Introdução: Com a evolução da civilização os problemas ambientais começaram a agravar devido as novas necessidades ocasionadas pela urbanização. Os problemas no ambiente urbanizado estão relacionados à expansão não planejada pelo poder público, sem um planejamento principalmente municipal, pois a municipalidade é que gerencia e fiscaliza o uso e ocupação do solo. (COELHO et. al., 2019). Esse crescimento sem planejamento adequado das cidades, gera degradação do meio ambiente por apenas considerar a necessidade do ser humano em se encaixar no estilo de vida capitalista da sociedade. A expansão do comércio por todo o planeta e as necessidades que foram criadas pelas sociedades humanas, intensificou-se a apropriação dos recursos naturais (ROSS, 1996). Com isso, percebe-se a necessidade de elaborar um planejamento para que o crescimento da cidade seja pautado no respeito aos recursos naturais, visando harmonia entre o urbano e natural.

Objetivo: Propor um estudo sobre a implantação de um parque urbano em uma área verde na região oeste da cidade de Cascavel-PR, enaltecendo a importância dos parques urbanos e as diretrizes de sua implantação.

Desenvolvimento: As áreas verdes estão diretamente ligadas com a qualidade de vida proporcionada a população, em um centro urbano tornam-se o refúgio do caos gerado pela rotina do cotidiano. No contexto da qualidade de vida urbana, as áreas verdes, além de atribuir melhorias ao meio ambiente e ao equilíbrio ambiental; contribuem para o desenvolvimento social e traz benefícios ao bem estar, a saúde física e psíquica da população, ao proporcionarem condições de aproximação do homem com o meio natural, e disporem de condições estruturais que favoreça a prática de atividades de recreação e de lazer. (LONDE; MENDES; 2014). O estudo refere-se ao município de Cascavel, localizado no Oeste do estado do Paraná, analisa a relação da cidade com a preservação de suas áreas verdes. Averiguando a expansão da cidade, loca-se a área definida para pesquisa, sendo a Área de Preservação Permanente (APP) da baixada do Rio São Francisco pertencente a Bacia Hidrográfica do Paraná 3, tendo sua nascente localizada no perímetro urbano de Cascavel segundo a Secretaria de Estado do Meio Ambiente e Recursos Hídricos - SEMA, divisa natural dos bairros Canadá e Cancelli (GEOPORTAL), a área da pesquisa abrange apenas entre as ruas Salgado Filho e Antônio Damian. O local atualmente não está em uso pela população, em alguns lugares o rio é canalizado para abertura de vias que atravessam os bairros, facilitando o fluxo de veículos para outras regiões da cidade. O local pussui um considerável declive, devido ao Rio São Francisco, segundo a Consulta Prévia do GEOPORTAL de Cascavel classifica-se como Zona de Fragilidade Ambiental Urbana - Subzona de Proteção (Área de Proteção) e Zona de Fragilidade Ambiental Urbana - Subzona de Uso e Ocupação Controlados 1. A implantação de um parque urbano favorece a recuperação e preservação dos recursos naturais, além de elevar a qualidade de vida dos moradores da região. Proporcionando um local para lazer e educação ambiental, onde o contato com o meio ambiente fortalece o vínculo entre o homem e a natureza. Um parque na região escolhida para o estudo dará um uso adequado para a área, evitando sua degradação e proporcionando aos moradores um ambiente de conexão com a natureza, lazer e saúde. Para a elaboração deste estudo, foi realizado um diagnóstico da área por meio da visita in loco e análise dos dados coletados via GEOPORTAL de Cascavel. Após o diagnóstico e análise dos dados da área, serão elaborados diretrizes para a implantação de um parque urbano seguindo as informações adquiridas durante o processo de estudo sobre o histórico, conceitos e funções dos parques urbanos, contribuindo com a criação de áreas verdes com o intuito de revitalizar a mesma para cessar a degradação, propondo áreas de lazer à população atendendo suas necessidades.

Conclusão: As vantagens de um parque urbano planejado corretamente para a área do estudo, estimulará a preservação do meio ambiente oferecendo ao mesmo tempo um espaço de aprendizagem e lazer. Auxiliando a implantação do projeto, a criação de diretrizes de manejo da área visando uma execução do projeto menos agressiva as áreas de preservação, alcançando a harmonia da vida urbana com a natureza.

\title{
Referências
}

COELHO, João M et al. Indagações e perspectivas sobre a educação ambiental no século XXI 
Cuiabá, Vol. 40, n. 26, p. 3, jan.jjul.2019.

CTMGEO. Geoportal Cascavel. Cascavel, 15 jul. 2020. Disponível em: . Acesso em: 15 jul. 2020.

LONDE, P. R.; MENDES, P. C. A INFLUÊNCIA DAS ÁREAS VERDES NA QUALIDADE DE VIDA URBANA. Hygeia - Revista

Brasileira de Geografia Médica e da Saúde, v. 10, n. 18, p. 264 - 272, 25 jul. 2014.

PARANÁ. Secretaria de Estado do Meio Ambiente e Recursos Hídricos. Bacias Hidrográfi cas do Paraná. Curitiba, 2010. Disponível em: Acesso em: 15 jul. 2020.

ROSS. J. S. (org). Geografia do Brasil. São Paulo: Edusp, 1996.

Coordenadoria de Pesquisa e Extensão - COPEX

Departamento de Editoraçāo e Divulgaçāo Científica - DEDIC 


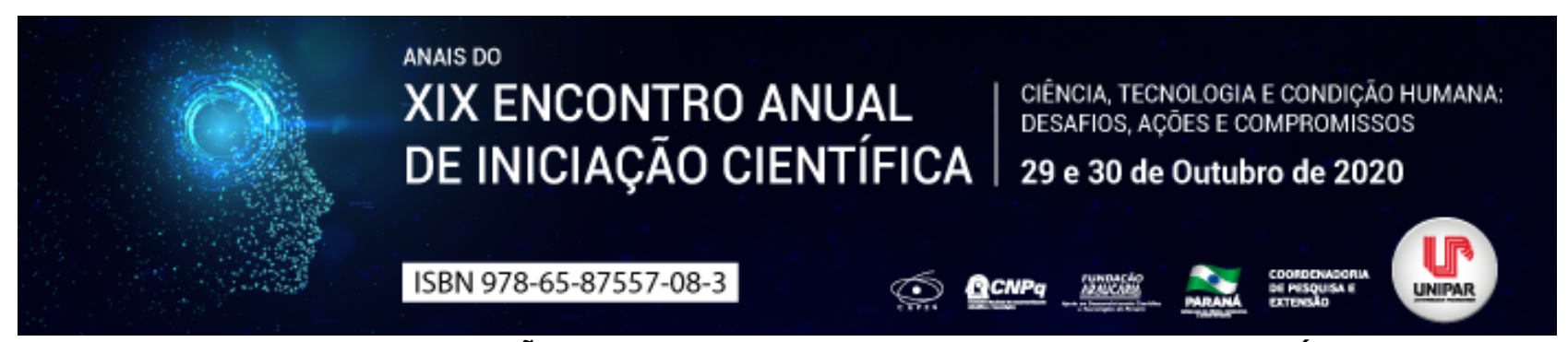

A NECESSIDADE DE IMPLEMENTAÇÃO DA HERANÇA DIGITAL NO ORDENAMENTO JURÍDICO BRASILEIRO

\author{
${ }^{1}$ MARIANNA ALVES DINIZ, ${ }^{2}$ VALDECIR PAGANI \\ ${ }^{1}$ ACADÊMICA DO CURSO DE DIREITO UNIPAR \\ ${ }^{1}$ Docente da UNIPAR
}

Introdução: A maioria das pessoas se tornou dependente dos serviços disponibilizados pelas redes sociais. Prova disso, é que perfis são criados diariamente em diversos aplicativos, em que diversos arquivos e informações do usuário são compartilhadas e se configuram em um repositório da existência digital do sujeito. Por isso, é essencial que as leis brasileiras tutelem esse legado, mesmo após o fim da vida de seus titulares.

Objetivo: Analisar o cabimento da Herança Digital no ordenamento jurídico brasileiro, a fim de verificar como será realizada a transmissão desses bens para os herdeiros, sem violar o direito de privacidade do falecido.

Desenvolvimento: Após o fenômeno morte, a transmissão dos bens é passada para os herdeiros legítimos de modo automático e imediato. Nesse sentido, a herança, de acordo com XISTO, (2018) é composta pelo patrimônio do falecido (conjunto de bens, direitos e obrigações) que se transmite aos herdeiros, salvo se for bem personalíssimo ou inerente à pessoa do de cujus. Nesse aspecto, quanto ao legado digital, LACERDA (2017, p. 74) defende que: (...) os bens digitais são incorpóreos, os quais são progressivamente inseridos na internet por um usuário, consistindo em informações de caráter pessoal que lhe trazem alguma utilidade, tenham ou não conteúdo econômico. Como exemplo, o referido autor (2017, p. 61) cita que tais bens (...) podem ser constituídos por textos, vídeos, fotografias, base de dados. Já os bens imateriais (incorpóreos) são considerados integrantes do patrimônio, mesmo sem resguardo no ordenamento. Diante disso, existem Projetos de Lei que com o propósito de suprir a necessidade das famílias em acessar o acervo digital deixado pelo falecido, uma vez que esses bens acumulados em vida fazem parte de um todo unitário estabelecido pelo Artigo 1791, do Código Civil, da relação jurídica de uma pessoa. Por isso, a Lege Ferenda, ou seja, antes de a lei prever, alguns aplicativos já possuem políticas próprias que ajudam a lidar com as contas do usuário falecido. O Google, por exemplo, fornece os conteúdos da conta do usuário, porém, não fornece senhas ou detalhes como o login. Já, o Whatsapp é um aplicativo protegido por criptografia, por isso, só terá acesso quem possuir o número do celular e a sua senha. Sendo assim, mesmo com regimes próprios, ainda, faz-se necessário a regulamentação dessa matéria no regimento brasileiro.

Conclusão: No Brasil, não há nenhum dispositivo que ampare de forma direta e eficaz a questão da herança digital. Portanto, é imprescindível que o sistema normativo passe por modificações legislativas, a fim de assegurar aos herdeiros e familiares os direitos dos bens digitais adquiridos em vida, contudo, sem ferir a privacidade do falecido e de terceiros, no fito de respeitar, sobretudo, o que está disposto na Constituição Federal acerca do direito fundamental da herança.

\title{
Referências
}

BRASIL. Código Civil. In: Vademecum. 29. ed. São Paulo: Saraiva, 2020.

LACERDA, Bruno Torquato Zampier. Bens Digitais. Indaiatuba: Foco Jurídico, 2017. p. 61-74.

XISTO, Ana Paula. Herança Digital: Extensão e tutela da personalidade civil post mortem em harmonia com o direito à privacidade na rede. 2018. Monografia (Graduação). Centro Universitário Toledo, Araçatuba, SP. Disponível em: https://bit.ly/3deT5ww. Acesso em: 06 de jun. de 2020. 


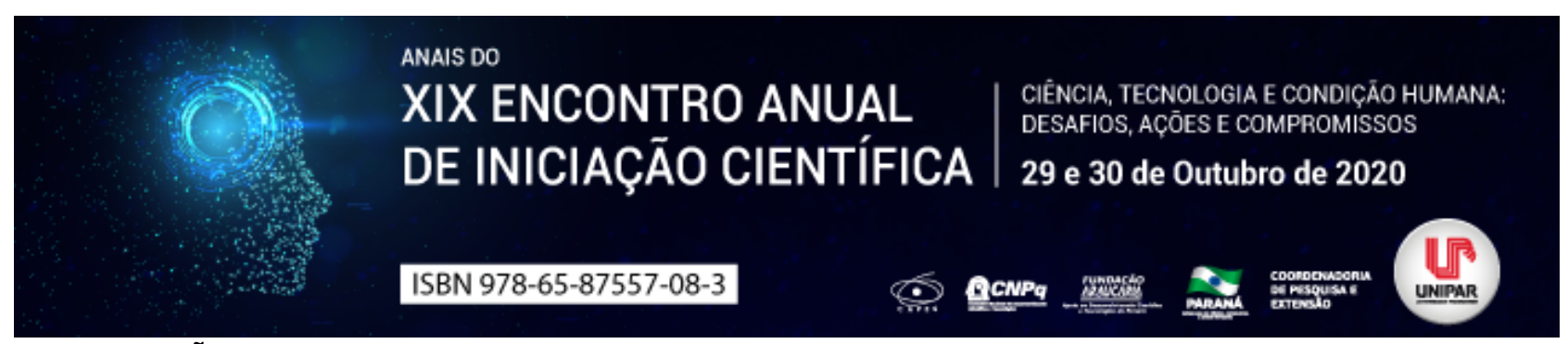

AÇÃO POPULAR: INSTRUMENTO DE DEFESA DOS INTERESSES DA COLETIVIDADE

\title{
${ }^{1}$ PEDRO FRANCISCO RIBEIRO, ${ }^{2}$ SIMONI RODRIGUES DE ALMEIDA, ${ }^{3}$ BRUNO SMOLAREK DIAS
}

\author{
${ }^{1}$ Mestrando do Programa de Mestrado em Direito Processual Civil e Cidadania da Universidade Paranaense, Acadêmico do \\ Programa de Iniciação C \\ ${ }^{1}$ Bacharel em Direito pela Universidade do Sul de Santa Catarina, Especialista em Gestão, Supervisão e Orientação Educacional \\ pela Faculdade d \\ ${ }^{2}$ Docente da UNIPAR
}

Introdução: As mudanças socioeconômicas ocasionadas de forma rápida, pelas transformações profundas que a sociedade passou nas últimas décadas, trouxe um constante desenvolvimento das economias de massa. O desenvolvimento do sistema de produção de bens, por conseguinte, repercutiu nas ofertas dos bens necessários a satisfação das necessidades humanas, dessa forma o individualismo foi deixado de lado, dando lugar a massificação. Essa transformação social se deu de forma acelerada, no entanto, os instrumentos jurídicos disponíveis até então, já não acompanharam essa evolução com a mesma celeridade, deixando a desejar nas soluções advindas dessa nova sociedade. Tal descompasso, cada vez mais evidente, desencadeou, na década de setenta, um movimento de busca pela efetividade do processo, visto que as fontes jurídicas não mais atendiam os interesses da coletividade, o conceito de público e privado já não mais abarcavam o conjunto de interesses que a sociedade moderna almejava (GONÇALVES, 2006, p. 1 e 2).

Desenvolvimento: Os instrumentos disponíveis de acesso à justiça, já não eram suficientes para assegurar a defesa do conjunto de interesses que se manifestavam frente a realidade social e econômica oriunda dessa nova ordem social e por conseguinte, obrigou a criação de instrumentos jurídicos, de ordem material e processual, que viessem ao encontro dessa nova realidade, bem como, houve uma mudança no entendimento afirmando a prevalência do coletivo sobre o individual. Dentre as formas de ações coletivas com previsão no ordenamento jurídico brasileiro, a Ação Popular pode ser proposta por qualquer cidadão, com o finco de pleitear a anulação ou declaração de nulidade de atos lesivos ao patrimônio da União, do Distrito Federal, dos Estados, dos Municípios, de autarquias, sociedade de economia, de serviços sociais autônomos, instituições ou fundações (LOVATO, 2006. p. 164-165). Trata-se de Ação Constitucional, de natureza civil cabível contra atos ilegais e imorais lesivos ao patrimônio público. Ao mencionar patrimônio público, não se refere apenas ao patrimônio material do Poder Público, não somente ao erário público, inclui-se ai também o patrimônio imaterial em toda sua dimensão, a Ação Popular não permite apenas a anulação do ato lesivo ao patrimônio público, traz também a possibilidade de declaração de nulidade dos referidos atos, com previsão expressa no artigo $4^{\circ}$ da lei $n^{\circ} 7.717 / 65$ (Lei da Ação Popular). Visando uma ordem impeditiva, a Ação Popular pode ser preventiva, devendo ser intentada quando houver a ameaça de lesão ao patrimônio público ou à moralidade administrativa, ou ao patrimônio cultural e histórico ou ao meio ambiente, ou seja, o dano ainda não foi causado, mas existe a eminencia disso acontecer. Caso o agente já tenha dado causa a lesão ao patrimônio público, a moralidade administrativa, ao patrimônio histórico e cultural ou mesmo ao meio ambiente, a Ação Popular será repressiva, cuja determinação será eminentemente corretiva (FERNANDES, 2011. p. 428430).

Conclusão: Criada originalmente para defender o interesse público, traz a possibilidade de ter pessoas privadas dentre os sujeitos passiveis da lide processual, o autor age como verdadeiro substituto do poder público, visto que o autor popular age na defesa da comunidade e não do interesse próprio, dessa forma a comunidade é o verdadeiro credor desse direito, devendo se limitar a busca da anulação de atos cujo interesse seja difuso ou coletivo, e nunca individual homogêneo, deste modo, a Ação Popular se faz presente no ordenamento jurídico brasileiro como um instrumento de garantia de maior acesso ao Poder Judiciário, pois a partir do momento que dá a possibilidade de um cidadão individualmente pleitear em juízo a defesa de interesse difuso, aumenta a possibilidade de defesa dos direitos e interesses da coletividade (LOVATO, 2006. p. 165-167).

\section{Referências}

BRASIL, lei no 7.717/65, Lei da Ação Popular.

Fernandes. Bernardo Gonçalves, Curso de Direito Constitucional. 3 ed. Rio de Janeiro: Lumen Juris. 2011. pg. 428-430.

Gonçalves, Marcus Vinícius Rios, Tutela de Interesses difusos e Coletivos - Coleção Sinopse Jurídica. Vol. 26, São Paulo: Saraiva, 2006.

Lovato. Luiz Gustavo, Curso de Processo Civil: procedimentos especiais, ações previstas em leis extravagantes e ações de direitos transindividuais. Rio de Janeiro: Lumen Juris, 2016. pg. 164-167. 
Coordenadoria de Pesquisa e Extensão - COPEX

Departamento de Editoraçāo e Divulgaçāo Científica - DEDIC 
${ }^{1}$ Discente UNIPAR

${ }^{1}$ Docente da UNIPAR

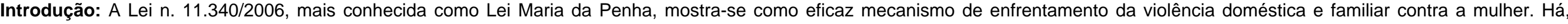

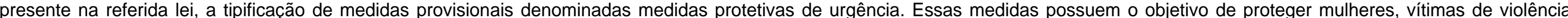

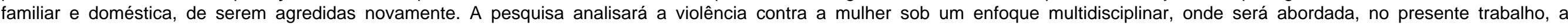
aplicabilidade ou inaplicabilidade dessas medidas provisionais em caso de concubinato adulterino.

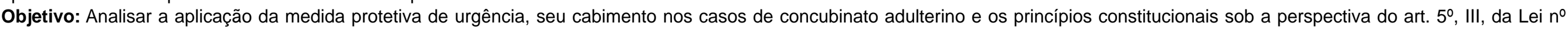
11.340/2006 e os valores fundamentais insertos no normativo.

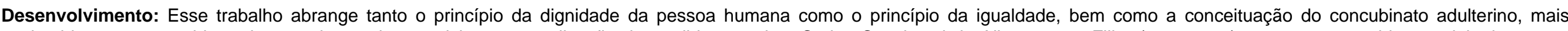

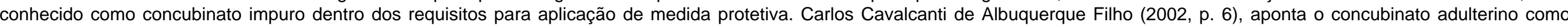

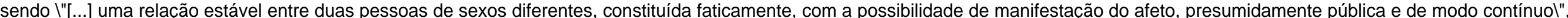

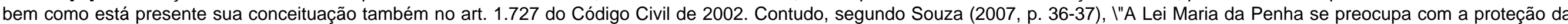

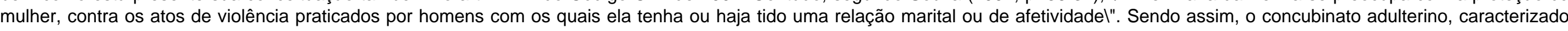

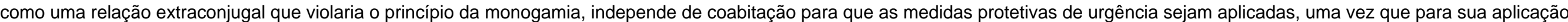

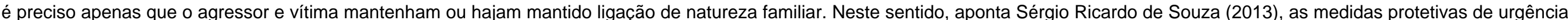

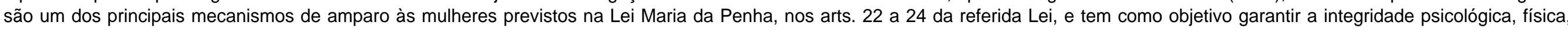

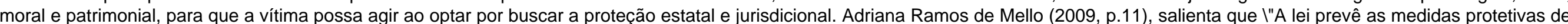

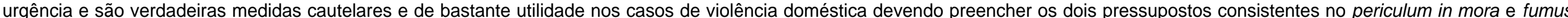

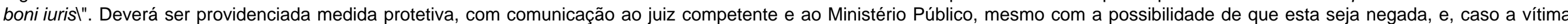

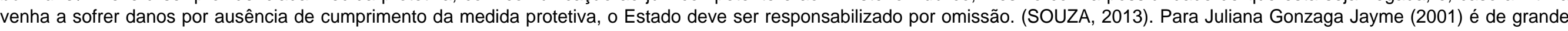

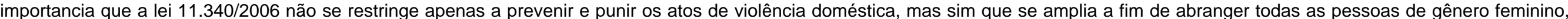

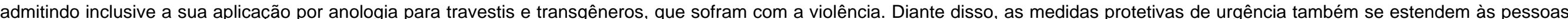

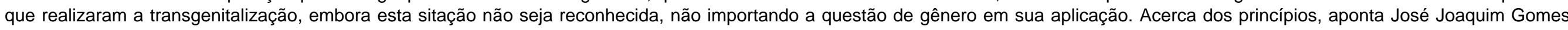

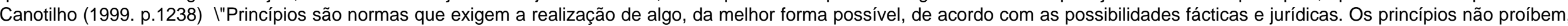

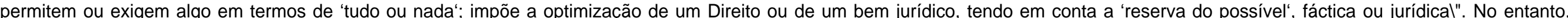

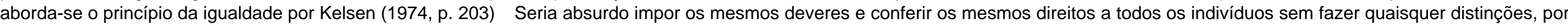

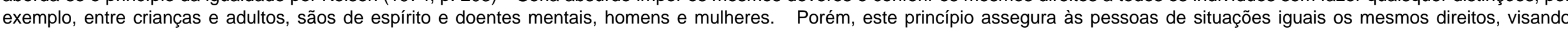

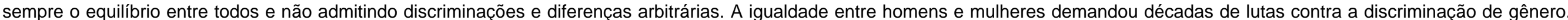
Não se trata de mera isonomia formal, pois não é simples igualdade perante a lei, mas sim igualdade em direitos e obrigações.

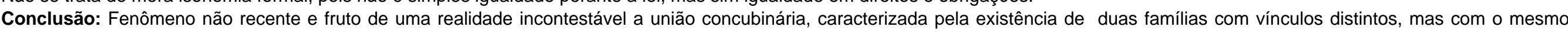

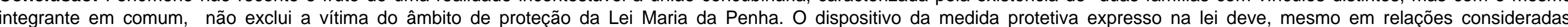

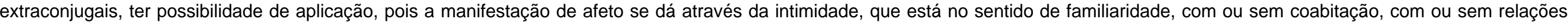
íntimas, bastando à convivência. 


\section{Referências}

BRASIL. Código Civil. Coordenação de Maurício Antônio Ribeiro Lopes. 5. ed.São Paulo: Revista dos Tribunais, 2002.

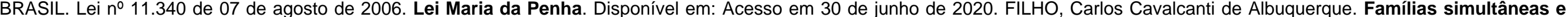
concubinato adulterino . Jus Navigandi, Teresina, ano 6, n. 56, abr. 2002. Disponível em <

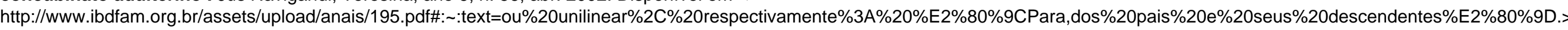
Acesso em 30 de junho de 2020

CANOTILHO, J. J. Gomes. Direito constitucional e teoria da constituição. 3.ed. Coimbra: Almedina, 1999, p. 1238.

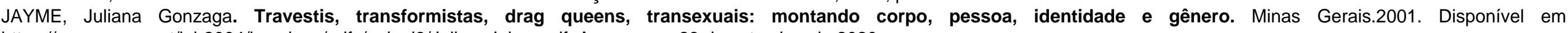
https://www.ces.uc.pt/lab2004/inscricao/pdfs/painel3/JulianaJaime.pdf. Acesso em: 23 de setembro de 2020.

KELSEN, H. Teoria Pura do Direito. Coimbra: Américo Amado, 1974.

MELLO, Adriana Ramos de. Comentários à Lei de Violência Doméstica e Familiar contra a Mulher. Rio de Janeiro, RJ: Lumen Juris, 2009. p. 11

SILVA, J. A. Curso de Direito Constitucional Positivo. 16ª edição, revista e atualizada nos termos da Reforma Constitucional, São Paulo: Malheiros Editores, 1999.

SOUZA, Sérgio Ricardo de. A Lei Maria da Penha Comentada: sob a perspectiva dos direitos humanos. 4. ed. rev. e atual. Curitiba: Juruá, 2013

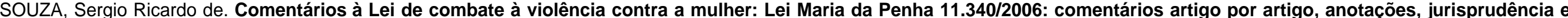
tratados internacionais. Curitiba: Juruá, 2007, p. 36-37

Coordenadoria de Pesquisa e Extensão - COPEX

Departamento de Editoraçāo e Divulgaçāo Científica - DEDIC 


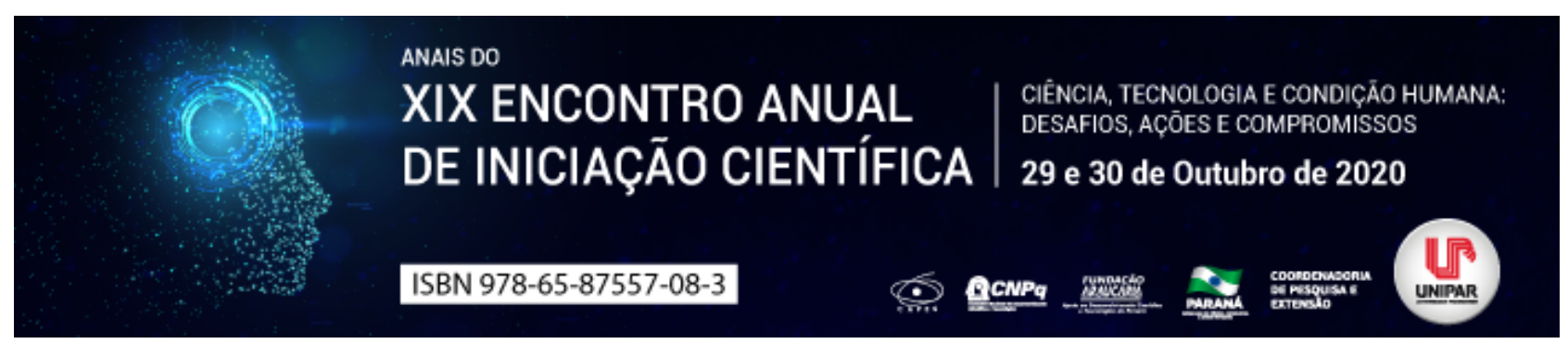

DISCURSO SOCIAL E RELIGIOSO ENTRELAÇADOS NA LINGUAGEM DO VIDEOCLIPE

\title{
${ }^{1}$ HENDREO ESTEVAO DOS SANTOS, ${ }^{2}$ RODRIGO OLIVA
}

\author{
${ }^{1}$ Acadêmico bolsista do PIBIC \\ ${ }^{1}$ Docente da UNIPAR
}

Introdução: Este resumo tem por objetivo fazer uma análise do videoclipe Alice, da banda gospel Palankin. Neste videoclipe, é possível evidenciar a confluência de dois discursos: o social, pois discute-se na imagem e cenas, uma narrativa de exploração e abusos, cujo enredo traduz também na discussão do tráfico de mulheres. Por outro lado, a base musical, evidencia-se um discurso de natureza religiosa. A análise pauta-se em discutir como se articulam os dois discursos e suas formas audiovisuais que, neste caso, se misturam e potencializam uma reflexão.

Objetivo: Discutir como se apresenta o discurso religioso e social no videoclipe Alice, da banda Palankin.

Desenvolvimento: $O$ videoclipe Alice, da Banda Palankin, se diferencia do formato de videoclipes com temática gospel. Tradicionalmente, os videoclipes de músicas gospel apresentam uma composição audiovisual centrado em bandas com os instrumentos ligados, em cenários externos ou mesmo dentro das igrejas. Segundo Thiago Soares (2013, p. 136), muitos videoclipes são vistos a partir da ideia de embalagem da cultura pop. Vemos neste caso que, atualmente, existe um mercado de videoclipes cujas representações de discursos de natureza religiosa são emolduradas também pelas ideias e formas dos videoclipes. Oliva (2019) discute que, atualmente, os videoclipes estão potencialmente estruturados a promoverem manifestos. Na primeira cena do videoclipe temos uma base documental, uma informação em lettering que diz: 2,5 milhões de pessoas são vítimas de tráfico humano no mundo inteiro. A partir daí, tem-se a representação narrativa a partir de uma série de cenas com a personagem Alice: Ela recebe uma proposta de emprego; Ela vai até um lugar combinado, onde uma caminhonete a espera; Depois a levam um lugar totalmente diferente. O videoclipe passa a discutir prostituição, uso de drogas, submissão, entre outros temas. Pode-se associar o nome da música a clássica história de Alice no País das Maravilhas, já que ambas personagens a partir de suas escolhas são transportadas a mundos distintos do que viviam. Percebe-se que a base audiovisual é marcadamente cinematográfica, com representações bastante documentais. Por outro lado, a música, principalmente a letra da canção, aponta para um discurso religioso. Segundo Samira Chalhub (1995), as funções da linguagem são identificadas a partir da ênfase que se dá a um elemento da comunicação. Identificamos que o uso da função emotiva da linguagem, personifica uma voz onipresente, mas que no universo da representação remete a I"Deus|". Como se Deus, conversasse com Alice, num discurso persuasivo e afetivo. I"Oh Alice essa noite não precisa usar seu vestido vermelho/Te fizeram acreditar em mentiras. Que seu corpo só para sexo serviria.l" Um outro aspecto que discute-se e que aponta para essa evidência do discurso religioso nas personificação da voz de Deus se dá a partir do uso da expressão filha. Em vários pontos da música essa expressão e utilizada como forma de aproximar Deus da personagem, como se o mesma zelasse pela sua vida, tal qual um pai zela pela vida dos seus filhos. Portanto, é percebido neste videoclipe um elo entre os discursos sociais e religioso o que demanda a possibilidade de discussão temática e exploração de conteúdos por meio da leitura do videoclipe.

Conclusão: Neste trabalho, pode-se verificar que os videoclipes, apesar de estarem tradicionalmente associados à cultura pop, são utilizados como parte da divulgação de bandas de gênero gospel. Ao trazer o videoclipe Alice, da banda Parlakin para a análise, foi possível identificar como este videoclipe apresenta-se de forma inovadora. Identificou-se que o discurso social que está projetado na base das imagens, como se fosse um filme documentário com cenas violentas e que discutem narrativas de abusos, está entrelaçado com o discurso religioso, que tem sua maior demarcação na letra da canção, que explora a onipresença da imagem de Deus.

\section{Referências}

ALICE, Banda Palankin. Videoclipe. Disponível em: https://www.youtube.com/watch?v=etKgunSG2Nw. Acesso em 13 ago. 2020. ALICE, Banda Palankin. Letra da canção. Disponivel em: https://www.letras.mus.br/palankin/alice/. Acesso em 13 ago. 2020. CHALHUB, Samira. Funções da linguagem. São Paulo: Ática, 1995.

OLIVA, Rodrigo. Videoclipe Manifesto: espaços sociais e políticos nas poéticas do videoclipe. Disponível em: https://portalintercom.org.br/anais/nacional2019/resumos/R14-0266-1.pdf. Acesso em 13 ago. 2020.

SOARES, Thiago. Estética do videoclipe. João Pessoa: Editora da UFPB, 2013. 


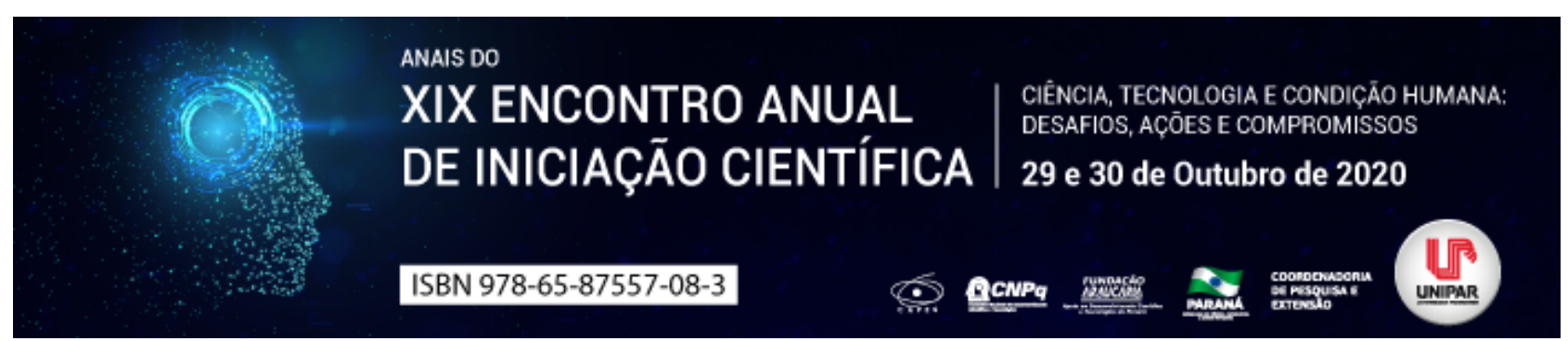

\title{
O EFEITO TESOURA E AS TÉCNICAS DE GESTÃO DO CAPITAL DE GIRO E SUA RELEVÂNCIA NO PLANEJAMENTO FINANCEIRO EMPRESARIAL
}

\author{
${ }^{1}$ JOAO VICTOR DA SILVA QUEIROZ, ${ }^{2}$ BRUNO BRAGA SOUZA, ${ }^{3}$ LUIZ CARLOS DE LIMA JUNIOR, ${ }^{4}$ VALDENILSON \\ ANDREAN, ${ }^{5}$ VITOR HUGO RAMOS MACHADO
}

\author{
${ }^{1}$ Acadêmico do Curso de Administração da UNIPAR \\ ${ }^{1}$ Acadêmico do Curso de Administração da UNIPAR \\ ${ }^{2}$ Acadêmico do Curso de Administração da UNIPAR \\ ${ }^{3}$ Docente da UNIPAR \\ ${ }^{4}$ Docente da UNIPAR
}

Introdução: A seara das ciências que estudam o mercado e as empresas são compostas por várias subáreas, dentre estás podemos citar uma de extrema Importância para a gestão financeira empresarial, que são os estudos voltados ao Capital de Giro das organizações, Braga (1991) ressalta que este assunto necessita de atenção constante por parte dos administradores da empresa, pois o mesmo é muitíssimo dinâmico e se tratado com descaso causará implicações sérias na rentabilidade e solvência da organização.

Objetivo: Demonstrar de forma breve as técnicas de Gestão do Capital de Giro, utilizando os princípios desenvolvidos pelo Professor Fleuriet.

Desenvolvimento: Para iniciarmos é necessário definir os termos, começaremos pelo conceito de Capital de Giro,, este termo segundo Neto e Silva (1995) refere-se a aqueles recursos que podem ser convertidos em caixa no prazo de até um ano, este conceito é de extrema Importância e deve ser constantemente monitorado, pois a ausência de Capital para girar os negócios empresariais poderá colocá-la em apuros, visto isso o professor Michel Fleuriet desenvolveu técnicas para o cálculo destas necessidades, para isso, o mesmo subdividiu o Balanço Patrimonial em três partes, a saber: Ativo e Passivo Cíclico que são contas Circulantes que tem relação direta com a atividade principal da empresa, Ativo e Passivo Errático são aquelas contas circulantes, porém, estás não tem necessariamente relação direta com a atividade fim da empresa e Ativo e Passivo Permanente que são todas as demais contas não circulantes (FLEURIET, KEHDY, BLANC, 2003) a partir disso desenvolve-se os cálculos das variáveis. O primeiro conceito é a Necessidade de Capital de Giro que é calculada através do Saldo de Ativo Cíclico diminuído do Passivo Cíclico, seu resultado se for Positivo expressa uma necessidade de Capital para o giro dos negócios e caso, teremos a indicação de que a mesma dispõe de fundos para financiar seu giro, logo, uma folga financeira e se a mesma for igual a zero teremos o indicativo de que não há necessidade de financiamentos para o giro (MACHADO, et al, 2005). Partindo do cálculo das necessidade da empresa, desembarcamos no conceito de Tesouraria que demonstra a proporção de fundos financeiros de curto prazo tomados pelo empresário para financiamento de Sua Necessidade de Capital de Giro ou Investimento em Ativos Permanentes (SILVA et al, 2003), é necessário considerar que a tendência Crescente e exclusiva de aquisição destes fundos em uma hipótese de recessão econômica podem resultar em consequências catastróficas para a saúde financeira da organização e lava-la até mesmo ao estado de insolvência, para que se evite tal fato, os autores da técnica recomendam que as necessidade de Giro sejam supridas pelo autofinanciamento, que é o ato de se sustentar através de suas operações, ou seja, gerar lucro através de sua atividade fim, a Tesouraria é calculada através de Ativo Errático diminuído do Passivo Errático e se seu saldo for positivo temos o indicativo da utilização de recursos de Curto Prazo e se Negativo utilizamos o raciocínio inverso. Segundo Monteiro e Moreno (2003), dizer que uma empresa está sob o efeito tesoura significa que a mesma possui um saldo de Tesouraria Negativo e crescente revelando uma dependência constante de empréstimo de curto prazo. Em situações de crises financeiras uma situação de gestão irregular pode ser fatal, pois, as receitas de vendas da empresa tendem a diminuir, consequentemente elevando a Necessidade de Giro, as instituições de crédito tendem a diminuir a oferta e a empresa se verá em sérios apuros e correrá riscos de insolvência, normalmente o efeito tesoura ocorre quando: as vendas crescem rapidamente no período, a relação necessidade de Giro dividido pelas Vendas se mantém mais elevadas que o Autofinanciamento dividido pelas Vendas e se durante o período de crescimento de vendas, fontes externas de Capital são aplicadas exclusivamente em Ativos Permanentes, tendo isto em visto a regra de Ouro para evitar o efeito tesoura é manter o autofinanciamento tendo saldo suficiente para suprir os aumentos da Necessidade de Capital de Giro, assim autofinanciando-se com recursos próprios e desse modo ter autonomia financeira para que não fique totalmente e exclusivamente dependente de recursos de terceiros. (FLEURIET, KEHDY, BLANC. 2003).

Conclusão: Tendo em vista, todas as disposições citadas acima, torna-se intuitivo que é de fundamental importância manter a boa gestão do Capital de Giro para que a empresa tenha base sólida, para enfrentar e superar as possíveis intempéries do 


\section{Referências}

ASSAF NETO, A; SILVA. C.A.T. Administração do Capital de Giro. São Paulo: Editora Atlas S.A, 1995.

BRAGA, Roberto. Análise Avançada do Capital de Giro. Caderno de Estudo Scielo, 03 Set. 1991. Disponível em: https://www.scielo.br/scielo.php?pid=S1413-92511991000100003\&script=sci_arttext. Acesso em: 14 ago. 2020.

COSTA, R.A.T; et al. Administração Financeira: Importância e evoluções. Revista de empreendedorismo e gestão de micro e pequenas empresas, 24 fev. 2016. Disponível em: https://drive.google.com/file/d/1VaczsrX8gvOeM8qvPrTI3cvqENZ91xLr/view? usp=drivesdk. Acesso em: 05 jun. 2020.

DA SILVA, Júlio Orestes da et al. Nível informacional entre a análise tradicional e avançada do capital de giro. Revista Pretexto. v. 13, n. 2, 2012. Disponível em: http://www.fumec.br/revistas/pretexto/article/view/1166/812. Acesso em: 15 ago. 2020.

FLEURIET, Michel; KEHDY, Ricardo. BLANC. Georges. O modelo Fleuriet. A dinâmica Financeira das Empresas Brasileiras. Um método de análise, Orçamento e Planejamento Financeiro. 6. Ed. Rio de Janeiro: Elsevier Editora Ltda, 2003.

MACHADO, Márcio André Veras et al. Análise dinâmica e o financiamento das necessidades de capital de giro das pequenas e médias empresas. :CONGRESSO USP CONTROLADORIA E CONTABILIDADE. 2005.

MONTEIRO, A.A.S.; MORENO, R.. Fluxos de Caixa e Capital de Giro Uma adaptação do Modelo de Fleuriet. ENCONTRO NACIONAL DOS PROGRAMAS DE PÓS-GRADUAÇÃO EM ADMINISTRAÇÃO, n. 27, 2003, Atibaia (SP). Anais..., Atibaia: ENANPAD, 2003.

Coordenadoria de Pesquisa e Extensāo - COPEX

Departamento de Editoraçāo e Divulgaçāo Científica - DEDIC 


\title{
-

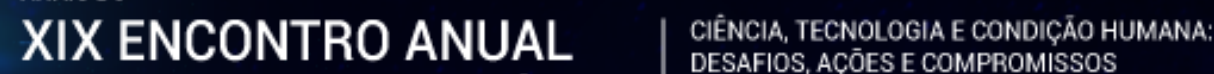

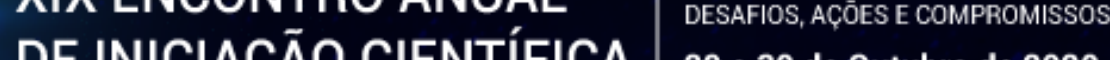 DE INICIAÇĀO CIENTIFICA 29 e 30 de Outubro de 2020 \\ ISBN 978-65-87557-08-3

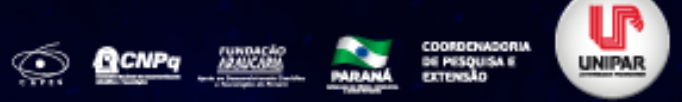 \\ REFLEXÕES PSICOSSOCIAIS DO FILME O POÇO COM AS FERRAMENTAS CONCEITUAIS DE FÉLIX GUATTARI E GILLES DELEUZE
}

\author{
${ }^{1}$ MATHEUS RICHTER NOGUEIRA , ${ }^{2}$ DANIELLE JARDIM BARRETO, ${ }^{3}$ TEREZA RODRIGUES VIEIRA
}

\author{
${ }^{1}$ Acadêmico bolsista do PIBIC/UNIPAR \\ ${ }^{1}$ Docente da UNIPAR \\ ${ }^{2}$ Docente da UNIPAR
}

Introdução: Inicialmente escrito para uma peça de teatro, O Poço retrata um experimento social que se assemelha a uma prisão vertical com níveis ou andares pelos quais correm uma plataforma carregando quantias consideráveis de comidas preparadas da forma mais exímia possível. É deste ponto que analisamos a trajetória de Goreng, aparente personagem principal dessa trama, que tem de se adequar e se adaptar a fim de sobreviver os mais diversos desafios e confrontos tanto internos quanto externos, a ponto de empurrá-lo aos limites da ética e da moral prévias ao experimento social.

Objetivo: Por meio de pesquisa bibliográfica e cinematográfica pretende-se identificar e analisar as problemáticas envolvendo os limites da ética em meio a necessidade e o confronto com noções pré-concebidas pelos quais o desejo, a ética e a vontade se entrelaçam, se constroem e se destroem de acordo com os territórios de subjetivações ocupados.

Desenvolvimento: Primariamente, o filme traz valiosas e contemporâneas reflexões acerca do que pode afinal um corpo, bem como sobre territórios subjetivos ocupados pelo mesmo tanto de forma literal tanto quanto figurada. Além disso, configuram-se várias relações de poder e saber importantíssimas para problematizações dos modos de produção de subjetividade e, tais princípios se conectam tanto com a sociedade disciplinar conceituada por Michel Foucault (1999, p. 173) tanto com a sociedade de controle proposta por Gilles Deleuze (1999, p. 220) e Félix Guattari (1986). Medidas extremas de desespero, os territórios interpessoais e sociais bem como os limites ultrajados pelas instituições de controle por meio da violência e da validação ou valorização do sujeito são temas recorrentes em toda a obra cinematográfica apresentada. O local também apresenta de pronto uma crítica para com a ideia meritocrática, vez que Goreng, a personagem com caráter idealizado, porta como ímpeto primordial para adentrar ao experimento a necessidade de se legitimar através de uma comprovação institucionalizada, por meio do certificado que ele busca. Contudo, ao encarar a realidade da desigualdade no Poço, Goreng se depara com uma realidade multifacetada, fazendo-o sentir na pele o lugar de privilégio subjetivo que ocupa na hierarquia social - homem, branco, escolarizado, entediado. Ademais, a narrativa nos compele e nos instiga a revisarmos a nossa realidade material e historicamente construída por meio de princípios que não destoam da ficção em tela, propondo um alinhamento entre a representação artística como forma de expressão dos diferentes territórios de subjetivação presente nas relações sociais. O filme também nos oferece uma reflexão acerca do nosso próprio sistema econômico pautado em divisões sociais não dessemelhantes com níveis existentes na própria Plataforma pelas quais a distribuição de riqueza, aqui representada cruamente pela comida disposta, entre os níveis superiores marcados pela ocupação de territórios privilegiados os demais inferiores que progressivamente aumentam a severidade, a exclusão e as condições que exprimem e oprimem o corpo ao extremo, às condições pelas quais a sobrevivência se torna regente no processo de desconstrução moral e reterritorialização da subjetividade através da violência como o único recurso possível, nos dando a ver que de fato o limite do corpo é uma ilusão de ótica.

Conclusão: Em menor ou maior nível, de forma consciente ou não, todos nós experimentamos este poder aparentemente compulsivo que nos impele a nos programarmos em processos de subjetivação massificada que inviabilizam a produção de singularidades. Quando a fragilização e a violência tomam conta de tais territórios desnivelados e o arrebatamento dos processos de efetivação do querer são controlados, registrados e consumidos pela produção, também medidas desproporcionais tomam conta da subjetivação como modo, muitas vezes, de sobreviver, de lutar e de se defender, nos forçando por vezes a performances ditas egoístas e por outras vezes, sucumbimos e nos submetemos aos modos hegemônicos de viver, e por fim, as vezes só nos resta a resignação e o desejo de morte. Isolados, deslumbrados e em uma obsessiva competição por sobrevivência não só os personagens mas também nós mesmos nos tornamos cegos aos dinamismo presente nos entrelaçamentos daquilo que sequestra o inesperado e surpreendente de nós, substituindo e justificando a cooperatividade possível entre os iguais pela implícita e silenciosa distribuição de um aparente poder.

\section{Referências}

DELEUZE, Gilles. Conversações. 1a. ed. São Paulo: Ed. 34, 1992.

FOUCAULT, Michel Vigiar e Punir: História da violência nas prisões. Petrópolis: Vozes, 1999.

GUATTARI, Félix.; ROLNIK, Suely. Micropolítica Cartografias do desejo. 7ª Edição Revisada. Petrópolis: Vozes, 1986. 
Coordenadoria de Pesquisa e Extensão - COPEX

Departamento de Editoraçāo e Divulgaçāo Científica - DEDIC 


\title{
a CIÊNCIA, TECNOLOGIA E CONDIÇĀO HUMANA: DESAFIOS, AÇŌES E COMPROMISSOS \\ 29 e 30 de Outubro de 2020 \\ ISBN 978-65-87557-08-3

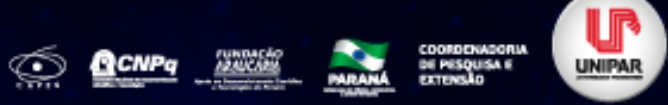 \\ PRECEITOS LEGAIS E PROBLEMÁTICAS PSICOSSOCIAIS RELACIONADAS AO ISOLAMENTO SOCIAL DEVIDO À COVID-19
}

\section{${ }^{1}$ MATHEUS RICHTER NOGUEIRA , ${ }^{2}$ TEREZA RODRIGUES VIEIRA}

\author{
${ }^{1}$ Acadêmico do curso de Psicologia e bolsista do PIBIC, na UNIPAR \\ ${ }^{1}$ Pós-Doutora em Direito pela Université de Montreal e Docente do Mestrado em Direito da UNIPAR
}

Introdução: De acordo com Bauman (2011), vivemos em uma sociedade fluídica onde poucas coisas se estabelecem como fixas, palpáveis ou passíveis de apreensão em longo prazo. É dentro desta sociedade fluídica, dinamicamente fugaz e extremamente conectada pelas mídias sociais que a COVID-19 tem forçado o isolamento social de forma horizontal (com amplas restrições de direitos) ou vertical (com parciais restrições de direitos) e trazendo com tais medidas, novos desafios físicos e também psicossociais.

Objetivo: Por meio de pesquisa bibliográfica pretende-se identificar e analisar as problemáticas envolvendo os preceitos legais do isolamento social, bem como as noções ampliadas de saúde que envolvem o bem estar psicossocial de uma sociedade contemporânea privada de contato e proximidade física.

Desenvolvimento: Medidas de prevenção ao contágio têm forçado de forma inédita a sociedade pós-moderna à reclusão social como uma maneira de mitigar o contágio e a mortalidade causada pela COVID-19, enquanto impõe o distanciamento físico como maneira de efetivar-se a preservação da saúde no sentido estrito da infecção e do contágio. Suas aplicações e implicações legais em nível mundial evidenciam a saúde pública e os sistemas públicos de saúde como bem maiores, em detrimento de certas garantias coletivas e individuais como ir e vir livremente e o direito de reunião. Contudo, como assegurar garantias se, mesmo antes de atingir-se um ponto crítico de contágio, já eram ignoradas em larga escala pelo Estado? Quais são as implicações psicossociais e colaterais do isolamento pela ausência de contato físico? Como garantir a saúde pública para quem já não era contemplado por morar na periferia, longe da concentração de renda municipal? Qual o preço dessas garantias cerceadas para pessoas que com elas contam para sua subsistência? Os efeitos contemporâneos destas medidas são analisados sob a ótica do direito à saúde tanto de forma individual quanto coletiva enquanto compreende-se a saúde de forma ampla e integral, abarcando fatores definidos pelos estudos das Determinantes Sociais de Saúde (DSS) que se transpassam e estendem-se para além do atual estado pandêmico. $O$ fato é que o sistema legal brasileiro prevê o isolamento como medida necessária de prevenção ao contágio por conta da Covid-19 devido a sua caracterização como pandemia pela Organização Mundial da Saúde, também respaldado na decretação do Estado de Calamidade Pública como medida excepcional dentro da legislação e na promulgação da lei 13.979/20 (BRASIL, 2020) que trata das medidas emergenciais estatais para a contenção e enfrentamento da situação pandêmica.

Conclusão: $O$ isolamento e o cerceamento do direito de ir e vir se garantem por meio da esfera social, legislativa e na garantia e promoção da saúde pública. Na esfera da saúde psicossocial observa-se que a ausência de contato físico por longo prazo demonstra-se como um fator influente até mesmo na mortalidade de seres historicamente entendidos com sociais. As comunidades virtuais e redes de conexões online propõem uma alternativa, embora não ideal, mas excepcional de contato e conexão ainda que de forma fluídica e imediata (por isso excepcional). Ainda que haja iniciativas que viabilizem o atendimento remoto de profissionais da psicologia, as ausências de medidas públicas de atendimento psicológico online gratuito ou acessível por meio de iniciativas governamentais são uma demonstração clara da inobservância do conceito amplo de saúde pelos órgãos estatais, mesmo com as atuais conjunturas tecnológicas que facilitariam tais medidas. Finalmente, as medidas propostas para o enfrentamento do surto indicam as desconsiderações de nuances e especialidades de pessoas e comunidades vulneráveis que se encontram afastadas do olhar governamental, o que não só dificulta o acesso a medidas preventivas para seu bem estar físico em relação à infecção causada pela Covid-19, mas também para um distanciamento das políticas públicas voltadas para o remédio econômico em face da crise financeira familiar por ausência de trabalho durante o isolamento.

\section{Referências}

BAUMAN, Zygmunt. 44 cartas do mundo líquido moderno. Rio de Janeiro: Jorge Zahar. 2011.

BRASIL. Lei № 13.979, de 6 de Fevereiro de 2020. Dispõe sobre as medidas para enfrentamento da emergência de saúde pública de importância internacional decorrente do coronavírus responsável pelo surto de 2019. Brasília, 2020. Disponível em: http://www.planalto.gov.br/ccivil_03/_ato2019-2022/2020/lei/l13979.htm. Acesso em: 20 mar. 2020.

Organização Mundial da Saúde. Mental health and psychosocial considerations during the CovID-19 outbreak. Disponível em: https://www.who.int/docs/default-source/coronaviruse/mental-health-considerations.pdf. Acesso em: 06 abr. 2020. 
Coordenadoria de Pesquisa e Extensão - COPEX

Departamento de Editoraçāo e Divulgaçāo Científica - DEDIC 


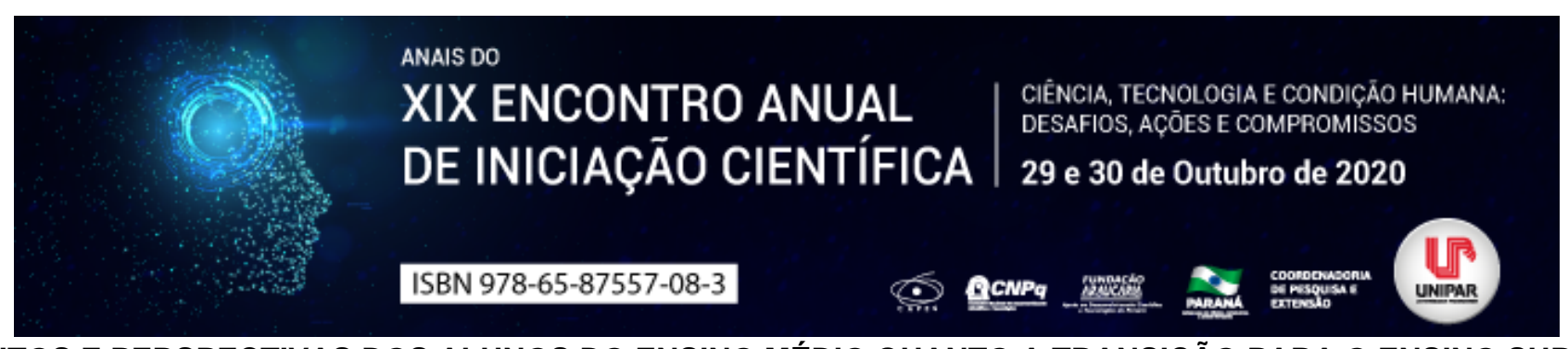

CONCEITOS E PERSPECTIVAS DOS ALUNOS DO ENSINO MÉDIO QUANTO A TRANSIÇÃO PARA O ENSINO SUPERIOR

\begin{abstract}
${ }^{1}$ MARIVANE DE SOUZA MARTIN
\end{abstract}
${ }^{1}$ Professor - PIC - Unipar

Introdução: Esta revisão foi desenvolvida com a preocupação em coletar informações e promover reflexões em torno de questões relacionadas com a transição dos alunos do Ensino Médio para o Ensino Superior. Aparentemente decidir sobre a carreira profissional parece fácil, mas ao se considerar a idade desses alunos, suas vivências e conflitos inerentes à idade, que em geral é de menos de dezoito anos, percebe-se que surgem diversos fatores.As pesquisas realizadas com o cunho de investigar os fatores que levam um indivíduo a decidir a escolha de uma carreira profissional, despertam reflexões importantes em torno do assunto. Existe uma diversidade de situações que conduz um aluno do Ensino Médio a optar pela continuidade dos estudos.Entender como ocorre o processo de transição do aluno oriundo do ensino médio e ingressante no ensino superior, tem uma importância estratégica valiosa para qualquer Instituição de Ensino Superior (IES). Estratégica porque, de posse das informações que circundam essa transição, diversas decisões poderão ser tomadas para que o aluno possa ser bem recebido e instruído.

Objetivo: Analisar, entre os alunos que estão na fase de transição do Ensino Médio/Superior suas perspectivas, expectativas e significados em relação ao Ensino Superior.

Desenvolvimento: A educação sempre cumpriu, ao longo da história, a função de preparar as pessoas para o mercado de trabalho. Com a globalização acentuou-se com perversidade esse comportamento, atribuindo à educação um sentido comercial, utilitarista, de mero treinamento para a força de trabalho (BRUNNER et al 2000).Kuenzer (2009) menciona a necessidade, exigida por algumas ocupações, de um nível de escolarização a cada dia maior e com um salário também maior, isso faz com que haja um distanciamento entre aqueles que possuem uma escolarização menor ou de baixa qualidade. Para Petters (2008) os olhares para a formação do jovem são direcionados de maneira que, após a passagem pelos diversos níveis de ensino, de fato haja a condição de uma inserção positiva no mundo ou mercado de trabalho. A possibilidade de uma continuidade nos estudos, com vistas ao ensino superior, encontra sustentação seja ela positiva ou negativa na possibilidade de ser inserir em atividades laborais inerentes à formação, desse modo, a perspectiva e a expectativa que se tem ao escolher uma profissão devem ser consideradas. Conforme Cosacov (2007) uma expectativa é uma variável de natureza cognitiva que sugere a ideia de antecipação, cuja inclusão nas analises psicológicas é importante para explicar e predizer vários comportamentos que vão desde a dinâmica social até os motivos dos estados de ânimo do ser humano. A escolha da carreira profissional da instituição de ensino superior deve ser cuidadosa, pois os alunos devem tomar essa decisão dentro de um contexto onde a variedade de opções seja ampla, diversificada. Para Camarena; González; Velarde (2009) o jovem tem ideias distintas, preconcebidas acerca das diferentes áreas de formação. A referida decisão implicará na inserção do aluno nas comunidades acadêmicas, no entanto, a permanência desse aluno pode estar relacionada com o próprio sistema acadêmico ou com o aspecto social, refletirá a integração pessoal e intelectual do estudante com a universidade diante das dificuldades que terá que enfrentar (TINTO, 2012).

Conclusão: Escolher a área profissional para a qual o jovem vai se dedicar por toda a sua vida, não é uma tarefa fácil. A decisão de escolher entre uma carreira ou outra é influenciada por diferentes fatores, entre os quais estão a vocação, orientação vocacional, experiência familiar em que os filhos escolhem suas profissões ao identificar-se com o trabalho dos pais, a disponibilidade e localização econômica e geográfica, tendências de áreas no mercado de trabalho e motivações pessoais.

\author{
Referências \\ BRUNNER, José Joaquín et al. Globalización y el futuro de la educación: tendencias, desafíos, estrategias. Seminario sobre \\ Prospectiva de la Educación en la Región de América Latina y el Caribe, p. 1-35, 2000. \\ CAMARENA, B. O.; GONZÁLEZ, D.; VELARDE, D. El programa de orientación educativa en bachillerato como mediador en la \\ elección de carrera. RMIE, 14(41), 539-562, 2009. Disponível em: http:// www.redalyc.org/articulo.0a?id=14004109. Acesso 27 \\ out 2020. \\ COSACOV, E. Diccionario de Términos Técnicos de la Psicología. 3ra Ed. Córdoba: Editorial Brujas, 2007. \\ ESCOBAR, Luisa Amelia Sibrián. Expectativas de la formación universitaria desde la perspectiva de los estudiantes. Diá-logos, \\ n. 19, p. 25-37, 2017. \\ KUENZER, A.Z. (Org). Ensino médio: construindo uma proposta para os que vivem do trabalho. 6.ed. Saõ Paulo: Cortez, \\ 2009. \\ PETTERS, L.C. F. Trajetórias e expectativas de jovens universitários: um estudo sobre os processos identitários dos \\ jovens do curso de Pedagogia na relação educação, trabalho e ações coletivas. Dissertação de Mestrado. UNIVALI, 2008.
}


TINTO, V. Completing college. Rethinking institutional action. EE.UU.: The University Chicago Press, 2012. COSACOV, E. Diccionario de Términos Técnicos de la Psicología. 3ra Ed. Córdoba: Editorial Brujas, 2007.

ESCOBAR, Luisa Amelia Sibrián. Expectativas de la formación universitaria desde la perspectiva de los estudiantes. Diá-logos, n. 19, p. 25-37, 2017.

KUENZER, A.Z. (Org). Ensino médio: construindo uma proposta para os que vivem do trabalho. 6.ed. Saõ Paulo: Cortez, 2009.

PETTERS, L.C. F. Trajetórias e expectativas de jovens universitários: um estudo sobre os processos identitários dos jovens do curso de Pedagogia na relação educação, trabalho e ações coletivas. Dissertação de Mestrado. UNIVALI, 2008.

TINTO, V. Completing college. Rethinking institutional action. EE.UU.: The University Chicago Press, 2012. 


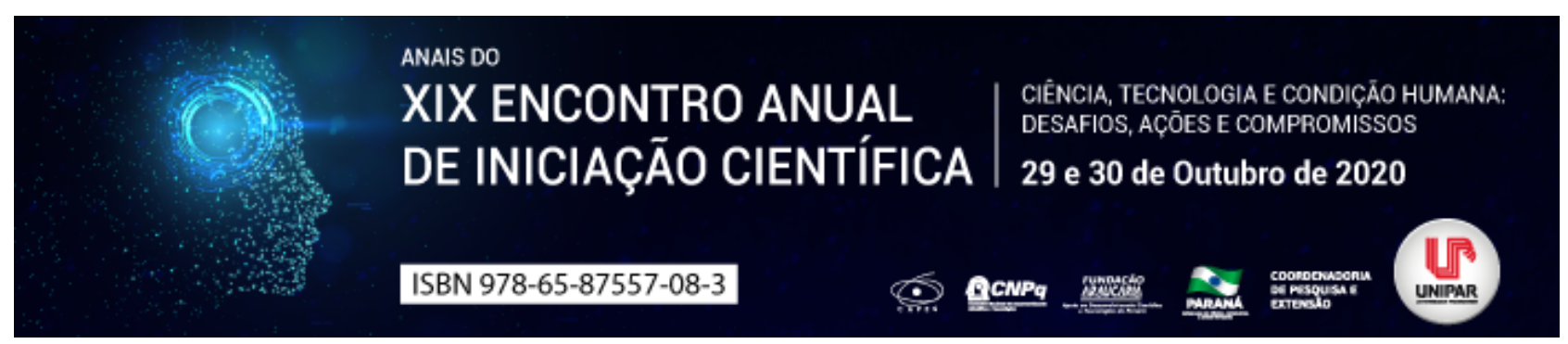

TUTELA JURISDICIONAL DOS IDOSOS EM TEMPOS DE PANDEMIA COVID-19

\title{
${ }^{1}$ TANIA ARNECKE PEREIRA, ${ }^{2}$ TEREZA RODRIGUES VIEIRA
}

\author{
${ }^{1}$ Mestranda em Direito Processual e Cidadania e integrante do PIC, na UNIPAR \\ ${ }^{1}$ Pós-Doutora em Direito pela Université de Montreal e Docente do Mestrado em Direito da UNIPAR
}

Introdução: Iniciando a terceira década dos anos 2000, vivemos um momento único em todo o mundo, o enfrentamento de uma das maiores, se não a maior crise de todos os tempos, colapso esse que vem afetando todos os setores, desde os mais ricos até os mais pobres: a pandemia COVID-19. O vírus não escolhe quem será contagiado, no entanto, hoje com mais de cem mil mortos no Brasil é evidente que os mais afetados são os idosos, sendo o principal grupo de risco, os quais merecem sem dúvida, cuidados especiais, principalmente no que diz respeito à tutela jurisdicional.

Objetivos: Analisar as medidas adotadas para garantir os direitos dos idosos no enfrentamento da pandemia COVID-19, por meio de pesquisa bibliográfica e legislativa.

Desenvolvimento: A Constituição Federal de 1988 assegura que a população exerça não só a cidadania, como uma vida pautada no princípio da dignidade da pessoa humana, afinal, o valor da pessoa idosa deve ser reconhecido não como uma forma de assistencialismo ou paternalismo condescendente, mas, sim, como o único modo de preservar uma parcela importante da população que precisa de atenção e cuidado (SOUZA, 2013, p.379). As pessoas idosas possuem uma série de cuidados a serem tomados por integrarem um dos principais grupos de risco diante da epidemia da Covid-19. Nesse sentido, os cuidados vão muito além daqueles tomados no âmbito doméstico ou no dia a dia, dizem respeito também ao alcance da tutela jurisdicional efetiva nesse momento que vivemos. Assim, o Brasil, devoto de uma política que proporcione proteção e melhor qualidade de vida para essa parcela populacional, vem há algum tempo criando legislações e medidas voltadas aos idosos (CALISSI; COIMBRA, 2013, p.361). A atual situação impõe a necessidade de reafirmar o direito à igualdade, disposto no artigo $2^{\circ}$ do Estatuto do Idoso, bem como o direito a liberdade assegurado no artigo $10, \S 1^{\circ}$ do mesmo Estatuto. Discute-se a prioridade na tramitação de processos que possuam como parte, pessoa com idade igual ou superior a 60 anos, de acordo com o artigo 1.048 do Código de Processo Civil, e artigo 71 do Estatuto do Idoso. Nesse sentido questiona-se, neste momento que vivemos, onde tanto se fala sobre a falta de leitos e respiradores para atender toda a demanda de pacientes que sofrem com os sintomas do vírus COVID-19, poderia um idoso nessa situação, demandar judicialmente buscando a prioridade na tramitação de seu processo, requerendo a urgência de disponibilidade de um leito a seu favor? Qual seria a providência a ser tomada pelo Estado? A vida do idoso vale mais do que a de um jovem? Muitos são os questionamentos, principalmente considerando o significativo número de idosos que perderam suas vidas em virtude da pandemia, sendo que muitos deles sequer tiveram acesso ao atendimento hospitalar em virtude da superlotação. Importante destacar ainda que entre os idosos com mais de 60 anos de idade, existe a prioridade para aqueles que possuem mais de 80 anos, e nesses casos, como proceder? São questionamentos como esses que a Bioética traz à tona, sobretudo nesse momento de pandemia, uma vez que a igualdade de direitos não pode ser afastada, por outro lado o princípio da proporcionalidade se mostra ainda mais importante nas relações, principalmente jurídicas.

Conclusão: Conclui-se, portanto, que nesse momento delicado que vivemos os idosos não devem ser afastados da apreciação da tutela jurisdicional, entretanto, quando falamos em prioridade com relação à pandemia COVID-19, o instituto deve ser analisado com muita cautela, utilizando o princípio da proporcionalidade com ainda mais detalhamento e precisão, em atenção ao princípio da isonomia. Destarte, a longevidade deve ser vivida com dignidade e com os direitos fundamentais assegurados para seguirem exercendo plenamente sua cidadania.

\section{Referências}

BRASIL. Constituição (1988). Constituição da República Federativa do Brasil: promulgada em 8 de outubro de 1988. Disponível em: . Acesso em: 08 set 2020.

. Lei n. ${ }^{\circ}$ 13.105, de 16 de março de 2015. Código de Processo Civil. Disponível em: . Acesso em: 08 set 2020.

Lei n. ${ }^{\circ} 10.741$, de $1^{\circ}$ de outubro de 2003. Dispõe sobre o Estatuto do Idoso e dá outras providências. Disponível em . Acesso em: 08 set 2020.

CALISSI, Jamile Gonçalves; COIMBRA, Mário. Conceitos básicos: o sistema jurídico brasileiro e os aspectos relacionados ao envelhecimento. In: Minorias \& grupos vulneráveis. Dirceu Pereira Siqueira e Nilson Tadeu Reis Campos Silva, organizadores. Birigui-SP: Boreal, 2013.

SOUZA, Jamille Fernanda Ferreira de. Políticas públicas e direitos fundamentais do idoso: abordagem brasileira. In: Minorias \& grupos vulneráveis. Dirceu Pereira Siqueira e Nilson Tadeu Reis Campos Silva, organizadores. Birigui-SP: Boreal, 2013. 
Coordenadoria de Pesquisa e Extensão - COPEX

Departamento de Editoraçāo e Divulgaçāo Científica - DEDIC 


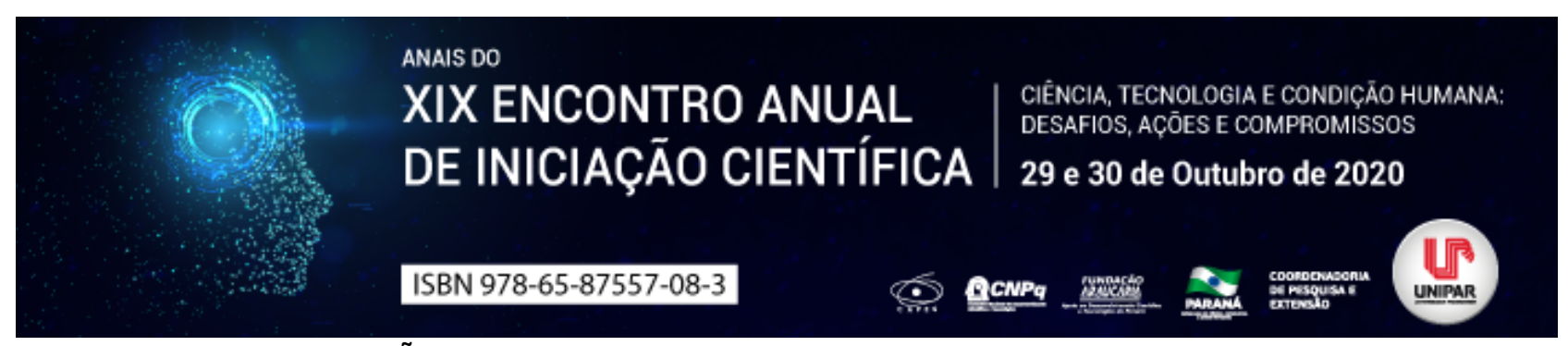

\title{
A NECESSIDADE DE APRIMORAÇÃO DOS MECANISMOS DE TUTELA ADMINISTRATIVA DO CONSUMIDOR ATRELADOS AO PROCON
}

\author{
${ }^{1}$ GABRIELY STHEFANI DE JESUS BATISTA, ${ }^{2}$ PAULO CESAR DE SOUSA
}

\author{
${ }^{1}$ Acadêmica do curso de Direito da UNIPAR \\ ${ }^{1}$ Docente da UNIPAR
}

Introdução: O Procon é um órgão destinado a proteção e defesa dos direitos dos consumidores, mas que carece de melhorias, especialmente quanto à falta de eficácia de seus métodos, conforme investigado.

Objetivo: Abordar os mecanismos do Órgão Consumerista e sua necessidade de aprimoração ao qual reforça a defesa e satisfação dos direitos conferidos ao Consumidor.

Desenvolvimento: Atualmente os mecanismos tutelados aos consumidores pelo Órgão consistem em "elaborar, coordenar e executar a política estatual ou municipal de defesa do consumidor, além de realizar o atendimento aos consumidores e fiscalizar as relações de consumo no âmbito de sua competência... Aplicando as sanções administrativas contidas no CDC (art. 56) que vão desde multa até apreensão de produtos, interdição e intervenção administrativa no estabelecimento" (BESSA, MOURA, 2014, pp. 34, 39). Conquanto verificado que o Procon possui atuação por meio de prevenção, mediação e repressão dos conflitos e é um Órgão Administrativo, no caso de desacordo entre as partes ou descumprimento, o Procon não detém atribuição de forçar o fornecedor a reparar os danos causados ao consumidor, ao qual terá que pleitear judicialmente para alcançar sua reparação. Além de que, uma sanção aplicada pelo Procon "com fundamento no artigo 56 do CDC, não se confunde com a indenização devida aos consumidores lesados pelas práticas infrativas aos direitos estabelecidos na lei" (MIRAGEM, p. 850). Assim, na hipótese da penalidade de multa, o valor desta reverte aos cofres públicos e o consumidor permanece prejudicado. Pelo que, são necessárias mudanças dos instrumentos disposto pelo Procon visando a efetiva defesa do consumidor a alcançar a sua reparação em vista dos seus direitos infringidos. A esse propósito há dois projetos de lei em trâmite na Câmara dos Deputados que visam readequar o Código Consumerista e conferir maior efetividade à norma, pois terão força de título executivo extrajudicial os acordos firmados entre as partes no PROCON (PL- 2091,2015). Ademais, nos casos em que a demanda tramite junto a um Juizado Especial Cível, o termo de audiência realizada em órgão público de proteção e defesa do consumidor que ateste ausência de conciliação entre as partes, a Secretaria do Juizado designará desde logo, audiência de instrução e julgamento, promovendo a citação do réu (PL-5196-A, 2013), provendo uma celeridade aos autos.

Conclusão: A proteção e defesa do consumidor, por meio da atuação do Procon, precisa ser aprimorada com a reestruturação dos mecanismos existentes, o que pode potencializar uma tutela administrativa eficaz.

\section{Referências}

BRASIL. Projeto de Lei no 5.196, de 20 de março de 2013. Acrescentando ao Capítulo VII da Lei no 8.078/1990 que dispõe sobre a proteção do consumidor. Poder Executivo, Brasília, 24 jan. 2011. Acesso em: 27 jul. 2020.

BRASIL. Projeto de Lei $n^{\circ} 2.091,25$ de junho de 2015. Acrescenta-se o seguinte parágrafo segundo ao artigo 83 da Lei 8.078, de 11 de setembro de 1990, que instituiu o Código de Defesa do Consumidor. Deputado Augusto Coutinho, Pernambuco, 25 jun. 2015. Acesso em: 27 jul. 2020.

BESSA, Leonardo Roscoe Bessa; MOURA, Walter José Faiad de. Manual de Direito do Consumidor. 4. ed. Brasília: Escola Nacional de Defesa do Consumidor, 2014.

MIRAGEM, Bruno. Curso de Direito do Consumidor. 6. ed. São Paulo: Revista dos Tribunais, 2016. 


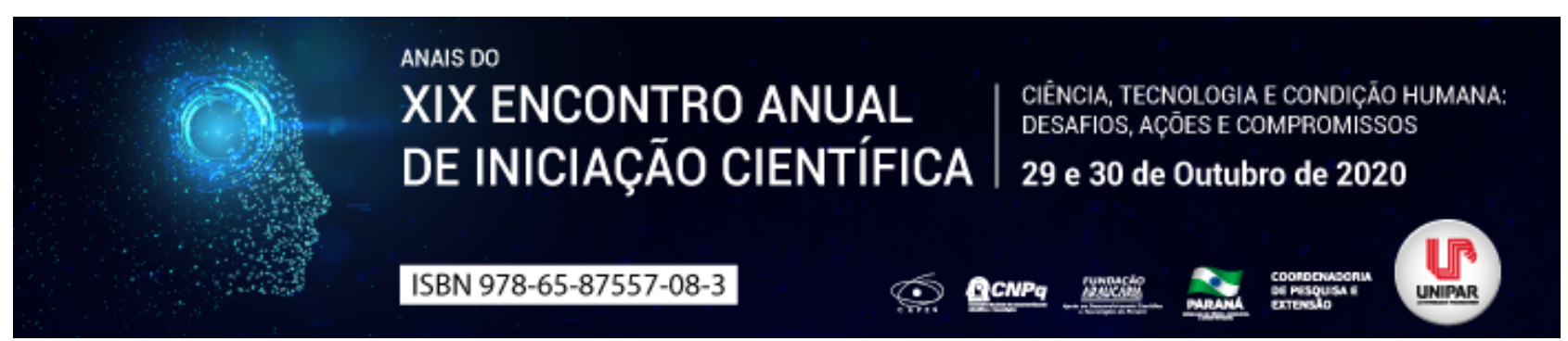

DIREITO À LICENÇA FUNERAL DO ADVOGADO

\title{
${ }^{1}$ LUANA GABRIELA DE OLIVEIRA SOUZA, ${ }^{2}$ CELSO HIROSHI IOCOHAMA
}

\author{
${ }^{1}$ Acadêmica do PIC/UNIPAR \\ ${ }^{1}$ Docente da Graduação em Direito e do Programa de Mestrado em Direito Processual e Cidadania da UNIPAR
}

Introdução: O advogado é indispensável à administração da justiça, conforme a Constituição Federal, art. 133. Com esse papel importante de colaborar para a realização de um Estado Democrático de Direito, sua atuação é fundamental para levar a conhecimento do Estado-juiz as pretensões das partes, através da sua capacidade postulatória, garantindo assim os direitos fundamentais de seus clientes.

Objetivo: Analisar o projeto de Lei no 381/2020, em trâmite pela Câmara dos Deputados, proposto pela então Deputada Renata de Abreu, que busca alterar a Lei n 13.105/2015 (Código de Processo Civil) e a Lei n 8.906/1994 (Estatuto da Advocacia e da $\mathrm{OAB})$.

Desenvolvimento: O projeto de Lei n. 381/2020 institui a licença-funeral para advogado, o qual concede a suspensão do processo por oito dias a partir da data do falecimento de cônjuge ou companheiro, ascendente ou descendente, irmão ou pessoa que viva sob a dependência econômica, quando for o único patrono da causa, fazendo-se diante da apresentação de certidão de óbito, desde que haja notificação ao cliente (BRASIL, 2020). Diante da perda de um ente querido, o sujeito passa a encontrar dificuldades de retomar a sua vida, trazendo tal acontecimento alteração no seu bem estar físico, social, econômico e emocional (MARTINS DA SILVA, 2019). A morte de um ente querido, influência de modo direto a atuação do profissional no seu exercício. Além disso, o direito à licença funeral se faz necessário para o restabelecimento emocional do profissional, por se tratar de notória circunstância que prejudica o exercício profissional da advocacia devendo-se, portanto, uma compreensão ao tempo de luto. Ademais, tal previsão legal se faz necessária em decorrência do princípio da igualdade previsto no art.5, caput", da Constituição Federal, segundo o qual todos são iguais perante a lei, pois verifica-se que tanto Magistrados art. 72, II, da Lei Complementar n 35 de 14 de março de 1979 (BRASIL, 1979), como membros do Ministério Público da União art. 203, da Lei Complementar n. 75, de 20 de maio de 1993 (BRASIL, 1993) e os membros do Ministério Público do Estado art. 52, da Lei 8.625, de 12 de fevereiro de 1993 (BRASIL,1993), possuem direito a licença remunerada pelo prazo de oito dias em razão do falecimento de cônjuge, ascendente, descendente ou irmão. Logo, tal previsão legal se faz necessária para advogados, considerando essencial para que os profissionais desta categoria não precisem recorrer ao motivo de força maior , ainda mais pela qualidade essencial para o exercício do contraditório, da ampla defesa e da administração da Justiça.

Conclusão: Diante do exposto, mostra-se evidente a necessidade da previsão legal objeto do Projeto n. 381/2020, em prol da saúde psíquica do advogado, para o efetivo desempenho de sua função após o período de luto e em atenção ao princípio da igualdade.

\section{Referências}

SILVA, Ivana de Souza Martins da. As Implicações do Luto na Saúde da Família . Psicologado, [S.I.]. (2019). Disponível em https://psicologado.com.br/atuacao/tanatologia/as-implicacoes-do-luto-na-saude-da-familia . Acesso em 7 Jul 2020.

BRASIL. Lei Complementar N 35, de 14 de março de 1979.Disponivel em: http://www.planalto.gov.br/ccivil_03/LEIS/LCP/Lcp35.htm. Acesso em:15/07/2020.

BRASIL. Lei Complementar N 75, de 20 de maio 1993. Disponivel em: http://www.planalto.gov.br/ccivil_03/leis/lcp/lcp75.htm. Acesso em:15/07/2020.

BRASIL. Lei Complementar N 8.625, de 12 de fevereiro de $1993 . \quad$ Disponivel em:http://www.planalto.gov.br/ccivil_03/leis/l8625.htm. Aceso em:15/07/2020. 


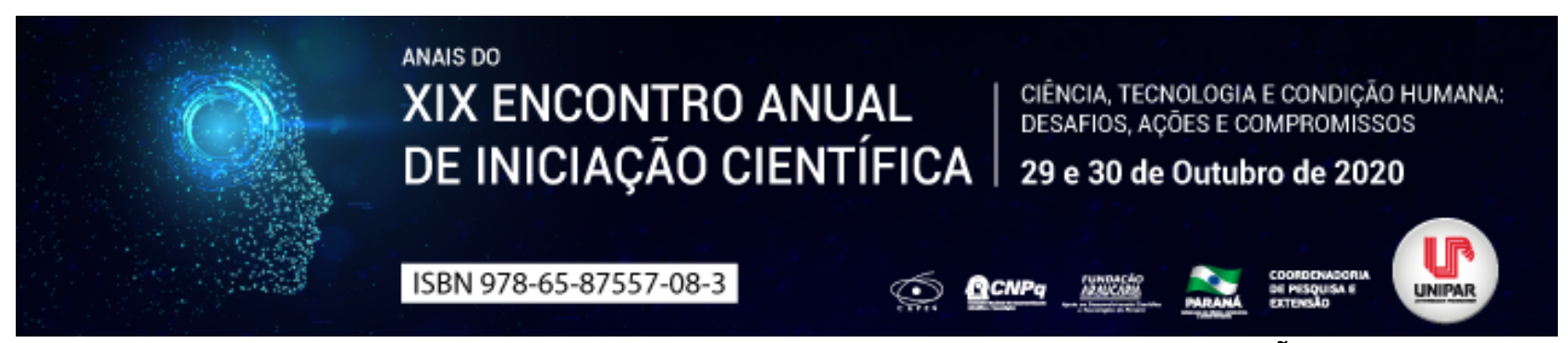

TREINAMENTO E DESENVOLVIMENTO: UM IMPORTANTE SUBSISTEMA NA GESTÃO DE PESSOAS

\author{
${ }^{1}$ VITOR HUGO DE SOUZA CICHOCKI, ${ }^{2}$ ELIZANGELA MARIA MENEGASSI DE LIMA
}

\author{
${ }^{1}$ Acadêmico do curso de Administração da UNIPAR \\ ${ }^{1}$ Docente da UNIPAR
}

Introdução: Treinamento e desenvolvimento são investimentos no capital humano tornando-se essenciais para o crescimento da empresa e para alcance das metas e objetivos, onde, treinamento está relacionado com a capacitação dos colaboradores para executarem atividades específicas dentro da empresa tendo como característica a curto prazo, enquanto, desenvolvimento é conjunto de todas práticas adotadas por uma empresa para melhorar o desempenho pessoal e profissional de um colaborador, tendo como característica a longo prazo.

Objetivo: Descrever o subsistema de treinamento e desenvolvimento na gestão de pessoas.

Desenvolvimento: Presentemente, o treinamento e desenvolvimento estão sendo vistos como "armas" estratégicas para as nações e organizações, visto como, contribuem positivamente para o desenvolvimento e o alcance dos objetivos e metas organizacionais, onde, possivelmente suscita em um aumento da lucratividade e desempenho da empresa. (BOUDREAU; MILKOVICH, 2000 apud FREIRE, 2014). Partindo desse pressuposto, os principais objetivos do treinamento e desenvolvimento estão relacionados com aprimoramento do desempenho dos colaboradores, a maximização da produtividade e a incrementação positiva das relações interpessoais. A posteriori, o programa de T\&D sem dúvida é de suma importância para qualquer organização, pois, através dele possibilita o crescimento e desenvolvimento dos colaboradores dentro da empresa, aumentando o nível de performance dos colaboradores, consequentemente gerando melhores resultados para empresa que está relacionado com: aumentando da produtividade, redução da taxa de TurnOver, melhoria do clima organizacional e vantagem competitiva no mercado. I"Quando um colaborador está em processo de treinamento e desenvolvimento dentro da empresa, este, automaticamente se aperfeiçoa em sua função e cargo, por conseguinte, irá ter uma mudança positiva no conjunto de seu conhecimento, habilidade e atitude (CHA)", (MARRAS, 2000, p. 145). Outro fator relevante está relacionado com a sua execução e aplicação, em que se faz necessário, definir pontos de execução, realizar a comunicação dos colaboradores do plano de T\&D e aplicar os métodos. Para o treinamento e desenvolvimento ser efetivo dentro de uma empresa a mesma terá que enfrentar alguns desafios que servirá para o aperfeiçoamento dos colaboradores e da empresa por excelência, são eles: identificar talentos, treinar e desenvolvê-los, patrocinar a criatividade, valorizar a atitude empreendedora e fomentar avaliaçõesl". (REICHEL, 2008, p. 12).

Conclusão: Destarte, para que o treinamento e desenvolvimento (T\&D) seja efetivo dentro de uma organização é necessária sua aplicação correta, seguindo os procedimentos e os passos adequadamente: Treinamento, planejamento, programação, execução, avaliação, levantamento de dados, gerência de T\&D, fluxo do processo de treinamento e diagnóstico. Isto posto, é um programa no qual contribuirá positivamente para o Desenvolvimento Organizacional (DO), para o desempenho dos colaboradores do cargo ocupado, consequentemente aumentará a probabilidade de assertividade e alcance das metas e objetivos empresariais estabelecidos.

\title{
Referências
}

FREIRE, Denilson A. L. Treinamento e desenvolvimento em Recursos Humanos. Curitiba: InterSaberes, 2014.

MARRAS, Jean Pierre Marras. Administração de recursos humanos: do operacional ao estratégico. 6. ed. São Paulo: Futura, 2002.

REICHEL, Harduin. Treinamento e Desenvolvimento. Curitiba: IESDE Brasil S.A., 2008.

Coordenadoria de Pesquisa e Extensão - COPEX

Departamento de Editoraçāo e Divulgaçāo Científica - DEDIC 


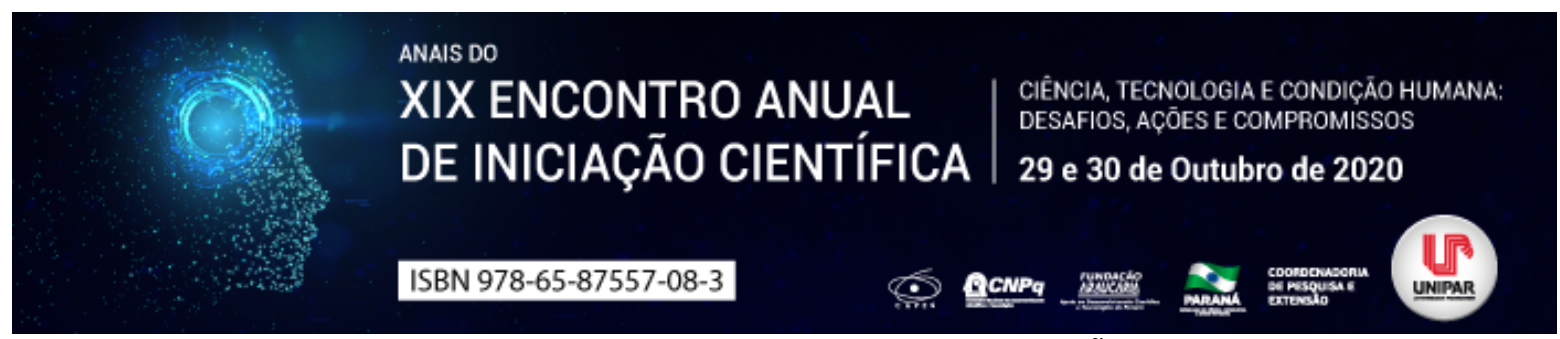

A OBRIGATORIEDADE DOS PRECEDENTES E A EVOLUÇÃO DO DIREITO

\title{
${ }^{1}$ LUANA GABRIELA TEIXEIRA SILVA, ${ }^{2}$ FERNANDO MENEGUETI CHAPARRO
}

\author{
${ }^{1}$ Acadêmica/PIC UNIPAR \\ ${ }^{1}$ Docente da UNIPAR
}

Introdução: Entre as alterações trazidas pela nova redação do Código de Processo Civil, estão os meios de uniformização das decisões judiciais, implementando a obrigatoriedade de se observar as decisões superiores em busca de isonomia e segurança jurídica. No entanto, a jurisprudência dos tribunais superiores não tem se mostrado igualitária e consistente, e por essa razão é necessário debater a obrigatoriedade dos precedentes como um impedimento no desenvolvimento do direito.

Objetivo: Analisar se o caráter obrigatório imposto a uniformização das decisões judiciais não causa atrasos a evolução do direito.

Desenvolvimento: $O$ art. 926 do Código de Processo Civil informa que os tribunais devem buscar uniformizar a sua jurisprudência. Segundo o legislador, a finalidade da norma é manter a mesma estável, integra e coerente. Já o artigo 927, do mesmo diploma, complementa que os juízes e tribunais deverão observar em suas decisões, fielmente, as manifestações do Supremo Tribunal Federal em controle concentrado de constitucionalidade (I), os enunciados de súmula vinculante (II), os acórdãos em incidente de assunção de competência ou de resolução de demandas repetitivas e em julgamento de recursos extraordinário e especial repetitivos (III) e os enunciados das súmulas do Supremo Tribunal Federal em matéria constitucional e do Superior Tribunal de Justiça em matéria infra constitucional a orientação do plenário ou do órgão especial aos quais estiverem vinculados (IV). Tais implementos foram realizados, de acordo com Fredie Didier Júnior (2015) sob pressuposto de que os tribunais não poderiam atuar sendo omissos quanto às divergências internas que possuem em relação a uma mesma questão jurídica. O tribunal tem o dever de resolver essa divergência, uniformizando o seu entendimento sobre o assunto. No entanto, o caráter obrigatório com que o NCPC trouxe o uso dos precedentes pode sinalizar um atraso para o reconhecimento de direitos que sequer foram debatidos e provocar uma radical transformação no direito processual brasileiro (VIANA, 2017). De acordo com Norberto Bobbio (2004), em seu discurso sobre a era dos direitos, é necessário observar que não se pode utilizar de um único argumento para fundamentar os direitos diversos, e nem mesmo considerar que haja um único direito fundamental a ser garantido. Por isso não seria razoável pensar que o que sustenta um direito sustentará outro. Se, porém, é a multiplicidade de pensamentos que ocasiona a divergência, e, por fim, chega-se a um denominador comum, querer suprimir entendimentos divergentes é querer suprimir o combustível que permite a evolução do Direito. Como bem observa Moraes (2012), por exemplo, as manifestações dos ministros do Supremo Tribunal Federal parecem possuir prazo de validade, pois só se aplicam no momento em que são tomadas, e acabam por não servirem de guia para casos futuros. A mesma observação pode ser feita em relação aos demais Tribunais Superiores, que ainda titubeiam na aplicação de sua própria jurisprudência dominante, não sendo raras decisões pontuais excepcionando entendimentos sedimentados.

Conclusão: Portanto, é preciso impor ressalvas a esse sistema redigido com a premissa de facilitar e resolver de forma isonômica, quando na verdade pode impedir a evolução do direito, pois, ainda com Norberto Bobbio (2004), não é sobre encontrar a resposta que será como fundamento absoluto, mas, sim, ao olhar a complexidade de cada caso concreto, todos os fundamentos que lhe são possíveis.

\section{Referências}

BOBBIO, Norberto. A era dos direitos. Rio de Janeiro: Elsevier, 2004. 96 p. v. 1. ISBN 13.978-85.352.161-8. E-book (96 p.).

BRASIL. Código de Processo Civil. 2015. Disponível em: http://www.planalto.gov.br/ccivil_03/_ato2015-2018/2015/lei/l13105.htm. Acesso em: 28/08/2020.

DIDIER JÚNIOR, Fredie. Sistema brasileiro de precedentes judiciais obrigatórios e os deveres institucionais dos Tribunais: uniformidade, estabilidade, integridade e coerência da jurisprudência. Revista da Faculdade Mineira de Direito, Minas Gerais, v. 18, n. 36, ed. 1, p. 114132, 2015.

VIANA, Antônio Aurélio de Souza. A Lei 13.256/16 e os perigos da inércia argumentativa no trato do direito jurisprudencial. 2017. p.121. Disponível em: https://d1wqtxts1xzle7.cloudfront.net/54011920/A_Lei_13.256_e_os_perigos_da_inercia_argumentativa.PDF? 1501421591=\&response-content-

disposition=inline\%3B+filename\%3DA_Lei_13_256_16_e os_perigos_da inercia.pdf\&Expires=1598888569\&Signature=Qw5ze6EtdO2Mq5WSOqYtnEPfX698b3vvQwEoEsgWxSZKAaGBfLuQ4-cyux8pIRtP i1iKdOS1ZtjHI4EzApeXnIBh96JQvCJYI46omArZmL7CWCG4IcWoEmqSdLW21zcBO uTzq3rgoXALH2RZiEAANrwbm51keVDDD7iKz2YUHxo9urmvjVxg095EDZoCKBJHKA-YqxDvcTo2yWuQ3ufq2UTrmOuLB6KeEgyDqFYuZQpvycR9J6cWXWLEV-VO0 fEZuZkEsDjflh4JOu71Xdmbi7hMtjOLOnTZWXKjEewqO315JLIHLt6gYiz6ipB82hKpgmkZODeF 54F6w_\&Key-Pair-Id=APKAJLOHF5GGSLRBV4ZA. Acesso em: 27 ago. 2020.

VOJVODIC, Adriana Moraes. Precedentes e argumentação no Supremo Tribunal Federal: entre a vinculação ao passado e a sinalização para o futuro. 2012. 269 f. Tese (Doutorado) - Faculdade de Direito, Universidade de São Paulo, São Paulo, 2012. 


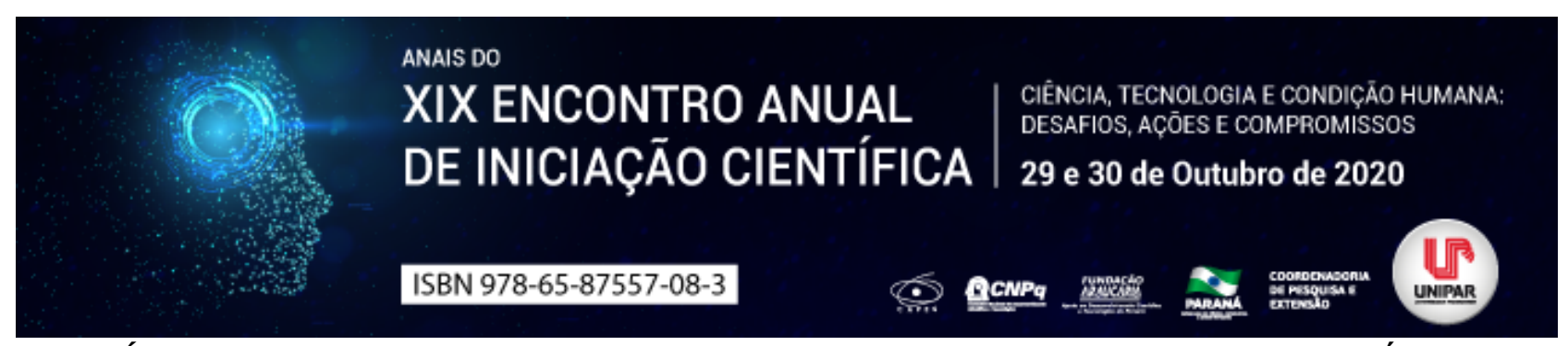

SALTOS, EQUILÍBRIO E SENTIMENTOS: UM RELATO SOBRE A PSICOLOGIA DO ESPORTE E A GINÁSTICA ARTÍSTICA

\author{
${ }^{1}$ GEISIANE GASPARIN RAMOS, ${ }^{2}$ ALESSANDRA VIEIRA FERNANDES
}

\author{
${ }^{1}$ Acadêmica do PIC/UNIPAR \\ ${ }^{1}$ Docente da UNIPAR
}

Introdução: A Psicologia, em seus diversos campos de atuação, possui um papel fundamental na promoção da saúde mental, inclusive no contexto esportivo. Conforme Weinberg e Gould (2017), a Psicologia do Esporte contribui para a compreensão dos aspectos psicológicos que envolvem o comportamento no esporte, assim como investiga e atua com estratégias para a saúde mental e o bem-estar de atletas. O acompanhamento psicológico no esporte colabora não somente com o rendimento mas, sobretudo, com o desenvolvimento psicossocial das pessoas envolvidas (DE ROSE JUNIOR et al., 2009). A ginástica artística, por sua vez, é uma modalidade complexa, pois exige das/os atletas habilidades como equilíbrio, força, flexibilidade, concentração, sendo demarcada por seu alto risco de lesão (HEINEN; VINKEN; VELENTZAS, 2014). Diante dessas características, compreendemos a relevância da atenção psicológica nessa modalidade, principalmente direcionada às crianças e adolescentes participantes (FERREIRA et al., 2020).

Objetivos: Descrever e discutir um projeto de intervenções psicológicas efetivadas com atletas de ginástica artística.

Material e Métodos: Realizamos intervenções psicológicas com cerca de 30 meninas atletas na faixa etária entre 08 a 14 anos de idade durante um período de 06 meses no ano de 2019. Essas atletas constituíam três equipes da modalidade, com tempo de experiência e horários de treinos diferentes. As intervenções ocorriam de forma grupal nos espaços de treino ou nas salas de atendimento de um serviço-escola de Psicologia. Os encontros foram estruturados a partir das demandas emergentes em entrevistas individuais, observações participantes, assim como nas próprias intervenções com os grupos. A descrição e avaliação das intervenções foram registradas em diários de campo, apresentadas a seguir.

Resultados e Discussões: Os encontros com as atletas aconteciam em três horários diferentes com cada equipe e possuíam duração de 01 hora. Participavam em média 10 atletas por equipe. Antes de iniciar as intervenções, coletamos informações a partir de observações participantes nos locais de treino e entrevistas individuais com as atletas e com a treinadora da equipe. Percebemos que para a maioria das atletas a ginástica artística ocupava um lugar importante em sua vida e rotina. Como demandas identificamos o relacionamento interpessoal entre as atletas, conflitos familiares, autoestima, ansiedade, inseguranças, dentre outras (algumas demandas emergiram nos próprios encontros). Desse modo, organizamos as intervenções com a finalidade de trabalhar essas questões, bem como possibilitar um espaço de expressão e escuta qualificada. No início dos encontros, conversamos com as atletas sobre a Psicologia e seu papel neste contexto, no sentido de uma psicoeducação. Para desenvolver as atividades, utilizamos recursos lúdicos, psicoterapêuticos e/ou audiovisuais, dinâmicas de grupo, técnicas de relaxamento e mentalização. A utilização dos recursos mediava a expressão de sentimentos e pensamentos a respeito das questões trabalhadas e as técnicas aplicadas objetivavam o manejo da ansiedade e da autoconfiança, assim como contribuíram para facilitar a aprendizagem de habilidades (WEINBERG; GOULD, 2017). Os encontros foram desenvolvidos nos momentos pré e pós competitivos e de treinamentos periódicos. Por conseguinte, trabalhamos com as atletas em diferentes situações, estas caracterizadas por distintos estados emocionais. Destacamos que neste processo interventivo foi fundamental viabilizar a compreensão de sentimentos e emoções, a ressignificação de experiências e o autoconhecimento. Consideramos o esporte um instrumento potente no desenvolvimento global do indivíduo, na promoção da autonomia, na transmissão de educação, na manutenção ou no alcance da saúde e no fortalecimento da autoestima (GABARRA; RUBIO; ANGELO, 2009). Observamos, a partir das intervenções, que esse espaço de expressão e verbalização constituía um momento importante para as atletas, pois identificamos a satisfação delas ao participarem de forma ativa dos encontro, além da construção de uma rede de apoio social e afetivo. Também percebemos o compartilhamento de vivências e sentimentos, bem como a viabilização de estratégias de enfrentamento diante das dificuldades e desafios experienciadas por elas, especialmente nesta fase da vida. A treinadora, por sua vez, relatou sobre mudanças percebidas nos comportamentos e nas relações entre as atletas. Tais aspectos observados permitiram compreender os significativos desdobramentos do acompanhamento psicológico neste contexto.

Conclusão: Constatamos que essas vivências proporcionadas às equipes de ginástica resultaram em mudanças nos aspectos psicossociais das atletas e dos grupos. Foram observadas, inclusive, melhorias no sentido dos relacionamentos interpessoais, bem como no desenvolvimento de habilidades importantes para a prática e execução do esporte. A partir desse processo interventivo, entendemos que a Psicologia é importante e necessária neste campo. Sugerimos o desenvolvimento de iniciativas como esta e a disseminação do conhecimento produzido.

\title{
Referências
}


DE ROSE JR, D. Esporte e atividade física na infância e na adolescência: uma abordagem multidisciplinar. Porto Alegre: Artmed, 2009.

GABARRA, L. M.; RUBIO, K.; ANGELO, L. F. A Psicologia do Esporte na iniciação esportiva infantil. Psicologia para América Latina, n. 18, 2009, p. 0-0, 2009.

HEINEN, T.; VINKEN, P. M.; VELENTZAS, K. A contribuição da psicologia do esporte à ginástica competitiva. In: SCHIAVON, L. M.; BORTOLETO, M. A. C.; NUNOMURA, M.; TOLEDO, E. (Orgs.). Ginástica de alto rendimento. Várzea Paulista: Fontoura, 2014.

FERREIRA, N. R. C.; OLIVEIRA, V.; BACIEGA, S. A. S.; TESSUTI, V. D.; TERTULIANO, I. W. (2020). Os aspectos psicológicos na ginástica artística: foco na categoria pré-infantil. Lecturas: Educación Física y Deportes, v. 25, n. 267, p. 132-146, 2020. WEINBERG, R.; GOULD, D. Fundamentos da Psicologia do Esporte e do Exercício. 6. ed. Porto Alegre: Artmed, 2017. 


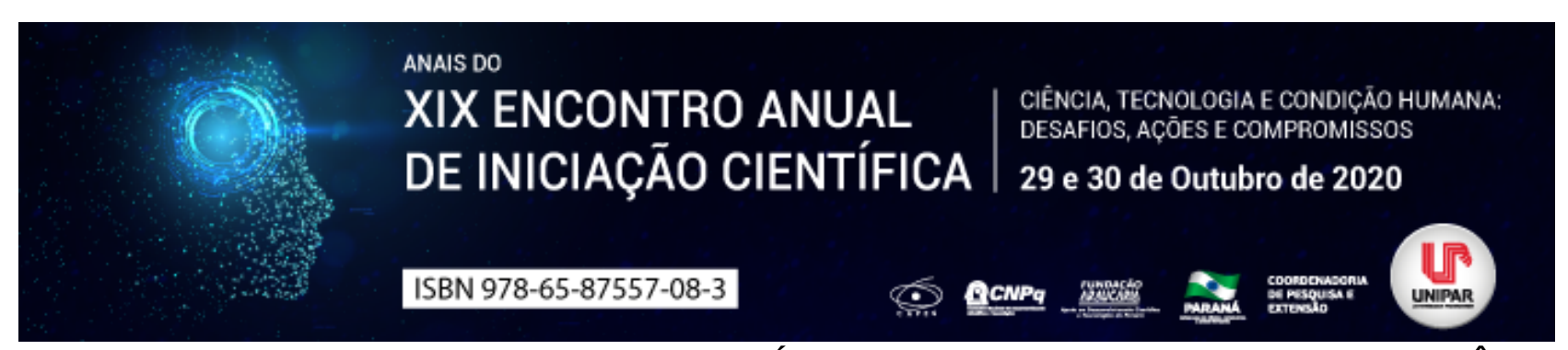

DA EXCLUDENTE DE CULPABILIDADE DO INFANTICÍDIO: DO ESTADO PUERPERAL E SUAS INFLUÊNCIAS PSICOLÓGICAS

\author{
${ }^{1}$ KEILA CRISTINA SARAGOCA TARINI, ${ }^{2}$ LORENA DIAS DA SILVA, ${ }^{3}$ LUIS WANDERLEY GAZOTO
}

${ }^{1}$ Acadêmica do curso de Direito da UNIPAR

${ }^{1}$ Acadêmica do Curso de Direito da UNIPAR

${ }^{2}$ Docente da UNIPAR

Introdução: O artigo 123 do vigente Código Penal define o crime de infanticídio como matar, sob a influência do estado puerperal, o próprio filho, durante o parto ou logo após , porém, a depender do grau desse estado, pode ser que a mulher não compreenda a ilicitude do fato, o que poderá trazer consequências na análise de sua culpabilidade.

Objetivos: Analisar a patologia influenciada pelo estado puerperal, bem como a possibilidade de inclusão da puérpera no rol de inimputáveis.

Desenvolvimento: Considera-se realizado o crime quando 'o agente tenha praticado uma ação típica, ilícita e culpável' (GRECO, 2017, p. 227). Caso a conduta não preencha esses três requisitos, a ação ou omissão efetuada não será considerada criminosa. Quanto à culpabilidade, o Código Penal dispõe que Art. 26 - É isento de pena o agente que, por doença mental ou desenvolvimento mental incompleto ou retardado, era, ao tempo da ação ou da omissão, inteiramente incapaz de entender o caráter ilícito do fato ou de determinar-se de acordo com esse entendimento (BRASIL, 1940, p. 5). Portanto, caso o indivíduo seja portador de alguma doença mental que o faça não entender a ilicitude do fato, será isento de pena, por falta de culpabilidade. Quanto à mulher em estado puerperal, ou seja, uma [...] perturbação psicológica que a mãe sofre entre o deslocamento e expulsão da placenta e à volta do organismo materno às condições normais (MESTIERI; MENEGUETTE; MENEGUETTE, 2005, p. 1), pode ser que esse estado possa causar alucinações auditivas ou visuais, inquietação, agitação e períodos de confusão mental intercalados com momentos de lucidez (ABREU, 2014, p. 3). Ou seja, haverá casos em que a mãe estará sem condições de entender a antijuricidade de sua conduta, ocasionando uma inevitável excludente de culpabilidade, pois não há o que se falar em imputabilidade quando o agente está sofrendo perturbação psicológica que o impeça de saber se o fato praticado está de acordo com as normas descritas pelo direito penal brasileiro. Neste sentido, não deverá ser imputado à mãe, em tais condições, o crime descrito pelo artigo 123 do Código Penal brasileiro, pois caso a impute estará violando o artigo 26 do Código Penal.

Conclusão: Quando a mulher, durante ou logo após o parto, encontra-se em um estado puerperal, em um estágio mais grave, podendo, por isso, ter perdido a conexão com a realidade, não há que se falar na imputação do crime do artigo 123 do Código Penal, em razão desta estar sem condições de entender a ilicitude do fato.

\title{
Referências
}

ABREU, Michele Oliveira de. Crime de infanticídio e a imputabilidade da portadora de puerpério. Disponível em: encurtador.com.br/hyEPU. Acesso em: 11 jun. 2020.

BRASIL. Decreto-lei no 2.848, de 7 de dezembro de 1940 . Código Penal. Disponível em: http://www.planalto.gov.br/ccivil_03/decreto-lei/del2848compilado.htm. Acesso em: 20 maio 2020.

GRECO, Rogério. Curso de Direito Penal: Parte geral. 19. ed. Niterói-RJ: Impetus, 2017.

MESTIERI, Luiz Henrique Mazzonetto; MENEGUETTE, Renata Ipólito; MENEGUETTE, Cícero. Estado Puerperal. Disponível em: encurtador.com.br/foKNZ. Acesso em: 11 jun. 2020. 


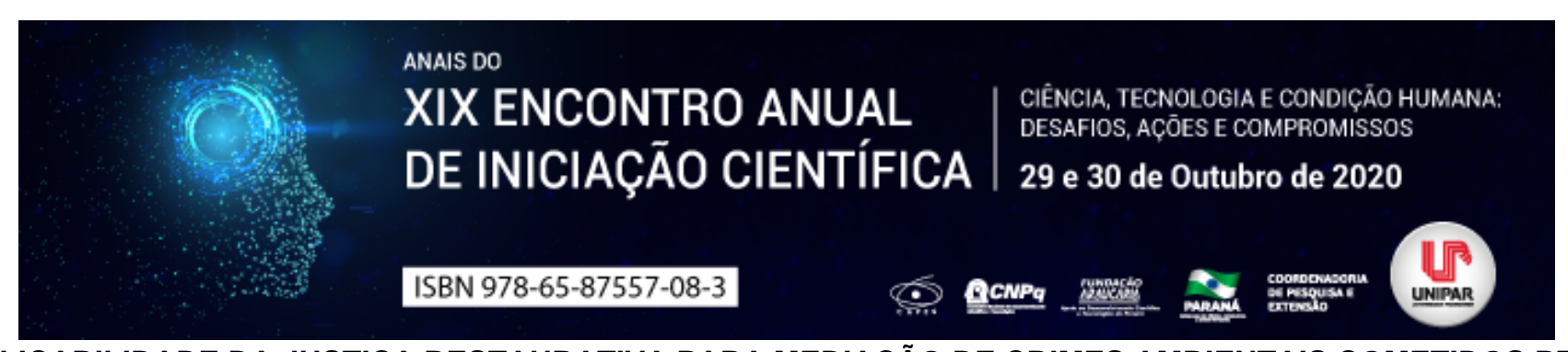

\title{
APLICABILIDADE DA JUSTIÇA RESTAURATIVA PARA MEDIAÇÃO DE CRIMES AMBIENTAIS COMETIDOS PELA PESSOA JURÍDICA
}

\author{
${ }^{1}$ KAUANE SILVEIRA REBERTI, ${ }^{2}$ MILENA TONINATO VIGNOTO, ${ }^{3}$ CELSO HIROSHI IOCOHAMA
}

\author{
${ }^{1}$ Acadêmica do Curso de Direito da UNIPAR \\ ${ }^{1}$ Acadêmica do Curso de Direito da UNIPAR \\ ${ }^{2}$ Docente da Graduação em Direito e do Programa de Mestrado em Direito Processual e Cidadania da UNIPAR
}

Introdução: Verifica-se, atualmente, o surgimento de uma nova criminalidade, caracterizada por figuras delitivas plurais e um destinatário final coletivo, como evidenciado nos crimes ambientais, nos quais a pessoa jurídica é o infrator. Por conseguinte, a justiça restaurativa emerge como uma alternativa eficaz, frente à limitação do paradigma penal tradicional, para mediação desse tipo de conflito.

Objetivo: Analisar a aplicabilidade da justiça restaurativa, para a resolução de delitos ambientais cometidos pela pessoa jurídica, a exemplo dos casos de Mariana e Brumadinho, estado de Minas Gerais.

Desenvolvimento: A pessoa jurídica é dotada de capacidade própria para responder por seus atos, inclusive os lesivos ao meio ambiente, que podem submetê-la a sanções previstas pelo direito posto, como consta no artigo 225 da Constituição Federal e na Lei 9.605/98. Prova disso é a responsabilização administrativa, civil e penal, aplicada às empresas Vale S.A e BHP Billiton, que compõem a mineradora Samarco, pela tragédia de Mariana, marcada pelo rompimento da barragem Fundão, em 2015, que causou grande impacto ambiental, além de várias vítimas. Porém, apesar de terem sido submetidas a punições, as pessoas jurídicas citadas cometeram, em 2019, um delito similar, em Brumadinho, o que denota certa ineficácia do sistema penal, uma vez que não houve no caso de Mariana, por parte das empresas, l"um aprendizado que resultasse na mudança de postura em relação a segurança de suas barragens, proteção ambiental e respeito a vida (REZENDE; SILVA, 2019, p. 12). Isso ocorre, amiúde, pois a justiça criminal possui bases punitivas/retributivas e aplica penas que têm [...] mais uma função de legitimação da ordem que um objetivo específico de revisão do conflito social (FERREIRA, 2015, p. 28). Nesse viés, em paralelo ao sistema penal, a justiça restaurativa surge como um meio relevante, que busca por alternativas que promovam a reparação dos danos causados pelo conflito, com foco em todas as partes afetadas: vítima, ofensor e comunidade (BALIM; MENDES; MOTA, 2014). Ademais, um dos métodos dessa prática é a mediação vítima-ofensor-comunidade, que visa a estimular a identificação dos danos causados, por ambas as partes, a fim de restaurá-los e responsabilizar, de forma mais direta, o infrator (SOUZA, 2019). Diante disso, nota-se a possível aplicação desse artifício no episódio de Brumadinho, mediante reuniões envolvendo todas as partes do delito, isto é, a vítima, nesse caso, representada pelo Ministério Público, o ofensor, que é a pessoa jurídica retratada pelos representantes e a sociedade afetada. Desse modo, o principal propósito do método supracitado é reparar o dano gerado e, sobretudo, restaurar o vínculo rompido, para que seja estabelecida uma harmonia entre os envolvidos e, assim, o ato não se repita, como ocorreu nos episódios em questão.

Conclusão: Infere-se, então, que no caso de Brumadinho, o método citado é aplicável, por meio de encontros entre a comunidade atingida, os representantes das empresas e do Ministério Público, autor da ação. Assim, evidencia-se a aplicabilidade da justiça restaurativa a conflitos desse gênero.

\section{Referências}

BALIM, Ana Paula Cabral; MENDES, Cláudia Marlice da Rosa; MOTA, Luiza Rosso. Justiça Restaurativa: uma medida alternativa para 0 modelo tradicional de justiça penal. Rio Grande do Sul. 2014 . Disponível em: https://online.unisc.br/acadnet/anais/index.php/sidspp/article/view/11817. Acesso em: 14 jun. 2020.

FERREIRA, Ana Gabriela Souza. Justiça Restaurativa Aplicada à Pessoa Jurídica: uma proposição de alternativa eficaz para responsabilização penal da corporação no direito penal ambiental. 2015. Dissertação de Mestrado Faculdade de Direito, Universidade Federal da Bahia, Salvador, 2015.

REZENDE, Elcio; SILVA, Victor Vartuli Cordeiro e. De Mariana a Brumadinho: a efetividade da responsabilidade civil ambiental para a adoção das medidas de evacuação. Revista do Direito, Santa Cruz do Sul, v. 1, n. 57, jul. 2019. Disponível em: . Acesso em: 14 de jun. 2020.

SOUZA, Carla Arantes de. Justiça Restaurativa, Mediação Vítima-Ofensor e Teorias Psicanalíticas de Grupo: Uma Possível Aproximação. Revista de Psicologia, Fortaleza, v.11 n.1, p. 108-116. 2020. 
Coordenadoria de Pesquisa e Extensão - COPEX

Departamento de Editoraçāo e Divulgaçāo Científica - DEDIC 


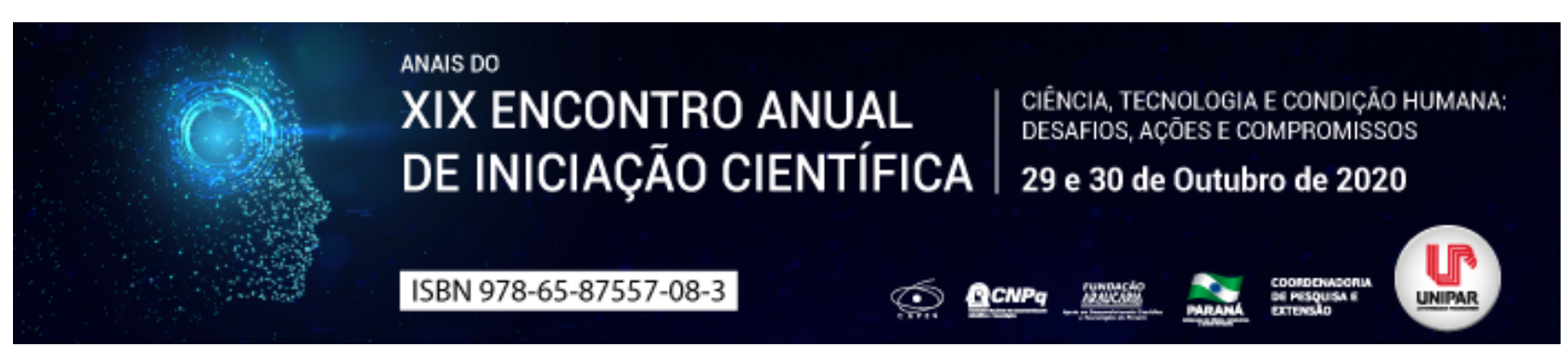

\title{
DOS INSTITUTOS PROCESSUAIS UTILIZADOS PARA CONTROLE JUDICIAL DO TOQUE DE RECOLHER NA PANDEMIA COVID-19
}

\author{
${ }^{1}$ WELLINGTON DOUGLAS QUIRINO DE PAULA, ${ }^{2}$ PAULO CESAR DE SOUSA
}

${ }^{1}$ Acadêmico do curso de Direito da UNIPAR

${ }^{1}$ Docente da UNIPAR

Introdução: Para controle da propagação da Covid-19, uma medida empregada pela administração pública é o toque de recolher. Como ato administrativo sujeita-se à controle judicial, feito por meio de várias espécies processuais.

Objetivo: Apontar as vias processuais adequadas para controle judicial do toque de recolher da pandemia da Covid-19, bem como expor os requisitos de cada uma delas.

Desenvolvimento: $O$ toque de recolher é um instituto aplicado por autoridade administrativa, que restringe o direito de ir e vir por determinado horário. Essa limitação tem sido aplicada em vários municípios, por meio de decretos, em virtude da pandemia da Covid-19. Insurgências contra atos dessa natureza têm sido apreciadas pelo judiciário por meio de várias técnicas processuais, para assegurar que nenhum direito seja violado em detrimento destas restrições. Vários institutos processuais podem ser utilizados para controlar a legalidade atos do poder executivo. Com efeito pode ser impetrada ordem de habeas corpus, que é uma garantia individual ao direito de locomoção, consubstanciada em uma ordem dada pelo juiz ou tribunal ao coator, fazendo cessar a ameaça ou coação à liberdade de locomoção em sentido amplo o direito do indivíduo de ir, vir e ficar (MORAES, 2017, p. 115). Igualmente, pode ser manejada uma reclamação constitucional, que está prevista no art. 102, I, I, da Carta de 1988, para preservar a competência e garantir a autoridade das decisões do Supremo Tribunal Federal. O modelo constitucional adotado consagra a admissibilidade de reclamação contra ato da Administração em desconformidade com a súmula 792 . (MENDES, BRANCO, 2018 p. 1629). Ainda, tem-se a ação direta de inconstitucionalidade, que é de competência do STF, sendo o pedido pautado em exame de lei ou ato normativo, visando [...]., obter a invalidação da lei, a fim de garantir-se a segurança das relações jurídicas, que não podem ser baseadas em normas inconstitucionais. A declaração da inconstitucionalidade, portanto, é o objeto principal da ação, diferentemente do ocorrido no controle difuso (MORAES, 2017, p. 531). Nesse diapasão, várias liminares foram concedidas, cassadas ou suspensas por órgãos do judiciário, desde a primeira instância até o Supremo Tribunal Federal. Contudo, alguns feitos foram reconhecidos como inadequados, motivo pelo qual é necessário conhecer a configuração de cada uma dessas vias processuais.

Conclusão: O ordenamento jurídico brasileiro disponibiliza de vias processuais para controle judicial do toque de recolher, sendo necessário conhecer os requisitos de cada uma, tanto para a aplicação correta do instituto quanto para efetivo controle de atos do poder executivo, com o objetivo de assegurar que não seja violado o direito de ir e vir.

\section{Referências}

MEIRELLES, Henrique Lopes. Mandado de Segurança. 16.ed. São Paulo: Malheiros Editores, 1995.

MENDES, Gilmar Ferreira. BRANCO, P. G. G. Curso de Direito Constitucional. 13. ed. São Paulo: Saraiva, 2018.

MORAES, Alexandre de. Direito Constitucional. 33. ed. São Paulo: Atlas, 2017. 


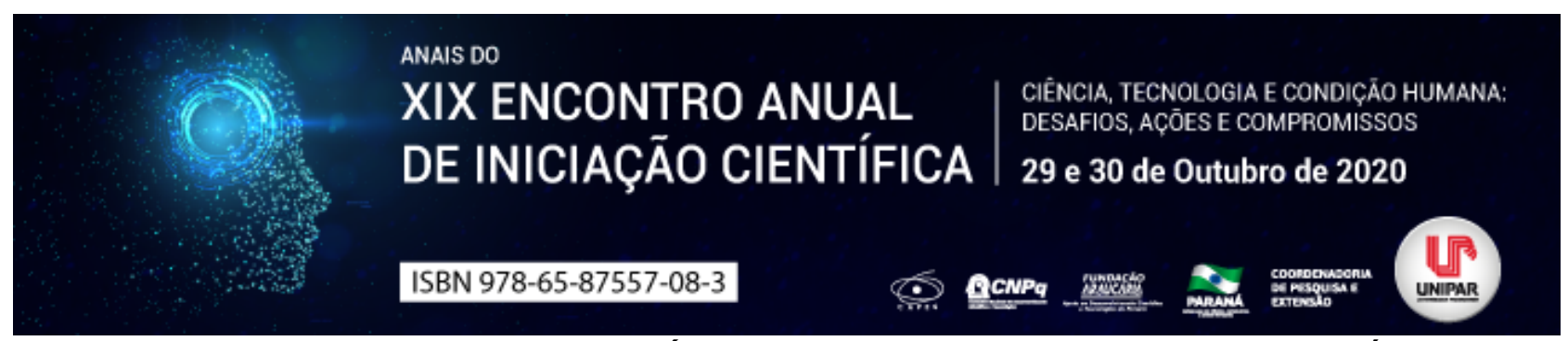

A PRIORIDADE DAS TUTELAS ESPECÍFICAS EM UM PROCESSO JUSTO E DEMOCRÁTICO

\author{
${ }^{1}$ MATHEUS BUCHNER GARCIA , ${ }^{2}$ ALBINO GABRIEL TURBAY JUNIOR
}

\author{
${ }^{1}$ Acadêmico do PIC/UNIPAR \\ ${ }^{1}$ Docente da UNIPAR
}

Introdução: O Estado Democrático de Direito está em constante reforma, acompanhando os preceitos sociais. Para tanto, o processo como meio de instrumentalidade deve apresentar as formas adequadas para obtenção da tutela jurisdicional. Nesse sentido, as tutelas específicas surgem com o objetivo de dar o deferimento daquilo que a parte efetivamente requereu em juízo, no entanto, é preciso analisar casos em que a conversão é possível.

Objetivo: Analisar a importância da tutela específica e as impossibilidades de sua conversão em perdas e danos nas obrigações de entregar coisa, fazer e não fazer.

Desenvolvimento: A percepção da tutela específica no processo civil brasileiro não é recente, bem como vem sofrendo constantes alterações a fim de garantir a segurança jurídica. Quando se pressupõe a análise da tutela específica, logo se vislumbra a satisfação da obrigação tal qual houvesse o cumprimento espontâneo pelo devedor. No entanto, em análise ao ordenamento jurídico do fim do século XIX e início do século XX, se nota a ampla influência do pensamento de Estado liberal, apresentando uma deficiência do sistema de tutelas (DINAMARCO, 1997, p. 152), garantindo ao devedor o direito de não cumprir o próprio dever, desde que ressarcido a obrigação em espécie pecuniária (DIDIER JR.; CUNHA; BRAGA; OLIVEIRA, 2017, p. 72). Com o passar do tempo, em razão da violação que se cometia a efetividade, e, em exceção ao princípio da congruência e da correlação, as obrigações de entregar coisa, fazer e não fazer incorporaram o princípio da primazia da tutela específica. Com a Lei n. 8.952/1.994, que altera expressiva parcela do Código de Processo Civil de 1973, há a consagração do princípio da primazia da tutela específica, fazendo surgir, pela primeira vez, as impossibilidades da conversão de tutelas específicas em perdas e danos nas obrigações de fazer ou não fazer, sendo que a partir de 2002 houve a extensão às obrigações de entregar coisa (DIDIER JR, 2017, p. 75). O Código de Processo Civil de 2015 absorveu todas as mudanças relativas as tutelas específicas, como se nota no Capítulo XIII, Seção IV. Em contrapartida, a tutela específica deve ser analisada conjuntamente com a tutela pelo equivalente, haja vista a sua possibilidade de conversão da obrigação em um equivalente em dinheiro ou ao adimplemento em resultado prático equivalente ao adimplemento voluntário, no entanto, a mesma deve ser aplicada como medida excepcional, tendo como regra a primazia da tutela específica. O art. 497 do Código de Processo Civil de 2015, em sua primeira parte, traz: Na ação que tenha por objeto a prestação de fazer ou não fazer, o juiz, se procedente o pedido, concederá a tutela específica [...] (BRASIL, 2015). Desta forma, deve-se priorizar a tutela específica, objetivando que a obrigação seja cumprida tal como se não houvesse a figura do Poder Judiciário, em seguida, o mesmo artigo traz em sua parte final: [...] ou determinará providências que assegurem a obtenção de tutela pelo resultado prático equivalente (BRASIL, 2015). Assim, deverá o magistrado, considerando o princípio da efetividade e postulado da proporcionalidade, além da adequação e necessidade, alcançar um resultado prático equivalente ao do adimplemento voluntário. Adiante, ao art. 499 do CPC, se observa que a conversão da obrigação em perdas e danos somente será deferida se requerido pelo autor ou se impossível a tutela específica ou a obtenção de tutela pelo resultado prático equivalente, a segunda hipótese se vale apenas a impossibilidades supervenientes, absolutas e imputáveis cumulativamente (ALBUQUERQUE Jr; COSTA FILHO, 2016, p. 1285). Vale ressaltar que é vedado ao autor a exigência da prestação pecuniária sem que haja o efetivo inadimplemento, ainda, fica vedada a conversão em perdas e danos aos direitos indisponíveis, como ao caso de um dano ambiental. Seguindo, é possível a conversão compulsória quando a execução na forma específica se tornar excessivamente onerosa ao devedor (DIDIER JR; CUNHA; BRAGA; OLIVEIRA, 2017, p. 593). Como disposto no caput do art. 805 do Código de Processo Civil de 2015, tal como segue (BRASIL, 2015): Quando por vários meios o exequente puder promover a execução, o juiz mandará que se faça pelo modo menos gravoso para o executado. Por fim, em especial a obrigação de entregar coisa, é possível a conversão quando objetivamente o credor não houver mais interesse na coisa, quando não entregue no prazo fixado, a coisa se deteriorar, a coisa não for encontrada ou quando não for reclamada do poder de terceiro adquirente (DIDIER JR.; CUNHA; BRAGA; OLIVEIRA, 2017, p. 653).

Conclusão: A tutela específica garante ao credor exatamente aquilo que se tem direito, desta maneira, deve o magistrado preservar a segurança jurídica, através do devido processo legal e seus corolários, o contraditório, ampla defesa e isonomia. Assim, no sentido de um processo devido e justo, o direito processual precisa apresentar modelos processuais e técnicas para proporcionar tutelas específicas, certificando um Estado Democrático de Direito e evitando a excessiva e onerosa conversão de obrigações em perdas e danos. 


\section{Referências}

ALBUQUERQUE Jr., Roberto Paulino de; COSTA FILHO, Venceslau Tavares. Do julgamento das ações relativas às prestações de fazer, de não fazer e de entregar coisa. In: STRECK, Lenio Luiz; NUNES, Dierle; CUNHA, Leonardo Carneiro da (org.); FREIRE, Alexandre (coord.). Comentários ao Código de Processo Civil. São Paulo: Saraiva, 2016.

BRASIL. Lei.13.105 de 16 março de 2015. Código de Processo Civil. Diário Oficial da União, Seção 1, 17 mar. 2015 , p.1.

DIDIER JR., Fredie; CUNHA, Leonardo Carneiro da; BRAGA, Paulo Sarno; OLIVEIRA, Rafael Alexandria. Curso de direito processual civil. 7. ed. Salvador: Editora JusPodivm, 2017. v. 5.

DINAMARCO, Cândido Rangel. A reforma do código de processo civil. 4. ed. São Paulo: Malheiros, 1997. 


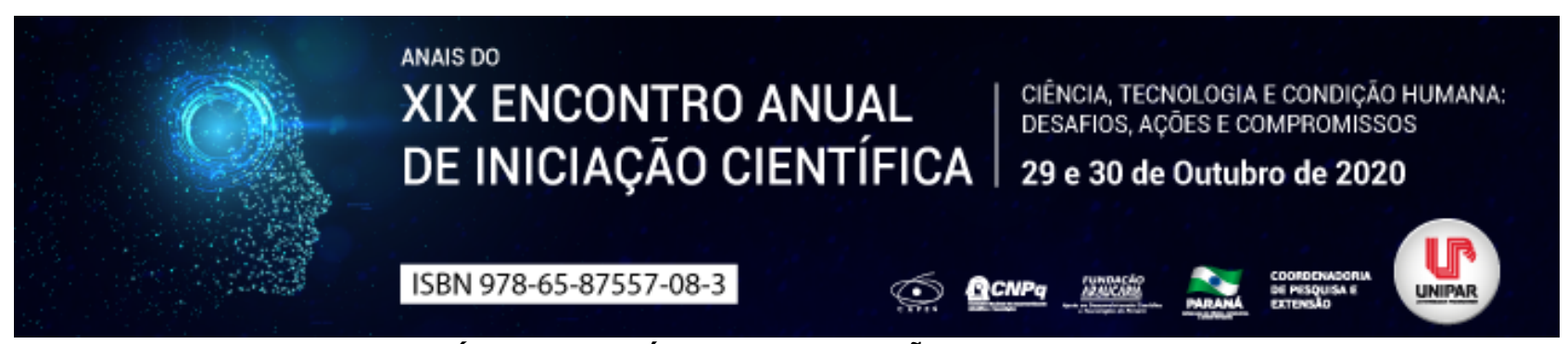

POLÍTICAS E PRÁTICAS DE GESTÃO DE PESSOAS

\begin{abstract}
1'LUCAS MATHEUS MOREIRA ROCHA, ${ }^{2}$ GABRIEL MAGALHAES DOS SANTOS, ${ }^{3}$ CARLOS EDUARDO FABRIL, ${ }^{4}$ DENISE CRISTINA DA SILVA, ${ }^{5}$ ELIZANGELA MARIA MENEGASSI DE LIMA
\end{abstract}

\author{
${ }^{1}$ Acadêmico do PIC/ Unipar \\ ${ }^{1}$ Acadêmico do Curso de AdministraÃßÃ£o da UNIPAR \\ ${ }^{2}$ Acadêmico do Curso de AdministraÃß̃̃£o da UNIPAR \\ ${ }^{3}$ Acadêmica do Curso de Secretariado da UNIPAR \\ ${ }^{4}$ Docente da UNIPAR
}

Introdução: Devido às mudanças no ambiente das empresas a gestão de pessoas vem tendo um papel de suma importância nas organizações e na conclusão de seus objetivos. As empresas necessitam de pessoas comprometidas com seu trabalho, para o sucesso empresarial. As pessoas por meio de seus conhecimentos, competências e habilidades ajudam no crescimento organizacional, de um mercado que tem exigido uma maior flexibilidade e adoção de instrumentos inovadores na gestão de relacionamentos entre empresas.

Desenvolvimento: O mercado organizacional caminha para uma maior valorização humana, para a prevalência do patrimônio intangível das organizações que são as pessoas. Vivemos na era do conhecimento e da valorização do capital humano, em que cada vez mais, apenas as pessoas capacitadas para atingirem os objetivos da organização terão espaço no mercado. Para construir o capital humano nas organizações, os gestores devem permanentemente desenvolver conhecimento superior, as habilidades e a experiência da força de trabalho, manter e promover funcionários com o melhor desempenho. (BOHLANDER E SNELL, 2015). Os clientes estão cada vez mais informados e, portanto, mais exigentes acerca dos produtos e serviços oferecidos no mercado. Merece destaque o fato de que de nada adianta as organizações adquirirem modernos equipamentos, se não houver pessoas capacitadas, motivadas e devidamente preparadas para o desenvolvimento de suas tarefas. A globalização transformou rapidamente o mundo dos negócios, onde tudo que acontece está sendo amplamente comunicado para todos os habitantes do planeta. E, nesse cenário concorrencial, as empresas têm que orientar os funcionários para saberem receber, processar e colocar em prática as informações impostas no dia-a-dia das organizações. Todas as organizações sejam públicas ou privadas dependem da administração e dos administradores para se manterem coesas e terem bom desempenho e até mesmo para existirem e sobreviverem. O capital humano é constituído das pessoas que fazem parte de uma organização. Capital humano significa talentos que precisam ser mantidos e desenvolvidos. Marras (2000) corrobora com sua ideia de capital humano, mencionando que, pelo próprio nome, a noção de capital humano não considera a pessoa como recurso perecível a ser consumido, mas como um bem valioso a ser desenvolvido. Nesse esboço, fica claro que o contexto no qual se situa a gestão de pessoas na atualidade, é a própria relação entre organização e pessoas, e não mais somente nas organizações diretamente voltadas para o capital de giro e lucro. Cabe até afirmar que todo processo produtivo, somente se realiza com a participação conjunta de diversos parceiros, cada qual contribuindo com algum recurso (CHIAVENATO, 2009), que the é cabido a exercer e desenvolver. O contexto que se situa a gestão de pessoas é representado, sobretudo, pelas empresas e pelas pessoas, pois se não houver essas duas correntes não haverá gestão de pessoas. De acordo com Chiavenato (2004, p.5), as organizações são constituídas de pessoas e dependem delas para atingir seus objetivos e cumprir suas missões. Para as pessoas, as empresas constituem o meio pelo qual as mesmas podem alcançar objetivos, metas e ideais. Assim, Gestão do capital humano é a função gerencial que visa à cooperação das pessoas que atuam nas organizações para o alcance dos objetivos tanto organizacionais quanto individuais. (GIL, 2001, p. 17). As pessoas são fundamentais para o sucesso das organizações. Atrair e manter talento é o grande desafio da administração de pessoas. O início desse desafio está em identificar a pessoa certa para o lugar certo nas empresas. Quando isso é feito, as pessoas irão contribuir com todo seu potencial, criatividade e motivação para o alcance dos objetivos organizacionais.

Conclusão: O principal desafio das organizações atuais é o gerenciamento de seus profissionais. A fim de vencer esta barreira, os profissionais ligados à área de gestão de pessoas devem trabalhar no desenvolvimento das competências e habilidades de seus profissionais, visando prepará-los para as constantes mudanças do mercado de trabalho, tendo em vista que, as organizações com ambientes dinâmicos estão em constante mudança para desenvolver e capacitar pessoas, visando a obtenção de melhores resultados nas atividades desenvolvidas.

\title{
Referências
}

BOHLANDER,G. W.; SNELL,S. A. Administração de Recursos Humanos. 16. ed. São Paulo: Cengage, 2015. 
CHIAVENATO, I. Recursos humanos: o capital humano das organizações. 7. ed. Rio de Janeiro: Elsevier, 2004. CHIAVENATO, I. Recursos humanos: o capital humano das organizações. 9. ed. Rio de Janeiro: Elsevier, 2009. GIL, A. C. Administração de recursos humanos: um enfoque profissional. São Paulo: Atlas, 2001.

Coordenadoria de Pesquisa e Extensão - COPEX

Departamento de Editoraçāo e Divulgaçāo Científica - DEDIC 


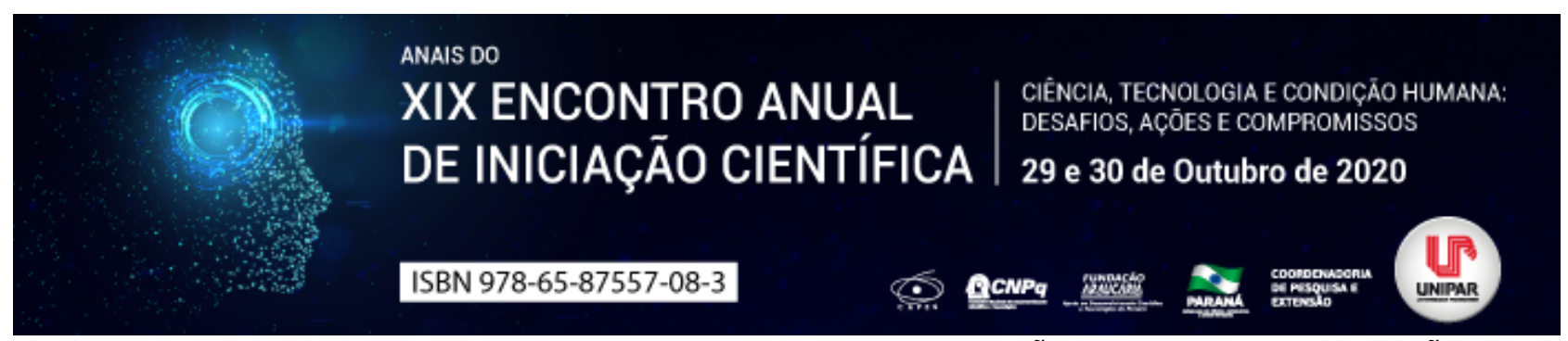

TRABALHO DO ADOLESCENTE MENOR APRENDIZ: PROTEÇÃO E PROFISSIONALIZAÇÃO

\section{${ }^{1}$ SUZANA FERREIRA DA COSTA SILVA, ${ }^{2}$ AMALIA MARINA MARCHIORO}

${ }^{1}$ Acadêmica do $4^{\circ}$ Ano do curso de Direito da UNIPAR

${ }^{1}$ Docente da UNIPAR

Introdução: O trabalho do adolescente aprendiz deve observar a condição peculiar da pessoa em desenvolvimento e o atendimento da capacitação profissional adequada ao mercado de trabalho. A proteção é uma tendência mundial, sobretudo com vista à escolarização dos menores.

Objetivo: Demonstrar as garantias legais do menor aprendiz, sua proteção e direito à profissionalização.

Desenvolvimento: O direito ao trabalho é fundamentado no artigo $7^{\circ}$ da Constituição, em seu inciso XXXIII permite o trabalho a partir dos 14 anos na condição de menor aprendiz. Para tanto, o Estatuto da Criança e do Adolescente (ECA) goza de capítulo próprio regulamentando a questão, bem como a Consolidação de Leis do Trabalho (CLT). Ensina Barboza (2009) que o ECA e a CLT asseguram aos menores todos os direitos fundamentais inerentes à pessoa humana, com vistas em sua proteção integral tanto no ambiente de trabalho, quanto fora dele, especificamente, o direito da criança e adolescente à vida, à dignidade, à educação, à saúde. Define-se, que a aprendizagem deve preconizar a escola frente ao trabalho. O ECA e a CLT ainda dispõem que é necessária a frequência no ensino regular, que a atividade seja compatível com o desenvolvimento do adolescente e que para tanto haja horário especial e local adequado para as atividades, objetivando a compatibilidade com horário escolar e o trabalho. Ainda, prevê a bolsa aprendizagem (valor de salário mínimo hora), bem como que sejam conferidos, à criança e ao adolescente, os direitos trabalhistas e previdenciários, desde a anotação de carteira e contrato especial de trabalho pelo prazo máximo de 02 anos, extinguindo-se automaticamente ao completar 18 anos. É vedada jornada superior a 06 horas, bem como jornada noturna (BRASIL, 1990; BRASIL, 1943). A atividade do menor aprendiz deve se intercalar em teoria e prática, sendo que o estabelecimento deve matricular o aprendiz nos cursos dos Serviços Nacionais de Aprendizagem (SESI, SENAI, SENAC, etc.). O Ministério do Trabalho por meio de suas delegacias, é o responsável pela fiscalização das relações de trabalho. Diante disso, Barboza (2009) argumenta que a inclusão do jovem em sistema de educação profissional é um fator importante para o combate das desigualdades sociais existentes. Assim, o direito à profissionalização, apresenta-se no novo contexto legal como uma das dimensões do direito do adolescente à cidadania plena.

Conclusão: Denota-se que o trabalho do adolescente é regulamentado com vistas a garantir a profissionalização e educação do jovem, de modo a contribuir com seu desenvolvimento, ao mesmo tempo que garante renda adequada, se apresentando como um direito essencial à plena cidadania do aprendiz.

\section{Referências}

BARBOZA, Adriana Firmiana. Trabalho do Melhor Aprendiz. Monografia (Especialização em Direito e Processo do Trabalho) Universidade Candido Mendes Instituto a Vez do Mestre. Rio de Janeir. 2009.

BRASIL. Lei $\mathbf{n}^{\circ} \mathbf{8 . 0 6 9}$, de 13 de julho de 1990. Dispõe sobre o Estatuto da Criança e do Adolescente e dá outras providências. Disponível em: encurtador.com.br/mrGl6. Acesso em: 22 jul 2020.

BRASIL. Decreto-Lei $n^{\circ}$ 5.452, de $1^{\circ}$ de maio de 1943 . Aprova a Consolidação das Leis do Trabalho. Disponível em: http://www.planalto.gov.br/ccivil_03/decreto-lei/del5452.htm. Acesso em: 22 jul 2020. 


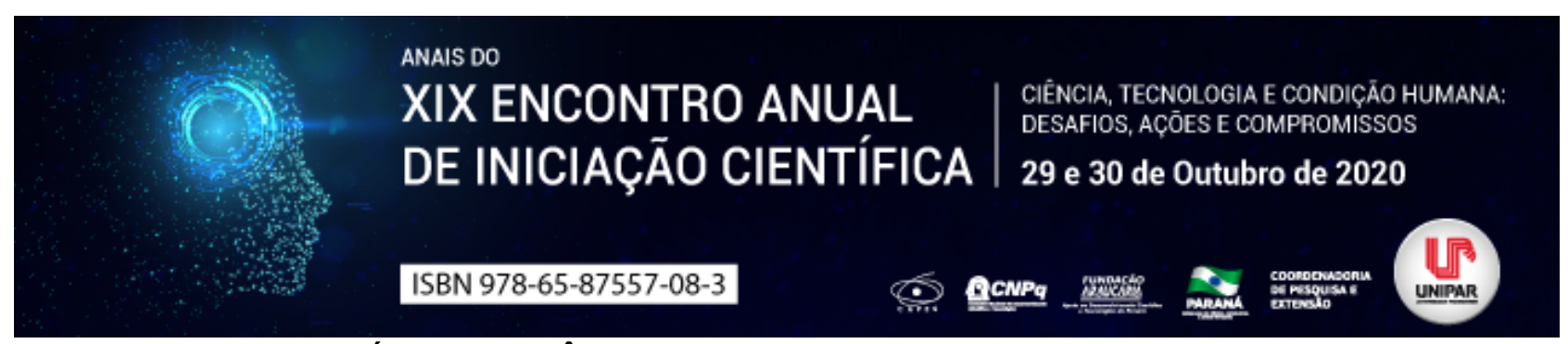

ANÁLISE ECONÔMICA DO DIREITO E O TEOREMA DE COASE

\title{
${ }^{1}$ NIELLY LUCKMANN, ${ }^{2}$ NATHALIA GRACINSKI RIPPEL, ${ }^{3}$ DIOGO LOPES CAVALCANTE
}

\author{
${ }^{1}$ Acadêmica do PIC/UNIPAR \\ ${ }^{1}$ Acadêmica do PIC/UNIPAR \\ ${ }^{2}$ Docente da UNIPAR
}

Introdução: O presente trabalho tem por intento realizar uma análise acerca do Teorema de Coase, desenvolvido por Ronald Coase em seu trabalho de 1960: I"O Problema do Custo Sociall". O foco da pesquisa é a discussão jurídica acerca da alocação eficiente de recursos, sob o crivo da Análise Econômica do Direito (AED). Delinear, portanto, como o Direito utiliza de premissas da Economia e vice-versa.

Objetivo: Definir o papel da Economia no Direito. Demonstrar a cooperação entre os indivíduos para reduzir os custos de transação e possibilitar uma solução mais eficiente dos conflitos. Debater sobre a interferência dos custos de transação nas soluções de conflitos, à luz do Teorema de Coase.

Desenvolvimento: A Análise Econômica do Direito tem o papel de reanalisar institutos jurídicos utilizando preceitos da Economia, em termos de eficiência alocativa. Antes do Teorema de Coase, a Análise Econômica do Direito era baseada, principalmente, no trabalho de Arthur Cecil Pigou The Economics of Welfare , traduzido como A Economia do Bem-Estar O referido economista foi o primeiro a analisar o conceito de externalidades - fundamental para o estudo do Teorema de Coase -, sendo a ação que um determinado sistema de produção ocasiona a outros sistemas externos . Para Coase (1960), a externalidade não é causada apenas por uma parte, mas uma parte será obrigada a sofrer um dano, a externalidade não deve necessariamente ser corrigida pela parte que a causou, mas sim pela parte que exaurir com menor custo. Em conformidade com Veiga Neto (2008), quando há uma separação entre os custos ou benefícios privados e os sociais de uma ação elaborada por um indivíduo ou instituição, denomina-se efeitos externos à Economia. Ao tratar do problema do custo social, Ronald Coase proporcionou debates em torno dos problemas sociais, indicando uma nova inferência para o conflito social, podendo ser solucionado extrajudicialmente, transversalmente por uma mudança de comportamento do indivíduo que sofreu o dano. Justo porque a referida teoria permitiu que a Economia explorasse os institutos do Direito de maneira mais realista, observando os conflitos e problemas de diferentes ângulos, não somente da perspectiva das normas jurídicas. Nesse contexto, Shapiro (2010, p. 225) esboça sobre a necessidade de o Direito diminuir os comportamentos oportunistas e incentivar a realização de transações benéficas, estimulando a opção por condutas compatíveis com interesses coletivos. Ainda, de acordo com a situação atual, Shapiro (2010, p. 240), expõe que há prevalência do pensamento de que apenas as regras jurídicas conferem proteção jurídica, sendo que existem alternativas institucionais a serem asseguradas pelo Direito, em favor da coletividade. Sobre o tema, Reato e Cabeda (2017, p. 11) esboçam que a aplicação do Teorema de Coase deve considerar e refletir qual dos envolvidos teria o menor prejuízo, pois mesmo que a norma sugira a responsabilização do causador do infortúnio, nem sempre será o adequado em termos econômicos. Consoante ao Teorema de Coase, defende-se que é fundamental a existência de normas jurídicas reguladoras de direitos e deveres; entretanto, deve-se relativizar essas normas para possibilitar a solução extrajudicial dos conflitos, buscando um I"resultado ótimol", ou seja, um resultado mais eficiente. A mudança de paradigma proposta pelo Teorema de Coase aponta defeitos básicos na antiga abordagem, com base na economia do bem-estar, e aborda uma maneira mais realista de ver o problema, além disso, [...] tem-se que levar em conta os custos envolvidos para operar os vários arranjos sociais [...], bem como os custos envolvidos na mudança para um novo sistema. Ao se projetar e escolher entre arranjos sociais, devemos considerar o efeito total. (COASE, 1960, p. 36).

Conclusão: Observa-se que o Teorema de Coase pode provocar uma transformação na construção das normas, de forma a explicar a razão pela qual muitas leis são ineficazes. Justo porque, para promover uma reforma jurídica, o Direito pode se aproximar da Economia, a fim de aplicar os critérios de eficiência econômica. Abrangendo a alternativa de cooperação como forma de eficiência, o Direito tem o papel de criar instituições sólidas na solução dos conflitos. Conclui-se que, visto que a eficiência se situa nas alternativas menos custosas, o Direito tem a função elementar de analisar os custos de cumprimento da norma e, em contrapartida, denotar uma solução que diminua esses custos através da cooperação.

\section{Referências}

COASE, Ronald H. O Problema do Custo Social. Tradução por Francisco Kümmel F. Alves e Renato Vieira Caovilla. Journal of Law and Economics. vol. III. University of Virginia. October 1960. Disponível em: https://edisciplinas.usp.br/pluginfile.php/2123990/mod_resource/content/1/custosocial.pdf. Acesso em: 28 de julho de 2020.

PEÑALOZA, Rodrigo. Externalidades e o Teorema de Coase. Dezembro 2015. Disponível

em: 
https://medium.com/@milesmithrae/externalidades-e-o-teorema-de-coase-rodrigo-pe\%C3\%B1aloza-dez-2015-6ebb29f90120. Acesso em: 23 de julho de 2020.

REATO, Talissa Truccolo; CABEDA, Taísa. A relação entre o imposto de Pigou e o Teorema de Coase em uma análise econômica do processo civil brasileiro. https://siaiap32.univali.br/seer/index.php/rdp/article/view/10404. Acesso em: 11 ago. 2020.

SHAPIRO, Mario Gomes. Repensando a relação entre Estado, Direito e desenvolvimento: os limites do paradigma rule of law e a relevância das alternativas institucionais. Janeiro-Junho de 2020.20 Disponível em: http://bibliotecadigital.fgv.br/ojs/index.php/revdireitogv/article/view/24216/22989. Acesso em: 30 de julho de 2020.

VEIGA NETO, Fernando Cesar da. A construção dos mercados de serviços ambientais e suas implicações para o desenvolvimento sustentável no Brasil. 2008. Tese (Doutorado em Ciências Sociais em Desenvolvimento, Agricultura e Sociedade) - Instituto de Ciências Humanas e Sociais, Universidade Federal Rural do Rio de Janeiro, Seropédica - RJ, 2008. Disponível em: https://tede.ufrrj.br/jspui/handle/tede/714. Acesso em: 24 de julho de 2020.

Coordenadoria de Pesquisa e Extensāo - COPEX

Departamento de Editoraçāo e Divulgaçāo Científica - DEDIC 


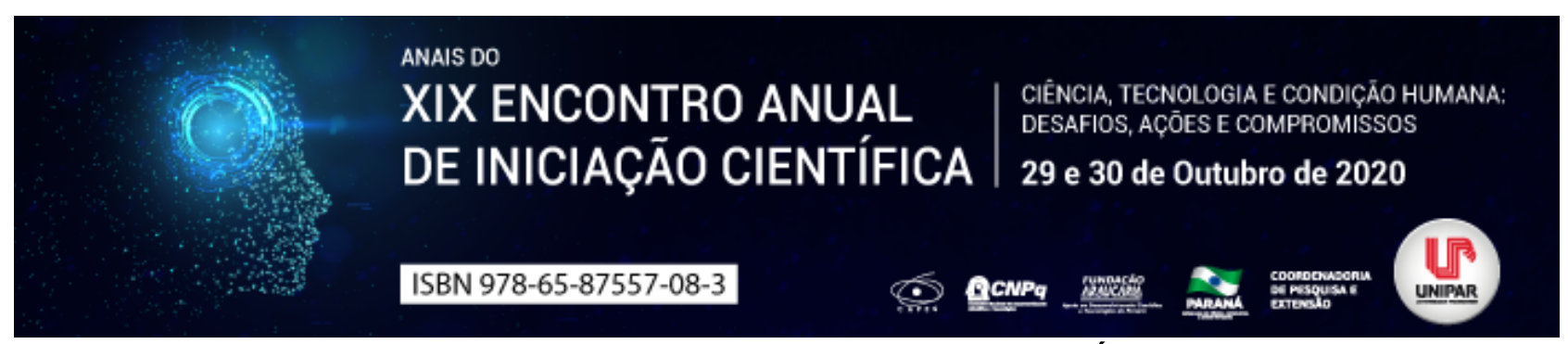

MEIOS DE PROVAS ANTE OS AVANÇOS TECNOLÓGICOS

\title{
${ }^{1}$ SUELEN ESCAMEZ POMINI, ${ }^{2}$ CLEVERSON IVAN MERLO
}

\author{
${ }^{1}$ Acadêmica do PIC/UNIPAR \\ ${ }^{1}$ Docente da UNIPAR
}

Introdução: Os constantes avanços tecnológicos trouxeram mudanças significativas no ordenamento jurídico e na realidade prática vivenciada pelas partes em um processo judicial, principalmente no quesito provas. Todavia, o sistema judiciário continua em constante adaptação e desenvolvimento, resultando, portanto, em uma certa relutância na aplicação e aceitação dos novos meios de provas, especialmente em relação as chamadas provas eletrônicas

Objetivo: Proceder com análise crítica sobre os meios de provas permitidos no ordenamento jurídico atual e o constante desenvolvimento que são submetidos, em decorrência dos avanços tecnológicos.

Desenvolvimento: O primeiro passo para a boa compreensão da matéria é a conceituação do termo provas. Provas são os meios processuais ou materiais considerados idôneos pelo ordenamento jurídico para demonstrar a verdade, ou não, da existência e verificação de um fato jurídico . (NERY JUNIOR, 1997). Trata-se, portanto, do meio utilizado para comprovar a veracidade de fatos alegados pelas partes em um processo, ou seja, é um direito garantido constitucionalmente às partes. A respeito do referido direito à prova, é imprescindível adentrarmos no assunto ônus probatório . Nas palavras de Mauro Schiavi, ônus da prova é um dever processual que incumbe ao autor quanto ao fato constitutivo do seu direito e ao réu quanto aos fatos modificativos, extintivos e impeditivos do direito do autor, que, uma vez não realizado, gera uma situação desfavorável à parte que detinha o ônus e favorável à parte contrária, na obtenção da pretensão posta em juízo. (SCHIAVI, 2013). No mesmo sentido, conforme o entendimento de Humberto Theodoro Júnior o ônus da prova refere-se à atividade processual de pesquisa da verdade acerca dos fatos que servirão de base ao julgamento da causa. Aquele a quem a lei atribui o encargo de provar certo fato, se não exercitar a atividade que lhe foi atribuída, sofrerá o prejuízo de sua alegação não ser acolhida na decisão judicial.

(THEODORO JÚNIOR, 2015). Visto isso, as partes poderão usufruir de inúmeros meios de provas, para alcançar o resultado almejado. No entanto, como é sabido, tanto o processo civil quanto o processo trabalhista, têm sofrido mudanças significativas ao longo dos anos, principalmente em relação aos meios de provas admitidas no ordenamento jurídico brasileiro. É de suma importância salientar que, vultosa parte de tais mudanças, são decorrentes dos constantes avanços tecnológicos, o que consequentemente, resultaram em grande influência sobre o direito e seus meios de aplicação, em especial, sobre a necessidade da aplicação dos meios tecnológicos no campo probatório. Referida aplicação, ainda que extremamente recente, vem se demonstrando significativamente útil e vantajosa. Em contrapartida, em razão de ser novidade e o ordenamento jurídico estar em fase de adaptação e desenvolvimento, algumas espécies de provas, como por exemplo as provas eletrônicas, ainda não são bem aceitas por alguns tribunais, tendo em vista que o conteúdo digital é de fácil manejo e adulteração.

Conclusão: Portanto, conclui-se que o ordenamento jurídico atual ainda carece de mudanças e atualizações, principalmente quanto a utilização e aproveitamento dos benefícios que os avanços tecnológicos tem a oferecer pois, trouxeram a oportunidade de maior celeridade jurisdicional e ampliaram as possibilidades de meios de provas admitidas no Direito.

\section{Referências}

THEODORO JÚNIOR, Humberto. Curso de Direito Processual Civil: Teoria geral do direito processual civil, processo de conhecimento e procedimento comum vol. I. 56a ed. Rio de Janeiro: Ed. Forense, 2015. p. 1289.

SCHIAVI, Mauro. Manual de Direito Processual do Trabalho: De acordo com o novo CPC, Reforma Trabalhista- Lei $n$. 13.467/2017 e a IN. N. 41/2018 do TST. 14a ed. São Paulo: Ed. Ltr, 2013. p. 722.

NERY JUNIOR, Nelson. et al. Código de Processo Civil comentado. 3. ed. São Paulo: RT, 1997. p. 611. 


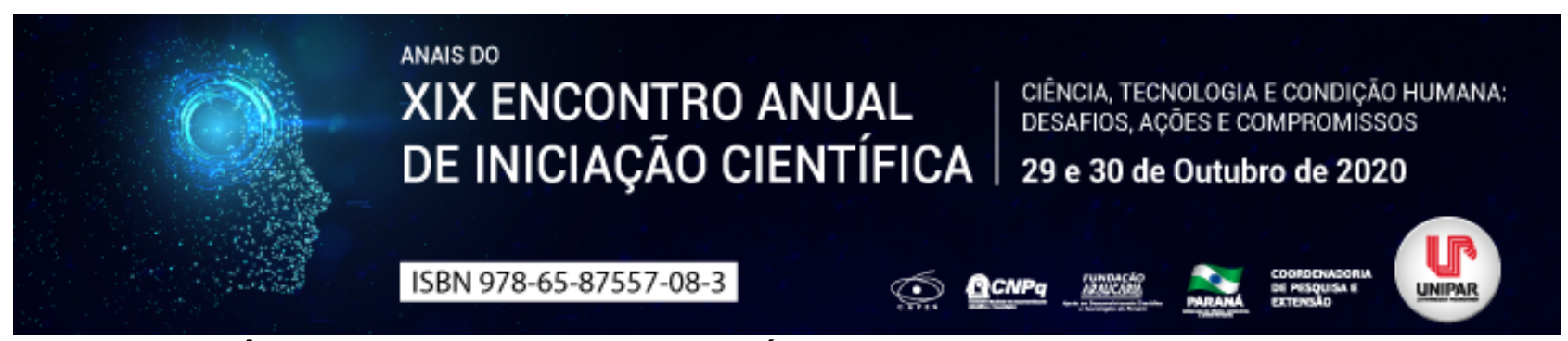

A NEUROCIÊNCIA E A ESCOLA: USO ESTRATÉGICO DA BIOFILIA EM AMBIENTES ESCOLARES

\title{
${ }^{1}$ ANDREIA BETIATTO, ${ }^{2}$ JAINE APARECIDA CAVALHEIRO, ${ }^{3}$ EMERSON SOUZA DOS SANTOS
}

\author{
${ }^{1}$ Acadêmica do PIC/UNIPAR \\ ${ }^{1}$ Acadêmica do Curso de Arquitetura e Urbanismo da UNIPAR \\ ${ }^{2}$ Docente da UNIPAR
}

Introdução: A neurociência é um campo de estudo cientifico do sistema nervoso humano. As descobertas desse ramo colaboram com diversas áreas de estudo, incluindo a arquitetura, onde é conhecida como neuroarquitetura, um ramo que estuda o impacto que ambiente físico provoca no cérebro humano, consciente ou inconscientemente, e como isso causa uma mudança de comportamento. (PAIVA, 2018). A neurociência quando aplicada ao ambiente escolar, através da biofilia, seu design, cores e texturas, gera uma influência no cérebro, que permite ao ser humano desfrutar sensações agradáveis, que proporcionam bemestar e saúde, aguçando áreas do cérebro, com intuito de transformar espaços físicos em lugares mais agradáveis de se viver (KELLERT,2015).

Objetivo: Abordar a conceituação da neurociência aplicada à arquitetura (neuroarquitetura) e sua relação com a biofilia e buscar compreender como isso pode ser utilizado em um ambiente escolar, impactando positivamente na vida dos usuários.

Desenvolvimento: $O$ cérebro humano evoluiu ao longo do tempo, com o intuito de observar o ambiente e garantir a sobrevivência, o comportamento humano é função da atividade dos circuitos neuronais que funcionam em diversas áreas do sistema nervoso (COSENZA; GUERRA, p.25, 2011). O sistema nervoso tem uma enorme capacidade de se moldar e remodelar, de fazer e desfazer ligações entre as células nervosas. Não é possível processar todas as informações que chegam ao cérebro, portanto, por meio da atenção ele pode dedicar-se aquilo que for julgado relevante, que faça sentido no contexto em que vive o indivíduo e que atenda a expectativas ou que seja estimulante e agradável (COSENZA E GUERRA, 2011). O cérebro humano passou por um processo evolutivo ao longo da história. A maior parte do período evolutivo, cerca de 90 mil anos, o homem estava imerso na natureza, se desenvolvendo biologicamente em resposta a ela, para só então mais tarde começar a formar as pequenas vilas e a viver em centros urbanos. O nosso cérebro não está totalmente adaptado ao processo de urbanização, pois ainda é programado para viver na natureza e tem a necessidade dessa conexão com o meio natural (PAIVA, 2018). Psicólogos e neurocientistas pesquisaram sobre os benefícios que o contato com a natureza pode proporcionar e os problemas que a privação desse contato provoca, como é o caso das doenças da modernidade (PAIVA, 2018). A biofilia é a necessidade biológica de se conectar, interagir e se relacionar com a natureza, para manter sua saúde e bem estar físico e psicológico (LADISLAU, 2019). Essa conexão pode ocorrer de forma direta (com a própria natureza) ou indireta, através de materiais, cores, formas e texturas, que mesmo não sendo naturais remetam aos elementos naturais (KELLERT,2015). As estratégias de aprendizagem com maior chance de sucesso são as que respeitam a forma como cérebro funciona. No ambiente de estudo, para facilitar o processo de aprendizagem, é importante a utilização de locais com poucos estímulos distraidores, mas que sejam agradáveis e despertem emoções positivas, o estresse tem efeito contrário e prejudica esse processo (COSENZA E GUERRA, 2011). Na concepção de ambientes, a imitação de elementos naturais e contato direto com a natureza, promovem experiências emocionais positivas, reduzem o estresse, aumentam o potencial criativo e restauram a capacidade de concentração (JOYE, 2007).

Conclusão: O estudo apresentado evidencia como o meio físico pode influenciar o comportamento através de estímulos cerebrais. A neuroarquitetura, apesar de pouco explorada, é uma grande estratégia, visto que permite maior compreensão acerca da importância de um ambiente planejado para a saúde e bem estar. O design biofílico e sua aplicação em ambientes escolares, é fundamental para a qualidade do meio físico, impactando diretamente no processo de aprendizagem.

\section{Referências}

COSENZA, Ramon; GUERRA, Leonor. Neurociência e educação. Artmed Editora, 2009.

LADISLAU, Amanda de Lurdes. Biofilia e sustentabilidade: Relação arquitetura-homem-natureza. Repositório de Trabalhos de Conclusão de Curso, 2019.

PAIVA, Andréa de. Neurociência para Arquitetura: Como o Design de Edifícios Pode Influenciar Comportamentos e Desempenho. 2018. 27 f. Dissertação (Mestrado) - Curso de Arquitetura, Fundação Getulio Vargas, Fgv, Instituto de Desenvolvimento Educacional, São Paulo, 2018.

JOYE, Y. Architectural Lessons from Environmental Psychology: the case of Biophilic Architecture. Review os General Psychology. v. 11, n. 4, p. 305-328, 2007.

KELLERT, S.; CALABRESE, E. The Practice of Biophilic Design. 2015. Disponível em:. Acesso em: 18 ago. 2020. 
Coordenadoria de Pesquisa e Extensão - COPEX

Departamento de Editoraçāo e Divulgaçāo Científica - DEDIC 


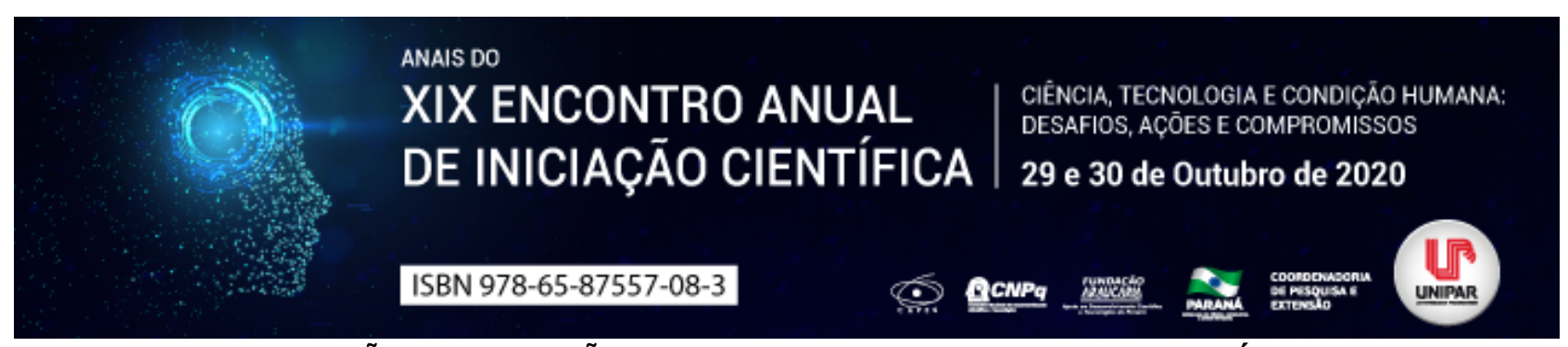

A MEDIAÇÃO NA SOLUÇÃO DE CONFLITOS CONTRA A FAZENDA PÚBLICA

\title{
${ }^{1}$ ANA CAROLINE CORREIA, ${ }^{2}$ ALEXANDRE MAGNO AUGUSTO MOREIRA
}

\author{
${ }^{1}$ Acadêmico do curso de Direito da UNIPAR \\ ${ }^{1}$ Docente da UNIPAR
}

Introdução: O presente trabalho tem por finalidade, realizar uma abordagem sobre eficácia da mediação na solução de conflitos, e, ainda, a aplicação deste instrumento, nos conflitos em que envolvam como litigante, a Fazenda Pública. Nesta perspectiva, desde $2010 \mathrm{com}$ a criação da Resolução $\mathrm{n}^{\circ} 125$ do $\mathrm{CNJ}$, despertou-se caminhos diversos para essa nova ferramenta perante o Poder Judiciário, com expansão na Lei no 13.140 e o Código de Processo Civil, ambos de 2015. Pretende-se, portanto, verificar a possibilidade de utilizar-se da mediação, nos litígios em que é parte a Fazenda Pública. A presente pesquisa desenvolveu-se sobre um método dedutivo com análise de cunho bibliográfico.

Objetivo: Realizar uma abordagem sobre eficácia da mediação na solução de conflitos, e, ainda, analisar a aplicação deste instrumento, nos conflitos em que envolvam como litigante, a Fazenda Pública.

Desenvolvimento: Para regular as relações sociais foi necessário adotar medidas para equilibrá-las, conforme Sales e Rabelo (2009, p. 75): Os mecanismos consensuais, assim, foram ganhando espaço nas sociedades em função, especialmente, da necessidade de se perceber o conflito, avaliá-lo e de encontrar caminhos para uma solução pacífica e construída, não apenas uma solução imposta. A legislação processual civil brasileira, nos termos do artigo $3^{\circ}$, $\S 3^{\circ}$, prescreve pelo dever dos colaboradores da Justiça em estimular os métodos adequados de solução de conflitos. Além das disposições processuais, a norma infraconstitucional prescreve, nos termos da Lei $n^{\circ}$ 13.140/2015 que a aplicabilidade é executável, com eficácia, em atenção ao exposto pelo CNJ (2019) em seu relatório sobre a Semana Nacional da Conciliação pelo Tribunal de Justiça do Paraná que diz: [...] de janeiro até o final do mês de setembro, mais de 300 mil audiências de conciliação e mediação foram realizadas pelo Poder Judiciário paranaense, com mais de 55 mil acordos firmados e quase 94 mil cidadãos atendidos Entretanto, o CPC também traz algumas objeções, segundo Viana e Viana (2016): A regra que autoriza a não realização da audiência no caso de inviabilidade de autocomposição (art. 334, § $4^{\circ}$, II, do novo CPC) tem sido sistematicamente invocada para afastar a realização do ato quando a Fazenda Pública está em juízo . Desta forma, observa-se que é contraditório que o Estado queira obter a pacificação social, mas quando a Fazenda Pública é parte envolvida, seja no polo ativo ou no polo passivo, ele recorra a indisponibilidade do interesse público. Nos dizeres de Azevedo (2016, p. 11): [...] o Poder Judiciário se aproxima de uma de suas mais belas funções: educar a sociedade para tornar-se mais consensual, ao mesmo tempo em que enfrenta de forma direta um de seus maiores desafios: o déficit operacional . É preciso levar em consideração o apontamento de Theodoro Jr (2017, p. 93) que diz: Não se trata de desacreditar a Justiça estatal, mas de combater o excesso de litigiosidade que domina a sociedade contemporânea, que crê na jurisdição como a única via pacificadora de conflitos [...] . Além disso, é válido frisar a imparcialidade sobre a figura do mediador e ainda o princípio da isonomia da vontade, pois a esta última, que se desencadeará todo o procedimento.

Conclusão: Tendo em vista a mediação como uma das políticas públicas de tratamento adequado dos conflitos de interesses, percebe-se a preocupação em explorar mais essa ferramenta, dando ênfase no que diz respeito a eficácia na solução de conflitos quanto a sua aplicabilidade, os benefícios para o Poder Judiciário e para as partes envolvidas, as quais também devem ser levadas em consideração quanto a Fazenda Pública. Analisou-se os métodos consensuais como forma de solucionar conflitos, obtendo um resultado muito benéfico, principalmente na sua eficácia, demonstrado por dados estatísticos do CNJ. Quanto aos benefícios para o Poder Judiciário, confirma-se que esses meios consensuais se tornam elementos essenciais em razão do tempo, das custas, da celeridade, atingindo diretamente as partes, que são beneficiadas, sujeitos ativos nessa relação.

\section{Referências}

AZEVEDO, Gomma de. Manual de Mediação Judicial. 5 ed. Brasília: MPDFT, 2016.

BRASIL. Lei no 13.105, de 16 de março de 2015. Código de Processo Civil. Disponível em: . Acesso em 24 ago. 2020.

CONSELHO NACIONAL DE JUSTIÇA. Conciliação: TJPR já realizou quase 3 mil audiências. Disponível em: . Acesso em: 24 ago. 2020.

SALES, Lilia Maia de Morais. RABELO, Cilana de Morais Soares. Meios consensuais de solução de conflito. 2009. Disponível em: . Acesso em: 24 ago. 2020.

THEODORO JÚNIOR, Humberto. Curso de Direito Processual Civil. Rio de Janeiro: Forense, 2017.

VIANA, Emilio de Medeiros, VIANA, lasna Chaves. Conciliação, mediação e a fazenda pública: mudança de paradigma e entraves por superar. Disponível em: . Acesso em: 24 ago. 2020. 
Coordenadoria de Pesquisa e Extensão - COPEX

Departamento de Editoraçāo e Divulgaçāo Científica - DEDIC 


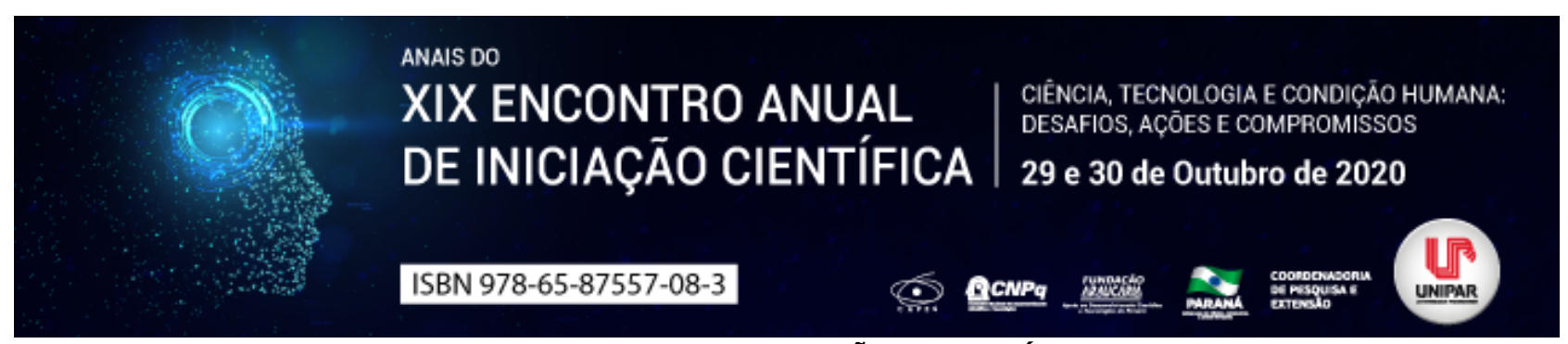

O STF E A JUDICIALIZAÇÃO DA POLÍTICA

\title{
${ }^{1}$ ERITON LIMA RODRIGUES, ${ }^{2}$ THIAGO MORETO FIORI
}

\author{
${ }^{1}$ Discente do programa de Iniciação Cientifica PIC, da UNIPAR, campus Guaíra/PR \\ ${ }^{1}$ Docente do programa de Iniciação Cientifica PIC, da UNIPAR, campus Guaíra/PR
}

Introdução: Na atualidade, ocorre uma maior atividade judiciária nas decisões políticas, acarretando dessa forma um fenômeno denominado judicialização da política. Tal atuação do Poder Judiciário, é causado pelas incontáveis questões que são trazidas ao seu acareamento, ocasionando isso uma perca de harmonia entre os poderes, visto que as questões são tratadas novamente em outro poder.

Objetivo: Analisar o fenômeno judicialização da política no cenário brasileiro, seu histórico de ocorrências e transformações com os novos direitos adquiridos ao passar do tempo. Incumbe também ao trabalho para que se discuta a legitimidade do Judiciário frente aos outros poderes, uma conceituação acerca da teoria da separação dos poderes. Distinguir-se-á judicialização em sentido amplo e ativismo judicial, diferenciando não somente em questão essencial, como também no sentido crítico e casos onde se ocorreu cada um destes.

Desenvolvimento: Entende-se por judicialização como um fenômeno onde questões de outros poderes por serem matéria normativa, são trazidos perante o Judiciário, que por sua vez acaba tomando visão perante a sociedade por dar a última palavra. Mello (2019, p. 02) defende que como consequência deste fenômeno, cada vez mais o STF e outros órgãos da esfera jurídica têm dado a última palavra em temas que são matéria de outros poderes, como políticas públicas, demarcação de terras e até mesmo questões do dia a dia, fazendo com que o poder Judiciário se destaque entre os demais . No mesmo sentido, os requisitos esperados por um juiz em uma decisão são a imparcialidade e a fundamentação, ou seja, não ter interesse na causa julgada e uma boa fundamentação, coisa que não é vista nos juízes que decidem questões públicas. Vale salientar que os membros do poder judiciário não são dotados de representatividade, isto é, eleitos pelo voto popular. Assim como também não possuem o artifício de intervenção no cenário político, atuando como um julgador de cunho político. Em outras linhas, Barroso (2017, p.7) defende que Atores políticos, muitas vezes, preferem que o Judiciário seja a instância decisória de certas questões polêmicas, em relação às quais exista desacordo moral razoável na sociedade. Com isso, evitam o próprio desgaste na deliberação de temas divisivosl". Para tanto, Castro (1994) em sua perspicaz obra une a judicialização ao cenário político dizendo que a judicialização da política ocorre porque os tribunais são chamados a se pronunciar onde o funcionamento do Legislativo e do Executivo se mostram falhos, insuficientes ou insatisfatórios. Neste momento, fica difícil saber onde está o direito e onde ocorre o interesse político. Destarte, fica dividido as partes doutrinárias quanto a judicialização, sendo que alguns autores a consideram como algo ilegítimo por parte do Judiciário, em outras linhas, outros defendem que é apenas consequência de um novo conceito de democracia

Conclusão: De certa forma, ao final do tema da judicialização se divide em três linhagens, a positiva, a negativa e por derradeiro, a justificativa e moderadora. A face benéfica é que muitas vezes tal atuação por parte do judiciário é unicamente para adequar os outros poderes aos pressupostos constitucionais, além do mais, apenas garantem direitos fundamentais preservados pela Constituição Federal de 1988. O lado negativo para tanto é que ao consentir que tudo há a necessidade de uma aprovação, uma palavra por parte do judiciário, acaba desprestigiando os outros poderes, em outras palavras, da um ar de autoridade e supremacia do poder Judiciário frente aos outros. Há também de se questionar a legitimidade deste poder, visto que os membros não são eleitos com essência representativa, isto é, não possuem o voto popular, e por sua vez, estão decidindo casos de importância perante a sociedade. Derradeiro sinaliza as mudanças que devem ser compreendidas, entendidas, e adaptadas, isto é, foi o objetivo buscado pelo originário na Constituição Federal de 1988. A parte de adaptação se dá pelo fato de moderar os casos de judicialização não contendo o judiciário de atuar, mas sim estimulando os outros poderes a agirem por si só, assim como também nos casos em que o judiciário atua, seja uma decisão unicamente resguardando os pressupostos constitucionais.

\section{Referências}

BARROSO, Luís Roberto. Constituição, democracia e supremacia judicial: direito e política no Brasil contemporâneo. 2017, Disponível http://www.luisrobertobarroso.com.br/wpcontent/uploads/2017/09/constituicao_democracia_e_supremacia_judicial.pdf. Acesso em: 25 Ago. 2020.

CASTRO, M.F. de. Dívida externa, globalização da economia e direitos humanos. Arquivos do Ministério da justiça, v. 47, n. 184, p. 125 144, 1994.

MELLO, Pedro Santoro de; RITA, Vitor Santa; A Judicialização da Política no Brasil: os Desafios, os Limites na Atuação do Judiciário e a Defesa Dos Princípios Constitucionais. Disponível em: https://ambitojuridico.com.br/edicoes/revista-182/a- 
judicializacao-da-politica-no-brasil-os-desafios-os-limites-na-atuacao-do-judiciario-e-a-defesa-dos-principios-constitucionais. Acesso em: 25 Ago. 2020.

Coordenadoria de Pesquisa e Extensão - COPEX

Departamento de Editoraçāo e Divulgaçāo Científica - DEDIC 


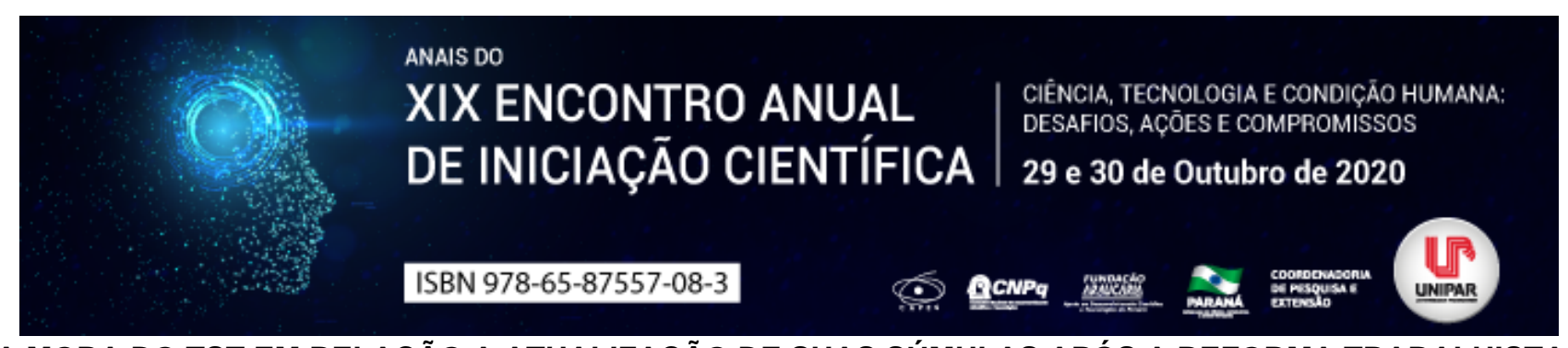

A MORA DO TST EM RELAÇÃO A ATUALIZAÇÃO DE SUAS SÚMULAS APÓS A REFORMA TRABALHISTA

\author{
${ }^{1}$ EMANUELI MARIA RICHTER, ${ }^{2}$ CLEVERSON IVAN MERLO
}

${ }^{1}$ Acadêmico do PIC/UNIPAR

${ }^{1}$ Docente da UNIPAR

Introdução: A ambivalência interpretativa presente no ordenamento jurídico acarreta insegurança ao sistema normativo, possibilitando múltiplas direções ao operador do Direito. Diante tantas possibilidades interpretativas, os precedentes, a jurisprudência e as súmulas surgem como forma de previsibilidade e segurança jurídica. Em 2017, no âmbito do Processo do Trabalho, a Reforma Trabalhista (Lei 13.467/2017) trouxe significativas alterações nos dispositivos da CLT, tornando desatualizadas várias súmulas do TST gerando insegurança e instabilidade jurídica em virtude da mora em relação à atualização. Objetivo: Proceder uma análise crítica a mora do TST em atualizar súmulas após a Reforma Trabalhista.

Desenvolvimento: Existem diversos mecanismos baseados no entendimento dos tribunais para concretizar os ideais de previsibilidade e segurança jurídica. O precedente, segundo sustentam Fredie Didier Junior, Paulo Sarna Braga e Rafael Alexandria de Oliveira (2015, p. 441), consiste em uma ... decisão judicial tomada à luz de um caso concreto, cujo elemento normativo pode servir como diretriz para o julgamento posterior de casos análogos . Portanto, define-se o precedente como uma diretriz, derivada dos argumentos relevantes de uma decisão judicial, capaz de influenciar decisões futuras de casos análogos. Já a jurisprudência revela-se mais ampla e abstrata que as demais, sendo definida como a pluralidade de decisões reiteradas em um determinado assunto que o Tribunal vem decidindo. Por fim as súmulas, subdividida também em súmula vinculante, serão o enunciado de determinado tribunal, sobre determinado tema, materializando a jurisprudência de forma objetiva, consolidando assim a matéria. No Direito do Trabalho, devido as taxas elevadas de desemprego apresentadas em meados de 2016 e 2017 , bem como a falta de modernidade da legislação trabalhista, datada majoritariamente da década de 40, houve a necessidade de uma readequação das normas ali contidas. Surgiu assim a chamada Reforma Trabalhista (Lei 13.467/2017). A Reforma Trabalhista sofreu diversas críticas devido ao seu tramite célere e pouco discutido no âmbito jurídico. Consoante as palavras de Maurício Godinho Delgado (2017, p. 39), a Lei 13467/2017 surgiu como um mecanismo retrogrado, totalmente antagônico às ideias fundamentais instituídas na Constituição de 1988. A novel legislação trouxe significativas mudanças no texto celetista, o qual ainda permanecia com sua redação de mais de 70 anos atrás, como em relação as horas in itinere as quais, agora, não são mais devidas ao empregado. Outro ponto que merece destaque são os honorários advocatícios, agora devidos a partir da mera sucumbência. Diante essas e outras tantas transformações trazidas pela Reforma Trabalhista, diversas súmulas do Tribunal Superior do Trabalho se encontraram em total desacordo com a legislação. Estas que deveriam refletir a unificação jurisprudencial, se mostram cada vez mais inseguras pela mora em sua atualização. Diversas súmulas em vigor refletem decisões desatualizadas, baseadas na legislação anterior, trazendo insegurança aos empregados, empregadores e operadores do Direito, refletindo negativamente na aplicação do direito material do trabalho e trazendo reflexos no direito processual, como por exemplo, na questão da admissibilidade do recurso de revista.

Conclusão: Deste modo, conclui-se que embora muito questionada, a Reforma Trabalhista foi necessária para adaptação social do momento, e cabe portanto, principalmente, ao Tribunal Superior do Trabalho zelar pela coerência e legalidade das suas súmulas, mitigando a imprevisibilidade e a insegurança jurídica atualmente presente no Direito do Trabalho.

\title{
Referências
}

DIDIER JR, F.; BRAGA, P.;OLIVEIRA, R. Curso de Direito Processual Civil: Volume 2. Juspodvm, 2015.

DELGADO, Maurício Godinho. A reforma trabalhista no Brasil: com os comentários à Lei n. 13.467/2017. São Paulo: LTr, 2017.

BENHEME, Maria Luca. Alteração de Súmulas do TST e a Reforma Trabalhista. Março 2018. Disponível em: https://www.conjur.com.br/2018-mar-01/maria-benhame-alteracao-sumulas-tst-reforma-trabalhista. Acesso em 27 de agosto de 2020. 


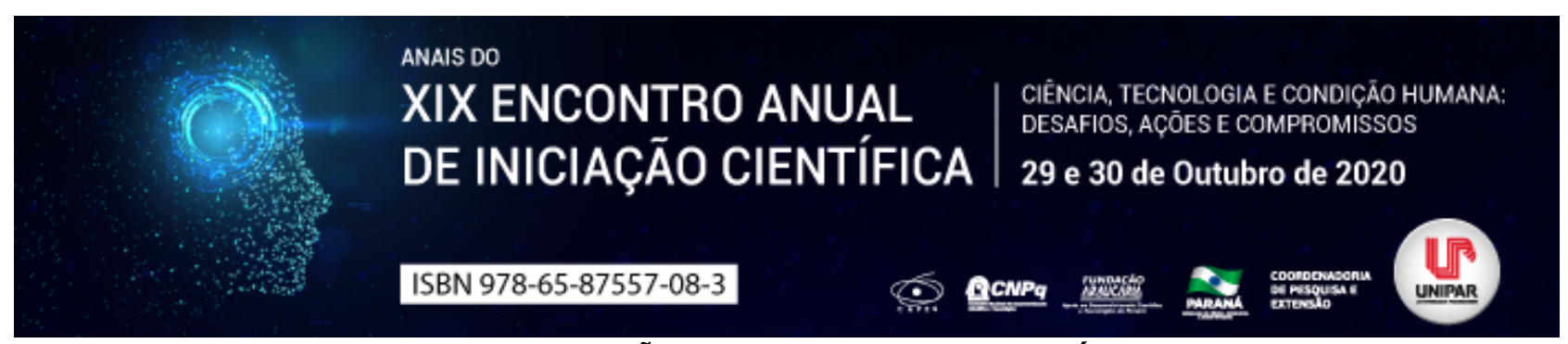

A EVOLUÇÃO DO CONCEITO DE BOA-FÉ

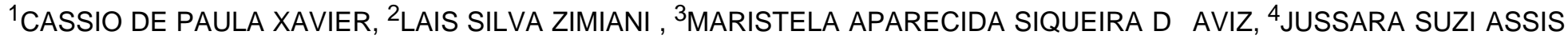
BORGES N. FERREIRA, ${ }^{5}$ HORACIO MONTESCHIO

\author{
${ }^{1}$ Discente do Mestrado em Direito Processual e Cidadania UNIPAR \\ ${ }^{1}$ Discente do Mestrado em Direito Processual e Cidadania UNIPAR \\ ${ }^{2}$ Discente do Mestrado em Direito Processual e Cidadania UNIPAR \\ ${ }^{3}$ Docente da UNIPAR \\ ${ }^{4}$ Docente da UNIPAR
}

Introdução: A gênese da boa-fé é a fides romana, da qual derivou o conceito no Direito pátrio. Esta evolução do conceito de boa-fé fora positivada apenas no Código Civil Francês e, posteriormente no BGB Alemão. A boa-fé subjetiva ingressou no Brasil com o Código Civil de 1916, já a boa-fé objetiva foi positivada com o Código Civil de 2002 e vem sendo desenvolvida desde então.

Objetivo: Demonstrar a origem do conceito de boa-fé e o seu desenvolvimento até os dias atuais.

Desenvolvimento: Para a compreensão acerca da definição do princípio da boa-fé, necessária a análise do apanhado histórico sobre o referido princípio, em especial, para compreensão do modo como foi operacionalizada sua introdução no sistema jurídico nacional. O início do conceito de boa-fé é a fides romana, da qual derivou o conceito no Direito Português e, por consequência, no Direito Brasileiro. No Direito Romano a boa-fé se apresentava em duas vertentes: a fides bona, a qual possuía um sentido objetivo como norma de comportamento, e a bona fides do bonae fidei possessio, a qual possuía um sentido subjetivo de elemento psicológico consistente na ignorância ou desconhecimento de vícios (GONTIJO, 2019, p. 58). No Direito Canônico, apenas a sua vertente subjetiva, significando ausência de pecado. E, no Direito Germânico, com o sentido de cumprimento dos deveres assumidos levando em consideração os interesses da contraparte. Apenas após a entrada em vigor do Código de Napoleão em 1804 é que o princípio da boa-fé fora positivado em um ordenamento jurídico. Nascido fruto de uma época que vigorava o Estado Liberal, quando da promulgação do Código Civil Francês, imperava a escola da exegese, a qual não possibilitou o desenvolvimento da boa-fé. Para tal escola da época era necessária, para a concretização da boa-fé objetiva, a atividade discricionária do julgador, o que era impossível na época e, por isso, houve pouca evolução (GONTIJO, 2009, p. 35-50). Portanto, a boa-fé objetiva não prosperou na França Napoleônica. Na Alemanha, com a promulgação do Código Civil alemão (BGB), se teve segunda codificação, consagrando a boa-fé subjetiva em termos ligados a ética e a boa-fé objetiva no âmbito contratual (CORDEIRO, 2007, p. 1.406). Com o avanço da jurisprudência alemã, na análise da aplicação da boa-fé em sentidos práticos, ocorreu a consolidação das três funções da boa-fé. A partir de então, a boa-fé objetiva se espalhou para as codificações de outros países. Em muitas delas, com base no Código de Napoleão, como é o caso do Código Civil brasileiro de 1916, em outras, como reflexo no alemão (DONNINI, 2016, p.4 - 8). No Brasil, o Código Civil de 1916 não possibilitava a aplicação da boafé objetiva, conceito ligado ao Estado Social, porém, vigoravam conceitos de um Estado Liberal. O Código de Defesa do Consumidor em 1990, levou a boa-fé à condição de princípio das relações de consumo, mas ainda não se aplicava aos contratos regidos pela legislação civil, o que somente ocorreu em 2002, com a promulgação do Código Civil. Portanto, apesar de existirem decisões esparsas acerca da aplicação da boa-fé objetiva no Brasil antes da entrada em vigor do CC/2002, a sua positivação ocorreu apenas após a sua promulgação, quando foram previstas as suas três funções: interpretativa, limitadora e integradora, nos artigos 113, 187 e 422 (MARTINS-COSTA, 2018, p. 173).

Conclusão: Diante da evolução de um Estado mais social, desenvolveu-se o conceito de boa-fé objetiva, levando a sua aplicação para todas as fases das negociações, criando assim regras de conduta impostas pelo Estado aos contratantes, gerando a exigência de segurança e equilíbrio nas relações contratuais.

\title{
Referências
}

CORDEIRO, António Menezes. Da boa fé no Direito Civil. Coimbra: Almedina, 2007.

DONNINI, Rogério José Ferras. Bona Fides: do direito material ao processual. Revista de Processo. vol. 251/2016. São Paulo: Revista dos Tribunais, 2016.

GONTIJO, Maísa Conceição Gomes. Análise do princípio da boa-fé objetiva estatuído no artigo 422 do Código Civil Brasileiro. Trabalho de Conclusão de Curso (Mestrado) - Pontifícia Universidade Católica De Minas Gerais, Belo Horizonte, 2009.

MARTINS-COSTA, Judith. A boa-fé no direito privado: critérios para a sua aplicação. 2 ed., São Paulo: Saraiva Educação, 
2018.

Coordenadoria de Pesquisa e Extensão - COPEX

Departamento de Editoraçāo e Divulgaçāo Científica - DEDIC 


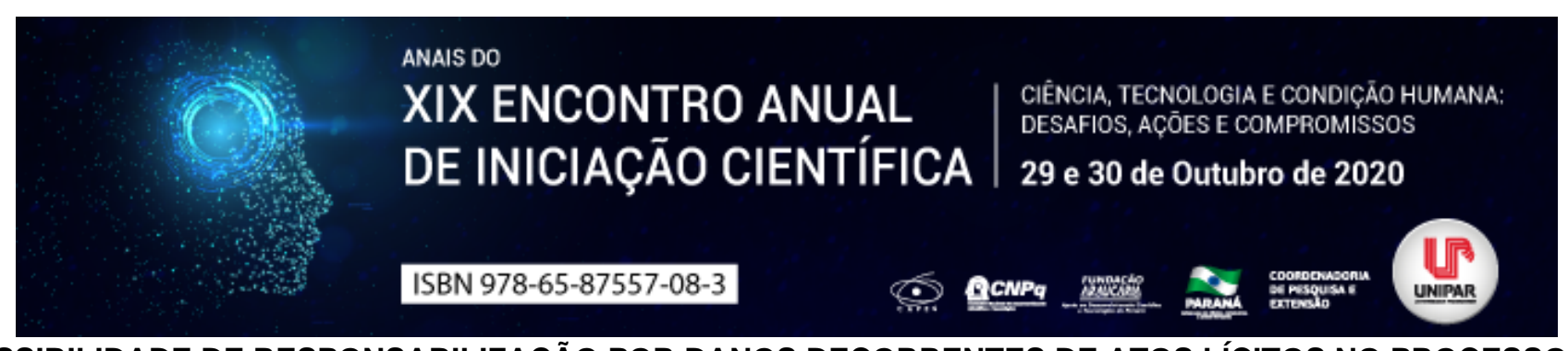

\title{
A POSSIBILIDADE DE RESPONSABILIZAÇÃO POR DANOS DECORRENTES DE ATOS LíCITOS NO PROCESSO CIVIL BRASILEIRO
}

\author{
${ }^{1}$ CASSIO DE PAULA XAVIER, ${ }^{2}$ TANIA ARNECKE PEREIRA, ${ }^{3}$ DIOGO DE ARAUJO LIMA, ${ }^{4}$ MARIANA SARTORI NOVAK
}

${ }^{1}$ Discente do Mestrado em Direito Processual e Cidadania UNIPAR

${ }^{1}$ Discente do Mestrado em Direito Processual e Cidadania UNIPAR

${ }^{2}$ Discente do Mestrado em Direito Processual e Cidadania UNIPAR

${ }^{3}$ Discente do Mestrado em Direito Processual e Cidadania UNIPAR

Introdução: O princípio do acesso à justiça, em sua acepção moderna, pressupõe a possibilidade de todo cidadão ter acesso a uma ordem jurídica justa e efetiva, também em tempo razoável. Se tem, portanto, a necessidade de as partes cumprirem com suas obrigações, homenageando o princípio da boa-fé processual, visto que, existem atos dos integrantes da relação jurídicoprocessual que podem vir a ferir direitos de outrem, portanto, impossibilitando, com isso, o pleno acesso à justiça.

Objetivo: Demonstrar a possibilidade de existirem danos decorrentes de atos lícitos no Processo Civil Brasileiro, bem como a possibilidade de sua responsabilização.

Desenvolvimento: Todos os integrantes do processo devem agir de acordo com a boa-fé processual e a sistemática do Processo Civil a luz da Constituição Federal, ou seja, do novo modelo de processo inaugurado pelo CPC/15 (DIDIER, 2012, p. 74). Aquele que pratica ato contrário ao ordenamento processual, litiga de má-fé e por isso deve ser responsabilizado por seu ato. Os referidos danos decorrentes de atos ilícitos no Processo Civil Brasileiro já possuíam disposição de reprimenda desde o Código de Processo Civil revogado (1973), o que fora novamente inserido no atual Código de Processo Civil. Estes danos têm como base um ato ilícito promovido por um dos integrantes de relação jurídico-processual e, estão dispostos claramente entre os artigos 79 a 81 do CPC/15 (atual). A sistemática de reparação dos danos causados a contraparte possui guarida e raiz na teoria da responsabilidade civil, onde se tem de forma clara os três elementos da mencionada teoria, quais sejam: a) dano; b) culpa e c) relação de causalidade entre o fato e o dano, portanto, pressupondo um ato ilícito (GONÇALVES, 2014, p. 46). Ainda, dispõe o código civil que aquele que praticar dano a outrem deve repará-lo, reestabelecendo, com isso, o equilíbrio econômico-jurídico alterado pelo ato danoso (DIAS, 2012, p. 43). Neste diapasão, pode-se inferir a possibilidade de serem trazidas, por analogia, a possibilidade de responsabilização no processo civil, já que existe a possibilidade de os danos causados no âmbito do processo, possuírem a mesma sistemática dos danos causados fora da relação jurídico-processual. Sendo assim, no processo civil, sendo comprovado o nexo entre a conduta e o dano, surge o dever de indenizar e/ou fazer retornar ao status quo ante. Após esta análise, deve-se ponderar se, nas relações jurídico-processuais, a responsabilidade pelo dano processual tem viés objetivo ou subjetivo. Porém, os danos processuais, por possuírem apenas como elemento configurante, o próprio dano, são enquadrados na teoria objetiva, não requerendo a análise do elemento culpa e muito menos a antijuridicidade da conduta. Não se confunda, todavia, os danos processuais decorrentes de atos lícitos com o abuso de direito. Quando se fala em abuso de direito, há um caráter subjetivo, sendo assim, necessário sempre analisar-se a culpa e antijuridicidade da conduta. Por isso, o que se analisa quando do dano processual é a lesão do ato e não a própria ilicitude, o que leva a se afirmar que existe a possibilidade de haver responsabilização por danos causados decorrentes de atos lícitos no decorrer do processo civil brasileiro, claro, evidenciando-se, o nexo entre a ação e o prejuízo sofrido pela parte ex adversa (STOCO, 2014, p. 251).

Conclusão: Resolve-se, assim, o problema da possibilidade de responsabilização por atos lícitos no processo civil brasileiro. Adota-se, nesse caso, a teoria objetiva supracitada. Ainda, toda responsabilização processual, além de possuir correspondência com a teoria da responsabilidade civil, se justifica, com o fim de dar força ao próprio princípio do acesso à justiça, coibindo assim, sua mitigação.

\section{Referências}

GONÇALVES, C. R.. Responsabilidade Civil. 15a ed. São Paulo: Saraiva, 2014.

STOCO, R. Tratado de responsabilidade civil: doutrina e jurisprudência. $10^{\mathrm{a}}$ ed. rev., atual. e reform. com acréscimo de acórdãos do STF e STJ. São Paulo: Editora Revista dos Tribunais, 2014.

DIDIER JR., F. Curso de Direto Processual Civil Introdução ao Direito Processual Civil e Processo de Conhecimento. 14a ed.rev., ampl. e atual. Salvador: Editora Juspodivm, 2012.

DIAS, J. A. Da Responsabilidade Civil. 12 ed. rev. e atual. Rio de Janeiro: Editora Lumen Juris, 2012. 
Coordenadoria de Pesquisa e Extensão - COPEX

Departamento de Editoraçāo e Divulgaçāo Científica - DEDIC 


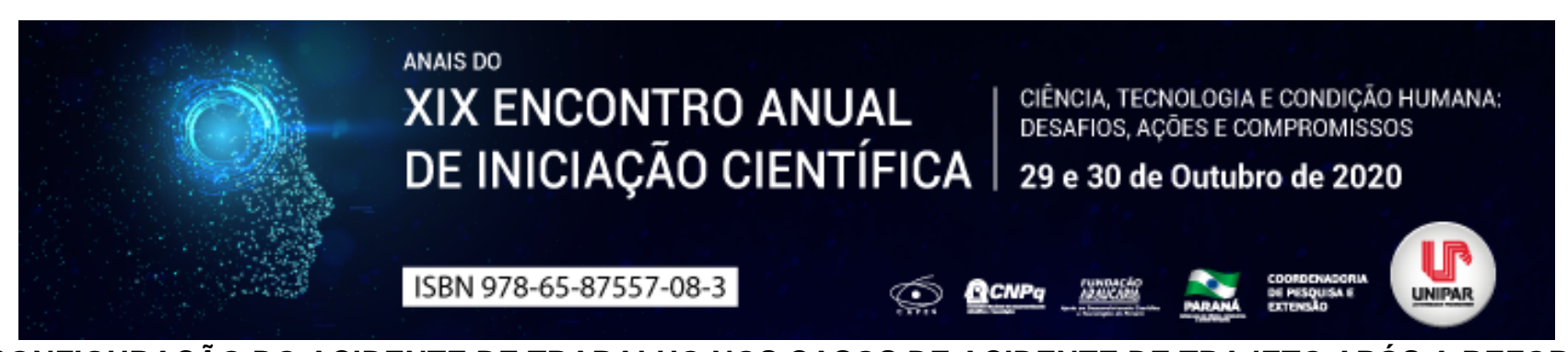

\title{
A CONFIGURAÇÃO DO ACIDENTE DE TRABALHO NOS CASOS DE ACIDENTE DE TRAJETO APÓS A REFORMA TRABALHISTA E SEUS EFEITOS
}

\author{
${ }^{1}$ HENRIQUE DA SILVA SOARES, ${ }^{2}$ CLARICE MENDES DALBOSCO
}

\author{
${ }^{1}$ Acadêmico do curso de Direito da UNIPAR \\ ${ }^{1}$ Docente da UNIPAR
}

Introdução: O presente trabalho tem a finalidade de abordar as mudanças no direito trabalhista e previdenciário, em razão da hipótese do trabalhador sofrer um acidente no percurso da residência para o local de trabalho ou deste para aquela, qualquer que seja o meio de locomoção, inclusive veículo de propriedade do segurado.

Objetivo: Demonstrar a importância deste instituto para o direito trabalhista e previdenciário decorrentes deste acidente, tendo em vista que a legislação trabalhista alterou o artigo $58, \S 2^{\circ}$ da $C L T$, excluindo o tempo a disposição do empregador o período de percurso I"in itinerel". Assim, o empregado perderá beneficios como por exemplo, reflexos previdenciários ao auxilio doença a partir do $16^{\circ}$ dia de afastamento em pensões por morte, cálculos de benefícios, carência, entre outros. Também refletidos na esfera trabalhista, como indenizações e estabilidade na empresa.

Desenvolvimento: Segundo Costa, (2006, p. 71), a definição de acidente de trabalho está conjugada a um acontecimento danoso a vitima, no exercício das atividades laborais na relação de emprego ou trabalho, ocasionando lesões permanentes ou temporárias da capacidade para o trabalho, podendo ocorrer até a morte do empregado. Ha certos requisitos para que haja a configuração de acidente de trabalho, aonde Martins (2006, p. 582), sustenta que primeiramente tem de haver o nexo de causalidade entre o trabalho do empregado e o acidente, portanto, envolve o trabalho, o acidente e consequentemente a lesão, temporária ou permanente. Segundo AMADO (2006, p.294), o acidente do percurso residência trabalho residência pode ser configurado como acidente de trabalho, pois há o nexo de causalidade, pois há uma prestação de serviço espontânea que acarretará benefícios para a empresa. Há responsabilidade civil, quando configura-se a presença de dolo ou culpa. A necessidade de ficar caracterizado o dever de indenizar decorre dos seguintes aspectos: a) Acidente é fato humano; b) causa dano ou prejuízo; c) violação de um direito da vítima; d) noção de culpa do empregador.

I"Cabe a reparação mediante indenização por perdas e danos materiais, bem como morais, nos casos em que decorre o dolo/culpa do empregador para com o empregado, respeitando sempre todos os requisitos acima expostosl" (CASTRO; LAZZARI, 2016, p. 582).

Conclusão: Por fim, quero demonstrar com o presente trabalho, a vulnerabilidade do trabalhador perante o contrato de trabalho. Fica evidente que o empregado está subordinado ao seu superior, assim, necessita ser amparado para que não ocorra prejuízos, sendo que sua remuneração tem natureza alimentar, para o trabalhador e sua família. Se a empresa não entender que o acidente de percurso não é equiparado ao acidente de trabalho, deixará então de emitir o CAT, e assim trará reflexos negativos para este trabalhador, como por exemplo prejuízos financeiros, pscilógicos e também materiais.

\section{Referências}

AMADO, Frederico. Direito previdenciário. 7 ed. Bahia: Juspodivm, 2016.

CASTRO, Carlos Alberto; LAZZARI, João Batista. Manual de direito previdenciário. 16. ed. Rio de Janeiro: Forense, 2014.

COSTA, Hertz Jacinto. Manual de Acidente do Trabalho. $2^{a}$ Ed. Curitiba: Juruá Editora, 2006. p.71.

MARTINS, Sérgio Pinto. Direito da Seguridade Social. 23ª Ed. São Paulo: Atlas, 2006. p. 128. 


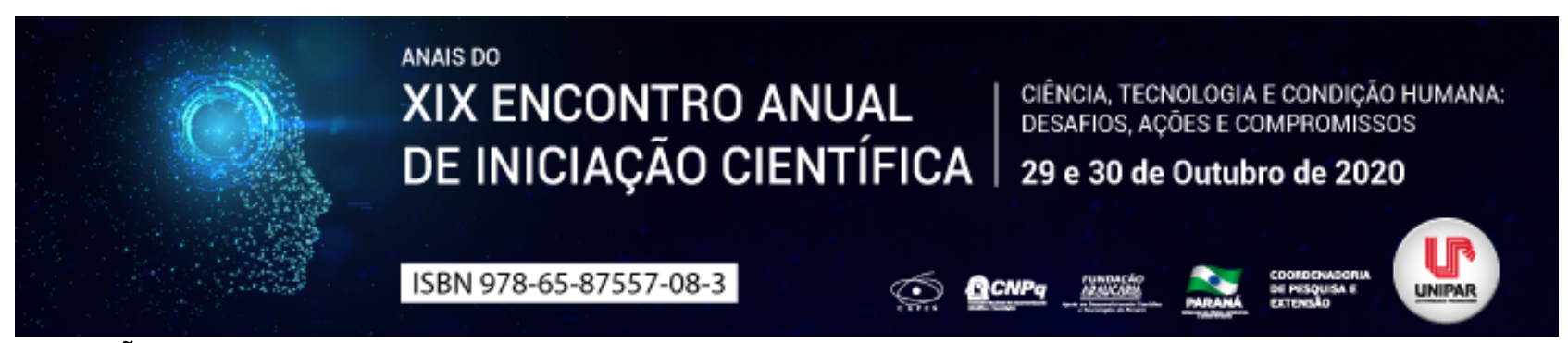

AVALIAÇÃO DE DESEMPENHO: UM INSTRUMENTO QUE POTENCIALIZA OS RESULTADOS EMPRESARIAIS

\author{
${ }^{1}$ NATHALIA FERREIRA DA SILVA, ${ }^{2}$ VITOR HUGO DE SOUZA CICHOCKI, ${ }^{3}$ ELIZANGELA MARIA MENEGASSI DE LIMA
}

${ }^{1}$ Acadêmica do Curso de Administração da UNIPAR

${ }^{1}$ Acadêmico do Curso de Administração da UNIPAR

${ }^{2}$ Docente da UNIPAR

Introdução: No cenário atual no mercado as empresas têm como metas estarem sempre competindo entre si. E para que a empresa continue nesse ramo de competição precisa estar avaliando sempre os seus métodos. Além da qualidade dos serviços que ela oferece de forma satisfatória para seus compradores, se mantendo flexível e inovando os serviços de forma eficiente e eficaz.

Objetivo: Descrever como a avaliação de desempenho nas empresas é importante.

Desenvolvimento: Para monitorar o desempenho de um processo, é preciso analisá-lo ao longo de um tempo, para que a análise seja satisfatória é necessário reconhecer os pontos que devem ser melhorados"(IZIDORO, 2015, p.7). Segundo Izidoro (2015) é importante que o administrador compreenda que a análise do desempenho e da qualidade de um processo para a criação de indicadores de desempenho não pode ser baseada na intuição ou no conhecimento de uma pessoa; e sim de um estudo detalhado dos processos da empresa, sempre considerando o erro e sua causa. Valeriano (2001, p.92) menciona que "é necessário levantar tendências de evolução para se fazer previsões de cenários e de caminhos futuros". Segundo Valeriano (2001) Para avaliar o desempenho do ambiente precisa passar por uma criteriosa avaliação para orientar as decisões a serem tomadas; as avaliações devem ser feitas de forma cooperativa envolvendo todos que estão ligados diretamente ou indiretamente com a empresa. Isso proporcionará oportunidades, que são circunstancias que levará a resultados desejáveis ou favoráveis e as ameaças ali existentes."É necessário que a avaliação de desempenho organizacional seja utilizada com o intuito de direcionar os funcionários no sentido de se atualizarem e adquirirem novos conhecimentos, habilidades e expertises capazes de auxiliar a organização a impulsionar seu negócios" Rocha (2012, p. 27). Partindo desse pressuposto, para que isso ocorra a organização deve desenhar e selecionar indicadores para que seja possível a visualização do processo de obtenção dos resultados. Desta forma, será possível a identificação do desempenho de cada funcionário, visualizando o potencial de cada colaborador as dificuldades e pontos que precisam ser melhorados.

Conclusão: A importância da Avaliação de Desempenho refere-se, principalmente, ao fato de poder diagnosticar, o desempenho dos coautores em determinado período de tempo. A Avaliação de Desempenho é um recurso audacioso tanto para empresas quanto para funcionários, pois o processo traz a oportunidade de receber feedback sobre o desempenho no cargo, possibilitando a melhoria do potencial dos colaboradores, por conseguinte, a instituição irá obter melhores frutos, tanto em termos de lucros quanto de imagem.

\title{
Referências
}

IZIDORO, Clayton (org.). Avaliação de desempenho de empresas. São Paulo: Pearson Education do Brasil, 2015.

VALERIANO, Dalton L. Gerenciamento estratégico e administração por projetos. Makron Books, São Paulo, 2001.

JARDEWISK, Cley Jonir Foster. JARDEWISK, Gustavo Luiz Foster. Técnicas e métodos de avaliação de desempenho. Curitiba: InterSaberes, 2014. 


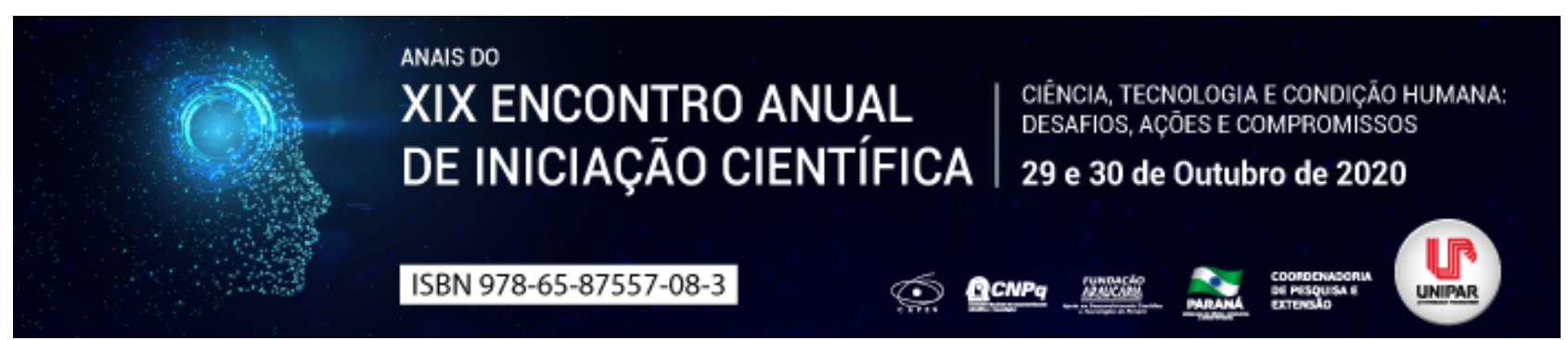

A BUSCA PELA VERDADE SUBSTANCIAL E A INSTRUMENTALIDADE DO PROCESSO CIVIL

\author{
1LUANA CRYSTINA RODRIGUES DOS SANTOS, ${ }^{2}$ ALBINO GABRIEL TURBAY JUNIOR
}

\author{
${ }^{1}$ Acadêmico do PIC/UNIPSR \\ ${ }^{1}$ Docente da UNIPAR
}

Introdução: Para uma sentença justa, indubitavelmente, é necessário buscar dentro do prazo razoável a verdade dos fatos, para tanto, a produção probatória tem esta função de investigar os fatos relevantes, interpretá-los e compreendê-los, afim de que a verdade revelada pelo processo represente substancialmente a realidade dos fatos, e contribua para que se venha a ter a correta aplicação e interpretação do direito material.

Objetivo: Analisar o conceito de verdade ao longo da história e sua aplicabilidade no processo civil.

Desenvolvimento: Primordialmente, na metade do século XIX, entre os teóricos do direito, não se tinha de forma clara a diferença entre o direito material e processual. O processo era tido como um apêndice do direito material, qual só se tinha uma ação através da violação de algum direito. A evolução do processo civil é constante e vem sendo a cada dia superada em algum aspecto (RIGUETTI, 2015, p. 3). Na fase autonomista, qual tinha como centro a visão endoprocessual, o processo era tido apenas como um acessório do direito material, ainda, entendia-se que a ação era um direito que nascia da violação de um outro direito, era a ideia de armado para a guerra ; isso ocorreu porque os teóricos da época não tinham de forma clara a diferenciação do direito processual e do direito material. A fase autonomista teve sua grande importância, contudo o processo civil evoluiu para uma nova análise crítica chamada de fase instrumental (RIGUETTI, 2015, p. 2). Assim, essa ideia de direito armado é quebrantada no século XIX, com a instauração da fase instrumentalista, em que o processo é de natureza pública e tido como um instrumento estatal, com base nos escopos de sociais, políticos e jurídicos. Embora a fase instrumentalista tenha trazido um novo paradigma de visão aos operadores do direito, ainda existe uma ideia de busca pela verdade absoluta, com o entendimento de que a verdade deve ser perseguida pelo magistrado ao decorrer de todo o processo, e, ao final se chegará a um resultado real e absoluto (ISAIA, 2012, p. 4). Acontece que não é possível alcançar a verdade absoluta, mas isso não significa que não se deva buscar uma verdade de forma substancial pelo meio adequado da prova, haja vista que a função da prova é a reconstrução real do fato, tendo como finalidade buscar a verdade como um ideal a ser alcançado para concretização de direitos básicos como a ampla defesa e o contraditório (PEREIRA, 2012, p. 9). O processo é o ambiente para a busca da verdade dos fatos, mas esta busca deve respeitar princípios como contraditório, ampla defesa, lealdade e cooperação, assim, o espaço de diálogo processual é democrático, afastando a ilusão de uma verdade absoluta. Em razão de sua instrumentalidade, o processo civil deve ter regras sobre provas que respeitem o ambiente democrático, mas que conduzam para a efetivação do direito material.

Conclusão: Deve ser desconsiderada as teorias de busca pela verdade absoluta/formal, assim, a prova para revelar a verdade substancial dos fatos deve ser alvo de esforço e empenho de todos, colocando em prática o princípio da cooperação. Deve haver um empenho maior por parte do magistrado que fará a prolação da sentença de forma mais justa, tendo em vista que os escopos estatais que devem ser efetivados no plano concreto por meio de tutela jurídica justa. Nesse sentido, o meio mais efetivo para se alcançar o que se busca é o respeito ao contraditório e a ampla defesa, assim, garantir uma justa utilização dos meios de provas, inclusive com a técnica de dinamização de ônus da prova prevista no parágrafo $1^{\circ}$ do seu art. 373 , pois impõe ao juiz o dever de realmente buscar a prova dos fatos, a fim de chegar o mais próximo possível daquilo que realmente ocorreu.

\title{
Referências
}

RIGUETTI, Gabriel Felipe Roqueto. Processo e verdade: Brevíssimas considerações sobre funções e conceitos. Revista de processo. Itália, v. 250/2015, p. 01-19, dez. 2015

ISAIA, Cristiano Becker. A jurisdição processual civil no Estado democrático de direito: verdades universais ou respostas corretas? Revista de direito brasileira. Santa Maria, v. 3/2012, p. 157, jul. 2012.

PEREIRA, Guilherme Setoguti J. Verdade e finalidade da prova. Revista de processo, São Paulo, v. 2013/20120, p. 161-189, nov. 2012. 


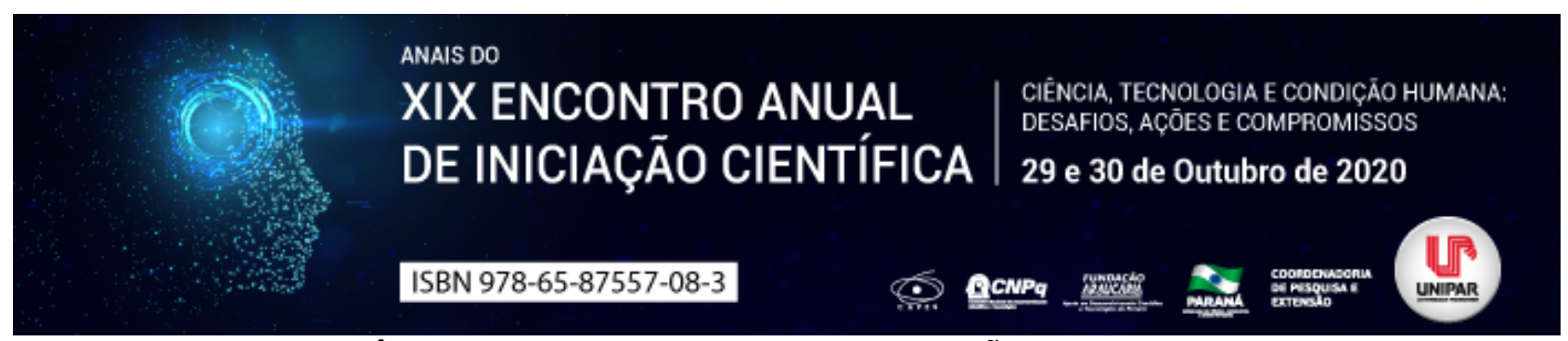

A IMPORTÂNCIA DO CONTRATO PARA PUBLICAÇÕES EM REDES SOCIAIS

\author{
${ }^{1}$ VICTOR HUGO VARGAS, ${ }^{2}$ VITOR APARECIDO SANTOS RODRIGUES, ${ }^{3}$ ANDRE ALVES DE OLIVEIRA, ${ }^{4}$ AMANDA \\ RODRIGUES CATTO, ${ }^{5}$ CELSO HIROSHI IOCOHAMA
}

\author{
${ }^{1}$ Academico do PIC/UNIPAR \\ ${ }^{1}$ Acadêmico do Curso de Direito da UNIPAR \\ ${ }^{2}$ Acadêmico do PIC/UNIPAR \\ ${ }^{3}$ Acadêmica do Curso de Direito da UNIPAR \\ ${ }^{4}$ Docente da Graduação em Direito e do Programa de Mestrado em Direito Processual e Cidadania da UNIPAR
}

Introdução: Com a expansão do marketing digital muitas vezes a contratação do influencers ocorre através das redes sociais. É preciso um contrato, assinado por ambas as partes, com todas as especificações, peculiaridades e como a campanha desenvolverá. Neste contexto, o estudo tratará dos elementos e da importância da formalização dos interesses das partes contratantes.

Objetivos: Identificar a importância do contrato em publicações na rede social, em especial no Instagram.

Desenvolvimento: Com o avanço tecnológico, houve considerável aumento na procura de publicidade em redes sociais por empresas de diversas marcas, tendo em vista o grande engajamento, utilizando o influencer como ponte entre a marca e o cliente. A ABRADI (Associação Brasileira de Agências Digitais) e com o apoio com da YOUPIX (plataforma digital que discute a cultura da internet e como o jovem a usa para criar movimentos culturais, sociais e informação), lançou o seu código de Conduta para Contratação de Influenciadores, e recomenda manter como prática permanente o cumprimento da legislação na contratação de influenciadores para campanhas publicitárias digitais, mediante contrato específico, conferindo profissionalismo e legitimidade aos acordos (ABRADI, 2017, p.4). Ademais, tratativas verbais, troca de e-mails ou de mensagens instantâneas podem não ser consideradas provas caso ocorra um conflito jurídico (ABRADI, 2017, p.4). Segundo Lemes (2020), para que haja proteção aos profissionais que trabalham com publicações é preciso um contrato entre as partes, como uma relação de emprego, um contrato trabalhista. Assim é necessário que no contrato formal haja observância de especificações como breafing de campanha, a captação de Leads, direitos autorais e sobre a quantidade e periodicidade das publicações. O contrato será prova da existência de obrigações entre as partes, podendo conter cláusulas de multa por descumprimento do pactuado. No Art. 927 do Código Civil (CC/02) é claro I"Aquele que, por ato ilícito (arts. 186 e 187), causar dano a outrem, fica obrigado a reparálol", assim tornando mais que inevitável o lavramento de um contrato específico para cada influencers ou empresa (SERENO, 2020). Ou seja, a importância do contrato é inevitável para ambas as partes.

Conclusão: Como identificado, percebe-se a importância do uso de contrato em situações como as identificadas, pois, na quebra dos termos do contrato poder-se-á desenvolver um grande conflito entre as partes, e consequentemente, se não resolvido, um futuro processo judicial. Deve-se, portanto, dar prioridade às cláusulas então postas no contrato, assim, assegurando os aspectos jurídicos e execução.

\title{
Referências
}

ABRADI. Código De Conduta Para Agências Digitais Na Contratação De Influenciadores. Disponível em: https://www.abradi.com.br/wp-content/uploads/2017/07/Abradi-Influenciadores.pdf. Acesso em: 14 jun. 2020.

LEMES, Daniele 0 contrato de influenciadores digitais. Disponível em: https://danilemes.jusbrasil.com.br/artigos/804687654/ocontrato-de-influenciadores-digitais. Acesso em: 11 jun. 2020.

SERENO, Ailana. Parceria com Influenciador Digital: fazer contrato é legal. Disponível em: https://serenoadvogados.adv.br/parceria-com-influenciador-digital/. Acesso em: 15 jun. 2020. 


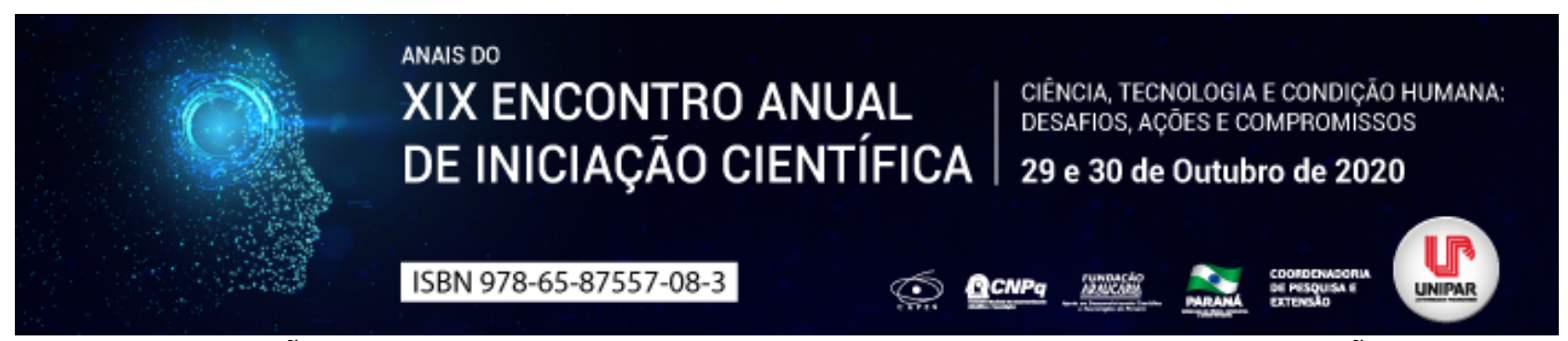

\title{
O CABIMENTO DE AÇÃO DIRETA DE INCONSTITUCIONALIDADE INTERVENTIVA POR OCASIÃO DAS MEDIDAS FEDERAIS DA COVID-19
}

\author{
${ }^{1}$ NATHALIA GRACINSKI RIPPEL, ${ }^{2}$ NIELLY LUCKMANN, ${ }^{3}$ DIOGO LOPES CAVALCANTE
}

\author{
${ }^{1}$ Academica do PIC/UNIPAR \\ ${ }^{1}$ Acadêmica do PIC/UNIPAR \\ ${ }^{2}$ Docente da UNIPAR
}

Introdução: O presente trabalho tem por intento realizar uma análise acerca da possibilidade em tese de se propor uma ação direta de inconstitucionalidade interventiva por ocasião da não implementação de medidas de combate da Pandemia da COVID19. Na qual, leva a utilizar a nova hermenêutica constitucional junto ao movimento neoconstitucionalista, compreendendo a necessidade e dever dos entes da federação de garantir os direitos fundamentais expressos na Constituição Federal de 1988.

Objetivo: Definir a possibilidade em tese de Ação Direta de Inconstitucionalidade Interventiva, para zelo pelos direitos fundamentais, considerando as medidas federais excepcionais no combate da Pandemia do novo Coronavírus.

Desenvolvimento: É fato que a Pandemia de COVID-19, doença respiratória aguda causada pelo novo coronavírus (SARS-CoV2), desencadeou crises, tanto na área da saúde como na economia de mais de 150 países, incluindo o Brasil. Como resultado, ocorreu uma profunda readaptação da sociedade diante os novos obstáculos. Dessa forma, o Estado implementou uma série de medidas e alternativas com a finalidade de regulamentar o novo contexto; ciente do dever de proteção dos direitos sociais como disposição no art. $6^{\circ}$ da CF/88 são direitos sociais a educação, a saúde, a alimentação, o trabalho, a moradia, o transporte, o lazer, a segurança, a previdência social, a proteção à maternidade e à infância, a assistência aos desamparados, na forma desta Constituição (BRASIL,1988, p.11). Por esse viés, ainda, é fato que os efeitos acarretados pela Pandemia não podem ser apenas observados no âmbito econômico e da saúde pública, mas também pelo viés judiciário. Ora, é obrigação do Estado intervir através de medidas emergenciais; porém, é dever do mesmo resguardar e efetivar as leis que por ele são aplicadas, como cita o secretário-geral assistente da ONU (2020) Alexandre Zouev: há desafios relacionados a ela que são consequências para contê-la e promover uma recuperação rápida e sustentável. A luta para defender o Estado de Direito e o papel da aplicação da lei nas sociedades estão entre eles (tradução). A vista disso, partindo do pressuposto que o Brasil é uma federação, com entes que gozam de relativa autonomia, cabe discutir a padronização de medidas e eventual possibilidade de intervenção federal. A Constituição Federal de 1988 dispõe a respeito das Ações Interventivas por meio de autorização do Supremo Tribunal Federal, em caso de violação dos princípios sensíveis estabelecidos no art, 34, VII. Em outras palavras, a inobservância dos determinados princípios sensíveis permitiria a União em suspender temporariamente a autonomia política dos Estados. Nota-se, nesse sentido, que em tempos de COVID-19, as medidas para apaziguar a transmissão foram adotadas por meio de decretos e leis como a lei $n^{\circ}$ 13.979/2020 regulamentada pela Portaria de $n^{\circ} 356 / 2020$. Todavia, tem-se percebido incongruências entre decretos vigentes, estabelecidos pela União e os demais entes, que permitiria em tese a intervenção. Conclusão que vai de encontro com a hermenêutica constitucional, que se adaptar as necessidades da população: compreender o sentido e o alcance de suas normas, pelo exato entendimento das suas expressões, de acordo com suas finalidades, e tendo em vista as condições e necessidades sociais de cada época (MEIRELLES TEIXEIRA, 1991, p.268).

Conclusão: Em tempos de calamidade pública do coronavírus que se vive, o Estado tem como dever amparar os indivíduos, com ações cooperativas entre os entes federativos. A vista disso, deve-se observar a atuação do poder judiciário acerca da saúde pública e da economia do país. Em consequência disso, para além do debate ideológico, é perfeitamente possível imaginar a utilização de Ações de Inconstitucionais Interventivas para proteção dos princípios constitucionais sensíveis.

\section{Referências}

BRASIL. Constituição (1988). Constituição da República Federativa do Brasil: promulgada em 5 de outubro de 1988. 8. ed. São Paulo: Revista dos Tribunais, 2003.

BRASIL. Lei $n^{\circ} 13.979$, de 06 de fevereiro de 2020. Dispõe sobre as medidas para enfrentamento da emergência de saúde pública de importância internacional decorrente do coronavírus responsável pelo surto de 2019. Diário Oficial da União, Brasília, DF, ed. 27, p.1, fev. 2020.

TEIXEIRA, J. H. Meirelles. Curso de direito constitucional. Rio de Janeiro: Forense Universitária, 1991, p.268.

ZOUEV, Alexandre. CoVID-19 and the Rule of Law, IPI The Global Observatory, junho, 2020. Disponível em: https://theglobalobservatory.org/2020/06/covid-19-and-rule-of-law/. Acesso em: 01 ago. 2020. 
Coordenadoria de Pesquisa e Extensão - COPEX

Departamento de Editoraçāo e Divulgaçāo Científica - DEDIC 


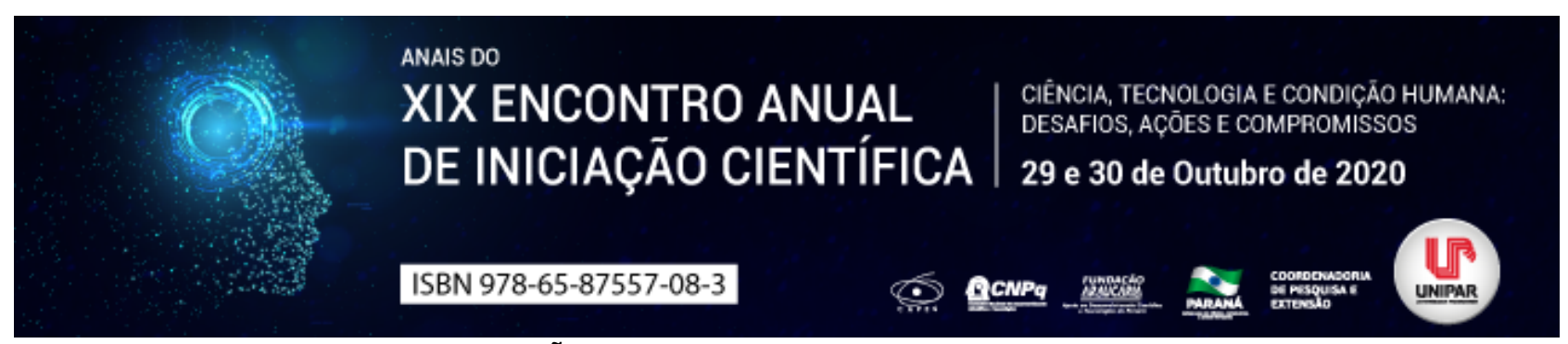

A FUNÇÃO SOCIAL DOS TRIBUTOS NO BRASIL

\author{
${ }^{1}$ FIDELIS VALDIR SCHMITT, ${ }^{2}$ LUDMILA KOLB DE VARGAS CAVALLI
}

\begin{abstract}
${ }^{1}$ Acadêmico da Unipar
${ }^{1}$ Docente da UNIPAR
\end{abstract}

Introdução: No Brasil a questão da necessidade de recolhimento dos tributos, incorretamente identificados pela população leiga como impostos, causa, já há algum tempo, discussões e por vezes controvérsias, especialmente, entre aqueles que defendem a necessidade de se diminuir a tributação, como o setor produtivo, e aqueles que apontam a falta de equidade na distribuição e cobrança dos tributos. O presente estudo se justifica na medida em que se busca entender a função social dos tributos, a partir da ótica constitucional.

Objetivo: Analisar o direito tributário brasileiro à luz da função social dos tributos e da garantia dos princípios constitucionais de igualdade e justiça social.

Desenvolvimento: A justiça e a igualdade social têm por objetivo garantir direitos e dignidade humana, tanto de indivíduos, como da coletividade protegida pelos direitos constitucionais. Tem como foco a busca, por um lado, de equidade social, e, por outro, a manutenção do equilíbrio entre o Estado Democrático e Estado Fiscal (PEREIRA, 2018), estabelecendo o respeito constitucional à vida humana sem que haja uma falência econômica do estado. A cobrança de tributos passou por três momentos distintos ao longo da história mundial e do Brasil. A fase absolutista, notadamente patrimonialista, em que o tributo serve para sustentar o Príncipe: a ruptura entre o público e o privado, caracterizado por um 'pacto tributário, que define juridicamente a propriedade privada, devendo uma parte dela destinada ao pagamento de tributos; e um terceiro período, em que o tributo passa a ser instrumento de promoção de satisfações coletivas e de distribuição de renda (NUNES, 2016, p.37). Com a Revolução Industrial, ocorrida durante o século XIX, na Europa, houve nos países capitalistas o agravamento do desequilíbrio social como aumento das diferenças econômicas entre pobres e ricos, o que, como se sabe, recrudesceu no século posterior. Isso exigiu dos sistemas de tributação uma nova estruturação, especialmente quanto à realização da justiça social, de modo que o tributo passa a ser utilizado como instrumento para a realização das necessidades públicas assumidas pelo estado (NUNES, 2016,p 37). No Brasil, o estado social se constitui depois da ascensão de Getúlio Vargas, em 1930, até esse período, a República se caracterizava como um estado liberal que dificultava a adoção de políticas nacionais visando a redução das desigualdades sociais e econômicas muito pronunciadas desde o final da escravidão (NUNES, 2016, p.58). Somente após a Constituição de 1988, iniciou-se, no Brasil a reflexão sobre a função social do tributo, visto que o Estado Democrático de Direito deve assegurar o exercício dos direitos sociais e individuais, a liberdade, a segurança, o bem-estar, o desenvolvimento, a igualdade e a justiça como valores supremos de uma sociedade fraterna, pluralista e sem preconceitos (RIBEIRO e GESTEIRO, 2019,p.235). Esse olhar mais social sobre os tributos vai ao encontro da Constituição, vista como cidadã, que aponta no art. $1^{\circ}$ a garantia da dignidade humana como seu papel preponderante na lei maior. (BRASIL, 1988). Assim, observa-se na Constituição a busca da garantia do uso dos recursos arrecadados em função do interesse público comum. Sendo que a função social dos tributos é restituir os valores arrecadados pelo estado, em serviços públicos, tais como, saúde, educação, moradia, entre outros, para a população.

Conclusão: A partir das leituras feitas para elaborar o referencial teórico do presente estudo, pode-se atribuir um significado ao termo função social do tributo, como sendo o dever do Estado em arrecadar tributos e, com esses, promover o bem comum dos cidadãos. No entanto, garantir a distribuição justa dos valores arrecadados sempre foi a maior dificuldade dos estados democráticos de direito, havendo em país, como o Brasil, uma arrecadação e uma distribuição injusta e não equitativa, exigindo a reflexão sobre o tema e que sabe, uma ação social e política buscando intervir nessa realidade.

\title{
Referências
}

BRASIL. Constituição (1988). Constituição da República Federativa do Brasil. Brasília: Senado Federal, 1988.

NUNES, Cleucio Santos. Justiça e equidade nas estruturas endógena e exógena da matriz tributária brasileira. Tese. (Doutorado em Direito) UNB, Brasília: UNB, 2016.

PEREIRA, Ricardo Utrabo. O dever fundamental de pagar tributos e a sua relevância para o Estado Democrático de Direito. Dissertação (Mestrado em Ciências Sociais e Aplicada).UENP Jacarezinho-PR, 2018.

RIBEIRO, Maria de Fatima; GESTEIRO, Natália Paludetto. A busca da cidadania fiscal no desenvolvimento econômico: Função Social do Tributo. ARGUMENTUM - Revista de Direito n. 5 . Marília-SP: UNIMAR, 2005, pp.59-73. 
Coordenadoria de Pesquisa e Extensão - COPEX

Departamento de Editoraçāo e Divulgaçāo Científica - DEDIC 


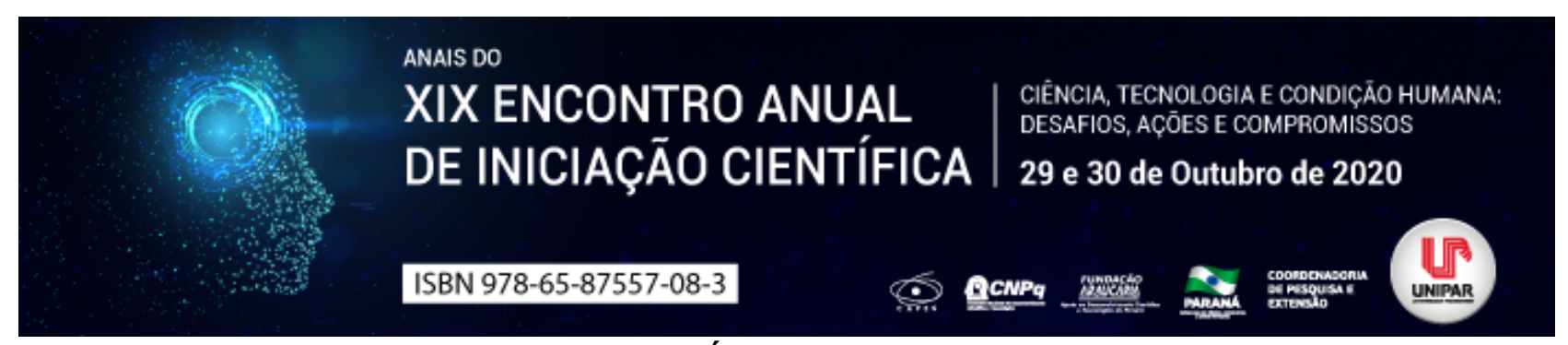

RESPONSABILIDADE INTERNACIONAL DA REPÚBLICA POPULAR DA CHINA NO CONTEXTO DE COVID-19

\author{
${ }^{1}$ VIRGINIA TELLES SCHIAVO WRUBEL, ${ }^{2}$ BRUNO SMOLAREK DIAS
}

\author{
${ }^{1}$ Acadêmico do PIC/UNIPAR \\ ${ }^{1}$ Docente da UNIPAR
}

Introdução: A pandemia de COVID-19 tem causado severos impactos nas vidas humanas, nos sistemas de saúde, na economia dos Estados e nas relações internacionais entre eles. A reabilitação mundial dos seus efeitos não possui termo certo, sabendose, porém, que desastres, mesmo globais, não produzem efeitos homogêneos, mas atingem de forma mais intensa às populações e países mais vulneráveis. Nesse contexto, interessa perscrutar quais medidas poderiam ser tomadas objetivando prevenir e indenizar danos causados por situações como a presente.

Objetivo: Analisar eventual responsabilidade internacional da República Popular da China, por condutas tomadas quando do início da pandemia de COVID-19, com fulcro em atos normativos do Direito Internacional, por meio de pesquisa de revisão de doutrina e legislação.

Resultados: O novo coronarívus tem aspecto zoonótico o que aponta para sua transmissão de animais a pessoas sinalizando a natureza de um grave problema ambiental global emergente. Depois de provocar as primeiras mortes, em Wuhan, província de Hubei, na China, e se espalhar a diferentes locais, a doença foi declarada como Emergência de Preocupação Internacional, em 30/01/2020, para, em 11/03/2020, ser formalizada como pandemia pela Organização Mundial de Saúde (CARVALHO, 2020, p. 245). Questionou-se, porém, desídia do governo chinês para o compartilhamento de dados internos a nível internacional, como, por exemplo, na comunicação à Organização Mundial de Saúde (OMS) de que a transmissão viral procedia de pessoa a pessoa, a qual restou efetivada apenas em 21/01/2020 (MAZZUOLI, 2020, p. 6). Segundo Mazzuoli (2020, p.17), nesse sentido, poder-se-ia aventar o descumprimento do Regulamento Sanitário Internacional da OMS, Tratado Internacional datado de 2005, do qual a China é signatária. Isso porque tal instrumento prescreve a obrigação de notificar a OMS, pelos mais eficientes meios de comunicação, no prazo de 24 horas da avaliação de informações de saúde pública, sobre todos os eventos que possam constituir emergência de saúde pública a nível internacional (OMS, 2005). A partir disso, tornar-se-ia imputável a responsabilidade internacional de tal país, composta de três elementos: a) a existência de um ato ilícito internacional; b) a presença da imputabilidade; e c) a existência de um prejuízo ou um dano a outro Estado. (MAZZUOLI, 2020, p.8). Contudo, verifica-se dificuldade, residente na pendência de ratificação do Projeto de Artigos sobre Responsabilidade do Estado por Atos Internacionalmente llícitos aprovado em 1966, pela Comissão de Direito Internacional (CDI) das Nações Unidas em primeira versão, e em 2001, em versão revista (ONU, 2001). Considerando, porém, que durante a $62^{\mathrm{a}}$ Sessão da Assembleia-Geral, em 2007, indicou-se a observação de tal ato, figurou passível a imputação da responsabilidade internacional, enquanto instituto fundamental do Direito Internacional Público, corolário da igualdade soberana dos Estados e voltado a reparar os danos materiais sofridos por um Estado, em decorrência de atos praticados por outro (MAZZUOLI, 2020, p.8). Nessa esteira, a China poderia ser demandada na Corte Internacional de Justiça (Haia) - após tentativa de solução pacífica do conflito, conforme dispõe o Regulamento da OMS. Seria provável, sob tal contexto, a alegação, pela China, de força maior , excludente de responsabilidade passível, porém, de ser contrariada pelo referido Projeto de Convenção da ONU, que obsta sua aplicação no caso de o Estado ter assumido o risco de produzir o resultado danoso. Lucidamente, porém, pontua Mazzuoli (2020, p.18) que a pretensão dos Estados em demonstrar que a China efetivamente violou norma vinculante do Direito Internacional Público é enfraquecida ante a consideração de que o raciocínio valeria para todos e que em todos os países pode haver o princípio de surtos, epidemias e pandemias congêneres.

Conclusão: Aferiu-se que o aparecimento de novas doenças zoonóticas constitui severo problema ambiental emergente, que a pandemia causada pelo coronavírus enceta graves e heterogêneas consequências e que isso impele à preocupação de resguardar a observância dos diplomas normativos de organizações internacionais em matéria sanitária. Constatou-se, em tal sentido, possibilidade de responsabilização internacional da China por inobservância justamente desses diplomas sanitários, especificamente do Regulamento da OMS, fato hábil inclusive para incitar seu julgamento perante a ClJ e eventualmente imputar-lhe uma condenação, em que pese o receio de se levar o país a tal julgamento, pelos motivos expostos.

\title{
Referências
}

CARVALHO, Délton Winter de. A Natureza Jurídica da Pandemia Covid-19 como um Desastre Biológico: Um ponto de partida necessário para o Direito. Revista dos Tribunais, v. 1017, p. 243- 267, jul. 2020.

MAZZUOLI, Valério de Oliveira. Responsabilidade Internacional dos Estados por Epidemias e

Pandemias Transnacionais: O Caso da Covid-19 provinda da República Popular da China. Revista de Direito Civil 
Contemporâneo, v. 23, jun. 2020.

ORGANIZAÇÃO MUNDIAL DA SAÚDE (OMS). Regulamento Sanitário Internacional, 2005. Disponível em: https://www.who.int/ihr/publications/9789241580496/en/ Acesso em: 23 ago. 2020.

ORGANIZAÇÃO DAS NAÇÕES UNIDAS (ONU). Projeto de Artigos sobre Responsabilidade do Estado por Atos Internacionalmente llícitos, 2001. Disponível em: http://iusgentium.ufsc.br/wp-content/uploads/2015/09/Projeto-da-CDI-sobreResponsabilidade-Internacional-dos-Estados.pdf Acesso em: 23 ago. 2020.

Coordenadoria de Pesquisa e Extensão - COPEX

Departamento de Editoraçāo e Divulgaçāo Científica - DEDIC 


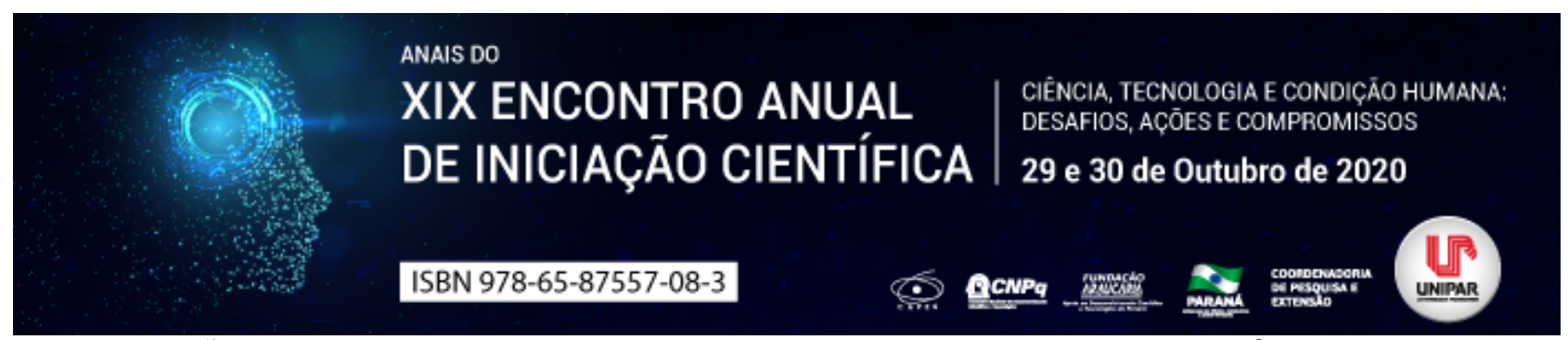

EDUCAÇÃO AMBIENTAL NO BRASIL: POR UM DESENVOLVIMENTO SUSTENTÁVEL E HUMANO

\begin{abstract}
${ }^{1}$ ANDRE ALVES DE OLIVEIRA, ${ }^{2}$ VITOR APARECIDO SANTOS RODRIGUES, ${ }^{3}$ VICTOR HUGO VARGAS, ${ }^{4}$ DORITA ZIEMANN HASSE
\end{abstract}

${ }^{1}$ Acadêmico do PIC/UNIPAR

${ }^{1}$ Acadêmico do Curso de Direito da UNIPAR

${ }^{2}$ Acadêmico do Curso de Direito da UNIPAR

${ }^{3}$ Docente da UNIPAR

Introdução: O Direito interno brasileiro reconhece os fundamentos de proteção à dignidade da pessoa humana através da construção de um desenvolvimento sustentável. A preocupação com ações prejudiciais ao meio ambiente exige dos Estados soberanos a adoção de políticas de desenvolvimento que priorizem a proteção de um ambiente ecologicamente equilibrado para preservação da qualidade de vida de todos.

Objetivo: Analisar a importância da educação ambiental para a construção de desenvolvimento sustentável e a proteção da vida. Desenvolvimento: $\mathrm{O}$ Brasil é considerado como área de grandes florestas e grande manancial hídrico e tem demonstrado grande preocupação, através do direito interno, com a relação que há entre os direitos humanos e o meio ambiente. A Constituição da República Federativa do Brasil em seu artigo 225 estabelece que Todos têm direito ao meio ambiente ecologicamente equilibrado, bem de uso comum do povo e essencial à sadia qualidade de vida, (BRASIL, 1988, Art. 225), colocando em destaque a preocupação com a vida em condições de dignidade. Analisando-se os três pontos fundamentais, Direitos humanos, desenvolvimento sustentável e educação ambiental, é possível perceber a importância e a necessidade de se efetivar uma educação ambiental consistente para que a sociedade possa produzir e preservar a sua dignidade. O inciso VI do artigo $225, \S 1^{\circ}$ da CF especifica essa preocupação com a educação ambiental quando informa que incumbe ao Poder Público

promover a educação ambiental em todos os níveis de ensino e a conscientização pública para preservação do meio ambiente , (BRASIL, 1988, Art. 225). Os sociólogos, estudiosos das ações humanas, já por volta da década de 70 foram de fundamental importância para identificar as evidências e os impactos negativos sobre a natureza e a importância de se educar o homem contemporâneo para essa preservação com valores ambientais que se induzem por diferentes meios e produzem efeitos educativos que não dependem exclusivamente de processos educativos formais. Portanto, pode-se afirmar que a construção de uma sociedade sustentável exige um trabalho gradativo de enfrentamento e a prevenção das mazelas sociais, ou seja, $\mathrm{O}$ modelo de desenvolvimento no Brasil pode e deve ser construído em função da conscientização de todos que vivem e/ou se encontram em solo brasileiro quanto a esse reconhecimento, como também em função das potencialidades brasileiras, de sua biodiversidade, território, riquezas minerais, água, energia solar e eólica disponível [...]. (MARTINS, 2017, p 231). Construir uma sociedade consciente e um mundo melhor, ancorado em uma cultura proativa de paz reconhecendo os valores e diferenças deve ser o propósito fundamental da humanidade, pois a cultura de paz e o desenvolvimento sustentável tratam o respeito ao próximo inclusive as gerações presentes e as gerações futuras, a diferença e a diversidade como valores éticos e centrais"(UNESCO,2005). Entende-se que todos os cidadãos deverão colaborar na construção de um meio ambiente sustentável, que proverá as mesmas uma vida digna.

Conclusão: Levando-se em consideração esses aspectos, conclui-se que, a educação ambiental no Brasil está crescendo e os legisladores se preocupam com o bem-estar dos cidadãos e com um desenvolvimento sustentável preservando e protegendo o meio ambiente.

\title{
Referências
}

BRASIL, Constituição (1988). Constituição da República Federativa do Brasil. Brasília, DF: Senado Federal: Centro Gráfico, 1988.

Direito ao meio ambiente: um direito humano? Coordenação de Antônio Augusto Cançado Trindade e César Barros LealFortaleza: Expressão Gráfica e Editora, 2017. 356 p. ISBN: 978-85-1074-9.

MARTINS, Racquel Valério. Educação ambiental no Brasil por um desenvolvimento sustentável. In: Direitos humanos e meio ambiente. Coordenação de Antônio Augusto Cançado Trindade e César Barros Leal. Fortaleza: Expressão Gráfica e Editora, 2017. 


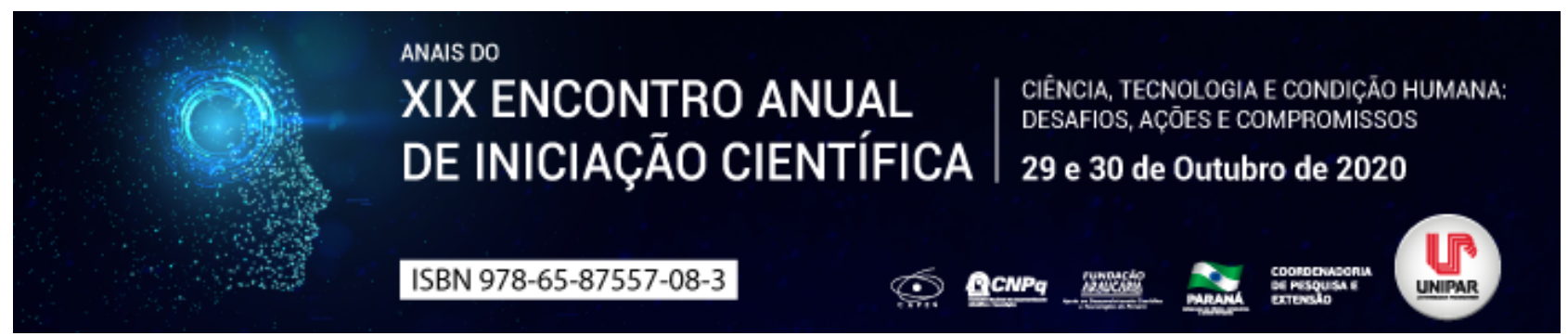

\title{
A CURATELA E A TOMADA DE DECISÃO APOIADA EM RELAÇÃO AOS AUTISTAS SOB A PERSPECTIVA DO PRINCÍPIO DA DIGNIDADE HUMANA
}

\author{
${ }^{1}$ EDUARDO FECCHIO BOTTER, ${ }^{2}$ MIRIAM FECCHIO CHUEIRI
}

\author{
${ }^{1}$ Acâdemico Bolsista do PIBIC/UNIPAR \\ ${ }^{1}$ Docente da UNIPAR
}

Introdução: Através do instituto da curatela e da tomada de decisão apoiada no novo Código de Processo Civil, nota-se grande avanço nas questões sociais e patrimoniais para Pessoas com Deficiência, inclusive para pessoas com autismo que valeu-se de um dispositivo de identificação que entrou em vigência no ano de 2020. Tais mecanismos auxiliam de maneira providencial quando solicitados para que tal pessoa possa não apenas deter direitos plenos como também exercê-los.

Objetivo: llustrar porque se faz necessário a possibilidade de tomada de decisão apoiada ou a curatela para o autista.

Desenvolvimento: O Estatuto da Pessoa com Deficiência promoveu igualdade ao deficiente o tornando plenamente capaz, com isso, saindo de vez do rol de relativamente incapaz (TEDESCO, 2017). Esse novo entendimento provoca mudanças em diversas situações como o direito de se casar, de constituir família, e até em questões patrimoniais, essa qual a interdição permanece. Em 8 de Janeiro de 2020, com a vigência da Lei no 13.977, ficou mais fácil a constatação da pessoa com transtorno do espectro autista, em seu Art. 3o-A, com a criação de uma carteira de identificação. O autista, desde o autismo-leve ao autismo-grave, também possui segurança jurídica apoiada no Estatuto, uma vez que mesmo sendo portador de um transtorno consegue tomar as mais diversas opções que sua capacidade Ihe permite. A curatela por anos foi um instituto imposto por um juiz, para que o curador cuidasse de alguém juridicamente incapaz de forma transitória ou permanente. Com o advento do Estatuto, que tornou a pessoa com deficiência plenamente capaz, tal instituto não se fez mais necessário em relação aos direitos existenciais (TARTUCE, 2015). No entanto, para atos relacionados aos direitos de natureza patrimonial e negocial, o instituto da curatela se mantém como um ato de necessidade, tornando medida extraordinária e não mais corriqueira. Ainda, caso a pessoa com deficiência sinta necessidade de ajuda para tomar decisões, ela poderá usar a tomada de decisão apoiada, uma via assistencial onde a pessoa com deficiência escolhe duas pessoas idôneas que com ele mantenha vínculos, para lhe auxiliar e prestar apoio sobre os atos da vida civil, fornecendo informações e elementos para que possa exercer a capacidade plena que Ihe é conferida (ANTONIO, 2018). Atentando-se ao fato de autistas por muitas vezes não conseguirem discernir ironias e sarcasmos, os apoiadores poderão ser de grande valia nessas situações. Lyons-Fitzgerald (2004, p. 523) traz uma defesa importante ao dizer: Há evidências de uma forte relação entre a habilidade de explicar mensagens não-literais, como piadas, ironias, sarcasmo, e a dificuldade que estes indivíduos demonstram na representação dos estados mentais deles próprios e dos outros

Conclusão: Assim sendo, a dignidade e o bem-estar da pessoa com deficiência se fazem essenciais para que possa viver da melhor maneira possível. E por meio de institutos e vias assistenciais para auxiliar a pessoa com deficiência, cada vez mais se poderá mitigar as dificuldades que situações transitórias ou permanentes assolam essa minoria.

\section{Referências}

ANTONIO, Thays. A interdição dos direitos civis, frente ao estatuto da pessoa com deficiência. Disponivel em: Acesso em: 11 mai. 2020.

BRASIL, Lei no 13.977 de 08 de janeiro de 2020. Institui a Carteira de Identificação da Pessoa com Transtorno do Espectro Autista (Ciptea), e dá outras providências. Disponível em: http://www.planalto.gov.br/ccivil_03/_Ato20192022/2020/Lei/L13977.htm Acesso em: 25 jul. 2020.

LYONS, Viktorya; FITZGERALD, Michael. Humor in Autism and Asperger Syndrome. Journal of Autism and Developmental Disorders, Vol. 34, No. 5, Outubro 2004. Disponivel em: Acesso em: 27 jul. 2020.

TARTUCE, Flávio. É o fim da interdição? Artigo de Pablo Stolze Gagliano. Disponivel em: Acesso em: 13 jun. 2020. TEDESCO, Raquel. Austimo, curatela e tomada de decisão apoiada. Disponivel em: Acesso em: 10 jul. 2020. 


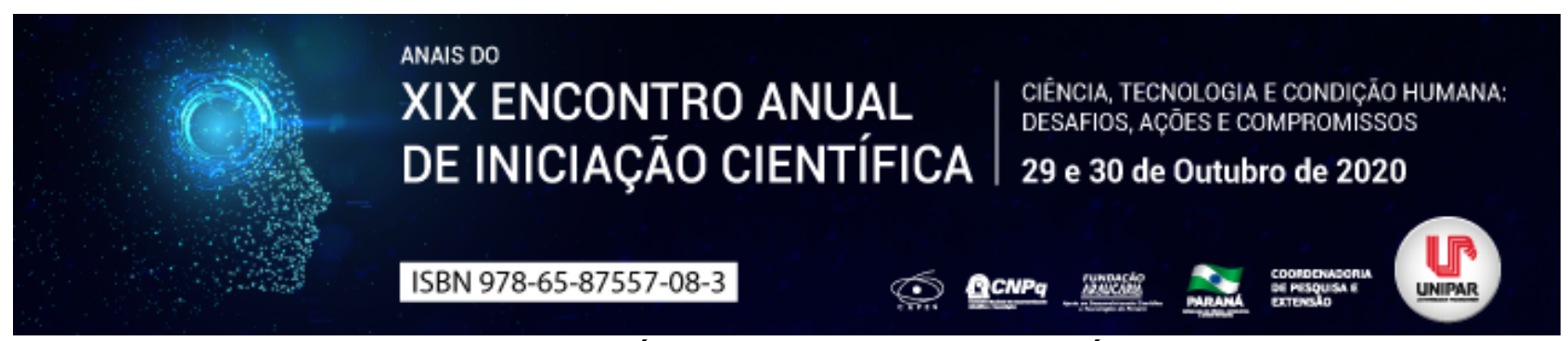

O ITCMD PELA DISCIPLINA DO INVENTÁRIO E ARROLAMENTO NO CÓDIGO DE PROCESSO CIVIL

\title{
${ }^{1}$ VIRGINIA TELLES SCHIAVO WRUBEL, ${ }^{2}$ BRUNO SMOLAREK DIAS
}

\author{
${ }^{1}$ Acadêmico do PIC/UNIPAR \\ ${ }^{1}$ Docente da UNIPAR
}

Introdução: O Novo Código de Processo Civil, ao regular o procedimento especial do inventário e da partilha, angariou importante inovação no tratamento do ITCMD o imposto de transmissão causa mortis e doação inclusive repercutindo na regra esposada pelo art. 192, do Código Tributário Nacional. Por outra parte, erro material, constante do $\S 4^{\circ}$ do art. 664 do diploma processual de 2015 pode dificultar o devido discernimento das disposições que tangem ao arrolamento comum.

Objetivo: Examinar o tratamento do ITCMD na disciplina do arrolamento segundo o CPC/15 e a relação de suas disposições com o que dispõe o Código Tributário Brasileiro, através de pesquisa de revisão de doutrina e legislação.

Resultados: O Estado, instituição humana de uma ordem jurídica soberana, tem por fim o bem comum do povo de um determinado território (DALLARI, 1995). Mormente sob forma de um Estado Social, irá realizar uma série de atividades visando à concreção de direitos fundamentais, como a saúde, a educação, a segurança, etc. Para tanto, disporá daquilo que lhe é devotado pela sociedade, na forma de tributos, enquanto insumos para o funcionamento da máquina estatal e concreção dos seus últimos fins. Assim, a tributação é fenômeno provocado pelo Estado, sendo responsável por tornar factíveis as pretensões constitucionais para toda a sociedade (SANTOS, 2005). Especificamente, O ITCMD representa um imposto estadual, cujo fato gerador atine a uma transmissão de bens ou direitos, ocasionada por um falecimento ou por uma doação, tendo suas alíquotas máximas fixadas pelo Senado Federal. Compete ao ente estadual da situação do bem, relativamente a bens imóveis e respectivos direitos; ou, relativamente a bens móveis, títulos e créditos, ao ente estadual onde se processar o inventário ou arrolamento (causa mortis) ou onde for localizado o domicílio do doador (doação) (BRASIL, 1988). Tal imposto se apresenta comumente nos processos de arrolamentos e inventários, já que neles está implicada a transmissão de bens e direitos por via sucessória. O inventário trata-se da modalidade de procedimento mais complexa, prevista do art. 610 ao art. 658 do CPC, para as hipóteses em que há testamento, presença de pessoa incapaz, ou inexiste consenso entre os interessados. Nesses casos, conforme dispõe o art. 654, o pagamento do imposto de transmissão é exigência do curso do processo, uma vez definida a partilha, como requisito à prolação da sentença (BRASIL, 2015). Por outra parte, no arrolamento procedimento simplificado constante do art. 658 e ss., dividido em comum e sumário tudo o que se refere ao ITCMD corre exclusivamente na esfera administrativa, quando já encerrado o processo judicial, não existindo vinculação da sentença ao pagamento do imposto, diferentemente do regime anterior disposto pelo art. 1.031, § $2^{\circ}$, do CPC/73 (COMEL, 2017). Quanto a essa desvinculação, questionou-se eventual conflito com o art. 192 do CTN, ao dispor que: Nenhuma sentença de julgamento de partilha ou adjudicação será proferida sem prova da quitação de todos os tributos relativos aos bens do espólio, ou às suas rendas (BRASIL, 1966). Porém, segundo resume Comel (2017), os referidos tributos relativos aos bens do espólio têm como fato gerador a propriedade, não sendo esse o caso do ITCMD. Ademais, trata o art. 192 de matéria de conteúdo residual, não reservada à lei complementar, o que, de todas as maneiras, faria preponderar a disposição do CPC. Sobre o arrolamento, ainda, aventou-se equívoco na remissão ordenada pelo art. 664 , $\S 4^{\circ}$, ao art. 672 , eis que este último não guarda funcionalidade com seu remissivo, sendo, por uma interpretação integrativa, forçoso reconhecer que o objetivo do legislador era o endereçamento para o art. 662 (COMEL, 2017).

Conclusão: A tributação permite ao Estado materializar prestações de direitos fundamentais, sendo o ITCMD um imposto de caráter estadual, amplamente visualizado em processos de arrolamento e inventário. Consoante nova sistemática do CPC/15, continua a sentença, no procedimento mais complexo, dependente da manifestação do Fisco no sentido de se haver cumprido a exigência do causa mortis. Já nos arrolamentos, a questão correrá após o processo, na via administrativa. Por sua vez, o art. 192 do CTN não conflita com as novas disposições processuais.

\section{Referências}

BRASIL. Lei n 13.105, de 16 de março de 2015. Código de Processo Civil. Diário Oficial da União, Brasília, DF, ano CLII, n.51, p. 1-51, 17 mar.2015.

BRASIL. Lei $n^{0}$ 5.172, de 25 de outubro de 1966. Dispõe sobre o Sistema Tributário Nacional e institui normas gerais de direito tributário aplicáveis à União, Estados e Municípios. Diário Oficial da União, DF, ano CM, n. 244, p. 1 - 9, 25 out. 1966.

BRASIL. Constituição da República Federativa do Brasil, de 1988. Diário Oficial da União, Brasília, DF, ano CXXVI, n. 191, 5 out. 1988.

COMEL, Denise Damo. Imposto de transmissão causa mortis no arrolamento. Revista de processo, v. 42, n. 268, p. 475-492, 
jun. 2017.

DALLARI, Dalmo de Abreu. Elementos de Teoria Geral do Estado. São Paulo: Saraiva, 1995.

SANTOS, Nélida Cristina dos. Breves Considerações a respeito do Sistema Constitucional Tributário Brasileiro. Revista de Direito Constitucional e Internacional, v. 51, p. 188-198, abr./jun. 2005.

Coordenadoria de Pesquisa e Extensão - COPEX

Departamento de Editoraçāo e Divulgaçāo Científica - DEDIC 


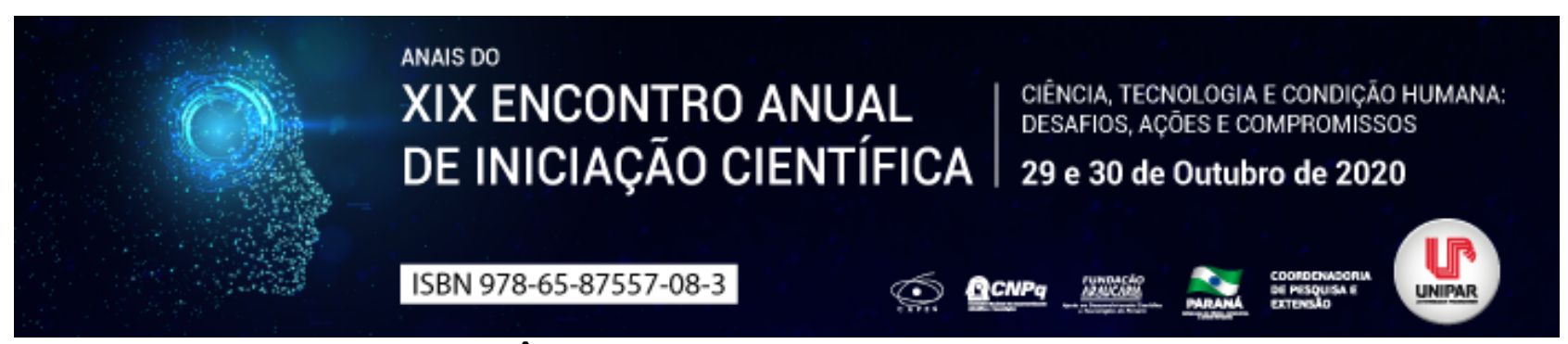

O ESTUDO DA IMPORTÂNCIA DO MARKETING PESSOAL NA VIDA PROFISSIONAL

\author{
${ }^{1}$ HELOISA ANDREIA AZARIAS, ${ }^{2}$ ANA CAROLINA DOMINGUES DE SOUZA, ${ }^{3}$ CAROLINE MESSIAS DE ANDRADE, ${ }^{4}$ DANIELY \\ DA SILVA CARMAZIN, ${ }^{5}$ HELOISY GABRIELY FARIA DA CUNHA, ${ }^{6}$ ANA PAULA DE LIMA DA SILVA
}

\footnotetext{
${ }^{1}$ Acadêmica do Curso de Administração da UNIPAR

${ }^{1}$ Acadêmica do Curso de Administração da UNIPAR

${ }^{2}$ Acadêmica do Curso de Administração da UNIPAR

${ }^{3}$ Acadêmica do Curso de Administração da UNIPAR

${ }^{4}$ Acadêmica do Curso de Administração da UNIPAR

${ }^{5}$ Docente da UNIPAR
}

Introdução: Com a forte concorrência no mercado de trabalho nos dias atuais, sobressair-se é fundamental, por isso, o conhecimento sobre o marketing pessoal é de extrema importância na vida profissional. Desse modo, é imprescindível que as pessoas tomem cuidados diante das oportunidades e ambiente de trabalho. Esses cuidados envolvem além da apresentação pessoal, como ela irá desenvolver a sua comunicação, seu relacionamento interpessoal, além de motivação, liderança, aprendizagem e, sobretudo, sua criatividade e poder de inovação no ambiente de trabalho.

Objetivo: Descrever a importância do marketing pessoal para a obtenção de sucesso na vida profissional.

Desenvolvimento: De acordo com Ritossa (2012, p. 36), o estudo do marketing pessoal tende [...] em vez de vendermos um objeto, vendemos a nós próprios. . Destarte, esse estudo sobre marketing pessoal é baseado em como promover-se, assim como se promove um produto, para tanto, é primordial o autoconhecimento para que, desse modo, possa-se alcançar com mais facilidade, a inserção no mercado de trabalho ou ainda de novas oportunidades na carreira. Ciletti (2014, p. 61) afirma que Ter autoconhecimento significa entender os vários fatores que modelam sua personalidade. O autoconhecimento pode ajudá-lo em muitas áreas de sua vida. . Assim, percebe-se que, não é apenas falar de si mesmo, mas sim, saber usar seus traços de personalidade e interesses, juntamente, com uma ótima comunicação a seu favor, com o intuito de causar uma boa impressão em sua apresentação pessoal. Ainda, segundo Ritossa (2012), são muitas as exigências em relação às competências dos funcionários nas empresas, tal como, liderança, comunicação, relacionamento interpessoal, motivação e negociação. Uma vez que, o funcionário está motivado, consequentemente, será mais criativo e aumentará a chance de inovar, juntamente, com esses fatores pode-se ainda acarretar um bom comportamento, de maneira que seu relacionamento interpessoal seja desenvolvido naturalmente sem nenhuma pressão. Logo, tudo isso só será possível se tiver um bom líder, pois, a liderança é capaz de engajar as pessoas a fazerem algo sem necessariamente o uso do poder, e uma boa liderança envolve boa comunicação e relacionamento interpessoal eficaz, essa combinação faz com que possa ter mais seguidores. Assim, percebe-se que o marketing pessoal não é apenas um floreio , ou seja, não é apenas uma preocupação com a imagem, como a forma que se está vestido. O marketing pessoal vai muito além, visto que, de nada adianta uma embalagem bonita se não há conteúdo que permita a prosperidade e crescimento no ambiente de trabalho. Enfim, em todas as áreas do conhecimento humano há uma constante inovação. Deixar de acompanhá-las é um grande risco à sua carreira que você, simplesmente, não pode correr. Por isso, continue aprendendo (BORDIN, 2013 p. 132). Portanto, torna-se necessário sempre estar em busca de um novo aprendizado, a atualização dos conhecimentos na área de atuação é imprescindível para que o indivíduo/profissional continue sendo um produto desejado pelo mercado de trabalho, e isso engloba ainda, um autoaperfeiçoamento, dado que, esse progresso no marketing pessoal só será possível se todos esses elementos forem desenvolvidos de forma adequada.

Conclusão: Diante do exposto é possível compreender que marketing pessoal é uma ferramenta fundamental para a obtenção de sucesso na vida profissional. Cabe ressaltar que, a partir do momento em que o indivíduo se torna parte da empresa, é imprescindível que ele coloque seus esforços e conhecimentos adquiridos, também pelo marketing pessoal, a favor do crescimento dos demais integrantes da equipe, e, consequentemente da empesa. Desta forma, há desenvolvimento tanto organizacional como individual, acontecendo assim o ganha-ganha .

\title{
Referências
}

BORDIN, Sady. Marketing pessoal: dez etapas para o sucesso. Rio de Janeiro: Best Seller, 2013.

CILETTI, Dorene. Marketing pessoal. São Paulo: Cengage Learning, 2014.

RITOSSA, Cláudia Mônica. Marketing pessoal: quando o produto é você. Curitiba: InterSaberes, 2012. 
Coordenadoria de Pesquisa e Extensão - COPEX

Departamento de Editoraçāo e Divulgaçāo Científica - DEDIC 


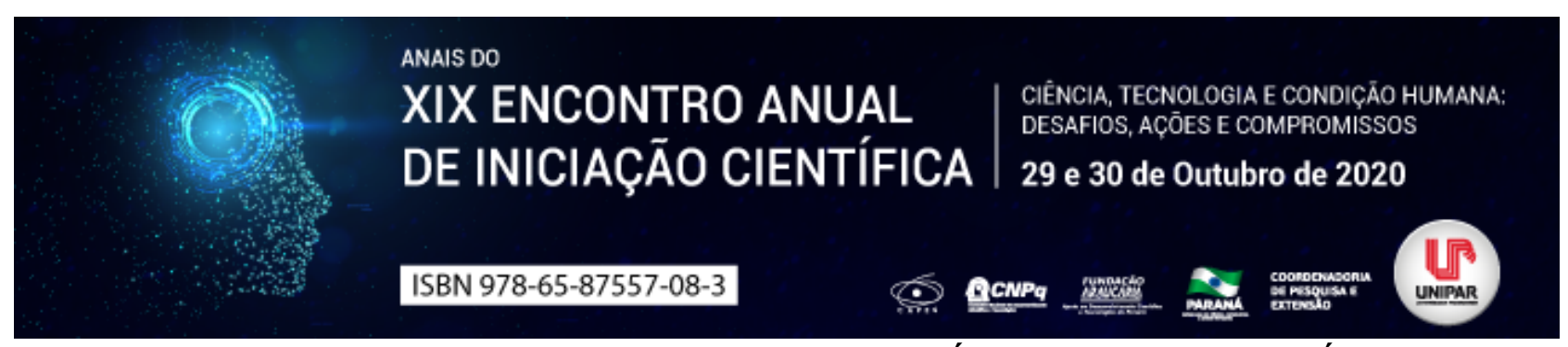

REGIMES ADUANEIROS ESPECIAIS: VANTAGENS ALÉM DE GANHOS TRIBUTÁRIOS

\title{
${ }^{1}$ DENISE CRISTINA DA SILVA, ${ }^{2}$ JOSE LUIZ BORSATTO JUNIOR
}

\author{
${ }^{1}$ Acadêmica do Curso de Tecnologia em Comércio Exterior Pesquisadora PIC Universidade Paranaense \\ ${ }^{1}$ Docente da UNIPAR
}

Introdução: Os regimes aduaneiros especiais são oferecidos pelo governo federal ao comércio exterior como incentivos fiscais para transações internacionais, sendo subsídios à exportação. Os regimes possuem uma série de procedimentos fiscais caracterizando-os conforme a finalidade de cada um (Vasquez, 2009). A Receita Federal do Brasil (RFB) permite aos importadores e exportadores benefícios de suspensão ou isenção de tributos na entrada ou na saída de mercadorias do território aduaneiro brasileiro, através de alguns desses regimes. (MDIC, 2016a).

Objetivo: Descrever e comparar os regimes de Drawback de Isenção e Recof Sped.

Desenvolvimento: O Drawback é um dos regimes especiais mais antigos, instituído em 1966 pelo Decreto de Lei nº 37 , de 21/11/66. Consiste na suspensão ou eliminação de tributos incidentes sobre insumos importados de produtos destinados a exportação. Isso reduz os custos e aumenta a competitividade de produtos exportáveis no mercado internacional, tornando-se assim um incentivo importante; na média dos últimos quatro anos, correspondeu a 29\% de todo benefício fiscal concedido pelo governo federal. Existem três modalidades de drawback: i) isenção reposição em quantidade e qualidade equivalente de insumos anteriormente importados com pagamentos de tributos e foram utilizados na industrialização de produtos exportados nos últimos 2 anos; ii) suspensão dos tributos incidentes na importação de mercadoria a ser utilizada na industrialização de produto que deve ser exportado; iii) restituição de tributos pagos na importação de insumo importado utilizado em produto exportado, praticamente não utilizado, sendo basicamente a modalidade isenção e suspensão (RFB, 2020). Já o Regime Aduaneiro Especial de Entreposto Industrial sob Controle Aduaneiro Informatizado (Recof) abrange um número maior de empresas exportadoras e facilita reduções tributárias e de custos em todo processo de exportação e possui dois formatos: Recof e Recof Sped. Entretanto, somente 62 empresas estão habilitadas ao Recof, e destas mais de 30\% foram habilitadas entre 2019 e 2020 . O Recof permite importar ou adquirir mercadorias no mercado interno, com suspensão do pagamento de tributos federais e, em alguns casos, estaduais para industrialização de bens destinados a exportação, ou comercializados no mercado interno. Já o Recof-Sped traz algumas facilidades no processo de habilitação, como a não obrigatoriedade de patrimônio líquido mínimo e a não exigência de sistema informatizado de controle do regime. No entanto, exigia um percentual maior do volume de exportações em relação ao montante das importações realizadas. Embora os dois formatos fossem similares, se distanciavam nos requisitos de manutenção e habilitação. Contudo, com as alterações promovidas pela IN 1.904/19, a RFB praticamente igualou os regimes em termos de requisitos para habilitação e manutenção. Ambos isentam os mesmos tributos: Imposto de Importação, Imposto sobre produto industrializado, PIS COFINS e AFRMM (Adicional ao Frete para Renovação da Marinha Mercante). Embora os dois regimes sejam fiscalizados pelas RFB eles diferem em relação ao controle: enquanto o Recof é analisado pela RFB através de formulários, o Drawback é feito via Ministério do Desenvolvimento, Indústria e Comércio (MDCl) através de ato concessório. Com isso, o Drawback vale por um ano, podendo ser prorrogado; já no Recof Sped o controle ocorre durante todo o processo desde a entrada da mercadoria até sua saída, de modo sistematizado. Outro ponto diferente é que no Drawback isenção é possível exportar um produto que teve tributação normal na entrada e comprar um novo insumo em quantidade equivalente com isenção, em relação ao Recof Speed o processo é o inverso e a obrigatoriedade é de exportar 50\%. As vantagens desses dois regimes são inúmeras, com a redução da carga tributária há um melhor desenvolvimento econômico e financeiro, ao diminuir o desembolso no pagamento de tributos, a empresa consegue aumentar seu capital de giro. (Dallacorte e Zeni, 2015). Com sua aplicação há também uma expansão de mercado com a entrada de mais produtos no país, melhorando a competitividade interna e externa; melhorando inclusive no desenvolvimento econômico com a entrada de divisas. Do ponto de vista administrativo e estratégico nem sempre os regimes serão vantajosos para todo dia de empresa, será necessário avaliar fatores internos e externos. (Moori, et al 2011). Além disso, a operação pode sofrer grandes oscilações das taxas de cambio, e ter custos onerosos em virtude da atuação ineficiente dos órgãos públicos podem ocasionar lentidões burocráticas, elevação do custo e outros problemas operacionais podem inviabilizar o processo.

Conclusão: Os regimes aduaneiros são importantes ferramentas estratégicas para a estratégia do negócio, tanto o drawback quanto o Recof apresentam benefícios e particularidades específicas, podendo ser usados isoladamente ou em conjunto conforme os perfis e necessidades de cada empresa. Assim, além das vantagens tributárias a escolha desses regimes pode proporcionar vantagens financeiras, redução de custos e melhoria da competitividade de produtos nacionais.

\section{Referências}


BRASIL. Decreto-Lei $\mathbf{n}$. 37, de 18 de novembro de 1966. Dispõe sobre o imposto de importação, reorganiza os serviços aduaneiros e dá outras providências. Disponível em Acesso em jul.2020.

IN RFB 1.904/19 - IN - Instrução Normativa RECEITA FEDERAL DO BRASIL - RFB no 1.904 de 31.07.2019 D.O.U.: 01.08.2019 MINISTÉRIO DO DESENVOLVIMENTO, INDÚSTRIA E COMÉRCIO EXTERIOR, Tratamento Tributário na Importação. Acesso em jul. 2020.

MOORI, R; TATENAUTI , K.S.; GARDESANI, R. Regime aduaneiro do drawback em empresas de bens de capital Gestão \& Regionalidade, vol. 27, núm. 80, mayo-agosto, 2011, pp. 85-96 Universidade Municipal de São Caetano do Sul Sao Caetano do Sul, Brasil.

VAZQUEZ, José Lopes. Comércio Exterior Brasileiro. São Paulo: Atlas, 2009. 


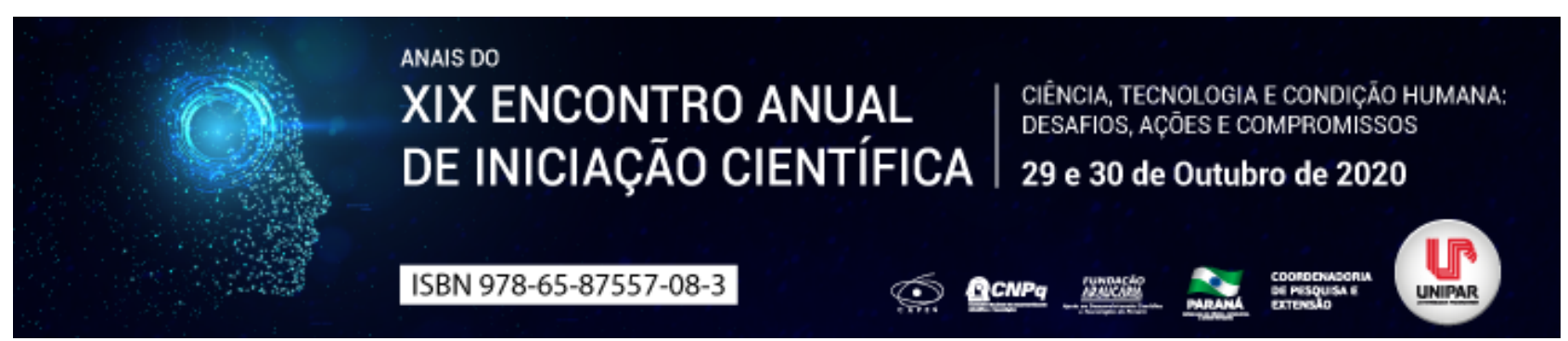

IMPORTÂNCIA DE TER UM BALANCED SCORECARD ALINHADO A GESTÃO DE COMPETÊNCIAS

\author{
${ }^{1}$ DENISE CRISTINA DA SILVA, ${ }^{2}$ ELIZANGELA MARIA MENEGASSI DE LIMA
}

\author{
${ }^{1}$ Acadêmica do Curso de Tecnologia em Secretariado Pesquisadora PIC Universidade Paranaense \\ ${ }^{1}$ Docente da UNIPAR
}

Introdução: Balanced Scorecard (BSC) é um modelo de gestão estratégica, que busca definir e desenhar o planejamento de forma integrada sob quatro perspectivas: financeira, clientes, processos e aprendizagem. A quarta perspectiva desenvolve medidas para orientar o aprendizado e crescimento organizacional, sendo ela a que mais provoca impacto na gestão por competências visto que orienta as lideranças sobre a gestão de talentos, competências e conhecimentos no que tange ao alcance das metas corporativas.

Objetivo: Elencar a importância e contribuição da utilização do modelo Balanced Scorecard (BSC) para a gestão por competências.

Desenvolvimento: Com o surgimento da gestão baseada na noção de competências e sua incorporação no ambiente organizacional, o termo competências adquire diferentes abordagens. (BRANDÃO; GUIMARÃES, 2001). As competências humanas ou profissionais podem ser como combinações sinérgicas de conhecimentos, habilidades e atitudes, expressas pelo desempenho profissional dentro de determinado contexto organizacional, que agregam valor a pessoas e organizações (CARBONE; BRANDÃO; LEITE, 2005). Um sistema de gestão de pessoas por competências é uma busca medir a contribuição dos indivíduos à organização segundo critérios de desempenho. As novas configurações de trabalho, o trabalho em equipe e a responsabilização na execução das estratégias, cada vez mais exigem novos conhecimentos, habilidades e atitudes dos indivíduos (MASCARENHAS, 2008). É preciso que compreendamos que as competências criam valor a longo prazo para os stakeholders da organização. Ao entendermos a importância do alinhamento e do desenvolvimento de competências à competitividade de uma organização, é preciso pensar de forma integrada, promovendo interações entre as pessoas e o intercâmbio entre os diversos tipos de conhecimentos (produção, marketingo, comercial, financeiro), promovendo a aprendizagem nos diversos níveis da organização (MASCARENHAS, 2008). Na instância corporativa e sob a forma de competência coletiva, a competência organizacional é associada aos elementos da estratégia competitiva da organização, tais como: missão, visão, valores e intenção estratégica (RUAS et al, 2005). As competências individuais podem ser relacionadas a um modelo que capacita as organizações a identificar as necessidades de conhecimentos, habilidades e atitudes para a execução da estratégia, analisar as lacunas entre as necessidades e o atual estado de prontidão dos empregados e desenvolver programas para fechar a lacuna entre demanda e disponibilidade. Sendo as funções estratégicas ocupadas por que são capazes de exercer o maior impacto sobre a melhoria desses processos internos mais estratégicos. As diferenças entre as especificações e as capacidades disponíveis constituem uma lacuna de competência que define a prontidão do capital humano de uma organização. A quarta perspectiva do BSC enfatiza a importância do alinhamento dos ativos intangíveis com a estratégia da organização. (KAPLAN; NORTON, 2004). Utilizar múltiplas fontes para as avaliações melhora a precisão na avaliação (EDWARDS; EWEN, 1996), visto que os vários feedbacks servem ao propósito de orientar o aprimoramento, a aprendizagem e o desenvolvimento (REIS, 2000). Nesse sentido, BSC é uma ferramenta imprescindível, pois alinham as competências individuais e coletivas as necessidades da organização com seus valores, proporcionando uma visão mais integrada do RH com as demais partes da organização. Para que o BSC seja significativo, ele deve conter apenas as medidas mais importantes para o objetivo e o plano estratégico da empresa; deve focar os resultados: medidas para gestão e retenção de talentos e produtividade são bastante significativas em relação ao alinhamento com o planejamento estratégico da empresa, visto da importância de utilizar as melhores competências direcionadas para obter o melhor resultado possível; validade: o sistema de medição deve conter métricas compreensíveis, alinhadas ao objetivo e suportadas com dados sólidos. Quando BSC é desenvolvido com sucesso, o quadro de avaliação dos profissionais que fazem a gestão por competências é extremamente útil ao alinhamento de RH com o plano estratégico da empresa. A chave para o sucesso é um planejamento cuidadoso e execução.

Conclusão: Ao vincular os objetivos e o desempenho claramente definidos, o BSC poderá orientar atividades que irão apoiar os objetivos da empresa. Isto também demonstra o valor estratégico do $\mathrm{RH}$, definindo e medindo sua contribuição em termos concretos e claramente entendidos

\title{
Referências
}

BRANDÃO, Hugo P.; GUIMARÃES, Tomás A gestão de competências e gestão de desempenho: tecnologias distintas ou instrumentos de um mesmo constructo? Revista de Administração de Empresas, v. 41, n. 1, p. 8-15, 2001.

CARBONE, Pedro Paulo; BRANDÃO, Hugo Pena; LEITE, João Batista Diniz. Gestão por competências e gestão do 
conhecimento. Rio de Janeiro: FGV, 2005.

EDWARDS, Mark; EWEN, A. $360^{\circ}$ feedback: the powerful model for employee assessment and performance improvement. New York: AMA, 1996.

KAPLAN, Robert S.; NORTON, David P. A estratégia em ação: balanced scorecard. Rio de Janeiro: Campus, 1997 MASCARENHAS, André Ofenhejm, Gestão Estratégica de Pessoas, $1^{\text {a }}$ Edição, Editora Cengage, 2008.

REIS, Germano. Avaliação $\mathbf{3 6 0}$ graus. São Paulo: Atlas, 2000. RICHARDSON, Roberto J. et al. Pesquisa social: métodos e técnicas. São Paulo: 2000.

RUAS, Roberto et al. O conceito de competência de A a Z: análise e revisão nas principais publicações nacionais entre 2000 e 2004. In: ENANPAD, 29. Anais... Brasília: Anpad, 2005. 


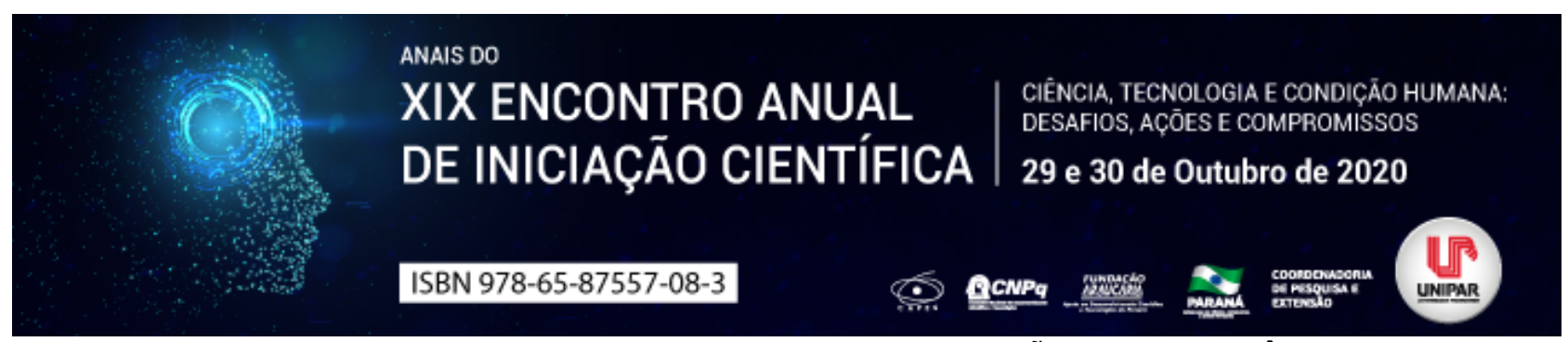

A RESPONSABILIDADE CIVIL GERADA POR FALHAS NA UTILIZAÇÃO DA INTELIGÊNCIA ARTIFICIAL

\author{
${ }^{1}$ FELIPE DE PAULA PINTO, ${ }^{2}$ ANGELICA GIOSA CANDIDO
}

\author{
${ }^{1}$ Acadêmico PIC/UNIPAR \\ ${ }^{1}$ Docente da UNIPAR
}

Introdução: A sociedade se encontra em constante evolução nos diversos aspectos existentes, em especial, nos digitais. O desenvolvimento tecnológico tem sido cada vez mais rápido e a inteligência artificial hoje é uma realidade muito presente nas cidades, nas casas, nos carros autônomos, nos aplicativos de celular, nos processos operacionais, nas plataformas governamentais, inclusive jurídicas. Contudo, tem-se identificado falhas em sua utilização, e, em razão disso, danos às pessoas e seus interesses levados a juízo. Portanto, sendo o direito um regulador social, quem deverá ser responsabilizado pelos danos decorrentes de falhas da Inteligência Artificial?

Objetivo: Analisar a responsabilidade civil determinada em razão das falhas causadas no uso da inteligência artificial.

Desenvolvimento: A ação que causa dano admite reparação no ordenamento jurídico. A responsabilidade civil consiste na efetivação da reparabilidade abstrata do dano em relação a um sujeito passivo de relação jurídica que se forma (PEREIRA, 1993, p. 11). Muitas dessas ações tem sido causadas pela influência da tecnologia na vida das pessoas. Considera-se a inteligência artificial como um ramo da ciência da computação que trabalha na automação do comportamento inteligente (LUGER, 2004, p.24). Para configuração da responsabilidade por uma ação que venha causar um dano, faz-se necessário o nexo causal entre a conduta do agente e o resultado, conforme dita o Código Civil vigente (BRASIL, 2002. Art. 186). Portanto, demonstrada a relação de causalidade entre a falha da inteligência artificial e dano causado na vida das pessoas, admite-se responsabilização. Em uma análise no direito comparado, destaca-se a atuação da Europa. O Parlamento Europeu editou Resolução em 16 de fevereiro de 2017, a qual continha recomendações à Comissão sobre disposições de Direito Civil sobre Robótica. Destaca-se o parágrafo 49, com a seguinte redação: (...) a responsabilidade civil pelos danos causados por robôs constitui uma questão crucial (...) a fim de garantir o mesmo nível de eficácia, de transparência e de coerência na execução da segurança jurídica (...) (Resolução do Parlamento Europeu). No Brasil a inteligência artificial está fortemente presente no judiciário, auxiliando na tomada de decisões, busca de jurisprudências, precedentes, cálculos financeiros. É de suma importância que se tenha a proteção jurídica adequada, para que não haja dano, e mais, para que não haja margem para injustiça. Atualmente não existe legislação especifica sobre a robótica no país, porém, em 2018 foi sancionado a Lei Geral de Proteção de Dados, com o objetivo de trazer mais segurança aos usuários de plataformas que colhem informações de caráter pessoal. A citada legislação trata do dever de reparar dano causado por falhas no tratamento de dados pessoais, sendo que o seu artigo 42 disciplina que: o controlador ou o operador que, em razão do exercício de atividade de tratamento de dados pessoais, causar a outrem dano patrimonial, moral, individual ou coletivo, em violação à legislação de proteção de dados pessoais, é obrigado a repará-lo (BRASIL, 2018). Tarcísio Teixeira e Vinicius Cheliga (2020, p. 74) entendem que o responsável por falhas operacionais e de segurança é o fabricante, uma vez que está presente nas fases de fabricação, desenvolvimento, aprendizagem e atualizações de software da IA. Contudo, o tema ainda está em estudo, uma vez que foi de entendimento do Tribunal de Justiça do Distrito Federal ao julgar uma ação de cobrança indevida, que não há o que se falar em responsabilização civil da IA, uma vez que a má-fé é inerente ao ser humano (BRASIL, TJDFT, 2018). Assim, a principal tendência é que a responsabilização dependerá do caso concreto, e, em determinados casos, poderá ser atribuída ao fabricante/desenvolvedor do sistema, e, em outros, à instituição em que a inteligência artificial está aplicada, ou em outros, a responsabilidade determinará apenas que seja sanado. Surge então o seguinte questionamento: quando as pessoas contratam serviços, pretendem que o mesmo se realizem a contento, certo? Também quando as pessoas buscam o judiciário, estão movidas pelo mesmo propósito. A segurança de uma decisão judicial pode vir a ser abalada se esta, proferida com o auxílio de softwares, face a presença da inteligência artificial em todas as áreas, vier a falhar, e, por isso, causar um dano a direitos fundamentais levados a juízo.

Conclusão: Conclui-se, que no Ordenamento Jurídico Brasileiro, a análise da responsabilidade civil no campo da inteligência artificial ainda é precoce. Contudo, é certo que sua utilização, inclusive no judiciário, onde um mínimo erro pode acarretar consequências gravíssimas às partes, a inteligência artificial é constante e crescente. Por hora, o que se tem é que a responsabilização dependerá do caso concreto. A realidade é relativamente nova e o ordenamento tende a se adequar com as possíveis demandas, bem como, com as prováveis falhas.

\title{
Referências
}

BRASIL. Código Civil: . Acesso em: 25.08.2020.

Lei de Proteção de Dados: http://www.planalto.gov.br/ccivil_03/_ato2015-2018/2018/lei/L13709.htm. Acesso em: 
25.08.2020.

TJ-DF 07150148120188070001 DF 0715014-81.2018.8.07.0001, Relator: EUSTÁQUIO DE CASTRO, Data de Julgamento: 14/03/2019, $8^{a}$ Turma Cível, Data de Publicação: Publicado no DJE : 06/05/2019 . Pág.: Sem Página Cadastrada. Disponível em https://www.tjdft.jus.br/. Acesso em: 25.08.2020.

Resolução do Parlamento Europeu, de 16 de fevereiro de 2017, que contém recomendações à Comissão sobre disposições de Direito Civil sobre Robótica. Disponível em: https://www.europarl.europa.eu/doceo/document/TA-8-2017-0051_PT.html. Acesso em: 25.08.2020.

LUGER, George F. Inteligência Artificial. 4. ed. Porto Alegre: Bookmann, 2004.

SILVA, Caio Mário Pereira. Instituições de direito civil. 3. ed. Rio de Janeiro: Forense, 1997.

TEIXEIRA, Tarcísio; CHELIGA, Vinicius. Inteligência Artificial, Aspectos Jurídicos. 2. ed. Salvador: Editora Juspodium, 2020.

Coordenadoria de Pesquisa e Extensão - COPEX

Departamento de Editoraçāo e Divulgaçāo Científica - DEDIC 


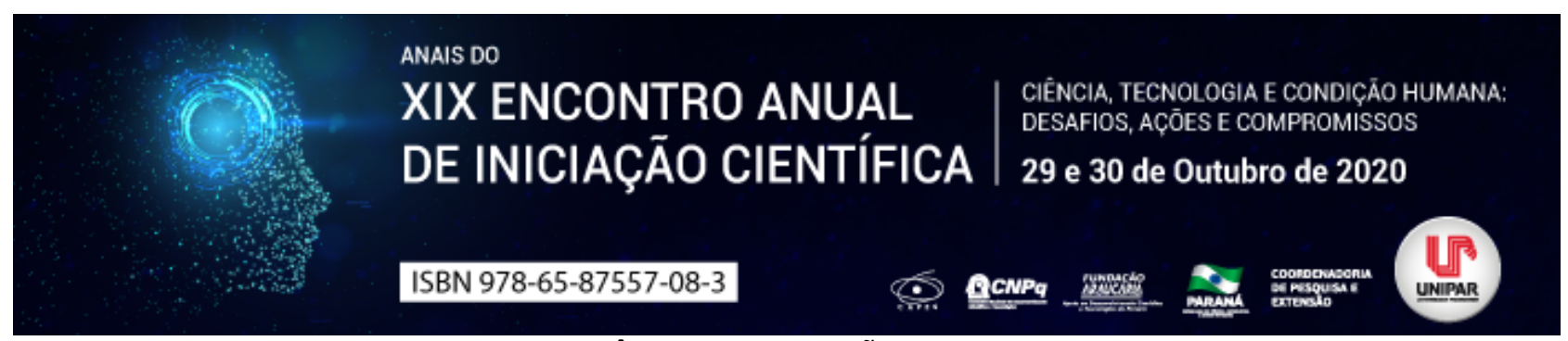

A IMPORTÂNCIA DA GESTÃO DE PESSOAS

\section{${ }^{1}$ NATHIELY RIBEIRO DA SILVA, ${ }^{2}$ GISELE DOS SANTOS COGO, ${ }^{3}$ ELIZANGELA MARIA MENEGASSI DE LIMA}

${ }^{1}$ Acadêmica do curso de Administração da UNIPAR

${ }^{1}$ Acadêmica do Curso de AdministraÃß̃̃̃o da UNIPAR

${ }^{2}$ Docente da UNIPAR

Introdução: Em primeiro plano, tendo como intuito desenvolver mutuamente as relações estabelecidas, bem como a satisfação mútua dos objetivos da organização e do projeto pessoal dos profissionais, a gestão de pessoas conduz o bom direcionamento das organizações, possibilitando através do incentivo e da capacitação dos funcionários a obtenção de bons resultados, além de uma alta produtividade. Em vista disso, a gestão de pessoas torná-se de suma importância para o sucesso das organizações na atualidade.

Objetivo: Conceituar a gestão de pessoas e sua importância para as empresas na atualidade

Desenvolvimento: A gestão de pessoas é um conjunto de ações que tem como objetivo desenvolver o capital humano, que por sua vez é a capacidade de produzir um trabalho de valor econômico. Nesse sentido, de acordo com Kops, Silva e Romero (2013, p.16) para atingir a transformação e a eficácia organizacional em suas diversas dimensões, é necessário desenvolver o capital humano , se tornando essencial para o engajamento e produtividade dos colaboradores. Dessa forma, a gestão de pessoas deve ponderar a capacidade técnica de cada funcionário com fatores subjetivos, a fim de investir nos talentos certos. Ademais, a empresa que capta, ambienta, desenvolve, monitora e mantém os colaboradores dentro da organização, isto é, gerencia as pessoas inseridas no ambiente de trabalho de maneira eficaz, lidando com seus conseguintes problemas, tendo, além disso, os objetivos organizacionais e profissionais alinhados, terá significativos benefícios. (STADLER; PAMPOLINI, 2014).

Nesse viés, é importante destacar que investimentos como, treinamentos periódicos, que focam no desenvolvimento individual e em grupo, como também condutas que evidenciam a valorização do trabalho dos colaboradores através de premiações por metas alcançadas, são substanciais para a obtenção de um gerenciamento de alta performance, bem como para a motivação por parte dos funcionários. Dentro desse contexto, a motivação, por conduzir um melhor desempenho por parte dos indivíduos inseridos no ambiente organizacional, faz com que a empresa fique à frente de seus concorrentes, adquirindo uma certa vantagem competitiva, uma vez que, como mencionado por Dutra (2002, p. 45) a organização conseguirá alavancar sua competitividade por meio das pessoas .

Conclusão: Portanto, é indubitável que para o sucesso das organizações contemporâneas, é imprescindível que as empresas invistam nos colaboradores para a implementação de uma gestão de pessoas eficaz, uma vez que, como apresentado, os lucros de uma determinada empresa são, em parte, derivados de um bom gerenciamento de pessoas

\section{Referências}

KOPS, Lúcia Maria; COSTA, Selma França da ; ROMERO, Sonia Mara Thater. Gestão de pessoas: conceitos e estratégias. Intersaberes, 2013.

STADLER, Adriano; PAMPOLINI, Cláudia Patricia Garcia. Gestão de pessoas: ferramentas estratégicas de competitividade. Intersaberes, 2014.

DUTRA, Joel Souza. Gestão de pessoas: modelo, processos, tendências e perspectivas. Atlas, 2002.

Coordenadoria de Pesquisa e Extensão - COPEX

Departamento de Editoraçāo e Divulgaçāo Científica - DEDIC 


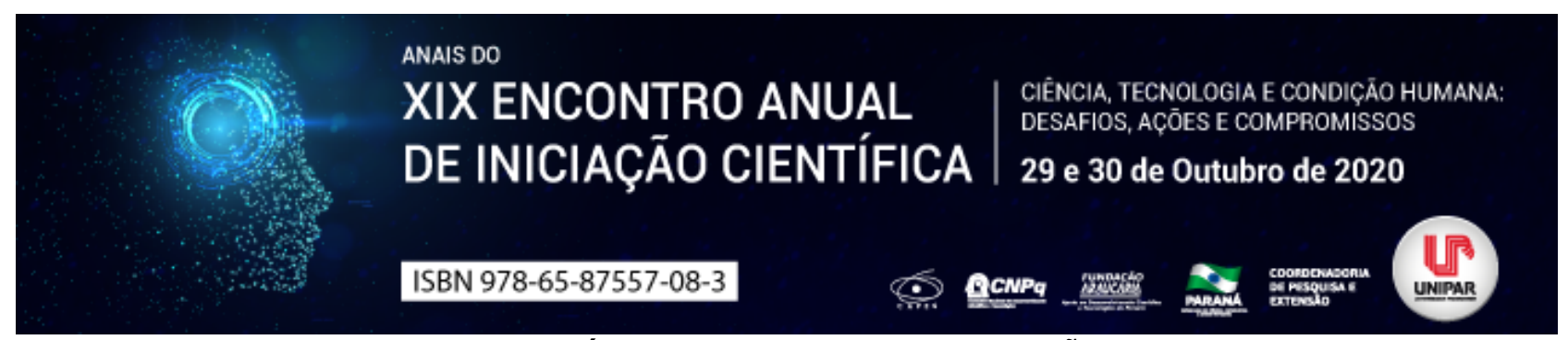

A POSTURA ATIVISTA DO PODER JUDICIÁRIO FRENTE A CONCRETIZAÇÃO DOS DIREITOS FUNDAMENTAIS

\title{
${ }^{1}$ DELMAR VIEIRA, ${ }^{2}$ JONATAS LUIZ MOREIRA DE PAULA,${ }^{3}$ ALEXANDRE MAGNO AUGUSTO MOREIRA
}

\author{
${ }^{1}$ Acadêmico PIC/UNIPAR \\ ${ }^{1}$ Docente da UNIPAR \\ ${ }^{2}$ Docente da UNIPAR
}

Introdução: O presente trabalho pretende abordar o ativismo judicial, partindo da ideia da tripartição dos poderes do Estado, sob o aspecto de uma atuação mais proativa do Poder Judiciário. Neste contexto, sob um método dedutivo de pesquisa, em análise de cunho bibliográfico, pretende-se compreender o instituto do ativismo judicial sob a perspectiva de concretização dos direitos fundamentais.

Objetivo: Contextualizar o Ativismo Judicial e analisá-lo frente a concretização dos direitos e garantias fundamentais.

Desenvolvimento: A convivência dos indivíduos em sociedade está baseada na criação de normas, as quais servem de alicerce para a organização da vivência social. Todavia, para tal, são necessárias instituições que garantam o respeito e o cumprimento ao ordenamento jurídico, garantindo, assim, a ordem social. Sob essa perspectiva, surge a base da noção dos poderes do Estado, bem como da separação dos poderes (FIGUEIREDO; GIBRAN, 2016, p.107). Todavia, o princípio da separação dos poderes se torna consagrado por Montesquieu, no que diz respeito a importância da tripartição dos poderes do Estado, concluindo que Tudo estaria perdido se o mesmo homem, ou o mesmo corpo dos principais, ou dos nobres, ou do povo exercesse os três poderes: o de fazer as leis, o de executar as resoluções públicas e o de julgar os crimes ou as querelas entre os particulares (MONTESQUIEU, 2000, p. 168). Neste contexto O pensamento de Montesquieu foi de fundamental importância, [...], consagrando a existência de três poderes distintos, com funções próprias a cada um e que devem agir harmonicamente para assegurar a liberdade política (FIGUEIREDO; GIBRAN, 2016, p. 109), razão pela qual, a Constituição da República Federativa do Brasil adotou a tripartição dos poderes em Legislativo, Executivo e Judiciário, nos termos do artigo $2^{\circ}$, garantindo a harmonia, bem como, a independência entre cada um (BRASIL, 1988). Entretanto, os Poderes Legislativo e Executivo não vêm cumprindo com o mandamento constitucional. Com isso, o Judiciário adentra na seara desses Poderes no afã de beneficiar a coletividade (GRANJA, 2014, p. 3465). Desta forma, ao assumir essa postura, o Poder Judiciário, [..], por vezes, é apontado como violador da competência que lhe é conferida pela Constituição, atuando, ora no âmbito de competência do Poder Executivo, ora no âmbito de competência do Legislativo, o que configura o famigerado ativismo judicial (MOREIRA, 2019, p.28). Nesse sentido A ideia de ativismo judicial está associada a uma participação mais ampla e intensa do Judiciário na concretização dos valores e fins constitucionais, com maior interferência no espaço de atuação dos outros dois Poderes (BARROSO, 2012, p. 25-26). Desta forma, o ativismo judicial representa a insuficiência do Estado em atender aos anseios da sua população, bem como em buscar a realização dos objetivos que lhe foram postos (FIGUEIREDO; GIBRAN, 2016, p. 115). Neste norte, [..] o ativismo pode ser conceituado como uma postura do magistrado que de modo proativo e expansivo vai além do que fora preconizado pelo legislador, potencializando o sentido e o alcance das normas jurídicas (ANDRADE, 2016, p. 126). À vista disso, surge o acirrado debate sobre as decisões ativistas do Poder Judiciário, especialmente do STF, onde supostamente ocorre interferência na competência dos demais poderes, e assim, a discussão que se põe é se tais decisões de cortes constitucionais violam o sistema de repartição de competências, interferindo na harmonia entre os poderes, ou se há apenas o exercício do resguardo das normas constitucionais (MOREIRA, 2019, p. 24). Por outro lado, o [...] maior receio é que o ativismo judicial corrompa a democracia e funde [..] uma juristocracia, exercida sob o falacioso argumento de ser apenas uma atividade técnica de interpretação normativa, natural à função jurisdicional contemporânea (ANDRADE, 2016, p. 135). Entretanto, diante das omissões dos outros poderes, o Judiciário atua sob o propósito de assegurar os direitos previstos na Constituição, o que não seria uma invasão na esfera dos Poderes Executivo e Legislativo, considerando que busca efetivar à

Suprema Lei , demandando ao Estado impender dos direitos sociais (GRANJA, 2014, p. 3484). Outrossim, hoje não há mais espaço para uma rígida divisão de poderes, considerando especialmente a complexidade das relações sociais e políticas, bem como as já consagradas garantias do indivíduo em relação ao Estado (MOREIRA, 2019, p. 29). Destarte, decisões ativistas do Judiciário estariam, nessa perspectiva, concretizando fins constitucionais, à proporção que, o intérprete final da Constituição é o Supremo Tribunal Federal. Seu papel é velar pelas regras do jogo democrático e pelos direitos fundamentais, [...] Portanto, a jurisdição constitucional bem exercida é antes uma garantia para a democracia do que um risco (BARROSO, 2012, p. 28).

Conclusão: Pelo exposto, conclui-se que não se pode olvidar que a tripartição dos Poderes é mecanismo fundamental para a organização do Estado. Todavia, a partir do momento em que os Poderes Legislativo e Executivo se quedam inertes aos anseios da população, cabe ao Poder Judiciário, como intérprete da Constituição, garantir que os direitos fundamentais sociais sejam concretizados. Neste norte, a atuação ativista não deve ser vista como uma violação as competências de cada um dos Poderes, 
mas sim, um mecanismo frente a demanda atual no tocante ao sistema de direitos e garantias sociais.

\section{Referências}

BARROSO, Luís Roberto. Judicialização, ativismo judicial e legitimidade democrática. (SYN) THESIS, v. 5, n. 1, p. 23-32, 2012. BRASIL. Constituição (1988). Constituição da República Federativa do Brasil de 08 de agosto de 1988.

ANDRADE, Fernando Gomes de. Da autolimitação ao ativismo judicial: um estudo acerca da releitura da teoria da separação dos poderes pelo poder judiciário brasileiro no Supremo Tribunal Federal. 2016. Tese (Doutorado em Direito) - Universidade de Lisboa, Faculdade de Direito, 2016. Disponível em: . Acesso em: jun. 2020.

FIGUEIREDO, Eduardo Fin; GIBRAN, Sandro Mansur. O ativismo judicial, o princípio da separação dos poderes e a ideia de democracia. Percurso, v. 1, n. 18, p. 104-124, 2016.

GRANJA, Cícero Alexandre. O ativismo judicial no Brasil como mecanismo para concretizar direitos fundamentais sociais, RIDB Revista do Instituto do Direito Brasileiro Faculdade de Direito da Universidade de Lisboa, Lisboa, Ano 3, $n^{\circ} 5$ p.3463-3490, 2014.

MONTESQUIEU, Charles de Secondat, Baron de. O espírito das leis. apresentação Renati Janine Ribeiro; tradução Cristina Murachco, 2.ed. São Paulo, Martins Fontes, 2000.

MOREIRA, João Victor Duarte. Jurisdição constitucional e equilíbrio entre poderes: uma análise da crise institucional brasileira à luz da jurisprudência do supremo tribunal federal. 2019. 100 f.: Dissertação (Mestrado em Direito) - Faculdade de Direito, Programa de Pós-Graduação em Direito, Universidade Federal do Ceará, Fortaleza, 2019. Disponível em: http://www.repositorio.ufc.br/handle/riufc/42111. Acesso em: abr. 2020. 


\section{ENCONTRO ANUAL | CIÊNCIA, TECNOLOGIA E CONDIC̄ĀO HUMANA:}

DE INICIAÇÃO CIENTÍFICA

A AUTODECLARAÇÃO NA CONVENÇÃO №169 DA ORGANIZAÇÃO INTERNACIONAL DO TRABALHO (OIT)

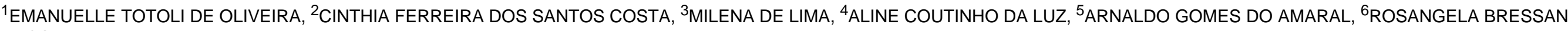
BUOSI

${ }^{1}$ Acadêmica do Curso de Pedagogia da UNIPAR - PIC

${ }^{1}$ Acadêmica do Curso de Pedagogia da UNIPAR - PIC

${ }^{2}$ Acadêmica do Curso de Engenharia Civil da UNIPAR - PIC

${ }^{3}$ Acadêmica do Curso de Engenharia Civil da UNIPAR - PIC

${ }^{4}$ Docente da UNIPAR

${ }^{5}$ Docente da UNIPAR

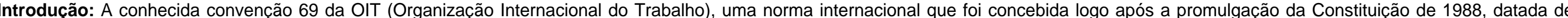

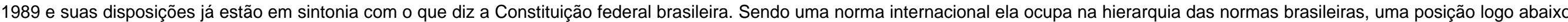
da Constituição federal, ou seja, é um importante instrumento dos polos, tratando de vários aspectos da vida e da comunidade indígena.

Objetivo: Compreender a autodeclaração negra ou indígena como conquista e orgulho de um povo.

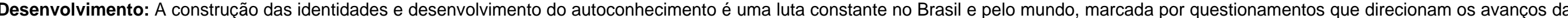

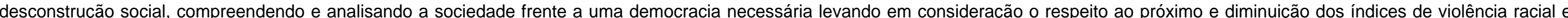

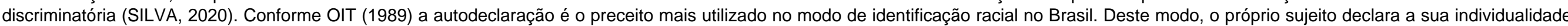

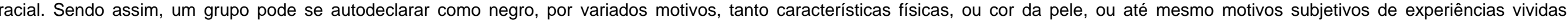

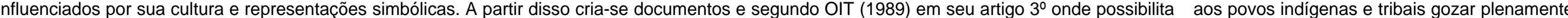

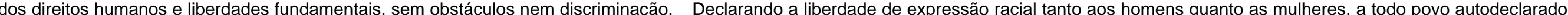

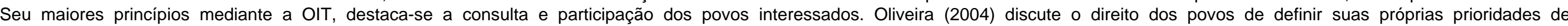

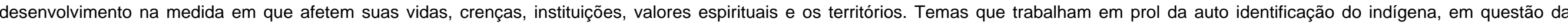
identidade cultural.

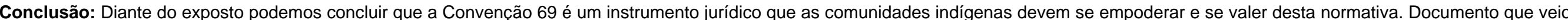

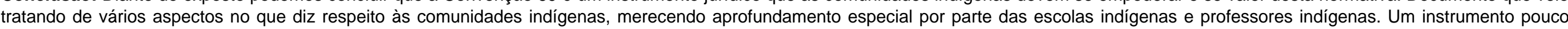
utilizado mas que detém grande importância e grande fundamento no ordenamento jurídico brasileiro.

\section{Referências}

OIT.

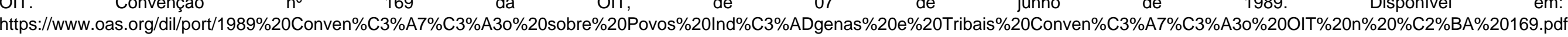
Acesso em 26. ago.2020.

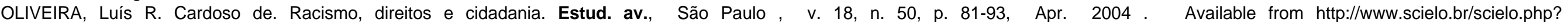
script=sci arttext\&pid=S0103-40142004000100009\&lng=en\&nrm=iso>. access on 26 Aug. 2020. https://doi.org/10.1590/S0103-40142004000100009.

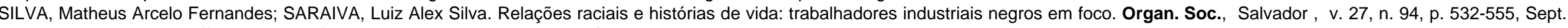
2020. Available from http://www.scielo.br/scielo.php?script=sci_arttext\&pid=S1984-92302020000300532\&lng=en\&nrm=iso>. access on 26 Aug. 2020. Epub Aug 10, 2020. 


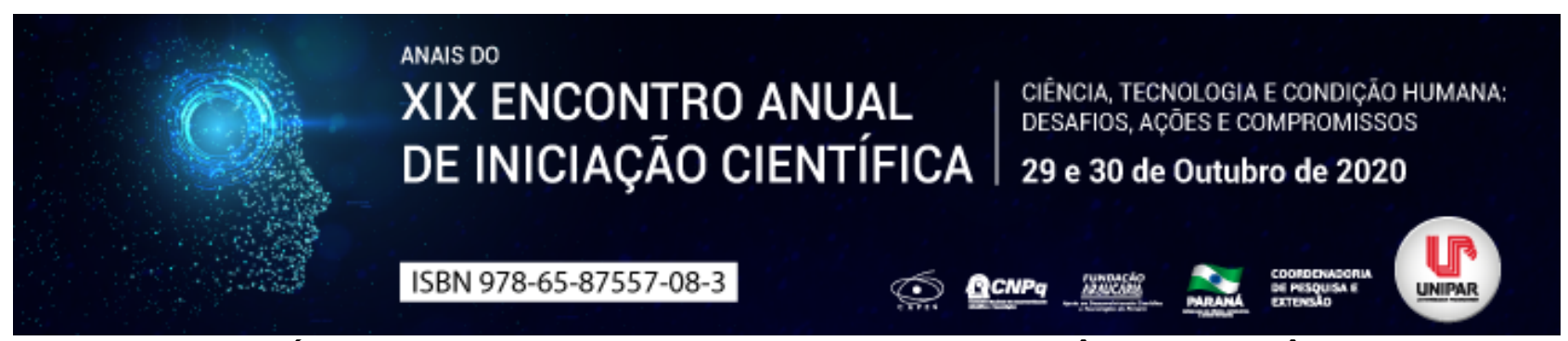

PRINCÍPIO DA FUNGIBILIDADE ENTRE A TUTELA DE URGÊNCIA E EVIDÊNCIA

\title{
${ }^{1}$ THIAGO MATTOS DE OLIVEIRA, ${ }^{2}$ PEDRO HENRIQUE MARANGONI, ${ }^{3}$ CELSO HIROSHI IOCOHAMA
}

\author{
${ }^{1}$ Acadêmico Mestrado Unipar \\ ${ }^{1}$ Acadêmico Mestrado Unipar \\ ${ }^{2}$ Docente da Graduação em Direito e do Programa de Mestrado em Direito Processual e Cidadania da UNIPAR
}

Introdução: Os institutos da tutela de urgência e evidência possuem características distintas, entretanto, almejam a mesma finalidade. Por tal razão, ainda que um instituto pleiteado no caso concreto não possua um conteúdo probatório que atenda perfeitamente a seus requisitos, poderá o Juízo, aplicar o outro, desde que satisfaça suas condições, sem qualquer prejuízo processual.

Objetivo: Analisar a possibilidade jurídica, por meio de uma visão instrumental, da aplicação do princípio da fungibilidade entre o instituto da tutela de urgência e evidência.

Desenvolvimento: Ainda que a aplicação do princípio da fungibilidade não gere dúvidas entre as tutelas provisórias de natureza cautelar e antecipada, em razão do texto do parágrafo único do art.305, o qual dispõe que Caso entenda que o pedido a que se refere o caput tem natureza antecipada, o juiz observará o disposto no art. 303 , não há qualquer previsão normativa da sua aplicação entre a tutela de urgência e evidência. Entretanto, não há vedação legal, o que permite sua realização ser fundamentada por meio de princípios gerais do direito. Nesse sentido, Araújo (2016, p. 965) esclarece que O juiz deverá conhecer do pedido de tutela provisória, aplicando medida mais adequada ao caso concreto, em cumprimento ao disposto no art. $5^{\circ}, \mathrm{XXXV}$, da CF/1988, que confere caráter atípico quanto ao meio de implementação da tutela provisória . Logo, a fundamentação apresentada baseia-se tão somente em um princípio constitucional sob o prisma de uma interpretação extensiva. Certamente, a fungibilidade só ocorrerá quando satisfeito os requisitos do instituto a ser aplicado. O emprego da fungibilidade nessas situações resulta da instrumentalidade e economia processual, segundo Araújo (2016), trata-se de um poder-dever do Juízo apontar a direção, inclusive adaptando o procedimento de ofício, prática não recente no sistema processual, onde já havia sua aplicação no Código de Processo Civil de 1973 na conversão do procedimento sumário para ordinário, diante da ausência de qualquer prejuízo. Ademais, o Processo Civil que busca resultados não compactua com o formalismo no campo da tutela provisória, onde justamente busca-se uma tutela jurisdicional diferenciada em busca da otimização da prestação da tutela jurisdicional.

Conclusão: Assim, na hipótese de um requisito da tutela de urgência não se mostrar amplamente configurado, como o perigo da demora, ou até menos a ausência do risco de irreversibilidade, porém, com conteúdo probatório suficiente para evidência do direito, deverá o juízo aplicar o instituto da tutela de evidência.

\section{Referências}

ARAÚJO, Fábio Caldas. Curso de Processo Civil: Tomo I parte geral atualizado com a Lei 13.256/2016. São Paulo: Malheiros, 2016.

BRASIL. Constituição da República Federativa do Brasil de 1988 Disponível em: http://www.planalto.gov.br/ccivil_03/constituicao/constituicao.htm. Acesso em 20 jul. 2020.

BRASIL. Lei $\mathbf{n}^{\circ}$ 13.105, de 16 de março de 2015. Código de Processo Civil. Disponível em: http://www.planalto.gov.br/ccivil_03/_ato2015-2018/2015/lei//13105.htm. Acesso em Acesso em 20 jul. 2020. 


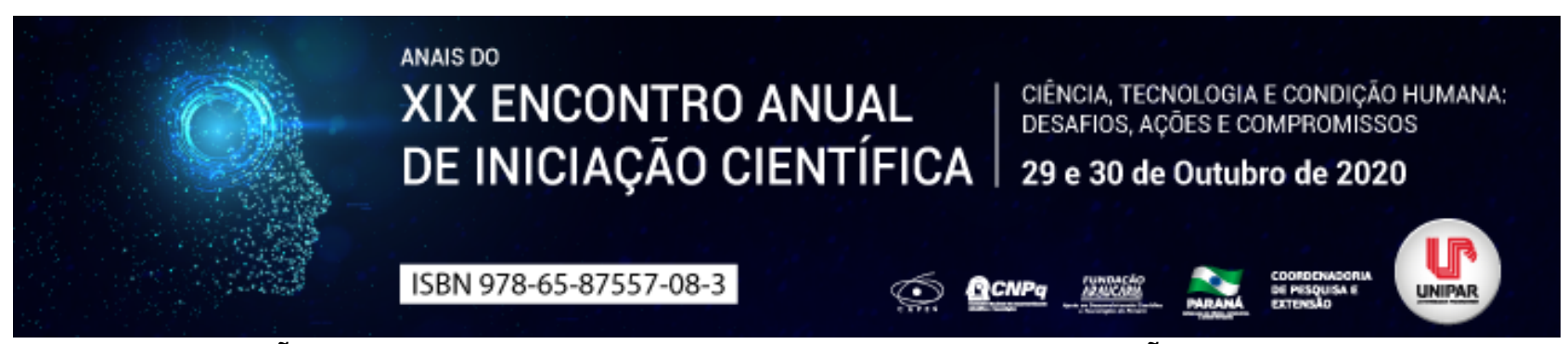

EDUCAÇÃO, POBREZA E DESIGUALDADES SOCIAIS: ARTICULAÇÕES PERTINENTES

\author{
${ }^{1}$ RAILA APARECIDA XAVIER SILVA, ${ }^{2}$ CLAUDIA LOPES PERPETUO
}

${ }^{1}$ Monitoria - Universidade Paranaense - UNIPAR

${ }^{1}$ Docente da UNIPAR

Introdução: $O$ acesso a educação, pela parcela mais pobre da população começou a se realizar somente no final do século XX e o atraso nesse acesso podemos ver hoje nos baixos índices de aprendizagem escolar desses alunos em situação de pobreza. Podemos ver então que desigualdade e pobreza denunciam a injustiça social presente na realidade dessas crianças nascidas nesse círculo de pobreza, que provavelmente ao se tornarem adultos não consigam romper com o círculo vicioso de pobreza e desigualdade, pois as mesma precisam trabalhar e assim não frequentem adequadamente a escola. Pensando nisso este trabalho pretende demonstrar os impactos da pobreza no processo educativo dos jovens.

Objetivo: Demonstrar a articulação pobreza, educação e desigualdade social.

Desenvolvimento: A pobreza é evidência concreta das desigualdades sociais, ela concretiza a extrema diferença entre aquelas pessoas que têm acesso a bens e serviços e aqueles que não tem. Pesquisa desenvolvida pelo IBGE (2019) mostram que a passagem do ensino fundamental para o médio acentua o abandono escolar, uma vez que aos 15 anos o percentual de jovens quase dobra em relação à faixa etária anterior, passando de 8,1\%, aos 14 anos, para 14,1\%, aos 15 anos. Pensando a partir destes dados podemos constatar, como nos coloca Guzzo (2016) que as pessoas que vivem sem a chances de mudanças estruturais, ou seja, enfrentam no seu dia-a-dia dificuldades de moradia, mobilidade, alimentação, acesso à saúde, a assistência e a educação, são marcadas por um cotidiano de sofrimentos e faltas de perspectivas, afetando e gerando a partir desta faltas, grandes impactos na vida e afetando o desenvolvimento da subjetividade dos mesmos. I"O processo de possibilitar acesso a educação de qualidade para todos precisa estar articulado necessariamente com enfrentamento a pobreza e consequentemente a desigualdade sociall" (YANNOULAS e GARCIA, 2017). Pensando na educação escolar como tendo grande parcela de responsabilidade no processo de enfrentamento das condições que produzem e reproduzem a pobreza, é preciso superar e muito, buscando um real comprometimento com a democratização do saber, e construindo novas práticas que valorizem e estimulem a construção de novos saberes e novas aprendizagens, pois como nos ensina Paulo Freire (1989, p.7) I"não basta ensinar a ler palavras, é preciso ensinar leitura de mundo.l" Assim torna-se importante rever e se produzir mais pesquisas referentes a essa relação entre educação, pobreza e desigualdade social, é preciso perceber a forma como a escola pública está organizada e qual papel tem cumprido.

Conclusão: Portanto a partir desse debate inicial, não podemos nos furtar a lutar por uma educação universal, mas também não devemos deixar de considerar o debate sobre educação e o papel que cumpre, que diz respeito a inovação e à reprodução da ordem social do capital. Pensando através de Saviani (1990) que diz que a educação não é outra coisa senão o processo através do qual se constitui em cada indivíduo a universalidade da espécie humana .

\title{
Referências
}

FREIRE, Paulo. A importância do Ato de Ler: em três artigos que se completam. São Paulo: Autores

Associados. Cortez, 1989.

GUZZO, Raquel, Souza Lobo. A (Des)igualdade social e a Psicologia:uma perspectiva para o debate sobre a pobreza. In: Ximenes, Verônica Morais, NEPOMUCENO, Bárbara Barbosa, CIDADE, Elívia Camurça, MOURA JUNIOR, James Ferreira. (orgs). Implicações psicossociais da pobreza: diversidades e resistências. Fortaleza : Expressão Gráfica e Editora, 2016.

IBGE. Pesquisa Nacional por Amostra de Domicílios (PNAD) Educação 2019. Disponível em: https://agenciadenoticias.ibge.gov.br/agencia-sala-de-imprensa/2013-agencia-de-noticias/releases/28285-pnad-educacao-2019mais-da-metade-das-pessoas-de-25-anos-ou-mais-nao-completaram-o-ensino-medio YANNOULAS, Silvia Cristina; GARCIA, Adir Valdemar. Educação, pobreza e desigualdade social. Rev. Em Aberto, Brasília, v.30, n.99, p.5-7, mai/ago, 2017. 


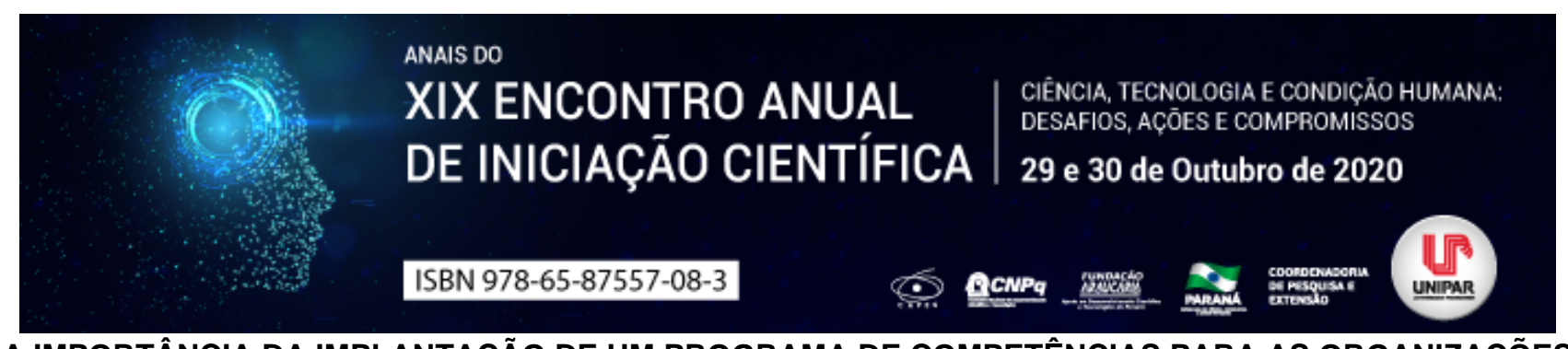

A IMPORTÂNCIA DA IMPLANTAÇÃO DE UM PROGRAMA DE COMPETÊNCIAS PARA AS ORGANIZAÇÕES

\title{
${ }^{1}$ CARLOS EDUARDO FABRIL, ${ }^{2}$ ELIZANGELA MARIA MENEGASSI DE LIMA
}

\author{
${ }^{1}$ Acadêmico do PIC/UNIPAR \\ ${ }^{1}$ Docente da UNIPAR
}

Introdução: A Gestão por Competências é uma tendência de planejamento estratégico voltado para a área de Recursos Humanos. Com a volatilidade sempre presente no mercado, as organizações buscam novos meios de atrair, desenvolver e reter pessoas mais adequadas ao que necessitam, essa prática de gestão vem sendo muito utilizado na atualidade, pois permite mais eficiência no aproveitamento de seus funcionários e auxiliando na contratação de novos.

Objetivo: Conceituar a Gestão por competência e descrever a importância da implantação de um programa de competências no contexto organizacional.

Desenvolvimento: De acordo com Pereira (2015), o conceito de competência vem sendo utilizado com eficácia no mundo dos negócios, apesar de ter ganhado atenção mais recentemente, quando passou a funcionar como instrumento de estratégia empresarial, saindo da teoria para a prática. Portanto, foi com o entendimento do que é a competência, que houve uma mudança na visão existente das organizações perante os trabalhadores, enxergando somente os funcionários que possuem um diferencial competitivo maior e, evidenciando a importância que tinha o gerenciamento do capital humano para obter melhores resultados. Com isso, Carbone et al. (2016) nos traz que, o ser humano começou a ser tratado como um novo ativo para as empresas, deixando para trás a ideia ultrapassada de simples força mecânica, para algo que possui a capacidade de transformar dados e informações em conhecimento aplicável e, com isso, melhorando processos, aumentando o desempenho, solucionando problemas e gerando mais resultados. Consequentemente, as organizações passaram a investir mais em treinamentos e qualificações para seus funcionários, promovendo essa capacitação coletiva e aguardando que resultasse em uma melhoria de desempenho da empresa. Brandão (2018) menciona, também, que com as evoluções das teorias administrativas, o termo competência, se refere a designação daquele que é capaz de agir de forma assertiva frente a uma situação, tomando as atitudes necessárias e apropriadas à circunstância. Isso ficou também conhecido como CHA , uma combinação de conhecimentos, habilidades e atitudes, exposto pelo desempenho individual em seu contexto profissional. Vale ressaltar que, a gestão por competências não se limita ao individual ou micro-organizacional, também é aplicável ao meso-organizacional, articulando as competências individuais dos membros da equipe. Da mesma forma acontece com o macro-organizacional, responsável por toda a organização, já que todos esses níveis interagem entre si e cada um deles influencia no desempenho do outro. Sendo assim, Brandão (2018) nos traz o método para a execução da gestão por competência, primeiramente a empresa deve ter de maneira clara seu objetivo e sua missão, estabelecendo indicadores de desempenho quantificável para isso. Em seguida, devem identificar quais são as competências necessárias para atingir o objetivo e quais já possuem, a partir daí, verificar como captar essas competências, através de novas admissões, ou podem escolher desenvolver essas competências em funcionários já existentes na empresa, disponibilizando novos projetos de treinamento e orientação. Após isso, irão acompanhar os resultados alcançados e comparar com o que era esperado, levando ao último passo, a retribuição, que dependendo do resultado, a empresa pode reconhecer e premiar o funcionário pelo bom desempenho da competência. Outra análise feita para acompanhar o desempenho da gestão por competência, é o chamado gap de competências, que pode ser organizado como um gráfico de competências necessárias $x$ tempo, na qual mostra o ponto em que a empresa está e a distância até onde precisam chegar para suprir as competências necessárias, esse espaço entre os dois é o chamado gap.

Conclusão: Portanto, a importância da aplicação da gestão por competências se mostra através de todas essas vantagens. As empresas conseguem ter um melhor aproveitamento e desenvolvimento de seus funcionários, na qual aprimora todos os níveis organizacionais, adquire e retêm pessoas talentosas, ganham vantagens competitivas perante as concorrentes e mantêm um controle sobre o gap.

\section{Referências}

CARBONE, Pedro Paulo, et al. Gestão por Competências. FGV: Rio de Janeiro, 2016.

BRANDÃO, Hugo Pena. Mapeamento de Competências. 2. ed. Atlas: São Paulo, 2018.

PEREIRA, Maria Célia Bastos. RH Essencial. Saraiva: São Paulo, 2014. 


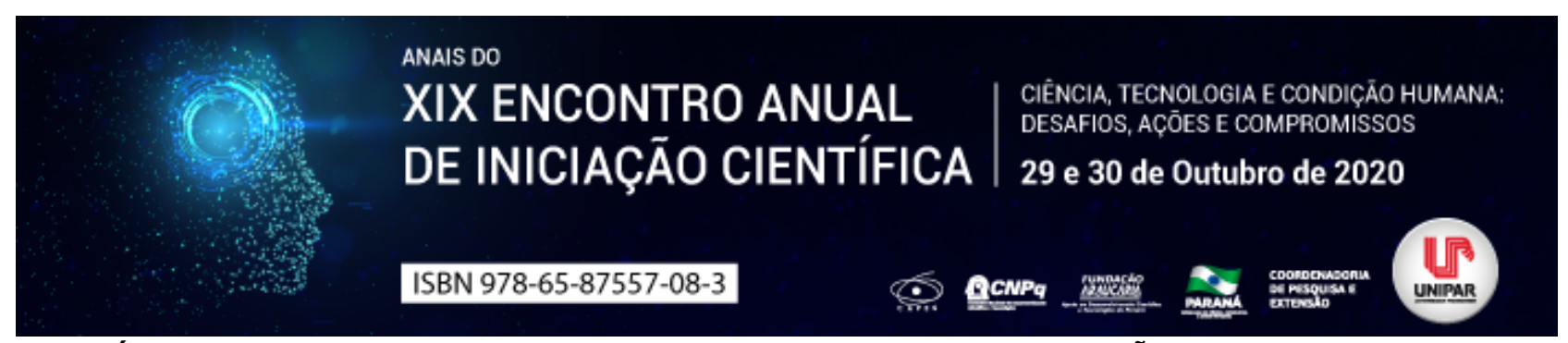

HISTÓRIA DO ESTATUTO DE IGUALDADE RACIAL E A AUTODECLARAÇÃO NO ESTATUTO RACIAL

\title{
${ }^{1}$ ALINE COUTINHO DA LUZ, ${ }^{2}$ CINTHIA FERREIRA DOS SANTOS COSTA, ${ }^{3}$ EMANUELLE TOTOLI DE OLIVEIRA, ${ }^{4}$ MILENA DE LIMA, ${ }^{5}$ ROSANGELA BRESSAN BUOSI, ${ }^{6}$ ARNALDO GOMES DO AMARAL
}

\author{
${ }^{1}$ Acadêmica do Curso de Engenharia Civil da UNIPAR \\ ${ }^{1}$ Acadêmica do Curso de Pedagogia da UNIPAR \\ ${ }^{2}$ Acadêmica do Curso de Pedagogia da UNIPAR \\ ${ }^{3}$ Acadêmica do Curso de Engenharia Civil da UNIPAR \\ ${ }^{4}$ Docente da UNIPAR \\ ${ }^{5}$ Docente da UNIPAR
}

Introdução: O colonialismo e o regime escravocrata deixou como herança no mundo todo, uma falsa ideologia de superioridade, onde houve o surgimento de classificações dos indivíduos, entre elas cor da pele e a descendência a qual pertencia. Pensando no fato de que o principal motivo para a criação de um estatuto ser em consequência da vulnerabilidade de uma parcela da população, houve então a necessidade do surgimento do Estatuto que trata da igualdade racial, buscando apoiar e amparar os que se enquadram no nicho que diz respeito à classificação adotada pelo Instituto Brasileiro de Geografia e Estatística IBGE (BRASIL, 2011).

Objetivo: Demonstrar o processo histórico para a criação do estatuto da igualdade racial e como é feita a autodeclaração racial dos indivíduos conforme o IBGE.

Desenvolvimento: No Brasil os primeiros relatos do surgimento da escravidão foi no século XVI, com o objetivo de utilizar-se da mão de obra dos escravos na produção de cana de açúcar. Conforme Figueiredo, Mathias e Noronha (2014, apud Freitas e Martos, 2018, p. 599) ela só teve fim com a assinatura da Lei Áurea em 1988 que trouxe de vez a abolição dos escravos. A ideia da criação de uma forma de amparo aos indivíduos que se autodeclararam negros teve um grande crescimento na conferência de Durban em Setembro de 2001, onde ficou claro que era necessária a adoção de medidas especiais e ações afirmativas para auxílio dos grupos discriminados (ALENCAR, 2010, p. 9), foi então apresentado em 2005 pelo deputado da época, Paulo Paim, como projeto de lei a PL 6264/2005 que institui então o estatuto da igualdade racial e estabelece critérios para o combate à discriminação racial de afro-brasileiros (BRASIL, 2005). Para haver uma organização dos grupos que fazem parte dos amparados pelas ações afirmativas adotadas pelo estatuto, é necessário que haja uma normatização da maneira da autodeclaração de cada indivíduo. Segundo Osorio (2003), os três métodos de identificação racial são: a autoatribuição de pertença que consiste no próprio indivíduo escolhendo o grupo a que pertence, a heteroatribuição de pertença que é quando uma outra pessoa é quem define o grupo de pertencimento do sujeito, e por fim, a identificação de grandes grupos populacionais que utiliza-se de técnicas biológicos como análise do DNA para identificar o grupo ao qual o indivíduo pertence. Para Telles (2003), as três classificações raciais são oficial, popular múltiplo e binário, sendo o primeiro subdividido entre branco, preto, pardo, amarelo e indígena, e que é o utilizado pelo IBGE por isso o nome oficial, enquanto o segundo que se enquadra todas as variações de classificação popularmente utilizadas por cada indivíduo, e o binário que é adotado por movimentos negros que se utilizam apenas dos termos branco e negro para a classificação. Existe uma grande importância em torno do conhecimento dessas classificações, conforme Petruccelli e Saboia (2013), na pesquisa feita pelo IBGE em 2008, aponta que cerca de $96 \%$ dos entrevistados sabiam dizer qual a sua cor ou raça, porém havia uma grande abrangência de termos para a classificação, chegando a 80 nos estados de São Paulo e Rio Grande do Sul. Conforme divulgado pelo próprio Censo (2010), a pesquisa de 2008, trouxe os seguintes resultados para as cinco diferentes classificações do IBGE: $49,0 \%$ se dizem branca, 1,4\% preta, 13,6\% parda, 1,5\% se autodeclaram amarela e $0,4 \%$ indígena, nota-se que $65,9 \%$ dos entrevistados utilizam-se das cinco classificações do IBGE, e os outros $34,1 \%$ fez o uso de outro termo para classificação.

Conclusão: Conforme demonstrado, a elaboração do estatuto da igualdade racial passou por um longo processo até sua criação, onde o principal fator para o seu surgimento foi a necessidade que a parcela da população prejudicada historicamente pela escravidão teve de se valer de um amparo e medidas para introduzi-los de maneira igualitária na sociedade. Para uma maior organização, o IBGE efetua pesquisas de classificação de cada indivíduo conforme cor ou raça para que seja possível então implantar as ações afirmativas que prevê o estatuto. Porém, se fazem necessárias ainda, mais políticas públicas para demonstrar à população o motivo de existir essa classificação que para muitos soa como uma separação, sendo que o principal objetivo é proporcionar mais igualdade de direitos entre os indivíduos.

\section{Referências}


ALENCAR, Rafael Augusto da Costa. Ações afirmativas do Brasil: Um estudo de caso sobre o Estatuto da Igualde Racial. 2010. Dissertação - Mestrado em Sociologia - Universidade de Brasilia. Brasília - DF. 2010. Disponível em: https://repositorio.unb.br/bitstream/10482/8780/3/2010_RafaelAugustodaCostaAlencar.pdf. Acesso em 20 ago. 2020.

BRASIL. lei a PL 6264/2005. Estabelece critérios para o combate à discriminação racial de afro-brasileiros; altera a Lei $n^{\circ} 6.015$, de 1973. 2005. Disponível em: https://www.camara.leg.br/proposicoesWeb/fichadetramitacao?idProposicao=307731. Acesso em 20 ago. 2020.

BRASIL. Presidência da República. Lei № 12.288, de 20 de julho de 2010. Institui o Estatuto da Igualdade Racial. Disponível em: http://www.planalto.gov.br/ccivil_03/_Ato2007-2010/2010/Lei/L12288.htm. Acesso em 20 ago. 2020.

BRASIL. IBGE divulga resultados de estudo sobre cor ou raça. 2011. Disponível em: https://biblioteca.ibge.gov.br/visualizacao/livros/liv63405.pdfhttps://censo2010.ibge.gov.br/noticias-censo.html?

busca=1\&id=1\&idnoticia=1933\&t=ibge-divulga-resultados-estudo-sobre-cor-raca\&view=noticia. . Acesso em 20 ago. 2020.

FREITAS, Mauro Henrique Ewbank de; MARTOS, Frederico Thales de Araújo. Estatuto da Igualdade Racial: Análise HistóricaJurídica. Revista de Iniciação Científica e Extensão da Faculdade de Direito de Franca. 2018. Disponível em: http://www.revista.direitofranca.br/index.php/icfdf/article/view/795/pdf. Acesso em 20 ago. 2020.

OSÓRIO, R. G. O sistema classificatório de cor ou raça do IBGE. Brasília, DF: IPEA, 2003.

PETRUCCELLI, José Luis. Raça, identidade, identificação: abordagem histórica conceitual. In: Características Étnico-raciais da População: Classificações e identidades. PETRUCCELLI, José Luis; SABOIA, Ana Lucia (Org.). Ministério do Planejamento, Orçamento e Gestão. Instituto Brasileiro de Geografia e Estatística IBGE. Rio de Janeiro, 2013. Disponível em: https://biblioteca.ibge.gov.br/visualizacao/livros/liv63405.pdf. Acesso em 15 jul. 2020.

TELLES, E. E. Racismo à brasileira: uma nova perspectiva sociológica. Rio de Janeiro: Relume Dumará, 2003. 


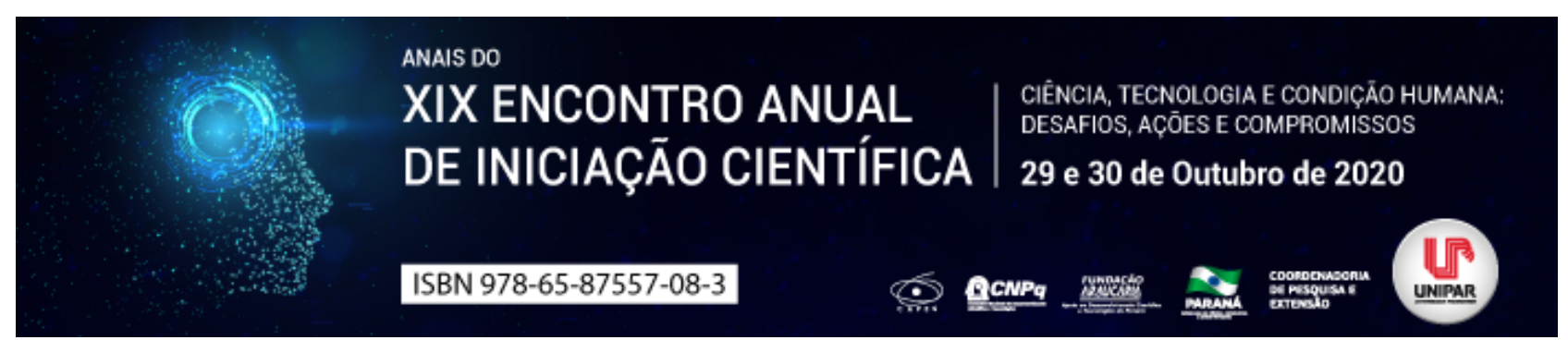

ACESSO À JUSTIÇA E ABUSO DO DIREITO DE LITIGAR: AJUIZAMENTO DE DEMANDAS EM MASSA

\title{
${ }^{1}$ TANIA ARNECKE PEREIRA, ${ }^{2}$ CASSIO DE PAULA XAVIER, ${ }^{3}$ DIOGO DE ARAUJO LIMA, ${ }^{4}$ MARIANA SARTORI NOVAK
}

\author{
${ }^{1}$ Aluna inscrita no Programa de Iniciação Científica (PIC) da UNIPAR. Discente do Mestrado em Direito Processual e Cidadania \\ UNIPAR \\ ${ }^{1}$ Aluno inscrito no Programa de Iniciação Científica (PIC) da UNIPAR. Discente do Mestrado em Direito Processual e Cidadania \\ UNIPAR \\ ${ }^{2}$ Discente do Mestrado em Direito Processual e Cidadania UNIPAR \\ ${ }^{3}$ Aluna inscrita no Programa de Iniciação Científica (PIC) da UNIPAR. Discente do Mestrado em Direito Processual e Cidadania \\ UNIPAR
}

Introdução: O acesso à justiça é uma garantia fundamental, prevista no artigo $5^{\circ}$, inciso XXXV, da Constituição Federal (BRASIL, 1988), possuindo característica instrumental, uma vez que por meio dela é possível obter a tutela dos demais direitos. Hodiernamente, vivemos uma era de litigiosidade, com milhares de processos em curso pelos mais variados tribunais de nosso país, sendo que muitos deles são ajuizados sem a devida cautela que deveria ser adotada pelos advogados, que ajuízam ações repetidas, com os mesmos argumentos e causa de pedir, alterando apenas as partes demandantes, causas essas, chamadas de ações em massa.

Objetivos: Por intermédio do método dedutivo pretende-se analisar inicialmente questões gerais do abuso do direito de litigar e o acesso formal a justiça, conseguinte analisar o problema principal, que é a questão do ajuizamento de ações massivas, e por fim quais seriam as consequências jurídicas de tal prática.

Desenvolvimento: Nos termos da Constituição Federal de 1988, mais precisamente no artigo $5^{\circ}$, inciso XXXV (BRASIL, 1988), a lei não excluirá da apreciação do Poder Judiciário, lesão ou ameaça a direito. A garantia constitucional de acesso à justiça está vinculada a edificação de mecanismos processuais de efetivação da prestação jurisdicional. A norma constitucional não se limita a entravar que alguma lei impeça o acesso à jurisdição, pois assegura o direito de exigir do Estado a tutela jurisdicional, nesse sentido são as palavras de Medina ao dizer que, o texto constitucional não se limita a obstar que alguma lei impeça o acesso à jurisdição, mas vai além, assegurando o direito de exigir do Estado a tutela jurisdicional (MEDINA, 2016). No mesmo sentido, as palavras do Professor Eduardo Cambi ao dizer que o acesso à justiça abrange não só o ingresso efetivo ao Judiciário e a entrega de uma qualquer prestação jurisdicional, mas que a resposta seja célere, adequada e efetiva (CAMBI, 2017). O que se questiona é: quando se fala em incidentes manifestamente descabidos, podemos entender que o ajuizamento de ações massificadas, muitas vezes sem fundamentação lógica, também faria parte dessa categoria? Tal prática poderia ser entendida como abuso de direito ou má-fé? Verifica-se que a maioria das ações massivas representa um risco zero, dado a frequência na obtenção da gratuidade da justiça. Durante certo tempo, alimentou-se a esperança de que a uniformização da jurisprudência, de forma contínua e sistemática, seria a solução ou pelo menos reduziria o número de processos judiciais, constituindo um obstáculo contra demandas massificadas. No entanto, a uniformização não atingiu seu propósito maior, que era o de reduzir a quantidade de processos por meio de uma jurisprudência pacificada, deduzindo as teses jurídicas repetidas pelo próprio sistema, de modo que o ideal seria a implantação de uma consequência jurídica aqueles que buscam o Poder Judiciário sem o mínimo de respeito e cautela. Buscando evidências de quais seriam as consequências jurídicas àqueles que realizam o ajuizamento de ações em massa, sem observar o mínimo das ordens legais e dos princípios éticos a serem respeitados no exercício de sua função encontramos apontamentos de que o ideal é a condenação por má-fé, uma vez que tal condenação desestimula a prática em virtude do aspecto econômico atingido.

Conclusão: Conclui-se, portanto, que quando se fala em ajuizamento de ações em massa, acabamos por confrontar o princípio do acesso à justiça com o abuso do direito de litigar. O Código de Processo Civil de 2015 (BRASIL, 2015), trouxe avanços e novidades que buscam desafogar o Poder Judiciário, como o julgamento de demandas repetitivas, precedentes, entre outros, no entanto, tais ferramentas apesar de eficazes não conseguem abarcar os casos de todo o País. Ocorre que mencionada prática, apesar de comum, ainda não possui mecanismo eficiente a fim de evitá-la, principalmente pelo fato de que o principal argumento é o princípio do acesso à justiça. No entanto, a condenação por má-fé nesses casos pode ser vista como uma solução por ora, até que se crie uma ferramenta mais eficaz, pois a condenação em valor pecuniário sem dúvidas irá diminuir a incidência das demandas que não possuem um mínimo de cautela e fundamento na pretensão jurisdicional.

\section{Referências}

BRASIL. Constituição (1988). Constituição da República Federativa do Brasil: promulgada em 8 de outubro de 1988. Disponível 
em: http://www.planalto.gov.br/ccivil_03/constituicao/constituicao.htm. Acesso em: 08 set 2020.

. Lei n. ${ }^{\circ} 13.105$, de 16 de março de 2015. Código de Processo Civil. Disponível em: . Acesso em: 08 set 2020.

$\overline{\mathrm{CAMBI}}$, Eduardo. CAMANHO, Matheus Gomes. Revista Jurídica da Escola Superior de Advocacia da OAB/PR. Ano 2. Número 1. Abril de 2017.

MEDINA, José Miguel Garcia. Direito processual civil moderno. 2 ed. rev. atual. e ampl. São Paulo: Editora Revista dos Tribunais, 2016.

Coordenadoria de Pesquisa e Extensão - COPEX

Departamento de Editoração e Divulgaçāo Científica - DEDIC 


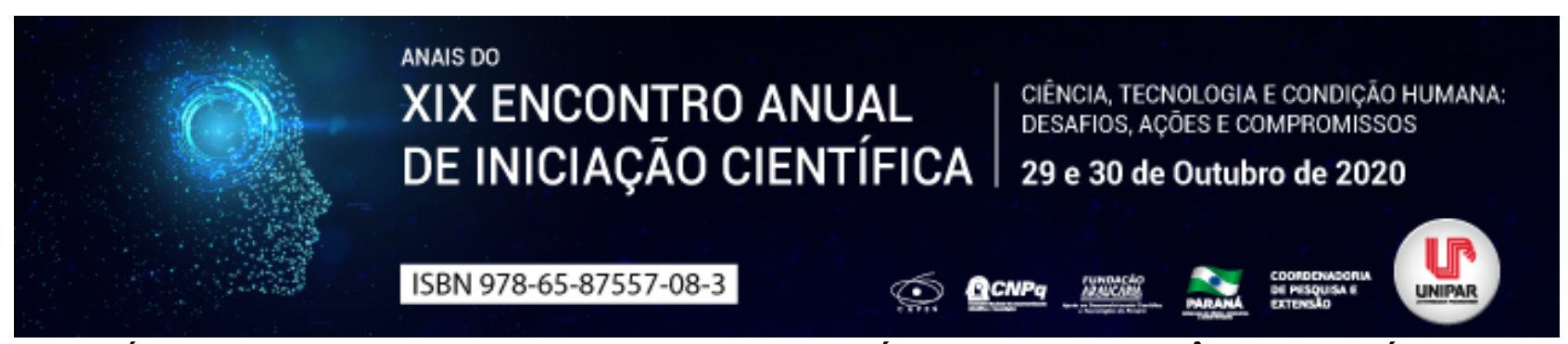

PRÁTICAS E DESAFIOS DOS PROFISSIONAIS DA SAÚDE FRENTE A VIOLÊNCIA OBSTÉTRICA

\author{
${ }^{1}$ ANY LOUIZE AIRES, ${ }^{2}$ CAMILA BEATRIZ KLEIN, ${ }^{3}$ ANA PAULA TEODORO DOS SANTOS, ${ }^{4}$ ELAINE CRISTINA MUSSI DE \\ LIMA, ${ }^{5}$ PATRICIA CRISTINA NOVAKI AOYAMA
}

\begin{abstract}
${ }^{1}$ Acadêmica PIC/Unipar
${ }^{1}$ Acadêmica PIC/Unipar

${ }^{2}$ Acadêmica PIC/Unipar

${ }^{3}$ Acadêmica PIC/Unipar

${ }^{4}$ Docente da UNIPAR
\end{abstract}

Introdução: Discorrer acerca da violência obstétrica (V.O.) sob um viés profissional é uma forma de possibilitarmos a desconstrução de práticas que são decorrentes de uma construção social, nas quais em muitos casos a mulher não tem controle sobre a maneira em que irá partejar, ou então não tem suas decisões respeitadas. Dessa forma, abordar sobre a violência obstétrica é um movimento urgente, necessário e que precisa afetar tanto a parturiente quanto os profissionais, uma vez que, se a mulher tiver acesso à informação a possibilidade de vivenciar V.O diminui, assim como os profissionais precisam compreender que algumas condutas que realizam e reproduzem podem ser violentas, e a partir desse reconhecimento pensar sobre novas práticas que findem esse ciclo (JARDIM, et al, 2020).

Objetivo: Identificar variáveis presentes no momento do parto pela perspectiva dos profissionais da equipe hospitalar, bem como qual a compreensão desses profissionais a respeito da violência obstétrica e ainda verificar como ocorre o processo de humanização no momento do parto.

Desenvolvimento: A violência obstétrica não é um fenômeno atual, uma vez que a violação de direitos e práticas desumanizadas sempre estiveram presentes na vida das mulheres durante o período de gestação, parto e puerpério, uma vez que, essa se caracteriza por qualquer expressão violência exercida por profissionais como maus tratos verbais, psíquicos ou físicos, uso de intervenções e/ou medicalização desnecessárias, entre outras condutas que resultem na perda de autonomia da mulher nesse processo, podendo ocorrer durante o pré-natal, parto ou ainda, no pós-parto (BUENO et al, 2019). Essa forma de violência é um movimento que se construiu social e culturalmente de acordo com as demandas que passaram a se potencializar ao modo que o partejar foi deixando de ser algo da mulher para ser do profissional que conduziria aquele momento. De acordo com Habigzang et al (2017) ao realizar os atendimentos, os profissionais pautam-se na sua experiência e nas ferramentas disponíveis no respectivo serviço de saúde, contudo, esses instrumentos nem sempre são suficientes para suprir as demandas dos usuários e possíveis problemas que podem vir a ocorrer, e por conseguinte, as usuárias aceitam o que lhes é imposto. Sens e Stamm (2019) afirmam que a relação entre médico e paciente durante o parto é permeada por diferentes emoções, sentimento e julgamentos, sendo marcada por expressões que em momentos configuram-se harmoniosa e em outros são desafiadoras. Em pesquisa com enfermeiras obstétricas Leal et al (2018) apontam que segundo as profissionais a baixa escolaridade e 0 conhecimento deficitário das mulheres referente ao processo do parto, bem como de seus direitos, são fatores que corroboram para práticas de VO. Concordando com essa afirmação, Sens e Stamm (2019) em sua pesquisa com médicos discorrem que esses conferem a informação como uma estratégia de prevenção a VO, contudo, no mesmo estudo, os dados mostram que as mulheres que indagam ou recusam determinados procedimentos são vistas como difíceis de lidar (p. 06). Assim, Bueno et al (2019) mencionam que para erradicar esta forma de violência, é preciso incentivar os profissionais da saúde a realizarem práticas humanizadas no momento do parto, promovendo um protagonismo da mulher. Contudo, ao refletir sobre o papel dos profissionais nesse momento é preciso considerar o ambiente no qual os mesmos estão inseridos. Sens e Stamm (2019) mencionam duas categorias ao falar dos médicos como vítimas, sendo que a primeira trata-se de uma violação institucional, uma vez que tange a precarização das condições de trabalho e também podem ser vítima das vítimas , sendo que esta situação é expressa em forma de hostilidade, agressão, ameaça, entre outras ações desrespeitosas para com os profissionais.

Conclusão: Diversas são as variáveis envoltas na violência obstétrica, sendo necessário ouvir as usuárias do serviços de saúde, bem como os profissionais que por vezes tem condições de trabalho insuficientes frente à grande demanda e complexidade dos casos obstétricos. Nesse sentido, conforme apontado por Habigzang (2017) é importante promover o acesso à saúde adequado às mulheres e também aos profissionais por meio de procedimentos regularizados e organizados de forma a promoverem um ambiente seguro para todos.

\title{
Referências
}

BUENO, Deolinda Marcia Pompeu. et al. Violência obstétrica: uma expressão nova para um problema histórico. Saúde em Foco, 
n 11, 2019. Disponível em: https://portal.unisepe.com.br/unifia/wp-content/uploads/sites/10001/2019/03/034_VIOL\%C3\%8ANCIAOBST\%C3\%89TRICA-Uma-express\%C3\%A3o-nova-para-um-problema-hist\%C3\%B3rico.pdf. Acesso em: 12 ago. 2020.

HABIGZANG, Luísa Fernanda. et al. Violência obstétrica no Brasil: uma revisão narrativa. Psicologia e Sociedade, vol. 29, jul, 2017. Disponível em: https://www.scielo.br/pdf/psoc/v29/1807-0310-psoc-29-e155043.pdf. Acesso em: 14 maio 2020.

JARDIM, Danubia Mariane Barbosa. et al. O olhar de residentes em Enfermagem Obstétrica para o contexto da violência obstétrica nas instituições. Interface, 2020. Disponível em: https://doi. org/10.1590/Interface.180664. Acesso em: 03 ago. 2020.

LEAL, Sarah Yasmin Pinto. et al. Percepção das enfermeiras obstétricas acerca da violência obstétrica. Cogitare Enfermagem, vol 23, n 2, 2018. Disponível em: https://revistas.ufpr.br/cogitare/article/view/52473. Acesso em: 12 ago. 2020.

SENS, Maristela Muller; STAMM, Ana Maria Nunes de Faria. Percepção dos médicos sobre a violência obstétrica na sutil dimensão da relação humana e médico-paciente. Interface: comunicação, saúde, educação, v. 23, n 10, Jul, 2019. Disponível em: https://www.scielo.br/pdf/icse/v23/1807-5762-icse-23-e180487.pdf. Acesso em: 29 maio 2020.

Coordenadoria de Pesquisa e Extensão - COPEX

Departamento de Editoração e Divulgaçāo Científica - DEDIC 


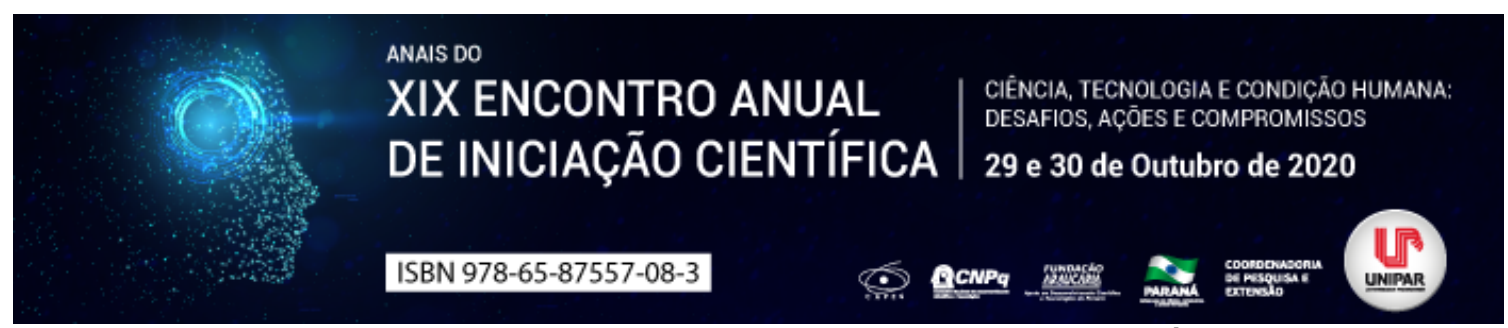

\title{
PROJETO DE LEI N 757/2015: RECONSIDERAÇÃO DO ABSOLUTAMENTE INCAPAZ MAIOR, ANÁLISE DAS MUDANÇAS DO ESTATUTO DA PESSOA COM DEFICIÊNCIA
}

\author{
${ }^{1}$ ALANA GENOVEZ, ${ }^{2}$ MIRIAM FECCHIO CHUEIRI
}

\author{
${ }^{1}$ Acadêmica do PIC/UNIPAR \\ ${ }^{1}$ Docente da UNIPAR
}

Introdução: Com o advento da Lei 13.146/2015 (Estatuto da Pessoa com Deficiência) ocorreu uma grande revolução na teoria das incapacidades no ordenamento jurídico brasileiro, passando a constar como absolutamente incapazes apenas os menores de dezesseis anos (menores impúberes). Sob a ótica do ordenamento vigente a pessoa portadora de deficiência é em regra plenamente capaz de exercer atos da vida civil, e excepcionalmente relativamente incapaz, não admitindo mais a curatela em forma de interdição, mas sim de maneira excepcional referente aos bens econômicos da pessoa curatelada não alcançando o seu corpo e privacidade. Tal instituto trouxe reflexos de divergência entre o Novo Código de Processo Civil e as alterações no Código de 2002, se tornando necessário analisar o Projeto de Lei $11.091 / 2018$ que busca a possibilidade de reconsiderar pessoas maiores de dezoito anos que não exprimem vontade alguma aos absolutamente incapazes e também sanar o abismo legislativo que existe entre os dois códigos.

Objetivo: Declinar a possibilidade de se incluir ao rol de absolutamente incapazes pessoas maiores de dezoito anos que não conseguem de modo algum exprimir vontades, assim como proceder à análise crítica ao choque de normas existentes entre o Estatuto da Pessoa com Deficiência e o Novo Código de Processo Civil, comentando quais os reflexos referentes à curatela no Código Civil de 2002, bem como demonstrar a solução para o problema através de uma terceira Lei (PL 757/2015, atual Projeto de Lei $n^{\circ} 11.091 / 2018$ da Câmara dos Deputados).

Desenvolvimento: Curatela é encargo deferido por lei a alguém capaz, para reger a pessoa e administrar os bens de quem, em regra maior, não pode fazê-lo por si mesmo (GONÇALVES, 2013), o objetivo da curatela é dar maior proteção a pessoa que mesmo maior por conta de fatores particulares se torna mais vulnerável para exercer atos da vida civil sozinha. Todas as pessoas com deficiência que em regra eram tratadas no anterior artigo $3^{\circ}$ do CC passaram a ser consideradas plenamente capazes após o advento do EPD, o objetivo foi a plena inclusão da pessoa com algum tipo de deficiência, tutelando a sua dignidade humana, deixa-se de lado, assim, a proteção de tais pessoas como vulneráveis, o que era retirado do sistema anterior, em outras palavras, a dignidade-liberdade substitui a dignidade-vulnerabilidade (TARTUCE, 2020), ou seja, mesmo aquelas pessoas que se encontram em coma, ou até mesmo aquelas que possuem retardo mental gravíssimo, tendo idade mental de uma criança de 9 anos de idade são tão capazes quanto um maior de 18 anos sem nenhuma deficiência e mais capazes que um adolescente de 17 anos saudável (art.6 $6^{\circ}$ do EPD). Nesse sentido seria interessante retomar alguma previsão para maiores absolutamente incapazes nos casos de pessoas que não têm qualquer condição de exprimir vontade e que não sejam necessariamente deficientes, por exemplo, pessoas em coma ou estágio avançado de Alzheimer, o Projeto de Lei 11.091/2018 em sua redação originária foi criado nesse sentido. Junto com as mudanças trazidas pelo EPD para a teoria das incapacidades, ficou evidenciado também atropelos legislativos entre o CPC/2015 e o EPD, de início constata-se que a última norma alterou o art.1.768 do CC, não mencionando mais o processo de interdição relativa, mas uma demanda que é nomeado um curador. Entretanto, esse dispositivo é revogado pelo CPC/2015, que está totalmente estruturado na ação de interdição (TARTUCE, 2020).

Conclusão: Não se pode ignorar a falta total de expressão de vontade, pessoas que não conseguem por meio algum exprimir vontade, são vulneráveis e precisam ser protegidas. O objetivo da Lei 13.146/2015 de promover a inclusão da pessoa com deficiência e dar a ela mais liberdade é válida, porém não podem ser tratados todos os casos da maneira abstrata como propôs o Estatuto, cada caso prático demanda de tratamentos diferentes. É de extrema necessidade que para maior proteção, dignidade e isonomia das pessoas vulneráveis que não exprimem vontade, que seja revisto esse pensamento abstrato trazido pelo Estatuto e que se consiga saber qual norma deve prevalecer, criando-se uma norma que padronize os códigos suprindo suas divergências nas quais um acaba por revogar o outro, quando na verdade deveriam seguir o mesmo caminho.

\section{Referências}

Gonçalves, Carlos Roberto. Da Curatela. In: Gonçalves, Carlos Roberto. Direito civil brasileiro, volume 6; Direito de família/Carlos Roberto Gonçalves.- 10 ed.- São Paulo: Saraiva, 2013.

Tartuce, Flávio. Parte Geral do Código civil de 2002. Da pessoa natural. In: Tartuce, Flávio. Manual de direito civil: volume único/ Flávio Tartuce. 10. Ed. Rio de Janeiro: Forense; São Paulo: MÉTODO, 2020.

Lei $\mathbf{n}^{\circ}$ 13.146, de 06 de julho de 2015. Disponível em: http://www.planalto.gov.br/ccivil_03/_ato20152018/2015/lei/l13146.htm. Acesso em: 03 de julho de 2020 .

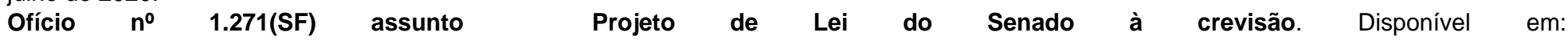
https://www.camara.leg.br/proposicoesWeb/prop_mostrarintegra;jsessionid=EB107D9D22219361721EA1849C66E4DB.proposicoesWebExterno2? codteor=1696382\&filename=PL+11091/2018. Acesso em: 03 de julho de 2020. 


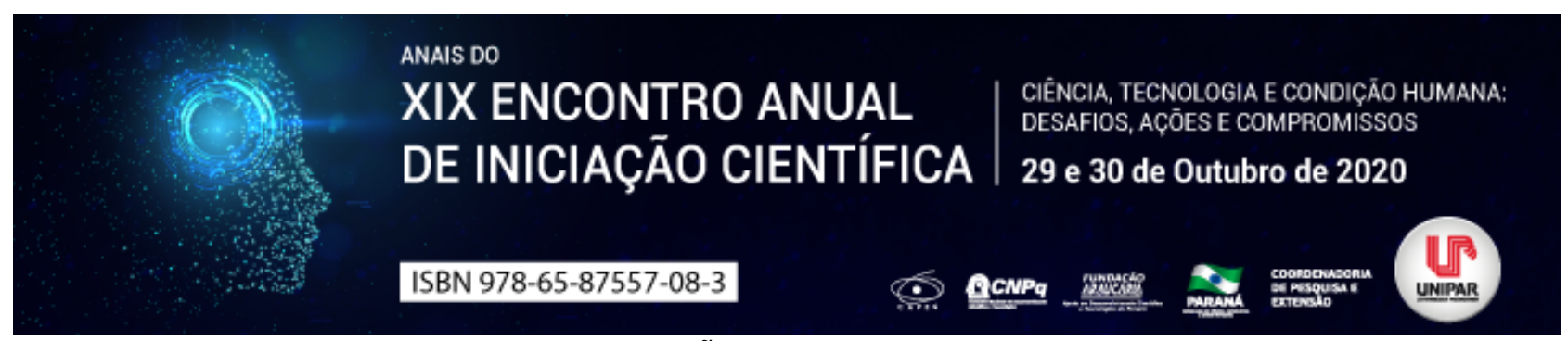

A TEORIA DOS JOGOS E SUA APLICAÇÃO NO DIREITO PROCESSUAL PENAL BRASILEIRO

\title{
${ }^{1}$ CLAUDINEI GULART, ${ }^{2}$ ALBINO GABRIEL TURBAY JUNIOR
}

\author{
${ }^{1}$ Acadêmico do Curso de Direito da Unipar \\ ${ }^{1}$ Docente da UNIPAR
}

Introdução: A teoria dos jogos foi desenvolvida inicialmente por John Von Neumann, para a tomada de decisões em situações conflitantes que envolvem a interação entre sujeitos racionais em um contexto de disputa, decisões estas, que são ancoradas em diversos fatores. Trazida para o ramo das ciências sociais aplicadas, a Teoria dos Jogos enseja uma nova dinâmica acerca da compreensão do processo penal.

Objetivo: Compreender a Teoria dos Jogos e analisar sua aplicação no processo penal brasileiro, diante das inúmeras variáveis subjetivas, comportamento dos sujeitos processuais e significantes pontuais, que compõem a lide processual penal.

Desenvolvimento: Alude a teoria em questão, tratar-se de compreender e buscar racionalidade em interações humanas, podendo ser aplicada para esclarecer decisões ou obter a melhor vantagem possível em um conflito. O processo penal, é um jogo assimétrico de informação, estruturado em 03(três) níveis: (a) o das normas processuais; (b) do discurso lançado processualmente e seus condicionantes internos/externos e, (c) da singularidade do processo (seu julgador e seus jogadores), sendo necessário constante reavaliações táticas, posto que, os jogadores não possuem todas as informações que comporão o acervo processual (ROSA, 2013). De qualquer sorte, por mais que se tenha estruturado teoricamente também, quem são os sujeitos do processo penal, ou seja, a figura do delegado e dos policiais, em um primeiro momento, passando para a figura do advogado, dos defensores públicos, dos promotores e dos juízes em um segundo momento. Importa dizer, que se tem uma lógica de cadeiras, pessoas físicas, cada qual com sua individualidade, que no contexto atual, há uma grande confusão no tocante ao que seria concepção individual (STRECK, 2010). Conforme Piero Calamandrei (2002, p.191) decorar as regras do jogo de xadrez, não tornam o sujeito um grande enxadrista, no processo penal a premissa é a mesma. $O$ direito processual penal brasileiro é um ramo do direito público, composto por normas e princípios que regulam a aplicação jurisdicional do direito penal, bem como as atividades persecutórias da Polícia Judiciária, e a estruturação dos órgãos da função jurisdicional e respectivos auxiliares (MARQUES, 2013). Desta forma, de acordo com Nucci (2014, p. 27), o Estado dispõe do direito de punir a partir da violação do Direito Penal e assevera que não há crime sem prévia lei que o defina, nem pena sem prévia lei que a comine . E nesse espeque, no tocante a sistemas processuais penais, historicamente tem-se a divisão entre: Sistema Inquisitório, Sistema Acusatório e Sistema Misto. Atualmente, para muitos doutrinadores, no Brasil é adotado o sistema acusatório, entretanto, de uma forma não pura, subsistindo resquícios do sistema inquisitório (MUELLER, 2018). Corroborando a ideia de que, conforme Lopes Jr. (2014. p. 232) devemos abandonar a ilusão de segurança da teoria do processo como relação jurídica, assumindo a dinamicidade das suas incertezas. Aplicando-se a teoria dos jogos ao processo penal, tem-se a seguinte correlação: o processo penal é um jogo mediado pelo juiz, em que a presunção de inocência, início do jogo, é atacado pelo acusador e defendida pelo defensor, alternando-se a cada jogada probatória, devido as variáveis determinantes e, estabelecendo um ambiente de interdependência em que as jogadas modificam o desenrolar do jogo de acordo com a destreza, capacidade teórica, sorte ou contingência dos jogadores, que a cada momento podem manter ou rever as táticas processuais, ligadas a estratégia (SOUZA, 2016).

Conclusão: Deflui-se que a teoria dos jogos é uma grande aliada do direito penal contemporâneo, entendendo o que é o comportamento dominante, o que é comportamento dominado, comportamento neutro, entender cada um dos jogadores em cada contexto processual pode se definir a melhor estratégia para obtenção da maximização dos resultados.

\section{Referências}

CALAMANDREI. Piero. O processo como jogo. Gênesis Revista de Direito Processual Civil, v. 07, n. 23, tradução de Roberto B. Del Claro, Curitiba: Gênesis, p. 191-209, jan. 2002.

LOPES JR., Aury. Fundamentos do processo penal: introdução crítica. 3. ed. São Paulo: Saraiva, 2017.

MARQUES, José Frederico. Elementos de direito processual penal. 19. ed. São Paulo: Millenniun Editora, 2013

MUELLER, Rafaela. Aplicação da teoria dos jogos no processo penal nas Comarcas de Estrela e Lajeado/RS. 2018. Monografia (Bacharelado em Direito). Universidade do Vale do Taquari UNIVATES, 2018.

$\mathrm{NUCCl}$, Guilherme de Souza. Manual de processo penal e execução penal. 11. ed. Rio de Janeiro: Forense, 2014.

ROSA, Alexandre Morais da. Guia compacto do processo penal conforme a teoria dos jogos. 1. ed. Rio de Janeiro: Lumen Juris, 2013.

SOUZA, Célia Regina Nilander de. A teoria dos jogos e o direito penal. Revista Pensamento Jurídico, São Paulo, v 10, n. 2, p. 
31-49, jul./dez. 2016. DOI: https://fadisp.com.br/revista/ojs/index.php/pensamentojuridico/article/view/62. Acesso 15 jun. 2020. STRECK, Lenio Luiz. O que é isto decido conforme minha consciência? 4.ed. Porto Alegre: Livraria do Advogado Editora, 2010.

Coordenadoria de Pesquisa e Extensão - COPEX

Departamento de Editoraçāo e Divulgaçāo Científica - DEDIC 


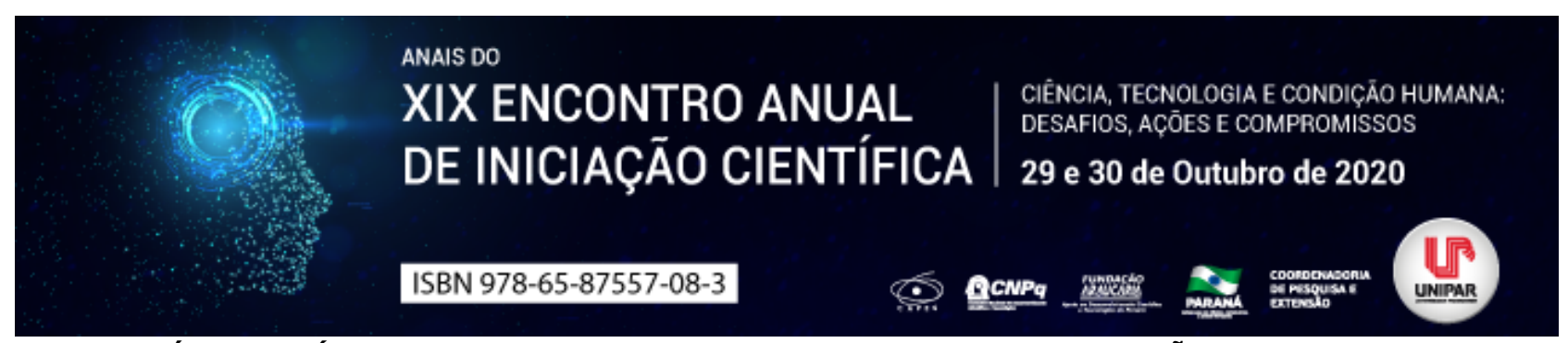

NEGÓCIO JURÍDICO CONTRATUAL EM SEDE DE CONTRATO DE ADESÃO CONSUMERISTA

\title{
${ }^{1}$ EDUARDO MAFFEI, ${ }^{2}$ RAQUEL LAURIANO RODRIGUES FINK, ${ }^{3}$ JUSSARA SUZI ASSIS BORGES N. FERREIRA
}

\author{
${ }^{1}$ Discente do Mestrado em Direito Processual e Cidadania UNIPAR \\ ${ }^{1}$ Discente do Mestrado em Direito Processual e Cidadania UNIPAR \\ ${ }^{2}$ Docente da UNIPAR
}

Introdução: $\mathrm{O} C P C / 15$, trouxe ao ordenamento diversas inovações aliadas aos seus princípios orientadores, dentre elas a possibilidade de celebração de negócios jurídicos processuais atípicos. Mais precisamente, o Art. 190, dispõe que versando o processo sobre direitos que admitam autocomposição, é lícito às partes plenamente capazes estipular mudanças no procedimento para ajustá-lo às especificidades da causa e convencionar sobre os seus ônus, poderes, faculdades e deveres processuais, antes ou durante o processo . Logo, passou a ser possível a negociação do processo, porém, muito se discute sobre os limites de aplicação deste novo instituto. Diante destas premissas, se investiga a possibilidade da inserção cláusulas que que versem sobre negócio jurídico processual em contrato consumerista de adesão. Para tanto, se realizará a análise da celebração de negócios jurídicos processuais atípicos e das regras relativas aos contratos de adesão regidos pelo CDC, confrontando as regras, para se extrair as possibilidade e vedações.

Objetivo: Com o presente trabalho se pretende investigar a possibilidade de celebração de negócios jurídicos processual por contratos de adesão regidos pela legislação consumerista.

Desenvolvimento: Ensina Medina (2017, p.43), que o processo não é apenas instrumento de proteção e realização dos direitos dos indivíduos: o próprio processo deve ser, também, espaço em que se permita exercitar democraticamente tais direitos . Logo, defende-se que as partes e o órgão jurisdicional devem ter uma participação ativa e racional no processo, cooperando pelo desiderato comum: a solução do litígio. Pelo Negócio Jurídico Processual, tem-se um autrorregramento, pelo qual, as partes ajustam entre si regras processuais disponíveis e sob a fiscalização judicial, com caráter vinculatório destas e do juízo no concatenado de procedimentos voltados à solução do litígio. Considerando que as partes que litigam almejam um resultado efetivo e célere a ser alcançado pelo processo, a grande vantagem da negociação processual, é permitir que as partes, ao regularem o procedimento que será adotado para solução do conflito, determinem o que se adequa a real necessidade do caso concreto. Ou seja, de maneira semelhante aos procedimentos de mediação e arbitragem em que as partes podem traçar as diretrizes da solução da controvérsia, o Art. 190, CPC, trouxe a possibilidade de, por avença entre as partes, flexibilizar as regras do processo judicial. No entanto, Casarotto e Medina (2018, p.05), entendem que, diferentemente do direito civil, no qual o negócio jurídico tem como base fundamental a autonomia da vontade, no direito processual o negócio jurídico possui tratamento diferenciado, pois as partes encontram limites também em normas de ordem pública ao postularem a solução do conflito ao Estado-Juiz . Corroborando, Araújo (2016, p. 754), ensina que a limitação ao negócio processual pode decorrer de norma cogente de direito material ou de direito processual. O art. 190 do CPC não realiza esta distinção, e o juiz deverá analisar o conteúdo do negócio com a leitura do direito material e do processual . Logo, os negócios jurídicos processuais atípicos, encontram limitações tanto em matéria processual (Art. 190, p.ú., CPC), quanto pelo direito material, não devendo esquecer da irradiação das normas constitucionais que afetam todo nosso ordenamento jurídico, podendo ser acordado sobre tudo que não conflite com tais regramentos e princípios. Diante destas premissas, passa-se a confrontar a matéria com o Direito do Consumidor. Para Tartuce (2018, p.01), I"a utilização de negócios jurídicos processuais em sede de contratos consumerista encontra sério entrave técnico. O CDC é expresso ao vedar um dos negócios jurídicos processuais típicos, qual seja a cláusula compromissória de arbitragem, quando esta for compulsória (art. 51, inc. VII, da Lei n. 8.078/1990) . Entende o jurista, que a proibição se enaltece ao fato do legislador, no parágrafo único do art. 190 do CPC, impor a recusa dos negócios jurídicos processuais quando da inserção abusiva em contrato de adesão ou em que alguma parte se encontre em manifesta situação de vulnerabilidade . Isso em razão da doutrina, ao interpretar o Art. 4, I, do CDC, entender o consumidor como presumidamente vulnerável ante à assimetria fático-presumida em que se encontra na relação. Logo, o posicionamento de Tartuce (2018, p.01), conclui pela total nulidade da celebração de negócios jurídicos processuais em contrato de adesão consumerista. Porém, se em situação de mais absoluta boa-fé, certo fornecedor resolva incluir em contrato de adesão cláusula que represente negócio jurídico processual em favor do consumidor, cabe refletir qual impedimento para validade da avença. Por exemplo, cláusula que faça previsão de que o fornecedor não apelará da decisão de primeiro grau nos processos em que for réu.

Conclusão: Embora exista na doutrina posicionamento pela nulidade do negócio jurídico processual se celebrado em contratos de adesão regidos pelo CDC, a matéria precisa de um enfrentamento que assista ao real interesse e proteção do consumidor, flexibilizando-se certas vedações legislativas para adequar o direito às necessidades sociais. 


\section{Referências}

ARAUJO, Fábio Caldas de. Curso de Processo Civil Tomo I. São Paulo: Malheiros, 2016.

BRASIL. Lei № 8.078, de 11 de setembro de 1990. Dispõe sobre a proteção do consumidor e dá outras providências. Diário Oficial da União, Brasília, Seção 1 - Suplemento, p. 01, 12 set.1990.

BRASIL. Lei № 13.105, de 16 de março de 2015. Código de Processo Civil. Diário Oficial da União, Brasília, p. 01,17 mar. 2015.

CASAROTTO, Moisés; MEDINA, José Miguel Garcia. Novo Código de Processo Civil e Negócios Jurídicos Processuais no Âmbito do Ministério Público. Revista dos Tribunais. v. 988/2018, p. 233-250. São Paulo: Revista dos Tribunais, 2018.

MEDINA, José Miguel Garcia. Novo Código de Processo Civil Comentado. 5. ed. São Paulo: Revista dos Tribunais, 2017.

TARTUCE, Flávio. Negócio jurídico processual em contrato de consumo. Debate. Jornal carta forense. Matéria de capa de janeiro de 2018. Disponível em https://flaviotartuce.jusbrasil.com.br/artigos/533954493/negocio-juridico-processual-em-contratode-consumo\#: :text=Como\%20\%C3\%A9\%20not\%C3\%B3rio\%2C\%20o\%20CDC,8.078\%2F1990. Acesso em: 31 ago. 2020.

Coordenadoria de Pesquisa e Extensão - COPEX

Departamento de Editoraçāo e Divulgaçāo Científica - DEDIC 


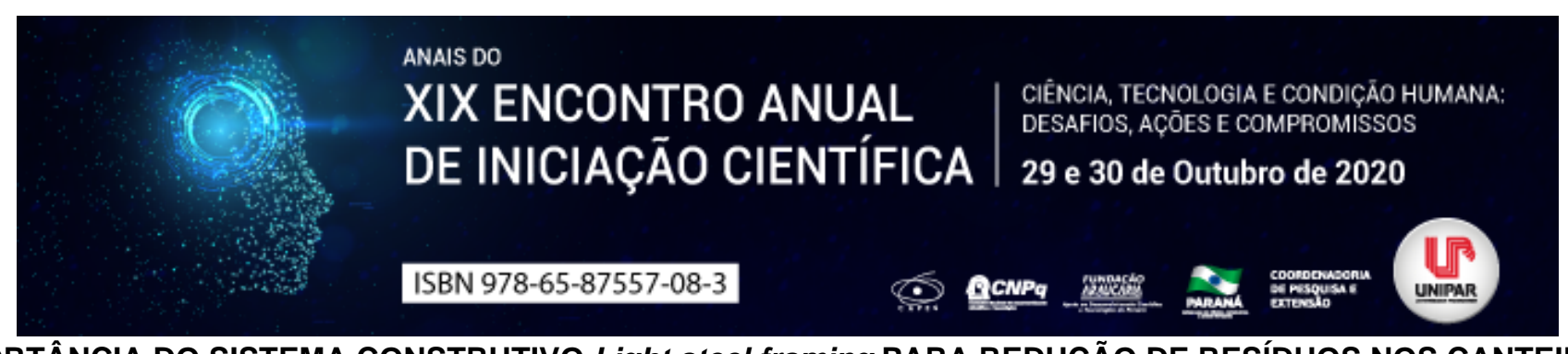

A IMPORTÂNCIA DO SISTEMA CONSTRUTIVO Light steel framing PARA REDUÇÃO DE RESÍDUOS NOS CANTEIROS DE OBRAS

\title{
${ }^{1}$ BRUNA ANTUNES PACHECO, ${ }^{2}$ THAYS LARA PEREIRA DOS SANTOS, ${ }^{3}$ DIANE GUZI FOMIN
}

\author{
${ }^{1}$ Acadêmica do Curso de Arquitetura e Urbanismo da UNIPAR \\ ${ }^{1}$ Acadêmica do Curso de Arquitetura e Urbanismo da UNIPAR \\ ${ }^{2}$ Docente da UNIPAR
}

Introdução: A construção civil é de grande importância para o crescimento econômico e social, mas por outro lado, é responsável por consideráveis impactos ambientais, devido ao alto consumo de recursos naturais, modificação da paisagem natural e geração de resíduos. No Brasil, a grande maioria das edificações são em alvenaria, onde por questões mão de obra barata e materiais com custo inferior acaba sendo a mais utilizada. Este método construtivo é composto por um conjunto de tijolos ou blocos, unidos entre si, com ou sem argamassa de ligação, em fiadas horizontais que se sobrepõem uma sobre as outras. Como alternativa e com o progresso tecnológico no âmbito da construção civil, tem se estudado variados métodos de construção mais eficazes, afim de aumentar a produtividade e resolver problemáticas crescentes devido à grande demanda por habitação. Uma das alternativas é usar o sistema construtivo já solidificado em outros países , conhecido por Light Steel Framing. O Steel Frame é um sistema construtivo racional constituído de perfis leves de aço galvanizado, que formam paredes estruturais e não estruturais depois de receber os painéis de fechamento. (TECNE apud HASS E MARTINS, 2011, p.9).

Objetivo: Apontar a viabilidade ao se aplicar o sistema construtivo Light Steel Framing para redução na geração de resíduos gerados nos canteiros de obras. Visto que esse método construtivo utiliza material incombustível e é considerado $100 \%$ reciclável, também encontramos maiores flexibilidades em projetos arquitetônicos, otimização de recursos naturais por se tratar de uma obra a seco e com menos desperdícios e maior agilidade na construção diminuindo assim o tempo hábil para obra ser entregue gerando assim menos resíduos.

Desenvolvimento: A construção civil é apontada como uma das maiores geradoras de poluição ambiental. Resíduos como concreto, argamassas, cerâmicos, madeira, gesso, papel, plástico e metais, gerados nas obras são responsáveis por cerca de $40 \%$ da produção de resíduos do país. Esses resíduos são prejudiciais à saúde da população e para o meio ambiente, ocasionando problemas respiratórios devido a desmatamentos, demolições, uso de materiais tóxicos como amianto e tintas, provocam também poluição de cursos de água e contaminação de solo. Light Steel Framing é um sistema construtivo a seco, cuja estrutura é composta por paredes, pisos e coberturas, que trabalham em conjunto para garantir a integridade da estrutura do edifício, sendo composto por estruturas metálicas galvanizadas e componentes industriais, reduzindo assim o desperdício de materiais e recursos durante a execução e a geração de resíduos nos canteiros de obras. Em comparação com os sistemas tradicionais, os edifícios construídos utilizando Light Steel Framing têm uma série de vantagens arquitetônicas. Por exemplo, edifícios secos podem minimizar o uso de recursos naturais e resíduos durante a execução do projeto, reduzem a perda de qualidade, o tempo de execução da obra, e a durabilidade da estrutura do perfil galvanizado gera conforto térmico e acústico, baixo custo de manutenção, alto controle do aço na fabricação do produto garante robustez e segurança estrutural, melhor acabamento e uso de materiais industrializados produzem menos resíduos para serem descartados. (CASTRO, R. C. M. 2005). Embora a sustentabilidade seja o carro-chefe deste tipo de construção, a estrutura de aço ainda proporciona facilidade de transporte, manuseio e montagem dos elementos, maior durabilidade e longevidade da estrutura, menor custo de fundações, redução do tempo de obra em aproximadamente 40\%, redução de gastos e também é considerada simples manutenção.

Conclusão: No que se refere ao meio ambiente e sustentabilidade a estrutura em Light Steel Frame garante um desenvolvimento mais sustentável já que os impactos são mínimos devido o aço ser totalmente reciclável e podendo ser reaproveitado inúmeras vezes sem perda de qualidade, apresentando ser uma alternativa potencialmente promissora para a indústria da construção civil no Brasil. Outro fator relevante é a questão da sustentabilidade. É importante considerar não apenas o bem estar dos usuários do edifício, mas também o impacto ambiental gerado no final da construção. Quando utilizado o sistema LSF, a utilização de água é mínima, sendo utilizada somente quando na fundação e não em toda a construção. O método tradicional de construção depende do uso de água até a conclusão da obra. Além disso, o sistema de construção industrializado ajuda a tornar o canteiro de obras mais limpo, sem desperdício de materiais. Seu custo é competitivo comparado com sistema de construção em alvenaria e pode ser ligeiramente superior. No entanto, considerando a facilidade de execução e a capacitação da mão de obra, o aumento do uso desses sistemas deverá reduzir custos. Percebe-se que, diante da falta de cultura relacionada ao uso, as condições patológicas que ocorrem no sistema de estrutura de aço leve podem dificultar a adoção desse sistema construtivo, porém é de extrema importância analisar antes da execução da obra a geração de resíduos que serão descartados, para que dessa forma seja implementado um sistema construtivo que gere menos resíduos nos canteiros de obras 
e posteriormente no meio ambiente.

\section{Referências}

CASTRO, R. C. M. Arquitetura e tecnologia em sistemas construtivos industrializados. Light steel framing. Dissertação (Mestrado). Departamento de Engenharia Civil, Universidade Federal de Ouro Preto. Ouro Preto, 2005.

RAMOS, Renata. Sem um único tijolo. In: Portal Casa e Cia: Casa e Construção: reportagens. [2010]. Disponível em: . Acesso em: 26 out. 2015 .

HASS, Deleine Christina Gessi e MARTINS, Louise Floriano. Viabilidade econômica do uso do sistema construtivo steel frame como método construtivo para habitações sociais. 2011, 76 f. Trabalho de conclusão de curso de graduação apresentado no curso de Engenharia de Produção Civil, na Universidade Tecnológica Federal do Paraná - UTFPR, Campus Curitiba.

Coordenadoria de Pesquisa e Extensão - COPEX

Departamento de Editoraçāo e Divulgaçāo Científica - DEDIC 


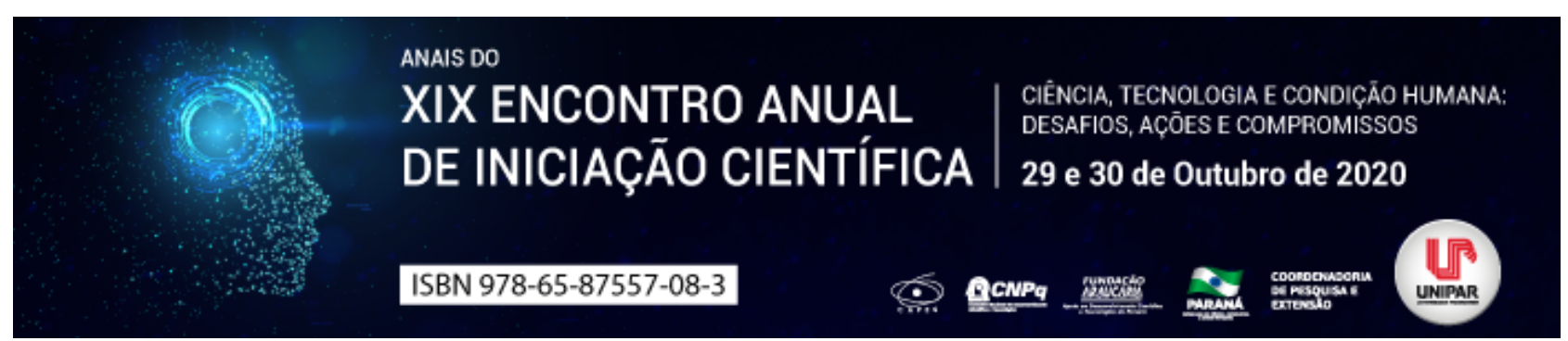

A IMPORTÂNCIA DOS JOGOS PARA O DESENVOLVIMENTO DAS HABILIDADES COGNITIVAS

\title{
${ }^{1}$ EMANUELLE TOTOLI DE OLIVEIRA, ${ }^{2}$ ROSANGELA BRESSAN BUOSI
}

\author{
${ }^{1}$ Acadêmica do Curso de Pedagogia da UNIPAR - PIBIM \\ ${ }^{1}$ Docente da UNIPAR
}

Introdução: Tudo que fazemos na vida está organizado pela cognição, ou seja, pelo pensamento organizado, pois quando o indivíduo vive experiências de uma educação cognitiva as dificuldades de aprendizagem, emocionais, físicas, sociais, quaisquer que sejam diminui significamente. A escola tradicional ainda está muito direcionada para o conteúdo, ensinando seus educandos para saber e para se apropriar desse conhecimento compartilhado socialmente pela cultura, porém quando nos referimos a educação Cognitiva não falamos de uma educação para saber, e sim para uma educação para pensar. O pensar para aprender não diz somente sobre um certo aluno que enfrenta dificuldades de aprendizagem ou o adulto que tem dificuldade de raciocínio, porém entende-se que a educação cognitiva pode ser um benefício para qualquer um.

Objetivo: Demonstrar a importância do desenvolvimento das habilidades cognitivas através de jogos na prática educacional.

Desenvolvimento: $O$ desenvolvimento das habilidades cognitivas está diretamente relacionado com atenção, memória, percepção visual, percepção auditiva, associação de ideias, compreensão e raciocínio, orientação temporal e constância e percepção. Nesse sentido, as habilidades cognitivas não tem relação com as atividades mnemônicas, mas com o desenvolvimento da intelectualidade. Segundo Carraher (2002) o modelo cognitivo do conhecimento em sua forma básica consiste na representação mental, o conhecimento da criança é uma representação mental; Aprender pensar sobre assuntos é mais importante que aprender fatos sobre os assuntos; O ensino é um convite a exploração e à descoberta; $O$ ensino deve partir de onde a pessoa se encontra. As habilidades cognitivas se iniciam com os estímulos cerebrais desde que o indivíduo nasce, ou seja, são habilidades desenvolvidas através do estímulo do meio em que vive. E para isso, a família e a escola exercem papel primordial estimulando através de várias atividades. Estas podem ser sem propósito, ou planejadas no caso da escola. É fundamental que os trabalhos com a cognição se iniciem na Educação Infantil e se estenda por toda a escolaridade do indivíduo. Para treino de habilidades cognitivas e atenção Cartiere et al. (2012) afirma que percebeu melhora significativa no desenvolvimento do indivíduo, melhorando problemas como hiperatividade e atenção utilizando jogos, tais como, tangram, sete erros, construção de blocos, domino, sudoku, jogo da memória, caça palavras, entre outros que podemos ver transformar nossa realidade diariamente. Alves (2010), evidencia a importância dos familiares, equipe escolar e professores no processo de desenvolvimento de habilidades cognitivas, visando a importância da ludicidade para o desenvolvimento cognitivo e emocional. Explorando sempre a realidade e a cultura em que se vive. Segundo Ramos (2017) baseando-se à problemática entre a visão positiva da facilidade e realização e prática de atividades, pode-se se perceber a aumento da atenção e o desenvolvimento das habilidades que captam informações entre questões simples do cotidiano e em âmbitos grandiosos, realizando tarefas de forma organizada e desenvolvida.

Conclusão: Diante do exposto conclui-se que jogos cognitivos vão além de quaisquer banalidade ou utilização dos jogos como simples atividade sem propósito ou argumento. Pois entendemos que a partir de uma real seleção e classificação, os instrumentos utilizados como estratégias pedagógicas na forma de desenvolver as habilidades cognitivas no ambiente escolar, promove um Aprender pensando (Carraher, 2002), e a diminuição do índice de TDAH, diminuição das dificuldades em raciocínio lógico matemático, resolução de problemas, ansiedade e aumento da auto estima, entre outras competências necessárias para o processo de construção do conhecimento (McGonical, 2012).

\section{Referências}

ALVES, Luciana; BIANCHIN, Maysa Alahmar. O jogo como recurso de aprendizagem. Rev. psicopedag. São Paulo, v. 27, n. 83, p. 282-287, 2010. Disponível em http://pepsic.bvsalud.org/scielo.php?script=sci_arttext\&pid=S0103$84862010000200013 \&$ lng=pt\&nrm=iso. Acesso em: 21 ago. 2020.

CANTIERE, Carla N. et al. Treino cognitivo em crianças e adolescentes com sinais de desatenção e hiperatividade: proposta de protocolo de intervenção neuropsicológica nos domínios verbal e executivo. Cadernos de Pós Graduação em Distúrbios do Desenvolvimento, v. 12, n. 1, 98-107, 2012.

FONSECA, Vitor da. Papel das funções cognitivas, conativas e executivas na aprendizagem: uma abordagem neuropsicopedagógica. Rev. psicopedag., São Paulo, v. 31, n. 96, p. 236-253, 2014. Disponível em: http://pepsic.bvsalud.org/scielo.php?script=sci_arttext\&pid=S0103-84862014000300002\&lng=pt\&nrm=iso. Acesso em: 25 ago. 2020. 
McGonical, J. (2012). A realidade em jogo: porque os games nos tornam melhores e como eles podem mudar o mundo. São Paulo: Record.

RAMOS, Daniela Karine. et al. O uso de jogos cognitivos no contexto escolar: contribuições às funções executivas. Psicol. Esc. Educ., Maringá, v. 21, n. 2, p. 265-275, Aug. 2017. Available from: http://www.scielo.br/scielo.php?script=sci_arttext\&pid=S141385572017000200265\&lng=en\&nrm=iso. Access on: 26 Aug. 2020.

SILVA, Valdenize Alves. Jogos educativos no processo de desenvolvimento cognitivo pedagógico. Revista Científica Multidisciplinar Núcleo do Conhecimento. Ano 03, Ed. 08, Vol. 14, pp. 107-114, Agosto de 2018.

Coordenadoria de Pesquisa e Extensão - COPEX

Departamento de Editoraçāo e Divulgaçāo Científica - DEDIC 


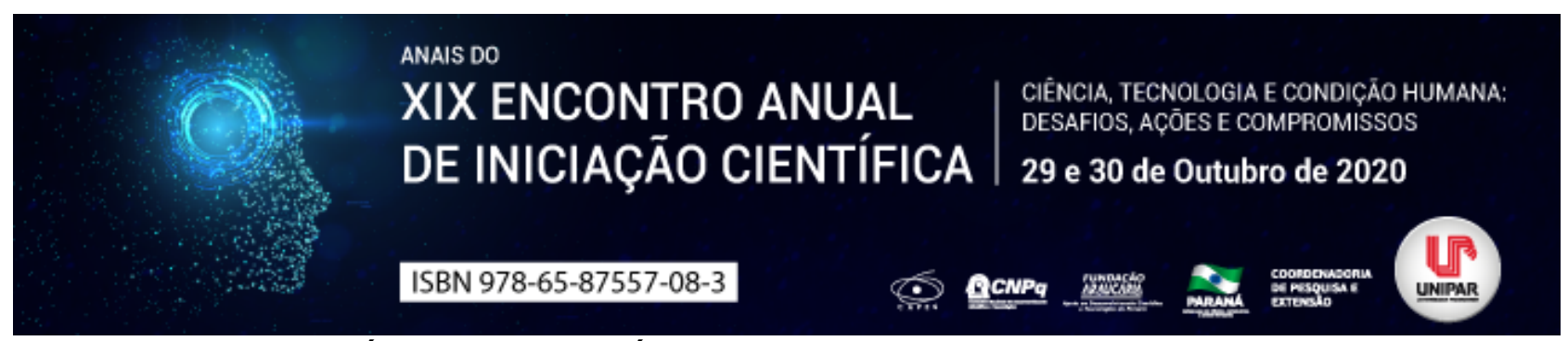

EUTANÁSIA E ORTOTANÁSIA: A QUEM CABE O DIREITO DE DECIDIR?

\begin{abstract}
${ }^{1}$ MAISA CASTANHEIRA FEITOSA, ${ }^{2}$ BRUNA DA SILVA SANTOS, ${ }^{3}$ MATHEUS HENRIQUE RAPHAEL DE PAULA, ${ }^{4}$ ALESSANDRO DORIGON
\end{abstract}

\author{
${ }^{1}$ Acadêmico do curso de Direito da UNIPAR \\ ${ }^{1}$ Acadêmica do Curso de Direito da UNIPAR \\ ${ }^{2}$ Acadêmico do Curso de Oratoria - Turma I da UNIPAR \\ ${ }^{3}$ Docente da UNIPAR
}

Introdução: A vida é um bem jurídico indisponível e tutelado pelo Código Penal e pela Carta Magna de 1988, sendo assim, há necessidade de um maior esclarecimento sobre o que significa falar de uma morte digna, por meios éticos necessários para que esse fim seja alcançado.

Objetivo: Analisar a descriminalização da eutanásia e ortotanásia para garantir a dignidade da pessoa humana, principalmente em pacientes em estado terminal.

Desenvolvimento: Um dos princípios fundamentais da Constituição Federal disposto no art. $1^{\circ}$, $\S 3^{\circ}$, é a dignidade da pessoa humana, sendo necessário esclarecer esse termo, visto não haver consenso sobre os seus sentidos. Ramos (2018, p. 84) define como uma qualidade inerente ao ser humano, que o protege contra todo tratamento degradante e discriminação odiosa, assegurando-Ihe condições materiais mínimas de sobrevivência. Trata-se, portanto, de um atributo que o indivíduo possui, inerente à sua condição humana, não importando qualquer outra condição. A palavra eutanásia vem do grego eu quer dizer bom e tanatos, morte. Portanto, segundo a etimologia, eutanásia significa boa morte. Já o termo ortotanásia, de forma etimológica, advém do grego orthós normal, correta e thánatos morte, designando a morte natural ou correta (CABETTE, 2013, p. 24). A eutanásia é entendida como morte provocada por um sentimento de piedade e desta forma, ao invés de deixar a morte acontecer, a eutanásia age sobre a morte, antecipando-a; já a ortotanásia é a morte pelo seu processo natural, ou seja, o doente já está em processo natural da morte e recebe uma contribuição do médico para que este estado siga seu curso natural, seguindo os cuidados paliativos necessários, sendo dessa forma, o oposto da distanásia que, por sua vez, se dedica a prolongar o máximo a quantidade de vida humana, combatendo a morte como o grande e último inimigo. Quanto aos aspectos penais, a missão principal é tutelar a vida, um bem jurídico indisponível, imprescritível e intangível, podendo ocorrer sua violação, seja por meio culposo, no caso em que o agente dá causa ao resultado por imprudência, negligência ou imperícia ou por meio doloso, isto é, quando o agente, por vontade consciente comete o ato. Foi dito que a eutanásia consiste na prática de abreviar a vida de um doente incurável, terminal ou não, a seu pedido provocando-lhe a morte. Trata-se, portanto, de uma atitude positiva, comissiva, em que o agente, livre e conscientemente, provoca o resultado morte no paciente. Não importa neste momento o fato de o agente ter praticado o ato a pedido do paciente, visto ser a vida um bem jurídico indisponível, conforme já descrito. Deste modo, aquele que atendendo ao pedido de um doente incurável, provocar sua morte, responderá pelo crime de homicídio doloso, art. 121, Capítulo I -Dos Crimes Contra a Vida, do código penal brasileiro. Nos países em estas práticas são regulamentadas, tais como, a Holanda, a Bélgica e alguns Estados americanos, como Oregon, por exemplo, defendem que viver é um direito e não uma obrigação, a escolha de uma das práticas busca evitar a dor e o sofrimento de pessoas sem qualidade de vida, portadoras de uma doença incurável. Uma das angústias mais comuns em pacientes portadores de uma doença incurável, é o temor da solidão e o medo de se tornar um peso para a família e amigos e, que a falta de esperança, de expectativa de tratamento ou cura, enseja outro direito, o direito à morte digna. Segundo Dorigon (2018) não se trata de agir ou deixar de agir para causar a morte de alguém, muito menos, utilizar-se de tratamentos extraordinários, desproporcionais e fúteis para manter a vida vegetativa, mas sim, humanizar o processo de morrer, sem prolongamentos desproporcionais, bem como, sem sofrimento para o doente e seus familiares.

Conclusão: A dignidade da pessoa humana se faz ausente nos casos de patologias em estado terminal quando se obriga uma pessoa a viver de forma sofrível. Dessa forma, por meio da conscientização social e mudanças nas normas vigentes, os direitos de escolha dos pacientes, deveriam ser avaliados, para que assim, a dignidade seja promovida de forma eficaz.

\title{
Referências
}

BRASIL. [Constituição (1988)]. Constituição da República Federativa do Brasil: promulgada em 05 outubro de 1988. Disponível em: http://www.planalto.gov.br/ccivil_03/constituicao/constituicao.htm. Acesso em: 24 maio 2020.

CABETE, E. L. S. Eutanásia e ortotanásia: comentários à Resolução 1.805/06 CFM. Aspectos éticos e jurídicos. Curitiba: Juruá, 2013. 
DORIGON, Alessandro. O direito de morrer com dignidade - Um estudo sobre a eutanásia, ortotanásia e o suicídio assistido. Conteúdo Jurídico, 2018. Disponível em: https://conteudojuridico.com.br/consulta/Artigos/51349/o-direito-de-morrer-comdignidade-um-estudo-sobre-a-eutanasia-ortotanasia-e-o-suicidio-assistido. Acesso em: 17 jul. 2020.

ETIMOLÓGICO, Dicionário. Etimologia e origem das palavras. Disponível em: https://www.dicio.com.br/. Acesso em: 17 jul. 2020. RAMOS, André de Carvalho. Curso de direitos humanos. 5. ed. São Paulo: Saraiva Educação, 2018.

Coordenadoria de Pesquisa e Extensão - COPEX

Departamento de Editoraçāo e Divulgaçāo Científica - DEDIC 


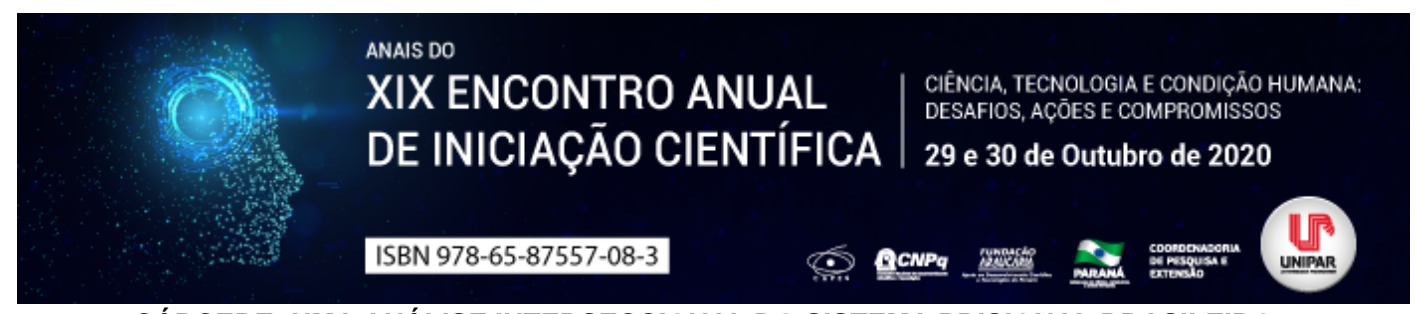

CÁRCERE: UMA ANÁLISE INTERSECCIONAL DO SISTEMA PRISIONAL BRASILEIRO

\author{
${ }^{1}$ GIOVANA LABIAK PEREIRA, ${ }^{2}$ CAMILA BATISTA DALLA VECCHIA, ${ }^{3}$ NIKITA DE FREITAS, ${ }^{4}$ MARIANA GUILHERME GONCALVES, ${ }^{5}$ KAROLYNE \\ RIBEIRO DA CUNHA, ${ }^{6}$ CLAUDIA LOPES PERPETUO
}

\author{
${ }^{1}$ Acadêmico do PIC/UNIPAR \\ ${ }^{1}$ Acadêmica do Curso de Psicologia da UNIPAR \\ ${ }^{2}$ Acadêmica do Curso de Psicologia da UNIPAR \\ ${ }^{3}$ Acadêmica do Curso de Psicologia da UNIPAR \\ ${ }^{4}$ Acadêmica do Curso de Psicologia da UNIPAR \\ ${ }^{5}$ Docente da UNIPAR
}

Introdução: Este resumo foi construído a partir de leituras e revisão bibliográfica, além das discussões realizadas no Programa de Iniciação Científica no projeto intitulado: Psicologia e Interseccionalidades: marcadores sociais de raças/etnias e gêneros, no qual investiga-se teoricamente o conceito de interseccionalidade, objetivando compreender as articulações dos diferentes marcadores sociais (raça/etnia, gênero, entre outros), como estes se relacionam e influenciam na sociedade. Desse modo, buscou-se analisar tais recortes sociais no contexto penitenciário brasileiro a fim de introduzir a discussão sobre o mito da democracia racial, levando em conta a pigmentocracia e seu reflexo neste sistema punitivo.

Objetivo: Demonstrar e analisar as interseccionalidades da população carcerária do Brasil, destacando o recorte social de raça e como isso se relaciona com o racismo e o colorismo no processo de embranquecimento nacional, resultando na miscigenação e a falta de identidade racial da população brasileira, com base numa análise de revisão bibliográfica.

Desenvolvimento: O Brasil foi construído, colonizado e catequizado sob os pilares cristãos e europeus e consequentemente a exploração de outras raças e etnias fizeram parte dessa construção de nação. O comércio e a escravização de povos negros sequestrados da África fizeram a nova população brasileira se enegrecer. Mas o governo apostou no milagre da miscigenação com políticas de imigração para europeus (Alemães, italianos, espanhóis...) com o objetivo da higienização racial (VIANNA, 1938), o embranquecimento ideal que a pintura Redenção de Cam (BROCOS, 1895), nos mostra. Essa miscigenação como projeto de governo, fruto do estupro de mulheres negras e indígenas, resultou em uma população que nasceu sem cor, claros demais para serem negros e escuros demais para serem brancos, desde então o termo pardo se popularizou para definir a cor desses negros de pele clara Desde o primeiro censo, a categoria pardo foi incluída para dimensionar o estrato da população que não se classificaria nem como branco, nem como preto (CAMPOS, 2013, p.82). O racismo estrutural se revela nos detalhes deste país, se autodeclarar negro ainda é visto com desvalor, na tentativa racista de apagar e invisibilizar uma raça, por isso a nomenclatura parda é muito mais utilizada pela população negra ao se autodeclararem. Segundo dados do Departamento Penitenciário Nacional DEPEN (2019), referente ao período de julho a dezembro de 2019, nos presídios estaduais de todos o país, temos um total de 748.009 pessoas cumprindo algum tipo de pena, dessas, 657.208 declararam sua raça, dos declarantes $49,87 \%$ se consideram pardos, $32,29 \%$ brancos, $16,82 \%$ pretos, e $0,29 \%$ se declararam amarelos e indígenas.

Conclusão: Portanto, a partir dos dados expostos, percebe-se que temos $66,98 \%$ de pessoas não brancas cumprindo algum tipo de pena no nosso sistema carcerário. O sistema racista atua mascarando a classe oprimida para que não tenham que pagar a reparação histórica por tantos séculos de escravidão, exploração e vidas roubadas e descartadas pelo critério de sua cor. O estado prende e encarcera a população que teve que se abrigar à margem das cidades após a assinatura da princesa Isabel em 1888, para a libertação do Brasil da escravidão que agradava os olhos dos ingleses, já que nunca houve projetos para a socialização e o pagamento da dívida histórica dessas pessoas escravizadas no nosso país. O estado racista apagou as histórias, as identidades e as raízes de um povo e agora os prende para deixá-los longe do centro urbano de poder capitalista, cria um estereótipo bem específico de bandido para a sociedade dos cidadãos de bem odiarem e pedirem mais encarceramento, já que a cadeia nos faz duvidar se um dia houve projeto ressocializador (SALLA e LOURENÇO, 2014) ou o objetivo de prender aqueles que descumprem a lei.

\title{
Referências
}

Departamento Penitenciário Nacional (DEPEN) - Levantamento nacional de Informações Penitenciárias. Período de Julho a Dezembro de 2019. Disponível em:

https://app.powerbi.com/view? r=eyJrljoiMmU4ODAwNTAtY2lyMS00OWJiLWE3ZTgtZGNjY2ZhNTYzZDliliwidCI6ImViMDkwNDIwLTQ0NGMtNDNmNy05MWYyLTRiOGRhNmJmZThIMSJ9, Acesso em: 15/08/2020.

VIANNA, Oliveira. Evolução do Povo Brasileiro. São Paulo: Companhia Editora Nacional, 1938.

SALLA, Fernando; LOURENÇO, Luiz Cláudio. Aprisionamento e prisões. São Paulo: Contexto, 2014.

CAMPOS, Luiz Augusto. O pardo como dilema político. Insight Inteligência. n. 62, p.80 a 91 . Dezembro de 2013

BROCOS, Modesto. A redenção de Cam.1895. Pintura, óleo sobre tela, 199 x $166 \mathrm{~cm}$.

Coordenadoria de Pesquisa e Extensão - COPEX

Departamento de Editoraçāo e Divulgaçāo Científica - DEDIC 


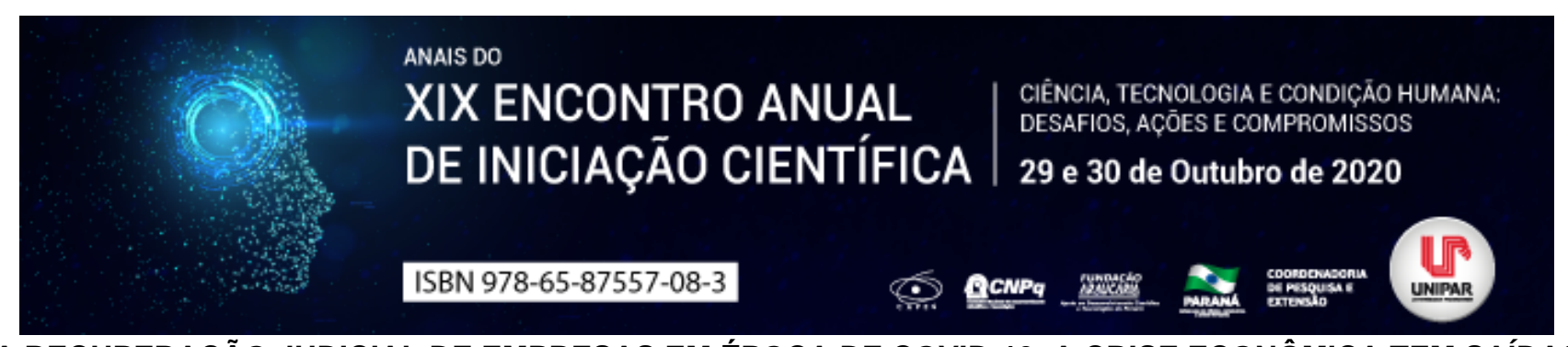

A RECUPERAÇÃO JUDICIAL DE EMPRESAS EM ÉPOCA DE COVID-19. A CRISE ECONÔMICA TEM SAÍDA?

\author{
${ }^{1}$ Adriane Heloísa Olenski March, ${ }^{2}$ GIANNA MARQUES ZAMBERLAN
}

\begin{abstract}
${ }^{1}$ Professora na Faculdade de Administração e Ciências Econômicas FACEC. Advogada. Especialista em Direito Civil e Processo Civil pela UEL.

${ }^{1}$ Advogada. Especialista em Ciências Penais pela UEM; Especialista em Direito Tributário pela Universidade Anhaguera.
\end{abstract}

Introdução: A pandemia da COVID-19 instaura ao redor do mundo crise econômica. No Brasil, atualmente epicentro da doença, não seria diferente. O mês de maio de 2020 apresentou recorde nos pedidos de Recuperação Judicial. Assim, o legislativo se move para aprovar neste intervalo o Projeto de Lei $n^{\circ} 1.397 / 20$, a fim de criar regras transitórias para as empresas em recuperação judicial, enquanto encontra-se em vigor a Recomendação no 63/2020 do CNJ. Porém, paira no ar o questionamento: Será que as medidas tomadas serão eficazes para a contenção da crise econômica?

Objetivo: Analisar o instituto da Recuperação Judicial face a pandemia de COVID-19 e averiguar se as medidas adotas no país são eficazes para superar a crise econômica.

Desenvolvimento: A Recuperação Judicial é prevista na Lei no 11.101/2005, tendo como base a consolidação dos princípios da preservação da empresa, sua função social e o estímulo à atividade econômica, conforme se verifica no teor do art. 47 da referida lei. Tarcísio Teixeira (2019, p. 442) expõe que a Lei de Recuperação Judicial e Falência é mais moderna, pois tem o intuito de recuperar o negócio, sendo uma tentativa de reorganização da empresa em crise, evitando o processo falimentar e consequente encerramento das atividades. Assim, a Recuperação Judicial é vista como um mecanismo para assegurar os princípios do Direito Empresarial, em especial a preservação da empresa e sua função social em momentos de crise. Diante da pandemia de COVID-19, inegável a desestabilização das economias mundiais, atingindo diretamente o setor empresarial, inclusive no Brasil, atual epicentro da doença. Tiago Angelo (2020) apresenta dados relatando que os pedidos de recuperação judicial no mês de maio de 2020 aumentaram 68,6\%. Com base nesta demanda, o Conselho Nacional de Justiça, editou a Resolução n 63/20, procedendo com diversas recomendações aos magistrados, como a flexibilização da modificação de plano de recuperação; possibilidade de prorrogação do prazo de duração da suspensão (stay period); e análise cautelosa sobre deferimento de medidas de urgência, decretação de despejo por falta de pagamento e a realização de atos executivos de natureza patrimonial em desfavor de empresas durante o período de calamidade pública, demonstrando meios aptos para a lidar, de modo imediato, com os caos expostos ao judiciário. Neste mesmo contexto, o deputado Hugo Leal (PSD-RJ) apresentou o Projeto de Lei $n^{\circ} 1.397 / 20$, em $1^{\circ}$ de abril de 2020, para criação de regras transitórias para empresas em recuperação judicial, bem como evitar que outras empresas cheguem a esse ponto. Já aprovado na Câmara dos Deputados, o projeto segue para o Senado Federal, constando em seu texto diversas medidas, como a suspensão por 60 (sessenta) dias, a contar da vigência da lei, de ajuizamento de ações judiciais, de caráter executivo, envolvendo discussões sobre obrigações vencidas após a decretação de calamidade pública no país e as ações revisionais de contrato, devendo as partes, no prazo de suspensão, proceder com a renegociação de forma extrajudicial e direta. Ainda, a proposta de lei apresenta o instituto da negociação preventiva, onde, findado o prazo de suspensão, o agente econômico poderá ajuizar, uma única vez, este procedimento de jurisdição voluntária, sendo nomeado negociador para que no período máximo e improrrogável de 60 (sessenta) dias proceda com o ajuste entre as partes envolvidas, apresentado relatório ao juiz competente sobre os trabalhos desenvolvidos. Ocorre que, se analisarmos os dados anteriores sobre o universo da Recuperação Judicial, apresentado por Erik Frederico Oioli e José Afonso Leirião Filho (2015, p. 133), tem-se que entre a vigência da Lei $n^{\circ} 11.101 / 2005$ até o mês de fevereiro de 2014, apenas $1 \%$ das empresas em Recuperação Judicial efetivamente se recuperaram. Assim, os dados apresentados podem demonstrar certa ausência de credibilidade no instituto da Recuperação Judicial antes da pandemia, quiçá neste momento de crise econômica mundial vivenciada, pois o instituto não está desempenhando o papel desejado, diante dos baixos índices de efetividade.

Conclusão: Levando-se em consideração os aspectos apresentados, a Recuperação Judicial apresenta-se como uma alternativa para as empresas manterem-se no mercado, efetivando os princípios da preservação da empresa e da função social. Inquestionável que a pandemia de COVID-19 ocasionará problemas financeiros em diversos setores, fazendo nascer o interesse em solicitar a Recuperação Judicial. Assim, o Poder Judiciário e o Legislativo estão apresentando alternativas para fazer com que a Recuperação Judicial seja mais interessante, como a instituição da negociação preventiva e recomendações mais cautelares aos magistrados, atento às necessidades conforme a atual configuração social e econômica. Resta averiguar se o Projeto de Lei $\mathrm{n}^{\circ} 1.397 / 20$ será aprovado e se o mesmo será efetivo para as empresas em crise, modificando os atuais dados sobre a Recuperação Judicial.

\title{
Referências
}


ANGELO, Tiago. Pedidos de falência sobem 30\% em maio; de recuperação judicial, 68\%. CoNJUR. São Paulo, 05 de jun. de 2020. Disponível em: . Acesso em: 20 de jul. de 2020.

BRASIL. Lei $n^{\circ}$ 11.101, de 9 de fev. de 2005. Regula a recuperação judicial, a extrajudicial e a falência do empresário e da sociedade empresária. Disponível em: . Acesso em: 15 de jul. de 2020.

OIOLI, Erick Frederico; LEIRÃO FILHO, José Afonso. Questões Atuais da Recuperação Judicial de Sociedades Empresárias. In: MEDEIROS NETO, Elias Marques de; SIMÃO FILHO, Adalberto. Direito dos negócios aplicado. São Paulo: Almedina, 2015.

TEIXEIRA, Tarcisio. Direito empresarial sistematizado: doutrina jurisprudência e prática. 8. ed. São Paulo: Saraiva Educação, 2019.

Coordenadoria de Pesquisa e Extensão - COPEX

Departamento de Editoraçāo e Divulgaçāo Científica - DEDIC 


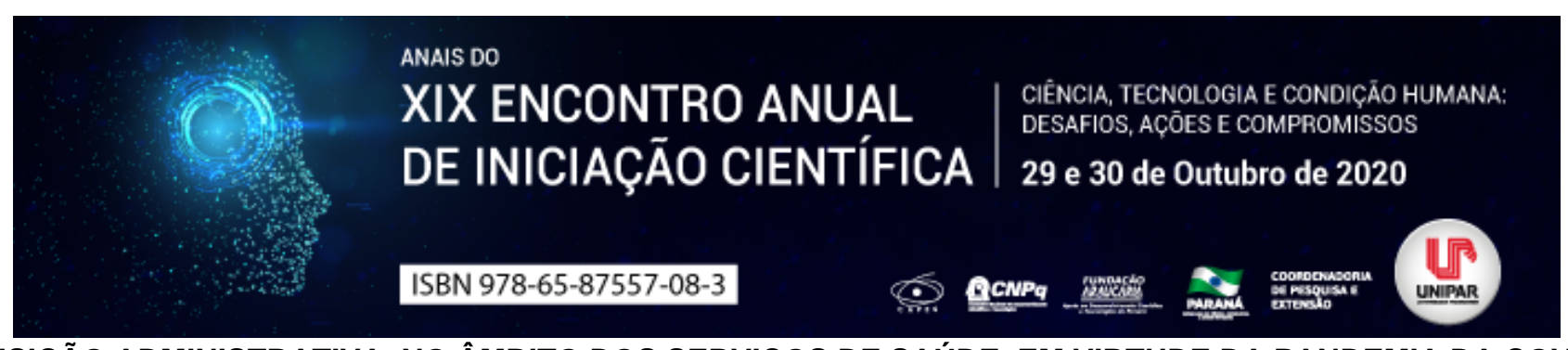

REQUISIÇÃO ADMINISTRATIVA, NO ÂMBITO DOS SERVIÇOS DE SAÚDE, EM VIRTUDE DA PANDEMIA DA COVID-19

\author{
${ }^{1}$ GABRIEL FERNANDES ARAUJO, ${ }^{2}$ PAULO CESAR DE SOUSA
}

${ }^{1}$ Acadêmico do curso de Direito da Unipar

${ }^{1}$ Docente da UNIPAR

Introdução: A requisição administrativa é uma medida utilizada como instrumento de intervenção estatal para atender necessidades coletivas em situações de perigo público iminente. Tendo amparo no artigo $5^{\circ}, \mathrm{XXV}$, da Constituição Federal. Por conseguinte, a situação de perigo iminente com que convive-se na atualidade, a Pandemia da Covid-19, justifica o emprego da requisição administrativa.

Objetivo: Examinar a pertinência do uso do instituto da requisição administrativa, na área da saúde pública, tendo em vista a pandemia da Covid-19.

Desenvolvimento: A requisição administrativa é a utilidade coativa de bens ou serviços particulares, pelo Poder Público, por ato de execução imediata e direta da autoridade requisitante e indenização ulterior, para atendimento de necessidades coletivas urgentes e transitórias (MEIRELLES, 1991, p. 525). É uma modalidade de intervenção estatal que pode ser adotada por ocasião de um perigo público, que autoriza o uso da propriedade privada, quanto limitar a liberdade das pessoas para evitar possíveis danos à coletividade. É imprescindível, para efetivar a requisição, a necessidade iminente do bem ou serviço requisitado pela administração pública, como por exemplo respiradores e equipamentos hospitalares. Sem a configuração da real necessidade de utilizar propriedade privada, não poderá ser utilizada a intervenção estatal. Com isso, não basta somente a existência do surto epidêmico, é preciso que a utilização do bem ou serviço requisitado sirva para combater ou auxiliar frente a pandemia. Constitucionalmente, cabe indenização se verificado dano à a propriedade. Logo, inexistindo dano, é possível a utilização sem pagamento de valor algum. Assim, é viável empregar a requisição administrativa na atualidade, vez que o cenário pandêmico decorrente da transmissão da Covid-19, sem dúvida é um episódio que se qualifica como um caso de iminente perigo ligado à saúde pública, que exige o enfrentamento em caráter de urgência por parte da administração pública, para impedir a transmissão da Covid-19, bem como auxiliar no tratamento de pessoas contaminadas. Tudo isso encontra fundamento jurídico no princípio da supremacia do interesse público, o qual confere legalidade para que a administração pública intervenha na propriedade privada, vez que atua focada no interesse público, sendo pressuposto de uma ordem social estável, em que todos e cada um possam sentir-se garantidos e resguardados (MELLO, 2015, p. 70). Isso porque, a requisição civil visa a evitar danos à vida, à saúde e aos bens da coletividade, diante de inundação, incêndio, sonegação de gênero de primeira necessidade, epidemias, catástrofe etc (ALEXANDRINO, PAULO, 2017, p. 1125), situações de grave ameaça.

Conclusão: A requisição administrativa é um mecanismo que pode ser utilizado pela administração pública em situações decorrentes da pandemia da Covid-19, vez que a situação se amolda ao regime constitucional previsto para a aplicação do instituto, para que seja efetivada a preservação da vida e garantido o bem-estar social.

\title{
Referências
}

MEIRELLES, Hely Lopes. Direito Administrativo Brasileiro. 16. ed. São Paulo: Revista dos Tribunais, 1991.

ALEXANDRINO, Marcelo; PAULO, Vicente. Direito Administrativo Descomplicado. 25. ed. Rio de Janeiro: Forense, 2017.

MELLO, Celso Antônio Bandeira de. Curso de Direito Administrativo. 32. ed. São Paulo: Malheiros Editores, 2015. 


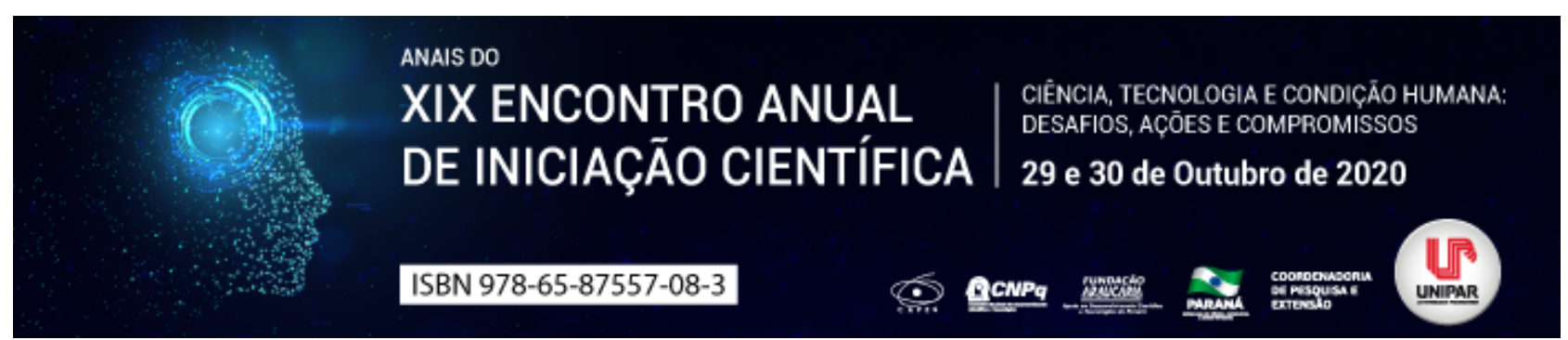

A IMPORTÂNCIA DOS ESPAÇOS PÚBLICOS- BAIRRO PADRE ULRICO - FRANCISCO BELTRÃO (PR)

\title{
${ }^{1}$ THAYS LARA PEREIRA DOS SANTOS, ${ }^{2}$ BRUNA ANTUNES PACHECO, ${ }^{3}$ MARIA FERNANDA MIRANDA PEZENTE
}

\author{
${ }^{1}$ Acadêmica do Curso de Arquitetura e Urbanismo da UNIPAR \\ ${ }^{1}$ Acadêmica do Curso de Arquitetura e Urbanismo da UNIPAR \\ ${ }^{2}$ Docente da UNIPAR
}

Introdução: Neste artigo, temos como finalidade analisar o território do bairro Padre Ulrico, localizado na cidade de Francisco Beltrão, evidenciando características de sua formação assim também como sua expansão, dando ênfase na situação de ocupação, na qual é chamado de Terra Nossa , tendo seu início em 10 de setembro de 2016. O local que se tem ênfase na pesquisa é de propriedade da prefeitura municipal de Francisco Beltrão, onde foi invadido por cerca de 700 famílias no ano de 2016 e hoje (2020) encontra-se ocupado por, pelo menos, o dobro desse número. Com quase nenhuma infraestrutura básica, ocupantes da área passam por necessidades, onde a falta de equipamentos urbanos é evidente no local.

Relato de caso: A finalidade principal deste trabalho é o exame das formas de apropriação do espaço urbano, cuja as características morfológicas e da população desse ambiente sejam diferenciadas. Para cumprir os objetivos propostos neste trabalho, tomamos a situação existente, na qual é nesta cidade, Francisco Beltrão, bairro Padre Ulrico, sendo o local de invasão conhecido como terra nossa

Discussões: As cidades são locais onde as pessoas se encontram para trocar ideias, comprar e vender, ou simplesmente relaxar e se divertir. O domínio público de uma cidade- suas ruas, praças e parques- é o palco catalisador dessas atividades. (ROGERS, Richard) E embora grande parte da população não tenha conhecimento sobre, as ruas e calçadas são os maiores espaços públicos de uma cidade, são os locais que proporcionam os encontros entre os cidadãos. Atualmente as ruas e estacionamentos no centro da cidade de Francisco Beltrão já estão ocupados quase que totalmente com veículos privados. Transitar pela cidade em horário de pico , torna o trajeto mais lento e um tanto quanto perigoso, principalmente para com os pedestres. A cidade não teve um planejamento urbano e à medida que ela cresce os problemas aumentam. Sendo assim analisaremos em especifico um local com uma grande falta de planejamento urbano. Sendo um bairro mais distante do centro da cidade, o Padre Ulrico é alvo de grande descriminalização social, cultural e econômica. É conhecido pelos próprios habitantes da cidade, por abrigar marginalizados e por ser um território que apresenta perigo. Não há muitos dados disponíveis sobre o local, porém, o que se sabe é que o investimento para com este é escasso. As ruas que deveriam ser asfaltadas, promovendo uma melhoria na mobilidade local, trazendo uma estrutura de maior qualidade para com os moradores, é de calçamento ou mesmo, estradas de terra. No bairro em análise, essa insegurança é colocada em questão. Sem a estrutura adequada as pessoas não conseguem se sentir seguras, aptas a circularem pelas ruas. Para entender melhor sobre o espaço em estudo, exemplificado em uma frase de JANE JACOBS (1961) que diz: Trata-se de uma área tradicional, de baixa renda, que se mistura à indústria pesada da orla e é considerada pelas autoridades como a pior zona de cortiços, uma vergonha municipal . Da mesma forma que o bairro Padre Ulrico em Francisco Beltrão - Paraná é nomeado na região, apesar de receber a fama de um bairro ruim ,a vários espaços de suma importância para o município, agregando muito para uma visão diferente do espaços, atributos que se analisados minuciosamente mostram o contrário de um bairro desagradável e introduz uma recepção diferente para aqueles que adentram ao espaço e observam as variadas atividades que o bairro oferece, trazendo indústrias que geram emprego na cidade, não só para quem mora no bairro mais para as demais pessoas da cidade e da região,

Conclusões: Após aplicado o método de estudo, feito pesquisas bibliográficas de livros e artigos, pode-se entender melhor como o espaço público se desenvolve, caracterizado pela inserção das pessoas e pela troca de informação que ocorre nesses meios. Espaços estes como as ruas, calçadas, museus, praças, parques entre todos os espaços de convívio social. O bairro analisado, Padre Ulrico, é esquecido socialmente pela população e pelo governo, sem verbas locais e melhorias na infraestrutura, principalmente no Loteamento Terra Nossa, que atualmente, e desde sua ocupação, está em situações desagradáveis. Ao adentrar no bairro, a visibilidade é igual ao restante da cidade, mais ao passar da entrada as coisas vão mudando aos poucos, a estrada que até então era de asfalto passa a ser de calçamento, e quando chega ao Loteamento da ocupação já nem estrada tem mais, e chão batido, restos de calçamento, que acabam ocasionando diferentes tamanhos de buracos na rua. Ao planejar um espaço adequado nesse loteamento, teria hoje uma visibilidade na sociedade, não considerada uma visão ideal, ao analisar o estudo percebe-se com clareza que a sociedade se comunica melhor em espaços onde seu entorno andam em sintonia, o melhor seria em um espaço com segurança, infraestrutura, espaços como comércio, restaurantes. E ao falar de segurança e infraestrutura o Loteamento Terra Nossa não é referência. Mas se pensar na apropriação do Parque Ambiental Irmão Cirilo, em prol desse espaço, ganharia um significado maior para todo o perímetro em análise. Evidenciar aquilo que já é belo por natureza e que tem grau elevado de importância em todo o território nacional e internacional. 


\section{Referências}

GEHL, Jan. Cidades para Pessoas. 2014.

JACOBS, jane. Morte e Vida de Grandes Cidades. $1^{\circ}$ Edição em 2000, Livraria. Martins Fontes Editora Ltda; São Paulo.

ROGERS, Richard. Cidades para um Pequeno Planeta. Reith Lectures (1995).

ARAGÃO ARRAIS, Emanuelle; DE MELO, Ana Cristina Claudino; ANDRADE,Ana Virgínia Alvarenga. Espaços Públicos e suas Implicações: Um estudo sobre a cidade de Teresina/PI. XII Fórum Ambiental; julho de 2017 -São Paulo.

CORRÊA, Roberto Lobato. O Espaço Urbano.

COUTO, Perla; MARTINS, Solismar FragA. Revitalização Urbana como Produto de Apropriação do Espaço Público.

DOS SANTOS, Filipa Catarina Antunes.Características físicas e sociais do espaço público. Universidade Técnica de Lisboa; Setembro de 2008.

HEEMANN, Jeniffer; SANTIAGO, Paula Caiuby. Guia do Espaço Público para Inspirar e Transformar; São Paulo.

HELEODOR, Talita Ines. A Rua como Espaço Livre Público. Instituto de Arquitetura e Urbanismo - USP; São Carlos - SP.

MENDONÇA, Eneida Maria Souza. Apropriação do Espaço Público: Alguns Conceitos. Estudos e Pesquisas em Psicologia, UERJ; Rio de Janeiro.

NUNES, Paulo Cezar; BATISTA, Janir Coutinho. FICA na rua: arte, cultura e poéticas de apropriação de espaço urbano. Minas Gerais.

PINHEIRO, Ricardo Lana; SILVA, Ana Paula Soares. Apropriação do espaço e psicologia histórico-cultural: reflexões e apontamentos para possíveis aproximações. Arquivos Brasileiros de Psicologia; Rio de Janeiro.

RIGATTI, Décio. Apropriação Social do Espaço Público: um Estudo Comparativo.

ROSANELI, Alessandro Fila; FRÓES, Ana Claudia Stangarlin; FURLAN, Debora Luiza Schumacher; GONCALVES, Felipe Timmermann; SENGER, sacha. Apropriação do Espaço Público na Metrópole Contemporânea: O Caso da Praça Tiradentes em Curitiba - PR. Universidade Federal do Paraná - UFPR.

SERDOURA, Francisco; SILVA, F. Nunes. Espaço Público, Lugar de Vida Urbana. Universidade Técnica de Lisboa, Departamento de Urbanismo; Instituto Superior Técnico, Departamento de Engenharia Civil e Arquitetura.

SILVA, Rooseman de Oliveira. Formas de Uso e Apropriação do Espaço Urbano Coletivo. Recife; Outubro de 2003.

Sudoeste Online. Parque Ecológico Irmão Cirilo Voltará a ser utilizado. 24 de maio de 2010. 


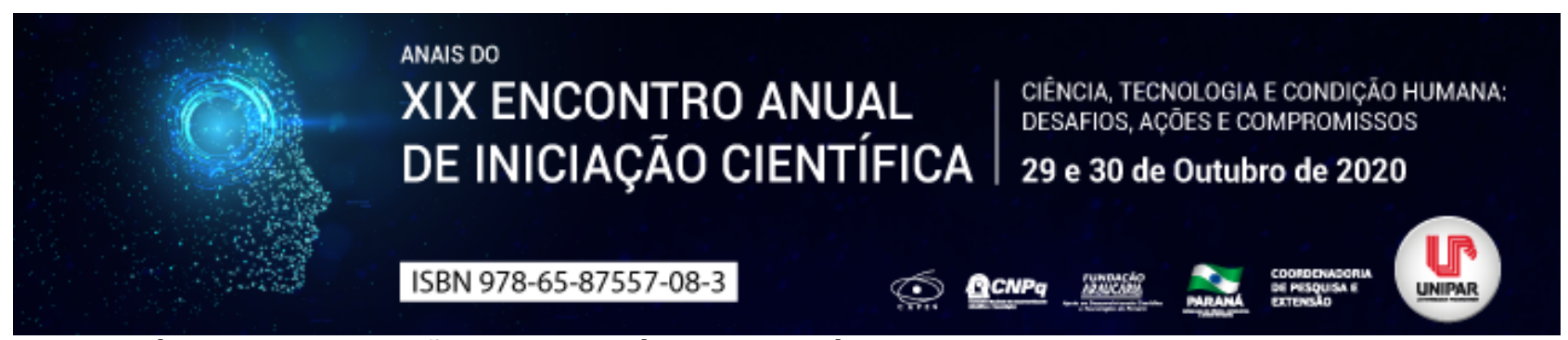

\title{
FONTES DA HISTÓRIA DA EDUCAÇÃO DO MUNICÍPIO DE GUAÍRA-PR (1954-1958): UM LEVANTAMENTO A PARTIR DAS PORTARIAS
}

\author{
${ }^{1}$ WELLINGTON RAMOS DE CARVALHO, ${ }^{2}$ LUCAS HENRIQUE DE FARIAS DA SILVA, ${ }^{3}$ ESTELLE JULI SANFELICE, ${ }^{4}$ GISELE \\ HERNANDES DE MENDONCA, ${ }^{5}$ ROSILEY BERTON PACHECO, ${ }^{6}$ JOSE RICARDO SKOLMOVSKI DA SILVA
}

\author{
${ }^{1}$ Acadêmico do PIC/UNIPAR \\ ${ }^{1}$ Acadêmico do PIC/UNIPAR \\ ${ }^{2}$ Acadêmica do PIC/UNIPAR \\ ${ }^{3}$ Acadêmica do PIC/UNIPAR \\ ${ }^{4}$ Docente da UNIPAR \\ ${ }^{5}$ Docente da UNIPAR
}

Introdução: O presente trabalho é fruto de um esforço coletivo de integrantes do Programa de Iniciação Científica (PIC) da UNIPAR, unidade de Guaíra. Trata-se de um desdobramento do projeto de pesquisa organizado em 2019 intitulado LEVANTAMENTO E CATALOGAÇÃO DE FONTES PRIMÁRIAS E SECUNDÁRIAS DA HISTÓRIA DA EDUCAÇÃO DO MUNICÍPIO DE GUAÍRA-PR que tinha por objetivo, a partir da compreensão da importância da História da Educação, realizar um levantamento de fontes Primárias e Secundárias da História da Educação do município de Guaíra, do ano de sua criação enquanto município (1953). Em 2019 o projeto se debruçou em estudar as fontes secundárias, com o foco de realizar uma revisão bibliográfica para perceber as pesquisas que já haviam avançado nessa temática. Percebeu-se uma carência de produções que evidenciam esta História e que constituiu-se como uma lacuna da qual poderíamos contribuir. Em 2020 o projeto continuou, nesta oportunidade com o intuito de investigar as fontes primárias. O trabalho que se apresenta aqui é resultado preliminar dos estudos empreendidos pelo grupo em um esforço no árduo trabalho com as fontes historiográficas.

Objetivo: Apresentar as portarias relacionadas à Educação, levantadas no Diário Oficial Eletrônico do município de Guaíra-PR, dos anos de 1954-1958.

Desenvolvimento: Ao analisar Diário Oficial Eletrônico do município de Guaíra-PR, com recorte temporal de cinco anos, 19541958, foi obtido o número de 77 portarias instituídas. No ano de 1954 nos deparamos com o número de 14 portarias, sendo que apenas 1 versa sobre a temática educação, mais especificamente sobre avaliação de ano letivo. A portaria de $n^{\circ} 14 / 54$, estabelecida pelo então prefeito Gabriel Fialho Gurgel (1952-1956), trata sobre a designação de alguns munícipes para compor a comissão examinadora da Escola de Palotina, para inspecionar o ano letivo (GUAíRA, 1954). Ainda na gestão do prefeito Gabriel F. Gurgel, no ano de 1955 dentre as 4 portarias abertas 1 se relaciona a educação, nomeando uma professora para a Escola Municipal do distrito de Dr. Oliveira Castro. No ano seguinte, 1956, temos 12 portarias sendo que apenas 3 se relacionam à educação: 1 nomeando professora para a Escola Municipal do distrito de Palotina; as outras 2 tratando da designação de professoras para a regência de escolas, uma para a Escola Municipal de Terra Roxa do Oeste e outra para a Escola Municipal de Carumbey (GUAíRA, 1955-1956). No ano de 1957, já na gestão do então prefeito Celino Rocha de Araujo (1956-1960), encontramos 23 portarias, das quais 7 são relativas à educação: 1 refere-se a contratação de uma zeladora para o Grupo Escolar Mendes Gonçalves; 5 versam sobre a nomeação de professoras para as cidades de Terra Roxa do Oeste, Palotina e para a Escola Municipal Carumbey; A última portaria traz a demissão de uma professora, por pedido da mesma (GUAíRA, 1957). Em 1958 nos deparamos com 24 portarias, sendo, dentre elas, 16 relacionadas a área da educação: 15 versam sobre a nomeação ou demissão de professores das seguintes localidades: Grupo Escolar Mendes Gonçalves, Escola Municipal de Carumbey, Escola Rural do Distrito Dr. Oliveira Castro, Escola Isolada de Terra Roxa do Oeste, Cidade de Palotina e Escola Rural da fazenda Primavera dessa mesma cidade, Distrito de Memória nas regiões da Gleba Palmital, São Roque e Novo Horizonte. Ainda nesse mesmo ano, percebemos pistas sobre a questão da laicidade no ensino do município de Guaíra. A portaria de $n^{\circ}$ 23/58 apresenta a proibição expressa de proselitismo religioso nas escolas distritais de Terra Roxa D'oeste, ficando especificado no nome de duas professoras (GUAÍRA, 1958).

Conclusão: Ao analisar as portarias no período em recorte pôde-se perceber que as mesmas podem ser divididas nos seguintes agrupamentos temáticos: nomeações e demissões de professores; instituição de comissão examinadora de ano letivo; e proibição de proselitismo religioso. Realizar o levantamento e catalogação de fontes primárias da História da Educação do Município de Guaíra-PR por meio de documentos oficiais, tais como as portarias, permitem entrever as discussões e tensões em torno da organização do ensino no recente município. Cabe relembrar que Guaíra era distrito de Foz do Iguaçu, e que, a partir da sua emancipação política, os gestores se deparam com diversos desafios, dentre eles o de organizar a educação pública em seu raio de abrangência. No decorrer dos anos seguintes diversos distritos também vão se emancipando, caracterizando um mapa 
geopolítico bem distinto da região oeste do Paraná. O estudo utilizando fontes oficiais, possibilita ainda compreender a forma como o sistema municipal de ensino se institucionalizou, verificando os sujeitos que fizeram parte das tomadas de decisão em torno da questão educacional. Este levantamento abre possibilidade para que outras pesquisas possam avançar na produção de uma História da Educação que compreenda as relações dialéticas que se davam na totalidade e suas apropriações na realidade do município de Guaíra, com suas características próprias.

\section{Referências}

GUAíRA. Portaria $n^{\circ}$ 14, de 23 de dezembro de 1954. Designa Domingo Francisco Zardo, Rui Guilich e Eurico Neneve para comissão examinadora da Escola de Palotina. Guaíra: Diário Oficial, [1954]. Disponível em: http://dioe.guaira.pr.gov.br/images/legislacao/Portarias\%20n-14-ano1954\%20001.jpg2. Acesso em: 24 ago. 2020.

GUAíRA. Portaria $n^{\circ}$ 07, de 30 de julho de 1956. Designa Sirley Rodrigues para reger a Escola Municipal de Terra Roxa do Oeste. Guaíra: Diário Oficial, [1955]. Disponível em: http://dioe.guaira.pr.gov.br/images/legislacao/Portarias\%20n-07ano1956\%20001.jpg. Acesso em: 24 ago. 2020.

GUAíRA. Portaria no 08, de 31 de julho de 1956. Designa Lucia Alcaraz para reger a Escola Municipal de Carumbei. Guaíra: Diário Oficial, [1955]. Disponível em: http://dioe.guaira.pr.gov.br/images/legislacao/Portarias\%20n-08-ano1956\%20001.jpg. Acesso em: 24 ago. 2020.

GUAÍRA. Portaria $\mathrm{n}^{\circ}$ 11, de 22 de maio de 1957. Admite Ely Colmann para a função de zeladora do Grupo Escolar Mendes Gonçalves. Guaíra: Diário Oficial, [1955]. Disponível em: http://dioe.guaira.pr.gov.br/images/legislacao/Portarias\%20n-11ano1957\%20001.jpg Acesso em: 24 ago. 2020.

GUAíRA. Portaria $n^{\circ} 23$, de 05 de novembro de 1958. Proibe pregação religiosa nas escolas distritais. Guaíra: Diário Oficial, [1958]. Disponível em: http://dioe.guaira.pr.gov.br/images/legislacao/Portarias\%20n-23-ano\%201958\%20001.jpg. Acesso em: 24 ago. 2020. 


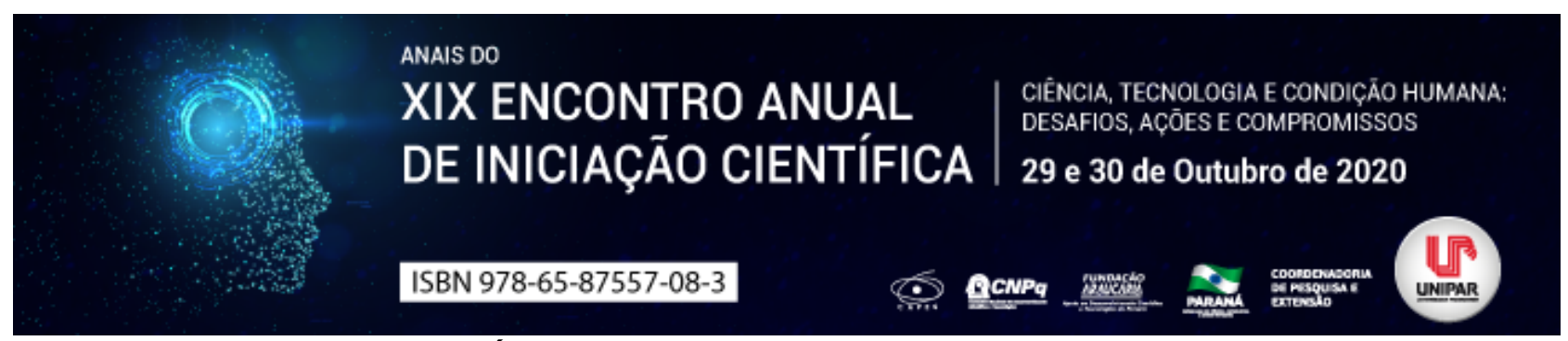

ASPECTOS JURÍDICOS DA TELEMEDICINA EM TEMPOS DE PANDEMIA

\author{
${ }^{1}$ OSCAR TOMIO YOSHIHARA SCHIAVONE, ${ }^{2}$ PAULO CESAR DE SOUSA
}

${ }^{1}$ Acadêmico do curso de Direito da UNIPAR

${ }^{1}$ Docente da UNIPAR

Introdução: Com o advento da pandemia da Covid - 19, a telemedicina foi amplamente utilizada. Surgiram os obstáculos que podem levar a equívocos inerentes do precário atendimento. Por um lado, o paciente pode sair prejudicado, e por outro, o médico, sem os artifícios ideais para a prática de uma boa medicina, pode ser responsabilizado civilmente.

Objetivo: Discutir a viabilidade da telemedicina como meio de atendimento médico e seus aspectos legais com relação à responsabilidade civil profissional.

Desenvolvimento: A telemedicina consiste no emprego da telecomunicação para realizar consultas médicas. Em 2002, a Resolução $n^{0}$ 1.643, do Conselho Federal de Medicina (CFM), definiu a prática do método. Em 2018, o CFM disciplinou a forma da prestação do serviço por meio da Resolução $n^{0}$ 2.227. Com Lei $n^{\circ} 13.989 / 20$, em caráter temporário e excepcional ficou autorizada a prática da telemedicina. Embora o avanço da tecnologia possibilite levar a saúde e seus benefícios a locais antes inacessíveis, por anos, essa metodologia foi encarada com receio pela comunidade médica. Mas, com a pandemia da Covid-19, tornou-se um canal importantíssimo para o acesso de pacientes a médicos. Concomitantemente, apareceram as falhas do método. A utilização da telemedicina, ainda, deixa a desejar quanto ao exame físico do paciente, ato fundamental para diagnóstico e que pode nortear melhor tratamento da doença. O médico precisa saber até onde poderá seguir seu atendimento com os recursos tecnológicos que possui para não prejudicar o paciente, nem ser responsabilizado por questões éticas e legais em virtude de eventuais danos na prestação do serviço, como o erro de diagnóstico, por exemplo. De acordo com Kfoury Neto (2013, p.101 - 102), o erro de diagnóstico caracteriza-se pela eleição do tratamento inadequado à patologia instalada no paciente, com resultado danoso. Em um país como o Brasil, com enormes diferenças sociais e onde a tecnologia e a capacidade de entendimento estão concentrados na minoria, não há, ainda, o preparo adequado para o uso em massa da telemedicina. Por conseguinte, exigir que um médico trabalhe com menos recursos para a investigação diagnóstica, e cobrar o maior zelo pelo paciente, é contraditório e induz ao erro grosseiro. Até o próprio CFM posicionou-se contra a telemedicina na perícia médica, mesmo durante a pandemia. De acordo com o Parecer $\mathrm{n}^{\circ}$. 03/2020, a falta do exame direto no periciando afronta o Código de Ética Médica, em especial o art. 92, que proíbe o médico de assinar laudos periciais, auditoriais ou de verificação médico-legal se não for realizado pessoalmente o exame.

Conclusão: Pela análise, a telemedicina como medida emergencial, consegue suprir de forma parcial as necessidades do médico e do paciente. O doente pode ficar exposto ao agravamento de sua saúde. O médico, mesmo com sua boa vontade, pode ser induzido ao erro grosseiro e as consequências da responsabilidade civil.

\title{
Referências
}

BARROS JÚNIOR, Edmilson. A Responsabilidade Civil do Médico. São Paulo: Atlas, 2007.

BRASIL. Lei n. 10.406, 10 de janeiro de 2002. Institui o Código Civil. Diário Oficial da União, Brasília, DF, 11 jan., 2002.

KFOURY NETO, Miguel. Responsabilidade civil dos médicos. 8 ed. São Paulo: Editora Revista dos Tribunais, 2013. 


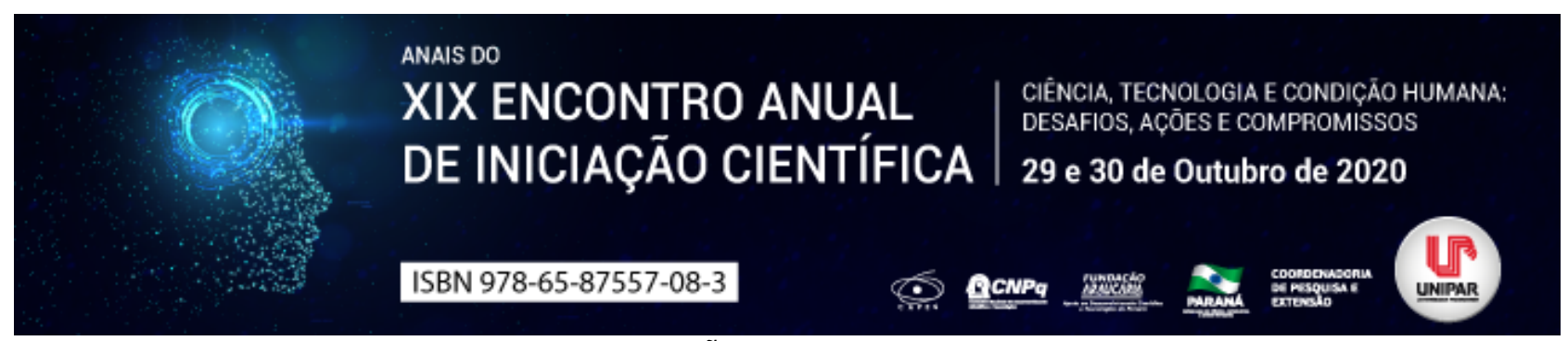

EDUCAÇÃO ANTIRRACISTA

\title{
${ }^{1}$ SABRINA LOPES ALVES, ${ }^{2}$ CLAUDIA LOPES PERPETUO, ${ }^{3}$ ROSANA VASCONCELOS VITO
}

\author{
${ }^{1}$ Acadêmica do curso de pedagogia pela Universidade Paranaense-UNIPAR \\ ${ }^{1}$ Docente da UNIPAR \\ ${ }^{2}$ Docente da UNIPAR
}

Introdução: O racismo é uma prática que envolve o processo do desenvolvimento do sujeito, gerando a desigualdade, conflitos e violências de diversas maneiras (econômicas, sociais e psicológicas), deixando marcas históricas que influenciam negativamente a vida do povo que pertence a raça negra em suas diferentes etnias (CARNEIRO, 2003). Muitas vezes, as situações de bullyng e práticas de discriminação e preconceito que ocorrem no 'chão' da escola, e passam despercebidas ou são ignoradas por profissionais que são incumbidos pela 'educação'. Desse modo, é importante destacar a necessidade da efetivação do trabalho docente, voltado ao enfrentamento dos problemas sociais, onde possam discutir com os alunos um conjunto de questões que envolvam direitos, deveres, tolerância, respeito entre outras (DELORS, 2006). É com essa preocupação que esse trabalho propõe a reflexão sobre a prática de orientação e intervenção pedagógica visando a responsabilidade dos docentes com relação aos direitos humanos.

Objetivo: Proporcionar reflexões sobre a importância do direcionamento e das práticas pedagógicas utilizadas (ou não!) Pelos professores diante da educação antirracista nos espaços escolares.

Desenvolvimento: $\mathrm{Na}$ contemporaneidade, a questão do racismo vem sendo muito discutida na sociedade, e com a grande presença do racismo estrutural, pois as práticas de discriminação e distanciamento entre determinados grupos sociais, ainda apresenta-se latente na sociedade de todas as nações. A discriminação estrutural reflete o modo com que a sociedade em si enxerga a questão, uma vez que o racismo faz parte da construção história e política de terra de brasilis e está tão incrustado que seria, de certa forma, a regra (OLIVERIA e CARVALHO, 2017). É importante destacar que, historicamente, o racismo manifesta-se por meio de práticas de violência e preconceito, que perpetua entre as gerações, causando a desigualdade, a classificação entre pessoas de grupos que entendem uma certa hierarquia que privilegia alguns (CARNEIRO, 2003). Para que essa situação tenha a possibilidade de reversão, é preciso haver transformação nas práticas educativas, por isso se faz necessário a conscientização e a mudança de comportamento dos sujeitos da escola, isto é, cabe aos profissionais da educação, trabalharem questões que ressaltam as origens do povo brasileiro espaços escolares. Tal mudança deve atingir toda a comunidade escolar, porém em especial, os docentes, mesmo aqueles que nunca praticaram (ou praticam) nenhum tipo de ato racista, mas também não interferem diante de situações que vivenciam na escola, afinal a omissão também é uma forma de ratificar a violência. É com essa compreensão que as escolas deverão direcionar o trabalho pedagógico e social, focando no ensino, a intenção de refletir e adquirir um novo olhar com a responsabilidade de possibilitar a transformação da sociedade. É preciso trabalhar o coletivo escolar, de maneira que as crianças reconheçam e valorizem as diferenças, as culturas e as etnias. É preciso fomentar a capacitação e qualificação docente, para que os mesmos saibam trabalhar um currículo escolar que proporcione o respeito e a valorização entre as diferentes culturas existentes na sociedade (LIMA, 2012). Trabalhar a educação antirracista começa com a elaboração do currículo escolar, promovendo projetos com adaptação da realidade dos alunos adequando o tema de forma interdisciplinar, afinal não é só no dia 20 de novembro que a escola deve lembrar os alunos, de que o negro existe e tem uma história. A Lei 10.639/2003, foi instituída para assegurar que a história das raízes do povo brasileiro não seja esquecida, por isso, a mesma determina a obrigatoriedade do ensino de história e cultura afro-brasileira e africana, e ressalta a importância da cultura negra na formação da sociedade brasileira.

Conclusão: A escola é um espaço de formação e transformação humana, por isso, é preciso que a instituição escolar trabalhe a conscientização e o respeito as diferentes culturas. É um ambiente de troca e disseminação do conhecimento, por isso, cabe aos professores e equipe pedagógica trabalhar de forma preventiva, ressaltando os direitos humanos e levando os estudantes ao reconhecimento de comportamentos preconceituosos e desiguais com o objetivo de combater essas práticas, tornando uma sociedade mais justa e igualitária.

\section{Referências}

CARNEIRO. L.T. Maria. O racismo na história do Brasil. São Paulo: Ática, 2003

DELORS. Jacques. Educação: Um tesouro a descobrir. Brasília: Cortez, 2006.

JUNIOR. W.E. Francisco. Educação Anti-Racista: reflexões e contribuições possíveis do ensino de ciências e de alguns pensadores, n.3, nov. 2007

LIMA. José rosamilton. Revista do Mestrado em Letras Linguagem, Discurso e Cultura

UNINCOR, v. 3, n.1, jan. /jul.2012. 
OLIVEIRA, Adriel Seródio; CARVALHO, Acelino Rodrigues. Revista Jurídica Direito, Sociedade e Justiça, v. 5, n. 1, p. 228/230, Nov-Dez/2017,

OLIVEIRA, Luiz Fernandes. Educação Antirracista: tensões e desafios para o ensino de sociologia, n.1, jan. /marc.2014. Disponível em: http://www.ufrgs.br/edu_realidade/

Coordenadoria de Pesquisa e Extensāo - COPEX

Departamento de Editoraçāo e Divulgaçāo Científica - DEDIC 


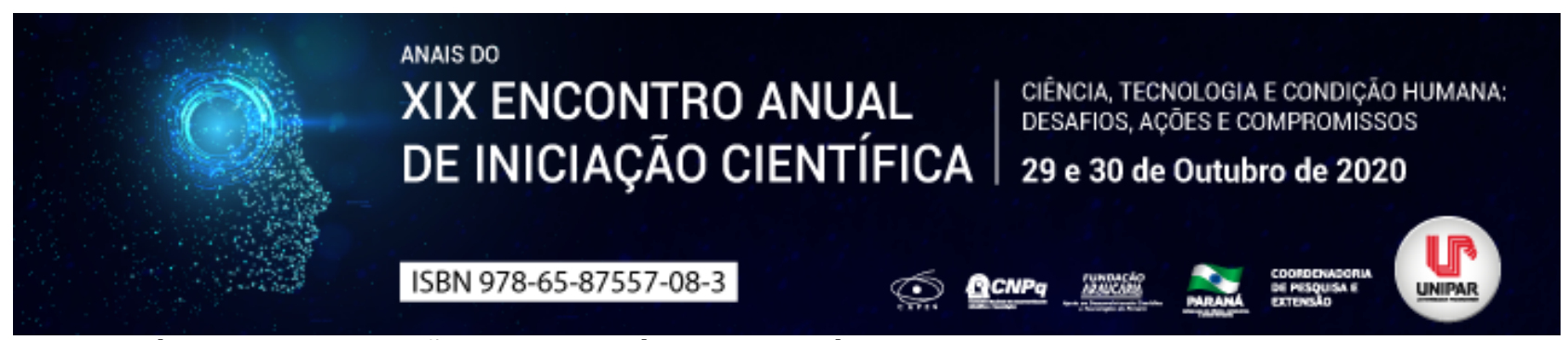

\title{
FONTES DA HISTÓRIA DA EDUCAÇÃO DO MUNICÍPIO DE GUAÍRA-PR (1959-1962): UM LEVANTAMENTO A PARTIR DAS PORTARIAS
}

\author{
${ }^{1}$ ESTELLE JULI SANFELICE, ${ }^{2}$ WELLINGTON RAMOS DE CARVALHO, ${ }^{3}$ LUCAS HENRIQUE DE FARIAS DA SILVA, ${ }^{4}$ GISELE \\ HERNANDES DE MENDONCA, ${ }^{5}$ ROSILEY BERTON PACHECO, ${ }^{6} \mathrm{JOSE}$ RICARDO SKOLMOVSKI DA SILVA
}

\author{
${ }^{1}$ Acadêmico do PIC/Unipar \\ ${ }^{1}$ Acadêmico do PIC/UNIPAR \\ ${ }^{2}$ Acadêmico do PIC/UNIPAR \\ ${ }^{3}$ Acadêmico do PIC/UNIPAR \\ ${ }^{4}$ Docente da UNIPAR \\ ${ }^{5}$ Docente da UNIPAR
}

Introdução: O presente trabalho é fruto de um esforço coletivo de integrantes do Programa de Iniciação Científica (PIC) da UNIPAR, unidade de Guaíra. Trata-se de um desdobramento do projeto de pesquisa organizado em 2019 intitulado LEVANTAMENTO E CATALOGAÇÃO DE FONTES PRIMÁRIAS E SECUNDÁRIAS DA HISTÓRIA DA EDUCAÇÃO DO MUNICÍPIO DE GUAÍRA-PR que tinha por objetivo, a partir da compreensão da importância da História da Educação, realizar um levantamento de fontes Primárias e Secundárias da História da Educação do município de Guaíra, do ano de sua criação enquanto município (1953). Em 2019 o projeto se debruçou em estudar as fontes secundárias, com o foco de realizar uma revisão bibliográfica para perceber as pesquisas que já haviam avançado nessa temática. Percebeu-se uma carência de produções que evidenciam esta História e que constituiu-se como uma lacuna da qual poderíamos contribuir. Em 2020 o projeto continuou, nesta oportunidade com o intuito de investigar as fontes primárias. O trabalho que se apresenta aqui é resultado preliminar dos estudos empreendidos pelo grupo em um esforço no árduo trabalho com as fontes historiográficas.

Objetivo: Apresentar as portarias relacionadas à Educação, levantadas no Diário Oficial Eletrônico do município de Guaíra-PR, dos anos de 1959-1962.

Desenvolvimento: Analisando o Diário Oficial Eletrônico de Guaíra-PR, foi observado que durante o período de 1959 a 1962 , foram instituídas 122 portarias, das quais 82 se relacionam com a área de educação.

No ano de 1959, houve 21 portarias publicadas sendo 11 delas na área de educação, tendo 1 demissão no Distrito de Terra Roxa e 1 no Distrito de São Camillo; 9 admissões distribuídas em Terra Roxa D'Oeste, Grupo Escolar Mendes Gonçalves, Escola Municipal da Cerâmica São Vicente no Distrito de Palotina, Escola Municipal Fazenda Paraizo no Distrito de Palotina e nas Escolas Rurais do Distrito de São Camillo, da Cidade Projetada no Maracaju e de Carumbeí. Em 1960, das 18 portarias publicadas, 7 foram demissões e 11 contratações, sendo estas nas seguintes localidades: Grupo Escolar de Guaíra, Distrito de Memoria, Distrito de Palotina, Maracaju dos Gauchos, Maracaju dos Gauchos no Distrito de Terra Roxa D'Oeste e na então região do Taturi entre Guaíra e Porto Mendes. Em 1961, ano que mais se deu publicações de portarias, sendo 40 e 28 delas relativas à educação. Destas 28 portarias, 25 tratavam de contratações e 3 de demissões. Tais demissões e contratações, ocorreram nos seguintes locais, Escola Isolada de Carumbeí, Corrego da Onça, das Fazendas no Distrito de Terra Roxa D'Oeste e São Pedro no Distrito de Palotina, do Taturi, José Lins do Rego, Rio do Peixe, Grupo Escolar Mendes Gonçalves, Distrito de Maripá e Nova Maripa, Escola Rural de Novo Horizonte e Curso Normal de Guaíra. Ainda neste mesmo ano de 1961 foi possível observar a portaria de nº 35/1961 que institui a Comissão Municipal de Inspeção da situação do Grupo Escolar Francisco Mendes Gonçalves (GUAÍRA, 1961). A mesma ocupou-se da verificação da quantidade de professores que integravam o quadro escolar, do número de zeladoras e da situação em que se encontrava o patrimônio do referido prédio escolar. Continuando na temática da situação de ensino, encontramos a portaria de número 68/1961 que versava sobre a designação de cinco pessoas para compor a Banca Examinadora das provas a serem realizadas na turma da $4^{\circ}$ série da Escola Municipal Gabriel Fialho Gurgel, entre elas o Pe. Eduardo Dagioz, o vereador Veliz Ojeda e Maria Odette Rolon, Diretora do Grupo Escolar Mendes Gonçalves (GUAíRA, 1961). Na análise do ano de 1962, foi possível notar que o número de portarias publicadas foram 36, das quais 25 eram da área de educação. $\mathrm{O}$ assunto tratado em tais portarias era de admissões e demissões nas seguintes localidades: Escola Isolada do Capivari, Distrito de Terra Roxa D'Oeste, Distrito de Maracaju dos Gauchos, Doutor Oliveira Castro e Santa Rita do Oeste. Na portaria de $N^{\circ}$ 27/1962, Marina Rodrigues de Souza foi contratada para exercer o cargo de professora na futura Escola de Santa Rita do Oeste, que até a data da portaria, se encontrava em construção (GUAíRA, 1962). A presente portaria, publicada em abril de 1962, passaria a valer no dia primeiro de maio, com a professora podendo assumir sua função após a conclusão da construção de tal escola.

Conclusão: A partir dos dados encontrados nas portarias levantadas é possível concluir que o período citado evidencia várias 
possibilidades de pesquisa. Os grupos escolares e escolas isoladas apontadas destacam a movimentação em torno da criação, institucionalização e expansão da educação pública no oeste do Paraná. Ademais, as nomeações de professores sugerem um campo investigativo de grande significado para a construção da história da educação, tendo em vista dar voz para os sujeitos em pesquisas com fontes orais por meio de entrevistas. Realizar o levantamento e a catalogação de fontes primárias no Diário Oficial Eletrônico do Município pôde contribuir no sentido de trazer elementos para pensar a micro-história da educação, tanto na perspectiva da Nova História Cultural, quanto na perspectiva do materialismo histórico dialético.

\section{Referências}

GUAíRA. Portaria $n^{\circ}$ 35, de 04 de abril de 1961. Designa Nolvodir de Almeida Prihamann e outro para compor a comissão municipal. Guaíra: Diário Oficial, [1961]. Disponível em: http://dioe.guaira.pr.gov.br/images/legislacao/Portarias\%20n-35ano\%201961\%20001.jpg. Acesso em: 26 ago. 2020.

GUAíRA. Portaria no 68, de 11 de dezembro de 1961. Designa padre Eduardo Dagiozx e outros para comporem a Banca Examinadora das provas dos alunos de $4^{\circ}$ série. Guaíra: Diário Oficial, [1961]. Disponível em: http://dioe.guaira.pr.gov.br/images/legislacao/Portarias\%20n-68-ano\%201961\%20001.jpg. Acesso em: 26 ago. 2020.

GUAíRA. Portaria $n^{\circ} 27$, de 23 de abril de 1962. Admite Marina Rodriggues de Souza para a função de professora da Escola Santa Rita do Oeste Terra Roxa. Guaíra: Diário Oficial, [1962]. Disponível em: http://dioe.guaira.pr.gov.br/images/legislacao/Portarias\%20n-27-ano1962\%20001.jpg. Acesso em: 26 ago. 2020. 


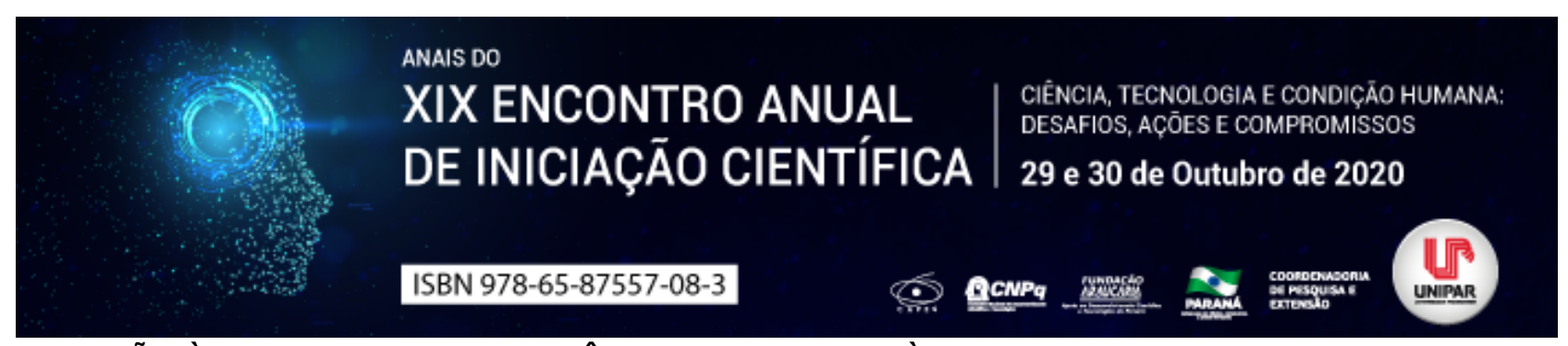

A PROTEÇÃO ÀS PESSOAS COM DEFICIÊNCIA SUBMETIDAS À CURATELA PELO PROJETO DE LEI 262/2017

\title{
${ }^{1}$ CAROLINA ROCHA MARTINS, ${ }^{2}$ CELSO HIROSHI IOCOHAMA
}

\author{
${ }^{1}$ Acadêmico do PIC/UNIPAR \\ ${ }^{1}$ Docente da Graduação em Direito e do Programa de Mestrado em Direito Processual e Cidadania da UNIPAR
}

Introdução: O Projeto de Lei 262/2017, proposto pelo Senador Romário, trata de dar maior proteção às pessoas com deficiência submetidas à curatela e sua autonomia de escolha na vida civil, com efeitos na alteração do Código de Processo Civil (Lei 13.105/2015).

Objetivo: Analisar a ampliação da legitimidade promovida no processo de interdição em caso de doença mental, diante da mudança pretendida pelo Projeto de lei 262/2017.

Desenvolvimento: A pessoa com deficiência, de acordo com o Código Civil brasileiro, necessita da atividade de curadoria para exercer atos da vida civil. Para tanto a definição de curatela ajuda a entender o conceito do Projeto de lei 262/2017, Gonçalves (2014, p. 167), define curatela como sendo o encargo deferido por lei a alguém capaz para reger a pessoa e administrar os bens de quem não pode fazê-lo por si mesmo . Já a personalidade jurídica é definida por Venosa (2013, p. 137), como a projeção da personalidade íntima, psíquica de cada um , levando em consideração que pessoa incapaz com deficiência também possui personalidade própria. O Projeto de Lei 262/2017 (BRASIL, 2017), pretende alterar os arts. 747 e 748 do Código de Processo Civil (Lei 13.105/2015), na parte que trata sobre a interdição da pessoa com doença mental. O art. 747, incisos I, II, III e IV, aborda sobre quem pode promover a interdição: inciso I, pelo cônjuge ou companheiro ; inciso II, pelos parentes ou tutores ; inciso III, pelo representante da entidade em que se encontra abrigado o interditando ; inciso IV, pelo Ministério Público , a mudança feita seria o acréscimo do inciso $\mathrm{V}$, que daria poder a própria pessoa com deficiência de promover sua interdição. A interdição seria especificada na petição inicial com documentação que comprove a incapacidade da pessoa para administrar seus bens e para praticar a atos da vida civil e quando a incapacidade surgiu, sob análise do juiz, como diz o parágrafo único do art. 747. Já o art. 748, em incisos I e II, trata sobre quando o Ministério Público promoverá a interdição em caso de doença mental grave: inciso I, se as pessoas designadas nos incisos I, II e III do art. 747 não existirem ou não promoverem a interdição ; inciso II, existirem e forem incapazes as pessoas mencionadas nos incisos I e II do art. 747 . Pelo Projeto de Lei, a primeira alteração seria feita no inciso I, acrescentando o inciso $\mathrm{V}$ do art. 747; já a segunda alteração abordaria o inciso II, incluindo, na narrativa, o menor de idade. A pessoa que tem a deficiência mental precisa de uma interdição para a prática de atos na vida civil. O senador Romário diz, na justificação do Projeto de Lei, que Tais medidas são de nítida razoabilidade, que exprimem a compreensão, dura e longamente construída, de que as pessoas submetidas a curatela não deixam de ser pessoas para passar a ser objetos, devendo ter sua humanidade, sua dignidade, sua vontade e sua autonomia preservadas ao máximo (BRASIL, 2017). A mudança feita será importante para corrigir a objetificação da pessoa deficiente, acrescentando poder de escolha, permitindo autonomia para que a própria pessoa com deficiência promova a curatela, levando em consideração a sua vontade e direitos.

Conclusão: As mudanças propostas pelo Projeto de Lei em estudo visam ampliar a legitimidade do processo de interdição às pessoas com deficiência sobre a sua vontade e opção de escolha segura, diminuindo a limitação de sua capacidade na vida civil.

\section{Referências}

BRASIL. Código de Processo Civil 2015. Disponível em http://www.planalto.gov.br/ccivil_03/_ato20152018/2015/lei//13105.htm Acesso em: 23 ago. 2020.

Senado Federal. Projeto de Lei 262/2017, Senador Romário. Disponivel em http://gg.gg/m45is Acesso em: 28 ago. 2020 GONÇALVES, Carlos Roberto. Direito de Família. 18. ed. São Paulo: Saraiva, 2014.

VENOSA, Sílvio de Salvo. Direito Civil. 13. ed. São Paulo: Atlas, 2013. 


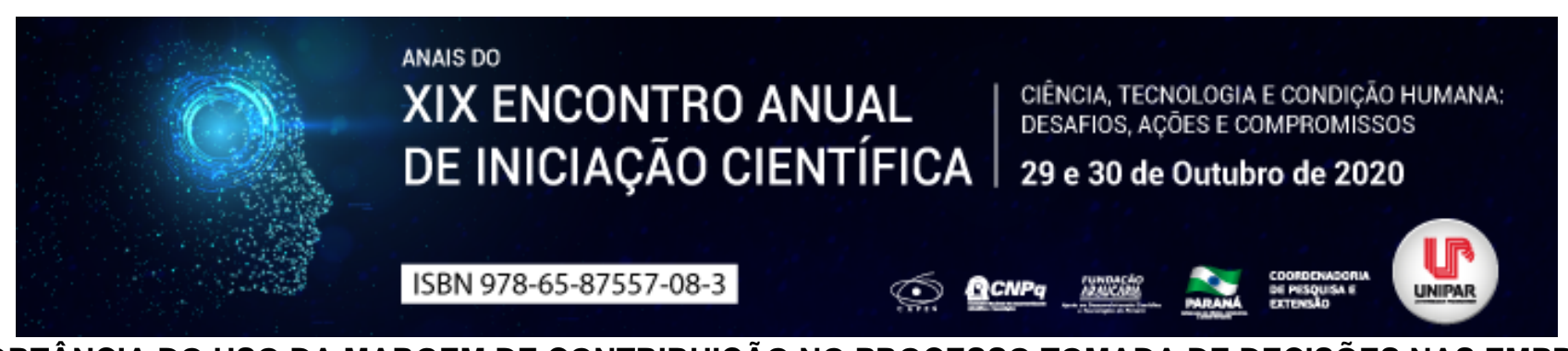

A IMPORTÂNCIA DO USO DA MARGEM DE CONTRIBUIÇÃO NO PROCESSO TOMADA DE DECISÕES NAS EMPRESAS

\title{
${ }^{1}$ CAMILA DA SILVA, ${ }^{2}$ MIGUEL SILVA TARIFA NAVARRO, ${ }^{3}$ LORENA MANZOLI LAVEIA, ${ }^{4}$ GERVALDO RODRIGUES CAMPOS
}

\author{
${ }^{1}$ Acadêmica do PIC/UNIPAR \\ ${ }^{1}$ Acadêmico do Curso de Ciências Contábeis da UNIPAR \\ ${ }^{2}$ Acadêmica do Curso de Ciências Contábeis da UNIPAR \\ ${ }^{3}$ Docente da UNIPAR
}

Introdução: A decisão dentro de uma empresa é uma tarefa que deve ser realizada com cautela, pois pode produzir consequências favoráveis e também desfavoráveis ao sucesso do negócio, dependendo da escolha realizada pelo tomador de decisão. A contabilidade gerencial, que consiste num ramo da contabilidade, propicia instrumentos e informações contábeis para auxiliar na tomada de decisão dentro de uma empresa, a qual mostra que as informações contábeis não se limitam às demonstrações contábeis, isto é, outros instrumentos são disponibilizados para demonstrar a saúde da entidade, dentre os quais, destaca-se a margem de contribuição.

Objetivo: Compreender e demonstrar a importância e a utilidade da margem de contribuição no processo de tomada de decisões dentro das empresas a partir da literatura existente sobre o assunto.

Desenvolvimento: A partir da primeira Revolução Industrial no século XVIII que marca o advento da indústria, surge a importância da contabilidade de custos já que a contabilidade financeira existente até aquele momento passou a não atender a necessidade de mensuração dos estoques dessa nova empresa, a indústria. Com o passar do tempo e evolução dos negócios a contabilidade de custos também evolui para a contabilidade gerencial e hoje desempenha novos papéis no contexto do processo de tomada de decisão dentro das empresas, isto é, hoje ela passou a ser um instrumento de apoio à gestão. Neste contexto ela desempenha duas novas missões, quais sejam: auxílio ao controle e ajuda na tomada de decisões. No âmbito do auxílio ao controle, sua mais importante missão é fornecer dados para o estabelecimento de padrões, orçamento e outras formas de previsão, para depois acompanhar com o efetivamente ocorrido e compará-los. Por outro lado, no tocante à decisão, possui papel fundamental considerando que ela produz informações determinantes no que diz respeito a decisões de curto prazo, como introdução ou corte de produtos, administração de preços de venda, opção de compra ou produção, dentre outras. Para cumprir com essas novas missões a contabilidade de custos utiliza-se de diversos conceitos, dentre os quais se destaca a margem de contribuição. A margem de contribuição é a diferença entre receita e a soma dos custos e despesas variáveis (SCHULTZ, 2019). Por conseguinte é uma ferramenta gerencial, e possui a capacidade de tornar mais fácil e visível o potencial de cada produto, demonstrando como cada um colabora para, primeiro, cobrir os gastos fixos, isto é, atingir o ponto de equilíbrio e, assim, constituir o lucro desejado, por isso o nome margem de contribuição, pois é a contribuição para a quitação dos custos com a obtenção do lucro (MARTINS, 2010). Ponte, Riccio e Lustosa (1999) separam a margem de contribuição em unitária e total. A unitária é quando reflete a diferença entre o preço de venda e a soma dos custos variáveis unitários do produto, serviço ou área custeada. A margem de contribuição total resulta da multiplicação da quantidade de produtos ou serviços por sua margem de contribuição unitária. Quando o preço de venda do produto estiver abaixo dos seus custos e despesas variáveis a margem de contribuição será negativa, e requer revisão dos gestores em relação ao preço. Lembrando que o negócio só começa a gerar lucro depois que a margem de contribuição total for suficiente para cobrir todos os custos e despesas fixos da empresa no período, isto é, suficiente para atingir o ponto de equilíbrio contábil do empreendimento. Às vezes os gestores admitem trabalhar com margem de contribuição negativa por estratégica de marketing, sendo assim, é necessário ter outro produto com uma margem de contribuição positiva que compense essa margem de contribuição negativa do produto.

Conclusão: Conclui-se que a margem de contribuição consiste em importante ferramenta gerencial disponível aos gestores, os quais podem tomar diversas decisões assertivas para o sucesso da empresa subsidiadas no conceito em questão, considerando que este evidencia o quanto cada produto ou serviço vendido contribui para o pagamento dos custos e despesas fixos e, sobretudo na formação do lucro

\section{Referências}

MARTINS, Eliseu. Contabilidade de Custos. 10. ed. São Paulo: Atlas, 2010.

MIRANDA, R. B; ALMEIDA, M. M. F; SIMAO, P. FC-ES.2012. Disponível em: https://www.aedb.br/seget/arquivos/artigos12/58016816.pdf . Acesso em 14/08/20 as 20:00 horas

PALMA, G L.; BORGES H. F; BARBOSA.C.J Estudo sobre a margem de contribuição em uma microempresa do ramo de distribuição alimentícia. Enegep. 2016. Disponível em: http://www.abepro.org.br/biblioteca/TN_STO_228_331_30614.pdf. Acesso 
em $14 / 08 / 20$ as 20:04 horas

SCHULTZ, FELIX. Margem de contribuição- O que é . Bom controle. 20/03/2019. Disponível em: < https://bomcontrole.com.br/margem-de-contribuicao/>. Acesso em 13/08/2020 às 20:00.

Coordenadoria de Pesquisa e Extensão - COPEX

Departamento de Editoraçāo e Divulgaçāo Científica - DEDIC 


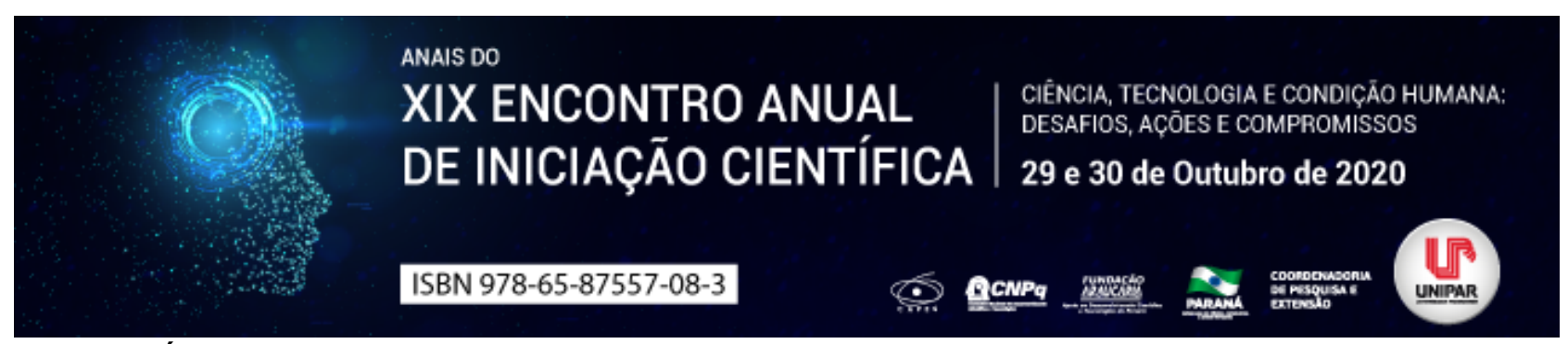

EUTANÁSIA: DIREITO FUNDAMENTAL DA AUTONOMIA DA VONTADE OU CRIME CONTRA A VIDA

\author{
${ }^{1}$ NATHAN GUILHERME LABONDE, ${ }^{2}$ JANE MARA DA SILVA PILATTI
}

\author{
${ }^{1}$ Discente da UNIPAR \\ ${ }^{1}$ Docente da UNIPAR
}

Introdução: A eutanásia é o ato de provocar a morte em alguém de forma indolor para aliviar o sofrimento causado por enfermidade grave. Essa prática é proibida no ordenamento jurídico pátrio podendo incorrer em quem aplica a outrem a sansão de Homicídio Privilegiado previsto no Código Penal. Todavia, em respeito aos princípios constitucionais da Dignidade da Pessoa Humana e da Autonomia da Vontade, não deveria ser direito da própria pessoa a eutanásia em casos de grande sofrimento?

Objetivo: Verificar a prevalência da vontade da pessoa perante ao ordenamento jurídico enquanto sofre de enfermidade grave, buscando a melhor solução de acordo com as particularidades de cada indivíduo enfermo.

Desenvolvimento: Esse trabalho versa sobre o Princípio da Autonomia da Vontade juntamente com o Princípio Constitucional da Dignidade da Pessoa Humana (BRASIL, 1988). Partindo deste pressuposto, vemos que a doutrinadora Maria Helena Diniz (2011, p. 40 - 41) conceitua acerca do princípio da Autonomia da Vontade, sendo o poder de estipular livremente, como melhor Ihes convier, mediante acordo de vontade, a disciplina de seus interesses, suscitando efeitos tutelados pela ordem jurídica.

Deste modo, cada indivíduo de acordo com suas crenças e seus próprios princípios pode julgar o que é melhor para si, tendo em vista o meio em que está inserido e suas questões individuais. Outro ponto indubitavelmente importante para falarmos sobre a eutanásia, é o princípio da dignidade da pessoa, para o qual cada indivíduo tem por si seu julgamento do que lhe é digno. No mesmo sentido, Luís Roberto Barroso (2010, p.8), em sua obra: Legitimidade da recusa de transfusão de sangue por Testemunhas de Jeová. Dignidade humana, liberdade religiosa e escolhas existenciais , discorre que a dignidade humana é um dos fundamentos da Constituição Federal, contudo, cada um projeta sua própria imagem de dignidade. Deste modo, é extremamente delicado o Estado proibir a prática da eutanásia sem levar em consideração estes princípios, no qual cada indivíduo tem autonomia para escolha do que é melhor para si, devendo o Estado somente garantir meio para concretizar sua vontade dentro dos parâmetros legais. A aplicação da eutanásia não deve ser vista como uma forma de suicídio, mas sim, uma forma necessária para acabar com o sofrimento do ser humano. Viver com a certeza de que a enfermidade irá tomar seu corpo como um todo é uma afronta aos princípios da autonomia e da dignidade, devendo, portanto, a pessoa escolher, se deseja que a doença tome seu curso natural, ou que em determinado momento o repouso eterno possa ser o melhor remédio. Um exemplo disso é a atleta paraolímpica Belga Marieke Vervoort, detentora de quatro medalhas olímpicas, que sofria de doença degenerativa, e obteve autorização para a eutanásia em seu país. Na matéria sobre sua morte divulgada pelo (EL PAís, 2019),

Dores estúpidas. Você conhece alguém que precise de morfina para treinar? . Mesmo com uma carreira vitoriosa, a felicidade da atleta era limitada ao seu corpo. Em entrevista (FANTÁSTICO, 11 set. 2016) disse a atleta: A qualquer momento posso pegar meus papéis e dizer chega! Isso me dá tranquilidade quando sinto muita dor. Não quero viver como um vegetal . A prática da eutanásia é proibida no ordenamento jurídico brasileiro, podendo incorrer na sansão de homicídio privilegiado, prevista no artigo 121, $\S 1^{\circ}$, do Código Penal, para quem realizar a prática da eutanásia em outro indivíduo (BRASIL,1940).

Conclusão: A eutanásia encontra-se em confronto com os interesses de muitos pacientes enfermos e a legislação pátria que proíbe sua aplicação. Todavia, a criminalização da eutanásia suscita diversos questionamentos quanto a efetividade de garantias constitucionais como da autonomia da vontade e da dignidade da pessoa humana. Em respeito aos preceitos contidos na Constituição e ao interesse individual de cada ser humano, aplicar esta solução para a enfermidade deve ser um direito inerente, devendo somente ele versar sobre sua vida.

\author{
Referências \\ BARROSO, Luís Roberto. Legitimidade da recusa de transfusão de sangue por Testemunhas de Jeová: Dignidade humana, \\ liberdade religiosa e escolhas existenciais, 2010. Disponível em: https://www.conjur.com.br/dl/testemunhas-jeova-sangue.pdf. \\ Acesso em 31/08/2020. \\ BRASIL. Constituição (1988). Constituição da República Federativa do Brasil. Brasília, DF: Senado Federal: Centro Gráfico, \\ 1988. \\ BRASIL. Lei n² 2.848, de 07 de dezembro de 1940. Código Penal. Diário Oficial da União, Rio de Janeiro. \\ DINIZ, Maria Helena, Curso de Direito Civil Brasileiro: Teoria Geral do Direito Civil, 29a edição, São Paulo: Editora Saraiva \\ 2012. \\ Atleta paraolímpica com grave doença degenerativa planeja eutanásia. FANTÁSTICO, Rio de Janeiro: Edição de 11 set. 2016. \\ Disponível em: http://g1.globo.com/fantastico/noticia/2016/09/atleta-paralimpica-com-grave-doenca-degenerativa-planeja-
}


eutanasia.html. Acesso em 31/08/2020.

SANCHÉZ, Álvaro. Morre a campeã paraolímpica Marieke Vervoort após passar por eutanásia. EL PAís, Bruxelas: 23 out. 2019.

Disponível em: https://brasil.elpais.com/brasil/2019/10/22/deportes/1571777795_278951.html. Acesso em 31/08/2020.

Coordenadoria de Pesquisa e Extensão - COPEX

Departamento de Editoraçāo e Divulgaçāo Científica - DEDIC 


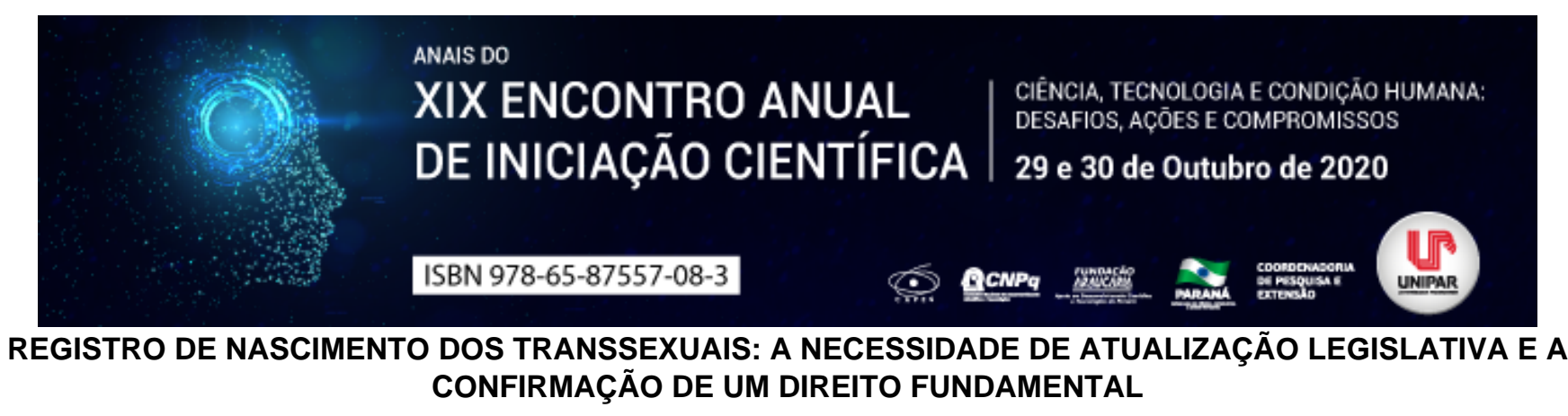

${ }^{1}$ NATHAN PEREIRA CAVALHEIRO, ${ }^{2}$ WELLINGTON RIBEIRO CAMPOS, ${ }^{3}$ VALÉRIA SILVA GALDINO CARDIN

${ }^{1}$ Acadêmico de Pós-Graduação em Direito homoafetivo e de gênero
${ }^{1}$ Mestrando em Ciências Jurídicas da Universidade Cesumar - UniCesumar
${ }^{2}$ Docente da Universidade Estadual de Maringá e Docente da Universidade Cesumar

Introdução: Com a publicação do provimento 73 do CNJ, a averbação da alteração do prenome e do gênero nos assentos de nascimento e casamento da pessoa transgênero nos cartórios de registro civil, finalmente passou a ser possível. Porém, será que todas as problemáticas acerca do tema foram solucionadas? As pessoas transexuais, conseguiram efetivamente alcançar todos os seus direitos em relação ao direito fundamental do nome? O provimento do CNJ foi capaz de regulamentar situações que envolvem terceiros de forma justa e sem violar os direitos das pessoas trans ? Essas são as principais problemáticas que o presente trabalho busca debater. Pretende-se analisar as omissões legislativas que ainda rondam este tema, e verificar se os direitos das pessoas transexuais, relacionados à alteração de nome e sexo diretamente no Registro Civil foram sanadas com a decisão do STF, e com o Provimento 73 , do $\mathrm{CNJ}$, a fim de concluir se a simplificação do respectivo procedimento permitiu o alcance efetivo e real do direito da dignidade da pessoa humana, e dos demais direitos correlatos.

Objetivos: Por meio do método teórico, buscou-se analisar questões controvertidas acerca dos direitos das pessoas transgêneros nos registros civis para elevar o debate acadêmico acerca do tema.

Desenvolvimento: O nome é o substantivo que se emprega para designar as coisas e as pessoas. A importância do nome que permite a individualização da pessoa humana, constituindo, um dos direitos mais essenciais da personalidade. Por tratar-se de direito da personalidade, o Código Civil e a Lei de Registros Públicos determinaram que o nome civil constitui um direito do indivíduo desde o seu nascimento e abrange o uso imprescindível e incondicional do direito ao nome em todos os atos da vida civil, seja público ou privado. O nome possui fundamental importância para a segurança jurídica na sociedade, visto que as relações jurídicas são estabelecidas entre pessoas, sejam elas naturais ou jurídicas e o exercício de seus direitos e exige o conhecimento dos titulares. No caso dos transgêneros, a viabilidade da alteração do nome no registro civil é uma medida positiva diferenciada e concretiza a capacidade de autodeterminação do indivíduo, uma vez que possui o propósito de efetivar a igualdade material. A tutela da identidade de gênero é o direito ao livre desenvolvimento da personalidade, que compreende a identidade sexual e de gênero é, portanto, um direito fundamental da pessoa humana, já que a partir do reconhecimento da identidade é que o sujeito desenvolve a sua personalidade autônoma e obtém o reconhecimento da comunidade social da qual pertence. Nesse sentindo o Supremo Tribunal Federal (STF) decidiu acerca da asserção do direito fundamental ao reconhecimento da identidade de gênero, e oportunizou às pessoas transgêneros serem tratadas de acordo com a autopercepção por elas mesmas reveladas. Embora o provimento 73 do CNJ manteve o caráter extrajudicial do procedimento e entendeu que somente apenas após a alteração do gênero e prenome no registro de nascimento, poderá o Requerente buscar a alteração na certidão de nascimento de seus filhos já nascidos. Há expressa previsão que a alteração do prenome nas certidões de nascimento dos descendentes da pessoa retificada, depende da anuência do filho(a) quando relativamente capazes ou maiores, bem como de ambos os pais. Ou seja, caso os filhos sejam maiores de idade, é necessário que o filho concorde com a alteração do nome do pai ou da mãe transexual, e, sendo eles menores de idade, é necessário que o(a) outro(a) pai/mãe concorde com a respectiva alteração. Ocorre que tal exigência prevista pelo provimento 73 é substancialmente inconstitucional, pois fere princípios da autonomia, da verdade real dos registros públicos e vai na contramão da decisão do Supremo Tribunal Federal que tutelou acerca dos direitos de retificação do nome da pessoa trans a fim de garantir o direito à dignidade, o direito à intimidade, à vida privada, à honra e à imagem, e principalmente o direito à liberdade de autopercepção.

Conclusão: Verifica-se que o tema em questão levanta questionamentos acerca de quem teria mais direito sobre a matéria discutida, sendo lúcido a conclusão de que a pessoa trans retificada é detentora principal de legitimidade para pleitear a alteração sem que haja qualquer anuência do filho/a ou cônjuge, mesmo esses sendo os possuidores das certidões de nascimento, haja vista que não há a presença de justo motivo para o filho/a ou cônjuge negarem a modificação, tão pouco a existência de prejuízo a terceiros, além, da própria pessoa trans que é quem sofre com falta da ação. A retificação do nome da pessoa trans na certidão de nascimento do filho/a ou em sua certidão de casamento é necessária não somente para respeitar os princípios aqui elencados, mas serve também para evitar situações vexatórias, pois sempre que houver a necessidade da utilização desses documentos, seria necessário apresentar uma longa documentação retratativa de histórico pessoal, e se delongar em um assunto de foro íntimo, o que levaria a pessoa transexual à uma exposição e humilhação desnecessária e certamente ilegal. 


\section{Referências}

SARLET, Ingo Wolfgang. Direitos Fundamentais e Relações Privadas. 2. ed. Rio de Janeiro: Lumen Juris, 2010.

VIEIRA, Tereza Rodrigues. Identidade sexual: aspectos éticos e jurídicos da adequação de prenome e sexo no registro civil. In: VIEIRA, Tereza Rodrigues; PAIVA, Luiz Airton Saavedra de (Orgs.). Identidade Sexual e Transexualidade. São Paulo: Rooca, 2009.

O impacto da genética sobre a vida do transexual: aspectos bioéticos e jurídicos. Anais Eletrônicos do Encontro de Bioética do Paraná, Bioética início da vida em foco. Curitiba: Champagnat, 2009. Disponível em: www2.pucpr.br/reol/index.php/BIOETIOCA?dd1=3317\&dd99=view. Acesso em: 16 set. 2020.

Transgêneros. Brasília: Zakarewicz, 2019. v. 1. p.778.

Coordenadoria de Pesquisa e Extensão - COPEX

Departamento de Editoraçāo e Divulgaçāo Científica - DEDIC 


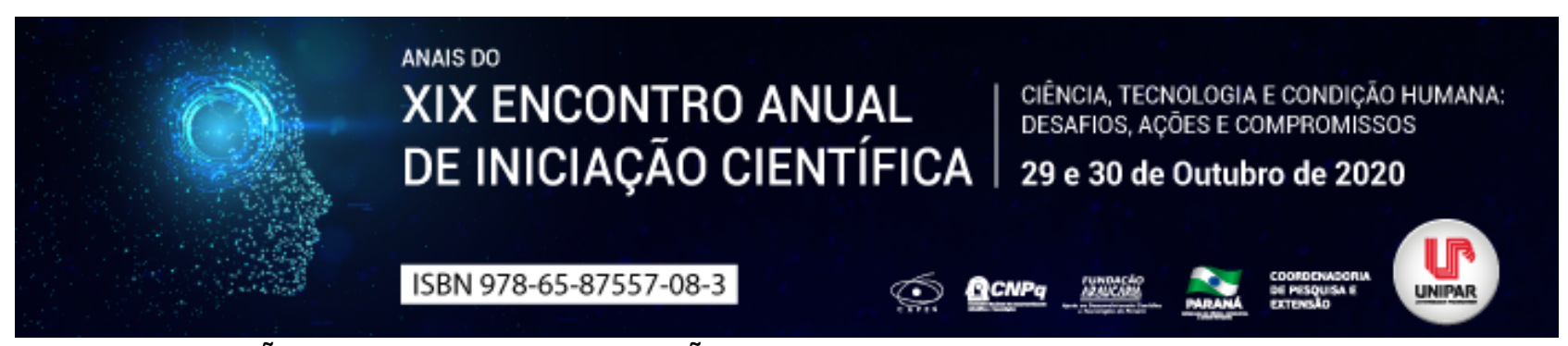

GAMIFICAÇÃO: CONCEITO E CONCEPÇÕES DA APRENDIZAGEM ESCOLAR NA ATUALIDADE

\begin{abstract}
${ }^{1}$ ANA CAROLINA MOLINA PETINATI, ${ }^{2}$ BIANCA GABRIELA DE SOUZA PRADO, ${ }^{3}$ SHEILA GONCALVES GOMES, ${ }^{4}$ MARIA DO CARMO DE O NOGUEIRA, ${ }^{5}$ LUCYELENA AMARAL PICELLI, ${ }^{6}$ VIVIANNE AUGUSTA PIRES
\end{abstract}

\author{
${ }^{1}$ Acadêmico do Curso de Pedagogia da Unipar - PIC \\ ${ }^{1}$ Acadêmica do Curso de Pedagogia da UNIPAR \\ ${ }^{2}$ Acadêmica do Curso de Pedagogia da UNIPAR \\ ${ }^{3}$ Docente da UNIPAR \\ ${ }^{4}$ Docente da UNIPAR \\ ${ }^{5}$ Docente da UNIPAR
}

Introdução: O termo gamificação começou a ser utilizado por volta de 2010 e basicamente, significa utilizar os fundamentos dos jogos em atividades fora do contexto de jogo, ou seja, tem como base a ação de se pensar como em um jogo, utilizando as sistemáticas e mecânicas do ato de jogar em um contexto fora do jogo. Porém, há uma dificuldade das instituições escolares se conectarem com o mundo vivido pelos jovens crescidos na cibercultura, pois algumas escolas são de uma estrutura fragmentada e hierarquizada enquanto os alunos se tornam cada vez mais sujeitos multitarefas. Diante desta realidade, segundo (FERNANDES E RIBEIRO, p 1, 2018), a gamificação surge como uma possibilidade de conectar a escola ao universo dos jovens com o foco na aprendizagem, com a finalidade de contribuir para a solução de um problema, através de um conhecimento aprofundado com estímulos emocionais que impactam no processo de aprendizagem, é importante reforçar que gamificar não significa utilizar games prontos, mas sim os recursos presentes nos games para promover estratégias diferenciadas que reforçam a motivação e o engajamento do aluno.

Objetivo: Analisar os diversos conceitos e concepções da gamificação na aprendizagem escolar.

Desenvolvimento: A tecnologia está cada vez mais relacionada à educação, os professores estão utilizando novas metodologias para que os alunos se tornem mais participativos e interessados com a aula, acrescentar a tecnologia faz com que essa prática se torne mais fácil. De acordo com Mendonça ( 1 1, 2016), a gamificação, por exemplo, neste momento está sendo implantada no ensino para tornar a aprendizagem mais simples e prática, ela nada mais é que usar elementos dos jogos para engajar pessoas para que o objetivo possa ser atingido, desse modo irá despertar o interesse, aumentar a participação, desenvolver a criatividade e autonomia, promover diálogo, por último resolver situações problemas. A gamificação é uma técnica que envolve dinâmicas, mecanismos e elementos dos video games e os aplica em contextos da vida real. Em geral, a gamificação oferece soluções criativas para muitos problemas e utiliza a diversão como componente básico nessa empreitada. A ideia atrelada a essa técnica é a de aprender com os jogos (KRAJDEN, 2017, p 22). Este método pode ser aplicado em qualquer situação, porém é mais utilizada na educação e nas empresas. Dentro da empresa equipes são formadas, objetivos, estipulados, metas, estabelecidas. Quem atinge as metas recebe pontos ou uma recompensa, e quem tem mais pontos passa a outro nível, ou seja, o status dessa pessoa se altera. Essa estrutura com objetivos, metas, pontos, níveis, recompensas, status é similar à dos jogos (KRAJDEN, 2017, p 23). De acordo com Fernandes e Ribeiro, ( 3 3, 2018), a gamificação não existe somente a parte lúdica, também tem a parte da aprendizagem e com isso requer uma recompensa. A recompensa serve para estimular dois tipos de motivação: a intrínseca e a extrínseca. A motivação intrínseca é quando o indivíduo é motivado a realizar determinada atividade ou demostrar certo comportamento por fatores internos, tais como orgulho, vontade, prazer, entre outros. A motivação extrínseca funciona ao contrário, o indivíduo realiza determinada tarefa ou apresenta determinado comportamento com a finalidade de conseguir uma recompensa externa, como prêmios, medalha, ou algo que o valha. Dentro da família isso gera um retorno positivo para os pais educarem seus filhos, um exemplo seria da mãe falar Você só vai jogar depois que organizar seu quarto ou Primeiro faça as suas obrigações, depois pode ir brincar , dessa forma os pais estão ensinando os filhos a terem obrigações e responsabilidades, através da recompensa e ao mesmo tempo os motivando. Isso também acontece dentro da sala de aula, o professor explica a teoria e depois a põem em prática com a gamificação, sendo uma recompensa para os alunos, dentro de uma empresa o patrão estipula metas, pontos, recompensas, assim o funcionário irá cumprir pois ficará interessado com a proposta, dando-lhe uma motivação para trabalhar de forma cuidadosa e com entusiasmo. A gamificação dentro da educação além de ser prazerosa deve trazer alguns desafios para que os alunos possam se desenvolver, fortalecendo a observação, atenção, organização de informações, tomada de decisão e entre outros sentidos. O que a gamificação permite fazer é escolher alguns elementos de jogos e integrá-los à educação. Essa interação gera oportunidades para um rico engajamento, de modo que os alunos sejam motivados e a aprendizagem seja divertida e não apenas tolerável (KRAJDEN, 2017, p 135). Dessa maneira, a relação professor-aluno é desenvolvida, se tornando amigável. 
Conclusão: Dessa forma, a gamificação ainda é um assunto recente, há vantagens e desvantagens. Entretanto, o objetivo da gamificação não é produzir jogos e sim atividades com elementos característicos de jogos, essa prática é comprovada, gera uma aprendizagem de qualidade e uma motivação do aluno para querer aprender, sendo assim, é um grande passo para uma qualidade de ensino melhor e para a educação.

\section{Referências}

FERNANDES, Carlos. RIBEIRO, Erick. Games, gamificação e o cenário educacional brasileiro. Disponível em: . Acesso em: 11 jul. 2020.

KRAJDEN, Marilena. O despertar da gamificação corporativa. $1^{a}$ edição, Curitiba: Intersaberes, 2017.

LORENZONI, Marcela. Gamificação: o que é e como pode transformar a aprendizagem. Disponível em: . Acesso em: 11 jul. 2020.

MENDONÇA, Bruno. O que é a gamificação e como ela funciona?. Disponível em: . Acesso em: 11 jul. 2020.

Coordenadoria de Pesquisa e Extensão - COPEX

Departamento de Editoraçāo e Divulgaçāo Científica - DEDIC 


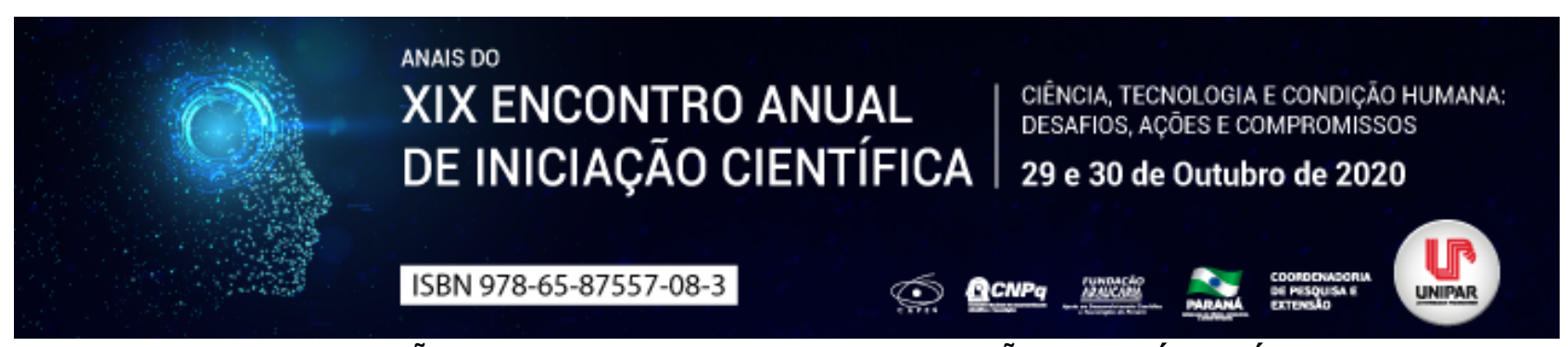

JUDICIALIZAÇÃO: O PODER JUDICIAL COMO SOLUÇÃO DA SAÚDE PÚBLICA

\section{${ }^{1}$ LUIS FERNANDO DINIZ CRISTINO, ${ }^{2}$ THIAGO MORETO FIORI}

${ }^{1}$ Discente do Programa de iniciação científica PIC/UNIPAR, campus Guaíra/PR

${ }^{1}$ Docente do Programa de iniciação científica PIC/UNIPAR, campus Guaíra/PR

Introdução: No Brasil, nos dias atuais, há um grande número de ações judiciais envolvendo a saúde pública e esse fenômeno conhecido como judicialização da saúde, era quase inexistente em meados dos anos 90 . Sendo assim, o presente trabalho, organizado pelo Projeto de Iniciação Cientifica (PIC) é uma continuação de um artigo elaborado no ano de 2019 e publicado no presente ano (2020). O mesmo se deu por conta das pesquisas realizadas que, diante a ineficácia do sistema de saúde e das políticas públicas, é necessário a intervenção do poder judiciário para que um direito básico do cidadão seja garantido, um direito que, por si só, deveria ser garantido desde seu nascimento.

Objetivo: Demonstrar com caso concreto, como acontece a judicialização na saúde no Brasil, obtendo como base fundamental as demandas de saúde pública no país.

Desenvolvimento: No Brasil, o conceito de direito a saúde vem sendo construído ao longo de anos, tendo como base a Constituição da República Federativa do Brasil do ano de 1988 (CRFB/88) (NEVES; PACHECO, 2017). A ideia do direito à saúde passou a ser universal, ou seja, direito para todos, de modo que passou a ser tratada como um direito fundamental, o que significa a necessidade de aplicação imediata, previsto e contemplado no rol dos direitos sociais do artigo $6^{\circ}$ da $\mathrm{CRFB} / 88$ (NEVES; PACHECO, 2017). Os direitos e garantias fundamentais são normas que vislumbram garantir o desenvolvimento a pessoa humana, possibilitando condições mínimas para a vida em sociedade. Por ser reconhecida como um direito a prestações, o Estado deve providenciar atos positivos para garanti-la, por meio de políticas públicas ou de manutenção de instrumentos já existentes que, no entanto, em inúmeros casos o Estado se abstém de seu dever constitucional, o que obriga o judiciário, após ser provocado, garantir o cumprimento dos textos constitucionais. Devido a precariedade do sistema dos serviços públicos e da ausência de políticas públicas, a população busca a tutela jurisdicional para garantir que seu direito seja garantido, tanto a tratamento médico, quanto a medicamentos. Segundo Barroso (2008), o judiciário deve intervir sempre que um direito fundamental não estiver sendo cumprido. Caso não seja provocado, o poder judiciário não poderá agir, pois a ele se impõe o princípio da inércia, ou seja, a parte interessada deve tomar a iniciativa. Porém, uma vez provocada, o mesmo não pode afastarse da prestação jurisdicional. A judicialização da saúde não é necessariamente negativa em um estado democrático de direito, pois na ótica da democracia, o fato de milhares de pessoas procurarem o judiciário para pleitear seus direitos a saúde, pode ser um indicativo de uma melhor consciência da população sobre seus direitos, em uma receptividade em relação a direitos sociais de pessoas mais vulneráveis, maior fiscalização e controle da sociedade sobre a administração pública. Segundo Teixeira (2012) a tal judicialização pública têm motivos diversos e vão desde falhas administrativas e corrupção, até desejos de pacientes e médicos por tratamentos que não são fornecidos pelo sistema. Sendo assim, no entendimento do STF o ativismo judicial e a judicialização representa apenas a insuficiência do Estado em atender sua população, bem como buscar e realizar os objetivos que Ihe foram postos, assim acaba transformando o judiciário numa esfera pública , que trata de questões fundamentais do Estado e questões banais do cotidiano dentro da sociedade.

Conclusão: Conclui-se que a judicialização não é um problema do judiciário, mas sim uma resposta do mesmo aos cidadãos, que de maneira ágil concede uma resposta frente a ineficácia e ineficiência do Estado, que não possui políticas publicas que consigam atender de maneira digna um direito primário e constitucional das pessoas, que seria o então acesso a saúde.

\footnotetext{
Referências

BARROSO, Luís Roberto. Da falta de efetividade à judicialização excessiva: direito à saúde, fornecimento gratuito de medicamentos e parâmetros para a atuação judicial. Em Revista Interesse Público, p. 1-37, 2008.

BRASIL. Constituição (1988). Constituição da República federativa do Brasil. Brasília, DF: Senado Federal: Centro Gráfico, 1988.

NEVES, Pilar Bacellar Palhano, Y PACHECO, Marcos Antônio. Saúde pública e Poder Judiciário: percepções de magistrados no estado do Maranhão. Revista Direito GV - São Paulo, vol. 13, n. ${ }^{\circ}$ 3, p. 749-768, 2017.

TEIXEIRA, Anderson Vichinkeski. Ativismo Judicial e Decisão Política. Revista Direito GV. São Paulo, v. 8, n. 1, p. 037-058, 2012. Disponível em: https://www.scielo.br/scielo.php?script=sci_arttext\&pid=S180824322012000100002\&lang=en\#41a. Acesso em: 27 ago. 2020.
} 
Coordenadoria de Pesquisa e Extensão - COPEX

Departamento de Editoraçāo e Divulgaçāo Científica - DEDIC 


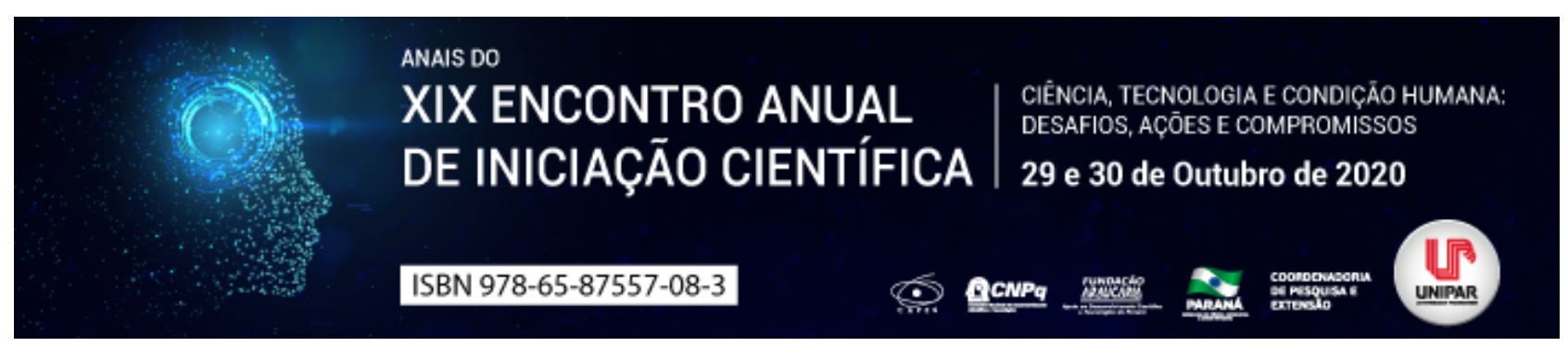

DIREITOS INDIVIDUAIS E COLETIVOS DOS MORADORES DE RUA

\title{
${ }^{1}$ EDIVANIA AZEVEDO BEZERRA, ${ }^{2}$ THAYANA GOMES PINHEIRO, ${ }^{3}$ CESAR AUGUSTO HOFFMANN
}

\author{
${ }^{1}$ Acadêmico do Curso de Arquitetura e Urbanismo da UNIPAR \\ ${ }^{1}$ Acadêmica do Curso de Arquitetura e Urbanismo da UNIPAR \\ ${ }^{2}$ Docente do Curso de Arquitetura e Urbanismo da UNIPAR
}

Introdução: O presente trabalho busca fazer uma análise sobre os direitos individuais e coletivos de pessoas em situação de rua, de forma a embasar a discussão acerca do tema sob a luz do Direito Constitucional e Direitos Humanos. O sistema de Seguridade Social, que pode ser definido como um conjunto de ações e iniciativas dos Poderes Públicos e da sociedade destinados ao amparo social em circunstâncias onde é impossibilitada a manutenção de necessidades básicas por meios próprios, estabelecendo assim um sistema integrado fundamentado na solidariedade, que se subdivide em três pilares: a saúde, a previdência e assistência social. Dentro desse contexto, os benefícios assistenciais configuram instrumentos de combate e erradicação da pobreza, redução das desigualdades sociais e proteção da dignidade humana, tendo como princípios e diretrizes a Carta Federal e a LOAS (Lei Orgânica de Assistência Social - Lei 8742/93), além de ter suas origens estabelecidas pelo Art. 203 da Constituição Federal, que manifesta a assistência social como um direito de todos, independente de contribuição. Os direitos sociais esclarecem o papel do Poder Público em relação ao amparo social de pessoas em condição de rua, os quais são apresentados de maneira sucinta no Art. $6^{\circ}$ da Constituição Federal que prevê direitos relacionados à moradia, alimentação, segurança, saúde e seguridade social a indivíduos dentro contexto de moradores de rua.

Objetivo: Explorar as condições de pessoas em situação de rua e os direitos que essa população detém, elucidando a viabilidade desses indivíduos exercerem sua civilidade em meio ao cenário da vida na rua.

Desenvolvimento: $\mathrm{Na}$ fase do aprofundamento teórico observou-se, que aos indivíduos moradores de rua são depositados estigmas e preconceitos pela própria sociedade circundante, caracterizando esses indivíduos como responsáveis pela questão social em que se encontram. Compreendidos pela vulnerabilidade social ou risco social, esses indivíduos são trazidos para o cenário de extrema carência material, sem recursos próprios para a obtenção de condições mínimas de salubridade e conforto, isso acontece devido a um conjunto de fatores, influenciados principalmente pela desfavorecida condição de abrigo e emprego, ou a ausência dos mesmos. Com relação aos direitos inerentes a todos, o texto da Constituição Federal, de forma geral, estabelece diretrizes que asseguram a igualdade de condições e tratamento, na execução dos direitos sociais. Segundo Moraes (2006), os chamados direitos sociais têm como objetivo conceber verdadeiras liberdades positivas que o homem tem como ser dentro de uma sociedade para que possam diminuir desigualdades geradas no meio e que possam influir na verdadeira igualdade social. Instituída pelo Decreto $s / n^{\circ}$, de 25 de outubro de 2006, a Política Nacional para Inclusão Social da População em Situação de Rua surgiu como forma de orientar a construção e execução de políticas públicas voltadas a este segmento da sociedade, historicamente à margem das prioridades dos poderes públicos (BRASIL, 2008, p.2). De acordo com LOAS (2005) o poder público deve oferecer programas e serviços destinados à população de rua, sendo que estes devem garantir padrões básicos de dignidade e não violência na concretização de mínimos sociais e dos direitos de cidadania a esses indivíduos. Os Direitos Humanos fundamentais existem para que a dignidade, própria da natureza humana seja garantida . DIREITO À SAÚDE: O indivíduo morador de rua está restrito a condições de higiene e salubridade precárias ou mesmo a falta destas, dadas às condições dos locais onde residem são propícios para a disseminação de doenças, ou piora das preexistentes. A saúde, pressuposto básico da preservação da vida humana, do desenvolvimento de sua dignidade e do livre exercício dos demais direitos e garantias fundamentais adquiridos ao longo da história, são conceituados pela OMS (Organização Mundial da Saúde) como o estado de completo bem-estar físico, mental e social não consistindo apenas na ausência de doenças ou enfermidades (Constituição da Organização mundial da Saúde 1946). De acordo com o Art. 196, que inicia com a seguinte redação a saúde é direito de todos e dever do Estado [...] , impondo de maneira expressa e na integralidade do texto normativo, o acesso universal e igualitário aos serviços de promoção, proteção e recuperação a saúde e a aplicação de políticas sociais e econômicas, que visem à redução dos riscos de doenças e outros agravos está bem distante destes moradores de rua, De Lima (2017).

Conclusão: A realidade a qual se encontra o morador de rua fere a sua condição mais básica enquanto indivíduo a dignidade, as condições em que se encontram por muitas vezes os expõe em um nível muito maior a violência exploração, preconceitos e condições de riscos variados, estando à margem da sociedade, muitas vezes indesejáveis, invisíveis aos olhos da comunidade. Como indivíduo e cidadão são detentores de direitos, contudo a real aplicação destes depende do engajamento da sociedade como um todo governo, movimentos, entidades e principalmente a sociedade civil. Dessa forma, é papel do Poder Público proporcionar condições para a obtenção de uma vida digna para indivíduos em condição de rua, por meio de dispositivos assistenciais que visem suprir a dificuldade de acesso a serviços para o atendimento de necessidades básicas. 


\section{Referências}

BRASIL. Constituição da República Federativa do Brasil de 1988 Promulgada em 05 de outubro de 1988. Disponível em: < http://www.planalto.gov.br/ccivil_03/constituicao/constituicaocompilado.htm. > Acesso em: 01 jul. 2020.

BRASIL. Governo Federal. Política nacional para inclusão social da população em situação de rua. Brasília, 2008. Disponível, em . Acesso em: Acesso em 01 jul. 2020.

Constituição da Organização Mundial da Saúde (OMS/WHO) 1946. Biblioteca Virtual de Direitos Humanos. Universidade de São Paulo - USP, 1946. Disponível em:< http://www.direitoshumanos.usp.br/index. php/OMS-Organiza\%C3\%A7\%C3\%A3oMundial-da-Sa\%C3\%BAde/constituicao-da-organizacao-mundial-da-saude omswho.html>. Acesso em 01 jul. 2020.

FERNANDES, Bernardo Gonçalves. Curso de Direito Constitucional. Rio de Janeiro: Lumen Juris. 2011.

GODOY, Luciano Souza. $O$ direito à moradia como expressão da dignidade da pessoa humana - acesso a casa própria por meio do mútuo. 2002. Tese (Doutorado em Direito Civil) Universidade de São Paulo, São Paulo, 2002.

Lei Orgânica da Assistência Social (LOAS), No 8.742, DE 7 DE DEZEMBRO 1993 Promulgada em 07 de dezembro de 1993. < Disponível em: http://www.planalto.gov.br/ccivil_03/Leis/L8742.htm, Acesso em: 19 abr. 2018.> Acesso em 01 jul. 2020.

LENZA, Pedro. Direito constitucional esquematizado. São Paulo: Saraiva, 2012.

DE LIMA, J. J.; DESAMPARO SOCIAL AO MORADOR DE RUA JOÃO. Trabalho de Conclusão de Curso (Graduação de Direito) - UniCesumar, Maringá PR, $2017 . \quad$ Disponível em:

http://rdu.unicesumar.edu.br/bitstream/123456789/470/1/Joao\%20de\%20Lima\%20Junior.pdf >. Acesso em: 1 jul. 2020.

MORAES, Alexandre de. Direito constitucional - 19o Ed. - São Paulo: Atlas, 2006.

MPDFT. Cartilha direitos das pessoas situação de rua Ministério Público do Distrito Federal e Territórios MPDFT. 1a

Edição-Julho/2018.

SILVA, José Afonso da. Curso de direito constitucional positivo. São Paulo: Editora Malheiros, 2014.

SOUZA NETO, Cláudio Pereira de; SARMENTO, Daniel. Direito Constitucional - teorias, história e métodos de trabalho. Belo Horizonte: Fórum, 2012. 


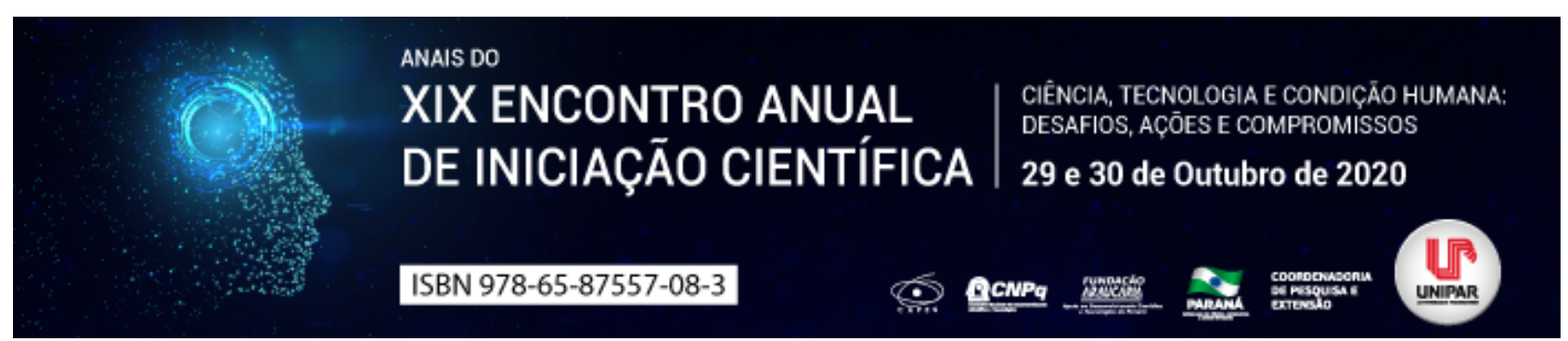

AS DIFERENÇAS NA EDUCAÇÃO NA REDE PÚBLICA E PRIVADA

\begin{abstract}
1JAIR RUZZENE JUNIOR, ${ }^{2}$ BEATRIZ MARIA ZUCARELLI VOSS, ${ }^{3}$ ANA CAROLINA MACHRI STECCA, ${ }^{4}$ JOAO PEDRO ZULIANELLI BARDELA, ${ }^{5}$ VIVIANNE AUGUSTA PIRES
\end{abstract}

\author{
${ }^{1}$ Acadêmico do Curso de Pedagogia na UNIPAR. \\ ${ }^{1}$ Acadêmica do Curso de Pedagogia da UNIPAR \\ ${ }^{2}$ Acadêmica do Curso de Pedagogia da UNIPAR \\ ${ }^{3}$ Acadêmico do Curso de Pedagogia da UNIPAR \\ ${ }^{4}$ Docente da UNIPAR
}

Introdução: A diferença entre o ensino na rede pública e na privada é um assunto bastante debatido, principalmente quando se fala da hora de uma criança adentrar a educação infantil, ou um adolescente ingressar no ensino médio. Este tema será abordado de maneira a apresentar as diferenças entre a da rede privada, mostrando suas vantagens e desvantagens, e assim o mesmo será feito com a pública, de maneira que não haja julgamentos pessoais para ambos lados.

Objetivos: Demonstrar de maneira clara e sucinta diferenças no ensino e na educação na rede pública e privada, demonstrando as possíveis causas e motivações.

Desenvolvimentos: No passado havia grandes discussões acerca do assunto Rede Pública X Rede Privada , giravam em torno das questões do conteúdo ético do ensino, da equidade e do papel do governo na educação. No Brasil, existem divergências a respeito de inúmeras questões sobre a educação, apesar de decreto em lei, não ser algo para todos, quando passamos a analisar a falta, ou desvio, de investimentos, de infraestrutura, profissionais e interesse pelos alunos da rede pública de ensino, podemos refletir acerca de condições diferentes de ensino. Uma nação que não investe na qualidade de sua educação acaba comprometendo a qualidade da sua cidadania e de seu desenvolvimento social, econômico e democrático. Segundo Sampaio e Guimarães (2007) estudos mostram que o estabelecimento de ensino, a qualidade dos professores a disponibilidade de laboratórios de qualidade, a organização e o nível dos demais alunos tem influência no desempenho dos estudantes. A qualidade do professor é função do seu conhecimento, que é fruto da sua formação acadêmica, da sua motivação e da sua assiduidade. Todos estes aspectos vão ser de fundamental importância no desempenho do estudante.

Segundo a Constituição Federal de 1988, (Art. 205 parágrafo único), A educação, direito de todos e dever do Estado e da família, será promovida e incentivada com a colaboração de sociedade, visando ao pleno desenvolvimento da pessoa, seu preparo para o exercício da cidadania e sua qualificação para o trabalho. Como já dito e mostrado, a educação pública, gratuita e de qualidade é um direito de todos, mas nem todos aprendemos sob as mesmas condições, e com a mesma qualidade. Se olharmos dentro da própria rede pública de ensino temos escolas e escolas , temos escolas com altos índices de aprovação em vestibulares e de aprendizagem, com projetos de incentivo a capacitação de professores, e que apoiam os alunos a ingressarem não apenas em faculdades, mas também em cursos técnicos e profissionalizantes, onde possam melhorar suas condições de vida. Também podemos falar a respeito de alunos que trabalham para ajudar em casa, muitas vezes em empregos que possam trazer riscos e danos a sua saúde e/ou vida, muitas vezes estes estudantes não veem que benefícios possam vir da escola, e não compreendem sua importância, isso se dá pelo fato de que a vida que conhecem, muitas vezes não tem tempo para estudos. A partir destes exemplos, podemos perceber que os alunos da rede particular de ensino, que além de terem a oportunidade de uma educação mais árdua, onde são preparados para vestibulares e outros tipos de prova, ainda tem a vantagem de não precisarem abrir mão de seus tempos de estudo para ajudarem na renda de suas famílias. Além dos fatores de ambientes propícios para a aprendizagem desses alunos. Os colégios públicos, não deixam de trabalhar as questões abertas, onde se considera a opinião e argumentação dos alunos, esse sistema ajuda com a parte de escrita e argumentação, mas pode deixar a desejar na questão preparatória para vestibulares. O que futuramente, poderá fazer com que um aluno do ensino particular e que possui condição de arcar com os custos do ensino superior, consiga a vaga que deveria ser de um aluno de ensino público, em uma faculdade pública. No entanto, o que podemos colocar na balança é a dedicação que os alunos têm com seus estudos, a dedicação dos professores ao ensinar, o ambiente de ensino e as condições às quais os alunos estão expostos.

Conclusão: As discussões entre as diferenças da rede pública e da rede privada nos levam a questionar o nível da educação no Brasil, o investimento na área da educação visando à melhoria na área escolar pública, mesmo com todas as dificuldades relacionadas ao governo, como desvio de verbas. Apesar disso, busca-se fornecer uma educação de ponta na rede pública, que possa muitas vezes se igualar ou até ultrapassar a rede de ensino privada.. Quando comparado o modo de trabalhar com o aluno podemos ver algumas diferenças tanto na rede pública como na rede privada com os tipos de conteúdo, o real comprometimento e preocupação do professor com a aprendizagem do conteúdo, e através dessas comparações podemos ver realmente a 
diferença entre a qualidade do ensino público para o privado. Mas apesar dos pontos de divergência entre si, os dois modos de ensino, possuem seus ônus e bônus, assim como tudo que existe hoje, mas o que devemos lembrar sempre é que, as pessoas que saem destas instituições são seres humanos, e que eles são, e deles virão o futuro.

\section{Referências}

BRASIL. Constituição (1988). Constituição da República Federativa do Brasil. Brasília, DF: Senado Federal: Centro Gráfico, 1988.

GUIMARÃES, J. F., SAMPAIO, B. The influence of family background and individual characteristics on entrance tests scores of Brazilian university students. Anais do XXXV Encontro Nacional de Economia - ANPEC - Associação Nacional dos Centros de Pós-Graduação em Economia, Recife, 2007.

SAMPAIO, Breno; GUIMARÃES, Juliana." Diferenças de eficiência entre ensino público e privado no Brasil.". Scielo. Disponível em: https://www.scielo.br/scielo.php? . Acesso em 03 jun. 2020.

Coordenadoria de Pesquisa e Extensão - COPEX

Departamento de Editoraçāo e Divulgaçāo Científica - DEDIC 


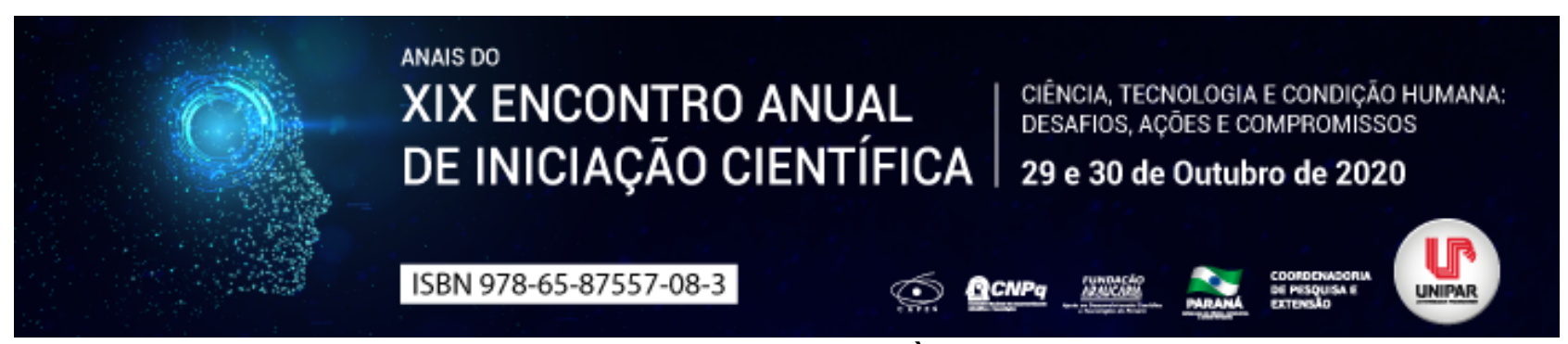

DIREITO FUNDAMENTAL DO CREDOR À TUTELA EXECUTIVA

\title{
${ }^{1}$ ANDREIA ALVES DE FREITAS, ${ }^{2}$ ALESSANDRO OTAVIO YOKOHAMA
}

\author{
${ }^{1}$ Acadêmica de Direito/UNIPAR \\ ${ }^{1}$ Docente da UNIPAR
}

Introdução: É incontroverso que o anseio para ver garantidos os direitos inerentes à natureza humana faz parte da própria humana desde os primórdios das civilizações (e antes delas), haja vista a instintiva aversão ao sofrimento de ver a si mesmo injustiçado. Tal ideia de justiça aperfeiçoou-se ao longo da história até originar o que hoje conhecemos por direitos humanos , dentre os quais se extraem alguns, em cada ordenamento jurídico, que são positivados, de modo a tornarem-se processualmente garantidos, momento a partir do qual passam a chamar direitos fundamentais. Assim tem-se a razão de ser do Princípio da Proporcionalidade e sua importância prática na missão estatal de assegurar que, em conflito, nenhum dos princípios elimine completamente a normatividade de outro, já que inexiste hierarquia entre normas constitucionais. Bem por isso, a proteção aos direitos fundamentais do credor tem um contraponto necessário na tutela do direito fundamental do credor, fazendo-se mister a utilização do princípio da proporcionalidade como forma de sopesamento racional entre ambos os valores em cada caso concreto.

Objetivo: Analisar a importância do sopesamento entre direitos fundamentais na relação jurídica devedor-credor, a necessidade de levar em conta as particularidades do caso concreto bem como a nocividade do paradigma da proteção demasiada ao devedor em detrimento do credor nas diversas situações em que o crédito resta indevidamente fulminado, sem motivação racional, tornando-o um apêndice do direto das obrigações, numa inversão perversa que já desautorizada pelo Direito Romano, cuja tônica estava no credor.

Desenvolvimento: Mediante a elaboração do presente trabalho concluiu-se que ao, numa relação jurídica, escolher um lado para proteger de toda forma, enquanto o outro fica à mercê da insegurança, nisso nada há de proporcional. Não há que se falar desamparo total ao devedor, deixando-o sem condições de sustento próprio e de se sua família, em situação de miséria. O que se entende aqui é que, dadas as circunstâncias do caso concreto, a ponderação entre o direito e a busca por caminhos alternativos é mais que possível: é necessária. Pense-se no caso em que o devedor possui salário suficiente para, mesmo havendo penhora de uma fração, manter dignamente o sustento próprio e familiar. Proteger, numa situação específica como essa, a totalidade do salário com o instituto da impenhorabilidade configura desserviço à ideia de Proporcionalidade, à segurança jurídica, ao direito do credor sobre seus ativos e até mesmo à economia nacional, já que não se trata de caso isolado. É o que ocorre no caso dos honorários advocatícios, legalmente reconhecidos como verba de natureza alimentar, mas sem exequibilidade garantida. No REsp 1.815.055 a Min. Nancy Andrighi justifica interpretação diversa da súmula 47 do STF sob o argumento de que: [...] vamos ter que enfrentar pedidos de prisão civil formulados por advogados quando não houver o pagamento de honorários . É nessa linha de entendimento que se perpetua o referido paradigma: uma disparidade indevida, evitando, por mero comodismo, o esforço para se chegar a uma justa e proporcional solução em cada caso. Assim leciona Maluf (p. 320, 2013), ao trazer à baila o que se entende por isonomia, desde que assim a definiu Aristóteles: Cabe ao Estado levar em conta todas as desigualdades humanas e sociais e tratar desigualmente os seres desiguais, na proporção em que se desigualam, para igualizá-los no plano jurídico

Mostra-se indispensável o respeito a premissas básicas, quando da existência de conflitos dessa natureza: a) definir o nível de lesão a um dos princípios, b) averiguar a relevância de privilegiar o princípio contrário e c) concluir se, de fato, a segunda situação justifica a primeira (ALEXY, p. 49, 2004). É necessário, em suma, é que, contrapesando as variáveis existentes, tenhase convicção acerca da proporcionalidade da medida. Consonante a esse entendimento, e corroborando com o ora defendido, Willis evidencia que a Proporcionalidade visa o respeito à dignidade humana por meio da ponderação entre o fim e o meio empregado, sendo esse o melhor possível, juridicamente, para se chegar àquele (GUERRA FILHO, p. 95, 2005)

Conclusão: No Brasil há escassa doutrina nesse sentido, havendo necessidade de entendimentos que mudem esse cenário promotor de desvantagens tanto a credores (que perdem de seu patrimônio e não mais confiam como antes na palavra de terceiros) quanto a devedores (que, além de entrarem em situação de inadimplência, não conseguirão financiamentos ou empréstimos futuros, sem alto preço em que a inadimplência será a causa número um). Nesse ínterim, se entende que a relativização de institutos como a impenhorabilidade é indispensável, sempre de acordo (e proporcionalmente) com os valores em choque no caso concreto.

\section{Referências}

ALEXY, Robert. Epílogo a la teoría de los derechos fundamentales. Madrid: Fundación beneficentia et perita iuris, 2004. 
BRASIL. Superior Tribunal de Justiça. REsp 1.815.055. Relatora: Min. NANCY ANDRIGHI. São Paulo, 05 de fevereiro de 2020. Disponível em: https://ww2.stj.jus.br/processo/revista/documento/mediado/? componente=ITA\&sequencial=1872095\&num_registro=201901412378\&data=20200826\&formato=PDF . Acesso em: 29 de agosto de 2020 .

GUERRA FILHO, Willis Santiago. Processo constitucional e direitos fundamentais. 4ª ed., São Paulo: RCS Editora, 2005. SAHID, Maluf. Teoria Geral do Estado. São Paulo: Saraiva, 2013.

Coordenadoria de Pesquisa e Extensāo - COPEX

Departamento de Editoraçāo e Divulgaçāo Científica - DEDIC 


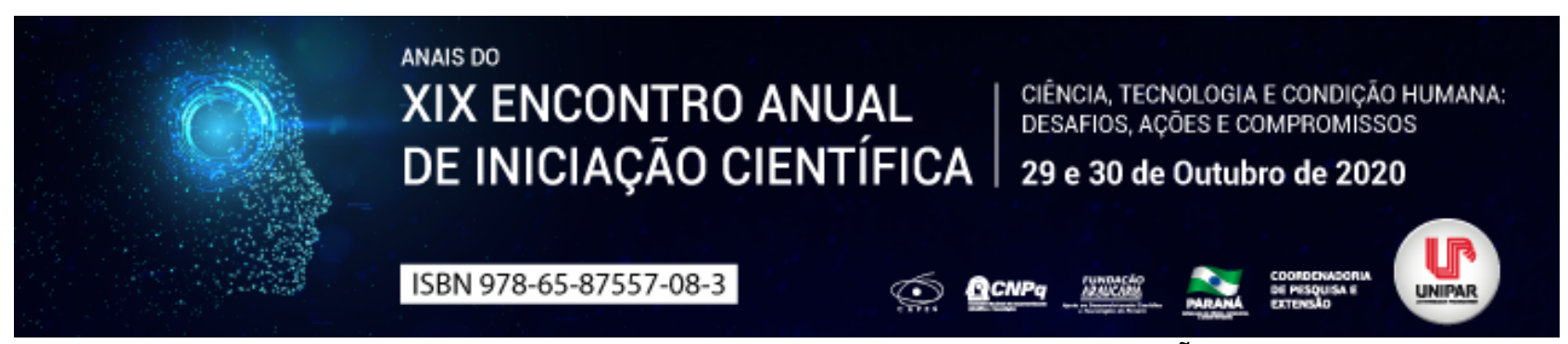

DA INCONSTITUCIONALIDADE DO REGISTRO SOCIOAFETIVO PARA MÃES TRANSEXUAIS

\title{
${ }^{1}$ NATHAN PEREIRA CAVALHEIRO, ${ }^{2}$ WELLINGTON RIBEIRO CAMPOS, ${ }^{3}$ VALÉRIA SILVA GALDINO CARDIN
}

\author{
${ }^{1}$ Acadêmico de Pós-Graduação em Direito Homoafetivo e de Gênero da Universidade de Santa Cecilia - Unisanta \\ ${ }^{1}$ Mestrando em Ciências Jurídicas da Universidade Cesumar - UniCesumar \\ ${ }^{2}$ Docente da Universidade Estadual de Maringá e Docente da Universidade Cesumar
}

Introdução: Após a decisão do Supremo Tribunal Federal acerca do direito à retificação do prenome e gênero das pessoas transgêneros no julgamento da ADI 4275, bem como a regularização do Provimento $n^{\circ} 73$, do Conselho Nacional de Justiça, todo o procedimento de retificação pode ser feito rapidamente e diretamente nos cartórios. A partir das determinações do STF e do CNJ, apareceram novas situações das quais os cartórios ainda não estão devidamente preparados o que leva consequentemente a decisões subjetivas dos registradores que muitas vezes prevalecem sob o direito da pessoa trans, e ainda a falta de uniformidade destas decisões que contaminam o sistema jurídico, gerando insegurança ao sistema e afetando direitos básicos das partes envolvidas.

Objetivos: Identificar e analisar, por meio de pesquisa bibliográfica, as questões ilegais que ocorrem em decorrência da falta de preparo e discriminação dos cartórios de registros civis contra as pessoas transexuais.

Desenvolvimento: Quando se trata de pessoas transexuais há em determinados casos uma incongruência que demonstra a discriminação que ainda ocorre constantemente. É o caso de Ágata Mostardeiro, que desde o nascimento de seu filho Bento tenta conseguir o registro como mãe biológica do menino, juntamente com sua esposa, Chaiane Cunha que também é mãe da criança, que na época foi quem engravidou. A gravidez de Chaiane ocorreu antes da transição de gênero de Ágata, o que significa que, biologicamente, Bento é filho das duas. Foi quando já estavam esperando Bento, que Ágata conseguiu retificar seus documentos e oficializar seu nome. Isso é possível, porque a orientação sexual e a identidade de gênero são dois fatores distintos e um não depende da outro, por isso o relacionamento afetivo sexual, de uma mulher trans com uma mulher cis existe e é possível a ocorrência de uma gravidez, caso a mulher transexual não tenha optado pela cirurgia de readequação sexual. Infelizmente a conquista do direito de em seu próprio registro não garantiu facilidade na hora de registrar Bento, gerando uma enorme falha nos trâmites registrais da criança, pois o cartório responsável registrou Ágata como mãe socioafetiva. A presunção de que duas pessoas do mesmo gênero não teriam a capacidade de gerar um filho é apenas verdade quando ambas são cisgêneras, isto é, pessoas não-trans. Se o próprio Estado reconhece que é legítima a identidade da pessoa transexual, então deve também cuidar das demais questões que envolve esse reconhecimento, como a possibilidade de gestar e ter filhos. Cabe ao Estado rever as regras e adaptá-las às necessidades da sua própria população.

Conclusão: Alude-se então que nesse caso específico o registro da mãe transexual deve ser feito como mãe biológica, como ela verdadeiramente é, e não como mãe socioafetiva. Esse fato ocorre regularmente nos cartórios brasilienses, pois há uma presunção inverídica de que duas mães não podem ser biologicamente relacionadas com o filho, o que, por si só, já é uma ação preconceituosa e que demonstra a completa ignorância acerca do tema, contribuindo com a exclusão e invisibilização das pessoas transexuais provocadas pelo sistema cis heteronormativo. Esses entraves geram uma lacuna inconstitucional que provocam além de situação vexatórias para as pessoas trans, inverdades que não respeitam os próprios princípios legais. Além de que o trâmite afronta o princípio da verdade real dos registros públicos e se enquadra no crime de falsidade ideológica estabelecido pelo Código Penal, no Art. 299.

\section{Referências}

SARLET, Ingo Wolfgang. Direitos Fundamentais e Relações Privadas. 2. ed. Rio de Janeiro: Lumen Juris, 2010.

VIEIRA, Tereza Rodrigues. Identidade sexual: aspectos éticos e jurídicos da adequação de prenome e sexo no registro civil. In: VIEIRA, Tereza Rodrigues; PAIVA, Luiz Airton Saavedra de (Orgs.). Identidade Sexual e Transexualidade. São Paulo: Rooca, 2009.

BRASIL. Supremo Tribunal Federal. Voto. Relator: Ministro Ayres Britto. Ação Direta de Inconstitucionalidade $\mathrm{n}^{\circ} 4277$. Brasília. Disponível em: . Acesso em: 13 ago. 2020. 


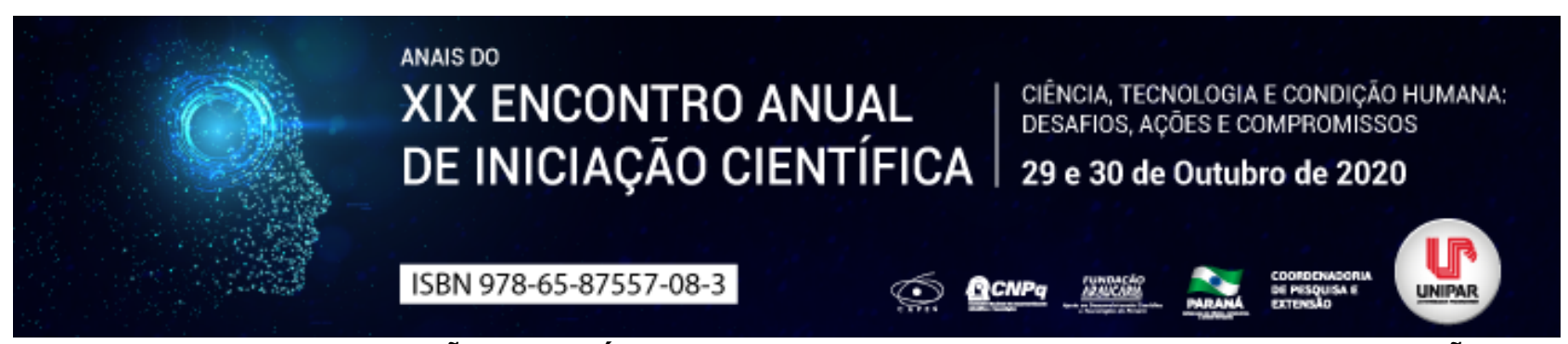

\title{
O DEVER ESTATAL NA PRESERVAÇÃO DA SAÚDE MENTAL DOS IDOSOS INTERNADOS EM INSTITUIÇÕES DE LONGA PERMANÊNCIA NA PANDEMIA
}

${ }^{1}$ ELYON GONCALVES GALDINO DA SILVA, ${ }^{2}$ BRUNO HENRIQUE PUCHETTI DE CENE, ${ }^{3}$ LUIZ ROBERTO PRANDI

\author{
${ }^{1}$ Acadêmico do PIC/UNIPAR \\ ${ }^{1}$ Acadêmico do Curso de Direito da UNIPAR \\ ${ }^{2}$ Professor Titular e Pesquisador da UNIPAR
}

Introdução: Com a pandemia do coronavírus (COVID-19), o poder público implementou medidas de distanciamento social, na tentativa de coibir a contaminação em massa, o que impossibilitou visitas aos internados nas Instituições de Longa Permanência para Idosos (ILPI). Ficando o Estado responsável em prestar assistência individual e especializada à saúde mental do idoso isolado nas ILPIs, para garantia de seu direito constitucional à saúde.

Objetivo: Verificar o dever estatal de garantir a saúde mental ao idoso e demonstrar sua importância em tempos de pandemia.

Desenvolvimento: A Constituição de 1988, no artigo 230, dispõe que é dever da família, da sociedade e do Estado amparar as pessoas idosas na defesa de sua dignidade e bem-estar, garantindo-lhe o direito à vida (BRASIL, 1988). No mesmo esteio, o artigo 15 do Estatuto do Idoso assegura atenção integral à saúde do idoso, e observância ás doenças que afetam preferencialmente os idosos (BRASIL, 2003). Evidencia-se que, mesmo não sendo citado no texto do Artigo 15 do Estatuto do Idoso, as palavras da lei são suficientes para compreender a aplicação do dispositivo durante a pandemia (OLIVEIRA JÚNIOR, 2020, [3] p.). Nesse esteio, a fim de preservar a saúde do idoso como um todo, a Sociedade Brasileira de Geriatria e Gerontologia (SBGG) publicou recomendações para prevenção e controle de infecções do COVID-19 nas instituições de longa permanência, como a restrição de visitas aos idosos por tempo indeterminado. No entanto, uma pesquisa publicada em 2014 por pesquisadores da University of Chicago concluiu que a solidão aos idosos pode majorar o risco de vida em até $14 \%$, visto que tal estresse pode diminuir a resposta imunológica de seu organismo (HARMS, 2014). Sendo assim, mesmo com a disposição do poder público em preservar, de modo geral, a saúde do idoso internado e isolado, o Estado deve, através de Projetos de Lei e/ou Medidas Provisórias, buscar medidas que preserve a saúde mental de forma específica, individual e especializada, como a inclusão de tecnologias nas ILPIs a fim de que os idosos tenham acesso aos conteúdos digitais como: séries, filmes, vídeo chamadas, sempre auxiliado por funcionário da instituição; liberação de verba para contratação de psicólogos, para que tais ambientes tenham, no mínimo, um profissional da saúde mental; bem como a abertura periódica para líderes religiosos, respeitando sempre os procedimentos sanitários recomendados.

Conclusão: Verificou-se a importância da assistência individualziada e especializada à saúde mental do idoso internado e isolado, bem como algumas medidas que poderão ser adotadas pelo Estado, para que a saúde e o bem estar do idoso, garantidos no Estatuto do Idoso e na Constituição Federal, sejam efetivados.

\section{Referências}

BRASIL. [Constituição (1988)]. Constituição da República Federativa do Brasil: promulgada em 5 de outubro de 1988. Brasília: Senado, 1988. Disponível em: http://www.planalto.gov.br/ccivil_03/constituicao/constituicao.htm. Acesso em: 17 ago. 2020.

BRASIL. Lei $\mathbf{n}^{\circ} \mathbf{1 0 . 7 4 1}$, de $\mathbf{1}^{\circ}$ de outubro de 2003. Dispõe sobre o Estatuto do Idoso e dá outras providências. Disponível em: https://www2.camara.leg.br/legin/fed/lei/2003/lei-10741-1-outubro-2003-497511-publicacaooriginal-1-pl.html. Acesso em: 17 ago. 2020.

HARMS, William. University of Chicago. AAAS 2014: Loneliness is a major health risk for older adults. 2014. Disponível em: https://news.uchicago.edu/story/aaas-2014-loneliness-major-health-risk-older-adults. Acesso em: 17 ago. 2020.

OLIVEIRA JÚNIOR, Eudes Quintino. Os idosos em asilo e a pandemia. Migalhas, 2020. Disponível em: https://www.migalhas.com.br/depeso/329764/os-idosos-em-asilo-e-a-pandemia. Acesso em: 17 jul. 2020. 


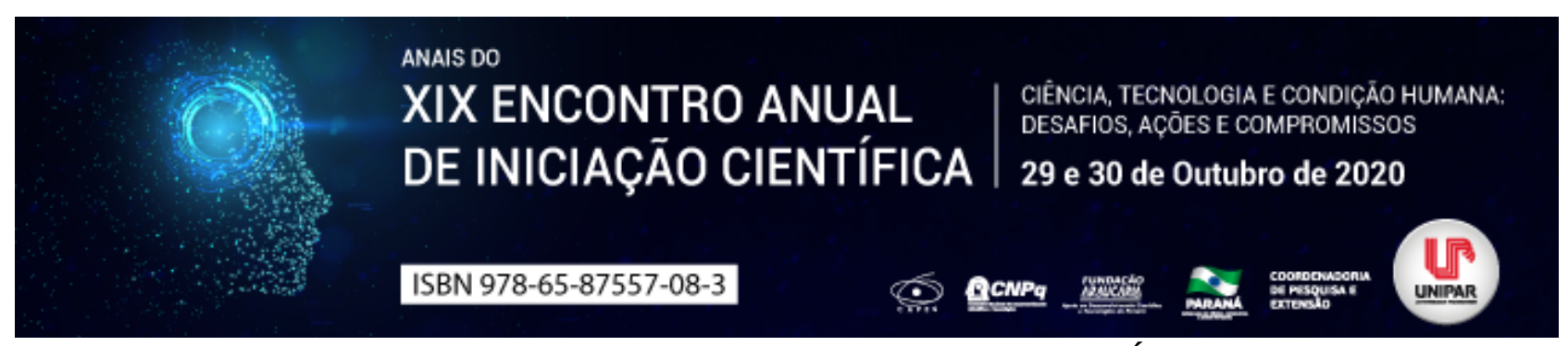

\title{
A RESPONSABILIDADE INTERNACIONAL POR DANO AO MEIO AMBIENTE: PRINCÍPIOS DO DIREITO INTERNACIONAL AMBIENTAL
}

\author{
${ }^{1}$ JANE DE OLIVEIRA PULGA, ${ }^{2}$ DORITA ZIEMANN HASSE
}

\author{
${ }^{1}$ Acadêmica do PIC/UNIPAR \\ ${ }^{1}$ Docente da UNIPAR
}

Introdução: A Responsabilidade Internacional é o instituto pelo qual o Direito Internacional responsabiliza o Estado pelo descumprimento de obrigação estabelecido em tratados, normas costumeiras, textos constitucionais, etc., que livremente foram avençados.

Objetivo: Analisar as teorias de natureza jurídica da responsabilidade internacional do Estado na proteção do meio ambiente priorizando a proteção a vida e a dignidade humana.

Desenvolvimento: A Responsabilidade Internacional como instituto, tem caráter preventivo e em último caso restituição ou reparação do dano causado à sociedade internacional. Ou seja, ela atua como forma de prevenir que danos aconteçam, principalmente, pelo fato de que, um dano causado ao meio ambiente produz consequências devastadoras e, em muitos casos, irreparáveis. A doutrina destaca a importância da responsabilidade internacional ao afirmar que [...] dentre os assuntos relevantes do Direito Internacional Público, não há outro de maior importância . (MAZZUOLI, 2015, p. 570). Por ser a responsabilidade internacional de caráter patrimonial e moral (PORTELA, 2019, p. 458) está ausente nesse instituto a possível vinculação com o direito penal ou repressivo significando que ninguém será privado de sua liberdade em caso de descumprimento ou violação. Ao se considerar como fundamento da responsabilidade internacional o dever de se cumprir livremente as obrigações oriundas do ato que foi praticado, a doutrina destaca as teorias sobre a natureza jurídica da responsabilidade internacional: a teoria subjetivista, a objetivista e a mista (PORTELA, 2019, p. 458). A corrente majoritária nas jurisprudências dos tribunais internacionais, é a teoria subjetivista (teoria da culpa) quando se trata de proteger o Estado, (MAZZUOLI, 2015), levando-se em conta a conduta dolosa ou culposa na prática omissiva ou comissiva do ente que a praticou. Por outro lado, a corrente objetivista ou do risco, tem como foco principal a identificação do nexo de causalidade que responsabiliza o Estado violador em relação ao prejuízo sofrido pelo outro Estado, (VARELLA, 2009), ou seja, está presente o risco assumido de praticar o dano. Em casos de derramamento de óleo, por exemplo, onde há imensos prejuízos, não somente ao meio ambiente, mas principalmente aos moradores que sobrevivem da pesca e de atrações turísticas, o dano causado fere fortemente o direito à vida e à saúde na medida em que interfere diretamente na possibilidade de manutenção do sustento e da dignidade familiar. É o que ocorre nos casos de derramamento de óleo nas áreas costeiras. Não se trata aqui de falar-se apenas em ato ilícito. Atos praticados de forma lícita também ensejam a responsabilização, são atos não proibidos, mas que ensejam riscos às pessoas.

Conclusão: Em face de todo exposto, é possível constatar que deve prevalecer como princípio básico do Direito Internacional Ambiental, a concepção de que nenhum Estado pode provocar alterações ambientais que venham a causar danos à humanidade, em que pese o direito de desenvolvimento e o progresso econômico e tecnológico, uma vez que todos têm direito a uma vida digna e a um ambiente saudável.

\section{Referências}

BRASIL, Constituição (1988). Constituição da República Federativa do Brasil. Brasília, DF: Senado Federal: Centro Gráfico, 1988.

MAZZUOLI, Valério de Oliveira. Curso de Direito Internacional Público. 9. ed. São Paulo:

PORTELA, Paulo Henrique Gonçalves. Direito Internacional Público e Privado: Incluindo Noções de Direitos Humanos e de Direito Comunitário. 11. ed.. Salvador: JusPODVM, 2019.

VARELLA, Marcelo. Direito internacional público. São Paulo: Saraiva, 2009. 


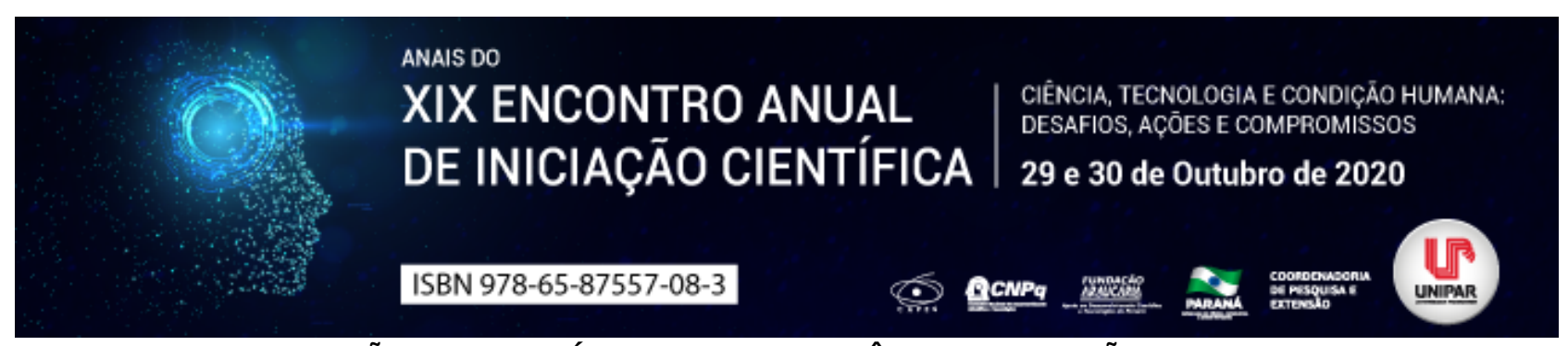

\title{
A POSSIBILIDADE DE APLICAÇÃO DO PRINCÍPIO DA INSIGNIFICÂNCIA NA PRISÃO EM FLAGRANTE PELO DELEGADO DE POLÍCIA
}

\author{
${ }^{1}$ AMANDA LUQUINI MENEGHETTI, ${ }^{2}$ FERNANDA GARCIA VELASQUEZ
}

\author{
${ }^{1}$ Acadêmica do Curso de Direito- Francisco Beltrão-PR \\ ${ }^{1}$ Docente da UNIPAR
}

Introdução: O objeto deste trabalho se constitui na análise da aplicabilidade do Princípio da Insignificância. A abordagem em questão diz respeito à possibilidade desta aplicação diretamente pela Autoridade Policial, ou seja, o Delegado de Polícia em determinados casos concretos dentro do limite da lei e garantindo assim os direitos fundamentais da pessoa, perfaz-se como forma legal de evitar procedimentos penais descabidos.

Objetivo: Demonstrar a possibilidade da Autoridade Policial em aplicar o Princípio da Insignificância.

Desenvolvimento: A importância de aplicar o Prícipio da Insignificância pelo Delegado de Polícia enquanto operador do direito, nos casos em que a conduta do agente não seja suficiente ao ponto de ensejar uma prisão em flagrante, possibilitando filtrar condutas consideradas insignificantes penalmente, tendo em vista que não trará resultado útil ao bem jurídico tutelado, diante da mínima ofensividade de sua conduta. É essencial a autoridade policial ao analisar o caso concreto, verifique a tipicidade, não se litimando a aplicar a lei e fazer a subsunção ao caso concreto. Sendo indispensável analisar o grau de lesividade e ofensividade ao bem jurídico, assim fundamentando com base na jurisprudência para sustentar a decisão e retirar da esfera penal condutas atípicas materialmente. Onerar o Estado, ou de outra forma incumbir uma persecução investigativa a um feito noticiado em que o bem tutelado não seria suficiente para a aplicação da norma penal de modo a não satisfazer o interesse social. Tal fato, resultaria na ineficiência do feito investigativo e, por conseguinte, na inaplicabilidade da norma. A exclusão da culpabilidade é formada por elementos fundamentais para sua composição, sendo eles a imputabilidade, a exigibilidade de conduta diversa e a potencial consciência da ilicitude. Diante da prática de conduta criminosa prevista pelo Código Penal realiza-se o exame de reprovabilidade pessoal do infrator, isentando-o de pena quando a lesão por si só for considerada inexpressiva para os fins penais, (CAPEZ, 2018, p. 496). Saliente-se que é justamente no campo da tipicidade material que incide o Princípio da Insignificância. Expostos argumentos dos quais demonstram a importância da aplicabilidade do Princípio em tese pelo delegado de polícia no ato da prisão em flagrante, assegurando os direitos e as garantias fundamentais, quando a conduta do agente não seja capaz de ofender o bem jurídico tutelado pela norma penal. Nos dizeres de Capez, a intervenção mínima é subsidiária do Princípio da Fragmentariedade, ou seja, não basta que a conduta do agente preencha a conduta tipificada como criminosa, é necessário que a ofensa seja penalmente relevante ao bem jurídico tutelado. Capez ainda afirma que: Se existe um recurso mais suave em condições de solucionar plenamente o conflito, torna-se abusivo e desnecessário aplicar outro mais traumático , (CAPEZ, 2013.p.39). E acrescenta, faltando justa causa, a autoridade policial pode (aliás, deve) deixar de instaurar o inquérito (CAPEZ, 2012 p. 145).

Conclusão: Nessa perspectiva, é saliente a possibilidade da Autoridade Policial aplicar o Princípio da Insignificância desempenhando um papel condizente com a estrutura legal de contenção do poder punitivo desnecessário, ratificando sua condição de garantidora dos direitos fundamentais da pessoa presa em flagrante, além da contribuição para a diminuição de custos aos cofres públicos, uma vez que o Direito Penal deve ser utilizado somente quando, de fato, for imprescindível.

\section{Referências}

CAPEZ, Fernando. Curso de direito penal, parte geral. 17.ed. São Paulo: Saraiva, 2013.

CAPEZ, Fernando. Curso de direito penal, parte geral. 22. ed. São Paulo: Saraiva, 2018.

CAPEZ, Fernando. Curso de Processo Penal. 19. ed. São Paulo: Saraiva, 2012.

GRECO, Rogério. Curso de Direito Penal, Parte Geral. 19. ed. Niterói: Impetus, 2017.

MASSON, Cleber. Direito Penal Esquematizado: Parte Geral. 11. ed. Rio de Janeiro: Forense; São Paulo: Método, 2017.

$\mathrm{NUCCl}$, Guilherme de Souza. Manual de processo penal e execução penal. Rio de Janeiro: Forense, 2014. 


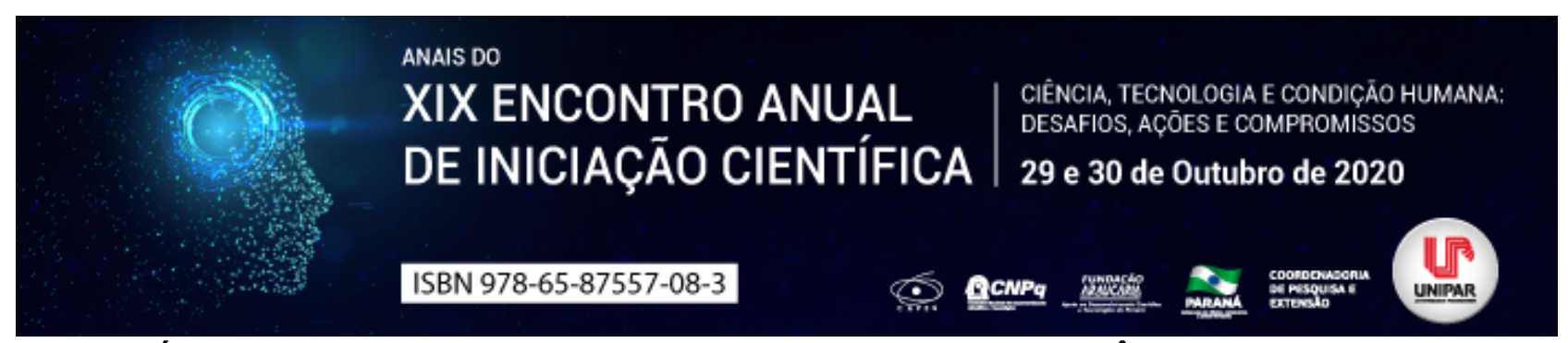

ESCRITÓRIO MODELO DE ARQUITETURA E URBANISMO: UMA EXPERIÊNCIA DE ENSINO REMOTO

\author{
${ }^{1}$ CAROLINE FAVORETTO, ${ }^{2}$ IARA CAMARGO NACLE MERLINI, ${ }^{3}$ TAYNARA CAROLINA BACCARIN ANIZELLI, ${ }^{4}$ PALOMA DE \\ SOUZA COMITRE, ${ }^{5}$ ANA PAULA TORQUETI GAVIOLI
}

\footnotetext{
${ }^{1}$ Acadêmica do curso de Arquitetura e Urbanismo da UNIPAR

${ }^{1}$ Acadêmica do Curso de Arquitetura e Urbanismo da UNIPAR

${ }^{2}$ Acadêmica do Curso de Arquitetura e Urbanismo da UNIPAR

${ }^{3}$ Acadêmica do Curso de Arquitetura e Urbanismo da UNIPAR

${ }^{4}$ Docente da UNIPAR
}

Introdução: A Universidade Paranaense na unidade de Cianorte, no curso de Arquitetura e Urbanismo desenvolve um projeto de extensão chamado Escritório Modelo. Tem como objetivo geral prestar serviços à comunidade interna e externa, ligados à arquitetura visando dar aos alunos a experiência de estagiar em um escritório físico, dentro da universidade. Os encontros são supervisionados pelos professores, porém com a pandemia do COVID-19 as reuniões passaram a ser extraordinariamente remotas.

Objetivo: Relatar a experiência do ensino remoto em estágio de escritório de arquitetura.

Desenvolvimento: $O$ trabalho remoto pode ser definido como o trabalho realizado à distância e por meio do uso das novas tecnologias de comunicação. Ou seja, o trabalho remoto pode ser exercido no interior de um escritório desde que contemple a condição de estar mediado por meios eletrônicos e, distante do gestor (Nogueira e Patini, 2012). Existem diversas vantagens no trabalho remoto e segundo Goulart (2009, p. 201) o teletrabalho reduz stress causado pelo trânsito; a empresa não tem atraso com o empregado; e a sociedade ganha com a diminuição da poluição . É uma situação onde todos podem ganhar e poupar tempo. Neste ano, o Escritório Modelo da Universidade Paranaense de Cianorte tem desenvolvido vários projetos como: 0 layout, a revitalização de fachadas, cartilhas explicativas relacionadas a arquitetura. Isso ocorre por meio de reuniões semanais online, objetivando a distribuição das atividades de cada integrante, ou da equipe. No período da tarde, no decorrer das tarefas, os acadêmicos recebem suporte online, no caso de dúvidas. Após a finalização das atividades, estas são postadas na platafroma educacional Google ClassRoom, a espera das correções efetuadas pelo professor responsavel, e isso feito, essas são encaminhadas aos devidos clientes.

Discussão: A experiência com essa metodologia tem sido muito recompensadora, pois uma grande quantidade de estudantes gosta de aprender dessa forma e já é perceptível, em alguns casos, que os estudantes começam a solicitar que outras disciplinas também adotem o ensino remoto (Araújo, 2009). Entretanto de acordo com Constantinou, Eliane et al (2009), foi realizado um questionário recente, que alcançou $82 \%$ dos estudantes da Faculdade de Arquitetura, 3\% afirmaram ter problemas com o acesso à internet, o que representa um sério problema à implementação do ensino remoto emergencial (ERE), além do mais, há registros de problemas de várias outras ordens física, emocionais, espaço físico para estudar, etc que exigem atenção.

Conclusão: Devido a pandemia, foi necessário a adaptação dos métodos de trabalho do escritório modelo de Arquitetura (EMA) para poder continuar as atividades, a solução adotada foi desenvolver o trabalho de modo virtual. Essa mudança tem feito com que se aprenda um novo meio de trabalho em equipe, e tem possibilitado maiores oportunidades para alunos participarem. Para os alunos do EMA, o trabalho remoto é uma experiência positiva, pois os discentes ganham tempo por não precisarem se deslocarem até a faculdade, já que alguns são de cidades vizinhas. Em relação ao aprendizado, não houve resultados negativos, já que os alunos recebem todo o suporte para aprender.

\title{
Referências
}

ARAÚJO, Ulisses Ferreira de; ARANTES, Valéria Amorim; FONSECA FILHO, Homero. Ensino de Sensoriamento Remoto através da Aprendizagem Baseada em Problemas e Por Projetos: uma proposta metodológica. 2009. 7 f.Universidade de São Paulo, São Paulo, 2009.

CONSTANTINOU, Eliane et al. Ensino remoto emergencial: desafios e estratégias para retomada. 2020.

GOULART, Joselma Oliveira. Teletrabalho: Alternativa de trabalho flexível. Brasília: Senac, 2009. NOGUEIRA, Arnaldo Mazzei; PATINI, Aline Campos. Trabalho remoto e desafios dos gestores. Review Of Administration And Innovation - Rai, [S.L.], v. 9, n. 4, p. 1-32, 22 dez. 2012. Faculdade de Economia, Administração e Contabilidade.

NOGUEIRA, Arnaldo Mazzei; PATINI, Aline Campos. Trabalho remoto e desafios dos gestores. RAI Revista de Administração e Inovação, v. 9, n. 4, p. 121-152, 2012. 
Coordenadoria de Pesquisa e Extensão - COPEX

Departamento de Editoraçāo e Divulgaçāo Científica - DEDIC 


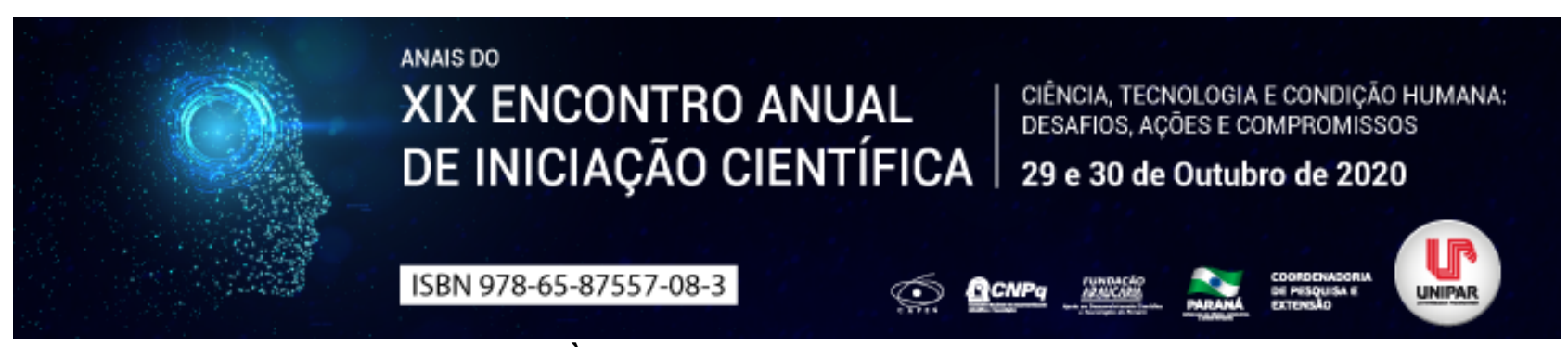

PROJETO DE LEI N 770, DE 2020: DIREITO À GRATUIDADE DA JUSTIÇA AOS PORTADORES DE DOENÇAS GRAVES

\author{
${ }^{1}$ GABRIEL SCHENATO ALTIMARI, ${ }^{2}$ CELSO HIROSHI IOCOHAMA
}

\author{
${ }^{1}$ Acadêmico do Curso de Direito PIC/UNIPAR \\ ${ }^{1}$ Docente da Graduação em Direito e do Programa de Mestrado em Direito Processual e Cidadania da UNIPAR
}

Introdução: O Projeto de Lei n $^{\circ} 770$, de 2020, proposto pelo Senador Jorginho Mello, prevê o direito à gratuidade da justiça para os portadores de doenças graves.

Objetivo: Utiliza-se do método dedutivo mediante a análise de legislação e revisão bibliográfica sobre as implicações do Projeto de Lei $n^{\circ} 770$, de 2020, do Senado Federal, para a proteção das pessoas portadoras de doenças graves quanto ao pagamento de custas processuais.

Desenvolvimento: Segundo o Senador Jorginho Mello (BRASIL, p. 2), com a reforma processual civil, resultante da Lei $n^{\circ}$ 13.105, de 16 de março de 2015 que regulamentou o novo Código de Processo Civil (BRASIL, 2015), várias críticas foram feitas com relação à pouca preocupação do legislador com as pessoas portadoras de doenças graves, pois, ao tratar dos benefícios processuais relacionados a essas pessoas, a lei apenas manteve a concessão de prioridade de tramitação do processo judicial em qualquer instância ou juízo, sem qualquer inovação em relação ao Código até então vigente. Neste diapasão, e com o intuito de equalizar a igualdade jurídica entre as pessoas portadoras de doenças graves das demais, segundo o Senador Jorginho Mello, chegou-se à conclusão de que é preciso ampliar os benefícios processuais às portadoras de doenças graves. De fato, é induvidosa a necessidade de se proteger o portador de doença grave, permitindo a ele que formule suas demandas perante o Poder Judiciário sem, por exemplo, o obstáculo do recolhimento das custas processuais ou da antecipação do pagamento das despesas do processo (BRASIL, 2020, p. 3). Assim, inspirando-se no art. 1.048, I, do Código de Processo Civil (BRASIL, 2015), que trata da prioridade da tramitação processual nos procedimentos judiciais em que, dentre outras hipóteses, figura como parte ou interessado pessoa portadora de doença grave, o Senador Jorginho Mello propõe a promoção das alterações necessárias no art. 98, tentando, sempre, manter a uniformidade e a coerência do texto processual civil, com a adoção da regra prevista no art. $6^{\circ}$, inciso XIV, da Lei no 7.713 , de 22 de dezembro de 1988, que aponta como sendo doenças graves as seguintes: tuberculose ativa, alienação mental, esclerose múltipla, neoplasia maligna, cegueira, hanseníase, paralisia irreversível e incapacitante, cardiopatia grave, doença de Parkinson, espondiloartrose anquilosante, nefropatia grave, hepatopatia grave, estados avançados da doença de Paget (osteíte deformante), contaminação por radiação, síndrome da imunodeficiência adquirida (AIDS) (BRASIL, 2020, p. 3). O projeto está no Plenário desde o dia 18 de março de 2020.

Conclusão: O Projeto de Lei $n^{\circ} 770$, de 2020 , se aprovado, poderá ajudar os portadores de doenças graves em suas demandas perante o Poder Judiciário, ampliando o acesso à justiça com a garantia da gratuidade.

\title{
Referências
}

BRASIL. Código de Processo Civil (2015). Brasília, DF: Presidência da República, [2020]. Disponível em: http://www.planalto.gov.br/ccivil_03/_ato2015-2018/2015/lei//13105.htm. Acesso em: 25 ago. 2020.

BRASIL. Senado Federal. Avulso do Projeto de Lei $\mathbf{n}^{\circ} \mathbf{7 7 0}$, de 2020. Senador Jorginho Mello PL/SC, Disponível em: https://legis.senado.leg.br/sdleg-getter/documento?dm=8076055\&ts=1594022675248\&disposition=inline. Acesso em: 1 ago. 2020. 


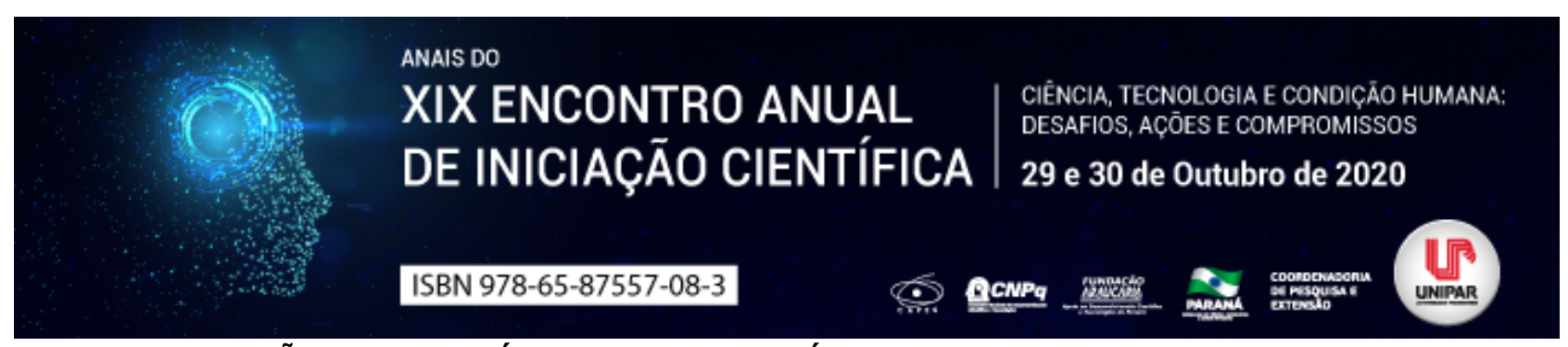

GERAÇÃO DE CONTEÚDO COMO ESTRATÉGIA DE MARKETING NO MEIO DIGITAL

\title{
${ }^{1}$ JULIANA EDUARDA VIEIRA, ${ }^{2}$ ANA CLEIA DE OLIVEIRA CIRINO
}

\author{
${ }^{1}$ Acadêmica do curso de Publicidade e Propaganda da Unipar \\ ${ }^{1}$ Docente da UNIPAR
}

Introdução: Com o avanço tecnológico, o meio digital possibilitou a disseminação de ideias, opiniões e informações, dando ao internauta a oportunidade de escolher e controlar o que deseja ter acesso. Através da estratégia de marketing de conteúdo, também conhecida como marketing content "[...] é possível atrair a atenção e conquistar consumidores por meio destes conteúdos [...]" (MARTINS, 2015, p. 59). Sendo assim, este estudo aponta a relevância de se construir a imagem de uma marca por meio do relacionamento com o consumidor utilizando como instrumento o conteúdo. As informações apresentadas neste estudo partem do Estágio Obrigatório Supervisionado do curso de Publicidade e Propaganda da UNIPAR, desenvolvido na Agência Experimental de Propaganda.

Objetivo: Abordar a estratégia de marketing de conteúdo, utilizando como base o marketing digital e a influência do mesmo na revolução tecnológica da comunicação.

Desenvolvimento: $O$ conteúdo que hoje é trabalhado pelos profissionais de marketing é uma nova maneira de se comunicar criando uma relação entre quem oferece conteúdo e quem consome, satisfazendo o público-alvo e excedendo as suas expectativas, essa transformação necessita de estratégias devidamente elaboradas, visto que a inclusão digital trouxe consumidores mais exigentes. De acordo com Rez (2016), incluir uma estratégia de marketing content melhora, além do marketing digital, todo o marketing da marca. Há alguns anos as marcas superficialmente trabalhavam o marketing de seus produtos, com foco na venda, utilizando discursos impactantes em grandes mídias. Com o avanço do digital, o que antes era um discurso sobre algo que se queria vender, agora se trata de um diálogo entre a marca e o público-alvo, utilizando um discurso sutil, subjetivo e emocional que atraia o interesse do consumidor, descaracterizando-se o discurso publicitário que esteve presente em grandes mídias durante anos, que visava exclusivamente a venda de um produto. O marketing digital flexibiliza o alcance, a distribuição de conteúdo e posicionamento de marca adequando-se ao necessário para elevar o interesse do público, visto que "[...] o consumidor busca informações na internet antes de decidir consumir uma marca [...]" (MARTINS, 2015, p. 59), no entanto, é necessário pensar em informações completas e relevantes, pois não basta apenas oferecer um bom serviço ou produto, é essencial se destacar dos demais. Quando se pensa em valores, é importante transmitir com clareza o que se pretende comunicar, pois o que o consumidor interpretará é a imagem que ele terá da marca. Hoje em dia, podemos dizer que se a marca tem conhecimento de que oferece um excelente serviço ela possui um grande potencial para desenvolver conteúdo de qualidade "[...] estar presente nas redes sociais é estar próximo do consumidor [...]" (MARTINS, 2015, p. 62), transformando-a em uma marca bem vista que cativa presença na mente dos consumidores. É importante salientar que produzir conteúdo não está limitado a textos em redes sociais, o impacto dessa estratégia na web depende de lógica e identificação de onde o públicoalvo busca conteúdo. Para Peçanha (2020), é uma estratégia de atração de clientes por meio da criação de conteúdo relevante (textos, vídeos, ebooks, posts em redes sociais). O Marketing de Conteúdo é uma estratégia que não faz promoção direta da marca, mas atrai o público-alvo ao trazer soluções para seus problemas. Segundo Martins (2015), é necessário pensar no público certo, na hora certa e no conteúdo correto. Quando deseja-se desenvolver um blog e gerar conteúdo, deve-se utilizar o posicionamento on para analisar os temas de interesse do público "[...] quanto mais conteúdo gerarmos e mais informações jogarmos na rede, maiores as chances de o cliente nos localizar [...]" (MARTINS, 2015, p. 60). Ou seja, na prática, se o conteúdo é eficiente e bem direcionado, mais relevante a marca se encontra nos buscadores e, pode-se concluir, que há uma construção de relacionamento com o consumidor e a comunicação passa a ser bilateral. Mediante a isso Rez (2016), explica que para as empresas é um desafio encontrar o momento exato em que o público-alvo está sujeito a receber suas mensagens e que, geralmente, estes momentos acontecem quando este possui uma procura por respostas, explora novidades e pretende tomar decisões.

Conclusão: Conteúdo é uma nova maneira de se comunicar e deve ser utilizado por marcas que possuem algo a dizer. Esta estratégia eficiente que traz como oportunidade desenvolver um bom relacionamento entre marca e público-alvo, o que se pensa como tendência é na verdade uma maneira de fazer parte da vida do público e satisfazer seus desejos e necessidades visando a experiência com informações criativas e relevantes. O consumo online vem se estabelecendo e cativando público de todas as idades e interesses diversos, não basta mais um discurso assertivo, o profissional de marketing precisa compreender o comportamento e o perfil dos internautas, inspirar e entreter. O marketing digital tornou-se o cenário de sucesso de várias marcas, deixando de ser uma aposta e transformando-se em uma oportunidade de grandes negócios. 


\section{Referências}

MARTINS, Thiago Garcia. Inovação Digital: Planejamento Online de Táticas e Estratégias de Marketing Digital. 4. ed. Joinville: Clube dos Autores, 2015.

PEÇANHA, Vitor. O que é Marketing de Conteúdo? São Paulo, Abril, 2020. Disponível em: https://rockcontent.com/br/blog/marketing-de-conteudo/. Acesso em: 21 set. 2020.

REZ, Rafael. Marketing de Conteúdo: A Moeda do Século XXI. 2. ed. São Paulo: DVS, 2016. TECNOCORP. Marketing Digital. Disponível em: http://ww3.tecnocorp.com.br/ebook/marketing-digital/ebookmarketing-digital.pdf Acesso em: 28 jul. 2020.

Coordenadoria de Pesquisa e Extensão - COPEX

Departamento de Editoraçāo e Divulgaçāo Científica - DEDIC 


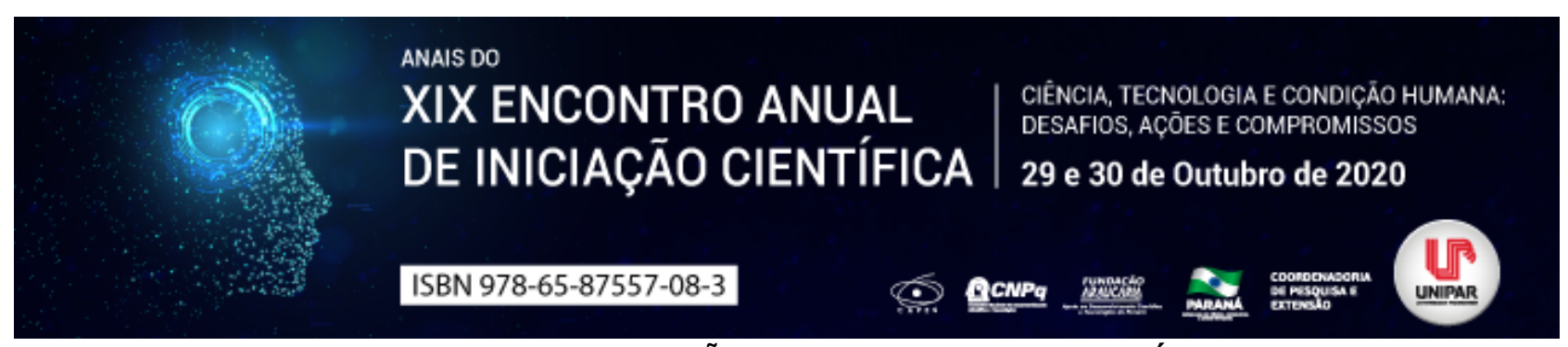

OS DESAFIOS DA EDUCAÇÃO INCLUSIVA NA ESCOLA PÚBLICA

\title{
${ }^{1}$ Cristina Ferreira Acencio, ${ }^{2}$ ROSE MARI BENNEMANN, ${ }^{3}$ ELSA MIDORI SHIMAZAKI, ${ }^{4}$ FABIO RICARDO ACENCIO
}

\author{
${ }^{1}$ Mestranda em Educação - Universidade estadual de Maringá \\ ${ }^{1}$ Docente da Universidade Cesumar \\ ${ }^{2}$ Docente - Universidade Estadual de Maringá \\ ${ }^{3}$ Docente da UNIPAR
}

Introdução: Os desafios enfrentados pelo sistema de ensino no atendimento as pessoas com deficiência, relaciona-se as desigualdades de uma sociedade de classes, onde faz necessária a luta contra a exclusão dos grupos marginalizados, grupos étnicos, grupos de crenças religiosas e grupos de gêneros, independente se os protagonistas são os deficientes ou outros marginalizados (EDLER, 2004). Neste sentido, o movimento mundial pela educação inclusiva, com intuito de confrontar as práticas discriminatórias e criar alternativas para superá-las, passa a repensar a escola, sua organização e estrutura para que todos os alunos tenham suas especificidades atendidas, sem qualquer forma de exclusão, discriminação ou abandono (MEC, 2008). Neste aspecto, Mantoan (2003) enfatiza que se pretendemos que a escola seja inclusiva é necessária uma educação voltada para a cidadania global, plena, livre de preconceitos que reconhece e valoriza as diferenças.

Objetivo: Refletir, por meio de revisão bibliográfica, os marcos históricos e legais das políticas promotoras da educação inclusiva, a partir da década de 1990.

Desenvolvimento: O processo de democratização da escola pública, universaliza o acesso ao sistema de ensino, mas continua excluindo indivíduos e grupos considerados fora dos padrões homogeneizadores da escola (KASSAR, 2012). Para superar essa barreira de desigualdade e efetivar a Educação Inclusiva no contexto das escolas públicas a Declaração dos Direitos Humanos (ONU, 1948) assegura que todas às pessoas com deficiência tem os mesmos direitos, à liberdade, a uma vida digna, à educação fundamental, ao desenvolvimento pessoal, social e à livre participação na vida em comunidade, bem como o direito de todos a educação pública, gratuita. Reforçando a integração de pessoas com deficiência, defendendo assim, oportunidades educacionais e sociais para todos, em 1994, a Declaração de Salamanca (UNESCO, 1994) delineou ações para inclusão de alunos com necessidades educacionais especiais no ensino regular, buscando garantir direitos iguais a todos os indivíduos independentemente de suas características, promovendo desta forma, processos educacionais democráticos e inclusivos. A lei $\mathrm{n}^{\circ}$ 9.394/96 de Diretrizes e Bases da Educação Nacional, assegura no art. 58, os serviços de apoio especializado, na escola regular, para atender às peculiaridades da educação especial, sendo o atendimento educacional, realizado em classes, escolas regulares ou serviços especializados (BRASIL,1996). A Convenção da Guatemala (1999), promulgada no Brasil pelo Decreto $\mathrm{n}^{\circ}$ 3.956/2001, determina que as pessoas com deficiência têm os mesmos direitos e liberdades que as demais pessoas, definindo como discriminação com base na deficiência toda diferenciação ou exclusão que possa impedir ou anular o exercício desses direitos. Isso justifica todo um debate acerca da Educação Inclusiva e a inserção de pessoas com deficiência, transtornos globais do desenvolvimento e altas habilidades/superdotação, interagindo nas instituições escolares, pois ao invés, da manutenção de

salas especiais que priorizam homogeneizar os grupos, é necessário que em função das diferenças individuais de cada aluno, o processo de ensino aprendizagem ocorre de maneira bastante heterogênea no contexto escolar, garantindo a transversalidade da modalidade da educação especial, que vai desde a educação infantil até o ensino superior (MEC, 2008). Nesta perspectiva, Mantoan (2001) afirma que, para inclusão escolar é fundamental que as instituições de ensino eliminem obstáculos arquitetônicas e adotem práticas pedagógicas adequadas às diferenças dos alunos, oferecendo possibilidades que atendam a diversidade, além de recursos e equipamentos especializados. Sob este enfoque, Sassaki (1998), Werneck (1999), Edler (2000), enfatizam que, para disponibilizar as estratégias transformadoras e concretizar as ações que o contexto de cada instituição educacional necessita, é preciso iniciativa política por parte dos dirigentes, recursos econômicos e competência dos sistemas educacionais, sendo fundamental também uma formação docente que ofereça competência técnica e compromisso profissional.

Conclusão: Embora os marcos históricos e legais evidenciem progressos nos aspectos da Educação Inclusiva, na prática ainda esbarramos em atitudes excludentes e discriminatórias. No processo de inclusão todos são responsáveis e não somente as instituições de ensino, embora sejam as mais afetadas, ainda precisam estar mais bem preparadas e equipadas para atender os alunos com deficiência, transtornos globais do desenvolvimento e altas habilidades/superdotação, oferecendo um espaço físico com acessibilidade, um currículo adequado, atendimento educacional especializado e professores especialistas. Neste contexto é dever do Estado universalizar o acesso à educação e promover a equidade, ampliando os meios e raios de ação da educação básica garantindo desta forma um ambiente adequado à aprendizagem. 


\section{Referências}

BRASIL. Decreto $\mathbf{N}^{\circ}$ 3.956, de 8 de outubro de 2001. Promulga a Convenção Interamericana para a Eliminação de Todas as Formas de Discriminação contra as Pessoas Portadoras de Deficiência. Guatemala: 2001.

BRASIL. Ministério da Educação. Secretaria de Educação Especial. Política Nacional de Educação Especial na Perspectiva da Educação Inclusiva. Brasília: MEC/SEESP, 2008.

BRASIL. Lei de Diretrizes e Bases da Educação Nacional (Lei nº 9394/96). Ministério da Educação, 1996.

EDLER, C. R. Removendo barreiras para aprendizagem: educação inclusiva. Porto Alegre: Mediação, 2000.

EDLER, C. R. Educação Inclusiva: com os pingos nos is . Porto Alegre: Mediação, 2004.

KASSAR, M. de C. M. Política de educação especial na perspectiva inclusiva e o atendimento educacional especializado. Natal, RN: EDUFRN, 2012.

MANTOAN, M. T. E. Caminhos pedagógicos da inclusão. São Paulo, Memnon Edições Científicas, 2001.

MANTOAN, M. T. E. Inclusão escolar: o que é? por quê? como fazer? Coleção cotidiano escolar. São Paulo, Moderna: 2003.

ONU - Organização das Nações Unidas. Declaração Universal dos Direitos Humanos. Brasília, 1948. Disponível em: http://unesdoc.org/images/0013/001394/139423por.pdf . Acesso em 2 de junho 2020.

SASSAKI, R. Entrevista especial à Revista Integração. Revista Integração. MEC:Brasília,v.8, n. 20, p.09-17, 1998.

UNESCO. Declaração de Salamanca e linha de ação sobre necessidades educativas especiais. Brasília, 1994.

WERNECK, C. Sociedade inclusiva, quem cabe no seu todo. RJ:WVA Ed., 1999.

Coordenadoria de Pesquisa e Extensão - COPEX

Departamento de Editoraçāo e Divulgaçāo Científica - DEDIC 


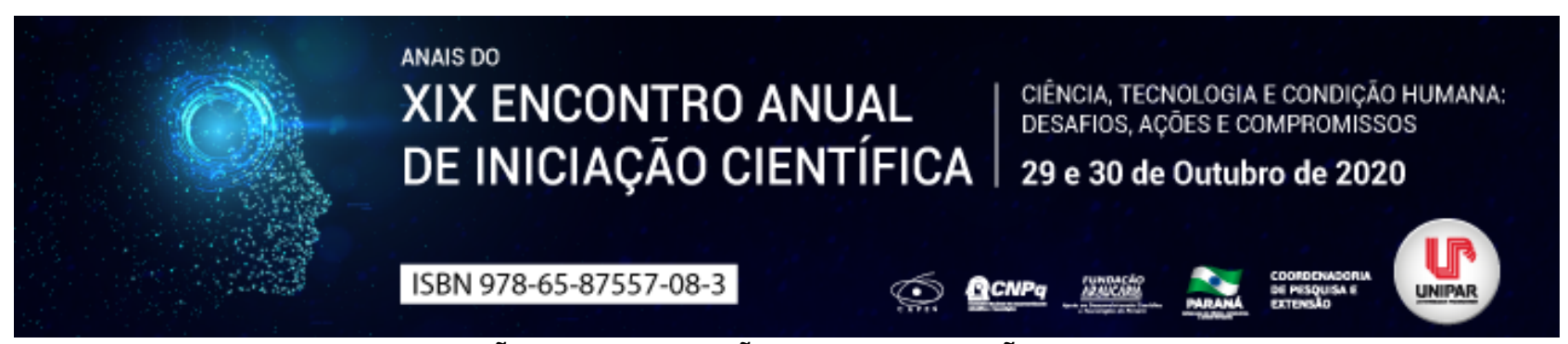

GAMIFICAÇÃO NA EDUCAÇÃO: CONTRIBUIÇÕES E DESAFIOS

\begin{abstract}
${ }^{1}$ BIANCA GABRIELA DE SOUZA PRADO, ${ }^{2}$ JOAO PEDRO ZULIANELLI BARDELA, ${ }^{3}$ ANDRESSA CAROLINE SANTOS DE SOUZA, ${ }^{4}$ LUCYELENA AMARAL PICELLI, ${ }^{5}$ VIVIANNE AUGUSTA PIRES, ${ }^{6}$ MARIA DO CARMO DE O NOGUEIRA
\end{abstract}

\author{
${ }^{1}$ Acadêmica PIC/UNIPAR \\ ${ }^{1}$ Acadêmico do Curso de Pedagogia da UNIPAR \\ ${ }^{2}$ Acadêmica do Curso de Pedagogia da UNIPAR \\ ${ }^{3}$ Docente da UNIPAR \\ ${ }^{4}$ Docente da UNIPAR \\ ${ }^{5}$ Orientadora / Docente da UNIPAR
}

Introdução: Em suas diversas faixas etárias

o ser humano tem atração por jogos, devido o entretenimento que ele proporciona. A gamificação, atualmente, é uma ferramenta no âmbito educacional para a fixação dos conteúdos e desenvolvimento cognitivo dos alunos. Segundo Fadel et al $(2014$, p. 12) [...] gamificação parte do conceito de estímulo ao pensamento sistematicamente como em um jogo, com o intuito de se resolver problemas, melhorar produtos, processos, objetos e ambientes com foco na motivação e no engajamento de um público determinado. De forma tecnológica e através de games online, tem um potencial imenso para educação, por se tratar de uma metodologia ativa da aprendizagem, ensinando através da ludicidade competências cognitivas e sócio-emocionais.

Objetivo: Discutir a importância, as contribuições e desafios da gamificação na educação e no processo ensino-aprendizagem.

Desenvolvimento: A gamificação é uma metodologia inovadora, que utiliza mecanismos tecnológicos, para elaboração de jogos pedagógicos, propondo atender as necessidades atuais do ensino. Visto que a humanidade mudou, as evoluções perpassam de geração em geração e o mundo nunca esteve tão conectado às tecnologias da informação como é atualmente. Silva (2016, p.3) indica que: Os jogos eletrônicos ou games tem se tornado cada vez mais comum na vida das pessoas de diversas gerações. Podemos encontrá-los, no computador, no celular, no tablet, na televisão, no console portátil e até mesmo em redes sociais, como, o Facebook. Os games estão presentes, não só entre crianças e adolescentes, mas também entre muitos adultos de gerações passadas como os da década de 80 , que são considerados da geração do Vídeo games e ainda hoje jogam com frequência. Não só na educação, mas também no mundo do trabalho, de acordo com Flora (2014, p. 129) As pessoas aprendem duas vezes mais rápido se comparado com os métodos de treinamento antigos e eles podem aplicar esses conhecimentos imediatamente ao chegar a seu local de trabalho [...] . Neste cenário, a gamificação entra como resposta para algumas dificuldades que os professores enfrentam, diante do ensino tradicional. Pode-se citar dois impasses principais, que são: o desinteresse do alunado e o aumento da evasão escolar. Fardo (2013, p.68) assinala que gamificação se apresenta como um fenômeno emergente com muitas potencialidades de aplicação em diversos campos da atividade humana, pois as linguagens, estratégias e pensamentos dos games são bastante populares, eficazes na resolução de problemas (pelo menos nos mundos virtuais) e aceitas naturalmente pelas atuais gerações que cresceram interagindo com esse tipo de entretenimento . Como recurso didático, torna a aprendizagem mais prazerosa e significativa. Ao deixar a sala de aula mais atrativa e divertida, os alunos aprendem de forma mais lúdica e autônoma, devido os jogos trabalhar uma série de estímulos nos alunos. Nos estímulos visuais: melhora a memória e desenvolve a concentração, nos estímulos psicológicos: desperta o interesse, através da competição saudável em grupos, os alunos aguçam a vontade de ganhar e assim dedicam-se em compreender o conteúdo para pontuar. Desta forma, como aponta Paulo Freire: I"É importante que os alunos percebam o esforço que faz o professor ou a professora procurando sua coerência. É preciso também que esse esforço seja de quando em vez discutido na classel" (FREIRE, p.116). Contudo, compreendemos que a melhora do processo de ensino e aprendizagem se dá através da compreensão dos sujeitos atores e protagonistas deste processo na integração e resiliência, qualidades do diálogo e das competências cognitivas e sócio-emocionais. Então, o que a gamificação propõe é falar a língua dos indivíduos inseridos nesse contexto da cultura digital e dos games. É introduzir um método que vise romper com o abismo que muitas vezes se apresenta entre os jovens e as escolas, entre os aprendizes e o conhecimento, entre a diversão e o trabalho (FARDO, 2013, p. 96). O ensino se transforma em processo autônomo para o alunado e se torna algo que faz sentido para sua realidade de vida, pois o mesmo tem liberdade de construir e buscar seu próprio conhecimento.

Conclusão: Portanto, utilizar a gamificação em sala de aula é uma oportunidade de solucionar problemas cotidianos da rede de ensino. Através de jogos bem selecionados é possível sair de um sistema de ensino bancário, conforme descrito por Paulo Freire (NOVAESCOLA, 2020), onde o professor é detentor do conhecimento e os alunos agentes passivos que recolhem todas as informações. Desta forma, buscam-se atualmente caminhos para uma educação mais ativa colocando o aluno como protagonista 
de sua aprendizagem, onde o professor é um mediador e o aluno um sujeito ativo no processo de aprendizagem se envolverá mais rica e interessadamente quando envolvido com a gamificação educativa.

\section{Referências}

FADEL, L. M.; ULBRICHT, V. R.; BATISTA, C. R.; VANZIN, T. Gamificação na educação. Pimenta Cultural, São Paulo. 2014. 300p. Disponível em: https://books.google.com.br/books? id=r6TcBAAAQBAJ\&lpg=PT6\&ots=faWF1SAlls\&dq=gamifica\%C3\%A7\%C3\%A30\%20na\%20educa\%C3\%A7\%C3\%A3o\&lr\&hl=ptBR\&pg=PT3\#v=twopage\&q\&f=false. Acesso em: 12 de Jul. 2020.

FARDO, Marcelo Luis. A gamificação como estratégia pedagógica: estudo de elementos dos games aplicados em processos de ensino e aprendizagem. (Dissertação (Mestrado) Universidade de Caxias do Sul, Programa de Pós-Graduação em Educação, 2013. Disponível

https://repositorio.ucs.br/xmlui/bitstream/handle/11338/457/Dissertacao\%20Marcelo\%20Luis\%20Fardo.pdf?

sequence=1\&isAllowed=y. Acesso em: 29 de Ago. 2020.

FLORA, Alves. Gamification como criar experiências de aprendizagem engajadoras: um guia completo do conceito à prática. 1. ed. São Paulo: DVS Editora, 2014 (E-BOOK). Disponível em: https://books.google.com.br/books? id=JnOwDQAAQBAJ\&pg=PT94\&lpg\#v=onepage\&q\&f=false. Acesso em: 20 de Ago. 2020.

FREIRE, Paulo. Pedagogia da Autonomia: Saberes necessários à prática educativa. São Paulo: Paz e Terra, 1998.

NOVA ESCOLA. Paulo Freire $O$ mentor da Educação para consciência. [S.I] 2020 . Disponível em: https://novaescola.org.br/conteudo/7241/paulo-freire. Acesso em: 28 Ago. 2020.

SILVA, Samara Salete da. Jogos Eletrônicos: contribuições para o processo de aprendizagem. (Trabalho de Conclusão de Curso - Psicopedagogia) UFPB Universidade Federal da Paraíba. - João Pessoa PB., 2016. Disponível em: https://repositorio.ufpb.br/jspui/bitstream/123456789/1889/1/SSS22062016. Acesso em: 20 de Ago. 2020.

Coordenadoria de Pesquisa e Extensão - COPEX

Departamento de Editoração e Divulgaçāo Científica - DEDIC 


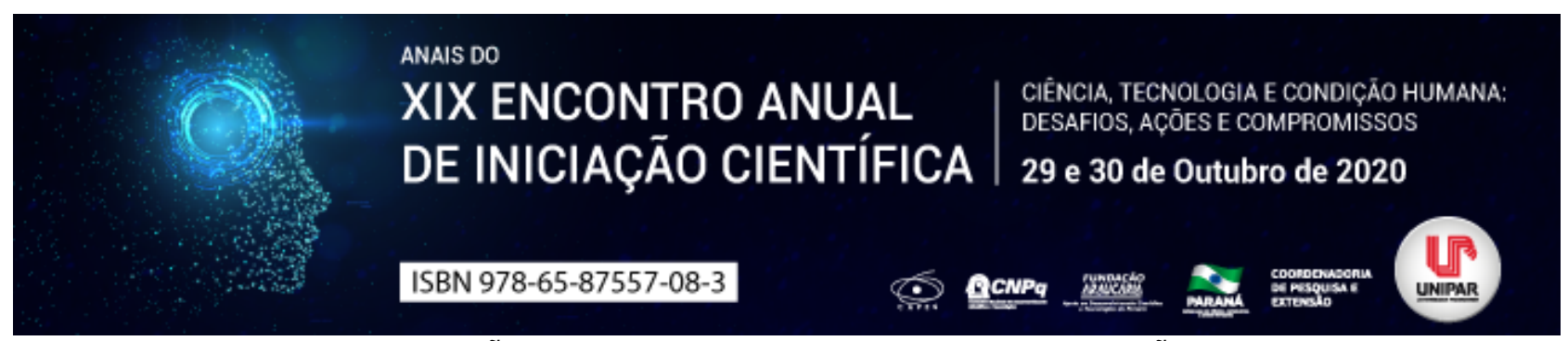

A IMPRESCINDIBILIDADE DA SUPERAÇÃO DA CULTURA PUNITIVA PARA A REDUÇÃO DA CRIMINALIDADE NO BRASIL

\section{${ }^{1}$ BEATRIZ CONSTANTINO DOS SANTOS, ${ }^{2}$ LUANA CARLA HERNANDES RODRIGUES, ${ }^{3}$ ALBINO GABRIEL TURBAY JUNIOR}

${ }^{1}$ Acadêmica do Curso de Direito da UNIPAR

${ }^{1}$ Acadêmica do Curso de Direito da UNIPAR

${ }^{2}$ Docente da UNIPAR

Introdução: A cultura punitiva, construída ao longo de séculos, exerce, hodiernamente, influência sobre as sanções penais aplicadas aos indivíduos que cometem delitos. Na sociedade brasileira, é possível perceber que essa cultura é fomentada por discursos punitivos e pela própria população, que almeja cada vez mais a aplicação de penas mais gravosas, sem compreender se esta cultura punitiva contribui para a diminuição da criminalidade.

Objetivos: Analisar a interferência negativa da cultura punitiva sobre a redução dos índices de criminalidade e compreender a importância de sua superação.

Desenvolvimento: O crime é um fato social, no qual o indivíduo que o pratica comete a transgressão de uma conduta regulamentada, afetando bens jurídicos tutelados pelo Direito Penal. Nesse viés, as condutas delituosas são reprimidas com sanções penais, que devem retribuir essas práticas com punições e prevenir sua reincidência. Logo, a pena implica uma afetação de bens jurídicos do autor do delito (de sua liberdade, na prisão ou reclusão; de seu patrimônio, na multa; de seus direitos, nas penas restritivas) (ZAFFARONI; PIERANGELI, 2008, p. 86). No Brasil impera uma cultura punitiva, na qual há o anseio pela retribuição da pena, na mesma medida que o crime praticado ou de forma mais gravosa, revelando um sério descaso com a prevenção à reincidência de delitos. Dessarte, justifica-se o alto índice de criminalidade no Brasil, haja vista que, apenas retribuir o delito com uma pena, é insuficiente para a redução dessa incidência. Logo, é de indubitável relevância a ressocialização do indivíduo que cometeu o delito, para readequar sua conduta ao que é devidamente regulamentado pelo Direito. As prisões, por exemplo, devem transformar os indivíduos (FOUCAULT, 1987, p. 196). Contudo, efetivamente, a maioria das prisões, no Brasil, meramente encarceram as pessoas, apesar da pena possuir finalidade de reprovação e prevenção. Porém, a prevenção, mediante ressocialização, limita-se a uma presunção, pois a pena se tornou uma realidade violenta e opressiva e serve apenas para reforçar os valores negativos do condenado (BITENCOURT, 2012, p. 222). Assim, percebe-se a influência exercida pela cultura punitiva no atual cenário brasileiro, visto que as sanções penais aplicadas apenas estigmatizam o indivíduo, marcando-o negativamente com penas demasiadamente repressivas e que não cumprem a função da ressocialização.

Conclusão: Constata-se, mediante a análise, a premência de se superar a cultura punitiva que permeia a sociedade brasileira, uma vez que, a mera repressão de indivíduos que cometeram delitos, é insuficiente para reduzir os altos índices de criminalidade. Por conseguinte, faz-se necessária a concretização das medidas destinadas à ressocialização, a fim de que haja uma efetiva readequação à lei desses comportamentos outrora transgressivos, inibindo-se, por conseguinte, sua reincidência.

\section{Referências}

BITENCOURT, Cezar Roberto. Tratado de direito penal: parte geral. 17. ed. São Paulo: Saraiva, 2012. v. 1.

FOUCAULT, Michel. Vigiar e Punir: nascimento da prisão. 20. ed. Rio de Janeiro: Vozes, 1987.

ZAFFARONI, Eugenio Raúl; PIERANGELI, José Henrique. Manual de direito penal brasileiro: parte geral. 7. ed. São Paulo: Revista dos Tribunais, 2008. v. 1. 


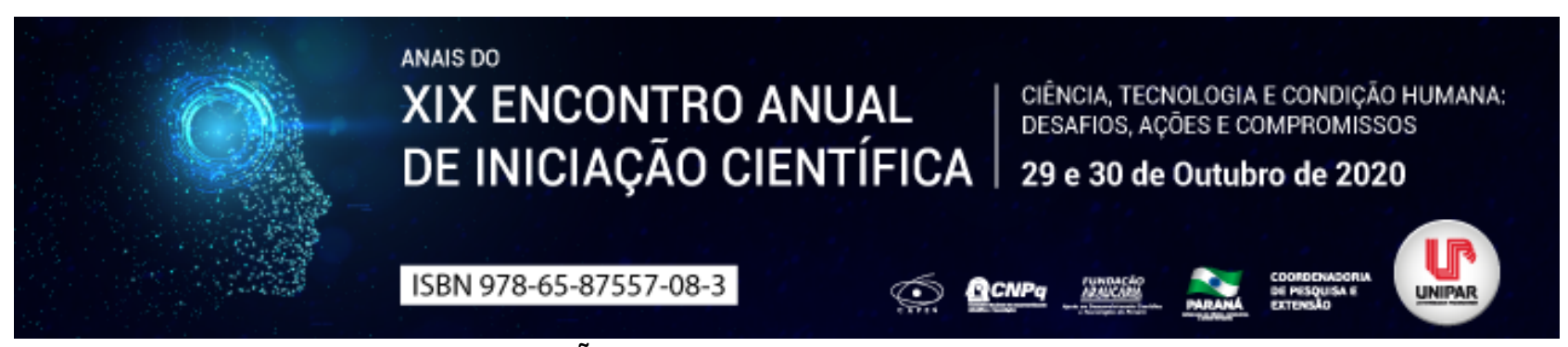

FORMAÇÃO DOCENTE NO ENSINO SUPERIOR

\title{
${ }^{1}$ ANDRE LUIS MAROSTICA FURTADO
}

\author{
${ }^{1}$ Acadêmico do Curso de Pós-Graduação em Fisiologia do Exercício da UNIPAR
}

Introdução: O exercício da docência no ensino superior requer conhecimentos e formação específica para a atuação dos profissionais nesse nível de ensino e a Universidade assumiu como missão promover a Educação Superior de qualidade, e deve proporcionar as condições necessárias para formar e capacitar profissionais para atuarem em prol do desenvolvimento do conhecimento e aprendizagem. Através desses objetivos se faz necessário investigar e entender quais ações devem ser tomadas no processo de formação do futuro docente do ensino superior, visto que são inúmeros os desafios encontrados por esses profissionais durante a formação e após durante o exercício atuando como docentes de ensino superior. Sendo assim o presente trabalho visa abordar questões sobre os modelos, métodos e políticas de ensino com objetivo de propiciar aos profissionais e as instituições de ensino medidas para uma formação mais completa e ampla no ponto de vista educacional e pedagógico.

Objetivo: Apresentar estudos e trabalhos técnicos, acadêmicos e científicos que possam contribuir com o processo de formação docente e profissional no ensino superior.

Desenvolvimento: A formação docente para o ensino superior ainda é um tema amplamente complexo e com múltiplas facetas devido a velocidade do conhecimento e inovações científicas. Pensando nisso afim de acompanhar esses processor os programas de formação docente devem estar em constante evolução afim de atender os desafios dessa profissao. O professor segundo dicionário Aurélio (2020) é o individuo que ensina, ministra disciplinas, matérias, numa escola ou universidade, aquele cuja especialização ou formação acadêmica é ensinar, Mediante essas características a formação do futuro docente dentro dos programas de pós-graduação em especial os strictu-sensu deveriam propiciar que o individuo vivencie experiências educacionais das mais variadas formas pedagógicas Lobo (2018, p55-70) porem, não é esta a realidade do que acontece na grande maioria dos cursos de pós graduação que visam formar futuros docentes de ensino superior. Como relatado por Melo \& Campos (2019. p44-63) esses programas visam uma formação altamente técnica e cientifica voltada principalmente para a área da pesquisa. situação essa que se agrava ainda mais devido a pouca importância dada a formação didático pedagógica segundo Zukowsky et al (2019. v30), Apresentando uma serie de dificuldades encontradas pelos docentes quando adentram na carreira como docentes do ensino superior por terem tido uma formação deficitária e por não encontrarem amparo das instituições de ensino segundo Sordi (2019. p135-154).

Conclusão: Afim de solucionar essa questão os autores relatam a necessidade de mudanças durante a formação dentro dos programas de pós graduação e a criação de políticas institucionais para melhor capacitar esse futuro profissional. E Sugerem a criação de diversos programas e atividades como, mesa redonda, reflexões coletivas entre os docentes, portfólio acadêmico, formação continuada, programa desenvolvimento do docente universitário, incentivar o desenvolvimento de pesquisas e metodologias no ensino superior Sordi (2019. p135-154) Mello \& Freitas (2018. p249-263) Lobo (2018. p55-70) Melo \& Campos (2019. p44-63).

\section{Referências}

LOBO, A. M. F. O Ato, a performance e a formação: tempos e processos de si na docência. Educar em Revista, Curitiba, Brasil, v. 34, n. 67, p. 55-70, jan./fev. 2018.

MELO, Geovana Ferreira; CAMPOS, Vanessa T. Bueno. Pedagogia universitária: por uma política institucional de desenvolvimento docente. Cadernos de Pesquisa, São Paulo, v. 49, n. 173, p. 44-63, jul./set. 2019. Disponivel em:http://www.scielo.br/scielo.php?script=sci_arttext\&pid=S0100-15742019000300044\&lang=pt. Acesso em: 28 mar.

MELLO, E. M. B.; FREITAS, D. P. S. Possibilidades formativas para os docentes universitários: compromisso institucional. Educar em Revista, Curitiba, Brasil, v. 34, n. 67, p. 249-263, jan./fev. 2018.

SORDI, M. R. L. Docência no ensino superior: interpelando os sentidos e desafios dos espaços institucionais de formação. Educar em Revista, Curitiba, Brasil, v. 35, n. 75, p. 135-154, mai./jun. 2019.

ZUKOWSKY, C. T. : CASTRO, P. L. : RUIZ, L. M. O portfólio e a construção de saberes docentes na pós-graduação em saúde 1 2. Pro-Posições, Campinas: SP, v. 30, e. 20170181, 2019. Disponivel em:http://www.scielo.br/scielo.php? script=sci_arttext\&pid=S0103-73072019000100544\&lang=pt. Acesso em: 28 mar. 2020. 



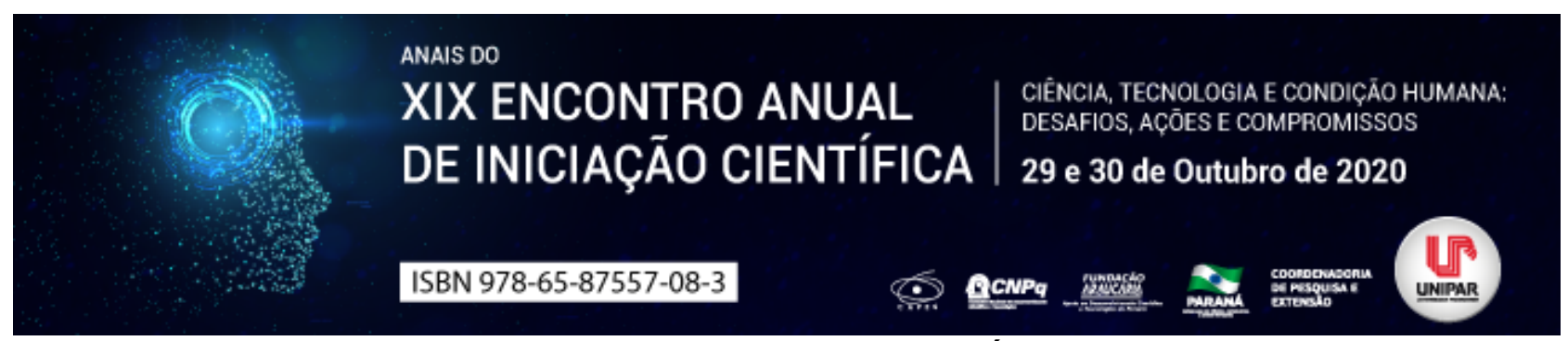

DOS DIREITOS DA PERSONALIDADE NO PÓS-HUMANISMO

\author{
1JULIANA LUIZA MAZARO, ²VALÉRIA SILVA GALDINO CARDIM
}

${ }^{1}$ Discente, Doutoranda em Direito pelo UniCesumar (2019-2022); Bolsista parcial PROSUP/CAPES pelo Programa de PósGraduação

${ }^{1}$ Pós-Doutora em Direito pela Universidade de Lisboa; Doutora e Mestre PUC/SP; Docente da UEM

Introdução: A expansão tecnológica colaborou para o crescimento do movimento pós-humanista, pois ela seria o meio para que o ser humano atingisse uma nova etapa evolutiva, superando os limites impostos pelos seus corpos. Não se pode duvidar da influência que o alto desenvolvimento da tecnologia impôs às pessoas, modificando vários paradigmas biológicos e sociais, inclusive, os direitos da personalidade, que ainda precisam ser devidamente observados e, preferencialmente, integrados aos objetivos daqueles que defendem a existência do pós-humano.

Objetivo: Conhecer o movimento pós-humanista, suas vertentes, objetivos e teorias que são baseados no desenvolvimento tecnológico e, assim, compreender como sua ideologia pode interferir, positiva ou negativamente, nos direitos da personalidade.

Desenvolvimento: Na década de 1980, um movimento se fortalece e se fundamenta na evolução do ser humano por meio da tecnologia, ele é chamado de pós-humanismo. Dividido em algumas vertentes, três se destacam: os precursores, que são chamados de extroprianos, cuja doutrina se alicerça no princípio de expansão ilimitada da pessoa, sem barreiras políticas, culturais, psíquicas e biológicas; a segunda, chamada de transtopianos seriam os mais extremistas, defendendo que [...] a pesquisa tecnológica deve ser vista como meio de liberar nossa capacidade de racionar a natureza humana , ou seja, corrigir as

falhas do ser humano; e, por fim, a terceira vertente, surge em 1998, conhecida como Aliança Mundial Trans-humanista, tenta estabelecer um equilíbrio entre os princípios das duas anteriores (RÜDIGER, 2008, p. 191). Todavia, existem preocupações quanto à expansão ilimitada da tecnologia e do seu uso na busca no melhoramento do indivíduo, por isso é importante conhecer o que é [...] a visão ou o conceito de ser humano que está operacionalizado, colocado em prática, quando estamos frente a inúmeras possibilidades de intervenção tecnocientífica que podem alterar profundamente a identidade do ser humano (PESSINI, 2017, p. 304). Esse grupo, portanto, pretenderia a ruptura daquilo que é natural do que é criado, no caso, originado/transformado pela tecnologia, e diante das possibilidades reais que tem se apresentado nos campos da genética e biotecnologia, bem como na expansão da vida social nas mídias de comunicação em ambiente virtual, os direitos humanos, por consequência, os da personalidade, ainda devem ser vistos como os principais meios de proteção da pessoa (SILVA, 2019, p.136). Assim, o que se percebe é que o grande progresso tecnológico tem alterado as finalidades para as quais as leis são criadas, interpretadas e/ou aplicadas, fazendo com que a comunidade jurídica tenha que repensar conceitos e abordagens tradicionais, para que consigam acompanhar as mudanças operadas pela tecnologia, respeitando movimentos, como o póshumanismo, ao mesmo tempo em que continua a tutelar os direitos das pessoas (KAUFFMAN; SOARES, 2018, p. 515). Os direitos da personalidade são normas que protegem posições jurídicas fundamentais da constituição do indivíduo, as quais Ihes são inerentes e essenciais (CANTALI, 2006, p. 66). Assim, existe razão para que sejam absorvidos e respeitados pelos ideais pós-humanistas, uma vez que, mesmo que a pessoa atinja outros níveis de evolução por meio da tecnologia como o grupo preconiza, ela ainda precisa ter alguns bens jurídicos protegidos, como sua dignidade, honra, imagem, liberdade, igualdade, etc. E, mesmo a tecnologia sendo capaz de promover grandes mudanças na vida dos indivíduos, quando as realiza no sentido de melhoria na sua qualidade de vida, ela não pode deixar de observar os direitos personalíssimos. Por isso, Nick Bostrom (2005, p. 215), filósofo que integra a Aliança Mundial Trans-humanista, defende que é necessário respeitar os direitos individuais, de maneira que o sujeito seja livre para escolher como utilizar a tecnologia em prol do seu desenvolvimento como ser humano. Para tanto, ele reconhece a existência de uma dignidade pós-humana, que vem complementar a dignidade da pessoa humana tradicional , tratando-a como aquilo [...] que somos e naquilo que temos o potencial de nos tornar, e não na nossa genealogia ou em nossas origens causais. O que somos não é uma função somente do nosso DNA, mas também do nosso contexto social e tecnológico . Logo, nada impede a evolução da noção de dignidade, pois, como uma categoria axiológica aberta, seu significado está em permanente processo de construção e desenvolvimento, para que, assim, continue atuando como a base de proteção dos direitos da pessoa.

Conclusão: O pós-humanismo se expandiu nas últimas três décadas, acompanhando o grande avanço tecnológico que o mundo experimenta e que se ramifica em várias áreas do conhecimento humano, incluindo, o direito. Este que, diante de tantas mudanças na vida e relações das pessoas, ocasionadas pela tecnologia, continua buscando meios de proteger seus direitos mais importantes, os da personalidade. Nesse ponto, o que se verifica é que alguns defensores do trashumanismo se preocupam em salvaguardar aspectos do ser humano, por exemplo, sua dignidade, na medida em que incorpora a ela novos conceitos e valores como a dignidade pós-humana 


\section{Referências}

BOSTROM, Nick. In defense of posthuman dignity. Bioethics, [S.I.], v. 3, n. 9, p. 202-214, dez. 2005. Disponível em: https://www.nickbostrom.com/ethics/dignity.html. Acesso em: 18 ago. 2020.

CANTALI, Fernanda Borghetti. Direitos da personalidade: disponibilidade relativa, autonomia privada e dignidade humana. Porto Alegre: Livraria do Advogado, 2009.

KAUFFMAN, Marcos E.; SOARES, Marcelo Negri. NEW TECHNOLOGIES AND DATA OWNERSHIP: wearables and the erosion of personality rights. Revista Direitos Sociais e Políticas Públicas (Unifafibe), [S.L.], v. 6, n. 1, p. 512,18 jul. 2018. Revista Direitos Sociais e Políticas Públicas UNIFAFIBE. http://dx.doi.org/10.25245/rdspp.v6i1.444

PESSINI, Leo. Bioética, humanismo e pós-humanismo no século XXI. Em busca de um novo ser humano? Revista Eclesiástica Brasileira, [S.L.], v. 77, n. 306, p. 301-347, 30 jun. 2017. Revista Eclesiastica Brasileira. http://dx.doi.org/10.29386/reb.v77i306.83.

RÜDIGER, Francisco. Cibercultura e pós-humanismo: exercícios de arqueologia e criticismo. Porto Alegre: EDIPUCRS, 2008.

SILVA, Wellington F. de Melo da. O transhumanismo e os direitos humanos: a perda da autonomia e da liberdade diante das pesquisas no âmbito da biotecnologia e os avanços das tecnociências. Abordagens, João Pessoa, v. 1, n. 1, p. 134-151, jun. 2019. Disponível em: https://periodicos.ufpb.br/index.php/rappgs/article/view/43715/28061. Acesso em: 17 ago. 2020. 


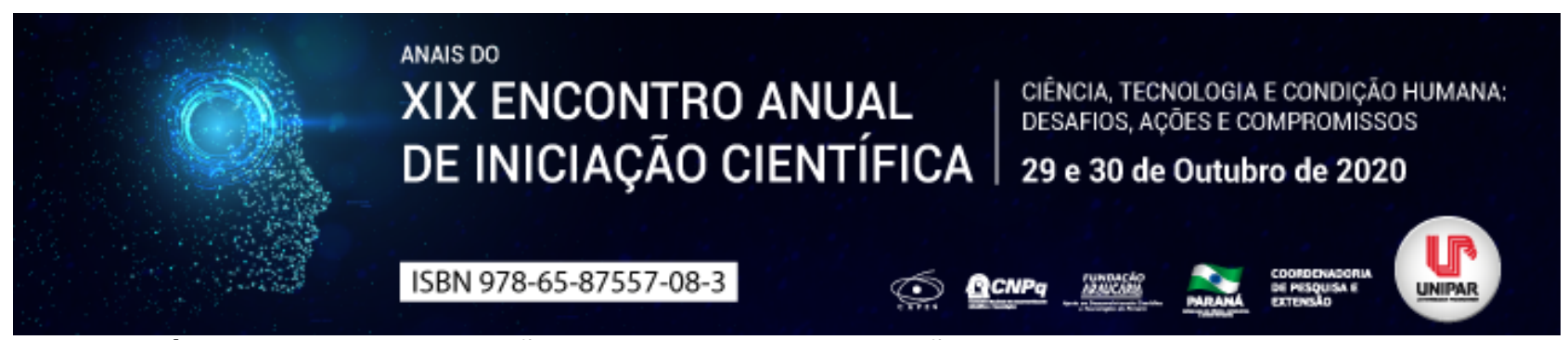

INFLUÊNCIA DA ARBORIZAÇÃO URBANA NA REGULAÇÃO DA TEMPERATURA DAS CIDADES

\begin{abstract}
${ }^{1}$ Matheus Henrique Soares de Camargo, ${ }^{2}$ GUSTAVO FERREIRA MANOEL, ${ }^{3}$ MARCELO APARECIDO MARQUES, ${ }^{4}$ DANIELI PINTO
\end{abstract}

${ }^{1}$ Acadêmico do curso de Engenharia Civil da Faculdade de Administração e Ciências Econômicas de Cianorte FACEC

${ }^{1}$ Acadêmico do curso de Engenharia Civil da Faculdade de Administração e Ciências Econômicas de Cianorte FACEC

${ }^{2}$ Docente da Faculdade de Administração e Ciências Econômicas de Cianorte FACEC

${ }^{3}$ Docente da Faculdade de Administração e Ciências Econômicas de Cianorte FACEC

Introdução: Arborização urbana é qualquer vegetação, seja ela de pequeno ou grande porte, que compõe a paisagem das cidades (MARTINI; BIONDI; BATISTA, 2013). Tem, dentre várias funções, auxiliar na regulação da temperatura, diminuir a poluição urbana, garantir a melhoria da qualidade de vida e a saúde física e mental dos indivíduos (BONAMETTI, 2003; RIBEIRO, 2009)

Objetivo: Verificar a influência das áreas arborizadas como meio de regulação da temperatura no cenário urbano.

Materiais e Métodos: A pesquisa foi realizada no município de Cianorte-PR. Para a coleta dos dados foram estabelecidos dois pontos. O PONTO I, uma avenida pouco arborizada, com plantas de palmeira real nos canteiros centrais e sibipiruna nas laterais das ruas; o PONTO II, uma avenida bem arborizada, com plantas de canelinha e ipê nos canteiros centrais e de sibipiruna nas laterais da rua. A temperatura foi aferida no asfalto com um termômetro digital da marca Minipa, de segunda a sexta-feira, no mês de novembro de 2019, no horário das $12 \mathrm{~h} 00$ e 13h30. Os dados foram organizados e tabulados no MS-Excel.

Resultados: Verificou-se no PONTO I uma média de temperatura no asfalto às $12 \mathrm{h00}$ de $56,64^{\circ} \mathrm{C}$ e $55,49^{\circ} \mathrm{C}$ às $13 \mathrm{~h} 30$. No PONTO II, observou-se uma temperatura média no asfalto de $35,09^{\circ} \mathrm{C}$ às $12 \mathrm{~h} 00$ e $33,78^{\circ} \mathrm{C}$ às $13 \mathrm{~h} 30$. Diante dos registros, verifica-se que nas áreas arborizadas a temperatura média do asfalto às $12 \mathrm{~h} 00$ e $13 \mathrm{~h} 30$ são respectivamente, 38,04 \% e 39,12 \% menores em comparação com as áreas com pouca arborização.

Discussão: É característico do mês de novembro a observação de altas temperaturas na região Noroeste do Paraná, uma vez que esse período marca o final da estação da primavera. No entanto, algumas ações podem amenizar o calor, sendo uma delas o plantio de árvores no ambiente urbano. Martini, Biondi e Batista (2013) afirmam que a arborização urbana tem o propósito de bloquear os raios solares das ruas e avenidas, como também de controlar a temperatura nas áreas urbanizadas. De acordo com Shams, Giacomeli e Sucomine (2009), áreas com ausência de sombras faz com que a radiação solar seja absorvida diretamente pela pavimentação e edificações e retorne ao meio externo na forma de calor. Os autores ressaltam que em áreas arborizadas esse processo é ameno, uma vez que as folhas das árvores retiram o calor do meio auxiliando na regulação da temperatura, sendo absorvido e emitido, dessa forma, menos calor pela pavimentação e edificações.

Conclusão: É evidente que a arborização é um dos fatores responsáveis pela regulação da temperatura no pavimento asfáltico e no cenário urbano como um todo. Isso mostra a necessidade de um planejamento por parte das secretarias municipais no que tange a escolha das espécies de árvores a serem plantadas, do local de plantio, da quantidade de plantas e do manejo aplicado. Sugere-se como estudos futuros a aferição da temperatura por um maior período e em mais pontos da cidade e a averiguação das espécies de árvores mais indicadas para tal finalidade.

\title{
Referências
}

BONAMETTI, João Henrique. Arborização urbana. Terra e Cultura, Londrina, v. 19, n. 36, p. 51 55, jan./jun. 2003.

MARTINI, Angeline; BIONDI, Daniela; BATISTA, Antonio Carlos. Variação diária e estacional do microclima urbano em ruas arborizadas de Curitiba-PR. Floresta e Ambiente, Rio de Janeiro, v. 20, n. 4, p. 460 469, out./dez. 2013.

RIBEIRO, Flávia Alice Borges Soares. Arborização Urbana Em Uberlândia: Percepção Da População. Revista da Católica, Uberlândia, v. 1, n. 1, p. 224 237, 2009.

SHAMS, Juliana Cristina Augusto; GIACOMELI, Daniele Cristina; SUCOMINE, Nivia Maria. Emprego da arborização na melhoria do conforto térmico nos espaços livres públicos. REVSBAU, Piracicaba, v. 4, n. 4, p. 1 16, 2009. 


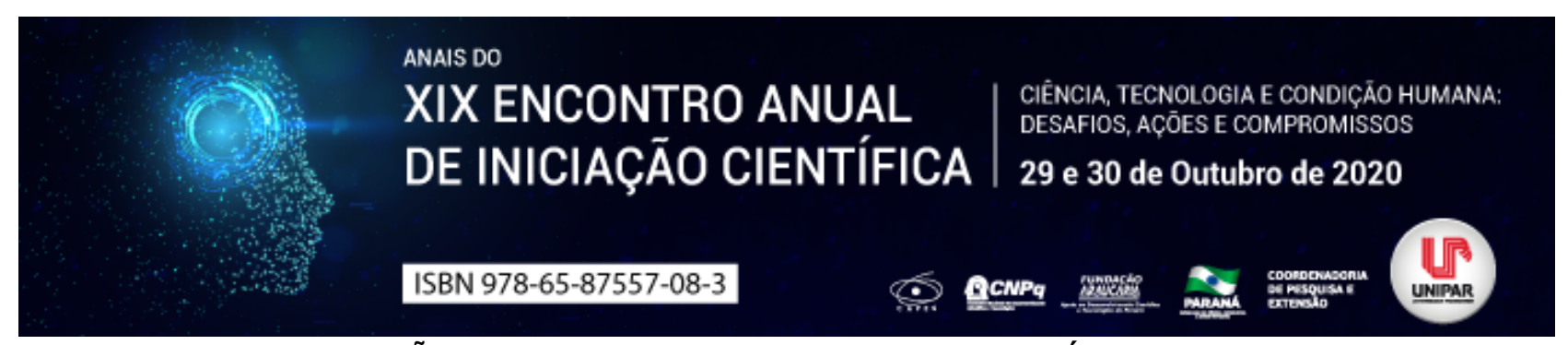

ESTADO DA ARTE DA FUNÇÃO SOCIAL DO DIREITO CONTRATUAL: ANÁLISE POR MEIO DE PARADIGMAS

\begin{abstract}
${ }^{1}$ BRUNO MARTINS DUARTE ORTIZ, ${ }^{2}$ MARIANA SARTORI NOVAK, ${ }^{3}$ JULIA IZABELLE TONETO ROMANO, ${ }^{4}$ JUSSARA SUZI ASSIS BORGES N. FERREIRA
\end{abstract}

${ }^{1}$ Discente do Programa de Mestrado em Direito Processual e Cidadania da UNIPAR

${ }^{1}$ Discente do Programa de Mestrado em Direito Processual e Cidadania da UNIPAR

${ }^{2}$ Discente do Programa de Mestrado em Direito Processual e Cidadania da UNIPAR

${ }^{3}$ Docente da UNIPAR

Introdução: A função social do contrato, conceito apresentado pelo Código Civil em seu art. 421, pode ser determinada conforme as circunstâncias históricas e sociais que permeiam os pactos civis e empresariais. Realiza-se, portanto, um recorte da realidade onde o contrato se insere para se depreender sua finalidade como instrumento constituinte da própria sociedade. Para tanto, debruça-se parte da doutrina em realizar a referida secção com base em dois paradigmas rivais: o paternalista e o econômico, que merecem criterioso estudo, ante a possibilidade de serem superados tão logo não deem conta de apresentar respostas a todos os questionamentos que a eles são dirigidos.

Objetivo: Analisar, brevemente, a atual função social do contrato, frente aos paradigmas paternalista/distributivo e de Direito e Economia, apresentados por Luciano Timm como forma de compreensão do contrato.

Desenvolvimento: O paradigma é o conjunto de realizações científicas universalmente reconhecidas que, durante algum tempo, fornecem problemas e soluções modelares para uma comunidade de praticantes de uma ciência (KUHN, 1997, p. 13). O conceito de Thomas Kuhn, aplicado ao Direito Contratual, segundo Timm (2008, p. 12), dá azo a duas principais abordagens da função social do pacto: sob a óptica intervencionista ou pela relação com o direito econômico. A primeira diz respeito à intervenção do Estado no contrato visando o equilíbrio entre as partes, ante a existência de fragilidade em negociar de uma delas. A segunda apreende de modo estrito a autonomia da vontade, onde as partes negociam em igualdade, distribuindo os benefícios advindos da contratação entre elas, evitando a redistribuição de prejuízos àqueles que não participaram da contratação, o que prejudicaria o próprio mercado (TIMM, 2008, p. 14-15). A função social naquela abordagem corresponde a ditames de justiça social, com a garantia do interesse público sob o privado, pautada na publicização e constitucionalização do contrato, evitando-se, assim, a tirania do vetusto e já anacrônico - pacta sunt servanda (GAGLIANO; PAMPLONA FILHO, 2006, p. 60). Neste, o contrato está inserido dentro de uma lógica de um mercado que se desenvolve com o aprimoramento dos contratos e ninguém melhor que as próprias partes para determinar como os benefícios devem ser distribuídos. O paternalismo/solidarismo tem seu locus relacionado, no ordenamento pátrio, principalmente, ao Código de Defesa do Consumidor (BRASIL, 1990). No âmbito das decisões proferidas até meados da última década, era possível constatar o manejo de tal paradigma como forma de garantia da função social do contrato: revendo cláusulas e disposições que onerassem apenas uma das partes em benefício exorbitante da outra. Ocorre que o paradigma paternalista vem se demonstrando ineficiente em trazer respostas acerca do desenvolvimento do mercado, que se aperfeiçoa, basicamente, por meio de contratos. Assim, apresenta-se uma nova tendência jurisprudencial, embora tímida, em se levar em consideração os prejuízos que o mercado pode ter que suportar ao se proteger uma das partes. Como exemplo cita-se o corte no fornecimento de energia elétrica (BRASIL, 2018). Considerada como essencial, sua interrupção ia de encontro ao princípio constitucional da dignidade humana, de caráter eminentemente publicístico, o que, ao paradigma paternalista, fundamentava decisões que vetavam, sempre, o corte. Atualmente, conforme entendimento prolatado em sede de julgamento de recursos repetitivos, a suspensão se mostra possível, em determinadas circunstâncias, para se evitar que o prejuízo do próprio fornecedor seja distribuído aos demais consumidores alheios à controvérsia. O mercado, portanto, como reflexo do interesse coletivo.

Conclusão: A abordagem via paradigmas, do estado da arte da função social do contrato enseja encerrar que não há que se falar em superação do paradigma paternalista para uma abordagem econômica, mas em possível caminhar daquele, por meio de questionamentos que vêm sendo respondidos, decisão a decisão.

\title{
Referências
}

BRASIL, Lei $n^{\circ} 10.406$ de 10 de janeiro de 2002. Institui o Código Civil. Disponível em: http://www.planalto.gov.br/ccivil_03/leis/2002//10406.htm. Acesso em: 08/07/2020.

Lei $n^{\circ} 8.078$ de 11 de setembro de 1990. Dispõe sobre as proteções do consumidor e dá outras providências. Disponível em: http://www.planalto.gov.br/ccivil_03/leis/l8078.htm. Acesso em: 08/07/2020.

Superior Tribunal de Justiça. Tema 699. REsp 1.412.433-RS, Rel. Min. Herman Benjamin, Primeira Seção, por 
https://ww2.stj.jus.br/processo/revista/documento/mediado/?

componente=ITA\&sequencial=1320464\&num_registro=201301120621\&data=20180928\&formato=PDF. Acesso em: 16/07/2020. GAGLIANO, Pablo Stolze; PAMPLONA FILHO, Rodolfo. Novo Curso de Direito Civil: contratos. Vol. 4. 2. ed. unificada. São Paulo: Saraiva Educação, 2019.

KUHN, Thomas S. A estrutura das revoluções científicas. 5. ed. São Paulo: Editora Perspectiva S.A, 1997.

TIMM, Luciano Benetti. Função Social do Direito Contratual no Código Civil Brasileiro: Justiça Distributiva versus Eficiência Econômica. Revista dos Tribunais. São Paulo. v. 97, n.876, p. 11-43, out. 2008.

Coordenadoria de Pesquisa e Extensāo - COPEX

Departamento de Editoraçāo e Divulgaçāo Científica - DEDIC 


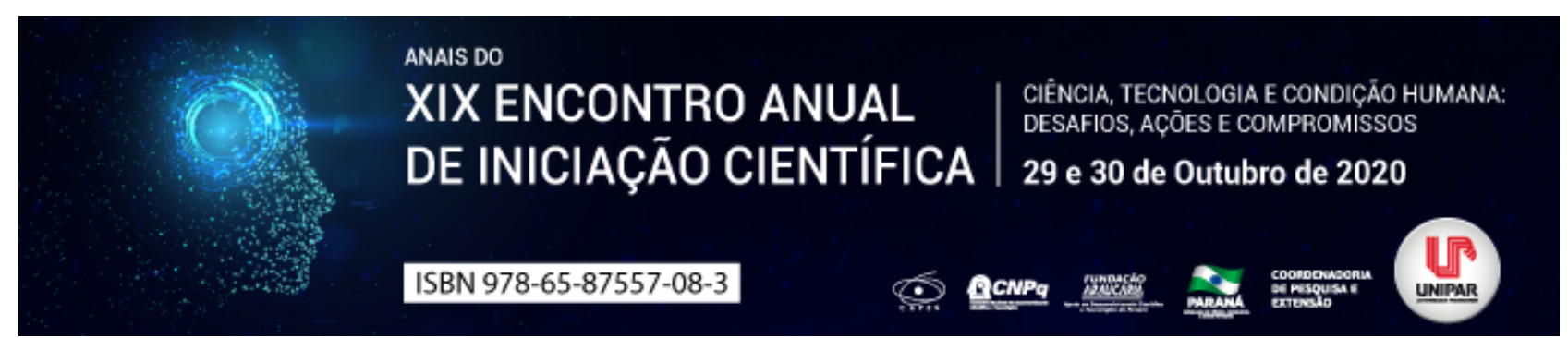

DA VIOLAÇÃO DE DIREITOS FUNDAMENTAIS E DA PERSONALIDADE PELA UTILIZAÇÃO DO IN DUBIO PRO SOCIETATE NA DECISÃO DE PRONÚNCIA DO TRIBUNAL DO JÚRI

\author{
${ }^{1}$ BRUNA DE OLIVEIRA ANDRADE, ${ }^{2}$ JULIANA LUIZA MAZARO
}

\author{
${ }^{1}$ Mestranda em Ciência Jurídicas - UniCesumar \\ ${ }^{1}$ Doutoranda em Direito - UniCesumar
}

Introdução: A decisão de pronúncia proferida na primeira fase do Tribunal do Júri que se fundamenta no princípio do in dubio pro societate, ou seja, na dúvida, o magistrado submete o réu ao crivo dos jurados. Isto deve ser tratado como inconstitucional, visto que vai na contramão de direitos fundamentais e da personalidade da pessoa, que são tutelados pela Constituição Federal (CF/88), como a dignidade da pessoa humana e o in dubio pro reo. Dentro dessa perspectiva, as decisões do Supremo Tribunal Federal (STF) convergem para determinar que além da falta de amparo constitucional, a fundamentação no brocardo in dubio pro societate conflita com as premissas de valorização racional das provas do processo penal, acabando por ser incongruente com o sistema bifásico do Tribunal do Júri no Brasil.

Objetivo: Conhecer do que se trata a decisão de pronuncia com fundamento no in dubio pro societate, e como isso afeta os direitos fundamentais e da personalidade, como a dignidade da pessoa humana e a presunção de inocência do acusado, demonstrando que sua utilização viola a valorização racional da prova e o sistema do Tribunal do Júri.

Desenvolvimento: O sistema processual penal brasileiro é acusatório, atuando separadamente as funções de acusação, defesa e julgamento, sendo que as duas primeiras atuam em igualdade de condições por seguirem as diretrizes constitucionais da ampla defesa e contraditório. O Júri é uma garantia constitucionalmente imposta no Brasil, pela qual o sujeito é julgado por seus semelhantes, ou seja, não por um juiz togado, mas por juízes leigos que deverão condená-lo ou absolve-lo de acordo com a sua consciência e os ditames da justiça, e após lhes serem apresentadas todas as informações necessárias pela acusação e pela defesa (TAVARES, 2016). Esse procedimento é considerado especial, se dividindo em duas fases, a primeira, a judicium accusatione corresponde a formação da culpa com a demonstração da existência de um crime contra a vida, consumado ou tentado, e a indicação de um possível autor. É nela que o magistrado deverá ser convencido por meio de provas colhidas em todo rito processual, realizando uma valoração racional das mesmas a fim de decidir pela absolvição sumária, pronúncia, impronúncia ou desclassificação do delito. A segunda, chamada de judicium causae, se inicia com a pronúncia e leva o réu ao julgamento pelo Tribunal do Júri (BRASIL, 1941). É nesse ponto que surge o problema, pois a pronuncia deveria ocorrer se, e somente se, houverem provas da materialidade do fato delitivo e indícios suficientes de autoria, que realmente levem a crer que determinado indivíduo concorreu para prática criminosa, contundo, não é o que ocorre, parece haver uma compulsão dos magistrados em levar todos os casos de crime contra à vida a deliberação popular, mesmo que haja possibilidade de incorrer em uma injustiça (MOREIRA, 2015). Quanto a ocorrência dos fatos comprovados não há controvérsias, contudo, quanto ao requisito de indícios suficientes de autoria muitas contradições jurisprudenciais e legais são encontradas. Atualmente, havendo dúvidas o juiz togado leva a decisão de condenar ou não ao crivo dos jurados, sob o fundamento in dubio pro societate. Ao pronunciar o réu sem provas suficientes de que foi o autor do delito, fere seu direito personalismo à dignidade, na medida em que ela reclama constante concretização e delimitação pela práxis constitucional (SARLET, 2005, p.27), o que não ocorre, pois da CF/88 (art. $5^{\circ}$, LVII) traz em seu texto o in dúbio pro reo como primazia em uma decisão jurídica e não o interesse social, portanto, o conteúdo jurídico do princípio da presunção de inocência é uma exigência a ser observada durante todo o processo penal, inclusive, na competência do Tribunal do Júri, a dúvida sobre a autoria do delito não extingue o estado de inocência do réu e se $o$ Ministério Público, que tem o dever de provar a culpabilidade não foi capaz de fazê-lo, a justificativa do bem social é insuficiente para pronunciar o indivíduo (BARRETO, 2017). Para isso se efetivar, deve o juiz da pronúncia realiza uma valoração racional da prova para que a decisão esteja de acordo com o princípio da legalidade e em acordo com a defesa de direitos fundamentais e personalíssimos, é o que a legitima, como defendeu o Ministro Gimar Mendes em seu voto na relatoria do ARE 1067392/CE ao dizer que o in dubio pro societate não tem base normativa e que não se pode admitir que os magistrados, em qualquer instância, se esconda atrás de um princípio inexistente no ordenamento jurídico brasileiro.

Conclusão: Os direitos fundamentais e personalíssimos existem para proteção da pessoa humana das ingerências do Estado em sua vida, a dignidade é o limite último de todo o direito que é violada quando o magistrado submete o acusado ao julgamento do Júri, fundamentando a decisão de pronúncia no in dubio pro societate em oposto a presunção de inocência. Situação que não tem encontrado guarida na doutrina especializada e nem em obras científicas, tão pouco na jurisprudência do STF, que defende a valoração racional da prova como meio de cumprimento do sistema bifásico do Tribunal do Júri.

\title{
Referências
}


BARRETO, Fabiana Costa Oliveira. Flagrante e prisão provisória na criminalização de furto: da presunção de inocência à antecipação da pena. 2006. 108 f. Dissertação (Mestrado) - Curso de Direito, Universidade de Brasília, Brasília, 2006. Disponível em: http://repositorio.unb.br/bitstream/10482/5179/1/2006_FabianaCostaOliveiraBarreto.pdf. Acesso em: 02 ago. 2020.

BRASIL. Constituição (1988). Constituição da República Federativa do Brasil. Lex. Brasília: Senado Federal, 2014.

BRASIL. Decreto-lei $\mathbf{n}^{\circ}$ 3.689, de 03 de outubro de 1941. Código de Processo Penal. Brasília, DF.

BRASIL. Supremo Tribunal Federal. Recurso Extraordinário Com Agravo $n^{\circ}$ 1.067.392. Relator: Ministro Gilmar Mendes. Diário

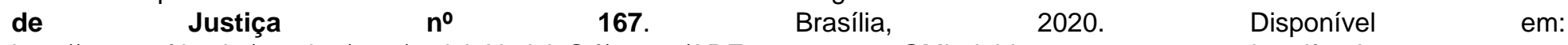
http://www.stf.jus.br/arquivo/cms/noticiaNoticiaStf/anexo/ARE1067392votoGMindubioproreopronu769ncia.pdf. Acesso em: 05 ago. 2020.

MOREIRA, Laura Carvalho. A supressão da justiça das decisões com a soberania dos veredictos e o in dubio pro societate no Tribunal do Júri. 2015. 40 f. Monografia (Especialização) - Curso de Direito, Universidade Federal de Juiz de Fora, Juiz de Fora, 2015. Disponível em: https://repositorio.ufff.br/jspui/bitstream/uff/3752/1/lauracarvalhomoreira.pdf. Acesso em: 02 ago. 2020.

SARLET, Ingo Wolfgang. As dimensões da dignidade da pessoa humana: construindo uma compreensão jurídico-constitucional necessária e possível. In: SARLET, Ingo Wolfgan (Org.) Dimensões da dignidade Ensaios de Filosofia do Direito e Direito Constitucional. Porto Alegre: Livraria do Advogado, 2005.

TAVARES, Quintino. Tribunal do Júri: manual de consulta rápida. 2. ed. Rio de Janeiro: Quentin T, 2016.

Coordenadoria de Pesquisa e Extensão - COPEX

Departamento de Editoraçāo e Divulgaçāo Científica - DEDIC 


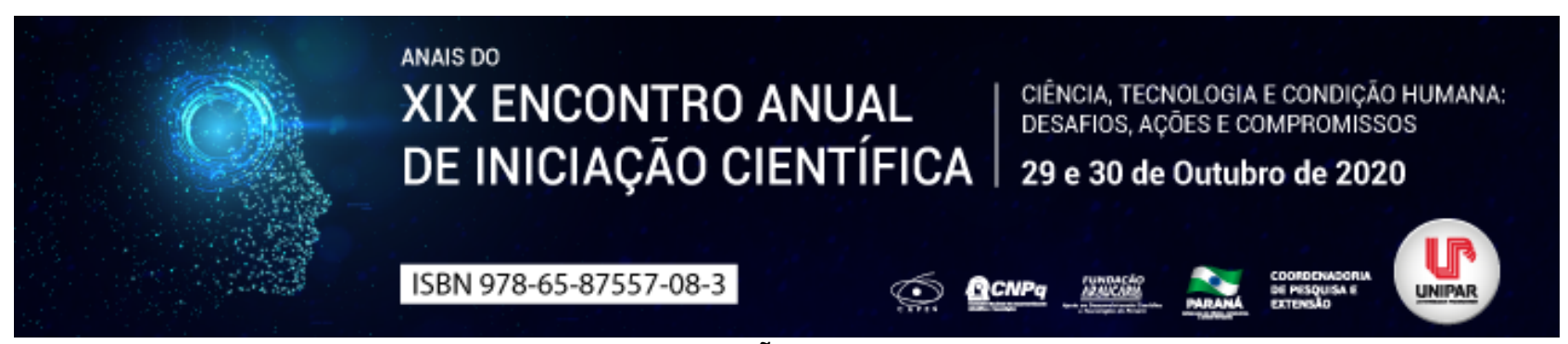

ESCOLA INOVADORAS SERÃO AS ESCOLAS DO FUTURO?

\title{
1JAINE APARECIDA CAVALHEIRO, ${ }^{2}$ ANDREIA BETIATTO, ${ }^{3}$ HENRIQUE FREZZA, ${ }^{4}$ EMERSON SOUZA DOS SANTOS
}

\author{
${ }^{1}$ ANDREIA BETIATTO, HENRIQUE FREZZA \\ ${ }^{1}$ Acadêmica do Curso de Arquitetura e Urbanismo da UNIPAR \\ ${ }^{2}$ Acadêmico do Curso de Arquitetura e Urbanismo da UNIPAR \\ ${ }^{3}$ Docente da UNIPAR
}

Introdução: As escolas inovadoras estão cada vez mais capacitadas usando a inovação e os recursos da tecnologia, o atual sistema educacional mostra distante das necessidades de jovens e adolescentes, por isso, uma escola inovadora dialoga com as novas tecnologias, sem vê-las como ameaça e, sobretudo, percebendo-as como aliadas no processo de ensino-aprendizagem. Ela também rompe barreiras, apostando na troca, nos ambientes coletivos compartilhados, nos trajetos pedagógicos que consideram o ritmo e necessidades de aprendizagem particulares de cada aluno/aprendiz. Uma escola que admite que se aprenda mais e melhor quando o conteúdo é significativo (AGUIAR, 1995), abrindo e ampliando os horizontes para a compreensão do aluno. A escola inovadora está se tornando um lugar que incentiva o trabalho em grupo, a resolução de problemas, a reflexão e a ação (MACHADO, 2006).

Objetivo: Compreender as instâncias metodológicas das escolas inovadoras partindo da comparação do método tradicionalista de ensino.

Desenvolvimento: Pundeck (2016) e Ortega (2019) evidenciam que o futuro das escolas está atrelado as mudanças sociais e tecnológicas que o mundo caminha e para tanto as escolas precisam desatrelar dos métodos tradicionalistas e garantir um processo de aprendizado firmado nas questões sócioemocionais e de um ensino significativo. Sob o olhar de Garcia (2018), a inserção do computador dentro da sala de aula não faz dela uma escola inovadora, mas sim possibilita ter contato com línguas contemporâneas com acesso à aprendizagem e o contato com diversas informações acumuladas, que poderão aprender a pensar dentro de uma lógica digital. As convencionais salas de aula já não atraem o alunado, tampouco lhe fornecem o preparo necessário para a vida e para o mercado profissional, ou seja, o mercado profissional busca por pessoas com diferentes competências, e uma escola inovadora traz em suas práticas o despertar de novas habilidades com o propósito de preparar os jovens e adolescentes para enfrentar adversidades.

No Século XVIII, surgiu o método tradicional de ensino/aprendizagem que por sinal tinha como principal objetivo expandir o acesso ao conhecimento, esse método possui um modelo firmado e resistência para aceitar as inovações que aconteceriam nas escolas que adotassem o conhecimento consolidado por eles (ALMEIDA, 2015). O método tradicional é centralizado no professor. Haddad, et al. (1993) circunscreve este cenário tendo o aluno como sujeito limitado a guardar e arquivar, preocupando-se apenas com a retransmissão sem criticidade sobre os conhecimentos que foram passados pelo professor, porém, pesquisas da ciência cognitiva sugerem que os alunos devem fazer algo mais do que simplesmente ouvir, para ter uma aprendizagem efetiva, uma aprendizagem significativa em outras palavras ativa. Conforme Bastos (2006), as metodologias ativas, método que abraça as escolas inovadoras, representam processos interativos de conhecimento, análise, estudos, pesquisas e decisões individuais ou coletivas, com a finalidade de encontrar soluções para um problema. Coloca-se assim uma ênfase nas relações interpessoais e no crescimento pessoal que delas resultam (STACCIARINI; ESPERDIÃO, 1999). Portanto, as metodologias de ensino estão sendo revistas, especialmente porque a escola do futuro apresenta novas possibilidades metodológicas (NOEMI, 2018). Berbel (2011) acredita no potencial de metodologias inovadoras, como a metodologia da problematização, e no papel efetivo da ação docente comprometida com o desenvolvimento e o crescimento do aluno.

Conclusão: $O$ estudo levantado elucida a comparação entre o método tradicionalista com relação aos métodos ativos que as escolas inovadoras estão implementando em seus currículos. Vale observar que independentemente do método de ensino o papel do professor é preponderante na relação do processo de ensino e aprendizagem, cabe a ele facilitar a percepção do aluno sobre a escola, problematizar situações com o foco de instigar a curiosidade aos fenômenos da realidade, cabe ainda ao professor, provocar, desafiar, estimular, relacionar, criar, selecionar, organizar.

\section{Referências}

AGUIAR, J. O. G. Mudança conceitual em sala de aula: o ensino de ciências numa perspectivaconstrutivista. 1995. Dissertação (Mestrado em Educação Tecnológica) Cefet-MG, Belo Horizonte, 1995.

ALMEIDA, Hélio Mangueira. A Didática no Ensino superior: Práticas e desafios, 2015.

BASTOS, C. C. Metodologias ativas. 2006. Disponível em: Acessado em: 30 junho 2020. 
BERBEL, Neusi Aparecida Navas. As metodologias ativas e a promoção da autonomia de estudantes. Semina: Ciências Sociais e Humanas, Londrina, v. 32, n. 1, p. 25-40, jan./jun. 2011

GARCIA, Debora. Como reconhecer uma escola inovadora?, 2018.

MACHADO, Regina. Educação - Escolas Inovadoras: O Futuro No Presente. Mineira de Juiz de Fora. Mãe de dois adolescentes. Arquiteta e Urbanista. Trabalhou com movimentos sociais de urbanização de favelas no Rio e em São Paulo. Trabalha com comunidades na organização de seus espaços físicos, sociais e políticos.

NOENI, Debora [Infográfico] Escola do século XXI: Quais os desafios da educação. Escolas Disruptivas, 2018.

ORTEGA, Graziele. Descubra como tornar sua escola inovadora e quais os benefícios: Descubra os benefícios da inovação nas escolas. Coordenadora de tecnologia educacional na Happy Code, 2019.

PUNDEK, Regina. O papel da escola para o futuro, 2016.

STACCIARINI, Jeanne Marie R.; ESPERIDIÃO, Elizabeth. Repensando Estratégias de ensino no processo de aprendizagem. Rev.latinoam.enfermagem, Ribeirão Preto, v. 7, n. 5, p. 59-66, dezembro 1999.

Coordenadoria de Pesquisa e Extensão - COPEX

Departamento de Editoraçāo e Divulgaçāo Científica - DEDIC 


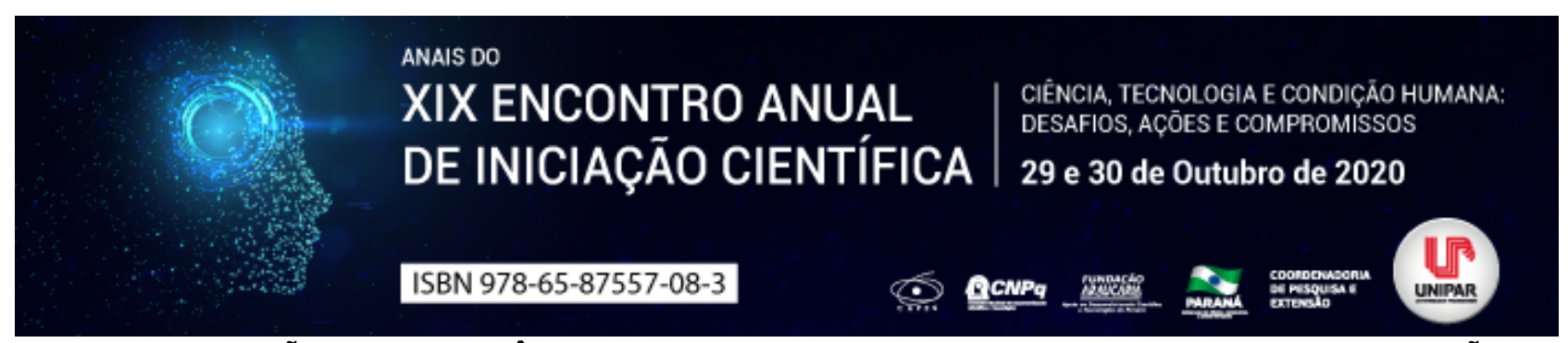

Hacksaw ridge: OBJEÇÃO DE CONSCIÊNCIA, LIBERDADE RELIGIOSA, PRECONCEITO, DISCRIMINAÇÃO E MAUS TRATOS

${ }^{1}$ LUIS IRAJA NOGUEIRA DE SA JUNIOR

${ }^{1}$ Professor do Curso de Direito da UNIPAR

Introdução: A objeção de consciência é tema complexo, pois há colisão entre a subjetividade do indivíduo (liberdade religiosa) com seus próprios limites éticos (conflito íntimo pela rejeição social à partir de suas escolhas) e a aceitação social (exclusão). A legislação constitucional protege a liberdade religiosa, incluindo-se a convicção do adventista do sétimo dia. Todavia, a intolerância e a falta de respeito a estes cristãos, que partem de diversos setores da sociedade organizada, provocam discussões e julgamentos morais e jurídicos intermináveis.

Objetivo: Provocar reflexões bioéticas e jurídicas a partir do filme Hacksaw Ridge (Até o Último Homem), com foco na objeção de consciência. Analisar o preconceito e a discriminação sofrida pelos adventistas na defesa do princípio da liberdade religiosa.

Desenvolvimento: O filme retrata a manipulação dos superiores hierárquicos de Doss que conspiraram de má fé, para expulsálo do Exercito, apesar de ser extremamente competente no que faz (Doss se recusava a impunhar armas e treinar aos sábados). Todos os dias, Doss sofreu calado os maus tratos dos colegas de pelotão. Foi excluído do grupo; foi espancado; foi submetido a trabalho humilhante; foi preso injustamente e tachado de doente mental, tudo planejado ardilosamente para que ele pedisse dispensa do Exército por conta própria. O autor aguça o debate religioso e bioético, bem como reforça o valor da dignidade humana. O debate religioso se integra aos estudos da bioética. Primeiro, porque as religiões influenciam diretamente nos parâmetros da sociedade; segundo, porque essa temática ajuda na permanência de determinados valores intrínsecos ao ser humano (dignidade). Léo Pessini (2015, p. 111) leciona que não há como separar os conceitos que regem a bioética das crenças e religiões predominantes na sociedade. Mudar essa posição é quase impossível e, certamente, desnecessário. Antes de refletir sobre a dignidade humana, convém vincar que a liberdade religiosa é garantida pela Constituição Federal como direito fundamental (art. 50, VI). Afonso da Silva (2017, p. 105) afirma que dignidade da pessoa humana é um valor supremo que atrai o conteúdo de todos os direitos fundamentais do homem, desde o direito à vida. É um princípio de tamanha importância e alcance, que recebe da doutrina o reconhecimento de produzir efeitos irradiantes multidirecionais. Sendo assim, só há dignidade quando a própria condição humana é entendida, compreendida e respeitada, em suas diversas dimensões, o que impõe, necessariamente, a expansão da consciência ética como prática diuturna de respeito à pessoa humana. Tal preceito, também é intrínseco aos princípios bioéticos. Todavia, para compreender o significado de liberdade religiosa, ponto alto da discussão no filme, antes é preciso esclarecer o que se entende por religião. Em sentido jurídico, a religião liga-se à pré-compreensão que o termo propicia. Será inequivocamente religião o sistema de crenças que se vincula a uma divindade, que professa uma vida além da morte, que possui um texto sagrado, que envolve uma organização e que apresenta rituais de oração e de adoração. Não será um culto religioso uma atividade comercial ou de ensino qualquer, apenas porque se inicia com uma oração. (MENDES, 2016, p. 417). Compreendido o significado do termo religião, vamos à compreensão da expressão liberdade religiosa. Na prática, é a liberdade que garante a autodeterminação de cada um em professar, exprimir, praticar ou alterar as suas convicções religiosas, individualmente ou com outras pessoas; liberdade à intimidade dessas convicções; proibição de discriminação por causa das mesmas convicções. (DINIZ, 2015, p.147-148). Assim, é possível definir a liberdade religiosa como o direito constitucionalmente positivado, espécie de liberdade gênero, que cuida de assegurar ao ser humano a prática ou não-prática subjetiva e objetiva da religião e os temas a ela conexos. Logo, no Brasil, assim como nos EUA, possuir convicção religiosa, ao ponto de não aceitar pegar em arma de fogo, treinar aos sábados e, matar alguém, não constitui insubordinação hierárquica e muito menos doença mental. Antes de tudo é direito personalíssimo, derivado da dignidade humana e, portanto, alma secreta da bioética.

Conclusão: A objeção de consciência é aplicável a quaisquer episódios coletivos que colidem com as crenças e convicções do cristão adventista. A aplicabilidade ampla de tal direito, encontra respaldo no fato de ser a escusa de consciência mais um direito fundamental decorrente do direito constitucional à liberdade religiosa, e, sendo um direito instrumental, por sua vez, se presta à efetividade das vertentes da liberdade de consciência e liberdade de crença. Entre o grave tormento moral e a insubmissão, o adventista escolhe esta, pois sua escolha não decorre de um capricho, nem de um interesse de pouca monta. Ao contrário, é invocável quando a submissão à norma é apta para gerar insuportável violência psicológica.

\section{Referências}

BRASIL. Constituição da República Federativa do Brasil. Saraiva: São Paulo, 2020.

DINIZ, Maria Helena. Dicionário Jurídico. Volumes I a IV. 2a Edição rev., atual. e aum. - São Paulo: Saraiva, 2015.

MENDES, Gilmar Ferreira. Curso de Direito Constitucional / Gilmar Ferreira Mendes...[et. al.]. $2^{\mathrm{a}}$ Edição rev. e atual., São 
Paulo: Saraiva, 2016.

PESSINI Léo. Bioética em tempos de globalização. São Paulo: Loyola, 2015.

SILVA, José Afonso. Curso de Direito Constitucional Positivo, 30ª Edição, São Paulo: Editora Malheiros, 2017.

Coordenadoria de Pesquisa e Extensão - COPEX

Departamento de Editoraçāo e Divulgaçāo Científica - DEDIC 


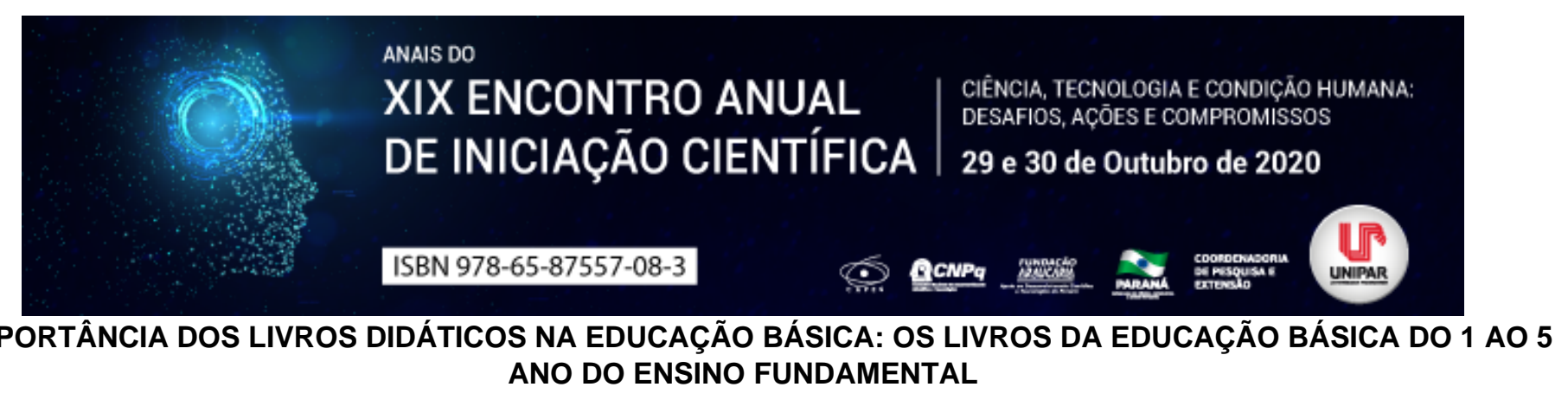

${ }^{1}$ ANDRESSA CAROLINE SANTOS DE SOUZA, ${ }^{2}$ VIVIANNE AUGUSTA PIRES

${ }^{1}$ Acadêmica do Curso de Pedagogia da UNIPAR- PIC
${ }^{1}$ Docente da UNIPAR

Introdução: O surgimentos dos livros didáticos no Brasil se deu no ano de 1808, com a chegada da família portuguesa e com a fundação da imprensa régia, as primeiras obras didáticas publicadas foram as traduções para a Escola Militar, já a dos livros didáticos foi impulsionada a partir de 1822, com a Independência do Brasil. Em 1930, durante o governo do Getúlio Vargas, foi criado o Ministério da Educação e, em 1938, a Comissão Nacional do Livro Didático. Com isso, tanto o número de estudantes quanto a circulação de livros aumentaram. Em 1985 o Programa Nacional do Livro Didático (PNLD) foi criado. Com ele, o governo assumiu a responsabilidade pela compra e pela distribuição das obras didáticas para os alunos da rede pública de ensino. Visto isso qual seria a importância deste na educação?

Objetivo: Verificar se o uso do livro didático realmente é o melhor meio de ensino hoje no brasil dentro da educação básica do ensino fundamental.

Desenvolvimento: A importância do livro didático como instrumento de ensino se deve ao fato de ele ser um facilitador no processo de aprendizagem e no desenvolvimento do aluno. Ele representa uma ferramenta essencial para o professor, contribuindo para a formação das estratégias de ensino. Considerando-se o baixo poder aquisitivo da população e a elevada taxa de evasão e repetência nas escolas, é possível dizer que o livro didático talvez, represente o único texto com que muitos brasileiros interagem durante suas vidas. (BANDEIRA, STANGE, SANTOS, 2012, p. 2). O livro didático é um ponto de apoio para auxiliar o educador, evitando que ocorram lacunas que prejudiquem o entendimento dos conteúdos, mesmo alguns livros sendo atrasados por conta da nossa tecnologia que hoje em dia evoluiu demais. Além disso, esse material representa uma fonte confiável de consulta, tanto para os docentes quanto para os alunos e as suas famílias. O professor precisa analisar os textos que encontra a seu dispor, antes de decidir sobre aquele a ser adotado. Não só para detectar erros de conteúdos ou distorções pedagógicas, mas principalmente para verificar se os objetivos e pressupostos do autor são adequados ao curso que planejou (ALVAREZ, 1991 apud BANDEIRA, STANGE, SANTOS, 2012, p. 3). Embora não seja o único meio, o livro didático ainda é o recurso mais utilizado na educação básica de ensino. Visto que o mesmo tem grande importância no desenvolvimento do estudante, afinal é por meio desses que lhe é ensinado as informações. Visamos explorar porque esse recurso é tão valioso, se este realmente é o melhor método para ser utilizado e também se realmente funciona nos dias atuais da educação básica do $1^{\circ}$ ao $5^{\circ}$ ano. Com o passar dos anos nos deparamos com mudanças, se torna impossível falar em evolução sem citar tecnologia. Graças à internet, o fluxo de informações e a facilidade que chegam até nós, dando um salto gigantesco nos últimos anos. Diante desses fatos, percebe-se que há um atraso dos livros didáticos em atualizar as informações, assim, ensinar com material sem informações corretas delonga desenvolvimento. Os professores acabam gastando boa parte de seu tempo extraclasse em planejamentos e preparações de aula, muitas vezes necessitando pesquisar e desenvolver materiais para suprir os atrasos dos livros didáticos utilizados. O acesso ao livro didático é um direito do aluno da educação básica no Brasil, garantido por diversos dispositivos legais, como a Lei de Diretrizes e Bases da Educação Nacional (LDB) e vários outros decretos, portarias e resoluções do Ministério da Educação (MEC). A tecnologia está muito presente nos dias atuais, além de ser super valiosa e facilitadora, é rápida. Mas infelizmente não são todos quem tem acesso a esse recurso. Que duelo não? Em um, todos têm direito ao acesso, mas a um retardo nas informações, o outro é um excelente meio de informações, se souber usar, mas nem todos tem acesso. O livro didático pode ter erros conceituais, pode ter abordagens metodológicas não muito boas para trabalhar alguns assuntos, mas tem que se pensar na realidade brasileira de diferenças e pouco acesso a outros recursos[...] (E-DOCENTE, 2019). Apesar de o livro didático oferecer um suporte para o professor, o educador continua tendo a autonomia para construir a sua aula e toda a sua dinâmica. A utilização do material ajuda na otimização do tempo, uma vez que fornece ao docente fontes de pesquisa e exercícios na própria obra. Dessa forma, o educador não precisa focar no o que ensinar , mas sim no como ensinar , descobrindo novas metodologias para tornar a aula mais atrativa e os alunos mais engajados.

Conclusão: Podemos perceber que mesmo com todas essas qualidades ditas sobre os livros didáticos, um dos grandes desafios das escolas, atualmente, consiste em manter a atenção e o interesse dos alunos e também percebe-se que há um atraso dos livros didáticos em atualizar as informações, assim, ensinar com material sem informações corretas delonga desenvolvimento. Entretanto, ele também tem suas vantagens pois ele dá suporte ao professor, e o mesmo deverá analisar o conteúdo para que tenha conhecimento dos textos, filtrando o que é mais relevante para a aula, sendo uma ferramenta de grande importância para o ensino. 


\section{Referências}

BANDEIRA, Andreia; STANGE, Carlos Eduardo Bittencourt; SANTOS, Julio Murilo Trevas dos; UMA PROPOSTA DE CRITÉRIOS PARA ANÁLISE DE LIVROS DIDÁTICOS DE CIÊNCIAS NATURAIS NA EDUCAÇÃO BÁSICA. III Simpósio Nacional de Ensino de Ciência e tecnologia. Ponta Grossa - P. Sinect. 2012. Disponível em: Acesso em 30 set. 2020.

E-Docente. A IMPORTÂNCIA DO LIVRO DIDÁTICO NA PRÁTICA PEDAGÓGICA. 2019. Disponível em: > Acesso em: 22 de jul. 2020

Portal Correio. MINISTÉRIO DA EDUCAÇÃO DESTINARÁ LIVROS DIDÁTICOS À EDUCAÇÃO INFANTIL. 2020. Disponível em: > Acesso 2 de jul. 2020

SAE, Digital. LIVROS DIDÁTICOS NA ERA DA INFORMAÇÃO: POR QUE A ATUALIZAÇÃO É IMPRESCINDÍVEL PARA A ESCOLA DO SÉCULO XXI? Disponível em: Acesso em: 16 ago.2020

THADEU, Victor. LIVRO DIDÁTICO: TUDO SOBRE ESTE RECURSO DIDÁTICO. 2019. Disponível em: . Acesso em: 15 ago. 2020.

VIEGAS, Amanda. DIA NACIONAL DO LIVRO DIDÁTICO: QUAL A IMPORTÂNCIA DESSE MATERIAL? 2020. Disponível em: Acesso em: 15 ago. 2020

Coordenadoria de Pesquisa e Extensão - COPEX

Departamento de Editoraçāo e Divulgaçāo Científica - DEDIC 


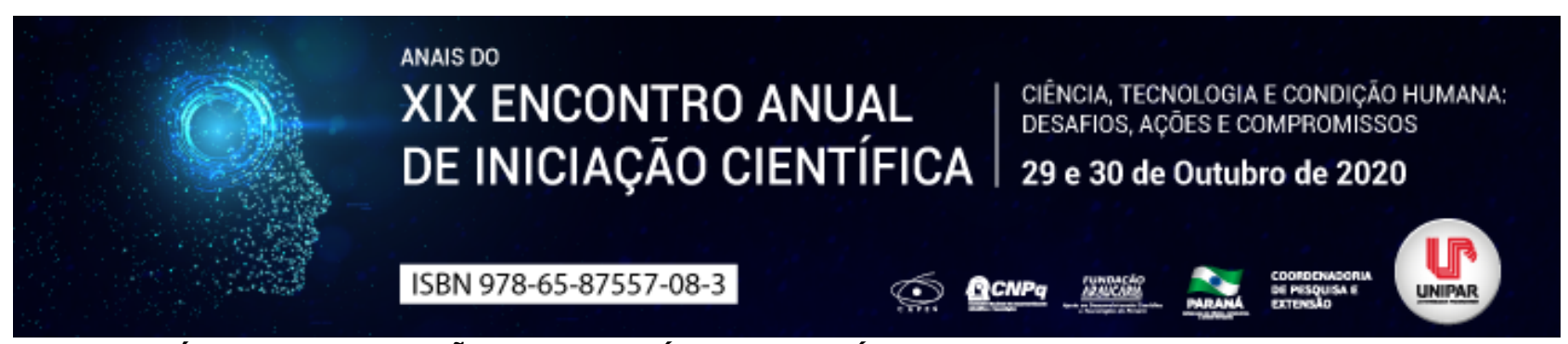

FONTES DA HISTÓRIA DA EDUCAÇÃO DO MUNICÍPIO DE GUAÍRA-PR (1953 a 1962): UM LEVANTAMENTO A PARTIR DAS LEIS

\footnotetext{
${ }^{1}$ GISELE HERNANDES DE MENDONCA, ${ }^{2}$ ESTELLE JULI SANFELICE, ${ }^{3}$ LUCAS HENRIQUE DE FARIAS DA SILVA, ${ }^{4}$ WELLINGTON RAMOS DE CARVALHO, ${ }^{5}$ ROSILEY BERTON PACHECO, ${ }^{6}$ JOSE RICARDO SKOLMOVSKI DA SILVA
}

\author{
${ }^{1}$ Academico do PIC/Unipar \\ ${ }^{1}$ Acadêmica do Curso de Pedagogia da UNIPAR \\ ${ }^{2}$ Acadêmico do Curso de Pedagogia da UNIPAR \\ ${ }^{3}$ Acadêmico do Curso de Pedagogia da UNIPAR \\ ${ }^{4}$ Docente da UNIPAR \\ ${ }^{5}$ Docente da UNIPAR
}

Introdução: O presente trabalho é fruto de um esforço coletivo de integrantes do Programa de Iniciação Científica (PIC) da UNIPAR, unidade de Guaíra. Trata-se de um desdobramento do projeto de pesquisa organizado em 2019 intitulado LEVANTAMENTO E CATALOGAÇÃO DE FONTES PRIMÁRIAS E SECUNDÁRIAS DA HISTÓRIA DA EDUCAÇÃO DO MUNICÍPIO DE GUAÍRA-PR que tinha por objetivo, a partir da compreensão da importância da História da Educação, realizar um levantamento de fontes Primárias e Secundárias da História da Educação do município de Guaíra, do ano de sua criação enquanto município (1953). Em 2019 o projeto se debruçou em estudar as fontes secundárias, com o foco de realizar uma revisão bibliográfica para perceber as pesquisas que já haviam avançado nessa temática. Percebeu-se uma carência de produções que evidenciam esta História e que constituiu-se como uma lacuna da qual pode-se contribuir. Em 2020 o projeto continuou, nesta oportunidade com o intuito de investigar as fontes primárias. O trabalho que se apresenta aqui é resultado preliminar dos estudos empreendidos pelo grupo em um esforço no árduo trabalho com as fontes historiográficas.

Objetivo: Apresentar as leis relacionadas à Educação, levantadas no Diário Oficial Eletrônico do município de Guaíra-Pr, dos anos de 1953 a 1962.

Desenvolvimento: Analisando o Diário Oficial Eletrônico de Guaíra-Pr, foi observado que durante o período de 1953 a 1962 , foram instituídas 232 leis, das quais 72 se relacionam com a área de educação. Apenas 27 se encaixam no recorte temporal estabelecido, entretanto, irei apresentar as 4 leis que marcaram a educação no município de Guaíra . No ano de 1955 foram criadas duas leis, sendo a primeira uma disposição sobre a transferência de endereço da escola rural, antes localizada no Passo Itá, remanejada a Carumbeý, e recebe o nome Escola Rural Monteiro Lobato. A segunda dispõe sobre a criação de uma Escola Rural localizada no Piquiri nomeada Escola Rural Capitão Heitor Mendes Gonçalves, e delineia uma vaga para professor padrão. Em 1961 foi autorizado pelo poder o executivo Municipal a construir uma Escola na Vila denominada Maracaju dos Gaúchos. Em 1962 fica estabelecida uma taxa de 10\% sobre os impostos do município para suprir os gastos da educação, prioritariamente para materiais escolares, pagamentos de professores municipais e construção de escolas. (GUAíRA, 1955, 1961,1962).

Conclusão: A partir dos dados encontrados nas leis levantadas é possível concluir que o período citado evidencia várias possibilidades de pesquisa, a elaboração de leis para investir na criação de escolas isoladas apontadas, destacam a movimentação da expansão da educação pública no oeste do Paraná. Ademais, realizar o levantamento e a catalogação de fontes primárias no Diário Oficial Eletrônico do Município pôde contribuir no sentido de trazer elementos para pensar a micro história da educação, tanto na perspectiva da Nova História Cultural, quanto na perspectiva do materialismo histórico dialético

\title{
Referências
}

GUAÍRA. Lei $n^{\circ}$ 26, de 28 de dezembro de 1955. Dispõe sobre a transferência da escola rural de Passo Itá, e lhe dá nova

http://dioe.guaira.pr.gov.br/images/legislacao/Lei_026_1955\%20001.jpg. Acesso em: 31 de agosto de 2020.

GUAíRA. Lei $\mathrm{n}^{\circ}$ 25, de 28 de dezembro de 1955. Cria escola rural e lhe dá denominação. Guaíra: Diário Oficial, [1955]. Disponível em: http://dioe.guaira.pr.gov.br/images/legislacao/Lei_025_1955\%20001.jpg. Acesso em: 31 de agosto de 2020.

GUAíRA. Lei $n^{\circ}$ 108/61, de 25 de janeiro de 1961. Cria e autoriza o executivo Municipal a construir uma Escola na Vila denominada Maracaju dos Gaúchos neste município e dá outras providências. Guaíra: Diário Oficial, [1961]. Disponível em: http://dioe.guaira.pr.gov.br/images/legislacao/Lei_108_1961\%20001.jpg. Acesso em: 31 de agosto de 2020.

GUAÍRA. Lei n 152/62, de março de 1962. Cria a Taxa Escolar e dá outras providências. Guaíra: Diário Oficial, [1962]. Disponível em: http://dioe.guaira.pr.gov.br/images/legislacao/Lei_152_1962\%20001.jpg. Acesso em: 31 de agosto de 2020. 
Coordenadoria de Pesquisa e Extensão - COPEX

Departamento de Editoraçāo e Divulgaçāo Científica - DEDIC 


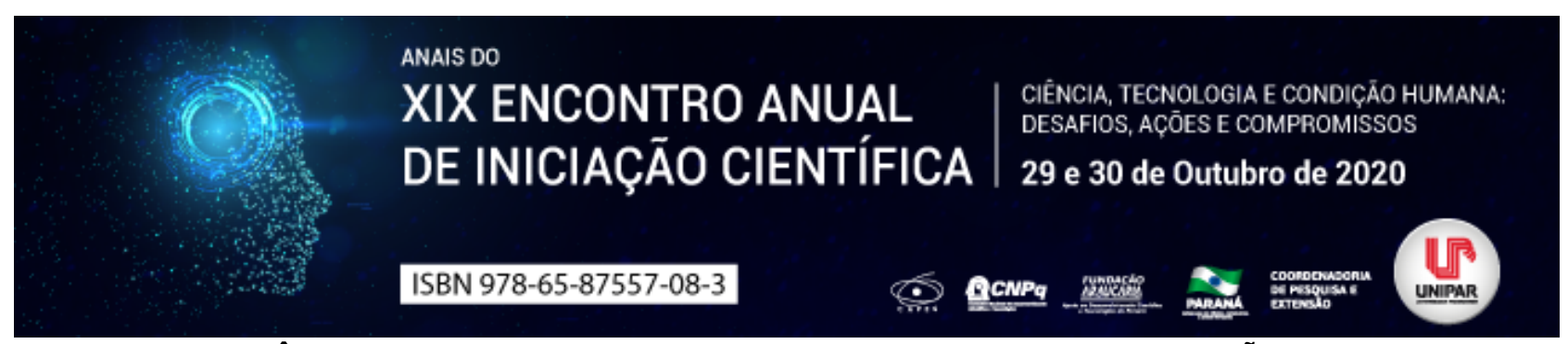

A IMPORTÂNCIA DO BRINCAR E O SEU DESENVOLVIMENTO NA EDUCAÇÃO INFANTIL

\author{
${ }^{1}$ PAULA REGINA DA SILVA SOUZA , ${ }^{2}$ ANY CAROLYNY KNUPP, ${ }^{3}$ DEBORA MARIA LIMA, ${ }^{4}$ ANA CAROLINA MOLINA \\ PETINATI, ${ }^{5}$ VIVIANNE AUGUSTA PIRES
}

\footnotetext{
${ }^{1}$ Acadêmica do curso de Pedagogia UNIPAR

${ }^{1}$ Acadêmica do Curso de Pedagogia da UNIPAR

${ }^{2}$ Acadêmica do Curso de Pedagogia da UNIPAR

${ }^{3}$ Acadêmica do Curso de Pedagogia da UNIPAR

${ }^{4}$ Docente da UNIPAR
}

Introdução: O brincar é importante para o desenvolvimento e aprendizagem da criança, pois é brincando que ela se expressa, interage e aprende a lidar com o mundo ao seu redor, formando sua personalidade. Na educação infantil observamos, frequentemente o brincar na vida da criança, pois é estimulado. Kishimoto (2000) defende que a brincadeira e o jogo interferem diretamente no desenvolvimento da imaginação, da representação simbólica, da cognição, dos sentimentos, do prazer, das relações, da convivência, da criatividade, do movimento e da autoimagem dos indivíduos.

Objetivo: Abordar sobre o brincar na educação infantil, e quais os benefícios para a vida da criança, trazendo algumas considerações sobre os jogos, brincadeiras e brinquedos.

Desenvolvimento: A importância do brincar é uma maneira da criança se comunicar e socializar, e por meio deste ato que a criança reproduz o seu cotidiano. Brincar é importante para o desenvolvimento humano, nos aspectos sociais, culturais, afetivo, cognitivo e emocional. Também auxilia no aprendizado, na criatividade, na autonomia e na construção da reflexão. Por tanto, os pais, educadores e a sociedade em geral, precisam estar conscientizados sobre a ludicidade que deve ser vivenciada na infância, sabendo que o brincar além de ser prazeroso e para o lazer, é também um ato de aprendizagem. Com base nisso, o brincar na educação infantil estabelece regras para a criança, o que contribui para a integração do indivíduo na sociedade. ( FANTACHOLI, 2009).

A atividade de brincar torna a aprendizagem mais enriquecedora, vai muito além da transmissão de conhecimento. A criança que brinca estimula sua coordenação motora, a atenção e a sociabilidade, pois sente a importância de vivenciar a partilha das brincadeiras bem como dos brinquedos com seus colegas. Essas crianças desenvolvem sua criatividade, favorecendo em princípios como de liderança, cooperação e competição. De forma que futuramente terão mais autonomia em expressar seus sentimentos, seu ponto de vista. A prática do brincar dentro da escola é possível, no CMEl (Centro Municipal de Educação Infantil) para a idade de 0 a 5 anos, é um exemplo desta prática, a criança tem o seu momento de brincar livremente, com os cantos que são estipulado pelo docente, onde os brinquedos são distribuidos de acordo com a sua categoria e as crianças brincam sentadas, o momento de brincar com macinha que estimula a coordenação motora e fina, além de proporcionar outras aprendizagens para as crianças, o brincar dentro do pedagógico possibilita o ensino-aprendizagem. Portanto, deve estipular um tempo para a brincadeira, e a possibilidade de experimentação para que possa crescer e se desenvolver. A mediação do docente não deixa de ser importante, Navarro e Prodócimo (2012) apontam que a mediação do professor na brincadeira passa por diferentes âmbitos. Ao brincar junto, intencionalmente e criativamente, o educador produz tal mediação. Mas essa mediação ocorre ainda a priori, desde a organização da sala de aula, oferecendo espaço com cadeiras e mesas afastadas e brinquedos dispostos intencionalmente para o brincar livre, ou ainda, preparando uma atividade a partir de uma brincadeira, baseando nela mesma para o desenvolvimento de capacidades ou aspectos cognitivos. Neste sentido, a observação participante e intencional é mediação decisiva, e o planejamento se torna elemento fundante para sustentação e preparo da atividade, que se constitui também em espontaneidade e liberdade. Não que seja possível planejar o espontâneo, mas é possível planejar para que momentos de espontaneidade emerjam e se tornem realidade nos cotidianos escolares.

Quando falamos em jogo, brinquedo e a brincadeira podemos dizer que eles possuem um determinado sentido, sabendo também que eles são elementos que desenvolvem na coordenação motora, ajudam no raciocínio, nas relações sociais, no envolvimento, bem como fortalecem os laços coletivos. (QUEIROZ e MARTINS, 2002, p.07). As crianças ao jogar ou brincar, atribuem as suas brincadeiras, sentimentos e ações relacionadas à sua realidade. Sendo assim, o jogo representa um fator relevante no desenvolvimento do ser humano, estimulando a criança a ter uma vida normal e saudável. Eles são muito diferente cada um tem seu objetivo, o jogo é uma ação de jogar, o brinquedo é um objeto que com ele a criança pode criar varias coisas, e a brincadeira é um conjunto de crianças em uma festinha, na rua, em casa. Eles podem ser considerados como ferramentas para o mundo infantil, pois é através deles que a criança constrói seu mundo imaginário e, muitas vezes a criança pode recorrer a um refúgio para um conflito famíliar criando um mundo aonde tudo é bom (BERTOLDO, 2000, p.10). 
Conclusão: Concluímos assim, que a criança aprende e se desenvolve enquanto brinca. Os benefícios do brincar são inesgotáveis, a brincadeira para a criança é uma preparação para a vida adulta, desenvolvendo assim suas potencialidades, portanto, deve-se sempre considerar o lúdico nas atividades das crianças, utilizando-o para a aprendizagem da criança, seja como educação formal ou informal. Para a criança brincar é preciso apenas usar a criatividade, não sendo necessário brinquedos caros ou de marca, o que enriquece sua imaginação é qualquer meio que permita a ela explorar suas capacidades em seus aspectos motor, afetivo, social e moral, bem como a linguagem. Contudo, o educador e os pais, são papéis essenciais nesse processo, conduzindo a criança a se conhecer e conhecer o meio em que vive, cabendo a eles criar um ambiente, atividades que reúna os elementos de motivação para as crianças.

\section{Referências}

FANTACHOLI, Fabiane das Neves. A importância do brincar na educação infantil. Disponível em:. Acesso em: 25 de MAR de 2020.

NAVARRO, Mariana Stoeterau; PRODÓCIMO, Elaine. Brincar e mediação na escola. Rev. Bras. Ciênc. Esporte, Porto Alegre, v. 34, n. 3, p. 633-648, 2012.

PERANZONI, Vaneza Cauduro. Os jogos, os brinquedos e as brincadeiras: recursos necessários na prática educacional cotidiana. Disponível em: Acesso em: 25 março 2020.

SILVA, Mário Augusto. A importância das brincadeiras no processo de ensino e aprendizagem na educação infantil. Disponível em: no-processo-ensino-aprendizagem-educacao-infantil.htm. Acesso em: 25 março 2020.

Coordenadoria de Pesquisa e Extensão - COPEX

Departamento de Editoraçāo e Divulgaçāo Científica - DEDIC 


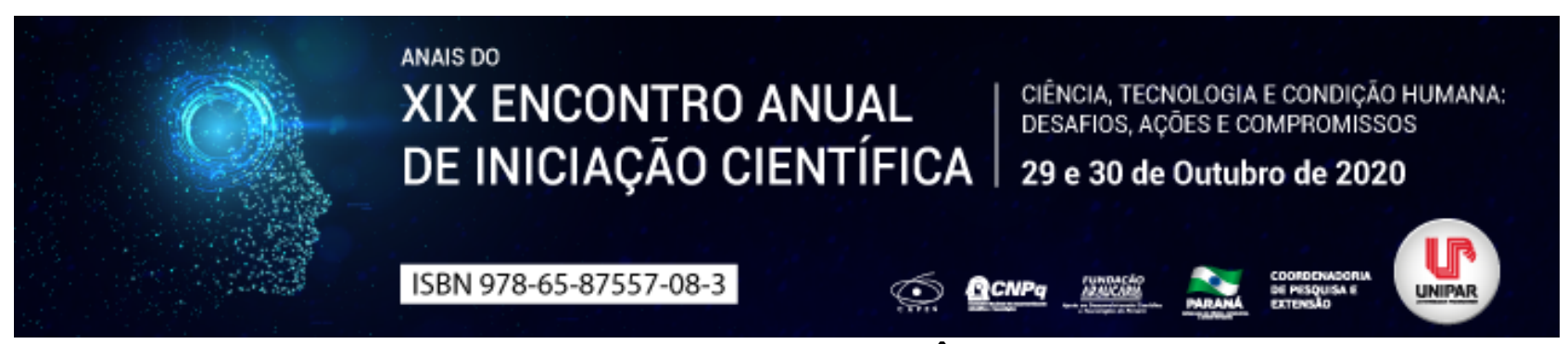

ARQUITETURA ENQUANTO PATRIMÔNIO CULTURAL

\begin{abstract}
${ }^{1}$ ANA CAROLINA FAGUNDES FERREIRA, ${ }^{2}$ JULIANA ESCARAMUCA SANTOS, ${ }^{3}$ MILLENA CARREIRO GRECO DE ALMEIDA, ${ }^{4}$ TAYS GOMES DA SILVA, ${ }^{5}$ WANDA TEREZINHA BONONI, ${ }^{6}$ PAULA ANDREIA GOMES DA CRUZ
\end{abstract}

\author{
${ }^{1}$ Acadêmica do Curso de Arquitetura e Urbanismo da UNIPAR \\ ${ }^{1}$ Acadêmica do Curso de Arquitetura e Urbanismo da UNIPAR \\ ${ }^{2}$ Acadêmica do Curso de Arquitetura e Urbanismo da UNIPAR \\ ${ }^{3}$ Acadêmica do Curso de Arquitetura e Urbanismo da UNIPAR \\ ${ }^{4}$ Docente da UNIPAR \\ ${ }^{5}$ Docente da UNIPAR
}

Introdução: Os aspectos associados à identidade e concepções culturais de determinada sociedade se relacionam a memória coletiva, conotações temporais, preservação e restauro, onde o patrimônio cultural tem a importância de moldar o pensamento preservacionista da sociedade e até mesmo contar a história de um povo por meio da arquitetura (LEMOS, 2006). Patrimônio cultural define-se como uma concepção do patrimônio entendido como o conjunto dos bens culturais, referente às identidades coletivas. Desta maneira, múltiplas paisagens, arquiteturas, tradições, gastronómicas, expressões de arte, documentos e sítios arqueológicos passaram a ser reconhecidos e valorizados pelas comunidades e organismos governamentais na esfera local, estadual, nacional ou internacional (ZANIRATO e RIBEIRO, 2006, p1). A cidade é formada por espaços e memórias, no qual o conjunto de bens culturais formado pela arquitetura, tem um papel importantíssimo na formação da memória histórica, cultural e afetiva da sociedade, pois passa a ser um testemunho vivo dessa trajetória pela qual passou, desde sua origem até o seu presente. A arquitetura está ligada a processos culturais, com a preservação de traços, marcas e identidades de grupos sociais, pois resguardar o patrimônio não está ligado somente em guardar um objeto de uma construção ou um pequeno centro de cidade velha, preservar é guardar depoimentos e fotos para recordar, ou seja, a preservação não se dá apenas em reformas de edifícios passados, mas sim pela linguagem da arquitetura ao longo do tempo. Sendo assim, este resumo visa tratar da arquitetura enquanto patrimônio cultural.

Objetivo: O presente resumo tem por finalidade agregar conhecimentos relacionados à edificações com foco na preservação de patrimônio cultural e identidade coletiva de várias épocas no qual todos devem ter o dever de preservar o mesmo.

Desenvolvimento: $O$ patrimônio cultural é um elo entre, presente, passado e futuro. Em contrapartida, um dos descasos encontrados nas metrópoles brasileiras na parte arquitetônica é valorizar o novo em primeiro lugar e desvalorizar a bagagem adquiridas por anos de técnicas, materialidade e conceito de edificações no entorno (FONSECA,2000, p.50). Nesse viés, existe certo desinteresse quanto ao patrimônio cultural tendo em vista a falta de uma política de educação centrada na preservação. Além disso a mão-de-obra e conhecimento das técnicas se tornaram escassos. A educação patrimonial é um instrumento de alfabetização cultural que possibilita ao indivíduo fazer a leitura do mundo que o rodeia, levando-o à compreensão do universo sócio-cultural e da trajetória histórico temporal em que está inserido (HORTA, 1999, p.6). Em virtude de tudo que foi dito, preservar o patrimônio não é somente guardar uma coisa, objeto de uma construção ou até mesmo o centro de cidade antiga, preservar é guardar depoimentos, fotos para recordar memórias passadas, sendo assim a experiência de cada pessoa com a arquitetura é única (BONONI, 2018, p.40).

Conclusão: Portanto, é evidente a existência de impasses na valorização do patrimônio cultural e, consequentemente, a preservação desse, existindo diversas razões para tal feito. No entretanto, preservar uma arquitetura significa classificá-la como parte viva da história e da memória de uma sociedade, dando a ela devido valor histórico cultural, compreendendo seus conceitos originais e signos adquiridos ao longo do tempo. Logo, preservar uma edificação significa deixar presente uma marca de uma determinada época em uma determinada sociedade, como testemunho vivo de sua história e objetos norteadores de novas criações contemporâneas.

\title{
Referências
}

7 LEMOS, Carlos A. C., O que é patrimônio histórico. São Paulo: Brasiliense, 2006. p.50-62.

FONSECA, Maria Cecília Londres. O patrimônio em processo: trajetória da política federal de preservação no Brasil. Rio de Janeiro:Ed. da UFRJ, 2005.

ZANIRATO, Silvia Helena e Ribeiro, Wagner Costa. Patrimônio cultural: a percepção da natureza com um bem não renovável. BONONI, Wanda Terezinha Bononi. Memória e preservação: Capela Imaculada Conceição em Cruzeiro do Oeste/PR. 
Coordenadoria de Pesquisa e Extensão - COPEX

Departamento de Editoraçāo e Divulgaçāo Científica - DEDIC 


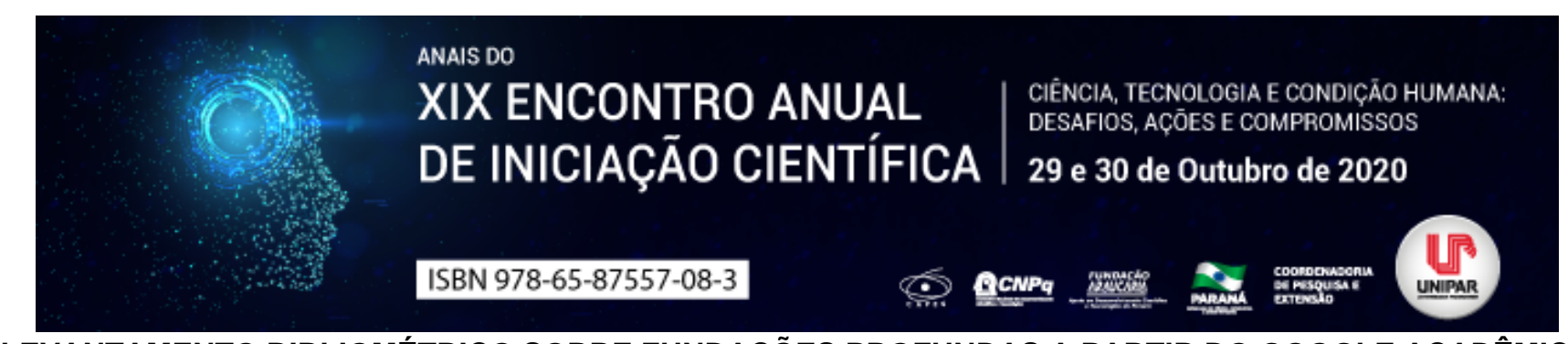

LEVANTAMENTO BIBLIOMÉTRICO SOBRE FUNDAÇÕES PROFUNDAS A PARTIR DO GOOGLE ACADÊMICO

\title{
${ }^{1}$ VANESSA HELOISA LOTICI, ${ }^{2}$ ANA KAROLINI CHIAPETTI, ${ }^{3}$ WILLIAN FERRAZ RIBEIRO, ${ }^{4}$ FABRICIO BALESTRIN
}

\author{
${ }^{1}$ Acadêmica do Curso de Arquitetura e Urbanismo da UNIPAR \\ ${ }^{1}$ Acadêmica do Curso de Arquitetura e Urbanismo da UNIPAR \\ ${ }^{2}$ Acadêmico do Curso de Arquitetura e Urbanismo da UNIPAR \\ ${ }^{3}$ Docente da UNIPAR
}

Introdução: A cienciometria mostra-se uma ferramenta significativa para analisar a disseminação da produção científica, ao quantificar a real produção em determinado nicho do conhecimento. Conforme destacado por Laurindo e Mafra (2010), a cienciometria não pode substituir um método analítico sobre determinado assunto, mas tem a capacidade de provocar maior visibilidade dos dados da pesquisa específicos sobre uma determinada área de conhecimento, permitindo interpretações consistentes que permitem caracterizar e quantificar as produções científicas. Já a bibliometria definida por Jean Tague Sutcliffe (1992), desenvolve padrões e modelos matemáticos para medir esses processos, usando seus resultados para elaborar previsões e apoiar tomadas de decisão. Os novos desafios da construção civil e o crescente aumento nas exigências das obras de engenharia, têm exigido elementos de fundações que resistam a carregamentos cada vez maiores, além de atenderem uma melhor relação custo benefício, qualidade e eficiência. Segundo a NBR 6122/2010, a fundação profunda é aquela que transmite a carga proveniente da superestrutura ao terreno pela base (resistência de ponta), por sua superfície lateral (resistência de fuste), ou pela combinação das duas.

Objetivo: Analisar de forma bibliométrica as publicações acerca do tema Fundações Profundas entre os anos de 2003 e 2019 presentes no Google Acadêmico.

Materiais e Métodos: O Primeiro passo foi a realização de uma pesquisa através da ferramenta Google Acadêmico, onde foram selecionados todos as publicações que continham a palavra "Fundações Profundas" no título entre os anos de 2003 a 2009 , contabilizando 51 trabalhos, a partir daí foram tabuladas nas planilhas google, onde as publicação duplicadas, incompletas e inacessíveis foram excluídas, restando um total de 34 trabalhos. Para melhor identificação dos dados e resultados na planilha eles foram classificados de acordo com o ano, instituição, tipos de trabalhos (artigo, trabalhos de conclusão de curso, dissertações, monografias ou teses,) e estado.

Resultado: Dentre esses 34 trabalhos publicados, destaca-se o ano de 2017 tendo um total de 8 trabalhos expostos, com $23,53 \%$ do total, em seguida temos os anos de 2018, com 6 trabalhos e 17,65\%, $2013 \mathrm{com} 4$ trabalhos e 11,76\%, e os anos de 2014 e 2015, com 3 artigos postados cada, tendo um percentual individual de 8,82\%. Ao total, foram encontradas 290 palavras chaves, sendo a palavra mais citada " capacidade de carga", aparecendo um total de 7 vezes e somando 2,4\%, seguida dela temos, " fundações profundas" com 3 citações e 1\%, "provas de cargas" e " estaca pré-moldada", ambas igualmente com 3 citações e 1\%. Em meio aos tipos de trabalhos publicados, temos em evidência o modelo de trabalho de conclusão de curso (TCC), com 20 publicações e $58,8 \%$ do total, em seguida reunimos os artigos, com 7 publicações e 20,6\%, as dissertações com 6 publicações e $17,6 \%$ e por fim, as teses, com apenas 1 trabalho exposto e 2,9\%. Entre as instituições mais citadas temos a UFRGS e a FEPESMIG com 4 trabalhos publicados por cada, ambas somando 11,8\%, em seguida temos, a USP e a UNESC, ambas com 3 publicações e 8,8\%, em seguimento encontra-se a UFSC e a UNIJUI com 2 trabalhos expostos e 5,9\%. Entre os estados com mais trabalhos divulgados, encontramos, o Rio Grande do Sul, com 10 trabalhos expostos, em seguida os estados de Minas Gerais com 6 publicações, Santa Catarina e São Paulo com 5, e Ceará e Paraná com um total de 2 trabalhos publicados cada.

Discussão: Nos últimos anos a produção de trabalhos sobre fundações profundas teve um aumento considerável, o que indica uma maior necessidade de se utilizar esses métodos de fundações nos dias atuais. Seja devido ao terreno onde se vai construir ou até mesmo a quantidade de pavimentos que o projeto solicita, o fato é que o tema sobre esses tipos de fundações vem sendo cada vez mais discutido no meio acadêmico. Observa-se através desses dados essa maior atenção, onde o número de trabalhos publicados vem crescendo gradativamente desde 2003, sendo o ano de 2017 de maior destaque. Pode-se observar que o maior número de trabalhos publicados encontram-se na região Sul e Sudeste do País, tendo como instituições de destaque a Fundação de Ensino e Pesquisa do Sul de Minas (FEPESMIG) e a Universidade Federal do Rio Grande do Sul (UFRGS). Verificando esses dados, identificamos uma maior tendência no desenvolvimento desses artigos na região Sul, logo uma maior necessidade em se utilizar fundações profundas em edificações, do que nas outras regiões, como Nordeste/Norte. Tendo em vista o grande número de trabalhos de conclusão de curso (TCC) publicados, concluímos que fundações profundas é um tema muito citado nas Instituições de Ensino Superior, devido a essa introdução, esse termo vem se tornando cada vez mais frequente e conhecido. 
Ainda existe pouca colaboração entre os autores em razão da maioria dos trabalhos desenvolvidos serem TCC, os quais normalmente são desenvolvidos apenas por um autor, porém, nota-se um grande aumento no número de artigos e dissertações referentes ao tema.

Conclusão: A partir dos dados apresentados, conclui-se que, fundações profundas, vem sendo um tema cada vez mais citado devido aos grandes avanços da construção civil através dos anos, prédios maiores e diferentes, necessitando de fundações adequadas para o melhor funcionamento das obras, sem patologias.

\section{Referências}

MALLMANN, Andressa Marx. Análise de capacidade de carga em fundações profundas: estudo de caso com utilização de planilha eletrônico para definição de soluções viáveis técnicas e economicamente. Orientador: André Luiz Böck. 2018. 93 f. Monografia (TCC em Engenharia Civil) - Universidade Regional do Noroeste do estado do Rio Grande do Sul, Rio Grande do Sul, 2018.

LUZZA, Luan Michel. Estudo da viabilidade técnica e econômica de diferentes tipos de fundações para uma residência de dois pavimentos na cidade de Pato Branco. Orientador: Diogo Rossetto. 2017. 138 f. Monografia (TCC em Engenharia Civil) Universidade Tecnológica Federal do Paraná, Paraná, 2017.

RAZERA, Júlio César Castilho. Contribuições da cienciometria para a área brasileira de Educação em Ciências. Ciênc. educ. (Bauru) vol.22 no.3 Bauru July/Sept. 2016. Disponivel em: https://www.scielo.br/scielo.php?script=sci_arttext\&pid=S151673132016000300557\&lng=pt\&tlng=pt Acesso em: 23 ago. 2020.

CHAPULA, César A. Macias. O papel da informetria e da cienciometria e sua perspectiva nacional e internacional. Ci. Inf. vol.27 n.2 Brasília. 1998. Disponivel em: https://www.scielo.br/scielo.php?script=sci_arttext\&pid=S0100-19651998000200005 Acesso em: 23 ago. 2020. 


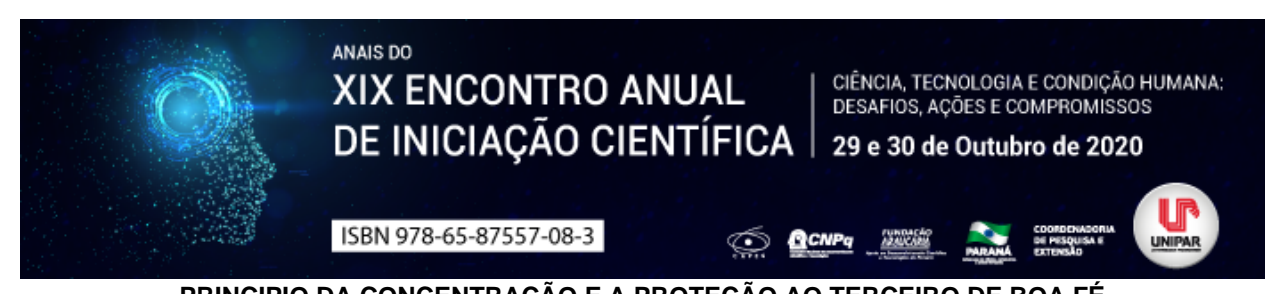

${ }^{1}$ GABRIEL PARREIRA DE LIMA, ${ }^{2}$ FABIO CALDAS DE ARAUJO

${ }^{1}$ Academico bolsista PIBIC/Unipar

${ }^{1}$ Docente da UNIPAR

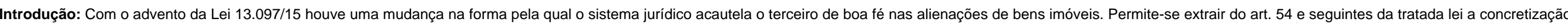
do Principio da Concentração como meio de conferir segurança jurídica na transmissão imobiliária.

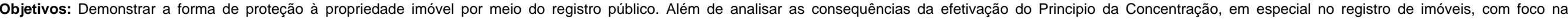
contraposição entre o proprietário lesado e o terceiro de boa fé.

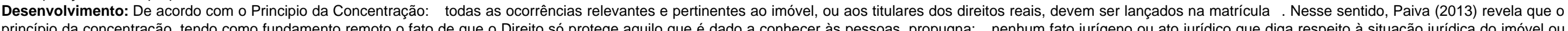

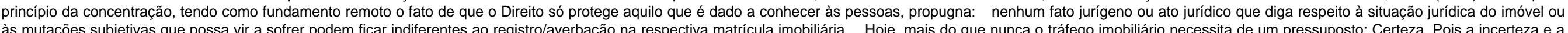

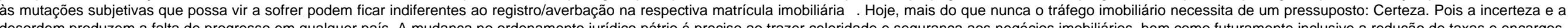

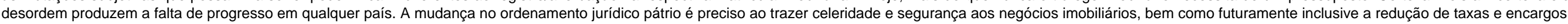
que podem refletir na economia de mercado como um todo.

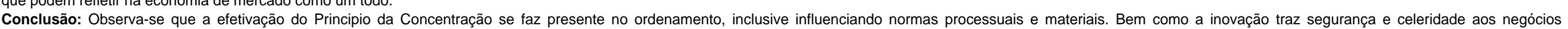
imobiliários, que pode representar uma das saídas para a crise econômica que vivenciamos hoje.

\section{Referências}

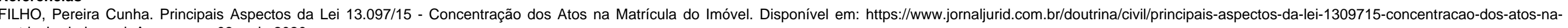

matricula-do-imovel. Acesso em: 03 maio 2020.

Acesso em: 03 maio 2020.

Coordenadoria de Pesquisa e Extensão - COPEX

Departamento de Editoraçāo e Divulgaçāo Científica - DEDIC 


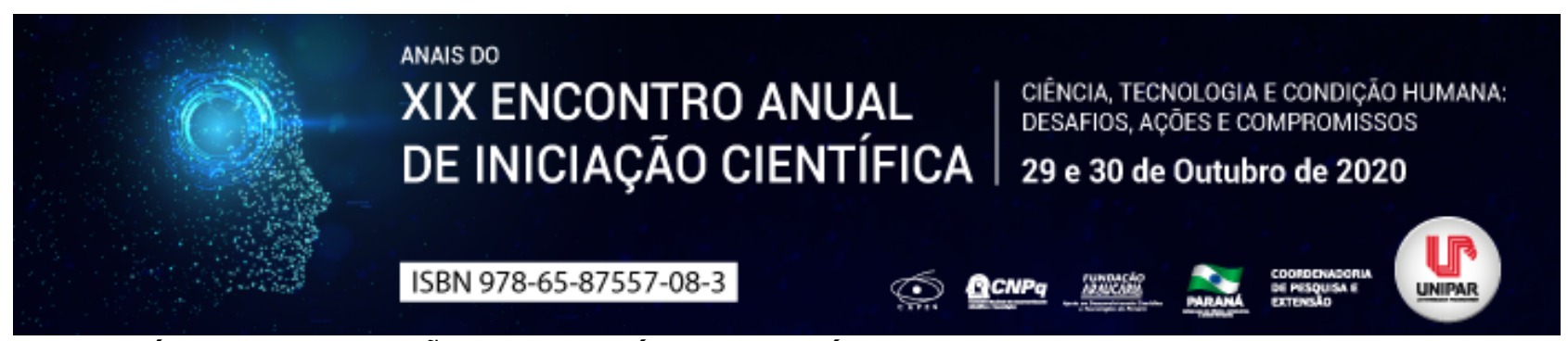

\title{
FONTES DA HISTÓRIA DA EDUCAÇÃO DO MUNICÍPIO DE GUAÍRA-PR (1953-1962): UM LEVANTAMENTO A PARTIR DOS DECRETOS
}

\author{
${ }^{1}$ LUCAS HENRIQUE DE FARIAS DA SILVA, ${ }^{2}$ WELLINGTON RAMOS DE CARVALHO, ${ }^{3}$ ESTELLE JULI SANFELICE, ${ }^{4}$ GISELE \\ HERNANDES DE MENDONCA, ${ }^{5}$ ROSILEY BERTON PACHECO, ${ }^{6}$ JOSE RICARDO SKOLMOVSKI DA SILVA
}

\author{
${ }^{1}$ PIC/UNIPAR \\ ${ }^{1}$ Acadêmico do Curso de Pedagogia da UNIPAR \\ ${ }^{2}$ Acadêmica do Curso de Pedagogia da UNIPAR \\ ${ }^{3}$ Acadêmica do Curso de Pedagogia da UNIPAR \\ ${ }^{4}$ Docente da UNIPAR \\ ${ }^{5}$ Docente da UNIPAR
}

Introdução: O presente trabalho é fruto de um esforço coletivo de integrantes do Programa de Iniciação Científica (PIC) da UNIPAR, unidade de Guaíra. Trata-se de um desdobramento do projeto de pesquisa organizado em 2019 intitulado LEVANTAMENTO E CATALOGAÇÃO DE FONTES PRIMÁRIAS E SECUNDÁRIAS DA HISTÓRIA DA EDUCAÇÃO DO MUNICÍPIO DE GUAÍRA-PR que tinha por objetivo, a partir da compreensão da importância da História da Educação, realizar um levantamento de fontes Primárias e Secundárias da História da Educação do município de Guaíra, do ano de sua criação enquanto município (1953). Em 2019 o projeto se debruçou em estudar as fontes secundárias, com o foco de realizar uma revisão bibliográfica para perceber as pesquisas que já haviam avançado nessa temática. Percebeu-se uma carência de produções que evidenciam esta História e que constituiu-se como uma lacuna da qual poderíamos contribuir. Em 2020 o projeto continuou, nesta oportunidade com o intuito de realizar um levantamento das fontes primárias. O trabalho que se apresenta aqui é resultado preliminar dos estudos empreendidos pelo grupo em um esforço no árduo trabalho com as fontes historiográficas (fontes documentais, legislação).

Objetivo: O presente trabalho tem por objetivo apresentar os decretos relacionados à educação na cidade de Guaíra, Paraná, no período de 1953 a 1962.

Desenvolvimento: A partir de uma investigação feita no Diário Oficial Eletrônico de Guaíra PR, no período de 1953 a 1962 , foi possível perceber um total de 86 decretos. No ano de 1953 encontramos o primeiro decreto relacionado a área educacional do município. O decreto de $\mathrm{n}^{\circ}$ 01/53 versa sobre as despesas orçamentárias previstas para o referido ano, nele encontramos um investimento de 50,500 cruzeiros no ensino primário durante a administração do governo de Gabriel Fialho Gurgel, se dividindo entre salário de professores, mobiliário e materiais escolares (GUAíRA, 1953).

No período de 1954-1955 dentre o 4 decretos publicados, 2 em cada ano, nenhum se relacionava à educação. Em 1956, já na gestão de Celino Rocha de Araujo, encontramos 7 decretos, sendo 3 deles relativos à educação, 2 nomeações e 1 exoneração. Ainda na gestão de Celino Rocha, no ano de 1957, foi possível encontrar 27 decretos, sendo 10 destes com ligação na área de educação. Estes se referem à nomeação e demissão de professores nas seguintes escolas do município: Escola Fazenda Paraizo, Grupo escolar Mendes Gonçalves, Escola da Barra do Piquiri. Nestas localidades houve 9 nomeações de professores e professores substitutos e 1 demissão. No ano seguinte, 1959, houve apenas 4 decretos, com apenas 1 deles abordando a temática de educação.

Em 1960 encontramos apenas 1 decreto, muito embora o mesmo não verse especificamente sobre educação, contribui para a compreensão acerca de como se situava a importância do ensino em tal período. 0 decreto de $n^{\circ} 30 / 60$ traz a criação da Biblioteca Pública Municipal, com o intuito de enriquecimento cultural dos cidadãos de Guaíra, em específico a classe estudantil do município (GUAÍRA, 1960).

No ano de 1961, encontramos 17 decretos publicados, dos quais, a partir da análise, 8 trazem a temática de educação. Os mesmos tratavam sobre nomeação de diretor, diretor substituto, secretário e professores para o Ginásio Municipal para o início de suas atividades em 1962. Os decretos no 42/61, 43/61, 44/61, 45/61 e n 46/61, evidenciam um pouco do perfil educacional da época, ao trazer a contratação de professores para ministrar as seguintes disciplinas no Ginásio Municipal: Latim, Francês, Desenho, Trabalhos Manuais, Economia Doméstica, Geografia, História do Brasil, História Geral e Educação Física (GUAíRA, 1961).

Conclusão: A partir dos documentos encontrados podemos perceber que dos 23 decretos relacionados com a área de educação, no período de 1952 até 1962, grande parte estão relacionados à nomeações para instituições escolares com diferentes nomenclaturas, tais como: Escola Fazenda, Grupo Escolar, Ginásio Municipal. Este levantamento, ainda que superficial, revela a multiplicidade de modelos de escola co-existindo e abre possibilidades para futuras pesquisas que envolvam 
a temática de Instituições Escolares. Outrossim, frisamos encontrar um decreto orçamentário, o que evidencia os investimentos previstos pelo governo municipal para a educação. Por fim, o que versa sobre a criação da Biblioteca Pública merece destaque, pois sinaliza um importante movimento de organização e provimento de material para a classe estudantil e comunidade. Apesar destes dois decretos não estarem especificamente relacionados à área da educação, por meio deles é possível perceber o valor que se dava a cultura e escolaridade na época. O presente estudo feito a partir de documentos oficiais da cidade de Guaíra, nos traz a possibilidade de refletir acerca das pessoas que estavam envolvidas no processo de construção da educação de Guaíra e também pode ser usado como ponto de partida para futuras pesquisas neste campo. Nosella e Buffa (2005) esclarecem que conhecer a História da Educação, das instituições escolares, permite que a sociedade valorize a História das instituições, reconheçam-na como patrimônio da comunidade. Torna-se assim um estudo rico, na perspectiva da Nova História Cultural.

\section{Referências}

GUAÍRA. Decreto no 1, de 10 de junho de 1953. Anexa documentos para o exercício de 1953. Guaíra: Diário Oficial, 1953.

GUAÍRA. Decreto $n^{\circ}$ 30, de 16 de dezembro de 1960. Cria Biblioteca Publica nesta Cidade. Guaíra: Diário Oficial, 1960.

GUAÍRA. Decreto $n^{\circ}$ 42, de 26 de agosto de 1961. O Professor LEONIDAS GIOPPO NASCIMENTO, para ministrar as disciplinas de Matematica, Geografia, e Latim, no Ginasio Municipal de Guaira. Guaíra: Diário Oficial, 1961.

GUAíRA. Decreto $n^{\circ}$ 43, de 26 de julho de 1961. O PROFESSOR DJALME TERAMOTO, para ministrar as disciplinas de Portugues, historia Geral e historia do Brasil. Guaíra: Diário Oficial, 1961.

GUAíRA. Decreto $\mathbf{n}^{\circ} \mathbf{4 4}$, de 26 de julho de 1961. O Professor LUIZ AUGUSTO MORAES REGO, para ministrar as disciplinas de Frances e Desenho, no Ginasio Municipal de Guaira. Guaíra: Diário Oficial, 1961.

GUAíRA. Decreto $n^{\circ}$ 45, de 26 de julho de 1961. O Professor ALBERTO FERNANDO BARDALL DRUMMOND, para ministrar a disciplina de Educaçao Fisica, no Ginasio Municipal de Guaira. Guaíra: Diário Oficial, 1961.

GUAíRA. Decreto $\mathbf{n}^{\circ}$ 46, de 26 de julho de 1961. A Professora BERTA COSTA NASCIMENTO,para as disciplinas de Trabalhos Manuais e Economico Demestica, no Ginasio Municipal de Guaira. Guaíra: Diário Oficial, 1961.

BUFFA, Ester; NOSELLA, Paolo. Instituições Escolares: por que e como pesquisar. 2. ed. Campinas: Alínea, 2005. 


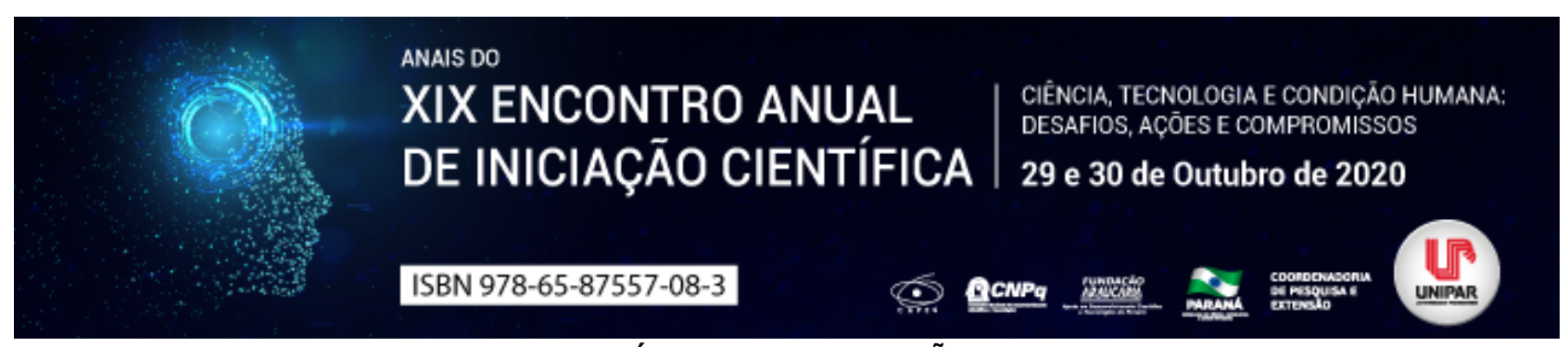

O DESAFIO DA ESCOLA BÁSICA NA FORMAÇÃO LEITORA DO ALUNADO

\title{
${ }^{1}$ KELLY BEATRIZ COSTA DOS ANJOS LIMEIRA, ${ }^{2}$ TATIANE HENRIQUE SOUSA MACHADO
}

\author{
${ }^{1}$ Acadêmica do curso de pedagogia da UNIPAR \\ ${ }^{1}$ Docente da UNIPAR
}

Introdução: $O$ ato de ler é considerado um processo mental que exige tempo e concentração, no contexto dos inúmeros conteúdos apresentados às turmas da educação básica. Sabe-se que numa sociedade grafocêntrica, gradativamente, a escrita e a leitura vão sendo inseridas na vida do estudante. Assim, cabe pensar qual o compromisso do educador no processo de alfabetização, cujo papel inclui fazer com que a leitura incorporada as práticas sociais escolares dos alunos.

Objetivo: Discorrer sobre as dificuldades enfrentadas pelo docente da educação básica para a formação do leitor.

Desenvolvimento: Nas palavras de Salles e Paula (2016, p. 53), a leitura é uma atividade complexa que envolve diversos processos, tais como identificação de letras, reconhecimento de palavras, acesso ao significado, integração sintática e semântica , nesses processos, a identificação/reconhecimento de palavras apesar de necessária para compreender um texto não é suficiente. Cabe ao leitor, a identificação de cada palavra, a partir da qual a memória de trabalho terá mais disponibilidade de recursos para realizar operações de análise sintática, de integração semântica dos constituintes da frase e de integração das frases na organização textual, processos importantes para a compreensão da leitura. Kleiman (1993, p. 38) aponta claramente como os educandos entendem: A leitura é vista pelo corpo discente como algo massacrante , imposta pelos mestres. Desde as séries iniciais, docentes fazem mau uso dos livros didáticos em salas de aula, de forma engessada e cansativa, em que os textos são apenas um grupo de componentes gramaticais, os quais foram trabalhados separadamente, de forma desconexa. Alertando ao educador Kleiman et al. (2000, p. 15) entende que: a leitura se baseia no desejo e no prazer, não em uma atividade desagradável visando à decifração de palavras, que leva o aluno a caracterizar o ato de ler como difícil demais, inacessível . Para tanto, cabe ao educador conduzir o processo de ensino de modo que a aprendizagem, que faça sentido ao educando. O papel do professor, no que tange à leitura, conduzir um trabalho, principalmente, em forma de estímulo, deixando com o que o aluno tenha liberdade de escolha e se sinta capaz de ler o que gosta de modo que o educando não se sinta pressionado, gerando desinteresse. A leitura escolar pressupõe um planejamento rico em soluções para as inquietações e desejos dos leitores, que seja desprovido de autoritarismo. É necessário comprometimento com o uso dos livros, favorecido pela ação do educador. Uma educação literária exige dos educadores uma ação profissional competente, que segundo a analogia de Steiner (2009, p. 04): [...] É um trabalho muito bonito ser professor, aquele que entrega as cartas, embora não as escreva [...] Somos os carteiros, e somos importantes. Os escritores precisam de nós para chegar a seu público . Diante do exposto, tornase possível propor caminhos para os profissionais que atuam com a leitura, respeitando as particularidades e auxiliando no processo de ensino-aprendizado, de forma a obter o prazer, advindo de forma natural de cada indivíduo.

As dificuldades na formação do hábito da leitura vivenciadas no dia a dia escolar são, sem dúvida, um tópico essencial. Cabe nesse sentido, ao professor, buscar uma metodologia adequada para superação das dificuldades encontradas, facilitando o processo de aquisição do conhecimento. Lajolo e Zilberman (1991, p. 121) elucidam a respeito que: [...] se a escola conseguir simular, nas atividades de leitura que patrocina, a circulação social que tais atividades de leitura têm fora do âmbito escolar, há uma possibilidade extremamente concreta de que estas atividades adquiram o sentido que elas precisam ter extramuros da escola e não se encerrem com as atividades que se encerram no final do ano letivo . Todavia, reconhece-se que depende muito da perspectiva de cada professor e de seu comprometimento em traçar um plano de trabalho, focado no desenvolvimento da leitura e que assim estabeleça objetivos que estimulem o alunado ao interesse póstumo à sala de aula, criando o vínculo do prazer ao ato de ler.

Conclusão: É evidente que a leitura é a base de qualquer ato educacional, grande parte do que se aprende é através da leitura, logo este ato se constitui como primordial na vida das pessoas, não se limitando apenas para compreensão mas também para a comunicação, ao abrir caminho para as primeiras experiências com o universo criativo, é manifestação de uma dimensão fundamental da infância: a possibilidade de transgredir o instituído, de recriar o mundo dado por meio de elaboração de outros mundos imaginados. Para vencer as barreiras encontradas na aquisição do hábito da leitura nos alunos, ou seja, para tornar alunos sujeitos leitores e desenvolver proficiência, o apreço e o compromisso frequente com a leitura, as instituições de ensino carecem pensar em estimulá-los a incorporar a leitura requer engajamento.

\section{Referências}

KLEIMAN, Ângela. Oficina de leitura: teoria e prática. São Paulo: Pontes, 1993.

KLEIMAN, Ângela et al. O ensino e a formação do professor: alfabetização de jovens e adultos. Porto Alegre: Artmed, 2000. 
LAJOLO, Marisa; ZILBERMAN, Regina. A leitura rarefeita: livro e literatura no Brasil. São Paulo: Ática, 1991.

SALLES, Jerusa Fumagalli, PAULA, Fraulein Vidigal de. Compreensão da leitura textual e sua relação com as funções executivas. Educ. rev., n.62, p. 53-67, 2016. Disponível em: https://doi.org/10.1590/0104-4060.48332. Acesso em: 28 ago. 2020 STEINER, George. O carteiro. Folha de São Paulo, São Paulo, p. 04-05, 18 jan. 2009. Disponível em: encurtador.com.br/lqGVX. Acesso em: 22 jul. 2020.

Coordenadoria de Pesquisa e Extensão - COPEX

Departamento de Editoraçāo e Divulgaçāo Científica - DEDIC 


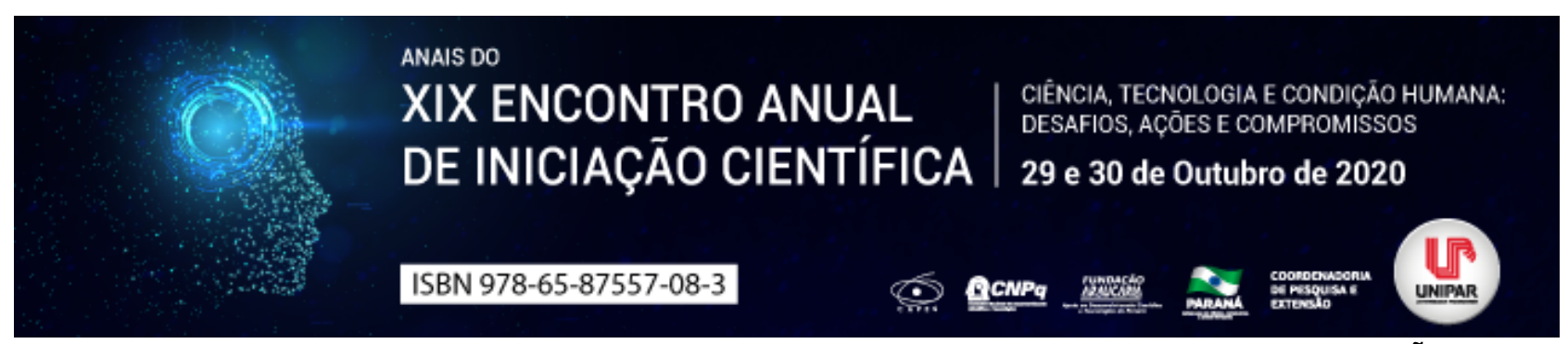

COMPLIANCE, A REAL EFETIVIDADE PERANTE AS LACUNAS DA LEI ANTICORRUPÇÃO

\title{
${ }^{1}$ OLIMPIA DE FATIMA DAMASIO TELES, ${ }^{2}$ ALEXANDRE MAGNO AUGUSTO MOREIRA
}

\author{
${ }^{1}$ Academica do curso de Direito Unipar \\ ${ }^{1}$ Docente da UNIPAR
}

Introdução: O Compliance é um sistema que possibilita um combate mais rígido no que tange a corrupção nas empresas, seja de caráter público ou privado, caracterizando-se por uma ordenação empresarial que visa a conformidade dos atos da empresa com a lei. Neste sentido, é possível estabelecer hipóteses de lacunas na Lei Anticorrupção no tocante aos Programas de Compliance, possibilitando a demonstração de irregularidades neste programa. Portanto, o presente trabalho busca contextualizar a ferramenta do Compliance como prática ética aos atos da atividade empresarial, estabelecendo como proposta, eventuais lacunas na legislação (Lei Anticorrupção). A pesquisa trabalha sobre o método hipotético-dedutivo, com análise a legislação e referências bibliográficas.

Objetivo: Explorar o conceito do Compliance, com vias a demonstrar a prática deste instrumento na política de organização de empresas, bem como evidenciar a importância do auxílio deste modelo no combate a corrupção empresarial, de forma a apresentar hipóteses de lacunas na lei anticorrupção acerca dos Programas de Compliance.

Desenvolvimento: A palavra Compliance tem sua origem na língua inglesa a qual significa, estar em conformidade (SCHRAMM, 2018, p. 195,). Neste norte, a função deste instrumento está diretamente relacionada com o disposto na legislação, em especial a Lei Anticorrupção, tipificada sob n 12.846 de 2013 (BRASIL, 2013). Em um contexto histórico, alguns eventos envolvendo escândalos de corrupção sempre foram alvo de discussões no Brasil. Em destaque, importa ilustrar alguns desses momentos históricos: I"Nos primeiros anos que se seguiram ao descobrimento, a fraude mais comum na jovem colônia estava relacionada ao contrabando de mercadoriasl" (KLEIN, 2017, p. 2). Antes do advento da Lei anticorrupção, visando a diminuição da corrupção no Brasil, surgiram algumas Leis com esse objetivo, como exemplo, a lei de improbidade administrativa, com prescrições legais discriminadas nos termos do artigo 10 da Lei (BRASIL, 1992), bem como, a lei de acesso a informação, com disposições especificas acerca do tema, mas quais destaca-se o artigo 33 da Lei (BRASIL, 2011). O Programa de Compliance ganhou força com a promulgação da lei anticorrupção. $\mathrm{O}$ artigo $7^{\circ}$ da referida lei, descreve o programa de compliance como função de cooperação da entidade pública ou privada, auxiliando na apuração de irregularidades internas. Neste raciocínio, I"(...) cabe à atividade do Compliance garantir que a organização cumpra todas as imposições dos órgãos de regulação e das normas internas em todas as esferasl" (MAFRA; JUNQUEIRA, 2018, p. 13). Porém, o sistema de compliance apresenta algumas lacunas quanto a sua aplicabilidade, especialmente no que tange a sua correlação com a lei anticorrupção. Uma dessas problemáticas é a responsabilidade objetiva da pessoa jurídica expressa na lei anticorrupção, independente de dolo ou culpa comprovados da empresa. Para melhor elucidar a problemática, I"Essa responsabilização será objetiva na acepção de que bastará a existência de um vínculo jurídico com a pessoa física infratoral" (SCHRAMM, 2018, p.169). Nota-se claramente na problemática abordada, a sanção imposta pelo legislador as empresas, excluindo, portanto, a responsabilidade da pessoa do infrator, recaindo a responsabilidade apenas no âmbito da empresa independentemente de culpa.

Conclusão: Ante o exposto, percebe-se a evolução legislativa no decorrer do tempo, com inovações normativas visando sempre acompanhar as mudanças impostas pelas várias circunstâncias do dia a dia. Assim conclui-se que o compliance é um programa que demanda engajamento de toda a empresa, bem como depende de integral responsabilidade de todos os colaboradores após sua adoção. Ainda, a Lei Anticorrupção, que estabelece políticas de implantação do programa de compliance no Brasil, não impõe de forma clara a obrigatoriedade das empresas prestarem as informações financeiras, inerentes a transparência, principal objetivo dos programas de integridade.

\section{Referências}

BRASIL. Lei 12.846, de 1 de agosto de 2013. Dispõe sobre a responsabilização administrativa e civil de pessoas jurídicas pela prática de atos contra a administração pública, nacional ou estrangeira, e dá outras providências. Disponível em: < http://www.planalto.gov.br/ccivil_03/_ato2011-2014/2013/lei//12846.htm >. Acesso em 26. Jun. de 2020.

BRASIL. Lei 12.527 de 18 de Novembro de 2011. Regula o acesso a informações previsto no inciso XXXIII do art. $5^{\circ}$, no inciso II do $\S 3^{\circ}$ do art. 37 e no $\S 2^{\circ}$ do art. 216 da Constituição Federal; altera a Lei $n^{\circ} 8.112$, de 11 de dezembro de 1990; revoga a Lei $n^{\circ}$ 11.111, de 5 de maio de 2005, e dispositivos da Lei no 8.159, de 8 de janeiro de 1991; e dá outras providências. Disponível em: < http://www.planalto.gov.br/ccivil_03/_ato2011-2014/2011/lei//12527.htm>. Acesso em 26. Jun. 2020.

BRASIL. Lei 8.429 de 02 de Junho de 1992. Dispõe sobre as sanções aplicáveis aos agentes públicos nos casos de enriquecimento ilícito no exercício de mandato, cargo, emprego ou função na administração pública direta, indireta ou fundacional 
e dá outras providências. Disponível em:. Acesso em 26. Jun. 2020.

KLEIN, Carla Luiza de Lima; DE ALENCAR, Joaquim Carlos Klein. Breve histórico da corrupção no Brasil. Revista Jurídica Direito, Sociedade e Justiça, v. 4, 2017. Disponível em: . Acesso em 23 jun. 2020.

MAFRA, Waldir Aparecido. JUNQUEIRA, Luciano A. Prates. Compliance para as Organizações da Sociedade Civil OSCs. Revista Científica Multidisciplinar Núcleo do Conhecimento. Ano 3, ed. 09, v. 10, p. 168-190, Set. 2018. Disponível em,: . Acesso em 23 jun. 20202.

SCHRAMM, Fernanda Santos. O compliance como instrumento de combate a corrupção no âmbito das contratações públicas. Dissertação pós graduação, UFSC, Florianópolis 2018. Disponível em: < https://repositorio.ufsc.br/bitstream/handle/123456789/190091/PDPC1368-D.pdf?sequence=-1\&isAllowed=y >. Acesso em 23. jun. 2020.

Coordenadoria de Pesquisa e Extensão - COPEX

Departamento de Editoraçāo e Divulgaçāo Científica - DEDIC 


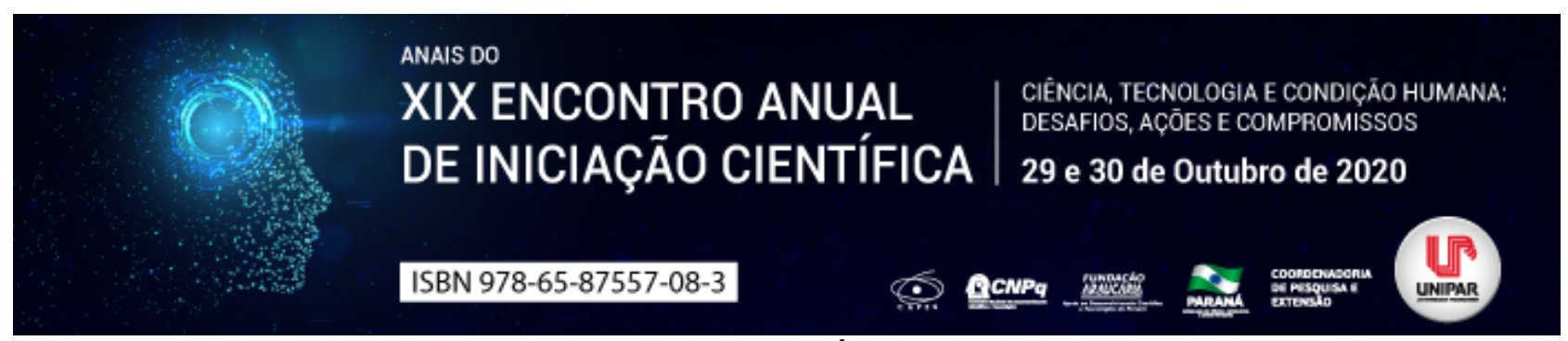

A INCOMPATIBILIDADE ENTRE O ARTIGO 58 PARÁGRAFO 2 DA CLT E A SUMULA 90 DO TST

\author{
${ }^{1}$ BRUNA CRISTINA PEREIRA CLARO, ${ }^{2}$ CLEVERSON IVAN MERLO, ${ }^{3}$ CLEVERSON IVAN MERLO
}

${ }^{1}$ Acadêmico do PIC/UNIPAR

${ }^{1}$ Docente da UNIPAR

${ }^{2}$ Docente da UNIPAR

Introdução: O advento da Consolidação das Leis do Trabalho se deu com o Decreto-Lei no 5254, de 01 de maio de 1943. Tratase de diploma legal com mais de 70 anos de vigência, sendo evidente a necessidade da atualização de seu texto legal, considerando o cenário social e econômico atual. Com a finalidade de adequação da norma aos tempos atuais foi editada a lei 13.467/2017, que trouxe alterações tanto de ordem material quanto processual ao Direito do Trabalho. Porém, em virtude dos debates acerca de constitucionalidade da nova legislação o TST ainda não revisou suas súmulas e orientações jurisprudenciais, o que acarreta insegurança para os operadores do Direito.

Objetivos: Demonstração da necessidade de revisão e adaptação das súmulas e orientações jurisprudenciais do TST de acordo com a Lei 13.467/2017.

Desenvolvimento: Conforme explanado na introdução, o TST, sob o argumento de se aguardar o julgamento de diversas ações envolvendo a constitucionalidade ou não de aspectos trazidos pela Lei 13.467/2017 (LGL20175978), o TST tem se furtado ao dever de atualizar suas súmulas e orientações jurisprudenciais. Enquanto persiste essa omissão, convivem súmulas tratando, por exemplo, das horas in itinere, ao passo que a legislação não mais prevê tal direito aos trabalhadores. Para contextualizar o leitor, Maurício Delgado e Gabriela Delgado conceituam tais horas como o tempo despendido pelo empregado até o local de trabalho e para o seu retomo, em condução fornecida pelo empregador, em se tratando de local de difícil acesso ou não servido por transporte público (2017. p. 120). As horas itinerárias na antiga redação do artigo 58 , parágrafo $2^{\circ}$ da Consolidação das Leis do Trabalho que fora inserida pela Lei 10.243/2001 (LGL19435) (Lei 10.243/2001 (LGL2001292), versava sobre o tempo que o empregado despendia até ao local de trabalho, o que era acrescentado como tempo à disposição do empregador. Porém, após a alteração implementada pela Lei 13.467/2017 (LGL20175978), restou suprimido de forma pura e simples todo esse tempo integrante a jornada de trabalho do empregado brasileiro, como explicam CORREIA e MIESSA: Todas as discussões doutrinárias e jurisprudenciais que envolviam a configuração e a remuneração das horas in itinere devem ser superadas com a nova redação do dispositivo (2018, p. 171). Não obstante tal fato, regras acerca das horas in itinere continuam sendo retratadas pela sumula 90 do Tribunal Superior do Trabalho, sem qualquer revisão, eis que ainda há discussões a cerca da constitucionalidade da Lei 13.467/2017 (LGL20175978).

Conclusão: Destarte, neste seguimento não restam dúvidas da real necessidade de manifestação por parte dos Tribunais do Trabalho a respeito das revisões das súmulas, sob pena de perpetuação da insegurança jurídica acarretada pela inércia do judiciário. Mesmo não se tratando de súmulas vinculantes, os impactos processuais são diretos, vez que o teor das súmulas do TST são legitimadoras, por exemplo, de admissão para o recurso de revista, como pode ser observado no artigo 896, alínea a da Consolidação das Leis do Trabalho. Além disso, inegável o peso das súmulas como fator de argumentação e convencimento.

\title{
Referências
}

BRASIL. Tribunal Superior do Trabalho. Súmula no 90, de 26 de setembro de 1978. Sumulas. RA 69/1978, DJ 26.09.1978

BRASIL. Lei no 10.243/2001, de 19 de junho de 2001. Acrescenta parágrafos ao art. 58 e dá nova redação ao $\S 2^{\circ}$ do art. 458 da Consolidação das Leis do Trabalho, aprovada pelo Decreto-Lei $n^{\circ} 5.452$, de $1^{\circ}$ de maio de 1943 . . Lex: BR: legislação Federal: 2001-06-19;

CORREIA, Henrique; MIESSA, Élisson. Manual da Reforma Trabalhista. Salvador: JusPodivm, 2018, p. 171.

DELGADO, Mauricio Godinho; DELGADO, Gabriela Neves. A reforma trabalhista no Brasil : com os comentários à Lei $n$. 13.467/2017. São Paulo : LTr, 2017, p. 120. 


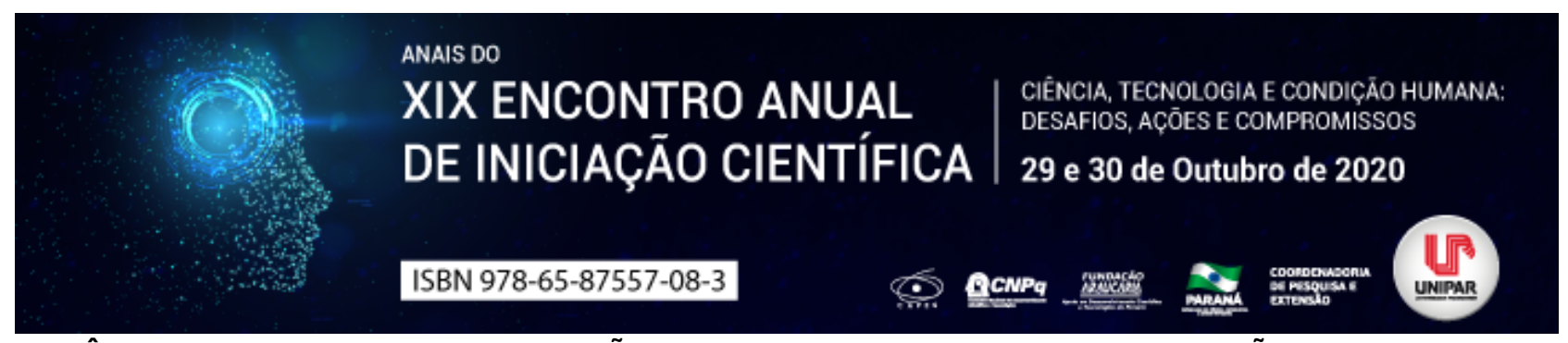

\title{
INTELIGÊNCIA ARTIFICIAL: DESAFIOS, AÇÕES E COMPROMISSOS EM SUA PRODUÇÃO E USO PELO PODER JUDICIÁRIO BRASILEIRO
}

\author{
${ }^{1}$ Quithéria Maria de Souza Rocha, ${ }^{2}$ MYLENE MANFRINATO DOS REIS AMARO
}

\author{
${ }^{1}$ Graduada em Direito pela instituição UNICESUMAR, Maringá/PR \\ ${ }^{1}$ Graduada em Direito pela instituição UNICESUMAR, Maringá/PR, Mestranda UNICESUMAR
}

Introdução: A análise do presente tema se faz de extrema importância tendo em vista a falta de lei especifica que regre as relações acerca da produção e uso de inteligência artificial (IA) no meio jurídico, dessa forma para orientar o desenvolvimentos dessas novas tecnologias é necessário examinar a recente Resolução $n^{\circ} 332$, de 21 de agosto de 2020 do Conselho Nacional de Justiça que dispõe da ética, transparência e governação na produção e uso de IA no poder judiciário visando identificar os desafios, ações e compromissos que o judiciário enfrentará para efetivar a finalidade de usar a inteligência artificial respeitando os preceitos fundamentais e a condição humana.

Objetivo: Esse estudo tem como propósito identificar problemas na infeliz dicotomia jurídica entre teoria frente realidade, tendo em vista que uso de inteligência artificial no judiciário é algo novo que está em processo de implementação e adaptação e, portanto, novos paradigmas e problemas surgirão. Dessa forma, por mais que a Resolução supracitada tenha o objetivo de elucidar dilemas, trazendo disposições jurídicas, esta não é suficiente pois a utilização de inteligência artificial no judiciário sucinta problemas que vão além do desenvolvimento ético da tecnologia.

Desenvolvimento: É evidente que o judiciário brasileiro está sobrecarregado de processos e que o número de funcionários não supre a demanda processual, o que gera muitos transtornos, principalmente na questão na demora de tramitação das lides. Dessa forma a utilização da IA no judiciário surge como uma ferramenta para auxiliar nesse problema, pois através dela é possível minimizar o tempo gasto em tarefas repetitivas, maximizando a produtividade, vez que as atividades automatizadas ficam a cargo da IA, liberando os funcionários a desempenharam maior tempo e dedicação a tarefas que necessitam maior capacidade cognitiva. Assim, a Resolução n⿳332 de 2020 do CNJ, nasce da falta de lei sobre o tema e da necessidade de regular o uso e produção da inteligência artificial no poder judiciário. A resolução traz clareza a várias questões que tinham sido levantadas, dispondo sobre a ética, transparência e governança na IA, apresentando desafios a serem superados, bem como ações e compromissos a serem cumprindo para que a inovação não se transforme em algo prejudicial a sociedade, principalmente aos jurisdicionados. Desta maneira, em síntese, o capítulo I da resolução (CNJ, 2020) traz as disposições gerais sobre inteligência artificial, conceituando o que é algoritmo, modelo de inteligência artificial, sinapses e diferenciando os tipos de usuários. Já o capítulo II dispõe sobre o respeito aos direitos fundamentais, observância a Constituição Federal, aos tratados internacionais, a segurança jurídica e a igualdade de tratamento aos casos absolutamente iguais. O capítulo III impõe a não discriminação, a igualdade, a pluralidade e a solidariedade. Enquanto que o capítulo IV dispõe sobre a publicidade, elencando em que consiste e transparência. $O$ capítulo $V$ traz que a inteligência artificial deverá observar regras de governança de dados, atribuindo deveres aos órgãos do poder judiciário. Já o capítulo VI retrata as medidas de segurança necessárias para utilização de dados no processo de treinamento dos modelos de IA, dando preferencialidade aos dados governamentais. Ainda, o capítulo VII refere-se ao controle do usuário, trazendo que as ferramentas de IA que auxiliarem na elaboração de decisão judicial devem ser feitas de modo que possibilitem a explicação dos passos que conduzem ao resultado. O capítulo VIII, preceitua que as equipes de pesquisa serão orientadas pela busca da diversidade de gênero, raça, etnia, cor, orientação sexual e de pessoas com deficiência, bem como dispõe que utilização de IA em matéria penal não deve ser estimulada. Já o capítulo IX traz o funcionamento da prestação de contas e a responsabilização de quem desenvolver sistemas de IA em desconformidade com a Resolução. Por último o capítulo $X$ preceitua as disposições finais.

Conclusão: Através da análise feita da resolução no 332 de 2020 do CNJ, e dos pontos por ela abordados, vê-se que muitas questões que geravam medo na utilização da inteligência artificial foram desmitificados, trazendo clareza sobre como os órgãos do judiciários utilizarão a IA. Entretanto observa-se que ainda há muito pela frente, pois a maioria dos problemas que podem vir a serem causados pela inteligência artificial baseia-se em vieses humanos ou em dados enviesados que serão implantados no software e que pode parecer imperceptível na hora da criação. Isso se dá, porque há preconceitos, injustiças e discriminações que estão tão enraizados na sociedade brasileira que infelizmente são normatizados e parecem irrelevantes. Portanto concluise que a Resolução isoladamente não é suficiente para lidar com os desafios práticos advindos das inovações, é necessário uma mudança estrutural de pensamento, que respeite os direitos e efetive a diversidade nos órgãos do judiciário, pois não adianta a resolução dispor que na criação da IA deverá ser respeitada as diversidades, mas não haver representatividade no quadro de funcionários. 


\section{Referências}

CONSELHO NACIONAL DE JUSTIÇA (CNJ). Resolução $n^{\circ}$ 332/2020, de 21 de agosto de 2017. Dispõe sobre a ética, a transparência e a governança na produção e no uso de Inteligência Artificial no Poder Judiciário e dá outras providências. Associação dos Notários e Registradores do Brasil. Disponível em: https://www.anoreg.org.br/site/2020/08/26/resolucao-no-332do-cnj-dispoe-sobre-o-uso-de-inteligencia-artificial-no-poder-judiciario/. Acesso em: 25 ago. 2020.

Coordenadoria de Pesquisa e Extensão - COPEX

Departamento de Editoraçāo e Divulgaçāo Científica - DEDIC 


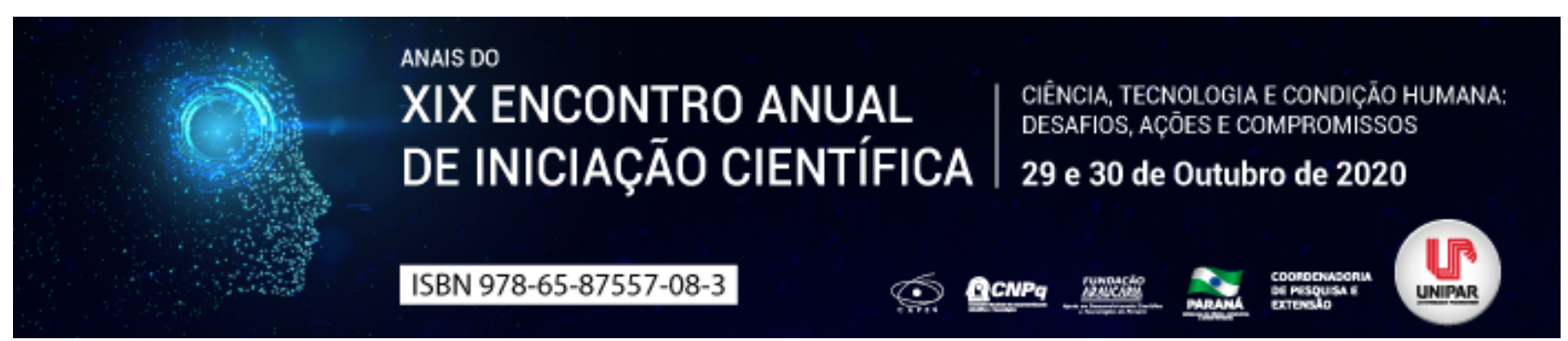

APLICAÇÃO DO DECRETO № 10.024/19 PARA ESTADOS, DISTRITO FEDERAL E MUNICÍPIOS

\title{
${ }^{1}$ NADIA APARECIDA DALL AGNOL, ${ }^{2}$ DELMAR VIEIRA, ${ }^{3}$ FABIANA KLUMP, ${ }^{4}$ ALEXANDRE MAGNO AUGUSTO MOREIRA
}

\author{
${ }^{1}$ Acadêmica do Curso de Direito da Unipar \\ ${ }^{1}$ Acadêmico do Curso de Direito da UNIPAR \\ ${ }^{2}$ Acadêmica do Curso de Direito da UNIPAR \\ ${ }^{3}$ Docente da UNIPAR
}

Introdução: O Decreto $\mathrm{n}^{\circ} 10.024$ de 2019 veio com o propósito de instituir uma nova realidade aos entes federativos ao realizar pregão na forma eletrônica. Da mesma forma que aprimorou as regras do procedimento, trouxe inovação e mais eficiência nos processos de contratação pública. Os impactos decorrentes das alterações desse decreto são inúmeros, destacamos a obrigatoriedade de utilização. Contudo, ainda existe um desconhecimento e resistência de alguns entes federativos a esse regramento. Portanto, por um método de pesquisa dedutivo, com revisão bibliográfica, pretende-se demonstrar as relevantes alterações da normativa.

Objetivo: Demonstrar a alterações advindas do novo regramento de pregão eletrônico, seus efeitos econômicos e funcionais, bem como, de que forma os Estados, Distrito Federal e Municípios devem encarar essa mudança.

Desenvolvimento: Os processos licitatórios na modalidade pregão são regidos pela Lei $n^{\circ} 10.520 / 02$, a qual estabelece normas gerais dos pregões na forma presencial e eletrônica, e, subsidiariamente a Lei $n^{\circ} 8.666 / 93$. Com o advento do novo decreto $n^{\circ}$ 10.024/19, houve a regulamentação de licitações na modalidade de pregão, na forma eletrônica, para a aquisição de bens e a contratação de serviços comuns. Não obstante, prevê que na utilização de recursos da União decorrentes de transferências voluntárias, tais como convênios e contratos de repasse, os Estados, Distrito Federal e Municípios torna obrigatória a utilização de pregão na forma eletrônica. Tal modalidade desburocratizou o procedimento administrativo e trouxe economias de recursos, tempo e custos, além do aumento do número de participantes, transparência e conquistas de melhores preços em virtude da quebra das barreiras geográficas com o uso da internet. Prém, os entes federativos devem ficar atentos as novidades do Decreto, pois há uma diferença entre as obrigatoriedades desses entes federados e as entidades e órgão federais. $\mathrm{O}$ novo Decreto $\mathrm{n}^{\circ}$ $10.024 / 19$, art. $2^{\circ}, \S 2^{\circ}$, dispõe que as normas disciplinadoras da licitação serão interpretadas em favor da ampliação da disputa entre os interessados, resguardados o interesse da administração, o princípio da isonomia, a finalidade e a segurança da contratação (BRASIL, 2019). À vista disso, é adequado que os municípios façam uma regulamentação específica de acordo com sua necessidade e peculiaridade, pois a aplicação na íntegra do decreto regulamentado inicialmente no âmbito federal causa insegurança juridica, do mesmo modo que, os entes federativos perdem a oportunidade de flexibilizar os procedimentos licitatórios de acordo com sua realidade. A normativa inova na capacitação por meio de iniciativas de treinamento para formação e atualização técnica de pregoeiros, membros da equipe de apoio e demais agentes encarregados da instrução do processo licitatório, conforme o art. 15, § $3^{\circ}$, sendo compulsória apenas para os órgãos da administração pública federal. Embora não seja obrigatória a realização de um plano de capacitação dos demais órgãos federativos, estes não estão isentos da devida capacitação, necessitando estudo incessante nas diferentes normativas que regulamentam as compras públicas. Teme a Administração Pública, principalmente Municipal, ao fomento local e regional. Porém, há prerrogativas disponíveis para que sejam elaboradas legislações próprias ou até mesmo a possiblidade de utilização da Lei Federal à fim de valorizar e priorizar Microempresa e Empresa de Pequeno Porte, até mesmo as locais e regionais. A LC $n^{\circ} 123 / 06$, alterada pela LC $n^{\circ} 147 / 14$, estabelecem normas gerais relativas ao tratamento diferenciado e favorecido a ser dispensado às microempresas e empresas de pequeno porte. Neste contexto, cabe a Administração Municipal ter conhecimento e estabelecer critérios que priorizem a contratação de MPE's sediadas local ou regionalmente, podendo ser aplicados nos processos de pregão eletrônico. Ademais, a obrigatoriedade do Decreto $n^{\circ} 10.024 / 19$ se torna um momento para que os entes federativos usufruam de forma positiva a normativa imposta pela União, e a partir disso revisem seu ordenamento jurídico, pensando no mercado de forma mais eficiente e moderna, visando a valorização dos fornecedores locais e regionais, sem infringir o regramento jurídico legal, mas utilizando-se das prerrogativas existentes.

Conclusão: O pregão eletrônico é uma excelente ferramenta de apoio nas compras públicas para realização de processos licitatórios com mais economia, desburocratização e transparência ao Poder Público. Para os entes federativos ainda se trata de uma inovação e desafio. Porém, não trata mais do futuro e sim do presente.

\section{Referências}

BRASIL. Lei n. 10.520/2002, de 17 de julho de 2002. Institui, no âmbito da União, Estados, Distrito Federal e Municípios, nos 
termos do art. 37, inciso XXI, da Constituição Federal, modalidade de licitação denominada pregão, para aquisição de bens e serviços comuns, e dá outras providências. Diário Oficial da União n. 137, Seção 1, de 18 de julho de 2002.

BRASIL. Decreto n. 5.450 de 31 de maio de 2005. Regulamenta o pregão, na forma eletrônica, para aquisições de bens e serviços comuns, e dá outras providências. Diário Oficial da União, Seção 1, de 10 de junho de 2005.

BRASIL, Lei Complementar no. 123/06, de 14 de dezembro de 2006. Institui o Estatuto Nacional de Microempresa e da Empresa de Pequeno Porte e dá outras providências. Diário Oficial da União, Poder Legislativo, Brasília, DF, 15 de dezembro de 2006.

BRASIL, Lei Complementar no. 147/14, de 7 de agosto de 2014. Altera a Lei Complementar no 123, de 14 de dezembro de 2006, e as Leis nos 5.889, de 8 de junho de 1973, 11.101, de 9 de fevereiro de 2005, 9.099, de 26 de setembro de 1995, 11.598, de 3 de dezembro de 2007, 8.934, de 18 de novembro de 1994, 10.406, de 10 de janeiro de 2002, e 8.666, de 21 de junho de 1993; e dá outras providências. Diário Oficial da União, Poder Legislativo, Brasília, DF, 08 de agosto de 2014.

BRASIL. Decreto n. 10.024 de 20 de setembro de 2019. Regulamenta a licitação, na modalidade pregão, na forma eletrônica, para a aquisição de bens e a contratação de serviços comuns, incluídos os serviços comuns de engenharia, e dispõe sobre o uso da dispensa eletrônica, no âmbito da administração pública federal. Diário Oficial da União, Seção 1 , de 23 de setembro de 2019.

JUSTEN FILHO, Marçal. Comentários à Lei de Licitações e Contratos Administrativos. 11. ed. São Paulo: Dialética, 2005. p.10 e 479 . 


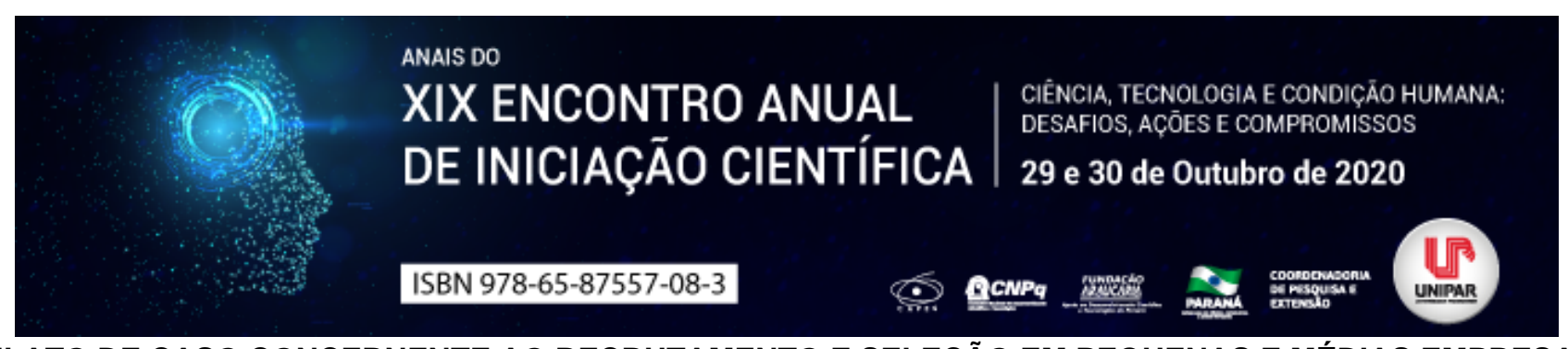

RELATO DE CASO CONCERNENTE AO RECRUTAMENTO E SELEÇÃO EM PEQUENAS E MÉDIAS EMPRESAS

\section{1'LEONARDO MATIOLI DOS SANTOS, ${ }^{2}$ ELIZANGELA MARIA MENEGASSI DE LIMA}

${ }^{1}$ Acadêmico do Curso de Administração da UNIPAR

${ }^{1}$ Docente da UNIPAR

Introdução: A administração correta dos recursos humanos vem se destacando dentro das organizações, para que uma empresa não seja fadada ao fracasso, a conscientização sobre a importância do recrutamento e seleção, deve estar presente dentro da organização empresarial.

Relato do Caso: Ao acompanhar durante 6 meses o funcionamento organizacional de uma empresa atuante no seguimento moveleiro, localizada na cidade de Umuarama-Pr, pôde-se verificar quão prejudicial é para uma empresa a falta de preparo ao realizar o processo de recrutamento e seleção. No período de análise, constatou-se que o recrutamento e seleção eram realizados pelo proprietário da empresa, o qual não dispunha de formação acadêmica, e o método utilizado para a contratação tratava-se de mera análise curricular, e aqueles que se destacavam eram convocados para uma entrevista complementar, onde o candidato precisava responder algumas perguntas formuladas pelo proprietário, as quais não se correlacionavam com o cargo oferecido ao candidato. Após a entrevista, acaso o candidato preenchesse os requisitos exigidos pelo proprietário, era designado a critério pessoal do proprietário qual função o candidato iria exercer, ou seja, o proprietário alocava seu novo funcionário em um cargo que muitas das vezes não correspondiam com sua formação e qualificação, acarretando em graves problemas de desempenho e produtividade. Discussão: Na atualidade uma boa gestão de pessoas é condição necessária para o sucesso (ROCHA, 1997, p. 20), e ao versar sobre o tema de recrutamento e seleção, pode-se visualizar a ferramenta chave para assertividade na gestão de pessoas dentro das organizações, ao considerar que por meio deste processo, as organizações estão deixando de ver pessoas como meros funcionários, e os tendo como aliados. Desta forma, lidar com as pessoas deixou de ser um desafio e passou a ser vantagem competitiva para as organizações bemsucedidas (CHIAVENATO, 2010, p. 20). O recrutamento pode ser descrito como a convocação e busca de pessoas para uma determinada função, já a seleção é tida como a priorização na escolha do candidato que conquistará o cargo oferecido. Tanto o recrutamento quanto a seleção fazem parte de um processo maior que é o de suprir e prover a organização de talentos e competências necessários à sua continuidade e sucesso em um contexto altamente dinâmico e competitivo (CHIAVENATO, 2009 , p. 68). Diante disso, é de suma importância a organização prévia das empresas, no que diz respeito ao planejamento estratégico, para que haja consistência e clareza nos processos de recrutamento e seleção.

Conclusão: A contratação de colaboradores capacitados se faz por meio de recrutamento e seleção, que quando feitos adequadamente garantirão a empresa custos baixos, bem como novos talentos com potencial e qualidade, motivados a se juntar ao processo de crescimento da empresa.

\section{Referências}

CHIAVENATO, Idalberto. Gestão de Pessoas. O novo papel de recursos humanos nas organizações. Rio de Janeiro: Campus, 2010.

CHIAVENATO, Idalberto. Planejamento, recrutamento e seleção de pessoal: como agregar talentos à empresa. 7 ed., Barueri, SP.: Manole, 2009.

ROCHA, José Antônio de Oliveira. Gestão de Recursos Humanos. Lisboa: Editorial Presença. 1997. 


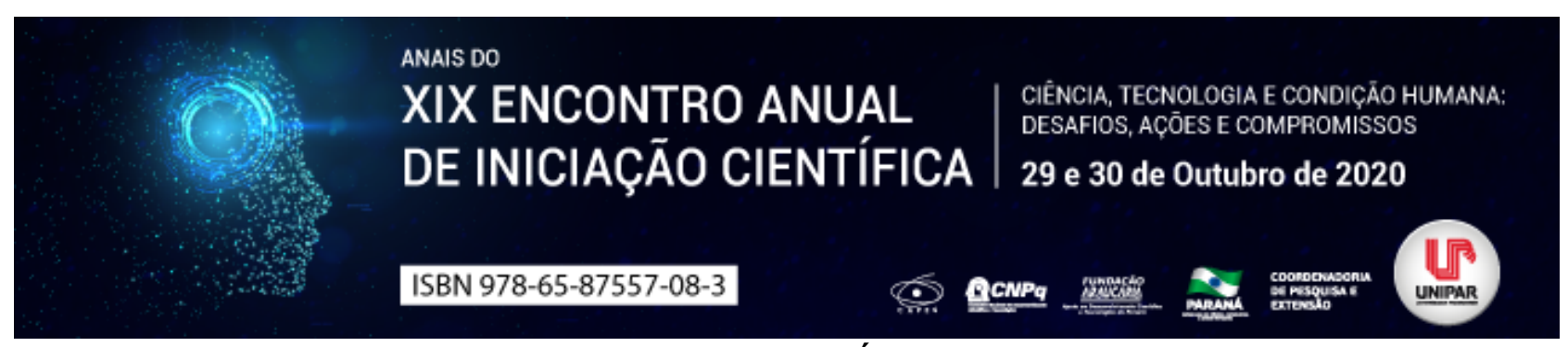

CRIMES CIBERNÉTICOS

\author{
${ }^{1}$ EMERSON LUAN GONCALVES, ${ }^{2}$ ANTONIO DA SILVA JUNIOR
}

\author{
${ }^{1}$ Acadêmico UNIPAR \\ ${ }^{1}$ Docente da UNIPAR
}

Introdução: Neste trabalho serão abordados os aspectos históricos e conceituais dos crimes cibernéticos, não obstante, o enfoque da presente pesquisa é um estudo mais aprofundado do exercício do direito a fim de se determinar os limites, como as repercussões dos ataques à honra e à imagem de um indivíduo através desse meio de comunicação global. Por fim, serão apresentadas possíveis soluções à indagação central do trabalho, a qual se refere aos possíveis meios de coibir o exercício arbitrário dos crimes cibernéticos.

Objetivo: O presente estudo tem como objetivo a compreensão e a repercussão dos ataques a honra e a imagem de um individuo através desse meio de comunicação e possíveis soluções de coibir o exercício arbitrário dos crimes cibernéticos.

Desenvolvimento: Antes de ser usada como ferramenta para o crime, a tecnologia na era moderna foi alvo de boicotes e rejeição por muitas pessoas. Em uma noção bastante rudimentar, os primeiros crimes informáticos foram atos de boicote a essas novas tecnologias implantadas nesse período histórico, como explicam Damásio de Jesus e José Antônio Milagre (2016, p. 22). Pode-se dizer que Turing foi o maior responsável pois expôs a fragilidade dos sistemas época, aprimorando-os (SCHECHTER, 2016). Além das alterações no Código Penal Brasileiro, que inseriu infrações cibernéticas no bojo da lei através da Lei 12.737/2012, apelidada de Lei Carolina Dieckmann , temos ainda o ECA (Lei 8.069/90), a Lei de Software (Lei antipirataria $n^{\circ}$ 9.609/98), a Lei de Segurança Nacional (Lei 7.170/83), compondo o conjunto de normas mais relevantes aplicáveis ao cibercrime. Os Cibercrime, ou o uso irresponsável da internet trazem, além de riscos à segurança das informações, comerciais ou pessoais, vulnerabilidade à honra e imagem do indivíduo, qualquer pessoa tem o direito de expressar suas opiniões desde que se identifique como responsável por elas, para preservar o direito do contraditório. Sob esse aspecto, Pedro Lenza (2012, p. 981) explica que: A Constituição assegurou a liberdade de manifestação do pensamento, vedando o anonimato. Caso durante a manifestação do pensamento se cause dano material, moral ou à imagem, assegurasse o direito de resposta, proporcional ao agravo, além da indenização como nenhum direito é absoluto, portanto sua extensão é limitada, cabe ao Estado, na sua forma judicial, corrigir os excessos em seu exercício, haja vista que cada direito acaba onde outro começa. Desta forma, a restrição é a única ferramenta capaz de amparar um direito violado pelo cometimento de excessos e abusos no exercício de outro direito.

Conclusão: Quando se pensa em cibercriminalidade, logo vem à mente a ideia de criminosos de carreira, agindo atrás da tela de um computador, a fim de obter lucro através da prática de atividades ilícitas. Como nenhum direito é absoluto, portanto sua extensão é limitada, cabe ao Estado, na sua forma judicial, corrigir os excessos em seu exercício, haja vista que cada direito acaba onde outro começa. Desta forma, a restrição é a única ferramenta capaz de amparar um direito violado pelo cometimento de excessos e abusos no exercício de outro direito.

\title{
Referências
}

BRASIL. LEI No 12.737, DE 30 DE NOVEMBRO DE 2012. Dispõe sobre a tipificação criminal de delitos informáticos; altera o Decreto-Lei $\mathrm{n}^{\circ}$ 2.848, de 7 de dezembro de 1940 - Código Penal; e dá outras providências http://www.planalto.gov.br/ccivil_03/_ato2011-2014/2012/lei//12737.htm Acesso em 20 de abril de 2020.

BRASIL. LEI № 9.609 , DE 19 DE FEVEREIRO DE 1998. Dispõe sobre a proteção da propriedade intelectual de programa de computador, sua comercialização no País, e dá outras providências http://www.planalto.gov.br/ccivil_03/leis/L9609.htm Acesso em 09 de maio de 2020.

BRASIL. LEI N 8.069, DE 13 DE JULHO DE 1990. Dispõe sobre o Estatuto da Criança e do Adolescente e dá outras providências. http://www.planalto.gov.br/ccivil_03/leis//8069.htm Acesso em 13 de abril de 2020.

BRASIL. LEI No 7.170, DE 14 DE DEZEMBRO DE 1983. Define os crimes contra a segurança nacional, a ordem política e social, estabelece seu processo e julgamento e dá outras providências.http://www.planalto.gov.br/ccivil_03/leis//7170.htm Acesso em 05 de abril de 2020.

JESUS, Damásio de. MILAGRE, José Antonio. Manual de Crimes de Informáticos. São Paulo: Saraiva, 2016.

LENZA, Pedro. Direito Constitucional Esquematizado. 16a ed. São Paulo: Saraiva, 2012

SCHECHTER, Luis Menasche. A Vida e o Legado de Alan Turing para a Ciência. Publicado pelo Departamento de Ciência da Computação/UFRJ, 2016. Disponível em 
Coordenadoria de Pesquisa e Extensão - COPEX

Departamento de Editoraçāo e Divulgaçāo Científica - DEDIC 


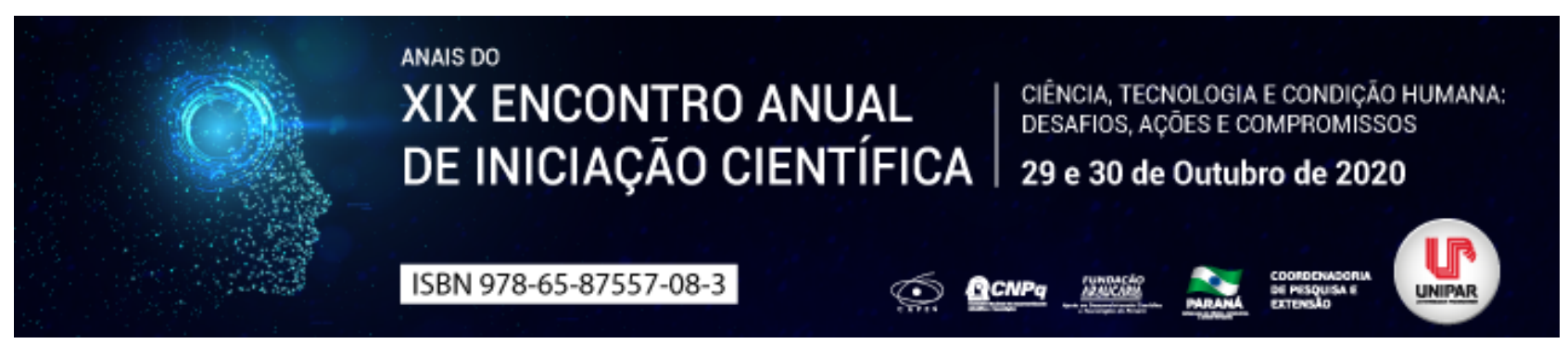

A TEORIA DOS LIMITES DOS LIMITES APLICADA AOS DIREITOS FUNDAMENTAIS

\author{
${ }^{1}$ ALESSANDRA FREI SILVA
}

${ }^{1}$ Mestranda em Direito Processual e Cidadania - UNIPAR

Introdução: O presente trabalho é relevante tendo em vista que os direitos fundamentais podem ser entendidos como relativos, e, portanto, restringíveis, com isso a Teoria dos Limites dos Limites dos direitos fundamentais busca ressaltar essa ideia, trazendo a concepção de que essas restrições possuem um limite que deve ser observado tanto pelo legislador, como pelo julgador diante de um caso concreto.

Objetivo: A pesquisa em comento objetiva demonstrar a necessidade primordial de que o núcleo essencial dos direitos fundamentais seja preservado, de modo a tornar mais efetiva a proteção a tais direitos.

Desenvolvimento: Os direitos fundamentais correspondem àqueles direitos sem os quais uma pessoa não tem condições de viver uma vida com dignidade. Os direitos fundamentais são muito mais do que um simples sistema de norma; consistem em um sistema e posições e de relações jurídicas entre o Estado e os cidadãos e entre os próprios cidadãos (CAMBI, 2020, p. 35). É justamente em razão dessa eficácia vertical e horizontal dos direitos fundamentais que os mesmos são dotados de irrefutável relevância e devem ser observados. Nesse sentido, conforme esclarece Canotilho (1997, p. 1353), há limites ao poder constituinte que possuem a sua base radicada justamente em determinados direitos fundamentais, ou seja, em que pese os direitos fundamentais em geral sejam relativos, há limites para a sua relativização que merecem ser respeitados. Nesse sentido ganha destaque a teoria dos limites dos limites (Schranken-Scharanken) dos direitos fundamentais, que vão balizar a ação do legislador quando restringe direitos fundamentais, sendo que os limites decorrem da própria Constituição Federal e dizem respeito à necessidade de se proteger um núcleo essencial do direito fundamental, bem como a aspectos referentes à clareza, determinação e proporcionalidade das restrições impostas. (MENDES; GONET, 2020, p. 211-212). Por essa razão, tomando como exemplo o direito fundamental á liberdade dereunião, esse pode ser restringido a depender da situação, mas nunca de tal maneira que acabe desnaturando a própria razão de existir do mencionado direito à liberdade de reunião. Nesse sentido, tratando de colisão entre dois direitos fundamentais, nesse caso temos outra situação em que um dos direitos deverá ser restringido para que o direito contraposto se efetive, o que vem a corroborar a situação de que os direitos fundamentais são restringíveis. Assim, Mendes e GONET (2020, p. 214-215) esclarecem que há divergência doutrinária acerca das teorias que estudam o núcleo essencial dos direitos fundamentais, e inclusive há a ideia de um limite do limite inclusive para o legislador ordinário, por isso é importante que o julgador faça uso de um critério de proporcionalidade (e seus subelementos) para que então possa verificar se a questão se apresenta ou não como uma afronta ao núcleo essencial dos direitos fundamentais.

Conclusão: Pelo trabalho foi possível verificar que os direitos fundamentais são restringíveis, até porque há situações em que o julgador se depara com um conflito de direitos, de modo que algum direito terá de ser limitado para que o direito contraposto considerado de maior peso no caso concreto, possa ser realizado. Nesse sentido a teoria dos limites dos limites dos direitos fundamentais surge como uma teoria importante para que os direitos fundamentais sejam estudados e aplicados, de maneira que não se perca de vista seu núcleo essencial, que merece especial atenção e proteção.

\title{
Referências
}

CAMBI, Eduardo. Neoconstitucionalismo \& neoprocessualismo: direitos fundamentais, políticas públicas e protagonismo judiciário. $3^{a}$ ed. Belo Horizonte: Editora D’Plácido, 2020.

CANOTILHO, José Joaquim Gomes. Direito Constitucional e Teoria da Constituição. $4^{a}$ ed. Coimbra: Almedina, 1997. MENDES, Gilmar Ferreira; GONET, Paulo Gustavo. Curso de direito constitucional. 15a ed. rev. e atual. São Paulo: Saraiva jur, 2020. 


\section{GRUPO 4: EXATAS E TECNOLÓGICAS E AFINS}




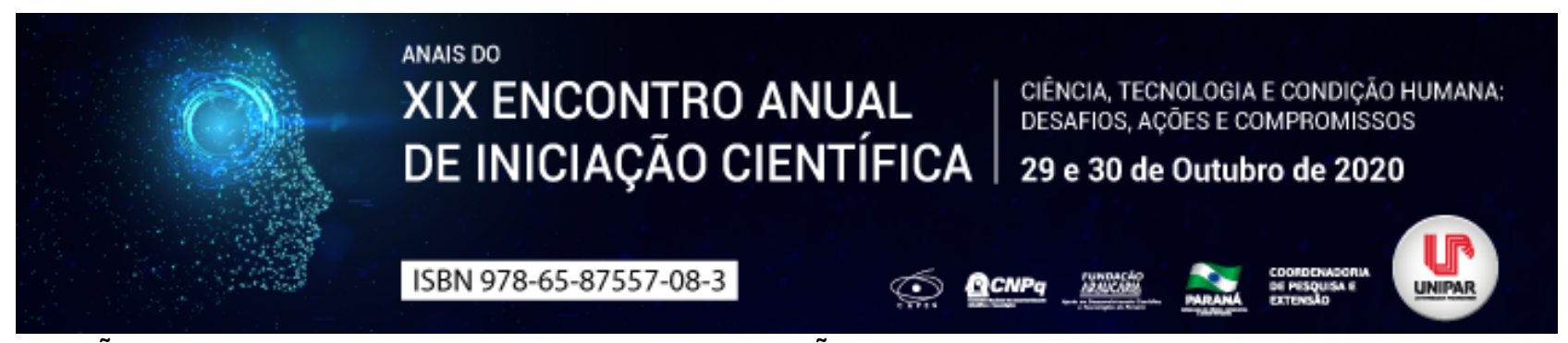

AVALIAÇÃO PRELIMINAR NO PROTOCOLO DE APLICAÇÃO DE HIDROGEL COMERCIAL EM SOLO ARENOSO

\author{
${ }^{1}$ Henrique Frederico girotto, ${ }^{2} \mathrm{JOÃO}$ PAULO FRANCISCO , ${ }^{3}$ VAGNER ROBERTO BATISTELA, ${ }^{4}$ ANDERSON ANTONIO DA \\ SILVA GUALBERTO , ${ }^{5}$ RAFAEL DA SILVA , ${ }^{6}$ FERNANDO RODRIGUES DE CARVALHO
}

${ }^{1}$ Acadêmico da UEM
${ }^{1}$ Docente da UEM
${ }^{2}$ Docente da UEM
${ }^{3}$ Docente da UEM
${ }^{4}$ Docente da UEM
${ }^{5}$ Docente da UEM

Introdução: Atualmente a agricultura sofre com severos períodos de seca, causando drásticas redução na produtividade agrícola e, consequentemente, na econômica global (LEITE; FEDERIZZI; BERGAMASCHI, 2012). A estiagem pode afetar ainda mais a produtividade quando se trata de solo arenoso, como é o caso da região noroeste do Paraná. Muitos esforços têm sido feitos para combater a queda na produtividade em solo arenoso. Tecnologia de hidrogeis tem sido aplicado como alternativa para aumentar a retenção de água no solo, visto que são materiais capazes de armazenar e disponibilizar água para as plantas de maneira gradativa (NEETHU; DUBEY; KASWALA, 2018). Apesar da utilização de hidrogeis na agricultura estar bem consolidado, há poucos estudos com relação ao protocolo de aplicação a ser usado (NETO et al., 2017). Muitos agricultores, sob orientação de fabricantes, aplicam o hidrogel no momento do plantio em sua forma hidratada, enquanto que outros aplicam em sua forma sólida. Alguns agricultores aplicam o hidrogel misturado com o solo, outros aplicam logo abaixo da raiz. FLANNERY e BUSSCHER (1982) mostraram que os hidrogeis devem ser sanduichados no solo, ao invés de misturados com toda região da raiz da planta. GRANDIZOLI et al. (2013) verificaram que apesar do fabricante indicar $8 \mathrm{~g}$ de hidrogel comercial por vaso, a melhor relação custo/benefício foi encontrada usando $4 \mathrm{~g}$. Desta forma, fica evidente a necessidade de estudos metódicos que avaliam o processo de aplicação e dosagens dos hidrogeis.

Objetivo: Verificar, metodicamente, a habilidade de absorção e retenção de água de hidrogel comercial em solo arenoso em diferentes condições de aplicação, assim como propor um modelo experimental simples que seja capaz de mimetizar as condições do solo com chuvas regulares.

Material e Métodos: O hidrogel utilizado foi o UPDT, comercializado pela empresa UPL. Para imitar a condição do solo, tubetes de PVC (com furos) foram utilizados. Tecido de TNT e fita foi usado para vedar a parte inferior dos tubetes. Frascos coletores foram empregados para coletar a água lixiviada. O solo foi seco numa estufa à $105{ }^{\circ} \mathrm{C}$ por $24 \mathrm{~h}$. $\mathrm{O}$ solo seco foi adicionado aos tubetes com e sem hidrogel (controle). Os hidrogeis sólidos e hidratados (em $10 \mathrm{~mL}$ de água) foram adicionados nas quantidades de 0,$5 ; 1,0$ e 1,5 g. Estes foram aplicados na forma sanduichado: solo/hidrogel/solo. Na parte inferior do tubete foi acoplado o frasco coletor. O experimento iniciou-se com adição de $78,5 \mathrm{~mL}$ de água destilada em cada tubete. Em seguida, os tubetes foram acondicionados sob uma cobertura de plástico. Os tubetes foram pesados, aproximadamente, de dois em dois dias. Após 15 dias da primeira adição, foi adicionado mais $78,5 \mathrm{~mL}$ de água. Este processo seguiu por 39 dias.

Resultados e Discussões: Dois dias depois da primeira adição, verificou-se que o solo com hidrogel reteve mais água do que o controle. Os tubetes de 0,5 e 1,0 g de hidrogel sólido perderam a eficiência em 5 dias. Os tubetes de $1,5 \mathrm{~g}$ de hidrogel sólido e hidrato perderam a eficiência após 7 e 16 dias, respectivamente. Assim, verifica-se que o hidrogel hidratado retém mais água do que o hidrogel sólido. Os tubetes de 0,5 e 1,0 g de hidrogel hidratado foram os que retiveram mais água. Contudo, entre estes dois tubetes, o de 1,0 g foi mais consistente na retenção de água. Ao final do experimento, ambos os tubetes, de 0,5 e 1,0 g de hidrogel hidratado, estavam com mais água do que o controle, $43,28 \mathrm{~mL}$ e 48,16 mL de água, respectivamente, contra 43,09 mL de água no controle. Vale ressaltar que houve perda de hidrogel pelos furos em alguns tubetes quando os mesmos receberam água na primeira adição, contribuindo com erros experimentais. Avaliando a perda de água, logo após a adição dos $78,5 \mathrm{~mL}$, observou-se que houve uma maior perda em alguns sistemas com hidrogel a partir da segunda adição. Este fato mostra que 0 hidrogel sanduichado no solo pode estar bloqueando a passagem de água para a parte inferior do tubete, pois nos tubetes com hidrogel praticamente não houve quantidades significativas de água lixiviada no frasco coletor. Com a maioria da água adicionada aprisionada na parte superior dos tubetes, a perda de água por evaporação é maior. Em contrapartida, observou-se água frequentemente no frasco coletor do tubete controle, sugerindo que a distribuição de água neste tubete é maior, contribuindo para a lixiviação. Este resultado mostra que a aplicação sanduichado do hidrogel pode prejudicar a retenção de água. O modelo experimental foi eficiente na mimetização da perda de água do solo. Contudo, os furos precisam ser menores e 
numa região diferente de onde o hidrogel foi alocado, para não haver perda de hidrogel.

Conclusão: Tubetes com hidrogel hidratado retiveram mais água. Entre os tubetes com hidrogel hidratado, destaca-se o tubete com $1,0 \mathrm{~g}$, que demonstrou maior capacidade de retenção de água. O processo de aplicação dos hidrogeis sanduichados pode não ser a melhor maneira para se alcançar a máxima eficiência na retenção de água. O modelo experimental proposto mimetizou a perda de água pelo solo, porém, ajustes deverão ser feitos.

\section{Referências}

FLANNERY, R. L.; BUSSCHER, W. J. Use of a synthetic polymer in potting soils to improve water holding capacity. Communications in Soil Science and Plant Analysis, vol. 13, no. 2, p. 103-11, 1982.

GRANDIZOLI M., T.; URBANO, V. R.; PERES, J. G.; SOUZA, C. F. Hidrogel como alternativa no aumento da capacidade de armazenamento de água no solo. Water Resources and Irrigation Management, vol. 2, no. 2, p. 87-92, 2013.

LEITE, J. G. D. B.; FEDERIZZI, L. C.; BERGAMASCHI, H. Mudanças climáticas e seus possíveis impactos aos sistemas agrícolas no Sul do Brasil. Revista Brasileirade Ciencias Agrarias, vol. 7, no. 2, p. 337-343, 2012.

NEETHU, T. M.; DUBEY, P. K.; KASWALA, A. R. Prospects and Applications of Hydrogel Technology in Agriculture. International Journal of Current Microbiology and Applied Sciences, vol. 7, no. 05, p. 3155-3162, 2018.

NETO, J. L. L. M.; ARAÚJO, W. F.; CHAGAS, E. A.; SIQUEIRA, R. H. da S.; OlIVEIRA, G. A.; RODRIGUEZ, C. A. Hydrogels in brazilian agriculture. Revista Agro@mbiente on-line, vol. 11, no. 4, 2017.

Coordenadoria de Pesquisa e Extensão - COPEX

Departamento de Editoraçāo e Divulgaçāo Científica - DEDIC 


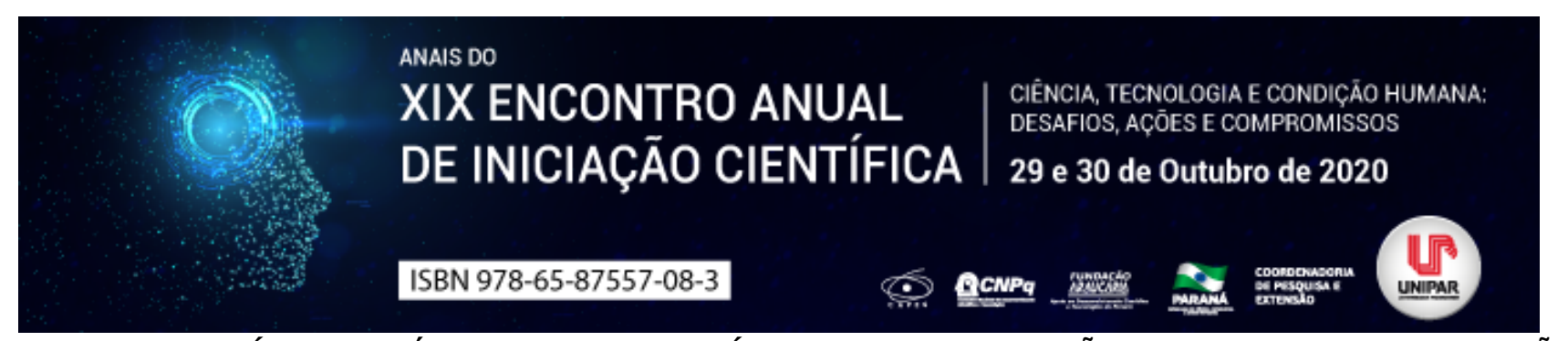

TEORIA DO EQUILÍBRIO ESTÁTICO EM CORPOS RÍGIDOS NA CONSTRUÇÃO CIVIL

ESTUDO DE REVISÃO

\title{
${ }^{1}$ JESSICA CAROLINE MERLUGO DEPONTI, ${ }^{2}$ DJESSICA TUANI KREIN, ${ }^{3}$ CRISTIANE ZUFFO DA SILVA MARASCA
}

\author{
${ }^{1}$ Acadêmico do Curso de Engenharia Civil da UNIPAR \\ ${ }^{1}$ Acadêmico do Curso de Engenharia Civil da UNIPAR \\ ${ }^{2}$ Docente da UNIPAR
}

Introdução: Dai-me um ponto de apoio que eu levanto o mundo. Essa frase foi dita pelo engenheiro e matemático Arquimedes de Siracusa, para explicar o poder das alavancas na Antiguidade Clássica. Com isso, Arquimedes afirmava que era possível elevar um objeto de massa desprezível a partir da criação de um sistema que dependesse do ponto de apoio. Assim, se o sistema estiver em equilíbrio estático ele terá duas somatórias: soma das forças externas (iguais a zero) e soma dos torques (em relação a um ponto ser zero) (DESCOMPLICA, 2015). No século XII, a Torre de Pisa começou a ser construída. Feita de mármore, com cinquenta e cinco metros de altura, a torre foi projetada para abrigar o sino da Catedral, no norte da Itália. Porém, a execução da obra não seguiu o projeto, resultando em uma inclinação nos seus três primeiros andares, devido ao afundamento do terreno e ao assentamento irregular das fundações (DESCOMPLICA, 2015). Atualmente, após diversas reformas, a inclinação da torre foi reduzida a aproximadamente quatro metros (ou quatro graus) em relação ao eixo vertical (y) (JÚNIOR, 2020). Apesar de inclinada, a torre não tombou pois está em equilíbrio estático.

Objetivo: Relacionar o equilíbrio de um corpo rígido mediante sua estática em obras da construção civil.

Desenvolvimento: O equilíbrio estático tem definição no repouso, isto é, quando não há existência de partícula constituinte que se move em relação a um dado referencial, na relação de determinado referencial externo. Em convergência a esse mesmo referencial, se as partículas apresentam movimento, o corpo rígido estará então em equilíbrio dinâmico. Nesse caso, para que haja condição equilíbrio, o torque deve ser igual a zero. Assim, quando a força e o binário são iguais a zero, o corpo rígido estará em equilíbrio estático (BEER; JOHNSTON; MAZUREK e EISENBERG, 2009).

Para resolver um problema de equilíbrio em um corpo rígido, é necessário considerar todas as forças atuantes sobre o corpo, realizando um diagrama de corpo livre. Nesse desenho deve-se apresentar todas as forças e momentos de binário exercidas do ambiente para o corpo, conceituando essas impressões quando as equações de equilíbrio são aplicadas. Dessa forma, o conhecimento de como desenhar um diagrama de corpo livre é fundamental para a resolução de problemas em mecânica (HIBBELER, 2011). Consoante a obra Estática das Estruturas (SORIANO, 2013), na Engenharia Civil a classificação quanto ao equilíbrio estático envolvendo as equações de equilíbrio tem variância em vigas, pórticos, grelhas e treliças; e divididas em três categorias: isostático, hiperestático e hipostático. Dessa forma, o equilíbrio isostático ocorre quando a quantidade de limitações oferecidas pelos apoios que mantém o material estável são iguais aos graus de liberdade possíveis da estrutura; quando o número de limitações oferecidas pelos apoios é superior aos graus de liberdade possíveis para o material, o equilíbrio é hiperestático; quando as limitações oferecidas pelos apoios são insuficientes para manter o material estável, o equilíbrio é hipostático. De acordo com Mello (2017), os vínculos podem ter finalidade de apoio e ligação, ou de transmissão, sem diferença rígida entre dois tipos, dependendo da função que o vínculo exerce no momento da análise. Ao analisar, por exemplo, o sistema laje viga pilar fundação, no subsistema laje viga, a viga exercerá a função de vínculo de apoio, mas se a análise for da laje viga pilar, o pilar é exercerá a função de vínculo de apoio, passando a viga para a condição de vínculo de ligação da laje com o pilar. Com isso, haverá casos semelhantes que impossibilitam a separação entre apoio e ligação.

Nesse contexto, os vínculos são classificados em: apoio móvel (primeiro gênero), este impede um movimento (y), deixando livre os outros dois $(x, z)$, ou seja, sem movimento na vertical; apoio fixo (segundo gênero), este impede dois movimentos ( $x, y$ ), deixando livre um (z), isto é, sem movimento na vertical e horizontal; engaste (terceiro gênero), este impede os três movimentos $(x, y, z)$, ou seja, sem movimento na vertical, horizontal e rotação. Na prática da engenharia, as vigas servem de exemplo para entender os vínculos em um sistema de equilíbrio estático. Este elemento estrutural possui uma das suas dimensões predominante (elemento de primeira categoria), e é classificado de acordo com os gêneros de apoio em vigas bi apoiadas, engastadas, bi apoiadas com balanço, inclinadas, gerber e contínuas; e apresentando sistema de cargas concentrada, distribuída (uniforme e não uniforme), conjugada e momento; além das cargas acidentais, permanentes, estáticas e dinâmicas.

Conclusão: Desta forma, sabe-se a importância de experimentos que traduzam as condições de equilíbrio estático e identificam as forças atuantes no sistema físico de uma simples viga até uma complexa estrutura predial em um todo, e da descrição vetorial das grandezas para a análise de um problema na construção. Contudo, deve-se levar em conta o comportamento de cada sistema da estrutura a ser construída, de modo a prever reações dos materiais e proceder com responsabilidade para evitar futuros problemas. 


\section{Referências}

BEER, Ferdinand P. et al. Mecânica Vetorial para Engenheiros Estática. Nona edição. Editora McGraw Hill e Bookman. Ano: 2009. Capítulo: 4. Páginas: 160, 161, 162, 163, 164, 165, 166.

DESCOMPLICA. O que a Torre de Pisa e o Levantamento de Peso têm em comum? O Equilíbrio Estático desvenda esse mistério. [SI]. Ano: 2015. Disponível em: https://descomplica.com.br/blog/materiais-de-estudo/fisica/torre-de-pisa-elevantamento-de-peso-tem-algo-em-comum-o-equilibrio-estatico-desvenda-esse-misterio/, acessado em 17/08/2020.

HIBBELER, Russel C.; JOHNSTON. Estática, Mecânica para Engenharia. Décima segunda edição. Editora Pearson. Ano: 2011. Capítulo 5. Páginas: 164, 165, 166 e 167.

JúNIOR, Joab S. S. Por que a Torre de Pisa não caí? Mundo Educação. [SI]. Ano: 2020. Disponível em: https://mundoeducacao.uol.com.br/fisica/por-que-torre-pisa-nao-cai.htm, acessado em: 17/08/2020.

MEDINA, Jorge. Conceitos básicos da mecânica da fratura. PUC Rio de Janeiro, volume 1, outubro de 2014. Disponível em: https://www.maxwell.vrac.puc-rio.br/24982/24982_3.PDF, acessado em 21/07/2020.

MELLO, Talles. Estática. Universidade Católica Dom Bosco - UCDB, 2017. Disponível em: http://www.tallesmello.com.br/wpcontent/uploads/2017/02/Est\%C3\%A1tica.pdf, acessado em 21/07/2020.

SCHÖN, Claúdio G. Fratura dos Materiais - Noções de Mecânica da Fratura. Departamento de Engenharia Metalúrgica e de Materiais / Escola Politécnica - USP, artigo volume 1, 2011. http://www.ebah.com.br/content/ABAAAAAjsAA/aula02-fratura-dos-materiais, acessado em 21/07/2020.

SMITH, William F.; HASHEMI, Javad. Fundamentos de Engenharia e Ciência dos Materiais. Quinta edição. Editora McGraw Hill e Bookman. Ano: 2015. Capítulo 7. Páginas: 197, 198, 199, 200, 201 e 202.

SORIANO, Humberto L. Estática das Estruturas. Terceira edição. Editora Ciência Moderna. Ano: 2013. Capítulo: 3 , 4 , 5 e 6. Páginas: 111, 172, 246 e 277. 


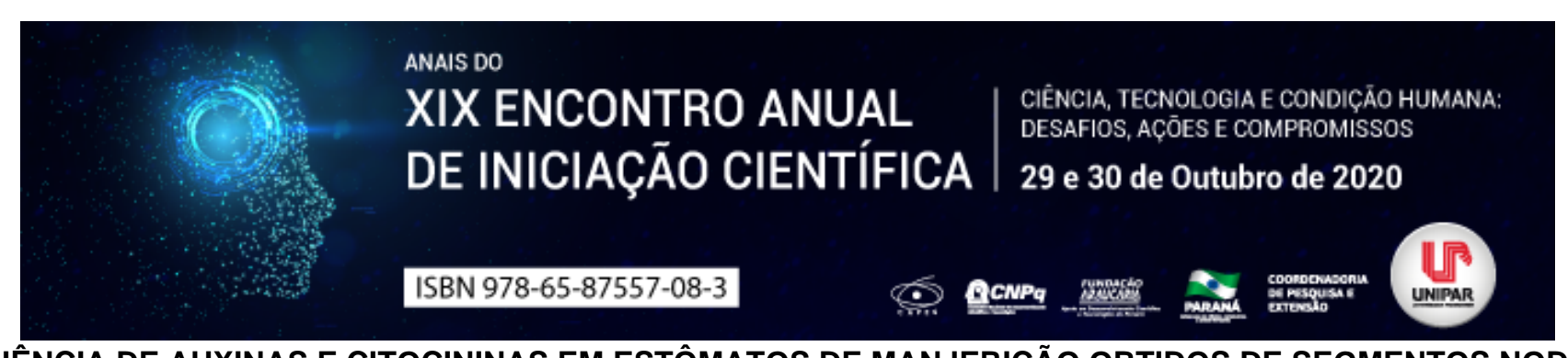

INFLUÊNCIA DE AUXINAS E CITOCININAS EM ESTÔMATOS DE MANJERICÃO OBTIDOS DE SEGMENTOS NODAIS In vitro

\title{
${ }^{1}$ GEYSIANE MOREIRA GEROTTI, ${ }^{2}$ FELIPE GORSKI, ${ }^{3}$ KAROLYNE DE AVILA, ${ }^{4}$ HELIDA MARA MAGALHAES
}

\author{
${ }^{1}$ Acadêmica de Medicina Veterinária e Bolsista PIBIC- UNIPAR \\ ${ }^{1}$ Acadêmico do Curso de Doutorado Em Biotecnologia Aplicada A Agricultura da UNIPAR \\ ${ }^{2}$ Acadêmica do Curso de Engenharia Agronômica da UNIPAR \\ ${ }^{3}$ Docente da UNIPAR
}

Introdução: Ocimum basilicum L. pertencente à família Lamiaceae, é um sub arbusto nativo da Ásia tropical e foi introduzido no Brasil pela colônia italiana. Em quase todo o território brasileiro, esta planta é muito cultivada, sobretudo, por pequenos produtores rurais, para a comercialização como condimentar e medicinal (MARQUES et al., 2015). Todavia é imprescindível avaliar essencialmente a concentração dos reguladores de crescimento e o tipo que influenciam diretamente no crescimento e na morfogênese da planta.

Objetivo: Avaliar a influência das auxinas e citocininas sobre os estômatos de manjericão obtidos de segmentos nodais in vitro. Material e Métodos: Os explantes foram inoculados em frascos com capacidade de $350 \mathrm{~mL}$, contendo $50 \mathrm{~mL}$ de meio de cultura MS (MURASHIGE; SKOOG, 1962), na concentração total dos sais, suplementado com 30g L-1 de sacarose, e 6,5g. L-1 de ágar com pH ajustado para 5.8, os segmentos nodais foram inoculados em meio suplementado com 6 concentrações de reguladores BAP- Benzilaminopurina e ANA- Ácido Naftalenoacético- Tratamento (SR: 0; 0; T1: 0,1; 0,05; T2: 0,2; 1,2; T3: 0,5; 0; T4: 0,1; 0,05; T5: 1,0; 0,5 mg.L-1 de BAP e ANA respectivamente). Após a inoculação dos explantes nos frascos estes foram fechados com tampas plásticas e vedados com parafilme. Os frascos foram mantidos em sala de crescimento com fotoperíodo de 24 horas, luz fornecida com o uso de lâmpadas LED $100-240 \mathrm{~V}-50 / 60 \mathrm{~Hz}$, à temperatura de $25^{\circ} \mathrm{C} \pm 2^{\circ} \mathrm{C}$ e intensidade luminosa de 2000 Lux. Ao final do experimento, foram coletadas folhas completamente expandidas do terço mediano da planta. Para a visualização dos estômatos, as lâminas foram montadas com a técnica de impressão, de acordo com Segatto et al. (2004), as análises foram realizadas na parte adaxial e abaxial das folhas. Após a montagem das lâminas, estas foram fotografadas em microscópio Olympus BX-60 sendo as imagens capturadas por meio do software Motic Images Plus 3.0. Os estômatos também tiveram mensurados: a densidade estomática $\left(\mathrm{mm}^{2}\right)$, o comprimento total $(\mu \mathrm{m})$, a largura das células guarda ( $\left.\mu \mathrm{m}\right)$, a largura das células subsidiárias $(\mu \mathrm{m})$ e a abertura do poro $(\mu \mathrm{m})$. As medições foram realizadas por meio do software Motic Images Plus 3.0. Os dados das medições anatômicas foram analisados em esquema fatorial $2 \times 6$ (face abaxial e adaxial das folhas e 6 concentrações dos reguladores de crescimento). As médias foram comparadas utilizando o teste de Tukey $(p<0,05)$. 0 software Sisvar®, versão 5.6 (FERREIRA, 2011) foi utilizado em todas as análises.

Resultado: Em meios de cultura com segmentos nodais, houve variação no número e no tamanho dos estômatos dependente da concentração dos reguladores e da posição da epiderme. A contagem da densidade estomática da epiderme adaxial foi a maior no meio sem reagente $(114,75 \mathrm{~mm} 2)$, sendo $40 \%$ superior ao menor tratamento $(2=70,56 \mathrm{~mm} 2)$. A densidade estomática da epiderme abaxial foi $50 \%$ maior no tratamento $3(134,12 \mathrm{~mm} 2)$ do que no tratamento $2(64,62 \mathrm{~mm} 2)$ que também apresentou a menor densidade para esta face da folha. O comprimento total do estômato foi $40 \%$ maior no tratamento 3, na epiderme adaxial $(132,28 \mathrm{~mm} 2)$, em relação ao tratamento $2(64,63 \mathrm{~mm} 2)$ que foi o mais baixo, e 30\% maior para a epiderme adaxial $(124,60 \mathrm{~mm} 2)$ em relação ao tratamento 4. Não houve interferência da face da folha para estes parâmetros. O tratamento 3 apresentou a largura da célula guarda 30\% maiores que o tratamento 4, na epiderme adaxial $(79,33 \mathrm{~mm} 2)$ e na epiderme abaxial $(100,09 \mathrm{~mm} 2)$. A largura da célula subsidiária na epiderme adaxial foi $40 \%$ maior em sem reagente $(50,17 \mathrm{~mm} 2)$, igual estatisticamente ao tratamento $3(48,99 \mathrm{~mm} 2)$, em relação tratamento 4. Já na parte inferior da folha, a maior largura das células subsidiárias foi 30\% superior no tratamento $2(43,42 \mathrm{~mm} 2)$ em relação ao tratamento 3 que ficou com a menor largura $(32,29 \mathrm{~mm} 2)$ diferentemente das outras medições. O tratamento 4 apresentou uma abertura de poro $40 \%$ maior do que o tratamento 1 (29,46mm2 frente a $16,72 \mathrm{~mm} 2)$ na parte adaxial, e o tratamento 2 obteve abertura do poro 50\% maior do que o tratamento 1 (36,68 mm2 a 19,08).

Discussão: A variação da densidade estomática foi influenciada pela concentração dos reguladores de crescimento vegetais exógenos. A citocinina pode aumentar a densidade estomática, reduzindo a resistência a água (FARBER et al., 2016). Estes podem estar causando uma espécie de estresse nas plantas. O estresse já foi demonstrado como responsável por aumentar o número de estômatos por área de folha em Ocimum basilicum (BARBIERI et al, 2012; JENSEN et al., 2018). Já foi sugerido que concentrações aumentadas de diferentes fitormônios podem promover fechamento dos estômatos, para promover a diminuição da perda de água (JANOWIAK et al., 2002). Além disso, auxinas endógenas normalmente regulam positivamente a abertura estomática, enquanto auxinas aplicadas a nível exógeno podem inibir a abertura estomática (LOHSE; HEDRICH, 1992; 
ACHARYA; ASSMANN, 2009).

Conclusão: Com base na influência das auxinas e citocininas afirma-se que o tratamento que apresentou um maior número de estômatos foi o 3 (0,5 BAP e 0 ANA), onde pode-se verificar que este apresentou mais resultados de acordo com a presença das citocininas. $E$ com isso pode-se afirmar que concentrações menores de regulares geram um efeito benéfico às plantas quando comparadas aos demais tratamentos.

\section{Referências}

ACHARYA, Biswa; ASSMANN, Sarah. Interações hormonais na função estomática. Biologia Molecular. v.69, p. 451-462. Pensilvânia, 2009. Disponível em: https://doi.org/10.1007/s11103-008-9427-0. Acesso em: 15 jun.2020.

BARBIERI, Giancarlo; et al. Stomatal density and metabolic determinants mediate salt stress adaptation and water use efficiency in basil (Ocimum basilicum L.). Journal of Plant Physiology. v. 169, n. 17, p. 1737-1746, 2012.

FARBER, Mika; et al. Cytokinin activity increases stomatal density and transpiration rate in tomato. Journal of experimental botany, p. 398, 2016.

FERREIRA, Daniel Furtado. Um programa para análises e ensino de estatística. Revista Symposium. SISVAR. v. 6, p. 36-41. Lavras, 2011. Disponível em: http://www.dex.ufla.br/ danielff/meusarquivospdf/art63.pdf. Acesso em: 18 jun. 2020.

JANOWIAK, Franciszek. et al. Importance of abscisic acid for chilling tolerance of maize seedlings. Journal of Plant Physiology. v. 159, n. 6, p. 635-643, 2002.

JENSEN, Nikolaj Bjerring. et al. Spectral quality of supplemental LED grow light permanently alters stomatal functioning and chilling tolerance in basil (Ocimum basilicum L.). Scientia Horticulturae. v. 227, p. 38-47, 2018.

LOHSE, Gabi; HEDRICH Rainer. Caracterização da H + -ATPase da membrana plasmática de células-guarda Vicia faba. Plantas. v. 188, p. 206-214. Hannover, 1992. Disponível em: https://doi.org/10.1007/BF00216815. Acesso em: 15 jun. 2020

MARQUES, Patrícia Angélica Alves. et al. Consumo hídrico do manjericão por meio de lisímetro de drenagem. Irriga. Botucatu, v. 20, n. 4, p. 745-761, out./dez., 2015

MURASHIGE, Toshio; SKOOG, Folke. A revised medium for rapid growth and bio assays with tobacco tissue cultures. Physiol Plant. n.5, p.473-497.1962.

SEGATTO, Fernanda Bastos. et al. A technique for the anatomical study of potato leaf epidermis. Santa Maria, setembro/outubro 2004. Disponível em: http://www.scielo.br/scielo.php?script=sciarttext\&pid=s0103$84782004000500042 \&$ Ing=pt\&tlng=pt. Acesso em: 20 jun. 2020. 


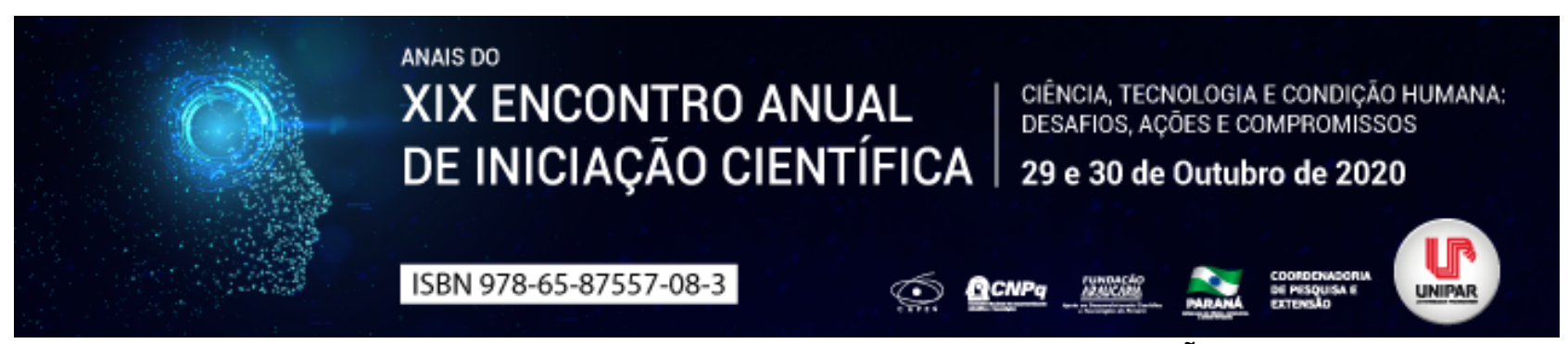

USO DE VIDRO EM FACHADAS, UM ESTUDO DE REVISÃO

\title{
${ }^{1}$ DJESSICA TUANI KREIN, ${ }^{2}$ JESSICA CAROLINE MERLUGO DEPONTI, ${ }^{3}$ RODRIGO MASCHIO DE FREITAS
}

\author{
${ }^{1}$ Acadêmica do curso de Engenharia Civil da Unipar \\ ${ }^{1}$ Acadêmica do Curso de Engenharia Civil da UNIPAR \\ ${ }^{2}$ Docente da UNIPAR
}

Introdução: Pode-se compreender com base em Figueiredo e Pisani (1970) que há um grande desafio em relação ao uso da luz e ventilação natural em edifícios pois a preocupação com a economia de energia e o uso de fontes de recursos naturais está aumentando consideravelmente em todo o mundo e com isso o aumento do uso de vidros em fachadas. Em edifícios de escritórios essas fachadas envidraçadas dão uma vista amplamente maior ao exterior além da iluminação natural que esses vidros trazem ao ambiente (OLIVEIRA; BERNARDINI; MOREIRA, 2018). Entretanto muitos pesquisadores ressaltam que fachadas com grandes áreas envidraçadas tem um baixo desempenho térmico e energético, questionando sua atuação nas condições climáticas Brasileiras, sendo o clima maioritariamente tropical, necessitando de um acondicionamento de ar dentro desses edifícios levantando então a questão do consumo energético. Santos (2017) ressalta que a iluminação artificial e o acondicionamento de ar estão entre os principais fatores de gasto de energia elétrica no Brasil, mais da metade do consumo se dá a esses dois fatores, e isso pode ser contornado com a utilização correta de vidros nas fachadas desses edifícios.

Objetivo: Realizar um estudo bibliométrico sobre o uso de vidro em fachadas, seus benefícios e malefícios e alguns tipos de vidros que podem agregar a esse sistema construtivo.

Desenvolvimento: Tigre (2016) salienta que para assegurar o conforto térmico e a economia com esse sistema construtivo de fachadas, é necessário ter conhecimento de variáveis: as condições climáticas da região e o uso que será destinado a essa edificação, com isso estabelecido, pode-se então definir o tipo de sistema que será usado, visando sempre o conforto térmico e energético, proporcionando bem-estar e segurança aos usuários. Umas das soluções para se obter o conforto térmico dentro da estrutura é o uso de vidro com isolamento térmico, que consiste em uma camada com enchimento de gases nobres, como, xénon, árgon ou crípton, pois gases pesados e reduzem a transmissão e convecção do ar na cavidade do vidro reduzindo a troca de temperatura entre o ambiente externo e interno, por mais que o crípton e o xénon são mais eficientes nessa função, o árgon é muito mais utilizado, pois é mais fácil de ser encontrado (BOGAS, 2011). Outra solução é o vidro insulado, com base em Pinto e Westphal (2017) esse tipo de vidro é uma composição por duas ou mais lâminas de vidros distribuídas, de uma maneira que formam entre elas câmaras de ar, ou um gás de baixa condutividade térmica, essa camada atua tanto para impedir a temperatura externa de adentrar na edificação, como a interna de sair dessa edificação, esse tipo de vidro, muitas vezes não traz real resultados em relação ao desempenho térmico e energético, porém, vendo pelo lado do conforto do usuário, o vidro insulado melhora o conforto térmico dos ocupantes quando se mantém o ambiente condicionado artificialmente. Outra saída é a utilização do vidro translúcido que é produzido com ácido hidrofluorídrico dando ao vidro uma camada fosca que reduz o ofuscamento e passagem de luz, entretanto pela sua produção, possui uma baixa resistência a impactos e esforços mecânicos. Assim entendese que a eficiência térmica e energética de um edifício pode ser trabalhada com o tipo de material e as estratégias que serão utilizadas, (Besen, Simon e Westphal (2014) afirmam que o vidro que será colocado na edificação terá influência direta sobre o consumo energético, portanto deve-se buscar entender os diferentes tipos de vidros com suas características e sua viabilidade econômica de investimento.

Conclusão: Com o conhecimento das variáveis climáticas e do uso da edificação fica mais fácil decidir qual tipo de vidro será utilizado, tendo em mente o conforto térmico dos usuários e a economia energética da edificação, além de as fachadas envidraçadas agradarem a visão estética que se tem do edifício, com a utilização do vidro correto pode-se agradar a todos que irão usufruir dessa edificação.

\section{Referências}

BESEN, Priscila; WESTPHAL, Fernando Simon. Fachadas de vidro no Brasil: um estudo comparativo de viabilidade econômica. XV Encontro Nacional de Tecnologia do Ambiente Construído, 2014.

BOGAS, Joana Maria Peixoto. Fachadas de vidro - Explorar os limites da utilização do vidro na construção. p. 112, 2011.

FIGUEIREDO, Erika Ciconelli de; PISANI, Maria Augusta Justi. Uso Da Luz Natural Em Edifícios De Escritório. p. 1 15, 1970.

PINTO, Mônica Martins; WESTPHAL, Fernando Simon. Viabilidade do uso de vidros insulados em edifícios de escritórios em climas brasileiros. 2017.

PINTO, Mônica Martins; WESTPHAL, Fernando Simon. Vidro insulado em escritórios com fachada envidraçada em Florianópolis ( SC ). 2019. 
SANTOS, Tatiane Borges Martinelli. Benefícios ambientais e energéticos com o uso inteligente do vidro nas edificações. 2017.

TIGRE, Ana Laurent. Eficiência energética em edifícios com fachada de vidro. 2016.

VANDERLEI, Paula Silva Sardeiro; CARAM, Rosana Maria. Vidros translúcidos utilizados nas fachadas das edificações e sua preocupação com o conforto ambiental. 2007.

WESTPHAL, Fernando Simon. Tecnologia de processos e sistemas construtivos. PARC Pesquisa em Arquitetura e Construção, v. 9, n. 3, p. 164 166, 2018.

Coordenadoria de Pesquisa e Extensão - COPEX

Departamento de Editoraçāo e Divulgaçāo Científica - DEDIC 


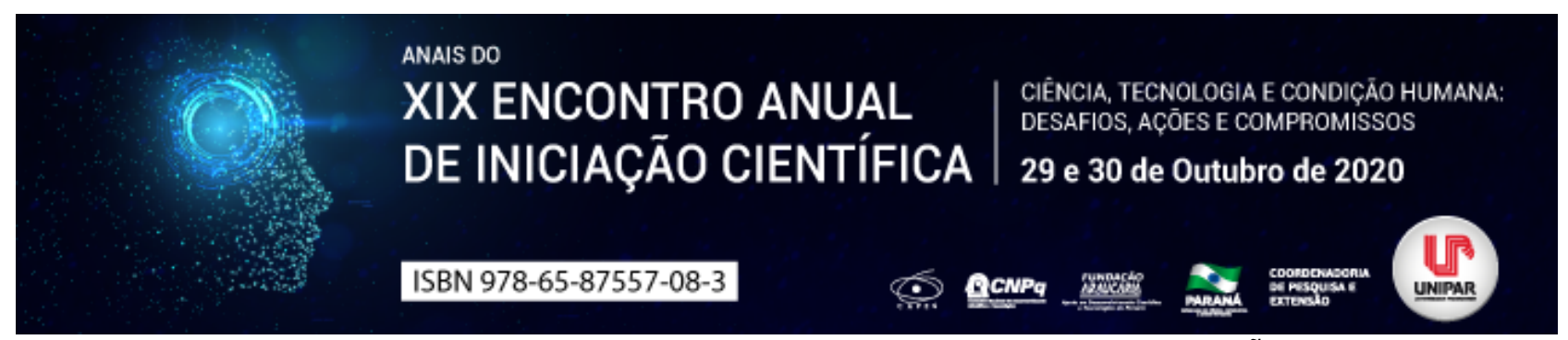

METIL JASMONATO E O COBRE SOBRE A ATIVIDADE ANTIOXIDANTE DE MANJERICÃO CULTIVADO In vitro

\begin{abstract}
${ }^{1}$ GABRIELA DE CARVALHO SANCHES, ${ }^{2}$ GEYSIANE MOREIRA GEROTTI, ${ }^{3}$ FELIPE GORSKI, ${ }^{4}$ ELIZABETH DANTAS, ${ }^{5}$ HELIDA MARA MAGALHAES
\end{abstract}

${ }^{1}$ Discente de Engenharia Agronômica e Bolsista PIBIC- UNIPAR
${ }^{1}$ Discente de Medicina Veterinária e Bolsista PIBIC- UNIPAR
${ }^{2}$ Doutorando pelo Programa de Pós-Graduação em Biotecnologia Aplicada à Agricultura- UNIPAR
${ }^{3}$ Discente de Engenharia Agronômica PIC-UNIPAR
${ }^{4}$ Docente do Programa de Biotecnologia Aplicada à Agricultura- UNIPAR

Introdução: O manjericão (Ocimum basilicum L.) é uma erva perene pertencente à família Lamiaceae, utilizada para fins medicinais ou também como aromatizantes e temperos na culinária. Seu óleo essencial tem grande valor no mercado de cosméticos e perfumarias. O.basilicum L. demonstra elevada ação antioxidante. Nele estão presentes diversos metabólitos, dentre eles os flavonóides, polifenóis (ácido rosmarínico derivado do ácido caféico) e zeaxantinas que são usadas popularmente como antioxidantes e anti-inflamatório (LEÃO et al., 2013 apud HENRIQUE; FERREIRA; NUNES, 2017). Os elicitores podem ser separados em diversas classes (TRETTEL et al., 2018), são substâncias que estimulam a produção de metabólitos secundários em vegetais.

Objetivo: $O$ objetivo deste trabalho foi analisar a atividade antioxidante de folhas frescas de plântulas de manjericão Grecco a Palla cultivados in vitro com um elicitor químico, o Cobre $(\mathrm{Cu})$ e um elicitor orgânico, metil jasmonato (MeJA).

Material e Métodos: Foram utilizadas sementes de O. basilicum da cultivar Grecco a Palla. As sementes foram desinfetadas em fluxo laminar e mantidas durante 2 minutos em álcool etílico 70\%. Em seguida foram mantidas em uma solução de hipoclorito de sódio $2 \%$ durante 15 minutos sob agitação. Posteriormente foram realizadas quatro lavagens sucessivas com água deionizada e autoclavada. Aos 60 dias de cultivo in vitro, serviram de doadoras de ápices caulinares. Os ápices tinham em média $1 \mathrm{~cm}$ e apresentavam dois cotilédones. Os explantes foram inoculados em frascos com capacidade de $350 \mathrm{~mL}$, contendo $50 \mathrm{~mL}$ de meio de cultura MS (MURASHIGE; SKOOG, 1962), na concentração de total dos sais, suplementado com $30 \mathrm{~g} \mathrm{~L}^{-1}$ de sacarose, e $6,5 \mathrm{~g}$ $\mathrm{L}^{-1}$ de ágar com pH ajustado para 5,8. O meio foi adicionado com diferentes concentrações de Cobre e Metil Jasmonato (T1: $0 \mu \mathrm{M}, 0 \mu \mathrm{M}$; T2: $25 \mu \mathrm{M}, 0 \mu \mathrm{M}$; T3: $75 \mu \mathrm{M}, 0 \mu \mathrm{M}$; T4: $0 \mu \mathrm{M}, 5 \mu \mathrm{M}$, T5: $25 \mu \mathrm{M}, 5 \mu \mathrm{M}$; T6: $75 \mu \mathrm{M}, 5 \mu \mathrm{M}$ respectivamente). O experimento foi conduzido em delineamento inteiramente casualizado (DIC) com 6 tratamentos, 5 repetições, sendo cada repetição composta por 6 frascos que continham 1 explante. O meio de cultura foi autoclavado por 20 minutos a $120^{\circ} \mathrm{C}$, sob $1 \mathrm{~atm}$. Após a inoculação dos explantes nos frascos estes foram fechados com tampas plásticas e vedados com parafilme. Os frascos foram mantidos em sala de crescimento com fotoperíodo de 24 horas luz fornecidas com o uso de lâmpadas light emitter diodes (LEDS) Blumenau ${ }^{\circledR}$, LED T8 10W 6.000K, 100-240V-50/60Hz, fator de potência: $\geq 0,92$ (Alto FP), à temperatura de $25^{\circ} \mathrm{C} \pm 2^{\circ} \mathrm{C}$ e intensidade luminosa de $72,02 \mu \mathrm{mol} \mathrm{m} \mathrm{m}^{-2} \cdot \mathrm{s}^{-1}$. A determinação da atividade antioxidante foi baseada na extinção da absorção do radical 2.2-difenil-1-

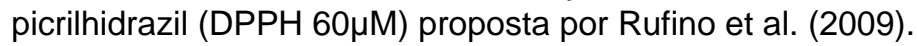

Resultado: T5 não apresentou oxidação e obteve a maior atividade antioxidante (8,65\%). Os outros tratamentos com aplicação de MeJA também apresentaram alta atividade antioxidante, T4 (4,53\%) e 3\% de plântulas oxidadas, e T6 (6,32\%) e 6\% de plântulas oxidadas. O meio sem elicitor, T1, teve atividade antioxidante de $2,4 \%$. A menor atividade antioxidante foi registrada em T2 (1,26\%), que apresentou 55\% de plântulas com oxidação. Não foi possível mensurar a atividade antioxidante em T3, pois todas as plântulas sofreram oxidação. Este resultado sugere que o Cu deve ter impedido a formação de compostos antioxidantes, aumentando assim a oxidação das plântulas. E o MeJA ofereceu proteção antioxidante, que foi potencializada com o aumento dos fenilpropanóides em manjericão Grecco a palla.

Discussão: A oxidação pode reduzir a contagem geral de açúcares, que podem ter sido protegidos por meio da eliminação de radicais livres reativos (FARAJI; LINDSAY, 2004), causar a inibição de reações químicas com a redução da atividade da água (BARBOSA et al., 2014) e agir como agente quelante de íons metálicos, como o $\mathrm{Cu}$, que poderiam atuar como catalisadores da oxidação de compostos fenólicos (YRUELA, 2005). O estresse oxidativo estimula a biossíntese de componentes antioxidantes e aumenta a atividade de enzimas antioxidante (SOARES, 2006). Diante disso, os resultados obtidos indicam que o $\mathrm{Cu}$ é responsável pela oxidação, no entanto com a aplicação de MeJA houve um estímulo para a produção de antioxidantes.

Conclusão: Com base nos resultados obtidos, pode-se concluir que o uso dos elicitores Cu e MeJA no manjericão Grecco a palla apresentaram resultados positivos como potencial antioxidante, uma vez que os valores com concentrações média e alta de $\mathrm{Cu}$ juntamente com o MeJA obtiveram uma maior atividade antioxidante, que são extremamente importante para a saúde 
humana e a qualidade dos alimentos, já que, a oxidação forma compostos com potencial tóxico.

\section{Referências}

BARBOSA, Marta Ribeiro et al. Geração e desintoxicação enzimática de espécies reativas de oxigênio em plantas. Ciência Rural, v. 44, n. 3, p. 453-460, 2014.

FARAJI, Habibollah; LINDSAY, Robert C. Characterization of the antioxidant activity of sugars and polyhydric alcohols in fish oil emulsions. Journal of agricultural and food chemistry, v.52, n. 23, p.7164-7171, 2004.

HENRIQUE, Vanessa Alves; FERREIRA, Larissa Pacheco; NUNES, Clara dos Reis. Análise físico-química e antioxidante de manjericão (Ocimum basilicum L.) orgânico. Revista Interdisciplinar do Pensamento Científico, v.3, n.2, 2017.

MURASHIGE, Toshio; SKOOG, Folke. A revised medium for rapid growth and bioassays with tobacco tissue cultures. Physiologia Plantarum, v.15, n. 3, p.473-497, 1962.

SOARES, Alexandra Martins dos Santos. Análise da resposta antioxidativa em plantas de Ricinus communis submetidas ao estresse por metil jasmonato. Orientador: Olga Lima Tavares Machado. 2004. Dissertação (Mestre em Biociências e Biotecnologia) - Universidade Estadual do Norte Fluminense Darcy Ribeiro, Rio de Janeiro, 2006.

TRETTEL, Jéssica Rezende et al. Effects of copper sulphate (CuSO 4) elicitation on the chemical constitution of volatile compounds and the in vitro development of Basil. Scientia Horticulturae, v. 234, p. 19-26, 2018.

YRUELA, Inmaculada. Copper in plants. Brazilian Journal of Plant Physiology, v. 17, n. 1, p. 145-156, 2005.

ZHANG, Changhe et al. Enhancement of tanshinone production in Salvia miltiorrhiza hairy root culture by Ag+ elicitation and nutrient feeding. Planta Medica, v.70, n.2, p.147-151, 2004. 


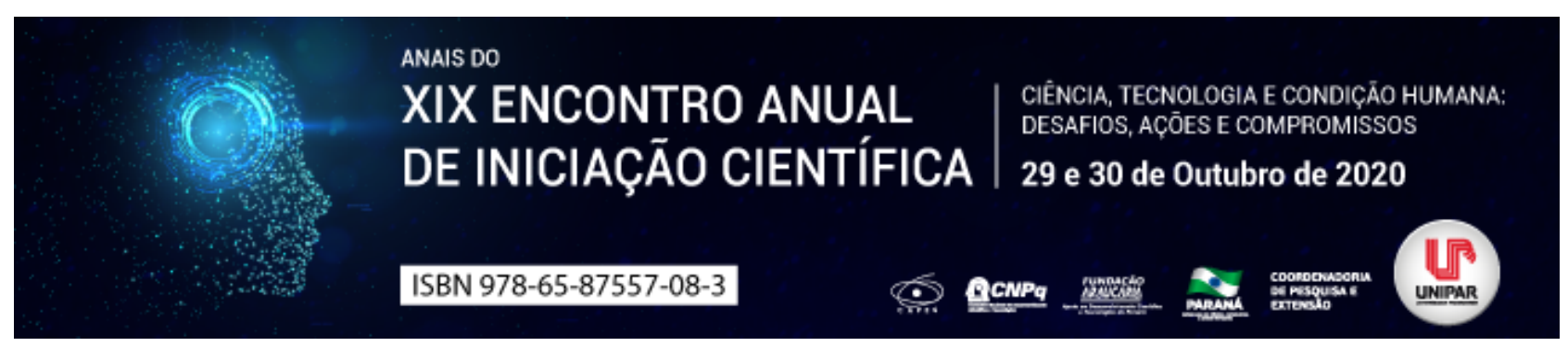

EXTRATOS DE BOLDO PARA CONTROLE DE FITONEMATOIDES

${ }^{1}$ Beatriz de Almeida e Silva, ${ }^{2}$ LUIS OTÁVIO DA SILVA CHICARELLI, ${ }^{3}$ LAIS FERNANDA FONTANA, ${ }^{4}$ CLAUDIA REGINA DIASARIEIRA

${ }^{1}$ Acadêmica do curso de Agronomia da UEM

${ }^{1}$ Acadêmico do curso de Agronomia da UEM

${ }^{2}$ Pós-doutoranda em Ciências Agronômicas da UEM

${ }^{3}$ Docente da UEM

Introdução: A busca de alternativas para controle de nematoides é fundamental, tendo em vista que produtos químicos podem ter efeitos deletérios à microbiota do solo, pois são não seletivos e apresentaram alta toxicidade ao homem (SANTOS, 2015). Os extratos vegetais são, de maneira geral, menos agressivos, de baixo custo, fácil obtenção e eficientes na redução de fitonematoides (WANG et al., 2012; MULLER et al., 2014; SOUZA, 2020).

Objetivo: Avaliar a atividade nematicida in vitro de extratos aquoso e etanólico de boldo (Plectranthus barbatus) em Meloidogyne javanica e Pratylenchus brachyurus.

Material e Métodos: Extratos de folhas frescas de boldo foram preparados na proporção 1:10 (p:v) triturados com água destilada (EA) ou álcool etílico (EE), separadamente, ficando em repouso por $24 \mathrm{~h}$ para obtenção do extrato bruto (EB). Com a obtenção do EB, estes foram filtrados em gaze esterilizada e diluídos a 0; 5; 10; 20; e 40\% (v:v) para ambos os extratos (EA e EE). Em seguida, adicionou-se $4 \mathrm{~mL}$ dos extratos, individualmente, em tubos Falcon e $1 \mathrm{~mL}$ de suspensão contendo, separadamente, 100 juvenis de $M$. javanica ou de $P$. brachyurus. Após $48 \mathrm{~h}$ realizou-se a contagem dos juvenis vivos e mortos, com adição de $10 \%$ de hidróxido de sódio 0,1 M. Os resultados foram submetidos a análise de regressão pelo programa estatístico SISVAR.

Resultados: Ambos os extratos (EA e EE) promoveram mortalidade das duas espécies de nematoides estudadas nas concentrações de 20 e 40\%, sendo $40 \%$ a melhor diluição. Para $M$. javanica a mortalidade de juvenis foi de 98 e $96 \%$, quando submetidos a EA e $100 \%$ em EE. Ainda para EE, observou-se mortalidade de 84 e $83 \%$ na população de $P$. brachyurus, como também EA causou mortalidade de $100 \%$ dos juvenis.

Discussão: Dados semelhantes foram encontrados utilizando extratos vegetais de outras plantas medicinais pertencentes a mesma família botânica (Laminaceae). Dentre eles, estão os extratos aquosos de alecrim, que promoveu redução de $83 \% \mathrm{em} M$. incognita (Muller et al., 2012) e um fertilizante a base do mesmo extrato vegetal, que ocasionou mortalidade de $88,9 \%$ de $P$. brachyurus (Souza, 2020). Ainda, o extrato de orégano aplicado ao solo, promoveu redução de $28 \%$ na população de Rotylenchulus reniformis (GARDIANO et al., 2011), entretanto, os mesmos autores utilizando o tratamento com P. barbatus, obtiveram aumento de $8 \%$ na população para esta espécie de nematoide. O extrato de boldo, bem como de alecrim e orégano, possui na composição de suas folhas o ácido rosmarínico (WANG et al., 2012; ALKAM et al., 2007), responsável pela inibição da enzima acetilcolinesterase, atuando no neurotransmissor acetilcolina (FALE et al., 2009), que pode ter afetado o sistema nervoso central dos nematoides. Nesse sentido, comprova-se a ação nematicida in vitro dos extratos de boldo, para ambas as espécies avaliadas. Contudo, estudos em casa de vegetação devem ser realizados para confirmar a viabilidade do uso in vivo.

Conclusão: Os extratos de boldo ( $P$. barbatus) promoveram mortalidade de $M$. javanica e de $P$. brachyurus, independente da forma de obtenção do extrato bruto, nas doses de 20 e $40 \%$.

\section{Referências}

ALKAM, T.; NITTA, A.; MIZOGUCHI, H.; et al. A natural scavenger of peroxynitrites, rosmarinic acid, protects against impairment of memory induced by A beta (25-35). Behavioural Brain Research, v.180, n.2, p.139-145, Jun, 2007.

FALE, P. L.; BORGES, C.; MADEIRA, P. J. A.; et al. Rosmarinic acid, scutellarein 4 '- methyl ether 7-O-glucuronide and (16S)coleon $\mathrm{E}$ are the main compounds responsible for the antiacetylcholinesterase and antioxidant activity in herbal tea of Plectranthus barbatus ("falso boldol"). Food Chemistry, v. 114, n. 3, p. 798-805, Jun. 2009.

MULLER, M. A.; MIORANZA, T. M.; FUCHS, F.; et al. Mortalidade e Motilidade de Meloidogyne incógnita em Extrato Aquoso de Alecrim. Scientia Agraria Paranaensis, v. 13, n. sup, p. 343-346, Ago./Out. 2014.

SANTOS, P. S. dos. Aplicação em sulco de nematicidas em soja. 2015. 52f. Dissertação (Mestrado em Engenharia Agrícola)

Universidade Federal de Santa Maria, Santa Maria RS, 2015.

SOUZA, D. H. G. Indução de resistência em soja e controle de Pratylenchus brachyurus com fertilizante foliar a base de alecrim (Rosmarinus officinalis L.). 2020. 53f. Dissertação (Mestrado em Agronomia) Universidade Estadual do Oeste do Paraná, Marechal Candido Rondon PR, 2020. 
WANG, J.; PAN, X.; HAN, Y.; et al. Rosmarinic acid from eelgrass shows nematicidal and antibacterial activities against pine wood nematode and it carrying bacteria. Marine Drugs, v.10, n.2, p.2729-2740, Dez. 2012.

Coordenadoria de Pesquisa e Extensão - COPEX

Departamento de Editoraçāo e Divulgaçāo Científica - DEDIC 


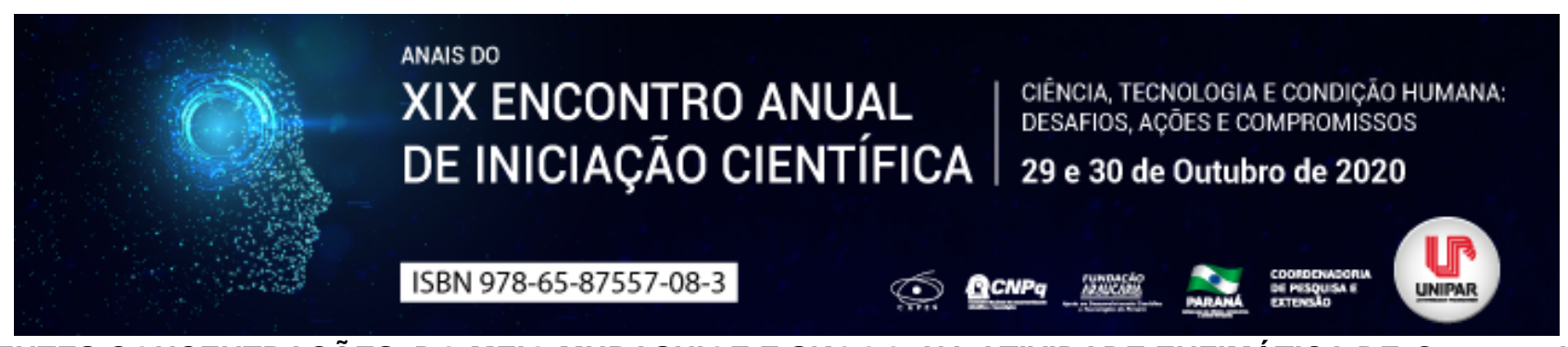

\title{
DIFERENTES CONCENTRAÇÕES DO MEIO MURASHIGE E SKOOG NA ATIVIDADE ENZIMÁTICA DE Curcuma Ionga L. CULTIVADA In vitro
}

\author{
${ }^{1}$ MATHEUS MARQUEZINI DE ANDRADE, ${ }^{2}$ MAYARA DOS SANTOS QUEIROZ, ${ }^{3}$ MEIRE PEREIRA DE SOUZA FERRARI, \\ ${ }^{4}$ HELEN KARLA FERREIRA DE MELLO, ${ }^{5}$ HELIDA MARA MAGALHAES
}

\author{
${ }^{1}$ Acadêmico do Curso de Engenharia Agronômica da Unipar \\ ${ }^{1}$ Engenheira Agrônoma \\ ${ }^{2}$ Doutora em Biotecnologia Aplicada à Agricultura \\ ${ }^{3}$ Acadêmica do Curso de Engenharia Agronômica Unipar \\ ${ }^{4}$ Doutora e docente da UNIPAR
}

Introdução: Curcuma longa L. é uma planta perene e herbácea, possui um rizoma rico em nutrientes e compostos do metabolismo secundário (Raina et al., 2005). O meio MS (Murashige e skoog, 1962) é utilizado universalmente em laboratórios de cultura de tecidos, é um meio caracterizado pela sua elevada concentração de nutrientes. Desta forma, torna-se necessário avaliar se a concentração dos diferentes constituintes do meio não prejudica o crescimento da plântula. Uma das formas de avaliar efeitos prejudiciais se dá por meio das enzimas antioxidantes que removem radicais livres da célula (Gill e Tuteja, 201). O estresse oxidativo tende aumentar a atividade das enzimas principalmente nas formulações do meio que não são adequadas.

Objetivo: O trabalho teve como objetivo avaliar a atividade enzimáticas em meio MS, com diferentes concentrações de sais, sacarose e carvão ativado.

Material e Métodos: A assepsia se deu pela imersão dos brotos em solução hipoclorito de sódio $2 \%$ por 20 minutos e lavagem em água destilada autoclavada por três vezes.Neste ensaio foram avaliadas o efeito da interação entre diferentes concentrações do meio MS (Murashige e Skoog 1962), sacarose e carvão ativado conforme descrito a seguir: T1 - 100\% do meio MS, 30,0 g.L-1 de sacarose e ausência de carvão ativado; T2 50\% de sais do meio MS, 30,0 g.L-1 de sacarose e ausência de carvão ativado; T3 - 50\% de sais do meio MS, 60 g.L-1 de sacarose e 4,5 g.L-1 carvão ativado; T4 - 70\% de sais do meio MS, 30 g.L-1 de sacarose e ausência de carvão ativado; T5 - 70\% de sais do meio MS, 60 g.L-1 de sacarose e 4,5 g.L-1 carvão ativado. O pH foi padronizado para 5,8. Após 90 dias foram avaliadas as enzimas extraídas de folhas frescas superóxido dismutase (SOD), ascorbato peroxidase (APX) e catalase (CAT) conforme metodologia de Giannopolis e Ries (1977), Havir e McHale (1987) e Nakano e Asada (1981). O experimento foi montado em delineamento inteiramente casualizado (DIC), com cinco tratamentos, cinco repetições e quatro frascos por parcela, totalizando 100 parcelas por ensaio. Os dados foram submetidas à análise de variância (ANOVA) a $\mathrm{p} \leq(0,05)$ e as médias comparadas por meio do teste Tukey $(p \leq 0,05)$ utilizando o software SISVAR 5.6 (Ferreira, 2011).

Resultados: A enzima APX apresentou atividade superior a 0,4 $\mathrm{mM} \mathrm{g}^{-1} \mathrm{FW}$ em todos os tratamentos, exceto para o tratamento 1 que ficou pouco abaixo desse valor. A maior média observada foram nos tratamentos 1 e 4 (acima de $0,2 \mathrm{mM} \mathrm{g}^{-1} \mathrm{FM}$ ), justamente aqueles que apresentaram melhor desempenho no crescimento (dados não demonstrados). Já a SOD das três enzimas avaliadas foi a que se revelou com uma atividade quase que constante entre os tratamentos. As atividades ficaram superiores a 1,200 mM mg-1 FM, apenas para o tratamento 5 esse valor foi levemente inferior. Já a CAT foi a enzima que mais sofreu variações ao longo dos tratamentos.

Discussão: Esses resultados podem estar associados ao fato da CAT trabalhar na remoção final do peróxido e oxidá-lo em água. Essa variação se daria em função do $\mathrm{H}_{2} \mathrm{O}_{2}$ presente em cada tratamento (Gill e Tuteja, 2010). A SOD tem se mostrado com atividades maiores, porque é a primeira linha de defesa contra os radicais livres. O oxigênio singleto sofre redução por esta enzima ou é dismutado em $\mathrm{H}_{2} \mathrm{O}_{2}$ por enzimas como a APX, peroxirredoxinas (PRX) (Noctor et al., 2018). A catalase age oxidando o peróxido $\mathrm{H}_{2} \mathrm{O}_{2}$ em água e um radical oxidado completando assim o ciclo de limpeza da célula, uma única molécula atua em milhares de $\mathrm{H} 2 \mathrm{O} 2$ (Gill e Tuteja, 2010).

Conclusão: As menores atividades para enzima catalase foram verificadas nos tratamentos dois e três.

\section{Referências}

ANTONIAZZI, Dirlane et al. Growth regulators, DNA content and anatomy in vitro-cultivated Curcuma longa seedlings. African Journal of Biotechnology, v. 15, n. 32, p. 1711-1725, 2016.

CALDAS, L.; HARIDASSAN, P.; FERREIRA, M. E. Meios nutritivos. In: TORRES, A. C; CALDAS, L. S.; BUSO, J.A. (Eds). Cultura de Tecidos e transformação genética de plantas. Brasilia: Embrapa-SPI/Embrapa-CNPH, 1998. 509 p. 
FERREIRA, Daniel Furtado. Sisvar: a computer statistical analysis system. Ciência e agrotecnologia, v. 35, n. 6, p. 1039-1042, 2011.

GIANNOPOLITIS, Constantine N.; RIES, Stanley K. Superoxide dismutases: I. Occurrence in higher plants. Plant physiology, v. 59, n. 2, p. 309-314, 1977.

GILL, Sarvajeet Singh; TUTEJA, Narendra. Reactive oxygen species and antioxidant machinery in abiotic stress tolerance in crop plants. Plant physiology and biochemistry, v. 48, n. 12, p. 909-930, 2010.

NOCTOR, Graham; REICHHELD, Jean-Philippe; FOYER, Christine H. ROS-related redox regulation and signaling in plants. In: Seminars in Cell \& Developmental Biology. Academic Press, 2018. p. 3-12.

HAVIR, Evelyn A.; MCHALE, Neil A. Biochemical and developmental characterization of multiple forms of catalase in tobacco leaves. Plant Physiology, v. 84, n. 2, p. 450-455, 1987.

MURASHIGE, Toshio; SKOOG, Folke. A revised medium for rapid growth and bio assays with tobacco tissue cultures. Physiologia plantarum, v. 15, n. 3, p. 473-497, 1962.

NAKANO, Yoshiyuki; ASADA, Kozi. Hydrogen peroxide is scavenged by ascorbate-specific peroxidase in spinach chloroplasts. Plant and cell physiology, v. 22, n. 5, p. 867-880, 1981.

RAINA, V. K.; SRIVASTAVA, S. K.; SYAMSUNDAR, K. V. Rhizome and leaf oil composition of Curcuma longa from the lower Himalayan region of northern India. Journal of Essential Oil Research, v. 17, n. 5, p. 556-559, 2005.

Coordenadoria de Pesquisa e Extensão - COPEX

Departamento de Editoraçāo e Divulgaçāo Científica - DEDIC 


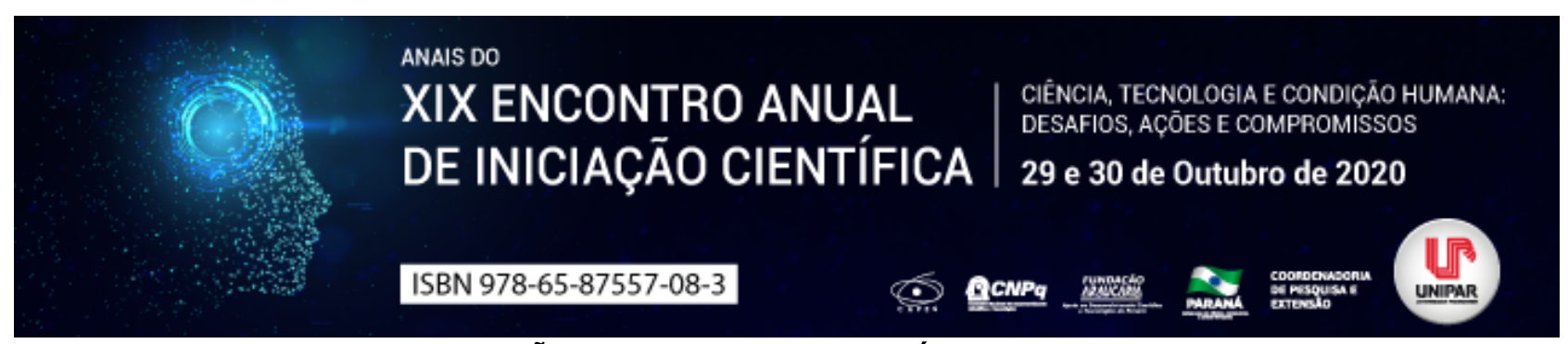

CONSTRUÇÃO DE UM SECADOR A VÁCUO DE BANCADA

\title{
${ }^{1}$ Luan Silva Scarassatti, ${ }^{2} \mathrm{JHONY}$ TIAGO TELEKEN, ${ }^{3}$ BARBARA DANIELE ALMEIDA PORCIUNCULA
}

\author{
${ }^{1}$ Acadêmico Bolsista do PIBITI - Fundação Araucária \\ ${ }^{1}$ Docente da UEM \\ ${ }^{2}$ Docente da UEM
}

Introdução: A secagem é uma operação unitária muito utilizada na indústria de alimentos. O principal objetivo dessa operação é reduzir o conteúdo de umidade até níveis que garantam a estabilidade microbiológica do produto. (DEFRAEYE, 2014; MENON et al., 2020). Na desidratação há um interesse particular em processos de secagem conduzidos em condições subatmosféricas. Ao reduzir a pressão do ambiente é possível conduzir a secagem em baixas temperaturas e, consequentemente, minimizar os efeitos térmicos de deterioração de macro e micronutrientes, e compostos bioativos do alimento. (ZOTARELLI et al., 2012; LINK et al., 2017; MONTEIRO et al., 2018).

Objetivo: O objetivo do presente trabalho foi construir um secador a vácuo utilizando materiais de laboratório.

Material e Métodos: Sistema Experimental: O aparato experimental consiste de uma câmara de secagem aquecida por água e conectada a uma bomba de vácuo. Um kitassato de vidro de $250 \mathrm{~mL}$ foi utilizado como câmara de secagem. Ele é mantido no interior de um béquer de vidro de $1500 \mathrm{~mL}$ preenchido com água aquecida por uma chapa aquecedora (Marconi, MA-085, 500W, Brasil). Para monitorar a temperatura da amostra durante a secagem, um termômetro digital do tipo espeto (Iconterm, AF1806, Brasil) foi adaptado na rolha de silicone que veda a câmara de secagem. O kitassato foi conectado a um sistema de condensação e em seguida a uma bomba de vácuo (Milipore Modelo WP611560, Brasil). O sistema de condensação, que consiste de um kitassato de vidro de $1000 \mathrm{~mL}$ preenchido com sílica granulada, foi instalado na linha de vácuo, com o objetivo de manter a eficiência da bomba, pela condensação do vapor de água vindo da câmara de secagem. Além disso, ele também tem a função de atuar como um tanque pulmão (volume do sistema de condensação é 4 vezes maior que o volume da câmara de secagem) para aumentar a velocidade de redução da pressão na câmara de vácuo. Para monitorar a pressão do sistema, um vacuômetro analógico do tipo rosca (Vulkan Lokring, 1/8 Eos, Brasil) foi adaptado a linha de vácuo na saída câmara de secagem. Um conjunto das 3 válvulas do tipo globo foi instalado na linha de vácuo para facilitar a operação do sistema. Procedimento Experimental, Amostra modelo: Batata inglesa (Salanum tuberosum) foi utilizada como amostra modelo na validação do sistema de secagem. O tubérculo foi obtido no comércio local de Umuarama-PR. Para o procedimento de secagem a batata foi cortada em formato cilíndrico utilizando um cortador de aço inox confeccionado para esse fim. Procedimento de secagem: Uma amostra de batata $(25 \times 10) \mathrm{mm}$ era colocada sobre corte de papel alumínio; o conjunto era então pesado em balança analítica e inserido na câmara de secagem já espetado no termômetro ficando em contato com a parede de fundo da câmara. A câmara com a amostra foi inserida dentro do béquer com água em ebulição. Quando o termômetro atingiu $80^{\circ} \mathrm{C}$, a pressão foi reduzida até 19 $\mathrm{KPa}$ através da abertura das válvulas. Em tempos pré-determinados $(0,30,60,90,120,150,180,210,270$ e 300 minutos) a pressão da câmara era reestabelecida e o conjunto, papel alumínio e amostra, era novamente pesado em balança analítica. 0 teor de umidade da amostra em cada tempo foi determinado através do método gravimétrico em estufa a $105{ }^{\circ} \mathrm{C}$ até peso constante (Instituto Adolfo Lutz, 2008).

Resultado e Discussões: O aumento da temperatura da amostra de $25^{\circ} \mathrm{C}$ até $80{ }^{\circ} \mathrm{C}$ em pressão atmosférica (101.325 kPa) ocorreu em um período de aproximadamente $30 \mathrm{~min}$. A perda de massa da amostra durante esse período foi desprezível. Subsequentemente, com a redução da pressão no interior da câmara, para o início da secagem, observou-se a redução da temperatura da amostra até uma faixa de valores compreendidos entre 60 e $70^{\circ} \mathrm{C}$. Essa redução da temperatura é resultado da evaporação da água e consequente resfriamento evaporativo da amostra. Entretanto, a partir dos 210 min de secagem, há uma tendência de aumento da temperatura da amostra. Esse comportamento ocorre devido a menor velocidade de evaporação da água, em virtude do conteúdo reduzido de umidade na amostra.

O conteúdo de umidade da amostra é reduzido de aproximadamente $4,5 \mathrm{~g}$ de água/ g de sólido seco para $0.08 \mathrm{~g}$ de água/ g de sólido seco em um período de 3 horas. De maneira geral, é um processo de secagem lento quando comparado a secagem com micro-ondas a vácuo, que leva em torno de 15 a 30 min para desidratar batata conforme estudado por Monteiro et al. (2016). Essa diferença se dá principalmente em termos dos níveis de pressão utilizados nas secagens (19 kPa no presente estudo, $4 \mathrm{kPa}$ no estudo de Monteiro et al. (2018)) e também do mecanismos de transferência de calor (a radiação micro-ondas é capaz de penetrar no alimento, resultando no aquecimento volumétrico e mais rápido da amostra).

Conclusão: O aparato experimental construido permitiu acompanhar a dinâmica da temperatura e da pressão no interior da câmara de secagem durante a desidratação de batata. Além disso, constatou-se que o sistema foi efetivo, reduzindo o conteúdo de umidade da amostra em mais de $80 \%$. Portanto, esse tipo de sistema pode ser útil para a pesquisa a nível de bancada. 


\section{Referências}

DEFRAEYE, T. Advanced computational modelling for drying processes a review. Applied Energy. 131, 323-344, 2014.

INSTITUTO ADOLFO LUTZ. Normas Analíticas do Instituto Adolfo Lutz. Métodos físico-químicos para análises de alimentos. $4^{a}$ ed. (1ª Edição digital), 2008. 1020 p.

LINK, Jade Varaschim; TRIBUZI, Giustino; LAURINDO, João Borges. Improving quality of dried fruits: a comparison between conductive multi-flash and traditional drying methods. : A comparison between conductive multi-flash and traditional drying methods. Lwt, v. 84, p. 717-725, out. 2017. Elsevier BV. http://dx.doi.org/10.1016/j.lwt.2017.06.045.

MENON, A., STOJCESKA, V., TASSOU, S. A systematic review on the recent advances of the energy efficiency improvements in non-conventional food drying technologies. Trends in Food Sci. \& Tech., In press, 2020.

MONTEIRO, Ricardo L. et al. Microwave vacuum drying and multi-flash drying of pumpkin slices. Food Eng. J.,v. 232, p.1-10, set. 2018. Elsevier BV. http://dx.doi.org/10.1016/j.jfoodeng.2018.03.015.

MONTEIRO, Ricardo L.; CARCIOFI, Bruno A.m.; LAURINDO, João B.. A microwave multi-flash drying process for producing crispy bananas. Food Eng. J., v. 178, p.1-11, jun. 2016. Elsevier BV. http://dx.doi.org/10.1016/j.jfoodeng.2015.12.024.

ZOTARELLI, Marta Fernanda; PORCIUNCULA, Barbara Daniela Almeida; LAURINDO, João Borges. A convective multi-flash drying process for producing dehydrated crispy fruits. Food Eng. J., v. 108, n. 4, p.523-531, fev. 2012. Elsevier BV. http://dx.doi.org/10.1016/j.jfoodeng.2011.09.014.

Coordenadoria de Pesquisa e Extensão - COPEX

Departamento de Editoraçāo e Divulgaçāo Científica - DEDIC 


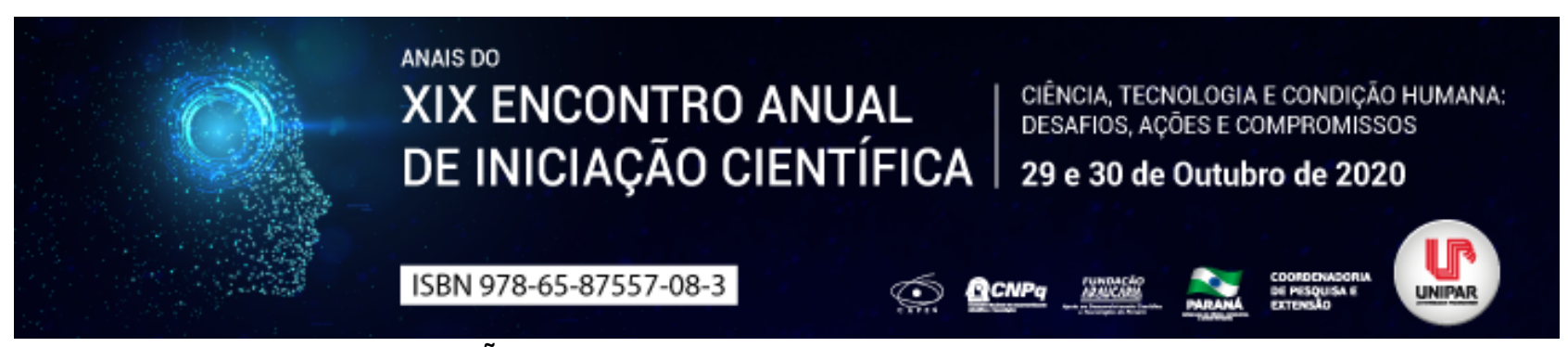

BIORREMEDIAÇÃO POR ORGANISMOS GENETICAMENTE MODIFICADOS

${ }^{1}$ Rhaysa Akemi Takeda

\section{${ }^{1}$ Mestranda PGEAGRI / UNIOESTE}

Introdução: A biotecnologia é um ramo da ciência que promove o desenvolvimento de processos biológicos que beneficiem a humanidade, como por exemplo a obtenção de organismos geneticamente modificados, utilizados em larga escala na agricultura, mas que também podem ser empregados na biorremediação de um ambiente contaminado.

Objetivo: Realizar um apanhado geral, por meio de estudos e artigos previamente publicados, da biorremediação de áreas contaminadas por organismos geneticamente modificados.

Desenvolvimento: Organismos Geneticamente Modificados (OGM's) são organismos manipulados de forma a favorecer ou alterar alguma característica desejada através de técnicas de engenharia genética. As modificações são feitas em trechos do genoma desse organismo, podendo ou não inserir genes externos, visando favorecer características desejadas, como por exemplo facilitar a biodegradação de um composto químico persistente. (XAVIER et al, 2009). A biorremediação é uma técnica desenvolvida para recuperar áreas do meio ambiente, que foram comprometidas pela contaminação por compostos tóxicos, com o auxílio de organismos vivos, tais como: bactérias, fungos, algas verdes ou suas enzimas, atuando na biodegradação do poluente. Sendo assim, uma técnica bastante promissora para a reestruturação de habitats naturais e mitigação de impactos antropológicos. (CARNEIRO, 2010). Os OGM's, também chamados de transgênicos, se difundiram rapidamente ao olhar agroquímico principalmente por empresas transnacionais pela ideia de melhoria nos seus produtos. A incorporação desses organismos na biorremediação possibilita contornar algumas limitações dessa técnica, como por exemplo a degradação parcial de um xenobiótico poluente, aumentando a taxa de biodegradação de compostos tóxicos, com a inserção de genes codificantes de enzimas catabólicas específicas para a molécula-alvo. Para então, transformar o composto tóxico em atóxico através do metabolismo microbiano. (GAYLARDE et al, 2005). Os primeiros registros do uso de OGM's com aplicação na biorremediação são de bactérias recombinantes desenvolvidas nos anos 70. A descoberta da técnica do DNA recombinante foi amplamente decisiva no desenvolvimento de tecnologias de degradação de compostos tóxicos livres na natureza. Foram obtidas bactérias capazes de degradar mais de um tipo de hidrocarboneto, como cânfora, naftalina, octano e xileno. (ALVES, 2004). No entanto, apesar do sucesso na biodegradação de compostos tóxicos, a liberação dos transgênicos no meio ambiente levantou questões acerca da segurança ambiental desses agentes biológicos. O grande problema na análise dos riscos dos organismos transgênicos é que os efeitos não podem ser previstos em sua totalidade. Uma das preocupações é a competição do OGM com organismos já presentes no meio ambiente causando um desequilíbrio na população microbiana indígena do meio ambiente. (ALTIERI, 2000). Entretanto, a biorremediação utilizando OGMs é uma técnica altamente promissora para recuperação de áreas contaminadas pelo fato de que permite a manipulação genética do organismo, somando ao fato que a degradação completa é mais provável quando o composto xenobiótico possui uma estrutura química semelhante a compostos naturais, e também de que os microrganismos presentes na natureza trocam material genético entre si. Se inserido na natureza o OGM será capaz de disseminar rapidamente seu gene codificante de enzima catabólica responsável pela biodegradação do composto xenobiótico, desenvolvendo assim uma reação em cadeia, potencialização a ação da biorremediação no local. (LACEY 2002)

Conclusão: Apesar de bastante promissora, a biorremediação utilizando organismos geneticamente modificados ainda prevê riscos ao meio ambiente, animais e seres humanos. Para a utilização bem-sucedida dessa técnica é necessário a presença e estudo de diversas áreas de atuação, desde a engenharia à biologia. Unindo profissionais dessas áreas, avaliando, caracterizando e tendo um bom planejamento da técnica a ser utilizada, é possível que a área seja remediada sem muitos efeitos adversos. Para isso, ainda seguem muitos estudos na biotecnologia e engenharia para otimização do prognóstico das áreas a serem tratadas.

\section{Referências}

ALVES, Gilcean Silva. A biotecnologia dos transgênicos: precaução é palavra de ordem. HOLOS, [S.I.], v. 2, dez. 2007. ISSN 1807-1600. Disponível em: . Acesso em: 14 ago. 2020. doi: https://doi.org/10.15628/holos.2004.33.

Altieri, Miguel A. The ecological impacts of transgenic crops on agroecosystem health. Ecosystem Health 6, 13-23. 2000. Disponível em: . Acesso em: 10 ago. 2020.

CARNEIRO, Danielle Arruda; GARIGLIO, Lucas Paulo. A biorremediação como ferramenta para a descontaminação de ambientes terrestres e aquáticos http://dx. doi. org/10.15601/1983-7631/rt. v3n4p82-95. Revista Tecer, v. 3, n. 4, p. 82-95, 2010. Acesso em: 6 ago. 2020.

Gaylarde, Christine Claire, Maria de Lourdes Bellinaso, and Gilson Paulo MANFIO. I"Biorremediação.I" Biotecnologia Ciência \& 
Desenvolvimento 34 (2005): 36-43. Disponível em: . Acesso em: 8 ago. 2020.

Lacey, Hugh. I"OGMs: A estrutura da controvérsia.l" ComCiência: Revista Eletrônica de Jornalismo Científico 32 (2002). Disponível em:. Acesso em: 10 ago. 2020

Xavier, E. G., D. C. N. Lopes, and M. D. P. Peters. I"Organismos geneticamente modificados.I" Archivos de zootecnia 58.224 (2009): 15-33. Disponível em: https://doi.org/10.21071/az.v58i224.5072 . Acesso em: 4 ago. 2020.

Coordenadoria de Pesquisa e Extensão - COPEX

Departamento de Editoraçāo e Divulgaçāo Científica - DEDIC 


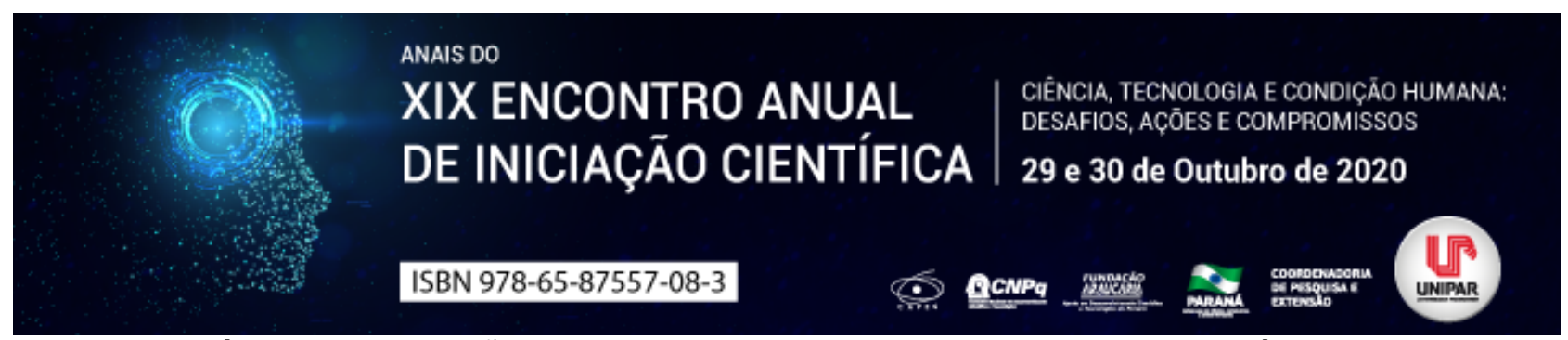

LÍTIO NA PRODUÇÃO DE Petroselinum crispum EM SISTEMA HIDROPÔNICO

\title{
${ }^{1}$ ORLANDO VAN UFFELEN, ${ }^{2}$ NELSON BARROS COLAUTO, ${ }^{3}$ LUCIMAR PEREIRA BONETT, ${ }^{4}$ ESTEVAO AUGUSTO LOMBERTI MELHORANCA, ${ }^{5}$ GIANI ANDREA LINDE COLAUTO
}

\author{
${ }^{1}$ Mestrando em Biotecnologia Aplicada à Agricultura - Bolsista PROSUP CAPES \\ ${ }^{1}$ Pesquisador Produtividade em Pesquisa do CNPq nível 1D, Docente UNIPAR \\ ${ }^{2}$ Dra. em Agronomia, Docente da UNIPAR \\ ${ }^{3}$ Ms. Eng. Agrônomo, Docente da UNIPAR \\ ${ }^{4}$ Pesquisador Produtividade em Pesquisa do CNPq nível 2, Docente UNIPAR
}

Introdução: O Lítio possui potencial para melhorar a qualidade de vida das pessoas (SCHRAUZER, 2002) e tem sido utilizado como antidepressivo e estabilizante de humor devido a sua ação neurológica (VANYO, 1991) e a prevenção de risco de suicídio durante a depressão (MÁRMOL, 2006), além do mais, esse elemento já é usado para tratamento de doenças neurológicas com ênfase no Transtorno Afetivo Bipolar (ANDRADE FILHO et al., 2013), havendo também uma relação inversamente proporcional entre concentrações de Lítio na água potável e taxas de suicídio entre homens (KUGIMIYA et al., 2020). Apesar da indicação sobre a necessidade de consumo diário de Lítio (SCHRAUZER, 2002), a concentração deste íon em alimentos é muito reduzida devido este não ser um nutriente essencial para plantas e ter baixa concentração em solos (Oliveira, 2013). Assim, o sistema hidropônico pode ser uma alternativa visto que se pode controlar a solubilidade e dispersão do Lítio e pode-se produzir alimentos bioacumulados com Lítio evitando-se o risco de contaminação do solo e do lençol freático (FURLANI, 1999).

Objetivo: Este trabalho objetiva avaliar a produção de biomassa vegetal de Petroselinum crispum (salsa) em cultivo hidropônico adicionado com diferentes concentrações de cloreto de Lítio (LiCl).

Material e Métodos: O experimento foi conduzido no campo experimental da Universidade Paranaense no município de

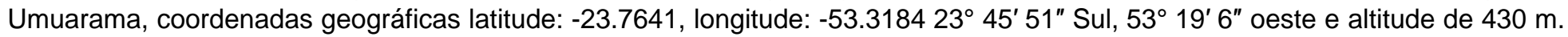
As plantas de $P$. crispum utilizadas neste ensaio foram da variedade Elisa da empresa TopSeed Premium. As plantas foram cultivadas em laboratório com iluminação artificial de 500 a 510 lux por dia, em solução nutritiva com oxigenação artificial com compressor de ar por períodos de duas horas três vezes ao dia e adubação indicada para a cultura (FURLANI, 1999), em potes de 2L. As concentrações de sal de Lítio utilizadas foram baseadas no trabalho de Hawrylak-nowak (2012) e Faria et al. (2019) e ajustadas para solução nutritiva e foram de $0,0,12,5,25,0$ e $50,0 \mathrm{mg} \cdot \mathrm{dm}^{-3}$ na forma de $\mathrm{LiCl}$ (Cloreto de Lítio) e adicionadas à solução nutritiva no décimo dia depois do transplante das mudas para os potes de $2 \mathrm{~L}$ com três repetições em cada tratamento em delineamento inteiramente casualizado. Depois de 21 dias de cultivo as plantas foram retiradas e a parte aérea pesada, seca até massa constante.

Resultados: $O$ Lítio adicionado até $10 \mathrm{mgL}^{-1}$ não afetou $(p \leq 0,05)$ a produção da biomassa úmida ou seca, já quando a 25 ou 50 $\mathrm{mg} \mathrm{L}^{-1}$ de LiCl a massa úmida passou de 4,32 no controle (sem adição de Lítio) para 3,55g (25mg de LiCl) e 1,45g (50mg de $\mathrm{LiCl})$. Esta redução $(p \leq 0,05)$ da massa foi também observada para a massa seca, que foi de $0,46 \mathrm{~g}$ no controle para $0,38 \mathrm{~g}(25 \mathrm{mg}$ de $\mathrm{LiCl}$ ) e $0,19 \mathrm{~g}$ (50mg de LiCl). Assim, o Lítio presente na solução nutritiva a 25 ou $50 \mathrm{mg}$ L $^{-1}$ reduz a massa úmida em 17,8\% e $66,4 \%$ respectivamente e a massa seca em $17,4 \%$ e 58,7\% respectivamente, indicando que este íon pode ser tóxico para $P$. crispum produzido em sistema hidropônico.

Discurssão: O efeito do Lítio na produção vegetal é descrito na literatura. Para Nascimento (2014) plantas de Lactuca sativa (alface) cultivadas em solo com 0,5; 1,0; 1,5 e 2,0 mg.dm- ${ }^{3}$ de Lítio apresentaram redução do crescimento em concentrações maiores que $0,71 \mathrm{mg} \cdot \mathrm{dm}^{-3}$. Em Phaseolus vulgaris L. (feijão) a adição de $4 \mathrm{mg} \cdot \mathrm{dm}^{-3}$ de Lítio no solo aumentou a área foliar e a massa fresca, em contrapartida, a presença de Lítio limitou o aparato estomático reduzindo sua abertura e consequentemente reduzindo a taxa de transpiração e a taxa fotossintética. Hawrylak-nowak (2012) demonstrou que plantas de girassol e milho apresentaram um aumento de $15 \%$ de biomassa a $5 \mathrm{mg} \mathrm{dm}^{-3}$ de Lítio e redução de $27 \%$ e $32 \%$ na biomassa dos brotos na concentração de $50 \mathrm{mg} \cdot \mathrm{dm}^{-3}$.

Conclusões: Concentrações de LiCl de até $10 \mathrm{mg} \cdot \mathrm{dm}^{-3}$ não causam alteração na biomassa de P. crispum indicando que esta concentração pode ser adicionada à adubação de forma segura para este vegetal. Concentrações de $25 \mathrm{mg} \mathrm{dm}^{-3}$ reduziram a massa seca e fresca em $17 \%$ e concentrações de 50 mg.dm ${ }^{-3}$ reduziram a massa seca e fresca em $58,7 \%$ e $66,4 \%$ respectivamente, indicando efeitos tóxicos. 


\section{Referências}

ANDRADE FILHO, A. S.; DE MIRANDA, M. L.; DE OLIVEIRA CUNHA, R. N.. NEUROTOXICIDADE POR USO DE CARBONATO DE LÍTIO: RELATO DE CASO. Revista Brasileira de Neurologia e Psiquiatria, v. 17, n. 2, 2013.

FARIA, M. G. I. et al. Lithium bioaccumulation in Lentinus crinitus mycelial biomass as a potential functional food. Chemosphere, v. 235, p. 538-542, 2019.

FURLANI, P. R. et al. Cultivo hidropônico de plantas. Campinas: Instituto Agronômico, 52p. Boletim Técnico IAC, $180,1999$.

HAWRYLAK-NOWAK, B.; KALINOWSKA, M.; SZYMAŃSKA, M. A study on selected physiological parameters of plants grown under lithium supplementation. Biological trace element research, v. 149, 3, p. 425 430, 2012. DOI:10.1007/s12011-012-94354.

KUGIMIYA, Tsuyoshi. et al. Lithium in drinking water and suicide prevention: The largest nationwide epidemiological study from Japan. Bipolar disorders, 2020.

MÁRMOL, F. Litio: 55 años de historia en el tratamiento. Med Clin (Barc), 127(5), 189-95, 2006.

NASCIMENTO, M. H. D.; Assimilação de Lítio, Sódio e Potássio por plantas de Alface - Cruz das Almas, BA, 52 f.; il, 2014. OLIVEIRA, L. F. C. et al; Sorção e mobilidade do lítio em solos de áreas de disposição final de resíduos sólidos urbanos. Engenharia Sanitária e Ambiental, v. 18, n. 2, p. 139-148, 2013.

SCHRAUZER, G, N. Lithium: Occurrence, Dietary Intakes, Nutritional Essentiality. Journal of the American College of Nutrition, vol. 21, No. 1, 14-21, 2002.

VANYO , L.; Lithium induced perturbations of vitamin B12, folic acid and DNA metabolism. In: G. N. Schrauzer, \& K. F. Klippe, Lithium in Biology and Medicine. Weinheim (pp. 17-30). Weinheim: VCH Verlag, 1991.

Coordenadoria de Pesquisa e Extensāo - COPEX

Departamento de Editoraçāo e Divulgaçāo Científica - DEDIC 


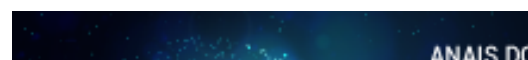 XIX ENCONTRO ANUAL DE INICIAÇÃO CIENTÍFICA 29 e 30 de Outubro de 2020 \\ ISBN 978-65-87557-08-3 \\ onen \\ PRODUÇÃO DE BIOCOMPÓSITOS FÚNGICOS PARA SUBSTITUIR O ISOPOR NA CONSTRUÇÃO CIVIL: IMPORTÂNCIA DA SELEÇÃO DOS SUBSTRATOS
}

\author{
${ }^{1}$ MARCELLA RIBEIRO DA COSTA, ${ }^{2}$ CRISTIANO GOULART, ${ }^{3}$ JULIANA SILVEIRA DO VALLE, ${ }^{4}$ NELSON BARROS COLAUTO, \\ ${ }^{5}$ EVERLEI CÂMARA, ${ }^{6}$ GIANI ANDREA LINDE
}

\begin{abstract}
${ }^{1}$ Doutorandos em Biotecnologia Aplicada à Agricultura, Unipar, Umuarama PR
${ }^{1}$ Doutorandos em Biotecnologia Aplicada à Agricultura, Unipar, Umuarama PR

${ }^{2}$ Docente do Programa de Pós-graduação em Biotecnologia Aplicada à Agricultura, Unipar, Umuarama PR

${ }^{3}$ Docente do Programa de Pós-graduação em Biotecnologia Aplicada à Agricultura, Unipar, Umuarama PR

${ }^{4}$ Docente do Programa de Pós-graduação em Biotecnologia Aplicada à Agricultura, Unipar, Umuarama PR

${ }^{5}$ Docente da UNIPAR
\end{abstract}

Introdução: O poliestireno expandido ou isopor tem como sigla internacional EPS (poliestireno expandido em inglês expanded polystyrene). A produção mundial de EPS em 2010 era de aproximadamente 14,9 milhões de toneladas anuais e, desde então, tem sido amplamente aplicado em diversos setores, e ainda, a previsão de crescimento da demanda global de EPS até 2020, é aproximadamente 4,7\% ao ano, o que levará a uma demanda global de EPS de 23,5 milhões de toneladas em 2020 (PLASTEMART, 2013). Segundo a Knauf Isopor (2019), só no Brasil a produção de isopor gira em torno de 100 mil toneladas anualmente. $O$ isopor possui baixíssima condutividade térmica entre 0,03 a $0,035 \mathrm{Wm}^{-1} \mathrm{~K}^{-1}$ e densidade entre 10 a $35 \mathrm{~kg} / \mathrm{m}^{3}$ (KHOUKHI, 2018; KANAUF ISOPOR, 2019). Devido a estas características o EPS é muito utilizado na construção civil como isolante termoacústico e, ainda reduz o peso da construção (PIRES et al., 2020). Apesar da importância do isopor para a construção civil o descarte inadequado deste material gera enorme impacto ambiental visto que demora 150 anos para se decompor naturalmente (NUKMAL et al., 2018). No Brasil 7,7 milhões de toneladas de plásticos são descartados em aterros sanitários (KANAUF ISOPOR, 2019). Diante deste contexto é necessária à busca de alternativas sustentáveis ao isopor. Uma das possibilidades é associação de resíduos agroindustriais e fungos basidiomicetos para produção de biocompósitos com características de isolante termoacústico, alta resistência mecânica e reduzida densidade semelhantes ao isopor (BRUSCATO et al., 2019). Entretanto, para a produção deste biomaterial é necessária à definição de substratos, fungos e condições de cultivo bem como a avaliação estrutural e das características de transferência de calor e de som (APPELS et al., 2018). Portanto, subprodutos agroindustriais podem ser biotransformados por fungos basidiomicetos para a produção de biocompósitos visando à substituição do isopor por produtos biodegradáveis.

Objetivo: Realizar um levantamento bibliográfico sobre a produção de biocompósitos indicando a importância da seleção dos substratos através da substituição total ou parcial do isopor para a prospecção na construção civil.

Desenvolvimento: A utilização de subprodutos e resíduos agroindustriais lignocelulósicos em processos biotecnológicos como a produção de biocompósitos renováveis e biodegradáveis para a substituição de EPS pode valorizar a cadeia produtiva e reduzir o impacto ambiental do agronegócio (ZHANG, ZHANG e XUE, 2015). Os subprodutos a serem utilizados para a produção de biocompósitos afetam as suas características físicas, químicas e mecânicas. Alguns fatores devem ser considerados para a seleção dos substratos como: disponibilidade regional, características físico química, mecânica e termoacústica, adequação de nutrientes para o crescimento do fungo, entre outros. Bruscato et al. (2019) desenvolveram biocompósitos constituídos com 94\% dos sólidos de serragem de Pinus spp., $5 \%$ de farelo de trigo e $1 \%$ de carbonato de cálcio $\left(\mathrm{CaCO}_{3}\right)$, e obtiveram resistência e densidade superior ao EPS, sendo elas $0,4 \mathrm{MPa}$ e $0,3 \mathrm{~g} / \mathrm{cm}^{3}$ respectivamente. Xing et al. (2018) produziram tijolos isolantes térmicos em resíduos de palha de trigo, pois apresenta uma elevada concentração de lignina em sua estrutura. Segundo Wösten (2014), substratos ricos em celulose, aumenta a velocidade de crescimento do fungo, evitando possíveis contaminações e, prediz uma alta resistência, devido a matriz de lignina rígida e incorporada. Para Royse e Bellman (2007), a base para a formulação do substrato depende da disponibilidade local dos resíduos sendo geralmente utilizada uma combinação de substratos ricos em carboidratos e outra em nitrogênio. Substratos ricos em açúcares simples promovem um melhor crescimento dos fungos e também, desempenha papel importante na eficiência da colonização e frutificação (BAYER et al., 2014). Haneef et al. (2016) analisaram as propriedades físicas e químicas dos basidiomicetos Ganoderma lucidum e Pleurotus ostreatus crescidos em celulose pura e uma mistura de celulose e caldo de dextrose de batata. Verificou-se que os micélios cultivados em celulose pura, são mecanicamente mais resistentes comparados com os micélios cultivados em celulose e caldo de dextrose de batata. Conforme a literatura, a produção de biocompósitos ainda são preliminares e em escala laboratorial e, as suas características físico-química, mecânicas e termoacústicas são variáveis, ou seja, sem parâmetros pré-estabelecidos considerados eficientes 
para a aplicação na construção civil, demonstrando ainda, ser um campo profícuo para o desenvolvimento de pesquisas, para a obtenção de características físico-químicas, mecânicas e termoacústicas em biocompósitos semelhantes ao isopor, para posteriormente ser aplicado como forros, revestimentos, placas e entre outros na construção civil.

Conclusão: Estes resultados evidenciam que o efeito do substrato no crescimento fúngico afeta as características físicoquímicas do biocompósito produzido, sendo assim uma etapa de suma importância. Entretanto, ainda são poucos os estudos relatados na literatura sobre o desenvolvimento de biocompósitos, gerando mais perguntas do que respostas. No entanto, devido ao alto impacto ambiental que o isopor proporciona, a busca por alternativas biodegradáveis pode ser um campo de inovação necessário para novas formas construtivas.

\section{Referências}

APPELS, Freek VW et al. Hydrophobin gene deletion and environmental growth conditions impact mechanical properties of mycelium by affecting the density of the material. Scientific reports, v. 8, n. 1, p. 1-7, 2018.

BAYER, Ilker S. et al. Direct transformation of edible vegetable waste into bioplastics. Macromolecules, v. 47, n. 15, p. 51355143, 2014.

BRUSCATO, Cláudia et al. High performance of macrofungi in the production of mycelium-based biofoams using sawdust Sustainable technology for waste reduction. Journal of Cleaner Production, v. 234, p. 225-232, 2019.

HANEEF, Muhammad et al. Advanced materials from fungal mycelium: fabrication and tuning of physical properties. Scientific reports, v. 7, n. 1, p. 1-11, 2017.

ISOPOR, Kanuf. EPS Isopor: Tudo o Que Você Precisa Saber. Disponível em: https://www.mundoisopor.com.br/knauf/epsisopor-tudo-o-que-voce-precisa-saber. Acesso em: 29 mai. 2020.

KHOUKHI, Maatouk. The combined effect of heat and moisture transfer dependent thermal conductivity of polystyrene insulation material: Impact on building energy performance. Energy and buildings, v. 169, p. 228-235, 2018.

NUKMAL, Nismah. Effect of styrofoam waste feeds on the growth, development and fecundity of mealworms (Tenebrio molitor). OnLine Journal of Biological Sciences, v. 18, n. 1, p. 24-28, 2018.

PIRES, Greiciane da Silva et al. Sistema de construção utilizando o isopor para confecção de parede. Revista Expressão, n. 2, p. $15,2020$.

PLASTEMART. Polystyrene and EPS market expected to grow at a healthy rate of $\mathbf{5 . 6 \%}$ from 2010-2020. Acesso em: 15 ago. 2020.

ROYSE, D. J.; BELLMAN, R. B. Six steps to mushroom farming. Pennsylvania, 2007.

WÖSTEN, Han. interview by R. Lelivelt. Interview: Alternate mycelium applications, 2014.

XING, Yangang et al. Growing and testing mycelium bricks as building insulation materials. In: IOP Conference Series: Earth and Environmental Science. IOP Publishing, 2018. p. 022032.

ZHANG, Daihui; ZHANG, Anjiang; XUE, Lixin. A review of preparation of binderless fiberboards and its self-bonding mechanism. Wood Science and Technology, v. 49, n. 4, p. 661-679, 2015. 


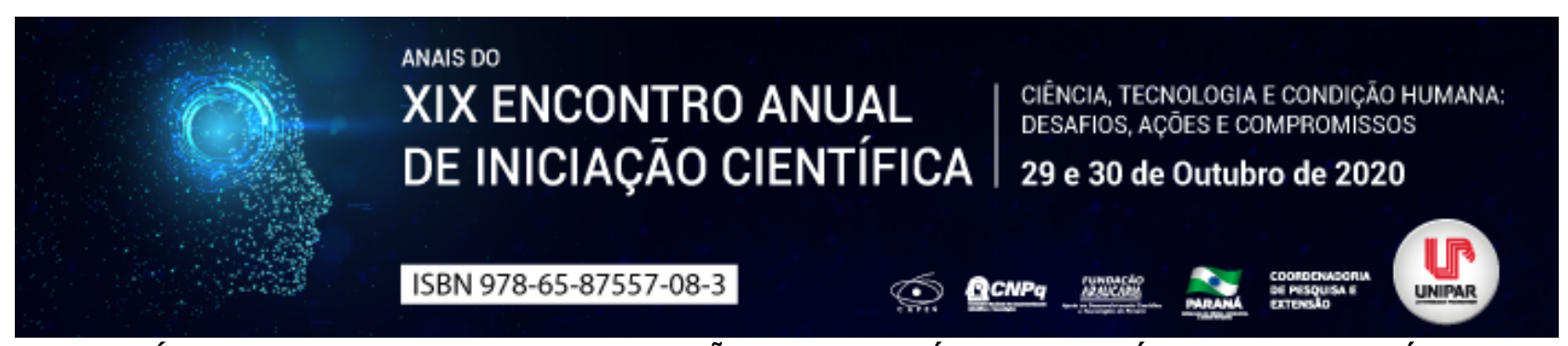

FUNGOS MICORRÍZICOS ARBUSCULARES E PRODUÇÃO DE METABÓLITOS PRIMÁRIOS E SECUNDÁRIOS EM OcimUm basilicum L. SUBMETIDO A SALINIDADE

\begin{abstract}
${ }^{1}$ CRISTINE BONACINA, ${ }^{2}$ ANA CRISTINA DA SILVEIRA, ${ }^{3}$ ODAIR ALBERTON, ${ }^{4}$ HELIDA MARA MAGALHAES, ${ }^{5}$ SILVIA GRACIELE HULSE DE SOUZA
\end{abstract}

${ }^{1}$ Discente do curso de Pós-Graduação em Biotecnologia Aplicada à Agricultura/UNIPAR

${ }^{1}$ Acadêmica do Curso de Mestrado Em Biotecnologia Aplicada à Agricultura da UNIPAR

${ }^{2}$ Docente da UNIPAR

${ }^{3}$ Docente da UNIPAR

${ }^{4}$ Docente da UNIPAR

Introdução: O manjericão ou manjericão doce (Ocimum basilicum L.) é uma planta da família Lamiaceae, utilizada como condimento, na produção de cosméticos, e, ainda, na área medicinal por ser anti-fúngica, anti-microbiana e principalmente antioxidante (CHIANG et al., 2005; MAKRI; KINTZIOS, 2008; BLANK et al., 2010). Na agricultura, um dos problemas que mais afetam o crescimento e metabolismo vegetal é a presença de sal no solo decorrente do uso inadequado de fertilizantes químicos, ou, ainda, pelo uso da água na irrigação ser de baixa qualidade, essa que muitas vezes já contém moléculas de sal (MUNNS; TESTER, 2008; ARANGUES et al., 2014). Dessa maneira, a utilização de microrganismos promotores do crescimento vegetal como os fungos micorrízicos arbusculares (FMAs) têm sido uma atividade sustentável frente as condições ambientais adversas, já que o seu papel principal é aumentar a absorção de nutrientes da água incorporada no solo e auxiliar na proteção frente ao estresse abiótico (ESTRADA et al., 2013).

Objetivo: Em função dessas condições, o objetivo desse trabalho foi avaliar o efeito da inoculação dos FMAs na produção dos metabólitos primários e secundários em plantas de manjericão submetidas ao estresse salino por $\mathrm{NaCl}$, a fim de verificar se esses microrganismos são efetivos em proteger o metabolismo em condições adversas.

Material e Métodos: Para o experimento, estacas de manjericão (Ocimum basilicum L.) foram plantadas em vasos de cloreto de polivinila (PVC), de três litros, que foram acondicionados no Campus III da UNIPAR (casa de vegetação), na cidade de Umuarama/PR. Nos vasos foi adicionado solo, vermiculita, areia e matéria orgânica (material vegetal e esterco animal)

3:0,5:1:1v. Em seguida foi inoculado três estirpes de FMAs (Claroideoglomus etunicatum (C.e.) (44 g), Rhizophagus clarus (R.c.) $(40 \mathrm{~g})$ e uma interação de C.e. $(22 \mathrm{~g})$ mais R.c. (20 g)), fornecidas pelo banco de Glomales da UNIPAR. Após trinta dias de cultivo, as plantas foram desbastadas e deixada uma em cada vaso. Em seguida, foi iniciado o estresse salino nas plantas com cloreto de sódio $(\mathrm{NaCl})$ em concentrações leves, moderadas e severas $(50,100$ e $150 \mathrm{mM})$, de maneira gradativa $(50 \mathrm{mM})$, e aplicado duas vezes na semana para evitar o choque osmótico e consequentemente danos severos ou até mesmo a morte vegetal. Além dos tratamentos com os FMAs e com o $\mathrm{NaCl}$, empregou-se controles com água $\left(\mathrm{H}_{2} \mathrm{O}\right)$. Para o experimento foi utilizado oito vasos para cada tratamento, com um total de cento e vinte e oito vasos. Como uma forma de auxiliar o crescimento do manjericão nessas condições, semanalmente foi adicionado em cada um dos respectivos vasos $180 \mathrm{~mL}$ de solução nutritiva de Hoagland e Arnon (1950), a cada 3 dias. Após dois meses, o experimento foi desmontado e realizada as análises bioquímicas dos metabólitos primários (açúcares totais e açúcares redutores) e secundários (compostos fenólicos, flavonóides e DPPH). O experimento foi realizado por delineamento experimental inteiramente casualizado (DIC), com esquema fatorial $4 \times 4$ (quatro estirpes de FMAs e quatro concentrações de $\mathrm{NaCl}$ ), e os dados foram submetidas a análise de variância (ANOVA) e as médias comparadas por teste de Scott-Knott $(p \leq 0,05)$, no programa estatístico Sisvar (5.6) (FERREIRA,2011).

Resultados: Os FMAs frente a salinidade agiram no metabolismo do manjericão de maneira eficaz quanto a produção e aumento da maioria dos metabólitos primários e secundários, no qual o melhor resultado foi observado diante das estirpes C.e. e C.e.+R.c. frente as concentrações de 50 e $150 \mathrm{mM}$ de NaCl . Porém, para os açúcares totais, na maioria das estirpes fúngicas utilizadas foi observado uma redução nessa variável, em que isso ocorreu diante de todas as concentrações de sal utilizadas.

Discussão: Os FMAs quando sob atividade nas plantas em condições ambientais adversas, como o estresse salino, ativam o metabolismo vegetal e auxiliam no aumento da produção de compostos antioxidantes não enzimáticos, para dessa maneira tentar inibir quase que totalmente os danos ocasionados pelo excesso de EROs geradas pelo acúmulo de íons de $\mathrm{Na}^{+}$e $\mathrm{Cl}^{-}$ (DAS; ROYCHOUDHURY, 2014). Em nosso trabalho, verificamos que os FMAs foram eficientes em mitigar os efeitos do estresse salino no manjericão, conferindo a proteção de seu metabolismo. Isso pode ser verificado diante das análises de açúcares redutores, fenóis, flavonóides e DPPH, no qual os FMAs beneficiaram a produção destes metabólitos, aumentando as suas concentrações.

Conclusão: Nos metabólitos primários e secundários, produtos estes do metabolismo vegetal que auxiliam na proteção oxidativa 
do manjericão, de forma geral os fungos beneficiaram a sua produção diante do estresse salino, em que houve o aumento em sua concentração. Desta forma, os FMAs podem ser utilizados na produção de O. basilicum L. uma vez que podem mitigar os efeitos adversos da salinidade.

\section{Referências}

CHIANG, Lien-Chai et al. Antiviral activities of extracts and selected pure constituents of Ocimum basilicum L. Clin. Exp. Pharmacol. Physiol. v. 32, n. 10, p. 811 816, oct. 2005.

MAKRI, Olga; KINTZIOS, Spiridon. Ocimum sp. (Basil): Botany, Cultivation, Pharmaceutical Properties, and Biotechnology. J. Herbs. Spices. Med. Plants. v. 13, n. 3, p. 123 150, oct. 2008.

BLANK, Arie F. et al. Comportamento fenotípico e genotípico de populações de manjericão. Hortic. Bras. v. 28, n. 3, p. 305-310, jul./sep. 2010.

MUNNS, Rana; TESTER, Mark. Mechanisms of salinity tolerance. Annu. Rev. Plant Biol. v. 59, n. 1, pp. 651-681, jan. 2008.

ARAGUES, Ramón et al. Efects of defcit irrigation strategies on soil salinization and sodifcation in a semiarid drip-irrigated peach orchard. Agric. Water Manag. v. 142, p. 1 9, jul. 2014.

ESTRADA, Beatriz et al. Native arbuscular mycorrhizal fungi isolated from a saline habitat improved maize antioxidant systems and plant tolerance to salinity. Plant. Sci. v. 202, n. 1, p. 42 51, mar. 2013.

HOAGLAND, Dennis Robert; ARNON, Daniel Israel. The water culture method for growing plants without soils. Calif. Agric. Exp. Stn. Circ. v. 347, p. 1-32, 1950.

FERREIRA, Daniel Furtado. Sisvar: a computer statistical analysis system. Cienc. Agrotec. v. 35, n. 6, p. 1039-1042, nov./dec. 2011.

DAS, Kaushik; ROYCHOUDHURY, Aryadeep. Reactive oxygen species (ROS) and response of antioxidants as ROS-scavengers during environmental stress in plants. Front. Environ. Sci. v. 2, p. 1 13, dec. 2014.

Coordenadoria de Pesquisa e Extensão - COPEX

Departamento de Editoraçāo e Divulgaçāo Científica - DEDIC 


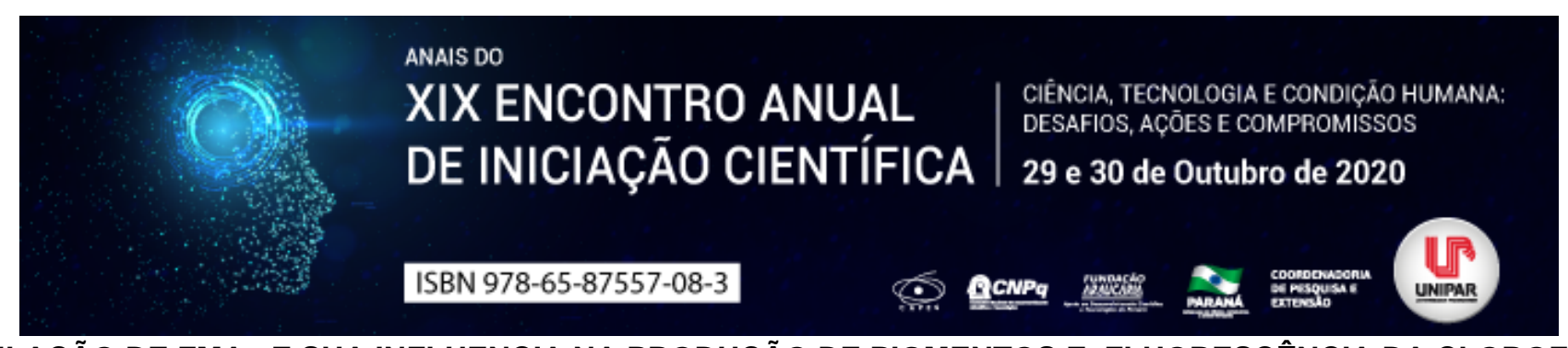

\title{
INOCULAÇÃO DE FMAs E SUA INFLUENCIA NA PRODUÇÃO DE PIGMENTOS E FLUORESCÊNCIA DA CLOROFILA EM Ocimum basilicum L. SUBMETIDO A SALINIDADE
}

\author{
${ }^{1}$ CRISTINE BONACINA, ${ }^{2}$ EDINARA MARIA BARBOSA, ${ }^{3}$ ANA CAROLINA RUMAO GASTALDI, ${ }^{4}$ ODAIR ALBERTON, ${ }^{5}$ SILVIA \\ GRACIELE HULSE DE SOUZA
}

${ }^{1}$ Discente do curso de Pós-Graduação em Biotecnologia Aplicada à Agricultura/UNIPAR

${ }^{1}$ Acadêmica do Curso de Doutorado em Biotecnologia Aplicada A Agricultura - Turma VII da UNIPAR

${ }^{2}$ Acadêmica do Curso de Engenharia Agronômica da UNIPAR

${ }^{3}$ Docente da UNIPAR

${ }^{4}$ Docente da UNIPAR

Introdução: Por ser uma planta medicinal de extensa empregabilidade no uso comum, o manjericão (Ocimum basilicum L.) é de grande importância na indústria em função do seu óleo essencial (SHIWAKOTI et al., 2017). Além disso, pode ser utilizado in natura na forma de chá, para tratar indisposições (BUTNARIU; CAUNII, 2013; SILVA et al., 2016). Devido a composição química das plantas medicinais, essas são sensíveis às condições ambientais externas. Dessa forma, é necessário encontrar maneiras de protegê-las dos efeitos do ambiente em que se encontram, no qual os fungos micorrízicos arbusculares (FMAs) é uma proposta viável e que não ocasiona agressões as mesmas e nem ao meio ambiente (WU et al., 2013; RODRIGUEZ; SANDERS, 2015).

Objetivo: O objetivo desse trabalho foi avaliar a inoculação dos FMAs na produção dos pigmentos e da fluorescência da clorofila em plantas de manjericão submetidas a diferentes concentrações de salinidade $(\mathrm{NaCl})$.

Material e Métodos: Estacas de manjericão (Ocimum basilicum L.) foram cultivadas em vasos plásticos de cloreto de polivinila (PVC), com capacidade de três litros, e acomodados na casa de vegetação da UNIPAR (Campus III), na cidade de Umuarama/PR. Nos respectivos vasos foi adicionado (em volume) 3 partes de solo; 0,5 parte de vermiculita; 1 parte de areia e 1 parte de matéria orgânica (material vegetal e esterco animal). Após foi realizada a inoculação de três estirpes de FMAs (Claroideoglomus etunicatum (C.e.) (44 g), Rhizophagus clarus (R.c.) (40 g) e uma interação de C.e. (22 g) mais R.c. (20 g)) obtidas por meio do banco de Glomales da UNIPAR. Posteriormente, foi realizado o estresse salino nas plantas com cloreto de sódio $(\mathrm{NaCl})$ nas concentrações de 50, 100 e $150 \mathrm{mM}$, de forma gradativa $(50 \mathrm{mM})$, para evitar danos irreversíveis nas plantas, essas que foram aplicadas duas vezes na semana. Empregou-se ainda controles com água $\left(\mathrm{H}_{2} \mathrm{O}\right)$. Para o experimento foi utilizado oito vasos em cada tratamento, totalizando cento e vinte e oito vasos. Para ajudar no crescimento do manjericão diante dessas condições adversas, foi adicionado semanalmente $180 \mathrm{~mL}$ de solução nutritiva completa de Hoagland e Arnon (1950) em cada vaso, a cada 3 dias. Após dois meses, realizou-se o desmonte dos vasos e as análises de clorofila e fluorescência da clorofila. $O$ experimento foi realizado por delineamento experimental inteiramente casualizado (DIC), com esquema fatorial $4 \times 4$ (quatro estirpes de FMAs e quatro concentrações de $\mathrm{NaCl}$ ).Os dados foram submetidas a análise de variância (ANOVA) e as médias comparadas por teste de Scott-Knott, pelo programa estatístico Sisvar versão $5.6(p \leq 0,05)$ (FERREIRA, 2011).

Resultados: Verificou-se nas análises que as estirpes de FMAs sob a salinidade aumentaram a concentração dos pigmentos a, b, $a+b$ e carotenoides. Entretanto, para a fluorescência Fo, Fm e Fv/Fm da clorofila, apenas no parâmetro Fv/Fm foi verificado diferença significativa na resposta dos FMAs perante ao estresse. A eficiência fotoquímica do PSII (Fv/Fm), foi menor nas plantas submetidas ao estresse salino e sem a presença do FMA, indicando que os FMAs foram importantes para a manutenção da eficiência do PII em condições de salinidade.

Discussão: Quando os íons salinos adentram o metabolismo vegetal, o danificam como um todo, principalmente o sistema fotossintético (PSII) (ZHU, 2003; APOSTOLOVA et al., 2006). Entretanto, no respectivo trabalho foi verificado que os FMAs protegeram o sistema fotossintético do manjericão frente ao estresse, em que essa proteção pode ter ocorrido em virtude dos fungos terem elevado a absorção de água e nutrientes, como o fósforo $(\mathrm{P})$ e o magnésio $(\mathrm{Mg})$ nas respectivas plantas, elementos esses que auxiliam na melhora da atividade da fotossíntese e consequentemente na produção dos pigmentos da clorofila (BORDE et al., 2010; RUIZ-LOZANO et al., 2012). Além disso, esses microrganismos podem ter elevado a capacidade de troca gasosa $\left(\mathrm{CO}_{2}\right)$ e os processos fotoquímicos do PSII (RUIZ-LOZANO et al., 2012).

Conclusão: Os FMAs no manjericão sob estresse salino promoveram uma resposta protetiva ao seu sistema fotossintético, em que a maior absorção de água, nutrientes e o aumento na quantidade de gás carbônico, por esses microrganismos, são condições fundamentais na proteção das plantas frente as adversidades do ambiente.

\section{Referências}


SHIWAKOTI, Santosh. et al. Yield, composition and antioxidant capacity of the essential oil of sweet basil and holy basil as influenced by distillation method. Chem. Biodiv. v. 14, n. 4, p. 1-6, mar. 2017.

BUTNARIU, Monica; CAUNII, Angela. Design management of functional foods for quality of life improvement. Ann. Agric. Environ. Med. v. 20, n. 4, p. 736-741, 2013.

SILVA, Viviane Araújo. et al. Ocimum basilicum: antibacterial activity and association study with antibiotics against bacteria of clinical importance. Pharm. Biol. v. 54, n. 5, pp. 863-867, jan. 2016.

WU, Haifeng. et al. Recent developments in qualitative and quantitative analysis of phytochemical constituents and their metabolites using liquid chromatography-mass spectrometry. J. Pharmaceut. Biomed. v. 72, n. 18, p. 267-291, jan. 2013.

RODRIGUEZ, Alia; SANDERS, lan R. The role of community and population ecology in applying mycorrhizal fungi for improved food security. ISME. J. v. 9, p. 1053 1061, jan. 2015.

HOAGLAND, Dennis Robert; ARNON, Daniel Israel. The water culture method for growing plants without soils. Calif. Agric. Exp. Stn. Circ. v. 347, p. 1-32, 1950.

FERREIRA, Daniel Furtado. Sisvar: a computer statistical analysis system. Cienc. Agrotec. v. 35, n. 6, p. 1039-1042, nov./dec. 2011.

ZHU, Jian Kang. Regulation of ion homeostasis under salt stress. Curr. Opin. Plant. Biol. v. 6, pp. 441-445, 2003.

APOSTOLOVA, Emilia L. et al. Relationship between the organization of the PS II super complex and the functions of the photosynthetic apparatus. J. Photochem. Photobiol. v. 83, p. 114-122, 2006.

BORDE, Mahesh; DUDHANE, Mayura; JITE, Paramjit Kaur. AM fungi influences the photosynthetic activity, growth and antioxidant enzymes in Allium sativum L. under salinity condition. Not. Sci. Biol. v. 2, p. 64-71, 2010.

RUIZ-LOZANO, J. M. et al. Regulation by arbuscular mycorrhizae of the integrated physiological response to salinity in plants: new challenges in physiological and molecular studies. J. Exp. Bot. v. 63, n. 11, p. 4033-4044, 2012. 


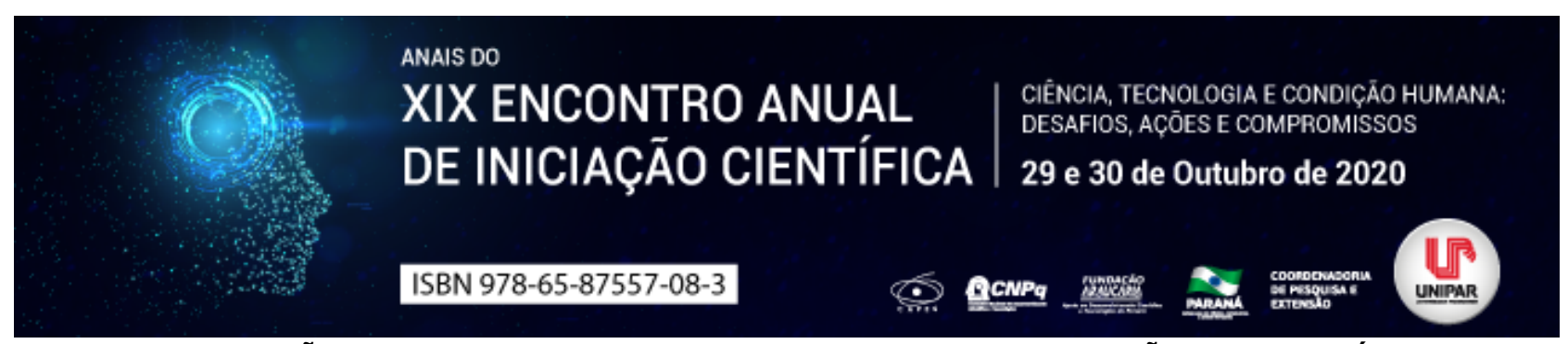

A CORROSÃO EM ARMADURAS DE CONCRETO ARMADO REVISÃO BIBLIOGRÁFICA

\title{
${ }^{1}$ JESSICA CAROLINE MERLUGO DEPONTI, ${ }^{2}$ DJESSICA TUANI KREIN, ${ }^{3}$ DIANE GUZI FOMIN
}

\author{
${ }^{1}$ Acadêmico do Curso de Engenharia Civil da UNIPAR \\ ${ }^{1}$ Acadêmico do Curso de Engenharia Civil da UNIPAR \\ ${ }^{2}$ Docente da UNIPAR
}

Introdução: A corrosão é a deterioração de um material com o ambiente, por meio da reação química, ou eletroquímica (PELLIZZER, 2015). É formada pelos processos de oxidação e corrosão propriamente dita: aquele por formação de película de óxido, este por ataque biológico, de natureza eletroquímica, ocorrendo em meio aquoso. Em relação a durabilidade do concreto, são vários processos que afetam o desempenho da estrutura de concreto (relações álcali-agregados, gelo e degelo e ataques químicos) (WALLY et al., 2019). A patologia do concreto armado é a ciência que estuda causas, mecanismos, origens e sintomas de manifestações patológicas encontradas em estruturas de concreto armado (TRINDADE, 2015).

Objetivo: Apresentar as principais causas de corrosão em armaduras de concreto armado, um estudo de revisão.

Desenvolvimento: De acordo com Freire (2005), são várias as causas de ocorrência da corrosão em estruturas. O ambiente onde a estrutura está exposta, a resistência do concreto, a penetração de cloretos, o oxigênio, a temperatura e a umidade, são fatores que ocasionam a corrosão em armaduras. Dessa maneira, os agentes causadores da deterioração de estruturas de concreto armado são divididos em três grupos: causas intrínsecas, causas extrínsecas e causas naturais. As causas intrínsecas estão ligadas a deficiência na concretagem e nas armaduras, inadequação de escoramentos e formas, ausência de manutenção e causas naturais. As causas extrínsecas envolvem a inadequação do ambiente, má avaliação de cargas, sobrecargas exageradas, ações mecânicas (choques de veículos, recalque de fundações) ações físicas (variação de temperatura, atuação da água), ações químicas e biológicas. Por último, o processo físico de corrosão está ligado a fissuração, desagregação e desgaste do concreto (TRINDADE, 2015). Nesse contexto Wally et al. (2019), afirmam que a corrosão das armaduras depende do ambiente da exposição, da concentração superficial de cloretos, do comprimento (c) do cobrimento da armadura, resistência do concreto à penetração de cloretos, presença de oxigênio, temperatura e umidade relativa. Dessa forma, a idade denominada como de vida útil da estrutura é compreendida como período de início do processo de corrosão das armaduras presentes no concreto armado (WALLY et al., 2019). Para Guerche (2018), o processo de corrosão é classificado em sete fases. A primeira é a carbonatação pela passagem de água e dióxido de carbono, do meio exterior para o interior da estrutura. Na segunda, há formação de uma camada de óxido férrico na superfície do reforço. Na terceira, ocorre o aumento do volume do metal por produtos da corrosão, expansão do concreto e surgimento de rachaduras. Na quarta fase, aparecem novas rachaduras, redução na ligação entre o concreto e o reforço. Na quinta fase, o concreto da cobertura começa a descascar e ocorre a redução do tamanho da barra de aço. Na sexta fase, há o rompimento das barras reduzidas, estalos nos estribos e diminuição das barras principais. Na sétima e última fase, ocorre o desprendimento da cobertura de concreto e a perda das barras principais de aço carbono, ocorrendo um colapso da estrutura. Para saber a integridade do concreto, pode-se realizar o teste de aplicação de fenolftaleína em corpos de prova de concreto removidos da estrutura ou pela quebra de amostra, estes devem ter cobrimento de concreto de 3,0 cm para face interna e 3,5 cm para face externa. Após borrifar a substância por toda a superfície do testemunho detecta-se a camada carbonada, sendo a reação cor rosa para concreto íntegro ( $\mathrm{pH}$ aproximado de 12,5 ) e reação incolor para concreto carbonatado ( $\mathrm{pH}<9$ ) (BREMENKAMP et al., 2020). Outra questão são as patologias em concreto armado em ambiente marinho. Com isso, após análise das estruturas em concreto armado na llha de Vitória, no Espírito Santo, concluiu-se a importância da geometria adequada, ou seja ao dimensionamento correto das armaduras, com espaçamento suficiente a inserção do concreto, para que garanta comprimento de cobrimento conveniente ao ambiente exposto e ao uso da estrutura, para amenizar efeitos da corrosão pela água do mar (ALMEIDA, 2017). Lima (2020), ainda afirmam que, após estudos com corpos de prova de concreto submetidos a um ambiente marinho, observa-se os íons cloreto como principal agente de corrosão. Pois reduzem o pH do concreto, reduzem a camada passivadora do aço e agem como catalizadores para corrosão da armadura.

Conclusão: Assim, nota-se que as patologias estão ligadas principalmente a erros de cálculo, inadequações durante o processo de execução, reações químicas durante a concretagem e despassivação da armadura. Visto as consequências da corrosão em armaduras de concreto, deve-se seguir métodos de prevenção, para evitar as patologias, como exemplo: uso de fita de magnésio com aço, para criação de circuito de troca de elétrons, preservando as características do material; a adição de metacalium no concreto, para aumento da resistência mecânica e diminuição da porosidade, a fim de reduzir as reações de carbonatação; e por último, utilização de cimentos adequados ao projeto e ao meio inserido (CP-RS, CP-IV e CP-BC, como os mais conhecidos).

\section{Referências}


ALMEIDA, E. C. Patologia das construções em concreto armado em ambientes marinhos - llha de Vitória - ES. Orientador: Artur Rodrigues. 2017. Tese (Bacharel em Arquitetura e Urbanismo) - Faculdade Brasileira - Multivix, Vitória - ES, 2017.

BREMENKAMP, C. et al. EasyChair preprint structural evaluation UFES energy substation after fire, Espírito Santo, número 2320, 2020. Disponível em: https://easychair.org/publications/preprint_open/Qzwb. Acesso em: 21 set. 2020.

FREIRE, K. R. R. Avaliação do desempenho de inibidores de corrosão em armaduras de concreto. 2005. Dissertação (PósGraduação em Engenharia, Área de Concentração: Engenharia e Ciências dos Materiais) - Universidade Federal do Paraná, Curitiba - PR, 15/02/2005.

GUERCHE, A. R. R. G. Corrosão de armaduras no concreto armado: características e processos inibidores. 2018. Tese (Bacharel em Engenharia Civil) - Universidade Anhanguera Uniderp, Campo Grande - MS, 2018.

LIMA, R. et al. Análise do concreto armado em relação à agressividade em ambiente marinho: Estudo comportamental quanto à influência de cloretos da água do mar. Brazilian Journal of Development, Curitiba - PR, 03/2020. Número 3, volume 6, p. 10692-10720, 2020.

PELLIZZER, G. P. Análise mecânica e probabilística da corrosão de armaduras de estruturas de concreto armado submetidas à penetração de cloretos. 2015. Dissertação (Mestrado em Engenharia das estruturas) - Escola de Engenharia de São Carlos da Universidade de São Paulo, São Carlos - SP, 2015.

TRINDADE, D. S. Patologia em estruturas de concreto armado em ambiente marítimo. 2015. Dissertação (Bacharel em Engenharia Civil) - Universidade federal de Santa Maria, Santa Maria - RS, 28/10/2015.

WALLY, G. et al. Estudo de Caso: Previsão da vida útil de uma estrutura de concreto armado em ambiente marinho por meio da análise de Monte Carlo. Retec Revista de Tecnologias, Ourinhos - SP, volume 12, número 1, p. 95 106, jan/jun. 2019. 


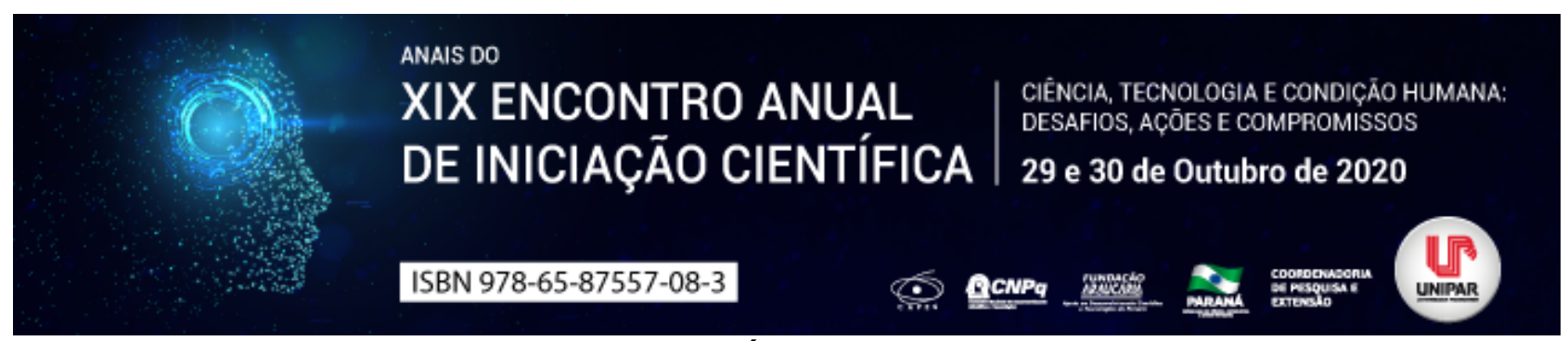

QUIMIOTIPOS DA ESPÉCIE Ageratum conyzoides

\title{
1'LUANA MARQUES, ${ }^{2}$ MATHEUS DE SOUZA MARTINUCI, ${ }^{3} 3$ ISADORA ALVES DE OLIVEIRA, ${ }^{4} 3$ LORENA CRISTINE DOS SANTOS DARTIBALE, ${ }^{5}$ ZILDA CRISTIANI GAZIM
}

\author{
${ }_{1}^{1}$ Discente do Programa Interno de Bolsa de Iniciação Científica-PIBIC \\ $1_{2}$ Discente do Programa de Iniciação Científico-PIC \\ 23Discente do Programa Externo de Bolsas de Iniciação Científica do Ensino Médio PEBIC EM \\ 33Discente do Programa Externo de Bolsas de Iniciação Científica do Ensino Médio PEBIC EM \\ ${ }^{4} 4$ Docente da Universidade Paranaense-UNIPAR
}

Introdução: Uma planta para se adequar ao clima, tipo de solo, altitude e outras condições de uma determinada região é capaz de modificar a sua estrutura química sem afetar de maneira significativa o seu fenótipo - que são todas as características visíveis de um organismo. Isto quer dizer que ela, com o objetivo de se adaptar a um ambiente particular, pode dar origem a uma variedade quimicamente nova, com propriedades morfológicas idênticas ou muito semelhantes àquelas da mesma espécie. O quimiotipo (QT), então, refere-se a esta variedade ou a raça química da planta- classificação esta de grande importância para os óleos essenciais uma vez que isto afeta diretamente seus ativos e, consequentemente, todas as suas propriedades (FRANCHOME, 1975).

Objetivo: Realizar uma revisão bibliográfica sobre os quimiotipos de Ageratum conyzoides

Desenvolvimento: Estudos em quimiotaxonomia consistem na investigação de compostos químicos que ocorrem em plantas, com o objetivo de evidenciar ou não a relação entre elas, devendo a ênfase ser dada aos compostos predominantes da espécie. A padronização das épocas de colheita, da parte colhida e do cultivo sob as mesmas condições ambientais auxilia na identificação de variedades que apresentam diferenças na sua composição química (CASTRO, et. al 2004). A variação genética em populações naturais de plantas e animais é a base da sua resistência perante as pressões do ambiente, sendo a matériaprima da seleção natural. A quimiotaxonomia consiste na investigação de compostos químicos que ocorrem em plantas, com o objetivo de evidenciar ou não a relação entre elas, devendo a ênfase ser dada aos compostos predominantes da espécie. Ageratum conyzoides L., é uma planta pertencente à família Asteraceae, é uma erva anual, originária da América Central e do Caribe, encontrada em vários países em regiões tropicais e subtropicais, incluindo o Brasil. No Brasil, $A$. conyzoides é conhecido como I"Erva-de-são-joãol", I"mentrastol" e I"mentrasto-roxol" sendo amplamente utilizado na medicina popular; e os óleos essenciais de $A$. conyzoides demonstram notável atividade biológica como cicatrizantes, bactericidas, fungicidas, inseticida (KASALI et al., (2002) e anti-gonadotrópicas (ZOGHBI, et. al 2007). Para o óleo essencial obtido com planta cultivada na região norte do Brasil os majoritários foram precoceno I e $\beta$-caryophyllene nas folhas, galhos, raízes e inflorescências (ZOGHBI et al., 2007). Para seis acessos de $A$. conizoydes cultivadas na cidade de Viçosa Minas Gerais - Brasil foram identificados três compostos majoritários: o precoceno I majoritário no acesso API, cariofileno majoritário no acesso TR e o precoceno II majoritário nos outros acessos (CASTRO et al., 2004). Plantas cultivadas em outros Países também apresentam dentre os majoritários precoceno I e II e cariofileno em diferentes percentuais. Para o óleo essencial de folhas e galhos de $A$. conyzoides do Paquistão os majoritários foram precoceno II, precoceno I e $\beta$-caryophyllene (RIAZ et al., 1995). O óleo essencial das flores e caules das plantas da Costa do Marfim-África indicaram a presença de precoceno I e $\beta$-caryophyllene nas flores e caules (KOUAME et al., 2018). Dung et al. (1989) encontraram como majoritários o precoceno II e Precoceno I em culturas de Hanoi, Vietnam. Zoghbi et al, (2007) encontraram dois quimiotipos na região norte do Brasil (um quimiotipo rico em precoceno I e outro rico em cariofileno); Castro et al., (2004) identificaram outro quimiotipo rico em precoceno II na região sudeste do Brasil. Estes quimiotipos irão influenciar diretamente nas atividades biológicas do óleo essencial, como observado para os precocenos que causaram impacto direto nos insetos agindo como hormônios anti-juvenis e causando genotoxicidade, mostrando com isso que os quimiotipos ricos em precocenos podem ser indicados com potencial inseticida como visto nos experimentos desenvolvidos por Ekundayo et al., (1988), Binder et al., (1991) e Kafi-Farashah et al., ( 2018).

Conclusão: A partir do levantamento bibliográfico realizado, pôde-se verificar a existência dos quimiotipos Precoceno I, Precoceno II e o $\beta$-caryophyllene no óleo essencial de Ageratum conyzoides cultivado no Brasil e em outros países, assim como a influência destes nas atividades biológicas como potencial inseticida e fungicida.

\section{Referências}

BINDER, B. F.; BOWERS, P. H. E.; EVANS, P. H.. Insect anti-juvenile hormone and juvenile hormone activity from plants in the genus Mana. Experientia, v. 47, n. 1, p.199-201, 1991. 
CASTRO, H. G.; OLIVEIRA, L. O.; BARBOSA, L. C. A.; et. al.. Teor e composição do óleo essencial de cinco acessos de mentrasto. Química Nova, v.. 27, n.1, 55-57, 2004.

DUNG, N. X. .; THO,P. T. T.; DAN, N. V.; LECLERCQ, P. A. Chemical Composition of the Oil of Ageraturn conyzoides L. from Vietnam. Journal of Essential Oil Research. v.1. p.135-136, 1989.

EKUNDAYO, O.; LAAKSO, I.; HILTUNEN, R.. Essential Oil of Ageratum conyzoides. Planta Medica, [s.I.], v. 54, n. 01, p.55-57, 1988.

FRANCHOME, P. Exact Aropatherapy. 1. ed. 1975

KAFI-FARASHAH, F.; FARAZMAND, H.; VAFAEI-SHOUSHTARI, R.; et.al.. Effects of Anti-Juvenike Hormone, Precocene-I, on Egg Development of Sunn Pest, Eurygaster integriceps, and Its Progenies. Journal of Agricultural Science and Technology v. 20, p. 979-986, 2018.

KASALI, A. A.; WINTERHALTER, P.; ADIO, A. M.; et.al.. Chromenes in Ageratum conyzoides L. Flavour And Fragrance Journal, v. 17, n. 4, p.247-250, 2002.

KOUAME, B. K. F. P.; TOURE, D.; KABLAN, L.; BEDI, G.; et. al.. Chemical constituents and antibacterial activity of essential oils from flowers and stems of Ageratum conyzoides from Ivory coast. Records of Natural Products, v. 12, n. 2, p. $160,2018$.

RIAZ, M. ; KHALID, M. R.; CHAUDHARY, F. M.. Essential Oil Composition of Pakistani Ageratum conyzoides L. Journal of Essential Oil Research, v. 7, n. 5, p. 551-553, 1995.

ZOGHBI, M. G. B.; BASTOS, M. N. C.; JARDIM, M. A. G.; et al.. Volatiles of inflorescences, leaves, stems and roots of Ageratum conyzoides L. growing wild in the north of Brazil. Journal of Essential Oil Bearing Plants, v. 10, n. 4, p. 297-303, 2007

Coordenadoria de Pesquisa e Extensão - COPEX

Departamento de Editoraçāo e Divulgaçāo Científica - DEDIC 


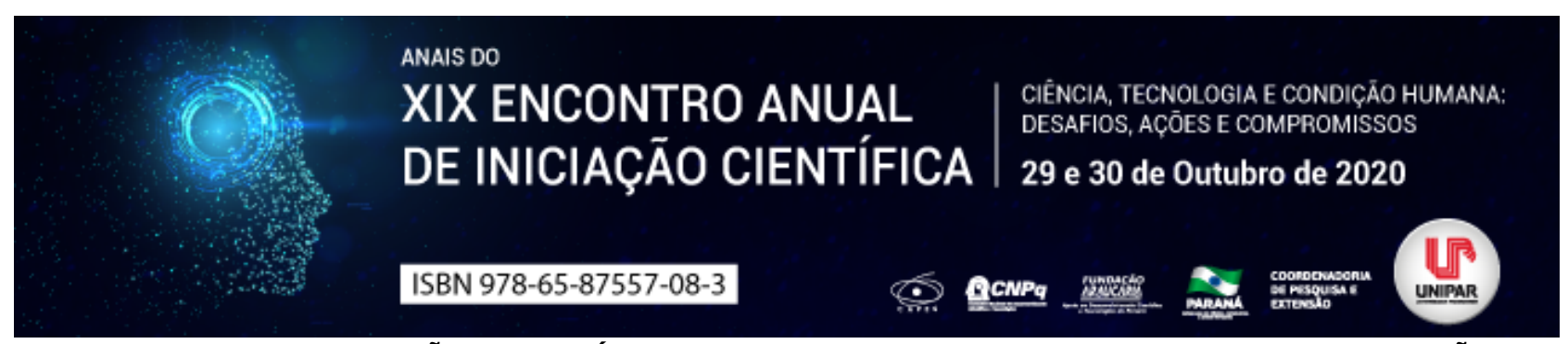

CONCRETO COM ADIÇÃO DE RESÍDUOS DE BORRACHA DE PNEU: UM ESTUDO DE REVISÃO

\author{
${ }^{1}$ MILENA GABRIELA FERREIRA HAYASHIDA, ${ }^{2}$ NATALIA PINHEIRO D ONOFRE DA SILVA, ${ }^{3}$ CHEILA BRAMBILLA FREIRE, \\ ${ }^{4}$ ROSILEY BERTON PACHECO, ${ }^{5}$ VANDA ZAGO LUPEPSA
}

\author{
${ }^{1}$ Acadêmico do PIC/UNIPAR \\ ${ }^{1}$ Acadêmica do Curso de Engenharia Civil da UNIPAR \\ ${ }^{2}$ Acadêmica do Curso de Engenharia Civil da UNIPAR \\ ${ }^{3}$ Docente da UNIPAR \\ ${ }^{4}$ Docente da UNIPAR
}

Introdução: Estudos realizados pelo Serviço Social do Transporte e Serviço Nacional de Aprendizagem do Transporte (SEST SENAT, 2019), resultaram na estimativa de aproximadamente 450 mil toneladas de pneus que são descartados por ano. Este descarte torna-se um grande problema social e ambiental pois além da demora de em média 600 anos para se decompor na Natureza, podem ser causadores e propagadores de inúmeras doenças. Diante da urgência do reaproveitamento deste material, Frade, Crippa e Melges (2016) afirmam que a borracha de pneu remanescente junto ao concreto surge como uma inovação, por ser um material gerado em superabundância, no qual oferece maior capacidade de deformação do concreto e reduz os impactos ambientais. Assim sendo, foi pensando em formas da substituição parcial do agregado miúdo por fibras deste material, analisando suas propriedades à fim de ser utilizado em calçadas, pavimentações flexíveis, contenções de taludes, sapatas, utilidades estruturais e entre outros.

Objetivo: Apresentar as características do comportamento do concreto inserindo resíduos de borracha de pneu como agregado miúdo.

Desenvolvimento: A adição de resíduos de borracha de pneu têm-se manifestado como promissor no mercado da construção civil, visto que mostra-se eficiente para a obtenção de resistência a tração e compressão, além de garantir a sustentabilidade e a preservação dos recursos naturais. Moreira, Fernandes, et. al. (2019) afirmam que, a transição de areia por borracha apresenta grande potencial na produção do concreto, visto que, comparado ao concreto convencional, origina um material com durabilidade, acessibilidade econômica e maior absorção de energia quando sujeito a impacto. Moreira, Fidelis e Dias (2014), realizaram estudos sobre as características do comportamento do concreto inserindo resíduos de borracha de pneu como agregado miúdo, à proporção de 50\%, $25 \%$ e $12,5 \%$ de borracha ao concreto. Assim sendo, observou-se que à medida que adicionasse maior quantidade deste aditivo, havia maior interferência negativa na trabalhabilidade e resistência mecânica. Em relação à resistência à compressão, há queda significativa nos dados coletados porém justifica-se pelo aumento do consumo de água para obter o mesmo abatimento do concreto. A proposta de estudo da substituição fracionária do volume de areia por este polímero, é considerada aceitável por atingir durabilidade compatível com o concreto tradicional, tornar-se um material leve em função da diminuição da massa específica resultante do aumento do volume das fibras (Cunha, 2019). Contudo, a condição de adição das fibras do pneu associado aos outros componentes do concreto é limitada para que suas características positivas possam permanecer íntegras. Izídio Júnior, Silva Junior e Ferreira (2016) mencionaram estas características positivas, tais como, diminuição de fissuras, maior ligação entre os materiais, baixo peso próprio e maior tenacidade. Além de proporcionar prolongamento dos recursos naturais e alternativa sustentável para a proteção do meio ambiente.

Conclusão: Diante do exposto, foi apresentado o comportamento das fibras de borracha com a junção de areia, água, agregado graúdo e cimento. O concreto adicionado ao resíduo de pneu é eficaz para a substituição parcial da areia, tendo condições negativas ao adicioná-lo em maior escala, como também pontos positivos que se sobressaem, tornando-os eficientes e favoráveis em obras, edificações e na própria Natureza. Entretanto, faz-se necessário o investimento em tecnologias, apoio de empresas do ramo da construção civil e instituições de ensino, bem como a invalidação de barreiras políticas, para a contribuição da sustentabilidade e progresso do mercado construtivo.

\title{
Referências
}

CUNHA, Fred Guedes. Efeito da adição de fibras como reforço de concreto leve formulado usando múltiplos resíduos. Tese (Doutorado em Ciência e Engenharia de Materiais) - Centro de Ciências Exatas e da Terra, Universidade Federal do Rio Grande do Norte, Natal, 2019. Disponível em: https://repositorio.ufrn.br/jspui/handle/123456789/27923. Acessado em: $17 / 08 / 2020$.

FRADE, Antonio Carlos Mauri; CRIPPA, Leopoldo Firmino; MELGES, José Luiz Pinheiro. Estudo da Dosagem de Concreto com Adição de Resíduo de Borracha de Pneu. Construção de Cidades Verdes: III Encontro Técnico e Científico, p. 241, 
Araçatuba-SP, out. 2016. Disponível em: https://www.eventoanap.org.br/data/inscricoes/914/form3244295.pdf. Acessado em: 17/08/2020.

FERNANDES, Jiulia Fernanda Aderno. et. al. Análise da resistência do concreto com resíduos de borracha de pneu. Inter American Journal of Development and Research - Faculdade de Ouro Preto do Oeste (UNEOURO), v. 2, n.1, 2 ed. Ouro Preto do Oeste, 2019. Disponível em: http://revistas.uneouro.edu.br/index.php/uneouro/article/download/47/11. Acessado em: 17/08/2020. IZÍDIO JÚNIOR, Lázaro Roberto; SILVA JÚNIOR, Francisco Alves; PEREIRA, Danielle Dantas. Estudo do comportamento do concreto produzido com adições de resíduos de borracha de pneu como parte do agregado miúdo. $\mathbf{2 2}^{\circ}$ CBECiMat - Congresso Brasileiro de Engenharia e Ciência dos Materiais. Natal, 2016. Disponível em: http://www.metallum.com.br/22cbecimat/anais/PDF/105-016.pdf. Acessado em: 17/08/2020.

MOREIRA, José Franklin; FIDELIS, Vanessa Rosa Pereira; DIAS, João Fernando. Concreto com borracha de pneu aplicado em ciclovia. Uberlândia, 2014. Disponível em: https://holos.emnuvens.com.br/holos/article/viewFile/8141/6348. Acessado em: $17 / 08 / 2020$.

SERVIÇO SOCIAL DO TRANSPORTE E SERVIÇO NACIONAL DE APRENDIZAGEM DO TRANSPORTE - SEST SENAT. Cerca de 450 mil toneladas de pneus são descartados por ano no Brasil. Brasília, 2019. Disponível em: https://www.sestsenat.org.br/. Acessado em: 17/08/2020. 


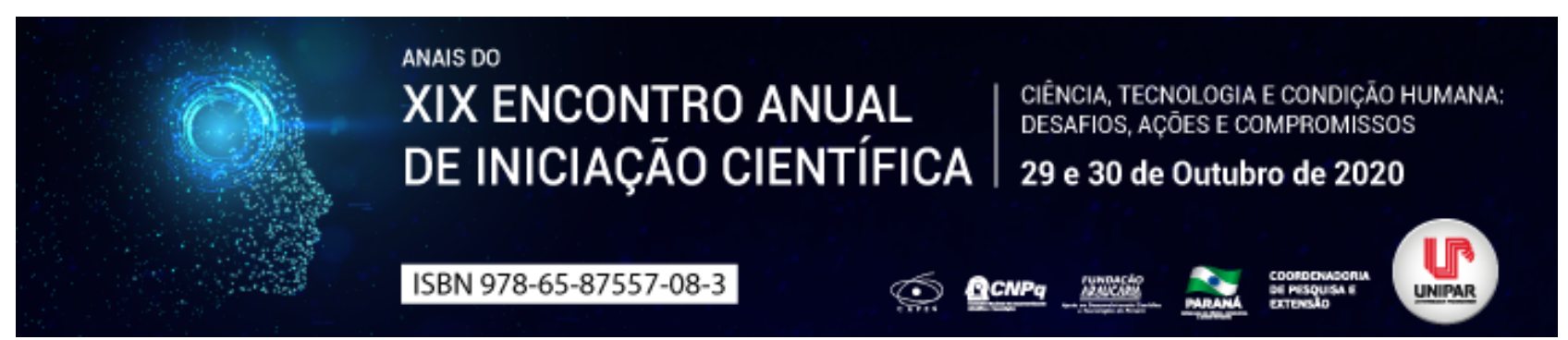

DESENVOLVIMENTO DE Echinodorus grandiflorus: ADIÇÃO DE FÓSFORO E STIMULATE® AO SOLO

\begin{abstract}
${ }^{1}$ HALISON MURILO DA SILVA OLIVEIRA, ${ }^{2}$ MARIANA MORAES PINC, ${ }^{3}$ JOICE KARINA OTENIO, ${ }^{4}$ MILENA DA SILVA LORENCETE,${ }^{5}$ EZILDA JACOMASSI, ${ }^{6}$ ODAIR ALBERTON
\end{abstract}

\begin{abstract}
${ }^{1}$ Acadêmico bolsista do PIBIC/UNIPAR
${ }_{1}$ Mestranda do Programa de Pós-Graduação em Ciência Animal com Ênfase em Produtos Bioativos

${ }^{2}$ Mestranda do Mestrado Profissional em Plantas Medicinais e Fitoterápicos na Atenção Básica

${ }^{3}$ Mestranda do Mestrado Profissional em Plantas Medicinais e Fitoterápicos na Atenção Básica

${ }^{4}$ Docente do Mestrado Profissional em Plantas Medicinais e Fitoterápicos na Atenção Básica

${ }^{5}$ Docente do Mestrado Profissional em Plantas Medicinais e Fitoterápicos na Atenção Básica
\end{abstract}

Introdução: Echinodorus grandiflorus (Cham. and Schltr.) Micheli (Alismataceae), popularmente conhecida como chapéu-decouro , cresce em solos úmidos com cobertura vegetativa de apoio (BONETTI et al., 2020). Suas folhas utilizadas na forma de chás, apresentam atividades farmacológicas como anti-inflamatório, antioxidante, diurética, analgésica, antirreumática, antihipertensiva e com efeitos cardioprotetores (PRANDO, 2015). A adição do fósforo (P) no solo é essencial para um bom crescimento e desenvolvimento das plantas em geral e pode modificar o metabolismo secundário das plantas alterando desse modo os bioativos (URCOVICHE et al., 2015). O Stimulate ${ }^{\circledR}$ é um estimulante vegetal que proporciona o desenvolvimento da raiz pelo aumento da absorção de água e nutrientes, facilitando o equilíbrio hormonal da planta e tendo efeitos sobre muitos processos fisiológicos (RODRIGUES et al, 2015).

Objetivo: Avaliar o desenvolvimento da planta E. grandiflorus, com ou sem a adição de fitohormônios, e com ou sem a adição de fósforo ao solo.

Metodologia: Echinodorus grandiflorus foi cultivada em canteiros no Horto Medicinal da Universidade Paranaense em Umuarama. O experimento foi conduzido em blocos de 4 tratamentos com 3 repetições cada, formando um total de 12 unidades

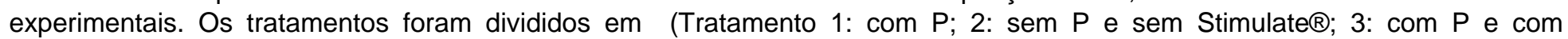
Stimulate ${ }^{\circledR}$; 4: com Stimulate ${ }^{\circledR}$ ) sendo que os tratamentos onde há $P$ foram adicionados $200 \mathrm{mg}$ de $\mathrm{P} \mathrm{kg}-1$ de solo e com Stimulate ${ }^{\circledR} 1 \mathrm{~L}$ ha-1. Após a planta completar seu ciclo, elas foram coletadas, pesadas em balança digital para a determinação da massa fresca da parte aérea (MFPA), e secas em estufa, até atingirem massa constante. Logo após a secagem, o material foi pesado em balança digital para a determinação da massa seca da parte aérea (MSPA) e triturado em trituradores industriais. A determinação do $\mathrm{P}$ da parte aérea (PPA) foi por colorimetria em espectrofotômetro usando filtro vermelho e comprimento de onda de 660nm conforme Silva (2009). O teor de nitrogênio da parte aérea (NPA) foi determinado pelo método de digestão sulfúrica a $450{ }^{\circ} \mathrm{C}$ e destilação pelo método de Kjeldahl conforme Silva, (2009). As médias calculadas foram submetidas à análise e variância (ANOVA) e teste de Duncan $(p \leq 0,05)$, utilizando o programa estatístico SPSS v. 22.

Resultados e discussão: Houve diferenças estatísticas entre a MSPA e MFPA onde o tratamento 3 (com P e com Stimulate ${ }^{\circledR}$ ) teve o melhor desempenho. Em estudos anteriores feitos com Mentha crispa realizada por Urcoviche (2013) não houve variações entre os tratamentos na MFPA, onde os valores menores foram na dose baixa de $\mathrm{P}$ no solo. O tratamento 3 também apresentou melhor desempenho na análise de NPA, entretanto os tratamentos não diferiram estatísticamente entre as análises de clorofila. Resultados semelhantes foram encontrados por Batista Filho et al. (2013) que ao estudar o efeito do Stimulate ${ }^{\circledR}$ nas características agronômicas da soja constatou que o NPA foi maior no tratamento com adição de $750 \mathrm{ml}$ de bioestimulante por $100 \mathrm{~kg}$ de sementes. Isso pode ser explicado devido ao fato do maior crescimento vegetativo do tratamento 3 causando um maior acúmulo de reservas de nutrientes. A quantidade de PPA obteve melhores resultados no tratamento 1 (com P). A adição de Stimulate ${ }^{\circledR}$ não afetou significantemente o PPA. Em estudo anterior feito com Mentha crispa, inoculada com micorriza e sob baixa e alta adição de $\mathrm{P}$ no solo, Urcoviche et al., (2015) observou que houve um aumento significativo na concentração do P nas plantas com a adição de $\mathrm{P}$ ao solo.

Conclusão: Pode-se observar que a planta teve o melhor desenvolvimento sob adição de fósforo e Stimulate ${ }^{\circledR}$ ao solo, obtendo maior quantidade de MFPA, MSPA e NPA. Não houve diferença estatística na clorofila e a concentração de PPA do chapéu-decouro apresentou melhor resultado no tratamento com adição de $P$, não tendo tanta influência sob adição ou não de fitohormônios.

\title{
Referências
}

BATISTA FILHO, C. G. et al. Efeito do Stimulate $®$ nas características agronômicas da soja. Acta Iguazu, v.2, n.4, p. 76-86, 2013. BONETTI, C. I. et al. Phytochemical profile and evaluation of the antimicrobial activity of Echinodorus grandiflorus crude extract of 
the leaves. Journal of agricultural studies, v.8, n.4, p. 176-192, 2020.

PRANDO, T. B. L. Prospeç̧ão farmacológica etno-guiada das atividades dietéticas de espécies medicinais nativas. Orientador: Arquimedes Gasparotto Junior. 2015. 103 f. Dissertação (Mestrado em Ciência Animal) - Universidade Paranaense, Umuarama, 2015.

RODRIGUES, L. A. et al. Avaliação fisiológica de sementes de arroz submetidas a doses de bioestimulante. Nucleus, v. 12, n.1, p. 207-217, 2015.

SILVA, C.F. Manual de análises químicas de Solos, plantas e fertilizantes. 2 ed. Brasília DF: Embrapa, 2009. 627p.

URCOVICHE, R. C. et al. Plant growth and essential oil content of Mentha crispa inoculated with arbuscular mycorrhizal fungi under different levels of phosphorus. Industrial crops and products, v.67, p. 103 107, 2015.

URCOVICHE, R. C. Fungos micorrízicos arbusculares em plantas medicinais e condimentares. Orientador: Odair Alberton. 2013, 63 f. Dissertação (Mestrado em Biotecnologia Aplicada à Agricultura) - Universidade Paranaense, Umuarama, 2013.

Coordenadoria de Pesquisa e Extensão - COPEX

Departamento de Editoraçāo e Divulgaçāo Científica - DEDIC 


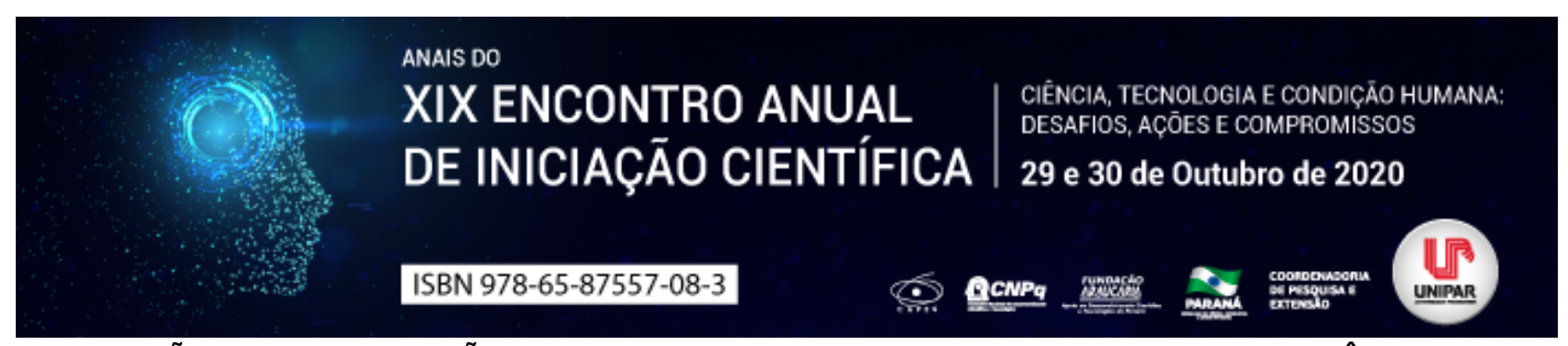

DETERMINAÇÃO DE COLONIZAÇÃO RADICULAR E MACRONUTRIENTES NO CULTIVO ORGÂNICO DE CUphea carthagenensis

\begin{abstract}
${ }^{1}$ JOICE KARINA OTENIO, ${ }^{2}$ ROSSELYN GIMENES BAISCH , ${ }^{3}$ JOAO VITOR PRADO ROBLE, ${ }^{4}$ WILLIAN YUJI YOSHIURA, ${ }^{5}$ ODAIR ALBERTON, ${ }^{6}$ EZILDA JACOMASSI
\end{abstract}

\author{
${ }^{1}$ Mestranda do Programa de Plantas Medicinais e Fitoterápicos na Atenção Básica/UNIPAR \\ ${ }^{1}$ Mestranda do Programa de Plantas Medicinais e Fitoterápicos na Atenção Básica/UNIPAR \\ ${ }^{2}$ Acadêmico do Curso de Farmácia PIC/UNIPAR \\ ${ }^{3}$ Acadêmico do Curso de Farmácia PIC/UNIPAR \\ ${ }^{4}$ Docente do Mestrado em Plantas Medicinais e Fitoterápicos na Atenção Básica/ UNIPAR \\ ${ }^{5}$ Docente do Mestrado em Plantas Medicinais e Fitoterápicos na Atenção Básica/ UNIPAR
}

Introdução: O cultivo de plantas medicinais, deve ser isento de agentes químicos, porque estes podem interferir no metabolismo e prejudicar a produção de seus compostos ativos. Tais compostos, são responsáveis pelas ações farmacológicas das plantas. A adubação orgânica, se mostra tão eficiente quanto o uso de fertilizantes químicos. Melhora a qualidade química e microbiológica do solo, retém grande quantidade de água e diminui problemas com erosão (VELOSO et al., 2014). Além disso, um adubo importante no enriquecimento do solo que melhora o desenvolvimento e crescimento de plantas medicinais, é o composto camade-aviário, rico em nutrientes e com baixo custo (WANG et al., 2018). Nesse sentido, o presente trabalho foi realizado, para melhorar a qualidade e padronizar o cultivo orgânico da espécie Cuphea carthagenensis (Jacq.) J. F. Macbr. Esta espécie pertence à família Lythraceae, conhecida como sete-sangrias, possui uso medicinal reconhecido e amplamente utilizada no tratamento de hipertensão arterial e dislipidemias (BARBOZA et al., 2016).

Objetivo: Determinar a influência da colonização radicular, concentração de nitrogênio e fósforo nas partes aéreas e raízes de $C$. carthagenensis, sob adição do composto orgânico cama-de-aviário.

Metodologia: O experimento foi realizado no Horto Medicinal da Universidade Paranaense (UNIPAR), em Umuarama - PR, cujas coordenadas geográficas são de 430 metros de altitude em relação ao nível do mar (S2347‘55-W5318‘48). A C. carthagenensis está catalogada no Herbário da UNIPAR sob o número 2401. O delineamento experimental foi simples inteiramente casualizado com 5 tratamentos nas doses de $\left(0 ; 10 ; 20 ; 30\right.$ e $\left.40 \mathrm{t} \mathrm{ha}^{-1}\right)$ em 3 parcelas subdivididas de $2 \mathrm{~m}^{2}$ cada. Sementes de $C$. carthagenensis foram coletadas no canteiro matriz do Horto Medicinal e semeadas aproximadamente 300 sementes por canteiro experimental. Ao final do cultivo, toda a planta foi coletada e secas em estufas de ventilação forçada de ar. A determinação do $P$ da parte aérea (PPA) e raízes (PR) por colorimetria em espectrofotômetro usando filtro vermelho e comprimento de onda de $660 \mathrm{~nm}$. A concentração do $\mathrm{N}$ da parte aérea (NPA) e raízes (NR) foi realizada por meio de digestão sulfúrica a $450{ }^{\circ} \mathrm{C}$ e destilação pelo método de Kjeldahl (SILVA et al., 2009). As raízes coletadas, receberam uma coloração específica e verificou-se a presença de hifa, arbúsculo e vesícula, com auxílio de microscópio estereoscópico, o resultado foi obtido em porcentagem (\%). Demais resultados, foram avaliados por análise de variância (ANOVA) e comparadas por meio do teste de Duncan ( $p \leq 0,05$ ), utilizando o programa estatístico SPSS v. 22.

Resultados e Discussão: Foi verificado que a dose de $30 \mathrm{t} \mathrm{ha}^{-1}$, aumentou de forma significativa os níveis de $\mathrm{P}$, nas partes aéreas, por grama de planta. O fósforo é essencial para o crescimento e desenvolvimento das plantas em geral e pode modificar e melhorar a quantidade dos compostos ativos (URCOVICHE et al., 2015). Entretanto, não se verificou diferença na presença de $\mathrm{P}$ nas raízes. A análise do elemento $\mathrm{N}$, nas partes aéreas e raízes, não foi influenciada com adição de doses de cama-de-aviário. Com a análise de colonização radicular, não foi verificado diferença significativa entre as doses com adição de cama-de-aviário e o solo sem adição. Um estudo de Smith e Read (2008), mostrou que os fungos presentes nas raízes das plantas, as deixam mais resistentes aos estresses bióticos e abióticos. Possuem a função de melhorar a troca de nutrientes entre o solo e a planta.

Dessa forma, os resultados encontrados, nas condições de cultivo deste experimento, podem se justificar por fatores climáticos. Além disso, outras análises devem ser realizadas, a fim de elucidar mecanismos químicos, microbiológicos e fúngicos do solo. A obtenção de extratos da espécie e realização de caracterização fitoquímica, nesse modelo de cultivo, se faz necessário, para garantir a eficácia ou ineficiência, da aplicação deste adubo no cultivo da espécie em questão.

Conclusão: Pode-se concluir com este estudo, que a cama-de-aviário na dose $30 \mathrm{t} \mathrm{ha}^{-1}$ administrada ao solo, no cultivo de $C$. carthagenensis, melhora o desenvolvimento, por deixar o nutriente fósforo mais disponível para absorção da planta e como consequência pode aumentar o rendimento de biomassa vegetal. 


\section{Referências}

BARBOZA, Lorena Neris et al. Atheroprotective effects of Cuphea carthagenensis (Jacq.) J.F. Macbr. in New Zealand rabbits fed with cholesterol-rich diet. J. Ethnopharmacol, v. 187, p. 134-145, 2016.

SILVA, A. P. D. et al. Resposta do Jaracatia spinosa à inoculação de fungos micorrizícos arbusculares em diferentes niveis de fósforo. Synergismus scyentifica UTFPR, v. 4, n. 1, 2009.

SMITH, S. E.; READ, D. J. Mycorrhizal Symbiosis. San Diego: Academic Press, 2008. 603 p.

URCOVICHE, R. C. et al. Plant growth and essential oil content of Mentha crispa inoculated with arbuscular mycorrhizal fungi under different levels of phosphorus. Industrial Crops and Products, v.67, p. 103 107, 2015.

VELOSO, R. A. et al. Teor e composição do óleo essencial de quatro acessos e duas cultivares de manjericão (Ocimum basilicum L.). Rev. bras. plantas med, v.16, n. 2, p. 364-371, 2014.

WANG, Ke; CHU, Chu; LI, Xiangkun; WANG, Wei; REN, Nanqi. Succession of bacterial community function in cow manure composing. Bioresour. Technol, v. 267, p. 63-70, 2018.

Coordenadoria de Pesquisa e Extensão - COPEX

Departamento de Editoraçāo e Divulgaçāo Científica - DEDIC 


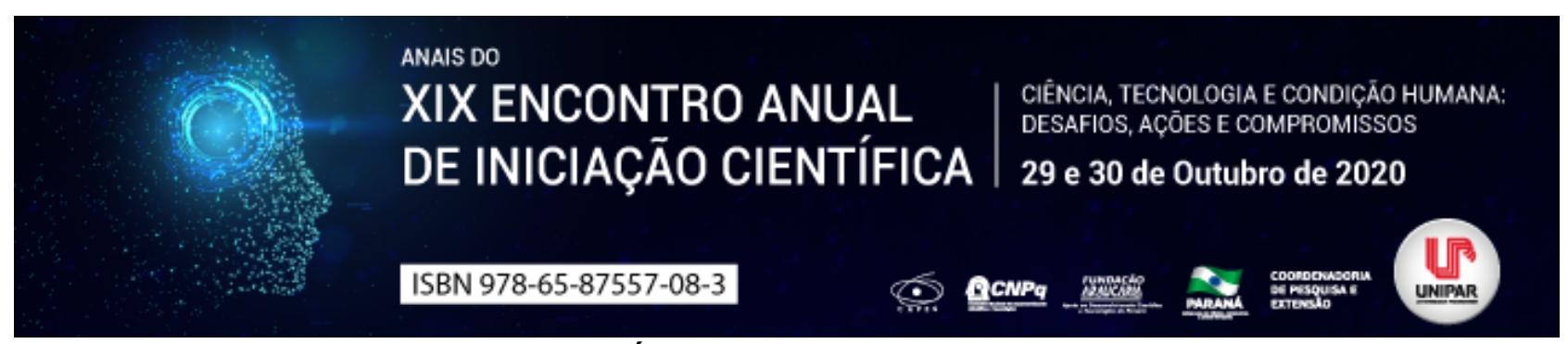

ATIVIDADE ANTIMICROBIANA DO ÓLEO ESSENCIAL DOS FRUTOS DE Gallesia integrifolia

\author{
${ }^{1}$ WANESSA DE CAMPOS BORTOLUCCI, ${ }^{2}$ MARCOS RODRIGO DA SILVA, ${ }^{3}$ HERIKA LINE MARKO DE OLIVEIRA, ${ }^{4}$ GIANI \\ ANDREA LINDE, ${ }^{5}$ NELSON DE BARROS COLAUTO, ${ }^{6}$ ZILDA CRISTIANI GAZIM
}

\author{
${ }^{1}$ Doutora em Biotecnologia Aplicada à Agricultura, Unipar, Umuarama-PR \\ ${ }^{1}$ Acadêmico PIC do Curso de Farmácia da UNIPAR \\ ${ }^{2}$ Doutoranda em Biotecnologia Aplicada à Agricultura, Unipar, Umuarama-PR \\ ${ }^{3}$ Docente da UNIPAR \\ ${ }^{4}$ Docente da UNIPAR \\ ${ }^{5}$ Docente da UNIPAR
}

Introdução: O Brasil possui uma vasta biodiversidade, tornando-o um dos primeiros em quantidade de espécies de plantas superiores identificadas, dentre estas, várias plantas nativas possuem grande potencial econômico devido à presença de compostos bioativos (NEGRINE et al., 2016). A guararema é o nome popular da Gallesia integrifolia (SPRENG.) Harms, conhecida pelo seu odor aliáceo em dias de maior umidade no ar, tem ampla ocorrência natural no Brasil de sul a norte (LORENZI, 2002). Não há relatos na literatura sobre a atividade antimicrobiana do OE dos frutos da guararema; porém, os produtos naturais podem ser uma alternativa para vários microrganismos, minimizando as resistências e os efeitos colaterais ocasionados pelos produtos químicos; visto que muitos fungos e bactérias estão relacionados com doenças humanas e ainda acarretam prejuízos à agricultura (SILVA e BASTOS, 2007; TINTINO et al., 2015). O objetivo deste estudo foi avaliar as atividades antibacteriana do OE dos frutos de $G$. integrifolia.

Material e Métodos: OE dos frutos de G. Integrifolia foi extraído por hidrodestilação (3 h) e identificado por cromatografia gasosa acoplada a espectometria de massa (CG/EM). Foram utilizados 5 espécies de bactérias: Escherichia coli (ATCC 35210), Pseudomonas aeruginosa (ATCC 27853), Enterobacter cloacae (isolado humano) bactéria Gram-positiva e bacterias Gramnegativa: Micrococcus flavus (ATCC 10240) e Staphylococcus aureus (ATCC 6538). O ensaio antimicrobiano foi realizado pelo método de microdiluição e determinado a concentração inibitória minima (CIM) (HANEL e RAETHER, 1988; ESPINEL-INGROFF, 2001).

Resultados: O melhor resultado da aplicação do OE de G. integrifolia foi sobre a bactéria $E$. coli (CIM $100 \mu \mathrm{g} / \mathrm{mL})$ seguido do $S$. aureus, M. flavus, E. cloacae e da $P$. aeruginosa (CIM $500 \mu \mathrm{g} / \mathrm{mL} ; 1500 \mu \mathrm{g} / \mathrm{mL} ; 2250 \mu \mathrm{g} / \mathrm{mL}$ e $6750 \mu \mathrm{g} / \mathrm{mL}$ ), respectivamente. Onde apenas para E. coli o OE foi mais efetivo que o controle positivo estreptomicina (CIM $200 \mu \mathrm{g} / \mathrm{mL}$ ). Por meio da caracterização química, verificou-se que $99,9 \%$ da composição química do OE dos frutos de G. integrifolia possuim atomos de enxofre, tendo como compostos majoritários o 2,8-dithianonane (63,87\%), o dimethyl trisulfide (18,30\%) e a lenthionine (17,34\%). Discussão: O OE de G. integrifolia foi mais efetivo que a estreptomicina apenas sobre a bactéria Gram-negativo E. coli, uma bactéria oportunista que contribui nos processos tóxicos e infecciosos humanos (DE ARAÚJO e LONGO, 2016). E pode ser proveniente de contaminação na água ou alimentos, pela falta de saneamento básico, más condições de higiene no processo ou preparo dos alimentos (SOUSA, 2006). Neste sentido, a G. integrifolia apresenta em sua constituição química 99,9\% de compostos sulfurados, sendo a lenthionine um dos composto majoritário. Haja visto que Morita e Kobayashi (1967) testou este composto o qual apresentou potencial antimicrobiano frente o S. aureus (MIC de $250.00 \mu \mathrm{g} / \mathrm{mL}$ ) e o E. coli (MIC de 250.00 $\mu \mathrm{g} / \mathrm{mL}$ ). Desta forma o OE dos frutos de $\mathrm{G}$. integrifolia pode ser considerado um agente favóravel na ação antimicrobiana encontrada no presente experimento.

Conclusão: Desta forma, o OE dos frutos de Gallesia integrifolia poderá ser uma alternativa na substituição dos produtos químicos para o tratamento da resistência microbiana, visto que se trata de um assunto de extrema relevância, o qual é uma ameaça à saúde pública e também resposável por grandes perdas de cultivos agrícolas.

\title{
Referências
}

DE ARAUJO, Márcio Martins; LONGO, Priscila Larcher. In vitro antibacterial activity of Origanum vulgare (oregano) essential oil against Escherichia coli and Staphylococcus aureus strains. Arquivos do Instituto Biológico, São Paulo, v. 83, p. 1-7, oct. 2016. ESPINEL-INGROFF, Ana. Comparison of the E-test with the NCCLS M38-P method for antifungal susceptibility testing of common and emerging pathogenic filamentous fungi. Journal of Clinical Microbiology, EUA, v. 39, p. 1360-1367, apr. 2001.

HÄNEL, Heinz; RAETHER, Wolfgang. A more sophisticated method of determining the fungicidal effect of water-insoluble preparations with a cell harvester, using miconazole as an example. Mycoses, Berlin, v. 31, p. 148-154, marc. 1988.

LORENZI, Harri. Árvores brasileiras: Manual de identificação e cultivo de plantas arbóreas nativas do Brasil, 4ed. São 
Paulo - SP: Instituto Plantarum de Estudos da Flora Ltda, Nova Odessa, 2002, 368p.

MORITA, Katsura; KOBAYASHI, Shigeru. Isolation, structure, and synthesis of lenthionine and its analogs. Chemical and Pharmaceutical Bulletin, Japan, v. 15, p. 988-993, july, 1967.

NEGRINE, Talita Costa et al. Nutritional value of native and exotic fruits from Brazil. Biosaúde, Londrina, v. 18, p. 82-96, dec, 2016.

SILVA, Danielle Mariana; BASTOS, Cleber. Antifungal activity of essential oils of Piper species against Crinipellis perniciosa, Phytophthora palmivora and Phytophthora capsici. Fitopatologia Brasileira, Brasilia, v. 32, p. 143-145, mar/abr, 2007.

SOUSA, Cristina Paiva. Segurança alimentar e doenças veiculadas por alimentos: utilização do grupo coliforme como um dos indicadores de qualidade de alimentos. Revista de APS, Juiz de Fora, v. 9: p. 83-88, jan/jun, 2006.

TINTINO, Saulo Relison et al. In vitro evaluation of antimicrobial activity and modulating the ethanol and hexane extracts of Costus arabicus bulb. Bioscence Journal, Uberlândia, v. 29, p. 732-738, apr, 2013.

Coordenadoria de Pesquisa e Extensão - COPEX

Departamento de Editoração e Divulgaçāo Científica - DEDIC 


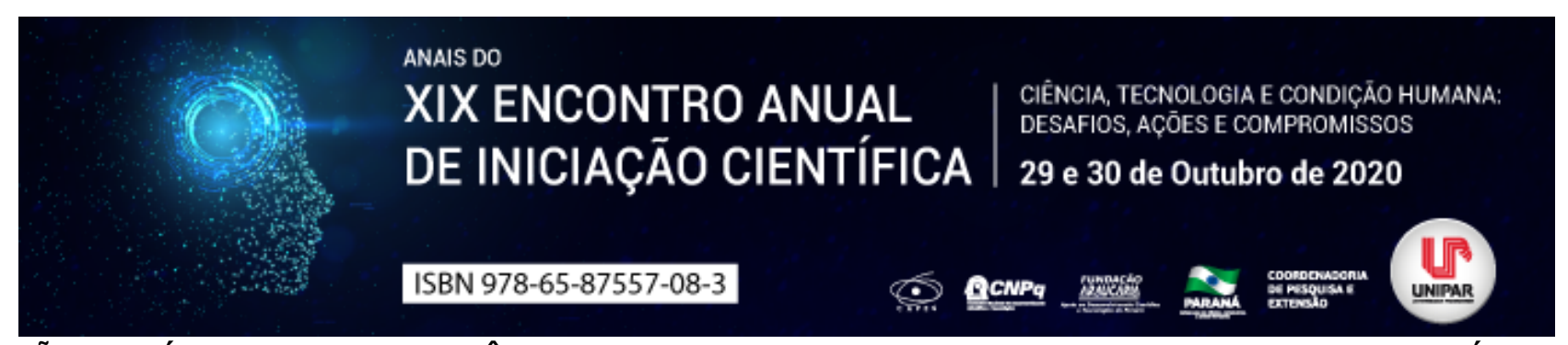

UTILIZAÇÃO DE TÉCNICAS DE INTELIGÊNCIA COMPUTACIONAL NO ESTUDO DE SINAIS ELETROMIOGRÁFICOS (EMG)

\author{
${ }^{1}$ Felipe Antonio dos Santos, ${ }^{2}$ ELAINE INACIO BUENO
}

\author{
${ }^{1}$ Estudante de Engenharia de Controle e Automação - Instituto Federal de São Paulo - Campus São Paulo \\ ${ }^{1}$ Professora - Instituto Federal de São Paulo - Campus São Paulo
}

Introdução: A integração de pessoas portadoras de necessidades especiais (PNE) na realização de tarefas diárias é um dos grandes problemas enfrentados pela sociedade; e, em decorrência disso, estudos nessa área têm sido estimulados com o propósito de estudar novas metodologias que estejam adaptadas ao perfil do PNE. Observa-se consideráveis avanços nas áreas de ergonomia, construção civil e projetos arquitetônicos para o PNE, porém, é necessário o desenvolvimento de equipamentos e tecnologia adequadas para cada caso (ORTOLAN et al., 2001). Nesse sentido, pesquisas têm sido realizadas, as quais podem ser destacadas: desenvolvimento de um sistema que utiliza eletromiografia de superfície e máquina de vetores de suporte para a caracterização de alguns tipos de movimentos de um braço humano, possibilitado integração futura em sistemas de reabilitação (NILSON, 2014); desenvolvimento de um sistema dedicado à análise de sinais eletromiográficos, baseados em métodos de extração e classificação desses sinais, para serem reconhecidos por uma prótese de membro superior com quatro graus de liberdade (BARROS, 2005); análise de técnicas de processamento de sinal mioelétrico, com o propósito de possibilitar a implementação de um circuito, que reconheça este sinal e apresente como saída, um sinal de controle que será utilizado em sistemas de reabilitação (ORTOLAN, 2002); desenvolvimento de uma mão robótica de baixo custo com o propósito de transformá-la em uma prótese de mão biônica para pessoas com deficiência (RIBEIRO et al., 2016); além do uso de Técnicas de Inteligência Computacional (IC) na reabilitação, como: Redes Neurais Artificias (RNAs) (BERMUDEZ, 2013; CRUZ, 2016) e Lógica Nebulosa (DELIS, 2010; SOBRINHO, 2016).

Objetivo: O objetivo deste trabalho é realizar um estudo das técnicas de IC em sinais eletromiográficos.

Material e Métodos: Miotool é um sistema de eletromiografia que permite, por meio de sensores superficiais, fazer a análise da atividade elétrica existente nos músculos, permitindo ao paciente o aprendizado das atividades de contração e relaxamento da musculatura. Isso torna a terapia de biofeedback eficaz a diversos tratamentos que são aplicados na musculatura. Redes Neurais Artificiais são sistemas paralelos compostos por unidades de processamento simples, dispostas em camadas e altamente interligadas, inspiradas no cérebro humano. Seu aprendizado é realizado a partir de um algoritmo, conhecido como algoritmo de aprendizagem, onde os pesos sinápticos são atualizados com o propósito de se alcançar o objetivo desejado. Existem três tipos de arquiteturas de RNA: redes com propagação para frente de uma camada; redes com propagação para frente de múltiplas camadas (MLP); e redes recorrentes. No que se refere ao treinamento, existem dois tipos: treinamento supervisionado: é necessário utilizar um vetor de entrada e um vetor de saída (vetor alvo) para o treinamento da RNA; e treinamento nãosupervisionado: utiliza-se apenas um vetor de entrada. O estudo foi dividido em duas etapas, sendo a primeira dedicada à obtenção dos sinais eletromiográficos de um determinado grupo muscular, observando o padrão desses sinais; e a segunda será dedicada ao uso de RNAs e GMDH para o estudo desses sinais. Durante a segunda etapa do estudo foi feita a utilização do Toolbox de Redes Neurais (Neural Network Toolbox) no MATLAB, que contém um Toolbox de Reconhecimento de Padrões, onde é possível desenhar, programar, visualizar, treinar e simular redes neurais artificiais de maneira fácil e rápida.

Resultados: Utilizou-se o Miotool para realizar a aquisição de sinais dos grupos musculares: Braquiorradial, Braquial e Palmar Longo. As informações coletadas foram armazenadas em uma base de dados, contendo três colunas, cada uma representando um grupo muscular, com 256 amostras de dados cada uma. Foram definidos três sinais de saída para a base de dados, cada uma representando um dos grupos musculares medidos. E, por fim, a base de dados foi dividida em dois arquivos, um para as entradas e outro para as saídas. Foi observado que o treinamento da rede neural foi concluído em 23 épocas. A performance do treinamento foi de 2,4 x 10-7, indicando uma grande redução da entropia, e o valor do gradiente foi de 5,53 x 10-7.

Discussão: Esse estudo permitiu verificar os padrões e características de cada tipo de sinal durante o treinamento da rede neural, assim como também as propriedades da rede, tais como o número de épocas necessárias para a conclusão do treinamento, assim como a sua performance. Apresentando valores muito baixos, isso demonstra que o treinamento alcançou os resultados desejados. Isso ficou evidente por meio das matrizes de convolução de cada grupo muscular, que fez a seleção de uma das saídas por vez para realizar a classificação.

Conclusão: Por meio do Toolbox de Reconhecimento de Padrões do MATLAB, foi possível observar que o treinamento da rede neural foi capaz de fazer a distinção e seleção dos dados gerados de cada tipo de grupo muscular. Isso ficou evidenciado por meio da apresentação das matrizes de convolução, que faziam a indicação de qual classe/grupo estava sendo identificado em cada etapa. 


\section{Referências}

BARROS, Kety Rosa. Metodologia para Classificação de Sinais EMG para Controle de Próteses com Baixo Esforço Computacional. Dissertação (Mestrado), Universidade Federal de Uberlândia, 60 p., Uberlândia, 2005.

BERMUDEZ, Rosa Maria Jimenez. Proposta de um Sistema Baseado em Redes Neurais e Wavelets para Caracterização de movimentos do segmento mão-braço. Dissertação (Mestrado), Universidade Federal do Rio Grande do Sul, 112 p., Porto Alegre, 2013.

CRUZ, Gizele Ginklings Fróes da. Classificação dos movimentos da mão baseados na aquisição não invasiva de sinais mioelétricos provenientes dos músculos do antebraço através de Redes Neurais Artificiais (RNAs). Trabalho de Conclusão de Curso (TCC), Universidade Federal de Santa Cataria, 96 p., Florianópolis, 2016.

DELIS, Alberto López. Metodologias de Estimação do ângulo do joelho para detecção da intenção de movimento. Tese (Doutorado), Universidade de Brasília Faculdade de Tecnologia, 171 p., Brasília, 2010.

NILSON, Clairê de Pauli. Aquisição, processamento de sinais mioelétricos e máquina de vetores de suporte para caracterização de movimentos do segmento mão-braço. Dissertação (Mestrado), Universidade Federal do Rio Grande do Sul, 89 p., Porto Alegre, 2014.

ORTOLAN, Rodrigo Lício. et al. Tendências em Biomecânica Ortopédica Aplicadas à Reabilitação. Acta Ortopédica Brasileira, v. 9, n. 3, p. 44-58, 2001.

ORTOLAN, Rodrigo Lício. Estudo e avaliação de Técnicas de Processamento do Sinal Mioelétrico para o controle de Sistemas de Reabilitação. Dissertação (Mestrado), Universidade de São Carlos Escola de Engenharia de São Carlos, 133 p., São Carlos, 2002.

RIBEIRO, William Cândido. et al. Desenvolvimento de Mão Robótica de Baixo Custo. Revista Eletrônica Científica, Inovação e Tecnologia, v. 1., n. 13, p. 93-99, 2016.

SOBRINHO, José Marques Basílio. Desenvolvimento de uma garra robótica acionada com atuadores de liga com memória de forma. IX Congresso Nacional de Engenharia Mecânica (CONEM), Fortaleza, 2016. 


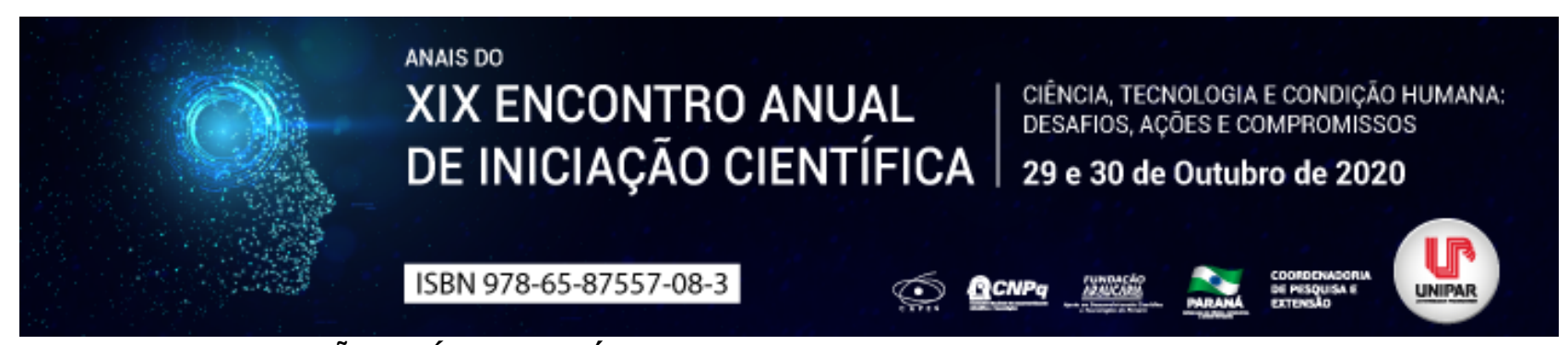

RENDIMENTO E IDENTIFIÇÃO QUÍMICA DO ÓLEO ESSENCIAL DA Melissa officinalis L. INOCULADA COM FUNGOS MICORRÍZICOS ARBUSCULARES SOB DIFERENTES DOSES DE FÓSFORO

\author{
${ }^{1}$ MARIANA MORAES PINC, ${ }^{2}$ LUCAS BRASIL DA SILVA, ${ }^{3}$ AMANDHA MELO DOS SANTOS, ${ }^{4}$ MICHAEL ALEXSANDER DA \\ SILVA, ${ }^{5}$ EZILDA JACOMASSI, ${ }^{6}$ ODAIR ALBERTON
}

\begin{abstract}
${ }^{1}$ Discente do Mestrado em Ciência Animal com Ênfase em Produtos Bioativos, (PROSUP/CAPES), UNIPAR.
${ }^{1}$ Discente de Engenharia Agronômica, PIBIC/UNIPAR.

${ }^{2}$ Discente de Engenharia Agronômica, UNIPAR.

${ }^{3}$ Discente de Engenharia Agronômica, UNIPAR.

${ }^{4}$ Docente do Mestrado Profissional em Plantas Medicinais e Fitoterápicos na Atenção Básica, UNIPAR.

${ }^{5}$ Docente do Mestrado Profissional em Plantas Medicinais e Fitoterápicos na Atenção Básica, UNIPAR.
\end{abstract}

Introdução: Nativa da região Sul da Europa, a melissa (Melissa officinalis L., Lamiaceae) também conhecida como erva cidreira verdadeira é calmante, digestiva, carminativa, antiespasmódica e antinevrálgica. (BRANT et al., 2009). O fósforo é crucial no metabolismo das plantas, desempenhando papel importante na transferência de energia da célula, na respiração e na fotossíntese além de ser componente estrutural de fosfoproteínas e fosfolipídeos (GRANT et al., 2011). Os óleos essenciais (OE) são formados por substâncias voláteis, lipofílicas geralmente odoríferas e líquidas, utilizados nas indústrias farmacêuticas, de cosméticos, perfumarias e alimentícia (MARTINS; PASTORI, 2004, URCOVICHE et al., 2015). Os principais benefícios dos fungos micorrízicos arbusculares (FMAs) à planta hospedeira está associado com a absorção de nutrientes, como o fósforo $(P)$ e a resistência a patógenos (FREITAS; MARTINS; CARVALHO, 2006, SMITH; READ, 2008). Para atender às crescentes demandas industriais e dos consumidores, uma das possibilidades promissoras para melhorar a biomassa e aumentar a qualidade das ervas pode ser a aplicação de fungos micorrizicos arbusculares durante seu cultivo (ENGEL et al., 2016).

Objetivo: Avaliar a influência dos FMAs Rhizophagus clarus e Claroideoglomus etunicatum, sob baixa e alta adição de P (20 e $200 \mathrm{mg}$ de $\mathrm{P} \mathrm{kg}^{1}$ de substrato) no rendimento e na identificação química de OE da $M$. officinalis.

Material e Métodos: Estacas de mudas de aproximadamente $5 \mathrm{~cm}$ de $M$. officinalis, foram transplantadas em substrato fumigado, provenientes do horto medicinal da Unipar. O delineamento experimental foi inteiramente casualizado com 8 repetições por tratamento em um fatorial de 3×2 (na ausência e presença de 2 FMAs, sob 2 níveis de P (URCOVICHE et al., 2015)), num total de 48 unidades experimentais. Após quatro meses do plantio, obteve-se o OE por hidrodestilação do tipo Clevenger modificado, e calculou-se o rendimento $(\mathrm{m} / \mathrm{m} \%)$. A caracterização química do OE foi realizada por meio da cromatografia em fase gasosa acoplada a espectrometria de massa (CG/EM). As médias calculadas foram submetidas à análise e variância (ANOVA) e teste de Duncan ( $\mathrm{p} \leq 0,05)$, utilizando o programa estatístico SPSS v. 22.

Resultados e Discussão: $O$ rendimento de OE variou entre 0,04 a $0,12 \%$, sendo maior com inoculação do FMA $R$. clarus tanto com alta, quanto com baixa adição de P. A inoculação do FMA $C$. etunicatum não diferiu significativamente o conteúdo de $O E$, entretanto foi maior que nos tratamentos controle. Resultados semelhantes foram encontrados por Cruz et al. (2016) que ao estudar o rendimento do OE da Salvia officinalis L. inoculada com FMAs sob alta e baixa dose de P ao solo, o rendimento de OE aumentou com a inoculação do FMA R. clarus e com alta e baixa adição de P. A análise de CG/EM detectou 30 compostos químicos. Os compostos químicos majoritários encontrados foram o Citral (variando de 54,93 a 43,96\%) seguido por 2,6Octadienal (34,66 a 29,25\%), e Geraniol (12,85 a 3,11\%). Segundo Engel, et al. (2016) os principais constituintes do óleo essencial de $M$. officinalis são citrais (geranial + neral, $39,9 \%)$, citronelal (13,7\%), limoneno (2,2\%), geraniol $(3,4 \%)$, $\beta$-cariofileno $(4,6 \%), \beta$-óxido de cariofileno $(1,7 \%)$, e germacreno $D(2,4 \%)$. Os tratamentos que apresentaram melhores resultados para os compostos químicos majoritários foram com inoculação do FMA $C$. etunicatum com alto nível de fósforo e com $R$. clarus com baixo nível de P. Karagiannidis, et al, (2011) em estudo realizado sobre os efeitos dos FMAs no desenvolvimento de orégano e hortelã, constatou que o uso de FMAs permite o crescimento vegetal em solos de baixa fertilidade, redução de insumos agrícolas e aumento da produção e qualidade de OE de plantas aromáticas.

Conclusão: $\mathrm{A}$ adição de $\mathrm{P}$ aliado à inoculação dos FMAs afetou positivamente o rendimento e identificação química do óleo essencial da M. officinalis. Recomenda-se a inoculação com o FMA R. clarus.

\title{
Referências
}

BRANT, R. S. et al. Crescimento, teor e composição do óleo essencial de melissa cultivada sob malhas fotoconversoras. Ciência Rural. Santa Maria, v.39, n.5, 2009. 
ENGEL, R. et al. Effect of arbuscular mycorrhizal fungi on the growth and polyphenol profile of marjoram, lemon balm, and marigold. Journal of Agricultural and Food Chemistry, v. 64, p. 3733-3742, 2016.

FREITAS, M. S. M.; MARTINS, M. A.; CARVALHO, A. J. C. Crescimento e composição mineral da menta em resposta à inoculação com fungos micorrízicos arbusculares e adubação fosfatada. Horticultura Brasileira, v. 24, 2006.

GRANT, C.A. et al. A importância do fósforo no desenvolvimento inicial da planta. Associação Brasileira para Pesquisa da Potassa e do Fosfato. Piracicaba, n. 95, 2001.

KARAGIANNIDIS, N., et al. Effect of three Greek arbuscular mycorrhizal fungi in improving the growth, nutrient concentration, and production of essential oils of oregano and mint plants. Scientia Horticulturae, v.129, p. 329 334, 2011.

MARTINS, M. B. G; PASTORI, A. P. Anatomia foliar com ênfase nos tricomas secretores e análise cromatográfica do óleo essencial de Melissa officinalis L. (Lamiaceae). Revista Brasileira de Plantas Medicinais, v. 6, n. 2, 2004.

MIMICA-DUKIC, N. et al. Antimicrobial and Antioxidant Activities of Melissa officinalis L. (Lamiaceae) Essential Oil. Journal of Agricultural and Food Chemistry, v. 52, p. 2485-2489, 2004.

SMITH, S. E.; READ, D. J. Mycorrhizal symbiosis, 3rd ed. Academic Press, New York. 2008, 787 p.

URCOVICHE, R.C. et al. Plant growth and essential oil content of Mentha crispa inoculated with arbuscular mycorrhizal fungi under different levels of phosphorus. Industrial Crops and Products, v.67, p. 103 107, 2015. 


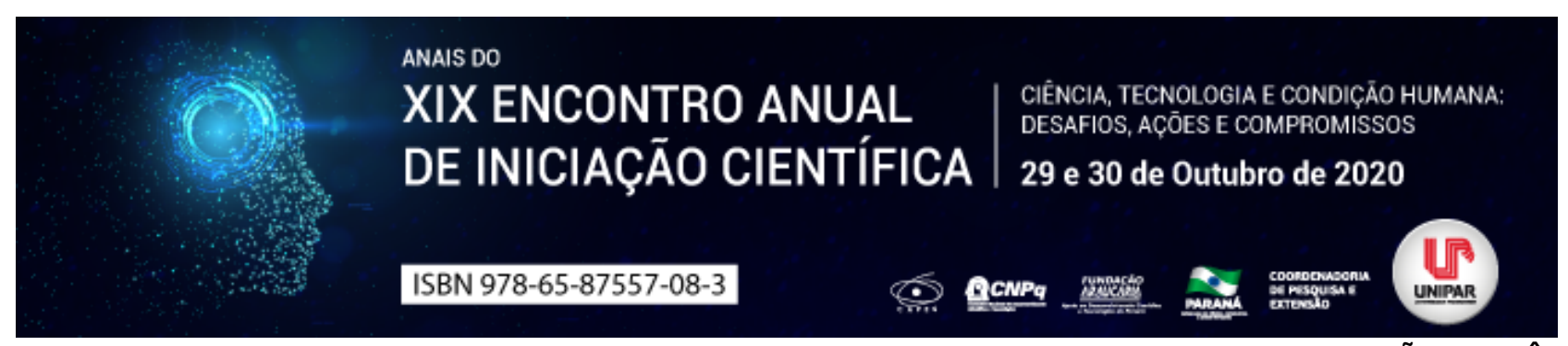

CRESCIMENTO E DESENVOLVIMENTO DE Cuphea carthagenensis (Jacq.) J. F. Macbr SOB ADUBAÇÃO ORGÂNICA EM DIFERENTES DOSES DE CAMA-DE-AVIÁRIO

\author{
${ }^{1}$ ROSSELYN GIMENES BAISCH, ${ }^{2}$ JOICE KARINA OTENIO, ${ }^{3}$ MARIANA MORAES PINC, ${ }^{4}$ EMERSON LUIZ BOTELHO \\ LOURENÇO, ${ }^{5}$ ODAIR ALBERTON, ${ }^{6}$ EZILDA JACOMASSI
}

\begin{abstract}
${ }^{1}$ Mestranda do Programa de Plantas Medicinais e Fitoterápicos na Atenção Básica/UNIPAR
${ }^{1}$ Mestranda do Programa de Plantas Medicinais e Fitoterápicos na Atenção Básica/UNIPAR

${ }^{2}$ Mestranda no Programa de Ciência Animal com ênfase em Produtos Bioativos/UNIPAR - PROSUP/CAPES

${ }^{3}$ Docente do Mestrado em Plantas Medicinais e Fitoterápicos na Atenção Básica/UNIPAR

${ }^{4}$ Docente do Mestrado em Plantas Medicinais e Fitoterápicos na Atenção Básica/UNIPAR

${ }^{5}$ Docente do Mestrado em Plantas Medicinais e Fitoterápicos na Atenção Básica/UNIPAR
\end{abstract}

Introdução: A espécie Cuphea carthagenensis (Jacq.) J. F. Macbr, popular sete-sangrias, pertence à família Lythraceae, é nativa do continente americano e possui hábito herbáceo com crescimento espontâneo (PRANDO et al. 2015). As partes aéreas são habitualmente utilizadas na medicina popular devido a presença de compostos importantes, como os flavonoides (OTENIO et al., 2020). Dessa forma, estudos farmacológicos comprovaram sua ação no controle de hipertensão e prevenção da arteriosclerose (BARBOZA et al., 2016). Por outro lado, o uso de adubação orgânica é empregado no cultivo de plantas, a fim de elevar a produtividade sem prejudicar os bioativos (Luz et al., 2009). Nesse sentido, diante da importância desta espécie e da inexistência de estudos envolvendo seu cultivo, fez-se necessário a verificação de seu crescimento e desenvolvimento sob a influência da cama-de-aviário.

Objetivo: Determinar o efeito da adubação orgânica, com a utilização de cama-de-aviário, em diferentes doses, sobre o crescimento e desenvolvimento das partes aéreas e raízes de $C$. carthagenensis.

Metodologia: O estudo foi desenvolvido no Horto Medicinal da Universidade Paranaense (UNIPAR), em Umuarama - PR, nas coordenadas S2347‘55-W5318‘48, 430 m. A espécie C. carthagenensis está catalogada no Herbário da UNIPAR número 2401. O experimento foi conduzido em delineamento experimental simples inteiramente casualizado com 5 tratamentos nas doses de (0; 10; 20; 30 e $40 \mathrm{t} \mathrm{ha}^{-1}$ ) em 3 parcelas subdivididas de $2 \mathrm{~m}^{2}$ cada. O terreno foi preparado antes do plantio e as sementes de $C$. carthagenensis obtidas no canteiro matriz do Horto Medicinal. A cama-de-aviário foi distribuída nos canteiros, nas doses descritas anteriormente, com aproximadamente $10 \mathrm{~cm}$ de profundidade do solo. As sementes foram lançadas diretamente nos canteiros de forma manual e distribuídas na mesma quantidade em todos os canteiros experimentais. As irrigações foram feitas por aspersão convencional duas vezes ao dia e o controle de plantas infestantes realizado manualmente. Ao final do cultivo, todas as plantas foram coletadas e pesadas em balança semi-analítica para obtenção da massa fresca. As partes aéreas foram secadas em estufas de ventilação forçada à $37^{\circ} \mathrm{C}$, por 5 dias, as raízes foram secadas em estufa a $65^{\circ} \mathrm{C}$ por 24 horas. Após a secagem do material vegetal, realizou-se a pesagem e determinação da massa seca das partes aéreas e raízes (AMARAL et al., 2008). Os resultados foram submetidos à análise de variância (ANOVA) e as médias comparadas por meio do teste de Duncan $(p \leq 0,05)$, utilizando-se o programa estatístico SPSS v. 22.

Resultados e Discussão: Dos resultados encontrados, na dose de $30 \mathrm{t} \mathrm{ha}^{-1}$ de cama-de-aviário, foi possível observar aumento significativo de biomassa, considerando a média e erro padrão da média para Massa Fresca das Partes Aéreas - MFPA $(828,66 \pm 63,37)$, Massa Fresca das Raízes - MFR $(160,66 \pm 21,73)$, Massa Seca das Partes aéreas - MSPA $(224,67 \pm 13,68)$, Massa Seca das Raízes - MSR $(24,66 \pm 4,37)$, Massa Seca Total - MST $(249,33 \pm 15,71)$ e MSPA/MSR $(9,75 \pm 1,84)$, comparando com o controle negativo. A média e erro padrão da média para o controle negativo foram, MFPA $(135,00 \pm 8,66)$, MFR $(22,00 \pm 5,77)$, MSPA $(39,00 \pm 1,73)$, MSR $(4,20 \pm 1,03)$, MST $(43,2 \pm 2,77)$ e MSPA/MSR $(10,42 \pm 2,37)$. O maior tratamento, dose de $40 \mathrm{t} \mathrm{ha}^{-1}$, apresentou resultados positivos, MFPA $(610,66 \pm 86,76)$, MFR $(97,33 \pm 17,52)$, MSPA $(183,33 \pm 32,67)$ e MSR $(15,33 \pm 0,66)$ entretanto a utilização em larga escala não é eficiente, por necessitar de maiores quantidades de adubo. A dose de $10 \mathrm{t} \mathrm{ha}^{-1}$ apresentou melhores resultados para MFPA $(282,66 \pm 40,15)$, MSPA $(80,67 \pm 11,85)$ e MST $(88,00 \pm 11,37)$, em relação ao tratamento 0. Quanto ao tratamento de $20 \mathrm{t} \mathrm{ha}^{-1}$, se observou aumento significativo na MFPA $(334,00 \pm 39,25)$, MFR $(100,00 \pm 32,14)$, MSPA $(114,00 \pm 14,42)$ e MSR $(16,33 \pm 2,02)$, consequentemente maiores quantidades de MST e MSPA/MSR, em comparação ao grupo controle. Desse modo, a cama-de-aviário administrada ao solo favorece o crescimento das plantas, por deixar disponível para absorção quantidades importantes de nutrientes, melhorando a qualidade química do solo (SANDMANN et al., 2013). Nesse sentido, Moreira, Omori e Donaduzzi (2014), no cultivo do feijão, encontraram resultados semelhantes com a 
dose de 30 t ha de cama-de-aviário. Outro estudo, de Napela e De Carvalho (2007) indicou que doses de cama-de-aviário, resultou na melhor produção de massa fresca e seca das plantas e, ainda, refletindo no aumento da quantidade de seus produtos finais, como os óleos essenciais e extratos padronizados.

Conclusão: A adição de cama-de-aviário na dose de $30 \mathrm{t} \mathrm{ha}^{-1}$ garantiu o melhor desenvolvimento da $C$. carthagenensis., com aumento significativo das médias em todas as variáveis analisadas, permitindo maior rendimento na produção das partes aéreas e de raízes.

\section{Referências}

AMARAL, W. et al. Desenvolvimento, rendimento e composição de óleo essencial de camomila [Chamomila recutita (L.)] sob adubação orgânica e mineral. Revista Brasileira de Plantas Medicinais, v. 10, p. 1-8, 2008.

BARBOZA, Lorena Neris et al. Atheroprotective effects of Cuphea carthagenensis (Jacq.) J.F. Macbr. in New Zealand rabbits fed with cholesterol-rich diet. Journal Ethnopharmacoly, v. 187, p. 134-145, 2016.

LUZ, José Magno Q. et al. Teor, rendimento e composição química do óleo essencial de manjericão sob doses de cama de frango. Horticultura Brasileira, v. 27, n. 3, p. 349-353, 2009.

MOREIRA, Carlos Roberto; OMORI, Franco Kendy; DONADUZZI, Fabio T. Utilização do composto de cama de aviário na cultura do feijão. Anais do $12^{\circ}$ Encontro Científico Cultural Interinstitucional, 14, 15, 16 de outubro de 2014.

NALEPA, Thiago; DE CARVALHO, Ruy Inacio Neiva. Produção de biomassa e rendimento de óleo essencial em camomila cultivada com diferentes doses de cama-de-aviário. Scientia Agraria, v. 8, n. 2, p. 161-167, 2007.

OTENIO, Joice Karina et al. Ethnopharmacology of Cuphea carthagenensis (Jacq.) J. F. Macbr: A review. Brazilian Journal of Development, v. 6, n. 3, p. 10206-10219, 2020.

PRANDO, Thiago Bruno Lima et al. Ethnopharmacological investigation of the diuretic and hemodynamic properties of native species of the Brazilian biodiversity. Journal Ethnopharmacoly, v. 174, p. 369-378, 2015.

SANDMANN, André. Maximização econômica em unidade produtiva agropecuária com reutilização dos efluentes gerados. Tese (Doutorado Engenharia Agrícola) - Universidade Federal de Campina Grande, Centro de Tecnologia e Recursos Naturais. 2013. 


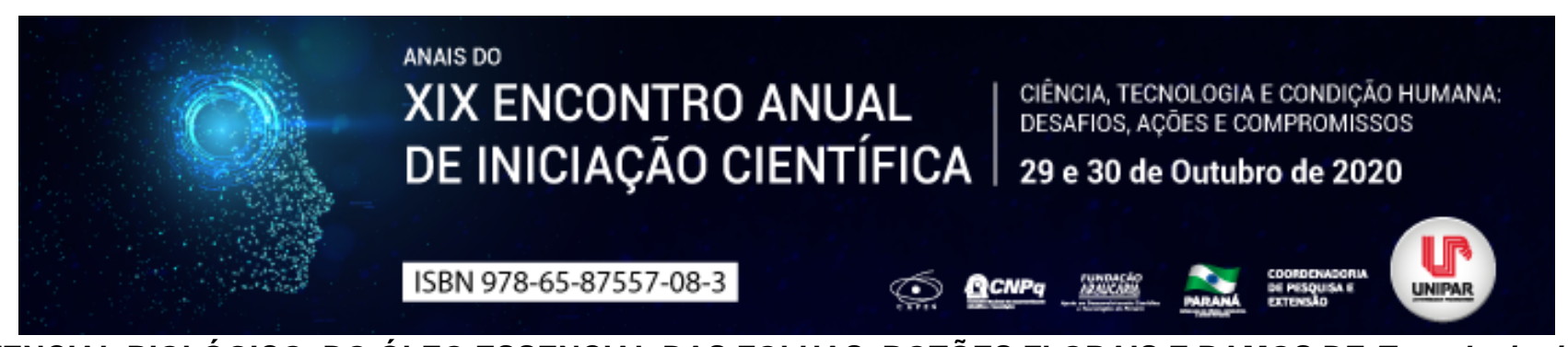

POTENCIAL BIOLÓGICO DO ÓLEO ESSENCIAL DAS FOLHAS, BOTÕES FLORAIS E RAMOS DE Tetradenia riparia

\author{
${ }^{1}$ GABRIELLA SANTANA DE OLIVEIRA, ${ }^{2}$ ZILDA CRISTIANI GAZIM
}

${ }^{1_{1}}$ Aluna (PEBIC)- FUNDAÇÃO ARAUCÁRIA- Universidade Paranaense.

${ }^{1}$ Docente da UNIPAR

Introdução: A espécie Tetradenia riparia (Hochst) Codd (Lamiaceae) é originária da África do Sul (GAIROLA et al., 2009), e no Brasil é conhecida popularmente como mirra, incenso, lavândula, limonete e pluma-de-névoa. Esta planta encontra-se bem aclimatada e disseminada em todas as regiões brasileiras onde é utilizada como planta ornamental disseminando um aroma intenso e agradável (MARTINS et al., 2008). Na medicina popular é utilizada para tratamentos da malária, angina, gastroenterite, diarréia, dor de cabeça e febre (VAN PUYVELDE et al., 1986). Pesquisas realizadas com o óleo essencial de T. riparia destacam as atividades acaricida, antimicrobiana, antioxidante e larvicida (GAZIM et al., 2010; GAZIM et al., 2011; FERNANDEZ et al., 2014; FERNANDEZ et al., 2017) porém não existem relatados sobre a atividade antioxidante dos ramos e botões florais, sendo este o propósito deste projeto. Os antioxidantes por sua vez, são compostos que agem neutralizando os radicais livres, inibindo as reações de oxidação de substrato no organismo, prevenindo o estresse oxidativo ou danos nas células (RAMALHO et al., 2006).

Objetivo: Investigação do potencial antioxidante do óleo essencial extraído das folhas, botões florais e ramos de T. riparia. Metodologia: As folhas, flores e ramos de T. riparia, foram coletadas no Horto Medicinal da UNIPAR - Umuarama-PR. Após secos em esteira à temperatura ambiente os óleos foram extraídos pelo método de hidrodestilação por 3 horas. A atividade antioxidante foi realizada pelo método de sequestro de radicais livres 2,2 difenil-1-picrilhidrazil (DPPH) descrita por Rufino et al. (2007), cujo método baseia-se em um ensaio fotométrico onde o radical livre DPPH que apresenta coloração roxa intensa em solução alcoólica, se reduz em presença de moléculas antioxidantes, formando o 2,2 difenil-1-picrilhidrazine de coloração amarelo. As concentrações dos óleos essenciais utilizadas neste ensaio foram 1,0;0,75;0,5 e 0,25 mg/mL $\mathrm{mL}^{-1}$. Todas as análises foram realizadas em triplicata, os resultados submetidos à análise de variância (ANOVA) e as diferenças entre as médias determinadas pelo teste de Tukey $(p \leq 0,05)$.

Resultados: Os resultados encontrados para o potencial antioxidante pelo método DPPH indicaram um efeito inibidor da oxidação com IC50 de 2,24 mg mL-1 ( ramos); $4,26 \mathrm{mg} \mathrm{mL}^{-1}$ ( folhas) e $5,15 \mathrm{mg} \mathrm{mL}^{-1}$ (botões florais).

Discussão: No óleo essencial dos ramos foram encontrados o maior potencial antioxidante, com uma concentração de $(2,24 \mathrm{mg}$ $\mathrm{mL}^{-1}$ ) necessária para inibir 50\% do radical 2,2 difenil-1-picrilhidrazil (DPPH). Ao analisar o potencial antioxidante do óleo essencial extraído das diferentes partes da T. riparia (folhas, botões florais e ramos), utilizando o método de DPPH, os resultados podem ser considerados como intermediário, quando comparado com o padrão quercetina IC50 de 0,01 $\mathrm{mg} \mathrm{mL}^{-1}$. Este resultado já era esperado, visto que o método de sequestro do radical livre 2,2 difenil-1-picrilhidrazil (DPPH) apresenta maior especificidade para compostos polares, e os óleos essenciais têm predominantemente características apolares. A procura por antioxidantes naturais apresenta grande importância, visto que o uso de antioxidantes sintéticos podem apresentar carcinogenicidade e toxicidade (BARBOSA et al., 2010).

Conclusão: Os óleos essenciais de T. riparia extraídos das folhas botões florais e ramos investigados apresentaram potencial intermediário de inibição da oxidação pelo método pelo sequestro de radicais livres 2,2 difenil-1-picrilhidrazil (DPPH). O óleo essencial dos ramos foi o que apresentou maior potencial antioxidante, com IC50 de 2,24 $\mathrm{mg} \mathrm{mL}^{-1}$, levando a concluir que a $T$. riparia. é uma espécie vegetal que pode ser incluída na lista de plantas com potencial antioxidante.

\title{
Referências
}

BARBOSA, K. B. F. et al. Estresse oxidativo: conceito, implicações e fatores modulatórios. Revista de Nutrição, v.23, p.629-643, 2010.

GAIROLA, S., NAIDOO, Y.,BHATT, A., NICHOLAS, A. An investigation of the foliar trichomes of Tetradenia riparia (Hochst.) Codd [Lamiaceae]: An important medicinal plant of Southern Africa. Flora (Jena) v.204, p.325 330, 2009.

GAZIM, Zilda Cristiani et al. Seasonal variation, chemical composition, and analgesic and antimicrobial activities of the essential oil from leaves of Tetradenia riparia (Hochst.) Codd in Southern Brazil. Molecules, v. 15, n. 8, p. 5509-5524, 2010.

GAZIM, Zilda Cristiani et al. Acaricidal activity of the essential oil from Tetradenia riparia (Lamiaceae) on the cattle tick Rhipicephalus (Boophilus) microplus (Acari; Ixodidae). Experimental Parasitology, v. 129, n. 2, p. 175-178, 2011.

FERNANDEZ, Carla Maria Mariano et al. Larvicidal activity of essential oil from Tetradenia riparia to control of Aedes aegypti larvae in function of season variation. Journal of Essential Oil Bearing Plants, v. 17, n. 5, p. 813-823, 2014. 
FERNANDEZ, Ana Claudia AM et al. Antimicrobial and antioxidant activities of the extract and fractions of Tetradenia riparia (Hochst.) Codd (Lamiaceae) leaves from Brazil. Current microbiology, v. 74, n. 12, p. 1453-1460, 2017.

MARTINS, Maria Bernadete Gonçalves; MARTINS, Raphael Gonçalves Martins; CAVALHEIRO, José Alberto. Histoquímica e atividade antibacteriana de folhas do incenso (Tetradenia riparia). Revista Biociências, v. 14, n. $2,2008$.

RAMALHO, Valéria Cristina; JORGE, Neuza. Antioxidantes utilizados em óleos, gorduras e alimentos gordurosos. Química nova, p. 755-760, 2006.

RUFINO, M. S. M. et al. Metodologia científica: determinação da atividade antioxidante total em frutas pela captura do radical livre DPPH. Fortaleza: EMBRAPA, 2007, 4 p.

VAN PUYVELDE, Luc et al. Active principles of Tetradenia riparia. I. Antimicrobial activity of 8 (14), 15-sandaracopimaradiene-7a, 18-diol. Journal of ethnopharmacology, v. 17, n. 3, p. 269-275, 1986.

Coordenadoria de Pesquisa e Extensão - COPEX

Departamento de Editoraçāo e Divulgaçāo Científica - DEDIC 


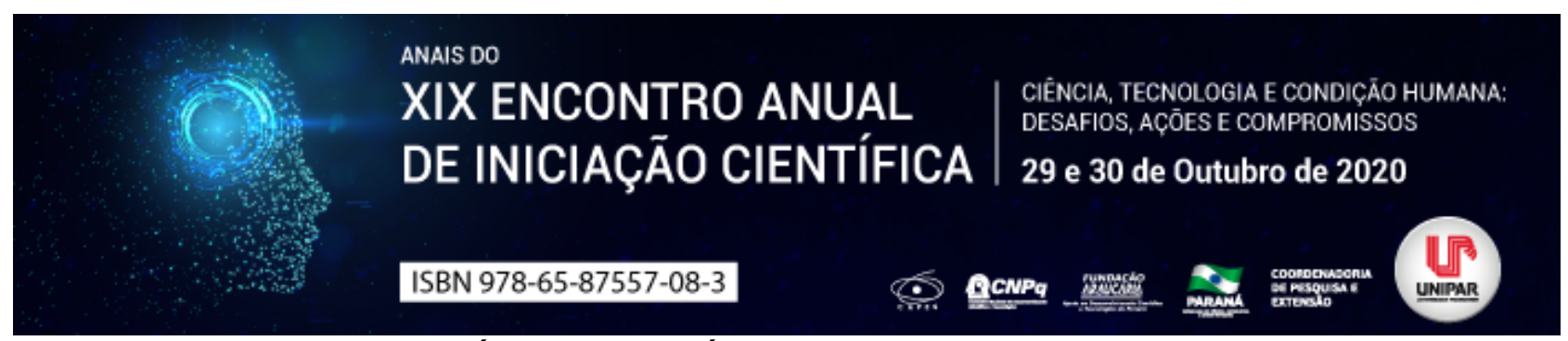

POTENCIAL BIOLÓGICO DA ESPÉCIE Campomanesia xanthocarpa O. BERG

${ }^{1}$ STEFANY CORDEIRO DE SOUZA, ${ }^{2}$ MARIANA RODRIGUES VILAS BOAS, ${ }^{3}$ ZILDA CRISTIANI GAZIM, ${ }^{4}$ CARLA MARIA MARIANO FERNANDEZ DE ANDRADE

${ }^{1}$ Mestranda em Biotecnologia Aplicada à Agricultura, Unipar, Umuarama PR

${ }^{1}$ Mestranda em Biotecnologia Aplicada à Agricultura, Unipar, Umuarama PR

${ }^{2}$ Docente da Pós-graduação em Biotecnologia Aplicada à Agricultura, Unipar, Umuarama-PR

${ }^{3}$ Docente da Pós-graduação em Biotecnologia Aplicada à Agricultura, Unipar, Umuarama-PR

Introdução: Campomanesia xanthocarpa O. Berg é uma árvore pertencente à família Myrtaceae, nativa do Brasil, com maior distribuição no Cerrado. Conhecida popularmente como gabiroba, guabiroba, guavirova, guabirobeira-do-mato e guabira, na medicina popular é utilizada como depurativo, anti-diarréico, anti-reumático e redutor de colesterol (BIAVATTI et al., 2004; MARKMAN et al., 2004). Esta espécie floresce nos meses de agosto a novembro e gera os frutos de setembro a fevereiro (VALLILO et al., 2006). A árvore atinge cerca de 15 metros de altura, tendo folhas na cor verde escura, dependendo da época tem flores brancas ou frutos amarelo-esverdeado, arredondados, casca fina e polpa esbranquiçada (VALLILO et al., 2006).

Objetivos: O estudo teve por objetivo de realizar um levantamento bibliográfico das atividades biológicas da espécie Campomanesia xanthocarpa.

Desenvolvimento: A Campomanesia xanthocarpa conhecida popularmente de gabiroba é utilizada na medicina tradicional para o tratamento de diarreia, reumatismo, altos níveis de colesterol e triglicerideos, obesidade, úlcera gástrica, cistites e uretrites (BIAVATTI et al., 2004; MARKMAN et al., 2004). Os frutos de gabiroba são comestíveis, e estudos científicos com os frutos mostraram a presença de carotenoides, compostos fenólicos, vitamina C e riboflavina (Vitamina B2), importantes compostos antioxidantes (VALLILO et al., 2006; Referências

ARAÚJO, MARCELA C. P M.; FERRAZ-FILHA, ZILMA S.; FERRARI, FERNANDA C.: SAUDE-GUIMARAES, DÊNIA A. Campomanesia velutina leaves extracts exert hypouricemic effectsthrough inhibition of xanthine oxidase and ameliorate inflammatory response triggered by MSU crystals. Revista Brasileira de Farmacognosia, v. 26, n. 6. p.720-727, 2016.

BIAVATTI, MAIQUE W. et al. Preliminary studies on Campomanesia xanthocarpa (Berg.) and Cuphea carthagenensis (Jacq.) J.F. Macbr. aqueous extract: weight control and biochemical parameters. Journal of Ethnopharmacology, v. 93, n. 2-3, p. 385-389, 2004.

KLAFKE, JONATAS ZENI. et al. Effects of Campomanesia xanthocarpa on biochemical, hematological and oxidative stress parameters in hypercholesterolemic patients. Journal of Ethnopharmacology, v. 127, n. 2, p. 299-305, 2010.

MARKMAN, BLANCA ELENA ORTEGA: BUGNO, ADRIANA: TABA. MITSUKO OHARA: KATO, EDNA TOMIKO MYIAKE. Atividade antimicrobiana do extrato hidroalcoólico de Campomanesia xanthocarpa. Revista Brasileira de Ciências Farmacêuticas, v. 36, 2000.

MARKMAN. BLANCA ELENA ORTEGA. Caracterização farmacognóstica de Campomanesia xanthocarpa Myrtaceae [dissertation]. Dissertação (mestrado) Faculdade de Ciências Farmacêuticas da Universidade de São Paulo, São Paulo, p.169, 2002.

MARKMAN, BLANCA ELENA ORTEGA: BACCHI, ELFRIEDE MARIANNE: KATO, EDNA TOMIKO MYIAKE. AntiulcerogeniC effects of Campomanesia xanthocarpa. Journal of Ethnopharmacology, v. 94, n. 1, p. 55-57, 2004.

MENDES, RICARDO DE MORAIS; PINTO, ELLEN GODINHO; SOARES, DAYANA BATISTA SILVA. Determinação dos compostos bioativos da gabiroba. Revista Agrarian. Instituto Federal Goiano - Campus Morrinhos (IF Goiano). Morrinhos- Goiás. v. 11, n. 39, p. 68-72, 2018.

SALMAZZO, G. R. et al. Chemical composition and antiproliferative, antioxidant and trypanocidal activities of the fruits from Campomanesia xanthocarpa (Mart.) O. Berg (Myrtaceae). Journal of Natural Product Research. v. 15. p. 1-5, 2019.

SANT'ANNA, LIANE SANTARIANO et al. Chemical Composition and Hypotensive Effect of Campomanesia xanthocarpa. Revista: Evidence-Based Complementary and Alternative Medicine, p.1-11, 2017.

SCHMEDA-HIRSCHMANN, G. Flavonoids from Calycorectes, Campomanesia. Eugenia and Hexachlamys species. Journal of Fitoterapia, v. 66, p.373-374, 1995.

SILVA, MARA REIS; LACERDA, DIRACY BETÂNIA CAVALCANTE LEMOS; SANTOS, GRAZIELLE GEBRIM ; MARTINS, DENISE MENDES DE OLIVEIRA. Chemical characterization of native species of fruits from savana ecosystem. Revista: Ciência Rural, v. 38, n. 6, p.1790-1793, 2008.

VALLILO, MARIA ISABEL et al. Chemical composition of Campomanesia adamantium (Cambessédes) O. BERG fruits. Ciência e 
Tecnologia de Alimentos, v. 26, n. 4, p. 805-810, 2006.

VALLILO. MARIA ISABEL et al. Composição química dos frutos de Campomanesia xanthocarpa Berg-Myrtaceae Ciência e

Tecnologia de Alimentos. Sociedade Brasileira de Ciência e Tecnologia de Alimentos, v.28, n.1, p.231-237, 2008.

Coordenadoria de Pesquisa e Extensão - COPEX

Departamento de Editoraçāo e Divulgaçāo Científica - DEDIC 


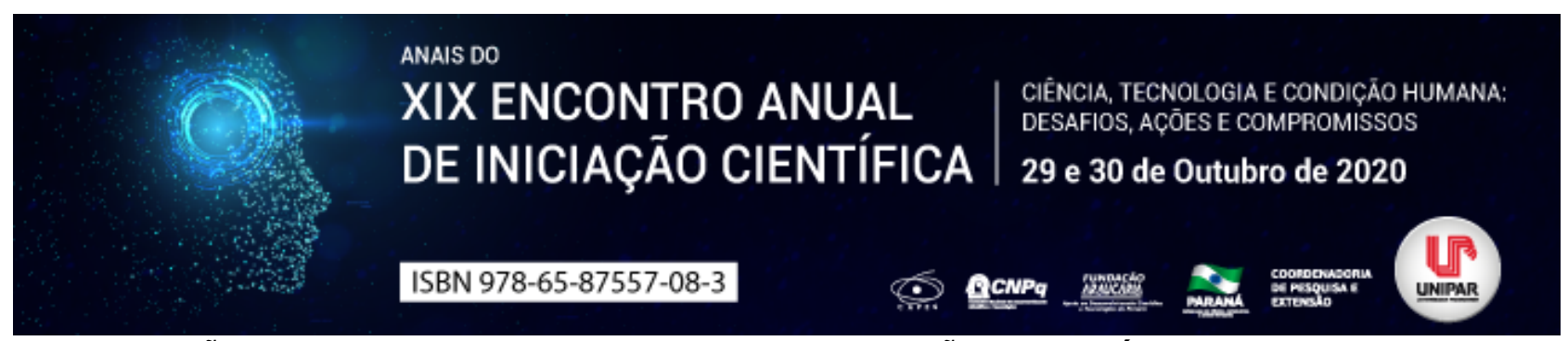

AVALIAÇÃO DA ROTULAGEM NUTRICIONAL DE MACARRÃO SEM GLÚTEN EM UMUARAMA, PR

\author{
${ }^{1}$ Yara Gentile Ribeiro, ${ }^{2}$ JEAN LOPES DA SILVA, ${ }^{3}$ LARINE KUPSKI, ${ }^{4}$ JULIANA SCANAVACCA, ${ }^{5}$ LUCAS CORREI, ${ }^{6}$ JULIANA \\ BUENO RUIZ
}

\begin{abstract}
${ }^{1}$ Dicente do curso de Engenharia de Alimentos pela UEM
${ }^{1}$ Dicente do curso de Tecnologia de Alimentos pela UEM

${ }^{2}$ Docente do Departamento de Tecnologia - DTC/UEM

${ }^{3}$ Docente do Departamento de Tecnologia - DTC/UEM

${ }^{4}$ Dicente do curso de Tecnologia de Alimentos pela UEM

${ }^{5}$ Docente do Departamento de Tecnologia - DTC/UEM
\end{abstract}

Introdução: A doença célica (DC) é uma doença caracterizada pela intolerância ao glúten, que afeta a membrana mucosa do intestino delgado (Morais et al, 2014; Bianchini et al, 2020). Atualmente no Brasil não há quantidade fixa de glúten que pode ser utilizada no alimento, algumas empresas aderem ao Codex Alimentarius podendo conter 20 ppm detectável. A legislação da Lei $\mathrm{n}^{\circ}$ 10.674, de 16 de maio de 2003 implementa que fornecedores de alimentos industrializados exibam, nas embalagens e rótulos, o termo contém glúten ou não contém glúten (Anvisa, 2003).

Objetivo: O estudo teve como objetivo identificar as irregularidades da rotulagem e informação nutricional de macarrões, encontrados nos supermercados de Umuarama, Paraná, declarados como sem glúten visando analisar a adequação com a legislação.

Material e Métodos: Foi realizado um levantamento nos supermercados da cidade de Umuarama-PR, onde sete supermercados foram visitados. Foram encontradas 16 amostras de macarrões de diferentes marcas e tipos, sem glúten. Avaliou-se a disponibilidade, variedade, preço e se estavam de acordo com a Anvisa nas RDC $n^{\circ} 26$ de 2015 , RDC $n^{\circ} 359$ de 2003 e na Lei 10.674 de 16 de maio de 2003 em relação a informações presentes nas embalagens.

Resultados: Em sete supermercados avaliados seis foram encontrados uma ou mais de uma marca de macarrão sem glúten. Em um mercado não foi encontrado nenhuma marca. Desses seis mercados foram encontrados no total 16 diferentes tipos de macarrão, de 6 marcas diferentes, de três tipos de forma: 7 tipos de penne, 6 tipos de fusilli (parafuso) e 3 tipos de espaguete. Das amostras analisadas 100\% estão de acordo com a resolução da Anvisa (RDC $n^{\circ} 26$ de 2015) que adverte quanto a escrita sobre alergênicos, 44\% contém a declaração conforme Anvisa (RDC n² 26 de 2015) estabelece Alergênicos: pode conter...

Nenhum macarrão contém em sua embalagem a informação do Códex Alimentarius (2008) sobre ter no máximo 20 ppm de glúten no alimento. Todos os produtos estão conforme a resolução da Anvisa (RDC $n^{\circ} 359$ de 2003) que confere uma porção de $80 \mathrm{~g}$, uma unidade. Verificou-se ainda que 100\% dos produtos analisados declaram corretamente as instruções sobre sem glúten com destaque, nitidez e de fácil leitura conforme a Lei $n^{\circ} 10.674$ de 16 de maio de 2003 . Em relação ao preço dos produtos duas marcas exibiram um valor superior as demais, três marcas tiveram um valor intermediário e uma teve um preço mais acessível.

Discussão: A rotulagem dos alimentos é muito importante, pois ela serve como um meio de comunicação entre o consumidor e o produto, ou seja, é indispensável que o indivíduo tenha à sua disposição diversas informações para compreensão do que ele está consumindo, melhorando assim a escolha do produto adequado e a qualidade de vida do cliente (Miranda, 2016). A Lei 10.674 de 16 de maio de 2003 diz que é obrigatório as indústrias de produtos alimentícios ter em suas embalagens a descrição de

contém glúten ou não contém glúten , de acordo com a lei referida, todos os alimentos industrializados devem ter essa informação em seus rótulos e bulas, essas informações devem ser destacadas, conforme diz a lei. Foi observado que a porção do produto está conforme a RDC n 359/2003, que declara uma determinada quantidade de porção para calcular seu valor energético e a composição do alimento. A porção de macarrão estabelecida conforme a resolução é de $80 \mathrm{~g}$, assim, $100 \%$ dos produtos atendem esse requisito.

Conclusão: No presente estudo, todos os rótulos de macarrões encontrados nos supermercados da cidade de Umuarama estão de acordo com as Leis e as resoluções da Anvisa, que foram apresentados. Diante do exposto, conclui-se que os supermercados de Umuarama-PR estão preparados para atender as necessidades dos consumidores desta dieta.

\title{
Referências
}

AGÊNCIA NACIONAL DE VIGILÂNCIA SANITÁRIA.Resolução n 359 de 23 de dezembro de 2003.Dispõe sobre regulamento técnico de porções de alimento embalados para fins de rotulagem nutricional.Ministerio da Saúde,Brasília,dez,2003.

AGÊNCIA NACIONAL DE VIGILÂNCIA SANITÁRIA.Resolução $n^{\circ}$ 26, de 02 de julho de 2015.Dispõe sobre rotulagem de alimentos alergênicos.Ministerio da Saúde,Brasília,jul,2015. 
BIANCHINI,Maria das Graças de Assis;CASAROTTI,Sabrina Neves;TEIXEIRA,Camila de Almeida;SILVA,Tatiane Ferreira; HERNANDES,Thais.Biscoito de chocolate sem glúten adicionado de farinha de Amaranto.Revista Braz. J. of Develop.,v.6,n.2,p.8393-8413 fev.2020.Disponível em:https://www.brazilianjournals.com/index.php/BRJD/article/view/705.Acesso em: 27 ago. 2020.

BRASIL.Lei $n^{\circ} 10.674$,de 16 de maio de 2003.Estabelece que toda embalagem de alimento deve conter a informação contém glúten.Anvisa: Agência Nacional de Vigilância Sanitária.Brasília,mai.2003.

CODEX ALIMENTARIUS Commission.CODEX STAN 118 1979:CODEX STANDARD FOR FOODS FOR SPECIAL DIETARY USE FOR PERSONS INTOLERANT TO GLUTEN.Roma;Rinevised 2008.

MIRANDA,Glaucianne Oliveira.Rotulagem de Alimentos:avaliação da conformidade frente à legislação de produtos diet,light,sem glúten e sem lactose comercializados em supermercados de Petrolina/PE.Orientadora:Profa. Dra ${ }^{a}$.Maria Emília da Silva Menezes.2016.Tese (Bacharel em Farmácia)-Universidade Federal de Campina Grande,Cuité,2016.

Coordenadoria de Pesquisa e Extensão - COPEX

Departamento de Editoraçāo e Divulgaçāo Científica - DEDIC 


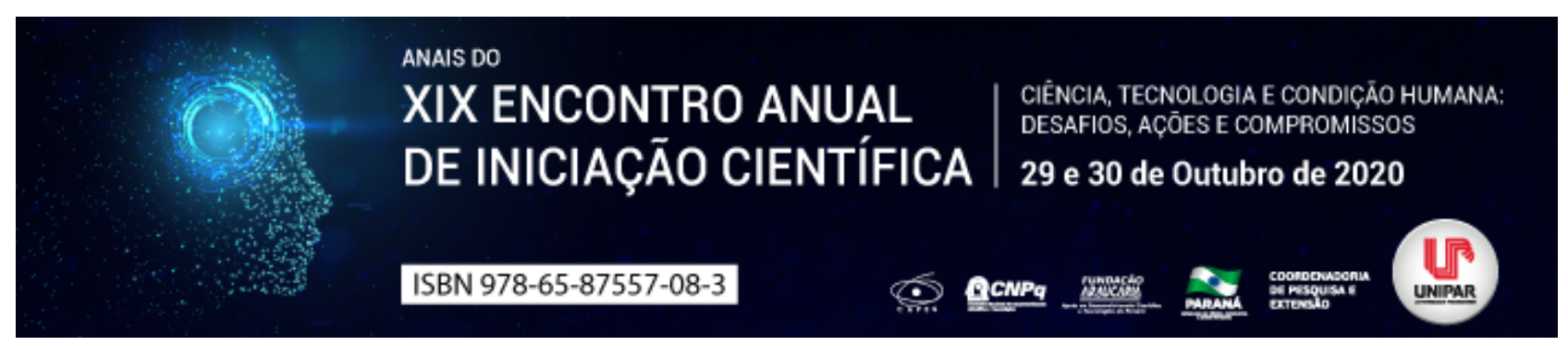

TRATAMENTO DE SEMENTES DE SOJA (Glycine max (L.) Merrill) NO CONTROLE DE Colletotrichum truncatum E Fusarium graminearum

\begin{abstract}
${ }^{1}$ Celso Martins França, ${ }^{2}$ GIOVANNA SERON, ${ }^{3}$ ÉDER JUNIOR DE OLIVEIRA ZAMPAR, ${ }^{4}$ LUCAS PEREIRA DA SILVA, ${ }^{5}$ PRISCILA ANGELOTTI ZAMPAR, ${ }^{6}$ DAURI JOSÉ TESSMANN
\end{abstract}

\begin{abstract}
${ }^{1}$ Bolsista MEC/SESu do Curso de Agronomia Universidade Estadual de Maringá
${ }^{1}$ Bolsista MEC/SESu do Curso de Agronomia Universidade Estadual de Maringá

${ }^{2}$ Mestrando do Programa de Pós-Graduação em Agronomia Universidade Estadual de Maringá

${ }^{3}$ Mestrando do Programa de Pós-Graduação em Agronomia Universidade Estadual de Maringá

${ }^{4}$ Coorientadora, Doutoranda do Programa de Pós-Graduação em Agronomia UEM

${ }^{5}$ Orientador, Professor Doutor, Departamento de Agronomia UEM
\end{abstract}

Introdução: Atualmente, o Brasil destaca-se como segundo maior produtor de soja do mundo, com uma produção estimada de aproximadamente 249,8 milhões de toneladas e uma área de aproximadamente 63,9 milhões de hectares para a safra de grãos 2019/2020 (CONAB, 2019). Diante de sua grande demanda, torna-se necessário o uso de novos métodos de controle visando o aumento da produtividade. Entre os fatores limitantes para a produção desta cultura, estão as doenças causadas por fungos. Dentre as doenças estão a fusariose (Fusarium graminearum) e a antracnose (Colletotrichum truncatum), ambas podem ser disseminadas via sementes, sendo assim o tratamento de sementes é uma opção para a redução do impacto dessas doenças no campo. (MACHADO, 2000; HENNING, 2015; MARTINELLI et. al., 2004; BEGUM et. al., 2008).

Objetivo: Avaliar a eficiência de diferentes fungicidas no tratamento de sementes de soja inoculada com $C$. truncatum e $F$. graminearum.

Materiais e Métodos: O experimento foi conduzido no Laboratório de Fitopatologia e casa de vegetação pertencentes a Universidade Estadual de Maringá (UEM). Iniciou-se com testes de emergência em caixas de areia, aos sete dias, contagem de plantas anormais e aos 28 dias, foi realizado o teste de patogenicidade e altura da parte aérea, utilizando sementes inoculadas. O método de inoculação empregado foi o de restrição hídrica, no qual adicionou-se um sal ao meio de cultura. O fungo foi cultivado em placas de Petri contendo meio batata-dextrose-ágar, o meio foi alterado com adição de manitol na concentração -0,9 $\mathrm{MPa}$, e esterilizado em autoclave. Após a solidificação do meio, foi depositado um disco contendo micélio do fungo C. truncatum no centro de cada placa, o mesmo foi realizado para o F. graminearum. As placas foram incubadas a $24 \pm 2{ }^{\circ} \mathrm{C}$ por sete dias, com regime de luz 12 horas. Após esse período, as placas receberam as sementes de soja e foram novamente incubadas por 36 horas. Em seguida, adicionou-se o fungicida e as sementes foram depositadas em bandejas plásticas, contendo areia esterilizada em autoclave. Foram utilizadas quatro bandejas para cada tratamento, com 100 sementes por bandeja, sendo 20 com $C$. truncatum, 20 com F. graminearum e 60 sem inoculação. O delineamento experimental adotado foi inteiramente casualizado composto por sete tratamentos nos quais: T1 corresponde a uma testemunha sem inoculação e sem tratamento, T2 testemunha composta por sementes inoculadas e não tratadas com fungicida, T3 a T7 sementes inoculadas e tratadas com os fungicidas: Carbendazim + Tiram, Tiofanato-metílico + Fluazinam, Piraclostrobina + Tiofanato-metílico + Fipronil, Metalaxil-M + Fludioxonil, Carbendazim, respectivamente. Após a semeadura, as bandejas foram submetidas a câmara úmida com temperatura de $23^{\circ} \mathrm{C}$ e regime de 12 horas de luz durante 48 horas. Aos sete dias, avaliou-se a germinação e aos 28 dias a patogenicidade, no qual as plantas foram retiradas das bandejas, e foram conferidas notas de 0 a 4 às raízes, sendo nota 0 para ausência de necrose e notas de 1 a 4 de acordo com a evolução do sintoma.

Resultados: De acordo com a análise de variância, a variável altura não apresentou médias com diferenças significativas entre os tratamentos. Enquanto nas variáveis emergência, plantas normais e severidade de plantas inoculadas, o tratamento Testemunha (Sem tratamento + Inoculação) apresentou a menor média, entretanto os tratamentos com diferentes controles químicos não apresentaram diferenças entre si, ou seja, todos os produtos controlaram os patógenos. Para a variável plantas anormais, os tratamentos Tiofanato-metílico + Fluazinam e Testemunha (Sem tratamento + Inoculação) obtiveram diferenças significativas entre as médias, no qual o tratamento Tiofanato-metílico + Fluazinam apresentou maior média. Todos os dados foram comparados pelo teste de Tukey a $5 \%$ de probabilidade.

Discussão: Pode-se confirmar que Colletotrichum truncatum e Fusarium graminearum são altamente patogênicos na cultura da soja quando observamos os dados das testemunhas sem tratamento e com inoculação dos patógenos, isso garante que sementes tratadas com fungicidas possuem um desempenho superior do que sementes que não são tratadas, inibindo o desenvolvimento de doenças. Os diferentes tratamentos químicos não divergiram entre os produtos analisados, mesmo possuindo composições distintas e atuarem em grupos de controle diferentes. Por ser efetivo o controle dos patógenos com a 
utilização de diferentes produtos, sugere-se que eles são sensíveis a químicos pertencentes aos grupos dos Benzimidazois, Dimetilditiocarbomato, Fenilpiridinilamina, Estrobirulinas, Pirazol e Fenilpirrol. Quanto a variável altura de planta, por não apresentar diferença significativa, mostra que os controles químicos não causam efeitos destrutivos ao crescimento das plantas, apenas sendo fungitóxicos, sem efeitos de redução de crescimento das plantas.

Conclusão: Os fungicidas avaliados no tratamento de sementes resultaram no controle dos patógenos $C$. truncatum e $F$. graminearum. Além disso, a ausência do tratamento químico resultou no maior número de plantas doentes e com anormalidade.

\section{Referências}

BEGUM, Mahbuba; MEON, Sariah; PUTEH, Adam; AHMAD, Zainal Abdin Mior . Pathogenicity of Colletotrichum truncatum and its influence on soybean seed quality. International Journal of Agriculture and Biology, v. 10, n.04. Serdang, Malaysia, 2008. p. 393-398, 2008.

CONAB Companhia Nacional de Abastecimento. Disponível em: https://www.conab.gov.br/. Acesso em Agosto, 2020.

HENNING, Ademir Assis. Patologia e tratamento de sementes: noções gerais. 2. ed. Londrina: Embrapa Soja, 2015. 52p. (Embrapa Soja. Documentos, 264).

MACHADO, José da Cruz. Tratamento de sementes no controle de doenças. Lavras: LAPS/UFLA/FAEPE, 2000. 138p.

MARTINELLI, José Antônio; BOCCHESE, Carla Azambuja Centeno; XIE, Weiping; DONNELL, Kerry; KISTLER, Harold. (2004). A podridão da podridão-da-soja e a podridão radicular causada por linhagens de Fusarium graminearum e a produção de micotoxinas. Fitopatologia brasileira, vol.29, 2005. p 492-498. 


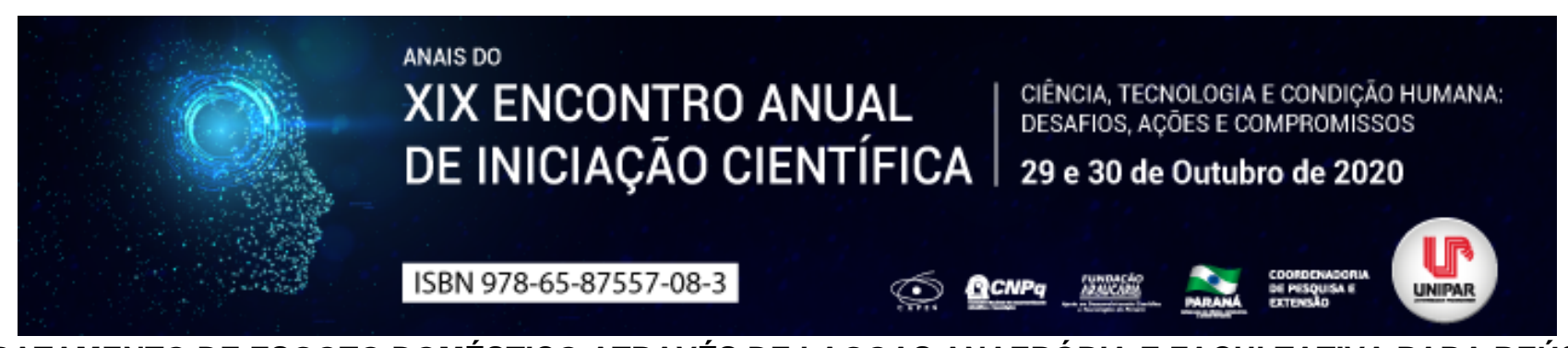

TRATAMENTO DE ESGOTO DOMÉSTICO ATRAVÉS DE LAGOAS ANAERÓBIA E FACULTATIVA PARA REÚSO AGRÍCOLA

\title{
${ }^{1}$ LEONARDO VAZ DA SILVA, ${ }^{2}$ MATHEUS RODRIGUES MARTINS
}

\author{
${ }^{1}$ Acadêmico do curso de Engenharia Civil da Universidade Paranaense \\ ${ }^{1}$ Docente da UNIPAR
}

Introdução: As comunidades isoladas são limitadas ao emprego de soluções individuais (TONETTI et al., 2018). Entretanto, a desconformidade dos métodos construtivos propicia a proliferação de patógenos e, consequentemente, a eclosão de diversas doenças de veiculação hídrica (TUNDISI, 2011). O método adotado neste estudo é conhecido como sistema australiano, e consiste em duas lagoas em série; uma lagoa anaeróbia e outra facultativa. Este sistema requer área total com redução de $30 \%$ em relação à adoção de somente uma lagoa facultativa (MENDONÇA, L.; MENDONÇA, S., 2017), além de dispensar o emprego de energia elétrica na operação do sistema (VON SPERLING, 2009). O efluente tratado através do sistema australiano pode ser reutilizado para irrigação agrícola de determinadas culturas, desde que atenda aos padrões de qualidade estabelecidos pela Organização Mundial da Saúde (WHO, 2006).

Objetivo: $O$ presente trabalho tem como objetivo apresentar um método alternativo de tratamento de esgoto sanitário predominantemente doméstico, com a finalidade de atenuar o risco de contaminação do solo e do corpo hídrico subterrâneo e possibilitar o reúso do efluente tratado para irrigação agrícola e outras destinações sustentáveis.

Materiais e método: $O$ dimensionamento da lagoa anaeróbia é estimado com base na vazão de esgoto produzida pelo número de habitantes, de acordo com a equação 1 (ABNT, 1986). $Q_{\text {méd }}=\left[\left(C^{*} P^{*} Q P C^{*} k_{1}{ }^{*} k_{2}\right) / F C\right]+q_{\text {inf. }}$ A área superficial da lagoa anaeróbia é obtida através da equação 2 (MENDONÇA, L.; MENDONÇA, S., 2017). $A=\left(Q_{m e ́} d^{\star} t\right) / h$. A equação 3 demonstra a eficiência esperada para redução da carga orgânica volumétrica da lagoa anaeróbia, conforme Nuvolari (2011). $S_{e}=S_{0}[1-$ $(E / 100)] \therefore E=\left[1-\left(S_{e} / S_{0}\right)\right] * 100$. A equação 4, apresentada por Mendonça, L. e Mendonça, S. (2017), demonstra que a carga orgânica máxima superficial a ser tratada pela lagoa facultativa é função da temperatura média mensal da água. Além disso, a capacidade de tratamento deve ser reduzida em 20\% devido à amônia decorrente do tratamento preliminar realizado em lagoa anaeróbia (MENDONÇA, L.; MENDONÇA, S., 2017 apud YANEZ, 1993). $\lambda_{\text {máx }}=350 *(1,107-0,002 T)^{T-25}$. O TDH (tempo de detenção hidráulica) mínimo do afluente da lagoa facultativa pode ser determinado de acordo com a equação 5 , em função da relação entre o produto da carga orgânica volumétrica do afluente e da profundidade adotada pela carga orgânica máxima superficial estimada (MENDONÇA, L.; MENDONÇA, S., 2017). $\lambda_{S}=\left(F C^{\star} S_{0}{ }^{\star} h\right) / t \quad \therefore t=\left(F C^{\star} S_{0}{ }^{\star} h\right) / \lambda_{S}$. A área superficial da lagoa facultativa pode ser estimada através da equação 6 , em que a área é função entre o produto da DBO do afluente e a vazão média de contribuição em relação à carga orgânica superficial aplicada (MENDONÇA, L.; MENDONÇA, S., 2017). $\lambda_{S}=$ $\left(F C * S_{0}{ }^{*} Q_{m e ́ d}\right) / A \therefore A=\left(F C * S_{0}{ }^{*} Q_{m e ́ d}\right) / \lambda_{S}$. A eficiência da remoção de $\mathrm{DBO}_{5}$ na lagoa facultativas secundária pode ser estimada através da equação 7 , apresentada por Kawai et al. (1983). $E=\left\{\left[\left(0,7702^{\star} \lambda_{S}\right)-5,4188\right] / \lambda_{S}\right\}^{\star} 100$. A eficiência na redução de ovos de helmintos pode ser mensurada de acordo com a equação 9, proposta por Ayres et al. (1992), que estima a eficiência de remoção a partir do tempo de retenção hidráulica das lagoas. $R=\left\{100 * 1-0,41 e^{\left.\left[-0,49^{*}+\left(0,0085^{*} 2\right)\right]\right\}}\right.$. A redução nos ovos de helmintos para as lagoas anaeróbia e facultativa pode ser verificada conforme a equação 10 , com base na eficiência estimada para cada lagoa. $N_{\text {final }}=N_{\text {inicial }} *\left[1-\left(R_{\text {total }} / 100\right)\right]$.

Discussão e resultados: O dimensionamento da lagoa anaeróbia é estimada em 230,4 $\mathrm{m}^{3} / \mathrm{dia}$. Deste modo, a lagoa anaeróbia deve possuir área superficial de 156,25 $\mathrm{m}^{2}$, profundidade de 4,5 m e TDH de 3 dias, com eficiência esperada de $55 \%$, resultando em efluente com carga orgânica volumétrica de $135 \mathrm{gDBO}_{5} / \mathrm{m}^{3}$.dia. A capacidade de depuração estimada para a lagoa facultativa é baseada na carga orgânica máxima superficial em função da temperatura média anual, adotada neste estudo como sendo de $23{ }^{\circ} \mathrm{C}$ (CLIMATE-DATA, 2012; WREGE et al., 2012). Com isto, tem-se que a carga orgânica máxima superficial seja de 249 $\mathrm{kgDBO}_{5} /$ ha.dia, devendo a lagoa possuir área de $1250 \mathrm{~m}^{2}$, profundidade de 1,5 m e TDH mínimo de 7 dias, sendo adotado TDH de 10 dias para otimização da redução de ovos de helmintos. Estas características possibilitam eficiência de $74,84 \%$ na redução da carga orgânica superficial aplicada, consistindo em efluente final com cerca de 33,97 gDBO5/m³.dia. Com base no número inicial de 800 ovos de helmintos a cada $100 \mathrm{~mL}$ no afluente a montante do sistema, é esperada redução de 99,93\% na redução dos ovos, resultando em cerca de 0,58 ovo/100 mL. Com relação à redução de coliformes fecais, deve-se esclarecer que o sistema não proporciona índices de redução confiáveis e plenamente seguros para finalidades mais nobres do efluente, pois requereria, para isso, a instalação de lagoas de maturação (VON SPERLING, 1996).

Conclusão: Os índices apresentados como resultados esperados para o projeto apontam que o efluente do sistema de 
tratamento proposto pode ser utilizado para fins que não estejam relacionados ao consumo humano direto. Neste contexto, podese dizer que a qualidade do efluente se enquadraria na classe B, recomendada nas diretrizes da Organização Mundial da Saúde (WHO, 2006), que indica os padrões de qualidade para reúso da água para irrigação de determinadas culturas.

\section{Referências}

ASSOCIAÇÃO BRASILEIRA DE NORMAS TÉCNICAS (Rio de Janeiro). Comissão de Estudo de Projetos de Sistemas de Esgoto Sanitário. 1986. NBR 9648 Estudo de concepção de sistemas de esgoto sanitário: procedimento, Rio de Janeiro: ABNT, p. 1-5, 1986.

CLIMA Paranaguá. Climate-Data.org, 2012. Disponível em: https://pt.climate-data.org/. Acesso em: 17 ago. 2020.

MENDONÇA, Sergio Rolim; MENDONÇA, Luciana Coêlho. Sistemas sustentáveis de esgotos: orientações técnicas para projeto e dimensionamento de redes coletores, emissários, canais, estações elevatórias, tratamento e reúso na agricultura. 2. ed. rev. São Paulo: Blucher, 2017. 364 p. ISBN 978-85-212-0961-4. E-book (364р.).

TONETTI, Adriano Luiz et al. Tratamento de esgotos domésticos em comunidades isoladas: Referencial para a Escolha de Soluções. 1. ed. Campinas, 2018. 153 p. ISBN 978-85-85783-94-5. Disponível em: http://www.fec.unicamp.br/ saneamentorural/wp-content/uploads/2018/11/Livro-Tratamento-de-Esgotos-Dom\%C3\%A9sticos-emComunidades-Isoladas-ilovepdf-compressed.pdf. Acesso em: 27 ago. 2019.

TUNDISI, José Galizia. Recursos hídricos no século XXI. 1. ed. São Paulo: Oficina de Textos, 2011. 328 p. ISBN 978-85-7975012-0.

VON SPERLING, Marcos. Princípios do tratamento biológico de águas residuárias: introdução à qualidade das águas e ao tratamento de esgotos. 2. ed. rev. Minas Gerais: Universidade Federal de Minas Gerais, 1996. 243.

Princípios do tratamento biológico de águas residuárias: lagoas de estabilização. 2. ed. Minas Gerais: ABES, 2009. 196 p. v. 3. ISBN 978-85-8526-606-6.

WREGE, Marcos Silveira et al. Atlas climático da região sul do Brasil: estados do Paraná, Santa Catarina e Rio Grande do Sul. 2. ed. Brasília: Embrapa, 2012. 334 p. ISBN 978-85-7035-013-8. E-book.

WHO (WORLD HEALTH ORGANIZATION). Guidelines for the safe use of wastewater, excreta and greywater: excreta and greywater use in agriculture. França: [s. n.], 2006. 182 p. v. 4. 


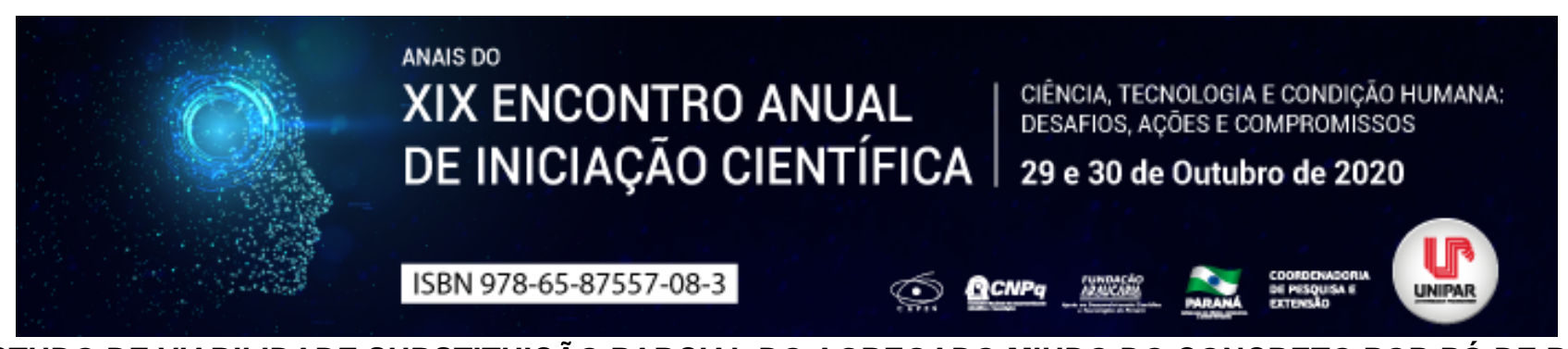

ESTUDO DE VIABILIDADE SUBSTITUIÇÃO PARCIAL DO AGREGADO MIUDO DO CONCRETO POR PÓ DE PET

\title{
${ }^{1}$ ARIELE RAIANNE DE SOUZA, ${ }^{2}$ EDUARDA CANTON, ${ }^{3}$ CRISTIANO GOULART
}

\author{
${ }^{1}$ Acadêmica do Curso de Engenharia Civil da UNIPAR \\ ${ }^{1}$ Acadêmica do Curso de Engenharia Civil da UNIPAR \\ ${ }^{2}$ Docente da UNIPAR
}

Introdução: O ramo da construção civil tem uma grande influência na economia e torna-se um grande fornecedor de emprego, auxiliando no crescimento do país (CHAVES; COSTA FILHO, 2019). No entanto a construção gera um grande impacto no meio ambiente, pois há uma grande exploração de recursos naturais causando uma escassez deles. (RODRIGUES; FUCALE, 2014). Um dos materiais de maior consumo da construção civil é o concreto, e com o tempo apresenta um aumento na sua utilização. Ele sendo decorrente da combinação de cimento, areia, brita e água (CHAVES; COSTA FILHO, 2019). O concreto contribui na degradação ambiental tanto na produção de entulho que apresenta um grande volume, como na produção dos materiais de sua composição, exemplo disso é o cimento, que tem um alto índice de consumo mundial e em sua fabricação há grande liberação de CO2 na atmosfera (AGOPYAN; JOHN, 2011). Em média no Brasil o emprego da areia no ramo da construção é de 320 milhões de $\mathrm{m}^{3}$ por ano, a remoção deste material é efetuada pelos leitos e nas baixadas de rios. Com a necessidade de suprir a demanda da construção civil, o elevado índice de remoção desse produto gera um grande impacto ambiental, devido à escassez do agregado e no transporte de longas distâncias até chegar a seu destino. Além do aumento no preço do produto (JÚNIOR MATTANA; DE MEDEIROS; DA SILVA; DA COSTA, 2012). Um material plástico que vem sendo reutilização no concreto é o PET (PoliTereftalato de Etileno), ele que em grande maioria proveniente de garrafas de refrigerantes, muitas vezes tendo seu descarte de forma incorreta. Sua utilização visa a degradação do ambiente em função da produção da matéria prima para o concreto e também dando uma reutilização para as embalagem em PET, assim evitando o acumulando lixo (GUERRA; ROCHA; OKABAYASHI, 2017).

Objetivo: De acordo com a NBR 6.118:2014 o concreto para ter sua utilização estrutural deve satisfazer algumas disposições de qualidade, estas sendo capacidade de resistência, desempenho em serviço e durabilidade. Pretendendo obter uma resistência aceitável por norma, este trabalho tem como objetivo a substituição de uma porcentagem do agregado miúdo do concreto por pó de PET.

Material e Métodos: Este trabalho composto por levantamento bibliográfico e método experimental. Prodanov e Freitas (2013) compreende que o método experimental é sujeitar um objeto de estudo a algumas variáveis, o pesquisador tendo o conhecimento e o controle das condições do experimento, para então analisar os efeitos que causa no objeto. Assim este estudo visa comparar o concreto convencional e o concreto com substituição parcial do agregado miúdo por pó de PET, como objetivo de obter uma resistência à compressão aceita por norma para utilizar como concreto estrutural. Para os concretos com substituição a porcentagem estabelecida será $15 \%$ e $35 \%$ da massa total da areia. Neste estudo para a fabricação do concreto utilizado cimento, areia, pó de PET, brita e água. Os traços desenvolvido segundo o método do ABCP com Fck de $25 \mathrm{MPa}$. O traço base utilizado foi: 1:1,76:2,49:0,42. Para a fabricação do concreto foi utilizado cimento CP II, brita n`1, areia média, água e pó de PET. O material plástico para a elaboração do experimento foi disponibilizado pela empresa especializada em recuperação de materiais plásticos. O concreto convencional os materiais adicionados na sequência: brita, cimento, areia, $2 / 3$ da água e depois o restante da água e no concreto com substituição a sequência foi: brita, cimento, areia, pó de pet, $2 / 3$ da água e depois o restante da água. Os concretos foram produzindo utilizando uma betoneira que tem sua capacidade de 400 litros. Com estes concretos foram feitos corpos de provas segundo a NBR 5738:2015 para obter a resistência a compressão do concreto, primeiramente os corpos de prova que tem suas dimensões de $10 \mathrm{~cm}$ de diâmetro e $20 \mathrm{~cm}$ de altura foram untados com óleo, em seguida aplicando o concreto no corpo de prova em 2 camada efetuando 12 golpes em cada camada, e por fim dando uma acabamento no capeamento dos corpos de provas. Após as moldagens os corpos de provas foram armazenados em local adequado, plaino e protegido de intempéries, para se obter a cura inicial e passado 24 horas desinformados e identificados, em seguida os corpos de provas foram submetidos à cura saturada até a data do rompimento, que foram estipuladas nas datas de 3 e 28 dias, foi definido 3 dias para que assim tenha um estudo do comportamento do concreto, pois em obras muitas vezes as escoras dos elementos estruturais são retiradas em poucos dias, e a data de 28 dias para obter dados da cura total. Foram feitos 7 corpos de provas para cada traço e cada dia de rompimento. Nas datas dos rompimentos foi realizado o ensaio de compressão axial, conforme a NBR. 5.739:2018, e com os resultados do ensaio efetuado a analise estatística, primeiramente realizado o teste de Chauveneut para ser eliminados outliers, feito então a estatística descritiva através da média, do desvio padrão e da variação, e por fim realizados testes estatísticos através dos métodos de Tukey e da anova.

Conclusão: É esperando para este estudo que aos 28 dias os corpos de provas atinja a resistência a compressão mínima de 
20MPa, para assim segundo a NBR 6.118:2014 passa ser considerado um concreto estrutural. Visando minimizar os impactos ambientais e respeitar as resistências características, pois em comparação ao outros materiais o concreto se torna mais vantajoso, assim ele tem uma grande utilização no ramo da construcao civil.

\section{Referências}

AGOPYAN, V.; JOHN, V. M. O desafio da sustentabilidade na construção civil. v.5. São Paulo, Blucher, 2011.

ASSOCIAÇÃO BRASILEIRA DE NORMAS TÉCNICAS. ABNT NBR 6118: Projeto de estruturas de concreto - Procedimento. Rio de Janeiro, 2014.

ASSOCIAÇÃO BRASILEIRA DE NORMAS TÉCNICAS. ABNT NBR 5738: Concreto Procedimento para moldagem e cura de corpos de prova. Rio de Janeiro, 2015.

ASSOCIAÇÃO BRASILEIRA DE NORMAS TÉCNICAS. ABNT NBR 5739: Concreto - Ensaio de compressão de corpos-de-prova cilíndricos. Rio de Janeiro, 2018.

CHAVES, A. O. P.; COSTA FILHO, N. B. da. Logística reversa de pós-consumo por meio da reutilização dos resíduos de concreto usinado nas obras de parque eólico administradas pela construtora alfa. Revista de Engenharia da UNI7, Fortaleza, v.3, n. 1, p. 013-048, 2019.

GUERRA, A.S.; ROCHA, E.R.D.; OKABAYASHI, J.Y. Estudo de viabilidade técnica para a realização de polietileno tereftalato (PET) residual em substituição ao agregado miúdo no concreto. Mix Sustentável, Florianópolis, v.3, n.3, p.35-40, 2017.

JÚNIOR MATTANA, A.; DE MEDEIROS, M. H. F.; DA SILVA, N. G.; DA COSTA, M. do R. de M. M. Análise hierárquica para escolha entre agregado natural e areia de britagem de rocha para confecção de argamassas de revestimento. Ambiente Construído, Porto Alegre, v.12, n. 4, p. 63-79. 2012.

PRODANOV, C. C; FREITAS, E. C. Metodologia do trabalho científico: métodos e técnicas da pesquisa e do trabalho acadêmico. 2.ed. Novo Hamburgo- Feevale, 2013.

RODRIGUES, C. R. DE SÁ; FUCALE, S. Dosagem de concretos produzidos com agregado miúdo reciclado de resíduo da construção civil. Ambiente Construído, Porto Alegre, v. 14, n. 1, p. 99-111, 2014. 


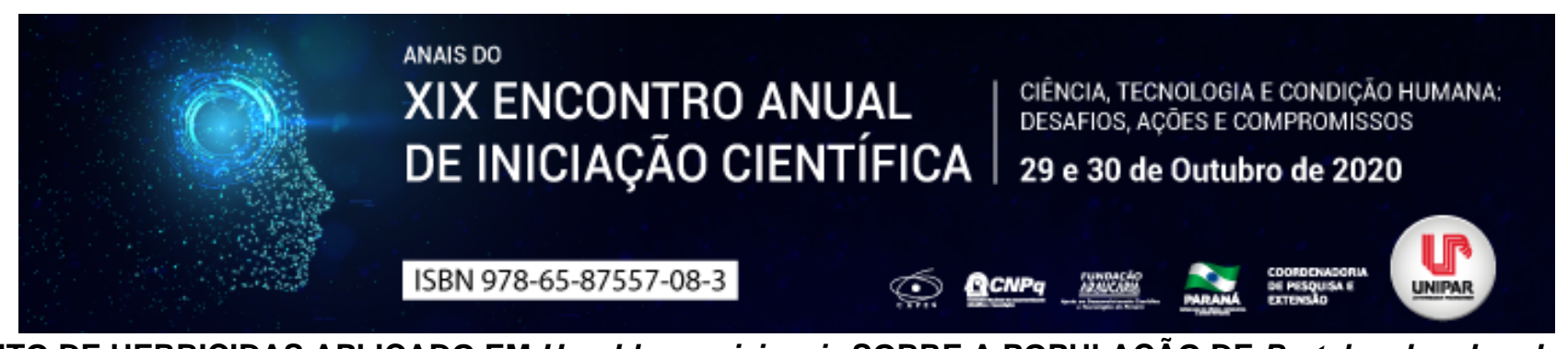

EFEITO DE HERBICIDAS APLICADO EM Urochloa ruziziensis SOBRE A POPULAÇÃO DE Pratylenchus brachyurus

\author{
${ }^{1}$ Guilherme Tarini, ${ }^{2}$ LAÍS FERNANDA FONTANA, ${ }^{3}$ ANGÉLICA SANCHEZ MELO, ${ }^{4}$ CAROLINA YUMI FUTIGAMI, ${ }^{5}$ BRUNA \\ ORLANDINI TONINATO, ${ }^{6}$ CLAUDIA R. DIAS-ARIEIRA
}

\author{
${ }^{1}$ Discente Graduação, UEM \\ ${ }^{1}$ Discente Pós-Graduação, UEM \\ ${ }^{2}$ Discente Graduação, UEM \\ ${ }^{3}$ Discente Graduação, UEM \\ ${ }^{4}$ Discente Pós-Graduação, UEM \\ ${ }^{5}$ Docente UEM, Umuarama
}

Introdução: O sistema de Integração lavoura pecuária (ILP) na região do Arenito Caiuá, noroeste do estado do Paraná, tem contribuído para a recuperação de áreas de pastagens degradadas, além de possibilitar o cultivo de soja em solos arenosos, sob palhada de braquiária. Nesta região, a braquiária ruziziensis (Urochloa ruziziensis) tem sido a mais cultivada. Contudo, trata-se de uma planta suscetível ao nematoide das lesões radiculares (Pratylenchus brachyurus) (INOMOTO et al., 2007), que por sua vez, tem sido assinalado como um dos patógenos mais prejudiciais para a cultura da soja (FAVORETO et al., 2019). $P$. brachyurus é um endoparasita migrador, cujas atividades de penetração e alimentação ocasionam lesões de coloração escura as raízes (UEBEL et al., 2014). Desta forma, é necessário encontrar estratégias que permitam adotar o sistema ILP, sem riscos de aumento da população de nematoides, acima do limiar de dano econômico. Dentro deste contexto, há trabalhos que relataram que alguns dessecantes de pastagens podem ter efeito sobre os nematoides das lesões radiculares, reduzindo a população nas plantas presentes nas áreas que antecedem a lavoura (KASHIWAQUI et al., 2016A, B).

Objetivo: Avaliar o efeito dos herbicidas aplicados em U. ruziziensis sob a população de $P$. brachyurus.

Material e métodos: O experimento foi conduzido em casa-de-vegetação, na Universidade Estadual de Maringá, em Umuarama, $\mathrm{PR}$, em delineamento inteiramente casualizado, com cinco tratamentos e 14 repetições. Os tratamentos corresponderam a aplicação de quatro herbicidas: Glifosato Nortox ${ }^{\circledR}$, Select ${ }^{\circledR}$, Verdict $R^{\circledR}$, Sanson Evo ${ }^{\circledR}$, e a testemunha simulando capina. $A$ espécie de braquiária utilizada foi a $U$. ruziziensis, sendo sete repetições para avaliação do nematoide na braquiária e sete repetições para bioteste em soja cultivar M6210 IPRO. Foi preparado os vasos contendo $1 \mathrm{~L}$ de solo: areia (2:1), previamente autoclavados por duas por 2 horas a $120^{\circ} \mathrm{C}$. Foram semeadas 10 sementes por unidade experimental, sendo feito o desbaste após sete dias, deixando apenas 1 planta/vaso. Então, fez-se a inoculação de uma suspensão de $1 \mathrm{~mL}$, contendo 500 espécimes de $P$. brachyurus por planta. O inóculo foi obtido de uma população pura, mantida em milho, e extraído das raízes conforme metodologia proposta por COOLEN E D'HERD (1972). Após 70 dias da inoculação, foram aplicados os herbicidas em cada tratamento, seguindo a dosagem recomendada pelo fabricante: Glifosato Nortox ${ }^{\circledR}$ (Nortox, Glifosato, $480 \mathrm{~g}$ de ia/L+ equivalente ácido de glifosato, $360 \mathrm{~g}$ de ia/L, na dose de $2 \mathrm{~L}$ de p.c./ha), Select ${ }^{\circledR}$ (Arysta, Cletodim, $240 \mathrm{~g}$ de ia/L e $646,52 \mathrm{~g}$ de ia/L de alquilbenzeno, na dose de $0,35 \mathrm{~L}$ de p.c ha-1), Verdict $\mathrm{R}^{\circledR}$ (Dow AgroSciences, Haloxifope-P-Metílico, $124,7 \mathrm{~g}$ de ia/L+ equivalente ácido de haloxifope-p-metílico, $120 \mathrm{~g}$ de ia/L na dose de 0,4 L de p.c ha ${ }^{-1}$ ), Sanson Evo ${ }^{\circledR}$ (ISK Biosciences, Nicossulfurom, $40 \mathrm{~g}$ de ia/L na dose de $1,25 \mathrm{~L}$ de p.c ha ${ }^{-1}$ ), e a testemunha sem a aplicação dos dessecantes, cortando as plantas na base do colo. Para as aplicações, utilizou-se um borrifador, simulando calda de 300 L/ha.

Sete dias após a aplicação, as raízes de sete repetições de cada tratamento foram retiradas, sendo feita a pesagem em balança semi-analítica. Em seguida, as raízes foram submetidas a mesma metodologia de extração e análise, determinando o número total de nematoides. Foi determinado também o Fator de Reprodução (FR), pela fórmula FR = população final/população inicial (OOSTENBRINK, 1966).

$\mathrm{Na}$ outra metade dos vasos, foi semeada soja, 15 dias após a dessecação, sendo cultivadas por 70 dias e avaliadas quanto à massa de raiz e os parâmetros nematológicos (os mesmos já citados). Os dados obtidos foram submetidos à análise estatística teste Scott-Knott a 5\% de probabilidade por meio do programa estatístico Sisvar (FERREIRA, 2011).

Resultados: O número de nematoides totais em $U$. ruziziensis foi reduzido com a aplicação dos herbicidas, exceto o tratamento Sanson Evo ${ }^{\circledR}$, que foi estatisticamente igual a testemunha, e este resultado se manteve para a variável fator de reprodução. Os tratamentos que diferiram da testemunha demonstraram reduções entre 62 e 87,7\%. Na avaliação da soja após o cultivo de $U$. ruziziensis, considerou-se a raiz remanescente desta gramínea, e foi observado que na variável nematoides totais, todos os herbicidas aplicados na dessecação foram capazes de reduzir a multiplicação de $P$. brachyurus, refletindo em reduções no fator 
de reprodução na ordem de 26,2 e $53,9 \%$.

Discussão: Os resultados do presente trabalho se assemelham aos encontrados por GREMASCHI E DIAS-ARIEIRA (2015), pois os autores observaram que Sanson Evo ${ }^{\circledR}$ demonstrou potencial para controle de $P$. brachyurus. Da mesma forma, os autores obtiveram controle utilizando o herbicida Aramo ${ }^{\circledR}$. KASHIWAQUI et al. (2016), avaliando herbicidas na dessecação de capim amargoso e em pós emergência de soja, observaram que nos tratamentos que havia presente Glifosato e Select ${ }^{\circledR}$ houve redução na população de $P$. brachyurus, sendo semelhantes aos encontrados no presente trabalho.

Conclusão: Os herbicidas podem auxiliar no manejo de nematoides do sistema de ILP, reduzindo a população de $P$. brachyurus no sistema.

\section{Referências}

COOLEN, W. A. D'HERDE, C. J. A method for the quantitative extraction of nematodes from plant tissue. A method for the quantitative extraction of nematodes from plant tissue, 1972.

FAVORETO, Luciany; MEYER, Maurício Conrado; DIAS-ARIEIRA, Claudia Regina; MACHADO, Andressa Cristina Zamboni; SANTIAGO, Débora Cristina; RIBEIRO, Neucimara Rodrigues. Diagnose e manejo de fitonematoides na cultura da soja. Informe Agropecuário, Belo Horizonte, v.40, n.306, p .18-29, 2019.

FERREIRA, Daniel Furtado. Sisvar: a computer statistical analysis system. Ciência e Agrotecnologia, 35.6: 1039-1042, 2011.

GREMASCHI, Anderson Patrício; DIAS-ARIEIRA, Claudia Regina. Efeito de herbicidas dessecantes sobre a população de Pratylenchus brachyurus. In: XXIV Encontro anual de Iniciação Científica e IV Encontro Anual de Iniciação Científica Junior da Universidade Estadual de Maringá, Maringá, 2015.

INOMOTO, Mário M.; MACHADO, Andressa C.Z.; ANTEDOMÊNICO, Sonia R. Reação de Brachiaria spp. E Panicum maximum a Pratylenchus brachyurus. Fitopatologia Brasileira. v. 32, p. 341-344, 2007.

KASHIWAQUI, Marcos M.; SEVERINO, José Junior.; DIAS-ARIEIRA, Claudia Regina; SILVA, André A. Pazinato; MACIEL, Cleber Daniel Goes. Dinâmica de nematoides em capim-amargoso submetido a controle químico na cultura do milho safrinha RR®. Anais: V Simpósio internacional sobre Glypohsate. 2016A.

KASHIWAQUI, Marcos M.; SEVERINO, José Junior; DIAS-ARIEIRA, Claudia Regina; SILVA, André A. Pazinato; MACIEL, Cleber Daniel Goes. Dinâmica de nematoides em sistemas de manejo químico de capim-amargoso na cultura da soja RR®. Anais: V Simpósio internacional sobre Glypohsate. 2016B.

OOSTENBRINK, M. Major characteristics of the relation between nematodes and plants. 1966.

UEBEL, Marcelo; GARBIN, Luiz Fernando; SILVA, Rosangela Aparecida.; SANTOS, Paulo Sergio. Reação de cultivares de Brachiaria spp. a Pratylenchus brachyurus. Connection line, $n^{\circ} 10,2014$. 


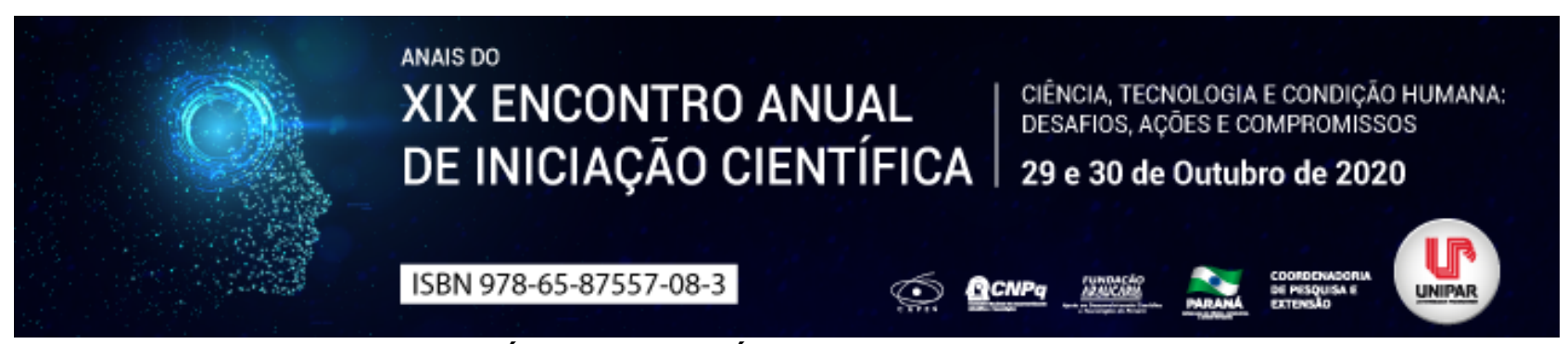

POTENCIAL BIOLÓGICO DA ESPÉCIE Piper corcovadensis (Miq.) C. DC.

\title{
${ }^{1}$ GABRIELA CATUZO CANONICO SILVA, ${ }^{2}$ ZILDA CRISTIANI GAZIM, ${ }^{3}$ CARLA MARIA MARIANO FERNANDEZ
}

\author{
${ }^{1}$ Discente do Programa de Iniciação Científica (PIC), Universidade Paranaense, Umuarama, Paraná, Brasil \\ ${ }^{1}$ Docente do Programa de Pós-graduação em Biotecnologia Aplicada à Agricultura, Universidade Paranaense, Umuarama, \\ Paraná, Brasil \\ ${ }^{2}$ Docente do Programa de Pós-graduação em Biotecnologia Aplicada à Agricultura, Universidade Paranaense, Umuarama, \\ Paraná, Brasil
}

Introdução: A planta Piper corcovadensis (Miq.) C. DC. pertencente à família Piperaceae, é nativa do Brasil com distribuição geográfica do Nordeste do Brasil até o Rio Grande do Sul conhecida popularmente como João brandinho e falso-jaborandi. Possui como sinonímias Ottonia corcovadensis Miq., Ottonia propinqua Kunth com as subespécies Piper corcovadensis (Miq.) C. DC. var. corcovadensis, Piper corcovadensis var. longiracemosum (Yunck.)Na medicina popular é empregada no tratamento de reumatismo,gripe e tosse, e suas raizes e ramos são mastigados para aliviar a dor de dente devido a sua ação anestesica (FACUNDO; MORAIS; FILHO, 2004).

Objetivo: Este estudo teve por objetivo realizar um levantamento bibliográfico sobre as atividades biológicas da espécie Piper corcovadensis.

Desenvolvimento: A especie Piper Corcovadensis é uma planta popularmente conhecida como João brandinho, encontrada principalmnete no norte e nordeste do Brasil. Na medicina popular a compressa das folhas é usada para o tratamento do reumatismo,e na forma de chá para gripe e tosse (FACUNDO;MORAIS;FILHO,2004). Estudos realizados com as folhas, caule e raízes de $P$. corcovadensis identificaram a presença dos alcaloides piperovatina, piperlonguminina, isopiperlonguminina, corcovadina, isocorcovadina e chingchengamida, também a presença dos flavonoides 3', 4',5,5',7-pentametoxiflavona, 3',4',5,7tetrametoxiflavona e 5-diidroxi-3',4',5',7-tetrametoxiflavona e o ácido cafeico (COSTA e MORS,1981; FACUNDO; MORAIS; FILHO, 2004; MARQUES, 2009; FERNANDEZ et al., 2018). Silva et al. (2016) avaliou a composição química do óleo essencial extraído das folhas secas da $P$. corcovadensis, que apresentou o 1-butil-3,4-metilenodioxibenzeno (30,62\%), como composto majoritário, seguido do terpinoleno (17,44\%), trans-cariofileno (6,27\%), $\alpha$-pineno (5,92\%), $\delta$-cadineno $(4,92 \%)$ e limoneno $(4,46 \%)$. Estudos da literatura demonstraram o potencial biológico desta espécie. Fernandez et al. (2018) mostrou em seus estudos que o extrato diclorometano das raízes de $P$. corcovadensis apresentou alta atividade acaricida in vitro sobre o Riphicephalus microplus ( $\left.\mathrm{CL}_{50} 15,27 \mu \mathrm{g} \mathrm{mL}-{ }^{-1} ; \mathrm{CL}_{50} 55,64 \mu \mathrm{g} \mathrm{mL}-1\right)$, assim como o composto isolado piperovatina $\left(\mathrm{CL}_{50}{ }_{5,17} \mu \mathrm{g}\right.$ mL-1; CL50 25,41 $\mu \mathrm{g} \mathrm{mL-1}$ ), no ensaio acaricida em condições ex situ mostraram eficácia de 95,52\% e 96,63\%, respectivamente. O óleo essencial das folhas e os compostos isolados 1-butil-3,4-metilenodioxibenzeno e terpinoleno de $P$. corcovadensis mostraram alta atividade larvicida sobre o Aedes aegypti com $\mathrm{CL}_{50}$ de 30,52; 22,11 e 31,16 $\mu \mathrm{g} \mathrm{mL-1}$, respectivamente, e foram capazes de interferir com a atividade das proteases das enzimas intestinais L4 das larvas do mosquito (SILVA et al., 2016). O extrato das raízes de $P$. corcovadensis e o composto isolado piperovatina também apresentaram alta atividade larvicida sobre o A. aegypti com $\mathrm{CL}_{50}$ de 4,86 e 17,78 $\mu \mathrm{g} \mathrm{mL-1}$, respectivamente, conforme relatado nos estudos de Fernandez et al. (2020). Fernandez et al. (2019) mostraram que o extrato bruto das raízes de Piper corcovadensis, piperavatina e a fração piperlonguminina/isopiperlonguminina (FRPI) isolados apresentam atividade antibacteriana contra Mycobacterium tuberculosis $\mathrm{H}_{37} \mathrm{Rv}$ com concentração inibitória mínima (CIM) de 15,60; 7,80 e 7,80 $\mu \mathrm{g} \mathrm{mL-1}$, respectivamente, e efeito sinérgico entre extrato bruto das raízes em combinação com a isoniazida e rifampicina, e a piperovatina e a FRPI apresentaram sinergismo em combinação com a rifampicina. Também mostraram atividade em isolados clínicos de $M$. tuberculosis com CIM entre 0,98 3,90 $\mu \mathrm{g} \mathrm{mL-1}$ para o extrato bruto das raízes, 0,48 $1,95 \mu \mathrm{g} \mathrm{mL-1}$ para a piperovatina e 0,48 3,90 $\mu \mathrm{g} \mathrm{mL-1}$ para a FRPI.

Conclusão: A partir dos estudos que envolvem a atividade biológica da espécie Piper corcovadensis,percebe-se que esta possui elevado potencial biológico, no entanto são necessarias outras investigações cientificas para avaliar as propriedades biológicas desta planta.

\section{Referências}

COSTA, S. S.; MORS, W. B. Amides of Ottonia corcovadensis. Phytochemistry, v. 20, n. 6, p. 1305-1307, 1981.

FACUNDO, V. A.; MORAIS, S. M.; FILHO, R. B. Constituintes químicos de Ottonia corcovadensis Miq. da Floresta Amazônica: atribuição dos deslocamentos químicos dos átomos de hidrogênio e carbono. Química Nova, v.. 27, n. 1, p. 79-83, 2004.

FERNANDEZ, C. M. M.; LORENZETTI, F. B.; BERNUCI, K. Z.; IWAGANA, C. C.; BORTOLUCCI, W. C.; ROMAGNOLO, M. B.; SIMÕES, M. R.; CORTEZ, D. A. G.; SCODRO, R. B. L.; GAZIM, Z. C.; FILHO, B. P. D. Larvicidal potential of piperovatine in the 
control of cattle tick. Veterinary Parasitology, v. 263, p. 5-9, 2018.

FERNANDEZ, C. M. M.; BALDIN, V. P.; IEQUE, A. L.; BERNUCI, K. Z.; ALMEIDA, R. T.; VALONE, L. M.; FONSECA, D. P.; MAKIMORI, R. Y.; ANDRADE, J. P. P.; PILAU, E. J.; ROMAGNOLO, M. B.; NAKAMURA, T. U.; CARDOSO, R. F.; CORTEZ, D. A. G.; GAZIM, Z. C.; SCODRO, R. B. L.; FILHO, B. P. D. Anti-Mycobacterium tuberculosis activity of dichloromethane extract of Piper corcovadensis (Miq.) C. DC. roots and isolated compounds. Industrial Crops and Products, v. 131, p. 341-347, 2019.

FERNANDEZ, C. M. M.; LORENZETTI, F. B.; LIMA, M. M. S.; KLEINUBING, S. A.; BORTOLUCCI, W. C.; ANDRADE, J. P. P.; ROMAGNOLO, M. B.; CORTEZ, D. A. G.; GAZIM, Z. C.; FILHO, B. P. D. Larvicidal activity of piperovatine and dichloromethane extract from Piper corcovadensis roots against mosquitoes Aedes aegypti. Boletin Latinoamericano y del Caribe de Plantas Medicinales y Aromaticas, v. 19, n. 1, p. 142-148, 2020

MARQUES, J. V. Atividade biológica de amidas e análogos de espécies de Piper e estudos biossintéticos. Orientador: Massuo Jorge Kato. 2009. 375 p. Tese - Programa de Pós-Graduação em Química Orgânica. Instituto de Química, Universidade de São Paulo, São Paulo, 2009.

SILVA, M. F. R.; BEZERRA-SILVA, P. C.; DE LIRA, C. S.; ALBUQUERQUE, B. N. L.; AGRA NETO, A. C.; PONTUAL, E. V.; MACIEL, J. R.; PAIVA, P. M. G.; NAVARRO, D. M. A. F. Composition and biological activities of the essential oil of Piper corcovadensis (Miq.) C. DC (Piperaceae). Experimental Parasitology, v. 165, p. 65-70, 2016) 


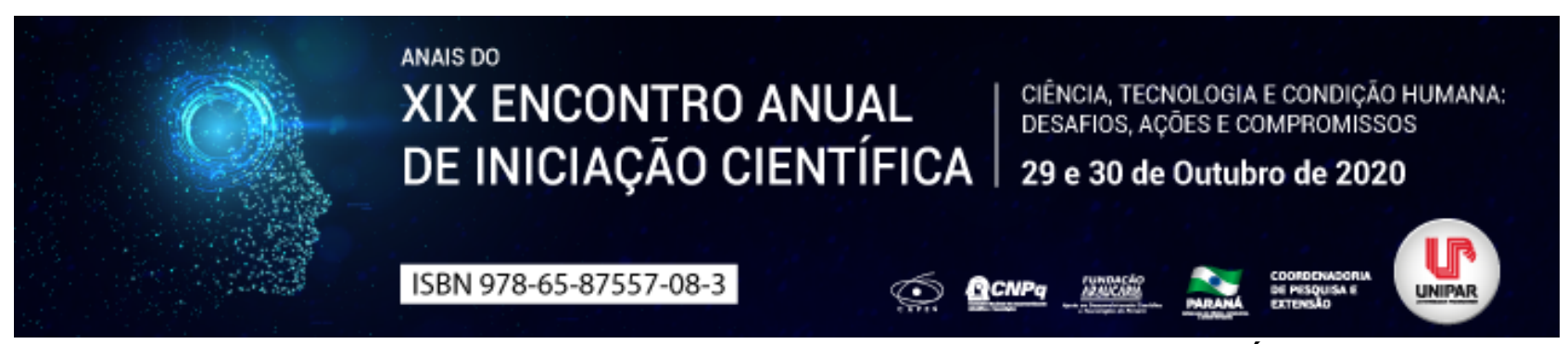

RESUMO ORIGINAL DE COMO ELABORAR UM BOM PLANO DE NEGÓCIOS

\title{
${ }^{1}$ KETLIN SCHNELL DE AZEVEDO, ${ }^{2}$ DJESSICA TUANI KREIN, ${ }^{3}$ JESSICA CAROLINE MERLUGO DEPONTI, ${ }^{4}$ CARINE ZAGO
}

\author{
${ }^{1}$ ACADÊMICO DO PIC/UNIPAR \\ ${ }^{1}$ Acadêmico do Curso de Engenharia Civil da UNIPAR \\ ${ }^{2}$ Acadêmica do Curso de Engenharia Civil da UNIPAR \\ ${ }^{3}$ Docente da UNIPAR
}

Introdução: Um projeto de sucesso inicia-se com a elaboração de um plano. O plano de negócios é o pontapé inicial de uma empresa, onde você terá uma noção prévia de como a empresa vai funcionar dentro do mercado, além de questões que serão necessárias para o funcionamento do projeto. Este instrumento irá facilitar o planejamento do seu empreendimento, ao mesmo tempo em que evitará que você abra um negócio baseado apenas num entusiasmo, sem qualquer estudo prévio (GONÇALVES, 2002).

Objetivo: Apresentar o passo a passo da elaboração de um plano de negócios.

Desenvolvimento: Um plano de negócios bom orienta o empreendedor a seguir etapas desde o início e do gerenciamento de seus negócios (DORNELAS, 1998). Este documento pode ser utilizado como tópicos de como desenvolver, gerenciar e ampliar seus negócios sempre com base nos seus negócios. Ao escrever seu plano de negócios, utiliza-se como guia sessões.

Sumário executivo: Descrição breve do que é a empresa e de que maneira será bem-sucedida. Deve conter informações básicas do produto, serviços, equipe de funcionários e de liderança, localização da empresa, como também informações financeiras.

Descrição da Empresa: Informações detalhadas sobre a empresa, os problemas que resolve, lista de consumidores, organização ou negócios que a empresa planeja atender (SANTOS; PINHEIRO, 2017). Explique as vantagens competitivas que tornarão o negócio um sucesso. A descrição da empresa é o lugar para se expor pontos fortes e convincentes. Análise de mercado: Entendimento das perspectivas do mercado e do mercado-alvo. Pesquisas competitivas mostrarão o que outras empresas estão fazendo e quais são seus pontos fortes. Em sua pesquisa de mercado, procure tendências e temas. Organização e gestão: Descrição da estrutura legal do seu negócio. Organograma para definir quem é o responsável e determinar funções. Projeções financeiras: Nessa etapa deverá ser convincente de que o negócio terá estabilidade financeira sendo assim um negócio de sucesso. Deve conter demonstrações de resultados, balanços patrimoniais e demonstrações de fluxo de caixa nos últimos anos, além de uma perspectiva financeira para os próximos cinco anos. Incluir declarações de renda previstas, bem como todos os orçamentos de despesas de capital. No primeiro ano, seja ainda mais específico e use projeções trimestrais ou mensais (SEBRAE). Certifique-se de esclarecer suas expectativas e correspondê-las às suas solicitações de financiamento, sendo viável a utilização de gráficos e tabelas financeira do seu negócio. Após concluir é sempre valido revisar para garantir que está realmente completo.

Conclusão: Os planos de negócios bem elaborados servem para favorecem a obtenção de financiamentos ou atração de novos parceiros de negócios, sendo um instrumento utilizado para convencer as pessoas de que trabalhar na sua empresa ou investir no negócio, é uma escolha inteligente, quando peremptório.

\section{Referências}

DORNELAS, José. PLANO DE NEGÓcIOS: o segredo do sucesso do empreendedor. Mito ou Realidade? v. 43, n. March, p. $19,1998$.

GONÇALVES, Vitor Hugo. Orientação para elaboração do plano de negócios. 2002.

PEREIRA, Clissie Eduarda Pinto; LOPES, Paloma de Louvor. PLANO DE NEGÓCIOS: Viabilidade de uma franquia da Ahoba Viagens no Sul Fluminense. p. 83 104, [s.d.].

SANTOS, Pedro Vieira Souza; PINHEIRO, Francisco Alves. O Plano De Negócios Como Ferramenta Estratégica Para O Empreendedor: Um Estudo De Caso. Revista Latino-Americana de Inovação e Engenharia de Produção, v. 5, n. 8, p. 150, 2017.

SEBRAE. Passo a passo para elaborar o plano de negócios de sua empresa. 2019. Disponível em: . Acesso em: 4 Jul. 2020. 


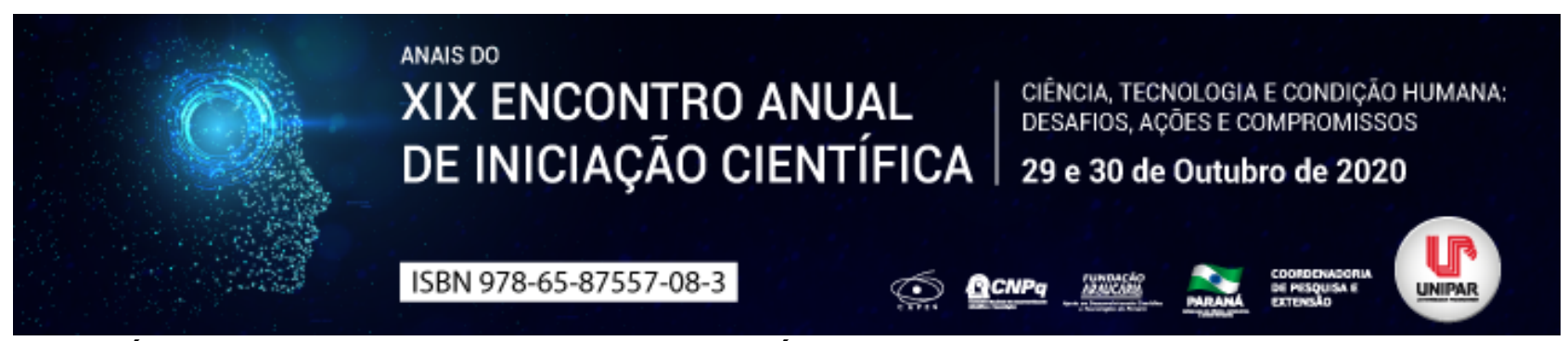

PLANO DE NEGÓCIOS COMO UMA FERRAMENTA ESTRATÉGICA PARA O EMPREENDEDOR, UM ESTUDO DE REVISÃO

\title{
${ }^{1}$ KETLIN SCHNELL DE AZEVEDO, ${ }^{2}$ DJESSICA TUANI KREIN, ${ }^{3}$ JESSICA CAROLINE MERLUGO DEPONTI, ${ }^{4}$ CARINE ZAGO
}

\author{
${ }^{1}$ ACADÊMICO DO CURSO DE ENGENHARIA CIVIL/ UNIPAR \\ ${ }^{1}$ Acadêmico do Curso de Engenharia Civil da UNIPAR \\ ${ }^{2}$ Acadêmica do Curso de Engenharia Civil da UNIPAR \\ ${ }^{3}$ Docente da UNIPAR
}

Introdução: O plano de negócios é uma importante ferramenta para o empreendedor, sendo ele o primeiro passo para a abertura de uma empresa. (GONÇALVES, 2002) assegura que o plano de negócios é uma linguagem de comunicação com o próprio empresário e com agentes externos. Ele mostra em detalhes quem são os empreendedores, qual é o produto, quais e quantos são os clientes, qual é o processo tecnológico de produção e vendas, qual é a estrutura de gerenciamento, quais são as projeções financeiras para fluxo de caixa, receitas, despesas, custos e lucros.

Objetivo: Apresentar os benefícios da realização de um plano de negócios para uma empresa.

Desenvolvimento: O plano de negócios deve ser realizado com a intenção de identificar possíveis ameaças e oportunidades, facilitando as decisões que o empreendedor vier a tomar, permitindo que o mesmo pesquise informações de mercado e concorrência de forma fácil e eficiente. A realidade brasileira sobre planejamentos e planos de negócios é duvidosa, o empreendedor brasileiro não tem costume de planejar seus passos antes de abrir o próprio negócio, e esse é um dos principais motivos de empresas quebrarem antes de completarem um ano no mercado, e quando há de fato a realização de um plano de negócios, muitas vezes resume-se a textos editados sobre um modelo pré-determinado e que não convencem ao próprio empreendedor, geralmente são escritos como parte dos requisitos de aprovação de um empréstimo, ingresso em uma incubadora de empresas, solicitação de bolsas ou recursos financeiros de órgãos do Governo etc, e que são feitos apenas para esse fim, às pressas, sem muita fundamentação (DORNELAS, 1998), e quando a empresa começa a passar por dificuldades reais, o empreendedor não tem nenhum documento de planejamento onde possa se apoiar para passar por essa crise da melhor forma possível, ocorrendo assim, na maioria dos casos a falência. A realização de um bom plano de negócios, envolve muita pesquisa de mercado e ideias inovadoras do empreendedor para sua empresa, e (PEREIRA; LOPES, [s.d.]) afirmam que isso proporciona um amplo conhecimento acerca do possível negócio para quem o elabora, e possibilita a prévia identificação de problemas no empreendimento antes de se inserir no mercado. Evitando, assim, prejuízos que ocorreriam se a empresa já estivesse em funcionamento. A constante manutenção do plano de negócios é importantíssima, pois o empreendedor caminha junto com o cenário atual, planejando seus passos de acordo com a realidade em que sua empresa se encontra, evitando assim passos em falso e problemas financeiros. (SANTOS; PINHEIRO, 2017) asseguram que a partir da idealização do negócio, entende-se que o empreendedor busque e adquira conhecimento sobre o ramo mercadológico no qual deseja atuar e com isso, notar as dificuldades que poderão surgir. Para este objetivo, o empreendedor pode utilizar o plano de negócios. Nele, o modelo de negócio é representado a fim de minimizar os erros e aumentar as possibilidades de sucesso dentro do setor desejado.

Conclusão: O plano de negócios irá nortear o empreendedor durante todo o empreendimento, facilitando a organização do negócio, e evitando dessa forma a abertura de um negócio sem planejamento, baseado em entusiasmo e sem qualquer estudo prévio.

\section{Referências}

DORNELAS, José. PLANO DE NEGÓcIOS: o segredo do sucesso do empreendedor. Mito ou Realidade? v. 43, n. March, p. $19,1998$.

GONÇALVES, Vitor Hugo. Orientação para elaboração do plano de negócios. 2002.

PEREIRA, Clissie Eduarda Pinto; LOPES, Paloma de Louvor. PLANO DE NEGócIOS: Viabilidade de uma franquia da Ahoba Viagens no Sul Fluminense. p. 83 104, [s.d.].

SANTOS, Pedro Vieira Souza; PINHEIRO, Francisco Alves. O Plano De Negócios Como Ferramenta Estratégica Para O Empreendedor: Um Estudo De Caso. Revista Latino-Americana de Inovação e Engenharia de Produção, v. 5, n. 8, p. 150, 2017. 


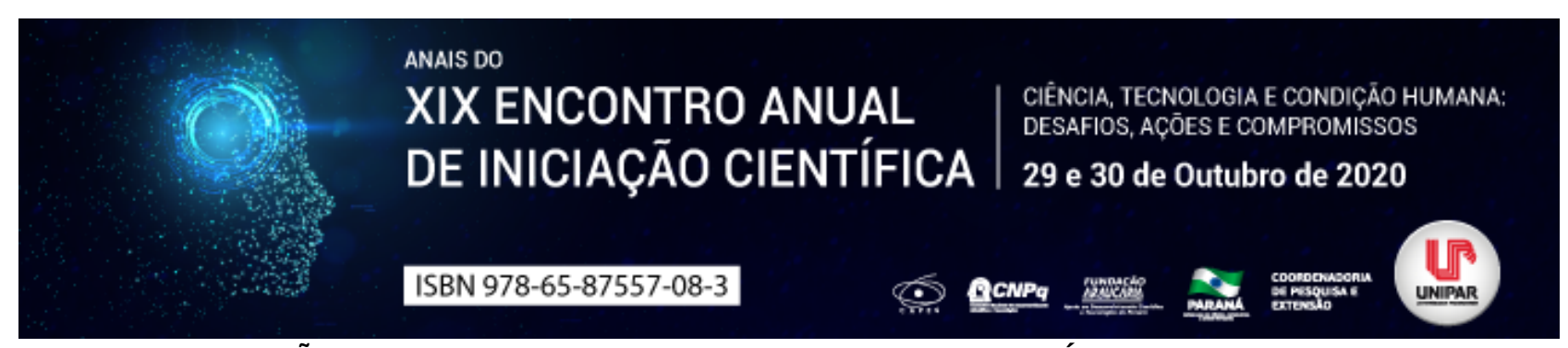

\title{
ISOTERMAS DE ADSORÇÃO DO CORANTE AMARELO TARTRAZINA EM RESÍDUOS AGROINDUSTRIAIS DE PALMITO PUPUNHA E MANDIOCA
}

\author{
${ }^{1}$ Carlos Eduardo Porto, ${ }^{2}$ LUCIANA NUNES DOS SANTOS, ${ }^{3}$ JHENNIFER DE ALMEIDA DOS SANTOS, ${ }^{4}$ MILENA KELLER \\ BULLA, ${ }^{5}$ VAGNER ROBERTO BATISTELA, ${ }^{6}$ BEATRIZ CERVEJEIRA BOLANHO BARROS
}

\begin{abstract}
${ }^{1}$ Discente do curso de Engenharia Civil/Graduação/Universidade Estadual de Maringá
${ }^{1}$ Discente do Programa de Pós-graduação em Sustentabilidade/Mestrado/Universidade Estadual de Maringá

${ }^{2}$ Discente do curso de Engenharia de Alimentos/Graduação/Universidade Estadual de Maringá

${ }^{3}$ Departamento de Tecnologia / Universidade Estadual de Maringá

${ }^{4}$ Departamento de Tecnologia / Universidade Estadual de Maringá

${ }^{5}$ Docente / Departamento de Tecnologia / Universidade Estadual de Maringá
\end{abstract}

Introdução: A região Noroeste do Paraná apresenta importante atuação industrial de produtos agroindustriais de Mandioca e de Palmito e, concomitantemente, a necessidade de que seus subprodutos (SM e SP, respectivamente) sejam adequadamente destinados. Com o objetivo de promover a valorização destes subprodutos propõe-se a destinação como adsorventes em especial para o tratamento de efluentes (PARMAR; THAKUR, 2013; CONAMA, 2005). Neste caso, há o reaproveitamento com certo potencial sustentável, gerando impactos ambientais positivos (FURLAN et al., 2018). Na adsorção, as isotermas descrevem o processo do ponto de vista matemático e fornecem informações sobre a situação de equilíbrio químico (NASCIMENTO et al., 2014). Existem diversos modelos matemáticos que descrevem o processo de adsorção e alguns deles são: Langmuir, Freundlich e Temkin (OLIVEIRA et al., 2019), como abordado neste trabalho. Dessa forma, consegue-se realizar diversas inferências sobre o mecanismo de adsorção de processos químicos, permitindo compará-los e otimizá-los.

Objetivo: Avaliar os ajustes de isotermas de adsorção para o corante Amarelo Tartrazina (TAR) em subproduto da mandioca (SM) e subproduto do palmito (SP), e comparar com o carvão ativado (CA) utilizado como material de referência.

Materiais e Métodos: Os experimentos de isotermas de adsorção foram realizados em triplicata nos valores de pH 1,0; 2,0 e 3,0 e nas concentrações de corante 2,$5 ; 5,0 ; 7,5 ; 10,0 ; 12,5 ; 15,0 ; 20,0$ e 25,0 $\mathrm{mg} \mathrm{L}^{-1}$. Para a obtenção das isotermas, foi utilizada a dosagem de $7,5 \mathrm{~g} \mathrm{~L}^{-1}$ de adsorvente, volume de $20 \mathrm{~mL}$ em erlenmeyers, temperatura fixa de $25,0{ }^{\circ} \mathrm{C}, 120 \mathrm{rpm}$ e tempo de 120 min. Após o equilíbrio, as amostras foram centrifugadas e os sobrenadantes foram analisados em espectrofotômetro (Femto, 700 Plus) em $428 \mathrm{~nm}$ analítico. Dessa forma, os valores de qe que corresponde a quantidade adsorvida por massa de adsorvente em $\mathrm{mg} \mathrm{g}^{-1}$ e $\mathrm{C}_{\mathrm{e}}$ que corresponde a concentração da espécie no equilíbrio em $\mathrm{mg} \mathrm{L}^{-1}$ foram determinados e avaliados por três modelos matemáticos: Langmuir, Freundlich e Temkin (NASCIMENTO et al., 2014).

Resultados: O CA apresentou o maior valor de coeficiente de determinação $\left(R^{2}\right.$ de 0,97$)$ e menor valor de soma residual ao quadrado (RSS zero) para o modelo de Freundlich, nos três pH estudados. Os valores do parâmetro $\mathrm{n}$ (intensidade da adsorção) foram de 1,36; 1,32 e 1,52 e $K_{F}$ (capacidade de adsorção) foram de 1,87; 1,89 e 1,90, respectivamente nos pH 1,0; 2,0 e 3,0. O SP apresentou o maior valor de $\mathrm{R}^{2}(0,96)$ e menor valor de RSS $(0,002)$ também com o modelo de Freundlich, com valores do parâmetro $n$ de 3,09; 3,09 e 2,79 e $\mathrm{K}_{\mathrm{F}}$ de 1,18; 1,19 e 1,21, respectivamente nos pH de 1,0; 2,0 e 3,0. Por fim, o SM apresentou o maior $\mathrm{R}^{2}(>0,97)$ e menor valor de RSS $(0,003)$ com o modelo de Langmuir, com a constante de equilíbrio de adsorção (K $\mathrm{K}_{\mathrm{L}}$ ) de 1,06; 1,12 e $0,93 \mathrm{~L} \mathrm{mg}^{-1}$ e máximas capacidades de adsorção na monocamada $\left(q_{\mathrm{m}}\right)$ de 1,$464 ; 1,414$ e $1,558 \mathrm{mg} \mathrm{g}^{-1}$, respectivamente nos três $\mathrm{pH}$ 1,0; 2,0 e 3,0. Os fatores de separação $\mathrm{R}_{\mathrm{L}}$ variaram de 0,14 a 0,33.

Discussões: Em todos os casos, a determinação dos melhores modelos de isotermas de adsorção foi realizada por meio dos seus maiores valores de $\mathrm{R}^{2}$ e menores valores de RSS. Uma vez que o modelo de Freundlich foi o melhor para o CA e SP, foi possível inferir que estes adsorventes possuem superfície heterogênea, sendo a adsorção em cobertura do tipo multicamada (NASCIMENTO et al., 2014). Para o SM, foi avaliado que o melhor modelo foi o de Langmuir, indicando a superfície de adsorção do SM é homogênea e que o processo ocorre em sítios específicos (RAFATULLAH et al., 2010). Sendo assim, a adsorção do SM foi caracterizada por ocorrer em monocamada, tornando-se máxima quando uma camada monomolecular cobrir totalmente a superfície do adsorvente (ALLEONI; CAMARGO; CASAGRANDE, 1998). O fator de separação $R_{L}$ da isoterma de Langmuir do CA, do SP e o do SM variou entre 0 e 1 e, por isso, demonstra que a adsorção ocorre em um processo favorável (DOTTO et al., 2011). Os valores de constante de adsorção indicaram que o processo de adsorção foi mais favorável nessa ordem: CA > SP > SM. O modelo de adsorção da TAR pelo CA difere do reportado na literatura (DOTTO et al., 2011) devido as diferentes dosagens 
de adsorvente e concentrações de corante. Para os demais adsorventes, não foram encontrados relatos nas mesmas condições. Apesar de também ser apresentado como testado, o modelo matemático de Temkin não caracterizou nenhum dos três adsorventes apresentados, demonstrando assim que nenhum dos três materiais seguem distribuição uniforme de energias de ligação (NASCIMENTO et al., 2014).

Conclusão: O modelo matemático que melhor descreveu o processo de adsorção do CA e do SP foi o de Freundlich, apontando que esses dois materiais possuem superfícies heterogêneas e que a adsorção ocorreu em cobertura do tipo multicamada. Para o $\mathrm{SM}$, o ajuste do modelo de Langmuir indicou que a superfície de adsorção é homogênea, que o processo ocorre em sítios específicos e a adsorção ocorre em monocamada. Em todos os casos, avaliou-se que tanto do SP quanto o SP podem ser aplicados como bons biossorventes para o corante TAR.

\section{Referências}

ALLEONI, L.R.F.; CAMARGO, O.A.; CASAGRANDE, J.C. Isotermas de Langmuir e de Freundlich na descrição da adsorção de boro em solos altamente intemperizados. Scientia Agricola, v. 55, n. 3, p. 379-387, 1998.

BRASIL. Resolução ${ }^{\circ}$ 357, de 17 de março de 2005. Dispõe sobre a classificação dos corpos de água e diretrizes ambientais para o seu enquadramento, bem como estabelece as condições e padrões de lançamento de efluentes, e dá outras providências. Brasília: Conselho Nacional de Meio Ambiente (CONAMA), 2005.

DOTTO, Guilherme Luiz et al. Remoção dos corantes azul brilhante, amarelo crepúsculo e amarelo tartrazina de soluções aquosas utilizando carvão ativado, terra ativada, terra diatomácea, quitina e quitosana: estudos de equilíbrio e termodinâmica. Química Nova, [S.L.], v. 34, n. 7, p. 1193-1199, 2011.

FURLAN, Fernanda Lansa et al. Use of agricultural and agroindustrial residues as alternative adsorbents of manganese and iron in aqueous solution. Ambiente e Água - An Interdisciplinary Journal of Applied Science, [S.L.], v. 13, n. 2, p. 1, 29 mar. 2018. Instituto de Pesquisas Ambientais em Bacias Hidrograficas (IPABHi).

NASCIMENTO, Ronaldo Ferreira do et al. Adsorção: aspectos teóricos e aplicações ambientais. Fortaleza: Imprensa Universitária, 2014. 256 p.

NASCIMENTO, Ronaldo Ferreira do et al. Uso de bioadsorventes lignocelulósicos na remoção de poluentes de efluentes aquosos. Fortaleza: Impr. Universitária, 2014. 274 p.

OLIVEIRA, André Vinícius Bueno de et al. Physicochemical modifications of sugarcane and cassava agro-industrial wastes for applications as biosorbents. Bioresource Technology Reports, v. 7, n. 100294, set. 2019.

PICCIN, J. S.; DOTTO, G. L.; PINTO, L. A. A. Adsorption isotherms and thermochemical data of FD\&C red $\mathrm{n}^{\circ} 40$ binding by chitosan. Brazilian Journal of Chemical Engineering., p. 295-304. jun. 2011.

RAFATULLAH, Mohd. et al. Adsorption of methylene blue on low-cost adsorbents: a review. Journal of Hazardous Materials, $v$. 177, n. 1-3, p. 70-80, maio 2010. 


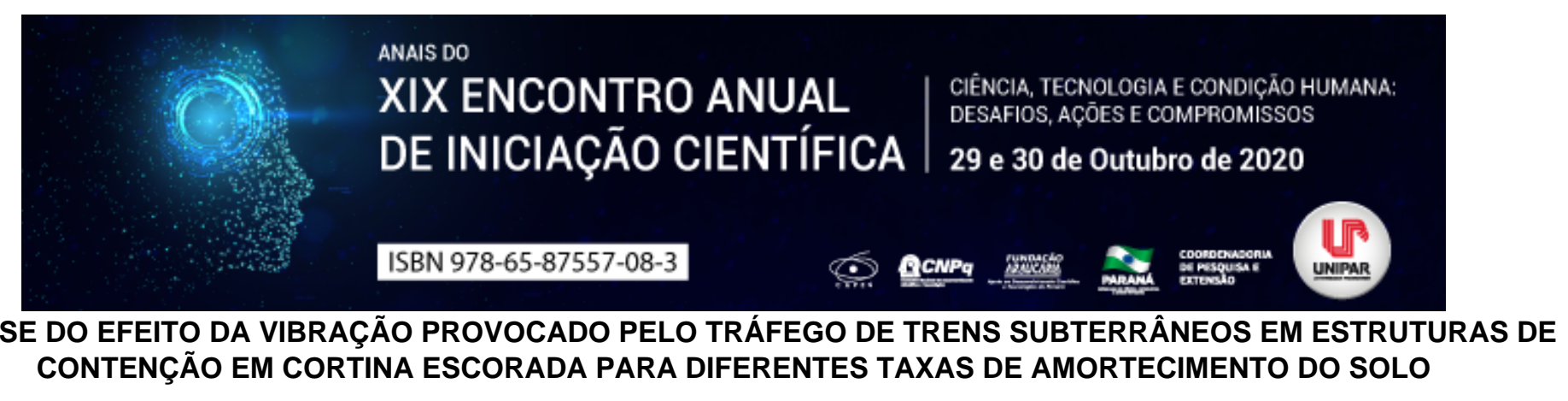

${ }^{1}$ ANDRE KAZUHIRO SHIOTANI, ${ }^{2}$ JESELAY HEMETÉRIO CORDEIRO DOS REIS

${ }^{1}$ Docente do Curso de Graduação em Engenharia Civil da UNIPAR
${ }^{1}$ Docente da Universidade Estadual de Maringá

Introdução: A necessidade de soluções de transportes em meios altamente urbanizados fez com que o subsolo fosse explorado para o escoamento de mercadorias e transporte de passageiros o que gerou interferências entre o sistema de transporte subterrâneo e as edificações circundantes. Uma das interferências que pode ocorrer está relacionado com a vibração gerada pelo tráfego de trens nos túneis que, além de gerar desconforto aos ocupantes do edifico, pode até mesmo ocasionar danos à edificação associados ao deslocamento induzido das estruturas(LOPES, 2015). Para as verificações dos deslocamentos de estruturas enterradas, Reis (2000) ressalta a importância da análise da interação solo-estrutura na resposta da estrutura às ações impostas à ela, uma vez que as reações da estruturas são dependentes das condições particulares do solo em que ela é apoiada. No entanto, a forma com que as vibrações interagem com a edificação não está esclarecida, devido à grande complexidade do fenômeno e às diversas variáveis envolvidas (FRANZA et al., 2017). Para o estudo destas interações entre os elementos do sistema estrutural, diversas abordagens podem ser utilizadas. $O$ uso de métodos numéricos em problemas de interação solo-estrutura tem sido amplamente empregados em diversas situações complexas com resultados muito bons quando comparados com as leituras de campo, como pode ser vistos nos trabalhos de Reis (2000), Medeiros (2005) e Oliveira (2012). Assim, a análise estrutural das edificações submetidas à esforços dinâmicos de vibração pode ser realizada utilizando modelos numéricos tornando-se de extrema importância para que as verificações de segurança possam ser atendidas.

Objetivo: Analisar parametricamente o efeito da vibração provocado pelo tráfego de trens subterrâneos em estruturas de contenção em cortina escorada para diferentes taxas de amortecimento do solo no programa PLAXIS 2D.

Material e Métodos: No trabalho buscou-se verificar os parâmetros que influenciam na resposta dinâmica de cortinas escoradas submetidas à esforços de vibração para de uma abordagem paramétrica baseado nos trabalhos de Godinho (2009), Medeiros (2005) e Silva \& Gomes (2016). Para isso, foi proposto uma seção genérica constituída por um túnel com relação profundidade/largura do túnel (H/D) variável e uma distância horizontal de $13 \mathrm{~m}$ da cortina de estacas com $9 \mathrm{~m}$ de desnível e $9 \mathrm{~m}$ de ficha, comprimento aterrado da cortina abaixo do desnível a ser vencido pela estrutura de contenção. O maciço de solos foi considerado um meio elástico linear e valores de referência foram adotados para os parâmetros geotécnicos. O modelo de MohrCoulomb foi adotado e o solo considerado é siltoso em toda a extensão do meio elástico. Utilizando o programa PLAXIS 2D, baseado no Método dos Elementos Finitos (MEF) avaliou-se a influência da taxa de amortecimento para dois cenários de relação $\mathrm{H} / \mathrm{D}$ diferentes. As relações H/D adotadas foram 0,60 e 0,90 e as taxas de amortecimento do solo foram $0 \%, 5 \%, 50 \%, 100 \%$ e $200 \%$. Foram extraídos das análises numéricas os deslocamentos, velocidades e acelerações do topo e base da cortina e de um ponto intermediário na laje de fundo da cortina. A carga dinâmica consistiu de um sinal harmônico com amplitude de 10,00, fase de onda $0^{\circ}$ e frequência de $10 \mathrm{~Hz}$, resultando em 5 ciclos de carregamento. Todas as análises levaram em consideração as etapas de construção do túnel, estrutura de contenção e uso da ferrovia, totalizando 15 fases construtivas.

Resultados: Através das análises numéricas observou-se que a taxa de amortecimento do solo é capaz de influenciar a resposta dinâmica da estrutura submetida aos efeitos da vibração do maciço. Para o modelo não amortecido, $\xi=0 \%$, verificou-se um aumento crescente do deslocamento induzido pela vibração mesmo após o encerramento da carga dinâmica, com deslocamento máximo de 44,025 mm. Verificou-se ainda que mesmo após o encerramento da carga dinâmica picos de aceleração foram obtidos e um comportamento muito anômalo. Ao inserir uma taxa de amortecimento ao sistema, $\xi=5 \%$ e $50 \%$, observou-se uma resposta mais branda do sistema em relação aos deslocamentos e acelerações obtidas. Foram obtidos os deslocamentos máximos de $31 \mathrm{~mm}$ e $30 \mathrm{~mm}$ no tipo da cortina para as taxas de amortecimento 5\% e 50\%, respectivamente. A partir de $\xi=$ $100 \%$, os ciclos de carregamento foram observados claramente nos gráficos deslocamento e aceleração da estrutura. Os deslocamentos obtidos para estas taxas são muito pequenas em relação ao deslocamento inicial da estrutura gerada pelas etapas construtivas.

Discussão: A validade da abordagem numérica utilizada para a verificação dos efeitos das etapas construtivas é verificada por Medeiros (2005), que compara os resultados obtidos nas análises numéricas com os valores obtidos nas instrumentações da obra estudada pelo autor. Os resultados obtidos para os pontos no topo e na base da cortina forma muito similares tanto para o deslocamento quanto para a aceleração. No entanto, na laje de fundo a resposta dinâmica se tornou mais regular apenas para taxas de amortecimento superiores a 100\%, para o deslocamento e aceleração. Por fim, verificou-se que a resposta dinâmica da cortina de estacas é influenciada diretamente pela taxa de amortecimento do maciço de solo. A análise paramétrica da resposta 
de estruturas de contenção utilizando programas baseados no MEF também é utilizada nos trabalhos de Godinho (2009), Medeiros (2005) e Silva \& Gomes (2016), onde os autores concluem que a abordagem permite a verificação dos parâmetros que mais influenciam na resposta estrutural e, consequentemente, uma calibração mais assertiva do modelo numérico.

Conclusão: De acordo com a abordagem utilizada, conclui-se que é possível analisar a influência da taxa de amortecimento na resposta dinâmica de estruturas de contenção em cortinas de estacas usando o programa PLAXIS 2D.

\section{Referências}

ASSOCIAÇÃO BRASILEIRA DE NORMAS TÉCNICAS. ABNT NBR 6118: Projetos de estruturas de concreto Procedimento. Rio de Janeiro, 2014.

FRANZA, Andrea; MARSHALL, Alec; HAJI, Twana; ABDELATIF, Amged; CARBONARI, Sandro; MORICI, Michele. A simplified elastic analysis of tunnel-piled structure interaction. Tunnelling and Underground Space Technology, v. 61, p. 104 121, jan. 2017.

GODINHO, Pedro Miguel Fernandes. MÉTOdOS DE DIMENSIONAMENTO DE CORTINAS DE CONTENÇÃO AUTOPORTANTES E MONO-APOIADAS: O PROBLEMA DAS CARGAS VERTICAIS. 2009. Dissertação (Mestrado em Engenharia Civil) - Faculdade de Ciências e Tecnologia da Universidade Nova de Lisboa, Lisboa, 2009.

LOPES, Carla Patrícia Filipe da Costa. Vibrações Induzidas Por Tráfego Ferroviário em Túneis. 2015. Tese (Doutorado em Engenharia Civil) - Universidade do Porto, Porto, 2015.

MEDEIROS, Alexandre Gil Batista. ANÁLISE NUMÉRICA DE ESTRUTURAS DE CONTENÇÃo EM BALANÇO E GRAMPEADAS DO TIPO ESTACA JUSTAPOSTA ASSENTES EM SOLO POROSO DO DF. 2005. Dissertação (Mesrado em Geotecnia) - Faculdade de Tecnologia da Universidade de Brasília, Brasília, 2005.

OLIVEIRA, Pedro Gustavo da Costa. Execução De Túneis Com Recurso Ao Método Cut and Cover. 2012. Dissertação (Mestrado em Engenharia Civil) - Instituto Superior de Engenharia de Lisboa, Lisboa, 2012.

REIS, Jeselay Hemetério Cordeiro. Interação Solo - Estrutura De Grupo De Edifícios Com Fundações. 2000. Dissertação (Mestrado em Geotecnia) - Escola de Engenharia de São Carlos da Universidade de São Paulo, São Carlos, 2000.

SILVA, Kamila Fernanda; GOMES, Romero César. Análise do Comportamento Tensão-Deformação de Cortinas Atirantadas. Anais do XVIII Congresso Brasileiro de Mecânica dos Solos e Engenharia Geotécnica. Anais...Belo Horizonte: 2016 


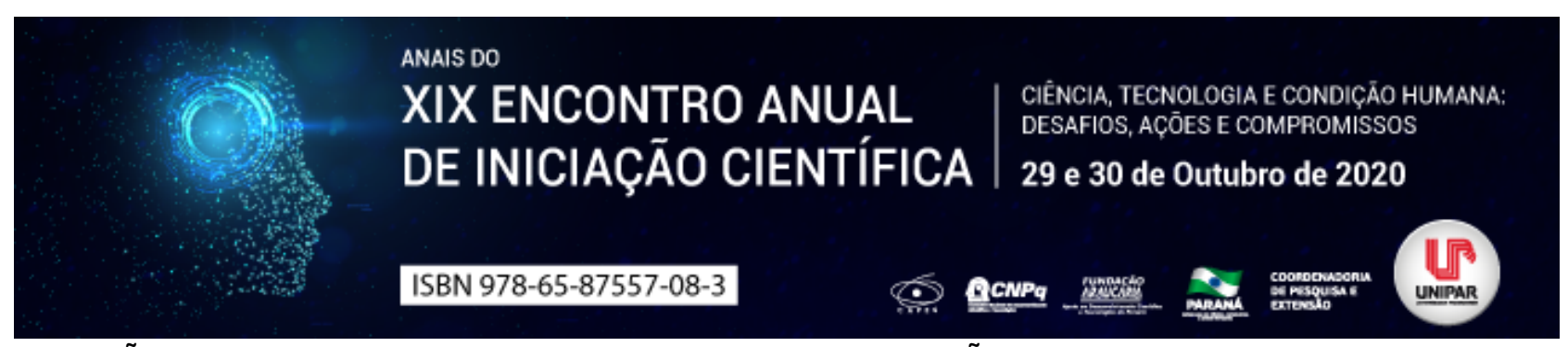

INVESTIGAÇÃO DO POTENCIAL ANTIOXIDANTE DAS FOLHAS, BOTÕES FLORAIS E CAULE DE Tetradenia riparia

\author{
${ }^{1}$ JULIANA APARECIDA MENDONCA, ${ }^{2}$ ZILDA CRISTIANI GAZIM
}

${ }^{1}$ Aluna do Programa externo de bolsas de Iniciação Científica PEBIC/PIBITI/CNPq/UNIPAR - Curso de Graduação em Ciências Biológicas da UNIPAR

${ }^{1}$ Docente da UNIPAR

Introdução: Tetradenia riparia Codd, pertencente à família Lamiaceae e apresenta forma arbustiva. As folhas são utilizadas na medicina popular para o tratamento de malária, angina, doença tropical de pele, gastroenterites, gonorreia, diarreia, abscessos dentários, dores de cabeça, bronquites, tosses, úlceras, esterilidade feminina, doenças renais, febres e outras (VAN PUYVELDE et al., 1986).

Objetivos: Investigar o potencial antioxidante do extrato bruto das folhas, botões florais e caule de Tetradenia riparia.

Metodologia: As folhas, botões florais e ramos de Tetradenia riparia foram coletadas no Horto Medicinal da Universidade Paranaense de Umuarama nas coordenadas S23 46.225' e WO 53 16.730' com altitude de $391 \mathrm{~m}$. O material vegetal foi seco à temperatura ambiente e o extrato bruto (EB) obtido pelo processo de maceração dinâmica com esgotamento de solvente. $\mathrm{O}$ filtrado foi concentrado sob pressão reduzida em evaporador rotativo (modelo Tecnal TE-211) à $40{ }^{\circ} \mathrm{C}$ até obtenção dos extratos brutos das folhas, botões florais e ramos. A atividade antioxidante foi realizada pelo método de sequestro de radicais livres 2,2 difenil-1-picrilhidrazil $\left(\mathrm{DPPH}^{\circ}\right.$ ) conforme protocolo descrito por Rufino et al. (2007). As concentrações utilizadas dos extratos neste ensaio foram 1,0; 0,75; 0,5 e 0,25 mg/mL. Uma alíquota de $0,1 \mathrm{~mL}$ das diferentes concentrações dos extratos brutos, foram adicionados em $3,9 \mathrm{~mL}$ de solução metanólica do radical livre $\mathrm{DPPH}^{\circ}$. Para o controle negativo foi utilizado $0,1 \mathrm{~mL}$ de metanol na solução de $\mathrm{DPPH}^{\circ}$. E como controle positivo, a quercetina. Todas as análises foram realizadas em triplicata; os resultados submetidos à análise de variância (ANOVA) e as diferenças entre as médias determinadas pelo teste de Tukey $(p \leq 0,05)$.

Resultados: Os resultados encontrados para o potencial antioxidante pelo método $\mathrm{DPPH}^{\circ}$ indicaram um efeito inibidor da oxidação com IC ${ }^{50}$ de $0,51 \mathrm{mg} / \mathrm{mL}$ (EB dos ramos); 0,91 mg/mL ( $E B$ dos botões florais) e 1,91 mg mL-1 (EB dos folhas).

Discussão: No extrato bruto dos ramos foram encontrados o maior potencial antioxidante, com uma concentração de $(0,51$ $\mathrm{mg} / \mathrm{mL}$ ) necessária para inibir $50 \%$ do radical 2,2 difenil-1-picrilhidrazil $\left(\mathrm{DPPH}^{\circ}\right)$. Ao analisar os resultados encontrados do potencial antioxidante dos extratos brutos das folhas, botões florais e ramos, utilizando o método de $\mathrm{DPPH}^{\circ}$, os resultados podem ser considerados intermediário, quando comparado com o padrão quercetina $I^{50}$ de $0,01 \mathrm{mg} / \mathrm{mL}$. Este resultado está em conformidade com o aspécto resinoso dos extratos brutos, conferindo a estes uma característica mais oleosa, e o método DPPH apresenta maior especificidade para compostos polares. Outro ponto a ser considerado é a busca por antioxidantes naturais, visto que os antioxidantes sintéticos podem apresentar carcinogenicidade e toxicidade (BARBOSA et al., 2010).

Conclusão: Os extratos brutos de Tetradenia riparia extraídos das folhas botões florais e ramos investigados apresentaram potencial intermediário de inibição da oxidação pelo método pelo sequestro de radicais livres 2,2 difenil-1-picrilhidrazil (DPPH ${ }^{\circ}$. O extrato bruto dos ramos foi o que apresentou maior potencial antioxidante, com IC $\mathrm{C}^{50}$ de $0,51 \mathrm{mg} / \mathrm{mL}$, levando a concluir que a Tetradenia riparia é uma espécie vegetal que pode ser incluída na lista de plantas com potencial antioxidante.

\title{
Referências
}

BARBOSA, K. B. F. et al. Estresse oxidativo: conceito, implicações e fatores modulatórios. Revista de Nutrição, v.23, p.629-643, 2010.

RUFINO, M. S. M. et al. Metodologia científica: determinação da atividade antioxidante total em frutas pela captura do radical livre DPPH. Fortaleza: Embrapa, 2007, 4 p.

VAN PUYVELDE,E, L., NYIRANKULIZA, S., PANEBIANCO, R., BOILY, Y., GEIZER, I., SEBIKALI, B., DE KIMPE, N., SCHAMP, N. Active principles of Tetradenia riparia.I. Antimicrobial activity of 8(14),15-sandaracopamaradiene-7a,18-diol. Journal of Ethnopharmacology. v.17, p.269- 275, 1986. 


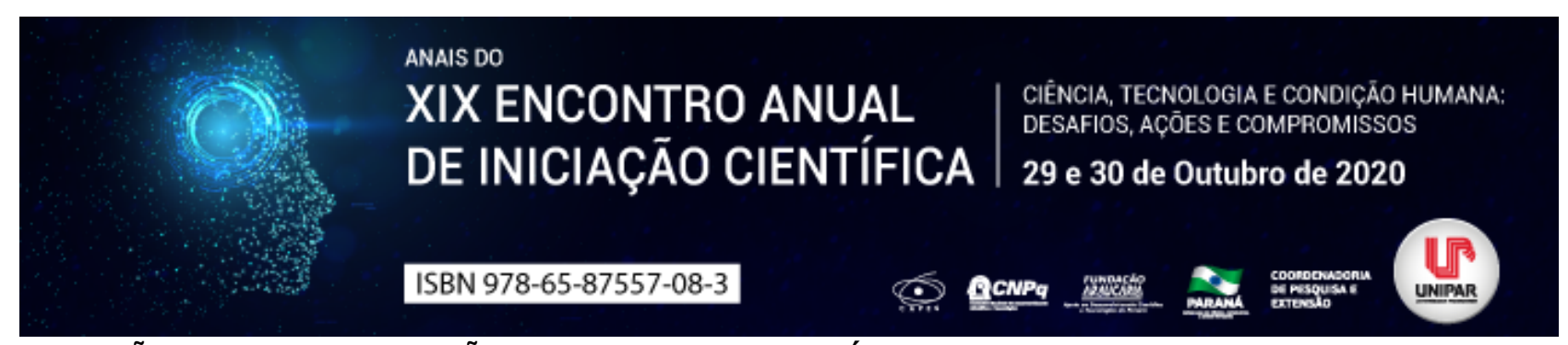

\title{
QUANTIFICAÇÃO E CARACTERIZAÇÃO DE COMPOSTOS FENÓLICOS DE EXTRATO AQUOSO DE Crambe abyssinica POR RMN E HPLC
}

\author{
${ }^{1}$ Lais Fernanda Fontana, ${ }^{2}$ MARIA HELENA SARRAGIOTTO, ${ }^{3}$ GUILHERME TARINI, ${ }^{4}$ BEATRIZ CERVEJEIRA BOLANHO, \\ ${ }^{5}$ BEATRIZ PEREIRA MORENO, ${ }^{6}$ CLÁUDIA REGINA DIAS-ARIEIRA
}

\author{
${ }^{1}$ Universidade Estadual de Maringá \\ ${ }^{1}$ Universidade Estadual de Maringá \\ 2Universidade Estadual de Maringá \\ ${ }^{3}$ Universidade Estadual de Maringá \\ 4Universidade Estadual de Maringá \\ ${ }^{5}$ Docente na Universidade Estadual de Maringá
}

Introdução: O crambe (Crambe abyssinica Hochst) é uma oleaginosa cuja torta é caracterizada por conter teores de glucosinolato, que podem atingir até $50 \mathrm{mg} \mathrm{g}^{-1}$ de torta. Os glucosinolatos constituem uma classe homogênea de tiossacarídeos naturais, que podem ser encontrados nas plantas da família Brassicaceae (Oka, 2010), que no solo, quando hidrolisado pela enzima mirosinase, produz D-glucose e outros compostos, especialmente isotiocianatos e nitrilas, dependendo das condições em que ocorre a hidrólise da molécula (Wu et al., 2011). Assim, o uso de extratos obtidos pela diluição do material em água, pode resultar na otimização do uso, além de possibilitar a extração de substâncias para, se possível, sintetizá-las, visando a produção de nematicidas naturais.

Objetivo: Realizar a quantificação e a caracterização de compostos fenólicos do extrato aquoso de crambe por Ressonância magnética nuclear (RMN) e cromatografia líquida de alta eficiência (HPLC).

Material e Métodos: O preparo da solução consistiu em adicionar a torta de crambe em erlenmeyers contendo água destilada em temperatura a $25^{\circ} \mathrm{C}$, na proporção $1: 10$ (m:v) e posteriormente colocado em mesa agitadora a $65 \mathrm{rpm}$ por 10 horas, seguida de 14 horas em repouso. Posteriormente, o material foi filtrado em gaze esterilizada e utilizado para análises. Para análise cromatográfica, o extrato bruto aquoso obtido em temperatura ambiente foi filtrado em membrana de $0,22 \mathrm{~mm}$ e submetido à metodologia proposta por Herzallah and Holley (2012), por meio de cromatografia líquida de alta eficiência (HPLC, LC 20A, Prominence, Shimadzu) Acoplado com um detector UV (SPD-20A, Shimadzu), e coluna de ${ }^{18} \mathrm{C}$ (Shim-pack CLC-ODS (H) , 25 $\mathrm{cm} \times 4,6 \mathrm{~mm} \times 5 \mathrm{~mm}$, Shimadzu) os quais doram mantidos em $25^{\circ} \mathrm{C}$ (CTO-20A, Shimadzu). O volume de injeção foi de $20 \mu \mathrm{L}$ (SIL-10A, Shimadzu). Foi usado acetonitrila (Sigma-Aldrich) e água ultrapura na proporção 60:40 como fase móvel, no modo isocrático, na vazão de $1,0 \mathrm{~mL} \mathrm{~min}^{-1}$, para determinar a presença de isotiocianato de alila (Sigma Aldrich), a $244 \mathrm{~nm}$. Para determinar os compostos fenólicos, o mesmo sistema de HPLC foi empregado, mas usando 280 e $320 \mathrm{~nm}$ no detector de UV. No entanto, um gradiente de eluição foi usado: $80 \%$ de água ultrapura com $0,05 \%$ (v: v) de ácido fórmico (Sigma-Aldrich) (eluente A) e 20\% de metanol (Sigma-Aldrich) 0,1\% (v: v) de ácido fórmico (eluente B) por 15 min, seguido pelo aumento na proporção do eluente B para $90 \%$ até 40 min. Soluções de ácido gálico, ácido hidroxibenzóico, ácido síngico, ácido cumárico, ácido ferrúlico, ácido transcinâmico e ácido clorogênico (todos da Sigma-Aldrich) foram usadas para traçar as curvas padrão (0,01 - 0,11 mg $\mathrm{mL}^{-1}$ ), com $\mathrm{R}^{2} \geq 0.99$. No intuito de determinar outras substâncias presentes no extrato, procedeu-se análise por ressonância magnética nuclear (RMN), para a qual, $4 \mathrm{~g}$ da fração aquosa da torta de crambe foi submetida a extração, por três vezes, em 50 $\mathrm{mL}$ de $\mathrm{H}_{2} \mathrm{O} \mathrm{MeOH}^{-1} 50 \%$ destilada. Posteriormente, fez-se a remoção do solvente, com o auxílio do concentrador de amostras Rocket Synergy (Genevac), à temperatura de $35^{\circ} \mathrm{C}$ sob vácuo, e obteve-se $1 \mathrm{~g}$ de extrato. Deste, $30 \mathrm{mg}$ foram solubilizados em água deuterada ou clorofórmio deuterado para serem analisados por RMN de ${ }^{1} \mathrm{H}$ e de ${ }^{13} \mathrm{C}$. Os espectros de $\mathrm{RMN}$ de ${ }^{1} \mathrm{H}$ e ${ }^{13} \mathrm{C}$ foram obtidos em espectrômetros de Ressonância Magnética Nuclear da marca Bruker, modelo AVANCE III HD, um de 7,1 Tesla, operando a uma frequência de $300,06 \mathrm{MHz}$ para ${ }^{1} \mathrm{H}$ e $75,46 \mathrm{MHz}$ para ${ }^{13} \mathrm{C}$.

Resultados: Assim, avaliou-se a presença de ácidos fenólicos no extrato bruto de crambe, sendo detectado os seguintes

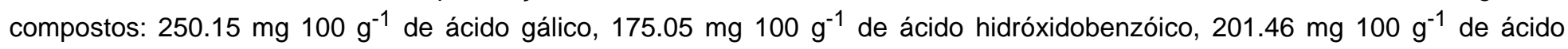

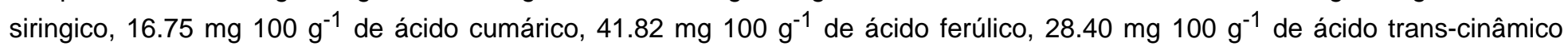
$129.81 \mathrm{mg} 100 \mathrm{~g}^{-1}$ de ácido clorigênico. Pela análise de RMN de ${ }^{1} \mathrm{H}$ e ${ }^{13} \mathrm{C}$ em água deuterada, observou-se que o extrato aquoso de $C$. abyssinica exibiu sinais característicos de uma mistura de açúcares e glicosinolato. Os constituintes dessa mistura foram caracterizados como sendo o dissacarídeo sacarose e o glicosinolato epi-progoitrina, sendo que os dados espectroscópicos 
obtidos foram comparados com a literatura para cada substância (Wishart et al., 2018). Essa mistura de substâncias exibe a proporção de $56,73 \%$ de sacarose e $43,27 \%$ de epi-progoitrina. Além disso, o extrato foi analisado por RMN em clorofórmio deuterado, pois apresentava uma parte insolúvel em água e, pela análise de $\mathrm{RMN}$ de ${ }^{1} \mathrm{H}$ e ${ }^{13} \mathrm{C}$ em clorofórmio deuterado, observou-se sinais característicos de ácidos graxos insaturados.

Discussão: As plantas da família Brassicaceae são conhecidas por apresentar a liberação de glicosinolatos em sua decomposição, estes são disponibilizados ao solo e, ao reagirem com a enzima mirosinase, formam compostos bioativos, como nitrilos e epinitrilas (Mayton et al., 1996) e, principalmente, isotiocianatos (Wu et al., 2011). Coltro-Roncato et al. (2016) relataram que apenas extratos hidroalcóolicos ou metanólicos apresentaram alil isotiocianatos em sua composição. Dentre estes, pode-se destacar os compostos fenólicos, presentes em concentração elevada no extrato estudado.

Conclusão: A utilização da água como solvente na extração dos compostos fenólicos de crambe, foi eficiente, sendo possível realizar o preparo de soluções aquosas para a extração destes compostos.

\section{Referências}

COLTRO-RONCATO, Sendoi; STANGARLIN, Jound Roiul; KUHN, Oothe Juoil; GONÇALVES, Elfien Duiof Voiel. Nematicidal effect of Crambe abyssinica leaf extracts to Meloidogyne javanica on tomato. Afr. J. Agric. Res. 11, 3004-3011, 2016.

HERZALLAH, Saquer; HOLLEY, Richard. Determination of sinigrin, sinalbin, allyl-and benzyl isothiocyanates by RP-HPLC in mustard powder extracts. LWT Food Sci. Technol. 47, 293-299, 2012.

LI, Zinfheng; LE, Hui Wen; LIANG, Xu; LIANG, Dong. Profiling of phenolic compounds and antioxidantactivity of 12 cruciferous vegetables. Molecules, 23, 1139. Disponível em: doi:10.3390/molecules23051139.

MAYTON, Houldin South; OLIVEIRA, Caroline; VAUGHN, Sinftoi Fuirpa; LORIA, Roeald. Correlation of fungicidal activity of Brassica species with allyl isothiocyanate production in macerated leaf tissue. Phytopathology 86, 267-271, 1996.

NGUYEN, Dang; SEO, Dong Jun; KIM, Kil Young. Nematicidal activity of 3,4-dihydroxybenzoic acid purified from Terminalia nigrovenulosa bark against Meloidogyne incognita. Microb. Pathog. 59, 60:52-59, Disponível em: doi: 10.1016/j.micpath.2013.04.005.

Oka, Yang. Mechanisms of nematode suppression by organics oil amendments-A review. Appl. Soil Ecol. 44, 101-115, 2010.

PRETTO, Alexandra; SILVA, Leila Picolli; GIACOMINI, Sandro José, MARTINELLI, Suziani Guedini. Nutrientes, antinutrientes e detoxificação do farelo de crambe para uso na nutrição animal. Semina 35, 3345-3354, 2014.

WISHART, David; FEUNANG, Yannick; MARCU, Ana; GUO, An Chin; LIANG Kevin; VAZQUEZ FRESNO, Rosa; SAJED, Tanvir. HMDB 4.0 - The Human Metabolome Database for 2018. Nucleic. Acids Res. 4, 608-617, 2018.

WU, Hua, WANG, Chao-Jun., BIAN, Xiao-Way. Nematicidal efficacy of isothiocynates against root knot nematode Meloidogyne javanica in cucumber. Crop Prot. 30, 33-37, JAN, 2011.

Coordenadoria de Pesquisa e Extensão - COPEX

Departamento de Editoraçāo e Divulgaçāo Científica - DEDIC 


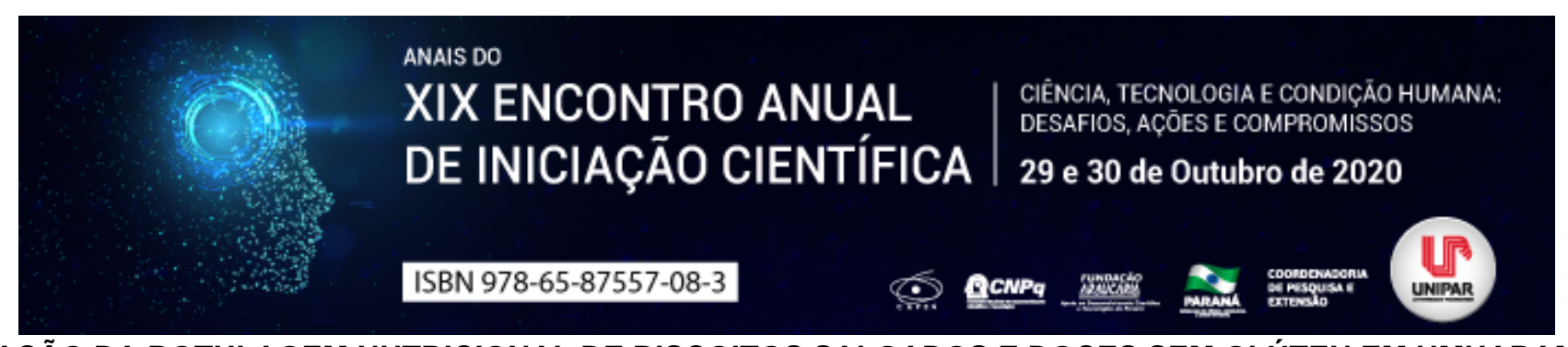

AVALIAÇÃO DA ROTULAGEM NUTRICIONAL DE BISCOITOS SALGADOS E DOCES SEM GLÚTEN EM UMUARAMA - PR

\author{
${ }^{1}$ Jean Lopes Da Silva, ${ }^{2}$ YARA GENTILE RIBEIRO, ${ }^{3}$ LUCAS CORREIA SILVA, ${ }^{4}$ JULIANA SCANAVACCA, ${ }^{5}$ LARINE KUPSKI, \\ 6 JULIANA BUENO RUIZ
}

${ }^{1}$ Discente do curso de Tecnologia de Alimentos pela Universidade Estadual de Maringá

${ }^{1}$ Discente do curso de Engenharia de Alimentos pela Universidade Estadual de Maringá

${ }^{2}$ Discente do curso de Tecnologia Alimentos pela Universidade Estadual de Maringá

${ }^{3}$ Docente do Departamento de Tecnologia, Universidade Estadual de Maringá UEM, Campus Umuarama

${ }^{4}$ Docente do Departamento de Tecnologia, Universidade Estadual de Maringá UEM, Campus Umuarama

${ }^{5}$ Docente do Departamento de Tecnologia, Universidade Estadual de Maringá UEM, Campus Umuarama

Introdução: O glúten é uma proteína responsável por uma enteropatia denominada doença celíaca (CD), sendo considerado um problema de saúde pública por diversos autores. Essa proteína pode ser encontrada em alimentos que contém cevada, centeio, trigo, malte. Segundo Biesiekiersk (2016) ainda falta no Brasil uma definição concreta sobre o termo sem glúten . Alguns países usam a quantidade inferior 20 ppm determinada pelo Codex Alimentarius nas embalagens de alimentos sem glúten, porém no Brasil a única exigência para as embalagens é estar escrito a expressão contém glúten ou não contém glúten , assim como a expressão de contaminação cruzada pode conter (ANVISA, 2003). A falta de informação nutricional correta e a enorme busca de informações nutricionais confiáveis geram a necessidade de legislações vigentes que regulamentem o setor alimentício no âmbito da qualidade (MALLET et al., 2017). Segundo Lemes (2009) e Mallet et al (2017) para alcançar uma dieta saudável é necessário uma quantidade mínima de informações sobre os alimentos, assim mostrando a real importância de uma tabela nutricional completa para portadores da doença celíaca.

Objetivo: O presente trabalho teve objetivo de avaliar os rótulos e informações de produtos de biscoitos doces e salgados, declarados sem glúten, analisando se estão adequados conforme a legislação visando identificar a disponibilidade desses alimentos nos supermercados do município de Umuarama, PR.

Materiais e métodos: Foi realizado um levantamento nos supermercados, analisando as informações nutricionais das embalagens de biscoitos salgados e doces, para criar um plano de amostragem de forma a conseguir uma amostra representativa destes produtos. Na sequência foram escolhidas 6 variáveis (preço, legibilidade do texto, declaração de alérgicos, quantidade máxima de glúten, RDC359/Porção, Indicação de destaque para alérgicos) dentro das legislações RDC ( ${ }^{\circ}$ 26, $n^{\circ} 137$, n³59) para usar como parâmetro nas análises de adequação.

Resultado: O total de amostras doces e salgadas encontradas foram de 28 em 7 supermercados o que acarreta uma média de 4 por supermercado. Nos resultados do parâmetro de preço foi calculada uma média aritmética que levou ao resultado de $\mathrm{R} \$$ 9,77. Para a legibilidade do texto (RDC 26/2015) 100\% dos alimentos encontrados estavam cumprindo essa legislação. Quanto a declaração de alérgicos, $89,3 \%$ dos biscoitos encontrados estavam cumprindo essa RDC, enquanto 10,7\% não estavam. Durante a avaliação da quantidade máxima de 20 ppm de glúten no alimento exigido pelo Codex, foi verificado que $100 \%$ dos alimentos apresentaram a ausência dessa informação. Ao avaliar o atendimento à RDC 359 que determina a quantidade da porção foi identificado que 77,7 \% dos biscoitos estavam cumprindo a legislação que exige $30 \mathrm{~g}$ na porção, enquanto 33,3\% não estavam cumprindo essa quantidade. Todos os alimentos apresentaram indicação de destaque para alérgicos.

Discussão: Os resultados de legibilidade e destaque seguem a legislação corretamente, já os resultados de porção e declaração de alergênicos apresentaram valores nas embalagens que não cumpre o estabelecido na RDC 26 (ANVISA 2015 ) e RDC 359 (ANVISA, 2003). Essas irregularidades não deveriam acontecer, pois esses parâmetros são importantes para o consumidor ter a certeza de que não existe contaminação cruzada de glúten no alimento e a porção serve para saber a média diária recomendada. Quanto a disponibilidade nos mercados o resultado obtido mostra a real falta de opções de alimentos no supermercado. Nogueira et al. (2020) encontrou resultados parecidos com a falta de cumprimento da legislação em suas embalagens de biscoitos e ainda verificou que os preços biscoitos sem glúten quando comparados com os com glúten, são mais elevados por causa das adaptações à falta da farinha de trigo e custo de produção dentro das indústrias.

Conclusão: A maioria dos biscoitos avaliados seguem as variáveis determinadas, e cumprem com os requisitos da legislação. 0 que mais se destaca é a ausência da quantidade de glúten nos alimentos sendo que nenhum apresentou em sua tabela nutricional e a falta de uma grande quantidade de alimentos sem glúten, o que influência na diversidade de alimentos consumidos, criando uma dieta repetitiva.

\title{
Referências
}


AGÊNCIA NACIONAL DE VIGILÂNCIA SANITÁRIA. Resolução RDCANVISA/MS n 137, de 29 de maio de 2003 , regras para a rotulagem de medicamentos que dispõe sobre frases de advertência de bulas e embalagens, Ministério da Saúde - MS. Agência Nacional de Vigilância Sanitária.

AGÊNCIA NACIONAL DE VIGILÂNCIA SANITÁRIA. Resolução RDCANVISA/MS n 26, de 02 de julho de 2015. Rotulagem de Alimentos Alergênicos. Ministério da Saúde - MS. Agência Nacional de Vigilância Sanitária.

BIESIEKIERSKI, J.R. What is gluten?, Journal of Gastroenterology and Hepatology, Leuven, v32, p.78-81, 2017.

BRASIL. Resolução RDC n.359, de 23 de dezembro de 2003. A Diretoria Colegiada da ANVISA/MS aprova o regulamento técnico de porções de alimentos embalados para fins de rotulagem nutricional. Diário Oficial da União. 200326 dez; (251):28; Seção 1

CODEX ALIMENTARIUS Commission. CODEX STAN 118 1979: codex standard for foods for special dietary use for persons intolerant to gluten. Roma; Rinevised 2008.

LEMES, E.O; LUCENA, A.F; MOREIRA, K.M; GEREMIAS, L.S; ALVES, N.A. Pesquisa sobre a Intolerância, Diagnóstico e Alternativas para os Pacientes com Intolerância ao Glúten, Ensaios e Cienc., v. 22, n. 2, p. 40-46, 2018.

MALLET, Aline Cristina Teixeira et al. Adequação das rotulagens alimentícias frente à legislação vigente. Cadernos UniFOA, v. 12, n. 35, p. 101-110, 2017.

NOGUEIRA, M.E.M; GUIMARÃES, N.S; ARAUJO, R.R.S; SOARES, A.D.N. Biscoitos sem glúten versus com glúten: composição nutricional, ingredientes e custo. Revista Higiene Alimentar, p 85-95, 2020.

Coordenadoria de Pesquisa e Extensão - COPEX

Departamento de Editoraçāo e Divulgaçāo Científica - DEDIC 


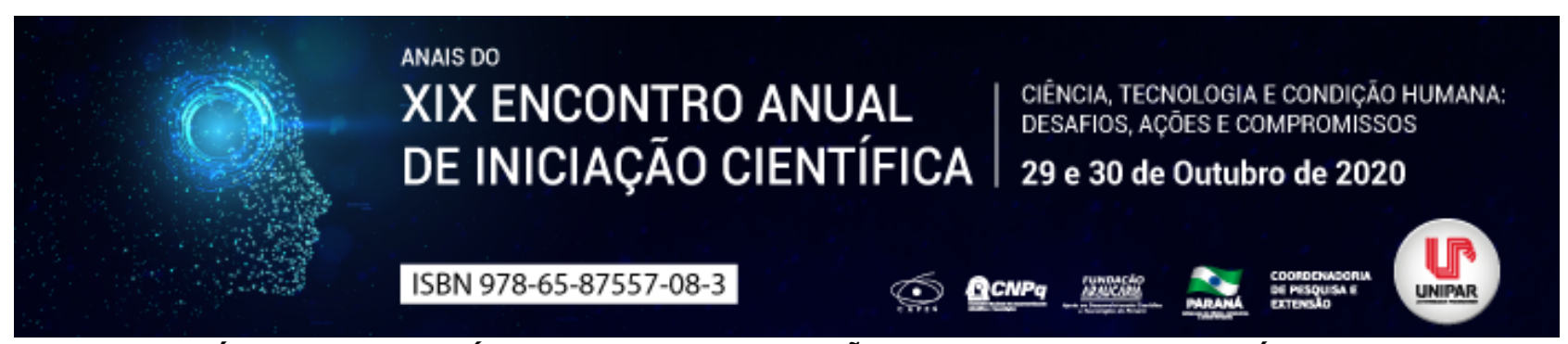

MÉTODOS FITOQUÍMICOS DE IDENTIFICAÇÃO DOS COMPOSTOS FENÓLICOS

\title{
${ }^{1}$ ISABELLE LUIZ RAHAL, ${ }^{2}$ JESSICA DA SILVA SENNA, ${ }^{3}$ WANESSA DE CAMPOS BORTOLUCCI, ${ }^{4}$ HERIKA LINE MARKO DE OLIVEIRA, ${ }^{5}$ MAX EMERSON RICKLI, ${ }^{6}$ ZILDA CRISTIANI GAZIM
}

\begin{abstract}
${ }^{1}$ Mestranda do Programa de Pós-graduação em Biotecnologia Aplicada à Agricultura, Unipar, Umuarama PR
${ }_{1}$ Mestranda do Programa de Pós-graduação em Biotecnologia Aplicada à Agricultura, Unipar, Umuarama PR

${ }^{2}$ Doutora do Programa de Pós-graduação em Biotecnologia Aplicada à Agricultura, Unipar, Umuarama PR.

${ }^{3}$ Doutorando do Programa de Pós-graduação em Biotecnologia Aplicada à Agricultura, Unipar, Umuarama PR.

${ }^{4}$ Doutorando do Programa de Pós-graduação em Biotecnologia Aplicada à Agricultura, Unipar, Umuarama PR

${ }^{5}$ Docente do Programa de Pós-graduação em Biotecnologia Aplicada à Agricultura, Unipar, Umuarama PR
\end{abstract}

Introdução: Os compostos fenólicos possuem uma estrutura simples composta de anéis aromáticos e hidroxilas (ANGELO; JORGE, 2007). Os compostos fenólicos são divididos em flavonoides e não flavonoides, no grupo dos flavonoides estão as antocianinas, antoxantinas e no grupo dos não flavonóides estão os ácidos fenólicos (DEGÁSPARI, 2004). Estes grupos são importantes, pois agem como antioxidantes, ou seja, tem a capacidade de doar hidrogênio ou elétrons combatendo os radicais livres (SILVA et al., 2010).

Objetivo: Realizar uma revisão de literatura sobre a identificação dos compostos fenólicos

Desenvolvimento: Os compostos fenólicos são produzidos pelas plantas para protegê-las de insetos, injúrias, animais, fatores ambientais e bióticos, além disso atraem os polinizadores (VIZZOTTO; KROLOW; WEBER, 2010). Os flavonoides possuem capacidade antioxidante, atividade antiinflamatória, antialérgica, antitumoral, efeito vasodilatador, antiulcerogênica; atuação antiplaquetária (LOPES et al., 2010). Dentro desta classe encontram-se as antocianinas que possuem potencial antioxidante, mecanismo de defesa, função biológica e por serem coloridas realizam papel essencial na dispersão de sementes e polinização (LOPES, et al., 2007). Pertencentes aos flavonóides encontram-se as antoxantinas que podem ser encontradas na forma livre ou de glicosídeos associados a açúcares e taninos, e são considerados pigmentos que são encontrados apenas em vegetais e são derivados do núcleo flavonóide (RIBEIRO; SERAVELLI, 2007). Os não flavonóides são os ácidos fenólicos e encontram-se divididos em dois grupos: os derivados do ácido benzóico (ácidos gálico, siríngico, vanílico, protocatequínico, gentísico, phidroxibenzóico) e os derivados do ácido cinâmico (ácido cafeico, ferulico, sináptico e orto, meta e para-cumárico) com alto potencial antioxidante (SOARES, 2002) . A forma como os flavonóides são identificados nas plantas, baseia-se em ensaios fitoquímicos preliminares, onde são realizados a partir de de um decocto $(1,0 \mathrm{~g}) \mathrm{com}$ a parte da planta a ser pesquisada, utilizando álcool a 70\% como solvente. A presença dos flavonóides é realizada a partir de reações específicas como a reação Shinoda, indicando a presença destes compostos quando houver o aparecimento de uma coloração rosa ou vermelha. $O$ segundo método de identificação é através da reação de Taubok, colocando $3 \mathrm{ml}$ do decocto em uma cápsula de porcelana e submetendo a secura; e sobre este adiciona-se cristais de ácido bórico e ácido oxálico, sendo dissolvidos $3 \mathrm{ml}$ em éter etílico. A presença de flavonóides nas amostras é confirmada pela fluorescência sob a luz ultravioleta. Uma terceira reação de confirmação da presença de flavonóides nas amostras é através da reação de Pew, adicionado $3 \mathrm{ml}$ do decocto em uma cápsula de porcelana levado ao banho-maria até secura, e sobre este adicionado $3 \mathrm{ml}$ de metanol e transferido o conteúdo da cápsula para um tubo de ensaio, sendo adicionado zinco metálico e 3 gotas de HCL concentrado (COSTA, 2002). Utiliza-se também as análises cromatográficas (cromatografia em camada delgada) para a confirmação da presença dos flavonóides. Para esta análise,o fármaco em pó $(1 \mathrm{~g})$ é extraído com $10 \mathrm{ml}$ de metanol por $5 \mathrm{~min}$ em banho-maria a $60^{\circ} \mathrm{C}$ e depois filtrado; 20-30 $\mu \mathrm{L}$ é utilizado para cromatografia (teor de flavonóides 0,5\% -1,5\%). Este método rápido extrai flavonóides lipofílicos e hidrofílicos. As fases móveis utilizadas são específicas para cada classe de flavonóides, sendo necessário consultar a literatura especializada (WAGNER; BLADT, 1996).

Conclusão: Pode-se concluir que a busca por flavonóides em plantas é de grande interesse científico, pois identificando estes compostos há uma grande possibilidade de ser aplicado na indústria como antioxidante, tendo assim a substituição de antioxidantes sintéticos que são muito utilizados em alimentos mesmo sendo tóxicos.

\section{Referências}

ANGELO, Priscila Milene; JORGE, Neuza. Phenolic compounds in foods-A brief review. Revista do Instituto Adolfo Lutz (Impresso), v. 66, n. 1, p. 01-09, 2007.

COSTA, Aloisio. Farmacognosia. 5 ed. Fundação Calouste Gulbenkian: São Paulo.2002

DEGÁSPARI, Cláudia Helena; WASZCZYNSKYJ, Nina. Propriedades antioxidantes de compostos fenólicos. Visão acadêmica, 
V. 5, n. 1, 2004.

LOPES, Renato Matos et al. Flavonóides. Biotecnologia Ciência\& Desenvolvimento, v. 3, n. 14, p. 18-22, 2010.

LOPES, Toni et al. Antocianinas: uma breve revisão das características estruturais e da estabilidade. Current Agricultural

Science and Technology, v. 13, n. 3, 2007.

RIBEIRO, Eliana Paula; SERAVALLI, Elisena. Química de alimentos. Editora Blucher, 2007.

SILVA, Marília Lordêlo Cardoso et al. Compostos fenólicos, carotenóides e atividade antioxidante em produtos vegetais. Semina:

Ciências Agrárias, v. 31, n. 3, p. 669-681, 2010.

SOARES, Sergio Eduardo. Ácidos fenólicos como antioxidantes. Revista de nutrição, v. 15, n. 1, p. 71-81, 2002.

VIZZOTTO, Márcia; KROLOW, A. C. R.; WEBER, Gisele Eva Bruch. Metabólitos secundários encontrados em plantas e sua importância. Embrapa Clima Temperado-Documentos (INFOTECA-E), 2010.

WAGNER, Hildebert; BLADT, Sabine. Plant drug analysis: a thin layer chromatography atlas. Springer Science \& Business Media, 1996.

Coordenadoria de Pesquisa e Extensão - COPEX

Departamento de Editoraçāo e Divulgaçāo Científica - DEDIC 


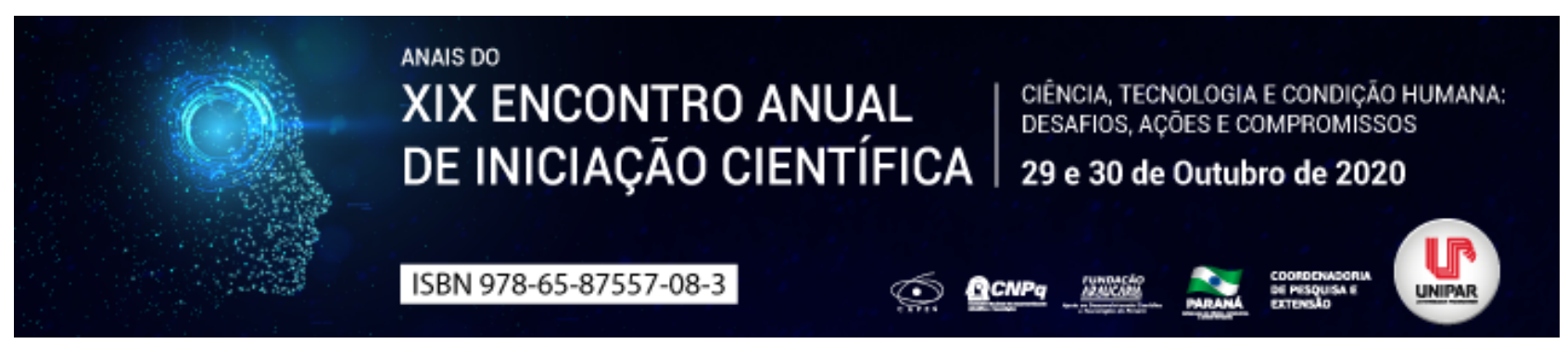

ESTUDO DO POTENCIAL ANTIOXIDANTE DO EXTRATO BRUTO DE Achillea millefolium

\author{
${ }^{1}$ BRUNA DE PAULA BELINI, ${ }^{2}$ ZILDA CRISTIANI GAZIM
}

${ }^{1}$ Discente PEBIC/ PIBITI/ CNPq da UNIPAR

${ }^{1}$ Docente da UNIPAR

Introdução: As reações de oxidação estão entre as mais frequentes em alimentos, sendo uma das principais causas de sua deterioração. A oxidação pode ser inibida de diferentes maneiras, incluindo a prevenção do acesso de oxigênio ou redução de sua pressão, uso de baixas temperaturas, inativação de enzimas que catalisam a reação de oxidação e utilização de embalagens adequadas. Outra forma de proteção é o uso de antioxidantes, aditivos específicos capazes de inibir a oxidação (RAMALHO; JORGE, 2006). Além disso, existe também uma tendência de substituir os antioxidantes sintéticos pelos naturais, uma vez que o uso dos primeiros têm sido restringidos em diversos países por seus possíveis riscos à saúde do consumidor (SILVA et al., 2010). Neste contexto, a planta Achillea millefolium (Pollard) D.D. Keck, pertencente da família Asteraceae, originária da Europa e muito bem aclimatada no Brasil (LORENZI; MATOS, 2002) pode ser uma opção como fonte de moléculas antioxidantes naturais. As atividades fitoterápicas desta planta medicinal são conhecidas mundialmente, principalmente, por seu extrato alcoólico e óleo essencial (CANDAN et al., 2003). Além disso, é popularmente conhecida por atuar no tratamento de infecções, febre, cicatrizes, inchaços, entre outros (LOPES et al., 2003; LOPES et al., 2005).

Objetivo: O objetivo desta pesquisa visa avaliar as atividades antioxidantes do extrato bruto das folhas da espécie Achillea millefolium.

Material e Métodos: As folhas de Achillea millefolium foram coletadas no período da manhã, secas em esteira à temperatura ambiente, pulverizadas e determinada a granulometria. O pó obtido foi submetido ao processo de maceração dinâmica com renovação do solvente utilizando álcool etílico $96 \%$ (v/v) até o esgotamento do material vegetal. Em seguida, o filtrado foi concentrado sob pressão reduzida em evaporador rotatório até obtenção do extrato bruto (EB). Os constituintes químicos do extrato bruto de Achillea millefolium foram analisados por cromatografia gasosa acoplada à espectrometria de massas. A capacidade antioxidante do extrato bruto das folhas foi avaliada pelo método de redução do ferro (FRAP) nas concentrações de 1,$0 ; 0,75 ; 0,5$ e $0,25 \mathrm{mg} \mathrm{mL}-1$. Os compostos foram identificados pela comparação de seus espectros de massas com a biblioteca NIST 11.0, bem como pela comparação dos índices de retenção (IR) obtidos pela série homóloga de padrões nalcanos (C 7 C 28) (ADAMS, 2017). Todas as análises foram realizadas em triplicatas. E os resultados submetidos à análise de variância (ANOVA), as diferenças entre as médias foram determinadas pelo teste de Tukey $(P \leq 0,05)$.

Resultados: Dois compostos se destacaram como majoritários: ácido ursólico metil éster (70,96\%) e Lupeol (15,65\%). Quanto ao potencial antioxidante, o extrato bruto de A. millefolium mostrou potencial pelo método FRAP com 1,35 $\mu \mathrm{M} \mathrm{Fe2+/mg} \mathrm{de} \mathrm{amostra.}$

Discussão: A atividade antioxidante pelo método FRAP evidencia que no extrato bruto os compostos responsáveis por esta atividade possam ter característica hidrofílica, visto que o método FRAP apresenta maior especificidade para detectar compostos mais solúveis polares.

Conclusão: No extrato bruto de A. millefolium foram identificados o ácido ursólico metil éster e o lupeol. O extrato mostrou potencial antioxidante pelo método FRAP com 1,35 $\mu \mathrm{M}$ Fe 2+/mg de amostra. Estes resultados abrem novas perspectivas para continuar as investigações com esta espécie.

\title{
Referências
}

ADAMS RP. Identification of essential oil components by gas chromatography/mass spectrometry, 41nd ed. Allured, Carol Stream; 2017. 804p.

CANDAN, F. et al. Antioxidant and antimicrobial activity of the essential oil and methanol extracts of Achillea Millefolium subsp. Millefolium Afan. (Asteraceae). Journal of Ethnopharmacology, Pretoria, v. 87, p.215-20, 2003.

LOPES, F. C. M. et al. Avaliação da atividade imunológica de Achillea amillefolium L. ( milfolhas ). Revista Brasileira de Farmacognosia, Maringá, v. 13 supl 2, p.11-13, 2003.

LOPES, F. C. M. et al. Effect of the essential oil of Achillea millefolium L. in the production of hydrogen peroxide and tumor necrosis 10 ompo- $\alpha$ in murine macrophages. Revista Brasileira de Ciências Farmacêuticas, São Paulo, v. 41, n. 3, p. 401-405, 2005.

LORENZI, H. E.; MATOS, F. J. A. Plantas medicinais no Brasil/ Nativas e exóticas. Nova Odessa: Instituto Plantarum. 2002. $129 \mathrm{p}$.

RAMALHO,V. C.; JORGE, N. Antioxidantes utilizados em óleos, gorduras e alimentos gordurosos. Química Nova, v. 29, n. 4, 755-760, 2006. 
SILVA, M. L.C. et al. Phenolic compounds, carotenoids and antioxidant activity in plant products; Semina: Ciências Agrárias, Londrina, v. 31, n. 3, p. 669-682, 2010.

Coordenadoria de Pesquisa e Extensão - COPEX

Departamento de Editoraçāo e Divulgaçāo Científica - DEDIC 


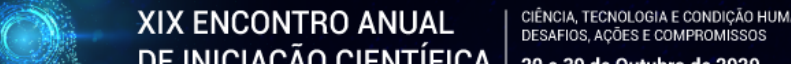 \\ DE INICIACAO CIENTIFICA 29 e 30 de Outubro de 2020 \\ ISBN 978-65-87557-08-3

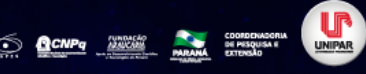

${ }^{1}$ WELLINGTON GABRIEL AGUIAR XAVIER, ${ }^{2}$ HHAINA COUTINHO DA LUZ, ${ }^{3}$ MATHEUS HENRIQUE ROSSATTO CASOLA, ${ }^{4}$ BEATRIZ OLIVEIRA BORELLA, ${ }^{5}$ NICOLE DO NASCIMENTO VIANA, ${ }^{6}$ IGO HENRIQUE SILVA NUNES

${ }^{1}$ Acadêmico do PICIUNIPAR

Acadêmica do Curso de Engenharia Civil da UNIPAR

Acadêmico do Curso de Engenharia Civil da UNIPAR

Acadêmica do Curso de Arquitetura e Urbanismo da UNIPAR

Academica do Curso deAr

DDocente da UNIPAR

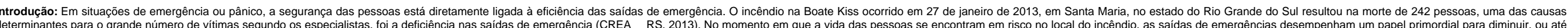

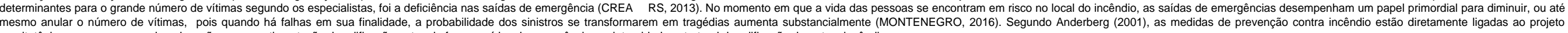
arquitetênico, como por exemplo, a locação e compartimentaçăo da edificaçăo, rotas de fugas, saídas de emergência e a integridade estrutural da edificicação durante o incêndio.

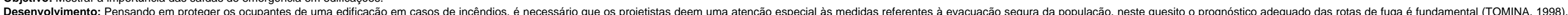

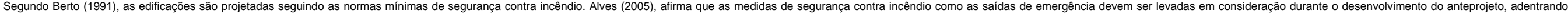

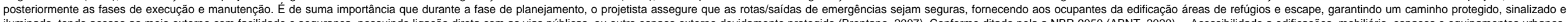

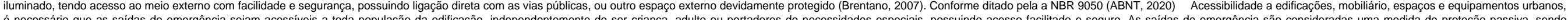

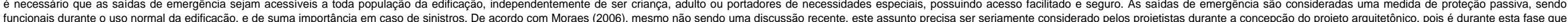
as soluçōes mais eficientes são obtidas. Ainda de acordo com o autor, tem-se percebido que os projetistas desconhecem os principios básicos para a concepção das saídas de emergência, sendo apresentados soluçōes paliativas afim de minimizar os projetos incorretos.

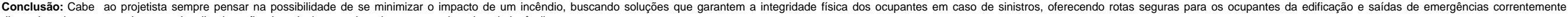
dimensionadas e estrategicamente localizadas, afim de reduzir ou anular o impacto ocasionado pelo incêndi

Referências

ABNT - ASSOCIACAO BRASILEIRA DE NORMAS TECNICAS. ABNT NBR 9050 Acessibilidade a edificacões, mobiliários, espaços e equipamentos urbanos. Rio de Janeiro, 2020.

ALVES, A. B. C. G. Incêndio em edificcações: a questão do escape em prédios altos em Brasília (DF). 2005. 205 f. Tese (Mestrado em Arquitetura e Urbanismo) Faculdade de Arqu ANDERBERG, Y. (2001) Medidas de protection pasiva contra incendios. In: Enciclopedia de Salud y Seguridad en el Trabajo. Organización Internacional del Trabajo. v.ll, p.41.19 a 41.23.

BRENTANO, T. A proteçáa connto

DE MORAES, Poliana Dias. Projeto de edificacões visando à segurança contra incêndio. 2006. Dissonível em: https://giem.ufsc.br/files/2017/02/Projeto-de-edifica\%C3\%A7\%C3\%B5es-visando-a-seguran\%C3\%A7a-contra-inc\%C3\%AAndio-2006.pdff. Acesso em: 24 de Agosto 2020.

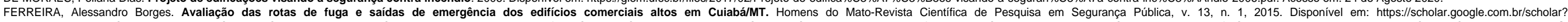

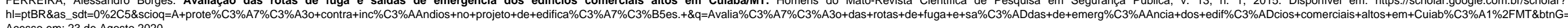
MONTENEGRO Mariana Lima

em: 23 de Agosto 2020.
TOMINA, José Carlos, Saídas, Simpósio de arquitetura e proteção contra incêndio, 1988, São Paulo. IPT 1988. Disponivel em: https://repositorio.uffsm.br/bitstream/handle/1/1023/Abaid_Francine_Drews.pdf?sequence=1\&isAllowed=y Acesso em: 23 de Agosto 2020. 


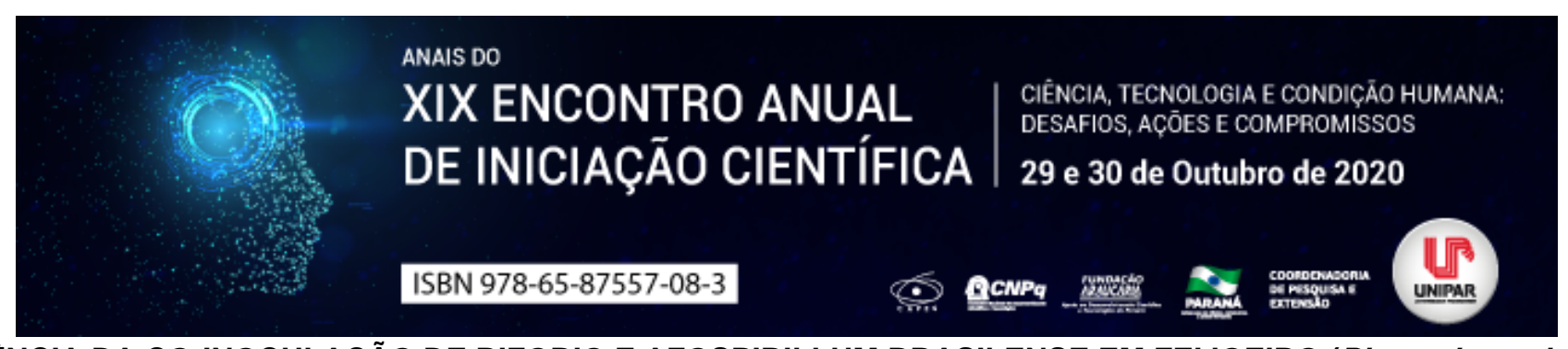

INFLUÊNCIA DA CO-INOCULAÇÃO DE RIZOBIO E AZOSPIRILLUM BRASILENSE EM FEIJOEIRO (Phaseolus vulgaris L)

\begin{abstract}
${ }^{1}$ WESLEY RIBEIRO RIVADAVEA, ${ }^{2}$ LARISSA LOURENCETO, ${ }^{3}$ GABRIEL SABATINI PEREIRA, ${ }^{4}$ AMANDHA MELO DOS SANTOS, ${ }^{5}$ JULLIANE DESTRO DE LIMA , ${ }^{6}$ GLACY JAQUELINE DA SILVA
\end{abstract}

\author{
${ }^{1}$ Acadêmico bolsista do PEBIC/CNPQ \\ ${ }^{1}$ Acadêmica do Curso de Engenharia Agronômica da UNIPAR \\ ${ }^{2}$ Acadêmico do Curso de Engenharia Agronômica da UNIPAR \\ ${ }^{3}$ Acadêmica do Curso de Engenharia Agronômica da UNIPAR \\ ${ }^{4}$ Acadêmica do Curso de Doutorado Em Biotecnologia Aplicada A Agricultura - Turma Vii da UNIPAR \\ ${ }^{5}$ Docente da UNIPAR
}

Introdução: O Brasil é um dos maiores produtores mundiais de feijão, com produção anual de em 245,8 milhões de toneladas, com um aumento na safra de 2020 de 1,6\%, ou seja, 3,9 milhões de toneladas a mais em relação à safra 2018/2019 (CONAB, 2020). No ranking mundial, fica com a $3^{\circ}$ posição. Dentro do Brasil, o maior destaque é para a Região Centro-Oeste, com previsão de atingir 893,3 mil toneladas no atual ano-safra, aumento de 6,8\% sobre a safra $2016 / 2017$, seguido da região Sul (885,2 mil toneladas), com redução de 6,1\% (FAOSTAT, 2018). Porém, apesar de se destacar entre os países do mundo, apresenta produtividade média relativamente baixa. Alternativas que possam aumentar a produtividade de forma sustentável devem ser preconizadas, tais como a redução do uso de fertilizantes nitrogenados pela adoção da fixação biológica de nitrogênio. Neste cenário, uma das técnicas alternativas é a de co-inoculação com bactérias simbióticas e assimbióticas. Atualmente o uso dessas técnicas tem sido estudada em leguminosas, por isso a importância de estudos com uso de inoculante na cultura do feijoeiro (Phaseolus vulgaris L.) pode ser importante para suprir as necessidades de nitrogênio pela cultura.

Objetivo: o objetivo deste trabalho foi avaliar a eficiência da inoculação e co-inoculação de feijão com Rhizobium tropici e Azospirillum brasilense em relação a desenvolvimento do feijoeiro.

Metodologia: O experimento foi conduzido no Laboratório de Biologia Molecular (UNIPAR), Casa de Vegetação (UNIPAR) no período de Agosto á Dezembro do ano de 2019. A cultivar utilizada no experimento foi a BRS campeiro. O delineamento experimental utilizado foi o de blocos ao acaso, com cinco repetições, tendo como tratamentos constituídos pela combinação de quatro formas de fornecimento de nitrogênio: controle (testemunha sem inoculação, porém, com o uso de fertilizante nitrogenado); inoculação de A. brasilense com 2x108 células viáveis por $\mathrm{ml} \mathrm{g}$; inoculação de $\mathrm{R}$. tropici com 3×109 células viáveis por $\mathrm{ml} \mathrm{g}$; e co-inoculação onde as sementes foram tratadas segundo a recomendação do fabricante na proporção de 2:1 de Rhizobium tropici com a concentração: 3×109 células viáveis por ml g e Azospirillum brasilense com concentração 2×108 células viáveis por $\mathrm{ml} \mathrm{g}$. Os vasos foram compostos por areia autoclavada. As sementes foram plantadas, mantendo-se 1 semente por vaso de $3 \mathrm{~kg}$. As plantas foram regadas com solução nutritiva Hoagland e Arnon (1950) com adaptações contendo cálcio, ferro, fósforo, magnésio, potássio manganês, e micronutrientes, regados 1 vez ao dia. As variáveis obtidas no experimento foram nodulação, parte aérea, peso semente, raiz e peso mil grãos. Foi avaliado peso fresco e seco de parte aérea e raiz (g), comprimento de parte aérea e raiz $(\mathrm{cm})$, produção de nódulos, peso de semente e peso de mil grãos. Os resultados foram comparados por teste de média a $5 \%$ de significância, a partir do programa Assistat.

Resultados: Segundo os dados apresentados neste estudo na avaliação da inoculação de rizóbios, isoladamente, comparados com a co-inoculação de $A$. brasilense, não foram detectadas diferenças $(p<0,05)$ quanto à parte aérea, quantidade de nódulos, comprimento e peso de raiz. De modo geral, não foram verificados ganhos da co-inoculação na nodulação das plantas. Contudo, verificou-se que a co-inoculação favoreceu uma nodulação mais abundante nas plantas de feijoeiro, cerca de $57 \%$ superior ao números de nódulos comparados ao tratamento somente com Azospirillum. Da mesma forma, Yadegari et al. (2010) verificaram que a co-inoculação de Rhizobium e Pseudomonas fluorescens resultou em aumento na nodulação, na produção de matéria seca da parte aérea, na fixação de nitrogênio e na produtividade de feijoeiros. Por outro lado, o desenvolvimento das plantas, os componentes de produção e a produtividade de grãos de feijoeiros não foram afetados pela inoculação com A. brasilense, quando as sementes não foram inoculadas com estirpes selecionadas de rizóbio (GITTI et al., 2012). Segundo DE SOUZA et al.,( 2011); COSTA et al.,( 2014) quando há um acréscimo de nódulos há porém um aumento na absorção de nitrogênio em associações com bactérias diazotróficas que fixa nitrogênio, que assim agregam o tamanho das raízes e o volume dessas. Este é um um fator importante, pois há mesmo sem aumento do rendimento da cultura, há a diminuição de gastos com adubos nitrogenados e só por isso, podemos considerar ganhos para o produtor.

Conclusão: O co-cultivo de Azospirillum brasilense conjuntamente com rizóbio propiciou uma maior nodulação das plantas, porém, não diferiu estatisticamente do controle para as outras características avaliadas. 


\section{Referências}

CONAB. COMPANHIA NACIONAL DE ABASTECIMENTO. Acompanhamento de safra brasileiro grãos: Nono levantamento, junho 2019 safra 2018/2019. : Brasília: Companhia Nacional de Abastecimento. 2020. Disponível em: . Acesso em: 20 agost. 2020.

COSTA, E. M.; CARVALHO, F.; ESTEVES, J. A.; NÓBREGA, R. S. A.; MOREIRA, F. M. S. Resposta da soja a inoculação e coinoculação com bactérias promotoras do crescimento vegetal e Bradyrhizobium. Enciclopédia Biosfera, v. 10, p. $1678-1689$. 2014.

FAOSTAT. Crops. Disponível em: http://www.fao.org/faostat/en/\#data/QC. Acesso em: 20 agost. 2020.

GITTI, D. C. et al. Inoculação de Azospirillum brasilense em cultivares de feijões cultivados no inverno. Agrarian, Dourados, v. 5, n. 15, p. 36-46, 2012.

HOAGLAND DR; ARNON DI. 1950. The waterculture method for growing plants without soil. Berkeley, CA: Agric. Exp. Stn., Univ. of California. (Circ. 347)

SOUZA, E. F. C.; SORATTO, R. P.; PAGANI, F. A. Aplicação de nitrogênio e inoculação com rizóbio em feijoeiro-comum cultivado após milho consorciado com braquiária. Pesquisa Agropecuária Brasileira, v. 46, n. 4, p. 370-377, 2011.

YADEGARI, M. et al. Plant growth promoting rhizobacteria increase growth, yield and nitrogen fixation in Phaseolus vulgaris. Journal of Plant Nutrition, New York, v. 33, n. 12, p. 1733-1743, 2010.

Coordenadoria de Pesquisa e Extensão - COPEX

Departamento de Editoraçāo e Divulgaçāo Científica - DEDIC 


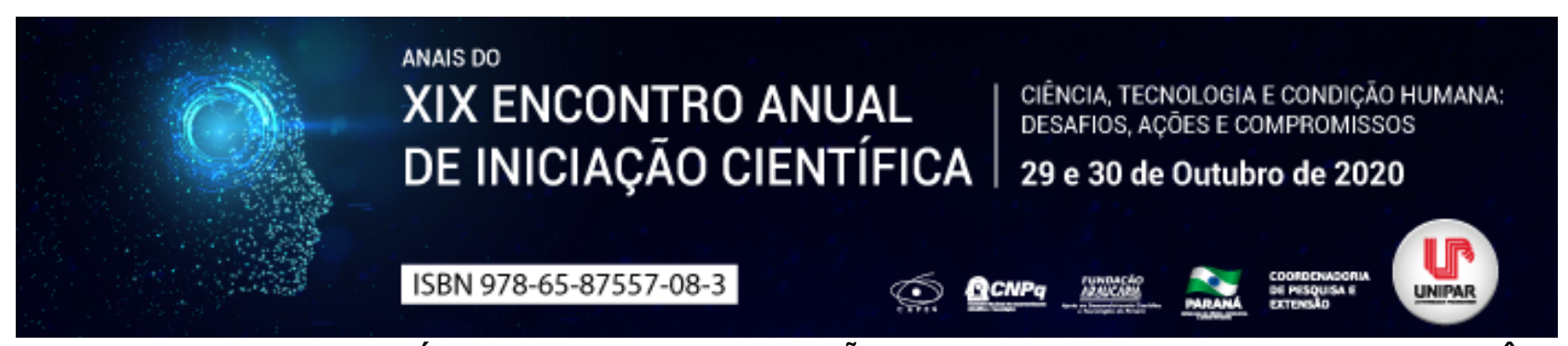

UM LEVANTAMENTO BIBLIOMÉTRICO SOBRE MANUTENÇÃO PREDIAL A PARTIR DO GOOGLE ACADÊMICO

\author{
${ }^{1}$ DJESSICA TUANI KREIN, ${ }^{2}$ ANA KAROLINI CHIAPETTI, ${ }^{3}$ FABRICIO BALESTRIN
}

\author{
${ }^{1}$ Acadêmica do Curso de Engenharia Civil da UNIPAR \\ ${ }^{1}$ Acadêmica do Curso de Arquitetura e Urbanismo da UNIPAR \\ ${ }^{2}$ Docente da UNIPAR
}

Introdução: A cienciometria segundo Parra, Coutinho e Pessano (2019), centra-se na objetividade, enfatiza-se na avaliação e produção científica e não se embasa em textos e trabalhos não científicos ou experimentais, pois se trata de pesquisas quantitativas, tendo em vista que um determinado assunto só pode ser compreendido após a pesquisa e levantamento de dados reais. A bibliometria é vista como um grupo de métodos e técnicas quantitativas para a gestão de bibliotecas e instituições envolvidas com o tratamento de informação, (PRITCHARD, 1969), significa, então, uma área da ciência de técnicas quantitativas, que transforma dados estatísticos em índices do produto científico. Hoje em dia, grande parte da população habita as cidades, vivendo em edificações construídas pelo homem, em função disso Bambirra (2019) salienta que o ambiente edificado é um suporte físico para a realização, direta ou indiretamente, de todas as atividades diárias das pessoas, tendo assim um papel social fundamental, portanto, é de suma importância que as edificações apresentem condições de uso adequadas para a qual se destina, resistindo a adversidades. A manutenção predial evita as mais variadas anomalias das edificações que podem causar sérios danos materiais e pessoais.

Objetivo: Analisar de forma bibliométrica as publicações acerca do tema Manutenção Predial entre os anos 1998 e 2020 presentes no Google Acadêmico.

Material e Métodos: A partir de um levantamento feito pela ferramenta Google acadêmico, foram selecionados os trabalhos que continham I"manutenção prediall" no título somando 74 publicações depois foram tabulados nas Planilhas Google onde foram excluídos os duplicados, incompletos ou os que não estavam acessíveis, restando um total de 60 trabalhos. Na planilha eles foram classificados de acordo com o ano, instituição, tipos de trabalhos (artigos, trabalhos de conclusão de curso, dissertações, monografias ou teses) e estado.

Resultados: O ano de 2018 é o que mais teve material escrito, com um total de 10 artigos divulgados (16,67\%), em seguida encontra-se 2017 e 2019 com 8 trabalhos (13,33\%), 2014 com 7 trabalhos (11,67\%), 2010 e 2016 com 5 trabalhos (8,33\%), 2007, 2011 e 2012 com 3 trabalhos (5\%), 1998, 2000, 2008, 2009 e 2013 com somente 1 trabalho publicado (1,67\%). Entre eles, localizam-se trabalhos do tipo: Artigos, trabalhos de conclusão de curso (TCC), dissertações, monografias e teses. Observa-se que o maior tipo de trabalhos publicados seriam trabalhos de conclusões de curso (TCC), tendo um total de 23 publicações, sendo 38,33\% do número total. Em seguida, temos os artigos, com 17 trabalhos publicados e 28,33\%, dissertações com 10 trabalhos e 16,67\%, após as Monografias com 09 trabalhos escritos e 15\%, e por fim, com apenas 1 trabalho publicado, tem-se a Tese, com 1,67\%. Dentre os estados com mais trabalhos publicados temos em primeiro, Rio Grande do Sul, com 10 trabalhos expostos, somando uma porcentagem de 16,67\%, em seguida os estados do Paraná e Distrito Federal, totalizando 8 trabalhos e 13,33\%, prosseguindo, encontram-se os estados de Minas Gerais, Santa Catarina e São Paulo, com 6 trabalhos publicados e $10 \%$ do total cada. Entre as instituições mais citadas, observa-se a Universidade Federal do Rio Grande do Sul, a qual produziu muitos trabalhos, em cada 10 trabalhos publicados 9 trabalhos eram da UFRGS, em seguida a Universidade Federal do Paraná e a UniCEUB (Centro Universitário de Brasília), tendo a cada 10 trabalhos publicados, 4 sendo seus, respectivamente temos a Universidade do Extremo Sul Catarinense (Unesc), a Universidade Federal de São Carlos, Campus Lagoa do Sino (UFSCAR), a Faculdade de Tecnologia do Estado de São Paulo (FATECS) e a Universidade Federal de Campina Grande (UFCG) com 3 trabalhos publicados, e outras 22 instituições com somente um trabalho publicado. Dos 60 trabalhos publicados, 52 deles foram escritos apenas por 1 autor, 4 deles, escrito por 2 autores, 2 deles escrito por 3 autores e 2 por 4 autores.

Discussão: Com o decorrer dos anos teve um considerável aumento na produção de trabalhos sobre manutenção predial, o que indica uma maior preocupação com as manutenções nas edificações. Observa-se através dos dados essa maior atenção, onde o número de trabalhos publicados vem crescendo desde 1998, sendo o ano de 2018 o de maior destaque. Pode-se observar que o maior número de trabalhos publicados encontram-se na região Sul e Centro Oeste do País, tendo como instituições de destaque a Universidade Federal do Rio Grande do Sul (UFRGS) e o Centro Universitário de Brasília (UNICEUB). Verificando esses dados, identificamos uma maior tendência no desenvolvimento desses artigos na região Sul, logo uma maior preocupação com o cuidado das edificações, do que nas outras regiões, como Nordeste. Tendo em vista o grande número de trabalhos de conclusão de curso (TCC) publicados, conclui-se que manutenção predial é um tema muito citado nas Instituições de ensino Superior, devido a essa introdução, esse termo vem se tornando cada vez mais frequente e conhecido. Ainda existe pouca colaboração entre os autores em razão da maioria dos trabalhos desenvolvidos serem TCC, os quais normalmente são desenvolvidos apenas 
por um autor.

Conclusão: Em vista dos dados apresentados, conclui-se que, o número de artigos publicados ao longos dos anos de 1998 á 2020 ainda é relativamente baixo, pois um assunto tão significativo deveria ter maior repercussão, afinal, quanto mais pessoas entendidas sobre, mais manutenções prediais serão executadas trazendo mais segurança e confiabilidade aos usuários dessas edificações.

\section{Referências}

BAMBIRRA, Filipe Starling. Análise de normas técnicas e a elaboração de programa de manutenção predial. p. $9,2019$.

PARRA, Maurício Rodrigues; COUTINHO, Renato Xavier; PESSANO, Edwrad Frederico Castro. Um Breve Olhar Sobre a Cienciometria: Origem, Evolução, Tendências E Sua Contribuição Para O Ensino De Ciências. Revista Contexto \& Educação, v. 34, n. 107, p. 129 130, 2019.

PRITCHARD, Alan. Statistical bibliography or bibliometrics. Journal of Documentation, Bingley United King- dom, v. 25, n. 4, p. 348-349, 1969. 


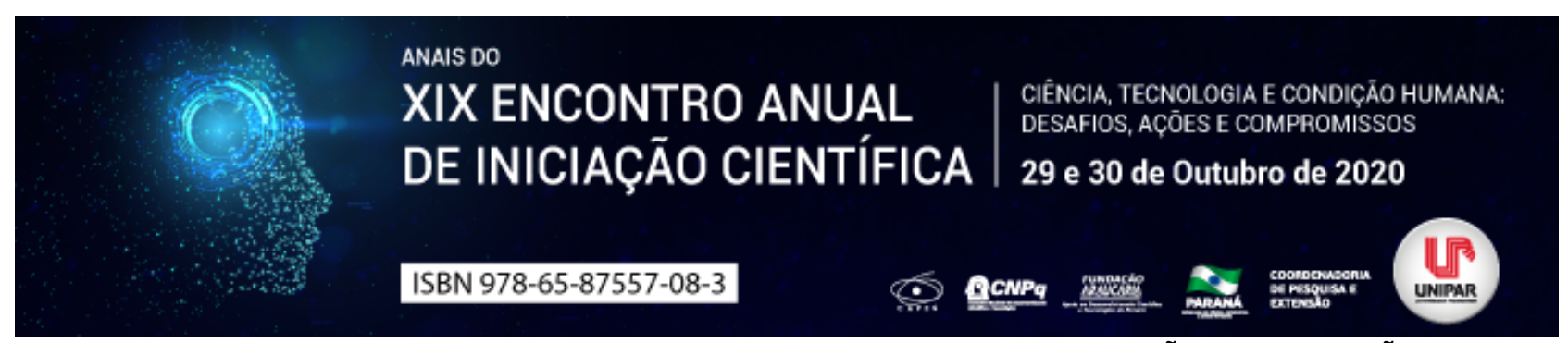

EXTRATO DE TORTA DE MAMONA OBTIDO COM E SEM ULTRASSOM NA SUPRESSÃO DA ECLOSÃO DE Meloidogyne javanica

\author{
${ }^{1}$ Guilherme Tarini, ${ }^{2}$ LAÍS FERNANDA FONTANA, ${ }^{3}$ ANGÉLICA SANCHEZ MELO, ${ }^{4}$ CAROLINA YUMI FUTIGAMI, ${ }^{5}$ BRUNA \\ ORLANDINI TONINATO, ${ }^{6}$ CLAUDIA R. DIAS-ARIEIRA
}

\author{
${ }^{1}$ Discente Graduação, UEM \\ ${ }^{1}$ Discente Pós-Graduação, UEM \\ ${ }^{2}$ Discente Graduação, UEM \\ ${ }^{3}$ Discente Graduação, UEM \\ ${ }^{4}$ Discente Pós-Graduação, UEM \\ ${ }^{5}$ Docente UEM, Umuarama
}

Introdução: A preocupação com manejo de nematoides é constante, visto que atualmente esses parasitas causam prejuízos à agricultura nacional superiores a 35 bilhões de reais anuais. A ocorrência de $M$. javanica nas plantas causa nodosidades denominadas de galhas. Estas são decorrentes da hipertrofia e hiperplasia das células de alimentação do nematoide, que se localizam no xilema ou próximas a ele e, comprometendo a translocação de água e nutrientes (AGRIOS, 2005). Os resíduos obtidos especialmente de partes vegetais, tem demonstrado grande potencial para o manejo de nematoides (ROLDI et al., 2013). A torta de mamona está entre os materiais promissores, porém há dificuldades na disponibilidade do material. Uma opção de otimizar o uso destes materiais é a extração de compostos bioativos a partir resíduos vegetais, que pode ser assistida por ultrassom. O método tem inúmeras vantagens quando comparado aos tradicionais, incluindo a possibilidade de se obter alta taxa de extração em um período reduzido de tempo (SHIRSATH et al., 2012). A extração ultrassônica demonstra inúmeros efeitos, incluindo a circulação de líquidos no sistema e a turbulência, que podem aumentar a transferência de massa (JADHAV et al., 2009). Neste método, a cavitação acústica gerada, facilita a penetração de solventes na parede da célula vegetal, liberando de forma rápida e eficiente o conteúdo intracelular (CORBIN et al., 2015).

Objetivo: objetivou-se avaliar a eficiência de extratos da torta de mamona, obtidos usando água e etanol, mediante técnica ultrassônica, na eclosão de Meloidogyne javanica.

Material e métodos: Experimento foi realizado na Universidade Estadual de Maringá em um delineamento inteiramente casualizado, em fatorial $4 \times 2 \times 6$ (4 diluições de álcool, com e sem ultrassom e 6 diluições do extrato obtido em água), com cinco repetições. A torta foi submetida a extração (1:10, m:v) nas diluições de álcool (em água destilada) a 0, 20, 40 e 60\%, usando ou não ultrassom com frequência de $40 \mathrm{kHz}$, potência de $132 \mathrm{~W}$ e duração de 30 minutos a $40^{\circ} \mathrm{C}$. Cada material obtido foi avaliado quanto ao efeito na eclosão de $M$. javanica, nas diluições de 0 (testemunha, água destilada), 5, 10, 15, 20 e 25\%. Para análise do experimento, foi realizada a extração da massa de ovos da raiz de soja, pela metodologia de Hussey e Barker (1972). A suspensão foi calibrada para 100 ovos $\mathrm{mL}^{-1}$. Em tubos de ensaio, foi adicionado $1 \mathrm{~mL}$ da suspensão de nematoides e $10 \mathrm{~mL}$ do material a ser avaliado. Os tratamentos foram incubados em BOD a $27 \pm 1{ }^{\circ} \mathrm{C}$, no escuro, por sete dias. Então, avaliou-se os juvenis eclodidos e os ovos remanescentes com auxílio de microscópio ótico e câmara de Peters. Os valores foram expressos em porcentagem de eclosão (\%). Os dados obtidos na avaliação dos parâmetros, foram analisados, por meio de análise de variância, com o software SISVAR, utilizando teste de Tukey a $(p<0,05)$ de probabilidade e análise de regressão para os dados quantitativos.

Resultados: Houve interação tripla entre os fatores para a eclosão de nematoides, contudo, foi feito o estudo das diluições do extrato dentro da \% de álcool usada na extração com o uso ou não do ultrassom, separadamente, e do efeito do ultrassom dentro de cada \% de álcool, independente da diluição, visto que não houve interação entre diluição e uso do ultrassom. No estudo das diluições 0, 20, 40,60\% de álcool em extração com ultrassom, houve redução de eclosão a partir da dose de 5\%. Realizando a derivada da equação para as porcentagens de álcool $(0,20,40,60 \%)$ foram observadas melhores diluições para reduzir a eclosão iguais a 16,0;15,4; 17,5; 17,1\%, respectivamente. Em geral, a extração usando $20 \%$ de álcool teve menor eficiência em reduzir eclosão, enquanto as demais porcentagens de álcool não diferiram entre si, incluindo a extração usando apenas água. Na avaliação de eclosão sem ultrassom, o uso das porcentagens de álcool equivalentes a 0, 20, e 60\% foram mais eficientes em reduzir a eclosão, quando aplicados nas diluições de 17,0; 24,0; 17,3\%, respectivamente, e não houve ajuste da equação para o extrato com álcool a 40\%. Neste ensaio a exemplo do que foi verificado na extração com ultrassom, o uso da água foi tão ou mais eficiente em reduzir a eclosão do que o álcool como solvente. Houve baixa influência do uso de ultrassom na eficiência dos extratos sobre a eclosão do nematoide. Assim, pode-se supor que os compostos nematicidas presentes na torta de mamona são 
hidrossolúveis e extraídos facilmente sem ultrassom.

Discussão: Os extratos oriundos da torta de mamona demonstraram potencial no controle de nematoides. Anteriormente, a torta de mamona e extratos oriundos de diferentes partes da planta apresentaram potencial para o controle de nematoides em outros patossistemas (ALMEIDA et al., 2012). Algumas substâncias já têm sido apontadas como responsáveis pelo efeito nematicida da mamona, como a ricina e ricinina (RICH et al., 1989).

Conclusão: A utilização do ultrassom para obtenção do extrato aquoso da torta de mamona possui baixa eficiência em extrair substâncias nematicidas, porém o extrato em si, é eficiente em controlar nematoide, mesmo com extração aquosa.

\section{Referências}

AGRIOS, George .N. Plant Pathology. (5aed). New York, Academic Press. 922p. 2005.

ALMEIDA, Fernandes Antonio; PETTER, Fabiano André; SIQUEIRA, V. C.; NETO, Francisco Alcântara.; ALVES, A. U.; LEITE, Maria Lúcia Tiburtino. Modos de preparo de extratos vegetais sobre Meloidogyne javanica no tomateiro. Nematropica, v.42, n.1, p.9-15, 2012.

CORBIN, Cyrielle; FIDEL, Thibaud; LECLERC, Emilie A; BARAKZOY, Esmatullah; SAGOT, Nadine; FALGUIÉRES, Annie; RENOUARD, Sullivan; BLONDEAU, Jean-Philippe.; FERROUD, Clotilde; DOUSSOT, Joël.; LAINÉ, Eric; HANO, Christophe Development and validation of an efficient ultrasound assisted extraction of phenolic compounds from flax (Linum usitatissimum L.) seeds. Ultrason Sonochemistry, v.26, p.176-185, 2015.

HUSSEY, Richard S.; BARKER, Kenneth R. A comparison of methods of collecting inocula of Meloidogyne spp., including a new technique. Plant Disease Reporter, v.57: p.1025- 1028, 1973.

JADHAV, Dnyaneshwar; REKHA, B.N.; GOGATE, Parag R.; RATHOD, Virendra Kisan. Extraction of vanillin from vanilla pods: a comparison study of conventional soxhlet and ultrasound assisted extraction. Journal of Food Engineering, v.93, n.4, p. 421426, 2009.

RICH, J.R., RAHI, G.S., OPPERMAN, C.H., and DAVIS, E.L. Influence of the castor bean (Ricinus communis) lectin (ricin) on motility of Meloidogyne incognita. Nematropica, v.19.1, p.99-103, 1989.

ROLDI, Miria; DIAS-ARIEIRA, Claudia Regina; ABE, Vinicius Hícaro Frederico; MATTEI, Danielle; SEVERINO, José Junior; RODRIGUES, Diego Beltrame; FELIX, Jaqueline Cazado. Agroindustrial waste and sewage sludge can control Pratylenchus brachyurus in maize. Acta Agriculturae Scandinavica, Section B Soil \& Plant Science, v.63, n.3, p.283-287, $2013 a$.

SHIRSATH, Sachin R.; SONAWANE, Shirish H.; GOGATE, Parag R. Intensification of extraction of natural products using ultrasonic irradiations a reviewof current status. Chemical Enginnering and Processing, v.53, p.10-23, 2012. 


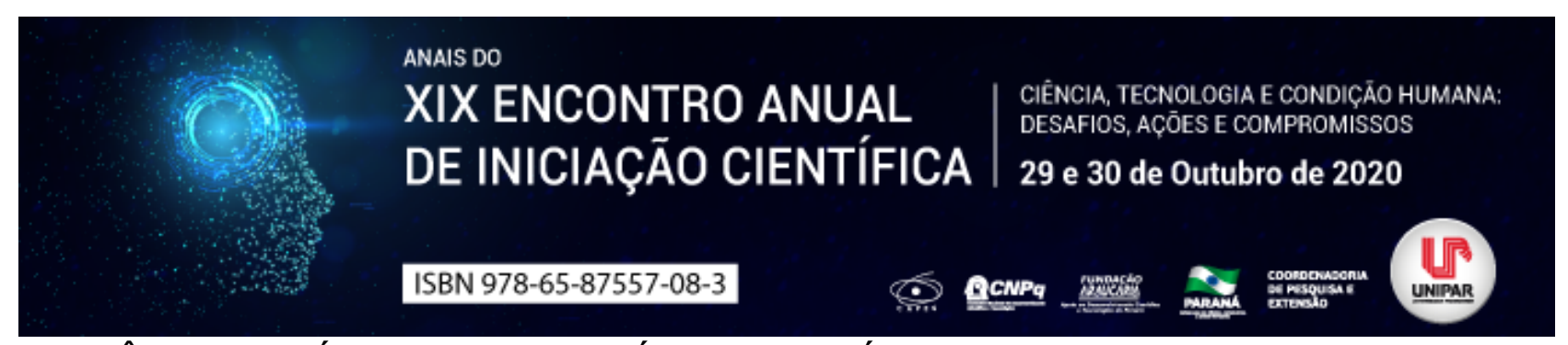

IMPORTÂNCIA ECOLÓGICA E FARMACOLÓGICA DA ESPÉCIE Baccharis dracunculifolia DC (Asteraceae)

\begin{abstract}
${ }^{1}$ ALYNE FERNANDA LEUCH DE SOUZA, ${ }^{2}$ DAYANE LILIAN GALLANI SILVA, ${ }^{3}$ ZILDA CRISTIANI GAZIM, ${ }^{4}$ GIANI ANDREA LINDE COLAUTO, ${ }^{5}$ NELSON BARROS COLAUTO
\end{abstract}

\author{
$1_{1}$ Bolsa Técnica do Programa FUNDAÇÃO ARAUCÁRIA- Universidade Paranaense \\ $1_{1}$ Bolsa Técnica do Programa FUNDAÇÃO ARAUCÁRIA- Universidade Paranaense \\ ${ }^{2}$ Docente da UNIPAR \\ ${ }^{3}$ Docente da UNIPAR \\ ${ }^{4}$ Docente da UNIPAR
}

Introdução: Baccharis dracunculifolia é uma planta nativa dos biomas brasileiros do Cerrado, Mata Atlântica e Pampa (HEIDEN; SCHNEIDER, 2015). Conhecida popularmente como alecrim-do-campo e vassourinha está presente em grande parte nos estados de São Paulo e Minas Gerais (MACHADO, et al.., 2016). Esta espécie tem sido descrita como a fonte vegetal mais importante do própolis no sudeste brasileiro, chamada de própolis verde devido à sua cor (DA SILVA FILHO et al., 2009).

Objetivo: O objetivo deste estudo consistiu em realizar um levantamento bibliográfico da importância de $B$. dracunculifolia.

Desenvolvimento: Esta espécie arbustiva tem 2 a $3 \mathrm{~m}$ de altura, é lenhosa, perene, dióica, reproduz por sementes (aquênios), tem caules bastante ramificados e densamente recobertos por tricomas que contém óleos essenciais com aroma melífero (Santos et al., 2012). Os óleos essenciais desta planta atuam como barreira contra o ataque de predadores e auxiliam na interação com abelhas para coleta do material resinoso que originara o própolis verde, um composto que consiste de $50 \%$ de resina, $30 \%$ de cera de abelha, $10 \%$ de óleos aromáticos e essenciais, $5 \%$ de pólen e $5 \%$ de outras substâncias (Sforcin et al., 2012). De acordo com Machado et al. (2016) o alecrim do campo é uma planta com potencial antioxidante, antimicrobiano, antiinflamatório, anti-malárico, leishmanicida. Segundo da Silva Filho et al. (2009) esta planta é utilizada pela medicina popular no tratamento de doenças gastrointestinais. Este própolis é utilizado em dentifrício com o objetivo de combater o crescimento de bactérias cariogênica (Ferronato et al., 2007) que está diretamente relacionado com a composição química da B.dracunculifolia. Alencar et al. (2005) encontrou altas concentrações de compostos fenólicos como o artepilin C e derivados do ácido cinâmico. Santos et al. (2012) identificaram no óleo essencial os monoterpenos: $\beta$-pineno, limoneno e terpinen-4-ol; sesquiterpenos hidrocarbonetos: $\beta$-cariofileno, $\alpha$-humuleno, germacreno $D$, trans- $\beta$-guaieno e delta-cadineno. Os sesquiterpenos oxigenados: trans-nerolidol e espatulenol são relatados como compostos majoritários. Ademais, o trans-nerolidol foi aprovado pela Food and Drug Administration (FDA) como um agente flavorizante utilizado em alimentos, apresentando também propriedade antineoplásica.

Conclusão: $B$. dracunculifolia é uma planta com uma relação direta com as abelhas para a produção de própolis e de importância ecológica. Tem propriedades biológicas e terapêutico, sendo os principais compostos encontrados trans-nerolidol e espatulenol.

\title{
Referências
}

ALENCAR, M. S.; AGUIAR, L. C.; GUZMAN, P. J.; PARK, K. Y. Composição química de Baccharis dracunculifolia, fonte botânica das própolis dos estados de São Paulo e Minas Gerais. Ciência Rural. v.35,n.4, p.909-9015, 2005.

DA SILVA FILHO, A.A.; RESENDE, D.O.; FUKUI, M.J.; SANTOS, F.F.; PAULETTI, P.M.; CUNHA,W.R.; SILVA, M.L.A.; GREGÓRIO,L.E.; BASTOS, J.K.; NANAYAKKARA, N.P.D. In vitro antileishmanial, antiplasmodial and cytotoxic activities of phenolics and triterpenoids from Baccharis dracunculifolia D. C. (Asteraceae). Fitoterapia.v. 80. p. 478 482, 2009.

FERRONATTO, R.; MARCHESAN, E. D.; BEDNARSKI, F.; RIBAS, T. T. Z.; ONOFRE, S. B. Efeitos do óleo essencial produzido por Baccharis dracunculifolia D. C. (asteraceae) sobre bactérias cariogênicas. Arquivos de Ciências da Saúde da Unipar. V. 11, n. 1, p. 15-18, 2007.

HEIDEN, G.; SCHNEIDER, A. Baccharis. In: Lista de Espécies da Flora do Brasil. Jardim Botânico do Rio de Janeiro, Rio de Janeiro, 2015.

SFORCIN, J. MÇ SOUSA, J.P.B.; SILVA FILHO, . A.AÇ BASTOS, J.K.; BÚFALO, M.C.; TONUCI, L.R.S. Baccharis dracunculifolia uma das principais fontes vegetais da própolis brasileira. São Paulo: Editora Unesp, 2012, 103p.

SANTOS, R.F.; ISOBE, M.T.C.; LALLA, J.G.; HABER,L.L.; MARQUES, M.O.M.; MING, L.C. Chemical composition and productivity of essential oil of Baccharis dracunculifolia DC. as affected by organic compound.

Revista Brasileira de plantas Medicinais. v. 14 no.spe. p. 224-234, 2012. 
Coordenadoria de Pesquisa e Extensão - COPEX

Departamento de Editoraçāo e Divulgaçāo Científica - DEDIC 


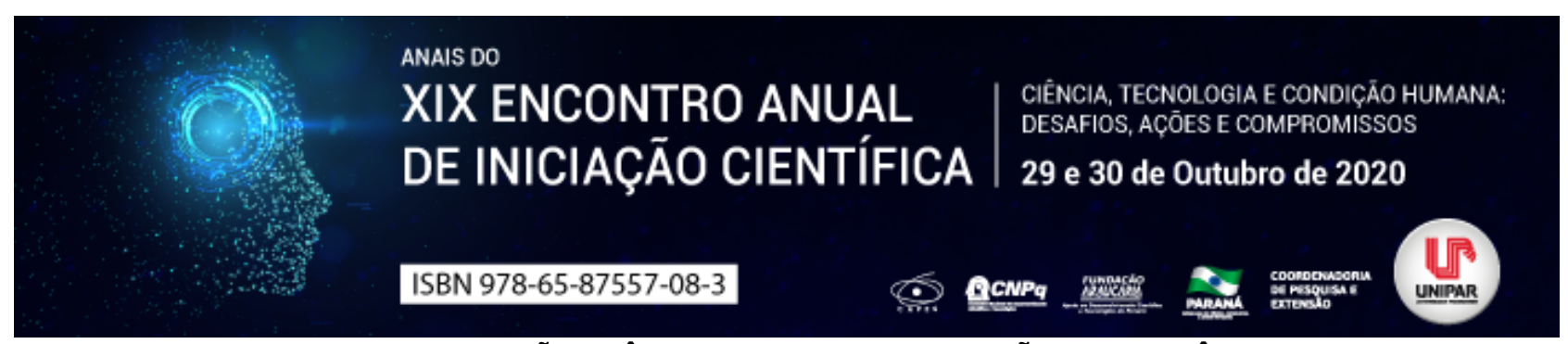

ESTUDO DE REVISÃO: PÂNICO FRENTE A SITUAÇÕES DE INCÊNDIO

\begin{abstract}
${ }^{1}$ MATHEUS HENRIQUE ROSSATTO CASOLA, ${ }^{2}$ BEATRIZ OLIVEIRA BORELLA, ${ }^{3}$ NICOLE DO NASCIMENTO VIANA, ${ }^{4}$ THAINA COUTINHO DA LUZ, ${ }^{5}$ WELLINGTON GABRIEL AGUIAR XAVIER, ${ }^{6}$ IGO HENRIQUE SILVA NUNES
\end{abstract}

${ }^{1}$ Acadêmico do curso de Engenharia Civil, UNIPAR
${ }^{1}$ Acadêmica do Curso de Arquitetura e Urbanismo da UNIPAR
${ }^{2}$ Acadêmica do Curso de Arquitetura e Urbanismo da UNIPAR
${ }^{3}$ Acadêmica do Curso de Engenharia Civil da UNIPAR
${ }^{4}$ Acadêmico do Curso de Engenharia Civil da UNIPAR
${ }^{5}$ Docente da UNIPAR

Introdução: Em situações emergenciais, o controle emocional das vítimas influencia diretamente o seu comportamento, e assim, nas suas tomadas de decisão. Dentre desse contexto, não existe um consenso sobre o assunto, pois a resposta de cada pessoa é individual, entretanto, Ludovico (2015) apresenta quatro hipóteses do comportamento humano, sendo elas: Rapidez na resposta, Luta ou fuga, Pânico, Vítimas são vítimas. Neste estudo, será apresentado uma síntese sobre a terceira hipótese, o pânico.

Objetivo: Demonstrar, através de revisão bibliográfica, a importância do bom planejamento de edificações para situações emergenciais, evitando o pânico dos ocupantes.

Desenvolvimento: Souza (1996) afirma que todas as edificações devem possuir uma rota de fuga apropriada, bem como um sistema de orientação para a evacuação imediata da população, garantindo que a saída dos ocupantes seja de forma rápida e sem gerar pânico ou acidentes no percurso. É importante ressaltar que cada indivíduo possui uma reação diferente frete às situações desfavoráveis. Seito et al (2008) diz que a tensão nervosa e o estresse são os comportamentos mais comuns, gerando assim uma aflição nos indivíduos, entretanto, quando as sensações ultrapassam esse ponto e começam a gerar medo e a perda do controle racional da situação, temos então o pânico. Nesse viés, o autor (HELBING 2013) define o pânico como quebra da ordem e do comportamento cooperativo de indivíduos devido a uma reação ansiosa provocada por um certo evento . Ludovico (2015) aput Quarantelli (1954) define que para o pânico existir, é necessário a somatória de três fatores, sendo eles: A sensação de aprisionamento, sensação de impotência e um profundo isolamento. Dito isso, é apresentado a seguir soluções práticas para o Projeto Técnico de Prevenção a Incêndio e a Desastre. Sobre a sensação de aprisionamento, o mesmo pode ser minimizado através de uma correta sinalização e iluminação das rotas de fuga, transmitindo assim, segurança para os usuários de que aquele é o caminho mais seguro. Já sobre a sensação de impotência, esta que é a insegurança do usuário, pode ser minimizada através de constantes treinamentos, os quais mostrem as rotas de fuga, bem como o correto manuseio dos sistemas de emergência, sendo eles um extintor, hidrante, alarme de incêndio, entre outros. Agora, tratando do profundo isolamento, uma medida simples e eficaz é repasse de informações mais completas e claras sobre a situação por parte das equipes de resposta a emergência, sendo elas a própria brigada de incêndio da edificação ou do Corpo de Bombeiros, esta medida também coopera no combate a sensação de impotência (Ludovico, 2015)

Conclusão: Conclui-se que um bom projeto técnico de prevenção a incêndio e a desastre (com saídas de emergência amplas, identificadas e iluminadas), juntamente com frequentes treinamentos (evacuação da edificação e manuseio dos equipamentos) auxiliam os indivíduos em situações emergenciais, amenizando o pânico e permitindo uma correta e ágil resposta frente ao incêndio.

\title{
Referências
}

HELBING, D.; JOHANSSON, A. Pedestrian, crowd, and evacuation dynamics. arXiv preprint arXiv:1309.1609, 2013.

LUDOVICO, Marcelo T. Apostila: Comportamento Humano e planejamento de emergência. Universidade Federal do Rio de Janeiro, Rio de Janeiro, 2015

SOUZA, J. C. A importância do projeto arquitetônico na prevenção contra incêndios. NUTAU, 11p. São Paulo, 1996.

SEITO, A. I. et al. (Coord.). A segurança contra incêndio no Brasil. Projeto Editora, 496p. São Paulo, 2008. 


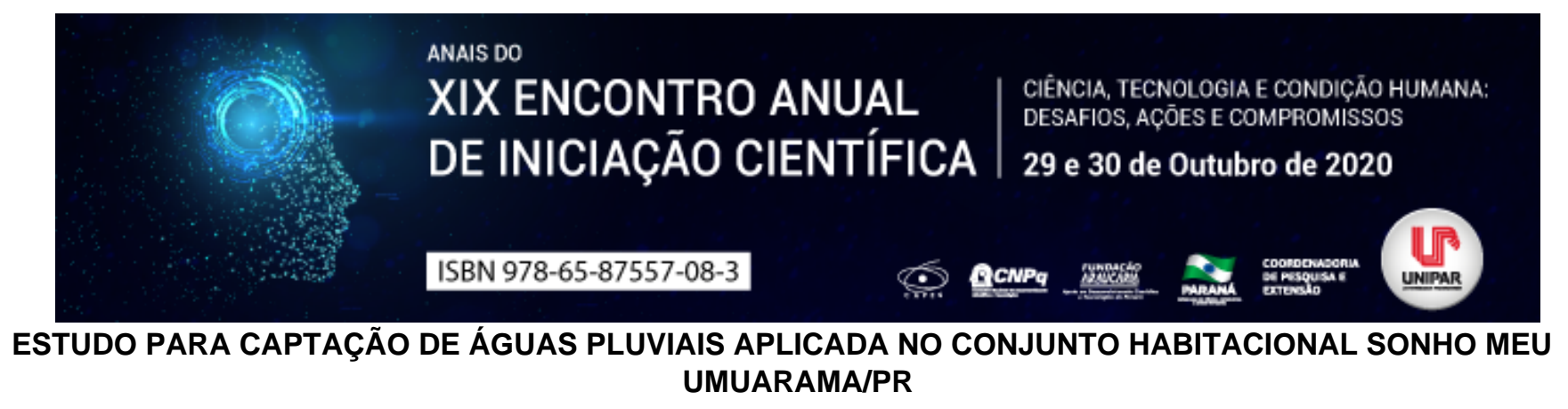

${ }^{1}$ MANOEL ARLINDO MENDES, ${ }^{2}$ ESTHEFFERSON ESTHESNE, ${ }^{3}$ CESAR AUGUSTO HOFFMANN

${ }^{1}$ Acadêmico do Curso de Engenharia Civil - Universidade Paranaense - UNIPAR
${ }^{1}$ Acadêmico do Curso de Engenharia Civil - Universidade Paranaense - UNIPAR
${ }^{2}$ Docente do Curso de Engenharia Civil - Universidade Paranaense - UNIPAR

Introdução: A escassez de água, seja ela causada pelo desperdício ou pelas variações climáticas, o que vem causando uma crise hídrica em diversos lugares, como no Estado do Paraná. A Agência Nacional de Águas em seu relatório pleno de Conjuntura dos Recursos Hídricos no Brasil (2017), relatou além da importância da água, a diminuição dos volumes hídricos e a escassez destes recursos, apontando que as dificuldades encontradas no abastecimento de água também são consequências da contaminação e poluição dos recursos hídricos e dos efeitos causados pelas indústrias. Ademais, o ciclo da água está diretamente ligado ao clima e, ocorre as variações climáticas causando as mudanças no mesmo como inundações ou longos períodos de seca, interferem na oferta e na demanda hídrica. Deste modo, o aproveitamento de águas da chuva ressurge, sendo uma importante prática na busca da sustentabilidade hídrica, podendo ser utilizados em residências, indústrias, comércios, etc.

Objetivo: O objetivo deste estudo é abordar a importância da captação da água pluvial e seu aproveitamento em residência unifamiliar de pequeno porte, contribuindo para a melhor compreensão e conscientização do leitor da existência de formas mais eficazes e sustentáveis no reaproveitamento de águas pluviais.

Material e Métodos: O material utilizado para o presente trabalho, se deu por coleta de dados e estatísticas, bem como levantamento bibliográfico, através da pesquisa explicativa, com fonte de pesquisa primária e secundária. $\mathrm{O}$ tipo de pesquisa utilizado é qualitativo e quantitativo. O método empregado é hipotético-dedutivo partindo da hipótese que a captação de águas pluviais aplicada no Conjunto Habitacional Sonho Meu é uma opção eficaz e sustentável.

Resultados: No estudo realizado sobre o loteamento Sonho Meu de residência unifamiliar de pequeno porte, se obteve uma vazão da calha de quase 100 litros por minuto, adotando a inclinação mínima de 0,5\% e a base da calha de $15 \mathrm{~cm}$ e altura da lamina de água de 0,06 metro. Os dados alcançados foram através da: fórmula de Manning-Strickler onde a calha ficou dimensionada com altura de 22,6 cm e base com $15 \mathrm{~cm}$, material de aço galvanizado. Pela mesma fórmula, obtivemos os diâmetros da tubulação horizontal e vertical de material PVC e diâmetro externo de 100mm baseado na altura da lamina de água 2-3 D seção circular e capacidade de condutor, segundo a NBR10844;198. Foi feito o dimensionamento da cisterna com capacidade de 2.800 litros, pelo os percentis de $0,25 \%$ a probabilidade de $75 \%$, baseado nos dados de alturas mensais de precipitação pluviométrica. Se obteve ainda o resultado de que o modelo de sistema apresentado nesta pesquisa tem um custo de implementação de $R \$ 6.123,95$, e tem a probabilidade de aproveitamento da água pluvial, proporcionada pela residência de área de contribuição $36 \mathrm{~m}^{2}$ do conjunto habitacional de $66,480.00$ litros por ano, gerando uma economia nas 3 fases de $96,196,560.00$ litros por ano, demostrando um sistema sustentável. Diante de todo o estudo, restou demonstrado como outra opção mais eficaz e sustentável no reaproveitamento de águas pluviais.

Discussão: Conforme o doutrinador Tomaz (2015), existe uma diferença entre a precipitação do volume de água e do volume a ser armazenado. Visto que, o volume da água é um fator muito importante a ser considerado que pode ser captado e armazenado. Para captação de água pluvial são necessárias calhas horizontais, fixadas o mais próximo da extremidade da cobertura, e de acordo com a NBR 10844 (ABNT, 1989), podem ser feitas de chapa de aço galvanizado, folhas de flandres, chapas de cobre, aço inoxidável, alumínio, fibrocimento PVC rígido, fibra de vidro concreto ou alvenaria, conduzindo para uma economia em relação aos valores empregados e favorecendo como opção sustentável. O Instituto Agronômico do Paraná IAPAR fornece as alturas mensais de precipitação de Umuarama do período de 1972 a 2018. Com base nesses dados foram efetuados os cálculos para dimensionamento da cisterna e para encontrar os parâmetros da intensidade, duração e frequência, os quais foram de grande importância para análise das precipitações que acontecem ao longo dos anos no município, assim como dados fundamentais para a realização dos dimensionamentos posteriores. O descarte first flush é usado um dispositivo automático, que segundo (LIMA 2011. P 35-47) serve para limpeza da primeira agua da chuva que cai na superfície do telhado contaminando, então o dispositivo automático descarta os primeiros milímetros de precipitações. Segundo a NBR 15527/07, aproveitamento de água de chuva é o coeficiente Runoff calculado com first flush: conquistando uma excelente melhoria na qualidade da água.

Conclusão: Através de dados levantados como as alturas mensais de precipitação de Umuarama fornecido pelo IAPAR, e levantamento bibliográficos, e partindo da hipótese apresentada, resultou no alcance do objetivo empregado na elaboração do presente trabalho, de modo que restou evidente que o tema trabalhado contribui sendo uma das melhores formas eficazes, 
conscientizando o leitor sobre o aproveitamento de águas da chuva e demonstrando a importância dela na busca da sustentabilidade hídrica.

\section{Referências}

ABNT ASSOCIAÇÃO BRASILEIRA DE NORMAS TÉCNICAS. NBR 15527: Água de chuva - Aproveitamento de coberturas em áreas urbanas para fins não potáveis - Requisitos. Rio de Janeiro, 2007.

ABNT ASSOCIAÇÃO BRASILEIRA DE NORMAS TÉCNICAS. NBR 10844: Instalações prediais de águas pluviais. Rio de Janeiro, 1989.

AEN AGÊNCIA DE NOTICÍAS DO PARANÁ. Paraná sofre com estiagem mais severa dos últimos anos [S.I], 2020. Disponível em:

Acesso em 30 de junho de 2020.

BRASIL, Agência Nacional de Águas. Conjuntura dos recursos hídricos no Brasil 2017: Relatório pleno. Brasília: ANA, 2017.

Disponível em: < http://conjuntura.ana.gov.br/static/media/Release_Conjuntura.77d10324.pdf>

INSTITUTO DAS ÁGUAS DO PARANÁ JUNHO SISTEMĀ DE INFORMAÇÕES HIDROLÓGICAS (2020). Relatório precipitação de altura mensais. Disponível em:

LIMA, Júlio César Azevedo de. Avaliação do desempenho de dispositivo de desvio das primeiras águas de chuva utilizando em cisternas no seminário pernambucano. Dissertação (Mestrado em Tecnologia Ambiental e Recursos Hídricos)

Universidade Federal de Pernambuco UFPE. Recife, Pernambuco 2011. Disponível em Acesso em 20/08/2020.

TOMAZ, Plinio., Aproveitamento de água da chuva. Livro Digital, 2015. Disponível em: < https://909d9be6-f6f1-4d9c-8ac9115276d6aa55.filesusr.com/ugd/0573a5_bfa504956e664155b22974ef016e05a7.pdf?index=true > Acesso em 8 de junho de 2020. 


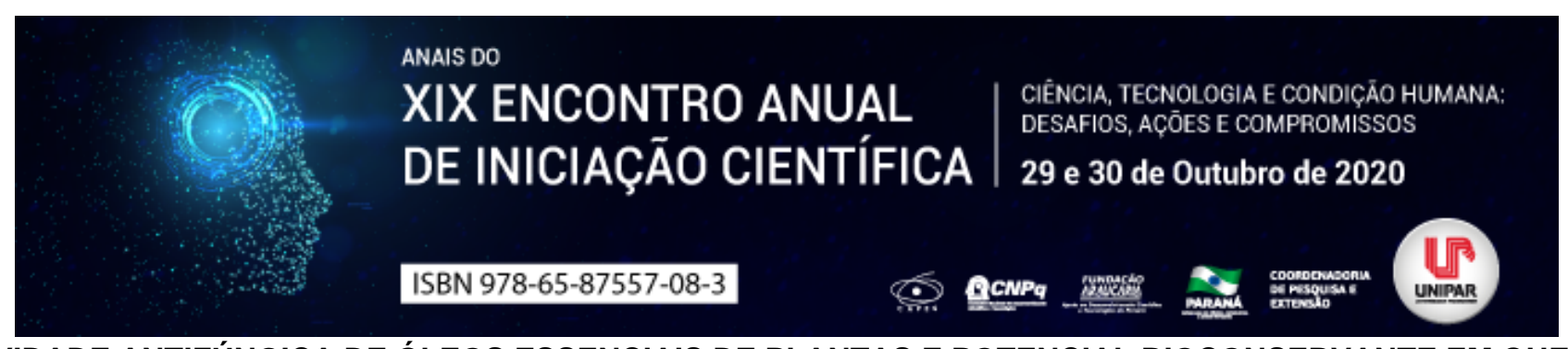

ATIVIDADE ANTIFÚNGICA DE ÓLEOS ESSENCIAIS DE PLANTAS E POTENCIAL BIOCONSERVANTE EM QUEIJOS

\begin{abstract}
${ }^{1}$ RUANA CARLA BOTARI, ${ }^{2}$ LETICIA DA SILVA MODESTO, ${ }^{3}$ KATIA CASTILHO DE OLIVEIRA, ${ }^{4}$ NELSON BARROS COLAUTO, ${ }^{5}$ GIANI ANDREA LINDE, ${ }^{6}$ SUELEN PEREIRA RUIZ HERRIG
\end{abstract}

\begin{abstract}
${ }^{1}$ Discente PIC e do Curso de Graduação em Nutrição, UNIPAR
${ }^{1}$ Discente PIC e do Curso de Graduação em Nutrição, UNIPAR

${ }^{2}$ Discente do Programa de Pós-graduação em Biotecnologia Aplicada à Agricultura, UNIPAR

${ }^{3}$ Docente do Programa de Pós-Graduação em Biotecnologia Aplicada à Agricultura, UNIPAR

${ }^{4}$ Docente do Programa de Pós-Graduação em Biotecnologia Aplicada à Agricultura, UNIPAR

${ }^{5}$ Docente do Programa de Pós-Graduação em Biotecnologia Aplicada à Agricultura, UNIPAR
\end{abstract}

Introdução: O queijo é um alimento de valor nutricional e ampla aceitação no consumo, condições inadequadas no processamento podem favorecer contaminações microbianas como fungos patogênicos, sendo responsáveis pela produção de micotoxinas (TROMBETE et al., 2013). A indústria de alimentos têm demonstrado crescente interesse em estudar os óleos essenciais (OE) como alternativa para substituição dos antimicrobianos sintéticos, devido a presença de seus compostos biologicamente ativos. Vários estudos relataram o potencial dos óleos essenciais como possíveis aditivos naturais, demonstrando ser uma alternativa para a indústria de alimentos (GOTTARDI et al., 2016).

Objetivos: O objetivo deste trabalho foi realizar revisão bibliográfica sobre o potencial antifúngico de óleos essenciais de plantas e aplicação como bioconservante em queijos.

Desenvolvimento: Foi Realizado uma revisão narrativa da literatura sobre o efeito antimicrobiano de óleos essenciais aplicados em queijos como bioconservantes. Foram pesquisados as seguintes bases de dados: Scielo, Science direct e Google acadêmico, no período de 2013 a 2020. Os termos de busca usados foram, óleos essenciais em queijos, bioconservantes e antifúngicos . O queijo é o derivado lácteo mais consumido, totalizando 92,3\% do consumo atual (JÚNIOR et al., 2020). É definido como produto fresco ou maturado obtido pelo processo de separação do soro após a coagulação do leite, e pode ser classificado como muito duro, duro, semi-mole e mole (ARAUJO et al., 2014). Por ser comum sua produção artesanal, torna-se suscetível a falhas no processo de fabricação e armazenamento, além disso, a composição e condições inadequadas de higiene propiciam meio favorável ao desenvolvimento de microrganismos. Dentre as contaminações microbianas em queijos, os principais gêneros de fungos associados são Cladosporium spp , Penicillium spp e Aspergillus spp e Fusarium spp (LAVOIE et al., 2012). A crescente demanda da população por produtos naturais despertou na indústria de alimentos o interesse pela pesquisa de compostos naturais que possam substituir os conservantes químicos sintéticos (GOTTARDI et al., 2016). Os OEs são compostos lipofílicos voláteis de origem vegetal que podem ser extraídos de diversas partes das plantas como raízes, sementes, folhas, ramos ou frutos. São provenientes do metabolismo secundário que agem no mecanismo de defesa das plantas, e podem ser utilizados em indústrias de alimentos, farmacêutica, agronômica, perfumaria e cosmética, devido sua característica aromática e ação antimicrobiana (KFOURY et al., 2016). Os principais compostos químicos presentes nos OEs são classificados como monoterpenos, sesquiterpenos e seus derivados oxigenados, o que justifica suas atividades antifúngica e antimicrobiana (HUSSEIN et al., 2015). Diversos OEs de plantas foram relatados com atividade frente aos fungos patogênicos e deteriorantes. Wang, et al. (2018), avaliaram a atividade antifúngica de 11 OEs contra fungos toxigênicos Aspergillus flavus, $A$. carbonarius e Penicillium viridicatum. Dentre os óleos, destacaram Cinnamomum cassia, Litsea cubeba, Cymbopogon martini e Thymus mongolicus Ronn com valores de concentração inibitória mínima (CIM) entre 1,67 a 5,0 $\mu \mathrm{L} / \mathrm{mL}$. Prakash et al., (2015) relataram que OE de Rosmarinus officinalis apresentou CIMs entre 0,25 a $1,5 \mu \mathrm{L} / \mathrm{mLe}$ seus principais compostos majoritários $\alpha$ pineno (22,2\%) 1,8-cineol (18,20\%) e cânfora (12,35\%) de 3,0 a 4,0 $\mu \mathrm{L} / \mathrm{mL}$, contra 12 fungos e micotoxinas de origem alimentar. Bukvicki et al., (2018) avaliaram a atividade antifúngica do OE de Thymus algeriensis em queijo macio contaminado com Penicillium aurantiogriseum, e na concentração de $20 \mu \mathrm{L} / \mathrm{mL}$ do OE obtiveram redução de $66 \%$ e na concentração de $25 \mu \mathrm{L} / \mathrm{mL}$ houve inibição total da contaminação. Mohajeri et al., (2018) avaliaram o efeito do OE de Zataria multiflora boiss no crescimento de Penicillium citrinum em meios de cultura ágar batata dextrose e queijo. Para esses autores, o OE teve efeito fungicida na concentração de 400 ppm in vitro e na matriz alimentar a inibição foi de 80,76\% a 1000 ppm, mostrando quantidades maiores de OE são requeridas para inibir o crescimento micelial em matriz alimentar quando comparado ao meio de cultura.

Conclusão: A contaminação de queijos representa riscos à saúde do consumidor e prejuízos econômico para indústria, tornando de extrema importância meios eficazes e seguros para conservação. Os estudos com OEs apresentaram resultados promissores contra fungos de origem alimentar presentes em queijos, demonstrando ser um potencial bioconservante para a indústria de alimentos, no controle ou inibição da contaminação por fungos e de micotoxinas. Embora apresente ser uma 
alternativa viável, há poucos relatos na literatura de OE aplicados em queijos como bioconservante, podendo ser mais explorado.

\section{Referências}

ARAUJO, C. et al. Alquimia dos alimentos. Brasilia: Senac, ed.3, p.312, 2014.

BUKVICKI,D. et al. Short communication: Cheese supplemented with Thymus algeriensis oil, a potential natural food preservative. Journal of Dairy Science, v.101, p.3859-3865,2018.

GOTTARDI, D. et al. Beneficial Effects of Spices in Food Preservation and Safety. Frontiers in Microbiology, v.7, p.1394, 2016. HUSSEIN, A. H. et al. T. Essential Oil Composition of Hyssopus officinalis L. Cultivated in Egypt. International Journal of Plant Research, v.1, n.2, p.49-53, 2015.

JUNIOR, J. C. R. et al . Perfil do consumidor brasileiro e hábitos de consumo de leite e derivado. Archives of Veterinary Science, v.25, n.2, p.21-31, 2020.

KFOURY, M. et al.. Development of a Total Organic Carbon method for the quantitative determination of solubility enhancement by cyclodextrins: Application to essential oils. Analytica Chimica Acta, v.918, p.21-25, 2016.

LAVOIE, K. et al. Characterization of the fungal microflora in raw milk and specialty cheeses of the province of Quebec. Dairy Science \& Tecnology, v.92, p.455-468, dez. 2012.

MOHAJERI, F. A. et al.. The effect of Zataria multiflora Boiss Essential oil on the growth and citrinin production of Penicillium citrinum in culture media and cheese. Food and Chemical Toxicology, v. 118, p.691-694, 2018.

PRAKASH, B. et al. Assessment of chemically characterised Rosmarinus officinalis L. essential oil and its major compounds as plant-based preservative in food system based on their efficacy against food-borne moulds and aflatoxin secretion and as antioxidant. International Journal of Food Science and Technology, v.50, p.1792 1798, 2015.

TROMBETE, F, M. et al. Contaminação de queijos por aflotoxinas M1: uma abordagem sobre ocorrência e prevenção. Revista do Instituto de Laticínios Cândido Tostes, v.68, n.392,p.40-48, 2013.

WANG, H. et al. Antifungal evaluation of plant essential oils and their major components against toxigenic fungi. Industrial Crops and Products, v.120, p.180-186, 2018. 


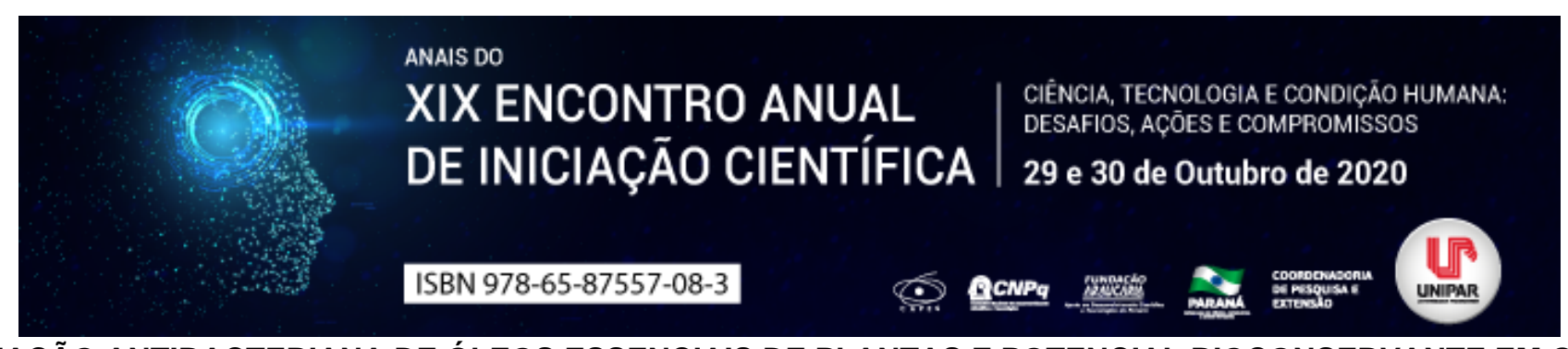

\title{
AVALIAÇÃO ANTIBACTERIANA DE ÓLEOS ESSENCIAIS DE PLANTAS E POTENCIAL BIOCONSERVANTE EM QUEIJO MINAS FRESCAL
}

\section{${ }^{1}$ LETICIA DA SILVA MODESTO, ${ }^{2}$ RUANA CARLA BOTARI, ${ }^{3}$ KATIA CASTILHO DE OLIVEIRA, ${ }^{4}$ NELSON BARROS COLAUTO, ${ }^{5}$ GIANI ANDREA LINDE, ${ }^{6}$ SUELEN PEREIRA RUIZ HERRIG}

\author{
${ }^{1}$ Discente PIC e do Curso de Graduação em Nutrição, UNIPAR \\ ${ }^{1}$ Acadêmica do Curso de Nutrição da UNIPAR \\ ${ }^{2}$ Acadêmica do Curso de Nutrição da UNIPAR \\ ${ }^{3}$ Docente do Programa de Pós-Graduação em Biotecnologia Aplicada à Agricultura, UNIPAR \\ ${ }^{4}$ Docente do Programa de Pós-Graduação em Biotecnologia Aplicada à Agricultura, UNIPAR \\ ${ }^{5}$ Docente da UNIPAR
}

Introdução: O queijo é um derivado lácteo com valor nutricional e perecível, que em condições de higiene inadequadas favorecem a contaminação por microrganismos. As principais bactérias relacionadas com surtos alimentares são Staphylococcus aureus, Escherichia coli, Salmonella e Listeria Monocytogenes (JESUS et al., 2016). Devido a preocupação com a saúde dos consumidores, as indústrias de alimentos buscam por compostos naturais para substituir aditivos sintéticos. Os óleos essenciais (OE) são compostos voláteis e versáteis que provenientes do metabolismo secundário das plantas e apresentam diversas propriedades biológicas com potencial antibacteriano para ser aplicado como conservantes em alimentos (DANNENBERG, et al., 2016).

Objetivo: Este trabalho teve por objetivo realizar uma revisão bibliográfica sobre o potencial antibacteriano de óleos essenciais de plantas e aplicação como bioconservante em queijo frescal.

Desenvolvimento: Queijo minas frescal é um alimento popular na dieta humana, constituído de gordura (17\% a 19\%), umidade (55\% a 58\%) e proteínas (16 à 22g/100g de produto), e pH em torno de 5,0 (SILVA, 2005). Por ser um produto de produção simples e baixo custo, é comum a comercialização na forma artesanal (BEZERRA et al., 2011) o que aumenta a probabilidade de contaminação do produto final. Segundo a Organização Mundial de Saúde (OMS) as principais causas das Doenças Transmitidas por Alimentos (DTAs) são por bactérias e estão principalmente relacionadas com Salmonella, E. coli e S. aureus (MS, 2020). Os compostos naturais são considerados promissores na inibição de microrganismos, dentre eles os óleos essenciais demonstram ser alternativa para potencial uso como bioconservante natural (BURT, 2004). Óleos essenciais são líquidos lipofílicos, metabólitos secundários que podem ser extraídos de várias partes das plantas como folhas, frutos raízes e ramos (AMATISTE et al., 2014). Apresentam diferentes compostos biologicamente ativos com atividade antimicrobiana como terpenos, p-cimeno e limoneno, terpenóides como timol e carvacrol e fenilpropenos (BURT, 2004; BODINI, 2011).

O óleo essencial de Lippia sidoides (pimenta de alecrim) foi avaliado contra $S$. aureus e E. coli isoladas de queijo Minas artesanal, e apresentou concentração inibitória mínima (CIM) de $13 \mu \mathrm{L} / \mathrm{mL}$ para ambas, sugerindo potencial para aplicação como conservante natural (CASTRO et al., 2011). O efeito sinérgico de OE de Origanum vulgare (MIC de $0,03 \mu \mathrm{L} / \mathrm{mL}$ ) e de Rosmarinus officinalis (MIC de 1,32 $\mu \mathrm{L} / \mathrm{mL}$ ) adicionados em queijo minas frescal reduziram 1,5 log/g e 3 log/g na contagem de $E$. coli O157: H7 após 6 e 15 dias de armazenamento, respectivamente (DINIZ-SILVA et al., 2019). Os resultados sugerem a incorporação de uma mistura sinérgica dos óleos essenciais avaliados em queijo fresco como uma estratégia para preservar o produto. Fernandes et al., (2015), avaliaram a atividade antimicrobiana do OE de Rosmarinus officinalis (alecrim) microencapsulado em proteína isolada do soro de leite e inulina foi aplicado em queijo minas frescal. Para esses autores, o OE microencapsulado na concentração de 0,5\% permitiu redução microbiana de 1,36 log ciclos após 3 dias de armazenamento e 0,73 log ciclos após 15 dias de armazenamento em comparação com o tratamento controle (sem óleo). Além disso, o processo de microencapsulação não alterou a composição química do óleo essencial de alecrim e foi eficaz no controle da acidez do queijo. Dannenberg et al. (2016) verificaram a atividade antimicrobiana óleo essencial do fruto de Schinus terebinthifolius Radd (pimenta rosa) in vitro e in situ (queijo minas frescal) contra Listeria monocytogenes. Para esses autores, o OE de frutos maduros apresentou atividade em testes in vitro (MBC de $6,8 \mathrm{mg} / \mathrm{mL}$ ) e exibiu atividade conservante in situ, tendo reduzido o desenvolvimento dessa espécie em 1,3 log UFC/g em 30 dias. Dessa forma, o óleo essencial de pimenta rosa demonstrou ser potencial substituto para conservantes químicos usados na indústria de alimentos.

Conclusão: O queijo frescal é um alimento susceptível a contaminação por bactérias patogênicos e deteriorantes, principalmente quando em condições de processamento inadequadas. Óleos essenciais são alternativa promissora para uso como bioconservante com eficácia em queijos. No entanto, é necessário propor novos estudos para avaliar as melhores estratégias para tornar o uso dos óleos essenciais na indústria de alimentos com viabilidade e benefícios para o setor. 


\section{Referências}

AMATISTE, S et al. Antimicrobial activity of essential oils against staphylococcus aureus in fresh sheep cheese. Italian Journal of Food Safety, v.3, n.3, p.148-150, 2014.

BEZERRA, J. R. M. V et al. Introdução à tecnologia de leite e derivados. Unicentro, 2011.

BURT, S. Essential oils: their antibacterial properties and potential applications in foods a review. International Journal of Food Microbiology, v.94, p.223-253, 2004.

CASTRO, C. E et al. Atividade antimicrobiana do óleo essencial de Lippia sidoides Cham. (Verbenaceae) contra Staphylococcus aureus e Escherichia coli. Revista brasileira de plantas medicinais, v.13, n.3, 2011.

DANNENBERG, G. DA S et al. Antimicrobial and antioxidant activity of essential oil from pink pepper tree (Schinus terebinthifolius Raddi) in vitro and in cheese experimentally contaminated with Listeria monocytogenes. Innovative Food Science and Emerging Technologies, v.36, p.120-127, 2016.

DINIZ-SILVA, H. T et al. Uma mistura sinérgica de óleos essenciais de Origanum vulgare L. e Rosmarinus officinalis L. para preservar a qualidade geral e controlar Escherichia coli O157: H7 em queijo fresco durante o armazenamento. LebensmittelWissenschaft \& Technologie, 2019.

FERNANDES, R. V. DE B et al. Microencapsulated rosemary (rosmarinus officinalis) essential oil as a biopreservative in minas frescal cheese. Journal of Food Processing and Preservation, 2015.

GUIMARÃES, A. C. et al. Antibacterial activity of terpenes and terpenoids present in essential oils. Molecules, v. $24,2471,2019$. JESUS, A. R. et al. Imagens digitais no estudo do armazenamento do queijo Minas frescal: Um estudo comparativo sobre diferentes embalagens. E-xacta, v.9, n.1, p.23-36, 2016.

MS - Ministério da Saúde, disponivel em: saude.gov.br/saude-de-a-z/doencas-transmitidas-por-alimentos acesso em 28 de junho de 2020.

SILVA, F. T. Queijo minas frescal. Embrapa Informação Tecnológica, p.50, 2005.

Coordenadoria de Pesquisa e Extensāo - COPEX

Departamento de Editoraçāo e Divulgaçāo Científica - DEDIC 


\section{ENCONTRO ANUAL \\ CIÊNCIA, TECNOLOGIA E CONDIÇĀO HUMANA DESAFIOS, AC̄ŌES E COMPROMISSOS}

DE INICIAÇĀO CIENTÍFICA 29 e 30 de Outubro de 2020

ISBN 978-65-87557-08-3
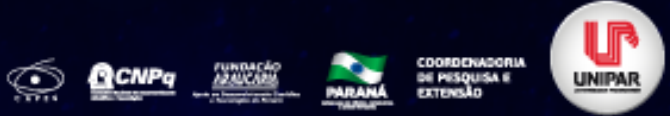

COMPARATIVO ENTRE SISTEMA CONSTRUTIVO STEEL FRAME E DE ALVENARIA CONVENCIONAL: ESTUDO DE REVISÃO

1LUANA DE LOURDES CARREIRA DO NASCIMENTO ALVES, ${ }^{2}$ IZABELA PASSAMANI DA CRUZ, ${ }^{3}$ JOSE AUGUSTO DA SILVA, ${ }^{4}$ LEONARDO GARCIA DIOSTI, ${ }^{5}$ EVERTON LUIS CONSONI DA SILVA, ${ }^{6}$ EVERLEI CAMARA

\footnotetext{
${ }^{1}$ Acadêmica bolsista do PIBIC/UNIPAR

${ }^{1}$ Acadêmica do Curso de Engenharia Civil da UNIPAR

${ }^{2}$ Acadêmico do Curso de Engenharia Civil da UNIPAR

${ }^{3}$ Acadêmico do Curso de Engenharia Civil da UNIPAR

${ }^{4}$ Acadêmico do Curso de Engenharia Civil da UNIPAR

${ }^{5}$ Docente da UNIPAR
}

Introdução: Stell Frame, ou Light Stell Frame, trata-se de um sistema construtivo industrializado estruturado por perfis leves de aço galvanizado, trabalhando em conjunto com outros tipos de sistemas, como placas cimentícias e gesso acartonado, garantindo o funcionamento da edificação. Esta tecnologia construtiva pode ser utilizada em todo tipo de obra, desde as de grande porte, como galpões, edifícios e aeroportos, até pequenas construções de residências (ROCHA, 2016). A estrutura em aço é totalmente pré-fabricada. Seu uso torna o canteiro de obras mais organizado, devido a ausência de grandes depósitos de areia, brita, cimento, madeiras e ferragens, reduzindo também o inevitável desperdício desses materiais. O ambiente limpo, com menor geração de entulho, oferece ainda melhores condições de segurança ao trabalhador, contribuindo para a redução dos acidentes na obra (CASSAR, 2018).

Objetivo: Apresentar as principais características e vantagens do Steel Frame, como método construtivo, em relação às construções de alvenaria convencional.

Desenvolvimento: Nas construções com Steel Frame, pode-se empregar qualquer sistema de fundações, mas as soluções mais utilizadas para construções de fundações são radier, sapata corrida e viga baldrame. Por utilizar perfis de aço leve, o peso estrutural da construção é consideravelmente menor, comparados às de concreto e aço convencional, motivo ao qual, chega-se a ter reduções de até $30 \%$ dos custos da fundação e menores tensões no solo (PRATES e CONFORTE, 2019). O contraventamento assegura a estabilidade da estrutura dos painéis e, sucessivamente da edificação do sistema (CASSAR, 2018). O Steel frame também suporta coberturas e lajes. A forma de trabalho dos seus elementos é de maneira bi-apoiada e desta forma, sempre que possível, transferem as cargas de forma contínua, ou seja, sem a presença de elementos de transição até a fundação. As lajes podem ser classificadas como duas: úmidas ou secas . As secas podem ser constituídas por placas cimentícias ou painéis de madeira OSB (Oriented Strand Board), ambas apoiadas em perfis metálicos estruturais. As úmidas são feitas por telhas galvanizadas (formas de aço) preenchidas por tela eletro-soldada e painéis de concreto, possibilitando o uso de perfis conformados com chapas finas de aço (ROCHA, 2016). As instalações para hidrossanitárias, elétricas, gás e dados são idênticas as instalações realizadas na alvenaria tradicional, porém no sistema Stell Frame há maior agilidade e praticidade na execução dos serviços. Como todo o projeto é bem detalhado antes do início da execução da obra, as instalações são feitas sempre de forma antecipada, evitando erros e retrabalhos. A execução desse serviço acontece antes do fechamento das paredes, evitando a prática comum de quebra-quebra quando executada na alvenaria convencional (MILAN, NOVELLO e REIS, 2011). Outro ponto de destaque é o desempenho e a qualidade do produto e, em adição a isso, sua vantagem ambiental, onde esta metodologia de construção à seco chega a reduzir cerca de $80 \%$ do consumo de água quando comparada com obras que utilizam projetos em alvenaria convencional (PETERSEN, 2012).

Conclusão: A escolha pelo sistema Stell Frame traz enormes benefícios à obra. As maiores vantagens são a diminuição de geração de resíduos da construção civil, tornando assim a obra mais limpa e seca. Em geral, as obras de Steel Frame possuem menor tempo de execução, menor produção de resíduos, melhor organização do canteiro de obras, mostrando-se como grande opção na realização de empreendimentos.

\section{Referências}

CASSAR, B. C. Análise comparativa de sistemas construtivos para empreendimentos habitacionais: alvenaria convencional X light steel frame. Rio de Janeiro, 2018.

PETERSEN, R. L. Sistema Light Steel Framing : comparativo de execução e custos com os sistemas convencionais em blocos de concreto, tijolos seis furos e tijolos maciços. Trabalho de conclusão de curso. Universidade Regional do Nordeste do Estado do Rio Grande do Sul. 72 p. ljuí, 2012. Disponível em: . Acesso em: 16 de jul. de 
2020.

PRATES, B. T ; CONFORTE, M. E. O uso do sistema Steel Frame como alternativa para melhor produtividade na Construção Civil. Revista boletim do gerenciamento, Rio de Janeiro, 2019.

ROCHA, P. P. Steel Frame: Tecnologia na construção civil. ISSN 2238- 8427, Goiás, Vol. 8., N.1, 2016.

Coordenadoria de Pesquisa e Extensão - COPEX

Departamento de Editoraçāo e Divulgaçāo Científica - DEDIC 


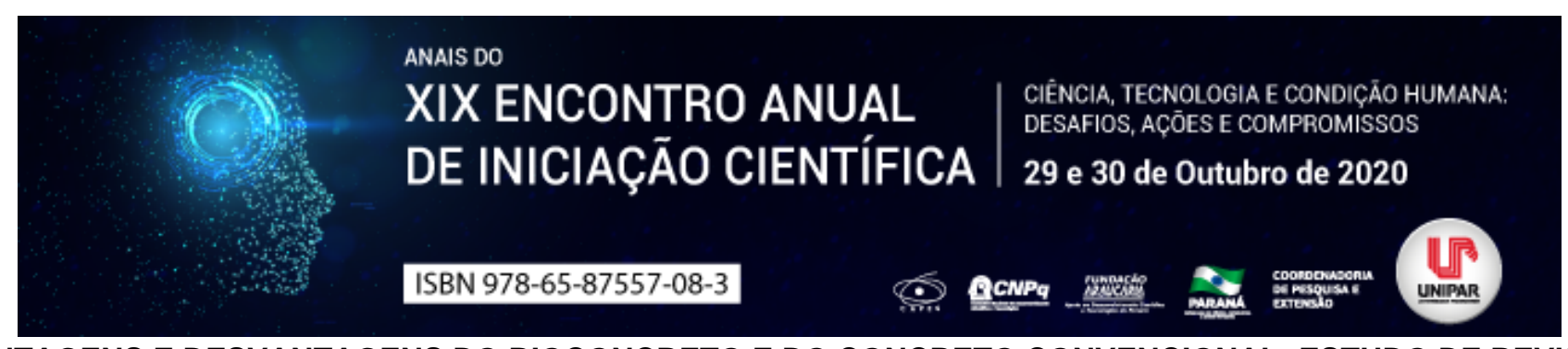

VANTAGENS E DESVANTAGENS DO BIOCONCRETO E DO CONCRETO CONVENCIONAL: ESTUDO DE REVISÃO

\author{
1'LUANA DE LOURDES CARREIRA DO NASCIMENTO ALVES, ${ }^{2}$ JOSE AUGUSTO DA SILVA, ${ }^{3}$ IZABELA PASSAMANI DA \\ CRUZ, ${ }^{4}$ LEONARDO GARCIA DIOSTI, ${ }^{5}$ EVERTON LUIS CONSONI DA SILVA, ${ }^{6}$ EVERLEI CAMARA
}

\author{
${ }^{1}$ Acadêmica bolsista do PIBIC/UNIPAR \\ ${ }^{1}$ Acadêmico do Curso de Engenharia Civil da UNIPAR \\ ${ }^{2}$ Acadêmica do Curso de Engenharia Civil da UNIPAR \\ ${ }^{3}$ Acadêmico do Curso de Engenharia Civil da UNIPAR \\ ${ }^{4}$ Acadêmico do Curso de Engenharia Civil da UNIPAR \\ ${ }^{5}$ Docente da UNIPAR
}

Introdução: O concreto convencional é uma mistura com base cimentícia e pode apresentar diversas patologias, sendo uma das principais, a corrosão da armadura, muito comum e a mais grave das patologias que acaba pondo em risco toda a estrutura da obra que ela ali sustenta. As principais causas do aparecimento de fissuras e trincas em estruturas de concreto convencional são as retrações térmicas e esforços de cargas (ARAUJO, ABREU e AMARANTE, 2019). O bioconcreto, ou concreto auto curável, é composto pelos mesmos materiais do concreto convencional, junto com as bactérias, geralmente Baccilus, e lactato de cálcio. Quando o concreto fissura, as bactérias são expostas à atmosfera, o ar e a umidade acionam a bactéria que começam a se alimentar do lactato de cálcio, iniciando o processo de precipitação, assim levando ao selando das aberturas. Segundo Pelegrino (2017), para uma cicatrização perfeita, a abertura do concreto não pode ter mais que 8 mm. Inspirado pela incrível capacidade do corpo humano para reparar ossos quebrados através de mineralização, com inúmeras pesquisas, foi possível contrastar as estruturas de concreto com a capacidade de auto cura (PELEGRINO, 2017).

Objetivo: Apresentar vantagens e desvantagens do uso do bioconcreto em relação ao concreto convencional em obras da construção civil.

Desenvolvimento: Uma das desvantagens do concreto convencional é a possibilidade de ocorrência de corrosão das armaduras de aço. A corrosão das armaduras se dá pelo fato de ter infiltrações, tanto por capilaridade ou fissuração existente, fazendo com que o oxigênio entre em contato com a armadura, oxidando assim o ferro, podendo leva-lo ao colapso, colocando em risco a estrutura e a segurança das pessoas. Este tipo de patologia requer manutenção, gerando muito consumo de materiais e energia (SILVA e PASSARINI, 2017).O bioconcreto apresenta como uma das vantagens à diminuição da necessidade de realização de manutenções e permite que estas sejam feitas em locais de difícil acesso, ambientes de difícil manutenção, como em túneis e em construções subterrâneas, que são ambientes mais propícios. O bioconcreto tem a capacidade de aumentar a durabilidade de uma estrutura de 50 para 500 anos, a diminuindo o impacto ambiental em até 10 vezes (SILVA E PASSARINI, 2017). Outra vantagem que se pode citar é a resistência, pois o bioconcreto é mais resistente que o concreto convencional, devido aos espaços vazios do concreto serem preenchidos pelo carbonato de cálcio precipitado pelas bactérias, diminuindo assim a sua permeabilidade (SILVA e PASSARINI, 2017). No teste de resistência à compressão, o concreto com a bactéria Bacillus Pasteurii alcançou, com 7 dias, resistência de 27,09 $\mathrm{MPa}$, sendo que o concreto convencional (sem a bactéria) teve um desempenho de 20,84 MPa. Aos 28 dias, o concreto com a bactéria teve resistência de 38,98 MPa e o concreto sem a bactéria de 29,99 MPa (SILVA e PASSARINI, 2017). Uma desvantagem do bioconcreto está relacionada à sua produção, que deve ser alcalino, para possibilitar a precipitação através de várias atividades fisiológicas das bactérias (ARAUJO, ABREU e AMARANTE, 2019). O custo inicial torna-se uma desvantagem para o bioconcreto que, segundo The Guardian (2015), é 40\% maior em relação ao concreto convencional, mas levando em conta os custos com manutenções futuras do concreto sem bactérias, o bioconcreto pode alcançar uma economia de milhões de dólares de investimentos em manutenções em infraestruturas e edificações. As manutenções do concreto geram custos elevados, apesar do custo do concreto convencional ser menor. Para reparação das estruturas de concreto será necessário o consumo de cimento. A indústria do cimento produz um dos principais materiais utilizados pela humanidade, sendo assim, é uma grande emissora de CO2 (com 5 a 8\% da emissão total na antropogênica), responsável pelo consumo de 10 a 15\% da energia industrial mundial. Com o uso do bioconcreto, reduzindo a manutenção e a necessidade de novas construções, isso acaba sendo remediado, colocando o bioconcreto como um material sustentável (OLIVEIRA, 2015).

Conclusão: Tem-se como vantagens potenciais do bioconcreto, comparado com o concreto convencional, a capacidade de autocura, redução de custos de manutenção e reparação, extensão da vida útil de construções de concreto, além de ser classificado como um material sustentável, apesar de seu alto custo inicial. 


\section{Referências}

ARAUJO, C ; ABREU, B ; AMARANTE, R. Bioconcreto. Revista Diálogos Interdisciplinares 2019 VOL. 8 N². Universidade Braz Cubas. Disponível em: . Acesso em: 15 de jul. de 2020.

OLIVEIRA, T.Y.M. Estudo sobre o uso de materiais de construção alternativos que otimizam a sustentabilidade em edificações. Trabalho de conclusão de curso. Universidade Federal do Rio de Janeiro. 114 p. Rio de Janeiro, 2015.

PELEGRINO, M. Estudo da influência do uso da bactéria na biocalcificação de argamassa. 2017.

SILVA, F ; PASSARINI, V. Bioconcreto: Tecnologia para construção sustentável. INOVAE - ISSN: 2357-7797, São Paulo, Vol.5, N.2, JUL-DEZ, 2017 - pág. 41-58

THE GUARDIAN. The self-healing concrete that can fix its own cracks. United Kingdom, UK: Rosie Spinks, 2015.

Coordenadoria de Pesquisa e Extensão - COPEX

Departamento de Editoraçāo e Divulgaçāo Científica - DEDIC 


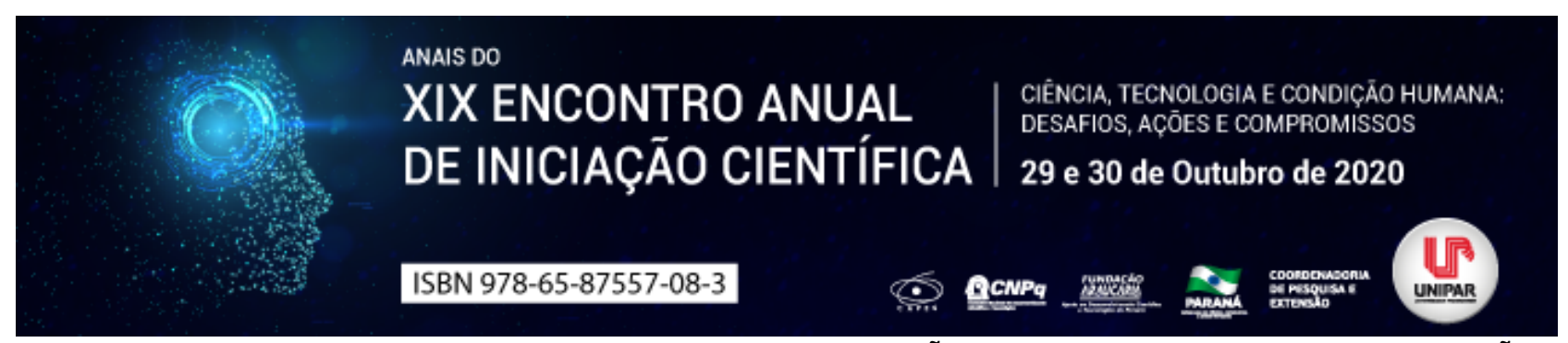

BIOCONCRETO E SUA FUNCIONALIDADE NA RECUPERAÇÃO DE FISSURAS: ESTUDO DE REVISÃO

\title{
1'LEONARDO GARCIA DIOSTI, ${ }^{2}$ EVERTON LUIS CONSONI DA SILVA, ${ }^{3}$ IZABELA PASSAMANI DA CRUZ, ${ }^{4}$ JOSE AUGUSTO DA SILVA, ${ }^{5}$ LUANA DE LOURDES CARREIRA DO NASCIMENTO ALVES, ${ }^{6}$ EVERLEI CAMARA
}

\author{
${ }^{1}$ Acadêmico do Curso de Engenharia Civil da UNIPAR \\ ${ }^{1}$ Acadêmico do Curso de Engenharia Civil da UNIPAR \\ ${ }^{2}$ Acadêmica do Curso de Engenharia Civil da UNIPAR \\ ${ }^{3}$ Acadêmico do Curso de Engenharia Civil da UNIPAR \\ ${ }^{4}$ Acadêmica do Curso de Engenharia Civil da UNIPAR \\ ${ }^{5}$ Docente da UNIPAR
}

Introdução: Desde o início da civilização, a moradia tem se tornado um requisito fundamental para a sobrevivência humana. A conservação dos alimentos, móveis, vestimentas e a própria preservação da vida caracterizam a necessidade e o objetivo dessas construções. Dessa forma, ao projetar uma estrutura, a vida útil é sempre um fator importante a ser considerado na escolha dos materiais e ferramentas, por isso o concreto é a primeira opção ao construir algo para ter uma vida útil longa, o que o torna um dos materiais mais utilizados nas construções em geral (ALVES et al., 2019). Mesmo com suas características, o concreto ainda apresenta patologias (falhas consideráveis) que o torna suscetível à expansão e compressão, possibilitando a aparição de fissuras que, futuramente, comprometerão a estrutura, além de exigir reparos constantes. Uma alternativa para a prevenção a esses danos, é a inserção de bactérias alcalifílicas e termofílicas no concreto para que essas sejam responsáveis pela cicatrização das fissuras aparentes no material. Uma característica dessas bactérias, especialmente do gênero Bacillus, é a capacidade da bactéria precipitar carbonato de cálcio $\left(\mathrm{CaCO}_{3}\right)$ quando em contato com o lactato de cálcio $\left(\mathrm{C}_{6} \mathrm{H}_{10} \mathrm{CaO}\right)$, processo responsável pela regeneração do material, também conhecida como biomineralização (KOTA et al., 2014).

Objetivo: Investigar, através do levantamento bibliográfico, a tecnologia do concreto autocurável, ensejando por meio deste, mostrar como se dá o processo de cicatrização das fissuras presentes no material através da biomineralização da bactéria do gênero Bacillus, especificamente.

Desenvolvimento: A fissuração em uma estrutura de concreto pode ocorrer por diversas causas distintas, como: mau posicionamento da armadura, sobrecargas nas estruturas, falhas no dimensionamento, cura deficiente, recalque das fundações e diversas outras. De acordo com Mehta e Monteiro (2014), a fissuração pode surgir nos primeiros minutos após o lançamento ou até mais do que 2 anos após a concretagem. Uma vez que essas fissuras aparecem, a estrutura está sujeita a entrada de água e agentes patológicos que se infiltraram no material, podendo alcançar a armadura e provocar corrosões, trazendo perda na resistência e rigidez do material, inutilizando-o como elemento estrutural. Segundo Wang et al. (2014), o concreto possui uma característica de recuperação devido ao tempo de hidratação de suas partículas, porém é uma ação vagarosa, então estudos buscam uma maneira mais viável de estimular a autocicatrização dessas fissuras através da biomineralização. A biomineralização é um processo bioquímico que tem por finalidade estimular a atividade metabólica de algumas bactérias, como as do gênero Bacillus, à precipitação de um mineral, ou seja, os microrganismos na presença de água e de nutrientes adequados, têm sua atividade metabólica ativada, iniciando a formação de cristais de carbonato de cálcio (MELLO, PACHECO e TUTIKIAN, 2019). O lactato de cálcio é a substância que tem apresentado resultados promissores como nutriente das bactérias, além de aumentar a resistência à compressão e não comprometer a armadura da estrutura. À medida que são produzidos, os cristais atuam como reparadores e vão fechando as trincas (WANG et al., 2014). Segundo Mello, Pacheco e Tutikian (2019), a autocicatrização através da adição de soluções bacterianas ocorre pela precipitação de calcita induzida microbiologicamente (MICP) (...) . As células possuem capacidade metabólica, onde retiram nutrientes do ambiente, os transformam e os devolvem ao ambiente. Cada bactéria possui um processo metabólico diferente que leva à precipitação do carbonato de cálcio, ocorrendo o processo de biomineralização. Sendo assim, com a precipitação da calcita, os cristais formados se depositam no interior das fissuras, causando a calcificação, evitando a entrada de agentes agressivos e deteriorantes, protegendo a estrutura da ação da água e de agentes químicos invasores (ALVES et al., 2019).

Conclusão: Uma solução bacteriana de capacidade metabólica, tendo uma fonte de alimento como substrato, pode acelerar o processo de precipitação do carbonato de cálcio, em meio a uma solução cimentícia. Esse processo leva à formação de cristais de carbonato, que se depositarão nas fissuras e, ao entrarem em contato com a água, calcificarão, restaurando-as e impedindo a entrada de agentes agressivos que prejudicam a estrutura. Deve-se levar em consideração que os estudos apresentados são relativamente recentes e que os resultados obtidos são em ambientes controlados em laboratório, devendo ter uma atenção maior em condições reais da estrutura. 


\section{Referências}

ALVES, Lais et al. Characterization of Bioconcrete and the Properties for Self-Healing. Proceedings, v. 38, n. 1, p. 4, 2019. KOTA, Krishna Priya et al. Bioconcrete Enhancement from Biofilm Producing Marine Bacterium. International Journal of Pharmaceutical Sciences Review and Research (ISSN 0976-044X), v. 25, n. 5, p. 276-279, 2014.

MEHTA, Povindar Kumar; MONTEIRO, Paulo José Melaragno. Concreto: microestrutura, propriedades e materiais. $2^{\mathrm{a}}$ edição Brasileira. 4ª Edição em inglês. São Paulo. Brasil, 2014.

MELLO, Vinícius; PACHECO, Fernanda; TUTIKIAN, Bernardo Fonseca. Técnicas e Metodologias de Biomineralização na Cicatrização de Fissuras do Concreto. Revista de Arquitetura IMED, v. 8, n. 2, p. 164-182, 2019.

SILVA, Felipe Portela Candido; DE CARVALHO PASSARINI, Victor; SANTOS, Fernanda Cristina Storte. BIOCONCRETO: A TECNOLOGIA PARA CONSTRUÇÃO SUSTENTÁVEL. INOVAE-Journal of Engineering, Architecture and Technology Innovation (ISSN 2357-7797), v. 5, n. 2, p. 41-58, 2017.

VIEIRA, Juliana Aparecida. Biodeposição de $\mathrm{CaCO} 3$ em materiais cimentícios: contribuição ao estudo da biomineralização induzida por Bacillus subtilis. 2017.

WANG, Jianyun et al. Application of hydrogel encapsulated carbonate precipitating bacteria for approaching a realistic self-healing in concrete. Construction and Building Materials, Ghent, v. 68, p. 110-119, 2014. 


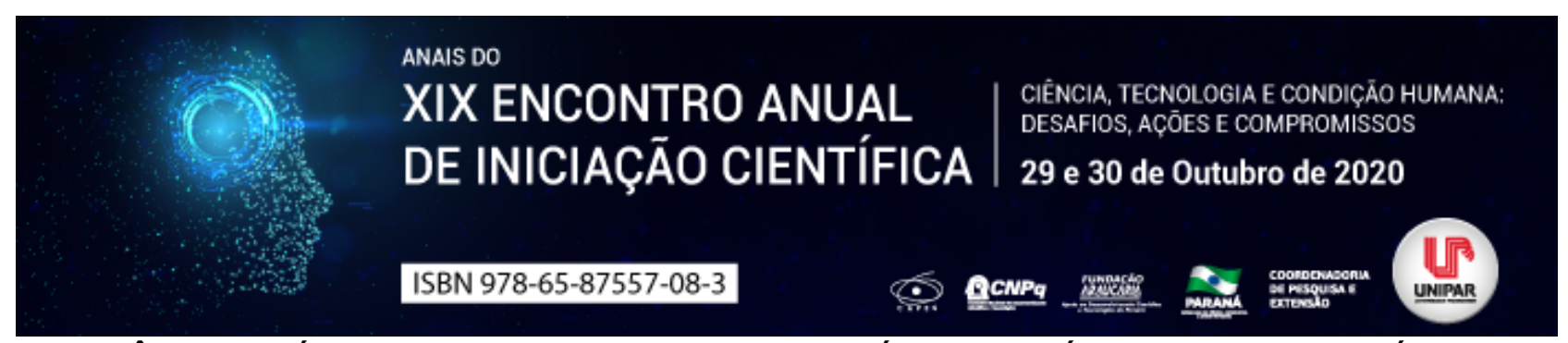

\title{
EFICIÊNCIA E MÁQUINAS DE FLUXO: CARNEIRO HIDRÁULICO E MÁQUINA TERMO HIDRÁULICA
}

\begin{abstract}
${ }^{1}$ ALEXSIA ROBERTA DELAI, ${ }^{2}$ RUAN VITOR BARRETO LOURENCO, ${ }^{3}$ THIAGO VALENTIM GIROTTO, ${ }^{4}$ MURILO CANDIANI ALMEIDA, ${ }^{5}$ ALEXANDRE DE CASTRO SALVESTRO
\end{abstract}

${ }^{1}$ Engenharia Mecânica, UNIPAR

Avenida Tiradentes, $n^{\circ} 3240$

${ }^{1}$ Engenharia Mecânica, UNIPAR Avenida Tiradentes, $n^{\circ} 3240$

${ }^{2}$ Engenharia Mecânica, UNIPAR Avenida Tiradentes, $n^{\circ} 324$

${ }^{3}$ Engenharia Mecânica, UNIPAR Avenida Tiradentes, $n^{\circ} 3240$

${ }^{4}$ Engenharia Mecânica, UNIPAR Tiradentes, $n^{\circ} 3240$,
Universidade Paranaense, alexsia.delai@edu.unipar.br, Telefone: (+55) 443621-2828,

Universidade Paranaense, ruan.lourenco@edu.unipar.br, Telefone: (+55) 443621-2828,

Universidade Paranaense, thiago.girotto@edu.unipar.br, Telefone: (+55) 443621-2828,

Universidade Paranaense, murilo.199559@edu.unipar.br, Telefone: (+55) 443621-2828,

Universidade Paranaense, alexandrecastro@unipar.br, Telefone: (+55) 443621-2828, Avenida

Introdução: A energia pode ser classificada em renovável e não renovável, onde a primeira seria proveniente de uma fonte capaz de ser reconstituída em um período de tempo relativamente curto, enquanto que a segunda, seria marcada por sua impossibilidade de renovação total ou, então, pela capacidade de renovação em um intervalo de tempo muito extenso. As principais vantagens do uso de fontes de energia renovável estão relacionadas ao planejamento econômico, ocasionado pelas estimativas de restituição dessas fontes, que permitem, além da estipulação quantitativa da energia gerada no decorrer dos anos, a implementação de sistemas favoráveis a ampliação desses resultados, assim como a diminuição dos poluentes emitidos, predominantemente, por complexos de geração de energia de fontes não renováveis, das quais o Brasil apresenta dependência significativa, evidenciada pela predominância de 58,8\% de participação dessas fontes na oferta de energia do país (MARIANI, 2017). Em adição aos complexos energéticos, participantes da oferta nacional de energia, os sistemas de pequena escala, fundamentados na utilização de fontes renováveis, também têm se destacado em residências e em propriedades rurais, com destaque para o carneiro hidráulico e a máquina termo hidráulica que, utilizando, respectivamente, fontes de energia hidráulica e solar, mantém a irrigação de áreas cultivadas de um modo sustentável.

Objetivo: Correlacionar a eficiência das máquinas de fluxo com a avaliação do carneiro hidráulico e da máquina de fluxo termo hidráulica.

Desenvolvimento: O carneiro hidráulico, em função da utilização da força da gravidade em associação a uma válvula de sucção adaptada, para incitar a movimentação da água por um canal de distribuição, é classificado como máquina de fluido geradora, decorrente do aumento de sua energia. O mesmo pode ser dito da máquina termo hidráulica, que também aumenta a energia do fluido, porém, nesse caso, pela amplificação da pressão no reservatório, através de seu aquecimento (HENN, 2006). Assim, considerando o fluxo do fluido em ambos os casos, tem-se que as condições de instalação serão fundamentais na avaliação do bom funcionamento dos mesmos, prática imprescindível na averiguação da viabilidade de implantação do equipamento em questão. Esse tópico, por sua vez, pode ser avaliado em termos da eficiência do sistema, que fornecerá o percentual de aproveitamento dos recursos disponibilizados, em relação as perdas ocorridas no decorrer do escoamento. Isto posto, tem-se que, no caso do carneiro hidráulico, a principal perda considerada será referente a quantidade de fluido desviado através da válvula de sucção. Assim, em analogia a definição de eficiência mecânica de Çengel (2007), dada pelo quociente da energia saindo do sistema, pela energia entrando no sistema $(=() /,()$,$) , a eficiência hidráulica do carneiro, que considera o bom$ aproveitamento do fluído, poderá ser obtida do quociente da vazão volumétrica no canal de distribuição, pela vazão volumétrica na entrada do sistema $(h=() /())$. Já no caso da máquina termo hidráulica, o ar contido em um dos recipientes auxiliares será responsável pela movimentação da água nas tubulações, de modo que, quanto maior for a pressão exercida por ele sobre a mesma, maior será sua velocidade e alcance no interior dos dutos. Nesse equipamento, a variação da pressão do fluido se dará em função da transferência de energia térmica decorrente da diferença das temperaturas interna e externa do sistema. Portanto, o melhor funcionamento da máquina será decorrente de uma transferência satisfatória de energia do ambiente para o reservatório (MELO, 2016). Nesse sentido, um dos fatores que deve ser considerado é a taxa de transmissão de calor por condução, que caracterizará o fluxo de calor em determinado intervalo de tempo. Em suma, com esse valor dado por ( $\Delta / \Delta$ ) $=\Delta /$, onde A é a área, $\Delta$ é a variação de temperatura entre as faces, d é a espessura do recipiente e k é a constante de condutividade térmica do material, tem-se que tanto o recipiente, quanto sua espessura, influenciarão no desempenho da máquina (DONOSO, 2008), assim como a forma com a qual o mesmo reage a radiação térmica recebida que, em função das variações na 
absortividade do material, propriedade que indica a quantidade de radiação absorvida em relação ao total em incidência sobre o meio, pode vir a apresentar uma maior ou menor absorção de energia e, por conseguinte, temperaturas variáveis no interior do sistema, caracterizando a pressão máxima que poderá vir a ser gerada no reservatório (ANUNCIAÇÃO, 2007; FRAGATA, 2015). Conclusão: A partir da conceituação da eficiência como a relação entre os elementos disponibilizados e aqueles que são essencialmente utilizados, infere-se que, para ambos os sistemas, carneiro hidráulico e máquina termo hidráulica, um melhor aproveitamento das fontes de energia seria obtido, respectivamente, por um controle de água desviada para fora do sistema durante a abertura da válvula de sucção e pela seleção de um material cabível à transmissão de energia térmica do meio externo para o reservatório de ar responsável pelo fluxo de água.

\section{Referências}

ANUNCIAÇÃO, Elenise Barreto Barbosa. Utilização de um secador solar para a desintoxicação da torta de mamona. Orientador: Prof. Dr. José Ubiragi de Lima Mendes. 2007. 88 p. Dissertação (Mestrado em Engenharia Mecânica) - Universidade Federal do Rio Grande do Norte. Disponível em: https://repositorio.ufrn.br/jspui/bitstream/123456789/15734/1/EleniseBBA.pdf. Acesso em: 1 set. 2020.

DONOSO, Prof. Dr. José Pedro. Calor, energia e transferência de calor. In: UNIVERSIDADE DE SÃO PAULO INSTITUTO DE FÍSICA DE SÃO CARLOS - IFSC (São Paulo). Prof. Dr. José Pedro Donoso. Calor, energia e transferência de calor. São Carlos, SP, 2008. Disponível em: http://www.ifsc.usp.br/ donoso/fisica_arquitetura/Transferencia_de_Calor.pdf. Acesso em: 26 jul. 2020. FRAGATA, F.; SENS, M.; SEBRAO, M.. Influência da cor de tintas de poliuretano na absorção e na dissipação de calor. Corros. Prot. Mater., Lisboa , v. 34, n. 2, p. 53-59, dez. 2015 . Disponível em: http://www.scielo.mec.pt/scielo.php? script=sci_arttext\&pid=S0870-11642015000200003\&lng=pt\&nrm=iso. acessos em: 01 set. 2020.

HENN, Érico Antônio Lopes. Perdas de energia em máquinas de fluxo. In: HENN, Érico Antônio Lopes. Máquinas de Fluído. 2. ed. Santa Maria: Editora UFSM, 2006. P. 7192.

MARIANI, Leidiane. Eficiência energética e qualidade de energia. Londrina, Paraná: Editora e Distribuidora Educacional S.A., 2017.

MELO, Washington Luiz de Barros. Irrigador Solar: Instruções De Montagem E De Funcionamento. São Carlos, SP: Embrapa Instrumentação, 2016. 16 p.

ÇENGEL, Yunus A. Mecânica dos Fluidos: Fundamentos e Aplicações. São Paulo: AMGH Editora Ltda., 2007. 


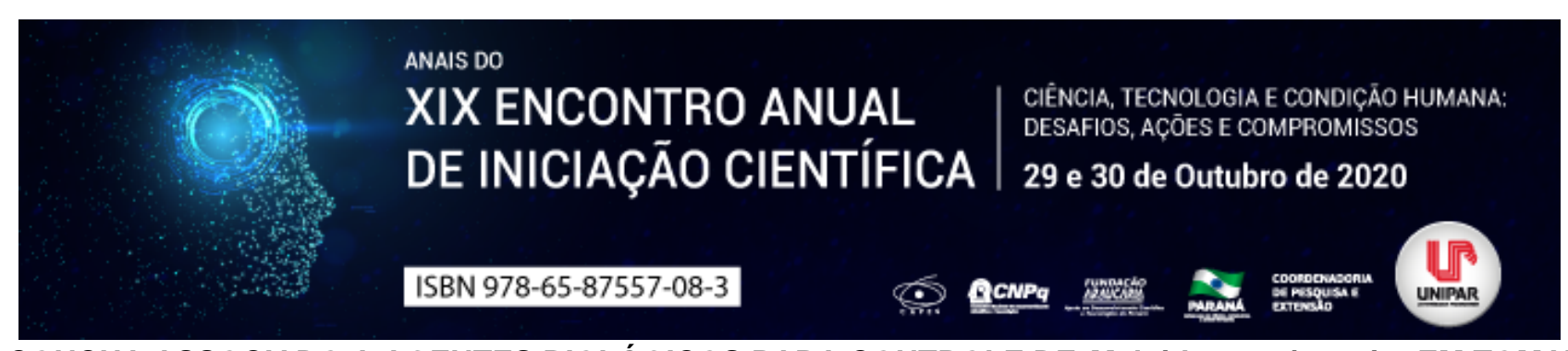

PÓ DE CONCHA ASSOCIADO A AGENTES BIOLÓGICOS PARA CONTROLE DE Meloidogyne javanica EM TOMATEIRO

\author{
${ }^{1}$ Vitor Vargas Schwan, ${ }^{2}$ ANGÉLICA MIAMOTO , ${ }^{3}$ CLAUDIA REGINA DIAS ARIEIRA
}

\author{
${ }^{1}$ Mestrando UEM \\ ${ }^{1}$ Doutoranda UEM \\ ${ }^{2}$ Docente da UEM
}

Introdução: O tomate (Solanum lycopersicum L.) é a hortaliça mais consumida in natura no mundo (HACHMANN et al., 2014). Um dos principais problemas fitossanitários da cultura é a presença de fitonematoides, causando perdas econômicas mundiais de USD \$157 bilhões por ano (NICOL et al., 2011; DAVIES; ELLING, 2015; SINGH; SINGH; SINGH, 2015). Comumente, o controle químico tem sido a estratégia mais utilizada, por fornecer resultados mais rápidos. No entanto, devido ao alto custo, baixa eficácia após repetidas aplicações e a crescente preocupação ambiental e com a saúde humana, os nematicidas químicos tendem a ser substituídos por práticas menos poluentes (DONG; ZHANG 2006; DESAEGHER, 2014). O controle biológico é uma alternativa de manejo dos nematoides, por meio do uso de organismos vivos (YANG; LI; JØRGENSEN, 2013), os quais agem por parasitismo, predação, antagonismo ou competição (SHAH; MAHAMOOD, 2017). Outro método de controle utilizado é o cultural, incluindo uso de plantas antagônicas, rotação de culturas e utilização de matéria orgânica (TONINATO et al., 2019). Dentro de matéria orgânica, pode ser utilizado a quitina. A quitina é o segundo polissacarídeo mais abundante na natureza, sendo um constituinte importante de fungos, algas, conchas e ovos de nematoide (WEISS; SCHÖNITZER, 2006; SILVA et al., 2010). A adição de quitina no solo pode estimular a atividade de organismos quitinolíticos, além de auxiliar no controle de nematoides (SUGANDA, 1999; RADWAN et al., 2011; MOTA; SANTOS, 2016), pois possui atividade nematostática e nematicida (KHALIL; BADAWY, 2012). Desta forma, há a hipótese de que a associação entre resíduos a base de quitina e fungos nematófagos quitinolíticos possa resultar em uma alternativa sustentável para o controle de nematoides.

Objetivo: Avaliar o efeito do pó de concha associado a agentes de controle biológico no manejo de Meloidogyne javanica em tomateiro.

Material e Métodos: O experimento foi realizado na Universidade Estadual de Maringá, em casa de vegetação. O pó de concha foi proveniente da trituração de conchas e mariscos. O experimento foi realizado em delineamento inteiramente casualizado (DIC), em fatorial 5x5, sendo cinco tratamentos biológicos (Trichoderma harzianum, Purpureocillium lilacinum, Pochonia chlamydosporia, Bacillus subtilis+Bacillus licheniformis e uma testemunha sem produto) x cinco doses do pó de concha (0, 250, 500, 750 e $1000 \mathrm{~kg} / \mathrm{ha}$ ). A mistura de solo argiloso e areia (1:1; v:v) foi depositada em copos de isopor de $500 \mathrm{~mL}$. Em seguida adicionou-se o pó de concha, de acordo com as quantidades de cada tratamento. Decorridos 15 dias, fez-se o transplante de mudas de tomateiro cv. Santa Clara 5800, com 15 dias de germinadas. No momento do transplante, aplicou-se os controles biológicos, com as respectivas doses recomendadas pelos fabricantes. Ainda, no momento do transplante, as plantas foram inoculadas com uma suspensão de $1 \mathrm{~mL}$ contendo 2000 ovos + juvenis de segundo estádio (J2) de M. javanica, sendo o inóculo obtido pela técnica de Boneti e Ferraz (1981). O inóculo foi depositado diretamente nas raízes de cada muda de tomate transplantada. O experimento foi mantido em casa de vegetação por 60 dias e, após este período, avaliou-se a quantidade de nematoide total nas raízes das plantas. Os dados foram submetidos a ANOVA e as médias entre os tratamentos biológicos comparadas pelo teste de Scott-Knott a $5 \%$ de probabilidade, enquanto as doses foram estudadas por regressão polinomial.

Resultados: Na dose de $250 \mathrm{~kg} / \mathrm{ha}, P$. lilacinum promoveu maior redução no número total de nematoides, com $50,46 \%$ de controle. Para a dose de $500 \mathrm{~kg} / \mathrm{ha}, T$. harzianum e $P$. chlamydosporia foram os melhores tratamentos no controle do nematoide, reduzindo a população em $76,87 \%$ e $43,38 \%$, respectivamente.

Discussão: Os resultados obtidos neste trabalho mostram que, para o agente biológico $P$. linacinum, a adição no solo de 250 $\mathrm{kg} / \mathrm{ha}$ de pó de concha potencializou o seu controle sobre $M$. javanica em tomate. Entretanto, para $T$. harzianum e $P$. chlamydosporia, a dose que maior potencializou o controle sobre os nematoides foi a de $500 \mathrm{~kg} / \mathrm{ha}$. A adição de quitina ao solo pode estimular o crescimento de bactérias, actinobacteria e um número ilimitado de espécies de fungos com propriedades quitinolíticas. Esses microrganismos podem atacar os ovos de nematoides e massas de ovos, reduzindo assim suas populações (SPIEGEL et al., 1987). Mota e Santos (2016) demonstraram que, ao adicionar quitina ao solo, houve aumento no crescimento da planta e redução de até $87,55 \%$ no fator de reprodução e no número de $M$. javanica/g de raiz.

$\mathrm{O}$ uso de quitina combinado com agentes biológicos já vem sendo estudado. Escudero et al. (2016) identificaram que $P$. chlamydosporia cultivada com quitina ou quitosana como principais fontes nutricionais, expressou grande número de proteínas, como a protease VCP1, o qual tem papel importante no processo de parasitismo.

Conclusão: Os agentes biológicos $P$. lilacinum, $T$. harzianum e $P$. chlamidosporia possuem potencial para controle de $M$. javanica quando associados a quitina nas doses de $250 \mathrm{~kg} / \mathrm{ha}(P$. linacinum) e $500 \mathrm{~kg} / \mathrm{ha}$ ( $T$. harzianum e $P$. chlamidosporia). 


\section{Referências}

BONETI, J. I. S.; FERRAZ, S. Modificação do método de Hussey e Barker para extração de ovos de Meloidogyne exígua de raízes de cafeeiro. Fitopatologia Brasileira, v. 6, n.3, p. 553, 1981.

DAVIES, L. J.; ELLING, A. A. Resistance genes against plantparasitic nematodes: a durable control strategy? Nematology, v. 17 , p. 249-263, 2015.

DESAEGHER, J. Nematicide discovery - opportunities and challenges. Journal of Nematology, p. 152-153, 2014.

DONG, L. K.; ZHANG, K. Q. Microbial control of plant-parasitic nematodes: a five-party interaction. Plant and Soil, v. 288, n. 1-2, p. 31-45, 2006. http://dx.doi.org/10.1007/s11104-006-9009-3.

HACHMANN, T. L. et al. Cultivo do tomateiro sob diferentes espaçamentos entre plantas e diferentes níveis de desfolha das folhas basais. Bragantia, v. 73, n. 4, p. 399-406, 2014. http://dx.doi.org/10.1590/1678-4499.0163.

MOTA, L. C. B. M.; SANTOS, M. A. Chitin and chitosan on Meloidogyne javanica management and on chitinase activity in tomato plants. Tropical Plant Pathology, v. 41, n. 2, p. 84-90, 2016. http://dx.doi.org/10.1007/s40858-016-0072-x.

NICOL, J. M. et al. Current nematode threats to world agriculture. Genomics and Molecular Genetics of Plant-nematode Interactions, p. 21-43, 2011. http://dx.doi.org/10.1007/978-94-007-0434-3_2.

SHAH, M. M.; MAHAMOOD, M. Nematology - concepts, diagnosis and control. Croatia: INTECH, 194 p, 2017.

SILVA, D. et al. Caracterização físico-química e microestrutural de conchas de moluscos bivalves provenientes de cultivos da região litorânea da ilha de Santa Catarina. Química Nova, v.33, n. 5, p. 1053-1058, 2010. http://dx.doi.org/10.1590/s010040422010000500009.

SINGH, S; SINGH, B; SINGH, A. P. Nematodes: a threat to sustainability of agriculture. Procedia Environmental Sciences, v. 29, p. 215-216, 2015. http://dx.doi.org/10.1016/j.proenv.2015.07.270.

SUGANDA, T. Natural chitinous amendment for controlling root-knot nematode (Meloidogyne spp.) of tomato. Jurnal Agrikultura, v. 10, p. 17-19, 1999.

TONINATO, B. O. et al. Meloidogyne javanica control in lettuce with fertilizers applied isolated or associated with biological product. Horticultura Brasileira, v. 37, n. 4, p. 384-389, 2019. http://dx.doi.org/10.1590/s0102-053620190404.

WEISS, I. M.; SCHÖNITZER, V. The distribution of chitin in larval shells of the bivalve mollusk Mytilus galloprovincialis. Journal of Structural Biology, v. 153, n. 3, p. 264-277, 2006. http://dx.doi.org/10.1016/j.jsb.2005.11.006.

YANG, F.; LI, W.; JøRGENSEN, H. J. L. Transcriptional reprogramming of wheat and the hemibiotrophic pathogen septoria tritici during two phases of the compatible interaction. Plos One, v. 8, n. 11, p. 1-15, 2013. http://dx.doi.org/10.1371/journal.pone.0081606. 


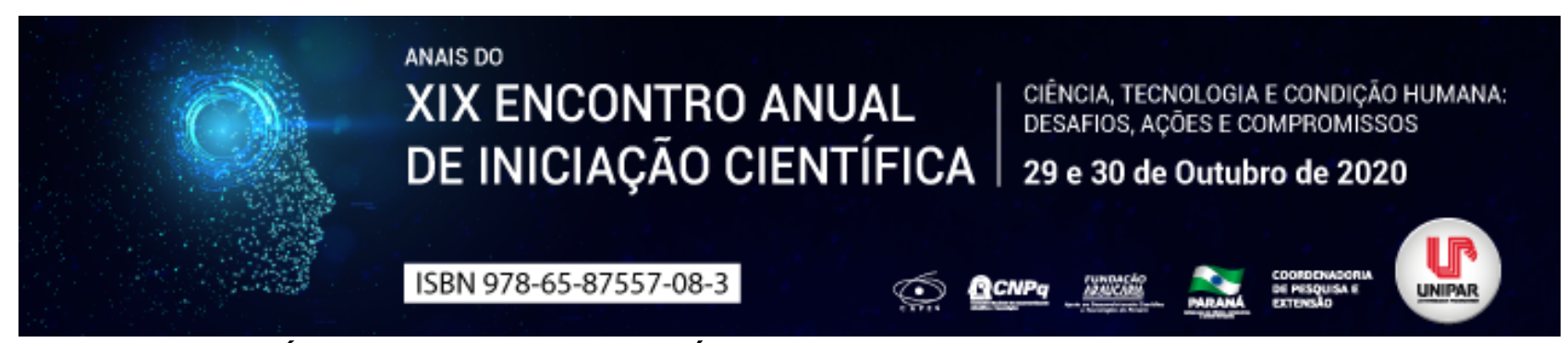

FERRO TOTAL DISPONÍVEL EM DIFERENTES ESPÉCIES DE ORA PRO NOBIS (Pereskia grandifolia haw e Pereskia aculeat mill)

\title{
${ }^{1}$ GABRIEL SABATINI PEREIRA, ${ }^{2}$ WESLEY RIBEIRO RIVADAVEA, ${ }^{3}$ AMANDHA MELO DOS SANTOS, ${ }^{4} \mathrm{JULLIANE}$ DESTRO DE LIMA, ${ }^{5}$ LARISSA LOURENCETO, ${ }^{6}$ GLACY JAQUELINE DA SILVA
}

\author{
${ }^{1}$ Acadêmico bolsista do PIBIC/UNIPAR \\ ${ }^{1}$ Acadêmico do Curso de Engenharia AgronÃ'mica da UNIPAR \\ ${ }^{2}$ Acadêmica do Curso de Engenharia AgronÃ'mica da UNIPAR \\ ${ }^{3}$ Acadêmica do Curso de Doutorado Em Biotecnologia Aplicada A Agricultura - Turma Vii da UNIPAR \\ ${ }^{4}$ Acadêmica do Curso de Engenharia AgronÃ'mica da UNIPAR \\ ${ }^{5}$ Docente da UNIPAR
}

Introdução: O Brasil possui uma vasta biodiversidade, nas quais são encontradas plantas que possuem nutrientes que podem ser utilizados na alimentação, como a Pereskia aculeata Miller. Conhecida mundialmente como ora-pro-nobis, esta planta é uma espécie altamente nutritiva da família Cactaceae, pertencente à Mata Atlântica brasileira. Esta espécie de hortaliça é um alimento não convencional, rica em proteínas e apresenta aminoácidos e minerais essenciais para nossa alimentação, além de possuir elevado teor de ferro, cálcio vitamina C, entre outros minerais solúveis e insolúveis. Quanto ao teor de ferro, a literatura mostra que a mesma apresenta em média 0,142 mg L em $100 \mathrm{~g}$ de amostra Pinto et al. (2015), Silva et al. (2017). O ferro é um mineral vital para a homeostase celular e é um elemento de suma importante para o funcionamento do nosso organismo. A falta deste elemento ou a carência consiste em inúmeras complicações como por exemplo a anemia ferropriva e cerca de 40\% da população brasileira apresenta essa doença (YAMAGISHI, 2017). A baixa quantidade de ferro no organismo humano acarreta umas das deficiências nutricionais de maior importância no mundo, visto que uma parte da população tem baixo acesso a esse nutriente. Por isso existe uma preocupação constante na busca de alimentos com baixo custo e qualidade, que possam suprir carências nutricionais.

Objetivo: O intuito deste trabalho foi avaliar a concentração de ferro total em duas espécies de ora-pro-nobis,( Pereskia grandifolia haw e Pereskia aculeat mill).

Metodologia: O trabalho foi conduzido no Laboratório de Biologia Molecular (UNIPAR), Casa de Vegetação (UNIPAR) e Laboratório de Química orgânica da Universidade estadual oeste do Paraná (UNIOESTE). As amostras de folhas de ora-pronobis amarela (Pereskia aculeat mill) e ora-pro-nobis rosa (Pereskia grandifolia haw) foram colhidas e secas em estufa de circulação de ar a $35^{\circ} \mathrm{C}$ por 28 dias, moídas em moinhos de facas da marca Marconi modelo especial 60 ciclos, peneiradas a 30 mesh, acondicionadas em embalagem plástica de polietileno e mantidas refrigeradas à aproximadamente $11^{\circ} \mathrm{C}$ até 0 momento das análises, para as concentrações de ferro utilizou-se a metodologia proposta por OFFICIAL METHODS OF ANALYSIS, Association of official analytical Chemists, 40a ed, USA, 1984.

Resultados e Discussão: Segundo os dados apresentados neste estudo a ora-pro-nobis mostrou-se altamente nutritiva, e seu potencial destaca-se pelo alto teor de ferro, superando a média nacional para as plantas desta mesma espécie. Em alguns estudos como de ALMEIDA e CORRÊA (2012) a ora-pro-nobis apresenta níveis de ferro 6 vezes maior que a maioria dos alimentos não convencionais. Os níveis de ferro presente em suas análises apresenta cerca de 18,51mg L em 100g-1 de matéria seca. ALMEIDA e CORRÊA (2012) cita as propriedades nutricionais desta planta, bem como apresenta valores de 3,60 mg $L$ de ferro em $100 \mathrm{~g}$ de folha de ora-pro-nobis amarela. Quando comparamos os resultados destas pesquisas e analisamos este estudo, encontramos em média 0,124 de ferro em $\mathrm{mg} \mathrm{L}$ em $100 \mathrm{~g}$ de amostra para a ora-pro-nobis amarela e 0,106 em mg L em $100 \mathrm{~g}$ de amostra para a ora-pro-nobis rosa, mostrando assim quantidades de ferro diferentes nas espécies estudadas. Em estudos sobre teores de ferro, P. aculeata apresentou maior teor de ferro quando comparada a P. grandifolia. TAKEITI et al. (2009). Em outros estudos como o de ALMEIDA et al. (2012) identificaram em P. aculeata um teor de 0,142 mg L $100 \mathrm{~g}$ de amostra, concluindo que as ora-pro-nobis são importantes fontes de proteínas, fibras e de minerais, principalmente Cálcio e Ferro e de compostos bioativos.

Conclusão: as folhas de ora-pro-nobis apresentam altas concentrações de ferro, sendo assim indicadas para suplementação deste mineral em dietas alimentares, principalmente em pessoas com deficiência de ferro.

\section{Referências}

ALMEIDA, M. E. F.; CORRÊA, A. D. Utilização de cactáceas do gênero Pereskia na alimentação humana em um município de Minas Gerais. Ciência Rural, Santa Maria, v.42, n.4, p.751-756, 2012. 
CARVALHO, M. C. et al. Anemia ferropriva e anemia de doença crônica: distúrbios do metabolismo de ferro. Segurança Alimentar e Nutricional, v. 13, n. 2, p. 54-63, 1984.

DIAS, A.C.P. et al. Avaliação do consumo de hortaliças não convencionais pelos usuários das Unidades do Programa Saúde da Família (PSF) de Diamantina - MG. Alimentos e Nutrição, v.16, n.3, p.279-284, 2005.

DUARTE, M.R.; HAYASHI, S.S. Estudo anatômico de folha e caule de Pereskia aculeata Mill. (Cactaceae). Revista Brasileira de Farmacognosia, v.15, n.2, p.103-109, 2005.

PINTO N. C. C. et al. Pereskia aculeata Miller leaves present in vivo topical anti-inflammatory activity in models of acute and chronic dermatitis. J Ethnopharmacol, v. 163, p. 330-337, 2015.

ROSA, S. M.; SOUZA, L. A. Morfo-anatomia do fruto (hipanto, pericarpo e semente) em desenvolvimento de Pereskia aculeata Miller (Cactaceae). Acta Scientarium Biological Sciences, v.25, n.2, p.415-428, 2003.

SILVA, D.O. et al. Acute Toxicity and Cytotoxicity of Pereskia aculeata, a Highly Nutritious Cactaceae Plant. J Med Food, v. 20, n. 4, p. 403-409, 2017.

TAKEITI, C.Y. et al. Nutritive evaluation of non-conventional leafy vegetable (Pereskia aculeata Miller). International Journal of Food Sciences and Nutrition, v.60, n.1, p.148-160, 2009.

UNIVERSIDADE ESTADUAL DE CAMPINAS. Tabela Brasileira de Composição de Alimentos (TACO). NEPA UNICAMP, Campinas, ed. 4, rev. e ampl.. -- Campinas: NEPA UNICAMP, 2011. 161p.

YAMAGISHI, J. A. et al. Anemia ferropriva: diagnóstico e tratamento. Revista Científica da Faculdade de Educação e Meio Ambiente, v. 8, n. 1, p. 99-110, 2017.

Disponível em: http://www.faema.edu.br/revistas/index.php/Revista-FAEMA/article/view/438. Acesso em: 22 ago. 2020. acesso em: 20/08/2020 


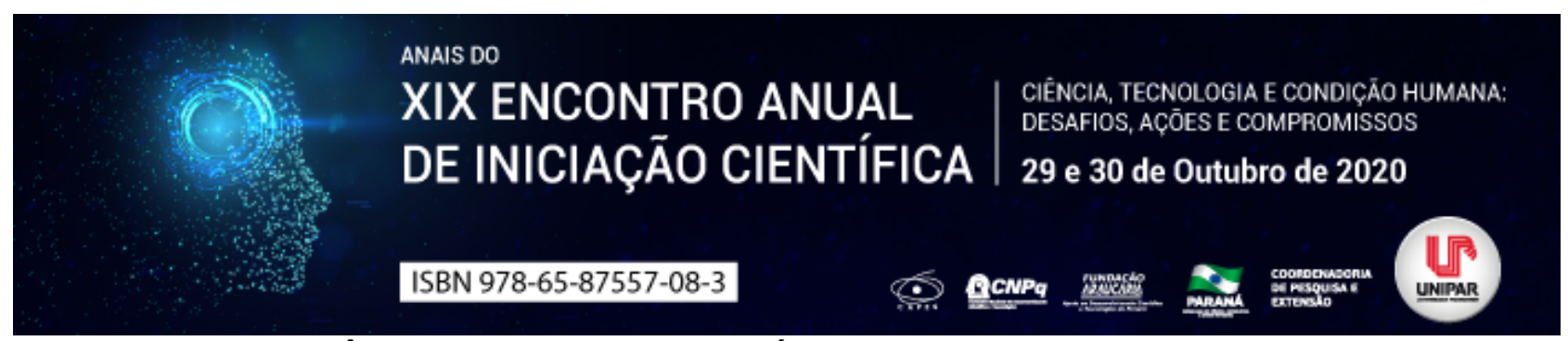

CAPACIDADE PATOGÊNICA DE DIFERENTES ESPÉCIES DE Fusarium spp. EM SEMENTES DE TRIGO

\begin{abstract}
${ }^{1}$ Celso Martins França, ${ }^{2}$ LUCAS PEREIRA DA SILVA, ${ }^{3}$ ANA CLÁUDIA DA SILVA MENDONÇA, ${ }^{4}$ BRUNA CRISTINA DE ANDRADE, ${ }^{5}$ GIOVANNA SERON, ${ }^{6}$ PRISCILA ANGELOTTI-ZAMPAR
\end{abstract}

\author{
${ }^{1}$ Acadêmico do Curso de Agronomia Universidade Estadual de Maringá \\ ${ }_{1}$ Mestrando do Programa de Pós-Graduação em Agronomia Universidade Estadual de Maringá \\ ${ }^{2}$ Mestranda do Programa de Pós-Graduação em Agronomia Universidade Estadual de Maringá \\ ${ }^{3}$ Mestranda do Programa de Pós-Graduação em Agronomia Universidade Estadual de Maringá \\ ${ }^{4}$ Acadêmica do Curso de Agronomia Universidade Estadual de Maringá \\ ${ }^{5}$ Mestre em Proteção de Plantas Fitopatologia - PGA Universidade Estadual de Maringá
}

Introdução: A triticultura é de grande importância para o cenário nacional, entretanto, há diversos entraves na produção do cereal, sendo uma delas acometidos por fitopatógenos, destacando-se a Giberela, causada por diferentes espécies de Fusarium spp. na cultura do trigo (Del Ponte et al. 2004). No Brasil, a espécie mais associada a Giberela no trigo é a Fusarium graminearum, entretanto há outras espécies ganhando notoriedade e se tornando um entrave nos campos de produção. Deste modo, é de suma importância entender quais patógenos possuem maior capacidade de infecção, e assim então classifica-los.

Objetivo: $O$ objetivo deste trabalho é avaliar se há diferenças na capacidade patogênica de $F$. graminearum sensu strictu, $F$. meridionale, $F$. cortaderie, $F$. subglutinans e $F$. verticillioides na emergência de sementes de trigo.

Material e Métodos: $O$ experimento foi realizado no Laboratório de Fitopatologia e na casa de vegetação pertencentes a Universidade Estadual de Maringá (UEM). A cultivar utilizada foi a TBIO Toruk. Foram utilizados um pool gênico de cada espécie, sendo eles de $F$. graminearum sensu strictu, F. meridionale, F. cortaderie, F. subglutinans e $F$. verticillioides. $O$ método empregado para a inoculação dos patógenos nas sementes de trigo foi o de restrição hídrica com manitol a -0,9 Mpa. Os fungos foram cultivados em meio de cultura batata-dextrose-ágar (BDA). As placas contendo cada isolado foram incubadas em câmara de crescimento a $24 \pm 2^{\circ} \mathrm{C}$ durante sete dias com 12 horas de luz. Após esses dias, as sementes de trigo sadias foram colocadas nas placas com os fungos. Foi colocado aproximadamente 30 gramas de sementes em cada placa no qual continha as diferentes espécies de fungo. As placas com sementes e os patógenos foram incubadas a $24 \pm 2^{\circ} \mathrm{C}$ por 48 horas com 12 horas de luz. Após as 48 horas, as sementes foram plantadas em sacos plástico para mudas, na dimensão de $10 \times 15 \mathrm{~cm}$, contendo uma proporção de 1:1:1 (solo, areia e substrato), sendo depositado 5 sementes por saco plástico. O delineamento utilizado foi o inteiramente casualizado, contendo 5 espécies de Fusarium spp., com 9 repetições, com 5 sementes em cada saco plástico, ao final, foi transformado os dados de cada unidade experimental em porcentagem, onde 5 sementes por saco plástico representavam 100\%. Para a testemunha, foi plantado apenas sementes de trigo desinfestadas, em 9 repetições. As avaliações de emergência ocorreram aos 7, 14, 21 e 28 dias após o plantio. Os dados foram submetidos à análise de variância, e as médias, comparadas pelo Teste Tukey a $5 \%$ de probabilidade, utilizando-se o programa computacional Sisvar.

Resultados: A análise de variância revelou diferença significativa entre as médias das espécies avaliadas. Através do teste tukey a $5 \%$ de probabilidade pode-se notar que não houve diferença quando comparado as médias entre os 7, 14, 21 e 28 dias, repetindo o resultado em todas as épocas de avaliação. O pool gênico de $F$. graminearum sensu strictu estabeleceu-se como o mais patogênico com média de $48,8 \%$ de emergência, já o pool gênico com menor capacidade de infecção foram as das espécies de $F$. cortaderie e $F$. verticillioides com capacidade de emergência do trigo em $86,6 \%$ e $91 \%$, respectivamente, não se diferenciando estatisticamente com a testemunha, no qual foi de $100 \%$ de emergência.

Discussão: Observou-se neste experimento que não houve diferença na germinação após os 7 dias após o plantio, sendo assim, foi capaz de aferir que as diferentes espécies de Fusarium spp. são capazes de infectar e interferir na emergência de sementes de trigo. Apesar de existir diferentes espécies de Fusarium spp., a espécie $F$. graminearum sensu strictu mostrou-se ser a mais patogênica, sendo assim, deve-se aplicar maior atenção à esse patógeno de solo. Kobayasti et al. (2011) ao fazer um levantamento da porcentagem de Fusarium spp. em sementes de trigo, encontrou um número surpreendente de $26 \%$ da incidência deste patógeno em sementes comercializadas. Já Junior et al. (2008), achou resultados semelhantes ao avaliar a inoculação de F. graminearum sensu strictu em sementes de trigo, com resultados de 39 a 44,5\% na interferência da emergência.

Conclusão: Pode-se concluir que dentre os diferentes pool gênicos avaliados, os da espécie $F$. graminearum sensu strictu mostrou-se ser a mais patogênico, interferindo na emergência das plantas de trigo, assim, merecendo maior atenção quando detectado nas áreas produtoras de trigo. 


\section{Referências}

DEL PONTE, E.M., FERNANDES, J.M.C., PIEROBOM, C.R. \& BERGSTROM, G.C. Giberela do trigo aspectos epidemiológicos e modelos de previsão. Fitopatologia Brasileira 29:587-605. 2004.

GARCIA JÚNIOR, D., VECHIATO, M. H., MENTEN, J. O.M. Efeito de fungicidas no controle de Fusarium graminearum, germinação, emergência e altura de plântulas em sementes de trigo. Summa Phytopathologica, v.34, n.3, p.280-283, 2008.

KOBAYASTI, L.; ALINE, P.P.. Levantamento De Fungos Em Sementes De Trigo. Pesquisa Agropecuária Tropical, vol. 41, núm.

4, octubre-diciembre, 2011.

Coordenadoria de Pesquisa e Extensão - COPEX

Departamento de Editoraçāo e Divulgaçāo Científica - DEDIC 


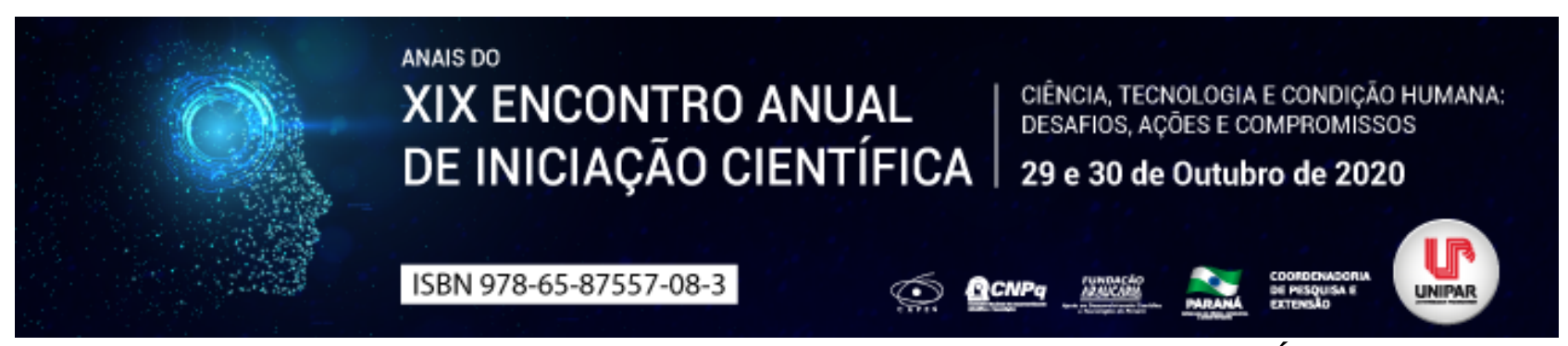

INFLUÊNCIA DO PROCESSO DE CURA DO CONCRETO NA VELOCIDADE DE ULTRASSOM E ÍNDICE ESCLEROMÉTRICO

\author{
${ }^{1}$ MATHEUS LUIS BELTRAME, ${ }^{2}$ RUBENS CARLOS OLIVEIRA, ${ }^{3}$ THALICE SADAE SIMONI ITO, ${ }^{4}$ ALBERTO EL ACHKAR, \\ ${ }^{5}$ THAUANA CRISTINA DE MATOS MELO, ${ }^{6}$ NEUSA APARECIDA MUNHAK BELTRAME
}

\begin{abstract}
${ }^{1}$ Acadêmico do PIC/UNIPAR
${ }^{1}$ Acadêmico do Curso de Engenharia Civil da UNIPAR

${ }^{2}$ Acadêmica do Curso de Engenharia Civil da UNIPAR

${ }^{3}$ Acadêmico do Curso de Engenharia Civil da UNIPAR

${ }^{4}$ Acadêmica do Curso de Engenharia Civil da UNIPAR

${ }^{5}$ Docente da UNIPAR
\end{abstract}

Introdução: O concreto é o material de construção mais empregado, composto da mistura de cimento Portland, areia, brita e água (MEHTA; MONTEIRO, 2014). A resistência à compressão é o principal método para avaliar a qualidade do concreto (VIEIRA FILHO, 2007). Essa propriedade pode ser influenciada por diversos fatores, entre elas, o tipo de cura (AMBROZEWICZ, 2012). A cura do concreto envolve uma combinação de condições que promovem a hidratação do cimento logo após a mistura (MEHTA, MONTEIRO, 2014) e os espaços inicialmente preenchidos com água são ocupados pelos produtos de hidratação do cimento (NEVILLE; BROOKS, 2013). No entanto, ensaios padrão representam apenas a resistência potencial, diferentemente de um concreto em serviço. Nestes casos, ensaios não destrutivos podem ser empregados para avaliar a qualidade dos concretos endurecidos (BERTOLINI, 2010). A velocidade de ultrassom permite constatar a homogeneidade e a qualidade do concreto, indicando a presença de fissuras (BERTOLINI, 2010). A medida que a porosidade diminui, as ondas se propagam mais rapidamente no meio sólido (MEHTA; MONTEIRO, 2014). A fase água-ar na pasta de cimento direciona a maior ou menor propagação de velocidade da onda ultrassônica nas primeiras idades (PANZERA et al., 2019). Já o método do esclerômetro oferece um meio rápido e simples de avaliar a uniformidade do concreto endurecido in loco (MEHTA; MONTEIRO, 2014). As medidas esclerométricas embora não substitua o método tradicional, fornece uma estimativa aproximada da resistência à compressão (BERTOLINI, 2010). Assim, algumas pesquisas (PALACIOS, 2012; SAMANIEGO, 2014) indicaram que, dependendo do método de ensaio empregado para avaliar a qualidade do concreto, os resultados podem apresentar uma variabilidade, já que o processo de cura tem um papel importante no desenvolvimento da porosidade e na resistência mecânica dos concretos.

Objetivo: Esta pesquisa teve como objetivo analisar a influência do processo de cura do concreto na velocidade de ultrassom, resistência à compressão tradicional e pelo método esclerométrico.

Material e Métodos: A metodologia foi baseada nas normas técnicas vigentes. A dosagem do concreto foi obtida pela $A B C P$, traço 1:1,50: 1,55: 0,36: 0,021 (cimento:areia:brita1:água:aditivo). Os materiais empregados foram o CP-V ARI 32, areia e brita natural e superplastificante para slump de $100 \pm 10 \mathrm{~mm}$ e $\mathrm{Fck}=25 \mathrm{MPa}$. Os corpos de prova receberam três tipos de cura distintos: câmara úmida sem contato direto com água (CP-U), submersa (CP-S) e ao ar (CP-A). A resistência à compressão tradicional e velocidade de ultrassom $(\varnothing 10 \times 20 \mathrm{~cm})$ e, esclerômetria $(30 \times 30 \times 10 \mathrm{~cm})$ foram realizados aos 7,14 e 28 dias com 4 repetições.

Resultados: Gráfico de barras foi utilizado para comparações. Em todas as idades analisadas, a velocidade de ultrassom dos CP-S foram 3\% maiores que as amostras CP-A e CP-U. No entanto, aos 28 dias, o concreto CP-U apresentou velocidade ultrassônica similar ao CP-S. No ensaio de resistência à compressão pelo esclerômetro, as amostras CP-A (29 MPa) foram 12\% menores que os espécimes CP-S e CP-U (33 MPa). Já o CP-U apresentou a maior dureza superficial em todas as idades analisadas, resultados que só foram alcançados pelo CP-S aos 28 dias de cura. Por outro lado, a resistência à compressão convencional do CP-S (34 MPa) foi superior às amostras CP-A e CP-U, contudo, após 14 dias de cura, o CP-U adquiriu resistência mecânica equivalente às amostras CP-S. Os concretos CP-A (30 MPa) foram em média 11\% inferior aos concretos CP-S (34 MPa).

Discussão: Pouca evolução de resistência foi observada dos 7 aos 28 dias. Isso se deve ao uso do cimento de alta resistência inicial. A cura submersa apresentou a maior propagação das ondas e maior resistência à compressão. Esse resultado já era esperado, pois a presença de água nos poros e a forma de concretagem perpendicular aos transdutores aumenta a velocidade de propagação das ondas (CÂMARA, 2006). Neste tipo de cura, a hidratação do cimento também é favorecida, reduzindo a porosidade do concreto pelo preenchimento com produtos da hidratação. Por outro lado, as amostras curadas ao ar apresentaram desempenho inferior em todos os ensaios realizados. A saída da água da mistura pode ter gerado maior quantidade de poros e consequentemente menor resistência mecânica, dureza superficial e velocidade de ultrassom. Já nas amostras com cura úmida, a resistência foi semelhante às amostras com cura submersa somente aos 28 dias. Esse resultado indica que a cura úmida é mais lenta, porém em períodos prolongados, o desempenho pode ser similar às amostras curadas 
imersas em água. O método do esclerômetro apresentou resistência à compressão similar ao ensaio convencional, se mostrando eficaz para avaliação da estrutura in loco. Já o método de ultrassom também indicou uma forma fácil de avaliar a qualidade do concreto, já que maiores velocidades foram similares com as maiores resistências à compressão.

Conclusão: Diante dos resultados apresentados, conclui-se que os métodos de avaliação não destrutivos foram similares aos resultados obtidos por meio do método convencional e o tipo de cura exerceu influência na qualidade do concreto.

\section{Referências}

AMBROZEWICZ, P.H.L. Materiais de construção: Normas, Especificações, Aplicação e Ensaios de Laboratório. São Paulo: Pini, 2012.

ASSOCIAÇÃO BRASILEIRA DE NORMAS TÉCNICAS. NBR NM 52: Agregado miúdo - Determinação da massa específica e massa específica aparente. Rio de Janeiro, 2009.

. NBR NM 67: Concreto Determinação da consistência pelo abatimento do tronco de cone. Rio de Janeiro, 1998.

. NBR NM 248: Agregados Determinação da composição granulométrica. Rio de Janeiro, 2003.

NBR 7584: Concreto endurecido Avaliação da dureza superficial pelo esclerômetro de reflexão Método de ensaio. Rio de Janeiro, 2012.

.NBR 8802: Concreto endurecido - Determinação da velocidade de propagação de onda ultrassônica. Rio de Janeiro, 2019.

BERTOLINI, J.C.P. Técnicas e práticas construtivas: da implantação ao acabamento. 1. Ed. São Paulo, Editora Érica, 2014.

CÂMARA, E. Avaliação da resistência à compressão de concretos utilizados na grande Florianópolis através de Ensaios não destrutivos. 193 f. Dissertação (Mestrado em Engenharia Civil). Universidade Federal de Santa Catarina, Florianópolis, 2006.

METHA, P. K.; MONTEIRO, P.J. M. Concreto: Microestrutura, Propriedades e Materiais. 2. ed. IBRACON. São Paulo, 2014. NEVILLE, A.M; BROOKS, J. J. Tecnologia do concreto. 2 ed. Porto Alegre, 2013.

PALACIOS, M. D. P. G. Emprego de ensaios não destrutivos e de extração de testemunhos na avaliação da resistência à compressão do concreto. 182 f. Dissertação (Mestrado em estruturas e construção civil) - Universidade de Brasília, Brasília, 2012.

PANZERA, T.H.; CHRISTOFORO, A.L.; COTA, F.P.; BORGES, P.H.R.; BOWEN, C.R. Ultrasonic pulse velocity evaluation of cementitious materials. Advances in Composite Materials-Analysis of Natural and Man-Made Materials. 2011. p.411-436.

SAMANIEGO, Y. T. M. Ensaios não destrutivos para avaliação da resistência do concreto: estudo de aplicações em obras. $182 \mathrm{f}$. Dissertação (Mestrado). Universidade de Brasília, Brasília, 2014.

VIEIRA FILHO, J.O. Avaliação da resistência à compressão do concreto através de testemunhos extraídos: contribuição à estimativa do coeficiente de correção devido aos efeitos do broqueamento. 216 f. Tese (Doutorado). Universidade de São Paulo, São Paulo, 2007. 


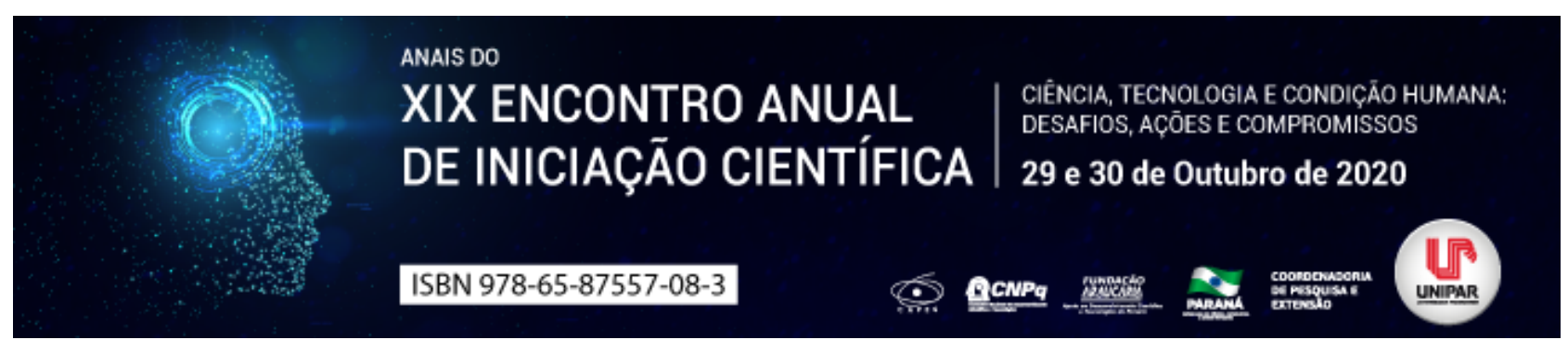

VANTAGENS QUANTO A UTILIZAÇÃO DO CONCRETO AUTOADENSÁVEL: ESTUDO DE REVISÃO

\title{
${ }^{1}$ LORENA MARCIELE VIANA ACOSTA, ${ }^{2}$ JORGELINO PEDRO DE SANTANA JUNIOR
}

\author{
${ }^{1}$ Acadêmica do Curso de Engenharia Civil da UNIPAR \\ ${ }^{1}$ Docente da UNIPAR
}

Introdução: No processo de concretagem de elementos estruturais o adensamento do concreto se faz essencial para bons resultados, como por exemplo, mais homogeneidade, menos espaços vazios, conferindo assim maior durabilidade e resistência à submissão de esforços (CAVALCANTI, 2006). Neste contexto, o Concreto AutoAdensável (CAA) tem sido uma proposta para otimização de tempo e mão-de-obra, já que o mesmo possui características que proporcionam que suas partículas preenchem todos os espaços necessários, garantindo a compactação necessária do concreto.

Objetivo: Avaliação das vantagens que a utilização do concreto autoadensável pode proporcionar.

Desenvolvimento: $O$ concreto autoadensável pode ser definido como aquele que se compacta em qualquer junta de uma fôrma, preenchendo todos os espaços da mesma sem a necessidade de utilização de um material ou equipamento que realize o seu adensamento como, por exemplo, um vibrador de concreto, ou ainda, de forma manual, através de socamento o apiloamento. Isso ocorre, pois, o processo de compactação do mesmo é realizado pelo seu próprio peso enquanto o material ainda está em estado fresco, por meio da ação da gravidade (GOMES; BARROS; 2009). A composição do CAA não difere muito da do concreto convencional, ambos são constituídos por aglomerante, agregados (miúdo e graúdo) e água, porém, são adicionados ao CAA aditivos minerais (materiais finos) e aditivos químicos superplastificantes, os quais conferem as características de fluidez, coesão e resistência à segregação (CAVALCANTI, 2006). De acordo com Carneiro (2018), as vantagens ao utilizar o concreto autoadensável são muitas, tais como a redução na mão-de-obra em relação ao espalhamento e também a exclusão da vibração, conferindo um tempo mais hábil para a execução da obra e diminuindo problemas como a poluição sonora causada pelo vibrador, assim como também é possível concretar estruturas densamente armadas, de pequenas dimensões ou de formas complexas, outra vantagem a ser citada é a de viés econômico, já que há uma redução de etapas na execução da obra, aumentando a produtividade e reduzindo os custos. Entretanto, o mesmo autor citado anteriormente destaca que devido a característica de superfluidez deve-se ter muita atenção às fôrmas utilizadas, as quais devem ser absolutamente estanques para que seja evitado desperdício de material e custos desnecessários.

Conclusão: Diante de todos os dados expostos, as vantagens ao utilizar o concreto autoadensável são irrefutáveis no processo da execução de elementos estruturais, todavia, se faz necessário acompanhamento em todas as etapas, desde a preparação do traço, a confecção (caso seja realizado na obra) até a seu lançamento na fôrma, pois se o mesmo não for bem executado haverá desperdícios, logo, um maior custo.

\section{Referências}

CARNEIRO, Roberto Carlos. Análise das propriedades do concreto autoadensável com fibras de aço no estado plástico e endurecido com sílica ativa e com fíler calcário. 2018. 169 f. Dissertação (Mestrado em Engenharia Civil) - Universidade Tecnológica Federal Paraná, Pato Branco, PR, 2018. $\quad$ Disponível em: https://repositorio.utfpr.edu.br/jspui/bitstream/1/3266/1/PB_PPGEC_M_Carneiro\%2 c\%20Roberto\%20Carlos_2 018.pdf. Acesso em 26 ago. 2020.

CAVALCANTI, Diogo Jatobá de Holanda. Contribuições ao estudo de propriedades do concreto autoadensável visando sua aplicação em elementos estruturais. 2006. 141 f. Dissertação (Mestrado em Engenharia Civil) - Centro de Tecnologia, Programa de Pós-Graduação em Engenharia Civil, Universidade Federal de Alagoas, Maceió, 2006. Disponível em: http://www.repositorio.ufal.br/bitstream/riufal/389/1/Programa\%20de\%20P\%c3\%b3s-Gradua\%c3\%a7 \%c3\%a3 o\%20em\%20Engenharia\%20Civil.pdf. Acesso em: 26 ago. 2020.

GOMES, Paulo César Correia; BARROS, Alexandre Rodrigues. Método de Dosagem do Concreto Autoadensável. São Paulo: PINI, 2009.

TUTIKIAN, Bernardo Fonseca. Método para dosagem de concretos auto-adensáveis. 2004. 149 f. Dissertação (Mestrado em Engenharia Civil) Universidade Federal do Rio Grande do Sul, Porto Alegre, RS, 2004. Disponível em: https://www.lume.ufrgs.br/bitstream/handle/10183/3918/000450678. pdf?sequence=1. Acesso em: 26 ago. 2020. 


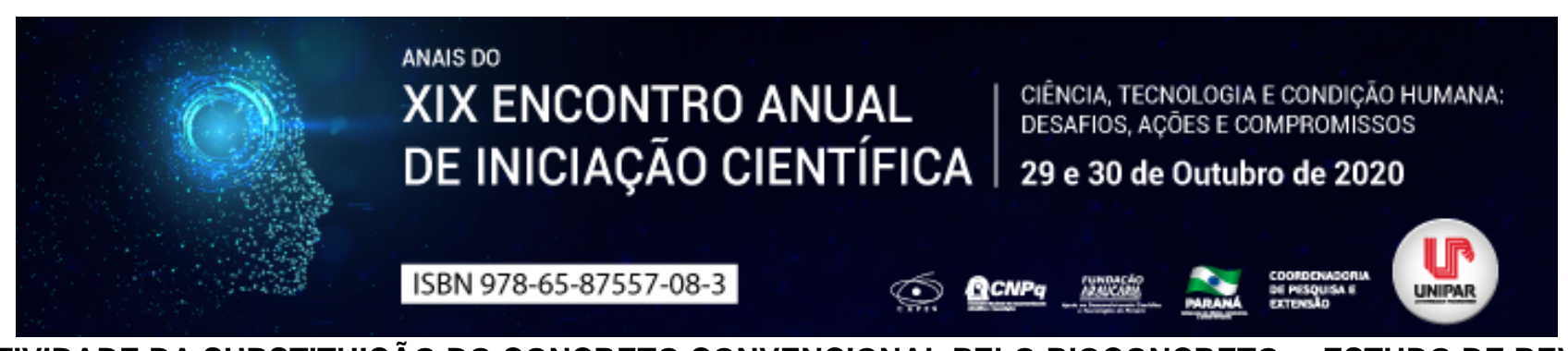

A EFETIVIDADE DA SUBSTITUIÇÃO DO CONCRETO CONVENCIONAL PELO BIOCONCRETO ESTUDO DE REVISÃO

\author{
${ }^{1}$ LORENA MARCIELE VIANA ACOSTA, ${ }^{2}$ MARIANA NATALE FIORELLI FABICHE
}

${ }^{1}$ Acadêmica do Curso de Engenharia Civil da UNIPAR

${ }^{1}$ Docente da UNIPAR

Introdução: O concreto é um material essencial na construção civil, e conforme os anos passam e as necessidades surgem novas tecnologias são empregadas a este artefato, para uma melhoria significativa tanto de sua resistência, quanto num viés mais sustentável, ou econômico. Segundo Silva (2018), alguns fatores externos como a variação de temperatura e grandes tensões podem causar problemas ao concreto, portanto, existiu a necessidade de pesquisas para solucionar as patologias existentes, e neste contexto surgiu o bioconcreto, o qual traz a uma proposta ainda inexistente no mercado, a de autorregeneração, onde o próprio concreto é capaz de sanar suas fissuras e trincas através da ação de bactérias produtoras de calcário, reduzindo assim futuros reparos e manutenções e evitando também problemas como, por exemplo, a corrosão de armaduras.

Objetivo: Estudar a efetividade da substituição do concreto convencional pelo bioconcreto.

Desenvolvimento: A tecnologia empregada ao bioconcreto está relacionada ao uso de bactérias, as quais conferem ao concreto a característica de autocicatrização, sanando os espaços vazios entre suas partículas e regenerando fissuras e trincas existentes (ARAÚJO, et al., 2009), logo os principais objetivos do bioconcreto são gerar resistência, sustentabilidade e economia (ARROYO, et al., 2016). Segundo Silva (2018), as bactérias são adicionadas ao concreto encapsuladas com argila expandida e lactato de cálcio, ficando em estado vegetativo até a ocorrência de fissuras, que é quando são ativadas, alimentando-se do lactato de cálcio, o qual reage com o carbono produzindo carbonato de cálcio (componente primário do calcário), o qual se solidifica preenchendo a falha. Logo, um dos grandes benefícios do bioconcreto é a economia em futuros reparos, manutenções e reformas, gerando também mais sustentabilidade, já que não haverá uso de novos materiais e descarte de outros, tendo em vista que a construção civil é uma das grandes responsáveis por geração de resíduos. Porém, o seu custo chega a ser cerca de $40 \%$ a mais do que o concreto convencional (PASSARINI, 2017), se comparado no mercado brasileiro pode-se dizer que o custo do concreto comum é em média de $R \$ 260$ o metro cúbico, já o bioconcreto custaria em torno de $R \$ 360$ a mesma quantidade (SALOMÃO; PINHEIRO, 2020), o que o torna um tanto quanto caro para ser utilizado em obras de pequenas dimensões, no entanto, em contrapartida abatem custos de futuros reparos e manutenções. Já no que diz respeito à resistência do concreto, estudos publicados por Passarini (2017) mostram que o bioconcreto apresenta resistência à compressão superior ao concreto convencional, pois aos 28 dias de cura dos corpos de prova obteve-se um resultado de 38,98 MPa e 29,99 $\mathrm{MPa}$ respectivamente.

Conclusão: Diante do exposto, o presente resumo confirma a eficácia na regeneração de fissuras, e embora seu custo a curto prazo seja relativamente alto, a longo prazo as vantagens ao utilizar o bioconcreto na construção civil são inúmeras. No entanto, ainda se faz necessário estudos que apresentem alternativas para que sejam superados os empecilhos econômicos de sua produção e comercialização.

\title{
Referências
}

ARAÚJO, Carlos Eduardo S. B. de. et. al. Bioconcreto. Revista Diálogos Interdisciplinares. v. 8, n. 2, p. 45-55. Disponível em: https://revistas.brazcubas.br/index.php/dialogos/article/view/686. Acesso em: 03 jul. 2020.

ARROYO, Leonardo Franco. et al. Concreto biológico: Uma proposta sustentável. In: VIII MOSTRA INTERNA DE TRABALHOS DE INICIAÇÃO CIENTÍFICA I MOSTRA INTERNA DE TRABALHOS DE INICIAÇÃO TECNOLÓGICA E INOVAÇÃO. Anais... Maringá, 2016. Disponível em: https://ww w.unicesumar.edu.br/mostra-2016/wpcontent/uploads/sites/154/2017/01/leonardo_franco_arroyo.pdf. Acesso em: 27 jul. 2020.

SALOMÃO, Pedro Emílio Amador; PINHEIRO, Alexandre Victor Silva. The Potential of Living Concrete as an Alternative to Regenerate Structures Exposed to Aggressive Environments. Research, Society and Development, 2020. Disponível em: https://rsdjournal.org/index.php/rsd/article/view/1819/1544. Acesso em 20 ago. 2020.

SILVA, Aline Marques da. Avaliação da viabilidade técnica e econômica do uso do

bioconcreto em substituição ao concreto comum. Monte Carmelo, dez. 2018. Disponível em: http://repositorio.fucamp.com.br/jspui/bitstream/FUCAMP/396/1/Avaliacaoviabilidadetecnica.pdf. Acesso em: 27 jul. 2020.

SILVA, Felipe Portela Candido; PASSARINI, Victor de Carvalho; SANTOS, Fernanda Cristina Storte. Bioconcreto: A tecnologia para construção sustentável. INOVAE - Journal of Engineering, Architecture and Technology Innovation. v. 5, n. 2, p. 41-58. Disponível em: http://www.revistaseletronic as.fmu.br/index.php/inovae/article/view/1678. Acesso em 27 jul. 2020. 
Coordenadoria de Pesquisa e Extensão - COPEX

Departamento de Editoraçāo e Divulgaçāo Científica - DEDIC 


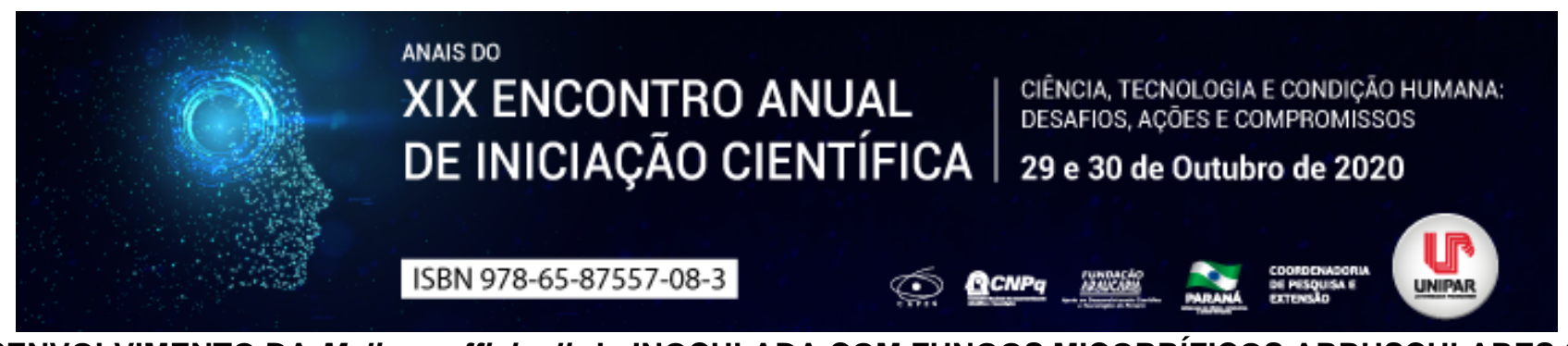

DESENVOLVIMENTO DA Melissa officinalis L. INOCULADA COM FUNGOS MICORRÍZICOS ARBUSCULARES SOB UTILIZAÇÃO DE FÓSFORO

\begin{abstract}
${ }^{1}$ LUCAS BRASIL DA SILVA, ${ }^{2}$ MARIANA MORAES PINC, ${ }^{3}$ AMANDHA MELO DOS SANTOS, ${ }^{4}$ GUILHERME DONADEL, ${ }^{5}$ SILVIO NOBUYUKI AKIYOSHI, ${ }^{6}$ ODAIR ALBERTON
\end{abstract}

\author{
${ }^{1}$ Discente de Engenharia Agronômica, PIBIC/UNIPAR \\ ${ }^{1}$ Acadêmica do Curso de Quimica Industrial da UNIPAR \\ ${ }^{2}$ Acadêmica do Curso de Engenharia Agronomica da UNIPAR \\ ${ }^{3}$ Acadêmico do Curso de Medicina Veterinaria da UNIPAR \\ ${ }^{4}$ Docente da UNIPAR \\ ${ }^{5}$ Docente da UNIPAR
}

Introdução: Planta originária da região que circunda o Mediterrâneo e também a Ásia, Melissa officinalis L. conhecida popularmente como erva-cidreira, é uma planta da família Lamiaceae, arbustiva, que pode atingir de 20 a $80 \mathrm{~cm}$ de altura (REIS et al., 2009), os caules ramificados a partir da base, formam touceiras. As folhas são verde-intensas na parte superior e verdeclaras na parte inferior. A associação com FMAs faz com que as plantas cresçam e se desenvolvam melhor devido a maior absorção de fósforo (P) e água pelas raízes (URCOVICHE et al., 2015; LERMEN et al., 2017; CRUZ et al., 2019: MERLIN et al., 2020 ).

Objetivo: Revisar e apresentar a tecnologia da inoculação com fungos sob fósforo e seu desenvolvimento na cultura da melissa.

Desenvolvimento: A inoculação de fungos micorrízicos arbusculares (FMAs) em plantas medicinais e aromáticas pode influenciar na produção de princípios ativos, melhorando o estado nutricional da planta ou como resposta de defesa do hospedeiro à presença do fungo. As plantas medicinais, condimentares e aromáticas são de importância fundamental para a humanidade, pois, além de serem utilizadas pela medicina como fitoterápicos, em substituição aos medicamentos sintéticos, apresentam teores elevados de óleos essenciais (OEs) utilizados nas indústrias farmacêuticas, de cosméticos, perfumarias e alimentícia (URCOVICHE et al., 2015). Além disso, muitas destas plantas servem de condimentos para o preparo de diferentes tipos de alimentos (RUSSOMANNO et al., 2008).

Os efeitos benéficos dos FMAs têm sido demonstrados nas mais variadas condições e espécies vegetais, na maioria dos casos estimulado no crescimento vegetal, como uma consequência de seu efeito sobre a nutrição mineral da planta, o fósforo é crucial no metabolismo das plantas, desempenhando papel importante na transferência de energia da célula, na respiração e na fotossíntese. Alguns autores relatam ainda que características fisiológicas relacionadas com a velocidade e com a eficiência de absorção de $P$ pelas raízes são modificadas quando estas estão associadas a fungos micorrízicos (SMITH; RAED, 2008). A partir de trabalhos de otimização de cultivo, a melissa pode vir a ser uma espécie potencial em termos de produtividade de óleo essencial devido a abundância de tricomas secretores presentes na epiderme foliar (SMITH; READ, 2008)

Conclusão: $A$ inoculaçao de fungos micorrízicos arbusculares aumenta o desenvlovimento da melissa e o conteúdo de $P$ na planta.

\title{
Referências
}

CRUZ, R.M.S. et al. Inoculation with arbuscular mycorrhizal fungi alters content and composition of essential oil of Sage (Salvia officinalis) under different phosphorous levels. Australian Journal of Crop Science, v.13, p.1617 $1624,2019$.

LERMEN, C. et al. Growth of Lippia alba (Mill.) N. E. Brown inoculated with arbuscular mycorrhizal fungi with different levels of humic substances and phosphorus in the soil. Journal of Applied Research on Medicinal and Aromatic Plants. v.7. p.48-53, 2017.

MERLIN, E. et al. Inoculation of arbuscular mycorrhizal fungi and phosphorus addition increase coarse mint (Plectranthus amboinicus Lour.) plant growth and essential oil content. Rhizosphere, v.15, e100217, 2020.

REIS, E. S., et al. Teor e composição química do óleo essencial de Melissa officinalis L. in vitro sob influência do meio de cultura. Acta Scientiarum. Agronomy, v.31, p. 331-335, 2009.

SMITH, S.E., READ, D.J. Mycorrhizal symbiosis, Academic Press, New York. 2008.

RUSSOMANNO, O.M.R., KRUPPA, P.C., MINHONI, M.T.A. Influência de fungos microrrízicos arbusculares no desenvolvimento de plantas de alecrim e manjericão. Arquivos do Instituto Biológico, v.75, p. 37-43, 2008.

URCOVICHE, R.C., et al. Plant growth and essential oil content of Mentha crispa inoculated with arbuscular mycorrhizal fungi under different levels of phosphorus. Industrial Crops and Products, v.67, p. 103 107, 2015. 
Coordenadoria de Pesquisa e Extensão - COPEX

Departamento de Editoraçāo e Divulgaçāo Científica - DEDIC 


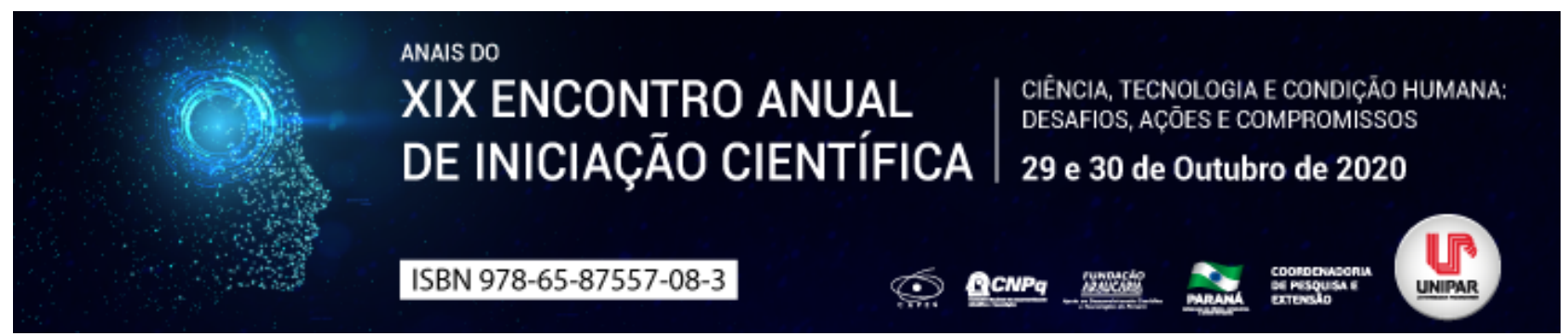

USO DE EXTRATO VEGETAL DE Azadirachta indica PARA CONTROLE DE NEMATOIDES (REVISÃO)

\begin{abstract}
${ }^{1}$ Ana Claudia da Silva Mendonça, ${ }^{2}$ LUCAS PEREIRA DA SILVA, ${ }^{3}$ NAYARA NASCIMENTO SOUZA, ${ }^{4}$ VITOR HENRIQUE GONÇALVES LOPES, ${ }^{5}$ MARIA ANDRESSA GALVÃO, ${ }^{6}$ WILLIAM MARIO DE CARVALHO NUNES
\end{abstract}

\author{
${ }^{1}$ Mestrando no Programa de Pós-graduação em agronomia UEM \\ ${ }^{1}$ Mestrando no Programa de Pós-graduação em agronomia UEM \\ ${ }^{2}$ Mestrando no Programa de Pós-graduação em agronomia UEM \\ ${ }^{3}$ Acadêmico bolsista do PIBIC/UEM \\ ${ }^{4}$ Acadêmico bolsista do PIBIC/UEM \\ ${ }^{5}$ Docente da UNIPAR
}

Introdução: Na produção agrícola os nematóides diminuem expressivamente o lucro dos produtores, uma vez que os danos são causados as culturas de pequena expressão até as de grande expressão como é o caso da soja. Desta forma, extratos vegetais é uma possibilidade que vem sendo estudada por diversos autores, a fim de se encontrar um produto nematicida natural, já que o ideal é que o manejo de nematóides seja realizado com a integração de diversos métodos, como a rotação de culturas, o controle químico, biológico e o uso de genótipos resistentes evitando a entrada do patógeno na área (RIBEIRO et al., 2010). Os estudos envolvendo as propriedades químicas do Neem revelaram seu potencial nematicida natural, onde os resultados se comparam a alguns nematicidas comerciais. As avaliações foram realizadas com óleo, extratos e pó das sementes (Vacari, 2004).

Objetivo: Existe a necessidade de difusão de conhecimentos sobre técnicas alternativas ao controle químico de nematóides, por isso essa revisão reuniu literatura sobre o extrato vegetal de Neem e seu potencial nematicida.

Desenvolvimento: Estudos dos ingredientes ativos existentes em diferentes partes da planta de Neem foram realizados e encontraram-se mais de 40 substâncias pertencentes ao grupo dos diterpenóides, triterpenóides, limonóides e flavonóides (Thakur et al., 1981). Mais recentemente houve aumento dos estudos com o ingrediente ativo azadiractina, pois é considerado o principal ingrediente ativo (Neves et al., 2003). Recentemente, Javed et al. (2008) testou o controle do estrato aquoso de semente de Neem para diversas culturas afetadas pelo Meloidogyne javanica (Treub) Chitwood e os resultados obtidos foram promissores. Estudos realizados na cultura da banana por Kosma et al. (2011), tiveram o resultado de que formulações de semente de Neem são capazes de matar $100 \%$ dos nematóides em no máximo 72 horas,sendo que quanto maior for a concentração utilizada, maior será a velocidade de mortalidade, ademais o Neem afetou positivamente o número de folhas e a altura da parte aérea após 80 dias da aplicação, quando comparado com a testemunha. Na cultura da soja, Javed et al. (2008) observou a diminuição no número de galhas e no número de ovos de M.javanica, quando as plantas foram submetidas a tratamentos de extrato aquoso de folhas de Neem em uma concentração de 1,5 e 3\%. Ainda na cultura da soja, Silva et al. (2008) obteve em seus experimentos resultados promissores com o nematoide Heterodera glycines, quando utilizou extratos aquoso e metanóico nas dosagens de 41,6 mg L-1e $1000 \mathrm{mg} \mathrm{L-1}$, respectivamente, onde o resultado foi redução de $90 \%$ no número de ovos e $84 \%$ no número de cistos.

Conclusão: Os danos causados por nematóides é uma preocupação para o agronegócio, sendo assim, os estudos científicos são essenciais para que o controle de nematóides seja eficiente. O uso de extrato vegetal de Azadirachta indica é promissor para se encontrar produtos de menor valor e com menor dano ao ambiente.

\title{
Referências
}

JAVED, N.; GOWEN, S. R.; EL-HASSAN, S. A.; INAM-UL-HAQ, M.; SHAHINA, F; PEMBROKE, B. Efficacy of neem (Azadirachta indica) formulations on biology of root-knot nematodes (Meloidogyne javanica) on tomato. Crop Protection, Guildford, v. 27, p. 36-43, 2008.

KOSMA, P.; AMBANG, Z.; BEGOUDE, B.A.D.; TEN HOOPEN, G.M.; KUATE, J. AND AKOA A.. Assessment of nematicidal properties and phytochemical screening of neem seed formulations using Radopholus similis, parasitic nematode of plantain in Cameroon. Crop Protection. 30(6):733-738, 2011.

NEVES, B.P., I.P. OLIVEIRA \& J.C.M. NOGUEIRA. Cultivo e Utilização do Nim Indiano.Empresa Brasileira de Pesquisa Agropecuária, Goiânia (GO), 12 p. (Circular técnica, 62).2003 RIBEIRO, N. R.; DIAS,W. P.; SANTOS, J. M. Distribuição de fitonematoides em regiões produtorasde soja do estado de Mato Grosso. Boletim de Pesquisa de Soja 2010, Fundação Mato Grosso, p. 289-296, 2010.

SILVA, J. C. T.; OLIVEIRA, R. D. L.; JHAM, G. N.; AGUIAR, N. D. C. Effect of neem seed extracts on the development of the soybean cysts nematode. Tropical Plant Pathology, v.33, n. 3, p. 171-179, 2008. 
THAKUR, R.S., S.B. SINGH \& A.GOSWAMI. Azadirachta indicaA. Juss -a review. Cromap 3, 135-40.1981 VACARI A. M. Et al. Seletividade de óleo de nim (Azadirachta indica A. Juss.) sobre Podisus nigrispinus(DALLAS, 1851) (Heteroptera: Pentatomidae). Arq.Inst.Biol., São Paulo, v.71, (supl.), p.1-749, 2004.

Coordenadoria de Pesquisa e Extensão - COPEX

Departamento de Editoraçāo e Divulgaçāo Científica - DEDIC 


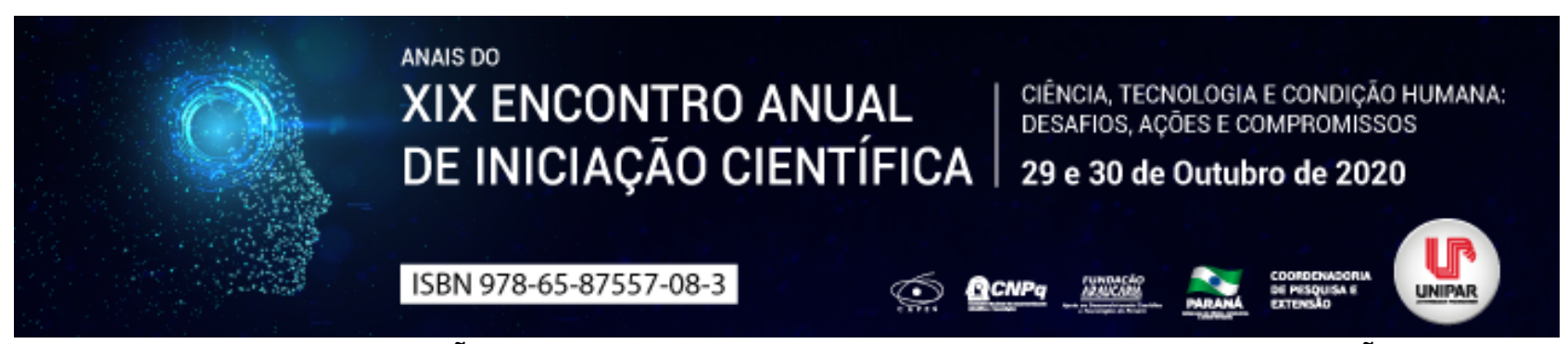

Dyscrete , INOVAÇÃO DE CONCRETO FOTOVOLTAICO: UM ESTUDO DE REVISÃO

\begin{abstract}
${ }^{1}$ CHEILA BRAMBILLA FREIRE, ${ }^{2}$ NATALIA PINHEIRO D ONOFRE DA SILVA, ${ }^{3}$ MILENA GABRIELA FERREIRA HAYASHIDA, ${ }^{4}$ ROSILEY BERTON PACHECO, ${ }^{5}$ VANDA ZAGO LUPEPSA
\end{abstract}

\begin{abstract}
${ }^{1}$ Discente do curso de Engenharia Civil da Unipar Unidade de Guaíra.
${ }^{1}$ Discente do curso de Engenharia Civil da Unipar Unidade de Guaíra.

${ }^{2}$ Discente do curso de Engenharia Civil da Unipar Unidade de Guaíra.

${ }^{3}$ Docente do curso de Medicina da Unipar Unidade de Umuarama.

${ }^{4}$ Docente do curso de Engenharia Civil da Unipar Unidade de Guaíra.
\end{abstract}

Introdução: Segundo Miyagi (2009), o setor da construção civil é um dos principais setores para a economia do país, e também é um dos maiores poluidores devido ao seu elevado consumo de matéria prima para a construção de obras de engenharia, como casas de alvenaria, em rodovias, em pontes, edifícios, etc. Por exemplo, o concreto é o segundo material mais utilizado no planeta, fica atrás somente da água (PEDROZO, 2009). Ademais, os padrões atuais de produção e consumo da população exigem cada vez mais energia para realizar os processos exigidos pela sociedade, energia essa que em sua maioria vem de fontes fósseis poluidores, que geram poluentes locais e emitem gases de efeito estufa, tendo-se isso em consideração se faz a busca por energia de fonte renováveis, como é o caso da energia solar (GOLDEMBERG; LUCON, 2007). Buscando a inovação e sustentabilidade em produtos, pesquisadores do globo inteiro realizam pesquisas para produzir materiais menos maléficos possíveis para o meio ambiente. Um tipo de material em pauta são as células solares sensibilizadas por corante, em inglês, dyesenstitized solar cells (DYSC) que quando incorporadas com o concreto, originam o concreto fotovoltaico denominado DysCrete , que faz a junção entre o material mais utilizado na construção civil e a energia que é tão almejada (PETERS, 2014).

Objetivo: Demonstrar as vantagens e desvantagens, e explicar o concreto fotovoltaico DysCrete

Desenvolvimento: $O$ concreto em desenvolvimento na Alemanha na Universidade de Kassel tem como orientadora, a professora e pesquisadora Heike Klussmann. O concreto ganhou o nome de DysCrete, pois é baseado nos princípios das DYSC e é uma inovação para a geração de energia. Esse concreto se baseia no conceito da fotossíntese realizado pelas plantas, o concreto faz uso de tintas orgânicas para absorver luz e produzir energia através de reações eletroquímicas, onde os estudos mostram uma alta compatibilidade entre as tecnologias do DYSC e as propriedades físicas e químicas do concreto (BROWNELL, 2017). Para sua fabricação são utilizadas peças pré fabricadas de concreto revestidas com camadas de DYSC em um processo híbrido de deposição entre sinterização e pulverização em múltiplos estágios, onde as células geram energia as quais são captadas pelos eletrodos de óxidos, um exemplo de substância utilizada é a clorofila de espinafre. Essa tecnologia possui como vantagem o custo de produção relativamente baixo dando ao sistema grande potencial como uma fonte de energia de baixo custo. Possui como desvantagem a instabilidade à longo prazo do comportamento das células (BROWNELL, 2017). Outra vantagem advinda deste concreto é a facilidade da aplicação, ele pode ser utilizado em fachadas de edifícios e em outros elementos construtivos, como lajes, paredes, pisos, etc, sem comprometer a estética das construções como é o caso dos sistemas fotovoltaicos convencionais que demandam espaço para a sua implantação. A utilização do concreto fotovoltaico abre uma gama de possibilidades dentro do campo da energia fotovoltaica estruturalmente integrada aos elementos construtivos (ADEM et al, 2018).

Conclusão: Com a busca da sociedade cada vez mais árdua em adaptar os métodos construtivos para métodos sustentáveis, visando a melhoria da qualidade de vida e preservação do meio ambiente, o concreto fotovoltaico se mostra uma excelente forma de captação de energia, quando completamente desenvolvido poderá ser amplamente utilizado nos edifícios e construções, onde as mesmas já estarão produzindo energia sem utilizar outro espaço físico para essa geração, diferente do que ocorre no caso das placas solares que utilizam de amplos espaços físicos para a instalação das mesmas.

\title{
Referências
}

ADEM, Samira Jama; MILHUISEM, Rebecca A.; KASHIF, Muhammad Kalin; BACH, Udo; KLUSSMANN, Heike. Dye - Sensitized Solar Concrete. Research Culture in Architecture: Cross-Disciplinary Collaboration. International Conference on CrossDisciplinary Collaboration 27-28 September 2018, Faculty of architecture, TU Kaiserslautern, Germany. Alemanha, 2018. Disponível em: . Acessado em: 19 de Agosto de 2020. BROWNELL, Blaine Erickson. Transmaterial next : a catalog of materials that redefine our future. Princeton Architectural Press. New York, 2017. Disponível em: . Acessado em: 18 de Agosto de 2020.

GOLDEMBERG, José; LUCON, Oswaldo. Energia e meio ambiente no Brasil. Estudos Avançados v. 21 n.59. São Paulo, 2007. 
Disponível em: . Acessado em: 18 de Agosto de 2020.

MIYAGI, Samara. A crise mundial e os impactos no setor da Construção Civil. Revista IBRACON. Ano 37 No 53 Jan. Fev. Mar. de 2009 ISSN 1809-7197 P. 14-19. São Paulo, 2009. Disponível em: . Acessado em: 19 de Agosto de 2020.

PEDROZO, Fábio Luís. Concreto: as origens e a evolução do material construtivo mais usado pelo homem. Revista IBRACON. Ano 37 N o 53 Jan. Fev. Mar. de 2009 ISSN 1809-7197 P. 14-19. São Paulo, 2009. Disponível em: . Acessado em: 19 de Agosto de 2020.

PETERS, Sascha. Material Revolution II: New Sustainable and Multi-purpose Materials for Design and Architecture. Editora Birkhäuser. Suiça, 2014.

Coordenadoria de Pesquisa e Extensão - COPEX

Departamento de Editoraçāo e Divulgaçāo Científica - DEDIC 


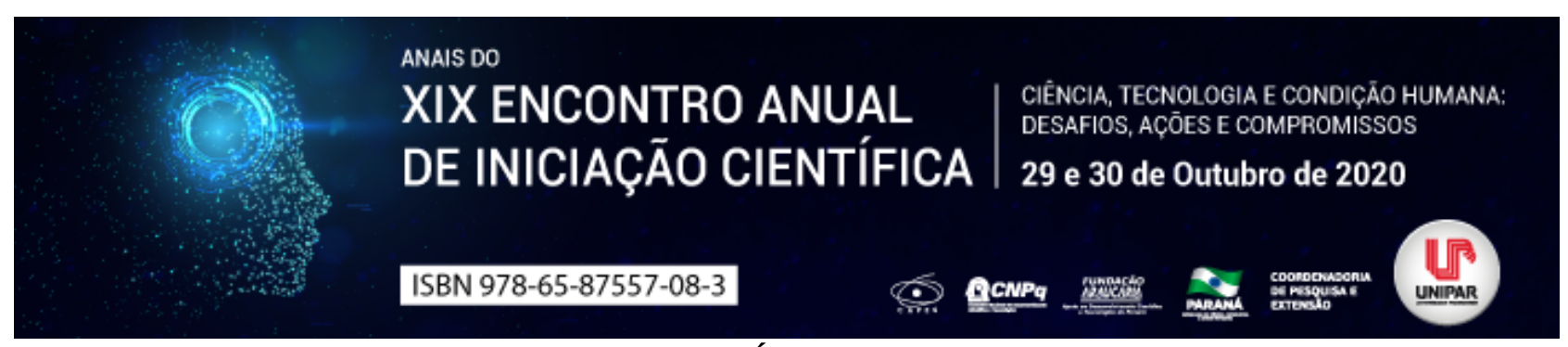

RESPOSTA DE Panicum sp. SUBMETIDO A ESTRESSE HÍDRICO E CULTIVADO EM SOLOS DE DIFERENTES REGIÕES DO PARANÁ

\author{
${ }^{1}$ THIAGO RODRIGUES DOS SANTOS, ${ }^{2}$ GUSTAVO HENRICH SIQUEIRA BARBOSA, ${ }^{3}$ MICHAEL ALEXSANDER DA SILVA, \\ ${ }^{4}$ GUSTAVO HENRIQUE DE FREITAS, ${ }^{5}$ ANDIRA PRICILA DANTAS, ${ }^{6}$ ANA DANIELA LOPES
}

\author{
${ }^{1}$ Discente de Engenharia Agronômica, PIC/UNIPAR \\ ${ }^{1}$ Acadêmico do Curso de Engenharia Agronômica da UNIPAR \\ ${ }^{2}$ Acadêmico do Curso de Engenharia Agronômica da UNIPAR \\ ${ }^{3}$ Acadêmico do Curso de Engenharia Agronômica da UNIPAR \\ ${ }^{4}$ Acadêmica do Curso de Engenharia Agronômica da UNIPAR \\ ${ }^{5}$ Docente da UNIPAR
}

Introdução: É de extrema importância os estudos com forrageiras do gênero Panicum sp. no estado do Paraná, pois, esta gramínea sempre esteve em destaque no Brasil por ser uma espécie altamente produtiva, de ótima qualidade e adaptada a várias regiões do país (JANK, 2003). Contudo, seu cultivo pode ser afetado por períodos de escassez de disponibilidade hídrica, os quais limitam seu desenvolvimento. O estresse pode ser definido, em sentido geral, como uma pressão excessiva de algum fator adverso que apresenta a tendência de inibir o normal funcionamento dos sistemas (CAVALCANTE et al., 2009). De acordo com Jacinto Junior et al. (2019), o estresse hídrico afeta todos os aspectos ligados ao crescimento da planta.

Objetivo: Avaliar a resposta fisiológica de Panicum sp. cultivada em solos oriundos de três diferentes municípios do estado do Paraná sob diferentes tensões de água.

Material e Métodos: O experimento foi conduzido na casa de vegetação da UNIPAR Umuarama em delineamento inteiramente casualizado, em esquema fatorial 3x3 totalizando 9 tratamentos e três repetições. Para isso foram avaliados solos de três municípios do Paraná: Ubiratã, Quarto Centenário e Perobal, previamente caracterizados quimicamente e três tensões de água no solo, monitoradas por tensiômetros $(5,25$ e $50 \mathrm{kPa})$. Vasos com capacidade para três litros foram preenchidos com os respectivos solos e semeados com sementes de Panicum sp. cultivar MG12 Paredão. Ao final do experimento avaliou-se: comprimento da parte aérea (CPA), comprimento de raiz (CR), massa fresca (MFR) e seca de raiz (MSR) e parte aérea (MFPA e MSPA). Os dados foram analisados por meio da análise de variância aplicando o teste $\mathrm{F}$ e desdobrando as análises sempre que a interação fosse significativa. Aos parâmetros qualitativos aplicou-se o teste de Tukey (5\%) utilizando o programa estatístico SISVAR (Ferreira, 2011).

Resultados: O CPA apresentou interação para os três solos. No desdobramento da interação entre solos e tensões, verificou-se que o solo de Ubiratã $(68,50 \mathrm{~cm})$ diferiu estatisticamente do solo de Perobal $(47,30 \mathrm{~cm})$ e Quarto Centenário $(49,70 \mathrm{~cm})$ para a tensão de $25 \mathrm{kPa}$. Para tensão de $50 \mathrm{kPa}$ o solo de Ubiratã $(59,80 \mathrm{~cm})$ diferiu do de Quarto Centenário (47,03cm), não sendo verificada diferença significativa entre estes e o solo de Perobal $(50,20 \mathrm{~cm})$. A tensão de $5 \mathrm{kPa}$ não diferiu entre os solos dos diferentes municípios. Com desdobramento para interação entre tensões e solos verificou-se que o solo Ubiratã apresentou diferença entre as tensões de 5 e 25kPa. Para a variável MFPA não se observou resultados significativos para a interação entre os fatores, apenas para as tensões e os diferentes tipos de solos. Não houve diferença estatística entre os solos de Perobal e Quarto Centenário ( $\mathrm{p} \leq 0,05)$, os quais apresentaram menor MFPA ao serem comparados com o solo de Ubiratã, com o qual diferiram significativamente. Como esperado, a tensão de $50 \mathrm{kPa}$ apresentou o menor valor de MFPA e não diferiu estatisticamente do tratamento de $5 \mathrm{kPa}$, diferindo apenas do tratamento de $25 \mathrm{kPa}$, o qual apresentou o maior valor de MFPA. O parâmetro MSPA foi significativo para tensões, tipos de solo e interação. O desdobramento de cada tensão dentro dos diferentes tipos de solo revelou que para a tensão de $25 \mathrm{kPa}$ o solo de Ubiratã diferiu dos demais, apresentando maior valor de MSPA, 8,42g. Já no desdobramento dos solos dentro das tensões, apenas o município de Ubiratã apresentou diferença no comportamento desta variável em relação às tensões avaliadas, uma vez que a tensão de $25 \mathrm{kPa}$ diferiu das demais promovendo maior valor de MSPA. As variáveis CR e MFR não foram significativas para nenhum dos fatores analisados e interação. A $\operatorname{MSR}(\mathrm{g})$ foi significativa apenas para os tipos de solo. O solo de Ubiratã e Quarto Centenário não diferiram entre si, sendo que este também não diferiu estatisticamente do solo de Perobal.

Discussão: A escassez de água no solo promove diversas alterações que afetam a produção, o desenvolvimento e o crescimento das plantas (TAIZ et al., 2017). Segundo (ARAÚJO, et al., 2010; SANTOS et al., 2012) algumas plantas adotam a estratégia de diminuir a área foliar a fim de favorecer o aumento do sistema radicular, de forma a se adaptarem a pouca disponibilidade hídrica, gerando por consequência uma menor produção de matéria seca, conforme observado neste trabalho. Entretanto, quando o solo apresenta maior capacidade de retenção de água, como é o caso do solo de Ubiratã por apresentar 
maiores teores de argila e matéria orgânica, mesmo sob tensões mais negativas (25 e 50kPa) os parâmetros CPA e MSPA tendem a superar os solos com menores teores de argila, os quais apresentam menor capacidade de retenção de umidade. Solos com maior capacidade de retenção de água tendem a garantir que as plantas cultivadas nestas condições tolerem por mais tempo o déficit hídrico, atingindo um possível estresse posterior às plantas cultivadas em solos com maiores teores de areia.

Conclusão: Solos com maior teor de argila e matéria orgânica, como o de Ubiratã favorecem mais o desenvolvimento da planta sob estresse hídrico, conferindo-Ihe maior tolerância em função da maior capacidade de retenção de água no solo.

\section{Referências}

ARAÚJO, Saulo Alberto do Carmo; VASQUEZ, Hernan Maldonado; CAMPOSTRINI, Eliemar; NETTO, Alena Torres; DEMINICIS Bruno Borges; LIMA Érico da Silva. (2010). Características fotossintéticas de genótipos de capim-elefante anão (Pennisetum purpureum Schum.), em estresse hídrico. Acta Scientiarum. Animal Sciences, Maringá, v. 32, n. 1, p. 1-7, 2010.

CAVALCANTE, Ana Clara Rodrigues; CAVALLINI, Maria Cecília; LIMA, Nino Rodrigo Cabral de Barros. Estresse por déficit hídrico em plantas forrageiras. Documentos/Embrapa Caprinos, Sobral-CE, 2009. 50p.

FERREIRA, Daniel Furtado. Sisvar: a computer statistical analysis system. Ciência e Agrotecnologia, Lavras, v. 35, n. 6, p. 1039-1042, 2011.

JACINTO JÚNIOR, Silvio Gentil; MORAES, João Gutemberg Leite; SILVA, Fred Denilson Barbosa; SILVA, Bruno do Nascimento; SOUSA, Geocleber Gomes; OLIVEIRA, Laís Lacerda Brasil; MESQUITA, Rosilene Oliveira. Respostas fisiológicas de genótipos de fava (Phaseolus lunatus L.) submetidas ao estresse hídrico cultivadas no Estado do Ceará. Revista Brasileira de Meteorologia, 34(3), 413-422. Epub October 21, 2019.https://doi.org/10.1590/0102-7786343047.

JANK, Liana. A história do Panicum maximum no Brasil. Revista Sementes JC Machieto, v. 1, n. 1, p. 14 , ago. 2003.

TAIZ et al. Fisiologia vegetal. Artmed, Porto Alegre, Brasil. 2017.

SANTOS, Diego dos et al. Cultivares de trigo submetidas a déficit hídrico no início do florescimento, em casa de vegetação. Revista Brasileira de Engenharia Agrícola e Ambiental, v. 16, n. 8, p. 836-842, 2012.

SOUSA, Geocleber Gomes; OLIVEIRA, Laís Lacerda Brasil; MESQUITA, Rosilene Oliveira. Respostas fisiológicas de genótipos de fava (Phaseolus lunatus L.) submetidas ao estresse hídrico cultivadas no Estado do Ceará. Revista Brasileira de Meteorologia, 34(3), 413-422. Epub October 21, 2019.https://doi.org/10.1590/0102-7786343047. 


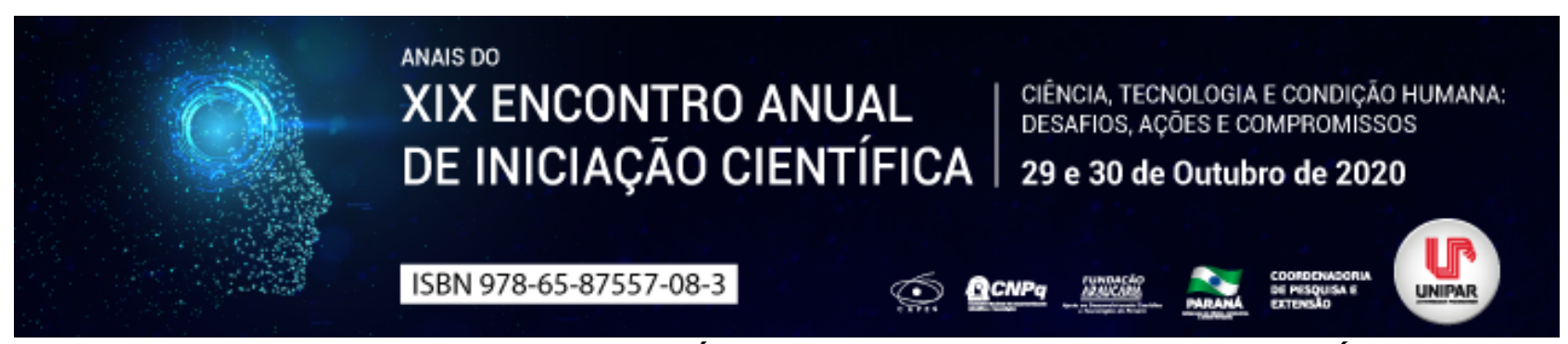

BIOESTIMULANTES EM CANA-DE-AÇÚCAR (Saccharum spp.) SOB ESTRESSE HÍDRICO

\begin{abstract}
${ }^{1}$ GUSTAVO HENRIQUE DE FREITAS, ${ }^{2}$ THIAGO RODRIGUES DOS SANTOS, ${ }^{3}$ VITOR AUGUSTO DA COSTA SANTOS, ${ }^{4}$ MARWAN CAMILO SIMOES, ${ }^{5}$ BIANCA DE ALMEIDA MARCHI , ${ }^{6}$ ANA DANIELA LOPES
\end{abstract}

\author{
${ }^{1}$ Discente de Engenharia Agronômica, PIC/UNIPAR \\ ${ }^{1}$ Acadêmico do Curso de Engenharia Agronômica da UNIPAR \\ ${ }^{2}$ Acadêmico do Curso de Engenharia Agronômica da UNIPAR \\ ${ }^{3}$ Acadêmico do Curso de Engenharia Agronômica da UNIPAR \\ ${ }^{4}$ Engenheira agrônoma \\ ${ }^{5}$ Docente da UNIPAR
}

Introdução: A cana-de-açúcar (Saccharum spp.) é uma das culturas de maior importância social e econômica no Brasil, tendo atingido uma produção de 642,7 milhões de toneladas no ano de 2019 , um aumento de $3,6 \%$ em relação à safra anterior (CONAB, 2020), o que faz do país o maior produtor mundial da cultura. O aumento da safra foi resultado de condições climáticas favoráveis, no entanto, anos que apresentam baixa disponibilidade hídrica afetam negativamente o crescimento dos cultivos agrícolas e é a principal causa da redução da produtividade (Pimentel, 2004; Flexas et al., 2006). Para contornar os efeitos do déficit diversas estratégias de manejo vem sendo estudadas, e uma das mais promissoras é o uso de bioestimulantes, uma vez que estes atuam como incremento hormonal e nutricional (SOUZA et al., 2012).

Objetivo: Objetivou-se avaliar o comportamento fisiológico de tolestes de cana-de-açúcar submetidos ao tratamento com dois bioestimulantes e submetidas a estresse hídrico.

Material e Métodos: A pesquisa foi conduzida em casa de vegetação da Universidade Paranaense (Campus 3 UmuaramaPR). O material vegetal utilizado foi a variedade de cana-de-açúcar CTC 9001, procedente da Usina Santa Terezinha. O solo utilizado no experimento foi classificado como argissolos vermelho distrófico, coletado na camada de 0,30m do perfil agricultável. O experimento seguiu delineamento inteiramente casualizado em esquema fatorial $3 \times 2+1$, sendo três tensões hídricas $(5,25$ e $50 \mathrm{kPa}$ ), dois produtos (Stimulate ${ }^{\circledR}$ e Fertiactyl Gramineas ${ }^{\circledR}$ ) e a testemunha, totalizando 9 tratamentos com três repetições. Para identificar as tensões referentes a cada tratamento foram utilizados tensiômetros. Ao final do experimento avaliou-se os seguintes parâmetros: número de perfilhos, comprimento da parte aérea e raiz e massa fresca e seca da parte aérea e raiz; índice de balanço de nitrogênio, antocianina, flavonoides e teor de clorofila.

Resultados: A média de irrigação para os tratamentos variou a cada 2,53; 4,20 e 6,28 dias, para as tensões de 5,25 e $50 \mathrm{kPa}$, respectivamente. Para as variáveis balanço de nitrogênio (NBI), teores de antocianina e flavonóides, número de perfilhos, comprimento da raiz, massa fresca e seca da parte aérea e raiz não foram observadas diferenças estatísticas $(p \leq 0,05)$ para a Testemunha, e tratamentos com Stimulate ${ }^{\circledR}$ e Fertiactyl Gramineas ${ }^{\circledR}$, tampouco para as tensões de água no solo $(5 \mathrm{kPa}, 25 \mathrm{kPa}$ e $50 \mathrm{kPa})$ e interação entre eles. O comprimento da parte aérea, apresentou significância $(p \leq 0,05)$ para as tensões de água, sendo que o maior comprimento foi observado na tensão de $25 \mathrm{kPa}$. O índice de clorofila foi afetado $(p \leq 0,05)$ no tratamento 50 kPa e ocasionou uma diminuição de 16,28\% e 17,93\% em relação às tensões de 5(testemunha) e $25 \mathrm{kPa}$, respectivamente. .

Discussão: Os resutados não significativos para os índices de flavonoides e antocianinas, sugerem uma possível tolerância da variedade CTC 9001 à baixas tensões de água no solo. Esta variedade caracteriza-se por apresentar alto teor de sacarose, precocidade, adaptabilidade em regiões onde o clima é limitante e boa tolerância a seca (Sesso, 2014). A sensibilidade do crescimento da parte aérea a decréscimos na disponibilidade de água pode ser vista como uma adaptação à seca, em vez de uma restrição fisiológica (Taiz et al., 2017) na qual a planta prioriza crescimento de raiz em detrimento da parte aérea. No entanto, este evento não foi observado, pois, o maior comprimento foi observado na tensão de $25 \mathrm{kPa}$. O decréscimo nos teores de clorofila sugerem uma possível degradação da clorofila em função da redução do potencial mátrico $(\Psi \mathrm{m})$ no solo, o qual induz a redução da abertura estomática ou fechamento completo destas estruturas, conservando a água disponível, impedindo a perda desnecessária de água e diminuindo, consequentemente, a capacidade fotossintética (Taiz et al., 2017). O teor de clorofila, constitui em um dos indicadores mais relevantes para correlacionar estimativas da produtividade de uma cultura, pois, a produção de matéria seca é limitada pela quantidade de clorofila (Dawson et al., 2003). A redução do teor de clorofila em função do aumento da severidade do estresse é um mecanismo de defesa, pois, reduz a captação e absorção de fótons, assim, diminui a transferência de elétrons entre os centros de reação e os fotossistemas.

Conclusão: Os bioestimulantes aplicados nos toletes de cana, antes do plantio, não se comportaram como atenuantes do estresse hídrico para a cultivar CTC 9001 de cana-de-açúcar. 


\section{Referências}

CONAB, Companhia Nacional de Abastecimento. Acompanhamento da safra brasileira Cana-de-açúcar 2019/2020

quarto levantamento maio 2020. Brasília: Conab, 2020.62p.

DAWSON, Terence. Forest ecosystem chlorophyll content: implications for remotely sensed estimates of net primary productivity. International Journal of Remote Sensing, Wilmington, v. 24, n. 3, p. 611-617, 2003.

FLEXAS, Jaume; RIBAS-CARBO, Miguel; BOTA, Josefina; GALMES, Jeroni; HENKLE, M.; MARTINEZ-CANELLAS, Sara; MEDRANO, Hipolito. Decreased Rubisco activity during water stress is not induced by decreased relative water content but related to conditions of low stomatal conductance and chloroplast CO2 concentration. New Phytologist, v. 172, p. 73-82, 2006.

PIMENTEL, Carlos. A relação da planta com a água. Seropédica: Edur, 2004. 191p.

SESSO, Fernando. Variedades de cana CTC e seu manejo. XIV Seminário da cana-de-açúcar. Vitória-ES, 2014;

SOUZA, Geocleber Gomes; MARINHO, Albanise Barbosa; ALBUQUERQUE, André Henrique Pinheiro; VIANA, Thales Vinícius de Araújo; AZEVEDO, Benito Moreira. Crescimento inicial do milho sob diferentes concentrações de biofertilizante bovino irrigado com águas salinas. Revista Ciência Agronômica. v. 43, n. 2, p. 237-245, 2012.

TAIZ, Lincoln; ZEIGER, Eduardo; MØLLER, Ian Max; MURPHY, Angus. Fisiologia e Desenvolvimento Vegetal. 6 ed. Porto Alegre: Artmed, 858 p. 2017. 


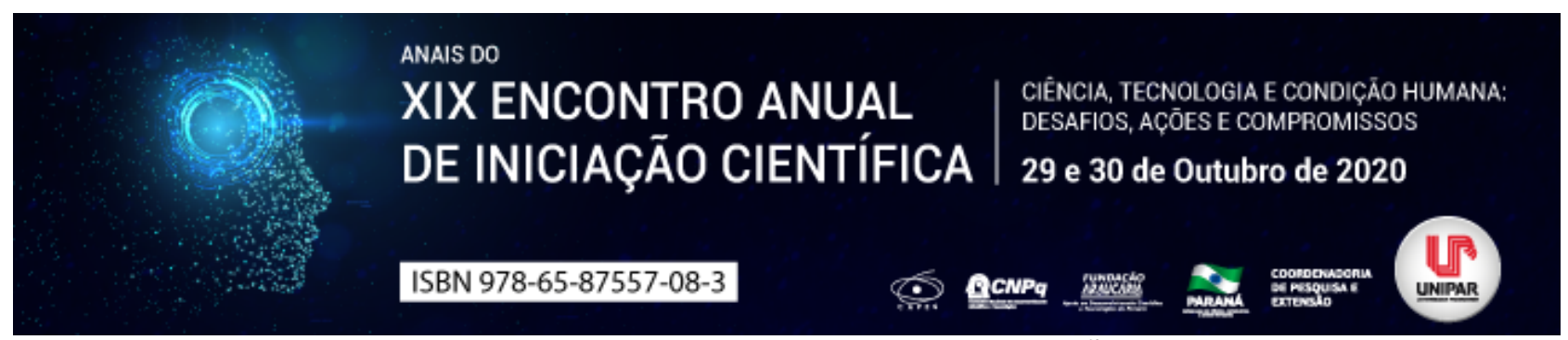

USO DA Curcuma Longa EM FRANGOS DE CORTE REVISÃO DE LITERATURA

\begin{abstract}
${ }^{1}$ HELOYSA MARIA SOTTORIVA, ${ }^{2}$ DHARA RIBEIRO MELO, ${ }^{3}$ MATHEUS SOUZA ROCHA, ${ }^{4}$ LUCIANA KAZUE OTUTUMI FARIAS, ${ }^{5}$ GILBERTO ALVES
\end{abstract}

\author{
${ }^{1}$ Acadêmica do Curso de Medicina Veterinária da UNIPAR - PIBIC \\ ${ }^{1}$ Acadêmica do Curso de Medicina Veterinária da UNIPAR - PIBIC \\ ${ }^{2}$ Acadêmico do Curso de Medicina Veterinária da UNIPAR - PIBIC \\ ${ }^{3}$ Docente da UNIPAR \\ ${ }^{4}$ Docente da UNIPAR
}

Introdução: As plantas medicinais vêm ganhando grande repercussão nas últimas décadas, sendo utilizadas em vários tipos de tratamento e na prevenção de doenças. Um dos motivos para o crescimento da fitoterapia como modalidade de tratamento é principalmente em função do alto custo dos medicamentos industrializados (GRASSO, et al., 2017). Os aditivos alternativos vêm sendo buscados para substituir antibióticos moduladores de crescimento que são utilizados na ração de animais para obter melhores índices zootécnicos, ou seja, para aumentar ganho de peso e melhorar a conversão alimentar. E um dos aditivos alternativos é o uso da Cúrcuma longa como promotora de crescimento em rações para frangos de corte (NASCIMENTO, 2016). A Cúrcuma longa L., também conhecida como açafrão da Índia, é originário do sudeste asiático e pertence à família Zingiberaceae (SOUSA. et al. 2017).

Objetivo: Apresentar os efeitos da cúrcuma no ganho de peso em frangos de corte.

Desenvolvimento/; Várias pesquisas comprovam os efeitos benéficos da suplementação de açafrão sobre o desempenho de frangos de corte. Souza et al (2017) demonstraram que a adição de $3,3 \mathrm{~g} / \mathrm{kg}$ de açafrão na ração teve efeito semelhante ao antibiótico promotor de crescimento sobre o desempenho produtivo, rendimento de carcaça e de cortes nobres, peso relativo de vísceras e comprimento de intestinos das aves, sendo que essa dose de administração teve a melhor rentabilidade econômica. Samarasinghe et al. (2003) observaram maior ganho de peso com 0,2 a 0,3\% de açafrão na ração de frangos de corte. Al-Sultan (2003) observou aumento no ganho de peso e melhor conversão alimentar quando utilizou 0,5\% de açafrão na alimentação das aves. Segundo Osawa et al. (1995), a curcumina, principal pigmento do açafrão, apresenta uma forte ação antioxidante, o que favorece a síntese proteica pelo sistema enzimático da ave, aumentando, consequentemente, a deposição de massa muscular. Outro trabalho que verificou ação positiva da Cúrcuma Longa na saúde das aves utilizou 1, 2 e $3 \%$ de inclusão de cúrcuma como promotor de crescimento e observaram melhor consumo de ração, ganho de peso e ação anticoccidiana nas aves que receberam 3\% de cúrcuma (ABBAS, et al., 2010). Kumari et al. (2007) observaram que a suplementação de açafrão em pó melhorou o consumo de ração e a eficiência quanto ao desempenho de frangos de corte.

Conclusão: O uso da Curcuma longa (açafrão) é um importante aditivo para suplementação de ração de frangos de corte, proporcionando melhorias de desempenho de ganho de peso e rendimento de carcaça, qualidade intestinal, assim como uma melhor conversão alimentar.

\title{
Referências
}

ABBAS, Rao Zahid, et al. Anticoccidial Activity of Curcuma longa L. in Broilers. Brazilian Archives of Biology and Technology an international journal. v.53, p. 266-273, 2010.

AL-SULTAN. The effect of Curcuma longa (turmeric) on overall performance of broiler chickens. International Journal of Poultry Science, Faisalabad, v.2, n.5, p. 354-353, 2003.

OSAWA, Toshihiko, et al. Antioxidative activity of tetrahydrocurcuminoids. Bioscience Biotechnology Biochemistry, Tokyo, v.59, no. 9, p.1609-1612, 1995.

GRASSO, Eliane da Costa, et al. Ação antiinflamatória de cúrcuma longa I. (zingiberaceae). Revista Eletrônica Thesis. São Paulo, n.28, p.117-129. 2017.

KUMARI, et al. Curcuma longa as feed additive in broiler birds and its patho-physiological effects. Indian Journal of Experimental Biology, v.45, p.272-277, 2007.

NASCIMENTO, Gisele Mendanha. Efeitos do açafrão (Cúrcuma longa L.) em frangos de corte inoculados experimentalmente com Salmonella Typhimurium. Orientadora: Maria Auxiliadora Andrade, Tese (Pós-graduação em ciência animal) Universidade Federal de Goiás, Goiania, 2016.

SAMARASINGHE, Kithsiri. Turmeric (Curcuma longa) root powder and mannanoligo saccharides as alternatives to antibiotics in broiler chicken diet. Asian-Australasian Journal of Animal Sciences, Gwanak-gu, v. 16, n.10, p.1495-1500, 2003. 
SOUSA, João Paulo Belém, et al. Açafrão em pó (curcuma longa I.) em dietas de frangos de corte. Colloquium Agrariae, v. 13, n.2, Mai/Ago. p.97-108. V.13. n.2/164. Goiânia. 2017.

Coordenadoria de Pesquisa e Extensão - COPEX

Departamento de Editoraçāo e Divulgaçāo Científica - DEDIC 


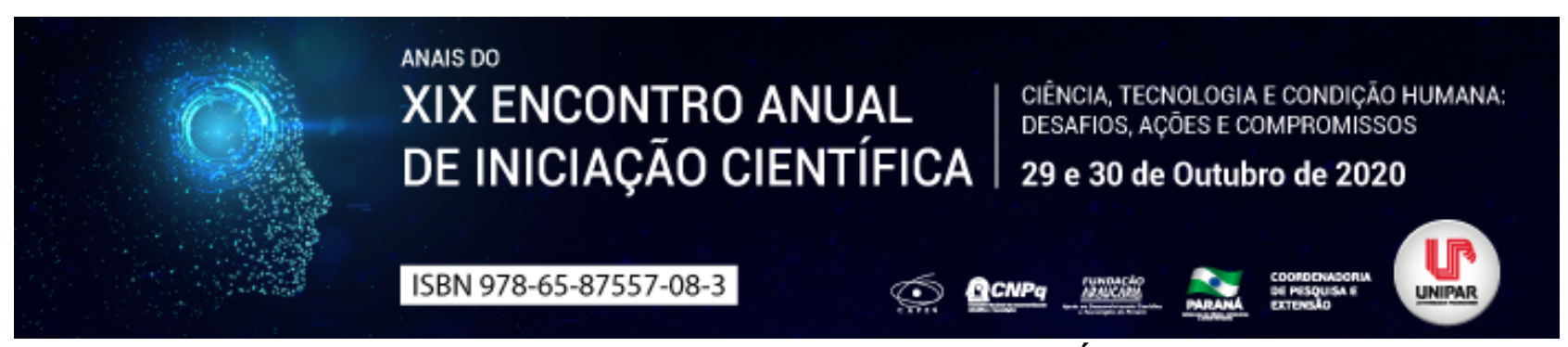

O IMPACTO DA ERA DIGITAL NO AGRONEGÓCIO

\title{
${ }^{1}$ IGOR BORGES MARDEGAM, ${ }^{2}$ ELYSSANDRO PIFFER
}

\author{
${ }^{1}$ Acadêmico do curso de Sistemas de Informação da UNIPAR \\ ${ }^{1}$ Docente dos cursos da área de TI da UNIPAR
}

Introdução: A agricultura no Brasil pode ser considerada como um modelo pelo fato de ser muito eficiente. Segundo o Ministério da Agricultura, o setor corresponde a uma parcela de 23\% do PIB brasileiro.(SEBRAE, 2019). Esse setor é de grande notoriedade para o Brasil já que o setor tem importância sociais na geração de empregos, alimentação dos brasileiros e desenvolvimento de negócios. O Brasil é um país com grandes perspectivas satisfatórias para o agronegócio, em via de suas características e diversidades, tanto de clima quanto o de solo. A tecnologia no agronegócio já começa a mudar os resultados das safras, aumentando a produtividade e reduzindo perdas no campo. A tecnologia é utilizada como principal aliada para o desenvolvimento rural, ela já está mudando o jeito de fazer agricultura e assim evoluindo o agronegócio brasileiro a fim de conseguir um equilíbrio entre o desenvolvimento do agronegócio e as inovações das tecnologias, buscando comprovar que o setor do agronegócio tende a colaborar com o desenvolvimento da economia brasileira.

Objetivo geral: Descrever tecnologias que influenciam os modelos de agronegócio com foco no aumento da renda e da produtividade.

Desenvolvimento: $O$ setor de agronegócio vem demandando altos investimentos em tecnologias, onde associado aos instrumentos de manejo, a tecnologia pode fornecer evoluções em lavouras e criações de ponta a ponta tendo em vista elevar a produtividade sem gastar muito, compensando as dificuldades já existentes no país. (Rocha, 2020) A tecnologia está sendo um dos fatores essenciais na nova gestão de produção com monitoramento remoto, visto que os drones podem monitorar áreas de lavouras em tempo real, no qual podem evitar prejuízos, monitorar animais, e também auxiliando na fiscalização e segurança da propriedade. Vale ressaltar que as inovações tecnológicas não param no setor da agronomia, onde temos sempre a presença de novas startups voltadas para o desenvolvimento de boas práticas e soluções tecnológicas para a agricultura (Maria, 2018). A mudança digital está em pleno andamento na agricultura. Satélites e sensores fornecem dados relevantes de maquinários, pastagens e campos. Hardware e software inteligentes se tornam uma ferramenta indispensável para operações eficientes e de economia de recursos (Melina, 2020). Na prática, aplicações digitais ajudam na proteção de culturas e no melhoramento genético na pecuária por exemplo. Para a agricultura de precisão, o maquinário agrícola é equipado com tecnologias inteligentes e se comunica entre si. Processos de trabalho automatizados chegam nas lavouras com o potencial de tornar as fazendas mais eficazes. As tecnologias digitais ajudam a otimizar processos no campo e em pastagens, dessa forma, o controle das máquinas agrícolas pode ser combinado com a mais recente tecnologia de sensor e medição para determinar as necessidades de água e nutrientes das culturas que foram ou serão semeadas. Se os dados atuais do satélite e do clima forem levados em conta, as plantas podem ser irrigadas ou fertilizadas conforme necessário. Isso aumenta a eficiência, minimiza o excesso de nutrientes e reduz o custo operacional, assim chegamos na agricultura de precisão e inicia a agricultura 4.0. (Melina, 2020).

Conclusão: A chegada desses softwares de gestão e monitoramento agrícola estão entre os mais recentes avanços digitais, já que com eles é possível gerenciar a propriedade facilmente na palma da mão com smartphones ou tablets, desde as finanças, tomada de decisão, recurso de equipamento e controle pessoal. É necessário saber se a agricultura tradicional irá suprir toda à necessidade alimentícia da população, por isso o investimento em tecnologia digital é fundamental para produzir mais com menos. Contudo mesmo havendo problemas em infraestruturas no país, o cenário agrícola tecnológico ganha totais condições de crescimento de produção e maior lucratividade, e essa será a oportunidade de um bom desenvolvimento do agronegócio brasileiro.

\section{Referências}

CHAGAS, Débora. A tecnologia como aliada da produção no agronegócio. SEBRAE, 2019. Disponível em: Acesso em: 20 de ago. de 2020.

MARIA, Rodrigo Santa. Novas tecnologias aplicadas ao agronegócio. GRUPO CULTIVAR, 2018. Disponível em: Acesso em: 20 de ago. de 2020.

MELINA. Agricultura digital: produzir mais com menos. AGROPRO, 2020. Disponível em Acesso em 23 de ago. de 2020.

MELINA. 10 vantagens de trazer novas tecnologias para a fazenda. AGROPRO, 2020. Disponível em: Acesso em 23 de ago. de 2020.

O impacto da era digital no agronegócio. ABAG, 2017 Disponível em Acesso em: 18 de ago. de 2020.

ROCHA, Debora Espindola Campista. A evolução da tecnologia no agronegócio.Portal DBO, 2020. Disponível em Acesso em 20 
em ago. de 2020.

Coordenadoria de Pesquisa e Extensão - COPEX

Departamento de Editoraçāo e Divulgaçāo Científica - DEDIC 


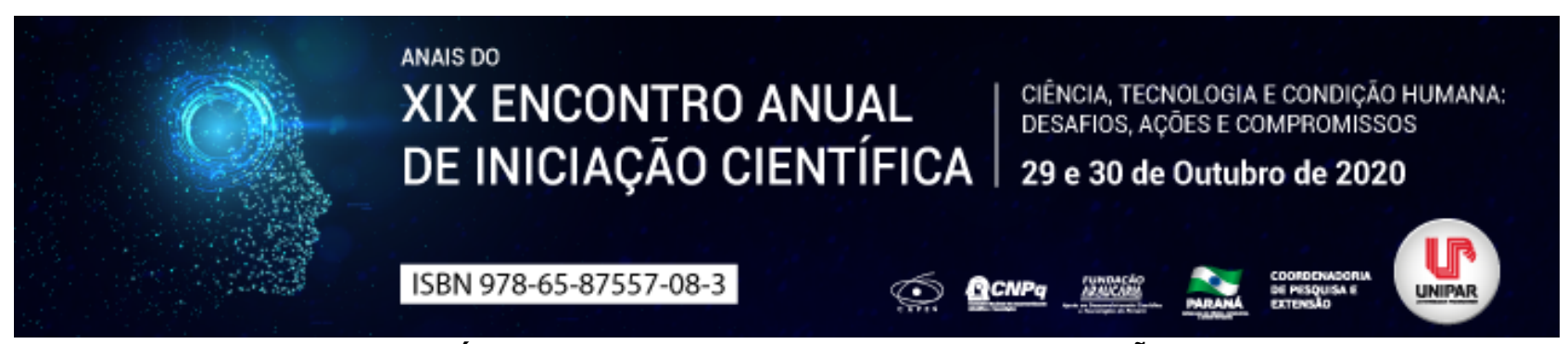

EFEITOS DOS PREBIÓTICOS PARA FRANGOS DE CORTE - REVISÃO DE LITERATURA

\begin{abstract}
${ }^{1}$ DHARA RIBEIRO MELO, ${ }^{2}$ HELOYSA MARIA SOTTORIVA, ${ }^{3}$ MATHEUS SOUZA ROCHA, ${ }^{4}$ LUCIANA KAZUE OTUTUMI FARIAS, ${ }^{5}$ GILBERTO ALVES
\end{abstract}

\begin{abstract}
${ }^{1}$ Acadêmica do curso de Medicina Veterinária PIBIC/UNIPAR
${ }^{1}$ Acadêmica do curso de Medicina Veterinária PIBIC/UNIPAR

${ }^{2}$ Acadêmico do curso de Medicina Veterinária PIBIC/UNIPAR

${ }^{3}$ Docente do curso de Medicina Veterinária UNIPAR

${ }^{4}$ Docente do curso de Medicina Veterinária- Unipar
\end{abstract}

Introdução: A avicultura se encontra em uma crescente amplificação no país por conta da sua capacitação nos mais avançados recursos tecnológicos, tendo assim um avanço na qualidade da carne, diminuindo os custos e aumentando o consumo pelo mercado externo (SOUZA, 2015). Embora os avanços tenham sido significativos, controlar e reduzir agentes que estão correlacionados a doenças transmissíveis por alimentos, ainda são um desafio. Visto que, estão presentes na microbiota normal dessas aves (MANI-LÓPEZ, et al., 2012). Com isso, antimicrobianos foram introduzidos na tentativa de tratar e prevenir possíveis infecções, fazendo que haja maior ganho de peso e a conversão alimentar (SANTOS, 2012). Porém, com a restrição de antibióticos como promotores de crescimento, torna-se necessário o uso de outros produtos (SANTOS 2010). Por isso tem sido crescente o uso de prebióticos como alternativa para esse problema, pois seu uso poderia eliminar problemas como resistência bacteriana e resíduos de antibióticos (ALBINO, 2006). Prebióticos são suplementos alimentares constituídos de microrganismos vivos que traz inúmeros benefícios a saúde do hospedeiro, equilibrando a microbiota intestinal (KAUR et al,. 2002).

Objetivo: Realizar uma revisão de literatura sobre o uso de prebióticos na dieta de frangos de corte.

Desenvolvimento: Gibson \& Roberfroid (1995) listaram algumas características indicadas para um prebiótico: não ser metabolizado ou absorvido durante a passagem pelo trato digestivo superior; servir como substrato para as bactérias intestinais benéficas (que serão estimuladas a crescer e/ou tornar-se metabolicamente ativas); ter capacidade de alterar a microbiota intestinal de forma benéfica ao hospedeiro; além de induzir efeitos benéficos sistêmicos ou apenas no intestino do hospedeiro. Um dos oligossacarídeos mais pesquisados de ação prebiótica são os mananoligossacarídeos (MOS), derivados da parede celular de leveduras. Segundo Spring (2000), a parede celular é separada do conteúdo intracelular e o líquido contendo MOS é evaporado à baixa temperatura (spray dry) para evitar a destruição da parte funcional da molécula de MOS, este autor relatou ainda que em frangos de corte submetidos ao desafio com dois tipos de Salmonella foram encontradas menores contagens destas bactérias no trato intestinal de aves suplementadas com MOS em relação ao tratamento controle. Já Swick (1996) observou melhora significativa da conversão alimentar e redução da mortalidade de animais alimentados suplementados com mananoligossacarídeos (MOS). Além de aumento de ganho de peso, na vigésima semana de vida ( PARKS et al., 2001).

Conclusão: Prebióticos na dieta de frangos de corte podem vir a ser uma possibilidade na substituição do uso de antimicrobianos e melhorar o rendimento das aves.

\title{
Referências
}

ALBINO, Luiz Fernando Teixeira, et al. Uso de prebióticos à base de mananoligossacarídeo em rações para frangos de corte. Revista Brasileira de Zootecnia, v.35, n.3, p.742-749, 2006

GIBSON, Glenn; ROBERFROID Marcel.Dietary modulation of the human colonic microbiota: introducing the concept of prebiotics. Journal of Nutrition, v.125, n.6, p.1401-1412, 1995.

KAUR, Indu Pal, et al. Probiotics: potential pharmaceutical applications. European Journal of Pharmaceutical Sciences, v.15, p.1 9, 2002.

MANI-LÓPEZ, Emmanuel, et al. Organic acids as antimicrobials to 1036 control Salmonella in meat and poultry products. Food Research International. v.45, 1037 p.713-721, 2012.

PARKS, CW. et al. The effect of mannanoligosaccharides, bambermycins, and virginiamycin on performance of large white male market turkeys. Poultry Science, v.80, n.6, p.718-723, 2001.

SANTOS, Milena Mendonça dos. Resistência antimicrobiana em cepas bacterianas isoladas de celulite aviária. 2012. viii, 58 f., il. Dissertação (Mestrado em Saúde Animal) - Universidade de Brasília, Brasília, 2012.

SANTOS, Graciene Conceição dos. Alternativas ao USP de promotores químicos de crescimento sobre o desempenho e características de carcaça de frangos de corte. 2010. 67 p. Dissertação (Mestrado) Zootecnia, Universidade Federal dos Vales de Jequitinhonha e Mucuri, Diamantina, 2010. 
SOUZA, DS. et al . Atividade antimicrobiana do óleo essencial de Lippia origanoides e Lippia rotundifolia frente a enterobactérias isoladas de aves. Arq. Bras. Med. Vet. Zootec., Belo Horizonte, v. 67, n. 3, p. 940-944, June 2015.

SPRING, P. et al. The effects of dietary mannaoligosaccharides on cecal parameters and the concentrations of enteric bacteria in the ceca of salmonella-challenged broiler chicks. Poultry Science, v.79, n.2, p.205-211, 2000.

SWICK, Robert. Role of growth promotants in poultry and swine feed. 1996.

Coordenadoria de Pesquisa e Extensão - COPEX

Departamento de Editoraçāo e Divulgaçāo Científica - DEDIC 


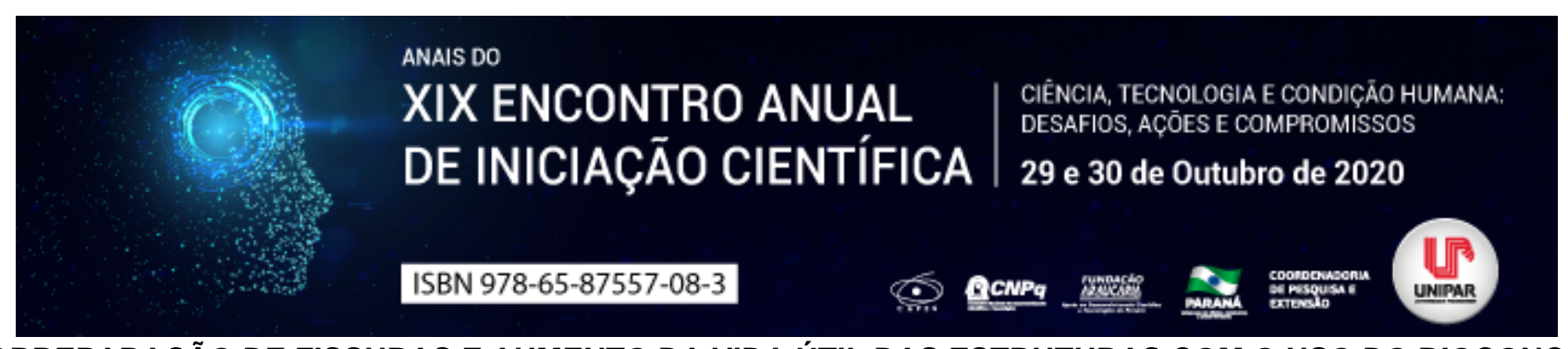

AUTORREPARAÇÃO DE FISSURAS E AUMENTO DA VIDA ÚTIL DAS ESTRUTURAS COM O USO DO BIOCONCRETO

\author{
1 IZABELA PASSAMANI DA CRUZ, ${ }^{2}$ LUANA DE LOURDES CARREIRA DO NASCIMENTO ALVES, ${ }^{3}$ JOSE AUGUSTO DA \\ SILVA, ${ }^{4}$ LEONARDO GARCIA DIOSTI, ${ }^{5}$ EVERTON LUIS CONSONI DA SILVA, ${ }^{6}$ EVERLEI CAMARA
}

\begin{abstract}
${ }^{1}$ Acadêmica do Curso de Engenharia Civil da UNIPAR
${ }^{1}$ Acadêmica do Curso de Engenharia Civil da UNIPAR

${ }^{2}$ Acadêmico do Curso de Engenharia Civil da UNIPAR

${ }^{3}$ Acadêmico do Curso de Engenharia Civil da UNIPAR

${ }^{4}$ Acadêmico do Curso de Engenharia Civil da UNIPAR

${ }^{5}$ Docente da UNIPAR
\end{abstract}

Introdução: O concreto é de grande importância para a humanidade devido às suas propriedades e relativo ao seu baixo custo de produção. Entretanto, esse material apresenta alta suscetibilidade à formação de trincas e rachaduras. Segundo Gardner et. al (2018), em estudo conduzido no Reino Unido, cerca de $90 \%$ dos entrevistados identificaram trincas e rachaduras em seus empreendimentos nos primeiros anos de vida, sendo as principais causadoras de manutenção em edificações no mundo. Diante disso, se faz necessário o uso de tecnologias que minimizem esses gastos e desempenhem o papel de reparação dessas edificações, dentre as quais, pode-se citar o bioconcreto. Na natureza existem organismos que resolvem problemas que os seres humanos passam carreiras para resolver (Benyus, 2005) e, no entanto, vivem em harmonia há séculos. Por isso, tomando notas de biomimética e biotecnologia, a investigação está sendo conduzida para criar concretamente a forma como a natureza faz com os microrganismos, e assim buscar alternativas que viabilizem a utilização deste material.

Objetivo: Apresentar o bioconcreto e sua viabilidade no autorreparo de fissuras em estruturas como contribuição para a diminuição de reparos e aumento da vida útil.

Desenvolvimento: $O$ bioconcreto é um grande avanço para todo o setor construtivo, este tem por principal objetivo a recuperação de trincas e rachaduras das estruturas. Para seu desenvolvimento há a incorporação de bactérias na matriz do concreto comum. Essas são formadas por cerca de 13\% de nitrogênio, que são conseguidos a partir da amônia (MANDIGAN, 2016). Através dessa necessidade, ocorre o MICP, um método onde há a precipitação de calcita induzida microbiologicamente, responsável pela reparação de rachaduras e trincas. A incorporação de bactérias no concreto data-se de 1994 com a Dra. Carolyn M. Dry da Universidade de Illinois. Posteriormente vários estudos surgiram com a intenção de aumentar a viabilidade e assim obter o emprego do material em grande escala. Dentro desses foi possível notar um aumento gradativo da capacidade regenerativa da peça. Segundo Jonkers et al. (2010), a largura máxima de fissura que pode sofrer cicatrização, em vários estudos relatados, era estimado entre 0,1 e 0,3 mm, já em estudo publicado recentemente por Jiang et al. (2020), foi obtido um de valor 1,24 mm da largura, completamente curada após 28 dias, demonstrando um grande avanço na técnica e assim tornando mais abrangente o seu emprego. Entretanto, alguns fatores devem ser observados para se obter uma maior e melhor recuperação das fissuras. Dentre as quais destaca-se a inserção das bactérias no concreto, essas precisam sobreviver em seu interior que, conforme apontam Jonkers et al. (2010), é altamente alcalino devido a presença natural de hidróxido de cálcio, o que pode levar, em casos extremos, à morte dos microrganismos. Além dessa, é necessária uma análise de confiabilidade dos diferentes mecanismos para o desenvolvimento da auto cicatrização, ensaiando de forma real a exposição da estrutura, e não limitando a pesquisa apenas em ensaios laboratoriais (LI e HERBERT, 2012). Para permitir a utilização dos materiais em escala real, deve-se trabalhar na busca da redução de custos na produção dos agentes cicatrizantes, como o lactato de cálcio, ao qual Patel (2015) define como tendo um custo elevado. Diante disso, percebe-se a necessidade de expansão e popularização da técnica a ser inserida no mercado, salientando sempre o uso de microrganismos não patogênicos na composição do material, o que dispensaria os efeitos nocivos a saúde humana.

Conclusão: $O$ bioconcreto pode ser um grande aliado para combater as principais preocupações enfrentadas pela construção civil, que é a deterioração de estruturas devido a fissuração. É possível estabelecer estruturas com custos reduzidos, devido a redução de reparos e de manutenção, que tem como consequência sua maior durabilidade e eficiência.

\title{
Referências
}

Benyus J. (2005) Biomimicry: Innovation inspired by Nature. 320p. Bioconcrete: A Sustainable Substitute for Concrete? GARDNER, Diane; LARK, Robert; JEFFERSON, Tony; DAVIES, Robert. A survey on problems encountered in current concrete construction and the potential benefits of self-healing cementitious materials. Case Studies In Construction Materials, [S.L.], v. 8, p. 238-247, jun. 2018. Elsevier BV. http://dx.doi.org/10.1016/j.cscm.2018.02.002. 
JIANG, Lu; JIA, Guanhua; JIANG, Chen; LI, Zhu. Sugar-coated expanded perlite as a bacterial carrier for crack-healing concrete applications. Construction And Building Materials, v. 232, p. 117222, jan. 2020. Elsevier BV. http://dx.doi.org/10.1016/j. conbuildmat.2019.117222.

JONKERS, $\mathrm{H}$. M. et al. Application of bacteria as self-healing agent for the development of sustainable concrete. Ecological Engineering, [S.L.], v. 36, n. 2, p. 230-235, fev. 2010. Elsevier BV. http://dx.doi.org/10.1016/j.ecoleng.2008.12.036

LI, V. C.; HERBERT, E. Robust Self-Healing Concrete for Sustainable Infrastructure. Journal of Advanced Concrete Technology, v. 10, p. 207 218, 2012.

MADIGAN, M. T. et al. Microbiologia de Brock. 14. ed. Porto Alegre: Grupo A Educação S.A., 2016.

PATEL, P. Helping Concrete Heal Itself. ACS Central Science, v. 1, n. 9, p. 470 472, 2015.

Coordenadoria de Pesquisa e Extensão - COPEX

Departamento de Editoraçāo e Divulgaçāo Científica - DEDIC 


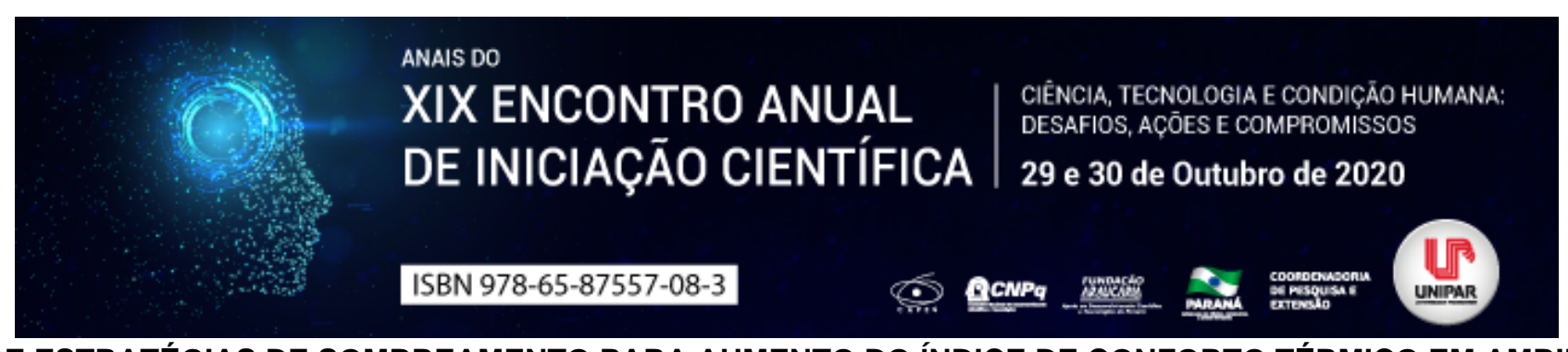

USO DE ESTRATÉGIAS DE SOMBREAMENTO PARA AUMENTO DO ÍNDICE DE CONFORTO TÉRMICO EM AMBIENTES

\author{
${ }^{1}$ Pamela de Sales Prospero, ${ }^{2}$ GUSTAVO dos SANTOS TAMAIO, ${ }^{3}$ CARLOS EDUARDO PORTO, ${ }^{4}$ GERMANO FRANCISCO \\ SIMON ROMERA, ${ }^{5}$ FRANK KIYOSHI HASSE
}

\begin{abstract}
${ }^{1}$ Participante do Projeto de Iniciação Científica (PIC) - Acadêmica de Engenharia Civil na Universidade Estadual de Maringá (UEM).

${ }^{1}$ Participante do Projeto de Iniciação Científica (PIC) - Acadêmico de Engenharia Civil na Universidade Estadual de Maringá (UEM).

${ }^{2}$ Acadêmico de Engenharia Civil na Universidade Estadual de Maringá (UEM)

${ }^{3}$ Co-orientador do Projeto de Iniciação Científica (PIC) na Universidade Estadual de Maringá - Docente do curso de Engenharia Civil na UEM

${ }^{4}$ Orientador do Projeto de Iniciação Científica (PIC) na Universidade Estadual de Maringá - Docente da Universidade Estadual de Maringá (UEM)
\end{abstract}

Introdução: O Projeto de Arquitetura que considera apenas a forma, dimensões e quantidades de ambientes, não supre as necessidades dos usuários. Nesse âmbito, o Conforto térmico é uma das áreas mais importantes a ser levada em consideração no projeto de uma edificação. Para o presente trabalho, foram realizados experimentos utilizando sensores acoplados a placa Arduino, a fim de coletar dados de temperatura e fazer a análise do desempenho do Sombrite como barreira de proteção térmica. Objetivo: Avaliar o desempenho da tela plástica como dispositivo de sombreamento de paredes externas voltadas a face oeste em dias críticos de verão.

Materiais e Métodos: Para proporcionar conforto térmico em uma edificação é necessário fazer uso dos estudos da geometria solar, do fluxo dos ventos e dos dados climáticos da região, e para aumentar os índices de conforto, há várias estratégias bioclimáticas que podem ser utilizadas, entre elas o sombreamento. Para a avaliação desses índices podem ser utilizados diversos métodos de captação de dados, como é o caso da placa Arduino, na qual sensores de temperatura e umidade do ar são acoplados, a fim de registrar índices em intervalos regulares pré-determinados. Para a realização do projeto, foram feitas análises de duas salas localizadas no bloco B do Campus de Umuarama da Universidade Estadual de Maringá. Primeiramente, foi feita a instalação de uma tela, do tipo Sombrite, na face Oeste das salas analisadas. A tela Sombrite é muito utilizada em várias áreas, como em projetos agrícolas, a fim de reduzir a temperatura e a incidência de sol nas plantações. A placa Arduino é uma plataforma eletrônica de código aberto baseada em hardware e software fáceis de usar, na qual sensores de temperatura e umidade do ar são acoplados, a fim de registrar índices em intervalos regulares pré-determinados. As placas são capazes de ler entradas como luzes num sensor e transformar em uma saída, por exemplo, publicando algo online, ativando um motor. (ARDUINO, 2020). No caso em questão, para a aquisição dos dados de temperatura e umidade, utiliza-se um sensor específico e configura-se o software para receber os dados. Tais dados foram recolhidos durante alguns dias e foram organizados em planilhas, e posteriormente compilados em gráficos. Depois disso, a Sombrite foi retirada, e foram recolhidos dados das salas sem a tela em questão, e foram organizados da mesma forma. A comparação dos dados foi feita considerando-se as temperaturas nos horários críticos e os índices de conforto térmico, baseados nos estudos de Lamberts. As sensações de conforto térmico são muito subjetivas e principalmente individuais pois dependem de condições psicológicas e fisiológicas de cada indivíduo, de modo que nem todas as pessoas poderão se sentir confortáveis no mesmo ambiente. Entretanto, este é considerado um ambiente confortável quando, após o tempo mínimo de 15 minutos, um grupo homogêneo em termos de atividade física e de uso de roupas obter $80 \%$ ou mais de pessoas satisfeitas em relação ao conforto térmico. (ABNT NBR 16401).

Resultados e discussão: Pôde-se perceber que a tela funciona como um bom anteparo, diminuindo a temperatura nos horários críticos, mas dificultou a saída do ar quente durante o período noturno e matutino. A diferença de temperatura entre a sala com e sem anteparo foi de cerca de $2,1^{\circ} \mathrm{C}$, o que é uma diferença considerável.

Conclusão: Conclui-se que a tela protetora tem um bom funcionamento em períodos específicos do dia (período crítico da incidência de sol), mas se mostra ineficaz quando utilizada durante todo o dia, pois dificulta a saída de ar quente. Sendo assim, pode-se dizer que há possibilidade de haver uma aplicabilidade da tela, desde que seja com dispositivo de rolamento, e utilizada apenas durante o período crítico. 
símbolos e unidades. NBR 15220-1. Rio de Janeiro, maio. 2005.

ARDUINO. About. 2016. Disponível em: . Acesso em: 27 abr. 2020.

D’AUSILIO, A. Arduino: A low-cost multipurpose lab equipment. Disponível em: . Acesso em 27 abr. 2020.

FROTA, Anésia Barros; SCHIFFER, S. R. Manual de Conforto Térmico. $2^{\mathrm{a}}$ edição. Studio Nobel, São Paulo, 1995. 243p.

FROTA, A.B. \& SCHIFFER, S.R. Manual do Conforto Térmico. $4^{a}$ ed. São Paulo: Studio Nobel. 2000.

OLIVEIRA, A. J. Jr. DISPOSITIVO MÓVEL PARA ANÁLISE DE CONFORTO TÉRMICO E AMBIÊNCIA. Repositório Institucional UNESP, 2016. Disponível em: Acesso em: 27 abr. 2020.

LAMBERTS, R. Desempenho térmico de edificações. Florianópolis: UFSC, Departamento de Engenharia civil, Laboratório de Eficiência Energética em Edificações, 2007. (Apostila)

LAMBERTS, R.; DUTRA, L.; PEREIRA, F. O. R. Eficiência energética na arquitetura. 3. ed. Florianópolis: UFSC, Departamento de Engenharia civil, Laboratório de Eficiência Energética em Edificações. Disponível em: http://www.labeee.ufsc.br/sites/default/files/apostilas/eficiencia_energetica_na_arquitetura.pd f. Acesso em: 30 mar. 2020.

RORIZ M., GHISI E., LAMBERTS R. UMA PROPOSTA DE NORMA TÉCNIICA BRASILEIRA SOBRE DESEMPENHO TÉRMICO DE HABITAÇõES POPULARES. In: V Encontro Nacional de Conforto no Ambiente Construído e II Encontro Latino-Americano de Conforto no Ambiente Construído (Anais Eletrônicos) Fortaleza, 1999. Disponível em: . Acesso em: 07/07/20.

Coordenadoria de Pesquisa e Extensão - COPEX

Departamento de Editoraçāo e Divulgaçāo Científica - DEDIC 


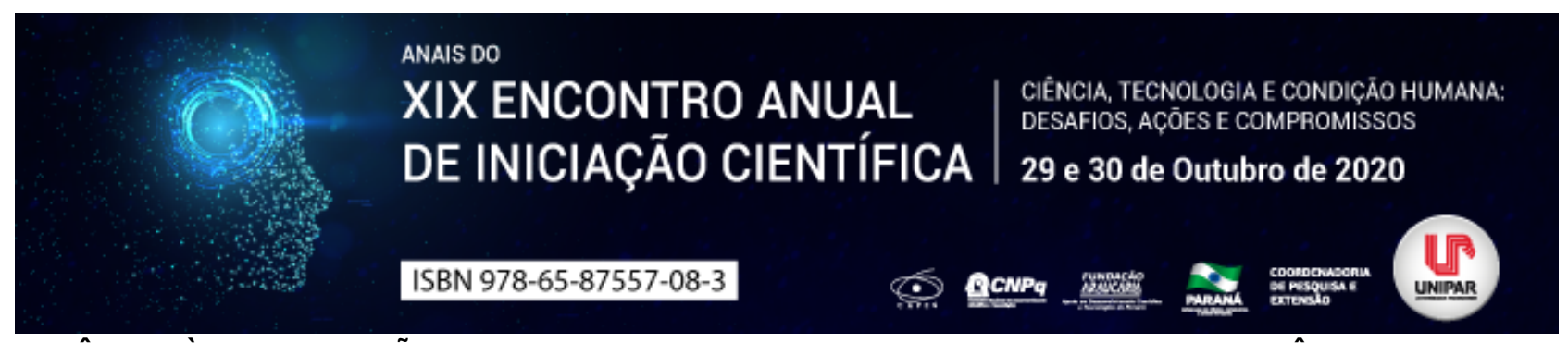

\title{
RESISTÊNCIA À COMPRESSÃO DIAMETRAL DE TUBOS DE CONCRETO DE 40 CM DE DIÂMETRO COM E SEM ARMAÇÃO
}

\author{
${ }^{1}$ Raquel Pedroso Dias , ${ }^{2}$ FERNANDO HENRIQUE MATTIELLO CRUZ, ${ }^{3}$ GUSTAVO SAVARIS \\ ${ }^{1}$ Mestranda em Engenharia Civil e bolsista da CAPES, Universidade Federal da Integração Latino-Americana \\ ${ }^{1}$ Bacharel em Engenharia Civil, Universidade Tecnológica Federal do Paraná \\ ${ }^{2}$ Doutor em Engenharia Civil, Docente da Universidade Tecnológica Federal do Paraná
}

Introdução: Tubos de concreto são peças pré-moldadas ou pré-fabricadas de concreto, de seção circular uniforme em toda a sua superfície longitudinal interna, exceto na região do encaixe, chamado de bolsa ou fêmea (ABNT, 2018). No Brasil são, em sua maioria, utilizados para redes de águas pluviais e esgotamento sanitário (ESCARIZ, 2012). Os projetos destes tubos devem ter o mesmo cuidado, ou até maior, apresentado nos projetos usuais de estruturas, visto que a falha de um tubo pode causar problemas sérios e onerosos (PETER et al., 2018; ACPA, 2011; SILVA, 2011). A NBR 8890 (ABNT, 2018) preconiza que deve ser realizado o controle de produção, o qual é definido como o conjunto de procedimentos realizados pelo produtor visando o atendimento dos requisitos estabelecidos para os tubos. Para isso, são selecionadas amostras aleatórias, compreendidas por tubos pertencentes a um mesmo lote, e estas são avaliadas visualmente e mecanicamente para determinar se estão dentro de um conjunto de parâmetros que garantam a qualidade do produto final.

Objetivo: Este trabalho apresenta um estudo experimental realizado com tubos de concreto produzidos por uma empresa instalada na região Oeste do estado do Paraná, avaliando a conformidade com a NBR 8890 (ABNT, 2018).

Materiais e Métodos: Durante a etapa de produção de tubos em uma fábrica de pré-moldados foram coletadas de forma aleatória seis amostras com diâmetro de $40 \mathrm{~cm}$, sendo três sem armadura e três com armadura. No laboratório de estruturas da Universidade Tecnológica Federal do Paraná, Campus Toledo, os tubos foram submetidos a inspeções visuais e dimensionais e ensaios de compressão diametral pelo método dos três cutelos, conforme NBR 8890 (ABNT, 2018), utilizando um pórtico de reação com capacidade de carga de 1500 kN.

Resultados: Na análise visual foi possível constatar apenas a presença da marca do fabricante e classe do tubo, porém segundo a NBR 8890 (ABNT, 2018) todos os tubos devem trazer, em caracteres legíveis gravados em baixo-relevo no concreto o nome ou marca do fabricante, o diâmetro nominal, a classe a que pertencem ou a resistência do tubo, a data de fabricação e um número para rastreamento de todas as suas características de fabricação. Nenhuma das amostras coletadas apresentou correções com nata de cimento ou outros materiais com o objetivo de esconder defeitos. Entretanto, na análise do acabamento da superfície interna dois tubos com armadura foram reprovados, pois apresentaram pequenas irregularidades que foram tocadas pelo gabarito de verificação na parte central. Nos ensaios de compressão diametral, os tubos sem armadura apresentaram uma carga média de ruptura de $40,0 \mathrm{kN} / \mathrm{m}$ e os tubos armados apresentaram força média de ruptura de $74,14 \mathrm{kN} / \mathrm{m}$.

Discussão: A falta de identificação dos tubos é evidenciada na indústria pela dificuldade de marcação em relevo do grande número de informações definidas na norma, o que poderia acarretar fissuração do tubo na desforma. Referente aos defeitos no acabamento interno dos tubos com armadura, como são utilizadas máquinas de mesmo modelo para produção dos dois tipos de tubo, constata-se então que os defeitos ocorrem devido à presença armadura, que dificulta o processo de conformação. Nos ensaios de compressão diametral, os tubos sem armadura apresentaram uma força média de ruptura superior a $24 \mathrm{kN} / \mathrm{m}$, podendo ser classificados na classe PS2. Os tubos armados apresentaram força média de ruptura superior à força mínima de ruptura de classe PA4, que é de $72 \mathrm{kN} / \mathrm{m}$, mas a força mínima de fissuração média foi de $43,83 \mathrm{kN} / \mathrm{m}$ que, apesar de próximo ao requisito da classe PA4 - $48 \mathrm{kN} / \mathrm{m}$ - classifica o tubo como PA3. Contudo ressalta-se que para comercialização a empresa classifica o tubo como PA2, para a qual são atendidos os requisitos de resistência.

Conclusão: A partir do estudo realizado conclui-se que apesar dos tubos não apresentarem alguns requisitos de identificação, estes apresentaram bom acabamento visual, não havendo indicação de reparos em fissuras. Entretanto, melhorias devem ser realizadas no processo de produção de tubos com armadura para evitar irregularidades internas. Nos ensaios de compressão diametral os tubos atenderam as recomendações normativas das classes definidas pela empresa para comercialização, podendo-se concluir que a presença de armadura resultou em aumento considerável da resistência final.

\section{Referências}

ASSOCIAÇÃO BRASILEIRA DE NORMAS TÉCNICAS. NBR 5739: Concreto Ensaio de compressão de corpos de prova cilíndricos. Rio de Janeiro, 2018.

ASSOCIAÇÃO BRASILEIRA DE NORMAS TÉCNICAS. NBR 8522: Concreto - Determinação dos módulos estáticos de elasticidade e de deformação à compressão. Rio de Janeiro, 2017. 
ASSOCIAÇÃO BRASILEIRA DE NORMAS TÉCNICAS. NBR 8890: Tubo de concreto de seção circular para água pluvial e esgoto sanitário - Requisitos e métodos de ensaios. Rio de Janeiro, 2018.

AMERICAN CONCRETE PIPE ASSOCIATION. Concrete Pipe Design Manual, [s.I.], n. 78-58624. 2011. Disponível em: . Acesso em: 31 ago. 2020.

ESCARIZ, Renata Campos. Análise comparativa de desempenho mecânico de tubos de concreto reforçados com macrofibras poliméricas e fibras de aço. 2011. Dissertação (Mestrado em Engenharia de Construção Civil e Urbana) - Escola Politécnica, Universidade de São Paulo, São Paulo, 2011.

PETER, Jane M. et al. Impact of soil erosion voids on reinforced concrete pipe responses to surface loads. Tunnelling and Underground Space Technology, [s.I.], v. 82, p. 111-124, 2018. Disponível em: . Acesso em: 31 ago. 2020.

SILVA, Jefferson Lins. Análise de tubos circulares de concreto armado para o ensaio de compressão diametral com base na teoria de confiabilidade. Tese (Doutorado-Programa de Pós-Graduação e Área de Concentração em Engenharia de Estruturas) - Escola de Engenharia de São Carlos da Universidade de São Paulo, 2011.

Coordenadoria de Pesquisa e Extensão - COPEX

Departamento de Editoraçāo e Divulgaçāo Científica - DEDIC 


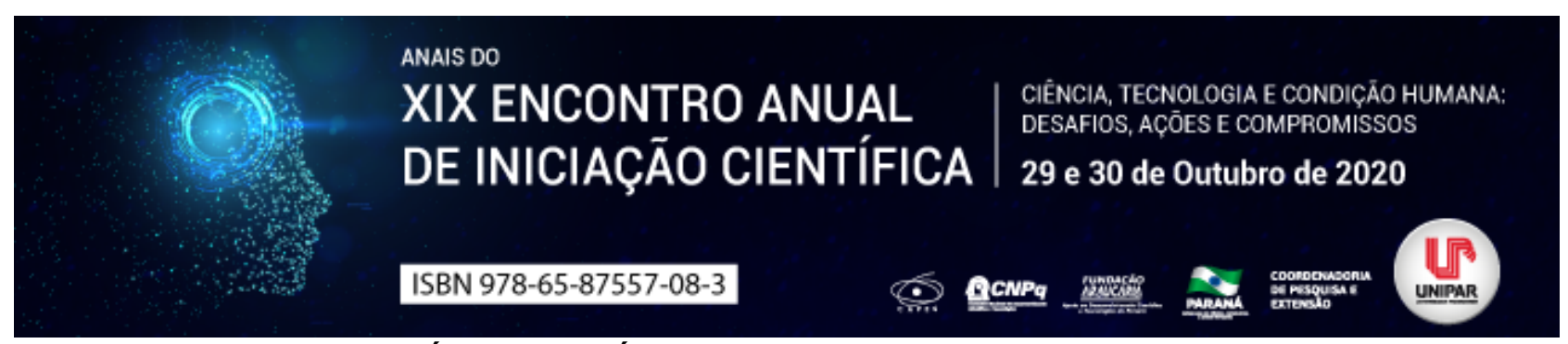

ATIVIDADES BIOLÓGICAS DO ÓLEO ESSENCIAL DAS FOLHAS DE Eugenia uniflora

\begin{abstract}
${ }^{1}$ MARIANA RODRIGUES VILAS BOAS, ${ }^{2}$ GESSICA GONÇALVES CHAGAS, ${ }^{3}$ HERIKA LINE MARKO DE OLIVEIRA, ${ }^{4}$ CARLA MARIA MARIANO FERNANDEZ, ${ }^{5}$ ZILDA CRISTIANI GAZIM, ${ }^{6}$ MARIA GRACIELA IECHER FARIA NUNES
\end{abstract}

\begin{abstract}
${ }^{1}$ Mestranda em Biotecnologia Aplicada à Agricultura, Unipar, Umuarama PR
${ }^{1}$ Acadêmica. do curso de Estética e cosmética, Unipar, Umuarama-PR

${ }^{2}$ Doutoranda em Biotecnologia Aplicada à Agricultura, Unipar, Umuarama PR

${ }^{3}$ Docente do Programa de Pós-graduação em Biotecnologia Aplicada à Agricultura, Unipar, Umuarama PR

${ }^{4}$ Docente do Programa de Pós-graduação em Biotecnologia Aplicada à Agricultura, Unipar, Umuarama PR

${ }^{5}$ Docente da UNIPAR
\end{abstract}

Introdução: Eugenia uniflora (Myrtaceae), conhecida popularmente como pitanga, é uma planta nativa com características de regiões tropicais e subtropicais, sendo de fácil acesso pois é encontrada por quase todo território nacional. Seus frutos têm valor econômico devido sua versatilidade pois fornecem geléias, sorvetes, vinhos, etc. De acordo com a medicina popular as folhas são utilizadas no tratamento de febre, doenças do estômago, hipertensão, obesidade, diabetes, reumatismo e bronquite (FIÚZA, 2008). O óleo essencial (OE) extraído das folhas apresenta propriedades de grande importância para as indústrias farmacêuticas e cosméticas devido aos ativos antioxidantes e antimicrobianos presentes em sua composição química.

Objetivo: Avaliar a atividade antioxidante e antimicrobiana do óleo essencial das folhas de Eugenia uniflora e sua aplicabilidade em afecções cutâneas descritas na literatura.

Desenvolvimento: Eugenia uniflora L. pertence à família Myrtaceae, é um arbusto denso que possui em média 2 a $4 \mathrm{~m}$ de altura, sua madeira é empregada na confecção de cabos de ferramentas e outros instrumentos agrícolas. A floração acontece entre os meses de agosto e novembro, seu fruto apresenta um aroma característico intenso e sabor doce e ácido e seu epicarpo varia a coloração de alaranjada até quase negro e costumam amadurecer entre outubro e janeiro. As folhas de $E$. uniflora são utilizadas na medicina popular por possuírem propriedades terapêuticas adstringente, antidiarréica, febrífuga, estimulante, refrescante, digestiva, aromática, tônica, balsâmica, antioxidante e antibiótica. (LIMA, V. L. A. G.; MELO; LIMA, D. E. S, 2002). O rendimento e a composição dos OE das plantas são influenciados por diversos fatores, sendo os mais importantes: idade da planta, época de colheita, condições ambientais, estresse e fertilizações (SERAFINI et al., 2002). Embora o nível de metabólitos secundários na planta seja geneticamente controlado, a quantidade e a concentração destes compostos está diretamente relacionada com as condições ambientais do local onde se encontra a cultura. Na composição química, Maia et al. (1999) estudaram o OE de folhas e ramos de E. uniflora, colhidos na cidade de Belém, no Pará, obtendo 1,8\% de rendimento, sendo germacreno (32,8\%), germacreno B (15,6\%) e curzereno $(30,0 \%)$ os componentes mais abundantes. Em outro estudo ainda identificaram no OE os seguintes compostos: biciclogermacreno, ledol, spatulenol, globulol, viridiflorol, guaiol, $\beta$-elemenona, $\delta$ cadinene, entre outros. Acredita-se que a atividade antioxidante exercida pelos compostos bioativos, atua de forma direta como sequestradores de radicais livre, quelantes de metais capazes de catalisar a peroxidação de lipídeos e em vias de sinalização celular. Em relação ao OE de E. uniflora L já existem relatos sobre a atividade antioxidante pela eliminação de DPPH ( IC50 = $833,3 \mathrm{~g} / \mathrm{mL}$ ) (VICTORIA et al., 2012). Também sabe-se que o germacreno $D$ é um forte antioxidante devido à sua porção extracíclica de metileno e também o -cariofileno que possui atividade de eliminação de radicais livres, determinado pelo ensaio DPPH (DAMIEN et al., 2010). Outra atividade biológica é a antimicrobiana que de acordo com Ogunwande et al. (2005) verificaram que o OE do fruto da pitanga exibiu uma forte ação antibacteriana contra Staphylococcus aureus, e OE da folha mostrou inibição contra Bacillus cereus. Auricchio e Bacchi (2003), observaram que extrato das folhas de E. uniflora apresentou atividade antimicrobiana contra Staphylococcus aureus, o extrato também apresentou atividade frente a Salmonella choleraesuis, Pseudomonas aeruginosa e Candida albicans. De acordo com Silva et al. (2012) o OE é eficaz frente a Staphylococcus aureus, Listeria monocytogenes. Além disso, encontraram no OE compostos da classe dos terpenóides, que segundo Bakkali et al. (2008), possuem propriedades antimicrobianas. Tem se observado um aumento na procura por cosméticos naturais a fim de substituir os produtos sintéticos, e na escolha do cosmético algumas informações são levadas em conta como, livres de corantes, hipoalergênico e não testados em animais. Os óleos essenciais podem ser utilizados como conservantes ou até mesmo como um princípio ativo. E o OE de pitanga vem sendo utilizado na indústria farmacêutica e cosmética por conta de suas propriedades adstringentes, que estão associados ao seu cheiro agradável e pela sensação de frescor, sendo suas principais aplicações em sabonetes, desodorantes, óleos corporais e perfumes (AMORIM et al., 2009).

Conclusão: De acordo com alguns estudos o óleo essencial das folhas de E. uniflora apresenta atividades antioxidante e antimicrobiana com resultados significativos, se fazendo interessante pesquisas relacionadas ao desenvolvimento de um 
conservante ou até mesmo de um princípio ativo natural para determinadas formulações, já que são escassos os estudos que o utilizam incorporados em cosméticos.

\section{Referências}

AMORIM, A. C. L.; LIMA, C. K. F.; HOVELL, A. M. C.; MIRANDA, A. L. P.; REZENDE, C. M., 2009. Antinociceptive and hypothermic evaluation of the leaf EO and isolated terpenoids from Eugenia uniflora L. (Brazilian Pitanga). Phytomed. 16, 923928.

AURICCHIO, M. T.; BACCHI, E. M. Folhas de Eugenia uniflora L. (pitanga): Revisão. Rev. Inst. Adolfo Lutz, v. 62, n.1, p. 55 61, 2003.

BAKKALI, F.; AVERBECK, S.; AVERBECK, D.; IDAOMAR, M. Biological effects of EO review. Food Chem. Toxicol., n. 46, p. 446-475, 2008.

DAMIEN, D. H. J.; CHRISTINA, F. A.; JOSE, B. Â. G.; STANLEY, D. G., 2010. In vitro evaluation of antioxidant activity of EO and their components. Flav. Frag. J. 15, 1216.

FIÚZA, T. S.; SABǑIA-MORAIS, S. M. T.; DE PAULA, J. R.; TRESVENZOL, L. M. F.; PIMENTA, F. C. Evaluation of antimicrobial activity of the crude ethanol extract of Eugenia uniflora L. leaves. Rev. Cienc. Farm. Basica. Apl. 2008;29(3):245-50.

LIMA, V. L. A. G.; MELO, E. A.; LIMA, D. E. S. Fenólicos e carotenóides totais em pitanga. Sci Agric, 59(3): 447-450, 2002. MAIA, J. G. S.; ANDRADE, M. H. L.; DA SILVA, M. H. L.; ZOGHBI, M. G. B. A new chemotype of Eugenia uniflora L. From north Brazil. J. Essent. Oil Res. 11, p. 727-729, 1999.

OGUNWANDE, I. A.; OLAWORE, N. O.; EKUNDAYO, O.; WALKER, T. M.; SCHMIDT, J. M.; SETZER, W. N. Studies on the EO composition, antibacterial and cytotoxicity of Eugenia uniflora L. Int J Aromatherap 2005;15(3):147 52.

SERAFINI, L.A.; SANTOS, A.C.A.; TOUGUINHA, L.A.; AGOSTINI, G.; DALFOVO, V. 2002. Extrações e aplicações de OE de plantas aromáticas e medicinais. Caxias do Sul: EDUCS.

SILVA, N. C. C.; BARBOSA, L.; SEITO, L. N.; FERNANDES JUNIOR, A. Antimicrobial activity and phytochemical analysis of crude extracts and EO from medicinal plants. Nat. Prod. Res. (2012) 26:16.

VICTORIA, F. N. et al. Essential oil of the leaves of Eugenia uniflora L.: Antioxidant and antimicrobial properties. Food Chem. Toxicol, v. 50, n. 8, p. 2668 2674, 2012. 


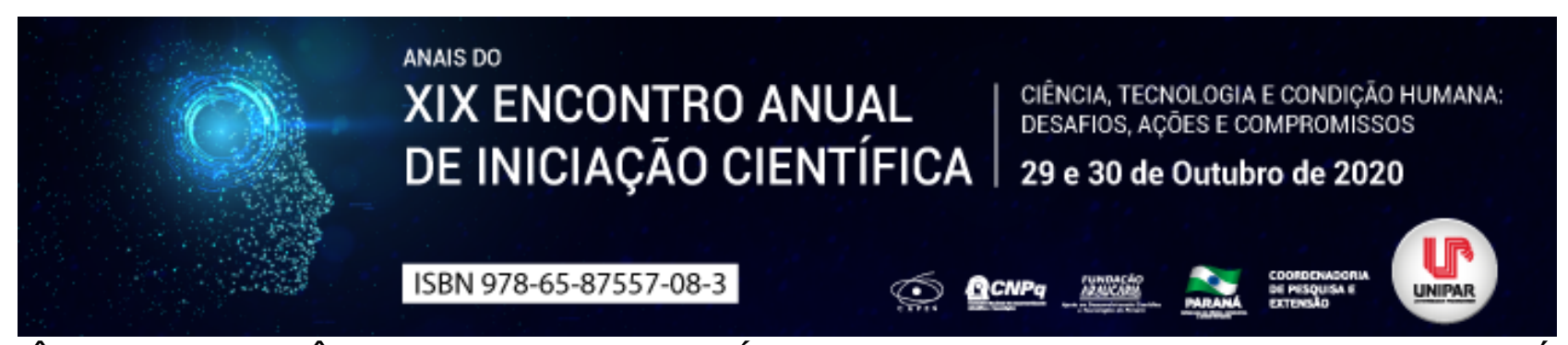

\title{
DEFICIÊNCIA DE NITROGÊNIO E TOXIDADE AO ALUMÍNIO ALTERA O TEOR DE CLOROFILA, NBI E METABÓLITOS SECUNDÁRIOS EM MILHO PIPOCA
}

\author{
${ }^{1}$ AMANDA BARRAVIEIRA, ${ }^{2}$ HELEN KARLA FERREIRA DE MELLO, ${ }^{3}$ LUIS EDUARDO PEDRINI DE SOUZA, ${ }^{4}$ CAIO CESAR \\ LEVORATO, ${ }^{5}$ SILVIA GRACIELE HULSE DE SOUZA
}

\author{
${ }^{1}$ Discente do curso de Engenharia Agronômica PIBIC/UNIPAR \\ ${ }^{1}$ Discente do curso de Engenharia Agronômica PIC/UNIPAR \\ ${ }^{2}$ Discente do curso de Engenharia Agronômica PIC/UNIPAR \\ ${ }^{3}$ Discente do curso de Engenharia Agronômica/UNIPAR \\ ${ }^{4}$ Docente do curso de Engenharia Agronômica e Pós-graduação em Biotecnologia Aplicada à Agricultura/UNIPAR
}

Introdução: O milho (Zea mays L.) é uma planta de origem tropical, e além de ser um dos cereais mais cultivados e usados no mundo, também é de grande importância na alimentação humana e animal, sendo geralmente cultivado em solos ácidos da América do Sul e Central (FAGERIA et al., 1988). O milho pipoca é uma variedade muito utilizada na alimentação humana e bastante apreciado no Brasil. Atualmente a produção de milho pipoca vem aumentando gradativamente no país, isso se deve à uma maior demanda pelo produto in natura ou na forma de produtos industrializados (MOTERLE et al., 2006). O estresse por Al é caracterizado especialmente por causar inibição do crescimento da raiz, como consequência da alteração de diferentes mecanismos e estruturas celulares (KOPITTKE et al., 2015). Na cultura do milho a maioria dos híbridos comerciais é suscetível ao $\mathrm{Al}^{+3}$, com sua produtividade fortemente depreciada em função da elevada acidez do solo (GALON et al., 2011). A utilização do cultivo vegetal em solução nutritiva tem se mostrado muito usual em programas de melhoramento, por constituir um meio rápido e bastante eficiente, com a possibilidade de avaliação e seleção de um grande número de genótipos em pouco tempo (CRESTANI et al., 2013).

Objetivo: avaliar o efeito dos diferentes níveis de nitrogênio e da toxicidade ao alumínio $\left(\mathrm{Al}^{3+}\right)$ sobre o teor de clorofila, NBI e metabólitos secundários em milho pipoca.

Material e Métodos: Sementes de milho pipoca (híbrido AP6005) foram semeadas em papel germitest umedecido 2,5 vezes a massa de água. Após 7 dias de germinação, os cotilédones foram retirados e as plântulas transferidas para recipientes pretos e cultivado hidroponicamente. As plântulas foram mantidas em solução nutritiva de Hoagland e Arnon (1950) por 7 dias. Após esse período, plantas semelhantes foram selecionadas e transferidas para uma solução nutritiva modificada de Hoagland e Arnon com diferentes concentrações de $\mathrm{N}$ e $\mathrm{Al}\left(\mathrm{Al}^{3+}\right)$. Para o tratamento com $\mathrm{N}$, as plantas foram mantidas com solução nutritiva contendo 2 $\mathrm{mM}$ de $\mathrm{KNO}_{3}$ e (nitrogênio baixo) e $\mathrm{KNO}_{3} 10 \mathrm{mM}$ (nitrogênio adequado). A toxicidade ao alumínio foi realizada pela adição de 2 $\mathrm{mM}$ de $\mathrm{Cl}_{3} \mathrm{Al}_{2}$. Os tratamentos foram: $10 \mathrm{mM}$ de $\mathrm{KNO}_{3}$ e sem alumínio, (T1, controle), $10 \mathrm{mM}$ de $\mathrm{KNO}_{3}$ e com alumínio (T2), $2 \mathrm{mM}$ de $\mathrm{KNO}_{3}$ e sem alumínio, (T3), $2 \mathrm{mM}$ de $\mathrm{KNO}_{3}$ e com alumínio (T4). Os parâmetros de teor de clorofila ( $\mu \mathrm{g} \mathrm{cm}^{-2}$ ), índice de balanço de nitrogênio (NBI), flavonoides $\left(\mu \mathrm{g} \mathrm{cm}^{-2}\right)$ e antocianinas $\left(\mu \mathrm{g} \mathrm{cm}^{-2}\right)$ foram determinados no terço médio das folhas em oito repetições de cada tratamento a partir do equipamento Sensor Dualex ${ }^{\circledR}$ Scientific aos 7, 14, 21 e 28 dias após o início do estresse. Os dados serão submetidos a análise de variância (ANOVA), e as médias comparadas pelo teste de Tukey ( $\mathrm{p} \leq 0,05$ ) utilizando o programa estatístico (SISVAR).

Resultados: Aos primeiros dias de cultivo notou-se que a presença do $\mathrm{Al}^{+3}$ não afetou significativamente o desenvolvimento das plantas de milho, no entanto, os tratamentos com ausência de nitrogênio T3(-N com $\mathrm{Al}^{+3}$ ) e $\mathrm{T}^{4}\left(-\mathrm{N}\right.$ sem $\mathrm{Al}^{+3}$ ) já apresentaram queda nos índices de clorofila e NBI (Índice de Balanço de Nitrogênio). Aos 21 dias de cultivo todos os tratamentos obtiveram uma aproximação destes mesmos índices, onde T1 $\left(28,41 \mu \mathrm{g} \cdot \mathrm{cm}^{-2}\right)$ mostrou um desempenho relativamente superior aos demais. Ao final de 28 dias T1, T3 e T4 apresentaram sinais evidentes de estresse, apenas T2 (22,9 e 23,49 $\left.\mu \mathrm{g} . \mathrm{cm}^{-2}\right)$ obteve aumento nos índices de clorofila e NBI respectivamente. Sob condições de estresse a planta reagiu com um aumento de metabólitos secundários como flavonoides e antocianinas. O T4 teve a produção de Antocianinas elevada aos 14 dias com $0,23 \mu$ g.cm ${ }^{-2}$ justamente o mesmo período de queda para clorofila ocorreu no mesmo tratamento. Os índices de Flavonoides apresentaram valores superiores aos 28 dias de cultivo, onde T3 obteve $1,17 \mu \mathrm{g} . \mathrm{cm}^{-2}$.

Discussão: Os tratamentos com ausência de nitrogênio demonstraram maior suscetibilidade ao estresse, Segundo Vilela et al. (2011), para o milho, a maioria das cultivares comerciais são suscetíveis ao alumínio, mas existem variabilidades genéticas dentro desta espécie quanto à tolerância ao alumínio, a qual é possível e precisa ser melhor estudada. O teor de clorofila no final 
da fase vegetativa tem sido relacionado com o estado nutricional de $\mathrm{N}$ de diversas culturas (ARGENTA et al., 2001). A disponibilidade de nitrogênio na planta favorece a formação das moléculas de clorofila. Na ausência de nitrogênio, os carboidratos que não foram utilizados no metabolismo de $\mathrm{N}$ podem ser utilizados para a biossíntese de antocianinas e acumulação desse pigmento também é um dos sintomas de deficiência. Os flavonoides são metabólitos secundários aromáticos das plantas e que desempenham importantes funções biológicas, entre elas, absorção de UV, resposta ao ataque de patógenos, resposta às baixas temperaturas e à deficiência de nutrientes (LEA et al., 2008; PETRONI, PILU E TONELLI, 2014).

Conclusão: As plantas com baixo teor de nitrogênio e submetidas à toxicidade ao alumínio apresentaram baixa produção de clorofila e um aumento na produção de metabólitos secundários como flavonoides e antocianinas.

\section{Referências}

ARGENTA, G.; SILVA, P. R. F.; BORTOLINI, C. G.; FORSTHOFER, E. L.; STRIEDER, M. L. Relação da leitura do clorofilômetro com os teores de clorofila extraível e de nitrogênio na folha de milho. Revista Brasileira de Fisiologia Vegetal, Campinas, v.13, n.2, p.158-167, 2001

CRESTANI, M., SILVA, J.A.G.S.; TESSMANN, E.W.; SILVEIRA, S.F.; NORNBERG, R.; RIBEIRO, G.; CARVALHO, F.I.F; OLIVEIRA, A.C. Protocolos para seleção quanto à tolerância ao alumínio em aveia sob cultivo hidropônico. Current Agricultural Science and Technology, v.17, n.3, p.311-320, 2013.

FAGERIA, N.K.; BALIGAR, V.C.; WRIGHT, R.J. Aluminum toxicity in crop plants. Journal Plant Nutrition, v.11, n.2, p.303-319, 1988.

GALON, L.; TIRONI, S.P.; DA ROCHA, A.A.; SOARES, E.R.; CONCENÇO, G.; ALBERTO, C.M. Influência dos fatores abióticos na produtividade da cultura do milho. Revista Trópica: Ciências Agrárias e Biológicas, v.4, n.3, p.18-38, 2011.

KOPITTKE, P. M.; MOORE, K. L.; LOMBI, E.; GIANONCELLI, A.; FERGUSON, B. J.; BLAMEY, F. P. C.; MENZIES, N. W.; NICHOLSON, T. M.; MCKENNA, B. A.; WANG, P.; GRESSHOFF, P. M.; KOUROUSIAS, G.; WEBB, R. I.; GREEN, K.; TOLLENAERE, A. Identification of the primary lesion of toxic aluminum in plant roots. Plant Physiology, Lancaster, v. 167, n. 4, p.1402-1411, 2015.

MOTERLE, Lia Mara et al. Germinação de sementes e crescimento de plântulas de cultivares de milho-pipoca submetidas ao estresse hídrico e salino. Revista Brasileira de Sementes, v. 28, n. 3, p. 169-176, 2006.

PETRONI, Katia; PILU, Roberto; TONELLI, Chiara. Anthocyanins in corn: a wealth of genes for human health. Planta, v. 240, n. 5, p. 901-911, 2014.

VILELA, L.A.; BELO, E.S.; CARVALHO, R.S.; FARIA, F.P.; SILVA, S.M. Influência de alumínio na taxa de respiração de sementes de Zea mays (milho). 2011. Disponível em: http://www.sbpcnet.org.br/livro/63ra/conpeex/mestrado/trabalhosmestrado/mestrado-larissaassis.pdf. Acesso em: 20 out. 2012. 


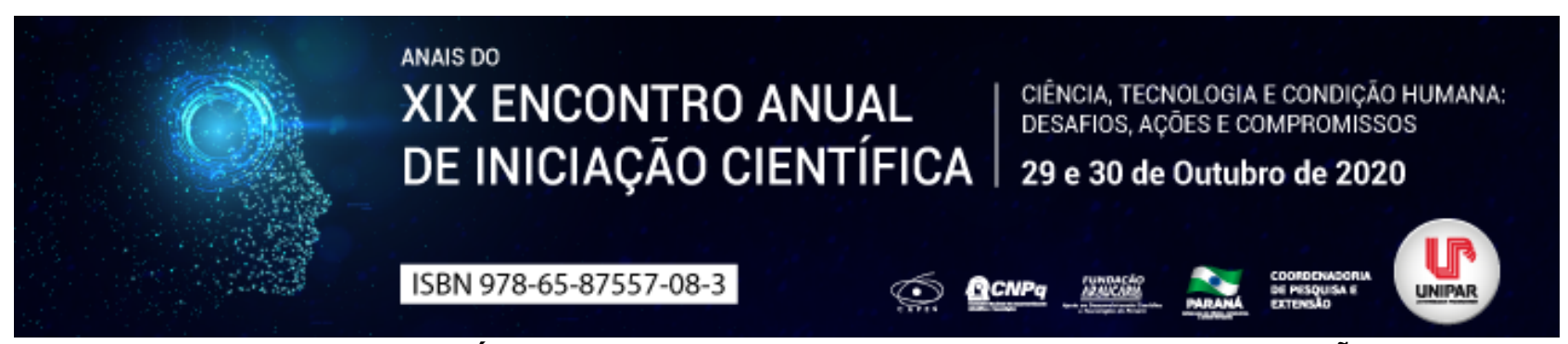

ATIVIDADES BIOLÓGICAS DOS SESQUITERPENOIDES: UMA BREVE REVISÃO

\title{
${ }^{1}$ HERIKA LINE MARKO DE OLIVEIRA , ${ }^{2}$ WANESSA DE CAMPOS BORTOLUCCI, ${ }^{3}$ ISABELLE LUIZ RAHAL, ${ }^{4} \mathrm{KÁTIA} \mathrm{CASTILHO}$ DE OLIVEIRA, ${ }^{5}$ MARIANA RODRIGUES VILAS BOAS, ${ }^{6}$ ZILDA CRISTIANI GAZIM
}

\author{
${ }^{1}$ Doutoranda em Biotecnologia Aplicada à Agricultura, Unipar, Umuarama PR \\ ${ }^{1}$ Doutora em Biotecnologia Aplicada à Agricultura, Unipar, Umuarama PR \\ ${ }^{2}$ Mestranda em Biotecnologia Aplicada à Agricultura, Unipar, Umuarama PR \\ ${ }^{3}$ Mestranda em Biotecnologia Aplicada à Agricultura, Unipar, Umuarama PR \\ ${ }^{4}$ Mestranda em Biotecnologia Aplicada à Agricultura, Unipar, Umuarama PR \\ ${ }^{5}$ Docente do Programa de Pós-graduação em Biotecnologia Aplicada à Agricultura, Unipar, Umuarama PR
}

Introdução: As plantas medicinais vêm sendo utilizadas há muito tempo, na tentativa de se descobrir novos princípios ativos para o tratamento de doenças (CZELUSNIAK et al., 2012). Óleos essenciais são considerados uma mistura de substâncias naturais voláteis, provenientes de metabólitos secundários de plantas, principalmente de substâncias lipofílicas como monoterpenos, sesquiterpenos e seus derivados oxigenados (álcoois, aldeídos, ésteres, éteres, cetonas, fenóis e óxidos), comumente associadas a importantes atividades biológicas (BAKKALI et al., 2008). Os compostos são classificados de acordo com a quantidade de unidades isoprênicas (C5) em: hemiterpenos (C5), monoterpenos (C10), sesquiterpenos (C15), diterpenos (C20), sesterpenos (C25), triterpenos (C30), tetraterpenos (C40) e politerpenos (>C40). Os sesquiterpenos constituem uma subclasse dos terpenos formados por três unidades isoprênicas (C15H24) (DEWICK, 2006).

Objetivo: Realizar um levantamento bibliográfico sobre o potencial biológico dos sesquiterpenóides.

Desenvolvimento: Estudos recentes demonstraram que óleos essenciais ricos em monoterpenos e sesquiterpenos são promissores para o manejo de estufas de Tetranychus urticae (BORN et al., 2018) por meio de mecanismos de toxicidade ao ácaro e afetando as preferências de alimentação e postura de ovos (MORAES et al., 2017). Os sesquiterpenos alfa-humuleno, e trans-cariofileno, presentes na composição química de muitos óleos essenciais, foram descritos com potencial efeito antiinflamatório, inibidores de canais de Ca2+ (FERNANDES et al., 2007; PINHO-DA-SILVA et al., 2012). O sesquiterpeno 7epizingibereno encontrado na espécie Solanum habrochaites possui ação repelente sobre a mosca-branca (Bemisia tabaci) (ROSEN et al., 2015). Simas et al. (2004) demonstraram que os sesquiterpenos oxigenados são larvicidas mais potentes que os fenilpropanoides e monoterpenos. Estudos pré-clínicos realizados por El-Beshbish et al. (2013) demonstraram a eficácia terapêutica do sesquiterpeno, arteméter que é o derivado do éter metílico da artemisinina, encontrado nas folhas de Artemisina annua e administrado em dose única de $400 \mathrm{mg} / \mathrm{kg}$ contra as formas de esquistossômulos e vermes jovens da linhagem Egípcia de Schistosoma mansoni, apresentaram taxas de redução de vermes de 86 e 91\%, respectivamente.

Conclusão: Muitas são as atividades biológicas desses compostos e são cada vez mais investigados quanto às suas propriedades, para a aplicação destas seja em indústrias farmacêuticas, alimentícias, cosméticos, defensivos agrícolas, pois são substâncias naturais e biodegradáveis.

\section{Referências}

BAKKALI, F.; AVERBECK, S.; AVERBECK, B.; IDAOMAR, M. Biological effects of essential oils a review. Food Chem Toxicol. v. 46, p. 446-475, 2008.

BORN, F. S.; DA CAMARA, C. A. G.; MELO, J. P. R.; MORAES, M. M. Acaricidal property of the essential oil from Lippia gracilisagainst Tetranychus urticae and a natural enemy, Neoseiulus californicus, under greenhouse conditions. Exp Appl Acarol. v. 75, p. 491-502, 2018.

CZELUSNIAK, K. E.; BROCCO, A.; PEREIRA, D. F.; FREITAS, G. B. L. Farmacobotânica, fitoquímica e farmacologia do guaco: revisão considerando Mikania glomerata Sprengel e Mikania laevigata Schulyz Bip. ex Baker. Rev Bras Plant Med. v. 14, n.2, p. 400-409, 2012.

DEWICK, P. M. Essentials of Organic Chemistry: For Students of Pharmacy, Medicinal Chemistry and Biological Chemistr. John Wiley \& Sons: London, 2006, p. 696.

EL-BESHBISH, S. N. et al. In vivo effect of single oral dose of artemether against early juvenile satges of Schistosoma mansoni Egyptian strain. Exp. Parasitol. v. 135, p. 240-245, 2013.

FERNANDES, E. S. et al. Anti-inflammatory effects of compounds alpha-humulene and (-) trans caryophyllene isolated from the essential oil of Cordia verbenacea. Eur. J. Pharmacol. v. 569, p. 228 236, 2007.

MORAES, M. M.; DA CAMARA, C. A. G.; ARAUJO, C. A. Chemical composition of essential oil from leaves of Ocotea 
limae Vattimo Gil. and Ocotea gardneri (Meisn.) Mez. growing wild in atlantic forest of North-Eastern Brazil. Plant Med Aromat, v. 16, p. 585-592, 2017.

PINHO-DA-SILVA, L. et al. Trans Caryophyllene, a Natural Sesquiterpene, Causes Tracheal Smooth Muscle Relaxation through Blockade of Voltage-Dependent Ca2+ Channels. Molecules. v. 17, p. 11965-11977, 2012.

ROSEN, R. et al. Persistent, circulative transmission of begomoviruses by whitefly vectors. Cur. Opin Virol, v. 15, p. 1 8, 2015. SIMAS, N. K. et al. Produtos naturais para o controle da transmissão da dengue-atividade larvicida de Myroxylon balsamum (óleo vermelho) e de terpenóides e fenilpropanóides. Quím. Nova. v. 27, n. 1, p. 46-49, 2004.

Coordenadoria de Pesquisa e Extensão - COPEX

Departamento de Editoraçāo e Divulgaçāo Científica - DEDIC 


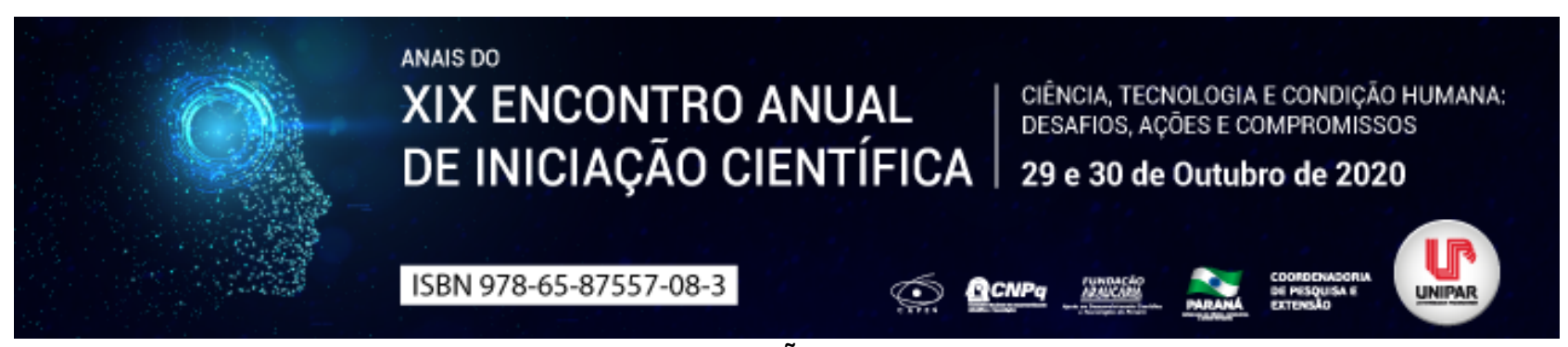

CONTROLE DA IRRIGAÇÃO POR TENSIOMETRIA

\begin{abstract}
${ }^{1}$ Natalia da Silva Volpato, ${ }^{2}$ LUCAS HIROSHI SUGUIURA, ${ }^{3}$ JOÃO VICTOR DA SILVA CREEM, ${ }^{4}$ ANDRESSA DE ALMEIDA LIMA, ${ }^{5}$ RAUL JOSÉ ROESLER, ${ }^{6}$ ANTÔNIO CARLOS ANDRADE GONÇALVES
\end{abstract}

\begin{abstract}
${ }^{1}$ Acadêmica do curso de Agronomia-Universidade Estadual de Maringá.
${ }^{1}$ Acadêmico do curso de Agronomia-Universidade Estadual de Maringá

${ }^{2}$ Acadêmico do curso de Agronomia-Universidade Estadual de Maringá

${ }^{3}$ Acadêmica do curso de Agronomia-Universidade Estadual de Maringá.

${ }^{4}$ Acadêmico do curso de Agronomia-Universidade Estadual de Maringá

${ }^{5}$ Professor-Universidade Estadual de Maringá
\end{abstract}

Introdução: A irrigação é uma prática que tem como o propósito de levar água aos cultivos de maneira eficiente, econômica e ambientalmente sustentável (BRAGA; CALGARO, 2010). No Brasil, nas últimas décadas, a área irrigada vem crescendo consideravelmente (MEDEIROS, 2019), o que demonstra a percepção dos produtores sobre a importância da prática da irrigação como uma alternativa para a elevação da produtividade. A irrigação somente promoverá benefício de maneira efetiva caso seja utilizada empregando-se critérios de manejo que resultem em aplicações de água em quantidades compatíveis com as necessidades das culturas irrigadas (AZEVEDO; SILVA, 1999). Uma vez implantado o equipamento de irrigação, o produtor necessita de uma estratégia de manejo de água que defina o momento certo e a quantidade de água adequada para atender às necessidades hídricas da cultura. Essa estratégia pode ser feita usando-se várias técnicas, porém, as mais corriqueiras são: uso de estimativas da evapotranspiração com frequência de irrigação fixa/variável, e ou pela determinação do teor de água no solo (BRAGA; CALGARO, 2010). Na determinação do teor de água no solo existem os métodos diretos e indiretos. Dentre os métodos indiretos temos o tensiômetro, o qual foi desenvolvido por Gardner em 1922 (CAMARGO et al.,1982), que é empregado para medir a tensão com que a água está retida pelas partículas do solo, também conhecido por potencial matricial. Dispondo-se da relação entre o conteúdo de água no solo e a tensão em que ela se encontra pode-se estabelecer, indiretamente, o teor de água no solo a partir das leituras desse aparelho. Segundo Campbell \& Mulla (1990), de todos os métodos disponíveis para o conhecimento dos potenciais de água no solo em irrigação, o tensiômetro é talvez o mais utilizado. Sendo assim, pode-se, com o auxílio deste aparelho, determinar o teor de água atual no solo, na profundidade de interesse e, consequentemente, a quantidade de água armazenada no perfil do solo.

Objetivo: Esclarecer as principais questões relacionadas ao uso da tensiometria no controle da irrigação por meio de uma revisão bibliográfica.

Desenvolvimento: O tensiômetro é composto basicamente de cápsula porosa de cerâmica, tubo de PVC de aproximadamente 1/2 polegada, e outras conexões para assegurar a inserção do vacuômetro ou da borracha siliconizada. Sendo que, os mais utilizados são tensiômetros de punção, tensiômetros com vacuômetro e os de mercúrio (BRAGA; CALGARO, 2010). O primeiro passo para realizar o controle de irrigação é instalar o equipamento de forma adequada que consiste em: profundidade correta na qual compreenda até $80 \%$ das raízes da cultura e as distâncias de instalação vão depender do tipo de irrigação que está sendo usado (BRAGA; CALGARO, 2010). Após instalar o tensiômetro no solo, deve-se preencher todo o tubo de PVC com água destilada e retirar todo $o$ ar do sistema pela extremidade aberta fluxando com o auxílio de uma pisceta, quando possível. $O$ tensiômetro tem uma grande limitação devido à sua estreita faixa de atuação, comparada com os valores dos limites superior e inferior de água no solo (Resende et al., 2002). Os diferentes tipos de tensiômetro podem apresentar certa variabilidade em suas determinações, de acordo com o sistema de leitura que é utilizado. Brito et al. (2009), por exemplo, mostrou que o tensímetro digital superestimou os valores de potencial mátrico em comparação aos valores obtidos pelo manômetro de mercúrio e vacuômetro de Bourdon. Alguns estudos sobre a tensiometria também abordaram uma preocupação na falta de padronização da porosidade e homogeneidade das cápsulas de cerâmica do tensiômetro em sistemas de irrigação e fertirrigação (FRANCO, 2015; SOCCOL et al., 2005), o que poderia interferir em sua condutância hidráulica e, por consequência, no seu tempo de resposta da medida do potencial matricial do solo. Franco (2015) em sua pesquisa, concluiu que o formato da cápsula de cerâmica e a lama do solo influenciaram nas medidas, principalmente em potenciais mais negativos. Já Moraes et al. (2006) realizou avaliações sobre cápsulas de cerâmica de diferentes procedências e demonstrou que cápsulas porosas dos Estados Unidos apresentaram menor variabilidade na condutância que as do Estado do Ceará, sendo que as deste Estado apresentaram condutância superior. Mesmo com tais diferenças os autores concluíram que as procedências das cápsulas, neste caso, apresentaram condutância superior sem significância estatística ( $p>0,05)$.

Conclusão: Existem interferências e variações nas leituras do tensiômetro, as quais são influenciadas principalmente pela falta 
de padronização dos materiais usados para sua produção. Porém, quando se observa sua utilidade em geral, essa técnica apresenta resultados satisfatórios quando aplicados de forma correta e seu uso pode auxiliar o técnico e o produtor na tomada de decisão, seja de quando ou quanto irrigar, possibilitando assim, o uso mais eficiente da água aplicada.

\section{Referências}

AZEVEDO, J. A.; SILVA, E. M. Tensiômetro: Dispositivo prático para controle da irrigação. Planaltina: Embrapa Cerrados,1999. BRAGA, M. B.; CALGARO, M. Uso da Tensiometria no Manejo da Irrigação. Pesquisa agropecuária Brasileira, v. 28, n. 1 , Dezembro, 2010. Disponivél em: http://www.cpatsa.embrapa.br

BRITO, A. S.; LIBERADI, P. L.; MOTA, J. C. A.; MORAES, S. O. Desempenho do tensiômetro com diferentes sistemas de leitura. Revista Brasileira de Ciência do Solo. v. 33, n. 1, p. 17-24,2009.

CAMARGO, A. P.; GROHMANN, F.; CAMARGO, M. B. Tensiômetro simples de leitura direta. Pesquisa agropecuária Brasileira, Brasilia, v. 12. p. 1963-1972, 1982.

CAMPBELL, G. S.; MULLA, D. J. Measurement of soil water content and potencial. In: STEWART, B. A.; NIELSEN, D. R, ed. Irrigation of agricultural crops. Madison: ASA, 1990.p.127-141.

FRANCO, Hélio Henrique Soares. Abordagem metodológica envolvendo tensiometria e determinação da curva de retenção de água num solo de textura média. Orientador: Álvaro Pires da Silva.2015.55p. Dissertação (Mestrado em Ciências: Área de Concentração: Solos e Nutrição de Plantas) Escola Superior de Agricultura Luiz de Queiroz , Piracicaba 2015.

MEDEIROS, F. Levantamento da agricultura irrigada por pivôs centrais no brasil (1985-2017). Pesquisa agropecuária Brasileira, v. 1, n. 1, 2019.

MORAES, M.B.; MEDEIROS, J.F.; LEVIEN, S.L.A.; OLIVEIRA, A.M.de. Avaliação de cápsulas de cerâmica e instrumentos de medida de tensão usados em tensiômetro. Revista Brasileira de Engenharia Agrícola e Ambiental, v.10, n.1 p.58-63,2006.

RESENDE, M.; ALBUQUERQUE, P. E. P.; Métodos e estratégias de manejo de irrigação: Circular Técnica da Embrapa Milho e Sorgo, 10p. Julho, 2003. Disponível em: http://www.agencia.cnptia.embrapa.br/Repositorio/circul19ID-wXaMEtmeDD.pdf. Acesso em: 27 ago. 2020.

SOCCOL, O. J.; CARARO, D. C.; SILVA, E. F. F.; ULLMANN, M. N. Condutância hidráulica e tempo de resposta de tensiômetros utilizados em cultivos fertirrigados. Revista de Ciências Agroveterinárias, Lages, v. 4, n. 1, p. 3-10, 2005. 


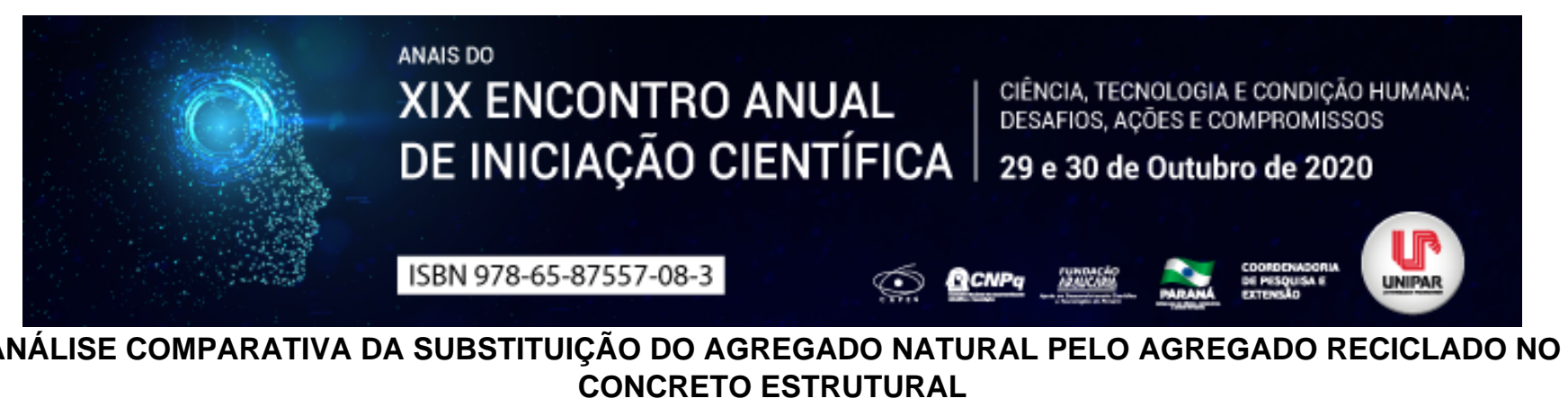

${ }^{1}$ FRANCIELE DIAS DOS SANTOS, ${ }^{2}$ CRISTIANE MARTINS RIBEIRO, ${ }^{3}$ LAIS FERNANDA JUCHEM DO NASCIMENTO

\author{
${ }^{1}$ Acadêmica do Curso de Engenharia Civil da UNIPAR. \\ ${ }^{1}$ Acadêmica do Curso de Engenharia Civil da UNIPAR \\ ${ }^{2}$ Docente da UNIPAR
}

Introdução: A construção civil é uma das principais atividades que impulsionam a economia de um país e uma grande geradora de impactos ambientais. Melo (2011) afirma que para a produção de concretos e argamassas exige grande demanda de recursos minerais providos de jazidas que são demasiadamente exploradas, por serem uma fonte limitada com o tempo surge a necessidade da exploração de novas jazidas, aumentando por consequência a degradação do meio ambiente. Por essa condição estudos buscam a substituição do agregado natural pelo agregado reciclado a fim de se obter resultados que se assemelham aos do concreto com agregado natural. Segundo Brasileiro, Matos (2015) com isso, alguns autores analisam as características do concreto com agregado reciclado a fim de inseri-lo cada vez mais, trazendo parâmetros para futuras adequações às normas existentes. Dessa maneira, faz se relevante o estudo da substituição dos agregados naturais por agregados reciclados visando a melhoria no quesito sustentabilidade na construção civil.

Objetivo: Apresentar de forma geral, a partir da analise de estudos publicados, os resultados de ensaios do concreto com agregado reciclado no seu estado fresco e endurecido.

Desenvolvimento: De acordo com a Resolução do Conselho Nacional do Meio Ambiente (CONAMA), resíduos de construção civil são aqueles gerados nas construções, reformas, reparos e demolições de obras de construção civil, bem como os resultantes da preparação e escavação de terrenos para obras civis. A NBR 15116 (2004) regulariza o uso de agregados da seguinte forma: resíduos de concreto, composto de no mínimo $90 \%$ de fragmentos de cimento Portland e rochas e resíduos mistos menos de $90 \%$ em massa de cimento Portland e rochas, todos pertencentes a classe A de resíduos de construção civil. Segundo Melo (2019), as características do concreto mais relevantes são, a granulometria, a absorção de água, a forma e a textura, a resistência à compressão, o módulo de elasticidade e os tipos de substâncias presentes nos resíduos sólidos. O traço que será utilizado apresenta relação direta com os resultados encontrados, pois influenciará diretamente nas características do concreto no seu estado fresco ou endurecido. De modo geral as características do concreto com agregado reciclado são alteradas conforme ocorre o aumento da substituição do agregado natural pelo reciclado, para dosagens maiores a resistência à compressão e módulo de elasticidade diminuem consideravelmente. Uma das principais propriedades afetadas pelo uso do agregado reciclado é a trabalhabilidade, pois o mesmo apresenta forma irregular, textura áspera e alta taxa de absorção de água. O concreto reciclado apresenta grande variabilidade na composição sendo assim e dificil identificar as propriedades relacionadas ao agregado reciclado com clareza. Para fins estruturais essa inconstância reduz a segurança de uso para esta finalidade, por apresentar grande variabilidade em sua composição é necessário ensaiar as amostras. Melo (2019) reuni a partir de uma análise de vários trabalhos que sobre a propriedade de resistência à compressão axial houve uma redução conforme o aumento do teor de substituição, e para a resistência à tração por compressão diametral até o teor de substituição de $40 \%$, os valores de resistências alcançados não são prejudiciais quanto ao desempenho do concreto com agregado reciclado. Para maiores dosagens é recomendável que se faça ensaios, para garantir a qualidade do concreto. Segundo Santos, Araújo Azeredo e Vereu, (2020), em amostras com material reciclado houve uma pequena redução na resistência mecânica do concreto, quando comparado com amostras com concreto produzido com agregados convencionais, conforme o traço tabelado para confecção de amostras com $30 \mathrm{Mpa}$, enquanto em concreto produzidos com uma porção de agregados reciclados, os resultados de resistência média, para este mesmo traço, foi de $25 \mathrm{MPa}$, possibilitando o uso, em pavimentação e em concreto não estrutural de qualquer obra. As normas brasileiras não regulamentam o uso do agregado reciclado para fins estruturais, mas muito se tem descoberto sobre as características do concreto com agregado reciclado, sabe-se que para as variantes dependem da porcentagem de substituição, da composição do agregado reciclado e do e do traço trabalhado. Existe viabilidade técnica e econômica para o uso estrutural, esses resíduos apresentam grande grade potencial para serem utilizados, conforme estudos apresentando suas propriedades forem surgindo.

Conclusão: Considerando os diversos estudos sobre a propriedades do concreto estrutural com agregado reciclado, ainda não temos resultados definitivos e normatizaçao que garantam a eficácia e a segurança para utilização dos resíduos da construção civil para fins estruturais. Faz-se necessário estudos mais aprofundados a fim de se obter resultados definitivos sobre o concreto com agregado reciclado para o uso estrutural e normatização do mesmo, a fim de diminuir o descarte de resíduos sólidos no meio ambiente e tornar as obras cada dia mais sustentáveis. 


\section{Referências}

ASSOCIAÇÃO BRASILEIRA DE NORMAS TÉCNICAS. NBR 15116: Agregados

reciclados de resíduos sólidos da construção civil: utilização em pavimentação e preparo

de concreto sem função estrutural-requisitos. ABNT, 2004.

BRASILEIRO, L. L.; MATOS, J. M. E. Revisão bibliográfica: reutilização de resíduos da construção e demolição na indústria da construção civil. Cerâmica, v. 61, n. 358, p. 178-189, 2015.

CONSELHO NACIONAL DO MEIO AMBIENTE (CONAMA); Resolução 307, de 05 de julho de 2002, Estabelece diretrizes, critérios e procedimentos para a gestão dos resíduos da construção civil. Disponível em http://www.mma.gov.br/port/conama/res/res02/res30702. Acesso em 08 de agosto de 2020.

MELO, Adriana Virgínia Santana. Diretrizes para a produção de agregado reciclado em usinas de reciclagem de resíduos da construção civil. 2011. Dissertação (Mestrado) - Escola Politécnica da Universidade Federal da Bahia, Salvador, Bahia, 2011.

MELO, Vitor Albuquerque Almeida de. Utilização de resíduos da construção e demolição (RCD) na produção de concretos: lacunas no conhecimento. 2019.Trabalho de Conclusão de Curso (Graduação em Engenharia Civil) - Faculdade Maria Milza Governador Mangabeira, Bahia, 2019.

SANTOS, Felipe Sombra do; ARAÚJO AZEREDO de, Pedro Henrique; VENEU, Diego Macedo. Avaliação de concreto sustentável contendo teores de resíduos de agregados reciclados. Brazilian Journal of Development, v. 6, n. 7, p. 4545745471, 2020. 


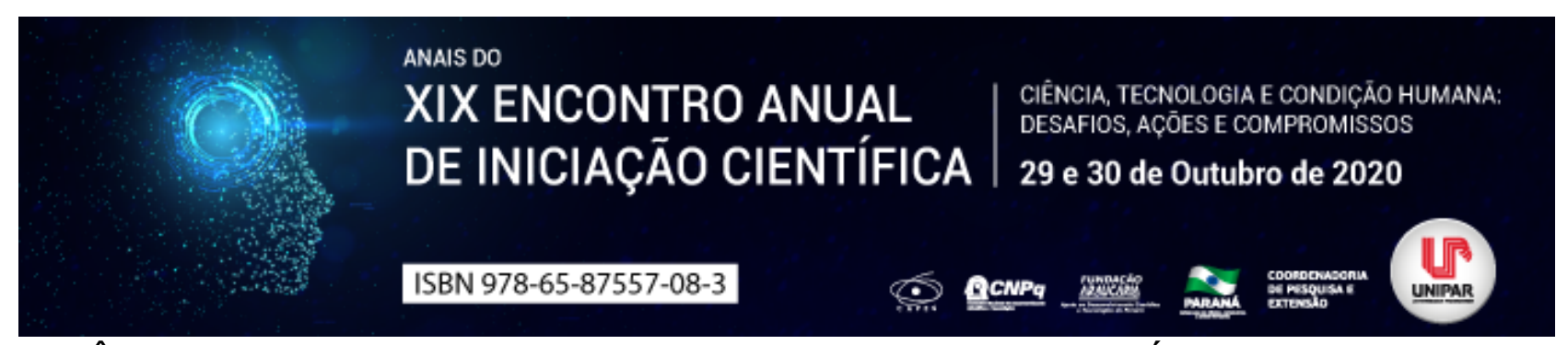

IMPORTÂNCIA DOS EQUIPAMENTOS AUXILIARES EM UMA CALDEIRA DA INDÚSTRIA SUCROALCOOLEIRA

\title{
${ }^{1}$ RUAN VITOR BARRETO LOURENCO, ${ }^{2}$ THIAGO VALENTIM GIROTTO, ${ }^{3}$ MAYKON CESAR SPOLTI FERREIRA
}

\author{
${ }^{1}$ Discente do Curso de Engenharia Mecânica da UNIPAR \\ ${ }^{1}$ Acadêmico do Curso de Engenharia Mecânica da UNIPAR \\ ${ }^{2}$ Docente da UNIPAR
}

Introdução: Exergia é o trabalho teórico máximo que pode ser obtido através do processo mais adequado de um sistema que esteja em um estado inicial até que atinja o estado final. Através da análise exergética é possível encontrar o local, a causa e os valores reais das perdas geradas. Este é um método que combina balanço de calor e massa com a segunda lei da termodinâmica. Com as informações é possível encontrar formas de melhorar a eficiência e o desempenho dos sistemas existentes (MITROVIC, 2018). A exergia é caracterizada pela energia que está fora de equilíbrio com o ambiente, sendo proporcional a quantidade de desvio com o estado de referência (SCOTT, 2003). As caldeiras a vapor são usadas para transformar energia química do combustível em energia térmica de vapor d'água. É importante maximizar a transferência de energia, identificando e quantificando essas perdas para a redução do consumo do bagaço.

Objetivo: Determinação dos impactos que os equipamentos auxiliares possuem na análise exergética de uma caldeira.

Desenvolvimento: A crise de energia que ocorreu nos anos de 1970, ocasionou buscas para o aumento da eficiência das caldeiras, desde então várias pesquisas sugerem melhorias no processo, para gerar economia do bagaço como também reduzir a emissão de CO2 (SOSA, 2007). Os projetos de caldeiras podem possuir três elementos de recuperação de calor, sendo eles, o pré-aquecedor de ar, economizador e o secador de bagaço de cana. O pré-aquecedor de ar está localizado na região de entrada do ar de combustão, e tem por função elevar a temperatura do ar, através da troca de calor com os produtos de combustão saindo da caldeira (BIZZO, 2003). Para realizar melhorias no processo é necessário conhecer as perdas de calor ao longo da caldeira, tais como, perda de calor por escórias e cinzas, perda de calor devido ao teor de umidade do bagaço, perda de calor por purgas, perda de calor devido à radiação e convecção da superfície, perdas de calor por combustão química incompleta, perda de calor dos gases de escape. Os gases de combustão quando deixam a caldeira após a troca térmica com os tubos, ainda possuem energia calorifica, passam pelo economizador e então são direcionados para aquecer o ar de entrada, tornando o processo mais eficiente. A utilização do economizador gera a redução do custo de operação, economia do combustível de alimentação da caldeira através da recuperação da energia dos gases de combustão. Sua utilização torna-se vantajosa, uma vez que, aumenta o rendimento térmico da unidade geradora de vapor. Entretanto, os custos gerados para implementação e manutenção, torna sua aplicação restrita às unidades de porte maior (BAZZO, 1995). A Secagem do bagaço da cana, combustão e a transferência de calor entre os gases são processos que ocorrem simultaneamente dentro da fornalha, ela pode ser realizada por secadores do tipo rotativos, pneumáticos, ciclones ou de leito fluidizado (SOSA, 2007). A secagem do bagaço de cana sendo realizada através da recuperação dos gases de saída da caldeira, pode aumentar seu poder calorifico causando a redução do consumo de combustível, além de reduzir a temperatura dos gases de exaustão. Através da análise de Primeira e Segunda Lei da Termodinâmica em sistema de geração de vapor, mostrou-se que a secagem de bagaço melhora a eficiência energética entre $71,44 \%$ a 84,98\%, e a eficiência exergética entre 19,09\% a 22,23\% (CARDENAS et al 1994). A vantagem do sistema que possui um pré-aquecedor é a redução do consumo de combustível, assim como, o aumento da velocidade de combustão, além de contribuir para uma queima uniforme e estável (BAZZO, 1995). Sendo assim, os componentes apresentados realizam diferentes funções no processo, entretanto, todos fornecem melhoras significativas na caldeira. Como também, reduz as emissões de gases poluentes na atmosfera e diminuem o consumo do combustível que pode ser destinado para outras aplicações. A escolha da composição e arranjo físico dos equipamentos auxiliares na caldeira deve ser feita levando em consideração a viabilidade econômica e as variáveis do processo.

Conclusão: A utilização do pré-aquecedor de ar, economizador e secador melhoram a eficiência do sistema de forma significativa gerando, também, uma redução de custo. Porém a escolha de qual componente depende do projeto da caldeira.

\section{Referências}

BAZZO, Edson. Geração de vapor. 2 ed. Florianópolis: UFSC, 1995.

BIZZO, Waldir Antonio. Apostila Geração, Distribuição e Utilização de vapor. UNICAMP, 2003.

CÁRDENAS, G., Paz, D., Wittwer, E. Energy and Exergy analysis of a combined bagasse dryer-boiler system. International Sugar Journal, 1994.

MITROVIC, D. M. et al. Exergy and Exergoeconomic Analysis of a Steam Boiler. Universidade de Nis: Nis, Siberia, 2018.

SCOTT, D.S. Exergy. International Journal of Hydrogen Energy 28, 2003. 
SOSA, Juan Harold. Caldeiras aquatubulares de bagaço

Universidade Estadual de Campinas, Campinas, 2007.

Coordenadoria de Pesquisa e Extensão - COPEX

Departamento de Editoraçāo e Divulgaçāo Científica - DEDIC estudo do sistema de recuperação e energia. Tese (Doutorado) 


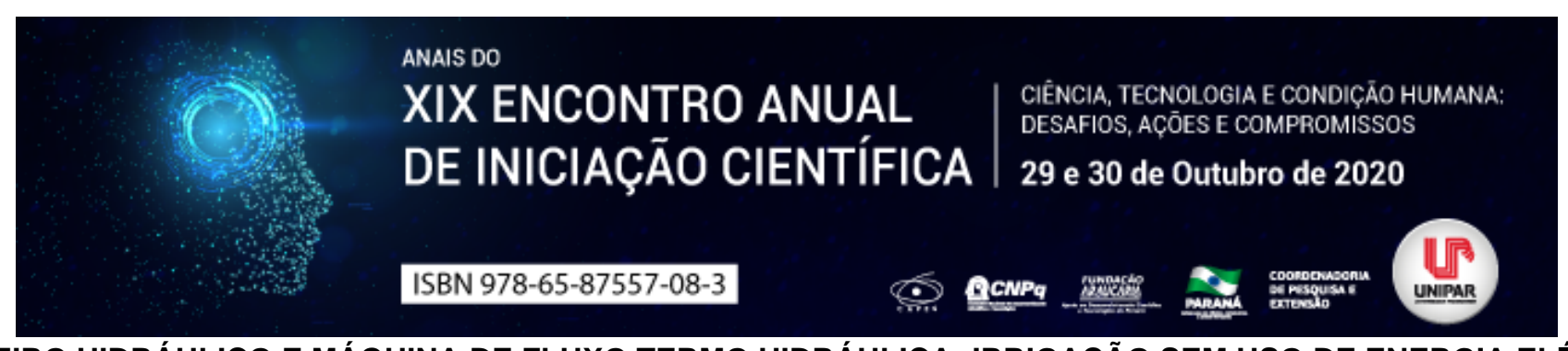

CARNEIRO HIDRÁULICO E MÁQUINA DE FLUXO TERMO HIDRÁULICA: IRRIGAÇÃO SEM USO DE ENERGIA ELÉTRICA

\author{
${ }^{1}$ RUAN VITOR BARRETO LOURENCO, ${ }^{2}$ THIAGO VALENTIM GIROTTO, ${ }^{3}$ ALEXSIA ROBERTA DELAI, ${ }^{4}$ MURILO CANDIANI \\ ALMEIDA, ${ }^{5}$ ALEXANDRE DE CASTRO SALVESTRO
}

\footnotetext{
${ }^{1}$ Discente do Curso de Engenharia Mecânica da UNIPAR

${ }^{1}$ Acadêmico do Curso de Engenharia Mecânica da UNIPAR

${ }^{2}$ Acadêmica do Curso de Engenharia MecÃđnica da UNIPAR

${ }^{3}$ Acadêmico do Curso de Engenharia MecÃđnica da UNIPAR

${ }^{4}$ Docente da UNIPAR
}

Introdução: A agricultura é muito importante para a economia brasileira. Entre 1990 e 2017, o saldo da balança agrícola do Brasil aumentou quase dez vezes, atingindo, em 2017, US\$ 81,7 bilhões (EMBRAPA, 2018). Em algumas situações a irrigação das plantações se mostram um verdadeiro desafio, seja pela difículdade de acesso à energia elétrica ou, até mesmo, a necessidade de um projeto de baixo custo. Nestes casos, a utilização de um carneiro hidráulico ou de uma máquina de fluxo termo hidráulica, podem contornar esses problemas.

Objetivo: Apresentar as vantagens e locais para utilização de um carneiro hidráulico e de uma máquina de fluxo termo hidráulica para irrigação.

Desenvolvimento: Máquinas de fluxo são equipamentos que realizam a troca de energia entre um sistema mecânica e um fluido, ou vice-versa, geralmente trabalhando com água, óleo, dentre outros fluidos considerados incompressíveis, nas aplicações normais. Em alguns casos trabalhando com até mesmo ar, neste caso quando se encontra em pressões até $1000 \mathrm{~mm}$ c.a. (GERMER, 2013). O carneiro hidráulico é um equipamento utilizado para elevação da água sem a utilização de fontes de energia externa para seu acionamento (DARDOT, 2012). Inventado em 1796 pelo francês Joseph Michal Montgolfier (CARVALHO, 1998), seu funcionamento se dá através da seguinte forma: a água que vem do local de abastecimento do carneiro, adquire velocidade até chegar ao aríete hidráulico e empurra o êmbolo da válvula externa, fechando-a de maneira rápida, criando uma pressão em toda a base do carneiro. A água sobre pressão ao voltar pela tubulação abre a válvula interna fazendo com que a água entre pela campânula comprimindo o ar no interior (BARBOSA, 2018). Suas vantagens consistem no baixo custo e a não necessidade de energia elétrica para seu funcionamento. Rojas (2002) determina que as principais variáveis que afetam o rendimento do carneiro são a pressão de alimentação, a pressão de recalque, o comprimento da tubulação e o assentamento da válvula de escape. A máquina de fluxo termo hidráulica utiliza o aquecimento do ar para impulsionar a água do interior de um recipiente para um sifão (STREETER, 1975). Também conhecido por irrigador solar, ele utiliza a luz solar para iniciar a escovação de sifões acoplados, que tem a função de fornecer água através do gotejamento de maneira controlada e econômica, geralmente utilizada para irrigação de jardins e pequenas hortas (MELO, 2016). Em seu pleno funcionamento é possível verificar três tipos de transferência de calor: o sol aquecendo um reservatório de ar através de irradiação, o reservatório ,por sua vez, aquece o ar que está nele por meio da condução, e esse ar aquece a água através da convecção (COLLADO et al., 2016). Sua principal vantagem está no fato de ser possível construí-lo utilizando materiais reciclados e por não necessitar de energia elétrica para seu funcionamento.

Conclusão: $O$ carneiro hidráulico e a máquina de fluxo termo hidráulica são soluções para irrigação, tendo como vantagem o baixo custo de implementação e sem necessidade de energia elétrica para seu funcionamento, a escolha do sistema dependendo apenas do tipo de aplicação.

\author{
Referências \\ BARBOSA, E. H. S. Fabricação e Estudo de um Carneiro Hidráulico de Baixo Custo. Natal: UFRN, 2018. \\ CARVALHO, J. A. Aproveitamento de Energia Hidráulica para Acionamento de Roda d'água e Carneiro Hidráulico. Lavras: \\ UFLA/FAEPE, 1998. \\ COLLADO, P. et al. Irrigador Solar. Sorocaba: UNESP, 2016. \\ DARDOT, J. P. Comportamento Hidráulico de Gotejadores Pressurizados por Carneiro Hidráulico. Lavras: UFLA, 2012. \\ EMBRAPA. Trajetória da Agricultura Brasileira. 2018. Disponível em: < https://www.embrapa.br/visao/trajetoria-da-agricultura- \\ brasileira>. Acessado em 15 de Julho de 2020. \\ GERMER, E. Máquinas de Fluxo. Curitiba: UTFPR, 2013. \\ MELO, W. L. B. Irrigador Solar: Instruções de Montagem e de Funcionamento. São Carlos: Embrapa, 2016. \\ ROJAS, R. N. Z. Modelagem, otimização, construção e avaliação de um protótipo de carneiro hidráulico. Piracicaba:
}


Escola Superior de Agricultura Luiz de Queiroz, 2002.

STREETER, V. L. Mecânica dos Fluidos. São Paulo: Editora McGraw-Hill do Brasil, 1975.

Coordenadoria de Pesquisa e Extensão - COPEX

Departamento de Editoraçāo e Divulgaçāo Científica - DEDIC 


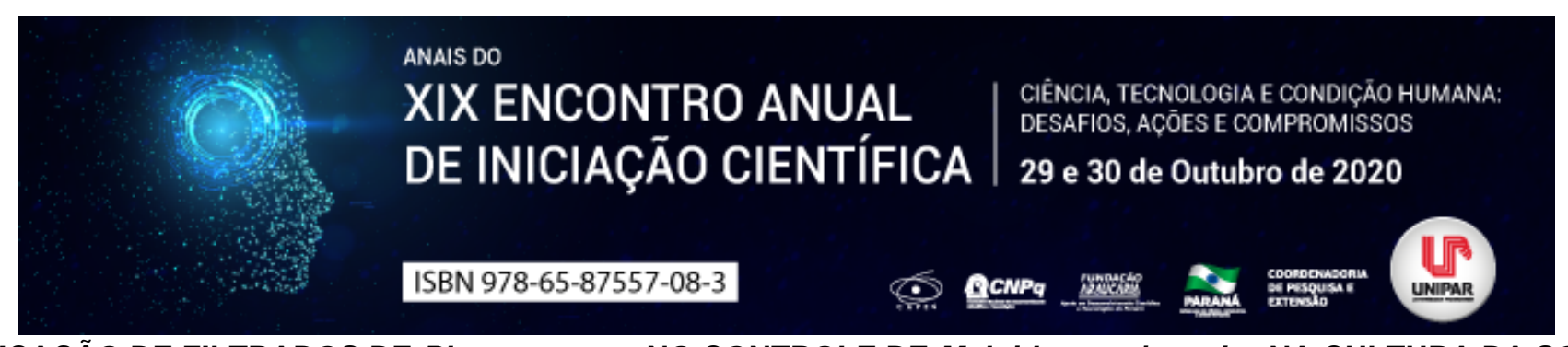

APLICAÇÃO DE FILTRADOS DE Pleurotus spp. NO CONTROLE DE Meloidogyne javanica NA CULTURA DA SOJA

\begin{abstract}
${ }^{1}$ Maria Claudia GuimarÃ£es Carpi, ${ }^{2}$ GLAUCIA LETÍCIA SETE DA CRUZ, ${ }^{3}$ JOAO HENRIQUE RODRIGUES DOS SANTOS, ${ }^{4}$ ENIO AMADO MARTIN, ${ }^{5}$ CLAUDIA REGINA DIAS ARIEIRA, ${ }^{6}$ SIMONE DE MELO SANTANA GOMES
\end{abstract}

\begin{abstract}
${ }^{1}$ Mestranda em Ciências Agrárias - UEM
${ }^{1}$ Discente do curso de Agronomia - UEM

${ }^{2}$ Discente do curso de Gestão de Serviços Jurídicos e Notariais UNIPAR EAD

${ }^{3}$ Discente do curso de Agronomia UEM

${ }^{4}$ Docente da graduação, do Programa de Pós-Graduação em Agronomia e Ciências Agrárias - UEM

${ }^{5}$ Pós-doutoranda em Nematologia Agrícola e docente do Mestrado em Ciências Agrárias UEM
\end{abstract}

Introdução: A soja é uma leguminosa mundialmente cultivada, sendo que o Brasil é um dos maiores exportadores, atingindo uma produtividade de 359,49 milhões de toneladas em 2018 (CONAB, 2018). Porém, a cultura pode ser negativamente afetada por fitonematoides como a espécie Meloidogyne javanica, promovendo redução de produtividade. Diante disso, o controle biológico surge como uma opção no manejo, por apresentar eficientes resultados (SOARES, 2006). Há relatos que o fungo Pleurotus libera uma toxina que paralisa o nematoide, favorecendo a penetração das hifas que digerem e absorvem os nutrientes do seu corpo (TRUONG, 2007).

Objetivo: Avaliar o efeito da aplicação de filtrados de Pleurotus spp. no sulco de semeadura, no solo e em parte aérea da soja no controle de M. javanica.

Material e Métodos: $O$ experimento foi realizado no laboratório de Fitopatologia e em condições de casa de vegetação da Universidade Estadual de Maringá, Campus Fazenda, no município de Umuarama, PR. Isolados de Pleurotus ostreatus (PO2), P. florida e P. pulmonarius (PP19) foram cultivados em placas de Petri contendo MEA (Malt Extract Agar) a 2\% por sete dias, em $\mathrm{BOD}$ a $27^{\circ} \mathrm{C}$, aproximadamente. Na sequência, três discos de cada espécie foram repicados para enlernmeyers contendo 100 $\mathrm{mL}$ de $\mathrm{ME}$, permanecendo por 14 dias em BOD a $27^{\circ} \mathrm{C}$. Passado esse período, o meio de cultura foi filtrado em papel qualitativo e filtro de Buchner acoplado à bomba à vácuo. Os filtrados foram imediatamente utilizados na instalação do experimento em casa de vegetação. Para tanto, uma mistura de solo e areia na proporção 2:1 foi autoclavada por $2 \mathrm{~h}$ a $120^{\circ} \mathrm{C}$, seguido de calagem e adubação. Realizou-se aberturas de sulcos de semeadura para deposição de $1 \mathrm{~mL}$ de suspensão nematológica, contendo 2000 ovos e eventuais juvenis de M. javanica, seguido da semeadura da soja cv. 6210 IPRO e aplicação de $1 \mathrm{~mL}$ de filtrado fúngico. $\mathrm{Na}$ aplicação no solo e parte aérea, foram borrifados $1 \mathrm{~mL}$ dos filtrados sobre os locais correspondentes, após a emergência das plântulas. No tratamento em parte aérea o solo foi coberto no ato da aplicação para evitar o contato dos filtrados com o mesmo. O experimento foi então constituído pela aplicação de três filtrados fúngicos e um tratamento testemunha (água) em três diferentes locais. Após 60 dias da inoculação, as plantas de soja foram coletadas, sendo analisados os parâmetros vegetativos e nematológicos. O experimento foi instalado em DIC, em arranjo fatorial $3 \times 3+1$, com quatro repetições, cujos resultados foram submetidos à análise de variância $(p \leq 0,05)$. Quando houve a interação, procedeu-se o desdobramento dos fatores, sendo as médias comparadas por Tukey a 5\% de significância no programa estatístico Sisvar (FERREIRA, 2011).

Resultados: Interação significativas não foram observadas para filtrados e locais de aplicação para as variáveis vegetativas e nematológicas avaliadas no experimento, contudo, as diferenças foram observadas apenas para os efeitos isolados $(p \leq 0,05)$. Os filtrados não interferiram na massa seca de parte aérea, cujas médias variaram de 1,59 a 1,95 g. Quando os mesmos foram aplicados no sulco de semeadura, as plantas apresentaram um menor desenvolvimento, com menor produção de massa seca $(1,38 \mathrm{~g})$, quando compara às aplicações sobre o solo (1,86 g) ou em parte aérea $(2,01 \mathrm{~g})$. A altura de parte aérea da soja foi 16,81 e 15,83 cm, quando foram aplicados os filtrados de $P$. ostreatus e $P$. florida, respectivamente, sendo as médias inferiores à testemunha, diferenças essas não observadas para os locais de aplicação, cujas médias oscilaram entre 15,64 e 19,18 cm. A menor população de nematoide/g de raiz foi verificada na ausência da aplicação dos filtrados (4923 espécimes), assim quando as aplicações foram feitas no sulco de semeadura (3788 espécimes). O mesmo comportamento foi constatado para a variável fator de reprodução, com médias variando de 7,74 a 25,24.

Discussão: Resultados diferentes foram constatados por Okorie (2011), na Nigéria, que observou atividade nematicida de Pleurotus ostreatus e $P$. tuberregium sobre Meloidogyne incognita. O autor também não observou efeito fitotóxico no desenvolvimento vegetativo das plantas. Em experimento in vitro foi verificada atividade nematicida do filtrado de $P$. ostreatus, em média de $96 \%$ de mortalidade, sobre Heterodera schachtii (PALIZI, 2008). Provavelmente, o fungo produza metabólitos tóxicos capazes de inativar os nematoides (THORNE et al., 2000). Ainda no trabalho de Palizi (2008), resultados positivos também foram observados para experimentos in vivo. Diante das discordâncias dos resultados apresentados com algumas 
pesquisas publicadas, faz-se necessário novos estudos com a utilização do micélio dos fungos, diluídos em diferentes solvente, bem como com demais ajustes metodológicos, em aplicações in vivo, que possa gerar mais informações sobre o assunto.

Conclusão: A aplicação de filtrados de Pleurotus spp. não foi eficiente no controle de $M$. javanica, além de terem sido prejudiciais ao desenvolvimento da cultura da soja, quando comparado ao tratamento testemunha, sem aplicação de filtrado. Contudo, as aplicações no sulco de semeadura demonstraram-se mais eficientes no controle dos nematoides.

\section{Referências}

CONAB Companhia Nacional de Abastecimento. Perspectivas para a agropecuária, v. 6, safra 2018/19, Brasília, 2018. FERREIRA, Daniel Furtado. Sisvar: a computer statistical analysis system. Ciência e Agrotecnologia, Lavras, v. 35, n. 6, p. 1039-1042, set/nov, 2011.

OKORIE, C. C; ONONUJU, Charles; OKWUJIAKO, Ikechukwu Adiele. Management of Meloidogyne incognita with Pleurotus ostreatus and P. tuberregium in Soybean. International Journal of Agriculture and Biology, p. 401-405, julho/jan, 2011.

PALIZI, Parisa et al. Potential of oyster mushrooms for the biocontrol, of sugar beet nematode (Heterodera schachtii). Journal of plant protection research, v. 49, p. 27-33, abril, 2009.

SOARES, Pedro Luiz Martins. Estudo do controle biológico de fitonematoides com fungos nematófagos. Orientador: Dr. Jaime Maia dos Santos 2006. 252 p. Tese (Doutorado em Agronomia) - Universidade Estadual Paulista Júlio De Mesquita Filho, Jaboticabal, novembro, 2006.

TRUONG, Binh Nguyen et al. Characterization of the nematocidal toxocyst in Pleurotus subgen. Coremiopleurotus. Mycoscience, v. 48, n. 1, p. 222 230, agosto, 2007.

WILLE, Caroline Neugebauer; GOMES, Cesar Bauer; MINOTTO, Elisandra; NASCIMENTO, José Soares. Potential of aqueous extracts of basidiomycetes to control root-knot nematodes on lettuce. Horticultura Brasileira 37, p. 54-59, jan/março, 2019. 


\title{
- trisem DE INICIAÇ̃̃O CIENTÍFICA DESAFIOS, AÇŌES E COMPROMISSOS DE INICIAÇĀO CIENTÍFICA 29 e 30 de Outubro de 2020 \\ ISBN 978-65-87557-08-3

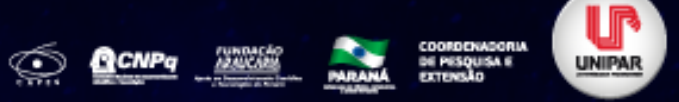 \\ BIOPLÁSTICOS COMO ALTERNATIVA À REDUÇÃO DOS IMPACTOS AMBIENTAIS GERADOS PELOS PLÁSTICOS CONVENCIONAIS
}

\section{${ }^{1}$ FERNANDO AUGUSTO MONTAI Y LOPES, ${ }^{2}$ JUNIO FERNANDO DE ALCÂNTARA, ${ }^{3}$ STELLA ALONSO ROCHA}

\author{
${ }^{1}$ Discente do Programa de Mestrado em Sustentabilidade (UEM/IFPR) \\ ${ }^{1}$ Discente do Programa de Mestrado em Sustentabilidade (UEM/IFPR) \\ ${ }^{2}$ Docente do IFPR
}

Introdução: O mundo produziu até 2016 aproximadamente 242 milhões de toneladas de resíduos plásticos (KAZA et al. 2018). Neste cenário os bioplásticos são apontados como alternativas ambientalmente adequadas, pois teriam a capacidade de mitigar os impactos ambientais gerados pelos plásticos convencionais (EUROPEAN BIOPLASTICS, 2016). No entanto, questiona-se se estes são realmente alternativas eficazes para mitigação deste problema.

Objetivo: Pesquisar e analisar o que são bioplásticos e se estes materiais minimizam os impactos ambientais típicos dos polímeros à base de nafta.

Desenvolvimento: Os bioplásticos são polímeros provenientes de biomassa renovável e/ou que possuam a capacidade de biodegradação. Assim, o conceito abrange produtos de origem renovável e que não são biodegradáveis; os originários de materiais renováveis e biodegradáveis e aqueles que são de origem fóssil e biodegradáveis. Ser de base biológica significa que o material plástico advém de recursos biológicos renováveis, como a cana-de-açúcar, milho, batata, trigo, beterraba (PRADELLA, 2006). A biodegradabilidade é um processo ocasionado por ação de enzimas e/ou decomposição química associada à organismos vivos, como bactérias, fungos e algas, que liberam algumas enzimas capazes de decompor o material (RAMALHO, 2009). Assim, o material será definido como bioplástico se for de base biológica ou biodegradável ou, ainda, possuir ambas as caraterísticas. O material de base biológica e aquele que pelo menos em parte é derivado de biomassa, enquanto que ser biodegradável indica que microrganismos presentes no ambiente podem converter o material em substâncias naturais, sem poluir o meio ambiente (CENTRE FOR ECONOMICS AND BUSINESS RESEARCH, 2015). Para compreensão do conceito de bioplástico, passa-se a análise exemplificativa de uma das possibilidades de espécies de bioplástico, já comercializável. O polietileno (PE) verde, desenvolvido pela Braskem a partir do etanol da cana-de-açúcar (BRASKEN, 2012). O processo de obtenção de eteno a partir de etanol da cana-de-açúcar ocorre por meio da desidratação do álcool na presença de catalisadores e a água gerada como subproduto pode ser reutilizada na própria etapa agrícola da produção da matéria prima ou ainda no processo industrial do PE Verde. O eteno resultante deste processo possui pureza adequada para qualquer processo de polimerização e permite a obtenção de qualquer tipo de polietileno (MARQUES, 2010). É considerado um polietileno de alto valor agregado e sustentável, pois reduz a emissão de gases de efeito estufa no processo produtivo (RESENDE, 2018). O PE Verde é tão versátil quanto o plástico convencional e possui as mesmas características químicas e mecânicas deste último. Não é biodegradável, mas é integralmente reciclável, possibilitando seu reúso sem diminuição de qualidade (BELLOLI, 2010). Possui como vantagem a utilização de recurso biológico renovável como matéria prima. No entanto, não detém a capacidade de degradar-se por meio da ação de fungos, bactérias e algas, demandando descarte adequado e reciclagem, entre outras possibilidades de bioplásticos, inclusive com diferentes características.

Conclusão: A partir dos trabalhos avaliados, constatou-se que o conceito de bioplásticos abrange um gama considerável de materiais, que não necessariamente são de origem biológica e/ou são biodegradáveis. A utilização destes materiais em larga escala dependente de análise de custo benefício por parte dos setores produtivos, além de demandarem educação ambiental quanto à forma adequada de descarte e compromisso com a reciclagem, minimizando a problemática ambiental associadas a utilização dos plásticos convencionais. Com isto, os bioplásticos se apresentam como alternativas que minimizam a problemática ambiental gerada pela utilização dos plásticos convencionais, mas não erradicam a degradação ambiental a eles associada.

\section{Referências}

BELLOLI, R. Polietileno verde do etanol da cana-de-açúcar Brasileira: biopolímero de classe mundial. 2010. Trabalho de Conclusão de Curso (Graduação em Engenharia Química) - Universidade Federal do Rio Grande do Sul. Porto Alegre, 2010. BRASKEM. Biopolímero Polietileno Verde, inovação transformando plástico em sustentabilidade. mar. 2012. Disponível em: http://www.braskem.com.br/Portal/Principal/Arquivos/Download/Upload/Catalogo_PE_Verde.pdf. Acesso em: 05 jul. 2020.

CENTRE FOR ECONOMICS AND BUSINESS RESEARCH. The future potential economic impacts of a bio-plastics industry in the UK. Londres, UK. BBIA. 2015. Disponível em: https://bbia.org.uk/wp-content/uploads/2015/11/BBIA-CEBRReport.compressed.pdf. Acesso em: 04 jul. 2020.

EUROPEAN BIOPLASTICS. What are bioplastics? Material types, terminology, and labels

an introduction. jan. 2016. 
Disponível em: http://docs.european-bioplastics.org/2016/publications/fs/EUBP_fs_what_are_bioplastics.pdf. Acesso em: 04 jul. 2020.

KAZA, S.; YAO, L. C.; BHADA-TATA, P.; VAN WOERDEN, F. What a Waste 2.0: A Global Snapshot of Solid Waste Management to 2050. Banco Mundial. Washington, DC. $2018 . \quad$ Disponível em: https://openknowledge.worldbank.org/handle/10986/30317. Acesso em: 06 jul. 2020.

MARQUES, J. J. O plástico I"verdel" e o mercado brasileiro de etanol. 2010. Dissertação (Mestrado em Ciências) Universidade de São Paulo. São Paulo, 2010.

PRADELLA, J. G. C. Biopolímeros e Intermediários Químicos. Centro de Gestão de Estudos Estratégicos (CGEE), Laboratório de Biotecnologia Industrial LBI/CTPP. São Paulo. Relatório técnico, n.84, p.205-396, 2006.

RAMALHO, M. Plásticos biodegradáveis proveniente da cana de açúcar: Polímeros biodegradáveis. Centro Paula Souza. São Paulo, 2009.

RESENDE, L. M. Análise das características do polietileno verde como alternativa a substituição do polietileno petroquímico. 2018. Trabalho de Conclusão de Curso (Graduação em Engenharia Química) - Centro Universitário de Formiga UNIFOR, Formiga, 2018. 


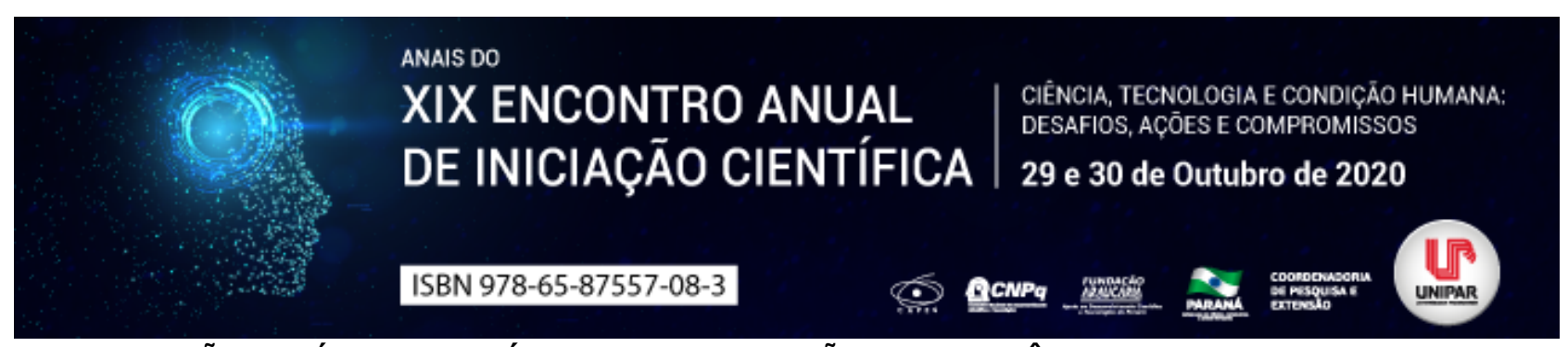

TEMPO DE EXPOSIÇÃO AO ÁCIDO SULFÚRICO NA SUPERAÇÃO DA DORMÊNCIA DE SEMENTES DE Sida cerradoensis

\begin{abstract}
${ }^{1}$ Cawana Parron Augusto, ${ }^{2}$ THAINARA FERREIRA ALVES PESSOA, ${ }^{3}$ ÉRICA MARUSA PERgo COELHO, ${ }^{4}$ ANDRÉIA CRISTINA PERES RODRIGUES DA COSTA
\end{abstract}

\author{
${ }^{1}$ Mestranda em Sustentabilidade UEM \\ ${ }^{1}$ Mestranda em Sustentabilidade UEM \\ ${ }^{2}$ Docente do Programa de Pós-graduação em Sustentabilidade UEM \\ ${ }^{3}$ Docente do Programa de Pós-graduação em Sustentabilidade UEM
}

Introdução: No mundo, são relatadas para o gênero Sida, cerca de 240 espécies. Dentre as quais 90 destas, de acordo com Brandão (2014), encontram-se no Brasil, sendo conhecidas como guanxumas. São plantas perenes e se reproduzem por sementes, em alguns casos, como a Sida rhombifolia, pode produzir até 28,2 mil sementes em um único ciclo de verão (FLECK et al., 2003). Embora que as plantas daninhas produzem muitas sementes elas contêm adaptações e passam a desenvolver mecanismos para garantir sua sobrevivência. A dormência das sementes é o fato em que sementes viáveis não germinam mesmo em condições ambientalmente favoráveis, acarretando assim um tempo extra para que a dispersão natural da semente possa acontecer (TAIZ; ZEIGER, 2004). A reprodução do gênero Sida acontece apenas por meio sementes e sua capacidade produção de sementes é elevada, acarretando assim um banco de sementes no solo. estudos demonstram a utilidade da superação da dormência em espécie do gênero Sida (BENEDINI, 2014). Os mecanismos de dormência podem ser fisiológico, morfológico, físico, químico e mecânico. Para a superação da dormência cada espécie contém um método diferente relacionado ao tipo de dormência (BENECH ARNOLD et al., 2000). Quando a dormência é acarretada devido à impermeabilidade do tegumento pode-se se utilizar vários métodos como a imersão em solventes e a escarificação química (ácido sulfúrico) (JAKELAITIS et al., 2016).

Objetivo: Avaliar a superação de dormência de sementes de Sida cerradoensis sob diferentes tempos de exposição a ácido sulfúrico concentrado $(98,0 \%)$.

Material e Métodos: O experimento foi realizado no Laboratório de Bioquímica da Universidade Estadual de Maringá Campus Fazenda no município de Umuarama, Estado do Paraná no decorrer do mês de julho de 2020. As sementes de Sida cerradoensis foram colhidas no bairro São Cristovão localizado no mesmo município onde foi realizado o experimento. Os tratamentos consistiram em três tempos de exposição ao ácido sulfúrico (H2SO4) por 5, 10 e 60 minutos, mais uma testemunha sem o ácido. $\mathrm{O}$ delineamento experimental foi inteiramente casualizado com quatro repetições. As sementes foram imersas em ácido sulfúrico (H2SO4) concentrado $(98,0 \%)$ e constantemente revolvidas com bastão de vidro, objetivando uniformizar a sua ação abrasiva nos períodos de imersão. Decorridos os períodos preestabelecidos, as sementes foram lavadas em água corrente por 10 minutos, para que o ácido sulfúrico $(\mathrm{H} 2 \mathrm{SO} 4)$ fosse totalmente removido. Os experimentos de germinação foram realizados com 4 repetições de 50 sementes distribuídas em caixas gerbox, contendo uma folha de papel mataborrão umedecido com $7 \mathrm{ml}$ de água destilada. Os ensaios de germinação permaneceram durante 14 dias em estufa tipo B.O.D. com temperatura de $28^{\circ} \mathrm{C}$ (dia/noite) e fotoperido de 12 horas. Os dados foram submetidos ao teste de tukey a $5 \%$ de significância.

Resultados: $\mathrm{O}$ tratamento com ácido sulfúrico $(\mathrm{H} 2 \mathrm{SO} 4)$ no tempo de 60 minutos foi o que promoveu a maior porcentagem de germinação das sementes (67,5\%). Nos tempos de 5 e 10 minutos a germinação foi de 25 e $24 \%$, respectivamente, não diferindo esses dois tratamentos estatisticamente em relação à testemunha. Quando se fez o teste de germinação sem a superação da dormência, obteve-se uma germinação de $2,17 \%$ das sementes de Sida cerradoensis.

Discussão: Azania (2003) relata que o ácido sulfúrico (H2SO4) destrói a camada impermeável das sementes, sem acarretar danos ao embrião. Há estudos com sementes de plantas daninhas demonstrando a eficácia da aplicação do ácido sulfúrico na superação da dormência. Baccin et al. (2019), avaliando a superação de dormência de sementes de Sida glaziovii, verificaram que o tempo de 60 minutos de imersão no ácido sulfúrico (H2SO4) proporcionou a maior germinação das sementes.

Conclusão: $\mathrm{O}$ tratamento em que as sementes foram imersas em ácido sulfúrico (H2SO4) no período de 60 minutos, foi o mais eficiente para superação de dormência das sementes de Sida cerradoensis em relação à testemunha.

\title{
Referências
}

AZANIA, A.A.P.M.; AZANIA, C.A.M.; PAVANI, M.C.M.D.; CUNHA, M.C.S. Métodos de superação de dormência em sementes de Ipomoeae Merremia. Planta Daninha, Viçosa v. 21 n2, p.203-209, 2003.

BACCIN, L. C.; REIS, F. C.; ALBRECHT, A. J. P.; ALBRECHT, L. P.; FILHO, R. V. Superação de dormência e índice de 
velocidade de germinação de sementes de Sida glaziovii K.Schum. Journal of Agronomic Sciences, v.8, n.2, p.273-282, 2019. BRANDÃO, J. L. O gênero Sida L. (Malvaceae) no estado de Pernambuco, Brasil. Dissertação de Mestrado.Universidade Federal Rural de Pernambuco, 2014.

BENECH-ARNOLD, R. L.;SANCHEZ, R. A.; FORCELLA, F.; KRUK, B. C.; GHERSA, C. M. Environmental control of dormancy in weed seed banks in soil. Field Crops Research, Amsterdam, v. 67, n 2, p. 105-122, 2000.

BENEDINI, F. P. Métodos de quebra de dormência, germinação e sanidade de Sida rhombifolia L. Trabalho de conclusão de curso. Faculdade Dr. Francisco Maeda , Ituverava, 2014.

FLECK, N.G.; RIZZARDI, M.A.; AGOSTINETTO, D.; VIDAL, R.A. Produção de sementes por picão preto e guanxuma em função de densidades das plantas daninhas e da época de semeadura da soja. Planta Daninha, Viçosa, v. 21, n 2, p. 191202, 2003.

JAKELAITIS, A.; MARTINS, D. A.; DA SILVA, L. A.; DE FÁTIMA SALES, J. Biometria, embebição e tratamentos pré-germinativos em sementes de capim falso-massambará. Cultura Agronômica: Revista de Ciências Agronômicas, Ilha Solteira, v.25, n.2, p.187-198, 2016.

Coordenadoria de Pesquisa e Extensão - COPEX

Departamento de Editoraçāo e Divulgaçāo Científica - DEDIC 


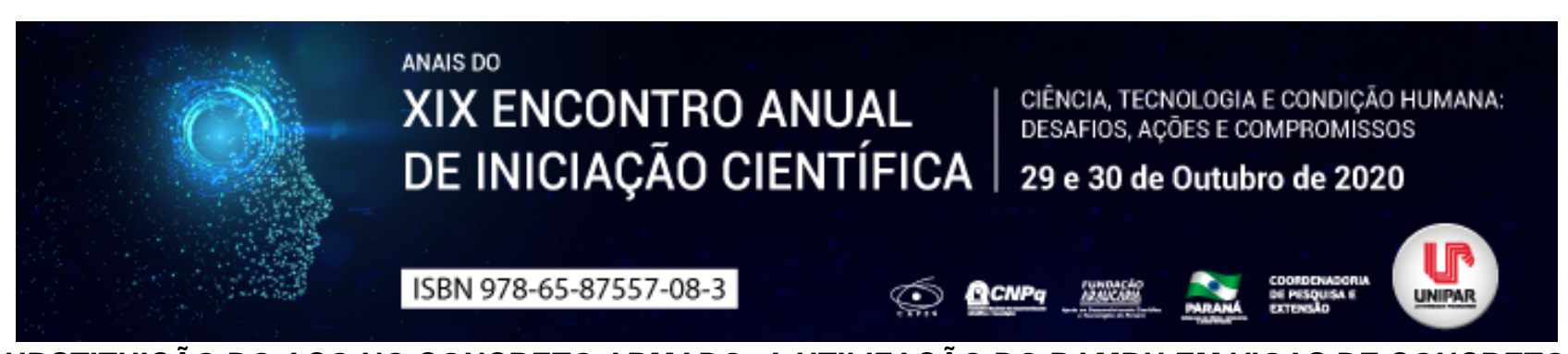

\title{
A SUBSTITUIÇÃO DO AÇO NO CONCRETO ARMADO: A UTILIZAÇÃO DO BAMBU EM VIGAS DE CONCRETO NA CONSTRUÇÃO CIVIL
}

\author{
${ }^{1}$ KAREN HELFENSTEIN DA SILVA, ${ }^{2}$ THIAGO BIACA DE SOUSA
}

${ }^{1}$ Discente do Curso Superior de Engenharia Civil UNIPAR, Guaíra-PR.

${ }^{1}$ Docente da UNIPAR

Introdução: O concreto é um dos materiais mais utilizados pelo homem, perdendo apenas pelo consumo de água, a sua composição base simples é feita pela mistura de cimento, agregados graúdos, agregados miúdo e água, para garantir as solicitações exigida pelas estruturas, vigas e pilares necessitam do aço para combater aos esforços de tração, pois o concreto resiste apenas a compressão. Padovan afirma (2010), que a construção civil tem sido uma das atividades que mais impacta o meio ambiente, devido à grande extração de recursos naturais não renováveis e escassos, para a fabricação de materiais como o aço, sendo base estrutural fundamental na engenharia civil, e tendo como elemento principal em sua composição o minério de ferro. Assim o bambu surge como material alternativo, de recurso renovável, versátil, de baixo impacto ao meio ambiente, pois é um objeto de fácil manejo, fácil cultivo, ciclo curto, e rapidez de crescimento quando comparado as demais madeiras, tornando-se capaz de contribuir com a sustentabilidade nas edificações onde é feita sua implementação, Oliveira e Vito (2012).

Objetivo: Apresentar, em resumo, um estudo sobre a viabilidade da substituição do aço pelo bambu na construção civil.

Desenvolvimento: Atualmente, o bambu é o material mais usado experimentalmente como reforço do concreto, devido a sua tensão de tração relativamente alta, chegando a $382 \mathrm{Mpa}$. Dependendo de diversos fatores como: espécie, tipo de solo, teor de umidade, clima, porção do colmo e idade o bambu apresenta altas variações em sua resistência de acordo com Silva (2007). Lima Júnior e et al (2010) afirma que a resistência do bambu à tração é maior do que da madeira e do concreto, sendo superada apenas pelo aço, as relações entre peso específico e resistência à tração do bambu, que possui uma alta eficiência estrutural, melhor do que os materiais estruturais mais utilizados, material de grande leveza e alta resistência mecânica, por ser constituído de fibras longas e alinhadas. O bambu pode ser utilizado como reforço estrutural no concreto pelo uso de taliscas ou varetas com dimensões previamente determinadas.

Conclusão: O uso do bambu como material alternativo viável, está em fase de estimativas e avaliações, onde tem demonstrado bons resultados de desempenho na resistência do bambu quando comparado ao sistema convencional de vigas e pilares, mostrando ser possível sua associação como elemento estrutural ao concreto armado.

\section{Referências}

LIMA JÚNIOR, Humberto Cavalcante; WILLRICH, Fábio Luiz; FABRO, Gilmar; ROSA, Maxer Antônio; TANABE, Leandro; SABINO, René B. G. Análise mecânica de pilares mistos bambu-concreto. Revista Brasileira de Engenharia Agrícola e Ambiental, v.14, n.5, p.545-553, 2010.

OLIVEIRA, Claiton Sommariva de; VITO, Márcio. Substituição total do aço, usando bambu como armadura de combate a flexão em vigas de concreto. 2012. Artigo científico Universidade do Extremo Sul Catarinense, Criciúma, 2012.

PADOVAN, Roberval Bráz. O BAMBU NA ARQUITETURA: DESIGN DE CONEXÕES ESTRUTU-RAIS. 2010. 184 p. Tese (Pósgraduação) Faculdade de arquitetura, artes e comunicação programa de pós-graduação em design, Universidade Estadual Paulista, Bauru, São Paulo, 2007.

SILVA, Osvaldo Ferreira. Estudo Sobre a Substituição do Aço Liso pelo Bambusa Vulgaris, como Reforço em Vigas de Concreto, para o Uso em Construções Rurais. 2007. 167f. Dissertação (Mestrado em Engenharia Civil) Universidade Federal de Alagoas, Maceió, 2007. 


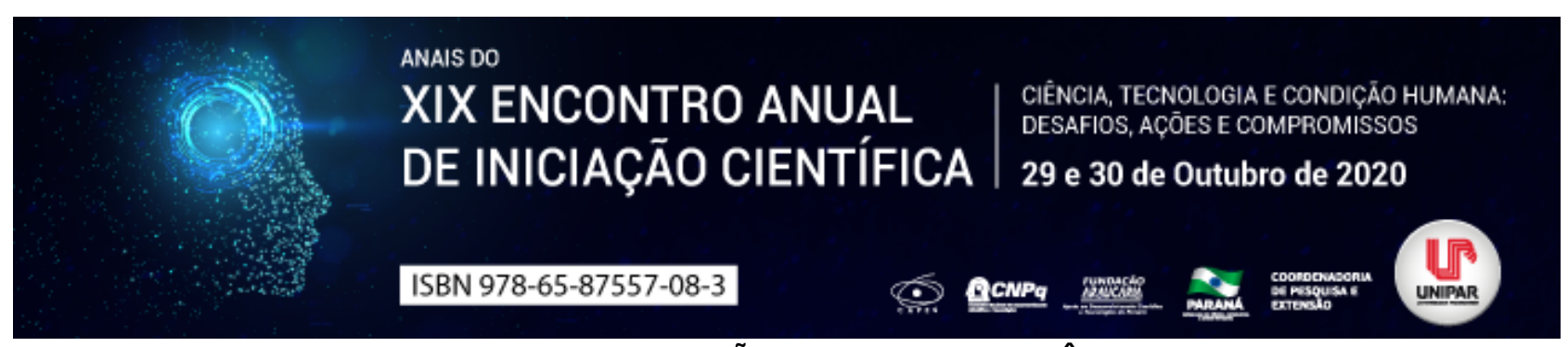

\title{
DIMENSIONAMENTO DE UM SISTEMA DE REFRIGERAÇÃO PARA UMA RESIDÊNCIA NO BAIRRO JARDIM NOVA MARIA EM MARIA HELENA-PR
}

\section{${ }^{1}$ MARLON MENDES MARCONDES, ${ }^{2}$ RAMON RUSSI TRENTINI, ${ }^{3}$ MAYKON CESAR SPOLTI FERREIRA}

\author{
${ }^{1}$ Acadêmico do Curso de Engenharia Mecânica da UNIPAR \\ ${ }^{1}$ Acadêmico do Curso de Engenharia Mecânica da UNIPAR \\ ${ }^{2}$ Docente da UNIPAR
}

Introdução: O sistema de ar condicionado é um equipamento que vai além de resfriar o ar de uma edificação ou cômodo, por ter uma circulação de ar constante a renovação de ar do ambiente diminuindo a chances de proliferação de vírus e bactérias, seja no ambiente ou de uma pessoa para outra. A importância de dimensionar se dá basicamente por atingir objetivos com o menor custo, suprindo necessidades, evitando desperdícios. A busca por conforto térmico pode significar um aumento evidente no consumo elétrico de uma residência, considerando isso, o dimensionamento do ar condicionado se torna fundamental (DUDERSTADT, 2014).

Objetivo: Dimensionar um sistema de refrigeração visando conforto térmico e custos para a residência do estudo.

Materiais e Métodos: Para calcular a carga térmica, utilizada para definição da potência do equipamento de refrigeração, foi utilizado como referência a NBR 16655-3/2017, para os cálculos é necessário o levantamento de dados como feito na sequência. Segundo a Norma ANSI/ASHRAE Standard 55-2004, conforto térmico é subjetivo, se trata de uma condição de satisfação com a temperatura do ambiente, sendo então particular a cada indivíduo. No entanto, a NBR 16401-2/2008 defini uma faixa de temperatura e umidade relativa indicadas para projeto, tanto para o verão quanto para o inverno. Com base nessa norma optouse pela temperatura de $21^{\circ} \mathrm{C}$ e $50 \%$ de umidade relativa. A temperatura externa foi definida com base nos dados obtidos IAPAR (2020). no período de 1972 a 2019, os quais apontam uma temperatura máxima de $40,4^{\circ} \mathrm{C}$ e uma umidade relativa média durante esse mês de 65\%. Para determinar as propriedades do ar externo e interno, como entalpia, volume específico e a razão de umidade é necessário a altura da cidade em relação ao nível do mar, que foi obtida através do site do município da cidade de Maria Helena. As propriedades do ar interno e externo foram obtidas com o site agaís, baseando-se na altura, na umidade relativa e na temperatura. As dimensões da casa e sua orientação cardeal, são necessárias, sendo obtidas com a planta. Fez-se necessário o levantamento das potencias de todos os aparelhos que produzem calor dentro da residência, além de sua utilização diária. O número de habitantes e suas atividades ao longo do dia também são levadas em conta. Com todos esses dados e NBR 16655-3/2017 em mãos, é possível o cálculo da carga térmica na residência, obtendo a carga térmica por condução, carga térmica por insolação, carga térmica por infiltração e carga térmica interna, a carga térmica total é a somatória de todas anteriormente citadas. Com esse valor, pode-se obter o aparelho que supra as condições de projeto.

Resultados: Os resultados são divididos em infiltração, transmissão, insolação e interna que é dividida por pessoas, iluminação e equipamentos, assim as resoluções de cada carga térmica somadas concluindo a carga térmica total do ambiente, podendo assim ser escolhido o equipamento e sua devida instalação na edificação. Com tudo, temos a soma de todas as cargas sendo ela de 87982,66 Btu/h.

Discussão: O valor da carga térmica é importante para a seleção de equipamento, sendo assim é muito complexo a seleção do ar condicionado de menor custo, por isso o dimensionamento é feito com uma análise do pior caso, não utilizando uma média térmica. O cálculo por transmissão horizontal foi executado como laje, supondo que todas as casas similares a essa em questão tem a sua área horizontal coberta pelo mesmo material. A carga térmica por equipamentos está com o CLP igual a um, isso quer dizer que ele não tem eficiência alguma, todo calor de trabalho vai pro ambiente.

Conclusão: Em virtude dos fatores apresentados, o estudo tem a sua carga total calculada, assim a carga térmica horizontal é referente a casas que possuem laje, assim conclui-se o processo de seleção do ar condicionado com foco em um equipamento que reduz os custos de refrigeração e beneficia com conforto térmico.

\section{Referências}

ABNT - Associação Brasileira de Normas Técnicas. ABNT NBR 16401-2:2008 :Instalações de arcondicionado sistemas centrais e unitários parte 2: parâmetros de conforto térmico. Rio de Janeiro: ABNT, 2008. 7 p.

ABNT - Associação Brasileira de Normas Técnicas. ABNT NBR 16655-3:2017 :Instalações de sistemas residências de arcondicionado split e unitário parte 3:Método de cálculo de carga térmica residencial. Rio de Janeiro: ABNT, 2017.27 p.

DUDERSTADT, F. S.; BAGNHUK, R. Projeto de um sistema de condicionamento de ar com refrigeração por absorção utilizando energia solar como fonte térmica. 2014. 192f. Trabalho de Conclusão de Curso (Graduação em Engenharia Mecânica Universidade) - Universidade Tecnológica Federal do Paraná. Curitiba. Disponível em: 
http://repositorio.roca.utfpr.edu.br/jspui/bitstream/1/6619/1/CT_COEME_2014-2_34.pdf Acesso em: 11 jul. 2020.

IAPAR Instituto Agronômico do Paraná. Londrina, PR. Disponível em: http://www.iapar.br Acesso em 13 jul. 2020.

Coordenadoria de Pesquisa e Extensão - COPEX

Departamento de Editoraçāo e Divulgaçāo Científica - DEDIC 


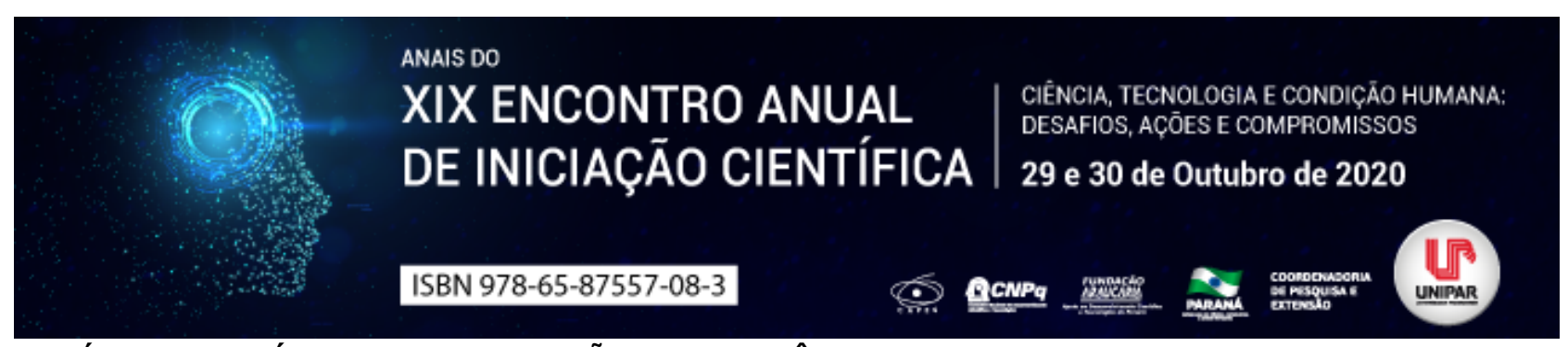

ÁCIDO SULFÚRICO NA SUPERAÇÃO DA DORMÊNCIA DE SEMENTES DE Sida santaremnensis

\begin{abstract}
${ }^{1}$ Cawana Parron Augusto, ${ }^{2}$ THAINARA FERREIRA ALVES PESSOA, ${ }^{3}$ ÉRICA MARUSA PERGO COELHO, ${ }^{4}$ ANDRÉIA CRISTINA PERES RODRIGUES DA COSTA
\end{abstract}

\author{
${ }^{1}$ Mestranda em Sustentabilidade UEM \\ ${ }^{1}$ Mestranda em Sustentabilidade UEM \\ ${ }^{2}$ Docente do Programa de Pós-graduação em Sustentabilidade UEM \\ ${ }^{3}$ Docente do Programa de Pós-graduação em Sustentabilidade UEM
}

Introdução: A espécie guanxuma (Sida santaremnensis) contém um ciclo anual ou perene, sua distrubuição é feita por sementes é uma planta invasora muito encontrada em áreas cultivadas. É uma planta infestante altamente prejudicial por competir com o cultivo agrícola (LORENZI, 2000). A germinação é um fenômeno biológico que surge com a retomada do crescimento do embrião das sementes, crescendo até formar uma nova planta com condições ideais de se nutrir tornando independente (KRAMER, 1972). A germinação acontece numa sequência de eventos fisiológicos influenciados por fatores externos ambientais: luz, temperatura, disponibilidade de água e de oxigênio e internos: dormência, inibidores e promotores da germinação, as sementes atuam por si ou por interações com os demais (NASSIF et al., 1998). As sementes de aproximadamente um terço das espécies germinam instantaneamente em condições ambientalmente favoráveis, porém algumas apresentam algum tipo de dormência (KRAMER, 1972). A dormência é a condição em que as sementes viáveis não germinam mesmo em condições favoráveis, levando um tempo extra para que ocorra a dispersão natural das sementes (TAIZ; ZEIGER, 2004). Os tipos de dormência podem ser fisiológico, morfológico, físico, químico e mecânico. Os processos mais comuns para a superação da dormência de sementes são a escarificação química, escarificação mecânica, estratificação fria e quente-fria, exposição à luz intensa, choque térmico, embebição em água fria e imersão em água quente (FOWLER, 2000).

Objetivo: Avaliar a utilização de ácido sulfúrico na superação da dormência de sementes de Sida santaremnensis.

Material e Métodos: O experimento foi realizado no Laboratório de Bioquímica da Universidade Estadual de Maringá Campus Fazenda no município de Umuarama, Estado do Paraná no decorrer do mês de julho de 2020. As sementes de Sida santaremnensis foram colhidas no bairro São Cristovão localizado no mesmo município onde foi realizado o experimento. Os tratamentos consistiram em dois tempos de exposição ao ácido sulfúrico (5 e 10 minutos), mais uma testemunha sem o ácido. 0 delineamento experimental foi inteiramente casualizado com quatro repetições. As sementes foram imersas em ácido sulfúrico concentrado e constantemente revolvidas com bastão de vidro, objetivando uniformizar a sua ação abrasiva nos períodos de imersão. Decorrido os períodos preestabelecidos, as sementes foram lavadas em água corrente por 10 minutos, para que o ácido sulfúrico fosse totalmente removido. Os experimentos de germinação foram realizados com 4 repetições de 50 sementes distribuídas em caixas gerbox, contendo uma folha de papel mataborrão umedecido com $7 \mathrm{ml}$ de água destilada. Os ensaios de germinação permaneceram durante 14 dias em estufa tipo B.O.D. com temperatura de $28^{\circ} \mathrm{C}$ (dia/noite) e fotoperido de 12 horas. Os dados foram submetidos ao teste de tukey a 5\% de significância.

Resultados: O tratamento com ácido sulfúrico no tempo de 10 minutos foi o que promoveu a maior germinação das sementes (49,5\%). Já os tratamentos com 5 minutos e a testemunha sem superação da dormência, não apresentaram diferença significativa, apresentando germinação de 18 e 5\%, respectivamente.

Discussão: $O$ ácido sulfúrico destrói a camada impermeável das sementes, sem acarretar danos ao embrião. Há estudos com sementes de plantas daninhas demonstrando a eficácia da aplicação do ácido sulfúrico na superação da dormência (AZANIA, 2003). A maioria das plantas daninhas com dificuldades de controle contém dormência do tipo progressiva e emergem durante todo o período do cultivo agrícola, causando prejuízos econômicos (ZAIDAN; BARBEDO, 2004).

Conclusão: $O$ tratamento de imersão em ácido sulfúrico por 10 minutos mostrou ser eficiente na superação da dormência das sementes de Sida santaremnensis.

\title{
Referências
}

AZANIA, A.A.P.M.; AZANIA, C.A.M.; PAVANI, M.C.M.D.; CUNHA, M.C.S. Métodos de superação de dormência em sementes de Ipomoeae Merremia. Planta Daninha, Viçosa v. 21 n2, p.203-209, 2003.

FOWLER, João A. P.; BIANCHETTI, Arnaldo. Dormência em sementes florestais. Colombo: EMBRAPA-Florestas, doc. 40, 2000.

KRAMER, Paul J. e KOZLOWSKI, T. Fisiologia das árvores. Lisboa: Fundação Calouste Gulbenkian, 1972. 745 p.

LORENZI, H. Plantas daninhas do Brasil: terrestres, aquáticas, parasitas e tóxicas, $3^{a}$ edição, Nova Odessa, SP: Instituto 
Plantarum, 2000.

NASSIF, Saraia M. L.; VIEIRA, Israel G.; FERNADES, Gelson D. (LARGEA/). Fatores Externos (ambientais) que Influenciam na Germinação de Sementes. Piracicaba: IPEF/LCF/ESALQ/USP,Informativo Sementes IPEF, Abr-1998. Disponível em: . Acesso em: 13/ago/2020.

TAIZ, L.; ZEIGER, E. Fisiologia vegetal. Porto Alegre: Artmed, 2004. p.449-484.

ZAIDAN, L.B.P.; BARBEDO, C. J.; Quebra de dormência em sementes. In: FERREIRA, A. G.; BORGUETTI, F. (Org.) Germinação do básico ao aplicado, Porto Alegre, Artmed, 2004. Cap.8, p.135-146.

Coordenadoria de Pesquisa e Extensão - COPEX

Departamento de Editoraçāo e Divulgaçāo Científica - DEDIC 


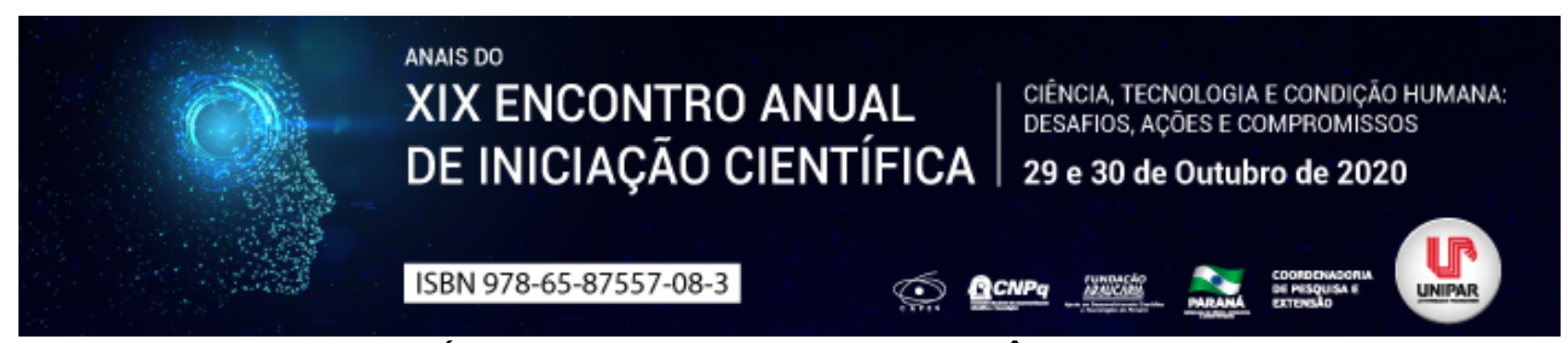

EFEITO DA TOXICIDADE AO ALUMÍNIO E DISPONIBILIDADE DE NITROGÊNIO NO CRESCIMENTO INICIAL DE MILHO PIPOCA

\title{
${ }^{1}$ LUIS EDUARDO PEDRINI DE SOUZA, ${ }^{2}$ AMANDA BARRAVIEIRA, ${ }^{3}$ CAIO CESAR LEVORATO, ${ }^{4}$ ANA CAROLINA RUMAO GASTALDI, ${ }^{5}$ SILVIA GRACIELE HULSE DE SOUZA
}

\author{
${ }^{1}$ Discente do curso de Engenharia Agronômica PIC/UNIPAR \\ ${ }^{1}$ Discente do curso de Engenharia Agronômica PIBIC/UNIPAR \\ ${ }^{2}$ Discente do curso de Engenharia Agronômica/UNIPAR \\ ${ }^{3}$ Discente do curso de Engenharia Agronômica/UNIPAR \\ ${ }^{4}$ Docente do curso de Engenharia Agronômica e Pós-graduação em Biotecnologia Aplicada à Agricultura/UNIPAR
}

Introdução: A pipoca (Zea mays L. var. Everta) ocupa uma posição de destaque devido conter $583 \mathrm{Kcal}^{100 g^{-1}}$ de energia e $49 \%$ de gorduras saturadas, $45 \%$ carboidratos e $7 \%$ proteínas, além do preço médio cobrado pela saca ser três vezes maior do que o milho comum (KHAN et al., 2020). O aumento no rendimento da colheita tem sido atribuído às técnicas de melhoramento de plantas e o uso extensivo de fertilizantes. Entre esses fertilizantes, o nitrogênio (N) é um fator principal na produção agrícola (ANDREWS; LEA, 2013). Em solos ácidos dos trópicos e subtrópicos, o alumínio é um dos principais fatores que limita a absorção de nutrientes e o crescimento das culturas (COLOMBO et al., 2014).

Objetivo: Avaliar o crescimento de plantas de milho pipoca cultivadas em diferentes níveis de nitrogênio e toxicidade ao alumínio $\left(\mathrm{Al}^{+3}\right)$.

Material e Métodos: Sementes de milho pipoca (híbrido AP6005) foram semeadas em papel germitest umedecido 2,5 vezes a massa de água. Após 7 dias de germinação, os cotilédones foram retirados e as plântulas transferidas para recipientes pretos e cultivados hidroponicamente. As plântulas foram mantidas em solução nutritiva de Hoagland e Arnon (1950) por 7 dias. Após esse período a plantas semelhantes foram selecionadas e transferidas para uma solução nutritiva modificada de Hoagland e Arnon com diferentes concentrações de $\mathrm{N}$ e adicionado $\mathrm{Al}\left(\mathrm{Al}^{+3}\right)$. Para o tratamento com $\mathrm{N}$, as plantas foram mantidas com solução nutritiva contendo $2 \mathrm{mM}$ de $\mathrm{KNO}_{3}$ (nitrogênio baixo) e $\mathrm{KNO}_{3} 10 \mathrm{mM}$ (nitrogênio adequado). A toxicidade ao alumínio foi realizada pela adição de $2 \mathrm{mM}$ de $\mathrm{Cl}_{3} \mathrm{Al}_{2}$. Os tratamentos foram: $10 \mathrm{mM}$ de $\mathrm{KNO}_{3}$ e sem alumínio, (T1, controle), 10 mM de $\mathrm{KNO}_{3}$ e com alumínio (T2), $2 \mathrm{mM}$ de $\mathrm{KNO}_{3}$ e sem alumínio (T3), $2 \mathrm{mM}$ de $\mathrm{KNO}_{3}$ e com alumínio (T4). Os parâmetros de massa fresca da raiz (MFRA) e parte aérea (MFPA) (g), comprimento da raiz (CRA) e parte aérea (CPA) (cm), número de folhas (NF) (n) e área foliar (AF) $\left(\mathrm{cm}^{2}\right)$ foram determinados em oito repetições de cada tratamento aos 30 dias após o início do estresse. Os dados foram submetidos à análise de variância (ANOVA), e as médias comparadas pelo teste de Tukey $(p \leq 0,05)$ utilizando 0 programa estatístico (SISVAR).

Resultados: Foi observado que as plantas com níveis adequados de $\mathrm{N}$ e sem $\mathrm{Al}^{+3}$ (T1) apresentaram as maiores médias para MFRA (29,71 g), MFPA (21,95 g), CPA (87,83 cm), CRA (56,67 cm), NF (8,11 folhas) e AF (588,66 cm²). Entretanto, as plantas com níveis baixos ou adequados de $\mathrm{N}$ e com $\mathrm{Al}^{+3}$ (T2 e T4) apresentaram reduções significavas para todos os parâmetros avaliados, indicando que a presença do Al é tóxico e limita o crescimento, principalmente do sistema radicular (T2-29,44 cm e T419,83 cm).

Discussão: A assimilação do nitrogênio é um importante processo metabólico da planta, que não apenas controla o crescimento e o desenvolvimento da planta, mas também desempenha um papel importante na sobrevivência da planta em condições de estresse (BURGER; JACKSON, 2003). Nesse trabalho, as plantas que cresceram com o nível adequado de nitrogênio foram as que apresentaram os melhores parâmetros agronômicos de crescimento, maior número de folhas e área foliar. Entretanto, a presença de íons $\mathrm{Al}^{+3}$ no meio de crescimento podem ter provocado alterações no processo de assimilação do nitrogênio, levando à redução no crescimento e no acúmulo de biomassa da raiz e da parte aérea (HUSSAIN et al., 2020). Além disso, a toxidez de Al inibe a elongação da raiz. Nos tecidos radiculares, o íon metálico se une ao fosfato na molécula de DNA, o qual acarreta redução da atividade de replicação e transcrição, impedindo que haja divisão celular nas raízes (PEREIRA et al., 2008).

Conclusão: Plantas de milho pipoca com níveis adequados de nitrogênio apresentaram um maior crescimento do que aquelas com níveis baixos de $\mathrm{N}$ e submetidas à toxicidade ao alumínio.

\section{Referências}

ANDREWS, M.; LEA, P. J. Our nitrogen 'footprint': The need for increased crop nitrogen use eficiency. Annals of Applied 
Biology, v.163, n.2, p.165 169, 2013.

BURGER, M.; JACKSON, L. E. Microbial immobilization of ammonium and nitrate in relation to ammonification and nitrification rates in organic and convention alcropping systems. Soil Biollogy and Biochemmistry, v.35, n.1, p. 29 36, 2003. COLOMBO et al. Fenotipagem de genótipos de milho em condições de estresse por alumínio e sua correlação com produtividade de grãos. Revista Agrarian, Dourados, v.7, n.23, p.60 71, 2014.

HOAGLAND, D.R.; ARNON, D. I. The water culture method for growing plants without soils. Berkeley: California Agricultural Experimental Station, 347p., 1950.

HUSSAIN et al. Metal Toxicity and Nitrogen Metabolism in Plants: An Overview. In: Carbon and Nitrogen Cycling in Soil. Ed. Datta R, RS Meena, Pathan SI, Ceccherini MT. Springer, 2020.

KHAN et al. Limited Nitrogen and Plant Growth Stages Discriminate Well Nitrogen Use, Uptake and Utilization Efficiency in Popcorn. Plants, v. 9, p. 893, 2020.

PEREIRA et al. Efeito do alumínio sobre a absorção, o acúmulo e o fracionamento do fósforo em sorgo. Bragantia, v. 67 , p. $961967,2008$.

Coordenadoria de Pesquisa e Extensão - COPEX

Departamento de Editoraçāo e Divulgaçāo Científica - DEDIC 


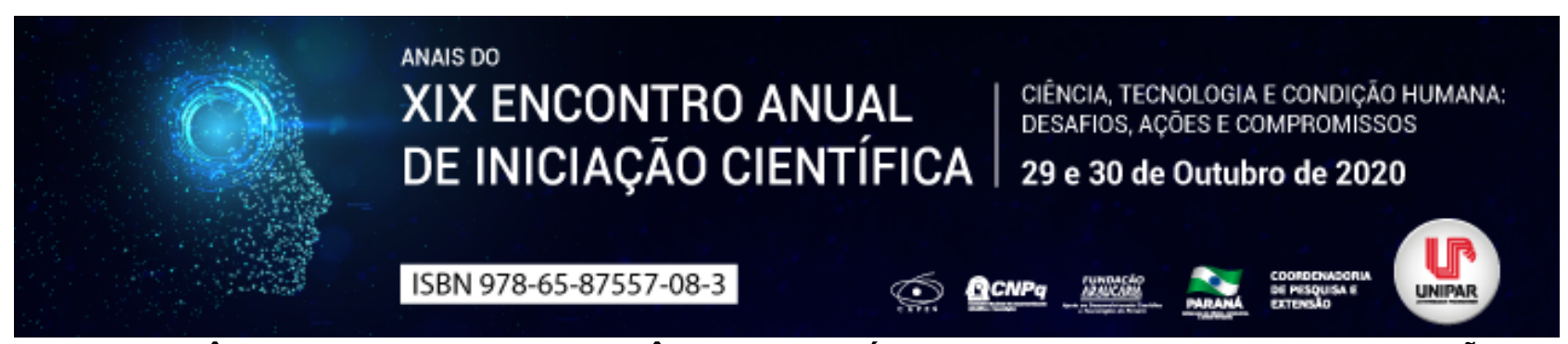

A IMPORTÂNCIA DE ANALISAR A EFICIÊNCIA EXERGÉTICA DE UMA CALDEIRA EM OPERAÇÃO

\title{
${ }^{1}$ THIAGO VALENTIM GIROTTO, ${ }^{2}$ RUAN VITOR BARRETO LOURENCO, ${ }^{3}$ MAYKON CESAR SPOLTI FERREIRA
}

\author{
${ }^{1}$ Acadêmico do curso de Engenharia Mecânica da UNIPAR \\ ${ }^{1}$ Acadêmico do curso de Engenharia Mecânica da UNIPAR \\ ${ }^{2}$ Docente da UNIPAR
}

Introdução: O estudo de eficiência exergética em caldeiras, tem por objetivo encontrar onde ocorre as maiores irreversibilidades do processo. Sua importância deve-se ao aprimoramento do rendimento da caldeira, consequentemente, uma possível redução de custos, uma vez que projetos de engenharia possuem grandes recursos de capital investidos. A análise exergética é um método que faz a junção do balanço de calor e massa com a segunda lei da termodinâmica. Também, permite identificar a localização, as causas e fontes de perdas (KOTAS, 1985).

Objetivo: Demonstrar a importância de realizar uma análise exergética em caldeiras, com o objetivo de reduzir o consumo de combustíveis e aproveitar a energia produzida pela fonte.

Desenvolvimento: $O$ conceito de exergia visa a utilização mais efetiva dos recursos energéticos. De acordo com Tsatsaronis (1993), a análise exergética nos fornece um meio de avaliar a quantidade de energia não aproveitada em relação com a energia fornecida ou transformada na planta total e no componente analisado; uma medida de qualidade de energia, a partir do ponto de vista termodinâmico; uma variável para definir as eficiências para sistemas energéticos. Para análise de exergia, é muito importante selecionar os parâmetros adequados do ambiente (estado do ambiente). Estes parâmetros referem-se à pressão de referência e temperatura de referência, como também à composição do ar fornecido para a combustão, pois para que o maior trabalho possa ser obtido do sistema é necessário que os dois sistemas não estejam em equilíbrio, e adquiram este o equilíbrio termodinâmico através de sua interação. Esta energia pode apresentar diferentes formas e características. Entende-se como qualidade, a capacidade de uma forma de energia para causar mudanças, o que depende da maneira de armazenamento (KOTAS, 1985). As perdas do processo ocorrem pela irreversibilidade, assim como, pela exergia desperdiçada. Para o cálculo da eficiência exergética em caldeiras é desconsiderado os efeitos nucleares, magnéticos e elétricos, sendo considerado apenas exergia física e química do processo. Sondermann (2013), concluiu que as maiores destruições de exergia ocorrem em componentes que possuem reações químicas envolvidas, isso ocorre pois há muito desequilíbrio, sendo, esses processos, reações irreversíveis, justificando assim a quantidade de destruição nesta região. Também observou que, em locais onde a diferença de temperatura entre o fluido quente e o fluido frio são menores, a destruição de exergia também é menor, pois quanto maior a diferença de temperatura maior a destruição. A realização de uma análise energética é necessária para se obter um controle eficiente dos equipamentos. Para se realizar uma análise deve-se considerar todo o calor gerado e todas as perdas presentes no sistema (BAZZO, 1995). As principais perdas de energia da caldeira ocorrem por gases de combustão, combustão incompleta, pelas paredes da caldeira, por radiação através das aberturas da fornalha, calor sensível das cinzas, calor sensível dos produtos de combustão, pela umidade presente no combustível, pela entalpia sensível dos produtos de combustão. De acordo com a análise exergética de uma caldeira de vapor apresentada por Mitrovi (2018), foi possível identificar a destruição de exergia na região da fornalha e na caldeira. A fornalha foi onde apresentou-se maior destruição de exergia, devido as reações químicas envolvidas no processo.

Conclusão: A análise exergética demonstra-se de suma importância para a verificação, localização e magnitude das causas de irreversibilidades e perdas exergéticas de cada componente do sistema, servindo de base para a otimização do sistema. Além de identificar, isoladamente, a eficiência exergética de cada componente do sistema, possibilitando, se necessário, realizar melhorias em componentes específicos ou no sistema completo.

\section{Referências}

BAZZO, Edson. Geração de vapor. 2 ed. Florianópolis: UFSC, 1995.

KOTAS, Tadeusz Jozef. The Exergy of Thermal Plant Analysis. London: Butterworths, 1985.

MITROVIC, Dejan. et al. Exergy and Exergoeconomic Analysis of a Steam Boiler. Nis: Thermal Science, 2018.

SONDERMANN, Carina Nogueira. Simulação e Análise de uma Planta de Cogeração Real Utilizando o Simulador de Processos IPSE-PRO. Rio de Janeiro: UFRJ, 2013.

TSATSARONIS, Georgeg. Thermoeconomic Analysis and Optimization of Energy System. Inglaterra: Prog. Energy Combustion Science, 1993. 
Coordenadoria de Pesquisa e Extensão - COPEX

Departamento de Editoraçāo e Divulgaçāo Científica - DEDIC 


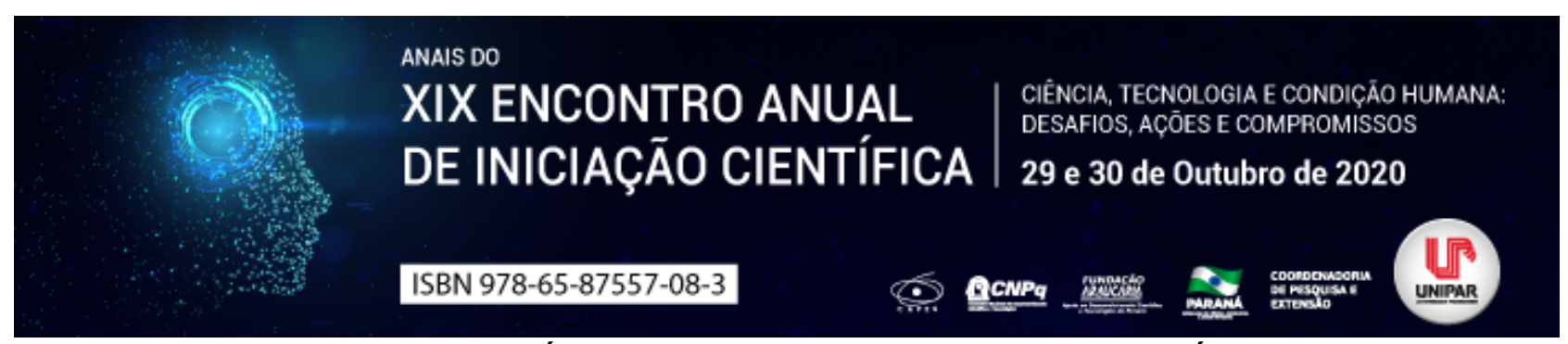

CARNEIRO HIDRÁULICO: UMA FONTE DE ENERGIA RENOVÁVEL

\author{
${ }^{1}$ THIAGO VALENTIM GIROTTO, ${ }^{2}$ RUAN VITOR BARRETO LOURENCO, ${ }^{3}$ ALEXSIA ROBERTA DELAI, ${ }^{4}$ MURILO CANDIANI \\ ALMEIDA, ${ }^{5}$ ALEXANDRE DE CASTRO SALVESTRO
}

\author{
${ }^{1}$ Acadêmico Bolsista do PIBIC/UNIPAR \\ ${ }^{1}$ Acadêmico Bolsista do PIBIC/UNIPAR \\ ${ }^{2}$ Acadêmica Bolsista do PIBIC/UNIPAR \\ ${ }^{3}$ Acadêmico do PIC/UNIPAR \\ ${ }^{4}$ Docente da UNIPAR
}

Introdução: A água é um elemento natural e essencial a vida, sendo um recurso limitado e com um papel significativo no desenvolvimento econômico e social de uma região. A agricultura familiar no Brasil é responsável por 33,2\% da produção nacional, (HOFFMANN, 2014). No cultivo é necessário fazer a irrigação, este acaba sendo necessária a utilização de energia elétrica ou de combustível para o acionamento do conjunto motobomba. Em algumas regiões rurais não há eletricidade, e o transporte de água acaba sendo inacessível ou inviável. Quando se deseja uma fonte de água, econômica e sustentável, pode ser utilizado o carneiro hidráulico.

Objetivo: Identificar os modelos de utilização do carneiro hidráulico para propriedades rurais, visando o desenvolvimento do setor energético e sua contribuição para o crescimento de energias limpas.

Desenvolvimento: As fontes renováveis de energias seja solar, eólica, hidráulica ou biocombustíveis são as únicas intrinsecamente limpas e que podem contribuir para suprir a demanda existente (SILVA, 2007). Atualmente o carneiro hidráulico destaca-se como uma fonte de energia hidráulica totalmente limpa, sendo uma bomba que transforma a energia cinética da água em energia potencial, amplamente empregado em muitos locais onde a energia elétrica é escassa ou inexistente, contribuindo assim para o desenvolvimento da localidade onde é instalado. O carneiro hidráulico trabalha de dia e noite sem agredir o meio ambiente, utilizando energia hidráulica sem a necessidade de outro meio de alimentação (ROJAS, 2002). A geração de energia é feita através da altura de queda d'água que é produzida através de uma barragem onde o carneiro é instalado. O bombeamento de água do carneiro é decorrente do fenômeno conhecido como, golpe de aríete causado pelo fechamento da válvula, após a interrupção do movimento da água em um nível superior (ABATE, 2002). A implantação do carneiro requer uma análise da área onde deseja-se instalar, o funcionamento correto dependente das caraterísticas do projeto, tais como, desnível entre o reservatório de alimentação do carneiro, altura de recalque, diâmetro das tubulações, quantidade de água e as batidas por minuto. Essas variáveis possuem grandes influências na qualidade do transporte do fluido. De acordo com o estudo apresentado por Foganholo e Salvestro (2019), onde utilizou-se o programa SISVAR para analisar a uniformidade do caneiro hidráulico, este demonstrou adequado para a distribuição em um sistema de irrigação. Os benefícios proporcionados do cultivo, é um dos principais motivos pelo qual realiza-se a irrigação, em locais onde houve a implantação do carneiro ocorreu o aumento da variedade produtiva (COSTA, 2011). Segundo Bonalumi et al. (2019), um carneiro hidráulico é capaz de atender uma propriedade rural com 70 cabeças de gado, para realizar o abastecimento do bebedouro, trabalhando 24 horas por dia.

Conclusão: O carneiro hidráulico demonstra-se como uma fonte de energia renovável e viável, apresentando-se como uma alternativa para a implementação de um sistema de irrigação ou transportar água em locais onde é possível sua instalação. Sendo assim, sua aplicação pode ser justificada pelos benefícios fornecidos ao cultivo quando a irrigação é aplicada.

\title{
Referências
}

ABATE, Caroline; BOTREL, Tarlei Arriel. Carneiro hidráulico com tubulação de alimentação em aço galvanizado e em PVC. Scientia Agricola, Piracicaba, v. 59, Jan./Mar, 2002. DOI: http://dx.doi.org/10.1590/S0103-90162002000100029. Disponível em:. Acesso em: 20 jul. 2020. P. 35-41.

BONALUMI, Victor. et al. Ultilizacão de Carneiro Hidraulico para Abastecimento de Bebedouro de Água para Gado. Congresso Internacional de Ciência Tecnologia e Inovação. Encontro Anual de Iniciação Científica da UNIPAR. Umuarama, 2019. Disponível em: https://sisweb02.unipar.br/eventos/anais/4354/html/19820.html. Acesso em: 5 agosto de 2020

FOGALHOLO, Renan; SALVESTRO, Alexandre. Avaliação do uso do Carneiro Hidráulico na Uniformidade de um Sistema de Irrigação. Congresso Internacional de Ciência Tecnologia e Inovação. Encontro Anual de Iniciação Científica da UNIPAR. Umuarama, 2019. Disponível em: https://sisweb02.unipar.br/eventos/anais/4354/html/18493.html. Acesso em: 5 agosto de 2020. HOFFMANN, Rodolfo. A agricultura familiar produz $70 \%$ dos alimentos consumidos no Brasil?. Segurança Alimentar e Nutricional, Campinas-SP, v. 21, n. 1, p. 417-421, 2014. 
ROJAS, Ricardo Nicolás Zárate. Modelagem, otimização e avaliação de um carneiro hidráulico. Tese (Doutorado em Agronomia), Universidade de São Paulo, Piracicaba, 2002.

SILVA, Rosana. Energias Renováveis. Boletim do Observatório Ambiental Alberto Ribeiro Lamego. Centro Federal de Educação Tecnológica de Campos. Observatório Ambiental Alberto Ribeiro Lamego, Campos dos Goytacazes v. 1, n. 1, p. 35-41, jun. 2007.

Coordenadoria de Pesquisa e Extensão - COPEX

Departamento de Editoraçāo e Divulgaçāo Científica - DEDIC 


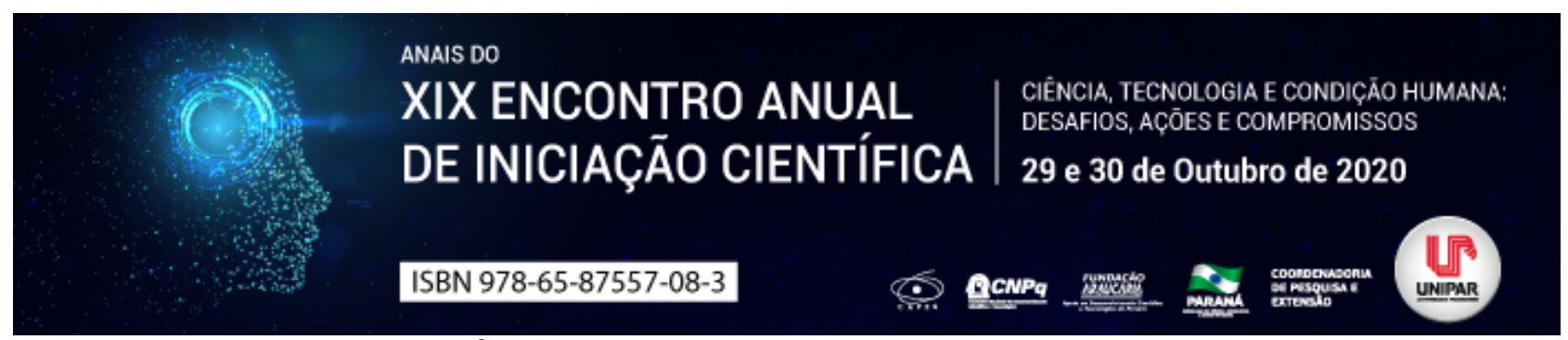

LEVANTAMENTO SOBRE OS PARÂMETROS DE QUALIDADE DO LEITE CRU EXIGIDOS PELO MINISTERIO DA AGRICULTURA, PECUÁRIA E ABASTECIMENTO NO BRASIL- REVISÃO DE LITERATURA

\author{
${ }^{1}$ DERICK DE ALMEIDA MARCHI, ${ }^{2}$ SARAH LISSONI COBO, ${ }^{3}$ FILIPE CORREA PACHECO, ${ }^{4}$ RANULFO PIAU JUNIOR
}

\author{
${ }^{1}$ Acadêmico do PIC/UNIPAR \\ ${ }^{1}$ Acadêmica do PIC/UNIPAR \\ ${ }^{2}$ Mestrando do curso de Pós-graduação de Ciência Animal com Ênfase em Produtos Bioativos \\ ${ }^{3}$ Docente da UNIPAR
}

Introdução: Atualmente, o leite bovino é um dos produtos mais consumidos no mundo. O leite é o produto das glândulas mamárias dos mamíferos fêmeas sadias e bem alimentadas, tendo destaque na alimentação humana por seu alto valor nutritivo, o qual pode ocorrer deterioração, servindo de meio para a proliferação de organismos deteriorantes e patógenos que alteram sua qualidade (CALLEFE; LANGONI, 2015). Partindo então deste pressuposto, temos que a qualidade do leite se inicia desde o processo de ordenha, seja ela mecânica ou manual, tanto pelas tecnologias investidas quanto pelo manejo adequado, sendo ainda um fator ao qual os laticínios buscam, e agregam valor cada vez mais (CALLEFE; LANGONI, 2015).

Objetivo: Evidenciar os parâmetros de qualidade do leite cru exigidos pelo Ministério da Agricultura, Pecuária e Abastecimento. Desenvolvimento: A qualidade influencia tanto no seu preço como, e principalmente, no produto final que chega à mesa do consumidor, seja ele leite ou seus derivados, e no seu tempo de prateleira. Sendo assim, é essencial que haja um meio de se atestar a qualidade do leite, agregando valor e confiança ao produto final, seja ele leite in natura ou derivados. Para tal, existem parâmetros básicos de aferimento de qualidade do leite cru segundo as diretrizes do Ministério da Agricultura, Pecuária e Abastecimento (MAPA, 2018), sob a Instrução Normativa $N^{\circ} 76$ de novembro de 2018. Sendo as principais características a serem atendidas: o produto deve ser observado e atender cor, odor e sabor característicos do mesmo (MONARDES, 1998, citado por XAVIER et al., 2018); teor mínimo de gordura, $3.0 \mathrm{~g} / 100 \mathrm{~g}$ a 5.0g/100g; teor mínimo de proteína, 2.9g/100g a 5.0g/100g; não deve apresentar substâncias estranhas; contagem bacteriana total igual ou menor a 300.000UFC/mL; contagem de células somáticas igual ou menor a $500.000 \mathrm{CS} / \mathrm{mL}$. Sendo que, os principais testes disponíveis para verificação destes critérios, assim como outros fatores adicionais, são: CCS (contagem de células somáticas), CBT (contagem bacteriana total), CIP (contagem com incubação preliminar), CTLP (contagem total do leite pasteurizado), CC (contagem de coliformes) e CT (cultura do tanque para a avaliação da mastite) (ALMEIDA et al., 2015 citado por LEIRA et al., 2018). Vale ressaltar que, no Brasil, tais parâmetros mínimos de qualidade são exigidos, cabendo penalidades quanto ao valor pago ao produtor no seu descumprimento (CARDOSO et al., 2004 citado por TEIXEIRA JÚNIOR; LOPES; RUAS; 2015).

Conclusão: Dessa forma, através do presente estudo, chega-se à conclusão que a qualidade do leite a ser consumido tem início desde a saúde do animal, assim como a higiene na ordenha dos animais e processamento do produto. Desse modo, para atender as normas do Ministério da Agricultura, Pecuária e Abastecimento, o produtor deve se atentar para tais cuidados e procurar sempre estar de acordo com estas diretrizes. Também laticínios e industrias, responsáveis pelo processamento do leite, devem se atentar a tais normas de forma que seja oferecido ao consumidor um produto de qualidade e seguro.

\title{
Referências
}

CALLEFE, J. L. R.; LANGONI, H. Qualidade do leite: uma meta a ser atingida. Vet. e Zootec. v. 22, n.2, p.151-161, jun., 2015. LEIRA, M. H. et al. Fatores que alteram a produção e a qualidade do leite: revisão. PUBVET, Maringá, v. 12, n. 5, p. 1-13, mai. 2018.

MINISTÉRIO DA AGRICULTURA, PECUÁRIA E ABASTECIMENTO. Instrução Normativa n 76 , de 26 de novembro de 2018. Diário oficial da União: seção 1. Brasília, nov. 2018. Edição 230, p. 9.

TEIXEIRA JÚNIOR, F. E. P.; LOPES, M. A.; RUAS, J. R. M.; Efeito do pagamento por qualidade do leite na rentabilidade da atividade leiteira. Revista Instituto Laticínios Cândido Tostes, Juiz de fora, v. 70, n. 1, p. 24-34, jan./fev. 2015.

XAVIER, B. C. P. et al. Impacto da assistência técnica sobre as características higiênicas de produção e sua relação com a melhoria da qualidade do leite. $\mathbf{1 2}^{\circ}$ Congresso interinstitucional de iniciação científica- CIIC 2018, Campinas, São Paulo, n. 18702, p. 1-11, ago. 2018. 


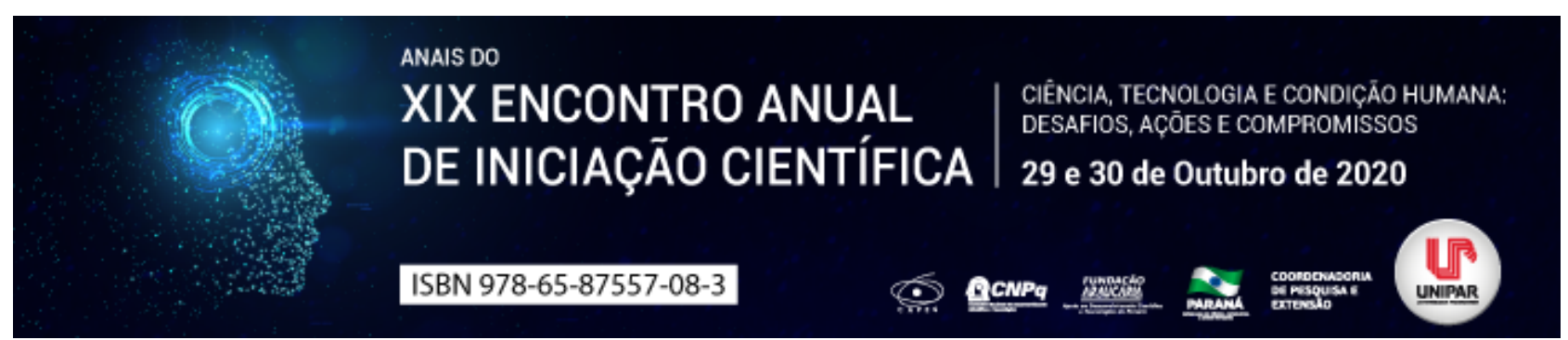

APLICAÇÃO DE PÓ DE ROCHA NO MANEJO DE Meloidogyne javanica NA CULTURA DA SOJA

\begin{abstract}
${ }^{1}$ Glaucia Leticia Sete da Cruz, ${ }^{2}$ SIMONE DE MELO SANTANA-GOMES, ${ }^{3}$ BEATRIZ DE ALMEIDA E SILVA, ${ }^{4}$ GUILHERME TARINI, ${ }^{5}$ CLAUDIA REGINA DIAS-ARIEIRA
\end{abstract}

\author{
${ }^{1}$ Discente do curso de Agronomia, UEM, Umuarama-PR \\ ${ }^{1}$ Pós-doutoranda em Nematologia Agrícola e docente do mestrado em Ciências Agrárias, UEM \\ ${ }^{2}$ Discente do curso de Agronomia, UEM, Umuarama-PR \\ ${ }^{3}$ Discente do curso de Agronomia, UEM, Umuarama-PR \\ ${ }^{4}$ Docente da Graduação e Pós-Graduação em Agronomia e Ciências Agrárias, UEM
}

Introdução: Meloidogyne javanica é uma das espécies de fitonematoides mais importante para a cultura da soja, o que justifica a necessidade de controle. Para tanto, faz-se necessário encontrar estratégias que causem menores impactos ambientais e ao homem, dentre elas, o uso de fertilizantes organominerais (FERREIRA et al., 2008). O uso de rochas moídas também pode ser uma alternativa na composição de fertilizantes organominerais, além de reciclar os rejeitos de minerações e pedreiras, responsáveis por impactos ambientais em todo o país (FERREIRA, 2014).

Objetivo: Avaliar o efeito da aplicação do pó de rocha no controle de Meloidogyne javanica e nos parâmetros vegetativos na cultura da soja.

Material e Métodos: O experimento foi conduzido em casa de vegetação, na Universidade Estadual de Maringá, em Umuarama

$\mathrm{PR}$, em copos de isopor com capacidade para de $950 \mathrm{~mL}$. Os tratamentos foram constituídos por solos autoclavado (2 h, 120 $\left.{ }^{\circ} \mathrm{C}\right)$ e não autoclavado, com aplicações de cinco doses de pó de rocha: 0, 1000, 2000, 3000 e $4000 \mathrm{~kg} \mathrm{ha}^{-1}$. As doses foram aplicadas vinte dias antes da semeadura da soja cv. Monsoy 6410 IPRO e a inoculação dos nematoides ocorreram após a emergência das plântulas, aproximadamente cinco dias após a semeadura. Em cada unidade experimental foram depositados 2000 ovos e eventuais juvenis extraídos conforme Hussey e Barker (1973) adaptada por Bonetti e Ferraz (1981). Após sessenta dias de cultivo, separou-se a parte aérea do sistema radicular, determinando-se a massa seca de parte aérea $\left(65^{\circ} \mathrm{C}\right.$, até atingir massa constante), nematoides por sistema radicular e nematoides por grama de raiz, obtido pela divisão do número total de nematoides pela massa radicular. Os nematoides foram extraídos conforme metodologia citada acima, quantificados em câmara de Peters, sob microscópio ótico. O experimento foi instalado em DIC, em arranjo fatorial $2 \times 5$, com cinco repetições. As médias foram submetidas à análise de variância $(p \leq 0,05)$. Quando a interação dos fatores foi significativa, os tipos de solos foram comparados por Tukey e as doses por regressão a $5 \%$ de significância, utilizando o programa estatístico Sisvar (FERREIRA, 2011).

Resultados: As variáveis analisadas apresentaram interação significativa entre os fatores. Para massa seca de parte aérea das plantas cultivadas no solo autoclavado, as doses demonstraram um comportamento quadrático, com o pico de massa seca $(13,23 \mathrm{~g})$ na dose de $2000 \mathrm{~kg} \mathrm{ha}^{-1}$ de rocha. Para nematoides por sistema radicular, as doses promoveram um ajuste quadrático (positivo) para o solo autoclavado, com médias variando de 1603 a 9120 e linear decrescente, para o não autoclavado, com variação de 967 a 5320 espécimes. O solo autoclavado demonstrou maior redução populacional nas doses de 1000 e $2000 \mathrm{~kg}$ $\mathrm{ha}^{-1}$. Para nematoides por grama de raiz os ajustes da regressão foram os mesmos observados para nematoides por sistema radicular, porém, quando não houve aplicação de pó de rocha, o solo autoclavado (1800 espécimes/g) promoveu maior reprodução do nematoide, quando comparado ao não autoclavado (518 espécimes/g).

Discussões: Trabalhos já demonstraram o efeito benéfico da utilização de pó de rocha nas características agronômicas na cultura da soja, como na altura, massa seca, o que corrobora com o presente trabalho, bem como aumento de produtividade da cultura (BATISTA, 2013). Além de fornecer macro e micronutrientes, os pós de rochas, considerados rejeitos, também proporcionam maior retenção de água pela formação de vesículas nos argilominerais e são condicionares do solo (OLIVEIRA, 2012). Possivelmente, a redução populacional dos nematoides esteja relacionada a essa disponibilização de nutrientes minerais do pó de rocha no solo. Todos os nutrientes essenciais influenciam a saúde das plantas e sua suscetibilidade à doença. Plantas que sofrem estresse nutricional serão mais suscetíveis a doenças, enquanto a nutrição adequada das culturas torna as plantas mais tolerantes ou resistentes. Embora a doença não possa ser totalmente eliminada por qualquer nutriente específico, a sua gravidade pode ser bastante reduzida, por uma nutrição adequada (ZAMBOLIM, VENTURA; ZANÃO, 2012).

Conclusão: As doses aplicadas de pó de rocha promoveram ganho de massa seca na parte aérea e reduziram a população de M. javanica no sistema radicular e por grama de raiz. 


\section{Referências}

BATISTA, Nayra Thais Ferreira. Atributos químicos do solo e componentes agronômicos na cultura da soja pelo uso da rochagem: Teor de nutrientes acumulado na parte aérea da planta de soja. Orientador: Vilmar Antonio Ragagnin. 2013. Dissertação (Mestre em produção vegetal) Universidade federal de Goias, Jataí, 2013.

Bonetti, J.I.S.; Ferraz, S. Modificação do método de Hussey e Barker para extração de ovos de Meloidogyne exígua de cafeeiro. Fitopatologia Brasileira, Brasília, v.6, n.3, p.553, 1981.

FERREIRA, Fernanda Carla. Controle de meloidogyne spp. em algodoeiro e quiabeiro com o fertilizante organomineral ufv-tm100 e o efeito da incorporação de pó de basalto ao fertilizante em tomateiro: Influência do fertilizante organomineral à base de torta de mamona UFV-TM100 no desenvolvimento do algodão e no controle de Meloidogyne incognita raça 3. Orientador: Silamar Ferraz. 2014. Tese (Pós-Graduação em Fitopatologia). Universidade Federal de Viçosa, Viçosa, 2014.

MARTINS, E.S; THEODORO, S.H. Congresso Brasileiro de Rochagem In: Congresso Brasileiro de Rochagem, 1, 2010: Brasília. Anais do I Congresso Brasileiro de Rochagem; editores Eder de Souza Martins, Suzi Huff Theodoro Planaltina, DF: EMBRAPA Cerrados. p. 322, 2010.

OLIVEIRA, P.C. Caracterização geológico-geotécnica de diferentes litotipos basálticos: basalto denso, basalto vesículoamigdaloidal e brecha alcalina. 159p. Dissertação (Mestrado) Escola de Engenharia de São Carlos. Universidade de São Paulo, São Carlos 2012.

ZAMBOLIM, Laercio. VENTURA, José Aires. ZANÃO JÚNIOR, Luiz Antônio. Efeito da nutrição mineral no controle de doenças de plantas, 22. ed. Viçosa: Paulo Afonso de Souza, 2012.

Coordenadoria de Pesquisa e Extensão - COPEX

Departamento de Editoraçāo e Divulgaçāo Científica - DEDIC 


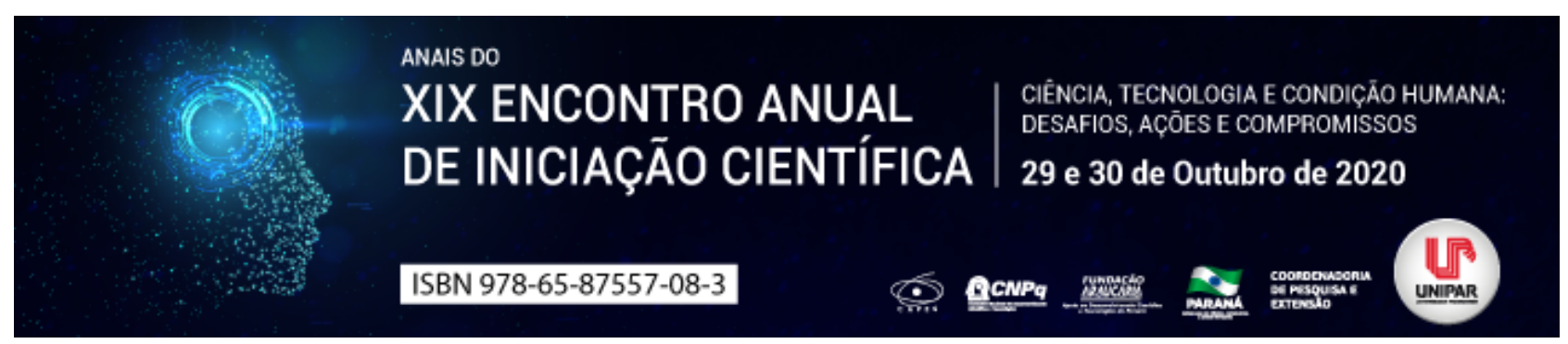

SECAGEM DE BATATA UTILIZANDO FORNECIMENTO INTERMITENTE DE ENERGIA MICRO-ONDAS

\title{
${ }^{1}$ Larissa Franciscatti Hoffmann, ${ }^{2}$ ADRYELEN CASSIANO MARTINS, ${ }^{3}$ BARBARA DANIELE ALMEIDA PORCIUNCULA, ${ }^{4}$ JHONY TIAGO TELEKEN
}

\author{
${ }^{1}$ Acadêmica do PIC/UEM \\ ${ }^{1}$ Acadêmica do curso de Engenharia de Alimentos UEM \\ ${ }^{2}$ Docente da UEM \\ ${ }^{3}$ Docente da UEM
}

Introdução: A utilização de energia eletromagnética na frequência das micro-ondas combinada a diferentes métodos de secagem tem sido muito utilizada na desidratação de frutas e hortaliças. Com o uso de energia micro-ondas, além de reduzir os tempos de secagem, é possível obter produtos desidratados de alta qualidade (Monteiro et al., 2018). As micro-ondas são capazes de penetrar os alimentos e dissipar energia na forma de calor. O aumento instantâneo da temperatura pode causar a evaporação da água presente no interior do material sendo que a geração de vapor aumenta a pressão dentro do alimento e promove o escoamento da umidade em direção a superfície do produto. Dessa forma, a remoção da água é mais rápida e, consequentemente, os tempos de secagem são menores (Teleken et al., 2020). Apesar da secagem com micro-ondas ser atrativa, o método apresenta limitações. Em virtude do comportamento oscilatório das ondas eletromagnéticas o aquecimento micro-ondas não é uniforme. Para uniformizar a distribuição de temperaturas, uma alternativa consiste no fornecimento intermitente de energia eletromagnética durante a secagem. Nesse processo o magnetron do secador opera em ciclos on-off. $\mathrm{O}$ alimento é aquecido por determinado período de tempo (magnetron on) e permanece outro período sem aquecimento (magnetron off). No período sem aquecimento os gradientes de temperatura do interior do meio são suavizados e, consequentemente, reduzse os efeitos térmicos sobre compostos termosensíveis do alimento (Kumar et al. 2014).

Objetivo: O estudo teve como objetivo avaliar o processo de secagem de batata utilizando fornecimento intermitente de energia eletromagnética. Para isso, cinéticas de perda de umidade e de aumento da temperatura foram obtidas em um forno de microondas doméstico.

Materiais e métodos: Batatas adquiridas no comercio local de Umuarama (PR) foram utilizadas nos experimentos de secagem. A umidade em base seca do material de $6.6 \pm 0.3 \mathrm{~kg} / \mathrm{kg}$ foi determinado pelo método gravimétrico em estufa (Marconi, MA035, Brasil) a $105^{\circ} \mathrm{C}$ por $24 \mathrm{~h}$ (AOAC, 2005). Um forno de micro-ondas doméstico, com frequência de $2450 \mathrm{MHz}$, potência nominal de $800 \mathrm{~W}$ e prato giratório com velocidade angular de 0,2 $\pi \mathrm{rad} \mathrm{s}^{-1}$ (Panasonic, NN-ST568WRUK, Brasil), foi utilizado para realizar os experimentos. O forno permite a utilização de 10 níveis de potência (10-100\%), sendo que em $100 \%$ o magnetron do forno opera continuamente. Os experimentos foram conduzidos no nível de potência de 10\% (4 s on e $18 \mathrm{~s}$ off) para um tempo de secagem de $1200 \mathrm{~s}$. As batatas foram lavadas e cortadas em formato cilíndrico (18 mm de diâmetro e $10 \mathrm{~mm}$ de altura). Após, uma amostra foi colocada próxima a borda do prato do forno, iniciando-se o fornecimento de energia. Para obter as cinéticas de secagem, o forno foi desligado em intervalos de tempo pré-determinados $(30,60,90,120,150,300,600,900$ e 1200 s) para as medidas do conteúdo de umidade e temperatura. O conteúdo de umidade foi determinado pelo método gravimétrico em estufa e a temperatura foi medida através de um termômetro digital de infravermelho (Minipa, MT-320A, Brasil). Para reduzir a variabilidade dos resultados, para cada intervalo de tempo uma nova amostra foi usada. Os resultados foram obtidos em triplicata.

Resultados: O conteúdo de umidade, em base seca (Xbs), foi reduzido de aproximadamente $6.6 \mathrm{~kg} / \mathrm{kg}$ para valores inferiores a $0.1 \mathrm{~kg} / \mathrm{kg}$ em um período de $1200 \mathrm{~s}$. A temperatura da superfície da batata aumentou rapidamente no início da secagem de $27^{\circ} \mathrm{C}$ para um valor constante de aproximadamente $70^{\circ} \mathrm{C}$ até o final da secagem visto que a temperatura de secagem é a temperatura fornecida pelo micro-ondas.

Discussão: A partir da cinética obtida pode-se observar que o processo de secagem passa por três períodos distintos: Primeiro, um curto período de aquecimento e baixa taxa de secagem (0-150 s). A maior parte da energia micro-ondas convertida em energia térmica é usada para aumentar a temperatura da batata onde a taxa de secagem aumenta gradualmente. Segundo, um período de temperatura e taxa de secagem que oscilam em torno de valores constantes de aproximadamente $75{ }^{\circ} \mathrm{C}$ e $0.006 \mathrm{~kg} /(\mathrm{kg} . \mathrm{s})$, respectivamente (150-1000 s). Tal fato indica que a energia micro-ondas absorvida pela batata é balanceada com a energia térmica liberada pela evaporação da água. No terceiro período, a taxa de secagem decresce e a temperatura tende a aumentar. Os três períodos também foram observados por Li et al. (2008), na secagem de madeira em micro-ondas a vácuo. Observou-se ainda um escurecimento do alimento próximo ao centro das amostras, indicando uma maior concentração de energia eletromagnética dissipada no ponto. O maior aumento da temperatura no centro de amostras cilíndricas é resultado do 
efeito de refração das ondas eletromagnéticas (Zhang et al., 2005).

Conclusão: $O$ processo de desidratação utilizando fornecimento intermitente de energia eletromagnética se mostrou uma alternativa interessante para secagem de batatas. Ao fornecer energia micro-ondas de forma pulsada ao alimento é possível reduzir o conteúdo de umidade evitando-se a possível carbonização do alimento decorrente da presença de hot spots.

\section{Referências}

A.O.A.C. Association of Official Analytical Chemists. Official Methods of Analysis, 18th ed., Gaithersburg, Maryland, 2005. KUMAR, Chandan; KARIM, Azharuk; JOARDDER, Mohammad Uzzal Hossain. Intermittent drying of food products: A critical review, Journal of Food Engineering, v. 121, janeiro, 2014. Disponível em: https://doi.org/10.1016/j.jfoodeng.2013.08.014. Acesso em: 05 jun 2020.

LI, Xian-Jun; ZHANG, Bi-Guang; LI, Wen-Jun. Microwave-Vacuum Drying of Wood: Model Formulation and verification, Drying Technology, v. 26, n. 11, outubro, 2008. Disponível em: https://doi.org/10.1080/07373930802333551. Acesso em: 05 jun 2020.

MONTEIRO, Ricardo Lemos; LINK, Jade Varaschim; TRIBUZI, Giustini; CARCIOFI, Bruno Augusto Mattar; LAURINDO, João Borges. Effect of multi-flash drying and microwave vacuum drying on the microstructure and texture of pumpkin slices, LWT Food Science and Technology, v. 96, outubro, 2018. Disponível em: https://doi.org/10.1016/j.Iwt.2018.06.023. Acesso em: 05 jun 2020.

TELEKEN, Jhony Tiago; QUADRI, Marintho Bastos; OLIVEIRA, Antonio Pedro Novaes; LAURINDO, João Borges; DATTA, Ashim; CARCIOFI, Bruno Augusto Mattar. Mechanistic understanding of microwave-vacuum drying of non-deformable porous media, Drying Technology, 2020. Disponível em: https://doi.org/10.1080/07373937.2020.1728303. Acesso em: 05 jun 2020.

ZHANG, Hua; DATTA, Ashim. Heating concentrations of microwaves in spherical and cylindrical foods. Part one: in planes waves, Food and Bioproducts Processing, v. 83, n.1, março, 2005. Disponível em: https://doi.org/10.1205/fbp.04046. Acesso em: 05 jun 2020.

ZHANG, Hua; DATTA. Heating concentrations of microwaves in spherical and cylindrical foods. Part two: in a cavity, Food and Bioproducts Processing, v. 83, n.1, março, 2005. Disponível em: https://doi.org/10.1205/fbp.04047. Acesso em: 05 jun 2020. 


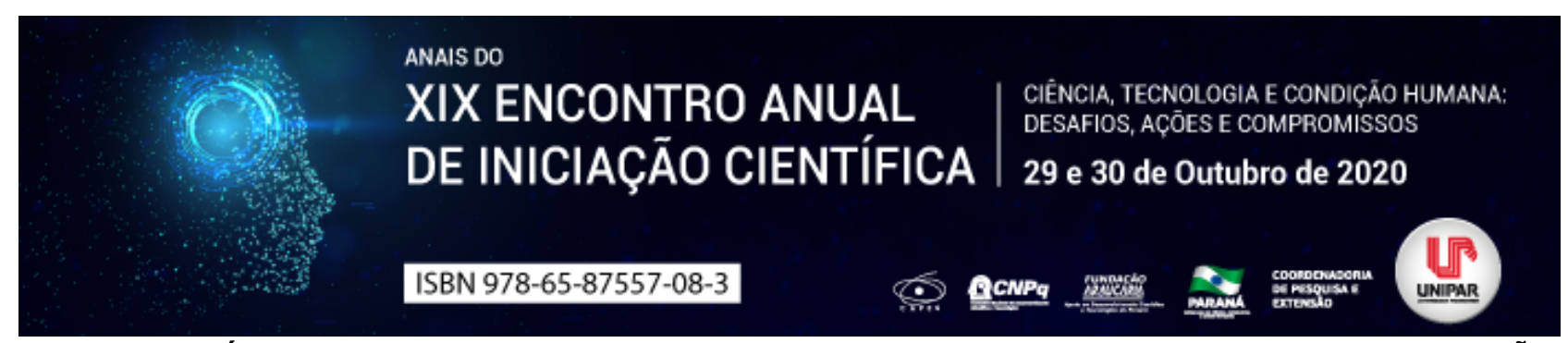

\title{
EFEITO ALELOPÁTICO DO EXTRATO DE GENGIBRE (Zingiber officinale Roscoe) SOBRE A GERMINAÇÃO DE SEMENTES DE CAPIM AMARGOSO
}

\author{
${ }^{1}$ GUSTAVO HENRICH SIQUEIRA BARBOSA, ${ }^{2}$ LUIS HIDEKI TAKAHARA, ${ }^{3}$ SONIVALDO RUZZENE BELTRAME , ${ }^{4}$ EVELINE \\ HENRIQUE DOS SANTOS, ${ }^{5}$ RENATO FERNANDO MENEGAZZO , ${ }^{6}$ ANA DANIELA LOPES
}

\begin{abstract}
${ }^{1_{1}}$ Discente de Engenharia Agronômica, PIC/UNIPAR
${ }^{1}$ Acadêmico do Curso de Mestrado Em Biotecnologia Aplicada A Agricultura - Turma Xv da UNIPAR

${ }^{2}$ Acadêmico do Curso de Doutorado Em Biotecnologia Aplicada A Agricultura - Turma V da UNIPAR

${ }^{3}$ Acadêmica do Curso de Doutorado Em Biotecnologia Aplicada A Agricultura - Turma Vii da UNIPAR

${ }^{4}$ Acadêmico do Curso de Doutorado Em Biotecnologia Aplicada A Agricultura - Turma V da UNIPAR

${ }^{5}$ Docente da UNIPAR
\end{abstract}

Introdução: O capim-amargoso (Digitaria insularis) é uma planta daninha de ciclo perene seu ciclo de vida pode durar mais de dois anos. rápida propagação desta espécie no Brasil tem aumentado principalmente em áreas agrícolas onde não há a presença de cobertura vegetal na entresafra , o que vem tornado-a uma das principais espécies daninhas em áreas de produção de grãos (GAZOLA, et al., 2011). Associado a este fato existe a dificuldade no controle desta espécie em função da resistência aos herbicidas disponíveis no mercado (Koger e Reddy, 2005). Uma vez que aleloquímicos são comuns nos vegetais e tóxicos para as plantas, mas de ação seletiva, o uso destas moléculas pode ser investigado como potencial herbicida com vantagens ecológicas, por serem produtos naturais, em substituição aos químicos (Pires et al., 2001).

Objetivo: O objetivo deste trabalho foi investigar o potencial alelopático do extrato aquoso de Zingiber officinale sobre sementes de capim amargoso.

Material e Métodos: Os rizomas de gengibre foram coletados no Horto Medicinal da UNIPAR fatiados, secos e pulverizados para a obtenção do extrato conforme metodologia descrita por Anvisa (2019) e Bardi et al. (2013); e posteriormente, concentrado em evaporador rotativo até obtenção do extrato bruto. A atividade alelopática foi avaliada em experimento com delineamento inteiramente casualizado, com cinco tratamentos e quatro repetições, sendo eles: extrato a 1\%; 0,75\%; 0,50\% e 0,25\%. Como controle foi utilizado uma solução de Tween 80 a 1,0\% e água destilada. Os extratos foram preparados a partir de uma solução padrão do extrato bruto de gengibre diluído em Tween $80 \%$ e água destilada.. O teste de germinação foi conduzido em caixas plásticas do tipo gerbox conforme recomendações da RAS (Regras para Análise de Sementes) (Brasil, 2009). Foram avaliados a porcentagem de germinação (PG) e o índice de velocidade de germinação (IVG). A avaliação dos resultados foi realizada no primeiro dia do início da germinação (protrusão da radícula) e ocorreu diariamente por 14 dias, sendo a primeira contagem aos 7 e a última aos 14 dias. A porcentagem de germinação e o índice de velocidade de germinação foram realizados de acordo com Labouriau e Valadares (1976) e Maguire (1962). Os dados foram analisados estatisticamente por meio de análise de variância aplicando-se o teste F, pelo teste qualitativos de Tukey e por análise de regressão a $5 \%$ de probabilidade no programa estatístico SISVAR (Ferreira, 2011).

Resultados: A variável PG foi significativa $(p \leq 0,05)$ na $1^{\mathrm{a}}$ e $2^{\mathrm{a}}$ contagem. O modelo de regressão significativo para a $1^{\circ}$ contagem foi o linear, enquanto para $2^{\circ}$ contagem o modelo significativo foi o quadrático. Em ambas as contagens observou-se redução no PG conforme aumento na concentração do extrato de gengibre. O PG observado aos 7 dias foi de $27 \%$, decaindo conforme aumento da concentração, com $1 \%$ de germinação na concentração de $1 \%$. Aos 14 dias, também observou-se redução no percentual de germinação na concentração de $1 \%$. O PG no tratamento controle foi de $33 \%$, o qual aumentou na concentração de $0,25 \%$, voltando a decair nas concentrações de $0,50 \%$ e $0,75 \%$ (37\% e $22 \%$, respectivamente), e apresentando apenas $5 \%$ germinação na concentração de 1\%. O IVG também foi significativo, indicando redução na velocidade de germinação conforme aumento da concentração do extrato. Nos tratamentos controle e para as concentrações de $0,25 \%$ e $0,50 \%$ as sementes germinaram mais rapidamente; ao contrário do que foi observado para as maiores concentrações do extrato de gengibre. Os tratamentos com as concentrações mais altas do extrato diferiram estatisticamente entre si $(p \leq 0,05)$, sendo que para a solução a $1 \%$ verificou-se diminuição da velocidade de germinação. O maior valor de porcentagem de germinação, avaliada 7 dias após a instalação do experimento, foi verificado no tratamento controle $(27,50 \%)$, o qual recebeu apenas a solução de Tween $80 \%$. As concentrações testadas não diferiram estatisticamente entre si, embora, a concentração de 1,0\% tenha apresentado apenas uma semente germinada na primeira contagem. Na segunda contagem foi possível verificar um maior número de sementes germinadas na concentração de $0,25 \%$.

Discussão: A eficácia do uso de extrato vegetal para o controle de capim amargoso já foi citado por alguns autores, como Melo (2018), o qual relatou sucesso no uso de Crotalaria juncea para redução da germinação de capim amargoso. Boehm e Simonetti 
(2014) observaram em seus estudos um grande índice de sementes mortas e o desenvolvimento de plântulas anormais na presença do extrato do fruto do crambe, evidenciando seu potencial alelopático também sobre capim amargoso. Conforme Sousa et al. (2011), o capim amargoso também é suscetível aos extratos de neem, mamona e eucalipto. Neste trabalho, os resultados referentes ao IVG sugerem que o extrato de gengibre apresenta potencial atividade alelopática sobre capim amargoso, retardando o início da germinação e, podendo, eventualmente, ser utilizado como uma alternativa no controle desta planta daninha.

Conclusão: O extrato aquoso de gengibre apresenta potencial atividade alelopática sobre o capim amargoso, retardando o início da germinação e tendo impacto direto sobre a germinação e sugerindo assim seu uso como controle pré-emergente.

\section{Referências}

BARDI, Daleya Abdulaziz; HALAB, Mohammed Farouq; ABDULLAH, Nor Azizan; ROUHOLLAHI, Elham; HAJREZAIE, Maryam; ABDULLA, Mahmood Ameen. In vivo evaluation of ethanolic extract of Zingiber officinale. rhizomes for its protective effect against liver cirrhosis. Bio Med Res. Int., New York, v.2013, n. esp, p.1-10, dez. 2013.

BOEHM, Nayara Rizo; SIMONETTI, Ana Paula Morais Mourão. Interferência alelopática do extrato de crambe sobre sementes de capim-amargoso. Cultivando o Saber, Cascavel, v.7, n.1, p. 83-93, jan./mar. 2014.

ANVISA. Farmacopédia Brasileira. 6 ed. ANVISA: Brasília, 2019. 874p.

BRASIL. Ministério da Agricultura, Pecuária e Abastecimento. Brasília: Mapa/ACS, 399 p. 2009.

FERREIRA, Daniel Furtado. Sisvar: sistema de análise de variância para dados balanceados. Ciênc. Agrotec., Lavras, v.35, n.6, nov./dez. 2011

GAZOLA, Tiago; DIAS, Marcio Furriela; BONATTO, Valdirene Mendonça; BELAPART, Diego; CARBONARI, Caio Antonio; VELINI, Edvaldo Domingues Velini. Crescimento e Desenvolvimento de Plantas do Capim-Amargoso Oriundas de Partes Vegetativas das Touceiras. Planta Daninha, v.37, n.1, 2019.

KOGER, Clifford Howard; REDDY, Krishna Nolan. Role of absorption and translocation in the mechanism of glyphosate resistance in horseweed (Conyza canadensis). Weed Science, New Delhi, v.53, n.1, p. 84-89, jan. 2005.

LABOURIAU Luiz Fernando Gouveia; VALADARES Mercia Eliana Bicalho. On the germination of seeds of Calotropis procera. Anais. Academia Brasileira de Ciências, Rio de Janeiro, v.48, n.1, p.263-284, 1976.

MAGUIRE, James. Dave Speed of germination-aid in selection and evaluation for seedling 362 emergence and vigor. Journal Crop Science, Madison, v.2, n.1, p 176-177, jan./fev. 1962.

MELO, Thais Stradioto; SILVA, Laryssa Barbosa Xavier; MARQUES, Rodolpho Freire; CONCENÇO, Germani. Efeito alelopático de crotalaria juncea sobre capim amargoso. In: JORNADA DE INICIAÇÃO À PESQUISA DA EMBRAPA, 2018, Anais [*..] Brasília: Embrapa Agropecuária Oeste, 2018. 


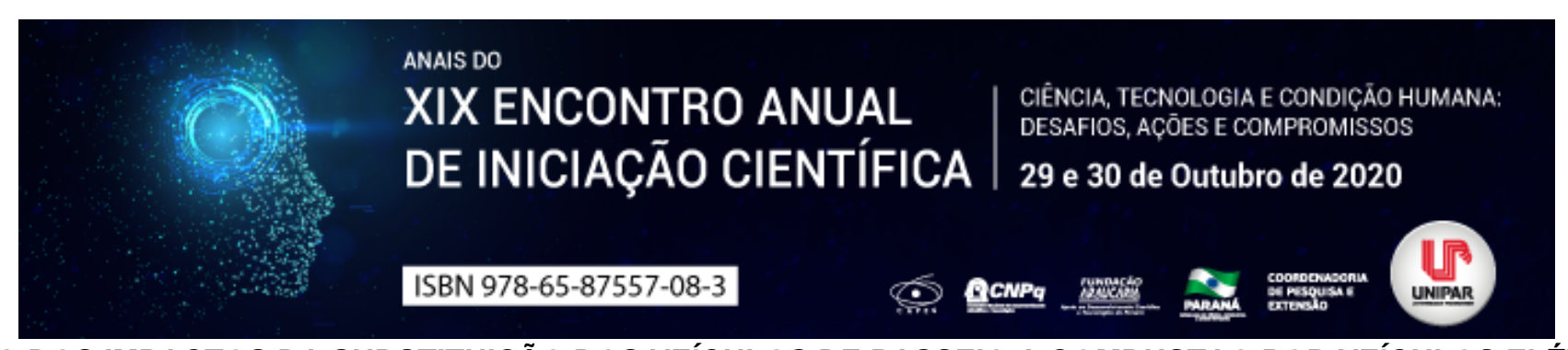

\title{
ESTUDO DOS IMPACTOS DA SUBSTITUIÇÃO DOS VEÍCULOS DE PASSEIO A COMBUSTAO POR VEÍCULOS ELÉTRICOS NO BRASIL
}

\section{${ }^{1}$ ALYSON VALENTIN MARCHI, ${ }^{2}$ HUGO HENRIQUE BERTI, ${ }^{3}$ MAYKON CESAR SPOLTI FERREIRA}

\author{
${ }^{1}$ Acadêmico do Curso de Engenharia Mecânica da UNIPAR \\ ${ }^{1}$ Acadêmico do Curso de Engenharia Mecânica da UNIPAR \\ ${ }^{2}$ Docente da UNIPAR
}

Introdução: Com o atual momento mundial, é visto a necessidade da mobilidade sustentável ou ao menos a preocupação de reduzir seu impacto ambiental. O que leva a discussão de como o veículo a combustão (VC) poderia ser substituído por outra tecnologia propulsora, já que o setor de transporte é um dos maiores responsáveis pela emissão dos gases de efeito estufa (DE ANDRADE; MATTEI, 2013). Inicialmente o veículo elétrico (VE) surge como uma relevante alternativa por não emitir diretamente poluentes em seu funcionamento. (BARAN; LEGEV, 2011). Os estudos nessa área são escassos, neste cenário geralmente se limita a análise na fase do uso dos veículos.

Objetivo: Analisar, por meio de uma revisão bibliográfica, os impactos ambientais causado pelo VE e VC em sua produção, analisando a extração da matéria prima necessária no item mais nocivo ao meio ambiente nos dois veículos.

Desenvolvimento: Segundo Held e Baumann (2011), o item mais nocivo ao meio ambiente na fase de produção do carro elétrico é a bateria de íon lítio, enquanto no carro a combustão interna são as partes metálicas do veículo. A bateria de íon lítio escolhida para a análise foi a óxido cobalto, manganês, níquel e lítio $(\mathrm{LiNiMnCoO})$ por conta de suas propriedades para a utilização nos VEs. Essa bateria possui um cátodo com níquel, manganês e cobalto além do ânodo de grafite (HANNAN et al., 2018). A extração de lítio pode ser feita por fontes minerais e por salmouras (SANTOS et al., 2020). Sua extração causa problemas como: poluição sonora; contaminação do ar e da água; mudança na fauna e na flora (GESTA/UFMG, s.d apud CETEM, 2013). O níquel pode ser extraído em minérios sulfetados e minérios lateríticos. Para que seja extraído desses minérios é necessário diferentes processos de mineração (POINTON, 2001 apud GOONAN, 2009). Sua mineração acarreta poluição do solo e da água; focos de incêndios; desmatamento (LIMA, 2011). O manganês é formado a partir de protominérios principalmente em ambientes sedimentares marítimos, sob a forma de uma rocha rica em carbonatos e silicatos de manganês (DAMASCENO, 2006). A extração é feita em céu aberto (SAMPAIO et al., 2008). Os principais danos causados por sua mineração são: desmatamento, poluição e contaminação da água, do solo e do ar e redução da biodiversidade (MECHI; SANCHES, 2010). O cobalto é extraído através da mineração com a ajuda de explosivos, após isso é refinado e então estará pronto para ser inserido na produção (SHERMAN, 2018). Por conta da crescente demanda de metais para a produção da bateria dos VEs, há estudos que preveem que por volta de 2030 a demanda do cobalto e do níquel será maior q a oferta desses metais (TURCHENIUK, 2018). Além dos impactos causados pela mineração como o desmatamento, a poluição da água e do solo, a extração do cobalto faz com que as pessoas trabalhem em péssimas condições e há até mesmo o uso de mão de obra infantil nas minas (SAFATLE; CORONATO, 2019). O grafite natural pode ser encontrado em 3 formas: veios cristalinos, agregada em flocos e amorfa. A grafita em veios cristalinos e em flocos são lavrados em céu aberto e por métodos subterrâneos, enquanto a grafita amorfa somente por método subterrâneo (SAMPAIO; BRAGA; DUTRA, 2008). Alguns dos impactos gerado pela extração do grafite são: assoreamento de corpos hídricos, poluição do ar, emissão de gases de efeito estufa e vibrações do solo (MECHI; SANCHES, 2010). Já para o VC, as principais matérias primas para produção das partes metálicas são o ferro e o carbono (FOGAÇA, 2009?). O ferro é um metal com muita abundancia na crosta terrestre e esta presente em todos os solos (Borkert et al., 2001 apud ASPIAZU, 2004). Sua extração é feita por mineração de rochas ígneas, sendo as principais: hematita, magnetita, siderita, limonita e pirita que gera impactos ambientais como: poluição da água e do solo, desmatamento e alteração na fauna e flora (FOGAÇA, 2010; BARRETO et al., 2001; TONIETTO; SILVA, 2011). O carbono é um elemento que apresenta alotropia, pode ser encontrado de diversas formas, por exemplo, na forma de compostos orgânicos na natureza e em minérios na forma de carbonatos, carbetos e bicarbonatos (FERREIRA, s.d). Sua extração causa desmatamento, poluição da água e do solo e emissão de dióxido de carbono (MECHI; SANCHES, 2010; FERREIRA, s.d). Diante disso, comparando a produção dos VEs com os VCs, o veículo elétrico apresenta um potencial de aquecimento global (PAG) duas vezes maior e um potencial de acidificação (PA) de duas a quatro vezes maior que o VC, devido aos componentes a mais necessário no VE. Muito disso por conta da produção do sistema de bateria dos VEs, que é responsável por cerca de $45 \%$ de todo o PAG e $65 \%$ do PA causado durante a fase de produção do VE (HELD; BAUMANN, 2011).

Conclusão: Na fase de produção dos veículos o carro a combustão se mostrou menos danoso ao meio ambiente, devido principalmente a extração dos materiais necessários para a produção da bateria do veículo elétrico que gera grandes impactos ambientais. Para um trabalho futuro, será realizado uma análise dos impactos oriundos da utilização e do descarte do item mais 


\section{Referências}

ASPIAZÚ, Ignacio. Extração de ferro e manganês por Mehlich-1, Mehlich-3 e DTPA em solos de Minas Gerais e da Bahia. 2004.

BARAN, Renato; LEGEY, Luiz Fernando Loureiro. Veículos elétricos: história e perspectivas no Brasil. 2011.

BARRETO, Maria Laura et al. Mineração e desenvolvimento sustentável: desafios para o Brasil. 2001.

CETEM. Exploração de lítio em Araçuaí (MG) causa impactos socioambientais negativos. 2013.

DAMASCENO, Eduardo Camilher. Disponibilidade, suprimento e demanda de minérios para metalurgia. 2006.

DE ANDRADE, André; MATTEI, Lauro. A (in) sustentabilidade da matriz energética brasileira. 2013.

FERREIRA, Victor Ricardo. I"Carbonol"; Brasil Escola. Acesso em 25 de agosto de 2020.

FOGAÇA, Jennifer Rocha Vargas. I"Açol"; Brasil Escola. 2009? Acesso em 26 de agosto de 2020.

FOGAÇA, Jennifer Rocha Vargas. I"Ferrol"; Brasil Escola. 2010? Acesso em 25 de agosto de 2020.

GOONAN, Thomas G. Nickel recycling in the United States in 2004. US Geological Survey: Reston, VA, 2009.

HANNAN, Mahammad A. et al. State-of-the-art and energy management system of lithium-ion batteries in electric vehicle applications: Issues and recommendations. 2018.

HELD, Michael; BAUMANN, Michael. Assessment of the environmental impacts of electric vehicle concepts. 2011.

LIMA, Helio. Mineração em Ourilândia do Norte. 2011.

MECHI, Andréa; SANCHES, Djalma Luiz. Impactos ambientais da mineração no Estado de São Paulo. 2010.

SAFATLE, Amalia; CORONATO, Marcos. Cobalto: um ingrediente necessário, mas tóxico para a sociedade e os negócios. 2019.

SAMPAIO, João Alves; BRAGA, Paulo Fernando Almeida; DUTRA, Achilles Junqueira Bourdot. Grafita. 2008.

SAMPAIO, João Alves et al. Manganês. 2008.

SHERMAN, Natalie. O metal precioso que está criando uma nova 'febre do ouro'. BBC em Nova York, 2018.

TONIETTO, Ângela; SILVA, Janaina JMC. Valoração de danos nos casos de mineração de ferro no Brasil.

TURCHENIUK, Kostiantyn et al. Ten years left to redesign lithium-ion batteries. 2018. 


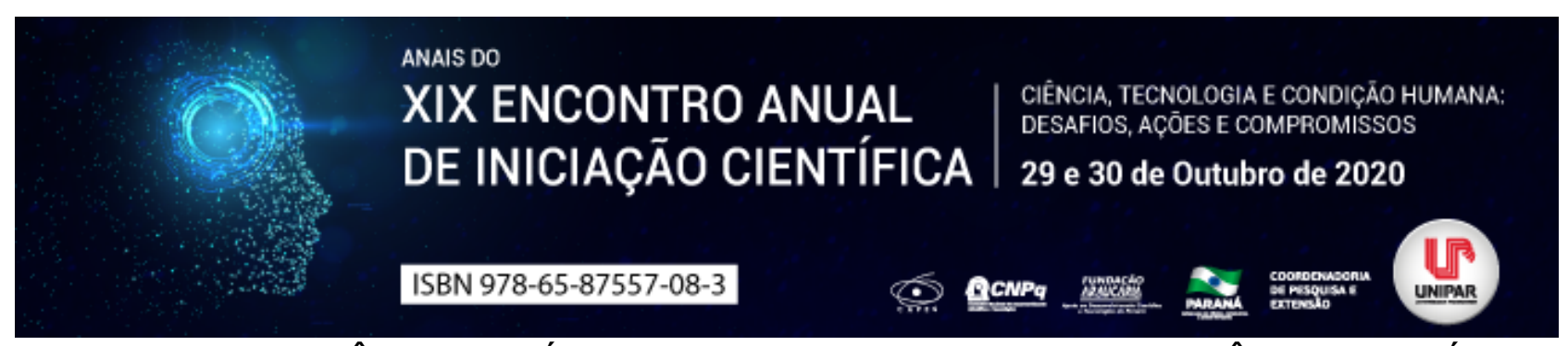

O RENDIMENTO ACADÊMICO EM CÁLCULOS FINANCEIROS NOS CURSOS DE CIÊNCIAS CONTÁBEIS E ADMINISTRAÇÃO

\author{
${ }^{1}$ LUCAS GOMES DE OLIVEIRA, ${ }^{2}$ AMANDA INES PALUDO FREDO, ${ }^{3}$ ANA LUIZA MACHADO STASIAK, ${ }^{4}$ BRENDA LEE \\ MONIQUE TOSATTI DA SILVA, ${ }^{5}$ LUCAS GOMES DE OLIVEIRA
}

\author{
${ }^{1}$ Professor Adjunto - UNIPAR \\ ${ }^{1}$ Acadêmica do Curso de CiÃanncias Cont $\tilde{A}_{j}$ beis da UNIPAR \\ ${ }^{2}$ Acadêmica do Curso de AdministraÃß̃̃£o da UNIPAR \\ ${ }^{3}$ Acadêmica do Curso de AdministraÃß̃̃£o da UNIPAR \\ ${ }^{4}$ Docente da UNIPAR
}

Introdução: Figueiredo (1997) destaca que a utilização de modelos contábeis baseados em métodos matemáticos tem se tornado cada vez mais frequentes, decorrentes do rápido desenvolvimento das tecnologias da informação, desta forma os contadores e administradores tem usado cada vez mais as ferramentas quantitativas, isso tem tornado possível a resolução de grande variedade de problemas, levando estas ciências mais próximas da objetividade eliminando possíveis desvios de interpretação, os profissionais da área devem desenvolver as habilidades de planejamento, organização e controle, além disso para que tenha um bom desempenho é indispensável que tenha grande facilidade e gosto de trabalhar com números. Brito (1996) afirma que as atitudes apresentam componentes do domínio afetivo, cognitivo e motor. Müller (2007) l"trata dos três componentes da atitude citados, denominando-os de: cognitivo(crenças), afetivo (sentimentos) e conativo (ações)l".

Objetivo: Descrever a percepção da importância bem como o sentimento dos acadêmicos de administração e ciências contábeis em relação ao desempenho na disciplina de cálculos financeiros.

Revisão Bibliográfica: Para (CARVALHO 2007) aprender matemática é definido como, enunciar o conceito a partir de conceitos anteriores, ou que remeta a uma axiomática, exibir um exemplo onde o conceito se expressa. O conceito é compreendido quando se consegue, delimitar claramente onde o conceito se aplica, assinalando também onde ele não se aplica, relacionar o conceito com outros conceitos estendendo-o a situações mais amplas, exibir variados exemplos e contra-exemplos onde o conceito respectivamente se aplica ou não, aplicar o conceito a outras situações, resolvendo novos problemas e consequentemente gerar novos conceitos. Observando o estudo desenvolvido por (FUENTES; LIMA; GUERRA, 2009) quando mediram a atitude dos acadêmicos de Administração em relação a matemática percebe-se que é positiva mas em comparação com o enfoque no aprendizado notasse uma associação direta porém estatisticamente o estudo mostrou-se não significante no corte transversal em Survey estruturada desenvolvido. Em relação a esses paradigmas já existe sistemas especializados em partilhar experiências no processo ensino/aprendizagem da matemática um desses serviços é o MATEAS (acrónimo para Matemática: ensino e avaliação no (ensino) superior ) como uma plataforma que permite a divulgação e partilha online de experiências pedagógicas realizadas na área da matemática no âmbito do ensino superior, (CAETANO, 2012).

Material e Métodos: O estudo tem um carácter exploratório descritivo foi realizado com os acadêmicos dos cursos de Ciências Contábeis e Administração da Unipar- Francisco Beltrão Pr durante o mês de agosto de 2018 e 2019, onde apresenta-se ainda dados descritivos de um censo realizado com todos os acadêmicos matriculados na disciplina de Cálculos Financeiros na UNIPAR unidade de Francisco Beltrão nesses dois anos. O questionário utilizado proposto por Gomes (2012) é composto de 32 questões fechadas, das quais 19 se referiam à Escala de Atitudes em relação à disciplina de Cálculos Financeiros (EACF) e 13 ao perfil do aluno, seu envolvimento com a área e a disciplina de Cálculos Financeiros e em trabalhos científicos, além de seu desempenho na disciplina.

A EAAF é uma escala do tipo Likert que busca expressar o sentimento dos alunos com relação à disciplina de Cálculos Financeiros afirmativas, das quais 11 exprimem sentimentos positivos (questões 18 a 28) e 17 negativos (questões 1 a 17).

Resultados: No ano de 2018 foram coletados 34 questionários, sendo 12 de acadêmicos de administração e 22 de ciências contábeis, 23 respondido por acadêmicas e 11 por acadêmicos, em 2019 aplicamos os mesmos 34 questionários mantendo também a quantidade por curso, sendo 17 acadêmicos de cada sexo. Quando questionados a respeito do seu desempenho na disciplina de cálculos financeiros obtemos respectivamente $67,65 \%, 61,76 \%$ consideraram bom e 32,35\%, 35,29\% sofrível, no quesito e analise foi a média de notas nas avaliações observou-se a média de 7,7 e 6,95 o que se considera um bom desempenho apesar da turma 2019 apresentar uma queda em relação a 2018.

Discussão: Quando o tema tratado é a importância da disciplina respetivamente em 2018 e 2019 90\% e 93,82\% dos entrevistados afirmam ser de extrema importância para sua área de atuação. Quanto a afinidade, os alunos acabam trazendo medos e certa aversão da sua formação básica tendo na grande maioria uma preocupação e dedicação que leva a um bom 
desempenho, o que mostra boa adaptação dos mesmos.

Conclusão: Observa-se no estudo, que nos dois anos há em sua grande maioria um entendimento muito grande em relação a importância da disciplina de Cálculos financeiros para a vida acadêmica e futura introdução no mercado de trabalho, apesar de perceber-se preocupação com o aprendizado o que ele acreditam que transformam em dedicação e superação em relação a disciplina.

\section{Referências}

BRITO, Marcia Regina Ferreira de; Um estudo sobre as atitudes em relação à Matemática em estudantes de $1^{\circ}$ e $2^{\circ}$ graus. Tese (Livre Docência) Faculdade de Educação da Universidade Estadual de Campinas, Campinas, 1996.

FIGUEIREDO, Sandra; CAGGIANO, Paulo Cesar . Controladoria Teoria e Prática São Paulo: Atlas, 1997.

GOMES, Ana Célia Chaves; NOGUEIRA Cinthya Muyrielle da Silva; MOL, Anderson Luiz Rezende; Concepções e atitudes em relação à disciplina de administração financeira. REGE, São Paulo SP, Brasil, v. 20, n. 2, p. 183-200, abr./jun. 2013.

MÜLLER, Fabrise de Oliveira; As emoções positivas e negativas, a atitude e a intenção de comportamento: um estudo exploratório no varejo. Dissertação (Mestrado em Administração e Negócios) Faculdade de Administração, Contabilidade e Economia da Pontifícia Universidade Católica do Rio Grande do Sul, Porto Alegre, 2007.

Coordenadoria de Pesquisa e Extensão - COPEX

Departamento de Editoraçāo e Divulgaçāo Científica - DEDIC 


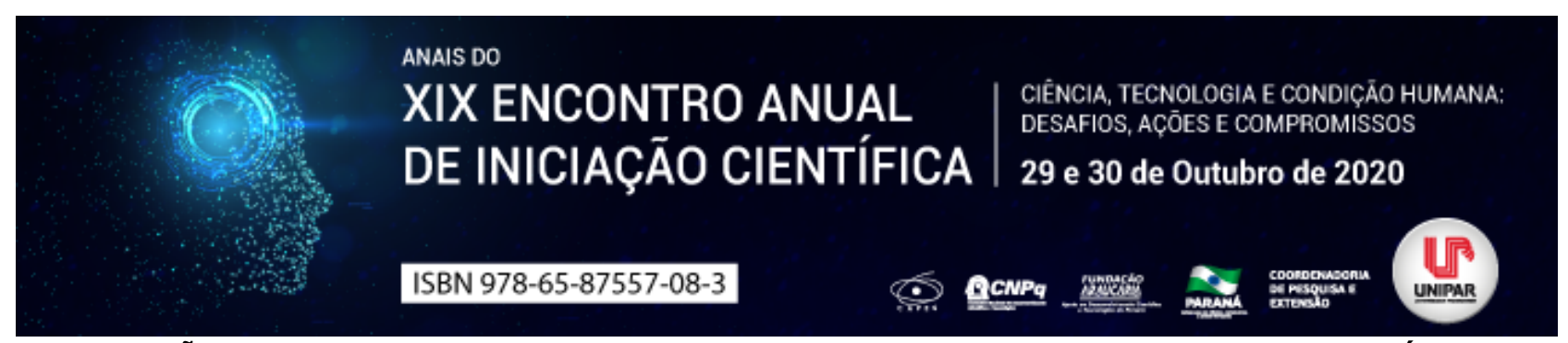

AVALIAÇÃO DO EFEITO DE DIFERENTES GEOMETRIAS NA SECAGEM CONVECTIVA DE CÚRCUMA

\author{
${ }^{1}$ Débora Lourenço Lemos, ${ }^{2}$ BÁRBARA DANIELE ALMEIDA PORCIUNCULA
}

\author{
${ }^{1}$ Acadêmico do PIC/UEM \\ ${ }^{1}$ Docente da UEM
}

Introdução: Alimentos, como frutas e vegetais, possuem alto teor de umidade favorecendo o desenvolvimento microbiano e deteriorações de origem físico-química. Processos tecnológicos têm sido explorados em escala industrial para preservá-los. Os métodos de conservação mais comuns incluem secagem, preservação química e refrigeração/congelamento (JERÔNIMO, 2013; FELLOWS, 2006; PEREDA et al., 2005). A técnica de secagem consiste na remoção de água de um produto com o intuito de diminuir sua umidade e atividade de água. Existem diferentes técnicas de secagem, dentre elas destaca-se a secagem convectiva. Este tipo de secagem pode ser utilizado para uma grande variedade de alimentos. Na secagem convectiva um fluxo de ar aquecido é utilizado fazendo com que ocorra evaporação da umidade da superfície do produto e ocasionando em seguida a difusão da água do interior para a superfície, onde se evapora para o ambiente (GAVA, 1997; OETTERER et al., 2006; FELLOWS, 2006).

Objetivo: O presente estudo teve como objetivo avaliar a qualidade final de cúrcumas secas em diferentes geometrias em relação ao teor de umidade, parâmetros de cor e propriedades mecânicas.

Material e Métodos: Matéria-prima: As amostras de cúrcuma foram selecionadas visualmente em relação à homogeneidade da cor e tamanho e caracterizadas em relação ao teor de sólidos solúveis, teor de umidade e cor. A concentração de sólidos solúveis foi determinada em um refratômetro ótico manual (AR200 Reichert, EUA). O teor de umidade das amostras foi determinado por método gravimétrico (INSTITUTO ADOLFO LUTZ, 2008). Para a determinação da cor, as amostras foram trituradas com auxílio de um triturador manual e adicionadas em placas de petri e então o parâmetro de cor foi avaliado em colorímetro (Koncka Minolta). Os parâmetros de cor foram expressos em valores de luminosidade $L^{*}$, croma $a^{*}$ e croma $\mathrm{b}^{\star}$. Preparo das amostras: As amostras foram cortadas com auxílio de um cortador metálico em fatias de $3 \mathrm{~mm}$ de espessuras. Para a obtenção das amostras trituradas, as mesmas foram trituradas em um ralador doméstico e colocadas em placas de Petri, cobrindo o fundo com espessura de $3 \mathrm{~mm}$. Secagem: As secagens das amostras de cúrcuma foram feitas em estufa (Marconi MA-035) com circulação e renovação de ar a $60^{\circ} \mathrm{C}$. Durante as 2 primeiras horas, foram realizadas pesagens a cada 15 minutos, após, foram realizadas pesagens a cada 30 minutos até peso constante. Os ensaios foram realizados em triplicata. Determinação da Cor: A análise das características da cor foi avaliada pelos parâmetros do sistema CIE-LAB. Foram realizadas cinco medições e os parâmetros foram expressos em valores de luminosidade $L^{*}$, croma $a^{*}$ e croma $b^{\star}$. Determinação das Propriedades Mecânicas dos Produtos Desidratados: As propriedades mecânicas dos produtos desidratados, foram efetuadas por meio de teste de compressão com probe cilíndrica de $70 \mathrm{~mm}$ de diâmetro, em analisador de textura TA-XT2 (Stable Micro System), controlado por microcomputador. Foram analisadas 7 amostras para cada uma das técnicas de secagem avaliadas. Os ensaios de compressão foram realizados até $30 \%$ da altura inicial das amostras.

Resultados: A cúrcuma adquirida no comércio local da cidade de Umuarama-PR apresentou 4,53 g de água/ $\mathrm{g}$ de sól. secos de umidade e $22{ }^{\circ}$ Brix de sólido solúveis. Em relação aos parâmetros de cor obteve-se os valores de $56,87 \pm 0,58$ em $L, 11,66 \pm 0,85$ em a e 51,02 $\pm 1,68 \mathrm{em}$ b para as amostras in natura, 61,69 $\pm 1,69 \mathrm{em} \mathrm{L,} \mathrm{16,56 \pm 0,96} \mathrm{em} \mathrm{a*} \mathrm{e} \mathrm{32,17 \pm 1,12} \mathrm{em} \mathrm{b*} \mathrm{para} \mathrm{as} \mathrm{amostras}$ desidratadas em fatias e de $54,76 \pm 0,64$ para $L, 5,50 \pm 0,67$ para $a^{\star}$ e $29,46 \pm 0,52$ para $b^{\star}$ para as amostras desidratadas

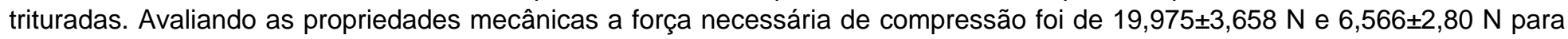
as amostras em fatias e trituradas, respectivamente.

Discussão: As amostras desidratadas trituradas apresentaram taxa de secagem mais elevada que as amostras em fatias. Este fato pode ter ocorrido, pois para as amostras trituradas a área superficial exposta ao ar de secagem é maior facilitando o processo difusão da água. As amostras trituradas atingiram a umidade de equilíbrio num tempo menor que as amostras em fatias. Avalianda a cor notou-se que as amostras em fatias tiveram um incremento na luminosidade, um pequeno aumento nos tons de vermelho e uma diminuição nos tons de amarelo. As amostras secas trituradas apresentaram uma redução na luminosidade e nos tons de vermelho e amarelo. A diferença entre os valores que pode estar relacionada a exposição das amostras a corrente de ar de secagem. As amostras secas em fatias necessitaram de uma maior força de compressão ao comparar com a força necessária para comprimir as amostras secas trituradas devido a estrutura mais rígida e encolhimento mais acentuado.

Conclusão: Por meio dos resultados obtidos pode-se concluir que a geometria influenciou nas taxa de secagem da cúrcuma e consequentemente no tempo de secagem. As amostras secas trituradas apresentaram uma maior taxa de secagem, uma menor degradação da cor e necessitaram de menor força de compressão ao se comparar com as amostras secas em fatias. 


\section{Referências}

FELLOWS, P. J. Tecnologia do processamento de alimentos: Princípios e Prática. 2 ed. Porto Alegre: Artmed, 2006.

GAVA, A. J. Princípios de tecnologia de alimentos. São Paulo: Nobel, 1984.

JERÔNIMO, C. E. M. Revista Verde de Agroecologia e Desenvolvimento Sustentável. Desidratação de rodelas de cenouras: avaliação dos pré-tratamentos na cinética de secagem e na qualidade do material produzido. Natal, 2013. p. 0917.

OETTERER, M.; REGITANO-D'ARCE, M. A. B.; SPOTO, M. H. F. Fundamentos de ciência e tecnologia de alimentos. Barueri, SP: Manole, 2006.

PeredA, J. A. O.; RODRIGUeZ, M. I. C.; ÁlvareZ, L. F.; SANZ, M. L. G.; Minguillón, G. D. G. F.; PERALES, L. H. CORTECERO, M. D. S. Tecnologia de alimentos Componentes dos alimentos e processos. Porto Alegre: Artmed, 2005.

Coordenadoria de Pesquisa e Extensão - COPEX

Departamento de Editoraçāo e Divulgaçāo Científica - DEDIC 


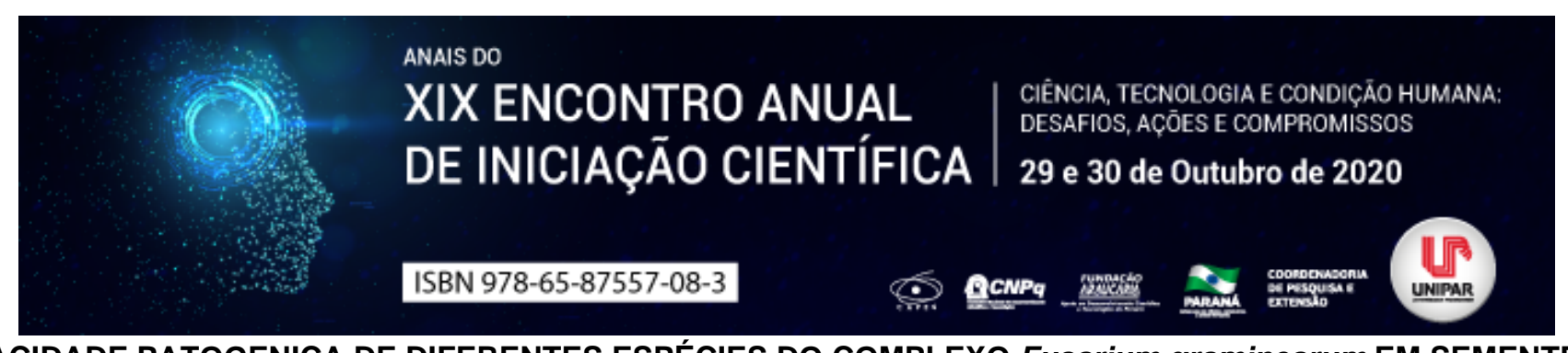

CAPACIDADE PATOGENICA DE DIFERENTES ESPÉCIES DO COMPLEXO Fusarium graminearum EM SEMENTES DE SOJA

\author{
${ }^{1}$ Lucas Pereira da Silva, ${ }^{2}$ ANA CLÁUDIA DA SILVA MENDONÇA, ${ }^{3}$ BRUNA CRISTINA DE ANDRADE, ${ }^{4}$ CELSO MARTINS \\ FRANÇA, ${ }^{5}$ GIOVANNA SERON, ${ }^{6}$ PRISCILA ANGELOTTI ZAMPAR
}

\begin{abstract}
${ }^{1}$ Engenheiro Agrónomo e Pós-graduando em Agronomia PGA Universidade Estadual de Maringá.
${ }^{1}$ Engenheiro Agrónomo e Pós-graduando em Agronomia PGA Universidade Estadual de Maringá

${ }^{2}$ Engenheiro Agrónomo e Pós-graduando em Agronomia PGA Universidade Estadual de Maringá

${ }^{3}$ Acadêmico do curso de Agronomia Universidade Estadual de Maringá

${ }^{4}$ Acadêmico do curso de Agronomia Universidade Estadual de Maringá

${ }^{5}$ Pesquisadora UEM - Universidade Estadual de Maringá
\end{abstract}

Introdução: Atualmente o Brasil ocupa o posto de maior produtor de soja do mundo segundo a Companhia Nacional de Abastecimento. Dos principais problemas fitossanitários que acometem a cultura da soja destaca-se as causados por fungos do gênero Fusarium spp., sendo capazes de reduzir o número final de plantas no stand, depauperando a cultura, além de afetar na produtividade final (Klingelfuss et al. 2007). Existem diversas espécies de Fusarium capazes de infectar e causar danos na cultura da soja, dentre elas, ganha-se atenção as espécies do complexo Fusarium graminearum, entretanto, ainda é pouco descrito se há diferenças na capacidade patogênica das diferentes espécies na cultura da soja.

Objetivo: O objetivo deste trabalho é avaliar se há diferenças na capacidade patogênica de diferentes isolados de $F$. graminearum sensu strictu, F. meridionale e F. cortaderie, na emergência e na proporção de sementes anormais de sementes de soja.

Material e Métodos: O experimento foi realizado no Laboratório de Fitopatologia e na casa de vegetação pertencentes a Universidade Estadual de Maringá (UEM). A cultivar utilizada foi a NA5909. Foram utilizados três isolados de cada espécie, sendo eles F. graminearum sensu strictu (3070, 3305, e 3315), F. meridionale (3325, 3309, e 3242), e F. cortaderie (3922, 3360, e 3428). O método empregado para a inoculação dos patógenos nas sementes de soja foi o de restrição hídrica com manitol a -0,9 Mpa. Os fungos foram cultivados em meio de cultura batata-dextrose-ágar (BDA). As placas contendo cada isolado foram incubadas em câmara de crescimento a $24 \pm 2^{\circ} \mathrm{C}$ durante sete dias com 12 horas de luz. Após esses dias, as sementes de soja sadias foram colocadas nas placas com os fungos. Foram postos aproximadamente 30 gramas de sementes em cada placa no qual continha os diferentes isolados de F. graminearum sensu strictu, F. meridionale e F. cortaderie. As placas com sementes e os patógenos foram incubadas a $24 \pm 2^{\circ} \mathrm{C}$ por 48 horas com 12 horas de luz. Após as 48 horas, as sementes foram plantadas em sacos plástico para mudas, na dimensão de 10×15 cm, contendo uma proporção de 1:1:1 (solo, areia e substrado), sendo depositado 5 sementes por saco plástico. O delineamento utilizado foi o inteiramente casualidado, contendo 3 espécies de patógenos com 3 isolados distintos, cada um com 3 repetições, com 5 sementes em cada saco plástico, ao final, foi transformado os dados de cada unidade experimental em porcentagem, onde 5 sementes por saco plástico representavam 100\%. Para a testemunha, foi plantado apenas sementes de soja desinfestadas, em 3 repetições. As avaliações de emergência ocorreram aos 7, 14, 21 e 28 dias após o plantio, e o número de plântulas anormais no final do experimento. Os dados foram submetidos à análise de variância, e as médias, comparadas pelo Teste Tukey a 5\% de probabilidade, utilizando-se o programa computacional Sisvar.

Resultados: A análise de variância revelou diferença significativa entre as médias das espécies avaliadas. Através do teste tukey a $5 \%$ de probabilidade pode-se notar que para a análise de 7 dias após o plantio foram agrupados os isolados de $F$. graminearum sensu strictu (3305) e F. cortaderie (3428) no qual possuíram a mesma capacidade patogênica, resultando em um valor de $26,66 \%$ de emergência, F. meridionale (3242) com 33,33\%, e F. cortaderie (3922) com 40\%. Ao avaliar os 14,21 e 28 dias após o plantio, apenas o isolado F. graminearum sensu strictu (3305) foi capaz de diferenciar da testemunha (100\%), com um resultado de $40 \%$ de emergência. Já ao analisar o número de plântulas anormais, os isolados que tiveram diferença estatística foram os de F. cortaderie (3922 e 3428), com um número médio de 33,33\% de plântulas anormais.

Discussão: Neste experimento, as maiores diferenças ocorreram após os 14 dias após o plantio, no qual o isolado de $F$. graminearum sensu strictu (3305) foi o mais patogênico na emergência da soja. Já ao analisarmos o número de plântulas anormais os isolados de F. cortaderie (3922 e 3428) foram os mais significativos na cultura da soja. Ao analisar a capacidade patogênica de F. graminearum sensu strictu em soja, Peruzzo et al. (2015) constatou que houve o aumento de plântulas anormais, redução de tamanho de parte aérea e peso seco de raízes, dados esses que corroboram com os encontrados neste estudo. 
Conclusão: Os isolados de F. graminearum sensu strictu (3305), F. cortaderie (3428 e 3922) e $F$. meridionale (3242) foram os mais patogênicos aos 7 dias após o plantio. Já aos 14, 21 e 28, o isolado de $F$. graminearum sensu strictu (3305) se diferenciou de todos os outros, sendo o que mais interferiu na emergência da soja. Os isolados de F. cortaderie (3922 e 3428) resultam no maior número de plântulas anormais.

\section{Referências}

KLINGELFUSS, L. H.; YORINORI, J. T.; DESTRO, D. Métodos de inoculação para quantificação de resistência em soja à Fusarium solani f. sp. glycines, em casa-de-vegetação. Fitopatologia Brasileira 32:050-055. 2007.

PERUZZO, A.; PIOLI, R. N.; SALINAS, A. R. efeito de Fusarium graminearum na qualidade fisiológica de sementes de soja e cariopse de trigo na argentina. Revista Caatinga, v. 28, n. 3, p. 1-11, 2015.

Coordenadoria de Pesquisa e Extensão - COPEX

Departamento de Editoraçāo e Divulgaçāo Científica - DEDIC 


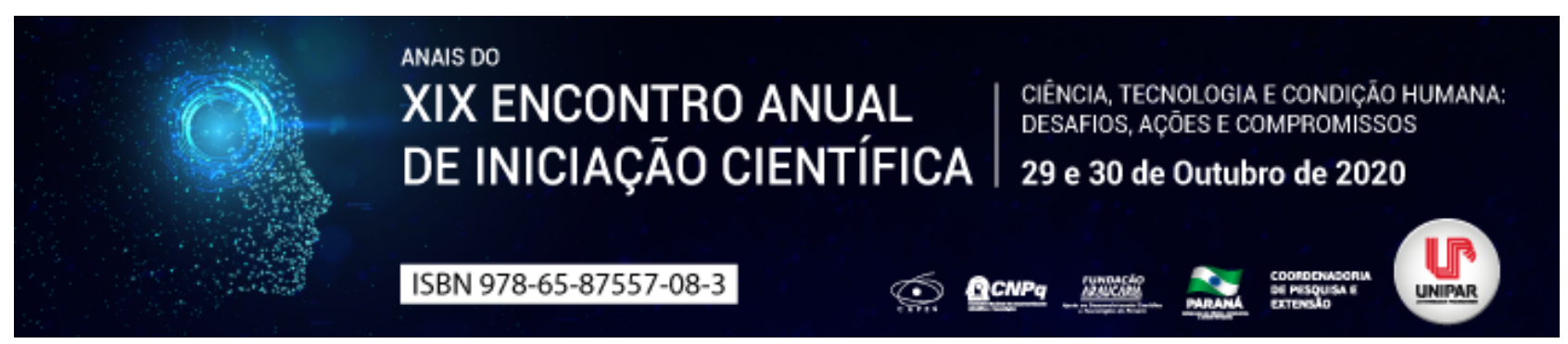

PARASITISMO DE Pratylenchus zeae EM CULTIVARES DE SOJA

\begin{abstract}
${ }^{1}$ Angelica Sanchez Melo, ${ }^{2}$ GUILHERME TARINI, ${ }^{3}$ RAIANE PEREIRA SCHWENGBER, ${ }^{4}$ SIMONE DE MELO SANTANA-GOMES, ${ }^{5}$ CLÁUDIA REGINA DIAS-ARIEIRA
\end{abstract}

\author{
${ }^{1}$ Discente do curso de Agronomia/ UEM \\ ${ }^{1}$ Discente do curso de Agronomia/ UEM \\ ${ }^{2}$ Engenheira Agrônoma, mestre em Ciências Agrárias/UEM \\ ${ }^{3}$ Discente de Pós-Graduação/ UEM \\ ${ }^{4}$ Docente da UNIPAR
}

Introdução: Com o intuito de aumentar o teor de matéria orgânica do solo e melhorar as condições de manejo da área, o sistema de integração lavoura-pecuária (ILP) tem ganhado cada vez mais espaço na agricultura, o que possibilitou a expansão do cultivo da soja para regiões de baixa aptidão, como no Arenito Caiuá, região noroeste do Paraná (FERREIRA et al., 2015; BALBINOT JUNIOR et al., 2016). Contudo, sempre que se altera o sistema de cultivo pode haver a seleção de organismos patogênicos que podem limitar a produtividade. Nesse contexto, a adoção do sistema ILP pode elevar os níveis populacionais de fitonematoides, especialmente Pratylenchus spp., já que algumas culturas inseridas no sistema, como milho e braquiária, são suscetíveis (GOULART, 2008; CARVALHO et al., 2013; BELLÉ et al., 2017), destacando a possibilidade de selecionar isolados de Pratylenchus zeae patogênicos à soja.

Objetivo: Avaliar a suscetibilidades de cultivares de soja a Pratylenchus zeae.

Material e Métodos: O experimento foi conduzido em delineamento inteiramente casualizado, com cinco tratamentos e seis repetições, em condições de casa de vegetação, na Universidade Estadual de Maringá, Campus Regional de Umuarama-PR. A unidade experimental foi composta por copos de isopor, nos quais foi depositado uma mistura de solo: areia (2:1) autoclavada (2 h a $120^{\circ} \mathrm{C}$ ). Os tratamentos foram constituídos por quatro cultivares de soja, M6210 IPRO, NS 5959 IPRO, TMG 7062 IPRO e DM 5958 RSF IPRO, e o milho híbrido Status, utilizado como testemunha. Em cada unidade foram depositadas duas sementes e, sete dias após a germinação, as plantas foram desbastadas e inoculadas. O inóculo foi obtido de uma população pura, extraído conforme a metodologia proposta por Coolen e D’Herde (1972), e calibrado para 500 nematoides por mL. Decorridos 80 após a inoculação, as plantas foram retiradas e a parte aérea descartada, o sistema radicular foi lavado e pesado. Posteriormente, realizou-se a extração de nematoides das raízes, sendo determinado o número total de nematoides em câmara de Peters, sob microscópio óptico, o qual foi dividido pela massa de raiz, obtendo-se o número de nematoides/g de raiz. Calculou-se também o fator de reprodução (FR), pela divisão da população final de nematoide pela população inicial. Os dados obtidos foram submetidos à análise de variância a 5\% de significância, e as médias comparadas pelo teste Tukey a 5\% de probabilidade, por meio do programa estatístico Sisvar (FERREIRA, 2011).

Resultados: Todas as cultivares avaliadas foram parasitadas pelo nematoide, contudo, o número de nematoides total e FR foram inferiores à testemunha, que apresentou fator de reprodução de 4,72 (milho híbrido Status), enquanto que, para as cultivaress estas variáveis foram de 0,43 (DM 5958 IPRO), 0,63 (TMG 7062 IPRO), 0,68 (NS 5959 IPRO), sendo classificadas como resistente (FR<1), enquanto que a cultivar M6210 IPRO, apresentou suscetibilidade, com FR de 1,19. Para a variável nematoide.g de raiz ${ }^{-1}$, não houve diferença estatística entre os tratamentos.

Discussão: $O$ parasitismo de $P$. zeae em soja ainda é pouco elucidado na literatura, mas alguns autores associam que o desenvolvimento deste nematoide possa estar relacionado à temperatura, visto tratar-se de uma espécie típica de países tropicais, com temperatura ótima de desenvolvimento próximas a $30{ }^{\circ} \mathrm{C}$ (DABABAT e FOURIE, 2018), o que correlaciona com os dados apresentados nesta pesquisa, cujas temperaturas médias durante o período de condução variaram de $19,4{ }^{\circ} \mathrm{C}$ a $34,1{ }^{\circ} \mathrm{C}$ (SIMEPAR, 2020) proporcionando o desenvolvimento do nematoide no sistema radicular. Corroborando com estes resultados, Acosta e Malek (1979) constataram maior desenvolvimento de $P$. zeae na soja, em condições de temperaturas mais elevadas, cujo número de nematoides por sistema radicular variou de 0,1 , sob temperatura de $15{ }^{\circ} \mathrm{C}$, há 138.5 quando avaliado a $30{ }^{\circ} \mathrm{C}$. Conclusão: As cultivares de soja DM 5958 RSF IPRO, TMG 7062 IPRO, NS 5959 IPRO apresentaram resistência ao nematoide, com valores de FRs inferiores ao milho. A cultivar M6210 IPRO comportou-se como suscetível a $P$. zeae.

\title{
Referências
}

ACOSTA, Nelia; MALEK, Riath Ben. Influence of temperature on population development of eight species of Pratylenchus on soybean. Journal of Nematology, v.11, n.3, p.229-232, 1979. 
BALBINOT, Junior Alvadi Antonio; FRANCHINI, Julio Cesar; DEBIASI, Henrique; WERNER, Florian.; FERREIRA, Ailton Silva. Nitrogênio mineral na soja integrada com a pecuária em solo arenoso. Revista Agro@mbiente On-line, v. 10, n. 2, p. 107-113, 2016.

BELLE, Cristiano; KASPARY, Tiago Edu; KUHN, Paulo Roberto; SCHMITT, Juliana; LIMA-MEDINA. Israel. Reproduction of Pratylenchus zeae on weeds. Planta Daninha, v. 35, e017158528, 2017.

CARVALHO, Cassia de; FERNANDES, Celso Dornelas; SANTOS, Jaime Maia dos.; MACEDO, Manuel Claudio Motta. Densidade populacional de Pratylenchus spp. em pastagens de Brachiaria spp. e sua influência na disponibilidade e na qualidade da forragem. Revista Ceres, v.60, n.1, p. 30-37, 2013.

COOLEN, W.A; D'HERDE, C.J. A Method for the Quantitative Extraction of Nematodes from Plant Tissue. Ghent, Bélgica. State Nematology and Entomology Research Station, 1972.

DABABAT, Abdelfattah A; FOURIE, Hendrika. Nematode parasites of cereal. In: Sikora, R.A.; Coyne, D.; Hallmann, J.; Timper, P. (Org.). Plant Parasitic Nematodes in Subtropical and Tropical Agriculture. Boston, MA: CABI, 2018, $3^{\mathrm{a}}$ edition, p. $163-221$.

FERREIRA, Gilberto Alves; OLIVEIRA, Paulo Sergio Rabello; ALVES, Sergio José; COSTA, Antonio Carlos Torres. Soybean productivity under different grazing heights of Brachiaria ruziziensis in an integrated crop-livestock system. Revista Ciência Agronômica, v. 46, n. 4, p. 755-763, 2015.

FERREIRA, Daniel Furtado. Sisvar: a computer statistical analysis system. Ciência e Agrotecnologia, v.35, n.6, p.1039-1042, 2011.

GOULART, Alexandre Moura Cintra. Aspectos gerais sobre nematoides das lesões radiculares (gênero Pratylenchus). Planaltina: Embrapa Cerrados, 2008. 30 p. (Documentos, 219).

SIMEPAR. Sistema Meteorológico do Paraná, 2019. Disponível file:///C:/Users/User/Desktop/UEM/Artigo/Meteorologia_2019.pdf. Acessado em: 13 de junho de 2020. 


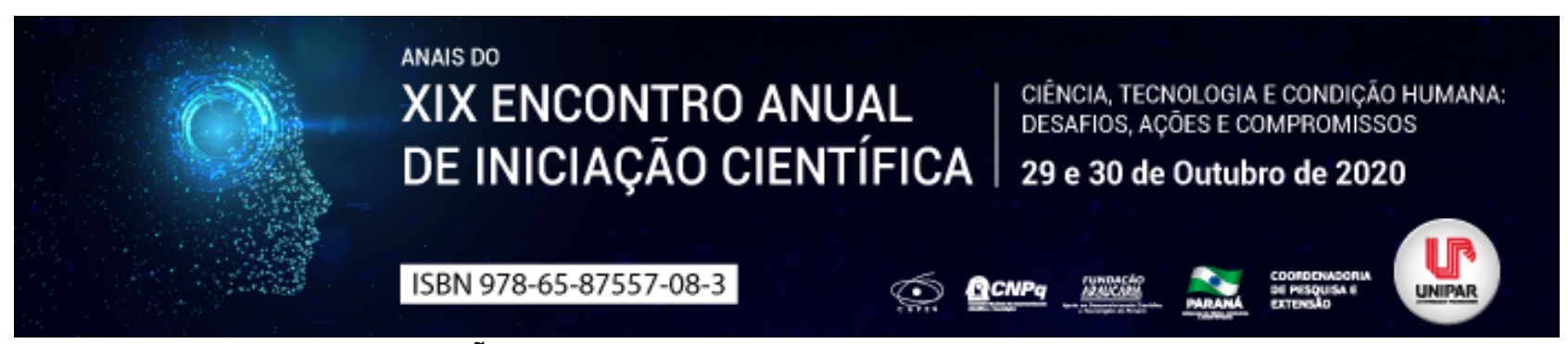

PENETRAÇÃO DE Pratylenchus zeae EM CULTIVARES DE SOJA

\author{
${ }^{1}$ Angelica Sanchez Melo, ${ }^{2}$ GUILHERME TARINI, ${ }^{3}$ BEATRIZ ALMEIDA E SILVA, ${ }^{4}$ LAIS FERNANDA FONTANA, ${ }^{5}$ BRUNA \\ ORLANDINI TONINATO, ${ }^{6}$ CLÁUDIA REGINA DIAS-ARIEIRA
}

1Discente de Graduação/ UEM
${ }^{1}$ Discente de Graduação/ UEM
${ }^{2}$ Discente de Graduação/ UEM
${ }^{3}$ Discente de Pós-Graduação/ UEM
${ }^{4}$ Discente de Pós-Graduação/ UEM
${ }^{5}$ Doscente do Departamento de Ciências Agronômicas, UEM

Introdução: As novas tecnologias utilizadas no cultivo da soja se destacam entre os principais responsáveis pela expansão em área cultivada no Brasil, principalmente em regiões de solo arenoso e de baixa fertilidade, que incluem a região do Arenito Caiuá, noroeste do Paraná (FERREIRA et al., 2015; BALBINOT JUNIOR et al., 2016). Dentre estas, tem-se a Integração LavouraPecuária (ILP), pelo cultivo simultâneo ou não, de grãos e forrageiras, contribuindo para melhoria das condições físicas e químicas do solo (NAIR et al., 2010; FRANCHINI, 2011; FERREIRA et al., 2015), tornando a produção de soja mais viável. Contudo, espécies forrageiras utilizadas na integração são suscetíveis aos nematoides das lesões radiculares (Pratylenchus spp.). Diante disso, surge a necessidade de estudar a reação de cultivares de soja a isolados de Pratylenchus zeae.

Objetivo: Avaliar a penetração de Pratylenchus zeae, em seis cultivares de soja.

Material e Métodos: $O$ experimento foi conduzido em delineamento inteiramente casualizado, com cinco tratamentos e seis repetições, em casa de vegetação, da Universidade Estadual de Maringá, Campus Regional de Umuarama-PR. A unidade experimental foi composta por copos de isopor, nos quais foi depositado $500 \mathrm{~mL}$ de uma mistura de solo: areia (2:1), autoclavada ( $2 \mathrm{~h}$ a $120^{\circ} \mathrm{C}$ ). Os tratamentos foram soja cv. M6210 IPRO, NS 5959 IPRO, TMG 7062 IPRO e DM 5958 RSF IPRO, e o milho híbrido Status foi utilizado como testemunha. Em cada unidade, foram depositadas duas sementes e, sete dias após a germinação, as plantas foram desbastadas e inoculadas. O inóculo foi obtido de uma população pura, extraído seguindo a metodologia proposta por Coolen e D'Herde, (1972), e calibrado para 500 nematoides por mL. Decorridos 7, 12, 17, e 22 dias após a inoculação (DAl) as raízes foram coletadas e submetidas à coloração com fucsina ácida (BYRD JÚNIOR et al., 1983). Posteriormente, foram confeccionadas lâminas temporárias, sendo estas avaliadas em microscópio estereoscópio, quanto ao número de nematoides. Os dados obtidos, foram submetidos à análise de variância e, as médias entre os tratamentos foram comparadas pelo teste Tukey e a época de avaliação por regressão, ambos a $5 \%$ de probabilidade, por meio do programa estatístico Sisvar (FERREIRA, 2011).

Resultados: Observou-se que a soja cultivares M6210 IPRO, TMG 7062 IPRO e DM 5958 IPRO apresentaram ajuste para regressão linear para épocas de avaliação, seguindo o mesmo comportamento do milho, com exceção da cv. NS 5959 IPRO, cuja penetração comportou-se de forma quadrática. Não houve diferença para a penetração do nematoide entre os tratamentos aos 7 DAl. Contudo, nas demais avaliações (12, 17 e 22 DAl), as cultivares de soja apresentaram média de $P$. zeae inferior ao milho, sem diferirem entre si.

Discussão: Diante da penetração do nematoide no sistema radicular da soja, é importante estar atento ao sistema de produção adotado, devido ao potencial de reprodução deste nematoide na cultura, destacando-se a importância da utilização de plantas que se comportem como más hospedeiras ou antagonista deste nematoide no sistema de rotação, incluindo Crotalaria juncea e C. spectabilis (SANTANA-GOMES et al., 2019a; SANTANA-GOMES et al., 2019b), feijão guandu cv. IPR 43 (Cajanus cajan) e mucuna preta (Stizolobium aterriumum) (SANTANA-GOMES et al., 2019b). Ressalta-se também, a necessidade de se fazer o cultivo solteiro de planta antagonistas e não consorciado com o milho, por se tratar de uma espécie suscetível à $P$. zeae.

Conclusão: Pratylenchus zeae penetra as raízes de soja e a população tende a aumentar ao longo do tempo, mesmo que em números inferiores ao milho.

\title{
Referências
}

BALBINOT, Junior Alvadi Antonio; FRANCHINI, Julio Cesar; DEBIASI, Henrique; WERNER, Florian.; FERREIRA, Ailton Silva. Nitrogênio mineral na soja integrada com a pecuária em solo arenoso. Revista Agro@mbiente On-line, v. 10, n. 2, p. 107-113, 2016.

BYRD Júnior, D. W.; KIRPATRICK, T; BARKER, K. R. An improved technique for clearing and staining plant tissues for detection of nematodes. Journal of Nematology, v. 15, p. 142-143, 1983. 
COOLEN, W.A.; D'HERDE, C.J. A Method for the Quantitative Extraction of Nematodes from Plant Tissue. Ghent, Bélgica. State Nematology and Entomology Research Station, 1972.

FERREIRA, Daniel Furtado. Sisvar: a computer statistical analysis system. Ciência e Agrotecnologia, v.35, n.6, p.1039-1042, 2011.

FERREIRA, Gilberto Alves; OLIVEIRA, Paulo Sergio Rabello; ALVES, Sergio José; COSTA, Antonio Carlos Torres. Soybean productivity under different grazing heights of Brachiaria ruziziensis in an integrated crop-livestock system. Revista Ciência Agronômica, v. 46, n. 4, p. 755-763, 2015.

FRANCHINI, J.; SILVA, V.P.; BALBINOT JUNIOR, A.A.; SICHIERI, F.; PADULLA, R.; DEBIASI, H.; MARTINS, S. Integração Lavoura-Pecuária-Floresta na Região Noroeste do Paraná. Embrapa Soja-Circular Técnica (INFOTECA-E), Londrina, 2011. NAIR, P.K.R.; NAIR, V.D.; KUMAR, M.; SHOWALTER, J.M. Carbon sequestration in agroforestry systems. Advances in Agronomy, v.108, p. 237-307, 2010.

SANTANA-GOMES, Simone Melo; DIAS-ARIEIRA, Claúdia Regina; BIELA, Fernando; RAGAZZI, M.R.; BALDISERA, S.S.; SCHWENGBER, Raiane Pereira. Planting different crops in succession to manage Pratylenchus zeae in sugarcane. Nematropica, v. 49, p.63-70, 2019a.

SANTANA-GOMES, Simone Melo; DIAS-ARIEIRA, Claúdia Regina; FERREIRA, Julio Cesar Antunes.; SCHWENGBER, Raiane Pereira.; BALDISERA, S.S. Reproduction of Pratylenchus zeae and $P$. brachyurus reproduction in cover crops. Revista Caatinga, v.32, p.295-301, 2019b.

Coordenadoria de Pesquisa e Extensão - COPEX

Departamento de Editoraçāo e Divulgaçāo Científica - DEDIC 


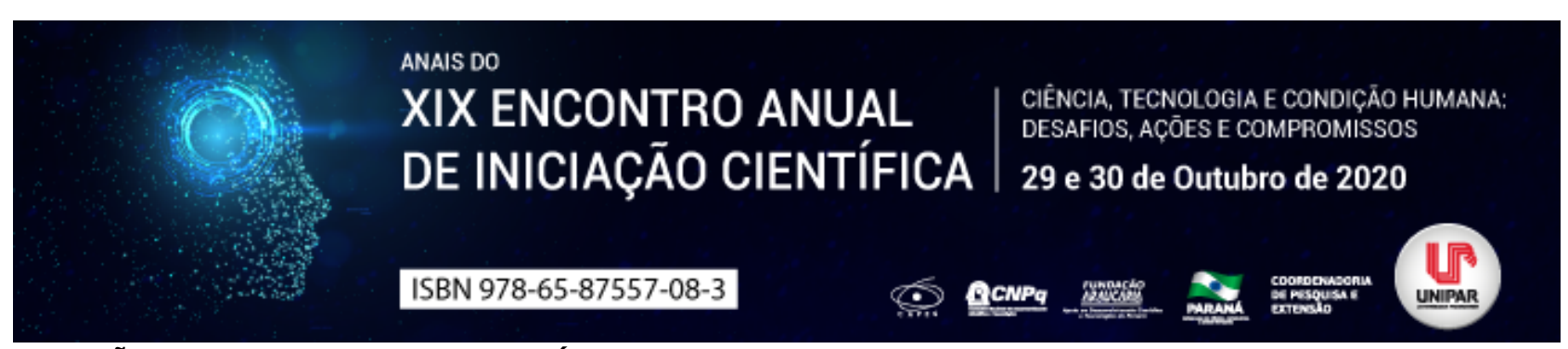

CONCENTRAÇÃO DE ZINCO TOTAL DISPONÍVEL EM FOLHAS DE ORA PRO NOBIS (Pereskia grandifolia haw e Pereskia aculeat mill)

\title{
${ }^{1}$ LARISSA LOURENCETO, ${ }^{2}$ WESLEY RIBEIRO RIVADAVEA, ${ }^{3}$ GABRIEL SABATINI PEREIRA, ${ }^{4}$ AMANDHA MELO DOS SANTOS, ${ }^{5}$ JULLIANE DESTRO DE LIMA, ${ }^{6}$ GLACY JAQUELINE DA SILVA
}

\author{
${ }^{1}$ Acadêmico, Bolsista do PEBIC/CNPQ \\ ${ }^{1}$ Acadêmico do Curso de Engenharia Agronômica da UNIPAR \\ ${ }^{2}$ Acadêmico do Curso de Engenharia Agronômica da UNIPAR \\ ${ }^{3}$ Acadêmica do Curso de Engenharia Agronômica da UNIPAR \\ ${ }^{4}$ Acadêmica do Curso de Doutorado Em Biotecnologia Aplicada A Agricultura - Turma VII da UNIPAR \\ ${ }^{5}$ Docente da UNIPAR
}

Introdução: A busca por uma dieta equilibrada e alimentos com maiores teores de micro e macro-nutrientes promove a manutenção da saúde. A carência de zinco também tem sido considerada como problema de saúde pública, pois a falta deste mineral favorece o aparecimento de doenças relacionadas às alterações das funções bioquímicas e imunológicas (MARQUES, 2006; MUSTACCHI, 2017), pois o zinco exerce importantes funções cognitivas, tireoidiana, mineralização óssea, secreção hormonal, regulação de genes, estabiliza a membrana celular, e está presente nos processos metabólicos, atuando na atividades enzimáticas e no metabolismo energético, dentre outras funções (CIAMPO, 2014).Trepadeira nativa da flora brasileira, com boas características agronômicas (SOUZA et al., 2014), a ora-pro-nóbis é uma hortaliça não-convencional e possui maior valor nutricional (OLIVEIRA, et al. 2013) como fibras, Ferro, carotenóides, Zinco, Magnésio, Cálcio, Potássio quando comparado com às hortaliças convencionais (TOFANELLI; RESENDE, 2011). Devido à quantidade relativamente grande de proteínas (Kinupp, et al., 2008; SILVA et al., 2018;), é considerada uma alternativa para o incremento na alimentação humana e animal. Seu potencial de produção e quantidade de nutrientes é de suma importância, embora seu consumo seja negligenciado, pois as informações referente a composição de zinco da ora-pro-nóbis na literatura ainda é pouca.

Objetivo: O intuito deste trabalho foi avaliar a concentração de zinco total, espécies ( Pereskia grandifolia haw e Pereskia aculeat mill.)

Metodologia: O trabalho foi conduzido no Laboratório de Biologia Molecular (UNIPAR), Casa de Vegetação (UNIPAR) e Laboratório de Química orgânica da Universidade estadual oeste do Paraná (UNIOESTE). As amostras de folhas de Ora-pronobis amarela (Pereskia aculeat mill) e Ora-pro-nobis rosa (Pereskia grandifolia haw). Para a determinação de zinco foi utilizado o seguinte método official methods of analysis, association of official analytical chemists, 40a ed, usa, 1984, que foram pesados $100 \mathrm{~g}$ de amostra que foram colhidas e secas em estufa de circulação de ar a $35{ }^{\circ} \mathrm{C}$ por 28 dias, moídas em moinhos de facas da marca marconi modelo especial 60 ciclos, peneiradas a 30 mesh, acondicionadas em embalagem plástica de polietileno e mantidas refrigeradas à aproximadamente $11^{\circ} \mathrm{C}$ até $\mathrm{o}$ momento das análises, para as concentrações de zinco utilizou-se a metodologia proposta por official methods of analysis, association of official analytical chemists, 40a ed, usa, 1984. que foram adicionados $1: 12$ de hno3 $1 \mathrm{~m}$ à $32^{\circ} \mathrm{c} 48 \mathrm{~h}$, aquecido a $100^{\circ} \mathrm{c}$ até evaporação, posteriormente adicionado $1: 6$ h2o2, filtrado e ajustado o volume para $10 \mathrm{ml}$. Após foram realizados a leitura espectrofotômetro de absorção atômica com chama (marca gbc modelo 932) no laboratório de química orgânica da universidade oeste do Paraná.

Resultados e Discussão: O conteúdo de teor zinco disponível para a Ora pro nobis amarela é de $36 \mathrm{mg} / 100 \mathrm{~g}$ para Ora pro nobis amarela e a quantidade de zinco para ora pro nobis rosa foi de $26 \mathrm{mg} / 100 \mathrm{~g}$. Segundo Takeiti et al. (2009) as folhas da orapro-nóbis são ricas fontes de zinco $(26,71 \mathrm{mg} / 100 \mathrm{~g})$. Oliveira et al. (2013)reportaram valores mais baixos de $5,9 \mathrm{mg} / 100 \mathrm{~g}$ para 0 zinco, Cremasco et al. (2016) obtiveram valores semelhantes, de $4 \mathrm{mg} / 100 \mathrm{~g}$ e 10,6 mg/100g para zinco.

Conclusão: Assim este estudo relata que as folhas de ora pro nobis amarela apresentam uma maior concentração de zinco quanto comparada a outra espécie, e ambas as espécies estão de acordo com as quantidade de zinco encontradas na literatura, confirmando seu alto teor deste nutriente, sendo essa planta recomendada para consumo humano e animal, como importante fonte de zinco.

\section{Referências}

ASSOCIATION OF OFFICIAL ANALYTICAL CHEMISTS. Official Methods of Analysis. 14th ed. 1984. CARVALHO, M. C. DE; BARACAT, E. C. E.; SGARBIERI, V. C. Anemia ferropriva e anemia de doença crônica: distúrbios do metabolismo de ferro. Segurança Alimentar e Nutricional, v. 13, n. 2, p. 54-63, 11.

TAKEITI, C.Y. et al. Nutritive evaluation of non-conventional leafy vegetable (Pereskia aculeata Miller). International Journal of 
Food Sciences and Nutrition, v.60, n.1, p.148-160, 2009.

CIAMPO, L. A. D.; CIAMPO, I. R. L. D. A importância do zinco para a saúde do adolescente. Adolescência \& Saude, Rio de Janeiro, v. 11, n. 2, p 90-96, 2014.

CREMASCO, C. P. et al. BROMATOLOGICAL AND SENSORIAL EVALUATION OF PERESKIA ACULEATA USE IN PASTA DOUGH C. Brazilian Journal of Biosystems Engineering, v. 10, n. 3, p. 234 240, 2016.

KINUPP VF; BARROS IBI. 2008. Teores de proteína e minerais de espécies nativas, potenciais hortaliças e frutas. Ciências e Tecnologia de Alimentos 28: 846-857.

MARQUES, R. C.; MARREIRO, D. N. Aspectos metabólicos e funcionais do zinco na Síndrome de Down. Revista de Nutrição, Campinas, v. 19, n. 4, p. 501- 510, 2006.

MUSTACCHI, Z.; SALMONA, P.; MUSTACCHI, R. Trissomia 21 ( Síndrome de Down): nutrição, educação e saúde. São Paulo: Memnon, 2017.

OLIVEIRA, Danyela de Cássia da S et al . Composição mineral e teor de ácido ascórbico nas folhas de quatro espécies olerícolas não-convencionais. Hortic. Bras., Vitoria da Conquista, v. 31, n. 3, p. 472-475, Sept. 2013.

SILVA, Débora $\mathrm{O}$ et al. Phenological and physicochemical properties of Pereskia aculeata during cultivation in south Brazil. Hortic. Bras., Vitoria da Conquista, v. 36, n. 3, p. 325-329, set. 2018.

SOUSA, Raquel. M. F. et al. Atividade de antioxidante de extratos de folhas de ora-Pronóbis (Pereskia aculeata Mill.) usando métodos espectrofotométricos e volumétricos in vitro. Biosci. J., v. 30, n. suplemento 1, p. $448457,2014$.

TOFANELLI, Mauro Brasil Dias.; RESENDE, Sueilo Gouveia. Sistemas de condução na produção de folhas de ora-pro-nobis. Pesquisa Agropecuária Tropical, v. 41, n. 3, p. 466 469, 2011. 


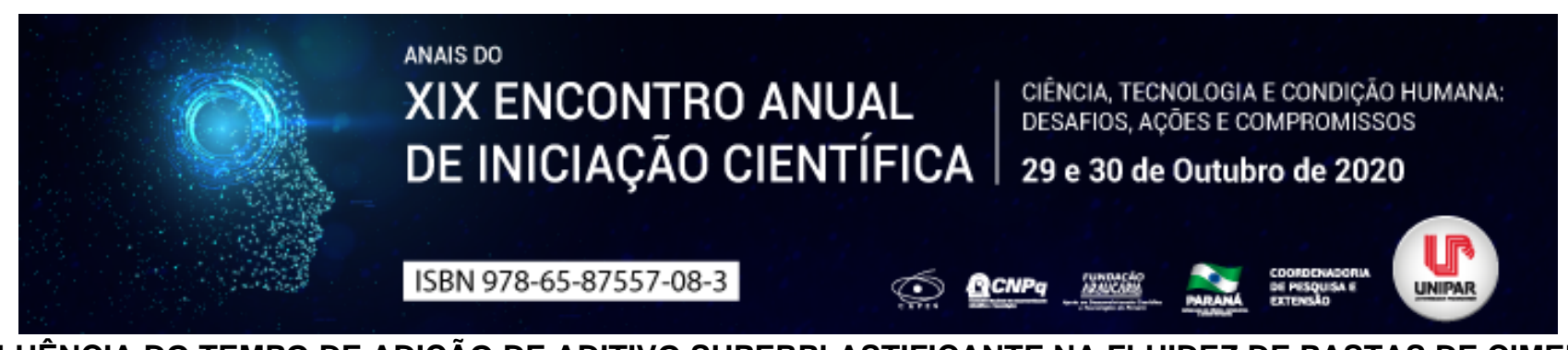

INFLUÊNCIA DO TEMPO DE ADIÇÃO DE ADITIVO SUPERPLASTIFICANTE NA FLUIDEZ DE PASTAS DE CIMENTO PORTLAND

\author{
${ }^{1}$ CARLOS NATA ZENATTI, ${ }^{2}$ VITORIA BOHLER PICCOLI, ${ }^{3}$ NATHALIA RAFAELA PONTIN, ${ }^{4}$ PAMMELLI AMANDA DANTAS \\ GUMIERO, ${ }^{5}$ DANIELE CHRISTINE NONATTO, ${ }^{6}$ CLEDISON ZATTA VALDAMERI
}

\begin{abstract}
${ }^{1}$ Acadêmica do Curso de Engenharia Civil da UNIPAR
${ }^{1}$ Acadêmica do Curso de Engenharia Civil da UNIPAR

${ }^{2}$ Acadêmica do Curso de Engenharia Civil da UNIPAR

${ }^{3}$ Acadêmica do Curso de Engenharia Civil da UNIPAR

${ }^{4}$ Acadêmica do Curso de Engenharia Civil da UNIPAR

${ }^{5}$ Docente da UNIPAR
\end{abstract}

Introdução: Aditivos químicos possuem suma importância na melhoria de propriedades de concretos e argamassas, viabilizando obras de grande complexidade e também aumentando a vida útil das estruturas. Tais aditivos são denominados de produtos adicionados durante a produção de concretos, em quantidades inferiores a 5\%, para melhoras suas propriedades (NBR 11768-1, 2019). Os principais aditivos utilizados são os redutores de água, onde possuem como função primária a capacidade de produção de concretos com dada trabalhabilidade e fator de compactação com redução da relação água-cimento em relação à de um concreto sem adição (RIXOM e MAILVAGANAM, 1999). Nesta contextualização, os aditivos redutores de água do tipo superplastificante são uma alternativa para concretos com necessidades de grandes resistências mecânicas e desempenhos superiores no estado fresco e podem ser classificados pelo ter seus desempenhos comparados pelos métodos apresentados pela NBR 11768-2 (2019). As reações iniciais de hidratação do cimento possuem cinéticas químicas diferentes em relação aos tipos de cimentos, já que, existem consideráveis diferenças químicas e físicas envolvendo suas composições, assim, o consumo de aditivo pode ser diferente para cada cimento e existe a possibilidade de desperdiçar o aditivo para as reações iniciais de hidratação, dependendo do momento que que o aditivo entra nas misturas, tendo em vista a rápida formação de uma camada de etringita na superfície do grão que bloqueia a hidratação temporariamente (AITICIN E BARON, 1996).

Objetivo: Avaliação da fluidez de pastas de cimento Portland produzidas com diferentes tempos de adição de aditivo superplastificante.

Metodologia: Para o estudo foram utilizados cimento Portland do tipo CPV e aditivo superplatificante de terceira geração, a base de policarboxilatos, em proporção de $0,6 \%$ em relação a massa de cimento. Foram produzidas três distintas misturas de pastas, todas com a mesma relação água-cimento e com a variável no tempo no qual o aditivo entrou na mistura. Os tempos utilizados foram: zero (P0), cinco (P5) e dez (10) minutos. No tempo P0 o aditivo foi diluído na água de amassamento, no demais, foi lançado sobre as pastas previamente misturadas. Os procedimentos de misturas foram: P0, diluição do aditivo em água, adição de água, posteriormente cimento em argamassadeira e mistura por 30 segundos em velocidade lenta e posterior 30 segundos em velocidade alta. P5, a água e o cimento foram misturados por 30 segundos em velocidade lenta, limpeza de pás e bordas de cuba por 15 segundos, repouso da pasta por 5 minutos, lançamento do aditivo e mistura em velocidade alta por 30 segundos. P10, o procedimento foi idêntico ao realizado com P5, sendo alterado o tempo de repouso, neste caso utilizando 10 minutos. Com as pastas produzidas, imediatamente as misturas, foram adicionadas ao funil a um funil de marsh para a avaliação de fluidez. Foram computados os tempos para verter todo o material pelo orifício inferior do funil, procedimento adaptado da NBR 7681-2 (2013). Ressalta-se que as pastas foram avaliadas em duplicata e os resultados apresentam suas médias.

Resultados: Pasta P0: 58,25 ; Pasta P5: 40,76 ; Pasta P10: 46,76

Discussão: Os resultados mostraram que a dissolução do aditivo em água, proporcionou menor fluidez, comparado aos demais tempos estudados. Isso é explicado já que, conforme Rojas e Cincotto (2013), os aditivos dispersantes são polímeros de estrutura combinada que se adsorvem às partículas do cimento e estabilizam o sistema por repulsão estérica. Neste sentido e comparando os resultados observados, pode-se destacar que as moléculas do aditivo utilizado não competiram nas reações iniciais, para formação da etringita, quando o aditivo foi adicionado de forma retardada, levando aos melhores resultados de fluidez, já que estavam em maior disponibilidade para cumprir a sua função de repulsão das partículas do cimento. $\mathrm{O}$ fator de P5 possuir o melhor resultado de fluidez pode representar uma hipótese de que existe um intervalo ótimo para a inserção, tendo em vista a própria estabilidade do aditivo dentro do sistema, ou reações posteriores a esse tempo na hidratação do cimento que levam ao seu consumo, já que P10 tendeu a retornar aos resultados de P0.

Conclusão: A adição retardada de aditivo superplastificante em pasta de cimento foi superior a dispersão em água de amassamento, tendo melhor desempenho ao ser adicionado com 5 minutos após a mistura com água. Como aos 10 minutos 
existiu tendência de redução de fluidez, cabe recomendações futuras para análises em tempos superiores ao estudo apresentado.

\section{Referências}

AITICIN, Pierre Claudete. Materials selection. In: AITICIN, Pierre Claudete, High Performance Concrete. Londres: E \& FN Spon, 1998. p. 170 - 192.

ASSOCIAÇÃO BRASILEIRA DE NORMAS TÉCNICAS. NBR 11768-1, Aditivos químicos para concreto de cimento Portland - Requisitos. Rio de Janeiro, 2019.

ASSOCIAÇÃO BRASILEIRA DE NORMAS TÉCNICAS. NBR 11768-2, Aditivos químicos para concreto de cimento Portland Ensaio de desempenho. Rio de Janeiro, 2019.

ASSOCIAÇÃO BRASILEIRA DE NORMAS TÉCNICAS. NBR 7682-2, Calda de cimento para injeção - Determinação do índice de fluidez e vida útil - Método de ensaio. Rio de Janeiro, 2013.

RIXOM, Roger; MAILVAGANAM, Noel. Chemical Admixtures for Concrete. 3. ed. E \& FN SPON, 1999.

ROJAS, Caroline Martínez; CINCOTTO, Maria Alba. Influência da estrutura molecular dos policarboxilatos na hidratação do cimento Portland. Ambiente Construído, Porto Alegre, v. 13, n. 3, p. 267-283, jul./set. 2013. 


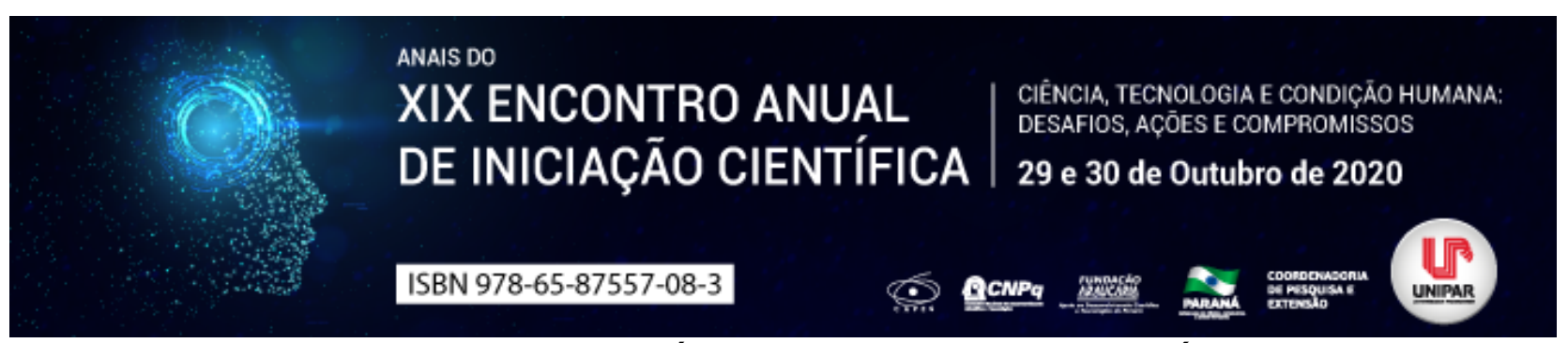

LEVANTAMENTO E DIAGNÓSTICO DE PROPRIEDADES AGRÍCOLAS

\begin{abstract}
${ }^{1}$ João Marcos Berto, ${ }^{2}$ RENILZA RITA dE CASSIA dA SILVA, ${ }^{3}$ WESLEI AUGUSTO MENDONÇA, ${ }^{4}$ JOÃO DE ANDRADE BONETTI
\end{abstract}

\begin{abstract}
${ }^{1}$ Discentes do curso de Agronomia da Universidade Estadual de Maringá e Bolsista PET-MEC/SESu.
${ }^{1}$ Discentes do curso de Agronomia da Universidade Estadual de Maringá e Bolsista PET-MEC/SESu.

${ }^{2}$ Discentes do curso de Agronomia da Universidade Estadual de Maringá e membro Não-Bolsista PET-MEC/SESu.

${ }^{3}$ Docente do Departamento de Agronomia da Universidade Estadual de Maringá
\end{abstract}

Introdução: O setor agrícola demanda de planejamento para que administrador tenha maior possibilidade de acerto nas tomadas de decisão. Frente a isso, o levantamento de dados gerais confiáveis e atualizados possibilitam priorizar alternativas mais viáveis economicamente e mais adequadas às condições locais de solo, infra-estrutura, comercialização e outros (EMBRAPA, 2006). Já o diagnóstico, resultado de um sistema de informações internas e externas da propriedade, envolve a coleta ou levantamento, registros, ordenação, análise ou interpretação e síntese de dados, fatos e informações, comparados a uma situação desejada (EMATER, 2004). Portanto, o administrador de uma empresa rural deve assumir ações eficazes com o intuito de diminuir os riscos causados por esses fatores, dispor de conhecimentos metodológicos para o desempenho de ações de assistência técnica e gerencial, para gerar melhorias tanto nos recursos financeiros, quanto nos processos culturais e ambientais.

Objetivo: O objetivo desse trabalho é discutir sobre a importância do levantamento e diagnóstico dentro de uma propriedade, visando alertar sobre seus benefícios para a sustentabilidade dos agricultores.

Desenvolvimento: Para realizar o levantamento e diagnóstico de uma propriedade agrícola deve-se considerar vários aspectos, sendo eles: caracterização do município, localização geográfica, Índice de Desenvolvimento Humano, Produto interno Bruto, renda per capita, clima, entre outros, pois afetam diretamente o valor da propriedade rural. Por exemplo, o clima possui uma relação determinante para o processo de produção, dessa forma é necessário realizar um levantamento dos dados climáticos para a região, com intuito de utilizar culturas mais adaptadas para a região e estabelecer estratégias de manejo visando evitar ou diminuir possíveis danos as culturas. A caracterização do produtor é uma etapa importante, pois a partir deste será realizado o planejamento. Algumas informações são obtidas, como; se é associado a cooperativas e quem é responsável técnico da propriedade. É também necessário identificar o seu nível de adoção de inovações tecnológicas, avaliada de acordo com Rogers \& Scott (1997). Após obter essas informações acima citadas deve-se realizar a caracterização e identificação da propriedade rural como: atividade comercial, área total, área de plantio, reserva legal, recursos humanos, área própria ou arrendada (neste caso identificar o tempo de contrato), entre outros. Recursos existentes na propriedade, como por exemplo o hídrico deve ser criteriosamente avaliado quanto a qualidade da água para uso agrícola (características físico-químicas) e consumo humano (potabilidade). Adicionalmente, deve-se realizar o levantamento de toda infraestrutura da propriedade rural, cada unidade produtiva necessária à atividade estabelecida, galpões de máquinas, instalações para a criação de animais, escritório, casas de colaboradores e outros. É indispensável fazer o levantamento dos maquinários considerando seu modelo, estado de conservação, valor atual e ano, para posterior cálculos de depreciação e avaliar se os itens citados estão aptos a atende a necessidade do produtor. Em relação ao solo, recomenda-se que seja efetuado um levantamento completo, que leva em consideração sua classificação de capacidade de uso, a análise de fertilidade para postular sobre a adubação correta, avaliar aspectos físicos e de conservação do solo para reduzir os impactos no crescimento e desenvolvimento das raízes de plantas e na possível erosão e contaminação da água. As atividades agrícolas da propriedade precisam ser descritas com detalhe, relatando as culturas cultivadas, tratos culturais (adubo, espaçamento, profundidade, produtos fitossanitários e suas respectivas doses) e a produtividade e produção final. Ao final de cada cultivo, o custo da produção deve ser realizado com objetivo de calcular custos fixos e variáveis da produção. Essa prática possibilita determinar se houve lucros com a atividade. Em adição, é fundamental a realização da análise de SWOT (Strengths Weaknesses Opportunities Threats) (GALVÃO, MELO, 2008), avaliação global que verifica os pontos fortes, fracos, oportunidades e ameaças, para estabelecer o planejamento estratégico para os próximos cultivos.

Conclusão: O levantamento e diagnóstico é uma ferramenta que aumenta o conhecimento do produtor e reduz os riscos na atividade agrícola. Possibilita observar os diferentes processos que fazem parte da atividade agrícola, além de calcular e interpretar indicadores técnicos e econômicos e realizar o planejamento estratégico da propriedade. Ao analisar o sistema de produção de uma empresa rural busca-se alternativas para melhorias necessárias, que possibilitem o planejamento dos ganhos conforme os objetivos do produtor na busca do desenvolvimento. A atividade agrícola planejada e realizada de forma adequada, pode ser rentável e ao mesmo tempo sustentável. A constante necessidade de buscar sistemas produtivos cada vez mais competitivos financeiramente, garante a viabilidade econômica da atividade, ressalta a importância da orientação profissional. 


\section{Referências}

GALVÃO, Nathallye de Souza Dantas; MELO, Rodrigo de Souza. O método de análise SWOT como ferramenta para promover o diagnóstico turístico de um local: o caso do município de Itabaiana (PB). Caderno Virtual de turismo, Vol. 8, № 1, 2008. Disponível em: http://www.ivt.coppe.ufrj.br/caderno/index.php/caderno/article/view/272. Acesso em: 24 ago. 2020.

OLIVEIRA, Stanley Robson de Madeiros; ROMANI, Luciana Alvim Santos; ASSAD, Eduardo Delgado; PINTO, Hilton Silveira; JÚNIOR, Jurandir Zullo; PEREIRA, Vanildo Heleno; SOUZA, Antônio Carlos. Sistema de suporte ao planejamento e levantamento agrícola municipal. EMBRAPA, comunicado técnico 73, Campinas, novembro de 2006. Disponível em: https://ainfo.cnptia.embrapa.br/digital/bitstream/CNPTIA/11385/1/ct73.pdf. Acesso 25 ago. 2020.

ROGERS, Everett. M.; SCOTT, Karyn, L. The diffusion of innovations Model and Outreach from the Nacional Network of Libraries of Medicine to Native American Communities. Draft paper prepared for the National Network of Libraries of Medicine, Pacific Northwest Region, Seattle. December 10, 1997. Disponível em: https://communitas.co.za/the-diffusion-of-innovations-modeland-outreach-from-the-national-network-of-libraries-of-medicine-to-native-american-communities-2/. Acesso em: 27 ago. 2020.

SEPULCRI, Odilio. Planejamento da propriedade rural familiar, EMATER, Curitiba, setembro de 2004. Disponível em: http://www.emater.pr.gov.br/arquivos/File/Biblioteca_Virtual/Premio_Extensao_Rural/1_Premio_ER/Planej_Prop_Rural_Fam.pdf. Acesso 25 ago. 2020. 


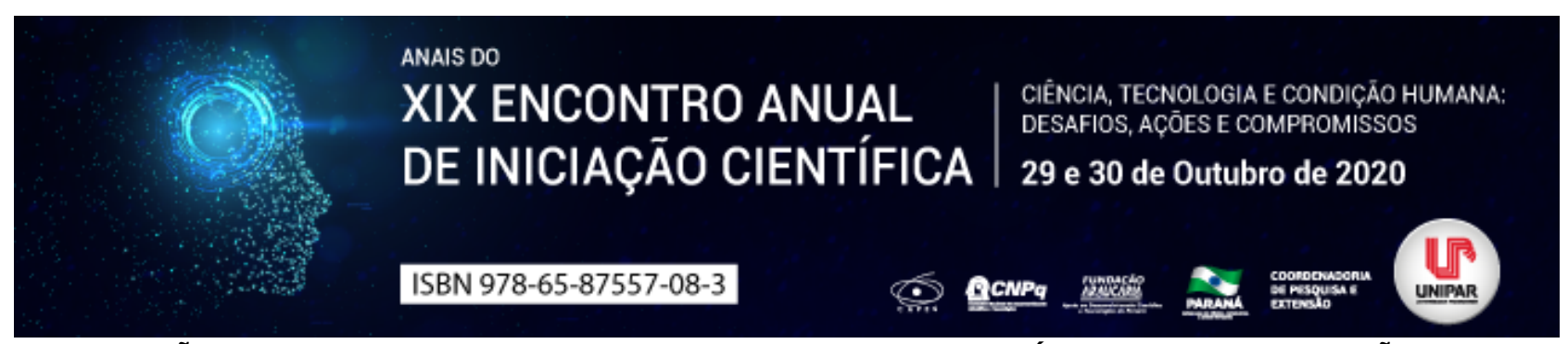

RELAÇÃO ENTRE O DESTINO E O APROVEITAMENTO DOS RESÍDUOS DA CONSTRUÇÃO CIVIL

\begin{abstract}
${ }^{1}$ NATALIA PINHEIRO D ONOFRE DA SILVA, ${ }^{2}$ CHEILA BRAMBILLA FREIRE, ${ }^{3}$ MILENA GABRIELA FERREIRA HAYASHIDA, ${ }^{4}$ ROSILEY BERTON PACHECO, ${ }^{5}$ VANDA ZAGO LUPEPSA
\end{abstract}

\author{
${ }^{1}$ Discente PIC do Curso de Engenharia Civil da UNIPAR \\ ${ }^{1}$ Discente PIC do Curso de Engenharia Civil da UNIPAR \\ ${ }^{2}$ Discente PIC do Curso de Engenharia Civil da UNIPAR \\ ${ }^{3}$ Docente da UNIPAR \\ ${ }^{4}$ Docente da UNIPAR
}

Introdução: No presente, uma das pautas mais discutidas no mundo é a sustentabilidade. A ideia de deixar para a próxima geração não só valores, mas também um mundo onde viver seja possível. Associada à expansão demográfica do país, e, segundo Fernandes (2015), com o crescimento acelerado do mercado da construção civil, ocorreu uma maior procura por matéria prima. A brita e areia, por exemplo, são recursos naturais, e por este motivo precisam de jazidas para exploração. Essa exploração compromete o meio ambiente, sem falar que é uma fonte esgotável, ou seja, pode acabar um dia. Eguchi et al (2007), citado por Lovato (2007), estimaram que a indústria da construção gerou 75 milhões de toneladas de resíduos industriais e que os resíduos de construção civil (RCC) representam, em média, 50\% da massa dos resíduos sólidos urbanos (RSU). Lovato (2007) ainda afirma que a questão ambiental na atividade da construção civil ganhou relevância nos últimos anos, assim como a preocupação com a escassez de recursos naturais, os impactos causados ao meio ambiente, e a geração e deposição inadequadas de resíduos. Segundo a resolução CONAMA n 307 (2002), que rege as diretrizes para a gestão de resíduos da construção civil, os geradores deverão ter como objetivo prioritário a não geração de resíduos e, secundariamente, a redução, a reutilização, a reciclagem e a destinação final.

Objetivo: Apresentar a relação entre a destinação e o aproveitamento dos resíduos da construção civil.

Desenvolvimento: São chamados de resíduos de construção aqueles que são os provenientes de construções, reformas, reparos e demolições de obras de construção civil, podendo ser citados os tijolos, blocos cerâmicos, concreto em geral, rochas, entre outros. Conforme a Resolução CONAMA nº 307 (2002), deverão ser reutilizados ou reciclados na forma de agregados, ou encaminhados a áreas de aterro de resíduos da construção civil, que são áreas onde serão empregadas técnicas de disposição de resíduos da construção civil Classe A no solo, visando a reservação de materiais segregados de forma a possibilitar seu uso futuro. Entre as alternativas para a reutilização dos resíduos, destaca-se a aplicação do mesmo como agregado alternativo, em substituição total ou parcial, ao natural. Os resíduos de construção e demolição (RCD) podem ser reciclados na forma de agregados reciclados através de um beneficiamento, constituído basicamente de operações de triagem, britagem e peneiramento (GRUBBA, 2009). Faz-se necessário ressaltar a distinção entre os termos empregados na hora de classificar a utilização de tais materiais, ainda dispostos pela Resolução CONAMA $n^{\circ} 307$, onde, reutilização é o processo de reaplicação de um resíduo, sem transformação do mesmo. Reciclagem é o processo de reaproveitamento de um resíduo, após ter sido submetido à transformação, e o beneficiamento é o ato de submeter um resíduo à operações e/ou processos que tenham por objetivo dotá-los de condições que permitam que sejam utilizados como matéria-prima ou produto. Um cuidado inadequado dos resíduos sólidos contribui para o aumento dos problemas ambientais. Ao passar pela etapa de descarte, os materiais devem ser separados corretamente entre si, começando nos próprios locais onde originalmente são gerados, em construções e reformas. A reciclagem de RCD traz benefícios econômicos e ambientais para as cidades em que é implantada. Além da diminuição dos custos de gerenciamento do resíduo, o custo do produto reciclado é bem menor que o agregado natural (BRASILEIRO e MATOS, 2015). Segundo Fernandez (2012), o Instituto de Pesquisa Econômica Aplicada (IPEA) ao realizar uma pesquisa sobre Diagnóstico de Resíduos Sólidos da Construção Civil, relata que alguns obstáculos encontrados para o planejamento de gerenciamento adequado é a ausência de conhecimento dos resíduos, falta da cultura de separação e aumento de novos materiais.

Conclusão: Com base da normativa, cabe a nós, geradores de resíduos quando possível, não gerar resíduos, mas uma vez que seja imprescindível, devemos visar a reutilização e reciclagem, e por fim, a destinação adequada dos mesmos. O uso de resíduos como agregado alternativo na produção de concreto mostra-se favorável em questões financeiras, mas principalmente no que se refere a redução de impactos ambientais, visto que minimiza a exploração por matéria-prima.

\title{
Referências
}

BRASILEIRO, Luzana Leite; MATOS, José Milton Elias de. Revisão bibliográfica: reutilização de resíduos da construção e demolição na indústria da construção civil. Cerâmica, v. 61, n. 358, p. 178-189, $2015 . \quad$ Disponível em: 
https://www.scielo.br/scielo.php?pid=S0366-69132015000200178\&script=sci_arttext. Acesso em 03 de set. de 2020.

FERNANDES, Bruna Cristina Mirandola. A utilização de resíduos na construção civil e demolição RCD como agregado para o concreto. UNIFOR, Formiga, 2015. Disponível em: https://www.passeidireto.com/arquivo/73861219/a-utilizacao-deresiduos-da-construcao-civil-e-demolicao-rcd. Acesso em: 18 ago. 2020.

FERNANDEZ, Jaqueline Aparecida Bória. Diagnóstico dos resíduos sólidos da construção civil. Brasília: IPEA, 2012. Disponível em: http://repositorio.ipea.gov.br/bitstream/11058/7669/1/RP_Diagnóstico_2012.pdf. Acesso em: 29 ago. 2020.

GRUBBA, David Christian Regis Pereira. Estudo do comportamento mecânico de um agregado reciclado de concreto para utilização na construção rodoviária. 2009. Tese de Doutorado. Universidade de São Paulo. Disponível em: https://teses.usp.br/teses/disponiveis//18/18143/tde-01122009-140152/pt-br.php. Acesso em: 25 ago. 2020.

LOVATO, Patrícia Silveira. Verificação dos parâmetros de controle de agregados reciclados de resíduos de construção e demolição para utilização em concreto. 2007. 180p. Dissertação (Mestrado em Engenharia) - Escola de Engenharia, Programa de Pós-graduação em Engenharia Civil, Universidade Federal do Rio Grande do Sul, Porto Alegre, 2007. Disponível em: https://www.lume.ufrgs.br/bitstream/handle/10183/10609/000598258.pdf?sequence=1. Acesso em: 03 de set. 2020.

RESOLUÇÃO CONAMA. № 307, de 05 de julho de 2002. Estabelece diretrizes, critérios e procedimentos para a gestão dos resíduos da construção civil. Publicada no DOU de $n^{\circ} 136$, v. 17, 2002. Disponível em: https://www.mma.gov.br/estruturas/a3p/_arquivos/36_09102008030504.pdf. Acesso em: 18 ago. 2020. 


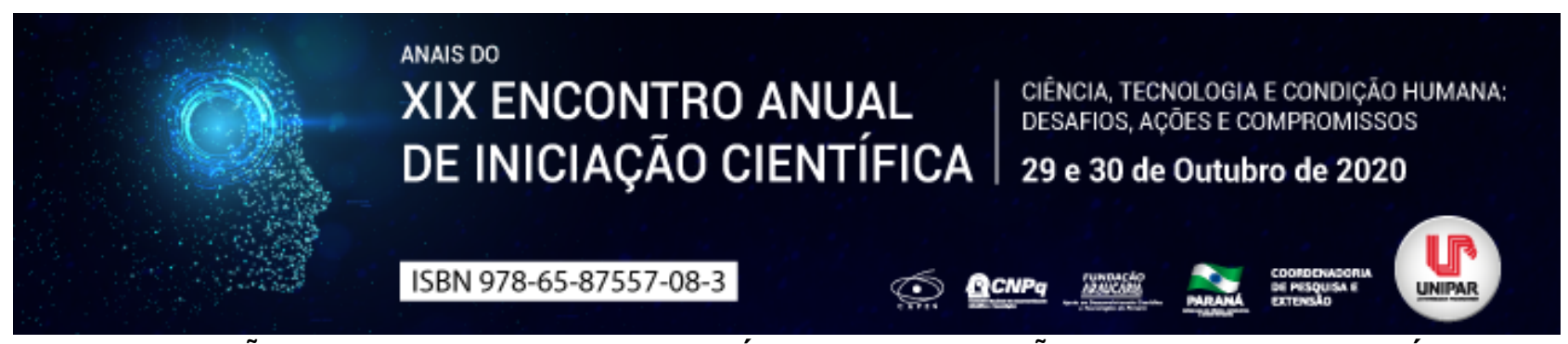

\title{
TESTE DE COMPRESSÃO DE CONCRETO LEVE ATRAVÉS DA SUBSTITUIÇÃO DO AGREGADO GRAÚDO POR GRÃOS DE PET (Poli Tereftalato de Etileno)
}

\author{
${ }^{1}$ EDUARDA CANTON, ${ }^{2}$ AMANDA MARTIN LIMA, ${ }^{3}$ ARIELE RAIANNE DE SOUZA, ${ }^{4}$ VERONICA CRISTINA DALLACORT \\ PASQUAL, ${ }^{5}$ SAVIO DE MELO SANTOS, ${ }^{6}$ CRISTIANO GOULART
}

\author{
${ }^{1}$ Acadêmico do PIC/UNIPAR \\ ${ }^{1}$ Acadêmica do Curso de Arquitetura e Urbanismo da UNIPAR \\ ${ }^{2}$ Acadêmica do Curso de Engenharia Civil da UNIPAR \\ ${ }^{3}$ Acadêmica do Curso de Arquitetura e Urbanismo da UNIPAR \\ ${ }^{4}$ Acadêmico do Curso de Engenharia Civil da UNIPAR \\ ${ }^{5}$ Docente da UNIPAR
}

Introdução: O concreto é um material utilizado em larga escala mundialmente e seu consumo vem crescendo a cada ano. Este material abrange uma enorme gama de utilizações, isto se dá por ele ser um material de elevada resistência e fácil moldagem, é amplamente usado, e é o segundo material mais consumido no mundo, seu consumo anual é estimado em 11 bilhões de toneladas, perdendo somente para o consumo de água. (PEDROSO, 2009). Cada vez mais presente nas obras, o concreto pré moldado se destaca devido à sua praticidade, rapidez e baixo custo. Uma obra com utilização de peças pré moldadas pode ser finalizada até 5 vezes mais rápido que uma obra convencional. O elevado peso das peças pré moldadas é o fator desvantajoso, sendo interessante inserir materiais alternativos com massa específica inferior aos agregados convencionais, acarretando em uma grande redução de peso, avaliando se esta substituição acarreta na perda de resistência do concreto. (GARCEZ, SANTOS E GATTO, 2013). O Politereftalato de etileno mais conhecido como PET, é um material de inúmeras utilizações do nosso cotidiano. Segundo a ABIPET o consumo anual do Brasil em 2016 foi de 840.000 toneladas de PET e este consumo vem aumentando a cada ano. A parte negativa desta grande produção, é que se este material amplamente utilizado não for reciclado da forma correta e redirecionado a utilizações que absorvam tudo isto, ele será descartado de forma inadequada, gerando um grande impacto ambiental e climático ao planeta. (LIMA, 2016). O presente artigo tem como objetivo propor a união desses materiais citados anteriormente concreto e PET, realizando então ensaios de compressão em corpos de prova de concreto com substituições parciais dos agregados por agregado PET, no intuito de definir se este concreto tem características similares ao concreto estrutural e avaliando se poderia ser utilizado como matéria prima de estruturas de pré moldadas, comparando peso e resistência do concreto pré moldado convencional com o concreto pré moldado com substituição parcial de agregado por PET, buscando um concreto com peso específico reduzido, mantendo sua resistência à compressão e mais sustentável, extraindo menos recursos naturais para produção de agregados, e substituindo parte deste material por PET, dando uma destinação correta e útil ao PET reciclado.

Objetivo: Testar a resistência à compressão do concreto substituindo o agregado graúdo (geralmente rocha) por PET (Poli Tereftalato de Etileno), por ser um material que possui boas características mecânicas e uma massa específica menor quando comparado aos agregados graúdos geralmente utilizados na produção de concreto e comparar o peso do concreto base aos concretos com substituição, analisando se estes podem ser considerados concretos leves. Outra análise será feita ao compararmos à resistência à compressão do concreto base aos concretos com substituição parcial do agregado para definirmos se poderão ser utilizados como concretos estruturais em peças pré moldadas.

Material e Métodos: Os materiais utilizados foram água, cimento, areia, brita 0 e grãos de PET (não houve utilização de aditivos), para confecção dos concretos foi utilizado balança e betoneira, e para moldagem dos corpos de prova foram utilizados os moldes e haste para adensamento do concreto. Os grãos de PET utilizados foram adquiridos de uma empresa de Brusque SC, e sua granulometria será obtida através de ensaio de peneiramento, conforme ABNT - NBR 7217. Para desenvolvermos nosso estudo fizemos três tipos de concreto para fabricação de peças pré moldadas, um concreto convencional, e dois concretos com substituições de 15 e $25 \%$ de agregado graúdo por agregado PET, foram feitos 16 corpos de prova de cada concreto para serem rompidos com 3 e 28 dias de idade do concreto. Os corpos de prova moldados foram retirados dos moldes após 24 horas e colocados submergidos num recipiente com água para cura do concreto. Antes de serem rompidos eles ficarão 24 horas fora da água para secarem e então serem pesados e rompidos, os pesos serão comparados e resistência do concreto convencional base com os concretos com substituição parcial de agregado graúdo por agregado PET. Escolhemos o PET para substituição do agregado graúdo por ter um peso específico reduzido comparado aos materiais utilizados como agregado graúdo nos concretos e ter resistência à compressão similar à estes materiais.

Resultados: Devido aos atrasos na liberação dos laboratórios ocasionado pela pandemia devido a Covid-19, ainda não foram 
realizadas as pesagens e os testes à compressão dos corpos de prova, portanto, temos apenas os resultados esperados para este estudo. O resultado esperado é obter concretos leves, dos concretos com substituição parcial do agregado por agregadp PET, que tenham massa específica seca igual o inferior à $2000 \mathrm{~kg} / \mathrm{m}^{3}$, e resistência igual ou similar à resistência do concreto base, pensando na utilização deste concreto como um concreto estrutural à ser utilizado em peças pré moldadas.

\section{Referências}

AGPYAN, Vahan; JOHN, Vanderley M. O Desafio da Sustentabilidade na Construção Civil. 5 ed. São Paulo, Blucher, 2011. GARCEZ, Mônica Regina; SANTOS, Thiara; GATTO, Darci Alberto. AVALIAÇÃO DAS PROPRIEDADES FísICA E MECÂNICAS DE CONCRETOS PRÉ MOLDADOS COM ADIÇÃO DE SERRAGEM EM SUBSTITUIÇÃO AO AGREGADO MIÚDO, 2013, Universidade Federal de Pelotas- UFPel, Pelotas, RS.

PEDROSO, Fábio Luís. Concreto: as origens e a evolução do material construtivo mais usado pelo homem. Concreto \& Construções IBRACON, Ano XXXVII, No 53, Jan. Fev. Mar. 2009, disponível em http://ibracon.org.br/publicacoes/revistas_ibracon/rev_construcao/pdf/Revista_Concreto_53.pdf, acessado em 13 de maio de 2020.

ABIPET [s.l.], disponível em http://www.abipet.org.br/uploads/File/Market\%200verview\%202013.pdf, acessado em 20 de abril de 2020.

ABNT NBR 5739: Concreto Ensaio de Compressão de Corpos de Prova Cilíndricos. Rio de Janeiro, 2018.

ABNT NBR 8953: Concreto para fins estruturais Classificação por grupos de resistência. Rio de Janeiro, 2015.

BOTELHO, Manoel Henrique Campos; MARCHETTI, Osvaldemar. Concreto armado eu te amo. vol 1, 8 ed. São Paulo, Blucher, 2015.

RECENA, Fernando Antonio Piazza. Dosagem e Controle da Qualidade de Concretos Convencionais de Cimento Portland. 3 ed. Porto Alegre, EdiPUCRS, 2011. 


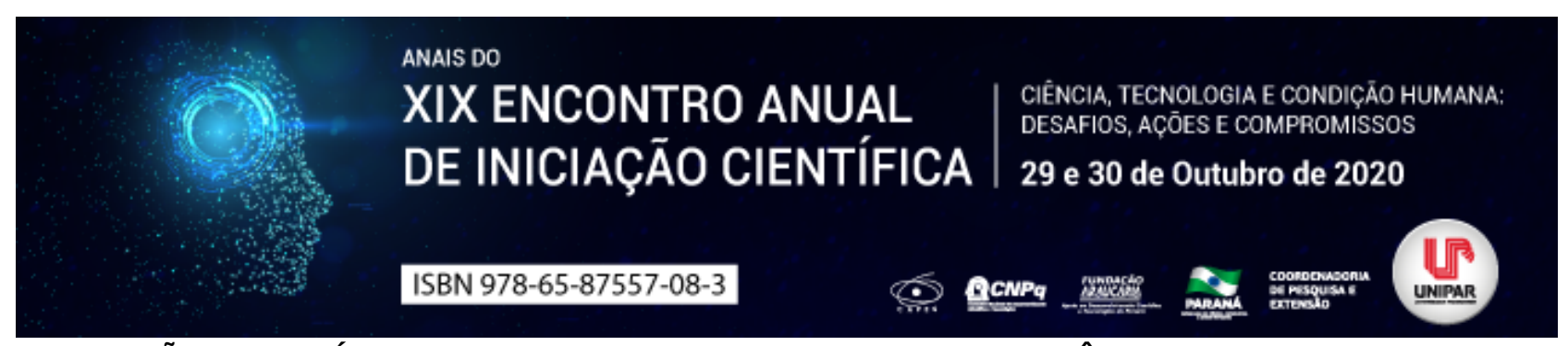

A IMPLEMENTAÇÃO DA LOGÍSTICA REVERSA DE PRODUTOS ELETROELETRÔNICOS NO BRASIL REGULAMENTADA PELO DECRETO No $10.240 / 2020$

\author{
${ }^{1}$ Junio Fernando de Alcântara, ${ }^{2}$ MÁRIAM TRIERVEILER PEREIRA
}

\author{
${ }^{1}$ Mestrando do Programa de Pós-Graduação em Sustentabilidade IFPR/UEM \\ ${ }^{1}$ Docente do Programa de Pós-Graduação em Sustentabilidade IFPR/UEM
}

Introdução: Em 2019, o Brasil gerou 2.143 milhões de toneladas de resíduos de equipamentos eletroeletrônicos (REEE), ou seja, 10,2 quilos por habitante segundo o relatório The Global E-waste Monitor, da Universidade das Nações Unidas (2020). O relatório também aponta que somente $0,7 \%$ deste montante é devidamente coletado, documentado e reciclado. Diante deste cenário, governos de diversas partes do mundo tem formulado leis e regramentos visando a gestão adequada dos REEE. Com a publicação do Decreto $n^{\circ}$ 10.240, de 12 de fevereiro de 2020, o Brasil avançou mais um passo neste tema, estabelecendo termos e regras para a implementação da logística reversa dos produtos eletroeletrônicos de uso doméstico e seus componentes (BRASIL, 2020).

Objetivo: Analisar como será a implementação e a operacionalização da logística reversa de produtos eletroeletrônicos de uso doméstico e seus componentes estabelecida pelo Decreto $\mathrm{n}^{\circ}$ 10.240, de 12 de fevereiro de 2020.

Desenvolvimento: A Política Nacional de Resíduos Sólidos (PNRS), instituída pela Lei no 12.305/2010, em seu artigo 33, obriga fabricantes, importadores, distribuidores e comerciantes de produtos eletroeletrônicos a estruturar e implementar sistemas de logística reversa, recolhendo produtos após o uso pelo consumidor e encaminhando estes para fabricantes ou importadores que poderão reaproveitar estes materiais no ciclo produtivo ou realizar a disposição final de forma ambientalmente adequada (BRASIL, 2010). Em outubro de 2019 foi assinado pelo governo federal o Acordo Setorial para a Logística Reversa de Eletroeletrônicos. Esse acordo foi elaborado por entidades que representam o setor eletroeletrônico no país e propõe termos e regras para a implementação da logística reversa de eletroeletrônicos de uso doméstico no Brasil. O documento foi submetido a consulta pública e recebeu 1.682 contribuições (BRASIL, 2019). Assim, o Decreto $n^{\circ}$ 10.240/2020 se baseou na proposta do Acordo Setorial e regulamentou o inciso VI do art. 33 e o art. 56 da PNRS, determinando que o sistema de logística reversa (SLR) dos produtos eletroeletrônicos de uso doméstico e seus componentes deve ser estruturado e implementado em duas fases. A primeira fase, de estruturação, inicia-se na data de publicação do decreto e tem conclusão prevista para 31/12/2020. Essa fase trata, entre outros temas, da formação do Grupo de Acompanhamento de Performance (GAP), da organização das empresas do setor de eletroeletrônicos referente a execução das atividades propostas pelo SLR e estruturação de mecanismos de financiamento e monitoramento do SLR. O GAP será integrado por entidades privadas que representam os fabricantes, importadores, distribuidores e comerciantes de produtos eletroeletrônicos em âmbito nacional. Este grupo tem como objetivos: i) acompanhar continuamente o andamento da implantação e operacionalização do SLR, ii) identificar possíveis obstáculos, iii) avaliar e debater resultados, e iv) propor revisões do cronograma e metas do sistema. A segunda fase terá início em 01/01/2021 e tratará da implementação e operacionalização do SLR. Nessa fase serão feitas as habilitações dos prestadores de serviços, serão estabelecidos os pontos de recebimento dos REEE e serão elaborados os planos de comunicação e divulgação da implantação do SLR. Com o decreto também se estabelece uma relação com 215 aparelhos eletroeletrônicos que abrange desde pequenos dispositivos, como cartão de memória, até grandes eletrodomésticos, como refrigeradores. Essa lista poderá ser revisada e alterada periodicamente pelo GAP e será publicada por meio do Sistema Nacional de Informações sobre a Gestão dos Resíduos Sólidos (SINIR) e por demais entidades participantes do SLR (BRASIL, 2020). Com relação as metas estabelecidas, a quantificação se dará pelo peso dos resíduos e o valor de referência será com base em estimativa do peso médio unitário dos produtos eletroeletrônicos comercializados no mercado interno no ano-base de 2018 , sendo esse cálculo uma obrigação dos fabricantes e importadores, podendo haver atualizações periódicas de acordo com a evolução do peso dos produtos. Seguindo esta metodologia, em um período de cinco anos (de 2021 a 2025) deverão ser coletados e corretamente destinados, respectivamente, 1, 3, 6, 12 e 17\% do peso total calculado dos REEE. A quantidade de municípios brasileiros atendidos pelo sistema também deverá aumentar gradualmente, iniciando em 24 no ano de 2021 e chegando a 400 em 2025. A instalação dos pontos de coleta dos REEE deverá ser de, no mínimo, 1 para cada 25 mil habitantes. Em razão de sua população estimada de 110.590 habitantes em 2018, segundo o IBGE, o município de Umuarama-PR ocupa a posição 287 na relação dos municípios contemplados pelo Anexo III do decreto, devendo ser atendido pelo SLR no ano de 2024 com, no mínimo, 4 pontos de coleta de REEE.

Conclusão: A publicação do Decreto $n^{\circ}$ 10.240/2020 representa um importante avanço da legislação ambiental, regulamentando a destinação adequada de uma classe de resíduos que tem crescido anualmente. Além disso, as novas regras estabelecidas proporcionarão mais transparência e informações sobre a gestão dos REEE. 


\section{Referências}

BRASIL. Lei Federal n. 12.305 de 2 de agosto de 2010: institui a Política Nacional de Resíduos Sólidos; altera a Lei no 9.605, de 12 de fevereiro de 1998; e dá outras providências. Disponível em: http://www.planalto.gov.br/ccivil_03/_ato20072010/2010/lei//12305.htm. Acesso em: 29 ago. 2020.

Ministério do Meio Ambiente celebra Acordo Setorial de Eletroeletrônicos. Brasília, DF. Ministério do Meio Ambiente. 2019. Disponível em: https://www.mma.gov.br/informma/item/15652-ministério-do-meio-ambiente-celebra-acordo-setorial-deeletroeletrônicos.html. Acesso em: 29 ago. 2020.

Decreto n. 10.240 de 12 de fevereiro de 2020: regulamenta o inciso VI do caput do art. 33 e o art. 56 da Lei no 12.305, de 2 de agosto de 2010, e complementa o Decreto n. 9.177, de 23 de outubro de 2017, quanto à implementação de sistema de logística reversa de produtos eletroeletrônicos e seus componentes de uso doméstico. 2020. Disponível em: http://www.planalto.gov.br/ccivil_03/_Ato2019-2022/2020/Decreto/D10240.htm. Acesso em: 29 ago. 2020.

FORTI, V., BALDÉ, C.P., KUEHR, R., BEL, G. The global e-waste monitor 2020: quantities, flows and the circular economy potential. United Nations University (UNU) / United Nations Institute for Training and Research (UNITAR) co-hosted SCYCLE Programme, International Telecommunication Union (ITU) \& International Solid Waste Association (ISWA), Bonn/Geneva/Rotterdam. Disponível em: http://ewastemonitor.info/wp-content/uploads/2020/07/GEM_2020_def_july1_low.pdf. Acesso em: 29 ago. 2020.

IBGE. Estimativas da população residente no Brasil e unidades da federação com data de referência em $1^{\circ}$ de julho de 2018. Disponível em: ftp://ftp.ibge.gov.br/Estimativas_de_Populacao/Estimativas_2018/estimativa_TCU_2018_20200622.pdf. Acesso em: 29 ago. 2020.

Coordenadoria de Pesquisa e Extensão - COPEX

Departamento de Editoraçāo e Divulgaçāo Científica - DEDIC 


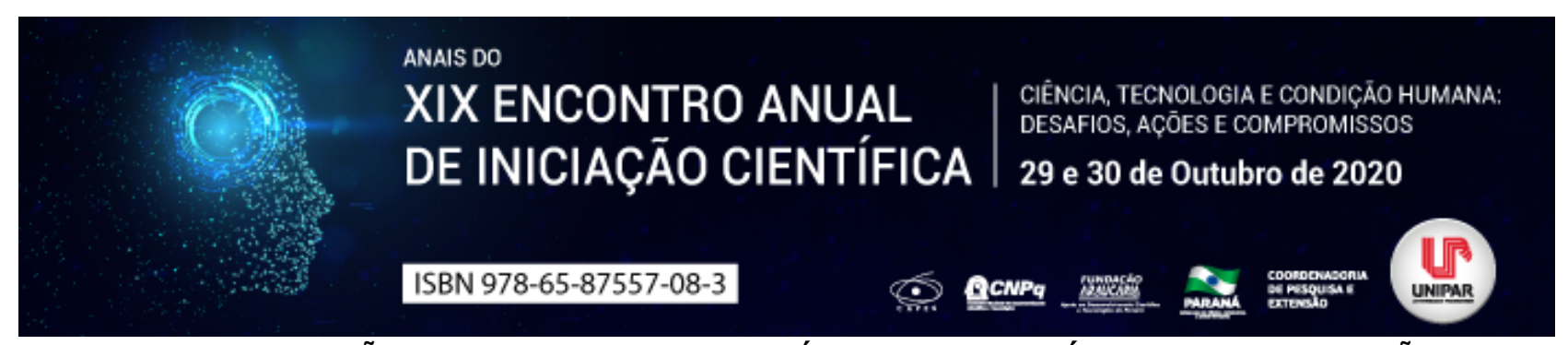

PANORAMA DA PRODUÇÃO NACIONAL DE MARACUJÁ NO BRASIL NÚMEROS DE PRODUÇÃO, CUSTO E RENTABILIDADE

\begin{abstract}
${ }^{1}$ Lucas Pereira da Silva, ${ }^{2}$ ANA CLÁUDIA DA SILVA MENDONÇA, ${ }^{3}$ BRUNA CRISTINA DE ANDRADE, ${ }^{4}$ CELSO MARTINS FRANÇA, ${ }^{5}$ GIOVANNA SERON, ${ }^{6}$ PRISCILA ANGELOTTI ZAMPAR
\end{abstract}

\begin{abstract}
${ }^{1}$ Engenheiro Agrónomo e Pós-graduando em Agronomia PGA Universidade Estadual de Maringá
${ }^{1}$ Engenheiro Agrônomo e Pós-graduando em Agronomia PGA Universidade Estadual de Maringá

${ }^{2}$ Engenheiro Agrônomo e Pós-graduando em Agronomia PGA Universidade Estadual de Maringá.

${ }^{3}$ Acadêmico do curso de Agronomia Universidade Estadual de Maringá

${ }^{4}$ Acadêmico do curso de Agronomia Universidade Estadual de Maringá

${ }^{5}$ Pesquisadora em Fitopatologia UEM - Universidade Estadual de Maringá
\end{abstract}

Introdução: Nos últimos anos, o cultivo do maracujá tem ganhado força, possuindo números representativos tanto na área produzida, como também nos números de produção e exportação. Os frutos produzidos aqui no Brasil possuem destinos como países Europeus e latino-americanos. No Brasil as espécies com maior expressão comercial e que ocupam mais de 90\% das áreas plantadas pelo fruto são correspondentes às espécies Passiflora edulis (Maracujá-azedo) e Passiflora alata (Maracujádoce), entretanto espécies como Passiflora setacea, Passiflora nitida, Passiflora cincinnata e híbridos interespecíficos de maracujás têm ganhado força e já representam uma parcela da produção nacional.

Objetivo: É nítido a importância do cultivo desta fruteira no nosso país, desta forma iremos abortar nesta revisão inúmeros pontos importantes, tais como números de produção, produtividade e custo de produção x rentabilidade.

Desenvolvimento: No Brasil, em números absolutos, a área destinada para produção de frutos de maracujá, segundo o IBGE Produção agrícola (IBGE, 2019), no qual o último ano aferido e calculado foi o de 2018, foi de 42.731 hectares plantados, sendo esta área responsável por produzir cerca de 602.651 toneladas de frutos, sendo assim chegando a uma produtividade de 14.103 quilogramas por hectare.

Quando afunilamos a pesquisa, e observamos as regiões, é nítido a importância da região Nordeste do Brasil, no qual é a mais tecnificada para a produção do fruto sendo ele responsável por plantar 29.144 hectares e colher 375.541 toneladas no ano de 2018, dando assim uma produtividade média de 12.886 quilogramas por hectare. Logo atrás, mas também muito importante, fica a região Sudeste, com 5.708 hectares plantados, colhendo 97.307 toneladas no ano de 2018, sendo assim, uma produtividade média de 17.047 quilogramas por hectare, bem acima da média nacional.

A Bahia é o estado que mais produz maracujá, no ano de 2018, foi responsável por quase um terço da produção nacional, sendo 15.660 hectares plantados e colhidos 160.902 toneladas, sendo uma produtividade média de 10.275 quilogramas por hectare. Já o segundo estado mais representativo na produção do maracujazeiro, é o estado do Ceará, que se mostra em uma alta ascensão, sendo 6.862 hectares plantados, com uma colheita de 147.458 toneladas, sendo uma produtividade média de 21.489 quilogramas por hectare.

O maracujazeiro, apresenta grande importância social e econômica no pais, sendo o Brasil o maior produtor e exportador do mundo desta fruta, no ano de 2019, segundo dados do Comex stat (Estatísticas de comércio exterior), foram exportados cerca de 28.748 quilogramas do fruto, desenvolvendo um valor de US\$ 63.249 dólares, sendo um preço médio de US\$2.200,12 dólares por tonelada de fruto. Países como Portugal e Austrália foram os que mais tiveram demanda, sendo 8.467 e 5.810 quilogramas de fruto, respectivamente, sendo assim, através desses dados conseguimos avaliar a grande importância que esse fruto desenvolve tanto economicamente e social no nosso país. Neste contexto, para quem se arrisca a entrar neste mercado, produzir o fruto não demanda um investimento tão alto, segundo Mendonça et al. (2018) para a implantação da lavoura de maracujás é necessário um investimento em média de 10 mil reais por hectare, que é reposto logo no primeiro ano de produção, sendo que o custo de implantação da lavoura é um fator determinante, de modo que seja vencido, pois precisa ser disponibilizado no início. Os custos ao longo dos anos são menores pois os custos de manutenção são mais baixos, de modo que os custos totais são diluídos no decorrer da cultura que já está implantada e produzindo. Por fim, fazendo um cálculo bem simples, se utilizarmos a média brasileira de produção que são de 14.103 quilogramas por hectare, e comercializar-mos a caixa de 16 quilos pelo valor médio de mercado que é de $\mathrm{R} \$ 50$ reais, o produtor já consegue pagar os custos operacionais e investimentos realizados na sua propriedade no primeiro ano.

Conclusão: O Brasil é o maior produtor e exportador do fruto de maracujá, desta forma, mostra a grande importância de se estudar a cadeia produtiva desta fruteira. De certo forma grande maioria da atenção nacional é voltada aos monocultivos (soja, milho, algodão, feijão, entre outros), e resultados como os apresentados nesta revisão mostram que existem possibilidades para 
pequenos e médios produtores entrarem em cadeiras produtivas competitivas, afim de produzir e exportar, bastam ter uma visão mais abrangente de que ao fruteiras ou então outros tipos plantas perenes, pode possibilitar um ganho monetário significativo.

\section{Referências}

IBGE, Instituto Brasileiro de geografia e estatística. Banco de dados agregados: Produção Agrícola Municipal, 2018. Disponível em: < https://sidra.ibge.gov.br/tabela/5457>. Acesso em: 29,AGOSTO,2020.

MENDONÇA, J.P; NOGUEIRA, J.C.M; CARNEIRO, V.A; OLIVEIRA, A.L.R; TAKEMOTO, S.Y. Viabilidade econômica da implantação de lavoura de maracujá cultivar brs gigante amarelo. Revista Mirante, Anápolis (GO), v. 11, n. 8, dez. 2018.

Coordenadoria de Pesquisa e Extensão - COPEX

Departamento de Editoraçāo e Divulgaçāo Científica - DEDIC 


\title{
XIX ENCONTRO ANUAL \\ CIÊNCIA, TECNOLOGIA E CONDIÇÃO HUMANA: DESAFIOS, AC̄ŌES E COMPROMISSOS
}

DE INICIAÇÃO CIENTÍFICA 29 e 30 de Outubro de 2020

ISBN 978-65-87557-08-3

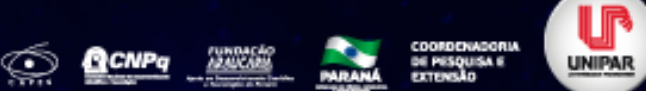

UTILIZAÇÃO DE FERRAMENTA COMPUTACIONAL PARA ELABORAÇÃO DE PROJETOS DE SEGURANÇA CONTRA INCÊNDIO - MÉTODO PERFORMANCE BASED DESIGN - PBD

\author{
${ }^{1}$ THAINA COUTINHO DA LUZ, ${ }^{2}$ NICOLE DO NASCIMENTO VIANA, ${ }^{3}$ BEATRIZ OLIVEIRA BORELLA, ${ }^{4}$ MATHEUS HENRIQUE \\ ROSSATTO CASOLA, ${ }^{5}$ WELLINGTON GABRIEL AGUIAR XAVIER, ${ }^{6}$ IGO HENRIQUE SILVA NUNES
}

\author{
${ }^{1}$ Acadêmica do PIC de Engenharia Civil - Unipar \\ ${ }^{1}$ Acadêmica do Curso de Arquitetura e Urbanismo da UNIPAR \\ ${ }^{2}$ Acadêmica do Curso de Arquitetura e Urbanismo da UNIPAR \\ ${ }^{3}$ Acadêmico do Curso de Engenharia Civil da UNIPAR \\ ${ }^{4}$ Acadêmico do Curso de Engenharia Civil da UNIPAR \\ ${ }^{5}$ Docente da UNIPAR
}

Introdução: Inúmeras vidas já foram ceifadas nos últimos anos por tragédias envolvendo fogo e os principais fatores que contribuíram foram, o pânico gerado pela situação de perigo e dificuldades em evadir da edificação, segundo MELO (2015). O pânico é um fator difícil de ser controlado, uma vez que cada pessoa se comporta de maneira diferente diante de situação de risco, entretanto a evacuação pode ser sempre melhorada, de forma que fique fácil encontrar rotas de fugas e deixar passagens livres destinadas ao evacuamento.

Objetivo: Justificar a utilização de ferramenta computacional, na busca por projetos de prevenção contra incêndio mais eficazes.

Desenvolvimento: $\mathrm{Na}$ busca por propor projetos mais eficientes, no tocante segurança contra incêndio, existe a possibilidade da utilização de softwares, para verificar o comportamento das pessoas na tentativa de evadir-se de uma situação perigosa. Essa ferramenta é um instrumento importante para os projetistas, por permitirem cálculo de tempo de fuga dos ocupantes de uma edificação e a verificação da eficácia das soluções de evacuamento adotadas em projeto, segundo SILVA (2015). Vale ressaltar a existência do método, Performance Based Design PBD, que se baseia justamente no desempenho do conjunto de soluções adotadas, segundo WAGNER (2008). Ainda segundo o mesmo autor, diferente do método tradicional, em que o projeto é elaborado se baseando somente em normas, no PBD são definidos objetivos de segurança que devem ser satisfeitos, e para tal recorre-se às ferramentas computacionais, que são capazes de simular a diversidade de situações na ocasião de um sinistro, porém como no método tradicional, o PBD também necessita passar por aprovação do órgão competente.

Conclusão: Conforme apresentado, um projeto bem elaborado e que considera o maior número de variáveis possível, precisa seguir não só as normas que regem a segurança contra incêndio, mas também fazer usos de ferramentas que simulem o comportamento das pessoas no layout da edificação.

\section{Referências}

MELO, E. N. O Efeito da simulação de evacuação de multidão na segurança e no estudo de Layout. Atena Repositório Digital da UFPE, $2015 . \quad$ Disponível https://repositorio.ufpe.br/handle/123456789/16513https://repositorio.ufpe.br/handle/123456789/16513 > Acessso em: 28 de Ago de 2020.

SILVA, E. C. M. O projeto arquitetônico e a antecipação do projeto de segurança contra incêndio: Interferência Mútua, interação necessária. Natal-RN, 2015. Disponível em: <

https://repositorio.ufrn.br/jspui/bitstream/123456789/19677/1/ProjetoArquitet\%c3\%b4nicoAntecipacao_Silva_2015.pdf > Acesso em: 28 de Ago de 2020.

WAGNER, R. Projeto para saídas de emergência: O conceito de desempenho em Santa Catarina. Florianópolis, 2008. Disponível em:<

https://repositorio.ufsc.br/bitstream/handle/123456789/91422/256620.pdf?sequence=1\&isAllowed=y > Acesso em: 29 de Ago de 2020. 


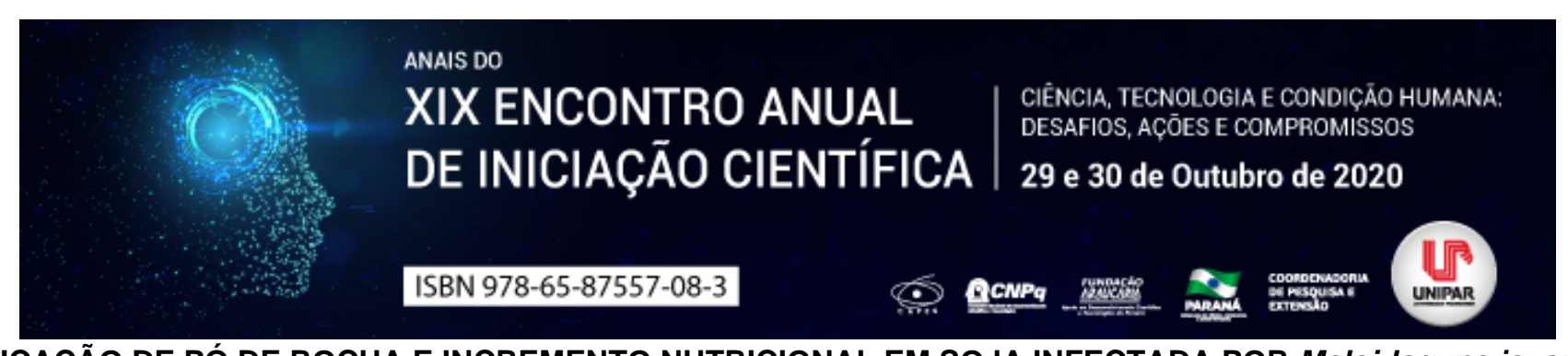

APLICAÇÃO DE PÓ DE ROCHA E INCREMENTO NUTRICIONAL EM SOJA INFECTADA POR Meloidogyne javanica

\begin{abstract}
${ }^{1}$ Glaucia Leticia Sete da Cruz, ${ }^{2}$ SIMONE DE MELO SANTANA-GOMES, ${ }^{3}$ BEATRIZ DE ALMEIDA E SILVA, ${ }^{4}$ CAROLINA YUMI FUTIGAMI, ${ }^{5}$ BRUNA ORLANDINI TONINATO, ${ }^{6}$ CLAUDIA REGINA DIAS-ARIEIRA
\end{abstract}

\author{
${ }^{1}$ Discente do curso de Agronomia, UEM, Umuarama-PR \\ ${ }^{1}$ Pós-doutoranda em Nematologia Agrícola e docente do mestrado em Ciências Agrárias, UEM \\ ${ }^{2}$ Discente do curso de Agronomia, UEM, Umuarama-PR \\ ${ }^{3}$ Discente do curso de Agronomia, UEM, Umuarama-PR \\ ${ }^{4}$ Discente do mestrado em Ciências Agrárias, UEM \\ ${ }^{5}$ Docente da Graduação e Pós-Graduação em Agronomia e Ciências Agrárias, UEM
}

Introdução: O uso de pó de rocha (rochas moídas), conhecida como rochagem, é obtida pelo beneficiamento simples de materiais minerais e pode ser proveniente de rejeitos de mineração, de solubilidade lenta, que disponibiliza nutrientes às plantas por um período maior do que o de fertilizantes convencionais (MARTINS el al., 2010). É uma prática agrícola que embora possa parecer uma novidade, já é praticada há vários anos (PADUA, 2012). Assim, uma hipótese é que a fertilização com pó de rocha promova um equilíbrio nutricional e auxilie no desenvolvimento de plantas sob ataque de fitonematoides.

Objetivo: Avaliar o efeito da aplicação do pó de rocha nos teores nutricionais de plantas de soja infectadas com M. javanica.

Material e Métodos: O experimento foi conduzido em casa de vegetação, na Universidade Estadual de Maringá, em Umuarama

$\mathrm{PR}$, em copos de isopor com capacidade para de $950 \mathrm{~mL}$. Os tratamentos foram constituídos por solos autoclavado $(2 \mathrm{~h}, 120$ $\left.{ }^{\circ} \mathrm{C}\right)$ e não autoclavado, com aplicações de cinco doses de pó de rocha: 0, 1000, 2000, 3000 e $4000 \mathrm{~kg} \mathrm{ha}^{-1}$. As doses foram aplicadas vinte dias antes da semeadura da soja cv. Monsoy 6410 IPRO e a inoculação dos nematoides ocorreram após a emergência das plântulas, aproximadamente cinco dias após a semeadura. Em cada unidade experimental foram depositados 2000 ovos e eventuais juvenis extraídos conforme Hussey e Barker (1973) adaptada por Bonetti e Ferraz (1981). Após sessenta dias de cultivo, separou-se a parte aérea do sistema radicular, determinando-se a massa seca de parte aérea $\left(65^{\circ} \mathrm{C}\right.$, até atingir massa constante). As amostras foram trituradas em moinho tipo Willey, para determinação dos teores nutricionais da parte aérea (MALAVOLTA; VITTI; OLIVEIRA, 1997). O experimento foi instalado em DIC, em arranjo fatorial $2 \times 5$, com cinco repetições. As médias foram submetidas à análise de variância $(p \leq 0,05)$. Quando a interação dos fatores foi significativa, os tipos de solos foram comparados por Tukey e as doses por regressão a 5\% de significância, utilizando o programa estatístico Sisvar (FERREIRA, 2011).

Resultados: As doses de pó de rocha não afetaram $(p>0,05)$ os teores nutricionais de nitrogênio $(N)$, fósforo $(P)$, manganês $(M n)$ e zinco (Zn), todavia, apenas o $\mathrm{N}$ foi superior $\left(32,26 \mathrm{~g} \mathrm{~kg}^{-1}\right)$ em plantas cultivadas em solo não autoclavado. Já para os demais, o comportamento foi o inverso. Para os nutrientes magnésio $(\mathrm{Mg})$ e enxofre $(\mathrm{S})$, as doses demonstraram um comportamento linear, ascendente para o primeiro e descendente para o segundo, quando as plantas foram cultivadas em solos autoclavado $(2,48-2,95$ $\mathrm{g} \mathrm{kg}^{-1}$ ) e não autoclavado $\left(1,11-1,61 \mathrm{~g} \mathrm{~kg}^{-1}\right)$, respectivamente. Para boro (B) ocorreu interação entre os fatores, cujas doses demonstraram um ajuste quadrático positivo, com o pico na dose de $2000 \mathrm{~kg} \mathrm{ha}^{-1}\left(46,31 \mathrm{mg} \mathrm{kg}^{-1}\right)$, para o solo autoclavado, o qual demonstrou médias superiores ao solo não autoclavado. O cobre $(\mathrm{Cu})$ também apresentou teores superiores para as plantas cultivadas em solo autoclavado, com o máximo incremento no tratamento $2000 \mathrm{~kg} \mathrm{ha}^{-1}\left(3,99 \mathrm{mg} \mathrm{kg}^{-1}\right)$. Para o fator doses, os teores de Cu observados em solo não autoclavado variaram de 2,60 a 3,86 mg kg.

Discussões: Incrementos nutricionais pela ação da rochagem já foram observados em outros trabalhos (SILVA et al., 2008; PADUA, 2012; BATISTA, 2013). No trabalho de Padua (2012), o pó de rocha contribuiu para uma melhor nutrição das plantas de soja, seja pelo seu maior efeito residual ou multinutrientes, devido à composição variada dos agrominerais, seja por uma condição mais equilibrada e favorável aos microrganismos fixadores de N (PADUA, 2012). Knapik (2005) observou maiores valores de N, P, K, Ca, Mg, B, Fe e Mn nas folhas de mudas de Prunus sellowii usando o pó de rocha basáltica como ingrediente do substrato. Apesar das raízes de soja estarem infectadas com $M$. javanica, as plantas conseguiram incrementar nutrientes em parte aérea, indicando que uma nutrição adequada pode reduzir consideravelmente a gravidade das doenças (ZAMBOLIM, VENTURA; ZANÃO, 2012).

Conclusão: A aplicação de pó de rocha aumentou os teores de Mg, Mn, Zn, B e Cu em parte aérea de soja, sobressaindo-se o solo autoclavado. 


\section{Referências}

BATISTA, Nayra; Thais Ferreira. Atributos químicos do solo e componentes agronômicos na cultura da soja pelo uso da rochagem: Teor de nutrientes acumulado na parte aérea da planta de soja. Orientador: Vilmar Antonio Ragagnin. 2013. Dissertação (Mestre em produção vegetal) Universidade federal de Goias, Jataí, 2013.

KNAPIK, Juliane Garcia. Utilização do pó de basalto como alternativa à adubação convencionalna produção de mudas de Mimosa scabrella (Benth) e Prunus sellowii (koehne). 42 2005. 163p. Dissertação (Mestrado) - Curso de Pós-Graduação em EngenhariaFlorestal. Setor de Ciências Agrárias, Universidade Federal do Paraná, Curitiba, 2005.

MARTINS, Eder de Souza; THEODORO, Suzi Huff. Congresso Brasileiro de Rochagem In: Congresso Brasileiro de Rochagem, 1, 2010: Brasília. Anais do I Congresso Brasileiro de Rochagem, DF: EMBRAPA Cerrados. p. 322, 2010.

MALAVOLTA, Euripedes., Vitti, Godofredo Cesar., et al. Avaliação do estado nutricional das plantas: princípios e aplicações. 2.ed. Piracicaba: POTAFOS, 1971. P. 319

PADUA, Eduane José. Rochagem como adubação complementar para culturas oleaginosas: Acúmulo de nutrientes na parte aérea da soja na época da colheita. Orientador: Antonio Eduardo Furtini Neto. 2012. Tese (PósGraduação em Ciência do Solo, área de concentração em Fertilidade do Solo e Nutrição de Plantas) ～Universidade Federal de Lavras, Lavras, 2012.

SILVA, Eloisa Aparecida, et al. Efeitos da rochagem e de resíduos orgânicos sobre aspectos químicos e microbiológicos de um subsolo exposto e sobre o crescimento de astronium fraxinifolium schott. R. Árvore, Viçosa-MG, v.32, n.2, p.323-333, 2008

ZAMBOLIM, Laercio. VENTURA, José Aires. ZANÃO JÚNIOR, Luiz Antônio. Efeito da nutrição mineral no controle de doenças de plantas, 22. ed. Viçosa: Paulo Afonso de Souza, 2012. 


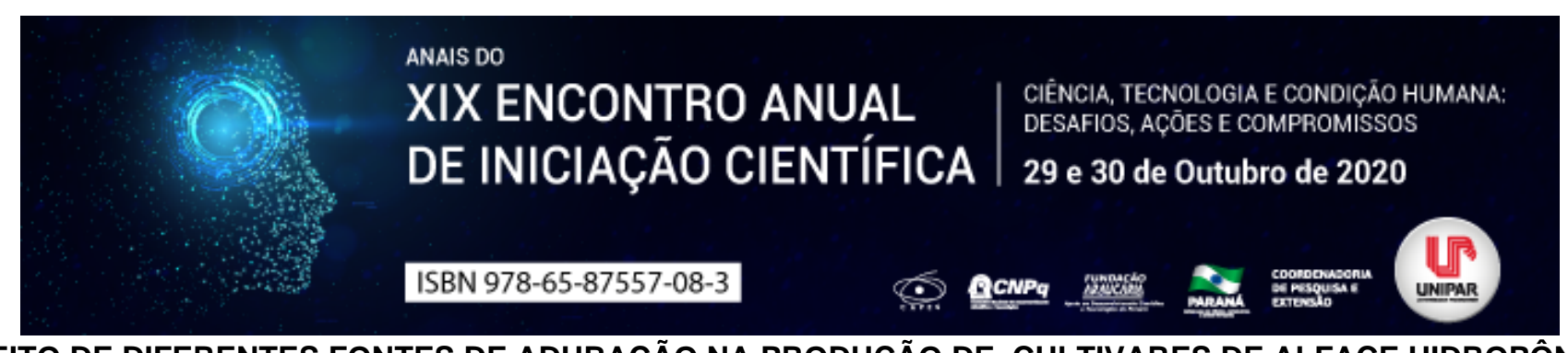

EFEITO DE DIFERENTES FONTES DE ADUBAÇÃO NA PRODUÇÃO DE CULTIVARES DE ALFACE HIDROPÔNICO

\author{
${ }^{1}$ CAROLINE MARINO, ${ }^{2}$ JOICE GONZAGA, ${ }^{3}$ LUIS FERNANDO ASSALIN PASSAMANI, ${ }^{4}$ MATHEUS ZANATA, ${ }^{5}$ LUCIMAR \\ PEREIRA BONETT
}

${ }^{1}$ Acadêmicos do curso de Engenharia Agronômica da UNIPAR

${ }^{1}$ Acadêmicos do curso de Engenharia Agronômica da UNIPAR

${ }^{2}$ Acadêmicos do curso de Engenharia Agronômica da UNIPAR

${ }^{3}$ Acadêmicos do curso de Engenharia Agronômica da UNIPAR

${ }^{4}$ Docente do curso de Engenharia Agronômica da UNIPAR

Introdução: A alface (Lactuca sativa L.) é considerada hortaliça folhosa com maior aceitação alimentar do Brasil, consequentemente tem uma elevada importância nutricional e econômica (COSTA e SALA, 2005). Nos últimos anos tem-se buscado novas alternativas que otimizem as produtividades bem como melhore a qualidade do produto. Neste sentido o cultivo hidropônico se mostra uma eficiente ferramenta (COMETTI et. al., 2019). Um aspecto fundamental para o sucesso do cultivo hidropônico é a escolha da solução nutritiva, esta deve ser formulada de modo a conter proporções adequadas de todos os nutrientes essenciais para o seu crescimento (GUIMARÃES, 2018).

Objetivo: Avaliar o efeito de fontes de nutrientes na produção de diferentes tipos de alface sob cultivo hidropônico.

Métodos: O experimento foi conduzido na estufa da Unipar campus III em Umuarama-PR no ano de 2020. Foram utilizadas três bancadas de hidroponia, cada uma com uma fonte de adubação comercial. A primeira teve um a fonte liquida (Plenan TM1+TM2), a segunda com (Plenan PM3+PM4) e a terceira com um sal (Flex azul e flex vermelho). Os grupos de alface utilizados foram americano, crespo e liso. Foi avaliado o peso de massa fresca da parte aérea, quando as plantas estavam com 35 dias. $O$ delineamento experimental utilizado foi inteiramente casualizado com dois fatores (fonte de nutriente $\mathrm{x}$ grupo comercial de alface) com três repetições. Os dados obtidos foram analisados no software SISVAR (FERREIRA, 2019).

Resultados: Analisando os dados é possível observar uma intenção significativa entre os fatores. As melhores interações obtidas entre as variedades de alface dentro das fontes de adubação, foram, para o grupo americana com o sais obteve uma massa fresca da parte aérea de 468,34 gramas (g), diferindo estatisticamente dos demais tratamentos, sendo $18 \%$ mais pesado que os demais tratamentos. Para o grupo comercial crespa o adubo PM3+PM4 (366,75 g) e o sal (371,75 g), mostraram um resultado superior ao tratamento com TM1+TM2 $(235,05 \mathrm{~g})$ com a diferença de $36,77 \%$. O grupo liso, também apresentou melhor resultado quando submetido a fonte de adubação sais $(461,75 \mathrm{~g})$, o segundo melhor resultado foi obtido pelo aduba do PM3+PM4 (354,05 g) com uma diferença de 23,32\%. E em relação a interação das fontes de adubação com as variedades, para o tratamento com TM1+TM2 foi a alface liso $(351,09 \mathrm{~g})$. Já com o adubo PM3+PM4 o grupo comercial com melhor desempenho foi americana (383,46 g), assim como, a adubação com sal, mais uma vez o grupo americano demonstrou uma massa fresca de $468,34 \mathrm{~g}$.

Discussão: Os adubos utilizados obteve um bom resultado na cultura do alface americano, crespo e liso em sistema hidropônico, porem o uso do sais como meio de adubação teve um resultado superior aos demais . Por outro lado Soares et.al. (2007), demonstrou que o uso de águas salinas elevou a salinização da solução nutritiva, com redução significativa no consumos hídrico e na produção de massa de matéria seca da parte aérea. Bennini.et.al(2002) ao trabalhar com alface no estado do Parana com diferente soluções nutritivas obteve uma media para matéria fresca da parte área da planta de $271 \mathrm{~g}$. Assim como Takahashi et.al. (2007) quem obteve uma media geral de peso de planta de 301g, para diferentes fontes de nutrientes .Esses trabalhos ressaltam a eficiências das soluções nutritivas utilizada no presente estudo. Os resultados encontrado são satisfatórios pois são superiores oas demais trabalhos citados, como no trabalho de Casaroli.et.al.(2003) apresentando média de produção em torno de 300 a $400 \mathrm{~g} /$ planta de matéria fresca da parte aérea.

Conclusao: A utilização do adubo TM1+TM2 para o alface liso obteve um melhor resultado, já para a adubação com sais foi superios para todos os grupos comerciais de alface. Para o adubo PM3+PM4 o grupo americano teve um melhor desempenho comparado aos de mais .variedades de alface.

\title{
Referências
}

ANTONIO, Isaac Cohen. Análise do comportamento da cultura da alface em sistema hidropônico, tipo NFT, com e sem o uso de nutrientes quelatizados na solução nutritiva. Embrapa Amazônia Ocidental-Tese/dissertação (ALICE), 1998.

BENNINI ERY; TAKAHASHI HW; NEVES CSVJ; FONSECA ICB. 2002. Teor de nitrato em alface cultivada em sistema hidropônico e convencional. Horticultura Brasileira 20: 183-186. 
CASAROLI D; FAGAN EB; SANTOS OS; BONNECARRÈRE RAG; NOGUEIRA FILHO H. 2003. Desempenho de onze cultivares de alface em duas formas diferentes de canais de cultivo, no sistema hidropônico. Revista da Faculdade de Zootecnia, Veterinária e Agronomia 10: 114-123.

COMETTI, Nilton Nélio; GALON, Karla; BREMENKAMP, Diene Maria. Comportamento de quatro cultivares de alface em cultivo hidropônico em ambiente tropical. Revista Eixo, v. 8, n. 1, 2019.

COSTA, C. P.; SALA, F. C. A. Evolução da alfacicultura brasileira. Horticultura Brasileira, Brasília, v. 23, n. 1, p. 118-120, 2005.

FERREIRA, Daniel Furtado. Sisvar: a computer analysis system to fixed effects split plot type designs. Revista Brasileira de Biometria, v. 37, n. 4, p. 529-535, 2019.

GUIMARÃES, Rafaela Felix Basilio et al. Cultivo hidropônico da alface crespa sob diferentes níveis de salinidade. 2018.

SOARES, Tales Miler et al. Produção de alface utilizando águas salinas em sistema hidropônico. Irriga, v. 12, n. 2, p. 235-248, 2007.

TAKAHASHI, Hideaki W. et al. Composição e manejo da solução nutritiva visando à diminuição do teor de nitrato nas folhas de alface hidropônica. Horticultura Brasileira, v. 25, n. 1, p. 6-9, 2007.

Coordenadoria de Pesquisa e Extensão - COPEX

Departamento de Editoraçāo e Divulgaçāo Científica - DEDIC 


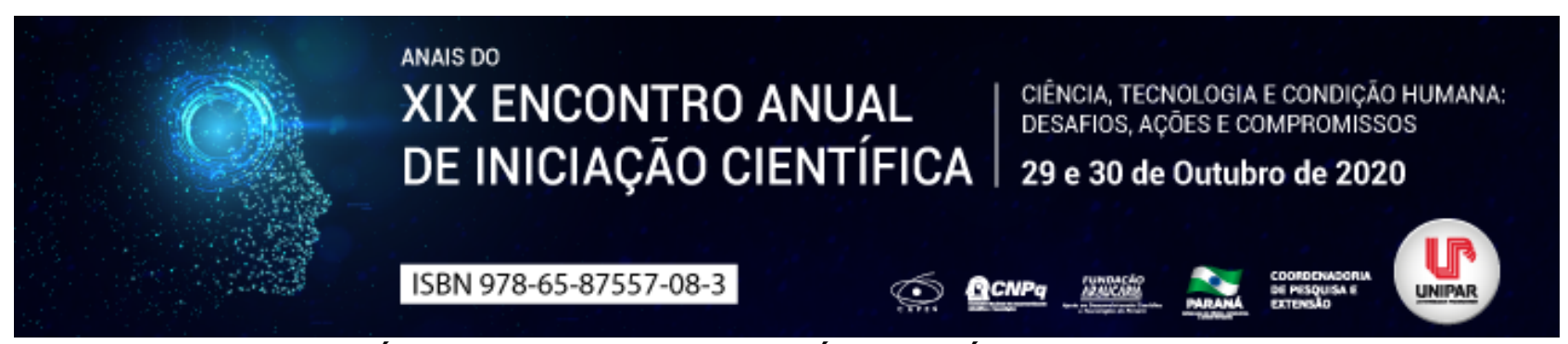

CINÉTICA DE SECAGEM DE CAFÉ PELO MÉTODO FOAM-MAT

\begin{abstract}
${ }^{1}$ Chrislayne Pais Vollbrecht, ${ }^{2}$ JHONY TIAGO TELEKEN, ${ }^{3}$ BARBARA DANIELE ALMEIDA PORCIUNCULA
\end{abstract}

\author{
${ }^{1}$ Acadêmico do PIC/UEM \\ ${ }^{1}$ Docente da UEM \\ ${ }^{2}$ Docente da UEM
}

Introdução: O café solúvel é o produto resultante da desidratação do extrato aquoso obtido do café torrado, através de métodos físicos utilizando água como único agente extrator seguido de método de desidratação (Marcucci et al., 2013). Na secagem por foam-mat os alimentos líquidos ou semilíquidos são submetidos ao processo de agitação e transformados em uma espuma estável, mediante à adição de agentes emulsificantes e estabilizantes. Essa espuma é distribuída em placas e submetida ao processo de secagem com ar aquecido até o teor de umidade que impeça o crescimento de microrganismos, reações químicas e/ou enzimáticas (Delmiro, 2016).

Objetivo: Desidratar extrato de café pelo método foam-mat utilizando diferentes agentes emulsificantes e condições de processo. Materiais e método: $O$ extrato de café foi fornecido pela indústria Cocam Cia de Café Solúvel e Derivados, e, utilizou-se Emustab ${ }^{\circledR}$ e a Albumina de ovo como agentes espumantes. Para a produção da espuma foi incorporado $100 \mathrm{~mL}$ de extrato de café ao agente espumante na concentração de $5 \%\left(\mathrm{~m} \cdot \mathrm{v}^{-1}\right)$, por uma batedeira doméstica, por 15 minutos. Para determinação do agente espumante ideal, avaliou-se quanto a densidade, expansão, estabilidade e sólidos solúveis. Após a agitação, as espumas foram transferidas para placas de Petri com diâmetro de $0,50 \pm 1,77 \times 10^{-4}$ e altura de $0,14 \pm 1,41 \times 10^{-3}$ em duplicata, com espessuras de $0,3,0,5$ e $0,7 \mathrm{~cm}$ medidas com o auxílio de paquímetro e encaminhadas para desidratação em estufa nas temperaturas de 50, 60 e $70^{\circ} \mathrm{C}$. Os resultados das análises foram submetidos à análise de variância (ANOVA) e as médias comparadas pelo teste de Tukey com significância de $5 \%$ de probabilidade. Às cinéticas de secagem foram ajustados, utilizando o software Matlab®, o modelo de Page (PAGE, 1949), modelo de Henderson \& Pabis (HENDERSON; PABIS, 1961) e o Modelo de Midilli (Midilli et al. 2002).

Resultado: As espumas contendo os agentes espumantes Emustab ${ }^{\circledR}$ e albumina, respectivamente, possuíram $49,00 \pm 1,14^{\mathrm{a}}$ e $51,00 \pm 0,00^{\mathrm{a}}{ }^{\circ}$ Brix, densidade de $0,25 \pm 0,02^{\mathrm{ab}}$ e $0,24 \pm 0,00^{\mathrm{a}} \mathrm{g} \cdot \mathrm{cm}^{-1}, 6,51 \pm 0,76 \%$ e $19,43 \pm 0,42^{\mathrm{b}}$ para coalescência e $337,5 \pm 10,6$ e $350,0 \pm 0,0^{\mathrm{b}} \%$ de expansão. A espuma com o agente espumante específico selecionado desidratada obteve os seguintes resultados para umidade em $\mathrm{gH}_{2} \mathrm{O} . \mathrm{gss}^{-1}$, sendo na espessura de $0,3 \mathrm{~cm}, 0,0932 \pm 0,0047^{\mathrm{a}}, 0,1482 \pm 0,0195^{\mathrm{b}}$ e $0,0201 \pm 0,0049^{\mathrm{c}}$, para $0,5 \mathrm{~cm} 0,1002 \pm 0,0020^{\mathrm{a}}, 0,1379 \pm 0,0062^{\mathrm{a}}$ e $0,0289 \pm 0,0259^{\mathrm{b}}$, e, para $0,7 \mathrm{~cm}, 0,1232 \pm 0,0048^{\mathrm{a}}, 0,1583 \pm 0,0094^{\mathrm{b}}$ e $0,0663 \pm 0,0091^{\mathrm{C}}$ nas temperaturas de 50,60 e $70{ }^{\circ} \mathrm{C}$ respectivamente. Ao ajuste dos modelos de acordo com as temperaturas, considerou-se o menor número de parâmetros, $\mathrm{a}, \mathrm{b}, \mathrm{k}$ e $\mathrm{n}, \mathrm{e}, \mathrm{o}$ valor de $\mathrm{R}^{2}$ mais próximo de 1 . O modelo de Page, possuiu 2 variáveis e o valor de $\mathrm{R}^{2}$ de 0,9997 , modelo de Henderson \& Pabis, também com o mesmo número de variáveis, obteve um valor menor de $\mathrm{R}^{2}$, de 0,9993, e, o modelo de Midili, com 4 variáveis, alcançou 0,9995 para $\mathrm{R}^{2}$.

Discussão: $O$ agente espumante selecionado foi o Emustab® a $5 \%$, uma vez que, alcançou alta expansão $(337,5 \pm 10,6 \%)$ e baixa coalescência $(6,51 \pm 0,76 \%)$ o que permitiu uma boa estabilidade à espuma em comparação à Albumina. Cruz et al. (2017) afirmaram que, quanto menor a coalescência, maior é a estabilidade da espuma. A capacidade de expansão e estabilidade da espuma desempenham papel importante na circulação de água durante a secagem, e consequentemente, na qualidade do produto final (Bag et al., 2011). De acordo com a Resolução ANVISA/MS RDC no 277/05, a umidade de um produto solúvel oriundo de café deve ser de no máximo $5 \mathrm{~g} .100 \mathrm{~g}^{1}$. As condições que apresentaram o menor teor de umidade da amostra foi obtido a $70^{\circ} \mathrm{C}$ com espessura de $0,3 \mathrm{~cm}$. Os modelos de Page e Midilli obtiveram o melhor ajuste em todas as temperaturas testadas. Entretanto, o modelo de Page foi selecionado devido ao seu menor número de parâmetros de ajuste e o valor de $\mathrm{R}^{2}$. Marques et al. (2016) também observaram que os melhores ajustes foram encontrados para o modelo Page na secagem de caldo de cana em leito de espuma, nas mesmas temperaturas estudadas.

Conclusão: Para obtenção do produto final café solúvel pelo método foam-mat, o agente espumante selecionado foi o Emustab® a $5 \%$, e, o melhor modelo para o ajuste à cinética de secagem foi o modelo Page em virtude do valor de $\mathrm{R}^{2}$ e a quantidade de parâmetros do mesmo.

\title{
Referências
}

BAG, Subrata Kumar; SRIVASTAV, Prem; MISHRA, Hari. Optimization of process parameters for foaming of bael (Aegle 
marmelos L.) fruit pulp. Food Bioprocess Technology, v. 4, n.1, novembro, 2011. Disponível em: https://doi.org/10.1007/s11947-009-0243-6. Acesso em: 11 set. 2019.

BRASIL. Decreto $\mathrm{n}^{\circ}$ 184, de 23 de setembro de 2005 Estabelece o Regulamento Técnico para café, cevada, chá, erva-mate e produtos solúveis. Diário Oficial da União, Brasília, v. 120, n.184, p. 379, 22 set. 2005.

CRUZ, Pamela Lemos; SARAIVA, Sérgio Henrique; TEIXEIRA, Luciano José Quintão. Otimização do processo de secagem em leito de espuma de extrato de café. Enciclopédia Biosfera, Centro Científico Conhecer, v. 14, n. 2, dezembro, 2017. Disponível em: https://doi.org/10.18677/EnciBio_2017B45. Acesso em: 06 jun. 2019.

DELMIRO, Thalita Marreiro. Secagem da cenoura (Daucus carota L.) pelo método foam-mat. Orientador: Maria de Fátima Dantas de Medeiros. 49 f. Dissertação (Trabalho de conclusão de curso de Engenharia Química) - Universidade Federal do Rio Grande do Norte, Natal, 2016.

HENDERSON, Silas. Milton.; PABIS, Stanislaw. Grain drying theory I. Temperature effect on drying coefficient. Journal of Agriculture Engineering Research, n. $3, \quad$ v. $6, \quad 1961 . \quad$ Disponível em: https://www.scielo.br/scielo.phpscript=sci_nlinks\&pid=S14154366201800100071300017\&lng=en. Acesso em: 20 jun. 2019.

MARCUCCI, Carolina Tolentino; BENASSI, Marta Toledo; ALMEIDA, Mariana Bortholazzi; NIXDORF, Suzana Lucy. Teores de trigonelina, ácido 5-cafeoilquínico, cafeína e melanoidinas em cafés solúveis. Química Nova, v. 36, n. 4, p. 544-548, 2013. Disponível em: https://doi.org/10.1590/S0100-40422013000400011. Acesso em: 18 jun. 2019.

MIDILLI, Adnan; KUCUK, Haydar; YAPAR, Z. A new model for single-layer drying. Drying Technology, v. 20, p. 1503-1513, 2002. Disponível em: https://doi.org/10.1080/07373937.2013.873047. Acesso em: 09 jun. 2019.

PAGE, Glen. Factors influencing the maximum of air drying shelled corn in thin layer. Orientador: H. J. Barre. 1949. Dissertação (Mestrado em Engenharia Mecânica. Purdue University, Purdue, 1949. 


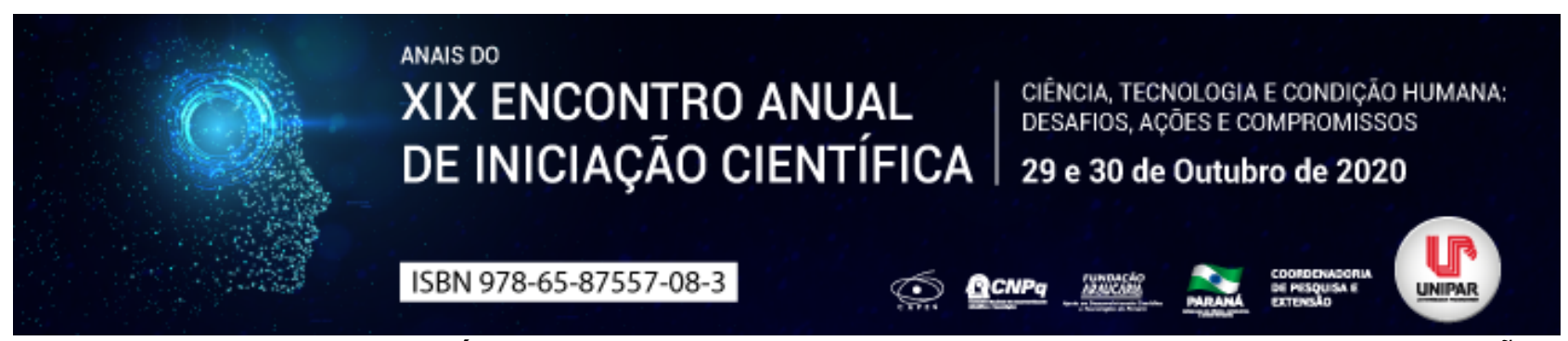

O USO DE CONCRETO AUTO ADENSÁVEL COM AREIA ARTIFICIAL: UM ESTUDO DE CASO NA FABRICAÇÃO DE PRÉFABRICADOS

\title{
${ }^{1}$ JEAN MARCELO MASSOCATO MARTINS, ${ }^{2}$ LUAN CARLOS DA ROSA, ${ }^{3}$ CLEDISON ZATTA VALDAMERI
}

\author{
${ }^{1}$ Acadêmico do Curso de Engenharia Civil da UNIPAR \\ ${ }^{1}$ Acadêmico do Curso de Engenharia Civil da UNIPAR \\ ${ }^{2}$ Docente da UNIPAR
}

Introdução: O mercado da construção civil é um dos setores mais relevantes da economia brasileira. Tendo essa relevância, segundo Barbora (2008), surgem desafios por processos e produtos que possam garantir e acompanhar o crescimento constante do mercado. Tem-se estudado novas tecnologias e materiais e segundo Jorge (2016), isso é para suprir a necessidade que a construção civil tem de recursos naturais como a areia natural. A quantidade de areia consumida anualmente na construção civil brasileira de acordo com Viacelli (2012), é de milhões de m3. Uma alternativa ecológica, para diminuir este impacto ambiental, causado pela extração da areia de rio, é a areia artificial, que vem sendo usada como agregado miúdo em concretos e argamassas. De acordo com Viacelli (2012) é através do uso de areia artificial é possível fazer o uso dos resíduos da britagem das rochas basálticas, onde essa é realizada para extração da pedra britada usada como material de construção. Segundo a mesma a substituição do agregado miúdo natural pelo artificial na produção de concretos demonstra-se viável tecnicamente e economicamente. Outro fator pontuado de acordo com Menossi (2004), é que o agregado artificial apresenta a vantagem de ser praticamente isento de impurezas de natureza orgânica e argilosas por se tratar de um produto obtido através de processos industriais. Dentro desse contexto, o objetivo deste trabalho é demonstrar a viabilidade técnica, de utilização da areia artificial, fabricada a partir da mineração do basalto, como agregado miúdo para produção de concreto auto adensável.

Relato de Caso: O elemento pré-moldado é o elemento que é executado fora do local de utilização definitiva da estrutura, com controle de qualidade e inspeção (NBR 9062, 2006). O CAA (Concreto Auto Adensável) apresenta melhor homogeneização da massa de concreto. O uso do CAA, ainda aumenta a vida útil das formas de concreto. Onde o CAA foi utilizado em substituição ao CCV, pois devido a forma de caixa vazada, que era movida com a vibração quando se utilizava o CCV. É necessário para um bom CAA o equilíbrio e atendimento aos três requisitos acima, pois é a capacidade de enchimento que faz o concreto fluir sobre o peso próprio e preencher os espaços da forma. Capacidade de passagem, mede-se quanto o concreto fluirá através dos espaços confinados. A resistência a segregação, esta é a capacidade da mistura fresca para manter a sua distribuição original durante o transporte, colocação e adensamento. Para o desenvolvimento da pesquisa foi acompanhado a produção das peças pré-moldadas da empresa, em todas as suas etapas de fabricação. Partindo da fase de elaboração do projeto, montagem das armaduras, montagem das formas, concretagem das peças, acabamento e estocagem do produto elaborado foi produzido no laboratório da empresa o concreto auto adensável (CAA), com e sem a areia artificial, a confecção do concreto e dos corpos de prova foi toda realizada no laboratório da indústria. Com diferentes porcentagens de areia artificial (100\%, 75\%, 50\%, 25\%, e sem areia) e para comparação dos resultados foi elaborado um traço de concreto apenas com a areia natural. Na elaboração do concreto utilizou-se de, cimento $\mathrm{CP}-\mathrm{V}$, areia natural e artificial, brita, água, aditivo superplastificante CQFlow 1865.No que se refere a dosagem do concreto foi utilizado o método a ABCP. O traço utilizado no concreto auto adensável é cimento (380,00kg), agregado miúdo $(930,00 \mathrm{~kg})$, agregado graúdo $(950,00 \mathrm{~kg})$, água $(115,00 \mathrm{l})$, aditivo (2,50 I). Para a obtenção de resultados qualitativos e quantitativos para as amostras produzidas, um dos ensaios elaborados é o Slumpflowles (Espalhamento) segundo Tutikian e Dal Molin (2008) esse ensaio é utilizado para medir a capacidade de fluir do CAA, livremente sem segregar, além disso, utilizou-se também do ensaio de resistência a compressão axial com idade de 7, 14, 21, e 28 dias.

Discussão: Após produção do concreto auto adensável com as diferentes concentrações de areia artificial encontra-se então o percentual ideal de agregado artificial para a relação custo/benefício, outro ponto é a relação de qualidade, analisado através dos ensaios, tais como o slumptest e o teste de espalhamento do CAA. Os ensaios de granulometria do agregado miúdo artificial também revelam que o material tem alto teor de material pulverulento, isso é consequência da forma de britagem do agregado, pois o mesmo não é lavado. O resultado do espalhamento das amostras indicou que a mistura se manteve coesa e resistente a segregação e com $25 \%$ de areia artificial, concentrações maiores de areia, já não tem a coesão necessária. De acordo com a NBR 15823-2 o concreto com 25\% de areia artificial pode-se classificar como SF3. Quanto a resistência a compressão axial, em todas as idades a amostra com $25 \%$ atingiu a resistência necessária para as peças pré-moldadas.

Conclusão: O desenvolvimento da indústria exige a da construção civil o desenvolvimento de técnicas para a industrialização da construção. Sendo assim temos o concreto auto adensável como importante alternativa. Conclui-se nessa pesquisa ainda que o uso de até $25 \%$ de areia artificial no CAA mantém as características necessárias para o concreto auto adensável, mantendo sua capacidade de enchimento, passagem e resistência a segregação. 


\section{Referências}

ASSOCIAÇÃO BRASILEIRA DE NORMAS TÉCNICAS (ABNT). NBR 9062. Projeto e execução de estruturas de concreto prémoldado. 2006.

ASSOCIAÇÃO BRASILEIRA DE NORMAS TÉCNICAS (ABNT). NBR 15823-1: Concreto auto-adensável. Parte 1: Classificação, controle e aceitação no estado fresco. Rio de Janeiro, 2010.

BARBOSA, Maria Teresa Gomes; COURA, Claudia Gáveo; MENDES, Larissa Oliveira. Estudo sobre a areia artificial em substituição à natural para confecção de concreto. Ambiente construído, v. 8, n. 4, p. 51-60, 2008.

BARETTA, Carolina; PIOVESAN, Angela Zamboni. Análise comparativa entre o uso de concreto convencional e autoadensável em peças pré-moldadas de concreto armado. Conhecimento Em Construção, v. 6, p. 7-20, 2019.

CALADO, Carlos Fernando de Araújo et al. Concreto auto-adensável (CAA), mais do que alternativa ao concreto convencional (CC). 2016.

GONÇALVES, J. P. Desenvolvimento e Caracterização de concretos de baixo impacto ambiental contendo argila calcinada e areia artificial. 2005, 273 f. Doutorado em Engenharia Civil) Programa de Engenharia Civil-COPPE/UFRJ, Rio de Janeiro, 2005. Disponível em: . Acesso em: 21 maio 2020.

LODI, V. H. Viabilidade Técnica e econômica do uso de areia de britagem e concretos de cimento portland na região de Chapecó-SC. Florianópolis: UFSC, v. Disertação (Mestrado), 2006. 130 p.

MENOSSI, R. T. Utilização do pó de pedra basáltica em substituição a areia natural do concreto. Ilha Solteira: UNESP, 2004.

TUTIKIAN, B. F.; DAL MOLIN, D. C. Concreto auto-adensável. São Paulo: PINI, v. 1, 2008. 148 p.

VIACELLI, Luana. Estudo da viabilidade da utilização do agregado miúdo britado em concreto convencional. 2012. Trabalho de Conclusão de Curso. Universidade Tecnológica Federal do Paraná. 


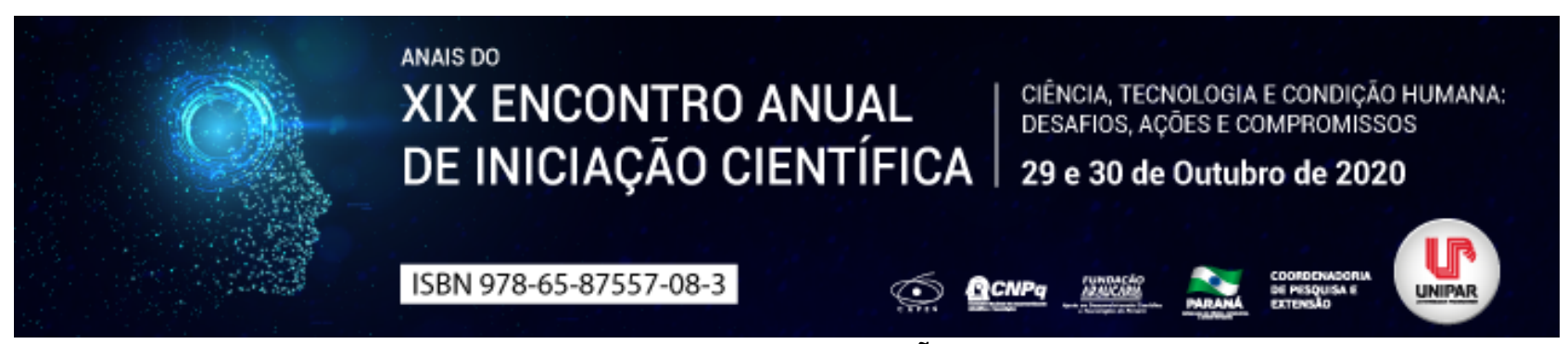

MADEIRA NA CONSTRUÇÃO CIVIL

\title{
${ }^{1}$ CARLOS NATA ZENATTI, ${ }^{2}$ NATHALIA RAFAELA PONTIN, ${ }^{3}$ FABRICIO BALESTRIN
}

\author{
${ }^{1}$ Acadêmica do Curso de Engenharia Civil da UNIPAR \\ ${ }^{1}$ Acadêmica do Curso de Engenharia Civil da UNIPAR \\ ${ }^{2}$ Docente da UNIPAR
}

Introdução: A madeira é tradicionamente um dos materiais mais empregados em qualquer etapa da construção civil, pela vasta diversidade de espécies, com aspectos e usos diferenciados. Em diversos países, a madeira é utilizada na construção de habitações e em projetos estruturais (CURY; TOMAZELLO FILHO, 2011). Por ser muito utilizada na construção civil, devido à seu fácil acesso e suas propriedades relevantes, a madeira tem uma ampla empregabilidade para diversas funções, como nas construções de pontes, passarelas, estruturas, vedações, tetos, pisos e etc. O uso da madeira também pode ser associada ao concreto e aço para ter um maior arsenal de aplicações (SORIANO, 2001). Atualmente existem diversos novos produtos de madeira processada, com características interessantes quanto à formas, dimensões, aspectos e, sobretudo, características físicas e mecânicas. Além das técnicas de ligação das peças que tiveram uma grande e importante evolução, voltada no desenvolvimento e criação de colas de alta resistência e durabilidade (CRUZ; NUNES, 2003).

Objetivo: Destacar a aplicação da madeira na construção civil.

Desenvolvimento: As construções rurais, na sua maioria, são executadas em madeira, devido ao fato da fonte deste recurso natural estar próxima. A sua fácil trabalhabilidade e uma baixa densidade são fatores importantes que contribuem para o intenso uso em relação aos outros materiais empregados na construção civil, dentre eles o concreto e o aço. Diferente dos dois materiais citados que requerem alto consumo energético de usinagem, a madeira é um material diretamente obtido da natureza e, após pouco processamento de serragem, já está pronto para a utilização (SORIANO, 2001). Ter conhecimento das propriedades físicas da madeira é de grande importância para sua devida aplicação. Destacam-se características como: umidade, densidade, retratibilidade, resistência ao fogo, durabilidade natural e resistência química. Outro fator a ser considerado é o seu comportamento diferente em relação à direção do crescimento das fibras (SZUCS et al., 2016). A vida útil da madeira, e por sua vez da estrutura na construção, está diretamente relacionada ao grau de exposição aos fatores ambientais (oxigênio, umidade e calor), já que sua interação pode causar um aumento dos agentes biodeterioradores que atacam a madeira, tais como fungos e bactérias. O clima tropical é um contruibuinte para a presença de insetos perfuradores, como os cupins e besouros que encontram na madeira sua fonte de energia e/ou habitação. $\mathrm{O}$ tratamento da madeira é fundamental para a durabilidade deste material ser significativamente prolongada (SORIANO, 2001). No Brasil, por exemplo, o total potencial deste material biológico não tem sido devidamente explorado em usos estruturais. Entre principais fatores que limitam o emprego da madeira, destacamse a falta de mão de obra qualificada e a falta de conhecimento das espécies e suas devidas propriedades, diminuindo a qualidade e a vida útil das construções (CURY; TOMAZELLO FILHO, 2011). Foram feitas pesquisas quanto à técnica da madeira laminada colada (MLC), que é produzida em pequena escala. Esta, possibilita a conquista de seções transversais maiores que as tipicamente encontradas em madeira serrada. Além desta vantagem, a MLC é produzida com lâminas de madeira selecionadas e previamente secas em estufas, e submetidas ao processo de tratamento preventivo assegurando uma melhor qualidade e durabilidade (SORIANO, 2001).

Conclusão: São inúmeras as utilizações da madeira na construção civil, que pode ser usada em estruturas, vedações, sistemas construtivos, tetos, pontes, passarelas. Os principais pontos para sua utilização na construção é sua acessibilidade, suas propriedades físicas e mecânicas relevantes, e ser de fácil trabalhabilidade, além dos diversos produtos fornecidos pelo mercado da construção originados da madeira, como laminados e chapas de vedações. Os principais cuidados com a madeiral devem-se ao processamento antes da sua aplicação, para evitar possíveis patologias devidas a ação de agentes biodeterioradores.

\section{Referências}

CURY, Graziela; TOMAZELLO FILHO, Mario. Descrição anatômica de espécies de madeira utilizadas na construção civil. São Paulo, setembro, 2011. Disponível em: https://floram.org/article/10.4322/floram.2011.042/pdf/floram-18-3-227.pdf. Acesso em: 18 agosto 2020.

CRUZ, Helena; NUNES, Lina. A madeira como material de construção. Lisboa, 2003. Disponível em: http://www.oasrn.org/3R/conteudos/areareservada/areareservada8/Madeira\%20material\%20de\%20construcao-\%2OHC.pdf. Acesso em: 18 agosto 2020.

SORIANO, Julio. Estruturas mistas em concreto e em madeira: análise de vigas e painéis e aplicações na construção $\begin{array}{lllll}\text { civil. São } & \text { Paulo, } & \text { julho, } & & \\ & & \text { Disponível } & \text { em: }\end{array}$ 
http://repositorio.unicamp.br/jspui/bitstream/REPOSIP/257646/1/Soriano_Julio_D.pdf. Acesso em: 18 agosto 2020.

SZUCS, Carlos Alberto et al. Estruturas de madeira. Florianópolis, agosto, 2016. Disponível em: https://moodle.ufsc.br/pluginfile.php/1313798/mod_resource/content/O/Apostilamadeiras2015-1.pdf. Acesso em: 18 agosto 2020.

Coordenadoria de Pesquisa e Extensão - COPEX

Departamento de Editoraçāo e Divulgaçāo Científica - DEDIC 


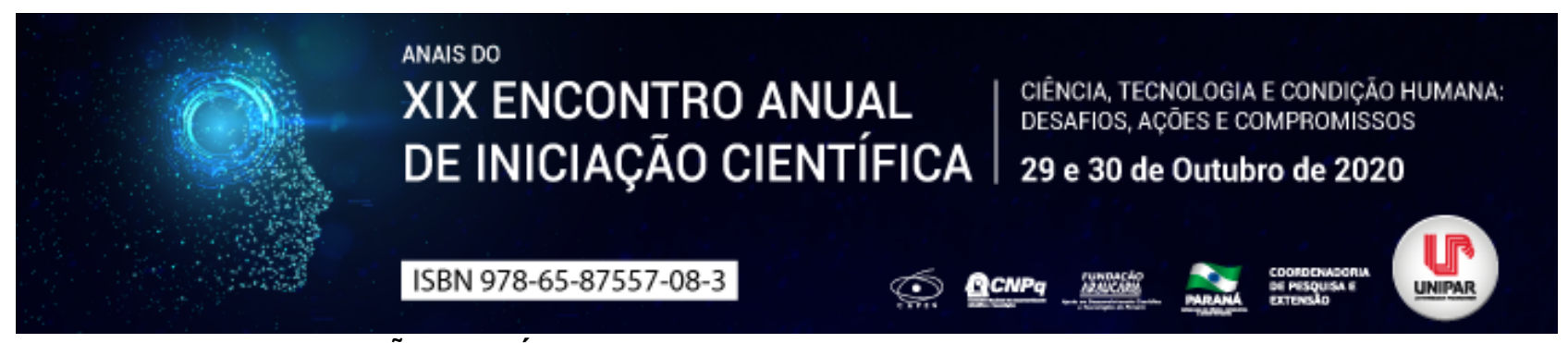

EFEITO DA DESIDRATAÇÃO OSMÓTICA COMO TRATAMENTO PRELIMINAR NA SECAGEM DE MANGAS

\title{
${ }^{1}$ Adryelen Cassiano Martins, ${ }^{2}$ LARISSA FRANCISCATTI HOFFMANN, ${ }^{3}$ BARBARA DANIELE ALMEIDA PORCIUNCULA
}

\author{
${ }^{1}$ Acadêmica do PIC/UEM \\ ${ }^{1}$ Acadêmica do PIC/UEM \\ ${ }^{2}$ Docente da UNIPAR
}

Introdução: A manga é uma das frutas mais populares do mundo, devido a sua cor atraente, seu sabor e suas propriedades nutricionais, sendo rica em vitaminas A e C, e potássio, além de alguns compostos antioxidantes (BALOCHI, 2013). A fruta apresenta alto teor de umidade na sua forma in natura (aproximadamente $75 \%$ ) o que acarreta numa alta perecibilidade. Visto isto, observa-se a necessidade de processos adequados de conservação. A desidratação osmótica é uma operação utilizada para a remoção parcial da água de tecidos celulares e vem sendo utilizada como um pré-tratamento para muitos processos para melhorar a nutrição, propriedades sensoriais e funcionais dos alimentos, sem alterar sua integridade (RASTOGI et al., 2005; TORREGGIANI, 1993). É geralmente empregada como uma etapa anterior ao processo de secagem convectiva (NOWAKUNDA et. al, 2004), liofilização (AGNIESZKA e ANDRZEJ, 2010), secagem por microondas e secagem a vácuo. Devido às alterações na microestrutura dos tecidos vegetais pela saída da água das células, pode-se incorporar sais de cálcio, que atuam como agentes de textura, que após sua impregnação podem ocasionar modificações benéficas na textura do fruto, devido às alterações na estrutura deste alimento (ANINO et. al, 2006; CYBULSKA et. al, 2011).

Objetivo: O presente estudo teve como objetivo avaliar o efeito da desidratação osmótica em soluções de sacarose com diferentes concentrações de cloreto de cálcio como tratamento preliminar na secagem de mangas da variedade Tommy Atkins.

Materiais e Métodos: As frutas utilizadas neste estudo foram mangas da variedade Tommy Atkins adquiridas no comércio local da cidade de Umuarama PR. A seleção das frutas foi realizada pelo grau de maturação, observado por análise visual, teor de umidade e pelo conteúdo de sólidos solúveis ( ${ }^{\circ} \mathrm{Brix}$ ). O teor de umidade foi determinado pelo método gravimétrico (INSTITUTO ADOLFO LUTZ, 2008). O conteúdo de sólidos solúveis ( ${ }^{\circ}$ Brix) determinado utilizando-se um refratômetro óptico manual. As frutas foram lavadas e descascadas manualmente. Após, as amostras foram preparadas cortando-se fatias paralelas ao eixo da manga e destas fatias retiradas as amostras, em formato de cubos de aproximadamente $1,0 \mathrm{~cm}$ de lado. As soluções de sacarose foram preparadas utilizando-se açúcar comercial (sacarose), cloreto de cálcio ( $\mathrm{CaCl}$ ) e água destilada. A concentração da solução foi determinada através de refratômetro óptico manual. Para a desidratação osmótica das mangas foi utilizada solução com concentração de $65^{\circ}$ Brix, e diferentes concentrações de $\mathrm{CaCl}\left(0,5,1,0\right.$ e 1,5\%) à temperatura de $30{ }^{\circ} \mathrm{C}$ durante 2 horas. Uma relação mássica fruta:solução de 1:10 foi utilizada. As amostras in natura e pré-tratadas em solução osmótica foram submetidas à secagem em estufa com circulação e renovação de ar (Marconi, MA035, BRASIL), a $60^{\circ} \mathrm{C}$ até peso constante. Foram realizadas pesagens a cada $15 \mathrm{~min}$ nas duas primeiras horas e a cada 30 minutos no tempo subsequente (ZOTARELLI et.al., 2012). A secagem foi realizada em quadriplicata de amostra e duplicata de experimento.

Resultados: As frutas in natura selecionadas apresentaram uma concentração de sólidos solúveis de $11,7 \pm 0,7{ }^{\circ}$ Brix e teor de umidade de $6,881 \pm 0,529 \mathrm{~g}$ de água/ $\mathrm{g}$ de sólidos secos. O teor de umidade das amostras de manga submetidas ao tratamento osmótico em soluções de sacarose com concentrações de cloreto de cálcio de 0,5\%, 1,0\% e 1,5\% foi de 2,471士0,177; $1,865 \pm 0,060$ e 1,974 $\pm 0,059$, respectivamente

Discussão: Foi possível notar que houve uma redução do teor de umidade das amostras com o aumento da concentração de cloreto de cálcio na solução desidratante. O processo mais eficiente foi o que utilizou a solução de sacarose enriquecida com 1,0\% cloreto de cálcio. A utilização de altas concentrações de cloreto de cálcio reduziu a perda de água, mas não restringiu a entrada de solutos, o que reduziu a eficiência do processo. O teor de umidade durante o processo de secagem diminuiu com o passar do tempo. Inicialmente, a superfície da amostra passa a ser aquecida e devido a temperatura do ar de secagem ocorre a evaporação da água superficial da amostra, por consequência da diferença de pressão entre vapor da superfície do alimento e do ar de secagem. Isso ocorre até que toda a livre do alimento seja evaporada (TADINI et al.,2016). Com relação a taxa de secagem, era esperado que as frutas submetidas ao pré-tratamento osmótico apresentassem menores taxas devido à incorporação de moléculas de sacarose a sua microestrutura, entretanto este fato não foi observado. As maiores taxas de secagem foram encontradas para as amostras submetidas à desidratação osmótica em soluções com as maiores concentrações de cloreto de cálcio. Provavelmente, a presença do cloreto de cálcio nas soluções osmóticas durante o pré-tratamento promoveu menor incorporação das moléculas de sacarose.

Conclusão: Foi possível avaliar que as maiores taxas de secagem foram observadas nas amostras submetidas à desidratação em solução de sacarose e 1\% de cloreto de cálcio. Maiores concentrações de cloreto de cálcio na solução desidratante resultou 


\section{Referências}

AGNIESZKA, C.; ANDREZEJ, L. Rehydration and sorption properties of osmotically pretreated freeze-dried strawberries. Journal of Food Engineering, Warsaw (Poland), v. 97, p. 267-274, March, 2010.

ANINO, S. V.; SALVATORI, D. M.; ALZAMORA, S. M. Changes in calcium level and mechanical properties of apple tissue due to impregnation with calcium salts. Food Research International, Argentina, v. 39, p. 154-164, March, 2006.

BALOCH, M. K.; BIBI, F.; JILANI, M. S. Effect of coatings over the quality and shelf life of mango (Mangifera indica L.) fruit. Journal of Food Processing and Preservation, Pakistan, v. 37, p. 66 73, March, 2013.

CYBULSKA, J., ZDUNEK, A., KONSTANKIEWICZ, K. Calcium effect on mechanical properties of model cell walls and apple tissue. Journal of Food Engineering, Lublin (Poland), v. 102, p. 217 223, 2011.

FOUST, A. S.; WENZEL, L. A.; CLUMP, C. W.; MAUS, L.; ANDERSEN, L. B. Princípios das Operações Unitárias. Editora LTC, 1980.

GEANKOPLIS, C. J. Procesos de transporte y operaciones unitárias. $3^{\mathrm{a}}$ ed. México: CECSA, 1998.

INSTITUTO ADOLFO LUTZ. Normas Analíticas do Instituto Adolfo Lutz: Métodos físico-químicos para análises de alimentos. $4^{\mathrm{a}}$ ed. (1 $1^{\mathrm{a}}$ Edição digital), 2008.

NOWAKUNDA, K.; ANDRÉS; FITO, P., Osmotic Dehydration of Banana Slices as a Pré Treatment for Drying Process. Proceedings of the 14th International Drying Symposium, São Paulo, v. C, p. 2077-2083, 2004.

RASTOGI, N. K.; RAGHAVARAO, K. S. M. S.; NIRANJAN, K. Developments in Osmotic Dehydration . Emerging Technologies for Food Processing Food Science Technology, International Series. Edited by Da-Wen Sun. Elsevier Academic Press, $p$. 221-249, 2005.

TORREGGIANI, D. Osmotic dehydration in fruit and vegetables processing. Food Research International, v.26, n.1, p.59-68, 1993.

ZOTARELLI, M. F.; PORCIUNCULA, B. D. A.; LAURINDO, J. B. A convective multi-flash drying process for producing dehydrated crispy fruits. Journal of Food Engineering, v. 108. p. 523-531, 2012. 


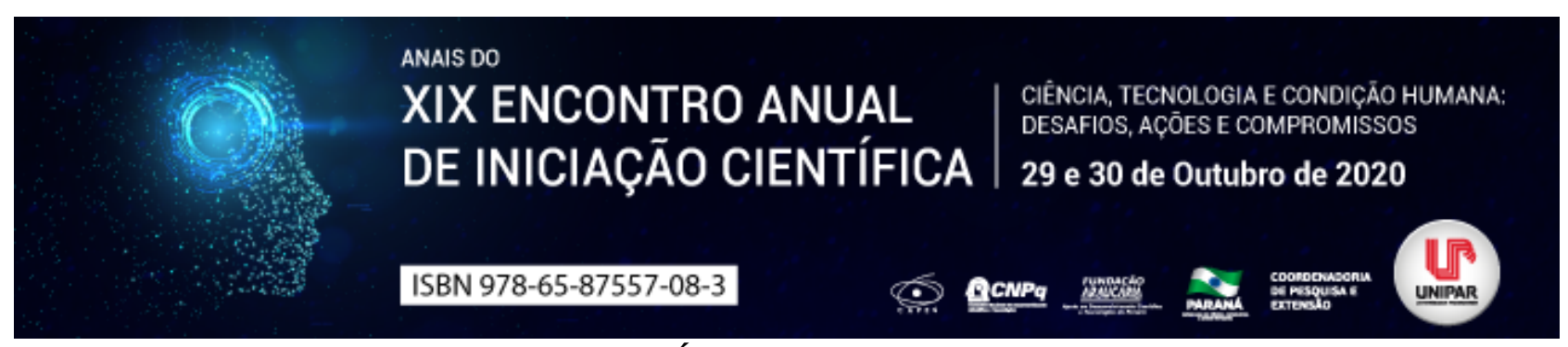

ESTUDO DE CONTROLE QUÍMICO DA MANCHA AMARELA DO TRIGO

\begin{abstract}
${ }^{1}$ Giovanna Seron, ${ }^{2}$ CELSO MARTINS FRANÇA, ${ }^{3}$ LUCAS PEREIRA DA SILVA, ${ }^{4}$ PRISCILA ANGELOTTI-ZAMPAR, ${ }^{5}$ DAURI JOSÉ TESSMANN
\end{abstract}

\author{
${ }^{1}$ Acadêmica do Curso de Agronomia - Universidade Estadual de Maringá \\ ${ }^{1}$ Acadêmico do Curso de Agronomia Universidade Estadual de Maringá \\ ${ }^{2}$ Mestrando do Programa de Pós-Graduação em Agronomia Universidade Estadual de Maringá \\ ${ }^{3}$ Doutoranda do Programa de Pós-Graduação em Agronomia Universidade Estadual de Maringá \\ ${ }^{4}$ Docente da Universidade Estadual de Maringá
}

Introdução: A produção de trigo (Triticum aestivum L.) encontra-se principalmente na região Sul do país, com cerca de $87 \%$ da produção nacional (CONAB, 2018). Na safra 2019/20 a expectativa é que a área plantada de trigo no Brasil cresça $14,1 \%$ e alcance 2,33 milhões de hectares, com uma produção recorde de 6,8 milhões de toneladas (CONAB, 2020). Essa cultura possui grande importância mercadológica e uma vasta aplicabilidade, no qual é amplamente consumido na alimentação (SCHEUER et al., 2011). A mancha amarela, causada por Pyrenophora tritici-repentis, é a doença foliar mais importante dessa cultura, tem como sintoma inicial o surgimento de manchas cloróticas na folha, onde posteriormente formará uma região necrosada (REIS et al., 2005). Devido a relevância desta doença, o controle químico é um aliado importante para diminuir a severidade do patógeno, e assim, evitando perdas na produtividade.

Objetivo: Estudar sobre a mancha amarela do trigo e suas formas de controle utilizando produtos químicos.

Desenvolvimento: Algumas doenças do trigo são beneficiadas pela condição climática do Sul do Brasil, uma delas é a mancha amarela, uma mancha foliar. Tais doenças são capazes de reduzir a qualidade e a quantidade de grãos produzidos, no qual essa perda pode reduzir em média 44,6\% no rendimento de grãos (PICININI et al., 1996). Conforme o aumento da incidência de doenças fúngicas e carência de matérias resistentes, o uso de fungicidas seria o melhor método para o controle (PICININI; FERNANDES, 2003). As doenças foliares afetam significativamente a capacidade fotossintética da planta, consequentemente prejudica o desenvolvimento vegetativo e reduz o rendimento (BEDENDO, 2011). Em relação a mancha amarela, os prejuízos então ligados ao enchimento de grãos, peso de grãos, tamanho de grãos e número de grãos por espiga (DE WOLF et al., 1998).

O fungo causador da mancha amarela é o Pyrenophora tritici-repentis (anamorfo: Drechslera tritici-repentis), esse sobrevive em restos culturais durante a entressafra, local onde são formados os pseudotécios, que posteriormente liberam ascósporos, responsáveis por infectar a planta (CIUFFETTI e TUORI, 1999). As condições climáticas favoráveis para o crescimento da doença é temperatura entre 18 e $28^{\circ} \mathrm{C}$ e molhamento foliar por no mínimo 30 horas (BACALTCHUK et al., 2006). Os sintomas podem aparecer logo após da emergência do trigo, inicialmente surgem pequenas manchas cloróticas nas folhas, que posteriormente amplificam e apresentam necrose na região central e circundada por um halo amarelo (REIS et al, 2005).

No controle da doença pode ser utilizado produtos químicos para o tratamento das sementes ou aplicações via foliar. O objetivo do tratamento de sementes é eliminar os patógenos presentes, para evitar a transmissão da doença aos órgãos aéreos da planta em uma área recém-estabelecida, devido a capacidade dos fungicidas em realizar a translocação na planta e permanecer por um longo período (PICININI e FERNANDES, 2001). Em relação ao controle da doença por aplicação foliar, pode beneficiar a planta com a melhora da qualidade do trigo (NAVARINI, BALARDIN, 2012). Em um estudo realizado por Ranzi e Forcelini (2013), mostrou que a utilização de fungicida a base de triazol ou uma mistura de triazol + estrobilurina foram eficientes para diminuir a expansão lesão da doença, enquanto somente fungicida a base de estrobilurina não apresentou controle efetivo. Evidenciando que o princípio ativo triazol é mais eficiente para o controle da mancha amarela. Os triazóis são sistêmicos e podem atuar de forma curativa ou protetora. Quando a aplicação é para proteção, o princípio ativo age sobre a formação do tubo germinativo e na formação do apressório, enquanto aplicado para forma curativa atua sobre o desenvolvimento do haustório e o crescimento micelial no hospedeiro (EHR e KEMMITT, 2002; FORCELINI, 1994; RODRIGUES, 2006).

Conclusão: Entre as doenças que atacam o trigo, a mancha amarela da folha se destaca devido à perda que causa na produtividade e na qualidade dos grãos. Para o controle da macha amarela é importante a utilização de alguns métodos, como tratamento de semente e aplicação foliar de produtos químicos, para um bom manejo da doença em todos os estádios da planta.

\title{
Referências
}

CONAB Companhia Nacional de Abastecimento. Disponível em: https://www.conab.gov.br/. Acesso em Agosto, 2020.

SCHEUER, P. M. et al. Trigo: Características e utilização na panificação. Revista Brasileira de Produtos Agroindustriais, Campina Grande, v.13, n.2, p.211-222, 2011. 
REIS, E. M.; CASA, R. T.; FORCELINI, C. A.; Doenças do trigo. In: KIMATI, H. et al. Manual de Fitopatologia: Doenças das plantas cultivadas. 3. ed. São Paulo: Ceres, 2005.

PICININI, E.C.; FERNANDES, J.M.C.; IGNAZACK, J.C. \& AMBROSI, I. Impacto econômico do uso do fungicida propiconazole na cultura do trigo (Triticum aestivum). Fitopatologia Brasileira, p. 326-368. 1996.

PICININI, E. C.; FERNANDES, J. M. C. Efeito do tratamento de sementes com fungicida sobre o controle de doenças na parte aérea do trigo. Fitopatologia Brasileira, Brasília, v. 28, n. 5, setembro/outubro. 2003.

BEDENDO, I. P. Manchas foliares. In: AMORIN, L; REZENDE, J. A. M.; BERGAMIN FILHO, A. Manual de Fitopatologia. 4 ed. São Paulo: Cerees, 2011. p. 459.

DE WOFL, E. D.; EFFERTZ, J.; ALI, S.; FRANCL, L. J. Vistas of tan spot research. Canadian Journal of Plant Pathology, Ottawa, v. 20, p. 349-370, 1998.

CIUFFETTI, L. M.; TUORI, R. P. Advances in the characterization of the Pyrenophora tritici-repentis wheat interaction. Phytopathology, Corvallis, v. 89, n. 6, p. 444-449, 1999.

BACALTCHUK, B. et al. Características e cuidados com algumas doenças do trigo. Passo Fundo: Embrapa Trigo, 2006. Disponível em: . Acesso em: Agosto. 2020

PICININI, E. C.; FERNANDES, J. M. Controle da ferrugem da folha e da mancha bronzeada da folha de trigo pelo uso de fungicidas em tratamento de sementes. Fitopatologia brasileira, Passo Fundo, v. 26, n. 1, p. 100-100, 2001.

NAVARINI, L.; BALARDIN, R. S. Doenças foliares e o controle por fungicidas na produtividade e qualidade de grãos de trigo. Summa Phytopathologica, Botucatu, v. 38, n. 4, p. 294-299, 2012.

RANZI, C.; FORCELINI, C. A. Aplicação curativa de fungicidas e seu efeito sobre a expansão de lesão da mancha-amarela do trigo. Ciência Rural, Santa Maria, v. 43, n. 9, p. 1576-1581, 2013.

EHR, R. J.; KEMMITT, G. Periodic table of the fungicides. Indianapolis: Dow Agrosciences, v. 1, 2002.

RODRIGUES, M. A. T. Classificação de fungicidas de acordo com o mecanismo de ação proposto pelo FRAC. 2006.291 f. Dissertação (Mestrado em Agronomia) - Faculdade de Ciências Agronômicas da UNESP- Botucatu, SP.

Coordenadoria de Pesquisa e Extensão - COPEX

Departamento de Editoraçāo e Divulgaçāo Científica - DEDIC 


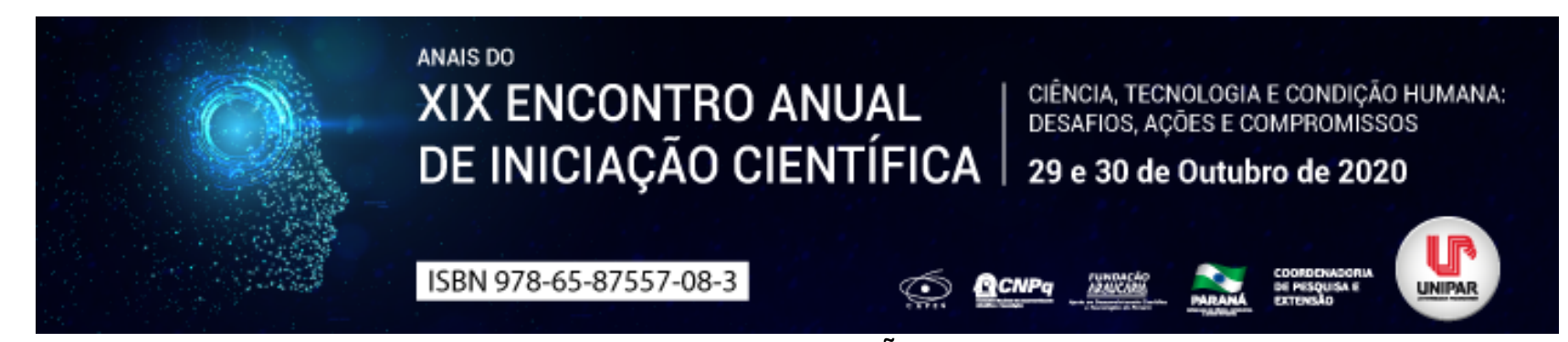

\title{
REGULADORES DE CRESCIMENTO PROMOVEM ALTERAÇÕES NO CRESCIMENTO DE Melissa officinalis L. CULTIVADA In vitro
}

\author{
${ }^{1}$ HELEN KARLA FERREIRA DE MELLO, ${ }^{2}$ ELIZABETH DANTAS, ${ }^{3}$ KAROLYNE DE AVILA, ${ }^{4}$ LEILA ISABEL DA SILVA, ${ }^{5}$ HELIDA \\ MARA MAGALHAES
}

${ }^{1}$ Acadêmica bolsista do PIC/UNIPAR

${ }^{1}$ Acadêmica do Curso de Engenharia AgronÃ'mica da UNIPAR

${ }^{2}$ Acadêmica do Curso de Engenharia Agronẽ'mica da UNIPAR

${ }^{3}$ Mestre em Biotecnologia Aplicada à Agricultura - UNIPAR

${ }^{4}$ Professora doutora do programa de pós graduação em Biotecnologia Aplicada à Agricultura- UNIPAR

Introdução: A espécie Melissa officinalis L. (Lamiaceae) é originária da Europa meridional (BEDUHN et al., 2016). Apresenta relevante importância para as indústrias farmacêutica, cosmética (KEIVAN; GHOLAMREZAEE, 2012). Devido principalmente ao seu óleo essencial rico em compostos como: fenilpropenoides e terpenoides (KEIVAN; GHOLAMREZAEE, 2012; LUZ et al., 2014). Os quais têm ação como calmante e controle do estresse, ansiedade, nervosismo e problemas digestivos (CUNHA et al., 2016). Entretanto, mesmo sendo uma espécie com grande potencial econômico e medicinal, há uma carência de informações em relação ao seu cultivo e métodos propagativos (RIBEIRO et al., 2007). No caso, das plantas medicinais que têm compostos de interesse industriais, a obtenção de protocolos de micropropagação é o primeiro passo para possibilitar a produção de metabólitos secundários in vitro (TRETTEL et al., 2019). Existem poucos estudos com reguladores de crescimento na melissa, sendo, portanto inconclusivos os efeitos no seu desenvolvimento (MEFTAHIZADE et al., 2010). As plantas que são expostas a concentrações e tipo de reguladores de forma balanceada se desenvolvem de maneira satisfatória. (GEORGE et al., 2008

Objetivo: Avaliar a ação de reguladores de crescimento sobre o crescimento e processos fisiológicos e bioquímicos de plantas de Melissa officinalis cultivadas in vitro.

Materiais e métodos: O experimento conduzido nos laboratórios da UNIPAR, montado em delineamento inteiramente casualizado (DIC). Com oitos tratamentos com dois tipos de reguladores de crescimento em diferentes concentrações. Foram utilizadas quarenta repetições para cada tratamento totalizando 320 parcelas e cada frascos continha quatro sementes. Sementes foram inoculadas em meio de cultura Murashige e Skoog com os reguladores benzilaminopurina - BAP e ácido naftaleno acético - ANA. Ao final de 90 dias foram avaliados: crescimento da planta, índices bioquímicos e fisiológicos.

Resultados: As folhas de melissa foram incrementadas no T2(0,2 $\mathrm{mgL}^{-1}$ BAP e 0,0 $\left.\mathrm{mgL}^{-1} \mathrm{ANA}\right)$ o qual promoveu um ganho de $54,71 \%$ em comparação ao meio sem reguladores (T1), 95,0 \% e 97,0\% em relação à T5(0,5 $\mathrm{mgL}^{-1} \mathrm{BAP}$ e $\left.0,5 \mathrm{mgL}^{-1} \mathrm{ANA}\right) \mathrm{e}$ T6 $\left(0,05 \mathrm{mgL}^{-1}\right.$ BAP e $\left.0,5 \mathrm{mgL}^{-1} \mathrm{ANA}\right)$ respectivamente. Como T2 e T1 foram superiores em folhas e comprimento isto refletiu na massa seca das brotações e das raízes de forma que nestas plântulas foram possíveis mensurar uma média de T2 $(0,2667 \mathrm{~g})$ e T1 $(0,1882 \mathrm{~g})$ de brotos secos. Estes foram 10 vezes maiores que T3(0,5 mgL-1 BAP e 0,0 $\left.\mathrm{mgL}^{-1} \mathrm{ANA}\right)$. Nas raízes os resultados foram similares. O T8(0,3 $\mathrm{mgL}^{-1}$ BAP e $\left.0,5 \mathrm{mgL}^{-1} \mathrm{ANA}\right)$ formou apenas calos compactos sem nenhuma emissão de raízes ou brotações. Os índices de nitrogênio e clorofila foram superiores nos T2 e T1 o que indicou que nestas condições a absorção de nitrogênio do meio a alocação nas folhas foi favorecida. Em T2 e na ausência de reguladores o NBI foi similar $(60,0)$ sendo que estes tratamentos promoveram um incremento de 85,74\% comparado a T5 que apresentou a menor média. Justamente àquelas plantas que se apresentaram menores e mais raquíticas. Para as plantas expostas ao T4(0,5 $\mathrm{mgL}^{-1} \mathrm{BAP}$ e $\left.0,05 \mathrm{mgL}^{-1} \mathrm{ANA}\right)$, T6 e T7(1,0 $\mathrm{mgL}^{-1}$ BAP e $0,0 \mathrm{mgL}^{-1}$ ANA) não foram observadas diferenças significativas para o NBI. Sobre o índice de flavonoides o meio que continha T3 obteve maior média, seguidas por T2, T1 e T7. As antocianinas foram incrementadas nas plantas expostas a T3 e T7 seguidas por T1, T2 e T4 que apresentaram médias iguais entre si.

Discussão: Neste estudo foi demonstrada a eficiência do BAP em promover um crescimento mais ajustado, isto é, como menos anormalidades, e formação de plantas vigorosas na concentração de $0,2 \mathrm{mg} \mathrm{L}^{-1}$. Neste tratamento houve maior emissão de folhas, raízes e mais produção de biomassa. A produção de folhas é essencial em protocolos de micropropagação, pois é nelas que se concentram glândulas produtoras de óleo essencial, portanto existe uma relação direta que quanto mais folhas, maior o rendimento de óleo (STOJIČIĆ et al. 2016; GIULIANI et al. 2017). Reis et al. (2008) relataram maior formação de brotações e também eficiência na aclimatização de plantas de melissa quando foi utilizado 1,0 $\mathrm{mg} \mathrm{L}^{-1}$ de BAP. Também Beduhn et al. (2016) propuseram a concentração de $1,0 \mathrm{mg} \mathrm{L}^{-1}$ de BAP e $0,5 \mathrm{mg} \mathrm{L}^{-1}$ ANA, para o aumento no comprimento das plantas e ainda, 
segundo estes autores a utilização de altas concentrações de BAP $(2,0 \mathrm{mg} \mathrm{L})$ durante a multiplicação in vitro demonstrou efeitos negativos, pois promoveu o menor crescimento na altura das plantas. O índice de NBI que demonstra a disponibilidade de nitrogênio na planta. De maneira igual também foi maior no T2.

Conclusão: As plantas de melissa que expostas a 0,2 $\mathrm{mg} \mathrm{L}^{-1}$ de BAP (T2) apresentaram-se mais vigorosas, maiores e com mais folhas, promovendo um sistema radicular bem formado com presença raízes primárias e secundárias. A combinação de $0,5 \mathrm{mg}$ $\mathrm{L}^{-1}$ de BAP e $0,5 \mathrm{mg} \mathrm{L}^{-1}$ de ANA resulta em plantas raquíticas e má formação do sistema radicular, com queda em nos índices de nitrogênio, clorofila, flavonóides e antocianinas. A combinação de $3,0 \mathrm{mg} \mathrm{L}^{-1}$ de BAP e $0,5 \mathrm{mg} \mathrm{L}^{-1}$ de ANA promoveu a formação de calos em todos os explantes avaliados.

\section{Referências}

BEDUHN, F.A.; LUCHO, S.R.; MILECH, C.; KLINOWSKI, A.M.; DUTRA, D.B.; GALLI, M.F.; BRAGA, E.J.B.; Estabelecimento in vitro, propagação e aclimatização de melissa (Melissa officinalis L.)Rev. Jornada de pós-graduação e pesquisa13 ${ }^{\circ}$ jornada de pós graduação e pesquisa - Congrega Urcamp, 2016.

CUNHA, A.L.; MOURA, K.S.; BARBOSA, J.C.; SANTOS, A.F.; Os metabólitos secundários e sua importância para o organismo, Diversitas Journal, v. 1, n. 2, p.175-181, 2016.

GEORGE EF, HALL MA, KLERK G. Plant propagation by tissue culture: the background, 3rd edn. Springer, Dordrecht, 2008.

GIULIANI, C. et al. Secretory structures and essential oil composition in Stachys officinalis (L.) Trevisan subsp. officinalis (Lamiaceae) from Italy. Natural product research, v. 31, n. 9, p. 1006-1013, 2017.

MURASHIGE, T.; SKOOG, F. A revised medium for rapid growth and bio assays with tobacco tissue cultures. Physiologia Plantarum, v. 15, n. 3, p. 473-497, 1962.

NEELAKANDAN, A. K.; WANG, K. Recent progress in the understanding of tissue culture-induced genome level changes in plants and potential applications. Plant Cell Reports, v.31, n.4, p.597-620, 2012.

REIS, E.S; PINTO, J. E. B.P; ROSADO, L.D.S; CORREAA, R.M; influencia do meio de cultura na germinação de sementes in vitro e taxa de multiplicação de Melissa officinalis L. Revista Ceres, p. 160-167, 2008.

RIBEIRO, M.V.; LIMA, C.S.M.;BANDEIRA, J.M.; RUBIN, S,; BENITEZ, L.C.; PETERS, J.A.; BRAGA, E.J.B.B; Concentrações de sacarose e tipos de vegetações no cultivo in vitro de Melissa officinalis L. Revista Brasileira Biociência v.5, supl. 2, p. 843-845, 2007.

STOJIČIĆ, Dragana et al. Glandular trichomes and essential oil characteristics of in vitro propagated Micromeria pulegium (Rochel) Benth.(Lamiaceae). Planta, v. 244, n. 2, p. 393-404, 2016.

TRETTEL, J. R.; NASCIMENTO, A.B.; BARBOSA, L. N.; MAGALHÃES, H. M. In vitro organogenesis and growth of Ocimum basilicum 'Genovese' (basil) cultivated with growth regulators. Australian Journal of Crop Science, v. 13, n. 07, p. 1131-1140, 2019. 


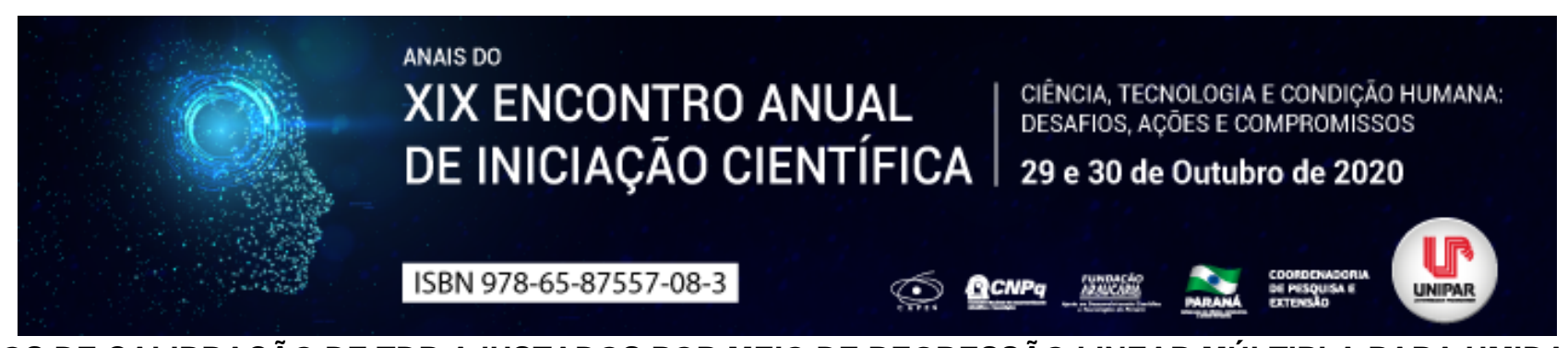

\title{
MODELOS DE CALIBRAÇÃO DE TDR AJUSTADOS POR MEIO DE REGRESSÃO LINEAR MÚLTIPLA PARA UMIDADES DO SOLO VOLUMÉTRICA E GRAVIMÉTRICA
}

\begin{abstract}
${ }^{1}$ Renilza Rita de Cassia da Silva, ${ }^{2}$ GEOVANA SECCATTO GARCIA, ${ }^{3}$ CELSO MARTINS FRANÇA, ${ }^{4}$ ANDRÉ PAULINO MORAES, ${ }^{5}$ ANTONIO CARLOS ANDRADE GONÇALVES
\end{abstract}

\begin{abstract}
${ }^{1}$ Discente do curso de Agronomia da Universidade Estadual de Maringá e Bolsista PET-MEC/SESU M
${ }^{1}$ Discente do curso de Agronomia da Universidade Estadual de Maringá e Bolsista PIBIC/CNPQ- UEM

${ }^{2}$ Discente do curso de Agronomia da Universidade Estadual de Maringá e Bolsista PET-MEC/SESU

${ }^{3}$ Discente do curso de Agronomia da Universidade Estadual de Maringá e Bolsista PET-MEC/SESu

${ }^{4}$ Docente do Departamento de Agronomia da Universidade Estadual de Maringá-UEM e tutor do grupo PET-Agronomia UEM
\end{abstract}

Introdução: Os métodos indiretos de medida de umidade do solo são aqueles que permitem determinar a quantidade de água presente e medidas de características do mesmo, relacionadas com a umidade (TRINTINALHA 2000). Dentre os métodos de medidas indiretas tem-se a Time-Domain Reflectometry (TDR). Topp et al. (1980) mostram que a principal aplicação da TDR, do ponto de vista agronômico, é a de determinação de água do solo, que é importante para otimizar o rendimento das culturas e a eficiência do uso da água (LEKSHMI et al., 2014). Segundo Gomide (1998) é uma técnica não destrutiva, que não utiliza radiação, de manuseio fácil, portátil e pode apresentar elevada exatidão. Em solos arenosos, o monitoramento da umidade do solo em sistemas de produção agrícola irrigados, ganha importância em função da sua reduzida capacidade de retenção de água. Por outro lado, é importante avaliar se as ações antrópicas podem alterar suas características de forma a que as curvas de calibração da TDR também sejam modificadas.

Objetivo: Ajustar e comparar modelos de calibração da TDR, a partir de dados obtidos em amostras deformadas e indeformadas de um GLEISSOLO, em dois ciclos de medidas, oriundas de área com cultivo anual e de mata natural.

Materiais e Métodos: $O$ experimento foi realizado no Centro de Treinamento em Irrigação CTI/UEM. Foram analisados dois ciclos de medidas de constante dielétrica (Ka) e de umidade do solo (U). No primeiro ciclo, foram obtidos dados em quatorze microlisímetros, preenchidos com material deformado e indeformado, obtido no ambiente sob cultivo e sob mata. No segundo ciclo foram utilizados dois frascos de PVC (microlisímetros) com amostras de solo indeformadas e seis com amostras de solo deformadas, para os quais o preenchimento foi feito com TFSA, submetida a diferentes níveis de compactação. Nos microlisímetros foram instaladas sondas de TDR, para obtenção de Ka, e a umidade foi obtida gravimetricamente. Após a saturação, uma sequência de leituras foi efetuada, em cada ciclo, durante o processo de secagem. Foi determinada a umidade do solo (ds).

Resultados: Os valores obtidos da constante dielétrica (Ka) variaram entre 25 e 5,1. Isto correspondeu a uma faixa de valores de umidade gravimétrica entre 0,014 e 0,286 KgKg-1. Estes valores deram origem aos valores de umidade base volume entre 0,024 e 0,390 m3m-3. Os valores de ds variaram entre 1,354 e 1,744 Mgm-3. Os valores de coeficiente de variação (CV) permitiram verificar que umidade do solo base massa (Um) e umidade do solo base volume (Uv) têm variabilidade semelhante, entre 45 e $50 \%$ de CV. A Ka tem variabilidade um pouco menor, de $37 \%$. Os valores de coeficientes de assimetria e de curtose, bem como os valores da estatística d do teste de kolmogorov smirnov revelam que as distribuições de valores destas variáveis são bastante simétricas e se aproximam suficientemente da normalidade, para fins de análises estatísticas. Por outro lado, a distribuição de valores de ds, em número muito inferior mostra-se menos simétrica, o que é expresso, sobretudo por um valor de d mais elevado (0.169).

Discussão: Buscando avaliar a geração de um modelo único que leve em conta o efeito da densidade do solo sobre este, conforme feito por Gonçalves et al. (2011), foi ajustado um modelo conforme descrito por Silva e Kay (1997), incorporando o efeito da densidade por meio de procedimento estatístico baseado em um processo Forward stepwise, desenvolvido no software Statística (StatSoft $\left.{ }^{\circledR}\right)$. Foi empregado um modelo geral expresso por: Uv $=a+b K a+c d s+d K a d s+$ eKa2 + fKa2ds. A análise dos valores experimentais obtidos, para o conjunto das séries 1 e 2, com dados de Uv em função de Ka e de ds e a superfície do modelo ajustado revelou que o modelo único tende a subestimar os valores de Uv para locais com baixa ds e superestimar Uv em locais com ds mais elevada. Isto ocorre mesmo com a incorporação de ds ao modelo, revelando que esta incorporação é insuficiente para corrigir por completo a influência de ds sobre as curvas de calibração. O mesmo procedimento foi feito para umidade com base em massa, Um. Revelou-se que a relação entre valores de Um e Ka pode ser suficientemente descrita por um modelo linear, e revela também o forte efeito da densidade do solo sobre a posição das curvas. Com os valores obtidos, pode-se supor que a qualidade do ajuste para Um é ligeiramente melhor que o ajuste para Uv, o que sugere a opção de se empregar curvas de calibração da TDR baseadas na Um em função de Ka e ds. Analisando o conjunto de valores de Um em função de Ka 
e de ds e modelo ajustado. Foi possível inferir que este tende a superestimar os valores estimados, em relação aos observados. Conclusões: A densidade do solo exerce influência sobre o modelo de calibração para o TDR; A incorporação da ds aos modelos melhora a qualidade dos mesmos, mas o modelo baseado em UV ainda tende a subestimar a umidade na região de alta densidade e subestimar valores para baixas densidades; deve-se fazer opção por empregar o modelo geral obtido para Uv em função de Ka e de ds e não o de Um, uma vez que este apresenta um erro sistemático de superestimativa, o qual é menos evidente no modelo para Uv.

\section{Referências}

GOMIDE, Reinaldo Lucio. Monitoramento para manejo da irrigação; instrumentos, automação e métodos. CONGRESSO BRASILEIRO DE ENGENHARIA AGRíCOLA, 27. Anais...Lavras: UFLA: SBEA, Poços de Caldas, p. 133- 238. ago. 1998.

GONÇALVES, Antônio Carlos Andrade; TRINTINALHA, Marcos Antônio; TORMENA, Cássio Antonio; FOLEGATTI, Marcos Vinicius. Influência da densidade do solo na estimativa da umidade em um Nitossolo Vermelho Distroférrico, por meio da técnica TDR. Revista Brasileira de Ciência do Solo, v. 8, n.35. p. 1551-1559.out. 2011.

SILVA, Alvaro Pires. Estimating the least limiting water range of soil from properties and management. Soil Science Society of America Journal,Viçosa, v. 61, n. 3, p. 877-883, Maio/jun. 1997.

TOPP, George Clarke. Electromagnetic determination of soil water content: Measurement in coaxial transmission lines. Water Resources Research, Estados Unidos, v. 16, p.576-583, Jul. 1980.

TRINTINALHA, Marcos Antonio. Avaliação da técnica da Reflectometria no Domínio do Tempo (TDR) na determinação da umidade em um Nitossolo Vermelho eutroférrico. Tese (Mestrado em Agronomia) Universidade Estadual de Maringá, Maringá, 2000.

LEKSHMI, Susha; SINGH, Devendra.; SHOJAEI, Maryem Baghini.. A critical review of soil moisture measurement. Measurement, India v. 54, p.92-105, ago. 2014. 


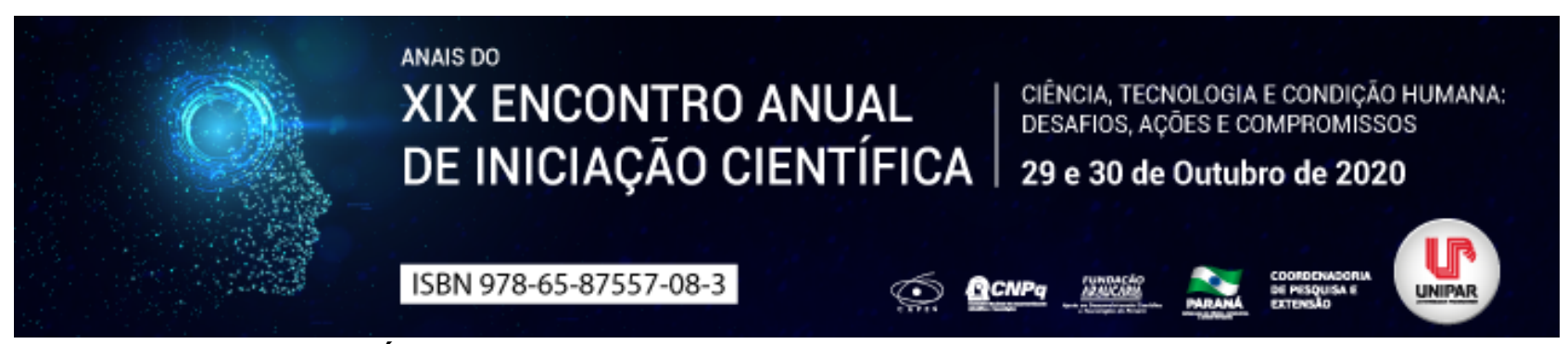

EXTRATO ETANÓLICO DE Digitaria insularis NO CONTROLE DE Meloidogyne javanica

\author{
${ }^{1}$ Enio Amado Martin, ${ }^{2}$ SIMONE DE MELO SANTANA-GOMES, ${ }^{3}$ MARCELO DE FARIAS OLIVEIRA, ${ }^{4}$ MARIA CLAUDIA \\ GUIMARÃES CARPI, ${ }^{5}$ CLAUDIA REGINA DIAS-ARIEIRA
}

\author{
${ }^{1}$ Discente do curso de Agronomia - UEM \\ ${ }^{1}$ Pós-doutoranda em Nematologia Agrícola e docente do Mestrado em Ciências Agrárias - UEM \\ ${ }^{2}$ Discente do curso de Agronomia - UEM \\ ${ }^{3}$ Mestranda de Ciências Agrárias - UEM \\ ${ }^{4}$ Docente da graduação em Agronomia, Pós- graduação em Agronomia e em Ciências Agrárias - UEM
}

Introdução: Dentre os nematoides de maior relevância na sojicultura nacional, os nematoides das galhas merecem destaque pela ampla gama de hospedeiros e alta taxa de reprodução. Tais nematoides são caracterizados como endoparasitas sedentários, que no processo de parasitismo têm uma relação complexa com seu hospedeiro, acarretando a formação de sítios de alimentação específicos, dos quais extraem nutrientes necessário para se desenvolverem e reproduzirem (FAVERY et al., 2016; LÓPEZ-GÓMEZ; VERDEJO-LUCAS, 2017). O emprego de extratos vegetais contendo propriedades nematicidas se apresenta como uma alternativa de controle com menores riscos de contaminação ambiental, uma vez que são oriundos de recursos renováveis (GARDIANO et al., 2009; FERRAZ et al., 2010).

Objetivo: Avaliar o efeito de diluições de extrato etanólico de $D$. insularis no manejo de $M$. javanica em soja.

Material e Métodos: $O$ experimento foi conduzindo em casa de vegetação, na Universidade Estadual de Maringá, em Umuarama- PR, em copos de isopor com capacidade para $500 \mathrm{~mL}$, contendo uma mistura de solo e areia (2:1), previamente autoclavado $\left(120^{\circ} \mathrm{C} ; 2 \mathrm{~h}\right.$ ). Para o preparo do extrato etanólico bruto, Digitaria insularis (capim amargoso) foi cultivada em vasos por 60 dias, a parte aérea foi coletada e submetida à secagem em temperatura de $45^{\circ} \mathrm{C}$, à massa constante. $\mathrm{O}$ extrato etanólico foi obtido a partir da trituração da massa seca da planta, diluído em etanol 80\%, na proporção 1:15 (m:v), cuja suspensão permaneceu em repouso por 24 horas, sendo filtrada após esse período, e posteriormente rotaevaporado por $2 \mathrm{~h}$ a $40{ }^{\circ} \mathrm{C}$ para remoção do etanol. Do extrato obtido foram feitas quatro diluições (0,10, 15 e 20\%) em água, que foram aplicadas no solo num volume de calda condizente a $400 \mathrm{~L} \mathrm{ha}^{-1}$. O inóculo foi obtido de populações puras de M.javanica, mantidas em raízes de tomateiros, extraído das raízes e calibrado para 2000 ovos e eventuais juvenis/mL, de acordo com metodologia de Hussey e Barker (1973) adaptada por Boneti e Ferraz (1981). Em cada unidade experimental, foi aberto um orifício ao centro, onde foram depositados $1 \mathrm{~mL}$ de inóculo, a soja cv. M6210 IPRO e as diluições dos extratos. Após 60 dias de cultivo, as plantas foram coletadas e avaliados os parâmetros vegetativos e nematológicos. Os nematoides foram extraídos das raízes conforme citado acima e quantificados em câmara de Peters, sob microscópio ótico. Para obtenção da variável nematoide/g de raiz dividiu-se o número total de nematoides encontrado no sistema radicular pela massa de raiz. Os dados foram submetidos à análise de variância $(p \leq 0,05)$ e as médias comparadas pelo teste de Tukey a $5 \%$ de significância, no programa estatístico Sisvar (FERREIRA, 2011).

Resultados: As diluições do extrato etanólico bruto de $D$. insularis não interferiram significativamente $(p>0,05)$ nos parâmetros vegetativos avaliados. As médias de altura variaram de 18,7 a 22,5 cm; massa fresca de parte aérea de 6,3 e $9 \mathrm{~g}$; massa seca de parte aérea de 1,8 a 2,4 e massa fresca de raiz de 2,9 a 4,1 g. Para os parâmetros nematológicos, as diluições não promoveram controle de M. javanica na soja, quando comparado à testemunha (30972 nematoides/sistema radicular), sendo estatisticamente iguais. A diluição de $20 \%$ promoveu redução populacional, com média de 14965 espécimes, quando comparada as diluições de 10 e 15\%, que apresentaram médias de 43087 e 48225 nematoides por sistema radicular, respectivamente. Para a variável nematoides/g de raiz foi observado o mesmo comportamento estatístico de nematoides por sistema radicular.

Discussão: O extrato não afetou o desenvolvimento da planta, demonstrando ausência de fitotoxidade. As diluições também não reduziram a reprodução do nematoide na cultura da soja. Isso pode estar relacionado a alguns fatores como degradação de moléculas nematicidas ou baixa quantidade de extrato aplicado, já que o tratamento de $20 \%$ apresentou redução populacional quando comparado a 10 e 15\%. A eficiência de controle utilizando extrato etanólico já foi constada por Alves (2019), quando trabalhou com Magonia pubescens em plantas de de jiló (Solanum gilo L.) inoculadas com M. javanica. Todavia, cada família botânica apresenta diferentes substâncias secundárias e com isso há variação na bioatividade. Diante disso, faz-se necessário a realização de novos trabalhos com extratos, alterando concentrações e formas de aplicação, buscando compostos que atuem no controle de fitonematoides.

Conclusão: As diluições do extrato etanólico bruto de capim amargoso não controlaram a população de M.javanica, quando comparado ao tratamento sem aplicação do extrato, contudo, o tratamento de $20 \%$ foi mais eficiente que 10 e $15 \%$. Os 
parâmetros vegetativos não sofreram interferência da aplicação do extrato.

\section{Referências}

ALVES, E. S. Extratos etanólicos de timbó do cerrado (Magonia pubescens St. Hil) no controle de Meloidogyne javanica. Trabalho de conclusão de curso (Curso de Bacharelado em Agronomia). Instituto Federal de Educação, Ciências e Tecnologia Goiano Campus Morrinhos, Morrinhos, GO, 40p, 2019.

BONETI, J. I. S.; FERRAZ, S. Modificação do método de HUSSEY e BARKER para extração de ovos de Meloidogyne exigua de raízes de cafeeiro. Fitopatologia Brasileira, Brasília, v.6, p.553, 1981.

FAVERY, B. et al. Gall-forming root-knot nematodes hijack key plant cellular functions to induce multinucleate and hypertrophied feeding cells. Journal of Insect Physiology, v. 84, p. 60-69, 2016.

FERRAZ, S.; FREITAS, L. G. de; LOPES, E. A.; DIAS-ARIEIRA, C. R. Manejo sustentável de fitonematoides. Viçosa: UFV, 2010, 306p.

FERREIRA, D. F. Sisvar: a computer statistical analysis system. Ciência e Agrotecnologia, Lavras, v. 35, p. 1039-1042, 2011. GARDIANO, C. G.; FERRAZ, S.; LOPES, E. A.; FERREIRA, P. A.; AMORA, D. X.; FREITAS, L. G. Avaliação de extratos aquosos de várias espécies vegetais, aplicados ao solo, sobre Meloidogyne javanica (TREUB, 1885) CHITWOOD, 1949. Semina: Ciências Agrárias, Londrina, v. 30, v. 3, p. 551-556, 2009.

LÓPEZ-GÓMEZ, M.; VERDEJO-LUCAS, S. Penetration and post-infection development of root-knot nematodes in watermelon. Spanish Journal of Agricultural Research, v. 15, n. 4, p. 1-8, 2017. 


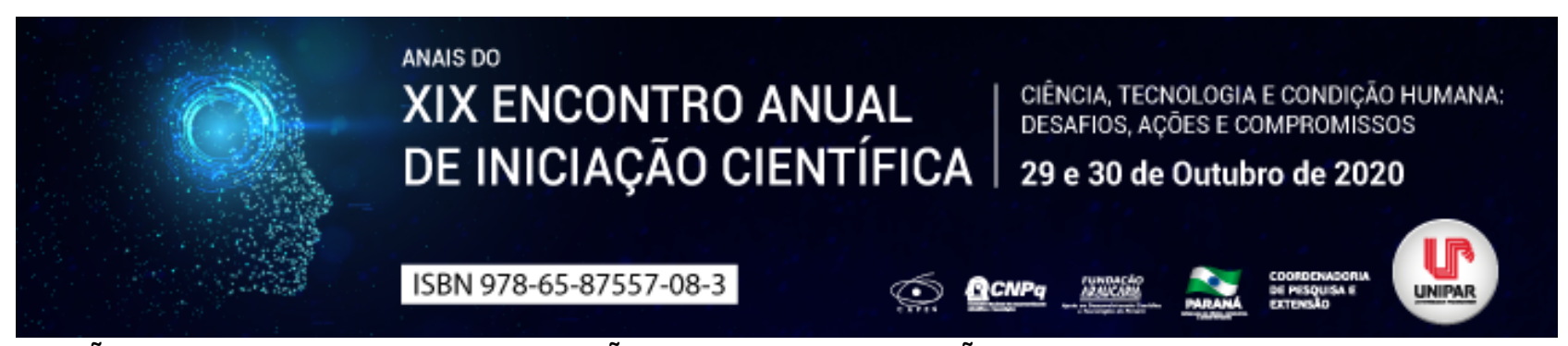

AVALIAÇÃO DA ROTULAGEM E INFORMAÇÃO NUTRICIONAL DE PÃES INTEGRAIS NOS SUPERMERCADOS DE UMUARAMA-PR PERANTE A LEGISLAÇÃO VIGENTE

\author{
${ }^{1}$ Lucas Correia Silva, ${ }^{2}$ JEAN LOPES DA SILVA, ${ }^{3}$ YARA GENTILE RIBEIRO, ${ }^{4}$ JULIANA SCANAVACCA, ${ }^{5}$ LARINE KUPSKI, \\ 6 JULIANA BUENO RUIZ
}

${ }^{1}$ Acadêmico do curso de Tecnologia em Alimentos pela Universidade Estadual de Maringá
${ }^{1}$ Discente do curso de Tecnologia em Alimentos pela Universidade Estadual de Maringá.
${ }^{2}$ Discente do curso de Engenharia de Alimentos pela Universidade Estadual de Maringá
${ }^{3}$ Docente do Departamento de Tecnologia, Universidade Estadual de Maringá UEM, Campus Umuarama.
${ }^{4}$ Docente do Departamento de Tecnologia, Universidade Estadual de Maringá UEM, Campus Umuarama.
${ }^{5}$ Docente do Departamento de Tecnologia, Universidade Estadual de Maringá UEM, Campus Umuarama.

Introdução: A procura por uma alimentação mais saudável tem feito com que a população brasileira consuma mais produtos que sejam ricos nutricionalmente, como o pão integral, substituindo o pão tradicional com farinha processada. Alimentos integrais possuem alta quantidade de fibra alimentar, que consumidas em quantidades apropriadas, podem auxiliar no tratamento ou prevenir o desenvolvimento de doenças cardiovasculares, diabetes, hipertensão arterial, câncer e obesidade. O Brasil possuía a RDC $n^{\circ} 90$ de 18 de outubro de 2000 (ANVISA, 2000), que definia pão integral como produto preparado, obrigatoriamente, com farinha de trigo e farinha de trigo integral e/ou fibra de trigo e ou farelo de trigo. Porém, essa lei foi substituída pela RDC $\mathrm{n}^{\circ} 263$ de 22 de setembro de 2005, que não apresenta nenhuma definição do que é alimento integral e retira a obrigatoriedade de descrever a porcentagem de cereais integrais nos rótulos dos produtos descritos como integrais. Dessa forma, a legislação vigente deixa brechas para que empresas rotulem pães sem nenhuma quantidade de farinha integral ou mesmo farelo, como produtos integrais, induzindo facilmente o consumidor a escolher e comprar produtos sem o real valor nutricional por não possuírem características de alimento integral de fato.

Objetivo: Avaliar as informações nutricionais de pães declarados como integrais, para analisar a composição de fibras e a adequação desses produtos perante a legislação vigente.

Material e Métodos: Foi realizado um estudo observacional, avaliativo e descritivo sobre os rótulos de 34 pães integrais de diversas marcas nos supermercados da cidade de Umuarama-PR. Para preservar as marcas dos produtos analisados, os mesmos foram identificados com números, considerando as embalagens que possuíam descrição como pão integral . Foram analisadas as seguintes características dos alimentos: farinha integral como primeiro ingrediente, farinha enriquecida com ferro e ácido fólico na composição, se o pão era considerado fonte de fibra ou alto teor de fibra acordo com a RDC no 54 de 12 de novembro de 2012, adequação à quantidade de porção estabelecida pela RDC no 359 , de 23 de dezembro de 2003 , que estabelece porção de $50 \mathrm{~g}$ para pães, descrição da porcentagem de farinha integral utilizada no alimento e a legalidade diante do projeto de lei 597/2019.

Resultados: Dos 34 produtos analisados, $79 \%$ possuíam farinha integral como primeiro ingrediente e 55\% continham farinha enriquecida com ferro e ácido fólico, conforme RDC $n^{\circ} 54,79 \%$ dos rótulos possuía a quantidade mínima para serem considerados fonte de fibra e apenas $5 \%$ continha alto teor de fibra por porção, portanto, apenas $16 \%$ dos produtos podem ser considerados pobres nutricionalmente em relação à quantidade de fibra. Em relação à RDC $n^{\circ} 359$, todas as embalagens apresentaram conformidade, utilizando o valor de $50 \mathrm{~g}$ por porção em sua tabela nutricional, mas nenhuma possuía a porcentagem de farinha integral utilizada no produto, o que impossibilitou a análise de adequação ou não ao projeto de lei $597 / 2019$.

Discussão: Diante dos resultados apresentados, observa-se que perante a legislação em vigor, $79 \%$ dos alimentos então dentro da regularidade para serem descritos como integrais, possuindo farinha integral como primeiro por SILVA et al. (2014) sobre pães integrais, esse número era de apenas 50\%, uma diferença significativa, pois alimentos integrais possuem maior quantidade de fibra, sendo considerados ricos nutricionalmente. Conforme a RDC n³59 que regulariza a quantidade de porção, todos os alimentos demonstram regularidade quanto ao descrito na tabela nutricional, não induzindo o consumidor ao engano, pois uma quantidade de porção maior que $50 \mathrm{~g}$ faz com que o alimento aparenta ter mais fibra do que o apresentado. Sobre a porcentagem de farinha integral utilizada, nenhum dos produtos descrevia a quantidade, o que não é irregular, porém limita o poder de escolha do consumidor devido à falta dessa informação.

Conclusão: As embalagens analisadas nessa pesquisa, em sua maioria, demonstraram conformidade com a legislação vigente e possuem as características nutricionais necessárias ao alimento integral. Entretanto, a definição ampla desse produto pela lei permite a rotulagem de produtos como integrais, mas sem o real valor nutricional. 


\section{Referências}

ANVISA. Resolução RDC no 54 de 12 de novembro de 2012. Dispõe sobre o regulamento técnico sobre informação nutricional complementar. Ministério da Saúde. Brasília, 2012.

ANVISA. Resolução RDC $n^{\circ} 90$ de 18 de outubro de 2000. Dispõe sobre o regulamento técnico para fixação de identidade e qualidade de pão (REVOGADA PELA RESOLUÇÃO RDC n 263 de 22 de setembro de 2005). Ministério da Saúde. Brasília, 2000.

ANVISA. Resolução RDC no 263 de 22 de setembro de 2005. Regulamento técnico para produtos de cereais, amidos farinhas e farelos. Ministério da Saúde. Brasília, 2005.

BERNAUD. F. S. R; RODRIGUES, T. C. Fibra alimentar Ingestão adequada e efeitos sobre a saúde do metabolismo. Arq Bras Endocrinol Metab, São Paulo, v. 57, n. 6, Ago. 2013. Disponível em: https://doi.org/10.1590/S0004-27302013000600001. Acesso em: 02/11/2019

BRASIL. Projeto de lei $n^{\circ}$ 597, de 12 de fevereiro de 2019. Altera o Decreto de lei $n^{\circ}$ 986, de 21 de outubro de 1969, que institui normas básicas sobre alimentos, para dispor sobre alimentos integrais. Câmara dos Deputados Anexo IV $6^{\mathrm{a}}$ andar Gabinete 646. Brasília, 2019.

SILVA, V. C. P.; GALLON, C. W.; THEODORO, H. Avaliação das rotulagens e informações nutricionais dos pães integrais: fibras, sódio e adequação com a legislação vigente. Demetra: Alimentação, Nutrição e Saúde, Rio de Janeiro, v. 9, n. 4. 2014. Disponível em: http://dx.doi.org/10.12957/demetra.2014.11979 Acesso em: 20/10/2019

ZORZANELLO, B. M.; WESCHENFELDER, S. Pães produzidos em escala industrial e comercializados com a denominação de integral : Análise da rotulagem e identificação dos ingredientes integrais e aditivos. Revista Ciência e Desenvolvimento, Vitória da Conquista, v. 10, n. 3, Set-Dez. 2017. Disponível em: http://srv02.fainor.com.br/revista/index.php/memorias/article/view/671. Acesso em: 20/10/2019. 


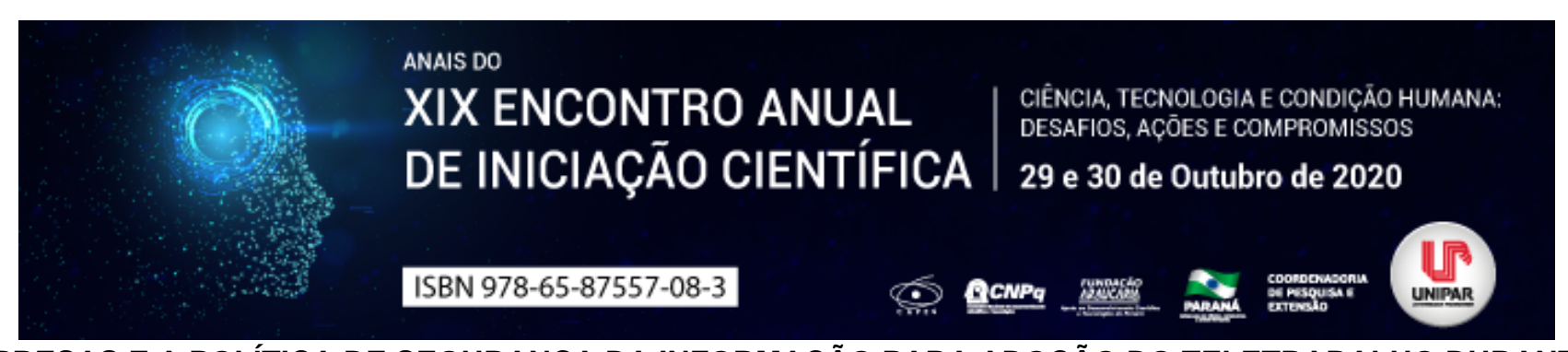

\title{
EMPRESAS E A POLÍTICA DE SEGURANÇA DA INFORMAÇÃO PARA ADOÇÃO DO TELETRABALHO DURANTE A PANDEMIA
}

\author{
${ }^{1}$ HALEF AUGUSTO DORIGAN DE ALMEIDA, ${ }^{2}$ CARLOS EDUARDO SIMOES PELEGRIN
}

\author{
${ }^{1}$ Discente do curso de Sistemas de Informação da UNIPAR \\ ${ }^{1}$ Docente do curso de Sistemas de Informação da UNIPAR
}

Introdução: Com o avanço exponencial no número de contágios confirmados do COVID-19 e o aumento nas ações de distanciamento social para redução da curva de transmissão do vírus em território brasileiro, tornou-se necessária a adaptação das pequenas, médias e grandes empresas a um novo cenário social e econômico nunca visto, onde a internet torna-se uma das principais ferramentas para que muitas destas empresas não possuam impactos significativos em seu orçamento. A adoção do teletrabalho vem se tornando uma das principais opções das empresas para manter o quadro de colaboradores, porém com o início da vigência da Lei Geral de Proteção de Dados (LGPD), tais empresas deverão estipular controles de acesso em sua Política de Segurança de Informação em relação aos dados sensíveis sob responsabilidade da empresa e que estão disponíveis em ambiente não controlado.

Objetivo: Frisar a necessidade de ajuste na Política de Segurança da Informação das empresas para a existência de regras específicas para colaboradores em regime de teletrabalho.

Desenvolvimento: A pandemia causada pelo vírus Sars-CoV-2 trouxe consigo uma grande quantidade de desafios para as empresas brasileiras, visto que ficaram expostas a uma série de riscos estratégicos e operacionais, dentre os quais podemos listar a falta de demanda de clientes, atrasos e problemas no recebimento de matérias-primas e de exportações, aumento exponencial de custos e falta de mão de obra (DELOITTE, 2020). Dados disponibilizados pelo IBGE mostram que a pandemia provocou o fechamento temporário ou definitivo de 1,3 milhão de empresas, sendo que destas, 522,7 mil tiveram a pandemia como principal causa (INDIO, 2020). Mesmo com as dificuldades impostas, muitas empresas embarcaram em um novo modo de trabalho, realizando através da internet a distribuição de serviços que antes eram realizados dentro do perímetro da empresa.

Segundo estudo da Fundação Instituto de Administração (FIA) com dados de 139 pequenas, médias e grandes empresas de diversas áreas de atuação no território Brasileiro, cerca de $46 \%$ adotaram o teletrabalho, mantendo os colaboradores em regime de home office (MELLO, 2020). A necessidade de adequação nos sistemas das organizações tiveram de ser preparados em um curto período de tempo para a disponibilização dos serviços fornecidos pela Tecnologia e Informação da empresa aos colaboradores remotos, prezando-se pela segurança e a qualidade da conexão, e deixando itens como a segurança dos dados sensíveis sem a devida atenção e tratamento.

A Política de Segurança da Informação (PSI) é um dos documentos de controle definidos na ISO 27001 - padrão internacional referência para a gestão da Segurança da Informação - que reúne um conjunto de ações, técnicas e boas práticas para o uso seguro dos dados empresariais, podendo ser comparada a um código de conduta interno de uma organização, onde se estabelece a forma com que os profissionais devem agir, o que é proibido ou não e quais as atitudes a serem tomadas em emergências (HSC, 2018). O conjunto de práticas abordadas na PSI tem um um papel fundamental no que diz respeito à proteção de dados e a garantia de que estes não sejam acessados por concorrentes e/ou pessoas não autorizadas.

Diversos hábitos comuns entre os colaboradores, tais como: anotar senhas em papel, utilizar datas como senhas, impressão de documentos sensíveis, entre outros; podem causar danos inestimáveis aos dados de uma organização devido a falta de preocupação com a segurança da informação, em parte pelo relaxamento de comportamentos antes naturais dentro do perímetro da empresa (MEETA, 2020). Esses hábitos devem ser descritos nas PSI's indicando inclusive como combatê-los.

A LGPD diz que a perda de dados sensíveis é considerada uma violação, sendo obrigação da empresa relatar e notificar às pessoas afetadas (NOCERA, 2020). São compreendidos como dados sensíveis: dado pessoal sobre raça, etnia, convicção religiosa, saúde, vida sexual, dados genéticos, entre outros. As empresas, como controladoras dos dados pessoais sob guarda, devem ter a autorização expressa do titular do dado e como irá utilizá-lo. Amparadas por essa lei, as empresas deverão ajustar as PSI's existentes e estendê-las também ao trabalho remoto.

Conclusão: A definição de conceitos básicos de segurança deve ser analisada e contextualizada dentro do ambiente organizacional visando a integridade, confiabilidade e disponibilidade dos dados. Ferramentas devem ser padronizadas para o controle, monitoramento e suporte de colaboradores remotos, além da conscientização destes sobre itens cotidianos que podem oferecer risco à saúde dos sistemas de informação de uma empresa, tais como: pontos que devem ser analisados para a detecção de e-mails inverídicos, utilização de senhas fortes contendo letras, números e caracteres especiais e que não possuam relação direta com o cotidiano, evitar o uso de redes públicas ou gratuitas, orientar quanto à correta instalação de atualizações de segurança, nos dispositivos utilizados para acesso aos sistemas da empresa e a atenção em demasia ao ambiente virtual, sendo 


\section{Referências}

DELOITTE. 10 ações para empresas diante de uma pandemia, [2020?]. Disponível em: https://www2.deloitte.com/br/pt/pages/about-deloitte/articles/10-acoes-empresas-pandemia.html. Acesso em: 30 ago. 2020.

HSC BRASIL. Política de segurança da informação: o que é e como funciona?, 28 jun. 2018. Disponível em: https://www.hscbrasil.com.br/politica-de-seguranca-da-informacao/. Acesso em: 30 ago. 2020.

INDIO, Cristina. Pandemia fecha 39,4\% das empresas paralisadas, diz IBGE, Rio de Janeiro, 16 jul. 2020. Disponível em: https://agenciabrasil.ebc.com.br/economia/noticia/2020-07/pandemia-fecha-394-das-empresas-paralisadas-diz-ibge. Acesso em: 30 ago. 2020.

MEETA SOLUTIONS. Segurança de dados x home office: Meu negócio protegido?, 18 jun. 2018. Disponível em: https://www.meeta.com.br/seguranca-da-informacao-no-homeoffice/. Acesso em: 30 ago. 2020.

MELLO, Daniel. Home office foi adotado por $\mathbf{4 6 \%}$ das empresas durante a pandemia, São Paulo, 28 jul. 2020. Disponível em: https://agenciabrasil.ebc.com.br/economia/noticia/2020-07/pandemia-fecha-394-das-empresas-paralisadas-diz-ibge. Acesso em: 30 ago. 2020.

NOCERA, Raquel. LGPD no trabalho home office, 27 mar. 2020. Disponível em: https://agenciabrasil.ebc.com.br/economia/noticia/2020-07/pandemia-fecha-394-das-empresas-paralisadas-diz-ibge. Acesso em: 1 set. 2020.

Coordenadoria de Pesquisa e Extensāo - COPEX

Departamento de Editoraçāo e Divulgaçāo Científica - DEDIC 


\title{
ANAIS DO XIX ENCONTRO ANUAL | CIĖNCIA, TECNOLOGIA E CONDIÇĀO HUMANA: XESAFIOS, AÇOEES E COMPROMISSOS DE INICIAÇĀO CIENTÍFICA 29 e 30 de Outubro de 2020 \\ ISBN 978-65-87557-08-3

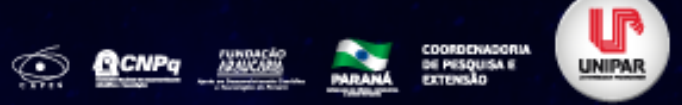 \\ AVALIAÇÃO DA ROTULAGEM E INFORMAÇÃO NUTRICIONAL DE BISCOITOS OU BOLACHAS DOCE INTEGRAIS NOS SUPERMERCADOS DE UMUARAMA-PR DIANTE DA LEGISLAÇÃO VIGENTE
}

\author{
${ }^{1}$ Lucas Correia Silva, ${ }^{2}$ JEAN LOPES DA SILVA, ${ }^{3}$ YARA GENTILE RIBEIRO, ${ }^{4}$ JULIANA SCANAVACCA, ${ }^{5}$ LARINE KUPSKI, \\ ${ }^{6}$ JULIANA BUENO RUIZ
}

${ }^{1}$ Discente do curso de Tecnologia em Alimentos pela Universidade Estadual de Maringá.

${ }^{1}$ Discente do curso de Tecnologia em Alimentos pela Universidade Estadual de Maringá.

${ }^{2}$ Discente do curso de Engenharia de Alimentos pela Universidade Estadual de Maringá

${ }^{3}$ Docente do Departamento de Tecnologia, Universidade Estadual de Maringá UEM, Campus Umuarama.

${ }^{4}$ Docente do Departamento de Tecnologia, Universidade Estadual de Maringá UEM, Campus Umuarama.

${ }^{5}$ Discente do curso de Tecnologia em Alimentos pela Universidade Estadual de Maringá.

Introdução: Biscoitos ou bolachas são alimentos ultra processados de fácil acesso e praticidade para o consumo, porém possuem alta quantidade de carboidratos e lipídios, que oferecem riscos quando consumidos em grandes quantidades (LIBANIO et al, 2019). Devido a essas características e buscando uma dieta mais saudável, a população brasileira tem substituído a ingestão de produtos tradicionais por biscoitos ou bolachas integrais, que proporcionam maior saciedade, digestão mais lenta dos carboidratos e uma quantidade maior de fibra alimentar, nutriente que ingerido em quantidades corretas pode ajudar no tratamento de doenças como acidente vascular cerebral (AVC), diabetes, hipertensão e obesidade, além de auxiliar no funcionamento gastrointestinal (BERNAUD e RODRIGUES, 2013). No Brasil, a procura por esses alimentos tem crescido e, consequentemente, as empresas têm aumentado sua oferta, porém, não há regularidade quanto às características exigidas aos biscoitos integrais. Legislativamente, há apenas a RDC no 263 de 22 de setembro de 2005, que define biscoito ou bolacha aqueles produtos processados por cocção com farinhas, amidos ou féculas, mas não apresenta referências aos produtos integrais. Com o aumento da demanda e essa lacuna na legislação, as indústrias oferecerem bolachas de baixo valor nutricional como integrais, e o consumidor fica vulnerável a adquirir esses alimentos integrais sem, de fato, melhorar a composição da dieta.

Objetivo: Diagnosticar a regularidade de biscoitos/bolachas descritos como integrais perante a legislação vigente e a quantidade de fibra.

Material e método: Foi realizado um estudo observacional, avaliativo e descritivo sobre 24 rótulos de diversas marcas de produtos declarados como biscoito ou bolacha doce e integral nos supermercados de Umuarama-PR. Para resguardar as marcas, os produtos analisados foram identificados com letras e números. Em cada tabela nutricional foram analisadas as seguintes características: Farinha integral como primeiro ingrediente, farinha enriquecida com ferro e ácido fólico na composição, conformidade com a RDC no 359 de 23 de dezembro de 2003 que estabelece porção de $30 \mathrm{~g}$ para biscoitos, se o produto é declarado como fonte de fibra ou alto teor de fibra de acordo com a RDC no 54 de 12 de novembro de 2012, a descrição da porcentagem de farinha integral no produto e se haveria regularidade quanto ao projeto de lei 597/2019, que descreve como alimentos integrais aqueles que possuem quantidade mínima de $50 \%$ de farinha integral.

Resultados: Dos 24 rótulos analisados, 84\% descrevem farinha integral como primeiro ingrediente e 50\% possuem adição de farinha enriquecida com ferro e ácido fólico. Com relação a RDC 359, 91\% dos produtos possuem a quantidade correta da porção descrita na Tabela Nutricional. Desconsiderando os biscoitos que não se adequaram a RDC 359, 41\% das marcas se enquadram como fonte de fibra de acordo com a RDC $n^{\circ} 54$ e nenhum apresenta alto teor de fibra. Das amostras investigadas $62 \%$ apresentam a porcentagem de farinha integral utilizada e dessa quantidade, apenas $47 \%$ possuía valor acima de $50 \%$ de cereais integrais na sua composição, sendo os únicos alimentos que se adequam ao projeto de lei 597/2019.

Discussão: De acordo com os resultados apresentados, os biscoitos ou bolachas integrais possuem baixa adequação quanto ao que se procura em alimentos integrais. Perante a legislação vigente, apenas $41 \%$ das amostras são consideradas fonte de fibra, principal nutriente buscado em um alimento integral. Agrupando todos os produtos analisados, inclusive aqueles que não aprestaram a porcentagem de farinha integral, apenas $29 \%$ se adequariam ao projeto de lei 597/2019, o que demonstra alta irregularidade na fabricação de produtos integrais pelas indústrias.

Conclusão: A maioria dos produtos analisados não apresentaram características de alimento integral. Desse modo, conclui-se que a falta de legislação que defina com clareza biscoitos ou bolachas integrais, deixa brechas para que as indústrias ofereçam produtos sem características de alimentos integrais ou com quantidade muito ínfima de cereal integral, o que pode lesar o consumidor que procura uma dieta diferenciada e paga pelo que considera alimentação saudável. 


\section{Referências}

ANVISA. Resolução RDC no 54 de 12 de novembro de 2012. Dispõe sobre o regulamento técnico sobre informação nutricional complementar. Ministério da Saúde. Brasília, 2012.

ANVISA. Resolução RDC no 263 de 22 de setembro de 2005. Regulamento técnico para produtos de cereais, amidos farinhas e farelos. Ministério da Saúde. Brasília, 2005.

ANVISA. Resolução RDC no 359 de 23 de dezembro de 2003. Dispõe sobre o regulamento técnico de porções de alimentos embalados para fins de rotulagem nutricional. Ministério da Saúde. Brasília, 2003.

BERNAUD. F. S. R; RODRIGUES, T. C. Fibra alimentar Ingestão adequada e efeitos sobre a saúde do metabolismo. Arq Bras Endocrinol Metab, São Paulo, v. 57, n. 6, Ago. 2013. Disponível em: https://doi.org/10.1590/S0004-27302013000600001. Acesso em: 18/10/2019

BRASIL. Projeto de lei $n^{\circ}$ 597, de 12 de fevereiro de 2019. Altera o Decreto de lei $n^{\circ}$ 986, de 21 de outubro de 1969, que institui normas básicas sobre alimentos, para dispor sobre alimentos integrais. Câmara dos Deputados Anexo IV $6^{\mathrm{a}}$ andar Gabinete 646. Brasília, 2019.

FEITOSA, B. F. et al. Avaliação da rotulagem de diferentes marcas de biscoitos recheados sabor chocolate comercializados em Pau dos Ferros RN. Rev. A Barriguda, Campina Grande, v. 6, n. 2, Mai-Ago. 2016 . Disponível em: http://dx.doi.org/10.24864/arepb.v6i2.293. Acesso em: 15/10/2019

LIBANIO, I. F. F. et al. Consumo de alimentos ultraprocessados em crianças atendidas pelo serviço de Atenção Básica na região Sul do Brasil. International Journal of Nutrology, Rio de Janeiro, v. 12, n. 1, Mai. 2019.

LIMA, A. E. C. M. et al. Avaliação da rotulagem de diferentes marcas de biscoitos integrais. Revista Brasileira de Gestão Ambiental, Pombal, v. 14, n, 2, Abr-Jun. 2020.

MATTOS, L. L.; MARTINS, I. S. Consumo de fibras alimentares em população adulta. Revista Saúde pública, São Paulo, v. 34, n. 1, Fev. 2000. 


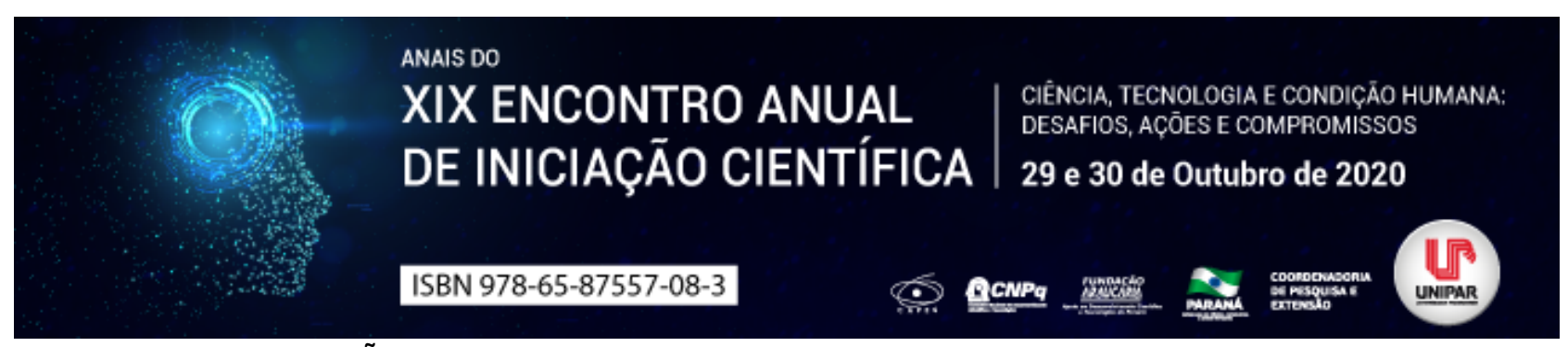

PRODUÇÃO DE MUDAS DE Tagetes patula EM DIFERENTES SUBSTRATOS

\begin{abstract}
${ }^{1}$ Gionelton Duarte de Castro, ${ }^{2}$ GUSTAVO ARANA DEMITTO, ${ }^{3}$ ADRIELY LAZARIM, ${ }^{4}$ MARCELO GONÇALVES BALAN, ${ }^{5}$ ARNEY EDUARDO DO AMARAL ECKER
\end{abstract}

\author{
${ }^{1}$ Engenheiro agrônomo \\ ${ }^{1}$ Engenheiro agrônomo \\ Mestrado Profissional em Agroecologia/UEM \\ Mestrado Profissional em Agroecologia/UEM \\ ${ }^{2}$ Engenheira agrônoma \\ Mestrado em Agronomia/UEM \\ ${ }^{3}$ Profo $^{\circ}$ Adjunto/Convidado \\ Centro Universitário Ingá (UNINGÁ)/Universidade Estadual de Maringá (UEM) \\ ${ }^{4}$ Profo Adjunto/Convidado \\ Centro Universitário Ingá (UNINGÁ)/Universidade Estadual de Maringá (UEM)
}

Introdução: O gênero Tagetes é composto por plantas anuais, com 20-30 cm de altura, pertencentes à família Asteraceae. São plantas nativas da América Central, mas com ampla distribuição mundial e são utilizadas na medicina tradicional em diversas regiões do mundo, bem como na ornamentação de ambientes. Existem cerca de 30 espécies de Tagetes, sendo T. patula uma das mais estudadas (XU et al., 2012). Para o desenvolvimento de qualquer muda, é ideal um substrato de qualidade, que apresente características como ausência de patógenos, riqueza em nutrientes essenciais, textura, estrutura e pH adequados, além de fácil aquisição e transporte (SILVA et al., 2001). Em função de cada espécie deve-se verificar qual melhor substrato ou combinação destes que proporcionem a formação de mudas de melhor qualidade. Neste sentido, o resíduo de poda de árvore pode ser uma alternativa de substrato na produção de mudas de tagetes.

Objetivo: Analisar a produção de mudas de Tagetes patula em função de diferentes substratos na região de Maringá-Paraná.

Metodologia: Experimento conduzido em ambiente protegido no Centro Universitário Ingá UNINGÁ-Maringá. Os substratos utilizados foram comerciais e resíduos de podas. O delineamento utilizado foi o de blocos casualizados, 06 tratamentos por bloco em 10 repetições. Cada tratamento (parcela) constitui-se de uma bandeja de produção de mudas de trinta células. Substratos comerciais: T1 Mac Plant (a base de casca de pinus) e T2 Carolina Soil (a base de turfa); Substratos alternativos (resíduos dos serviços de manutenção da arborização urbana do município de Marialva, região metropolitana de Maringá): T3 Resíduo de poda autoclavado; T4 Resíduo de poda não autoclavado; T5 Resíduo de poda autoclavado mais adubação química (NPK) e T6 Resíduo de poda autoclavado mais adubação orgânica (cama de frango). Os resíduos foram peneirados manualmente em peneira com trama de $5 \mathrm{~mm}$, posteriormente, parte dos resíduos foi preservada sem autoclavar e outra parte foi autoclavado, T5 foi enriquecido com adubação química (NPK 4-14-8) e T6 foi enriquecido com adubação orgânica (Cama de frango 2,8\% de N). A concentração de Nitrogênio (1 grama de $\mathrm{N}$ por litro de substrato) foi a mesma para ambas adubações. A semente utilizada no experimento foi da espécie de flor Tagetes Tagetes patula de coloração amarela. Aos 21 dias após a semeadura (DAS) foi realizado a análise entre os tratamentos. Oito mudas centrais foram avaliadas os seguintes parâmetros agronômicos: tamanho da parte aérea; tamanho de raiz; massa fresca da parte aérea; massa fresca de raiz; massa seca da parte aérea e massa seca de raiz. Os parâmetros estatísticos utilizados foram teste $F$ para verificar diferenças entre os tratamentos e $o$ teste de média para verificar as melhores médias (Tukey a 5\%). Os dados foram trabalhados no software Sisvar (FERREIRA, 2014).

Resultados: Houve diferença significativa entre os tratamentos, para as seguintes variáveis: tamanho da parte aérea; massa fresca da parte aérea; massa fresca de raiz; massa seca da parte aérea e massa seca de raiz, ( $p$-valor $<0,05)$. Sendo assim, um dos tratamentos diferiu dos demais, portanto os tratamentos foram submetidos a teste de médias (Tukey à $5 \%$ ). Os tratamentos T2 e T5 diferiram e superaram os tratamentos T1, T3 e T4 para as variáveis tamanho da parte aérea, massa fresca da parte aérea e massa seca da parte aérea. Os tratamentos não diferiram entre si para a variável tamanho de raiz. $\mathrm{O}$ tratamento T2 diferiu e superou os demais tratamentos para as variáveis massa fresca de raiz e massa seca de raiz. O tratamento T6 diferiu e superou os tratamentos T3 e T4 para a variável massa fresca da parte aérea.

Discussão: O substrato comercial Carolina Soil a base de turfa apresentou os melhores resultados de modo geral em todas as variáveis, principalmente no desenvolvimento de raiz, possivelmente, devido sua densidade ser menor que a dos demais substratos a base de resíduos arbóreos, de modo que, quanto maior a densidade, maior é a limitação de crescimento de plantas (KÄMPF, 2005). Contudo, o substrato a partir do resíduo de poda com adubação química apresentou resultados positivos em diversas variáveis, indicando um potencial de uso alternativo aos substratos comerciais estudados. Corrobora a isto, a pesquisa de Baratta Junior (2007), que obteve resultados significativos com substratos a partir de resíduos de poda. Neste trabalho, o resíduo de poda com adição de adubação química se mostrou melhor do que com adição de adubação orgânica, entretanto, Silva (2011) observou melhores resultados em substratos oriundos de resíduo de podas acrescidos com adubo orgânico. Estudos são necessários para explorar demais formas e doses de adubação orgânica na adição ao substrato oriundo do resíduo de poda. 
Conclusão: A prática de utilizar o substrato proveniente de resíduo de poda com adubação para produção de tagetes apresentou resultados superiores aos do substrato comercial Mac Plant em todas as variáveis, e resultados iguais aos do substrato comercial Carolina Soil nas variáveis da parte aérea. Portanto, recomenda-se a continuidade de pesquisas do substrato proveniente do resíduo de poda, haja vista, o indicativo de potencial de uso e o menor custo ao produtor mudas.

\section{Referências}

BARATTA JUNIOR, Alamir Punaro. Utilização do composto de resíduos da poda da arborização urbana em substratos para produção de mudas. Orientador: Luís Mauro Sampaio Magalhães. 2007. 53 f. Dissertação (Mestrado em Ciências Ambientais e Florestais) Universidade Federal Rural do Rio de Janeiro Instituto de Florestas, Seropédica, 2007.

FERREIRA, Daniel Furtado. Sisvar: a Guide for its Bootstrap procedures in multiple comparisons. Ciênc. agrotec. [online], vol. 38, n. 2, p.109-112, Mar./Abr., 2014. Disponível em: http://www.scielo.br/scielo.php?script=sci_arttext\&pid=S141370542014000200001\&lng=es\&nrm=iso. Acesso em: 24 Set. 2020.

KÄMPF, Atelene Normann. Substratos. In: KÄMPF, Atelene Normann. Produção Comercial de Plantas Ornamentais. 2 ed. Guaiba: Agrolivros, 2005. p. 47.

SILVA, Flávia Gomes da. Substrato com composto de lixo e poda de árvore para a produção de mudas de Pterogyne nitens. Orientador: João Antonio Galbiatti. 2011. 53 f. Dissertação (Mestrado em Agronomia) Universidade Estadual Paulista (Unesp) Faculdade de Ciências Agrárias e Veterinárias, Campos de Jaboticabal, Jaboticabal, 2011.

SILVA, Rogério Pereira da; PEIXOTO, José Ricardo e JUNQUEIRA, Nilton Tadeu Vilela. Influência de diversos substratos no desenvolvimento de mudas de maracujazeiro azedo (Passiflora edulis Sims f. flavicarpa DEG). Revista Brasileira de Fruticultura, Jaboticabal, v. 23, n. 2, p. 377-381, Ago., 2001. Disponível em: https://www.scielo.br/scielo.php?pid=S0100$29452001000200036 \&$ script=sci_abstract\&tlng=pt. Acesso em: 23 Jul. 2020.

XU, Li-wei; CHEN, Juan; QI, Huan-yang e SHI, Yan-ping. 2012. Phytochemicals and their biological activities of plants in Tagetes L. Chinese Herbal Medicines, Tianjin, v. 4, n. 2, p. 103-117. 2012. Disponível em: http://www.tiprpress.com/chmen/article/abstract/CHM20110701001. Acesso em: 23 Jul. 2020. 


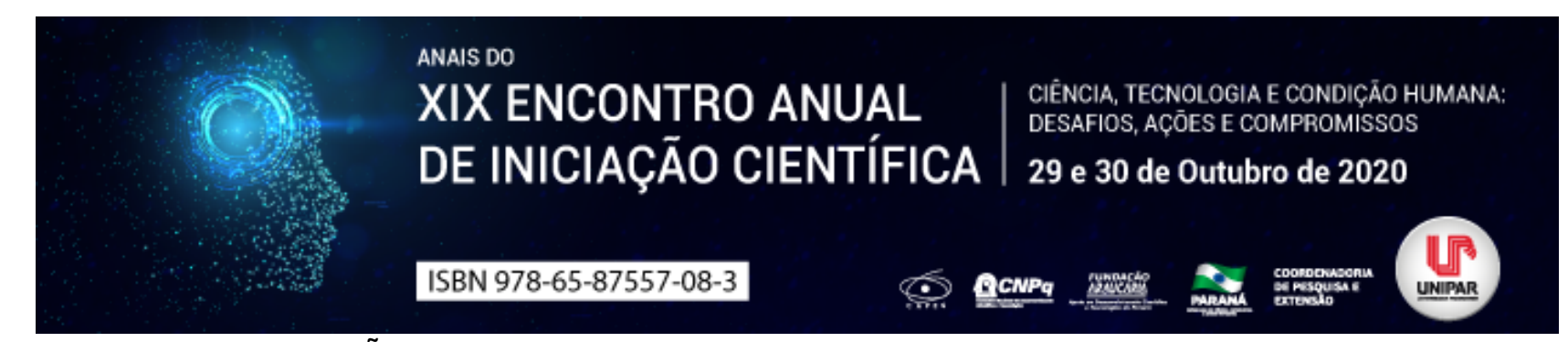

EFEITOS DAS ALTERAÇÕES DA ABNT NBR 7188:2013 NO PROJETO DE UMA PONTE EXECUTADA EM 1986

\author{
${ }^{1}$ PÂMELA ANGÉLICA CANTARELLI
}

${ }^{1}$ Especialista em Estruturas de concreto e fundações/INBEC

Introdução: Nas últimas decádas houve um aumento do volume do tráfego e do peso dos veículos em circulação nas obras de arte especiais. Estes fatores podem acarretar problemas de fissuração e fadiga das armaduras das pontes de concreto armado (MONTEIRO, 2017). As pontes também sofrem as agressões decorrentes do uso, da ação de agentes deletérios e dos impactos. Estes efeitos devem ser avaliados para garantir a estabilidade e funcionalidade dessas obras, visto que os danos nas estruturas e aumento da velocidade de degradação podem ter origem na falta de manutenção (SCHMIDT, 2017). Desde 1946 foram implementados carregamentos e coeficientes as normas relacionadas as pontes. A norma vigente para determinação da carga móvel em ponte é a ABNT NBR 7188:2013, a qual está em revisão (VITÓRIO, 2015). Diante do exposto, surge a questão: Quais os impactos das alterações das cargas móveis modificadas pela NBR 7188:2013 em uma ponte em concreto armado construída em 1986?

Objetivos: Analisar as cargas móveis atuantes em uma ponte em concreto armado a partir das diretrizes da NBR 7188:1984 e comparar os resultados com os requisitos da NBR 7188:2013, a fim identificar as intervenções necessárias para adequar a ponte aos padrões das normas vigentes.

Material e métodos: Não existem registros sobre o dimensionamento e construção da ponte. Através da observação visual e medição pôde-se analisar o atendimento das condições da ponte as normas vigentes. Para correlacionar os valores da carga móvel adotou-se o carregamento do Trem tipo TB 450, por este ser comum nas duas versões e apresentar a maior carga para roda do veículo. A maior diferença no dimensionamento se encontra no coeficiente de majoração da carga. Na versão antiga se considerava somente o coeficiente de impacto. $\mathrm{Na}$ versão atual, foram implementados o coeficiente de impacto vertical, de número de faixas e de impacto adicional. Com base nestes dados pôde-se calcular a carga de uma roda do veículo majorada (Q) e a carga móvel uniformemente distribuída majorada (q).

Resultados: $\mathrm{Na}$ visita realizada verificou-se a falta de placas de sinalização. A largura da pista é estreita para a passagem simultânea de dois veículos. Não constataram-se deformações ou vibrações excessivas. No tabuleiro existe sistema de drenagem e fissuras no pavimento. Os elementos estruturais não apresentam fissuras, trincas, desplacamentos, desagregações, eflorescências e corrosão de armaduras. Nos pontos de apoio das vigas nos pilares não foram identificados recalques de apoios ou mau funcionamento. Quanto as fundações, não se constataram erosões ou descalçamentos na altura visível ao nível da água. A ponte não possui guarda rodas e os guarda corpos não apresentam altura e espaçamento de acordo com as normas, apresentando trechos degradados, exposição e presença de corrosão na armadura. Os resultados do dimensionamento da carga móvel uniformemente distribuída de acordo com a NBR 7188:1984 foi de 5,6kN/m² e conforme a NBR 7188:2013 foi de 8,8kN/m². Na primeira versão o coeficiente de impacto possuía o valor de 1,12, já na versão atual seu valor é de 1,75.

Discussão: A maioria das pontes brasileiras foram projetadas e executadas a mais de 30 anos, expondo a importância das inspeções para identificar as manifestações patológicas e as adequações para atender as classes dos veículos que trafegam pela mesma. Na ponte estudada, constatou-se a necessidade de limpeza das cabeceiras e colocação placas de sinalização. Considerando o fluxo, a largura da ponte atende as necessidades locais. As fissuras no pavimento do tabuleiro podem ter sido originadas devido a falta de juntas de dilatação e juntas de concretagem do recapeamento. O sistema de drenagem contribui para escoamento da água, minimizando o acúmulo e infiltração da água, porém devem ser realizadas manutenções para retirada de solo e de folhas nas laterais do tabuleiro. Devem-se adequar o guarda rodas e os guarda corpos. Na consideração da NBR 7188:2013, observou-se que deveria ser acrescida uma margem de segurança à intensidade das cargas de aproximadamente $64 \%$ para às cargas distribuídas na estrutura.

Conclusão: A partir do estudo de caso pôde-se observar que o coeficiente de impacto considerado na NBR 7188:1984, majorava em valor mais baixo as cargas atuantes e podendo indicar um subdimensionamento, em que os elementos estruturais apresentam área de aço insuficiente para os carregamentos atuais, sendo necessária uma análise mais detalhada de cada caso para determinar o tipo de reforço adequado. Este fato isolado não significa necessariamente que a ponte entrará em colapso, no entanto, pode favorecer a ocorrência de manifestações patológicas nos elementos. Contudo, constatou-se que os procedimentos de inspeção e acompanhamento das obras de arte especiais são uma boa alternativa para garantir o bom desempenho e utilização das mesmas. Além de que se pode conciliar a identificação das manifestações patológicas com a adequação das pontes para atendimento das normas vigentes, implementando assim um sistema de gestão de obras de arte especiais eficiente e completo. 


\section{Referências}

ASSOCIAÇÃO BRASILEIRA DE NORMAS TÉCNICAS. NBR 7188: Carga Móvel em Ponte Rodoviária e Passarela de Pedestre. Rio de Janeiro, 1984.

2013.

NBR 7188: Carga móvel rodoviária e de pedestres em pontes, viadutos, passarelas e outras estruturas. Rio de Janeiro,

MONTEIRO, Patrícia Schipitosk. Definição de parâmetros aplicáveis à modelagem da informação de pontes de concreto armado com enfoque no gerenciamento de manutenções. 2017. Dissertação (Mestrado em Engenharia de Construção Civil). Universidade Federal do Paraná, Curitiba, 2017.

SCHMIDT, Erika Pina. Metodologia para análise de pontes curvas sob o efeito de tráfego pesado. 2017. Dissertação (Mestrado em Engenharia Civil). Escola Politécnica da Universidade de São Paulo, São Paulo, 2017.

VITÓRIO, José Afonso Pereira. Soluções adotadas em projetos de reforço de fundações de pontes cujos tabuleiros foram alargados. 57 Congresso Brasileiro do Concreto. CBC2015 57CBC. Bonito - MS, 2015.

Coordenadoria de Pesquisa e Extensão - COPEX

Departamento de Editoraçāo e Divulgaçāo Científica - DEDIC 


\title{
- tramem DE INICIAÇ̃̃O CIENTÍFICA DESAFIOS, AÇŌES E COMPROMISSOS DE INICIAÇÃO CIENTÍFICA 29 e 30 de Outubro de 2020 \\ ISBN 978-65-87557-08-3

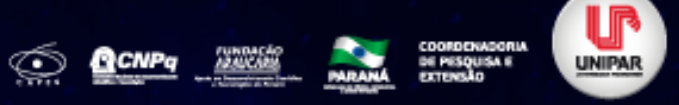 \\ ESTUDO DE CASO SOBRE O GERENCIAMENTO DE RESÍDUOS DE CONSTRUÇÃO CIVIL EM UM MUNICÍPIO DE PEQUENO PORTE
}

\author{
${ }^{1}$ Guilherme Emanuel de Queiros Souza, ${ }^{2}$ CAROLE SILVEIRA
}

\author{
${ }^{1}$ Discente do programa de Pós-Graduação em Engenharia Ambiental Universidade Federal do Paraná - UFPR \\ ${ }^{1}$ Docente da Universidade Estadual de Maringá - UEM
}

Introdução: Nos últimos anos, é possível observar um grande crescimento populacional junto à urbanização em todo o mundo. Tal crescimento, atrelado ao avanço tecnológico, fez com que a geração de resíduos sólidos crescesse de forma desenfreada e sem planejamento. Sendo assim, uma das formas de minimizar tal impacto, se da por meio do Gerenciamento Integrado de Resíduos Sólidos Urbanos (GIRSU), que é enquadrada como uma das atividades do saneamento básico (ZANTA e FERREIRA, 2003, p.14). Mediante todas essas preocupações com o meio ambiente, foi promulgado, em 02 de agosto de 2010, a Lei Federal n 12.305/2010, que instituiu a Política Nacional de Resíduos Sólidos (PNRS), que determina princípio e diretrizes para o gerenciamento de resíduos e gestão integrada. Desta forma, minimizando os impactos causados. No Paraná também se aplica a Política Nacional de Resíduos Sólidos, bem como, a Lei de Resíduos Sólidos do Paraná, Lei n 12.493 de 22 de Janeiro de 1999, alterada pela Lei 15.862 de 18 de junho de 2008, que tem como objetivo controlar a poluição e contaminação, além de minimizar os impactos ambientais. Ela também estabelece que as atividades geradoras de resíduos, de qualquer natureza, são responsáveis pelo gerenciamento (que vai desde acondicionamento, armazenamento, coleta, transporte, tratamento, até destinação final dos resíduos sólidos gerados), pelo passivo ambiental oriundo da desativação de sua fonte geradora, como pela recuperação de áreas degradadas (PARANÁ, 1999).

Relato de caso: Os Resíduos de Construção Civil - RCC são compostos por entulhos, fragmento ou restos de tijolos, concreto, argamassa, aço, madeiras, entre outros resíduos provenientes dos restos de construções. Estes materiais podem ocasionar sérios problemas ambientais, isto se deve ao volume que é gerado com este tipo de resíduo e por ele ser praticamente inerte. No município estudado, os RCC são de responsabilidade de cada gerador, fato que se torna um grande problema, uma vez que em muitos casos a população deixa seu material em qualquer local do município (esquinas, terrenos baldios e casas abandonadas). Com o objetivo de conhecer melhor o gerenciamento dos resíduos sólidos no município, foi realizado uma visita técnica na região, a qual ocorreu no dia 30 de agosto de 2019, sendo acompanhado pelo responsável técnico do meio ambiente do município, onde o mesmo, apresentou todos os locais de destinação final dos resíduos. Foi possível observar no decorrer da visita, alguns pontos (também conhecidos como l"bota forasl"), onde moradores lançam diversos tipos de resíduos como os RCC, entulhos, móveis usados, resíduos domiciliares, entre outros. Nesses locais, a prefeitura realiza a limpeza e coleta dos materiais, destinando-os de forma errônea ao aterro controlado municipal. O aterro controlado, e um terreno baldio localizado no centro da cidade, foram os dois maiores pontos de concentração de resíduos de construção civil.

Discussão: A Resolução CONAMA $n^{\circ} 307$, de 5 de junho de 2002, estabelece diretrizes, critérios e procedimentos sobre a gestão dos resíduos de construção civil, tendo como objetivo reduzir os impactos gerados ao meio ambiente. De acordo com esta resolução, os geradores dos RCC devem ter como objetivo a não geração, a redução, a reutilização e a reciclagem dos resíduos. Caso não seja cabível as alternativas anteriores, se deve realizar a destinação final ambientalmente adequada (em um aterro licenciado para este fim). A resolução também estabelece que os resíduos não poderão ser dispostos em aterros de resíduos domiciliares ou em áreas de bota fora , lotes vazios ou áreas protegidas por lei. No município estudado, os RCC estão sendo dispostos em um I"bota foral" localizado na área urbana, há meses estavam sendo destinados diretamente ao aterro controlado. Uma das medidas que estão sendo tomadas para maior cumprimento da lei e minimização dos impactos causados ao meio ambiente, é o licenciamento de uma área adequada para disposição final dos mesmos. Ainda em fase de planejamento, uma alternativa é a terceirização dos serviços de caçamba no município, o qual é de grande importante para melhorar o gerenciamento dos RCC. Para resolver os problemas sobre o gerenciamento dos resíduos de construção civil, o município deve cumprir o que estabelece no Art. $5^{\circ}$ da Resolução CONAMA 307/2002. Este artigo descreve que os municípios devem elaborar o Plano Integrado de Gerenciamento de Resíduos da Construção Civil, onde serão incorporados programas e projetos de gerenciamento de RCC. Os programas deverão conter: diretrizes técnicas e procedimentos para o gerenciamento dos resíduos pelos grandes geradores, cadastramento de áreas para recebimento, triagem e armazenamento temporário, proibição da disposição em áreas não licenciadas, ações educativas visando à redução de resíduos.

Conclusão: Atualmente percebe-se que o município se preocupa em realizar de forma correta o gerenciamento dos resíduos sólidos. Porém a falta de uma secretária do meio ambiente e de recursos financeiros, dificulta muito todo o avanço legal e melhorias nesta gestão dos resíduos sólidos. Observa-se também o grande desinteresse por parte dos geradores em realizar de forma correta o gerenciamento dos resíduos sólidos. 


\section{Referências}

BRASIL, 2010. Presidência da República. Lei n 12.305, de 02 de agosto de 2010. Institui a Política Nacional de Resíduos Sólidos.

CONAMA - CONSELHO NACIONAL DE MEIO AMBIENTE. Resolução CONAMA n 307 de 05 de julho de 2002. Estabelece diretrizes, critérios e procedimentos para a gestão dos resíduos da construção civil.

PARANÁ. Lei Estadual no 12.493 de 22 de Janeiro de 1999. Estabelece princípios, procedimentos, normas e critérios referentes a geração, acondicionamento, armazenamento, coleta, transporte, tratamento e destinação final dos resíduos sólidos no Estado do Paraná, visando controle da poluição, da contaminação e a minimização de seus impactos ambientais e adota outras providências.

ZANTA, Viviana Maria; FERREIRA, Cynthia Fantoni Alves. Capítulo 1: Gerenciamento Integrado de Resíduos Sólidos Urbanos. IN: CASTILHOS JUNIOR, Armando Borges (coord.). Alternativas de disposição de resíduos sólidos urbanos para pequenas comunidades. Rio de Janeiro: ABES; RiMA, 2003. p. 01-16. 


\title{
- tramem DE INICIAÇ̃̃O CIENTÍFICA DESAFIOS, AÇŌES E COMPROMISSOS DE INICIAÇÃO CIENTÍFICA 29 e 30 de Outubro de 2020 \\ ISBN 978-65-87557-08-3

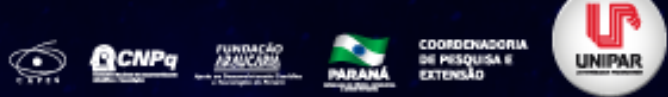 \\ REVISÃO DA TERMODINÂMICA DE PÓRTICOS: FERRAMENTA DE ANÁLISE ESTRUTURAL PARA AVALIAÇÃO DA FISSURAÇÃO E DA CORROSÃO
}

\author{
${ }^{1}$ Deborah Cristina Nardi, ${ }^{2}$ SAMANTA A. KLERING, ${ }^{3}$ THIAGO BERTUZZO
}

\author{
${ }^{1}$ Acadêmica Engenharia Civil de Infraestrutura - UNILA \\ ${ }^{1}$ Acadêmica Engenharia Civil de Infraestrutura - UNILA \\ 2Docente da UNIPAR e Mestrando do Programa de Pós-Graduação em Engenharia Civil da UNILA
}

Introdução: Para descrever o comportamento mecânico de estruturas de concreto armado estão presentes na literatura diversos modelos de cálculo, sejam eles lineares ou não lineares. De acordo com Amorim (2016), a fim de se ter uma maior precisão da descrição do comportamento estrutural, propõem-se as teorias não lineares, como a teoria da plasticidade, mecânica da fratura e mecânica do dano. Outra teoria disponível para tal fim é a teoria do dano concentrado (TDC) proposta por Flórez-López, Marante e Picón (2015). Essa considera que variáveis de plasticidade e dano estão acopladas em rótulas inelásticas. Além disso, estudos embasados na ciência da termodinâmica permitem uma análise ainda mais aprofundada do comportamento estrutural, possibilitando a avaliação da troca e liberação de energia dos elementos estruturais bem como a observação e quantificação de fenômenos físicos e químicos como a fissuração e corrosão, por exemplo.

Objetivo: Busca-se realizar uma breve revisão bibliográfica referente a Termodinâmica de Pórticos, uma vez que tal teoria permite a obtenção de leis constitutivas, as quais descrevem o comportamento material devido a fatores externos, e, as quais, por sua vez, possibilitam analisar a evolução do dano e da corrosão em estruturas de concreto armado.

Desenvolvimento: A Termodinâmica de Pórticos foi proposta por Dahmer (2018) e Brant (2019) e tal teoria se ergue e se fundamenta nos conceitos básicos da Termodinâmica de Sólidos apresentada por Lemaitre e Chaboche (1995). Dahmer (2018) e Brant (2019) escrevem o Princípio das Potências Virtuais e a Equação do Equilíbrio Dinâmico, a Primeira e a Segunda Lei da Termodinâmica para um elemento de pórtico bem como a escolha de um potencial termodinâmico adequado para o estudo, o qual vem a ser a Energia Livre de Gibs. Tal escolha se dá ao fato que esse potencial permite descrever a tendência da reação de um metal com o seu ambiente, segundo estudos de Shaw e Kelly (2006). Assim, com a união desses conceitos, viabiliza-se a obtenção das leis de estado. A primeira lei de estado postula que a derivada do potencial de Gibs em relação aos momentos fletores deve ser igual as deformações; a segunda postula que a derivada do mesmo potencial em relação as temperatura absoluta deve ser igual a entropia do sistema; e, a terceira que, derivando também tal potencial em relação as variáveis internas, o que se obtém são as forças termodinâmicas associadas as variáveis internas (que podem ser plasticidade, dano ou corrosão, por exemplo). Por meio de tais leis de estado torna-se possível a obtenção das leis constitutivas. De tal maneira, Dahmer (2018) e Brant (2019) propõem formulações termodinâmicas para pórticos elásticos, para pórticos elastoplásticos, para pórticos com encruamento cinemático e dano e para pórticos com encruamento cinemático, dano e corrosão. Todos os modelos fazem uso das mesmas relações cinemáticas que as propostas pela TDC de Flórez-López, Marante e Picón (2015). Além disso, apesar de se obter a equação de equilíbrio dinâmico por intermédio do caminho da termodinâmica, essa é a mesma que a utilizada pela TDC, teoria a qual vale ressaltar que se estrutura no conceito de energia potencial complementar. O mesmo ocorre para as leis constitutivas: a lei de elasticidade é comum entre os modelos, bem como a lei de plasticidade e lei de dano. Porém, a TDC não contempla uma avaliação da evolução da corrosão em estruturas de concreto armado. Tal avaliação só é possível devido a introdução dos modelos termodinâmicos citados, uma vez que viabilizam tanto estudo da dissipação de energia bem como definir se o processo é termodinamicamente admissível ou não.

Conclusão: As formulações termodinâmicas disponíveis na literatura são de grande relevância para estudos de comportamento mecânico de elementos estruturais de concreto armado uma vez que por meio delas pode-se fazer um estudo minucioso da evolução tanto da fissuração quanto da corrosão. Esses fenômenos atraem suma atenção a Engenharia Civil devido ao fato de que colocam em risco critérios de estabilidade, vida útil e segurança das estruturas. Possuir uma ferramenta como essa, que permite a implementação computacional viável e eficaz, sendo capaz de quantificar esses fenômenos ao longo do tempo, indubitavelmente agrega de forma marcante ao campo de estudos estruturais.

\section{Referências}

AMORIM, D. L. N. D. F. On the lumped damage mechanics for nonlinear structural analyses: new developments and applications. Tese (Doutorado em Engenharia de Estruturas) - Universidade de São Paulo, São Carlos, 2016.

BRANT, C. A. C. Formulação Termodinâmica do Acoplamento Corrosão-fissuração em Estruturas de Concreto Armado. Tese (Mestrado em Engenharia Civil) - Universidade Federal da Integração Latino-Americana, Foz do Iguaçu, 2019.

DAHMER, R. R. Modelo para Análise de Estruturas Submetidas a Solicitações Químico-mecânicas. Trabalho de conclusão 
de curso (Bacharelado em Engenharia Civil de Infraestrutura) - Univerisidade Federal da Integração Latino-Americana, Foz do Iguaçu, 2018.

FLÓREZ-LÓPEZ, J.; MARANTE, M. E.; PICÓN, R. Fracture and Damage Mechanics for Structural Engineering of Frames. [S.I.]: IGI Global, 2015.

LEMAITRE, J.; CHABOCHE, J.-L. Mechanics of solid materials. Nova York, Cambridge University Press, 1990.

SHAW, B. A.; KELLY, R. G. What is corrosion? Electrochemical Society Interface, mar. 2006.

Coordenadoria de Pesquisa e Extensão - COPEX

Departamento de Editoraçāo e Divulgaçāo Científica - DEDIC 


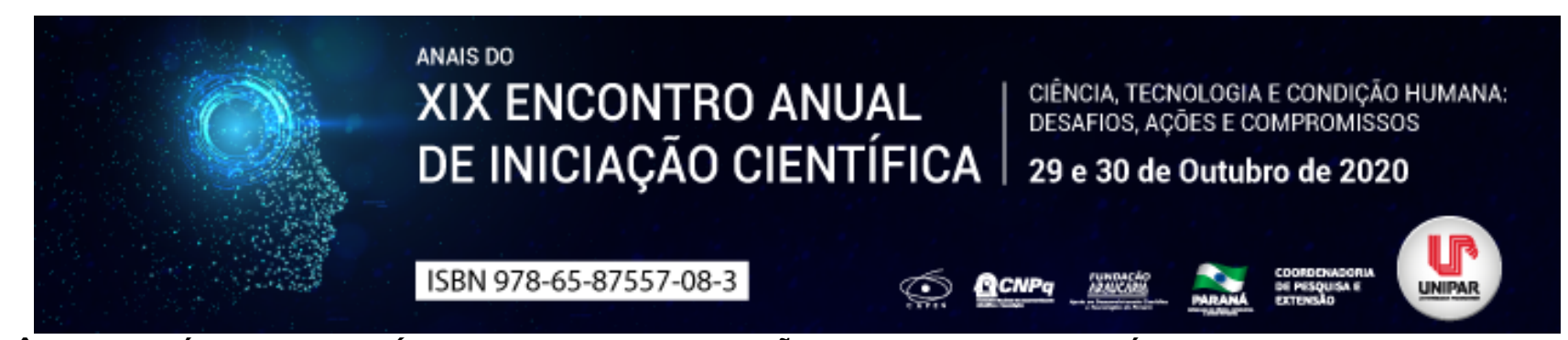

LÂMINA DE ÁGUA DISPONÍVEL EM VASO, EM FUNÇÃO DO POTENCIAL DE ÁGUA AVALIADO POR MEIO DE TENSIÔMETROS DE SOLO

\begin{abstract}
${ }^{1}$ Weslei Augusto Mendonça, ${ }^{2}$ PEDRO HENRIQUE GUIMARÃES GIMENES, ${ }^{3}$ RENILZA RITA DE CASSIA DA SILVA, ${ }^{4}$ JOÃO MARCOS BERTO, ${ }^{5}$ GIOVANNI VONSOWSKI GUARIDO, ${ }^{6}$ ANTONIO CARLOS ANDRADE GONÇALVES
\end{abstract}

\begin{abstract}
${ }^{1}$ Discente do curso de Agronomia da Universidade Estadual de Maringá e membro Não-Bolsista PET-MEC/SESu
${ }^{1}$ Discente do curso de Agronomia da Universidade Estadual de Maringá e Bolsista PET-MEC/SESU

${ }^{2}$ Discente do curso de Agronomia da Universidade Estadual de Maringá e Bolsista PET-MEC/SESU

${ }^{3}$ Discente do curso de Agronomia da Universidade Estadual de Maringá e Bolsista PET-MEC/SESU

${ }^{4}$ Discente do curso de Agronomia da Universidade Estadual de Maringá e Bolsista PET-MEC/SESU

${ }^{5}$ Docente do Departamento de Agronomia da Universidade Estadual de Maringá e tutor do grupo PET-Agronomia UEM
\end{abstract}

Introdução: A curva de retenção de água no solo (CRAS) é essencial para o manejo da irrigação, pois ela fornece informações sobre a proporção entre água e solo, com base em volume. Os métodos mais habituais para obtenção da curva empregam a câmara de pressão (RICHARDS, 1965). O uso do tensiômetro apresenta-se como alternativa para determinar a CRAS. Para Almeida et al. (2010), a tensiometria foi eficiente na mensuração dos potenciais de retenção de água no solo.

A lâmina de água disponível para as plantas que se desenvolvem em um vaso pode ser determinada a partir da CRAS obtida para o material de preenchimento do vaso, por meio de tensiometria. A partir desta, tendo-se a identificação da umidade do material na capacidade de vaso e o potencial limite empregado para a irrigação, pode-se identificar o valor desta lâmina de água e definir a irrigação.

Objetivo: O objetivo foi determinar a CRAS na faixa de operação de tensiômetro (0 a 100kPa) a partir de amostras deformadas TFSA, avaliar a persistência temporal dos modelos ajustados e identificar os valores de lâmina de água disponível, a ser reposta via irrigação.

Material e Métodos: O solo utilizado é classificado como NITOSSOLO VERMELHO distroférrico. A amostra foi peneirada (peneira de $4 \mathrm{~mm}$ ), acondicionada em cinco vasos de $5900 \mathrm{ml}$, e profundidade de $0,25 \mathrm{~m}$. Com a massa do solo obtida (7000g) adicionou-se os volumes de água de 1200mL (vaso 1); 1000mL (2); 900mL (3); 750mL (4) e 600mL (5). Foi inserido em cada vaso um tensiômetro. Realizou-se, diariamente, a medição das massas durante dois períodos de 2019 e 2020 (CRAS1/CRAS2, respectivamente) e após, determinou-se com tensiômetros o valor absoluto do potencial de água. Ajustou-se um modelo único, o qual foi empregado para se ajustar um modelo matemático aos valores obtidos para lâmina de água disponível (H) para cada valor de potencial matricial de água no solo, que foi obtido pela equação: $H=(U c v$ Upl)x DS x L.

Resultado: Os valores absolutos de potencial variaram entre $5 \mathrm{kPa}$, no início, a $100 \mathrm{kPa}$, ao final. Os valores de umidade com base em massa variaram de um máximo de $0,52 \mathrm{kgkg}^{-1}$, no início, até um mínimo de $0,26 \mathrm{kgkg}^{-1}$. Em ambos os ciclos, o fenômeno de retenção de água foi adequadamente descrito por um modelo potencial (U=0.7881xP-0.192 CRAS1 e $U=0.758 \times P^{-0.185}$ CRAS2) de umidade $(U)$ em função de potencial $(P)$, os quais apresentaram coeficiente de determinação $\left(R^{2}\right)$ semelhante, da ordem de 96\%. Promoveu-se a linearização dos dados obtidos $(\ln (U)=0.1890 \ln (P)+0.2575$ CRAS1 e $\ln (U)=0.1883 \ln (P)+0.2575$ CRAS2), fixando-se o coeficiente linear de ambos em um valor único, comum aos dois, como forma de se poder comparar o coeficiente angular gerado com esta restrição. Os coeficientes angulares foram praticamente idênticos, com $0,37 \%$ de variação. O modelo único ( $U=0.7835 \times \mathrm{P}^{-0.191} \mathrm{CRAS}_{\mathrm{C}}$ ) é uma equação de $U$ em função de $\mathrm{P}$, e foi ajustado ao conjunto dos dados obtidos nos dois ciclos, com $\mathrm{R}^{2}$ de $97 \%$, será empregado para avaliar a relação entre água e material de preenchimento dos vasos e permitirá a realização dos cálculos necessários para as irrigações. Os dados de ambos os ciclos se mantiveram, bem como o modelo geral, com $\mathrm{p}<0,0001$. Foram gerados os valores de conteúdo de água para cada potencial na faixa operacional dos tensiômetros. Assumindo-se a capacidade de vaso de $60 \mathrm{hPa}$, e considerando a profundidade do vaso, determinou-se a lâmina de água disponível entre a capacidade de vaso e o valor empregado para o potencial limite para fins de irrigação, entre 100 e 1000hPa. Aos valores obtidos ajustou-se um modelo linear de $H(H=10.921 \ln (P)-41.348)$ em função do módulo do logaritmo natural do módulo do potencial, P. Apresentando $\mathrm{R}^{2}$ de $99 \%$. A lâmina de água disponível nos vasos para utilização pelas plantas e o potencial limite empregado para o manejo de água, varia entre $7,5 \mathrm{~mm}$, no potencial limite de $100 \mathrm{hPa}$, até $34 \mathrm{~mm}$, para o potencial de $1000 \mathrm{hPa}$.

Discussão: Considerou-se, ETo, igual a 5,0 mm/dia e constou-se então que a adoção de um potencial limite para irrigação nos vasos de $100 \mathrm{hPa}$ acarretaria a adoção de irrigações frequentes, uma vez que neste caso o valor de $\mathrm{H}$ seria da ordem de $7,5 \mathrm{~mm}$, o que atenderia à demanda estimada em cerca de 1.5 dias. Por outro lado, a opção por irrigar quando os tensiômetros chegarem 
ao limite prático operacional de $900 \mathrm{hPa}$, a lâmina de água disponível seria de $32,5 \mathrm{~mm}$, o que possibilitaria a realização das irrigações a cada 6,5 dias em cada vaso. Entretanto, a evapotranspiração atual das plantas depende de fatores ambientais e varia durante o ciclo da cultura.

Conclusões: A avaliação da CRAS com o uso de tensiômetros e determinação gravimétrica da umidade do solo mostrou-se eficaz; Os dois ciclos de avaliação mostraram que a persistência da retenção de água no solo é muito elevada, fazendo com que as curvas de ambos sejam praticamente idênticas, o que agrega confiabilidade aos procedimentos; Um modelo único de CRAS pode ser identificado, com $\mathrm{R}^{2}$ da ordem de $97 \%$, descrevendo com fidelidade a distribuição dos valores experimentais;

Para experimentos com vasos, o modelo apresentado pode ser empregado para identificar a lâmina de água a ser reposta via irrigação, para cada valor de potencial limite.

\section{Referências}

ALMEIDA, A.S.; ARAÚJO, F. S.; SOUZA G. S. Determinação da curva parcial de retenção de água de um Latossolo Vermelho por tensiometria. Scientia Plena, v. 6, n.9, 09/2010. Disponível em: https://www.scientiaplena.org.br/sp/article/view/145/59 Acesso em: 18/08/2020

RICHARDS L.A. Physical conditions of water in soil. In: BLACK, C.A.; EVANS, D.D.; WHITE, J.L.; ENSMINGER, L.E.;, L.A. CLARK, F.E. (Ed.). Methods of soil analysis: physical and mineralogical properties, including statistics of measurements and sampling. Madison: American Society of Agronomy.1965. 


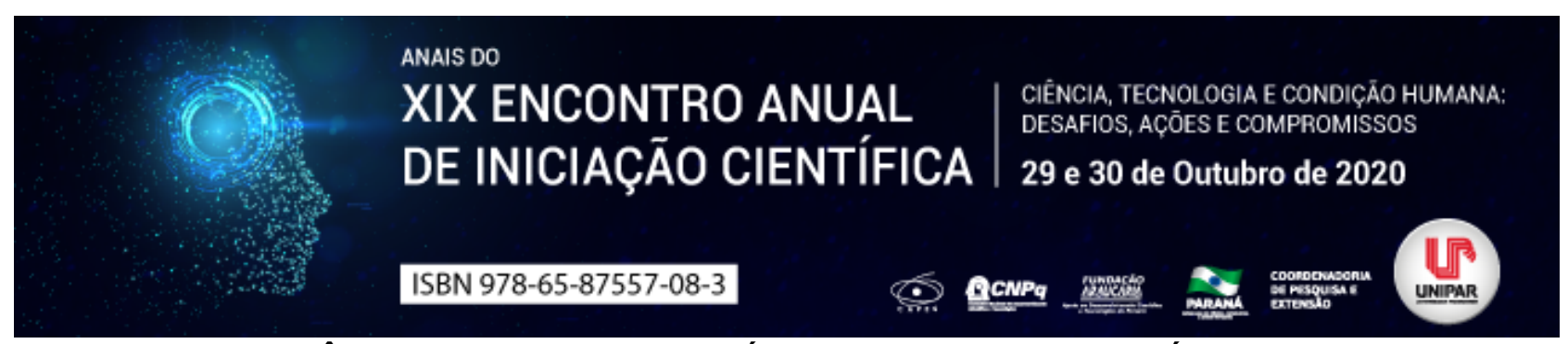

EFICIÊNCIA DE PRODUTOS BIOLÓGICOS NA CULTURA DE GÉRBERAS

\begin{abstract}
${ }^{1}$ Renan Santos Uhdre, ${ }^{2}$ ADRIELY LAZARIM, ${ }^{3}$ MARCIO EVANGELISTA BEZERRA, ${ }^{4}$ MAYRA SOARES, ${ }^{5}$ DANIELA HELOISA GASPAR SALA, ${ }^{6}$ ARNEY EDUARDO DO AMARAL ECKER
\end{abstract}

\author{
${ }^{1}$ Academico do curso de Pós Graduação em Genética e Melhoramento da Universidade Estadual de Maringá UEM. \\ ${ }^{1}$ Acadêmico do curso de Pós-Graduação em Proteção de Plantas da Universidade Estadual de Maringá - UEM \\ ${ }^{2}$ Academico do curso de Graduação em Agronomia UNINGÁ. \\ ${ }^{3}$ Acadêmico do curso de Pós-Graduação em Proteção de Plantas da Universidade Estadual de Maringá - UEM \\ ${ }^{4}$ Acadêmica do curso de Graduação em Agronomia UNINGÁ \\ ${ }^{5}$ Docente do Centro Universitário Ingá - UNINGA
}

Introdução: A perspectiva da floricultura no mercado brasileiro está crescendo nos setores de produção, distribuição e comercialização de flores, ganhando foco em diferentes estados brasileiros por seu retorno econômico favorável e rentável ao produtor rural (CERATTI, 2007). A produção de flores no Estado do Paraná ocupa a nona posição em consumo e sexto lugar em valor de mercado, devido às condições edafoclimáticas ser favoráveis a produção de flores (IBRAFLOR, 2019). As Gérberas são consideradas uma das cinco flores de corte mais importantes no mercado brasileiro. Em ambiente protegido existe a necessidade de diversos métodos para controlar fatores bióticos e abióticos, sendo controle químico o mais utilizado em doenças. O controle biológico por microrganismos apresenta-se como alternativa ecológica podendo reduzir o uso de agroquímicos e o impacto socio ambiental no manejo da doença. Considerando a constante demanda por parte dos viveiristas e produtores de flores por recomendações de controle, aliada à ausência de produtos químicos registrados, torna-se interessante um direcionamento das pesquisas para o controle alternativo dessas doenças (BIZI, 2008).

Objetivo: Avaliar a eficiência de produtos biológicos a base de enzimas e microrganismos no desenvolvimento de Gérberas sob ambiente protegido.

Metodologia: O experimento foi realizado no Núcleo Experimental de Agronomia do Centro Universitário Ingá UNINGÁ em Maringá, Pr, no mês de maio de 2020. A cultivar estudada foi Gérbera Mega Revoluxion Mix, variedade de ciclo precoce ideal para cultivo em vaso. Os tratamentos foram: T1 (Testemunha água destilada contendo Tween); T2 (Testemunha absoluta); T3 (mananoligossacarídeos fosforilado proveniente da parede celular de Saccharomyces cerevisiae); T4 ( $\mathrm{S}+\mathrm{Cu}+\mathrm{Fe}+\mathrm{Mn}+\mathrm{Zn}+$ C, aminoácidos e exsudados), T5 (Bacillus subtilis, B. licheniformis, proteases, xilases e celulases) e T6 (Cu, N e C). O delineamento utilizado foi o de blocos completos com tratamentos ao acaso com 7 repetições. Os tratamentos foram aplicados cinco vezes com intervalos de 15 dias, cada parcela constituiu de 1 vaso com $15 \mathrm{~cm}$ de diâmetro e $11,5 \mathrm{~cm}$ de altura, com um volume de 1,3 L), preenchidos com substratos Mac Plant ${ }^{\circ}$. Aos 25 dias de transplantio, as plantas receberam a primeira aplicação dos tratamentos, e a cada 15 dias a partir desta data foi realizado as aplicações de acordo com as recomendações do fabricante. Após 45 dias de transplantio as plantas foram conduzidas em câmera úmida por 24 horas, realizando a inoculação artificial do patógeno Botrytis cinera. A suspensão de esporos dos patógenos foi calibrada em $2,3 \times 10^{6}$ esporos mL-1 e adicionado espalhante adesivo Tween 80 a 0,05\%. aplicando-se $10 \mathrm{~mL}$ por planta e mantida sob câmera úmida por 48 horas. As características agronômicas avaliadas foram: Número de folhas (NF); Diâmetro do capitulo da flor (DF). Altura da haste (AP) e Diâmetro da haste (D). Os resultados das avaliações após atender os pressupostos básicos, foram submetidos à análise de variância e Teste $\mathrm{F}$ no programa Genes. Os dados qualitativos quando significativos a um nível $\alpha 5 \%$ de probabilidade de erro no teste $F$, foram submetidos ao teste pós médias, Tukey $(p<0,05)$.

Resultados: Após a coleta de dados, observou-se que, houve diferenças estatística significantes para as características agronômicas DF e D. Para a característica DF os tratamentos 2, 3 e 6 diferiram e superaram os tratamentos 1 e 5 . Para a característica D o tratamento 2 diferiu e superou os tratamentos 1 e 5 . Para as características NF, DF, AP e D o quadrado médio do resíduo observados na ANOVA foram 25,9; 2,046; 15,71 e 0,48 respectivamente.

Discussão: Para a característica DF a média foi de $7,77 \mathrm{~cm}$, discordando dos resultados encontrados por Singh e Mandhar (2002), que observaram em cultivares de gérbera Tiramise, diâmetro da flor de 10,70 cm. Tais divergências no DF corroboram com trabalhos realizados por Ludwig (2008), que descreveu respostas diferenciadas em relação ao DF para diferentes variedades de Gérberas. Importante citar que, alguns tratamentos foram expressivos para o DF, resultados estes que se fazem importante como alternativa econômica e ecologicamente viável para a nutrição da cultura de Gérberas. Para a característica agronômica DF, assim como a cominação de $\mathrm{Cu}, \mathrm{N}$ e C, o tratamentos à base de mananoligossacarídeosfosforilado proveniente da parede celular de Saccharomyces cerevisiae obtiveram eficiência sobre os demais tratamentos, corroborando com Soroa et 
al., (2003), em que observaram diferenças estatísticas superiores em relação a característica diâmetro da flor de Gérberas quando inoculados com G. fasciculatum. Mesmo diante da escassez de resultados relacionados ao diâmetro da flor e a inoculação de microrganismos benéficos, resultados em tomate, berinjela, pimenta e algodão, demonstram efeito positivo no uso de diferentes microrganismos (BASHAN, et al., 1996).

Conclusão: Concluímos que nas condições em que foi realizado o experimento e para os tipos de produtos utilizados, o tratamento 3, pela sua composição forneceu maior condição de desenvolvimento para a Gerbera jamesonii quando comparados com os demais produtos.

\section{Referências}

BASHAN, Y. et al. Interacciones entre plantas y microorganismos benéficos. II Bacterias asociativas de la rizosfera. Terra, vol. 1, no. 2, p. 195-242. 1996.

BIZI, R.M.; GRIGOLETTI JUNIOR, A.; AUER, C.G.; MAY de MIO, L. L. Produtos alternativos no controle do oídio em mudas de eucalipto. Summa Phytopathologica, v.34, n.2, p.144-148, 2008.

CERATTI. M, Paiva, P. D. O. Sousa, M; Tavares, T. S. Comercialização de Flores e Plantas Ornamentais no Segmento Varejista no Município de Lavras/MG. Ciênc. agrotec., Lavras, v. 31, n. 4, p. 1212-1218, 2007. Disponivel em: < https://www.scielo.br/pdf/cagro/v31n4/40.pdf> Acesso em 25 ago. 2020.

IBRAFLOR Instituto Brasileiro de Floricultura. Mercado de flores prevê crescimento médio de $9 \%$ no Brasil e faturamento de R\$ 7 bi, em 2017. IBRAFLOR, 2019. Disponível em: ibraflor.com/site/2017/11/04/mercado-de-flores-veralonguini/. Acessado em: 14 ago.2020.

LUDWIG, F., FERNANDES, D., M; MOTA, P., R., D; VILLAS BOAS, R. Macronutrientes em cultivares de gérbera sob dois níveis de fertirrigação. Horticultura Brasileira. 26: 068-073. 2008.

SINGH, K. P.; MANDHAR, S. C. Performace of gérbera (Gerbera jamesonii) cultivars under fan and pad cooled greenhouse environments. Indiam Journal of Applied Horticulture. vol 4. N. 1, p. 56-59. 2002.

SOROA, M., R; CORTÉS, S., L; HERNANDEZ, A. Estudio del efecto de la aplicación de biofertilizantes sobre algunas variables de crecimiento y rendimiento en Gerbera jamesonii cv. Bolus. Cultivos Tropicales, vol. 24, no. 2, p. 15-17. 2003. 


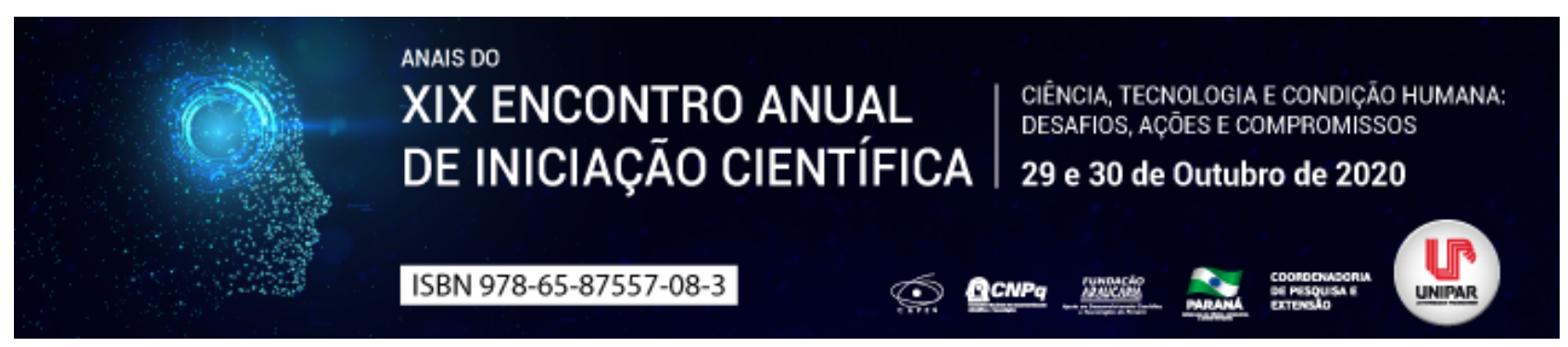

DIVERSIDADE CULTURAL E DESIGUALDADE SOCIALBRASILEIRA

\title{
${ }^{1}$ YASNAI LUELI BOLA, ${ }^{2}$ YASMIN LUANA BOLA, ${ }^{3}$ GILBERTO ANTES
}

\author{
${ }^{1}$ Acadêmica do Curso Engenharia Civil - Unipar \\ ${ }^{1}$ Acadêmica do Curso de Arquitetura e Urbanismo da UNIPAR \\ ${ }^{2}$ Docente da UNIPAR
}

Introdução: A cultura diversificada do povo brasileiro se mostra em constante com a desigualdade social. Desigualdade está que se caracteriza de forma marcante em nosso país, é fundamentada pela evidente hegemonia e estratificação de classe social, raça, gênero e religião. O combate a essas desigualdades está associado a educação, que desta forma, necessita combate-las.

Objetivo: $O$ artigo tem como objetivo geral reconhecer a diversidade cultural brasileira, assim como a desigualdade social que caracterizam nosso país, bem como apresentar como uma das formas de combate à desigualdade, o desenvolvimento de um projeto nacional de educação.

Desenvolvimento: A diversidade cultural está presente, e é uma das grandes marcas em nossa sociedade, de forma que, cada povo ou grupo, diferenciam suas características dos demais e expressando-se de formas mais variadas seus valores e costumes culturais. Em diferentes épocas e lugares estes grupos se comportam distintamente, compartilhando da mesma cultura, porem atribuindo sentidos diferentes.

Ao reconhecer que a sociedade brasileira é multicultural passa a se compreender a diversidade étnica e cultural dos diferentes grupos sociais que a compõem (CANEN, 2001 p. 207), o que significa perceber as desigualdades por determinantes de classes sociais, raça, gênero, econômica, de oportunidades e cultural. A sociedade brasileira está organizada sobre a base da diversidade cultural e da desigualdade social, através da qual o poder, os direitos e os bens, estão distribuídos de forma desigual, entre os diferentes grupos sociais. Para que a igualdade possa ser um atributo da sociedade, conforme o multiculturalismo se faz necessária a redistribuição e o reconhecimento dos grupos mais afetados. (RAMALHO, 2015, p.20). Deste modo nos leva a refletir, em como tratar os indivíduos igualmente sendo que os acessos são tão desiguais tanto aos bens, serviços e espaços de poder. Para Carrara as questões de gênero, religião, raça/etnia ou orientação sexual a sua combinação direcionam práticas preconceituosas e discriminatórias da sociedade contemporânea. Se o estereótipo e o preconceito estão no campo das ideias, a discriminação está no campo da ação, ou seja, é uma atitude. É a atitude de discriminar, de negar oportunidades, de negar acesso, de negar humanidade. Nessa perspectiva, a omissão e a invisibilidade também são consideradas atitudes, também se constituem em discriminação. (CARRARA, 2009, p. 27). A abordagem da diversidade cultural no âmbito escolar é de extrema relevância pois torna-se necessário desenvolver um projeto de educação social que procure atender a diversidade sociocultural de todo o povo brasileiro e suas realidades. É deste modo que a escola, deve proporcionar uma educação voltada ao reconhecimento das diferenças e construção de uma sociedade baseada em uma justiça social, são inúmeros esses abismos entre a sociedade, mas o predominante dentre estes está à educação brasileira. A educação nunca foi um direito de todos neste país de proporções continentais, passado escravocrata e estruturada concentração de renda (Lilian Moritz Schwarcz, 2019, p. 107). Desta forma devemos pensar uma escola que proporcione realmente educação, possibilite educação, oferecendo significado, para que desta forma possamos oportunizar e produzir diferentes saberes e níveis de aprendizagem para ambas as classes sociais, gêneros, religiões, e raças brasileiras. Sabendo que são estes de fato, um processo social e cultural da nossa sociedade, e não somente para explicar que homens e mulheres, negros e brancos se diferem entre si,ou seja, seu papel também é entender que, ao longo da história, diferenças foram produzidas e usadas como critérios de inclusão e exclusão. Desta forma ao compreendermos que somos marcados por uma imensa diversidade e infelizmente por uma grande desigualdade, é que está por sua vez, tem suas raízes na dinâmica das relações sociais, econômicas e culturais de nossa sociedade, podemos refletir estas relações, e por meio de uma educação inclusiva podemos criar condições para inserirmos oportunidades para que os indivíduos possam ser mais atuantes na sociedade para que a mesma seja justa e democrática para todos.

Seguindo esta realidade, a educação brasileira tende a encontrar seu caminho para a diversidade, engajando o indivíduo no mundo das diferenças, bem como, priorizar o ensino e aprendizagem sob uma pedagogia pautada na democracia, de modo a reduzir ou excluir todas as formas de preconceito, dando o direito ao acesso aos mecanismos de poder, bem como, admitir a existência de diferenças, e auxiliar em ensinamentos de respeito às mesmas, produzindo assim indivíduos que possam viver em perfeita união.

Conclusão: Constatou-se que a maneira mais eficaz de pensar e refletir sobre o preconceito é a partir da educação, a educação brasileira necessita encontrar seu caminho para a diversidade, para assim o indivíduo aderir e compreender o mundo das diferenças, para desta forma prepara-los para ser legítimos cidadãos. 


\section{Referências}

CANEN, Ana. UNIVERSOS CULTURAIS E REPRESENTAÇÕES DOCENTES: SUBSíDIOS PARA A FORMAÇÃO DE PROFESSORES PARA A DIVERSIDADE CULTURAL. Educação \& Sociedade, Rio de Janeiro, RJ, 2001. Ano XXII, n 77, p. 207-227. Disponível em: https://www.scielo.br/pdf/es/v22n77/7051.pdf. Acesso em: 27 jul. 2020.

CARRARA, Sérgio et al. Educação, diferença, diversidade e desigualdade: Diversidade. In: GÊNERO e Diversidade na Escola: Formação de Professoras/es em Gênero, Sexualidade, Orientação Sexual e Relações Étnico-Raciais. [S. l.: s. n.], 2009. v. 1, cap. 1, p. 13-36.

ETNOCENTRISMO, ESTEREÓTIPOS, ESTIGMAS, PRECONCEITO E DISCRIMINAÇÃO: Conceitos de etnocentrismo, estereótipos, estigmas, preconceito e discriminação. https://meuartigo.brasilescola.uol.com.br/sociologia/etnocentrismo-estereotipos-estigmas-preconceito-discriminacao.htm. Acesso em: 27 jul. 2020.

GOMES, Nilma Lino. EDUCAÇÃO E DIVERSIDADE CULTURAL: REFLETINDO SOBRE AS DIFERENTES PRESENÇAS NA ESCOLA, [s. I.], 1999. Disponível em: https://www.sinprodf.org.br/wp-content/uploads/2012/01/educa\%C3\%87\%C3\%83o-ediversidade-cultural.pdf. Acesso em: 27 jul. 2020.

PORFíRIO, Francisco. I"Cultura brasileira: da diversidade à desigualdadel"; Brasil Escola. Disponível em: https://brasilescola.uol.com.br/sociologia/cultura-brasileira-diversidade-desigualdade.htm. Acesso em: 27 jul. 2020.

QUALIDADE dos espaços verdes urbanos: In: FRANCISCO, Wagner de Cerqueira e. A DIVERSIDADE CULTURAL

BRASILEIRA EM SALA DE AULA: A pluralidade cultural do Brasil. Disponível em: https://educador.brasilescola.uol.com.br/estrategias-ensino/a-diversidade-cultural-brasileira-sala-aula.htm. Acesso em: 27 jul. 2020.

RAMALHO, Lays da Silva. DIVERSIDADE CULTURAL NA ESCOLA. Revista Diversidade e educação, Rio Grande Do Sul, RS, 2015. V. 3, N.36, p.29-36.

SCHWARCZ, Lilia Moritz. Desigualdade social. In: SOBRE o autoritarismo brasileiro. 1. ed. [S. I.]: Campanha das letras, 2019. cap. 5, p. 101-123. 


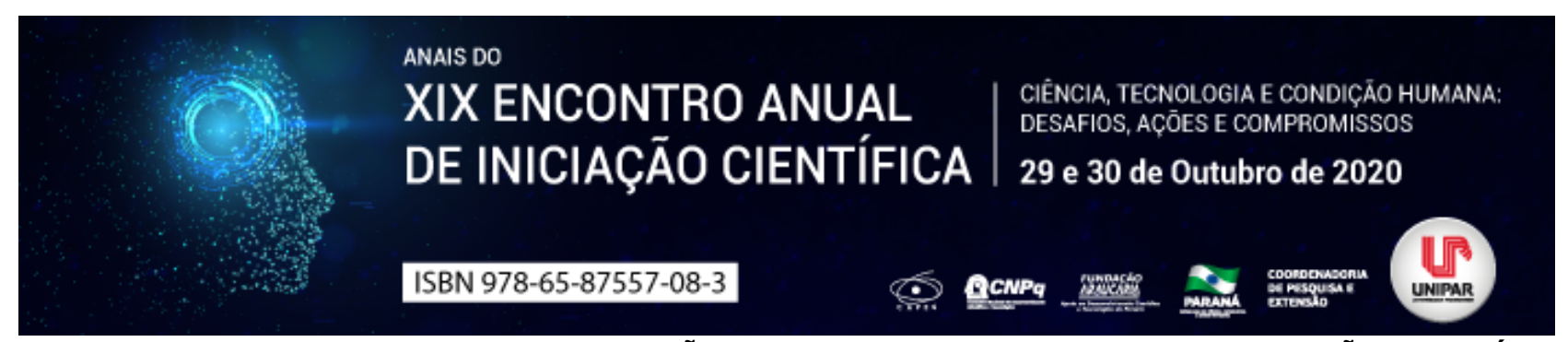

A USABILIDADE DE Data Science NA DETECÇÃO DE FRAUDES EM COMPRAS COM CARTÃO DE CRÉDITO

\title{
${ }^{1}$ HEDON NATHAN DE OLIVEIRA STRALHOTI, ${ }^{2}$ ELYSSANDRO PIFFER
}

\author{
${ }^{1}$ Acadêmico do curso de Sistemas de Informação da Unipar \\ ${ }^{1}$ Docente dos cursos da área de TI da UNIPAR
}

Introdução: Tendo em vista o cenário tecnológico dos últimos anos, pode-se destacar os grandes investimentos em infraestrutura de negócio e consequentemente o grande poder de processamento de dados em uma empresa. Este fato abre um leque para as organizações garantindo que praticamente todos os processos de uma organização estão aptos para a coleta de dados. (PROVOST; FAWCETT, 2016, p.1). Sabendo da atual situação em relação ao grande volume de dados produzido é possível apresentar uma solução para o manuseio desses dados a Data Science, que traz consigo um conjunto de métodos que auxiliam a análise de dados e como resultado, apresenta Insights que podem subsidiar a tomada de decisão.(GOMES, 2018)

Objetivo: Apresentar a usabilidade de Data science em um projeto que visa detectar fraudes em compras com cartão de crédito.

Desenvolvimento: Data Science refere-se a um conjunto de princípios, conceitos e técnicas que organizam o pensamento e a análise, com o objetivo de extrair dados para construir modelos preditivos que forneça informações úteis para tomada de decisão(PROVOST; FAWCETT, 2016, p.14). Todo projeto de Data Science possui um ciclo de vida cujo qual é muito importante, pois, auxilia na compreensão das oportunidades e desafios de extrair o máximo dos dados. O ciclo de vida dos dados propõe uma série de ações e transformações nos dados realizadas em etapas de um ciclo que se repetem quantas vezes forem necessárias (BERMAN, RUTENBAR, HAILPERN, 2018). Esse ciclo é composto pelas seguintes etapas; Compreensão de negócio, entendimento dos dados, preparação dos dados, modelagem, avaliação e implantação, neste ciclo repetição é uma regra, portanto se mesmo ao passar por todas as etapas o resultado não for satisfatório, não significa que o projeto é um fracasso, muitas vezes o processo é uma mineração de dados, e após a primeira passagem pelo ciclo, a equipe saberá muito mais, logo a próxima repetição apresentará resultados muito mais agradáveis PROVOST; FAWCETT, 2016, p.27). O Machine Learning (aprendizado de máquina) é uma área da ciência da computação que tem o objetivo de estudar métodos nos quais possibilitem as máquinas serem capazes de aprender por meio de dados existentes, extraindo padrões e efetuando predições, de maneira a tentar se equiparar a inteligência humana (SILVA, 2019, p. 20). Uma maneira de avaliar o modelo de machine learning é mediante a acurácia, que é utilizada para mostrar a qualidade de uma grandeza observada ou parâmetro estimado (MONICO et al, 2009). A acurácia varia de 0 a 1 (0 a 100\%), quanto mais o valor se aproxima de 1 , mais confiável o modelo será (FORMIGONI, 2010.).O protótipo elaborado para analisar a usabilidade de data science foi realizada sobre um conjunto de dados (dataset) que a empresa Nubank disponibilizou na internet durante uma competição de data science, o banco possui 43 colunas e 45.000 linhas. O protótipo seguiu o ciclo de vida data science, portanto iniciou-se com a etapa de compreensão de negócio, nessa etapa foi realizada uma análise mais detalhada sobre o problema. Dando sequência no ciclo, na etapa de entendimento dos dados realizou-se uma análise exploratória a fim de conhecer a base dados, esse conhecimento é essencial para próxima etapa que visa preparar os dados, tratando as imperfeições da base de dados deixando-a pronta para a próxima fase do ciclo, a modelagem e treinamento, a qual se encontra em fase inicial de implementação.

Conclusão: Por intermedio da data science é possível treinar algoritmos capazes de realizar predições, gerando insights que podem solucionar problemas ou até mesmo auxiliar em tomadas de decisões de uma empresa. O Protótipo apresentado foi realizado mediante ao ciclo de vida data science, sendo possível notar uma ótima organização das tarefas que foram desenvolvidas até o momento, proporcionando manter o foco na resolução do problema e a possibilidade de retornar a uma etapa anterior a qualquer momento que for preciso.

\section{Referências \\ BERMAN,F ;RUTENBAR, R.; HAILPERN, B.; Realizing the potential of Data Science. 2018 . Communications of the ACM. Vol. 61 No. 4, April 2018 .Disponível em: https://cacm.acm.org/magazines/2018/4/226372-realizing-the-potential-of-data-} science/fulltextAcesso em: 12/08/2020.

FORMIGONI, I. Acurácia: relação de risco para as decisões de seleção. 2010. Disponível em: https://www.scotconsultoria.com.br/imprimir/noticias/21830 Acesso em 25/08/2020.

MONICO, J; PÓZ, A; GALO, M.; Santos, M; Oliveira, L. Acurácia e Precisão: Revendo os conceitos de forma acurada. Curitiba: Boletim de Ciências Geodésicas, v. 15, n. 3, julio-septiembre, $2009 . \quad$ Disponível em: https://www.redalyc.org/pdf/3939/393937709010.pdf Acesso em 25/08/2020.

PROVOST, F.; FAWCETT, T. Data Science para negócios.1. ed. Rio de Janeiro: Editora Alta Books, 2016.

GOMES, P. O que é data science? O guia completo sobre o assunto. 05 de jun. 2018 Disponível em: 
https://www.datageeks.com.br/o-que-e-data-science/ Acesso em:08/06/2020.

SILVA, J. Sistema de gestão para localização indoor utilizando wifi fingerprints e machine learning. Orientador: Prof. Dr. Alixandre Thiago Ferreira de Santana. 2019. 68f. Monografia (grau de Bacharel)- Universidade Federal Rural de Pernambuco, Recife,

2019.

Disponível

em: https://www.repository.ufrpe.br/bitstream/123456789/1510/1/tcc_jos\%c3\%a9kellisondealmeidasilva.pdf Acesso em: 24/08/2020.

Coordenadoria de Pesquisa e Extensão - COPEX

Departamento de Editoraçāo e Divulgaçāo Científica - DEDIC 


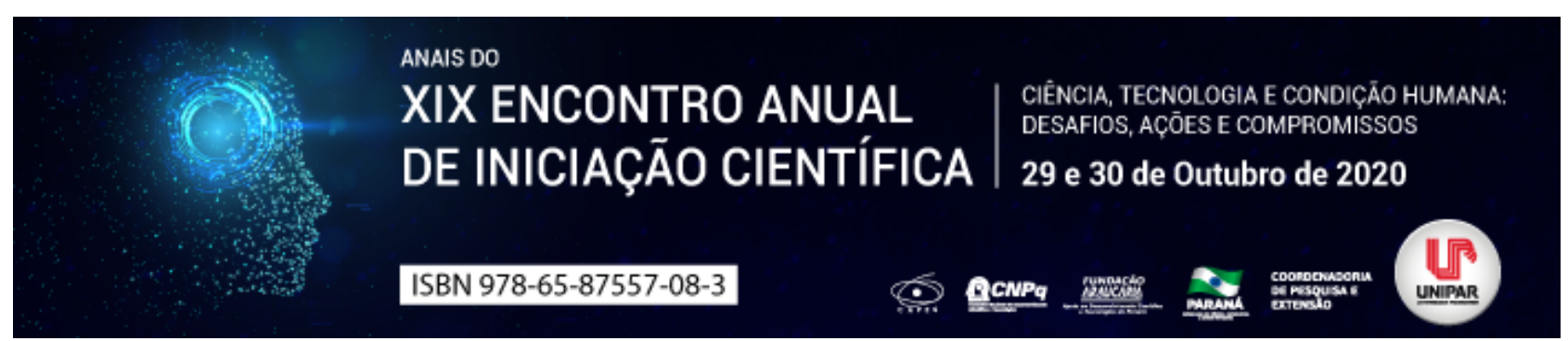

TERCEIRIZAÇÃO DE TI: UM ESTUDO SOBRE FERRAMENTAS UTILIZADAS EM HELP DESK

\title{
${ }^{1}$ CLEITON PASSARELI ALVES, ${ }^{2}$ LEANDRO CLEMENTINO DE LIMA
}

\author{
${ }^{1}$ Acadêmico do curso de Sistemas de Informação da Unipar \\ ${ }^{1}$ Docente da UNIPAR
}

Introdução: A terceirização de serviços relacionados às tecnologias da informação vem de encontro à necessidade de controle de custos, fazendo com que as empresas busquem alternativas que possam oferecer níveis adequados de qualidade no suporte e atendimento ao usuário.

Objetivo: Apresentar ferramentas utilizadas em acesso remoto para o serviço de Help Desk com o foco em atendimento aos usuários da área de $\mathrm{TI}$.

Desenvolvimento: A busca de ferramentas alternativas tem-se tornado constante no ambiente corporativo. Como em qualquer outra atividade, a tecnologia de informação também segue esta tendência, especificamente para manter o controle sobre custos, prazos e qualidade dos serviços de TI (LEITE, 1994). Um serviço bastante utilizado é o Help Desk, um suporte que deve ser acionado em problemas de baixa complexidade, como configurações de impressoras, internet, e-mail, que podem ser feitas pelo cliente ou de forma remota. Para prestar um bom serviço é necessário selecionar aplicativos confiáveis e eficientes. Dentre eles destacam-se: o TeamViewer que, de acordo com Techtudo (2015), é um software rápido e fácil para ser utilizado em empresas de pequeno e médio porte, oferecendo suporte ao cliente, contém recursos essenciais para acesso remoto como bate-papo, compartilhamento de arquivos e gravação de sessões, além de oferecer segurança aos usuários visto que gera uma senha a cada conexão, disponível para Linux, MACoS, Windows e Mobile; o AnyDesk, que, segundo o fabricante, é um software de acesso a computadores remotos, baseado no codec DeskRT, capaz de comprimir e transferir dados entre computadores, o qual possibilita a colaboração virtual com baixa latência, suporte multiplataforma, desde celulares, notebooks e computadores, essa ferramenta é muito popular em pequenas e médias empresas; o Freshdesk além dos recursos citados nas outras ferramentas, possui recurso de rastreamento e gerenciamento de chamadas ao suporte, permite estabelecer datas limite para a resposta e a resolução de chamados para diferentes categorias ou horários comerciais, Status de chamados personalizados, detecção de colisão de Agentes para garantir que diversos agentes não trabalhem no mesmo chamado por acidente, compartilhamento das propriedades dos chamados com outras equipes sem perder visibilidade sobre o progresso na resolução do problema e mecanismo de feedback.

Conclusão: Durante o estudo apresentamos ferramentas que auxiliam no serviço de Help Desk, as três ferramentas atendem aos critérios necessários ao suporte remoto, TeamViewer e AnyDesk, devido aos recursos atendem a usuários domésticos e corporativos, porém, para que possam exercer o papel no Help Desk, será necessário a complementação com outras ferramentas capazes de exercer o controle dos chamados. O Freshdesk atende a esses requisitos, possuindo a gama de ferramentas que contempla o acesso remoto e o controle de chamados sendo então recomendado para usuários corporativos que pretendem implantar o serviço de help desk. Como perspectiva para um novo estudo, sugerimos as ferramentas que complementam as características de controle de chamados para o TeamViewer e o AnyDesk.

\section{Referências}

ANYDESK. A história por trás do AnyDesk. Empresa. 2018. Disponível em:

. Acesso em 23 de agosto de 2020.

FLASHWORKS. Freshdesk. Recursos. 2018. Disponível em: < https://freshdesk.com/br/recursos/>. Acesso em: 24 de agosto de 2020.

LEITE, Jaci C. Terceirização em informática. São Paulo: Makron Books, 1994.

TECHTUDO. TeamViewer. Download. 2015. Disponível em: < https://www.techtudo.com.br/tudo-sobre/teamviewer.html>. Acesso em: 23 de agosto de 2020. 


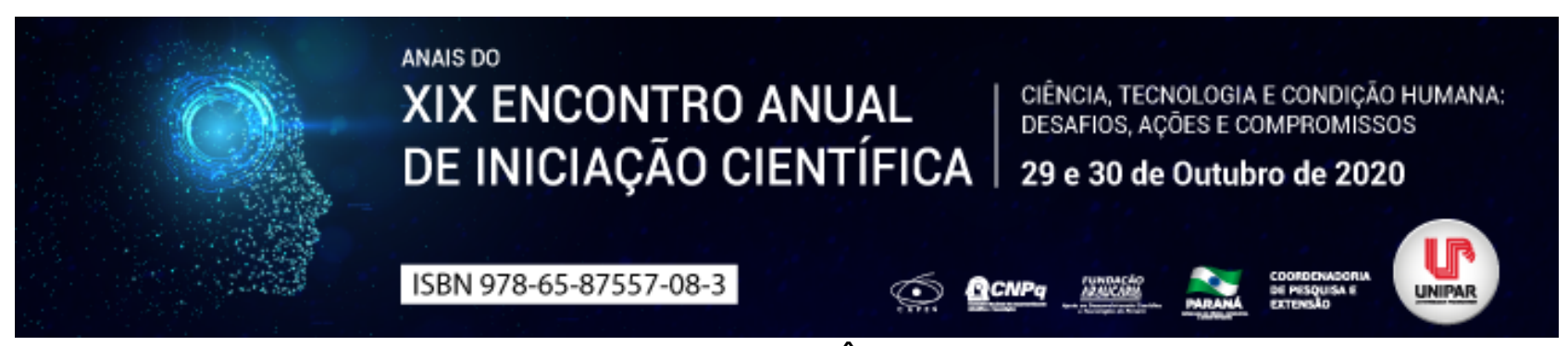

MANUAL DO JOGO ENGENHEIRANDO PARA DINÂMICAS DE GERENCIAMENTO DE OBRAS

\author{
${ }^{1}$ BRUNO RUAN DE CASTRO, ${ }^{2}$ EDUARDA LEANDRA SBARDELOTTO, ${ }^{3}$ DAYANE DOS SANTOS DA ROCHA, ${ }^{4}$ DIANE GUZI \\ FOMIN
}

${ }^{1}$ Acadêmico do Curso de Engenharia da Computação da UNIPAR

${ }^{1}$ Acadêmica do Curso de Engenharia Civil da UNIPAR

${ }^{2}$ Acadêmica do Curso de Engenharia Civil da UNIPAR

${ }^{3}$ Docente da UNIPAR

Introdução: Dentre as atribuições profissionais de engenheiros e arquitetos está o gerenciamento de obras. De acordo com Solis e O’Brien (2013), gerentes de obras ocupam uma posição-chave em projetos de construção, pois são responsáveis pela coordenação dos recursos disponíveis para a produção do empreendimento. A execução de funções de gerenciamento, exige do profissional, além do conhecimento teórico, habilidades como: liderança, comunicação, negociação e solução de problemas (Edum-Fotwe e McCaffer, 2000). Tais exigências fomentam a busca por oportunidades de melhorias no processo de ensino tradicional. Abordagens alternativas aos métodos convencionais de ensino precisam ser adotadas de modo a atender as novas e crescentes exigências na formação acadêmica (Oliveira e Sauaia, 2011). Para Colombo (2017), é preciso ir além das metodologias tradicionais de ensino para dar significado ao processo de aprendizagem e torna-lo verdadeiramente relevante. Tratar de aprendizagem vivencial (aprender fazendo) usando a convencional aula expositiva suscita uma clara dissonância cognitiva (Oliveira e Sauaia, 2011). Para Escrivão Filho e Ribeiro (2007), existe o esforço das instituições de ensino superior, onde novas técnicas integrativas e construtivistas ganham espaço como formas de apreender conceitos, desenvolver habilidades e atitudes de forma integrada sem que haja a necessidade de criação de disciplinas específicas.

Nesse contexto, simulações e jogos são ferramentas que podem auxiliar o processo de ensino de diversas áreas da Engenharia (Depexe, 2010), além da oportunidade para os educadores incrementarem as aulas com relevância, dinamismo e interatividade (Colombo, 2017). O jogo Engenheirando (Fomin e Clemente, 2015) é a associação dos termos engenheiro + ganhando .É um jogo de tabuleiro criado para estimular estudantes e profissionais a desenvolver habilidades gerenciais em projetos de construção. O jogo é uma proposta lúdica para ser trabalhado em sala de aula ou em treinamento profissionais, sendo uma atividade dinâmica para a fixação e prática dos conceitos teóricos de gerenciamento de projetos. O jogo explora os conceitos de gerenciamento de projetos, com base no PMBOK (2014).

Objetivo: Elaborar um manual de uso do jogo Engenheirando para ser utilizado como dinâmica em salas de aula.

Material e Métodos: Para o desenvolvimento do manual foram utilizadas as descrições do jogo pelos autores em um artigo científico, fotos de uma simulação de aplicação do jogo na Pós Graduação de Gerenciamento de Obras da UNIPAR Francisco Beltrão em 2015 e o contato com os autores do jogo.

Discussão: O manual elaborado descreve o funcionando do jogo, como peças, objetivo, descrição de cada item do jogo, as regras, o modo de iniciar e concluir o jogo. As peças do jogo são 10 capacetes, 1 tabuleiro, a moeda do jogo denominada de \$engenheta\$, Cartas de perguntas, 1 roleta, 400 paredes casa/shopping, 50 Laterais shopping, 100 Lajes casa/shopping, 100 Telhados casa/shopping, 40 Trilhos de trem, 20 Vigas centrais shopping, 20 Computadores N1, 20 Computadores N2, 10 Trens e 10 Vagões N2, 3 e 4 e um tabuleiro com o cenário do jogo. O ganhador do jogo será aquele que construir o maior número de casas, shoppings e linhas de trens possíveis e terminar o jogo com a maior valorização do capital inicial adquirido e com o maior montante financeiro. O manual elaborado descreve com ilustrações cada etapa ficando no formato de um folder para acompanhar o jogo e também a descrição para servir de roteiro para ser aplicado em sala de aula.

Conclusão: $O$ manual elaborado atende às expectativas de descrever e explicar o funcionando do jogo a fim de ser utilizado como uma opção de dinâmica e atividade lúdica para treinamentos e salas de aulas, de qualquer área que necessite desenvolver habilidades em gerenciamento. $\mathrm{O}$ tema de fundo do jogo, a construção civil, se adequa perfeitamente às rotinas administrativas de um canteiro de obras e é uma excelente opção para os cursos de engenharia civil. Espera-se aplicar o jogo em futuro breve em sala de aula para testar o entendimento do manual e realizar as melhorias necessárias para o perfeito entendimento.

\title{
Referências
}

CLEMENTE, F.; FOMIN, D.G. O ensino do gerenciamento de obras: 0 Jogo Engenheirando. Congresso Brasileiro de Administração, Ponta Grossa, PR, 2015.

COLOMBO, A.A, Gameficação nas aulas de filosofia. Instituto Federal do Paraná, Curitiba, PR, 2017.

DEPEXE, M.D., Simulação com jogos de montar: um instrumento de ensino para o planejamento e programação de 
obras. Universidade Federal de Santa Catarina, 2010. Engevista, V.12, n.2, p. 108-116.

EDUM-FOTWE, F.T.; MCCAFFER, R. Developing project management competency: perspectives from the construction industry. International Journal of Project Management. v. 18, p. 11-124, 2000.

ESCRIVÃO FILHO, E., RIBEIRO, L. R. C., Inovando no ensino de administração: uma experiência com a aprendizagem baseada em problemas (PBL). Cadernos EBAPE.BR, 2008, 6(Ed. Especial), 1-9.

Project Management Institute. A guide to the project management body of knowledge: PMBOK guide. $5^{\mathrm{a}}$ ed. Newtown Square, PA, 2014.

OLIVEIRA, M.A., SAUAIA, A. C. A., Impressão docente para aprendizagem vivencial: um estudo dos benefícios dos jogos de empresas. Administração: Ensino e Pesquisa. Rio de Janeiro, V.12, n.3, p. 355-391, 2011.

SOLIS, F.; O'BRIEN, W. Cognitive Design of Safety Supervision Instruction. Computing in Civil Engineering. p. 435-442, 2013.

Coordenadoria de Pesquisa e Extensão - COPEX

Departamento de Editoraçāo e Divulgaçāo Científica - DEDIC 


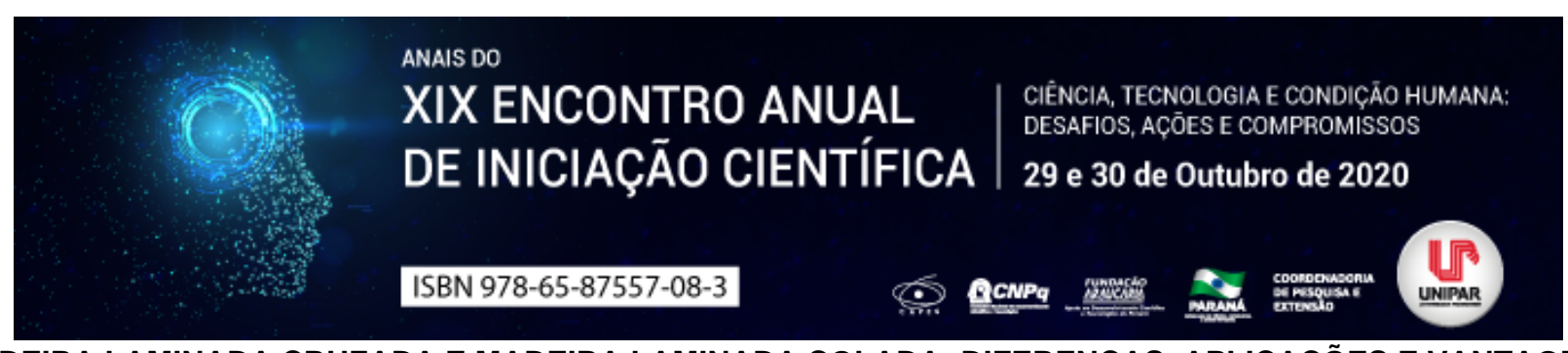

MADEIRA LAMINADA CRUZADA E MADEIRA LAMINADA COLADA: DIFERENÇAS, APLICAÇÕES E VANTAGENS

\author{
${ }^{1}$ YASNAI LUELI BOLA, ${ }^{2}$ YASMIN LUANA BOLA, ${ }^{3}$ DIANE GUZI FOMIN
}

\author{
${ }^{1}$ Acadêmica do Curso de Engenharia Civil - Unipar \\ ${ }^{1}$ Acadêmica do Curso de Arquitetura e Urbanismo da UNIPAR \\ ${ }^{2}$ Docente da UNIPAR
}

Introdução Devido à crescente preocupação com a sustentabilidade e conservação da natureza nas últimas décadas, o uso da madeira proveniente de fontes renováveis, passaram a ser vistos como uma possibilidade para reduzir os impactos do setor da construção civil no meio ambiente e vem aumentando a sua participação frente aos materiais convencionais (PASSARELI, 2013). A Madeira Laminada Colada e a Madeira Laminada Cruzada têm papel fundamental na construção civil,por ser um material sustentável, renovável, aplicados em residências e edifícios, além de proporcionar maior facilidade na construção de grandes estruturas, possuem diferenças, como a forma como são produzidas, facilitam a construção por ser um material prático.

Objetivo: O estudo teve como objetivo geral destacar as aplicações da madeira laminada colada e da madeira laminada cruzada, bem como as vantagens e diferenças entre ambas.

Desenvolvimento: Os dois tipos de madeira podem ser utilizados, bem como a MLC Madeira laminada colada, na construção de pergolados, residências, abrigos externos, espaços urbanos, pontes, adegas, templos religiosos, arenas, pavilhões, entre diversas outras construções. O painel de CLT Madeira laminada cruzada, por sua vez, vem sendo de grande utilidade devido aos seus tantos benefícios, são utilizados como paredes de residências ou edifícios, pisos, telhados, forros e em mobiliários, entre outros. A madeira laminada colada, MLC e a madeira laminada cruzada, CLT vêem sendo destaques por sua resistência, aparência, versatilidade e sustentabilidade. segundo o site Carpintaria 2018, a MLC apresenta uma alta flexibilidade com curvaturas, alta capacidade de cargas e baixo peso próprio, com uma alta resistência ao fogo, as substanciam químicas e agressivas. A MLC é um material leve o que facilita para sua montagem e desmontagem, além disso, é um material sustentável, pois é renovável e não precisa da queima de combustíveis fosseis durante sua produção, com alta resistência mecânica,resistência a umidade e alta durabilidade. A CLT possui grandes vantagens, tais como, facilidade na construção de grandes estruturas, resistência do material, podendo assim construir edifícios, com grande resistência ao fogo, fazendo com que o local fabricado de CLT queime com menos precisão e mais lentamente (Carpintaria, 2018). Esta, não possui danos contra terremotos na sua estrutura, alta ductibilidade, é um material de peso leve, ótimo isolamento acústico e térmico, absorve a umidade, não tóxico, com a manutenção adequada este material é de longa durabilidade e baixo custo na produção etem redução de tempo em seus projetos. Os dois tipos de madeira podem ser utilizados para diversas partes da construção civil, bem como a MLC sendo aplicada em diversos locais, tais como, na construção de pergolados, residências, abrigos externos, espaços urbanos, pontes, adegas, templos religiosos, arenas, pavilhões, entre diversas outras construções. O painel de CLT, por sua vez, vem sendo de grande utilidade devido aos seus tantos benefícios, são utilizados como paredes de residências ou edifícios, pisos, telhados, forros e em mobiliários, entre outros. A MLC e a CLT apesar de conterem bastantes aspectos comuns, possui algumas diferenças. A Madeira Laminada Colada, ou MLC, é um produto elaborado a partir da colagem de lâminas de madeira serradas, com a utilização de adesivos a base de resorcinol e poliuretano, de forma seletiva para diminuir a influência dos defeitos nas peças, com a direção das fibras paralela ao eixo longitudinal da peça (Duarte 2004). Deste modo, a MLC é feita através de um conjunto de muitas pequenas partes da madeira, que juntas seformam, gerando peças lineares, inclinados ou retos, porém sempre lineares. Os painéis de CLT são geralmente constituídos por três, cinco ou sete camadas de lâminas de madeira, coladas perpendicularmente umas as outras com adesivo e prensadas a quente. Estes são produzidos em grandes dimensões, chegando a 3 metros de largura por 16,5 metros de comprimento, porém, as dimensões podem variar de acordo com cada fabricante (PASSARELI 2013). Sendo assim, a CLT, é feita através de um conjunto de tábuas em camadas de forma cruzada, que são coladas e prensadas a quente, formando placas, paredes ou faces externas.

Conclusão: Constatou-se que a MLC, Madeira Laminada Colada e a CLT, Madeira Laminada Cruzada, são de grande importância para construção civil devido sua sustentabilidade, resistência, versatilidade, aparência, alta capacidade de carga e baixo peso próprio. Ambas possuem desvantagens, como uso de adesivos de custo elevado na MLC e maquinário específico para prensa, na CLT, porem suas vantagens como a facilidade na montagem e desmontagem, alta resistência ao fogo, e baixo peso próprio além de outras vantagens, sendo aplicadas em estruturas, residências e edifícios o que as tornam práticas e sustentáveis devido a ser renováveis e não precisarem da queima de combustíveis fósseis durante sua produção.

\title{
Referências
}

A VERSATILIDADE DA MADEIRA LAMINADA COLADA: THE VERSATILITY GLUED LAMINATED TIMBER. Revista CONSTRUINDO, Belo Horizonte, v. 8, 1 Ed., p. $01 \quad$ 14, Jan - Jun, 2017, Belo Horizonte, v. 8, ed. 1², 2017.Acesso em: 27 jul. 2020.

CONHEÇA AS VANTAGENS DA MLC MADEIRA LAMINADA COLADA (GLULAM). In: CONHEÇA AS VANTAGENS DA MLC MADEIRA LAMINADA COLADA (GLULAM). São Paulo, 2018. Disponível em: https://carpinteria.com.br/2018/11/02/conheca-asvantagens-da-mlc-madeira-laminada-colada/. Acesso em: 27 jul. 2020. 
FRANCO, José Tomás. A MADEIRA Laminada Cruzada (CLT) é o concreto do futuro?. [S. I.]. 2019. Disponível em: https://www.archdaily.com.br/br/922665/a-madeira-laminada-cruzada-clt-e-o-concreto-do-futuro. Acesso em: 27 jul. 2020.

MADEIRA LAMINADA COLADA CRUZADA (CLT): PRODUÇÃo E DESENVOLVIMENTO. São Paulo, 2018. Disponível em: https://carpinteria.com.br/2018/04/08/madeira-laminada-cruzada-

clt/\#: :text=A\%20lamina\%C3\%A7\%C3\%A30\%20cruzada\%20cria\%20propriedades,a\%20madeira\%20nunca\%20foi\%20adequada.Acesso em: 27 jul. 2020.

O QUE é Madeira Laminada Colada (MLC ou Glulam). [S. I.], 2019. Disponível em: https://www.celuloseonline.com.br/madeiralaminada-colada/.

Acesso em: 27 jul. 2020.

POTENCIAL DA MADEIRA LAMINADA COLADA CRUZADA NO BRASIL. II Congresso Brasileiro de Ciência e Tecnologia da Madeira Belo Horizonte - 20 a 22 set 2015, [s. I.], 2015.

Acesso em: 27 jul. 2020.

SOUZA, Eduardo. MADEIRA Laminada Cruzada: o que é e como utilizá-la. [S. I.]: 2018. Disponível em: https://www.archdaily.com.br/br/893433/madeira-laminada-cruzada-o-que-e-e-como-utiliza-la.

Acesso em: 27 jul. 2020.

Coordenadoria de Pesquisa e Extensão - COPEX

Departamento de Editoraçāo e Divulgaçāo Científica - DEDIC 


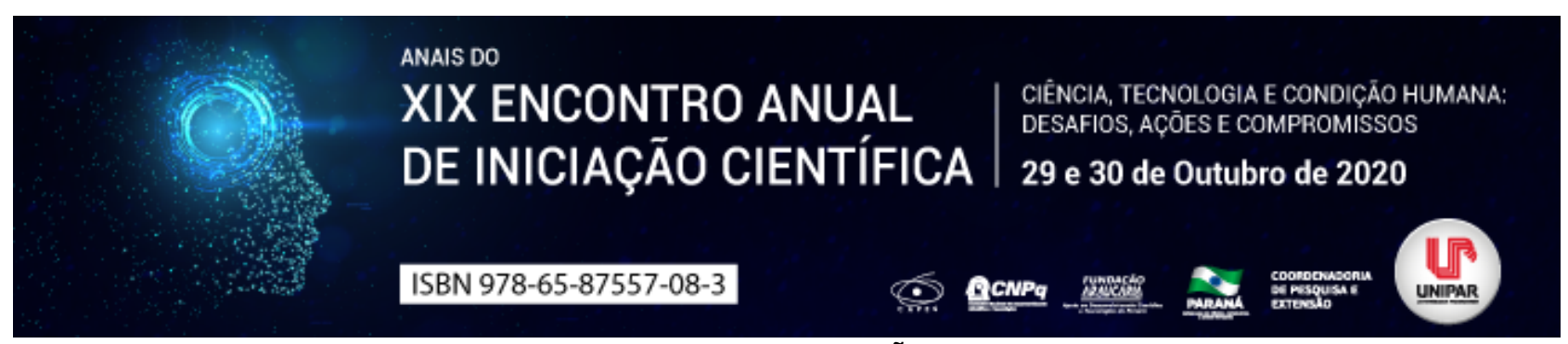

QUALIDADE DO SOLO E RELAÇÃO SUSTENTAVEL

\author{
${ }^{1}$ MIGUEL SILVA BAZZANELLA, ${ }^{2}$ LUCIMAR PEREIRA BONETT
}

${ }^{1}$ Acadêmico do Curso de Administração da UNIPAR

${ }^{1}$ Docente da UNIPAR

Introdução: Nas últimas décadas têm se falado muito em sustentabilidade, principalmente com a preocupação voltada para degradação dos recursos naturais, a sustentabilidade agrícola que, segundo Gliessman (2000), é conceituada como a capacidade de um sistema agrícola produzir alimentos e fibras sem comprometer as condições que viabilizam esse processo de produção. Portanto, a relação entre qualidade do solo e sustentabilidade agrícola consiste na produção de alimentos e fibras num solo capaz de cumprir suas funções, num processo de produção ambientalmente seguro, economicamente viável e socialmente aceito. Muitos cientistas do solo refletem, uma forma de como identificar quais os melhores índices de qualidade do solo, desde o início da discussão sobre qualidade do solo e sustentabilidade agrícola.

Objetivo: Constatar a existência de índices que sirvam como indicador da qualidade do solo voltado para a sustentabilidade agrícola

Desenvolvimento: Assim como existem indicadores para verificar a qualidade do ar e da água, cientistas do solo, procuram estabelecer um índice que seja capaz de servir como indicador, da qualidade do solo (VEZZANI; MIELNICZUK, 2009). Cujo índice facilite a avaliação de solos, em relação à degradação, indicativo de práticas de manejo, com foco no monitoramento de mudanças nas propriedades e nos processos do solo, na sustentabilidade e na qualidade ambiental, em resposta ao seu uso (GRANATSTEIN; BEZDICEK, 1992). De acordo com Doran Parkin (1994), um índice de qualidade do solo deve priorizar uma série de propriedades do solo, que esteja fundamentado em alguns pilares como: elucidar processos do ecossistema e relacionar aos processos-modelo; integrar propriedades biológicas, físicas e químicas do solo e os respectivos processos; ser acessível a muitos usuários e aplicável a condições de campo; ser sensível a variações de manejo e de clima ao longo; do tempo; ser práticos para uso tanto por cientistas como por agricultores, extensionistas, ecologistas e instituições governamentais, numa ampla classe de situações ecológicas e socioeconômicas. Várias propostas de indicadores, formas e fórmulas para avaliar a qualidade do solo surgiram e, geralmente, estão relacionadas com a área de concentração dos pesquisadores, conforme Vezzani e Mielniczuk (2009), uma corrente procura identificar quais os melhores índices tanto de ordem biológica, física ou química, outra corrente posiciona-se a favor da matéria orgânica do solo, outra corrente citada como alternativa, foca em atributos indicadores e analisa processos no sistema solo-planta.

Conclusão: Temos como conclusão que existem manejos primordiais para a qualidade do solo visando a busca por atributos do solo como índice de qualidade do solo; matéria orgânica do solo como indicativo de qualidade e, sistema biológico do solo, tudo isso tendo em vista também as qualidades fisicas e quimicas.

Dessa abordagem destacamos o avanço da ciência do solo em relação à qualidade do solo e que o solo por si só não atinge qualidade, e sim o sistema solo-planta integrados e adaptados ao seu local no ambiente.

\title{
Referências
}

DORAN, J. W.; PARKIN, T. B. Defining and assessing soil bquality. In: Defining soil quality for a sustainable environment. Madison: SWCS, 1994. p. 3-21.

GLIESSMAN, S. R. Agroecologia: Processos ecológicos em agricultura sustentável. 2. ed. Porto Alegre: Ed. Universidade UFRGS, 2000.

GRANATSTEIN, D.; BEZDICEK, D. F. The need for a soil quality index: Local and regional perspectives. American Journal Alternative Agriculture, Arlington, v. 7. n. 1, p. 12-16, 1992.

VEZZANI, F. M; MIELNICZUK, J. Uma visão sobre qualidade do solo. Revista Brasileira de Ciência do Solo. Visoça, v. 33, n. 4, p. 743-755, 2009. 


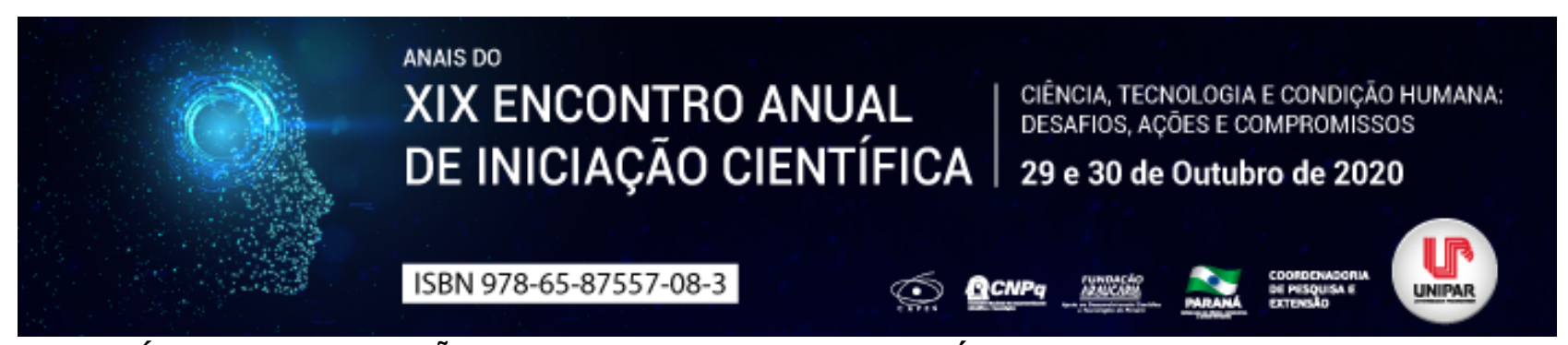

OS BENEFÍCIOS DA UTILIZAÇÃO DE PLATAFORMAS DIGITAIS LÚDICAS NAS ATIVIDADES EDUCACIONAIS

\author{
${ }^{1}$ Eduardo Zafalon Tampelini, ${ }^{2}$ RAFAEL AUGUSTO DA SILVA, ${ }^{3}$ GABRIEL ARTUR RAVASIO, ${ }^{4}$ DANIELI PINTO, ${ }^{5}$ MARCELO \\ APARECIDO MARQUES
}

\begin{abstract}
${ }^{1}$ Acadêmico do curso de Análise e Desenvolvimento de Sistemas da Faculdade de Administração e Ciências Econômicas de Cianorte FACEC

${ }^{1}$ Acadêmico do curso de Análise e Desenvolvimento de Sistemas da Faculdade de Administração e Ciências Econômicas de Cianorte FACEC

${ }^{2}$ Acadêmico do curso de Análise e Desenvolvimento de Sistemas da Faculdade de Administração e Ciências Econômicas de Cianorte FACEC

${ }^{3}$ Docente da Faculdade de Administração e Ciências Econômicas de Cianorte FACEC

${ }^{4}$ Docente da Faculdade de Administração e Ciências Econômicas de Cianorte FACEC
\end{abstract}

Introdução: A tecnologia está em constante evolução na sociedade contemporânea. É aplicada tanto nos meios informativos e educacionais (portais de notícia, artigos científicos e EAD) como nos meios lúdicos (jogos e redes sociais) (SILVEIRA; MARASCHIN, 2018). Das formas lúdicas os jogos eletrônicos vêm se instalando cada vez mais em nossa cultura, unificando-se com áreas como educação e saúde (BRANDÃO et al., 2019). Em tal contexto a programação está cada vez mais sendo reivindicada em nosso ambiente social, necessitando gradativamente de mais pessoas capacitadas no mercado de trabalho.

Objetivo: Apresenta os benefícios da utilização de plataformas digitais lúdicas nas atividades educacionais.

Desenvolvimento: $\mathrm{Na}$ área da educação existem várias formas de motivar o aprendizado. Embasado no pensamento de Vygotsky, o pensamento propriamente dito é gerado pela motivação, isto é, por nossos desejos e necessidades, nossos interesses e emoções (VYGOTSKY, 2002). Em nossas instituições de ensino fundamental e médio aos poucos estão inserindo a programação nas grades curriculares (SILVEIRA; MARASCHIN, 2018). Contudo a programação é uma matéria onde o método teórico é difícil de ser explicada e dependendo das condições da instituição de ensino a respeito do financiamento de recursos para a prática, pode haver a ausência da mesma(ALVES; HOSTINS, 2019). Tendo em vista essa circunstâncias, podemos introduzir as ferramentas digitais lúdicas, onde se espera que o educando irá encarar a programação com mais tranquilidade usando um artificio que ele tem mais afinidade e familiaridade (BRANDÃO et al., 2019). Além dos métodos voltados na área educacional, as formas lúdicas também aperfeiçoam no trabalho em equipe dos alunos e no espírito esportivo, e também a benéficos físicos e psicológicos como a coordenação motora, reflexo, agilidade, memoria, paciência, entrosamento social (SILVEIRA; MARASCHIN, 2018).

Conclusão: A maneiras lúdicas digitais, se mostram um bom método para o ensino de programação para os estudantes de nível fundamental e médio, seja pelo maior interesse dos educandos nessa área ou pela facilidade no qual eles aprendem Entretanto o financiamento e o incentivo nesse método tenha um contra tempo, por causa do custo e dos requisitos que esse método necessita e muitas instituições de ensino não conseguem atender ou por ter poucos profissionais especializados nessas áreas, ou seja, embora a ideia da utilização dessas ferramentas seja muito agradável na teoria, ao analisarmos essa ideia na prática pode haver complicações.

\title{
Referências
}

ALVES, A. G.; HOSTINS, R. C. L. Elaboração Conceitual por meio da Criação Colaborativa e Coletiva de Jogos Digitais na Perspectiva da Educação Inclusiva. Revista Brasileira de Educação Especial, v. 25, n. 4, p. $709728,2019$.

BRANDÃO, I. DE A. et al. Jogos eletrônicos na atenção à saúde de crianças e adolescentes: revisão integrativa. Acta Paulista de Enfermagem, v. 32, n. 4, p. 464 469, 2019.

SILVEIRA, R. F. DA; MARASCHIN, C. Jogos Digitais: Dispositivos para Pensar Práticas Escolares. REVISTA DE PSICOLOGIA DA IMED Jogos, v. 10, n. 1, p. 56 72, 2018.

VYGOTSKY, L. S. Sobre pensamento e linguagem. São Paulo: Edição eletrônica: Ridendo Castigat Mores, 2002. 


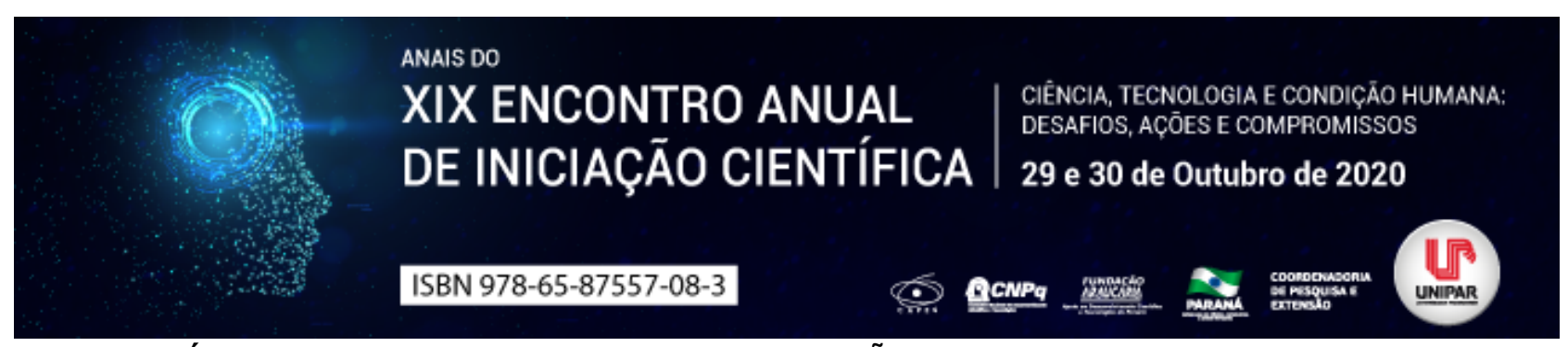

MÉTODOS E USOS DE BANCADAS DE VIBRAÇÕES CONTROLADAS POR ARDUINO

\title{
${ }^{1}$ PEDRO SETTE ISRAEL, ${ }^{2}$ PATRIK AMERICO POLLIZELLO LOPES
}

\author{
${ }^{1}$ Academico do PIC/UNIPAR \\ ${ }^{1}$ Docente da UNIPAR
}

Introdução: A análise de vibrações vem sendo, nas últimas décadas, um importante objeto de estudo para a resolução de problemas em diferentes áreas das engenharias. Tais aplicações podem ser utilizadas com as atualizações de modelos de elementos finitos, identificação de propriedades mecânicas, controle de vibrações, identificação do dano e monitoramento da saúde estrutural, entre outros (EWINS, 2000). Na área tecnológica, o estudo de vibrações para a engenharia moderna tem importantes aplicações em projetos de máquinas, estruturas, motores, sistemas de controle e outros que relevam questões relacionadas a vibração (SOEIRO, 2008). Devido ao elevado custo dos equipamentos e a complexidade da instrumentação, o trabalho de analisar continuamente esse fenômeno se torna uma tarefa difícil. A fim de evitar o alto custo dos equipamentos envolvidos, opta-se por utilizar equipamentos de baixo custo, onde são incluídos sensores acelerômetros compatíveis com microcontroladores, como por exemplo o Arduino.

Objetivo: Comparar métodos no uso de bancadas de vibrações controladas por Arduino.

Desenvolvimento: Santos Jr et al. (2018) desenvolveram uma bancada para a análise de vibrações e foi comparada aos resultados de Jesus e Cavalcante (2011). Para o acionamento do motor e monitoramento das vibrações foram instalados sensores acelerômetros, um tacômetro, uma placa de Arduino e os devidos materiais para compor o sistema. Os testes foram realizados em quatro condições: inicial, desbalanceada, com desalinhamento angular e com roçamento. As medições foram realizadas em três posições, sendo: radial horizontal, radial vertical e axial. Para o primeiro teste, admitiu-se como um sistema balanceado, os testes foram feitos até a sétima harmônica, onde na primeira harmônica apresentou os resultados desejados (um pico de 3,4*10-3 G), mas nas seguintes, após uma comparação feita com o trabalho de Jesus e Cavalcante (2011), percebeu-se que a bancada dos mesmos apresentou folga mecânica decorrente de imperfeições na montagem. Em seguida, na condição de desbalanceamento, esse teste foi feito em duas etapas, onde uma se constitui da adição de uma massa e na segunda a adição de duas massas. Na primeira, percebeu-se um aumento na amplitude que foi de $3,4{ }^{*} 10-3$ G para $12{ }^{*} 10-3 \mathrm{G}$, ficando claro 0 desbalanceamento, com esses resultados da amplitude percebeu-se também um defeito de flexão no eixo. No segundo, com a adição de uma segunda massa, percebeu-se um grande aumento na amplitude que foi de 12 * 10-3 G para 79 * $10^{-3} \mathrm{G}$. No terceiro teste, na condição de desalinhamento linear, foi efetuada a medição do espectro limitando-se em uma frequência de 0 a $100 \mathrm{~Hz}$, nessa primeira análise, percebeu-se que havia alto nível de ruído e excitações em altas frequências (frequências entre $100 \mathrm{~Hz}$ a $250 \mathrm{~Hz}$ ). Essas altas frequências se dão por defeitos mecânicos, e isso foi relacionado ao defeito de flexão no eixo. No quarto teste, na condição de roçamento, há um aumento na amplitude na frequência fundamental e em suas harmônicas, segundo Bilosová e Bilos (2012) afirmaram que podem surgir componentes inter-harmônicos e subsíncronos da frequência fundamental neste tipo de defeito. Neste teste, na posição radial vertical, é possível visualizar um aumento na amplitude da frequência fundamental, da segunda, terceira e quarta harmônica, nas inter-harmônicas e na subsíncrona. As vibrações de alta frequência deste teste são decorrentes do atrito contínuo do eixo com o parafuso. Segundo Jesus e Cavalcante (2011), isto ocorreu devido ao roçamento contínuo provocar a ressonância das partes mecânicas da bancada. Na posição radial horizontal, também é possível visualizar um aumento na frequência fundamental, na segunda harmônica e na subsíncrona. Não se verificou aumento nas componentes interharmônicos, na terceira harmônica e na quarta harmônica verificou-se uma diminuição de amplitude. Comparando os resultados encontrados com o trabalho de Santos Jr et al. (2018) verificou-se que os mesmos encontraram resultados semelhantes ao trabalho de Jesus e Cavalcante (2011). Porém, o mesmo não encontrou uma diminuição da amplitude na posição radial horizontal. Portanto, pode-se inferir que este efeito de diminuição de energia, possa ter sido causado pelos defeitos encontrados na bancada.

Conclusão: Com base nos estudos e suas comparações pôde-se observar que é possível montar bancadas de baixo custo para o estudo de vibrações do tipo inicial, desbalanceada, com desalinhamento ângular e com roçamento, utilizando para isso o Arduino como controlador. Apesar de alguns erros de montagem foi possível obter resultados satisfatórios, mesmo que tenham encontrado alguns defeitos que atrapalharam na exatidão dos resultados.

\section{Referências}

BILOSOVÁ, A.; BILOS,. Vibration diagnostics. Investments in Education Development book. Ostrava, Tchéquia. 2012.

EWINS, D. J. Modal testing: theory, practice and application. Hertfordshire: UK. Research studies press Baldock, 2000.

JESUS, S. S. D.; CALVACANTE, P. F. Utilização de bancadas de ensaio para estudos do comportamento dinâmico de máquinas 
rotativas. HOLOS, Natal, v. 3, p. 18-40, junho 2011.

SANTOS Jr, A. N. S.; TONON, D. B.; BASSANI, M. J.; PEREIRA, V. T. Simulador de defeitos e falhas geradores de vibração em equipamentos rotativos. Aracruz: FAACZ, 2018.

SOEIRO, N. S. Curso de Fundamentos de Vibração e Balanceamento de Rotores. Belém: UFPA-ELETRONORTE, 2008.

Coordenadoria de Pesquisa e Extensão - COPEX

Departamento de Editoraçāo e Divulgaçāo Científica - DEDIC 


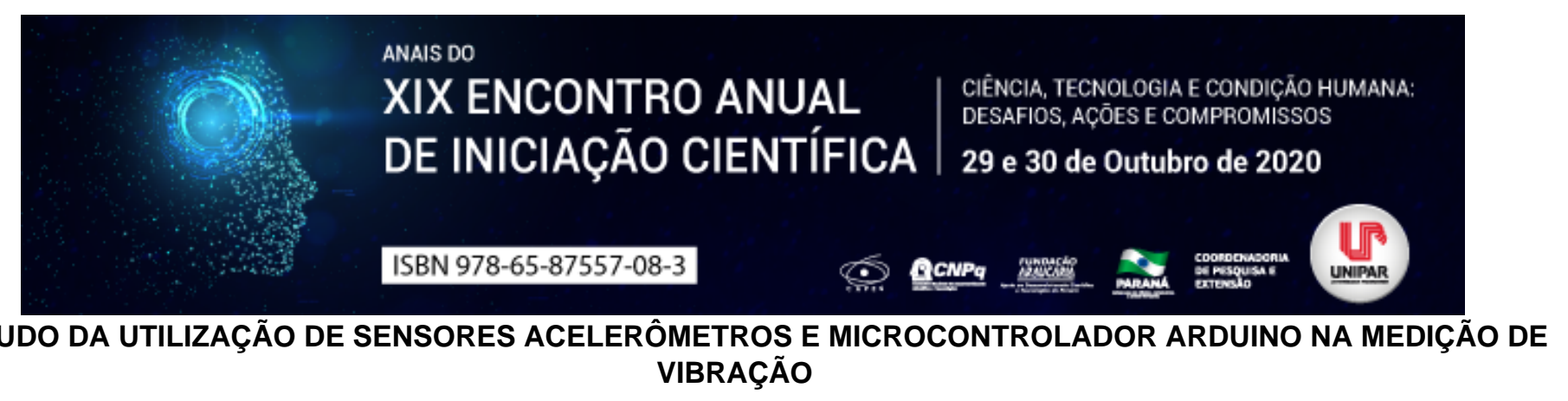
${ }^{1}$ TIAGO HENRIQUE RUFINO DA SILVA, ${ }^{2}$ PEDRO SETTE ISRAEL, ${ }^{3}$ XENIA MAIRA LOUBACK NOMURA COPCESKI, ${ }^{4}$ PATRIK
AMERICO POLLIZELLO LOPES

\author{
${ }^{1}$ Acadêmico do PIC/UNIPAR \\ ${ }^{1}$ Acadêmico do PIC/UNIPAR \\ ${ }^{2}$ Acadêmica do PIC/UNIPAR \\ ${ }^{3}$ Docente da UNIPAR
}

Introdução: Toda máquina que realiza movimentos dinâmicos possui uma característica específica de vibração, que é conhecida por assinatura espectral. Essa assinatura pode ser mensurada por aparelhos como sensores acelerômetros muito sensíveis, que captam os milímetros que se movimentam nessas máquinas. Qualquer variação diferente de sua assinatura espectral pode significar alguma mudança, e uma possível falha pode vir a ocorrer. O uso desses dispositivos aliados a um software, que hoje é muito comum a utilização por engenheiros, podem economizar recursos e também facilitará o desenvolvimento de novos métodos para análise de vibração. Como exemplo, o Arduino é um microcontrolador de código aberto que se tornou muito popular entre estudantes e profissionais, por ser uma boa opção para o projeto e também porque o chip pode ser trocado com baixo custo, sem a necessidade de placas mais avançadas. Existem diversos módulos que podem ser ligados ao Arduino na forma de sensores, como medidores de temperatura, deslocamento e acelerômetros (PATEL \& PATEL, 2017).

Objetivo: Conhecer métodos para uso de sensores acelerômetros e microcontrolador Arduino em medição de vibração.

Desenvolvimento: Diversos estudos sobre a utilização de microcontroladores arduino e sensores acelerômetros têm mostrado bons resultados para medição de vibrações em máquinas e componentes mecânicos. Os autores Patel \& Patel (2017) utilizaram um sistema de monitoramento on-line, onde foi usada a ferramenta de análise de sinal LAbView da NI (National Instrument), e um módulo sensor MEMS ADXL335 de mensuração de vibração, por ser o menos sensível a temperatura. A unidade desenvolvida realiza a detecção baseada em um microprocessador coletando vibrações 3D, onde o sensor de vibração e o amplificador fazem parte do módulo ADXL335, conseguindo medir sinais de baixas amplitudes, sendo o sinal amplificado e coletado pelo arduíno. 0 módulo acelerômetro é formado por um capacitor diferencial com placas fixas independentes e fixadas a uma massa em movimento para mensurar a deflexão, e para determinar a magnitude e a direção da aceleração é usada uma técnica de desmodulação sensíveis a fase. Já o microcontrolador Arduino é um sistema independente de aquisição de dados com recurso de buffer de dados, reduzindo a carga de computação no sistema principal, contendo também um hardware que pode ser instalado próximo ao motor e em ambientes severos. Os autores Patel \& Patel (2017) conectaram os 5 pinos do acelerômetro na placa do Arduino, conforme padrão do módulo. Finalizando essa etapa fizeram a programação do controlador ATmega328 via USB para o programador serial, utilizando o LabVIEW que captura qualquer tipo de dado serial disponível com a ajuda dos drivers VISA (Virtual Instrument Software Architecture) da NI (National Instrument), onde os dados recebidos pelo Arduíno são de 0 a 1024 valores diferentes, que serão convertidos de analógico para digital de 10 bits. Após obtenção de dados do arduino, o LabVIEW construiu a forma de onda com base nos dados seriais disponíveis e processados rigorosamente. Para finalizar eles executaram a função de leitura/gravação serial para comunicação com a placa Arduino e obtiveram tensões analógicas dos pinos $\mathrm{X}, \mathrm{Y}$ e Z do sensor. Em outro trabalho, os autores Hjort \& Holmberg (2015) montaram um hardware e um software para medições de vibrações mecânicas programado usando a linguagem Arduino baseada em C++. Eles utilizaram um Arduíno Uno R3 como microcontrolador, que possui frequência de $16 \mathrm{MHz}$ e memória flash de $32 \mathrm{kB}$. Para medir frequências também usaram o acelerômetro de 3 eixos ADXL335, porém montaram em uma placa de interrupção da SparkFun que vem com capacitores de 0,1 $\mu \mathrm{F}$ que atua como filtro e limita a largura da banda de cada eixo a $50 \mathrm{~Hz}$. Esses autores fizeram a comunicação do Arduino por conector serial D-sub 9, que envia dados com níveis de tensão TTL que estão no intervalo de $0 \mathrm{~V}$ a $5 \mathrm{~V}$. Esse tipo de conexão visa integrar o arduino ao EPICS (ambiente de software de código aberto) ou MATLAB (ambiente de computação numérica com linguagem fácil e de análise rápido). Usaram nesse projeto o Scientific Linux 6 como sistema operacional, e após o preparo do protocolo e banco de dados, a maneira mais comum de interagir e ler os dados foi criar uma GUI, mas a mais fácil foi usar o caget no terminal. Os testes foram realizadas em uma bomba de vácuo, presa ao chão de concreto por parafusos. Um acelerômetro foi preso a bomba e outro ao chão, a fim de medir as vibrações sendo transmitidas da bomba para o chão. Os resultados foram satisfatórios, onde os autores concluíram que é possível realizar medições e fazer análises de vibrações com equipamentos de baixo custo e softwares de simulação.

Conclusão: Com base nos dados encontrados nesses estudos podemos perceber que há condições de desenvolver um 
mecanismo de medição de vibrações de baixo custo apresentando dados confiáveis. Os métodos incluem a comunicação de módulos acelerômetros e microcontrolador arduíno com software de simulação numérica, como MATLAB, LabVIEW ou similares.

\section{Referências}

HJORT, Adam.; HOLMBERG, Mans. Measuring mechanical vibrations using an Arduino as a slave I/O to an EPICS control system. Physics Project with a Research Connection. Uppsala. FREIA Report 2015/04, p. 24, jun. 2015.

PATEL, Viral. K.; PATEL, Maitri. N. Development of Smart Sensing Unit for Vibration Measurement by Embedding Accelerometer with the Arduino Microcontroller. International Journal of Instrumentation Science. v. 6, n. 1, p. 1-7, 2017.

Coordenadoria de Pesquisa e Extensão - COPEX

Departamento de Editoraçāo e Divulgaçāo Científica - DEDIC 


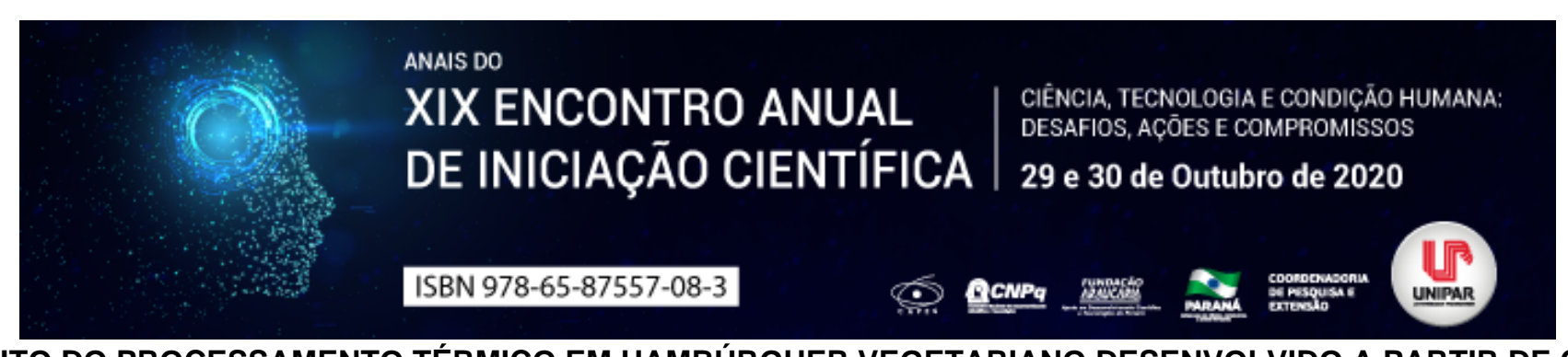

EFEITO DO PROCESSAMENTO TÉRMICO EM HAMBÚRGUER VEGETARIANO DESENVOLVIDO A PARTIR DE CHIA

\begin{abstract}
${ }^{1}$ Claudia Marques da Silva, ${ }^{2}$ ALOISIO HENRIQUE PEREIRA DE SOUZA, ${ }^{3}$ ALINE KIRIE GOHARA, ${ }^{4}$ ELIZA MARIANE ROTTA, ${ }^{5}$ SANDRA TEREZINHA MARQUES GOMES, ${ }^{6}$ MAKOTO MATSUSHITA
\end{abstract}

\author{
${ }^{1}$ Doutora em Ciências/UEM \\ ${ }^{1}$ Docente IFSC \\ ${ }^{2}$ Doutora em Ciência de Alimentos/UEM \\ ${ }^{3}$ Doutora em Ciências/UEM \\ ${ }^{4}$ Docente UEM \\ ${ }^{5}$ Docente UEM
}

Introdução: Os hambúrgueres são produzidos a partir de cortes bovinos de baixo custo comercial juntamente com tecidos de gordura de origem subcutânea. No entanto, os lipídios de origem animal apresentam altos teores de colesterol e de ácidos graxos saturados, os quais estão associados a diversos tipos de doenças cardiovasculares e coronarianas, além do risco de obesidade (FAO, 2010). Diante disto, a utilização de fontes vegetais de lipídios, como a Chia (Salvia hispanica, L.) que possui elevado teor de ácido graxo alfa-linolênico (18:3 n-3), poderia resultar em produtos considerados mais saudáveis, devido ao aumento de teores de ácidos graxos poli-insaturados, especialmente os da série ômega-3, que possuem efeito positivo na saúde humana (ZANQUI et al., 2015).

Objetivo: Avaliar a aplicação de farinha de chia em hambúrguer vegetal e investigar o efeito do tratamento térmico na composição de ácidos graxos deste produto.

Material e Métodos: Dois lotes de $5 \mathrm{~kg}$ de grãos de chia foram adquiridos da empresa Giroil Agroindustria Ltda. (St. Angelo-RS). Os grãos de chia, trigo integral, alho desidratado, orégano e pimenta calabresa desidratada foram moídos e passados numa peneira de 14 mesh. Para as formulações dos hambúrgueres, imergiu-se 139,50 $\mathrm{g} \mathrm{kg}^{-1}$ de proteína texturizada de soja (PTS) em água a $25{ }^{\circ} \mathrm{C}\left(50,00 \mathrm{~g} \mathrm{~kg}^{-1}\right)$ por duas horas. Posteriormente, foram adicionados $99,00 \mathrm{~g} \mathrm{~kg}^{-1}$ de trigo integral, $51,40 \mathrm{~g} \mathrm{~kg}^{-1} \mathrm{de}$ farinha de chia, $50,00 \mathrm{~g} \mathrm{~kg}^{-1}$ de óleo de soja, $15,00 \mathrm{~g} \mathrm{~kg}^{-1}$ de sal, 5,00 $\mathrm{g} \mathrm{kg}^{-1}$ de orégano em pó, 5,00 $\mathrm{g} \mathrm{kg}^{-1}$ de alho em pó, 0,10 $\mathrm{g} \mathrm{kg}^{-1}$ de pimenta calabresa em pó, $15,00 \mathrm{~g} \mathrm{~kg}^{-1}$ de colorau em pó, e como agente emulsificante $10,00 \mathrm{~g} \mathrm{~kg}^{-1}$ de goma xantana foi hidratada em $100,00 \mathrm{~g} \mathrm{~kg}^{-1}$ de água com posterior incorporação de $10,00 \mathrm{~g} \mathrm{~kg}^{-1}$ de carboximetilcelulose. $O$ gel foi obtido a partir da mistura dos sólidos em água $\left(\sim 25^{\circ} \mathrm{C}\right)$, e posterior aquecimento até $60^{\circ} \mathrm{C}$. Os ingredientes foram misturados até a formação de uma massa homogênea, e após procedeu-se a prensagem e moldagem em hamburgueira manual, obtendo-se hambúrgueres de $100,00 \mathrm{~g}( \pm 0,05)$ a unidade. Após, os hambúrgueres foram submetidos ao processo de cocção em chapa de teflon a $300{ }^{\circ} \mathrm{C}$ por $3 \mathrm{~min}$ com duas inversões do produto conforme Souza et al., (2015). Os lipídios totais foram extraídos segundo Bligh e Dyer (1959). A composição em ácidos graxos consistiu na conversão dos lipídios totais em ésteres metílicos de ácidos graxos (EMAG), conforme o método de metilação descrito por Hartman e Lago (1973). Os EMAG foram separados em cromatógrafo a gás utilizando as condições cromatográficas utilizadas por Souza et al., (2013), e quantificados segundo Joseph e Ackman (1992) e Visentainer (2012). A análise de composição dos somatórios de ácidos graxos saturados (AGS), monoinsaturados (AGMI), poliinsaturados (AGPI), série ômega $6(n-6)$ e ômega 3 (n-3) no hambúrguer cru e após a cocção foram realizadas em triplicata. Foram calculadas as médias e os desvios padrão no programa Excel software, versão 2007. Os resultados foram submetidos à análise de variância (ANOVA) e os valores médios foram comparados pelo teste de Tukey, usando o Software Statistica, versão 8.0. As concentrações a seguir estão expressas em mg ácido graxo $100 \mathrm{~g}^{-1}$ de alimento, e as médias seguidas de letras sobrescritas diferentes demonstram diferença significativa pelo teste de Tukey $(p<0,05)$.

Resultados: Os valores de AGS foram de $450,98^{\mathrm{b}} \pm 0,36$ e $462,45^{\mathrm{a}} \pm 2,51$, AGMI de $1971,56^{\mathrm{b}} \pm 0,06$ e $1998,72^{\mathrm{a}} \pm 7,65$, AGPI de $2020,76^{\mathrm{b}} \pm 2,56$ e $2069,11^{\mathrm{a}} \pm 7,81, \mathrm{n}-6$ de $1184,29^{\mathrm{b}} \pm 2,02$ e $1196,61^{\mathrm{a}} \pm 4,55, \mathrm{n}-3$ de $836,47^{\mathrm{b}} \pm 0,54$ e $872,50^{\mathrm{a}} \pm 3,25$, e por fim calculouse a razão $n-6 / n-3$ obtendo-se $1,41 \pm 0,00^{\mathrm{a}}$ e $1,37 \pm 0,00^{\mathrm{b}}$ para as condições de hambúrguer cru e assado, respectivamente.

Discussão: Os resultados apontam que houve variação significativa entre as concentrações. Embora o aquecimento tenha favorecido o aumento de AGS, observa-se que este processo também provocou o aumento de AGMI, AGPI, $n-6$ e $n-3$, que contribuiu para a redução da razão n-6/n-3 no hambúrguer assado, proporcionando assim um alimento nutrionalmente mais balanceado. Pois, a proporção recomendada para esta razão é de 1:1, visto que os ácidos graxos da série n-3 possuem efeito anti-inflamatório no organismo, enquanto os da série n-6 podem contribuir para o aumento de resposta inflamatória e 
desencadear doenças (SIMOPOULOS, 2011).

Conclusão: $O$ uso da farinha de chia e de goma xantana/carboximetilcelulose foi promissor para a formulação de hambúrgueres vegetais, além disso o processo de cocção contribuiu positivamente para a melhoria da composição e razão de ácidos graxos no produto.

\section{Referências}

BLIGH, E. G.; DYER, W. J. A rapid method of total lipid extraction and purification. Canadian Journal of Biochemistry and Physiology, v. 37, n. 8, p. 911-917, 1959.

FAO. Food and Nutrition Paper. Fats and fatty acids in human nutrition: Report of an expert consultation, FAO: Rome, IT, 2010.

HARTMAN, L.; LAGO, R. A Rapid preparation of fatty acid methyl esters. Laboratory Practice, v. 22, n.6, p. 475-494, 1973.

JOSEPH, J. D.; ACKMAN, R. G. Capillary column gas chromatographic method for analysis of encapsulated fish oils and fish oil ethyl esters: collaborative study. Journal of the American Oil Chemists' Society, v. 75, n. 3, p. 488-506, 1992.

SIMOPOULOS, A. P. Evolutionary aspects of diet: the omega-6/omega-3 ratio and the brain. Molecular Neurobiology, v. 44, p. 203-215, 2011.

SOUZA, A. H. P. et al. Sacha inchi as potential source of essential fatty acids and tocopherols: multivariate study of nut and shell. Acta Scientiarum. Technology, v. 35, n. 4, p. 757-763, 2013.

SOUZA, A. H. P. et al. Effect of the addition of chia's by-product on the composition of fatty acids in hamburgers through chemometric methods. Journal of the Science of Food and Agriculture, v. 95, n. 5, p. 928-935, 2015.

VISENTAINER, J. V. Aspectos analíticos da resposta do detector de ionização em chama para ésteres de ácidos graxos em biodiesel e alimentos. Química Nova, v. 35, n. 2, p. 274-279, 2012.

ZANQUI, A. B. et al. Subcritical extraction of Salvia hispanica L. oil with n-propane: composition, purity and oxidation stability as compared to the oils obtained by conventional solvent extraction methods. Journal of the Brazilian Chemical Society, v. 26, $n$. 2, p. 282-289, 2015.

Coordenadoria de Pesquisa e Extensão - COPEX

Departamento de Editoraçāo e Divulgaçāo Científica - DEDIC 


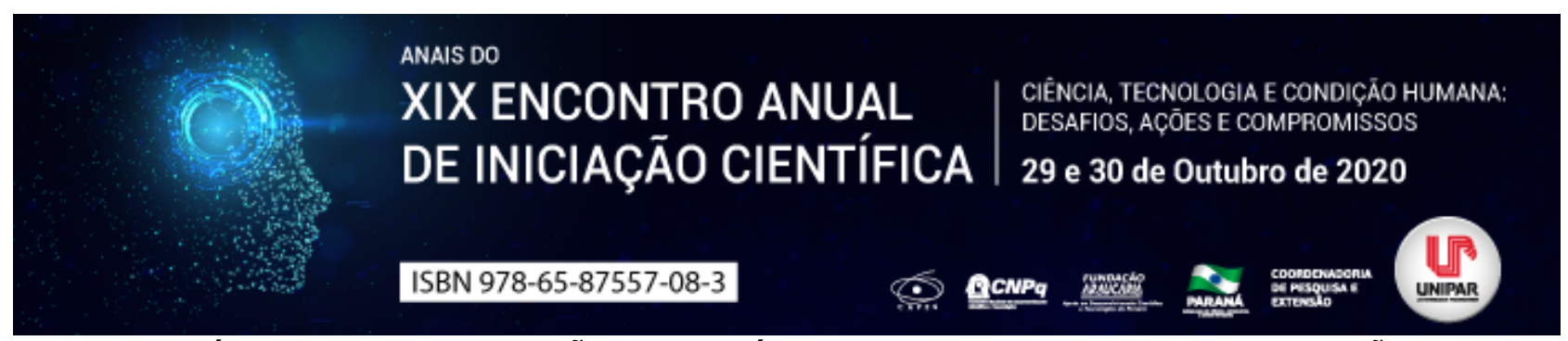

ANÁLISE DE MANIFESTAÇÕES PATOLÓGICAS EM ESTRUTURAS DE CONTENÇÃO

\section{${ }^{1}$ GENAINE DE SOUZA PORTO, ${ }^{2}$ VANDA ZAGO LUPEPSA}

${ }^{1}$ Acadêmica do Curso de Engenharia Civil da UNIPAR

${ }^{1}$ Docente da UNIPAR

Introdução: A execução de taludes deve ser devidamente calculada, de acordo com a função do talude e também das futuras construções que podem surgir ao redor desse talude, segundo a NBR 11682, o grau de segurança do talude depende das consequências que possam surgir, caso haja um rompimento. Para a melhor execução de muros de contenção deve-se seguir a norma correspondente a esse topo de estrutura, uma vez que haja o descumprimento dessa norma, a estrutura começa a apresentar patologias e em pior dos casos pode chegar à inviabilização da obra.

Objetivo: analisar as possíveis patologias que possam causar uma movimentação ou ruinas de um muro de contenção.

Desenvolvimento: A cada dia cresce o ramo da construção civil, e com esse crescimento surgem novos desafios, novos riscos, e se torna necessário à precaução para execução de algumas obras, como é o caso de obras de contenção, as obras de contenção são estruturas que devem conter certa quantidade de material, e manter uma estabilidade, entre material contido e corpo do maciço, logo tais contenções devem ser dimensionadas de forma que se haja um rompimento, os danos não sejam catastróficos. No Brasil existem períodos de chuvas, onde o volume de chuva costuma ser alto, logo começam a surgir noticias que muros de contenção que falharam ao executar suas funções, segundo Oliveira, Branco, Tavares (2018), após a falha da contenção se realiza uma perícia, e com isso chega-se a conclusão que mesmo a obra sendo executadas com a presença de profissionais, tais estruturas acaba apresentando um desenvolvimento não satisfatório. Segundo Gerscovich (2009) as maiores falhas dos muros de contenção acontecem devido ao acumulo de agua do maciço, sendo algo altamente desfavorável ao muro, a falha na drenagem faz com que aumente o empuxo aplicado na parte interior do muro, fazendo com que o muro perca a resistência, devido ao aumento de pressão. Assim como qualquer outra estrutura, as estruturas de contenção devem receber um acompanhamento de sua vida útil, podendo assim constatar se houve algum tipo de manifestação patológica que possa chegar a comprometer a durabilidade e a capacidade de carga da estrutura. (REVISTA DE ENGENHARIA CIVIL 2020). Ainda segunda a revista citada anteriormente, a falha de uma estrutura esta liga a falta de estudo do local onde a obra será executada que pode acarretar em uma sobrecarga da estrutura, por conseguinte os problemas patológicos surgem pela existência de uma ou mais falhas de uma ou mais etapas da construção, podem ser falhas no projeto, falhas na execução ou até falha no concreto. Lamentavelmente, nem todas as obras de contenções recebem o dimensionamento correto e nem o acompanhamento devido por um profissional competente para a execução de contenções, podendo ocasionar ruinas pelas falhas apresentadas anteriormente.

Conclusão: Conclui-se que é necessário o estudo do local onde a obra será executada e assim poder fazer o dimensionamento correto para a contenção visando o bem estar e a segurança de obras vizinhas, logo é imprescindível o acompanhamento de execução da obra, para garantir que o projeto foi devidamente executado, para assim evitar futuros problemas patológicos.

\section{Referências}

GERSCOVICH, Denise. Apostila Estruturas de contenção muros de arrimo. Rio de Janeiro, 2010. Faculdade de EngenhariaDepartamento de Estruturas e Fundações. Disponível em: $<$ http://www.eng.uerj.br/ denise/pdf/muros.pdf>Acesso em: 28 de agosto de 2020.

OLIVEIRA, Charles Ferreira de; BRANCO, Luiz Antônio Melgaço Nunes; TAVARES, Karine Almeida. Análise de deslizamento de muro de arrimo provocado por falha no projeto. PATORREB 2018.

REVISTA DE ENGENHARIA CIVIL 2020, Método para análise do risco em estruturas de arrimo em concreto armado. Disponível em http://www.civil.uminho.pt/revista/artigos/n57/Pag.36-49. Acesso em 30 de agosto de 2020.

NBR 11682- Estabilidades de taludes. 1991 


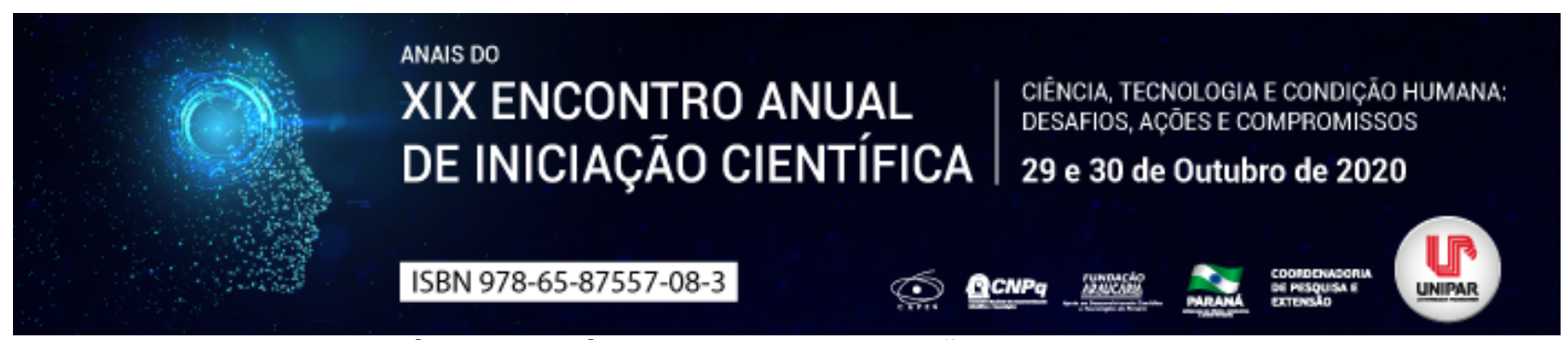

ESTRESSE HÍDRICO E TÉRMICO NA GERMINAÇÃO DE Pennisetum glaucum

\begin{abstract}
${ }^{1}$ Vinicius Melo Rocha, ${ }^{2}$ VITOR AMAdO MARTIN, ${ }^{3}$ WILLIAM GUTIERREZ, ${ }^{4}$ EDUARDO HENRIQUE DE LIMA SOUZA, ${ }^{5}$ ENIO AMADO MARTIN, ${ }^{6}$ VALDIR ZUCARELI
\end{abstract}

${ }^{1}$ Acadêmico de Agronomia da UEM
${ }^{1}$ Acadêmico de Agronomia da UEM
${ }^{2}$ Acadêmico de Agronomia da UEM
${ }^{3}$ Acadêmico de Agronomia da UEM
${ }^{4}$ Acadêmico de Agronomia da UEM
${ }^{5}$ Docente do Departamento de Ciências Agronômicas da UEM, Campus Regional de Umuarama, PR

Introdução: Nativo da África, o milheto (Pennisetum glaucum) adapta-se bem ao clima tropical, razão pela qual a área cultivada desta espécie vem expandindo no Brasil, onde é utilizada como planta de cobertura em sistemas de plantio direto, ademais, também pode ser utilizado como forrageira anual para pastejo, feno, silagem e colheita de grãos (Alcantara \& Bufarah, 1986 e Salton \& Kichel, 1997).

A semente pode ser a razão do sucesso ou do fracasso das culturas, por tanto é relevante estudar e compreender como cada semente se comporta (Toledo \& Marcos Filho, 1977). Embebição é um tipo especial de difusão, provocada pela atração entre moléculas de água e a superfície matricial, essa atração gera um movimento de água entre dois sistemas, o qual baseia-se na diferença de potencial hídrico (Carvalho \& Nakagawa 2000; Marcos Filho, 2015).

Existe uma relação direta entre a velocidade de embebição e a temperatura. A elevação da temperatura aumenta a energia da água, provocando um aumento na pressão de difusão, resultando em uma absorção mais rápida (Carneiro \& Braccini, 1996). Além disso a temperatura pode influenciar na porcentagem, velocidade e uniformidade da germinação (Marcos Filho, 2005).

Ao avaliarem a condutividade elétrica em função da temperatura Gaspar \& Nakagawa (2002) observaram que a temperatura ideal para a germinação do milheto é de $25^{\circ} \mathrm{C}$. Entretanto essa espécie possui grande capacidade de aclimatação, o que gera uma demanda para mais estudos para conhecer melhor a fisiologia da cultura (Coimbra \& Nakagawa, 2006).

Objetivo: Estudar a influência dos estresses hídrico e térmico, na germinação de sementes de Pennisetum glaucum.

Material e Métodos: O experimento foi desenvolvido no Laboratório de Fisiologia Vegetal da Universidade Estadual de Maringá

UEM, Campus Regional de Umuarama (CAU/Fazenda).

Foram utilizadas sementes de Pennisetum glaucum Matsuda cv. BRS 1501. O experimento foi instalado em delineamento experimental inteiramente casualizado em esquema fatorial $4 \times 4$ (temperatura $\times$ potencial hídrico), com quatro repetições de 50 sementes por parcela. Os tratamentos foram constituídos pela combinação entre as temperaturas de $20 ; 25 ; 30$ e $35^{\circ} \mathrm{C}$ e quatro potenciais hídricos $(0,0 ;-0,3,-0,6$ e -0,9Mpa). Para simular os potenciais osmóticos foi utilizado PEG 6000.

As sementes sanitizadas com hipoclorito de sódio (2,5\% por 2 minutos) e colocadas para germinar em caixas do tipo gerbox sobre três folhas de papéis germitest umedecidos com $10 \mathrm{~mL}$ das respectivas soluções, e então, mantidas em câmaras de germinação com fotoperíodo de 12 horas.

Ao final do experimento foram calculados a porcentagem de germinação e o índice de velocidade de germinação (Maguire, 1962). Os dados foram submetidos à análise de variância e, quando significativos, submetidas ao estudo de regressão.

Resultados: Observou-se que para a germinação houve diferença significativa somente para o fator potencial hídrico, com médias ajustadas a uma equação quadrática e ponto de máxima em 92,67\%. Para a testemunha houve 91,86\% de germinação, já para o tratamento com menor potencial hídrico, -0,9Mpa, houve germinação de $86,50 \%$, demonstrando que a espécie tem capacidade de germinar em situações com baixa disponibilidade de água.

Para o IVG, observou-se interação entre os fatores estudados. De modo geram observou-se que, quanto menor a temperatura, e menor o potencial hídrico, menor a velocidade de germinação. Pode-se observar que as temperaturas $20 ; 25$ e $30^{\circ} \mathrm{C}$ apresentaram ajustes lineares crescentes, enquanto para a temperatura de $35^{\circ} \mathrm{C}$ as médias ajustaram-se a uma equação quadrática com ponto de máxima em 41,98.

Discussão: Santarém et al. (1996) ao trabalharem com PEG 6000 observaram que não houve diferença significativa na germinação de sementes de Senna macranthera entre os potenciais osmóticos de 0 a -0,49Mpa, o que sugere a possibilidade dessa espécie ser tolerante ao estresse hídrico. Uma similaridade foi observada no presente trabalho, onde o Pennisetum glaucum, apresentou tolerância ao défice hídrico, com alta germinação $(86,50 \%)$ mesmo no potencial mais negativo $(-0,9 \mathrm{Mpa})$.

A influência da temperatura no IVG, com interações entre os fatores temperatura e potencial hídrico, se deve pela embebição ser um processo físico, que ocorre mais rapidamente sob temperaturas elevadas, no entanto, a quantidade final de água absorvida é 
praticamente a mesma, independente da temperatura (Nobrega \& Rodrigues, 1995). Além disso também influencia na cinética enzimática, ativando metabolismo, pois dentro das temperaturas biológicas, quanto maior a temperatura, maior o metabolismo (Marcos Filho, 2015). Razão que explica a germinação semelhante entre os tratamentos, demostrando alta amplitude térmica da espécie, mesmo em situações adversas.

Conclusão: A temperatura e o potencial hídrico influenciaram na germinação de sementes. Para a espécie estudada são mais indicados, temperaturas intermediarias de 25 a $30^{\circ} \mathrm{C}$, e potencial osmótico de até -0,6Mpa.

\section{Referências}

ALCANTARA, P.B. \& BUFARAH, G. Plantas forrageiras: gramíneas e leguminosas. 3.ed. São Paulo: Nobel, 1986. 162p.

CARNEIRO, J. W. P.; BRACCINI, A. L. Relações hídricas durante a germinação. Informativo ABRATES, Londrina, v. 6, n. 1, p. 46-55, 1996.

CARVALHO, N.M. De; NAKAGAWA, J. Sementes: Ciência. Tecnologia e produção, v. 4, 2000.

COIMBRA, R. A; NAKAGAWA, J. Época de semeadura, produção e qualidade fisiológica de sementes de milheto. Revista Brasileira de Sementes, p. 53-59, 2006.

GASPAR, C. M.; NAKAGAWA, J. Teste de condutividade elétrica em função do período e da temperatura de embebição para sementes de milheto. Revista Brasileira de Sementes, p. 82-89, 2002.

LABOURIAU, L. G.; OSBORN, J. H. Temperature dependence of the germination of tomato seeds. 1984.

MAGUIRE, James D. Speed of Germination Aid In Selection And Evaluation for Seedling Emergence And Vigor 1. Crop science, v. 2, n. 2, p. 176-177, 1962.

MARCOS-FILHO, J. Fisiologia de sementes de plantas cultivadas. Piracicaba: FEALQ, 2015.

MARCOS-FILHO, J. Fisiologia de sementes de plantas cultivadas. Piracicaba: FEALQ, 2005.

SANTARÉM, Eliane Romanato et al. Efeito do estresse hídrico na germinação e crescimento inicial de três espécies de leguminosas. Acta Bot. Bras, v. 10, p. 213-221, 1996.

TOLEDO, F.F. \& MARCOS FILHO, J. Manual das sementes - tecnologia da produção. São Paulo: Agronômica Ceres, 1977. $224 p$.

Coordenadoria de Pesquisa e Extensão - COPEX

Departamento de Editoraçāo e Divulgaçāo Científica - DEDIC 


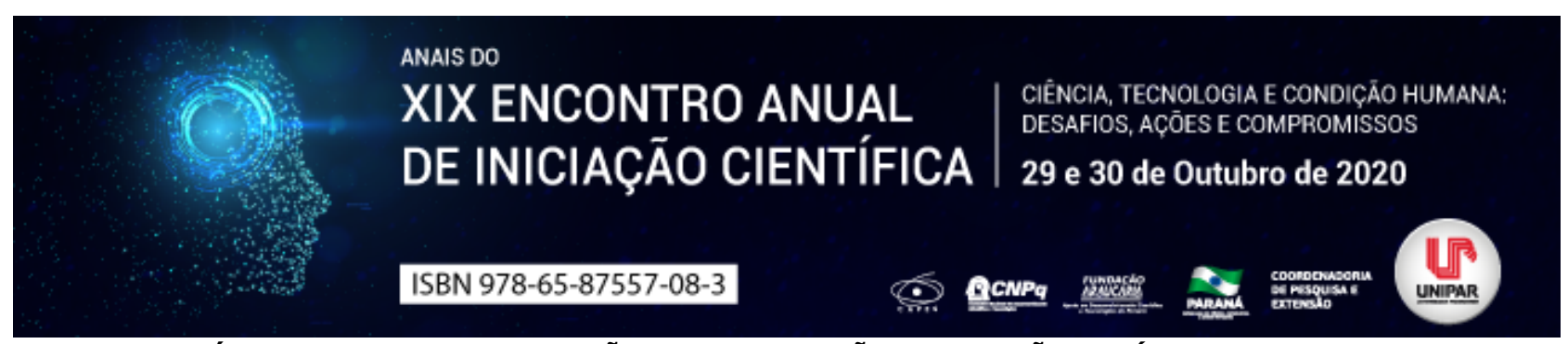

MÉTODO PARA ACELERAÇÃO DA CORROSÃO POR AÇÃO DE ÍONS CLORETO

\begin{abstract}
${ }^{1}$ Samanta Andrize Klering, ${ }^{2}$ DEBORAH CRISTINA NARDI, ${ }^{3}$ THIAGO AUGUSTO BERTUZZO
\end{abstract}

\begin{abstract}
${ }^{1}$ Acadêmica de Engenharia Civil de Infraestrutura, Universidade Federal da Integração Latino-Americana
${ }^{1}$ Acadêmica de Engenharia Civil de Infraestrutura, Universidade Federal da Integração Latino-Americana

${ }^{2}$ Mestrando do Programa de Pós-Graduação em Engenharia Civil, Universidade Federal da Integração Latino-Americana; Docente da UNIPAR
\end{abstract}

Introdução: De acordo com Broomfield (2006), o concreto armado é destacado majoritariamente pela sua durabilidade, resistência e bom desempenho ao longo do tempo. Contudo, em especial quando a estrutura está exposta a ambientes agressivos, onde a degradação progride geralmente num ritmo mais acelerado, é indubitável a possibilidade de deterioração do elemento devido à corrosão (KIVELL, PALERMO E SCOTT, 2011). Dado a alta alcalinidade do concreto (i.e., pH>12,5), o aço presente nas estruturas de concreto armado permanece majoritariamente durante longos períodos de tempo em um estado passivo, sem corrosão. Contudo, de acordo com Song e Saraswathy (2006) poderá haver a quebra desse estado passivo, seja por redução da alcalinidade do concreto (resultante da carbonatação) ou pela penetração de íons cloreto. Ainda, o tempo para o início da corrosão é condicionado em especial pela espessura e qualidade do cobrimento de concreto na seção transversal, bem como a permeabilidade desse. Dessa forma, principalmente em ambientes de forte agressividade ambiental necessita-se de um concreto durável e de alta qualidade, para assim frear a rápida deterioração do concreto devido a formação de fissuras, e consequentemente postergar o processo de iniciação e de propagação da corrosão. De acordo com Hunkeler (2005), no caso da carbonatação o mais comum é a corrosão geral acarretando em trincas e fragmentação precoce do concreto, entretanto, na corrosão decorrente de ataque por íons-cloreto tem-se a formação de cavidades pontuais nas barras de aço reduzindo a seção transversal. No entanto, ainda que a abordagem do presente trabalho se refere à segunda forma de aparição da corrosão (ataque local) pretende-se realizar um estudo apenas qualitativo, evidenciando essencialmente a formação de corrosão.

Objetivo: Pretende-se definir uma metodologia experimental para simular um ambiente de alta agressividade ambiental, levando assim, à aceleração da corrosão por ação de íons cloreto nas armaduras de aço, viabilizando, dessa forma, estudos futuros de comparação do comportamento estrutural de elementos, não somente sob ação de cargas mecânicas, como também sob fenômenos químicos.

Metodologia: Inicialmente concretou-se 3 corpos de prova cilíndricos $(10 \times 20 \mathrm{~cm})$ para avaliar a capacidade de absorção de água por capilaridade do concreto definido para a realização do experimento, seguindo as diretrizes da NBR 9779 (ABNT, 2013). O traço utilizado foi de 1: 3,17: 3,71: 0,65 com cimento $C P \vee$, areia natural fina, brita 1 e 0,5\% de aditivo plastificante em relação a massa de cimento. Feito essa etapa moldou-se 3 vigas esbeltas de seção quadrada $(b=h=7 \mathrm{~cm})$ e 2,0m de comprimento. Para o processo de aceleração de corrosão, definiu-se já no dimensionamento das vigas um cobrimento de $1 \mathrm{~cm}$, garantidos por espaçadores de torre, objetivando dessa forma uma maior proximidade entre a armadura e a face inferior da viga facilitando a penetração por cloretos. A solução de cloreto de sódio $(\mathrm{NaCl})$ foi preparada com uma concentração de $3,5 \%$, (massa/volume) e foi aplicada por meio de borrifador pela parte inferior da viga ao longo de seu comprimento, e esse processo era realizado 3 vezes por semana. As vigas foram enroladas com manta geotêxtil para que o período de umidade fosse ampliado tendo-se dessa forma fases mais simétricas de molhagem e secagem.

Resultados: Os CPs apresentaram $0,67 \%$ de absorção de água por capilaridade com altura de ascensão de $3,95 \mathrm{~cm}$. Realizaram-se medidas de potencial de corrosão com um multímetro em 6 diferentes pontos laterais nas 3 vigas em 4 datas (28, 50, 63 e 77, tomando como dia 0 o primeiro dia de aplicação de $\mathrm{NaCl}$ ) e apenas um dos pontos de uma viga apresentou leitura menos eletronegativa que $-350 \mathrm{mV}$. Entretanto, essa leitura foi no inicio (dia 28), para as demais datas todas as leituras foram mais eletronegativas que $-350 \mathrm{mV}$. Ademais, detectou-se visualmente entre algumas fissuras a presença de uma coloração característica de ferrugem.

Discussão: Analisando os resultados do ensaio de absorção de água por capilaridade nos CPs constatou-se que o cobrimento e o traço escolhido atenderiam o objetivo, uma vez que, registrou-se a ascensão da água e essa foi bem superior aos $1 \mathrm{~cm}$ definidos, o que, permitiria a entrada e ação dos íons cloretos nas armaduras, dessa forma, não houve nenhuma alteração e prosseguiu-se com o experimento. Em relação às leituras de potencial de corrosão realizadas com o multímetro, verificou-se que, de acordo com a ASTM C876 (2015) todas as vigas a partir da segunda leitura realizada apresentaram 90\% de probabilidade de estarem sob ação corrosiva.

Conclusão: Pode-se afirmar que a metodologia desenvolvida para acelerar o processo de corrosão em estruturas de concreto armado mostrou-se efetiva, dado que, com apenas 28 dias houve apenas uma única leitura com probabilidade inferior a 90\% de estar sob corrosão, e ainda, de forma visual constatou-se produtos da ação corrosiva. Contudo, se o escopo fosse uma análise 
quantitativa faz-se necessário equipamentos que forneçam intensidade de corrosão ou também, por meio da diferença de massa da armadura após a abertura da viga, a obtenção de taxa de corrosão.

\section{Referências}

ABNT. NBR 9779:Argamassa e concreto endurecidos - Determinação da absorção de água por capilaridade. Rio de Janeiro: [s.n.], 2013.

AMERICAN SOCIETY FOR TESTING AND MATERIALS (ASTM). ASTM C876: Standard Test Method for Corrosion Potentials of Uncoated Reinforcing Steel in Concrete. West Conshohocken (EUA), 2015.

BROOMFIELD, J. P. Corrosion of Steel in Concrete:Understanding, investigation and repair. 2. ed. Nova York: Taylor \& Francis, 2006.

HUNKELER, F. Corrosion in reinforced concrete structures.Cambridge: [s.n.], 2005. 1-55 p.

KIVELL, A.; PALERMO, A.; SCOTT, A. Effects of Bond Deterioration due to Corrosion in Reinforced Concrete. PCCE. Building an Earthquake-Resilient Society, Auckland, April 2011. 14-16.

SONG, H.-W.; SARASWATHY, V. Studies on the corrosion resistance of reinforced steel in concrete with ground granulated blastfurnace slag - an overview. Journal of Hazardous Materials, v. 138, n. 2, p. 226-233, 2006.

Coordenadoria de Pesquisa e Extensão - COPEX

Departamento de Editoraçāo e Divulgaçāo Científica - DEDIC 


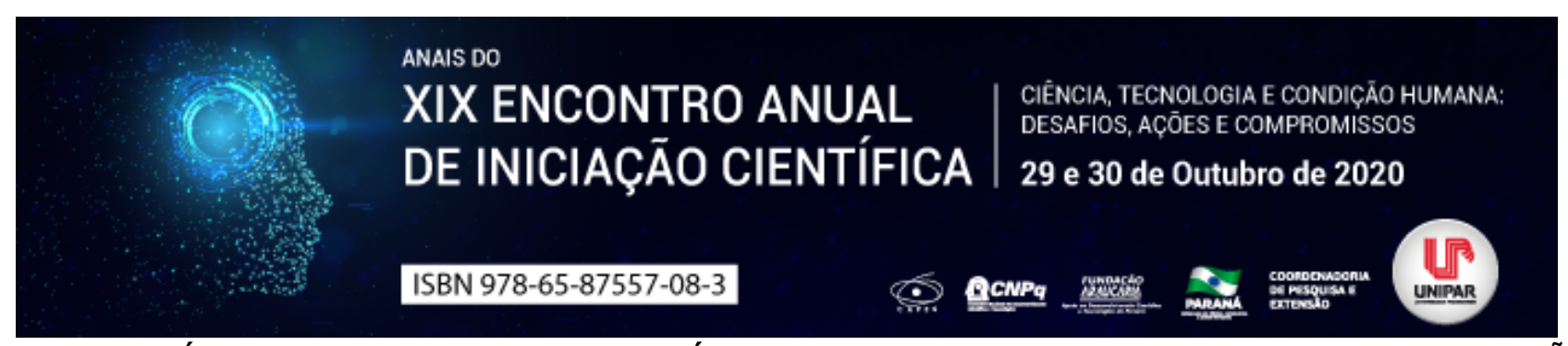

EFEITO ALELOPÁTICO DO EXTRATO DE PARTE AÉREA E DE RAIZ DE Pennisetum glaucum NA GERMINAÇÃO DE SEMENTES DE Ipomea triloba

\author{
${ }^{1}$ EDUARDO HENRIQUE DE LIMA SOUZA, ${ }^{2}$ WILLIAM GUTIERREZ, ${ }^{3}$ HUGO FELIPE ALVES PEREIRA, ${ }^{4}$ VINICIUS MELO \\ ROCHA, ${ }^{5}$ ANDRÉIA CRISTINA PÉREZ RODRIGUES SOUZA, ${ }^{6}$ VALDIR ZUCARELI
}

\author{
${ }^{1}$ Acadêmico de Agronomia da UEM \\ ${ }^{1}$ Acadêmico de Agronomia da UEM \\ ${ }^{2}$ Acadêmico de Agronomia da UEM \\ ${ }^{3}$ Acadêmico de Agronomia da UEM \\ ${ }^{4}$ Docente do Centro de Ciências Agrárias da UEM \\ ${ }^{5}$ Docente do Programa de Pós Graduação em Sustentabilidade da UEM
}

Introdução: O termo alelopatia é utilizado para se referir ao efeito que um organismo pode ter sob outro, este pode ser tanto benéfico quanto maléfico e ocorre devido a substâncias liberadas denominadas aleloquímicos (FERREIRA; AQUILA, 2000). O milheto (Pennisetum glaucum), gramínea originária da África, é uma alternativa para rotação de culturas devido sua versatilidade e a alta capacidade de absorver nutrientes, o que também a torna uma ótima opção para adubação verde (GUIMARÃES et al., 2015). A corda de viola (Ipomea triloba) é uma planta daninha altamente competitiva, que possui comportamento trepador, e além de reduzir produtividade da cultura de interesse comercial, também pode trazer problemas para o processo de colheita com colhedoras mecânicas (AZANIA et al., 2011). Desse modo apesar de grande número de trabalhos com essas espécies, na literatura, a interação alelopática entre elas ainda é pouco estudada.

Objetivo: Estudar o efeito alelopático do extrato de parte aérea e de raíz de Pennisetum glaucum na germinação de sementes de Ipomea triloba.

Metodologia: As sementes de Ipomea triloba foram coletadas na Fazenda Experimental da UEM, CAU/Fazenda. Para o preparo dos extratos foram utilizadas plantas de milheto, separadas em parte aérea e raiz, secas em estufa a $40^{\circ} \mathrm{C}$, moídas em moinho, em seguida foram colocadas $0,5 \mathrm{~g}$ do resultado da moagem em $500 \mathrm{~mL}$ de água e depois agitado por 30 minutos, subsequentemente esta foi coada com gase formando assim a solução de 1000 ppm, a qual foi diluída nas demais concentrações, com excessão da concentração de 0 ppm, onde foi utilizada água destilada. O delineamento experimental foi inteiramente casualizado, em esquema fatorial $2 \times 4$. Sendo utilizados extratos de parte aérea e de raiz, e estes diluídos nas concentrações de 0 250, 500 e 750 ppm, totalizando 8 tratamentos com 4 repetições de 50 sementes. As sementes foram escarificadas com ácido sulfúrico por 20 minutos. Para germinação foram usadas caixas do tipo Gerbox, com duas folhas de papel umedecidas com $12 \mathrm{~mL}$ das soluções, mantidas em câmara de germinação à temperatura de $25^{\circ} \mathrm{C}$ por 7 dias (BRASIL, 1992). O foto período foi de 12 horas de luz e 12 horas escuro. A contagem da germinação foi realizada diariamente para calculo do índice de velocidade de germinação IVG - (MAGUIRRE,1962). Os dados de germinação, IVG e massa seca de plântulas foram submetidos à análise de variância e as médias comparadas pelo teste Tukey a $5 \%$ de probabilidade.

Resultados: Para extratos de parte aérea e raiz, indiferentemente da concentração, não houve efeito na germinação e no IVG. Porém, para a variável massa seca houve interação entre os fatores extratos de PA e raíz em relação as concentrações. É possível observar que dentro de cada concentração os tratamentos se comportam de forma diferente, sendo que, quando comparados os extratos de parte aérea e de raízes, houve efeito negativo do extrato de parte aérea 250 ppm, e de raízes 500 ppm.

Discussão: O efeito dos extratos na massa seca de plântulas, demostram que os mesmos apresentam efeito na mobilização de reservas e crescimento de plântulas. Para Inderjit e Dakshini (1995), a germinação não é o melhor fator para avaliar efeito alelopático, sendo o crescimento de plântulas mais utilizado em ensaios de laboratório, eventualmente por sua maior sensibilidade a aleloquímicos, o que pode explicar os resultados observados. A menor massa seca também foi relatada por Reigosa et al (1999), que mencionam que os aleloquímicos podem atuar em diferentes processos sincronicamente e possuir respostas variadas para o mesmo ou diferentes processos, de acordo com a concentração. O maior efeito em concentrações menores do extrato de PA (250 ppm) se dá, pois, de maneira geral, o órgão mais ativo metabolicamente da planta é a folha, logo é compreensível que estas apresentem maior multiplicidade de aleloquímicos, em comparação com as raízes (RIBEIRO, 2009).

Conclusão: Os extratos de parte aérea e de raíz não interferiram na germinação de Ipomea triloba, porém influenciaram negativamente no acúmulo de massa de plântulas, nas concentrações de 250 e 500 ppm.

\title{
Referências
}


AZANIA, C. A. M.; HIRATA, A. C. S.; AZANIA, A. A. P. M. Boletim Técnico: Biologia e Manejo Químico de corda-de-viola em cana-de-açúcar. Boletim Técnico IAC 209, 2011.

BRASIL, Ministério da Agricultura e Reforma Agrária. Regras para análise de sementes. Brasília: SNDA/DNDV/CLAV, 365p, 1992.

FERREIRA, A.G.; AQUILA, M.E.A. Alelopatia: uma área emergente da ecofisiologia. Revista Brasileira de Fisiologia Vegetal, v.12, p.175-204, 2000.

GUIMARÃES, R. Jr., GONÇALVES, L. C., JAYME, D. G., PIRES, D. A. A., RODRIGUES, J. A. S., \& TOMICH, T. R. Degradabilidade in situ de silagens de milheto em ovinos. Ciência Animal Brasileira, v. 29, n.2 p.334-343, 2010.

INDERJIT; DAKSHINI, K.M.M. On laboratory bioassays in allelopathy. The Botanical Review, v.61, n.1, p.28-44, 1995.

MAGUIRE, J. D. Speed of germination aid in selection and evaluation for seedling emergence and vigor. Crop Science, v. 2 , n. 2, p. 176-177, 1962.

REIGOSA, M.J.; SÁNCHEZ-MOREIRAS, A. e GONZÁLES, L. Ecophysiological approach in allelopathy. Critical Reviews in Plant Science v.18 n.5, p. 577-608. 1999

RIBEIRO, J. P. N., MATSUMOTO, R. S., TAKAO, L. K., VOLTARELLI, V. M. e LIMA, M. I. S. Efeito alelopáticos de extratos aquosos de Crinum americanum L. Brazilian Journal of Botany, São Paulo, v. 32, n. 1, p. 183-188, jan.-mar. 2009. 


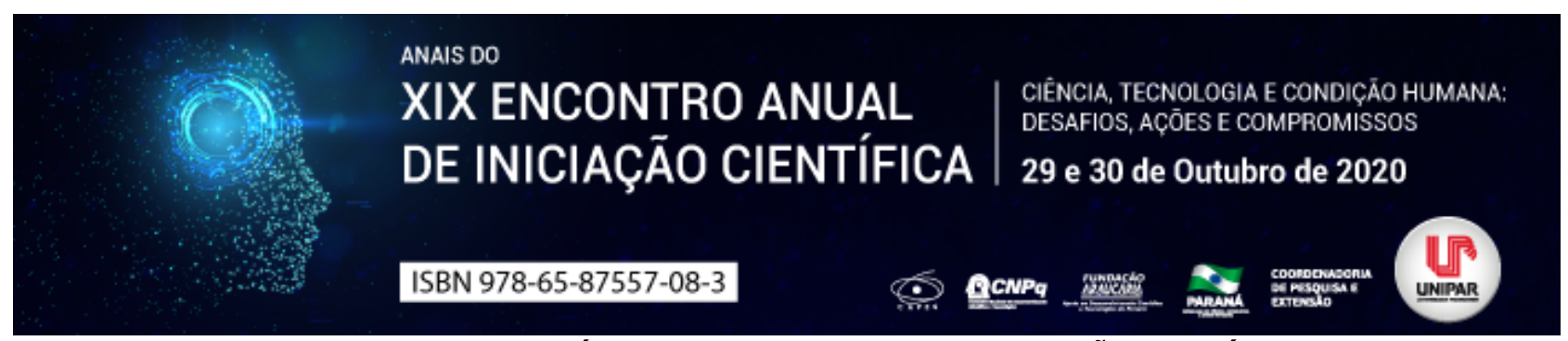

USO DE PRODUTOS BIOLÓGICOS E MINERAIS NA PRODUÇÃO DE GÉRBERAS

\begin{abstract}
${ }^{1}$ Adriely Lazarim@gmail.com, ${ }^{2}$ RENAN SANTOS UHDRE, ${ }^{3}$ MAYRA SOARES, ${ }^{4}$ MARCIO EVANGELISTA BEZERRA, ${ }^{5}$ ANA GABRIELLI RANTIN, ${ }^{6}$ ARNEY EDUARDO DO AMARAL ECKER
\end{abstract}

\footnotetext{
${ }^{1}$ Acadêmico do curso de Pós-Graduação em Proteção de Plantas da Universidade estadual de Maringá - UEM

${ }^{1}$ Acadêmico do curso de Pós-Graduação em Genética e Melhoramento da Universidade Estadual de Maringá UEM

${ }^{2}$ Acadêmica do curso de Pós-Graduação em Proteção de Plantas da universidade Estadual de Maringá - UEM

${ }^{3}$ Acadêmico do curso de Graduação em Agronomia UNINGÁ.

${ }^{4}$ Acadêmico do curso de Graduação em Agronomia UNINGÁ.

${ }^{5}$ Docente da UNINGÁ
}

Introdução: No Brasil, 15 mil hectares são utilizados para o cultivo de plantas ornamentais e flores, destacando-se com enorme importância na geração de emprego e renda. Com o aumento da procura por flores e plantas ornamentais, o estado do Paraná tem destaque ocupando a nona posição no consumo per capita, sendo o sexto produtor no mercado brasileiro, principalmente por suas condições edafoclimáticas serem propicias para à produção de flores (BRAINER, 2019). Nos dias atuais as flores são fundamentais em decoração de ambientes quanto na celebração de ocasiões especiais. As flores ornamentais têm como principal destino o mercado interno no Brasil, nesse seguimento as Gerbera jamesonii são consideradas uma das cinco flores de corte mais importantes na comercialização. Para atender a demanda do consumidor, as Gerberas cultivadas em vaso, devem possuir hastes florais com inflorescências grandes, adequada ramificação de folhas, porte baixo, tendo sua parte vegetativa e reprodutiva equilibrada (LUDWING et al., 2010). Para acelerar o desenvolvimento são utilizados diversos biofertilizantes que estimulam a atividade biológica no substrato, contribuindo com melhorias na qualidade das raízes e partes aéreas dos vegetais (OLIVEIRA, et al., 1986). Os biofertilizantes são substâncias orgânicas geralmente, de maneira natural que são translocados pela planta para locais de intensa atuação, influenciando no desenvolvimento e crescimento dos vegetais (ZUCUNI e ARENHARDT, 2015; MEDEIROS et al., 2003). Para o cultivo em flor, não existem informações especificas, ocorrendo um manejo de maneira empírica.

Objetivo: Avaliar o efeito do uso de diferentes produtos minerais e biológicos na produção de Gerberas jamesonii.

Metodologia: O experimento foi realizado no Núcleo Experimental de Agronomia do Centro Universitário Ingá UNINGÁ em Maringá-PR, no mês de maio de 2020. A espécie ornamental estudada foi a Gerbera jamesonii. Os tratamentos foram compostos por diferentes enraizadores comerciais sendo estes T1 (Peter's ${ }^{\circledR}$ 9N-45P-15K, dose 1,5 g/L); T2 (Bacillus subtilis, B. licheniformis, dose 1,5 g/L) T3 (Bacillus subtilis + Bactérias repositoras, dose $1 \mathrm{~g} / \mathrm{L}$ ); T4 (Bacillus subtilis, B. licheniformis + Polissacarídeos oriundo de fermentação, dose $1 \mathrm{ml} / \mathrm{L}$ ) e $T 5$ (Bacillus subtilis + Bactérias repositoras+ Polissacarídeos oriundo de fermentação, dose $1 \mathrm{ml} / \mathrm{L}$ ). Cada parcela constituiu de 10 vasos de polipropileno, com dimensão de $13 \mathrm{~cm}$ de diâmetro na porção superior e 10,5 cm de diâmetro na porção inferior e altura de 9,8 cm constituindo assim a área útil da parcela. Os tratamentos foram aplicados cinco vezes com intervalos de 15 dias. O delineamento utilizado foi o de blocos completos com tratamentos ao acaso com 7 repetições. As características agronômicas avaliadas foram: Altura da haste (AP); Diâmetro da haste (D); Número de folhas (NF) e Diâmetro do capitulo da flor (DF). Os resultados das avaliações após atender os pressupostos básicos, foram submetidos à análise de variância e Teste $F$ no programa Genes. Os dados qualitativos quando significativos a um nível $\alpha 5 \%$ de probabilidade de erro no teste $F$, foram submetidos ao teste pós médias, Tukey $(p<0,05)$.

Resultados: Após coleta dos dados, observou-se que, houve diferença estatística significante para as características agronômicas AP, D e DF. Para a característica AP os tratamentos 1, 3 e 5 foram superiores aos demais. Para a característica $D$ os tratamentos 1 e 2 superaram o 4 e 5 . Para a característica DF o fornecimento nutricional feito pelo tratamento 1 (Peter's $\AA$ ) superou estatisticamente todos os tratamentos, em seguida se destacam os tratamentos 2 e 3 superando os tratamentos 4 e 5 . Para as características AP, D, NF e DF o quadrado médio do resíduo observados na ANOVA foram 6,46, 0,17, 20,02 e 0,13 respectivamente.

Discussão: Para todas as características avaliadas, o tratamento com Peters ${ }^{\circ}$ apresentou bons resultados, demostrando a necessidade de suprir a demanda nutricional das plantas de gérbera. Enquanto, as soluções biológicas apresentaram bons resultados, porém observou que faltou o aporte nutricional para suprir a necessidade das plantas e melhorar seu desempenho. Para a característica DF a média foi de $9,39 \mathrm{~cm}$ quando aplicado o tratamento Peters ${ }^{\circledR}$, resultados semelhantes foram encontrados por Fayaz et al., (2016), em que, avaliando o efeito de NPK em plantas de gérberas observou um DF de 10,2 cm quando utilizado NPK na concentração 10-20-30 g/ $/ \mathrm{m}^{2}$. Como média geral, a característica DF foi de 8,37 cm, abaixo dos valores 
encontrados por Fayaz et al., (2016), possivelmente tais resultados se dão pela formulação de NPK utilizada no presente trabalho. Singh (2014), relatou que o efeito de NPK que resultou a qualidade, crescimento, floração e produção da gérbera sob condição de sombra foi a formulação $20-20-15 \mathrm{~g} / \mathrm{m}^{2}$.

Conclusão: Concluímos que nas condições em que foi realizado o experimento, o produto Peters ${ }^{\circledR}$ pela sua composição mineral forneceu maior suprimento de nutrientes para Gerbera jamesonii quando comparados aos produtos biológicos, sendo necessário, contudo, novos estudos para verificar o efeito dos microrganismos associados à nutrição mineral no desenvolvimento da gérbera.

\section{Referências}

BRAINER. M. S. C .P. Flores e Plantas Ornamentais. Caderno Setorial ETENE. Fortaleza-CE. ano 4, n. 95. 2019.

FAYAZ, K., SINGH, D; KUMAR, S, V. BASHIR, D; KULLER, L. R. Effect of NPK on plant growth, flower quality and yield of gerbera (Gerbera jamesonii). Res. Environ. Life Sci. 9(11). 1361-1363. 2016.

LUDWIG, F.; GUERRERO, A.C.; FERNANDES, R.L.; VILLAS BÔAS, R.L. Análise de crescimento de gérbera de vaso conduzida em diferentes substratos. Horticultura Brasileira, 28:70-74, 2010.

MEDEIROS, M.B.; WANDERLEY, P.A.; FRANKLIN, F.; FERNANDES, F.S.; ALVES, G.R.; DANTAS, P.; CORDÃO, R.P.; XAVIER, W.M.R.; LEAL NETO, J.S. Uso de biofertilizantes líquidos no manejo ecológico de pragas agrícolas. In: ENCONTRO TEMÁTICO MEIO AMBIENTE E EDUCAÇÃO AMBIENTAL DA UFPB 2., 2003, João Pessoa. Anais... João Pessoa, 2003. p.1923.

OLIVEIRA, I. P.; SOARES, M.; MOREIRA, J.A.A.; ESTRELA, M. F. C.; DAL'ACQUA, F.M.; PACHECO FILHO, O. Resultados técnicos e econômicos da aplicação de biofertilizante bovino nas culturas de feijão, arroz e trigo. Goiânia: EMBRAPA-CNPAF. 1986.

SINGH, V.K., SINGH, D., KUMARI, S., ALI, J. and PRASAD, V.M.: Evaluation of gerbera (Gerbera jamesonii) cultivars under shade net house condition. New Agriculturist, 25: 105-109. 2014.

ZUCUNI, L.; ARENHARDT, M.H. Fisiologia vegetal. Santa Maria-RS. Ed.UFMS, 2015. 


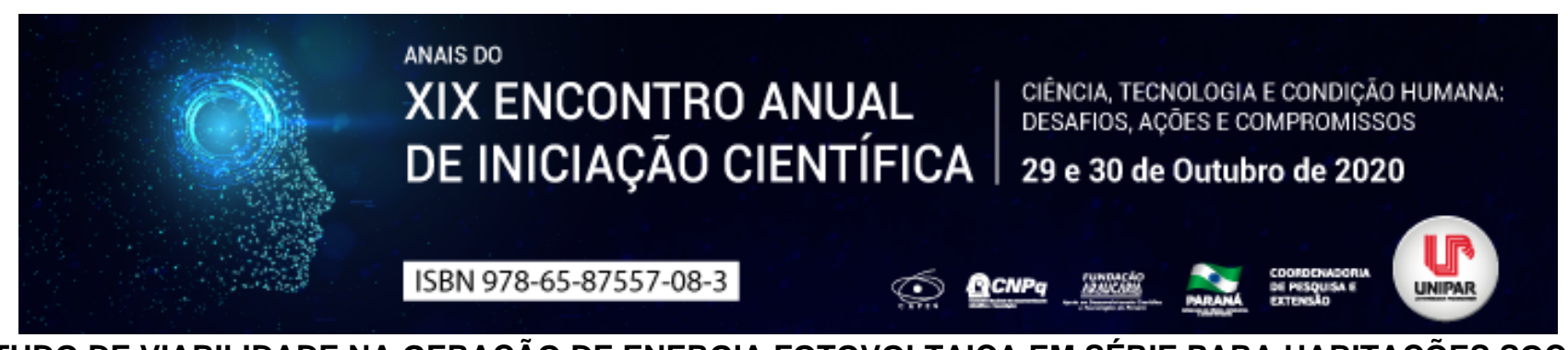

ESTUDO DE VIABILIDADE NA GERAÇÃO DE ENERGIA FOTOVOLTAICA EM SÉRIE PARA HABITAÇÕES SOCIAIS

\title{
1 JOAO VITOR BARBOSA DA SILVA, ${ }^{2}$ BENNY ROGER PEREIRA DOS SANTOS, ${ }^{3}$ DIEGO GABRIEL METZ
}

\author{
${ }^{1}$ Acadêmico do curso de Engenharia Civil da UNIPAR \\ ${ }^{1}$ Acadêmico do Curso de Engenharia Civil da UNIPAR \\ ${ }^{2}$ Docente da UNIPAR
}

Introdução: Tendo em vista o desenvolvimento sustentável e as demandas futuras de energia é indiscutível a necessidade de expandir as matrizes energéticas no Brasil, país que depende muito da fonte hidrelétrica, que vem enfrentando sérias críticas sociais, ambientais e também econômicas devido à severa estiageme o Paraná tem forte influência nesse contexto, uma vez que é o estado que mais produz energia, principalmente de fontes hídricas (TIEPOLO, 2015). Baseado nisso a geração distribuída, normatizada pela Resolução $n^{\circ}$ 482/2012 da Agência Nacional de Energia Elétrica (ANEEL), se mostra como ensejo importante na expansão da matriz energética. A geração fotovoltaica se encaixa perfeitamente nessa categoria pois parte do princípio de que cada unidade consumidora é uma unidade de produção elétrica em potencial, capaz de abastecer total ou parcialmente a sua demanda e, caso a geração seja superior a demanda, o excedente é injetado na rede (ZILLES, 2012). Dessa forma esse estudo poderá incentivar a criação de novas políticas públicas governamentais voltadas para o setor energético com responsabilidade social e ambiental, promovendo o desenvolvimento econômico de maneira sustentável.

Objetivo: O objetivo deste estudo é avaliar a viabilidade de aplicação de sistemas fotovoltaicos em série nas habitações de interesse social, aproveitando o abundante potencial solar da região Noroeste do Paraná. A partir disso projetar-se-á um bairro fotovoltaico visando alinhar inovação tecnológica com a sociedade, de modo que, por consequência, alivie o sistema elétrico do Brasil e favoreça economicamente as famílias atendidas por programas habitacionais.

Metodologia: A população estudada é constituída por famílias atendidas pelo Programa Nacional Minha Casa, Minha Vida Foi realizada pesquisa de campo nos conjuntos habitacionais da cidade de Paranavaí, situada na região Noroeste do Paraná, bem como consulta a companhias de energia com o intuito de traçar o perfil de consumo dessas famílias. Fora realizado o levantamento técnico-financeiro nas bibliografias concernente ao tema da pesquisa, buscando o melhor arranjo do sistema fotovoltaico concomitante a melhor relação custo-benefício. Em ato contínuo, houve a visita técnica a uma usina solar na cidade de Paranavaí para observação do modelo já existente e análise para adaptação nos telhados das habitações sociais. Por fim, pôs-se à escolha de um terreno com inclinação adequada objetivando maiores níveis de insolação, bem como o projeto do 'bairro fotovoltaico' em software específico.

Resultados: Como resultados parciais esse estudo traçou o perfil de consumo de energia elétrica nas habitações sociais e, partindo de valores médios e valores máximos de demanda, constatou que $200 \mathrm{kWh} / \mathrm{mês}$ é o que mais representa o consumo nessas edificações. Procedendo com este dado foi realizado o pré-dimensionamento do sistema fotovoltaico, levando em consideração o HSP (horas de Sol-pico) de Paranavaí e utilizando como base placas solares policristalinas da fabricante Komeco, com potência de $330 \mathrm{~W}$ resultando em um módulo fotovoltaico com $2 \mathrm{kWp}$ de potência, composto por 6 painéis solares que devem ocupar uma área no telhado de $12 \mathrm{~m}^{2}$ em cada edificação. O custo para instalação desse sistema será de aproximadamente $10 \%$ do valor total do imóvel, valor este considerado coerente visto o retorno econômico a médio prazo. A escolha da melhor configuração para inverter a corrente contínua dos painéis para corrente alternada compatível com a rede elétrica ainda é objeto de estudo desta pesquisa e se fará resoluta ao fim do trabalho.

Discussão: A partir dos levantamentos realizados foi possível constatar que a aplicação de sistemas fotovoltaicos nos telhados das habitações sociais será proveitosa, devido a fatores como: abundância de incidência solar na região, que faz com que o sistema opere com eficiência satisfatória, e o custo de aplicação que vem caindo, podendo ser diluído junto às parcelas do financiamento da própria edificação, uma vez que se trata de uma iniciativa governamental. Adicionalmente as famílias atendidas por tais programas também gozam da política de isenção de tarifa de energia, fato este que pode ser mitigado por meio da geração distribuída e utilizando sistemas fotovoltaicos que geram energia limpa e sustentável.

Conclusão: Em virtude do que foi apresentado, conclui-se que a geração distribuída é uma importante ferramenta na expansão da matriz energética do Brasil, postergando ou aliviando a necessidade de instalação de grandes usinas. Os sistemas fotovoltaicos apresentam benefícios significativos para aplicação no meio urbano, pois não emitem contaminantes nem ruídos durante a operação, além de possuírem baixo índice de manutenção. No que diz respeito a eficiência do sistema o estudo mostrou ser factível a possibilidade de atender $100 \%$ da demanda das habitações sociais usando apenas metade de uma das águas do telhado, possibilitando a expansão desse sistema no intuito de desafogar o sistema elétrico no Brasil e expandir de fato a matriz geradora. 


\section{Referências}

AGÊNCIA NACIONAL DE ENERGIA ELÉTRICA. Resolução Normativa $n^{\circ}$ 482, de 17 de abril de 2012. Estabelece as condições gerais para o acesso de microgeração e minigeração distribuída aos sistemas de distribuição de energia elétrica, o sistema de compensação de energia elétrica, e dá outras providências. Diário Oficial da União: seção 1. Brasília, abril 2012.

TIEPOLO, Gerson Maximo. Estudo do potencial de geração de energia elétrica através de sistemas fotovoltaicos conectados à rede no estado do Paraná. Orientador: Osíris Canciglieri Jr. 2015. 228 f. Tese (Doutorado em Engenharia de Produção e Sistemas) Escola Politécnica da Pontifícia Universidade Católica, Paraná, 2015.

ZILLES, Roberto; MACÊDO, Wilson Negrão; GALHARDO, Marcos André Barros; OLIVEIRA, Sérgio Henrique Ferreira. Sistemas fotovoltaicos conectados à rede elétrica. 1. ed. São Paulo, Oficina de Textos, 2012.

Coordenadoria de Pesquisa e Extensão - COPEX

Departamento de Editoraçāo e Divulgaçāo Científica - DEDIC 


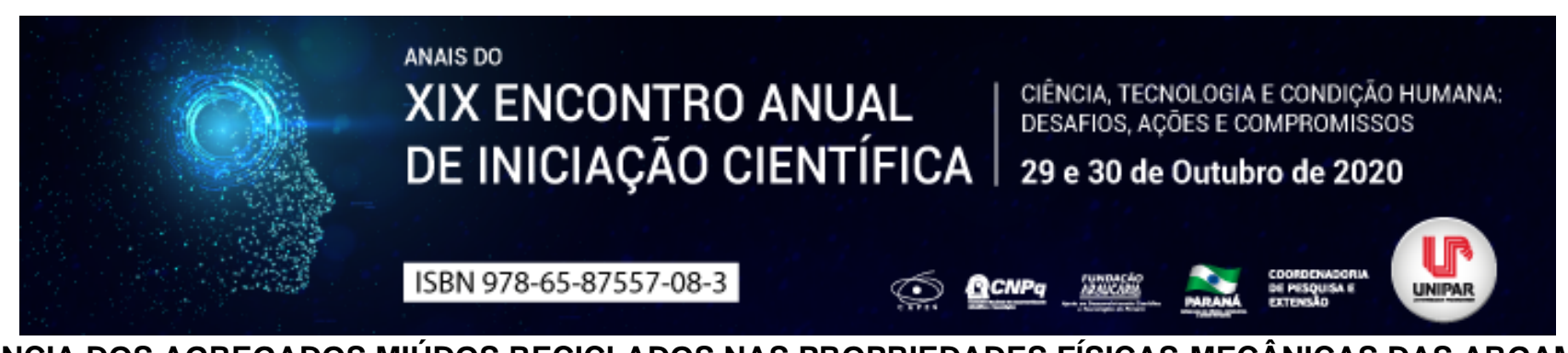

INFLUÊNCIA DOS AGREGADOS MIÚDOS RECICLADOS NAS PROPRIEDADES FÍSICAS-MECÂNICAS DAS ARGAMASSAS

\begin{abstract}
${ }^{1}$ DANIEL VICTOR MONDADORI, ${ }^{2}$ MATHEUS LUIS BELTRAME, ${ }^{3}$ THALICE SADAE SIMONI ITO, ${ }^{4}$ ALBERTO EL ACHKAR, ${ }^{5}$ THAUANA CRISTINA DE MATOS MELO, ${ }^{6}$ NEUSA APARECIDA MUNHAK BELTRAME
\end{abstract}

\begin{abstract}
${ }^{1}$ Acadêmico do PIC/UNIPAR
${ }^{1}$ Acadêmico do Curso de Engenharia Civil da UNIPAR

${ }^{2}$ Acadêmica do Curso de Engenharia Civil da UNIPAR

${ }^{3}$ Acadêmico do Curso de Engenharia Civil da UNIPAR

${ }^{4}$ Acadêmica do Curso de Engenharia Civil da UNIPAR

${ }^{5}$ Docente da UNIPAR
\end{abstract}

Introdução: A argamassa é uma mistura homogênea de agregado miúdo, aglomerante e água (AMBROZEWICZ, 2012), usada no assentamento da alvenaria, revestimentos e outros (ISHIKAWA; OLIVEIRA, 2012). O agregado miúdo tem a função de diminuir a retração e o custo das argamassas (AMBROZEWICZ, 2012). A resistência mecânica dos componentes cimentícios podem ser influenciados por vários fatores, entre eles o tipo do agregado (ISAIA, 2014). Os agregados naturais são encontrados na natureza e requer processos simples de lavagem e seleção, diâmetro entre 0,075mm e 4,75mm (AMBROZEWICZ, 2012; BAUER, 2013). Por outro lado, os agregados reciclados podem apresentar grande variabilidade (ISAIA, 2011). Esses materiais são obtidos pela trituração dos resíduos de construção e demolição (RCD), constituídos por fragmentos de concretos, argamassas, cerâmicas e outros (ISAIA, 2011). Além da forma, textura e granulometria, são mais porosos. A porosidade das partículas de cerâmicas pode chegar a 24\%, enquanto que o concreto ou argamassa podem alcançar 15\% (ISAIA, 2011). A necessidade de água adicional foi indicada por Dang et al. (2018) empregando resíduos de tijolos. Aumento de $26 \%$ da resistência à compressão foi relatado por Leite et al. (2014) com substituição total da areia natural por RCD. Já Jesus et al. (2019) concluiu que a incorporação de até 15\% de RCD misto, aumentou a resistência mecânica cerca de 105\% em relação à referência, diminuindo $9 \%$ em proporções maiores (20\%). Esse aumento se deve ao travamento das partículas, misturas sem compensação de água, presença de partículas anidras de cimento e materiais pozolânicos (SILVA et al., 2016). Materiais pozolânicos na presença de umidade, reage quimicamente com o hidróxido de cálcio do cimento formando compostos cimentícios (NEVILLE; BROOKS, 2013). Já a redução da resistência foi associada a maior porosidade das misturas com RCD (JESUS et al., 2019).

Objetivo: Investigar o desempenho das argamassas com a substituição total e parcial do agregado miúdo natural por agregado de RCD.

Material e Métodos: A metodologia baseou-se nas normas técnicas NBR NM 52, NBR NM 248 e NBR 7215. Foi utilizado CP VARI, areia natural, areia de RCD e aditivo superplastificante. $O$ agregado natural foi substituído nas proporções, nomeadas de $\mathrm{M} 0 \%, \mathrm{M} 10 \%, \mathrm{M} 20 \%, \mathrm{M} 30 \%, \mathrm{M} 50 \%, \mathrm{M} 75 \%$ e $\mathrm{M} 100 \%$. As amostras $(\varnothing 5 \times 10 \mathrm{~cm})$ foram confeccionadas no traço 1:3:0,48 (cimento: areia: água), curadas em água e retificados com disco. O espalhamento da mistura M0\% foi obtida e tomada como referência para as demais misturas e, corrigidas com aditivo quando necessário. No estado endurecido, a resistência à compressão e a absorção de água foram realizadas aos 7 e 28 dias (4 repetições). O ensaio de absorção de água foi baseado no método simples de massa seca e massa saturada indicado por Bertolini (2010) com amostras moldadas em copos plásticos de $50 \mathrm{ml}$.

Resultados: As argamassas com RCD demandaram maior quantidade de água, contudo, espalhamentos similares de $25 \pm 2 \mathrm{~cm}$ foram obtidos com o uso de aditivo. A areia natural apresentou $M_{e}=2,90 \mathrm{~g} / \mathrm{cm}^{3}$ e MF de 1,88, enquanto que a areia reciclada foi de $M_{e}=2,82 \mathrm{~g} / \mathrm{cm}^{3}$ e MF de 2,25. Aos 7 dias, as amostras $M 30 \%, M 50 \%, M 75 \%$ e M100\% apresentaram absorção média de 13$15 \%$ e aos 28 dias de 11-13\%. As demais foram similares à M0\% (10-11\%). Decréscimo na resistência foi observado em todas as amostras com RCD nas duas idades analisadas, exceto para a mistura M100\% que apresentou aumento de $24 \%$ aos 7 dias e de $39 \%$ aos 28 dias em relação a M0\%. As amostras M30\% e M50\% apresentaram as maiores reduções, sendo de $50 \%$ e 21 $31 \%$ aos 7 e 28 dias respectivamente.

Discussão: As massas específicas das areias foram similares, porém a areia reciclada apresentou granulometria mais grossa e com $11,9 \%$ de material fino $(\leq 0,075 \mathrm{~mm})$. A presença de materiais pulverulentos e a porosidade das partículas maiores demandou maior quantidade de água. Proporções de até $50 \%$ de RCD promoveram a redução da resistência mecânica nas duas idades analisadas, no entanto, a partir desses teores, acréscimo gradual de resistência foi observado, principalmente com a substituição total. O maior travamento das partículas irregulares pode ter contribuindo para esse aumento, mas pressupõem que as reações 
pozolânicas pode ter exercido maior influência nos resultados, já que grande parte da areia reciclada era composta por tijolos triturados. Estes resultados corroboram com o estudo de Leite et al., (2014), porém contraria os resultados indicados por Jesus et al., (2019), já que o incremento de resistência foi observado apenas em proporções acima de $50 \%$. A absorção de água apresentou variação de 2-3\% nas duas idades, porém parece não ter influenciado as propriedades mecânicas, já que a mistura M100\% apresentou bom desempenho mecânico, porém maior índice de absorção em relação ao M0\%.

Conclusão: Conclui-se que a substituição total da areia natural por reciclada apresentou resistência superior às argamassas de referência, porém teores menores a resistência mecânica foi afetada negativamente. Assim, a dosagem deve ser cautelosa pela variabilidade de seus materiais constituintes e ensaios prévios são necessários para o bom desempenho das argamassas.

\section{Referências}

AMBROZEWICZ, P. H. L. Materiais de construção - Normas, Especificações, Aplicação e Ensaios de Laboratório. Ed.Pini, São Paulo, 2012.

ASSOCIAÇÃO BRASILEIRA DE NORMAS TÉCNICAS. NBR NM 52: Agregado miúdo - Determinação da massa específica e massa específica aparente. Rio de Janeiro, 2009.

ASSOCIAÇÃO BRASILEIRA DE NORMAS TÉCNICAS. NBR NM 248: Agregados Determinação da composição granulométrica. Rio de Janeiro, 2003.

ASSOCIAÇÃO BRASILEIRA DE NORMAS TÉCNICAS. NBR 7215: Cimento Portland: determinação da resistência à compressão. Rio de Janeiro, 1997.

BAUER, L. A. F. Materiais de Construção. Ed. LTC. vol 1. 2013.

BERTOLINI, J.C.P. Técnicas e práticas construtivas: da implantação ao acabamento. 1. Ed. São Paulo, Editora Érica, 2014.

DANG, J.; ZHAO, J.; HU, W.; DU, Z.; GAO, D. Properties of mortar with waste clay bricks as fine aggregate. Construction and Building Materials. v.166, 2018. p. 898-907.

ISAIA, G.C. Concreto: Ciência e Tecnologia. 1.Ed. São Paulo, IBRACON, 2011.

ISHIKAWA, P.H.; OLIVEIRA, L.P. Propriedades da Argamassa com Areia Artificial para Revestimento de Alvenaria. In: Anais do $4^{\circ}$. Congresso Português de Argamassas e ETICS, APFAC, Coimbra, 2012.

JESUS, S.; MAIA, C.; FARINHA, C.B.; BRITO, J.; VEIGA, R. Rendering mortars with incorporation of very fine aggregates from construction and demolition waste. Construction and Building Materials. v.229, 2019.

LEITE, M. B.; PEDROZO, P.H.; OLIARI, G.F.; ALVES, M.F.; DAL MOLIN, D.C.C. Utilização de agregado reciclado de concreto para produção de argamassas. Porto Alegre: UFRGS, 2014.

NEVILLE, A.M; BROOKS, J. J. Tecnologia do concreto. 2 ed. Porto Alegre, 2013.

SILVA, R.V.; BRITO, J.; RHIR, R.K. Performance of cementitious renderings and masonry mortars containing recycled aggregates from construction and demolition wastes. Construction and Building Materials, v.105, 2016. p. 400415. 


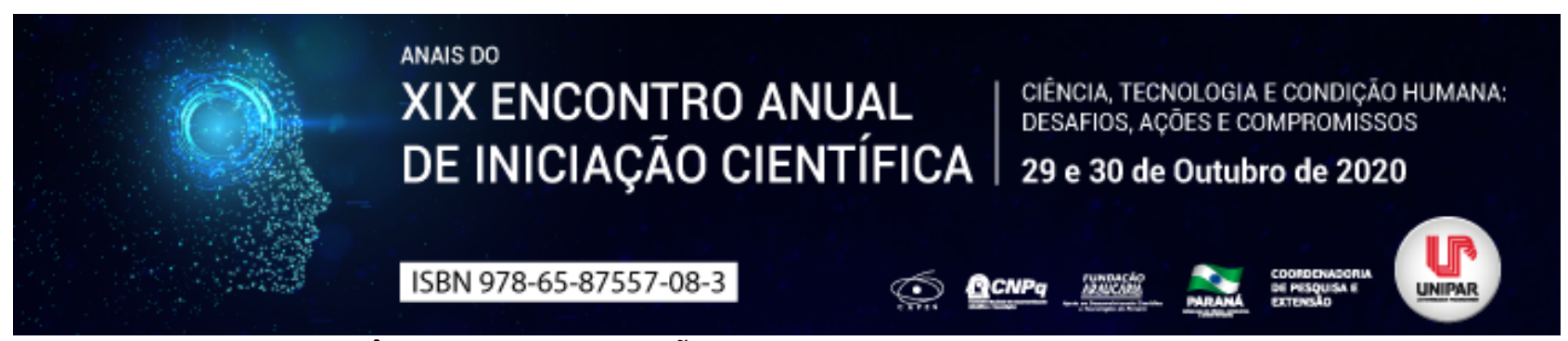

IMPORTÂNCIA DA UTILIZAÇÃO DE CHATBOTS PARA AGENDAMENTOS

\title{
${ }^{1}$ ISABELA BARROS DE OLIVEIRA, ${ }^{2}$ CARLOS EDUARDO SIMOES PELEGRIN
}

\author{
${ }^{1}$ Acadêmica do curso de Sistemas de Informação da UNIPAR \\ ${ }^{1}$ Docente do curso de Sistemas de Informação da UNIPAR
}

Introdução: No contexto atual que se vive onde se preza por experiência do usuário e otimização de processos, um assunto que merece destaque são chatbots. Na era da tecnologia onde tudo está em constante evolução, as pessoas passam um boa parte do dia conectadas possibilitando uma vasta exploração comercial automatizada. Com isso muitas empresas utilizam chatbots para potencializar serviços e melhorar o relacionamento com o usuário.

Objetivo: Apresentar a importância da utilização de chatbots para agendamentos

Desenvolvimento: A Inteligência Artificial (IA) pode ser conceituada como uma área da ciência da computação que busca a automação do comportamento inteligente. Diversas áreas utilizam dessas técnicas para resolver problemas de forma automatizada e para que isso ocorra, é necessário relacionar algoritmos de IA com dados, possibilitando assim elaborar sistemas que possam simular o raciocínio humano (LUGER, 2004 p.56). Um dos segmentos que merece destaque na área de IA é o chatbot, que utiliza técnicas de Processamento de Linguagem Natural (Natural Language Processing - NLP) para extrair informações a partir da realização do contato com usuários. Chatbots (junção das palavras chat + robot) são agentes de conversação que simulam uma conversa humana, interagindo com o usuário através de sites, aplicativos de mensagens, assistentes virtuais, e outras plataformas. (TAKE, 2019). A utilização de chatbots está cada vez mais comum em vários segmentos. Segundo uma pesquisa divulgada pela Cedro Technologies (2018, ONLINE), cerca de $90 \%$ dos processos cotidianos podem ser realizados com o uso de chatbot, $74 \%$ dos clientes conseguem solucionar suas solicitações em até 2 minutos e $87 \%$ das pessoas que utilizaram chatbots consideram suas experiências de uso como ótimas e boas (apud INFOMONEY, 2018, ONLINE). No Contexto histórico, o chatbot Eliza foi desenvolvido por Joseph Weizenbaum no ano de 1966 e simboliza um dos mais antigos chatbots, onde foi simulada uma conversa onde o bot interagia e fazia perguntas de acordo com os termos inseridos pelo usuário (OLIVEIRA, 2018 p.97). .Como consequência dos avanços da tecnológicos e da inteligência artificial os chatbots estão gradualmente mais robustos, desempenhado cada dia mais funções humanas de comunicação, raciocínio e reconhecimento de padrões, possibilitando facilitar os conteúdos de interação e substituir serviços humanos em tarefas repetitivas, como por exemplo agendamentos (TAKE, 2019).Segundo o site Universidade da Beleza, disponibilizar atendimento online e automatizado é essencial para a inovação na área de salões de beleza. Há mais de 100 milhões de usuários conectados a internet que podem ser convertidos facilmente em clientes, aumentando o público alvo. O tempo gasto atendendo ligações telefônicas pode ser convertido em tempo de trabalho, aumentando assim o faturamento do (ZANAROLI, 2020). O Agendamento automatizado, não só no setor de beleza, mas também em clínicas médicas, advocacias, academias, reservas em restaurantes, entre outros, pode não só trazer eficiência e lucratividade ao estabelecimento, como também melhorar a experiência do usuário, proporcionando assim um aumento de público.

Conclusão: O chatbot é uma ferramenta excelente para a otimização dos atendimentos em geral, inclusive de agendamentos, oferecendo mais praticidade para o usuário, mantendo ou melhorando uma experiência já conhecida, assim impactando de maneira positiva. Além de reduzir custos, manter o estabelecimento aberto $24 \mathrm{hrs}$ por dia, otimiza processos, e proporciona uma experiência satisfatória ao cliente devido a praticidade.

\section{Referências}

$\begin{array}{llcccccc}\text { INFOMONEY. } & \text { Estudo } & \text { global } & \text { constata } & \text { o } & \text { poder dos } & \text { Chatbot } & \text { Disponível } \\ \text { https://www.infomoney.com.br/patrocinados/cedro/estudo-global-constata-o-poder-dos-chatots/ Acesso em: } & 30 \text { ago } 20 .\end{array}$

LUGER, F. Inteligência Artificial: Estruturas e Estratégias para a Solução de Problemas Complexos. 4ª ed. Porto Alegre: Bookman, 2004.

OLIVEIRA, F. Inteligência Artificial. Londrina: Educação, 2018.

TAKE. Tudo sobre NLP: o que é processamento de linguagem natural e seus desafios na Inteligência Artificial Disponível em: https://take.net/blog/devs/nlp-processamento-linguagem-natural Acesso em: 30 ago 20.

ZANAROLI, L. Como o agendamento online te ajuda a se destacar no mercado da beleza. Disponível em: https://www.universidadedabeleza.com/agendamento-online-se-destacar-no-mercado-da-beleza/ 30 ago 20 



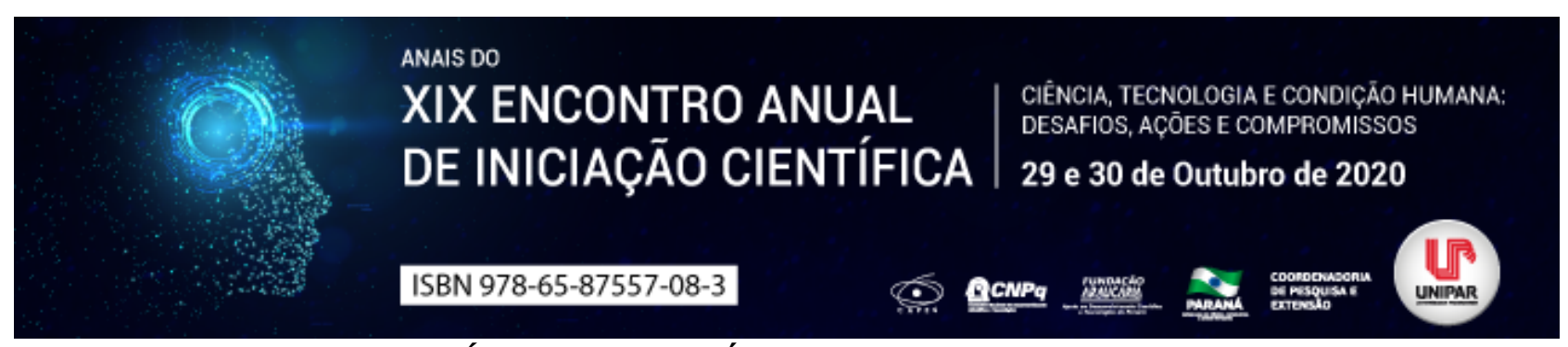

REVESTIMENTO DE GRAU ALIMENTÍCIO A BASE DE ÓLEO DE SOJA E AMIDO DE MANDIOCA PARA FRUTAS: UMA REVISÃO

\begin{abstract}
${ }^{1}$ JESSICA DE SOUZA ALVES, ${ }^{2}$ JEAN SILVA DE SOUZA, ${ }^{3}$ PATRICIA DANIELE SILVA DOS SANTOS, ${ }^{4}$ GEOVANE APARECIDO RAMOS DA SILVA, ${ }^{5}$ ANGÉLICA DE FÁTIMA BORTOLATO PICCIOLI, ${ }^{6}$ OSCAR DE OLIVEIRA SANTOS JUNIOR
\end{abstract}

\author{
${ }^{1}$ Programa de Pós-Graduação em Química - Universidade Estadual de Maringá - UEM - Maringá-PR \\ ${ }^{1}$ Programa de Pós-Graduação em Bioinformática - Universidade Federal do Paraná - UFPR - Curitiba-PR \\ ${ }^{2}$ Programa de Pós-Graduação em Química - Universidade Estadual de Maringá - UEM - Maringá-PR \\ ${ }^{3}$ Programa de Pós-Graduação em Química - Universidade Estadual de Maringá - UEM - Maringá-PR \\ ${ }^{4}$ Programa de Pós-Graduação em Química - Universidade Estadual de Maringá - UEM - Maringá-PR \\ ${ }^{5}$ Docente do Programa de Pós-Graduação em Química - Universidade Estadual de Maringá - UEM - Maringá-PR
}

Introdução: Apesar de estar entre os maiores produtores de frutas, o Brasil exporta pouco mais de $3 \%$ de tudo o que produz, porém, pesquisas apontam que o país desperdiça cerca de 30\% das frutas que produz (AGROLINK, 2019). Algumas frutas contêm uma cera natural chamada pruína, importante para a manutenção da sua qualidade (ROCHA et al., 2020). Contudo, no processo de beneficiamento dos frutos, essa cera é perdida com o amadurecimento e acaba sendo removida, diminuindo o tempo de prateleira das frutas (DE LIMA; GUERRA, 2018). Uma possível solução seria o recobrimento da superfície da fruta, um método que tem sido empregado extensivamente para reduzir a perda de água, difusão de gases, movimentação de óleos e gorduras, a perda de sabores e aromas. Neste trabalho, apresenta-se uma revisão dos estudos de revestimentos de grau alimentício para recobrimento de frutas, utilizando óleo de soja e amido de mandioca, sendo uma camada protetora para preservação de frutos pós - colheita.

Objetivo: Pesquisa bibliográfica de desenvolvimentos de revestimento de grau alimentício para recobrimento de frutas.

Desenvolvimento: Nosso país possui grandes extensões territoriais e condições favoráveis para o agronegócio, por exemplo, o setor fruticultor brasileiro persegue a meta de exportar US\$ 1 bilhão de frutas frescas e derivados semi-processados e processados em 2020 de acordo com dados da Associação Brasileira dos Produtores Exportadores de Frutas e Derivados (Abrafrutas) (BRASIL, 2019). De acordo com dados da FAO (2019), em 2017 o Brasil foi o terceiro maior produtor mundial de frutas com 42,2 milhões de toneladas, atrás apenas da China e da Índia mas tem exportado bem pouco e aumentando o desperdício. Fatores como diminuição de tempo de prateleira influenciam na baixa exportação de frutas e o alto desperdício das mesmas. Coberturas comestíveis são camadas finas e contínuas de substâncias alimentícias formada ou depositada sobre o alimento, oferecendo barreira aos gases, vapor-de-água, aromas, óleos, etc, propiciando proteção mecânica e também conduzindo antioxidantes, aromas, antimicrobianos aos alimentos (VINOD, 2020). Elas são geralmente aplicadas em frutas e hortaliças frescas para melhorar sua aparência e para evitar perdas de umidade (CHEN et al., 2019). Para frutas muito sensíveis, elas desempenham funções de proteção contra danos mecânicos e contaminação microbiana, pós-colheita (CHIUMARELLI; HUBINGER, 2012). Os revestimentos comestíveis podem ser constituídos de uma mistura de polissacarídeos, proteínas e/ou lipídios. Essa abordagem permite utilizar as características funcionais distintas de cada classe de formador de revestimento (GREENDER; FENNEMA, 1989). A fécula de mandioca é um biofilme de polissacárido tendo como principais vantagens o aumento da eficiência, resistência e baixo custo, e a inclusão do óleo de soja, como barreira eficiente à água e podem prevenir a perda de massa. Desta forma, um revestimento comestível, a base de óleo de soja e amido de mandioca, pode contribuem para a manutenção da qualidade das frutas, pós-colheita em produção em larga escala.

Conclusão: Desta forma, sintetizar um revestimentos de grau alimentício a base de óleo de soja e amido de mandioca para frutas em larga escala, resultou em um projeto de pesquisa que foi submetido ao CNPq e está no processo de avaliação.

\title{
Referências
}

AGROLINK. Os rumos da produção de frutas no Brasil. Disponível em: https://www.agrolink.com.br/noticias/os-rumos-daproducao-de-frutas-no-brasil_425861.html. Acesso em 31 ago. 2020.

BRASIL. MINISTÉRIO DO DESENVOLVIMENTO, INDÚSTRIA E COMÉRCIO EXTERIOR SECRETARIA DE COMÉRCIO EXTERIOR. Barreiras Externas às Exportações Brasileiras. 2019. Disponível em: http://www.mdic.gov.br/arquivos/ dwnl_1196772454.pdf. Acesso em: 12 jun. 2020.

CHIUMARELLI, M., HUBINGER, M.D. Stability, solubility, mechanical and barrier properties of cassava starch - Carnauba wax edible coatings to preserve fresh-cut apples. Food Hydrocolloids, v. 28, p. 59-67. 2012.

DE LIMA, M. A. C., GUERRA, C. C. (2018). Colheita e pós-colheita. Embrapa Semiárido-Capítulo em livro científico (ALICE). 
FOOD AND AGRICULTURE ORGANIZATION OF THE UNITED NATIONS (FAO). FAOSTAT Database result: banco de dados. Disponível em: http://www.fao.gov. br. Acesso em: 10 jun. 2020.

GREENER, I.K., FENNEMA, O. Evaluation of Edible, Bilayer Films for Use as Moisture Barriers for Food. J Food Science, v. 54, p. 1400-1406. 1989.

ROCHA, A. M. et al. Aplicação do biopolímero de amido de cassava e amido de milho na conservação pós-colheita de guava. BJD, v. 6, p. 6658-6680. 2020.

VINOD, A.;SIENGCHIN, S.; PARAMESWARANPILLAI, J. Renewable and sustainable biobased materials: An assessment on biofibers, biofilms, biopolymers and biocomposites. Journal of Cleaner Production, 120978, 2020.

Coordenadoria de Pesquisa e Extensão - COPEX

Departamento de Editoraçāo e Divulgaçāo Científica - DEDIC 


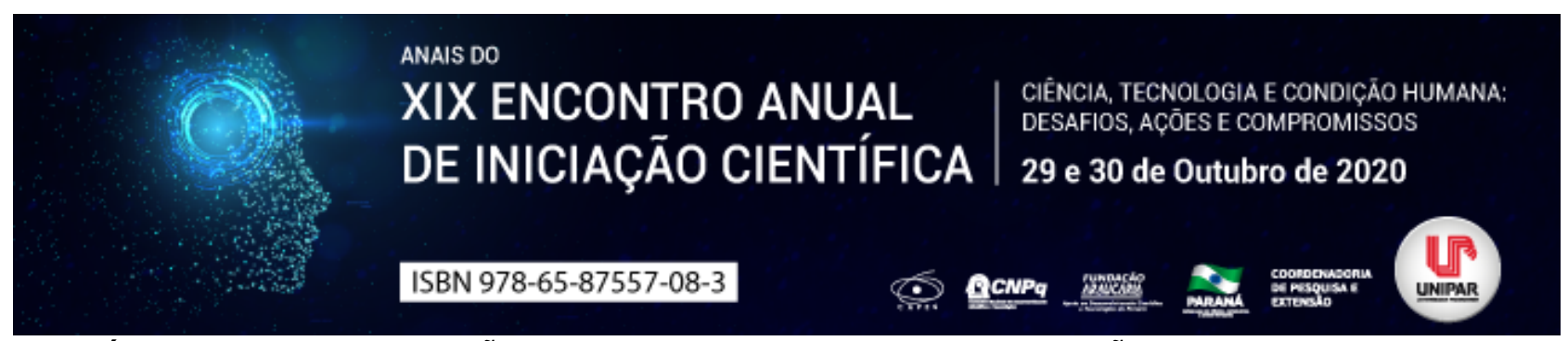

\title{
ANÁLISE PARA ELABORAÇÃO DE UM DISPOSITIVO DE ELETROFIAÇÃO A PARTIR DE ARDUINO PARA DESENVOLVIMENTO E APLICAÇÃO DE MATERIAIS
}

\author{
${ }^{1}$ MASSAMI BRUNO TSUNETO, ${ }^{2}$ GABRIEL NARDI FRAGA, ${ }^{3}$ ARNALDO GOMES DO AMARAL
}

\author{
${ }^{1}$ Discente do Curso de Engenharia da Computação UNIPAR Universidade Paranaense. \\ ${ }^{1}$ Discente do mestrado em Química UNIOESTE Universidade Estadual do Oeste do Paraná. \\ ${ }^{2}$ Docente da UNIPAR
}

\begin{abstract}
Introdução: Dispositivos de eletrofiação são utilizados para a criação de nanofibras, criando produtos ou estruturas variadas, esses dispositivos têm um valor elevado e a partir de uma necessidade surgiu o projeto para o desenvolvimento do mesmo utilizando produtos com um valor aquisitivo menor. As fibras sintetizadas permitem sua aplicação podendo ser obtidas com materiais que atingem a escala nanométrica.
\end{abstract}

Objetivo: Analisar a função e necessidades para desenvolvimento de um dispositivo de eletrofiação a partir de Arduino.

Desenvolvimento: A eletrofiação abrangem um enorme leque de áreas de atuação e desenvolvimento, para o projeto primeiramente à necessidade do entendimento do funcionamento do dispositivo, de acordo com Liang (2007) o sistema eletrofiação geralmente consiste-se em três componentes principais: uma fonte de alta tensão, um sistema de seringa e uma placa coletora metálico aterrado podendo ser uma placa ou sistema rotativo conectado à fonte que oferece carga de polaridade dentro da solução de polímero com solvente através da agulha da seringa, que então é acelerada para o coletor devido a diferença de potência. A seringa contem solução polimérica, quando sob um campo elétrico externo aplicado ao capilar da seringa, é formada uma gota cônica suspensa, conhecido como Cone de Taylor segundo Sill e Recum (2008). Quando o campo elétrico aplicado é forte o suficiente para superar a tensão superficial, um pequeno jato é ejetado da superfície da gota e atraído em direção à placa coletora. Durante a propagação do jato em direção à placa coletora, o solvente na corrente do jato evapora gradualmente (MIRANDA, 2017). O produto resultante é um scaffold fibroso não tecido com uma grande área de superfície / volume e um pequeno tamanho de poro (em mícrons) (LIANG, 2007). O desenvolvimento do dispositivo se divide em três, o primeiro será a seringa, onde irá se adotar um sistema para o bombeamento do polímero contido na seringa, tem a necessidade de um bombeamento preciso, assim o uso de motores de passos conectados a fusos trapezoidal T8, como sistema de pistão de alta precisão e controle, controlados pelo Arduino, a segunda parte será o sistema de coletor onde adota-se o sistema rotativo de formato tubular será rotacionado por um motor de passo conectado a um acoplador flexível com gap não condutível, esse motor também será controlado pelo Arduino, e pôr fim a fonte de alta tensão que terá seu controle de voltagem feito no Arduino, através do Arduino será controlada as entradas e saídas dos parâmetros necessários para o correto funcionamento do sistema. Alcobia (2013) relata que há muitos parâmetros envolvidos no processo de eletrofiação entre eles condições ambientais, como temperatura e umidade e também de processamento tais como tensão aplicada, espaço entre capilar e anteparo e fluxo de injeção além de outros, ao analisar essa informação parte-se para um novo componente, uma estufa controlada pelo Arduino no intuito de controlar o ambiente de produção, permitindo o ajuste e medição de temperatura e humidade selecionado o sensor DHT22 que atende a estes requisitos em um único sensor, para o controle efetivo de temperatura estuda-se a o uso da pastilha peltier que quando ligada a um controlador de um lado aquece e o outro esfria, permitindo o controle na troca de calor do equipamento com o meio ambiente.

Conclusão: Com base no que foi pesquisado e analisado a eletrofiação abrangem uma grande necessidade de funções e controles além de parâmetros diversos como temperatura, humidade, potência de bombeamento e jato ejetado, com isso o Arduino se torna uma opção como ferramenta para a prototipagem do dispositivo de eletrofiação.

\section{Referências}

ALCOBIA, Daniel de Souza, Produção de nanofibras linhadas de polímeros biodegradáveis para crescimento e regeneração de células neurais. 2013, Dissertação de Mestrado (Química Orgânica) - Universidade de São Paulo - USP, 2013.

LIANG, Dehai. Functional Electrospun Nanofibrous Scaffolds for Biomedical Applications. Advanced Drug Delivery Reviews Volume 59, Edição 14, 10 de dezembro de 2007, Páginas 1392-1412 Disponível em: https://www.sciencedirect.com/science/article/abs/pii/S0169409X07001858?via\%3Dihub Acesso em: 07 ago. 2020.

MIRANDA, Diego Oliveira. Desenvolvimento e Estudo do Efeito de Diferentes Nanoestruturas no Desempenho de Dispositivos Baseados em Hidrogéis Contendo Polímeros Conjugados 2017, Tese de Doutorado (Ciência e Engenharia de Materiais) Universidade Federal de Minas Gerais - UFMG, 2017.

SILL Travis J, RECUM Horst A. Electrospinning: Applications In Drug Delivery And Tissue Engineering. Biomaterials, Elsevier, Volume 29, Edição13, maio 2008, Páginas 1989-2006, Disponível 
em: https://www.sciencedirect.com/science/article/pii/S0142961208000203?via\%3Dihub Acesso em: 14 ago. 2020.

Coordenadoria de Pesquisa e Extensão - COPEX

Departamento de Editoraçāo e Divulgaçāo Científica - DEDIC 


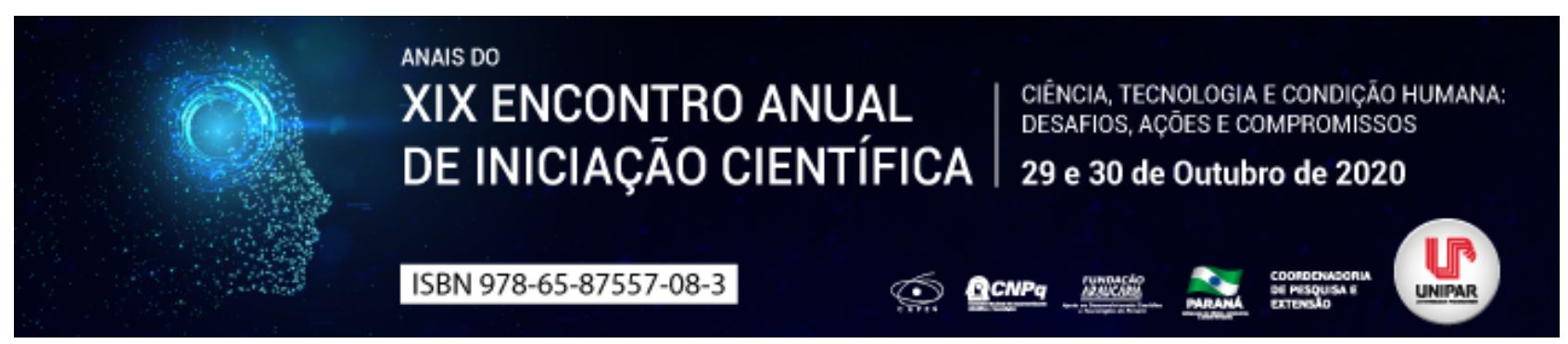

HACKING COM ARDUINO

\author{
${ }^{1}$ MASSAMI BRUNO TSUNETO, ${ }^{2}$ ARNALDO GOMES DO AMARAL
}

${ }^{1}$ Discente do curso de Engenharia da Computação UNIPAR Universidade Paranaense.

${ }^{1}$ Docente da UNIPAR

Introdução: As possibilidades de uso do Arduino são enormes, uma delas é hardware hacking, que utilizar ou alterar um hardware para melhorar ou utilizar para algum outro fim ou para utilizá-los em testes de intrusão. O trabalho tematiza sobre hacking, Arduino e apresenta exemplos de ataques harcker que podem ser efetuados através de um dispositivo Arduino com uma interface wireless, como ataque de desautenticação, packet sniffing e beacon spoofing, o intuito do trabalho e informar possibilidades de uso para pentests e não para ataques criminosos.

Objetivo: Demonstrar a possibilidade de uso do Arduino para hacking com a finalidade de estudo cientifico

Desenvolvimento: Hacking, com o passar do tempo essa palavra recebeu várias definições no mundo digital, antes a palavra era atribuída a pessoas que detinha um grande conhecimento em um determinado assunto (BRUNVAND, 1996). De acordo com Raymond (1999) o termo no mundo digital era usado para denominar os estudantes que fuçavam (exploravam) os computadores

ratos de laboratórios. Com o passar do tempo o termo harcking virou sinônimo de cibercrime (MORELLI, 2015). Não muito distante desse sinônimo o presente trabalho demonstra algumas possibilidades de usar o Arduino para hacking, no intuito de trazer o conhecimento, e não para que pessoas usem de ferramenta para crimes, Segundo Fraga (2019) hacker ético diz que para se defender é preciso conhecer o inimigo e as ameaças que nos cercam. De acordo com Thomsen (2014) o Arduino é um dispositivo composto por microcontrolador Atmel, com circuitos de entrada/saída que podem ser facilmente conectados e programados em um computador, utilizando de uma linguagem $\mathrm{c} / \mathrm{c}++$, ainda ressalta que as possibilidades de uso são praticamente infinitas, que tudo depende da criatividade. Usar o Arduino com uma interface wireless, pode-se fazer vários tipos de ataques harckers como exemplo cita-se três formas, começando pelo ataque de desautenticação, esse tipo de ataque pode ser usado para achar ssid oculto, capturar handshake do WPA gerar requisições de ARP ou simplesmente para parar uma rede. Packet Sniffing, sniffing na sua tradução literal é farejador através do Arduino além de transmitir por Wi-Fi, também podese ouvir uma rede, assim é possível utilizar o Arduino para analisar dados relevantes em uma rede e interceptar os mesmos. Beacon Spoofing, beacon, é um pacote usado por um ponto de acesso para anunciar seu nome e informações básicas para qualquer dispositivo no alcance, esses pacotes são o que faz com que um dispositivo liste uma rede na lista de redes próximas que é exibida quando o usuário está procurando por uma rede para se conectar. Ao falsificar esses pacotes de beacon, pode-se simular a aparência de qualquer rede para qualquer dispositivo no alcance. Atualmente o hardware hacking é uma técnica utilizada para efetuar pentests fisicos e para a prática de invasão de sistemas e através de um dispositivo Arduino consegue-se efetuar muitas coisas, seja filtrar dados de uma rede até mesmo incapacitar a disponibilidade de serviços wireless.

Conclusão: O Arduino se apresenta como uma opção de ferramenta para prototipagem, até no que se diz respeito a hardware hacking, dessa maneira o Arduino possibilita criar ambientes reais de hacking para pentests. Desta forma, o processo de teste se torna seguro tendo em vista que será utilizado sistemas em tempo real que são acessados por usuários.

\title{
Referências \\ BRUNVAND, Erik. The Heroic Hacker: Legends of the Computer Age, 1996. Disponível
} em: https://www.researchgate.net/publication/2665101_The_Heroic_Hacker_Legends_of_the_Computer_Age. Acesso em: 25 ago. 2020.

FRAGA, Bruno. Aprenda as técnicas usadas por hackers em invasões a empresas, redes e sistemas, Tecnicasdeinvasao. 2019, Disponível em: https://tecnicasdeinvasao.com/. Acesso em: 25 ago. 2020.

MORELLI, Marina. É preciso diferenciar hacker de cibercriminoso Veja, 2015. Disponível em: https://veja.abril.com.br/tecnologia/e-preciso-diferenciar-hacker-de-cibercriminoso/. Acesso em: 25 ago. 2020.

RAYMOND, Eric S. A Brief History of Hackerdom. Publicado em 1999. Disponível em: http://www.catb.org/ esr/writings/cathedralbazaar/hacker-historyl. Acesso em: 25 de ago. 2000.

THOMSEN, Adilson. O que é Arduino? Filipeflop, 2014. Disponível em: https://www.filipeflop.com/blog/o-que-e-arduino/. Acesso em: 25 ago. 2020. 


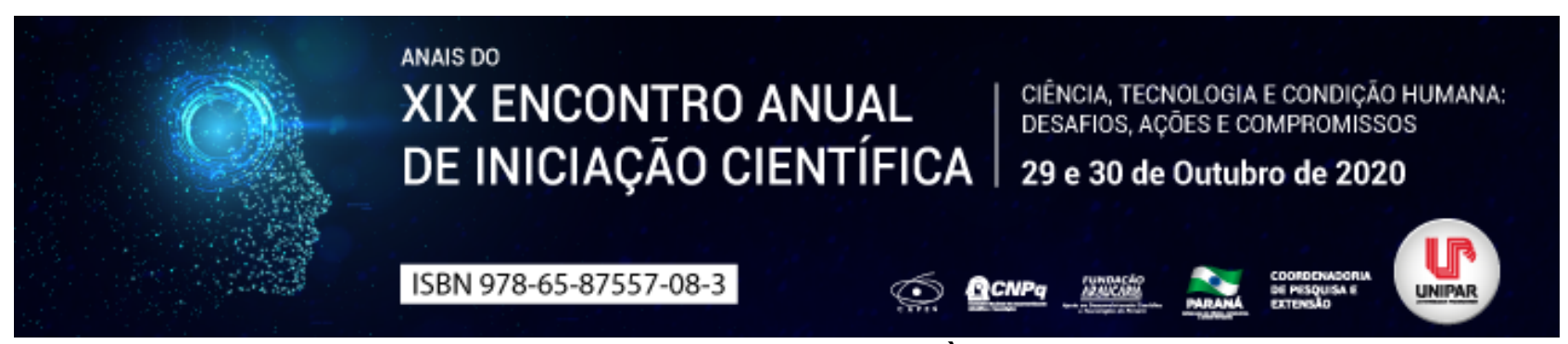

TECNOLOGIA AVANÇADA NO AUXILIO À SAUDE HUMANA

\title{
${ }^{1}$ LUAN FRANCISCO GUIMARAES GUEDES, ${ }^{2}$ CARLOS EDUARDO SIMOES PELEGRIN
}

\author{
${ }^{1}$ Acadêmico do Curso de Sistemas de Informação da Unipar \\ ${ }^{1}$ Docente do Curso de Sistemas de Informação da UNIPAR
}

Introdução: Com o avanço da tecnologia e dos meios computacionais, se torna cada vez mais presente no cotidiano, utensílios tecnológicos no corpo humano, auxiliando ou substituindo tarefas que eram funções do próprio organismo.

Objetivo: Entender o uso da tecnologia no auxílio à vida e à funções do corpo humano.

Desenvolvimento: Com o passar dos anos, novas tecnologias apareceram para auxiliar ou substituir funções do próprio corpo humano. Segundo Gartner (2019), avanços tecnológicos estão mudando o conceito de humano na medida em que indivíduos passam a encarar essas soluções como aprimoramento de suas próprias habilidades. (apud LG, 2019).

A tecnologia já auxilia em tarefas que o ser humano exerce como profissão, muitas vezes até substituindo o próprio ser humano por inteiro que é o caso da automação de processos, que já é um assunto que gera muita polêmica, mas é o desenvolvimento do nível de consciência, da maturidade humana é que vai fazer com que o crescimento da tecnologia seja algo mais positivo do que negativo. (MEIRA, 2020). Seguindo esse pensamento é que se deve abrir a mente para aceitar as novas tecnologias, que tendem a ser usadas para melhorar a qualidade de vida ou até mesmo prolongar a mesma.

A tecnologia tem se mostrado útil para substituir as funções do próprio corpo humano, como já pode ser observado a algum tempo, como no caso das próteses ortopédicas eletrônicas, que oferecem uma melhor mobilidade ao usuário frente às próteses tradicionais, pois são capazes de substituir quase que por completo um membro inteiro do corpo humano replicando a maioria das funções motoras. Um exemplo disso é um protótipo de uma luva extensora, desenvolvida pelo designer Ubiratã Bizarro Costa, que após algumas versões, trouxe o movimento dos dedos do músico João Carlos Martins que há muitos anos só conseguia tocar com muito esforço e usando apenas os polegares. (VARELLA, 2020). Outro avanço na medicina tecnológica trouxe a tona uma cápsula que pode registrar cerca de 50 mil fotografias de todo o trato intestinal pois possui uma câmera, a cápsula funciona bem e pode inclusive identificar pequenos tumores que provocam o câncer, a vantagem desse procedimento em relação a uma endoscopia é que dispensa o uso de anestesia, assim auxiliando nas funções de monitoramento em saúde. (SAURIN, 2014). Um exemplo muito recente de aplicação da tecnologia no corpo humano foi apresentado pela empresa Neuralink em uma live: um microchip capaz de conectar o cérebro a computadores. O dispositivo foi demonstrado conectado ao cérebro de um porco e a premissa é de que ele execute funções semelhantes à um wearable (vestível), tal como um smartwatch. A ideia é colar o dispositivo ao crânio de forma invisível, deixando apenas uma cicatriz que será coberta pelo cabelo. $O$ processo não vai demandar anestesia geral e será possível deixar o hospital no mesmo dia do procedimento. Além disso, segundo Musk(2020), a empresa visa utilizar o equipamento para proporcionar alternativas para condições neurológicas como a perda de memória, disfunções motoras, entre outras comorbidades. (apud MARQUES, 2020).

Conclusão: A tecnologia se mostra cada vez mais útil, mesmo que sutilmente. Desde implantes cerebrais até capsulas para exames, essa área da ciência tecnológica cresce exponencialmente melhorando a vida dos humanos. Tecnologia aplicada a medicina não surgiu agora, mas, com o aumento do poder computacional projetos de grande valia estão sendo realizados, como no exemplo de implantes neurais devolvendo movimentos ou combatendo males de memória, tornando a vida de seus usuários normal novamente.

\section{Referências}

LG. Como a tecnologia está mudando o que é ser humano e como se beneficiar disso. 13 nov. 2019. Disponível em: https://www.lg.com.br/blog/tecnologia-e-ser-humano. Acesso em: 26 de ago. de 2020

MEIRA, Luciano. Como a tecnologia está mudando o que é ser humano e como se beneficiar disso.13 nov. 2019. Disponível em: https://www.lg.com.br/blog/tecnologia-e-ser-humano. Acesso em: 29 de ago. de 2020

VARELLA, Thiago. Ele criou luva revolucionária para músico, mas não lucra nada com invenções. Sumaré, 26 jan. 2020. Disponível em: https://www.uol.com.br/tilt/noticias/redacao/2020/01/26/ele-criou-luva-revolucionaria-para-musico-mas-naolucra-nada-com-invencoes.htm. Acesso em: 01 de set. de 2020

IPOBRASIL. Próteses Eletrônicas. Campinas. Disponível em: https://proteses.ipobrasil.com.br/proteses-eletronicas. Acesso em: 29 de ago. de 2020.

SAURIN, Jean. Novas tecnologias entram no corpo humano. 23 jul. 2014. Disponível em: https://exame.com/ciencia/novastecnologias-entram-no-corpo-humano. Acesso em: 30 de ago. de 2020

MARQUES, Ana. Elon Musk revela chip da Neuralink que conecta cérebro a computadores. 28 ago. 2020. Disponível em: 
https://tecnoblog.net/362978/elon-musk-revela-chip-da-neuralink-que-conecta-cerebro-a-computadores/. Acesso em: 31 de ago. de 2020

Coordenadoria de Pesquisa e Extensão - COPEX

Departamento de Editoraçāo e Divulgaçāo Científica - DEDIC 


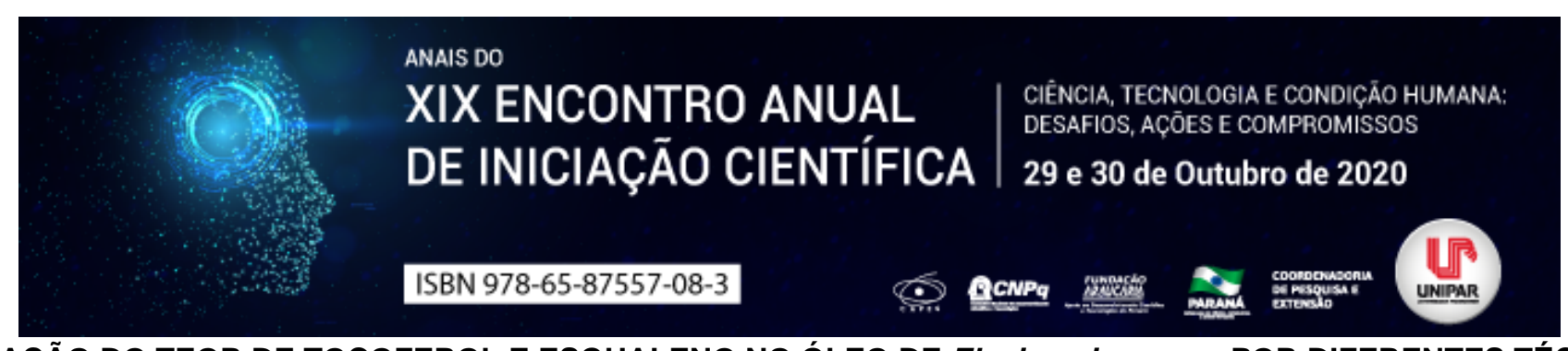

AVALIAÇÃO DO TEOR DE TOCOFEROL E ESQUALENO NO ÓLEO DE Elaeis guineenses POR DIFERENTES TÉCNICAS DE EXTRAÇÃO

\author{
${ }^{1}$ Claudia Marques da Silva, ${ }^{2}$ ANA BEATRIZ ZANQUI, ${ }^{3}$ LÚCIO CARDOZO FILHO, ${ }^{4}$ MAKOTO MATSUSHITA
}

\author{
${ }^{1}$ Doutora em Ciências/UEM \\ ${ }^{1}$ Doutora em Ciências/UEM \\ ${ }^{2}$ Docente UEM \\ ${ }^{3}$ Docente UEM
}

Introdução: O óleo de palma obtido do fruto da palmeira Elaeis guineensis Jacq., é o óleo vegetal mais consumido no mundo; e sua aplicação é cerca de 80\% na indústria alimentícia (FAO, 2020). O óleo de palma possui coloração vermelho-alaranjada, em razão da elevada concentração de carotenoides, além de estado físico semissólido em temperatura ambiente, devido à presença de ácidos graxos saturados em sua composição, sendo que a proporção de ácidos graxos saturados para ácidos graxos insaturados é aproximadamente de 1:1 (SILVA et al., 2020). Este óleo possui ainda conteúdo de outros compostos bioativos, como os tocoferóis e esqualeno. Os tocoferóis são compostos que apresentam atividade biológica da vitamina E e possuem ação antioxidante, atuando na prevenção da oxidação lipídica. O consumo desta vitamina está relacionado com a redução do risco de doenças hipertensivas e inflamatórias, além de proteger contra o declínio cognitivo (EITENMILLER; LEE, 2004). Já o esqualeno é um hidrocarboneto alifático insaturado, que participa da precursão da biossíntese do colesterol e outros esteróis. O esqualeno também possui ação antioxidante, e contribui para a prevenção e tratamento de câncer, diminuindo os efeitos colaterais causados pela quimioterapia (REDDY; COUVREUR, 2009). A maioria dos métodos tradicionais de extração lipídica baseiam-se em extrações líquido-sólido como Soxhlet (SE) e Bligh e Dyer (BD), no entanto estas técnicas apresentam as desvantagens de uso de solventes tóxicos e longos tempo de operação. Em vista disso, novas técnicas são requeridas a fim de suprir estas desvantagens e fornecer produtos de qualidade. Assim, a Extração por Fluido Subcrítico (EFS) tem despertado a atenção devido não utilizar solventes tóxicos, permitir uma extração mais seletiva, mais rápida e menos laboriosa (SILVA et al., 2015; SILVA et al., 2020). A limitação da EFS envolve o alto custo de investimento para a aquisição e manutenção do equipamento. No entanto, a recuperação e reciclagem do solvente e o uso de simulações por modelos matemáticos, permitem minimizar os custos associados a cada etapa em escala industrial (DEL VALLE, 2015).

Objetivo: Avaliar a composição de tocoferol total e esqualeno em óleo de palma de espécie Elaeis guineensis Jacq. através das técnicas convencionais SE e BD em comparação com o método alternativo de EFS.

Material e Métodos: Três lotes de $1 \mathrm{~kg}$ de mesocarpo de palma liofilizado foram fornecidos pela Embrapa Amazônia Ocidental (Manaus, AM, Brasil). Os mesocarpos foram moídos em moinho de facas e homogeneizados. Em seguida, sua granulometria foi padronizada através de uma peneira da série Tyler de 9 mesh. Os lipídios foram extraídos segundo Soxhlet (1879) utilizando éter etílico e éter de petróleo $\left(1: 1 \mathrm{v} \mathrm{v}^{-1}\right)$ a $65^{\circ} \mathrm{C}$, por Bligh e Dyer (1959) através da mistura de clorofórmio:metanol:água (2:2:1,8 v v v ${ }^{-1}$ ) a $25^{\circ} \mathrm{C}$ e por fluido subcrítico empregando propano na condição de $60{ }^{\circ} \mathrm{C}, 80$ bar e $6 \%$ de etanol (SILVA et al., 2018). Os compostos foram derivatizados utilizando N,O-bis (trimetilsilil) trifluoroacetamida, sem prévia saponificação (BEVERIDGE; LI; DROVER, 2002), e separados em cromatógrafo gasoso acoplado a espectrômetro de massas nas condições técnicas e quantificados segundo Silva et al., (2015). As análises foram realizadas em triplicata. Os resultados foram submetidos à análise de variância (ANOVA) e os valores médios foram comparados pelo teste de Tukey, usando o Software Statistica, versão 8.0. As concentrações a seguir estão expressas em mg $100 \mathrm{~g}^{-1}$ de lipídios totais. As médias seguidas de letras sobrescritas diferentes demonstram diferença significativa pelo teste de Tukey $(p<0,05)$.

Resultados: Os valores de tocoferol total obtidos em EFS foi $22,74^{a_{ \pm}} 0,25, B D 2,40^{b} \pm 0,18$ e $S E 4,77^{c} \pm 0,12$. Enquanto, de esqualeno foi $29,34^{b} \pm 0,37,49,80^{a} \pm 2,41$ e $33,01^{b} \pm 3,51$ para os métodos EFS, BD e SE, respectivamente.

Discussão: Observa-se que a concentração destes compostos variaram de acordo com a metodologia de extração. Os maiores teores de tocoferol total foram determinados no experimento utilizando EFS. Este resultado pode estar relacionado a fotodegradação, devido a amostra permanecer em contato com a luz direta durante o processo de BD e SE, enquanto em EFS ela permanece dentro de uma coluna no escuro. Além disso, ressalta-se a degradação térmica em SE, proveniente do aquecimento durante um maior período de extração (NIMET et al., 2011). Segundo Zou et al., (2012), o óleo de palma possui de 20 a $50 \mathrm{mg}$ de esqualeno $100 \mathrm{~g}^{-1}$ de lipídios totais. Portanto, os valores obtidos neste estudo estão próximos aos descritos na literatura. BD forneceu o maior conteúdo de esqualeno, enquanto EFS e SE tiveram concentrações estatisticamente iguais, indicando que a técnica alternativa apresentou eficiência similar ao método tradicional de SE para estes compostos. 
Conclusão: O óleo de palma é uma fonte natural que possui elevada concentração de compostos de ação antioxidante, sendo que o método de extração por fluido subcrítico, utilizando propano e etanol, mostrou-se viável para a extração destes, obtendo concentrações maiores ou iguais em relação aos métodos tradicionais, além de ser uma técnica ambientalmente amigável.

\section{Referências}

BEVERIDGE, T. H. J.; LI, T. S. C.; DROVER, J. C. G. Phytosterols content in American ginseng seed oil. Journal of Agricultural and Food Chemistry, v. 50, p. 744-750, 2002.

BLIGH, E. G; DYER, W. J. A rapid method of total lipid extraction and purification. Canadian Journal of Biochemistry and Physiology, v. 37, p. 911-917, 1959.

DEL VALLE, J. M. Extraction of natural compounds using supercritical $\mathrm{CO}_{2}$ : Going from the laboratory to the industrial application. The Journal of Supercritical Fluids, v. 96, p. 180-199, 2015.

EITENMILLER, R. R.; LEE, J. Vitamin E: Food chemistry, composition and analysis. 1. ed. Boca Raton, FL: CRC Press, 2004.

FAO. Food and agriculture organization of the United Nations. Food and agriculture data. Disponível em: http://www.fao.org/faostat/en/\#data/QC. Acesso em: 29 ago. 2020.

NIMET, G. et al. Extraction of sunflower (Heliantus annuus L.) oil with supercritical $\mathrm{CO}_{2}$ and subcritical propane: Experimental and modeling. Chemical Engineering Journal, v. 168, p. 262-268, 2011.

REDDY, L. H.; COUVREUR, P. Squalene: A natural triterpene for use in disease management and therapy. Advanced Drug Delivery Reviews, v. 61, p. 1412-1426, 2009.

SILVA, C. M. et al. Compressed n-propane extraction of lipids and bioactive compounds from perilla (Perilla frutescens). The Journal of Supercritical Fluids, v. 102, p. 1-8, 2015.

SILVA, C. M. et al. Extraction of oil from Elaeis spp. using subcritical propane and cosolvent: experimental and modeling. The Journal of Supercritical Fluids, v. 133, p. 401-410, 2018.

SILVA, C. M. et al. Quality and composition of three palms oils isolated by clean and sustainable process. Journal of Cleaner production, v. 259, p. 120905, 2020.

SOXHLET, F. Die gewichtsanalytische Bestimmung des Milchfettes. Dingler's Polytechnisches Journal, v. 232, p. 461-465, 1879.

ZOU, Y. et al. Minor constituents of palm oil: Characterization, processing, and application. Palm Oil: production, processing, characterization, and uses. p. 471- 526, Urbana, USA: AOCS Press, 2012. DOI: http://dx.doi.org/10.1016/j.fbio.2015.01.003 


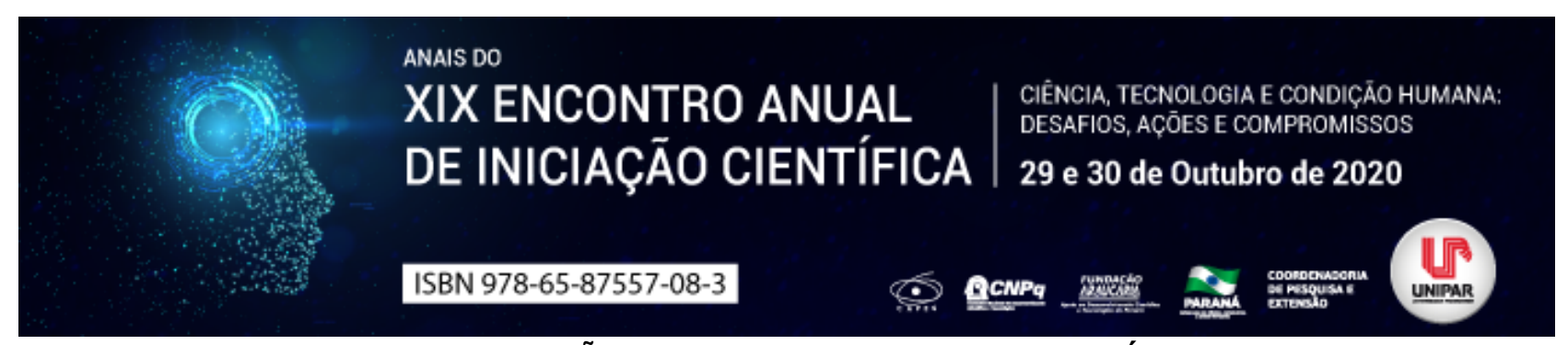

\title{
ANÁLISE DE VIABILIDADE DE IMPLANTAÇÃO DE PEQUENA CENTRAL HIDRELÉTRICA NO OESTE DO PARANÁ ESTUDO DE REVISÃO
}

\author{
${ }^{1}$ VINICIUS DE FREITAS OLIVEIRA, ${ }^{2}$ EDUARDO VEDOVETTO SANTOS
}

\author{
${ }^{1}$ Acadêmico do curso de Engenharia Civil da UNIPAR \\ ${ }^{1}$ Docente da UNIPAR
}

Introdução: Com o crescimento populacional e industrial no decorrer dos anos, expandiu-se a necessidade de demanda elétrica nacional. Dentre diversas alternativas para produção de energia no país, a principal fonte é a água, apresentando $65,2 \%$ da geração de energia elétrica, embasado no aproveitamento hidrelétrico da Empresa de Pesquisa Energética (2018). A associação brasileira de pequenas centrais hidrelétricas e centrais geradoras $(A B R A P C H, 2019)$, aponta que o estado do Paraná tem o terceiro maior potencial elétrico nacional, graças a sua grande bacia hidrográfica, porém ainda existem obstáculos com relação a aproveitamento do potencial hídrico, sendo por fatores políticos ou ambientais, resultando no emprego de outras fontes de energia. É nesse contexto que se encaixam as pequenas centrais hidrelétricas $\quad(\mathrm{PCH})$.

Objetivo: Realizar uma avaliação prévia para instalação de uma pequena central hidrelétrica entre os municípios de Mercedes e Terra Roxa, no rio Arroio Guaçu, observando suas características para sucesso desse empreendimento.

Desenvolvimento: Para a Agência Nacional de Energia Elétrica (ANEEL, 2004) as Pequenas Centrais Hidrelétricas PCH representam, atualmente, uma forma rápida e eficiente de promover a expansão da oferta de energia elétrica, visando suprir a crescente demanda verificada no mercado nacional. Esse tipo de empreendimento possibilita um melhor atendimento às necessidades de carga de pequenos centros urbanos e regiões rurais, uma vez que, na maioria dos casos, complementa o fornecimento realizado pelo sistema interligado. Conforme a Associação Brasileira de Geração de Energia Limpa (ABRAGEL, 2020), todo empreendimento para implantação de uma $\mathrm{PCH}$ é dividido em fases, sendo a primeira associada ao levantamento dos dados relevantes ao local como instalação, informações topográficas, geográficas e ambientais que autorizem o desenvolvimento do projeto, com foco principal nas características do curso d'água e na bacia hidrográfica. Depois de identificado um potencial hidrelétrico o próximo passo é apurar se o rio já possui inventário, caso não tenha, faz-se um estudo para o detalhamento do potencial do curso d'água e a partição de quedas. A efetividade do projeto vai depender quase em sua totalidade do impacto ambiental ocasionado. Athayde (2008), afirma que a cota altimétrica mais baixa da bacia do paraná III é de 86 metros sobre o nível do mar, próximo ao reservatório de ITAIPU, ligado ao rio paraná, já as cotas mais elevadas da bacia situam-se perto do município de Cascavel com altitude de 768 metros sobre o nível do mar. Próximo a esta região localiza-se a nascente do rio Arroio Guaçu, um dos principais rios que abastecem esta bacia, composta por vários afluentes. Em concordância com Rocha e Bade (2018), próximo à jusante junto ao rio Paraná, que é caracterizado sendo um território moderadamente plano, sua densidade de drenagem possui um valor de $0,9 \mathrm{~km} / \mathrm{km}^{2}$, que de acordo com Beltrame (1994) é denominado como mediano, sendo favorável para o fator do potencial hidráulico. Segundo Batista, et al. (2012) os impactos provocados pela implantação de uma hidrelétrica são notáveis, cabendo ao gestor deste negócio a utilização racional dos recursos naturais, visto que, todo o impacto ecossistêmico pode ser reduzido com planejamento eficiente e execução sustentável abrangente. Com respeito a área inundada, uma boa proposta é a implantação de uma PCH à fio d'água, onde o encadeamento de impactos ambientais será em sua grande maioria reduzido, pela diminuição demasiada de sua área alagada, que por consequência reduz o desmatamento e protege a fauna. Visto que, essa é uma região com regime chuvoso ativo, onde pode-se fazer o aproveitamento de seu potencial hidrelétrico oferecendo impactos ambientais em escala muito menor.

Conclusão: A região analisada tem um alto índice de sucesso com a inserção deste empreendimento, trazendo um desenvolvimento socioeconômico para a localidade. O Brasil necessita diversificar suas alternativas de abastecimento, para amparar sua demanda e melhor qualidade da população, utilizando novas fontes geradoras bem como tecnologias para obtenção de energia elétrica a baixo custo e maior preservação do meio ambiente.

\section{Referências}

AGÊNCIA NACIONAL DE ENERGIA ELÉTRICA. Boletim Energia, n¹44, 2004. Disponível em: < https://www.aneel.gov.br/>. Acesso em: 14 ago. 2020.

ALBARELLO, Leonardo. Guia para a Implantação de Pequenas Centrais Hidrelétricas PCHs: Eficiência energética aplicada em processos produtivos. 2014. 37 f. Curso de Pós-Graduação Universidade Federal de Santa Maria, Educação a Distância da UFMS, Universidade Aberta do Brasil, Panambi, 2014.

ATHAYDE, Gustavo Barbosa. Análise Estrutural e Hidro química do Aquífero Serra Geral na Bacia Hidrográfica do Paraná III. 2008. 128 f. Dissertação (Curso de Pós-Graduação) Universidade Federal do Paraná, Curitiba, 2008. 
BATISTA, Bruna Maria Faria; et al. REVISÃO DOS IMPACTOS AMBIENTAIS GERADOS NA FASE DE INSTALAÇÃO DAS HIDRELÉTRICAS: UMA ANÁLISE DA SUB-BACIA DO ALTO JURUENA MT. 2012. 85 f. Mestrandas do PPG em Ciências Florestais e Ambientais Universidade Federal de Mato Grosso. Campos de Julio, 2012.

BRASIL. Associação Brasileira de Geração de Energia Limpa. Fase de Estudos e Projetos. Disponível em: < https://www.abragel.org.br/fase-de-estudos-e-projetos/>. Acesso em: 19 ago. 2020.

BRASIL. Associação Brasileira de PCHs e CGHs. O que são PCHs e CGHs. Disponível em: < https://abrapch.org.br/2019/12/12/com-terceiro-maior-potencial-hidreletrico-do-brasil-parana-debate-implantacao-de-pchs-e-cghs/ >. Acesso em: 12 ago. 2020.

DA VEIGA BELTRAME, Angela. Diagnóstico do meio físico de bacias hidrográficas: modelo e aplicação. Universidade Federal de Santa Catarina, 1994.

EICK, Guilherme et al. Viabilidade Econômica e Financeira de uma pequena central hidrelétrica no brasil. 2010.

Empresa de Pesquisa Energética: Matriz Energética e Elétrica. Rio de Janeiro, RJ, 2018. Disponível em: < https://www.epe.gov.br/pt/abcdenergia/matriz-energetica-e-eletrica >. Acesso em: 17 ago, 2020.

ROCHA, Anderson Sandro da; BADE, Maicol Rafael. Geografia da bacia hidrográfica do Paraná 3: fragilidades e potencialidades socioambientais. Jundiaí: In House, 2018. (312 p.). ISBN: 978-85-7899-591-1. Disponível em: http://repositorio.utfpr.edu.br:8080/jspui/bitstream/1/4117/3/geografiabaciahidrograficaparana.pdf. Acesso em: 16 ago, 2020. 


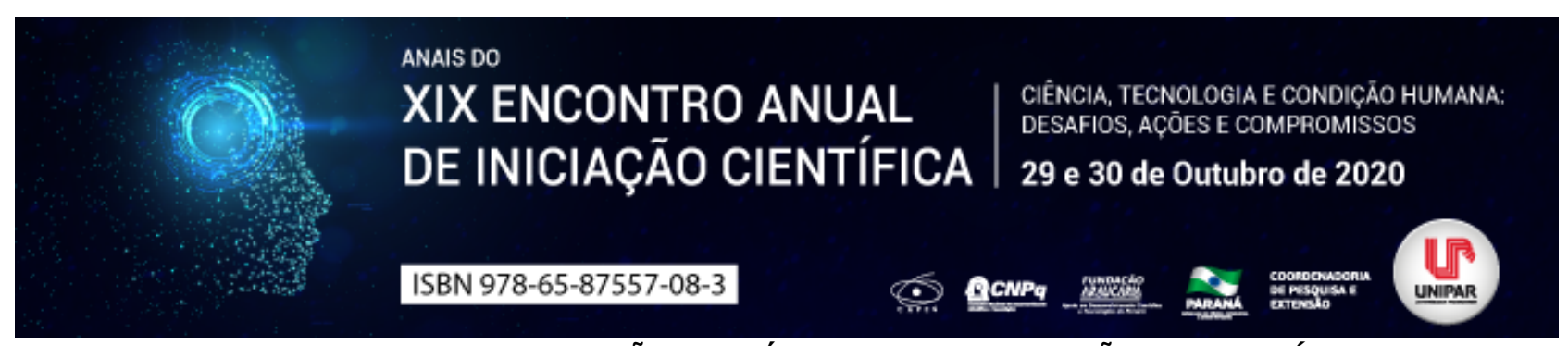

FATORES QUE INFLUENCIAM NA CONSIDERAÇÃO A ANÁLISE LINEAR OU A NÃO LINEAR FÍSICA DE ESTRUTURAS

\author{
${ }^{1}$ EVERTON LUIS CONSONI DA SILVA, ${ }^{2}$ MATHEUS HENRIQUE ROSSATTO CASOLA, ${ }^{3}$ WELLINGTON GABRIEL AGUIAR \\ XAVIER, ${ }^{4}$ ANDRE KAZUHIRO SHIOTANI
}

\author{
${ }^{1}$ Acadêmico PIC/Unipar \\ ${ }^{1}$ Acadêmico do Curso de Engenharia Civil da UNIPAR \\ ${ }^{2}$ Acadêmico do Curso de Engenharia Civil da UNIPAR \\ ${ }^{3}$ Docente da UNIPAR
}

Introdução: Dentro da engenharia é necessária a busca pela correta discretização do comportamento de uma estrutura de forma que se aproxime ao máximo da realidade, permitindo assim, a concepção de estruturas mais seguras e ao mesmo tempo mais econômicas. Dessa forma, uma escolha do método de tratativa o qual será submetido é fundamental (FILHO 2005). Dentro desse contexto se destacam duas abordagens, a linear e a não linear. Para a consideração de uma análise linear segundo Bathe (2014) deve-se respeitar a lei de Hooke onde há uma linearidade entre os fatores carga - deslocamento. Entretanto, a partir do aumento do carregamento a estrutura deixar de apresentar essa resposta linear, necessitando formulação não linear para determinar seu verdadeiro comportamento. Dentro da análise não linear destaca-se a linearidade física (NLF) que está relacionada diretamente a deterioração do corpo durante o processo de carregamento, com essa consideração, consegue-se determinar resultados com maior exatidão para grandes carregamentos (LACERDA, 2014). Portanto, o presente trabalho visa apresentar a importância da consideração NLF no estudo de estruturas.

Objetivo: Destacar os fatores que devem ser levados em consideração para aplicação de análise linear ou não linear para real obtenção dos esforços a qual a estrutura está submetida.

Desenvolvimento: Para efeito de projeto, deseja-se obter os esforços últimos de colapso concebendo uma estrutura segura e ao mesmo tempo econômica. Dessa forma, dependendo das características do arranjo, esta resposta pode ser linear ou não linear. Em uma grande parcela dos problemas de análise estrutural a teoria da elasticidade serve de base para o dimensionamento dos elementos que a compõem, visto que a maioria das estruturas da engenharia civil possuem comportamento linear (REIS, 2019). Assim, para uma análise linear eficiente Bathe (2014) descreve que certos fatores devem ser respeitados, onde os deslocamentos devem ser infinitamente pequenos, as condições iniciais de contorno que não se alteram com o aumento do carregamento e o material possui comportamento linear elástico, ou seja, sua deformação pode ser obtida através da lei de Hooke, apresentando linearidade entre o fator carga-deslocamento. Entretanto, quando isso não ocorre é porque existe uma não linearidade no sistema estrutural, necessitando de uma nova formulação a fim de se obter a melhor resposta perante o carregamento. De acordo com Souza (2015), na abordagem não linear especificamente a NLF leva-se em consideração fenômenos tais como dano, fraturamento, entre outros, os quais mudam substancialmente as propriedades de rigidez do sistema. Segundo Lacerda (2014), a NLF está ligada diretamente às propriedades constituintes dos materiais, a perda de rigidez do elemento e ao histórico de carregamento da estrutura, ou seja, a partir de certos valores de carga há a perda da seção resistente do material, onde os elementos que compõem a estrutura perdem a capacidade de recuperar a sua forma inicial quando descarregados e passam a apresentar deformações plásticas. Em estudos realizados por Santos (2002), Rodrigues e Venturini (2005) e Reis (2019) com treliças planas, foi possível observar que na não-linearidade física, os deslocamentos apresentaram grande diferença para o mesmo valor do carregamento, gerando solicitações adicionais a estrutura que não se foi possível obter através da análise linear. No estudo de Marques (2017) com vigas de concreto em balanço, na análise linear encontrou-se deslocamentos de 0,005 metros com o incremento de $100 \%$ da carga percentual, entretanto, quando levado em consideração a não linearidade física o mesmo deslocamento foi obtido com apenas $52 \%$ da carga percentual.

Conclusão: Em vista dos argumentos apresentados, dentro dos parâmetros supracitados a análise linear é válida, entretanto, para grandes carregamentos é necessário se atentar a perda de rigidez da peça e, dessa forma verificar o real estado em que a peça está submetida a fim de melhor dimensioná-la.

\title{
Referências
}

BATHE, Klaus Jürgen Finite Element Procedures. Prentice Hall, 2014.

FILHO, Avelino Alves. Elementos Finitos: A base da tecnologia CAE. 6. ed. São Paulo: Érica Ltda, 2005. 445 p.

LACERDA, Estéfane George Macedo de. Análise não linear de treliças pelo método dos elementos finitos posicional. 2014. 107 f. Dissertação (Mestre em Engenharia Civil), Universidade Federal do Rio Grande do Norte, Natal, 2014. MARQUES, Guilherme José Bandeira Jovino. ANÁLISE NÃo LINEAR FíSICA DE ESTRUTURAS DE CONCRETO ARMADO 
UTILIZANDO O MÉTODO DAS MICRO TRELIÇAS. 2017. 79 f. Dissertação (Mestrado) - Curso de Engenharia Civil., Universidade Federal de Pernambuco, Recife, 2017.

REIS, Reinaldo Antonio. Implementação de um Código Computacional Destinado à Solução de Sistemas de Equações Lineares e Não lineares via Métodos Iterativos: Aplicações em Treliças Metálicas. Dissertação (Mestrado) 2019. $94 \mathrm{f}$ Universidade Federal de Ouro Preto, Ouro Preto 2019.

RODRIGUES, Rogério de Oliveira; VENTURINI, Wilson Sergio. Análise dinâmica bidimensional não linear física e geométrica de treliças de aço e pórticos de concreto armado. Cadernos de Engenharia de Estruturas, São Carlos, v. 7, n. 23, p. 61-93, 2005.

SANTOS, Rogerio Mitsuo dos. Análise de estruturas metálicas reticuladas planas considerando a não-linearidade física em sistemas não-conservativos. Dissertação de Mestrado, Faculdade de Engenharia, Departamento de Estruturas, Campinas, SP, Brasil, 2002.

SOUZA, Luiz Antonio Farani de. Análise não linear física de treliças planas por elementos finitos considerando a mecânica do dano. In: IX EPCC Encontro Internacional de Produção Científica UniCesumar, 9., 2015, Maringá. Anais... Maringá: Universidade Tecnológica Federal do Paraná, 2015. pp. 4-8. 


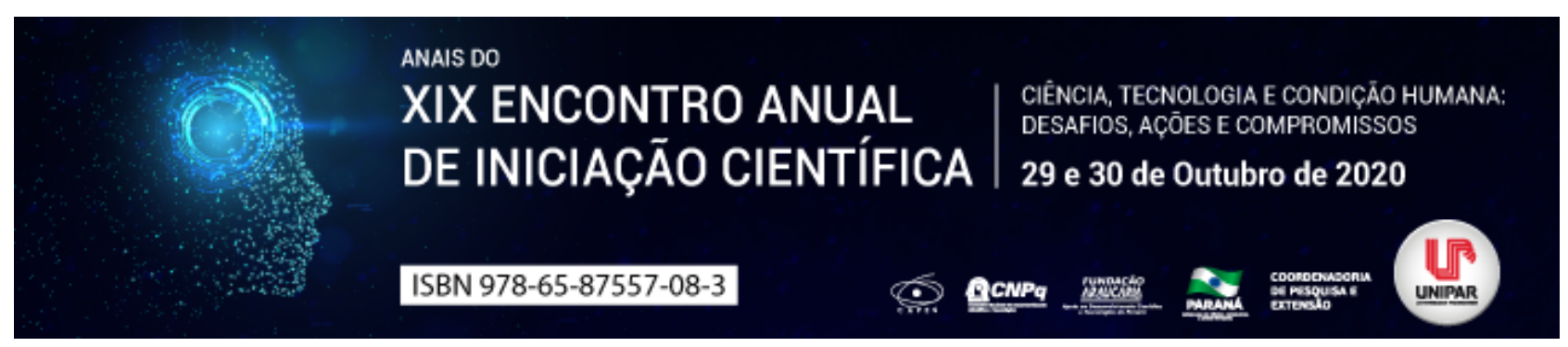

EXTRATO AQUOSO DE Digitaria insularis NO CONTROLE DE Meloidogyne javanica

\begin{abstract}
${ }^{1}$ Enio Amado Martin, ${ }^{2}$ SIMONE DE MELO SANTANA-GOMES, ${ }^{3}$ MARIA CLAUdIA GUIMARÃES CARPI, ${ }^{4}$ MARCELO DE FARIAS OLIVEIRA, ${ }^{5}$ CLÁUDIA REGINA DIAS-ARIEIRA
\end{abstract}

\author{
${ }^{1}$ Discente do curso de Agronomia - UEM \\ ${ }^{1}$ Pós-doutoranda em Nematologia Agrícola e docente do Mestrado em Ciências Agrárias - UEM \\ ${ }^{2}$ Mestranda de Ciências Agrárias - UEM \\ ${ }^{3}$ Discente do curso de Agronomia - UEM \\ ${ }^{4}$ Docente da graduação em Agronomia, Pós- graduação em Agronomia e em Ciências Agrárias - UEM
}

Introdução: Nematoides parasitas de plantas estão entre os organismos mais prejudiciais para a agricultura, com perdas mundiais anuais estimadas em mais de 100 bilhões de dólares (RALMI et al., 2016). No Brasil, os nematoides de maior relevância na cultura da soja são os nematoides das galhas (Meloidogyne javanica e M. incognita), o nematoide das lesões radiculares (Pratylenchus brachyurus), o nematoide de cisto da soja (Heterodera glycines) e o nematoide reniforme (Rotylenchulus reniformis) (FAVORETO et al., 2019).

Recentemente, Lopes et al. (2019) observaram que o extrato do capim amargoso (Digitaria insularis) reduziu significativamente a eclosão de juvenis de Meloidogyne spp. Devido ao menores riscos ambientais, o emprego de extratos vegetais contendo propriedades nematicidas pode ser uma alternativa de controle sustentável dos fitonematoides (GARDIANO et al., 2009).

Objetivo: Avaliar diluições do extrato aquoso bruto de $D$. insularis no controle de $M$. javanica em soja.

Material e Métodos: O experimento foi conduzido em casa de vegetação, na Universidade Estadual de Maringá, em Umuarama$\mathrm{PR}$, em copos de isopor com capacidade para $500 \mathrm{~mL}$, preenchido com uma mistura de solo e areia (2:1), previamente autoclavado $\left(120^{\circ} \mathrm{C} ; 2 \mathrm{~h}\right)$. Para o preparo do extrato, $D$. insularis foi cultivada em vasos por 60 dias, depois sua parte aérea foi coletada e submetida à secagem em temperatura de $45^{\circ} \mathrm{C}$,_até_massa constante. $\mathrm{O}$ extrato aquoso foi obtido a partir da trituração da massa seca da planta, diluída em água destilada, na proporção 1:15 (m:v), cuja suspensão permaneceu em repouso por 24 horas, sendo filtrada após esse período. Do extrato obtido foram feitas cinco diluições (0, 5, 10, 15 e 20\%) em água que foram aplicadas no solo num volume de calda equivalente_a $400 \mathrm{~L} \mathrm{ha}^{-1}$. O inóculo foi obtido de populações puras de $M$. javanica, mantidas em raízes de tomateiros e calibrado para 2000 ovos e eventuais juvenis $/ \mathrm{mL}$. Em cada unidade experimental, foi aberto um orifício no centro, onde se depositou $1 \mathrm{~mL}$ de inóculo, seguido da semeadura da soja cv. M6210 IPRO e, por fim, das diluições do extrato. Após 60 dias de cultivo, as plantas foram coletadas, sendo avaliado os parâmetros vegetativos e nematológicos. Os nematoides foram extraídos pela metodologia de Hussey e Barker (1973) adaptada por Boneti e Ferraz (1981), quantificados em câmara de Peters, sob microscópio ótico. Os dados foram submetidos à análise de variância $(p \leq 0,05)$ e as médias foram comparadas pelo teste de Tukey a 5\% de significância, no programa estatístico Sisvar (FERREIRA, 2011).

Resultados: As diluições do extrato aquoso de $D$. insularis não promoveram controle de $M$. javanica na cultura da soja. Embora as médias populacionais de nematoide por sistema radicular tenham sido iguais à testemunha (30972 espécimes), as diluições de 10 (21165 espécimes), 15 (23575 espécimes) e 20\% (18902 espécimes) promoveram menores reproduções do nematoide quando comparado à diluição de 5\% (66782 espécimes). A variável número de nematoides por grama de raiz apresentou o mesmo comportamento de nematoides por sistema radicular. Os parâmetros vegetativos avaliados não foram _afetados_(p $>0,05)$. As médias de altura, massa fresca e seca de parte aérea e massa fresca de raiz foram, respectivamente, $22,1 \mathrm{~cm} ; 6,9 \mathrm{~g} ; 1,9 \mathrm{~g} \mathrm{e}$ $2,9 \mathrm{~g}$.

Discussão: Mesmo não havendo efeito aditivo no desenvolvimento vegetal, os resultados demonstraram a ausência de efeito fitotóxico, o que é interessante quando se trabalha com extratos. A ausência da atividade nematicida pode estar relacionada a fatores como degradação da molécula no solo, lixiviação do princípio ativo e quantidade insuficiente do extrato aplicado. Diferente do que foi observado aqui, extratos oriundos de plantas daninhas de outras famílias botânicas apresentaram efeito nematicida in vivo, a exemplo do extrato aquoso de buva (Conyza bonariensis) e leiteiro (Euphorbia heterophylla) sobre $M$. incognita em testes in vitro e em casa de vegetação, na cultura do tomate (KUHN et al., 2015). Porém, é importante ressaltar que plantas de diferentes famílias podem produzir substâncias secundárias diferentes, com bioatividade variada. A baixa atividade do extrato em casa de vegetação sugere a necessidade de pesquisas adicionais, buscando avaliar novas formas de aplicação de doses do extrato para o controle da reprodução do nematoide em plantas suscetíveis.

Conclusão: $O$ extrato aquoso de capim amargoso não reduziu a reprodução de $M$. javanica e não afetou o desenvolvimento vegetativo da soja cultivada em casa de vegetação. 


\section{Referências}

BONETI, J. I. S.; FERRAZ, S. Modificação do método de HUSSEY e BARKER para extração de ovos de Meloidogyne exigua de raízes de cafeeiro. Fitopatologia Brasileira, Brasília, v.6, p.553, 1981.

FAVORETO, L.; MEYER, M. C.; DIAS-ARIEIRA, C. R.; MACHADO, A. C. Z.; SANTIAGO, D. C.; RIBEIRO, N. R. Diagnose e manejo de fitonematoides na cultura da soja. Informe Agropecuário, Uberlândia, v. 40, p. 18-29, 2019.

FERREIRA, D. F. Sisvar: a computer statistical analysis system. Ciência e Agrotecnologia, Lavras, v. 35, p. 1039-1042, 2011.

GARDIANO, C. G.; FERRAZ, S.; LOPES, E. A.; FERREIRA, P. A.; AMORA, D. X.; FREITAS, L. G. Avaliação de extratos aquosos de várias espécies vegetais, aplicados ao solo, sobre Meloidogyne javanica (TREUB, 1885) CHITWOOD, 1949. Semina: Ciências Agrárias, Londrina, v. 30, v. 3, p. 551-556, 2009.

KUHN, P. R.; BELLÉ, C.; REINEHR, M.; KULCZYNSKI., S. M. Extratos aquosos de plantas daninhas, aromáticas e oleaginosa no controle de Meloidogyne incognita. Nematropica, Auburn, v. 45, p. 150-157, 2015.

LOPES, A. P. M.; SOARES, M. R. C.; CHIDICHIMA, L. P. S.; DIAS-ARIEIRA, C. R. Weed hosts of Meloidogyne spp. and the effect of aqueous weed extracts on egg hatching. Weed Research, v. 2019, p. 1-8, 2019. https://doi.org/10.1111/wre.12399 RALMI, N. H. A. A.; KHANDAKER, M. M.; MAT, N. Occurrence and control of root knot nematode in crops: A review. Australian Journal of Crop Science, v. 10, p. 1649-1654, 2016. 